\title{
Proteomics analysis reveals involvement of Krt17 in areca nut-induced oral carcinogenesis
}

Supporting Information

Chang-Hsu Chianga,b, Chih-Ching Wu ${ }^{\mathrm{a}, \mathrm{b}, \mathrm{c}, \mathrm{d}}$, Li-Yu Lee ${ }^{\mathrm{e}}$, Yi-Chen Li ${ }^{\mathrm{a}}$, Hao-Ping Liu ${ }^{\mathrm{f}}$, Chia-Wei Hsu ${ }^{\mathrm{c}}$, Ya-Ching Lu ${ }^{\mathrm{a}}$, Joseph T. Chang, Ann-Joy Cheng ${ }^{\mathrm{a}, \mathrm{b}}$

a Department of Medical Biotechnology and Laboratory Science, College of Medicine, Chang Gung University, Kwei-Shan, Tao-Yuan, Taiwan

${ }^{\mathrm{b}}$ Graduate Institute of Biomedical Sciences, College of Medicine, Chang Gung University, Kwei-Shan, Tao-Yuan, Taiwan

c Molecular Medicine Research Center, Chang Gung University, Kwei-Shan, Tao-Yuan, Taiwan

d Department of Otolaryngology-Head \& Neck Surgery, Chang Gung Memorial Hospital, Linkou, Taiwan

e Department of Pathology, Chang Gung Memorial Hospital, Tao-Yuan, Taiwan

${ }^{\mathrm{f}}$ Department of Veterinary Medicine, National Chung Hsing University, Tai-Chung, Taiwan

g Department of Radiation Oncology, Chang Gung Memorial Hospital, Tao-Yuan, Taiwan

\section{Table of contents}

- Supplemental Materials and Methods.

- Table S-1. Names and sequences of oligonucleotides used for quantitative PCR analysis

- Table S-2. List of antibodies used for western blot and immunohistochemistry

- Table S-3. Information of peptides identified in areca nut extract (ANE)-trained cell lines (set 1)

- Table S-4. Information of peptides identified in areca nut extract (ANE)-trained cell lines (set 2)

- Table S-5. List of differentially expressed proteins in areca nut extract (ANE)-trained cell lines

Table S-5-1. List of differentially expressed proteins in areca nut extract (ANE)-trained SAS cell lines

Table S-5-2. List of differentially expressed proteins in areca nut extract (ANE)-trained OECM1 cell lines

Table S-5-3. List of differentially expressed proteins in areca nut extract (ANE)-trained CGHNK2 cell lines

Table S-5-4. List of differentially expressed proteins in areca nut extract (ANE)-trained CGHNC9 cell lines

- Figure S-1. ANE induced cell migration and invasion in normal keratinocytes.

- Figure S-2. Krt17 expression was increased in advanced stage oral cancers. 


\section{Supplemental Materials and Methods}

Preparation of cell extracts and digestion of protein mixtures for proteome analysis

Cells were lysed in buffer containing $100 \mathrm{mM}$ triethylammonium bicarbonate (TEABC, Sigma-Aldrich, St. Louis, MO, USA) and 0.1\% RapiGest ${ }^{\mathrm{TM}}$ SF (Waters Corporation, Milford, MA, USA) on ice for $15 \mathrm{~min}$. The cell lysate was collected and sonicated on ice, followed by centrifugation at $10000 \mathrm{x}$ g for $25 \mathrm{~min}$ at $4^{\circ} \mathrm{C}$. The resulting supernatant was used as the cell extract. For tryptic in-solution digestion, protein mixtures were denatured with $8 \mathrm{M}$ urea containing $50 \mathrm{mM}$ TEABC, reduced with $10 \mathrm{mM}$ tris-(2-carboxyethyl)-phosphine (TCEP, Sigma-Aldrich) at $37^{\circ} \mathrm{C}$ for 90 min and then alkylated with $10 \mathrm{mM}$ methyl methanethiosulfonate (MMTS, Sigma-Aldrich) at room temperature for $20 \mathrm{~min}$. After desalting, the protein mixtures were in-solution digested with modified, sequencing grade trypsin (Promega, Madison, WI, USA) at $37^{\circ} \mathrm{C}$ overnight [1].

\section{iTRAQ reagent labeling and fractionation by strong cation exchange (SCX) chromatography}

The peptides were labeled with iTRAQ reagent (Applied Biosystems, Foster City, CA, USA) according to the manufacturer's protocol. One unit for labeling (defined as the amount of reagent required to label $100 \mu \mathrm{g}$ of protein) was thawed and reconstituted in ethanol $(70 \mu \mathrm{L})$. The peptide mixtures were reconstituted with $25 \mu \mathrm{L}$ iTRAQ dissolution buffer. In the experiment set 1, the aliquots of iTRAQ 114 and 115 were combined with peptide mixtures from parental and ANE-trained SAS cells, respectively. The peptides from parental and ANE-trained OECM1 cells were labeled 
with iTRAQ 116 and 117, respectively. For the experiment set 2, the iTRAQ 114 and 115 reagents were added into peptide mixtures of parental and ANE-trained CGHNK2 cells, respectively. And the peptides from parental and ANE-trained CGHNC9 cells were labeled with iTRAQ 116 and 117, respectively. After incubation at room temperature for $1 \mathrm{~h}$, the peptide mixtures in each set were then pooled and dried by vacuum centrifugation. The dried peptide mixture was reconstituted and acidified with $0.5 \mathrm{~mL}$ buffer $\mathrm{A}(0.1 \%$ formic acid and $25 \%$ acetonitrile, $\mathrm{pH} 2.5)$ for fractionation by SCX chromatography using the Ettan MDLC system (GE Healthcare).

For peptide fractionation, the iTRAQ-labeled peptides were loaded onto a $2.1 \times 250 \mathrm{~mm}$ BioBasic SCX column containing 5- $\mu \mathrm{m}$ particles with $300-\mu \mathrm{m}$ pore size (Thermo Electron). The peptides were eluted at a flow rate of $100 \mu \mathrm{L} / \mathrm{min}$ with a gradient of $0 \%-10 \%$ buffer $\mathrm{B}\left(300 \mathrm{mM} \mathrm{NH}_{4} \mathrm{Cl}, 0.1 \%\right.$ formic acid and $25 \%$ acetonitrile, $\mathrm{pH} 2.5$ ) for $20 \mathrm{~min}, 10 \%-20 \%$ buffer B for 35 min, 20\%-50\% buffer B for $15 \mathrm{~min}$, and $50 \%-100 \%$ buffer B for $10 \mathrm{~min}$. The elution was monitored by absorbance at $220 \mathrm{~nm}$, and fractions were collected every 1 min. Each fraction was vacuum dried and then resuspended in $0.1 \%$ formic acid $(20 \mu \mathrm{L})$ for further desalting and concentration using the ziptip home-packed with $\mathrm{C}_{18}$ resin (5-20 $\mu \mathrm{m}$, LiChroprep RP-18, Merck, Taipei, Taiwan).

\section{LC-ESI MS/MS analysis by LTQ-Orbitrap PQD}

To analyze the iTRAQ-labeled peptide mixtures, each peptide fraction was reconstituted in buffer $\mathrm{C}(0.1 \%$ formic acid), loaded across a trap column (Zorbax 300SB-C18, $0.3 \times 5 \mathrm{~mm}$, Agilent Technologies, Wilmington, DE, USA) at a flow rate of 
$0.2 \mu \mathrm{L} / \mathrm{min}$ in buffer $\mathrm{C}$, and separated on a resolving $10-\mathrm{cm}$ analytical $\mathrm{C}_{18}$ column (inner diameter, $75 \mu \mathrm{m}$ ) with a $15-\mu \mathrm{m}$ tip (New Objective, Woburn, MA, USA). The peptides were eluted using a linear gradient of 2-30\% buffer D (acetonitrile containing 0.1\% formic acid) for $63 \mathrm{~min}, 30-45 \%$ buffer D for $5 \mathrm{~min}$, and 45-95\% buffer D for 2 min with a flow rate of $0.25 \mu \mathrm{L} / \mathrm{min}$. The LC apparatus was coupled with a two-dimensional linear ion trap mass spectrometer (LTQ-Orbitrap Discovery, Thermo Fisher Scientific, CA, USA) operated using the Xcalibur 2.0 software package (Thermo Fisher Scientific). Polycyclodimethylsiloxane ion ( $\mathrm{m} / \mathrm{z} 445.120025)$ was used as lock-mass ion for internal calibration. Peptides were detected in the Orbitrap at a resolution of 30000. Peptides were selected for MS/MS using the PQD operating mode with a normalized collision energy setting of $27 \%$, and fragment ions were detected in the LTQ [1]. The data-dependent procedure that alternated between one MS scan followed by three MS/MS scans for the three most abundant precursor ions in the MS survey scan was applied. The $m / z$ values selected for MS/MS were dynamically excluded for 3 min. The electrospray voltage applied was $1.8 \mathrm{kV}$. Both MS and MS/MS spectra were acquired using the 4 microscan with a maximum fill-time of 1000 and 100 ms for MS and MS/MS analyses, respectively. Automatic gain control was used to prevent over-filling of the ion trap, and $5 \times 10^{4}$ ions were accumulated in the ion trap for generation of PQD spectra. For MS scans, the $m / z$ scan range was 350 to $2000 \mathrm{Da}$.

\section{Sequence database searching and quantitative data analysis}

The MS/MS spectra were searched against the Swiss-Prot human sequence database (released Jun 15, 2010, selected for Homo sapiens, 20367 entries) using the Mascot search engine (Matrix Science, London, UK; version 2.2.04). For protein 
identification, 10 ppm mass tolerance was permitted for intact peptide masses and 0.5 Da for PQD fragment ions, with allowance for two missed cleavages made from the trypsin digest: oxidized methionine (+16 $\mathrm{Da})$ as a potential variable modification, and iTRAQ ( $\mathrm{N}$ terminal, +144 Da), iTRAQ (K, +144 Da) and MMTS (C, +46 Da) as the fixed modifications. Protein identification and quantification were validated using the default setting of open source trans-proteomic pipeline (TPP) software (Version 4.0). The MASCOT search resulted in a DAT file for each LC-MS/MS run. The MS raw data and DAT files containing peak list information for identified peptides were then processed and analyzed using TPP software, which includes PeptideProphet and ProteinProphet. In this study, we used ProteinProphet probability scores $\geq 0.95$ to ensure an overall false-positive rate less than $1.0 \%$. The ratio of each protein was quantified using the Libra program, a module within the TPP software package that performs quantification on MS/MS spectra that have multiplexed labeled peptides. The minimum peak intensity threshold of a reporter ion was zero in the spectrum of a LIBRA peptide. The default parameters of the LIBRA program were used to remove the outlier ratios of peptides quantitation. Each quantified protein contained at least three LIBRA peptides. Information about the PeptideProphet, ProteinProphet, and Libra programs in the TPP software can be obtained from the Seattle Proteome Center at the Institute for Systems Biology (http://www.proteomecenter.org/). The analytical reliability of iTRAQ coupling with Moscot search engine and TPP software has been shown in our previous work [2,3]. Proteins with single peptide hits were removed, and quantitative data were exported and manually normalized such that the log2 of iTRAQ ratios displayed a median value of zero for all peptides in a given protein. This was performed across an entire labeling experiment to correct for variation in protein abundance. The cut-off value for determining whether a protein is considered 
dysregulated was selected according to the analysis using comparison of protein ratios between equal amounts of the same cell extract [1]. Based on this, proteins with log2 ratios below the mean of all log2 ratios minus one standard deviation (SD) of all log2 ratios were considered to be under-expressed. Proteins above the mean plus one SD were considered to be over-expressed.

\section{References:}

1. Kuo RL, Lin YH, Wang RY, Hsu CW, Chiu YT, Huang HI, Kao LT, Yu JS, Shih SR, Wu CC. Proteomics analysis of EV71-infected cells reveals the involvement of host protein NEDD4L in EV71 replication. J Proteome Res 2015;14:1818-1830.

2. Liu HP, Wu CC, Kao HY, Huang YC, Liang Y, Chen CC, Yu JS, Chang YS. Proteome-wide dysregulation by PRA1 depletion delineates a role of PRA1 in lipid transport and cell migration. Mol Cell Proteomics 2011;10:M900641MCP200.

3. Chen CL, Chung T, Wu CC, Ng KF, Yu JS, Tsai CH, Chang YS, Liang Y, Tsui $\mathrm{KH}$, Chen YT. Comparative tissue proteomics of microdissected specimens reveals novel candidate biomarkers of bladder cancer. Mol Cell Proteomics 2015;14:2466-2478. 
Table S-1. Names and sequences of oligonucleotides used for quantitative PCR analysis

\begin{tabular}{|c|c|c|c|}
\hline Gene & Sequence (5' to 3') & Gene & Sequence (5' to 3') \\
\hline \multirow[t]{2}{*}{ ITGB4 } & F: 5' CAAGGGCCGTGACGTGGTCC 3' & CRNKL1 & F: 5' TCTТССАССТССАССТСААС 3' \\
\hline & R: 5' GGGCGCCATCAGCACTGTGT 3' & & R: 5' TGCGTATTTCAGCCAGAGTG 3' \\
\hline \multirow[t]{2}{*}{ IQGAP1 } & F: 5' GCTGCCCCAGGTGTATCCAT 3' & NDUFAF2 & F: 5' GCAGGGGATATTCCAACAGA 3' \\
\hline & R: 5' TCTCTGCATGTGCCTGAGCC 3' & & R: 5' GCAGGAGTTCCTCACTGGTC 3' \\
\hline \multirow[t]{2}{*}{ HMGCS1 } & F: 5' ATAGTGGCCTGGAAGCCTTT 3' & THBS1 & F: 5' TCCTGGACTCGCTGTAGGTT 3' \\
\hline & R: 5' TGGGTGTCCTCTCTGAGCTT 3' & & R: 5' GCCTATGTGACGAGGGTCAT 3' \\
\hline \multirow[t]{2}{*}{ KRT17 } & F: 5' CAGTTCACСТCСТCСAGCTC 3' & TPM2 & F: 5' CCACCAAAGAAGATAAATATGAAG 3' \\
\hline & R: 5' TCTTGTTCTGCAGCTCCTCA 3' & & R: 5' CAGTTCCTCGCTAATGGC 3' \\
\hline \multirow[t]{2}{*}{ IL1A } & F: 5' ACCTGGAGGCCATCGCCAAT 3' & PDLIM5 & F: 5' TCCACAAACAACATGGCCTA 3' \\
\hline & F: 5' TGCAGCAGCCGTGAGGTACT 3' & & R: 5' TCAGTGCAGATGGAGACTGG 3' \\
\hline \multirow[t]{2}{*}{ NDRG1 } & F: 5' CAAACTGCCAAAAACAAGAC 3' & BYSL & F: 5' CTGGTTCAAAGGGATCCTGA 3' \\
\hline & R: 5' TTGCTGCACATTAAGAGGAT 3' & & R: 5' AGTCGCAGGAAGATGCTGTT 3' \\
\hline \multirow[t]{2}{*}{ ITGA6 } & F: 5' TTGGAGCTTTTGTGATGGGC 3' & HDAC2 & F: 5' ATAAAGCCACTGCCGAAGAA 3' \\
\hline & R: 5' GCTCAGTCTCTCCACСААСТ 3' & & R: 5' TCCTCCAGCCCAATTAACAG 3' \\
\hline \multirow[t]{2}{*}{ HMGA2 } & F: 5' CAGCCTAAGCAACAGCAG 3' & RAB3GAP1 & F: 5' TCACCCCGGGATTATATTGA 3' \\
\hline & R: 5' AGCACCTTTCGGGAGATG 3' & & R: 5' GAGCAAGGTCTGCAGGTTTC 3' \\
\hline \multirow[t]{2}{*}{ NT5E } & F: 5' CGCAACAATGGCACAATTAC 3' & POP1 & F: 5' GAGGCCAGTGAAAACCATGT 3' \\
\hline & R: 5' CTCGACACTTGGTGCAAAGA 3' & & R: 5' GCAAGCCTCTCTGGTCAATC 3' \\
\hline \multirow[t]{2}{*}{ STAT1 } & F: 5' CCGTTTTCATGACCTCCTGT 3' & ERP44 & F: 5' CATTCTGCTCCGGATATGGT 3' \\
\hline & R: 5' TGAATATTCCCCGACTGAGC 3' & & R: 5' GCCGAGCTACTTCATTCTGG 3' \\
\hline \multirow[t]{2}{*}{ VIM } & F: 5' GAGAACTTTGCCGTTGAAGC 3' & WRNIP1 & F: 5' GGCCCAGTGTGTGGTCTACT 3' \\
\hline & R: 5' TCCAGCAGCTTCCTGTAGGT 3' & & R: 5' TCGCTGTACATGGGGTTGTA 3' \\
\hline \multirow[t]{2}{*}{ SH3KBP1 } & F: 5' GGCGACATCATAGAGGTGGT 3' & S100A2 & F: 5' GGCTGTGCTGGTCACTACCT 3' \\
\hline & R: 5' CTTGAGTCACCCCСАTCACT 3' & & R: 5' CCTGCTGGTCACTGTTCTCA 3' \\
\hline \multirow[t]{2}{*}{ GPRC5A } & F: 5' TGCTCACAAAGCAACGAAAC 3' & ARHGDIA & F: 5' GAGCCTGCGAAAGTACAAGG 3' \\
\hline & R: 5' TGGTTCTGCAGCTGAAAATG 3' & & R: 5' TCCTTCAGCACAAACGACTG 3' \\
\hline \multirow[t]{2}{*}{ DBN1 } & F: 5' GAGGAAGTGGAAGGGGAGTC 3' & SLC1A5 & F: 5' ACATCCTGGGCTTGGTAGTG 3' \\
\hline & R: 5' TCGATCTCTGGAGGCTTGTT 3' & & R: 5' GGGCAAAGAGTAAACCCACA 3' \\
\hline \multirow[t]{2}{*}{ WDR7 } & F: 5' TCCTCGAGCACTGTTGTTTG 3' & & \\
\hline & R: 5' AATGTCCGTGGCATAAAAGC 3' & & \\
\hline
\end{tabular}


Table S-2. List of antibodies used for western blot and immunohistochemistry

\begin{tabular}{lll}
\hline Primary antibody & Clonality & Source \\
\hline KRT17 & Polyclonal & Abcam \\
E-cadherin & Polyclonal & Santa cruz \\
N-cadherin & Polyclonal & Santa cruz \\
Slug & Polyclonal & Santa cruz \\
GAPDH & monoclonal & Chemicon \\
\hline Secondary antibody & Conjugation & Source \\
\hline goat anti-rabbit & Horseradish Peroxidase (HRP) & Millipore \\
donkey anti-goat & Horseradish Peroxidase (HRP) & Santa cruz \\
goat anti-mouse & Horseradish Peroxidase (HRP) & Santa cruz \\
\hline
\end{tabular}


Table S-3. Information of peptides identified in areca nut extract (ANE)-trained cell lines (set 1)

\begin{tabular}{|c|c|c|c|c|c|c|c|c|c|}
\hline \multirow[b]{2}{*}{$\begin{array}{l}\text { Unique and } \\
\text { stable accession } \\
\text { no. of a } \\
\text { UniProtKB } \\
\text { entry }\end{array}$} & \multirow[b]{2}{*}{$\begin{array}{l}\text { Mnemonic } \\
\text { accession } \\
\text { no. of a Gene } \\
\text { UniProtKB names } \\
\text { entry }\end{array}$} & \multirow[b]{2}{*}{ Protein names } & \multirow[b]{2}{*}{$\begin{array}{l}\mathrm{MW} \\
(\mathrm{kDa})\end{array}$} & \multirow{2}{*}{\multicolumn{2}{|c|}{ 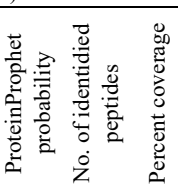 }} & \multicolumn{4}{|c|}{ Log2 ratio of ANE-trained/parental cells } \\
\hline & & & & & & $\begin{array}{c}\text { SAS } \\
(115 / 114)\end{array}$ & $\begin{array}{l}\text { SD of } \\
\text { peptide } \\
\text { ratios } \\
\text { from the } \\
\text { protein }\end{array}$ & $\begin{array}{c}\text { OECM1 } \\
(117 / 116)\end{array}$ & $\begin{array}{l}\text { SD of } \\
\text { peptide } \\
\text { ratios } \\
\text { from the } \\
\text { protein }\end{array}$ \\
\hline
\end{tabular}

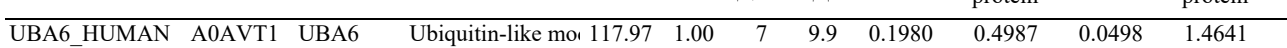

Peptide sequence

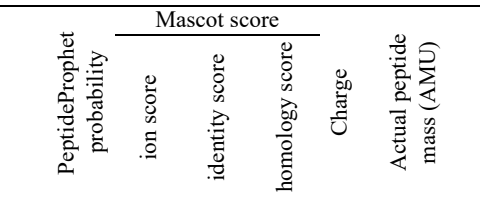
$\begin{array}{llllllllllll}\text { AIPAIATTTATVSGLVALEMIK } & 0.53 & 67.69 & 22.23 & 80.69 & 3 & 2212.2781 & 2212.2752 & 738.4323 & 0.0029 & 1.3091 & 1.765 \\ \text { IIPAIATTTATVSGLVALEMIK } & 0.53 & 37.81 & 22.23 & 50.81 & 3 & 2212.2784 & 2212.2752 & 738.4323 & 0.0032 & 1.4445 & 17.270\end{array}$

\section{KPDHVPISSEDER}

KPDHVPISSEDER

$\begin{array}{llllllllllll}1.00 & 27.13 & 27.74 & 21.38 & 4 & 1795.9313 & 1795.9308 & 449.9900 & 0.0005 & 0.2778 & 3974.707 & 43\end{array}$

DPPEEEIPFCTLK

$\begin{array}{llllllllllll}1.00 & 19.69 & 27.73 & 14.95 & 4 & 1795.9337 & 1795.9308 & 449.9900 & 0.0029 & 1.6111 & 856.730 & \\ 1.00 & 48.42 & 27.02 & 22.40 & 2 & 1850.9034 & 1850.9038 & 926.4592 & 0.0004 & 0.2159 & 61.513 & \end{array}$

DPPEEEIPFCTLK

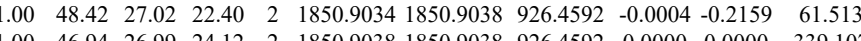

LFLVYRPNTGK

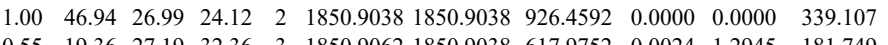

$\begin{array}{llllllllllll}0.55 & 19.36 & 27.19 & 32.36 & 3 & 1850.9062 & 1850.9038 & 617.9752 & 0.0024 & 1.2945 & 181.749 \\ 0.94 & 25.86 & 27.56 & 26.29 & 3 & 1306.7398 & 1306.7397 & 436.5872 & 0.0001 & 0.0763 & 44.423\end{array}$ $\begin{array}{lllllllllll}0.94 & 25.86 & 27.56 & 26.29 & 3 & 1306.7398 & 1306.7397 & 436.5872 & 0.0001 & 0.0763 & 44.423 \\ 0.99 & 38.10 & 27.51 & 27.75 & 2 & 1306.7400 & 1306.7397 & 654.3771 & 0.0003 & 0.2292 & 16.815\end{array}$ $\begin{array}{llllllllllll}0.99 & 38.10 & 27.51 & 27.75 & 2 & 1306.7400 & 1306.7397 & 654.3771 & 0.0003 & 0.2292 & 16.815 \\ 0.98 & 26.81 & 27.26 & 24.35 & 3 & 1306.7404 & 1306.7397 & 436.5872 & 0.0007 & 0.5344 & 67.875\end{array}$ $\begin{array}{lllllllllllll}0.98 & 26.81 & 27.26 & 24.35 & 3 & 1306.7404 & 1306.7397 & 436.5872 & 0.0007 & 0.5344 & 67.875 \\ 1.00 & 56.13 & 27.56 & 28.35 & 2 & 1306.7394 & 1306.7397 & 654.3771 & -0.0003 & -0.2292 & 18.277\end{array}$ $\begin{array}{llllllllllll}1.00 & 56.13 & 27.56 & 28.35 & 2 & 1306.7394 & 1306.7397 & 654.3771 & -0.0003 & -0.2292 & 18.27 \\ 0.96 & 27.09 & 27.56 & 24.85 & 3 & 1306.7398 & 1306.7397 & 436.5872 & 0.0001 & 0.0763 & 78.258\end{array}$ $\begin{array}{llllllllllll}0.96 & 27.09 & 27.56 & 24.85 & 3 & 1306.7398 & 1306.7397 & 436.5872 & 0.0001 & 0.0763 & 78.258 \\ 0.97 & 27.93 & 27.51 & 20.52 & 3 & 1306.7401 & 1306.7397 & 436.5872 & 0.0004 & 0.3054 & 80.269\end{array}$ $\begin{array}{lllllllllll}0.97 & 27.52 & 27.51 & 20.74 & 3 & 1306.7401 & 1306.7397 & 436.5872 & 0.0004 & 0.3054 & 47.892\end{array}$ $\begin{array}{llllllllllllll}0.92 & 21.91 & 27.26 & 23.31 & 3 & 1306.7404 & 1306.7397 & 436.5872 & 0.0007 & 0.5344 & 81.893\end{array}$ LFLVYRNTG LFLVYRPNTGK LFIYRPNTGK LFLVYRPNTGK LFVYRTTG $\begin{array}{lllllllllllll}\text { FIQTTASTRPSVSAPTVR } & 1.00 & 38.00 & 26.39 & 20.81 & 3 & 2062.1293 & 2062.1293 & 688.3837 & 0.0000 & 0.0000 & 176.923\end{array}$ $\begin{array}{llllllllllll}\text { FIQTTASTRPSVAPTVR } & 0.99 & 30.90 & 26.34 & 17.49 & 3 & 2062.1302 & 2066.1293 & 688.3837 & 0.0009 & 0.4358 & 415.036 \\ \text { FIQTASTRPVSAPTVR } & 1.00 & 34.02 & 26.09 & 16.89 & 3 & 2062.1329 & 2062.1293 & 688.3837 & 0.0036 & 1.7432 & 371.867\end{array}$ $\begin{array}{llllllllllllll} & \text { FIQTTASTRPSVSAPTVR } & 0.99 & 30.81 & 26.06 & 16.62 & 3 & 2062.1335 & 2062.1293 & 688.3837 & 0.0042 & 2.0337 & 631.934 & 69\end{array}$

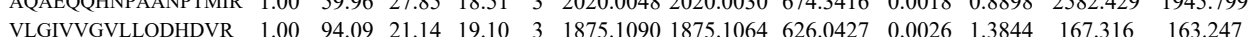
NLILSAFPR

NLILSAFPR
ITHCPTLLTR

ITHCPTLLTR
TLPLFYGSIVR

TLPLFYGSIVR

TLPLFYGSIVR

ANLGVFSVFAPR

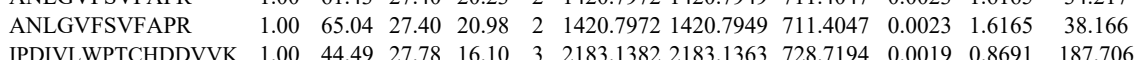

$\begin{array}{lllllllllllll}1.00 & 48.64 & 26.82 & 40.20 & 2 & 1173.7010 & 1173.6992 & 587.8569 & 0.0018 & 1.5310 & 3106.084 & 3049.626 & 275.318 \\ 1.00 & 38.92 & 26.82 & 32.60 & 2 & 1173.7010 & 1173.6992 & 587.8569 & 0.0018 & 1.5310 & 2470.768 & 2416.932 & 333.658\end{array}$

$\begin{array}{llllllllllllll}1.00 & 38.92 & 26.82 & 32.60 & 2 & 1173.7010 & 1173.6992 & 587.8569 & 0.0018 & 1.5310 & 2470.768 & 2416.932 & 333.65 \\ 0.98 & 35.17 & 27.85 & 19.58 & 3 & 1343.7292 & 1343.7175 & 448.9131 & 0.0117 & 8.6876 & 3784.638 & 3775.245 & 1226.87\end{array}$

$\begin{array}{lllllllllllll}1.00 & 43.12 & 25.51 & 28.80 & 2 & 1408.8202 & 1408.8200 & 705.4173 & 0.0002 & 0.1418 & 942.514 & 902.540\end{array}$

$\begin{array}{lllllllllll}1.00 & 50.03 & 25.47 & 28.66 & 2 & 1408.8212 & 1408.8200 & 705.4173 & 0.0012 & 0.8506 & 780.973\end{array}$

$\begin{array}{llllllllllll}1.00 & 38.39 & 25.56 & 22.71 & 2 & 1408.8210 & 1408.8200 & 705.4173 & 0.0010 & 0.7088 & 275.756\end{array}$

$\begin{array}{lllllllllll}1.00 & 61.43 & 27.40 & 20.23 & 2 & 1420.7972 & 1420.7949 & 711.4047 & 0.0023 & 1.6165 & 34.217\end{array}$ $\begin{array}{llllllllllll}\text { IPDIVLWPTCHDDVVK } & 1.00 & 40.52 & 27.82 & 21.79 & 3 & 2183.1391 & 2183.1363 & 728.7194 & 0.0028 & 1.2808 & 446.897\end{array}$ $\begin{array}{llllllllllll}\text { GFDPNQLSVATLLFEGDR } & 1.00 & 85.58 & 28.76 & 21.32 & 2 & 2122.0834 & 2122.0817 & 1062.0481 & 0.0017 & 0.8003 & 89.311\end{array}$ $\begin{array}{llllllllllllll}\text { GFDPNQLSVATLLFEGDR } & 1.00 & 75.74 & 28.72 & 25.17 & 2 & 2122.0854 & 2122.0817 & 1062.0481 & 0.0037 & 1.7419 & 50.099\end{array}$ $\begin{array}{llllllllllllll}\text { YGSVAFPNFEQGVACLR } & 1.00 & 77.60 & 26.70 & 21.20 & 2 & 2046.9794 & 2046.9777 & 1024.4961 & 0.0017 & 0.8297 & 90.134\end{array}$ YPLSGMGLPTFK

YPLSGMGLPTFK

NCPHVVVGTPGR

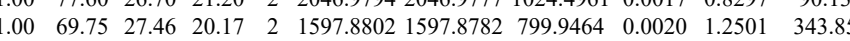

$\begin{array}{llllllllllll}1.00 & 69.62 & 27.462 & 2.17 & 2 & 1597.8802 & 1597.8782 & 79.9464 & 0.0020 & 1.2501 & 343.853 & 423.390\end{array}$

$\begin{array}{llllllllllllll}1.00 & 69.62 & 27.52 & 23.52 & 2 & 1597.8808 & 1597.8782 & 799.9464 & 0.0026 & 1.6251 & 463.420 & 406.348 & 52\end{array}$

NCPHVVVGTPGR

NCPHVVVGTPGR

$\begin{array}{lllllllllll}0.99 & 38.55 & 27.37 & 25.10 & 3 & 1424.7235 & 1424.7139 & 475.9119 & 0.0096 & 6.7239 & 10128.881\end{array}$

762.273
185.837 
CGTGIVGVFVK

CGTGIVGVFK

LMDEVAGIVAAR

CVAALAR

ATLWYVPLSL

ATLWYVPLSLK

CVAALAR

CVPVPLAR

9 IICDLVEEK

ICDLVEEK

GDVVLQSDHVIETLTK GIIILDEECLRPGEATDL WAAQTIR

YLGLLENLR

MSLLQLVEILQSK

MSLLQLVEILQSK

MSLLQLVEILQSK

MSLLQLVEILQSK

MSLLQLVEILQSK

MSLLQLVEILQSK

VNSININQGSITFAGGPG

VNSININQGSITFAGGPGR

VNSININQGSITFAGGPG
VNSININQGSITFAGGPG

VNSININQGSITFAGGPG
TSFLLNLR

HCCGVAQMR

LPVWETIVCTMR

DPVISTHLAK

DDPIISTHLAK

LQATLDMQSGIIHAAEEK

LQATLDMQSGIIHAAEEK

TGQAAELGGLLK

YQEALHLGSQLLR

YQEALHLGSQLLR

YQEALHLGSQLLR

YQEALHLGSQLLR

7 WSTLVEDYGMELR

WSTLVEDYGMELR

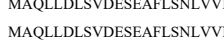

LQEVIETLLSLEK

LQEVIETLLSLEK

LQEVIETLLSLEK

LQEVIETLLSLEK

LQEVIETLLSLEK

LQEVIETLLSLEK

LQEVIETLLSLEK

LQEVIETLLSLEK

LQEVIETLLSLEK

LQEVIETLLSLEK

LCLAVK

LFTTMELMR \begin{tabular}{llllllllllllll} 
& \\
\hline
\end{tabular} $\begin{array}{lllllllllllllll}1.00 & 64.33 & 26.16 & 18.17 & 4 & 3444.6633 & 3444.6557 & 862.1712 & 0.0076 & 2.2037 & 6.126 & 11.251 & 0.000 & 6.167 & \text { No }\end{array}$

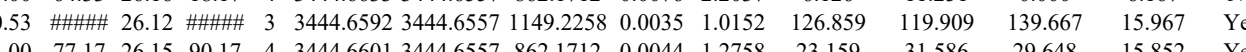
$\begin{array}{lllllllllllll} & \end{array}$

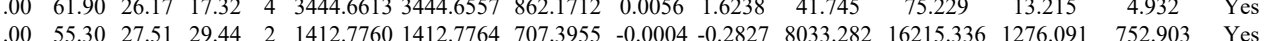

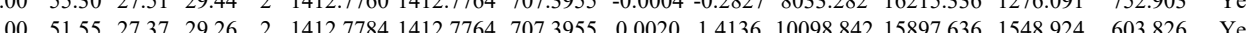

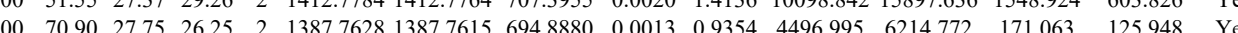
$\begin{array}{llllllllllllll} & 13.918 & \text { Yes }\end{array}$ $\begin{array}{lllllllllllll} & \end{array}$ $\begin{array}{lllllllllllllll}0.93 & 35.56 & 28.80 & 31.66 & 2 & 82.4824 & 82.4744 & 44.2445 & 0.008 & 8.9436 & 74154.398 & 83313.462 & 2821.650 & 2255.925 & \text { Yes }\end{array}$ $\begin{array}{llllllllllllllll}1.00 & 39.85 & 22.36 & 18.37 & 2 & 1577.9438 & 1577.9425 & 789.9785 & 0.0013 & 0.8228 & 502.027 & 535.058 & 229.579 & 79.461 & \text { Yes }\end{array}$

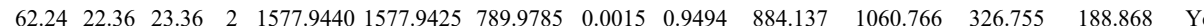
$\begin{array}{llllllllllllllll}0.76 & 26.73 & 28.18 & 25.68 & 2 & 892.4788 & 892.4744 & 4472445 & 0.0044 & 4.9190 & 36680.013 & 42948.868 & 2797.019 & 1764.655 & \text { Yes }\end{array}$ \begin{tabular}{lllllllllllllll}
00 & 59.80 & 26.37 & 17.73 & 2 & 1968.0682 & 1968.0659 & 985.0402 & 0.0023 & 1.1675 & 275.585 & 246.440 & 243.754 & 98.733 & No \\
\hline
\end{tabular} $\begin{array}{lllllllllllllll}.00 & 58.08 & 27.75 & 26.68 & 2 & 1394.7420 & 1394.7393 & 698.3769 & 0.0027 & 1.9330 & 3875.709 & 3568.495 & 7.665 & 102.065 & \text { Yes } \\ 00 & 58.12 & 27.80 & 26.23 & 2 & 1394.7424 & 1394.7393 & 698.3769 & 0.0031 & 2.2194 & 3605.672 & 2826.877 & 34.503 & 96.898 & \text { Yes }\end{array}$

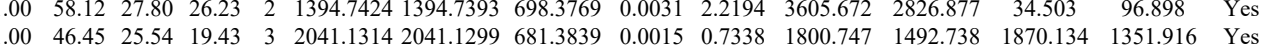
$\begin{array}{ccccccccccccccc}0.55 & 43.50 & 25.48 & 56.50 & 3 & 2041.1320 & 2041.1299 & 681.3839 & 0.0021 & 1.0273 & 1515.524 & 1401.062 & 1853.948 & 1509.082 & \text { Yes } \\ 0.93 & 16.75 & 25.66 & 29.75 & 4 & 2995.5613 & 2995.5489 & 749.8945 & 0.0124 & 4.1339 & 13.605 & 24.312 & 13.733 & 18.093 & \text { No }\end{array}$

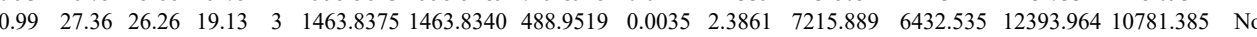
$\begin{array}{lllllllllllllll}0.58 & 26.25 & 28.33 & 26.41 & 2 & 988.5636 & 988.5576 & 495.2861 & 0.0060 & 6.0571 & 30232.708 & 24369.368 & 3164.635 & 2047.311 & \text { Yes }\end{array}$ $\begin{array}{llllllllllllllll}1.00 & 59.02 & 26.77 & 36.02 & 2 & 1233.7222 & 1233.7203 & 617.8674 & 0.0019 & 1.5375 & 12979.571 & 11246.300 & 555.704 & 1544.866 & \text { Yes }\end{array}$ $\begin{array}{lllllllllllllll}1.00 & 27.37 & 21.04 & 15.27 & 3 & 1789.0666 & 1789.0627 & 597.3615 & 0.0039 & 2.1762 & 99.697 & 127.167 & 41.551 & 19.193 & \text { Yes }\end{array}$

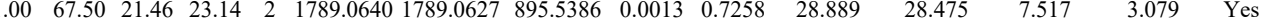

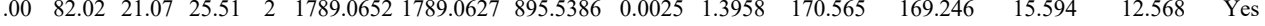
$\begin{array}{lllllllllllllll}0.69 & 9.27 & 20.97 & 13.91 & 3 & 1789.0669 & 1789.0627 & 597.3615 & 0.0042 & 2.3436 & 65.645 & 36.434 & 33.421 & 26.885 & \text { Yes }\end{array}$

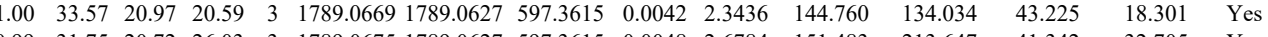
$\begin{array}{lllllllllllllll}0.99 & 31.75 & 20.72 & 26.03 & 3 & 1789.0675 & 1789.0627 & 597.3615 & 0.0048 & 2.6784 & 151.483 & 213.647 & 41.342 & 32.705 & \text { Yes }\end{array}$

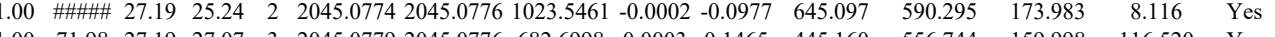

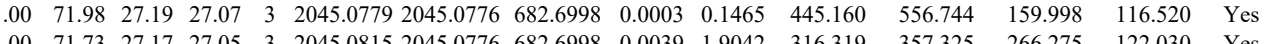
$\begin{array}{lllllllllllll} & 12.0030 & \text { Yes } \\ \end{array}$

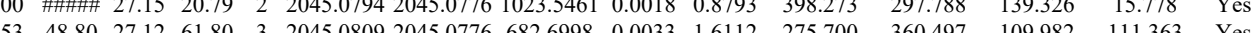

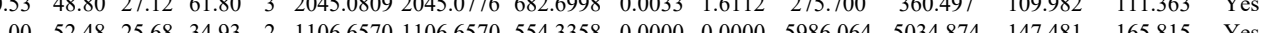

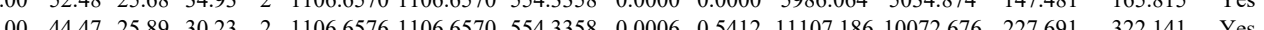
$\begin{array}{llllllllllllllll}0.99 & 22.79 & 16.13 & 16.76 & 3 & 1239.4966 & 1239.4925 & 414.1714 & 0.0041 & 3.52997 & 6508.529 & 6941.216 & 1324.382 & 632.937 & \text { Yes }\end{array}$ $\begin{array}{llllllllllllll} & \end{array}$

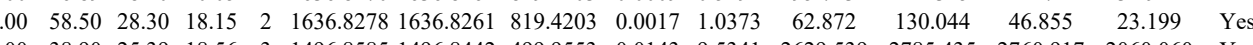
$\begin{array}{lllllllllllllll}.00 & 38.90 & 25.39 & 18.56 & 3 & 1496.8585 & 1496.8442 & 499.9553 & 0.0143 & 9.5341 & 2629.539 & 2785.435 & 2760.917 & 2060.060 & \text { Yes }\end{array}$ \begin{tabular}{lllllllllllllll}
1.00 & 46.54 & 26.03 & 18.00 & 3 & 1496.8570 & 1496.8442 & 499.9553 & 0.0128 & 8.5340 & 3476.336 & 3434.834 & 2731.899 & 2661.950 & Yes \\
\hline
\end{tabular}

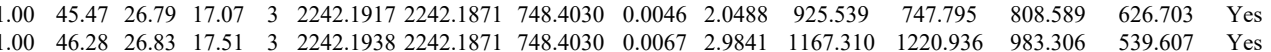
$\begin{array}{lllllllllllllll}1.00 & 54.82 & 25.29 & 34.66 & 2 & 1444.8634 & 1444.8493 & 723.4319 & 0.0141 & 9.7451 & 1105.703 & 965.233 & 672.394 & 187.476 & \text { Yes }\end{array}$ $\begin{array}{lllllllllllllllll}1.00 & 54.53 & 27.52 & 23.42 & 3 & 1670.9233 & 1670.9226 & 557.9815 & 0.0007 & 0.4182 & 3679.553 & 4407.877 & 1804.212 & 254.996 & \text { Yes }\end{array}$ $\begin{array}{llllllllllllllll}1.00 & 50.91 & 27.49 & 22.52 & 3 & 1670.9239 & 1670.9226 & 557.9815 & 0.0013 & 0.7766 & 8267.763 & 9432.451 & 3808.845 & 557.618 & \text { Yes }\end{array}$ $\begin{array}{llllllllllllllll}1.00 & 44.55 & 27.75 & 16.54 & 3 & 1670.9224 & 1670.9226 & 557.9815 & -0.0002 & -0.1195 & 7385.979 & 7682.260 & 3288.320 & 385.487 & \text { Yes }\end{array}$ $\begin{array}{lllllllllllllll}1.00 & 79.85 & 27.60 & 25.05 & 2 & 1670.9230 & 1670.9226 & 836.4686 & 0.0004 & 0.2391 & 1335.338 & 1084.087 & 569.425 & 68.646 & \text { Yes }\end{array}$ $\begin{array}{lllllllllllllll}1.00 & 54.43 & 27.49 & 18.17 & 3 & 1670.9239 & 1670.9226 & 557.9815 & 0.0013 & 0.7766 & 6887.542 & 7308.720 & 2173.134 & 476.996 & \text { Yes }\end{array}$

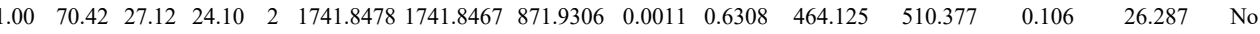

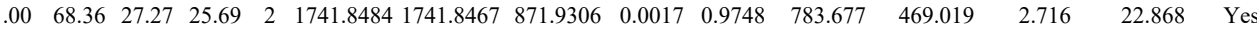

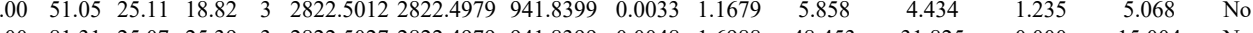

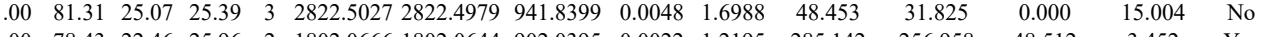

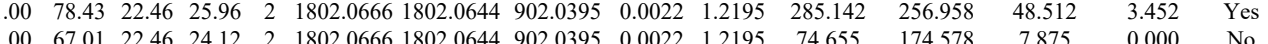
$\begin{array}{lllllllllllllll}1.00 & 67.01 & 22.46 & 24.12 & 2 & 1802.0666 & 1802.0644 & 902.0395 & 0.0022 & 1.2195 & 74.655 & 174.578 & 7.875 & 0.000 & \text { No }\end{array}$ \begin{tabular}{lllllllllllllll}
1.50 & 22.36 & 22.05 & 3 & 1802.0677 & 1802.0644 & 601.6954 & 0.0033 & 1.8282 & 108.291 & 72.135 & 38.775 & 29.922 & Yes \\
\hline
\end{tabular} $\begin{array}{lllllllllllllll}1.00 & 45.67 & 22.17 & 22.30 & 3 & 1802.0689 & 1802.0644 & 601.6954 & 0.0045 & 2.4929 & 240.568 & 147.681 & 48.383 & 28.842 & \text { Yes }\end{array}$

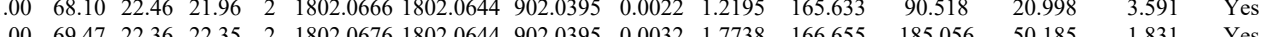

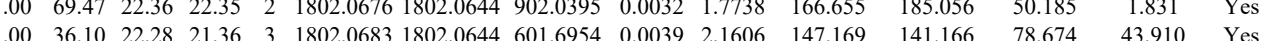

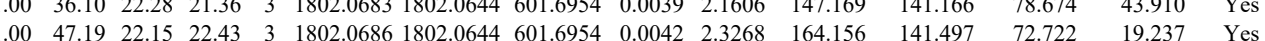

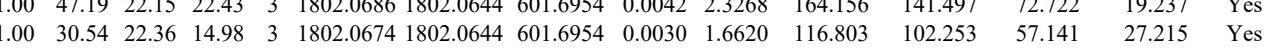

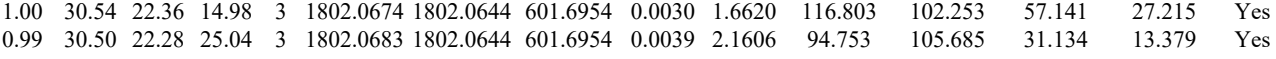
$\begin{array}{lllllllllllllll}100 & 64.68 & 24.98 & 19.05 & 3 & 2557.3759 & 2557.3662 & 853.4627 & 0.0097 & 3.7885 & 39.825 & 37.729 & 31.298 & 1.790 & \text { No }\end{array}$

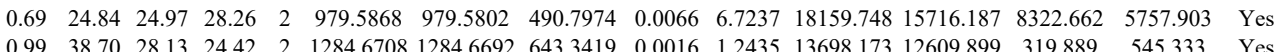


LFTTMELMR LNSLMSLVNK LNSLMSLVNK LNSLMSLVNK LNSLMSLVNK GSLESPATDVFGSTEEG YLSNAYAR YLSNAYAR YLSNAYAR IEEFLEAVLCPPR IEEFLEAVLCPPR IEEFLEAVLCPPR LHIVQVVCK LHIVQVVCK LHIVQVVCK LHIVQVVCK

LHIVQVVCK

LHIVQVVCK

LHIVQVVCK

LHIVQVVCK

LHIVQVVCK

LHIVQVVCK

LHIVQVVCK

IGNCPFSQR

IGNCPFSQR

IGNCPFSQR

LFMVLWLK

NSNPALNDNLEK

SNALNDNEK

NSNPALNDNLEK FLMSLVNQVPK FLMSLVNQVPK AYVSTLMGVPGR AYVSTLMGVPGR FLMSLVNQVPK FLMSLVNQVPK FLMSLVNQVPK AYVSTLMGVPGR AYVSTLMGVPGR

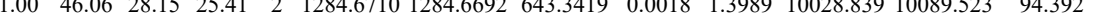
$\begin{array}{llllllllllllll}1.00 & 47.38 & 25.49 & 22.69 & 2 & 1405.8214 & 1405.8206 & 703.9176 & 0.0008 & 0.5682 & 10791.446 & 9433.940 & 763.396 & 1\end{array}$ $\begin{array}{llllllllllllll}1.00 & 53.02 & 25.55 & 25.45 & 2 & 1405.8218 & 1405.8206 & 703.9176 & 0.0012 & 0.8524 & 17804.973 & 15795.332 & 836.297\end{array}$

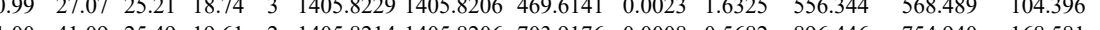
$\begin{array}{lllllllllllll}1.00 & 41.09 & 25.49 & 19.61 & 2 & 1405.8214 & 1405.8206 & 703.9176 & 0.0008 & 0.5682 & 896.446 & 754.940 & 168.581 \\ 1.0 & 69.99 & 27.72 & 24.99 & 3 & 2227.0771 & 2227.0736 & 743.365 & 0.0035 & 1.5694 & 38.598 & 77.449 & 110.032\end{array}$

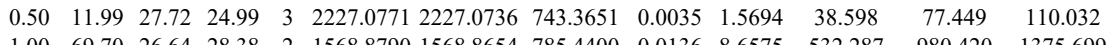

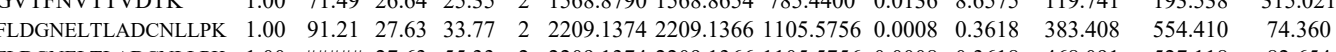

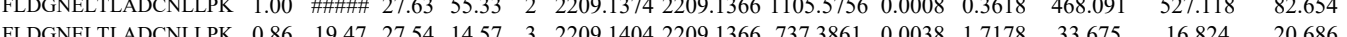
$\begin{array}{lllllllllllll} & \text { HLDGNELC }\end{array}$

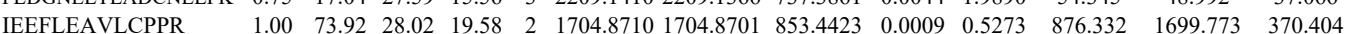
$\begin{array}{llllllllllllll}\text { IEEFLEAVLCPPR } & 0.96 & 23.67 & 28.10 & 24.11 & 3 & 1704.8719 & 1704.8701 & 5692973 & 0.0018 & 1.0539 & 72.112 & 62.332 & 61.670\end{array}$

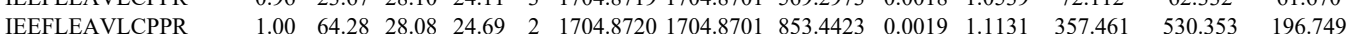
$\begin{array}{lllllllllllll}45.01 & 27.04 & 26.60 & 2 & 1100.5780 & 1100.5736 & 551.2941 & 0.0044 & 3.9906 & 14488.323 & 20301.176 & 732.628\end{array}$ $\begin{array}{llllllllllllll}0.99 & 42.30 & 27.06 & 26.70 & 2 & 1100.5786 & 1100.5736 & 551.2941 & 0.0050 & 4.5348 & 13531.103 & 18851.098 & 681.317 \\ 0 & 67.58 & 1317\end{array}$ $\begin{array}{llllllllllllll}0.76 & 16.50 & 28.11 & 14.90 & 3 & 1704.8722 & 1704.8701 & 569.2973 & 0.0021 & 1.2296 & 178.593 & 163.714 & 29.117\end{array}$ $\begin{array}{lllllllllllll}1.00 & 69.46 & 28.11 & 21.83 & 2 & 1704.8722 & 1704.8701 & 853.4423 & 0.0021 & 1.2303 & 62.730 & 113.757 & 10.167\end{array}$ $\begin{array}{llllllllllllll}1.00 & 78.54 & 28.08 & 25.13 & 2 & 1704.8728 & 1704.8701 & 853.4423 & 0.0027 & 1.5818 & 219.419 & 289.875 & 45.583\end{array}$ $\begin{array}{lllllllllllll}1.00 & 62.11 & 25.28 & 30.48 & 2 & 1371.8096 & 1371.7974 & 686.9060 & 0.0122 & 8.8803 & 5561.013 & 6448.194 & 368.189\end{array}$ $\begin{array}{lllllllllllllll}1.00 & 65.26 & 25.28 & 31.10 & 2 & 1371.8098 & 1371.7974 & 686.9060 & 0.0124 & 9.0259 & 9222.751 & 11103.690 & 682.310\end{array}$ $\begin{array}{llllllllllllll}0.92 & 25.60 & 24.96 & 15.71 & 3 & 1371.8104 & 1371.7974 & 458.2731 & 0.0130 & 9.4557 & 10411.063 & 12614.571 & 2042.742\end{array}$

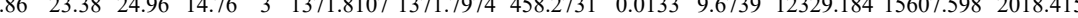
$\begin{array}{lllllllllllll}1.00 & 65.05 & 25.40 & 27.85 & 2 & 1371.8004 & 1371.7974 & 686.9060 & 0.0030 & 2.1837 & 13135.215 & 17986.007 & 1455.609\end{array}$

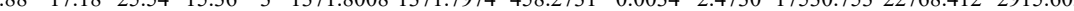
$\begin{array}{llllllllllllll}0.94 & 20.24 & 25.54 & 21.46 & 3 & 1371.8008 & 1371.7974 & 458.2731 & 0.0034 & 2.4730 & 13972.362 & 18732.010 & 1442.578\end{array}$

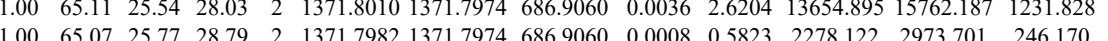
$\begin{array}{llllllllllllll}1.00 & 65.07 & 25.77 & 28.79 & 2 & 1371.7982 & 1371.7974 & 686.9060 & 0.0008 & 0.5823 & 2278.122 & 2973.701 & 246.170 \\ 0.99 & 27.19 & 25.66 & 16.17 & 3 & 1371.7999 & 1371.7974 & 4582731 & 0.0025 & 1.8184 & 2438.357 & 3179.833 & 396.860\end{array}$ $\begin{array}{llllllllllllll}0.99 & 27.19 & 25.66 & 16.17 & 3 & 1371.7999 & 1371.7974 & 458.2731 & 0.0025 & 1.8184 & 2438.357 & 3179.833 & 396.860 & 172 \\ 0.99 & 28.45 & 25.28 & 21.32 & 3 & 1371.8014 & 1371.7974 & 458.2731 & 0.0040 & 2.9095 & 3855.512 & 6292.444 & 452.257 & 29.5\end{array}$ $\begin{array}{llllllllllllll}0.99 & 28.45 & 25.28 & 21.32 & 3 & 1371.8014 & 1371.7974 & 458.2731 & 0.0040 & 2.9095 & 3855.512 & 6292.444 & 452.257 & 298 \\ 0.96 & 35.06 & 25.63 & 20.22 & 2 & 1210.5802 & 1210.5709 & 6062927 & 0.0093 & 7.6695 & 10018590 & 17873.612 & 5509.589 & 178\end{array}$ $\begin{array}{llllllllllllll}0.96 & 35.06 & 25.63 & 20.22 & 2 & 1210.5802 & 1210.5709 & 606.2927 & 0.0093 & 7.6695 & 10018.590 & 17873.612 & 5509.589 & 1782 \\ 0.99 & 37.86 & 25.69 & 18.26 & 2 & 1210.5806 & 1210.5709 & 606.2927 & 0.0097 & 7.9994 & 8976.852 & 16393.191 & 5306.271 & 1\end{array}$ $\begin{array}{llllllllllllll}1.00 & 42.82 & 25.47 & 20.45 & 2 & 1210.5818 & 1210.5709 & 606.2927 & 0.0109 & 8.9890 & 2913.118 & 5372.198 & 1501.786\end{array}$ $\begin{array}{lllllllllllllll}0.99 & 32.90 & 22.74 & 22.94 & 2 & 1336.8188 & 1336.8185 & 669.4165 & 0.0003 & 0.2241 & 42.850 & 76.417 & 68.264\end{array}$

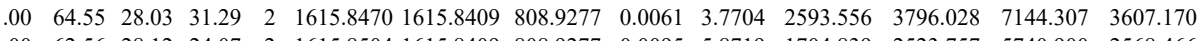

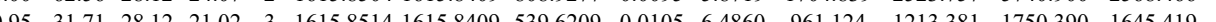

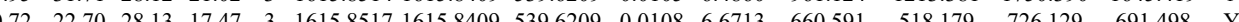
$\begin{array}{llllllllllllll}0.72 & 22.70 & 28.13 & 17.47 & 3 & 1615.8517 & 1615.8409 & 539.6209 & 0.0108 & 6.6713 & 660.591 & 518.179 & 726.129\end{array}$ $\begin{array}{llllllllllll} & \end{array}$ \begin{tabular}{llllllllllllllll}
\hline RDALSTVLOYAEDVLSGK & 0.99 & 16.36 & 25.51 & 16.37 & 4 & 2337.2725 & 2337.2671 & 585.3241 & 0.0054 & 2.3064 & 112.185 & 109.633 & 57.969
\end{tabular} $\begin{array}{llllllllllllll}\text { LQDALSTVLQYAEDVLSGK } & 1.00 & 53.88 & 25.47 & 16.91 & 3 & 2337.2731 & 2337.2671 & 780.0963 & 0.0060 & 25638 & 232.209 & 87.823 & 180.797\end{array}$

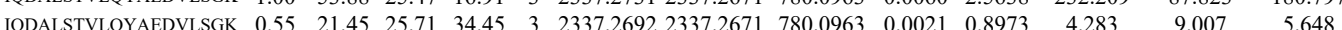

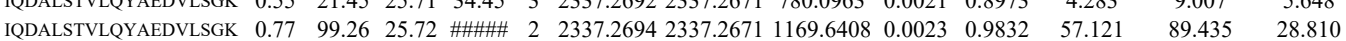

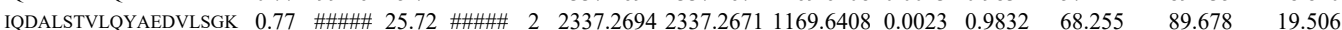
$\begin{array}{llllllllllllll}\text { IODALSTVLOYAEDVISGK } & 0.55 & 6.34 & 25.47 & 19.01 & 4 & 2337.2729 & 2337.2671 & 585.3241 & 0.0058 & 2.4773 & 168.451 & 168.796 & 50.271\end{array}$ $\begin{array}{llllllllllllll} & 0.34 & 25.47 & 19.01 & 4 & 2337.2729 & 2337.267 & 585.3241 & 0.0058 & 2.475 & 168.451 & 168.796 & 50.271\end{array}$ $\begin{array}{llllllllllllll}\text { IQDALSTVLQYAEDVLSGK } & 0.99 & 28.44 & 25.60 & 16.54 & 3 & 2337.2707 & 2337.2671 & 780.0963 & 0.0036 & 1.5383 & 16.160 & 18.065 & 1.971\end{array}$ $\begin{array}{llllllllllllll}\text { TMGVMFTPLTVK } & 1.00 & 50.14 & 26.18 & 18.20 & 2 & 1611.8984 & 1611.8972 & 806.9559 & 0.0012 & 0.7435 & 956.109 & 842.671 & 76.851\end{array}$ $\begin{array}{lllllllllllllll}\text { FLMSLVNQVPK } & 0.75 & 13.23 & 24.77 & 16.86 & 3 & 1562.9128 & 1562.9098 & 521.9772 & 0.0030 & 1.9158 & 152.159 & 158.188 & 89.514\end{array}$ $\begin{array}{llllllllllllllll} & \text { FLMSLVNQVPK } & 0.99 & 27.74 & 24.77 & 16.18 & 3 & 1562.9131 & 1562.9098 & 521.9772 & 0.0033 & 2.1074 & 87.614 & 99.832 & 2.814\end{array}$ $\begin{array}{llllllllllllll}\text { FLMSLVNQVPK } & 1.00 & 65.30 & 24.56 & 28.84 & 2 & 1562.9110 & 1562.9098 & 782.4622 & 0.0012 & 0.7668 & 3220.935 & 2575.646 & 157.120 \\ \text { FLMSLVNQVPK } & 1.00 & 76.41 & 24.79 & 30.53 & 2 & 1562.9120 & 1562.9098 & 782.4622 & 0.0022 & 1.4058 & 1935.118 & 2467.179 & 78.099\end{array}$ IFSIAEGEMHEAIK SIIAEGEMHEAIK IFSIIAEGEMHEAIK $\begin{array}{llllllllllllll}0.67 & 11.54 & 24.79 & 21.33 & 3 & 1562.9122 & 1562.9098 & 521.9772 & 0.0024 & 1.5326 & 163.890 & 228.376 & 26.595 \\ 1.00 & 45.30 & 24.77 & 21.74 & 3 & 1562.9125 & 1562.9098 & 521.9772 & 0.0027 & 1.7242 & 319.397 & 276.348 & 73.790\end{array}$ $\begin{array}{lllllllllllllll}1.00 & 45.30 & 24.77 & 21.74 & 3 & 1562.9125 & 1562.9098 & 521.9772 & 0.0027 & 1.7242 & 319.397 & 276.348 & 73.790 & & \\ 1.00 & 74.83 & 28.28 & 21.80 & 2 & 1393.7550 & 1393.7510 & 697.8828 & 0.0040 & 2.8658 & 13786.815 & 15220.817 & 442.349 & 70\end{array}$ $\begin{array}{llllllllllllll}1.00 & 74.83 & 28.28 & 21.80 & 2 & 1393.7550 & 1393.7510 & 697.8828 & 0.0040 & 2.8658 & 13786.815 & 15220.817 & 442.349 & 70 \\ 1.00 & 77.66 & 28.26 & 26.27 & 2 & 1393.7560 & 1393.7510 & 697.8828 & 0.0050 & 3.5823 & 18025.287 & 19902.492 & 503.813 & 32 .\end{array}$ $\begin{array}{lllllllllllll}1.00 & 77.66 & 28.26 & 26.27 & 2 & 1393.7560 & 1393.7510 & 697.8828 & 0.0050 & 3.5823 & 18025.287 & 19902.492 & 503.813 \\ 1.00 & 49.68 & 24.79 & 23.58 & 2 & 1562.9120 & 1562.9098 & 782.4622 & 0.0022 & 1.4058 & 1133.485 & 1064.267 & 340.032\end{array}$ $\begin{array}{lllllllllllll}1.00 & 49.68 & 24.79 & 23.58 & 2 & 1562.9120 & 1562.9098 & 782.4622 & 0.0022 & 1.4058 & 1133.485 & 1064.267 & 340.032 \\ 1.00 & 34.58 & 24.79 & 23.63 & 3 & 1562.9122 & 1562.9098 & 521.9772 & 0.0024 & 1.5326 & 210.280 & 297.415 & 18.403\end{array}$ $\begin{array}{llllllllllllll}1.00 & 34.58 & 24.79 & 23.63 & 3 & 1562.9122 & 1562.9098 & 521.9772 & 0.0024 & 1.5326 & 210.280 & 297.415 & 18.403 \\ 1.00 & 36.94 & 24.55 & 22.01 & 3 & 1562.9134 & 1562.9098 & 521.9772 & 0.0036 & 2.2989 & 419.462 & 649.442 & 98.693\end{array}$ $\begin{array}{lllllllllllll}1.00 & 36.94 & 24.55 & 22.01 & 3 & 1562.9134 & 1562.9098 & 521.9772 & 0.0036 & 2.2989 & 419.462 & 649.442 & 98.693 \\ 1.00 & 71.41 & 27.96 & 22.34 & 2 & 1393.7516 & 1393.7510 & 697.8828 & 0.0006 & 0.4299 & 5899.297 & 7235.542 & 142.764\end{array}$ $\begin{array}{llllllllllllll}1.00 & 73.38 & 28.06 & 24.34 & 2 & 1393.7524 & 1393.7510 & 697.8828 & 0.0014 & 1.0030 & 8239.390 & 9497.130 & 261.215\end{array}$ $\begin{array}{lllllllllllll}1.00 & 57.05 & 26.83 & 18.29 & 3 & 1975.0717 & 1975.0692 & 659.3637 & 0.0025 & 1.2638 & 190.897 & 153.064 & 57.924 \\ 1.00 & 53.80 & 26.69 & 20.99 & 3 & 1975.0729 & 1975.0692 & 659.3637 & 0.0037 & 1.8705 & 104.688 & 90.345 & 23.959\end{array}$

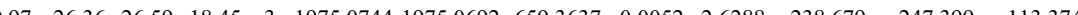
$\begin{array}{llllllllllllll}1.00 & 35.98 & 26.62 & 16.43 & 3 & 1975.0747 & 1975.0692 & 659.3637 & 0.0055 & 2.7805 & 261.595 & 284.905 & 130.25\end{array}$

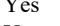


$\begin{array}{llllllllllll}1.00 & 54.64 & 26.50 & 20.83 & 3 & 2423.1346 & 2423.1316 & 808.7178 & 0.0030 & 1.2365 & 119.012 & 143.643\end{array}$

HLHSIMVLK

$\begin{array}{llllllllllllll}0.95 & 26.90 & 23.38 & 18.64 & 3 & 1364.8303 & 1364.8206 & 455.9475 & 0.0097 & 7.0914 & 6144.447 & 6993.945 & 244 \\ 0.97 & 27.94 & 23.07 & 18.45 & 3 & 1364.8318 & 1364.8206 & 455.9475 & 0.0112 & 8.1880 & 7625.455 & 8739.485\end{array}$

LLIPYLDNLVK

$\begin{array}{llllllllllll}0.99 & 38.99 & 18.45 & 30.96 & 2 & 1675.0204 & 1675.0164 & 838.5155 & 0.0040 & 2.3852 & 395.992 & 349.270\end{array}$

2441.885

$\begin{array}{lllllllllll} & & \end{array}$

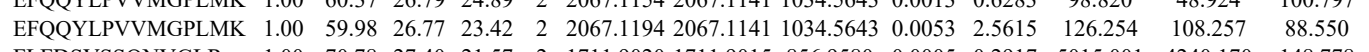

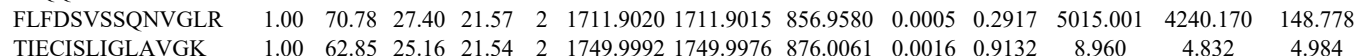

TIECISLIGLAVGK

TIECISLIGLAVGK

TIECISLIGLAVGK

TIECISLIGLAVGK

LMVPLLK
LMVPLLK

TIECISLIGLAVGK

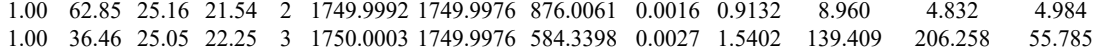

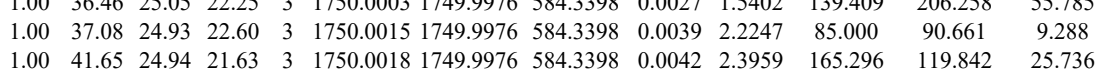

$\begin{array}{llllllllllllll}0.78 & 15.62 & 24.90 & 17.10 & 3 & 1750.0027 & 1749.9976 & 584.3398 & 0.0051 & 2.9093 & 105.642 & 96.280 & 32.209\end{array}$

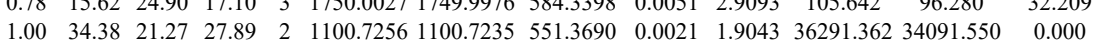
VSDILHSIFSSYK $\begin{array}{lllllllllllll}0.98 & 38.28 & 21.21 & 36.27 & 2 & 1100.7264 & 1100.7235 & 551.3690 & 0.0029 & 2.6298 & 27193.167 & 20579.792\end{array}$ $\begin{array}{lllllllllllll}0.51 & 10.40 & 25.05 & 18.72 & 3 & 1750.0012 & 1749.9976 & 584.3398 & 0.0036 & 2.0536 & 151.546 & 154.872 & 40.072\end{array}$ VSDILHSIFSSYK $\begin{array}{lllllllllllll}0.53 & 34.19 & 26.77 & 47.19 & 3 & 1782.9790 & 1782.9760 & 595.3326 & 0.0030 & 1.6797 & 3127.353 & 3065.855 & 48.188\end{array}$ VSDILHSIFSSYK

QMAAVLLR

LMVPLLK

LMVPLLK

QMAAVLLR

QMAAVLLR

QMAAVLLR

QMAAVLLR

QMAAVLLR

$\begin{array}{llllllllllllll}1.00 & 74.23 & 26.77 & 28.57 & 2 & 1782.9790 & 1782.9760 & 892.4953 & 0.0030 & 1.6807 & 1305.335 & 1486.551 & 0.000\end{array}$

$\begin{array}{rllllllllllll}1.00 & 33.94 & 26.83 & 16.95 & 3 & 1782.9799 & 1782.9760 & 595.3326 & 0.0039 & 2.1836 & 1902.858 & 1869.775 & 46.997 \\ 0.70 & 2525 & 25.85 & 25.26 & 2 & 1044.6318 & 1044.6236 & 523.3191 & 0.0082 & 7.8345 & 14492.698 & 13088.431 & 3186.436\end{array}$

$\begin{array}{lllllllllllll}1.00 & 39.06 & 21.27 & 26.83 & 2 & 1100.7258 & 1100.7235 & 551.3690 & 0.0023 & 2.0857 & 25795.316 & 20875.723 & 61.804\end{array}$

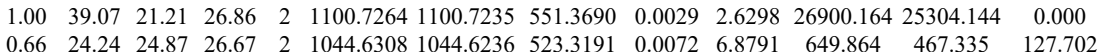

$\begin{array}{lllllllllllll}0.66 & 24.24 & 24.87 & 26.67 & 2 & 1044.6308 & 1044.6236 & 523.3191 & 0.0072 & 6.8791 & 649.864 & 467.335 & 127.702 \\ 0.94 & 32.43 & 25.84 & 28.43 & 2 & 104.6324 & 1044.6236 & 5233191 & 0.0088 & 8.4078 & 1120759 & 977.172 & 230.950\end{array}$

$\begin{array}{lllllllllllll}0.94 & 32.43 & 25.84 & 28.43 & 2 & 1044.6324 & 1044.6236 & 523.3191 & 0.0088 & 8.4078 & 1120.759 & 977.172 & 230.950 \\ 0.75 & 24.52 & 26.02 & 28.79 & 2 & 1044.6334 & 1044.6236 & 523.3191 & 0.0098 & 9.3632 & 29262780 & 30269.554 & 3376.750\end{array}$

$\begin{array}{lllllllllllllll}0.75 & 24.52 & 26.02 & 28.79 & 2 & 1044.6334 & 1044.6236 & 523.3191 & 0.0098 & 9.3632 & 29262.780 & 30269.554 & 3376.750 & 1361 & \\ 0.79 & 25.35 & 26.02 & 32.18 & 2 & 1044.6338 & 1044.6236 & 523.3191 & 0.0102 & 9.7454 & 27606.418 & 26488.901 & 3313.285\end{array}$ $\begin{array}{lllllllllllll}0.79 & 25.35 & 26.02 & 32.18 & 2 & 1044.6338 & 1044.6236 & 523.3191 & 0.0102 & 9.7454 & 27606.418 & 26488.901 & 3313.285 \\ 0.71 & 25.49 & 25.17 & 18.78 & 2 & 1044.6286 & 1044.6236 & 523.3191 & 0.0050 & 4.7772 & 201.902 & 217.560 & 92.387\end{array}$ $\begin{array}{lllllllllllll} & \end{array}$ $\begin{array}{llllllllllllll}\text { QLALEVIVTLSETAAAMLR } & 1.00 & 36.65 & 23.50 & 15.30 & 3 & 2172.2326 & 2172.2309 & 725.0842 & 0.0017 & 0.7815 & 15.653 & 29.161 & 3.967\end{array}$

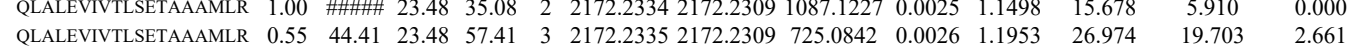

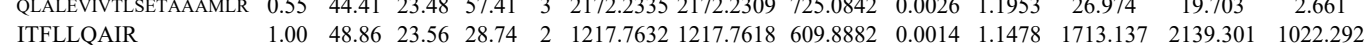




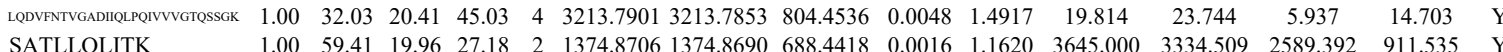

$\begin{array}{lllllllllllllllll}\text { SATLLQLITK } & 1.00 & 55.48 & 19.96 & 22.68 & 2 & 1374.8708 & 1374.8690 & 688.4418 & 0.0018 & 1.3073 & 4049.039 & 3824.015 & 3394.286 & 1092.386 & \text { Yes }\end{array}$ $\begin{array}{llllllllllllllll}\text { SATLLQLITK } & 1.00 & 49.62 & 18.92 & 22.64 & 2 & 1374.8704 & 1374.8690 & 688.4418 & 0.0014 & 1.0168 & 708.107 & 1013.306 & 555.343 & 143.532 & \text { Yes }\end{array}$ $\begin{array}{llllllllllllllll}\text { SATLLQLITK } & 1.00 & 56.56 & 19.96 & 24.54 & 2 & 1374.8714 & 1374.8690 & 688.4418 & 0.0024 & 1.7431 & 1288.545 & 1148.757 & 881.549 & 274.816 & \text { Yes }\end{array}$

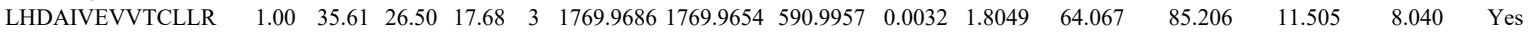

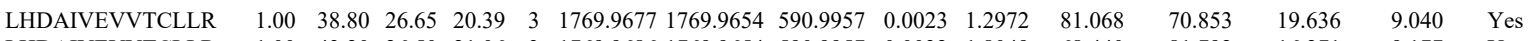

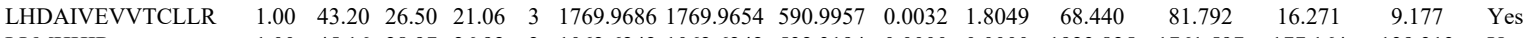
LLMHHIR

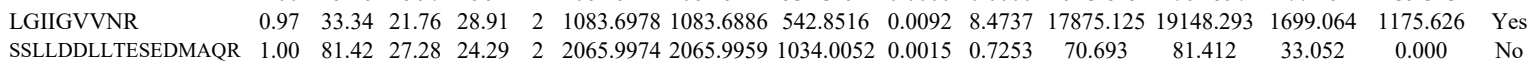

$\begin{array}{lllllllllllllll}1.00 & 45.16 & 28.97 & 26.92 & 2 & 1062.6242 & 1062.6242 & 532.3194 & 0.0000 & 0.0000 & 1923.825 & 1761.597 & 177.164 & 139.313 & \text { Yes }\end{array}$

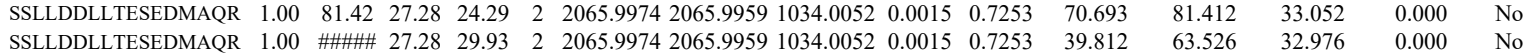

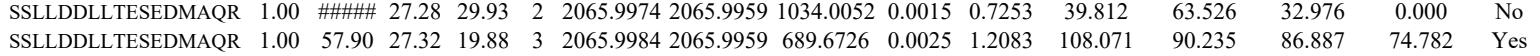

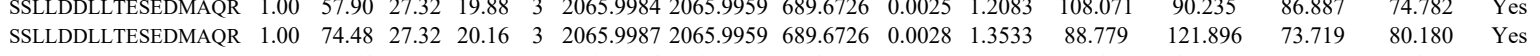

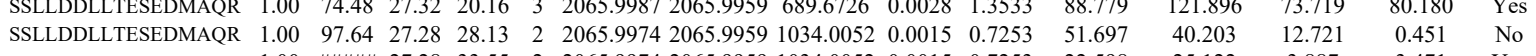

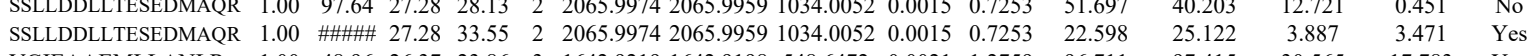

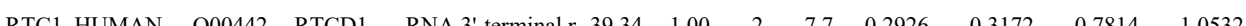

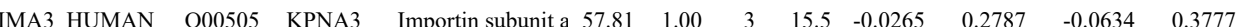

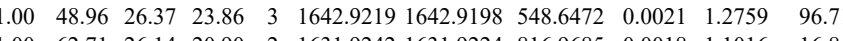

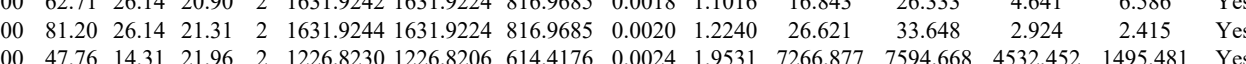
SGILPILVK

KDQVEYLVQQNVIPPFCNLLSVK

KDQVEYLVQQNVIPPFCNLL

NVTWVIVNLCR

NVTWVIVNLCR

NVTWVIVNLCR

NVTWVIVNLCR

$\begin{array}{llllllllllllll} & \end{array}$

GPWALEEESLVGR

$\begin{array}{llllllllllll}0.99 & 15.09 & 22.46 & 16.23 & 4 & 3151.7209 & 3151.7139 & 788.9358 & 0.0070 & 2.2182 & 16.736\end{array}$

$\begin{array}{llllllllllll}1.00 & 43.81 & 27.85 & 31.87 & 2 & 1505.7976 & 1505.7969 & 753.9057 & 0.0007 & 0.4642 & 50.604 \\ 1.00 & 55.70 & 27.90 & 23.68 & 2 & 1505.7998 & 1505.7969 & 753.9057 & 0.0029 & 1.9233 & 35.952\end{array}$

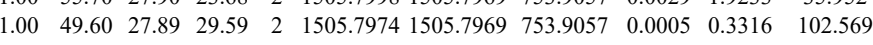

$\begin{array}{lllllllllll}1.00 & 59.58 & 27.87 & 30.35 & 2 & 1505.7988 & 1505.7969 & 753.9057 & 0.0019 & 1.2601 & 58.639\end{array}$

$\begin{array}{lllllllllll}1.00 & 57.81 & 28.03 & 26.55 & 2 & 1505.7996 & 1505.7969 & 753.9057 & 0.0027 & 1.7907 & 27.414\end{array}$

$\begin{array}{lll}20.097 & 24.237 \\ 12.963 & 16.912\end{array}$

$24.405 \quad 20.716$

5

5.122

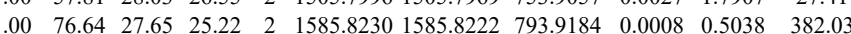

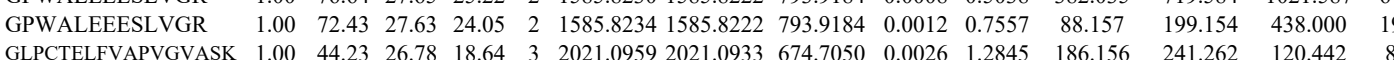
$\begin{array}{lllllllllllllll} & \text { GLPCTELFVAPVGVASK } & 1.00 & 41.32 & 26.78 & 21.56 & 3 & 2021.0959 & 2021.0933 & 674.7050 & 0.0026 & 1.2845 & 186.156 & 241.262 & 120.442 \\ 88.69 & 2021.0933 & 674.7050 & 0.0032 & 1.5809 & 265.607 & 247.803 & 99.858\end{array}$ $\begin{array}{lllllllllllllll}\text { GLPCTELFVAPVGVASK } & 1.00 & 64.46 & 26.68 & 23.53 & 3 & 2021.0947 & 2021.0933 & 674.7050 & 0.0014 & 0.6917 & 232.102 & 220.081 & 75.472 & 8\end{array}$ $\begin{array}{lllllllllllllllll}\text { GLPCTELFVAPVGVASK } & 0.98 & 25.55 & 26.73 & 16.46 & 3 & 2021.0950 & 2021.0933 & 674.7050 & 0.0017 & 0.8399 & 93.596 & 107.046 & 29.468 & 160 .\end{array}$ $\begin{array}{lllllllllllllll}\text { GLPCTELFVAPVGVASK } & 1.00 & 32.29 & 26.73 & 19.28 & 3 & 2021.0950 & 2021.0933 & 674.7050 & 0.0017 & 0.8399 & 172.425 & 96.334 & 72.947 & \end{array}$ $\begin{array}{lllllllllllllll}\text { SLAPGMALGSGR } & 1.00 & 65.69 & 28.41 & 37.71 & 2 & 1259.6866 & 1259.6778 & 630.8462 & 0.0088 & 6.9747 & 907.660 & 1563.502 & 102.366 \\ \text { SLAPGMALGSGR } & 1.00 & 51.16 & 28.32 & 34.98 & 2 & 1259.6874 & 1259.6778 & 630.8462 & 0.0096 & 7.6088 & 383.734 & 895.802 & 36.756\end{array}$

YPTFIDALR YPTFIDALR LQLSLADFR LQLSLADFR

$\begin{array}{llllllllll}28.32 & 34.98 & 2 & 1259.6874 & 1259.6778 & 630.8462 & 0.0096 & 7.6088 & 383.734 & 895.802\end{array}$ $\begin{array}{lllllllllllll}1.00 & 42.29 & 27.47 & 23.37 & 2 & 1238.6808 & 1238.6781 & 620.3463 & 0.0027 & 2.1762 & 2306.225 & 2056.426 & 1438.060\end{array}$ $\begin{array}{lllllllllllll}0.97 & 32.68 & 27.56 & 22.80 & 2 & 1238.6816 & 1238.6781 & 620.3463 & 0.0035 & 2.8210 & 2262.921 & 1889.252 & 1482.690\end{array}$ $\begin{array}{lllllllllllllll}1.00 & 56.80 & 28.10 & 24.17 & 2 & 1205.6914 & 1205.6890 & 603.8518 & 0.0024 & 1.9872 & 10953.101 & 9272.293 & 0.000 & 161.537\end{array}$ LQLSLADF

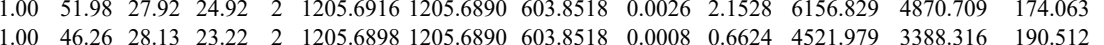

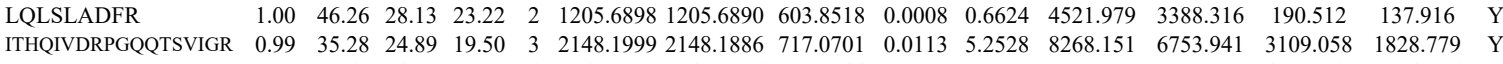
\begin{tabular}{lllllllllllllllll} 
ITHQIVDRPGQQTSVIGR & 1.00 & 30.67 & 24.90 & 16.97 & 4 & 2148.2005 & 2148.1886 & 538.0544 & 0.0119 & 5.5291 & 7328.857 & 8080.311 & 4592.367 & 1964.116 & Yes \\
\hline
\end{tabular}

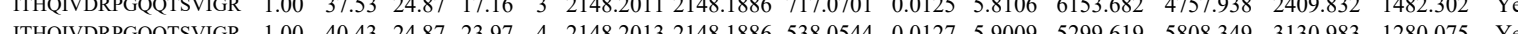
$\begin{array}{lllllllllllllllll}\text { ITHQIVDRPGQQTSVIGR } & 1.00 & 37.48 & 24.87 & 18.18 & 3 & 2148.2014 & 2148.1886 & 717.0701 & 0.0128 & 5.9501 & 2553.373 & 2753.827 & 1167.324 & 894.560 & \text { Ye }\end{array}$ 

$\begin{array}{llllllllllllllllll}\text { MSQVAPSLSALIGEAVGAR } & 1.00 & 68.67 & 26.68 & 21.00 & 3 & 2000.0890 & 2000.0846 & 667.7021 & 0.0044 & 2.1966 & 228.691 & 233.072 & 98.796 & 44.598 & \text { Yes }\end{array}$

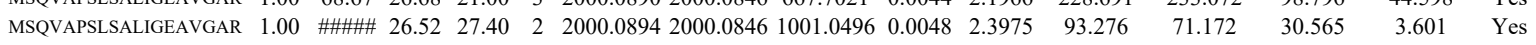

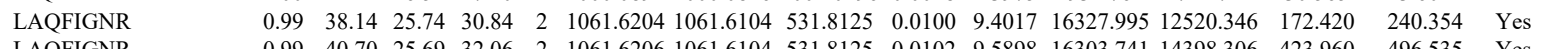

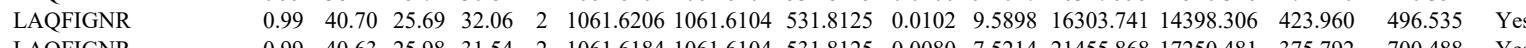

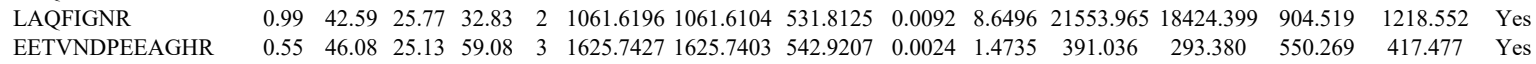
$\begin{array}{lllllllllllllll}1.00 & 81.65 & 27.32 & 25.94 & 2 & 1761.8702 & 1761.8689 & 881.9417 & 0.0013 & 0.7370 & 43.767 & 59.081 & 384.091 & 264.561 & \mathrm{No}\end{array}$ $\begin{array}{llllllllllllllll} & \end{array}$ \begin{tabular}{llllllllllllllll}
1.00 & 63.71 & 27.69 & 30.45 & 2 & 1450.7898 & 1450.7871 & 726.4008 & 0.0027 & 1.8585 & 17534.139 & 12949.302 & 6594.050 & 4231.066 & Yes & \\
\hline & 1.00 & 60.48 & 27.71 & 27.41 & 2 & 150.7900 & 150.7871 & 726.408 & 0.002 & 1.9961 & 1943.533 & 1508.020 & 8190.034 & 5104834 & $Y e s$
\end{tabular}

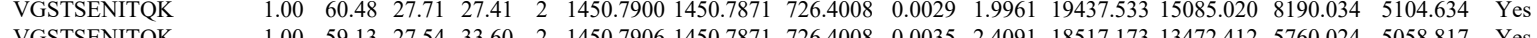
$\begin{array}{lllllllllllllllll} & \text { VGSTSENTQK } & 1.00 & 59.13 & 27.54 & 33.60 & 2 & 1450.7906 & 1450.7871 & 726.4008 & 0.0035 & 2.4091 & 18517.173 & 13472.412 & 5760.024 & 5058.817 & \text { Yes }\end{array}$

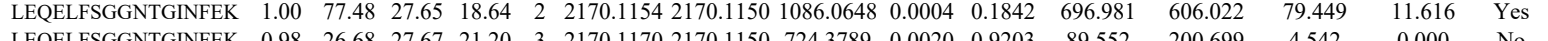

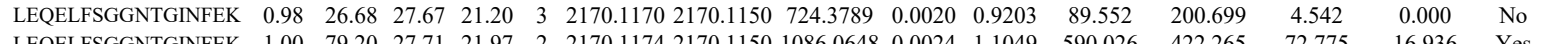

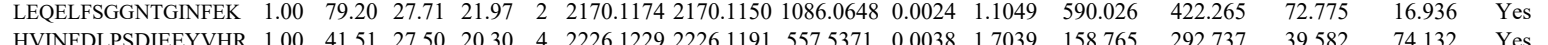

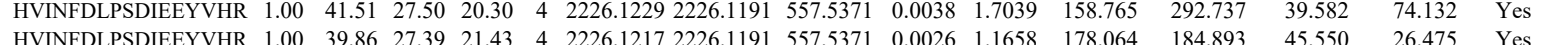

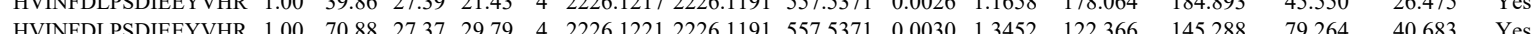

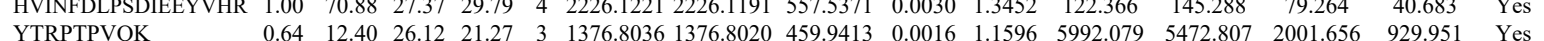
$\begin{array}{lllllllllllllll}\text { YTRPTPVQK } & 0.64 & 12.40 & 26.12 & 21.27 & 3 & 1376.8036 & 1376.8020 & 459.9413 & 0.0016 & 1.1596 & 5992.079 & 5472.807 & 2001.656 & 92 \\ \text { YTRPTPVQK } & 0.80 & 15.52 & 26.18 & 21.67 & 3 & 1376.8042 & 1376.8020 & 459.9413 & 0.0022 & 1.5944 & 4267.598 & 3753.354 & 1458.660 & 55\end{array}$

YTRPTPVQK
YTRPTPVQK

YTRPTPVQK

YTRPTPVQK

SFLLDLLNATGK

SFLLDLLNATGK

SFLLDLLNATGK

SFLLDLLNATGK

FSGGFGAR

FSGGGFGAR

SFLLDLLNATGK

SFLLDLLNATGK

SFLLDLLNATGK

SFLLDLLNATGK

VGNLGLATSFFNER

VGNLGLATSFFNER

VGNLGLATSFFNER

VGNLGLATSFFNER

FSGGFGAR

FSGGFGAR

SFLLDLLNATGK

SFLLDLLNATGK

VGNLGLATSFFNER
VGNLGLATSFFNER

VGNLGLATSFFNER

VGNLGLATSFFNER

FSGGFGAR $\begin{array}{llllllllllllll}0.82 & 18.05 & 26.64 & 18.23 & 3 & 1376.8033 & 1376.8020 & 459.9413 & 0.0013 & 0.9421 & 3174.161 & 2571.431 & 1040.010\end{array}$ $\begin{array}{lllllllllllllll}0.54 & 12.85 & 26.64 & 16.79 & 3 & 1376.8033 & 1376.8020 & 459.9413 & 0.0013 & 0.9421 & 3537.708 & 3143.313 & 1260.454\end{array}$ $\begin{array}{llllllllllllll}0.51 & 14.51 & 26.18 & 22.59 & 2 & 1376.8040 & 1376.8020 & 689.4083 & 0.0020 & 1.4505 & 569.407 & 467.303 & 152.432\end{array}$ $\begin{array}{lllllllllllll}1.00 & 84.67 & 24.86 & 31.89 & 2 & 1578.9256 & 1578.9225 & 790.4685 & 0.0031 & 1.9609 & 3791.176 & 3045.853 & 284.618\end{array}$ $\begin{array}{lllllllllllll}1.00 & 73.56 & 24.86 & 26.68 & 2 & 1578.9260 & 1578.9225 & 790.4685 & 0.0035 & 2.2139 & 11133.681 & 8437.729 & 30.383\end{array}$ $\begin{array}{llllllllllllll}1.00 & 47.78 & 24.71 & 21.87 & 3 & 1578.9262 & 1578.9225 & 527.3148 & 0.0037 & 2.3389 & 361.743 & 218.622 & 16.939\end{array}$ $\begin{array}{llllllllllllllll}0.83 & 15.73 & 24.70 & 16.44 & 3 & 1578.9268 & 1578.9225 & 527.3148 & 0.0043 & 2.7182 & 93.949 & 129.076 & 28.068\end{array}$ $\begin{array}{llllllllllllll}0.54 & 22.86 & 25.75 & 26.73 & 2 & 941.4890 & 941.4841 & 471.7493 & 0.0049 & 5.1934 & 6437.892 & 4293.589 & 281.574 \\ 0.92 & 32.87 & 25.74 & 31.18 & 2 & 941.4898 & 941.4841 & 417.7493 & 0.0057 & 6.0413 & 658.349 & 5021.797 & 352.457\end{array}$ $\begin{array}{llllllllllllll}0.92 & 32.87 & 25.74 & 31.18 & 2 & 941.4898 & 941.4841 & 471.7493 & 0.0057 & 6.0413 & 6528.349 & 5021.797 & 352.457 \\ 1\end{array}$ $\begin{array}{llllllllllllll}1.00 & 74.96 & 24.94 & 26.91 & 2 & 1578.9244 & 1578.9225 & 790.4685 & 0.0019 & 1.2018 & 2141.006 & 1534.657 & 117.135 \\ 1.00 & 78.50 & 24.86 & 32.13 & 2 & 1587.9254 & 1588.9225 & 790.485 & 0.0029 & 1.8344 & 3244.458 & 2426.031 & 149.446\end{array}$ $\begin{array}{lllllllllllll}1.00 & 87.50 & 24.86 & 32.13 & 2 & 1578.9254 & 1578.9225 & 790.4685 & 0.0029 & 1.8344 & 3244.458 & 2426.031 & 149.446\end{array}$ $\begin{array}{lllllllllllll}0.94 & 20.47 & 24.71 & 18.24 & 3 & 1578.9262 & 1578.9225 & 527.3148 & 0.0037 & 2.3389 & 159.001 & 102.868 & 30.751 \\ 1.00 & 29.99 & 2.71 & 18.45 & 3 & 1578.9262 & 1578.9225 & 527.3148 & 0.0037 & 23389 & 227.223 & 142.040 & 72.379\end{array}$ $\begin{array}{llllllllllllll}1.00 & 29.99 & 24.71 & 18.45 & 3 & 1578.9262 & 1578.9225 & 527.3148 & 0.0037 & 2.3389 & 227.223 & 142.040 & 72.379\end{array}$ $\begin{array}{lllllllllllllll}1.00 & 74.76 & 27.87 & 30.17 & 2 & 1667.8772 & 1667.8753 & 834.9449 & 0.0019 & 1.1378 & 4316.028 & 3125.477 & 250.731\end{array}$ $\begin{array}{llllllllllllll}1.00 & 72.07 & 27.88 & 33.45 & 2 & 1667.8774 & 1667.8753 & 834.9449 & 0.0021 & 1.2576 & 4749.313 & 3821.822 & 311.258\end{array}$ $\begin{array}{llllllllllllll}0.97 & 25.70 & 27.85 & 15.25 & 3 & 1667.8783 & 1667.8753 & 556.9657 & 0.0030 & 1.7954 & 374.655 & 450.417 & 100.530 & 57 \\ 1.00 & 33.60 & 27.83 & 15.56 & 3 & 1667.8789 & 1667.8753 & 556.9657 & 0.0036 & 2.1545 & 269.184 & 413.753 & 148.267\end{array}$ $\begin{array}{lllllllllllllll}1.00 & 33.60 & 27.83 & 15.56 & 3 & 1667.8789 & 1667.8753 & 556.9657 & 0.0036 & 2.1545 & 269.184 & 413.753 & 148.267 & 14.1 \\ 1.00 & 43.00 & 25.77 & 34.17 & 2 & 941.4856 & 941.4841 & 471.7493 & 0.0015 & 1.5898 & 77439.205 & 61914.178 & 1470.484 & 1281\end{array}$ $\begin{array}{llllllllllllll}1.00 & 45.69 & 25.47 & 31.74 & 2 & 941.4856 & 941.4841 & 471.7493 & 0.0015 & 1.5898 & 77439.205 & 61914.178 & 1470.484 & 1281.4841 \\ 1.771 .7493 & 0.0025 & 2.6497 & 87269.253 & 60603.693 & 2125.671\end{array}$

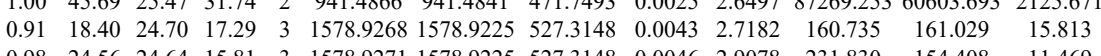
$\begin{array}{llllllllllllll}0.98 & 24.56 & 24.64 & 15.81 & 3 & 1578.9271 & 1578.9225 & 527.3148 & 0.0046 & 2.9078 & 231.830 & 154.408 & 11.469 \\ 1 & 100 & 79.86 & 27.82 & 25.98 & 2 & 1667.8752 & 1667.8753 & 834.949 & 0.0001 & 0.0599 & 2458.863 & 2586.36 & 14.461\end{array}$

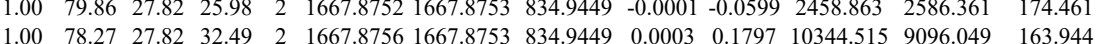
$\begin{array}{lllllllllllll}1.00 & 38.99 & 27.83 & 18.37 & 3 & 1667.8771 & 1667.8753 & 556.9657 & 0.0018 & 1.0773 & 796.758 & 879.724 & 118.011 \\ 0.98 & 29.42 & 27.86 & 16.88 & 3 & 1667.8804 & 1667.8753 & 556.9657 & 0.0051 & 3.0522 & 901.530 & 920.777 & 51.220\end{array}$ $\begin{array}{llllllllllllll}0.98 & 29.42 & 27.86 & 16.88 & 3 & 1667.8804 & 1667.8753 & 556.9657 & 0.0051 & 3.0522 & 901.530 & 920.777 & 51.220\end{array}$ $\begin{array}{llllllllllllll}1.00 & 40.13 & 25.47 & 28.47 & 2 & 941.4860 & 941.4841 & 471.7493 & 0.0019 & 2.0138 & 29335.210 & 22202.903 & 1943.361\end{array}$ 


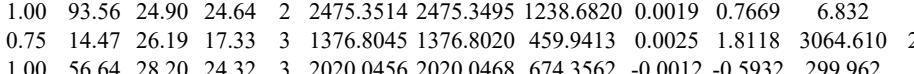

$\begin{array}{llllllllllll} & 0.75 & 14.47 & 26.19 & 17.33 & 3 & 1376.8045 & 1376.8020 & 459.9413 & 0.0025 & 1.8118 & 3064.610\end{array}$ $\begin{array}{lllllllllllllllll} & \end{array}$ $\begin{array}{llllllllll} & 0\end{array}$ $\begin{array}{lllllllllllllll}\text { GDIGQQIR } & 0.95 & 23.48 & 28.14 & 18.34 & 3 & 2020.0489 & 2020.0468 & 674.3562 & 0.0021 & 1.0380 & 10.618 & 16.112 & 4.623\end{array}$ $\begin{array}{lllllllllllllll} & \end{array}$ $\begin{array}{llllllllllllllll}\text { VRPCVVYGGADIGQQIR } & 1.00 & 67.79 & 28.11 & 22.15 & 3 & 2020.0513 & 2020.0468 & 674.3562 & 0.0045 & 2.2243 & 932.095 & 937.479 & 504.961 & 546.8\end{array}$ $\begin{array}{lllllllllllllll}\text { VRPCVVYGGADIGQQIR } & 1.00 & 50.71 & 28.08 & 27.29 & 3 & 2020.0483 & 2020.0468 & 674.3562 & 0.0015 & 0.7414 & 819.336 & 1235.784 & 1136.459 & 1622.733\end{array}$ $\begin{array}{lllllllllllllll}\text { VRPCVVYGGADIGQQIR } & 1.00 & 47.34 & 28.11 & 22.52 & 3 & 2020.0507 & 2020.0468 & 674.3562 & 0.0039 & 1.9278 & 523.222 & 766.584 & 1795.710 & 1932.535\end{array}$ SPILVATAVAAR GCHLLVATPGR GCHLLVVATPGR GCHLLVATPGR SILVATAVAAR SPILVATAVAAR SPILVATAVAAR SPILVATAVAAR SPILVATAVAAR

GCHLLVATPGR

GCHLLVATPGR

GCHLLVATPGR

QYPISLVLAPTR

QYPISLVLAPTR

QYPISLVLAPTR SPILVATAVAAR SPILVATAVAAR GCHLLVATPGR GCHLLVATPGR QYPISLVATR QPILLVTAVAAR SPLVATAVAAR SPILVATAVAAR

SPILVATAVAAR

SPILVATAVAAR

SPILVATAVAAR SPILVATAVAAR SPILVATAVAAR SPILVATAVAAR QYPISLVLAPTR QYPISLVLAPTR SPILVATAVAAR SPILVATAVAAR

QYPISLVLAPTR

YLVLDEADR

YLVLDEADR

VVWVEESDKR

VVWVEESDKR

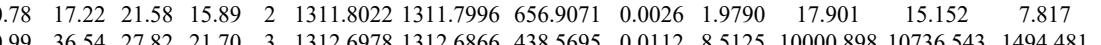
$\begin{array}{llllllllllllll}0.98 & 34.23 & 27.83 & 25.75 & 3 & 1312.6987 & 1312.6866 & 438.5695 & 0.0121 & 9.1965 & 10497.533 & 11554.484 & 1437.522 & \end{array}$ $\begin{array}{llllllllllllll}1.00 & 74.95 & 27.82 & 25.46 & 2 & 1312.6988 & 1312.6866 & 657.3506 & 0.0122 & 9.2796 & 2644.454 & 2598.211 & 554.129\end{array}$ $\begin{array}{lllllllllllll}0.98 & 27.65 & 22.01 & 21.70 & 2 & 1311.8006 & 1311.7996 & 656.9071 & 0.0010 & 0.7611 & 26.275 & 14.767 & 12.719\end{array}$ $\begin{array}{lllllllllllll}0.96 & 23.68 & 21.85 & 16.67 & 2 & 1311.8010 & 1311.7996 & 656.9071 & 0.0014 & 1.0656 & 27.985 & 5.822 & 10.132\end{array}$ $\begin{array}{llllllllllllll}0.55 & 19.34 & 22.04 & 19.47 & 2 & 1311.8042 & 1311.7996 & 656.9071 & 0.0046 & 3.5012 & 13.750\end{array}$

14.876

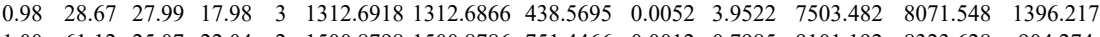
$\begin{array}{llllllllllllll}1.00 & 61.12 & 25.07 & 22.04 & 2 & 1500.8798 & 1500.8786 & 751.4466 & 0.0012 & 0.7985 & 9101.192 & 8323.628 & 904.274 \\ 1.00 & 59.96 & 24.76 & 17.81 & 2 & 1500.8806 & 1500.8786 & 751.4466 & 0.0020 & 1.3308 & 1305.601 & 1327.994 & 138.098\end{array}$ $\begin{array}{lllllllllllll}1.00 & 59.96 & 24.76 & 17.81 & 2 & 1500.8806 & 1500.8786 & 751.4466 & 0.0020 & 1.3308 & 1305.601 & 1327.994 & 138.098\end{array}$ $\begin{array}{llllllllllllll}0.77 & 13.41 & 24.53 & 15.18 & 3 & 1500.8818 & 1500.8786 & 501.3001 & 0.0032 & 2.1278 & 165.068 & 174.519 & 22.222\end{array}$ $\begin{array}{lllllllllllll}1.00 & 71.73 & 21.58 & 26.25 & 2 & 1311.8026 & 1311.7996 & 656.9071 & 0.0030 & 2.2834 & 842.750 & 716.721 & 379.493\end{array}$ $\begin{array}{lllllllllllll}1.00 & 67.84 & 22.04 & 27.16 & 2 & 1311.8040 & 1311.7996 & 656.9071 & 0.0044 & 3.3490 & 802.461 & 604.512 & 445.268\end{array}$

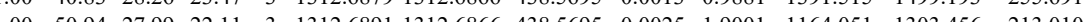

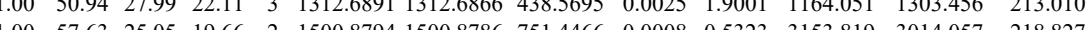

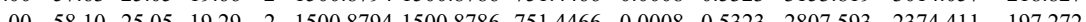

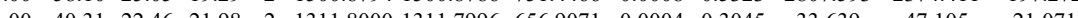
$\begin{array}{llllllllllllll}0.99 & 32.42 & 21.85 & 19.98 & 2 & 13118012 & 1311.7996 & 6569071 & 0.0016 & 1.2178 & 43.673 & 33.228 & 16.569\end{array}$ $\begin{array}{llllllllllllll}1.00 & 47.45 & 22.01 & 20.94 & 2 & 13118006 & 13117996 & 6569071 & 0.0010 & 0.7611 & 33.339 & 40.154 & 22.458\end{array}$ $\begin{array}{llllllllllllll}1.00 & 47.28 & 21.85 & 24.25 & 2 & 1311.8014 & 1311.7996 & 656.9071 & 0.0018 & 1.3701 & 46.428 & 49.718 & 47.882\end{array}$ $\begin{array}{lllllllllllll}1.00 & 44.76 & 25.07 & 17.74 & 2 & 1500.8804 & 1500.8786 & 751.4466 & 0.0018 & 1.1977 & 75.093 & 56.065 & 17.525\end{array}$ $\begin{array}{llllllllllllll}1.00 & 47.42 & 22.38 & 24.24 & 2 & 1311.8002 & 1311.7996 & 6569071 & 0.0006 & 0.4567 & 25.814 & 41.985 & 21.702\end{array}$ $\begin{array}{lllllllllllll}1.00 & 45.44 & 21.82 & 20.63 & 2 & 1311.8008 & 1311.7996 & 656.9071 & 0.0012 & 0.9134 & 29.738 & 41.900 & 19.700\end{array}$ $\begin{array}{llllllllllllll}1.00 & 52.84 & 22.46 & 22.30 & 2 & 1311.8000 & 1311.7996 & 6569071 & 0.0004 & 0.3045 & 80.778 & 52.299 & 24.663\end{array}$ $\begin{array}{lllllllllllll}1.00 & 55.09 & 22.38 & 24.98 & 2 & 1311.8004 & 1311.7996 & 656.9071 & 0.0008 & 0.6089 & 47.663 & 77.516 & 21.817\end{array}$ $\begin{array}{lllllllllllll}0.99 & 31.98 & 25.05 & 18.59 & 2 & 1500.8794 & 1500.8786 & 751.4466 & 0.0008 & 0.5323 & 83.236 & 72.427 & 6.760\end{array}$ $\begin{array}{lllllllllllllll}1.00 & 53.99 & 24.73 & 16.99 & 2 & 1500.8810 & 1500.8786 & 751.4466 & 0.0024 & 1.5969 & 72.999 & 64.271 & 18.532\end{array}$ $\begin{array}{lllllllllllll}1.00 & 57.53 & 22.46 & 22.81 & 2 & 1311.8000 & 1311.7996 & 656.9071 & 0.0004 & 0.3045 & 64.325 & 101.909 & 30.196\end{array}$

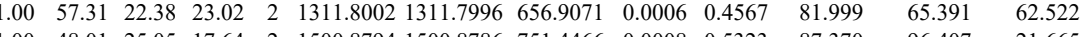

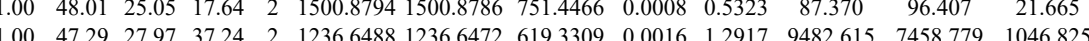
$\begin{array}{lllllllllllll}1.00 & 47.29 & 27.97 & 37.24 & 2 & 1236.6488 & 1236.6472 & 619.3309 & 0.0016 & 1.2917 & 9482.615 & 7458.779 & 1046.825\end{array}$ $\begin{array}{llllllllllllll}0.99 & 45.94 & 28.11 & 42.81 & 2 & 1236.6494 & 1236.6472 & 619.3309 & 0.0022 & 1.7761 & 10179.378 & 9046.691 & 1405.601 & 76 \\ 1.00 & 44.56 & 28.06 & 25.05 & 3 & 1533.8515 & 1533.8395 & 5122871 & 0.0120 & 7.8081 & 24384.489 & 21461.246 & 1817.920 & 98\end{array}$ $\begin{array}{llllllllllllll}1.00 & 44.56 & 28.06 & 25.05 & 3 & 1533.8515 & 1533.8395 & 512.2871 & 0.0120 & 7.8081 & 24384.489 & 21461.246 & 1817.920 & 98 \\ 1.00 & 44.81 & 27.63 & 20.26 & 3 & 1533.8539 & 1533.8395 & 5122871 & 0.0144 & 9.3697 & 28592.433 & 23977.305 & 1784.027 & 34 \\ 0.92 & 32.46 & 8.24 & 23.84 & 2 & 188.6548 & 1188.647 & 595.3296 & 0.001 & 8.4826 & 1281.68 & 1674.288 & 1682.93 & 86\end{array}$ $\begin{array}{lllllllllllll}1.00 & 44.81 & 27.63 & 20.26 & 3 & 1533.8539 & 1533.8395 & 512.2871 & 0.0144 & 9.3697 & 28592.433 & 23977.305 & 1784.027 \\ 0.92 & 32.46 & 28.24 & 23.84 & 2 & 1188.6548 & 1188.6447 & 595.3296 & 0.0101 & 8.4826 & 1281.680 & 1674.288 & 1682.193\end{array}$ $\begin{array}{llllllllllllll}47.10 & 28.19 & 21.84 & 2 & 1188.6558 & 1188.6447 & 595.3296 & 0.0111 & 9.3225 & 792.226 & 1108.402 & 1188.971 & 625.184\end{array}$

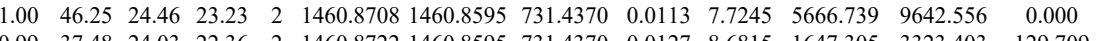
$\begin{array}{llllllllllllll}0.99 & 37.48 & 24.03 & 22.36 & 2 & 1460.8722 & 1460.8595 & 731.4370 & 0.0127 & 8.6815 & 1647.305 & 3323.403 & 129.709 & 359 \\ 0.86 & 32.81 & 28.48 & 25.90 & 2 & 1060.5714 & 1060.5643 & 531.2894 & 0.0071 & 6.6818 & 21262.216 & 40994.722 & 831.496 & \end{array}$

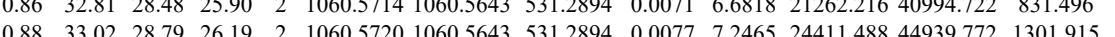
$\begin{array}{llllllllllllll}0.88 & 33.02 & 28.79 & 26.19 & 2 & 1060.5720 & 1060.5643 & 531.2894 & 0.0077 & 7.2465 & 24411.488 & 44939.772 & 1301.915 & 31\end{array}$

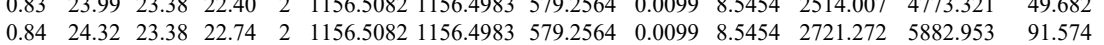
$\begin{array}{lllllllllllllll}0.89 & 28.07 & 23.22 & 26.16 & 2 & 1156.5068 & 1156.4983 & 579.2564 & 0.0085 & 7.3369 & 6016.387 & 12971.405 & 460.391 & 1\end{array}$ $\begin{array}{lllllllllllllll}0.91 & 28.07 & 23.20 & 26.15 & 2 & 1156.5072 & 1156.4983 & 579.2564 & 0.0089 & 7.6822 & 5393.797 & 11674.949 & 435.026\end{array}$ 


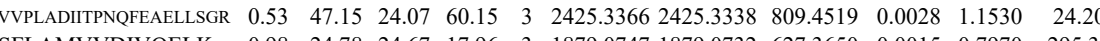
$\begin{array}{lllllllllllll} & \text { SEAMVVIVQELK } & 0.98 & 24.78 & 24.67 & 17.96 & 3 & 1879.0747 & 1879.0732 & 627.3650 & 0.0015 & 0.7970 & 245.304\end{array}$ $\begin{array}{lllllllllllll}\text { SFLAMVVDIVQELK } & 0.55 & 35.13 & 24.62 & 48.13 & 3 & 1879.0753 & 1879.0732 & 627.3650 & 0.0021 & 1.1158 & 246.750 & 362\end{array}$ $\begin{array}{llllllllllllll}\text { SFLAMVVDIVQELK } & 0.53 & 32.02 & 24.58 & 45.02 & 3 & 1879.0759 & 1879.0732 & 627.3650 & 0.0027 & 1.4346 & 266.435 & 302.1\end{array}$ TVSTLHHVLQR $\begin{array}{lllllllllllll} & \end{array}$ $\begin{array}{llllllllllll}\text { TVSTLHHVLQR } & 1.00 & 77.61 & 26.20 & 19.43 & 3 & 1433.8258 & 1433.8225 & 478.9481 & 0.0033 & 2.2967 & 5799.726\end{array}$ $\begin{array}{llllllllllll}\text { WEAAEGLLQEALDK } & 0.61 & 13.49 & 27.47 & 16.13 & 3 & 1859.9902 & 1859.9872 & 621.0030 & 0.0030 & 1.6103 & 132.683\end{array}$ $\begin{array}{lllllllllllll}\text { MEDLEDATTOLTIWVSLATGGEK } & 1.00 & 23.64 & 26.59 & 14.99 & 4 & 3051.5357 & 3051.5314 & 763.8901 & 0.0043 & 1.4073 & 17.086\end{array}$ $\begin{array}{llllllllllll}\text { FGVVLDEIKPSSAPELQAVR } & 0.55 & 57.16 & 22.46 & 70.16 & 3 & 2442.3748 & 2442.3726 & 815.1315 & 0.0022 & 0.8996 & 568.492\end{array}$ $\begin{array}{llllllllllllll} & \end{array}$

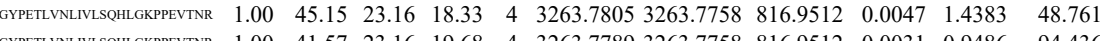

\section{AYGELPEHAK}

AYGELPEHAK

VWINTSDIILVGL

VWINTSDIILVGLR

VWINTSDIILVGLR

VWINTSDIILVGLR

VWINTSDIILVGLR

VWINTSDIILVGLR

VWINTSDIILVGLR

VWINTSDIILVGLR

VWINTSDIILVGLR

VWINTSDIILVGLR

VWINTSDILVGLR

WINTDLVLR

WINDDLUR

VWINTSDILVGLR

VWINTSDILVGLR

VWINTSDILVGLR

VWINTSDIILVGLR

VWINTSDIILVGLR

VWINTSDIILVGLR

VWINTSDIILVGLR

VWINTSDIILVGLR

VWINTSDIILVGLR

VWINTSDIILVGLR

VWINTSDIILVGLR

VWINTSDIILVGLR

VWINTSDIILVGL

VWINTSDIILVGLR

VWINTSDIILVGLR

VWINTSDIILVGLR

VWINTSDIILVGLR

VWINTSDIILVGLR

VWINTSDIILVGLR

VWINTSDIILVGLR

VWINTSDIILVGLR

VWINTSDIILVGLR

VWINTSDIILVGLR

VWINTSDIILVGLR

VWINTSDILVGLR

VWINTSDHLVGLR

WINDILVR $\begin{array}{llllllllllll}41.57 & 23.16 & 19.68 & 4 & 3263.7789 & 3263.7758 & 816.9512 & 0.0031 & 0.9486 & 94.436 & 76.982\end{array}$ $\begin{array}{lllllllllllll} & 4.04 & 27.82 & 28.12 & 3 & 1401.7531 & 1401.7496 & 468.2571 & 0.0035 & 2.4915 & 9808.570 & 8743.345\end{array}$ $\begin{array}{lllllllllllll}1.00 & 40.73 & 28.07 & 22.69 & 3 & 1401.7585 & 1401.7496 & 468.2571 & 0.0089 & 6.3355 & 7908.040 & 8007.081\end{array}$ $\begin{array}{lllllllllllll}0.96 & 28.73 & 26.61 & 30.32 & 2 & 1136.5564 & 1136.5553 & 569.2849 & 0.0011 & 0.9661 & 226.297 & 184.305 \\ 1.00 & 75.98 & 23.38 & 26.65 & 2 & 1742.0222 & 1742.0212 & 872.0179 & 0.0010 & 0.5734 & 44.645 & 53.834\end{array}$ \begin{tabular}{llllllllllll} 
& 7.98 & 23.38 & 26.65 & 2 & 1742.0222 & 1742.0212 & 872.0179 & 0.0010 & 0.5734 & 44.645 & 53.834 \\
\hline & 16.34 & 23.38 & 15.08 & 3 & 1742.022 & 1742.0212 & 581.6810 & 0.0012 & 0.6877 & 12.465 & 38.888
\end{tabular} $\begin{array}{llllllllllll}0.88 & 16.34 & 23.38 & 15.08 & 3 & 1742.0224 & 1742.0212 & 581.6810 & 0.0012 & 0.6877 & 12.465 & 38.888 \\ 1.00 & 62.52 & 22.74 & 28.97 & 2 & 1742.0238 & 1742.0212 & 872.0179 & 0.0026 & 1.498 & 72.417 & 79.469\end{array}$ $\begin{array}{llllllllllll}1.00 & 62.52 & 22.74 & 28.97 & 2 & 1742.0238 & 1742.0212 & 872.0179 & 0.0026 & 1.4908 & 72.417 & 79.469 \\ 1.00 & 51.21 & 23.48 & 18.01 & 3 & 1742.0194 & 1742.0212 & 581.6810 & -0.0018 & -1.0315 & 1.294 & 13.992\end{array}$

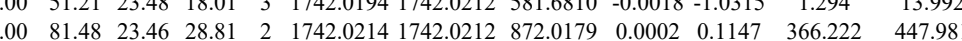
$\begin{array}{llllllllllll}1.00 & 81.48 & 23.46 & 28.81 & 2 & 1742.0214 & 1742.0212 & 872.0179 & 0.0002 & 0.1147 & 366.222 & 447.981 \\ 1.00 & 79.98 & 23.46 & 28.53 & 2 & 1742.0216 & 1742.0212 & 872.0179 & 0.0004 & 0.2294 & 260.644 & 295.840\end{array}$

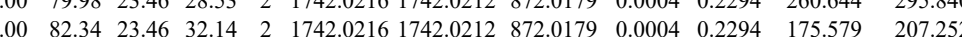

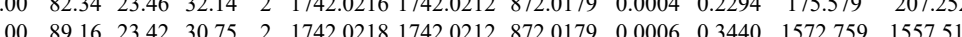

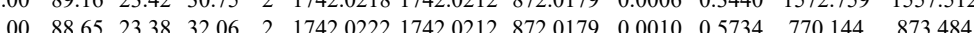
$\begin{array}{llllllllllll}1.00 & 73.65 & 23.40 & 28.95 & 2 & 1742.0224 & 1742.0212 & 872.0179 & 0.0012 & 0.6881 & 274.389 & 308.816\end{array}$ $\begin{array}{llllllllllllll}.00 & 83.15 & 23.24 & 29.32 & 2 & 1742.0228 & 1742.0212 & 872.0179 & 0.0016 & 0.9174 & 214.347 & 234.23 \\ \end{array}$ $\begin{array}{llllllllllll}1.00 & 83.15 & 23.24 & 29.32 & 2 & 1742.0228 & 1742.0212 & 872.0179 & 0.0016 & 0.9174 & 214.347 & 234.235 \\ 1.00 & 81.91 & 23.24 & 29.21 & 2 & 1742.0228 & 1742.0212 & 872.0179 & 0.0016 & 0.9174 & 151.489 & 177.875 \\ & 28.14 & 2 & 1742.0230 & 1742.0212 & 872.0179 & 0.018 & 1.032 & 25.634 & 231.943\end{array}$

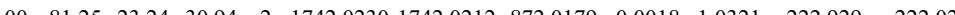

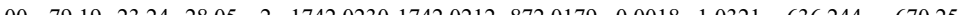

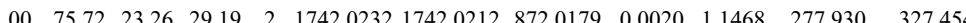
$\begin{array}{lllllllllllll}100 & 87.07 & 23.26 & 29.00 & 2 & 17420232 & 1742.0212 & 872.0179 & 0.0020 & 1.1468 & 640.424 & 816.612\end{array}$ $\begin{array}{llllllllllllll}1.00 & 79.47 & 23.26 & 28.40 & 2 & 1742.0232 & 1742.0212 & 872.0179 & 0.0020 & 1.1468 & 231.783 & 227.488\end{array}$ $\begin{array}{llllllllllll}1.00 & 79.43 & 22.79 & 30.22 & 2 & 1742032 & 1742.0212 & 872.0179 & 0.0022 & 1.2614 & 118.637 & 154.359\end{array}$ $\begin{array}{llllllllllllll}1.00 & 45.24 & 22.74 & 21.90 & 3 & 1742.0236 & 1742.0212 & 581.6810 & 0.0024 & 1.3753 & 11.505 & 17.435\end{array}$ $\begin{array}{llllllllllll}0.99 & 23.52 & 22.74 & 1.54 & 3 & 1742.0239 & 1742.0212 & 581.6810 & 0.0027 & 1.5472 & 102.580 & 114.104\end{array}$ $\begin{array}{lllllllllllll}1.00 & 37.71 & 22.79 & 17.98 & 3 & 1742.0242 & 1742.0212 & 581.6810 & 0.0030 & 1.7192 & 99.419 & 95.771\end{array}$ $\begin{array}{llllllllllll}1.00 & 37.71 & 22.79 & 17.98 & 3 & 1742.0242 & 1742.0212 & 881.6810 & 0.0030 & 1.7192 & 99.49 & 95.771 \\ 1.00 & 79.33 & 22.79 & 23.48 & 2 & 1742.0242 & 1742.0212 & 872.0179 & 0.0030 & 1.7201 & 258.296 & 375.713\end{array}$ $\begin{array}{lllllllllllll}1.00 & 79.33 & 22.76 & 29.41 & 2 & 1742.0244 & 1742.0212 & 872.0179 & 0.0032 & 1.8348 & 116.853 & 114.88\end{array}$ $\begin{array}{llllllllllllll}0.98 & 22.65 & 22.76 & 15.28 & 3 & 1742.0245 & 1742.0212 & 581.6810 & 0.0033 & 1.8911 & 70.159 & 61.26\end{array}$ $\begin{array}{llllllllllll}0.87 & 14.04 & 22.76 & 15.12 & 3 & 1742.0245 & 1742.0212 & 581.6810 & 0.0033 & 1.8911 & 74.694 & 86.287\end{array}$ $\begin{array}{lllllllllllll}1.00 & 29.29 & 22.67 & 15.40 & 3 & 1742.0257 & 1742.0212 & 581.6810 & 0.0045 & 2.5787 & 56.065 & 89.393\end{array}$ $\begin{array}{llllllllllll}1.00 & 77.99 & 23.40 & 29.06 & 2 & 1742.0220 & 1742.0212 & 872.0179 & 0.0008 & 0.4587 & 126.967 & 139.546\end{array}$ $\begin{array}{lllllllllllll}1.00 & 79.50 & 23.38 & 28.40 & 2 & 1742.0222 & 1742.0212 & 872.0179 & 0.0010 & 0.5734 & 145.339 & 153.991 \\ 1.00 & 79.41 & 23.24 & 2.22 & 2 & 1742.0226 & 1742.0212 & 872.0179 & 0.0014 & 0.8027 & 164.711 & 141.909\end{array}$ $\begin{array}{lllllllllllll}1.00 & 79.41 & 23.24 & 26.22 & 2 & 1742.0226 & 1742.0212 & 872.0179 & 0.0014 & 0.8027 & 164.711 & 141.909 \\ 0.60 & 10.45 & 23.24 & 15.02 & 3 & 1742.0227 & 1742.0212 & 581.6810 & 0.0015 & 0.8596 & 77.411 & 66.966\end{array}$ $\begin{array}{llllllllllll}0.60 & 10.45 & 23.24 & 15.02 & 3 & 1742.0227 & 1742.0212 & 581.6810 & 0.0015 & 0.8596 & 77.411 & 66.966\end{array}$ $\begin{array}{lllllllllllll}1.00 & 94.70 & 23.24 & 35.67 & 2 & 1742.0228 & 1742.0212 & 872.0179 & 0.0016 & 0.9174 & 134.505 & 179.205\end{array}$ $\begin{array}{lllllllllllll}1.00 & 91.13 & 23.24 & 26.06 & 2 & 1742.0228 & 1742.0212 & 872.0179 & 0.0016 & 0.9174 & 127.536 & 114.66\end{array}$ $\begin{array}{llllllllllllll}1.00 & 60.65 & 23.24 & 23.14 & 2 & 1742.0228 & 1742.0212 & 872.0179 & 0.0016 & 0.9174 & 13.686 & 26.615\end{array}$

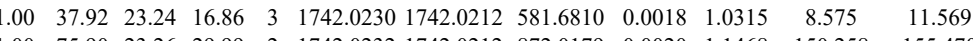

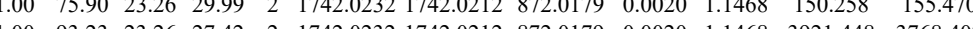

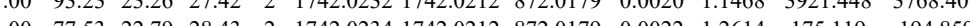
$\begin{array}{llllllllllllll}1.00 & 77.53 & 22.79 & 28.43 & 2 & 1742.0234 & 1742.0212 & 82.0179 & 0.022 & 1.2684 & 175.119 & 194.859\end{array}$

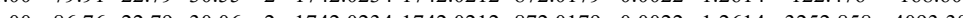

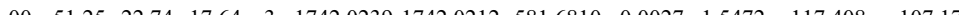
$\begin{array}{lllllllllll}1.00 & 31.97 & 22.74 & 15.39 & 3 & 17420239 & 17420212 & 581.6810 & 0.0027 & 1.5472 & 33.424\end{array}$ 
VWINTSDIILVGLR VWINTSDIILVGLR VWINTSDIILVGLR VWINTSDIILVGLR VWINTSDIILVGLR VWINTSDIILVGLR VWINTSDIILVGLR VWINTSDIILVGLR VWINTSDIILVGLR VWINTSDILLVGLR YWINTDR

EDGQEYAQVIK

EDGQEYAQVIK

AYGELPEHAK

AYGELPEHAK

AYGELPEHAK

AYGELPEHAK

AYGELPEHAK

AYGELPEHAK

AYGELPEHAK

AYGELPEHAK

$\begin{array}{lllllllllllll}\text { PDCD5_HUMAI } & \text { O14737 } & \text { PDCD5 } & \text { Programmed cell } 14.29 & 1.00 & 3 & 28 & -0.2252 & 0.1502 & -1.4301 & 2.3647 & 8 & \text { VSEQGLIEILK }\end{array}$

VSEQGLIEILK

VSEQGLIEILK

VSEQGLIEILK

LSNLALVKPEK

NSILAQVLDQSAR

NSILAQVLDQSAR

NSILAQVLDQSAR

NSILAQVLDQSAR

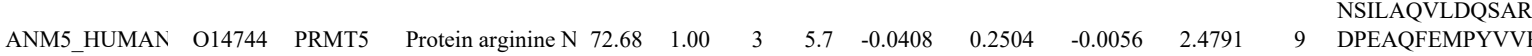

GPLVNASLR

GPLVNASLR

GPLVNASLR

QGFDFLCMPVF

QGFDFLCMPVFHPR

QGDLCMP

GFDFLCMPVFHPR

GPPPPTASEPTR

GPPPPPT ASEPTR

GPPPPPTASEPTR

GPPPPPTASEPTR

GPPPPPTASEPTR

RGPPPPPTASEPTR

RGPPPPPTASEPTR

VFFYNPTTR

VFFYNPTTR

NLLLYDAGTLADSVGHHLNO

\section{LMPPLIQK}

NLLLYDALGTLADSYGHHLNQPEY

EVLASHLVQLIPILVNGM

EVLASHLVQLIPILVNGMK

CSAAALDVLANVFR

$\begin{array}{llllllllllllll}\text { PSA7_HUMAN } & \text { O14818 } & \text { PSMA7 } & \text { Proteasome subun } 27.89 & 1.00 & 4 & 25 & 0.2695 & 0.5545 & -0.1545 & 1.3495 & 8 & \begin{array}{l}\text { LTVEDPVTVEYITR } \\ \text { LTVEDPVTVEYITR }\end{array} \\ & & & & & & & & & & & & & \end{array}$

NTVESPDGHLFQVEYAOEAVK

ITVFSPDGHLFOVEYAQEA

RPFGISALIVGFDFDGT

RPFGISALIVGFDFDGTPR

YVAEIEK $\begin{array}{ccccccccccccc}0.71 & 15.81 & 26.44 & 14.15 & 3 & 2208.1867 & 2208.1814 & 737.0677 & 0.0053 & 2.3969 & 18.339 & 7.715 & 0.000\end{array}$

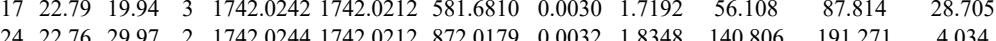

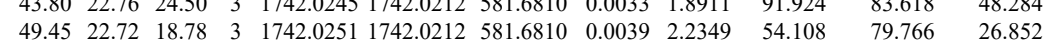
$\begin{array}{llllllllllllll}.78 & 12.81 & 22.67 & 20.79 & 3 & 1742.0254 & 1742.0212 & 581.6810 & 0.0042 & 2.4068 & 84.503 & 120.100 & 44.470\end{array}$ $\begin{array}{llllllllllll}0.78 & 12.81 & 22.67 & 20.79 & 3 & 1742.0254 & 1742.0212 & 581.6810 & 0.0042 & 2.4068 & 84.503 & 120.100\end{array}$ $\begin{array}{lllllllllll} & \end{array}$ $\begin{array}{llllllllllll} & \end{array}$ $\begin{array}{lllllllllll}0.49 & 23.24 & 15.23 & 3 & 1742.0230 & 1742.0212 & 581.6810 & 0.0018 & 1.0315 & 73.212\end{array}$ $\begin{array}{lllllllllll} & 23.24 & 24.19 & 2 & 1742.0230 & 1742.0212 & 872.0179 & 0.0018 & 1.0321 & 30.918\end{array}$ 29.095 9.156 $5401.524 \quad 5430.739 \quad 5641.399 \quad 32$ $\begin{array}{lllllllllllll} & \end{array}$ $\begin{array}{lllllllllllll}59.75 & 27.33 & 30.66 & 2 & 15668188 & 15668133 & 784.4139 & 0.0055 & 3.5058 & 8799.853 & 9262998 & 9256042 & 5503.365\end{array}$ $\begin{array}{lllllllllllllll}1.00 & 62.09 & 27.93 & 24.45 & 2 & 1401.7522 & 1401.7496 & 701.8821 & 0.0026 & 1.8522 & 14599.995 & 16964.244 & 0.000 & 463.312 & \end{array}$

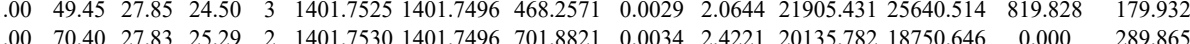
$\begin{array}{lllllllllllllllll}1.00 & 45.26 & 27.89 & 27.67 & 3 & 1401.7534 & 1401.7496 & 468.2571 & 0.0038 & 2.7051 & 36367.041 & 43207.846 & 436.360 & 451.814 & & \end{array}$ $\begin{array}{lllllllllllllll}1.00 & 55.00 & 27.93 & 23.73 & 2 & 1401.7522 & 1401.7496 & 701.8821 & 0.0026 & 1.8522 & 8474.328 & 8411.888 & 207.205 & 319.012 & \text { Ycs }\end{array}$

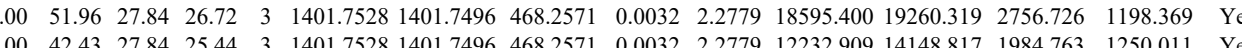
$\begin{array}{llllllllllllllllll}1.00 & 42.43 & 27.84 & 25.44 & 3 & 1401.7528 & 1401.7496 & 468.2571 & 0.0032 & 2.2779 & 12232.909 & 14148.817 & 1984.763 & 1250.011 & \text { Yes } \\ 1.00 & 54.93 & 27.83 & 23.92 & 2 & 1401.7528 & 1401.7496 & 701.8821 & 0.0032 & 2.2796 & 6103.332 & 6167.632 & 282.285 & 397.067 & \text { Y s }\end{array}$ $\begin{array}{lllllllllllllll}1.00 & 51.91 & 22.53 & 24.63 & 2 & 1515.9146 & 1515.9116 & 758.9631 & 0.0030 & 1.9764 & 2534.610 & 2013.193 & 492.701 & 1.904 & \text { Yes }\end{array}$

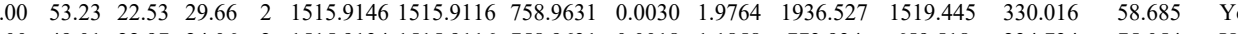
$\begin{array}{lllllllllllllll} & \end{array}$

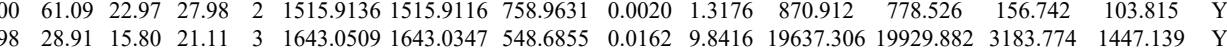
$\begin{array}{llllllllllllll} & \end{array}$ \begin{tabular}{lllllllllllllll}
1.00 & 78.40 & 26.54 & 26.02 & 2 & 1557.8672 & 1557.8596 & 779.9371 & 0.0072 & 4.6157 & 527.903 & 662.472 & 257.962 & 207.824 & \\
\hline
\end{tabular} $\begin{array}{lllllllllllllll}1.00 & 94.37 & 27.20 & 33.40 & 2 & 1557.8622 & 1557.8596 & 779.9371 & 0.0026 & 1.6668 & 6876.507 & 6086.741 & 1207.377 & 470.837 & \text { Yes }\end{array}$

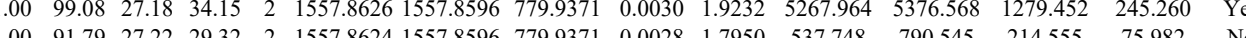

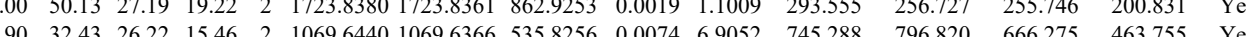

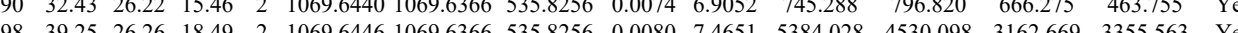

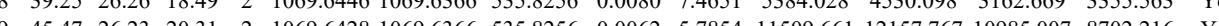
$\begin{array}{lllllllllllllllll} & \end{array}$

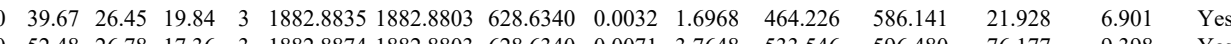
$\begin{array}{lllllllllllllll} & \end{array}$ $\begin{array}{lllllllllllllll}1.00 & 41.68 & 26.46 & 16.54 & 3 & 1882.8841 & 18828803 & 628.6340 & 0.0038 & 2.0149 & 240.906 & 176.404 & 19.830 & 10.869 & \text { Yes }\end{array}$ $\begin{array}{llllllllllllllll}100 & 50.15 & 28.39 & 20.15 & 2 & 1446.7604 & 1446.7589 & 7243867 & 0.0015 & 1.0354 & 11407.040 & 9659.178 & 5303.127 & 5813.811 & \text { Yes }\end{array}$ $\begin{array}{llllllllllllllll}0.89 & 25.82 & 28.40 & 19.96 & 2 & 1446.7606 & 1446.7589 & 724.3867 & 0.0017 & 1.1734 & 695.239 & 722.484 & 380.428 & 420.889 & \text { Yes }\end{array}$ $\begin{array}{llllllllllllllll}1.00 & 52.42 & 28.47 & 23.16 & 2 & 1446.7608 & 1446.7589 & 724.3867 & 0.0019 & 1.3115 & 15323.453 & 12795.927 & 7984.701 & 7607.718 & \text { Yes }\end{array}$ $\begin{array}{llllllllllllllll}1.00 & 56.03 & 28.48 & 20.52 & 2 & 1446.7610 & 1446.7589 & 724.3867 & 0.0021 & 1.4495 & 16561.849 & 13306.786 & 8019.021 & 7623.952 & \text { Yes }\end{array}$ $\begin{array}{llllllllllllllll}1.00 & 72.14 & 28 & 30 & 25.18 & 2 & 1446.7582 & 1446.7589 & 724.3867 & -0.0007 & -0.4832 & 6960.769 & 4863.897 & 3378.727 & 3557.745 & \text { Yes }\end{array}$ $\begin{array}{lllllllllllllll}1.00 & 40.70 & 28.12 & 22.47 & 3 & 1602.8611 & 1602.8600 & 535.2939 & 0.0011 & 0.6850 & 251.910 & 265.279 & 302.394 & 233.388 & \text { Yes }\end{array}$ $\begin{array}{lllllllllllllll}0.55 & 55.23 & 28.22 & 68.23 & 3 & 1602.8617 & 1602.8600 & 535.2939 & 0.0017 & 1.0586 & 229.135 & 227.842 & 233.323 & 163.075 & \text { Yes }\end{array}$ $\begin{array}{lllllllllllllll}1.00 & 47.69 & 28.39 & 25.66 & 2 & 1287.6852 & 1287.6734 & 644.8440 & 0.0118 & 9.1494 & 12589.328 & 10875.208 & 117.963 & 114.104 & \text { Yes }\end{array}$ $\begin{array}{llllllllllllllll}1.00 & 50.90 & 28.14 & 29.37 & 2 & 1287.6860 & 1287.6734 & 644.8440 & 0.0126 & 9.7697 & 14408.011 & 12209.677 & 0.000 & 138.783 & \text { No }\end{array}$ \begin{tabular}{llllllllllllll}
34.75 & 23.32 & 47.75 & 4 & 3422.8485 & 3422.8441 & 856.7183 & 0.0044 & 1.2840 & 9.215 & 18.387 & 6.907 & 4.747 & Yes \\
\hline
\end{tabular}

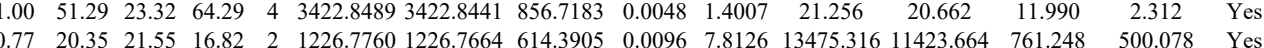

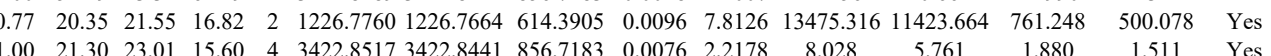

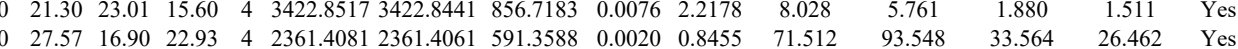
$\begin{array}{lllllllllllllll}1.00 & 27.57 & 16.90 & 22.93 & 4 & 2361.4081 & 2361.4061 & 591.3588 & 0.0020 & 0.8455 & 71.512 & 93.548 & 33.564 & 26.462 & \text { Yes } \\ 1.00 & 25.29 & 16.90 & 16.92 & 3 & 2361.4087 & 2361.4061 & 788.1426 & 0.0026 & 1.0996 & 15.772 & 27.867 & 7.866 & 3.059 & \text { Yes }\end{array}$ $\begin{array}{lllllllllllll} & & \end{array}$ $\begin{array}{lllllllllllll} & & \end{array}$

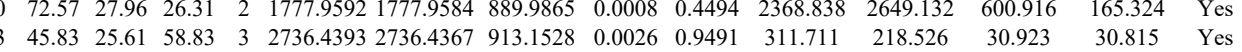

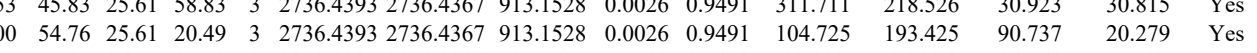
$\begin{array}{lllllll}0.000 & 0.000 & 6.377 & \text { No }\end{array}$ 

$\begin{array}{lllllllllllllllll}\text { DGFIDKEDLHDMLASLGK } & 0.83 & 16.57 & 26.49 & 29.57 & 4 & 2435.2757 & 2435.2732 & 609.8256 & 0.0025 & 1.0249 & 1034.523 & 1116.734 & 1493.451 & 944.952 & \text { Yes }\end{array}$ $\begin{array}{llllllllllllllll}\text { DGFIDKEDLHDMLASLGK } & 0.97 & 22.31 & 26.33 & 35.31 & 4 & 2435.2789 & 2435.2732 & 609.8256 & 0.0057 & 2.3367 & 541.945 & 586.713 & 972.409 & 516.130 & \text { Yes } \\ \text { ATSNVFAMFDQSOIQEFK } & 1.00 & 67.59 & 27.20 & 29.62 & 2 & 2378.1834 & 2378.1820 & 1190.0983 & 0.0014 & 0.5882 & 131.230 & 166.093 & 109.827 & 20.220 & \text { Yes }\end{array}$

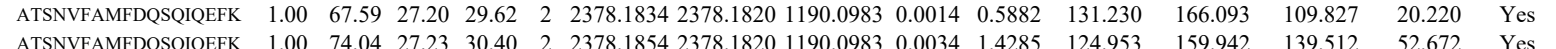

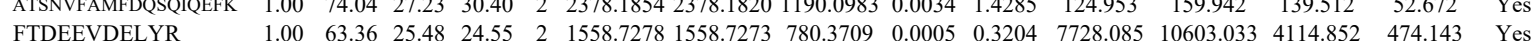

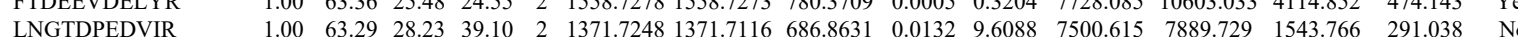

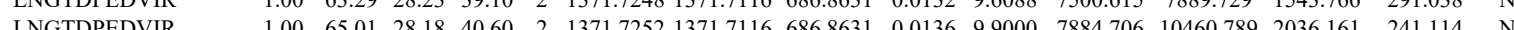

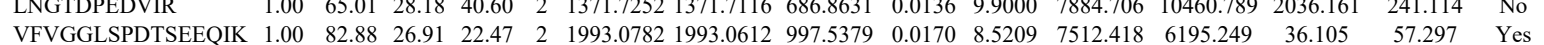
$\begin{array}{lllllllllllllllll}\text { VFVGGLSPDTSEEOIK } & 1.00 & 80.71 & 26.87 & 23.26 & 2 & 1993.0796 & 1993.0612 & 997.5379 & 0.0184 & 9.2226 & 1894.088 & 1594.173 & 233.019 & 5.802 & \text { Yes }\end{array}$

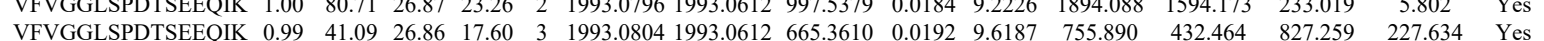
$\begin{array}{llllllllllllllll}\text { VFVGGLSPDTSEEQIK } & 1.00 & 62.24 & 26.90 & 23.43 & 3 & 1993.0810 & 1993.0612 & 665.3610 & 0.0198 & 9.9193 & 1233.219 & 1161.034 & 736.211 & 407.896 & \text { Yes }\end{array}$

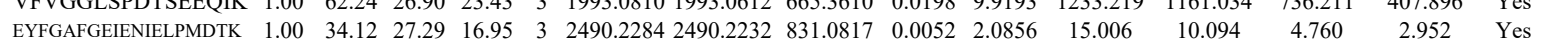

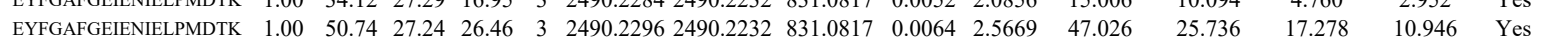

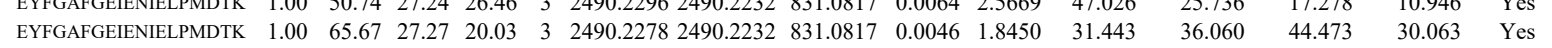

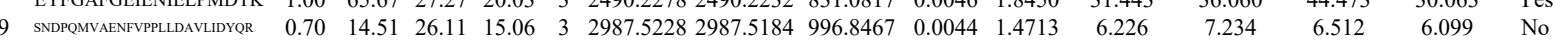
$\begin{array}{llllllllllllllll}\text { SNDPQMVAENFYPLLDAVLIDYQR } & 1.00 & 70.40 & 26.22 & 20.75 & 2 & 2987.5194 & 2987.5184 & 1494.7665 & 0.0010 & 0.3345 & 1.515 & 2.692 & 2.896 & 0.000 & \text { No }\end{array}$

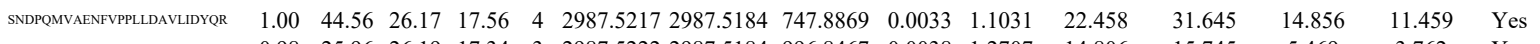

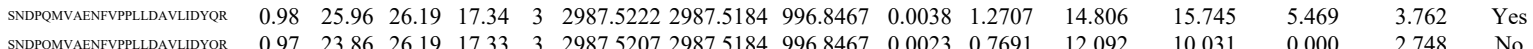
$\begin{array}{lllllllllllllllll}0.97 & 23.86 & 26.19 & 17.33 & 3 & 2987.5207 & 2987.5184 & 996.8467 & 0.0023 & 0.7691 & 12.092 & 10.031 & 0.000 & 2.748 & \text { No }\end{array}$

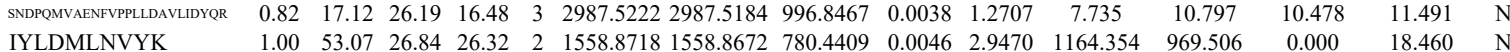
$\begin{array}{llllllllllllllll}\text { IYLDMLNVYK } & 1.00 & 53.07 & 26.84 & 26.32 & 2 & 1558.8718 & 1558.8672 & 780.4409 & 0.0046 & 2.9470 & 1164.354 & 969.506 & 0.000 & 18.460 & \text { No } \\ \text { IYLDMLNVYK } & 1.00 & 52.92 & 26.79 & 28.85 & 2 & 1558.8730 & 1558.8672 & 780.4409 & 0.0058 & 3.7158 & 1211.843 & 1061.601 & 28.756 & 26.739 & \text { Yes }\end{array}$

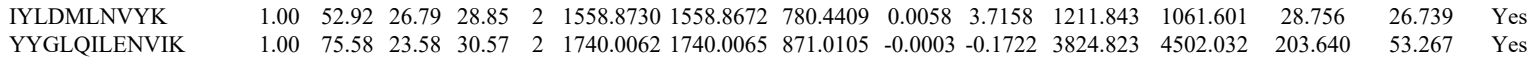
\begin{tabular}{llllllllllllllll} 
YYGLQILENVIK & 1.00 & 75.58 & 23.58 & 30.57 & 2 & 1740.0062 & 1740.0065 & 871.0105 & -0.0003 & -0.1722 & 3824.823 & 4502.032 & 203.640 & 53.267 & Yes \\
\hline
\end{tabular}

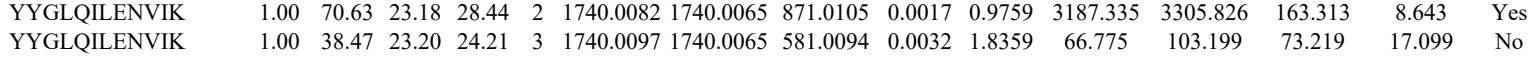

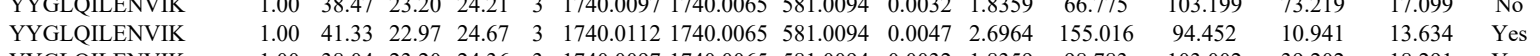

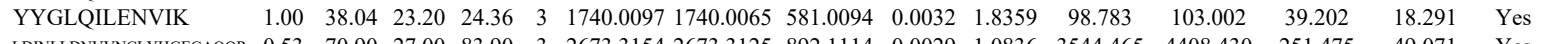

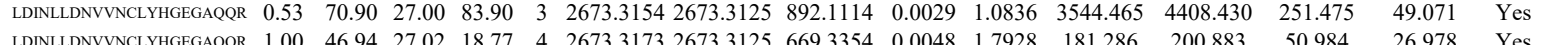
\begin{tabular}{llllllllllllllll} 
LDINLDNVUNCLYHGEGAQQR & 1.00 & 46.94 & 27.02 & 18.77 & 4 & 2673.3173 & 2673.3125 & 669.3354 & 0.0048 & 1.7928 & 181.286 & 200.883 & 50.984 & 26.978 & Yes \\
\hline
\end{tabular}

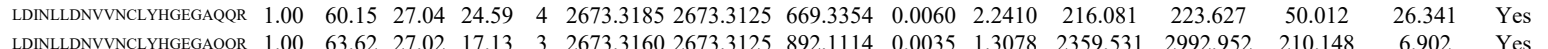
$\begin{array}{llllllllllllllll}\text { LDINLLDNVWNCLHGGGAQQR } & 1.00 & 60.36 & 27.01 & 19.66 & 4 & 2673.3165 & 2673.3125 & 669.3354 & 0.0040 & 1.4940 & 168.615 & 181.984 & 38.214 & 36.310 & \text { Yes }\end{array}$

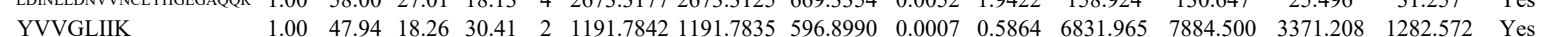


$\begin{array}{lclllllllllllll}\text { VANLLK } & 1.00 & 41.80 & 22.25 & 23.70 & 3 & 3173.7352 & 3173.7328 & 1058.9182 & 0.0024 & 0.7555 & 6.248 & 5.353 & 14.796 \\ \text { GASR } & 1.00 & 56.34 & 27.44 & 26.21 & 3 & 1728.9109 & 1728.9070 & 577.3096 & 0.0039 & 2.2518 & 234.221 & 309.649 & 123.709\end{array}$

HWPTFISDIVGASR

HWPTFISDIVGASR

LFVTGLFSLNQD

QLYLPMLPK

HWPTFISDIVGASR
HWPTFISDIVGASR

HWPTFISDIVGASR

LFVTGLFSLN

LNMILVQILK

LNMILVQILK

LNMILVQILK

LNMILVQILK

$\begin{array}{lllllllllllll} & 128.02 & 3 & 1728.9109 & 1728.9070 & 577.3096 & 0.0039 & 2.2518 & 178.743 & 239.635 & 101.484\end{array}$

$\begin{array}{lllllllllllll}1.00 & 42.11 & 23.07 & 16.10 & 3 & 2197.2412 & 2197.2391 & 733.4203 & 0.0021 & 0.9544 & 19.373 & 52.273 & 1.032\end{array}$

$\begin{array}{lllllllllllll}1.00 & 38.66 & 25.08 & 32.86 & 2 & 1439.8470 & 1439.8454 & 720.9300 & 0.0016 & 1.1097 & 1582.260 & 1315.179 & 16.229 \\ 0.99 & 37.55 & 25.08 & 32.97 & 2 & 1439.8470 & 1439.8454 & 720.9300 & 0.0016 & 1.1097 & 1210.606 & 1216.811 & 6.914\end{array}$

$\begin{array}{lllllllllllll}0.99 & 37.55 & 25.08 & 32.97 & 2 & 1439.8470 & 1439.8454 & 720.9300 & 0.0016 & 1.1097 & 1210.606 & 1216.811 & \end{array}$

$\begin{array}{llllllllllll}1.00 & 39.14 & 27.45 & 21.56 & 3 & 1728.9076 & 1728.9070 & 577.3096 & 0.0006 & 0.3464 & 476.065 & 488.149\end{array}$

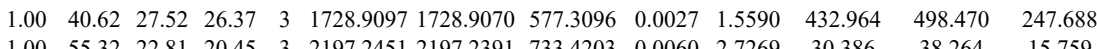

$\begin{array}{lllllllllllll}1.00 & 55.32 & 2.81 & 20.45 & 3 & 2197.2451 & 2197.2391 & 733.4203 & 0.0060 & 2.7269 & 30.386 & 38.264 & 15.759\end{array}$

$\begin{array}{lllllllllllll}0.76 & 25.48 & 26.96 & 31.13 & 2 & 861.5268 & 861.5228 & 431.7687 & 0.0040 & 4.6321 & 45143.770 & 43879.410 & 2631.706\end{array}$ $\begin{array}{lllllllllllll}.00 & 68.14 & 18.39 & 23.20 & 2 & 1471.9424 & 1471.9404 & 736.9775 & 0.0020 & 1.3569 & 1352.910 & 1632.056 & 332.431\end{array}$ $\begin{array}{lllllllllllll}1.00 & 68.14 & 18.39 & 23.20 & 2 & 1471.9424 & 1417.9404 & 736.975 & 0.0020 & 1.3569 & 1352.910 & 1632.056 & 332.431 \\ 0.99 & 27.44 & 18.39 & 24.52 & 3 & 1471.9429 & 1471.9404 & 491.6541 & 0.0025 & 1.6950 & 237.283 & 304.755 & 69.262\end{array}$

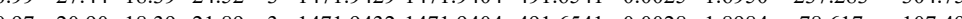

AVGHPFVIQLGR

ANGHILVQILK
LNMILI

LNMLVQILK

LNMILVQILK
FLNVPMFR

FLNVPMFR

FLNVPMFR

FLNVPMFR
FLNVPMFR

FLNVPMFR

FLNVPMFR

FLNVPMFR

FLNVPMFR

FLNVPMFR

FLNVPMFR

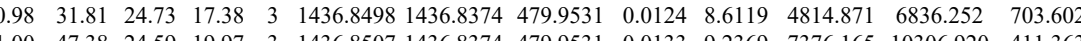
$\begin{array}{llllllllllllllll}1.00 & 65.70 & 18.13 & 22.40 & 2 & 1471.9416 & 1471.9404 & 736.9775 & 0.0012 & 0.8141 & 100.567 & 155.320 & 35.250\end{array}$ $\begin{array}{lllllllllllll}1.00 & 65.15 & 18.39 & 24.19 & 3 & 147.9420 & 1471.9404 & 491.6541 & 0.0016 & 1.0848 & 108.470 & 128.612 & 11.250\end{array}$ $\begin{array}{lllllllllllll}1.00 & 58.03 & 18.39 & 22.30 & 2 & 1471.9424 & 1471.9404 & 736.9775 & 0.0020 & 1.3569 & 109.911 & 137.292 & 1.2607\end{array}$ $\begin{array}{lllllllllllll}0.95 & 29.32 & 27.75 & 28.61 & 2 & 11666406 & 1166.6392 & 584.3269 & 0.0014 & 1.1980 & 2547.552 & 2259.101 & 83.434\end{array}$ $\begin{array}{lllllllllllll}0.69 & 19.79 & 27.75 & 22.89 & 2 & 1166.6406 & 1166.6392 & 584.3269 & 0.0014 & 1.1980 & 31.078 & 37.349 & 19.4397\end{array}$

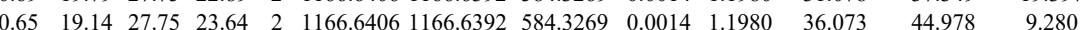
$\begin{array}{lllllllllllllll}0.97 & 31.26 & 27.63 & 28.67 & 2 & 1166.6412 & 1166.6392 & 584.3269 & 0.0020 & 1.7114 & 1831.950 & 1912.652 & 53.039\end{array}$ $\begin{array}{lllllllllllll}0.61 & 17.92 & 27.77 & 23.21 & 2 & 1166.6408 & 1166.6392 & 584.3269 & 0.0016 & 1.3691 & 109.049 & 107.335 & 53.039\end{array}$ $\begin{array}{llllllllllllll}0.94 & 27.97 & 27.77 & 27.07 & 2 & 1166.6410 & 1166.6392 & 584.3269 & 0.0018 & 1.5402 & 7947.971 & 8188.274 & 26.665\end{array}$ $\begin{array}{llllllllllllll}0.98 & 34.17 & 27.77 & 28.74 & 2 & 1166.6410 & 1166.6392 & 584.3269 & 0.0018 & 1.5402 & 19503.379 & 19560.035 & 352.359\end{array}$ $\begin{array}{llllllllllllll}0.93 & 29.54 & 27.90 & 23.79 & 2 & 1166.6426 & 1166.6392 & 584.3269 & 0.0034 & 2.9093 & 69.763 & 70.622 & 15.820\end{array}$

FLNVPMFR

$\begin{array}{llllllll} & \end{array}$ $\begin{array}{llllllllllllll} & \text { AIIASNMYIVGQYPR } & 1.00 & 96.03 & 26.75 & 25.63 & 2 & 1952.0686 & 1952.0675 & 977.0410 & 0.0011 & 0.5629 & 210.759 & 267.252\end{array}$ $\begin{array}{lllllllllllll}\text { AlIASNIMYIVGQYPR } & 1.00 & 99.50 & 26.59 & 25.86 & 2 & 1952.0688 & 1952.0675 & 977.0410 & 0.0013 & 0.6653 & 135.317 & 175.116\end{array}$

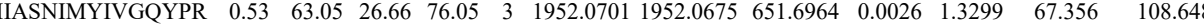
$\begin{array}{lllllllllllllll}\text { AIIASNIMYIVGQYPR } & 0.53 & 46.07 & 26.61 & 59.07 & 3 & 1952.0704 & 1952.0675 & 651.6964 & 0.0029 & 1.4833 & 102.585 & 130.780\end{array}$ $\begin{array}{llllllllllllll}\text { AIIASNIMYIVGQYPR } & 0.53 & 28.78 & 26.61 & 41.78 & 3 & 1952.0707 & 1952.0675 & 651.6964 & 0.0032 & 1.6368 & 12.033 & 19.673\end{array}$ $\begin{array}{lllllllllllll} & \end{array}$ $\begin{array}{lllllllllllll}\text { MAKPEEVLVVENDQGEVVR } & 0.92 & 23.48 & 25.98 & 26.70 & 3 & 2428.2928 & 2428.2875 & 810.4364 & 0.0053 & 2.1799 & 84.576\end{array}$ 

$\begin{array}{lllllllllllllllll}\text { LNFSTPTSTNIVSVCR } & 1.00 & 83.86 & 27.56 & 27.32 & 2 & 1927.9628 & 1927.9618 & 964.9882 & 0.0010 & 0.5181 & 798.754 & 672.290 & 108.510 & 3.258 & \text { Yes }\end{array}$

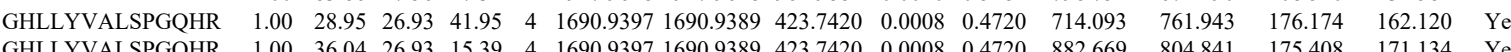
$\begin{array}{llllllllllllllll}\text { ASSEGGTAAGAGLDSLHK } & 1.00 & 95.30 & 27.82 & 24.78 & 3 & 1915.9957 & 1915.9843 & 639.6687 & 0.0114 & 5.9405 & 3998.696 & 5032.972 & 6955.330 & 2377.718 & \text { Yes }\end{array}$ $\begin{array}{llllllllllllllll}\text { ASSEGGTAAGAGLDSLHK } & 1.00 & 96.02 & 27.85 & 27.63 & 3 & 1915.9960 & 1915.9843 & 639.6687 & 0.0117 & 6.0969 & 3703.540 & 5683.197 & 3707.203 & 2073.472 & \text { Yes }\end{array}$ $\begin{array}{lllllllllllllllll}\text { ASSEGGTAAGAGLDSLHK } & 1.00 & 85.85 & 27.97 & 23.24 & 3 & 1915.9969 & 1915.9843 & 639.6687 & 0.0126 & 6.5659 & 2571.137 & 3473.363 & 4106.551 & 1710.967 & \text { Yes }\end{array}$ $\begin{array}{llllllllllllllll}\text { TWKPTLVILR } & 1.00 & 44.18 & 19.44 & 18.56 & 3 & 1513.9564 & 1513.9588 & 505.6602 & -0.0024 & -1.5821 & 3879.553 & 5664.452 & 696.191 & 221.932 & \text { No }\end{array}$

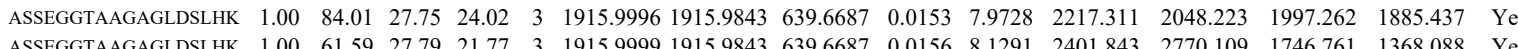

$\begin{array}{lllllllllll}\text { ARPC2_HUMAI } & \text { O15144 } & \text { ARPC2 } & \text { Actin-related prot، } 34.33 & 1.00 & 3 & 13 & 0.4028 & 0.1588 & 0.1293 & 2.5374\end{array}$

$\begin{array}{llllllllllll}\text { ARPC3 HUMAI } & \text { O15145 } & \text { ARPC3 } & \text { Actin-related prots } 20.55 & 1.00 & 4 & 23.6 & 0.3040 & 0.3312 & 0.1293 & 1.8565\end{array}$
IIEETLALK

IIEETLALK DDETMYVESK DDETMYVESK EPPLELK

DTDIVDEAIYYFK

DTDIVDEAIYYFK

DTDIVDEAIYYFK

DTDIVDEAIYYFK

VFDPQNDKPSK

VFDPQNDKPSK

VFDPQNDKPSK

AYLQQLR

AYLQQLR

AYLQQLR

LIGNMALLPIR

LIGNMALLPIR $\begin{array}{llllllllllllllll}1.00 & 61.59 & 27.79 & 21.77 & 3 & 1915.9999 & 1915.9843 & 639.6687 & 0.0156 & 8.1291 & 2401.843 & 2770.109 & 1746.761 & 1368.088 & \text { Yes }\end{array}$

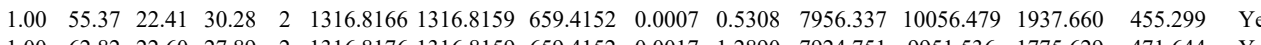

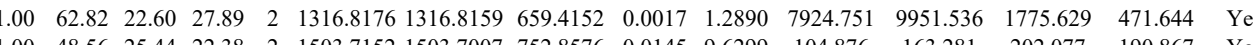
$\begin{array}{lllllllllllllll}1.00 & 48.56 & 25.44 & 22.38 & 2 & 1503.7152 & 1503.7007 & 752.8576 & 0.0145 & 9.6299 & 104.876 & 163.281 & 202.077 & 190.867 & \text { Yes }\end{array}$

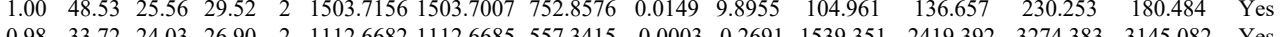
$\begin{array}{lllllllllllllll}0.98 & 33.72 & 24.03 & 26.90 & 2 & 1112.6682 & 1112.6685 & 557.3415 & -0.0003 & -0.2691 & 1539.351 & 2419.392 & 3274.383 & 3145.082 & \text { Yes } \\ 0.95 & 5.91 & 24.20 & 2.06 & 2 & 112.6694 & 112.6685 & 557.3415 & 0.0009 & 0.8074 & 1863.399 & 2320.117 & 3858.024 & 2717.723 & \text { Yes }\end{array}$ $\begin{array}{ccccccccccccccc}0.95 & 25.91 & 24.20 & 26.06 & 2 & 1112.6694 & 1112.6685 & 557.3415 & 0.0009 & 0.8074 & 1863.399 & 2320.117 & 3858.024 & 2717.723 & \text { Yes } \\ 0.99 & 31.19 & 27.92 & 23.06 & 3 & 1878.9514 & 1878.9495 & 627.3238 & 0.0019 & 1.0096 & 96.239 & 141.139 & 82.088 & 65.996 & \text { Yes }\end{array}$

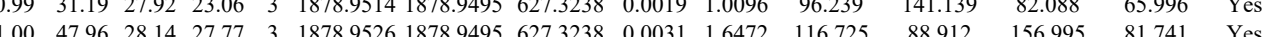

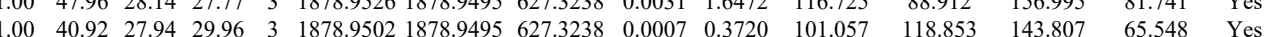

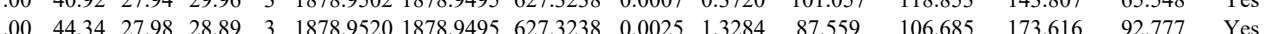
$\begin{array}{lllllllllllllll}0.80 & 27.88 & 26.33 & 29.54 & 3 & 1705.9453 & 1705.9365 & 569.6528 & 0.0088 & 5.1493 & 28844.510 & 37274.896 & 15630.641 & 4379.525 & \text { Yes }\end{array}$ $\begin{array}{llllllllllllllll}0.66 & 27.65 & 26.28 & 31.91 & 3 & 1705.9456 & 1705.9365 & 569.6528 & 0.0091 & 5.3249 & 22288.117 & 26004.177 & 14938.083 & 2846.142 & \text { Yes }\end{array}$ $\begin{array}{lllllllllllllll}0.67 & 1.974 & 26.58 & 24.08 & 3 & 17059435 & 17059365 & 569.6528 & 0.0070 & 4.0960 & 16984.462 & 24312.561 & 11283.684 & 5075.405 & \text { Yes }\end{array}$ $\begin{array}{lllllllllllllll}0.54 & 17.89 & 26.73 & 23.71 & 3 & 1705.9438 & 1705.9365 & 569.6528 & 0.0073 & 42716 & 16382.398 & 19416.673 & 11277.144 & 4330.655 & \text { Yes }\end{array}$ $\begin{array}{llllllllllllllll}0.78 & 28.19 & 27.02 & 25.90 & 2 & 1034.6074 & 1034.5994 & 518.3070 & 0.0080 & 7.7174 & 30966.101 & 36310.649 & 3720.609 & 3137.113 & \text { Yes }\end{array}$ $\begin{array}{llllllllllllllll}0.91 & 32.60 & 27.02 & 31.92 & 2 & 1034.6074 & 1034.5994 & 518.3070 & 0.0080 & 7.7174 & 32653.773 & 42263.575 & 4663.913 & 2818.098 & \text { Yes }\end{array}$ $\begin{array}{lllllllllllllll}0.63 & 25.06 & 27.02 & 20.80 & 2 & 1034.6074 & 1034.5994 & 518.3070 & 0.0080 & 7.7174 & 1005.607 & 1057.487 & 274.506 & 61.704 & \text { Yes }\end{array}$ $\begin{array}{lllllllllllllll}1.00 & 50.87 & 22.04 & 23.99 & 2 & 1353.8280 & 1353.8288 & 677.9217 & -0.0008 & -0.5900 & 733.436 & 1419.110 & 15.733 & 14.802 & \text { Yes }\end{array}$ $\begin{array}{llllllllllllllll}1.00 & 61.48 & 22.04 & 20.56 & 2 & 1353.8286 & 1353.8288 & 677.9217 & -0.0002 & -0.1475 & 830.763 & 1439.341 & 3.843 & 19.755 & \text { Yes }\end{array}$

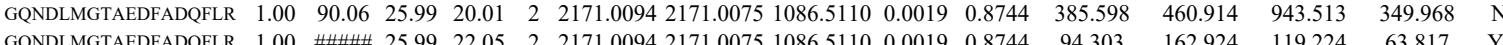

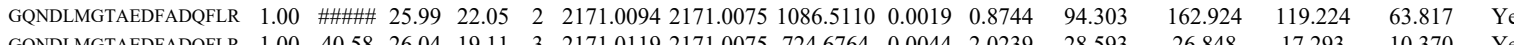
$\begin{array}{lllllllllllllllll}\text { GQNDLMGTAEDFADQFLR } & 1.00 & 40.58 & 26.04 & 19.11 & 3 & 2171.0119 & 2171.0075 & 724.6764 & 0.0044 & 2.0239 & 28.593 & 26.848 & 17.293 & 10.370 & \text { Yes }\end{array}$ $\begin{array}{llllllllllllllll}\text { GQNDLMGTAEDFADQFLR } & 1.00 & 83.37 & 25.91 & 18.61 & 2 & 2171.0074 & 2171.0075 & 1086.5110 & -0.0001 & -0.0460 & 291.105 & 278.677 & 334.868 & 229.578 & \text { Yes }\end{array}$

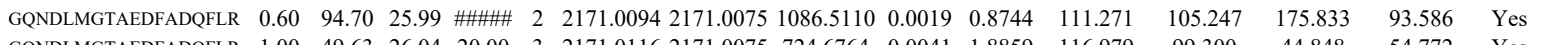
$\begin{array}{lllllllllllllll} & 20.00 & 3 & 2171.0116 & 2171.0075 & 724.6764 & 0.0041 & 1.8859 & 116.979 & 99.300 & 44.848 & 54.772 & \text { Yes }\end{array}$

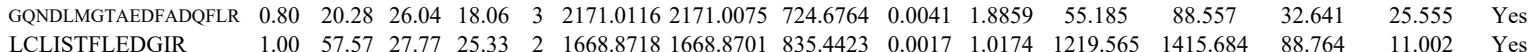

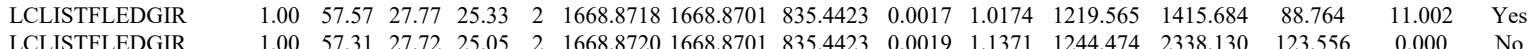

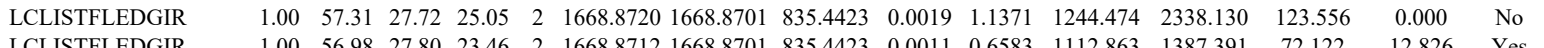

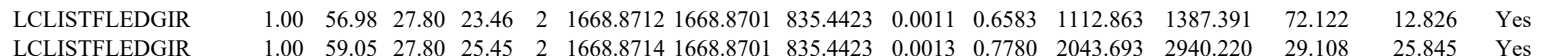

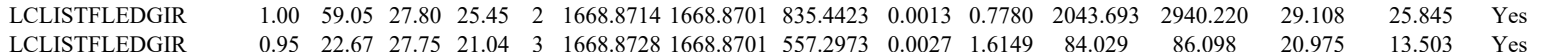

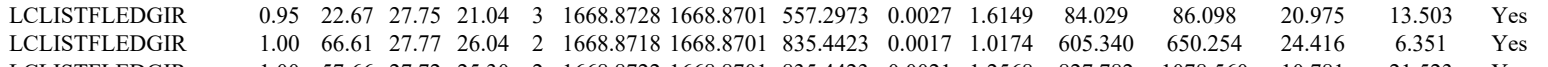

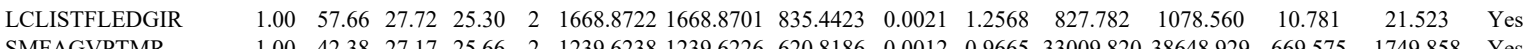

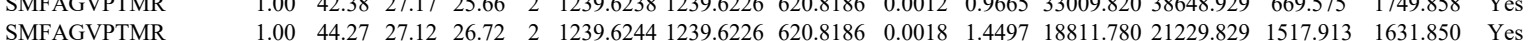


$\begin{array}{llllllllllll}.00 & 74.52 & 26.96 & 33.69 & 2 & 1545.8724 & 1545.8606 & 773.9376 & 0.0118 & 7.6233 & 533.834\end{array}$ $\begin{array}{llllllllllllllllll}\text { NLPPEEQMISALPDIK } & 0.99 & 29.27 & 26.63 & 19.42 & 3 & 2082.1303 & 2082.1274 & 695.0497 & 0.0029 & 1.3908 & 391.413 & 307.341 & 387.191 & 110.552 & \text { Yes }\end{array}$ $\begin{array}{llllllllllllllll}\text { NLPPEEQMISALPDIK } & 0.98 & 25.35 & 26.63 & 17.40 & 3 & 2082.1303 & 2082.1274 & 695.0497 & 0.0029 & 1.3908 & 303.216 & 258.860 & 194.615 & 80.186 & \text { Yes }\end{array}$

$\begin{array}{llllllllllllll}0.81 & 30.59 & 28.01 & 28.08 & 2 & 1072.6156 & 1072.6111 & 537.3128 & 0.0045 & 4.1875 & 18114.560 & 15762.783 & 2315.258 & 11\end{array}$ 198.509 Yes $\begin{array}{llllllllllllllll} & 0.003\end{array}$

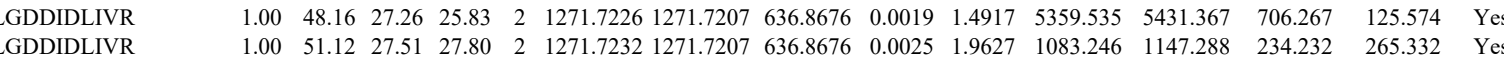

GAVIATELK $\begin{array}{lllllllllllllll}1.00 & 51.12 & 27.51 & 27.80 & 2 & 1271.7232 & 1271.7207 & 636.8676 & 0.0025 & 1.9627 & 1083.246 & 1147.288 & 234.232 & 265.332 & \text { Yes }\end{array}$ $\begin{array}{lllllllllllllllll} & & & \end{array}$ \begin{tabular}{lllllllllllllllll} 
& NAMEATYNHNFSQQCLR & 1.00 & 62.28 & 26.41 & 17.52 & 3 & 2442.1420 & 2442.1364 & 815.0527 & 0.0056 & 2.2902 & 2196.264 & 2179.552 & 152.468 & 52.532 & Yes \\
\hline
\end{tabular}

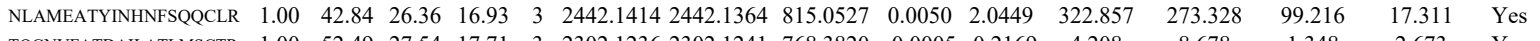

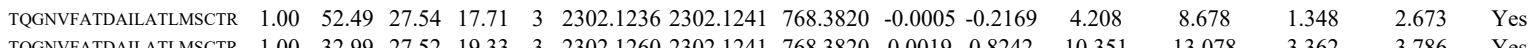

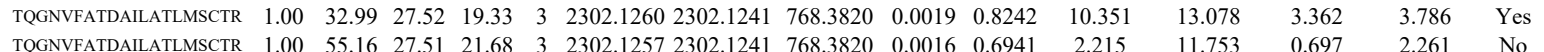

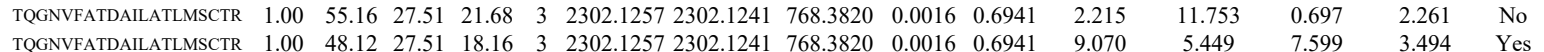

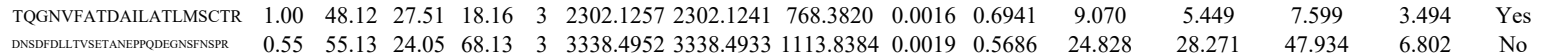

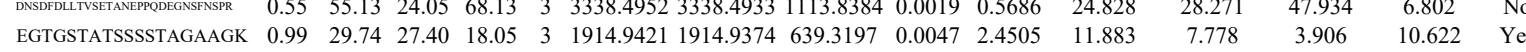
$\begin{array}{lllllllllllll}\text { KEGTGSTATSSSSTAGAAGK } & 1.00 & 53.40 & 27.28 & 20.80 & 3 & 2187.1348 & 2187.1344 & 730.0521 & 0.0004 & 0.1826 & 5.560\end{array}$

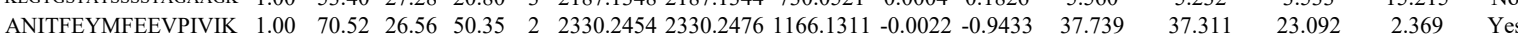

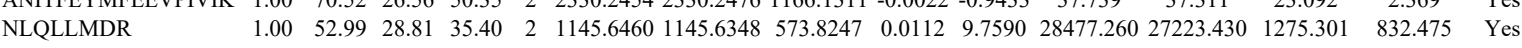

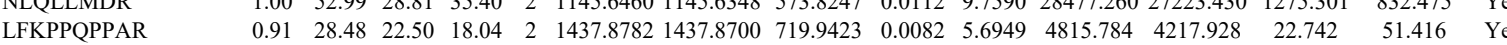

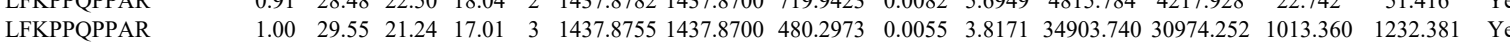

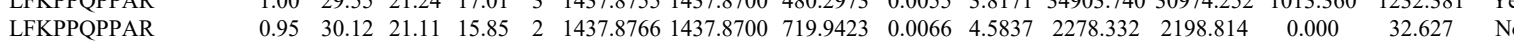
$\begin{array}{llllllllllllllll}\text { LFKPPQPPAR } & 0.90 & 27.63 & 21.55 & 17.69 & 2 & 1437.8770 & 1437.8700 & 719.9423 & 0.0070 & 4.8615 & 3331.951 & 2895.465 & 55.430 & 31.481 & \text { Yes }\end{array}$ $\begin{array}{llllllllllllllll}\text { LFKPPQPPAR } & 0.55 & 24.04 & 22.15 & 37.04 & 3 & 1437.8722 & 1437.8700 & 480.2973 & 0.0022 & 1.5268 & 712.273 & 673.814 & 79.040 & 24.122 & \text { Yes }\end{array}$ $\begin{array}{llllllllllllllll}\text { EGTGSTATSSSSTAGAAGK } & 1.00 & 65.05 & 27.42 & 17.47 & 3 & 1914.9397 & 1914.9374 & 639.3197 & 0.0023 & 1.1992 & 35.376 & 36.233 & 26.597 & 27.952 & \text { Yes }\end{array}$ $\begin{array}{llllllllllllllll}\text { EGTGSTATSSSSTAGAAGK } & 1.00 & 68.19 & 27.51 & 20.05 & 3 & 1914.9400 & 1914.9374 & 639.3197 & 0.0026 & 1.3556 & 46.551 & 25.420 & 13.200 & 21.051 & \text { Yes }\end{array}$ $\begin{array}{llllllllllllllll}\text { EGTGSTATSSSSTAGAAGK } & 1.00 & 50.77 & 27.51 & 17.05 & 3 & 1914.9400 & 1914.9374 & 639.3197 & 0.0026 & 1.3556 & 41.740 & 33.851 & 42.497 & 29.339 & \text { No }\end{array}$

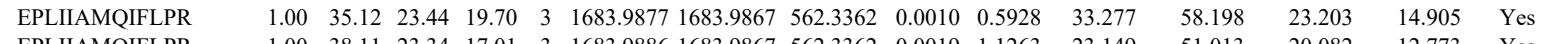

$\begin{array}{lllllllllllllll}\text { IPO8_HUMAN } & \text { O15397 } & \text { IPO8 } & \text { Importin-8 } & 119.94 & 1.00 & 2 & 3.2 & 0.5727 & 0.6451 & 0.5118 & 1.7672 & 3 & \begin{array}{l}\text { EPLIIAMQIFLPR } \\ \text { EPLIIAMQIFLP } \\ \text { IINFAPSLLR }\end{array}\end{array}$ LHKPPADSGVDLR LHKPPADSGVDLR LHKPPADSGVDLR LHKPPADSGVDLR LHKPPADSGVDLR LHKPPADSGVDLR LLDLSVFR EPQPEVAAAEEEK EPQPEVAAAEEEK GGAVVDEGPTGVK GGAVDEGTGK YGAVDEGPT

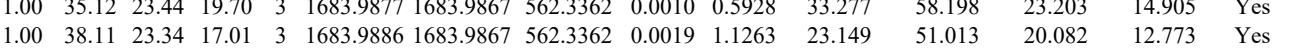

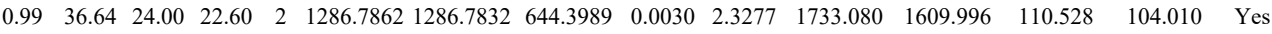
$\begin{array}{lllllllllllllll}0.98 & 34.86 & 25.50 & 19.30 & 3 & 1691.9548 & 1691.9562 & 564.9927 & -0.0014 & -0.8260 & 11464.938 & 9879.476 & 22166.977 & 5232.419 & \text { Yes }\end{array}$

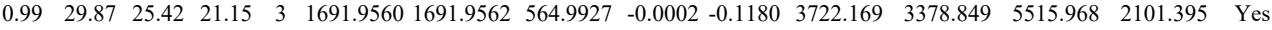

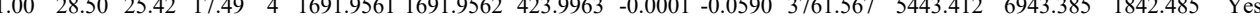
$\begin{array}{lllllllllllllll}1.00 & 25.48 & 25.51 & 16.61 & 4 & 1691.9565 & 1691.9562 & 423.9963 & 0.0003 & 0.1769 & 5822.770 & 5740.274 & 11692.955 & 2981.910 & \text { Yes }\end{array}$

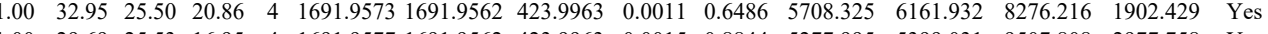

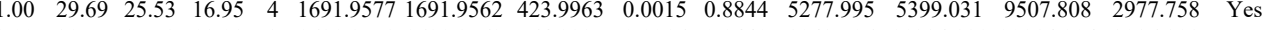

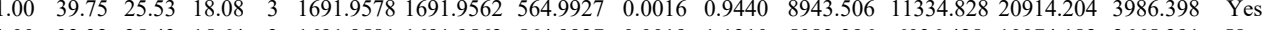
$\begin{array}{lllllllllllllll}1.00 & 32.32 & 25.43 & 15.64 & 3 & 1691.9581 & 1691.9562 & 564.9927 & 0.0019 & 1.1210 & 5083.396 & 6036.428 & 10074.182 & 3665.291 & \text { Yes }\end{array}$

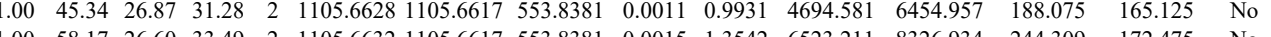

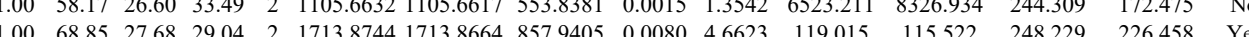

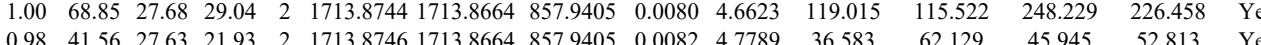

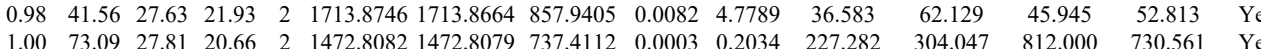
$\begin{array}{ccccccccccccccc}1.00 & 73.09 & 27.81 & 20.66 & 2 & 1472.8082 & 1472.8079 & 737.4112 & 0.0003 & 0.2034 & 227.282 & 304.047 & 812.000 & 730.561 & \text { Yes } \\ 1.00 & 75.91 & 27.47 & 22.28 & 2 & 1472.8124 & 1472.8079 & 737.4112 & 0.0045 & 3.0512 & 774.028 & 2081.391 & 6891.195 & 5760.213 & \text { Yes }\end{array}$

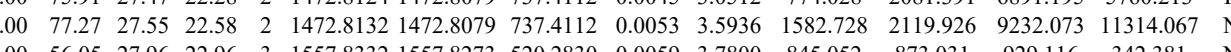
$\begin{array}{lllllllllllllll}1.00 & 56.05 & 27.96 & 22.96 & 3 & 1557.8332 & 1557.8273 & 520.2830 & 0.0059 & 3.7800 & 845.052 & 873.031 & 929.116 & 342.381 & \end{array}$ 
RGVACTQPP

$\begin{array}{lllllllllll}1.00 & 34.42 & 27.48 & 20.49 & 3 & 2019.0157 & 2019.0138 & 674.0119 & 0.0019 & 0.9396 & 71.300\end{array}$

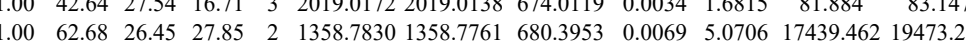

GGIVDEGALLR

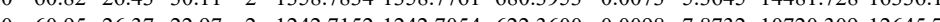

ILQDGGLQVVEK

CGEEIAVQFVDMVK

CGEEIAVQFVDMVK

CGEEIAVQFVDMVK QIPQATASMK

QIPQATASMK
VLISDSLDPCCR
VLISDSLDPCCR

GTIQVITQGTSLK

GTIQVITQGTSLK

$\begin{array}{llllllllllllll}.00 & 71.85 & 26.47 & 25.03 & 2 & 1242.7162 & 1242.7054 & 622.3600 & 0.0108 & 8.6766 & 6754.722 & 6875.909 & 1288.889\end{array}$

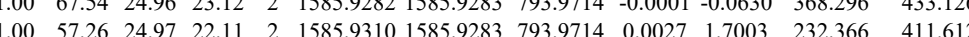

$\begin{array}{lllllllllllll}0.98 & 26.94 & 27.38 & 20.53 & 3 & 1900.9375 & 1900.9341 & 634.6520 & 0.0034 & 1.7858 & 140.457 & 112.935\end{array}$

$\begin{array}{lllllllllllll}1.00 & 38.12 & 27.42 & 20.59 & 3 & 1900.9381 & 1900.9341 & 634.6520 & 0.0040 & 2.1009 & 105.290 & 89.527\end{array}$ $\begin{array}{llllllllllll}1.00 & 35.22 & 27.30 & 21.98 & 3 & 1900.9366 & 1900.9341 & 634.6520 & 0.0025 & 1.3131 & 171.178 & 230.197\end{array}$ $\begin{array}{llllllllllll}17.39 & 27.47 & 17.97 & 3 & 1900.9390 & 1900.9341 & 634.6520 & 0.0049 & 2.5736 & 176.754 & 197.410\end{array}$ $\begin{array}{lllllllllllll}1.00 & 49.27 & 24.20 & 17.24 & 2 & 1361.7626 & 1361.7580 & 681.8863 & 0.0046 & 3.3730 & 4039.171 & 4100.514 \\ 1555.7002 & 1555.6989 & 778.8567 & 0.0013 & 0.8346 & 482.737 & 492.122\end{array}$ $\begin{array}{llllllllllll}0.99 & 37.63 & 24.38 & 16.99 & 2 & 1555.7018 & 1555.6989 & 778.8567 & 0.0029 & 1.8617 & 117.096 & 260.614\end{array}$ $\begin{array}{llllllllllll}1.00 & 69.96 & 22.25 & 37.62 & 2 & 1632.9760 & 1632.9654 & 817.4900 & 0.0106 & 6.4832 & 2015.152 & 1780.031\end{array}$ $\begin{array}{lllllllllllll}\text { GTIQVITQGTSLK } & 1.00 & 69.91 & 22.10 & 36.21 & 2 & 1632.9780 & 1632.9654 & 817.4900 & 0.0126 & 7.7065 & 5433.194 & 5239.53 \\ \text { TOTSDPAMLPTMIGLAEAGVR } & 1.00 & 82.51 & 26.67 & 19.31 & 2 & 2415.2634 & 2415.2623 & 1208.6384 & 0.0011 & 0.4551 & 62.943 & 68.356\end{array}$

$\begin{array}{llllllllllll}1.00 & 73.70 & 22.04 & 38.05 & 2 & 1632.9764 & 1632.9654 & 817.4900 & 0.0110 & 6.7279 & 3208.456 & 3881.81\end{array}$ $\begin{array}{lllllllllllll}\text { TQTSDPAMLPTMIGLLAEAGVR } & 1.00 & \text { \#\#\#\# } & 26.67 & 19.31 & 2 & 2415.2634 & 2415.2623 & 1208.6384 & 0.0011 & 0.4551 & 62.943 & 68.356 \\ & 22.46 & 2 & 2415.2634 & 2415.2623 & 1208.6384 & 0.0011 & 0.4551 & 62.001 & 84.12\end{array}$ $\begin{array}{lllllllllllll}\text { TPTSDPAMLPTMIGLLAEAGVR } & 1.00 & 65.56 & 26.74 & 22.19 & 3 & 2415.2641 & 2415.2623 & 806.0947 & 0.0018 & 0.7443 & 30.352 & 31.171\end{array}$ $\begin{array}{lllllllllllll}\text { TQTSDPAMLPTMIGLLAEAGVR } & 1.00 & 79.87 & 26.61 & 22.88 & 3 & 2415.2656 & 2415.2623 & 806.0947 & 0.0033 & 1.3646 & 11.409 & 26.353\end{array}$ $\begin{array}{lllllllllllll}\text { TQTSDPAMLPTMIGLLAEAGVR } & 1.00 & 71.56 & 26.65 & 21.24 & 3 & 2415.2629 & 2415.2623 & 806.0947 & 0.0006 & 0.2481 & 166.035 & 267.167\end{array}$ $\begin{array}{llllllllllllll}\text { TQTSDPAMLPTMIGLAEAGVR } & 1.00 & 95.61 & 26.67 & 23.21 & 2 & 2415.2634 & 2415.2623 & 1208.6384 & 0.0011 & 0.4551 & 24.431 & 46.797\end{array}$ $\begin{array}{lllllllllllll}\text { TQTSDPAMLPTMIGLLAEAGVR } & 1.00 & 97.47 & 26.67 & 23.24 & 2 & 2415.2634 & 2415.2623 & 1208.6384 & 0.0011 & 0.4551 & 61.570 & 30.495\end{array}$ $\begin{array}{lllllllllllll}\text { TQTSDPAMLPTMIGLLAEAGVR } & 1.00 & 38.43 & 26.73 & 22.02 & 3 & 2415.2644 & 2415.2623 & 806.0947 & 0.0021 & 0.8684 & 51.794 & 48.881\end{array}$ $\begin{array}{lllllllllllll}\text { TQTSDPAMLPTMIGLLAEAGVR } & 0.55 & 38.33 & 26.73 & 51.33 & 3 & 2415.2644 & 2415.2623 & 806.0947 & 0.0021 & 0.8684 & 27.868 & 52.649\end{array}$

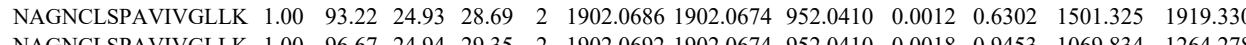

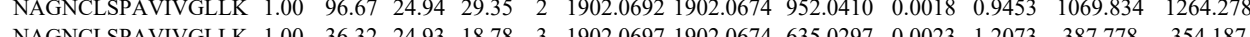

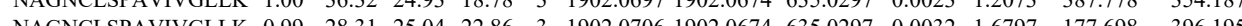

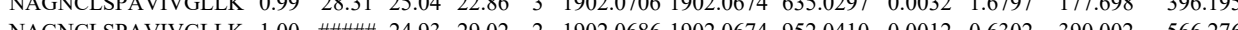

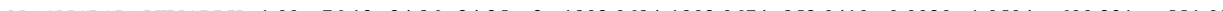
$\begin{array}{llllllllllllll}\text { NAGGNCLAVIVGLLK } & 1.00 & 37.47 & 24.93 & 22.15 & 3 & 1902.0700 & 1902.0674 & 635.0297 & 0.0026 & 1.3648 & 168.889 & 179.167\end{array}$ 
$\begin{array}{llllllllllllll} & \end{array}$ $\begin{array}{llllllllllllllll} & \text { LLDSPEDAEFIVAK } & 1.00 & 86.91 & 26.88 & 19.84 & 2 & 1962.0570 & 1962.0553 & 982.0349 & 0.0017 & 0.8655 & 762.601 & 1347.980 & 189.034\end{array}$

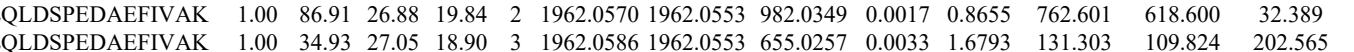
FNQVLDQFGEK

YLYYTGR

(107.565

AVQGFFTSNNATR

\begin{tabular}{llllllllllll}
27.45 & 33.24 & 2 & 1611.8658 & 1611.8501 & 806.9323 & 0.0157 & 9.7281 & 131.303 & 109.824 & 202.565 & 2 \\
\hline
\end{tabular}

AVQGFFTSNNATR

$\begin{array}{lllllllllll} & \end{array}$ AVQGFFTSNNATR

LQAQSLSTVGPR

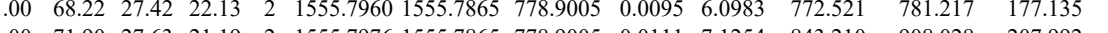
$\begin{array}{llllllllllllll}1.00 & 71.90 & 27.63 & 21.19 & 2 & 1555.7976 & 1555.7865 & 778.9005 & 0.0111 & 7.1254 & 843.210 & 908.028 & 207.992 \\ 1.00 & 65.91 & 26.73 & 24.52 & 2 & 1399.7960 & 1399.7905 & 700.9025 & 0.0055 & 3.9235 & 2775.193 & 2661.745 & 896.497\end{array}$ LQAQSLSTVGR GLAAALLLCQNK GLAAALLLCQNK GLAAALLLCQNK GLAAALLLCQNK

$\begin{array}{llllllllllllllll}1.00 & 65.91 & 26.73 & 24.52 & 2 & 1399.7960 & 1399.7905 & 700.9025 & 0.0055 & 3.9235 & 2775.193 & 2661.745 & 896.497 & 18 .\end{array}$

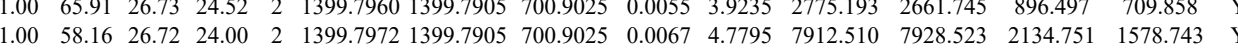
$\begin{array}{lllllllllllllll}1.00 & 56.88 & 26.61 & 24.53 & 2 & 1399.7980 & 1399.7905 & 700.9025 & 0.0075 & 5.3502 & 7285.508 & 7110.617 & 1709.033 & 1288.309 & \text { Yes }\end{array}$

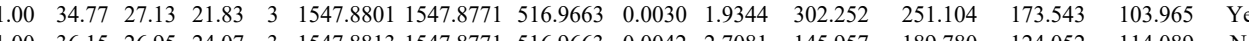
$\begin{array}{llllllllllllllll}1.00 & 36.15 & 26.95 & 24.07 & 3 & 1547.8813 & 1547.8771 & 516.9663 & 0.0042 & 2.7081 & 145.957 & 189.780 & 124.052 & 114.089 & \text { No } \\ 1.00 & 35.46 & 2.113 & 23.42 & 3 & 1547.8801 & 1547.8771 & 516.9663 & 0.0030 & 1.9344 & 222.820 & 158.203 & 99.377 & 33.402 & \text { Yes }\end{array}$ $\begin{array}{lllllllllllllll}1.00 & 35.46 & 27.13 & 23.42 & 3 & 1547.8801 & 1547.8771 & 516.9663 & 0.0030 & 1.9344 & 222.820 & 158.203 & 99.377 & 33.402 & \text { Yes } \\ 1.00 & 34.99 & 26.88 & 22.03 & 3 & 1547.8816 & 1547.8771 & 516.9663 & 0.0045 & 2.9015 & 184.673 & 141.603 & 88.854 & 39.118 & \text { Yes }\end{array}$

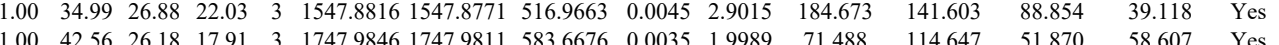

NLATTVTEEILEK

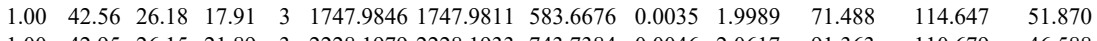
$\begin{array}{llllllllllllll}\text { VTEGLVDVILYHQPDDK } & 1.00 & 42.95 & 26.15 & 21.89 & 3 & 2228.1979 & 2228.1933 & 743.7384 & 0.0046 & 2.0617 & 91.363 & 110.679 & 46.588 \\ \text { VTEGLVDVLYHQPDDK } & 1.00 & 39.86 & 26.32 & 20.38 & 3 & 2228.1964 & 2228.1933 & 743.7384 & 0.0031 & 1.3894 & 439.287 & 203.413 & 194.189\end{array}$

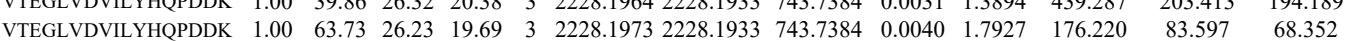
$\begin{array}{lllllllllllllll}\text { LMMDPLSGQNR } & 0.99 & 41.39 & 27.54 & 24.56 & 2 & 1404.7114 & 1404.6975 & 703.3560 & 0.0139 & 9.8811 & 6980.326 & 5926.812 & 264.602 & 4\end{array}$ GYAFITSGGK

GYAFITFCGK

NLATTVTEEILEK

NLATTVTEEILEK

NLATTVTEEILEK

NLATTVTEEILEK

NLATTVTEEILEK NLATTVTEEILEK NLATTVTEEILEK $\begin{array}{lllllllllllllll}1.00 & 81.86 & 26.24 & 27.40 & 2 & 1747.9830 & 1747.9811 & 874.9978 & 0.0019 & 1.0857 & 4111.407 & 3959.648 & 2330.322 & 241.328 & \text { Yes }\end{array}$ $\begin{array}{lllllllllllllll}1.00 & 97.71 & 26.24 & 30.75 & 2 & 1747.9830 & 1747.9811 & 874.9978 & 0.0019 & 1.0857 & 5891.376 & 5911.901 & 3376.232 & 205.161 & \text { Yes }\end{array}$ $\begin{array}{lllllllllllllll}1.00 & 49.71 & 26.17 & 20.37 & 3 & 1747.9840 & 1747.9811 & 583.6676 & 0.0029 & 1.6562 & 82.249 & 115.193 & 109.585 & 101.451 & \text { No }\end{array}$

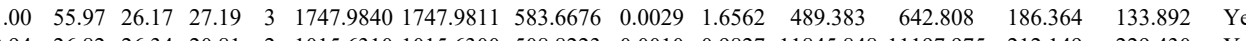
$\begin{array}{llllllllllllllll}0.94 & 26.82 & 26.34 & 20.81 & 2 & 1015.6310 & 1015.6300 & 508.8223 & 0.0010 & 0.9827 & 11845.848 & 11197.975 & 212.149 & 229.430 & \text { Yes }\end{array}$ $\begin{array}{lllllllllllllll}0.66 & 17.93 & 26.34 & 21.07 & 2 & 1015.6310 & 1015.6300 & 508.8223 & 0.0010 & 0.9827 & 79.984 & 84.657 & 27.273 & 8.517 & \text { Yes }\end{array}$

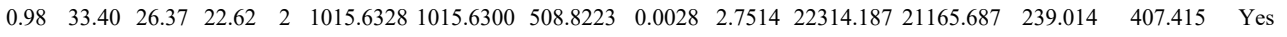

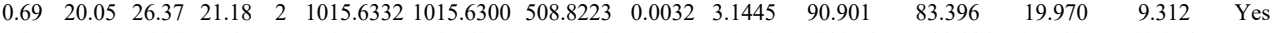
$\begin{array}{llllllllllllllll}0.95 & 27.89 & 26.38 & 19.49 & 2 & 1015.6312 & 1015.6300 & 508.8223 & 0.0012 & 1.1792 & 10841.049 & 9544.446 & 111.435 & 82.374 & \text { Yes }\end{array}$ \begin{tabular}{lllllllllllllll}
0.63 & 16.97 & 26.27 & 19.76 & 2 & 1015.6318 & 1015.6300 & 508.8223 & 0.0018 & 1.7688 & 18.361 & 28.745 & 8.192 & 2.476 & Yes \\
\hline
\end{tabular} $\begin{array}{lllllllllllllll}0.96 & 28.84 & 26.41 & 18.92 & 2 & 1015.6320 & 1015.6300 & 508.8223 & 0.0020 & 1.9653 & 7003.221 & 7023.362 & 0.000 & 71.642 & \text { No } \\ 0.97 & 29.42 & 26.27 & 22.29 & 2 & 1055314 & 5015.600 & 508.8223 & 0.004 & 1.3757 & 2772.056 & 2605.465 & 19.654 & 29.515 & \text { Yos }\end{array}$

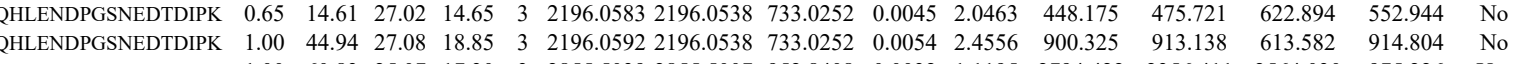
$\begin{array}{llllllllllllllll} & \end{array}$

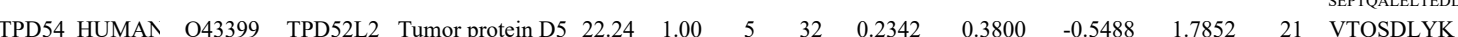
VTQSDLYK

$\begin{array}{llllllllllllllll}.00 & 50.16 & 26.72 & 26.88 & 2 & 1240.6936 & 1240.6907 & 621.3526 & 0.0029 & 2.3336 & 37310.552 & 42155.666 & 16593.856 & 4352.597 & \text { Yes } & \end{array}$

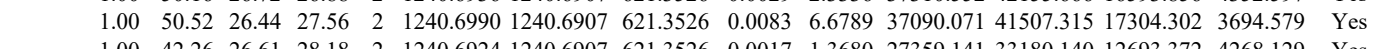
$\begin{array}{lllllllllllllll} & \end{array}$

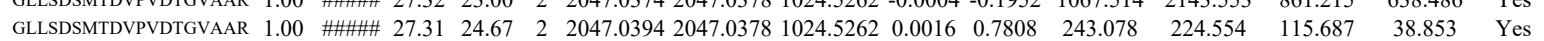




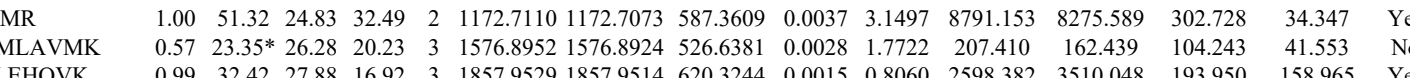
$\begin{array}{llllllllllllll}0.99 & 32.42 & 27.88 & 16.92 & 3 & 1857.9529 & 1857.9514 & 620.3244 & 0.0015 & 0.8060 & 2598.382 & 3510.048 & 193.950 & 158.96\end{array}$ $\begin{array}{llllllllllllllll} & \end{array}$ $\begin{array}{llllllllllllllll} & \end{array}$ \begin{tabular}{llllllllllllllll} 
& \\
QASLADCLNHAVGFASR & 1.00 & 83.47 & 22.12 & 18.92 & 2 & 1638.9802 & 1638.9790 & 820.4968 & 0.0012 & 0.7313 & 725.470 & 790.914 & 64.403 & 4.941 & Yes \\
\hline
\end{tabular}

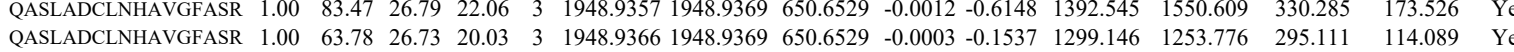
$\begin{array}{lllllllllllllllll}\text { LNQPPEDGISSVK } & 1.00 & 60.85 & 27.52 & 28.67 & 2 & 1670.9232 & 1670.9083 & 836.4614 & 0.0149 & 8.9065 & 2879.663 & 2090.353 & 1352.768 & 414.890 & \text { Yes }\end{array}$

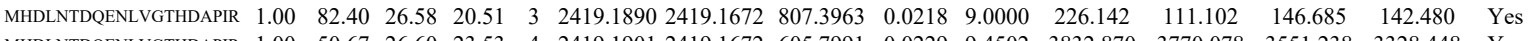
$\begin{array}{llllllllllllllll}\text { MHDLNTDQENLVGTHDAPIR } & 1.00 & 50.67 & 26.60 & 23.53 & 4 & 2419.1901 & 2419.1672 & 605.7991 & 0.0229 & 9.4502 & 3832.870 & 3770.078 & 3551.238 & 3328.448 & \text { Yes }\end{array}$ $\begin{array}{lllllllllllllllll}\text { MHDLNTDQENLVGTHDAPIR } & 1.00 & 56.79 & 26.60 & 16.79 & 4 & 2419.1901 & 2419.1672 & 605.7991 & 0.0229 & 9.4502 & 4070.871 & 4457.683 & 4286.318 & 2828.645 & \text { Yes }\end{array}$ $\begin{array}{llllllllllllllll}\text { LNQPPEDGISSVK } & 1.00 & 57.86 & 27.50 & 27.39 & 2 & 1670.9234 & 1670.9083 & 836.4614 & 0.0151 & 9.0260 & 2514.996 & 2238.891 & 1105.482 & 494.076 & \text { Yes }\end{array}$

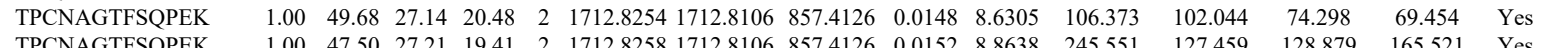

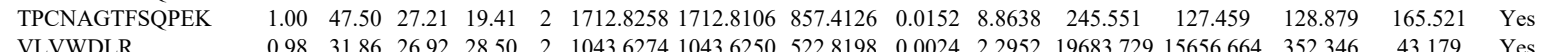

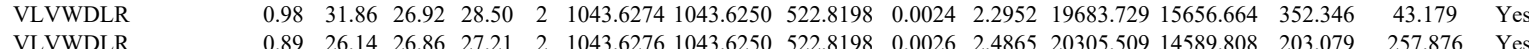

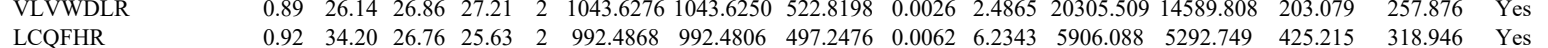

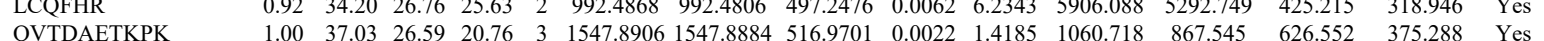

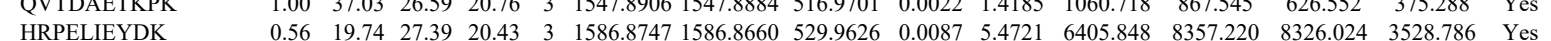
$\begin{array}{lllllllllllllllll}\text { LVSIGAEEIVDGNAK } & 0.97 & 25.02 & 25.93 & 17.90 & 3 & 1802.0044 & 1802.0029 & 601.6749 & 0.0015 & 0.8310 & 24.406 & 33.741 & 32.979 & 21.519 & \text { Yes }\end{array}$ $\begin{array}{lllllllllllllllll}\text { KDDPVTNLNNAFEVAEK } & 1.00 & 62.52 & 26.79 & 17.44 & 3 & 2335.2400 & 2335.2385 & 779.4201 & 0.0015 & 0.6415 & 2296.799 & 4884.031 & 2310.343 & 1967.822 & \text { Yes }\end{array}$

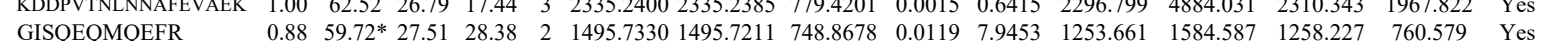

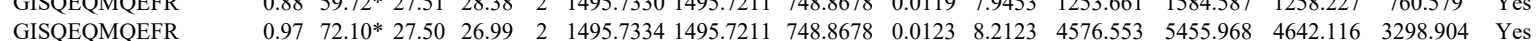
$\begin{array}{llllllllllllllll}\text { KDDPVTNLNNAFEVAEK } & 1.00 & 56.31 & 26.71 & 18.99 & 3 & 2335.2412 & 2335.2385 & 779.4201 & 0.0027 & 1.1547 & 1599.131 & 2251.534 & 2048.755 & 860.362 & \text { Yes }\end{array}$ $\begin{array}{llllllllllllllll}\text { NFITAEELR } & 0.99 & 44.87 & 28.00 & 36.05 & 2 & 1235.6736 & 1235.6632 & 618.8389 & 0.0104 & 8.4028 & 9473.069 & 12157.915 & 355.236 & 725.441 & \text { Yes }\end{array}$ $\begin{array}{llllllllllllllll}\text { NFITAEELR } & 0.99 & 46.57 & 28.00 & 36.02 & 2 & 1235.6740 & 1235.6632 & 618.8389 & 0.0108 & 8.7259 & 9650.143 & 11575.133 & 281.549 & 655.941 & \text { Yes }\end{array}$ $\begin{array}{lllllllllllllllll}\text { GISQEQMQEFR } & 0.88 & 59.85 * & 27.54 & 27.70 & 2 & 1495.7328 & 1495.7211 & 748.8678 & 0.0117 & 7.8117 & 6658.835 & 8552.594 & 6312.576 & 2995.064 & \text { Yes }\end{array}$

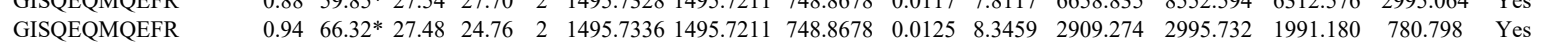
$\begin{array}{llllllllllllllllll}\text { NFITAEELR } & 0.99 & 43.67 & 28.09 & 37.87 & 2 & 1235.6744 & 1235.6632 & 618.8389 & 0.0112 & 9.0491 & 4187.707 & 4388.089 & 494.842 & 447.124 & \text { Yes }\end{array}$ $\begin{array}{llllllllllllllll}\text { GISQEQMQEFR } & 0.71 & 50.24 * 27.54 & 21.59 & 2 & 1495.7328 & 1495.7211 & 748.8678 & 0.0117 & 7.8117 & 488.098 & 565.110 & 385.738 & 198.124 & \text { Yes }\end{array}$

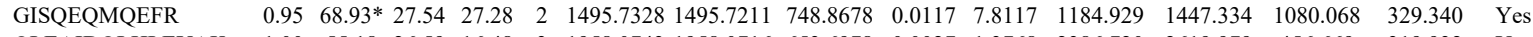
$\begin{array}{llllllllllllllll}\text { QLEAIDQLHLEYAK } & 1.00 & 55.18 & 26.59 & 16.48 & 3 & 1958.0743 & 1958.0716 & 653.6978 & 0.0027 & 1.3768 & 2386.720 & 2619.979 & 456.669 & 319.932 & \text { Yes }\end{array}$ $\begin{array}{lllllllllllllllll}\text { QLEAIDQLHLEYAK } & 1.00 & 49.50 & 26.57 & 16.89 & 3 & 1958.0755 & 1958.0716 & 653.6978 & 0.0039 & 1.9887 & 2857.517 & 3522.465 & 468.564 & 499.310 & \text { Yes }\end{array}$ $\begin{array}{llllllllllllllll}\text { MAPYQGPDAVPGALDYK } & 1.00 & 84.20 & 27.74 & 26.16 & 2 & 2080.0714 & 2080.0543 & 1041.0344 & 0.0171 & 8.2129 & 1067.270 & 1232.570 & 337.049 & 19.840 & \text { Yes }\end{array}$ $\begin{array}{llllllllllllllll}\text { VEQIAAAQELNELDYYDSHNVNTR } & 0.99 & 15.84 & 26.16 & 28.84 & 4 & 3048.4961 & 3048.4910 & 763.1300 & 0.0051 & 1.6707 & 0.000 & 31.443 & 7.022 & 0.000 & \text { No }\end{array}$ $\begin{array}{llllllllllllllll}\text { VEEIAAIAQELNELDYYDSHNVNTR } & 1.00 & 27.55 & 26.46 & 40.55 & 4 & 3048.5029 & 3048.4910 & 763.1300 & 0.0119 & 3.8984 & 202.011 & 184.530 & 49.659 & 74.668 & \text { Yes }\end{array}$ $\begin{array}{llllllllllllllll}\text { VEQIAAIAQELNELDYYDSHNVNTR } & 1.00 & 27.50 & 26.35 & 18.54 & 4 & 3048.4981 & 3048.4910 & 763.1300 & 0.0071 & 2.3259 & 23.195 & 5.795 & 11.541 & 12.854 & \text { Yes }\end{array}$

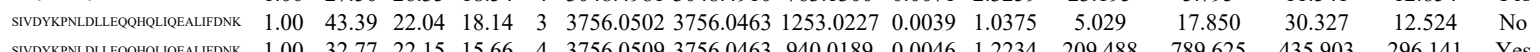

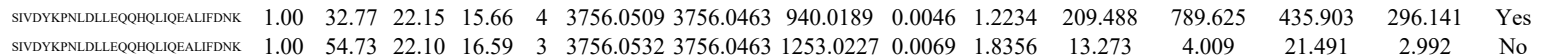

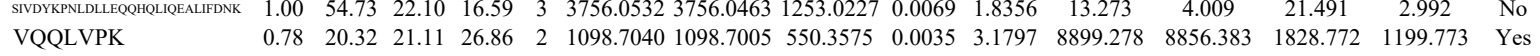

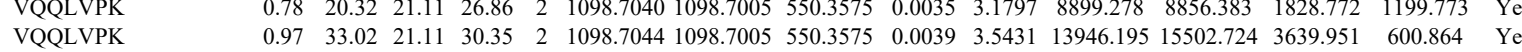

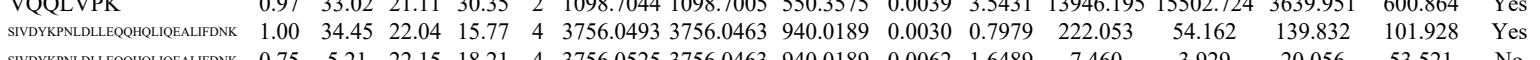

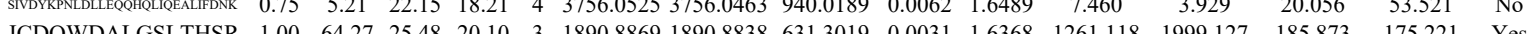
$\begin{array}{llllllllllllllll}\text { ICDQWDALGSLTHSR } & 1.00 & 68.92 & 25.59 & 21.70 & 3 & 1890.8872 & 1890.8838 & 631.3019 & 0.0034 & 1.7952 & 1143.951 & 1273.112 & 145.429 & 162.829 & \text { Yes }\end{array}$ 


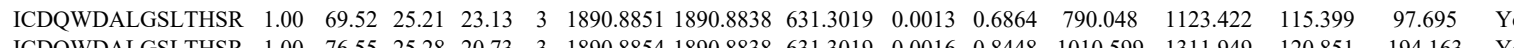

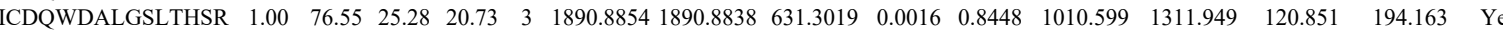
$\begin{array}{llllllllllllllll}\text { QFASQANVVGPWIQTK } & 0.51 & 10.67 & 26.46 & 14.48 & 3 & 2061.1273 & 2061.1251 & 688.0490 & 0.0022 & 1.0658 & 2164.808 & 3388.688 & 717.286 & 386.478 & \text { Yes }\end{array}$ $\begin{array}{llllllllllllllll}\text { NVNVQNFHISWK } & 1.00 & 56.43 & 27.00 & 23.86 & 3 & 1772.9701 & 1772.9566 & 591.9928 & 0.0135 & 7.6014 & 9788.726 & 13520.240 & 3015.461 & 1493.740 & \text { Yes }\end{array}$ $\begin{array}{llllllllllllllll}\text { NVNVQNFHISWK } & 1.00 & 61.60 & 26.63 & 21.90 & 3 & 1772.9722 & 1772.9566 & 591.9928 & 0.0156 & 8.7838 & 4638.903 & 6711.348 & 1462.944 & 1060.175 & \text { Yes }\end{array}$

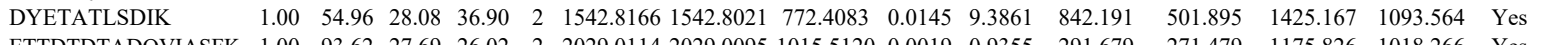

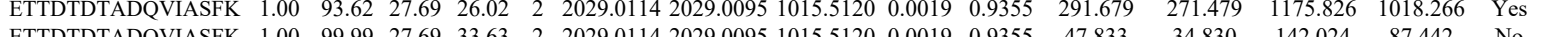

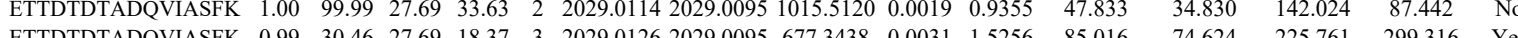

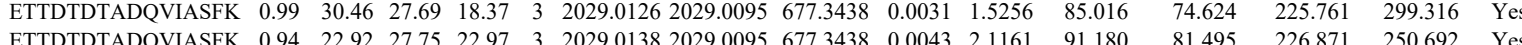
\begin{tabular}{lllllllllllllll}
\hline & & &
\end{tabular} \begin{tabular}{llllllllllllll}
\hline & 0.395 .043 & 1100.355 & Yes
\end{tabular}

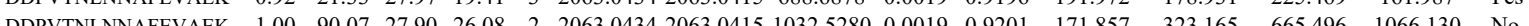

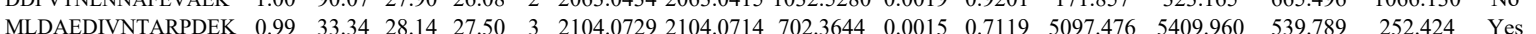

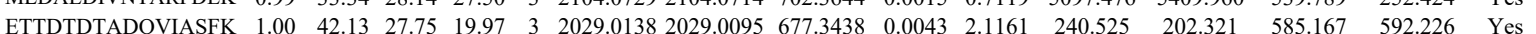
$\begin{array}{llllllllllllllll}\text { ETTDTDTADQVIASFK } & 1.00 & 38.55 & 27.77 & 21.25 & 3 & 2029.0147 & 2029.0095 & 677.3438 & 0.0052 & 25590 & 166.744 & 136.024 & 245.566 & 180.667 & \text { Yes }\end{array}$

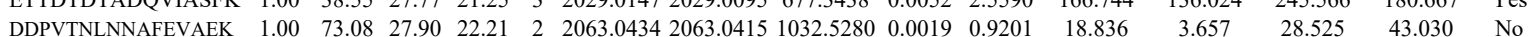
$\begin{array}{llllllllllllllll}\text { DDPVTNLNNAFEVAEK } & 1.00 & 62.62 & 27.91 & 20.25 & 3 & 2063.0446 & 2063.0415 & 688.6878 & 0.0031 & 1.5004 & 235.149 & 136.338 & 313.848 & 554.010 & \text { No }\end{array}$ $\begin{array}{llllllllllllllll}\text { DDPVTNLNNAFEVAEK } & 1.00 & 52.95 & 27.91 & 19.41 & 3 & 2063.0446 & 2063.0415 & 688.6878 & 0.0031 & 1.5004 & 189.848 & 182.240 & 405.329 & 491.209 & \text { Yes }\end{array}$ $\begin{array}{llllllllllllllll}\text { MLDAEDIVNTARPDEK } & 1.00 & 39.22 & 28.12 & 22.27 & 3 & 2104.0738 & 2104.0714 & 702.3644 & 0.0024 & 1.1390 & 7379.733 & 7301.035 & 404.970 & 193.465 & \text { Yes }\end{array}$ $\begin{array}{llllllllllllllll}\text { MLDAEDIVNTARPDEK } & 1.00 & 40.39 & 28.06 & 26.38 & 3 & 2104.0756 & 2104.0714 & 702.3644 & 0.0042 & 1.9933 & 12847.894 & 16532.799 & 1539.569 & 225.499 & \text { Yes }\end{array}$ $\begin{array}{lllllllllllllllll}\text { SFSTALYGESDL } & 0.80 & 23.31 & 25.68 & 16.64 & 2 & 1432.6848 & 1432.6844 & 717.3495 & 0.0004 & 0.2788 & 110.331 & 64.176 & 118.177 & 78.194 & \text { Yes }\end{array}$ $\begin{array}{lllllllllllllllll}\text { HRPELIEYDK } & 0.74 & 23.60 & 27.40 & 20.97 & 3 & 1586.8756 & 1586.8660 & 529.9626 & 0.0096 & 6.0381 & 11294.278 & 12709.427 & 11048.203 & 5322.657 & \text { Yes }\end{array}$

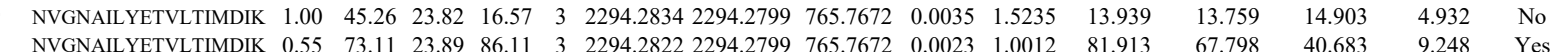

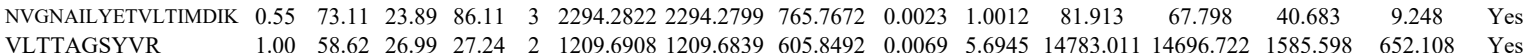
$\begin{array}{llllllllllllllll}\text { VLTTAGSYVR } & 1.00 & 58.62 & 26.99 & 27.24 & 2 & 1209.6908 & 1209.6839 & 605.8492 & 0.0069 & 5.6945 & 14783.011 & 14696.722 & 1585.598 & 652.108 & \text { Yes } \\ \text { VLTTAGSYVR } & 1.00 & 56.85 & 27.03 & 31.35 & 2 & 1209616 & 1209.683 & 605892 & 0.0077 & 6.3547 & 21383.799 & 21467.502 & 1829.144 & 966.806 & \text { Yes }\end{array}$

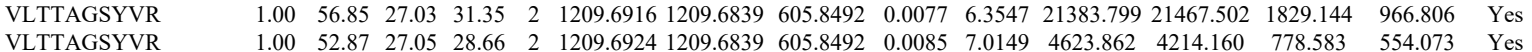
$\begin{array}{llllllllllllllll} & \\ \text { VLTTAGSYVR } & 1.00 & 52.87 & 27.05 & 28.66 & 2 & 1209.6924 & 1209.6839 & 605.8492 & 0.0085 & 7.0149 & 4623.862 & 4214.160 & 778.583 & 554.073 & \text { Yes } \\ \text { LVPQLVR } & 0.74 & 21.18 & 17.71 & 28.25 & 2 & 967.6388 & 967.6300 & 484.8223 & 0.0088 & 9.0754 & 18356.280 & 18624.587 & 3579.661 & 493.476 & \text { Yes }\end{array}$ LVPQLVR AALCAVHVIR AALCAVHVIR AALCAVHVIR VLAINILGR

VLAINILGR

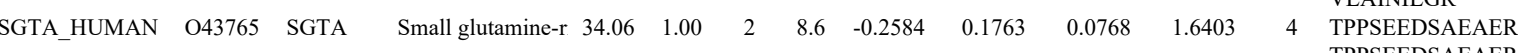
TPPSEEDSAEAER LAYAIIQFLHDQLR $\begin{array}{llllllllllllllllll}1.00 & 40.04 & 26.25 & 20.46 & 3 & 1241.6959 & 1241.6858 & 414.9025 & 0.0101 & 8.1143 & 16264.601 & 22426.474 & 2707.924 & 832.845 & \text { Yes } & \\ \end{array}$ $\begin{array}{lllllllllllllll}0.99 & 29.24 & 26.41 & 17.57 & 3 & 1241.6881 & 1241.6858 & 414.9025 & 0.0023 & 1.8478 & 9551.207 & 10731.934 & 1485.904 & 893.117 & \text { Yes }\end{array}$ $\begin{array}{llllllllllllllll}1.00 & 43.18 & 26.41 & 25.21 & 3 & 1241.6881 & 1241.6858 & 414.9025 & 0.0023 & 1.8478 & 7345.834 & 8946.189 & 1355.351 & 546.888 & \text { Yes }\end{array}$ $\begin{array}{lllllllllllllll}1.00 & 48.58 & 18.51 & 42.21 & 2 & 1111.7212 & 1111.7199 & 556.8672 & 0.0013 & 1.1672 & 2245.307 & 2036.879 & 49.689 & 0.000 & \text { No }\end{array}$

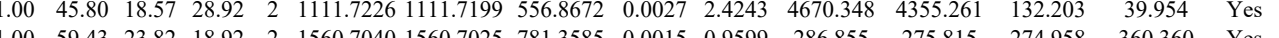

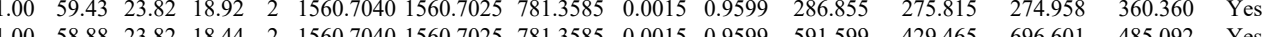
$\begin{array}{lllllllllllllll}1.00 & 58.88 & 23.82 & 18.44 & 2 & 1560.7040 & 1560.7025 & 781.3585 & 0.0015 & 0.9599 & 591.599 & 429.465 & 696.601 & 485.092 & \text { Yes } \\ 1.00 & 78.01 & 25.42 & 17.99 & 3 & 1844.0455 & 1844.0430 & 615.6883 & 0.0025 & 1.3535 & 66.210 & 60.228 & 35.942 & 7.298 & Y\end{array}$

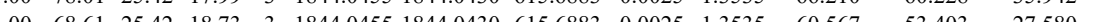

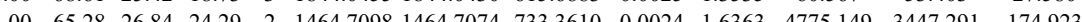

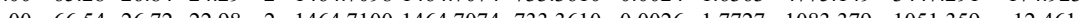

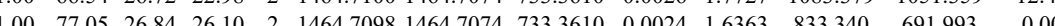
1 LEDLVCDVVDR LEDLVCDVVDR

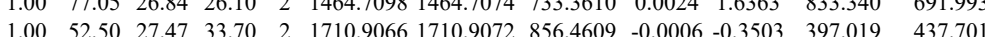

EPFPTIYVDSQK $\begin{array}{llllll} & 0.09010\end{array}$ $\begin{array}{rrrrrrrrrrrrr}1.00 & 74.47 & 27.49 & 39.11 & 2 & 1710.9078 & 1710.9072 & 856.4609 & 0.0006 & 0.3503 & 479.188 & 234.908 & 333.071 \\ 1.00 & 57.82 & 27.74 & 27.51 & 2 & 1671.8990 & 1671.8963 & 836.9554 & 0.0027 & 1.6130 & 444.049 & 369.146 & 10.508\end{array}$ IFDSEEILAGYK

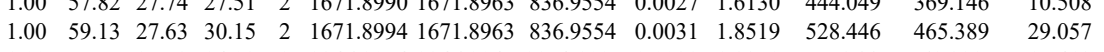
$\begin{array}{lllllllllllll}\text { LTESVDVLMPNVGEIVGGSMR } & 1.00 & \text { \#\#\#\# } 27.53 & 24.02 & 2 & 2346.2074 & 2346.2045 & 1174.1095 & 0.0029 & 1.2350 & 75.866 & 61.322 & 17.413\end{array}$ $\begin{array}{llllllllllllll}\text { LTESVDVLMPNVGEIVGGSMr } & 1.00 & \text { \#\#\#\# } 27.53 & 28.92 & 2 & 2346.2074 & 2346.2045 & 1174.1095 & 0.0029 & 1.2350 & 49.463 & 38.015 & 16.050\end{array}$

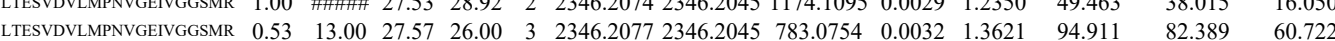
$\begin{array}{lllllllllllllll}\text { LTESVDVLMPNVGEIVGGSMR } & 0.96 & 24.77 & 27.63 & 16.42 & 3 & 2346.2086 & 2346.2045 & 783.0754 & 0.0041 & 1.7453 & 106.983 & 86.801 & 15.866\end{array}$ $\begin{array}{lllllllllllllll}\text { MNYSDAIVWLK } & 1.00 & 47.92 & 27.68 & 24.90 & 2 & 1626.8778 & 1626.8683 & 814.4414 & 0.0095 & 5.8322 & 864.979 & 807.585 & 24.799\end{array}$ $\begin{array}{llllllllllllll}\text { LMTDTINEPILLCR } & 1.00 & 83.99 & 28.04 & 22.16 & 2 & 1820.9338 & 1820.9320 & 911.4733 & 0.0018 & 0.9874 & 743.576 & 522.445 & 51.209 \\ \text { LMTDTINEPILLCR } & 1.00 & 78.70 & 28.06 & 21.71 & 2 & 1820.9342 & 1820.9320 & 911.4733 & 0.0022 & 1.2068 & 540.405 & 529.267 & 55.481\end{array}$ LMTDTINEPILLCR

VFGWVHR

NLMFLVLR

NLMFLVLR

NLMFLVLR

NLMFLVLR

NLMFLVLR

NLMFLVLR

FLTWILNR

FLTWILNR

FLTWILNR

FLTWILNR

FLTWILNR

FLTWILNR

FLTWILNR $\begin{array}{llllllllllllll}1.00 & 80.23 & 28.06 & 24.09 & 2 & 1820.9350 & 1820.9320 & 911.4733 & 0.0030 & 1.6457 & 1293.102 & 884.669\end{array}$ $\begin{array}{lllllllllllll}0.98 & 34.22 & 27.33 & 25.89 & 2 & 1043.5818 & 1043.5787 & 522.7966 & 0.0031 & 2.9648 & 9346.763 & 7780.350 & 352.853\end{array}$ $\begin{array}{llllllllllllll}1.00 & 50.69 & 26.54 & 20.55 & 2 & 1148.6870 & 1148.6862 & 575.3504 & 0.0008 & 0.6952 & 1161.709 & 1198.413 & 65.024\end{array}$ $\begin{array}{lllllllllllll}0.99 & 33.30 & 25.90 & 19.15 & 2 & 1148.6844 & 1148.6862 & 575.3504 & 0.0012 & 1.0428 & 1763.061 & 1724.011 & 150.512\end{array}$ $\begin{array}{lllllllllllll}1.00 & 39.29 & 25.91 & 19.41 & 2 & 1148.6880 & 1148.6862 & 575.3504 & 0.0018 & 1.5643 & 1515.122 & 1618.734 & 132.967\end{array}$ $\begin{array}{llllllllllll} & \end{array}$ $\begin{array}{llllllllllllll}0.99 & 36.70 & 25.91 & 18.26 & 2 & 1148.6880 & 1148.6862 & 575.3504 & 0.0018 & 1.5643 & 205.788 & 225.710\end{array}$ $\begin{array}{lllllllllllll}0.98 & 37.87 & 28.25 & 25.65 & 2 & 1061.6026 & 1061.6022 & 531.8084 & 0.0004 & 0.3761 & 24.862 & 48.132\end{array}$

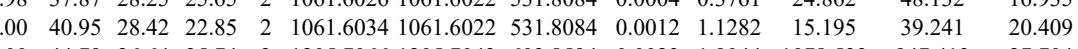

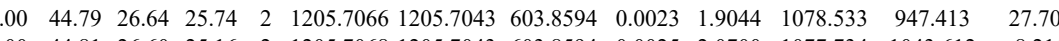
$\begin{array}{llllllllllll}1.00 & \end{array}$

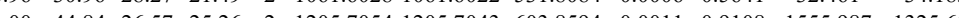

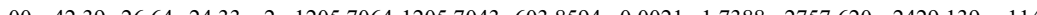
$\begin{array}{lllllllllllll}1.00 & 41.25 & 26.57 & 24.70 & 2 & 1205.7054 & 1205.7043 & 603.8594 & 0.0011 & 0.9108 & 447.462 & 339.924\end{array}$ 


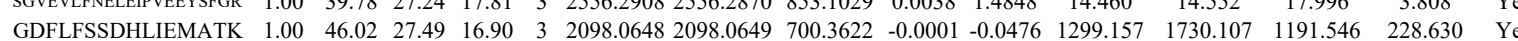
$\begin{array}{llllllllllllllll}\text { GDFLFSSDHLIEMATK } & 1.00 & 35.73 & 27.49 & 18.63 & 3 & 2098.0654 & 2098.0649 & 700.3622 & 0.0005 & 0.2380 & 727.746 & 1251.172 & 692.726 & 155.032 & \text { Yes }\end{array}$ $\begin{array}{llllllllllllllll}\text { LEDLATLIOK } & 1.00 & 57.32 & 24.12 & 33.73 & 2 & 1430.8604 & 1430.8588 & 716.4367 & 0.0016 & 1.1166 & 592.410 & 896.221 & 267.520 & 16.651 & \text { Yes }\end{array}$

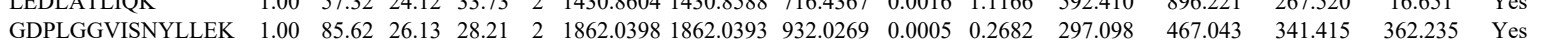

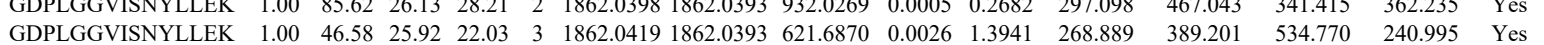
$\begin{array}{lllllllllllllllll}\text { GDPLGGVISNYLLEK } & 1.00 & 84.36 & 25.81 & 22.23 & 2 & 1862.0428 & 1862.0393 & 932.0269 & 0.0035 & 1.8776 & 226.100 & 360.810 & 467.653 & 280.564 & \text { Yes }\end{array}$ $\begin{array}{lllllllllllllllll}\text { GDPLGGVISNYLLEK } & 1.00 & 39.51 & 25.79 & 29.02 & 3 & 1862.0431 & 1862.0393 & 621.6870 & 0.0038 & 2.0375 & 239.966 & 352.452 & 264.411 & 318.214 & \text { No }\end{array}$ $\begin{array}{lllllllllllllllll}\text { GDPLGGVISNYLLEK } & 1.00 & 70.32 & 26.16 & 22.79 & 2 & 1862.0380 & 1862.0393 & 932.0269 & -0.0013 & -0.6974 & 660.955 & 818.798 & 1155.916 & 824.052 & \text { Yes }\end{array}$ $\begin{array}{llllllllllllllll}\text { GDPLGGVISNYLLEK } & 1.00 & 42.87 & 26.15 & 22.89 & 3 & 1862.0395 & 1862.0393 & 621.6870 & 0.0002 & 0.1072 & 380.265 & 439.196 & 497.049 & 396.159 & \text { Yes }\end{array}$ $\begin{array}{llllllllllllllllll}\text { GDPLGGVISNYLLEK } & 1.00 & 55.27 & 25.95 & 25.68 & 3 & 1862.0413 & 1862.0393 & 621.6870 & 0.0020 & 1.0723 & 313.065 & 295.344 & 170.738 & 142.252 & \text { Yes }\end{array}$

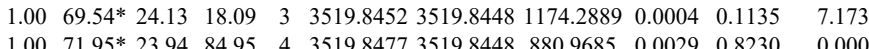

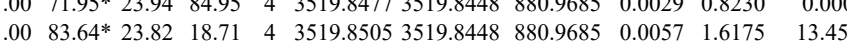
RPPTAGSQFK RPPTAGSQFK RPPTAGSQFK RPPTAGSQFK $\begin{array}{lllllllllll}0.92 & 27.68 & 27.81 & 18.16 & 3 & 1375.7806 & 1375.7816 & 459.6011 & -0.0010 & -0.7253 & 565.415\end{array}$ $\begin{array}{lllllllllllll}0.96 & 25.19 & 27.84 & 15.08 & 3 & 1375.7824 & 1375.7816 & 459.6011 & 0.0008 & 0.5802 & 771.243\end{array}$ $\begin{array}{lllllllllllll}0.59 & 25.57 & 28.08 & 16.68 & 2 & 1375.7810 & 1375.7816 & 688.8981 & -0.0006 & -0.4355 & 204.391\end{array}$ $\begin{array}{lllllllllll}0.99 & 34.81 & 28.08 & 18.29 & 3 & 1375.7815 & 1375.7816 & 459.6011 & -0.0001 & -0.0725 & 1267.356 \\ 1.00 & 74.60 & 24.94 & 18.04 & 3 & 2929.5634 & 2929.5649 & 977.5289 & -0.0015 & -0.5115 & 22.315\end{array}$

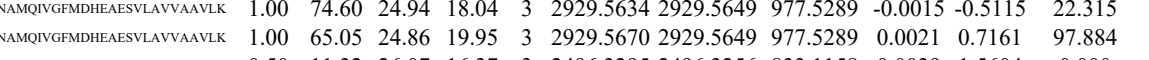
$\begin{array}{lllllllllllll}\text { NFHVFYQLLSGASEELLNK } & 0.50 & 11.32 & 26.07 & 16.37 & 3 & 2496.3295 & 2496.3256 & 833.1158 & 0.0039 & 1.5604 & 0.000\end{array}$ $\begin{array}{llllllllllll}\text { NFHVFYQLLSGASEELLNK } & 1.00 & 63.99 & 26.02 & 21.98 & 4 & 2496.3297 & 2496.3256 & 625.0887 & 0.0041 & 1.6398 & 141.607 \\ \text { NFHVFYQLLSGASEELLNK } & 1.00 & 61.88 & 26.03 & 24.64 & 4 & 2496.3301 & 2496.3256 & 625.0887 & 0.0045 & 1.7997 & 115.577\end{array}$ $\begin{array}{lllllllllllll}\text { NFHVFYQLLSGASEELLNK } & 1.00 & 61.88 & 26.03 & 24.64 & 4 & 2496.3301 & 2496.3256 & 625.0887 & 0.0045 & 1.7997 & 115.577 & 177 \\ \text { NAMEIVGFMDEAASSLAVVAAVLK } & 1.00 & 76.48 & 24.71 & 22.14 & 3 & 2929.5682 & 2929.5649 & 977.5289 & 0.0033 & 1.1253 & 10.928 & 103\end{array}$

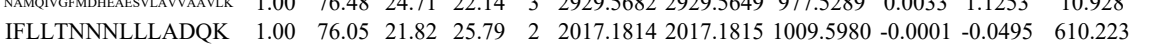
$\begin{array}{lllllllllllll}\text { IFLLTNNNLLLADQK } & 0.81 & 12.80 & 21.64 & 18.08 & 3 & 2017.1824 & 2017.1815 & 673.4011 & 0.0009 & 0.4455 & 525.940 & 43\end{array}$

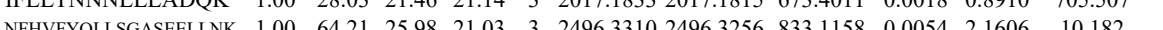
$\begin{array}{llllllllllllll}\text { IFLLTNNNLLLADQK } & 0.99 & 29.01 & 21.82 & 21.54 & 3 & 2017.1815 & 2017.1815 & 673.4011 & 0.0000 & 0.0000 & 528.642 & 631.00\end{array}$ $\begin{array}{lllllllllllll}\text { SSALVIQSYIR } & 1.00 & 45.67 & 27.52 & 22.07 & 2 & 1379.7892 & 1379.7894 & 690.9020 & -0.0002 & -0.1447 & 2182.972 & 2988.3\end{array}$

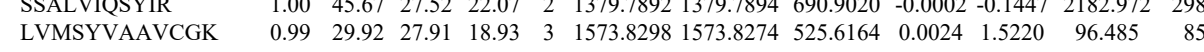
$\begin{array}{lllllllllllll}\text { IFHLWR } & 0.78 & 24.14 & 27.11 & 30.13 & 2 & 1014.5886 & 1014.5885 & 508.3015 & 0.0001 & 0.0984 & 1287.841 & 17.38\end{array}$ $\begin{array}{lllllllllllll}0.67 & 21.77 & 27.11 & 27.89 & 2 & 1014.5886 & 1014.5885 & 508.3015 & 0.0001 & 0.0984 & 2039.134\end{array}$

$\begin{array}{lllllllllllll}\text { IFHLWR } & 0.67 & 21.77 & 27.11 & 27.89 & 2 & 1014.5886 & 014.5885 & 58.3015 & 0.0001 & 0.0984 & 1287.841\end{array}$ $\begin{array}{llllllllllll}\text { LPHVLLLQLGTTFFK } & 0.69 & 99.79 & 16.81 & \text { \#\#\#\# } 2 & 2014.2254 & 2014.2223 & 1008.1184 & 0.0031 & 1.5375 & 8.139\end{array}$ $\begin{array}{llllllllllll}\text { LPGGELNPGEDEVEGLK } & 1.00 & 64.30 & 27.65 & 20.22 & 2 & 2040.0614 & 2040.0619 & 1021.0382 & -0.0005 & -0.2448 & 534.835\end{array}$ $\begin{array}{llllllllllll}\text { LPGGELNPGEDEVEGLK } & 0.99 & 31.65 & 27.52 & 15.70 & 3 & 2040.0634 & 2040.0619 & 681.0279 & 0.0015 & 0.7342 & 182.018\end{array}$ $\begin{array}{lllllllllllll}\text { LPGGELNPGEDEVEGLK } & 1.00 & 70.98 & 27.55 & 19.21 & 2 & 2040.0634 & 2040.0619 & 1021.0382 & 0.0015 & 0.7345 & 642.488\end{array}$ $\begin{array}{lllllllllllll}\text { LPGGELNPGEDEVEGLK } & 1.00 & 33.35 & 27.44 & 18.49 & 3 & 2040.0649 & 2040.0619 & 681.0279 & 0.0030 & 1.4684 & 247.820\end{array}$

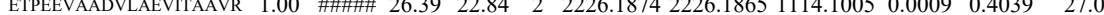

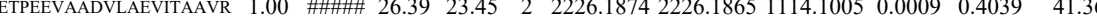

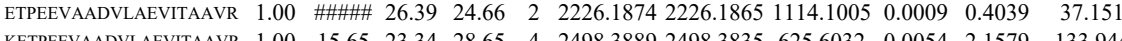
$\begin{array}{llllllllllllll}\text { KETPEEVAADVLAEVITAAVR } & 1.00 & 15.65 & 23.34 & 28.65 & 4 & 2498.3889 & 2498.3835 & 625.6032 & 0.0054 & 2.1579 & 133.944\end{array}$ $\begin{array}{llllllllllll}\text { ETPEEVAADVLAEVITAAVR } & 1.00 & \text { \#\#\#\# } 26.39 & 22.59 & 2 & 2226.1874 & 2226.1865 & 1114.1005 & 0.0009 & 0.4039 & 12.503\end{array}$ $\begin{array}{llllllllllll}\text { ETPEEVAADVLAEVITAAVR } & 1.00 & \text { \#\#\#\# } 26.40 & 26.02 & 2 & 2226.1894 & 2226.1865 & 1114.1005 & 0.0029 & 1.3015 & 4.979\end{array}$

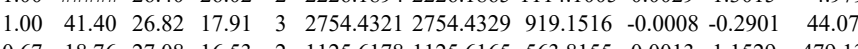
$\begin{array}{llllllllllll} & & & \end{array}$ $\begin{array}{llllllllllll}\text { NIANPTAMLLSASNMLR } & 1.00 & \text { \#\#\# } 27.58 & 28.91 & 2 & 1960.0370 & 1960.0355 & 981.0250 & 0.0015 & 0.7645 & 123.186\end{array}$

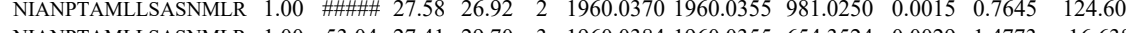
$\begin{array}{lllllllllllll}\text { NIANPAAMLLSASNMLR } & 1.00 & 53.04 & 27.41 & 29.70 & 3 & 1960.0384 & 1960.0355 & 654.3524 & 0.0029 & 1.4773 & 16.638\end{array}$ $\begin{array}{lllllllllllll}\text { NIANPTAMLLSASNMLR } & 1.00 & 46.17 & 27.40 & 23.80 & 3 & 1960.0387 & 1960.0355 & 654.3524 & 0.0032 & 1.6301 & 24.557\end{array}$

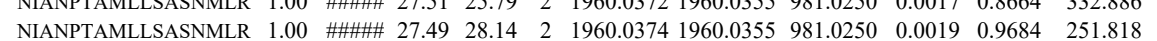
$\begin{array}{llllllllllll}\text { NIANPTAMLSSASNMLR } & 1.00 & 70.99 & 27.42 & 23.87 & 3 & 1960.0393 & 1960.0355 & 654.3524 & 0.0038 & 1.9358 & 23.548\end{array}$ $\begin{array}{llllllllllll}\text { NIANPTAMLLSASNMLR } & 1.00 & 63.70 & 27.42 & 24.07 & 3 & 1960.0393 & 1960.0355 & 654.3524 & 0.0038 & 1.9358 & 37.934\end{array}$ 
YQALMDGLSLESLLSFVK YQALMDGLSLESLLSFVK

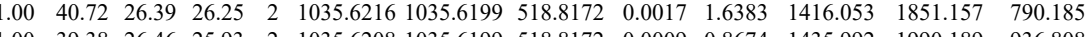
$\begin{array}{llllllllllllll}1.00 & 49.39 & 26.46 & 26.59 & 2 & 1035.6212 & 1035.6199 & 518.8172 & 0.0013 & 1.2528 & 1095.821 & 1397.993 & 637.421\end{array}$

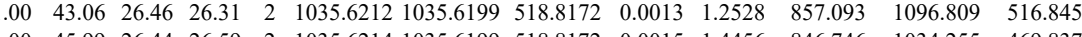

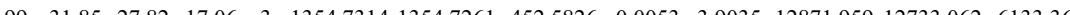
$\begin{array}{lllllllllllll}1.00 & 57.30 & 26.33 & 24.47 & 2 & 1698.9344 & 1698.9327 & 850.4736 & 0.0017 & 0.9994 & 632.301 & 538.619 & 64.416\end{array}$ \begin{tabular}{lllllllllllll}
\hline & 132.008 & 1.886 \\
\hline
\end{tabular} $\begin{array}{lllllllllllll}1.00 & 63.22 & 26.33 & 32.32 & 2 & 1698.9330 & 1698.9327 & 850.4736 & 0.0003 & 0.1764 & 214.549 & 188.429 & 3.622 \\ 1.968 .9327 & 850.4736 & 0.0017 & 0.999 & 132.802 & 180.610 & 3.714\end{array}$ $\begin{array}{lllllllllllll}1.00 & 64.62 & 26.31 & 32.13 & 2 & 1689.9330 & 1698.9327 & 850.4736 & 0.0003 & 0.1764 & 130.811 & 125.716 & 6.7203\end{array}$ $\begin{array}{llllllllllllll}1.00 & 29.11 & 23.46 & 21.55 & 3 & 1624.7218 & 1624.7195 & 542.5804 & 0.0023 & 1.4130 & 10.785 & 10.938 & 27.433\end{array}$ $\begin{array}{llllllllllllll}1.00 & 63.91 & 23.38 & 24.53 & 2 & 1624.7220 & 1624.7195 & 813.3670 & 0.0025 & 1.5368 & 7.694 & 13.401 & 35.975\end{array}$ $\begin{array}{lllllllllllll}0.99 & 28.50 & 23.44 & 22.87 & 3 & 1624.7227 & 1624.7195 & 5425804 & 0.0032 & 1.9659 & 23.891 & 15.253 & 31.204\end{array}$ $\begin{array}{lllllllllllll}0.99 & 38.24 & 27.13 & 23.72 & 2 & 1105.6416 & 1105.6406 & 553.8276 & 0.0010 & 0.9028 & 4833.146 & 4135.848 & 94.671\end{array}$ $\begin{array}{llllllllllllll}1.00 & 38.54 & 27.13 & 24.13 & 2 & 1105.6422 & 1105.6406 & 553.8276 & 0.0016 & 1.4445 & 3910.153 & 3129.082 & 63.492 \\ 0.06 & 17.67 & 27.28 & 22.76 & 3 & 1460.8336 & 1460.8295 & 487.9504 & 0.0041 & 2.8008 & 7.489 & 19.663 & 10.223\end{array}$ $\begin{array}{llllllllllllll}17.67 & 27.28 & 22.76 & 3 & 1460.8336 & 1460.8295 & 487.9504 & 0.0041 & 2.8008 & 7.489 & 19.663 & 10.223 \\ 1.00 & 70.58 & 26.86 & 32.70 & 2 & 1567.8650 & 1567.8562 & 784.9354 & 0.0088 & 5.6055 & 1847.166 & 1913.482 & 1034.329\end{array}$

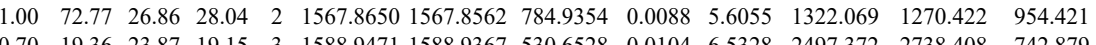
$\begin{array}{lllllllllllllll}1.70 & 19.36 & 23.87 & 19.15 & 3 & 1588.9471 & 1588.9367 & 530.6528 & 0.0104 & 6.5328 & 2497.372 & 2738.408 & 742.879\end{array}$ $\begin{array}{lllllllllllll}1.00 & 57.60 & 28.63 & 22.89 & 2 & 1364.7290 & 1364.7278 & 683.3712 & 0.0012 & 0.8780 & 4561.137 & 4435.900 & 502.978\end{array}$ $\begin{array}{llllllllllllll}1.00 & 59.45 & 28.57 & 23.04 & 2 & 1364.7300 & 1364.7278 & 683.3712 & 0.0022 & 1.6097 & 7425.156 & 7502.431 & 275.519\end{array}$ $\begin{array}{lllllllllllllll}1.00 & 59.39 & 28.32 & 23.78 & 2 & 1364.7308 & 1364.7278 & 683.3712 & 0.0030 & 2.1950 & 12411.211 & 12053.777 & 328.521 \\ 0.98 & 27.05 & 27.42 & 19.98 & 3 & 1337.7286 & 1337.7265 & 446.9161 & 0.0021 & 1.5663 & 1405.078 & 1425.678 & 153.728\end{array}$ $\begin{array}{llllllllllllll}0.98 & 27.05 & 27.42 & 19.98 & 3 & 1337.7286 & 1337.7265 & 446.9161 & 0.0021 & 1.5663 & 1405.078 & 1425.678 & 153.728 \\ 1.00 & 41.91 & 27.44 & 21.82 & 3 & 1337.7289 & 1337.7265 & 446.9161 & 0.0024 & 1.7900 & 1947.872 & 2000.373 & 209.177\end{array}$ $\begin{array}{llllllllllllll}1.00 & 41.91 & 27.44 & 21.82 & 3 & 1337.7289 & 1337.7265 & 446.9161 & 0.0024 & 1.7900 & 1947.872 & 2000.373 & 209.177 \\ 0.98 & 26.87 & 27.37 & 18.73 & 3 & 1337.7280 & 1337.7265 & 446.9161 & 0.0015 & 1.1188 & 533.097 & 446.625 & 77.858\end{array}$ $\begin{array}{lllllllllllll}1.00 & 4.91 & 27.44 & 21.82 & 3 & 1337.7289 & 1337.7265 & 46.9161 & 0.0024 & 1.7900 & 1947.872 & 200.373 & 209.177\end{array}$

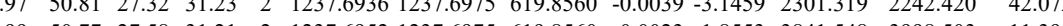

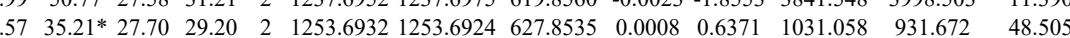
$\begin{array}{llllllllllll}0.73 & 39.92 * 27.37 & 23.92 & 2 & 1253.6942 & 1253.6924 & 627.8535 & 0.0018 & 1.4335 & 1098.944 & 1211.970 & 37.384\end{array}$ $\begin{array}{llllllllllllll}0.98 & 49.34 & 27.60 & 33.15 & 2 & 1237.6948 & 1237.6975 & 619.8560 & -0.0027 & -2.1779 & 2795.743 & 2628.448 & 39.220\end{array}$

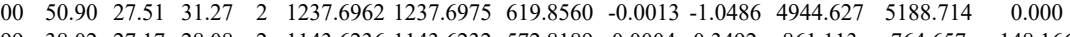
$\begin{array}{lllllllllllllll}0.99 & 36.17 & 27.25 & 27.96 & 2 & 1143.6240 & 1143.6232 & 572.8189 & 0.0008 & 0.6983 & 1381.439 & 1335.753 & 263.743\end{array}$ $\begin{array}{lllllllllllll}0.99 & 36.28 & 27.25 & 29.08 & 2 & 1143.6240 & 1143.6232 & 572.8189 & 0.0008 & 0.6983 & 349.766 & 322.239 & 81.029\end{array}$

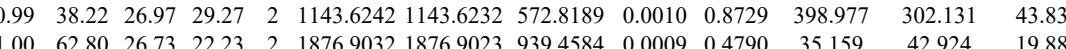
$\begin{array}{lllllllllllll}1.50 & 68.64 & 26.67 & 26.48 & 2 & 1876.9052 & 1876.9023 & 939.4584 & 0.0029 & 1.5434 & 17.083 & 29.226 & 8.868\end{array}$ $\begin{array}{lllllllllllll}1.00 & 39.11 & 23.65 & 16.60 & 2 & 1112.6744 & 1112.6740 & 557.3443 & 0.0004 & 0.3588 & 62.454 & 117.031 & 25.687\end{array}$ $\begin{array}{llllllllllllll}1.00 & 43.90 & 22.25 & 27.77 & 2 & 1256.7776 & 1256.7760 & 629.3953 & 0.0016 & 1.2711 & 1674.995 & 2041.551 & 65.912\end{array}$

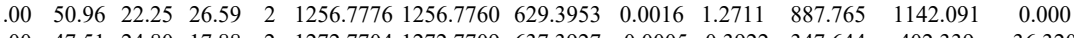
$\begin{array}{llllllllllllll}.00 & 47.51 & 24.80 & 17.88 & 2 & 1272.7704 & 1272.7709 & 637.3927 & -0.0005 & -0.3922 & 347.644 & 402.339 & 36.320\end{array}$ $\begin{array}{lllllllllllll}1.00 & 48.30 & 24.77 & 23.70 & 2 & 1272.7710 & 1272.7709 & 637.3927 & 0.0001 & 0.0784 & 370.840 & 543.274 & 60.086 \\ 1.00 & 46.59 & 22.30 & 26.18 & 2 & 256.7766 & 2567760 & 6293953 & 0.0006 & 0.4766 & 279.693 & 389.247 & 7.980\end{array}$ $\begin{array}{llllllllllllll}1.00 & 46.59 & 22.30 & 26.18 & 2 & 1256.7766 & 1256.7760 & 629.3953 & 0.0006 & 0.4766 & 279.693 & 389.247 & 7.980 \\ 1.00 & 52.58 & 24.80 & 19.22 & 2 & 1272.7706 & 1272.7709 & 637.3927 & -0.0003 & -0.2353 & 325.415 & 417.630 & 52.29\end{array}$ $\begin{array}{lllllllllllll}1.00 & 51.61 & 24.76 & 18.31 & 2 & 1272.7722 & 1272.7709 & 637.3927 & 0.0013 & 1.0198 & 305.633 & 390.356 & 39.815\end{array}$ $\begin{array}{lllllllllllll}1.00 & 44.88 & 22.38 & 26.17 & 2 & 1256.7760 & 1256.7760 & 629.3953 & 0.0000 & 0.0000 & 318.058 & 411.377 & 12.677\end{array}$ $\begin{array}{llllllllllllll}1.00 & 56.27 & 22.30 & 32.12 & 2 & 1256.7766 & 1256.7760 & 629.3953 & 0.0006 & 0.4766 & 357.735 & 494.466 & 0.000\end{array}$ $\begin{array}{llllllllllllll}0.60 & 7.30 & 20.17 & 15.28 & 3 & 1452.9043 & 1452.9030 & 485.3083 & 0.0013 & 0.8929 & 13925.360 & 16116.655 & 4379.906 & 45\end{array}$

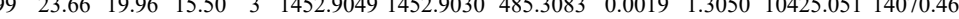
$\begin{array}{lllllllllllll}0.61 & 30.04 & 28.29 & 40.96 & 2 & 1060.5622 & 1060.5522 & 531.2834 & 0.0100 & 9.4111 & 220.700 & 341.491 \\ 0.94 & 30.33 & 26.60 & 20.32 & 2 & 1539.8606 & 1539.8603 & 770.9374 & 0.0003 & 0.1946 & 144.430 & 193.709\end{array}$ $\begin{array}{lllllllllllll}0.94 & 30.33 & 26.60 & 20.32 & 2 & 1539.8606 & 1539.8603 & 770.9374 & 0.0003 & 0.1946 & 144.430 & 193.709 \\ 0.88 & 26.62 & 26.60 & 20.71 & 2 & 1539.8606 & 1539.8603 & 770.9374 & 0.0003 & 0.1946 & 117.088 & 128.069\end{array}$ $\begin{array}{llllllllllllll}0.88 & 26.62 & 26.60 & 20.71 & 2 & 1539.8606 & 1539.8603 & 770.9374 & 0.0003 & 0.1946 & 117.088 & 1\end{array}$ $\begin{array}{llllllllllllll}0.52 & 12.62 & 26.61 & 15.86 & 3 & 1539.8614 & 1539.8603 & 514.2940 & 0.0011 & 0.7130 & 843.370 & 10\end{array}$ $\begin{array}{lllllllllllll}0.52 & 12.62 & 26.61 & 15.86 & 3 & 1539.8614 & 1539.8603 & 514.290 & 0.011 & 0.7130 & 84.370 & 10\end{array}$ $\begin{array}{llllllllllllll} & 0.001 & 0.3243 & 185.103 & 246.109\end{array}$ $\begin{array}{lllllllllllll}0.98 & 36.31 & 26.58 & 24.72 & 2 & 1539.8608 & 1539.8603 & 710.9374 & 0.0005 & 0.3243 & 185.103 & 246.109\end{array}$ 393.002 

$\begin{array}{llllllllllll}0.55 & 8.14 * & 9.03 & 21.14 & 2 & 883.6346 & 883.6340 & 442.8243 & 0.0006 & 0.6775 & 44.158\end{array}$ $\begin{array}{llllllllllllll}\text { APILALVAGEAAGMENSDDVVGR } & 0.93 & 22.38 & 22.17 & 17.23 & 3 & 2850.5641 & 2850.5646 & 951.1955 & -0.0005 & -0.1752 & 6.023 & 7.773 \\ \text { CDAVLCTLPLGVLK } & 1.00 & 35.48 & 27.67 & 23.01 & 3 & 1823.9668 & 1823.9625 & 608.9948 & 0.0043 & 2.3536 & 142.565 & 196.382 \\ \text { CDAVLCTLPLGVLK } & 0.84 & 18.98 & 27.60 & 19.88 & 3 & 1823.9662 & 1823.9625 & 608.9948 & 0.0037 & 2.0252 & 172.695 & 133.836\end{array}$

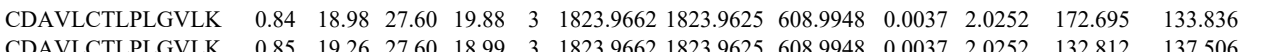
$\begin{array}{llllllllllllll}\text { NYPATVHGALLSGLR } & 1.00 & 64.94 & 26.66 & 21.96 & 3 & 1711.9483 & 1711.9491 & 571.6570 & -0.0008 & -0.4665 & 2141.253 & 3145.182 & 575.1\end{array}$ $\begin{array}{llllllllllllll}\text { NYPATVHGALLSGLR } & 1.00 & 64.94 & 26.66 & 21.96 & 3 & 171.9483 & 1711.9491 & 571.6570 & -0.0008 & -0.4665 & 2141.253 & 3145.182 & \\ \text { NYPATVHGALLSGLR } & 1.00 & 65.88 & 26.64 & 20.32 & 3 & 1711.9489 & 1711.9491 & 571.6570 & -0.0002 & -0.1166 & 3116.650 & 4159.470 & 777.5\end{array}$ $\begin{array}{llllllllllllll}\text { VIIIGSGVSGLAAAR } & 1.00 & 77.37 & 21.52 & 31.17 & 2 & 1526.9270 & 1526.9266 & 764.4706 & 0.0004 & 0.2616 & 31.163 & 64.584 & 0.04\end{array}$

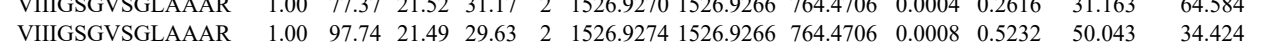
$\begin{array}{lllllllllllll}\text { VIIIGSGVSGLAAAR } & 1.00 & 97.74 & 21.49 & 29.63 & 2 & 1526.9274 & 1526.9266 & 764.4706 & 0.0008 & 0.5232 & 50.043 & \\ \text { VIIIGSGVSGLAAAR } & 1.00 & 45.12 & 21.55 & 24.14 & 3 & 1526.9278 & 1526.9266 & 509.9828 & 0.0012 & 0.7843 & 27.809 & 3 .\end{array}$ $\begin{array}{lllllllllll}1.00 & 45.12 & 21.55 & 24.14 & 3 & 1526.9278 & 1526.9266 & 509.9828 & 0.0012 & 0.7843 & 27.809 \\ 1.00 & 54.18 & 21.55 & 16.61 & 3 & 1526.9284 & 1526.9266 & 509.9828 & 0.0018 & 1.1765 & 20.537\end{array}$ VFLFIR

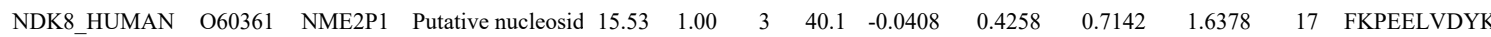
FKPEELVDYK FKPEELVDYK FKPEELVDYK FKPEELVDYK FKPEELVDYK FKPEELVDYK FKPEELVDYK FKPEELVDYK FKPEELVDYK $\begin{array}{lllllllllllll}1.00 & 54.18 & 21.55 & 16.61 & 3 & 1526.9284 & 1526.9266 & 509.9828 & 0.0018 & 1.1765 & 20.537 & 30.739 \\ 0.67 & 19.10 & 27.40 & 17.33 & 2 & 937.5878 & 937.5871 & 469.8008 & 0.0007 & 0.7450 & 697.668 & 908.705\end{array}$ $\begin{array}{llllllllllll}0.98 & 26.90 & 25.59 & 18.63 & 3 & 1698.9607 & 1698.9558 & 567.3259 & 0.0049 & 2.8790 & 1880.865 & 1572.922\end{array}$ $\begin{array}{llllllllllll}0.97 & 27.33 & 25.53 & 19.91 & 3 & 1698.9616 & 1698.9558 & 567.3259 & 0.0058 & 3.4078 & 1999.165 & 1625.102\end{array}$ $\begin{array}{llllllllllll}0.70 & 13.12 & 25.65 & 13.87 & 3 & 1698.9586 & 1698.9558 & 567.3259 & 0.0028 & 1.6451 & 17.903 & 17.112 \\ 0.54 & 1.34 & 25.67 & 14.45 & 3 & 1698.964 & 1698.958 & 57.3259 & 0.0046 & 2.7027 & 239.996 & 23.453\end{array}$ $\begin{array}{lllllllllllll}0.54 & 12.40 & 25.67 & 14.45 & 3 & 1698.9604 & 1698.9558 & 567.3259 & 0.0046 & 2.7027 & 238.996 & 234.573\end{array}$ $\begin{array}{lllllllllllllll}0.99 & 45.28 & 25.53 & 22.74 & 2 & 1698.904 & 1698.9558 & 850.4852 & 0.0046 & 2.7043 & 1961.711 & 1946.190 & 5128.005 & 4451.501\end{array}$ $\begin{array}{lllllllllllllll}0.97 & 28.26 & 25.62 & 17.08 & 3 & 1698.9622 & 1698.9558 & 567.3259 & 0.0056 & 3.2922 & 3569.875 & 3121.377 & 7340.486 & 6618.478 & \\ 0\end{array}$ $\begin{array}{llllllllllllllll}0.96 & 28.24 & 25.63 & 18.65 & 3 & 1698.9634 & 1698.9558 & 567.3259 & 0.0064 & 0.0076 & 4.4654 & 13247.259 & 12738.158 & 31874.083 & 33744.436 & \text { Yes }\end{array}$ YMNSGPVVAMVWEGL $\begin{array}{llllllllllllllll}0.97 & 31.09 & 25.12 & 16.36 & 3 & 1698.9715 & 1698.9558 & 567.3259 & 0.0157 & 9.2245 & 8018.293 & 8509.101 & 17705.124 & 18096.905 & \text { Yes } \\ 0.96 & 29.25 & 25.15 & 16.07 & 3 & 1698.9718 & 1698.9558 & 567.3259 & 0.0160 & 9.4007 & 8204.702 & 7238.900 & 16819.431 & 16107.521 & \text { Yes }\end{array}$

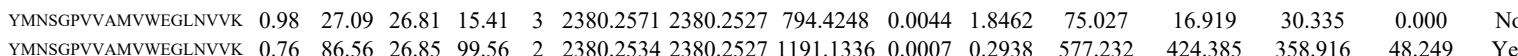

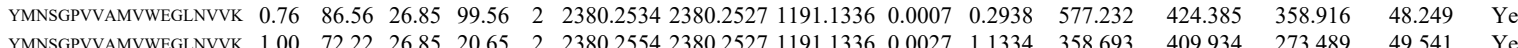

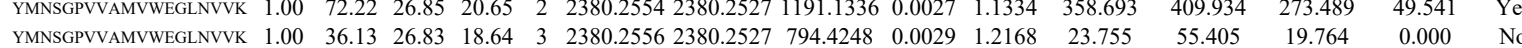

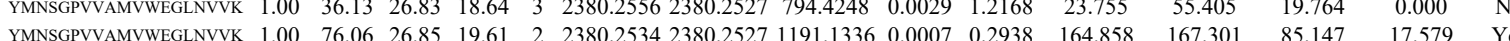

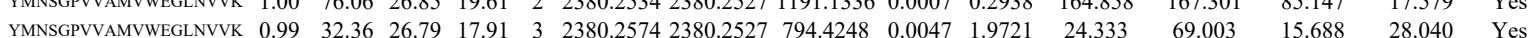

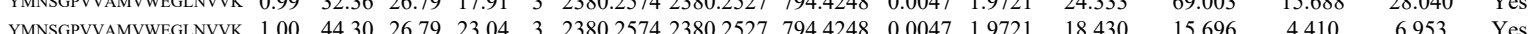
$\begin{array}{llllllllllllllll}\text { YMNSGPVVAMVWEGINVVK } & 0.94 & 21.23 & 26.79 & 19.90 & 3 & 2380.2544 & 2380.2527 & 794.4248 & 0.0017 & 0.7133 & 7.157 & 34.537 & 5.980 & 0.000 & \text { No }\end{array}$

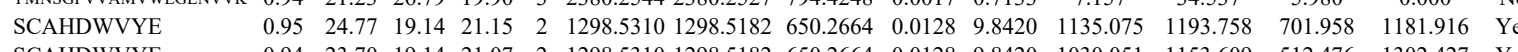

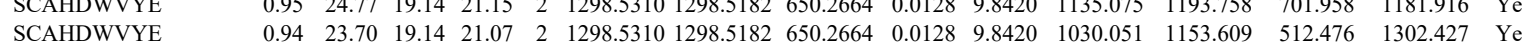

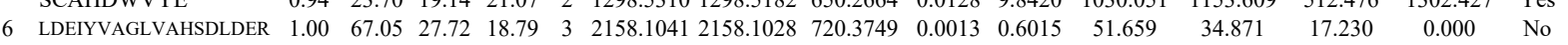

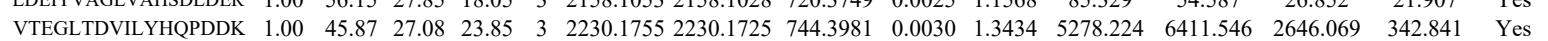
$\begin{array}{llllllllllllllll}\text { VTEGLTDVILYHQPDDK } & 1.00 & 51.51 & 27.08 & 29.52 & 3 & 2230.1755 & 2230.1725 & 744.3981 & 0.0030 & 1.3434 & 2595.683 & 3238.330 & 869.131 & 262.976 & \text { Yes }\end{array}$ $\begin{array}{llllllllllllllll}\text { LMMDPLTGLNR } & 1.00 & 50.91 & 28.15 & 26.80 & 2 & 1403.7422 & 1403.7387 & 702.8766 & 0.0035 & 2.4898 & 15049.166 & 15223.113 & 0.000 & 244.841 & \text { No }\end{array}$

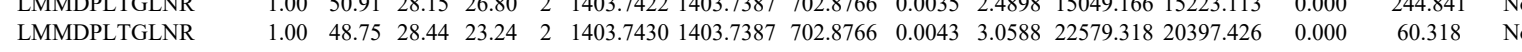
$\begin{array}{lllllllllllllllll}\text { LMMDPLTGLNR } & 0.99 & 47.32 & 28.42 & 23.87 & 2 & 1403.7446 & 1403.7387 & 702.8766 & 0.0059 & 4.1970 & 18177.260 & 19514.687 & 0.000 & 125.513 & \text { No }\end{array}$ LMMDPLTGLNR GYAFVTFCTK GYAFVTFCTK GYAFVTFCTK GYAFVTFCTK HIGVCISVANNR DLFEDELVPLFEK DLFEDELVPLFEK NLANTVTEEILEK NLANTVTEEILEK NLANTVTEEILEK NLANTVTEEILEK DLFEDELVPLFEK DLFELV NLANTVTEEILEK $\begin{array}{lllllllllllllllll}1.00 & 51.33 & 28.39 & 24.09 & 2 & 1403.7450 & 1403.7387 & 702.8766 & 0.0063 & 4.4816 & 22038.998 & 21550.459 & 0.000 & 167.811 & \text { No }\end{array}$ $\begin{array}{lllllllllllllll}0.99 & 43.36 & 27.73 & 26.35 & 2 & 1469.7366 & 1469.7291 & 735.8718 & 0.0075 & 5.0960 & 3517.531 & 2269.042 & 1310.794 & 636.286 & \text { Yes }\end{array}$ $\begin{array}{lllllllllllllll}0.99 & 45.46 & 27.80 & 23.10 & 2 & 1469.7372 & 1469.7291 & 735.8718 & 0.0081 & 5.5036 & 753.876 & 438.454 & 226.048 & 152.505 & \text { Yes }\end{array}$ $\begin{array}{llllllllllllllll}1.00 & 60.53 & 27.39 & 26.77 & 2 & 1469.7306 & 1469.7291 & 735.8718 & 0.0015 & 1.0192 & 1584.398 & 973.277 & 881.728 & 405.404 & \text { Yes }\end{array}$ $\begin{array}{llllllllllllllll}1.00 & 48.71 & 27.32 & 25.69 & 2 & 1469.7310 & 1469.7291 & 735.8718 & 0.0019 & 1.2910 & 1757.782 & 1578.916 & 1242.110 & 627.570 & \text { Yes }\end{array}$ $\begin{array}{llllllllllllllll}0.72 & 31.76 * 28.02 & 25.95 & 3 & 1471.7542 & 1471.7510 & 491.5909 & 0.0032 & 2.1698 & 1959.096 & 1598.291 & 576.737 & 255.968 & \text { Yes }\end{array}$

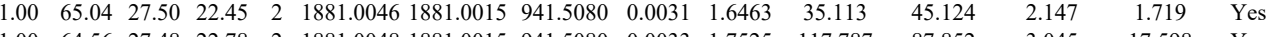

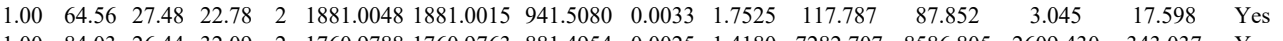

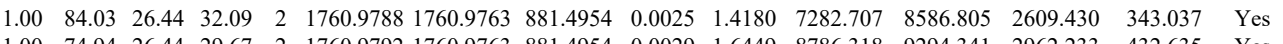

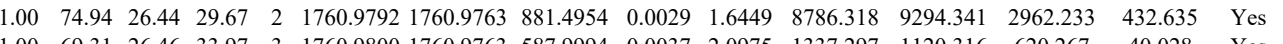
$\begin{array}{lllllllllllllll}1.00 & 69.31 & 26.46 & 33.97 & 3 & 1760.9800 & 1760.9763 & 587.9994 & 0.0037 & 2.0975 & 1337.297 & 1120.316 & 620.267 & 40.028 & \text { Yes } \\ 1\end{array}$

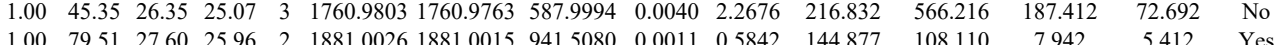
$\begin{array}{lllllllllllllll}1.00 & 79.51 & 27.60 & 25.96 & 2 & 1881.0026 & 1881.0015 & 941.5080 & 0.0011 & 0.5842 & 144.877 & 108.110 & 7.942 & 5.412 & \text { Yes } \\ 1.00 & 69.16 & 27.48 & 24.98 & 2 & 1881.00361881 .0015 & 941.5080 & 0.0021 & 1.1152 & 109.423 & 90.430 & 0.000 & 6.014 & \text { No }\end{array}$ $\begin{array}{lllllllllllllll}1.00 & 69.16 & 27.48 & 24.98 & 2 & 1881.0036 & 1881.0015 & 941.5080 & 0.0021 & 1.1152 & 109.423 & 90.430 & 0.000 & 6.014 & \text { No } \\ 1.00 & 85.15 & 26.54 & 29.12 & 2 & 1760.9774 & 1760.9763 & 881.4954 & 0.0011 & 0.6239 & 873.568 & 944.774 & 432.832 & 14.869 & \text { Yes } \\ \end{array}$

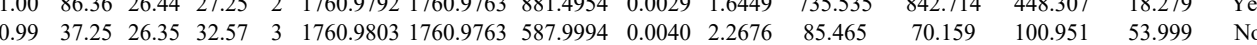


NLANTVTEEILEK

DLFEDELVPLFEK

GFDVFNALDLMENK

GFDVFNALDLMENK GFDVFNALDLMENK VAPVLIR VAPVLIR

VAPVLIR

LVGFISAIPANIR

$\begin{array}{lllllllllllll}1.00 & 40.69 & 26.43 & 24.92 & 3 & 1760.9809 & 1760.9763 & 587.9994 & 0.0046 & 2.6077 & 59.693 & 57.130 & 92.231\end{array}$ $\begin{array}{llllllllllll}1.00 & 83.46 & 27.57 & 21.23 & 2 & 1899.9662 & 1899.9644 & 950.9895 & 0.0018 & 0.9464 & 105.958 & \\ 1.04 & 73.78 & 27.61 & 27.75 & & \end{array}$ $\begin{array}{llllllllllll}1.00 & 73.78 & 27.61 & 21.30 & 2 & 1899.9666 & 1899.9644 & 950.9895 & 0.0022 & 1.1567 & 345.489 & 4\end{array}$ $\begin{array}{lllllllllll}1.00 & 42.70 & 27.51 & 27.15 & 3 & 1899.9682 & 1899.9644 & 634.3287 & 0.0038 & 1.9969 & 254.281 \\ 1.00 & 53.62 & 27.57 & 29.24 & 3 & 1899.9688 & 1899.9644 & 634.3287 & 0.0044 & 23122 & 271.455\end{array}$

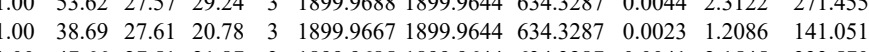
$\begin{array}{llllllllll} & \end{array}$ $\begin{array}{lllllllllll} & \end{array}$ $\begin{array}{llllllllllllllll}0.95 & 26.79 & 17.56 & 18.43 & 2 & 910.6158 & 910.6086 & 456.3116 & 0.0072 & 7.8893 & 16530.703 & 17875.631 & 928.639 & 6\end{array}$ $\begin{array}{lllllllllllll}0.88 & 15.10 & 22.12 & 17.83 & 3 & 1513.9117 & 1513.9102 & 505.6440 & 0.0015 & 0.9888 & 11.240 & 23.314\end{array}$

LSVEEFFMDLHNFR LSVEEFFMDLHNFR LSVEEFFMDLHN LIEECISQIVLHK LIEECISQIVLHK LIEECISQIVLHK LIEECISQIVLHK LIEECISQIVLHK LGLHQVLQDLR LGLHQVLQDLR LGLHQVLQDLR

LGLHQVLQDLR

VGCLQLINALITAEELDF

TAQNLSIFLGSFR

TAQNLSIFLGSFR

TAQNLSIFLGSFR

TAQNLSTFGSFR QDLEAEVSOLTGEVAK

FPDELAHVEK

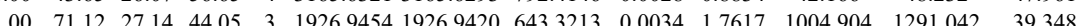

$\begin{array}{llllllllllllll}100 & 66.75 & 27.02 & 33.50 & 3 & 1926.9439 & 1926.9420 & 643.3213 & 0.0019 & 0.9845 & 2229.577 & 2447.058 & 88.404\end{array}$

$\begin{array}{llllllllllllll}100 & 70.56 & 27.13 & 33.04 & 3 & 1926.9445 & 1926.9420 & 6433213 & 0.0025 & 12954 & 2512407 & 2438.706 & 154.498\end{array}$ $\begin{array}{lllllllllllll}1.00 & 47.85 & 26.43 & 25.49 & 3 & 1858.0348 & 1858.0300 & 620.3506 & 0.0048 & 2.5792 & 1698.147 & 1690.456 & 172.901\end{array}$ $\begin{array}{lllllllllllll}.00 & 54.66 & 26.43 & 26.00 & 3 & 1858.0348 & 1858.0300 & 620.3506 & 0.0048 & 2.5792 & 1688.373 & 1792.152 & 138.049\end{array}$ $\begin{array}{lllllllllllll}.00 & 57.81 & 26.52 & 29.37 & 3 & 1858.0339 & 1858.0300 & 620.3506 & 0.0039 & 2.0956 & 725.856 & 857.870 & 42.851\end{array}$ $\begin{array}{lllllllllllll}1.00 & 55.91 & 26.51 & 26.30 & 3 & 1858.0342 & 1858.0300 & 620.3506 & 0.0042 & 2.2568 & 2306.214 & 2675.339 & 0.000\end{array}$ $\begin{array}{lllllllllllll}0.97 & 25.34 & 26.55 & 21.67 & 3 & 1858.0336 & 1858.0300 & 620.3506 & 0.0036 & 1.9344 & 19.860 & 20.532 & 5.566\end{array}$ $\begin{array}{llllllllllllll}.99 & 29.84 & 26.43 & 24.41 & 3 & 1858.0351 & 1858.0300 & 620.3506 & 0.0051 & 2.7404 & 40.914 & 49.624 & 0.000 \\ \end{array}$ $\begin{array}{llllllllllll}34.41 & 24.77 & 18.64 & 3 & 1434.8464 & 1434.8429 & 479.2882 & 0.0035 & 2.4342 & 3808.813 & 3601.765 & 781 .\end{array}$ $\begin{array}{llllllllllllll}1.00 & 34.00 & 24.42 & 18.91 & 3 & 1434.8473 & 1434.8429 & 479.2882 & 0.0044 & 3.0601 & 2060.764 & 258.7530 & 783.52 \\ 1.00 & 30.30 & 24.90 & 16.06 & 3 & 1434.8446 & 1434.8429 & 479.2882 & 0.0017 & 1.1823 & 2019.551 & 1681.658 & 567.418\end{array}$ $\begin{array}{lllllllllllll}1.00 & 32.70 & 24.77 & 18.61 & 3 & 1434.8467 & 1434.8429 & 479.2882 & 0.0038 & 2.6428 & 2119.849 & 2887.092 & 378.827\end{array}$ $\begin{array}{lllllllllllll}0.55 & 32.55 & 26.76 & 45.55 & 3 & 2404.2637 & 2404.2616 & 802.4278 & 0.0021 & 0.8724 & 8.223 & 15.003 & 5.477\end{array}$ $\begin{array}{lllllllllllll}1.00 & 74.07 & 27.32 & 24.06 & 2 & 1596.8754 & 1596.8746 & 799.4446 & 0.0008 & 0.5003 & 442.287 & 492.303 & 16.218\end{array}$

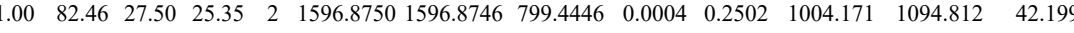
$\begin{array}{lllllllllllll}1.00 & 86.70 & 27.49 & 25.38 & 2 & 1596.8752 & 1596.8746 & 799.4446 & 0.0006 & 0.3753 & 419.821 & 444.933 & 11.850\end{array}$

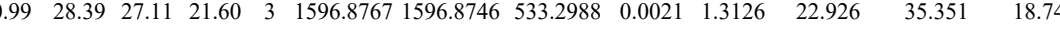
$\begin{array}{lllllllllllll}1.00 & 34.57 & 26.98 & 22.15 & 3 & 1596.8776 & 1596.8746 & 533.2988 & 0.0030 & 1.8751 & 25.625 & 26.870 & 9.218\end{array}$ \begin{tabular}{lllllllllllll}
1.00 & 34.57 & 26.98 & 22.15 & 3 & 1596.8776 & 1596.8746 & 533.2988 & 0.0030 & 1.8751 & 25.625 & 26.870 & 9.218 \\
\hline & 27.36 & 23.64 & 2 & 1596.8758 & 1596.8746 & 799.4446 & 0.0012 & 0.7505 & 298.152 & 362.342 & 36.102
\end{tabular}

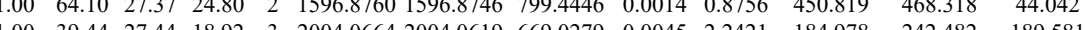

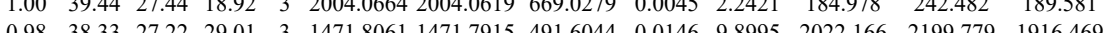
$\begin{array}{llllllllllllll}0.98 & 38.33 & 27.22 & 29.01 & 3 & 1471.8061 & 1471.7915 & 491.6044 & 0.0146 & 9.8995 & 2022.166 & 2199.779 & 1916.469 & 21 \\ 1.00 & 79.77 & 27.92 & 37.03 & 2 & 1480.7872 & 1480.7799 & 741.3972 & 0.0073 & 49231 & 106.381 & 1900.248 & 2872.699 & 78\end{array}$

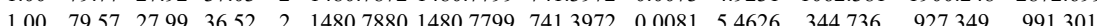
VSGAQEMVSSAK $\begin{array}{llllllllllllllll}0.89 & 21.77 & 27.08 & 27.73 & 3 & 1582.8589 & 1582.8558 & 528.6259 & 0.0031 & 1.9547 & 4728.772 & 7042.492 & 18361.201 & 18369.797 & \text { No }\end{array}$

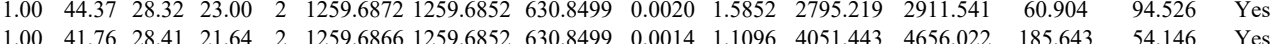

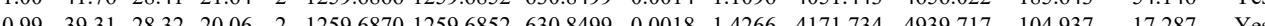

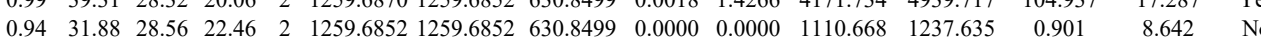


USO1_HUMAN O60763 USO1

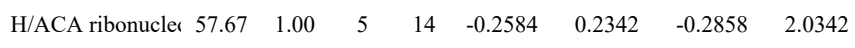

TPAILEASAGAIQNLCAGR

TPAILEASAGAIQNLCAGR

$\begin{array}{llllllllllll}\text { TPAILEASAGAIQNLCAGR } & 1.00 & 62.83 & 27.56 & 17.06 & 3 & 2045.0545 & 2045.0519 & 682.6912 & 0.0026 & 1.2695 & 42.465 \\ \text { TPAILEASAGAIQNLCAGR } & 1.00 & 70.71 & 27.51 & 18.51 & 3 & 2045.0551 & 2045.0519 & 682.6912 & 0.0032 & 1.5624 & 30.294 \\ \text { TPAIIEASAGAIQNLCAGR } & 1.0 & \# \# \# \# & 27.49 & 26.39 & 2 & 2045.0554 & 2045.0519 & 1023.5332 & 0.0035 & 1.7098 & 53.684\end{array}$

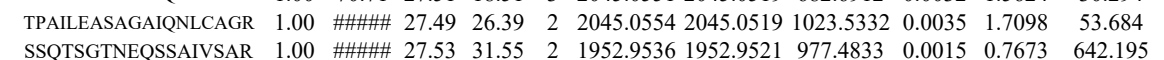

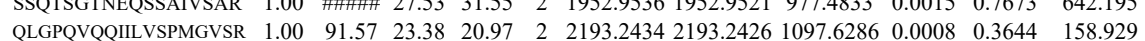

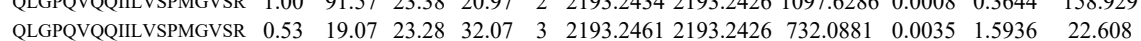
$\begin{array}{lllllllllllll}\text { QLGPQVQQIILVSPMGVSR } & 1.00 & 37.75 & 23.34 & 15.63 & 3 & 2193.2446 & 2193.2426 & 732.0881 & 0.0020 & 0.9106 & 5.550\end{array}$ $\begin{array}{llllllllllll}\text { QLGPQVQQIILVSPMGVSR } & 1.00 & 31.22 & 23.22 & 17.01 & 3 & 2193.2455 & 2193.2426 & 732.0881 & 0.0029 & 1.3204 & 17.049\end{array}$ $\begin{array}{lllllllllllll}\text { VTNLHLMLQLVR } & 1.00 & 37.61 & 22.60 & 16.58 & 3 & 1579.9357 & 1579.9354 & 527.6524 & 0.0003 & 0.1895 & 92.854\end{array}$ $\begin{array}{lllllllllllll}\text { EQDDLLVLLADQDQK } & 0.97 & 24.09 & 27.08 & 19.00 & 3 & 2030.0794 & 2030.0775 & 677.6998 & 0.0019 & 0.9345 & 102.763\end{array}$

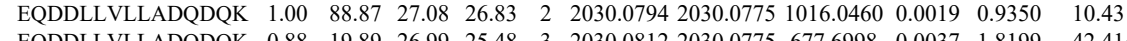
$\begin{array}{llllllllllll}\text { EQDDLLVLLADQDQK } & 0.88 & 19.89 & 26.99 & 25.48 & 3 & 2030.0812 & 2030.0775 & 677.6998 & 0.0037 & 1.8199 & 42.414\end{array}$

EQDDLLVLLADQDQK

APQVVAEAAK

APQVVAEAAK $\begin{array}{lllllllllllll}\text { LDTSQWPLLLK } & 1.00 & 57.31 & 23.82 & 32.74 & 2 & 1600.9514 & 1600.9432 & 801.4789 & 0.0082 & 5.1155 & 551.128 & 651.787 \\ \text { ALETLTGALFRPPPLIAAVK } & 0.53 & 43.03 & 14.62 & 56.03 & 3 & 2396.4433 & 2396.4399 & 799.8206 & 0.0034 & 1.4170 & 2423.210 & 1912.963\end{array}$

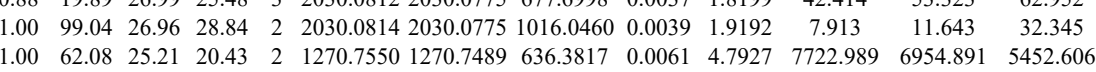

$\begin{array}{llllllllllll}1.00 & 2.13 & 25.21 & 21.20 & 2 & 1270.7550 & 1270.7489 & 636.3817 & 0.0061 & 4.7927 & 12847.594 & 9894.61\end{array}$ $\begin{array}{lllllllllllllll}\text { ALETLTGALFQRPPLIAAVK } & 0.53 & 40.04 & 14.62 & 53.04 & 3 & 2396.4433 & 2396.4399 & 799.8206 & 0.0034 & 1.4170 & 1059.924 & 1120.393 & 990.177\end{array}$

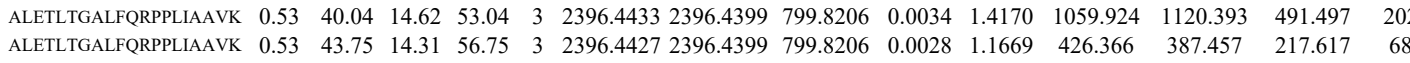
\begin{tabular}{lllllllllllllll} 
ALETLTGALFORPPLIAAVK & 0.53 & 40.18 & 14.62 & 53.18 & 3 & 2396.4430 & 2396.4399 & 799.8206 & 0.0031 & 1.2920 & 703.029 & 602.040 & 317.386 & 87.15 \\
\hline
\end{tabular} $\begin{array}{lllllllllllllll}\text { ALETLTGALFQRPPLIAAVK } & 1.00 & 13.53 & 14.15 & 26.53 & 4 & 2396.4441 & 2396.4399 & 600.1173 & 0.0042 & 1.7497 & 75.384 & 92.090 & 43.074 & 27.84 \\ \text { ALETLTGALFORPPLIAAVK } & 1.00 & 21.62 & 14.47 & 34.62 & 4 & 2396.4445 & 2396.4399 & 600.1173 & 0.0046 & 1.9163 & 105.605 & 89.521 & 61.739 & 8.36\end{array}$

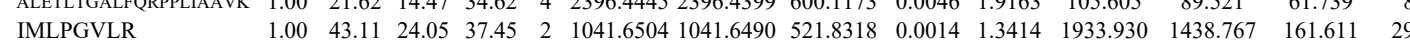

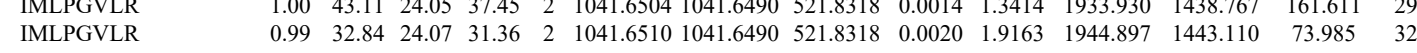

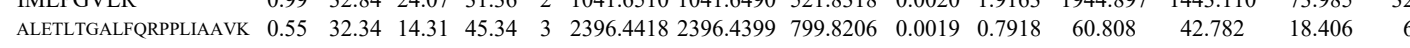
$\begin{array}{llllllllllllll}\text { ALETLTGALFQRPPLIAAVK } & 0.53 & 47.87 & 14.62 & 60.87 & 3 & 2396.4433 & 2396.4399 & 799.8206 & 0.0034 & 1.4170 & 100.645 & 103.695 & 67.002\end{array}$ IMLPGVLR IMLPGVLR IMLPGVLR IMLPGVLR

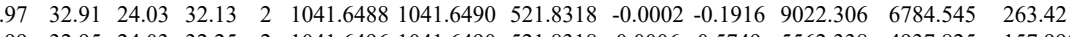

KSPDSDVAAATLK IPQQLESK $\begin{array}{llllllllllllll}0.64 .95 & 24.03 & 32.25 & 2 & 1041.6496 & 1041.6490 & 521.8318 & 0.0006 & 0.5749 & 5562.338 & 4937.825 & 157.990 & 40.8 & \\ 0.64 & 18.92 & 26.30 & 20.97 & 2 & 1057.6466 & 1057.6440 & 529.8293 & 0.0026 & 2.4536 & 3667.763 & 2911293 & 108.677 & 25.0\end{array}$ $\begin{array}{llllllllllllll}0.98 & 35.70 & 24.03 & 32.36 & 2 & 1041.6494 & 1041.6490 & 521.8318 & 0.0004 & 0.3833 & 5346.925 & 3971.771 & 54.960 & 56.00\end{array}$ $\begin{array}{lllllllllllllll}0.99 & 32.84 & 24.05 & 32.07 & 2 & 1041.6498 & 1041.6490 & 521.8318 & 0.0008 & 0.7665 & 5791.289 & 4456.203 & 161.893 & 60.2 & \end{array}$ $\begin{array}{llllllllllllllll}1.00 & 48.84 & 23.78 & 27.77 & 3 & 1662.9634 & 1662.9518 & 555.3245 & 0.0116 & 6.9628 & 8516.189 & 8521.554 & 4375.363 & 3487.443 & \text { Yes } & \\ 0.98 & 37.50 & 25.90 & 28.95 & 2 & 1229.7310 & 1229.7223 & 615.8684 & 0.0087 & 7.0631 & 4505.841 & 3932.145 & 2180.290 & 1665.003 & \text { Ycs } \\ 0.98 & 37.86 & 25.85 & 29.27 & 2 & 1229.7322 & 1229.7223 & 615.8684 & 0.0099 & 8.0374 & 5108.633 & 4025.317 & 2431.149 & 2357.393 & Y & \end{array}$ $\begin{array}{lllllllllllllllll}\text { EGDTIIVPGVEGPIVTQIR } & 1.00 & 88.84 & 24.91 & 22.21 & 2 & 2136.1934 & 2136.1912 & 1069.1029 & 0.0022 & 1.0289 & 94.741 & 120.558 & 153.704 & 126.583 & \text { Yes }\end{array}$

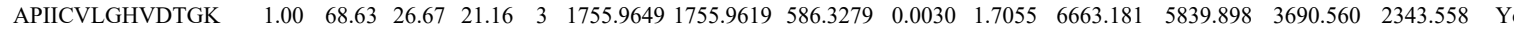
$\begin{array}{lllllllllllllllll}\text { APIICVLGHVDTGK } & 1.00 & 57.06 & 26.76 & 20.37 & 3 & 1755.9661 & 1755.9619 & 586.3279 & 0.0042 & 2.3877 & 5006.461 & 4777.895 & 2803.373 & 2648.472 & \text { Yes }\end{array}$

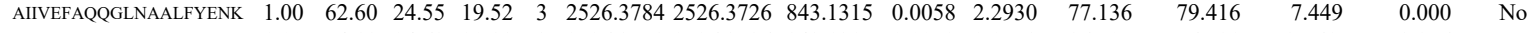
$\begin{array}{llllllllllllllll}\text { AIVEFAQQGLNAALFYENK } & 1.00 & 74.18 & 24.62 & 20.88 & 3 & 2526.3778 & 2526.3726 & 843.1315 & 0.0052 & 2.0558 & 86.505 & 76.591 & 25.617 & 3.976 & \text { Yes }\end{array}$

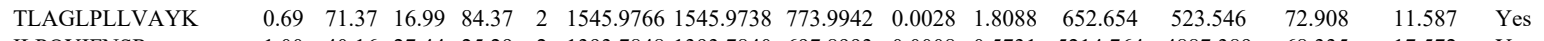
ILPQYIFNSR

ILPQYIFNSR

ILPQYIFNSR

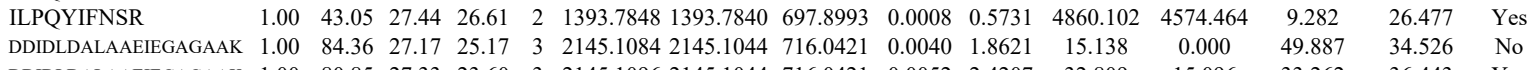

$\begin{array}{lllllllllllll}1.00 & 40.16 & 27.44 & 25.29 & 2 & 1393.7848 & 1393.7840 & 697.8993 & 0.0008 & 0.5731 & 5214.764 & 4887.389 & 68.335\end{array}$ $\begin{array}{llllllllllllllll}1.00 & 49.65 & 27.42 & 26.96 & 2 & 1393.7842 & 1393.7840 & 697.8993 & 0.0002 & 0.1433 & 5415.429 & 4793.496 & 0.000 & 51.251 & \text { No }\end{array}$ $\begin{array}{lllllllllllllll} & \end{array}$

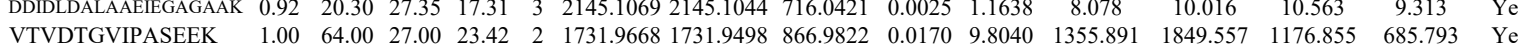
$\begin{array}{lllllllllllllllll}\text { VTVDTGVIPASEEK } & 1.00 & 90.14 & 27.00 & 30.06 & 2 & 1731.9668 & 1731.9498 & 866.9822 & 0.0170 & 9.8040 & 1488.490 & 1774.669 & 1325.124 & 598.864 & \text { Yes }\end{array}$

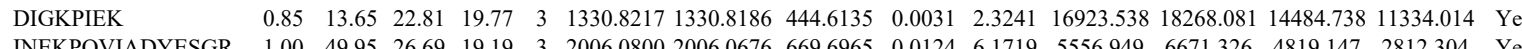




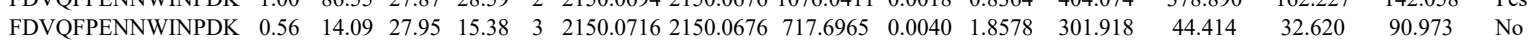

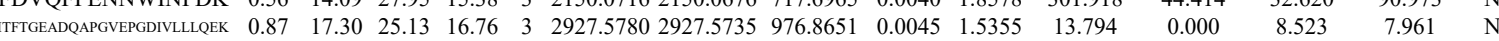
$\begin{array}{lllllllllllllll} & \end{array}$ $\begin{array}{lllllllllllllllll}\text { FDVQFPENNWINPDK } & 1.00 & 57.07 & 27.87 & 21.74 & 2 & 2150.0694 & 2150.0676 & 10760411 & 0.0018 & 0.8364 & 523.244 & 424.971 & 316.338 & 259.941 & \text { Yes }\end{array}$ $\begin{array}{llllllllllllllll}\text { FDVQFPENNWINPDK } & 1.00 & 54.96 & 27.98 & 18.99 & 2 & 2150.0714 & 2150.0676 & 1076.0411 & 0.0038 & 1.7657 & 468.355 & 320.956 & 270.066 & 115.481 & \text { Yes }\end{array}$ $\begin{array}{lllllllllllllllll}\text { GEDMMHPLK } & 0.58 & 18.46 & 26.68 & 18.36 & 3 & 1344.6844 & 1344.6774 & 449.2331 & 0.0070 & 5.1940 & 5761.532 & 6266.419 & 6526.270 & 4924.643 & \text { Yes }\end{array}$

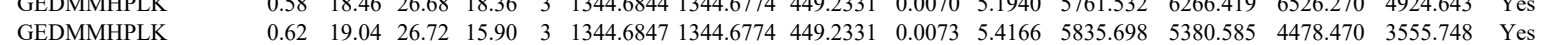

$\begin{array}{lllllllllll}\text { WDR1_HUMAN } & \text { O75083 } & \text { WDR1 } & \text { WD repeat-contail } 66.19 & 1.00 & 4 & 7.9 & 0.3487 & 0.2051 & -0.1545 & 2.1801\end{array}$ $\begin{array}{llllllll}60.13 & 1.00 & 4 & 8.8 & -0.1455 & 0.2779 & -0.0634 & 1.8338\end{array}$

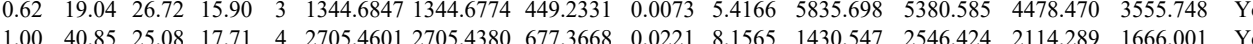
$\begin{array}{llllllllllllllll}\text { SIQCLTVHK } & 0.80 & 26.53 & 28.52 & 28.19 & 3 & 1361.7523 & 1361.7403 & 454.9207 & 0.0120 & 8.7927 & 6883.503 & 6760.251 & 1966.461 & 540.096 & \text { Yes }\end{array}$ $\begin{array}{lllllllllllllllll}\text { SIQCLTVHK } & 1.00 & 40.80 & 28.52 & 25.91 & 3 & 1361.7523 & 1361.7403 & 454.9207 & 0.0120 & 8.7927 & 11775.732 & 13838.830 & 4334.787 & 1107.666 & \text { Yes }\end{array}$ $\begin{array}{llllllllllllllllll}\text { LYSILGTTLK } & 1.00 & 47.92 & 20.33 & 19.57 & 2 & 1395.8592 & 1395.8581 & 698.9363 & 0.0011 & 0.7869 & 9050.701 & 12703.633 & 209.204 & 597.191 & \text { Yes }\end{array}$ LYSILGTTLK YTSLMLR YTSLMLR LYSILGTTLK LYSILGTTLK

YTSLMLR

YTSLMLR

YTSLMLR YTSLMLR $\begin{array}{llllllllllllll} & \end{array}$ $\begin{array}{llllllllllllllll}0.89 & 30.21 & 26.19 & 27.24 & 2 & 1026.5748 & 1026.5654 & 514.2900 & 0.0094 & 9.1387 & 6412.341 & 8623.817 & 6466.521 & 2300.895 & \text { Yes }\end{array}$ $\begin{array}{llllllllllllllll}0.94 & 31.64 & 26.28 & 26.57 & 2 & 1026.5752 & 1026.5654 & 514.2900 & 0.0098 & 9.5276 & 5789.537 & 8424.231 & 6254.887 & 2180.362 & \text { Yes }\end{array}$ $\begin{array}{lllllllllllllll}1.00 & 48.84 & 20.33 & 17.12 & 2 & 1395.8592 & 1395.8581 & 698.9363 & 0.0011 & 0.7869 & 18793.206 & 23019.916 & 374.276 & 215.619 & \text { Yes }\end{array}$ $\begin{array}{llllllllllllllll}1.00 & 50.55 & 20.37 & 17.68 & 2 & 1395.8596 & 1395.8581 & 698.9363 & 0.0015 & 1.0731 & 18605.798 & 20680.908 & 432.600 & 123.998 & \text { Yes }\end{array}$ $\begin{array}{llllllllllllllll}0.73 & 25.51 & 26.36 & 27.07 & 2 & 1026.5746 & 1026.5654 & 514.2900 & 0.0092 & 8.9443 & 20880.688 & 26212.392 & 21092.941 & 7853.396 & \text { Yes }\end{array}$ $\begin{array}{lllllllllllllll}0.85 & 28.72 & 26.19 & 25.54 & 2 & 1026.5748 & 1026.5654 & 514.2900 & 0.0094 & 9.1387 & 16278.298 & 22375.185 & 16569.811 & 5432.260 & \text { Yes }\end{array}$ $\begin{array}{lllllllllllllll}0.63 & 23.57 & 26.36 & 24.79 & 2 & 1026.5746 & 1026.5654 & 514.2900 & 0.0092 & 8.9443 & 8044.903 & 10798.686 & 7456.355 & 2389.339 & \text { Yes }\end{array}$ $\begin{array}{llllllllllllllll}0.72 & 24.09 & 26.28 & 27.35 & 2 & 1026.5752 & 1026.5654 & 514.2900 & 0.0098 & 9.5276 & 7553.934 & 10067.810 & 6773.523 & 2380.110 & \text { Yes }\end{array}$ $\begin{array}{lllllllllllllllll}0.93 & 39.01 & 26.89 & 37.51 & 2 & 1434.8220 & 1434.8173 & 718.4159 & 0.0047 & 3.2711 & 1782.062 & 1545.255 & 549.918 & 232.243 & \text { Yes }\end{array}$ $\begin{array}{lllllllllllllll} & \end{array}$

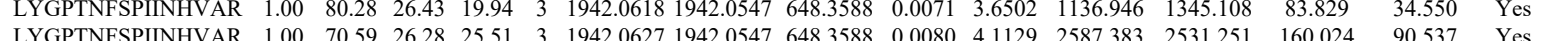

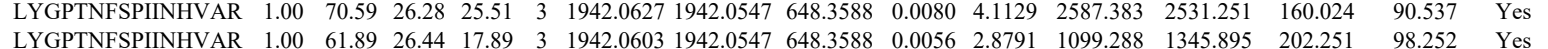

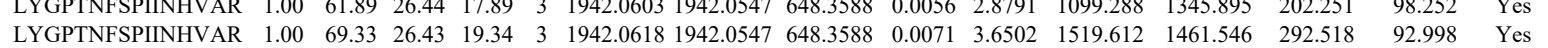
$\begin{array}{llllllllllllllll}\text { SSPVEFECINEK } & 1.00 & 72.33 & 26.80 & 24.13 & 2 & 1714.8172 & 1714.8150 & 858.4148 & 0.0022 & 1.2814 & 2095.594 & 1445.725 & 504.202 & 466308 & \text { Yes }\end{array}$

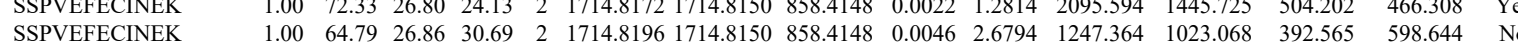
18 QELVDAFVEHR $\quad \begin{array}{lllllllllllllll}1.00 & 66.21 & 27.32 & 20.77 & 3 & 14857753 & 14857698 & 4962639 & 0.0055 & 3.6943 & 1168.106 & 989621 & 219004 & 147.026 & \text { Yes }\end{array}$ $\begin{array}{lllllllllllllllll}\text { QELVDAFVEHR } & 1.00 & 66.30 & 27.40 & 20.89 & 3 & 1485.7765 & 1485.7698 & 496.2639 & 0.0067 & 4.5003 & 1168.564 & 858.397 & 162.158 & 127.919 & \text { Yes }\end{array}$

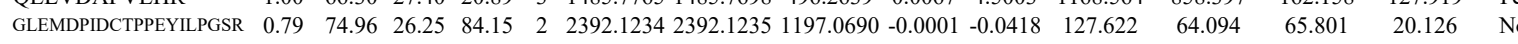

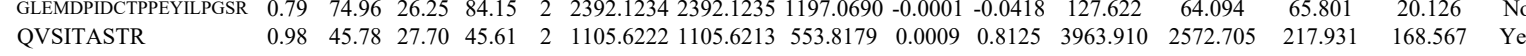
$\begin{array}{llllllllllllllllll}\text { VLELVLR } & 0.96 & 31.07 & 20.49 & 35.42 & 2 & 984.6478 & 984.6453 & 493.3299 & 0.0025 & 2.5338 & 13738.860 & 8433.081 & 309.777 & 92.573 & \text { Yes }\end{array}$

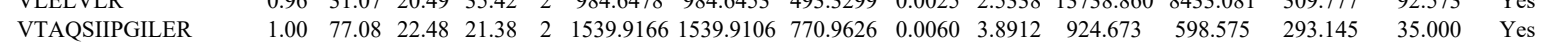
$\begin{array}{llllllllllllllll}\text { VTAQSIIPGILER } & 1.00 & 64.61 & 21.99 & 24.16 & 2 & 1539.9180 & 1539.9106 & 770.9626 & 0.0074 & 4.7992 & 847.182 & 669.671 & 260.934 & 88.744 & \text { Yes }\end{array}$ VIAQSITPILER VLELVLR VTAQSIIPGILER VTAQSIIPGILER VALSHHLVAR VALSHHLVAR CLTQQAVALQR CLTQQAVALQR VALSHHLVAR VALSHHLVAR CLTQQAVALQR CLTQQAVALQR VALSHHLVAR

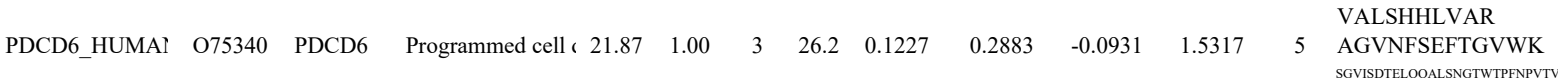

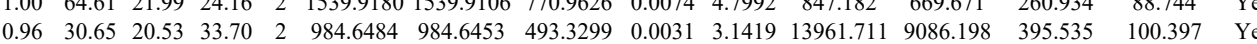
$\begin{array}{llllllllllllllllll}0.95 & 28.93 & 20.53 & 32.68 & 2 & 984.6484 & 984.6453 & 493.3299 & 0.0031 & 3.1419 & 17220.573 & 10474.074 & 570.638 & 92.220 & \text { Yes }\end{array}$ $\begin{array}{lllllllllllllll}1.00 & 69.00 & 22.90 & 19.02 & 2 & 1539.9148 & 1539.9106 & 770.9626 & 0.0042 & 2.7239 & 1441.846 & 933.071 & 318.574 & 148.515 & \text { Yes }\end{array}$ $\begin{array}{lllllllllllllll}1.00 & 72.24 & 22.90 & 22.33 & 2 & 1539.9148 & 1539.9106 & 770.9626 & 0.0042 & 2.7239 & 1529.507 & 888.920 & 406.257 & 130.874 & \text { Yes } \\ 1.00 & 51.19 & 25.82 & 25.56 & 3 & 1245.7438 & 1245.7428 & 416.259 & 0.002 & 0.2008 & 5705.756 & 420.934 & 978.514 & 335.156 & \text { Yes }\end{array}$ $\begin{array}{llllllllllllllllll}1.00 & 51.19 & 25.82 & 25.56 & 3 & 1245.7438 & 1245.7428 & 416.2549 & 0.0010 & 0.8008 & 5705.756 & 4280.934 & 978.514 & 335.156 & \text { Yes } \\ \end{array}$ $\begin{array}{lllllllllllllll}1.00 & 50.13 & 25.63 & 18.52 & 3 & 1245.7450 & 1245.7428 & 416.2549 & 0.0022 & 1.7617 & 8255.433 & 5587.095 & 1396.876 & 419.937 & \text { Yes } \\ 1.00 & 80.84 & 28.46 & 35.81 & 2 & 1419.7552 & 1419.7448 & 710.8797 & 0.0104 & 7.3148 & 12799.448 & 7887.707 & 194.483 & 239.242 & \text { Yes }\end{array}$ $\begin{array}{lllllllllllllll}1.00 & 75.43 & 28.48 & 25.79 & 2 & 1419.7554 & 1419.7448 & 710.8797 & 0.0106 & 7.4555 & 6961.971 & 4629.664 & 241.614 & 161.106 & \text { Yes }\end{array}$ $\begin{array}{lllllllllllllll}1.00 & 51.67 & 25.82 & 18.18 & 3 & 1245.7438 & 1245.7428 & 416.2549 & 0.0010 & 0.8008 & 6566.361 & 4853.299 & 1813.241 & 613.773 & \text { Yes }\end{array}$

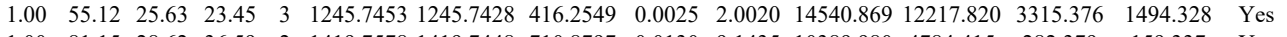
$\begin{array}{llllllllllllllll}1.00 & 81.15 & 28.62 & 36.59 & 2 & 1419.7578 & 1419.7448 & 710.8797 & 0.0130 & 9.1435 & 10389.980 & 4784.415 & 282.379 & 159.337 & \text { Yes }\end{array}$ $\begin{array}{lllllllllllllllll}1.00 & 7.00 & 28.74 & 35.63 & 2 & 1419.7580 & 1419.7448 & 710.8797 & 0.0132 & 9.2842 & 4321.545 & 2571.587 & 174.627 & 107.316 & \text { Yes }\end{array}$ $\begin{array}{lllllllllllllll}1.00 & 43.53 & 25.76 & 20.41 & 3 & 1245.7444 & 1245.7428 & 416.2549 & 0.0016 & 1.2813 & 5073.202 & 4096.303 & 3167.003 & 1955.044 & \text { No } \\ 1.00 & 39.67 & 25.76 & 19.75 & 3 & 1255.7447 & 1255.7428 & 416.254 & 0.0019 & 1.525 & 4855.56 & 3929.042 & 2443.748 & 1326.198 & \text { No }\end{array}$

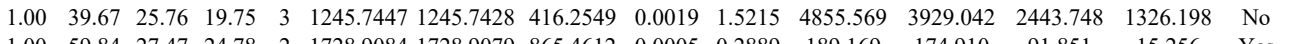

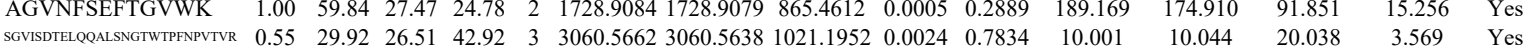

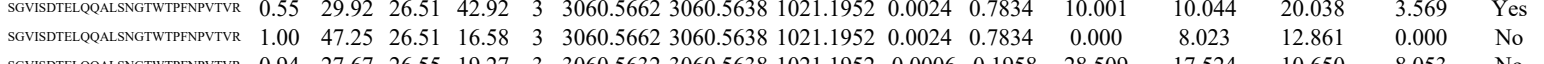

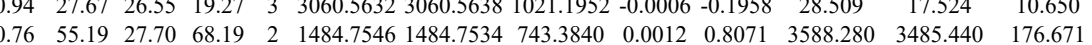



$\begin{array}{lllllllllll}\text { Tubulin-specific c } & 12.85 & 1.00 & 4 & 32.4 & -0.0848 & 0.0953 & 0.7977 & 1.1201 & 6 & \text { LVLDSVK }\end{array}$ LVLDSVK LEAAYLDLQR MMIPDCQR MMIPDCQR AEDGENYDIK AEDGENYDIK 15 NCLALADDKK QTAAQLILK QTAAQLILK

FVIHCNSPVWGADK FVIHCNSPVWGADK SIAFPSIGSGR SIAFPSIGSGR SIAFPSIGSGR
AGVIFPVGR AGVIFPVGR SIAFPSIGSGR SIAFPSIGSGR
SIAFPSIGSGR SIAFPSIGSGR
AGVIFPVGR AGVIFPVGR AGVIFPVGR AGVIFPVGR AGVIFPVGR

ANEPTHFTVDCTEAGEGDVSVG

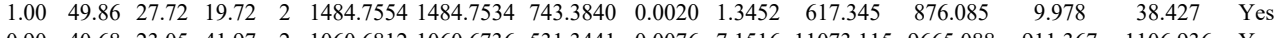

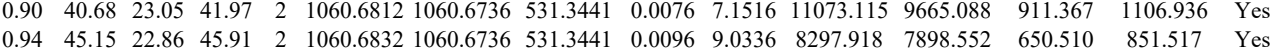

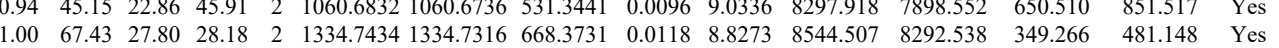

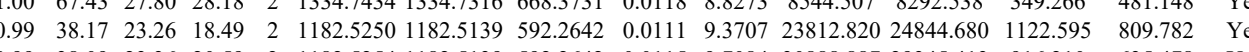

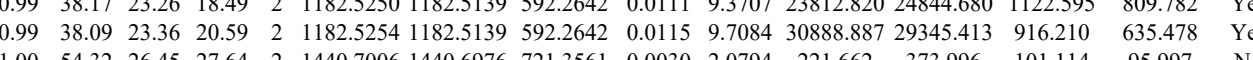
$\begin{array}{lllllllllllllll}1.00 & 54.32 & 26.45 & 27.64 & 2 & 1440.7006 & 1440.6976 & 721.3561 & 0.0030 & 2.0794 & 221.662 & 373.996 & 101.114 & 95.997 & \text { No } \\ 1.00 & 58.77 & 26.65 & 27.45 & 2 & 1440.724 & 1440.676 & 71.3561 & 0.0048 & 3.3271 & 316.672 & 328.63 & 117.09 & 52.013 & \text { Y }\end{array}$ $\begin{array}{lllllllllllllll}1.00 & 58.77 & 26.65 & 27.45 & 2 & 1440.7024 & 1440.6976 & 721.3561 & 0.0048 & 3.3271 & 316.672 & 328.683 & 117.093 & 52.013 & \text { Yes } \\ 0.99 & 35.02 & 27.40 & 20.19 & 3 & 1567.8541 & 1567.8427 & 523.6215 & 0.0114 & 7.2571 & 19553.585 & 23603.353 & 3466.972 & 863.173 & \text { Y }\end{array}$ $\begin{array}{lllllllllllllll}0.99 & 35.02 & 27.40 & 20.19 & 3 & 1567.8541 & 1567.8427 & 523.6215 & 0.0114 & 7.2571 & 19553.585 & 23603.353 & 3466.972 & 863.173 & \text { Yes } \\ 1.00 & 38.29 & 21.46 & 15.66 & 4 & 2220.2765 & 2220.2721 & 556.0753 & 0.0044 & 1.9781 & 219.242 & 128.193 & 58.371 & 63.520 & \text { No }\end{array}$

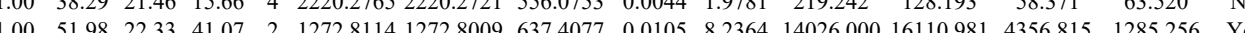

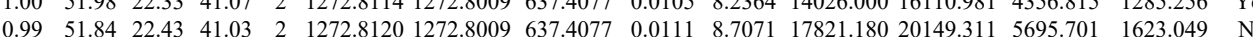
$\begin{array}{llllllllllllllll}1.00 & 40.81 & 27.62 & 18.47 & 3 & 1905.9493 & 1905.9473 & 6363230 & 0.0020 & 1.0477 & 6248.343 & 6626.675 & 1441.396 & 297.919 & \text { Ye }\end{array}$ $\begin{array}{lllllllllllllll}0.97 & 26.48 & 27.63 & 26.23 & 3 & 1905.9520 & 1905.9473 & 636.3230 & 0.0047 & 2.4621 & 7546.414 & 8925.928 & 1240.068 & 296.971 & \text { Y }\end{array}$ $\begin{array}{llllllllllllllll}1.00 & 54.82 & 28.84 & 41.67 & 2 & 1234.6798 & 1234.6792 & 618.3469 & 0.0006 & 0.4852 & 15015.592 & 21876.208 & 53.424 & 345.504 & \text { Yes }\end{array}$ $\begin{array}{lllllllllllllll}1.00 & 56.29 & 28.84 & 36.25 & 2 & 1234.6798 & 1234.6792 & 618.3469 & 0.0006 & 0.4852 & 25057.576 & 34500.793 & 0.000 & 619.320 & \mathrm{No}\end{array}$ $\begin{array}{lllllllllllllll}0.96 & 33.67 & 24.84 & 32.54 & 2 & 1058.6454 & 1058.6359 & 530.3252 & 0.0095 & 8.9567 & 36683.864 & 41673.245 & 3143.238 & 603.373 & \text { Y }\end{array}$ $\begin{array}{llllllllllllllll}0.97 & 33.38 & 25.08 & 28.11 & 2 & 1058.6456 & 1058.6359 & 530.3252 & 0.0097 & 9.1452 & 18301.543 & 24211.943 & 1366.890 & 543.886 & \text { Yes }\end{array}$ $\begin{array}{lllllllllllllll}1.00 & 52.00 & 28.74 & 35.80 & 2 & 1234.6782 & 1234.6792 & 618.3469 & -0.0010 & -0.8086 & 9903.806 & 13633.539 & 760.057 & 335.033 & \text { Yes }\end{array}$

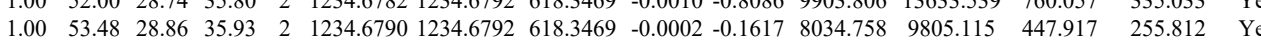
$\begin{array}{lllllllllllllll}0.97 & 33.71 & 24.84 & 24.07 & 2 & 1058.6454 & 1058.6359 & 530.3252 & 0.0095 & 8.9567 & 36207.148 & 45205.171 & 2534.336 & 110.415 & \text { Yes }\end{array}$

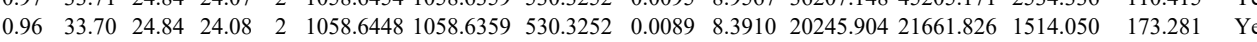
$\begin{array}{llllllllllllllll}0.96 & 33.56 & 24.84 & 32.49 & 2 & 1058.6454 & 1058.6359 & 530.3252 & 0.0095 & 8.9567 & 19573.928 & 21896.010 & 1021.469 & 224.799 & \text { Yes }\end{array}$ $\begin{array}{llllllllllllllll}0.88 & 23.19 & 26.06 & 30.78 & 2 & 1058.6368 & 1058.6359 & 530.3252 & 0.0009 & 0.8485 & 1378.104 & 1713.749 & 111.297 & 32.242 & \text { Yes }\end{array}$ $\begin{array}{lllllllllllllll}0.95 & 27.56 & 26.06 & 26.15 & 2 & 1058.6370 & 1058.6359 & 530.3252 & 0.0011 & 1.0371 & 1352.790 & 1724.526 & 105.685 & 15.638 & \text { Yes }\end{array}$ $\begin{array}{lllllllllllllll}0.99 & 38.97 & 27.84 & 30.91 & 2 & 1196.6050 & 1196.6024 & 599.3085 & 0.0026 & 2.1692 & 9472.130 & 10747.756 & 257.348 & 211.405 & \text { Yes }\end{array}$ ANEPTHFTVDCTEAGEGDVSVGIK ANEPTHFTVDCTEAGEGDVS
ADIEMPFDPSK ADIEMPFDPSK SPFEVSVDK SPFEVSVDK

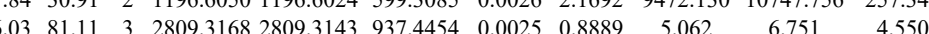

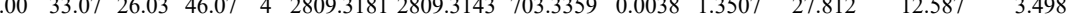

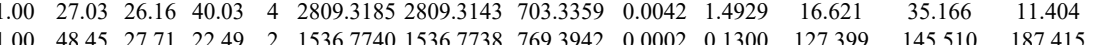

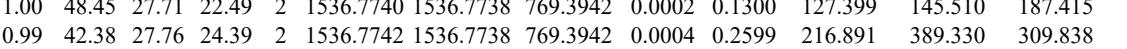

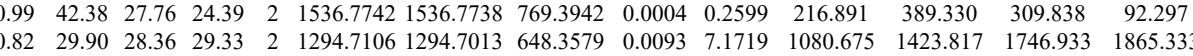
$\begin{array}{llllllllllllll}0.99 & 59.37 & 28.46 & 48.99 & 2 & 1294.7106 & 1294.7013 & 648.3579 & 0.0093 & 7.1719 & 1080.675 & 1423.817 & 1746.933 & 1865.333 \\ & 1294.3013 & 648.3579 & 0.0095 & 7.3261 & 1865.267 & 2829.968 & 2846.096 & 2594.074 & N\end{array}$

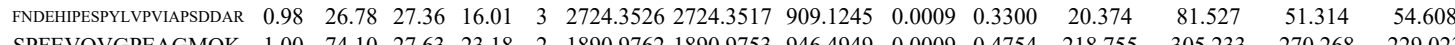

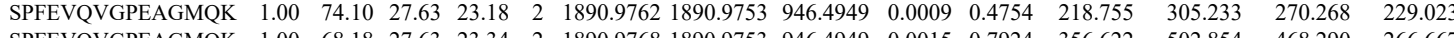

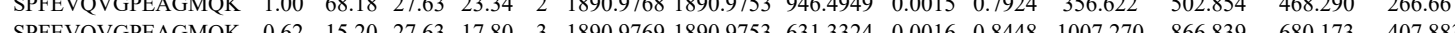
$\begin{array}{llllllllllllllllll}\text { SPFEVQVGPEAGMQK } & 0.62 & 15.20 & 27.63 & 17.80 & 3 & 1890.9769 & 1890.9753 & 631.3324 & 0.0016 & 0.8448 & 1007.270 & 866.839 & 680.173 & 407\end{array}$

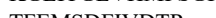
TFEMSDFIVDTR

YAPTEVGLHEMHIK

IGNLQTDLSDGLR

IGNLQTDLSDGLR

VAVTEGCQPSR

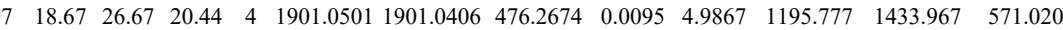
$\begin{array}{lllllllllllll}1.00 & 64.85 & 26.85 & 23.14 & 2 & 1603.7684 & 1603.7674 & 802.8910 & 0.0010 & 0.6227 & 313.016 & 542.243 & 18.625\end{array}$

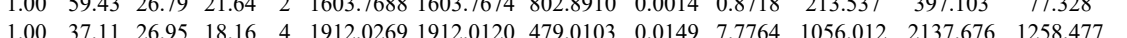
$\begin{array}{lllllllllllll}1.00 & 73.33 & 27.80 & 31.47 & 2 & 1544.8408 & 1544.8280 & 773.4213 & 0.0128 & 8.2749 & 1880.176 & 3063.791 & 894.363\end{array}$ $\begin{array}{llllllllllllll}1.00 & 69.20 & 27.72 & 31.15 & 2 & 1544.8422 & 1544.8280 & 773.4213 & 0.0142 & 9.1799 & 2562.818 & 4278.349 & 1022.436 & 184.924\end{array}$ $\begin{array}{llllllllllllllll}1.00 & 56.00 & 26.73 & 26.94 & 2 & 1335.6500 & 1335.6397 & 668.8271 & 0.0103 & 7.7000 & 8602.982 & 12428.750 & 1670.423 & 563.025 & & \\ 1\end{array}$ $\begin{array}{llllllllllllllll}1.00 & 59.35 & 26.73 & 27.21 & 2 & 1335.6502 & 1335.6397 & 668.8271 & 0.0105 & 7.8495 & 7313.306 & 11209.435 & 1687.461 & 555.067\end{array}$

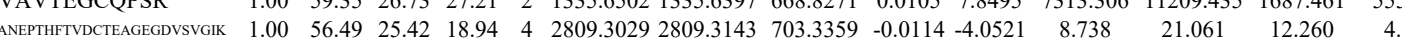

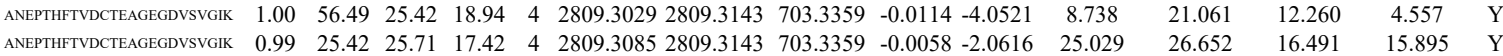

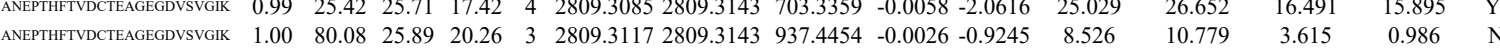

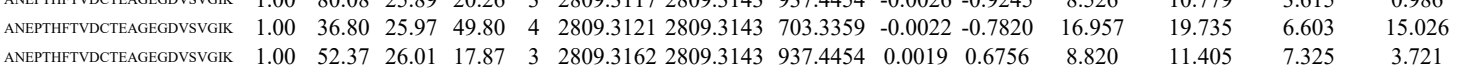

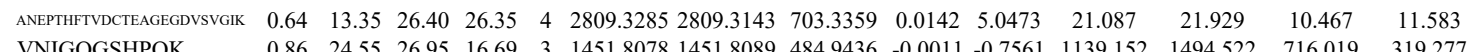
$\begin{array}{lllllllllllllll}\text { VNIGQGSHPQK } & 0.86 & 24.55 & 26.95 & 16.69 & 3 & 1451.8078 & 1451.8089 & 484.9436 & -0.0011 & -0.7561 & 1139.152 & 1494.522 \\ \text { GEAGVPAEFSIWTR } & 1.00 & 58.14 & 27.85 & 27.70 & 2 & 1662.8500 & 1662.8488 & 832.4317 & 0.0012 & 0.7208 & 447.594 & 633.259\end{array}$

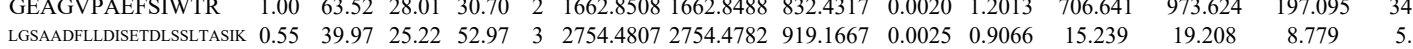

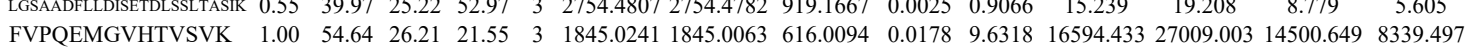

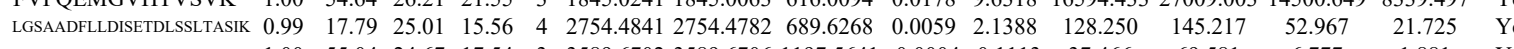

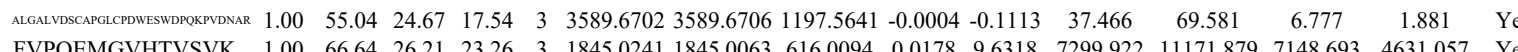
$\begin{array}{llllllllllllllll}\text { FVPQEMGVHTVSVK } & 1.00 & 66.64 & 26.21 & 23.26 & 3 & 1845.0241 & 1845.0063 & 616.0094 & 0.0178 & 9.6318 & 7299.922 & 11171.879 & 7148.693 & 4631.057 & \text { Yes }\end{array}$

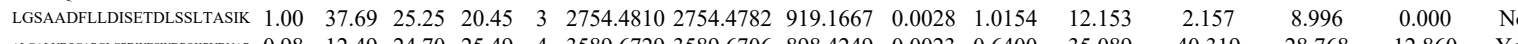

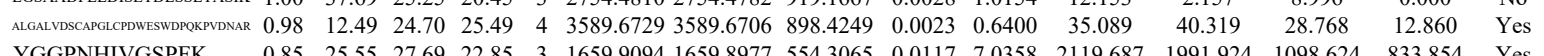
$\begin{array}{llllllllllllllll}\text { YGGPNHIVGSPFK } & 0.85 & 25.55 & 27.69 & 22.85 & 3 & 1659.9094 & 1659.8977 & 554.3065 & 0.0117 & 7.0358 & 2119.687 & 1991.924 & 1098.624 & 833.854 & \text { Yes }\end{array}$

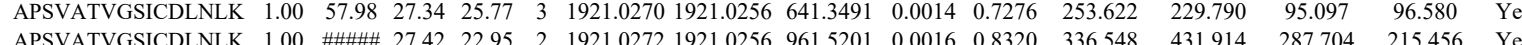

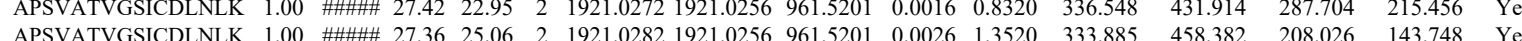

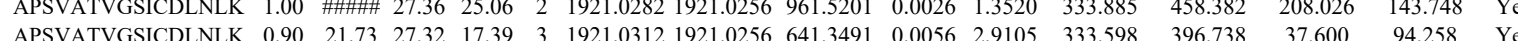

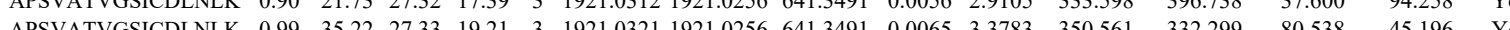

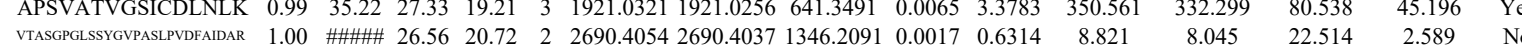




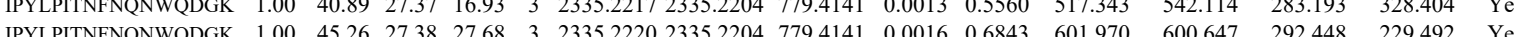

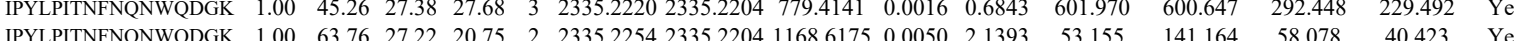

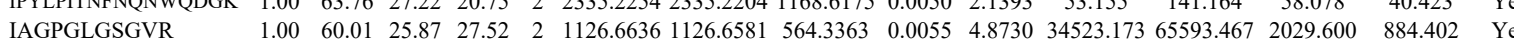
$\begin{array}{llllllllllllllll}\text { IAGPGLGSGVR } & 1.00 & 60.01 & 25.87 & 27.52 & 2 & 1126.6636 & 1126.6581 & 564.3363 & 0.0055 & 4.8730 & 34523.173 & 65593.467 & 2029.600 & 884.402 & \text { Yes } \\ \text { IAGPGLGSGVR } & 1.00 & 66.84 & 25.88 & 29.81 & 2 & 1126.6638 & 1126.6581 & 564.3363 & 0.0057 & 5.0502 & 20861.836 & 31716.231 & 559.510 & 1700.602 & \text { Yes } \\ \text { VNGPASFAR } & 0.99 & 46.83 & 27.42 & 29.60 & 2 & 1245.7010 & 1245.6951 & 623.8548 & 0.0059 & 4.7286 & 9842.362 & 17344.130 & 827.367 & 713.066 & \text { Yes }\end{array}$ VNQPASFAIR

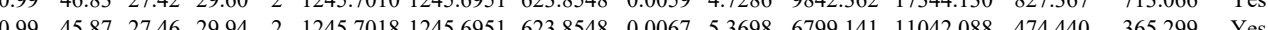

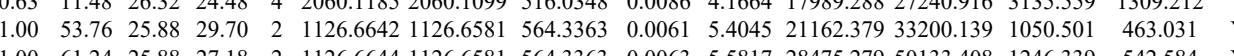
IAGPGLGSGVR IATVPGLGSGVR VTVLFAGQHISK VLFASQEIPASPFR VLFASQEIPASPFR IAGPGLGSGVR VTVLFAGQHISK $\begin{array}{lllllllllllllll}\text { VTVLFAGQHISK } & 1.00 & 48.19 & 23.16 & 24.32 & 3 & 1586.9494 & 1586.9388 & 529.9869 & 0.0106 & 6.6668 & 9897.900 & 20499.376 & 4065.858 \\ \text { VLFASQEIPASPFR } & 1.00 & 63.97 & 27.66 & 30.03 & 2 & 1704.9338 & 1704.9321 & 853.4733 & 0.0017 & 0.9959 & 946.140 & 1603.110 & 314.747\end{array}$

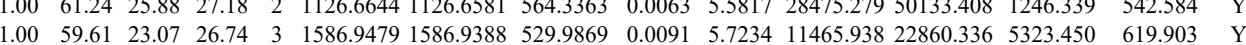
$\begin{array}{llllllllllllllll}1.00 & 54.04 & 23.07 & 25.05 & 3 & 1586.9479 & 1586.9388 & 529.9869 & 0.0091 & 5.7234 & 14406.848 & 24315.336 & 4819.505 & 668.615 & Y\end{array}$ $\begin{array}{lllllllllllllll}1.00 & 58.97 & 27.51 & 26.02 & 2 & 1704.9326 & 1704.9321 & 853.4733 & 0.0005 & 0.2929 & 2593.746 & 4597.897 & 0.000 & 18.109\end{array}$ $\begin{array}{lllllllllllllllll}1.00 & 60.76 & 27.48 & 24.49 & 2 & 1704.9330 & 1704.9321 & 853.4733 & 0.0009 & 0.5273 & 2161.753 & 3594.026 & 103.899 & 0.000\end{array}$ $\begin{array}{lllllllllllllll}1.00 & 70.56 & 25.75 & 27.85 & 2 & 1126.6648 & 1126.6581 & 564.3363 & 0.0067 & 5.9361 & 6500.341 & 11355.581 & 149.441 & 119.308\end{array}$ $\left.\begin{array}{llllllllllllll}1.00 & 67.78 & 23.16 & 27.96 & 3 & 1586.9494 & 1586.9388 & 529.9869 & 0.0106 & 6.6668 & 5549.328 & 10333.815 & 2129.552 & 777.465\end{array}\right)$ $\begin{array}{lllllllllllllll} & 1.00 & 63.97 & 27.66 & 30.03 & 2 & 1704.9338 & 1704.9321 & 853.4733 & 0.0017 & 0.9959 & 946.140 & 1603.110 & 314.747 & 12\end{array}$

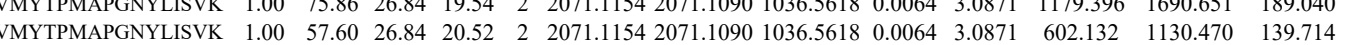

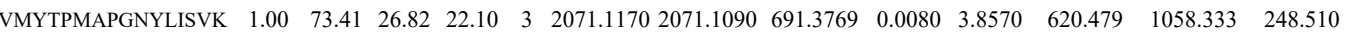
$\begin{array}{llllllllllllllll}\text { VSYFPTVPGVYIVSTK } & 0.76 & 67.57 & 24.61 & 80.57 & 2 & 2044.1494 & 2044.1489 & 1023.0817 & 0.0005 & 0.2444 & 890.419 & 1620.392 & 60.526\end{array}$ $\begin{array}{llllllllllllll}\text { VSYFPTVPGVYIVSTK } & 0.76 & 79.82 & 24.61 & 92.82 & 2 & 2044.1494 & 2044.1489 & 1023.0817 & 0.0005 & 0.2444 & 692.348 & 1462.928 & 2.055\end{array}$ AWGPGLHGGIVGR AWGPGLHGGIVGR AWGPGLHGGIVGR AWGPGLHGGIVGR AWGPGLHGGIVGR LPNNHIGISFIPR

VVPCLVTPVTGR

VVPCLVTPVTGR

VTCLVTPVGR

VVPCLVTPVTGR

VVPCLVTPVTGR

VVPCLVTPVTGR

VVPCLVTPVTGR

VVPCLVTPVTGR

AEITFDDHK

AEITFDDHK

NTVELLVEDK

NTVELLVEDK

NEPTHFTVDCTEAGEGDVSVG $\begin{array}{llllllllllllll}1.00 & 57.89 & 27.48 & 20.28 & 3 & 1419.7933 & 1419.7857 & 474.2692 & 0.0076 & 5.3415 & 10897.569 & 15984.763 & 1173.425 & 667.797 \\ 1.00 & 67.48 & 27.59 & 22.08 & 3 & 1419.7942 & 1419.7857 & 474.2692 & 0.0085 & 5.9741 & 11060.827 & 18358.836 & 853.999 & 765.21\end{array}$ $\begin{array}{llllllllllllll}.00 & 59.13 & 27.33 & 18.01 & 3 & 1419.7969 & 1419.7857 & 474.2692 & 0.0112 & 7.8717 & 15124.145 & 23588.316 & 1283.945\end{array}$ $\begin{array}{lllllllllllllll}1.00 & 52.72 & 27.26 & 22.94 & 3 & 1419.7966 & 1419.7857 & 474.2692 & 0.0109 & 7.6609 & 7929.783 & 10963.070 & 1426.147 & 379.76\end{array}$

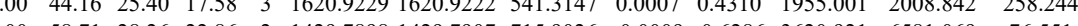

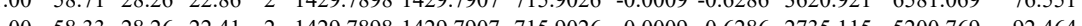

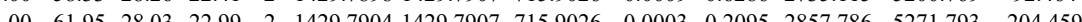

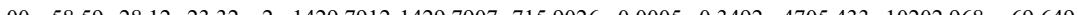

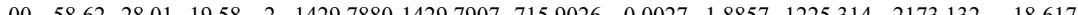

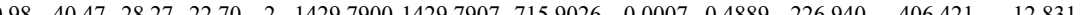

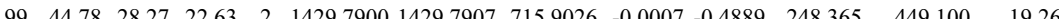
$\begin{array}{lllllllllllll}0.99 & 38.02 & 28.03 & 19.97 & 2 & 1429.7906 & 1429.7907 & 715.9026 & -0.0001 & -0.0698 & 74.227 & 117.882 & 0.384\end{array}$ $\begin{array}{llllllllllllll}100 & 43.18 & 27.99 & 21.78 & 3 & 13627060 & 1362.7023 & 455.2414 & 0.0037 & 2.7092 & 7261.362 & 12781.915 & 3961.573\end{array}$ $\begin{array}{lllllllllllll}1.00 & 42.10 & 27.99 & 20.48 & 3 & 1362.7060 & 1362.7023 & 455.2414 & 0.0037 & 2.7092 & 8334.367 & 14825.713 & 4645.087\end{array}$

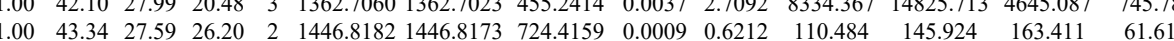
$\begin{array}{lllllllllllllll}1.00 & 55.08 & 27.59 & 25.31 & 2 & 1446.8182 & 1446.8173 & 724.4159 & 0.0009 & 0.6212 & 119.822 & 238.963 & 82.372 & 74.370\end{array}$

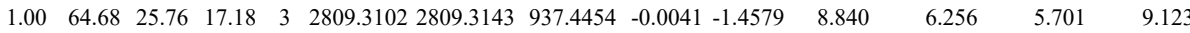

ANEPTHETVCTEAGEG

ADIEMPFDPSK

20 HLPNDPMFK

$\begin{array}{lllllllll}19.05 & 3 & 2809.3159 & 2809.3143 & 937.4454 & 0.0016 & 0.5689 & 11.400\end{array}$

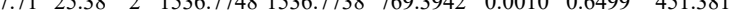
$\begin{array}{lllllllllllll}5.06 & 27.69 & 25.06 & 2 & 1536.7750 & 1536.7738 & 769.3942 & 0.0012 & 0.7798 & 298.585 & 581.441 & 283.237 & 187\end{array}$ $\begin{array}{lllllllllll} & \end{array}$ $\begin{array}{lllllllllllll}0.76 & 22.84 & 27.36 & 18.05 & 3 & 1385.7481 & 1385.7369 & 462.9196 & 0.0112 & 8.0647 & 7662.466 & 8710.826 & 3009.776\end{array}$ $\begin{array}{lllllllllllll}1.00 & 55.29 & 24.33 & 68.29 & 4 & 3969.8357 & 3969.8350 & 993.4660 & 0.0007 & 0.1762 & 208.904 & 194.896 & 129.749 \\ 1.00 & 67.17 & 24.67 & 80.17 & 4 & 3969.8445 & 3969.8350 & 993.4660 & 0.0095 & 2.3906 & 24.240 & 35.796 & 22.935\end{array}$

EGGGGAADSNDDWSHNTT

VVPGYGHAVLR

VVPGYGHAVLR

VVPGYGHAVLR

VVPGYGHAVLR

ALGVLAQLIWSR $\begin{array}{lllllllllllll}.00 & 6.17 & 24.67 & 80.17 & 4 & 3969.8445 & 3969.8350 & 993.4660 & 0.0095 & 2.3906 & 24.240 & 35.796 & 22.935\end{array}$

$\begin{array}{lllllllllllllll}1.95 & 30.46 & 23.07 & 22.03 & 2 & 1121.7144 & 1121.7052 & 561.8599 & 0.0092 & 8.1870 & 10730.471 & 9161.180 & 811.380 & 850\end{array}$ $\begin{array}{lllllllllllll}1.00 & 48.67 & 25.73 & 22.28 & 3 & 1310.7673 & 1310.7581 & 437.9266 & 0.0092 & 7.0026 & 12128.402 & 11249.617 & 2493.352\end{array}$

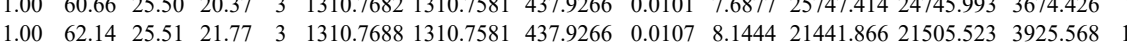

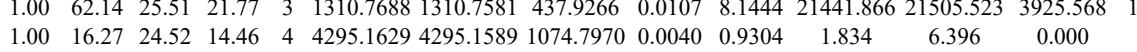

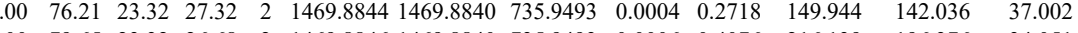
$\begin{array}{lllllllllllll}1.00 & 38.03 & 23.34 & 16.72 & 3 & 1469.8852 & 1469.8840 & 490.9686 & 0.0012 & 0.8147 & 11.832 & 16.587 & 8.254\end{array}$ $\begin{array}{lllllllllllll}1.00 & 60.65 & 25.73 & 21.80 & 3 & 1310.7679 & 1310.7581 & 437.9266 & 0.0098 & 7.4593 & 24077.906 & 28684.738 & 4581.604\end{array}$

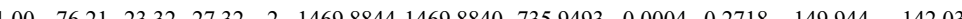


ALGVLAQLIWSR ALGVLAQLIWSR ALGVLAQLIWSR ALGVLAQLIWSR ALGVLAQLIWSR ALGVLAQLIWSR ALGVLAQLIWSR GLVYETSVLDPDEG GLVYETSVLDPDEG GLVYETSVLDPDEGIR

DLQQYQSQAK

DLQQYQSQAK
DLQQYQSQAK

DLQQYQSQAK

NLGSINTELQDVQR NLGSINTELQDVQR

VLLTMIAR

VLLTMIAR

VLLTMIAR

VLLTMIAR

QAAPPIELDAVWEDIR

VPSNASWEQAMK

FTNMLGQPGSTALDLFK FTNMLGQPGSTALDL
EPAFEDITLESER

TLESER

FQTMSDQIIGR

TVQDLTSVVQTLLQQMQDK

$\begin{array}{llllllllllll}\text { TVQDLTSVVQTLLQQMQDK } & 1.00 & 82.92 & 25.19 & 22.11 & 2 & 2462.3314 & 2462.3294 & 1232.1720 & 0.0020 & 0.8116 & 16.725 \\ \text { TVQDLTSVVQTLLQMQDK } & 1.00 & 94.37 & 25.19 & 21.34 & 2 & 2462.3314 & 2462.3294 & 1232.1720 & 0.0020 & 0.8116 & 9.652\end{array}$ $\begin{array}{llllllllllll}\text { NIADLMTQAGVEELESENK } & 1.00 & 47.22 & 27.28 & 16.66 & 3 & 2378.1922 & 2378.1879 & 793.7366 & 0.0043 & 1.8058 & 10.811\end{array}$ $\begin{array}{llllllllllll}\text { NAADLMTQAGVELESENK } & 1.00 & 83.24 & 27.31 & 19.82 & 3 & 2378.1928 & 2378.1879 & 793.7366 & 0.0049 & 2.0578 & 9.255\end{array}$ $\begin{array}{llllllllllll}\text { NIADLMTQAGVEELESENK } & 1.00 & 73.74 & 27.29 & 22.04 & 3 & 2378.1919 & 2378.1879 & 793.7366 & 0.0040 & 1.6798 & 21.223 \\ \text { DFVAEPMGEKPVGSLAGIGEVLGK } & 0.69 & 3.34 & 22.88 & 16.34 & 4 & 2831.5501 & 2831.5468 & 708.8940 & 0.0033 & 1.1638 & 51.119\end{array}$ DFVAEPMGEKPVGSLAGIGEVLGK AYVVLGQFLVLK AYVVLGQFLVLK AYVVLGQFLVLK AYVVLGQFLVLK AYVVLGQFLVLK AYVVLGQFLVLK AYVVLGQFLVLK AYVVLGQFLVLK AYVVLGQFLVLK AYVVLGQFLVLK AYVVLGQFLVLK AYVVLGQFLVLK AYVVLGQFLVLK AYVVLGQFLVLK AYVVLGQFLVLK AYVVLGQFLVLK AYVVLGQFLVLK AYVVLGQFLVLK AYVVLGQFLVLK AYVVLGQFLVLK AYVVLGQFLVLK AYVVLGQFLVLK AYVVLGQFLVLK AYVVLGQFLVLK AYVLGQLVK AYV LGQLVLK

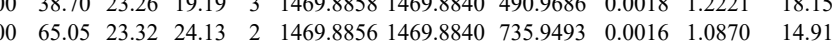
$\begin{array}{lllllllllll}1.00 & 68.58 & 23.34 & 19.08 & 2 & 1469.8862 & 1469.8840 & 735.9493 & 0.0022 & 1.4947 & 22.210\end{array}$ $\begin{array}{llllllllllll}1.00 & 63.53 & 23.32 & 24.34 & 2 & 1469.8856 & 1469.8840 & 735.9493 & 0.0016 & 1.0870 & 45.902 \\ 1.00 & 66.46 & 23.32 & 23.83 & 2 & 1469.8856 & 1469.8840 & 735.9493 & 0.0016 & 1.0870 & 53.644 \\ 1.00 & 1.99 & 23.30 & 2.24 & 2 & 149.8854 & 149.8840 & 735.9493 & 0.004 & 0.9512 & & \end{array}$ $\begin{array}{lllllllllll}1.00 & 71.99 & 23.30 & 20.24 & 2 & 1469.8854 & 1469.8840 & 735.9493 & 0.0014 & 0.9512 & 29.432\end{array}$

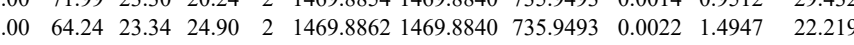
$\begin{array}{lllllllllll}1.00 & 6.85 & 27.95 & 24.90 & 2 & 1469.882 & 1409.8840 & 735.9493 & 0.0022 & 1.4947 & 22.219\end{array}$ $\begin{array}{lllllllllll}1.00 & 72.04 & 27.90 & 22.23 & 2 & 1905.9830 & 1905.9806 & 953.9976 & 0.0024 & 1.2579 & 346.780\end{array}$ $\begin{array}{lllllllllll} & \end{array}$

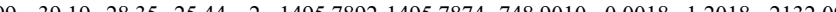
$\begin{array}{llllllllllll} & \end{array}$ $\begin{array}{lllllllllll}0.97 & 44.24 & 28.25 & 25.66 & 2 & 1495.7850 & 1495.7874 & 748.9010 & 0.0024 & -1.6024 & 8527.326\end{array}$ $\begin{array}{llllllllll} & \end{array}$ $\begin{array}{lllllllllllll}1.00 & 86.04 & 27.55 & 29.46 & 2 & 1729.9208 & 1729.9081 & 865.9613 & 0.0127 & 7.3328 & 498.262\end{array}$ $\begin{array}{lllllllllllll}1.05 & 34.87 & 26.54 & 26.11 & 2 & 1059.6592 & 1059.6596 & 530.8371 & -0.0004 & -0.3768 & 3019208 & 38.22164\end{array}$ $\begin{array}{llllllllllll}0.91 & 31.55 & 26.54 & 26.13 & 2 & 1059.6594 & 1059.6596 & 530.8371 & -0.0002 & -0.1884 & 2266.155 & 3001.784\end{array}$ $\begin{array}{llllllllllllll}0.81 & 32.44 & 26.6 & 26.28 & 2 & 1059.6584 & 1059.6596 & 530.8371 & -0.0012 & -1.1303 & 5456.865 & 6815.520 & 805.987\end{array}$ $\begin{array}{lllllllllllll}0.86 & 29.28 & 26.54 & 26.12 & 2 & 1059.6596 & 1059.6596 & 530.8371 & 0.0000 & 0.0000 & 4756.280 & 6677.661 & 609.304\end{array}$

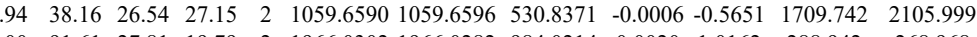

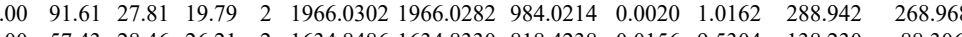
$\begin{array}{lllllllllll}.53 & 41.57 & 26.88 & 54.57 & 3 & 2127.1312 & 2127.1278 & 710.0499 & 0.0034 & 1.5961 & 35.378\end{array}$ $\begin{array}{llllllllllll}1.00 & 62.73 & 26.82 & 28.59 & 2 & 1678.8172 & 1678.8172 & 840.4159 & 0.0000 & 0.0000 & 142.584\end{array}$ $\begin{array}{llllllllllll}1.00 & 66.68 & 26.99 & 26.31 & 2 & 1678.8192 & 1678.8172 & 840.4159 & 0.0020 & 1.1899 & 43.222 \\ 1.00 & 70.50 & 27.82 & 28.33 & 2 & 1438.7502 & 1438.7360 & 720.3753 & 0.0142 & 9.8559 & 2794.360\end{array}$ $\begin{array}{lllllllllll}1.00 & 70.50 & 27.82 & 28.33 & 2 & 1488.7502 & 1438.7360 & 720.3753 & 0.0142 & 9.8559 & 2794.360\end{array}$ $\begin{array}{llllllllllll}1.00 & 65.94 & 27.77 & 27.31 & 2 & 1438.7496 & 1438.7360 & 720.3753 & 0.0136 & 9.4394 & 3940.221 \\ 0.53 & 50.54 & 25.17 & 63.54 & 3 & 24623326 & 2462 & 3294 & 821.7837 & 0.0032 & 1.2980 & 61.936\end{array}$ $\begin{array}{lllllllllll}0.98 & 11.95 & 22.94 & 14.83 & 4 & 2831.5521 & 2831.5468 & 708.8940 & 0.0053 & 1.8691 & 60.889\end{array}$ $\begin{array}{lllllllllll}1.00 & 75.15 & 17.32 & 26.25 & 2 & 1637.0166 & 1637.0160 & 819.5153 & 0.0006 & 0.3661 & 283.067\end{array}$

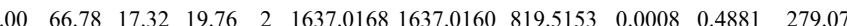
$\begin{array}{lllllllllll}1.00 & 73.40 & 17.32 & 26.03 & 2 & 1637.0170 & 1637.0160 & 819.5153 & 0.0010 & 0.6101 & 305.571\end{array}$ $\begin{array}{lllllllllll} & 1637.0170 & 1637.0160 & 819.5153 & 0.0010 & 0.6101 & 17.139\end{array}$ $\begin{array}{lllllllllll}1.00 & 55.80 & 17.16 & 18.31 & 2 & 1637.0172 & 1637.0160 & 819.5153 & 0.0012 & 0.7321 & 2.251\end{array}$ $\begin{array}{lllllllllllll}1.00 & 69.99 & 17.16 & 25.14 & 2 & 1637.0172 & 1637.0160 & 819.5153 & 0.0012 & 0.7321 & 393.321\end{array}$ $\begin{array}{lllllllllll}0.96 & 15.27 & 16.72 & 17.89 & 3 & 1637.0185 & 1637.0160 & 546.6793 & 0.0025 & 1.5244 & 605.041\end{array}$ $\begin{array}{lllllllllll}1.00 & 56.36 & 16.72 & 22.12 & 2 & 1637.0188 & 1637.0160 & 819.5153 & 0.0028 & 1.7083 & 29.322\end{array}$ $\begin{array}{llllllllllll}0.98 & 17.97 & 16.81 & 17.48 & 3 & 1637.0191 & 1637.0160 & 546.6793 & 0.0031 & 1.8902 & 648.930\end{array}$ $\begin{array}{llllllllllll}1.00 & 68.27 & 16.53 & 17.72 & 2 & 1637.0202 & 1637.0160 & 819.5153 & 0.0042 & 2.5625 & 24.284\end{array}$ $\begin{array}{llllllllllll}0.61 & 77.55 & 17.32 & 90.55 & 2 & 1637.0162 & 1637.0160 & 819.5153 & 0.0002 & 0.1220 & 9.698\end{array}$ $\begin{array}{llllllllllll}1.00 & 53.63 & 17.32 & 16.42 & 2 & 1637.0164 & 1637.0160 & 819.5153 & 0.0004 & 0.2440 & 68.254 \\ 0.76 & 61.33 & 17.32 & 74.33 & 2 & 1637.0170 & 1637.0160 & 819.5153 & 0.0010 & 0.6101 & 15.502\end{array}$ $\begin{array}{lllllllllll}0.76 & 52.68 & 17.32 & 65.68 & 2 & 1637.0170 & 1637.0160 & 819.5153 & 0.0010 & 0.6101 & 18.558\end{array}$ $\begin{array}{lllllllllll}1.00 & 74.01 & 17.32 & 18.94 & 2 & 1637.0170 & 1637.0160 & 819.5153 & 0.0010 & 0.6101 & 32.944\end{array}$ $\begin{array}{lllllllllllll}0.76 & 63.28 & 17.16 & 76.28 & 2 & 1637.0174 & 1637.0160 & 819.5153 & 0.0014 & 0.8542 & 15.390\end{array}$ $\begin{array}{llllllllllll}0.98 & 14.77 & 16.72 & 15.12 & 3 & 1637.0185 & 1637.0160 & 546.6793 & 0.0025 & 1.5244 & 322.690\end{array}$ $\begin{array}{llllllllllll}0.93 & 18.17 & 16.72 & 22.66 & 3 & 1637.0188 & 1637.0160 & 546.6793 & 0.0028 & 1.7073 & 30.137 \\ 0.53 & 30.36 & 16.72 & 43.36 & 3 & 1637.0188 & 1637.0160 & 546.6793 & 0.0028 & 1.7073 & 20.025\end{array}$ $\begin{array}{llllllllllll}0.53 & 30.36 & 16.72 & 43.36 & 3 & 1637.0188 & 1637.0160 & 546.6793 & 0.0028 & 1.7073 & 20.025 \\ 1.00 & 54.72 & 16.72 & 19.65 & 2 & 1637.0200 & 1637.0160 & 819.5153 & 0.0040 & 2.4405 & 31.279\end{array}$ $\begin{array}{llllllllllll}1.00 & 54.72 & 16.72 & 19.65 & 2 & 1637.0200 & 1637.0160 & 819.5153 & 0.0040 & 2.4405 & 31.279 \\ 0.93 & 18.12 & 17.92 & 15.44 & 3 & 1637.0152 & 1637.0160 & 546.6793 & -0.0008 & -0.4878 & 31.108\end{array}$ $\begin{array}{lllllllllll}0.93 & 18.12 & 17.92 & 15.44 & 3 & 1637.0152 & 1637.0160 & 546.6793 & -0.0008 & -0.4878 & 31.108 \\ 0.99 & 23.98 & 16.99 & 19.17 & 3 & 1637.0179 & 1637.0160 & 546.6793 & 0.0019 & 1.1585 & 80.251 \\ 0.99 & 19.04 & 6.72 & 17.26 & 3 & 637.015 & 1637.060 & 56.6793 & 0.025 & 1.5244 & 5.320\end{array}$ $\begin{array}{lllllllllll}0.99 & 19.04 & 16.72 & 17.26 & 3 & 1637.0185 & 1637.0160 & 546.6793 & 0.0025 & 1.5244 & 95.320\end{array}$ $\begin{array}{lllllllllllll}0.99 & 19.04 & 16.72 & 17.26 & 3 & 1637.0185 & 1637.0160 & 546.6793 & 0.0025 & 1.5244 & 95.320 \\ 1.00 & 54.27 & 17.85 & 16.43 & 2 & 1637.0160 & 1637.0160 & 819.5153 & 0.0000 & 0.0000 & 10.202\end{array}$ $\begin{array}{llllllllllll}0.98 & 16.55 & 17.16 & 14.68 & 3 & 1637.0173 & 1637.0160 & 546.6793 & 0.0013 & 0.7927 & 10.458\end{array}$ $\begin{array}{llllllllllll}1.00 & 28.65 & 16.99 & 20.28 & 3 & 1637.0176 & 1637.0160 & 546.6793 & 0.0016 & 0.9756 & 7.090\end{array}$

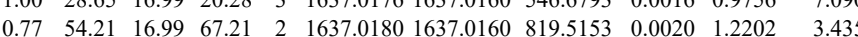



$\begin{array}{lllllllllllllllllll}\text { WDQTADQTPGATPK } & 1.00 & 70.11 & 28.04 & 20.46 & 2 & 1802.9156 & 1802.9043 & 902.4594 & 0.0113 & 6.2606 & 1229.077 & 863.988 & 1112.078 & 1010.228 & \mathrm{~N} 0\end{array}$ $\begin{array}{llllllllllllll}1.00 & 70.11 & 28.04 & 20.46 & 2 & 1802.9156 & 1802.9043 & 902.4594 & 0.0113 & 6.2606 & 1229.077 & 863.988 \\ 1.00 & 73.54 & 28.00 & 22.80 & 2 & 1802.9186 & 1802.9043 & 902.4594 & 0.0143 & 7.9227 & 1225.468 & 830.961\end{array}$

$\begin{array}{lllllllllll}0 & \end{array}$

$\begin{array}{lllllllll}-1 & 0\end{array}$

LLGYVATLK

LLGYVATLK

LLGYVATLK

QRPGQQVATCVR

QRPGQQVATCVR

QRPGQQVATCVR

QRPGQQVATCVR

QRPGQQVATCVR

QRPGQQVATCVR

QRPGQQVATCVR

QRPGQQVATCVR

\begin{tabular}{llllllllllllll}
\hline & 20.25 & 22.99 & 2 & 1264.8020 & 1264.7998 & 633.4072 & 0.0022 & 1.7366 & 35388.780 & 30573.992 & 425.705
\end{tabular}

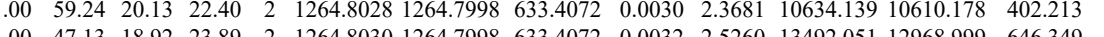

$\begin{array}{lllllllllllll}1.00 & 47.13 & 18.92 & 23.89 & 2 & 1264.8030 & 1264.7998 & 633.4072 & 0.0032 & 2.5260 & 13492.051 & 12968.999 & 646.349 \\ 1.00 & 62.19 & 18.81 & 2.22 & 2 & 1264.8044 & 1264.7998 & 633.4072 & 0.0046 & 3.6311 & 15377.112 & 13974.304 & 446.275\end{array}$

$\begin{array}{llllllllllllll}1.00 & 62.19 & 18.81 & 22.22 & 2 & 1264.8044 & 1264.7998 & 633.4072 & 0.0046 & 3.6311 & 15377.112 & 13974.304 & 446.275 & 538 . \\ 0.96 & 25.21 & 27.99 & 17.25 & 3 & 1531.7845 & 1531.7833 & 511.6017 & 0.0012 & 0.7819 & 297.635 & 323.190 & 38.521 & 25.9\end{array}$

$\begin{array}{llllllllllllll}0.99 & 30.34 & 28.08 & 18.92 & 3 & 1531.7857 & 1531.7833 & 511.6017 & 0.0024 & 1.5637 & 414.521 & 408.701 & 55.882 \\ 0.89 & 28.62 & 27.87 & 19.49 & 2 & 1531.7834 & 1531.7333 & 7168989 & 0.0001 & 0.0552 & 1233.410 & 1288.959 & 46.174\end{array}$

$\begin{array}{llllllllllllll}0.89 & 28.62 & 27.87 & 19.49 & 2 & 1531.7834 & 1531.7833 & 766.8989 & 0.0001 & 0.0652 & 1243.410 & 1278.959 & 46.174 \\ 1.00 & 55.92 & 27.90 & 20.01 & 3 & 1531.7839 & 1531.7833 & 511.6017 & 0.0006 & 0.3909 & 5906.201 & 5771.938 & 424.838 & 50 \\ 0.98 & 32.73 & 27.99 & 20.84 & 2 & 1531.7842 & 1531.783 & 766.8989 & 0.000 & 0.5868 & 974.217 & 793.774 & 87.996\end{array}$ $\begin{array}{lllllllllllllll}1.00 & 55.92 & 27.90 & 20.01 & 3 & 1531.7839 & 1531.7833 & 511.6017 & 0.0006 & 0.3909 & 5906.201 & 5771.938 & 424.838 & & \\ 0\end{array}$ $\begin{array}{lllllllllllllll}0.98 & 32.73 & 27.99 & 20.84 & 2 & 1531.7842 & 1531.7833 & 766.8989 & 0.0009 & 0.5868 & 974.217 & 793.774 & 87.996 & & \\ 1.00 & 49.08 & 28.03 & 21.76 & 3 & 1531.7851 & 1531.7833 & 511.6017 & 0.0018 & 1.1728 & 13305.156 & 13271.491 & 876.640 & 1 & \end{array}$ $\begin{array}{lllllllllllllll}1.00 & 49.08 & 28.03 & 21.76 & 3 & 1531.7851 & 1531.7833 & 511.6017 & 0.0018 & 1.1728 & 13305.156 & 13271.491 & 876.640 & 14 & \\ 1.00 & 43.31 & 28.06 & 17.90 & 3 & 1531.7854 & 1531.7833 & 51.6017 & 0.002 & 1368 & 246.792 & 237.752 & 31.496 & \end{array}$ $\begin{array}{lllllllllllll}1.00 & 43.31 & 28.06 & 17.90 & 3 & 1531.7854 & 1531.7833 & 511.6017 & 0.0021 & 1.3683 & 246.792 & 237.752 & 31.496 \\ 1.00 & 42.20 & 28.06 & 20.11 & 3 & 1531.7854 & 1531.7833 & 511.6017 & 0.0021 & 1.3683 & 204.445 & 199.706 & 24.047\end{array}$ $\begin{array}{llllllllllllllll} & \end{array}$ $\begin{array}{llllllllllllll} & & & \end{array}$ GPDNSMGFGAER NITLDDASAPR

NITLDDASAPR

ASFPQGPIGGANR ASFPQGPIGGANR ASFPQGPIGGANR

LAGVTALSCWLPLR LAGVTALSCWLPLR LAGVTALSCWLPLR LAGVTALSCWLPLR LAGVTALSCWLPLR LAGVTALSCWLPLR

$\begin{array}{llllllllllllll}1.00 & 63.08 & 24.42 & 19.81 & 2 & 1380.6328 & 1380.6214 & 691.3180 & 0.0114 & 8.2451 & 6454.716 & 7330.592 & 4080.700\end{array}$ $\begin{array}{llllllllllllll}1.00 & 75.63 & 27.66 & 23.79 & 2 & 1315.6960 & 1315.6854 & 658.8500 & 0.0106 & 8.0443 & 15736.880 & 13198.837 & 1099.464\end{array}$ $\begin{array}{lllllllllllllll}100 & 77.38 & 27.47 & 28.75 & 2 & 1414.7528 & 1414.7439 & 708.3792 & 0.0089 & 6.2819 & 12871.656 & 11864.565 & 3492.567 & 377.751 & \text { Yes }\end{array}$ $\begin{array}{lllllllllllllll}1.00 & 68.54 & 27.51 & 30.36 & 2 & 1414.7540 & 1414.7439 & 708.3792 & 0.0101 & 7.1289 & 10169.076 & 10248.677 & 3139.758 & 609.995 & \text { Yes }\end{array}$ $\begin{array}{llllllllllllllll}1.00 & 63.58 & 27.13 & 27.57 & 2 & 1414.7512 & 1414.7439 & 708.3792 & 0.0073 & 5.1526 & 3148.738 & 2958.343 & 766.027 & 256.462 & \text { Yes }\end{array}$ $\begin{array}{llllllllllllllll}1.00 & 70.30 & 27.13 & 30.39 & 2 & 1414.7514 & 1414.7439 & 708.3792 & 0.0075 & 5.2937 & 10606.342 & 7769.801 & 3055.244 & 187.818 & \text { Yes }\end{array}$ $\begin{array}{lllllllllllllll}1.00 & 70.00 & 27.89 & 24.54 & 2 & 1688.9238 & 1688.9228 & 845.4687 & 0.0010 & 0.5914 & 54.573 & 75.368 & 7.008 & 4.054 & \text { Yes }\end{array}$

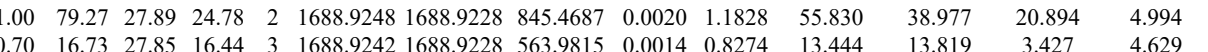

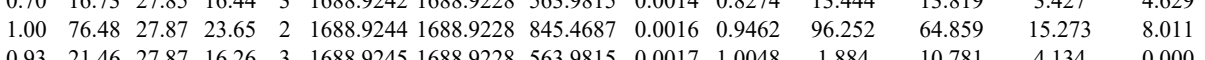
$\begin{array}{llllllllllllll}0.93 & 21.46 & 27.87 & 16.26 & 3 & 1688.9245 & 1688.9228 & 563.9815 & 0.0017 & 1.0048 & 1.884 & 10.781 & 4.134 & 0.000 \\ 1.00 & 82.49 & 27.75 & 23.84 & 2 & 1688.9250 & 1688.9228 & 845.4687 & 0.0022 & 1.3011 & 67.819 & 42.251 & 8.748 & 7.960\end{array}$ $\begin{array}{llllllllllllll}1.00 & 82.49 & 27.75 & 23.84 & 2 & 1688.9250 & 1688.9228 & 845.4687 & 0.0022 & 1.3011 & 67.819 & 42.251 & 8.748 & 7.960 \\ 1.00 & 73.81 & 27.91 & 26.02 & 2 & 1688.9228 & 1688.9228 & 845.468 & 0.0000 & 0.0000 & 21.074 & 21.832 & 6.206 & 0.000\end{array}$ KPVIVFVPSR

KPVIVFVPSR KLPEEVVK TLVEDLFADK TLVEDLFADK DEPTGEVLSLVGK DEPTGEVLSLVGK KLPEEVVK

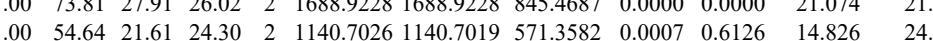
$\begin{array}{lllllllllllllll}1.00 & 46.65 & 21.61 & 19.79 & 2 & 1140.7026 & 1140.7019 & 571.3582 & 0.0007 & 0.6126 & 20.151 & 12.594 & 25.614 & 5.315\end{array}$ $\begin{array}{llllllllllllll}0.99 & 31.22 & 20.13 & 21.01 & 3 & 1372.8769 & 1372.8655 & 458.6291 & 0.0114 & 8.2855 & 22833.064 & 20519.871 & 11595.407 & 2388.799\end{array}$ $\begin{array}{lllllllllllllll}1.00 & 60.33 & 26.97 & 37.17 & 2 & 1437.7986 & 1437.7959 & 719.9052 & 0.0027 & 1.8752 & 2351.714 & 1943.815 & 0.000 & 21.814 & \text { No }\end{array}$ KLPEEVVK HLSDHLSELVEQTLS QLPHFTSEHIK

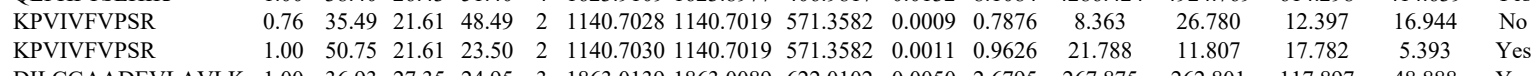

$\begin{array}{lllllllllllllll}1.00 & 61.22 & 26.97 & 30.72 & 2 & 1437.7986 & 1437.7959 & 719.9052 & 0.0027 & 1.8752 & 1224.332 & 1019.698 & 0.000 & 19.393\end{array}$

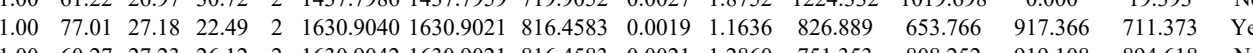

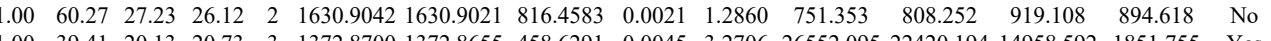
$\begin{array}{llllllllllllllll}1.00 & 39.41 & 20.13 & 20.73 & 3 & 1372.8700 & 1372.8655 & 458.6291 & 0.0045 & 3.2706 & 26552.095 & 22420.194 & 14958.592 & 1851.755 & \text { Yes } \\ 1.00 & 33.99 & 19.82 & 20.81 & 3 & 1372.8718 & 13728655 & 458.6291 & 0.0063 & 4.5788 & 23417.935 & 21330.722 & 11082.203 & 2271.667 & \text { Yes }\end{array}$ $\begin{array}{llllllllllllllll}1.00 & 24.69 & 26.36 & 15.74 & 4 & 2695.3901 & 2695.3908 & 674.8550 & -0.0007 & -0.2593 & 120.821 & 143.936 & 106.002 & 74.976 & \text { Yes } \\ 0 & 26.43 & 51.40 & 4 & 1623.9109 & 1623.8977 & 406.9817 & 0.0132 & 8.1084 & 4286.424 & 4924.769 & 614.298 & 414.639 & \text { Ys }\end{array}$ $\begin{array}{llllllllllllllll} & & & \end{array}$ 

LVEQLFSSGAIQVVV

TNLLLQAHLSR
IIYIAPMR

IYYAPMR

KPVIVFVPSR

KPVIVFVPSR
KPVIVFVPSR

KPVIVFVPSR

KPVIVFVPSR

KPVIVFVPSR

KPVIVFVPSR

KPVIVFVPSR

INVLLQAFISQLK

INVLLQAFISQLK

INVLLQAFISQLK

ADEVLEILK

$\begin{array}{llllllllllll}1 & \end{array}$

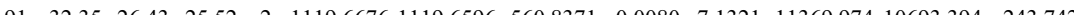

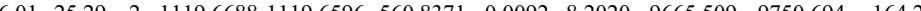
$\begin{array}{llllllllllllll} & \end{array}$ $\begin{array}{lllllllllllll}1.00 & 49.60 & 17.78 & 18.81 & 2 & 1428.9070 & 1428.9061 & 715.4603 & 0.0009 & 0.6290 & 2514.172 & 2283.779 & 2077.591\end{array}$ $\begin{array}{lllllllllllll}0.77 & 46.07 & 17.78 & 59.07 & 2 & 1428.9076 & 1428.9061 & 715.4603 & 0.0015 & 1.0483 & 2572.008 & 2316.813 & 2373.056\end{array}$ $\begin{array}{llllllllllllll}0.55 & 57.16 & 17.08 & 70.16 & 3 & 1428.9085 & 1428.9061 & 477.3093 & 0.0024 & 1.6761 & 6889.728 & 7722.989 & 7101.154\end{array}$ $\begin{array}{lllllllllllll}1.00 & 42.10 & 17.78 & 22.34 & 2 & 1428.9060 & 1428.9061 & 715.4603 & -0.0001 & -0.0699 & 170.095 & 173.986 & 188.312\end{array}$ $\begin{array}{lllllllllllllll}0.55 & 56.54 & 17.78 & 69.54 & 3 & 1428.9079 & 1428.9061 & 4773093 & 0.0018 & 1.2570 & 945.479 & 913.667 & 518.010\end{array}$ $\begin{array}{lllllllllllllll}1.00 & 38.51 & 23.48 & 22.31 & 2 & 1340.5994 & 1340.5983 & 671.3064 & 0.0011 & 0.8193 & 2240.322 & 2049.576 & 0.000\end{array}$ $\begin{array}{lllllllllllll}1.00 & 30.61 & 18.20 & 18.09 & 3 & 1774.0963 & 1774.0960 & 592.3726 & 0.0003 & 0.1688 & 38.739 & 42.940 & 17.172\end{array}$

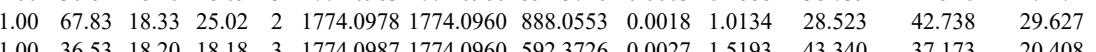

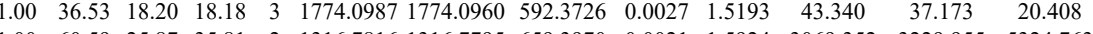
$\begin{array}{llllllllllllll}1.00 & 60.59 & 25.87 & 35.81 & 2 & 1316.7816 & 1316.7795 & 659.3970 & 0.0021 & 1.5924 & 3069.352 & 3229.955 & 5324.763\end{array}$ $\begin{array}{lllllllllllll}1.00 & 60.71 & 25.87 & 29.32 & 2 & 1316.7816 & 1316.7795 & 659.3970 & 0.0021 & 1.5924 & 2915.321 & 3152.844 & 4467.906 \\ 1.00 & 48.03 & 23.84 & 17.48 & 3 & 2471.3773 & 2471.3726 & 824.7981 & 0.0047 & 1.8995 & 7.627 & 4.186 & 6.267\end{array}$

GNIAEDTEVDILVTVQNL

NSFAYQPLLDLVVQLAR

$\begin{array}{lllllllllll}\text { NU155_HUMA } & \text { O75694 } & \text { NUP155 } & \text { Nuclear pore com] } 155.20 & 1.00 & 3 & 3.8 & 0.4343 & 0.2028 & -1.5906 & 1.1230\end{array}$ $\begin{array}{lllllllllllll}0.58 & 18.66 & 24.33 & 23.37 & 3 & 1329.8116 & 1329.8012 & 444.2743 & 0.0104 & 7.8029 & 3490.292 & 3082.881 & 1673.27\end{array}$ $\begin{array}{lllllllllllllll}\text { MTQNPNYYNLQGISHR } & 1.00 & 56.60 & 27.60 & 19.01 & 3 & 20790205 & 20790078 & 6940099 & 0.0127 & 60998 & 1454.532 & 1908.416 & 396767 & 28\end{array}$

AIFEIVLNR $\begin{array}{llllllllllllll}1.00 & 53.35 & 26.66 & 25.59 & 2 & 1217.7276 & 1217.7254 & 609.8700 & 0.0022 & 1.8037 & 4139.472 & 4246.062 & 243.063\end{array}$

MTONPNYYNLQGISHR

$\begin{array}{lllllllllllllll} & \text { LTAIDILTTCAADIQR } & 1.00 & 56.39 & 27.61 & 18.27 & 3 & 1907.0011 & 1906.9978 & 636.6732 & 0.0033 & 1.7277 & 218.881 & 159.723 & 64.900\end{array}$

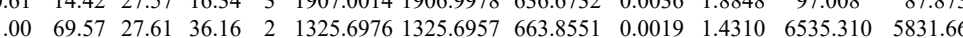

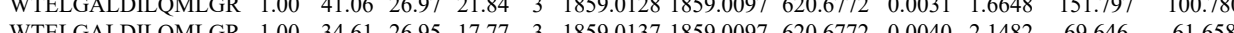
$\begin{array}{lllllllllllll}\text { WISLGTQLPVSR } & 1.00 & 34.51 & 26.95 & 17.77 & 3 & 1859.0137 & 1859.0097 & 62.6772 & 0.0040 & 2.1482 & 69.646 & 61.658\end{array}$ LVEQLSSGAVVVVASR \begin{tabular}{lllllllllll}
1.00 & 64.56 & 27.62 & 25.35 & 2 & 1754.8624 & 1754.8606 & 878.4376 & 0.0018 & 1.0245 & 294.933 \\
\hline 5 & 43.31 & 23.38 & 56.31 & 3 & 2046.1621 & 2046.1595 & 683.0604 & 0.0026 & 1.2688 & 25.025
\end{tabular} 61.658
372.194

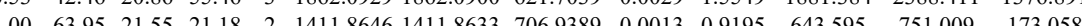
$\begin{array}{lllllllllllll}1.00 & 63.95 & 21.55 & 21.18 & 2 & 1411.8646 & 1411.8633 & 706.9389 & 0.0013 & 0.9195 & 643.595 & 751.009 & 173.058 \\ 1.00 & 62.37 & 21.55 & 20.95 & 2 & 1411.8646 & 1411.8633 & 7069389 & 0.0013 & 0.9195 & 383.304 & 576.206 & 147.239\end{array}$

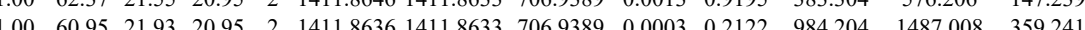

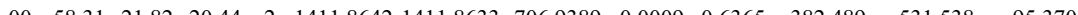



$\begin{array}{llllllllllllllll}0.96 & 30.86 & 26.88 & 16.52 & 3 & 1438.8151 & 1438.8024 & 480.6081 & 0.0127 & 8.8082 & 11868.472 & 10384.800 & 1888.322 & 1006.745 & \text { Yes }\end{array}$ $\begin{array}{lllllllllllllll}0.99 & 35.35 & 26.93 & 16.68 & 3 & 1438.8154 & 1438.8024 & 480.6081 & 0.0130 & 9.0163 & 15117.273 & 14535.374 & 1943.669 & 619.909 & \text { Yes }\end{array}$ $\begin{array}{lllllllllllllll}0.99 & 37.23 & 27.05 & 16.77 & 3 & 1438.8136 & 1438.8024 & 480.6081 & 0.0112 & 7.7679 & 18197.171 & 18414.182 & 2836.045 & 1316.891 & \text { Yes }\end{array}$ $\begin{array}{llllllllllllllll}0.99 & 34.50 & 26.94 & 16.98 & 3 & 1438.8148 & 1438.8024 & 480.6081 & 0.0124 & 8.6001 & 13026.861 & 12627.768 & 2440.710 & 1365.852 & \text { Yes }\end{array}$

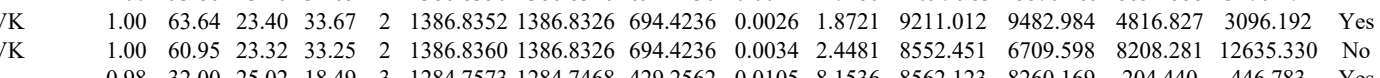
$\begin{array}{lllllllllllllllllll}0.98 & 32.00 & 25.02 & 18.49 & 3 & 1284.7573 & 1284.7468 & 429.2562 & 0.0105 & 8.1536 & 8562.123 & 8260.169 & 204.440 & 446.783 & \text { Yes }\end{array}$ $\begin{array}{llllllllllllllll} & \\ \text { HASSGSFLPSANEHLK } & 1.00 & 26.41 & 27.49 & 21.71 & 4 & 1969.0341 & 1969.0261 & 493.2638 & 0.0080 & 4.0546 & 1821.558 & 1937.189 & 1918.105 & 1355.464 & \text { Yes } \\ \text { HASSGSFLPSANEHLK } & 0.99 & 23.87 & 27.71 & 21.24 & 4 & 1969.0417 & 1969.0261 & 493.2638 & 0.0156 & 7.9065 & 2532.371 & 3005.128 & 2708.116 & 1942.144 & Y \text { Yes }\end{array}$ YEISSVTFLFK YEISSVPTFLFFK YEISSVPTFLFFK

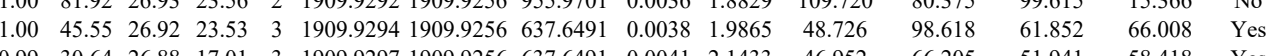

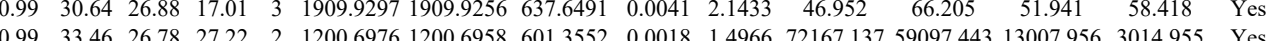
$\begin{array}{llllllllllllllllll}0 & 3.46 & 26.78 & 27.22 & 2 & 1200.6976 & 1200.6958 & 601.3552 & 0.0018 & 1.4966 & 72167.137 & 59097.443 & 13007.956 & 3014.955 & \text { Yes } \\ 0.00 & 40.35 & 26.74 & 28.86 & 2 & 1200.6980 & 1200.6958 & 601.3552 & 0.0022 & 1.8292 & 50316.538 & 37788.031 & 10044.703 & 2397.184 & \text { Yes }\end{array}$ \begin{tabular}{lllllllllllllll}
\hline 0.86 & 22.48 & 25.94 & 25.53 & 2 & 998.5276 & 998.5267 & 5002706 & 0.0009 & 0.8995 & 47.000 & 26.350 & 29.607 & 17.519 & Yes
\end{tabular}

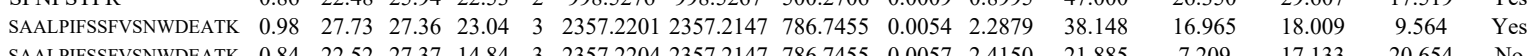
FFTTPSK

FFTTPSK

LLSSFDFFLTDAR

LLSSFDFFLTDAR

VPVSVNLLSK

LLSSFDFFLTDAR

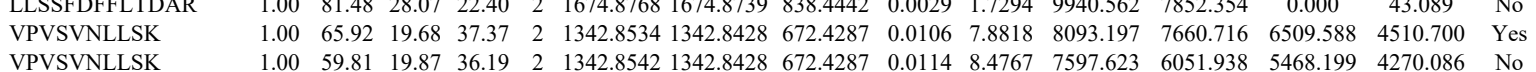

$\begin{array}{llllllllllllll}0.84 & 22.52 & 27.37 & 14.84 & 3 & 2357.2204 & 2357.2147 & 786.7455 & 0.0057 & 2.4150 & 21.885 & 7.209 & 17.133 & 20.65 \\ 0.99 & 44.32 & 27.2 & 24.31 & 2 & 14.6362 & & \end{array}$

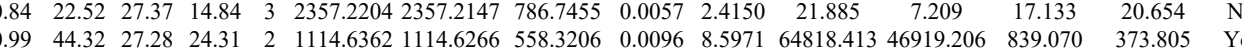

$\begin{array}{llllllllllllllll}1.00 & 47.86 & 27.28 & 26.24 & 2 & 1114.6366 & 1114.6266 & 558.3206 & 0.0100 & 8.9553 & 64165.430 & 41487.507 & 0.000 & 717.192 & \text { No }\end{array}$ $\begin{array}{lllllllllllllll}0.99 & 44.24 & 27.07 & 24.31 & 2 & 1114.6370 & 1114.6266 & 558.3206 & 0.0104 & 9.3136 & 32683.640 & 25746.565 & 552.444 & 502.786 & \text { Yes }\end{array}$

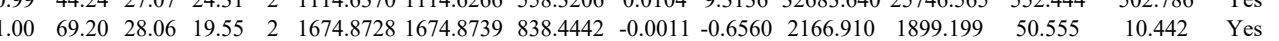
$\begin{array}{lllllllllllllll}1.00 & 71.75 & 28.03 & 22.06 & 2 & 1674.8772 & 1674.8739 & 838.4442 & 0.0033 & 1.9679 & 1840.183 & 1266.704 & 69.076 & 0.000 & \text { No }\end{array}$ $\begin{array}{llllllllllllllll}0.77 & 43.28 & 19.08 & 51.76 & 2 & 1342.8556 & 1342.8428 & 672.4287 & 0.0128 & 9.5176 & 6733.735 & 7645.943 & 4561.433 & 3235.998 & \text { Yes }\end{array}$ $\begin{array}{llllllllllllllll}\text { IGHVGMQIEHIIENIVAVTK } & 1.00 & 59.81 & 19.87 & 36.19 & 2 & 1342.8542 & 1342.8428 & 672.4287 & 0.0114 & 8.4767 & 7597.623 & 6051.938 & 5468.199 & 4270.086 & \text { No }\end{array}$ $\begin{array}{lllllllllllllllll} & & & \end{array}$ $\begin{array}{llllllllllllllll}\text { IGHVGMQIEHIENIVAVTK } & 1.00 & 37.58 & 21.30 & 17.69 & 4 & 2488.4149 & 2488.4079 & 623.1093 & 0.0070 & 2.8085 & 194.600 & 399.238 & 86.935 & 48.625 & \text { No }\end{array}$

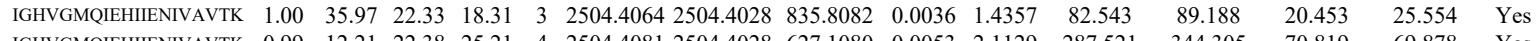
$\begin{array}{llllllllllllllll}\text { IGHVGMQIEHIIENIVAVTK } & 0.99 & 12.21 & 22.38 & 25.21 & 4 & 2504.4081 & 2504.4028 & 627.1080 & 0.0053 & 2.1129 & 287.521 & 344.305 & 70.819 & 69.878 & \text { Yes }\end{array}$

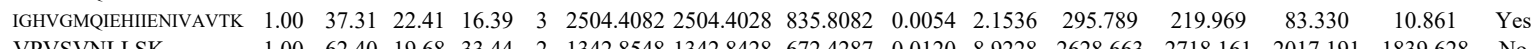

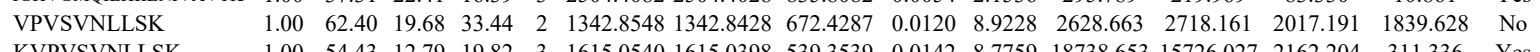

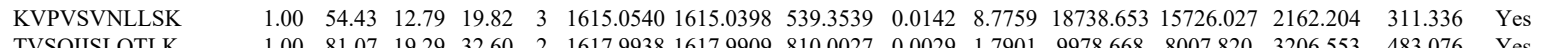
$\begin{array}{llllllllllllllll}\text { TVSQIISLQTLK } & 1.00 & 81.07 & 19.29 & 32.60 & 2 & 1617.9938 & 1617.9909 & 810.0027 & 0.0029 & 1.7901 & 9978.668 & 8007.820 & 3206.553 & 483.076 & \text { Yes } \\ \text { TVSQIISLQTLK } & 0.98 & 21.65 & 18.26 & 1.54 & 3 & 1617.9955 & 1617.9909 & 540.3376 & 0.0046 & 2.8377 & 579.017 & 479.519 & 580.506 & 264.192 & \text { No }\end{array}$ \begin{tabular}{lllllllllllllllll} 
TVSQIISLQTLK & 0.98 & 21.65 & 18.26 & 18.54 & 3 & 1617.9955 & 1617.9909 & 540.3376 & 0.0046 & 2.8377 & 579.017 & 479.519 & 580.506 & 264.192 & No \\
\hline IGUGPEFHENIAVTK & 1.00 & 54.14 & 21.49 & 18.48 & 3 & 2488.4122 & 2488.4079 & 830.4766 & 0.0043 & 1.7259 & 283.540 & 362.200 & 239.364 & 203.723 & No
\end{tabular} $\begin{array}{llllllllllllllll}\text { IGHVGMQIEHIIENIVAVTK } & 1.00 & 54.14 & 21.49 & 18.48 & 3 & 2488.4122 & 2488.4079 & 830.4766 & 0.0043 & 1.7259 & 283.540 & 362.200 & 239.364 & 203.723 & \text { No } \\ \text { IGHVGMIEHUENIVAVTK } & 0.95 & 8.98 & 21.30 & 16.50 & 4 & 2488.4149 & 2488.4079 & 623.1093 & 0.0070 & 2.8085 & 135.978 & 217.700 & 98.686 & 24.274 & \text { Yes }\end{array}$

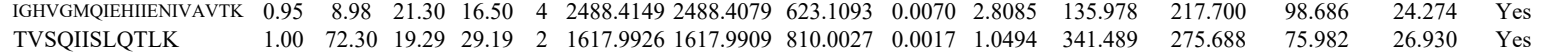

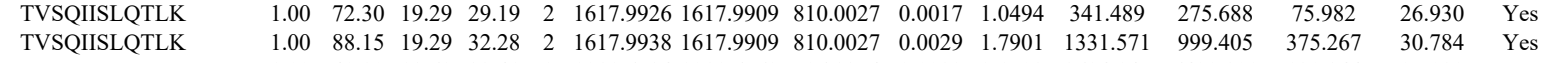
\begin{tabular}{llllllllllllllll} 
LLPSLIGR & 1.00 & 40.90 & 18.69 & 33.41 & 2 & 1011.6584 & 1011.6562 & 506.8354 & 0.0022 & 2.1703 & 8694.147 & 6490.800 & 130.844 & 97.080 & Yes \\
\hline & 0.96 & & & & & &
\end{tabular} 


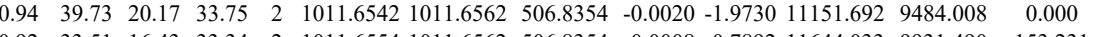

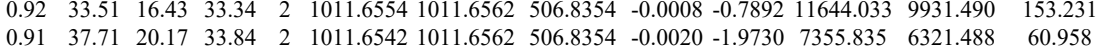

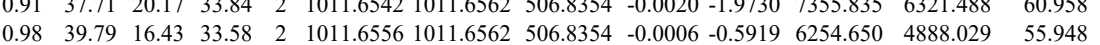

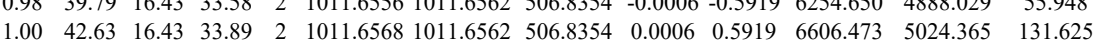
$\begin{array}{lllllllllllll}1.00 & 38.67 & 16.43 & 31.68 & 2 & 1011.6572 & 1011.6562 & 506.8354 & 0.0010 & 0.9865 & 5537.936 & 4636.104 & 66.225\end{array}$

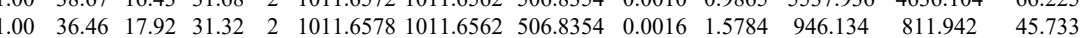
$\begin{array}{llllllllllllll}0.97 & 39.64 & 17.92 & 42.90 & 2 & 1011.6578 & 1011.6562 & 506.8354 & 0.0016 & 1.5784 & 1593.620 & 1364.845 & 20.429\end{array}$ $\begin{array}{lllllllllllllll}\text { GTQGATAGASSELDASK } & 1.00 & \text { \#\#\#\# } 28.05 & 32.55 & 2 & 1837.9266 & 1837.9261 & 919.9703 & 0.0005 & 0.2717 & 525.901 & 527.468 & 483.671 & 292.108 & \text { Yes }\end{array}$ $\begin{array}{lllllllllllllllll}\text { GTQGATAGASSELDASK } & 1.00 & 97.81 & 28.07 & 26.25 & 2 & 1837.9270 & 1837.9261 & 919.9703 & 0.0009 & 0.4891 & 389.286 & 418.923 & 334.876 & 321.299 & \text { Yes }\end{array}$

\begin{tabular}{lllllllllllllllll}
\hline & LTVPDDIAANCIYLNIPNK & 1.00 & 52.31 & 26.50 & 17.85 & 3 & 2420.2726 & 2420.2687 & 807.7635 & 0.0039 & 1.6094 & 140.772 & 186.297 & 45.727 & 61.055 & Yes
\end{tabular}

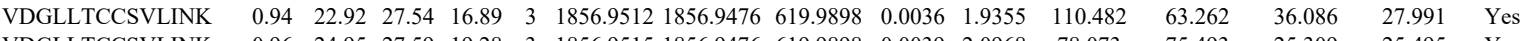
$\begin{array}{llllllllllllllllll}\text { VDGLLTCCSVLINK } & 0.96 & 24.95 & 27.59 & 19.28 & 3 & 1856.9515 & 1856.9476 & 619.9898 & 0.0039 & 2.0968 & 78.073 & 75.493 & 25.309 & 25.495 & \text { Yes }\end{array}$

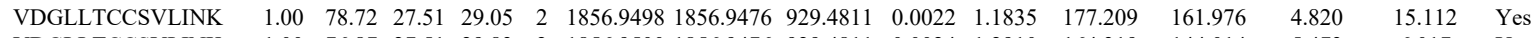

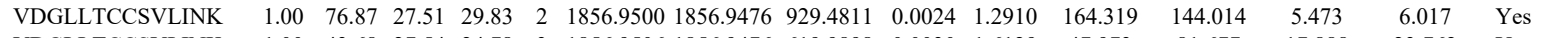
$\begin{array}{llllllllllllllll}\text { VDGLLTCCSVLINK } & 1.00 & 43.68 & 27.54 & 24.78 & 3 & 1856.9506 & 1856.9476 & 619.9898 & 0.0030 & 1.6129 & 47.973 & 81.677 & 17.888 & 23.762 & \text { Yes }\end{array}$ $\begin{array}{lllllllllllllllll}\text { VDGLLTCCSVLINK } & 0.98 & 28.70 & 27.59 & 27.80 & 3 & 1856.9518 & 1856.9476 & 619.9898 & 0.0042 & 2.2581 & 23.241 & 68.241 & 51.079 & 17.675 & \text { Yes }\end{array}$

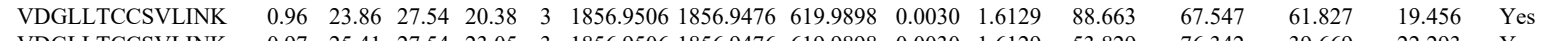
$\begin{array}{llllllllllllllll}\text { VDGLLTCCSVLINK } & 0.97 & 25.41 & 27.54 & 23.05 & 3 & 1856.9506 & 1856.9476 & 619.9898 & 0.0030 & 1.6129 & 53.829 & 76.342 & 39.669 & 22.293 & \text { Yes }\end{array}$

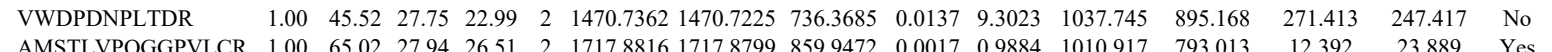

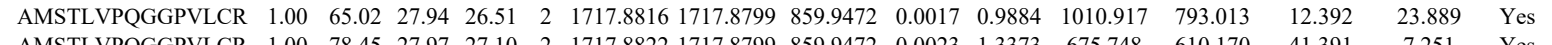

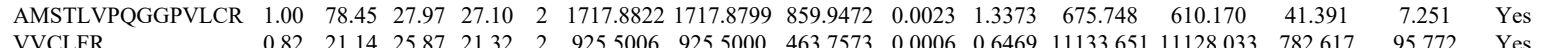

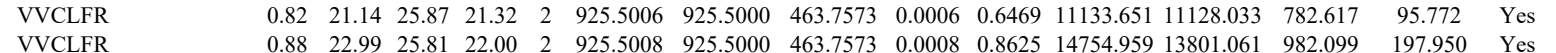
VVCLFR VVCLFR $\begin{array}{llllllllllllllllll}0.88 & 22.99 & 25.81 & 22.00 & 2 & 925.5008 & 925.5000 & 463.7573 & 0.0008 & 0.8625 & 14754.959 & 13801.061 & 982.099 & 197.950 & \text { Yes } \\ 0.65 & 1.91 & 26.61 & 1.55 & 2 & 925.5012 & 9255000 & 463.573 & 0.002 & 1.2938 & 5720.603 & 5426.993 & 308.007 & 117.421 & \text { Yes }\end{array}$ 

$\begin{array}{lllllllllll}1.00 & 37.21 & 24.01 & 15.89 & 3 & 3152.6782 & 3152.6736 & 789.1757 & 0.0045 & 1.4255 & 3.907 \\ 0.9985 & 0.0046 & 1.4577 & 1.760\end{array}$

$\begin{array}{llllllllllll}1.00 & 45.21 & 20.25 & 34.92 & 2 & 1410.8694 & 1410.8680 & 706.4413 & 0.0014 & 0.9909 & 191.040\end{array}$

$\begin{array}{llllllllllll}88.65 & 27.76 & 38.93 & 2 & 1631.8584 & 1631.8600 & 816.9373 & -0.0016 & -0.9793 & 1152.840\end{array}$

SDQNLQTALELT

$\begin{array}{llllllllllll}1.00 & 90.33 & 27.76 & 38.95 & 2 & 1631.8584 & 1631.8600 & 816.9373 & -0.0016 & -0.9793 & 1215.945 & 8 \\ 1.00 & 73.03 & 27.45 & 34.35 & 2 & 1514.8308 & 1514.8174 & 758.4160 & 0.0134 & 8.8341 & 843.594 & \end{array}$

$\begin{array}{lllllllllll}1.00 & 70.67 & 27.45 & 27.45 & 2 & 1514.8308 & 1514.8174 & 758.4160 & 0.0134 & 8.8341 & 767.328\end{array}$

QLQDIATLADQR

$\begin{array}{lllllllllll}1.00 & 82.28 & 27.36 & 34.32 & 2 & 1631.8734 & 1631.8600 & 816.9373 & 0.0134 & 8.2013 & 937.249\end{array}$

$\begin{array}{lllllllllllll}\text { GIDQCIPLFVEAALER } & 1.00 & 55.37 & 28.22 & 22.12 & 2 & 1963.0044 & 1963.0029 & 982.5087 & 0.0015 & 0.7634 & 143.822 & 7\end{array}$

$\begin{array}{lllllllllllll} & \end{array}$

$\begin{array}{llllllllllll}\text { GIDQCIPLFVAALER } & 1.00 & 54.41 & 28.19 & 25.89 & 2 & 1963.0066 & 1963.0029 & 982.5087 & 0.0037 & 1.8829 & 24.445 \\ \text { GIDQCIPLFVEAALER } & 1.00 & 38.21 & 28.16 & 26.30 & 3 & 1963.0075 & 1963.0029 & 655.3416 & 0.0046 & 2.3397 & 69.362\end{array}$ $\begin{array}{llllllllllll}\text { GIDQCIPLFVEAALER } & 1.00 & 44.92 & 28.26 & 24.03 & 2 & 1963.0060 & 1963.0029 & 982.5087 & 0.0031 & 1.5776 & 44.006\end{array}$ $\begin{array}{lllllllllllll}\text { GIDQCIPLFVEAALER } & 1.00 & 65.72 & 28.18 & 27.61 & 2 & 1963.0064 & 1963.0029 & 982.5087 & 0.0035 & 1.7812 & 34.634\end{array}$ $\begin{array}{llllllllllll}\text { GIDQCIPLFVEAALER } & 1.00 & 38.61 & 28.26 & 24.41 & 3 & 1963.0060 & 1963.0029 & 655.3416 & 0.0031 & 1.5768 & 78.174\end{array}$ $\begin{array}{llllllllllll}\text { GIDQCIPLFVEAALER } & 1.00 & 56.49 & 28.14 & 18.52 & 2 & 1963.0072 & 1963.0029 & 982.5087 & 0.0043 & 2.1883 & 13.683\end{array}$

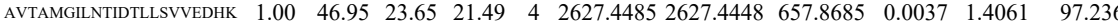
$\begin{array}{llllllllllll}\text { AVTAMGILNTIDTLLSVVEDHK } & 1.00 & 93.66 & 23.50 & 23.84 & 3 & 2627.4490 & 2627.4448 & 876.8222 & 0.0042 & 1.5967 & 241.402\end{array}$ $\begin{array}{lllllllllll}\text { AVTAMGILNTIDTLLSVVEDHK } & 1.00 & \text { \#\#\#\# } 23.28 & 25.48 & 3 & 2627.4508 & 2627.4448 & 876.8222 & 0.0060 & 2.2810 & 163.056\end{array}$ $\begin{array}{lllllllllllll}\text { AVTAMGILNTIDTLLSVVEDHK } & 1.00 & 36.38 & 23.28 & 19.90 & 4 & 2627.4513 & 2627.4448 & 657.8685 & 0.0065 & 2.4701 & 94.640 \\ \text { AVTAMGILNTITLSVVEDHK } & 0.65 & 3.97 & 23.64 & 14.70 & 4 & 2643.4441 & 2643.4397 & 661.8672 & 0.0044 & 1.6620 & 164.349\end{array}$ $\begin{array}{lllllllllllll}\text { AVTAMGILNTIDTLLSVVEDHK } & 0.65 & 3.97 & 23.64 & 14.70 & 4 & 2643.4441 & 2643.4397 & 661.8672 & 0.0044 & 1.6620 & 164.349 & 22 \\ \text { AVTAMGLNTDTLSVEDH } & 1.00 & 16.58 & 23.64 & 16.20 & 4 & 2643.4445 & 2643.4397 & 661.8672 & 0.0048 & 1.8130 & 223.496 & 22\end{array}$ $\begin{array}{llllllllllllll}\text { AVTAMGILNTIDTLLSVVEDHK } & 1.00 & 16.58 & 23.64 & 16.20 & 4 & 2643.4445 & 2643.4397 & 661.8672 & 0.0048 & 1.8130 & 223.496 & 22 \\ \text { AVTAMGILNTIDTLLSVVEDHK } & 1.00 & 38.79 & 23.46 & 16.91 & 4 & 2627.4497 & 2627.4448 & 657.8685 & 0.0049 & 1.8621 & 125.812 & 10\end{array}$ $\begin{array}{llllllllllllll}\text { AVTAMGILNTIDTLLVVEDHK } & 1.00 & 38.79 & 23.46 & 16.91 & 4 & 2627.4497 & 2627.4448 & 657.8685 & 0.0049 & 1.8621 & 125.812 & 10 \\ \text { AVTAMGILNTIDTLLSVVEDHK } & 1.00 & 44.74 & 23.24 & 18.50 & 4 & 2627.4509 & 2627.4448 & 657.8685 & 0.0061 & 2.3181 & 115.093 & 10\end{array}$ $\begin{array}{llllllllllll}\text { AVTAMGILNTIDTLLSVVEDHK } & 1.00 & 44.74 & 23.24 & 18.50 & 4 & 2627.4509 & 2627.4448 & 657.8685 & 0.0061 & 2.3181 & 115.093\end{array}$ $\begin{array}{llllllllllll}\text { DGALHMIGSLAEILLK } & 0.99 & 60.80 & 22.90 & 57.73 & 3 & 1968.1363 & 1968.1321 & 657.0513 & 0.0042 & 2.1307 & 152.661\end{array}$ $\begin{array}{lllllllllllll}\text { DGALHMIGSLAEILLK } & 0.65 & 50.27 & 23.05 & 59.83 & 3 & 1968.1369 & 1968.1321 & 657.0513 & 0.0048 & 2.4351 & 244.206\end{array}$ \begin{tabular}{llllllllllll} 
& AFAVGVQQVLLK \\
\hline
\end{tabular} $\begin{array}{lllllllllllll}\text { YLEMIYSMCK } & 1.06 & 80.90 & 20.57 & 31.90 & 2 & 1559.9664 & 1559.9643 & 780.9894 & 0.0021 & 1.3444 & 13726.826 & 11352.906\end{array}$ $\begin{array}{llllllllllll}0.96 & 55.03 * 26.05 & 19.85 & 2 & 1613.7586 & 1613.7569 & 807.8857 & 0.0017 & 1.0521 & 205.477 & 183.322 \\ 0.74 & 41.47 * 26001 & 16.69 & 2 & 1613.7594 & 1613.7569 & 807.8857 & 0.025 & 1.5472 & 63.406 & 6132.02\end{array}$ $\begin{array}{llllllllll} & \end{array}$ \begin{tabular}{llllllllllll}
\hline FSAPVYPSSFNFGGPAPGUN & 0.69 & 66.46 & 27.32 & 79.46 & 2 & 2123.0294 & 2123.0268 & 1062.5207 & 0.0026 & 1.2235 & 25.616
\end{tabular} $\begin{array}{lllllllllllll} & 0.025\end{array}$ AIFQTIQNR $\begin{array}{lllllllllllll}0.99 & 44.94 & 27.29 & 29.45 & 2 & 1233.7024 & 1233.6951 & 617.8548 & 0.0073 & 5.9075 & 7487.078 & 5013.018\end{array}$ $\begin{array}{llllllllllllll} & \end{array}$ $\begin{array}{lllllllllllll} & 41.38 & 27.32 & 20.19 & 2 & 2123.0294 & 2123.0268 & 10625207 & 0.0026 & 1.2235 & 5.066 & 14.592\end{array}$ AIFQTIQNR AIFQTIQNR AIFQTIQNR
AIFQTIQNR VQLTTCIHHIIK VQLTTCIHHIIK VQLTTCIHHIIK $\begin{array}{lllllllllllll}1.00 & 52.18 & 27.29 & 31.26 & 2 & 1233.7026 & 1233.6951 & 617.8548 & 0.0075 & 6.0694 & 23652.059 & 19946.946 & 1047.531\end{array}$ $\begin{array}{lllllllllllllll}1.00 & 29.82 & 24.64 & 22.42 & 4 & 1738.9865 & 1738.9830 & 435.7530 & 0.0035 & 2.0080 & 2871.995 & 3527.738 & 333.405\end{array}$ $\begin{array}{lllllllllllllll} & \end{array}$ $\begin{array}{lllllllllllllll} & \text { SPLVAAMQHFLPVLK } & 0.53 & 43.34 & 20.93 & 56.34 & 3 & 1938.1396 & 1938.1368 & 647.0529 & 0.0028 & 1.4424 & 311.184 & 263.001 & 146.351\end{array}$ $\begin{array}{llllllllllllllll} & \end{array}$ $\begin{array}{llllllllllllll}\text { SPLVAAMQHFLPVLK } & 0.76 & 70.86 & 20.97 & 83.86 & 2 & 1938.1382 & 1938.1368 & 970.0757 & 0.0014 & 0.7216 & 52.485 & 40.490\end{array}$ $\begin{array}{llllllllllllll}\text { SPLVAAMQHFLPVLK } & 1.00 & 60.96 & 20.97 & 22.51 & 2 & 1938.1386 & 1938.1368 & 970.0757 & 0.0018 & 0.9278 & 63.855 & 65.460\end{array}$ $\begin{array}{lllllllllllllll}\text { SPLVAAMQHFLPVLK } & 0.55 & 44.72 & 20.93 & 57.72 & 3 & 1938.1390 & 1938.1368 & 647.0529 & 0.0022 & 1.1333 & 211.200 & 160.317 & 9 \\ \text { SPLVAAMQHFLPVLK } & 1.00 & 52.62 & 20.93 & 18.06 & 3 & 1938.1396 & 1938.1368 & 647.0529 & 0.0028 & 1.4424 & 240.285 & 211.058 & 1\end{array}$

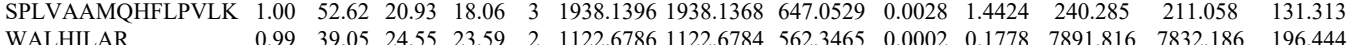

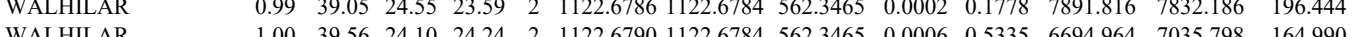

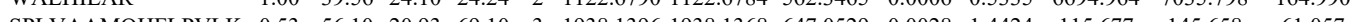

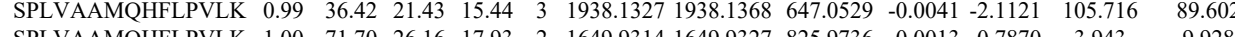
$\begin{array}{lllllllllllll}\text { SPLVAAMOHFLPVK } & 0.06 & 65.12 & 26.16 & 78.12 & 2 & 1649.9326 & 1649.9327 & 825.9736 & -0.0001 & -0.0605 & 6.262 & 1.926\end{array}$ $\begin{array}{llllllllllllll}\text { SPLVAAMQHFLPVLK } & 1.00 & 45.73 & 26.13 & 20.44 & 3 & 1649.9344 & 1649.9327 & 550.9848 & 0.0017 & 1.0285 & 5.270 & 7.071\end{array}$ $\begin{array}{lllllllllllll}\text { DVPNETLOVEEDDPPELPWWK } & 0.97 & 26.46 & 27.44 & 19.56 & 3 & 2882.4337 & 2882.4330 & 961.8183 & 0.0007 & 0.2426 & 232.393 & 204.899\end{array}$ 

$\begin{array}{llllllllllllllll}\text { VETTOELVATHAP ATEADR } & 1.00 & 66.38 & 26.78 & 17.76 & 3 & 2588.3392 & 2588.3357 & 863.7858 & 0.0035 & 1.3506 & 2577.448 & 1737.207 & 955.998 & 265.284 & \text { Yes }\end{array}$

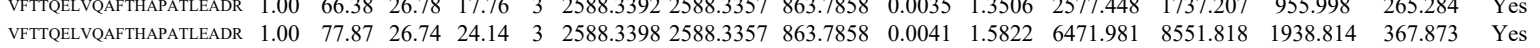
$\begin{array}{llllllllllllllll}\text { LNWTGTSK } & 0.92 & 32.98 & 27.60 & 30.84 & 2 & 1193.6742 & 1193.6648 & 597.8397 & 0.0094 & 7.8616 & 3960.786 & 4010.952 & 565.196 & 466.816 & \text { Yes }\end{array}$

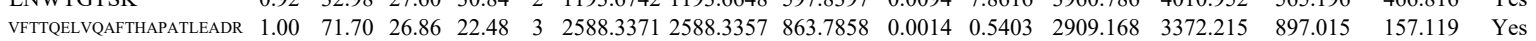
$\begin{array}{llllllllllllllllll}\text { VFTTQELVQAFTHAPATLEADR } & 1.00 & 63.93 & 26.87 & 22.30 & 3 & 2588.3377 & 2588.3357 & 863.7858 & 0.0020 & 0.7718 & 1580.577 & 1894.102 & 481.043 & 106.993 & \text { Yes }\end{array}$

DEPDTNLVALMK

CEVTEVSK

DEPDTNLVALMK

DEPDTNLVALN

IPAILYLCYTDVMK

APLGLLLHPFK

LPLGLLLHPFK

LPLGLLLHPFK

IIAFISWLR

$\begin{array}{lllllllllllllllll}1.00 & 57.20 & 28.34 & 22.18 & 2 & 1632.8658 & 1632.8636 & 817.4391 & 0.022 & 1.3457 & 729.820 & 426.674 & 1070.279 & 980.889 & \text { No } \\ 1.00 & 45.26 & 27.09 & 31.83 & 2 & 1227.6198 & 1227.6083 & 614.8114 & 0.0115 & 9.3524 & 36894.034 & 31639.126 & 13195381 & 5215.767 & \text { Yes }\end{array}$

$\begin{array}{lllllllllllllll}1.00 & 61.52 & 28.34 & 23.83 & 2 & 1632.8660 & 1632.8636 & 817.4391 & 0.0024 & 1.4680 & 56.249 & 67.931 & 108.571 & 88.943 & \text { Yes }\end{array}$ $\begin{array}{lllllllllllllll}1.00 & 72.19 & 28.30 & 26.23 & 2 & 1632.8662 & 1632.8636 & 817.4391 & 0.0026 & 1.5903 & 56.787 & 34.794 & 73.461 & 66.817 & \text { No }\end{array}$

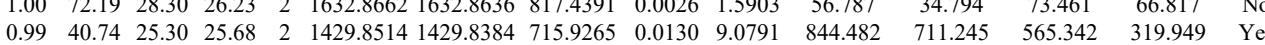

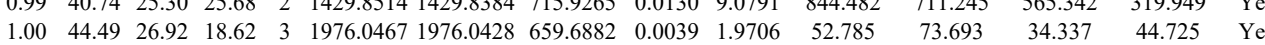
$\begin{array}{lllllllllllllll}1.00 & 53.47 & 22.83 & 18.35 & 3 & 1778.7694 & 1778.7676 & 593.9298 & 0.0018 & 1.0102 & 664.906 & 751.940 & 568.180 & 207.575 & \text { Yes }\end{array}$ $\begin{array}{lllllllllllllll}0.55 & 40.13 & 14.77 & 53.13 & 3 & 1534.9867 & 1534.9843 & 512.6687 & 0.0024 & 1.5605 & 248.011 & 247.699 & 95.299 & 53.157 & \text { Yes }\end{array}$ $\begin{array}{llllllllllllll}00 & 42.30 & 14.62 & 18.19 & 3 & 1534.9870 & 1534.9843 & 512.6687 & 0.0027 & 1.7555 & 251.602 & 249.814 & 137.498\end{array}$ $\begin{array}{llllllllllllll}1.00 & 60.39 & 14.77 & 19.61 & 3 & 1534.9864 & 1534.9843 & 512.6687 & 0.0021 & 1.3654 & 173.389 & 153.224 & 66.553\end{array}$ $\begin{array}{llllllllllllll}1.00 & 39.29 & 24.97 & 20.08 & 2 & 1261.7688 & 1261.7668 & 631.8907 & 0.0020 & 1.5825 & 28.715 & 11.978 & 7.022\end{array}$ $\begin{array}{lllllllllllll}0.55 & 15.61 & 24.47 & 28.61 & 3 & 2144.2093 & 2144.2076 & 7157431 & 0.0017 & 0.7917 & 38.929 & 51.074\end{array}$ $\begin{array}{llllllllllllll}\text { VSVFQTQLPSLGAGLLQSR } & 1.00 & \text { \#\#\#\# } 24.47 & 21.30 & 2 & 2144.2094 & 2144.2076 & 1073.1111 & 0.0018 & 0.8387 & 30.461 & 33.236\end{array}$ $\begin{array}{llllllllllllll}\text { VSVFQTQLPSLGAGLLQSR } & 0.53 & 21.05 & 24.38 & 34.05 & 3 & 2144.2102 & 2144.2076 & 715.7431 & 0.0026 & 1.2109 & 36.045 & 33.022\end{array}$ $\begin{array}{lllllllllllll}\text { VSVFQTQLPSLGAGLLQSR } & 1.00 & \text { \#\#\#\# } 24.47 & 21.29 & 2 & 2144.2094 & 2144.2076 & 1073.1111 & 0.0018 & 0.8387 & 115.356 & 113.341\end{array}$ $\begin{array}{lllllllllllll}\text { VSVFQTQLPSLGAGLLQSR } & 1.00 & \text { \#\#\#\# } 24.47 & 20.94 & 2 & 2144.2094 & 2144.2076 & 1073.1111 & 0.0018 & 0.8387 & 92.537 & 104.794\end{array}$ $\begin{array}{lllllllllllllll}\text { VSVFQTQLPSLGAGLLQSR } & 0.53 & 15.25 & 24.39 & 28.25 & 3 & 2144.2105 & 2144.2076 & 715.7431 & 0.0029 & 1.3506 & 44.636 & 56.921 & 2.606\end{array}$ $\begin{array}{lllllllllllll}\text { VSVFPTQLPSLGAGLLQSR } & 1.00 & 52.95 & 24.38 & 18.37 & 3 & 2144.2108 & 2144.2076 & 715.7431 & 0.0032 & 1.4903 & 40.914\end{array}$ LFPLYVLALLK LFPLYVLALLK LFPLYVLALLK LFPLYVLALLK LPLGLLLHPFR $\begin{array}{lllllllllll}1.00 & 74.98 & 11.14 & 25.07 & 2 & 1577.0202 & 1577.0200 & 789.5173 & 0.0002 & 0.1267 & 141.050\end{array}$ $\begin{array}{llllllllllll}1.00 & 73.61 & 11.14 & 22.00 & 2 & 1577.0204 & 1577.0200 & 789.5173 & 0.0004 & 0.2533 & 150.762\end{array}$

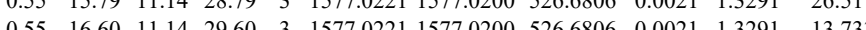

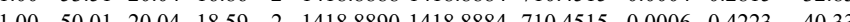

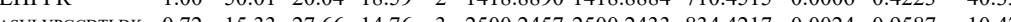
$\begin{array}{lllllllllllll}\text { SVNSLDGLASVLYPGCDTLDK } & 0.53 & 13.21 & 27.60 & 26.21 & 3 & 2500.2463 & 2500.2433 & 834.4217 & 0.0030 & 1.1984 & 20.750 & 5\end{array}$ $\begin{array}{llllllllllll} & \text { GDTSM }\end{array}$ $\begin{array}{llllllllllll}\text { GDTSMLKPTLMAAVPEIMDR } & 0.81 & 45.01 * & 26.63 & 24.61 & 3 & 2463.2848 & 2463.2779 & 822.0999 & 0.0069 & 2.7977 & 685.300\end{array}$

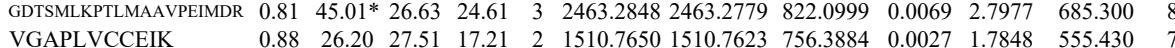
$\begin{array}{lllllllllllllll}\text { NTPLCDSFVFR } & 1.00 & 56.42 & 24.96 & 23.21 & 2 & 1487.7030 & 1487.7023 & 744.8584 & 0.0007 & 0.4699 & 1473.635 & 2574.254 & 55.057\end{array}$ $\begin{array}{lccccccccccccc}\text { EVLNEEDEVQPNGK } & 1.00 & 62.26 & 24.96 & 28.96 & 2 & 1487.7040 & 1487.7023 & 744.8584 & 0.0017 & 1.1412 & 983.052 & 1390.390 & 11.688\end{array}$

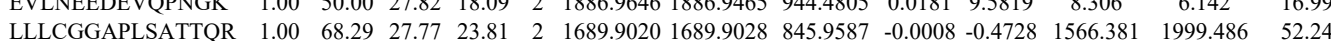
$\begin{array}{llllllllllllll}\text { LLLCGGAPLSATTQR } & 1.00 & 69.91 & 27.78 & 24.88 & 2 & 1689.9022 & 1689.9028 & 845.9587 & -0.0006 & -0.3546 & 1120.590 & 1703.502 & 69.357\end{array}$ $\begin{array}{lllllllllllllll}\text { LLLCGGAPLSATTQR } & 0.92 & 24.61 & 27.80 & 19.89 & 3 & 1689.9031 & 1689.9028 & 564.3082 & 0.0003 & 0.1772 & 403.273 & 446.679 & 73.215\end{array}$ $\begin{array}{llllllllllllll}\text { LLLCGGAPLSATTQR } & 1.00 & 76.20 & 27.77 & 28.39 & 2 & 1689.9020 & 1689.9028 & 845.9587 & -0.0008 & -0.4728 & 490.789 & 727.790 & 3.870\end{array}$

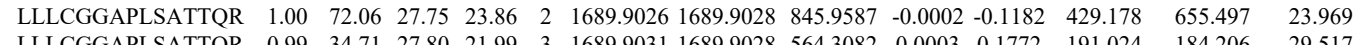

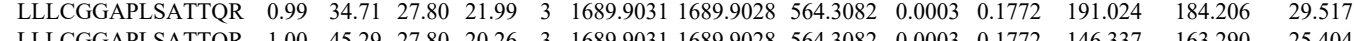
$\begin{array}{lllllllllllllll}\text { LLLCGGAPLSATTQR } & 1.00 & 45.29 & 27.80 & 20.26 & 3 & 1689.9031 & 1689.9028 & 564.3082 & 0.0003 & 0.1772 & 146.337 & 163.290 & 25.404\end{array}$ $\begin{array}{lllllllllllllll}\text { LLLCGGAPLSATTQR } & 1.00 & 66.06 & 27.77 & 26.85 & 2 & 1689.9020 & 1689.9028 & 845.9587 & -0.0008 & -0.4728 & 146.388 & 249.261 & 0.000\end{array}$ $\begin{array}{llllllllllllllll}\text { LLLCGGAPLSATTQR } & 0.99 & 33.48 & 27.74 & 21.12 & 3 & 1689.9028 & 1689.9028 & 564.3082 & 0.0000 & 0.0000 & 56.280 & 80.612 & 13.611\end{array}$

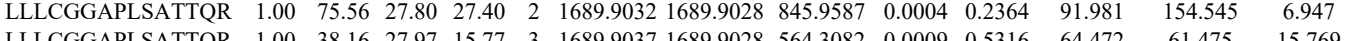
$\begin{array}{llllllllllllllll}\text { LLLGGAPLSATTQR } & 1.00 & 38.16 & 27.97 & 15.77 & 3 & 1689.9037 & 1689.9028 & 564.3082 & 0.0009 & 0.5316 & 64.472 & 61.475 & 15.769\end{array}$ RPPLMASGK RPPLMASGK RPPLMASGK

RPPLMASGK FNPSVFFLDFLVVPSSR AVIHLLLCQLR AVIHLLLCQLR $\begin{array}{llllllllllllll}0.93 & 24.03 & 26.80 & 21.50 & 3 & 1243.7314 & 1243.7314 & 415.5844 & 0.0000 & 0.0000 & 3393.748 & 3184.923 & 1581.637 & 75 \\ 0.95 & 23.08 & 26.69 & 15.54 & 3 & 1243.7323 & 1243.7314 & 415.5844 & 0.0009 & 0.7219 & 4531.547 & 4360.265 & 1845.591 & 81\end{array}$ $\begin{array}{lllllllllllllll}0.95 & 23.08 & 26.69 & 15.54 & 3 & 1243.7323 & 1243.7314 & 415.5844 & 0.0009 & 0.7219 & 4531.547 & 4360.265 & 1845.591 & 812.856\end{array}$

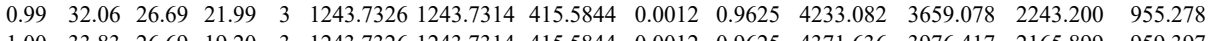

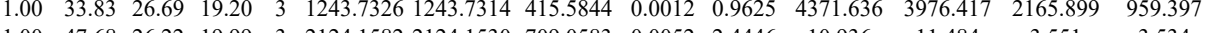

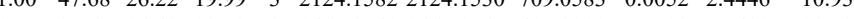
$\begin{array}{lllllllllll}1.00 & 37.60 & 24.42 & 22.72 & 3 & 1467.8548 & 1467.8540 & 490.2919 & 0.0008 & 0.5439 & 28.535\end{array}$

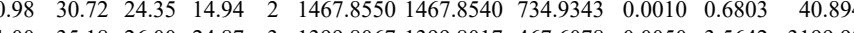
$31.87 .701-1193.148$ LEELEGFMLSK VVLASASPR 
$\begin{array}{llllllllllll}1.00 & 46.36 & 27.52 & 17.42 & 3 & 1820.9545 & 1820.9512 & 607.9910 & 0.0033 & 1.8092 & 269.652\end{array}$

$\begin{array}{lllllllllll}1.00 & 23.06 & 27.32 & 36.06 & 4 & 2599.2841 & 2599.2812 & 650.8276 & 0.0029 & 1.1140 & 1873.346\end{array}$ 


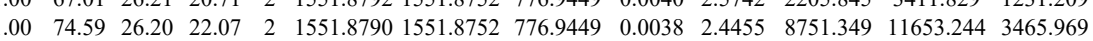

$\begin{array}{llllllllllllll}1.00 & 66.37 & 26.13 & 22.92 & 2 & 1551.8796 & 1551.8752 & 776.9449 & 0.0044 & 2.8316 & 2893.590 & 3679.222 & 1111.577 & 223.595\end{array}$ QVVESAYEVIK $\begin{array}{lllllllllllllll}1.00 & 79.58 & 25.97 & 22.69 & 2 & 1551.8800 & 1551.8752 & 776.9449 & 0.0048 & 3.0890 & 2596.322 & 3513.627 & 1376.188 & 240.929 \\ 1.00 & 72.53 & 25.73 & 21.31 & 2 & 1551.8808 & 15518752 & 776.9449 & 0.0056 & 3.6038 & 6632853 & 9136.346 & 3284.740 & 219.726\end{array}$ QVVVESAYEVIK QVVESAYEVIK

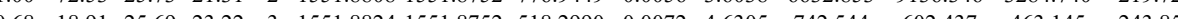
QADTLWGIQK

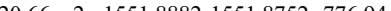

TLTSEEEAR

DLADELALVDV $\begin{array}{lllllllllllll} & \end{array}$

$\begin{array}{lllllllllllllll} & 22.09\end{array}$

ADTLWGIQK

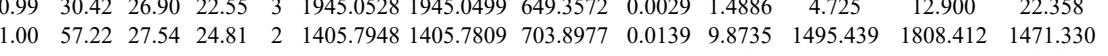

$\begin{array}{llllllllllllll}\text { GEMMDLQHGSLFLR } & 0.95 & 24.04 & 27.37 & 22.53 & 3 & 1776.8788 & 1776.8773 & 593.2997 & 0.0015 & 0.8427 & 202.050 & 207.622 & 147.422 \\ \text { GEMMDLQHGSLFLR } & 0.99 & 29.23 & 27.41 & 20.93 & 3 & 1776.8794 & 1776.8773 & 593.2997 & 0.0021 & 1.1798 & 285.714 & 293.719 & 147.239\end{array}$

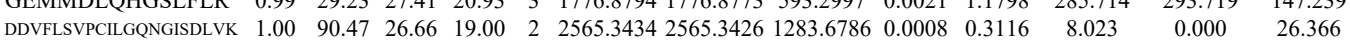

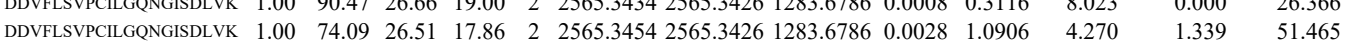

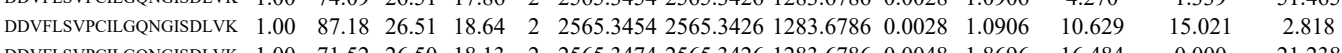
$\begin{array}{lllllllllllll}\text { DDVFLSVPCILGQNGISDLVK } & 1.00 & 71.52 & 26.50 & 18.13 & 2 & 2565.3474 & 2565.3426 & 1283.6786 & 0.0048 & 1.8696 & 16.484\end{array}$ VHPVSTMIK

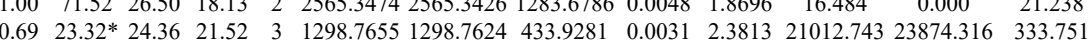
$\begin{array}{llllllllllllllll} & \end{array}$ $\begin{array}{llllllllllllll}\text { GYTSWAIGLSVADLAESIMK } & 1.00 & 45.88 & 26.87 & 16.82 & 3 & 2399.2669 & 2399.2650 & 800.7623 & 0.0019 & 0.7909 & 12.450 & 28\end{array}$ $\begin{array}{lllllllllllll}\text { GYTSWAIGLSVADLAESIMK } & 1.00 & 67.52 & 26.82 & 17.25 & 3 & 2399.2675 & 2399.2650 & 800.7623 & 0.0025 & 1.0407 & 15.252 & 28 \\ \end{array}$ $\begin{array}{lllllllllllllll}\text { GYTSWAIGLSVADLAESIMK } & 1.00 & 87.48 & 26.82 & 26.01 & 2 & 2399.2674 & 2399.2650 & 1200.6398 & 0.0024 & 0.9995 & 149.671 & 15 & \\ \text { VTLTSEEEAR } & 0.98 & 35.46 & 28.65 & 24.32 & 2 & 1277.6610 & 1277.6585 & 639.8365 & 0.0025 & 1.9536 & 60.453 & 66\end{array}$ VTLTSEEEAR $\begin{array}{llllllllllll}\text { DLADELALVDVIEDK } & 1.00 & 47.88 & 26.96 & 25.96 & 3 & 1945.0516 & 1945.0499 & 649.3572 & 0.0017 & 0.8727 & 29.648\end{array}$ DLADELALVDVIEDK FIPNVK

(1)

FIIPNVVK

$\begin{array}{llllllllllll}1.00 & 35.44 & 26.90 & 17.32 & 3 & 1945.0528 & 1945.0499 & 649.3572 & 0.0029 & 1.4886 & 22.898\end{array}$ $\begin{array}{llllllllllllll}1.00 & 37.52 & 20.72 & 24.96 & 2 & 1216.7798 & 1216.7787 & 609.3966 & 0.0011 & 0.9025 & 33189.579 & 45796.815 & 15101.806 & 2074.870\end{array}$ RVHPVSTMK RVHPSTMK $\begin{array}{lllllllllllllll}0.94 & 39.33 & 19.34 & 40.66 & 2 & 1216.7900 & 1216.7787 & 6909.3966 & 0.0113 & 9.2714 & 21811.124 & 31282.843 & 10999.835 & 1485.628\end{array}$

RVHPVSTMIK $\begin{array}{llllllllllllll}0.94 & 37.77 & 19.34 & 38.44 & 2 & 1216.7906 & 1216.7787 & 609.3966 & 0.0119 & 9.7637 & 20833.215 & 33521.170 & 12114.195 & 1881.890\end{array}$ $\begin{array}{llllllllllllll}1.00 & 38.56 & 23.91 & 22.73 & 3 & 1454.8624 & 1454.8635 & 485.9618 & -0.0011 & -0.7545 & 1017.264 & 1409.977 & 533.288 & 270.870 \\ 1.00 & 45.99 & 23.91 & 19.85 & 2 & 1454.8622 & 1454.8635 & 728.4390 & -0.0013 & -0.8923 & 412.624 & 588.849 & 94.490 & 23.80\end{array}$

DLADELALVDVEDDK

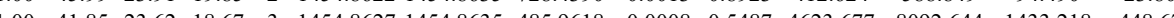
$\begin{array}{llllllllllllll}0.57 & 8.37 & 23.62 & 14.07 & 3 & 1454.8657 & 1454.8635 & 485.9618 & 0.0022 & 1.5090 & 2330.778 & 2312.619 & 969.105\end{array}$ $\begin{array}{lllllllllllll}0.57 & 8.37 & 23.18 & 14.07 & 3 & 1454.8657 & 1454.8635 & 485.9618 & 0.0022 & 1.5090 & 2330.778 & 23\end{array}$ $\begin{array}{llllllllllll}\text { DLADELALVDVIEDK } & 1.00 & 99.05 & 26.93 & 24.25 & 2 & 1945.0522 & 1945.0499 & 973.5322 & 0.0023 & 1.1813 & 16.072\end{array}$ $\begin{array}{lllllllllllll}\text { DLADELALVDVIEDK } & 0.53 & 11.59 & 26.90 & 16.74 & 3 & 1945.0528 & 1945.0499 & 649.3572 & 0.0029 & 1.4886 & 35.585\end{array}$ LVIITAGAR LVIITAGAR LVIITAGAR LVITAGAR LVIITAGAR LVIITAGAR LVIITAGAR LVIITAGAR LVIITAGAR LVIITAGAR $\begin{array}{llllllllllll}0.80 & 23.78 & 21.73 & 24.78 & 2 & 1056.6772 & 1056.6777 & 529.3461 & -0.0005 & -0.4723 & 21.238\end{array}$ $\begin{array}{lllllllllll}1.00 & 44.25 & 21.73 & 27.41 & 2 & 1056.6776 & 1056.6777 & 529.3461 & -0.0001 & -0.0945 & 30.156\end{array}$ $\begin{array}{lllllllllll}0.97 & 28.84 & 21.73 & 23.54 & 2 & 1056.6782 & 1056.6777 & 529.3461 & 0.0005 & 0.4723 & 68.493\end{array}$ $\begin{array}{llllllllllll}1.00 & 37.58 & 21.73 & 26.43 & 2 & 1056.6782 & 1056.6777 & 529.3461 & 0.0005 & 0.4723 & 39.584\end{array}$ $\begin{array}{lllllllllll}1.00 & 44.22 & 21.73 & 27.40 & 2 & 1056.6782 & 1056.6777 & 529.3461 & 0.0005 & 0.4723 & 25.295\end{array}$ $\begin{array}{lllllllllll}0.95 & 28.67 & 21.73 & 30.58 & 2 & 1056.6782 & 1056.6777 & 529.3461 & 0.0005 & 0.4723 & 15.452\end{array}$ $\begin{array}{lllllllllllll}0.99 & 39.59 & 21.70 & 35.70 & 2 & 1056.6786 & 1056.6777 & 529.3461 & 0.0009 & 0.8501 & 34.362\end{array}$ $\begin{array}{llllllllllll}0.90 & 43.61 & 21.70 & 51.86 & 2 & 1056.6786 & 1056.6777 & 529.3461 & 0.0009 & 0.8501 & 30.296\end{array}$ $\begin{array}{lllllllllllll}0.78 & 31.70 & 21.70 & 44.19 & 2 & 1056.6786 & 1056.6777 & 529.3461 & 0.0009 & 0.8501 & 62.204\end{array}$ $\begin{array}{llllllllllll}0.98 & 41.98 & 21.70 & 43.85 & 2 & 1056.6786 & 1056.6777 & 529.3461 & 0.0009 & 0.8501 & 35.871 \\ 0.81 & 44.62 & 21.70 & 56.34 & 2 & 1056.6786 & 10566777 & 529.3461 & 0.0009 & 0.8501 & 25.342\end{array}$ $\begin{array}{llllllllllll}0.81 & 44.62 & 21.70 & 56.34 & 2 & 1056.6786 & 1056.6777 & 529.3461 & 0.0009 & 0.8501 & 25.342 \\ 0.98 & 35.75 & 1.70 & 35.69 & 2 & 1056.67861056 .6777 & 529.3461 & 0.0009 & 0.8501 & 38.812\end{array}$ $\begin{array}{lllllllllllll}0.80 & 36.69 & 21.70 & 48.75 & 2 & 1056.6788 & 1056.6777 & 529.3461 & 0.0011 & 1.0390 & 40.646\end{array}$ $\begin{array}{lllllllllllll}0.76 & 29.32 & 21.70 & 42.24 & 2 & 1056.6790 & 1056.6777 & 529.3461 & 0.0013 & 1.2279 & 38.606\end{array}$ $\begin{array}{llllllllllll}0.96 & 33.74 & 21.70 & 37.49 & 2 & 1056.6790 & 1056.6777 & 529.3461 & 0.0013 & 1.2279 & 27.526 \\ 0.90 & 35.72 & 21.70 & 44.20 & 2 & 1056.6792 & 1056.6777 & 529.3461 & 0.0015 & 1.4168 & 43.857\end{array}$ $\begin{array}{lllllllllll}0.90 & 35.72 & 21.70 & 44.20 & 2 & 1056.6792 & 1056.6777 & 529.3461 & 0.0015 & 1.4168 & 43.857 \\ 0.90 & 44.65 & 21.70 & 52.90 & 2 & 1056.6792 & 10566777 & 529.3461 & 0.0015 & 1.4168 & 36.246\end{array}$ $\begin{array}{lllllllllllll}0.90 & 44.65 & 21.70 & 52.90 & 2 & 1056.6792 & 1056.6777 & 529.346 & 0.0015 & 1.4168 & 36.246\end{array}$ $\begin{array}{llllllllllll}0.85 & 33.04 & 22.65 & 43.86 & 2 & 1056.6796 & 1056.6777 & 529.3461 & 0.0019 & 1.7947 & 44.889\end{array}$ $\begin{array}{llllllllllll}0.82 & 28.12 & 22.65 & 39.87 & 2 & 1056.6796 & 1056.6777 & 529.3461 & 0.0019 & 1.7947 & 32.329\end{array}$ $\begin{array}{llllllllllll}0.93 & 26.26 & 22.65 & 33.57 & 2 & 1056.6798 & 1056.6777 & 529.3461 & 0.0021 & 1.9836 & 26.978\end{array}$

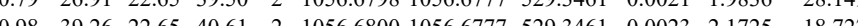
$\begin{array}{llllllllllll}0.79 & 29.32 & 22.65 & 41.90 & 2 & 10566800 & 10566777 & 529.3461 & 0.0023 & 2.1725 & 25.075\end{array}$ $\begin{array}{llllllllllllll}0.99 & 32.67 & 21.73 & 26.66 & 2 & 1056.6776 & 1056.6777 & 529.3461 & -0.0001 & -0.0945 & 47.975\end{array}$ 
$\begin{array}{lllllllllllll}45.31 & 22.65 & 42.90 & 2 & 1056.6802 & 1056.6777 & 529.3461 & 0.0025 & 2.3614 & 73944.165 & 94367.048 & 3876.402\end{array}$

$\begin{array}{llllllllllllll}45.70 & 21.73 & 29.76 & 2 & 1056.6780 & 1056.6777 & 529.3461 & 0.0003 & 0.2834 & 13579.961 & 15697.788 & 620.939\end{array}$

$\begin{array}{lllllllllllllll}0.99 & 45.72 & 21.70 & 43.53 & 2 & 1056.6786 & 1056.6777 & 529.3461 & 0.0009 & 0.8501 & 27629.076 & 38471.283 & 1000.335\end{array}$

$\begin{array}{lllllllllllll}0.82 & 21.79 & 21.70 & 33.08 & 2 & 1056.6786 & 1056.6777 & 529.3461 & 0.0009 & 0.8501 & 51.218 & 92.310 & 8.567\end{array}$

$\begin{array}{llllllllllll}0.78 & 18.76 & 21.70 & 30.81 & 2 & 1056.6790 & 1056.6777 & 5293461 & 0.0013 & 1.2279 & 53.071\end{array}$

$\begin{array}{lllllllllll}0.79 & 16.14 & 21.70 & 23.49 & 2 & 1056.6792 & 1056.6777 & 529.3461 & 0.0015 & 1.4168 & 19.088\end{array}$ $\begin{array}{lllllllllllll}0.90 & 28.09 & 22.65 & 36.95 & 2 & 1056.6794 & 1056.6777 & 529.3461 & 0.0017 & 1.6058 & 55.642\end{array}$ $\begin{array}{llllllllllll}0.81 & 24.15 & 22.65 & 36.03 & 2 & 1056.6802 & 1056.6777 & 529.3461 & 0.0025 & 2.3614 & 85.335 \\ 0.90 & 27.02 & 22.65 & 35.93 & 2 & 1056.6802 & 1056.6777 & 529.3461 & 0.0025 & 2.3614 & 53.162\end{array}$ $\begin{array}{lllllllllll}0.66 & 15.64 & 22.65 & 26.31 & 2 & 1056.6810 & 1056.6777 & 529.3461 & 0.0033 & 3.1170 & 49.076\end{array}$ $\begin{array}{llllllllll} & \end{array}$

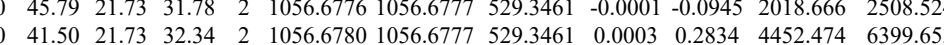

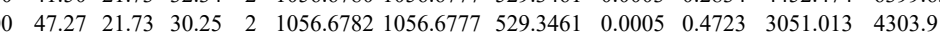
$\begin{array}{lllllllllllll}0.99 & 45.74 & 21.70 & 43.54 & 2 & 1056.6786 & 1056.6777 & 529.3461 & 0.0009 & 0.8501 & 3825.846 & 4778.146 & 21\end{array}$ $\begin{array}{lllllllllllll}1.00 & 47.33 & 21.73 & 32.29 & 2 & 1056.6772 & 1056.6777 & 529.3461 & -0.0005 & -0.4723 & 1968.007 & 2463.024 \\ 1.00 & 58.50 & 1.73 & 32.98 & 2 & 1056.6772 & 10566777 & 52.3461 & -0.0005 & -0.4723 & 3233.417 & 4040.211 & 32\end{array}$ $\begin{array}{llllllllllllll}1.00 & 58.50 & 21.73 & 32.98 & 2 & 1056.6772 & 1056.6777 & 529.3461 & -0.0005 & -0.4723 & 3233.417 & 4040.211 & 329 \\ 0.99 & 45.82 & 22.86 & 35.78 & 2 & 1056.6766 & 1056.6777 & 529.3461 & -0.0011 & -1.0390 & 2070.815 & 2772.637 & 196 .\end{array}$ $\begin{array}{lllllllllllll}0.99 & 45.82 & 22.86 & 35.78 & 2 & 1056.6766 & 1056.6777 & 529.3461 & -0.0011 & -1.0390 & 2070.815 & 2772.637 & 1 \\ 1.00 & 58.59 & 21.73 & 33.12 & 2 & 1056.6774 & 1056.6777 & 529.3461 & -0.0003 & -0.2834 & 1179.322 & 1585.398 & 82.5\end{array}$ $\begin{array}{lllllllllllll}0.99 & 36.76 & 21.73 & 30.30 & 2 & 1056.6776 & 1056.6777 & 529.3461 & -0.0001 & -0.0945 & 584.464 & 682.920 & 20839 \\ 0.99 & 36.98 & 11.73 & 29.99 & 2 & 1056.6776 & 0566.6777 & 592.3461 & -0.0001 & -0.0945 & 670.657 & 795.767 & 181.41\end{array}$ $\begin{array}{llllllllllllll}0.99 & 36.98 & 21.73 & 29.99 & 2 & 1056.6776 & 1056.6777 & 529.3461 & -0.0001 & -0.0945 & 670.657 & 795.767 & 181.416\end{array}$ $\begin{array}{llllllllllll}0.99 & 38.62 & 26.16 & 23.75 & 2 & 1133.5568 & 1133.5564 & 567.7855 & 0.0004 & 0.3522 & 12.193 & 15.162\end{array}$ $\begin{array}{lllllllllllll}1.00 & 40.68 & 27.06 & 23.47 & 2 & 1133.5574 & 1133.5564 & 567.7855 & 0.0010 & 0.8806 & 14.868 & 14.111\end{array}$ $\begin{array}{llllllllllll}0.99 & 33.90 & 21.73 & 23.43 & 2 & 1056.6776 & 1056.6777 & 529.3461 & -0.0001 & -0.0945 & 176.505 & 205.687 \\ 0.99 & 32.35 & 21.73 & 8.27 & 2 & 1056.6782 & 1056.6777 & 529.3461 & 0.0005 & 0.4723 & 339.035 & 42.31\end{array}$

VTLTSEEEAR $\begin{array}{llllllllllll}.76 & 24.20 & 27.63 & 29.50 & 2 & 1260.6554 & 1260.6554 & 631.3350 & 0.0000 & 0.0000 & 57.008\end{array}$ $\begin{array}{cr}424.313 & 80.142 \\ 63.151 & 89.848\end{array}$

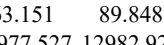
$\begin{array}{lllllllllllll}1.00 & 61.61 & 28.44 & 31.92 & 2 & 1277.6608 & 1277.6585 & 639.8365 & 0.0023 & 1.7973 & 57.000 .944 & 21977.527 & 12982.920\end{array}$ $\begin{array}{lllllllllll}1.00 & 54.13 & 28.57 & 24.68 & 2 & 1277.6614 & 1277.6585 & 639.8365 & 0.0029 & 2.2662 & 18594.755 \\ 0.98 & 34.98 & 27.07 & 28.77 & 3 & 1945.0489 & 1945.0499 & 649.3572 & -0.0010 & -0.5133 & 83.260\end{array}$

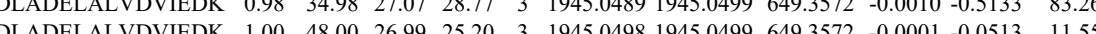
$\begin{array}{lllllllllllll}\text { DLADELALVDVIEDK } & 0.94 & 25.01 & 26.95 & 27.51 & 3 & 1945.0513 & 1945.0499 & 649.3572 & 0.0014 & 0.7187 & 69.510\end{array}$

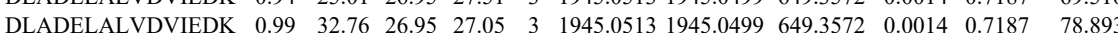
$\begin{array}{llllllllllll}\text { DLADELALVDVIEDK } & 0.97 & 23.89 & 26.95 & 22.62 & 3 & 1945.0519 & 1945.0499 & 649.3572 & 0.0020 & 1.0267 & 97.962\end{array}$ $\begin{array}{lllllllllllll}\text { DLADELALVDVIEDK } & 0.99 & 27.08 & 26.92 & 24.31 & 3 & 1945.0522 & 1945.0499 & 649.3572 & 0.0023 & 1.1807 & 64.506\end{array}$ $\begin{array}{llllllllllll}\text { DLADELALVDVIEDK } & 0.96 & 22.53 & 26.92 & 20.74 & 3 & 1945.0522 & 1945.0499 & 649.3572 & 0.0023 & 1.1807 & 69.346\end{array}$ $\begin{array}{llllllllllll}\text { DLADELALVDVIEDK } & 1.00 & 35.79 & 26.92 & 27.41 & 3 & 1945.0522 & 1945.0499 & 649.3572 & 0.0023 & 1.1807 & 114.306\end{array}$ $\begin{array}{lllllllllll}\text { DLADELALVDVIEDK } & 1.00 & \text { \#\#\#\# } 26.93 & 26.68 & 2 & 1945.0522 & 1945.0499 & 973.5322 & 0.0023 & 1.1813 & 549.881\end{array}$

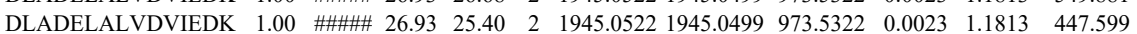
$\begin{array}{llllllllllllll}\text { DLADELALVDVIEDK } & 0.81 & 16.69 & 26.93 & 19.30 & 3 & 1945.0525 & 1945.0499 & 649.3572 & 0.0026 & 1.3347 & 79.663\end{array}$ $\begin{array}{llllllllllll}\text { DLADELALVDVIEDK } & 0.99 & 27.65 & 26.93 & 24.96 & 3 & 1945.0525 & 1945.0499 & 649.3572 & 0.0026 & 1.3347 & 75.129\end{array}$

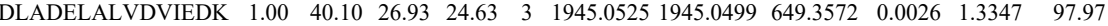
$\begin{array}{llllllllllll}\text { DLADELALVDVIEDK } & 1.00 & 48.38 & 26.90 & 27.17 & 3 & 1945.0528 & 1945.0499 & 649.3572 & 0.0029 & 1.4886 & 12.988\end{array}$ $\begin{array}{lllllllllllll}\text { DLADELALVDVIEDK } & 0.77 & 15.85 & 26.94 & 22.19 & 3 & 1945.0531 & 1945.0499 & 649.3572 & 0.0032 & 1.6426 & 65.254\end{array}$ $\begin{array}{lllllllllllll}\text { DLADELALVDVIEDK } & 1.00 & 45.04 & 26.94 & 19.52 & 3 & 1945.0531 & 1945.0499 & 649.3572 & 0.0032 & 1.6426 & 1153.267 \\ \text { DLADEEALVDVIEDK } & 0.65 & 15.24 & 26.94 & 26.37 & 3 & 1945.0534 & 1945.0499 & 649.3572 & 0.0035 & 17966 & 71.674\end{array}$ $\begin{array}{lllllllllllll}\text { DLADELALVDVIEDK } & 0.65 & 15.24 & 26.94 & 26.37 & 3 & 1945.0534 & 1945.0499 & 649.3572 & 0.0035 & 1.7966 & 71.674 \\ \text { DLDELALVVIEDK } & 0.92 & 20.14 & 26.94 & 24.02 & 3 & 1945.0534 & 1945.0499 & 649.3572 & 0.0035 & 1.7966 & 67.509\end{array}$ $\begin{array}{lllllllllllll}\text { DLADELALVDVIEDK } & 0.92 & 20.14 & 26.94 & 24.02 & 3 & 1945.0534 & 1945.0499 & 649.3572 & 0.0035 & 1.7966 & 67.509 \\ \text { DLADELALVDVIEDK } & 1.00 & 87.71 & 26.97 & 26.56 & 2 & 1945.0536 & 1945.0499 & 973.5322 & 0.0037 & 1.9003 & 16.257\end{array}$ $\begin{array}{llllllllllllll}\text { DLADELALVDVIEDK } & 1.00 & 87.71 & 26.97 & 26.56 & 2 & 1945.0536 & 1945.0499 & 973.5322 & 0.0037 & 1.9003 & 16.257 \\ \text { DLADELALVDVIEDK } & 0.98 & 25.90 & 26.97 & 25.28 & 3 & 1945.0537 & 1945.0499 & 649.3572 & 0.0038 & 1.9506 & 80.717\end{array}$ $\begin{array}{lllllllllllll}\text { DLADELALVDVIEDK } & 0.98 & 25.90 & 26.97 & 25.28 & 3 & 1945.0537 & 1945.0499 & 649.3572 & 0.0038 & 1.9506 & 80.717 \\ \text { DLADELALVDVIEDK } & 0.95 & 24.54 & 26.97 & 26.68 & 3 & 1945.0537 & 1945.0499 & 649.3572 & 0.0038 & 1.9506 & 99.324\end{array}$ $\begin{array}{lllllllllllll}\text { DLADELALVDVIEDK } & 0.95 & 24.54 & 26.97 & 26.68 & 3 & 1945.0537 & 1945.0499 & 649.3572 & 0.0038 & 1.9506 & 99.324 \\ \text { DLADELALVDVIEDK } & 0.66 & 15.55 & 26.95 & 21.15 & 3 & 1945.0546 & 1945.0499 & 649.3572 & 0.0047 & 2.4126 & 68.987\end{array}$ $\begin{array}{llllllllllll}\text { DLADELALVDVIEDK } & 0.66 & 15.55 & 26.95 & 21.15 & 3 & 1945.0546 & 1945.0499 & 649.3572 & 0.0047 & 2.4126 & 68.987 \\ \text { DLADELALVDVIEDK } & 0.92 & 25.06 & 26.89 & 19.16 & 3 & 1945.0555 & 1945.0499 & 649.3572 & 0.0056 & 2.8746 & 79.256\end{array}$ \begin{tabular}{lllllllllllll} 
DLADELALVDVIEDK & 0.92 & 25.06 & 26.89 & 1.15 & 3 & 1945.0546 & 1945.0499 & 649.3572 & 0.0047 & 2.4126 & 68.987 & 1945.0559 \\
\hline
\end{tabular} $\begin{array}{lllllllllllll}\text { DLADELALVDVIEDK } & 1.00 & 55.78 & 26.97 & 27.73 & 3 & 1945.0561 & 1945.0499 & 649.3572 & 0.0062 & 3.1826 & 1479.538\end{array}$ LVIITAGAR $\begin{array}{llllllllllll}0.99 & 32.40 & 21.73 & 24.56 & 2 & 1056.6780 & 1056.6777 & 529.3461 & 0.0003 & 0.2834 & 367.786\end{array}$ $\begin{array}{lrl}95.449 & 87.962 \\ 25.717 & 33.185\end{array}$ 


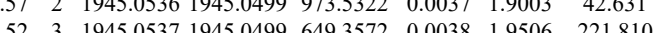
LVIITAGAR $\begin{array}{lllllllllll}1.00 & 59.72 & 26.97 & 27.52 & 3 & 1945.0537 & 1945.0499 & 649.3572 & 0.0038 & 1.9506 & 221.81 \\ 0.87 & 31.07 & 22.86 & 24.76 & 2 & 1056.6762 & 1056.6777 & 529.3461 & -0.0015 & -1.4168 & 152.74\end{array}$

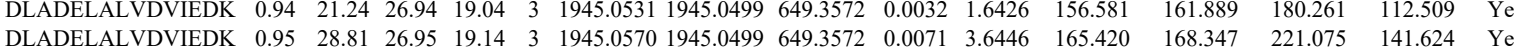

$\begin{array}{lllllllllllllllll}\text { DLADELALVDVIEDK } & 0.95 & 28.81 & 26.95 & 19.14 & 3 & 1945.0570 & 1945.0499 & 649.3572 & 0.0071 & 3.6446 & 165.420 & 168.347 & 221.075 & 141.624 & \text { Yes } \\ \text { TLHPDLGTDK } & 0.84 & 30.94 & 27.41 & 20.14 & 2 & 1383.7656 & 1383.7602 & 692.8874 & 0.0054 & 3.8967 & 3688.350 & 4241.443 & 4435.841 & 1915.956 & \text { Yes }\end{array}$ TLHPDLGTDK $\begin{array}{lllllllllllllllll}0.92 & 27.89 & 27.32 & 15.98 & 3 & 1383.7711 & 1383.7602 & 462.2607 & 0.0109 & 7.8599 & 11745.787 & 12923.031 & 3094.215 & 1214.977 & \text { Yes } & \\ 0.94 & 29.64 & 27.32 & 15.81 & 3 & 1383.7711 & 1383.7602 & 462.267 & 0.0109 & 7.8599 & 11714.521 & 15196.196 & 3639.274 & 1710.105 & \text { Yes }\end{array}$

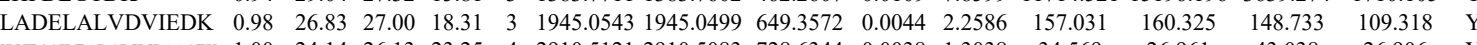
$\begin{array}{lllllllllllll}\text { TFVVQGFGNVGLHSMR } & 1.00 & 56.68 & 28.14 & 17.00 & 3 & 1891.9846 & 1891.9849 & 631.6689 & -0.0003 & -0.1583 & 37.233\end{array}$ $\begin{array}{lllllllllllll}\text { TFVVQGFGNVGLHSMR } & 1.00 & \text { \#\#\#\# } 28.10 & 22.76 & 3 & 1891.9870 & 1891.9849 & 631.6689 & 0.0021 & 1.1082 & 40.478\end{array}$ $\begin{array}{llllllllllll}\text { TFVVQGFGNVGLHSMR } & 0.99 & 29.93 & 28.10 & 19.50 & 3 & 1891.9870 & 1891.9849 & 631.6689 & 0.0021 & 1.1082 & 33.936\end{array}$ $\begin{array}{lllllllllllll}\text { TFVVQGFGNVGLHSMR } & 1.00 & 77.28 & 28.07 & 27.76 & 3 & 1891.9876 & 1891.9849 & 631.6689 & 0.0027 & 1.4248 & 33.117\end{array}$ $\begin{array}{llllllllllllll}\text { TFVVQGFGNVGLHSMR } & 1.00 & 35.20 & 28.07 & 17.30 & 3 & 1891.9876 & 1891.9849 & 631.6689 & 0.0027 & 1.4248 & 27.546\end{array}$ $\begin{array}{lllllllllllll}\text { TFVVQGFGNVGLHSMR } & 1.00 & 86.24 & 28.03 & 22.27 & 3 & 1891.9891 & 1891.9849 & 631.6689 & 0.0042 & 2.2163 & 14.154\end{array}$ $\begin{array}{lllllllllllll}\text { YSTDVSVDEVK } & 1.00 & 50.34 & 27.94 & 30.93 & 2 & 1528.8008 & 1528.7865 & 765.4005 & 0.0143 & 9.3414 & 482.200 & 567\end{array}$ $\begin{array}{llllllllllllll}\text { YSTDVSVDEVK } & 1.00 & 64.91 & 27.92 & 30.22 & 2 & 1528.7888 & 1528.7865 & 765.4005 & 0.0023 & 1.5025 & 1374.413 & 161 & \\ \end{array}$

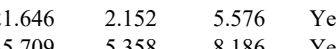

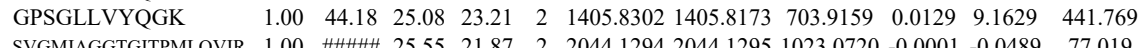

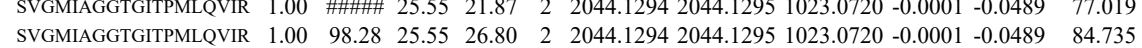
$\begin{array}{llllllllllll}\text { SVGMIAGGTGITPMLQVIR } & 1.00 & 98.28 & 25.55 & 26.80 & 2 & 2044.1294 & 2044.1295 & 1023.0720 & -0.0001 & -0.0489 & 84.735 \\ \text { SVGMIAGGTGITPMLQVIR } & 1.00 & 63.25 & 25.50 & 27.73 & 3 & 2044.1311 & 2044.1295 & 682.3838 & 0.0016 & 0.7816 & 49.432\end{array}$ $\begin{array}{llllllllllll}\text { SVGMIAGGTGITPMLQVIR } & 1.00 & 63.25 & 25.50 & 27.73 & 3 & 2044.1311 & 2044.1295 & 682.3838 & 0.0016 & 0.7816 & 49.432 \\ \text { SVGMIAGGTITPMLQVIR } & 1.00 & 64.39 & 25.31 & 19.29 & 3 & 2044.1320 & 2044.1295 & 682.3838 & 0.0025 & 1.2212 & 75.951\end{array}$ $\begin{array}{lllllllllllll}\text { SVGMIAGGTGITPML QVIR } & 1.00 & 51.93 & 25.50 & 22.47 & 3 & 2044.1311 & 2044.1295 & 622.3838 & 0.0016 & 0.7816 & 28.992\end{array}$ $\begin{array}{llllllllllllll}\text { ILYMTDEVNDPSLTIK } & 1.00 & 91.00 & 26.88 & 29.83 & 2 & 2139.1394 & 2139.1377 & 1070.5761 & 0.0017 & 0.7940 & 563.426\end{array}$ (3..494 36.987 


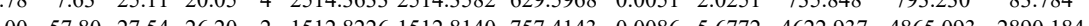
60.776 Yes

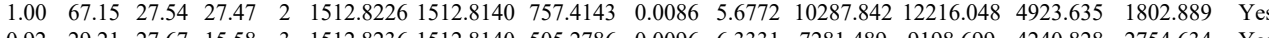

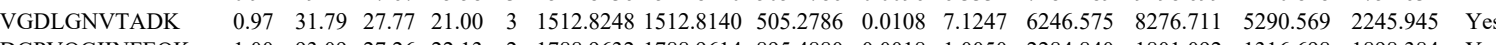
$\begin{array}{lllllllllllllllll}\text { GDGPVQGIINFEQK } & 1.00 & 93.09 & 27.26 & 22.13 & 2 & 1788.9632 & 1788.9614 & 895.4880 & 0.0018 & 1.0050 & 2284.840 & 1801.092 & 1316.698 & 1898.384 & Y & Y\end{array}$ $\begin{array}{lllllllllllllllll}\text { GDGPVQGIINFEQK } & 0.77 & 91.25 & 27.24 & \# \# \# \# & 2 & 1788.9634 & 1788.9614 & 895.4880 & 0.0020 & 1.1167 & 1847.228 & 2359.984 & 1629.866 & 2115.687 & \text { Yes }\end{array}$ $\begin{array}{llllllllllllllll}\text { GDGPVQGINFEQK } & 0.81 & 16.99 & 27.29 & 17.28 & 3 & 1788.9649 & 1788.9614 & 597.3277 & 0.0035 & 1.9531 & 176.124 & 215.267 & 331.788 & 220.855 & \text { Yes }\end{array}$ $\begin{array}{llllllllllllllll}\text { GDGPVQGIINFEQK } & 0.81 & 75.29 & 27.26 & 22.05 & 2 & 1788.9638 & 1788.9614 & 895.4880 & 0.0024 & 1.3400 & 1490.081 & 1561.941 & 1273.731 & 1509.380 & \text { Yes }\end{array}$ $\begin{array}{lllllllllllllllll}\text { GDGPVQGIINFEQK } & 0.99 & 30.50 & 27.29 & 15.33 & 3 & 1788.9649 & 1788.9614 & 597.3277 & 0.0035 & 1.9531 & 205.219 & 188.025 & 159.269 & 157.550 & \text { Yes }\end{array}$

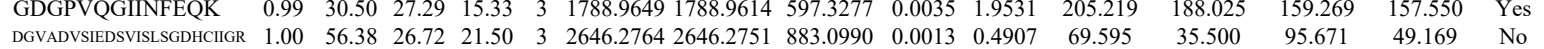
$\begin{array}{lllllllllllllllll}\text { DGVAVIESVISSGHIGR } & . .00 & 56.38 & 26.72 & 21.50 & 3 & 2646.2764 & 2646.2751 & 883.0990 & 0.0013 & 0.4907 & 69.595 & 35.500 & 95.671 & 49.169 & \text { No } \\ \text { DGVADSIEDVVISGGHCIGR } & 1.00 & 67.65 & 26.67 & 17.35 & 3 & 2646.2767 & 2646.2751 & 883.0990 & 0.0016 & 0.6039 & 24.178 & 87.018 & 107.268 & 88.579 & \text { No }\end{array}$ \begin{tabular}{llllllllllllllll} 
GDGPVQGINFEQK & 1.00 & 80.71 & 27.35 & 21.87 & 2 & 1788.9614 & 1788.9614 & 895.4880 & 0.0000 & 0.0000 & 983.381 & 784.025 & 630.468 & 506.492 & Yes \\
\hline
\end{tabular} \begin{tabular}{llllllllllllllll} 
DGVADVSIEDSVISLSGDHCIIGR & 1.00 & 72.11 & 26.67 & 22.50 & 3 & 2646.2767 & 2646.2751 & 883.0990 & 0.0016 & 0.6039 & 186.886 & 331.456 & 235.764 & 45.653 & Yes \\
\hline
\end{tabular} $\begin{array}{llllllllllllllll}\text { DGVADVSIEDSVISLSGDHCIIGR } & 1.00 & 79.11 & 26.75 & 18.06 & 3 & 2646.2761 & 2646.2751 & 883.0990 & 0.0010 & 0.3775 & 31.592 & 68.622 & 16.568 & 40.536 & \text { Yes }\end{array}$ $\begin{array}{llllllllllllllll}\text { DGVADVSIEDSVISLSGDHCIIGR } & 0.53 & 76.22 & 26.56 & 89.22 & 3 & 2646.2782 & 2646.2751 & 883.0990 & 0.0031 & 1.1701 & 32.136 & 62.350 & 45.348 & 58.867 & \text { Yes }\end{array}$ $\begin{array}{llllllllllllllll}\text { VWGSIK } & 0.82 & 28.13 & 25.01 & 30.17 & 2 & 976.6024 & 976.5949 & 489.3047 & 0.0075 & 7.6639 & 38178.853 & 36461.184 & 1797.370 & 1551.751 & \text { Yes }\end{array}$

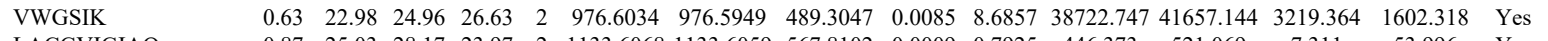

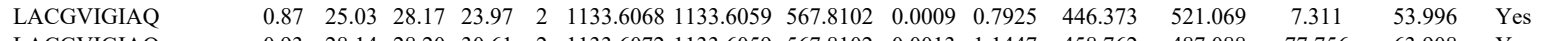
LACGVIGIAQ LACGVIGIAQ LACGVIGIAQ HVGDLGNVTADK HVGDLGNVTADK HVGDLGNVTADK

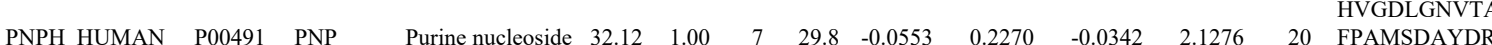
FPAMSDAYDR FPAMSDAYDR FPAMSDAYDR FEVGDIMLIR FEVGDIMLIR

FEVGDIMLIR

FEVGDIMLIR $\begin{array}{lllllllllllllll}0.93 & 28.14 & 28.20 & 30.61 & 2 & 1133.6072 & 1133.6059 & 567.8102 & 0.0013 & 1.1447 & 458.762 & 487.088 & 77.756 & 63.908 & \text { Yes }\end{array}$ $\begin{array}{llllllllllllllll}1.00 & 42.13 & 28.41 & 32.17 & 2 & 1133.6080 & 1133.6059 & 567.8102 & 0.0021 & 1.8492 & 664.371 & 759.407 & 62.454 & 88.915 & \text { Yes }\end{array}$ $\begin{array}{lllllllllllllll}0.99 & 36.50 & 28.17 & 23.11 & 2 & 1133.6068 & 1133.6059 & 567.8102 & 0.0009 & 0.7925 & 1592.758 & 1497.653 & 145.083 & 63.143 & \text { Yes }\end{array}$ $\begin{array}{llllllllllllllll}1.00 & 65.71 & 27.54 & 24.03 & 2 & 1512.8226 & 1512.8140 & 757.4143 & 0.0086 & 5.6772 & 19510.995 & 20700.369 & 9791.352 & 4012.108 & \text { Yes }\end{array}$ $\begin{array}{lllllllllllllll}0.97 & 32.64 & 27.53 & 21.94 & 3 & 1512.8230 & 1512.8140 & 505.2786 & 0.0090 & 5.9373 & 7509.902 & 8929.652 & 4978.492 & 2423.934 & \text { Yes }\end{array}$ $\begin{array}{llllllllllllllll}1.00 & 44.65 & 27.76 & 23.36 & 2 & 1512.8232 & 1512.8140 & 757.4143 & 0.0092 & 6.0733 & 12628.594 & 16632.043 & 8434.532 & 2832.723 & \text { Yes }\end{array}$ $\begin{array}{llllllllllllllll}0.98 & 34.79 & 27.81 & 23.58 & 3 & 1512.8242 & 1512.8140 & 505.2786 & 0.0102 & 6.7289 & 7603.505 & 10247.205 & 4658.256 & 2856.320 & \text { Yes } & \\ 1.00 & 45.34 & 25.07 & 25.10 & 2 & 1315.6110 & 1315.5989 & 658.8067 & 0.0121 & 9.1832 & 153.232 & 1430.86 & 1339.728 & 95.866 & \text { No }\end{array}$ $\begin{array}{llllllllllllllll}1.00 & 45.34 & 25.07 & 25.10 & 2 & 1315.6110 & 1315.5989 & 658.8067 & 0.0121 & 9.1832 & 1530.232 & 1430.869 & 1339.728 & 985.866 & \mathrm{No} & \\ 1.00 & 53.83 & 25.00 & 25.55 & 2 & 1315.6114 & 1315.5989 & 658.8067 & 0.0125 & 9.4868 & 1444.032 & 1493.793 & 1158.562 & 691.708 & \mathrm{Yes}\end{array}$ $\begin{array}{lllllllllllllll}1.00 & 53.83 & 25.00 & 25.55 & 2 & 1315.6114 & 1315.5989 & 658.8067 & 0.0125 & 9.4868 & 1444.032 & 1493.793 & 1158.562 & 691.708 & \text { Ycs }\end{array}$

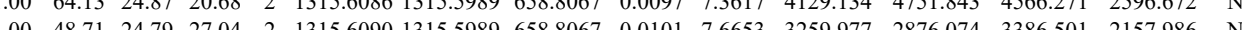
$\begin{array}{lllllllllllllll}1.00 & 45.12 & 27.71 & 28.26 & 2 & 1335.7372 & 1335.7342 & 688.8744 & 0.0030 & 2.2426 & 9814.780 & 9562.850 & 5647.479 & 1813.118 & \text { Yes }\end{array}$ $\begin{array}{llllllllllllllll}1.00 & 45.72 & 27.65 & 28.13 & 2 & 1335.7384 & 1335.7342 & 668.8744 & 0.0042 & 3.1396 & 15752.272 & 15762.932 & 8688.207 & 2204.216 & \text { Yes } & \\ 1.00 & 47.68 & 27.85 & 28.42 & 2 & 1335.7366 & 1335.7342 & 668.8744 & 0.0024 & 1.7941 & 9064.493 & 8259.824 & 5223.849 & 1405.342 & \text { Yes }\end{array}$ $\begin{array}{llllllllllllllllll}1.00 & 45.13 & 27.75 & 28.25 & 2 & 1335.7378 & 1335.7342 & 668.8744 & 0.0036 & 2.6911 & 11409.780 & 11841.012 & 5272.496 & 2235.065 & \text { Yes }\end{array}$

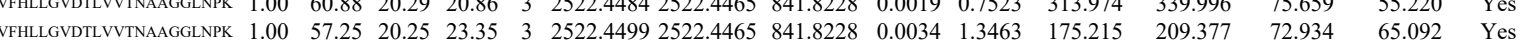

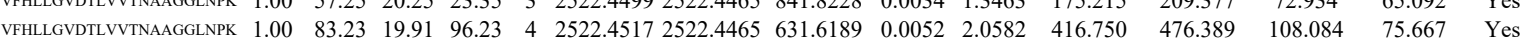

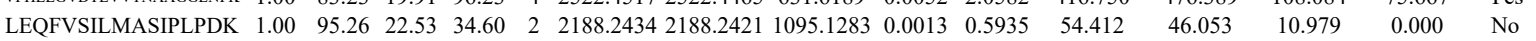
$\begin{array}{llllllllllllllll}\text { LEQFVSILMASIPLPDK } & 1.00 & 98.92 & 22.25 & 28.80 & 2 & 2188.2454 & 2188.2421 & 1095.1283 & 0.0033 & 1.5067 & 38.103 & 38.666 & 22.409 & 0.000 & \text { No }\end{array}$

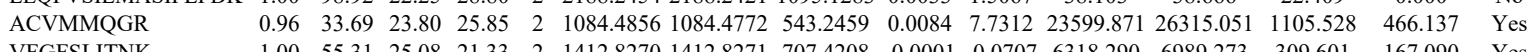
$\begin{array}{llllllllllllllll}\text { VFGFSLITNK } & 1.00 & 55.31 & 25.08 & 21.33 & 2 & 1412.8270 & 1412.8271 & 707.4208 & -0.0001 & -0.0707 & 6318.290 & 6989.273 & 309.601 & 167.090 & \text { Yes }\end{array}$

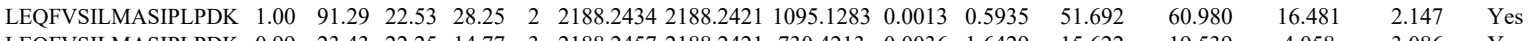

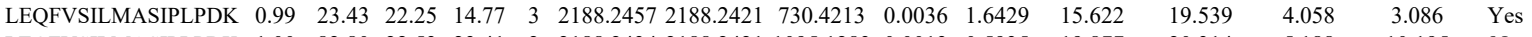
$\begin{array}{lllllllllllll} & \end{array}$ LVFGFLNGR LVFGFLNGR LVFGFLNGR LVFGFLNGR LVFGFLNGR LVFGFLNGR LVFGFLNGR

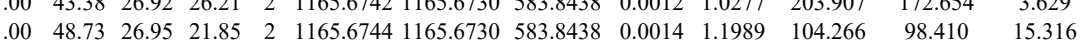
\begin{tabular}{lllllllllllll}
.00 & 55.42 & 24.62 & 18.93 & 3 & 1715.9944 & 1715.9913 & 573.0044 & 0.0031 & 1.8034 & 98.453 & 119.329 & 89.361 \\
\hline
\end{tabular} $\begin{array}{llllllllllllll}1.00 & 44.86 & 24.42 & 16.23 & 3 & 1715.9950 & 1715.9913 & 573.0044 & 0.0037 & 2.1524 & 84.387 & 112.935 & 47.576\end{array}$

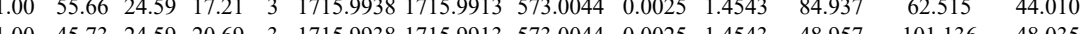



\begin{tabular}{llllllllllllllll}
1.00 & 39.75 & 26.49 & 20.07 & 3 & 1440.8170 & 1440.8033 & 481.2750 & 0.0137 & 9.4886 & 8689.756 & 9357.755 & 932.590 & 28.882 & Yes \\
\hline
\end{tabular} $\begin{array}{llllllllllllll}1.00 & 61.86 & 26.80 & 21.04 & 2 & 1304.7624 & 1304.7608 & 653.3877 & 0.0016 & 1.2244 & 1383.551 & 1699.905 & 35.437 & 18.136 \\ 1.00 & 66.91 & 26.80 & 2.03 & 2 & 1304.7624 & 1304.7608 & 653.3877 & 0.0016 & 1.2244 & 3327.116 & 3927.377 & 53.483 & 17.077\end{array}$

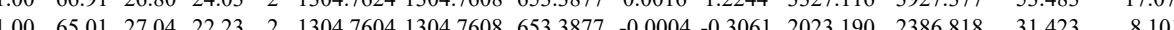
$\begin{array}{llllllllllllllllll}1.00 & 65.01 & 27.04 & 22.23 & 2 & 1304.7604 & 1304.7608 & 653.3877 & 0.0004 & 0.3061 & 2023.190 & 2386.818 & 31.423\end{array}$

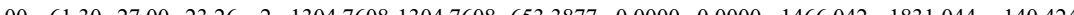

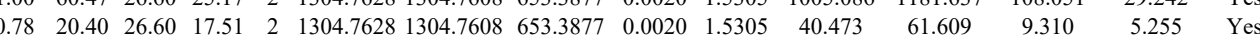

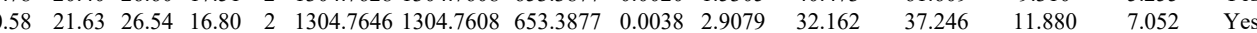

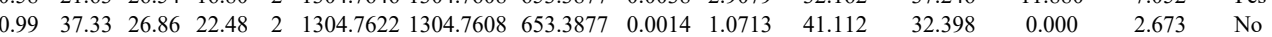
$\begin{array}{lllllllllllllll}1.00 & 38.12 & 22.48 & 20.40 & 3 & 1360.8412 & 1360.8403 & 454.6207 & 0.0009 & 0.6599 & 2770.562 & 2975.320 & 1199.624 & 433.764 & \text { Yes }\end{array}$ $\begin{array}{llllllllllllllll}1.00 & 32.61 & 21.55 & 18.73 & 3 & 1360.8430 & 1360.8403 & 454.6207 & 0.0027 & 1.9797 & 3776.141 & 3241.834 & 1409.227 & 475.985 & \text { Yes }\end{array}$ $\begin{array}{llllllllllllllll}0.88 & 29.95 & 27.56 & 34.21 & 2 & 1217.7112 & 1217.7012 & 609.8579 & 0.0100 & 8.1986 & 8989.351 & 7576.645 & 3254.255 & 1278.769 & \text { Yes }\end{array}$ $\begin{array}{llllllllllllllll}0.86 & 28.61 & 27.53 & 33.34 & 2 & 1217.7122 & 1217.7012 & 609.8579 & 0.0110 & 9.0184 & 12404.455 & 10915.748 & 4741.780 & 2166.228 & \text { Yes }\end{array}$ $\begin{array}{lllllllllllllllll}0.99 & 45.05 & 26.31 & 25.11 & 2 & 1281.6318 & 1281.6257 & 641.8201 & 0.0061 & 4.7521 & 8233.944 & 8843.717 & 9885.440 & 6043.455 & \text { Yes }\end{array}$ $\begin{array}{llllllllllllllll}1.00 & 47.51 & 26.31 & 25.76 & 2 & 1281.6318 & 1281.6257 & 641.8201 & 0.0061 & 4.7521 & 7446.533 & 7795.956 & 8535.083 & 5433.990 & \text { Yes }\end{array}$ $\begin{array}{lllllllllllllll}1.00 & 68.71 & 26.79 & 27.63 & 2 & 1922.9028 & 1922.8998 & 962.4572 & 0.0030 & 1.5585 & 171.375 & 154.576 & 15.166 & 20.864 & \text { Yes }\end{array}$

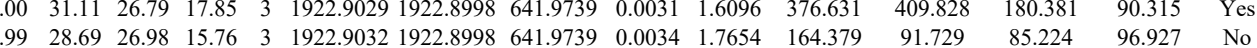
$\begin{array}{lllllllllllllll}0.90 & 26.73 & 27.09 & 15.39 & 3 & 1746.9643 & 1746.9508 & 583.3242 & 0.0135 & 7.7143 & 5888.213 & 5240.923 & 6215.906 & 6002.235 & \text { No }\end{array}$ $\begin{array}{lllllllllllllll}1.00 & 32.45 & 26.92 & 19.26 & 3 & 1922.9038 & 1922.8998 & 641.9739 & 0.0040 & 2.0769 & 112.062 & 83.476 & 62.384 & 59.597 & \text { Yes }\end{array}$

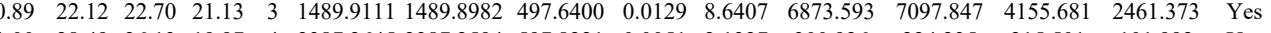

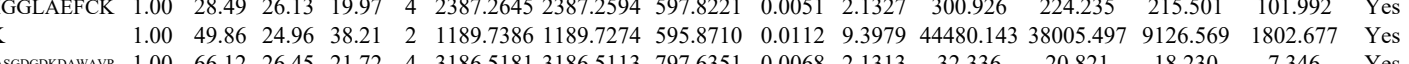

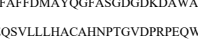

IAAAILNTPDLR

IPEQSVLLLHACAHNTGVDPRR
IAAAILNTPDLR

\section{IAAAILNTPDLR}

IAAAILNTPDLR

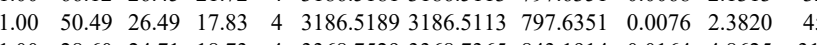

IAAAILNTPDLR

MNLGVGAYR

MNLGVGAYR

VGAFTMVCK

MNLGVGAYR

MNLGVGAYR

MNLGVGAYR

MNLGVGAYR
VGAFTMVCK

VGAFTMVCK

MNLGVGAYR

MNLGVGAYR

VGAFTMVCK

VGAFTMVCK

IGASFLQR

IGASFLQR

IGASFLQR

IGASFLQR

FVTVQTISGTGALR

FVTVQTISGTGALR

IGASFLQR

IGASFLQR

FVTVQTISGTGALR $\begin{array}{lllllllllllllll}1.00 & 71.18 & 24.90 & 32.73 & 2 & 1410.8318 & 1410.8316 & 706.4231 & 0.0002 & 0.1416 & 11508.293 & 10768.074 & 2061.121 & 547.493 & \text { Yes }\end{array}$ $\begin{array}{lllllllllllllll}1.00 & 69.29 & 24.90 & 31.87 & 2 & 1410.8322 & 1410.8316 & 706.4231 & 0.0006 & 0.4247 & 7101.947 & 7070.546 & 760.959 & 407.010 & \text { Yes } \\ 1.00 & 63.09 & 24.90 & 30.41 & 2 & 1410.8322 & 1410.8316 & 706.4231 & 0.0006 & 0.4247 & 11077.709 & 11098.076 & 993.286 & 260.665 & \text { Yes }\end{array}$

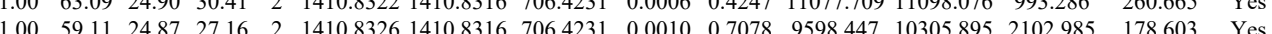

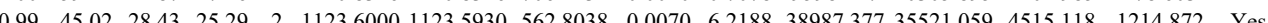

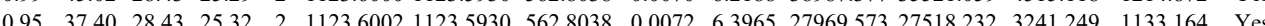
$\begin{array}{lllllllllllllll}1.00 & 51.56 & 27.85 & 31.12 & 2 & 1288.6600 & 1288.6586 & 645.3366 & 0.0014 & 1.0847 & 32038.560 & 29606.937 & 5197.733 & 854.678 & \text { Yes }\end{array}$ $\begin{array}{lllllllllllllll}1.00 & 51.50 & 27.94 & 33.04 & 2 & 1288.6606 & 1288.6586 & 6453366 & 0.0020 & 1.5496 & 27412.958 & 28420.814 & 3213.015 & 1410.184 & \text { Yes }\end{array}$

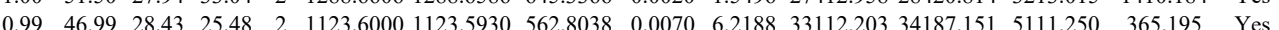
$\begin{array}{lllllllllllllll}0.99 & 44.61 & 28.62 & 25.41 & 2 & 1123.6008 & 1123.5930 & 5628038 & 0.0078 & 6.9295 & 14225.936 & 14185185 & 1728.479 & 437.251 & \text { Yes }\end{array}$ $\begin{array}{llllllllllllllll}1.00 & 41.96 & 27.21 & 19.62 & 2 & 1139.5886 & 1139.5879 & 570.8012 & 0.0007 & 0.6132 & 4644.237 & 4571.266 & 468.339 & 262.779 & \text { Yes }\end{array}$ $\begin{array}{lllllllllllllll}1.00 & 51.54 & 27.83 & 28.89 & 2 & 1288.6598 & 1288.6586 & 645.3366 & 0.0012 & 0.9297 & 29133.542 & 31037.488 & 3805.688 & 879.374 & \text { Yes }\end{array}$ $\begin{array}{llllllllllllllll}1.00 & 51.58 & 27.93 & 28.87 & 2 & 1288.6614 & 1288.6586 & 645.3366 & 0.0028 & 2.1694 & 24264.270 & 23033.834 & 3622.618 & 423.458 & \text { Yes }\end{array}$ $\begin{array}{llllllllllllllll}0.98 & 41.60 & 28.47 & 25.69 & 2 & 1123.5996 & 1123.5930 & 562.8038 & 0.0066 & 5.8635 & 26158.282 & 26595.587 & 2830.927 & 847.364 & \text { Yes }\end{array}$ $\begin{array}{lllllllllllllllll}0.94 & 36.68 & 28.47 & 24.81 & 2 & 1123.5998 & 1123.5930 & 562.8038 & 0.0068 & 6.0411 & 19480.748 & 17684.570 & 2919.947 & 349.221 & \text { Yes }\end{array}$ $\begin{array}{lllllllllllllll}1.00 & 46.69 & 27.90 & 28.97 & 2 & 1288.6592 & 1288.6586 & 645.3366 & 0.0006 & 0.4649 & 8587.806 & 7651.453 & 1323.625 & 356.849 & \text { Yes }\end{array}$ $\begin{array}{lllllllllllllll}1.00 & 47.59 & 27.96 & 28.97 & 2 & 1288.6610 & 1288.6586 & 645.3366 & 0.0024 & 1.8595 & 14143.486 & 12843.091 & 2331.765 & 785.974 & \text { Yes }\end{array}$ $\begin{array}{lllllllllllllll}0.97 & 38.28 & 26.99 & 33.99 & 2 & 1034.6084 & 1034.5995 & 518.3070 & 0.0089 & 8.5856 & 26282.661 & 24492.745 & 4834.916 & 867.295 & \text { Yes }\end{array}$ $\begin{array}{lllllllllllllll}0.97 & 36.81 & 27.08 & 26.86 & 2 & 1034.6088 & 1034.5995 & 518.3070 & 0.0093 & 8.9714 & 49754.635 & 45002.412 & 7951.661 & 802.637 & \text { Yes }\end{array}$ \begin{tabular}{lllllllllllllllll}
0.99 & 43.32 & 27.02 & 29.39 & 2 & 1034.6068 & 1034.5995 & 518.3070 & 0.0073 & 7.0421 & 38103.476 & 39169.690 & 6863.776 & 985.932 & Yes \\
\hline
\end{tabular}

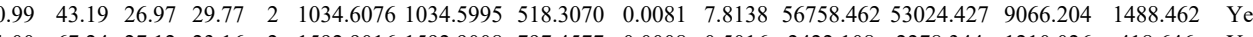
$\begin{array}{lllllllllllllll}1.00 & 67.24 & 27.12 & 23.16 & 2 & 1592.9016 & 1592.9008 & 797.4577 & 0.0008 & 0.5016 & 2422.108 & 2278.344 & 1210.026 & 418.646 & \text { Yes }\end{array}$ $\begin{array}{lllllllllllllll}1.00 & 77.54 & 26.97 & 22.93 & 2 & 1592.9032 & 1592.9008 & 797.4577 & 0.0024 & 1.5048 & 2159.550 & 1720.474 & 1032.655 & 655.132 & \text { Yes } \\ 0.97 & 36.25 & 26.96 & 26.85 & 2 & 1034.6090 & 1034.5995 & 518.3070 & 0.0095 & 9.1644 & 23653.744 & 23415.366 & 3233.193 & 563.264 & \text { Yes }\end{array}$ $\begin{array}{lllllllllllllll}0.97 & 36.25 & 26.96 & 26.85 & 2 & 1034.6090 & 1034.5995 & 518.3070 & 0.0095 & 9.1644 & 23653.744 & 23415.366 & 3233.193 & 563.264 & \text { Yes }\end{array}$

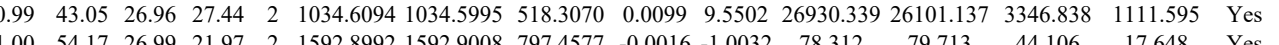

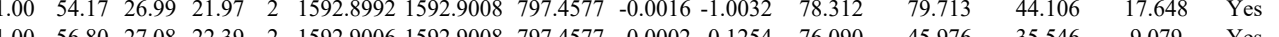

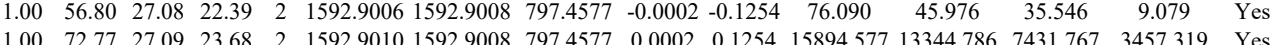

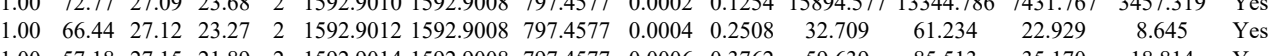

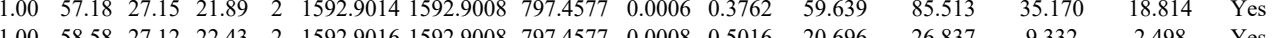

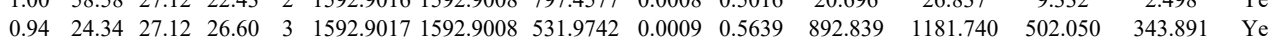



$\begin{array}{llllllllllll}\text { ASAELALGENSEVLK } & 0.55 & 26.53 & 26.72 & 39.53 & 3 & 1817.9995 & 1817.9978 & 607.0065 & 0.0017 & 0.9335 & 24.901\end{array}$

$\begin{array}{llllllllllllll}\text { GDSFTHTPPLDPQELDILK } & 1.00 & 39.69 & 27.34 & 20.87 & 3 & 2410.2646 & 2410.2624 & 804.4281 & 0.0022 & 0.9116 & 269.710\end{array}$ $\begin{array}{lllllllllllllll}\text { GDSFTHTPLDPQELDILK } & 0.99 & 30.76 & 27.34 & 18.00 & 3 & 2410.2646 & 2410.2624 & 804.4281 & 0.0022 & 0.9116 & 35.729 & 102.465 & 30.000 & 4\end{array}$ $\begin{array}{lllllllllllllll}\text { LTQLGTFEDHFLSLQR } & 1.00 & 86.37 & 27.25 & 19.07 & 3 & 2048.0914 & 2048.0813 & 683.7010 & 0.0101 & 4.9242 & 8718.807 & 10062.091 & 1211.419\end{array}$ $\begin{array}{lllllllllllllll}\text { LTQLGTFEDHFLSLQR } & 1.00 & 75.62 & 27.36 & 17.85 & 3 & 2048.0896 & 2048.0813 & 683.7010 & 0.0083 & 4.0466 & 3077.332 & 3182.474 & 684.391\end{array}$ IPLENLQIIR IPLENLQIIR IPLENLQIIR IPLENLQIIR WMALESILHR WMALESILHR WMALESILHR $\begin{array}{llllllllllllll}1.00 & 39.69 & 21.34 & 24.37 & 2 & 1351.8350 & 1351.8309 & 676.9227 & 0.0041 & 3.0284 & 3922.795 & 4783.798 & 5516.670 & 45\end{array}$ $\begin{array}{lccccccccccccccc}\text { WMALESILHR } & 1.00 & 53.05 & 27.83 & 25.83 & 3 & 1398.7573 & 1398.7563 & 467.2594 & 0.0010 & 0.7134 & 2237.717 & 1677.129 & 126.691 & 22.995 & \text { Yes } \\ \text { WMALESILHR } & 1.00 & 53.18 & 27.98 & 28.46 & 3 & 1398.7585 & 1398.7563 & 467.2594 & 0.0022 & 1.5694 & 2306.633 & 1837.469 & 47.121 & 21.182 & \text { Yes } \\ \text { TIQEVAGYVLIALNTVER } & 1.00 & 37.44 & 24.25 & 26.43 & 3 & 2132.2006 & 2132.1963 & 711.7394 & 0.0043 & 2.0138 & 3.028 & 4.446 & 6.248 & 4.072 & \text { Yes }\end{array}$ $\begin{array}{llllllllllllllll}1.00 & 50.72 & 21.37 & 23.86 & 2 & 1351.8334 & 1351.8309 & 676.9227 & 0.0025 & 1.8466 & 3414.315 & 3808.337 & 3867.121 & 3601.216 & \text { Yes } & \\ \end{array}$ $\begin{array}{llllllllllllllll}1.00 & 52.46 & 21.37 & 27.50 & 2 & 1351.8334 & 1351.8309 & 676.9227 & 0.0025 & 1.8466 & 4179.021 & 4212.894 & 4679.795 & 3804.782 & \text { Yes }\end{array}$ $\begin{array}{llllllllllllllll}1.00 & 51.61 & 27.92 & 25.57 & 3 & 1398.7594 & 1398.7563 & 467.2594 & 0.0031 & 2.2115 & 4489.773 & 3423.411 & 58.884 & 0.000 & \text { No } \\ 1.00 & 53.05 & 27.83 & 25.83 & 3 & 1398.7573 & 1398.7563 & 467.2594 & 0.0010 & 0.7134 & 2237.717 & 1677.129 & 126.691 & 22.995 & \text { Y }\end{array}$ $\begin{array}{llllllllllllllll} & \end{array}$ $\begin{array}{lllllllllllll} & \end{array}$ 
RPAGSVQNPVYHNOPLNPAPSR NNQITNNQR VLNNMEIGTSLFDEEGAK YSLEPVAVELK YSLEPVAVELK

YSLEPVAVELK

YSLEPVAVELK

YSLEPVAVELK

YSLEPVAVELK

YSLEPVAVELK

ITLPVDFVTADKFDENAK ITLPVDFVTADKFDENAK YSLEPVAVELK

ITLPVDFVTADKFDENAK ITLPVDFVTADKFDENAK ITLPVDFVTADK

\section{FCLDNGAK}

ITLPVDFVTADKFDENAK

ITLPVDFVTADKFDENAK

ITLPVDFVTADK

ITLPVDFVTADK

ITLPVDFVTADK

ITLPVDFVTADK

VLPGVDALSNI

ITLPVDFVTADK

ITLPVDFVTADK

ITLPVDFVTADK

ITLPVDFVTADK

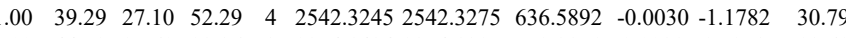
$\begin{array}{lllllllllll}1.00 & 4.72 & 27.60 & 22.36 & 3 & 2254.1434 & 2254.1395 & 752.3871 & 0.0039 & 1.7278 & 18.614\end{array}$

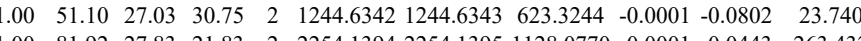

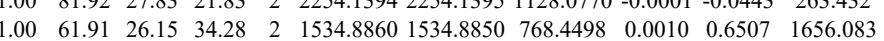
$\begin{array}{llllllllllll}0.94 & 21.81 & 26.15 & 19.21 & 3 & 1534.8862 & 1534.8850 & 512.6356 & 0.0012 & 0.7803 & 59.238\end{array}$ $\begin{array}{lllllllllllll}.00 & 51.41 & 26.15 & 27.31 & 2 & 1534.8862 & 1534.8850 & 768.4498 & 0.0012 & 0.7808 & 1245.962 & 9\end{array}$ $\begin{array}{lllllllllllll}1.00 & 36.27 & 25.82 & 23.85 & 3 & 1534.8865 & 1534.8850 & 512.6356 & 0.0015 & 0.9754 & 96.714 & 41\end{array}$ $\begin{array}{lllllllllll}1.00 & 59.48 & 24.84 & 25.34 & 2 & 1534.8982 & 1534.8850 & 768.4498 & 0.0132 & 8.5886 & 3523.537 \\ 0.99 & 38.97 & 24.84 & 26.49 & 3 & 1534.8985 & 1534.8850 & 512.635 & 0.0135 & 8.778 & 94.612\end{array}$ $\begin{array}{lllllllllll}1.00 & 49.79 & 24.80 & 27.15 & 2 & 1534.8986 & 1534.8850 & 768.4498 & 0.0136 & 8.8489 & 1533.447\end{array}$ $\begin{array}{llllllllllllll}0.99 & 33.36 & 24.76 & 22.37 & 3 & 1534.8988 & 1534.8850 & 512.6356 & 0.0138 & 8.9732 & 115.071 & 7 & & \end{array}$

$\begin{array}{llllllllllll}1.00 & 50.40 & 25.02 & 16.30 & 3 & 2454.3391 & 2454.3372 & 819.1197 & 0.0019 & 0.7732 & 3097.873 & 3\end{array}$ $\left.\begin{array}{llllllllllll}0.99 & 22.54 & 24.84 & 14.53 & 4 & 2454.3397 & 2454.3372 & 614.5916 & 0.0025 & 1.0169 & 85.333 & 23\end{array}\right]$ $\begin{array}{llllllllllll}1.00 & 55.36 & 24.80 & 34.09 & 2 & 1534.8986 & 1534.8850 & 768.4498 & 0.0136 & 8.8489 & 428.291 & 77\end{array}$ $\begin{array}{lllllllllllllll}1.00 & 55.45 & 24.23 & 30.86 & 2 & 1534.8998 & 1534.8850 & 768.4498 & 0.0148 & 9.6297 & 406.963 & 487 & \end{array}$ $\begin{array}{llllllllllll}1.00 & 48.64 & 25.02 & 17.12 & 3 & 2454.3391 & 2454.3372 & 819.1197 & 0.0019 & 0.7732 & 6730.377\end{array}$

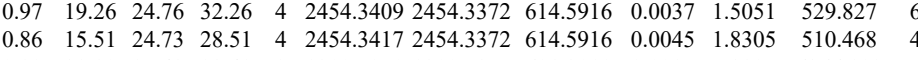
$\begin{array}{lllllllllllllll}0.99 & 39.90 & 25.42 & 22.49 & 2 & 1200.5970 & 1200.5875 & 601.3010 & 0.0095 & 7.8995 & 6366.102 & 7178.423 & 7884.737 & 1013.633 & \text { Yes } \\ 0.99 & 44.65 & 24.84 & 18.12 & 3 & 24543397 & 2454.3372 & 819.1197 & 0.0025 & 1.0174 & 2444.270 & 3298.719 & 12990.449 & 10054.127 & \text { No }\end{array}$ $\begin{array}{lllllllllllllll}1.00 & 64.84 & 24.83 & 17.61 & 3 & 2454.3403 & 2454.3372 & 819.1197 & 0.0031 & 1.2615 & 2402.978 & 3616.854 & 14950.681 & 12573.349 & \text { No }\end{array}$

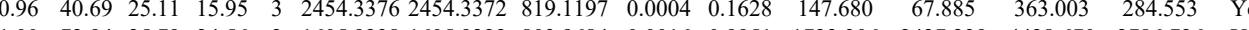

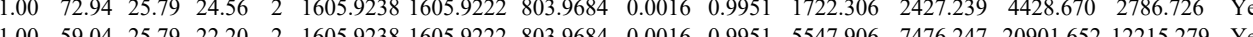
$\begin{array}{lllllllllllllllll}1.096 & 5.04 & 25.79 & 22.20 & 2 & 1605.9238 & 1605.9222 & 803.9684 & 0.0016 & 0.9951 & 5547.906 & 7476.247 & 20901.652 & 12215.279 & \text { Yes }\end{array}$ $\begin{array}{lllllllllllllll}0.99 & 32.98 & 25.50 & 28.60 & 3 & 1605.9247 & 1605.9222 & 536.3147 & 0.0025 & 1.5538 & 146.058 & 195.326 & 620.463 & 407.766 & \text { Yes }\end{array}$ $\begin{array}{llllllllllllllll}0.68 & 17.42 & 25.53 & 14.74 & 2 & 1240.7162 & 1240.7149 & 621.3647 & 0.0013 & 1.0461 & 208.993 & 328.103 & 273.461 & 218.887 & \text { Yes } \\ 1 & 1.00 & 69.47 & 25.4 & 24.04 & 2 & 105.925 & 105.922 & 803.984 & 0.002 & 1.744 & 252.097 & 3394.310 & 8758.653 & 515.811 & \text { Yes }\end{array}$ $\begin{array}{llllllllllllllll}1.00 & 6.47 & 25.49 & 24.04 & 2 & 1605.9250 & 1605.9222 & 803.9684 & 0.0028 & 1.7414 & 2542.097 & 3304.310 & 8758.653 & 5157.811 & \text { Yes }\end{array}$ $\begin{array}{llllllllllllllll}1.00 & 68.89 & 25.42 & 25.08 & 2 & 1605.9258 & 1605.9222 & 803.9684 & 0.0036 & 2.2389 & 4783.205 & 5905.859 & 17760.091 & 10020.371 & \text { Yes }\end{array}$

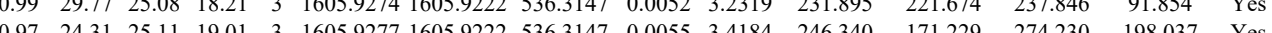
$\begin{array}{llllllllccccccc} & \end{array}$

VLPGVDALSNI

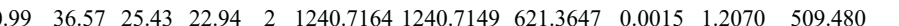

\section{AGGFLMK}

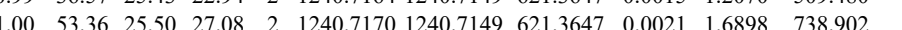

\begin{tabular}{llll}
$5.044 \quad \mathrm{No}$ \\
\hline
\end{tabular} $\begin{array}{llllllll} & \end{array}$ \begin{tabular}{llllllllllllllll} 
& \\
\hline
\end{tabular} $\begin{array}{llllllllllllllll}\text { AHSSMVGVNLPQK } & 1.00 & 69.57 & 27.11 & 33.43 & 2 & 1654.9176 & 1654.9068 & 828.4607 & 0.0108 & 6.5181 & 738.062 & 1174.105 & 2649.376 & 82.054 & \text { Yes }\end{array}$ $\begin{array}{llllllllllllllll}\text { AHSSMVGVNLPQK } & 0.74 & 21.98 & 26.94 & 21.11 & 3 & 1654.9183 & 1654.9068 & 552.6429 & 0.0115 & 6.9363 & 12157.638 & 16037.767 & 12049.333 & 14636.108 & \text { Yes }\end{array}$

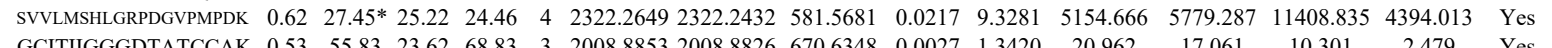

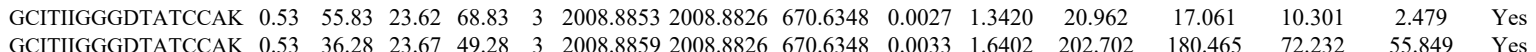

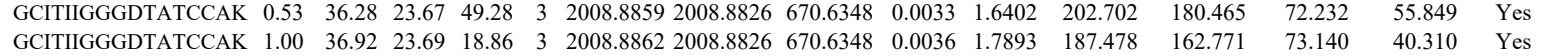

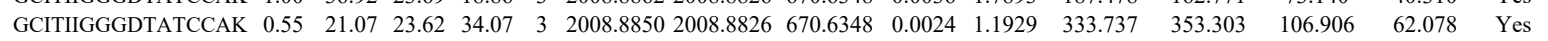

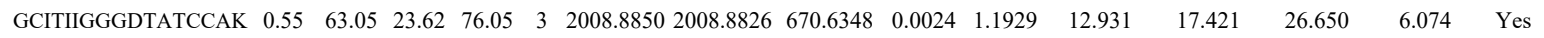
$\begin{array}{llllllllllllllll}\text { GCITIIGGGDTATCCAK } & 0.53 & 21.70 & 23.62 & 34.70 & 3 & 2008.8853 & 2008.8826 & 670.6348 & 0.0027 & 1.3420 & 345.819 & 313.025 & 83.889 & 47.147 & \text { Yes }\end{array}$ $\begin{array}{lllllllllllllllll}\text { GCITIIGGGDTATCCAK } & 0.53 & 10.52 & 23.67 & 23.52 & 3 & 2008.8859 & 2008.8826 & 670.6348 & 0.0033 & 1.6402 & 221.302 & 238.050 & 43.239 & 29.347 & \text { Yes }\end{array}$ $\begin{array}{llllllllllllllll}\text { GCITIIGGGDTATCCAK } & 0.53 & 59.93 & 23.67 & 72.93 & 3 & 2008.8859 & 2008.8826 & 670.6348 & 0.0033 & 1.6402 & 35.509 & 56.550 & 25.334 & 4.627 & \text { Yes }\end{array}$ $\begin{array}{llllllllllllllll}\text { ALESPERPFLAILGGAK } & 1.00 & 54.75 & 21.58 & 17.24 & 2 & 2056.1934 & 2056.1924 & 1029.1035 & 0.0010 & 0.4859 & 234.175 & 310.528 & 579.140 & 34.953 & \text { Yes }\end{array}$ $\begin{array}{llllllllllllllll}\text { ALESPERPFLAILGGAK } & 0.76 & 66.68 & 21.58 & 79.68 & 2 & 2056.1934 & 2056.1924 & 1029.1035 & 0.0010 & 0.4859 & 142.777 & 262.264 & 437.081 & 28.711 & \text { Yes }\end{array}$

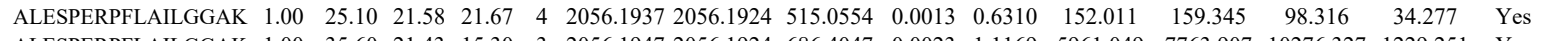
$\begin{array}{llllllllllllllll}\text { ALESPERPFLAILGGAK } & 1.00 & 35.60 & 21.43 & 15.30 & 3 & 2056.1947 & 2056.1924 & 686.4047 & 0.0023 & 1.1169 & 5961.049 & 7763.907 & 10276.327 & 1229.251 & \text { Yes }\end{array}$

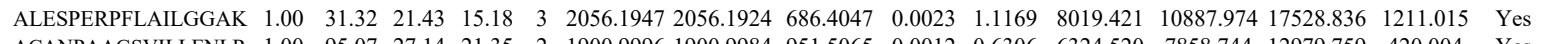

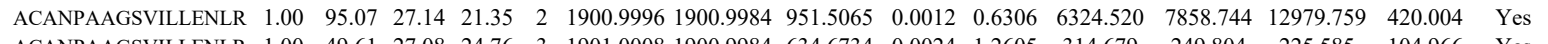
$\begin{array}{llllllllllllllll}\text { ACANPAAGSVILLENLR } & 1.00 & 49.61 & 27.08 & 24.76 & 3 & 1901.0008 & 1900.9984 & 634.6734 & 0.0024 & 1.2605 & 314.679 & 249.804 & 225.585 & 104.966 & \text { Yes }\end{array}$ $\begin{array}{llllllllllllllll}\text { ACANPAAGSVILLENLR } & 1.00 & \text { 2lm } & 27.07 & 20.01 & 2 & 1901.0008 & 1900.9984 & 951.5065 & 0.0024 & 1.2612 & 4185.302 & 5461.714 & 9791.358 & 354.706 & \text { Yes }\end{array}$

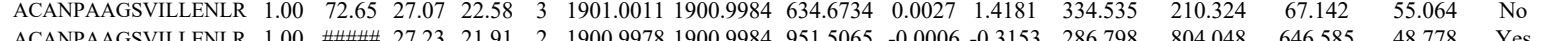
$\begin{array}{llllllllllllllll}\text { ACANPAAGSVILLENLR } & 1.00 & \text { mam } & 27.23 & 21.91 & 2 & 1900.9978 & 1900.9984 & 951.5065 & -0.0006 & -0.3153 & 286.798 & 804.048 & 646.585 & 48.778 & \text { Yes } \\ \text { ACANPAAGSVILLENLR } & 1.00 & 68.76 & 27.23 & 24.94 & 3 & 1900.9993 & 1900.9984 & 634.6734 & 0.0009 & 0.4727 & 113.193 & 201.467 & 97.792 & 34.452 & \text { Yes }\end{array}$ $\begin{array}{llllllllllllll}\text { ACANPAAGSVILLENLR } & 0.76 & \# \# \# \# \text { 27.22 \#\#\#\# } 2 & 1900.9994 & 1900.9984 & 951.5065 & 0.0010 & 0.5255 & 2347.382 & 2735.419 & 4245.255 & 124.462 & \text { Yes }\end{array}$ $\begin{array}{llllllllllllllll}\text { ACANPAAGSVILLENLR } & 1.00 & 70.81 & 27.08 & 20.51 & 3 & 1901.0008 & 1900.9984 & 634.6734 & 0.0024 & 1.2605 & 57.222 & 365.983 & 140.734 & 23.779 & \text { No }\end{array}$ 
$\begin{array}{lllllllllll} & 0\end{array}$

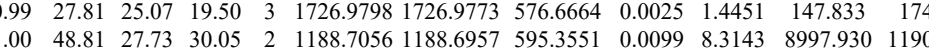

\begin{tabular}{llcc}
2647.812 & Yes \\
\hline 69.269 & 127.225 & 41.377 & Yes
\end{tabular}

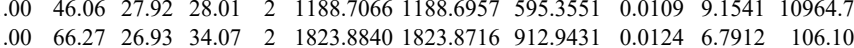

$\begin{array}{lllllllllll}1.00 & 73.08 & 26.88 & 34.92 & 2 & 1823.8854 & 1823.8716 & 912.9431 & 0.0138 & 7.5579 & 215.351 \\ 1.00 & 76.93 & 28.23 & 23.16 & 3 & 1805.9116 & 1805.9112 & 602.9777 & 0.0004 & 0.2211 & 24.741\end{array}$

$\begin{array}{lllllllllllll}\text { ASSHSSQTQGGGSVTK } & 1.00 & 40.01 & 28.27 & 18.31 & 3 & 1805.9119 & 1805.9112 & 602.9777 & 0.0007 & 0.3870 & 11.015\end{array}$

$\begin{array}{llllllllllll}\text { MQQQLDEYQELLDIK } & 0.99 & 29.41 & 28.27 & 25.60 & 3 & 2181.1264 & 2181.1231 & 728.0483 & 0.0033 & 1.5109 & 93.107\end{array}$

$\begin{array}{lllllllllllll}\text { MQQQLDEYQELLDIK } & 1.00 & 44.29 & 28.27 & 26.64 & 3 & 2181.1264 & 2181.1231 & 728.0483 & 0.0033 & 1.5109 & 48.137\end{array}$ $\begin{array}{llllllllllllll}\text { ASSHSSQTQGGGSVTK } & 1.00 & 72.86 & 28.23 & 17.65 & 3 & 1805.9116 & 1805.9112 & 602.9777 & 0.0004 & 0.2211 & 24.894 & 48.593 \\ \text { ASSHSSQTQGGGSVTK } & 1.00 & 75.26 & 28.23 & 25.25 & 3 & 1805.9125 & 1805.9112 & 602.9777 & 0.0013 & 0.7187 & 8.347 & 29.587\end{array}$ $\begin{array}{llllllllllllllll}\text { ASSHSSQTQGGGSVTK } & 1.00 & 72.86 & 28.23 & 17.65 & 3 & 1805.9116 & 1805.9112 & 602.9777 & 0.0004 & 0.2211 & 24.894 & 48.593 & 109.047 & 33.759 & \text { Y } \\ \text { ASSHSSQTQGGGSVTK } & 1.00 & 75.26 & 28.23 & 25.25 & 3 & 1805.9125 & 1805.9112 & 602.9777 & 0.0013 & 0.7187 & 8.347 & 29.587 & 42.050 & 17.677 & \text { Y } \\ \text { NSNLVGAAHEELQQSR } & 1.00 & 77.74 & 27.85 & 22.09 & 3 & 1895.9656 & 1895.9571 & 632.9930 & 0.0085 & 4.4761 & 4367.577 & 5915.256 & 9062.557 & 2971.686 & \text { Y } \\ \text { NSNLVGAAHEELQQSR } & 1.00 & 71.68 & 27.73 & 20.57 & 3 & 1895.9677 & 1895.9571 & 632.9930 & 0.0106 & 5.5819 & 3553.927 & 6619.812 & 10206.175 & 2695.933 & \text { Y s }\end{array}$ $\begin{array}{lllllllllllllll} & \end{array}$ $\begin{array}{llllllllllllll} & \end{array}$ \begin{tabular}{lllllllllllllllll} 
& TALINSTGEEVAMR & 1.00 & 96.86 & 28.41 & 30.35 & 2 & 1634.8572 & 1634.8419 & 818.4282 & 0.0153 & 9.3471 & 3719.159 & 4006.862 & 2030.386 & 128.545 & Yes \\
\hline
\end{tabular} $\begin{array}{llllllllllllllll}\text { ASSHSSQTQGGGSVTK } & 1.00 & 60.97 & 28.23 & 19.91 & 3 & 1805.9116 & 1805.9112 & 602.9777 & 0.0004 & 0.2211 & 14.755 & 19.849 & 19.183 & 2.790 & \text { YeS }\end{array}$

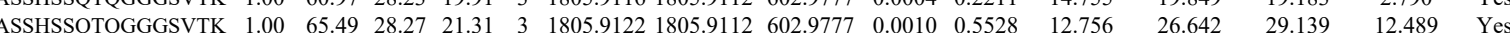

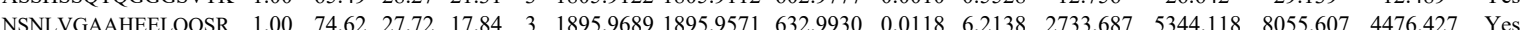
$\begin{array}{llllllllllllllll}\text { NSNLVGAAHEELQQSR } & 1.00 & 80.07 & 27.74 & 21.90 & 3 & 189.9689 & 1859.9571 & 632.9930 & 0.0118 & 6.2138 & 2733.687 & 5344.118 & 8055.607 & 4476.427 & \text { Yes }\end{array}$ $\begin{array}{lllllllllllllll}\text { TALINSTGEEVAMR } & 1.00 & \# \# \# \# 28.56 & 30.84 & 2 & 1634.8542 & 1634.8419 & 818.4282 & 0.0123 & 7.5143 & 6868.463 & 8137.733 & 3661.015 & 306.903 & \text { Yes }\end{array}$ DLEALLNSK TALINSTGEEVAMR LADALQELR LADALQELR DLEALLNSK SGAQASSTPLSPTR SGAQASSTPLSPTR SGAQASSTPLSPTR LSPSPTSQR

\section{LSPSPTSQR}

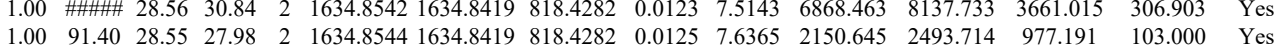

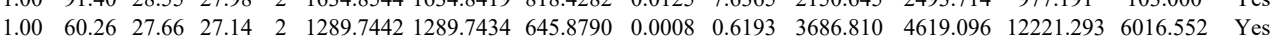
$\begin{array}{lllllllllllllll}1.00 & 60.47 & 27.91 & 27.38 & 2 & 1289.7450 & 1289.7434 & 645.8790 & 0.0016 & 1.2386 & 2851.945 & 2946.319 & 8169.027 & 4205.238 & \text { Yes }\end{array}$ $\begin{array}{lllllllllllllll}1.00 & 91.51 & 28.56 & 29.35 & 2 & 1634.8542 & 1634.8419 & 818.4282 & 0.0123 & 7.5143 & 481.112 & 699.852 & 236.447 & 64.214 & \text { Yes }\end{array}$ $\begin{array}{llllllllllllllll}1.00 & 45.36 & 27.01 & 32.01 & 2 & 1171.6794 & 1171.6682 & 586.8414 & 0.0112 & 9.5425 & 5454.925 & 6684.262 & 168.190 & 86.626 & \text { Yes }\end{array}$ $\begin{array}{llllllllllllllll}1.00 & 46.92 & 27.01 & 34.91 & 2 & 1171.6794 & 1171.6682 & 586.8414 & 0.0112 & 9.5425 & 5497.569 & 7181.590 & 150.591 & 74.107 & \text { No }\end{array}$ $\begin{array}{lllllllllllllllll}1.00 & 57.72 & 27.72 & 36.16 & 2 & 1289.7550 & 1289.7434 & 645.8790 & 0.0116 & 8.9799 & 5403.286 & 6215.712 & 10581.040 & 4841.299 & \text { Yes }\end{array}$ $\begin{array}{llllllllllllllll}1.00 & 80.67 & 27.53 & 24.56 & 2 & 1502.7800 & 1502.7811 & 752.3978 & -0.0011 & -0.7310 & 404.003 & 500.178 & 1320.350 & 942.089 & \text { No }\end{array}$ $\begin{array}{lllllllllllllllll}1.00 & 81.93 & 27.46 & 28.07 & 2 & 1502.7812 & 1502.7811 & 752.3978 & 0.0001 & 0.0665 & 272.557 & 584.508 & 954.172 & 762.700 & \mathrm{No}\end{array}$ $\begin{array}{lllllllllllllll}1.00 & 87.82 & 27.37 & 29.00 & 2 & 1502.7796 & 1502.7811 & 752.3978 & -0.0015 & -0.9968 & 200.806 & 260.445 & 613.626 & 448.201 & \text { No }\end{array}$

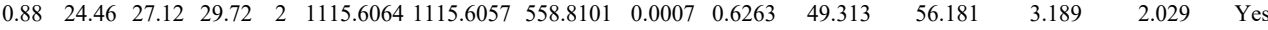
$\begin{array}{ccccccccccccccc}0.99 & 41.40 & 27.12 & 37.64 & 2 & 1115.6064 & 1115.6057 & 558.8101 & 0.0007 & 0.6263 & 98.136 & 145.086 & 3.942 & 3.226 & \text { No }\end{array}$

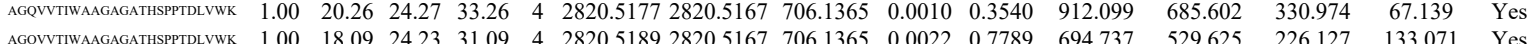
$\begin{array}{lllllllllllllllll}\text { AGGVVT } & & \end{array}$ $\begin{array}{llllllllllllllll}\text { NGM } & 12.81 & 24.17 & 14.43 & 4 & 2820.5197 & 2820.5167 & 706.1365 & 0.0030 & 1.0621 & 649.276 & 607.730 & 280.995 & 232.465 & \text { Yes } \\ \end{array}$ $\begin{array}{llllllllllllllll}\text { AGQVVTIWAAGAGATHSPPDDVWK } & 0.98 & 23.88 & 24.22 & 17.21 & 3 & 2820.5191 & 2820.5167 & 941.1795 & 0.0024 & 0.8500 & 7.392 & 20.476 & 23.282 & 9.349 & \text { Yes } \\ \text { AQNTWGGGNSLR } & 0.89 & 27.29 & 24.97 & 15.92 & 2 & 1495.6888 & 1495.6782 & 748.8464 & 0.0106 & 7.0775 & 99.732 & 93.949 & 48.810 & 1.5 & \text { YS }\end{array}$

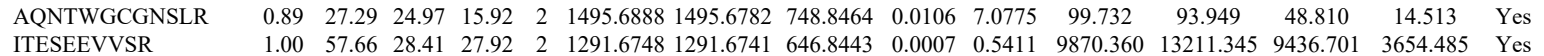

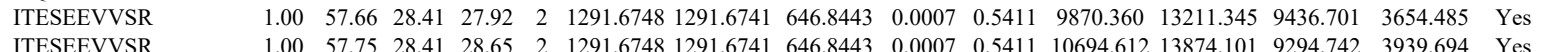

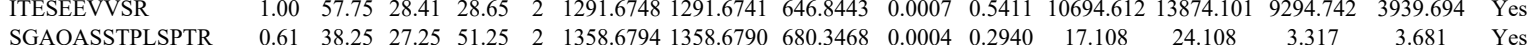
LEAALGEAK

YEAALGEAK

$\begin{array}{lllllllllllllll}\text { ALBU_HUMAN } & \text { P02768 } & \text { ALB } & \text { Serum albumin } & 69.37 & 1.00 & 5 & 12.3 & 0.2461 & 1.2243 & 1.1548 & 1.3490 & 15 & \text { YICEN }\end{array}$ $\begin{array}{lllllllllllllll}0.76 & 37.08 & 27.17 & 50.08 & 2 & 1358.6802 & 1358.6790 & 680.3468 & 0.0012 & 0.8819 & 19.435 & 30.959 & 1.903 & 4.715 & \text { Yes }\end{array}$

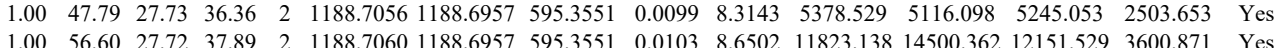
$\begin{array}{lllllllllllllllll}1.00 & 56.60 & 27.72 & 37.89 & 2 & 1188.7060 & 1188.6957 & 595.3551 & 0.0103 & 8.6502 & 11823.138 & 14500.362 & 12151.529 & 3600.871 & \text { Yes } & \\ 0.76 & 25.95 & 27.12 & 21.59 & 2 & 1719.8198 & 1719.8051 & 860.9098 & 0.0147 & 8.5374 & 272.349 & 193.300 & 312.508 & 167.128 & \text { Yes }\end{array}$ $\begin{array}{lllllllllllllll}0.75 & 25.72 & 27.27 & 18.98 & 2 & 1719.8202 & 1719.8051 & 860.9098 & 0.0151 & 8.7697 & 834.922 & 401.801 & 716.380 & 555.973 & \text { Yes }\end{array}$ 


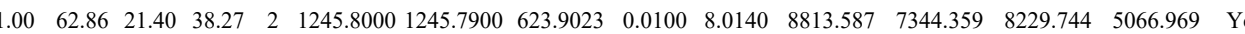
$\begin{array}{llllllllllllllll}\text { LAQMFSDMVLK } & 1.00 & 63.77 & 27.56 & 25.39 & 2 & 1569.8536 & 1569.8502 & 785.9324 & 0.0034 & 2.1630 & 2067.023 & 1873.922 & 91.287 & 18.248 & \text { Yes }\end{array}$

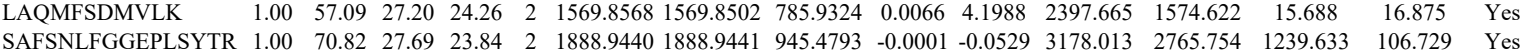
$\begin{array}{llllllllllllllll}\text { SAFSNLFGGEPLSYTR } & 1.00 & 69.88 & 27.72 & 26.39 & 2 & 1888.9446 & 1888.9441 & 945.4793 & 0.0005 & 0.2644 & 4050.354 & 4328.673 & 1626.058 & 73.675 & \text { Yes }\end{array}$ $\begin{array}{lllllllllllllllll}\text { SAFSNLFGGEPLSYTR } & 1.00 & 95.65 & 27.63 & 29.04 & 2 & 1888.9460 & 1888.9441 & 945.4793 & 0.0019 & 1.0048 & 1348.302 & 903.710 & 297.145 & 36.578 & \text { Yes }\end{array}$

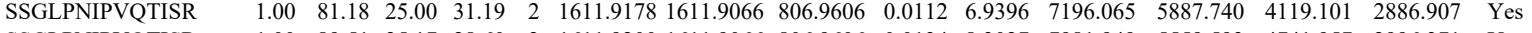
SSGLPNIPVQTISR SSGLPNIPVQTISR SSGLPNIPVQTISR SSGLPNIPVQTIS YNSQLLSFVR YNSQLLSFV ILNIFGVIK

ILNIFGVIK

YNSQLLSFVR

YNSQLLSFVR

ENIFGVIK

ILNIFGVIK

LTTDFGNAEK

SSGLPNIPVQTISR

SSGLPNIPVQTISR

SSGLPNIPVQTISR

LAVDEEENADNNTK LAVDEEENADNNTK DAWGPGAAK SSGLPNIPVQTISR SSGLPNIPVQTISR DAWGPGAAK

\section{LTTDFGNAEK}

SSGLPNIPVQTISR

SSGLPNIPVQTISR

SSGLPNIPVQTISR

SSGLPNIPVQTISR

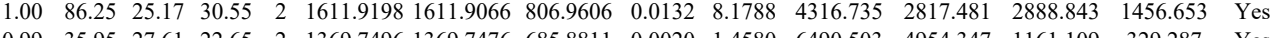
$\begin{array}{lllllllllllllllll}0.99 & 35.95 & 27.61 & 22.65 & 2 & 1369.7496 & 1369.7476 & 685.8811 & 0.0020 & 1.4580 & 6490.503 & 4954.347 & 1161.109 & 329.287 & \text { Yes } \\ 0.87 & 25.79 & 27.42 & 16.85 & 2 & 1369.7502 & 1369.7476 & 685.8811 & 0.026 & 1.8954 & 6394.58 & 4234.636 & 1490.510 & 462.364 & \text { Yes }\end{array}$ \begin{tabular}{lllllllllllllll}
0.87 & 25.79 & 27.42 & 16.85 & 2 & 1369.7502 & 1369.7476 & 685.8811 & 0.0026 & 1.8954 & 6394.581 & 4234.636 & 1490.510 & 462.364 & Yes \\
\hline
\end{tabular} $\begin{array}{llllllllllllllll}0.99 & 46.38 & 19.49 & 42.75 & 2 & 1303.8496 & 1303.8471 & 652.9308 & 0.0025 & 1.9144 & 44442.512 & 34796.749 & 479.471 & 640.044 & \text { Yes } \\ 0.98 & 47.65 & 19.49 & 46.14 & 2 & 1303.8502 & 1303.8471 & 652.9308 & 0.0031 & 23739 & 37699.803 & 26892.848 & 582.475 & 420.982 & \text { Yes }\end{array}$ $\begin{array}{llllllllllllllll}0.98 & 47.65 & 19.49 & 46.14 & 2 & 1303.8502 & 1303.8471 & 652.9308 & 0.0031 & 2.3739 & 37699.803 & 26892.848 & 582.475 & 420.982 & \text { Yes } \\ 1.00 & 65.79 & 27.32 & 25.43 & 2 & 1369.7510 & 1369.7476 & 685.8811 & 0.0034 & 2.4786 & 638.785 & 437.665 & 82.329 & 33.285 & \text { Yes }\end{array}$

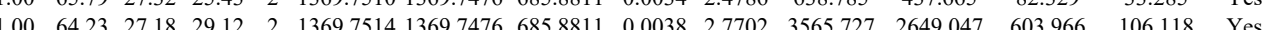

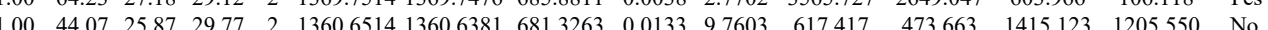
$\begin{array}{lllllllllllllll}0.98 & 47.65 & 19.49 & 46.20 & 2 & 1303.8504 & 1303.8471 & 652.9308 & 0.0033 & 2.5271 & 5902.890 & 5000.234 & 145.937 & 183.476 & \text { Yes }\end{array}$ $\begin{array}{llllllllllllllll}0.00 & 56.62 & 27.32 & 22.96 & 2 & 1369.7510 & 13697476 & 6858811 & 0.0034 & 2.4786 & 492.764 & 457.905 & 85.656 & 64.428 & \text { Yes }\end{array}$

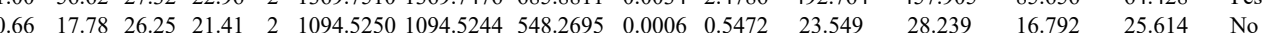

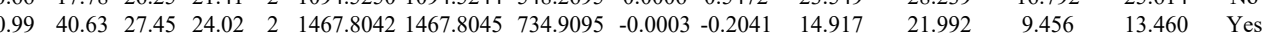

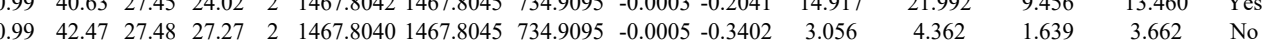

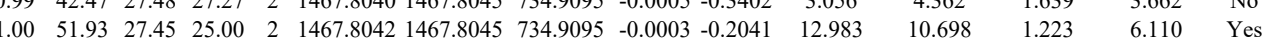

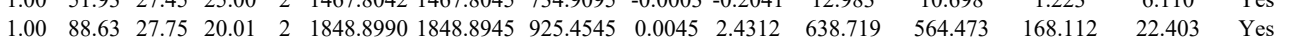
$\begin{array}{llllllllllllllll}1.00 & 76.20 & 27.75 & 23.12 & 2 & 1848.8994 & 1848.8945 & 925.4545 & 0.0049 & 2.6473 & 622.366 & 414.417 & 146.931 & 29.492 & \text { Yes }\end{array}$ $\begin{array}{lllllllllllllll}0.71 & 18.83 & 23.28 & 19.15 & 2 & 871.4188 & 871.4188 & 436.7167 & 0.0000 & 0.0000 & 24.372 & 67.870 & 27.385 & 13.618 & \text { Yes }\end{array}$

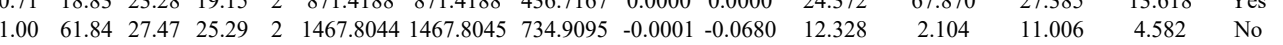

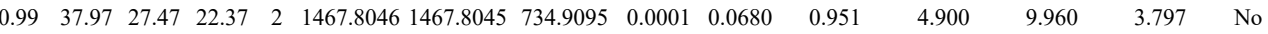
$\begin{array}{lllllllllllllll}0.70 & 15.90 & 23.60 & 16.17 & 2 & 871.4194 & 871.4188 & 436.7167 & 0.0006 & 0.6869 & 24.574 & 37.254 & 20.486 & 5.620 & \text { Yes }\end{array}$

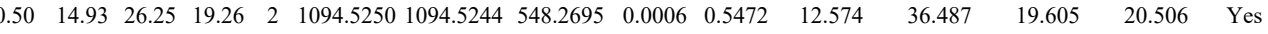
$\begin{array}{lllllllllllllll}0.97 & 34.21 & 27.47 & 26.31 & 2 & 1467.8044 & 1467.8045 & 734.9095 & -0.0001 & -0.0680 & 9.530 & 5.191 & 4.793 & 0.000 & \text { No } \\ 1.00 & 4.60 & 27.41 & 25.45 & 2 & 1467.8048 & 1467.8045 & 73.9095 & 0.000 & 0.2041 & 7.078 & 12.272 & 9.951 & 1.311 & \text { Yes }\end{array}$

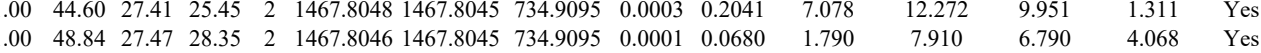
$\begin{array}{lllllllllllllll} & & & \end{array}$ $\begin{array}{llllllllllllllll} & \text { Yes }\end{array}$

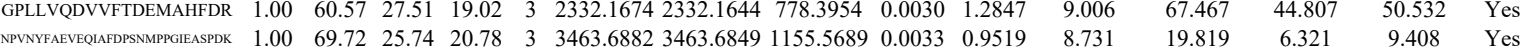

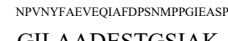
GILAADESTGSIAK GILAADESTGSIAK GIAADESTGSIAK GILAADESTGSIAK $\begin{array}{lllllllllllll}1.00 & 6.72 & 25.74 & 20.78 & 3 & 3463.6882 & 3463.6849 & 1155.5689 & 0.0033 & 0.9519 & 8.73\end{array}$ $\begin{array}{lllllllllll}0.97 & 12.76 & 25.74 & 25.76 & 4 & 3463.6885 & 3463.6449 & 866.9285 & 0.0036 & 1.0381 & 24.187\end{array}$ 

$\begin{array}{lllllllllllllll}0.96 & 36.54 & 28.05 & 29.86 & 2 & 1187.6724 & 1187.6632 & 594.8389 & 0.0092 & 7.7331 & 17173.577 & 19473.957 & 3613.586 & 739.789 & \text { Yes } \\ 0.99 & 42.38 & 27.98 & 28.40 & 2 & 1187.6728 & 1187.6632 & 594.8389 & 0.0096 & 8.0693 & 21488.074 & 23130.524 & 3838.443 & 905.274 & \text { Yes }\end{array}$ $\begin{array}{llllllllllllllll}0.99 & 42.38 & 27.98 & 28.40 & 2 & 1187.6728 & 1187.6632 & 594.8389 & 0.0096 & 8.0693 & 21488.074 & 23130.524 & 3838.443 & 905.274 & \text { Yes } \\ 1.00 & 91.53 & 26.56 & 42.06 & 2 & 1619.9092 & 1619.8974 & 810.9560 & 0.0118 & 7.2753 & 5157.747 & 6710.578 & 13664.272 & 12685.172 & \text { No }\end{array}$ $\begin{array}{lllllllllllllllll}1.00 & 91.53 & 26.56 & 42.06 & 2 & 1619.9092 & 1619.8974 & 810.9560 & 0.0118 & 7.2753 & 5157.747 & 6710.578 & 13664.272 & 12685.172 & \text { No } \\ 1.00 & 91.23 & 26.67 & 43.16 & 2 & 1619.9098 & 1619.8974 & 810.9560 & 0.0124 & 7.6452 & 3031.158 & 2953.390 & 8871.449 & 6330.302 & \text { Yes }\end{array}$

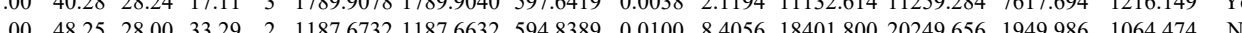

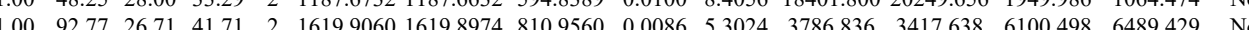
$\begin{array}{lllllllllllllll}1.00 & 9.71 .41 & 26.74 & 42.31 & 2 & 169.90066 & 16198974 & 810.9560 & 0.009 & 5.6723 & 1629.503 & 2156.447 & 4070.052 & 3385.955 & \text { Yes }\end{array}$

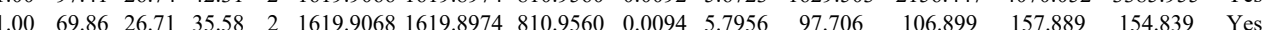

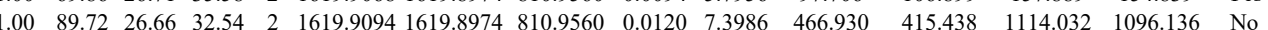

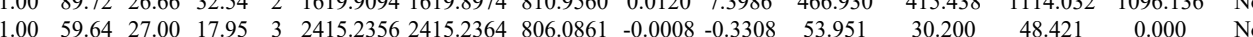

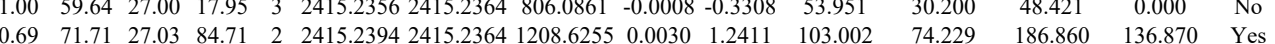

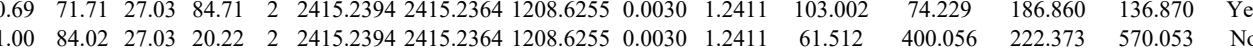
$\begin{array}{lllllllllllllll}0.53 & 48.93 & 27.04 & 61.93 & 3 & 2415.2398 & 2415.2364 & 806.0861 & 0.0034 & 1.4060 & 25.460 & 53.561 & 31.455 & 36.098 & \text { Yes }\end{array}$

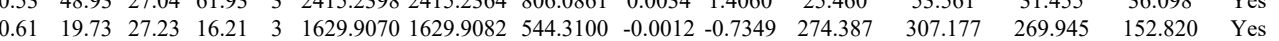
$\begin{array}{llllllllllllllll}0.68 & 15.64 & 27.19 & 18.78 & 3 & 1629.9094 & 1629.9082 & 544.3100 & 0.0012 & 0.7349 & 313.376 & 364.193 & 254.199 & 139.592 & \text { Yes }\end{array}$ $\begin{array}{lllllllllllllll}0.68 & 15.68 & 27.20 & 20.66 & 3 & 1629.9097 & 1629.9082 & 544.3100 & 0.0015 & 0.9186 & 141.623 & 204.454 & 176.786 & 63.581 & \text { Yes }\end{array}$ $\begin{array}{llllllllllllllll}0.61 & 14.57 & 26.77 & 19.53 & 3 & 1629.9136 & 1629.9082 & 544.3100 & 0.0054 & 3.3069 & 341.263 & 324.332 & 260.204 & 178.482 & \text { Yes }\end{array}$ $\begin{array}{llllllllllllllll}1.00 & 68.89 & 26.73 & 30.50 & 2 & 1629.9202 & 1629.9082 & 815.9614 & 0.0120 & 7.3532 & 956.737 & 963.989 & 1732.174 & 613.349 & \text { Yes }\end{array}$ $\begin{array}{lllllllllllllll}1.00 & 62.71 & 26.81 & 29.52 & 2 & 1629.9204 & 1629.9082 & 815.9614 & 0.0122 & 7.4758 & 844.488 & 1045.997 & 1726.973 & 811.962 & \text { Yes }\end{array}$ $\begin{array}{lllllllllllllll}1.00 & 39.53 & 26.38 & 20.23 & 3 & 1629.9226 & 1629.9082 & 544.3100 & 0.0144 & 8.8184 & 8122.477 & 10471.039 & 13019.109 & 5718.544 & \text { Yes }\end{array}$ $\begin{array}{lllllllllllllll}0.81 & 25.62 & 26.35 & 26.33 & 3 & 1629.9229 & 1629.9082 & 544.3100 & 0.0147 & 9.0021 & 12147.540 & 16986.101 & 20277.296 & 11190.074 & \text { Yes }\end{array}$ $\begin{array}{lllllllllllllll}0.99 & 44.90 & 27.51 & 23.06 & 2 & 1721.9348 & 1721.9232 & 861.9689 & 0.0116 & 6.7287 & 1587.305 & 1768.632 & 2999.048 & 966.609 & \text { Yes }\end{array}$

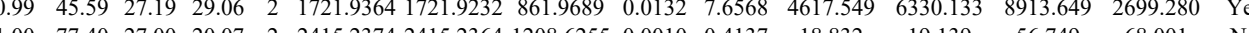

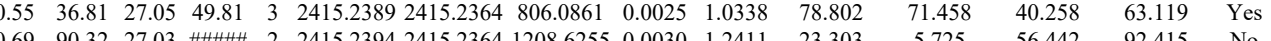

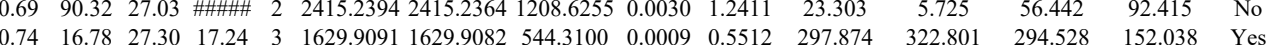

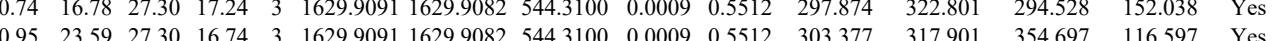

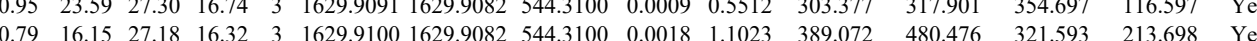

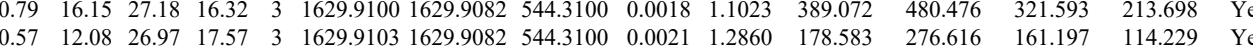

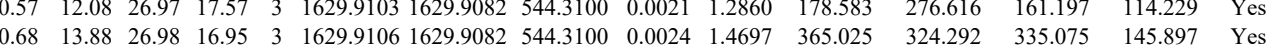
$\begin{array}{lllllllllllllll}0.68 & 14.07 & 26.97 & 18.73 & 3 & 1629.9109 & 1629.9082 & 5443100 & 0.0027 & 1.6535 & 109.295 & 110.966 & 147.879 & 54316 & \text { Yes }\end{array}$ $\begin{array}{llllllllllllllll}0.86 & 18.69 & 26.65 & 21.07 & 3 & 1629.9127 & 1629.9082 & 544.3100 & 0.0045 & 2.7558 & 359.703 & 462.735 & 434.717 & 207.102 & \text { Yes }\end{array}$

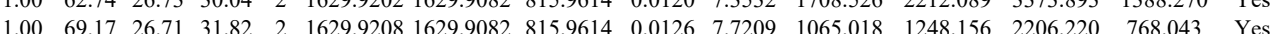

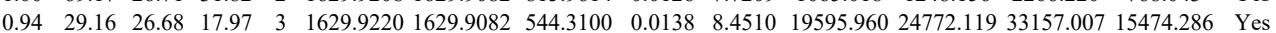

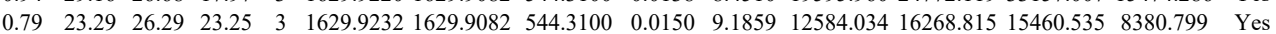
$\begin{array}{llllllllllllllll}0.99 & 46.63 & 27.35 & 23.42 & 2 & 1721.9358 & 1721.9232 & 861.9689 & 0.0126 & 7.3088 & 2468.470 & 3954.137 & 4270.538 & 1886.720 & \text { Yes }\end{array}$ $\begin{array}{lllllllllllllll}1.00 & 55.25 & 27.26 & 28.63 & 2 & 1721.9366 & 1721.9232 & 861.9689 & 0.0134 & 7.7728 & 1414.339 & 1323.241 & 2548.124 & 865.317 & \text { Yes }\end{array}$ $\begin{array}{lllllllllllllll}0.93 & 27.77 & 26.61 & 19.78 & 3 & 1629.9178 & 1629.9082 & 544.3100 & 0.0096 & 5.8790 & 22724.176 & 30011.956 & 35467.702 & 13941.541 & \text { Yes }\end{array}$ $\begin{array}{llllllllllllllll}1.00 & 66.15 & 26.63 & 31.15 & 2 & 1629.9182 & 1629.9082 & 815.9614 & 0.0100 & 6.1277 & 1988.494 & 2013.927 & 3128.237 & 1303.236 & \text { Yes }\end{array}$

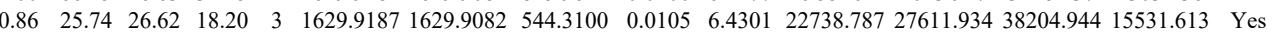

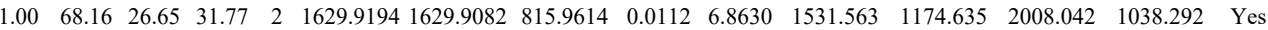

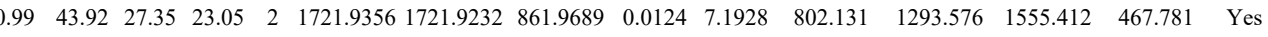

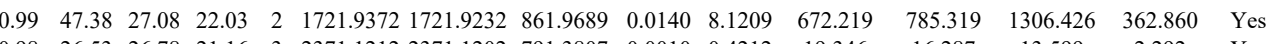
$\left.\begin{array}{llllllllllll}0.98 & 26.53 & 26.78 & 21.16 & 3 & 2371.1212 & 2371.1202 & 791.3807 & 0.0010 & 0.4212\end{array}\right]$

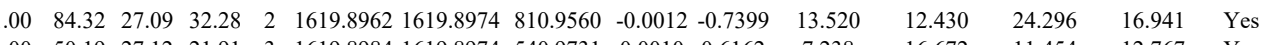

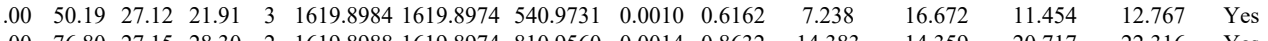

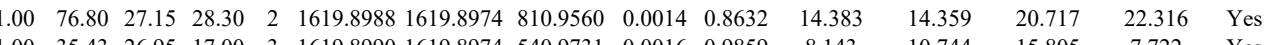

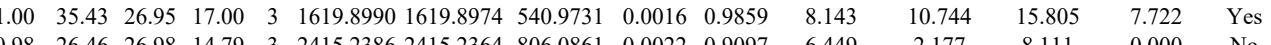

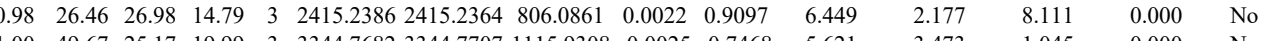

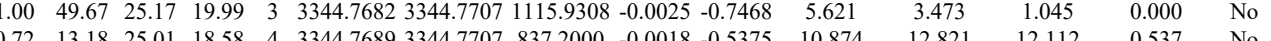

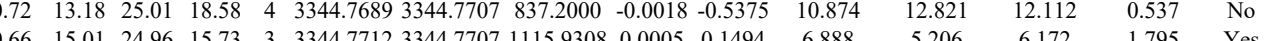
$\begin{array}{lllllllllll}0.86 & 9.37 & 24.61 & 22.37 & 4 & 3344.7765 & 3344.7707 & 837.2000 & 0.0058 & 1.7320 & 20.894\end{array}$ $\begin{array}{lllllllllll}0.96 & 12.67 & 24.59 & 25.67 & 4 & 3344.7781 & 3344.7707 & 837.2000 & 0.0074 & 2.2097 & 10.964\end{array}$ $\begin{array}{llllllllll}24.96 & 18.85 & 3 & 3344.7712 & 3344.7707 & 1115.9308 & 0.0005 & 0.1494 & 22.218\end{array}$ $7.976-6.802$ $\begin{array}{rr}7.976 & 6.802 \\ 24.371 & 11.353\end{array}$ 


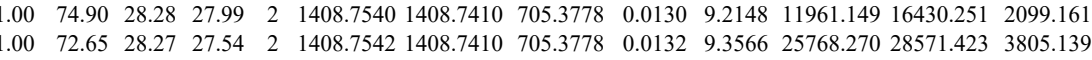

$\begin{array}{lllllllllllll}1.00 & 70.73 & 28.29 & 26.11 & 2 & 1408.7516 & 1408.7410 & 705.3778 & 0.0106 & 7.5136 & 6303.003 & 6489.345 & 1272.838\end{array}$

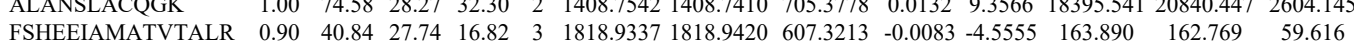


$\begin{array}{llllllllllll}\text { VNPCIGGVILFHETLYQK } & 1.00 & 69.55 & 26.36 & 20.86 & 3 & 2364.2599 & 2364.2578 & 789.0932 & 0.0021 & 0.8871 & 85.715 \\ \text { VNPCIGGVILFHETLYQK } & 1.00 & 46.39 & 26.36 & 16.50 & 3 & 2364.2599 & 2364.2578 & 789.0932 & 0.0021 & 0.8871 & 116.918\end{array}$ $\begin{array}{llllllllllll}\text { VNPCIGGVILFHETLYQK } & 1.00 & 46.39 & 26.36 & 16.50 & 3 & 2364.2599 & 2364.2578 & 789.0932 & 0.0021 & 0.8871 & 116.918\end{array}$ $\begin{array}{llllllllllll}\text { VNPCIGGVILFHETLYQK } & 1.00 & 61.88 & 26.36 & 21.91 & 3 & 2364.2599 & 2364.2578 & 789.0932 & 0.0021 & 0.8871 & 47.733 \\ \text { VNPCIGGVILFHETLYQK } & 1.00 & 23.31 & 26.44 & 36.31 & 4 & 2364.2601 & 2364.2578 & 592.0717 & 0.0023 & 0.9712 & 105.505\end{array}$

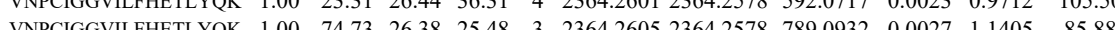
$\begin{array}{lllllllllllll}\text { VNPCIGGVILFHETLYQK } & 1.00 & 88.99 & 26.33 & 22.68 & 3 & 2364.2608 & 2364.2578 & 789.0932 & 0.0030 & 1.2673 & 2927.007\end{array}$

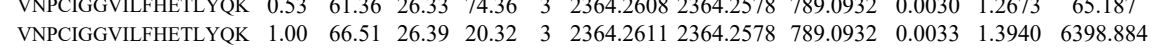
$\begin{array}{llllllllllllll}\text { VNPCIGGVILFHETLYQK } & 1.00 & 23.64 & 26.37 & 36.64 & 4 & 2364.2613 & 2364.2578 & 592.0717 & 0.0035 & 1.4779 & 84.583\end{array}$ $\begin{array}{lllllllllllll}\text { VNPCIGGVILFHETLYQK } & 1.00 & 55.42 & 26.33 & 21.51 & 3 & 2364.2620 & 2364.2578 & 789.0932 & 0.0042 & 1.7742 & 15.238\end{array}$ $\begin{array}{llllllllllllll}\text { VNPCIGGVILFHETLYQK } & 1.00 & \# \# \# 26.17 & 22.38 & 3 & 2364.2629 & 2364.2578 & 789.0932 & 0.0051 & 2.1544 & 100.908 & 1 \\ \text { VNPCIGGVILFHETLYQK } & 1.00 & 65.96 & 26.36 & 20.70 & 3 & 2364.2599 & 2364.2578 & 789.0932 & 0.0021 & 0.8871 & 931.817 & 1063 .\end{array}$ $\begin{array}{lllllllllllll}\text { VNPCIGGVILFHETLYQK } & 1.00 & 61.05 & 26.33 & 18.99 & 3 & 2364.2608 & 2364.2578 & 789.0932 & 0.0030 & 1.2673 & 1318.808 & 1342 .\end{array}$ $\begin{array}{lllllllllllll}\text { GGVVGIK } & 0.56 & 17.21 & 24.47 & 20.14 & 2 & 916.5946 & 916.5950 & 459.3048 & -0.0004 & -0.4354 & 67.342 & 62 .\end{array}$ $\begin{array}{lllllllllllll}\text { CPLLKPWALTFSYGR } & 0.96 & 25.73 & 28.23 & 15.01 & 3 & 1796.9146 & 1796.9106 & 599.9775 & 0.0040 & 2.2223 & 104.933 & 85 . \\ \text { CPLLKPWALTFSYGR } & 0.99 & 30.38 & 26.98 & 22.99 & 3 & 2085.1171 & 2085.1147 & 696.0455 & 0.0024 & 1.1493 & 45.186 & \end{array}$ $\begin{array}{llllllllllll}\text { CPLLKPWALTFSYGR } & 0.99 & 32.26 & 28.22 & 21.38 & 3 & 1796.9134 & 1796.9106 & 599.9775 & 0.0028 & 1.5556 & 5.145\end{array}$ $\begin{array}{lllllllllllll}\text { CPLLKPWALTFSYGR } & 0.69 & 24.04 & 28.20 & 37.04 & 2 & 1796.9134 & 1796.9106 & 899.4626 & 0.0028 & 1.5565 & 1.883\end{array}$

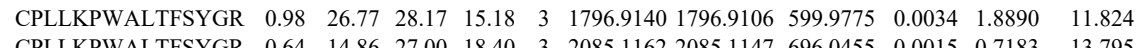
$\begin{array}{lllllllllllll}\text { CPLLKPWALTFSYGR } & 0.64 & 14.86 & 27.00 & 18.40 & 3 & 2085.1162 & 2085.1147 & 696.0455 & 0.0015 & 0.7183 & 13.795\end{array}$

LQSIGTENTEENR

LQSIGTENTEENR

LQSIGTENTEENRR

LQSIGTENTEENRR

LQSIGTENTEENRR

LQSIGTENTEENRR

LQSIGTENTEENRR

LQSIGTENTEENRR $\begin{array}{lllllllllllll}0.64 & 14.86 & 27.00 & 18.40 & 3 & 205.1162 & 2085.1147 & 69.045 & 0.0015 & 0.7183 & 13.795 & 9.551 & 12.277\end{array}$

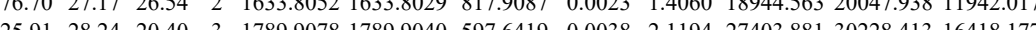

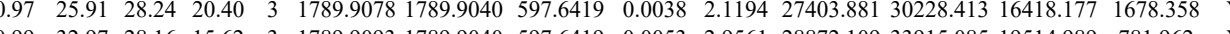
$\begin{array}{lllllllllllllll}0.99 & 32.97 & 28.16 & 15.62 & 3 & 1789.9093 & 1789.9040 & 597.6419 & 0.0053 & 2.9561 & 28872.109 & 33915.085 & 19514.989 & 781.962 & \text { Yes } \\ 1.00 & 68.99 & 28.17 & 28.25 & 2 & 1789.9062 & 1789.9040 & 895.9593 & 0.0022 & 1.2277 & 4736.814 & 4790.950 & 3154.694 & 187.295 & \text { Yes } \\ 1.00 & 52.10 & 28.26 & 22.86 & 2 & 1789.974 & 1789.940 & 85.9593 & 0.0034 & 1.8974 & 3698.235 & 4529.215 & 2985.521 & 79.89 & \text { Yes }\end{array}$ $\begin{array}{llllllllllllllll}1.00 & 52.10 & 28.26 & 22.86 & 2 & 1789.9074 & 1789.9040 & 895.9593 & 0.0034 & 1.8974 & 3698.235 & 4529.215 & 2985.521 & 79.879 & \text { Y }\end{array}$ $\begin{array}{llllllllllllllll}0.99 & 30.25 & 28.11 & 16.08 & 3 & 1789.9087 & 1789.9040 & 597.6419 & 0.0047 & 2.6214 & 26246.087 & 35859.476 & 18885.994 & 709.011 & \text { Yes }\end{array}$ $\begin{array}{lllllllllllllll}1.00 & 43.71 & 28.23 & 22.38 & 3 & 1789.9105 & 1789.9040 & 597.6419 & 0.0065 & 3.6253 & 41447.444 & 50171.755 & 32527.528 & 1773.743 & \text { Yes }\end{array}$

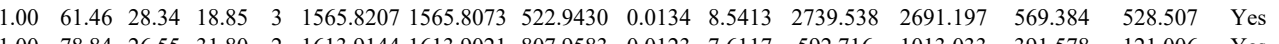
$\begin{array}{llllllllllllllll}1.00 & 78.84 & 26.55 & 31.80 & 2 & 1613.9144 & 1613.9021 & 807.9583 & 0.0123 & 7.6117 & 592.716 & 1013.033 & 391.578 & 121.006 & \text { Yes } \\ 1.00 & 92.30 & 26.21 & 33.42 & 2 & 1613.9166 & 1613.9021 & 807.9583 & 0.0145 & 8.9732 & 3190.459 & 3700.008 & 1911.026 & 423.413 & \text { Yes }\end{array}$

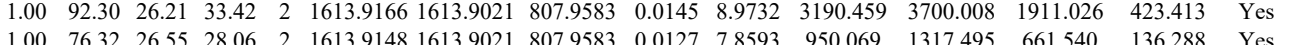
$\begin{array}{lllllllllllllll}1.00 & 76.32 & 26.55 & 28.06 & 2 & 1613.9148 & 1613.9021 & 807.9583 & 0.0127 & 7.8593 & 950.069 & 1317.495 & 661.540 & 136.288 & \text { Yes } \\ 1.00 & 75.50 & 26.28 & 27.49 & 2 & 1613.9156 & 1613.9021 & 807.9583 & 0.0135 & 83543 & 806.320 & 861.750 & 566.221 & 202.193 & \text { Yes }\end{array}$ $\begin{array}{ccccccccccccccc}1.00 & 75.50 & 26.28 & 27.49 & 2 & 1613.9156 & 1613.9021 & 807.9583 & 0.0135 & 8.3543 & 806.320 & 861.750 & 566.221 & 202.193 & \text { Yes } \\ 0.78 & 25.91 & 23.98 & 17.72 & 2 & 924.5738 & 924.5677 & 463.2911 & 0.0061 & 6.5833 & 12226.433 & 14828.055 & 35223.558 & 31347.206 & \text { No }\end{array}$

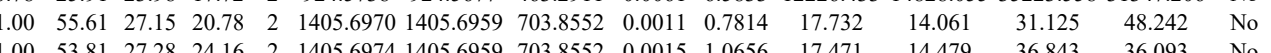




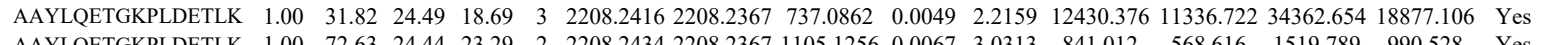

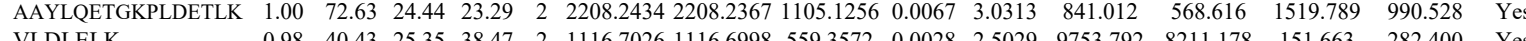

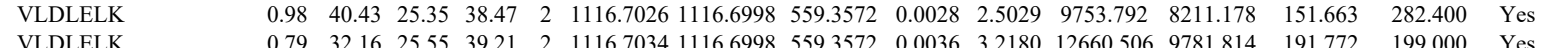

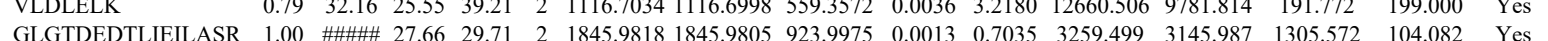

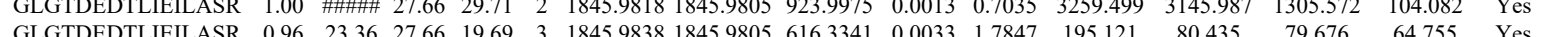

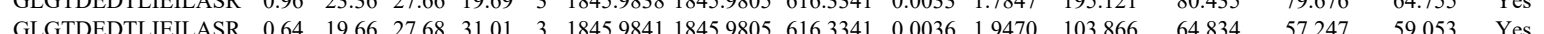

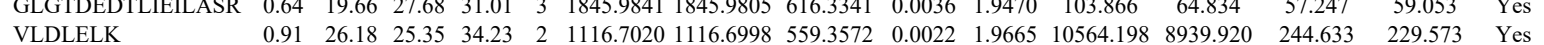

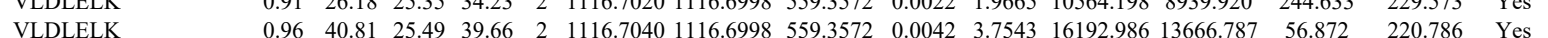

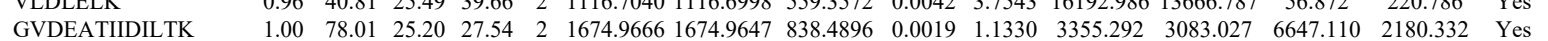

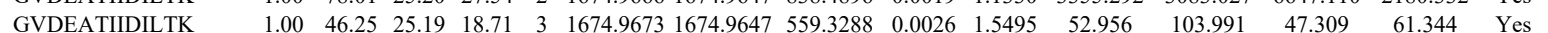

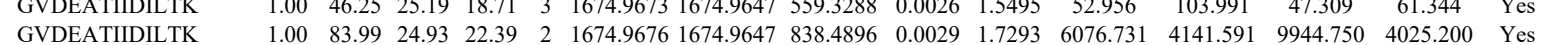
$\begin{array}{lllllllllllllllll}\text { GVDEATIIDILTK } & 1.00 & 32.60 & 24.93 & 15.21 & 3 & 1674.9685 & 1674.9647 & 559.3288 & 0.0038 & 2.2646 & 130.562 & 219.947 & 310.656 & 173.621 & \text { Yes }\end{array}$

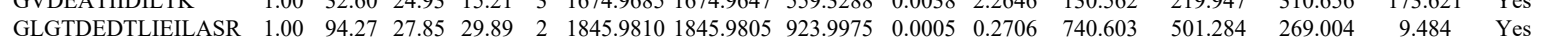

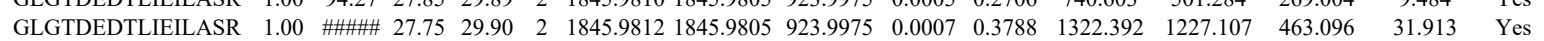

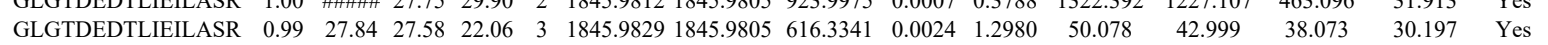
$\begin{array}{llllllllllllllll}\text { GLGTDEDTLIEILASR } & 1.00 & 32.20 & 27.72 & 23.18 & 3 & 1845.9835 & 1845.9805 & 616.3341 & 0.0030 & 1.6225 & 31.378 & 54.062 & 36.598 & 38.813 & \text { Yes }\end{array}$ $\begin{array}{lllllllllllllllll}\text { VLDLELK } & 0.95 & 40.86 & 25.31 & 38.32 & 2 & 1116.7046 & 1116.6998 & 559.3572 & 0.0048 & 4.2906 & 9663.612 & 8023.430 & 207.623 & 231.092 & \text { Yes }\end{array}$

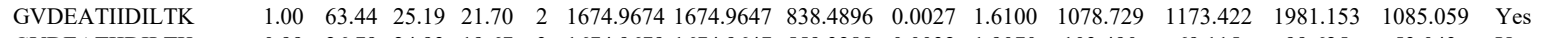
$\begin{array}{llllllllllllllll}\text { GVDEATIIDILTK } & 0.99 & 26.79 & 24.93 & 19.67 & 3 & 1674.9679 & 1674.9647 & 559.3288 & 0.0032 & 1.9070 & 103.490 & 69.115 & 99.625 & 53.043 & \text { Yes }\end{array}$ $\begin{array}{llllllllllllllll}\text { GVDEATIIDILTK } & 0.53 & 14.76 & 24.93 & 27.76 & 3 & 1674.9679 & 1674.9647 & 559.3288 & 0.0032 & 1.9070 & 59.441 & 52.404 & 47.617 & 21.229 & \text { Yes }\end{array}$ $\begin{array}{llllllllllllllll}\text { GVDEATIIDILTK } & 1.00 & 73.07 & 24.94 & 20.53 & 2 & 1674.9680 & 1674.9647 & 838.4896 & 0.0033 & 1.9678 & 1880.514 & 1838.647 & 2422.045 & 1198.064 & \text { Yes }\end{array}$ $\begin{array}{llllllllllllllll}\text { GVDEATIIDILTK } & 0.92 & 19.31 & 24.93 & 20.32 & 3 & 1674.9685 & 1674.9647 & 559.3288 & 0.0038 & 2.2646 & 52.745 & 103.668 & 76.228 & 65.958 & \text { Yes }\end{array}$ $\begin{array}{llllllllllllllll}\text { GLGTDEDTLIEILASR } & 1.00 & 87.61 & 27.68 & 26.79 & 2 & 1845.9824 & 1845.9805 & 923.9975 & 0.0019 & 1.0281 & 148.615 & 112.917 & 51.948 & 10.186 & \text { Yes }\end{array}$

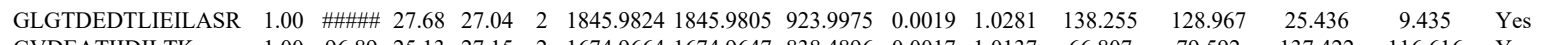
$\begin{array}{llllllllllllllll}\text { GVDEATIIDILTK } & 1.00 & 96.89 & 25.13 & 27.15 & 2 & 1674.9664 & 1674.9647 & 838.4896 & 0.0017 & 1.0137 & 66.807 & 79.592 & 137.422 & 116.616 & \text { Yes }\end{array}$

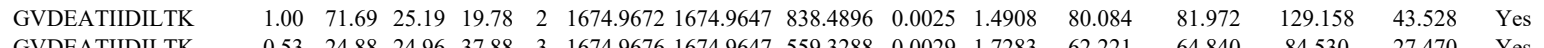

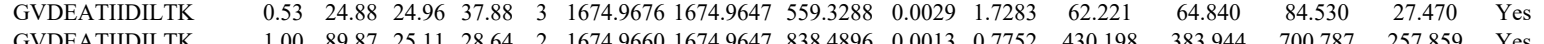
$\begin{array}{llllllllllllllll}\text { GVDEATIDILTK } & 1.00 & 89.87 & 25.11 & 28.64 & 2 & 1674.9660 & 1674.9647 & 838.4896 & 0.0013 & 0.7752 & 430.198 & 383.944 & 700.787 & 257.859 & \text { Yes }\end{array}$

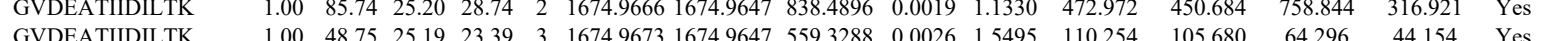

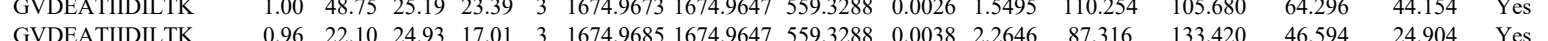

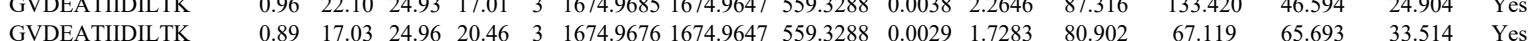

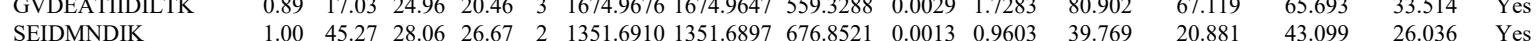
SPAQPDADE

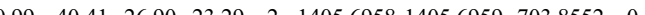
$\begin{array}{lllllllllllllll} & \\ \text { TPAQRDADELR } & 1.00 & 45.34 & 27.01 & 18.78 & 2 & 1405.6964 & 1405.6959 & 703.8552 & 0.0005 & 0.3552 & 18.275 & 21.176\end{array}$ $\begin{array}{llllllllllllllll}\text { MYGISLCQAILDETK } & 1.00 & \text { \#\#\#\# } 27.87 & 26.78 & 2 & 2018.0154 & 2018.0130 & 1010.0138 & 0.0024 & 1.1881 & 1367.799 & 1466.096 & 7\end{array}$

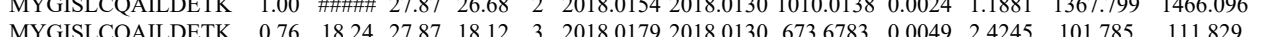
$\begin{array}{llllllllllllll}\text { MYGISLCQAILDETK } & 0.93 & 21.87 & 27.87 & 16.56 & 3 & 2018.0164 & 2018.0130 & 673.6783 & 0.0034 & 1.6823 & 200.288 & 150.577 & 72.664\end{array}$

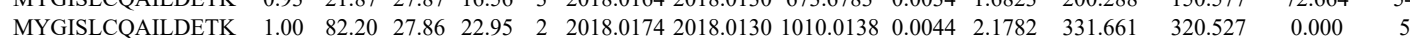

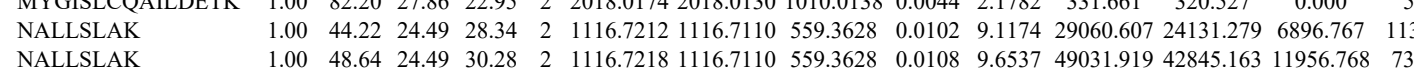
NALLSLAK $\begin{array}{llllllllllllll}\text { ALTGHLEEVVLALLK } & 1.00 & 25.28 & 16.43 & 38.28 & 4 & 1893.1573 & 1893.1543 & 474.2959 & 0.0030 & 1.5813 & 104.765 & 80.800 & 89.864 \\ \end{array}$ $\begin{array}{lllllllllllllll}\text { ALTGHLEEVVLALLK } & 0.53 & 57.98 & 16.43 & 70.98 & 3 & 1893.1576 & 1893.1543 & 632.0587 & 0.0033 & 1.7403 & 3700.370 & 3409.390 & 532.976\end{array}$ $\begin{array}{lllllllllllllll}\text { ALTGHLEEVVLALLK } & 1.00 & 57.25 & 16.43 & 17.27 & 3 & 1893.1579 & 1893.1543 & 632.0587 & 0.0036 & 1.8986 & 3696.436 & 2854.549 & 377.509\end{array}$ $\begin{array}{lllllllllllllll}\text { ALTGHLEEVVLALLK } & 1.00 & 35.79 & 16.02 & 15.49 & 4 & 1893.1585 & 1893.1543 & 474.2959 & 0.0042 & 2.2138 & 1654.651 & 1379.644 & 358.165\end{array}$ $\begin{array}{lllllllllllllll} & \end{array}$ $\begin{array}{llllllllllllll}\text { MYGISLCQAILDETK } & 1.00 & 70.29 & 27.87 & 21.96 & 2 & 2018.0154 & 2018.0130 & 1010.0138 & 0.0024 & 1.1881 & 72.818 & 62.870 & 4.616\end{array}$ $\begin{array}{llllllllllllll}\text { MYGISLCQAILDETK } & 0.53 & 14.41 & 27.87 & 18.37 & 3 & 2018.0179 & 2018.0130 & 673.6783 & 0.0049 & 2.4245 & 107.333 & 113.725 & 53.796 \\ \text { MYGISLCQAILDETK } & 1.00 & 48.82 & 27.84 & 23.83 & 3 & 2018.0185 & 2018.0130 & 673.6783 & 0.0055 & 2.7214 & 371.799 & 413.796 & 98.212\end{array}$

$\begin{array}{llllllllllllll}\text { MYGISLCQAILDETK } & 1.00 & 48.82 & 27.84 & 23.83 & 3 & 2018.0185 & 2018.0130 & 673.6783 & 0.0055 & 2.7214 & 371.799 & 413.796 & 98.212 \\ \text { NALLSLAK } & 1.00 & 44.54 & 24.49 & 22.74 & 2 & 1116.7208 & 1116.7110 & 559.3628 & 0.0098 & 8.7599 & 36389.743 & 28238.113 & 8612.728\end{array}$ NALLSLAK

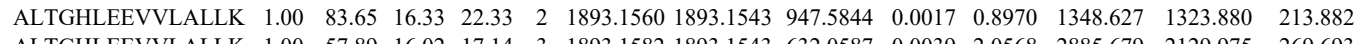
$\begin{array}{lllllllllllllll}\text { ALTGHLEEVVLALLKK } & 1.00 & 57.89 & 16.02 & 17.14 & 3 & 1893.1582 & 1893.1543 & 632.0587 & 0.0039 & 2.0568 & 2885.679 & 2129.975 & 269.693 \\ \end{array}$

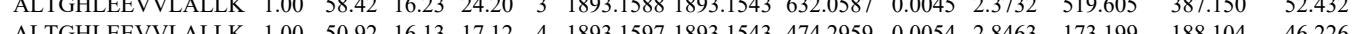
$\begin{array}{llllllllllllll}\text { ALTGHLEEVVLALLK } & 1.00 & 50.92 & 16.13 & 17.12 & 4 & 1893.1597 & 1893.1543 & 474.2959 & 0.0054 & 2.8463 & 173.199 & 188.104\end{array}$

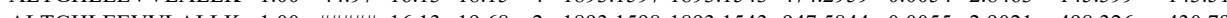
$\begin{array}{llllllllllllll}\text { ALTTHEEVVALK } & 1.00 & 39.55 & 15.56 & 52.55 & 4 & 1893.1617 & 1893.1543 & 474.2959 & 0.0074 & 3.9005 & 123.813 & 124.765\end{array}$ 
$\begin{array}{llllllllllllllll}\text { GTDVNVFNTILTTR } & 1.00 & 99.38 & 27.92 & 25.78 & 2 & 1693.9114 & 1693.9121 & 847.9633 & -0.0007 & -0.4128 & 730.676 & 791.609 & 1827.797 & 1284.555 & \text { Yes }\end{array}$ $\begin{array}{llllllllllllll} & \end{array}$

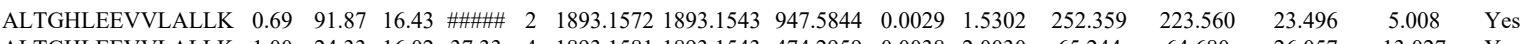
$\begin{array}{llllllllllllllll}\text { ALTGHLEEVVLALLK } & 1.00 & 24.33 & 16.02 & 37.33 & 4 & 1893.1581 & 1893.1543 & 474.2959 & 0.0038 & 2.0030 & 65.244 & 64.680 & 26.057 & 13.027 & \text { Yes }\end{array}$

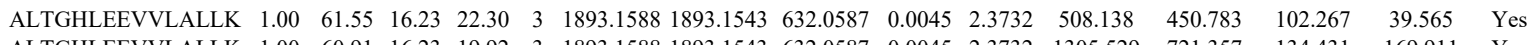
$\begin{array}{llllllllllllllll}\text { ALTGHLEEVVLALLK } & 1.00 & 60.91 & 16.23 & 19.92 & 3 & 1893.1588 & 1893.1543 & 632.0587 & 0.0045 & 2.3732 & 1305.529 & 721.357 & 134.431 & 169.911 & \text { Yes }\end{array}$

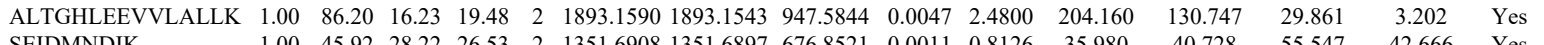

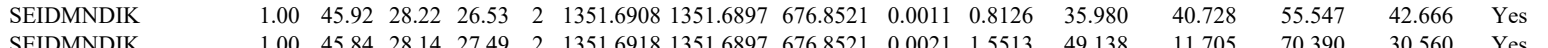

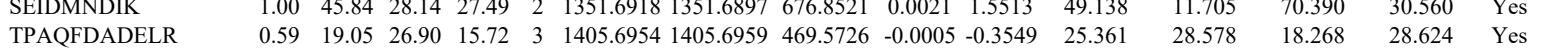

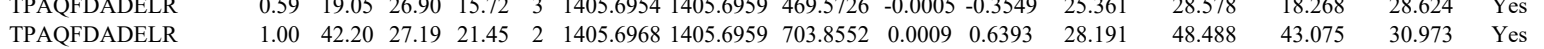

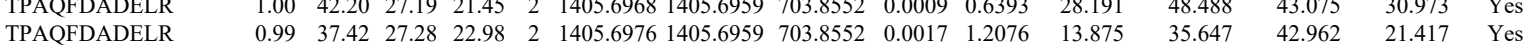

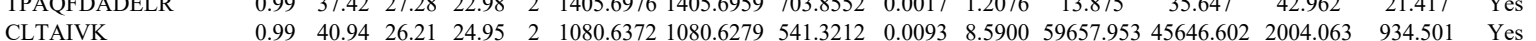
GTDVNVFNTILTTR GTDVNVFNTILTTR

GTDVNVFNTILTTR

CLTAIVK

CLTAIVK

GTDVNVFNTILTTR (8.5900 $59657.95345646 .602 \quad 2004.063$ 934.501 Yes

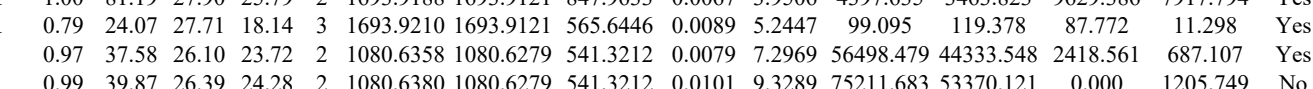
$\begin{array}{lllllllllllllllll} & 0.99 & 39.87 & 26.39 & 24.28 & 2 & 1080.6380 & 1080.6279 & 541.3212 & 0.0101 & 9.3289 & 75211.683 & 53370.121 & 0.000 & 1205.749 & \text { No }\end{array}$ $\begin{array}{llllllllllllllllll} & \end{array}$ $\begin{array}{llllllllllllllll}\text { GTDVNVFNTILTTR } & 0.96 & 30.51 & 27.90 & 16.65 & 3 & 1693.9189 & 1693.9121 & 565.6446 & 0.0068 & 4.0072 & 147.962 & 130.241 & 42.779 & 62.369 & \text { Yes }\end{array}$ $\begin{array}{llllllllllllllllll}\text { GTDVNVFNTILTTR } & 0.93 & 28.07 & 27.79 & 17.48 & 3 & 1693.9192 & 1693.9121 & 565.6446 & 0.0071 & 4.1840 & 77.908 & 141.248 & 45.262 & 50.861 & \text { Yes }\end{array}$ $\begin{array}{llllllllllllllll}\text { KGTDVNVFNTILTTR } & 1.00 & 56.72 & 24.41 & 18.56 & 3 & 1966.1116 & 1966.1091 & 656.3770 & 0.0025 & 1.2696 & 1598.231 & 2071.677 & 1888.620 & 754.727 & \text { Yes }\end{array}$

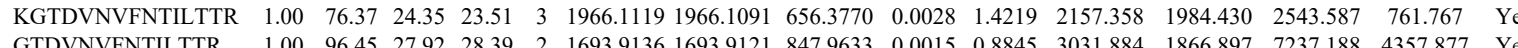
$\begin{array}{llllllllllllllllll}\text { GTDVNVFNTILTTR } & 1.00 & 96.45 & 27.92 & 28.39 & 2 & 1693.9136 & 1693.9121 & 847.9633 & 0.0015 & 0.8845 & 3031.884 & 1866.897 & 7237.188 & 4357.877 & \text { Yes } \\ \text { KGTDVNVFNTILTTR } & 1.00 & 71.93 & 24.35 & 21.21 & 3 & 1966.1119 & 1966.1091 & 656.3770 & 0.0028 & 1.4219 & 2147.699 & 2283.006 & 3669.278 & 1195.946 & \text { Yes }\end{array}$ $\begin{array}{llllllllllllllll}\text { KGTDVNVFNTILTTR } & 1.00 & 66.20 & 24.53 & 22.79 & 3 & 1966.1143 & 1966.1091 & 656.3770 & 0.0028 & 1.4219 & 2147.699 & 2283.006 & 3669.278 & 1195.946 & \text { Yes } \\ \text { KGTDVN } & 2.60508 & 2517.695 & 2871.562 & 3508.911 & 1903.077 & \text { Yes }\end{array}$ $\begin{array}{llllllllllllllll}\text { KGTDVNVFNTILTTR } & 1.00 & 81.81 & 24.50 & 24.19 & 3 & 1966.1110 & 1966.1091 & 656.3770 & 0.0019 & 0.9649 & 2313.908 & 2336.399 & 2694.174 & 1224.257 & \text { Yes }\end{array}$ $\begin{array}{lllllllllllllllll}\text { KGTDVNVFNTILTTR } & 1.00 & 60.62 & 24.38 & 21.25 & 3 & 1966.1122 & 1966.1091 & 656.3770 & 0.0031 & 1.5743 & 1235.047 & 1684.828 & 1954.037 & 825.040 & \text { Yes }\end{array}$ ILVALCGGN

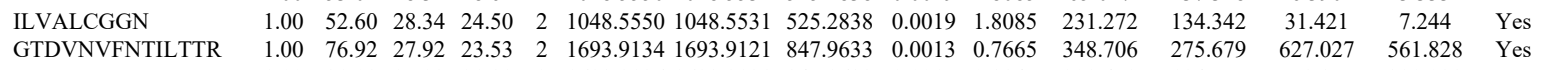
$\begin{array}{lllllllllllllll}1.00 & 53.02 & 28.34 & 18.61 & 2 & 1048.5550 & 1048.5531 & 525.2838 & 0.0019 & 1.8085 & 65.027 & 137.348 & 6.390 & 3.333 & \text { No }\end{array}$

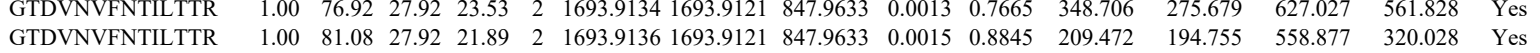

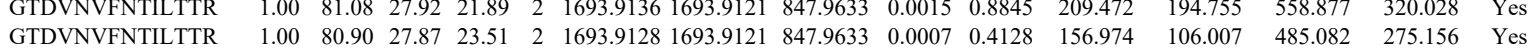

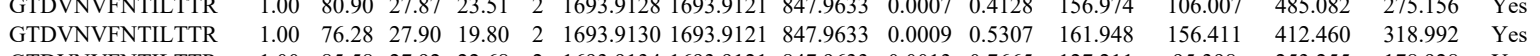
$\begin{array}{lllllllllllllllll}\text { GTDVNVFNTILTTR } & 1.00 & 85.58 & 27.92 & 22.68 & 2 & 1693.9134 & 1693.9121 & 847.9633 & 0.00013 & 0.5707 & 161.948 & 156.411 & 412.460 & 318.992 & \text { Yes } \\ \end{array}$ $\begin{array}{llllllllllllllll}\text { GTDVNVFNTILTTR } & 1.00 & 85.58 & 27.92 & 22.68 & 2 & 1693.9134 & 1693.9121 & 847.9633 & 0.0013 & 0.7665 & 127.211 & 95.398 & 253.255 & 178.928 & \text { Yes } \\ \text { GTDVNVFNTILTTR } & 1.00 & 77.57 & 28.00 & 22.02 & 2 & 1693.9116 & 1693.9121 & 847.9633 & -0.0005 & -0.2948 & 14.560 & 28.652 & 23.489 & 25.991 & \text { Yes } \\ \text { GTDVNVFNTILTTR } & 1.00 & 82.36 & 27.90 & 21.18 & 2 & 1693.9132 & 1693.9121 & 847.9633 & 0.0011 & 0.6486 & 34.332 & 36.376 & 43.572 & 25.854 & \text { Yes }\end{array}$ GTDVNVFTILTTR GTDVNVFNTIL

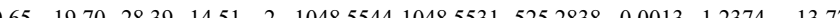

$36.376 \quad 43.572$

GTDVNVFNTILTTR $\begin{array}{lllllllllll}1.00 & 92.69 & 27.92 & 25.48 & 2 & 1693.9134 & 1693.9121 & 847.9633 & 0.0013 & 0.7665 & 13.1\end{array}$

GTDVNVFNTILTTR

GTDVNVFNTLTTTR

GTDVNVFNTILTTR

GTDVNVFNTILTTR

GTDVNVFNTILTTR SEIDMNDIK GTDVNVFNTILTT $\begin{array}{llllllllllllllll}\text { SEIDMNDIK } & 1.00 & 48.67 & 28.14 & 30.39 & 2 & 1351.6916 & 1351.6897 & 676.8521 & 0.0019 & 1.4036 & 3469.367 & 3444.750 & 6490.965 & 3385.691 & \text { Yes } \\ \text { VLPMNTGVEAGETACK } & 1.00 & 75.58 & 27.89 & 20.45 & 2 & 1952.9764 & 1952.9613 & 977.4879 & 0.0151 & 7.7238 & 1441.327 & 2151.748 & 282.791 & 69.801 & \text { Yes }\end{array}$ $\begin{array}{lllllllllllllll}1.00 & 85.21 & 27.87 & 23.00 & 2 & 1693.9126 & 1693.9121 & 847.9633 & 0.0005 & 0.1948 & 23.912 & 14.658 & 24.186 & 27.119 & \text { Yes }\end{array}$ $\begin{array}{lllllllllllllll}1.00 & 80.46 & 27.92 & 20.51 & 2 & 1693.9134 & 1693.9121 & 847.9633 & 0.0013 & 0.7665 & 11.922 & 19.594 & 28.611 & 20.956 & \text { Yes }\end{array}$

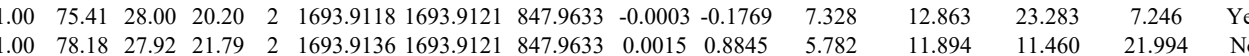

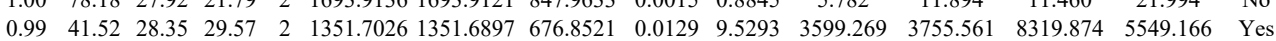

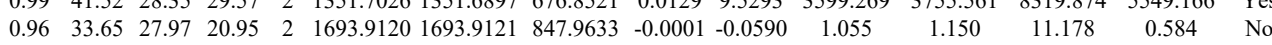
$\begin{array}{llllllllllllllll} & \\ \text { GIYLWDVEGR } & 1.00 & 75.58 & 27.89 & 20.45 & 2 & 1952.9764 & 1952.9613 & 977.4879 & 0.0151 & 7.7238 & 1441.327 & 2151.748 & 282.791 & 69.801 & \text { Yes } \\ \end{array}$ $\begin{array}{llllllllllllllllll}\text { LPSDVVTAVR } & 0.93 & 30.72 & 26.05 & 18.47 & 2 & 1199.7098 & 1199.6996 & 600.8571 & 0.0102 & 8.4878 & 7587.231 & 10302.908 & 4041.592 & 3076.017 & \text { No }\end{array}$ $\begin{array}{llllllllllllllllll}\text { LPSDVVTAVR } & 0.96 & 33.76 & 26.04 & 24.28 & 2 & 1199.7108 & 1199.6996 & 600.8571 & 0.0112 & 9.3199 & 2832.763 & 3582.215 & 1122.732 & 1335.413 & \text { No }\end{array}$

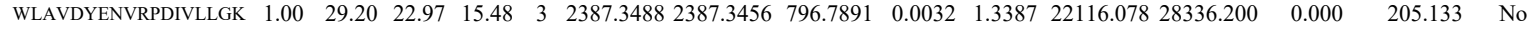

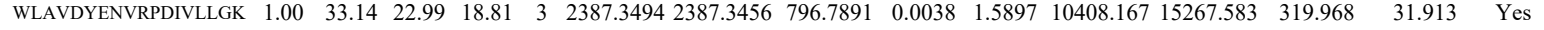
$\begin{array}{llllllllllllllll}\text { WLAVDYENVRPDIVLLGK } & 0.55 & 24.80 & 23.12 & 37.80 & 3 & 2387.3479 & 2387.3456 & 796.7891 & 0.0023 & 0.9622 & 5960.815 & 7403.294 & 422.928 & 57.383 & \text { Yes }\end{array}$

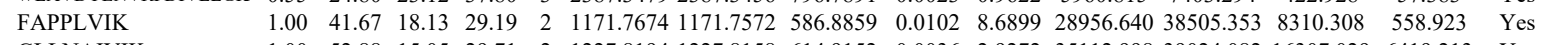
GLLNAIVIK GLLNAIVIK FAPPLVIK FAPPLVIK GLLNAIVIK GLLNAIVIK FAPPLVIK GLLNAIVIK
GLLNAIVIK

GLLNAIVIK $\begin{array}{lllllllllllllll}1.00 & 52.88 & 15.05 & 29.71 & 2 & 1227.8194 & 1227.8158 & 614.9152 & 0.0036 & 2.9272 & 35112.998 & 39024.082 & 16307.029 & 6419.213 & \text { Yes }\end{array}$

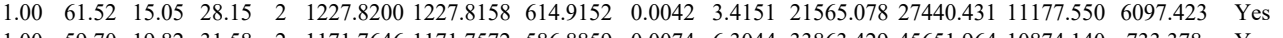

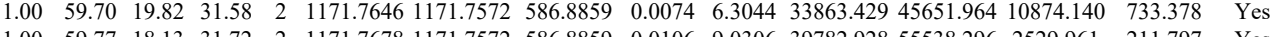
$\begin{array}{llllllllllllllll}1.00 & 59.77 & 18.13 & 31.72 & 2 & 1171.7678 & 1171.7572 & 586.8859 & 0.0106 & 9.0306 & 39782.928 & 55538.296 & 2529.961 & 211.797 & \text { Yes }\end{array}$ $\begin{array}{lllllllllllllll}1.00 & 61.75 & 15.19 & 28.22 & 2 & 1227.8174 & 1227.8158 & 614.9152 & 0.0016 & 1.3010 & 23763.922 & 30809.389 & 11592.843 & 5509.301 & \text { Yes } \\ 1.00 & 61.40 & 15.05 & 2.00 & 2 & 1227.8190 & 1227.8158 & 61.9152 & 0.0032 & 2.6020 & 15953504 & 21528970 & 9359.738 & 3043.371 & \text { Yes }\end{array}$ $\begin{array}{lllllllllllllll}1.00 & 61.40 & 15.05 & 28.00 & 2 & 1227.8190 & 1227.8158 & 614.9152 & 0.0032 & 2.6020 & 15953.504 & 21528.970 & 9359.738 & 3043.371 & \text { Yes } \\ 0.91 & 23.30 & 18.06 & 14.88 & 2 & 1171.7666 & 1171.7572 & 586.8859 & 0.0094 & 8.0083 & 13730.601 & 15887.495 & 521.510 & 398.923 & \text { Yes }\end{array}$ $\begin{array}{lllllllllllllll}0.91 & 23.30 & 18.06 & 14.88 & 2 & 1171.7666 & 1171.7572 & 586.8859 & 0.0094 & 8.0083 & 15730.601 & 15887.495 & 521.510 & 398.923 & \text { Yes } \\ 1.00 & 62 & 14.91 & 30.22 & 2 & 1227.8164 & 1227.8158 & 614.9152 & 0.0006 & 0.4879 & 444.603 & 5948.392 & 1996.653 & 904.693 & \text { Yes }\end{array}$

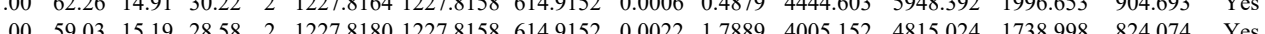
$\begin{array}{lllllllllllllll}0.50 & 13.96 * 15.31 & 20.10 & 2 & 827.5710 & 827.5714 & 414.7930 & -0.0004 & -0.4822 & 85.157 & 96.092 & 29.629 & 11.821 & \text { Yes }\end{array}$ $\begin{array}{lllllllllllllll}1.00 & 51.31 & 27.94 & 24.71 & 2 & 1380.7430 & 1380.7424 & 691.3785 & 0.0006 & 0.4339 & 2598.757 & 3756.402 & 73.534 & 21.835 & \text { Yes }\end{array}$

Table S-3 page 47 of 499 
$\begin{array}{lllllllllll} & \end{array}$

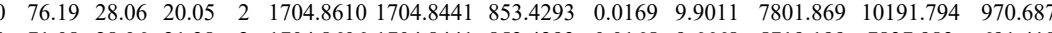
$\begin{array}{lllll}2564.2384 & 2564.2349 & 855.7522 & 0.0035 & 1.3633\end{array}$ $\begin{array}{lllllllllllll} & \end{array}$ $\begin{array}{lllllllllllllll} & \end{array}$

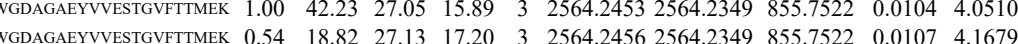

YDNSLK $\begin{array}{lllllllllll}1.08 & 40.61 & 27.16 & 22.70 & 3 & 2564.2483 & 2564.2349 & 855.7522 & 0.0134 & 5.2196 & 16.233\end{array}$ $\begin{array}{lllllllllllll}\text { GDAGAEYVVESTGVFTTMEK } & 0.98 & 34.42 & 27.15 & 18.64 & 3 & 2564.2486 & 2564.2349 & 855.7522 & 0.0137 & 5.3364 & 2.189 \\ \text { GDAGAEYVVESTGVFTMEK K } & 0.55 & 17.43 & 26.59 & 30.43 & 3 & 2580.2320 & 2580.2298 & 861.0839 & 0.0022 & 0.8516 & 7.597\end{array}$ TVDGPSGK $\begin{array}{llllllllllll} & \text { TVDGPU }\end{array}$ $\begin{array}{llllllllllll} & \text { W }\end{array}$ $\begin{array}{lllllllllll} & 0\end{array}$ W $\begin{array}{llllllll} & 0\end{array}$ $\begin{array}{lllllllllllll}\text { AGAHLQGGAK } & 1.00 & 49.66 & 26.24 & 19.77 & 2 & 1196.6876 & 1196.6869 & 599.3507 & 0.0007 & 0.5840 & 58.454\end{array}$

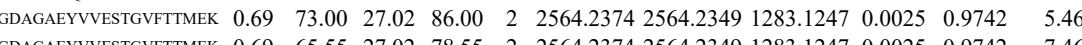

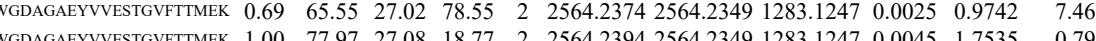
$\begin{array}{llllllllllll} & \end{array}$ \begin{tabular}{llllllllllll}
\hline & 69.09 & 27.08 & 20.54 & 2 & 2564.2394 & 2564.2349 & 1283.1247 & 0.0045 & 1.7535 & 6.033
\end{tabular} $\begin{array}{llllllllllll}\text { WGDAGAEYYVESTGYFTTMEK } & 0.51 & 68.29 & 27.07 & 81.29 & 2 & 2564.2454 & 2564.2349 & 1283.1247 & 0.0105 & 4.0916 & 19.792\end{array}$ $\begin{array}{llllllllllll}\text { WGDAGAEYVVESTGVFTTMEK } & 0.51 & 78.92 & 27.07 & 91.92 & 2 & 2564.2454 & 2564.2349 & 1283.1247 & 0.0105 & 4.0916 & 4.095\end{array}$

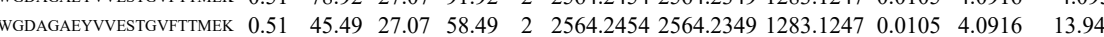

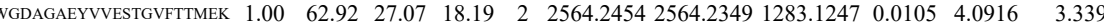

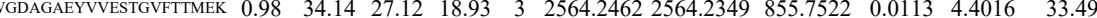

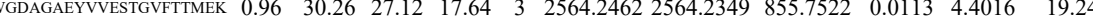

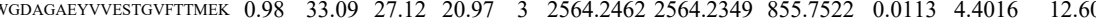

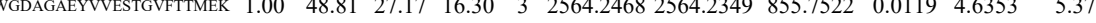

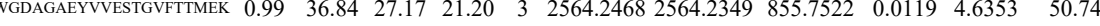

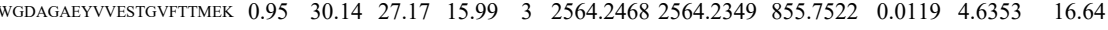

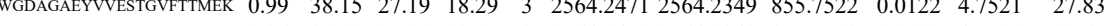

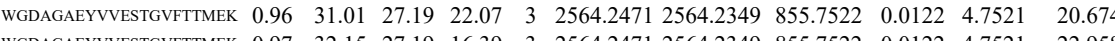

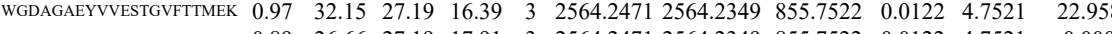
WGDAGAEYWVESTGFTIMEK $0.89 \begin{array}{llllllllllll}0.86 & 26.66 & 27.19 & 17.91 & 3 & 2564.2471 & 2564.2349 & 855.7522 & 0.0122 & 4.7521 & 0.000\end{array}$ $\begin{array}{lllllllllllll}\text { WGDAGAEYWESTGVFTMEK } & 0.68 & 21.51 & 27.19 & 14.40 & 3 & 2564.2471 & 2564.2349 & 855.7522 & 0.0122 & 4.7521 & 24.912\end{array}$

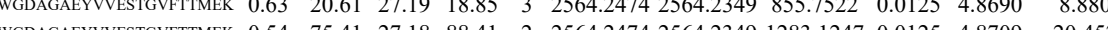

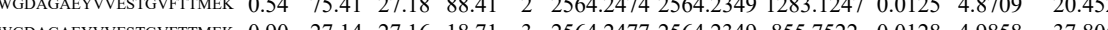

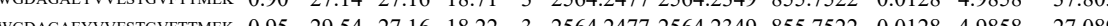
$\begin{array}{lllllllll} & 0.989\end{array}$ $\begin{array}{lllllllllll} & \end{array}$ 


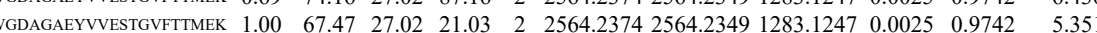
$\begin{array}{llllllllllll}\text { WGDAGAEYVYESTGVFTTMEK } & 1.00 & 95.10 & 27.02 & 20.07 & 2 & 2564.2374 & 25642349 & 1283.1247 & 0.0025 & 0.9742 & 4.54\end{array}$ $\begin{array}{llllllllllll}\text { WGDAGAEYVVESTGVFTTMEK } & 0.69 & 89.39 & 27.02 & \text { \#\#\#\# } & 2 & 2564.2374 & 2564.2349 & 1283.1247 & 0.0025 & 0.9742 & 3.239\end{array}$

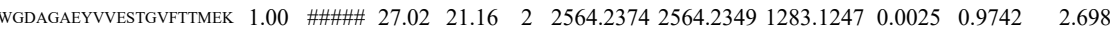

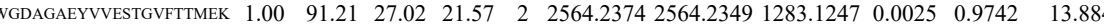
$\begin{array}{lllllllllllll}\text { WGDAGAEYVVESTGVFTTMEK } & 1.00 & 76.04 & 27.02 & 20.24 & 2 & 2564.2374 & 2564.2349 & 1283.1247 & 0.025 & 0.9742 & 0.000\end{array}$

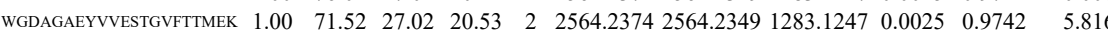

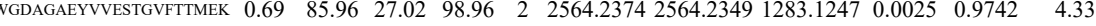
WGDAGAEYVVESTGVFTTMEK $0.69 \quad 77.74 \quad 27.02 \quad 90.74 \quad 2 \quad 2564.23742564 .2349 \begin{array}{llllllll}1283.1247 & 0.0025 & 0.9742 & 10.247\end{array}$

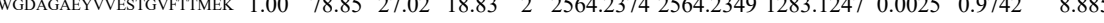

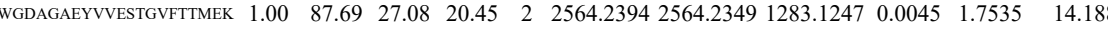
$\begin{array}{llllllllllllll}\text { WGDAGAEYVVESTGVFTTMEK } & 1.00 & 56.41 & 27.08 & 18.51 & 3 & 2564.2417 & 2564.2349 & 855.7522 & 0.0068 & 2.6487 & 32.372\end{array}$ $\begin{array}{llllllllllllll}\text { WGDAGAEYVVESTGVFTTMEK } & 1.00 & 55.13 & 27.19 & 17.07 & 3 & 2564.2420 & 2564.2349 & 855.7522 & 0.0071 & 2.7656 & 48.404\end{array}$ $\begin{array}{llllllllllll}\text { WGDAGAEYVVESTGVFTTMEK } & 1.00 & 53.18 & 27.15 & 17.03 & 3 & 2564.2423 & 2564.2349 & 855.7522 & 0.0074 & 2.8824 & 27.131\end{array}$ $\begin{array}{llllllllllll}0.98 & 33.60 & 27.14 & 17.66 & 3 & 2564.2426 & 2564.2349 & 855.7522 & 0.0077 & 2.9993 & 71.157\end{array}$ $\begin{array}{llllllllllll}\text { WGDAGAEYYWESTGFTMEK K } & 1.00 & 51.57 & 27.14 & 22.25 & 3 & 2564.2426 & 2564.2349 & 855.7522 & 0.0077 & 2.9993 & 0.000\end{array}$

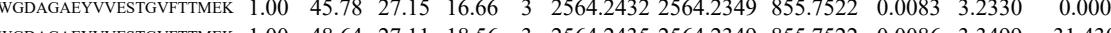
$\begin{array}{llllllllllll}\text { WGDAGAEYVESTGVFTMEK K } & 1.00 & 48.64 & 27.11 & 18.56 & 3 & 2564.2435 & 2564.2349 & 855.7522 & 0.0086 & 3.3499 & 31.430\end{array}$ $\begin{array}{lllllllllll} & 0.300\end{array}$

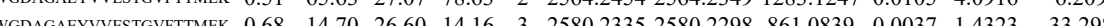
$\begin{array}{llllllllll} & \text { W }\end{array}$ $\begin{array}{llllllllll} & \text { WGD }\end{array}$ $\begin{array}{lllllllllll}1.00 & 40.57 & 24.42 & 53.57 & 4 & 4324.0789 & 4324.0917 & 1082.0302 & -0.0128 & -2.9574 & 11.312\end{array}$

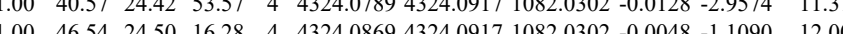

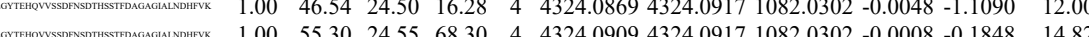

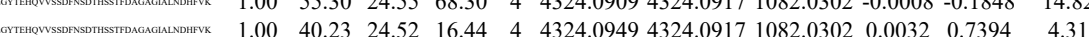
$\begin{array}{llllllllllll}1.00 & 42.66 & 24.89 & 55.66 & 4 & 4324.0989 & 4324.0917 & 1082.0302 & 0.0072 & 1.6635 & 7.331\end{array}$

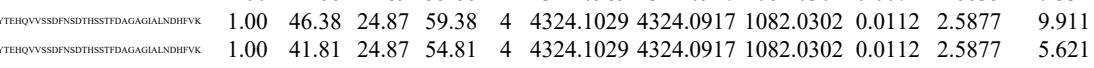

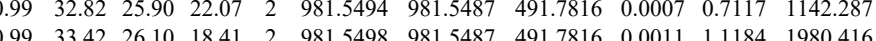
AGAHLQGGAK $\begin{array}{llllllllllll}1.00 & 48.72 & 26.24 & 22.64 & 2 & 1196.6874 & 1196.6869 & 599.3507 & 0.0005 & 0.417\end{array}$ $\begin{array}{llllllllllll}1.00 & 52.62 & 25.79 & 21.77 & 2 & 1196.6878 & 1196.6869 & 599.3507 & 0.0009 & 0.7508 & 106.454\end{array}$ $\begin{array}{llllllllllll} & & \end{array}$

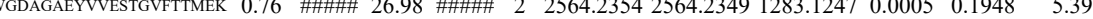

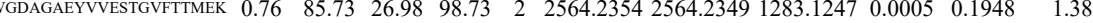
$\begin{array}{llllllllllll}\text { WGDAGAEYVVESTGVFTTMEK } & 0.76 & 89.06 & 26.98 & \# \# \# \text { 2 } & 2564.2354 & 2564.2349 & 1283.1247 & 0.0005 & 0.1948 & 2.35\end{array}$ $\begin{array}{llllllllllll}\text { WGDAGAEYVVESTGVFTTMEK } & 0.69 & 99.78 & 27.02 & \text { \#\#\#\# } & 2 & 2564.2374 & 2564.2349 & 1283.1247 & 0.0025 & 0.9742 & 12.025\end{array}$ $\begin{array}{llllllllllll}\text { WGDAGAEYVVESTGVFTTMEK } & 1.00 & 91.22 & 27.02 & 18.75 & 2 & 2564.2374 & 2564.2349 & 1283.1247 & 0.0025 & 0.9742 & 10.178\end{array}$ $\begin{array}{lllllllllllll}\text { WGDAGAEYVESTGVFTTMEK } & 1.00 & 78.04 & 27.02 & 18.41 & 2 & 2564.2374 & 2564.2349 & 1283.1247 & 0.0025 & 0.9742 & 41.029\end{array}$ $\begin{array}{llllllllllll}\text { WGDAGAEYVVESTGVFTTMEK } & 1.00 & \text { 27.02 } & 21.03 & 2 & 2564.2374 & 2564.2349 & 1283.1247 & 0.0025 & 0.9742 & 2.198\end{array}$

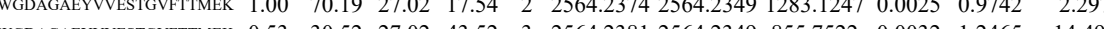
$\begin{array}{llllllllllll}\text { WGDAGAEYWESTGVTMEK } & 0.53 & 30.52 & 27.02 & 43.52 & 3 & 2564.2381 & 2564.2349 & 855.7522 & 0.0032 & 1.2465 & 14.497\end{array}$

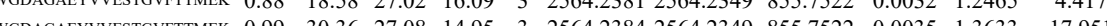
$\begin{array}{llllllllll} & 0.303\end{array}$ $\begin{array}{lllllllllll} & \text { W }\end{array}$

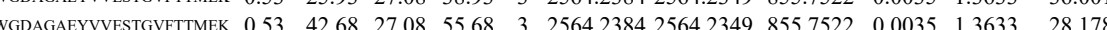




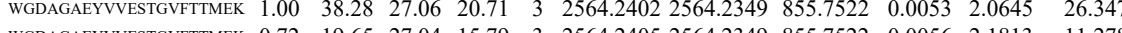

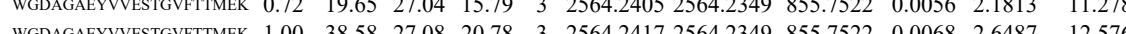

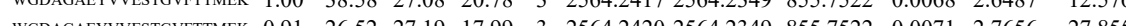

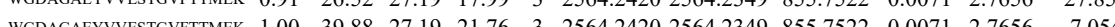
$\begin{array}{llllllllll} & \end{array}$

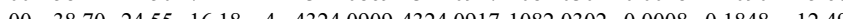

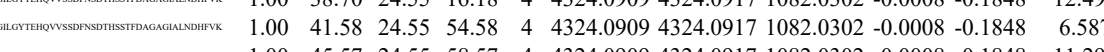

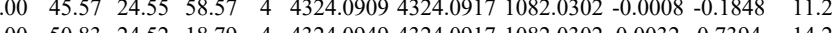

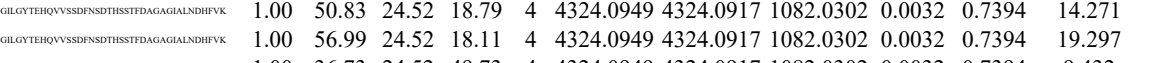
$\begin{array}{llllllllllll}1.00 & 56.99 & 24.52 & 18.11 & 4 & 4324.0949 & 4324.0917 & 1082.0302 & 0.0032 & 0.7394 & 19.297 \\ 1.00 & 36.73 & 24.52 & 49.73 & 4 & 4324.0949 & 4324.0917 & 1082.0302 & 0.0032 & 0.7394 & 9.432\end{array}$ $\begin{array}{lllllllllll}1.00 & 46.28 & 24.52 & 19.81 & 4 & 4324.0949 & 4324.0917 & 1082.0302 & 0.0032 & 0.7394 & 0.000\end{array}$

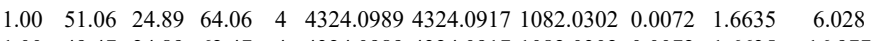
$\begin{array}{lllllllllll}1.00 & 49.47 & 24.89 & 62.47 & 4 & 4324.0989 & 4324.0917 & 1082.0302 & 0.0072 & 1.6635 & 16.977 \\ 1.00 & 40.79 & 24.87 & 15.86 & 4 & 4324.1029 & 4324.0917 & 1082.0302 & 0.0112 & 2.5877 & 7.567\end{array}$

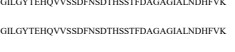
$\begin{array}{lllllllllll}1.00 & 46.18 & 24.87 & 59.18 & 4 & 4324.1029 & 4324.0917 & 1082.0302 & 0.0112 & 2.5877 & 13.924 \\ 0.97 & 37.40 & 25.82 & 25.27 & 2 & 981.5480 & 981.5487 & 491.7816 & -0.0007 & -0.7117 & 462.181\end{array}$ $\begin{array}{lllllllllllll}0.99 & 36.90 & 26.09 & 22.41 & 2 & 981.5492 & 981.5487 & 491.7816 & 0.0005 & 0.5084 & 717.117 & 836 & \\ 0.99 & 35.03 & 24.36 & 23.78 & 2 & 1156.7082 & 1156.7059 & 579.3602 & 0.0023 & 1.9849 & 274.476\end{array}$ $\begin{array}{lllllllllllll}0.97 & 27.55 & 24.25 & 20.76 & 2 & 1156.7084 & 1156.7059 & 579.3602 & 0.0025 & 2.1575 & 284.349\end{array}$ $\begin{array}{lllllllllllll}0.97 & 36.60 & 24.22 & 21.46 & 2 & 1156.7114 & 1156.7059 & 579.3602 & 0.0055 & 4.7466 & 131.032\end{array}$ VIPELNGK VIPELNGK VIPELNGK VIPELNGK AGAHLQGGAK

$\begin{array}{llllllllllll}0.94 & 31.98 & 24.01 & 23.86 & 2 & 1156.7144 & 1156.7059 & 579.3602 & 0.0085 & 7.3456 & 309.288 & 3\end{array}$ $\begin{array}{lllllllllll}1.00 & 41.72 & 23.91 & 22.56 & 2 & 1156.7158 & 1156.7059 & 579.3602 & 0.0099 & 8.5438 & 75817.431\end{array}$ GAHLQGGAK

$\begin{array}{lllllllllll}.94 & 29.34 & 23.91 & 23.07 & 2 & 156.7162 & 156.7059 & 579.3602 & 0.0103 & 8.8890 & 277.657 \\ 1.00 & 41.75 & 22.65 & 21.34 & 2 & 1156.7170 & 1156.7059 & 579.3602 & 0.0111 & 9.5794 & 98043.088\end{array}$ $\begin{array}{llllllllllll}1.00 & 51.34 & 26.30 & 20.37 & 2 & 1196.6860 & 1196.6869 & 599.3507 & -0.0009 & -0.7508 & 29.154\end{array}$ $\begin{array}{lllllll} & \end{array}$

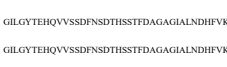
$\begin{array}{lllllllllll}39.84 & 24.55 & 52.84 & 4 & 4324.0909 & 4324.0917 & 1082.0302 & -0.0008 & -0.1848 & 31.472\end{array}$

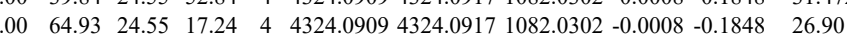
$\begin{array}{lllllllllll}1.00 & 45.08 & 24.55 & 58.08 & 4 & 4324.0909 & 4324.0917 & 1082.0302 & -0.0008 & -0.1848 & 31.502\end{array}$ $\begin{array}{lllllllllll}1.00 & 36.11 & 24.55 & 49.11 & 4 & 4324.0909 & 4324.0917 & 1082.0302 & -0.0008 & -0.1848 & 20.004 \\ 1.00 & 63.51 & 24.55 & 76.51 & 4 & 4324.0909 & 4324.0917 & 1082.0302 & -0.0008 & -0.1848 & 24.937\end{array}$

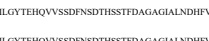

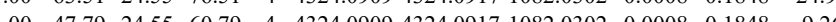

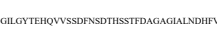
$\begin{array}{lllllllllll}1.00 & 5.738 & 24.55 & 60.78 & 4 & 4324.0909 & 4324.0917 & 082.0302 & 0.0008 & 0.1848 & 9.261\end{array}$

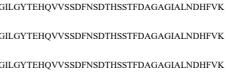
$\begin{array}{lllllllllll}1.00 & 4.78 & 24.552 & 18.88 & 4 & 4324.0949 & 4324.0917 & 1082.0302 & 0.0032 & 0.7394 & 29.801\end{array}$

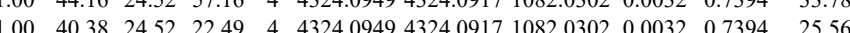
$\begin{array}{llllllllllll}1.00 & 50.89 & 24.52 & 19.69 & 4 & 4324.0949 & 4324.0917 & 1082.0302 & 0.0032 & 0.7394 & 34.830\end{array}$ $\begin{array}{llllllllllll}1.00 & 37.58 & 24.52 & 15.53 & 4 & 4324.0949 & 4324.0917 & 1082.0302 & 0.0032 & 0.7394 & 32.042\end{array}$ $\begin{array}{llllllllllll}1.00 & 60.56 & 24.52 & 73.56 & 4 & 4324.0949 & 4324.0917 & 1082.0302 & 0.0032 & 0.7394 & 12.470\end{array}$ $\begin{array}{lllllllllll}1.00 & 45.03 & 24.52 & 58.03 & 4 & 4324.0949 & 4324.0917 & 1082.0302 & 0.0032 & 0.7394 & 24.213\end{array}$ $\begin{array}{llllllllllll}1.00 & 43.07 & 24.89 & 56.07 & 4 & 4324.0989 & 4324.0917 & 1082.0302 & 0.0072 & 1.6635 & 26.671 \\ 1.00 & 39.80 & 24.89 & 52.80 & 4 & 4324.0989 & 4324.0917 & 1082.0302 & 0.0072 & 1.6635 & 30.646\end{array}$

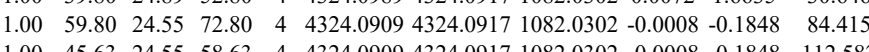
$\begin{array}{lllllllllll}1.00 & 45.63 & 24.55 & 58.63 & 4 & 4324.0909 & 4324.0917 & 1082.0302 & -0.0008 & -0.1848 & 112.582\end{array}$ $\begin{array}{lllllllllll}1.00 & 45.36 & 24.55 & 16.05 & 4 & 4324.0909 & 4324.0917 & 1082.0302 & -0.0008 & -0.1848 & 81.651 \\ 1.00 & 45.60 & 24.55 & 58.60 & 4 & 4324.0909 & 4324.0917 & 1082.0302 & -0.0008 & -0.1848 & 67.260\end{array}$ $\begin{array}{llllllllllll}1.00 & 70.99 & 24.52 & 83.99 & 4 & 4324.0949 & 4324.0917 & 1082.0302 & 0.0032 & 0.7394 & 79.947\end{array}$ $\begin{array}{lllllllllll}1.00 & 51.49 & 24.52 & 64.49 & 4 & 4324.0949 & 4324.0917 & 1082.0302 & 0.0032 & 0.7394 & 27.752 \\ 1.00 & 4.97 & 24.52 & 54.97 & 4 & 4324.0949 & 4324.0917 & 1082.0302 & 0.0032 & 0.7394 & 45.215\end{array}$ $\begin{array}{llllllllllll}1.00 & 41.97 & 24.52 & 54.97 & 4 & 4324.0949 & 4324.0917 & 1082.0302 & 0.0032 & 0.7394 & 45.215 \\ 1.00 & 54.38 & 24.52 & 67.38 & 4 & 4324.0949 & 4324.0917 & 1082.0302 & 0.0032 & 0.7394 & 49.628\end{array}$ $\begin{array}{llllllllllll}1.00 & 54.38 & 24.52 & 67.38 & 4 & 4324.0949 & 4324.0917 & 1082.0302 & 0.0032 & 0.7394 & 49.628 \\ 1.00 & 61.51 & 24.52 & 74.51 & 4 & 4324.0949 & 4324.0917 & 1082.0302 & 0.0032 & 0.7394 & 154.022\end{array}$ $\begin{array}{lllllllllll}1.00 & 61.51 & 24.52 & 74.51 & 4 & 4324.0949 & 4324.0917 & 1082.0302 & 0.0032 & 0.7394 & 154.022 \\ 1.00 & 67.78 & 24.52 & 21.09 & 4 & 4324.0949 & 4324.0917 & 1082.0302 & 0.0032 & 0.7394 & 96.677\end{array}$ $\begin{array}{llllllllllll}1.00 & 67.78 & 24.52 & 21.09 & 4 & 4324.0949 & 4324.0917 & 1082.0302 & 0.0032 & 0.7394 & 96.677 \\ 1.00 & 49.96 & 24.52 & 22.60 & 4 & 4324.0949 & 4324.0917 & 1082.0302 & 0.0032 & 0.7394 & 68.417\end{array}$ $\begin{array}{lllllllllll}1.00 & 49.96 & 24.52 & 22.60 & 4 & 4324.0949 & 4324.0917 & 1082.0302 & 0.0032 & 0.7394 & 68.417 \\ 1.00 & 50.76 & 24.52 & 17.73 & 4 & 4324.0949 & 4324.0917 & 1082.0302 & 0.0032 & 0.7394 & 217.587\end{array}$ $\begin{array}{lllllllllll}1.00 & 50.29 & 24.52 & 63.29 & 4 & 4324.0949 & 4324.0917 & 1082.0302 & 0.0032 & 0.7394 & 84.689\end{array}$ $\begin{array}{llllllllllll}1.00 & 47.41 & 24.52 & 18.48 & 4 & 4324.0949 & 4324.0917 & 1082.0302 & 0.0032 & 0.7394 & 85.292\end{array}$ $\begin{array}{llllllllllll}1.00 & 50.31 & 24.52 & 63.31 & 4 & 4324.0949 & 4324.0917 & 1082.0302 & 0.0032 & 0.7394 & 157.60 \\ 1.00 & 52.87 & 24.89 & 16.50 & 4 & 4324.0989 & 4324.0917 & 1082.0302 & 0.0072 & 1.6635 & 158.077\end{array}$ $\begin{array}{llllllllllll}1.00 & 47.76 & 24.89 & 60.76 & 4 & 4324.0989 & 4324.0917 & 1082.0302 & 0.0072 & 1.6635 & 61.900\end{array}$

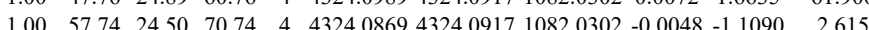



$\begin{array}{lllllllllllll}\text { WGDAGAEYYVESTGYFTTMEK } & 0.90 & 20.62 & 27.04 & 17.51 & 3 & 2564.2387 & 2564.2349 & 855.7522 & 0.0038 & 1.4802 & 1.913\end{array}$ $\begin{array}{llllllllllllll}\text { WGDAGAEYVVESTGVFTTMEK } & 1.00 & 43.05 & 27.04 & 19.18 & 3 & 2564.2411 & 2564.2349 & 855.7522 & 0.0062 & 2.4150 & 9.805\end{array}$ $\begin{array}{lllllllllllll}\text { WGDAGAEYVUESTGVFTTMEK } & 1.00 & 47.11 & 27.16 & 18.15 & 3 & 2564.2441 & 2564.2349 & 855.7522 & 0.0092 & 3.5836 & 7.963\end{array}$ $\begin{array}{llllllllllllll}\text { WGDAGAEYVVESTGVFTTMEK } & 0.60 & 25.21 & 27.45 & 15.53 & 3 & 2564.2567 & 2564.2349 & 855.7522 & 0.0218 & 8.4915 & 7.681\end{array}$

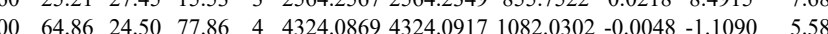

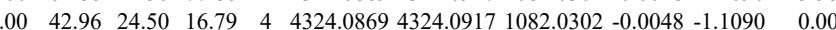
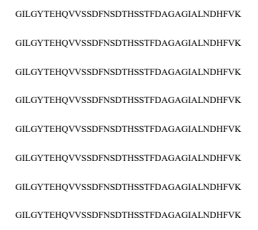

LISWYDNEFGYSNR

LISWYDNEFGYSNR GALQNIIPASTGAAK GALQNIIPASTGAAK

GALQNIIPASTGAAK

VPTANVSVVDLTCR

VPTANVSVVDLTCR

VPTANVSVVDLTCR VPTANVSVVDLTCR VPTANVSVVDLTCR VPTANVSVVDLTCR VPTANVSVVDLTCR GALQNIIPASTGAAK GALQNIIPASTGAAK VPTANVSVVDLTCR VPTANVSVVDLTCR

VPTANVSVVDLTCR

VPTANVSVVDLTCR

VPTANVSVVDLTCR
VPTANVSVVDLTCR

VPTANVSVVDLTCR VPTANVSVVDLTCR VPTANVSVVDLTCR VPTANVSVVDLTCR VPTANVSVVDLTCR $\begin{array}{lllllllllll}1.00 & 56.70 & 24.55 & 69.70 & 4 & 4324.0909 & 4324.0917 & 1082.0302 & -0.0008 & -0.1848 & 3.423 \\ 1.00 & 49.04 & 24.52 & 18.90 & 4 & 4324.0949 & 4324.0917 & 1082.0302 & 0.0032 & 0.7394 & 5.702\end{array}$ $\begin{array}{lllllllllll}1.00 & 49.04 & 24.52 & 18.90 & 4 & 4324.0949 & 4324.0917 & 1082.0302 & 0.0032 & 0.7394 & 5.702\end{array}$ $\begin{array}{llllllllllll}1.00 & 42.53 & 24.52 & 55.53 & 4 & 4324.0949 & 4324.0917 & 1082.0302 & 0.0032 & 0.7394 & 0.000 \\ 1.00 & 46.85 & 24.52 & 59.85 & 4 & 4324.0949 & 4324.0917 & 1082.0302 & 0.0032 & 0.7394 & 3.267\end{array}$ $\begin{array}{lllllllllll}1.00 & 46.85 & 24.52 & 59.85 & 4 & 4324.0949 & 4324.0917 & 1082.0302 & 0.0032 & 0.7394 & 3.267 \\ 1.00 & 34.60 & 24.52 & 47.60 & 4 & 4324.0949 & 4324.0917 & 1082.0302 & 0.0032 & 0.7394 & 0.000\end{array}$ $\begin{array}{lllllllllll}1.00 & 34.60 & 24.52 & 47.60 & 4 & 4324.0949 & 4324.0917 & 1082.0302 & 0.0032 & 0.7394 & 0.000 \\ 1.00 & 33.99 & 24.89 & 46.99 & 4 & 4324.0989 & 4324.0917 & 1082.0302 & 0.0072 & 1.6635 & 1.495\end{array}$ $\begin{array}{lllllllllll}1.00 & 33.99 & 24.89 & 46.99 & 4 & 4324.0989 & 4324.0917 & 1082.0302 & 0.0072 & 1.6635 & 1.495 \\ 1.00 & 49.49 & 24.87 & 62.49 & 4 & 4324.1029 & 4324.0917 & 1082.0302 & 0.0112 & 2.5877 & 1.852\end{array}$ $\begin{array}{lllllllllll}1.00 & 49.49 & 24.87 & 62.49 & 4 & 4324.1029 & 4324.0917 & 1082.0302 & 0.0112 & 2.5877 & 1.852 \\ 1.00 & 46.18 & 24.87 & 59.18 & 4 & 4324.1029 & 4324.0917 & 1082.0302 & 0.0112 & 2.5877 & 0.000\end{array}$ $\begin{array}{lllllllllll}1.00 & 27.32 & 24.87 & 49.18 & 4 & 4324.1029 & 4324.0917 & 4082.0302 & 0.0112 & 2.5877 & 0.0031 \\ 1.00 & 46.0329 & 24.89 & 4324.0917 & 1082.0302 & 0.0112 & 2.5877 & 6.431\end{array}$

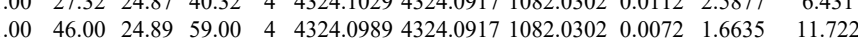

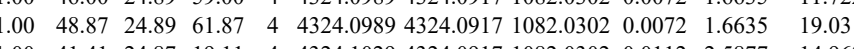

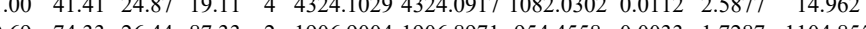

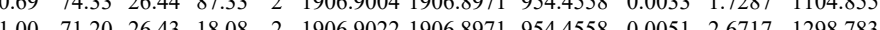

$\begin{array}{llllllllllll} & \end{array}$

$\begin{array}{llllllllllllll}100 & 77.70 & 23.58 & 24.47 & 2 & 1698.9996 & 1698.9872 & 850.5009 & 0.0124 & 7.2898 & 2765.189 & 4817.762 & 4312.771 & 329\end{array}$

$\begin{array}{llllllllllllll}1.00 & 75.32 & 23.50 & 19.92 & 2 & 1699.0034 & 1698.9872 & 850.5009 & 0.0162 & 9.5237 & 9212.774 & 11314.190 & 10064.822 & 7791.338\end{array}$

$\begin{array}{llllllllllllllll}0.99 & 41.29 & 27.88 & 19.19 & 2 & 1662.8552 & 1662.8555 & 832.4350 & -0.0003 & -0.1802 & 72.280 & 76.637 & 53.263 & 40.082 & \text { Y s }\end{array}$

$\begin{array}{ccccccccccccccc}1.00 & 89.81 & 27.87 & 19.41 & 2 & 1662.8556 & 1662.8555 & 832.4350 & 0.0001 & 0.0601 & 1249.472 & 2443.725 & 1861.233 & 732.698 & \text { Yes } \\ 0.93 & 21.77 & 27.98 & 17.95 & 3 & 1662.8572 & 1662.8555 & 555.2924 & 0.0017 & 1.0205 & 60.989 & 75.809 & 59.091 & 40.171 & \text { Yes }\end{array}$ $\begin{array}{llllllllllllllll}1.00 & 89.38 & 27.97 & 23.54 & 2 & 1662.8572 & 1662.8555 & 832.4350 & 0.0017 & 1.0211 & 3817.641 & 3503.875 & 3254.061 & 2539.116 & \text { Yes }\end{array}$ $\begin{array}{llllllllllllllll}0.72 & 15.58 & 28.02 & 23.02 & 3 & 1662.8575 & 1662.8555 & 555.2924 & 0.0020 & 1.2006 & 100.036 & 95.455 & 138.894 & 43.835 & \text { Yes }\end{array}$ $\begin{array}{llllllllllllllll}1.00 & 82.57 & 27.66 & 18.90 & 2 & 1662.8614 & 1662.8555 & 832.4350 & 0.0059 & 3.5438 & 2070.672 & 2072.037 & 1681.260 & 981.775 & \text { Yes } \\ 1.00 & 74.37 & 27.70 & 24.34 & 2 & 16628620 & 16628555 & 832.4350 & 0.0065 & 3.9042 & 978.683 & 932.808 & 1057.336 & 550.505 & \text { Yes }\end{array}$ $\begin{array}{lllllllllllllll}1.00 & 75.80 & 23.64 & 21.04 & 2 & 1699.0012 & 1698.9872 & 850.5009 & 0.0140 & 8.2304 & 3664.736 & 5473.014 & 4141.548 & 3570.925 & \text { Yes }\end{array}$

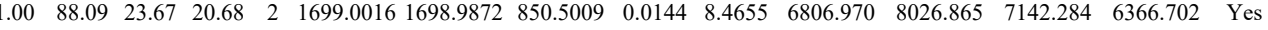

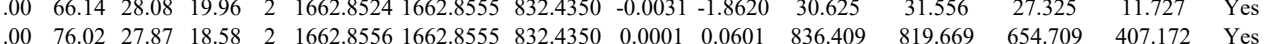
$\begin{array}{lllllllllllllll}1.00 & 64.59 & 27.85 & 19.13 & 2 & 1662.8558 & 1662.8555 & 832.4350 & 0.0003 & 0.1802 & 31.802 & 27.197 & 25.439 & 10.803 & \text { Yes }\end{array}$ \begin{tabular}{lllllllllllllll}
1.00 & 50.37 & 27.85 & 16.46 & 2 & 1662.8558 & 1662.8555 & 832.4350 & 0.0003 & 0.1802 & 26.693 & 28.439 & 7.525 & 15.079 & Yes \\
\hline
\end{tabular} $\begin{array}{lllllllllllllll}1.00 & 84.61 & 27.85 & 19.41 & 2 & 1662.8560 & 1662.8555 & 832.4350 & 0.0005 & 0.3003 & 2827.544 & 3869.987 & 2676.536 & 1989.871 & \text { Yes } \\ \end{array}$ $\begin{array}{llllllllllllllll}1.00 & 63.73 & 27.94 & 18.41 & 2 & 1662.8564 & 1662.8555 & 832.4350 & 0.0009 & 0.5406 & 369.185 & 662.256 & 575.307 & 491.540 & \text { Yes }\end{array}$ $\begin{array}{llllllllllllllll}1.00 & 79.32 & 27.99 & 20.84 & 2 & 1662.8576 & 1662.8555 & 832.4350 & 0.0021 & 1.2614 & 4229.506 & 6768.463 & 6310.596 & 3330.613 & \text { Yes }\end{array}$

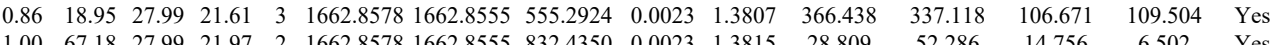

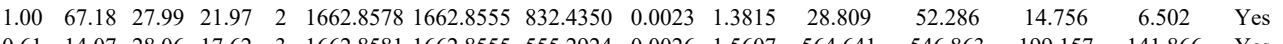
$\begin{array}{lllllllllllllll}0.61 & 14.07 & 2.06 & 17.62 & 3 & 1662.8581 & 1662.8555 & 555.2924 & 0.0026 & 1.5607 & 564.641 & 546.863 & 199.157 & 141.866 & \text { Yes } \\ \end{array}$ $\begin{array}{lllllllllllllll}1.00 & 80.20 & 27.70 & 22.10 & 2 & 1662.8620 & 1662.8555 & 832.4350 & 0.0065 & 3.9042 & 2761.547 & 3558.724 & 3324.915 & 1999.721 & \text { Yes } \\ 1.00 & 92.82 & 27.60 & 22.35 & 2 & 16628630 & 16628555 & 832.4350 & 0.0075 & 4.5048 & 2721.507 & 3870.361 & 3730.316 & 1344.161 & \text { Yes }\end{array}$

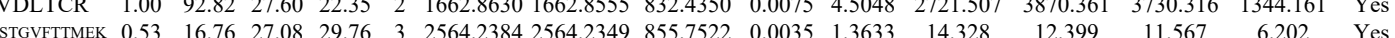

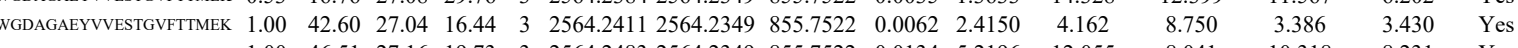

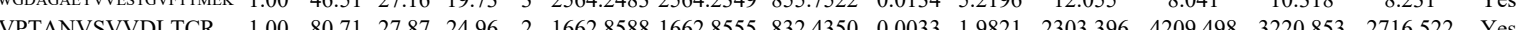




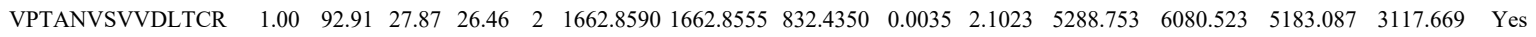

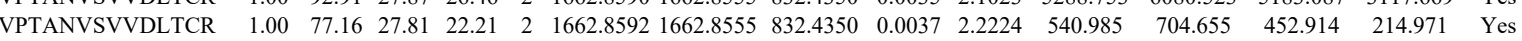
$\begin{array}{llllllllllllllll}\text { VPTANVSVVDLTCR } & 1.00 & 82.71 & 27.81 & 28.82 & 2 & 1662.8594 & 1662.8555 & 832.4350 & 0.0039 & 2.3425 & 611.176 & 796.566 & 582.373 & 591.011 & \text { Yes }\end{array}$ $\begin{array}{llllllllllllllll}\text { VPTANVSVVDLTCR } & 0.95 & 36.58 & 27.63 & 24.26 & 2 & 162.8622 & 1628.8555 & 832.4350 & 0.006 & 4.0243 & 10.674 & 27.879 & 4.555 & 8.487 & \text { Yes }\end{array}$

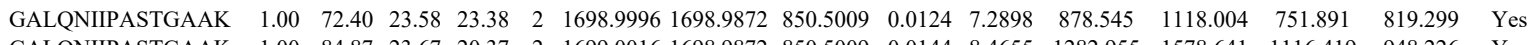

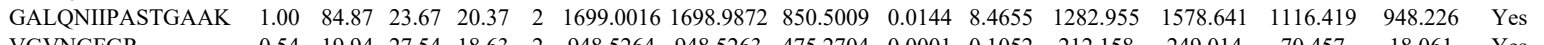

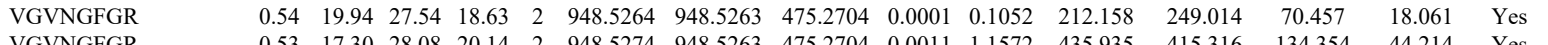

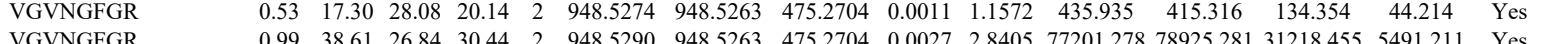

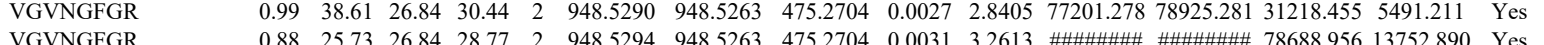

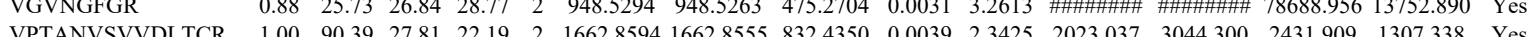
$\begin{array}{llllllllllllllll} & \end{array}$

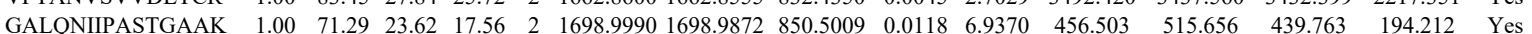

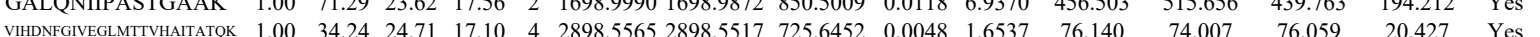

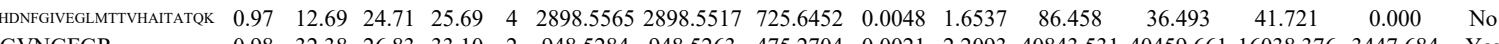
$\begin{array}{llllllllllllllll}\text { VGVNGFGR } & 0.98 & 32.38 & 26.83 & 33.10 & 2 & 948.5284 & 948.5263 & 475.2704 & 0.0021 & 22093 & 40843.531 & 40459.661 & 16038.376 & 3447.684 & \text { Yes }\end{array}$ $\begin{array}{llllllllllllllll}\text { VGVNGFGR } & 0.99 & 34.87 & 26.79 & 30.14 & 2 & 948.5288 & 948.5263 & 475.2704 & 0.0025 & 2.6301 & 74700.071 & 74148.877 & 28531.980 & 4750.931 & \text { Yes }\end{array}$ $\begin{array}{llllllllllllllll}\text { VPTANVSVVDLTCR } & 1.00 & 82.78 & 27.85 & 18.96 & 2 & 1662.8562 & 1662.8555 & 832.4350 & 0.0007 & 0.4205 & 913.062 & 1017.043 & 1084.027 & 790.347 & \text { Yes }\end{array}$

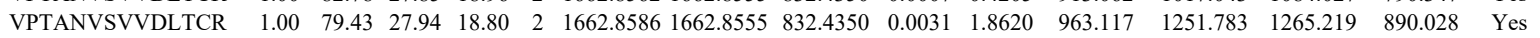
$\begin{array}{llllllllllllllll}\text { GALQNIIPASTGAAK } & 1.00 & 67.65 & 23.58 & 18.39 & 2 & 1699.0000 & 1698.9872 & 850.5009 & 0.0128 & 7.5249 & 2326.888 & 2599.546 & 1277.239 & 580.257 & \text { Yes }\end{array}$ VGVNGFGR $\begin{array}{llllllllllllllll}1.00 & 73.43 & 23.64 & 23.30 & 2 & 1699.0012 & 1698.9872 & 850.5009 & 0.0140 & 8.2304 & 2488.044 & 2717.467 & 1343.544 & 791.568 & \text { Yes } & \end{array}$ $\begin{array}{llllllllllllllllll}0.99 & 37.73 & 27.54 & 30.51 & 2 & 948.5264 & 948.5263 & 475.2704 & 0.0001 & 0.1052 & 65623.103 & 66262.517 & 21981.919 & 1925.734 & \text { Yes }\end{array}$ $\begin{array}{lllllllllllllllll}0.98 & 34.10 & 28.08 & 30.43 & 2 & 948.5274 & 948.5263 & 475.2704 & 0.0011 & 1.1572 & 74268.600 & 72785.261 & 25672.718 & 4147.404 & \text { Yes }\end{array}$ $\begin{array}{llllllllllllllll}0.99 & 40.42 & 25.97 & 28.05 & 2 & 1756.9958 & 1756.9957 & 879.5051 & 0.0001 & 0.0569 & 2384.716 & 3354.715 & 86.436 & 33.515 & \text { Yes }\end{array}$ LVINGNPITIFOE $\begin{array}{lllllllllllll}1.90 & 41.06 & 25.88 & 29.00 & 2 & 1756.9972 & 1756.9957 & 879.5051 & 0.0015 & 0.8528 & 1929.971 & 2385.795 & 53.8582\end{array}$

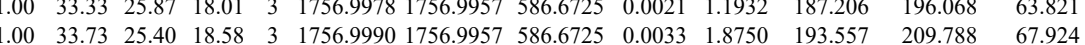
IIDNFGIVEGLMTTVHAITATOK GMDFGIVEGLMTTHHATATOK

\section{VGVNGFGR}

LVINGNPITIFQER

LVINGNPITIFQER

LVINGNPITIFQER

LVINGNTITQR

LVINGNPITIFQER

LVINGNPITIFQER

LVINGNPTIFQER

LVINGNPITIFQER

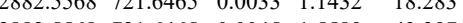

$5.887-0.000$

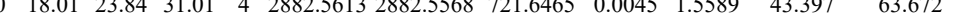

$\begin{array}{llllllllllllll}0.98 & 31.31 & 26.81 & 28.55 & 2 & 948.5280 & 948.5263 & 475.2704 & 0.0017 & 1.7885 & 21311.654 & 2 \\ 1.00 & 77.21 & 25.97 & 30.43 & 2 & 1756.9962 & 1756.9957 & 879.501 & 0.0005 & 0.2843 & 186.11 & \end{array}$

$9.196 \quad 2.36$ $\begin{array}{llllllllllll}1.00 & 74.91 & 25.97 & 30.04 & 2 & 1756.9962 & 1756.9957 & 879.5051 & 0.0005 & 0.2843 & 109.201 & 14\end{array}$

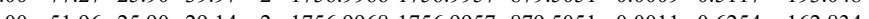
$\begin{array}{lllllllllll}1.00 & & \end{array}$

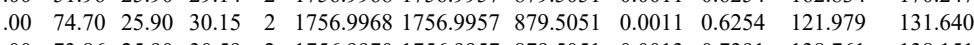
$\begin{array}{llllllllllll}1.00 & 73.86 & 25.90 & 30.59 & 2 & 1756.9970 & 1756.9957 & 879.5051 & 0.0013 & 0.7391 & 138.761 & 138.151\end{array}$

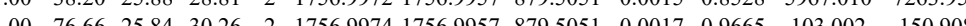

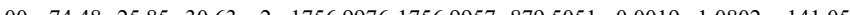

$\begin{array}{lllllllllllll}1.61 & 12.49 & 25.56 & 18.88 & 3 & 1756.9996 & 1756.9957 & 586.6725 & 0.0039 & 2.2159 & 1113.190 & 1\end{array}$ $\begin{array}{llllllllllllll} & \end{array}$ $\begin{array}{llllllllllll} & \end{array}$

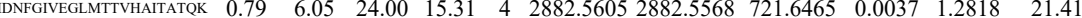
$\begin{array}{lllllllllllll}\text { VIDNFGIVEGLMTTVHATTATQK } & 1.00 & 43.02 & 23.84 & 15.88 & 4 & 2882.5613 & 2882.5568 & 721.6465 & 0.0045 & 1.5589 & 8.496\end{array}$ $\begin{array}{llllllllllll} & \end{array}$ $\begin{array}{lllllllllllll} & \end{array}$

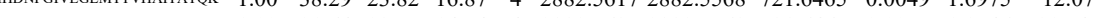

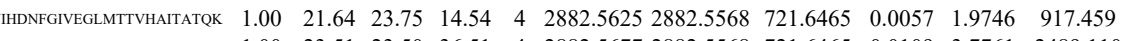
76.707 78.631 37.969 


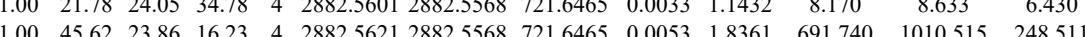

VIHDNFGIVEGL $\begin{array}{lllllllllllll}1.00 & 45.62 & 23.86 & 16.23 & 4 & 2882.5621 & 2882.5568 & 721.6465 & 0.0053 & 1.8361 & 691.740 & 1010.515 & 248.511 \\ 1.00 & 49.75 & 23.42 & 62.75 & 4 & 2882.5665 & 28825568 & 721.6465 & 0.0097 & 3.3604 & 1096.003 & 1801.011 & 355.242\end{array}$

LTGMAFR $\begin{array}{lllllllllllll}0.96 & 29.40 & 27.49 & 32.26 & 2 & 938.5138 & 938.5130 & 470.2638 & 0.0008 & 0.8506 & 989.040 & 1153.994 & 73.864 \\ 0.90 & 25.42 & 27.3 & 27.36 & 2 & 938.5140 & 938.5130 & 470.263 & 0.0010 & 1.0632 & 887.794 & 1033.582 & 44.964\end{array}$

LTGMAFR $\begin{array}{llllllllllllll}0.95 & 28.83 & 27.39 & 24.20 & 2 & 938.5140 & 938.5130 & 470.2638 & 0.0010 & 1.0632 & 387.343 & 381.538 & 27.047\end{array}$ $\begin{array}{llllllllllllll}0.94 & 27.60 & 27.39 & 30.54 & 2 & 938.5140 & 938.5130 & 470.2638 & 0.0010 & 1.0632 & 371.177 & 411.651 & 24.608\end{array}$ $\begin{array}{lllllllllllllll}0.90 & 25.29 & 27.36 & 30.55 & 2 & 938.5142 & 938.5130 & 470.2638 & 0.0012 & 1.2759 & 981.122 & 945.929 & 83.720\end{array}$ $\begin{array}{llllllllllllll}0.96 & 29.37 & 27.36 & 32.83 & 2 & 938.5142 & 938.5130 & 470.2638 & 0.0012 & 1.2759 & 947.146 & 1104.559 & 41.745\end{array}$

LTGMAFR $\begin{array}{llllllllllllll}0.87 & 24.36 & 27.36 & 31.62 & 2 & 938.5142 & 938.5130 & 470.2638 & 0.0012 & 1.2759 & 721.898 & 847.860 & 58.531\end{array}$ $\begin{array}{lllllllllllllll}0.96 & 31.53 & 27.10 & 35.67 & 2 & 938.5146 & 938.5130 & 470.2638 & 0.0016 & 1.7012 & 791.719 & 901.285 & 58.969\end{array}$ $\begin{array}{llllllllllllll}0.91 & 25.23 & 27.10 & 27.59 & 2 & 938.5146 & 938.5130 & 470.2638 & 0.0016 & 1.7012 & 846.740 & 958.349 & 46.565\end{array}$ $\begin{array}{lllllllllllllll}0.90 & 25.25 & 27.26 & 29.89 & 2 & 938.5148 & 938.5130 & 470.2638 & 0.0018 & 1.9138 & 859.598 & 950.826 & 48.849\end{array}$ $\begin{array}{llllllllllllll}0.90 & 32.70 & 26.66 & 18.08 & 2 & 938.5184 & 938.5130 & 470.2638 & 0.0054 & 5.7414 & 75180.649 & 87473.534 & 4646.650 & 898\end{array}$

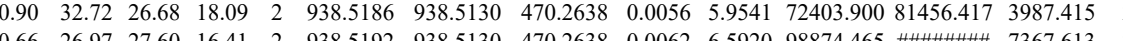

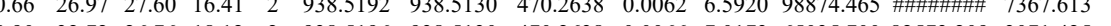
$\begin{array}{llllllllllllll}0.90 & 32.72 & 26.76 & 18.12 & 2 & 938.5196 & 938.5130 & 470.2638 & 0.0066 & 7.0173 & 65035.700 & 82573.209 & 3071.425 \\ 0.81 & 28.97 & 27.71 & 28.98 & 2 & 938.5220 & 938.5130 & 470.2638 & 0.0090 & 9.5690 & 10271.788 & 11089.360 & 1245.001\end{array}$ $\begin{array}{llllllllllllll}0.81 & 28.97 & 27.71 & 28.98 & 2 & 938.5220 & 938.5130 & 470.2638 & 0.0090 & 9.5690 & 10271.788 & 11089.360 & 1245.001 \\ 0.92 & 26.54 & 25.88 & 25.22 & 2 & 954.5104 & 954.5079 & 478.2612 & 0.0025 & 2.6136 & 47363.269 & 56095.875 & 1285.809\end{array}$ $\begin{array}{llllllllllllll}0.92 & 26.54 & 25.88 & 25.22 & 2 & 954.5104 & 954.5079 & 478.2612 & 0.0025 & 2.6136 & 47363.269 & 56095.875 & 1285.809 \\ 0.97 & 30.84 & 25.92 & 25.45 & 2 & 954.5108 & 954.5079 & 478.2612 & 0.0029 & 3.0318 & 51107.778 & 61511.086 & 585.552\end{array}$ $\begin{array}{llllllllllllll}0.97 & 30.84 & 25.92 & 25.45 & 2 & 954.5108 & 954.5079 & 478.2612 & 0.0029 & 3.0318 & 51107.778 & 61511.086 & 585.552 \\ 0.69 & 25.25 & 25.38 & 22.20 & 2 & 954.5132 & 954.5079 & 478.2612 & 0.0053 & 5.5409 & 9861.351 & 10056.560 & 426.257\end{array}$ $\begin{array}{llllllllllllll}0.69 & 25.25 & 25.38 & 22.20 & 2 & 954.5132 & 954.5079 & 478.2612 & 0.0053 & 5.5409 & 9861.351 & 10056.560 & 426.257 \\ 0.61 & 23.89 & 25.43 & 21.01 & 2 & 954.5136 & 954.5079 & 478.2612 & 0.0057 & 5.9591 & 9618.098 & 11068.822 & 493.763\end{array}$ $\begin{array}{lllllllllllll}0.61 & 23.89 & 25.43 & 21.01 & 2 & 954.5136 & 954.5079 & 478.2612 & 0.0057 & 5.9591 & 9618.098 & 11068.822 & 493.763 \\ 1.00 & 71.43 & 25.94 & 30.68 & 2 & 1756.9928 & 1756.9957 & 879.5051 & -0.0029 & -1.6487 & 12284.624 & 12624.385 & 1005.149\end{array}$

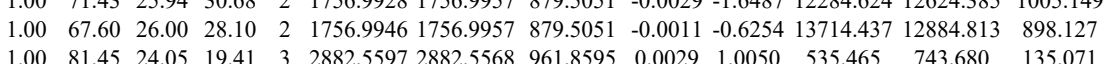

LTGAF

LVINGNPITIFQER

VIHDNFGIVEGLMTTVHATATO

LTGMAFR

LTGMAFR

LTGMAFR

LTGMAFR

LTGMAFR

LTGMAFR

LTGMAFR

LTGMAFR

LVINGNPITIFQER

LVINGNPITIFQER

LTGMAFR

LTGMAFR

LTGMAFR

LTGMAFR

LVINGNPITIFQER

LVINGNPITIFQER

LTGMAFR

LTGMAFR

LVINGNPITIFQER

LTGMAFR

LTGMAFR

AAFS

QASEGPLK

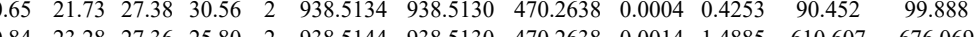
$\begin{array}{lllllllllllllll}0.92 & 25.93 & 27.10 & 30.35 & 2 & 938.5146 & 938.5130 & 4702638 & 0.0016 & 1.7012 & 640.958 & 692.867 & 32.607 & 3\end{array}$ $\begin{array}{lllllllllllllll}0.86 & 30.45 & 27.02 & 26.10 & 2 & 938.5210 & 938.5130 & 470.2638 & 0.0080 & 8.5058 & 28173.309 & 33360.504 & 30.657 .486\end{array}$ $\begin{array}{lllllllllllllll}0.76 & 30.82 & 27.02 & 36.66 & 2 & 938.5212 & 938.5130 & 470.2638 & 0.0082 & 8.7184 & \text { \#\#\#\#\#\#\#\#\#\#\# } 5390.109 & 717\end{array}$

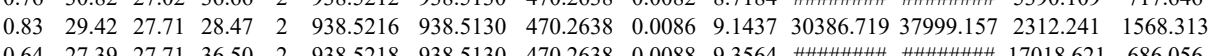
$\begin{array}{lllllllllllllllll}0.93 & 26.56 & 26.50 & 25.26 & 2 & 954.5084 & 954.5079 & 478.2612 & 0.0005 & 0.5227 & 29816.012 & 34528.070 & 1400.595 & 1164.448 & \text { Y }\end{array}$ $\begin{array}{lllllllllllllllll}0.99 & 34.62 & 26.58 & 25.74 & 2 & 954.5088 & 954.5079 & 478.2612 & 0.0009 & 0.9409 & 56429.906 & 62505.869 & 1498.718 & 365.099 & \text { Yes }\end{array}$ $\begin{array}{llllllllllllllll}1.00 & 71.21 & 25.99 & 28.27 & 2 & 1756.9944 & 1756.9957 & 879.5051 & -0.0013 & -0.7391 & 10541.731 & 10505.374 & 1163.666 & 188.853 & \text { Yes }\end{array}$ $\begin{array}{lllllllll} & \end{array}$

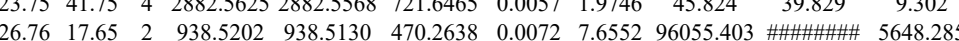
$\begin{array}{llllllllllllllll}0.91 & 32.83 & 27.02 & 26.88 & 2 & 938.5206 & 938.5130 & 470.2638 & 0.0076 & 8.0805 & 51607.547 & 67063.922 & 1381.944 & 1\end{array}$ $\begin{array}{llllllllllllll}0.93 & 26.16 & 26.58 & 19.85 & 2 & 954.5088 & 954.5079 & 478.2612 & 0.0009 & 0.9409 & 7140.993 & 8010.259 & 541.665\end{array}$ $\begin{array}{lllllllllllllll}0.97 & 30.90 & 26.58 & 25.63 & 2 & 954.5088 & 954.5079 & 478.2612 & 0.0009 & 0.9409 & 18413.610 & 19661.517 & 1086.545\end{array}$ $\begin{array}{lllllllllllll}1.00 & 77.37 & 25.97 & 42.41 & 2 & 1756.9956 & 1756.9957 & 879.5051 & -0.0001 & -0.0569 & 4429.679 & 4670.052 & 530.238\end{array}$ $\begin{array}{lllllllllllll}0.55 & 37.56 & 25.48 & 50.56 & 3 & 1756.9981 & 1756.9957 & 586.6725 & 0.0024 & 1.3636 & 313.049 & 523.519 & 216.767\end{array}$ $\begin{array}{llllllllllllll}0.89 & 31.88 & 27.02 & 26.74 & 2 & 938.5210 & 938.5130 & 470.2638 & 0.0080 & 8.5058 & 49919.064 & 58853.359 & 2045.002\end{array}$ $\begin{array}{lllllllllllll}0.72 & 29.91 & 27.71 & 37.41 & 2 & 938.5216 & 938.5130 & 470.2638 & 0.0086 & 9.1437 & 48469.075 & 57370.230 & 973.607\end{array}$ $\begin{array}{llllllllllllll}0.95 & 27.16 & 26.47 & 20.03 & 2 & 954.5094 & 954.5079 & 478.2612 & 0.0015 & 1.5682 & 5047.068 & 5590.585 & 390.397 \\ 1.00 & 75.56 & 25.97 & 30.80 & 2 & 17569956 & 1756.9957 & 879.5051 & 0.0001 & 0.0569 & 121.585 & 1273.573 & 113.470\end{array}$ $\begin{array}{lllllllllllllll}1.00 & 7.56 & 25.97 & 3.80 & 2 & 1756.9956 & 1756.9957 & 87.5051 & -0.0001 & -0.0569 & 1214.585 & 1273.573 & 113.470\end{array}$ $\begin{array}{llllllllllllll}0.96 & 29.75 & 27.39 & 23.32 & 2 & 938.5140 & 938.5130 & 470.2638 & 0.0010 & 1.0632 & 11808.703 & 13480.285 & 188.021 \\ 0.98 & 31.83 & 27.10 & 24.13 & 2 & 938.5146 & 938.5130 & 4702638 & 0.0016 & 1.7012 & 13599.026 & 1569.291 & 38.165\end{array}$ $\begin{array}{llllllllllllll}0.98 & 31.83 & 27.10 & 24.13 & 2 & 938.5146 & 938.5130 & 470.268 & 0.0016 & 1.7012 & 1359.026 & 15693.291 & 388.165\end{array}$

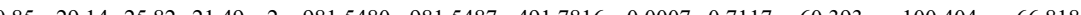

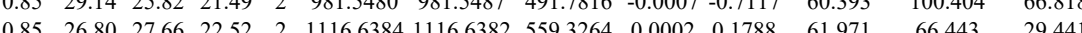


LVINGNPITIFQER

LTGMAFR

LTGMAFR

AAFNSGK

AAFNSGK

VPTANVSVVDLTCR

LTGMAFR

LTGMAFR

AAFNSGK

LTGMAFR

LTGMAFR

LTGMAFR

LTGMAFR

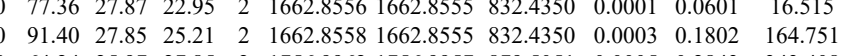

$\begin{array}{lllllllllll}1.00 & 64.24 & 25.97 & 27.85 & 2 & 1756.9962 & 1756.9957 & 879.5051 & 0.0005 & 0.2843 & 343.408\end{array}$

$\begin{array}{ccccccccccc}1.00 & 80.02 & 25.90 & 32.89 & 2 & 1756.9970 & 1756.9957 & 879.5051 & 0.0013 & 0.7391 & 653.044 \\ 0.82 & 29.86 & 27.44 & 23.36 & 2 & 938.5120 & 938.5130 & 470.2638 & -0.0010 & -1.0632 & 3455.600\end{array}$

$\begin{array}{llllllllllll}0.93 & 30.11 & 27.38 & 21.51 & 2 & 938.5132 & 938.5130 & 470.2638 & -0.0010 & -1.0632 & 3455.600 & 3510.271\end{array}$

$\begin{array}{llllllllllll}0.93 & 3.11 & 27.38 & 21.51 & 2 & 938.5132 & 938.5130 & 470.2638 & 0.0002 & 0.2126 & 1944.301 & 2595.523\end{array}$

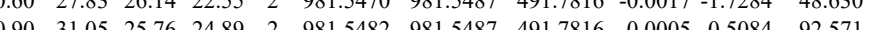
$\begin{array}{llllllllllll}0.90 & 31.05 & 25.76 & 24.89 & 2 & 981.5482 & 981.5487 & 491.7816 & -0.0005 & -0.5084 & 92.571\end{array}$ $\begin{array}{lllllllllll}1.00 & 8.03 & 26.24 & 21.76 & 2 & 1196.6874 & 1196.6869 & 599.3507 & 0.0005 & 0.4171 & 30.207\end{array}$

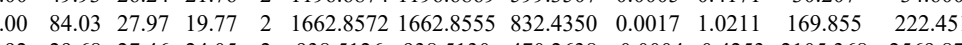

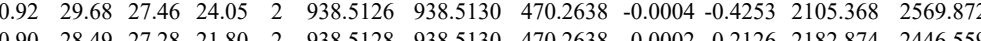

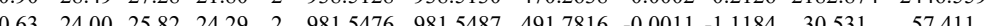
$\begin{array}{lllllllllllll}0.82 & 25.37 & 27.38 & 26.05 & 2 & 938.5132 & 938.5130 & 470.2638 & 0.0002 & 0.2126 & 1082.607 & 1247.911 & 22.708 .619\end{array}$

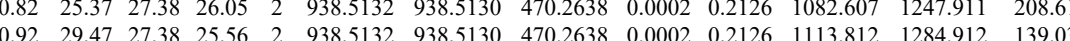
$\begin{array}{llllllllllllll}0.92 & 29.52 & 27.38 & 23.96 & 2 & 9385134 & 9385130 & 470.2638 & 0.0004 & 0.4253 & 1519215 & 1688.730 & 236.802\end{array}$ $\begin{array}{lllllllllllllll}0.83 & 25.70 & 27.38 & 22.32 & 2 & 938.5134 & 938.5130 & 470.2638 & 0.0004 & 0.4253 & 1872.629 & 2056.740 & 142.053\end{array}$ $\begin{array}{lllllllllllllll}0.92 & 26.53 & 27.46 & 25.05 & 2 & 938.5136 & 938.5130 & 470.2638 & 0.0006 & 0.6379 & 1598.164 & 1764.517 & 134.436\end{array}$ $\begin{array}{llllllllllllll}0.96 & 29.46 & 27.49 & 24.79 & 2 & 938.5138 & 938.5130 & 470.2638 & 0.0008 & 0.8506 & 1659.821 & 1874.270 & 104.038\end{array}$ $\begin{array}{llllllllllllllll} & \end{array}$

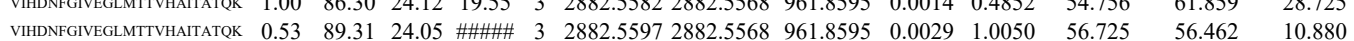

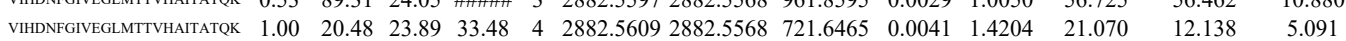
VIHDNFGIVEGLMTTVHATTATQK $\begin{array}{lllllllllll}0.84 & 6.75 & 23.84 & 19.75 & 4 & 2882.5613 & 2882.5568 & 721.6465 & 0.0045 & 1.5589 & 25.068\end{array}$

LTGMAFR
LTGMAFR VIHDNFGIVEGLMTTVHATTAT $\begin{array}{llllllllllll}0.94 & 6.75 & 23.84 & 19.75 & 4 & 2882.5613 & 2882.5568 & 721.6465 & 0.0045 & 1.5989\end{array}$

LTGMAFR

15.179
43.833

LTGMAFR

YDNSLK

YDNSLK

VPTANVSVVDLTCR $\begin{array}{llllllllllllll}0.88 & 27.65 & 27.38 & 25.06 & 2 & 938.5132 & 938.5130 & 470.2638 & 0.0002 & 0.2126 & 370.365 \\ 0.93 & 30.13 & 27.38 & 23.62 & 2 & 938.5134 & 938.5130 & 470.2638 & 0.0004 & 0.4253 & 530.576\end{array}$ $\begin{array}{llllllllllll}0.92 & 28.76 & 26.90 & 21.03 & 2 & 1026.5590 & 1026.5589 & 514.2867 & 0.0001 & 0.0972 & 52.311\end{array}$ GALQNIPASTGAAK LTGMAFR

LTGMAFR

AAFNSGK

AGAHLQGGAK

$\begin{array}{llllll}1.00 & 71.95 & 24.35 & 23.58 & 2 \\ 0.53 & 13.01 & 2.55 & 26.01 & 3\end{array}$

$\begin{array}{llllllllllll}0.53 & 13.01 & 24.55 & 26.01 & 3 & 1698.9898 & 1698.9872 & 567.3363 & 0.0026 & 1.5276 & 71.286\end{array}$ $\begin{array}{llllllllllllll}0.91 & 29.03 & 27.38 & 25.07 & 2 & 938.5132 & 938.5130 & 470.2638 & 0.0002 & 0.2126 & 670.760\end{array}$ $\begin{array}{llllllllllll}0.91 & 29.20 & 27.38 & 24.63 & 2 & 938.5134 & 938.5130 & 470.2638 & 0.0004 & 0.4253 & 909.942 & \\ 0.92 & 32.12 & 25.76 & 18.86 & 2 & 981.5482 & 981.5487 & 491.7816 & -0.0005 & -0.5084 & 43.736\end{array}$ $\begin{array}{lllllllllll}0.92 & 32.12 & 25.76 & 18.86 & 2 & 981.5482 & 981.5487 & 491.7816 & -0.0005 & -0.5084 & 43.736 \\ 0.97 & 37.65 & 26.30 & 23.01 & 2 & 1196.6860 & 1196.6869 & 599.3507 & -0.0009 & -0.7508 & 16.296\end{array}$ $\begin{array}{llllllllllll}0.99 & 40.48 & 26.24 & 18.10 & 2 & 1196.6874 & 1196.6869 & 599.3507 & 0.0005 & 0.4171 & 15.984\end{array}$

\section{(1)}

VPTANVSVVDLTCR

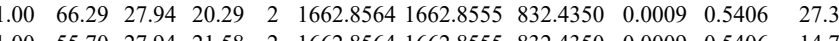

GALQNIIPASTGAAK

LTGMAFR

$\begin{array}{llllllclllll}\text { LTGMAFR } & 0.95 & 28.52 & 27.49 & 22.84 & 2 & 938.5138 & 938.5130 & 470.2638 & 0.0008 & 0.8506 & 369.443 \\ \text { AGAHLQGGAK } & 1.00 & 41.30 & 26.32 & 21.17 & 2 & 1196.6882 & 1196.6869 & 599.3507 & 0.0013 & 1.0845 & 22.37\end{array}$

$\begin{array}{llllllllllll}1.00 & 82.40 & 24.58 & 24.22 & 2 & 16989870 & 16989872 & 850.5009 & -0.0002 & 0.1176 & 43.852\end{array}$

$\begin{array}{llllllllllll}1.00 & 81.41 & 24.39 & 20.02 & 2 & 1698.9878 & 1698.9872 & 850.5009 & 0.0006 & 0.3527 & 24.357\end{array}$

$\begin{array}{lllllllllllll}0.91 & 29.00 & 27.28 & 25.42 & 2 & 938.5130 & 938.5130 & 470.2638 & 0.0000 & 0.0000 & 605.635\end{array}$

$\begin{array}{llllllllllllll}\text { VPTANVSVVDLTCR } & 1.00 & 91.31 & 27.92 & 20.58 & 2 & 1662.8546 & 1662.8555 & 832.4350 & -0.0009 & -0.5406 & 25.998\end{array}$ $\begin{array}{llllllllllll}\text { VPTANVSVVDLTCR } & 1.00 & 77.90 & 27.87 & 24.50 & 2 & 1662.8554 & 1662.8555 & 832.4350 & -0.0001 & -0.0601 & 17.864 \\ \text { GALQNIIPASTGAAK } & 1.00 & 61.21 & 24.38 & 20.47 & 2 & 1698.9880 & 1698.9872 & 850.5009 & 0.0008 & 0.4703 & 13.937\end{array}$ GALQNIIPASTGAAK

LTGMAFR
LTGMAFR

AAFNSGK

AAFNSGK

AGAHLQGGAK

VPTANVSVVDLTCR $\begin{array}{lllllllllllll}0.94 & 30.62 & 27.28 & 25.71 & 2 & 938.5128 & 938.5130 & 470.2638 & -0.0002 & -0.2126 & 722.273\end{array}$ $\begin{array}{lllllllllllll}0.95 & 31.83 & 27.38 & 23.87 & 2 & 938.5132 & 938.5130 & 470.2638 & 0.0002 & 0.2126 & 925.438 & \end{array}$ $\begin{array}{llllllllllll}0.96 & 35.21 & 25.82 & 19.44 & 2 & 981.5480 & 981.5487 & 491.7816 & -0.0007 & -0.7117 & 47.317\end{array}$ $\begin{array}{lllllllllllll}0.92 & 24.70 & 25.98 & 17.77 & 2 & 981.5510 & 981.5487 & 491.7816 & 0.0023 & 2.3384 & 46.646\end{array}$ GALQNIIPASTGAAK LTGMAFR LTGMAFR AAFNSGK AGAHLQGGAK AGAHLQGGAK 
VPTANVSVVDLTCR

GALQNIIPASTGAAK
LVINGNPITIFQER

LVINGNPITIFQER
LVINGNPITIFQER

LVINGNPITIFQER

VPTANVSVVDLTCR
LVINGNPITIFQER

$\begin{array}{lllllllllll}.05 & 65.13 & 27.85 & 19.88 & 2 & 1662.8558 & 1662.8555 & 832.4350 & 0.0003 & 0.1802 & 23.030\end{array}$

$\begin{array}{lllllllllll}1.00 & 88.33 & 27.94 & 22.18 & 2 & 1662.8564 & 1662.8555 & 832.4350 & 0.0009 & 0.5406 & 35.180 \\ 1.00 & 69.81 & 24.58 & 18.57 & 2 & 1698.9868 & 1698.9872 & 850.5009 & -0.0004 & -0.2352 & 43.510\end{array}$

$\begin{array}{llllllllllll}1.00 & 73.93 & 25.90 & 29.19 & 2 & 1756.9968 & 1756.9957 & 879.5051 & 0.0011 & 0.6254 & 106.395\end{array}$

$\begin{array}{llllllllllll}1.00 & 72.30 & 25.88 & 31.35 & 2 & 1756.9972 & 1756.9957 & 879.5051 & 0.0015 & 0.8528 & 81.964 \\ 1.00 & 88.86 & 27.98 & 21.88 & 2 & 1662.8566 & 16628555 & 832.4350 & 0.0011 & 0.6607 & 38.193\end{array}$

$\begin{array}{lllllllllll}1.00 & 88.86 & 27.98 & 21.88 & 2 & 1662.8566 & 1662.8555 & 832.4350 & 0.0011 & 0.6607 & 38.193 \\ 1.00 & 73.77 & 25.97 & 29.54 & 2 & 1756.9962 & 1756.9957 & 879.5051 & 0.0005 & 0.2843 & 51.207\end{array}$

TVDGPSGK

VPTANVSVVDLTCR

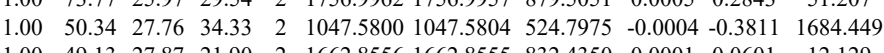

33.076

TVAPGSK

$\begin{array}{rrrrrrrrrrrrr}1.00 & 49.13 & 27.87 & 21.90 & 2 & 1662.8556 & 1662.8555 & 832.4350 & 0.0001 & 0.0601 & 12.129 & 4.191 \\ 1.00 & 47.65 & 28.01 & 34.50 & 2 & 1047.5818 & 1047.5804 & 524.7975 & 0.0014 & 1.3338 & 1651.874 & 2030.54\end{array}$

QASEGPLK

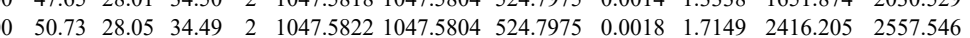

$\begin{array}{lllllllllllll}0.99 & 36.49 & 27.57 & 20.49 & 2 & 1116.6396 & 1116.6382 & 559.3264 & 0.0014 & 1.2515 & 4834.523 & 5217.464 & 2298.222\end{array}$ 1.00

YDNSLK $\begin{array}{lllllllllllll}1.00 & 43.99 & 27.57 & 21.88 & 2 & 1116.6398 & 1116.6382 & 559.3264 & 0.0016 & 1.4303 & 7604.966 & 789 .\end{array}$

YDNSLK

YDNSLK

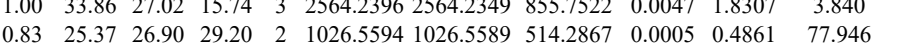

WGDAGAEYVVESTGVFTTMEK

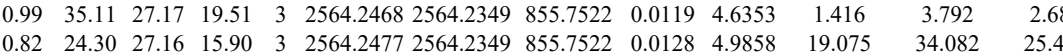

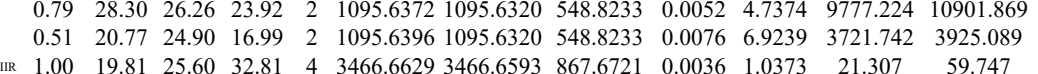

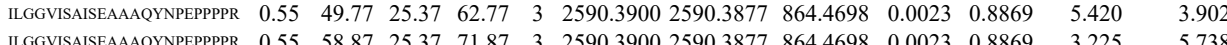

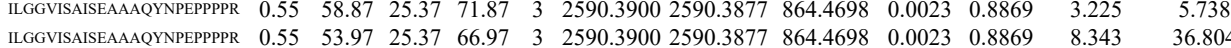
$\begin{array}{llllllllllllll}\text { ILGGVISAISEAAAQYNPEPPPPR } & 0.76 & 7.03 & 25.29 & 20.03 & 4 & 2590.3917 & 2590.3877 & 648.6042 & 0.0040 & 1.5418 & 132.542 & 118.122 & 10\end{array}$ $\begin{array}{lllllllllllll}\text { ILGGVISAISEAAAQYNPEPPPPR } & 0.86 & 8.41 & 25.20 & 21.41 & 4 & 2590.3921 & 2590.3877 & 648.6042 & 0.0044 & 1.6959 & 169.873 & 181.387\end{array}$ $\begin{array}{llllllllllllll}\text { ILGGVISAISEAAAQYNPEPPPPR } & 0.95 & 11.41 & 25.29 & 24.41 & 4 & 2590.3917 & 2590.3877 & 648.6042 & 0.0040 & 1.5418 & 66.144 & 97.262\end{array}$ $\begin{array}{llllllllllllllll}\text { ILGGVISAISEAAAQYNPEPPPRR } & 1.00 & 20.11 & 25.16 & 33.11 & 4 & 2590.3929 & 2590.3877 & 648.6042 & 0.0052 & 2.0043 & 56.460 & 86.099\end{array}$

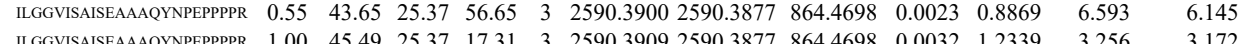
$\begin{array}{llllllllllllll}\text { ILGGVISAISEAAAQYNPEPPPR } & 1.00 & 45.49 & 25.37 & 17.31 & 3 & 2590.3909 & 2590.3877 & 864.4698 & 0.0032 & 1.2339 & 3.256 & 3.172\end{array}$ SMVAVMDSDTTGK

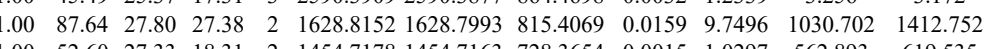
$\begin{array}{llllllllllll}1.00 & 52.60 & 27.33 & 18.31 & 2 & 1454.7178 & 1454.7163 & 728.3654 & 0.0015 & 1.0297 & 562.893 & 619.535 \\ 1.00 & 53.77 & 27.33 & 18.36 & 2 & 1454.7176 & 1454.7163 & 728.3654 & 0.0013 & 0.8924 & 411.868 & 468.124\end{array}$ $\begin{array}{llllllllllll}1.00 & 53.77 & 27.33 & 18.36 & 2 & 1454.7176 & 1454.7163 & 728.3654 & 0.0013 & 0.8924 & 411.868 & 468.124 \\ 1.00 & 41.87 & 28.06 & 26.82 & 2 & 1052.6006 & 1052.5988 & 527.3067 & 0.0018 & 1.7068 & 1433.500 & 1384.520\end{array}$ 
$\begin{array}{llllllllllll}1.00 & 32.04 & 1.33 & 16.51 & 3 & 125.8011 & 1251.7907 & 418.2708 & 0.0104 & 8.2880 & 17149.084 & 1681.807\end{array}$ $\begin{array}{lllllllllllllllll}\text { VTAEVVLAHLGGGSTSR } & 1.00 & 62.18 & 26.50 & 17.94 & 3 & 1796.9881 & 1796.9867 & 600.0028 & 0.0014 & 0.7778 & 1775.214 & 1760.892 & 1937.462 & 654.393 & \text { Yes }\end{array}$ VTAEVVLAHLGGGSTSR $\begin{array}{lllllllllllllll}1.00 & 62.18 & 26.50 & 17.94 & 3 & 1796.9881 & 1796.9867 & 600.0028 & 0.0014 & 0.7778 & 1775.214 & 1760.892 & 1937.462 & 654.393 & \text { Yes } \\ 1.00 & 59.64 & 26.63 & 17.32 & 3 & 1796.9899 & 1796.9867 & 600.0028 & 0.0032 & 1.7778 & 2839.509 & 4000.788 & 3176.892 & 1021.089 & \text { Yes }\end{array}$ $\begin{array}{ccccccccccccccc}0.98 & 35.11 & 26.22 & 22.42 & 2 & 1238.7060 & 1238.7056 & 620.3601 & 0.0004 & 0.3224 & 163.107 & 144.175 & 112.875 & 62.799 & \text { Yes } \\ 0.98 & 31.29 & 26.12 & 22.18 & 2 & 1238.7076 & 1238.7056 & 620.3601 & 0.0020 & 1.6120 & 7283.755 & 7745.084 & 9057.243 & 5752.711 & \text { Yes }\end{array}$ $\begin{array}{lllllllllllllllll}0.98 & 31.52 & 26.18 & 22.90 & 2 & 1238.7080 & 1238.7056 & 620.3601 & 0.0024 & 1.9344 & 11201.370 & 11364.025 & 12482.414 & 7670.425 & \text { Yes }\end{array}$ $\begin{array}{lllllllllllllll}0.53 & 26.93 & 26.46 & 20.12 & 2 & 1238.7040 & 1238.7056 & 620.3601 & -0.0016 & -1.2896 & 122.842 & 178.200 & 63.497 & 68.779 & \text { Yes }\end{array}$

作

FPLFGGWK

FPLFGGWK

FPLFGGWK

GEDEEENNLEVR

GEDEEENNLEVR

FPLFGGWK

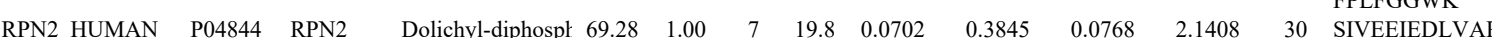

$\begin{array}{llllllllllllllll}1.00 & 40.55 & 26.06 & 20.98 & 2 & 1238.7066 & 1238.7056 & 620.3601 & 0.0010 & 0.8060 & 12443.887 & 15089.014 & 19184.261 & 12538.105 & \text { Yes }\end{array}$

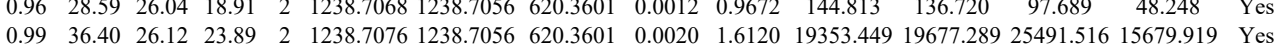
$\begin{array}{lllllllllllllll}0.99 & 36.40 & 26.12 & 23.89 & 2 & 1238.7076 & 1238.7056 & 620.3601 & 0.0020 & 1.6120 & 19353.449 & 19677.289 & 25491.516 & 15679.919 & \text { Yes } \\ 0.99 & 33.34 & 26.04 & 23.20 & 2 & 1238.7068 & 1238.7056 & 620.3601 & 0.0012 & 0.9672 & 6336.025 & 6251.972 & 7660.536 & 4644.933 & \text { Yes }\end{array}$ $\begin{array}{llllllllllllllll}0.99 & 33.34 & 26.04 & 23.20 & 2 & 1238.7068 & 1238.7056 & 620.3601 & 0.0012 & 0.9672 & 6336.025 & 6251.972 & 7660.536 & 4644.933 & \text { Yes } \\ 0.99 & 33.24 & 26.04 & 23.79 & 2 & 1238.7070 & 1238.7056 & 620.3601 & 0.0014 & 1.1284 & 4250.300 & 5084.337 & 5111.156 & 3460.744 & \text { Yes } \\ 1.00 & 3.38 & 24.79 & 23.34 & 2 & 1575.7156 & 1575.714 & 788.840 & 0.002 & 1.3944 & 83.877 & 78.92 & 155.613 & 143.073 & \text { No }\end{array}$

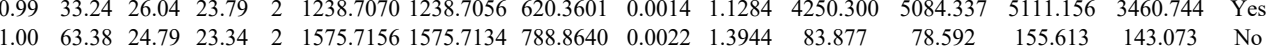
$\begin{array}{lllllllllllllll}1.00 & 63.38 & 24.79 & 23.34 & 2 & 1575.7156 & 1575.7134 & 788.8640 & 0.0022 & 1.3944 & 83.877 & 78.592 & 155.613 & 143.073 & \text { No } \\ 1.00 & 70.86 & 24.87 & 18.40 & 2 & 1575.7170 & 1575.7134 & 788.8640 & 0.0036 & 2.2818 & 52.714 & 85.894 & 107.391 & 78.677 & \text { No }\end{array}$ $\begin{array}{lllllllllllllllll}1.00 & 70.86 & 24.87 & 18.40 & 2 & 1575.7170 & 1575.7134 & 788.8640 & 0.0036 & 2.2818 & 52.714 & 85.894 & 107.391 & 78.677 & & \\ 0.95 & 27.16 & 26.04 & 23.37 & 2 & 1238.7068 & 1238.7056 & 620.3601 & 0.0012 & 0.9672 & 1206.077 & 1306.821 & 1450.251 & 849.911 & \text { Yes } & \\ 0.98 & 31.68 & 26.04 & 23.16 & 2 & 238.7670 & 1238.056 & 220.360 & 0.0014 & 1.128 & & \end{array}$ $\begin{array}{llllllllllllllllll}0.95 & 31.68 & 26.04 & 23.16 & 2 & 1238.7070 & 1238.7056 & 620.3601 & 0.0014 & 1.1284 & 1449.997 & 1471.164 & 1905.387 & 1292.357 & \text { Yes } & \\ 1.00 & 72.10 & 28.03 & 38.72 & 2 & 1515.8284 & 1515.8266 & 758.9206 & 0.018 & 1.185 & 1234.125 & 149.227 & 90.502 & 23.59 & \end{array}$ SIVEEIEDLVAR STEEIEDLVAR SIVEEEDLVAR DLVAR

ETVLATVQALOTSSHLSQQADER

EETVLATVQALTASHLSQQADLR EETVLATVQALLTASHLSQQA NPILWNVADVVIK NPILWNVADVVIK NPILWNVADVVIK EDQVIQLMNAIFSK EDQVIQLMNAIFSK EDQVIQLMNAIFSK EDQVIQLMNAIFSK $\begin{array}{lllllllllll}0.97 .35 & 2 & 1515.8290 & 1515.8266 & 758.9206 & 0.0024 & 1.5812 & 173.786\end{array}$

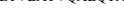
NPILWNVADVVIK NPILWNVADVVIK NPILWNVADVVIK NPILWNVADVVIK EDQVIQLMNAIFSK EDQVIQLMNAIFSK EDQVIQLMNAIFSK EDQVIQLMNAIFSK $\begin{array}{lllllllllllllll}1.00 & 88.24 & 26.00 & 29.16 & 3 & 2752.4458 & 2752.4477 & 918.4898 & -0.0019 & -0.6895 & 1533.064 & 1999.255 & 3086.065 & 2098.241 & \text { Yes }\end{array}$

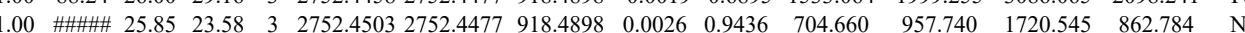
$\begin{array}{lllllllllllllll}0.76 & 59.56 & 20.25 & 72.56 & 2 & 1768.0504 & 1768.0491 & 885.0318 & 0.0013 & 0.7344 & 1312.124 & 1096.521 & 1213.862 & 1208.885 & \mathrm{Y}\end{array}$ $\begin{array}{lllllllllllllllll}1.00 & 75.60 & 20.17 & 17.96 & 2 & 1768.0514 & 1768.0491 & 885.0318 & 0.0023 & 1.2994 & 1654.268 & 2153.593 & 1471.865 & 1452.184 & \text { Yes }\end{array}$ $\begin{array}{lllllllllllllll}1.00 & 36.91 & 20.17 & 19.10 & 3 & 1768.0522 & 1768.0491 & 590.3570 & 0.0031 & 1.7504 & 112.365 & 86.491 & 59.148 & 21.858 & \text { Yes }\end{array}$ $\begin{array}{lllllllllllllll}1.00 & 59.10 & 20.45 & 32.30 & 3 & 1768.0537 & 1768.0491 & 590.3570 & 0.0046 & 2.5973 & 138.641 & 147.726 & 142.856 & 60.337 & \text { Yes }\end{array}$

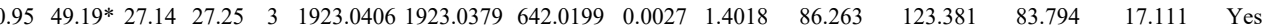

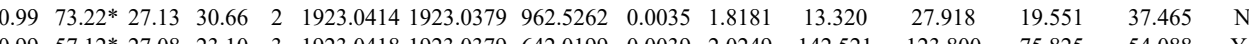

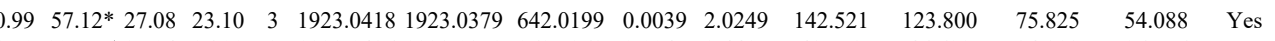

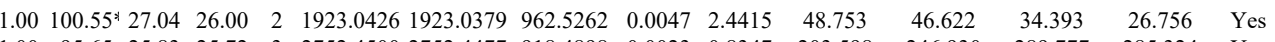

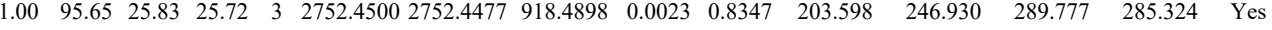
$\begin{array}{llllllllllllllll}.00 & 65.82 & 20.25 & 23.94 & 2 & 1768.0504 & 1768.0491 & 885.0318 & 0.0013 & 0.7344 & 338.079 & 290.591 & 511.890 & 391.218 & \text { Yes }\end{array}$

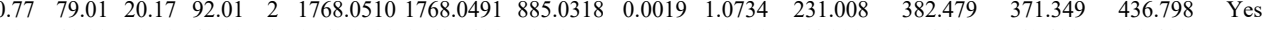
$\begin{array}{lllllllllllllll}0.97 & 41.83 & 20.53 & 42.10 & 3 & 1768.0528 & 1768.0491 & 590.3570 & 0.0037 & 2.0891 & 64.399 & 106.935 & 60.490 & 30.489 & \text { Yes }\end{array}$ $\begin{array}{lllllllllllllll}0.99 & 48.85 & 20.45 & 44.16 & 3 & 1768.0531 & 1768.0491 & 590.3570 & 0.0040 & 2.2585 & 115.104 & 131.340 & 60.659 & 53.582 & \text { Yes }\end{array}$ $\begin{array}{llllllllllllll}0.89 & 41.37 * 27.07 & 20.48 & 3 & 1923.0394 & 1923.0379 & 642.0199 & 0.0015 & 0.7788 & 57.752 & 43.134 & 26.817 & 26.630 & \text { Yes }\end{array}$

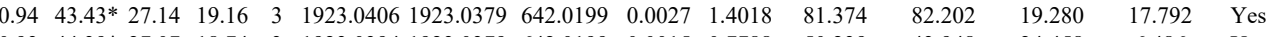

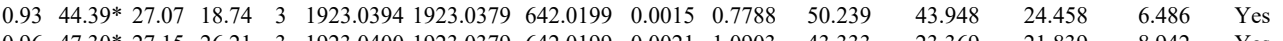
$\begin{array}{llllllllllllll} & \end{array}$

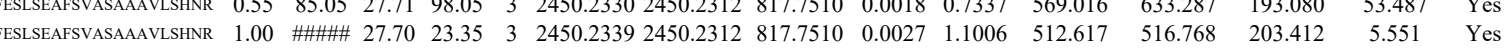
$\begin{array}{lllllllllllllll} & \end{array}$ $\begin{array}{llllllllllllllll} & \end{array}$ $\begin{array}{llllllllllllllll} & \end{array}$

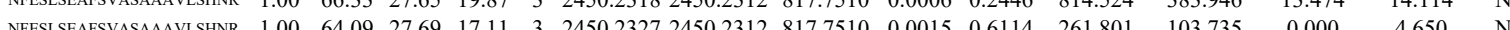



$\begin{array}{lllllllllllll}\text { AVVYSNTIQSIMAIVK } & 1.00 & \text { \#\#\#\# } 27.28 & 30.73 & 2 & 1735.9550 & 1735.9542 & 868.9844 & 0.0008 & 0.4603 & 9.311\end{array}$

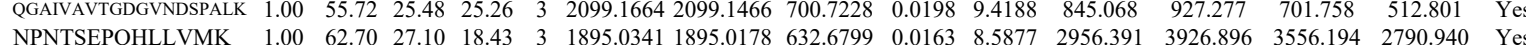

\section{YQLSIHK}

CSSILLHGK

NMVPQQALVIR

NMVPQQALVIR

NMVPQQALVIR

LNIPVSQVNPR

LNIPVSQVNPR

LNIPVSQVNPR

TSATWLALSR

TSATWLALSR

IAGLCNR

IAGLCNR

IAGLCNR

IAGLCNR

DMTSEQLDDILK

VDNSSLTGESEPQTR

VDNSSLTGESEPQTR

YEPAAVSEQGDKK GVGIISEGNETVEDIAA
SPDFTNENPLETR

GVGIISEGNETVEDIAAR AVAGDASESALLK

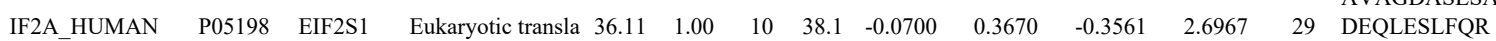

\section{DEQLESLFQR}

DEQLESLFQR

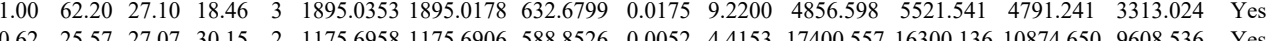

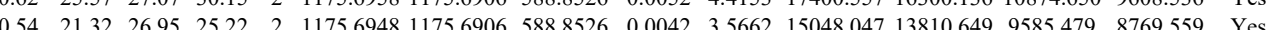
$\begin{array}{llllllllllllllll}0.61 & 22.32 & 28.45 & 19.60 & 3 & 1290.7129 & 1290.7032 & 431.2417 & 0.0097 & 7.4977 & 21799.888 & 21242.149 & 1844.797 & 773.901 & \text { Yes }\end{array}$ $\begin{array}{lllllllllllllllll}0.60 & 20.70 & 28.42 & 17.43 & 3 & 1290.7108 & 1290.7032 & 431.2417 & 0.0076 & 5.8745 & 25119.455 & 20469.248 & 958.646 & 937.286 & \text { Yes }\end{array}$ $\begin{array}{lllllllllllllllll}1.00 & 42.62 & 25.56 & 23.87 & 2 & 1411.8198 & 1411.8091 & 706.9118 & 0.0107 & 7.5681 & 19469.031 & 16137.709 & 1487.995 & 223.832 & \text { Yes }\end{array}$ $\begin{array}{llllllllllllllll}1.00 & 48.00 & 25.56 & 23.24 & 2 & 1411.8198 & 1411.8091 & 706.9118 & 0.0107 & 7.5681 & 18741.078 & 16828.341 & 968.663 & 233.969 & \text { Yes } \\ 0.99 & 37.91 & 25.26 & 22.85 & 2 & 1411.8232 & 1411.8091 & 706.9118 & 0.0141 & 9.9729 & 3394.656 & 3598.572 & 266.412 & 108.363 & \text { Yes }\end{array}$ $\begin{array}{llllllllllllllll}1.00 & 71.25 & 25.30 & 2.762 & 2 & 1379.8114 & 1379.8007 & 690.9076 & 0.0107 & 7.7434 & 9645.917 & 8335.594 & 1745.900 & 257.105 & \text { Yes }\end{array}$ $\begin{array}{llllllllllllllll}1.00 & 75.38 & 25.30 & 25.78 & 2 & 1379.8114 & 1379.8007 & 690.9076 & 0.0107 & 7.7434 & 28775.803 & 28602.609 & 2320.347 & 235.750 & \text { Yes }\end{array}$ $\begin{array}{lllllllllllllllll}0.96 & 29.15 & 25.50 & 16.52 & 3 & 1379.8141 & 1379.8007 & 460.9408 & 0.0134 & 9.6902 & 1871.663 & 1758.748 & 1302.790 & 306.846 & \text { Yes }\end{array}$ $\begin{array}{lllllllllllllll}1.00 & 75.29 & 25.60 & 25.19 & 2 & 1379.8120 & 1379.8007 & 690.9076 & 0.0113 & 8.1776 & 19453.523 & 16805.109 & 2907.992 & 592.524 & \text { Yes }\end{array}$ $\begin{array}{llllllllllllllll}1.00 & 55.64 & 25.60 & 22.15 & 2 & 1379.8120 & 1379.8007 & 690.9076 & 0.0113 & 8.1776 & 28338.648 & 22924.204 & 2936.611 & 300.492 & \text { Yes }\end{array}$ $\begin{array}{llllllllllllllll}1.00 & 52.36 & 28.60 & 34.24 & 2 & 1248.6948 & 1248.6948 & 625.3547 & 0.0000 & 0.0000 & 14875.051 & 14492.830 & 434.857 & 436.166 & \text { Yes }\end{array}$ $\begin{array}{lllllllllllllllll}1.00 & 55.23 & 28.41 & 40.65 & 2 & 1248.6968 & 1248.6948 & 625.3547 & 0.0020 & 1.5991 & 21763.450 & 20552.349 & 891.903 & 602.711 & \text { Yes }\end{array}$ $\begin{array}{llllllllllllllll}1.00 & 55.37 & 25.33 & 21.52 & 2 & 1379.8126 & 1379.8007 & 690.9076 & 0.0119 & 8.6118 & 6977.795 & 7465.353 & 691.062 & 134.433 & \text { Yes }\end{array}$ $\begin{array}{llllllllllllllll}0.66 & 27.32 & 27.97 & 30.99 & 2 & 935.4874 & 935.4803 & 468.7474 & 0.0071 & 7.5733 & 41060.448 & 32737.239 & 1368.458 & 764.713 & \text { Yes }\end{array}$ $\begin{array}{lllllllllllllll}0.78 & 29.33 & 28.08 & 30.04 & 2 & 935.4886 & 935.4803 & 468.7474 & 0.0083 & 8.8533 & 43900.290 & 40708.875 & 1183.942 & 912.614 & \text { Yes }\end{array}$ $\begin{array}{lllllllllllllllll}0.77 & 29.06 & 28.82 & 29.70 & 2 & 935.4888 & 935.4803 & 468.7474 & 0.0085 & 9.0666 & 28475.997 & 24990.459 & 1082.116 & 478.746 & \text { Yes }\end{array}$ $\begin{array}{lllllllllllllllll}0.76 & 28.73 & 28.82 & 29.44 & 2 & 935.4892 & 935.4803 & 468.7474 & 0.0089 & 9.4933 & 21957.299 & 20280.921 & 748.679 & 671.766 & \text { Yes }\end{array}$

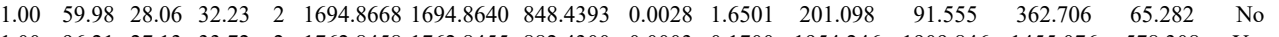

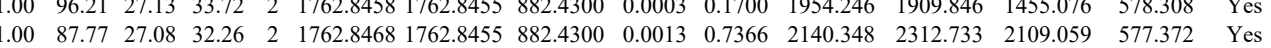
$\begin{array}{lllllllllllllllll}0.75 & 16.70 & 27.42 & 20.60 & 3 & 1852.9939 & 1852.9896 & 618.6705 & 0.0043 & 2.3168 & 2167.165 & 1998.174 & 1309.044 & 2430.033 & \text { No }\end{array}$

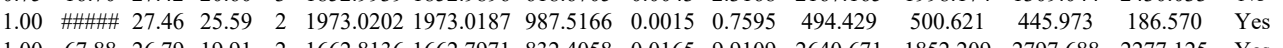
$\begin{array}{lllllllllllllll}1.00 & 67.88 & 26.79 & 19.91 & 2 & 1662.8136 & 1662.7971 & 832.4058 & 0.0165 & 9.9109 & 2640.671 & 1852.209 & 2797.688 & 2277.125 & \text { Yes } \\ 1.00 & 92.74 & 27.28 & 23.18 & 2 & 1973.0218 & 1973.0187 & 987.5166 & 0.0031 & 1.5696 & 1042.247 & 1097.691 & 608.009 & 333.147 & \text { Yes }\end{array}$

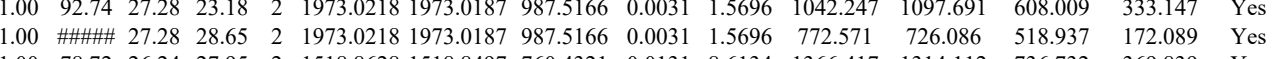
$\begin{array}{lllllllllllllll}1.00 & 78.72 & 26.24 & 27.95 & 2 & 1518.8628 & 1518.8497 & 760.4321 & 0.0131 & 8.6134 & 1366.417 & 1314.112 & 736.732 & 369.839 & \text { Yes } \\ 1.00 & 54.17 & 27.69 & 27.79 & 2 & 1407.7134 & 1407.7116 & 704.8631 & 0.0018 & 12768 & 7158.018 & 5925.392 & 14060.651 & 10690.080 & \text { Yes }\end{array}$ $\begin{array}{llllllllllllllll}1.00 & 54.17 & 27.69 & 27.79 & 2 & 1407.7134 & 1407.7116 & 704.8631 & 0.0018 & 1.2768 & 7158.018 & 5925.392 & 14060.651 & 10690.080 & \text { Yes } \\ 1.00 & 49.34 & 27.62 & 27.66 & 2 & 1407.7138 & 1407.7116 & 704.8631 & 0.0022 & 1.5606 & 4158.677 & 2629.325 & 8305.344 & 7610.331 & \text { Yes }\end{array}$

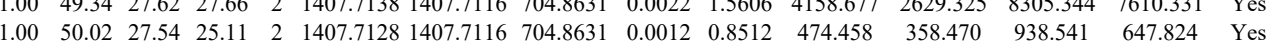




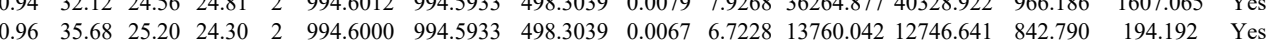
$\begin{array}{llllllllllllllll}0.96 & 35.67 & 25.04 & 22.30 & 2 & 994.6008 & 994.5933 & 498.3039 & 0.0075 & 7.5255 & 17694.974 & 15214.338 & 1166.200 & 562.802 & \text { Yes }\end{array}$ $\begin{array}{llllllllllllllll} & 0.99 & 42.35 & 23.60 & 30.67 & 2 & 1036.6606 & 1036.6515 & 519.3330 & 0.0091 & 8.7612 & 40312.426 & 40997.842 & 5998.820 & 1377.711 & \text { Yes } \\ \text { INLIAPPR } & 1.00 & 40.82 & 23.46 & 28.15 & 2 & 1036.6616 & 1036.6515 & 519.3330 & 0.0101 & 9.7239 & 44536.257 & 46839.470 & 8601.135 & 882.842 & \text { Yes }\end{array}$

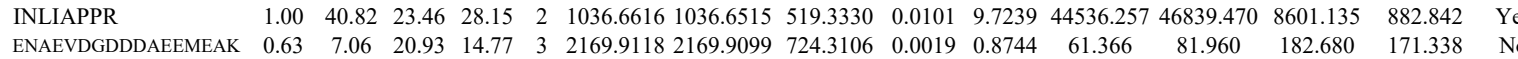
$\begin{array}{lllllllllllllll}1.00 & 41.01 & 23.46 & 28.40 & 2 & 1036.6612 & 1036.6515 & 519.3330 & 0.0097 & 9.3388 & 43430.360 & 41289.767 & 8486.801 & 171.338 & \text { No }\end{array}$

INLIAPPR
INLIAPPR

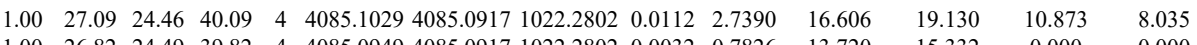
$\begin{array}{lllllllllllllll}\text { Menix } & 1.00 & 42.93 & 24.42 & 55.93 & 4 & 4085.0989 & 4085.0917 & 1022.2802 & 0.0072 & 1.7608 & 15.110 & 4.028 & 22.327 & 3.485\end{array}$ $\begin{array}{llllllllllllll} & \end{array}$

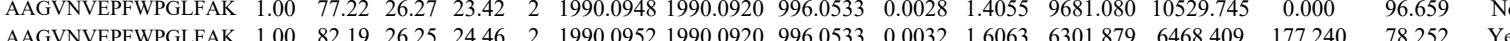

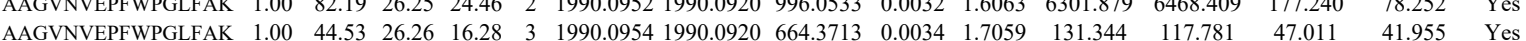

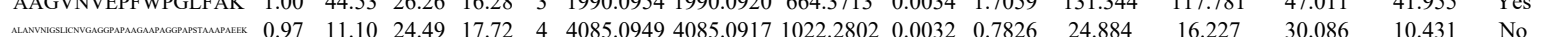
$\begin{array}{llllllllllllllll}\text { AAGVNVEPFWPGLFAK } & 1.00 & 80.69 & 26.31 & 24.53 & 2 & 1990.0942 & 1990.0920 & 996.0533 & 0.0022 & 1.1044 & 3404.306 & 3019.109 & 10.647 & 30.142 & \text { Yes }\end{array}$ $\begin{array}{lllllllllllllllll}\text { AAGVNVEPFWPGLFAK } & 1.00 & 36.69 & 26.26 & 16.65 & 3 & 1990.0954 & 1990.0920 & 664.3713 & 0.0034 & 1.7059 & 423.454 & 523.704 & 300.844 & 324.983 & \text { Yes }\end{array}$ $\begin{array}{llllllllllllllllll}\text { AAGVNVEPFWPGLFAK } & 1.00 & 82.71 & 26.27 & 25.02 & 2 & 1990.0950 & 1990.0920 & 996.0533 & 0.0030 & 1.5059 & 3394.564 & 2934.518 & 138.032 & 37.451 & \text { Yes }\end{array}$ \begin{tabular}{llllllllllllllll} 
AAGVNVEPFWPGLFAK & 1.00 & 70.75 & 26.26 & 20.56 & 2 & 1990.0954 & 1990.0920 & 996.0533 & 0.0034 & 1.7067 & 2284.614 & 1764.845 & 93.656 & 4.381 & Yes \\
\hline
\end{tabular}

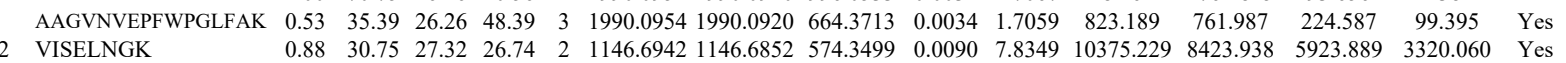
$\begin{array}{llllllllllllllll}\text { VISELNGK } & 0.96 & 35.70 & 27.32 & 26.30 & 2 & 1146.6942 & 1146.6852 & 574.3499 & 0.0090 & 7.8349 & 17417.236 & 13661.341 & 10751.604 & 3122.004 & \text { Yes }\end{array}$

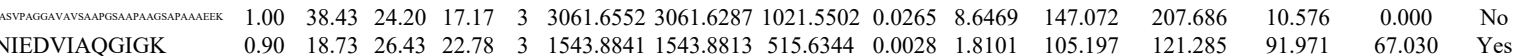
$\begin{array}{lllllllllllllllll} & \\ \text { NIEDVIAQGIGK } & 0.90 & 18.73 & 26.43 & 22.78 & 3 & 1543.8841 & 1543.8813 & 515.6344 & 0.0028 & 1.8101 & 105.197 & 121.285 & 91.971 & 67.030 & \text { Yes } \\ & 1.00 & 48.29 & 26.30 & 20.72 & 3 & 1543.8853 & 1543.8813 & 515.6344 & 0.0040 & 2.5858 & 464.757 & 507.603 & 255.155 & 0.000 & \text { No }\end{array}$ $\begin{array}{llllllllllllllll}\text { NIEDVIAQGIGK } & 1.00 & 44.35 & 26.15 & 20.99 & 3 & 1543.8856 & 1543.8813 & 515.6344 & 0.0043 & 2.7797 & 1652.104 & 1625.911 & 1082.124 & 206.380 & \text { Yes }\end{array}$ $\begin{array}{llllllllllllllll}\text { NIEDVIAQGIGK } & 1.00 & 87.43 & 26.15 & 23.06 & 2 & 1543.8856 & 1543.8813 & 772.9479 & 0.0043 & 2.7816 & 24130.397 & 23340.011 & 8759.900 & 1749.464 & \text { Yes }\end{array}$ $\begin{array}{llllllllllllllll}\text { NIEDVIAQGIGK } & 1.00 & 78.16 & 26.13 & 23.31 & 2 & 1543.8866 & 1543.8813 & 772.9479 & 0.0053 & 3.4284 & 29544.831 & 30818.327 & 13760.070 & 2051.983 & \text { Yes }\end{array}$

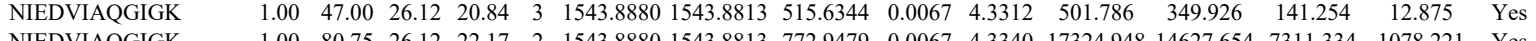

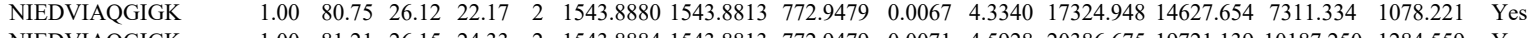

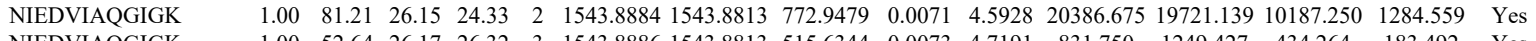
$\begin{array}{llllllllllllllll}\text { NIEDVIAQGIGK } & 1.00 & 52.64 & 26.17 & 26.32 & 3 & 1543.8886 & 1543.8813 & 515.6344 & 0.0073 & 4.7191 & 831.750 & 1249.427 & 434.264 & 183.492 & \text { Yes }\end{array}$

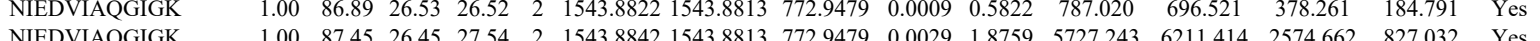

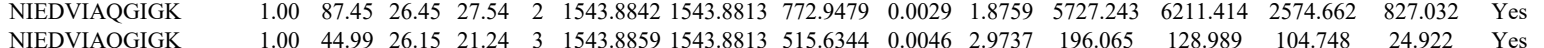

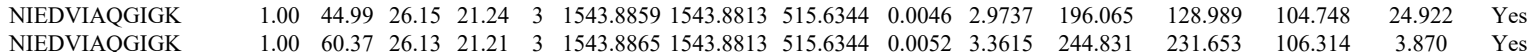

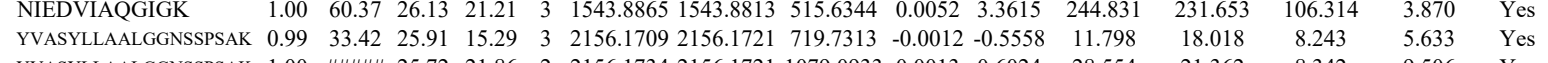
$\begin{array}{lllllllllllll} & \text { YVASYLLALSG }\end{array}$ 


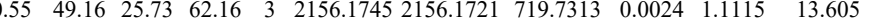
$\begin{array}{llllllllllll}\text { IIQLLDDYPK } & 1.00 & 57.68 & 25.39 & 25.60 & 2 & 1504.8782 & 1504.8745 & 753.4445 & 0.0037 & 2.4554 & 401.224 \\ \text { AGAIAPCEVTVPAQNTGLGPEK } & 1.00 & 68.07 & 27.71 & 33.76 & 2 & 2456.2654 & 2456.2647 & 1229.1396 & 0.0007 & 0.2848 & 51.109\end{array}$

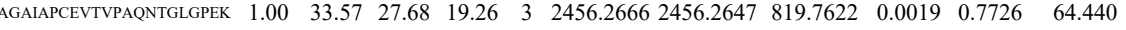

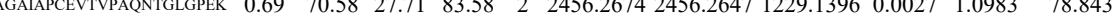
IIQLLDDYPK $\begin{array}{llllllllllll}1.00 & 51.08 & 25.42 & 24.58 & 2 & 1504.8776 & 1504.8745 & 753.4445 & 0.0031 & 2.0572 & 4232.604 \\ 1.00 & 51.13 & 25.39 & 24.83 & 2 & 1504.8782 & 1504.8755 & 753.4445 & 0.0037 & 2.4554 & 1414.664 & 13\end{array}$ GTIEILSDVQLIK GTIEILSDVQLIK GTIEILSDVQLIK GTIEILSDVQLIK $\begin{array}{llllllllllll}0.52 & 6.80 & 22.50 & 17.18 & 3 & 1716.0298 & 1716.0277 & 573.0165 & 0.0021 & 1.2216 & 168.275\end{array}$ $\begin{array}{lllllllllll}0.98 & 20.51 & 22.50 & 19.14 & 3 & 1716.0298 & 1716.0277 & 573.0165 & 0.0021 & 1.2216 & 115.311 \\ 1.00 & 78.29 & 22.48 & 20.91 & 2 & 1716.0298 & 1716.0277 & 859.0211 & 0.021 & 1.2223 & 627.989\end{array}$ $\begin{array}{lllllllllll}1.00 & 78.29 & 22.48 & 20.91 & 2 & 1716.0298 & 1716.0277 & 859.0211 & 0.0021 & 1.2223 & 627.989\end{array}$ $\begin{array}{lllllllllll}1.00 & 70.99 & 22.48 & 19.99 & 2 & 1716.0298 & 1716.0277 & 859.0211 & 0.0021 & 1.2223 & 772.012 \\ 1.00 & 56.19 & 21.93 & 21.62 & 3 & 1716.0310 & 1716.0277 & 573.0165 & 0.0033 & 1.9197 & 99.754\end{array}$ GTIEILSDVQLIK $\begin{array}{llllllllllll}1.00 & 56.19 & 21.93 & 21.62 & 3 & 1716.0310 & 1716.0277 & 573.0165 & 0.0033 & 1.9197 & 99.754\end{array}$

$\begin{array}{lllllllllllll} & \end{array}$

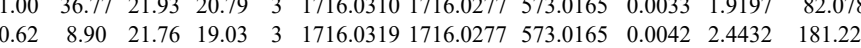
$\begin{array}{lllllllllllll} & \end{array}$

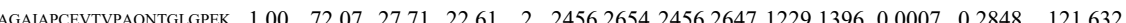
\begin{tabular}{lllllllllllll}
\hline AGNAPCETVPAONTGGGPK & 1.00 & 39.63 & 27.67 & 20.55 & 3 & 2456.2681 & 24562647 & 819.7622 & 0.0034 & 1.3825 & 220.021
\end{tabular} AGAIAPCEVTVPAQNTG GTIEILSDVQLIK GTIEILSDVQLIK GTIEILSDVQLIK GTIEILSDVQLIK GTIEILSDVQLIK GNVGFVFTK GNVGFVFTK

GNVGFVFTK

GNVGFVFTK

GNVGFVFTK

GNVGFVFTK $\begin{array}{llllllllllll}1.00 & 82.61 & 22.58 & 29.80 & 2 & 1716.0276 & 1716.0277 & 859.0211 & -0.0001 & -0.0582 & 450.218 & 35\end{array}$

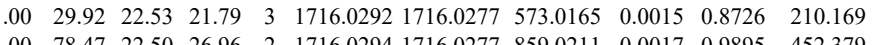
$\begin{array}{lllllllllll} & 1716.0294 & 1716.0277 & 859.0211 & 0.0017 & 0.9895 & 452.379\end{array}$ $\begin{array}{lllllllllll}1.00 & 44.24 & 21.82 & 23.52 & 3 & 1716.0301 & 1716.0277 & 573.0165 & 0.0024 & 1.3961 & 183.090 \\ 1.0325 & 1716.0277 & 573.0165 & 0.0048 & 27922 & 41.267\end{array}$

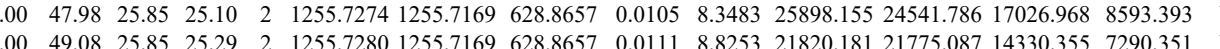
$\begin{array}{llllllllllllllll}1.00 & 49.08 & 25.85 & 25.29 & 2 & 1255.7280 & 1255.7169 & 628.8657 & 0.0111 & 8.8253 & 21820.181 & 21775.087 & 14330.355 & 7290.351 & \text { Yes }\end{array}$

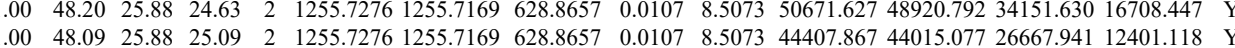
$\begin{array}{llllllllllllllll}1.00 & 49.07 & 26.38 & 24.55 & 2 & 1255.7256 & 1255.7169 & 628.8657 & 0.0087 & 6.9172 & 30303.146 & 29308.763 & 16161.340 & 8553.330 & \text { Yes } & \end{array}$ $\begin{array}{llllllllllllllll}1.00 & 63.70 & 25.90 & 28.16 & 2 & 1255.7266 & 1255.7169 & 628.8657 & 0.0097 & 7.7122 & 33390.625 & 30282.132 & 17084.730 & 8593.542 & \text { Yes } & \end{array}$ $\begin{array}{llllllllllllll} & \end{array}$

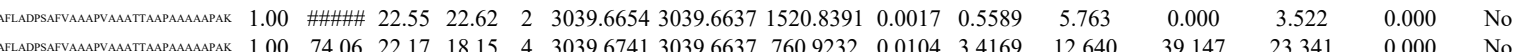
$\begin{array}{llllllllllllllll} & 74.06 & 22.17 & 18.15 & 4 & 3039.6741 & 3039.6637 & 760.9232 & 0.0104 & 3.4169 & 12.640 & 39.147 & 23.341 & 0.000 & \text { No }\end{array}$

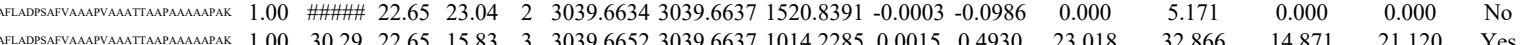
$\begin{array}{llllllllllll} & \end{array}$ $\begin{array}{llllllllllllllll} & \end{array}$

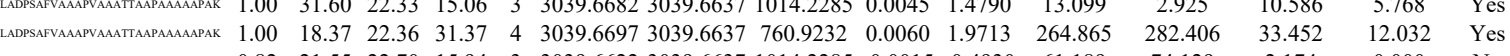

TSFFQALGITTK TSFFQALGITTK

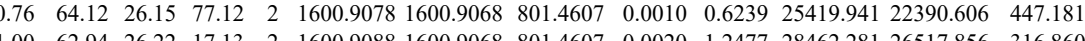
$\begin{array}{llllllllllllll}0.70 & 13.46 & 26.12 & 17.96 & 3 & 1600.9093 & 1600.9068 & 534.6429 & 0.0025 & 1.5587 & 527.867 & 441.476 & 263.349\end{array}$ $\begin{array}{llllllllllllll}0.75 & 15.13 & 25.72 & 20.89 & 3 & 1600.9108 & 1600.9068 & 534.6429 & 0.0040 & 2.4939 & 518.046 & 756.972 & 205.347\end{array}$ 
TSFFQALGITTK TSFFQALGITTK

TSFFQALGITTK

TSFFQALGITTK

LLPHIR

TSFFQALGITTK

TSFFQALGITTK

TSFFQALGITTK

TSFFQALGITTK

LPHI

LLPHIR

TSFFQALGITTK

GHLENNPALEK

GHLENNPALEK

1 AAQPGSGK

GFPTDATLDDIK

SPSKPLPEVTDEYK

EDLHILFSNHGEIK

LDEGWVPLEIMIK

LDEGWVPLEIMIK

LDEGWVPLEIMIK

LDEGWVPLEIMIK

LDEGWVPLEIMIK

LDEGWVPLEIMIK

GSIFVVFDSIESAK

GSIFVVFDSIESAK

GSIFVVFDSIESAK

GSIFVVFDSIESAK

LDEGWVPLEIMIK

GSIFVVFDSIESAK

GSIFVVFDSIESAK

LTTDFNVIVEALSK

LTTDFNVIVEALSK

LTTDFNVIVEALSK

LTTDFNVIVEALSK

IGCLLK

GQVLNIQMR

GQVLNIQMR

IGCLLK

GQVLNIQMR

GQVLNIQMR

IIEDQQESLNK

IIEDQQESLNK

LDEGWVPLEIMIK

EVTWEVLEGEVEK

FSGDLDDQTCR

SPSKPLPEVTDEYK

$\begin{array}{lllllllllllll}\text { K1C18_HUMA^ } & \text { P05783 } & \text { KRT18 } & \text { Keratin, type I cyt } 48.06 & 1.00 & 17 & 53.7 & 0.3377 & 0.5649 & 0.4717 & 1.8398 & 134 & \text { LEAEIATYR } \\ \text { LEAEIATYR }\end{array}$

YETELAMR

YETELAMR

VIDDTNITR

VIDDTNITR

(1)

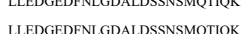

LLEDGEDFNLGDALDSSNSMQTIOK

LLEDGEDFNLGDALDSSNSMQTIQK

VIDDTNITR

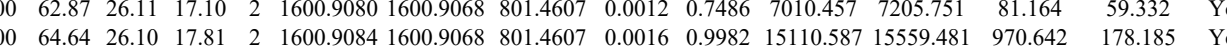

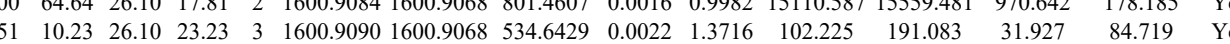
$\begin{array}{lllllllllllllll}0.96 & 22.56 & 26.01 & 24.09 & 3 & 1600.9099 & 1600.9068 & 534.6429 & 0.0031 & 1.9328 & 223.251 & 185.288 & 158.513 & 73.565 & \text { Yes }\end{array}$ $\begin{array}{lllllllllllllllll}0.56 & 20.84 & 26.02 & 23.96 & 2 & 891.5816 & 891.5776 & 446.7961 & 0.0040 & 4.4763 & 35285.796 & 38361.286 & 2426.234 & 1074.525 & \text { Yes }\end{array}$ $\begin{array}{llllllllllllllll}0.77 & 72.24 & 26.22 & 85.24 & 2 & 1600.9088 & 1600.9068 & 801.4607 & 0.0020 & 1.2477 & 8574.018 & 9293.832 & 477.175 & 856.637 & \text { Yes }\end{array}$ $\begin{array}{lllllllllllllll}0.99 & 27.66 & 26.12 & 17.19 & 3 & 1600.9093 & 1600.9068 & 534.6429 & 0.0025 & 1.5587 & 261.122 & 178.648 & 36.660 & 19.568 & \text { Yes } \\ 1.09 & 73.25 & 26.14 & 25.87 & 2 & 1600.904 & 1600.908 & 80.1607 & 0.026 & 1.6220 & 8301.744 & 72.5424 & 336.392 & 338.946 & \text { Yes }\end{array}$ $\begin{array}{lllllllllllllll}1.00 & 73.30 & 26.14 & 25.87 & 2 & 1600.9094 & 1600.9068 & 801.4607 & 0.0026 & 1.6220 & 8301.744 & 7225.241 & 336.392 & 338.946 & \text { Yes } \\ 0.98 & 25.25 & 26.01 & 18.53 & 3 & 1600.909 & 1600.906 & 534.6429 & 0.0031 & 1.9328 & 289.149 & 315.085 & 72.548 & 2.647 & \text { Yes }\end{array}$

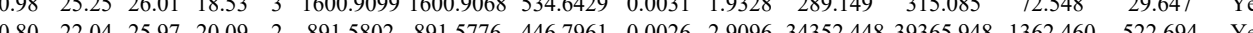

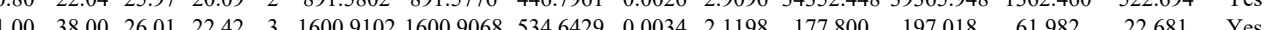

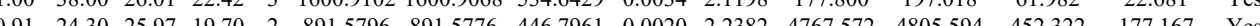

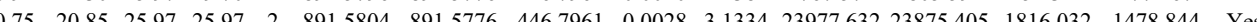
$\begin{array}{lllllllllllllll}0.61 & 54.47 & 27.60 & 67.47 & 2 & 1312.7028 & 1312.7027 & 657.3586 & 0.0001 & 0.0761 & 50.032 & 87.971 & 38.282 & 24.205 & \text { Yes }\end{array}$

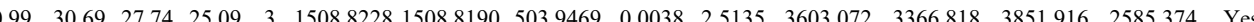

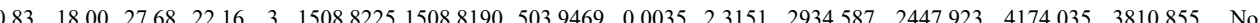
$\begin{array}{llllllllllllllll}0.89 & 24.86 & 27.31 & 18.53 & 2 & 10025716 & 10025702 & 502.2924 & 0.0014 & 1.3936 & 102.976 & 88.828 & 62.896 & 33.281 & \text { Y }\end{array}$ $\begin{array}{lllllllllllllll}1.00 & 56.39 & 27.90 & 24.61 & 2 & 1579.8354 & 1579.8337 & 790.9241 & 0.0017 & 1.0747 & 2638.958 & 2431.662 & 2121.384 & 1187.380 & \text { Yes }\end{array}$ $\begin{array}{llllllllllllllll}1.00 & 56.98 & 28.09 & 23.30 & 2 & 1579.8362 & 1579.8337 & 790.9241 & 0.0025 & 1.5804 & 1870.194 & 1865.383 & 1624.167 & 627.511 & \text { Yes }\end{array}$ $\begin{array}{llllllllllllllll}0.96 & 32.69 & 25.58 & 15.53 & 3 & 2021.1238 & 2021.1046 & 674.7088 & 0.0192 & 9.4855 & 8242.611 & 8681.447 & 5909.936 & 5306.996 & \text { Yes }\end{array}$ $\begin{array}{lllllllllllllll}1.00 & 36.30 & 27.18 & 26.94 & 4 & 1939.0441 & 1939.0407 & 485.7675 & 0.0034 & 1.7498 & 61.573 & 57.082 & 126.461 & 76.771 & \text { No }\end{array}$ $\begin{array}{lllllllllllllll}1.00 & 51.97 & 26.06 & 28.40 & 2 & 1830.0238 & 1830.0205 & 916.0175 & 0.0033 & 1.8013 & 617.281 & 454.504 & 45.024 & 0.000 & \text { No }\end{array}$ $\begin{array}{lllllllllllllll}1.00 & 52.27 & 25.99 & 28.49 & 2 & 1830.0240 & 1830.0205 & 916.0175 & 0.0035 & 1.9104 & 89.159 & 66.361 & 15.844 & 6.948 & \text { Yes }\end{array}$ $\begin{array}{lllllllllllllll}1.00 & 52.61 & 26.02 & 26.18 & 2 & 1830.0236 & 1830.0205 & 916.0175 & 0.0031 & 1.6921 & 765.602 & 793.214 & 24.794 & 34.408 & \text { Yes }\end{array}$

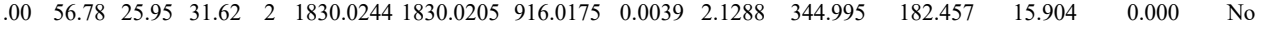
$\begin{array}{llllllllllllll} & \end{array}$

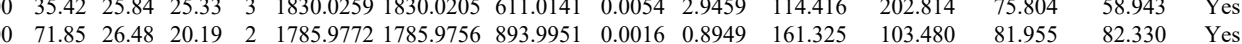
$\begin{array}{lllllllllllllll}.00 & 69.27 & 26.49 & 20.22 & 2 & 1785.9772 & 1785.9756 & 893.9951 & 0.0016 & 0.8949 & 161.325 & 103.480 & 81.955 & 82.33 & \text { Yes } \\ 1.00 & 50.18 & 26.4 & 23.99 & 3 & 1785.9793 & 1785.9756 & 893.9951 & 0.0032 & 1.7897 & 165.466 & 215.097 & 154.462 & 68.804 & \text { Yes }\end{array}$ $\begin{array}{llllllllllllllll}1.00 & 50.18 & 26.47 & 23.99 & 3 & 1785.9793 & 1785.9756 & 596.3325 & 0.0037 & 2.0682 & 152.664 & 132.954 & 143.082 & 18.400 & \text { Yes }\end{array}$ $\begin{array}{lllllllllllllll}1.00 & 62.35 & 26.46 & 24.99 & 3 & 1785.9799 & 1785.9756 & 596.3325 & 0.0043 & 2.4036 & 178.835 & 259.127 & 70.895 & 54.122 & \text { Yes }\end{array}$ $\begin{array}{llllllllllllllll}1.00 & 58.50 & 25.90 & 31.13 & 2 & 1830.0252 & 1830.0205 & 916.0175 & 0.0047 & 2.5654 & 377.742 & 318.760 & 30.122 & 22.078 & \text { Yes }\end{array}$ $\begin{array}{lllllllllllllll}1.00 & 37.60 & 26.52 & 19.20 & 3 & 1785.9784 & 1785.9756 & 596.3325 & 0.0028 & 1.5651 & 213.897 & 247.743 & 143.385 & 66.311 & \text { Yes }\end{array}$

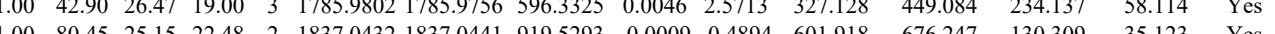

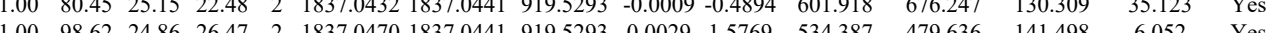

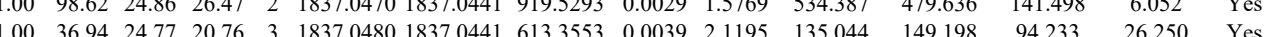

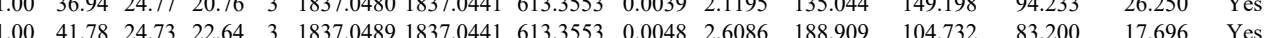
$\begin{array}{llllllllllllllll} & \end{array}$

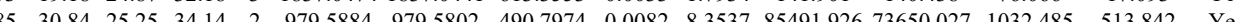

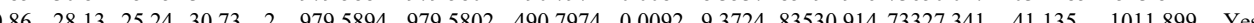

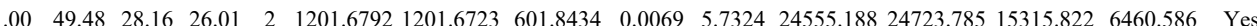
$\begin{array}{lllllllllllllll}1.00 & 51.02 & 28.16 & 31.41 & 2 & 1201.6794 & 1201.6723 & 6018434 & 0.0071 & 5.8985 & 22595.648 & 20619.497 & 15542.115 & 5279.599 & \text { Yes }\end{array}$ $\begin{array}{lllllllllllllllll}0.82 & 28.12 & 24.98 & 30.72 & 2 & 979.5874 & 979.5802 & 490.7974 & 0.0072 & 7.3349 & 74755.751 & 73790.258 & 0.000 & 458.065 & \text { No }\end{array}$ $\begin{array}{llllllllllllllll}1.00 & 49.56 & 27.90 & 26.48 & 2 & 1201.6798 & 1201.6723 & 601.8434 & 0.0075 & 6.2308 & 26008.749 & 24749.482 & 16864.955 & 7601.148 & \text { Yes }\end{array}$ $\begin{array}{llllllllllllllllll}0.99 & 47.92 & 27.87 & 25.98 & 2 & 1201.6796 & 1201.6723 & 601.8434 & 0.0073 & 6.0647 & 6934.455 & 6540.527 & 4724.169 & 1607.149 & \text { Yes }\end{array}$ $\begin{array}{lllllllllllllllll}1.00 & 47.88 & 27.82 & 25.89 & 2 & 1201.6800 & 1201.6723 & 601.8434 & 0.0077 & 6.3970 & 9258.710 & 9206.519 & 5522.627 & 3088.429 & \text { Yes }\end{array}$ $\begin{array}{llllllllllllllll}1.00 & 57.81 & 27.71 & 30.45 & 2 & 1603.8714 & 1603.8661 & 802.9403 & 0.0053 & 3.3004 & 2541.820 & 2142.444 & 639.460 & 90.265 & \text { Yes }\end{array}$ $\begin{array}{lllllllllllllllll}1.00 & 56.98 & 27.70 & 28.22 & 2 & 1603.8724 & 1603.8661 & 802.9403 & 0.0063 & 3.9231 & 1938.762 & 1882.514 & 554.865 & 64.872 & \text { Yes }\end{array}$ $\begin{array}{llllllllllllllll}0.58 & 12.39 & 25.90 & 17.43 & 3 & 1830.0250 & 1830.0205 & 611.0141 & 0.0045 & 2.4549 & 68.602 & 99.478 & 95.901 & 83.149 & \text { No }\end{array}$

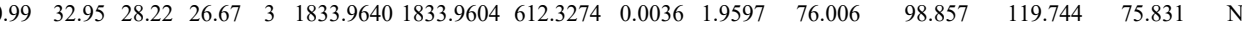

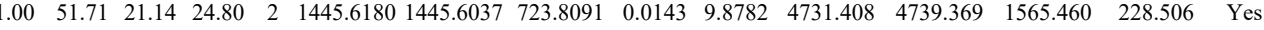

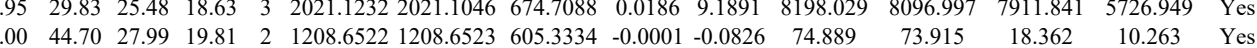
$\begin{array}{lllllllllllllll}0.98 & 33.38 & 28.10 & 28.45 & 2 & 1208.6534 & 1208.6523 & 605.3334 & 0.0011 & 0.9086 & 68.996 & 71.941 & 9.977 & 5.875 & \text { Yes }\end{array}$

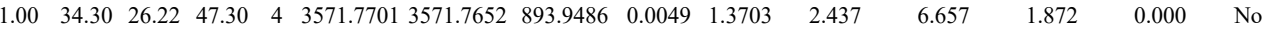
$\begin{array}{lllllllllllllll}0.99 & 44.23 & 26.82 & 20.91 & 2 & 1155.5792 & 1155.5716 & 578.7931 & 0.0076 & 6.5653 & 15964.080 & 21753.361 & 9766.450 & 6134.867 & \text { Yes }\end{array}$ $\begin{array}{llllllllllllllll}0.99 & 44.43 & 26.52 & 21.13 & 2 & 1155.5802 & 1155.5716 & 578.7931 & 0.0086 & 7.4292 & 17995.568 & 25360.499 & 13317.579 & 8285.546 & \text { Yes }\end{array}$ $\begin{array}{lllllllllllllll}1.00 & 50.96 & 28.34 & 33.23 & 2 & 1189.6498 & 1189.6425 & 595.8285 & 0.0073 & 6.1259 & 42141.510 & 52923.686 & 1244.606 & 1193.907 & \text { Yes }\end{array}$ $\begin{array}{lllllllllllllll}1.00 & 51.40 & 28.38 & 32.63 & 2 & 1189.6504 & 1189.6425 & 595.8285 & 0.0079 & 6.6294 & 39772.938 & 48141.729 & 2691.214 & 1946.788 & \text { Yes }\end{array}$

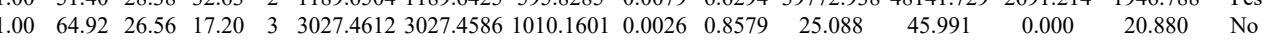

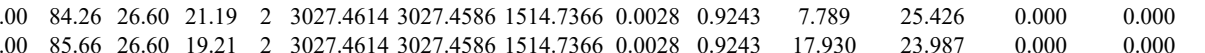
$\begin{array}{llllllllllllll} & 0.000 & \text { No }\end{array}$

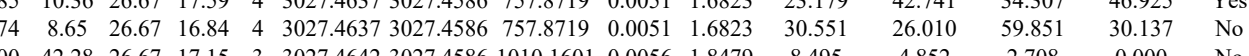
$\begin{array}{llllllll} & \\ 0\end{array}$

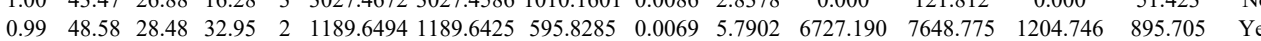

Table S-3 page 60 of 499 
$\begin{array}{llllllllllllll}1.00 & 56.97 & 28.10 & 39.71 & 2 & 1208.6636 & 1208.6523 & 605.3334 & 0.0113 & 9.3336 & 31714.415 & 48574.528 & 1827.911 & 4\end{array}$

LLEDGEDFNLGDALDSSNSMQT|OK

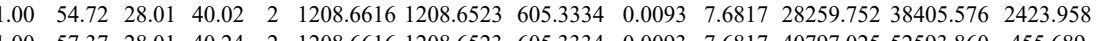
13.352 Y 
GGMGGGLATGIAGGLAGMGGIPN

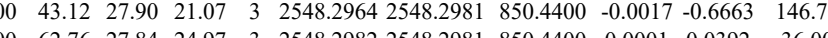

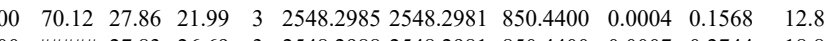

GGMGSGGLATGIAGLLAMGGIONEK $\begin{array}{llllllllll}100 & \text { \#\#\# 27.83 } 26.69 & 3 & 2548.2988 & 2548.2981 & 850.4400 & 0.0007 & 0.2744 & 18.801\end{array}$

GGMGSGLLATGLGGLAGMGGIPNE $\begin{array}{lllllllllll}1.00 & 82.13 & 27.82 & 21.25 & 3 & 2548.3009 & 2548.2981 & 850.4400 & 0.0028 & 1.0975 & 15.305\end{array}$

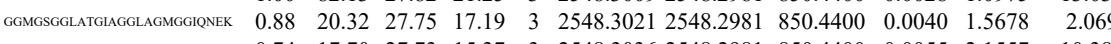

$\begin{array}{lllllllllllll}\text { GGMGSGGLATGIAGLLGMGGioneK } & 1.00 & 74.66 & 27.84 & 23.37 & 3 & 2548.3036 & 2548.2981 & 850.4400 & 0.0055 & 2.1557 & 10.389\end{array}$

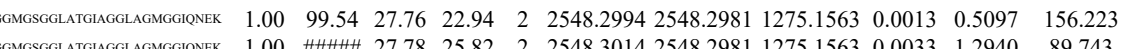

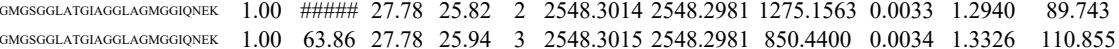
$\begin{array}{llllllllll}1.00 & \# \# \# \# 27.75 & 27.65 & 3 & 2548.3021 & 2548.2981 & 850.4400 & 0.0040 & 1.5678 & 438.759\end{array}$

GMGGSGLLATGAaGGLAGMGGIPN

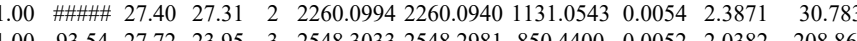

MGSGGLATGIAGGLAGMGGIINEK $\begin{array}{llllllllllll} & 93.54 & 27.72 & 23.95 & 3 & 2548.3033 & 2548.2981 & 850.4400 & 0.0052 & 2.0382 & 208.862\end{array}$ $\begin{array}{llllllllllll}\text { YALQMEQLNGLLLHLESELAQTR } & 0.53 & 38.74 & 26.39 & 51.74 & 3 & 2669.3878 & 2669.3846 & 890.8021 & 0.0032 & 1.1974 & 5.956\end{array}$ LEAEIATYR $\begin{array}{lllllllllllll}0.99 & 35.70 & 28.10 & 28.89 & 2 & 1208.6532 & 1208.6523 & 605.3334 & 0.0009 & 0.7434 & 72.868\end{array}$

LEAEIATYR

VIDDTNITR

STFSTNYR

STFSTNYR

QSVENDIHGLR

VIDDTNITR

QSVENDIHGLR

VIDDTNITR

QSVENDIHGL

$\begin{array}{llllllllll}72.55 & 28.22 & 22.89 & 2 & 1649.8442 & 1649.8416 & 825.9281 & 0.0026 & 1.5740 & 23.354\end{array}$

$\begin{array}{llllllllllll}1.91 & 27.95 & 26.21 & 22.49 & 2 & 1045.5400 & 1045.5404 & 523.7775 & -0.0004 & -0.3818 & 60.474\end{array}$

$\begin{array}{lllllllllll}0.80 & 26.31 & 26.62 & 35.33 & 2 & 1118.5478 & 1118.5478 & 560.2812 & 0.0000 & 0.0000 & 138.710\end{array}$

$\begin{array}{llllllllllll}0.9 & 22.28 & 26.73 & 34.43 & 2 & 1118.5484 & 1118.5478 & 560.2812 & 0.0006 & 0.5354 & 173.518 \\ 0.99 & 30.87 & 27.47 & 18.68 & 3 & 1266.6322 & 1266.6317 & 423.2178 & 0.0005 & 0.3938 & 220.021\end{array}$

$\begin{array}{llllllllllll}0.94 & 29.96 & 26.21 & 22.06 & 2 & 1045.5404 & 1045.5404 & 523.7775 & 0.0000 & 0.0000 & 51.841\end{array}$ $\begin{array}{llllllllllll}0.97 & 29.46 & 25.89 & 23.97 & 2 & 1045.5410 & 1045.5404 & 523.7775 & 0.0006 & 0.5728 & 38.718\end{array}$ $\begin{array}{llllllllllll}0.96 & 27.25 & 27.43 & 15.50 & 3 & 1266.6319 & 1266.6317 & 423.2178 & 0.0002 & 0.1575 & 117.775 \\ 0.81 & 28.50 & 26.27 & 21.06 & 2 & 1045.5396 & 1045.5404 & 523.7775 & -0.0008 & -0.7637 & 16.031\end{array}$ $\begin{array}{lllllllllll}0.97 & 29.69 & 25.89 & 22.01 & 2 & 1045.5410 & 1045.5404 & 523.7775 & 0.0006 & 0.5728 & 19.830\end{array}$ $\begin{array}{llllllllllll}1.00 & 40.85 & 27.43 & 16.95 & 3 & 1266.6319 & 1266.6317 & 423.2178 & 0.0002 & 0.1575 & 78.522\end{array}$ $\begin{array}{lllllllll}7.84 & 26.18 & 3 & 2548.2979 & 2548.2981 & 850.4400 & -0.0002 & -0.0784 & 27.915\end{array}$

STFSTNYR

QSTENDIHGLR $\begin{array}{llllllllllll}0.94 & 30.40 & 26.74 & 33.40 & 2 & 1118.5480 & 1118.5478 & 560.2812 & 0.0002 & 0.1785 & 105.730 \\ 0.94 & 30.48 & 26.73 & 36.21 & 2 & 118.5484 & 1118.5478 & 560.2812 & 0.006 & 0.5354 & 86.537\end{array}$ $\begin{array}{lllllllllll}0.86 & 21.66 & 27.43 & 16.59 & 3 & 1266.6319 & 1266.6317 & 423.2178 & 0.0002 & 0.1575 & 33.537\end{array}$

$\begin{array}{cc}227.161 & 57.188 \\ 33.183 & 7.727\end{array}$
$\begin{array}{llllllllllll}1.00 & 83.25 & 27.89 & 25.62 & 3 & 2548.2970 & 2548.2981 & 850.4400 & -0.0011 & -0.4311 & 0.000\end{array}$

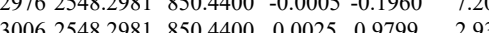
$\begin{array}{llllllllll}6 & 27.64 & 26.10 & 3 & 2564.2924 & 2564.2931 & 855.7716 & -0.0007 & -0.2727 & 5.933\end{array}$ $\begin{array}{llllllllllll}0.82 & 28.76 & 26.21 & 21.46 & 2 & 1045.5398 & 1045.5404 & 523.7775 & -0.0006 & -0.5728 & 28.469\end{array}$ $\begin{array}{lllllllllll}27.81 & 26.21 & 20.39 & 2 & 1045.5404 & 1045.5404 & 523.7775 & 0.0000 & 0.0000 & 10.722\end{array}$

STFSTNYR $\begin{array}{lllllllllll}0.83 & 26.66 & 26.63 & 34.87 & 2 & 1118.5476 & 1118.5478 & 560.2812 & -0.0002 & -0.1785 & 62.867\end{array}$

QSVENDIHGLR $\begin{array}{llllllllllll}0.83 & 26.66 & 26.63 & 34.87 & 2 & 118.5476 & 1118.5478 & 560.2812 & 0.0002 & -0.1785 & 62.867 \\ 1.00 & 50.98 & 27.63 & 33.80 & 2 & 1118.5476 & 1118.5478 & 560.2812 & -0.0002 & -0.1785 & 110.445 \\ 0.94 & 24.97 & 27.43 & 16.17 & 3 & 1266.6318 & 1266.6317 & 634.3231 & 0.0001 & 0.0788 & 14.970\end{array}$

QSVENDIHGLR $\begin{array}{lllllllllll}0.94 & 24.97 & 27.43 & 16.17 & 3 & 1266.6319 & 1266.6317 & 423.2178 & 0.0002 & 0.1575 & 58.542\end{array}$ $\begin{array}{llllllllllll}0.96 & 26.37 & 27.47 & 20.29 & 3 & 1266.6322 & 1266.6317 & 423.2178 & 0.0005 & 0.3938 & 50.984\end{array}$

VIDDTNITR $\begin{array}{lllllllllll}1.00 & 67.64 & 27.43 & 25.75 & 2 & 1266.6318 & 1266.6317 & 634.3231 & 0.0001 & 0.0788 & 19.334\end{array}$ $\begin{array}{llllllllllll}0.98 & 29.36 & 27.43 & 15.98 & 3 & 1266.6319 & 1266.6317 & 423.2178 & 0.0002 & 0.1575 & 80.377\end{array}$ $\begin{array}{lllllllllll}1.00 & 37.11 & 27.43 & 20.67 & 3 & 1266.6319 & 1266.6317 & 423.2178 & 0.0002 & 0.1575 & 83.693\end{array}$ 

$\begin{array}{lllllllllll}1.00 & \text { \#\#\# } 27.84 & 28.88 & 3 & 2548.2982 & 2548.2981 & 850.4400 & 0.0001 & 0.0392 & 22.017 \\ 1.00 & 96.97 & 27.76 & 28.20 & 3 & 2588.2994 & 2548.2981 & 850.4400 & 0.0013 & 0.5095 & 6.636\end{array}$

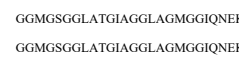

GGMGSGLLATGIAGGLAGMGGienEK

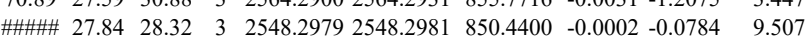
$\begin{array}{llllllllll}1.0 .63 & 27.83 & 24.93 & 3 & 2548.2988 & 2548.2981 & 850.4400 & 0.0007 & 0.2744 & 26.903\end{array}$ GGMGSGGLATGiagGLagmGGione 83.93
3 $\begin{array}{lllllllllll}1.00 & 58.70 & 27.54 & 26.33 & 3 & 2564.2948 & 2564.2931 & 855.7716 & 0.0017 & 0.6622 & 12.628\end{array}$ $\begin{array}{llllllllllll}0.93 & 33.86 & 26.37 & 25.66 & 2 & 1045.5394 & 1045.5404 & 523.7775 & -0.0010 & -0.9546 & 13.767\end{array}$ $\begin{array}{lllllllllll}0.99 & 31.75 & 27.47 & 16.79 & 3 & 1266.6322 & 1266.6317 & 423.2178 & 0.0005 & 0.3938 & 81.598\end{array}$

KVIDDTNITR

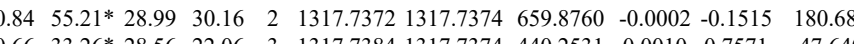

\section{GGMGGGLLATGIAGLLAMGGIPN}

VIDDTNITR

QSVENDIHGLR

QSVENDIHGLR

QSVENDIHGLR

QSVENDIHGLR

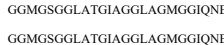

QSVENDIHGL

QSVENDIHGL

QSVENDIHGLR

QSVENDIHGLR

YETELAMR

YETELAMR

VIDDTNITR

QSVENDIHGLR

QSVENDIHGLR

QSVENDIHGLR

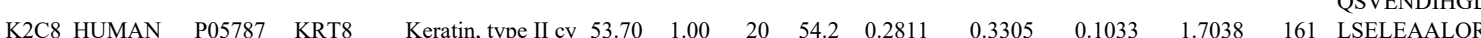

\section{LQEAEIEGLK}

AEAESMYQIK

AEAESMYQIK

ASLEAIADAEQR

ASLEAAIADAEQR

ASLEAAIADAEQR
AQYEDIANR

AQYEDIANR

AEAESMYQIK

AEAESMYQIK

ASLEAAIADAEQR

TEMENEFVLIK

AEAESMYQIK

AEAESMYQIK

LVSESSDVLPK

LVSESSDVLPK

LVSESSDVLPK

LQAEIEGLK

LQAEIEGLK

LQAEIEGLK

LQAEIEGLK

LQAEIEGLK

LQAEIEGLK

LQAEIEGLK

LVSESSDVLPK

LVSESSDVLPK

SLDMDSIIAEVK $\begin{array}{lllllllllll}0.66 & 33.26 * 28.56 & 22.06 & 3 & 1317.7384 & 1317.7374 & 440.2531 & 0.0010 & 0.7571 & 47.640 \\ 1.00 & 96.59 & 27.81 & 25.22 & 3 & 2548.3000 & 25482981 & 850.4400 & 0.0019 & 0.7447 & 24.368\end{array}$ $\begin{array}{llllllllllll}1.00 & \# \text { \#\#\# } 27.81 & 25.94 & 3 & 2548.3000 & 2548.2981 & 850.4400 & 0.0019 & 0.7447 & 20.003 \\ 0.91 & 27.95 & 26.20 & 22.36 & 2 & 1045.5406 & 1045.5404 & 523.7775 & 0.0002 & 0.1909 & 47.220\end{array}$ $\begin{array}{llllllllllll}0.91 & 27.95 & 26.20 & 22.36 & 2 & 1045.5406 & 1045.5404 & 523.7775 & 0.0002 & 0.1909 & 47.220\end{array}$ $\begin{array}{lllllllllll}1.00 & 75.15 & 27.51 & 26.39 & 2 & 1266.6312 & 1266.6317 & 634.3231 & -0.0005 & -0.3941 & 17.319\end{array}$ $\begin{array}{lllllllllll}1.00 & 54.24 & 27.47 & 25.36 & 2 & 1266.6316 & 1266.6317 & 634.3231 & -0.0001 & -0.0788 & 21.698\end{array}$ $\begin{array}{llllllllllll}1.00 & 37.15 & 27.43 & 19.10 & 3 & 1266.6319 & 1266.6317 & 423.2178 & 0.0002 & 0.1575 & 55.252\end{array}$ $\begin{array}{llllllllllll}1.00 & 39.54 & 27.47 & 15.57 & 3 & 1266.6322 & 1266.6317 & 423.2178 & 0.0005 & 0.3938 & 68.504\end{array}$

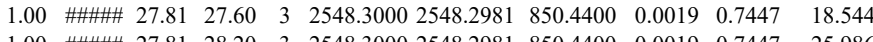
$\begin{array}{lllllllll} & \end{array}$ $\begin{array}{lllllllllll}1.00 & 69.18 & 27.81 & 20.15 & 3 & 2548.3006 & 2548.2981 & 850.4400 & 0.0025 & 0.9799 & 0.000\end{array}$

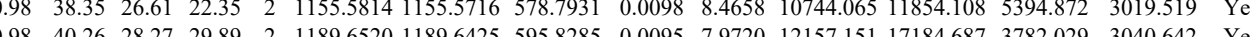
$\begin{array}{lllllllllllllll}0 & 0.26 & 28.27 & 29.89 & 2 & 1189.6520 & 1189.6425 & 595.8285 & 0.0095 & 7.9720 & 12157.151 & 17184.687 & 3782.029 & 3040.642 & \text { Yes } \\ 0.51 & 23.80 & 27.83 & 17.02 & 2 & 1410.7418 & 1410.7337 & 7063741 & 0.0081 & 5.7335 & 1324.866 & 1923.809 & 1382.334 & 1551.835 & \text { Yes }\end{array}$ $\begin{array}{lllllllllllllll}0.50 & 54.81 & 27.80 & 25.45 & 3 & 1410.7423 & 1410.7337 & 471.2518 & 0.0086 & 6.0831 & 18667.293 & 24301007 & 4347.830 & 2194.073 & Y e s\end{array}$

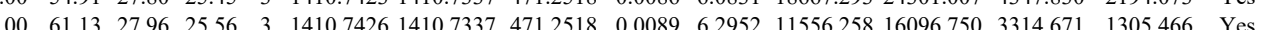
$\begin{array}{llllllllllllllll}1.99 & 4.43 & 27.90 & 28.46 & 2 & 1410.7436 & 1410.7337 & 7063741 & 0.0099 & 7.0076 & 3338.420 & 5292.670 & 986.104 & 1647.823 & \text { Yes }\end{array}$ $\begin{array}{lllllllllllll} & 16.120 & \text { Ycs }\end{array}$ $\begin{array}{lllllllllllll}0.381 & \text { Yes }\end{array}$ $\begin{array}{llllllllllll} & \end{array}$

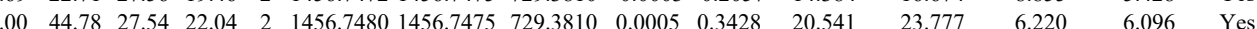

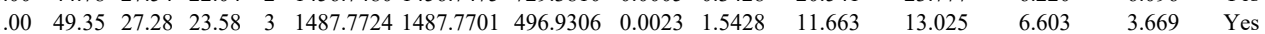

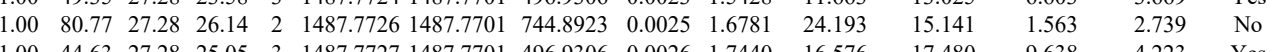

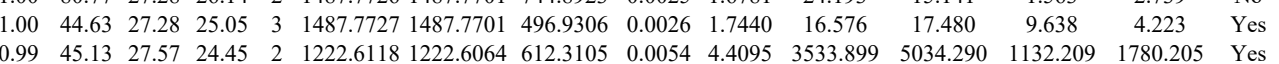
$\begin{array}{lllllllllllllllll}0.99 & 45.13 & 27.57 & 24.45 & 2 & 1222.6118 & 1222.6064 & 612.3105 & 0.0054 & 4.4095 & 3533.89 & 504.290 & 1132.209 & 4780.205 & \text { Yes } \\ 0.94 & 36.41 & 27.48 & 27.28 & 2 & 22.6124 & 1222.64 & 62.3105 & 0.0060 & 4.8995 & 3067.114 & 3786.095 & 1164.790 & 1928.329 & \text { Yes }\end{array}$

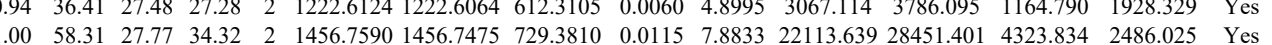
$\begin{array}{llllllllllllllll}100 & 58.59 & 27.76 & 34.72 & 2 & 1456.7592 & 1456.7475 & 729.3810 & 0.0117 & 8.0204 & 14273.938 & 22774.807 & 3348.544 & 1029.988 & \text { Yes }\end{array}$ $\begin{array}{lllllllllllllll}1.00 & 95.46 & 27.36 & 30.45 & 2 & 1487.7712 & 1487.7701 & 744.8923 & 0.0011 & 0.7384 & 279.950 & 492.342 & 116.418 & 0.961 & \text { No }\end{array}$ $\begin{array}{llllllllllllllll}1.00 & 90.28 & 27.30 & 27.47 & 2 & 1487.7718 & 1487.7701 & 744.8923 & 0.0017 & 1.1411 & 462.928 & 576.354 & 163.997 & 36.387 & \text { Yes }\end{array}$

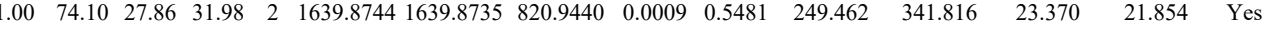
$\begin{array}{lllllllllllllll}1.00 & 57.70 & 27.77 & 35.52 & 2 & 1456.7578 & 1456.7475 & 729.3810 & 0.0103 & 7.0607 & 2245.125 & 2580.212 & 439.969 & 140.284 & \text { Yes }\end{array}$

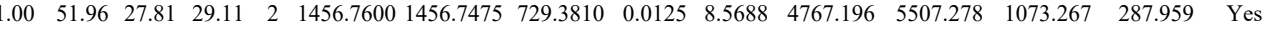
$\begin{array}{lllllllllllllll}1.00 & 51.06 & 26.62 & 34.52 & 2 & 1460.8420 & 4460.8330 & 731.4238 & 0.0090 & 6.1523 & 5410.334 & 6065.832 & 170.781 & 89.180 & \text { Yes }\end{array}$

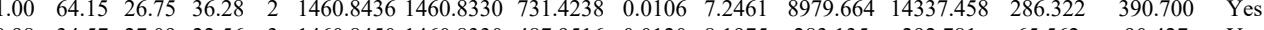
$\begin{array}{lllllllllllllll}0.98 & 34.57 & 27.09 & 22.56 & 3 & 1460.8450 & 1460.8330 & 487.9516 & 0.0120 & 8.1975 & 283.135 & 292.781 & 65.562 & 90.427 & \text { Yes }\end{array}$ $\begin{array}{lllllllllllllll}0.83 & 36.72 & 26.10 & 28.67 & 2 & 1287.7614 & 1287.7642 & 644.8894 & -0.0028 & -2.1709 & 215.164 & 291.867 & 157.908 & 113.024 & \text { Yes }\end{array}$

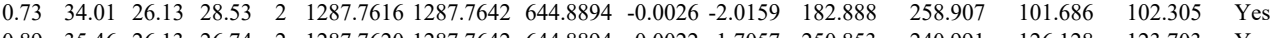

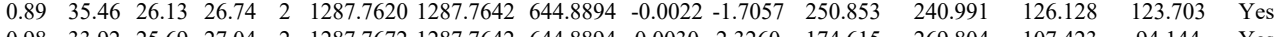

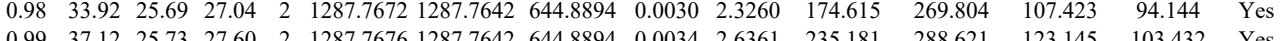

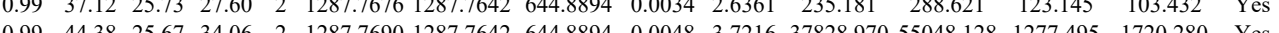
$\begin{array}{llllllllllllllll}0.99 & 44.38 & 25.67 & 34.06 & 2 & 1287.7690 & 1287.7642 & 644.8894 & 0.0048 & 3.7216 & 37828.970 & 55048.128 & 1277.495 & 1720.280 & \text { Yes } \\ 0.99 & 46.99 & 25.81 & 35.56 & 2 & 1287.7700 & 1287.7642 & 644.8894 & 0.0058 & 4.4969 & 71328.233 & \# \# \# \# \# & 1349.151 & 356.035 & \text { Yes }\end{array}$

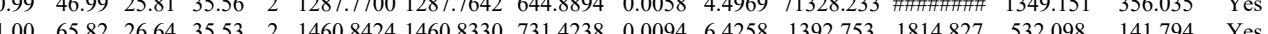
$\begin{array}{lllllllllllllll}1.00 & 65.82 & 26.64 & 35.53 & 2 & 1460.8424 & 1460.8330 & 731.4238 & 0.0094 & 6.4258 & 1392.753 & 1814.827 & 532.098 & 141.794 & \text { Yes } \\ 1.00 & 63.65 & 27.02 & 29.28 & 2 & 1460.8452 & 1460.8330 & 731.4238 & 0.0122 & 83398 & 10566.039 & 15186746 & 393.960 & 408.615 & \text { Yes }\end{array}$

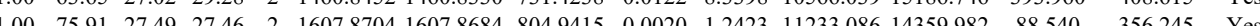
$\begin{array}{lllllllllllllll}1.00 & 74.38 & 27.49 & 27.91 & 2 & 1607.8704 & 1607.8684 & 804.9415 & 0.0020 & 1.2423 & 16628.715 & 25535.956 & 0.000 & 167.780 & \text { No }\end{array}$ 
SYTSGPGSR $\begin{array}{lllllllllllll}0.94 & 27.00 & 26.14 & 22.89 & 2 & 1054.5174 & 1054.5165 & 528.2655 & 0.0009 & 0.8518 & 49.583 & 30.703 & 4.701\end{array}$

SYTSGPGSR

$\begin{array}{ccccccccccccc}0.97 & 29.21 & 26.14 & 19.66 & 2 & 1054.5178 & 1054.5165 & 528.2655 & 0.0013 & 1.2304 & 105.967 & 91.213 & 6.417 \\ 1.00 & 70.85 & 27.45 & 26.18 & 2 & 1607.8696 & 1607.8684 & 804.9415 & 0.0012 & 0.7454 & 2226.616 & 3195.212 & 21.403\end{array}$

SLDMDSIIAEVK

SLDMDSIIAEVK

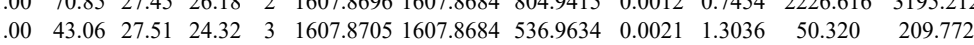

SLDMDSIAEVK

$\begin{array}{lllllllllllll}1.00 & 77.57 & 27.51 & 28.71 & 2 & 1607.8710 & 1607.8684 & 804.9415 & 0.0026 & 1.6150 & 3629.822 & 5743.557 & 160.937\end{array}$

SLDMDSIIAEVK

$\begin{array}{llllllllllllll}1.00 & 37.62 & 27.44 & 22.50 & 3 & 1607.8714 & 1607.8684 & 536.9634 & 0.0030 & 1.8623 & 139.691 & 165.396 & 23.836\end{array}$

LESGMQNMSHTK

LESGMQNMSHTK

$\begin{array}{lllllllllllll}0.68 & 31.11 * 27.47 & 15.11 & 3 & 1778.8915 & 1778.8899 & 593.9706 & 0.0016 & 0.8979 & 6920.627 & 12765.316 & 3721.535 & 223\end{array}$

$\begin{array}{llllllllllll} & 27.69 & 30.35 & 3 & 2080.0786 & 2080.0754 & 694.3657 & 0.0032 & 1.5362 & 211.440 & 258.484 & 88.875\end{array}$

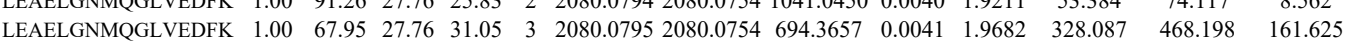

$\begin{array}{llllllllllllll} & 1.00 & 68.21 & 27.46 & 23.65 & 2 & 1607.8702 & 1607.8684 & 804.9415 & 0.0018 & 1.1181 & 796.012 & 908.831 & 106.271 \\ \text { SLDMDSIIAEVK } & 1.00 & 70.48 & 27.46 & 26.99 & 2 & 1607.8702 & 1607.8684 & 804.9415 & 0.0018 & 1.1181 & 458.72 & 848.623 & 60.022\end{array}$

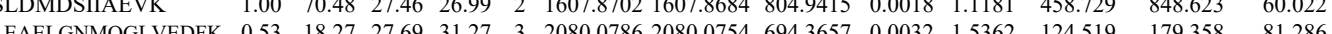

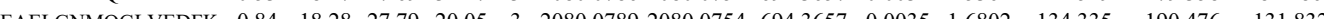

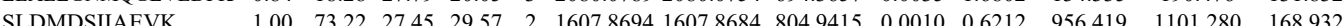

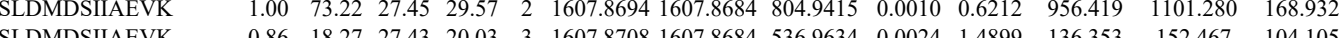

$\begin{array}{llllllllllllll}0.86 & 18.27 & 27.43 & 20.03 & 3 & 1607.8708 & 1607.8684 & 536.9634 & 0.0024 & 1.4899 & 136.353 & 152.467 & 104.105\end{array}$

VSTSGPR

$\begin{array}{lllllllllll}.00 & 61.70 & 23.71 & 74.70 & 4 & 2465.3609 & 2465.3565 & 617.3464 & 0.0044 & 1.7818 & 141.710\end{array}$

$\begin{array}{llllllllllll}0.92 & 30.65 & 28.27 & 27.76 & 2 & 846.4686 & 846.4681 & 424.2413 & 0.0005 & 0.5893 & 111.880 & 1 \\ 1.00 & 73.24 & 27.98 & 77.79 & 2 & 1562.8452 & 1562.8426 & 78.286 & 0.0026 & 1.6615 & 742826 & 8\end{array}$

$213.121 \quad 83.301$

LEGLTDEINFLR

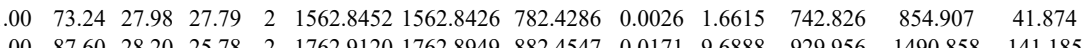

$\begin{array}{lllllllllllllll} & & \end{array}$

$\begin{array}{lllllllllllllll} & & \end{array}$

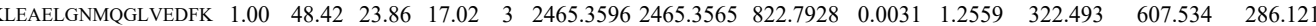

LKLEAELGNMQGLVEDFK

VSTSGPR

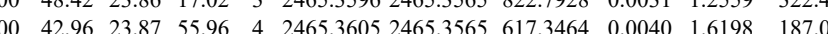

LELTDEINFL

LEGLTDEINFLR

$\begin{array}{llllllllllllll}0.87 & 35.43 & 28.27 & 27.75 & 2 & 846.4692 & 846.4681 & 424.2413 & 0.0011 & 1.2964 & 176.256 & 137.437 & 66.482\end{array}$

LEGLTDEINFLR

LESGMQNMSIHTK

LESGMQNMSIHTK

LKLEAELGNMQG

$\begin{array}{llllllllllllll}1.00 & 78.76 & 27.98 & 31.84 & 2 & 1562.8444 & 1562.8426 & 782.4286 & 0.0018 & 1.1503 & 23017.170 & 27510.753 & 670.832\end{array}$

$\begin{array}{lllllllllllll}.00 & 50.82 & 28.03 & 35.25 & 3 & 1562.8450 & 1562.8426 & 521.9548 & 0.0024 & 1.5327 & 89.042 & 113.219 & 70.393\end{array}$

LQAEIEGLK

LQAEIEGLK

AEAESMYQIK

LVSESSDVLPK

ASLEAAIADAEQR 


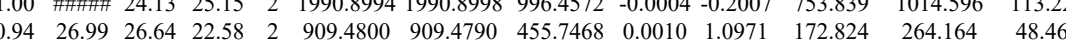

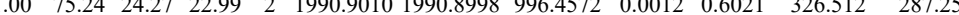
$\begin{array}{lllllllllllll}1.00 & 67.43 & 21.37 & 80.43 & 4 & 4068.1469 & 4068.1436 & 1018.0432 & 0.0033 & 0.8104 & 0.000\end{array}$ $\begin{array}{llllllllllll}0.55 & 13.34 & 26.90 & 19.01 & 3 & 1472.7433 & 1472.7424 & 491.9214 & 0.0009 & 0.6099 & 16.824 \\ 0.57 & 15.84 & 25.94 & 17.89 & 2 & 909.4804 & 909.4790 & 455.7468 & 0.0014 & 1.5359 & 28.847 \\ 0.99 & 46.56 & 27.85 & 26.53 & 2 & 122.7152 & 122.7159 & 637.3652 & 0.007 & 0.5491 & 117.357\end{array}$ $\begin{array}{lllllllllll}0.99 & 46.56 & 27.85 & 26.53 & 2 & 1272.7152 & 1272.7159 & 637.3652 & -0.0007 & -0.5491 & 117.357\end{array}$ $\begin{array}{lllllllllll}0.54 & 15.68 & 26.43 & 27.31 & 2 & 909.4802 & 909.4790 & 455.7468 & 0.0012 & 1.3165 & 47.254\end{array}$ $\begin{array}{llllllllllll}0.96 & 33.62 & 28.07 & 20.45 & 2 & 1272.7156 & 1272.7159 & 637.3652 & -0.0003 & -0.2353 & 70.958\end{array}$ $\begin{array}{llllllllllll}0.99 & 42.99 & 28.10 & 19.09 & 2 & 1272.7162 & 1272.7159 & 637.3652 & 0.0003 & 0.2353 & 75.571 \\ 0.59 & 19.70 & 26.56 & 22.00 & 2 & 909.4794 & 909.4790 & 455.7468 & 0.0004 & 0.4388 & 56.625\end{array}$ $\begin{array}{llllllllllll}0.59 & 19.70 & 26.56 & 22.00 & 2 & 909.4794 & 909.4790 & 455.7468 & 0.0004 & 0.4388 & 56.625 \\ 1.00 & 50.05 & 27.93 & 23.90 & 2 & 1272.7148 & 1272.7159 & 637.3652 & -0.0011 & -0.8629 & 90.116\end{array}$ $\begin{array}{lllllllllll}1.00 & 47.47 & 28.00 & 27.56 & 2 & 1272.7160 & 1272.7159 & 637.3652 & 0.0001 & 0.0784 & 108.23\end{array}$ 


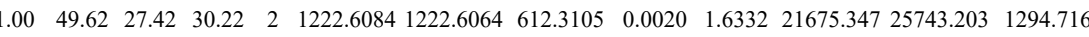
$\begin{array}{llllllllllll}0.98 & 49.28 & 27.73 & 20.65 & 2 & 1456.7446 & 1456.7475 & 729.3810 & -0.0029 & -1.9880 & 49.728\end{array}$ $\begin{array}{lllllllllll}0.97 & 42.84 & 27.77 & 25.88 & 2 & 1456.7454 & 1456.7475 & 729.3810 & -0.0021 & -1.4396 & 78.272\end{array}$ $\begin{array}{lllllllllll}0.98 & 37.05 & 27.56 & 26.18 & 2 & 1456.7472 & 1456.7475 & 729.3810 & -0.0003 & -0.2057 & 58.838\end{array}$

AEAESMYQIK

AEAESMYQIK

AEAESMYQIK $\begin{array}{llllllllllll}0.98 & 36.58 & 27.62 & 24.61 & 2 & 1456.7474 & 1456.7475 & 729.3810 & -0.0001 & -0.0686 & 59.060\end{array}$ $\begin{array}{llllllllllll}0.99 & 42.57 & 27.61 & 21.37 & 2 & 1456.7478 & 1456.7475 & 729.3810 & 0.0003 & 0.2057 & 99.225\end{array}$

AEAESMYQIK $\begin{array}{lllllllllll}0.63 & 21.60 & 27.61 & 21.65 & 2 & 1456.7478 & 1456.7475 & 729.3810 & 0.0003 & 0.2057 & 35.094\end{array}$

AEAESMYQIK $\begin{array}{llllllllllll}1.00 & 45.04 & 27.62 & 22.47 & 2 & 1456.7494 & 1456.7475 & 729.3810 & 0.0019 & 1.3025 & 85.397\end{array}$ $\begin{array}{lllllllllll}1.00 & 53.25 & 27.68 & 17.73 & 2 & 1456.7498 & 1456.7475 & 729.3810 & 0.0023 & 1.5767 & 88.272\end{array}$

AEAESMYQIK

AEAESMYQIK

AEAESMYQIK

$\begin{array}{llllllllllll}1.00 & 46.55 & 27.99 & 23.97 & 2 & 1456.7518 & 1456.7475 & 729.3810 & 0.0043 & 2.9477 & 76.661\end{array}$

80.825

61.387

51.797
27.971
17.049

$\begin{array}{lllllllllllll}1.00 & 47.26 & 27.80 & 29.73 & 2 & 1456.7604 & 1456.7475 & 729.3810 & 0.0129 & 8.8430 & 17615.557 & 295\end{array}$

\begin{tabular}{l}
23.403 \\
6.982 .139 \\
\hline
\end{tabular}

12.203

AEAESMYQIK

ASLEAAIADAEQR

ASLEAAIADAEQR

ASLEAAIADAEQR

TEMENEFVLIK

$\begin{array}{llllllllllllll}1.00 & 49.88 & 27.68 & 27.22 & 3 & 1456.7617 & 1456.7475 & 486.5898 & 0.0136 & 9.3165 & 920.300 & 1268.784 & 1058.079\end{array}$

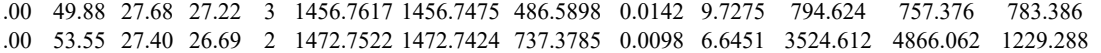
$\begin{array}{lllllllllllll}1.00 & 95.64 & 27.39 & 30.04 & 2 & 1487.7710 & 1487.7701 & 744.8923 & 0.0009 & 0.6041 & 1928.488 & 2779.938 & 412.744\end{array}$ $\begin{array}{llllllllllllll}1.00 & 93.15 & 27.26 & 29.24 & 2 & 1487.7722 & 1487.7701 & 744.8923 & 0.0021 & 1.4096 & 2572.056 & 4468.405 & 687.744\end{array}$

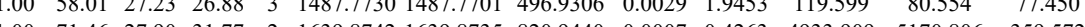

TEMENFEIK

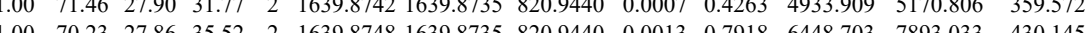

TEMENEFVLIK $\begin{array}{lllllllllll} & \end{array}$

$\begin{array}{llllllllllll}10 & 3.52 & 27.74 & 26.29 & 3 & 1639.8760 & 1639.8735 & 547.6318 & 0.0025 & 1.5217 & 49.363\end{array}$

$\begin{array}{lll}2.644 & 64.902 \\ 37.448 & 31.355 \\ 97.727 & 68.133\end{array}$

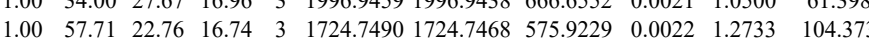

37.448

AAEDDEDDDVDTK

$\begin{array}{lllllllllllll}1.00 & 57.71 & 22.76 & 16.74 & 3 & 1724.7490 & 1724.7468 & 575.9229 & 0.0022 & 1.2733 & 104.373 \\ 1.00 & 91.60 & 22.76 & 21.95 & 2 & 1724.7490 & 1724.7468 & 863.3807 & 0.0022 & 1.2741 & 251.917\end{array}$

AAEDDEDDDVDTK

$\begin{array}{lllllllllll}.00 & 49.24 & 22.74 & 18.55 & 3 & 1724.7493 & 1724.7468 & 575.9229 & 0.0025 & 1.4470 & 75.119\end{array}$

$\begin{array}{llllllllllll}\text { AAEDDEDDDVDTK } & 1.00 & 75.01 & 22.23 & 19.99 & 2 & 1724.7500 & 1724.7468 & 863.3807 & 0.0032 & 1.8532 & 309.942\end{array}$ $\begin{array}{lllllllllllll} & \end{array}$ $\begin{array}{lllllllllllllll}\text { AAEDDEDDDVDTKK } & 0.99 & 38.65 & 27.60 & 16.69 & 3 & 1996.9432 & 1996.9438 & 666.6552 & -0.0006 & -0.3000 & 45.903\end{array}$ $\begin{array}{llllllllllll}\text { AAEDDEDDDVDTKK } & 1.00 & 43.56 & 27.60 & 16.65 & 3 & 1996.9432 & 1996.9438 & 666.6552 & -0.0006 & -0.3000 & 45.894\end{array}$ $\begin{array}{lllllllllllll}\text { AAEDDEDDDVDTKK } & 0.55 & 33.34 & 27.69 & 46.34 & 3 & 1996.9456 & 1996.9438 & 666.6552 & 0.0018 & 0.9000 & 27.813\end{array}$

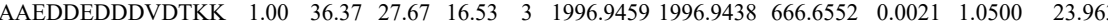
EVVEEAENGR

\begin{tabular}{lllllllllll}
9.95 & 21.93 & 2 & 1274.6260 & 1274.6224 & 638.3185 & 0.0036 & 2.8199 & 1606.286 & 1239.027 & 6688.039 \\
\hline
\end{tabular} $\begin{array}{llllllllllllllll} & \end{array}$ $\begin{array}{lllllllllllllll} & 1.04\end{array}$ $\begin{array}{lllllllllllllll}\text { AAEDDEDDDVDTKK } & 0.98 & 44.35 & 26.92 & 16.77 & 3 & 1996.9387 & 1996.9438 & 666.6552 & -0.0051 & -2.5501 & 89.318\end{array}$ $\begin{array}{llllllllllll}\text { AAEDDEDDDVDTKK } & 0.95 & 39.43 & 26.99 & 19.88 & 3 & 1996.9390 & 1996.9438 & 666.6552 & -0.0048 & -2.4000 & 80.542 \\ \text { AAEDDEDDDVDTKK } & 0.99 & 36.49 & 27.61 & 19.56 & 3 & 1996.9426 & 1996.9438 & 666.6552 & -0.0012 & -0.6000 & 31.933\end{array}$

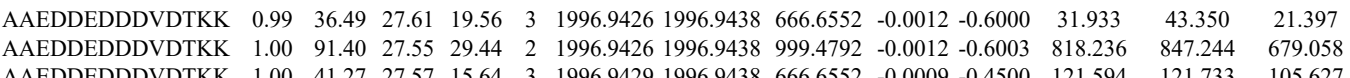
$\begin{array}{llllllllllllll}\text { AAEDDEDDDVDTKK } & 0.99 & 36.49 & 27.61 & 19.56 & 3 & 1996.9426 & 1996.9438 & 666.6552 & -0.0012 & -0.6000 & 31.933 & 43.350 & 21.397 \\ \text { AAEDDEDDDVDTKK } & 1.00 & 91.40 & 27.55 & 29.44 & 2 & 1996.9426 & 1996.9438 & 999.4792 & -0.0012 & -0.6003 & 818.236 & 847.244 & 679.058 \\ \text { AAEDDEDDDVDTKK } & 1.00 & 41.27 & 27.57 & 15.64 & 3 & 1996.9429 & 1996.9438 & 666.6552 & -0.0009 & -0.4500 & 121.594 & 121.733 & 105.627\end{array}$ $\begin{array}{lllllllllllll} & \text { AAADDD }\end{array}$

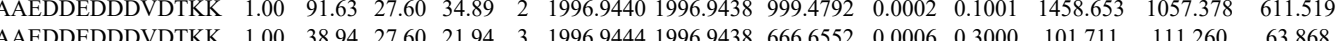
$\begin{array}{llllllllllllll}\text { AAEDDEDDDVDTKK } & 1.00 & 53.59 & 27.63 & 16.68 & 3 & 1996.9447 & 1996.9438 & 666.6552 & 0.0009 & 0.4500 & 120.011 & 122.031 & 68.136\end{array}$

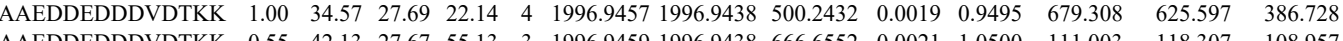
$\begin{array}{lllllllllllll} & \text { AAEDP.957 }\end{array}$ 


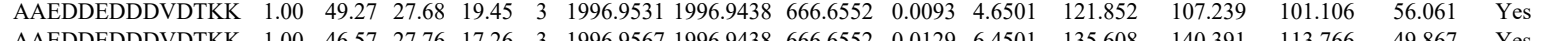

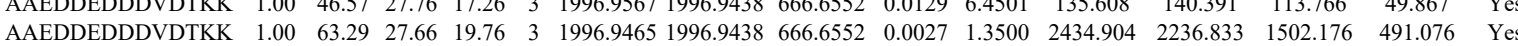

$\begin{array}{llllllllllllllll}1.00 & 48.62 & 22.74 & 28.00 & 3 & 1843.0822 & 1843.0780 & 615.3666 & 0.0042 & 2.2751 & 1866.622 & 1486.796 & 1538.299 & 1176.912 & \text { Yes }\end{array}$ $\begin{array}{llllllllllllllllll} & 1176.912 & \text { Yes } & \end{array}$

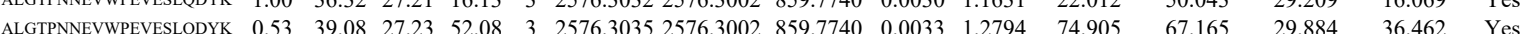
$\begin{array}{lllllllllllllllll}\text { SPEVLLGSAR } & 1.00 & 49.51 & 27.01 & 31.53 & 2 & 1171.6794 & 1171.6683 & 586.8414 & 0.0111 & 9.4573 & 3698.327 & 2891.847 & 3723.170 & 3404.846 & \text { Yes }\end{array}$ $\begin{array}{llllllllllllllll}\text { WKPGSLASHVK } & 1.00 & 27.56 & 21.40 & 17.50 & 4 & 1640.9881 & 1640.9728 & 411.2505 & 0.0153 & 9.3008 & 40000.784 & 33356.715 & 1342.496 & 984.406 & \text { Yes }\end{array}$

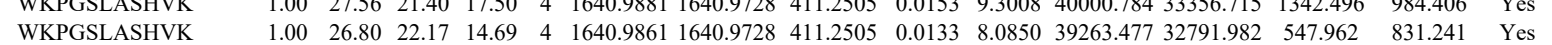

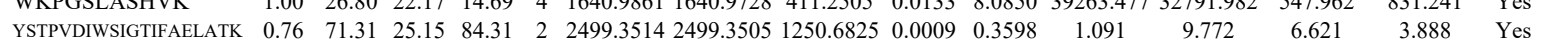

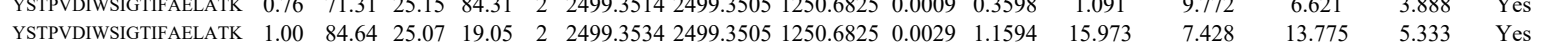

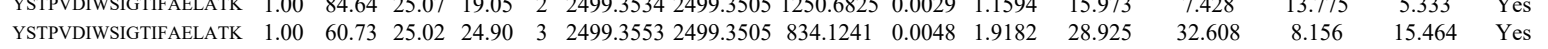

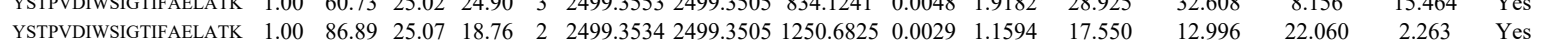

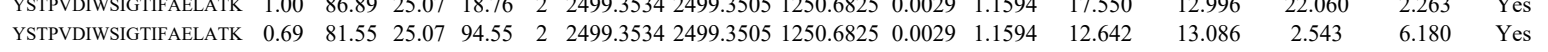

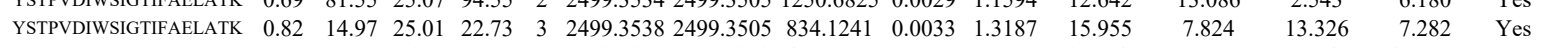
$\begin{array}{llllllllllllllll}\text { AFGIPIR } & 0.88 & 26.99 & 26.67 & 16.32 & 2 & 916.5618 & 916.5616 & 459.2881 & 0.0002 & 0.2177 & 26108.415 & 22158.290 & 1087.455 & 400.909 & \text { Yes }\end{array}$ AFGIPIR

\section{NLDENGLDLLSK}

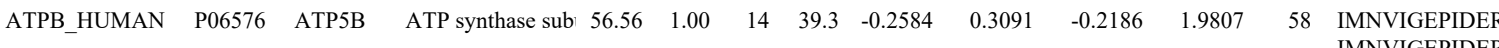
$\begin{array}{lllllllllllllllll}0.85 & 25.77 & 23.34 & 19.78 & 2 & 916.5702 & 916.5616 & 459.2881 & 0.0086 & 9.3622 & 17453.601 & 13435.022 & 1206.528 & 221.384 & \text { Yes }\end{array}$ $\begin{array}{ccccccccccccccc}1.00 & 57.34 & 27.79 & 34.76 & 2 & 1617.8852 & 1617.8817 & 809.9481 & 0.0035 & 2.1606 & 1698.894 & 1483.195 & 59.899 & 245.453 & \text { Yes } \\ 1.00 & 55.02 & 27.90 & 25.77 & 2 & 1528.8062 & 1528.8041 & 765.4093 & 0.0021 & 1.3718 & 164.009 & 136.578 & 26.697 & 48.953 & \text { Yes }\end{array}$ $\begin{array}{lllllllllllllll}1.00 & 53.63 & 27.93 & 27.22 & 2 & 1528.8066 & 1528.8041 & 765.4093 & 0.0025 & 1.6331 & 479.248 & 600.303 & 37.346 & 43.744 & \text { Yes } \\ 1.00 & 61.24 & 27.87 & 28.24 & 2 & 1528.8048 & 1528.8041 & 765.4093 & 0.0007 & 0.4573 & 1285.598 & 1304.814 & 15.769 & 29.058 & \text { Yes }\end{array}$ IMNVIGEPIDER IMNVIGEPIDER TIAMDGTEGLVR IMNVIGEPIDER TINTER

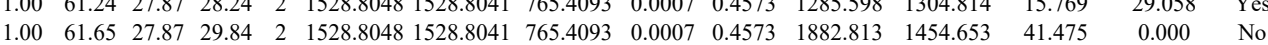
$\begin{array}{llllllllllllllll}1.00 & 60.46 & 28.46 & 34.18 & 2 & 1405.7480 & 1405.7357 & 703.8751 & 0.0123 & 8.7373 & 11927.708 & 9767.753 & 226.513 & 571.415 & \text { Yes }\end{array}$ $\begin{array}{lllllllllllllll}1.00 & 73.05 & 28.54 & 31.65 & 2 & 1405.7482 & 1405.7357 & 703.8751 & 0.0125 & 8.8793 & 11798.383 & 10068.516 & 291.838 & 634.804 & \text { Yes }\end{array}$ $\begin{array}{lllllllllllllll}1.00 & 55.27 & 27.79 & 27.41 & 2 & 1528.8026 & 1528.8041 & 765.4093 & -0.0015 & -0.9799 & 2130.682 & 1744.304 & 183.179 & 148.316 & \text { Yes }\end{array}$ $\begin{array}{lllllllllllllll}1.00 & 54.91 & 27.90 & 30.18 & 2 & 1528.8046 & 1528.8041 & 765.4093 & 0.0005 & 0.3266 & 1030.601 & 865.730 & 25.272 & 43.737 & \text { Yes } \\ \end{array}$ $\begin{array}{lllllllllllllllll} & \end{array}$ $\begin{array}{lllllllllllllllll} & 1323.528 & 862.285 & \text { Yes }\end{array}$ $\begin{array}{llllllllllllllllll} & \text { VLDSGAPIK } & 0.99 & 43.33 & 25.08 & 26.82 & 2 & 1186.7256 & 1186.7165 & 594.3655 & 0.0091 & 7.6552 & 14025.558 & 11520.639 & 3247.074 & 2204.647 & \text { Yes }\end{array}$ $\begin{array}{lllllllllllllllll} & \text { VLDSGAPIK } & 0.99 & 43.82 & 25.07 & 34.77 & 2 & 1186.7258 & 1186.7165 & 594.3655 & 0.0093 & 7.8234 & 26131.425 & 19636.835 & 3573.524 & 3374.692 & \text { Yes }\end{array}$ $\begin{array}{lllllllllllllllllll}\text { TIAMDGTEGLVR } & 1.00 & 56.47 & 28.62 & 26.84 & 2 & 1405.7468 & 1405.7357 & 703.8751 & 0.0111 & 7.8849 & 8552.843 & 6357.572 & 1927.697 & 1100.819 & \text { Yes }\end{array}$ $\begin{array}{llllllllllllllll} & \end{array}$ $\begin{array}{lllllllllllllllll}\text { IMDPNIVGSEHYDVAR } & 1.00 & 73.63 & 27.13 & 25.02 & 3 & 1958.9827 & 1958.9642 & 653.9953 & 0.0185 & 9.4291 & 2134.374 & 1896.099 & 624.967 & 431.511 & \text { Yes }\end{array}$ $\begin{array}{llllllllllllllll}\text { DQEGQDVLLFIDNIFR } & 1.00 & 80.75 & 27.38 & 18.29 & 2 & 2065.0614 & 2065.0602 & 1033.5374 & 0.0012 & 0.5805 & 109.419 & 74.374 & 381.639 & 282.140 & \text { No }\end{array}$ $\begin{array}{lllllllllllllll}\text { DQEGQDVLLFIDNIFR } & 1.00 & \text { \#\#\#\# } 27.45 & 27.19 & 2 & 2065.0634 & 2065.0602 & 1033.5374 & 0.0032 & 1.5481 & 39.680 & 24.170 & 87.753 & 45.948 & \text { No }\end{array}$

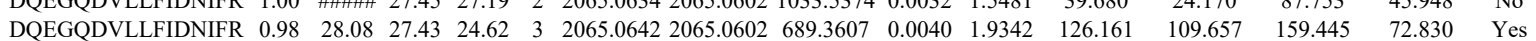
$\begin{array}{llllllllllllllll}\text { DQEGQDVLLFIDNIFR } & 0.87 & 20.56 & 27.33 & 18.32 & 3 & 2065.0657 & 2065.0602 & 689.3607 & 0.0055 & 2.6595 & 117.820 & 83.154 & 108.994 & 70.280 & \text { Yes }\end{array}$

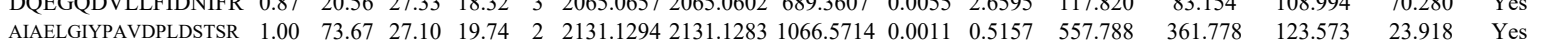
$\begin{array}{lllllllllllllllll}\text { AIAELGIYPAVDPLDSTSR } & 1.00 & 81.51 & 27.10 & 25.55 & 2 & 2131.1294 & 2131.1283 & 1066.5714 & 0.0011 & 0.5157 & 928.132 & 1033.416 & 282.413 & 0.000 & \text { No }\end{array}$ $\begin{array}{llllllllllllllll}\text { AIAELGIYPAVDPLDSTSR } & 0.73 & 15.05 & 27.08 & 17.53 & 3 & 2131.1314 & 2131.1283 & 711.3834 & 0.0031 & 1.4526 & 24.836 & 24.335 & 95.982 & 10.877 & \text { No }\end{array}$ $\begin{array}{lllllllllllllllll}\text { DQEGQDVLLFIDNIFR } & 1.00 & 79.25 & 27.38 & 19.67 & 2 & 2065.0614 & 2065.0602 & 1033.5374 & 0.0012 & 0.5805 & 53.118 & 34.802 & 277.776 & 187.517 & \text { No }\end{array}$ $\begin{array}{llllllllllllllll}\text { DQEGQDVLLFIDNIFR } & 1.00 & 85.54 & 27.45 & 25.08 & 2 & 2065.0634 & 2065.0602 & 1033.5374 & 0.0032 & 1.5481 & 72.019 & 31.325 & 284.222 & 209.042 & \text { No }\end{array}$ $\begin{array}{llllllllllllllll}\text { DQEGQDVLLFIDNIFR } & 1.00 & 44.19 & 27.46 & 24.77 & 3 & 2065.0639 & 2065.0602 & 689.3607 & 0.0037 & 1.7891 & 88.459 & 109.693 & 88.443 & 80.677 & \text { No }\end{array}$ $\begin{array}{llllllllllllllll}\text { DQEGQDVLLFIDNIFR } & 1.00 & 51.01 & 27.42 & 23.03 & 3 & 2065.0645 & 2065.0602 & 689.3607 & 0.0043 & 2.0792 & 84.954 & 74.553 & 91.205 & 41.066 & \text { Yes }\end{array}$ $\begin{array}{llllllllllllllllll}\text { AIAELGIYPAVDPLDSTSR } & 1.00 & 83.74 & 27.10 & 28.12 & 2 & 2131.1294 & 2131.1283 & 1066.5714 & 0.0011 & 0.5157 & 171.892 & 130.604 & 41.537 & 42.804 & \text { Yes }\end{array}$ $\begin{array}{lllllllllllllllll}\text { AIAELGIYPAVDPLDSTSR } & 1.00 & 81.86 & 27.10 & 27.84 & 2 & 2131.1294 & 2131.1283 & 1066.5714 & 0.0011 & 0.5157 & 407.399 & 247.012 & 48.477 & 7.703 & \text { Yes }\end{array}$

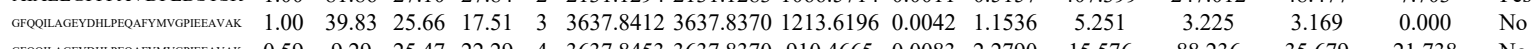

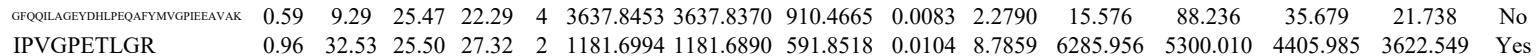

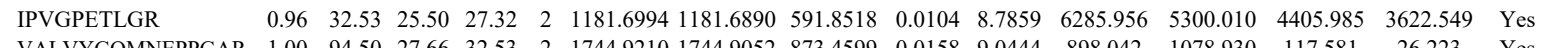

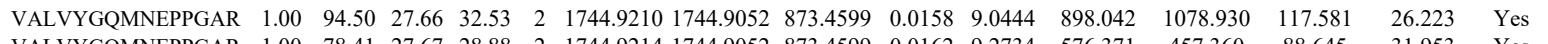

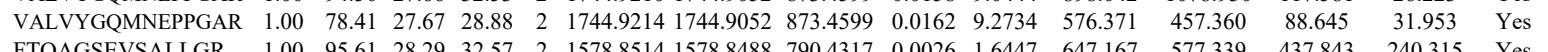

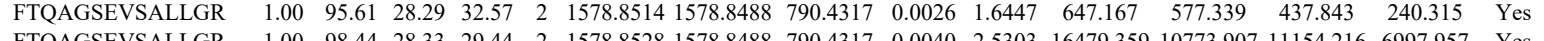

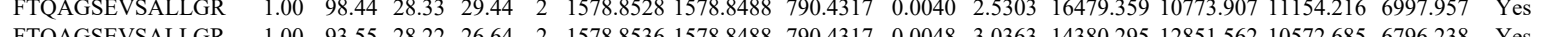

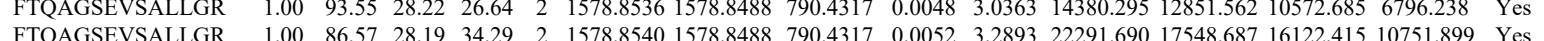
$\begin{array}{lllllllllllllllllllll}\text { FTQAGSEVSALLGR } & 1.00 & 86.57 & 28.19 & 34.29 & 2 & 1578.8540 & 1578.8488 & 790.4317 & 0.0052 & 3.2893 & 22291.690 & 17548.687 & 16122.415 & 10751.899 & \text { Yes } \\ \text { FTQAGSEVSALLGR } & 1.00 & 74.01 & 28.29 & 23.91 & 2 & 1578.8512 & 1578.8488 & 790.4317 & 0.0024 & 1.5182 & 3976236 & 3219.041 & 3167.769 & 1872843 & \text { Yes }\end{array}$ $\begin{array}{lllllllllllllllll}\text { FTQAGSEVSALLGR } & 1.00 & 72.35 & 28.19 & 25.25 & 2 & 1578.8554 & 1578.8488 & 790.4317 & 0.0066 & 4.1749 & 4246.115 & 2931.161 & 3356.081 & 1951.451 & \text { Yes }\end{array}$ 
TVLIMELINNVAK

TVLIMELINNVAK

TVLIMELINNVAK

FLSQPFQVAEVFTGHMGK FLSQPFQVAEVFTGHMG

VALTGLTVAEYFR

VALTGLTVAEYFR

VALTGLTVAEYFR

TVLIMELINNVAK

TVLIMELINNVAK

VALTGLTVAEYFR

VALTGLTVAEYFR

VALTGLTVAEYFR

VALTGLTVAEYFR

VALTGLTVAEYF

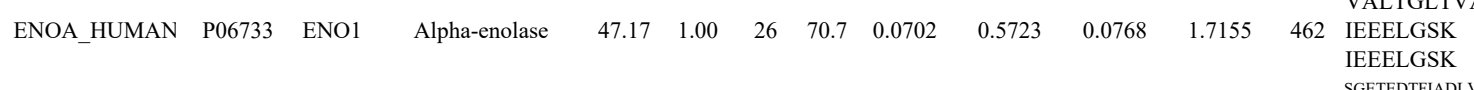

YDLDFK

YDLDFK

YDLDFK

YDLDFK

YDLDFK
YDLDFK
YDLDFK

YDLDFK
YDLDFK

YDLDFK
YDLDFK

YDLDFK
YDLDFK

YDLDFK
YDLDFK

YDLDFK
YDLDFK

YDLDFK

YDLDFK
YDLDFK

YDLDFK
YDLDFK

YDLDFK

YDLDFK
YDLDFK

YDLDFK

YDLDFK

YDLDFK

YDLDFK

YDLDFK

YDLDFK

AVEHINK

DYPVVSIEDPFDQDDWGAWQK

DYPVVSIEDPFDQDDWGAWQK
DYPVVIIEDPFDQDDWGAWQK

YDLDFK

YDLDFK

YDLDFK

YDLDFK

YDLDFK
YDLDFK

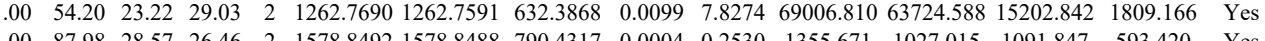

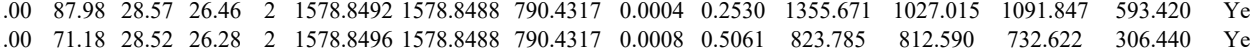
$\begin{array}{lllllllllllllll}1.00 & 41.60 & 21.79 & 22.79 & 3 & 1745.0410 & 1745.0364 & 582.6861 & 0.0046 & 2.6315 & 166.819 & 171.427 & 60.911 & 30.359 & \text { Yes }\end{array}$

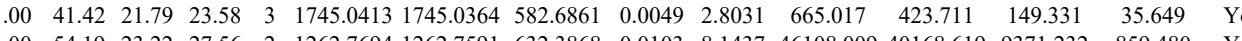

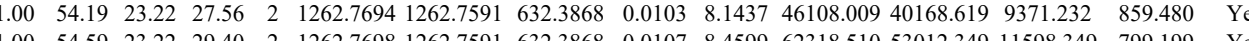
$\begin{array}{lllllllllllllll}1.00 & 54.59 & 23.22 & 29.40 & 2 & 1262.7698 & 1262.7591 & 632.3868 & 0.0107 & 8.4599 & 62318.510 & 53012.349 & 11598.349 & 799.199 & \text { Yes }\end{array}$ $\begin{array}{lllllllllllllll}1.00 & 82.82 & 22.01 & 34.47 & 2 & 1745.0392 & 1745.0364 & 873.5255 & 0.0028 & 1.6027 & 587.800 & 384.437 & 54.128 & 17.843 & \text { Yes } \\ 1.00 & 86.76 & 22.01 & 36.96 & 2 & 1745.0392 & 1745.0364 & 873.5255 & 0.0028 & 1.6027 & 959.459 & 717.517 & 222.850 & 50.370 & \text { Yes }\end{array}$ $\begin{array}{llllllllllllllll}1.00 & 86.76 & 22.01 & 36.96 & 2 & 1745.0392 & 1745.0364 & 873.5255 & 0.0028 & 1.6027 & 959.459 & 717.517 & 222.850 & 50.370 & \text { Yes } \\ 0.99 & 23.16 & 21.90 & 14.73 & 3 & 1745.0398 & 1745.0364 & 582.6861 & 0.0034 & 1.9450 & 169.297 & 99.270 & 66.947 & 39.873 & \text { Yes }\end{array}$

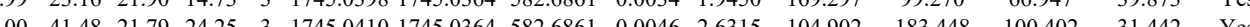
$\begin{array}{lllllllllllllll}1.07 & 71.59 & 26.97 & 21.22 & 3 & 2310.2116 & 2310.2075 & 771.0764 & 0.0041 & 1.7724 & 10892.780 & 10055541 & 1978.738 & 270.111 & \text { Yes }\end{array}$

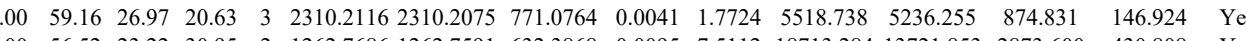

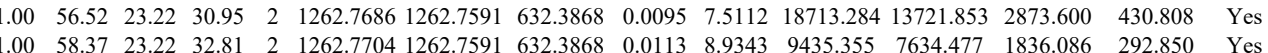
$\begin{array}{llllllllllllllll}1.00 & 88.51 & 21.85 & 43.66 & 2 & 1745.0388 & 1745.0364 & 873.5255 & 0.0024 & 1.3737 & 954.809 & 939.404 & 128.743 & 25.963 & \text { Yes }\end{array}$ $\begin{array}{llllllllllllllll}1.00 & 85.11 & 21.85 & 34.04 & 2 & 1745.0388 & 1745.0364 & 8735255 & 0.0024 & 1.3737 & 1155.064 & 1018.767 & 25.534 & 15.892 & \text { Yes }\end{array}$ $\begin{array}{llllllllllllllll}1.00 & 48.91 & 21.79 & 25.80 & 3 & 1745.0410 & 1745.0364 & 582.6861 & 0.0046 & 2.6315 & 826.726 & 949.606 & 84.554 & 87.965 & \text { Yes }\end{array}$ $\begin{array}{llllllllllllllll}1.00 & 45.60 & 21.79 & 25.78 & 3 & 1745.0413 & 1745.0364 & 582.6861 & 0.0049 & 2.8031 & 286.433 & 452.986 & 69.615 & 54.595 & \text { Yes }\end{array}$ $\begin{array}{lllllllllllllll}1.00 & 66.87 & 26.93 & 20.55 & 3 & 2310.2107 & 2310.2075 & 771.0764 & 0.0032 & 1.3833 & 3874.043 & 4130.125 & 701.808 & 0.000 & \text { No }\end{array}$ $\begin{array}{llllllllllllllll} & \end{array}$ $\begin{array}{lllllllllllllll}0.88 & 17.78 & 26.21 & 17.80 & 3 & 1582.8865 & 1582.8841 & 528.6353 & 0.0024 & 1.5133 & 87.664 & 150.731 & 388.502 & 54.537 & \text { No }\end{array}$

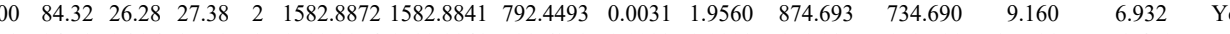

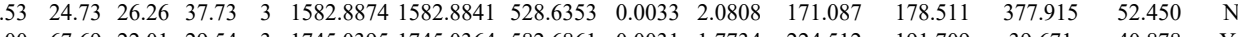

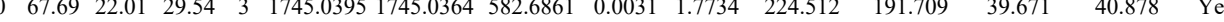

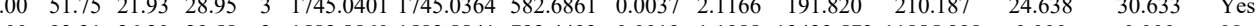
$\begin{array}{llllllllllllllll}1.00 & 93.21 & 26.20 & 29.58 & 2 & 1582.8860 & 1582.8841 & 792.4493 & 0.0019 & 1.1988 & 13423.573 & 11885.998 & 0.000 & 0.000 & \text { No }\end{array}$ $\begin{array}{lllllllllllllllll}1.00 & 77.89 & 26.20 & 28.63 & 2 & 1582.8860 & 1582.8841 & 792.4493 & 0.0019 & 1.1988 & 2006.257 & 2550.489 & 82.392 & 19.628 & \text { Yes }\end{array}$

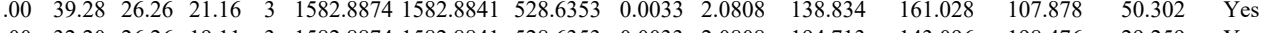
$\begin{array}{llllllllllllllll}1.00 & 32.20 & 26.26 & 19.11 & 3 & 1582.8874 & 1582.8841 & 528.6353 & 0.0033 & 2.0808 & 194.713 & 143.096 & 198.476 & 29.259 & \text { Yes } \\ 1.00 & 92.21 & 26.21 & 25.70 & 2 & 1582866 & 1582841 & 792.4493 & 0.025 & 1.5774 & 62.508 & 671.512 & 15.256 & 6.036 & \text { Yes }\end{array}$

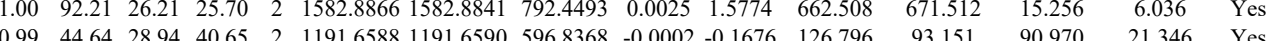

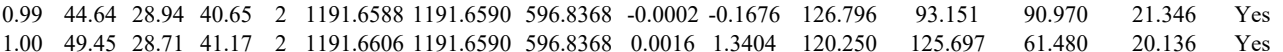

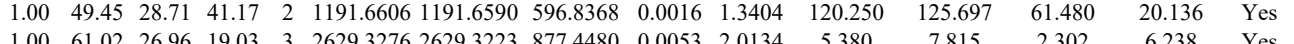

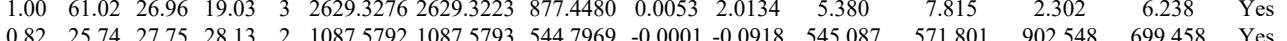

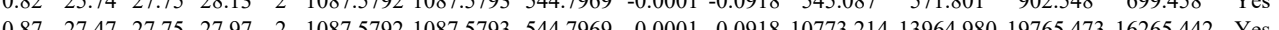

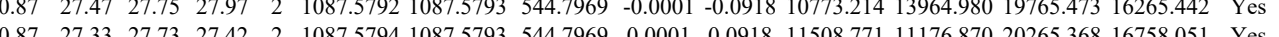
$\begin{array}{lllllllllllllll}0.81 & 25.56 & 27.73 & 27.43 & 2 & 1087.5796 & 1087.5793 & 544.7969 & 0.0003 & 0.2753 & 392.193 & 441.316 & 721.571 & 538.060 & \text { Yes }\end{array}$

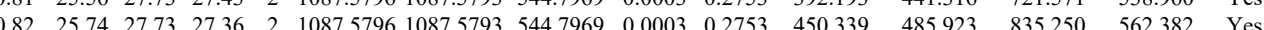

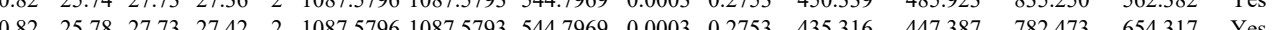

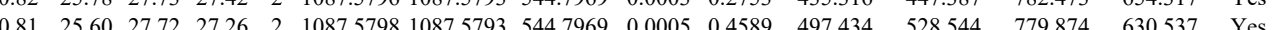
$\begin{array}{llllllllllllllll}0.51 & 19.47 & 27.72 & 26.64 & 2 & 1087.5798 & 1087.5793 & 544.7969 & 0.0005 & 0.4589 & 517.155 & 627.544 & 1009.278 & 659.826 & \text { Yes }\end{array}$ $\begin{array}{lllllllllllllll}0.55 & 20.21 & 27.72 & 26.40 & 2 & 1087.5798 & 1087.5793 & 544.7969 & 0.0005 & 0.4589 & 380.617 & 466.032 & 711.416 & 608.163 & \text { Yes }\end{array}$

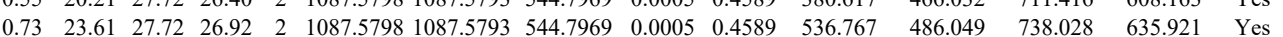
$\begin{array}{lllllllllllllll}0.55 & 20.19 & 27.72 & 26.41 & 2 & 1087.5798 & 1087.5793 & 544.7969 & 0.0005 & 0.4589 & 439.670 & 423.125 & 637.844 & 546.297 & \text { Yes }\end{array}$ $\begin{array}{lllllllllllllll}0.90 & 25.70 & 27.72 & 27.56 & 2 & 1087.5800 & 1087.5793 & 544.7969 & 0.0007 & 0.6424 & 514.863 & 550.744 & 847.784 & 653.929 & \text { Yes }\end{array}$ $\begin{array}{llllllllllllllll}0.68 & 19.68 & 27.72 & 26.98 & 2 & 1087.5802 & 1087.5793 & 544.7969 & 0.0009 & 0.8260 & 467.823 & 527.031 & 831.459 & 700.296 & \text { Yes }\end{array}$ $\begin{array}{llllllllllllllll}0.71 & 20.31 & 27.72 & 26.48 & 2 & 1087.5802 & 1087.5793 & 544.7969 & 0.0009 & 0.8260 & 518.489 & 536.344 & 858.217 & 658.394 & \text { Yes }\end{array}$ $\begin{array}{lllllllllllllll}0.73 & 20.62 & 27.72 & 26.83 & 2 & 1087.5802 & 1087.5793 & 544.7969 & 0.0009 & 0.8260 & 576.065 & 592.533 & 929.908 & 797.874 & \text { Yes }\end{array}$ $\begin{array}{llllllllllllllll}0.89 & 25.59 & 27.72 & 27.28 & 2 & 1087.5802 & 1087.5793 & 544.7969 & 0.0009 & 0.8260 & 440.583 & 453.338 & 730.471 & 511.800 & \text { Yes }\end{array}$ $\begin{array}{llllllllllllllll}0.93 & 27.34 & 27.72 & 27.50 & 2 & 1087.5802 & 1087.5793 & 544.7969 & 0.0009 & 0.8260 & 509.602 & 540.366 & 750.699 & 622.804 & \text { Yes }\end{array}$ $\begin{array}{lllllllllllllll}0.68 & 19.65 & 27.72 & 27.06 & 2 & 1087.5802 & 1087.5793 & 544.7969 & 0.0009 & 0.8260 & 401.539 & 417.520 & 673.789 & 563.148 & \text { Yes }\end{array}$ $\begin{array}{lllllllllllllll}0.72 & 20.45 & 27.72 & 26.60 & 2 & 1087.5802 & 1087.5793 & 544.7969 & 0.0009 & 0.8260 & 489.655 & 574.062 & 750.053 & 658.102 & \text { Yes }\end{array}$ $\begin{array}{lllllllllllllll}0.72 & 20.36 & 27.61 & 26.48 & 2 & 1087.5804 & 1087.5793 & 544.7969 & 0.0011 & 1.0095 & 493.795 & 545.414 & 846.556 & 673.089 & \text { Yes }\end{array}$ $\begin{array}{lllllllllllllll}0.90 & 25.62 & 27.61 & 27.48 & 2 & 1087.5804 & 1087.5793 & 544.7969 & 0.0011 & 1.0095 & 407.523 & 578.741 & 768.961 & 611.726 & \text { Yes }\end{array}$ $\begin{array}{llllllllllllllll}0.67 & 26.12 & 27.42 & 27.72 & 2 & 1087.5870 & 1087.5793 & 544.7969 & 0.0077 & 7.0668 & 37993.133 & 41755.950 & 72012.668 & 60865.658 & \text { Yes }\end{array}$ $\begin{array}{lllllllllllllll}0.70 & 25.94 & 27.40 & 27.60 & 2 & 1087.5884 & 1087.5793 & 544.7969 & 0.0091 & 8.3517 & 18787.811 & 20475.980 & 40567.543 & 33741.676 & \text { Yes }\end{array}$ $\begin{array}{llllllllllllllll}1.00 & 39.60 & 25.48 & 33.99 & 2 & 1097.6444 & 1097.6437 & 549.8291 & 0.0007 & 0.6366 & 1968.867 & 2235.661 & 1405.971 & 456.346 & \text { Yes }\end{array}$

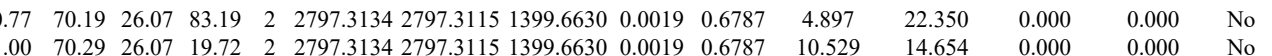

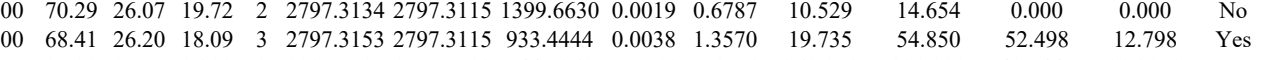
$\begin{array}{lllllllllllllll}0.80 & 25.29 & 27.75 & 26.93 & 2 & 1087.5790 & 1087.5793 & 544.7969 & -0.0003 & -0.2753 & 360.151 & 331.220 & 490.440 & 386.203 & \text { Yes }\end{array}$ $\begin{array}{lllllllllllllll}0.51 & 19.59 & 27.75 & 25.69 & 2 & 1087.5792 & 1087.5793 & 544.7969 & -0.0001 & -0.0918 & 321.572 & 372.385 & 449.955 & 363.814 & \text { Yes } \\ 0.81 & 25.65 & 27.73 & 27.81 & 2 & 1087.5794 & 1087.5793 & 5447969 & 0.0001 & 0.0918 & 598.693 & 520.762 & 821.517 & 644.227 & \text { Yes }\end{array}$ $\begin{array}{lllllllllllllll}0.81 & 25.65 & 27.73 & 27.81 & 2 & 1087.5794 & 1087.5793 & 544.7969 & 0.0001 & 0.0918 & 598.693 & 520.762 & 821.517 & 644.227 & \text { Yes } \\ 0.87 & 27.57 & 27.73 & 28.54 & 2 & 1087.5796 & 1087.5793 & 544.7969 & 0.0003 & 0.2753 & 444.843 & 413.631 & 593.391 & 504.763 & \text { Yes }\end{array}$

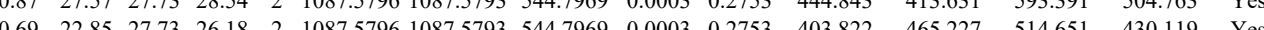

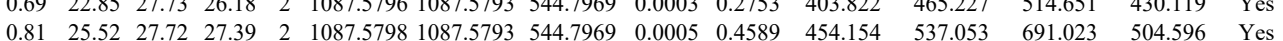

Table S-3 page 68 of 499 

$\begin{array}{lllllllllllll}\text { SGETEDTFIADLVVGLCTGQIK } & 1.00 & 42.57 & 26.97 & 16.63 & 3 & 2629.3252 & 2629.3223 & 877.4480 & 0.0029 & 1.1017 & 9.193\end{array}$ $\begin{array}{lllllllllllll} & \text { HEDTFIADLVVGLCTGIK } & 1.00 & 67.96 & 27.02 & 20.39 & 3 & 2629.3285 & 2629.3223 & 877.4480 & 0.0062 & 2.3553 & 11.367\end{array}$ 


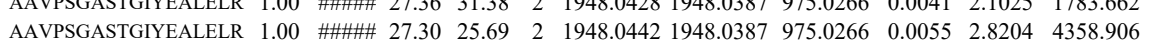
$\begin{array}{llllllllllllll}\text { FTASAGIQVVGDDLTVTNPK } & 0.53 & 44.89 & 25.89 & 57.89 & 3 & 2320.2550 & 2320.2518 & 774.4245 & 0.0032 & 1.3774 & 14.231\end{array}$ $\begin{array}{lllllllllllll}\text { SGETEDTFIADLVVGLCTGQIK } & 1.00 & 67.60 & 26.80 & 17.48 & 3 & 2629.3234 & 2629.3223 & 877.4480 & 0.0011 & 0.4179 & 16.122\end{array}$ $\begin{array}{llllllllllll}\text { SGETEDTFIADLVVGLCTGOIK } & 1.00 & 52.26 & 26.77 & 18.74 & 3 & 2629.3237 & 2629.3223 & 877.4480 & 0.0014 & 0.5318 & 17.959\end{array}$

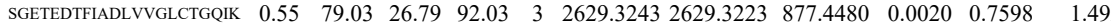

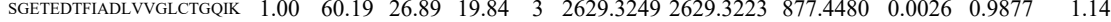

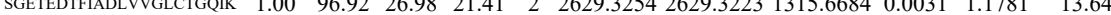

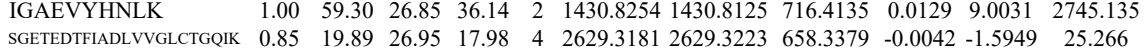

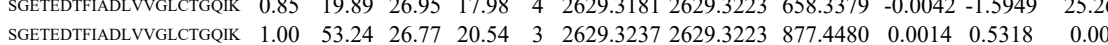
$\begin{array}{llllllllllll}\text { SGETEDTFIADLVVGLCTGIKK } & 0.55 & 45.03 & 26.78 & 58.03 & 3 & 2629.3240 & 2629.3223 & 877.4480 & 0.0017 & 0.6458 & 0.000\end{array}$ $\begin{array}{llllllllllll}\text { SGETEDTFIADLVVGLCTGQIK } & 1.00 & 42.19 & 26.80 & 16.06 & 3 & 2629.3246 & 2629.3223 & 877.4480 & 0.0023 & 0.8737 & 16.350\end{array}$ $\begin{array}{llllllllllll}\text { SGETEDTFIADLVVGLCTGQIK } & 0.53 & 57.81 & 26.89 & 70.81 & 3 & 2629.3249 & 2629.3223 & 877.4480 & 0.0026 & 0.9877 & 26.948\end{array}$ $\begin{array}{llllllllllll}\text { SGETEDTFIADLVVGLCTGQIK } & 1.00 & 53.43 & 26.89 & 19.53 & 3 & 2629.3249 & 2629.3223 & 877.4480 & 0.0026 & 0.9877 & 37.302\end{array}$ $\begin{array}{llllllllllll}\text { SGETEDTFIADLVVGLCTGQIK } & 1.00 & 67.12 & 26.89 & 18.12 & 3 & 2629.3249 & 2629.3223 & 877.4480 & 0.0026 & 0.9877 & 6.150\end{array}$ $\begin{array}{llllllllllll}\text { SGETEDTFIADLVVGLCTGIIK } & 1.00 & 43.36 & 26.89 & 18.49 & 3 & 2629.3249 & 2629.3223 & 877.4480 & 0.0026 & 0.9877 & 3.510\end{array}$ $\begin{array}{llllllllllll}\text { SGETEDTFIADLVVGLCGGK } & 1.00 & 53.07 & 26.89 & 17.87 & 3 & 2629.3249 & 2629.3223 & 877.4480 & 0.0026 & 0.9877 & 7.534\end{array}$

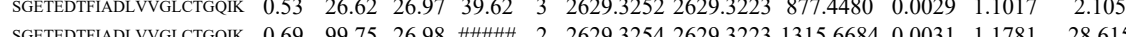

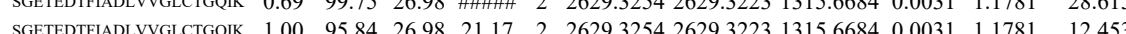

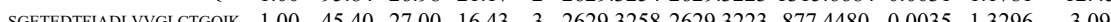

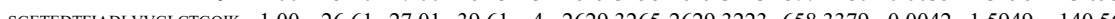
$\begin{array}{lllllllllllll}\text { SGETEDTFLDLVVGLCTGOIK } & 1.00 & 72.27 & 26.97 & 19.72 & 3 & 2629.3270 & 2629.3223 & 877.4480 & 0.0047 & 1.7855 & 31.453\end{array}$ $\begin{array}{lllllllllllll}\text { SGETEDTPIDLVYGLCTGOKK } & 1.00 & 28.01 & 26.80 & 41.01 & 4 & 2629.3321 & 2629.3223 & 658.3379 & 0.0098 & 3.7215 & 47.034\end{array}$ $\begin{array}{lllllllllllll}\text { SGETEDTFIDDLVGLCTGOIK } & 1.00 & 97.35 & 26.79 & 19.33 & 2 & 2629.3234 & 2629.3223 & 1315.6684 & 0.0011 & 0.4180 & 24.792\end{array}$ $\begin{array}{lllllllllllll}\text { SGETEDTFIDLVVGLCTGOIK } & 0.69 & 83.24 & 26.98 & 96.24 & 2 & 2629.3254 & 2629.3223 & 1315.6684 & 0.0031 & 1.1781 & 13.840\end{array}$ $\begin{array}{llllllllllll}\text { SGETEDTFIADLVVGLCTGOIK } & 0.53 & 25.66 & 66.98 & 38.66 & 3 & 2629.3255 & 2629.3223 & 877.4480 & 0.0032 & 1.2156 & 4.628\end{array}$ $\begin{array}{lllllllllllll}\text { SGETEDTFIADLVVGLCTGQIK } & 1.00 & 55.26 & 27.02 & 18.66 & 3 & 2629.3285 & 2629.3223 & 877.4480 & 0.0062 & 2.3553 & 79.870\end{array}$ $\begin{array}{llllllllllllll}\text { SGETEDTFIADLVVGLCTGIIK } & 1.00 & 49.51 & 26.86 & 17.02 & 3 & 2629.3303 & 2629.3223 & 877.4480 & 0.0080 & 3.0391 & 0.000\end{array}$ TIAPALVSK $\begin{array}{llllllllllll}1.00 & 45.68 & 21.67 & 16.26 & 2 & 1186.7644 & 1186.7529 & 594.3837 & 0.0115 & 9.6738 & 61435.262 & \\ & & \end{array}$

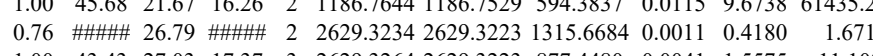
\begin{tabular}{llllllllllll} 
SGETEDTFIADLVVGLCTGOIK & 1.00 & 78.56 & 26.96 & 19.79 & 3 & 2629.3264 & 2629.3223 & 877.4480 & 0.0041 & 1.5575 & 11.109 \\
\hline
\end{tabular}

0.0998 .327930491 .223 


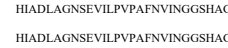

HIADLGGNEEVILVVAANVINGGSHAC

VVIGMDVAASEFFR

VVIGMDVAASEFFR

VVIGMDVAASEFFR

VVIGMDVAASEFFR

VVIGMDVAASEFFR

VVIGMDVAASEFFR

VVIGMDVAASEFFR

VVIGMDVAASEFFR

VVIGMDVAASEFFR

VVIGMDVAASEFFR

VVIGMDVAASEFFR

VVIGMDVAASEFFR

VVIGMDVAASEFFR

VVIGMDVAASEFFR

VVIGMDVAASEFFR
VVIGMDVAASEFFR

VVIGMDVAASEFFR
VVIGMDVAASEFFR

VVIGMDVAASEFFR
VVIGMDVAASEFFR

VVIGMDVAASEFFR
VVIGMDVAASEFFR

VVIGMDVAASEFFR

VVIGMDVAASEFFR

VVIGMDVAASEFFR

$\begin{array}{llllllllllll} & & \end{array}$

$\begin{array}{llllllllllll} & 0.768 .78 & 2 & 1683.8796 & 1683.8776 & 842.9461 & 0.0020 & 1.1863 & 194.171 & 264.142\end{array}$

\begin{tabular}{llllllllllll}
1.00 & 7.82 & 8.10 & 26.78 & 2 & 1683.8796 & 1683.8776 & 842.946 & 0.0020 & 1.1863 & 194.171 & 264.142 \\
1.00 & 93.34 & 28.14 & 19.70 & 3 & 1683.8797 & 1683.8776 & 562.2998 & 0.0021 & 1.2449 & 137.066 & 174.286 \\
\hline
\end{tabular}

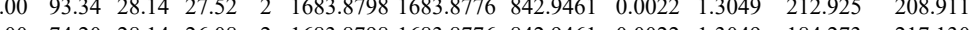

$\begin{array}{llllllllllll}1.00 & 93.34 & 28.14 & 27.52 & 2 & 1683.8798 & 1683.8776 & 842.9461 & 0.0022 & 1.3049 & 212.925 & 208.911\end{array}$

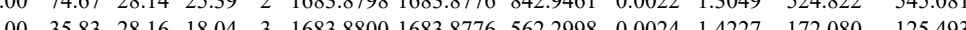

$\begin{array}{llllllllllll}1.00 & 75.94 & 28.16 & 21.49 & 2 & 1683.8800 & 1683.8776 & 842.9461 & 0.0024 & 1.4236 & 407.565 & 466.230\end{array}$

$\begin{array}{llllllllllllll}.00 & 80.45 & 28.16 & 26.65 & 2 & 1683.8800 & 1683.8776 & 842.9461 & 0.0024 & 1.4236 & 354.491 & 419.822\end{array}$

$\begin{array}{llllllllllll}1.00 & 73.13 & 28.16 & 24.04 & 2 & 1683.8800 & 1683.8776 & 842.9461 & 0.0024 & 1.4236 & 681.395 & 1123.378\end{array}$

$\begin{array}{llllllllllll}1.00 & 74.64 & 28.10 & 25.04 & 2 & 163.8800 & 1683.8776 & 842.9461 & 0.0024 & 1.4236 & 37.557 & 289.379\end{array}$

$\begin{array}{llllllllllll}1.00 & 75.23 & 28.10 & 26.01 & 2 & 1683.8802 & 1683.8776 & 842.9461 & 0.0026 & 1.5422 & 417.974 & 446.714\end{array}$

$\begin{array}{lllllllllllll}1.00 & 64.06 & 28.10 & 21.94 & 2 & 1683.8802 & 1683.8776 & 842.9461 & 0.0026 & 1.5422 & 262.758 & 398.765\end{array}$

$\begin{array}{lllllllllllll}100 & 81.43 & 28.10 & 31.24 & 2 & 1683.8802 & 1683.8776 & 842.9461 & 0.0026 & 1.5422 & 79.211\end{array}$

$\begin{array}{lllllllllllll}0.99 & 28.33 & 28.10 & 17.65 & 3 & 1683.8803 & 1683.8776 & 562.2998 & 0.0027 & 1.6006 & 125.817\end{array}$

$\begin{array}{llllllllllll}0.61 & 14.05 & 28.10 & 21.60 & 3 & 1683.8803 & 1683.8776 & 562.2998 & 0.0027 & 1.6006 & 184.150\end{array}$

$\begin{array}{llllllllllll}.99 & 31.17 & 28.10 & 18.52 & 3 & 1683.8803 & 1683.8776 & 562.2998 & 0.0027 & 1.6006 & 166.138\end{array}$

$\begin{array}{lllllllllllll}0.96 & 23.98 & 28.10 & 15.34 & 3 & 1683.8803 & 1683.8776 & 562.2998 & 0.0027 & 1.6006 & 158.728 \\ 0.84 & 18.52 & 28.10 & 16.35 & 3 & 1683803 & 1683.876 & 562.2998 & 0.0027 & 1.6006 & 130.678\end{array}$

$\begin{array}{lllllllllllll}0.84 & 18.52 & 28.10 & 16.35 & 3 & 1683.8803 & 1683.8776 & 562.2998 & 0.0027 & 1.6006 & 130.678 & 13 \\ 1.00 & 37.83 & 28.10 & 15.58 & 3 & 1683.8803 & 16838776 & 562.2998 & 0.0027 & 1.006 & 113.015 & 12\end{array}$

$\begin{array}{lllllllllllll}1.00 & 78.03 & 28.10 & 21.58 & 3 & 1683.8803 & 1683.8776 & 562.2998 & 0.0027 & 1.6006 & 113.015 & \\ 1.00 & 22.49 & 28 & 1683.8804 & 1683.8776 & 842.9461 & 0.0028 & 1.6608 & 704.681 & 720 .\end{array}$

$\begin{array}{lllllllllll}1.00 & 92.49 & 28.12 & 22.31 & 2 & 1683.8804 & 1683.8776 & 842.9461 & 0.0028 & 1.6608 & 1078.467\end{array}$

$\begin{array}{llllllllllll}1.00 & 80.68 & 28.12 & 23.20 & 2 & 1683.8804 & 1683.8776 & 842.9461 & 0.0028 & 1.6608 & 155.586 & 21\end{array}$

$\begin{array}{lllllllllllll}0.62 & 28.08 & 18.14 & 3 & 1683.8806 & 1683.8776 & 562.2998 & 0.0030 & 1.7784 & 143.104 & 98.336\end{array}$

$\begin{array}{lllllllllllll}0.99 & 30.38 & 28.08 & 23.37 & 3 & 1683.8806 & 1683.8776 & 562.2998 & 0.0030 & 1.7784 & 138.333 & 100.974 \\ 1.00 & 74.78 & 28.08 & 25.41 & 2 & 1683.8806 & 1683.8776 & 842.9461 & 0.0030 & 1.7795 & 429.038 & 473.205\end{array}$

$\begin{array}{llllllllllll}1.00 & 74.78 & 28.08 & 25.41 & 2 & 1683.8806 & 1633.8776 & 842.9461 & 0.0030 & 1.7795 & 429.038 & 473.205 \\ 1.00 & 74.16 & 28.08 & 25.41 & 2 & 1683.8806 & 1683.8776 & 842.9461 & 0.0030 & 1.7795 & 1019.079 & 1191.418\end{array}$

$\begin{array}{llllllllllll}.00 & 87.95 & 28.08 & 23.53 & 2 & 1683.8806 & 1683.8776 & 842.9461 & 0.0030 & 1.7795 & 151.311 & 171.146\end{array}$

$\begin{array}{lllllllllllll}.00 & 40.95 & 28.09 & 22.21 & 3 & 1683.8809 & 1683.8776 & 562.2998 & 0.0033 & 1.9562 & 144.767 & 119.03\end{array}$

$\begin{array}{llllllllllll}1.00 & 76.00 & 28.18 & 27.13 & 2 & 1683.8810 & 1683.8776 & 842.9461 & 0.0034 & 2.0167 & 580.030 & 674.549 \\ 1 & 1683.8810 & 1683.8776 & 842.9461 & 0.0034 & 2.0167 & 439.462 & 426.459\end{array}$

$\begin{array}{lllllllllllll}0.98 & 26.94 & 28.21 & 17.73 & 3 & 1683.8812 & 1683.8776 & 562.2998 & 0.0036 & 2.1341 & 139.120 & 167.267\end{array}$

$\begin{array}{lllllllllllll}1.00 & 67.01 & 28.18 & 22.21 & 2 & 1683.8812 & 1683.8776 & 842.9461 & 0.0036 & 2.1354 & 547.644 & 543.428\end{array}$

$\begin{array}{llllllllllll}16.40 & 28.18 & 25.10 & 2 & 1683.8812 & 1683.8776 & 842.9461 & 0.0036 & 2.1354 & 1467.320 & 966.270 \\ 1.00 & 74.71 & 28.18 & 25.50 & 2 & 1683.8816 & 1683.8776 & 842.9461 & 0.0040 & 2.3726 & 623.807 & 651.858\end{array}$

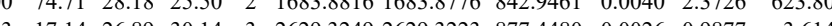
$\begin{array}{lllllllllllll}63.99 & 27.00 & 76.99 & 3 & 2629.3258 & 2629.3223 & 877.4480 & 0.0035 & 1.3296 & 3.549\end{array}$ $\begin{array}{llllllllllll}9.81 & 24.31 & 14.65 & 4 & 3298.7653 & 3298.7666 & 825.6989 & -0.0013 & -0.3936 & 35.619\end{array}$ $\begin{array}{llllllllllll}1.00 & 19.98 & 24.27 & 16.21 & 4 & 3298.7677 & 3298.7666 & 825.6989 & 0.0011 & 0.3331 & 204.138 & 321\end{array}$ $\begin{array}{lllllllllll}00 & 16.93 & 24.27 & 14.56 & 4 & 3298.7681 & 3298.7666 & 825.6989 & 0.0015 & 0.4542 & 26.249\end{array}$ $\begin{array}{llllllllllll}100 & 65.75 & 24.22 & 17.53 & 3 & 3298.7692 & 3298.7666 & 1100.5961 & 0.0026 & 0.7875 & 95.081\end{array}$ $\begin{array}{llllllllllll}1.00 & 75.61 & 28.14 & 26.89 & 2 & 1683.8784 & 1683.8776 & 842.9461 & 0.0008 & 0.4745 & 102.063 & 10\end{array}$ $\begin{array}{llllllllllll}95 & 25.05 & 28.22 & 17.33 & 3 & 1683.8788 & 1683.8776 & 562.2998 & 0.0012 & 0.7114 & 116.224\end{array}$ $\begin{array}{lllllllllllll}1.00 & 64.26 & 28.23 & 20.39 & 2 & 1683.8790 & 1683.8776 & 842.9461 & 0.0014 & 0.8304 & 36.133\end{array}$ $\begin{array}{llllllllllll}1.00 & 93.86 & 28.08 & 29.32 & 2 & 1683.8792 & 1683.8776 & 842.9461 & 0.0016 & 0.9491 & 1154.603\end{array}$ $\begin{array}{lllllllllll}1.00 & 79.05 & 28.08 & 25.18 & 2 & 1683.8792 & 1683.8776 & 842.9461 & 0.0016 & 0.9491 & 118.225 \\ 1.00 & 36.76 & 28.08 & 23.24 & 3 & 1683.8794 & 1683.8776 & 5622998 & 0.0018 & 1.0670 & 75.645\end{array}$ $\begin{array}{lllllllllll}1.00 & 79.72 & 28.09 & 25.74 & 2 & 1683.8794 & 1683.8776 & 842.9461 & 0.0018 & 1.0677 & 256.728\end{array}$ $\begin{array}{llllllllllll}1.00 & 95.40 & 28.09 & 27.03 & 2 & 1683.8794 & 1683.8776 & 842.9461 & 0.0018 & 1.0677 & 100.022 & 9\end{array}$ $\begin{array}{llllllllllll}1.00 & 80.23 & 28.09 & 21.62 & 2 & 1683.8794 & 1683.8776 & 842.9461 & 0.0018 & 1.0677 & 1397.413 \\ 1.00 & 77.94 & 28.09 & 20.32 & 2 & 1683.8794 & 1683.8776 & 842.9461 & 0.0018 & 1.0677 & 54.620\end{array}$ $\begin{array}{lllllllllllll}1.00 & 81.82 & 28.10 & 21.91 & 2 & 1683.8796 & 1683.8776 & 842.9461 & 0.0020 & 1.1863 & 79.603\end{array}$ $\begin{array}{llllllllllll}.00 & 67.68 & 28.10 & 20.76 & 2 & 1683.8796 & 1683.8776 & 842.9461 & 0.0020 & 1.1863 & 46.502\end{array}$ $\begin{array}{lllllllllllll}1.00 & 52.91 & 28.14 & 20.94 & 2 & 1683.8798 & 1683.8776 & 842.9461 & 0.0022 & 1.3049 & 2067.344 & 2\end{array}$ $\begin{array}{llllllllllll}0.97 & 25.66 & 28.16 & 16.98 & 3 & 1683.8800 & 1683.8776 & 562.2998 & 0.0024 & 1.4227 & 140.582 \\ 1.00 & 75.96 & 28.10 & 24.47 & 2 & 1683.8802 & 1683.8776 & 842.9461 & 0.0026 & 1.5422 & 481.652\end{array}$ $\begin{array}{llllllllllll}0.99 & 3.96 & 28.10 & 24.47 & 2 & 1683.8802 & 1683.8776 & 842.9461 & 0.0026 & 1.5422 & 481.652 \\ 0.98 & 23.51 & 3 & 1683.8803 & 1683.8776 & 5622998 & 0.0027 & 1.6006 & 76.778\end{array}$

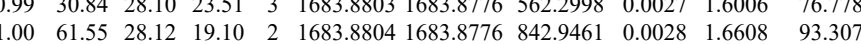

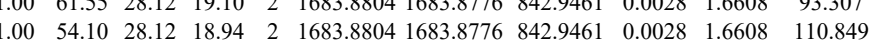
$\begin{array}{llllllllllll}1.00 & 75.63 & 28.08 & 22.86 & 2 & 1683.8806 & 1683.8776 & 842.9461 & 0.0030 & 1.7795 & 84.495\end{array}$ $\begin{array}{llllllllllll}1.00 & 82.05 & 28.09 & 20.36 & 2 & 1683.8808 & 1683.8776 & 842.9461 & 0.0032 & 1.8981 & 27.555 \\ 1.00 & 78.48 & 28.18 & 25.35 & 2 & 1683.8810 & 1683.8776 & 842.9461 & 0.0034 & 2.0167 & 240.050\end{array}$ $\begin{array}{llllllllllll}1.00 & 78.48 & 28.18 & 25.35 & 2 & 1683.8810 & 1683.8776 & 842.9461 & 0.0034 & 2.0167 & 240.050 \\ 1.00 & 83.88 & 28.18 & 26.21 & 2 & 1683.8810 & 1683.8776 & 842.9461 & 0.0034 & 2.0167 & 516.08\end{array}$ $\begin{array}{llllllllllll}1.00 & 83.88 & 28.18 & 26.21 & 2 & 1683.8810 & 1683.8776 & 842.9461 & 0.0034 & 2.0167 & 516.081\end{array}$ $\begin{array}{llllllllllll}1.00 & 71.03 & 28.18 & 20.95 & 2 & 1683.8812 & 1683.8776 & 842.9461 & 0.0036 & 2.1354 & 191.155 & 256.273\end{array}$

\section{(2.761}

332 
GLCTGQIK $\begin{array}{llllllllllll}1.00 & 53.22 & 26.89 & 21.92 & 3 & 2629.3249 & 2629.3223 & 877.4480 & 0.0026 & 0.9877 & 11.292 & 9.980\end{array}$ $\begin{array}{llllllllllll}1.00 & 48.50 & 26.89 & 18.76 & 3 & 2629.3249 & 2629.3223 & 877.4480 & 0.0026 & 0.9877 & 11.741\end{array}$ $\begin{array}{lllllllllll}1.00 & 16.12 & 24.03 & 29.12 & 4 & 3298.7713 & 3298.7666 & 825.6989 & 0.0047 & 1.4230 & 22.760\end{array}$

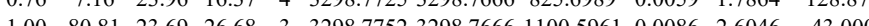

HADDLANEEVILVPAANVINGGSSACC)

$\begin{array}{lllllllllllll}\text { HIADLAGNEVILPVAANVINGGSHAGNK } & 1.00 & 68.41 & 23.98 & 23.54 & 3 & 3298.7782 & 3298.7666 & 1100.5961 & 0.0116 & 3.5132 & 51.319 \\ \text { VVIGMDVAASEFFR } & 1.00 & 52.74 & 28.24 & 26.76 & 2 & 1683.8788 & 1683.8776 & 842.9461 & 0.0012 & 0.7118 & 16.476 \\ \text { VVIGMDVAASEFFR } & 1.00 & 88.07 & 28.09 & 26.33 & 2 & 1683.8794 & 1683.8776 & 842.9461 & 0.0018 & 1.0677 & 111.238\end{array}$ $\begin{array}{lllllllllll}.00 & 68.41 & 23.98 & 23.54 & 3 & 3298.7782 & 3298.7666 & 1100.5961 & 0.0116 & 3.5132 & 51.319\end{array}$

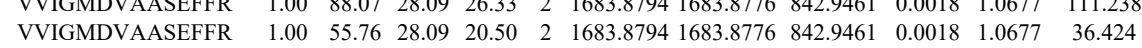

$\begin{array}{lllllllllll}1.00 & 55.76 & 28.09 & 20.50 & 2 & 1683.8794 & 1683.8776 & 842.9461 & 0.0018 & 1.0677 & 36.424 \\ 1.00 & 66.51 & 28.18 & 29.60 & 2 & 1683.8810 & 1683.8776 & 842.9461 & 0.0034 & 2.0167 & 35.844\end{array}$ $\begin{array}{lllllllllll}1.00 & 72.28 & 25.98 & 85.28 & 4 & 3260.5801 & 3260.5793 & 816.1521 & 0.0008 & 0.2451 & 20.319\end{array}$

SGETEDTFADLVVGLLCGQIKTGA $\begin{array}{lllllllllll}1.00 & 35.52 & 25.98 & 15.65 & 4 & 3260.5805 & 3260.5793 & 816.1521 & 0.0012 & 0.3676 & 12.838\end{array}$

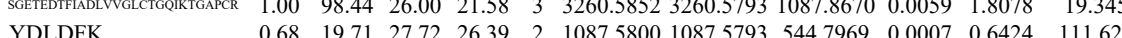

YDLDFK

IEEELGSK $\begin{array}{llllllllllll}0.68 & 19.71 & 27.72 & 26.39 & 2 & 1087.5800 & 1087.5793 & 544.7969 & 0.0007 & 0.6424 & 111.627 & \\ 0.99 & 45.82 & 28.71 & 41.04 & 2 & 1191.6606 & 1191.6590 & 596.8368 & 0.0016 & 1.3404 & 234.205\end{array}$ $\begin{array}{lllllllllll}0.99 & 45.82 & 28.71 & 41.04 & 2 & 1191.6606 & 1191.659 & 596.8368 & 0.0016 & 1.3404 & 234.205 \\ 0.99 & 44.89 & 29.16 & 40.69 & 2 & 1191.6616 & 1191.6590 & 5968368 & 0.0026 & 2.1781 & 213669\end{array}$

IEEELGSK $\begin{array}{llllllllllll}\text { LMIEMDGTENK } & 0.99 & 36.13 & 27.64 & 32.01 & 3 & 1567.7842 & 1567.7829 & 523.6016 & 0.0013 & 0.8276 & 43.959 \\ \text { SGETEDTFIADLVVGLCTGIIK } & 1.00 & 56.65 & 26.78 & 19.35 & 3 & 2629.3231 & 2629.3223 & 877.4480 & 0.0008 & 0.3039 & 2.546\end{array}$ $\begin{array}{llllllllllll}0.95 & 34.04 & 28.73 & 39.82 & 2 & 1247.6984 & 1247.6965 & 624.8555 & 0.0019 & 1.5203 & 9.15\end{array}$ $\begin{array}{llllllllllll}\text { SGETEDTFIADLVVGLCTGIK } & 1.00 & 59.70 & 26.82 & 17.02 & 3 & 2629.3312 & 2629.3223 & 877.4480 & 0.0089 & 3.3810 & 3.412\end{array}$ GVPLYR
YNQLLR

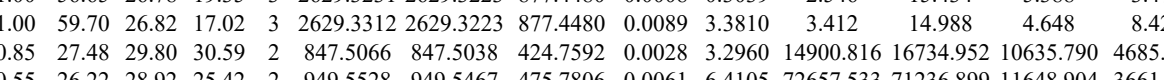

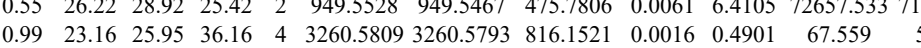

YNQLLR $\begin{array}{lllllllllllll}0.58 & 26.16 & 28.37 & 25.28 & 2 & 949.5512 & 949.5467 & 475.7806 & 0.0045 & 4.7290 & 68937.250 & 71692.694\end{array}$

YNOLLR $\begin{array}{lllllllllllll}0.51 & 24.89 & 28.31 & 24.80 & 2 & 949.5518 & 949.5467 & 475.7806 & 0.0051 & 5.3596 & 48941.749 & 49550.764\end{array}$

SCNCLLLK

SCNCLLLK

SCNCLLLK $\begin{array}{llllllllllllll}0.51 & 24.89 & 28.31 & 24.80 & 2 & 949.558 & 949.567 & 475.786 & 0.0051 & 5.3596 & 4894.749 & 4550.764 & 10121.213 & 2\end{array}$

SCNCLLLK

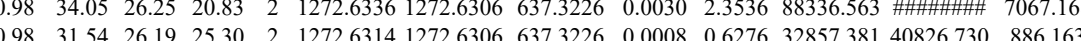

SCNCLLLK

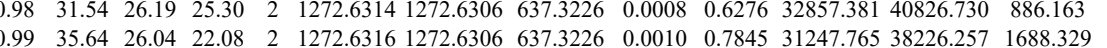

SCNCLLLK $\begin{array}{llllllllllllll}0.98 & 31.75 & 26.10 & 25.43 & 2 & 1272.6322 & 1272.6306 & 637.3226 & 0.0016 & 1.2552 & 41504.523 & 47431.429 & 1561.821\end{array}$ $\begin{array}{llllllllllllll}0.98 & 31.56 & 26.00 & 24.70 & 2 & 1272.6312 & 1272.6306 & 637.3226 & 0.0006 & 0.4707 & 13194.827 & 15798.386 & 896.218\end{array}$ $\begin{array}{llllllllllllll}0.71 & 18.70 & 26.19 & 21.99 & 2 & 1272.6314 & 1272.6306 & 637.3226 & 0.0008 & 0.6276 & 9759.381 & 11011.263 & 763.891\end{array}$ $\begin{array}{llllllllllllll} & \text { LAMPE }\end{array}$ $\begin{array}{llllllllllllll} & \text { LAMQEFMLPVGAANR } \\ \text { LAMQEFMILPVGAANFR } & 0.97 & 29.15 & 27.15 & 19.77 & 3 & 2051.0878 & 2051.0818 & 684.7012 & 0.0060 & 2.9210 & 75.120 & 114.929 & 74.856 \\ \text { SCNCLLLK } & 0.77 & 19.78 & 26.00 & 19.79 & 2 & 1272.6312 & 1272.6306 & 637.3226 & 0.0006 & 0.4707 & 7430.472 & 8458.249 & 531.681\end{array}$ $\begin{array}{llllllllllllll}\text { LAQANGWGVMVSHR } & 0.98 & 29.80 & 27.69 & 17.03 & 3 & 1668.8638 & 1668.8640 & 557.2953 & -0.0002 & -0.1196 & 31.511 & 56.901 & 7.679\end{array}$

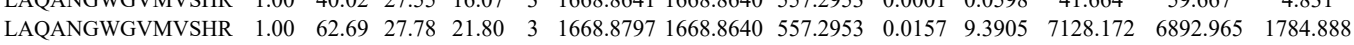
$\begin{array}{llllllllllllll}\text { LAQANGWGVMVSHR } & 1.00 & 73.30 & 27.72 & 20.75 & 3 & 1668.8806 & 1668.8640 & 557.2953 & 0.0166 & 9.9288 & 5098.785 & 5179.533 & 769.054\end{array}$

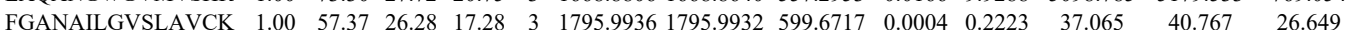

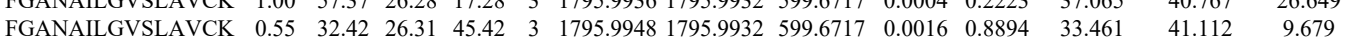

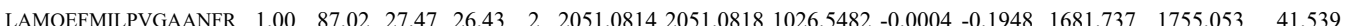
$\begin{array}{llllllllllllll}\text { LAMOEFMILPVGAANFR } & 1.00 & 96.71 & 27.57 & 25.52 & 2 & 2051.0834 & 2051.0818 & 1026.5482 & 0.0016 & 0.7793 & 2667.103 & 3433.033 & 168.572\end{array}$

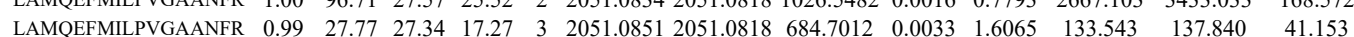
$\begin{array}{llllllllllllll}\text { LAMQEFMILPVGAANFR } & 1.00 & 40.22 & 27.14 & 18.30 & 3 & 2051.0881 & 2051.0818 & 684.7012 & 0.0063 & 3.0670 & 83.463 & 190.407 & 32.417\end{array}$ SCNCLLLK

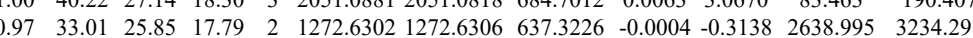
SCNCLLLK

$\begin{array}{llllllllllll}0.97 & 33.01 & 25.85 & 17.79 & 2 & 1272.6302 & 1272.6306 & 637.3226 & -0.0004 & -0.3138 & 2338.995 & 3234.298 \\ 0.90 & 24.12 & 26.05 & 23.00 & 2 & 1272.6320 & 1272.6306 & 637.3226 & 0.0014 & 1.0983 & 3691.612 & 4064.394\end{array}$ $\begin{array}{llllllllllllllll}\text { LAQANGWGVMVSHR } & 1.00 & 35.86 & 27.55 & 20.81 & 3 & 1668.8641 & 1668.8640 & 557.2953 & 0.0001 & 0.0598 & 121.698 & 152.705 & 30.061\end{array}$

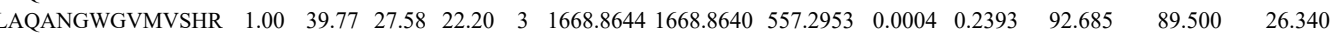

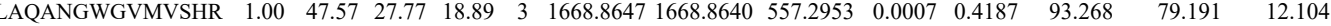
$\begin{array}{llllllllllllll}\text { LAQANGWGVMVSHR } & 0.95 & 24.67 & 27.77 & 17.83 & 3 & 1668.8647 & 1668.8640 & 557.2953 & 0.0007 & 0.4187 & 44.800 & 59.250 & 4.955\end{array}$ $\begin{array}{llllllllllllll}\text { LAQANGWGVMVSHR } & 1.00 & 53.16 & 27.69 & 20.61 & 3 & 1668.8650 & 1668.8640 & 557.2953 & 0.0010 & 0.5981 & 55.287 & 90.600 & 18.086\end{array}$ $\begin{array}{llllllllllllll}\text { LAQANGWGVMVSHR } & 1.00 & 45.10 & 27.72 & 20.65 & 3 & 1668.8653 & 1668.8640 & 557.2953 & 0.0013 & 0.7776 & 135.129 & 120.936 & 23.893\end{array}$ $\begin{array}{llllllllllllll}\text { LAQANGWGVMVSHR } & 0.99 & 29.27 & 27.72 & 17.18 & 3 & 1668.8653 & 1668.8640 & 557.2953 & 0.0013 & 0.7776 & 115.490 & 120.065 & 10.388\end{array}$ $\begin{array}{llllllllllllll}\text { LAQANGWGVMVSHR } & 1.00 & 40.02 & 27.72 & 23.94 & 3 & 1668.8653 & 1668.8640 & 557.2953 & 0.0013 & 0.7776 & 79.236 & 85.839 & 15.493\end{array}$ $\begin{array}{llllllllllllll}\text { LAQANGWGVMVSHR } & 1.00 & 98.22 & 27.79 & 27.57 & 2 & 1668.8782 & 1668.8640 & 835.4393 & 0.0142 & 8.4985 & 10331.091 & 8567.956 & 1545.243 \\ \text { LAQANGWGVMVSHR } & 1.00 & \# \# \# & 27.73 & 28.34 & 2 & 1668.8784 & 1668.8640 & 835.4393 & 0.0144 & 8.6181 & 10735.817 & 9824.195 & 1451.003\end{array}$ $\begin{array}{lllllllllllllll}\text { LAQANGWGVMVSHR } & 1.00 & \text { \#\#\#\# } & 27.73 & 28.34 & 2 & 1668.8784 & 1668.8640 & 835.4393 & 0.0144 & 8.6181 & 10735.817 & 9824.195 & 1451.003 \\ \text { LAQANGWGVMVSHR } & 1.00 & 62.45 & 27.73 & 22.07 & 3 & 1668.8788 & 1668.8640 & 557.2953 & 0.0148 & 8.8522 & 8652.597 & 7140.977 & 1716.562\end{array}$ $\begin{array}{lllllllllllllll}\text { LAQANGWGVMVSHR } & 1.00 & 62.45 & 27.73 & 22.07 & 3 & 1668.8788 & 1668.8640 & 557.2953 & 0.0148 & 8.8522 & 8652.597 & 7140.977 & 1716.562 \\ \text { LAQANGWGVMVSHR } & 1.00 & 60.29 & 27.88 & 20.38 & 3 & 1668.8794 & 1668.8640 & 557.2953 & 0.0154 & 9.2111 & 10616.408 & 12625.754 & 3662.077\end{array}$

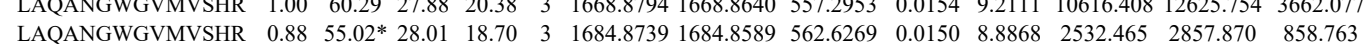

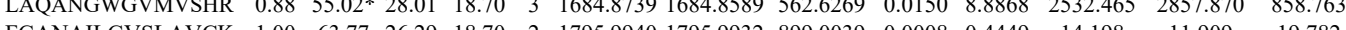

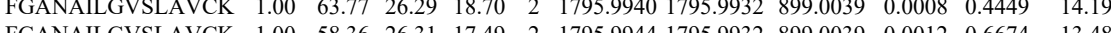
$\begin{array}{lllllllllllll}\text { FANALGSACK } & 1.00 & 58.36 & 26.31 & 17.49 & 2 & 1795.9944 & 1795.9932 & 899.0039 & 0.0012 & 0.6674 & 13.480\end{array}$ $\begin{array}{llllllllllllll}\text { FGANAILGVSLAVCK } & 0.55 & 62.37 & 26.31 & 75.37 & 3 & 1795.9948 & 1795.9932 & 599.6717 & 0.0016 & 0.8894 & 17.26\end{array}$ $\begin{array}{lllllllllllllll}\text { FGANAILGVSLAVCK } & 1.00 & 58.51 & 26.31 & 18.63 & 2 & 1795.9948 & 1795.9932 & 899.0039 & 0.0016 & 0.8899 & 13.807\end{array}$ 


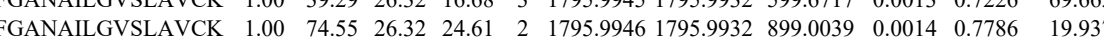

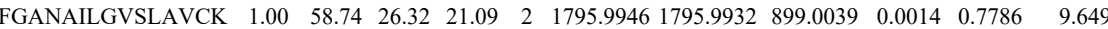
$\begin{array}{llllllllllllll}\text { GAANAILGVSLAVCK } & 0.55 & 53.19 & 26.31 & 66.19 & 3 & 1795.9948 & 1795.9932 & 599.6717 & 0.0016 & 0.8894 & 70.848\end{array}$

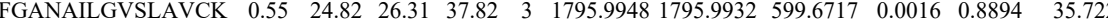

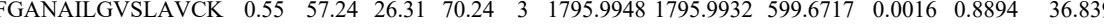

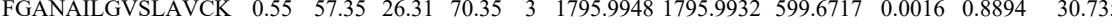
$\begin{array}{llllllllllllll}\text { FGANAILGVSLAVCK } & 1.00 & 74.63 & 26.31 & 21.23 & 2 & 1795.9948 & 1795.9932 & 899.0039 & 0.0016 & 0.8899 & 23.01\end{array}$ $\begin{array}{lllllllllllll}\text { FGANAILGVSLAVCK } & 0.77 & 72.96 & 26.33 & 85.96 & 2 & 1795.9952 & 1795.9932 & 899.0039 & 0.0020 & 1.1123 & 21.120\end{array}$ $\begin{array}{llllllllllll}\text { FGANAILGVSLAVCK } & 0.55 & 62.31 & 26.34 & 75.31 & 3 & 1795.9954 & 1795.9932 & 599.6717 & 0.0022 & 1.2229 & 34.449\end{array}$ $\begin{array}{llllllllllll}\text { FGANAILGVSLAVCK } & 1.00 & 62.61 & 26.32 & 18.81 & 2 & 1795.9954 & 1795.9932 & 899.0039 & 0.0022 & 1.2236 & 20.437\end{array}$

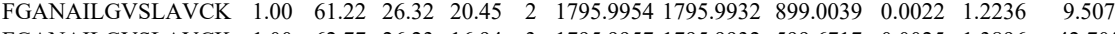
$\begin{array}{lllllllllllll} & \text { GANAILGVSLAVCK } & 1.00 & 62.77 & 26.23 & 16.94 & 3 & 1795.9957 & 1795.9932 & 599.6717 & 0.0025 & 1.3896 & 42.705\end{array}$ $\begin{array}{llllllllllll}\text { FGANAILGVSLAVCK } & 0.55 & 60.28 & 26.23 & 73.28 & 3 & 1795.9957 & 1795.9932 & 599.6717 & 0.0025 & 1.3896 & 34.891\end{array}$ $\begin{array}{lllllllllll} & \end{array}$

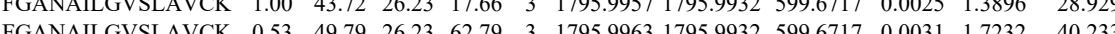

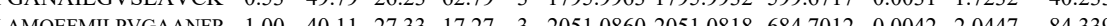
$\begin{array}{llllllllllll} & \end{array}$

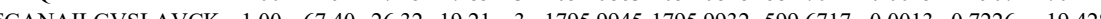

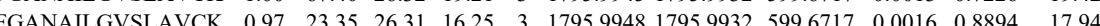
FTASAGIOVVGDDITVTNPK $\begin{array}{llllllllllllllll}1.00 & 71.42 & 26.312 & 17.94 & 3 & 2320.2523 & 2320.2518 & 774.4245 & 0.0005 & 0.2152 & 0.000\end{array}$ $\begin{array}{lllllllllllllll}\text { FTASAGIQVVGDDLTVTNPK } & 1.00 & 77.58 & 26.14 & 19.95 & 3 & 2320.2529 & 23202518 & 774.4245 & 0.0011 & 0.4735 & 2.166\end{array}$ $\begin{array}{llllllllllll}\text { GVPLYR } & 0.56 & 22.61 & 30.01 & 21.30 & 2 & 847.5038 & 847.5038 & 424.7592 & 0.0000 & 0.0000 & 1214.776\end{array}$

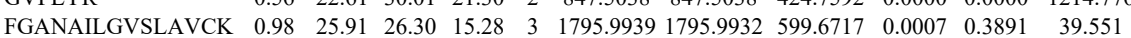
$\begin{array}{lllllllllllllll}\text { GVPLYR } & 0.73 & 25.94 & 30.01 & 21.35 & 2 & 847.5038 & 847.5038 & 424.7592 & 0.0000 & 0.0000 & 711.896 & 82\end{array}$ $\begin{array}{llllllllllllll}\text { FGANAILGVSLAVCK } & 0.97 & 25.57 & 26.30 & 16.51 & 3 & 1795.9939 & 1795.9932 & 599.6717 & 0.0007 & 0.3891 & 13.724\end{array}$ $\begin{array}{lllllllllllll}\text { FGANAILGVSLAVCK } & 1.00 & 50.96 & 26.32 & 18.65 & 3 & 1795.9945 & 1795.9932 & 599.6717 & 0.0013 & 0.7226 & 13.705\end{array}$ $\begin{array}{llllllllllllll}\text { FGANAILGVSLAVCK } & 0.55 & 42.84 & 26.31 & 55.84 & 3 & 1795.9948 & 1795.9932 & 599.6717 & 0.0016 & 0.8894 & 12.646\end{array}$

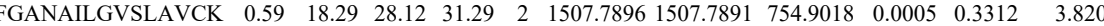
$\begin{array}{lllllllllllll}\text { FGANAILGVSLAVCK } & 0.88 & 25.30 & 28.14 & 23.29 & 2 & 1507.7902 & 1507.7891 & 754.9018 & 0.0011 & 0.7286 & 5.856\end{array}$ $\begin{array}{lllllllllllll}\text { FGANAILGVSLAVCK } & 1.00 & 45.99 & 27.91 & 20.43 & 2 & 1507.7916 & 1507.7891 & 754.9018 & 0.0025 & 1.6558 & 3.990 \\ \text { FGANALGSLAVK } & 0.55 & 28.11 & 2631 & 41.11 & 3 & 1795.9948 & 1795.9932 & 599.6717 & 0.0016 & 0.8894 & 4.354\end{array}$ $\begin{array}{llllllllllllll}\text { FGANAILGVSLAVCK } & 0.55 & 28.11 & 26.31 & 41.11 & 3 & 1795.9948 & 1795.9932 & 599.6717 & 0.0016 & 0.8894 & 4.354 \\ \end{array}$ $\begin{array}{llllllllllll}\text { FGANAILGVSLAVCK } & 0.55 & 44.53 & 26.31 & 57.53 & 3 & 1795.9951 & 1795.9932 & 599.6717 & 0.0019 & 1.0561 & 34.749 \\ \text { FGANAILGVSAVCK } & 0.55 & 22.42 & 26.23 & 35.42 & 3 & 1795.9957 & 1795.9932 & 599.6717 & 0.0025 & 1.3896 & 13.189\end{array}$

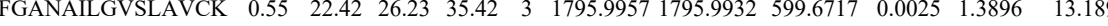
$\begin{array}{llllllllllllll}\text { FGANAILGVSLAVCK } & 0.53 & 16.04 & 26.13 & 29.04 & 3 & 1795.9960 & 1795.9932 & 599.6717 & 0.0028 & 1.5564 & 39.068\end{array}$ $\begin{array}{lllllllllllll}\text { FGANAILGVSLAVCK } & 1.00 & 32.93 & 26.16 & 19.84 & 3 & 1795.9987 & 1795.9932 & 599.6717 & 0.0055 & 3.0572 & 10.506\end{array}$ $\begin{array}{llllllllllll}\text { YNQLLR } & 0.54 & 17.66 & 28.27 & 19.91 & 2 & 949.5476 & 949.5467 & 475.7806 & 0.0009 & 0.9458 & 861.502 \\ \text { IGAEVYHNLK } & 0.99 & 34.55 & 27.67 & 21.98 & 3 & 1430.8126 & 1430.8125 & 477.9448 & 0.0001 & 0.0697 & 655.526 \\ \text { IGAEYYNLK } & 0.88 & 20.63 & 27.6 & 19.29 & 3 & 1430.8135 & 1430.725 & 477.9448 & 0.0010 & 0.6976 & 68.074\end{array}$

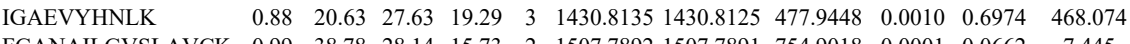
$\begin{array}{llllllllllll}\text { FGANAILGVSLAVCK } & 0.99 & 38.78 & 28.14 & 15.73 & 2 & 1507.7892 & 1507.7891 & 754.9018 & 0.0001 & 0.0662 & 7.445 \\ \text { FGANAILGVSLAVCK } & 0.99 & 39.35 & 28.14 & 15.47 & 2 & 1507.7892 & 1507.7891 & 754.9018 & 0.0001 & 0.0662 & 11.812\end{array}$ $\begin{array}{lllllllllllll} & \text { GANAILGVLAVCK } & 0.99 & 39.35 & 28.14 & 15.47 & 2 & 1507.7892 & 1507.7891 & 754.9018 & 0.0001 & 0.0662 & 11.812\end{array}$ $\begin{array}{lllllllllllll} & \text { GANAILGVSAAVK } & 0.57 & 20.96 & 28.10 & 15.22 & 2 & 1507.7894 & 1507.7891 & 754.9018 & 0.0003 & 0.1987 & 6.945\end{array}$ $\begin{array}{llllllllllll}\text { FGANAILGVSLAVCK } & 1.00 & 53.90 & 28.12 & 24.22 & 2 & 1507.7896 & 1507.7891 & 754.9018 & 0.0005 & 0.3312 & 7.928\end{array}$

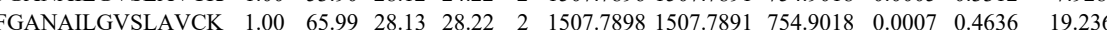
$\begin{array}{llllllllllllll}\text { FGANAILGVSLAVCK } & 1.00 & 63.13 & 28.14 & 25.18 & 2 & 1507.7902 & 1507.7891 & 754.9018 & 0.0011 & 0.7286 & 16.593\end{array}$ 

$\begin{array}{llllllllllll}\text { FGANAILGVSLAVCK } & 0.55 & 21.53 & 26.23 & 34.53 & 3 & 1795.9957 & 1795.9932 & 599.6717 & 0.0025 & 1.3896 & 15.821 \\ \text { FGANAILGVSAVCK } & 0.55 & 30.74 & 26.23 & 43.74 & 3 & 1795.9957 & 1795.9932 & 599.6717 & 0.0025 & 1.3896 & 21.893\end{array}$

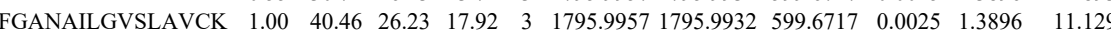

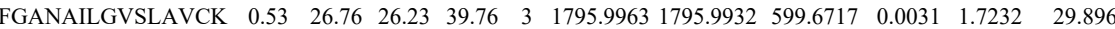
$\begin{array}{lllllllllllll}\text { IGAEVYHNLK } & 0.99 & 27.32 & 27.36 & 16.38 & 3 & 1430.8150 & 1430.8125 & 477.9448 & 0.0025 & 1.7436 & 200.703\end{array}$ $\begin{array}{llllllllllllll} & \text { FGANAILGVSLAVCK } & 0.99 & 44.97 & 28.00 & 22.86 & 2 & 1507.7930 & 1507.7891 & 754.9018 & 0.0039 & 2.5831 & 3.275\end{array}$ $\begin{array}{lllllllllllll}\text { LAQANGWGVMVSHR } & 1.00 & 35.45 & 27.70 & 22.85 & 3 & 1668.8656 & 1668.8640 & 557.2953 & 0.0016 & 0.9570 & 90.588\end{array}$ \begin{tabular}{lllllllllllll} 
LAQANGWGVMVSHR & 1.00 & 49.64 & 27.57 & 21.80 & 3 & 1668.8677 & 1668.8640 & 557.2953 & 0.0037 & 2.2131 & 93.668 \\
\hline
\end{tabular} $\begin{array}{llllllllllllll}\text { FGANAILGVSLAVCK } & 0.53 & 42.13 & 26.23 & 55.13 & 3 & 1795.9963 & 1795.9932 & 599.6717 & 0.0031 & 1.7232 & 20.343\end{array}$ $\begin{array}{llllllllllll}\text { GVPLYR } & 0.57 & 25.00 & 27.81 & 21.56 & 2 & 847.5032 & 847.5038 & 424.7592 & -0.0006 & -0.7063 & 258.369\end{array}$ 

$\begin{array}{llllllllllll}\text { FGANAILGVSLAVCK } & 0.99 & 42.65 & 26.61 & 17.52 & 3 & 1795.9906 & 1795.9932 & 599.6717 & -0.0026 & -1.4452 & 4.018 \\ \text { FGANAILGVSLAVCK } & 1.00 & 69.79 & 26.48 & 18.43 & 2 & 1795.9922 & 1795.9932 & 899.0039 & -0.0010 & -0.5562 & 12.383\end{array}$ $\begin{array}{llllllllllllll}\text { FGANAILGVSLAVCK } & 1.00 & 46.29 & 26.19 & 17.01 & 3 & 1795.9927 & 1795.9932 & 599.6717 & -0.0005 & -0.2779 & 0.964\end{array}$ $\begin{array}{llllllllllllll} & \text { FGANAILGVLAVCK } & 1.00 & 51.08 & 26.32 & 16.47 & 3 & 1795.9933 & 1795.9932 & 599.6717 & 0.0001 & 0.0556 & 7.764\end{array}$ $\begin{array}{lllllllllllll} & \end{array}$ $\begin{array}{lllllllllllll} & 0.45\end{array}$

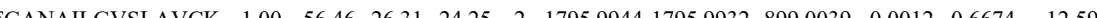

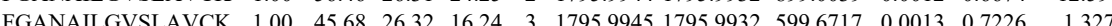
$\begin{array}{llllllllllllll}\text { FGANAILGVSLAVCK } & 0.55 & 58.08 & 2631 & 71.08 & 3 & 1795.9948 & 17959932 & 599.6717 & 0.0016 & 0.8894 & 51.258\end{array}$ $\begin{array}{llllllllllllll}\text { FGANAILGVSLAVCK } & 0.55 & 74.03 & 26.31 & 87.03 & 3 & 1795.9951 & 1795.9932 & 599.6717 & 0.0019 & 1.0561 & 37.577\end{array}$ $\begin{array}{lllllllllllll}\text { FGANAILGVSLAVCK } & 0.55 & 58.08 & 26.34 & 71.08 & 3 & 1795.9954 & 1795.9932 & 599.6717 & 0.0022 & 1.2229 & 60.523\end{array}$ $\begin{array}{lllllllllllll}\text { FGANAILGVSLAVCK } & 1.00 & 45.42 & 26.34 & 19.73 & 3 & 1795.9954 & 1795.9932 & 599.6717 & 0.0022 & 1.2229 & 11.455\end{array}$ $\begin{array}{lllllllllllll}\text { FGANAILGVSLAVCK } & 1.00 & 52.94 & 26.34 & 18.59 & 3 & 1795.9954 & 1795.9932 & 599.6717 & 0.0022 & 1.2229 & 41.063\end{array}$ $\begin{array}{llllllllllllll} & \text { TASAGIOVVGDDLTVTNPK } & 1.00 & 74.03 & 26.06 & 20.87 & 3 & 2320.2532 & 2320.2518 & 774.4245 & 0.0014 & 0.6026 & 7.303\end{array}$ $\begin{array}{lllllllllllll}\text { FGANAILGVSLAVCK } & 0.71 & 27.77 & 28.01 & 16.15 & 2 & 1507.7882 & 1507.7891 & 754.9018 & -0.0009 & -0.5961 & 4.849\end{array}$ $\begin{array}{lllllllllllll} & \text { FGANAILGVSLAVCK } & 1.00 & 59.49 & 28.14 & 19.50 & 2 & 1507.7892 & 1507.7891 & 754.9018 & 0.0001 & 0.0662 & 1.600\end{array}$ $\begin{array}{lllllllllllll}\text { FGANAILGVSLAVCK } & 0.88 & 28.08 & 28.10 & 15.34 & 2 & 1507.7894 & 1507.7891 & 754.9018 & 0.0003 & 0.1987 & 5.747\end{array}$ $\begin{array}{llllllllllllll}\text { FGANAILGVSLAVCK } & 0.76 & 50.45 & 27.87 & 63.45 & 2 & 1507.7904 & 1507.7891 & 754.9018 & 0.0013 & 0.8610 & 0.967\end{array}$ $\begin{array}{llllllllllll}\text { FGANAILGVSLAVCK } & 1.00 & 49.13 & 27.91 & 24.76 & 2 & 1507.7916 & 1507.7891 & 754.9018 & 0.0025 & 1.6558 & 1.472\end{array}$ $\begin{array}{lllllllllllll}\text { LAQANGWGVMVSHR } & 1.00 & 62.89 & 27.69 & 23.45 & 3 & 1668.8650 & 1668.8640 & 557.2953 & 0.0010 & 0.5981 & 66.446\end{array}$ $\begin{array}{llllllllllll}\text { LAQANGWGVMVSHR } & 1.00 & 55.60 & 27.58 & 24.47 & 3 & 1668.8665 & 1668.8640 & 557.2953 & 0.0025 & 1.4953 & 71.616\end{array}$ $\begin{array}{lllllllllllll}\text { FGANAILGVSLAVCK } & 0.92 & 37.02 & 26.88 & 19.81 & 3 & 1795.9870 & 1795.9932 & 599.6717 & -0.0062 & -3.4463 & 13.960\end{array}$ $\begin{array}{llllllllllll}\text { FGANAILGVSLAVCK } & 1.00 & 57.40 & 26.44 & 23.29 & 2 & 1795.9918 & 1795.9932 & 899.0039 & -0.0014 & -0.7786 & 3.974\end{array}$ $\begin{array}{llllllllllll}\text { FGANAILGVSLAVCK } & 1.00 & 73.26 & 26.30 & 18.56 & 2 & 1795.9938 & 1795.9932 & 899.0039 & 0.0006 & 0.3337 & 14.597\end{array}$ $\begin{array}{lllllllllllll} & \text { FGANAILGVSLAVCK } & 1.00 & 86.03 & 26.29 & 29.70 & 2 & 1795.9940 & 1795.9932 & 899.0039 & 0.0008 & 0.4449 & 9.945\end{array}$ $\begin{array}{lllllllllllll} & \text { FANAILGVSLAVCK } & 0.76 & 52.21 & 26.31 & 65.21 & 2 & 1795.9944 & 1795.9932 & 899.0039 & 0.0012 & 0.6674 & 2.363\end{array}$ $\begin{array}{llllllllllll}\text { FGANAILGVSLAVCK } & 0.55 & 53.61 & 26.34 & 66.61 & 3 & 1795.9954 & 1795.9932 & 599.6717 & 0.0022 & 1.2229 & 7.816 \\ \text { FGANAILGVSLAVCK } & 1.00 & 38.14 & 26.34 & 16.10 & 3 & 1795.9954 & 1795.9932 & 599.6717 & 0.0022 & 1.2229 & 10.990\end{array}$ $\begin{array}{llllllllllllll}\text { FGANAILGVSLAVCK } & 1.00 & 38.14 & 26.34 & 16.10 & 3 & 1795.9954 & 7795.9932 & 599.6717 & 0.0022 & 1.2229 & 10.990 \\ \text { FGANAILGVSLAVCK } & 0.55 & 58.31 & 26.34 & 71.31 & 3 & 1795.9954 & 1795.9932 & 599.6717 & 0.0022 & 1.2229 & 10.820\end{array}$ $\begin{array}{lllllllllllll}\text { FGANAILGVSLAVCK } & 0.55 & 58.31 & 26.34 & 71.31 & 3 & 1795.9954 & 1795.9932 & 599.6717 & 0.0022 & 1.2229 & 10.820 \\ \text { FGANAILGVSLAVCK } & 0.55 & 41.01 & 26.34 & 54.01 & 3 & 1795.9954 & 1795.9932 & 599.6717 & 0.0022 & 1.2229 & 7.286\end{array}$

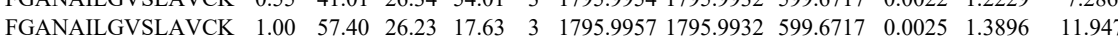
$\begin{array}{llllllllllllll}\text { TASAGIQVVGDDLTVTNPK } & 0.63 & 15.65 & 26.09 & 18.10 & 3 & 2320.2517 & 2320.2518 & 774.4245 & -0.0001 & -0.0430 & 10.331\end{array}$ $\begin{array}{lllllllllllll} & \end{array}$ AGAVEK

AGYTDK $\begin{array}{llllllllllllll}0.72 & 24.11 & 28.11 & 35.00 & 2 & 861.5168 & 861.5163 & 431.7654 & 0.0005 & 0.5790 & 833.820 & \\ 0.79 & 29.12 & 28.11 & 38.43 & 2 & 861.5168 & 861.5163 & 431.7654 & 0.0005 & 0.5790 & 1180.823 & \end{array}$ $\begin{array}{lllllllllllll}0.77 & 22.22 & 25.38 & 35.01 & 2 & 941.5070 & 941.5062 & 471.7604 & 0.0008 & 0.8479 & 812.899\end{array}$ $\begin{array}{lllllllllllll}\text { FGANAILGVSLAVCK } & 0.53 & 41.49 & 26.23 & 54.49 & 3 & 1795.9963 & 1795.9932 & 599.6717 & 0.0031 & 1.7232 & 6.975\end{array}$ $\begin{array}{llllllllllllll}\text { TASAGIQVVGDDLTVTNPK } & 1.00 & 81.00 & 26.14 & 21.67 & 3 & 2320.2529 & 2320.2518 & 774.4245 & 0.0011 & 0.4735 & 3.410\end{array}$ $\begin{array}{lllllllllllll}\text { AGAVEK } & 0.54 & 25.37 & 28.67 & 31.71 & 2 & 861.5154 & 861.5163 & 431.7654 & -0.0009 & -1.0422 & 1060.456 & 1002.462\end{array}$ AGAVEK AGYYDK AGYTDK $\begin{array}{lllllllllllll}0.85 & 26.18 & 28.11 & 36.50 & 2 & 861.5174 & 861.5163 & 431.7654 & 0.0011 & 1.2738 & 1231.751\end{array}$ LMIEMDGTENK LMIEMDGTENK $\begin{array}{llllllllllllll}0.62 & 2.20 & 25.13 & 35.0 & 2 & 94.5062 & 94.5062 & 471.7604 & 0.000 & 0.000 & 618.840 & 615.600 \\ 0.77 & 2.16 & 25.38 & 34.96 & 2 & 941.5070 & 941.5062 & 471.7604 & 0.0008 & 0.8479 & 584.060 & 693.857\end{array}$

MIEMDGTENK $\begin{array}{llllllllllll}0.76 & 27.18 & 2.78 & 25.59 & 3 & 1567.7797 & 1567.7829 & 523.6016 & -0.0032 & -2.0372 & 103.487 & 115.713\end{array}$

LMIEMDGTENK $\begin{array}{llllllllllllll}1.00 & 57.97 & 27.69 & 30.17 & 2 & 1567.7848 & 1567.7829 & 784.8987 & 0.0019 & 1.2103 & 19048.070 & 19\end{array}$ $\begin{array}{llllllllllll}0.85 & 18.57 & 27.75 & 23.51 & 3 & 1567.7857 & 1567.7829 & 523.6016 & 0.0028 & 1.7825 & 88.332\end{array}$

LMIEMDGTENK $\begin{array}{llllllllllll}1.00 & 58.87 & 27.75 & 33.29 & 3 & 1567.7857 & 1567.7829 & 523.6016 & 0.0028 & 1.7825 & 456.277 & 4 \\ 1.00 & 41.09 & 27.75 & 29.51 & 3 & 1567.7860 & 1567.7829 & 523.6016 & 0.0031 & 1.9735 & 272.801 & 3\end{array}$ $\begin{array}{lllllllllll}0.99 & 37.33 & 27.51 & 29.518 & 3 & 1567.7860 & 1567.7829 & 523.6016 & 0.0031 & 1.9735 & 272.801 \\ 1567.7829 & 523.6016 & 0.0079 & 5.0292 & 96.646\end{array}$

$\begin{array}{lllllllllllll}\text { DANNGD } & 27.625 .97 & 2248.1234 & 2248.1215 & 1125.0680 & 0.0019 & 0.8444 & 151.070 & 17\end{array}$ $\begin{array}{lllllllllllll}\text { DATNVGDEGGFAPNILENK } & 0.94 & 21.97 & 27.58 & 17.96 & 3 & 2248.1239 & 2248.1215 & 750.3811 & 0.0024 & 1.0661 & 138.733 & 113 \\ \text { DATNVGDEGGFAPNIENK } & 0.96 & 23.98 & 27.60 & 15.43 & 3 & 2248.1242 & 2248.1215 & 750.3811 & 0.0027 & 1.1994 & 86.182\end{array}$

YDLDFK

KLNVTEQEK

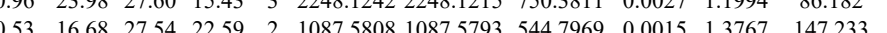
LMIEMDGTENK $\begin{array}{lllllllllllll}1.00 & 32.90 & 24.76 & 22.48 & 3 & 1519.8964 & 1519.8935 & 507.6384 & 0.0029 & 1.3942 & 25241.751 & 2844 & \end{array}$

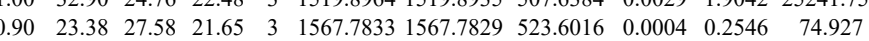
$\begin{array}{llllllllllll}0.99 & 41.15 & 27.59 & 17.96 & 2 & 1567.7834 & 1567.7829 & 784.8987 & 0.0005 & 0.3185 & 76.204\end{array}$ $\begin{array}{llllllllllll}0.89 & 25.03 & 27.58 & 16.88 & 2 & 1567.7836 & 1567.7829 & 784.8987 & 0.0007 & 0.4459 & 70.744\end{array}$ $\begin{array}{lllllllllllll}\text { DATNVGDEGGFAPNILENK } & 0.66 & 14.15 & 27.63 & 14.10 & 3 & 2248.1236 & 2248.1215 & 750.3811 & 0.0021 & 0.9329 & 52.635\end{array}$ $\begin{array}{lllllllllllll}\text { YDLDFK } & 0.58 & 17.22 & 27.56 & 25.44 & 2 & 1087.5810 & 1087.5793 & 544.7969 & 0.0017 & 15602 & 255.543\end{array}$ 

$\begin{array}{llllllllllllllll}0.91 & 32.58 & 28.59 & 21.41 & 2 & 1219.6468 & 1219.6353 & 610.8249 & 0.0115 & 9.4134 & 9483.446 & 9866.476 & 2035.536 & 2524.109 & \text { Yes } & \\ 1.00 & 61.85 & 26.62 & 24.22 & 2 & 1330.7762 & 1330.7700 & 6663923 & 0.0062 & 4.6519 & 9829.727 & 11543.847 & 14564.378 & 11811.377 & & \end{array}$ SNTPILVDGK

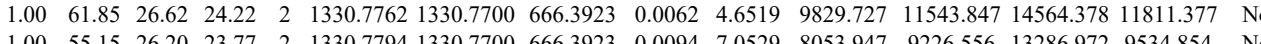
SNTPILVDGK $\begin{array}{llllllllllllllll}1.00 & 55.15 & 26.20 & 23.77 & 2 & 1330.7794 & 1330.7700 & 666.3923 & 0.0094 & 7.0529 & 8053.947 & 9226.556 & 13286.972 & 9534.854 & \mathrm{No} & \end{array}$ SNTPILVDGK

\section{HFVALSTNTTK} $\begin{array}{lllllllllllllllll}1.00 & 52.57 & 26.37 & 23.51 & 2 & 1330.7768 & 1330.7700 & 666.3923 & 0.0068 & 5.1021 & 11610.256 & 14245.479 & 14718.315 & 9883.993 & \text { Yes } & \\ 1.00 & 52.39 & 26.24 & 23.21 & 2 & 1330.7778 & 1330.7700 & 6663923 & 0.0078 & 5.8524 & 11056585 & 12772.809 & 13367.306 & 8965.611 & \text { Yes }\end{array}$ $\begin{array}{llllllllllllllllll}1.00 & 52.39 & 26.24 & 23.21 & 2 & 1330.7778 & 1330.7700 & 666.3923 & 0.0078 & 5.8524 & 11056.585 & 12772.809 & 13367.306 & 8965.611 & \text { Yes } & \\ 0.90 & 19.24 & 26.97 & 17.75 & 3 & 1505.8480 & 1505.8446 & 502.9555 & 0.0034 & 2.2533 & 13099.097 & 12738.517 & 3280.566 & 1709.577 & \text { Yes }\end{array}$

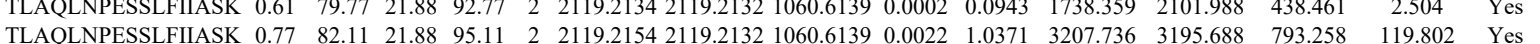
$\begin{array}{llllllllllllllll}\text { VFEGNRPTNSIVFTK } & 1.00 & 44.48 & 25.30 & 21.15 & 2 & 1996.1122 & 1996.0986 & 999.0566 & 0.0136 & 6.8064 & 1793.141 & 2128.297 & 576.896 & 26.067 & \text { Yes }\end{array}$ $\begin{array}{lllllllllllllllll}\text { VFEGNRPTNSIVFTK } & 1.00 & 49.35 & 25.53 & 21.18 & 2 & 1996.1154 & 1996.0986 & 999.0566 & 0.0168 & 8.4079 & 2667.881 & 2600.973 & 733.330 & 45.669 & \text { Yes }\end{array}$

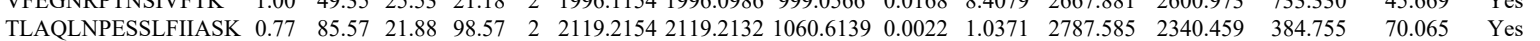

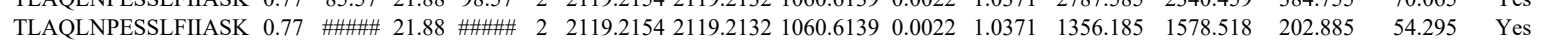

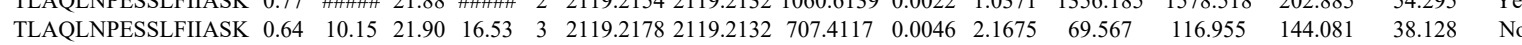
$\begin{array}{lllllllllllllllll}\text { VFEGNRPTNSIVFTK } & 0.98 & 38.87 & 25.53 & 23.00 & 2 & 1996.1154 & 1996.0986 & 999.0566 & 0.0168 & 8.4079 & 631.316 & 611.333 & 75.208 & 7.862 & \mathrm{Y}\end{array}$ $\begin{array}{llllllllllllllll}\text { VFEGNRPTNSIVFTK } & 0.98 & 43.59 & 25.56 & 23.63 & 2 & 1996.1184 & 1996.0986 & 999.0566 & 0.0198 & 9.9093 & 1604.650 & 1344.083 & 435.925\end{array}$ $\begin{array}{lllllllllllllllll}\text { VFEGNRPTNSIVFTK } & 0.51 & 17.85 & 25.48 & 18.00 & 3 & 1996.1143 & 1996.0986 & 666.3735 & 0.0157 & 7.8534 & 9090.164 & 9933.844 & 4178.374 & 395.786\end{array}$ $\begin{array}{lllllllllllllllll} & \text { nscorp } & 1.00 & 24.49 & 22.43 & 37.49 & 4 & 3615.9493 & 3615.9426 & 904.9929 & 0.0067 & 1.8508 & 6.044 & 27.304 & 16.375 & 3.980\end{array}$

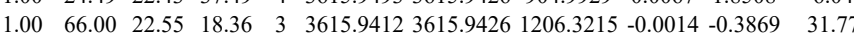
$\begin{array}{lllllllllll}0.65 & 2.65 & 22.25 & 15.65 & 4 & 3615.9469 & 3615.9426 & 904.9929 & 0.0043 & 1.1879 & 4.285\end{array}$

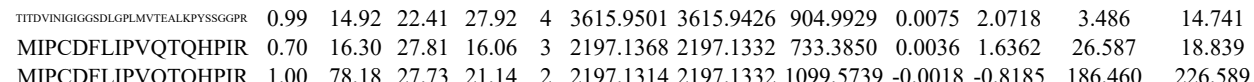
$\begin{array}{lllllllllllll}\text { MIPCDFLIPVQTQHPIR } & 1.00 & 78.18 & 27.73 & 21.14 & 2 & 2197.1314 & 2197.1332 & 1099.5739 & -0.0018 & -0.8185 & 186.460 & 226.589\end{array}$ $\begin{array}{lllllllllllllll}\text { MIPCDFLIPVQTQHPIR } & 1.00 & 25.14 & 27.79 & 20.02 & 4 & 2197.1333 & 2197.1332 & 550.2906 & 0.0001 & 0.0454 & 86.381 & 105.440\end{array}$ $\begin{array}{lllllllllllll}\text { MIPCDFLIPVQTQHPIR } & 1.00 & 80.79 & 27.76 & 18.93 & 2 & 2197.1334 & 2197.1332 & 1099.5739 & 0.0002 & 0.0909 & 298.765 & 367.596\end{array}$ $\begin{array}{lllllllllllll}\text { MIPCDFLIPVQTQHPIR } & 0.94 & 25.85 & 27.77 & 27.92 & 3 & 2197.1341 & 2197.1332 & 733.3850 & 0.0009 & 0.4091 & 15.504 & 18.945\end{array}$

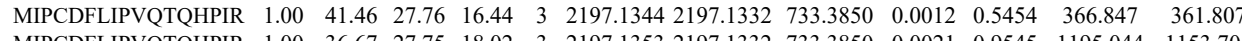

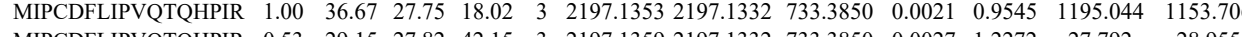

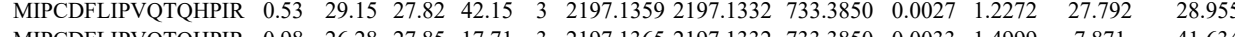

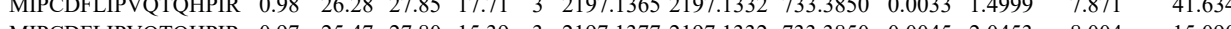
$\begin{array}{llllllllllll} & \text { MPCD }\end{array}$

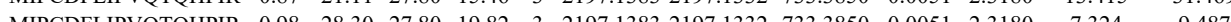

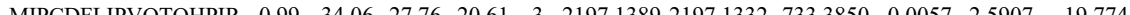
$\begin{array}{llllllllllllll}\text { MIPCDFLIPVQTOHPIR } & 0.97 & 30.06 & 27.62 & 15.99 & 3 & 2197.1392 & 2197.1332 & 733.3850 & 0.0060 & 2.7271 & 17.237 & 21.351\end{array}$

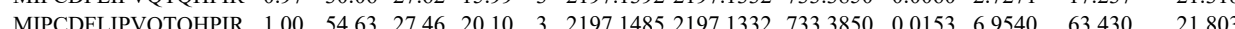
$\begin{array}{lllllllllllll}\text { MIPCDELPVOTOHPIR } & 1.00 & 46.43 & 27.76 & 2208 & 3 & 2197.1350 & 2197.1332 & 733.3850 & 0.0018 & 0.8181 & 588.927 & 546.348\end{array}$ $\begin{array}{llllllllllllll}\text { MILCDEL PQTELMR } & 1.00 & 73.52 & 25.08 & 18.43 & 2 & 1847.0466 & 1847.0460 & 924.5303 & 0.0006 & 0.3245 & 23.722 & 38.453\end{array}$ $\begin{array}{lllllllllllll}\text { ILLANFLAQTEALMR } & 0.76 & 88.82 & 24.98 & \text { \#\#\#\# } & 2 & 1847.0472 & 1847.0460 & 924.5303 & 0.0012 & 0.6490 & 22.106 & 38.453\end{array}$ $\begin{array}{llllllllllllll}\text { ILLANFLAQTEALMR } & 1.00 & 31.72 & 24.94 & 21.99 & 3 & 1847.0473 & 1847.0460 & 616.6893 & 0.0013 & 0.7027 & 12.942 & 22.473\end{array}$ $\begin{array}{lllllllllllll}\text { ILLANFLAQTEALMR } & 0.55 & 31.18 & 24.90 & 44.18 & 3 & 1847.0479 & 1847.0460 & 616.6893 & 0.0019 & 1.0270 & 16.903 & 9.217\end{array}$ $\begin{array}{llllllllllll}\text { ILLANFLAQTEALMR } & 1.00 & \text { \#\#\#\# } 24.94 & 24.88 & 2 & 1847.0474 & 1847.0460 & 924.5303 & 0.0014 & 0.7571 & 443.450 & 605.358\end{array}$

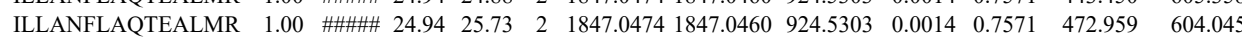
$\begin{array}{llllllllllllll}\text { ILLANFLAQTEALMR } & 0.55 & 39.17 & 24.91 & 52.17 & 3 & 1847.0485 & 1847.0460 & 616.6893 & 0.0025 & 1.3513 & 62.606 & 57.364\end{array}$ $\begin{array}{lllllllllllllll}\text { ILLANFLAQTEALMR } & 0.53 & 85.98 & 24.94 & 98.98 & 3 & 1847.0488 & 1847.0460 & 616.6893 & 0.0028 & 1.5135 & 45.522 & 90.84\end{array}$ $\begin{array}{llllllllllllll}\text { ILLANFLAQTEALMR } & 1.00 & 96.81 & 26.06 & 19.70 & 2 & 1863.0422 & 1863.0410 & 932.5278 & 0.0012 & 0.6434 & 46.220 & 76.979\end{array}$ $\begin{array}{lllllllllllll}\text { ILLANFLAQTEALMR } & 0.53 & 61.44 & 26.01 & 74.44 & 3 & 1863.0436 & 1863.0410 & 622.0209 & 0.0026 & 1.3933 & 59.825 & 65.988\end{array}$ $\begin{array}{lllllllllllllll}\text { MIPCDFLIPVQTQHPIR } & 1.00 & 44.52 & 27.76 & 22.37 & 3 & 2197.1344 & 2197.1332 & 733.3850 & 0.0012 & 0.5454 & 63.714 & 73.566\end{array}$ $\begin{array}{lllllllllllll}\text { MIPCDFLIPVQTQHPIR } & 0.55 & 29.08 & 27.76 & 42.08 & 3 & 2197.1350 & 2197.1332 & 733.3850 & 0.0018 & 0.8181 & 39.132 & 79.205\end{array}$ $\begin{array}{llllllllllllll}\text { ILLANFLAQTEALMR } & 1.00 & 97.73 & 26.06 & 22.06 & 2 & 1863.0422 & 1863.0410 & 932.5278 & 0.0012 & 0.6434 & 30.709 & 60.046\end{array}$ $\begin{array}{llllllllllllll}\text { ILLANFLAQTEALMR } & 1.00 & 49.90 & 26.04 & 19.40 & 3 & 1863.0442 & 1863.0410 & 622.0209 & 0.0032 & 1.7148 & 36.899 & 31.4\end{array}$ $\begin{array}{lllllllllllll}\text { TFTTQETITNAETAK } & 1.00 & \text { \#\#\# } 27.13 & 28.13 & 2 & 1943.0280 & 1943.0091 & 972.5118 & 0.0189 & 9.7170 & 4118.511 & 4054.840 & 2098.906\end{array}$

$\begin{array}{lllllllllllll}\text { TFTTQETITNAETAK } & 1.00 & \# \# \# \# \text { 27.18 } & 19.87 & 2 & 1943.0284 & 1943.0091 & 972.5118 & 0.0193 & 9.9227 & 3826.294 & 3785.648 & 2968.239\end{array}$ $\begin{array}{lllllllllllll} & \end{array}$ 
$\begin{array}{llllllllllll}1.00 & 90.65 * & 26.98 & 25.37 & 2 & 1962.9388 & 1962.9380 & 982.4763 & 0.0008 & 0.4071 & 381.480 & 440.562\end{array}$ $\begin{array}{lllllllllllll}\text { MTDQEAIQDLWQR } & 1.00 & 81.26 * 26.97 & 23.80 & 2 & 1962.9404 & 1962.9380 & 982.4763 & 0.0024 & 1.2214 & 1892.540 & 1736.584\end{array}$ $\begin{array}{llllllllllllll}\text { MTDQEAIQDLWQWR } & 1.00 & 38.89 & 26.99 & 20.39 & 3 & 1962.9418 & 1962.9380 & 655.3199 & 0.0038 & 1.9329 & 116.234 & 236.582\end{array}$ $\begin{array}{llllllllllllll} & \end{array}$

VTLATLK

VTLATLK

VTLATLK

FINYVK

FINYVK

VTLATLK

VTLATLK

FINYVK

FINYVK

FINYVK

FINYVK

VTLATLK

VILATVK

FINYVK

VDNDENEHQLSLR

VDNDENEHQLSLR

VDNDENEHQLSLR

VDNDENEHQLSLR

VDNDENEHOLSLR

VDNDENEHQLSLR

VDNDENEHQLSLR

VDNDENEHQLSLR

VDNDENEHQLSLR

VDNDENEHQLSLR

VDNDENEHQLSLR

VTLATLK

VTLATL

FINYVK

VTLATLK \begin{tabular}{lll}
48.168 & 46.6 \\
\hline 4.305 & 21.2 \\
\hline 4.027 & 127.965 & 57.9
\end{tabular} $\begin{array}{llllllllllllll}0.73 & 30.80 & 19.08 & 21.68 & 2 & 1032.6742 & 1032.6787 & 517.3466 & -0.0045 & -4.3491 & 485.674 & 494.027 & 127.965 & 57.97\end{array}$ $\begin{array}{lllllllllllll}1.00 & 52.53 & 17.71 & 27.34 & 2 & 1032.6882 & 1032.6787 & 517.3466 & 0.0095 & 9.1814 & \text { \#\#\#\#\#\# \#\#\#\#\#\# 25461.712 } & 1666.776\end{array}$ $\begin{array}{lllllllllllllll}1.00 & 52.97 & 17.71 & 27.65 & 2 & 1032.6886 & 1032.6787 & 517.3466 & 0.0099 & 9.5680 & 94521.253 & 87524.022 & 13106.285 & 1657.234 & \text { Yes }\end{array}$

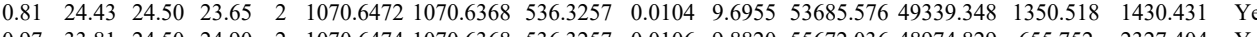
$\begin{array}{lllllllllllllll}0.97 & 33.81 & 24.50 & 24.90 & 2 & 1070.6474 & 1070.6368 & 536.3257 & 0.0106 & 9.8820 & 55672.036 & 48974.829 & 655.752 & 2327.404 & \text { Yes }\end{array}$ \begin{tabular}{llllllllllllllll}
1.00 & 53.00 & 17.71 & 27.39 & 2 & 1032.6880 & 1032.6787 & 517.3466 & 0.0093 & 8.9881 & 61005.463 & 57400.328 & 9924.918 & 1918.547 & Yes \\
\hline
\end{tabular}

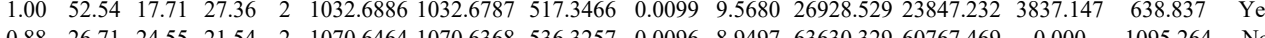

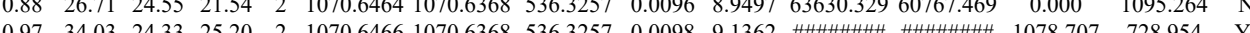
$\begin{array}{lllllllllllllll}0.97 & 34.03 & 24.33 & 25.20 & 2 & 1070.6466 & 1070.6368 & 536.3257 & 0.0098 & 9.1362 & \text { mmm mm mm } 1078.707 & 728.954 & \text { Yes } \\ 1.00 & 52.94 & 17.71 & 27.51 & 2 & 1032.6872 & 1032.6787 & 517.3466 & 0.0085 & 8.2149 & 55324.908 & 50264.916 & 7553.890 & 1648.876 & \text { Yes }\end{array}$ $\begin{array}{lllllllllllllll}0.00 & 52.94 & 17.71 & 27.51 & 2 & 1032.6872 & 1032.6787 & 517.3466 & 0.0085 & 8.2149 & 55324.908 & 50264.916 & 7553.890 & 1648.876 & \text { Yes }\end{array}$ $\begin{array}{llllllllllllll}0.93 & 29.77 & 23.40 & 22.88 & 2 & 1070.6460 & 1070.6368 & 536.3257 & 0.0092 & 8.25768 & 78659.361 & 68334.051 & 0.000 & 771.675\end{array}$

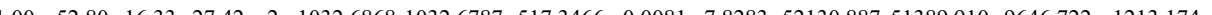

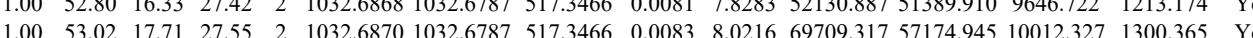

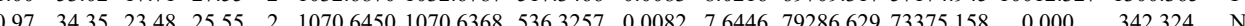
$\begin{array}{llllllllllllll} & 0.972 .324 & \text { No }\end{array}$ $\begin{array}{llllllllllllll}0.96 & 31.83 & 23.40 & 24.21 & 2 & 1070.6458 & 1070.6368 & 536.3257 & 0.0090 & 8.3904 & 83235.256 & 60899.341 & 0.000 & 538.868 \\ 0 & 36.82 & 26.77 & 21.54 & 3 & 1711.8232 & 1711.8247 & 571.6155 & -0.0015 & -0.8747 & 46.288 & 76.175 & 25.123 & 29.461\end{array}$

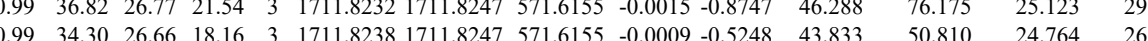

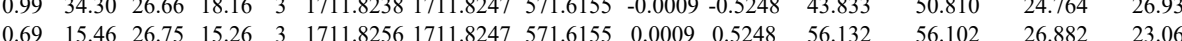
$\begin{array}{lllllllllllll}1.00 & 63.67 & 26.73 & 19.91 & 3 & 1711.8259 & 1711.8247 & 571.6155 & 0.0012 & 0.6998 & 75.572\end{array}$ $\begin{array}{llllllllllll}0.55 & 24.45 & 26.80 & 37.45 & 3 & 1711.8268 & 1711.8247 & 571.6155 & 0.0021 & 1.2246 & 35.485\end{array}$ $\begin{array}{lllllllllllll}0.53 & 15.16 & 26.86 & 28.16 & 3 & 1711.8274 & 1711.8247 & 571.6155 & 0.0027 & 1.5745 & 47.36\end{array}$ $\begin{array}{llllllllllll}0.92 & 20.28 & 26.79 & 15.41 & 3 & 1711.8277 & 1711.8247 & 571.6155 & 0.0030 & 1.7494 & 37.156\end{array}$ $\begin{array}{lllllllllllll}0.53 & 24.40 & 26.88 & 37.40 & 3 & 1711.8280 & 1711.8247 & 571.6155 & 0.0033 & 1.9244 & 42.502\end{array}$ $\begin{array}{llllllllllll}0.76 & 16.31 & 26.79 & 18.69 & 3 & 1711.8286 & 1711.8247 & 571.6155 & 0.0039 & 2.2743 & 51.886\end{array}$ $\begin{array}{lllllllllll}0.61 & 14.65 & 26.84 & 16.10 & 3 & 1711.8295 & 1711.8247 & 571.6155 & 0.0048 & 2.7991 & 55.635\end{array}$ $\begin{array}{lllllllllll}0.61 & 14.65 & 26.84 & 16.10 & 3 & 1711.8295 & 1711.8247 & 571.6155 & 0.0048 & 2.7991 & 55.635\end{array}$ 67.214 44.449 44.449
61.778 29.376 50.026

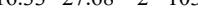
$\begin{array}{lllllllllllll}1.00 & 52.78 & 17.71 & 27.70 & 2 & 1032.6876 & 1032.6787 & 517.3466 & 0.0089 & 8.6015 & 19274.520 & 18396.281 & 3842.357\end{array}$ $\begin{array}{llllllllllllllllll}0.87 & 26.15 & 24.50 & 19.36 & 2 & 1070.6474 & 1070.6368 & 536.3257 & 0.0106 & 9.8820 & 48044.611 & 37721.847 & 880.336 & 62 & & \\ 0.99 & 40.07 & 6.33 & 25.91 & 2 & 032.6854 & 1032.6787 & 517.3466 & 0.0067 & 6.453 & 784.267 & 6821.671 & & \end{array}$

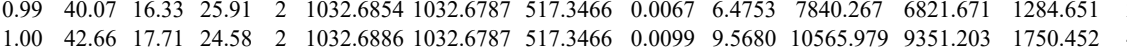
$\begin{array}{llllllllllllll}\text { MSVQPTVSLGGFEITPPVVLR } & 0.53 & 29.99 & 25.00 & 42.99 & 3 & 2386.3081 & 2386.3052 & 796.4423 & 0.0029 & 1.2137 & 48.270 & 102.701 & 11.749 \\ \text { MSVOPTVSLGGFEITPPVVLR } & 0.76 & 78.07 & 23.84 & 91.07 & 2 & 2370.3114 & 2370.3103 & 1186.1624 & 0.0011 & 0.4637 & 449.883 & 439.714 & 118.869\end{array}$

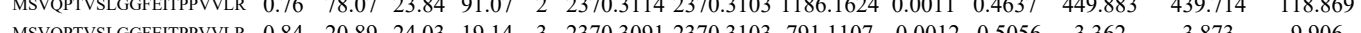

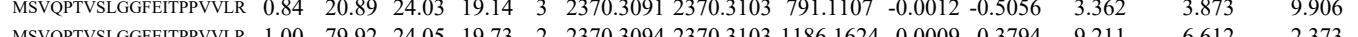

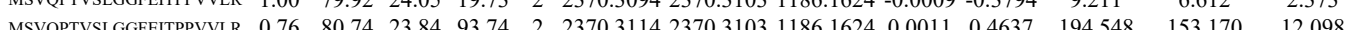

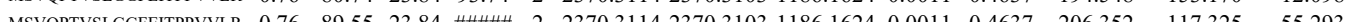
$\begin{array}{lllllllllllllll}\text { MSVPPTVSLGGFETPPVYVR R } & 1.00 & 82.05 & 23.84 & 20.55 & 2 & 2370.3114 & 2370.3103 & 1186.1624 & 0.0011 & 0.4637 & 1631.182 & 1537.821 & 418.162\end{array}$

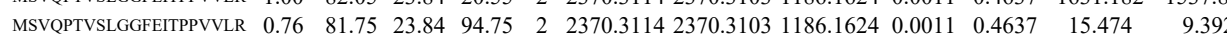




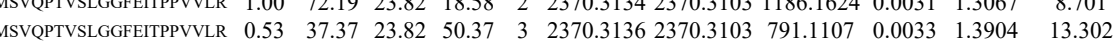

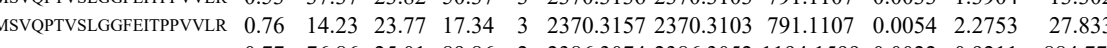
$\begin{array}{llllllllllll}\text { MSVQPTVSLGGFEITPPVVLR } & 0.77 & 76.86 & 25.01 & 89.86 & 2 & 2386.3074 & 2386.3052 & 1194.1599 & 0.0022 & 0.9211 & 884.773 \\ \text { MSVQPTVSLGGFEITPPVVLR } & 1.00 & 88.21 & 23.84 & 21.81 & 2 & 2370.3114 & 2370.3103 & 1186.1624 & 0.0011 & 0.4637 & 1226.919\end{array}$ $\begin{array}{lllllllllllll} & \text { USVQPVSLGGFETPPVVLR } & 1.00 & 88.21 & 23.84 & 21.81 & 2 & 2370.3114 & 2370.3103 & 1186.1624 & 0.0011 & 0.4637 & 1226.919\end{array}$

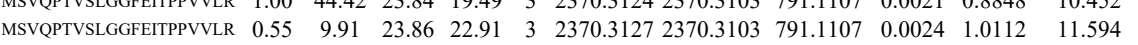
$\begin{array}{llllllllllll}\text { MSVQPTVSLGGFEITPPVVLR } & 0.69 & 86.86 & 23.82 & 99.86 & 2 & 2370.3134 & 2370.3103 & 1186.1624 & 0.0031 & 1.3067 & 2109.460\end{array}$ $\begin{array}{lllllllllllll}\text { MSVQPTVSLGGFEITPPVVLR } & 0.61 & 63.93 & 24.98 & 76.93 & 2 & 2386.3054 & 2386.3052 & 1194.1599 & 0.0002 & 0.0837 & 265.523\end{array}$

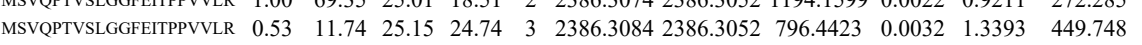
$\begin{array}{llllllllllll}\text { MSVQPTVSLGGFEITPPVVLR } & 1.00 & 92.92 & 23.84 & 21.21 & 2 & 2370.3114 & 2370.3103 & 1186.1624 & 0.0011 & 0.4637 & 934.677\end{array}$ $\begin{array}{llllllllllll}\text { MSVQPTVSLGGFEITPPVVLR } & 0.76 & 82.24 & 23.84 & 95.24 & 2 & 2370.3114 & 2370.3103 & 1186.1624 & 0.0011 & 0.4637 & 370.627\end{array}$ $\begin{array}{lllllllllllll}\text { MSVQPTVSLGGFEITPPVVLR } & 0.55 & 23.48 & 23.86 & 36.48 & 3 & 2370.3121 & 2370.3103 & 791.1107 & 0.0018 & 0.7584 & 6.986\end{array}$

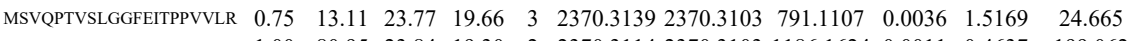
$\begin{array}{llllllllllllll}\text { MSVQPTVSLGGFEITPPVVLR } & 1.00 & 80.95 & 23.84 & 19.30 & 2 & 2370.3114 & 2370.3103 & 1186.1624 & 0.0011 & 0.4637 & 199.062\end{array}$ $\begin{array}{llllllllllll}\text { MSVQPTVSLGGFEITPPVVLR } & 0.76 & 84.53 & 23.84 & 97.53 & 2 & 2370.3114 & 2370.3103 & 1186.1624 & 0.0011 & 0.4637 & 319.902\end{array}$ $\begin{array}{llllllllllll}\text { MSVQPTVSLGGFEITPPVVLR } & 1.00 & 46.89 & 23.84 & 16.53 & 3 & 2370.3115 & 2370.3103 & 791.1107 & 0.0012 & 0.5056 & 20.974\end{array}$ $\begin{array}{lllllllllllll}\text { MSVQPTVSLGGFEITPPVVLR } & 1.00 & 48.31 & 23.80 & 17.15 & 3 & 2370.3133 & 2370.3103 & 791.1107 & 0.0030 & 1.2640 & 13.057\end{array}$ $\begin{array}{llllllllllll}\text { VDNDENEHQLSLR } & 0.95 & 24.95 & 26.70 & 21.45 & 3 & 1711.8247 & 1711.8247 & 571.6155 & 0.0000 & 0.0000 & 66.341 \\ \text { VDNDENEHQLSR } & 0.78 & 15.72 & 26.80 & 1.16 & 3 & 1711.8265 & 1711.8247 & 571.6155 & 0.0018 & 1.0497 & 63.905\end{array}$ $\begin{array}{lllllllllllll}\text { VDNDENEHQLSLR } & 0.78 & 15.72 & 26.80 & 16.16 & 3 & 1711.8265 & 1711.8247 & 571.6155 & 0.0018 & 1.0497 & 63.905\end{array}$ $\begin{array}{lllllllllllll}\text { VDNDENEHQLSLR } & 0.55 & 33.29 & 26.84 & 46.29 & 3 & 1711.8271 & 1711.8247 & 571.6155 & 0.0024 & 1.3995 & 72.357\end{array}$ $\begin{array}{llllllllllllll}\text { VDNDENEHQLSLR } & 0.76 & 15.27 & 26.84 & 16.19 & 3 & 1711.8271 & 1711.8247 & 571.6155 & 0.0024 & 1.3995 & 71.06\end{array}$ $\begin{array}{llllllllllllll}\text { VDNDENEHQLSLR } & 0.53 & 19.77 & 26.88 & 32.77 & 3 & 1711.8280 & 1711.8247 & 571.6155 & 0.0033 & 1.9244 & 62.218\end{array}$ $\begin{array}{llllllllllll}\text { VDNDENEHQLSLR } & 0.97 & 24.59 & 26.88 & 22.36 & 3 & 1711.8280 & 1711.8247 & 571.6155 & 0.0033 & 1.9244 & 81.315\end{array}$ $\begin{array}{lllllllllllll}\text { VDNDENEHQLSLR } & 0.89 & 23.84 & 26.88 & 14.61 & 3 & 1711.8307 & 1711.8247 & 571.6155 & 0.0060 & 3.4988 & 73.812 \\ \text { VDNDENEHQLSLR } & 0.53 & 17.77 & 26.79 & 19.30 & 3 & 1711.8322 & 1711.8247 & 571.6155 & 0.0075 & 4.3736 & 11.725\end{array}$ $\begin{array}{lllllllllllll}\text { VDNDENEHQLSLR } & 0.53 & 17.77 & 26.79 & 19.30 & 3 & 1711.8322 & 1711.8247 & 571.6155 & 0.0075 & 4.3736 & 11.725 \\ \text { MSVOPTVSLGGFEITPPVVLR } & 0.76 & 81.75 & 23.84 & 94.75 & 2 & 2370.3114 & 2370.3103 & 1186.1624 & 0.0011 & 0.4637 & 140.178\end{array}$ $\begin{array}{lllllllllllll}\text { MSVQPTVSLGGFEITPPVVLR } & 0.76 & 81.75 & 23.84 & 94.75 & 2 & 2370.3114 & 2370.3103 & 1186.1624 & 0.0011 & 0.4637 & 140.178 \\ \text { MSVQPTVSLGGFEITPVVLR } & 1.00 & 82.87 & 23.84 & 18.65 & 2 & 2370.3114 & 2370.3103 & 1186.1624 & 0.0011 & 0.4637 & 161.900\end{array}$ $\begin{array}{llllllllllll}\text { MSVQPTVSLGGFEITPPVVLR } & 1.00 & 82.87 & 23.84 & 18.65 & 2 & 2370.3114 & 2370.3103 & 186.1624 & 0.0011 & 0.4637 & 161.900 \\ \text { MSVQPTVSLGGFEITPPVVLR } & 1.00 & 36.51 & 23.87 & 17.49 & 3 & 2370.3118 & 2370.3103 & 791.1107 & 0.0015 & 0.6320 & 10.707\end{array}$

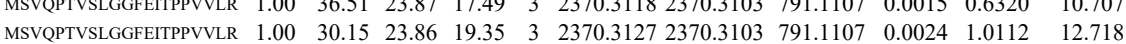

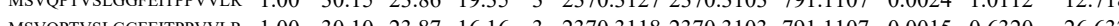

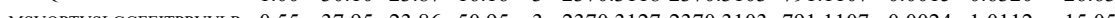
$\begin{array}{llllllllllll}\text { TVSLGAGAK } & 1.00 & 52.60 & 26.48 & 33.88 & 2 & 1090.6630 & 1090.6590 & 546.3368 & 0.0040 & 3.6607 & 776.383\end{array}$ TVSLGAGAK $\begin{array}{lllllllllll}1.00 & 52.60 & 26.48 & 33.88 & 2 & 1090.6630 & 1090.6590 & 546.3368 & 0.0040 & 3.6607 & 776.383 \\ 1.00 & 47.31 & 26.45 & 30.26 & 2 & 1090.6632 & 1090.6590 & 546.3368 & 0.0042 & 3.8438 & 679.280\end{array}$ $\begin{array}{lllllllllllll} & \text { MSVOPTVSLGGFETPPVYLR } & 0.99 & 25.22 & 23.80 & 15.30 & 3 & 2370.3130 & 2370.3103 & 791.1107 & 0.0027 & 1.1376 & 16.028\end{array}$ $\begin{array}{llllllllllll}\text { TVSLGAGAK } & 1.00 & 51.76 & 26.44 & 32.68 & 2 & 1090.6616 & 1090.6590 & 546.3368 & 0.0026 & 2.3795 & 390.616\end{array}$ TVSLGAGAK TVSLGAGAK VTLATLK VTLATLK TVSLGAGAK VTLATLK TVSLGAGAK TVSLGAGAK VDNDENEHQLSLR $\begin{array}{lllllllllllll}1.00 & 51.76 & 26.44 & 32.68 & 2 & 1090.6616 & 1090.6590 & 546.3368 & 0.0026 & 2.3795 & 390.616 & \\ 1.00 & 50.81 & 26.18 & 32.85 & 2 & 1090.6620 & 1090.6590 & 5463368 & 0.0030 & 2.7456 & 506.145\end{array}$ $\begin{array}{llllllllllll}0.99 & 43.05 & 26.48 & 31.90 & 2 & 1090.6628 & 1090.6590 & 546.3368 & 0.0038 & 3.4777 & 256.963 & 202\end{array}$ $\begin{array}{cc}256.963 & 202.216 \\ 1206.485 & 938.554 \\ 1029.394 & 708.075\end{array}$ $\begin{array}{lllllllllllll}1.00 & 39.59 & 13.62 & 25.96 & 2 & 1032.6826 & 1032.6787 & 517.3466 & 0.0039 & 3.7692 & 1029.394 & 708.075\end{array}$ $\begin{array}{llllllllllll}1.00 & 39.66 & 26.48 & 31.78 & 2 & 1090.6604 & 1090.6590 & 546.3368 & 0.0014 & 1.2813 & 447.492\end{array}$ $\begin{array}{llllllllllll}1.00 & 36.73 & 15.80 & 22.62 & 2 & 1032.6814 & 1032.6787 & 517.3466 & 0.0027 & 2.6095 & 434.766\end{array}$ $\begin{array}{llllllllllllll}1.00 & 49.09 & 26.40 & 34.40 & 2 & 1090.6610 & 1090.6590 & 546.3368 & 0.0020 & 1.8304 & 228.192 & 202.742\end{array}$ $\begin{array}{lllllllllll}1.00 & 53.32 & 26.48 & 32.08 & 2 & 1090.6626 & 1090.6590 & 546.3368 & 0.0036 & 3.2947 & 205.263\end{array}$ VDNDENEHQLSL $\begin{array}{lllllllllll}1.00 & 46.00 & 26.72 & 20.04 & 3 & 1711.8226 & 1711.8247 & 571.6155 & -0.0021 & -1.2246 & 136.670\end{array}$ VDNDENEHQLSLR VDNDENEHQLSLR VDNDENEHQLSLR VDNDENEHQLSLR VDNDENEHQLSLR VDNDENEHQLSLR VDNDENEHQLSLR VDNDENEHQLSLR VDNDENEHQLSLR VDNDENEHQSLR VDNDENEHQLSLR

VDSTEK

VTLATLK $\begin{array}{lllllllllll}0.86 & 26.84 & 26.77 & 18.31 & 3 & 1711.8232 & 1711.8247 & 571.6155 & -0.0015 & -0.8747 & 32.102\end{array}$ $\begin{array}{llllllllllll}0.99 & 30.47 & 26.62 & 20.28 & 3 & 1711.8244 & 1711.8247 & 571.6155 & -0.0003 & -0.1749 & 130.078 & \\ 0.55 & 26.80 & 6.80 & 39.80 & 3 & 1711.8265 & 1711.8247 & 571.6155 & 0.0018 & 1.0497 & 121.328\end{array}$ $\begin{array}{lllllllllll}0.55 & 32.37 & 26.80 & 45.37 & 3 & 1711.8265 & 1711.8247 & 571.6155 & 0.0018 & 1.0497 & 85.437\end{array}$ $\begin{array}{lllllllllllll}1.00 & 31.49 & 26.84 & 18.55 & 3 & 1711.8271 & 1711.8247 & 571.6155 & 0.0024 & 1.3995 & 122.887 & 1\end{array}$

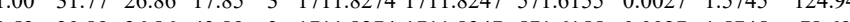
$\begin{array}{llllllllllll}0.53 & 30.89 & 26.86 & 43.89 & 3 & 1711.8274 & 1711.8247 & 571.6155 & 0.0027 & 1.5745 & 78.698\end{array}$ $\begin{array}{lllllllllll}1.00 & 34.63 & 26.79 & 18.56 & 3 & 1711.8277 & 1711.8247 & 571.6155 & 0.0030 & 1.7494 & 118.289\end{array}$ $\begin{array}{lllllllllll}1.00 & 47.41 & 26.88 & 19.47 & 3 & 1711.8280 & 1711.8247 & 571.6155 & 0.0033 & 1.9244 & 112.112\end{array}$

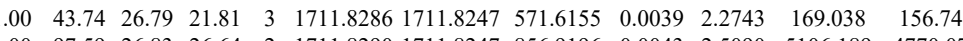
$\begin{array}{llllllllllll}.00 & 97.59 & 26.83 & 26.64 & 2 & 1711.8290 & 1711.8247 & 856.9196 & 0.0043 & 2.5090 & 5106.189 & 4770.073 \\ 1.00 & 94.89 & 26.82 & 25.95 & 2 & 1711.8296 & 1711.8247 & 856.9196 & 0.0049 & 2.8591 & 8674.621 & 7685.484\end{array}$

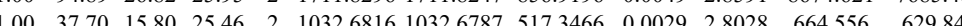
$\begin{array}{lllllllllllll}1.00 & 37.29 & 13.62 & 25.09 & 2 & 1032.6826 & 1032.6787 & 517.3466 & 0.0039 & 3.7692 & 610.069\end{array}$ 


\section{VTLATLK}

$\begin{array}{lllllllllll}1.00 & 4.60 & 26.44 & 32.83 & 2 & 109.6614 & 1090.6590 & 546.3368 & 0.0024 & 2.1964 & 253.023\end{array}$

$\begin{array}{llllllllllll} & 89.67 & 26.79 & 29.71 & 2 & 1711.8262 & 1711.8247 & 856.9196 & 0.0015 & 0.8752 & 1906.459 & 1871.273\end{array}$ VDNDENEHQLSLR $\begin{array}{lllll}1.00 & 79.16 & 26.80 & 27.39 & 2 \\ 0.53 & 71.98 & 26.79 & 84.98 & 3 \\ 1.00 & 50.89 & 27.38 & 20.82 & 3\end{array}$

$\begin{array}{llllllllllllll}0.53 & 71.98 & 26.79 & 84.98 & 3 & 1711.8277 & 1711.8247 & 571.6155 & 0.0030 & 1.7494 & 18382.815 & 17417.225\end{array}$ $\begin{array}{llllllllllllll} & 24.211 & 2432.2137 & 811.7452 & 0.0004 & 0.1643 & 20.297 & 22.769\end{array}$

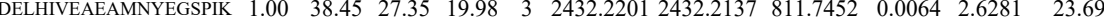

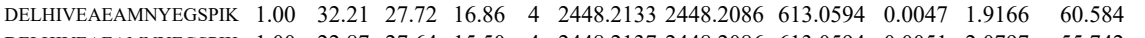
DELHIVEAEAMNYEGSPIK 


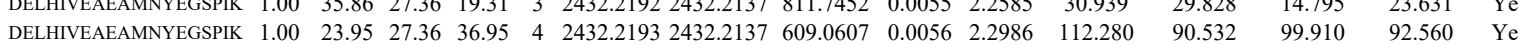

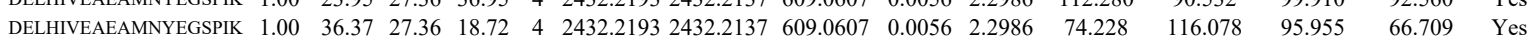
$\begin{array}{llllllllllllllll}\text { DELHIVEAEAMNYEGSPIK } & 1.00 & 38.89 & 27.36 & 16.63 & 4 & 2432.2193 & 24322137 & 609.0607 & 0.0056 & 2.2986 & 78.286 & 89.544 & 110.405 & 79.983 & \text { Yes }\end{array}$

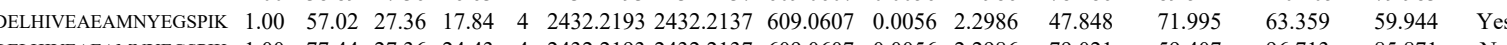
$\begin{array}{llllllllllllllll}\text { DELHIVEAEAMNYEGSPIK } & 1.00 & 77.44 & 27.36 & 24.43 & 4 & 2432.2193 & 2432.2137 & 609.0607 & 0.0056 & 2.2986 & 79.021 & 59.407 & 96.713 & 85.871 & \text { No }\end{array}$ $\begin{array}{llllllllllllllll}\text { DELHIVEAEAMNYEGSPIK } & 1.00 & 48.07 & 27.36 & 20.68 & 4 & 2432.2197 & 2432.2137 & 609.0607 & 0.0060 & 2.4628 & 235.224 & 172.437 & 639.425 & 247.672 & \text { No }\end{array}$

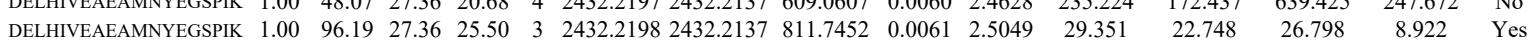

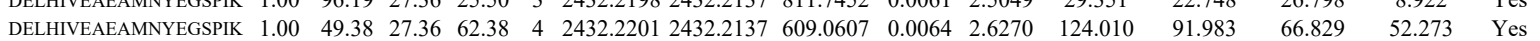

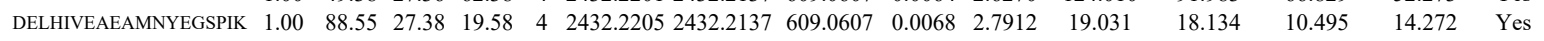
$\begin{array}{llllllllllllllll}\text { DELHIVEAEAMNYEGSPIK } & 1.00 & 24.38 & 27.67 & 15.23 & 4 & 2448.2125 & 2448.2086 & 613.0594 & 0.0039 & 1.5904 & 117.577 & 250.483 & 210.052 & 198.640 & \text { Yes }\end{array}$ $\begin{array}{llllllllllllllll}\text { SAPGGGSK } & 1.00 & 46.28 & 27.68 & 27.87 & 2 & 947.5288 & 947.5280 & 474.7713 & 0.0008 & 0.8425 & 1076.727 & 903.871 & 257.174 & 73.682 & \text { Yes }\end{array}$

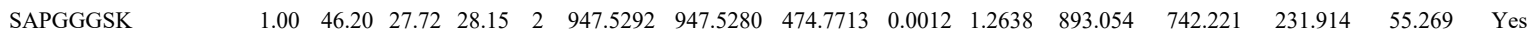

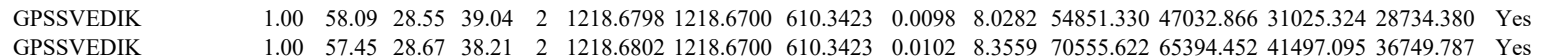

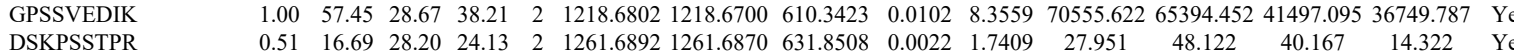
$\begin{array}{llllllllllllllll}\text { VDNDENEHQLSLR } & 1.00 & 67.26 & 27.03 & 20.09 & 3 & 1711.8394 & 1711.8247 & 571.6155 & 0.0147 & 8.5721 & 10205.769 & 8856.063 & 3109.176 & 1752.735 & \text { Yes }\end{array}$ $\begin{array}{llllllllllllllll}\text { VDNDENEHQLSLR } & 1.00 & 79.27 & 27.16 & 21.65 & 3 & 1711.8403 & 1711.8247 & 571.6155 & 0.0156 & 9.0969 & 10828.693 & 8865.079 & 2384.878 & 2096.413 & \text { Yes }\end{array}$

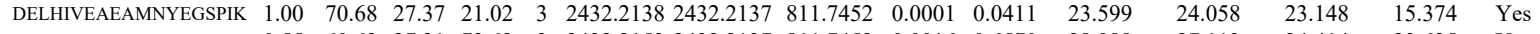
$\begin{array}{lllllllllllllllll}\text { DELHIVEAEAMNYEGSPIK } & 0.55 & 60.62 & 27.31 & 73.62 & 3 & 2432.2153 & 2432.2137 & 811.7452 & 0.0016 & 0.6570 & 28.988 & 27.113 & 24.414 & 23.625 & \text { Yes }\end{array}$

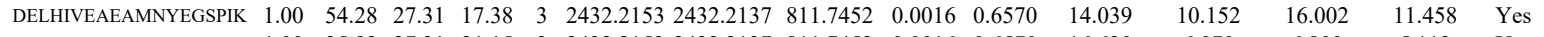

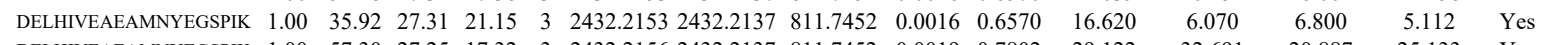
$\begin{array}{llllllllllllllll}\text { DELHIVEAEAMNYEGSPIK } & 1.00 & 57.30 & 27.25 & 17.32 & 3 & 2432.2156 & 2432.2137 & 811.7452 & 0.0019 & 0.7802 & 29.122 & 32.691 & 20.887 & 25.133 & \text { Yes }\end{array}$ $\begin{array}{llllllllllllllll}\text { DELHIVEAEAMNYEGSPIK } & 0.76 & 8.75 & 27.28 & 14.67 & 4 & 2432.2161 & 2432.2137 & 609.0607 & 0.0024 & 0.9851 & 101.083 & 126.635 & 85.178 & 91.520 & \text { Yes }\end{array}$

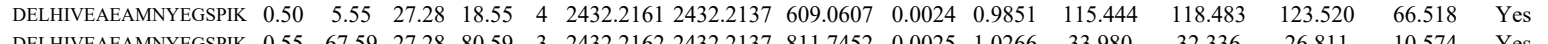
$\begin{array}{llllllllllllllll}\text { DELHIVEAEAMNYEGSPIK } & 0.55 & 67.59 & 27.28 & 80.59 & 3 & 2432.2162 & 2432.2137 & 811.7452 & 0.0025 & 1.0266 & 33.980 & 32.336 & 26.811 & 10.574 & \text { Yes }\end{array}$ \begin{tabular}{llllllllllllllll} 
DELHIVEAEAMNYEGSPIK & 0.55 & 68.04 & 27.28 & 81.04 & 3 & 2432.2162 & 2432.2137 & 811.7452 & 0.0025 & 1.0266 & 27.942 & 16.023 & 23.278 & 21.214 & Yes \\
\hline
\end{tabular}

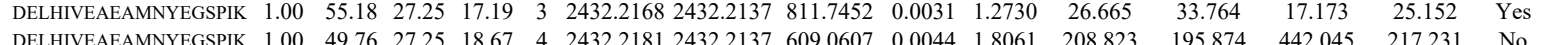

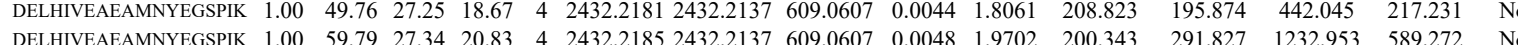

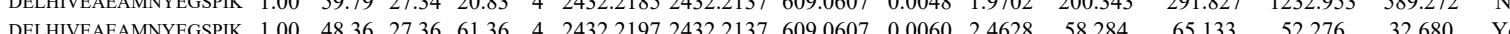

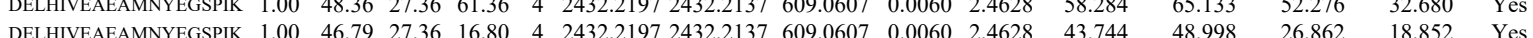

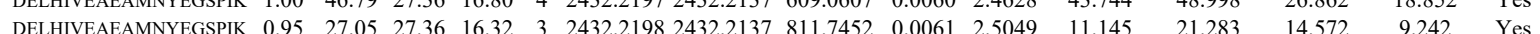

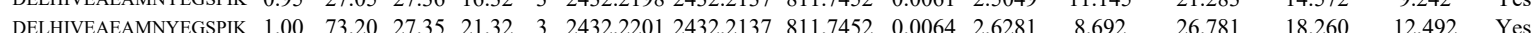

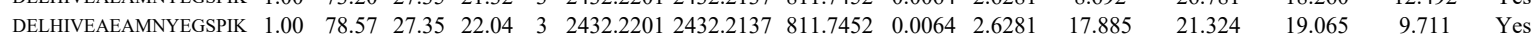

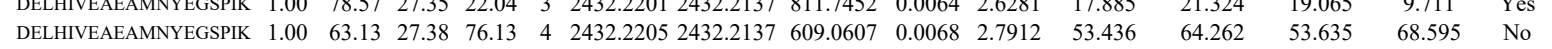
$\begin{array}{llllllllllllllll}\text { DELHIVEAEAMNYEGSPIK } & 0.98 & 35.55 & 27.35 & 29.11 & 3 & 2432.2213 & 2432.2137 & 811.7452 & 0.0076 & 3.1208 & 24.823 & 15.191 & 30.574 & 20.134 & \text { Yes }\end{array}$

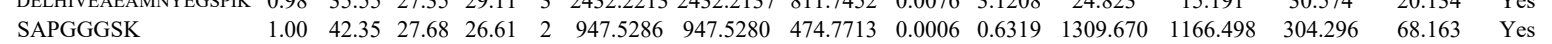
$\begin{array}{llllllllllllllll}\text { SAPGGGSK } & 1.00 & 46.47 & 27.45 & 29.39 & 2 & 947.5294 & 947.5280 & 474.7713 & 0.0014 & 1.4744 & 1469.213 & 1116.534 & 333.751 & 40.627 & \text { Yes }\end{array}$

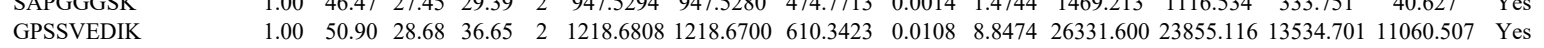
$\begin{array}{llllllllllllllll}\text { GPSSVEDIK } & 0.98 & 39.57 & 28.69 & 27.57 & 2 & 1218.6810 & 1218.6700 & 610.3423 & 0.0110 & 9.0113 & 25277.935 & 20675.145 & 13162.367 & 8979.194 & \text { Yes }\end{array}$

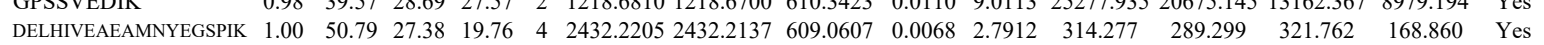
$\begin{array}{lllllllllllllllll}\text { DELHIVEAEAMNYEGSPIK } & 1.00 & 51.50 & 27.40 & 64.50 & 4 & 2432.2269 & 2432.2137 & 609.0607 & 0.0132 & 5.4181 & 32.960 & 41.557 & 50.390 & 21.110 & \text { Yes }\end{array}$ $\begin{array}{llllllllllllllll}\text { DELHIVEAEAMNYEGSPIK } & 1.00 & 43.14 & 27.40 & 16.24 & 3 & 2432.2303 & 2432.2137 & 811.7452 & 0.0166 & 6.8165 & 46.493 & 18.658 & 14.488 & 21.959 & \text { Yes }\end{array}$ $\begin{array}{lllllllllllllllll}\text { DELHIVEAEAMNYEGSPIK } & 0.50 & 23.16 & 27.29 & 16.08 & 3 & 2432.2369 & 2432.2137 & 811.7452 & 0.0232 & 9.5267 & 16.283 & 13.339 & 6.674 & 5.246 & \text { Yes }\end{array}$

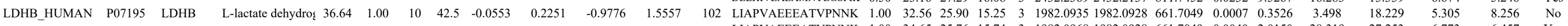
$\begin{array}{lllllllllllllllll}\text { LIAPVAEEEATVPNNK } & 1.00 & 34.65 & 25.76 & 15.74 & 3 & 1982.0968 & 1982.0928 & 661.7049 & 0.0040 & 2.0150 & 28.319 & 27.253 & 6.773 & 6.457 & \text { Yes }\end{array}$ $\begin{array}{llllllllllllllll}\text { SADTLWDIQK } & 1.00 & 59.42 & 27.67 & 26.90 & 2 & 1463.7936 & 1463.7864 & 732.9005 & 0.0072 & 4.9120 & 16372.714 & 13959.950 & 2852.595 & 840.422 & \text { Yes }\end{array}$ $\begin{array}{llllllllllllllll}\text { SADTLWDIQK } & 1.00 & 59.06 & 27.67 & 26.75 & 2 & 1463.7936 & 1463.7864 & 732.9005 & 0.0072 & 4.9120 & 10880.450 & 10790.676 & 2671.953 & 356.479 & \text { Yes }\end{array}$ $\begin{array}{llllllllllllllll}\text { SADTLWDIQK } & 1.00 & 58.41 & 28.21 & 26.64 & 2 & 1463.7968 & 1463.7864 & 732.9005 & 0.0104 & 7.0950 & 8529.181 & 7698.729 & 2545.799 & 228.242 & \text { Yes }\end{array}$

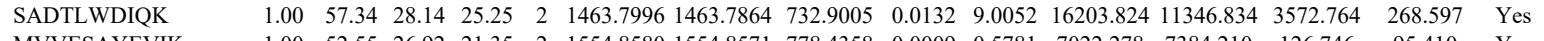

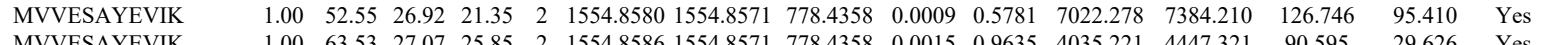

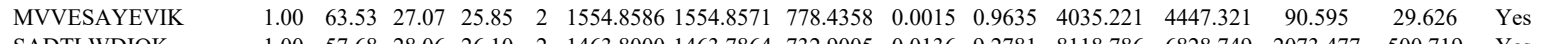

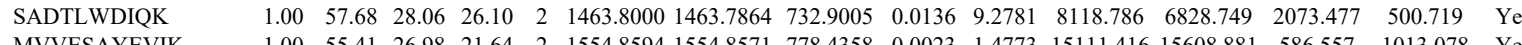

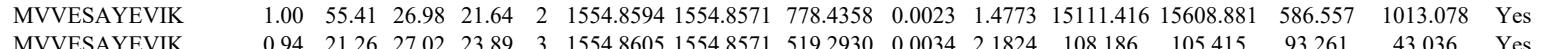

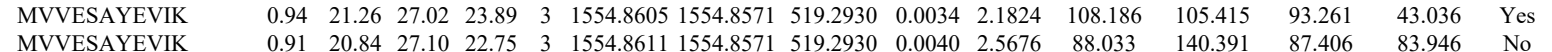

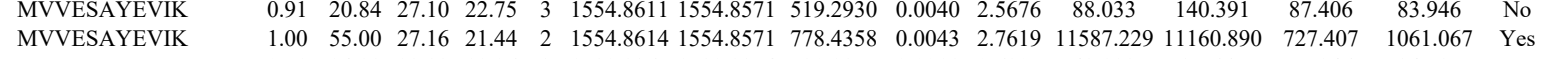
$\begin{array}{llllllll}24.98 & 23.82 & 19.96 & 3 & 1589.9365 & 1589.9354 & 530.9857 & 0.00\end{array}$ 

$\begin{array}{lllllllllllllllll}0.60 & 32.47 * 24.36 & 25.84 & 2 & 1298.7656 & 1298.7624 & 650.3885 & 0.0032 & 2.4601 & 17037.393 & 20074.831 & 257.270 & 207.451 & \text { Yes } \\ 0.85 & 33.91 * 25.16 & 23.28 & 3 & 1298.764 & 1298.724 & 433.928 & 0.000 & 3.0727 & 13170.435 & 13128.493 & 521350 & 468.27 & \text { Yes }\end{array}$ $\begin{array}{llllllllllllllll}0.85 & 33.91 * & 25.16 & 23.28 & 3 & 1298.7664 & 1298.7624 & 433.9281 & 0.0040 & 3.0727 & 13170.435 & 13128.493 & 521.350 & 468.271 & \text { Yes } & \\ 0\end{array}$ IHPVSTMVK

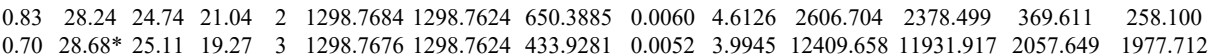
$\begin{array}{lllllllllllllll} & \end{array}$

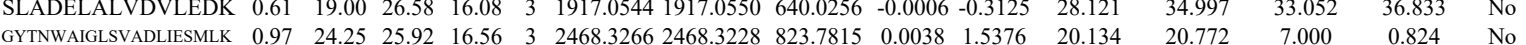

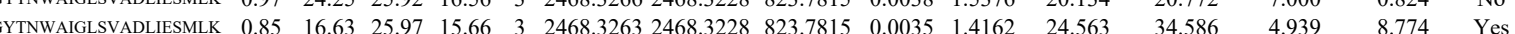
$\begin{array}{llllllllllllllll}1.00 & 30.88 & 19.19 & 23.03 & 2 & 1244.8116 & 1244.8100 & 623.4123 & 0.0016 & 1.2833 & 459.091 & 449.593 & 88.975 & 38.686 & \text { Yes }\end{array}$

FIPQIVK

FIIPQIVK

FIIPOIVK

FIIPOIVK

FIIPQIVK

FIIPQIVK

FIIPQIVK

FIIPQIVK

FIIPQIVK

FIIPQIVK

IVVVTAGVR

IVVVTAGVR

IVVVTAGVR

IVVVTAGVR

IVVVTAGVR

IVVVTAGVR

FIIPQIVK

FIIPQIVK

IVVVTAGVR

IVVVTAGVR

IVVVTAGVR

IVVVTAGVR

IVVVTAGVR

FIPQIVK

IVVVTAGVR

IVVVAGVR

FIIPQIVK

FIIPQIVK

IVVVTAGVR

IVVVTAGV

IVVVTAGVR

IVVVTAGVR

IVVVTAGVR

IVVVTAGVR

IVVVTAGVR

IVVVTAGVR

IVVVTAGV

IVVVTAGVR

IVVVTAGVR

IVVVTAGVR

IVVVTAGVR

IVVVTAGVR

IVVVTAGVR

IVVVTAGVR

IVVVTAGVR

IVVVTAGVR

IVVVTAGVR

FIIPQIVK

IVVTTAGV

IVVVTAGVR
IVVVTAGVR

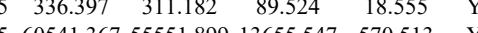

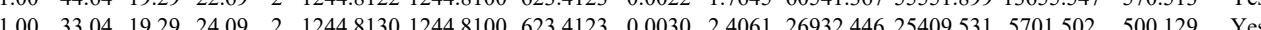

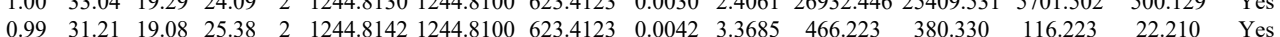

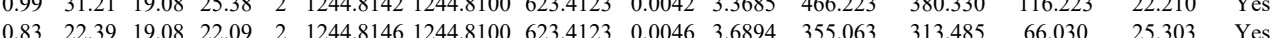

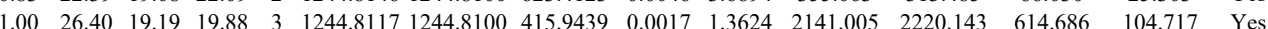
$\begin{array}{llllllllllllllll}0.97 & 26.07 & 19.29 & 27.81 & 3 & 1244.8123 & 1244.8100 & 415.9439 & 0.0023 & 1.8432 & 2298.127 & 1843.080 & 451.264 & 59.527 & \text { Yes }\end{array}$ $\begin{array}{lllllllllllllll}1.00 & 34.66 & 19.29 & 19.98 & 2 & 1244.8128 & 1244.8100 & 623.4123 & 0.0028 & 2.2457 & 12902.821 & 11070.190 & 2473.098 & 284.161 & \text { Yes }\end{array}$ $\begin{array}{lllllllllllllll}0.99 & 33.13 & 19.08 & 22.90 & 2 & 1244.8138 & 1244.8100 & 623.4123 & 0.0038 & 3.0477 & 52338.983 & 52406.554 & 11315.252 & 800.330 & \text { Yes }\end{array}$ $\begin{array}{lllllllllllllll}0.51 & 15.75 & 19.08 & 19.33 & 2 & 1244.8156 & 1244.8100 & 623.4123 & 0.0056 & 4.4914 & 385.167 & 325.383 & 86.572 & 43.598 & \text { Yes }\end{array}$ $\begin{array}{llllllllllllllll}1.00 & 44.82 & 19.19 & 22.06 & 2 & 1244.8136 & 1244.8100 & 623.4123 & 0.0036 & 2.8873 & 39048.481 & 37448.447 & 7427.072 & 253.018 & \text { Yes }\end{array}$ $\begin{array}{llllllllllllllll}1.00 & 44.88 & 19.08 & 22.16 & 2 & 1244.8138 & 1244.8100 & 623.4123 & 0.0038 & 3.0477 & 21423.309 & 22086.526 & 4853.706 & 180.570 & \text { Yes }\end{array}$ $\begin{array}{lllllllllllllll}0.94 & 25.60 & 21.73 & 27.00 & 2 & 1056.6780 & 1056.6777 & 529.3461 & 0.0003 & 0.2834 & 55.131 & 60.591 & 14.881 & 13.841 & \text { Yes }\end{array}$

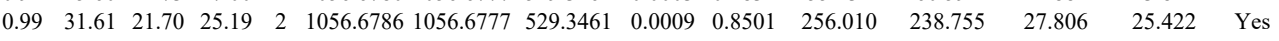
$\begin{array}{lllllllllllllll}1.00 & 36.83 & 21.70 & 26.57 & 2 & 1056.6792 & 1056.6777 & 529.3461 & 0.0015 & 1.4168 & 64.458 & 54.866 & 25.714 & 2.303 & \text { Yes }\end{array}$

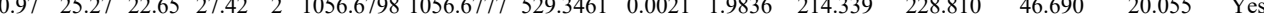

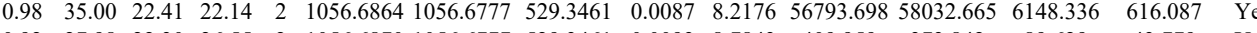
$\begin{array}{lllllllllllllll}0.92 & 27.98 & 22.30 & 26.55 & 2 & 1056.6870 & 1056.6777 & 529.3461 & 0.0093 & 8.7843 & 409.959 & 373.842 & 89.629 & 43.779 & \text { Yes }\end{array}$

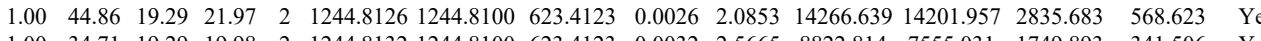
$\begin{array}{llllllllllllllll}1.00 & 34.71 & 19.29 & 19.98 & 2 & 1244.8132 & 1244.8100 & 623.4123 & 0.0032 & 2.5665 & 8822.814 & 7555.031 & 1749.893 & 341.506 & \text { Yes }\end{array}$

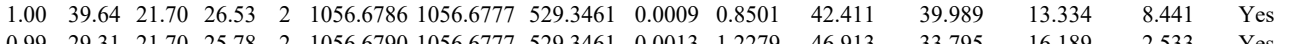

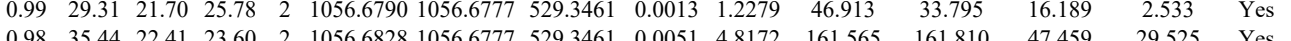
$\begin{array}{lllllllllllllll}0.98 & 35.44 & 22.41 & 23.60 & 2 & 1056.6828 & 1056.6777 & 529.3461 & 0.0051 & 4.8172 & 161.565 & 161.810 & 47.459 & 29.525 & \text { Yes } \\ 0.98 & 35.07 & 22.30 & 21.45 & 2 & 1056.6866 & 10566777 & 529.3461 & 0.0089 & 8.4065 & 95636.573 & 88853.336 & 12406287 & 1035.986 & \text { Yes }\end{array}$ $\begin{array}{lllllllllllllllll}0.98 & 35.07 & 22.30 & 21.45 & 2 & 1056.6866 & 1056.6777 & 529.3461 & 0.0089 & 8.4065 & 95636.573 & 88853.336 & 12406.287 & 1035.986 & \text { Yes } \\ 1.00 & 41.85 & 22.30 & 28.32 & 2 & 10566872 & 10566777 & 529.3461 & 0.0095 & 8.9733 & 46209.793 & 49197.471 & 5601.060 & 247.070 & \text { Yes }\end{array}$ $\begin{array}{llllllllllllllll}1.00 & 41.85 & 22.30 & 28.32 & 2 & 1056.6872 & 1056.6777 & 529.3461 & 0.009 & 8.9733 & 46209.793 & 49197.471 & 5601.060 & 247.070 & \text { Yes } \\ 1.00 & 44.90 & 19.29 & 20.72 & 2 & 1244.8122 & 1244.8100 & 623.4123 & 0.0022 & 1.7645 & 8780.614 & 8643.657 & 2376.715 & 300.326 & \text { Yes }\end{array}$

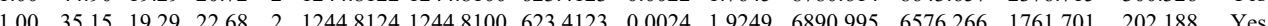
$\begin{array}{lllllllllllllll}0.99 & 41.36 & 22.15 & 30.62 & 2 & 10566876 & 10566777 & 529.3461 & 0.0099 & 9.3511 & 25575.675 & 25634.777 & 2503.066 & 573.265 & \text { Yes }\end{array}$ $\begin{array}{lllllllllllllll}0.99 & 37.59 & 22.15 & 29.76 & 2 & 1056.6876 & 1056.6777 & 529.3461 & 0.0099 & 9.3511 & 44546.759 & 47262.135 & 4436.110 & 838.156 & \text { Y }\end{array}$

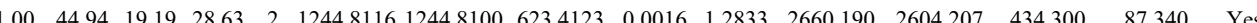
$\begin{array}{lllllllllllllll}1.00 & 46.98 & 19.19 & 20.92 & 2 & 1244.8116 & 1244.8100 & 623.4123 & 0.0016 & 1.2833 & 3459.790 & 3155.045 & 532.987 & 110.216 & \text { Yes }\end{array}$ $\begin{array}{llllllllllllllll}100 & 41.47 & 22.15 & 28.18 & 2 & 1056.6876 & 1056.6777 & 529.3461 & 0.0099 & 9.3511 & 12284.536 & 12421.935 & 1277.042 & 70.124 & \text { Yes }\end{array}$ $\begin{array}{lllllllllllllll}1.00 & 41.60 & 22.15 & 28.40 & 2 & 1056.6878 & 1056.6777 & 529.3461 & 0.0101 & 9.5400 & 17086.671 & 15978.792 & 1648.614 & 212.166 & \text { Yes }\end{array}$ $\begin{array}{lllllllllllllll}1.00 & 34.45 & 19.29 & 23.18 & 2 & 1244.8124 & 1244.8100 & 623.4123 & 0.0024 & 1.9249 & 2852.929 & 2825.053 & 678.251 & 42.787 & \text { Yes }\end{array}$ $\begin{array}{lllllllllllllll}0.99 & 33.01 & 21.70 & 28.85 & 2 & 1056.6788 & 1056.6777 & 529.3461 & 0.0011 & 1.0390 & 1574.226 & 1530.972 & 464.058 & 218.154 & \text { Yes }\end{array}$

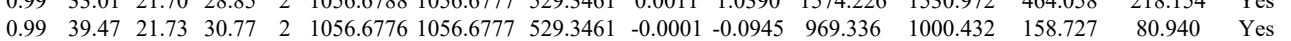
$\begin{array}{lllllllllllllll}0.97 & 28.87 & 21.73 & 28.94 & 2 & 1056.6778 & 1056.6777 & 529.3461 & 0.0001 & 0.0945 & 848.601 & 673.037 & 129.981 & 76.465 & \text { Yes }\end{array}$

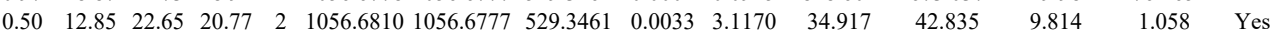

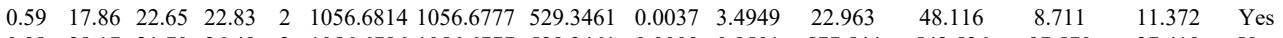

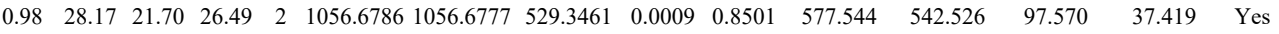

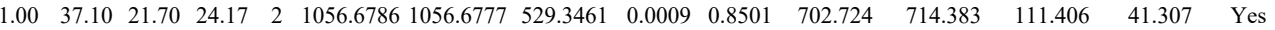

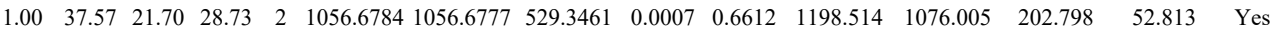
$\begin{array}{lllllllllllllll}0.99 & 33.39 & 21.70 & 27.75 & 2 & 1056.6788 & 1056.6777 & 529.3461 & 0.0011 & 1.0390 & 744.191 & 796.837 & 106.965 & 47.654 & \text { Yes }\end{array}$ $\begin{array}{lllllllllllllll}0.99 & 32.01 & 21.70 & 29.46 & 2 & 1056.6786 & 1056.6777 & 529.3461 & 0.0009 & 0.8501 & 346.457 & 380.159 & 77.179 & 2.889 & \text { Yes }\end{array}$

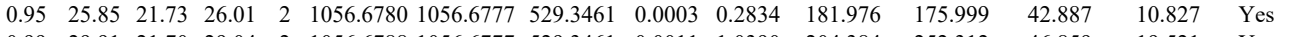
$\begin{array}{lllllllllllllll}0.99 & 29.91 & 21.70 & 29.04 & 2 & 1056.6788 & 1056.6777 & 529.3461 & 0.0011 & 1.0390 & 204.384 & 252.312 & 46.859 & 19.521 & \text { Yes }\end{array}$

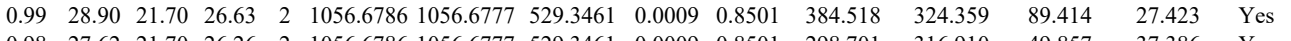

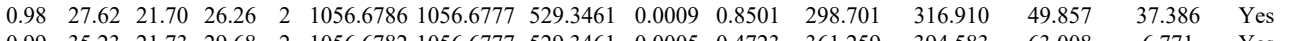

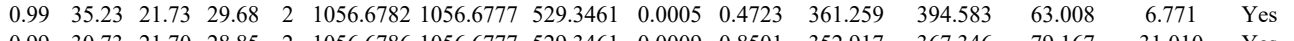
$\begin{array}{lllllllllllllll}0.99 & 30.73 & 21.7 & 28.85 & 2 & 1056.6786 & 1056.6777 & 529.3461 & 0.0009 & 0.8501 & 352.917 & 367.346 & 79.167 & 31.010 & \text { Yes } \\ 0.99 & 34.68 & 21.73 & 27.50 & 2 & 1056.6780 & 1056.6777 & 529.3461 & 0.0003 & 0.2834 & 433.217 & 427.562 & 54.961 & 2.488 & \text { Yes }\end{array}$

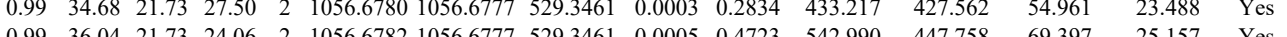

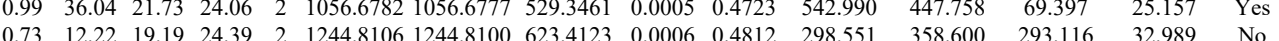
$\begin{array}{lllllllllllllll}0.73 & 12.22 & 19.19 & 24.39 & 2 & 1244.8106 & 1244.810 & 623.4123 & 0.0006 & 0.4812 & 298.551 & 358.600 & 293.116 & 32.989 & \text { No } \\ 0.93 & 18.81 & 19.19 & 25.03 & 2 & 12448108 & 1244.8100 & 623.4123 & 0.0008 & 0.6416 & 305.453 & 382082 & 282.651 & 19.784 & \text { Yes }\end{array}$

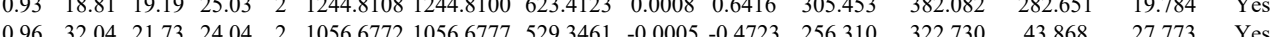
$\begin{array}{lllllllllllllll}0.99 & 34.40 & 21.73 & 23.88 & 2 & 1056.6776 & 1056.6777 & 529.3461 & -0.0001 & -0.0945 & 435.432 & 429.345 & 71.270 & 23.198 & \text { Yes }\end{array}$

Table S-3 page 82 of 499 
FIIPQIVK

IVVVTAGVR

IVVVTAGVR

FIIPQIVK

IVVVTAGVR

IVVVTAGVR

FIIPQIVK

IVVVTAGVR

IVVVTAGVR

IVVVTAGVR

IVVVTAGVR

IVVVTAGVR

LKDDEVAQLK

LKDDEVAQLK

LKDDEVAQLK

LKDDEVAQLK

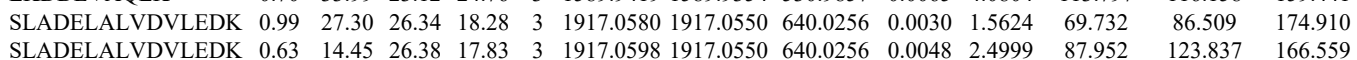
$\begin{array}{lllllllllllllllll}\text { SLADELALVDVLEDK } & 1.00 & 14.45 & 26.38 & 17.83 & 3 & 1917.0598 & 1917.0550 & 640.0256 & 0.0048 & 2.4999 & 87.952 & 123.837 & 166.559 \\ \end{array}$

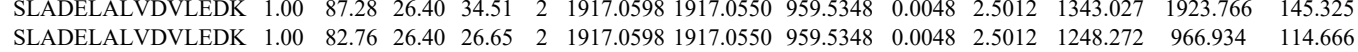

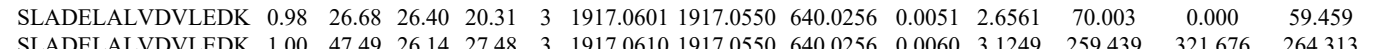

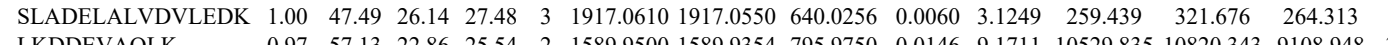

LKDDEVAQLK

LKDDEVAQLK

LKDDEVAQLK

$\begin{array}{lllllllllllll}0.97 & 57.13 & 22.86 & 25.54 & 2 & 1589.9500 & 1589.9354 & 795.9750 & 0.0146 & 9.1711 & 10529.835 & 10820.343 & 9108.948\end{array}$

$\begin{array}{lllllllllllll} & \end{array}$

$\begin{array}{lllllllllllll} & \end{array}$

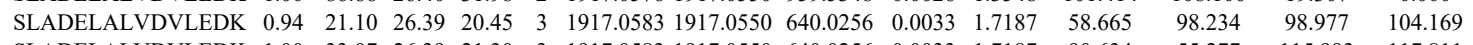

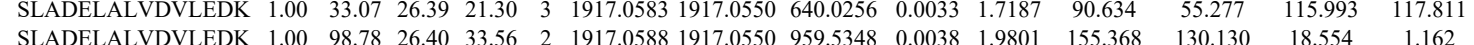
$\begin{array}{llllllllllllllll}\text { SLADELALVDVLEDK } & 1.00 & 98.78 & 26.40 & 33.56 & 2 & 1917.0588 & 1917.0550 & 959.5348 & 0.0038 & 1.9801 & 155.368 & 130.130 & 18.554 & 1.162 & \mathrm{Y}\end{array}$ $\begin{array}{llllllllllllllll}\text { LIAPVAEEEATVNNK } & 1.00 & 92.27 & 25.76 & 19.33 & 2 & 1982.0966 & 1982.0928 & 992.0537 & 0.0038 & 1.9152 & 7794.666 & 7973.067 & 6754.225 & 1228.922 & \text { Yeres }\end{array}$ $\begin{array}{llllllllllllllll}\text { LIAPVAEEEANFNK } & 1.00 & 94.88 & 25.76 & 21.16 & 2 & 1982.0966 & 1982.0928 & 992.0537 & 0.0038 & 1.9152 & 2597.956 & 2186.709 & 1718.915 & 399.469 & \text { Yes }\end{array}$

$\begin{array}{lllllllllllllll}0.97 & 57.45 & 22.86 & 26.23 & 2 & 1589.9500 & 1589.9354 & 795.9750 & 0.0146 & 9.1711 & 15520.204 & 15490.431 & 15058.097 & 3848.222\end{array}$ $\begin{array}{lllllllllllllllll}\text { QFLQAAEAIDDIFGITSNSDVFSK } & 0.99 & 28.73 & 26.51 & 16.24 & 3 & 3000.5362 & 3000.5324 & 1001.1847 & 0.0038 & 1.2652 & 7.766 & 2.465 & 0.000 & 0.000 & \text { No }\end{array}$

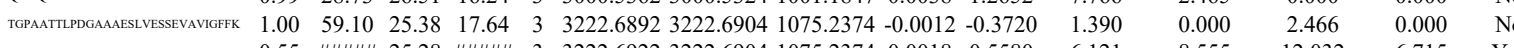

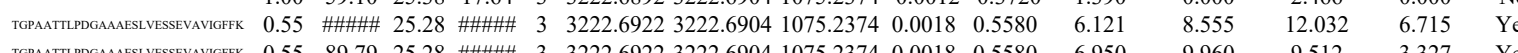

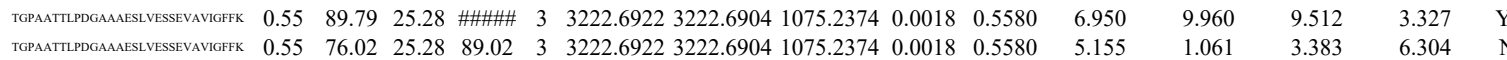

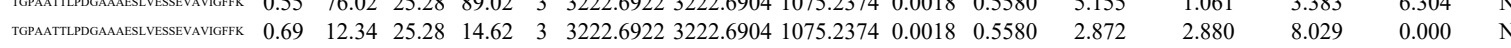

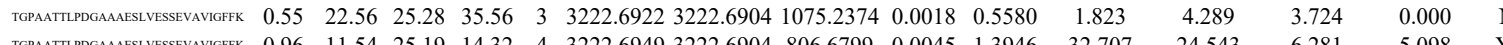

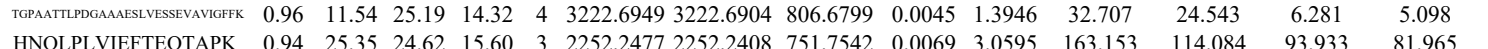
$\begin{array}{llllllllllllllll}\text { HNQLPLVIEFTEQTAPK } & 1.00 & 54.73 & 24.62 & 17.05 & 3 & 2252.2477 & 2252.2408 & 751.7542 & 0.0069 & 3.0595 & 30.379 & 165.964 & 24.822 & 43.680 & \text { No }\end{array}$ $\begin{array}{llllllllllllllll}\text { QFLQAAEAIDDIFFGITSNSDVFSK } & 1.00 & 32.39 & 26.51 & 15.76 & 3 & 3000.5362 & 3000.5324 & 1001.1847 & 0.0038 & 1.2652 & 9.796 & 6.217 & 10.436 & 0.000 & \text { No }\end{array}$ $\begin{array}{llllllllllllllll}\text { QFLQAAEAIIDIFGGITSNSDVFSK } & 1.00 & 34.88 & 26.51 & 20.32 & 3 & 3000.5362 & 3000.5324 & 1001.1847 & 0.0038 & 1.2652 & 5.257 & 0.000 & 0.000 & 0.000 & \text { No }\end{array}$

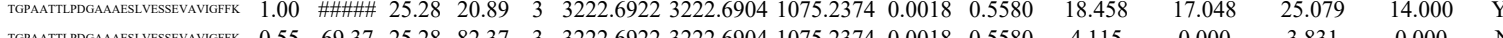

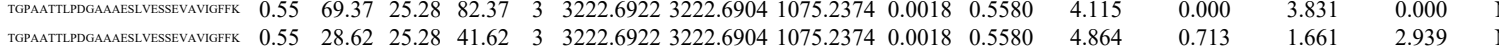

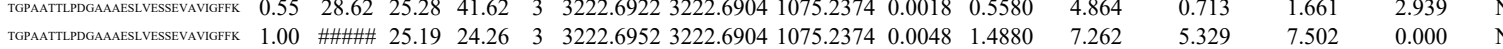

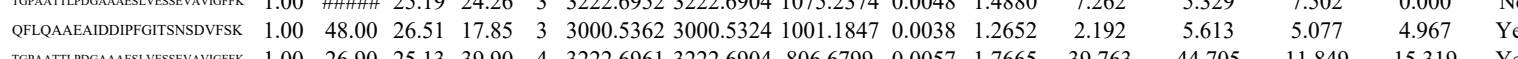
$\begin{array}{llllllllllllllll}\text { TGPAATLPDGAAAELLESSEVAVGGFKK } & 1.00 & 26.90 & 25.13 & 39.90 & 4 & 3222.6961 & 3222.6904 & 806.6799 & 0.0057 & 1.7665 & 39.763 & 44.705 & 11.849 & 15.319 & \text { Yes }\end{array}$

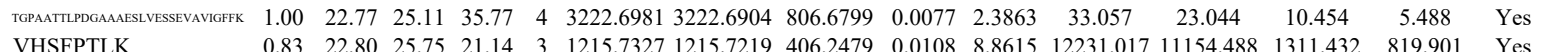

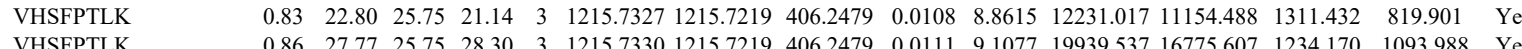

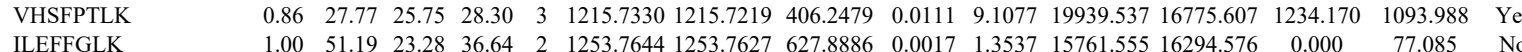

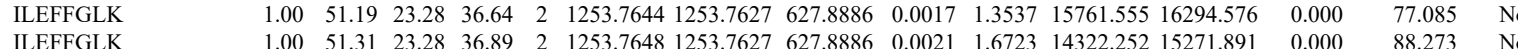

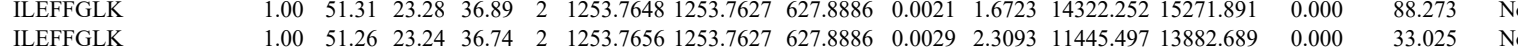

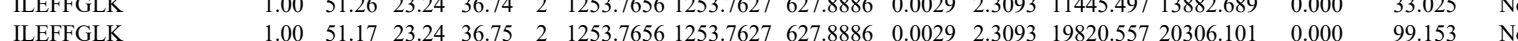

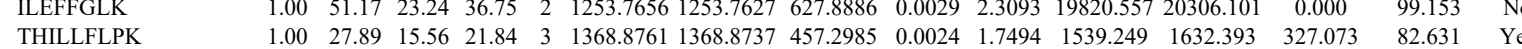



$\begin{array}{llllllllllllllll}1.00 & 42.27 & 28.35 & 20.21 & 3 & 1445.7880 & 1445.7870 & 482.9363 & 0.0010 & 0.6902 & 294.426 & 295.227 & 403.923 & 275.280 & \text { Yes }\end{array}$

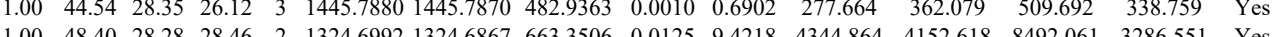

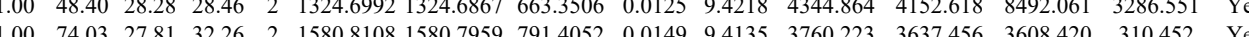

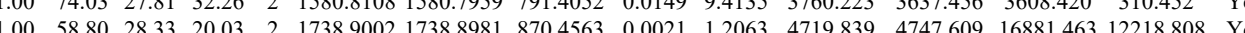
$\begin{array}{lllllllllllllll}1.00 & 51.39 & 28.33 & 21.28 & 2 & 1738.9002 & 17388.891 & 870.4563 & 0.0021 & 1.2063 & 3558.186 & 4092.921 & 11700.114 & 11541.384 & \text { No }\end{array}$

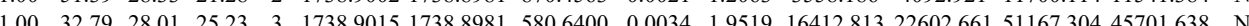

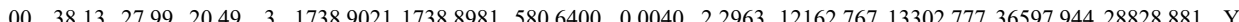
$\begin{array}{lllllllllllllll}1.00 & 40.30 & 28.10 & 23.25 & 3 & 1738.9060 & 1738.8981 & 580.6400 & 0.0079 & 4.5352 & 7549.504 & 10579.720 & 24809.405 & 21977.593 & \text { No }\end{array}$ $\begin{array}{lllllllllllllll}1.00 & 44.85 & 28.10 & 23.70 & 3 & 1738.9060 & 1738.8981 & 580.6400 & 0.0079 & 4.5352 & 9880.968 & 9469.453 & 22132.153 & 18922.392 & \text { Yes }\end{array}$ $\begin{array}{lllllllllllllll}1.00 & 44.85 & 28.10 & 23.70 & 3 & 1738.9060 & 1738.8981 & 580.6400 & 0.0079 & 4.5352 & 9880.968 & 9469.453 & 22132.153 & 18922.392 & \text { Yes } \\ \end{array}$ VSTLPAITLK $\begin{array}{lllllllllllllll} & 92.56 & 27.49 & 22.65 & 2 & 1923.9326 & 1923.9296 & 962.9721 & 0.0030 & 1.5577 & 2965.267 & 3716.836 & 1663.408 & 106.934 & \text { Yes }\end{array}$ $\begin{array}{lllllllllllllll}1.00 & 63.49 & 27.22 & 25.40 & 2 & 1493.8268 & 1493.8254 & 747.9200 & 0.0014 & 0.9359 & 8550.775 & 7984.830 & 7.933 & 184.389 & Y \text { Yes } \\ 1.00 & 62.32 & 27.22 & 23.94 & 2 & 143.8274 & 1493.8254 & 747.9200 & 0.0020 & 1.3370 & 14093.690 & 14115.009 & 0.000 & 145.155 & \mathrm{No}\end{array}$

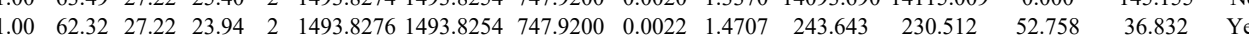

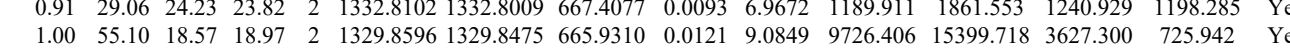

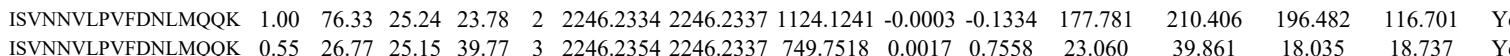
$\begin{array}{llllllllllllllll}\text { ISVNNVLPVFDNLMQK } & 0.55 & 26.77 & 25.15 & 39.77 & 3 & 2246.2354 & 2246.2337 & 749.7518 & 0.0017 & 0.7558 & 23.060 & 39.861 & 18.035 & 18.737 & \text { Yes }\end{array}$ \begin{tabular}{llllllllllllllll} 
ISVNNVLPVFNLMQQK & 1.00 & 93.58 & 25.17 & 24.78 & 2 & 2246.2354 & 2246.2337 & 1124.1241 & 0.0017 & 0.7561 & 69.683 & 136.841 & 113.951 & 39.989 & Yes \\
\hline
\end{tabular}

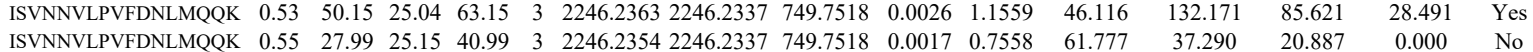

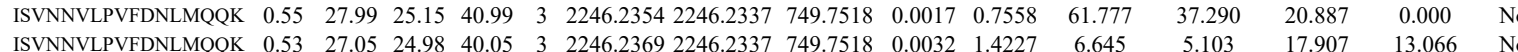

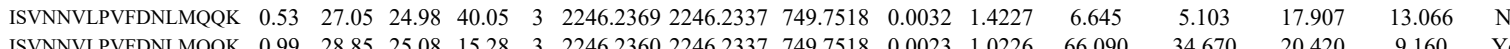

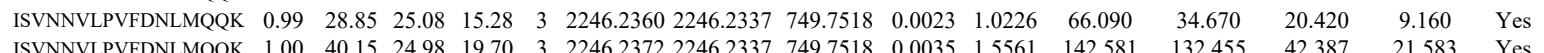
$\begin{array}{llllllllllllllll}\text { ISVNNVLPVFDNLMQQK } & 1.00 & 40.15 & 24.98 & 19.70 & 3 & 2246.2372 & 2246.2337 & 749.7518 & 0.0035 & 1.5561 & 142.581 & 132.455 & 42.387 & 21.583 & \text { Yes } \\ \text { DPDAQPGGELMLGGTDSK } & 1.00 & 96.42 & 27.79 & 22.48 & 2 & 2075.0274 & 2075.0085 & 1038.5115 & 0.0189 & 9.0995 & 104.527 & 229.322 & 144.683 & 203.937 & \text { Yes }\end{array}$ $\begin{array}{llllllllllll} & & & & & & & & & & & \\ \text { DPDAQPGGELMLG }\end{array}$ TPAQYDASELK TPAQYDASELK TPAQYDASELK TPAQYDASELK $\begin{array}{llllllllllllll}0.98 & 34.83 & 28.24 & 23.38 & 2 & 1509.7930 & 1509.7918 & 755.9032 & 0.0012 & 0.7938 & 10.114 & 12.044 & 7.905 & 14.937\end{array}$

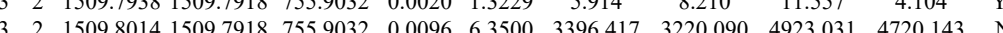
$\begin{array}{llllllllllllllll}0.99 & 42.72 & 28.24 & 17.92 & 2 & 1509.8022 & 1509.7918 & 755.9032 & 0.0104 & 6.8791 & 2417.931 & 2511.302 & 4268.646 & 3765.684 & \mathrm{~N}\end{array}$ $\begin{array}{llllllllllllll} & 18.428 & \text { No }\end{array}$

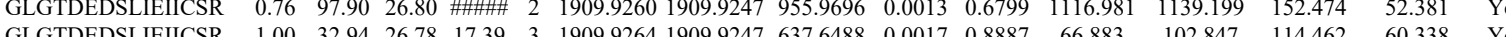

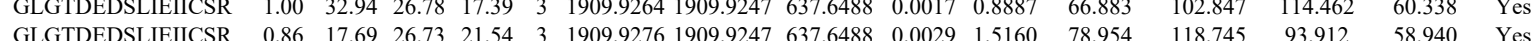
$\begin{array}{llllllllllllll} & \end{array}$ $\begin{array}{lllllllllllllll} & \end{array}$

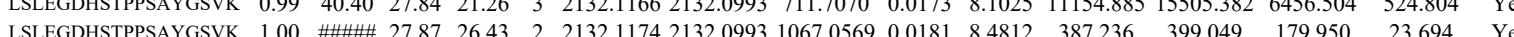

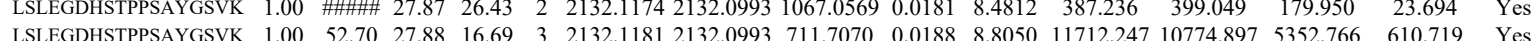

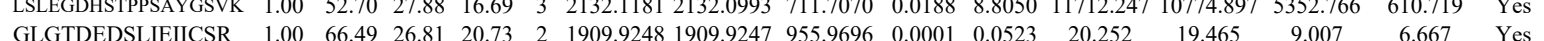

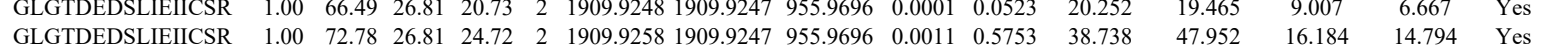

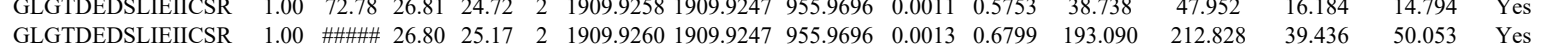

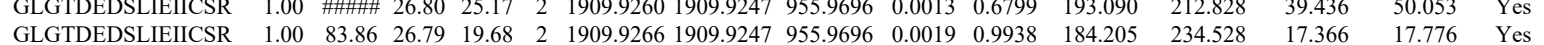

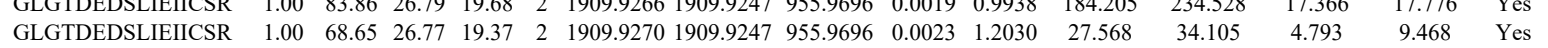

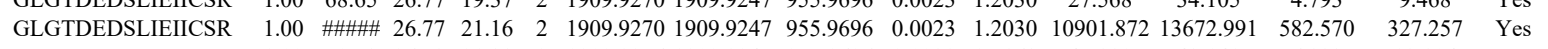
\begin{tabular}{lllllllllllllllll} 
GLGTDEDSLIEIICSR & 1.00 & 70.73 & 26.73 & 21.38 & 2 & 1909.9276 & 1909.9247 & 955.9696 & 0.0029 & 1.5168 & 47.880 & 43.141 & 6.833 & 13.804 & Yes \\
\hline
\end{tabular} $\begin{array}{llllllllllllllll}\text { GLGTDEDSLIEIICSR } & 1.00 & 55.03 & 26.73 & 24.40 & 2 & 1909.9276 & 1909.9247 & 955.9696 & 0.0029 & 1.5168 & 18.266 & 39.207 & 5.243 & 9.908 & \text { Yes }\end{array}$

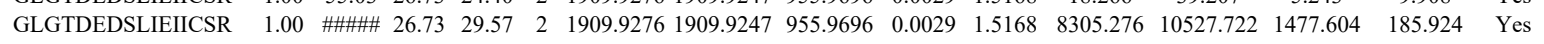
$\begin{array}{lllllllllllllllllll}\text { GLGTDEDSLIEIICSR } & 1.00 & 34.73 & 26.82 & 19.54 & 3 & 1909.9282 & 1909.9247 & 637.6488 & 0.0035 & 1.8296 & 46.200 & 195.086 & 98.366 & 42.586 & \text { Yes }\end{array}$ $\begin{array}{llllllllllllllll}\text { GLGTDEDSLIEIICSR } & 1.00 & 41.43 & 26.77 & 19.56 & 3 & 1909.9285 & 1909.9247 & 637.6488 & 0.0038 & 1.9865 & 80.710 & 149.765 & 86.895 & 25.473 & \text { Yes }\end{array}$ $\begin{array}{lllllllllllllllll}\text { GLGTDEDSLIEIICSR } & 1.00 & 66.44 & 26.93 & 19.78 & 2 & 1909.9292 & 1909.9247 & 955.9696 & 0.0045 & 2.3536 & 30.946 & 51.705 & 9.980 & 11.569 & \text { Yes }\end{array}$ $\begin{array}{llllllllllllllll}\text { GLGTDEDSLIEIICSR } & 1.00 & 81.14 & 26.88 & 26.55 & 2 & 1909.9298 & 1909.9247 & 955.9696 & 0.0051 & 2.6674 & 22.188 & 34.050 & 11.717 & 11.897 & \text { Yes }\end{array}$ $\begin{array}{llllllllllllllll}\text { GLGTDEDSLIEIICSR } & 1.00 & 64.44 & 27.24 & 19.20 & 2 & 1909.9338 & 1909.9247 & 955.9696 & 0.0091 & 4.7595 & 41.739 & 26.499 & 15.367 & 12.544 & \text { Yes }\end{array}$ $\begin{array}{llllllllllllllll}\text { LSLEGDHSTPPSAYGSVK } & 1.00 & 46.83 & 27.81 & 17.38 & 3 & 2132.1163 & 2132.0993 & 711.7070 & 0.0170 & 7.9620 & 3116.504 & 5217.407 & 3013.740 & 861.055 & \text { Yes }\end{array}$ $\begin{array}{llllllllllllllll}\text { LSLEGDHSTPPSAYGSVK } & 1.00 & 49.51 & 27.85 & 16.43 & 3 & 2132.1172 & 2132.0993 & 711.7070 & 0.0179 & 8.3835 & 699.857 & 557.477 & 285.603 & 229.545 & \text { Yes }\end{array}$ \begin{tabular}{llllllllllllllll} 
LSLEGDHSTPPSAYGSVK & 1.00 & 86.33 & 27.87 & 29.06 & 2 & 2132.1174 & 2132.0993 & 1067.0569 & 0.0181 & 8.4812 & 419.275 & 632.245 & 229.398 & 12.874 & Yes \\
\hline ALLYLCGGDD & 1.00 & 66.04 & 23.18 & 19.81 & 2 & 1228.5610 & 1228.5590 & 615.286 & 0.0020 & 1.6253 & 154.366 & 198.078 & 40.32 & 52.28 & Yse
\end{tabular} $\begin{array}{llllllllllllllll}\text { ALLYLCGGDD } & 1.00 & 66.04 & 23.18 & 19.81 & 2 & 1228.5610 & 1228.5590 & 615.2868 & 0.0020 & 1.6253 & 154.366 & 198.078 & 40.321 & 52.285 & \text { Yes } \\ \text { ALLYLCGGDD } & 0.77 & 67.57 & 23.18 & 80.57 & 2 & 1228.5610 & 1228.5590 & 615.2868 & 0.0020 & 1.6253 & 186.194 & 165.358 & 61.158 & 21.966 & \text { Yes }\end{array}$

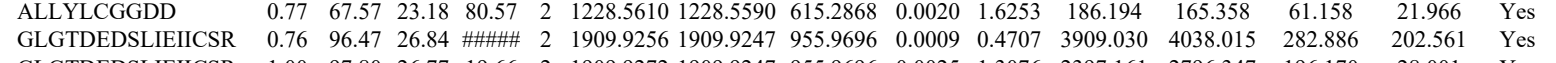

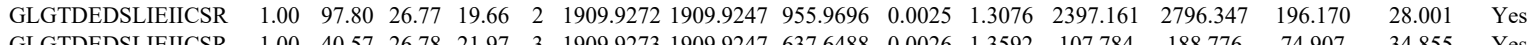
$\begin{array}{llllllllllllllll}\text { GLGTDEDSLIEICSR } & 1.00 & 40.57 & 26.78 & 21.97 & 3 & 1909.9273 & 1909.9247 & 637.6488 & 0.0026 & 1.3592 & 107.784 & 188.776 & 74.907 & 34.855 & \text { Yes } \\ \text { GLGTDEDSLIEIICSR } & 1.00 & 39.41 & 26.73 & 23.25 & 3 & 1909.9276 & 1909.9247 & 637.6488 & 0.0029 & 1.5160 & 125.285 & 166.787 & 69.397 & 21.460 & \text { Yes }\end{array}$ 
LMVALAK

LMISIMTER

$$
0.96
$$




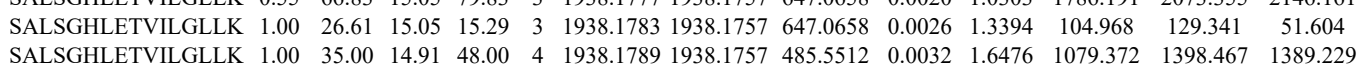
$\begin{array}{lllllllllllllll}\text { SALSGHLETVILGLLK } & 1.00 & 21.03 & 14.91 & 34.03 & 4 & 1938.1789 & 1938.1757 & 485.5512 & 0.0032 & 1.6476 & 91.087 & 91.585 & 38.829\end{array}$ $\begin{array}{lllllllllllll}\text { SALSGHLETVILGLLK } & 1.00 & 33.07 & 14.91 & 18.99 & 3 & 1938.1795 & 1938.1757 & 647.0658 & 0.0038 & 1.9576 & 142.225\end{array}$ $\begin{array}{llllllllllllll}\text { SALENAFLNLVQCQNKPLYFADR } & 1.00 & 33.74 & 26.22 & 46.74 & 4 & 3114.5889 & 3114.5874 & 779.6541 & 0.0015 & 0.4810 & 15.935\end{array}$ $\begin{array}{llllllllllllll} & 0.0028 & 0.8981 & 566.987\end{array}$

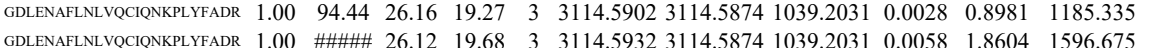

$\begin{array}{llllllllllll}\text { GDLENAFLNLVQCINNKPLYFADR } & 1.00 & \text { \#\#\#\# } 26.12 & 19.68 & 3 & 3114.5932 & 3114.5874 & 1039.2031 & 0.0058 & 1.8604 & 1596.675\end{array}$ 1642.735 $\begin{array}{lllllllllllll}\text { ODLENAFLNLVQCIQNKPLYFADR } & 1.00 & 32.84 & 26.07 & 45.84 & 4 & 3114.5985 & 3114.5874 & 779.6541 & 0.0111 & 3.5593 & 362.604\end{array}$ $\begin{array}{lllllllllllll} & 23.24 & 64.69 & 3 & 1649.9734 & 1649.9716 & 550.9978 & 0.0018 & 1.0889 & 65.501\end{array}$ $\begin{array}{lllllllllllll}\text { SALSGHLETVILGLLK } & 0.53 & 50.86 & 14.91 & 63.86 & 3 & 1938.1792 & 1938.1757 & 647.0658 & 0.0035 & 1.8030 & 203.571 & 32\end{array}$ $\begin{array}{lllllllllllll}\text { GDLENAFLNLVQCIONKRLYFADR } & 0.53 & 98.73 & 26.16 & \text { \#\#\#\# } 3 & 3 & 3114.5902 & 3114.5874 & 1039.2031 & 0.0028 & 0.8981 & 163.324 & 33\end{array}$

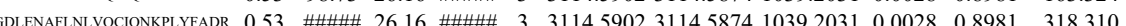
$\begin{array}{lllllllllllll}\text { GDENAFINLVOCIONKPIYFADR } & 1.00 & 22.70 & 26.14 & 35.70 & 4 & 3114.5917 & 31145874 & 779.6541 & 0.0043 & 1.3788 & 4.720\end{array}$

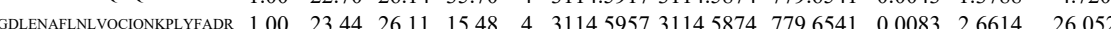
$\begin{array}{lllllllllllll}\text { SALSGHLETVILGLLK } & 0.55 & 51.74 & 23.24 & 64.74 & 3 & 1649.9734 & 1649.9716 & 550.9978 & 0.0018 & 1.0889 & 46.579\end{array}$ $\begin{array}{lllllllllllll}\text { SALSGHLETVILGLLK } & 0.55 & 52.13 & 15.05 & 65.13 & 3 & 1938.1777 & 1938.1757 & 647.0658 & 0.0020 & 1.0303 & 162.890\end{array}$ $\begin{array}{llllllllllllll} & \text { GALENAFINLVOCIONKPIYFADR } & 1.00 & \text { \#\#\#\#\# } 26.28 & 24.70 & 3 & 3114.5872 & 3114.5874 & 1039.2031 & -0.0002 & -0.0642 & 47.299\end{array}$

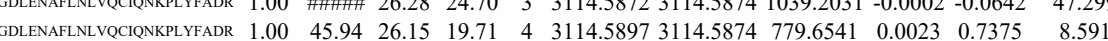

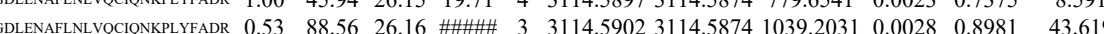
$\begin{array}{llllllllllllll}\text { GDLENAFLNLVQCIQNKPLYFADR } & 1.00 & 38.97 & 26.17 & 16.57 & 4 & 3114.5909 & 3114.5874 & 779.6541 & 0.0035 & 1.1223 & 6.540\end{array}$

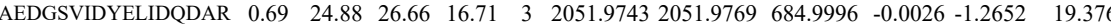

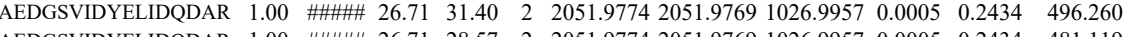

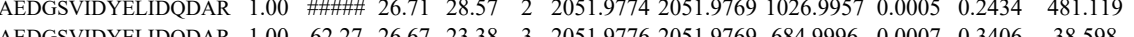
$\begin{array}{llllllllllll}\text { AEDGSVIDYELIDQDAR } & 1.00 & 62.27 & 26.67 & 23.38 & 3 & 2051.9776 & 2051.9769 & 684.9996 & 0.0007 & 0.3406 & 38.598\end{array}$

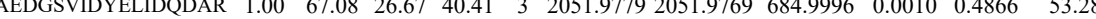

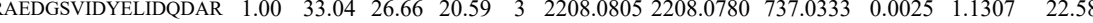

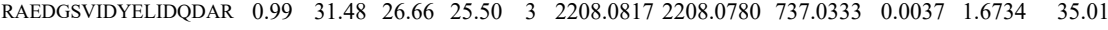
$\begin{array}{lllllllllllll}\text { GVDEVTIVNILTNR } & 1.00 & 41.26 & 26.73 & 16.03 & 3 & 1685.9437 & 1685.9434 & 562.9884 & 0.0003 & 0.1776 & 22.067\end{array}$ $\begin{array}{llllllllllll}\text { SALSGHLETVILGLLK } & 1.00 & 45.03 & 14.91 & 15.89 & 3 & 1938.1750 & 1938.1757 & 647.0658 & -0.0007 & -0.3606 & 16.87\end{array}$ $\begin{array}{llllllllllllll}\text { SALSGHLETVILGLLK } & 0.53 & 42.10 & 14.91 & 55.10 & 3 & 1938.1792 & 1938.1757 & 647.0658 & 0.0035 & 1.8030 & 9.107\end{array}$ $\begin{array}{llllllllllll}\text { SALSGHLETVILGLLK } & 1.00 & 51.93 & 15.05 & 17.36 & 3 & 1938.1771 & 1938.1757 & 647.0658 & 0.0014 & 0.7212 & 22.392\end{array}$ $\begin{array}{llllllllllll}0.5 & 1.41 & 14.91 & 64.41 & 3 & 1938.1792 & 1938.1757 & 647.0658 & 0.0035 & 1.8030 & 13.824\end{array}$

GTDVPK

TNQELQEINR TNQELQEINR TPAQYDASELK

AYTNDAER 
TPAQYDASELK TPAQYDASELK

TPAQYDASELK

TPAQYDASELK

LEICNLTPDALK RPTELLSNPQFIVDGAT

LYELIITR

LYELIITR

GQVVSLIR

NYPATFWVNPQFK

GQVVSLIR

LGLVEFNILWNR

LGLVEFNILWNR

LGLVEFNILWNR

LGLVEFN
NYLSIFR

NYLSIFR

LGLVEFNILWNR

NYLSIFR

NYLSIFR

CLQSGTLFR
CLQSGTLFR

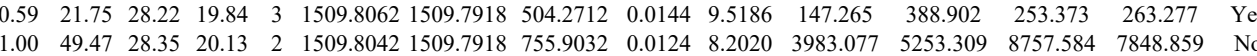
$\begin{array}{lllllllllllllll}0.99 & 39.75 & 28.35 & 20.13 & 2 & 1509.8042 & 1509.7918 & 755.9032 & 0.0124 & 8.2020 & 3983.077 & 5253.309 & 8757.584 & 7848.859 & \mathrm{No} \\ & 3 & 1509.8053 & 1509.7918 & 504.2712 & 0.0135 & 8.9237 & 344.293 & 384.931 & 567.706 & 482.644 & \text { Yes }\end{array}$ $\begin{array}{llllllllllllllll}1.00 & 67.11 & 27.99 & 29.83 & 2 & 1662.8954 & 1662.8928 & 832.4537 & 0.0026 & 1.5616 & 343.017 & 695.413 & 60.728 & 33.848 & \text { Yes }\end{array}$

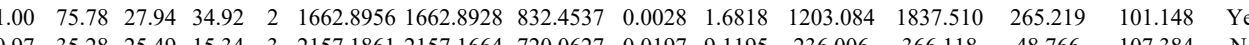
$\begin{array}{lllllllllllllll}0.97 & 35.28 & 25.49 & 15.34 & 3 & 2157.1861 & 2157.1664 & 720.0627 & 0.0197 & 9.1195 & 236.006 & 366.118 & 48.766 & 107.384 & \text { No } \\ 1.00 & 43.8 & 24.28 & 25.99 & 2 & 1163.7036 & 1163.7036 & 582.8591 & 0.0000 & 0.0000 & 16463.499 & 27012.016 & 1709.898 & 498.705 & \text { Yes }\end{array}$ $\begin{array}{lllllllllllllll}1.00 & 43.18 & 24.28 & 25.99 & 2 & 1163.7036 & 1163.7036 & 582.8591 & 0.0000 & 0.0000 & 16463.499 & 27012.016 & 1709.898 & 498.705 & \text { Yes } \\ 1.00 & 45.02 & 24.28 & 28.29 & 2 & 1163.7038 & 1163.7036 & 582.8591 & 0.0002 & 0.1716 & 12581.401 & 17816.696 & 1249.714 & 354.118 & \text { Yes }\end{array}$ $\begin{array}{lllllllllllllll}1.00 & 45.02 & 24.28 & 28.29 & 2 & 163.738 & 163.736 & 582.8591 & 0.002 & 0.1716 & 12581.401 & 17816.696 & 1249.714 & 354.118 & \text { Yes } \\ 0.98 & 40.15 & 6.15 & 23.07 & 2 & 1014.6364 & 1014.6308 & 508.3227 & 0.0056 & 5.5083 & 20800.897 & 30702.458 & 26700.473 & 6238.366 & \text { No }\end{array}$

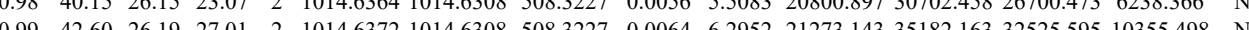

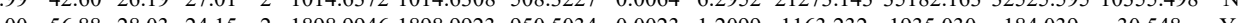

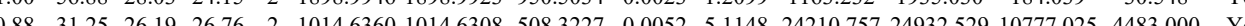

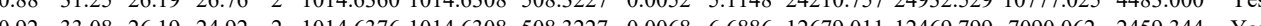
$\begin{array}{lllllllllllllll}1.00 & 69.55 & 26.63 & 26.83 & 2 & 1616.9150 & 1616.9160 & 809.4653 & -0.0010 & -0.6177 & 1134.885 & 1979.268 & 124.508 & 40.362 & \text { Yes }\end{array}$

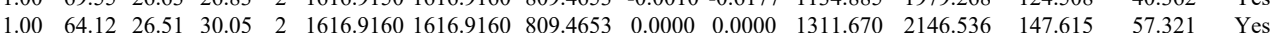
$\begin{array}{lllllllllllllll}1.00 & 55.99 & 2630 & 25.06 & 3 & 1616.9173 & 16169160 & 539.9793 & 0.0013 & 0.8025 & 117.319 & 138.145 & 40.772 & 8.371 & \text { Yes }\end{array}$

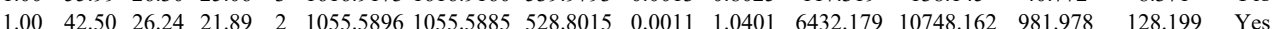
$\begin{array}{llllllllllllllll}0.99 & 37.53 & 26.24 & 20.89 & 2 & 1055.5900 & 1055.5885 & 528.8015 & 0.0015 & 1.4183 & 18561.946 & 28884085 & 2165.360 & 787.268 & \text { Yes }\end{array}$ $\begin{array}{lllllllllllllll}1.00 & 71.40 & 26.57 & 27.92 & 2 & 1616.9162 & 1616.9160 & 809.4653 & 0.0002 & 0.1235 & 488.023 & 528.966 & 62.734 & 18.853 & \text { Yes }\end{array}$ $\begin{array}{lllllllllllllll}1.00 & 44.94 & 26.40 & 25.45 & 2 & 1055.5892 & 1055.5885 & 528.8015 & 0.0007 & 0.6619 & 2025.174 & 3297.322 & 313.278 & 41.818 & \text { Yes }\end{array}$ $\begin{array}{lllllllllllllll}1.00 & 40.64 & 26.24 & 20.49 & 2 & 1055.5896 & 1055.5885 & 528.8015 & 0.0011 & 1.0401 & 1817.266 & 3065.172 & 144.660 & 108.172 & \text { Yes }\end{array}$ $\begin{array}{llllllllllllllll}0.99 & 45.01 & 27.17 & 25.38 & 2 & 1213.6156 & 1213.6069 & 607.8107 & 0.0087 & 7.1568 & 6639.894 & 8837.369 & 37.505 & 142.799 & \text { Yes }\end{array}$ $\begin{array}{llllllllllllllll}0.99 & 40.67 & 27.18 & 24.96 & 2 & 1213.6172 & 1213.6069 & 607.8107 & 0.0103 & 8.4730 & 3944.038 & 5068.660 & 39.808 & 160.922 & \text { Yes }\end{array}$

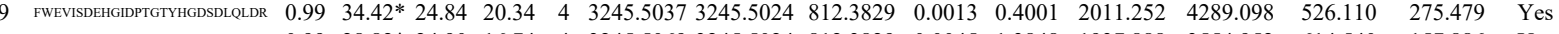

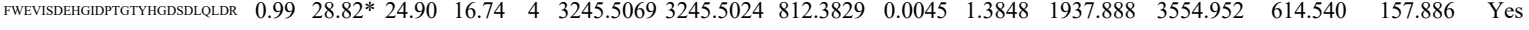

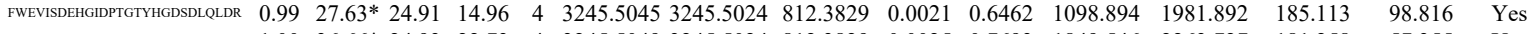

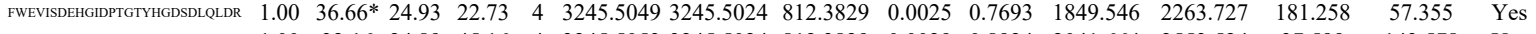
$\begin{array}{lllllllllllllllll} & 1.00 & 32.16 & 24.89 & 45.16 & 4 & 3245.5053 & 3245.5024 & 812.3829 & 0.0029 & 0.8924 & 2041.664 & 2553.524 & 37.599 & 143.578 & \text { Yes } \\ \text { FWEVISDE }\end{array}$ $\begin{array}{llllllllllllll} & \end{array}$

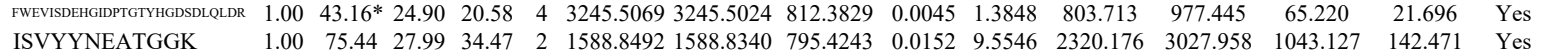
$\begin{array}{llllllllllllllll}\text { ISVYYNEATGGK } & 1.00 & 75.44 & 27.99 & 34.47 & 2 & 1588.8492 & 1588.8340 & 795.4243 & 0.0152 & 9.5546 & 2320.176 & 3027.958 & 1043.127 & 142.471 & \text { Yes } \\ \text { IST } & 1.00 & 73.17 & 28.06 & 33.98 & 2 & 1588.498 & 1588.8340 & 795.4243 & 0.0158 & 9.9317 & 12051.505 & 12909.669 & 5742.608 & 345.471 & \text { Yes }\end{array}$

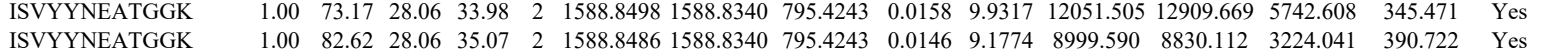
$\begin{array}{llllllllllllllllll}\text { ALTVPELTQQVFDAK } & 1.00 & 59.81 & 25.39 & 17.83 & 2 & 1947.0934 & 1947.0921 & 974.5533 & 0.0013 & 0.6670 & 1022.446 & 967.873 & 391.045 & 28.554 & \text { Yes }\end{array}$

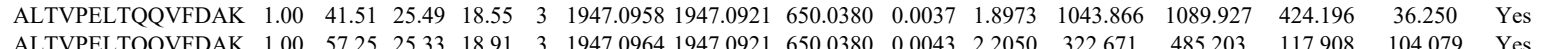
$\begin{array}{llllllllllllllll}\text { ALTVPELTQQVFDAK } & 1.00 & 57.25 & 25.33 & 18.91 & 3 & 1947.0964 & 1947.0921 & 650.0380 & 0.0043 & 2.2050 & 322.671 & 485.203 & 117.908 & 104.079 & \text { Yes } \\ \text { ALTVPELTQQVFDAK } & 1.00 & 67.11 & 25.30 & 22.57 & 2 & 1947.0970 & 1947.0921 & 974.5533 & 0.0049 & 25140 & 591.895 & 814.580 & 282.825 & 15.067 & \text { Yes }\end{array}$

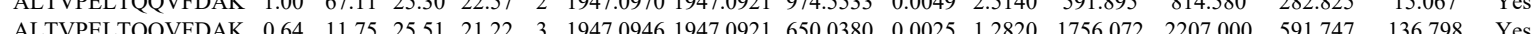
\begin{tabular}{llllllllllllll}
\hline &
\end{tabular} $\begin{array}{lllllllllllllll} & \end{array}$ $\begin{array}{lllllllllllllllll}\text { ALTVPELTQQVFDAK } & 0.53 & 26.95 & 25.49 & 39.95 & 3 & 1947.0949 & 1947.0921 & 650.0380 & 0.0028 & 1.4358 & 3427.821 & 4935.872 & 1307.491 & 18.777 & \text { Yes }\end{array}$ $\begin{array}{llllllllllllllll}\text { ALTVPELTQQVFDAK } & 1.00 & 58.97 & 25.22 & 25.92 & 2 & 1947.0972 & 1947.0921 & 974.5533 & 0.051 & 2.6166 & 1027.169 & 1362.498 & 450.617 & 50.877 & \text { Yes }\end{array}$

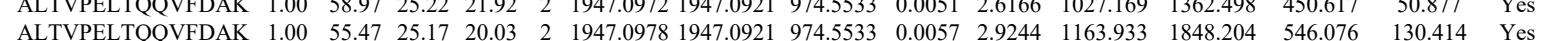

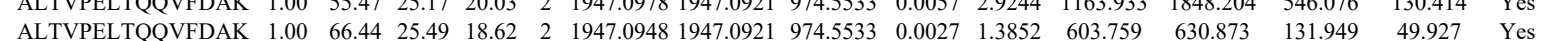

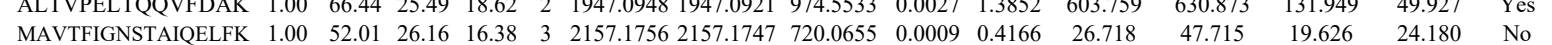
$\begin{array}{llllllllllllllll}\text { MAVTFIGNSTAIQELFK } & 1.00 & 35.92 & 25.95 & 26.68 & 3 & 2157.1771 & 2157.1747 & 720.0655 & 0.0024 & 1.1110 & 64.145 & 62.161 & 17.137 & 0.000 & \text { No }\end{array}$

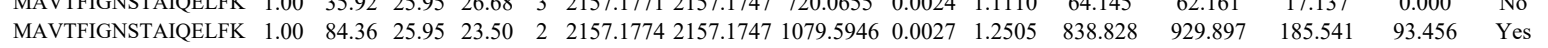

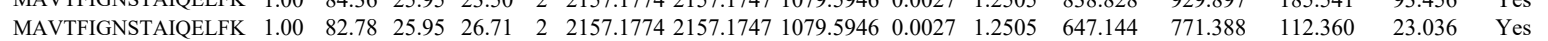
$\begin{array}{llllllllllllllll}\text { MAVTFIGNSTAIQELFK } & 1.00 & 89.44 & 26.17 & 21.67 & 2 & 2157.1754 & 2157.1747 & 1079.5946 & 0.0007 & 0.3242 & 903.398 & 1237.427 & 255.975 & 52.981 & \text { Yes }\end{array}$ $\begin{array}{lllllllllllllllll}\text { MAVTFIGNSTAIQELFK } & 1.00 & 80.50 & 26.17 & 25.51 & 2 & 2157.1754 & 2157.1747 & 1079.5946 & 0.0007 & 0.3242 & 1169.124 & 1137.546 & 169.558 & 39.586 & \text { Yes }\end{array}$

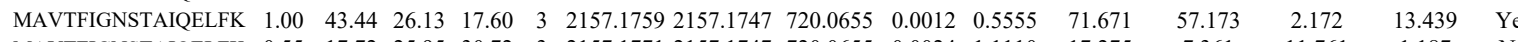
$\begin{array}{llllllllllllllll}\text { MAVTFIGNSTAIQELFK } & 0.55 & 17.72 & 25.95 & 30.72 & 3 & 2157.1771 & 2157.1747 & 720.0655 & 0.0024 & 1.1110 & 17.275 & 7.361 & 11.761 & 1.187 & \text { No }\end{array}$

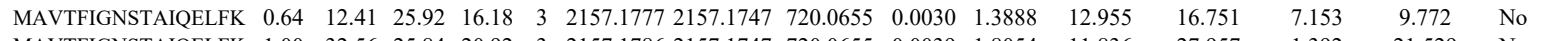

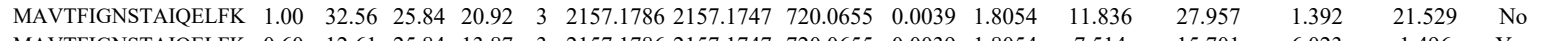

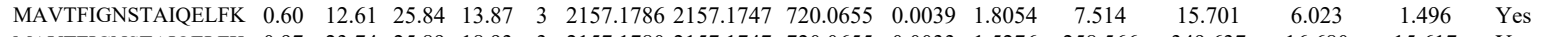

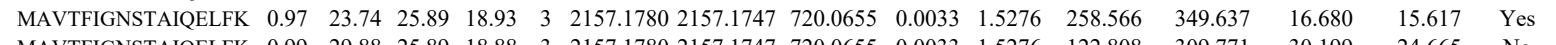

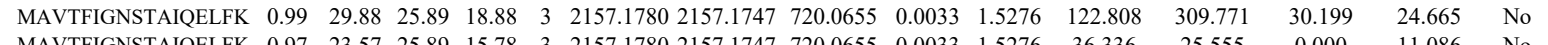

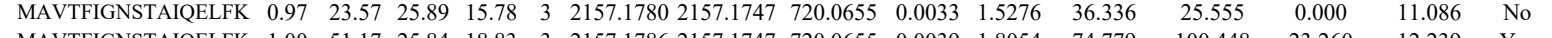

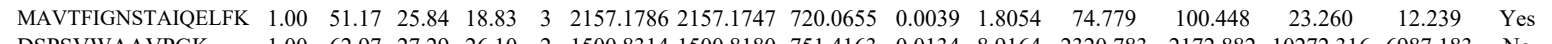

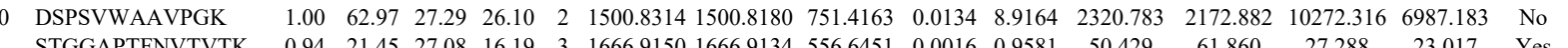

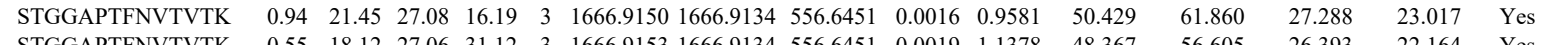

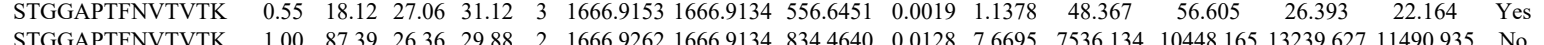
$\begin{array}{llllllllllllllll}\text { STGGAPTFNVTVTK } & 1.00 & 87.39 & 26.36 & 29.88 & 2 & 1666.9262 & 1666.9134 & 834.4640 & 0.0128 & 7.6695 & 7536.134 & 10448.165 & 13239.627 & 22.1490 .935 & \text { No } \\ \text { STGGAPTFNVTVTK } & 1.00 & 83.62 & 26.38 & 24.98 & 2 & 1666.9266 & 1666.9134 & 834.4640 & 0.0132 & 7.9092 & 5239.599 & 6606.949 & 7538.047 & 6930.502 & \text { No }\end{array}$ $\begin{array}{llllllllllllllll}\text { STGGAPFNV } & 1.00 & 83.62 & 26.38 & 24.98 & 2 & 1666.9266 & 666.9134 & 834.4640 & 0.0132 & 7.9092 & 5239.599 & 6606.949 & 7538.047 & 6930.502 & \text { No } \\ \text { CYEMASHLR } & 1.00 & 53.69 & 23.65 & 24.86 & 3 & 1298.5792 & 1298.5691 & 433.8636 & 0.0101 & 7.7597 & 15715.292 & 19181.351 & 526.529 & 245.894 & \text { Yes }\end{array}$

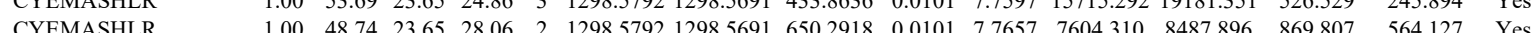
$\begin{array}{lllllllllllllllllll}\text { CYEMASHLR } & 1.00 & 48.74 & 23.65 & 28.06 & 2 & 1298.5792 & 1298.5691 & 650.2918 & 0.0101 & 7.7657 & 7604.310 & 8487.896 & 869.807 & 564.127 & \text { Yes } \\ \text { CYEMASHLR } & 1.00 & 58.57 & 23.65 & 25.58 & 2 & 1298.5792 & 1298.5691 & 6502918 & 0.0101 & 7.7657 & 13870.960 & 16980.409 & 543.747 & 474.232 & \text { Yes }\end{array}$ 

$\begin{array}{llllllllllllllllll}\text { TFVNITPAEVGVLVGK } & 1.00 & 87.34 & 21.04 & 30.34 & 2 & 1931.1410 & 1931.1336 & 966.5741 & 0.0074 & 3.8279 & 1560.375 & 2103.519 & 601.946 & 31.107 & \text { Yes }\end{array}$

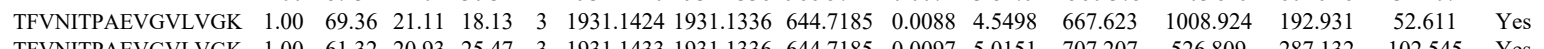

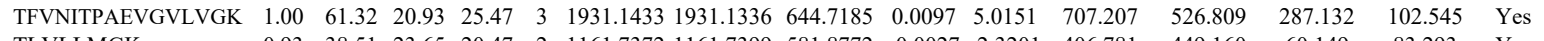

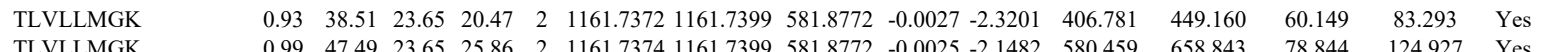
$\begin{array}{lllllllllllllll} & 0.924 .927 & \text { Yes }\end{array}$

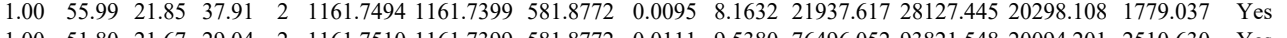

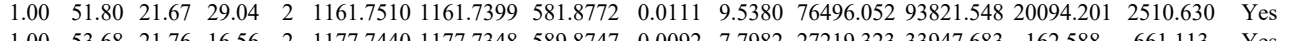

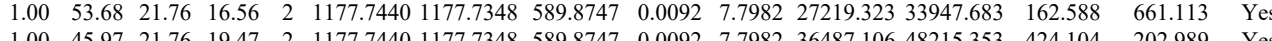
$\begin{array}{lllllllllllllll}1.00 & 45.97 & 21.76 & 19.47 & 2 & 1177.7440 & 1177.7348 & 589.8747 & 0.0092 & 7.7982 & 36487.106 & 48215.353 & 424.104 & 202.989 & \text { Yes } \\ 0.98 & 37.68 & 23.40 & 21.00 & 2 & 1161.7386 & 1161.7399 & 581.8772 & -0.0013 & -1.1171 & 272.128 & 312.482 & 70.069 & 68.136 & \text { Yes }\end{array}$

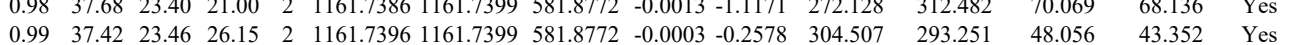

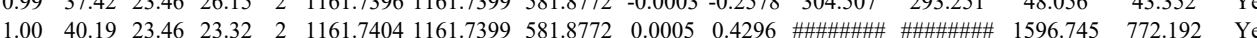

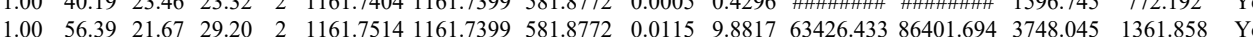

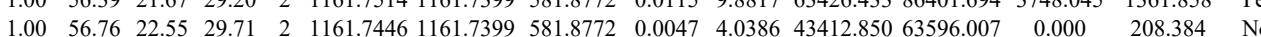
$\begin{array}{lllllllllllllll}1.00 & 56.76 & 22.55 & 29.71 & 2 & 1161.7446 & 1161.7399 & 581.8772 & 0.0047 & 4.0386 & 43412.850 & 63596.007 & 0.000 & 208.384 & \text { No } \\ 1.00 & 56.71 & 22.53 & 29.83 & 2 & 1161.7456 & 1161.7399 & 581.8772 & 0.0057 & 4.8979 & 49912.122 & 60383.311 & 0.000 & 198.096 & \text { No }\end{array}$

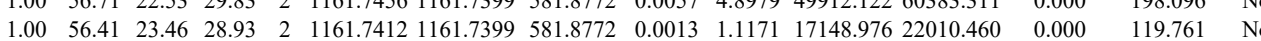
$\begin{array}{lllllllllllllll}1.00 & 56.41 & 23.46 & 28.93 & 2 & 1161.7412 & 1161.7399 & 581.8772 & 0.0013 & 1.117 & 17148.976 & 22830.460 & 0.0014 & 119.761 & \mathrm{No} \\ 1.00 & 61.86 & 23.46 & 31.09 & 2 & 1161.7422 & 1161.7399 & 581.8772 & 0.0023 & 1.9764 & 21933.790 & 30435.899 & 5.814 & 309.078 & \text { Yes }\end{array}$

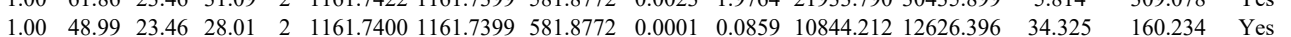

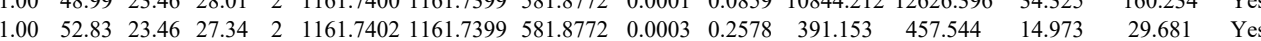

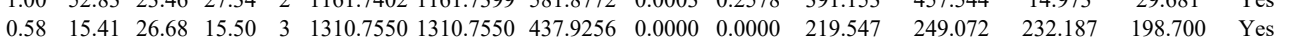
$\begin{array}{llllllllllllllll}0.53 & 14.71 & 26.68 & 17.22 & 3 & 1310.7550 & 1310.7550 & 437.9256 & 0.0000 & 0.0000 & 183.270 & 226.727 & 249.901 & 190.879 & \text { Yes }\end{array}$ $\begin{array}{lllllllllllllll}0.65 & 19.45 & 26.68 & 27.63 & 3 & 1310.7550 & 1310.7550 & 437.9256 & 0.0000 & 0.0000 & 230.785 & 303.463 & 283.607 & 327.360 & \text { No }\end{array}$ TFVNITPAEVG $\begin{array}{lllllllllllll}0.51 & 37.95 & 22.97 & 48.15 & 3 & 1298.5690 & 1298.5691 & 433.8636 & -0.0001 & -0.0768 & 118.110 & 149.226\end{array}$ TLVLLMGK

TLVLLMGK

TLVLLMGK

TLVLLMGK
TLVLLMGK $\begin{array}{lllllllllll}0.95 & 19.92 & 21.67 & 18.68 & 3 & 1931.1334 & 1931.1336 & 644.7185 & -0.0002 & -0.1034 & 52.428\end{array}$

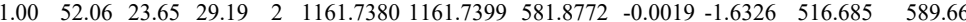
$\begin{array}{lllllllllll}1.00 & 56.59 & 23.32 & 29.44 & 2 & 1161.7394 & 1161.7399 & 581.8772 & -0.0005 & -0.4296 & 703.338\end{array}$

TFVNITPAEVGVLVGK

TFVNITPAEVGVLVGK TFVNITPAEVGVLVGK DSLLQDGEFSMDLR
DSLLQDGEFSMDLR DSLLQDGEFSMDLR
DSLLQDGEFSMDLR DSLLQDGEFSMDLR DSLLQDGEFSMDLR DSLLQDGEFSMDLR
DSLLQDGEFSMDLR DSLLQDGEFSMDLR $\begin{array}{lllllllllll}0.99 & 45.40 & 23.65 & 2.664 & 2 & 1161.7380 & 1161.7399 & 581.8772 & -0.0019 & -1.6326 & 249.841\end{array}$ $\begin{array}{llllllllllll}0.94 & 39.22 & 23.65 & 27.22 & 2 & 1161.7368 & 1161.7399 & 581.8772 & -0.0031 & -2.6638 & 289.319\end{array}$ $\begin{array}{lllllllllll} & \end{array}$ $\begin{array}{llllllllllll}1.00 & 43.76 & 21.73 & 21.09 & 3 & 1931.1355 & 1931.1336 & 644.7185 & 0.0019 & 0.9823 & 12.696 \\ 1.00 & 58.97 & 21.73 & 21.36 & 3 & 1931.1355 & 1931.1336 & 644.7185 & 0.0019 & 0.9823 & 9.071\end{array}$

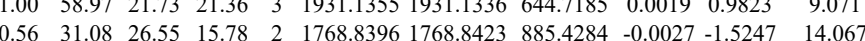
$\begin{array}{lllllllllll}0.56 & 31.08 & 26.55 & 15.78 & 2 & 1768.8396 & 1768.8423 & 885.4284 & -0.0027 & -1.5247 & 14.067 \\ 1.00 & 57.90 & 26.69 & 17.49 & 2 & 1768.8418 & 1768.8423 & 885.4284 & -0.0005 & -0.2823 & 7.358\end{array}$ $\begin{array}{lllllllllll}1.00 & 74.86 & 26.63 & 22.95 & 2 & 1768.8418 & 1768.8423 & 885.4284 & -0.0005 & -0.2823 & 7.358 \\ 1.00 & 78.78 & 26.63 & 27.65 & 2 & 1768.830 & 1768.8423 & 885.4284 & 0.0007 & 0.3953 & 328.986\end{array}$

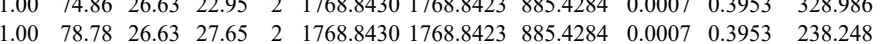
$\begin{array}{llllllllllll}1.00 & 62.67 & 26.79 & 22.95 & 2 & 1768.8434 & 1768.8423 & 885.4284 & 0.0011 & 0.6212 & 12.199\end{array}$ $\begin{array}{llllllllllll}1.00 & 40.23 & 26.81 & 19.13 & 2 & 1768.8438 & 1768.8423 & 885.4284 & 0.0015 & 0.8470 & 20.207\end{array}$ $\begin{array}{llllllllllll}1.00 & 45.90 & 26.90 & 20.65 & 3 & 1768.8448 & 1768.8423 & 590.6214 & 0.0025 & 1.4109 & 39.276\end{array}$

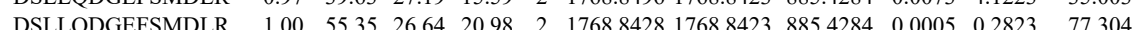

Table S-3 page 88 
$\begin{array}{lllllllllllll} & \end{array}$

$\begin{array}{llllllllllllll}1.00 & 39.69 & 27.78 & 24.98 & 2 & 1608.8460 & 1608.8423 & 805.4284 & 0.0037 & 2.2969 & 1106.590 & 10356.681\end{array}$

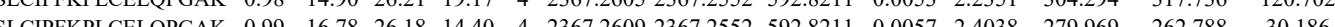
$\begin{array}{lllllllllllll} & \text { SLC }\end{array}$

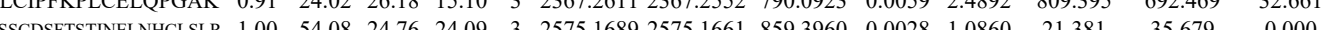

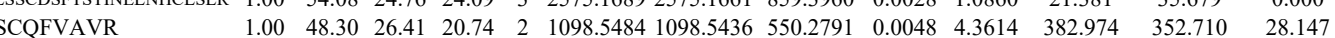

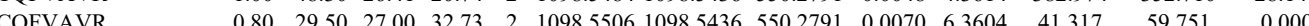
$\begin{array}{llllllllllllllll} & \text { QFAYQNSWGLTTR } & 1.00 & 66.32 & 27.23 & 24.41 & 2 & 1714.8688 & 1714.8549 & 858.4347 & 0.0139 & 8.0961 & 1665.475 & 1598.008 & 66.426\end{array}$ $\begin{array}{lllllllllllllll} & \text { SLCIPFKPLCELQPGAK } & 0.73 & 9.44 & 26.12 & 13.88 & 4 & 2367.2621 & 2367.2552 & 592.8211 & 0.0069 & 2.9098 & 234.500 & 215.549 & 48.291\end{array}$ $\begin{array}{lllllllllllllll}\text { SLCIPFKPLCELQPGAK } & 0.95 & 13.96 & 26.04 & 16.97 & 4 & 2367.2625 & 2367.2552 & 592.8211 & 0.0073 & 3.0785 & 201.176 & 218.444 & 100.850\end{array}$ $\begin{array}{llllllllllllll}\text { SCQFVAVR } & 0.97 & 38.24 & 26.58 & 17.44 & 2 & 1098.5500 & 1098.5436 & 550.2791 & 0.0064 & 5.8152 & 1164.928 & 1338.727 & 109.406 \\ \text { SCOFVAVR } & 0.98 & 40.06 & 26.58 & 20.07 & 2 & 10985500 & 10985336 & 50.2791 & 0.064 & 5.8152 & 950.032 & 906.347 & 45.871\end{array}$ SCQFVAVR GSQFGQSCCLR

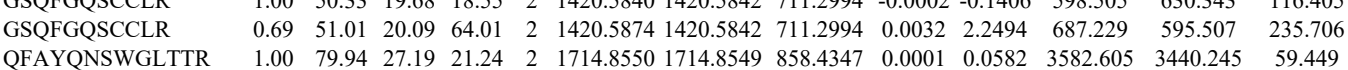
$\begin{array}{lllllllllll}1.00 & 50.33 & 19.68 & 18.55 & 2 & 1420.5840 & 1420.5842 & 7112994 & -0.0002 & 0.81406 & 598.505\end{array}$ $\begin{array}{lllllllllllllll} & \end{array}$ $\begin{array}{lllllllllllllll} & \text { LSSCDSFTSTINELNHCLSLR } & 1.00 & 70.44 & 24.76 & 21.75 & 3 & 2575.1680 & 2575.1661 & 859.3960 & 0.0019 & 0.7370 & 165.317 & 168.938 & 20.497\end{array}$ $\begin{array}{lllllllllllllll} & \text { LSSCDSFTSTINELNHCLSLR } & 1.00 & 58.05 & 24.79 & 20.44 & 3 & 2575.1692 & 2575.1661 & 859.3960 & 0.0031 & 1.2024 & 33.880 & 7.047 & 0.000\end{array}$

$\begin{array}{llllllllllllll}\text { LNQWCNVVR } & 1.00 & 46.67 & 27.30 & 21.65 & 2 & 1320.6564 & 1320.6553 & 661.3349 & 0.0011 & 0.8317 & 5265.078 & 5527.220 & 281.225\end{array}$

$\begin{array}{lllllllllllllll}\text { LNQWCNVVR } & 1.00 & 45.13 & 27.35 & 21.28 & 2 & 1320.6570 & 1320.6553 & 661.3349 & 0.0017 & 1.2853 & 3409.384 & 3118.568 & 150.054\end{array}$

LNQWCNVVR

$\begin{array}{llllllllllllll}1.00 & 46.62 & 27.39 & 21.45 & 2 & 1320.6560 & 1320.6553 & 661.3349 & 0.0007 & 0.5292 & 3965.756 & 3730.519 & 57.471\end{array}$

LTVAENEAETK

$\begin{array}{lllllllllllll}.00 & 66.74 & 28.25 & 27.11 & 2 & 1491.8070 & 1491.8024 & 746.9085 & 0.0046 & 3.0794 & 9514.753 & 9485.880 & 6785.084\end{array}$

LTVAENEAETK

$\begin{array}{llllllllllllll}1.00 & 68.88 & 28.25 & 29.24 & 2 & 1491.8074 & 1491.8024 & 746.9085 & 0.0050 & 3.3471 & 8870.144 & 10336.103 & 7758.884\end{array}$

$\begin{array}{llllllllllllll}1.00 & 55.31 & 28.07 & 24.27 & 2 & 1629.8480 & 1629.8453 & 815.9299 & 0.0027 & 1.6546 & 1889.357 & 1747.393 & 1303.376 & \end{array}$ $\begin{array}{lllllllllllll}1.00 & 45.20 & 28.07 & 22.54 & 2 & 1629.8482 & 1629.8453 & 815.9299 & 0.0029 & 1.7771 & 2009.206 & 1882.734 & 1613.707 \\ 0.99 & 44.97 & 26.93 & 21.62 & 2 & 1654.8188 & 1654.8116 & 828.4131 & 0.0072 & 4.3456 & 159.092 & 134.456 & 30.012\end{array}$

$\begin{array}{llllllllllll} & \end{array}$ $\begin{array}{llllllllllllllll} & \end{array}$ $\begin{array}{llllllllllllll}\text { NQGGLSSSGAGEGQGPK } & 0.94 & 21.81 & 27.21 & 16.06 & 3 & 1874.9347 & 1874.9326 & 625.9848 & 0.0021 & 1.1182 & 249.943 & 313.235 & 233.243\end{array}$

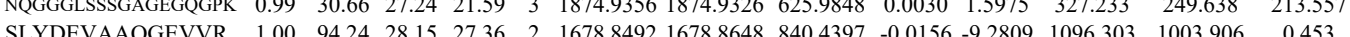

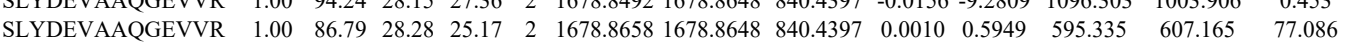
$\begin{array}{llllllllllll} & \text { NGG }\end{array}$ $\begin{array}{llllllllllllll}\text { NPDDITNEEYGEFYK } & 0.92 & 20.46 & 25.69 & 15.62 & 3 & 2120.9797 & 2120.9782 & 708.0000 & 0.0015 & 0.7062 & 5.843 & 5.343 & 4.913\end{array}$ 
$\begin{array}{lllllllllllll}1.00 & 77.54 & 27.54 & 24.17 & 2 & 1837.9008 & 1837.9011 & 919.9578 & -0.0003 & -0.1631 & 77.817\end{array}$

$\begin{array}{lllllllllll}00 & 67.86 & 27.54 & 25.71 & 2 & 1837.9010 & 1837.9011 & 919.9578 & -0.0001 & -0.0544 & 49.213\end{array}$

$\begin{array}{lllllllllll}1.00 & 76.64 & 27.56 & 21.49 & 2 & 1837.9016 & 1837.9011 & 919.9578 & 0.0005 & 0.2718 & 54.565 \\ 18.89 & 1837.9016 & 1837.9011 & 919.9578 & 0.0005 & 0.2718 & 47.959\end{array}$ $\begin{array}{llllllllllll}0.81 & 18.67 & 27.56 & 18.39 & 3 & 1837.9018 & 1837.9011 & 613.6410 & 0.0007 & 0.3802 & 170.487\end{array}$ $\begin{array}{lllllllllll}1.00 & 93.42 & 27.62 & 23.92 & 2 & 1837.9028 & 1837.9011 & 919.9578 & 0.0017 & 0.9240 & 51.713\end{array}$ $\begin{array}{lllllllllll}0.77 & 55.22 & 27.63 & 68.22 & 2 & 1837.9030 & 1837.9011 & 919.9578 & 0.0019 & 1.0327 & 24.415\end{array}$ $\begin{array}{llllllllllll}.82 & 17.27 & 27.54 & 14.83 & 3 & 1837.9036 & 1837.9011 & 613.6410 & 0.0025 & 1.3580 & 165.601 \\ 0.77 & 16.17 & 27.54 & 14.73 & 3 & 1837.9036 & 1837.9011 & 613.6410 & 0.0025 & 1.3580 & 18.648\end{array}$ $\begin{array}{llllllllllll}1.00 & 59.51 & 27.57 & 20.38 & 2 & 1837.9044 & 1837.9011 & 919.9578 & 0.0033 & 1.7936 & 48.476\end{array}$

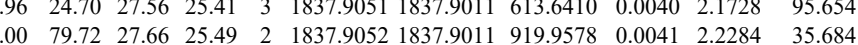
$\begin{array}{lllllllllll}0.55 & 13.63 & 27.66 & 20.36 & 3 & 1837.9054 & 1837.9011 & 613.6410 & 0.0043 & 2.3358 & 134.178\end{array}$ $\begin{array}{llllllllllll}0.91 & 24.80 & 27.60 & 28.42 & 3 & 1837.9060 & 1837.9011 & 613.6410 & 0.0049 & 2.6617 & 107.82\end{array}$ $\begin{array}{lllllllllll}1.00 & 88.58 & 27.67 & 22.52 & 2 & 1837.9072 & 1837.9011 & 919.9578 & 0.0061 & 3.3154 & 45.385\end{array}$ $\begin{array}{lllllllllll}1.00 & 97.53 & 27.60 & 23.66 & 2 & 1837.9134 & 1837.9011 & 919.9578 & 0.0123 & 6.6850 & 353.153\end{array}$ $\begin{array}{lllllllllll}1.00 & 63.27 & 27.61 & 19.70 & 2 & 1743.8680 & 1743.8667 & 872.9406 & 0.0013 & 0.7446 & 124.625\end{array}$ $\begin{array}{lllllllllll}1.00 & 57.94 & 27.58 & 25.85 & 2 & 1743.8686 & 1743.8667 & 872.9406 & 0.0019 & 1.0883 & 123.404\end{array}$

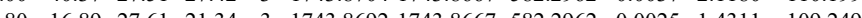

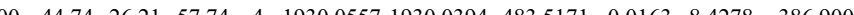
$\begin{array}{llllllllllll}1.00 & 34.09 & 26.19 & 47.09 & 4 & 1930.0561 & 1930.0394 & 483.5171 & 0.0167 & 8.6346 & 423.552\end{array}$ $\begin{array}{llllllllllllll}0.77 & 60.78 & 27.13 & 73.78 & 2 & 1511.8252 & 1511.8228 & 756.9187 & 0.0024 & 1.5854 & 25405.950 & 31011.199 & 11601.719\end{array}$ $\begin{array}{lllllllllllll}1.00 & 47.89 & 27.24 & 16.12 & 2 & 1511.8256 & 1511.8228 & 756.9187 & 0.0028 & 1.8496 & 35541.303 & 33858.974 & 13547.401\end{array}$ $\begin{array}{llllllllllllll}0.98 & 27.34 & 27.07 & 22.12 & 3 & 1511.8258 & 1511.8228 & 504.9482 & 0.0030 & 1.9804 & 77.373 & 75.126 & 48.388 \\ 0 & 1511.8279 & 1511.8228 & 504.9482 & 0.0051 & 3.3667 & 5008.797 & 6197.118 & 4129.310 & 19\end{array}$ $\begin{array}{llllllllllllll}0.98 & 32.30 & 26.68 & 19.88 & 3 & 1511.8342 & 1511.8228 & 504.9482 & 0.0114 & 7.5255 & 2299.707 & 1279.367 & 905.783\end{array}$ $\begin{array}{lllllllllllll}.00 & 37.51 & 26.78 & 50.51 & 4 & 1930.0405 & 1930.0394 & 483.5171 & 0.0011 & 0.5687 & 127.897 & \end{array}$ $\begin{array}{lllllllllll}.00 & 21.49 & 26.77 & 15.40 & 4 & 1930.0409 & 1930.0394 & 483.5171 & 0.0015 & 0.7756 & 101.86\end{array}$ $\begin{array}{llllllllllll}.00 & 36.03 & 26.66 & 49.03 & 4 & 1930.0425 & 1930.0394 & 483.5171 & 0.0031 & 1.6028 & 155.297 & \\ 1.00 & 35.45 & 26.66 & 21.95 & 4 & 1930.0425 & 1930.0394 & 483.5171 & 0.0031 & 1.628 & 119.272 & 1\end{array}$ $\begin{array}{lllllllllll}1 & 26.66 & 21.95 & 4 & 1930.0425 & 1930.0394 & 483.5171 & 0.0031 & 1.6028 & 119.272\end{array}$ $\begin{array}{lllllllllll}1.00 & 33.35 & 26.66 & 46.35 & 4 & 1930.0433 & 1930.0394 & 483.5171 & 0.0039 & 2.0165 & 151.489\end{array}$ $\begin{array}{llllllllllll}.00 & 26.68 & 26.66 & 22.46 & 4 & 1930.0433 & 1930.0394 & 483.5171 & 0.0039 & 2.0165 & 87.927\end{array}$ $\begin{array}{lllllllllllll}1.00 & 28.18 & 26.60 & 14.97 & 4 & 1930.0437 & 1930.0394 & 483.5171 & 0.0043 & 2.2233 & 146.875 & 1\end{array}$ $\begin{array}{lllllllllllll}0.87 & 22.63 & 26.59 & 15.93 & 3 & 1930.0456 & 1930.0394 & 644.3537 & 0.0062 & 3.2073 & 187.022\end{array}$ $\begin{array}{lllllllllllll}1.00 & 26.55 & 26.62 & 15.64 & 4 & 1930.0465 & 1930.0394 & 483.5171 & 0.0071 & 3.6710 & 141.197 & 13 \\ 0.51 & 23.30 & 27.22 & 23.91 & 2 & 1251.6356 & 1251.6370 & 626.8258 & -0.0014 & -1.1167 & 191.321 & 19\end{array}$ $\begin{array}{lllllllllll}0.51 & 23.30 & 27.22 & 23.91 & 2 & 1251.6356 & 1251.6370 & 626.8258 & -0.0014 & -1.1167 & 191.321 \\ 0.85 & 30.90 & 27.55 & 21.65 & 2 & 1251.6362 & 1251.6370 & 626.8258 & -0.0008 & -0.6381 & 181.984\end{array}$ $\begin{array}{llllllllllll}0.85 & 30.90 & 27.55 & 21.65 & 2 & 1251.6362 & 1251.6370 & 626.8258 & -0.0008 & -0.6381 & 181.984 \\ 0.91 & 29.29 & 27.53 & 21.31 & 2 & 1251.6374 & 1251.6370 & 626.8258 & 0.0004 & 0.3191 & 157.854\end{array}$ $\begin{array}{llllllllllll}0.91 & 29.29 & 27.53 & 21.31 & 2 & 1251.6374 & 1251.6370 & 626.8258 & 0.0004 & 0.3191 & 157.854 \\ 0.98 & 33.82 & 27.30 & 22.85 & 2 & 1251.6378 & 1251.6370 & 626.8258 & 0.0008 & 0.6381 & 143.840 \\ 0.66 & 18.84 & 27.34 & 20.95 & 2 & 1251.6382 & 1251.6370 & 626.8258 & 0.0012 & 0.9572 & 208.913\end{array}$ $\begin{array}{lllllllllll}0.98 & 33.82 & 27.30 & 22.85 & 2 & 1251.6378 & 1251.6370 & 626.8258 & 0.0008 & 0.6381 & 143.840 \\ 0.66 & 18.84 & 27.34 & 20.95 & 2 & 1251.6382 & 1251.6370 & 626.8258 & 0.0012 & 0.9572 & 208.913\end{array}$ $\begin{array}{llllllllllll}0.66 & 18.84 & 27.34 & 20.95 & 2 & 1251.6382 & 1251.6370 & 626.8258 & 0.0012 & 0.9572 & 208.913 & \\ 0.97 & 31.31 & 27.32 & 21.94 & 2 & 1251.6388 & 1251.6370 & 626.8258 & 0.0018 & 1.4358 & 202.128\end{array}$ $\begin{array}{llllllllllll}0.66 & 20.64 & 27.51 & 20.21 & 2 & 1251.6404 & 1251.6370 & 626.8258 & 0.0034 & 2.7121 & 189.792\end{array}$ $\begin{array}{lllllllllll}0.87 & 29.54 & 27.51 & 21.39 & 2 & 1251.6406 & 1251.6370 & 626.8258 & 0.0036 & 2.8716 & 163.820\end{array}$

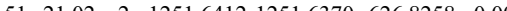

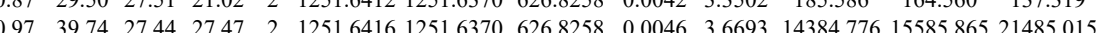




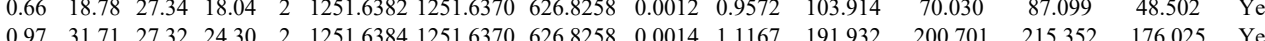

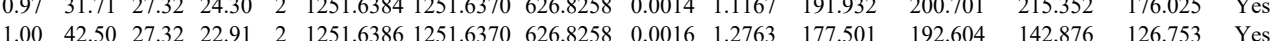

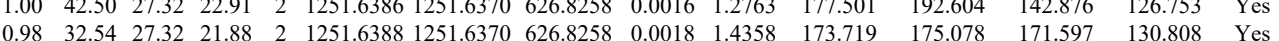

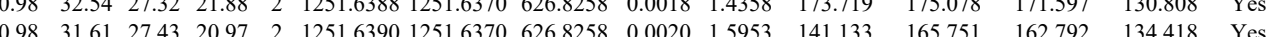
$\begin{array}{lllllllllllllll}0.90 & 39.13 & 27.41 & 22.48 & 2 & 1251.6392 & 1251.6370 & 626.8258 & 0.0022 & 1.7549 & 188.764 & 169.827 & 212.007 & 134.476 & \text { Yes }\end{array}$ $\begin{array}{lllllllllllllll}0.74 & 20.29 & 27.41 & 20.50 & 2 & 1251.6394 & 1251.6370 & 626.8258 & 0.0024 & 1.9144 & 119.006 & 175.055 & 194.404 & 103.658 & \text { Yes }\end{array}$ $\begin{array}{llllllllllllllll}0.99 & 39.14 & 27.41 & 22.50 & 2 & 1251.6396 & 1251.6370 & 626.8258 & 0.0026 & 2.0739 & 221.331 & 233.267 & 238.579 & 169.328 & \text { Yes }\end{array}$ $\begin{array}{lllllllllllllll}0.98 & 34.35 & 27.41 & 33.35 & 2 & 1251.6396 & 1251.6370 & 626.8258 & 0.0026 & 2.0739 & 18549.883 & 21758.936 & 30981308 & 12043.808 & \text { Yes }\end{array}$ $\begin{array}{lllllllllllllllll}0.99 & 39.86 & 27.51 & 26.70 & 2 & 1251.6404 & 1251.6370 & 626.8258 & 0.0034 & 2.7121 & 23086.303 & 26251.282 & 34872.551 & 26461.953 & \text { Yes }\end{array}$ $\begin{array}{llllllllllllllll}100 & 61.32 & 27.04 & 18.64 & 2 & 1511.8282 & 1511.8228 & 756.9187 & 0.0054 & 3.5671 & 6701.610 & 5888.367 & 2119.477 & 304.515 & \text { Yes }\end{array}$ $\begin{array}{llllllllllllllll} & 0.98 & 32.26 & 26.97 & 18.05 & 3 & 1511.8306 & 1511.8228 & 504.9482 & 0.0078 & 5.1490 & 4233.257 & 3848.548 & 2180.336 & 1186.869 & \text { Yes }\end{array}$ $\begin{array}{lllllllllllllll} & & & \end{array}$ $\begin{array}{llllllllllllllll} & \end{array}$

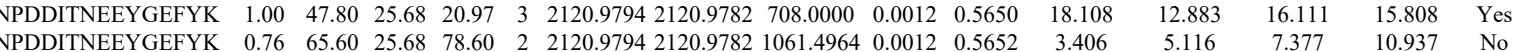
$\begin{array}{lllllllllllllllll} & 10.937 & \text { No }\end{array}$

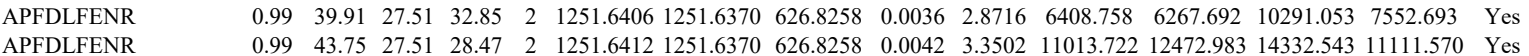

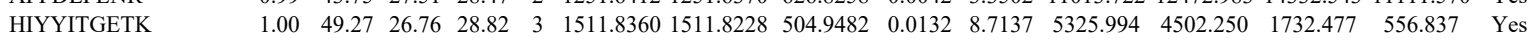

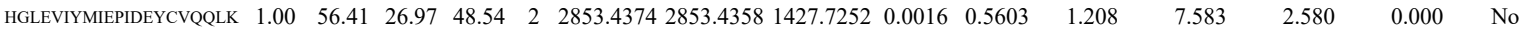

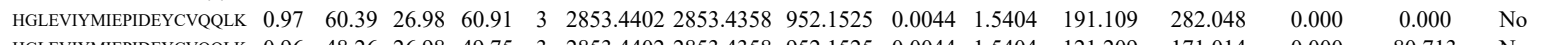

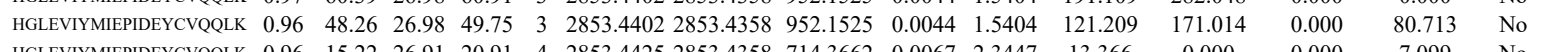

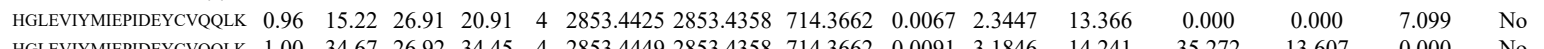

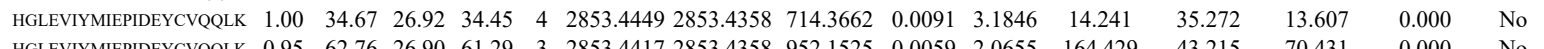

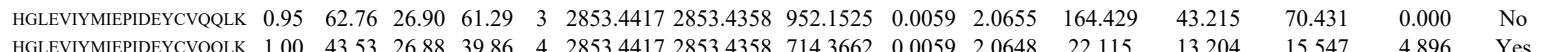

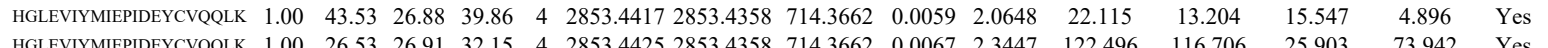

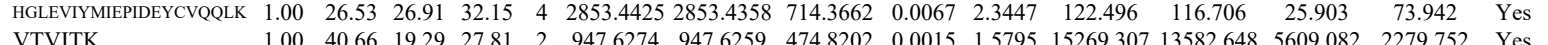
$\begin{array}{llllllllllllllll}\text { VTVITK } & 1.00 & 40.66 & 19.29 & 27.81 & 2 & 947.6274 & 947.6259 & 474.8202 & 0.0015 & 1.5795 & 15269.307 & 13582.648 & 5609.082 & 2279.752 & \text { Yes } \\ \text { VTVITK } & 1.00 & 4.73 & 19.29 & 28.76 & 2 & 947.6274 & 947.6259 & 474.8202 & 0.0015 & 1.5795 & 17584.906 & 16494.846 & 8825.720 & 3280.833 & \text { Yes }\end{array}$

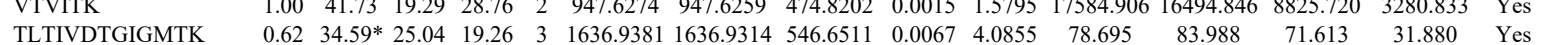
$\begin{array}{llllllllllllllll}\text { TLTIVDTGIGMTK } & 0.62 & 34.59 & 25.04 & 19.26 & 3 & 1636.9381 & 1636.9314 & 546.6511 & 0.006 & 4.0855 & 78.695 & 83.988 & 71.613 & 31.880 & \text { Yes }\end{array}$

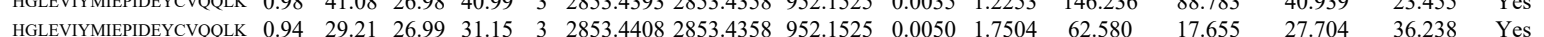
$\begin{array}{lllllllllllll} & \text { HCO. }\end{array}$

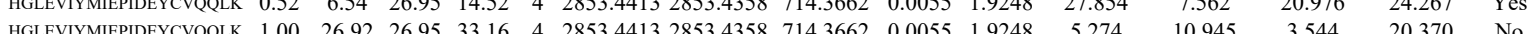

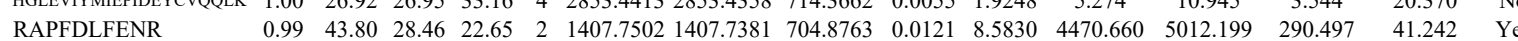
RAPFDLFENR RAPFDLFENR RAPFDLFENR $\begin{array}{lllllllllllll}0.99 & 43.80 & 28.46 & 22.65 & 2 & 1407.7502 & 4407.7381 & 704.8763 & 0.0121 & 8.5830 & 4470.660 & 5012.199 & 290.497 \\ 0.99 & 40.50 & 28.37 & 23.44 & 3 & 1407.7510 & 1407.7381 & 470.533 & 0.0129 & 9.1439 & 5812.640 & 7441.409 & 1521.922\end{array}$ $\begin{array}{llllllllllllll}0.99 & 42.84 & 28.34 & 23.69 & 2 & 1407.7514 & 1407.7381 & 704.8763 & 0.0133 & 9.4342 & 4857.820 & 6151.478 & 475.984 & 3\end{array}$ $\begin{array}{lllllllllllll}1.00 & 61.54 & 28.34 & 24.21 & 3 & 1407.7519 & 1407.7381 & 470.2533 & 0.0138 & 9.7819 & 4974.256 & 8432.798 & 455.407\end{array}$ $\begin{array}{lllllllllllllll} & 1.40\end{array}$ DLVLLYETALSSGGFLEPPTHANR RLVILYYTALLLSGGFLLD $\begin{array}{lllllllllllll}1.00 & 37.03 & 25.20 & 50.03 & 4 & 3145.6477 & 3145.6417 & 787.4177 & 0.0060 & 1.9050 & 7.189 & 5.927 & 5.115\end{array}$ $\begin{array}{lllllllllllll}1.00 & 81.74 & 25.19 & 19.14 & 3 & 3145.6492 & 3145.6417 & 1049.5545 & 0.0075 & 2.3820 & 105.780 & 72.311 \\ 0.99 & 44.46 & 28.34 & 22.35 & 2 & 1407.7518 & 1407.7381 & 704.8763 & 0.0137 & 9.7179 & 3480.146 & 4529.77\end{array}$ GFSLEDPTHAN

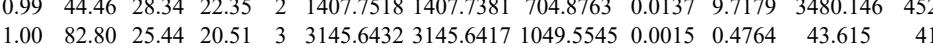

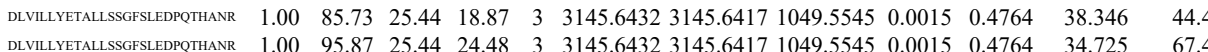
$\begin{array}{lllllllllllll}\text { DLVILLYETALSSGFSLEPPTHANR } & 1.00 & 35.94 & 25.26 & 16.36 & 4 & 3145.6461 & 3145.6417 & 787.4177 & 0.0044 & 1.3970 & 20.311 & 50.337\end{array}$

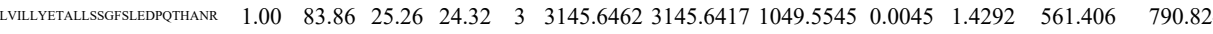




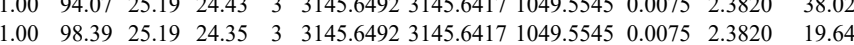
$\begin{array}{llllllllllll} & 0.98 & 31.71 & 27.32 & 22.26 & 2 & 1251.6388 & 1251.6370 & 626.8258 & 0.0018 & 1.4358 & 39.046\end{array}$

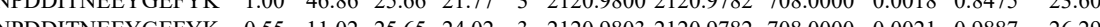

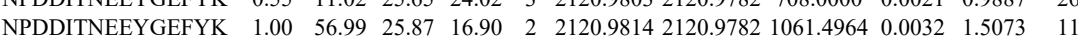

HSQFIGYPITFVEK

HSQFIGYPITLFVEK

HSQFIGYPITLFVEK

HSQFIGYPITLFVEK

HSQFIGYPITLFVEK

HSQFIGYPITLFVEK

HSQFIGYPITLFVEK

HSQFIGYPITLFVEK

HSQFIGYPITLFVEK

$\begin{array}{lllllllllllll}1.00 & 79.96 & 24.98 & 20.22 & 2 & 2066.1494 & 2066.1444 & 1034.0795 & 0.0050 & 2.4176 & 2266.910 & 2320.163\end{array}$

$\begin{array}{lllllllllllll}1.00 & 41.17 & 24.80 & 23.28 & 3 & 2066.1517 & 2066.1444 & 689.7221 & 0.0073 & 3.5280 & 2621.976 & 2636.049 & 3\end{array}$

$\begin{array}{llllllllllllll}.00 & 44.93 & 24.81 & 21.32 & 3 & 2066.1529 & 2066.1444 & 689.7221 & 0.0085 & 4.1079 & 3113.422 & 2552.633 & 187.391 \\ 1.00 & 35.08 & 25.30 & 21.69 & 3 & 2066.1481 & 2066.1444 & 689.722 & 0.0037 & 1.7782 & 1510.777 & 1712.428 & 590.796\end{array}$

$\begin{array}{llllllllllllll}0.94 & 20.68 & 25.30 & 18.78 & 3 & 2066.1481 & 2066.1444 & 689.7221 & 0.0037 & 1.7882 & 1510.777 & 1712.428 & 590.796 \\ 0 & 589.7221 & 0.0037 & 1.7882 & 2127.465 & 2169.288 & 1250.265\end{array}$

$\begin{array}{lllllllllllll}1.00 & 33.99 & 25.33 & 20.29 & 3 & 2066.1475 & 2066.1444 & 689.7221 & 0.0031 & 1.4982 & 1888.244 & 2126.606 & 384.202\end{array}$

$\begin{array}{llllllllllllll}0.99 & 28.99 & 25.07 & 20.03 & 3 & 2066.1490 & 2066.1444 & 689.7221 & 0.0046 & 2.2231 & 1699.841 & 1569.694 & 309.886 & 12 \\ 1.00 & 39.33 & 25.33 & 1.99 & 3 & 2066.1475 & 2066.1444 & 689.7221 & 0.0031 & 1.4982 & 2341.453 & 2198.136 & 1494.545 & 27\end{array}$

$\begin{array}{llllllllllllll}1.00 & 39.33 & 25.33 & 19.99 & 3 & 2066.1475 & 2066.1444 & 689.7221 & 0.0031 & 1.4982 & 2341.453 & 2198.136 & 1494.545 \\ 0.96 & 22.57 & 25.33 & 18.01 & 3 & 2066.1484 & 2066.1444 & 689.7221 & 0.0040 & 1.9331 & 2933.166 & 2866.296 & 836.869\end{array}$

$\begin{array}{llllllllllllll}1.00 & 45.46 & 25.30 & 22.90 & 3 & 2066.1481 & 2066.1444 & 689.7221 & 0.0037 & 1.7882 & 1461.740 & 1138.001 & 639.450\end{array}$

HSQFIGYPITLFVEK

$\begin{array}{lllllllllllll}0.99 & 31.05 & 24.90 & 24.46 & 3 & 2066.1499 & 2066.1444 & 689.7221 & 0.0055 & 2.6581 & 1113.829 & 1427.271\end{array}$

LVTSPCCIVTSTYGWTANMER

LVTSPCCIVTSTYGWTANMER

LGIHEDSQNR

LGIHEDSQNR

LGIHEDSQNR

LGIHEDSQNR

LGIHEDSQNR

LGIHEDSQNR

$\begin{array}{lllllllllllll} & 3.78 & 25.30 & 23.46 & 3 & 2066.1481 & 2066.1444 & 689.7221 & 0.0037 & 1.7882 & 580.229 & 584.251\end{array}$

$\begin{array}{lllllllllllll}38.37 & 25.30 & 22.64 & 3 & 2066.1481 & 2066.1444 & 689.7221 & 0.0037 & 1.7882 & 514.419 & 596.566 & 219.227\end{array}$

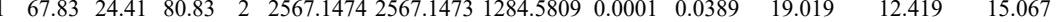
$\begin{array}{lllllllllllll}0.53 & 16.01 & 24.05 & 29.01 & 3 & 2567.1508 & 2567.1473 & 856.7230 & 0.0035 & 1.3618 & 22.096\end{array}$ $\begin{array}{llllllllllll}0.83 & 19.54 & 27.92 & 17.68 & 3 & 1311.6661 & 1311.6653 & 438.2290 & 0.0008 & 0.6085 & 151.758\end{array}$ $\begin{array}{llllllllllll}0.87 & 20.89 & 28.04 & 18.31 & 3 & 1311.6667 & 1311.6653 & 438.2290 & 0.0014 & 1.0649 & 124.801\end{array}$ $\begin{array}{llllllllllll}0.89 & 21.55 & 28.04 & 15.44 & 3 & 1311.6667 & 1311.6653 & 438.2290 & 0.0014 & 1.0649 & 137.898\end{array}$ $\begin{array}{lllllllllll}0.86 & 22.15 & 27.90 & 19.58 & 3 & 1311.6655 & 1311.6653 & 438.2290 & 0.0002 & 0.1521 & 66.722\end{array}$ $\begin{array}{llllllllllll}0.65 & 20.89 & 27.84 & 18.99 & 3 & 1311.6646 & 1311.6653 & 438.2290 & -0.0007 & -0.5324 & 64.005\end{array}$ $\begin{array}{llllllllllll}0.80 & 20.60 & 27.94 & 18.67 & 3 & 1311.6655 & 1311.6653 & 438.2290 & 0.0002 & 0.1521 & 75.799\end{array}$

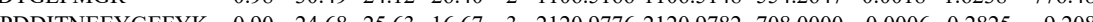

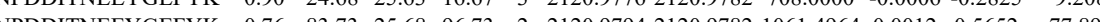

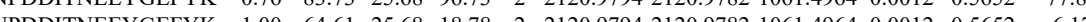

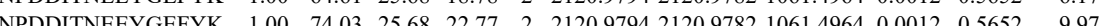

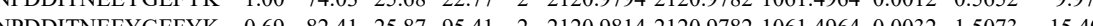
$\begin{array}{llllllllllll}\text { NPDDINEEYGEFYK } & 1.00 & 41.45 & 25.87 & 17.92 & 2 & 2120.9814 & 2120.9782 & 1061.4964 & 0.0032 & 1.5073 & 17.485\end{array}$ $\begin{array}{lllllllllllll}\text { NPDDITNEEYGEFYK } & 0.69 & 49.91 & 25.87 & 62.91 & 2 & 2120.9814 & 2120.9782 & 1061.4964 & 0.0032 & 1.5073 & 27.367\end{array}$ $\begin{array}{llllllllllllll}\text { NPDDITNEEYGEFYK } & 0.99 & 38.66 & 25.87 & 1630 & 2 & 2120.9814 & 2120.9782 & 1061.4964 & 0.0032 & 1.5073 & 4.682\end{array}$ $\begin{array}{lllllllllllll}\text { NPDDITNEEYGEFYK } & 1.00 & 53.30 & 25.87 & 18.67 & 2 & 2120.9814 & 2120.9782 & 1061.4964 & 0.0032 & 1.5073 & 6.945\end{array}$ $\begin{array}{lllllllllllll}\text { NPDDITNEEYGEFYK } & 0.99 & 38.48 & 25.87 & 15.65 & 2 & 2120.9814 & 2120.9782 & 1061.4964 & 0.0032 & 1.5073 & 10.005\end{array}$ $\begin{array}{llllllllllll}\text { NPDDITNEEYGEFYK } & 1.0 & 67.35 & 25.99 & 19.05 & 2 & 2120.9834 & 2120.9782 & 1061.4964 & 0.0052 & 2.4494 & 10.733\end{array}$ $\begin{array}{llllllllllllll}\text { NPDDITNEEYGEFYK } & 1.00 & 67.05 & 25.99 & 21.10 & 2 & 2120.9834 & 2120.9782 & 1061.4964 & 0.0052 & 2.4494 & 17.126\end{array}$

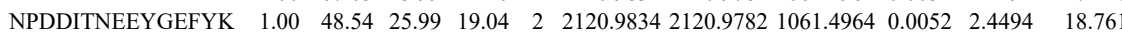
$\begin{array}{llllllllllll}\text { NPDDITNEEYGEFYK } & 0.98 & 38.94 & 25.99 & 16.17 & 2 & 2120.9834 & 2120.9782 & 1061.4964 & 0.0052 & 2.4494 & 11.706\end{array}$ $\begin{array}{lllllllllllll}\text { NPDDITNEEYGEFYK } & 1.00 & 56.93 & 25.99 & 17.59 & 2 & 2120.9834 & 2120.9782 & 1061.4964 & 0.0052 & 2.4494 & 4.408\end{array}$ $\begin{array}{lllllllllllll}\text { NPDDITNEEYGEFYK } & 1.00 & 47.35 & 25.99 & 21.18 & 2 & 2120.9834 & 2120.9782 & 1061.4964 & 0.0052 & 2.4494 & 12.789\end{array}$

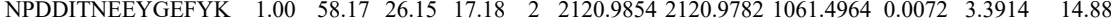
$\begin{array}{lllllllllllll}\text { NPDDITNEEYGEFYK } & 1.00 & 50.23 & 26.15 & 18.07 & 2 & 2120.9854 & 2120.9782 & 1061.4964 & 0.0072 & 3.3914 & 7.437\end{array}$ $\begin{array}{llllllllllll}\text { NPDDITNEEYGEFYK } & 1.00 & 55.19 & 26.15 & 17.44 & 2 & 2120.9854 & 2120.9782 & 1061.4964 & 0.0072 & 3.3914 & 18.313\end{array}$ NPDDITNEEYGEFYK

APFDLFENR APFDLFENR $\begin{array}{lllllllllll}1.00 & 53.58 & 26.38 & 18.23 & 2 & 2120.9894 & 2120.9782 & 1061.4964 & 0.0112 & 5.2755 & 7.505\end{array}$ $\begin{array}{lllllllllllll}0.96 & 30.23 & 27.29 & 23.04 & 2 & 1251.6380 & 1251.6370 & 626.8258 & 0.0010 & 0.7977 & 75.208 \\ 0 & 0.99 & 34.26 & 27.34 & 25.33 & 2 & 1251.6382 & 1251.6370 & 626.8258 & 0.0012 & 0.9572 & 84.936\end{array}$ $\begin{array}{llllllllllll} & 0.99 & 34.26 & 27.34 & 25.33 & 2 & 1251.6382 & 1251.6370 & 626.8258 & 0.0012 & 0.9572 & 84.936\end{array}$

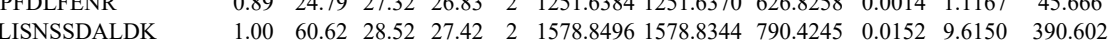
$\begin{array}{lllllllllllll} & \end{array}$

$\begin{array}{llllllll} & \\ 0\end{array}$ 710.791 

$\begin{array}{lllllllllllllll}1.00 & 59.70 & 27.40 & 26.81 & 2 & 1446.8198 & 1446.8173 & 724.4159 & 0.0025 & 1.7255 & 20658.709 & 18779.801 & 9736.154 & 2251.552 & \text { Yes } \\ 1 & 56.15 & 27.40 & 3.53 & 2 & 1446.818 & 1446.8173 & 724.459 & 0.0025 & 1.7255 & 11837.693 & 9987.201 & 5275.350 & 1177.643 & \text { Yes }\end{array}$ $\begin{array}{lllllllllllllll}1.00 & 56.15 & 27.40 & 30.53 & 2 & 1446.8198 & 1446.8173 & 724.4159 & 0.0025 & 1.7255 & 11837.963 & 9987.201 & 5275.350 & 1177.643 & \text { Yes } \\ 1\end{array}$

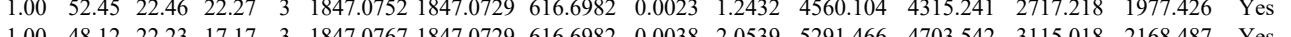

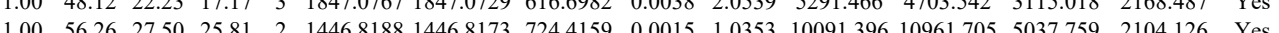
$\begin{array}{lllllllllllllll}1.00 & 66.26 & 27.50 & 25.81 & 2 & 1446.8188 & 144.8173 & 724.4159 & 0.0015 & 1.0353 & 10091.396 & 10961.755 & 5037.759 & 2104.126 & \text { Yes } \\ 1.00 & 56.60 & 27.40 & 25.28 & 2 & 1446.8202 & 14468173 & 724.4159 & 0.0029 & 2.0016 & 4078.615 & 3980.395 & 1695.982 & 674.253 & \text { Yes }\end{array}$ $\begin{array}{llllllllllllllll}0.97 & 56.45 & 20.45 & 27.69 & 2 & 1531.9430 & 1531.9299 & 766.9722 & 0.0131 & 8.5400 & 21610.111 & 29547.901 & 3437.695 & 1528.905 & \text { Yes }\end{array}$ $\begin{array}{lllllllllllllll}0.80 & 44.21 & 20.41 & 26.73 & 2 & 1531.9438 & 1531.9299 & 766.9722 & 0.0139 & 9.0615 & 26271.817 & 25599.580 & 5992.850 & 680.200 & \text { Yes }\end{array}$

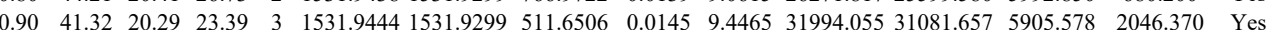
$\begin{array}{lllllllllllllll}0.72 & 34.19 & 20.49 & 21.35 & 3 & 1531.9447 & 1531.9299 & 511.6506 & 0.0148 & 9.6419 & 55275.310 & 55922.575 & 11175.608 & 1560.688 & \text { Yes }\end{array}$ $\begin{array}{lllllllllllllll}0.98 & 54.29 & 22.46 & 29.87 & 2 & 1847.0752 & 1847.0729 & 924.5437 & 0.0023 & 1.2439 & 1158.992 & 1163.556 & 704.105 & 395.817 & \text { Yes }\end{array}$ $\begin{array}{lllllllllllllllll}1.00 & 57.91 & 22.23 & 24.37 & 3 & 1847.0767 & 1847.0729 & 616.6982 & 0.0038 & 2.0539 & 10372.089 & 9098.477 & 5144.624 & 3881.337 & \text { Yes }\end{array}$ $\begin{array}{llllllllllllllll}1.00 & 46.62 & 22.01 & 21.15 & 3 & 1847.0770 & 1847.0729 & 616.6982 & 0.0041 & 2.2161 & 7470.548 & 8327.322 & 4705.364 & 2582.904 & \text { Yes }\end{array}$ $\begin{array}{lllllllllllllllll}0.97 & 55.60 & 20.04 & 25.10 & 2 & 1531.9396 & 1531.9299 & 766.9722 & 0.0097 & 6.3235 & 5191.734 & 5435.825 & 1367.586 & 360.784 & \text { Yes }\end{array}$ $\begin{array}{llllllllllllllllll}0.93 & 49.55 & 20.21 & 24.16 & 2 & 1531.9414 & 1531.9299 & 766.9722 & 0.0115 & 7.4970 & 8048.370 & 7523.524 & 1645.933 & 247.657 & \text { Yes }\end{array}$ $\begin{array}{lllllllllllllll}0.86 & 42.98 & 20.45 & 26.49 & 3 & 1531.9435 & 1531.9299 & 511.6506 & 0.0136 & 8.8601 & 33892.399 & 31029.440 & 7885.996 & 1337.285 & \text { Yes }\end{array}$ $\begin{array}{llllllllllllllll}1.00 & 47.47 & 24.81 & 30.10 & 2 & 1554.9110 & 1554.8983 & 778.4564 & 0.0127 & 8.1571 & 6560.320 & 6657.954 & 1424.113 & 112.144 & \text { Yes }\end{array}$ $\begin{array}{lllllllllllllll}1.00 & 49.20 & 24.50 & 30.23 & 2 & 1554.9122 & 1554.8983 & 778.4564 & 0.0139 & 8.9278 & 15088.721 & 13358.988 & 2959.593 & 479.897 & \text { Yes }\end{array}$ $\begin{array}{lllllllllllllllll}1.00 & 42.16 & 24.53 & 23.33 & 3 & 1554.9127 & 1554.8983 & 519.3067 & 0.0144 & 9.2430 & 13135.584 & 9462.981 & 4629.798 & 2645.153 & \text { Yes } \\ 1.00 & 43.55 & 24.28 & 24.29 & 3 & 1554.9133 & 1554.8983 & 519.3067 & 0.0150 & 9.6281 & 13435.391 & 14039.613 & 4695.222 & 2796.129 & \text { Yes }\end{array}$ $\begin{array}{lllllllllllllllll}0.88 & 22.65 & 25.53 & 21.89 & 2 & 887.5694 & 887.5684 & 444.7915 & 0.0010 & 1.1241 & 5959.111 & 5328.267 & 3301.440 & 1777.858 & \text { Yes }\end{array}$ $\begin{array}{lllllllllllllllll}0.99 & 33.55 & 25.53 & 19.87 & 2 & 887.5696 & 887.5684 & 444.7915 & 0.0012 & 1.3489 & 3518.103 & 3172.790 & 1889.629 & 1150.440 & \text { Yes }\end{array}$ \begin{tabular}{lllllllllllllll}
0.93 & 25.33 & 25.53 & 21.34 & 2 & 887.5692 & 887.5684 & 444.7915 & 0.0008 & 0.8993 & 3480.106 & 2955.590 & 1759.580 & 1019.425 & Yes \\
\hline
\end{tabular} $\begin{array}{llllllllllllllll} & 0.98 & 31.77 & 25.53 & 25.28 & 2 & 887.5692 & 887.5684 & 444.7915 & 0.0008 & 0.8993 & 3493.202 & 2949.137 & 1882.731 & 959.328 & \text { Yes } \\ \text { MIAGQVLDINLAAEPK } & 1.00 & 96.10 & 24.81 & 24.39 & 2 & 1970.1136 & 1970.1114 & 986.0630 & 0.0022 & 1.1155 & 1457.429 & 1083.858 & 469.071 & 72.948 & \text { Yes }\end{array}$

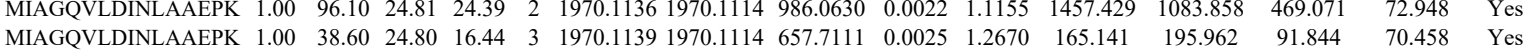
$\begin{array}{llllllllllllllllll} & \text { Mes }\end{array}$

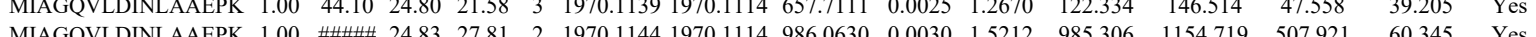

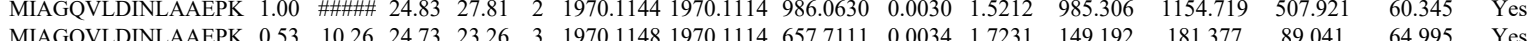

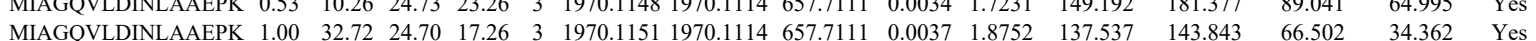

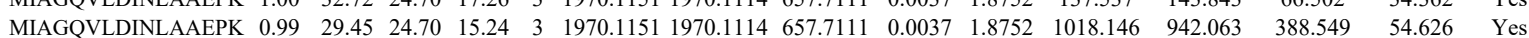
$\begin{array}{lllllllllllllllll}\text { MIAGQVLDINLAAEPK } & 1.00 & 46.00 & 24.56 & 19.97 & 3 & 1970.1160 & 1970.1114 & 6577711 & 0.0046 & 2.3313 & 764294 & 926.004 & 297.026 & 104.674 & \text { Yes }\end{array}$

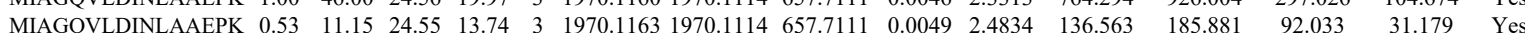

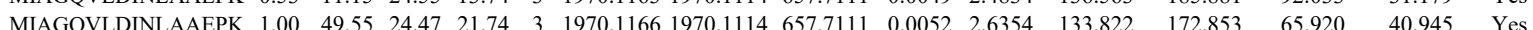

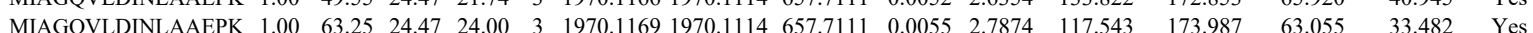
$\begin{array}{lllllllllllllllll}\text { MIAGQVLDINLAAEPK } & 1.00 & 36.76 & 24.23 & 19.76 & 3 & 1970.1184 & 1970.1114 & 657.7111 & 0.0070 & 3.5476 & 157.936 & 175.473 & 74.652 & 45.092 & \text { Yes }\end{array}$

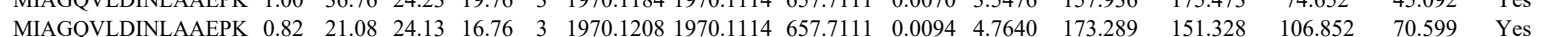

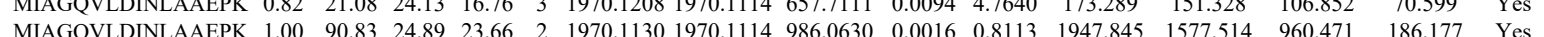

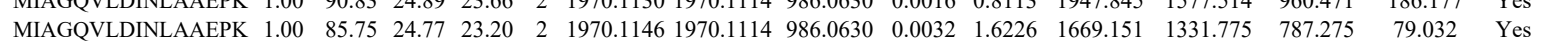
$\begin{array}{llllllllllllllll}\text { MIAGQVLDINLAAEPK } & 1.00 & 33.02 & 24.47 & 19.74 & 3 & 1970.1157 & 1970.1114 & 657.7111 & 0.0043 & 2.1793 & 158.486 & 142.329 & 78.790 & 51.093 & \text { Yes }\end{array}$

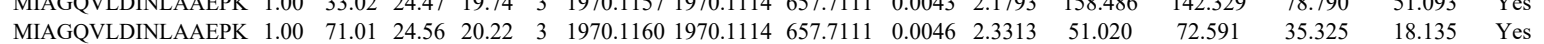

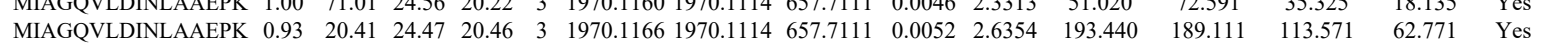

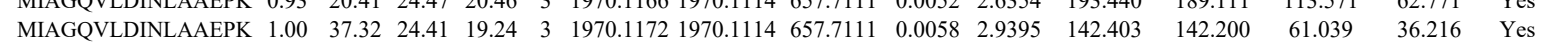
$\begin{array}{llllllllllllllll}\text { MIAGQVLDINLAAEPK } & 0.99 & 28.56 & 24.56 & 14.86 & 3 & 1970.1160 & 1970.1114 & 657.7111 & 0.0046 & 2.3313 & 252.695 & 244.052 & 128.577 & 54.380 & \text { Yes }\end{array}$ $\begin{array}{lllllllllllllllll}\text { VPPPPPIAR } & 0.97 & 32.99 & 24.73 & 20.82 & 2 & 1086.6708 & 1086.6671 & 544.3408 & 0.0037 & 3.3986 & 19833.385 & 23656.757 & 4334.155 & 1770.187 & \text { Yes }\end{array}$

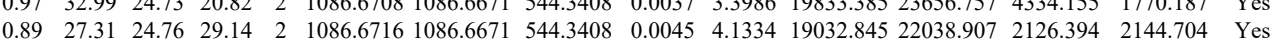

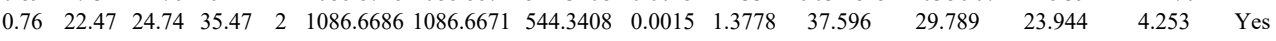

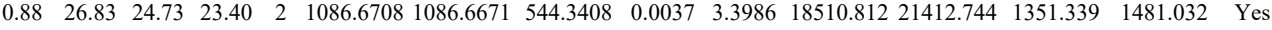
$\begin{array}{lllllllllllllllll}0.98 & 35.08 & 24.76 & 21.87 & 2 & 1086.6712 & 1086.6671 & 544.3408 & 0.0041 & 3.7660 & 23311.590 & 27979.994 & 5418.866 & 1794.519 & \text { Yes }\end{array}$ $\begin{array}{llllllllllllllll}0.87 & 26.44 & 24.76 & 20.14 & 2 & 1086.6710 & 1086.6671 & 544.3408 & 0.0039 & 3.5823 & 10547.728 & 12590.991 & 7574.313 & 6054.020 & \text { Yes }\end{array}$ $\begin{array}{lllllllllllllll}0.95 & 31.66 & 24.76 & 22.01 & 2 & 1086.6714 & 1086.6671 & 544.3408 & 0.0043 & 3.9497 & 10325.545 & 12517.931 & 6600.958 & 5917.879 & \text { Yes }\end{array}$ $\begin{array}{lllllllllllllll}0.77 & 26.47 & 24.76 & 23.06 & 2 & 1086.6720 & 1086.6671 & 544.3408 & 0.0049 & 4.5008 & 5864.935 & 6064.418 & 5064.215 & 4952.772 & \text { No }\end{array}$ $\begin{array}{llllllllllllllll}0.75 & 26.08 & 24.79 & 27.50 & 2 & 1086.6728 & 1086.6671 & 544.3408 & 0.0057 & 5.2357 & 3693.440 & 3264.935 & 4755.763 & 4695.090 & \text { No }\end{array}$ $\begin{array}{lllllllllllllll}0.80 & 27.27 & 24.76 & 27.82 & 2 & 1086.6724 & 1086.6671 & 544.3408 & 0.0053 & 4.8682 & 1929.159 & 2053.791 & 909.156 & 830.372 & \text { Yes } \\ 0.79 & 26 & 24.01 & 27.92 & 2 & 1086742 & 1066671 & 544348 & 0.0071 & 6.5216 & 1967.976 & 2214.719 & 1428.82 & 1186934 & \text { Yes }\end{array}$ $\begin{array}{llllllllllllllll}0.79 & 26.19 & 24.01 & 27.92 & 2 & 1086.6742 & 1086.6671 & 544.3408 & 0.0071 & 6.5216 & 1967.976 & 2214.719 & 1428.821 & 1186.934 & \text { Yes } \\ 1.00 & 70.52 & 19.68 & 22.88 & 2 & 1603.9916 & 1603.9905 & 803.0025 & 0.0011 & 0.6849 & 26296.702 & 25735.086 & 0.000 & 1030.206 & \text { No }\end{array}$ $\begin{array}{llllllllllllllll}1.00 & 70.52 & 19.68 & 22.88 & 2 & 1603.9916 & 1603.9905 & 803.0025 & 0.0011 & 0.6849 & 26296.702 & 25735.086 & 0.000 & 1030.206 & \text { No } \\ 1.00 & 85.09 & 19.59 & 27.17 & 2 & 1603.9926 & 1603.9905 & 803.0025 & 0.0021 & 1.3076 & 22879.420 & 19939.992 & 545.558 & 1412.706 & \text { No }\end{array}$

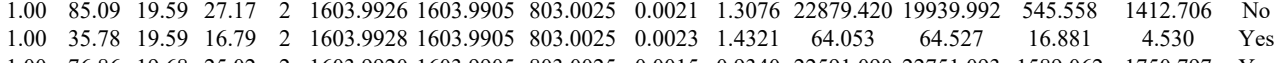
$\begin{array}{lllllllllllllll}1.00 & 76.86 & 19.68 & 25.02 & 2 & 1603.9920 & 1603.9905 & 803.0025 & 0.0015 & 0.9340 & 22591.090 & 22751.093 & 1589.062 & 1750.797 & \text { Yes }\end{array}$

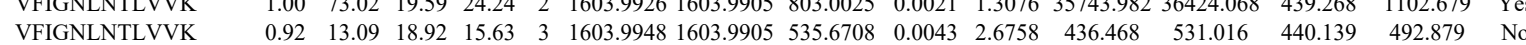


VFIGNLNTLVVK VFIGNLNTLVVK VFIGNLNTLVVK AAVAGEDGR

$\begin{array}{lllllllllll}\text { LAMB1_HUMA } & \text { P07942 } & \text { LAMB1 } & \text { Laminin subunit b } 198.07 & 1.00 & 3 & 2.7 & 0.5051 & 0.1892 & -2.6781 & 0.5406\end{array}$

FUMH_HUMAN P07954 FH

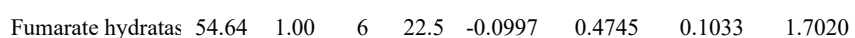

TSP1_HUMAN P07996 THBS1

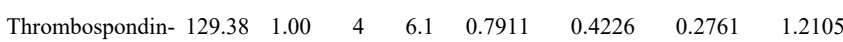
AFLTDSADLDSIEA AVITVQRPGR
AVITVQRPGR AVITVQRPGR AVITVQRPGR $\begin{array}{llllllllll} & \end{array}$

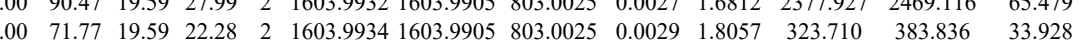
$\begin{array}{llllllllllllll}1.00 & 51.07 & 25.59 & 21.20 & 2 & 988.5068 & 988.5060 & 495.2603 & 0.0008 & 0.8077 & 189.822 & 176.839 & 132.719\end{array}$ $\begin{array}{lllllllllll}1.00 & 64.02 & 26.15 & 30.82 & 3 & 2679.3883 & 2679.3847 & 894.1355 & 0.0036 & 1.3421 & 4.980\end{array}$ $\begin{array}{lllllllllllllll}0.62 & 26.73 & 24.25 & 35.32 & 3 & 1239.7534 & 1239.7533 & 414.2584 & 0.0001 & 0.0805 & 751.864 & 1108.542 & 476.697\end{array}$ $\begin{array}{lllllllllllll}0.89 & 31.47 & 24.18 & 34.48 & 3 & 1239.7537 & 1239.7533 & 414.2584 & 0.0004 & 0.3219 & 502.439 & 831.980 & 317.197\end{array}$ $\begin{array}{lllllllllll}0.88 & 24.25 & 24.28 & 22.53 & 2 & 1239.7530 & 1239.7533 & 620.8839 & -0.0003 & -0.2416 & 64.75\end{array}$

82.530

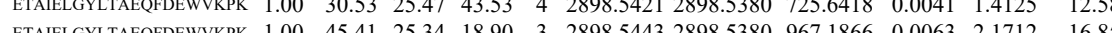
$\begin{array}{lllllllllll} & \end{array}$

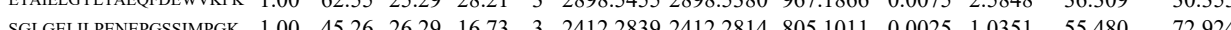
\begin{tabular}{llllllllllllll}
\hline SGLGELIPENEPGSSMPGK & 1.00 & 42.64 & 26.28 & 15.68 & 3 & 2412.2848 & 2412.2814 & 805.1011 & 0.0034 & 1.4077 & 80.386 & 52.069
\end{tabular} $\begin{array}{lllllllllllll}\text { ETAIELGYLTAEFPDEWYKPK } & 1.00 & 66.07 & 25.43 & 20.97 & 3 & 28985431 & 28985380 & 967.1866 & 0.0051 & 1.7577 & 101.675 & 56.881\end{array}$ $\begin{array}{lllllllllllllll} & \text { ETAIELGYLTAEOFDENVKPK } & 1.00 & 61.68 & 25.42 & 17.72 & 3 & 2898.5434 & 2898.5380 & 967.1866 & 0.0054 & 1.8611 & 78.839 & 100.012\end{array}$ $\begin{array}{lllllllllllllll}\text { SGLGELLPENEPGSSIMPGK } & 1.00 & 68.07 & 26.18 & 22.16 & 2 & 2412.2814 & 2412.2814 & 1207.1480 & 0.0000 & 0.0000 & 48.679 & 65.860\end{array}$ $\begin{array}{lllllllllllll}\text { SGLGELILPENEPGSSIMPGK } & 1.00 & 64.37 & 26.25 & 22.12 & 2 & 2412.2834 & 2412.2814 & 1207.1480 & 0.0020 & 0.8284 & 65.156\end{array}$ $\begin{array}{llllllllllll}\text { SGLGELLPENEPGSSIMPGK } & 0.53 & 32.23 & 26.30 & 45.23 & 3 & 2412.2842 & 2412.2814 & 805.1011 & 0.0028 & 1.1593 & 10.117\end{array}$ $\begin{array}{lllllllllllll}\text { SGLGELLPENEPGSSIMPGK } & 0.53 & 29.19 & 26.28 & 42.19 & 3 & 2412.2848 & 2412.2814 & 805.1011 & 0.0034 & 1.4077 & 300.147\end{array}$ $\begin{array}{llllllllllllll}\text { IYELAAGGTAVGTGLNTR } & 1.00 & 88.45 & 26.49 & 30.67 & 2 & 1907.0404 & 1907.0234 & 954.5190 & 0.0170 & 8.9049 & 27.997\end{array}$ $\begin{array}{lllllllllllll}\text { FEALAAHDALVELSGAMNTTACSLMK } & 1.00 & 74.47 & 27.08 & 19.50 & 3 & 3027.4822 & 3027.4781 & 1010.1666 & 0.0041 & 1.3529 & 62.748\end{array}$ $\begin{array}{llllllllllll}\text { FEALAAHDALVELSGAMNTTACSLMK } & 1.00 & 42.40 & 27.08 & 21.89 & 3 & 3027.4822 & 3027.4781 & 1010.1666 & 0.0041 & 1.3529 & 20.568\end{array}$

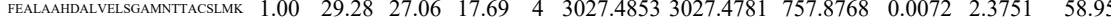
$\begin{array}{llllllllllll}\text { FEALAAHDALVESGAMNTTACSLMKK } & 0.77 & 12.80 & 27.05 & 14.09 & 4 & 3027.4857 & 3027.4781 & 757.8768 & 0.0076 & 2.5070 & 18.08\end{array}$ $\begin{array}{lllllllllllll}\text { FEALAAHDALVELSGAMNTTACSLMK } & 0.96 & 23.98 & 27.08 & 15.14 & 3 & 3027.4822 & 3027.4781 & 1010.1666 & 0.0041 & 1.3529 & 13.472\end{array}$ $\begin{array}{lllllllllllll}\text { FEALAAHDALVELSGAMNTTACSLMK } & 1.00 & 39.99 & 27.08 & 52.99 & 4 & 3027.4825 & 3027.4781 & 757.8768 & 0.0044 & 1.4514 & 34.659\end{array}$ $\begin{array}{llllllllllllll}\text { FEALAAHDALVELSGAMNTTACSLMK } & 0.90 & 11.78 & 27.05 & 24.78 & 4 & 3027.4833 & 3027.4781 & 757.8768 & 0.0052 & 1.7153 & 15.610\end{array}$ $\begin{array}{lllllllllllll} & \text { VAALTGLPFVTAPNK } & 1.00 & \# \text { \#\#\#\# } 22.38 & 24.49 & 2 & 1786.0614 & 1786.0596 & 894.0371 & 0.0018 & 1.0067 & 1359.297 & 1161.279\end{array}$ $\begin{array}{llllllllllllll}\text { VAALTGLPFVTAPNK } & 1.00 & 98.32 & 22.38 & 25.35 & 2 & 1786.0614 & 1786.0596 & 894.0371 & 0.0018 & 1.0067 & 957.856 & 1289.509 & 45\end{array}$ $\begin{array}{llllllllllll} & \end{array}$ $\begin{array}{llllllllllll}\text { AAAEVNQDYGLDPK } & 1.00 & 74.95 & 27.82 & 22.10 & 2 & 1777.9116 & 1777.9090 & 889.9618 & 0.0026 & 1.4607 & 266.739\end{array}$

$\begin{array}{llllllllllllllll} & \text { ARESGGDNSVFDFELTGAAR } & 1.00 & 94.31 & 27.73 & 21.37 & 2 & 2338.1574 & 2338.1563 & 1170.0854 & 0.0011 & 0.4701 & 42.097\end{array}$ $\begin{array}{lllllllllllllllll} & \text { IESGGDNSVFDIFELTGAAR } & 0.76 & 82.12 & 27.73 & 95.12 & 2 & 2338.1574 & 2338.1563 & 1170.0854 & 0.0011 & 0.4701 & 95.193\end{array}$ $\begin{array}{lllllllllllll} & \text { ILSGGDNVIDIFLTGAAR } & 1.00 & 37.99 & 27.70 & 17.29 & 3 & 2338.1584 & 2338.1563 & 780.3927 & 0.0021 & 0.8970 & 32.742\end{array}$

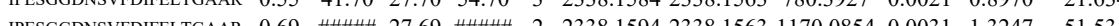

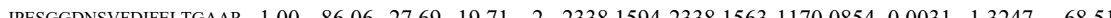
$\begin{array}{llllllllllllll}\text { NALWHTGNTPGQVR } & 0.98 & 33.88 & 27.87 & 19.29 & 3 & 1693.8844 & 1693.8770 & 565.6329 & 0.0074 & 4.3609 & 3527.358 & 1038\end{array}$

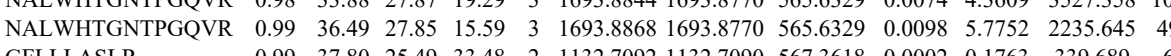

GFLLLASLR

GFLLLASLR

GFLLLASLR

GFLLLASLR

GFLLLASLR

GFLLLASLR

GFLLLASLR

GFLLLASLR

GFLLLASLR

GFLLLASLR

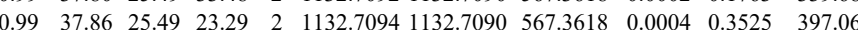

$\begin{array}{lllllllllllll}0.99 & 35.82 & 25.49 & 21.50 & 2 & 1132.7092 & 1132.7090 & 567.3618 & 0.0002 & 0.1763 & 325.727\end{array}$

$\begin{array}{llllllllllll}0.89 & 26.40 & 25.77 & 28.45 & 2 & 1132.7090 & 1132.7090 & 567.3618 & 0.0000 & 0.0000 & 119.214\end{array}$

$\begin{array}{llllllllllll}0.99 & 32.60 & 25.49 & 25.63 & 2 & 1132.7096 & 1132.7090 & 567.3618 & 0.0006 & 0.5288 & 170.983\end{array}$

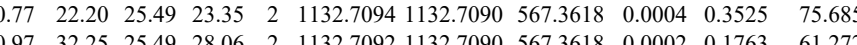
$\begin{array}{lllllllllllll}0.97 & 32.25 & 25.49 & 28.06 & 2 & 1132.7092 & 1132.7090 & 567.3618 & 0.004 & 0.3525 & 751.685 & 61.272 \\ 0.99 & 33.56 & 25.49 & 24.90 & 2 & 1132.7096 & 11327090 & 567.3618 & 0.0006 & 0.5288 & 54.690\end{array}$ $\begin{array}{llllllllllll}0.81 & 28.14 & 25.81 & 25.00 & 2 & 1132.7080 & 1132.7090 & 567.3618 & -0.0010 & -0.8813 & 20.394\end{array}$ $\begin{array}{llllllllllll}0.78 & 22.88 & 25.77 & 23.01 & 2 & 1132.7090 & 1132.7090 & 567.3618 & 0.0000 & 0.0000 & 20.251\end{array}$

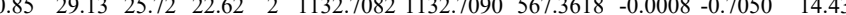
$\begin{array}{lllllllllll}0.98 & 29.55 & 25.29 & 19.72 & 2 & 1132.7112 & 1132.7090 & 567.3618 & 0.0022 & 1.9388 & 12.936\end{array}$

$\begin{array}{lllllllllll}0.98 & 29.55 & 25.29 & 19.72 & 2 & 1132.712 & 1132.7090 & 567.3618 & 0.0022 & 1.9388\end{array}$

$\begin{array}{lllllllllllll}\text { ATAGDTHLGGEDFDNR } & 0.98 & 31.21 & 24.58 & 15.36 & 3 & 1818.8248 & 1818.8255 & 607.2824 & -0.0007 & -0.3842 & 10.653\end{array}$ $\begin{array}{lllllllllllll}1.00 & 66.82 & 28.00 & 24.32 & 2 & 1509.7860 & 1509.7741 & 755.8943 & 0.0119 & 7.8714 & 4816.753 & 5716.661 & 8996.2\end{array}$ (1) FGPV QSDMK FGDPVVQSDMK FGDPVVQSDMK FGDPVVQSDMK FGDPVVQSDMK KFGDPVVQSDM NSTIPTK

NSTPTK

LVNTHEFE

LVNHFVEEFK

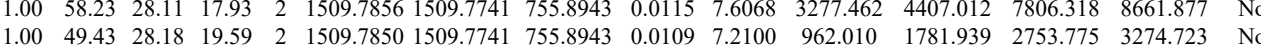

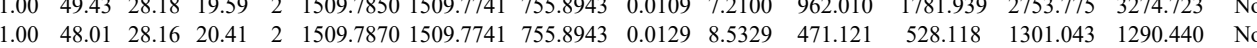

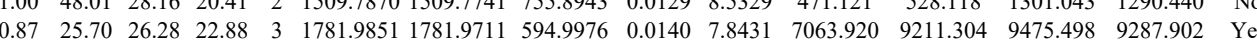

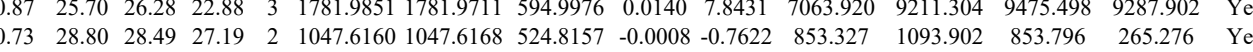

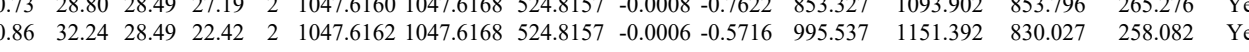

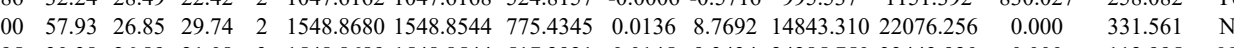

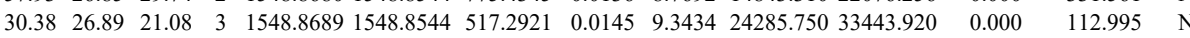
$\begin{array}{llllllllllllllll}1.00 & 62.00 & 26.69 & 31.12 & 2 & 1548.8696 & 1548.8544 & 775.4345 & 0.0152 & 9.8009 & 15557.512 & 18378.752 & 301.217 & 16.142 & \text { Yes }\end{array}$ 
$\begin{array}{llllllllllllll} & \end{array}$

$\begin{array}{llllllllllllll} & \\ \end{array}$ $\begin{array}{lllllllllllllll} & \text { AFYPEEISSMVLTK } & 0.52 & 13.14 & 27.68 & 15.60 & 3 & 1902.0088 & 1902.0052 & 635.0090 & 0.0036 & 1.8897 & 164.246 & 49.106 & 43.135\end{array}$

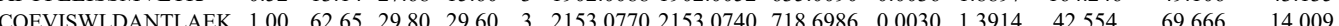

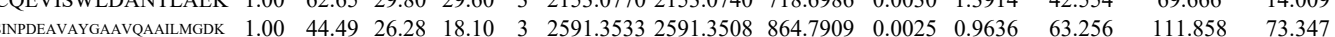

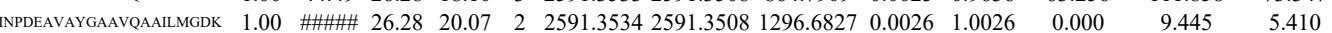

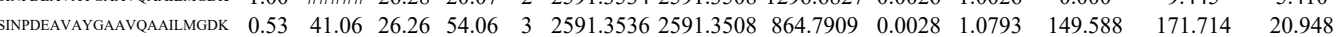
$\begin{array}{lllllllllllllll} & \text { SNPDEAVAYGAAVQAALMGDK } & 1.00 & 74.99 & 26.59 & 23.23 & 3 & 2607.3502 & 2607.3458 & 870.1225 & 0.0044 & 1.6856 & 78.369 & 111.564 & 66.650\end{array}$ $\begin{array}{llllllllllllll}\text { FEELCSDLFR } & 1.00 & 43.19 & 24.31 & 26.64 & 2 & 1447.6628 & 1447.6597 & 724.8371 & 0.0031 & 2.1384 & 1000.872 & 1288.059 & 48.206\end{array}$ FEELCSDLFR $\begin{array}{lllllllllllll}1.00 & 43.19 & 24.31 & 26.64 & 2 & 1447.6628 & 1447.6597 & 724.8371 & 0.0031 & 2.1384 & 1000.872 & 1288.059 & 48.206 \\ 1.00 & 48.21 & 24.39 & 21.52 & 2 & 1447.6632 & 1447.6597 & 724.8371 & 0.0035 & 2.4143 & 3884.868 & 4226.197 & 58.953\end{array}$ $\begin{array}{lllllllllll}1.07 & 41.186 & 21.129\end{array}$ $\begin{array}{llllllllllllll}\text { INPDEAVAYGAAVQAAILMGDK } & 0.55 & 49.40 & 26.27 & 62.40 & 3 & 2591.3530 & 2591.3508 & 864.7909 & 0.0022 & 0.8480 & 195.477 & 174.067 & 8.445\end{array}$

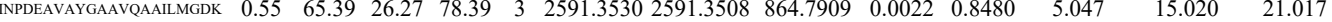

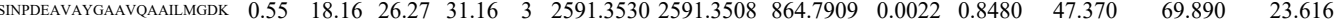
$\begin{array}{llllllllllllll}\text { INPDEAVAYGAAVQAAILMGDK } & 0.55 & 25.02 & 26.27 & 38.02 & 3 & 2591.3530 & 2591.3508 & 864.7909 & 0.0022 & 0.8480 & 50.402 & 82.224 & 1.962\end{array}$

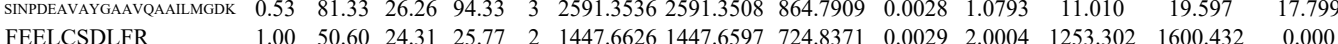
$\begin{array}{lllllllllllll}1.00 & 50.60 & 24.31 & 25.77 & 2 & 1447.6626 & 1447.6597 & 724.8371 & 0.0029 & 2.0004 & 1253.302 & 1600.432 & 0.000 \\ 1.00 & 49.29 & 4.39 & 26.90 & 2 & 1447.6632 & 1447.6597 & 724.8371 & 0.0035 & 2.4143 & 6121.392 & 7123.666 & 69.468\end{array}$ $\begin{array}{llllllllllllll} & \end{array}$

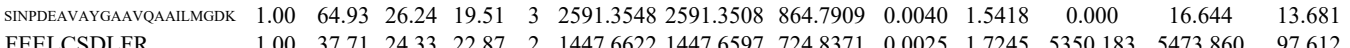
FEELCSDLFR FEELCSDLFR $\begin{array}{llllllllllllll}.00 & 84.08 & 25.67 & 32.45 & 2 & 1608.9186 & 1608.9070 & 805.4608 & 0.0116 & 7.2008 & 9086.785 & 12369.095 & 7242.636\end{array}$ $\begin{array}{llllllllllll}1.00 & 65.20 & 26.28 & 21.45 & 4 & 3331.6629 & 3331.6573 & 833.9216 & 0.0056 & 1.6788 & 15.738 & 0.216\end{array}$

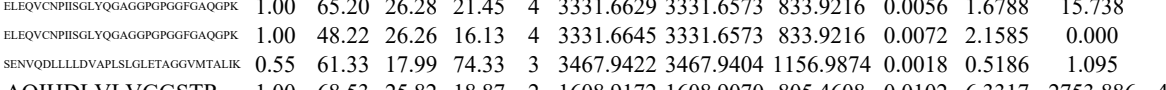

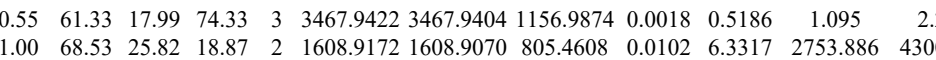

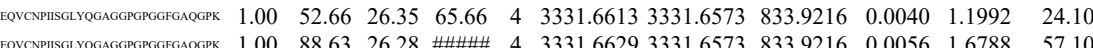

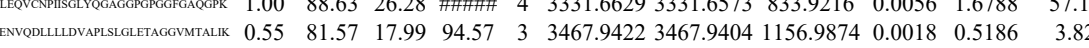
$\begin{array}{lllllllllll} & \end{array}$

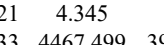

$\begin{array}{llllllllllllll} & \end{array}$ $\begin{array}{lllllllllllllll}\text { AQIHDLVLVGGSTR } & 1.00 & 38.64 & 25.69 & 16.35 & 3 & 1608.9184 & 1608.9070 & 537.3096 & 0.0114 & 7.0722 & 1827.103 & 1832.797 & 411.902\end{array}$

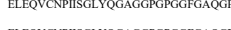

(a)

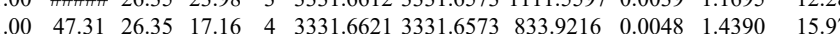

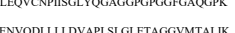

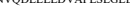
$\begin{array}{lllllllllll}0.55 & 78.67 & 17.99 & 91.67 & 3 & 3467.9422 & 3467.9404 & 1156.9874 & 0.0018 & 0.5186 & 1.315\end{array}$ $\begin{array}{llllllllllll} & \end{array}$

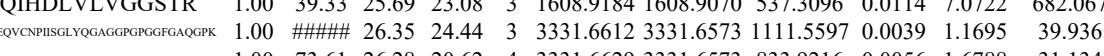
$\begin{array}{lllllllllll}1.00 & 73.61 & 26.28 & 20.62 & 4 & 3351.6629 & 3331.6573 & 833.9216 & 0.0056 & 1.6788 & 31.134\end{array}$ 


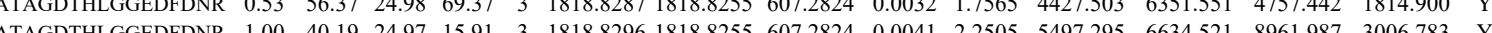

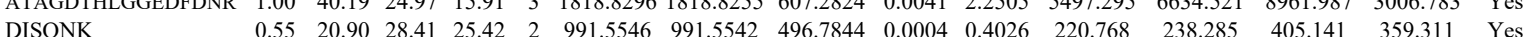

$\begin{array}{lllllllllllllllll}0.55 & 20.90 & 28.41 & 25.42 & 2 & 991.5546 & 991.5542 & 496.7844 & 0.0004 & 0.4026 & 220.768 & 238.285 & 405.141 & 359.311 & \text { Yes } & \\ 1.00 & 57.98 & 28.08 & 25.02 & 2 & 1539.8044 & 1539.8024 & 770.9085 & 0.0020 & 1.2972 & 329.120 & 245.151 & 1629.414 & 1111.986 & \mathrm{No} & \\ \end{array}$ $\begin{array}{llllllllllllllll}\text { DDVAQTDLLOIDPNFGSK } & 0.84 & 17.56 & 27.37 & 20.46 & 3 & 2263.1593 & 2263.1576 & 755.3931 & 0.0017 & 0.7502 & 103.418 & 336.128 & 701.512 & 357.818 & \text { No }\end{array}$

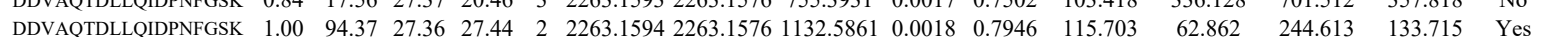
$\begin{array}{lllllllllllllll}\text { DDVAQTDLLOIDPNFGSK } & 1.00 & \text { \#\#\#\# } 27.36 & 31.64 & 2 & 2263.1594 & 2263.1576 & 1132.5861 & 0.0018 & 0.7946 & 46.914 & 20.033 & 88.336 & 26.768 & \text { No }\end{array}$

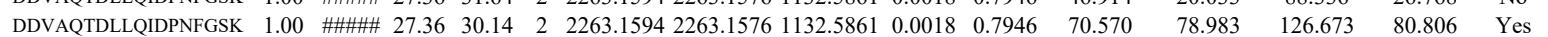
$\begin{array}{lllllllllllllll}\text { DDVAQTDLLIDPNFGSK } & 1.00 & \text { \#\#\#\# } 27.43 & 28.15 & 2 & 2263.1614 & 2263.1576 & 1132.5861 & 0.0038 & 1.6776 & 93.414 & 60.532 & 163.154 & 86.018 & \text { Yes }\end{array}$ $\begin{array}{llllllllllllllll}\text { GENSWFSTQVDTVATK } & 1.00 & 82.47 & 26.98 & 28.25 & 2 & 2057.0314 & 2057.0309 & 1029.5227 & 0.0005 & 0.2428 & 416.370 & 243.961 & 336.843 & 191.713 & \text { Yes }\end{array}$ $\begin{array}{llllllllllllllll}\text { GENSWFSTOVDTVATK } & 1.00 & 74.49 & 26.95 & 30.63 & 2 & 2057.0334 & 2057.0309 & 1029.5227 & 0.0025 & 1.2142 & 478.443 & 271.937 & 409.914 & 233.566 & \text { Yes }\end{array}$ $\begin{array}{llllllllllllllll}\text { VAEDEAEAAAAAK } & 1.00 & 68.31 & 28.04 & 29.97 & 2 & 1532.7952 & 1532.7925 & 767.4035 & 0.0027 & 1.7592 & 13.328 & 7.032 & 5.895 & 1.784 & \text { Yes }\end{array}$ $\begin{array}{llllllllllllllll}\text { VAEDEAEAAAAAK } & 0.99 & 31.00 & 28.04 & 22.57 & 3 & 1532.7955 & 1532.7925 & 511.9381 & 0.0030 & 1.9534 & 13.636 & 32.480 & 19.980 & 3.570 & \text { Yes }\end{array}$

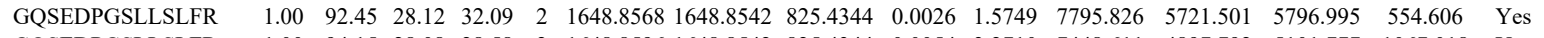
$\begin{array}{lllllllllllllllll}\text { GQSEDPGSLLSLFR } & 1.00 & 94.15 & 28.08 & 28.58 & 2 & 1648.8596 & 1648.8542 & 825.4344 & 0.0054 & 3.2710 & 7448.611 & 4897.792 & 5101.777 & 1067.018 & \text { Yes }\end{array}$ $\begin{array}{llllllllllllllll}\text { GQSEDPGSLLSLFR } & 1.00 & 90.67 & 28.08 & 28.71 & 2 & 1648.8572 & 1648.8542 & 825.4344 & 0.0030 & 1.8172 & 6670.700 & 4563.770 & 4975.114 & 606.678 & \text { Yes }\end{array}$ GQSEDPGSLLSLFR ADLLLSTQPGR ADLLLSTQPGR GQSEDPGSLLSLFR GQSEDPGSLLSLF ADLLLSTQPGR GLVLGPIHK GLVLGPIHK GLVLGPIHK GLVLGPIHK GLVGAHK VILDLTPNYR

VILDLTPNYR

VILDLTPNY

VAEDEAEA

VAGSPGWVR VAGSPGWVR VAGSPGWVR
VAGSPGWVR
VAGSPGWVR VAGSPGWVR WWHTGALYR WCSWSLSQAR
WCSWSLSQAR WCSWSLSQAR WCSWSLSQAR WCSWSLSQAR WCSWSLSQAR WCSWSLSQAR LLTSFLPAQLLR

LLTSFLPAQLLR

LLTSFLPAQLLR

LLTSFLPAQLLR

LLTSFLPAQLLR
LLTSFLPAOLLR

LLTSFLPAQLLR
LLTSFLPAQLLR

LLTSFLPAQLLR

LLTSFLPAQLLR $\begin{array}{llllllllllllllll}1.00 & 94.42 & 28.13 & 33.60 & 2 & 1648.8574 & 1648.8542 & 825.4344 & 0.0032 & 1.9384 & 9653.600 & 6596.881 & 6381.441 & 911.796 & \text { Yes }\end{array}$

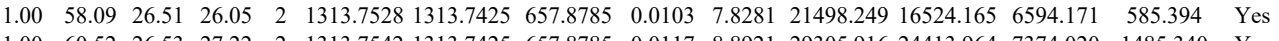
$\begin{array}{lllllllllllllll}1.00 & 60.52 & 26.53 & 27.22 & 2 & 1313.7542 & 1313.7425 & 657.8785 & 0.0117 & 8.8921 & 29305.916 & 24413.964 & 7374.020 & 1485.340 & \text { Yes }\end{array}$

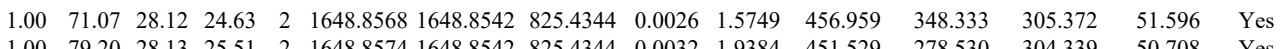

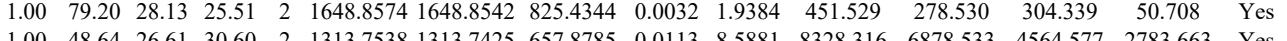

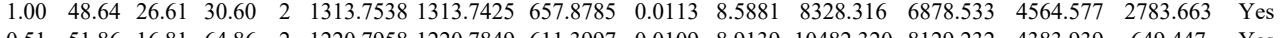
$\begin{array}{lllllllllllllll}0.51 & 51.86 & 6.81 & 64.86 & 2 & 1220.7958 & 1220.7849 & 61.3997 & 0.0109 & 8.9139 & 10482.320 & 8129.232 & 4383.939 & 649.447 & \text { Yes }\end{array}$ $\begin{array}{lllllllllllllll}1.00 & 43.62 & 16.81 & 20.47 & 3 & 1220.7961 & 1220.7849 & 407.9356 & 0.0112 & 9.1517 & 23468.900 & 14064.998 & 9088.236 & 446.415 & \text { Yes } \\ 1.00 & 41.83 & 15.44 & 15.87 & 3 & 1220.7967 & 1220.7849 & 407.9356 & 0.0118 & 9.6420 & 30018.805 & 21141.181 & 13860.356 & 956.781 & \text { Yes }\end{array}$ $\begin{array}{lllllllllllllll}1.00 & 41.83 & 15.44 & 15.87 & 3 & 1220.7967 & 1220.7849 & 407.9356 & 0.0118 & 9.6420 & 30018.805 & 21141.181 & 13860.356 & 956.781 & \text { Yes } \\ 1.00 & 43.43 & 16.81 & 16.21 & 3 & 1220.7952 & 1220.7849 & 407.9356 & 0.0103 & 8.4163 & 30817.139 & 21513.372 & 13550.915 & 853.614 & \text { Yes }\end{array}$ $\begin{array}{lllllllllllllll}1.00 & 43.43 & 16.81 & 6.21 & 3 & 1220.7952 & 1220.7849 & 407.9356 & 0.0103 & 8.4163 & 30817.139 & 21513.372 & 13550.915 & 853.614 & \text { Yes } \\ 0.51 & 51.89 & 16.81 & 64.89 & 2 & 1220.7954 & 1220.7849 & 611.3997 & 0.0105 & 8.5868 & 6191.313 & 4058.137 & 1899.490 & 231.785 & \text { Yes }\end{array}$

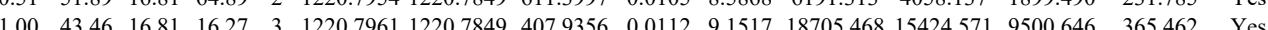
$\begin{array}{lllllllllllllll}1.00 & 46.07 & 26.67 & 28.52 & 2 & 1346.7810 & 1346.7680 & 6743913 & 0.0130 & 9.6382 & 5517.724 & 4026.015 & 503.760 & 178.458 & \text { Yes }\end{array}$

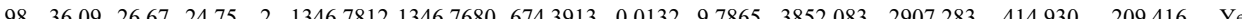

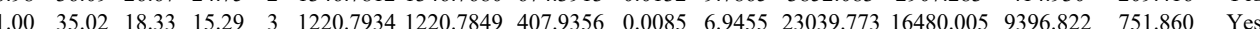

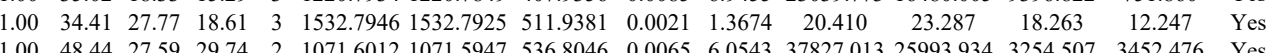

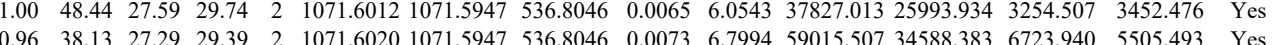

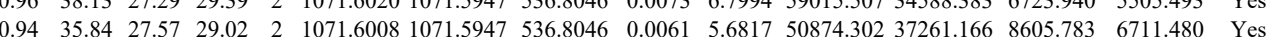

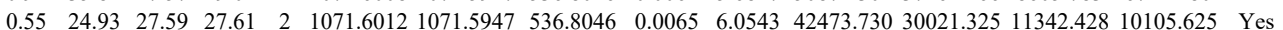

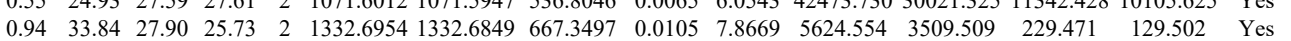
$\begin{array}{lllllllllllllll}1.00 & 67.21 & 25.25 & 26.57 & 2 & 1412.6460 & 1412.6451 & 707.3298 & 0.0009 & 0.6362 & 3336.450 & 2223.630 & 74.654 & 20.568 & \text { Yes }\end{array}$ $\begin{array}{lllllllllllllll}1.00 & 62.80 & 25.43 & 25.79 & 2 & 1412.6466 & 1412.6451 & 707.3298 & 0.0015 & 1.0603 & 2635.246 & 1828.086 & 112.776 & 9.687 & \text { Yes }\end{array}$ $\begin{array}{llllllllllllllll}0.99 & 37.33 & 25.37 & 19.08 & 2 & 1412.6482 & 1412.6451 & 707.3298 & 0.0031 & 2.1913 & 52.197 & 26.796 & 3.947 & 2.735 & \text { Yes }\end{array}$ $\begin{array}{lllllllllllllll}1.00 & 67.04 & 25.25 & 23.32 & 2 & 1412.6458 & 1412.6451 & 707.3298 & 0.0007 & 0.4948 & 5331.781 & 3442.525 & 142.724 & 8.238 & \text { Yes }\end{array}$ $\begin{array}{lllllllllllllll}1.00 & 69.94 & 25.21 & 26.80 & 2 & 1412.6462 & 1412.6451 & 707.3298 & 0.0011 & 0.7776 & 8758.177 & 5160.975 & 113.777 & 19.119 & \text { Yes }\end{array}$ $\begin{array}{lllllllllllllll}1.00 & 64.89 & 25.34 & 23.84 & 2 & 1412.6464 & 1412.6451 & 707.3298 & 0.0013 & 0.9189 & 2174.137 & 1247.369 & 28.709 & 10.610 & \text { Yes }\end{array}$

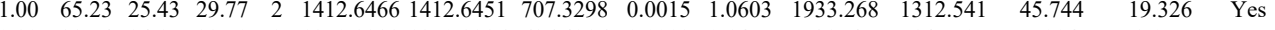
$\begin{array}{lllllllllllllll}0.99 & 38.74 & 24.17 & 22.50 & 2 & 1370.8288 & 1370.8286 & 686.4216 & 0.0002 & 0.1457 & 6.254 & 14.759 & 5.904 & 3.057 & \text { Yes }\end{array}$

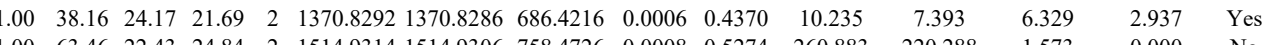
$\begin{array}{lllllllllllllll}1.00 & 63.46 & 22.43 & 24.84 & 2 & 1514.9314 & 1514.9306 & 758.4726 & 0.0008 & 0.5274 & 260.883 & 220.288 & 1.573 & 0.000 & \text { No }\end{array}$

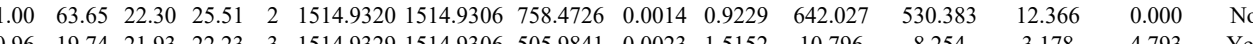
$\begin{array}{lllllllllllllll}0.96 & 19.74 & 21.93 & 22.23 & 3 & 1514.9329 & 1514.9306 & 505.9841 & 0.0023 & 1.5152 & 10.796 & 8.254 & 3.178 & 4.793 & \text { Yes }\end{array}$

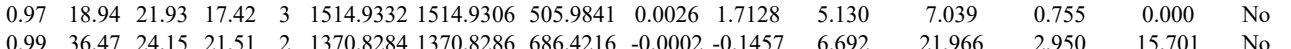

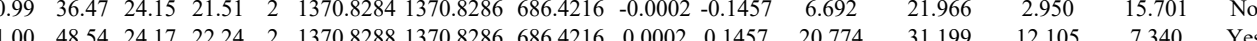

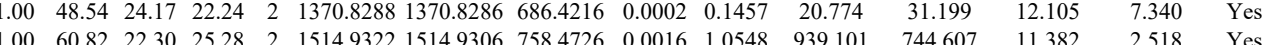

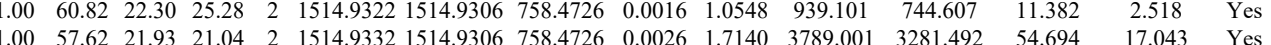
$\begin{array}{lllllllllllllll}1.00 & 31.06 & 21.93 & 17.01 & 3 & 1514.9335 & 1514.9306 & 505.9841 & 0.0029 & 1.9105 & 22.903 & 29.034 & 0.000 & 1.679 & \text { No }\end{array}$

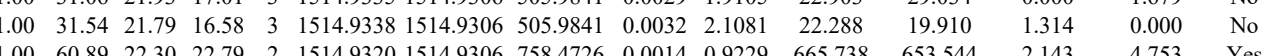
$\begin{array}{lllllllllllll}1.00 & 60.89 & 22.30 & 22.79 & 2 & 1514.9320 & 1514.9306 & 758.4726 & 0.0014 & 0.9229 & 665.738 & 653.544\end{array}$

Table S-3 page 96 of 499 
LLTSFLPAQLLR

LLTSFLPAQLLR

LLTSFLPAQLLR

LLTSFLPAQLLR

LLTSFLPAQLLR

LLTSFLPAQLLR
LLTSFLPAQLLR

LLTSFLPAQLLR

LLTSFLPAQLLR

EDFDSLLQSAK
EDFDSLLQSAK

DDVAQTDLLOIDNA

DDV

IFANTPDSGCVLGMR

IGLIQGNR

IGLIQGNR

VGIFTGAR
VGIFTGAR

VGIFTGAR

LRPILK

$\begin{array}{llllllllllll}\text { HS90B_HUMAI } & \text { P08238 } & \text { HSP90AB1 Heat shock proteir } 83.26 & 1.00 & 13 & 40.5 & 0.0568 & 0.3074 & 0.2527 & 2.2601 & 212 & \text { IDIIPNPQER }\end{array}$

HLEINPDHPIVETLR

NPDDITQEEYGE

CLELFSELAEDK

CLELFSELAEDK

CLELLFSELAEDK

CLELFSELAEDK

CLELFSELAEDK

CLELFSELAEDK

CLELFSELAEDK

YHTSQSGDEMTSLSEYVSR

YHTSQSGDEMTSLSEY
CLELFSELAEDK

CLELFSELAEDK

CLELFSELAEDK

CLELFSELAEDK

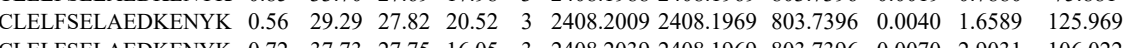

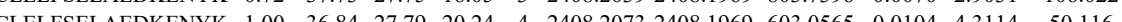

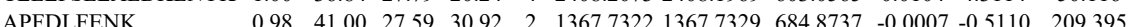

APFDLFENK

APFDLFENK

APFDLFENK

APFDLFENK

APFDLFENK

APFDLFENK

APFDLFENK

APFDLFENK

APFDLFENK

APFDLFENK

APFDLFENK

APFDLFENK

APFDLFENK

APFDLFENK

APFDLFENK

APFDLFENK

HLEINPDHPIVETLR

HLEINPDHPIVETLR
HLEINPDHPIVETLR

HLEINDPHIVETLR

HLEINPDHPIVETLR

HLEINPDHPIVETLR

HLEINPDHPIVETLR

HLEINPDHPIVETLR

HLEINPDHPIVETLR $\begin{array}{llllllllllll}1.00 & 73.63 & 27.19 & 29.55 & 2 & 1729.8548 & 1729.8510 & 865.9328 & 0.0038 & 2.1942 & 73.328\end{array}$

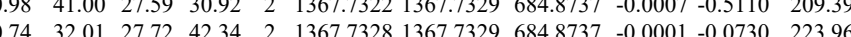
$\begin{array}{llllllllllll}1.00 & 74.75 & 27.83 & 34.71 & 2 & 1367.742 & 1367.7329 & 684.8737 & 0.013 & 0.941 & 403.321 \\ 0.78 & 16.58 & 27.75 & 21.01 & 3 & 1367.7346 & 1367.7329 & 456.9182 & 0.0017 & 1.2402 & 67.366\end{array}$

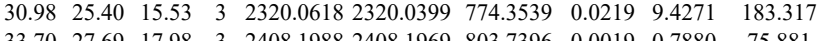

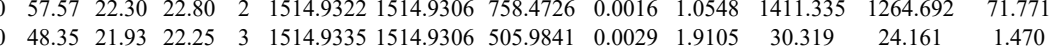

$\begin{array}{llllllllllll} & \end{array}$

$\begin{array}{lllllllllll}63.54 & 22.43 & 24.79 & 2 & 1514.9312 & 1514.9306 & 758.4726 & 0.0006 & 0.3955 & 419.712 & 390.543\end{array}$ $\begin{array}{llllllllllll} & \end{array}$ $\begin{array}{lllllllllll} & \end{array}$

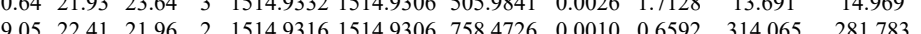
$\begin{array}{llllllllllll}63.37 & 22.30 & 24.30 & 2 & 1514.9320 & 1514.9306 & 758.4726 & 0.0014 & 0.9229 & 435.840 & 336.130\end{array}$ $\begin{array}{lllllllllll} & \end{array}$

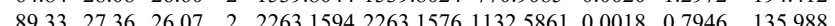
\begin{tabular}{lllllllllllll}
30.07 & 27.72 & 25.81 & 2 & 963.5710 & 963.5624 & 482.7885 & 0.0086 & 8.9065 & 7070.116 & 8054.212 & 690.870 & 226 \\
\hline
\end{tabular}

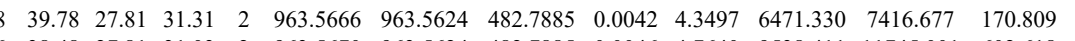
$\begin{array}{llllllllllllll}0.96 & 38.48 & 27.81 & 31.03 & 2 & 963.5670 & 963.5624 & 482.7885 & 0.0046 & 4.7640 & 9538.411 & 11745.001 & 602.618\end{array}$

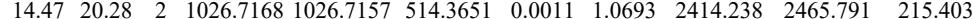
$\begin{array}{llllllllllll}0.53 & 28.67 & 27.23 & 26.47 & 2 & 1337.7438 & 1337.7425 & 669.8785 & 0.0013 & 0.9703 & 54.065\end{array}$ $\begin{array}{llllllllllll}28.16 & 27.19 & 28.02 & 3 & 1729.8544 & 1729.8510 & 577.6243 & 0.0034 & 1.9621 & 96.960\end{array}$ $\begin{array}{lllllllllll}0 & 62.89 & 27.13 & 26.16 & 2 & 1729.8544 & 1729.8510 & 865.9328 & 0.0034 & 1.9632 & 31.679 \\ 0.91 & 21.04 & 27.20 & 21.74 & 3 & 1729.8547 & 1729.8510 & 577.6243 & 0.0037 & 2.1352 & 61.539\end{array}$ $\begin{array}{llllllllllll}20.61 & 27.19 & 25.25 & 3 & 1729.8541 & 1729.8510 & 577.6243 & 0.0031 & 1.7889 & 79.686\end{array}$ $\begin{array}{lllllllllll}1.00 & 62.07 & 27.17 & 26.78 & 2 & 1729.8542 & 1729.8510 & 865.9328 & 0.0032 & 1.8477 & 105.432\end{array}$ $\begin{array}{lllllllllll}.99 & 32.04 & 27.27 & 24.64 & 3 & 1729.8553 & 1729.8510 & 577.6243 & 0.0043 & 2.4814 & 66.883\end{array}$ $\begin{array}{lllllllllll}1.00 & 73.14 & 25.43 & 22.12 & 3 & 2320.0597 & 2320.0399 & 774.3539 & 0.0198 & 8.5232 & 399.420 \\ 1.00 & 66.44 & 25.43 & 20.82 & 3 & 2320.0612 & 2320.0399 & 774.3539 & 0.0213 & 9.1689 & 780.111\end{array}$ $\begin{array}{lllllllllll}.00 & 88.21 & 27.26 & 28.96 & 2 & 1729.8534 & 1729.8510 & 865.9328 & 0.0024 & 1.3858 & 780.657\end{array}$ $\begin{array}{lllllllllll}40.57 & 27.19 & 26.84 & 3 & 1729.8544 & 1729.8510 & 577.6243 & 0.0034 & 1.9621 & 128.943\end{array}$ $\begin{array}{lllllllllll}1.00 & 4.57 & 27.19 & 26.84 & 3 & 1729.8544 & 1729.8510 & 577.6243 & 0.0034 & 1.9621 & 128.943\end{array}$

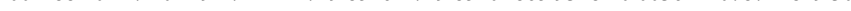
$\begin{array}{llllllllllll}0.82 & 25.95 & 27.75 & 26.38 & 2 & 1367.7330 & 1367.7329 & 684.8737 & 0.0001 & 0.0730 & 203.129\end{array}$ $\begin{array}{lllllllllllll}0.73 & 18.89 & 27.75 & 21.05 & 3 & 1367.7331 & 1367.7329 & 456.9182 & 0.0002 & 0.1459 & 118.205\end{array}$ $\begin{array}{llllllllllllll}0.73 & 18.87 & 27.75 & 20.52 & 3 & 1367.7334 & 1367.7329 & 456.9182 & 0.0005 & 0.3648 & 239.059\end{array}$ $\begin{array}{llllllllllll}0.88 & 25.00 & 27.68 & 17.38 & 2 & 1367.7336 & 1367.7329 & 684.8737 & 0.0007 & 0.5110 & 238.464\end{array}$ $\begin{array}{lllllllllllll}0.87 & 24.79 & 27.83 & 29.73 & 2 & 1367.7338 & 1367.7329 & 684.8737 & 0.0009 & 0.6571 & 327.834\end{array}$ $\begin{array}{llllllllllll}0.92 & 27.15 & 27.83 & 28.37 & 2 & 1367.7338 & 1367.7329 & 684.8737 & 0.0009 & 0.6571 & 242.287\end{array}$ $\begin{array}{llllllllllllll}0.97 & 31.29 & 27.83 & 28.16 & 2 & 1367.7338 & 1367.7329 & 684.8737 & 0.0009 & 0.6571 & 254.702\end{array}$ $\begin{array}{lllllllllllll}0.82 & 19.02 & 27.83 & 19.90 & 3 & 1367.7340 & 1367.7329 & 456.9182 & 0.0011 & 0.8025 & 339.111\end{array}$ $\begin{array}{llllllllllll}1.00 & 74.75 & 27.83 & 34.77 & 2 & 1367.7342 & 1367.7329 & 684.8737 & 0.0013 & 0.9491 & 4035.321 \\ 0.78 & 16.58 & 27.75 & 21.01 & 3 & 1367.7346 & 1367.7329 & 456.9182 & 0.0017 & 1.2402 & 67.366\end{array}$ $\begin{array}{llllllllllll}0.65 & 13.91 & 27.46 & 25.17 & 3 & 1367.7352 & 1367.7329 & 456.9182 & 0.0023 & 1.6779 & 9.015\end{array}$ $\begin{array}{lllllllllllll}1.00 & 74.65 & 27.44 & 32.70 & 2 & 1367.7352 & 1367.7329 & 684.8737 & 0.0023 & 1.6791 & 10509.148 & 93 \\ 1.00 & 43.63 & 27.44 & 32.02 & 2 & 1367.7356 & 1367.7329 & 684.8737 & 0.0027 & 1.9712 & 217.579 & 21\end{array}$ $\begin{array}{lllllllllll}1.00 & 43.63 & 27.44 & 32.02 & 2 & 1367.7356 & 1367.7329 & 684.8737 & 0.0027 & 1.9712 & 217.579 \\ 0.93 & 32.22 & 27.40 & 37.65 & 2 & 1367.7362 & 1367.7329 & 684.8737 & 0.0033 & 2.4092 & 233.009\end{array}$ $\begin{array}{lllllllllllll}0.93 & 32.22 & 27.40 & 37.65 & 2 & 1367.7362 & 1367.7329 & 684.8737 & 0.0033 & 2.4092 & 233.009 \\ 0.91 & 27.40 & 27.40 & 27.17 & 2 & 1367.7362 & 1367.7329 & 684.8737 & 0.0033 & 2.4092 & 210.838 & 1\end{array}$ $\begin{array}{lllllllllllll}0.91 & 27.40 & 27.40 & 27.17 & 2 & 1367.7362 & 1367.7329 & 684.8737 & 0.0033 & 2.4092 & 210.838 & 19 \\ 1.00 & 24.96 & 27.12 & 37.96 & 4 & 1926.0449 & 1926.0445 & 482.5184 & 0.0004 & 0.2072 & 108.854 & 10 \\ 0.99 & 16.67 & 27.20 & 14.46 & 4 & 1926.0465 & 1926.0445 & 482.5184 & 0.0020 & 1.0362 & 12.720 & 23\end{array}$ $\begin{array}{lllllllllll}1.00 & 24.96 & 27.12 & 37.96 & 4 & 1926.0449 & 1926.0445 & 482.5184 & 0.0004 & 0.2072 & 108.854 \\ 0.99 & 16.67 & 27.20 & 14.46 & 4 & 1926.0465 & 1926.0445 & 482.5184 & 0.0020 & 1.0362 & 12.720\end{array}$ $\begin{array}{lllllllllllll}0.99 & 16.67 & 27.20 & 14.46 & 4 & 1926.0465 & 1926.0445 & 482.5184 & 0.0020 & 1.0362 & 12.720 \\ 1.00 & 19.29 & 27.22 & 15.87 & 4 & 1926.0473 & 1926.0445 & 482.5184 & 0.0028 & 1.4507 & 86.940\end{array}$ $\begin{array}{llllllllllll}1.00 & 23.22 & 27.11 & 36.22 & 4 & 1926.0493 & 1926.0445 & 482.5184 & 0.0048 & 2.4869 & 97.84\end{array}$ $\begin{array}{llllllllllll}0.97 & 14.93 & 27.11 & 20.38 & 4 & 1926.0493 & 1926.0445 & 482.5184 & 0.0048 & 2.4869 & 93.498\end{array}$ $\begin{array}{lllllllllll}1.00 & 24.49 & 26.93 & 37.49 & 4 & 1926.0509 & 1926.0445 & 482.5184 & 0.0064 & 3.3159 & 35.424\end{array}$

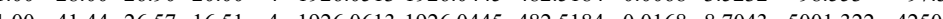

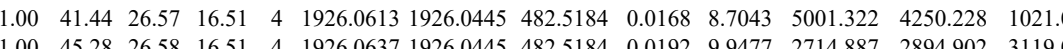
32.656 1.593

56.855

301.749

100.974

64.819

471.912 703.706
738.672 738.672
159.699 767.555 767.555
118.420 180.84 97.812 116.463 


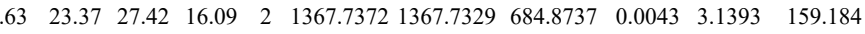
$\begin{array}{ccccccccccccccc}0.70 & 27.41 & 27.42 & 27.39 & 2 & 1367.7376 & 1367.7329 & 684.8737 & 0.0047 & 3.4313 & 218.315 & 203.529 & 147.647 & 84.935 & \text { Ycs } \\ 1.00 & 74.66 & 27.47 & 31.75 & 2 & 1367.7452 & 1367.7329 & 684.8737 & 0.0123 & 8.9797 & 7225.943 & 7749.644 & 6774.573 & 7008.499 & \text { No } \\ 1.00 & 58.53 & 27.28 & 29.54 & 2 & 1367.7458 & 1367.7329 & 684.8737 & 0.0129 & 9.4177 & 9866.056 & 1092.190 & 10229.179 & 10540.074 & \text { No }\end{array}$

$\begin{array}{llllllllllll}1.00 & 71.83 & 26.55 & 28.16 & 2 & 1926.0586 & 1926.0445 & 964.0295 & 0.0141 & 7.3130 & 6122.260 & 7089.889\end{array}$

$\begin{array}{lllllllllllll}71.83 & 26.55 & 28.16 & 2 & 1926.0586 & 1926.0445 & 964.0295 & 0.0141 & 7.3130 & 6122.260 & 7089.889 & 42.524 \\ 63.73 & 26.57 & 23.23 & 2 & 1926.0600 & 1926.0445 & 964.0295 & 0.0155 & 8.0391 & 8144.172 & 8298.947 & 693.198\end{array}$

$\begin{array}{llllllllllllll}1.00 & 77.65 & 26.58 & 21.09 & 3 & 1926.0607 & 1926.0445 & 643.0221 & 0.0162 & 8.3978 & 21174.455 & 21068.661 & 5707.374 \\ 1.00 & 42.36 & 26.55 & 16.39 & 4 & 1926.0633 & 1926.0445 & 482.5184 & 0.0188 & 9.7405 & 13157.560 & 15363.996 & 1601.267\end{array}$

$\begin{array}{lllllllllllll}1.00 & 37.35 & 26.58 & 50.35 & 4 & 1926.0637 & 1926.0445 & 482.5184 & 0.0192 & 9.9477 & 23004.406 & 26781.523 & 3660.497\end{array}$

$\begin{array}{lllllllllllll}1.00 & 49.14 & 27.49 & 31.72 & 2 & 1337.7552 & 1337.7425 & 669.8785 & 0.0127 & 9.4792 & 22289.002 & 24526.069 & 2740.747\end{array}$

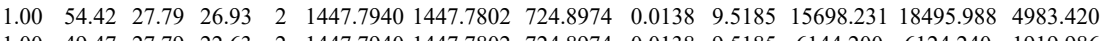

$\begin{array}{llllllllllllll}1.00 & 49.47 & 27.79 & 22.63 & 2 & 1447.7940 & 1447.7802 & 724.8974 & 0.0138 & 9.5185 & 6144.200 & 6124.240 & 1919.986 \\ 1.00 & 79.77 & 26.55 & 26.65 & 2 & 1926.0608 & 1926.0445 & 964.0295 & 0.0163 & 8.4540 & 1529.786 & 1604.089 & 248.713 \\ 1.00 & 6.2 & 26.55 & 22.60 & 2 & & \end{array}$

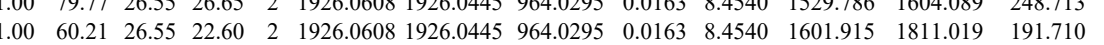

$\begin{array}{lllllllllllll}1.00 & 72.16 & 26.58 & 24.07 & 3 & 1926.0625 & 1926.0445 & 643.0221 & 0.0180 & 9.3309 & 7707.130 & 8958.010 & 1577.991\end{array}$

$\begin{array}{llllllllllllll}1.00 & 63.11 & 26.62 & 21.26 & 3 & 1926.0628 & 1926.0445 & 643.0221 & 0.0183 & 9.4864 & 6858.323 & 6366.026 & 1232.659\end{array}$

$\begin{array}{lllllllllllll}1.00 & 43.17 & 26.60 & 16.15 & 4 & 1926.0629 & 1926.0445 & 482.5184 & 0.0184 & 9.5332 & 4752.136 & 6772.428 & 1369.855 \\ 1.00 & 52.95 & 28.01 & 22.51 & 2 & 1447.7936 & 1447.7802 & 724.8974 & 0.0134 & 9.2426 & 4409.706 & 4679.177 & 1142.480\end{array}$ $\begin{array}{lllllllllllllll}0.84 & 24.60 & 27.32 & 24.99 & 2 & 1337.7454 & 1337.7425 & 669.8785 & 0.0029 & 2.1646 & 64.445 & 46.353 & 24.466\end{array}$ $\begin{array}{lllllllllllll}0.64 & 24.60 & 27.32 & 24.99 & 2 & 1337.7454 & 337.7425 & 669.8785 & 0.029 & 2.1646 & 64.445 & 46.353 & 24.466 \\ 0.70 & 23.98 & 28.76 & 29.37 & 2 & 832.4892 & 832.4888 & 417.2517 & 0.0004 & 0.4793 & 247.685 & 306.324 & 119.228\end{array}$

\section{DLVVLLETALLSSGGSLEPPTTHS} $\begin{array}{llllllllllllll}0.66 & 23.15 & 28.76 & 29.25 & 2 & 832.4890 & 832.4888 & 417.2517 & 0.0002 & 0.2397 & 162.433 & 167.829 & 79.982 \\ 0.95 & 6.94 & 28.71 & 19.23 & 2 & 20.61554 & 20961550 & 1049.048 & 0.004 & 0.1906 & 1170.150 & 1257.627 & 75.918\end{array}$

DLVVLLFETALSSGFFLEDPQTHS $\begin{array}{lllllllllllll}1.00 & 97.88 & 25.66 & 19.47 & 3 & 3131.6212 & 3131.6261 & 1044.8826 & -0.0049 & -1.5632 & 12.356 & 18.001\end{array}$

HSQFIGYPITLYLTLLSSGFLEDPQTHSN

DLVVLLFETALLSSGFLLEDPQTHSN $\begin{array}{llllllllllll}1.00 & 88.03 & 25.62 & 19.19 & 3 & 3131.6302 & 3131.6261 & 1044.8826 & 0.0041 & 1.3080 & 17.606 & 24.154\end{array}$ $\begin{array}{llllllllllll}0.80 & 61.96 * 23.93 & 20.90 & 2 & 2096.1754 & 2096.1550 & 1049.0848 & 0.0204 & 9.7227 & 2149.443 & 2482.205\end{array}$ $\begin{array}{lllllllllllll}1.00 & 33.85 & 25.56 & 46.85 & 4 & 3131.6293 & 3131.6261 & 783.9138 & 0.0032 & 1.0205 & 17.001 & 6.958 \\ 1.00 & 18.34 & 25.62 & 1511 & 4 & 331.629 & 3131.626 & 78.9138 & 0.0036 & 1.1481 & 4.662 & 12.407\end{array}$ $\begin{array}{lllllllllll}1.00 & 18.34 & 25.62 & 15.11 & 4 & 3131.6297 & 3131.6261 & 783.9138 & 0.0036 & 1.1481 & 4.662 \\ 1.00 & 87.82 & 25.75 & 21.36 & 3 & 3131.6332 & 3131.6261 & 1044.8826 & 0.0071 & 2.2650 & 50.258\end{array}$

DLVVLFETALLSSGFSLEPQTHSNI

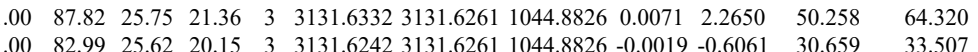

DLVVLLFETALLSSGFSLEDPQTHSNR

DLVLLLFTALLSGGSLEDPRTHSN

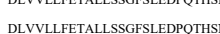
$\begin{array}{llllllllllll}0.98 & 13.44 & 55.59 & 15.73 & 4 & 3131.6277 & 3131.6261 & 783.9138 & 0.0016 & 0.5103 & 11.079\end{array}$ $\begin{array}{lllllllllll}.91 & 10.03 & 25.62 & 19.83 & 4 & 3131.6297 & 3131.6261 & 783.9138 & 0.0036 & 1.1481 & 17.373\end{array}$

\section{IDIIPNPQER} $\begin{array}{lllllllllll}1.00 & 96.42 & 25.62 & 23.28 & 3 & 3131.6302 & 3131.6261 & 1044.8826 & 0.0041 & 1.3080 & 194.515\end{array}$

IDIIPNPQER
NPDDITQEEYGEFYK $\begin{array}{lllllllllllll}1 & 0.87 & 25.62 & 20.93 & 3 & 3131.6302 & 3131.6261 & 1044.8826 & 0.0041 & 1.3080 & 39.713 \\ 1.00 & 4.05 & 25.83 & 21.69 & 4 & 3131.6321 & 3131.6261 & 783.9138 & 0.0060 & 1.9135 & 10.254\end{array}$

NPDDITQEEYGEFYK
DLVVLLFETALSSGGSLEDPOTHS

DLVLLLETALLSSGFSLEDPQTHSNR HSQFIGYPITLYLEK $\begin{array}{llllllllllll}1.00 & 44.05 & 25.83 & 21.69 & 4 & 3131.6321 & 3131.6261 & 783.9138 & 0.0060 & 1.9135 & 10.254\end{array}$ $\begin{array}{llllllllllll}0.96 & 31.17 & 27.34 & 27.36 & 2 & 1337.7456 & 1337.7425 & 669.8785 & 0.0031 & 2.3138 & 68.334 \\ 0.84 & 28.04 & 27.30 & 27.45 & 2 & 1337.7460 & 1337.7425 & 669.8785 & 0.0035 & 2.6124 & 46.676\end{array}$ $\begin{array}{lllllllllllll}0.84 & 28.04 & 27.30 & 27.45 & 2 & 1337.7460 & 1337.7425 & 669.8785 & 0.0035 & 2.6124 & 46.676\end{array}$ $\begin{array}{llllllllllll}0.55 & 37.23 & 25.84 & 50.23 & 3 & 2134.9957 & 2134.9939 & 712.6719 & 0.0018 & 0.8419 & 9.493\end{array}$ $\begin{array}{llllllllllll}0.53 & 59.77 & 25.82 & 72.77 & 3 & 2134.9966 & 2134.9939 & 712.6719 & 0.0027 & 1.2629 & 13.410 & 11.603\end{array}$ $\begin{array}{llllllllllll}0.86 & 32.22 & 25.62 & 18.47 & 3 & 3131.6302 & 3131.6261 & 1044.8826 & 0.0041 & 1.3080 & 93.038 & 65.661\end{array}$ $\begin{array}{lllllllllllll}0.86 & 32.93 & 25.48 & 16.18 & 3 & 2096.1577 & 2096.1550 & 699.7256 & 0.0027 & 1.2862 & 2529.223 & 2326.629\end{array}$

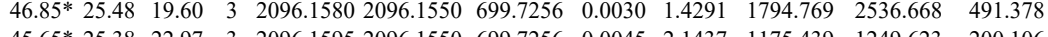
$\begin{array}{lllllllllllll}0.88 & 29.86 & 23.52 & 31.57 & 2 & 972.6234 & 972.6242 & 487.3194 & -0.0008 & -0.8208 & 32.453 & 63.367\end{array}$ $\begin{array}{lllllllllllll}0.94 & 28.51 & 23.52 & 31.15 & 2 & 972.6238 & 972.6242 & 487.3194 & -0.0004 & -0.4104 & 38.062 & 47.040\end{array}$ $\begin{array}{llllllllllll}0.85 & 23.18 & 23.52 & 30.67 & 2 & 972.6240 & 972.6242 & 487.3194 & -0.0002 & -0.2052 & 40.633 & 44.919 \\ 0.95 & 28.02 & 23.52 & 29.52 & 2 & 972.6242 & 972.6242 & 487.3194 & 0.0000 & 0.0000 & 25.998 & 35.289\end{array}$ $\begin{array}{llllllllllllll}0.95 & 31.01 & 23.71 & 33.16 & 2 & 972.6244 & 972.6242 & 487.3194 & 0.0002 & 0.2052 & 21.040 & 45.009\end{array}$ $\begin{array}{lllllllllllll}0.90 & 24.63 & 23.71 & 26.66 & 2 & 972.6246 & 972.6242 & 487.3194 & 0.0004 & 0.4104 & 111.536 & 89.413\end{array}$ 

$\begin{array}{lllllllllll}0.96 & 29.10 & 23.71 & 32.74 & 2 & 972.6250 & 972.6242 & 487.3194 & 0.0008 & 0.8208 & 197.344\end{array}$ $\begin{array}{lllllllllllll}0.97 & 34.58 & 23.71 & 36.68 & 2 & 972.6250 & 972.6242 & 487.3194 & 0.0008 & 0.8208 & 66.120\end{array}$ $\begin{array}{llllllllllll}0.95 & 25.46 & 23.71 & 27.90 & 2 & 972.6250 & 972.6242 & 487.3194 & 0.0008 & 0.8208 & 52.718 \\ 0.86 & 20.25 & 23.71 & 24.34 & 2 & 972.6250 & 972.6242 & 487.3194 & 0.0008 & 0.8208 & 50.348\end{array}$

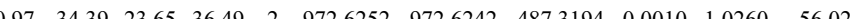

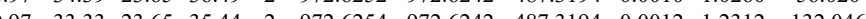
$\begin{array}{llllllllllll}0.93 & 23.44 & 23.65 & 28.92 & 2 & 972.6254 & 97.672 .622 & 48.3194 & 0.0012 & 1.2312 & 132.046\end{array}$

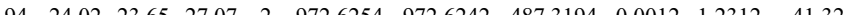

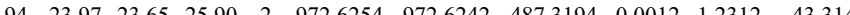
$\begin{array}{lllllllllll}0.95 & 25.33 & 23.65 & 28.92 & 2 & 972.6254 & 972.6242 & 487.3194 & 0.0012 & 1.2312 & 37.503\end{array}$ $\begin{array}{lllllllllllll}0.95 & 24.96 & 23.65 & 27.73 & 2 & 972.6256 & 972.6242 & 487.3194 & 0.0014 & 1.4364 & 29.986\end{array}$ $\begin{array}{lllllllllllll}0.86 & 19.70 & 23.65 & 28.09 & 2 & 972.6258 & 972.6242 & 487.3194 & 0.0016 & 1.6416 & 23.320\end{array}$ $\begin{array}{llllllllllllll}0.94 & 23.97 & 23.65 & 27.04 & 2 & 972.6260 & 972.6242 & 487.3194 & 0.0018 & 1.8468 & 50.547\end{array}$ $\begin{array}{lllllllllllll}0.98 & 32.16 & 23.65 & 34.40 & 2 & 972.6260 & 972.6242 & 487.3194 & 0.0018 & 1.8468 & 43.966\end{array}$ $\begin{array}{llllllllllllll}0.98 & 28.61 & 23.54 & 29.80 & 2 & 972.6262 & 972.6242 & 487.3194 & 0.0020 & 2.0520 & 26.847\end{array}$ $\begin{array}{lllllllllllll}0.79 & 19.43 & 23.54 & 24.49 & 2 & 972.6268 & 972.6242 & 487.3194 & 0.0026 & 2.6676 & 33.574\end{array}$ $\begin{array}{lllllllllllll}0.95 & 28.11 & 23.71 & 26.69 & 2 & 972.6244 & 972.6242 & 487.3194 & 0.0002 & 0.2052 & 15.526\end{array}$ $\begin{array}{lllllllllllll}0.97 & 31.27 & 23.65 & 33.37 & 2 & 972.6254 & 972.6242 & 487.3194 & 0.0012 & 1.2312 & 187.233\end{array}$ $\begin{array}{llllllllllll}0.97 & 20.20 & 23.65 & 30.44 & 2 & 972.6254 & 972.6242 & 487.3194 & 0.0012 & 1.2312 & 217.883\end{array}$ $\begin{array}{llllllllllll}0.88 & 23.50 & 23.52 & 26.55 & 2 & 972.6240 & 972.6242 & 487.3194 & -0.0002 & -0.2052 & 127.968\end{array}$ $\begin{array}{lllllllllllll}0.73 & 19.50 & 23.71 & 23.70 & 2 & 972.6246 & 972.6242 & 487.3194 & 0.0004 & 0.4104 & 130.502\end{array}$ $\begin{array}{llllllllllllll}0.77 & 18.40 & 23.71 & 30.99 & 2 & 972.6248 & 972.6242 & 487.3194 & 0.0006 & 0.6156 & 252.092\end{array}$ $\begin{array}{lllllllllllll}0.94 & 24.07 & 23.65 & 26.53 & 2 & 972.6252 & 972.6242 & 487.3194 & 0.0010 & 1.0260 & 175.349 \\ 0.85 & 19.84 & 23.65 & 27.17 & 2 & 972.6252 & 972.6242 & 487.3194 & 0.0010 & 1.0260 & 104.139\end{array}$ $\begin{array}{llllllllllll}0.85 & 19.84 & 23.65 & 27.17 & 2 & 972.6252 & 972.6242 & 487.3194 & 0.0010 & 1.0260 & 104.139\end{array}$ $\begin{array}{llllllllllll}0.97 & 29.93 & 23.65 & 32.23 & 2 & 972.6252 & 972.6242 & 487.3194 & 0.0010 & 1.0260 & 228.144 \\ 0.95 & 25.34 & 23.65 & 27.64 & 2 & 972.6252 & 972.6242 & 487.3194 & 0.0010 & 1.0260 & 133.864\end{array}$ $\begin{array}{lllllllllllll}0.95 & 25.34 & 23.65 & 27.64 & 2 & 972.6252 & 972.6242 & 487.3194 & 0.0010 & 1.0260 & 133.864\end{array}$ $\begin{array}{llllllllllll}0.89 & 21.11 & 23.65 & 26.22 & 2 & 972.6254 & 972.6242 & 487.3194 & 0.0012 & 1.2312 & 278.055\end{array}$ $\begin{array}{llllllllllll}0.96 & 25.68 & 23.65 & 27.71 & 2 & 972.6254 & 972.6242 & 487.3194 & 0.0012 & 1.2312 & 179.300\end{array}$ $\begin{array}{llllllllllll}0.93 & 23.19 & 23.65 & 28.73 & 2 & 972.6254 & 972.6242 & 487.3194 & 0.0012 & 1.2312 & 148.900 & 187.311\end{array}$

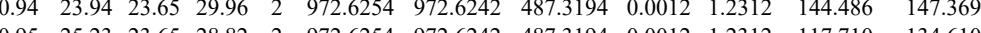

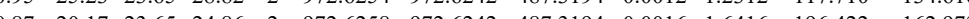

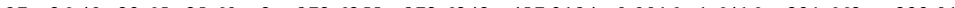

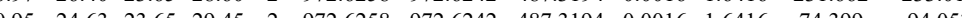
$\begin{array}{llllllllllllll}0.98 & 34.85 & 23.65 & 36.83 & 2 & 972.6258 & 972.242 & 487.3194 & 0.0016 & 1.6416 & 58.669 & 62.957\end{array}$ $\begin{array}{llllllllllll}0.93 & 22.84 & 23.65 & 28.78 & 2 & 972.6260 & 972.6242 & 48.33194 & 0.0018 & 1.8468 & 131.670 & 131.954\end{array}$ $\begin{array}{llllllllllll}0.86 & 21.50 & 27.29 & 16.72 & 3 & 1284.6541 & 1284.6544 & 429.2254 & -0.0003 & 0.2330 & 190.098 & 202.707\end{array}$ $\begin{array}{llllllllllll}0.87 & 22.12 & 27.49 & 16.88 & 3 & 1284.6547 & 1284.6544 & 429.2254 & 0.0003 & 0.2330 & 209.542 & 229.983\end{array}$ $\begin{array}{llllllllllllll}0.90 & 27.11 & 23.65 & 35.54 & 2 & 972.6252 & 972.6242 & 487.3194 & 0.0010 & 1.0260 & 4842.435 & 5179.023\end{array}$ $\begin{array}{llllllllllllll}0.97 & 34.15 & 23.65 & 36.48 & 2 & 972.6252 & 972.6242 & 4873194 & 0.0010 & 1.0260 & 402.228 & 426.985\end{array}$ $\begin{array}{lllllllllllllll}0.96 & 27.05 & 23.65 & 30.71 & 2 & 972.6252 & 972.6242 & 487.3194 & 0.0010 & 1.0260 & 362.657 & 435.363\end{array}$ $\begin{array}{llllllllllllll}0.97 & 35.20 & 23.65 & 37.21 & 2 & 972.6252 & 972.6242 & 487.3194 & 0.0010 & 1.0260 & 394.853 & 482.151\end{array}$ $\begin{array}{llllllllllllll}0.97 & 34.94 & 23.65 & 37.01 & 2 & 972.6252 & 972.6242 & 487.3194 & 0.0010 & 1.0260 & 312.291 & 432.682\end{array}$ $\begin{array}{lllllllllllll}0.98 & 33.19 & 23.65 & 34.32 & 2 & 972.6252 & 972.6242 & 487.3194 & 0.0010 & 1.0260 & 354.313 & 414.428\end{array}$ $\begin{array}{lllllllllllll}0.97 & 28.41 & 23.65 & 31.88 & 2 & 972.6252 & 972.6242 & 487.3194 & 0.0010 & 1.0260 & 294.713 & 319.911\end{array}$ $\begin{array}{llllllllllllll}0.97 & 35.13 & 23.65 & 37.28 & 2 & 972.6252 & 972.6242 & 487.3194 & 0.0010 & 1.0260 & 121.982 & 126.591\end{array}$ $\begin{array}{llllllllllllll}0.97 & 31.58 & 23.65 & 34.14 & 2 & 972.6254 & 972.6242 & 487.3194 & 0.0012 & 1.2312 & 384.602 & 375.039 \\ 0.97 & 36.00 & 23.65 & 38.19 & 2 & 972.6254 & 972.6242 & 487.3194 & 0.0012 & 1.2312 & 1049.956 & 1044.186\end{array}$ $\begin{array}{lllllllllllll}0.97 & 36.00 & 23.65 & 38.19 & 2 & 972.6254 & 972.6242 & 487.3194 & 0.0012 & 1.2312 & 1049.956 & 1044.186 \\ 0.97 & 32.57 & 23.65 & 35.07 & 2 & 972.6254 & 972.6242 & 487.3194 & 0.0012 & 1.2312 & 646.905 & 804.053\end{array}$ $\begin{array}{lllllllllllllll}0.96 & 27.12 & 23.65 & 30.85 & 2 & 972.6254 & 972.6242 & 487.3194 & 0.0012 & 1.2312 & 4368.668 & 4393.175\end{array}$ $\begin{array}{lllllllllllll}0.97 & 32.58 & 23.65 & 34.94 & 2 & 972.6254 & 972.6242 & 487.3194 & 0.0012 & 1.2312 & 473.354 & 492.880\end{array}$ $\begin{array}{llllllllllllll}0.97 & 35.08 & 23.65 & 37.13 & 2 & 972.6254 & 972.6242 & 487.3194 & 0.0012 & 1.2312 & 442.847 & 464.765\end{array}$ $\begin{array}{llllllllllllll}0.96 & 27.85 & 23.65 & 31.43 & 2 & 972.6254 & 972.6242 & 487.3194 & 0.0012 & 1.2312 & 511.012 & 568.206\end{array}$ $\begin{array}{llllllllllll}0.97 & 32.44 & 23.65 & 34.84 & 2 & 972.6254 & 972.6242 & 487.3194 & 0.0012 & 1.2312 & 478.466 & 445.941\end{array}$ $\begin{array}{llllllllllllll}0.97 & 33.22 & 23.65 & 35.62 & 2 & 972.6254 & 972.6242 & 487.3194 & 0.0012 & 1.2312 & 522.538 & 513.351 \\ 0.97 & 33.54 & 23.5 & 35.73 & 2 & 972.6254 & 972.6242 & 487.3194 & 0.0012 & 1.2312 & 351.056 & 39.885\end{array}$ $\begin{array}{lllllllllllll}0.97 & 33.54 & 23.65 & 35.73 & 2 & 972.6254 & 972.6242 & 487.3194 & 0.0012 & 1.2312 & 351.066 & 396.885\end{array}$ $\begin{array}{lllllllllllll}0.98 & 31.53 & 23.65 & 33.04 & 2 & 972.6254 & 972.6242 & 487.3194 & 0.0012 & 1.2312 & 431.101 & 475.656 \\ 0.97 & 35.16 & 23.65 & 37.20 & 2 & 972.6254 & 972.6242 & 487.3194 & 0.0012 & 1.2312 & 338.487 & 494.698\end{array}$ $\begin{array}{lllllllllllll}0.97 & 35.16 & 23.65 & 37.20 & 2 & 972.6254 & 972.6242 & 487.3194 & 0.0012 & 1.2312 & 338.487 & 494.698\end{array}$ $\begin{array}{lllllllllllll}0.97 & 35.67 & 23.65 & 37.84 & 2 & 972.6254 & 97.6242 & 487.3194 & 0.0012 & 1.2312 & 48.587 & 435.975\end{array}$

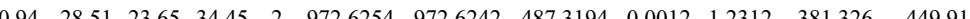
$\begin{array}{lllllllllllll}0.94 & 28.51 & 23.65 & 34.45 & 2 & 972.6254 & 972.6242 & 487.3194 & 0.0012 & 1.2312 & 381.326 & 449.916 \\ 0.97 & 32.45 & 23.65 & 34.85 & 2 & 972.6254 & 972.6242 & 487.3194 & 0.0012 & 1.2312 & 308.018 & 371.382\end{array}$ 


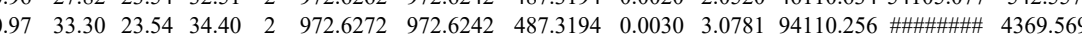

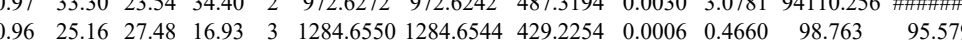

$\begin{array}{lllllllllllll}0.45 & 27.48 & 15.92 & 3 & 1284.6550 & 1284.6544 & 429.2254 & 0.0006 & 0.4660 & 113.713 & 107.048 & 34.799\end{array}$ $\begin{array}{lllllllllllll}0.60 & 27.80 & 23.44 & 32.52 & 2 & 972.6226 & 972.6242 & 487.3194 & -0.0016 & -1.6416 & 40957.768 & 47093.075 & 108.182\end{array}$

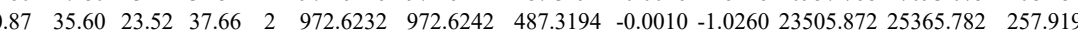
$\begin{array}{lllllllllllllll}0.97 & 35.08 & 23.65 & 37.18 & 2 & 972.6254 & 972.6242 & 487.3194 & 0.0012 & 1.2312 & 448.220 & 515.611 & 0.000\end{array}$ $\begin{array}{llllllllllllll}0.97 & 32.96 & 23.65 & 35.39 & 2 & 972.6254 & 972.6242 & 487.3194 & 0.0012 & 1.2312 & 562.285 & 496.968 & 7.552\end{array}$ $\begin{array}{lllllllllllllll}0.97 & 28.36 & 23.65 & 31.82 & 2 & 972.6254 & 972.6242 & 487.3194 & 0.0012 & 1.2312 & 259.539 & 245.643 & 20.243\end{array}$ $\begin{array}{llllllllllllll}0.94 & 28.43 & 23.65 & 34.14 & 2 & 972.6254 & 972.6242 & 487.3194 & 0.0012 & 1.2312 & 255.558 & 265.978 & 5.523\end{array}$ $\begin{array}{llllllllllllll}0.97 & 35.89 & 23.65 & 38.08 & 2 & 972.6256 & 972.6242 & 487.3194 & 0.0014 & 1.4364 & 79.494 & 94.151 & 5.745\end{array}$ $\begin{array}{llllllllllllll}0.97 & 27.17 & 23.65 & 30.61 & 2 & 972.6256 & 972.6242 & 487.3194 & 0.0014 & 1.4364 & 463.991 & 518.62\end{array}$ $\begin{array}{lllllllllllllll}0.97 & 36.50 & 23.65 & 38.45 & 2 & 972.6256 & 972.6242 & 487.3194 & 0.0014 & 1.4364 & 291.560 & 258.082\end{array}$ $\begin{array}{llllllllllllll}0.97 & 34.87 & 23.65 & 36.90 & 2 & 972.6256 & 972.6242 & 487.3194 & 0.0014 & 1.4364 & 266.798 & 290.138\end{array}$ $\begin{array}{llllllllllllll}0.97 & 36.40 & 23.65 & 38.49 & 2 & 972.6256 & 972.6242 & 487.3194 & 0.0014 & 1.4364 & 183.680 & 224.850\end{array}$ $\begin{array}{llllllllllllll}0.97 & 34.00 & 23.65 & 36.26 & 2 & 972.6256 & 972.6242 & 487.3194 & 0.0014 & 1.4364 & 136.426 & 200.047\end{array}$ $\begin{array}{llllllllllllll}0.98 & 33.76 & 23.65 & 35.99 & 2 & 972.6258 & 972.6242 & 487.3194 & 0.0016 & 1.6416 & 529.598 & 631.674\end{array}$ $\begin{array}{llllllllllllll}0.98 & 35.02 & 23.65 & 37.09 & 2 & 972.6258 & 972.6242 & 487.3194 & 0.0016 & 1.6416 & 486.251 & 487.781\end{array}$ $\begin{array}{llllllllllllll}0.98 & 35.02 & 23.65 & 37.09 & 2 & 972.6258 & 972.6242 & 487.3194 & 0.0016 & 1.6416 & 376.234 & 420.024\end{array}$ $\begin{array}{llllllllllllll}0.97 & 34.01 & 23.65 & 36.39 & 2 & 972.6258 & 972.6242 & 487.3194 & 0.0016 & 1.6416 & 289.504 & 370.181\end{array}$ $\begin{array}{llllllllllllll}0.97 & 28.53 & 23.65 & 32.29 & 2 & 972.6258 & 972.6242 & 487.3194 & 0.0016 & 1.6416 & 270.348 & 276.336\end{array}$ $\begin{array}{lllllllllllllll}0.93 & 29.46 & 23.65 & 36.56 & 2 & 972.6258 & 972.6242 & 487.3194 & 0.0016 & 1.6416 & 222.702 & 201.892\end{array}$ $\begin{array}{llllllllllll}0.93 & 34.64 & 23.65 & 41.81 & 2 & 972.6258 & 972.6242 & 487.3194 & 0.0016 & 1.6416 & 77.615 & 98.567\end{array}$

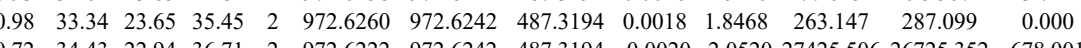

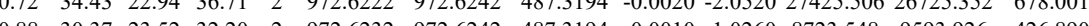

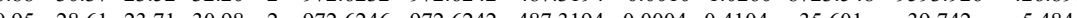
$\begin{array}{lllllllllllll}0.95 & 28.61 & 23.71 & 30.98 & 2 & 972.6232 & 972.6242 & 487.3194 & 0.0010 & -1.0260 & 8723.548 & 9593.926 & 4.6 .890 \\ 0.77 & 17.50 & 23.71 & 29.92 & 2 & 972.6250 & 972.6242 & 47.3194 & 0.004 & 0.4104 & 35.615 & 39.742 & 5.484\end{array}$

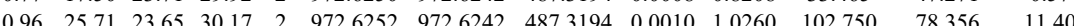
$\begin{array}{llllllllllllll}0.96 & 25.98 & 23.65 & 29.65 & 2 & 972.6254 & 972.6242 & 487.3194 & 0.0012 & 1.2312 & 87.121 & 83.779 & 7.946\end{array}$ $\begin{array}{llllllllllllll}0.94 & 25.10 & 23.65 & 30.70 & 2 & 972.6256 & 972.6242 & 487.3194 & 0.0014 & 1.4364 & 133.693 & 113.463 & 13.093\end{array}$ $\begin{array}{llllllllllllll}0.90 & 21.63 & 23.65 & 29.58 & 2 & 972.6256 & 972.6242 & 487.3194 & 0.0014 & 1.4364 & 75.349 & 120.159 & 14.888\end{array}$ $\begin{array}{lllllllllllll}0.92 & 22.56 & 23.65 & 26.01 & 2 & 972.6256 & 972.6242 & 487.3194 & 0.0014 & 1.4364 & 117.406 & 77.326 & 14.8874\end{array}$ $\begin{array}{lllllllllllllll}0.95 & 24.57 & 23.65 & 27.64 & 2 & 972.6260 & 972.6242 & 4873194 & 0.0018 & 1.8468 & 74.008 & 80.808 & 2.113\end{array}$ $\begin{array}{lllllllllllllll}0.98 & 32.98 & 23.65 & 34.86 & 2 & 972.6260 & 972.6242 & 487.3194 & 0.0018 & 1.8468 & 49.369 & 31.574 & 2.064\end{array}$ $\begin{array}{lllllllllllllll}0.93 & 23.07 & 23.54 & 27.96 & 2 & 972.6266 & 972.6242 & 487.3194 & 0.0024 & 2.4624 & 64.376 & 81.600 & 8.562\end{array}$ $\begin{array}{lllllllllllll}0.86 & 32.33 & 23.52 & 34.95 & 2 & 972.6236 & 972.6242 & 487.3194 & -0.0006 & -0.6156 & 8840.201 & 9217.334 & 213.199\end{array}$ $\begin{array}{llllllllllllll}0.93 & 27.60 & 23.52 & 31.36 & 2 & 972.6242 & 972.6242 & 487.3194 & 0.0000 & 0.0000 & 21941.648 & 23955.034 & 316.098\end{array}$ $\begin{array}{lllllllllllll}0.95 & 23.81 & 27.50 & 17.98 & 3 & 1284.6556 & 1284.6544 & 429.2254 & 0.0012 & 0.9319 & 128.236 & 138.476 & 60.816\end{array}$ $\begin{array}{lllllllllllllll}0.98 & 30.54 & 23.71 & 32.41 & 2 & 972.6250 & 972.6242 & 487.3194 & 0.0008 & 0.8208 & 2717.609 & 3182.037 & 75.314\end{array}$ $\begin{array}{lllllllllllll}0.93 & 26.34 & 23.71 & 32.83 & 2 & 972.6250 & 972.6242 & 487.3194 & 0.0008 & 0.8208 & 5798.612 & 6582.687 & 73.673\end{array}$

ALLFIPR
ALLFIPR $\begin{array}{lllllllllllll}0.97 & 28.66 & 23.71 & 32.07 & 2 & 972.6250 & 972.6242 & 487.3194 & 0.0008 & 0.8208 & 683.271 & 690.150\end{array}$ $\begin{array}{llllllllllll}0.97 & 34.92 & 23.71 & 36.97 & 2 & 972.6250 & 972.6242 & 487.3194 & 0.0008 & 0.8208 & 683.271 & 690.150 \\ 0.6250 & 972.6242 & 487.3194 & 0.0008 & 0.8208 & 277.227 & 299.293\end{array}$

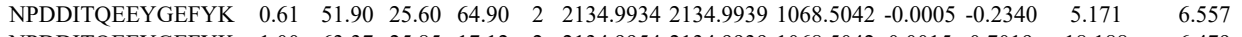

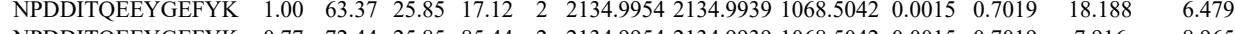
\begin{tabular}{llllllllllllll} 
& NDDDIQEEYGEFYK & 0.77 & 72.44 & 25.85 & 85.44 & 2 & 2134.9954 & 2134.9939 & 1068.5042 & 0.0015 & 0.7019 & 7.916 & 8.965 \\
\hline
\end{tabular}

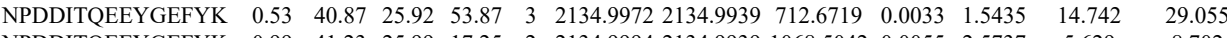

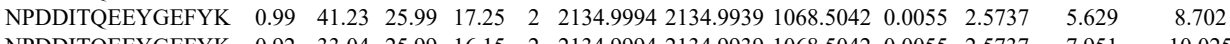

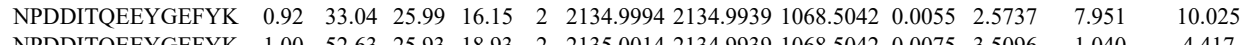

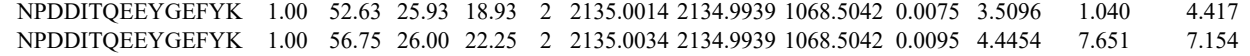

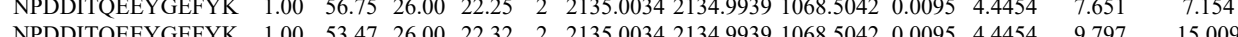
$\begin{array}{lllllllllllll}\text { NPDDIPQEEYGFY } & 1.00 & 53.47 & 26.00 & 22.32 & 2 & 2135.0034 & 2134.9939 & 068.5042 & 0.0095 & 4.4454 & 9.797 & 15.04 \\ \text { ALLFIPR } & 0.93 & 26.24 & 23.71 & 30.11 & 2 & 972.6244 & 972.6242 & 487.3194 & 0.0002 & 0.2052 & 401.586 & 534.418\end{array}$ 

$\begin{array}{lllllllllllll}0.97 & 34.09 & 23.65 & 36.41 & 2 & 972.6254 & 972.6242 & 487.3194 & 0.0012 & 1.2312 & 487.220 & 5 & \end{array}$ $\begin{array}{lllllllllllll}0.98 & 30.63 & 23.71 & 32.43 & 2 & 972.6248 & 972.6242 & 487.3194 & 0.0006 & 0.6156 & 721.347 & 83 & \\ 0.97 & 1.76 & 23.65 & 34.23 & 2 & 92.6254 & 92.6242 & 48.3194 & 0.002 & 1.2312 & 394.42 & 44\end{array}$ $\begin{array}{lllllllllll}0.97 & 31.76 & 23.65 & 34.23 & 2 & 972.6254 & 972.6242 & 487.3194 & 0.0012 & 1.2312 & 394.442\end{array}$ $\begin{array}{lllllllllll} & 3.76 & 23.65 & 32.23 & 2 & 972.6254 & 972.6242 & 487.3194 & 0.0012 & 1.2312 & 394.342\end{array}$ $\begin{array}{llllllllllll}.97 & 33.41 & 23.71 & 35.88 & 2 & 972.6248 & 972.6242 & 487.3194 & 0.0006 & 0.6156 & 842.997 & 945.339\end{array}$ $\begin{array}{llllllllllll}0.97 & 28.61 & 23.65 & 32.07 & 2 & 972.6252 & 972.6242 & 487.3194 & 0.0010 & 1.0260 & 615.505 & 734.702\end{array}$

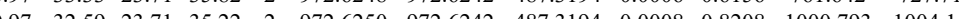

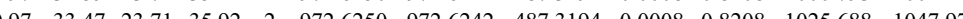
$\begin{array}{lllllllllllllll}0.96 & 26.96 & 23.65 & 30.70 & 2 & 972.6254 & 972.624 & 487.3194 & 0.0012 & 0.82312 & 9258.264 & 999.692\end{array}$

\begin{tabular}{lllll} 
& 0.54 \\
\hline
\end{tabular}

\begin{tabular}{llllllllllllllll} 
& \\
\hline
\end{tabular}

$\begin{array}{llllllllllllll} & \\ \text { MQPIR } & 0.77 & 52.87 & 25.65 & 65.87 & 2 & 1698.9636 & 1698.9613 & 850.4879 & 0.0023 & 1.3522 & 2804.182 & 2230.95 \\ \text { MQPIR } & 1.00 & 49.26 & 25.65 & 19.63 & 2 & 1698.9634 & 1698.9613 & 850.4879 & 0.0021 & 1.2346 & 687.622 & 806.725\end{array}$

TAVDPLFGMQPIR

LAVVDPLFGMQPIR

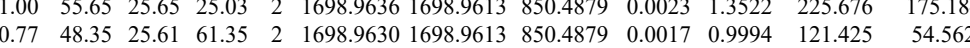

$\begin{array}{lllllllllll}\text { HEM3_HUMAN } & \text { P08397 } & \text { HMBS } & \text { Porphobilinogend } 39.33 & 1.00 & 2 & 10.8 & 0.3377 & 0.7095 & 1.5411 & 1.1767\end{array}$

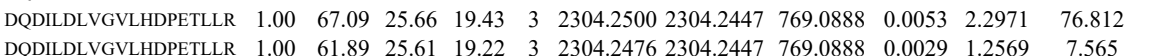

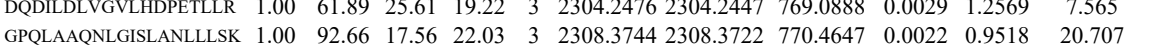
$\begin{array}{llllllllllll}\text { GPQLAAQNLGISLANLLLSK } & 1.00 & \text { \#\#\#\# } & 17.56 & 23.60 & 3 & 2308.3750 & 2308.3722 & 770.4647 & 0.0028 & 1.2114 & 26.538\end{array}$

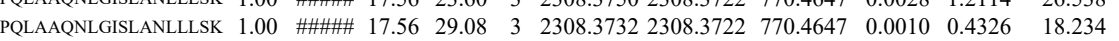
$\begin{array}{llllllllllll}\text { SLANLLLSK } & 1.00 & 72.80 & 17.56 & 19.52 & 3 & 2308.3732 & 2308.3722 & 770.4647 & 0.0010 & 0.4326 & 14.750\end{array}$ RPGPSPLPHR

DPIPYLPPLEK

\section{YDERPGPSPLPH}

YDERPGPSPLPHR

YDERPGPSPLPHR

DPIPYLPPLEK

DPIPYLPPLEK

YDERPGPSPLPHR MWDPHNDPNAQGDAFK

7 LQDEIQNMK LQDEIQNMK FADLSEAANR FADLSEAANR $\begin{array}{llllllllllll} & \end{array}$ $\begin{array}{llllllllllllllll}0.94 & 20.57 & 28.23 & 17.01 & 4 & 1663.8537 & 1663.8552 & 416.9711 & -0.0015 & -0.8993 & 8449.445 & 10553.504 & 8332.286 & 6188.470 & \text { Yes }\end{array}$ $\begin{array}{lllllllllllllll}0.97 & 28.13 & 28.19 & 18.14 & 3 & 1663.8553 & 1663.8552 & 555.6257 & 0.0001 & 0.0600 & 6806.521 & 8590.469 & 6039.991 & 4992.135 & \text { Yes }\end{array}$

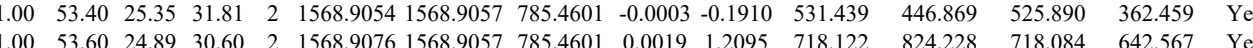
$\begin{array}{lllllllllllllll}0.99 & 23.03 & 28.22 & 16.76 & 4 & 1663.8545 & 1663.8552 & 416.9711 & -0.0007 & -0.4197 & 3318.220 & 4057.735 & 2925.940 & 2333.925 & \text { Yes }\end{array}$ $\begin{array}{ccccccccccccccc}0.99 & 45.08 & 28.58 & 28.65 & 2 & 1405.7590 & 1405.7479 & 703.8812 & 0.0111 & 7.8848 & 299.506 & 1055.592 & 9902.388 & 932.406 & \text { Yes } \\ 1.00 & 47.95 & 28.47 & 27.45 & 2 & 1405.7598 & 1405.7479 & 703.8812 & 0.0119 & 8.4531 & 537.472 & 748.451 & 12676.216 & 1031.695 & \text { Yes } \\ 0.99 & 46.06 & 27.94 & 27.91 & 2 & 1236.6310 & 1236.6220 & 619.3183 & 0.0090 & 7.2660 & 764.394 & 757.706 & 13251.453 & 159.593 & \text { Ycs }\end{array}$ $\begin{array}{lllllllllllllllll}0.99 & 46.06 & 27.94 & 27.91 & 2 & 1236.6310 & 1236.6220 & 619.3183 & 0.0090 & 7.2660 & 764.394 & 757.706 & 13251.453 & 1085.593 & \text { Yes } \\ 0.99 & 45.34 & 27.94 & 32.78 & 2 & 1236.6310 & 1236.6220 & 619.3183 & 0.0090 & 7.2660 & 745.351 & 1349.457 & 10704.944 & 140.638 & \text { Yes }\end{array}$ $\begin{array}{llllllllllllllll} & & & \end{array}$ $\begin{array}{lllllllllllllllll} & \text { ISLPLPNFSSLNLR } & 1.00 & 57.29 & 24.74 & 31.34 & 2 & 1713.9912 & 1713.9899 & 858.0022 & 0.0013 & 0.7576 & 21.688 & 23.541 & 386.757 & 15.700 & \text { Yes }\end{array}$ $\begin{array}{llllllllllllllll} & 1.00 & 30.67 & 23.98 & 21.57 & 3 & 1713.9922 & 1713.9899 & 572.3372 & 0.0023 & 1.3395 & 46.484 & 42.948 & 56.814 & 10.869 & \text { No }\end{array}$ $\begin{array}{llllllllllllllll}\text { ISLPLPNFSSLNLR } & 1.00 & 69.35 & 24.74 & 27.07 & 2 & 1713.9914 & 1713.9899 & 858.0022 & 0.0015 & 0.8741 & 13.184 & 12.388 & 715.684 & 50.314 & \text { Yes } \\ \text { ISLPLPNFSSLNLR } & 1.00 & 54.08 & 24.74 & 32.49 & 2 & 1713.9916 & 1713.9899 & 858.0022 & 0.0017 & 0.9907 & 12.103 & 0.000 & 430.722 & 17.340 & \text { No }\end{array}$ $\begin{array}{llllllllllllllll}\text { ISLPLPNFSSLNLR } & 1.00 & 54.08 & 24.74 & 32.49 & 2 & 1713.9916 & 1713.9899 & 858.0022 & 0.0017 & 0.9907 & 12.103 & 0.000 & 430.722 & 17.340 & \text { No } \\ \text { DGQVINETSQHHDLE } & 1.00 & 32.55 & 25.20 & 16.47 & 3 & 1979.8975 & 1979.8943 & 660.9720 & 0.0032 & 1.6138 & 3547.643 & 1721.803 & 5370.312 & 4689.857 & \text { Yes }\end{array}$ $\begin{array}{llllllllllllllll}\text { DGQVINETSQHHDDLE } & 1.00 & 32.55 & 25.20 & 16.47 & 3 & 1979.8975 & 1979.8943 & 660.9720 & 0.0032 & 1.6138 & 3547.643 & 1721.803 & 5370.312 & 4689.857 & \text { Yes } \\ \text { DGQVINETSQHHDDLE } & 1.00 & 38.71 & 25.20 & 15.89 & 3 & 1979.8984 & 1979.8943 & 660.9720 & 0.0041 & 2.0677 & 1236.608 & 1953.135 & 4050.941 & 4323.914 & \text { Yes }\end{array}$ $\begin{array}{lllllllllllllllll}\text { DGQVINETSQHHDDLE } & 1.00 & 38.71 & 25.20 & 15.89 & 3 & 1979.8984 & 1979.8943 & 660.9720 & 0.0041 & 2.0677 & 1236.608 & 1953.135 & 4050.941 & 4323.914 & \text { Yes } \\ \text { TYSLGSALRPSTSR } & 0.96 & 27.34 & 27.99 & 15.55 & 3 & 1638.8812 & 1638.8811 & 547.3010 & 0.0001 & 0.0609 & 80.762 & 168.070 & 688.184 & 165.079 & \text { Yes }\end{array}$ $\begin{array}{llllllllllllllll}\text { TYSLGSALRPSTSR } & 0.96 & 27.34 & 27.99 & 15.55 & 3 & 1638.8812 & 1638.8811 & 547.3010 & 0.0001 & 0.0609 & 80.762 & 168.070 & 688.184 & 165.079 & \text { Yes } \\ \text { TYSLGSALRPSTSR } & 0.50 & 15.61 & 28.05 & 14.70 & 3 & 1638.8815 & 1638.8811 & 547.3010 & 0.0004 & 0.2436 & 49.890 & 138.605 & 478.812 & 118.586 & \text { Yes }\end{array}$

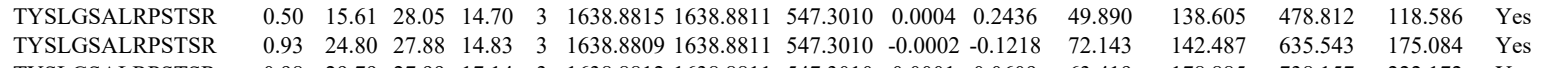
$\begin{array}{llllllllllllllll}\text { TYSLGSALRPSTSR } & 0.93 & 24.80 & 27.88 & 14.83 & 3 & 1638.8809 & 1638.8811 & 547.3010 & -0.0002 & -0.1218 & 72.143 & 142.487 & 635.543 & 175.084 & \text { Yes } \\ \text { TYSLGSALRPSTSR } & 0.98 & 29.79 & 27.99 & 17.14 & 3 & 1638.8812 & 1638.8811 & 547.3010 & 0.0001 & 0.0609 & 63.419 & 178.885 & 738.157 & 222.172 & \text { Yes }\end{array}$ $\begin{array}{llllllllllllllllll}\text { TYSLGSALRPSTSR } & 0.98 & 29.79 & 27.99 & 17.14 & 3 & 1638.8812 & 1638.8811 & 547.3010 & 0.0001 & 0.0609 & 63.419 & 178.885 & 738.157 & 222.172 & \text { Ycs } \\ \text { MFGGPGTASRPSSR } & 0.99 & 32.83 & 28.47 & 18.47 & 3 & 1637.8069 & 1637.8066 & 546.9428 & 0.0003 & 0.1828 & 50.483 & 161.130 & 498.802 & 469.010 & \text { Yes }\end{array}$ $\begin{array}{llllllllllllllll}\text { MFGGPGTASRPSSSR } & 0.98 & 31.09 & 28.47 & 18.63 & 3 & 1637.8069 & 1637.8066 & 546.9428 & 0.0003 & 0.1828 & 61.086 & 130.609 & 660.192 & 552.913 & \text { Yes } \\ \end{array}$

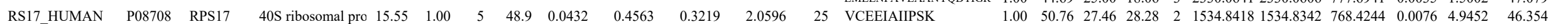

\footnotetext{
(1)
}

Table S-3 page 101 of 499 
$\begin{array}{llllllllllllll}0.51 & 23.00 & 27.05 & 26.92 & 2 & 993.5598 & 993.5518 & 497.7832 & 0.0080 & 8.0356 & 9206.009 & 10967.067 & 283.711\end{array}$

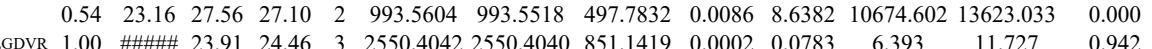
$\begin{array}{llllllllllllll}\text { FGAOLAHIOALIGGIEAQLGDVR } & 1.00 & 76.41 & 24.03 & 19.15 & 3 & 2550.4054 & 2550.4040 & 851.1419 & 0.0014 & 0.5483 & 7.765 & 8.875 & 9.584\end{array}$

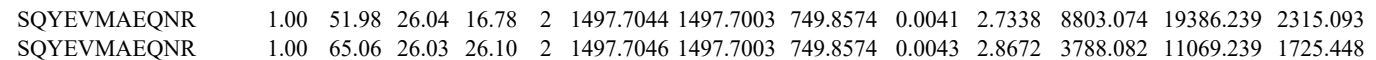

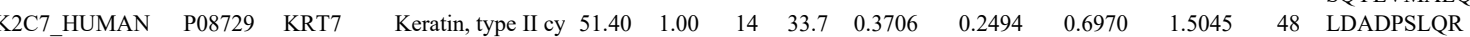

LDADPSLQR

AKQEELEAALQR

LQAEIDNIK

LQAEIDNIK

GQLEALQVDGGR

GQLEALQVDGGR

AKQEELEAALQR

AKQEELEAALQR

AKQEELEAALQR
AKQEELEAALQR

LQAEIDNIK

LQAEIDNIK

$\begin{array}{lllllllllllll}1.00 & 65.06 & 26.03 & 26.10 & 2 & 1497.7046 & 1497.7003 & 749.8574 & 0.0043 & 2.8672 & 3788.082 & 11069.239 & 1725.448 \\ 0.99 & 41.75 & 28.14 & 34.01 & 2 & 1157.6252 & 1157.6162 & 579.8154 & 0.0090 & 7.7610 & 27475.385 & 32892.421 & 2458.537\end{array}$ $\begin{array}{llllllllllllll}0.99 & 41.75 & 28.14 & 34.01 & 2 & 1157.6252 & 1157.6162 & 579.8154 & 0.0090 & 7.7610 & 27475.385 & 32892.421 & 2458.537 \\ 0.98 & 39.17 & 27.82 & 28.81 & 2 & 1157.6270 & 1157.6162 & 579.8154 & 0.0108 & 9.3132 & 19121.683 & 22070.225 & 1551.606\end{array}$ $\begin{array}{llllllllllllll}0.70 & 37.51 & 26.15 & 22.03 & 3 & 1672.9495 & 1672.9351 & 558.6523 & 0.0144 & 8.5920 & 4134.651 & 4264.888 & 1051.384 & 482 . \\ 0.99 & 52.73 & 26.62 & 39.42 & 2 & 1330.7762 & 1330.7700 & 666.3923 & 0.0062 & 4.6519 & 39947.948 & 54532.582 & 0.000 & 6.5\end{array}$ $\begin{array}{llllllllllllll}0.99 & 52.73 & 26.62 & 39.42 & 2 & 1330.7762 & 1330.7700 & 666.3923 & 0.0062 & 4.6519 & 39947.948 & 54532.582 & 0.000 \\ 0.99 & 51.37 & 26.24 & 40.17 & 2 & 1330.7778 & 1330.7700 & 666.3923 & 0.0078 & 5.8524 & 26627.827 & 37727.630 & 0.000\end{array}$ $\begin{array}{lllllllllllll}0.99 & 51.37 & 26.24 & 40.17 & 2 & 1330.7778 & 1330.7700 & 666.3923 & 0.0078 & 5.8524 & 26627.827 & 37727.630 & 0.000 \\ 1.00 & 63.67 & 27.82 & 26.74 & 2 & 1385.7498 & 1385.7385 & 693.8765 & 0.0113 & 8.1426 & 10339.723 & 13350.080 & 393.009\end{array}$ $\begin{array}{lllllllllllll}1.00 & 63.67 & 27.82 & 26.74 & 2 & 1385.7498 & 1385.7385 & 693.8765 & 0.0113 & 8.1426 & 10339.723 & 13350.080 & 393.009 \\ 1.00 & 72.28 & 27.80 & 33.89 & 2 & 1385.7502 & 1385.7385 & 693.8765 & 0.0117 & 8.4308 & 7169.313 & 10043.747 & 15.847\end{array}$ $\begin{array}{llllllllllllll}1.00 & 72.28 & 27.80 & 33.89 & 2 & 1385.7502 & 1385.7385 & 693.8765 & 0.0117 & 8.4308 & 7169.313 & 10043.747 & 15.847 \\ 1.00 & 73.85 & 26.20 & 20.91 & 2 & 1672.9474 & 1672.9351 & 837.4748 & 0.0123 & 7.3435 & 8467.537 & 12604.526 & 0.000\end{array}$ $\begin{array}{llllllllllllll}1.00 & 73.85 & 26.20 & 20.91 & 2 & 1672.9474 & 1672.9351 & 837.4748 & 0.0123 & 7.3435 & 8467.537 & 12604.526 & 0.000 \\ 1.00 & 71.96 & 26.16 & 20.40 & 2 & 1672.9482 & 1672.9351 & 837.4748 & 0.0131 & 7.8211 & 10358.346 & 14265.684 & 0.000\end{array}$ $\begin{array}{lllllllllllllll}0.80 & 39.84 & 26.15 & 19.52 & 3 & 1672.9492 & 1672.9351 & 558.6523 & 0.0141 & 8.4130 & 25449.666 & 35273.553 & 642.416\end{array}$ $\begin{array}{lllllllllllll}0.70 & 37.51 & 26.18 & 18.11 & 3 & 1672.9498 & 1672.9351 & 558.6523 & 0.0147 & 8.7710 & 14495.883 & 21768.732 & 822.027\end{array}$ $\begin{array}{lllllllllllll}1.00 & 51.06 & 26.39 & 39.28 & 2 & 1330.7734 & 1330.7700 & 666.3923 & 0.0034 & 2.5510 & 31698.328 & 42233.020 & 0.000 \\ 1.00 & 57.48 & 26.20 & 30.95 & 2 & 1330.7792 & 1330.7700 & 6663923 & 0.0092 & 6.9028 & 26774.925 & 34366.438 & 114.172\end{array}$ 
$\begin{array}{lllllllllllll}70.94 & 27.80 & 27.46 & 2 & 1385.7502 & 1385.7385 & 693.8765 & 0.0117 & 8.4308 & 10798.647 & 16733.544 & 68.995 & 227.013\end{array}$ $\begin{array}{lllllllllllll} & \end{array}$ $\begin{array}{llllllllllllll}1.00 & 32.58 & 25.54 & 23.11 & 3 & 1559.9035 & 1559.9014 & 520.9744 & 0.0021 & 1.3436 & 653.423 & 1085.699 & 269.636\end{array}$ $\begin{array}{llllllllllllll}0.99 & 31.05 & 25.49 & 27.74 & 3 & 1559.9041 & 1559.9014 & 520.9744 & 0.0027 & 1.7275 & 1061.045 & 1371.819 & 130.070\end{array}$ $\begin{array}{lllllllllllll}1.00 & 78.57 & 25.43 & 33.47 & 2 & 1559.9032 & 1559.9014 & 780.9580 & 0.0018 & 1.1524 & 16937.890 & 21183.075 & 0.000\end{array}$

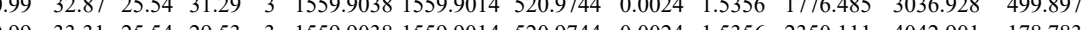
$\begin{array}{llllllllllllll}0 & 0.90 & 32.87 & 25.54 & 31.29 & 3 & 1559.9038 & 1559.9014 & 520.9744 & 0.0024 & 1.5356 & 1776.485 & 3036.928 & 499.897\end{array}$ $\begin{array}{lllllllllllll}1.00 & 64.26 & 25.54 & 30.65 & 2 & 1559.9038 & 1559.9044 & 780.9580 & 0.0024 & 1.5356 & 9598.967 & 15825.595 & 0.000\end{array}$

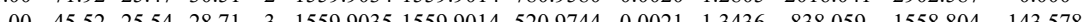
$\begin{array}{lllllllllllllll}0.99 & 27.74 & 25.49 & 26.02 & 3 & 1559.9041 & 1559.9014 & 520.9744 & 0.0027 & 1.7275 & 537.777 & 899.435 & 137.043\end{array}$

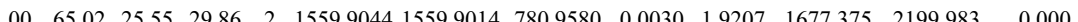
$\begin{array}{llllllllllllllll}1.00 & 62.12 & 28.33 & 38.49 & 2 & 1561.8236 & 1561.8222 & 781.9184 & 0.0014 & 0.8952 & 1288.695 & 1685.510 & 67.393\end{array}$ $\begin{array}{lllllllllllllll}100 & 60.25 & 27.23 & 32.72 & 2 & 1379.7738 & 1379.7652 & 690.8899 & 0.0086 & 6.2238 & 39178.974 & 51236.194 & 0.000\end{array}$ $\begin{array}{lllllllllllll}1.00 & 62.07 & 27.20 & 32.87 & 2 & 1379.7754 & 1379.7652 & 690.8899 & 0.0102 & 7.3817 & 44428.61159554 .033 & 0.000\end{array}$ $\begin{array}{llllllllllllll}0.67 & 14.02 & 25.63 & 16.83 & 3 & 1559.9026 & 1559.9014 & 520.9744 & 0.0012 & 0.7678 & 354.875 & 413.843 & 70.750\end{array}$ $\begin{array}{lllllllllllllll}1.00 & 61.25 & 25.68 & 31.14 & 2 & 1559.9028 & 1559.9014 & 780.9580 & 0.0014 & 0.8963 & 182.829 & 135.854 & 25.547\end{array}$ $\begin{array}{lllllllllllll}1.00 & 59.35 & 25.47 & 25.17 & 2 & 1559.9034 & 1559.9014 & 780.9580 & 0.0020 & 1.2805 & 216.805 & 209.336 & 5.477\end{array}$ $\begin{array}{lllllllllllll}1.00 & 66.38 & 28.39 & 29.73 & 2 & 1561.8226 & 1561.8222 & 781.9184 & 0.0004 & 0.2558 & 12398.290 & 17010.754 & 0.000\end{array}$ $\begin{array}{lllllllllllll}1.00 & 67.71 & 28.33 & 25.15 & 2 & 1561.8236 & 1561.8222 & 781.9184 & 0.0014 & 0.8952 & 3110.033 & 4292.212 & 59.185\end{array}$ $\begin{array}{lllllllllllllll}0.61 & 17.90 & 27.14 & 18.41 & 3 & 1379.7718 & 1379.7652 & 460.9290 & 0.0066 & 4.7729 & 2322.751 & 2131.276 & 1683.899\end{array}$ $\begin{array}{llllllllllllll}1.00 & 54.66 & 27.15 & 38.44 & 2 & 1379.7724 & 1379.7652 & 690.8899 & 0.0072 & 5.2106 & 71000.203 & 90403.325 & 0.000\end{array}$ $\begin{array}{llllllllllllll}0.78 & 22.37 & 27.17 & 21.69 & 3 & 1379.7727 & 1379.7652 & 460.9290 & 0.0075 & 5.4238 & 2227.747 & 3227.506 & 1236.401 \\ 1.00 & 62.04 & 27.21 & 34.07 & 2 & 1379.7732 & 1379.7652 & 690.8899 & 0.0080 & 5.7896 & 49078.522 & 67037.023 & 0.000\end{array}$ $\begin{array}{lllllllllllllll}1.00 & 61.87 & 28.33 & 29.28 & 2 & 1561.8236 & 1561.8222 & 781.9184 & 0.0014 & 0.8952 & 9469.735 & 12720.065 & 208.067\end{array}$ $\begin{array}{lllllllllllll}1.00 & 62.58 & 28.27 & 30.47 & 2 & 1561.8240 & 1561.8222 & 781.9184 & 0.0018 & 1.1510 & 4882.140 & 7312.412 & 121.067\end{array}$ $\begin{array}{lllllllllllllll}1.00 & 53.93 & 27.20 & 40.13 & 2 & 1379.7754 & 1379.7652 & 690.8899 & 0.0102 & 7.3817 & 34231.481 & 42001.231 & 0.000\end{array}$ $\begin{array}{lllllllllllll}1.00 & 59.11 & 27.46 & 33.68 & 2 & 1379.7756 & 1379.7652 & 690.8899 & 0.0104 & 7.5265 & 33316.702 & 43091.955 & 0.000\end{array}$ $\begin{array}{llllllllllllll}1.00 & 53.59 & 27.50 & 26.99 & 2 & 1344.7010 & 1344.7006 & 673.3576 & 0.0004 & 0.2970 & 64.079 & 116.665 & 17.235 \\ 1.00 & 57.74 & 27.41 & 29.57 & 2 & 1344.7030 & 1344.7006 & 673.3576 & 0.0024 & 1.7821 & 35.447 & 38.143 & 11.099\end{array}$ $\begin{array}{llllllllllllll}1.00 & 57.74 & 27.41 & 29.57 & 2 & 1344.7030 & 1344.7006 & 673.3576 & 0.0024 & 1.7821 & 35.447 & 38.143 & 11.099\end{array}$ $\begin{array}{lllllllllllll}1.00 & 43.54 & 26.03 & 28.92 & 2 & 1332.7776 & 1332.7645 & 667.3895 & 0.0131 & 9.8143 & 15182.599 & 22095.724 & 0.000 \\ 1.00 & 64.94 & 29.04 & 25.47 & 2 & 1247.6776 & 1247.6744 & 624.8445 & 0.0032 & 2.5606 & 46799.881 & 52525.262 & 270.165\end{array}$ $\begin{array}{lllllllllllll}1.00 & 64.94 & 29.04 & 25.47 & 2 & 1247.6776 & 1247.6744 & 624.8445 & 0.0032 & 2.5606 & 46799.881 & 52525.262 & 270.165 \\ 1.00 & 56.93 & 29.01 & 26.23 & 2 & 1247.6782 & 1247.6744 & 624.8445 & 0.0038 & 3.0407 & 58630.526 & 62780.191 & 0.000\end{array}$ $\begin{array}{llllllllllllll}1.00 & 56.93 & 29.01 & 26.23 & 2 & 1247.6782 & 1247.6744 & 624.8445 & 0.0038 & 3.0407 & 58630.526 & 62780.191 & 0.000\end{array}$ $\begin{array}{lllllllllllll}1.00 & 57.74 & 29.04 & 27.13 & 2 & 1247.6776 & 1247.6744 & 624.8445 & 0.0032 & 2.5606 & 33461.310 & 37796.733 & 910.801\end{array}$

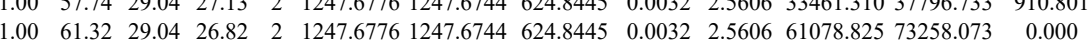
$\begin{array}{lllllllllllllll}1.00 & 62.37 & 28.95 & 26.57 & 2 & 1247.6774 & 1247.6744 & 624.8445 & 0.0030 & 2.4006 & 42890.603 & 42581.437 & 584.913\end{array}$

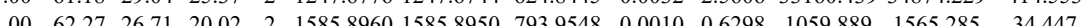

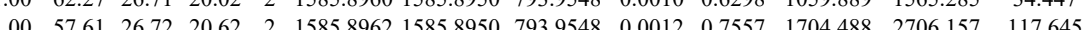
$\begin{array}{lllllllllllllll}0.58 & 11.97 & 26.46 & 13.88 & 3 & 1585.8976 & 1585.8950 & 529.6389 & 0.0026 & 1.6363 & 108.079 & 129.179 & 97.798\end{array}$ $\begin{array}{llllllllllllll}100 & 57.95 & 26.72 & 19.09 & 2 & 1585.8962 & 15858950 & 793.9548 & 0.0012 & 0.7557 & 7136.617 & 8527.806 & 0.000\end{array}$ $\begin{array}{lllllllllllll}1.00 & 53.90 & 26.67 & 19.60 & 2 & 1585.8968 & 1585.8950 & 793.9548 & 0.0018 & 1.1336 & 4570.378 & 6046.031 & 93.967\end{array}$ $\begin{array}{llllllllllllll}1.00 & 57.37 & 26.50 & 29.66 & 3 & 1585.8970 & 1585.8950 & 529.6389 & 0.0020 & 1.2587 & 61.174 & 360.600 & 107.922\end{array}$ $\begin{array}{lllllllllllll}100 & 55.59 & 26.67 & 20.37 & 2 & 15858968 & 15858950 & 793.9548 & 0.0018 & 1.1336 & 3994.297 & 5646.467 & 459.401\end{array}$ $\begin{array}{llllllllllllll}1.00 & 66.48 & 26.44 & 20.83 & 2 & 1585.8984 & 1585.8950 & 793.9548 & 0.0034 & 2.1412 & 3712.317 & 6297.962 & 11.087\end{array}$ $\begin{array}{llllllllllllll}0.99 & 39.41 & 26.92 & 31.51 & 2 & 1157.6166 & 1157.6162 & 579.8154 & 0.0004 & 0.3449 & 49.818 & 63.487 & 10.923\end{array}$ $\begin{array}{llllllllllllll}0.96 & 29.15 & 27.14 & 23.43 & 2 & 1157.6172 & 1157.6162 & 579.8154 & 0.0010 & 0.8623 & 60.353 & 58.048 & 14.067\end{array}$ $\begin{array}{llllllllllllll}1.00 & 56.49 & 27.60 & 27.98 & 2 & 1344.7016 & 1344.7006 & 673.3576 & 0.0010 & 0.7425 & 60.458 & 96.288 & 10.467\end{array}$ $\begin{array}{lllllllllllllll}0.55 & 18.43 & 28.92 & 20.98 & 2 & 1247.6756 & 1247.6744 & 624.8445 & 0.0012 & 0.9602 & 332.918 & 479.639 & 95.202\end{array}$ $\begin{array}{lllllllllllll}0.55 & 18.43 & 28.92 & 20.98 & 2 & 1247.6756 & 1247.6744 & 624.8445 & 0.0012 & 0.9602 & 332.918 & 479.639 & 95.262\end{array}$ $\begin{array}{llllllllllll}37.37 & 27.45 & 22.17 & 2 & 1344.6988 & 1344.7006 & 673.3576 & -0.0018 & -1.3366 & 76.045 & 59.223 & 28.632\end{array}$ $\begin{array}{llllllllllllll}1.00 & 64.37 & 27.68 & 32.78 & 2 & 1329.7048 & 1329.7010 & 665.8578 & 0.0038 & 2.8535 & 34268.992 & 44764.021 & 0.000 & 4\end{array}$ $\begin{array}{lllllllllllllll}1.00 & 60.61 & 27.70 & 29.27 & 2 & 1329.7052 & 1329.7010 & 665.8578 & 0.0042 & 3.1538 & 18476.332 & 24769.204 & 842.569 & 48 & \\ 0.79 & 43.41 * 27.28 & 29.15 & 2 & 148.7436 & 48.7425 & 743.378 & 0.001 & 0.7399 & 9354.369 & 1214.232 & 210.12 & 10 & \end{array}$ $\begin{array}{llllllllllllll}0.79 & 43.41 * 27.28 & 29.15 & 2 & 1484.7436 & 1484.7425 & 743.3785 & 0.0011 & 0.7399 & 9354.369 & 12148.232 & 210.172 & 10 & \\ 0.87 & 47.73 * & 27.36 & 32.64 & 2 & 1484.7448 & 14847425 & 743.3785 & 0.0023 & 1.5470 & 9666.055 & 11455.651 & 62.731 & 13\end{array}$ $\begin{array}{llllllllllllll}0.87 & 47.73 * & 27.36 & 32.64 & 2 & 1484.7448 & 1484.7425 & 743.3785 & 0.0023 & 1.5470 & 9666.055 & 11455.651 & 62.731 & \\ 0.99 & 41.68 & 28.10 & 34.01 & 2 & 1157.6264 & 1157.6162 & 579.8154 & 0.0102 & 8.7958 & 30168.721 & 36751.187 & 1159.561 & \end{array}$ $\begin{array}{lllllllllllllll}0.99 & 41.68 & 28.10 & 34.01 & 2 & 1157.6264 & 157.6162 & 579.8154 & 0.0102 & 8.7958 & 30168.721 & 36751.187 & 1159.561 & 1292.232 \\ 0.96 & 36.18 & 28.10 & 28.51 & 2 & 1157.6266 & 1157.6162 & 579.8154 & 0.0104 & 8.9683 & 25365.174 & 31443.715 & 1699206 & 1762.909\end{array}$

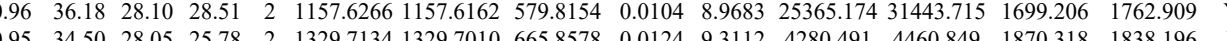
$\begin{array}{lllllllllllllll}1.00 & 53.07 & 28.05 & 33.91 & 2 & 1329.7134 & 1329.7010 & 665.8578 & 0.0124 & 9.3112 & 4280.491 & 4460.849 & 1870.318 & 1838.196 & \text { No } \\ 1.00 & 74.76 & 87.88 & 32.20 & 2 & 1493.7674 & 1329.7010 & 665.8578 & 0.0124 & 9.3112 & 9268.238 & 12252.510 & 755.696 & 1192.683 & \text { Y }\end{array}$ $\begin{array}{lllllllllllllll}1.00 & 74.76 & 27.88 & 32.20 & 2 & 1483.7670 & 1483.7551 & 742.8848 & 0.0119 & 8.0093 & 1263.662 & 2171.849 & 83.906 & 58.436 & \text { Yes }\end{array}$

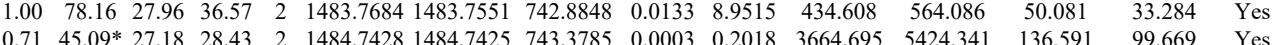

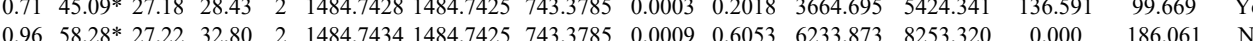

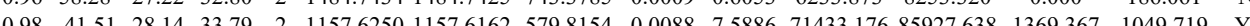
$\begin{array}{lllllllllllllll}0.99 & 41.74 & 28.10 & 34.07 & 2 & 1157.6250 & 1157.6162 & 579.8154 & 0.0088 & 7.5886 & 71433.176 & 85927.638 & 1369.367 & 1049.719 & \text { Yes } \\ & & & & & & & 579.8154 & 0.0096 & 8.2784 & 57833.507 & 59471.669 & 886.069 & 1540.324 & \text { Yes }\end{array}$ 


\section{DPDAGIDAQVEDDAQA}

ALLLLCGEDD GTVTDFPGFDER
GTVTDFPGFDER ALLLLCGEDD GTVTDFPGFDER GTVTDFPGFDER ALLLLCGEDD LYDAYELK

QEISAAFK

QEISAAFK

QEISAAFK

SEIDLFNIR

GTVTDFPGFDER

DPDAGIDEAQVEDEDAQALFAGG

GLGTDEESILTLLTS GLGTDEESILTLLTS GLGTDEESILTLLTS

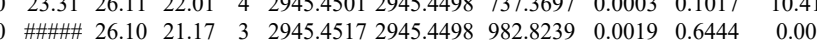
$\begin{array}{lllllllllll}1.00 & 32.53 & 26.05 & 45.53 & 4 & 2945.4541 & 2945.4498 & 737.3697 & 0.0043 & 1.4579 & 5.904\end{array}$

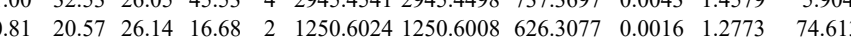
$\begin{array}{llllllllllll}1.00 & 57.78 & 26.19 & 19.31 & 2 & 1483.7098 & 1483.7065 & 742.8605 & 0.0033 & 2.2211 & 2474.234 & 4534 \\ 1.00 & 57.12 & 26.22 & 20.27 & 2 & 1483.7114 & 1483.7065 & 742.8605 & 0.0049 & 3.2981 & 3242.562 & 5779\end{array}$ $\begin{array}{llllllllllllll}1.00 & 57.12 & 26.22 & 20.27 & 2 & 1483.7114 & 1483.7065 & 742.8605 & 0.0049 & 3.2981 & 3242.562 & 57 & & \\ 0.72 & 18.79 & 26.14 & 25.44 & 2 & 1250.6020 & 1250.600 & 6263077 & 0.0012 & 0.9580 & 15.001 & 5 & & \end{array}$ $\begin{array}{lllllllllll}1.00 & 47.65 & 26.14 & 2.14 & 2 & 1250.6020 & 1250.6008 & 626.3077 & 0.0012 & 0.9580 & 15.001\end{array}$

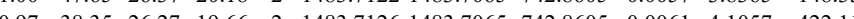
$\begin{array}{lllllllllll}0.77 & 19.59 & 26.214 & 20.50 & 2 & 1250.6024 & 1250.6008 & 6263077 & 0.0016 & 1.2773 & 59.795\end{array}$ $\begin{array}{lllllllllllllll}.77 & 19.59 & 26.14 & 20.50 & 2 & 1250.6024 & 1250.6008 & 626.3077 & 0.0016 & 1.2773 & 59.795 & 78.677 & 83.314 & 54.171 & \text { Yes } \\ 1.00 & 40.81 & 28.34 & 25.67 & 2 & 1301.7126 & 1301.7111 & 651.8628 & 0.0015 & 1.1505 & 12292.042 & 15193.925 & 338.831 & 694.041 & \text { Yes }\end{array}$ $\begin{array}{lllllllllllllll}4.22 & 28.30 & 2.37 & 2 & 1301.7134 & 1301.7111 & 651.8628 & 0.0023 & 1.7642 & 12514.355 & 14046.764 & 893.498 & 752.995 & \text { Yes }\end{array}$ \begin{tabular}{llllllllllllllll}
\hline & 38.91 & 27.07 & 33.31 & 2 & 1180.6758 & 1180.6695 & 591.3420 & 0.0063 & 5.3268 & 4936.111 & 6122.624 & 10084.205 & 2017.874 & Yes
\end{tabular} $\begin{array}{llllllllllllllll}0.99 & 47.02 & 27.25 & 29.69 & 2 & 1180.6764 & 1180.6695 & 591.3420 & 0.0069 & 5.8342 & 6732.180 & 6507.602 & 14988.224 & 2969.016 & \text { Y }\end{array}$ $\begin{array}{lllllllllllllll}100 & 52.37 & 28.85 & 37.86 & 2 & 1249.6826 & 1249.6788 & 625.8467 & 0.0038 & 3.0359 & 13039.668 & 14542.349 & 26406.641 & 2358.235 & \text { Yes }\end{array}$ $\begin{array}{llllllllll}0.53 & \text { \#\#\#\# } 26.15 \text { \#\#\#\# } 3 & 2945.4529 & 2945.4498 & 982.8239 & 0.0031 & 1.0514 & 3.758\end{array}$

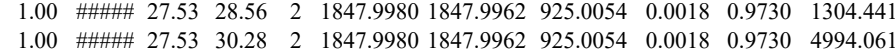
$\begin{array}{lllllllllll}1.00 & 39.55 & 27.61 & 27.43 & 3 & 1847.9992 & 1847.9962 & 625.0054 & 0.0018 & 0.9730 & 4994.061 \\ 1.0060 & 0.0030 & 1.6207 & 120.954\end{array}$ $\begin{array}{cccc}17.628 & 20.927 & 7.966 & \text { Y } \\ 0.000 & 1.417 & 2.687 & \end{array}$ $\begin{array}{llllllllllllllllll} & \text { \#27 }\end{array}$ $\begin{array}{lllllllllllllllll} & \end{array}$ $\begin{array}{lllllllllllllll} & 191.1092 & 1901.1077 & 951.5611 & 0.0015 & 0.7882 & 39.956 & 194.703 & 1511.602 & 1392.078 & \text { Nes }\end{array}$ $\begin{array}{llllllllllllllll} & & & \end{array}$ $\begin{array}{lllllllllllllllll}\text { ETSGNLEQLLLAVVK } & 1.00 & 55.20 & 23.01 & 21.67 & 3 & 1901.1106 & 1901.1077 & 634.7098 & 0.0029 & 1.5230 & 134.946 & 104.027 & 128.543 & 160.86 & \text { No }\end{array}$ $\begin{array}{llllllllllll}\text { ETSGNLEQLLLAVVK } & 1.00 & 47.26 & 23.01 & 21.69 & 3 & 1901.1106 & 1901.1077 & 634.7098 & 0.0029 & 1.5230 & 203.075\end{array}$ $\begin{array}{llllllllllll}\text { GLGTDEESILTLLTSR } & 1.00 & \# \# \# \# 27.53 & 36.10 & 2 & 1847.9980 & 1847.9962 & 925.0054 & 0.0018 & 0.9730 & 316.375\end{array}$ $\begin{array}{lllllllllll}\text { GLGTDEESILTLLTSR } & 1.00 & \text { \#\#\#\# } 27.54 & 27.82 & 2 & 1847.9984 & 1847.9962 & 925.0054 & 0.0022 & 1.1892 & 758.399\end{array}$ $\begin{array}{llllllllllll}\text { ETSGNLEQLLLAVVK } & 1.00 & 85.91 & 23.24 & 21.88 & 2 & 1901.1088 & 1901.1077 & 951.561 & 0.0011 & 0.5780 & 266.831\end{array}$

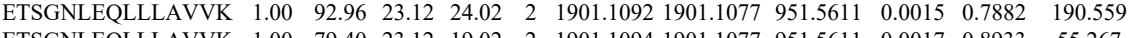
$\begin{array}{lllllllllllll}\text { ETSGNLEQLLLAVVK } & 1.00 & 79.40 & 23.12 & 19.02 & 2 & 1901.1094 & 1901.1077 & 951.5611 & 0.0017 & 0.8933 & 55.267 & 5\end{array}$ $\begin{array}{llllllllllll}\text { ETSGNLEQLLLAVVK } & 1.00 & 32.14 & 23.01 & 17.21 & 3 & 1901.1106 & 1901.1077 & 634.7098 & 0.0029 & 1.5230 & 230.110\end{array}$

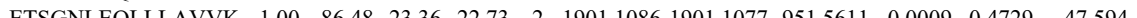

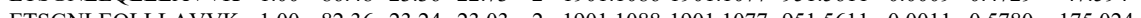
$\begin{array}{llllllllllllll} & \text { ETSGNLELLLAVVK } & 1.00 & 41.70 & 23.01 & 17.78 & 3 & 1901.1100 & 1901 & 1077 & 634.7098 & 0.0023 & 1.2079 & 258.301\end{array}$

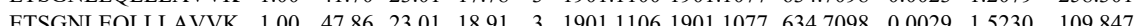
$\begin{array}{llllllllllll}100 & 98.98 & 26.02 & 22.68 & 3 & 2945.4508 & 2945.4498 & 982.8239 & 0.0010 & 0.3392 & 3.380\end{array}$

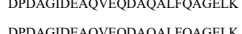
NFATSLYSMIK NFATSLYSMIK NFATSLYSMIK NFATSLYSMIK NFATSLYSMIK NFATSLYSMIK NFATSLYSMI NFATSLYSMIK $\begin{array}{lllllllllll} & 26.02 & 62.35 & 4 & 2945.4509 & 2945.4498 & 737.3697 & 0.0011 & 0.3729 & 13.859\end{array}$ $\begin{array}{llllllllllll}0.97 & 14.33 & 26.12 & 27.33 & 4 & 2945.4520 & 2945.4498 & 982.8239 & 0.0022 & 0.7461 & 0.000\end{array}$ $\begin{array}{llllllllllll}1.00 & 72.98 & 27.60 & 22.33 & 2 & 1561.8442 & 1561.8418 & 781.9282 & 0.0024 & 1.5347 & 9049.651 & 135\end{array}$ $\begin{array}{lllllllllll}1.00 & 63.86 & 27.63 & 29.65 & 2 & 1561.8446 & 1561.8418 & 781.9282 & 0.0028 & 1.7904 & 6033.459\end{array}$ $\begin{array}{lllllllllll}1.00 & 45.77 & 27.64 & 28.77 & 3 & 1561.8451 & 1561.8418 & 521.6212 & 0.0033 & 2.1088 & 199.214\end{array}$ $\begin{array}{llllllllllllll}1.00 & 6.86 & 27.63 & 29.65 & 2 & 1561.8446 & 1561.8418 & 781.9282 & 0.0028 & 1.7904 & 6033.459 & 7785.866 \\ 1.00 & 41.60 & 27.38 & 28.30 & 3 & 1561.8463 & 1561.8418 & 521.6212 & 0.0045 & 2.8756 & 261.650 & 302.414\end{array}$ $\begin{array}{lllllllllllll}1.00 & 48.23 & 27.44 & 29.02 & 2 & 1561.8420 & 1561.8418 & 781.9282 & 0.0002 & 0.1279 & 4538.445 & 5059.946\end{array}$ $\begin{array}{lllllllllllll}1.00 & 57.93 & 27.32 & 24.66 & 2 & 1561.8426 & 1561.8418 & 781.9282 & 0.0008 & 0.5116 & 4922.242 & 4984.939\end{array}$

SIPAYLAETLYYAMK $\begin{array}{lllllllllllll}\text { SIPAYLAETLYYAMK } & 1.00 & 40.15 & 26.95 & 25.77 & 3 & 2021.0818 & 2021.0787 & 674.7002 & 0.0031 & 1.5315 & 146.777 \\ \text { SIPAYLAETLYYAMK } & 1.00 & 44.78 & 26.95 & 25.02 & 3 & 2021.0818 & 2021.0787 & 674.7002 & 0.0031 & 1.5315 & 193.655\end{array}$ SIPAYLAETLYYAMK \begin{tabular}{llllllllllll} 
SIPAYLAETLYYAMK & 1.00 & 86.84 & 27.20 & 24.48 & 2 & 2021.0794 & 2021.0787 & 1011.5466 & 0.0007 & 0.3460 & 1374.705 \\
\hline
\end{tabular}

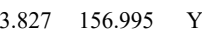
$\begin{array}{llllllllllll}\text { SIPAYLAETLYYAMK } & 1.00 & 88.36 & 26.96 & 24.95 & 2 & 2021.0814 & 2021.0787 & 1011.5466 & 0.0027 & 1.3346 & 1201.862 \\ \text { SIPAYLAETLYYAMK } & 0.99 & 30.80 & 26.92 & 18.82 & 3 & 2021.0824 & 2021.0787 & 674.7002 & 0.0037 & 1.8280 & 134.294\end{array}$ $\begin{array}{llllllllllll}\text { SIPAYLAETLYYAMK } & 1.00 & 63.97 & 26.98 & 27.42 & 3 & 2021.0824 & 2021.08787 & 674.7002 & 0.0037 & 1.8280 & 134.294 \\ \text { SI } & 2021.0787 & 674.7002 & 0.0046 & 2.2726 & 136.495\end{array}$ $\begin{array}{llllllllllll}\text { SIPAYLAETLYYAMK } & 1.00 & 81.95 & 27.20 & 22.28 & 2 & 2021.0794 & 2021.0787 & 1011.5466 & 0.0007 & 0.3460 & 220.709\end{array}$ $\begin{array}{llllllllllll}\text { STAYLAETLYYAMK } & 1.00 & 9.99 & 27.20 & 24.54 & 2 & 2021.074 & 2021.0787 & 1011.5466 & 0.0007 & 0.3460 & 86.879\end{array}$

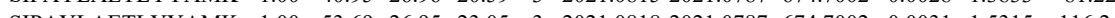

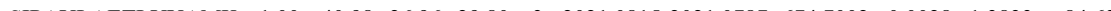
$\begin{array}{lllllllllllll}\text { FITIFGTR } & 0.60 & 20.05 & 26.60 & 23.24 & 2 & 1097.6356 & 1097.6355 & 549.8250 & 0.0001 & 0.0909 & 19.150\end{array}$

$4.960 \quad \mathrm{Y}$

Table S-3 page 104 of 499 


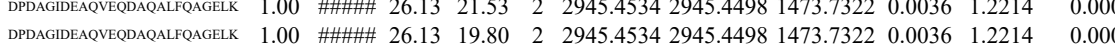
$\begin{array}{lllllllllllll}\text { DPDAGIDEAQVEDDAQALFQAGELK } & 1.00 & 48.64 & 26.13 & 19.15 & 3 & 2945.4535 & 2945.4498 & 982.8239 & 0.0037 & 1.2549 & 5.642\end{array}$ $\begin{array}{lllllllllllll}\text { DPDAGIDEAQVEDAAQLFPAGELK } & 1.00 & 72.78 & 26.13 & 22.05 & 3 & 2945.4535 & 2945.4498 & 982.8239 & 0.0037 & 1.2549 & 1.48\end{array}$ $\begin{array}{lllllllllllll}\text { DPDAGIDEAQVEQDAQALFQAGELK } & 1.00 & 60.42 & 26.06 & 16.89 & 3 & 2945.4550 & 2945.4498 & 982.8239 & 0.0052 & 1.7636 & 0.000\end{array}$ $\begin{array}{lllllllllllll}\text { DPDAGIDEAQVEQDAQALFEAGELK } & 1.00 & 59.50 & 26.12 & 17.84 & 3 & 2945.4562 & 2945.4498 & 982.8239 & 0.0064 & 2.1706 & 0.000\end{array}$ $\begin{array}{llllllllllll}\text { DPDAGIDEAQVEQDAQALFAGGELK } & 0.96 & 14.32 & 26.14 & 15.68 & 4 & 2945.4565 & 2945.4498 & 737.3697 & 0.0067 & 2.2716 & 9.929\end{array}$ $\begin{array}{llllllllllll}\text { DPDAGIDEAQVEQDAQALFAAGELK } & 1.00 & 37.65 & 26.14 & 50.65 & 4 & 2945.4565 & 2945.4498 & 737.3697 & 0.0067 & 2.2716 & 16.870\end{array}$

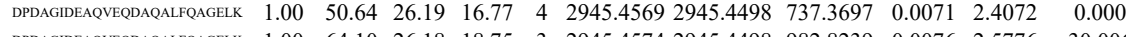
$\begin{array}{llllllllllll}\text { DPDAGIDEAQVEEDAQALFPAGELK } & 1.00 & 64.10 & 26.18 & 18.75 & 3 & 2945.4574 & 2945.4498 & 982.8239 & 0.0076 & 2.5776 & 30.006\end{array}$

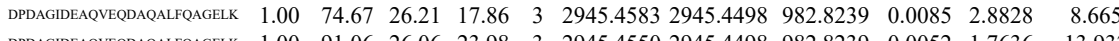

\section{DPAAGIDEAQVEDDAQALFO}

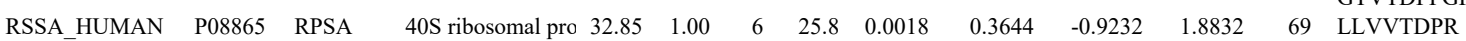

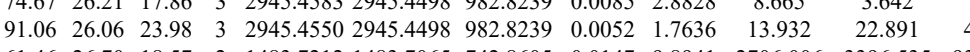

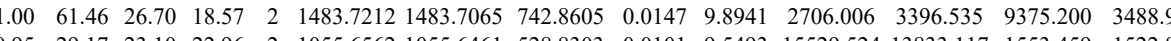



$\begin{array}{lllllllll} & 0\end{array}$

$\begin{array}{llllllllllll} & \end{array}$

$\begin{array}{lllllllllllll}30.62 & 27.66 & 15.75 & 2 & 1841.9558 & 1841.9546 & 921.9846 & 0.0012 & 0.6508 & 37.087 \\ -3.9560 & 1841.9546 & 614.9921 & 0.0014 & 0.7588 & 13.18\end{array}$

$\begin{array}{llllllllllll}1.64 & 27.68 & 23.97 & 2 & 1841.9564 & 1841.9546 & 921.9846 & 0.0018 & 0.9762 & 693.417\end{array}$

$\begin{array}{llllllllllll}.00 & 79.79 & 27.66 & 25.39 & 2 & 1841.9550 & 1841.9546 & 921.9846 & 0.0004 & 0.2169 & 54.2039\end{array}$

$\begin{array}{lllllllllll}1.00 & 65.96 & 27.69 & 22.10 & 2 & 1841.9554 & 1841.9546 & 921.9846 & 0.0008 & 0.4338 & 40.939 \\ 1.00 & 76.14 & 27.69 & 25.30 & 2 & 1841.9554 & 1841.9546 & 921.9846 & 0.0008 & 0.4338 & 37.443\end{array}$

$\begin{array}{llllllllllll}1.00 & 70.64 & 27.63 & 21.93 & 2 & 1841.9556 & 1841.9546 & 921.9846 & 0.0010 & 0.5423 & 51.671\end{array}$

$\begin{array}{llllllllllll}1.98 & 28.16 & 27.66 & 18.40 & 3 & 1841.9560 & 1841.9546 & 614.9921 & 0.0014 & 0.7588 & 22.298 \\ 1.00 & 67.28 & 27.67 & 23.70 & 2 & 1841.9560 & 1841.9546 & 921.9846 & 0.0014 & 0.7592 & 31.234\end{array}$

$\begin{array}{lllllllllll}1.00 & 67.28 & 27.67 & 23.70 & 2 & 1841.9560 & 1841.9546 & 921.9846 & 0.0014 & 0.7592 & 31.234 \\ 1.00 & 87.74 & 27.67 & 24.08 & 2 & 1841.9562 & 1841.9546 & 921.9846 & 0.0016 & 0.8677 & 247.566\end{array}$

$\begin{array}{lllllllllll}1.00 & 87.74 & 27.67 & 24.08 & 2 & 1841.9562 & 841.9546 & 21.9846 & 0.0016 & 0.8677 & 247.566 \\ 1.00 & 55.62 & 27.67 & 21.69 & 2 & 1841.9562 & 1841.9546 & 921.9846 & 0.0016 & 0.8677 & 48.736\end{array}$

$\begin{array}{lllllllllll}1.00 & 70.07 & 27.67 & 22.43 & 2 & 1841.9562 & 1841.9546 & 921.9846 & 0.0016 & 0.8677 & 37.494 \\ 0.55 & 23.75 & 27.67 & 36.75 & 3 & 184.19563 & 1841.9546 & 614.9921 & 0.0017 & 0.9214 & 40.187\end{array}$

$\begin{array}{lllllllllll}1.00 & 9.07 & 27.67 & 2.43 & 2 & 1841.9562 & 1841.9546 & 921.9846 & 0.0016 & 0.8677 & 37.494\end{array}$

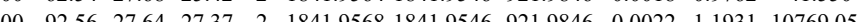

$\begin{array}{lllllllllll}1.00 & 87.79 & 27.64 & 22.30 & 2 & 1841.9568 & 1841.9546 & 921.9846 & 0.0022 & 1.1931 & 211.803\end{array}$

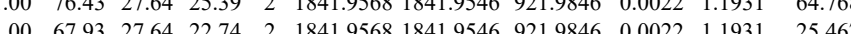

$\begin{array}{llllllllllll}100 & 57.99 & 27.63 & 22.11 & 2 & 1841.9570 & 1841.9546 & 921.9846 & 0.0024 & 1.3015 & 66.748\end{array}$

$\begin{array}{llllllllllll}0.96 & 23.58 & 27.63 & 15.52 & 3 & 1841.9572 & 1841.9546 & 614.9921 & 0.0026 & 1.4092 & 32.791\end{array}$ $\begin{array}{lllllllllllll}0.59 & 13.03 & 27.63 & 14.38 & 3 & 1841.9572 & 1841.9546 & 614.9921 & 0.0026 & 1.4092 & 41.405\end{array}$ $\begin{array}{lllllllllll}1.00 & 61.81 & 27.63 & 23.58 & 2 & 1841.9572 & 1841.9546 & 921.9846 & 0.0026 & 1.4100 & 32.424\end{array}$ $\begin{array}{lllllllllll}0.58 & 13.20 & 27.69 & 15.08 & 3 & 1841.9575 & 1841.9546 & 614.9921 & 0.0029 & 1.5718 & 34.225\end{array}$ $\begin{array}{llllllllllll}1.00 & 82.48 & 27.70 & 23.28 & 2 & 1841.9576 & 1841.9546 & 921.9846 & 0.0030 & 1.6269 & 52.227 \\ 0.80 & 17.02 & 27.63 & 14.38 & 3 & 1841.9578 & 1841.9546 & 614.9921 & 0.0032 & 1.7344 & 33.195\end{array}$ $\begin{array}{lllllllllllll} & \end{array}$ $\begin{array}{lllllllllll}1.00 & 90.84 & 27.72 & 27.35 & 2 & 1841.9586 & 1841.9546 & 921.9846 & 0.0040 & 2.1692 & 25126.320\end{array}$ $\begin{array}{lllllllllll}74.17 & 27.70 & 23.83 & 2 & 1841.9588 & 1841.9546 & 921.9846 & 0.0042 & 2.2777 & 21.092\end{array}$ $\begin{array}{llllllllllll}82.02 & 28.26 & 25.93 & 2 & 1346.7428 & 1346.7428 & 674.3787 & 0.0000 & 0.0000 & 208.147 & 203.165\end{array}$

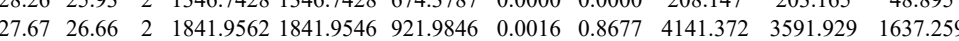
$\begin{array}{lllllllllll}1.00 \text { m } 27.69 & 27.17 & 2 & 1841.9574 & 1841.9546 & 921.9846 & 0.0028 & 1.5185 & 8155.483 & 6687.167 & 2811.122\end{array}$

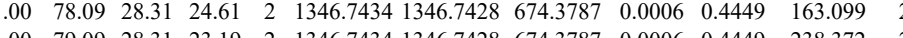
$\begin{array}{llllllllllll} & 23.19 & 2 & 1346.7434 & 1346.7428 & 674.3787 & 0.0006 & 0.4449 & 238.372 & 229.229 & 30.074\end{array}$ \begin{tabular}{llllllllllll}
1.00 & $\#$ \#\#\#\# 27.74 25.12 & 2 & 1841.9544 & 1841.9546 & 921.9846 & -0.0002 & -0.1085 & 2384.302 & 2242.645 & 1114.031 \\
\hline & 2641.9552 & 1841.9546 & 921.9846 & 0.0006 & 0.3254 & 1674.331 & 1686.699 & 767.460
\end{tabular} $\begin{array}{lllllllllllll}1.00 & 32.14 & 27.67 & 20.57 & 3 & 1841.9563 & 1841.9546 & 614.9921 & 0.0017 & 0.9214 & 839.953 & 727.603 & 196.206 \\ 1.00 & 87.07 & 27.62 & 26.11 & 2 & 1841.9546 & 1841.9546 & 921.9846 & 0.0000 & 0.0000 & 540.331 & 631.180 & 206.274\end{array}$ $\begin{array}{lllllllllllll}.00 & 85.83 & 27.63 & 23.73 & 2 & 1841.9556 & 1841.9546 & 921.9846 & 0.0010 & 0.5423 & 783.297 & 644.303 & 280.942\end{array}$ $\begin{array}{lllllllllllll}1.00 & 85.95 & 27.64 & 23.37 & 2 & 1841.9548 & 1841.9546 & 921.9846 & 0.0002 & 0.1085 & 1538.778 & 1264.236 & 634.730\end{array}$

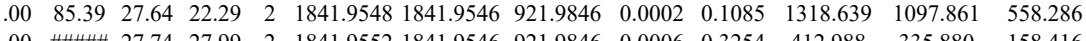

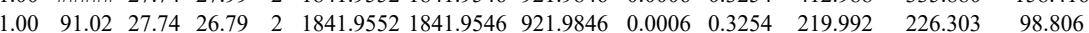

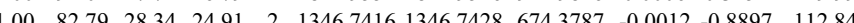


$\begin{array}{lllllllllllll}0.98 & 26.35 & 27.67 & 15.48 & 3 & 1841.9563 & 1841.9546 & 614.9921 & 0.0017 & 0.9214 & 11.636\end{array}$ FTPGTFTNQIQAAF $\begin{array}{lllllllll} & \end{array}$

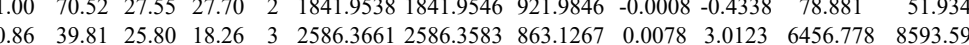
$\begin{array}{lllllllllll} & \end{array}$

$\begin{array}{lllllllllllllll}0.99 & 44.76 & 26.42 & 23.08 & 2 & 1038.6400 & 1038.6317 & 520.3231 & 0.0083 & 7.9757 & 33485.094 & 36070.252 & 2647.309 & 1529 & \end{array}$

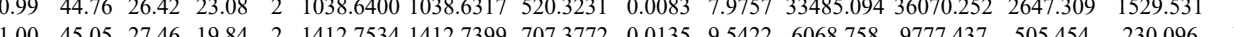

$\begin{array}{llllllllllll} & \end{array}$

$\begin{array}{llllllllllllllll}\text { ALPOQLE } & \end{array}$

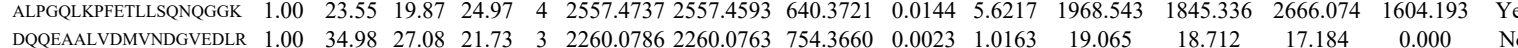

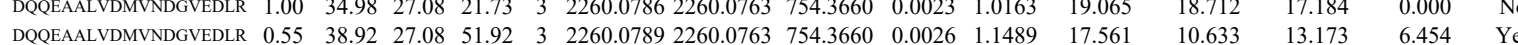
$\begin{array}{llllllllllllllll}\text { ALPGQLKPFETLLSQNQGGK } & 1.00 & 22.69 & 20.25 & 16.06 & 4 & 2557.4713 & 2557.4593 & 640.3721 & 0.0120 & 4.6848 & 3052.002 & 2939.439 & 3544.560 & 1870.098 & \text { Yes }\end{array}$

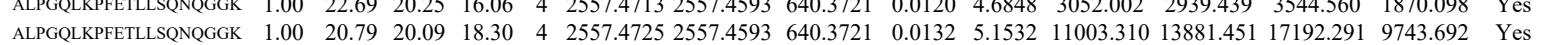

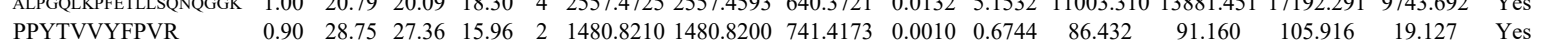

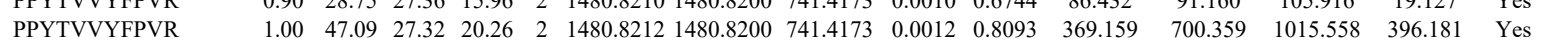
$\begin{array}{lllllllllllllllll}\text { PPYTVVYFPVR } & 0.58 & 49.00 & 27.36 & 62.00 & 2 & 1480.8210 & 1480.8200 & 741.4173 & 0.0010 & 0.6744 & 4221.862 & 6674.480 & 6793.899 & 3575.150 & \text { Yes }\end{array}$ $\begin{array}{llllllllllllllll}\text { PPYTVVYFPVR } & 0.74 & 20.87 & 27.36 & 14.65 & 3 & 1480.8211 & 1480.8200 & 494.6139 & 0.0011 & 0.7413 & 138.044 & 144.274 & 36.930 & 24.738 & \text { No }\end{array}$ $\begin{array}{llllllllllllllll}\text { PPYTVVYFPVR } & 1.00 & 52.95 & 27.32 & 18.58 & 2 & 1480.8212 & 1480.8200 & 741.4173 & 0.0012 & 0.8093 & 10589.785 & 14835.021 & 16170.323 & 9409.305 & \text { Yes }\end{array}$

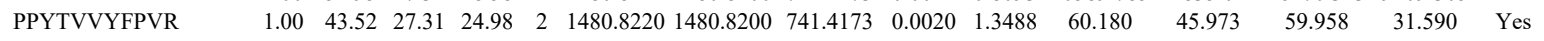
$\begin{array}{lllllllllllllllll}\text { PPYTVVYFPVR } & 0.58 & 38.86 & 27.41 & 51.86 & 2 & 1480.8206 & 1480.8200 & 741.4173 & 0.0006 & 0.4046 & 2842.705 & 4384.228 & 4973.859 & 3120.605 & \text { Yes }\end{array}$ $\begin{array}{llllllllllllllll}\text { PPYTVVYFPVR } & 0.71 & 18.74 & 27.38 & 14.89 & 3 & 1480.8217 & 1480.8200 & 494.6139 & 0.0017 & 1.1457 & 212.427 & 189.260 & 39.543 & 25.694 & \text { No }\end{array}$ PPYTVYTPR TPYTVYTVYR MPPYTVVYFPVR

$\begin{array}{llllllllllll}0.71 & 18.73 & 27.38 & 21.89 & 3 & 1480.8217 & 1480.8200 & 494.6139 & 0.0017 & 1.1457 & 257.852\end{array}$ $\begin{array}{llllllllllll}0.62 & 21.53 & 27.32 & 15.34 & 2 & 1480.8212 & 1480.8200 & 741.4173 & 0.0012 & 0.8093 & 936.659\end{array}$ $\begin{array}{lllllllllll}1.00 & 57.67 & 27.57 & 23.03 & 2 & 1611.8622 & 1611.8605 & 806.9375 & 0.0017 & 1.0534 & 162.292\end{array}$ $\begin{array}{lllllllllllll}1.00 & 65.12 & 27.63 & 26.03 & 2 & 1611.8624 & 1611.8605 & 806.9375 & 0.0019 & 1.1773 & 344.036 \\ 1.00 & 57.42 & 27.63 & 18.36 & 2 & 1611.8620 & 1611.8605 & 806.9375 & 0.0015 & 0.9294 & 102.982\end{array}$ $\begin{array}{ccccccccccc}1.00 & 57.42 & 27.63 & 18.36 & 2 & 1611.8620 & 1611.8605 & 806.9375 & 0.0015 & 0.9294 & 102.982 \\ 0.99 & 40.10 & 27.50 & 23.08 & 2 & 1611.8640 & 1611.8605 & 806.9375 & 0.0035 & 2.1687 & 6.482\end{array}$

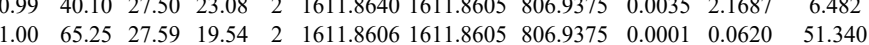

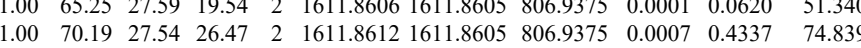
$\begin{array}{lllllllllllll} & \end{array}$ $\begin{array}{lllllllllllll} & \end{array}$ $\begin{array}{lllllllllllll}\text { DQRe } & 27.13 & 21.44 & 3 & 2260.0804 & 2260.0763 & 754.3660 & 0.0041 & 1.8117 & 7.059\end{array}$

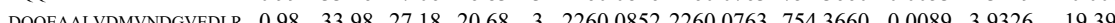

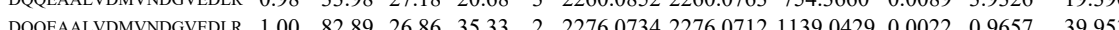

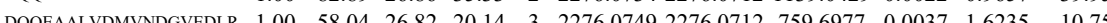

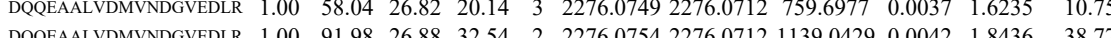

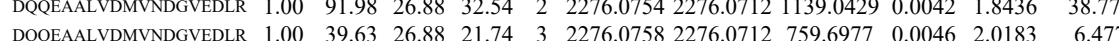
$\begin{array}{lllllllllllll}\text { PPYTVVYFPVR } & 0.99 & 39.91 & 27.38 & 20.17 & 2 & 1480.8216 & 1480.8200 & 741.4173 & 0.0016 & 1.0790 & 68.009\end{array}$ $\begin{array}{llllllllllll}\text { PPYTVVYFPVR } & 0.99 & 42.76 & 27.39 & 23.55 & 2 & 1480.8208 & 1480.8200 & 741.4173 & 0.0008 & 0.5395 & 39.924\end{array}$

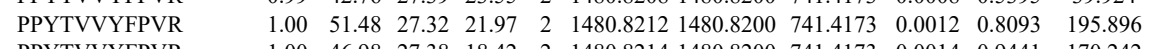
$\begin{array}{llllllllllll}\text { PPYTVVYFPVR } & 1.00 & 46.98 & 27.38 & 18.42 & 2 & 1480.8214 & 1480.8200 & 741.4173 & 0.0014 & 0.9441 & 170.242\end{array}$

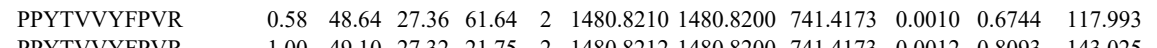

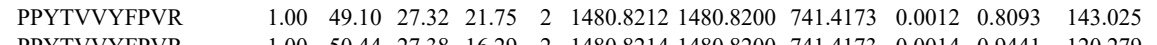
$\begin{array}{llllllllllll}\text { PPYTVVYFPVR } & 1.00 & 50.44 & 27.38 & 16.29 & 2 & 1480.8214 & 1480.8200 & 741.4173 & 0.0014 & 0.9441 & 120.279 \\ \text { PPYTVVYFPVR } & 0.99 & 42.13 & 27.41 & 16.36 & 2 & 1480.8202 & 1480.8200 & 741.4173 & 0.0002 & 0.1349 & 109.506\end{array}$ $\begin{array}{lllllllllllll}\text { PPYTVVYFPVR } & 0.99 & 42.13 & 27.41 & 16.36 & 2 & 1480.8202 & 1480.8200 & 741.4173 & 0.0002 & 0.1349 & 109.506 \\ \text { EEVVTVETWQEGSLK } & 0.90 & 21.41 & 27.44 & 17.37 & 3 & 2021.0575 & 2021.0561 & 674.6926 & 0.0014 & 0.6917 & 27.765\end{array}$ $\begin{array}{lllllllllllll}\text { EEVVTVETWQEGSLK } & 0.97 & 23.83 & 27.33 & 17.51 & 3 & 2021.0581 & 2021.0561 & 674.6926 & 0.0020 & 0.9881 & 72.190\end{array}$ $\begin{array}{lllllllllllll}\text { EEVVTVETWQEGSLK } & 0.99 & 28.28 & 27.35 & 21.49 & 3 & 2021.0587 & 2021.0561 & 674.6926 & 0.0026 & 1.2845 & 50.834\end{array}$ $\begin{array}{llllllllllll}\text { EEVVTVETWQEGSLK } & 1.00 & 41.50 & 27.43 & 28.59 & 3 & 2021.0593 & 2021.0561 & 674.6926 & 0.0032 & 1.5810 & 11.099\end{array}$ $\begin{array}{llllllllllll}\text { EEVVTVETWQEGSLK } & 0.71 & 15.99 & 27.42 & 22.75 & 3 & 2021.0599 & 2021.0561 & 674.6926 & 0.0038 & 1.8774 & 87.870\end{array}$ $\begin{array}{llllllllllll}\text { EEVVTVETWQEGSLK } & 0.91 & 21.41 & 27.42 & 21.31 & 3 & 2021.0599 & 2021.0561 & 674.6926 & 0.0038 & 1.8774 & 19.631\end{array}$ $\begin{array}{llllllllllll}\text { EEVVTVETWQEGSLK } & 0.97 & 25.28 & 27.45 & 21.82 & 3 & 2021.0602 & 2021.0561 & 674.6926 & 0.0041 & 2.0256 & 46.328\end{array}$ $\begin{array}{llllllllllll}\text { EEVVTVETWQEGSLK } & 0.87 & 19.76 & 27.46 & 20.23 & 3 & 2021.0605 & 2021.0561 & 674.6926 & 0.0044 & 2.1738 & 72.326\end{array}$ $\begin{array}{lllllllllllll}\text { EEVVIVETWQEGSK K } & 0.75 & 17.66 & 27.45 & 22.74 & 3 & 2021.0608 & 2021.0561 & 674.6926 & 0.0047 & 2.3220 & 54.403\end{array}$

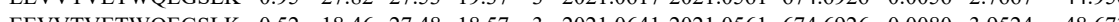

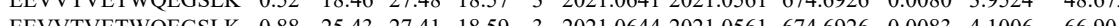

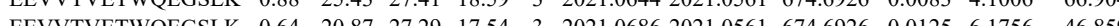

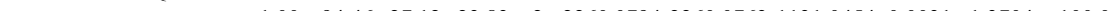
$\begin{array}{lllllllllllll}\text { DQROEALVDMVDGVEDLR } & 1.00 & 85.12 & 27.12 & 23.67 & 2 & 2260.0794 & 2260.0763 & 1131.0454 & 0.0031 & 1.3704 & 100.186\end{array}$

$\begin{array}{lll}185.415 & 51.226 & 19.978\end{array}$



$\begin{array}{lllllllllll} & \end{array}$ $\begin{array}{llllllllllll} & \end{array}$ $\begin{array}{llllllllll} & \end{array}$

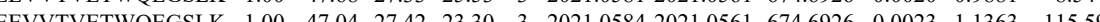
$\begin{array}{llllllllllll} & \end{array}$ $\begin{array}{llllllllllll} & \end{array}$ $\begin{array}{llllllllllllll}\text { EEVVTVETWQEGSLK } & 1.00 & 39.86 & 27.42 & 21.06 & 3 & 2021.0584 & 2021.0561 & 674.6926 & 0.0023 & 1.1363 & 76.479\end{array}$ $\begin{array}{lllllllllllll}\text { EEVVTVETWQEGSLK } & 1.00 & 34.63 & 27.42 & 24.23 & 3 & 2021.0584 & 2021.0561 & 674.6926 & 0.0023 & 1.1363 & 47.115\end{array}$ $\begin{array}{lllllllllllll}\text { EEVVTVETWQEGSLK } & 1.00 & 55.29 & 27.35 & 22.82 & 3 & 2021.0587 & 2021.0561 & 674.6926 & 0.0026 & 1.2845 & 68.602\end{array}$ $\begin{array}{llllllllllll}\text { EEVVTVETWQEGSLK } & 1.00 & 49.15 & 27.35 & 29.63 & 3 & 2021.0587 & 2021.0561 & 674.6926 & 0.0026 & 1.2845 & 75.638\end{array}$ $\begin{array}{lllllllllllll}\text { EEVVTVETWQEGSLK } & 1.00 & 43.05 & 27.35 & 26.65 & 3 & 2021.0587 & 2021.0561 & 674.6926 & 0.0026 & 1.2845 & 67.799\end{array}$ $\begin{array}{lllllllllllll}\text { EEVVTVETWQEGSLK } & 1.00 & 45.23 & 27.35 & 27.43 & 3 & 2021.0587 & 2021.0561 & 674.6926 & 0.0026 & 1.2845 & 44.16\end{array}$ $\begin{array}{lllllllllllll}\text { EEVVTVETWQEGSLK } & 1.00 & 42.83 & 27.35 & 26.59 & 3 & 2021.0587 & 2021.0561 & 674.6926 & 0.0026 & 1.2845 & 54.920\end{array}$ $\begin{array}{llllllllllll}\text { EEVVTVETWQEGSLK } & 1.00 & 31.92 & 27.35 & 15.47 & 3 & 2021.0587 & 2021.0061 & 64.6926 & 0.026 & 1.245 & 15.494 \\ \text { EEVVTVETWQEGSLK } & 1.00 & 43.01 & 27.36 & 27.04 & 3 & 2021.0590 & 2021.0561 & 674.6926 & 0.0029 & 1.4327 & 70.931\end{array}$ $\begin{array}{llllllllllllll}\text { EEVVTVETWQEGSLK } & 1.00 & 42.69 & 27.43 & 24.40 & 3 & 2021.0593 & 2021.0561 & 674.6926 & 0.0032 & 1.5810 & 87.430\end{array}$ $\begin{array}{lllllllllllll} & \text { EEVVTVETWQEGSLK } & 1.00 & 33.11 & 27.43 & 21.31 & 3 & 2021.0593 & 2021.0561 & 674.6926 & 0.0032 & 1.5810 & 58.668\end{array}$ $\begin{array}{lllllllllllll}\text { EEVVTVETWQEGSLK } & 1.00 & 40.27 & 27.43 & 25.99 & 3 & 2021.0593 & 2021.0561 & 674.6926 & 0.0032 & 1.5810 & 71.942\end{array}$

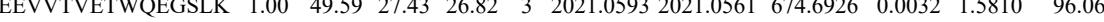

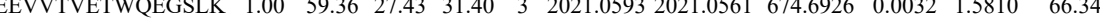

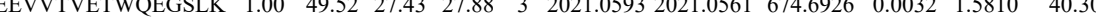
$\begin{array}{llllllllllllll}\text { EEVVTVETWQEGSLK } & 1.00 & 67.16 & 27.42 & 26.47 & 2 & 2021.0594 & 2021.0561 & 1011.5353 & 0.0033 & 1.6312 & 8.262\end{array}$

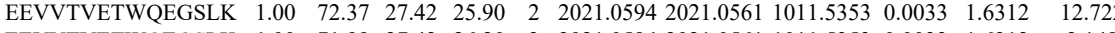
$\begin{array}{llllllllllll}\text { EEVVTVETWQEGSLK } & 1.00 & 71.99 & 27.42 & 26.20 & 2 & 2021.0594 & 2021.0561 & 1011.5353 & 0.0033 & 1.6312 & 2.149\end{array}$ $\begin{array}{llllllllllll}\text { EEVVTVETWQEGSLK } & 1.00 & 61.83 & 27.42 & 23.33 & 2 & 2021.0594 & 2021.0561 & 1011.5353 & 0.0033 & 1.6312 & 9.303\end{array}$

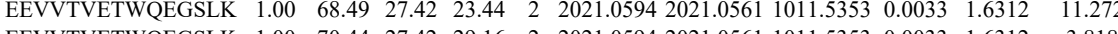

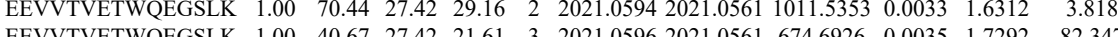

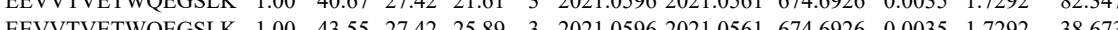
$\begin{array}{lllllllllll} & \text { EEVIVET }\end{array}$

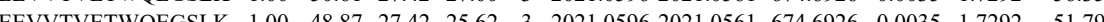
$\begin{array}{lllllllllll} & \end{array}$ $\begin{array}{llllllllllll} & \end{array}$ $\begin{array}{lllllllllll} & \end{array}$ $\begin{array}{lllllllllllllll} & \text { EEVVTVETWQEGSLK } & 1.00 & 44.62 & 27.46 & 25.13 & 3 & 2021.0605 & 2021.0561 & 674.6926 & 0.0044 & 2.1738 & 80.492\end{array}$

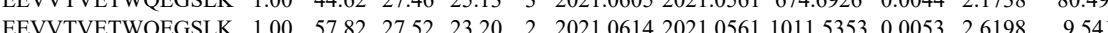

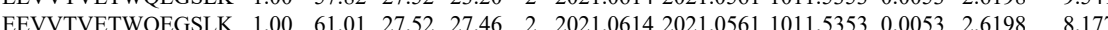
$\begin{array}{lllllllllllll} & \text { EEVVTVETWQEGSLK } & 1.00 & 57.81 & 27.52 & 19.25 & 2 & 2021.0614 & 2021.0561 & 1011.5353 & 0.0053 & 2.6198 & 8.360\end{array}$ $\begin{array}{lllllllllllll} & \text { EEVVTVETWQEGSLK } & 1.00 & 75.15 & 27.48 & 21.85 & 2 & 2021.0634 & 2021.0561 & 1011.5353 & 0.0073 & 3.6084 & 11.053\end{array}$ $\begin{array}{lllllllllllll}\text { EEVVTVETWOEGSLK } & 1.00 & 73.48 & 27.36 & 19.15 & 2 & 2021.0654 & 2021.0561 & 1011.5353 & 0.0093 & 4.5970 & 17.376\end{array}$ $\begin{array}{llllllllllll}\text { EEVVTVETWQEGSLK } & 1.00 & 58.00 & 27.36 & 21.62 & 2 & 2021.0654 & 2021.0561 & 1011.5353 & 0.0093 & 4.5970 & 5.685\end{array}$

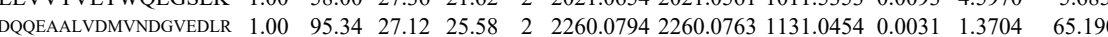
$\begin{array}{lllllllllllll}\text { DQQEAALVDMVNDGVEDLR } & 1.00 & 54.00 & 27.13 & 24.52 & 3 & 2260.0810 & 2260.0763 & 754.3660 & 0.0047 & 2.0768 & 68.874\end{array}$ DQQEAALVDMVNDGVEDLR $1.00 \quad 96.46 \begin{array}{llllllllllll}27.05 & 24.32 & 2 & 2260.0814 & 2260.0763 & 1131.0454 & 0.0051 & 2.2545 & 34.132\end{array}$

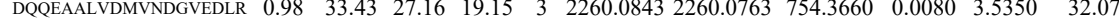


$\begin{array}{lllllllllll}\text { DHPR_HUMAN } & \text { P09417 } & \text { QDPR } & \text { Dihydropteridine 1 25.79 } & 1.00 & 2 & 22.1 & 0.1227 & 0.3297 & 0.1799 & 0.5723\end{array}$

$\begin{array}{lllllllllll}\text { HMGB1_HUMA } & \text { P09429 } & \text { HMGB1 } & \text { High mobility gro } 24.89 & 1.00 & 7 & 32.1 & -0.2252 & 0.3124 & 0.6970 & 0.6008\end{array}$

$\begin{array}{lllllllllllllll}0.97 & 37.38 & 24.71 & 21.08 & 2 & 1164.7182 & 1164.7110 & 583.3628 & 0.0072 & 6.1711 & 11581.087 & 64597.086 & 14020.965 & 11194.357 & \text { Y }\end{array}$ GEVAPDAK

$\begin{array}{lllllllllllllllll}0.98 & 37.67 & 24.70 & 21.42 & 2 & 1164.7192 & 1164.7110 & 583.3628 & 0.0082 & 7.0282 & 11557.654 & 52379.143 & 9623.429 & 6945.198 & \text { Yes }\end{array}$

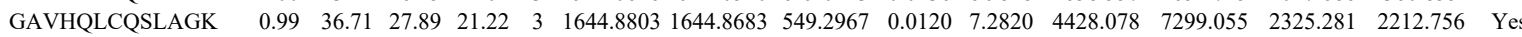

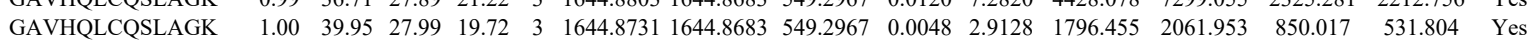
$\begin{array}{lllllllllllllllll}\text { GAVHQLCQSLAGK } & 0.99 & 33.52 & 27.99 & 19.10 & 3 & 1644.8731 & 1644.8683 & 5492967 & 0.0048 & 2.9128 & 2604.090 & 2423.845 & 1291.091 & 1070.741 & \text { Yes }\end{array}$ GEHPGLSIGDVAK GEHPGLSIGDVAK GEHPGLSIGDVAK GEHPGLSIGDVAK GEHPGLSIGDVAK GEHPGLSIGDVAK GEHPGLSIGDVAK GEHPGLSIGDVAK GEHPGLSIGDVAK GEHPGLSIGDVAK GEHPGLSIGDVAK GEHPGLSIGDVAK GEHPGLSIGDVAK GEHPGLSIGDVAK GEHPGLSIGDVAK GEHPGLSIGDVAK GEHPGLSIGDVAK HPDASVNFSEFSK HPDASVNFSEFSK HPDASVNFSEFSK HPDASVNFSEFSK HPDASVISETK KHASVISESK

IKGEHPGLSIGDVAK IKGEHPGLSIGDVAK GEHPGLSIGDVAK GEHPGLSIGDVAK LGEMWNNTAADDK GEHPGLSIGDVAK GEHPGLSIGDVAK LGEMWNNTAADDK GKPDAAK

$\begin{array}{lllllllllllllllll}0.99 & 33.52 & 27.99 & 19.10 & 3 & 1644.8731 & 1644.8683 & 549.2967 & 0.0048 & 2.9128 & 2604.090 & 2423.845 & 1291.091 & 1070.741 & \text { Yes } \\ 0.98 & 3.8 & 27.25 & 15.67 & 3 & 1566.868 & 1566.809 & 52.3294 & 0.059 & 3.7582 & 35.837 & 22.859 & 18.525 & 15.389 & \text { Yes }\end{array}$

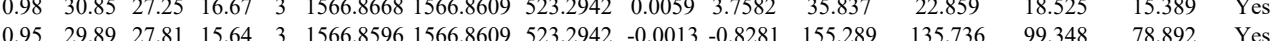

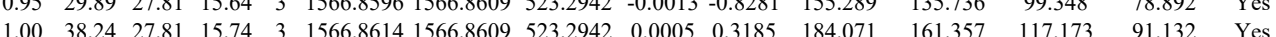
$\begin{array}{lllllllllllllll}1.00 & 36.51 & 27.82 & 16.81 & 3 & 15668617 & 15668609 & 5232942 & 0.0008 & 0.5096 & 61.440 & 89.361 & 50.055 & 42.492 & \text { Yes }\end{array}$ $\begin{array}{lllllllllllllll}0.96 & 25.68 & 27.77 & 19.39 & 3 & 1566.8620 & 1566.8609 & 523.2942 & 0.0011 & 0.7007 & 88.519 & 92.710 & 63.084 & 52.986 & \text { Yes }\end{array}$

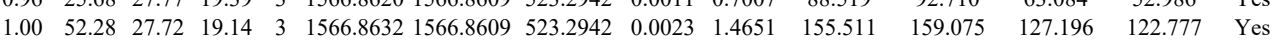

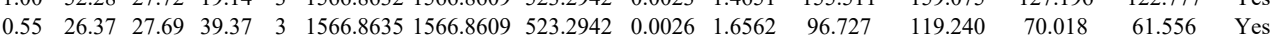

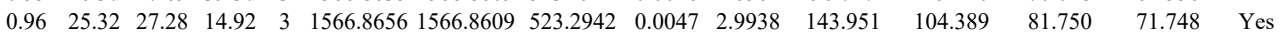
$\begin{array}{lllllllllllllll}1.00 & 75.96 & 27.12 & 23.04 & 2 & 1566.8730 & 1566.8609 & 784.4377 & 0.0121 & 7.7125 & 13591.263 & 11877.525 & 7548.798 & 6626.080 & \text { Yes }\end{array}$

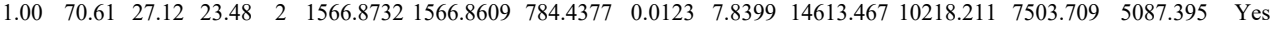
$\begin{array}{llllllllllllllll}1.00 & 49.39 & 27.22 & 16.67 & 3 & 1566.8743 & 1566.8609 & 523.2942 & 0.0134 & 8.5356 & 15485.111 & 12804.896 & 10907.980 & 7689.095 & \text { Yes }\end{array}$ $\begin{array}{lllllllllllllll}1.00 & 72.27 & 27.18 & 21.86 & 2 & 1566.8678 & 1566.8609 & 784.4377 & 0.0069 & 4.3980 & 8996.026 & 6893.129 & 4951.286 & 3620.305 & \text { Yes }\end{array}$ $\begin{array}{llllllllllllllll}1.00 & 61.21 & 27.29 & 25.80 & 2 & 1566.8710 & 1566.8609 & 784.4377 & 0.0101 & 6.4377 & 8865.072 & 7098.405 & 5104.993 & 4637.099 & \text { Yes }\end{array}$ $\begin{array}{lllllllllllllll}1.00 & 54.38 & 27.12 & 19.75 & 3 & 1566.8728 & 1566.8609 & 523.2942 & 0.0119 & 7.5801 & 16097.521 & 13691.837 & 10256.038 & 7571.501 & \text { Yes }\end{array}$

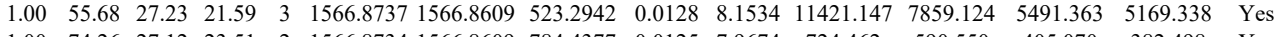
$\begin{array}{lllllllllllllll}1.00 & 74.26 & 27.12 & 23.51 & 2 & 1566.8734 & 1566.8609 & 784.4377 & 0.0125 & 7.9674 & 724.462 & 590.550 & 405.070 & 382.498 & \text { Yes }\end{array}$ $\begin{array}{llllllllllllllll}1.00 & 55.00 & 27.25 & 21.20 & 3 & 1566.8740 & 1566.8609 & 523.2942 & 0.0131 & 8.3445 & 8648.752 & 7092.034 & 3978.465 & 3101.154 & \text { Yes }\end{array}$ $\begin{array}{llllllllllllllll}1.00 & 65.56 & 27.19 & 20.43 & 3 & 1566.8752 & 1566.8609 & 523.2942 & 0.0143 & 9.1089 & 6339.292 & 5096.257 & 2991.703 & 1713.819 & \text { Yes }\end{array}$

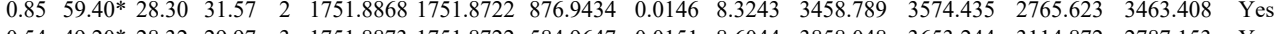
$\begin{array}{lllllllllllllll}0.54 & 49.20 & 28.32 & 29.97 & 3 & 1751.8873 & 1751.8722 & 584.9647 & 0.0151 & 8.6044 & 3858.048 & 3653.244 & 3114.872 & 2787.153 & \text { Yes }\end{array}$ $\begin{array}{lllllllllllllll}0.83 & 74.36 & 28.27 & 43.12 & 2 & 1751.8874 & 1751.8722 & 876.9434 & 0.0152 & 8.6664 & 5648.484 & 3275.512 & 3398.601 & 4304.614 & \text { Yes } \\ 0.91 & 83.73 * & 28.16 & 45.21 & 2 & 1751.8850 & 1751.8722 & 876.9434 & 0.0128 & 7.2980 & 6091.659 & 3564.852 & 3309.517 & 5317.131 & \text { No }\end{array}$

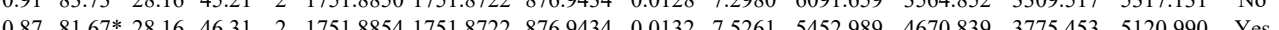

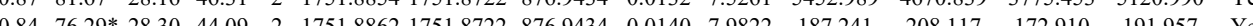

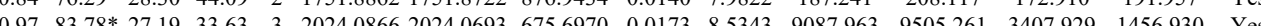
$\begin{array}{lllllllllllllll}0.98 & 18.19 & 22.01 & 16.91 & 4 & 1952.1441 & 1952.1420 & 489.0428 & 0.0021 & 1.0735 & 34.448 & 19.888 & 31.149 & 6.741 & \text { No }\end{array}$ $\begin{array}{lllllllllllllll}0.96 & 20.46 & 19.91 & 33.46 & 4 & 1952.1593 & 1952.1420 & 489.0428 & 0.0173 & 8.8437 & 2570.272 & 2469.979 & 2879.974 & 2041.881 & \text { Yes }\end{array}$ $\begin{array}{lllllllllllllll}1.00 & 36.68 & 27.70 & 20.43 & 3 & 1566.8638 & 1566.8609 & 523.2942 & 0.0029 & 1.8473 & 19.707 & 32.675 & 29.885 & 7.645 & \mathrm{~N} \\ 0.75 & 21.72 & 27.02 & 9 & & \end{array}$

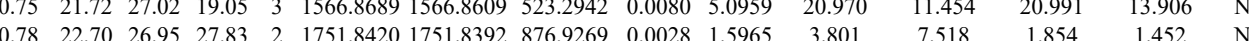

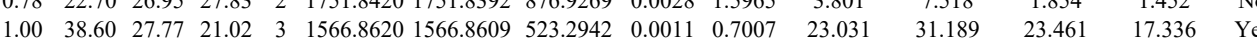

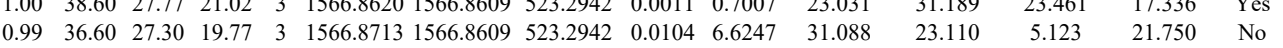

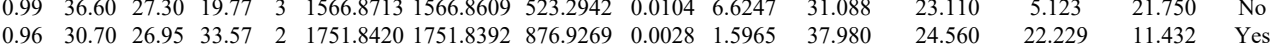

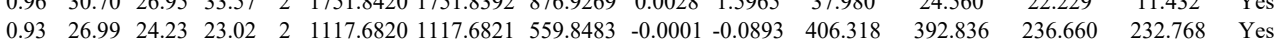
$\begin{array}{lllllllllllllll}0.53 & 26.99 & 27.12 & 18.91 & 3 & 1356.7459 & 1356.7437 & 453.2552 & 0.0022 & 1.6179 & 28955.034 & 25590.132 & 12111.693 & 10018.210 & \text { Yes }\end{array}$

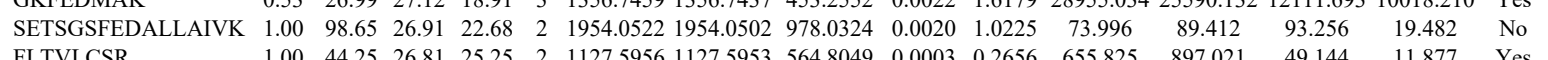
FLTVLCSR FLTVLCSR FLTVLCSR FLTVLCSR FLTVLCSR

NLGLEELGIELDP IDVSIEAASGGK IPNIYAIGDVVAGPMLAH $\begin{array}{llllllllllllllll}\text { ALTGGIAHLFK } & 1.00 & 55.00 & 22.97 & 31.32 & 3 & 1414.8679 & 1414.8540 & 472.6253 & 0.0139 & 9.8033 & 29703.189 & 31778.962 & 1937.586 & 364.734 & \text { Yes } \\ \text { ALTGGIAHLFK } & 1.00 & 48.70 & 22.94 & 22.80 & 3 & 1414.8667 & 1414.8540 & 472.6253 & 0.0127 & 8.9570 & 26984.122 & 24700.060 & 1597.861 & 1057.311 & \text { Yes }\end{array}$

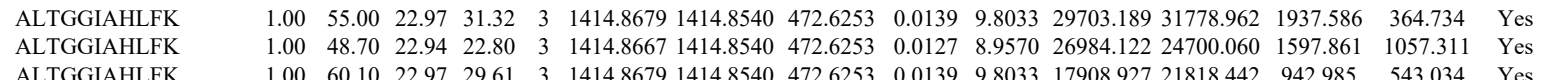
$\begin{array}{lllllllllllllll}1.00 & 44.54 & 26.76 & 27.44 & 2 & 1127.5960 & 127.5953 & 564.8049 & 0.0007 & 0.6197 & 692.910 & 987.351 & 31.465 & 30.280 & \text { Yes }\end{array}$

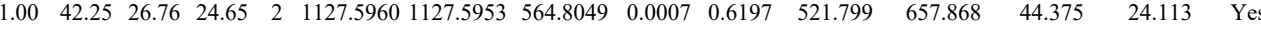

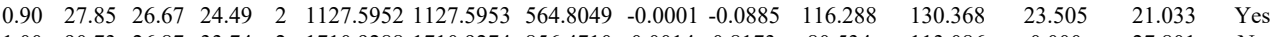

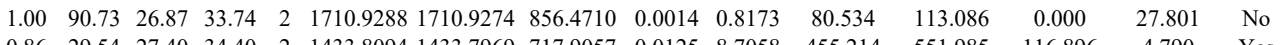

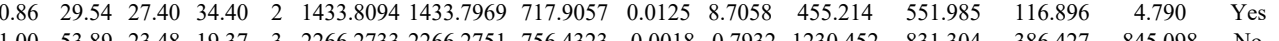

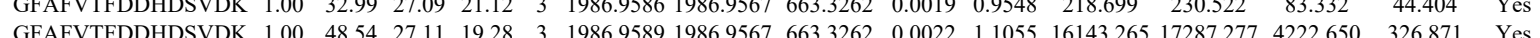

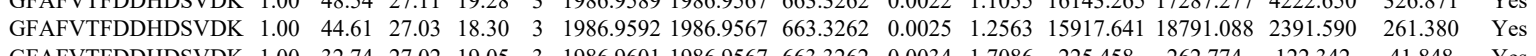

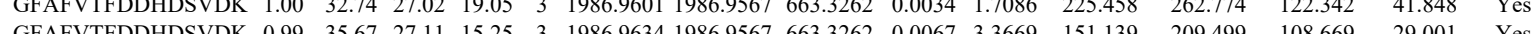
$\begin{array}{llllllllllllllll}\text { GFAFVTFDDHDSVDK } & 0.99 & 34.23 & 27.15 & 15.62 & 3 & 1986.9637 & 1986.9567 & 663.3262 & 0.0070 & 3.5176 & 291.666 & 269.352 & 146.883 & 84.547 & \text { Yes }\end{array}$

Table S-3 page 110 of 49 


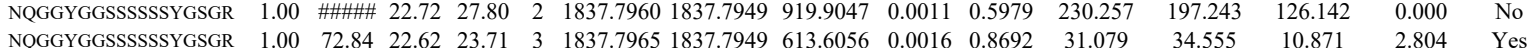

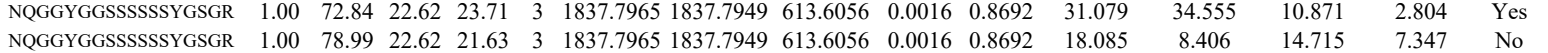

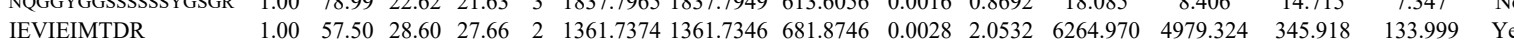

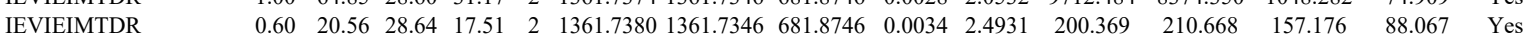
$\begin{array}{lllllllllllllllll}\text { EDSQRPGAHLTVK } & 0.97 & 21.43 & 26.90 & 16.74 & 4 & 1724.9397 & 1724.9413 & 432.2426 & -0.0016 & -0.9254 & 1498.351 & 1703.542 & 2128.823 & 1684.570 & \text { No }\end{array}$

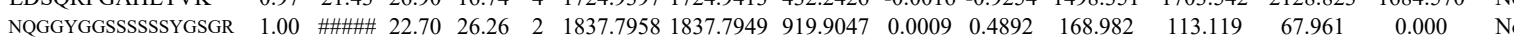

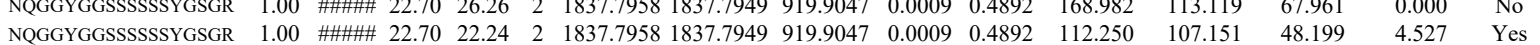
\begin{tabular}{llllllllllllllll} 
NQGGYGGSSSSSSYGSGR & 1.00 & 42.50 & 22.62 & 17.05 & 3 & 1837.7971 & 1837.7949 & 613.6056 & 0.0022 & 1.1951 & 10.280 & 15.262 & 7.320 & 4.122 & Yes \\
\hline
\end{tabular} $\begin{array}{lllllllllllllllll}\text { NQGGYGGSSSSSSYGSGR } & 0.55 & 57.72 & 22.62 & 70.72 & 3 & 1837.7971 & 1837.7949 & 613.6056 & 0.0022 & 1.1951 & 20.801 & 14.676 & 0.000 & 9.598 & \text { No }\end{array}$ $\left.\begin{array}{lllllllllllllll}\text { IEVIEIMTDR } & 1.00 & 64.82 & 28.46 & 31.11 & 2 & 1361.7368 & 1361.7346 & 681.8746 & 0.0022 & 1.6132 & 23819.220 & 22990.176 & 1839.133 & 312.155 \\ \text { IEVIEIMTDR } & 1.00 & 58.99 & 28.6 & 30.96 & 2 & 131.7374 & 1361.7346 & 681.876 & 0.002 & 2.0532 & 1023.164 & 8893.749 & 1054.840 & 91.091\end{array}\right)$

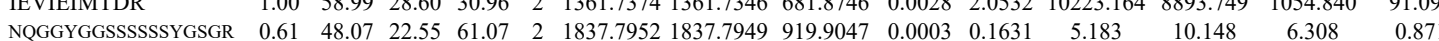

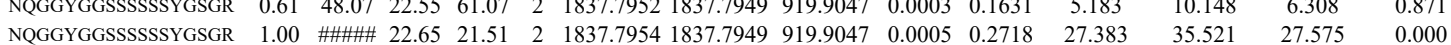
$\begin{array}{lllllllllllllll}\text { IEVIEIMTDR } & 1.00 & 54.21 & 28.65 & 30.55 & 2 & 1361.7372 & 1361.7346 & 681.8746 & 0.0026 & 1.9065 & 16419.297 & 16334.584 & 1055.546 & 364 .\end{array}$

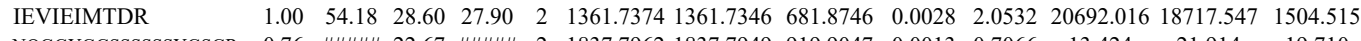
$\begin{array}{llllllllllllll}\text { NQGGYGGSSSSSSYGSGR } & 0.76 & \text { \#\#\#\# } 22.67 & \text { \#\#\#\# } & 2 & 1837.7962 & 1837.7949 & 919.9047 & 0.0013 & 0.7066 & 13.424 & 21.914 & 19.710 \\ \text { IEVIEIMTDR } & 1.00 & 54.41 & 28.48 & 29.50 & 2 & 1361.7366 & 1361.7346 & 681.8746 & 0.0020 & 1.4665 & 4613.591 & 3797.661 & 473.883\end{array}$

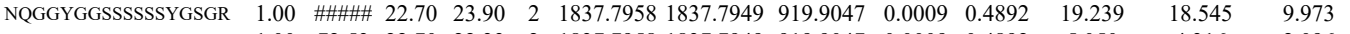
$\begin{array}{lllllllllllllll}\text { NQGGYGGSSSSSSYGSGR } & 1.00 & 72.53 & 22.70 & 22.33 & 2 & 1837.7958 & 1837.7949 & 919.9047 & 0.0009 & 0.4892 & 5.050 & 4.316 & 2.096\end{array}$ NQGGYGGSSSSSSYGSGR $\begin{array}{llllllllll}1.00 & \# \# \# \# 22.58 & 23.28 & 2 & 1837.7966 & 1837.7949 & 919.9047 & 0.0017 & 0.9240 & 34.862\end{array}$ $\begin{array}{lllllllllllll}\text { NQGGYGGSSSSSSYGSGR } & 1.00 & 99.56 & 22.83 & 26.66 & 2 & 1837.7980 & 1837.7949 & 919.9047 & 0.0031 & 1.6850 & 13.430 & 9.7 \\ \text { LFIGGLSFETTDESLR } & 1.00 & 88.86 & 27.71 & 22.48 & 2 & 1928.0016 & 1928.0013 & 965.0079 & 0.0003 & 0.1554 & 4023.573 & 3997\end{array}$ $\begin{array}{lllllllllllll}\text { LFIGGLSFETTDESLR } & 1.00 & 88.86 & 27.71 & 22.48 & 2 & 1928.0016 & 1928.0013 & 965.0079 & 0.0003 & 0.1554 & 4023.573 & 3974.8 \\ \text { LFIGGLSFETTDESLR } & 1.00 & 34.14 & 27.45 & 18.57 & 3 & 1928.0038 & 1928.0013 & 643.6744 & 0.0025 & 1.2946 & 545.822 & 499.6\end{array}$ $\begin{array}{llllllllllllll}\text { LFIGGLSFETTDESLR } & 1.00 & 58.40 & 27.44 & 20.74 & 3 & 1928.0053 & 1928.0013 & 643.6744 & 0.0040 & 2.0714 & 522.693 & 660.4\end{array}$ $\begin{array}{llllllllllllll}\text { LFIGGLSFETTDESLR } & 1.00 & 94.57 & 27.47 & 41.91 & 2 & 1928.0072 & 1928.0013 & 965.0079 & 0.0059 & 3.0570 & 558.234 & 503.0 \\ \text { LFIGGLSFETTDESLR } & 1.00 & 48.69 & 27.39 & 22.26 & 3 & 1928.0083 & 1928.0013 & 643.6744 & 0.0070 & 3.6250 & 17.996 & 24.72\end{array}$ $\begin{array}{lllllllllllll}\text { LFIGGLSFETTDESLR } & 1.00 & 48.69 & 27.39 & 22.26 & 3 & 1928.0083 & 1928.0013 & 643.6744 & 0.0070 & 3.6250 & 17.996 & 24.7\end{array}$

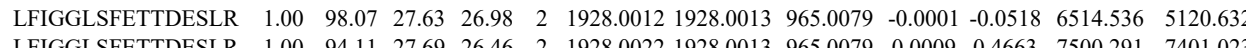
$\begin{array}{llllllllllllll}\text { LFIGGLSFETIDESLR } & 1.00 & 94.11 & 27.69 & 26.46 & 2 & 1928.0022 & 1928.0013 & 965.0079 & 0.0009 & 0.4663 & 7500.291 & 7401.023\end{array}$

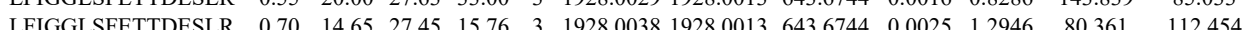
$\begin{array}{lllllllllllll}\text { LFIGGLSFETTDESLR } & 0.55 & 39.59 & 27.45 & 52.59 & 3 & 1928.0038 & 1928.0013 & 643.6744 & 0.0025 & 1.2946 & 31.310 & 42.862\end{array}$ $\begin{array}{llllllllllllll}\text { LFIGGLSFETTDESLR } & 1.00 & 73.85 & 27.50 & 41.51 & 2 & 1928.0040 & 1928.0013 & 965.0079 & 0.0027 & 1.3990 & 243.519 & 234.926\end{array}$ $\begin{array}{llllllllllllll}\text { LFIGGLSFETTDESLR } & 1.00 & 64.75 & 27.50 & 22.46 & 3 & 1928.0041 & 1928.0013 & 643.6744 & 0.0028 & 1.4500 & 355.674 & 24.926\end{array}$

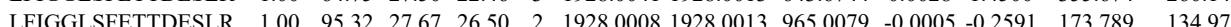
$\begin{array}{llllllllllllll}\text { LFIGGLSFETTDESLR } & 1.00 & 94.78 & 27.69 & 23.15 & 2 & 1928.0014 & 1928.0013 & 965.0079 & 0.0001 & 0.0518 & 248.398 & 235.875\end{array}$

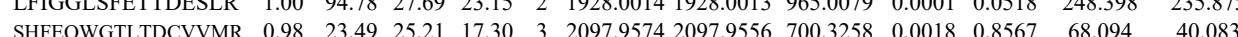
$\begin{array}{llllllllllllll}\text { SHFEOWGTLTDCVVMR } & 0.55 & 35.43 & 25.17 & 48.43 & 3 & 2097.9580 & 2097.9556 & 700.3258 & 0.0024 & 1.1423 & 179.159 & 147.398\end{array}$ $\begin{array}{llllllllllllll}\text { SHFEOWGTLTDCVVMR } & 0.99 & 26.41 & 25.17 & 19.12 & 3 & 2097.9580 & 2097.9556 & 700.3258 & 0.0024 & 1.1423 & 122.518 & 126.949\end{array}$ $\begin{array}{lllllllllllll}\text { SHFEQWGTLTDCVVMR } & 0.53 & 33.79 & 25.13 & 46.79 & 3 & 2097.9586 & 2097.9556 & 700.3258 & 0.0030 & 1.4279 & 88.568 & 58.847\end{array}$ $\begin{array}{llllllllllllll}\text { SHFEQWGTLTDCVVMR } & 1.00 & 52.37 & 25.30 & 19.13 & 3 & 2097.9601 & 2097.9556 & 700.3258 & 0.0045 & 2.1419 & 181.779 & 1.77 .136\end{array}$ $\begin{array}{llllllllllllll}\text { SHFEQWGTLTDCVVMR } & 1.00 & 59.72 & 25.34 & 24.03 & 3 & 2097.9610 & 2097.9556 & 700.3258 & 0.0054 & 2.5702 & 150.638 & 146.859\end{array}$ $\begin{array}{lllllllllllllll}\text { SHFEQWGTLTDCVVMR } & 0.55 & 39.47 & 25.20 & 52.47 & 3 & 2097.9577 & 2097.9556 & 700.3258 & 0.0021 & 0.9995 & 4675.742 & 3934.362\end{array}$ $\begin{array}{llllllllllllll}\text { SHFEOWGTLTDCVVMR } & 1.00 & 34.59 & 25.13 & 16.40 & 3 & 2097.9586 & 2097.9556 & 700.3258 & 0.0030 & 1.4279 & 36.046\end{array}$ IEVIEIMTDR $\begin{array}{llllllllllll}0.97 & 32.18 & 28.48 & 21.93 & 2 & 1361.7366 & 1361.7346 & 681.8746 & 0.0020 & 1.4665 & 32.266\end{array}$

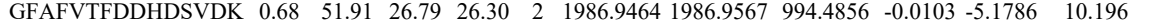
$\begin{array}{lrl}34.362 & 891.297 \\ 5.945 & 25.93 \\ 4.411 & 7.611\end{array}$ $\begin{array}{lllllllllllllll}\text { GFAFVTFDDHDSVDK } & 0.99 & 31.85 & 27.06 & 15.36 & 3 & 1986.9577 & 1986.9567 & 663.3262 & 0.0010 & 0.5025 & 335.155 & 344.993 & 116.633\end{array}$

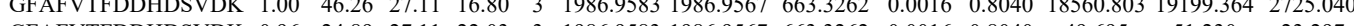
$\begin{array}{lllllllllllllll}\text { GFAFVTFDDHDSVDK } & 0.96 & 24.89 & 27.11 & 22.03 & 3 & 1986.9583 & 1986.9567 & 663.3262 & 0.0016 & 0.8040 & 49.695 & 51.230 & 23.297\end{array}$ $\begin{array}{lllllllllllllll}\text { GFAFVTFDDHDSVDK } & 0.98 & 24.93 & 27.11 & 15.24 & 3 & 1986.9589 & 1986.9567 & 663.3262 & 0.0022 & 1.1055 & 314.146 & 359.884 & 113.962\end{array}$ $\begin{array}{llllllllllllll}\text { GFAFVTFDDHDSVDK } & 1.00 & 72.98 & 27.03 & 25.94 & 2 & 1986.9590 & 1986.9567 & 994.4856 & 0.0023 & 1.1564 & 951.243 & 1341.487 & 245.846\end{array}$ $\begin{array}{llllllllllllll}\text { GFAFVTFDDHDSVDK } & 1.00 & 59.88 & 27.03 & 18.21 & 3 & 1986.9592 & 1986.9567 & 663.3262 & 0.0025 & 1.2563 & 2175.468 & 2121.199 & 366.652 \\ \text { GFAFVTFDDHDSVDK } & 1.00 & 38.10 & 27.05 & 16.11 & 3 & 1986.9595 & 1986.9567 & 663.3262 & 0.0028 & 1.4070 & 141.797 & 152.755 & 59.848\end{array}$ $\begin{array}{lllllllllllllll}\text { GFAFVTFDDHDSVDK } & 1.00 & 38.10 & 27.05 & 16.11 & 3 & 1986.9595 & 1986.9567 & 663.3262 & 0.0028 & 1.4070 & 141.797 & 152.755 & 59.848\end{array}$

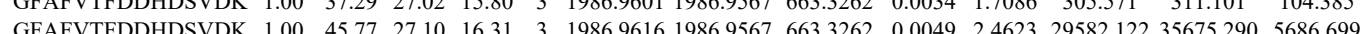

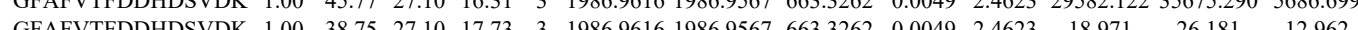
$\begin{array}{lllllllllllll} & \text { GFAFA }\end{array}$

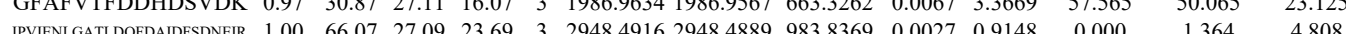




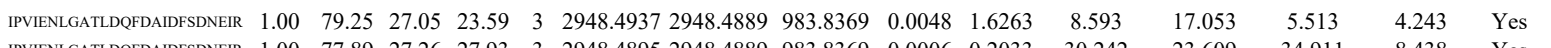

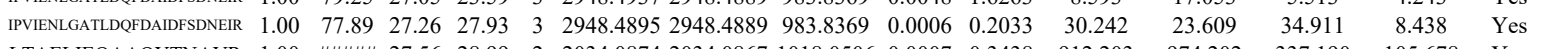

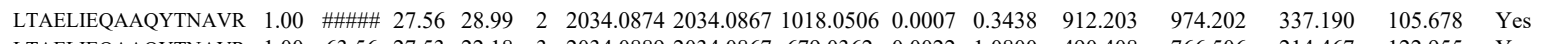

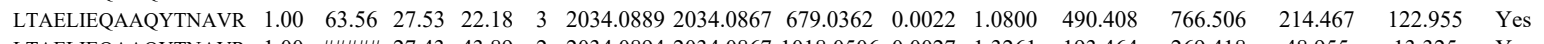

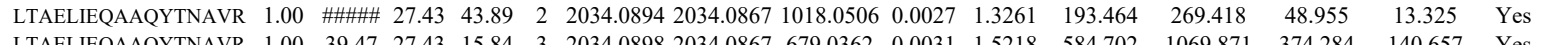

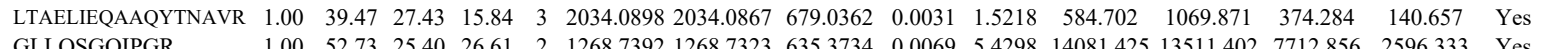

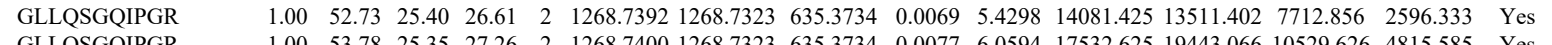
\begin{tabular}{llllllllllllllll} 
GLLQSGQIPGR & 1.00 & 53.78 & 25.35 & 27.26 & 2 & 1268.7400 & 1268.7323 & 635.3734 & 0.0077 & 6.0594 & 17532.625 & 19443.066 & 10529.626 & 4815.585 & Yes \\
\hline GLPSGPGR & 1.00 & 53.09 & 25.25 & 28.84 & 2 & 1268.7406 & 1268.7323 & 635.3734 & 0.0083 & 6.5315 & 13960.051 & 15765.574 & 8472.447 & 344.011 & Yes
\end{tabular}

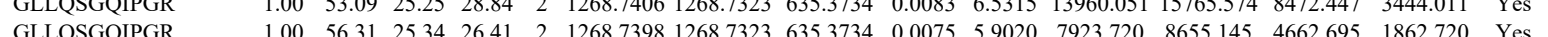

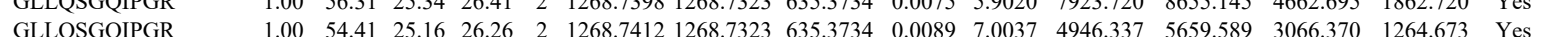

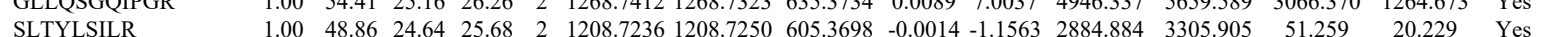
SLTYLSLR SLTYLSILR

SLTYLSILR GGPSPGDVEAIK GGPSPGDVEAIK

AEPVEVVAPR QQVPSGESAILDR LEQMPSK

TLGDFAAEYAK TLGDFAAEYAK TLGDFAAEYAK TLGDFAAEYAK

MVDPEKPQLGMIDR MVDPEKPQLGMI

MIFDVESMK

VFSATLGLVDIVK

VFSATLGLVDIVK

VFSATLGLVDIVK
VFSATLGLVDIVK

VFSATLGLVDIVK

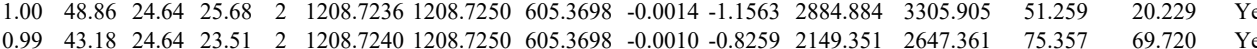

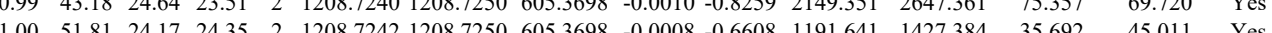
$\begin{array}{lllllllllllllll}0.99 & 43.61 & 24.17 & 24.10 & 2 & 1208.7242 & 12087250 & 6053698 & 0.0008 & 0.6608 & 1366800 & 1561.267 & 28.444 & 10.394 & \text { Yes }\end{array}$ $\begin{array}{lllllllllllllll}0.99 & 43.61 & 24.17 & 24.10 & 2 & 108.7242 & 1288.7250 & 05.368 & 0.008 & 0.608 & 1191.641 & 1427.384 & 35.692 & 45.011 & \text { Yes } \\ 1.00 & 70.58 & 27.56 & 29.17 & 2 & 1413.7832 & 1413.7707 & 707.8926 & 0.0125 & 8.8289 & 686.137 & 705.167 & 603.374 & 639.604 & \text { Yes }\end{array}$ $\begin{array}{lllllllllllllll}1.00 & 71.25 & 27.51 & 28.42 & 2 & 1413.7842 & 1413.7707 & 707.8926 & 0.0135 & 9.5353 & 559.059 & 639.746 & 416.333 & 642.563 & \text { No }\end{array}$

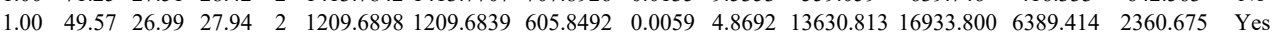
$\begin{array}{llllllllllllllll}1.00 & 64.10 & 27.80 & 34.23 & 2 & 1542.8252 & 1542.8124 & 772.4135 & 0.0128 & 8.2856 & 2128.963 & 1966.058 & 1122.908 & 520.013 & \text { Yes }\end{array}$ $\begin{array}{lllllllllllllll}1.00 & 65.31 & 27.69 & 39.08 & 2 & 1542.8258 & 1542.8124 & 772.4135 & 0.0134 & 8.6740 & 3290.230 & 3072.641 & 1558.114 & 667.661 & \text { Yes }\end{array}$ $\begin{array}{llllllllllllllll}1.00 & 40.17 & 28.42 & 29.82 & 2 & 1119.6218 & 1119.6201 & 560.8173 & 0.0017 & 1.5156 & 16317.194 & 15102.318 & 5119.645 & 2738.304 & \text { Yes }\end{array}$ $\begin{array}{lllllllllllllll}1.00 & 78.08 & 28.38 & 28.89 & 2 & 1472.7810 & 1472.7755 & 737.3950 & 0.0055 & 3.7293 & 2752.869 & 2826.994 & 0.000 & 108.834 & \text { No }\end{array}$ $\begin{array}{llllllllllllllll}1.00 & 71.71 & 28.46 & 24.81 & 2 & 1472.7826 & 1472.7755 & 737.3950 & 0.0071 & 4.8142 & 979.092 & 1163.885 & 8.304 & 25.451 & \text { Yes }\end{array}$

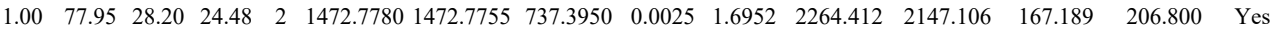
$\begin{array}{lllllllllllllll}1.00 & 72.39 & 28.13 & 19.75 & 2 & 1472.7792 & 1472.7755 & 737.3950 & 0.0037 & 2.5088 & 1029.908 & 1191.111 & 180.212 & 123.612 & \text { Yes }\end{array}$

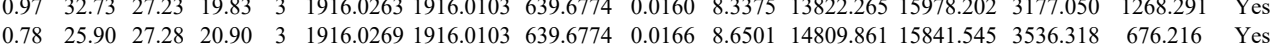
$\begin{array}{llllllllllllllllll}1.00 & 50.91 & 27.23 & 28.83 & 2 & 1386.7248 & 1386.7131 & 694.3638 & 0.0117 & 8.4249 & 10673.577 & 11726.033 & 153.799 & 232.146 & \text { Yes }\end{array}$ $\begin{array}{llllllllllllllll}1.00 & 52.50 & 27.20 & 26.46 & 2 & 1386.7250 & 1386.7131 & 694.3638 & 0.0119 & 8.5689 & 11993.752 & 12589.291 & 0.000 & 311.550 & \text { No }\end{array}$

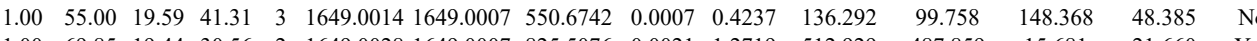
$\begin{array}{lllllllllllllll}1.00 & 69.85 & 19.44 & 30.56 & 2 & 1649.0028 & 1649.0007 & 825.5076 & 0.0021 & 1.2719 & 512.929 & 487.859 & 15.681 & 21.660 & \text { Yes }\end{array}$ $\begin{array}{lllllllllllllll}0.90 & 28.38 & 19.03 & 34.12 & 3 & 1649.0035 & 1649.0007 & 550.6742 & 0.0028 & 1.6949 & 138.648 & 184.929 & 177.067 & 74.228 & \text { Yes }\end{array}$

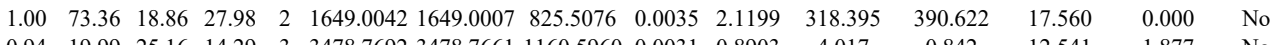

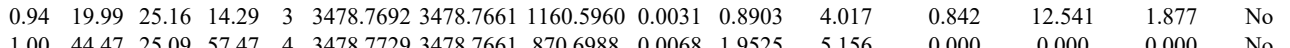

FYTLIPHDFGMK FYTLIPHDFGMK
FYTLIPHDFGMK FYTLIPHDFGMK TYTLFOTK

WYHPGCFVK

WYHPGCFVK
WYHPGCFVK

LIWHGSR

LLWHFAGR

TTNFAGILSQGLR

TTNFAGILSOGLR

TTNFAGILSQGLR

TTNFAGILSQGLR

TTNFAGILSQGLR

TTNFAGILSQGLR

TTNFAGILSQGLR

KGDEVDGVDEVAK

KGDEVDGVDEVAK

LQLLEDDKENR

LQLLEDDKENR

GGAADVDPGLEHSAHVLEK GGAAVDPDSGLEH
AEPVEVVAPR AEPVEVVAPR

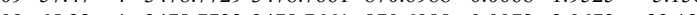

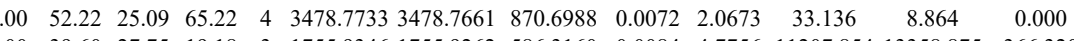
$\begin{array}{lllllllllllll}1.00 & 39.60 & 27.75 & 19.18 & 3 & 1755.9346 & 1755.9262 & 586.3160 & 0.0084 & 4.7756 & 11207.854 & 13358.875 & 366.320\end{array}$

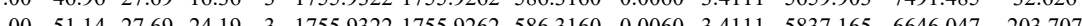

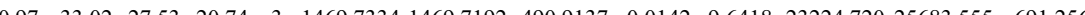
$\begin{array}{llllllllllllllll}0.94 & 29.51 & 27.39 & 22.90 & 3 & 1469.7313 & 1469.7192 & 490.9137 & 0.0121 & 8.64159 & 20867.722 & 23727.352 & 131.289 & 4\end{array}$

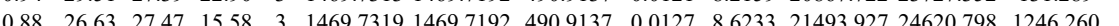
$\begin{array}{lllllllllllllll}0.93 & 27.29 & 25.89 & 26.11 & 2 & 1011.5762 & 1011.5736 & 506.7941 & 0.0026 & 25651 & 4905.432 & 6012.899 & 254.207 & 109\end{array}$ $\begin{array}{llllllllllllll}1.00 & 80.84 & 27.57 & 26.49 & 2 & 1520.8430 & 1520.8433 & 761.4289 & -0.0003 & -0.1970 & 540.582 & 559.207 & 54.564 & 0.00\end{array}$ $\begin{array}{lllllllllllllll}1.00 & 75.06 & 27.78 & 25.20 & 2 & 1520.8446 & 1520.8433 & 761.4289 & 0.0013 & 0.8537 & 1552.284 & 1762.512 & 32.565 & 27.532\end{array}$ $\begin{array}{lllllllllllllll}0.99 & 28.48 & 27.72 & 26.84 & 3 & 1520.8453 & 1520.8433 & 507.9550 & 0.0020 & 1.3125 & 130.643 & 103.043 & 53.492 & 16.372\end{array}$ $\begin{array}{llllllllllllll}0.95 & 22.81 & 27.71 & 19.66 & 3 & 1520.8456 & 1520.8433 & 507.9550 & 0.0023 & 1.5093 & 126.318 & 141.508 & 27.565 & 18.939\end{array}$

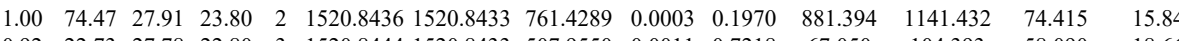

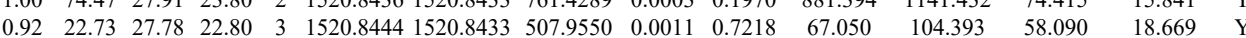
$\begin{array}{lllllllllllllll}0.99 & 29.37 & 27.71 & 15.89 & 3 & 1520.8456 & 1520.8433 & 507.9550 & 0.0023 & 1.5093 & 91.783 & 125.751 & 46.256 & 23.547 & \text { Yes }\end{array}$ $\begin{array}{lllllllllllllll}1.00 & 61.85 & 27.92 & 22.27 & 2 & 1520.8440 & 1520.8433 & 761.4289 & 0.0007 & 0.4597 & 105.438 & 120.232 & 25.610 & 9.765 & \text { Yes }\end{array}$ $\begin{array}{lllllllllllllll}1.00 & 66.50 & 27.76 & 25.43 & 3 & 1791.9670 & 1791.9580 & 598.3266 & 0.0090 & 5.0140 & 8897.748 & 10487.004 & 3464.905 & 1973.065 & \text { Yes } \\ 1.00 & 58.19 & 27.77 & 26.60 & 3 & 1791.9673 & 1791.9580 & 598.326 & 0.093 & 5.1811 & 8233.047 & 7629.965 & 4274.082 & 1419.545 & \text { Y }\end{array}$ $\begin{array}{lllllllllllllll}1.00 & 58.19 & 27.77 & 26.60 & 3 & 1791.9673 & 1791.9580 & 598.3266 & 0.0093 & 5.1811 & 8233.047 & 7629.965 & 4274.082 & 1419.545 & \text { Yes } \\ 0.89 & 37.63 & 27.81 & 19.64 & 3 & 1659.9085 & 1659.9035 & 554.3084 & 0.0050 & 3.0067 & 9871.819 & 11399.350 & 952.412 & 1149.560 & \text { Yes }\end{array}$ $\begin{array}{llllllllllllllllll}0.91 & 38.36 & 27.81 & 16.89 & 3 & 1659.9085 & 1659.9035 & 554.3084 & 0.0050 & 3.0067 & 16589.276 & 17189.558 & 1575.254 & 1158.371 & \text { Yes }\end{array}$ $\begin{array}{llllllllllllllll}1.00 & 41.89 & 27.21 & 54.89 & 4 & 2276.1741 & 2276.1641 & 570.0483 & 0.0100 & 4.3856 & 1813.567 & 1974.174 & 1032.804 & 1663.223 & \mathrm{~N} 0\end{array}$

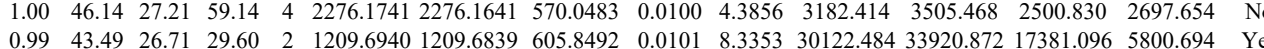
$\begin{array}{lllllllllllllll}0.99 & 43.49 & 26.71 & 29.60 & 2 & 1209.6940 & 1209.6839 & 605.8492 & 0.0101 & 8.3353 & 30122.484 & 33920.872 & 17381.096 & 5800.694 & \text { Yes } \\ 1.00 & 50.72 & 26.89 & 20.64 & 2 & 1209.6952 & 1209.6839 & 055.8492 & 0.0113 & 9.3257 & 27504.542 & 32250.132 & 15092.353 & 549.424 & \text { Yes }\end{array}$ $\begin{array}{llllllllllllllll} & 1.00 & 50.72 & 26.89 & 20.64 & 2 & 1209.6952 & 1209.6839 & 655.8492 & 0.0113 & 9.3257 & 27504.542 & 32250.132 & 15092.353 & 5497.424 & \text { Yes }\end{array}$ $\begin{array}{llllllllllllllll}\text { LVVDLTDIPDAYSVYEK } & 0.96 & 22.45 & 26.87 & 16.81 & 3 & 2625.3685 & 2625.3669 & 876.1296 & 0.0016 & 0.6087 & 84.341 & 151.680 & 80.626 & 98.370 & \text { No }\end{array}$

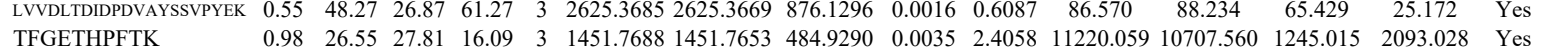

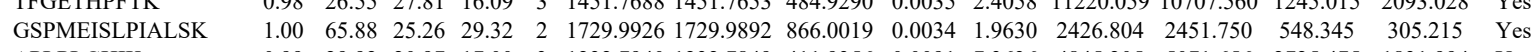
APLPLGHK APLPLGHIK APPLOHT

ASMHPVTAMLVGK

ASMHPVTAMLVGK $\begin{array}{llllllllllllllll}0.99 & 29.92 & 20.97 & 17.00 & 3 & 1232.7940 & 1232.7849 & 411.9356 & 0.0091 & 7.3636 & 4845.205 & 5071.656 & 2725.475 & 1831.994 & \text { Yes } \\ 1.00 & 46.04 & 18.20 & 19.56 & 3 & 1232.7946 & 1232.7849 & 411.9356 & 0.0097 & 7.8491 & 9420.088 & 12158.086 & 5600.325 & 3297.953 & \text { Yes }\end{array}$

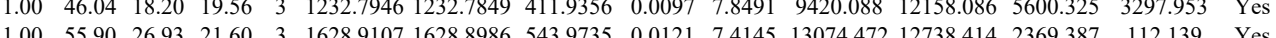

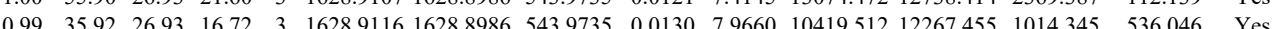
$\begin{array}{lllllllllllllll}1.00 & 50.92 & 26.79 & 16.83 & 3 & 1628.9137 & 1628.8986 & 543.9735 & 0.0151 & 9.2528 & 6489.840 & 6189.430 & 678.214 & 517.479 & \text { Yes }\end{array}$ 

GDEELDSLIK

ATIAGGGVIPHIHK ATIAGGGVIPHIHK ATIAGGGVIPHIHK ATIAGGGVIPHIHK ATIAGGGVIPHIHK ATIAGGGVIPH GDEELDSLIK

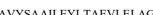

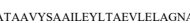

GATAAVYSALLEYLTAEVUELAGNASK

GDEELDSLIK

GDEELDSLIK

GDEELDSLIK

GDEELDSLIK

GDEELDSLIK

GDEELDSLIK

HLQLAIRGDEELDSLIK

HLQLAIRGDEELDSLIK 0.8

VPDFSEYR

GKPLFVR

GKPLFVR

16 ATGAATPK

ATGAATPK

ATGAATPK

ATGAATPK

KPAAAAGAK

KPAAAAGAK

KPAAAAGAK

KPAAAAGAK

KATGAATPK

KPAAAAGA

KPAAAAGAK

KPAAAAGAK

KPAAAAGAK

KPAAAAGAK

KPAAAAGAK

$\begin{array}{llllllllllll}\text { VPLPSLSPTMQAGTTK } & 1.00 & 40.79 & 25.67 & 19.15 & 3 & 1804.0216 & 1804.0186 & 602.3468 & 0.0030 & 1.6602 & 131.748\end{array}$ $\begin{array}{lllllllllllll}\text { VPLPSLSPTMQAGTIAR } & 1.00 & 82.93 & 25.89 & 19.30 & 2 & 1882.0492 & 1882.0468 & 942.0307 & 0.0024 & 1.2738 & 550.735 \\ \text { VPLST } & 25.71 & 24.94 & 2 & 1882.0510 & 1882.0468 & 942.0307 & 0.0042 & 22292 & 178.881 & 18\end{array}$ $\begin{array}{llllllllllllll}\text { VPLPSLSPTMQAGTIAR } & 0.98 & 26.40 & 25.72 & 21.50 & 3 & 1882.0513 & 1882.0468 & 628.3562 & 0.0045 & 2.3872 & 99.053\end{array}$

29 TAFQEALDAAGDK TAFQEALDAAGDK

EKLEATINELV

LEATINELV

TAFQEALDAAGDK

TAFQEALDAAGDK

CMPTFQFFK

CMPTFQFFK

CMPTFQFFK

CMPTFQFFK

CMPTFQFFK

CMPTFQFFK

CMPTFQFFK

CMPTFQFFK

CMPTFQTK

CMPTFQFK

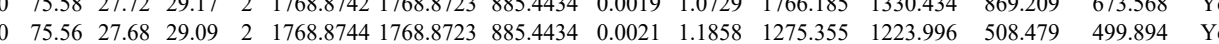

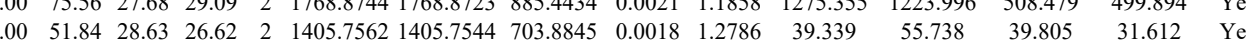
\begin{tabular}{llllllllllllll}
1.00 & 51.84 & 28.63 & 26.62 & 1405.7562 & 1405.7544 & 03.8845 & 0.018 & 1.2786 & 39.339 & 55.738 & 39.805 & 31.612 & Yes \\
\hline
\end{tabular}

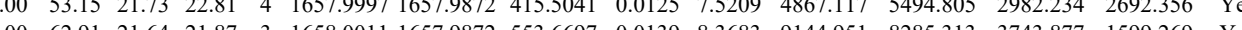

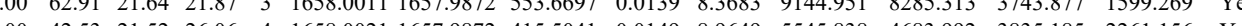
\begin{tabular}{lllllllllllllll}
1.00 & 62.91 & 1.64 & 21.87 & 3 & 1658.0011 & 1657.9872 & 553.667 & 0.013 & 8.3683 & 944.951 & 8285.313 & 3743.877 & 1599.269 & Yes \\
\hline
\end{tabular}

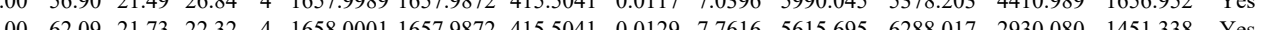
$\begin{array}{lllllllllllllll}0.00 & 56.89 & 28.37 & 35.66 & 2 & 140.7544 & 1405.7544 & 703.8845 & 0.000 & 0.0000 & 77.250 & 82.739 & 59.627 & 60.083 & \text { Yes }\end{array}$ $\begin{array}{llllllllllllll} & \end{array}$ $\begin{array}{llllllllllllll} & \end{array}$

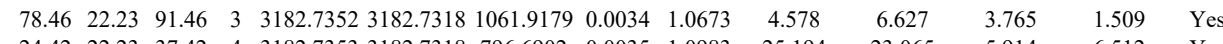

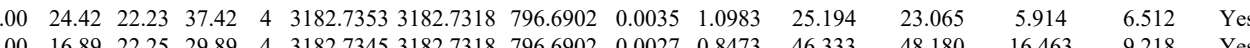

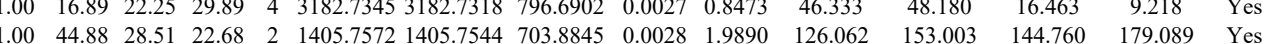

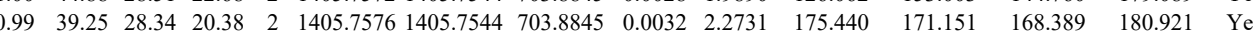
$\begin{array}{lllllllllllllll}1.00 & 39.09 & 28.66 & 30.37 & 3 & 1405.7551 & 1405.7544 & 469.5921 & 0.0007 & 0.4969 & 20.237 & 27.003 & 27.441 & 75.375 & \text { No }\end{array}$

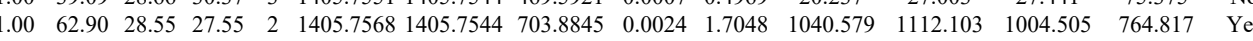
$\begin{array}{lllllllllllllll}1.00 & 62.79 & 28.51 & 28.64 & 2 & 1405.7574 & 1405.7544 & 703.8845 & 0.0030 & 2.1310 & 833.094 & 820.360 & 873.004 & 861.108 & \text { Yes }\end{array}$ $\begin{array}{lllllllllllllll}0.94 & 39.11 & 28.36 & 35.03 & 3 & 1405.7683 & 1405.7544 & 469.5921 & 0.0139 & 9.8666 & 18.935 & 38.075 & 48.775 & 51.918 & \text { Yes }\end{array}$

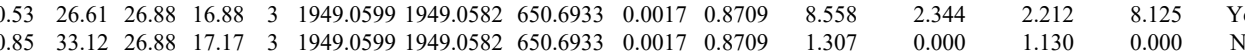

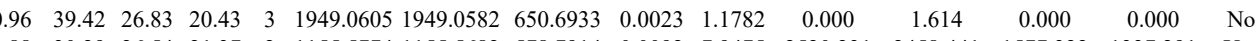

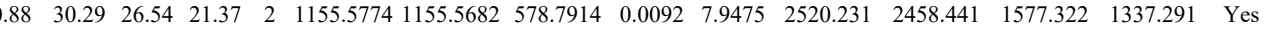

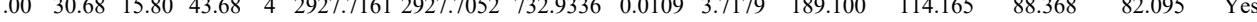
$\begin{array}{lllllllllllllll}0.98 & 29.54 & 22.50 & 21.56 & 2 & 1103.7086 & 1103.7059 & 552.8602 & 0.0027 & 2.4418 & 14690.115 & 14709.107 & 1006.693 & 428.343 & \text { Yes }\end{array}$ $\begin{array}{llllllllllllllll}0.98 & 29.60 & 22.36 & 21.52 & 2 & 1103.7090 & 1103.7059 & 552.8602 & 0.0031 & 2.8036 & 19864.475 & 19325.327 & 846.954 & 257.928 & \text { Yes } \\ 0.99 & 34.86 & 27.14 & 2.36 & 2 & 1003.5916 & 1003.590 & 5028026 & 0.031 & 0.994 & 202.330 & 204.438 & 275.62 & 228.59 & \text { Yes }\end{array}$ $\begin{array}{lllllllllllllll}0.94 .86 & 27.14 & 28.36 & 2 & 1003.5916 & 1003.5906 & 502.8026 & 0.0010 & 0.9944 & 202.330 & 204.438 & 275.629 & 228.597 & \text { Yes }\end{array}$ $\begin{array}{llllllllllllllll}0.99 & 36.58 & 27.98 & 30.47 & 2 & 1003.5920 & 1003.5906 & 502.8026 & 0.0014 & 1.3922 & 535.510 & 500.184 & 605.275 & 481.540 & \text { Yes }\end{array}$ \begin{tabular}{lllllllllllllll}
0.94 & 32.11 & 27.47 & 35.01 & 2 & 1003.5910 & 1003.5906 & 502.8026 & 0.0004 & 0.3978 & 91.665 & 127.470 & 139.943 & 123.201 & Yes \\
\hline
\end{tabular}

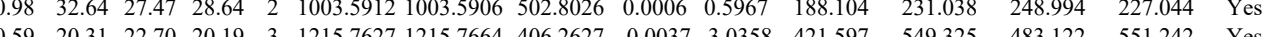

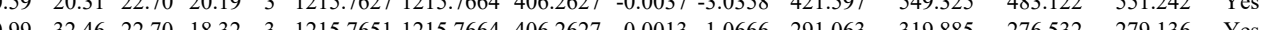

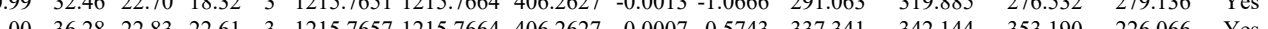

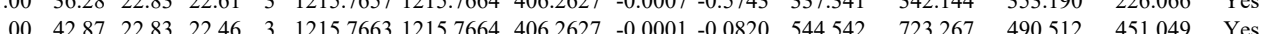

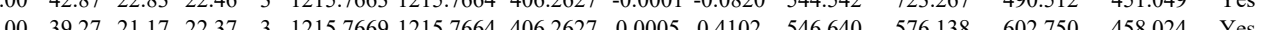
$\begin{array}{lllllllllllll} & \end{array}$

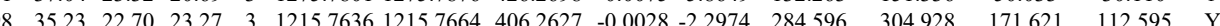
$\begin{array}{lllllllllllll} & 111.874 & \text { Y }\end{array}$ $\begin{array}{lllllllllllllll}0 & 38.88 & 22.83 & 24.29 & 3 & 1215.7660 & 1215.7664 & 4062627 & -0.0004 & -0.3282 & 195.829 & 204.308 & 227.747 & 170.673 & \text { Yes }\end{array}$ $\begin{array}{lllllllllllllll}1.00 & 41.65 & 21.17 & 23.57 & 3 & 1215.7666 & 1215.7664 & 4062627 & 0.0002 & 0.1641 & 218.914 & 223.511 & 215.280 & 165.460 & \text { Yes }\end{array}$

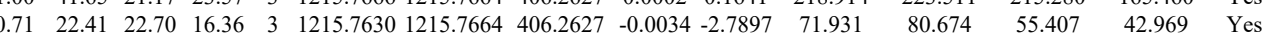
$\begin{array}{lllll}71.931 & 172.702 & 76.093 & 75.200 & \text { Yes }\end{array}$

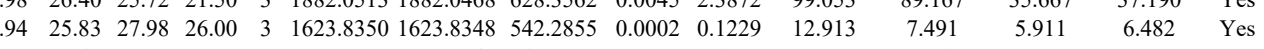

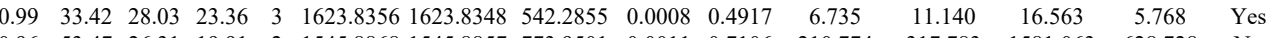
$\begin{array}{lllllllllllllll}0.96 & 53.47 & 26.31 & 19.91 & 2 & 1545.8868 & 1545.8857 & 773.9501 & 0.0011 & 0.7106 & 210.774 & 317.783 & 1581.063 & 628.728 & \text { No } \\ 1.00 & 51.52 & 27.71 & 24.84 & 2 & 1144.6478 & 1144.6461 & 573.3303 & 0.0017 & 1.4826 & 84.049 & 78.257 & 73.616 & 28.771 & \text { Yes }\end{array}$ $\begin{array}{llllllllllllllll}1.00 & 41.47 & 27.71 & 21.00 & 2 & 1144.6478 & 1144.6461 & 573.3303 & 0.0017 & 1.4826 & 87.022 & 39.409 & 66.767 & 35.783 & \text { Yes }\end{array}$

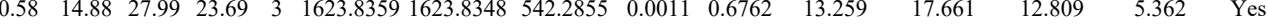

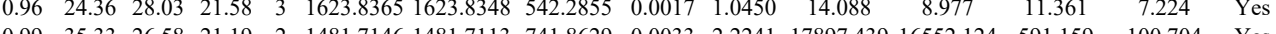
$\begin{array}{lllllllllllllll}0.99 & 35.33 & 26.58 & 21.19 & 2 & 1481.7146 & 1481.7113 & 741.8629 & 0.0033 & 2.2241 & 17897.439 & 16552.124 & 591.159 & 100.704 & \text { Yes } \\ 0.93 & 31.77 & 2.6 & 21.09 & 2 & 1481.7152 & 141.7113 & 741.829 & 0.003 & 2.285 & 1480166 & 17088.212 & 545.457 & 209.559 & \text { Yes }\end{array}$ $\begin{array}{lllllllllllllll}0.93 & 31.77 & 26.68 & 21.09 & 2 & 1481.7152 & 1481.7113 & 741.8629 & 0.0039 & 2.6285 & 14801.166 & 17088.212 & 545.457 & 209.059 & \text { Yes }\end{array}$

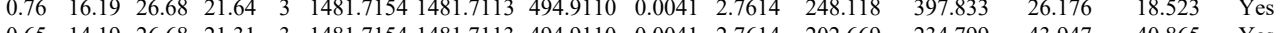
$\begin{array}{lllllllllllllll}0.65 & 14.19 & 26.68 & 21.31 & 3 & 1481.7154 & 1481.7113 & 494.9110 & 0.0041 & 2.7614 & 202.669 & 234.799 & 43.947 & 40.865 & \text { Yes } \\ 0.99 & 37.88 & 26.69 & 20.47 & 2 & 1481.7130 & 1481.7113 & 741.8629 & 0.0017 & 1.1458 & 6364298 & 71698139 & 3187.774 & 341.789 & \text { Yes }\end{array}$ $\begin{array}{llllllllllllllll}0.99 & 37.88 & 26.69 & 20.47 & 2 & 1481.7130 & 1481.7113 & 741.8629 & 0.0017 & 1.1458 & 63642.298 & 71698.139 & 3187.774 & 341.789 & \text { Yes } \\ 1.00 & 31.54 & 26.67 & 25.66 & 3 & 1481.7133 & 1481.7113 & 494.9110 & 0.0020 & 1.3470 & 1451.972 & 1217.999 & 79.985 & 0.009 & \text { No }\end{array}$

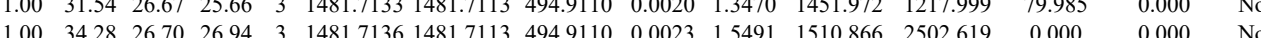

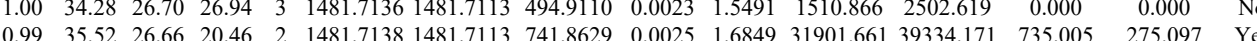

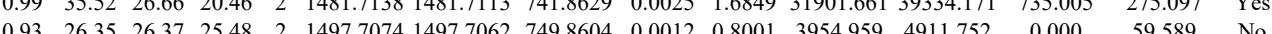
$\begin{array}{lllllllllllllll}0.96 & 28.30 & 26.28 & 15.68 & 2 & 1497.7078 & 1497.7062 & 749.8604 & 0.0016 & 1.0669 & 4296294 & 513.570 & 121.315 & 33.389 & \text { Yes }\end{array}$

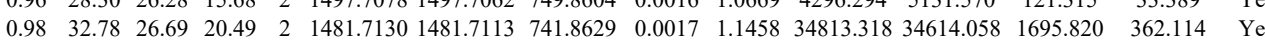

Table S-3 page 113 of 499 

$\begin{array}{lllllllllllll}\text { TALLDAAGVASLLTTAEVVVTEIPKK } & 1.00 & 34.31 & 16.43 & 47.31 & 4 & 2769.6033 & 2769.5983 & 693.4069 & 0.0050 & 1.8027 & 13.33\end{array}$ \begin{tabular}{llllllllllll} 
TALLDAAGVASLLTAAEVVVTEIPR & 1.00 & 10.53 & 16.43 & 23.53 & 4 & 2769.6033 & 2769.5983 & 693.4069 & 0.0050 & 1.8027 & 7.044 \\
\hline THDAG
\end{tabular} $\begin{array}{llllllllllll}\text { TALLDAAGVASLLTAAEVVTEIPK } & 1.00 & 13.79 & 16.43 & 26.79 & 4 & 2769.6037 & 2769.5983 & 693.4069 & 0.0054 & 1.9469 & 13.033\end{array}$ $\begin{array}{lllllllllllll}\text { TALLDAAGALLATAWVWN } & 0.80 & 0.01 & 16.33 & 13.01 & 4 & 2769.6041 & 2769.5983 & 693.4069 & 0.0058 & 2.0911 & 13.801\end{array}$

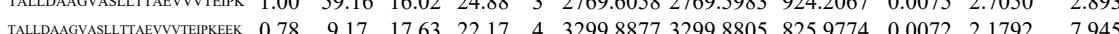
$\begin{array}{llllllllll} & 1\end{array}$

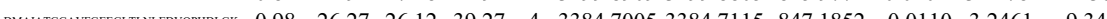
$\begin{array}{llllllllll}0.98 & 26.27 & 26.12 & 39.27 & 4 & 3299.80093299 .8805 & 825.9774 & 0.0104 & 3.1478 & 14.387\end{array}$

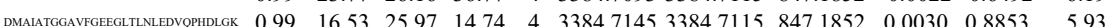

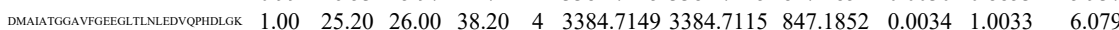

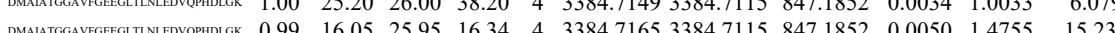
$\begin{array}{lllllllllllll} & \end{array}$ $\begin{array}{llllllllllllll} & \end{array}$ $\begin{array}{lllllllllllll}\text { DMAATGGAVGGEGLITINLDVPPHDLGK } & 1.00 & 50.69 & 25.98 & 17.32 & 4 & 3384.7213 & 3384.7115 & 847.1852 & 0.0098 & 2.8919 & 9.975\end{array}$ $\begin{array}{llllllllllll} & & 33.74 & 25.7217 & 3384.7115 & 847.1852 & 0.0102 & 3.0100 & 1.284\end{array}$

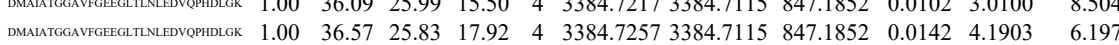

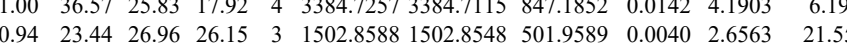
$\begin{array}{llllllllllll}\text { NAGVEGSLIVEK } & 1.00 & 57.21 & 26.70 & 31.95 & 2 & 1502.8680 & 1502.8548 & 752.4347 & 0.0132 & 8.7714 & 235.202\end{array}$ $\begin{array}{lllllllllllll}\text { TtATVLAR } & 1.00 & \text { \#\#\#\# } 26.86 & 41.96 & 2 & 1502.8686 & 1502.8548 & 752.4347 & 0.0138 & 9.1701 & 299.269 \\ & 0.53 .52 & 2 & 2703.3434 & 2703.3433 & 1352.6789 & 0.0001 & 0.0370 & 16.490\end{array}$ $\begin{array}{llllllllll} & 32.33 & 27.04 & 2703.3469 & 2703.3433 & 902.1217 & 0.0036 & 1.3302 & 134.983\end{array}$ $\begin{array}{lllllllllllll}\text { EIGNIISDAMK } & 0.79 & 23.19 & 28.75 & 18.17 & 2 & 1493.8010 & 1493.8003 & 747.9074 & 0.0007 & 0.4680 & 373.604\end{array}$

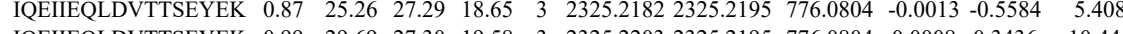
$\begin{array}{llllllllllll}\text { IQEIIEQLDVTTSEYEK } & 0.99 & 29.69 & 27.30 & 19.58 & 3 & 2325.2203 & 2325.2195 & 776.0804 & 0.0008 & 0.3436 & 10.446\end{array}$ $\begin{array}{llllllllllll}\text { IQEIIEQLDVTTSEYEK } & 1.00 & 53.17 & 27.08 & 22.41 & 3 & 2325.2224 & 2325.2195 & 776.0804 & 0.0029 & 1.2456 & 20.050\end{array}$

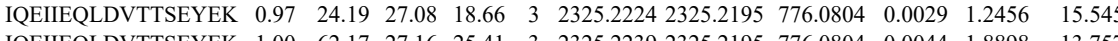
$\begin{array}{llllllllllll}\text { IQEIIEQLDVTISEYK } & 1.00 & 62.17 & 27.16 & 25.41 & 3 & 2325.2239 & 2325.2195 & 776.0804 & 0.0044 & 1.8898 & 13.757\end{array}$

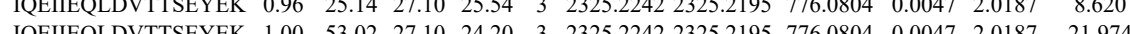

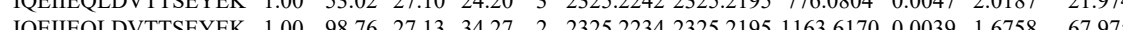

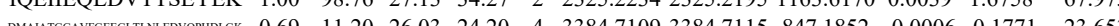
$\begin{array}{llllllllllll}1.00 & 58.60 & 26.22 & 18.82 & 4 & 3384.6973 & 3384.7115 & 847.1852 & -0.0142 & -4.1904 & 0.000\end{array}$ 

$\begin{array}{lllllllllll}1.00 & 80.31 & 25.97 & 23.62 & 3 & 3384.7132 & 3384.7115 & 1129.2444 & 0.0017 & 0.5018 & 43.248 \\ 1.00 & 86.64 & 25.97 & 24.22 & 3 & 3384.7132 & 3384.7115 & 1129.2444 & 0.0017 & 0.5018 & 32323\end{array}$

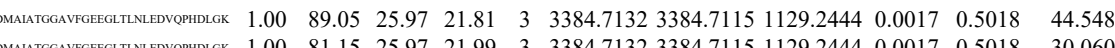
$\begin{array}{lllllllllll}1.00 & 81.15 & 25.97 & 21.99 & 3 & 3384.7132 & 3384.7115 & 1129.2444 & 0.0017 & 0.5018 & 30.060\end{array}$

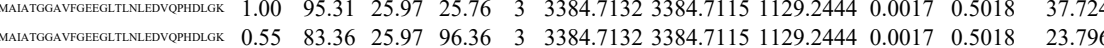

$\begin{array}{llllllllllll}\text { DMALATGGAVGGEGLINLLEDVPHDLGK } & 1.00 & 77.18 & 25.97 & 23.31 & 3 & 3384.7132 & 3384.7115 & 1129.2444 & 0.0017 & 0.5018 & 32.106\end{array}$ $\begin{array}{lllllllllll}0.55 & 90.52 & 25.97 & \# \# \# \text { 3 } & 3384.7132 & 3384.7115 & 1129.2444 & 0.0017 & 0.5018 & 14.181\end{array}$

$\begin{array}{lllllllllll}0.69 & 6.82 & 25.98 & 14.08 & 4 & 3384.7153 & 3384.7115 & 847.1852 & 0.0038 & 1.1214 & 14.041\end{array}$

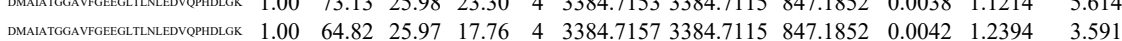
$\begin{array}{lllllllllll}1.00 & 64.82 & 25.97 & 17.76 & 4 & 3384.7157 & 3384.7115 & 847.1852 & 0.0042 & 1.2394 & 3.591 \\ 1.00 & 61.23 & 25.98 & 74.23 & 4 & 3384.7161 & 3384.7115 & 847.1852 & 0.0046 & 1.3574 & 4.315\end{array}$ $\begin{array}{lllllllllll}0 & 85.77 & 25.98 & 28.13 & 3 & 3384.7162 & 3384.7115 & 1129.2444 & 0.0047 & 1.3874 & 28.247\end{array}$

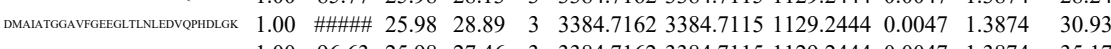
$\begin{array}{lllllllllll}1.00 & 96.63 & 25.98 & 27.46 & 3 & 3384.7162 & 3384.7115 & 1129.2444 & 0.0047 & 1.3874 & 35.173\end{array}$

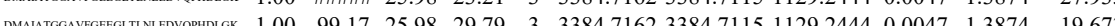

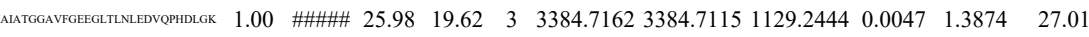
$\begin{array}{lllllllll}1 & \end{array}$ $\begin{array}{lllllllllll}1 & & \end{array}$

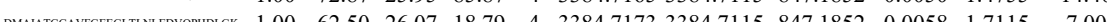

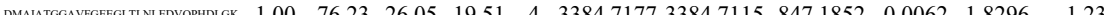
$\begin{array}{lllllllllllll}\text { DMAATGGAVEGEGLITINLDVPPHLCKK } & 1.00 & 69.33 & 25.99 & 82.33 & 4 & 3384.7181 & 3384.7115 & 847.1852 & 0.0066 & 1.9476 & 11.377\end{array}$

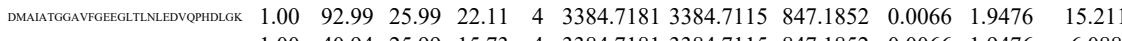
$\begin{array}{lllllllllllll} & & \end{array}$

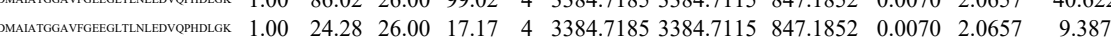

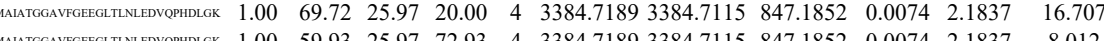
$\begin{array}{llllllllllll}\text { DMALTGGAVGGEGGLINLLDVYPHDLCK } & 1.00 & 64.93 & 25.97 & 18.19 & 4 & 3384.7189 & 3384.7115 & 847.1852 & 0.0074 & 2.1837 & 8.125\end{array}$

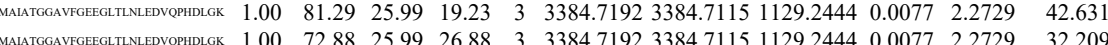
$\begin{array}{lrllllllllll} & \text { N. }\end{array}$

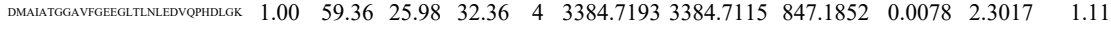
$\begin{array}{llllllllll}1.00 & 64.48 & 25.98 & 77.48 & 4 & 3384.7193 & 3384.7115 & 847.1852 & 0.0078 & 2.3017\end{array}$ $\begin{array}{llllllllllllll} & \end{array}$ $\begin{array}{lllllllllllll} & & \end{array}$ $\begin{array}{lllllllllll}1.00 & 63.78 & 25.98 & 19.28 & 4 & 3384.7213 & 3384.7115 & 847.1852 & 0.0098 & 2.8919 & 5.435\end{array}$ $\begin{array}{lllllllllll}1.00 & 51.63 & 24.70 & 31.30 & 2 & 1131.7198 & 1131.7107 & 566.8626 & 0.0091 & 8.0266 & 49296.153 \\ 1.00 & 51.70 & 24.70 & 31.44 & 2 & 1131.7202 & 1131.7107 & 5668626 & 0.0095 & 8.3794 & 68205.666\end{array}$ $\begin{array}{llllllllllll}1.00 & 51.70 & 24.70 & 31.44 & 2 & 1131.7202 & 1131.7107 & 566.8626 & 0.0095 & 8.3794 & 68205.666 \\ 0.54 & 24.58 * & 27.63 & 23.34 & 3 & 1477.8070 & 1477.8054 & 493.6091 & 0.0016 & 1.0805 & 198.843\end{array}$ $\begin{array}{lllllllllll}0.98 & 64.89 * & 27.64 & 28.15 & 2 & 1477.8074 & 1477.8054 & 739.9100 & 0.0020 & 1.3515 & 1005.203\end{array}$ $\begin{array}{llllllllllllll}\text { CIPALDSLTPANEDQK } & 1.00 & 76.46 & 27.54 & 22.85 & 2 & 2048.0174 & 2048.0162 & 1025.0154 & 0.0012 & 0.5854 & 843.099\end{array}$ $\begin{array}{llllllllllll}0.55 & 17.80 & 16.72 & 30.80 & 3 & 2769.6007 & 2769.5983 & 924.2067 & 0.0024 & 0.8656 & 23.618\end{array}$ 

$\begin{array}{lllllllllll}1.00 & 90.25 & 26.06 & 21.83 & 3 & 3384.7102 & 3384.7115 & 1129.2444 & -0.0013 & -0.3837 & 13.224\end{array}$ $\begin{array}{llllllllll}1.00 & \text { m m } 26.06 & 20.75 & 3 & 3384.7102 & 3384.7115 & 1129.2444 & -0.0013 & -0.3837 & 13.608\end{array}$

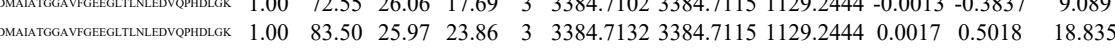
$\begin{array}{llllllllllll}1.00 & 86.02 & 25.97 & 28.22 & 3 & 3384.7132 & 3384.7115 & 1129.2444 & 0.0017 & 0.5018 & 16.319\end{array}$ $\begin{array}{lllllllllll}1.00 & 65.84 & 25.97 & 19.85 & 3 & 3384.7132 & 3384.7115 & 1129.2444 & 0.0017 & 0.5018 & 8.605\end{array}$

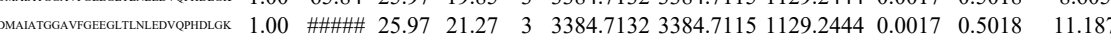

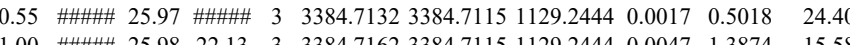

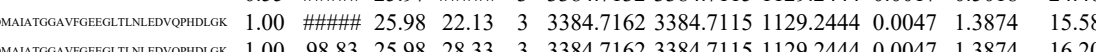
$\begin{array}{lllllllllll} & 0.38\end{array}$

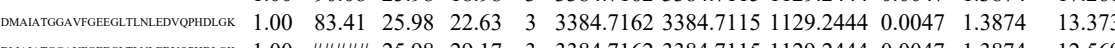

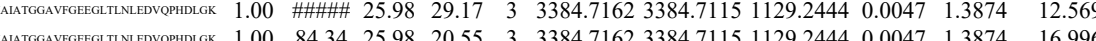

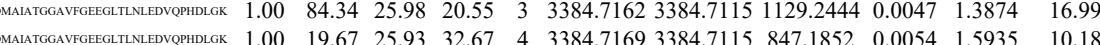

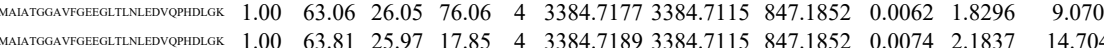
$\begin{array}{lllllllllllll}\text { DMALAGGANGGEGLLTLNLEDVPPLLCK } & 1.00 & 59.73 & 25.98 & 19.47 & 4 & 3384.7197 & 3384.7115 & 847.1852 & 0.0082 & 2.4198 & 10.806\end{array}$ $\begin{array}{lllllllllllll} & \end{array}$

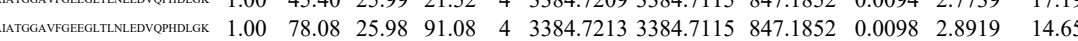

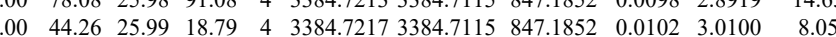
$\begin{array}{lllllllllll}0.84 & 13.30 & 25.94 & 16.90 & 4 & 3384.7221 & 3384.7115 & 847.1852 & 0.0106 & 3.1280 & 9.305\end{array}$

$\begin{array}{llllllllllll}\text { DMAATGGANFGEGLLTILLDVPPHLLGK } & 1.00 & 43.72 & 25.83 & 15.89 & 4 & 3384.7237 & 3384.7115 & 847.1852 & 0.0122 & 3.6001 & 10.920\end{array}$

$\begin{array}{llllllllllll}1.00 & 59.95 & 25.84 & 17.53 & 3 & 3384.7252 & 3384.7115 & 1129.2444 & 0.0137 & 4.0440 & 7.72 .998 & 11.721\end{array}$

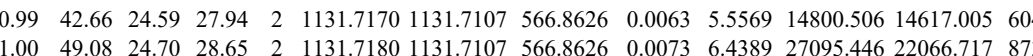


$\begin{array}{lllllllllllll}1.00 & 84.47 & 25.83 & 36.89 & 2 & 1631.9262 & 1631.9126 & 816.9636 & 0.0136 & 8.3234 & 3158.743 & 2949.542 & \\ 1.00 & 80.81 & 25.72 & 35.31 & 2 & 1631.9274 & 1631.9126 & 816.9636 & 0.0148 & 9.0578 & 6386.510 & 5176.090 & 3\end{array}$

$\begin{array}{lllllllllllll}\text { DPGMGAMGGMGGGMGGMMF } & 0.77 & 79.65 & 17.92 & 92.65 & 2 & 1817.7172 & 1817.7150 & 909.8648 & 0.0022 & 1.2090 & 39.239\end{array}$

$\begin{array}{lllllllllllll}\text { DPGMGAMGGMGGGMGGGMF } & 0.69 & 54.14 & 18.06 & 67.14 & 2 & 1817.7176 & 1817.7150 & 909.8648 & 0.0026 & 1.4288 & 0.000\end{array}$ $\begin{array}{lllllllllllll}\text { KPLVIIAEDVDGEALSTLVLNR } & 1.00 & 34.98 & 19.49 & 47.98 & 4 & 2652.5305 & 2652.5305 & 664.1399 & 0.0000 & 0.0000 & 180.945\end{array}$ $\begin{array}{lllllllllllll}\text { KPLVIAEDVDGEALSTLVLNR } & 0.55 & 79.98 & 19.34 & 92.98 & 3 & 2652.5326 & 2652.5305 & 885.1841 & 0.0021 & 0.7908 & 4.711 \\ \text { KPLVIAEDVDGEALSTLVLNR } & 0.55 & 41.70 & 19.34 & 54.70 & 3 & 2652.5326 & 2652.5305 & 885.1841 & 0.0021 & 0.7908 & 4.459\end{array}$ $\begin{array}{llllllllllll}\text { KPLVIIAEDVDGEALSTLVLNR } & 0.55 & 41.70 & 19.34 & 54.70 & 3 & 2652.5326 & 2652.5305 & 885.1841 & 0.0021 & 0.7908 & 4.459 \\ \text { KPLVIIAEDVDGEALSTLVLNR } & 0.55 & 40.21 & 19.40 & 53.21 & 3 & 2652.5329 & 2652.5305 & 885.1841 & 0.0024 & 0.9038 & 5.230\end{array}$

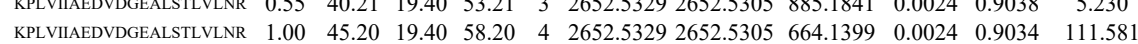

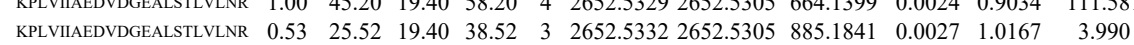
$\begin{array}{llllllllllll}\text { KPLVIIAEDVDGEALSTLVLNR } & 0.53 & 25.57 & 19.40 & 38.57 & 3 & 2652.5332 & 2652.5305 & 885.1841 & 0.0027 & 1.0167 & 6.888\end{array}$ $\begin{array}{lllllllllllll}\text { KPLVIAEDVDGEALSTLVLNR } & 1.00 & 83.19 & 19.40 & 96.19 & 4 & 2652.5333 & 2652.5305 & 664.1399 & 0.0028 & 1.0540 & 35.221\end{array}$ $\begin{array}{lllllllllllll}\text { KPLVIIAEDVDGEALSTLVLNR } & 1.00 & 51.17 & 19.40 & 64.17 & 4 & 2652.5333 & 2652.5305 & 664.1399 & 0.0028 & 1.0540 & 38.923\end{array}$ $\begin{array}{lllllllllllll}\text { KPLVIIAEDVDGEALSTLVLNR } & 1.00 & 41.19 & 19.29 & 54.19 & 4 & 2652.5337 & 2652.5305 & 664.1399 & 0.0032 & 1.2046 & 88.747\end{array}$ $\begin{array}{lllllllllllll}\text { KPLVIIAEDVDGEALSTLVLNR } & 1.00 & 36.24 & 18.75 & 49.24 & 4 & 2652.5361 & 2652.5305 & 664.1399 & 0.0056 & 2.1080 & 144.677\end{array}$ $\begin{array}{lllllllllllll}\text { KPLVIAEDVDGEALSTLVLNR } & 1.00 & 66.37 & 18.75 & 79.37 & 4 & 2652.5381 & 2652.5305 & 664.1399 & 0.0076 & 2.8608 & 95.254\end{array}$ $\begin{array}{lllllllllllll}\text { TALLDAGVASLLTTAEVVVTEIPK } & 0.53 & 51.80 & 16.72 & 64.80 & 3 & 2769.6010 & 2769.5983 & 924.2067 & 0.0027 & 0.9738 & 1.849\end{array}$ $\begin{array}{lllllllllllll}\text { TALLDAAGVASLITAEVVVTEIPK } & 0.53 & 34.14 & 16.72 & 47.14 & 3 & 2769.6013 & 2769.5983 & 924.2067 & 0.0030 & 1.0820 & 0.000\end{array}$ $\begin{array}{lllllllllllll}\text { TALLDAAGVASLITAEVVVTEIPK } & 1.00 & 28.80 & 16.43 & 41.80 & 4 & 2769.6029 & 2769.5983 & 693.4069 & 0.0046 & 1.6585 & 99.392\end{array}$

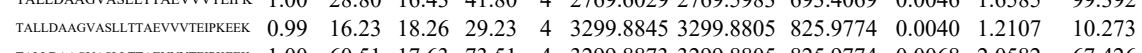
$\begin{array}{llllllllllll}\text { TALDAAGVASLITAEVVVTERPKEKK } & 1.00 & 60.51 & 17.63 & 73.51 & 4 & 3299.8873 & 3299.8805 & 825.9774 & 0.0068 & 2.0582 & 67.426 \\ \text { DPG }\end{array}$ $\begin{array}{llllllllllll}\text { DPGMGaMGgMGGGMGGGMF } & 0.76 & 57.41 & 17.92 & 70.41 & 2 & 1817.7164 & 1817.7150 & 909.8648 & 0.0014 & 0.7693 & 135.382\end{array}$ $\begin{array}{lllllllllllll}\text { KPLVIIAEDVDGEALSTLVLNR } & 1.00 & 62.73 & 19.49 & 75.73 & 4 & 2652.5313 & 2652.5305 & 664.1399 & 0.0008 & 0.3011 & 55.677\end{array}$ $\begin{array}{llllllllllll}\text { KPLVIIAEDVDGEALSTLVLNR } & 0.76 & 82.32 & 19.49 & 95.32 & 2 & 2652.5314 & 2652.5305 & 1327.2725 & 0.0009 & 0.3390 & 11.135\end{array}$ $\begin{array}{llllllllllll}\text { KPLVIIAEDVDGEALSTLVLNR } & 1.00 & 83.79 & 19.34 & 96.79 & 4 & 2652.5325 & 2652.5305 & 664.1399 & 0.0020 & 0.7529 & 22.012\end{array}$

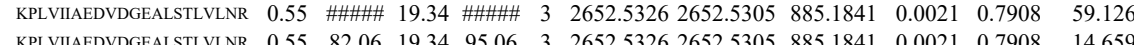

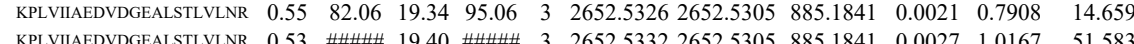

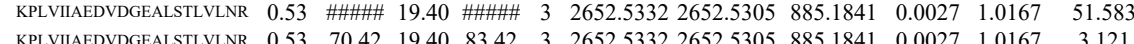
$\begin{array}{llllllllllll}\text { KPLVIIAEDVDGEALSTLVLNR } & 0.53 & 70.42 & 19.40 & 83.42 & 3 & 2652.5332 & 2652.5305 & 885.1841 & 0.0027 & 1.0167 & 3.121 \\ \text { KPLVIAEDVDGEALSTLVLNR } & 0.53 & 97.87 & 19.40 & \text { \#\#\#\# } & 3 & 2652.5332 & 2652.5305 & 885.1841 & 0.0027 & 1.0167 & 1.579\end{array}$ $\begin{array}{llllllllllll}\text { KPLVIAEDVDGEALSTLVLNR } & 0.53 & 97.87 & 19.40 & \text { \#\#\#\# } & 3 & 2652.5332 & 2652.5305 & 885.1841 & 0.0027 & 1.0167 & 1.579 \\ \text { KPLVIAEDVDGEALSTLVLNR } & 1.00 & 65.90 & 19.40 & 17.56 & 4 & 2652.5333 & 2652.5305 & 664.1399 & 0.0028 & 1.0540 & 70.429\end{array}$ $\begin{array}{lllllllllllll}\text { KPLVIIAEDVDGEALSTLVLNR } & 1.00 & 65.90 & 19.40 & 17.56 & 4 & 2652.5333 & 2652.5305 & 664.1399 & 0.0028 & 1.0540 & 70.429 \\ \text { KPLVIAEDVDGEALSTLVLNR } & 1.00 & 42.70 & 19.40 & 55.70 & 4 & 2652.5333 & 2652.5305 & 664.1399 & 0.0028 & 1.0540 & 35.33\end{array}$ $\begin{array}{llllllllllll}\text { KPLVIIAEDVDGEALSTLVLNR } & 1.00 & 42.70 & 19.40 & 55.70 & 4 & 2652.5333 & 2652.5305 & 664.1399 & 0.0028 & 1.0540 & 35.331 \\ \text { KPLIIAEDVDGEALSTLVLNR } & 1.00 & 58.38 & 19.29 & 71.38 & 4 & 2652.5337 & 2652.5305 & 664.1399 & 0.0032 & 1.2046 & 88.12\end{array}$ $\begin{array}{lllllllllllll}\text { KPLVIIAEDVDGEALSTLVLNR } & 0.53 & 85.87 & 19.24 & 98.87 & 3 & 2652.5338 & 2652.5305 & 885.1841 & 0.0033 & 1.2427 & 16.065\end{array}$

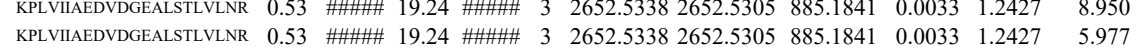

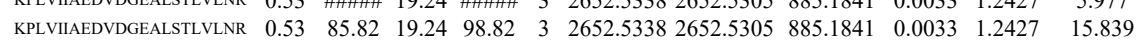
$\begin{array}{lllllllllllll}\text { KPLVIIAEDVDGEALSTLVLNR } & 1.00 & 82.69 & 19.19 & 95.69 & 4 & 2652.5345 & 2652.5305 & 664.1399 & 0.0040 & 1.5057 & 81.772\end{array}$ $\begin{array}{llllllllllll}\text { KPLVIIAEDVDGEALSTLVLNR } & 1.00 & 72.16 & 19.19 & 85.16 & 4 & 2652.5345 & 2652.5305 & 664.1399 & 0.0040 & 1.5057 & 86.533\end{array}$

$\begin{array}{cccc}5176.090 & 368.073 & 133.376 & \text { Ye } \\ 261.323 & 120.623 & 64.131 & \text { Ye } \\ 30.800 & 23.968 & 37.952 & \text { No } \\ 53.513 & 37.016 & 0.000 & \text { No } \\ 17.0624 & 11.1973 & 65.004 & \text { Ye } \\ 11.483 & 2.546 & 1.909 & \text { No } \\ 0.000 & 3.468 & 7.960 & \text { No } \\ 1.030 & 4.809 & 1.598 & \text { Ye } \\ 103.366 & 84.465 & 49.400 & \text { Ye } \\ 7.194 & 10.520 & 4.843 & \text { Ye } \\ 6.245 & 2.869 & 1.693 & \text { Ye } \\ 29.879 & 30.696 & 10.462 & \text { Ye } \\ 72.881 & 36.599 & 12.132 & \text { Ye } \\ 131.593 & 83.032 & 34.889 & \text { Ye } \\ 158.715 & 90.733 & 41.811 & \text { Ye } \\ 120.604 & 71.883 & 54.220 & \text { Ye } \\ 2.196 & 2.792 & 3.793 & \text { No } \\ 4.145 & 13.297 & 0.000 & \text { No } \\ 114.566 & 87.401 & 36.986 & \text { Ye } \\ 28.205 & 14.436 & 4.827 & \text { Ye } \\ 47.154 & 0.000 & 15.075 & \text { No } \\ 109.503 & 82.706 & 51.944 & \text { Ye } \\ 66.769 & 36.461 & 22.187 & \text { Ye } \\ 9.011 & 11.782 & 20.241 & \text { No } \\ 22.722 & 20.681 & 10.782 & \text { Ye } \\ 40.876 & 40.945 & 46.419 & \text { Ye } \\ 0.850 & 12.605 & 3.025 & \text { No } \\ 44.907 & 169.639 & 79.464 & \text { No } \\ 6.232 & 0.000 & 6.042 & \text { No } \\ 3.159 & 1.882 & 2.822 & \text { No } \\ 50.964 & 38.337 & 28.763 & \text { Ye } \\ 28.136 & 23.880 & 12.243 & \text { Ye } \\ 126.997 & 91.157 & 66.605 & \text { Ye } \\ 16.780 & 8.259 & 12.112 & \text { Ye } \\ 6.401 & 18.425 & 16.320 & \text { No } \\ 12.905 & 7.294 & 1.741 & \text { Ye } \\ 3.118 & 23.974 & 7.903 & \text { No } \\ 123.852 & 68.311 & 54.256 & \text { Ye } \\ 107.199 & 75.405 & 56.054 & \text { Ye } \\ 87.736 & 65.909 & 42.701 & \text { Ye } \\ & & & \end{array}$



$\begin{array}{llllllllllll}\text { KPLVIIAEDVDGEALSTLVLNR } & 1.00 & 59.83 & 19.08 & 72.83 & 4 & 2652.5357 & 2652.5305 & 664.1399 & 0.0052 & 1.9574 & 136.266\end{array}$ $\begin{array}{lllllllllllll}\text { KPLVIIAEDVDGEALSTLVLNR } & 1.00 & 46.94 & 19.08 & 59.94 & 4 & 2652.5357 & 2652.5305 & 664.1399 & 0.0052 & 1.9574 & 105.558\end{array}$ $\begin{array}{llllllllllll}\text { KPLVIIAEDVDGEALSTLVLNR } & 1.00 & 33.11 & 19.08 & 46.11 & 4 & 2652.5357 & 2652.5305 & 664.1399 & 0.0052 & 1.9574 & 212.193 \\ \text { KPLVIIAEDVDGEALSTLVLNR } & 1.00 & 66.74 & 18.75 & 79.74 & 4 & 2652.5361 & 2652.5305 & 664.1399 & 0.0056 & 2.1080 & 101.140\end{array}$ $\begin{array}{lllllllllllll}\text { KPLVIIAEDVDGEALSTLVLNR } & 1.00 & 72.55 & 18.75 & 85.55 & 4 & 2652.5361 & 2652.5305 & 664.1399 & 0.0056 & 2.1080 & 122.909\end{array}$ $\begin{array}{llllllllllllll}\text { KPLVIIAEDVDGEALSTLVLNR } & 1.00 & 44.48 & 18.75 & 57.48 & 4 & 2652.5361 & 2652.5305 & 664.1399 & 0.0056 & 2.1080 & 75.022\end{array}$ $\begin{array}{llllllllllllll}\text { KPLVIIAEDVDGEALSTLVLNR } & 1.00 & 46.78 & 18.75 & 59.78 & 4 & 2652.5365 & 2652.5305 & 664.1399 & 0.0060 & 2.2586 & 61.512\end{array}$ $\begin{array}{lllllllllllll}\text { KPLVIIAEDVDGEALSTLVLNR } & 1.00 & 75.63 & 18.39 & 88.63 & 4 & 2652.5397 & 2652.5305 & 664.1399 & 0.0092 & 3.4631 & 83.403\end{array}$ $\begin{array}{lllllllllllll}\text { TALLDAGVASLITAAEVVVTEIPK } & 0.53 & 24.13 & 16.72 & 37.13 & 3 & 2769.6010 & 2769.5983 & 924.2067 & 0.0027 & 0.9738 & 0.000\end{array}$ $\begin{array}{llllllllllll}\text { TALLDAGVASLLTTAEVVVTEIPK } & 1.00 & 36.31 & 16.72 & 18.37 & 3 & 2769.6016 & 2769.5983 & 924.2067 & 0.0033 & 1.1902 & 1.619\end{array}$ $\begin{array}{lllllllllllll}\text { TALLDAGGVASLITAEVVVTEIPK } & 1.00 & 36.63 & 16.72 & 49.63 & 4 & 2769.6017 & 2769.5983 & 693.4069 & 0.0034 & 1.2258 & 82.579\end{array}$ $\begin{array}{llllllllllllll}\text { TALLDAGGASLLTAAVVVTEIPK } & 1.00 & 13.87 & 16.13 & 26.87 & 4 & 2769.6069 & 2769.5983 & 693.4069 & 0.0086 & 3.1006 & 22.920\end{array}$ $\begin{array}{lllllllllllll}\text { TALDAAGVASLITAEVVVTERKEEK } & 1.00 & 45.74 & 17.63 & 58.74 & 4 & 3299.8869 & 3299.8805 & 825.9774 & 0.0064 & 1.9371 & 29.766\end{array}$ $\begin{array}{llllllllllll}\text { TALLDAAGVASLLTAEVVVTERREEKK } & 1.00 & 37.00 & 17.48 & 50.00 & 4 & 3299.8893 & 3299.8805 & 825.9774 & 0.0088 & 2.6635 & 0.000\end{array}$ $\begin{array}{lllllllllllll}\text { TALDAAGVALLTTAEVVTEEPRKEK } & 1.00 & 42.81 & 17.48 & 55.81 & 4 & 3299.8917 & 3299.8805 & 825.9774 & 0.0112 & 3.3899 & 91.896 \\ \text { GVMLAVDAVIAELK } & 1.00 & 39.73 & 22.99 & 18.07 & 3 & 1716.0118 & 1716.0099 & 573.0106 & 0.0019 & 1.1053 & 183.288\end{array}$ $\begin{array}{llllllllllll}\text { GVMLAVDAVIAELK } & 1.00 & \text { \#\#\# } 23.12 & 30.39 & 2 & 1716.0120 & 1716.0099 & 859.0122 & 0.0021 & 1.2223 & 123.422\end{array}$ $\begin{array}{llllllllllll}\text { GVMLAVDAVIAELK } & 1.00 & 52.92 & 23.12 & 18.61 & 3 & 1716.0121 & 1716.0099 & 573.0106 & 0.0022 & 1.2798 & 174.071\end{array}$ $\begin{array}{llllllllllll}\text { GVMLAVDAVIAELK } & 1.00 & 43.09 & 23.12 & 16.96 & 3 & 1716.0124 & 1716.0099 & 573.0106 & 0.0025 & 1.4543 & 178.793\end{array}$ $\begin{array}{lllllllllllll}\text { GVMLAVDAVIAELK } & 1.00 & 28.86 & 23.12 & 20.67 & 3 & 1716.0124 & 1716.0099 & 573.0106 & 0.0025 & 1.4543 & 114.305 \\ \text { GVMLAVDAVIAELK } & 1.00 & 59.52 & 23.14 & 22.61 & 3 & 1716.0127 & 1716.0099 & 573.0106 & 0.0028 & 1.6288 & 45.648\end{array}$ $\begin{array}{llllllllllll}\text { GVMLAVDAVIAELK } & 1.00 & 47.96 & 23.14 & 24.33 & 3 & 1716.0127 & 1716.0099 & 573.0106 & 0.0028 & 1.6288 & 165.511\end{array}$

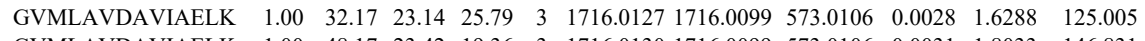
$\begin{array}{llllllllllll}\text { GVMLAVDAVIAELK } & 1.00 & 48.17 & 23.42 & 19.36 & 3 & 1716.0130 & 1716.0099 & 573.0106 & 0.0031 & 1.8033 & 146.831 \\ \text { GVMLAVDAVIAELK } & 1.00 & 47.33 & 23.42 & 23.77 & 3 & 1716.0136 & 1716.0099 & 573.0106 & 0.0037 & 2.1524 & 202.778\end{array}$ $\begin{array}{llllllllllll}\text { GVMLAVDAVIAELK } & 1.00 & 47.33 & 23.42 & 23.77 & 3 & 1716.0136 & 1716.0099 & 573.0106 & 0.0037 & 2.1524 & 202.778 \\ \text { GVMLAVDAVIAELK } & 1.00 & 36.60 & 23.42 & 22.77 & 3 & 1716.0136 & 1716.0099 & 573.0106 & 0.0037 & 2.1524 & 167.461\end{array}$

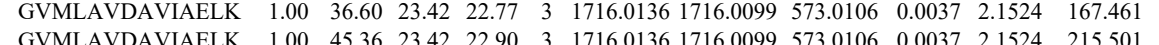

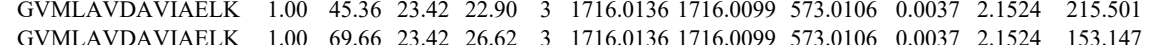

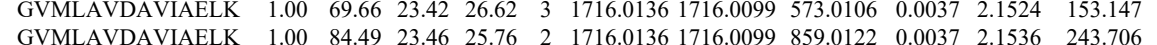

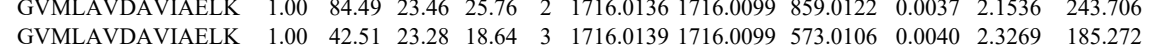
$\begin{array}{llllllllllll}\text { GVMLAVDAVIAELK } & 1.00 & 42.51 & 23.28 & 18.64 & 3 & 1716.0139 & 1716.0099 & 573.0106 & 0.0040 & 2.3269 & 185.272 \\ \text { GVMLAVDAVIAELK } & 1.00 & 41.73 & 23.16 & 21.67 & 3 & 1716.0142 & 1716.0099 & 573.0106 & 0.0043 & 2.5014 & 174.303\end{array}$ $\begin{array}{llllllllllll}\text { GVMLAVDAVIAELK } & 1.00 & 55.80 & 23.16 & 25.12 & 3 & 1716.0145 & 1716.0099 & 573.0106 & 0.0046 & 2.6759 & 137.133\end{array}$

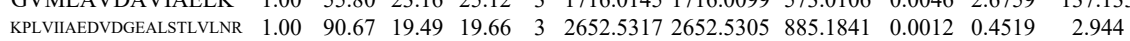
$\begin{array}{lllllllllllll}\text { KPLVIAEDVDGEALSTLVLNR } & 0.55 & 60.37 & 19.34 & 73.37 & 3 & 2652.5323 & 2652.5305 & 885.1841 & 0.0018 & 0.6778 & 33.472\end{array}$ $\begin{array}{lllllllllllll}\text { KPLVIIAEDVDGEALSTLVLNR } & 1.00 & 40.03 & 19.34 & 53.03 & 4 & 2652.5325 & 2652.5305 & 664.1399 & 0.0020 & 0.7529 & 79.386\end{array}$ $\begin{array}{lllllllllllll}\text { KPLVIIAEDVDGEALSTLVLNR } & 0.55 & 91.05 & 19.40 & \text { \#\#\#\# } & 3 & 2652.5329 & 2652.5305 & 885.1841 & 0.0024 & 0.9038 & 18.500\end{array}$ $\begin{array}{lllllllllllll}\text { KPLVIIAEDVDGEALSTLVLNR } & 1.00 & 75.58 & 19.40 & 88.58 & 4 & 2652.5329 & 2652.5305 & 664.1399 & 0.0024 & 0.9034 & 101.440\end{array}$

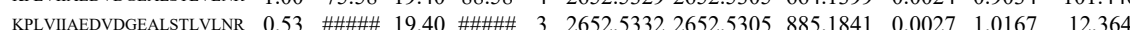
$\begin{array}{llllllllllll}\text { KPLVIIAEDVDGEALSTLVLNR } & 1.00 & 47.33 & 19.29 & 60.33 & 4 & 2652.5337 & 265525305 & 664.1399 & 0.0032 & 1.2046 & 118.443\end{array}$ $\begin{array}{lllllllllllll}\text { KPLVIIAEDVDGEALSTLVLNR } & 1.00 & 78.18 & 19.29 & 91.18 & 4 & 2652.5337 & 2652.5305 & 664.1399 & 0.0032 & 1.2046 & 30.803\end{array}$ $\begin{array}{lllllllllllll}\text { KPLVIIAEDVDGEALSTLVLNR } & 0.53 & 84.78 & 19.24 & 97.78 & 3 & 2652.5338 & 2652.5305 & 885.1841 & 0.0033 & 1.2427 & 303.160\end{array}$ $\begin{array}{llllllllllll}\text { KPLVIIAEDVDGEALSTLVLNR } & 0.53 & 85.54 & 19.24 & 98.54 & 3 & 2652.5338 & 2652.5305 & 885.1841 & 0.0033 & 1.2427 & 33.964\end{array}$ $\begin{array}{llllllllllll}\text { KPLVIIAEDVDGEALSTLVLNR } & 0.53 & 85.13 & 19.24 & 98.13 & 3 & 2652.5338 & 2652.5305 & 885.1841 & 0.0033 & 1.2427 & 18.009\end{array}$ $\begin{array}{llllllllllllll}\text { KPLVIIAEDVDGEALSTLVLNR } & 0.53 & 73.14 & 19.24 & 86.14 & 3 & 2652.5338 & 2652.5305 & 885.1841 & 0.0033 & 1.2427 & 5.614\end{array}$ $\begin{array}{llllllllllll}\text { KPLVIIAEDVDGEALSTLVLNR } & 1.00 & 85.70 & 19.24 & 98.70 & 4 & 2652.5341 & 2652.5305 & 664.1399 & 0.0036 & 1.3551 & 156.395\end{array}$ $\begin{array}{llllllllllllll}\text { KPLVIIAEDVDGEALSTLVLNR } & 1.00 & 56.76 & 19.19 & 69.76 & 4 & 2652.5345 & 2652.5305 & 664.1399 & 0.0040 & 1.5057 & 90.395\end{array}$ $\begin{array}{lllllllllllll}\text { KPLVIIAEDVDGEALSTLVLNR } & 1.00 & 51.72 & 19.19 & 64.72 & 4 & 2652.5345 & 2652.5305 & 664.1399 & 0.0040 & 1.5057 & 109.419\end{array}$ $\begin{array}{llllllllllll}\text { KPLVIIAEDVDGEALSTLVLNR } & 1.00 & 75.81 & 19.19 & 88.81 & 4 & 2652.5349 & 2652.5305 & 664.1399 & 0.0044 & 1.6563 & 92.067 \\ \text { KPVIS }\end{array}$ $\begin{array}{lllllllllllll}\text { KPLVIIAEDVDGEALSTLVLNR } & 1.00 & 58.17 & 19.08 & 71.17 & 4 & 2652.5353 & 2652.5305 & 664.1399 & 0.0048 & 1.8068 & 130.402 \\ \text { KPLVE } & 1.00 & 39.41 & 19.08 & 52.41 & 4 & 26525353 & 26525305 & 664.1399 & 0.0048 & 1.8068 & 106.970\end{array}$ $\begin{array}{lllllllllllll}\text { KPLVIIAEDVDGEALSTLVLNR } & 1.00 & 39.41 & 19.08 & 52.41 & 4 & 2652.5353 & 2652.5305 & 664.1399 & 0.0048 & 1.8068 & 106.970 \\ \text { KPLVIIAEDVDGEALSTLVLNR } & 1.00 & 42.34 & 19.08 & 55.34 & 4 & 2652.5353 & 2652.5305 & 664.1399 & 0.0048 & 1.8068 & 163.064\end{array}$ $\begin{array}{lllllllllllll}\text { KPLVIIAEDVDGEALSTLVLNR } & 1.00 & 42.34 & 19.08 & 55.34 & 4 & 2652.5353 & 2652.5305 & 664.1399 & 0.0048 & 1.8068 & 163.064 \\ \text { KPLVIIAEDVDGEALSTLVLNR } & 1.00 & 73.05 & 19.08 & 86.05 & 4 & 2652.5357 & 2652.5305 & 664.1399 & 0.0052 & 1.9574 & 80.696\end{array}$ $\begin{array}{llllllllllll}\text { KPLVIIAEDVDGEALSTLVLNR } & 1.00 & 73.05 & 19.08 & 86.05 & 4 & 2652.5357 & 2652.5305 & 664.1399 & 0.0052 & 1.9574 & 80.696 \\ \text { KPLVIAEDVDGEALSTLVLNR } & 1.00 & 69.80 & 18.69 & 82.80 & 4 & 2652.5373 & 2652.5305 & 664.1399 & 0.0068 & 2.5597 & 77.888\end{array}$ $\begin{array}{llllllllllll}\text { KPLVIIAEDVDGEALSTLVLNR } & 1.00 & 69.80 & 18.69 & 82.80 & 4 & 2652.5373 & 2652.5305 & 664.1399 & 0.0068 & 2.5597 & 77.888 \\ \text { KPLVIIAEDVDGEALSTLVLNR } & 1.00 & 58.98 & 18.75 & 71.98 & 4 & 2652.5377 & 2652.5305 & 664.1399 & 0.0072 & 2.7103 & 105.824\end{array}$ $\begin{array}{llllllllllll}\text { KPLVIAEDVDGEALSTLVLNR } & 1.00 & 58.98 & 18.75 & 71.98 & 4 & 2652.5377 & 2652.5305 & 664.1399 & 0.0072 & 2.7103 & 105.824 \\ \text { TALDAAGVASLTTAEVVVTEIPK } & 1.00 & 57.43 & 16.72 & 16.86 & 3 & 2769.6013 & 2769.5983 & 924.2067 & 0.0030 & 1.0820 & 0.000\end{array}$ $\begin{array}{llllllllllll}\text { TALLDAAGVASLLTTAEVVVTEIPK } & 1.00 & 57.43 & 16.72 & 16.86 & 3 & 2769.6013 & 2769.5983 & 924.2067 & 0.0030 & 1.0820 & 0.000 \\ \text { TALLDAAGVASLTTAEVVVTEPK } & 1.00 & 65.30 & 16.33 & 19.52 & 3 & 2769.6025 & 2769.5983 & 924.2067 & 0.0042 & 1.5148 & 5.751\end{array}$ $\begin{array}{llllllllllllll}\text { TALLDAGGASLLTTAEVVVTEPRK } & 0.94 & 3.18 & 16.33 & 16.18 & 4 & 2769.6045 & 2769.5983 & 693.4069 & 0.0062 & 2.2353 & 90.868\end{array}$ $\begin{array}{llllllllllllll}\text { TALDAAGVASLTTAEVVVTERKEFK } & 1.00 & 32.12 & 17.63 & 45.12 & 4 & 3299.8869 & 3299.8805 & 825.9774 & 0.0064 & 1.9371 & 45.362\end{array}$ $\begin{array}{lllllllllll}\text { TALD } & \end{array}$ 
$\begin{array}{lllllllllll}1.00 & 40.23 & 23.14 & 17.85 & 3 & 1716.0127 & 1716.0099 & 573.0106 & 0.0028 & 1.6288 & 120.114\end{array}$

$\begin{array}{llllllllllll}1.00 & 94.70 & 23.46 & 28.31 & 2 & 1716.0128 & 1716.0099 & 859.0122 & 0.0029 & 1.6880 & 4315.696 \\ 1.00 & \# \# \# \# & 23.46 & 26.01 & 2 & 1716.0128 & 1716.0099 & 859.0122 & 0.0029 & 1.6880 & 1734.833 & 2 .\end{array}$

$\begin{array}{lllllllllll}1.00 & 54.81 & 23.42 & 20.34 & 3 & 1716.0128 & 1716.0099 & 859.0122 & 0.0029 & 1.6880 & 1734.833 \\ 1.00 & 38.47 & 23.42 & 23.4 & 3 & 1716.0099 & 573.0106 & 0.0031 & 1.8033 & 188.152\end{array}$

2253.609 $\begin{array}{llllllllllll}\text { KPLVIAEDVDGEALSTLVLNR } & 0.53 & 27.40 & 19.40 & 40.40 & 3 & 2652.5332 & 2652.5305 & 885.1841 & 0.0027 & 1.0167 & 10.710\end{array}$ $\begin{array}{llllllllllll}\text { KPLVIAEDVDGEALSTLVLNR } & 0.83 & 9.66 & 19.40 & 13.79 & 3 & 2652.5332 & 2652.5305 & 885.1841 & 0.0027 & 1.0167 & 6.096\end{array}$

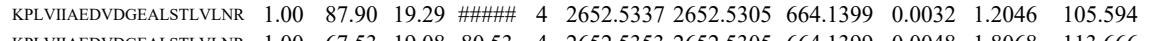
$\begin{array}{llllllllllll}\text { KPLVIIAEDVDGEALSTLVLNR } & 1.00 & 67.53 & 19.08 & 80.53 & 4 & 2652.5353 & 2652.5305 & 664.1399 & 0.0048 & 1.8068 & 113.666\end{array}$

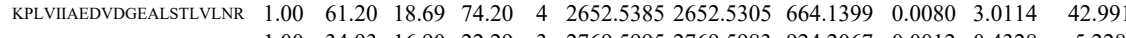
$\begin{array}{llllllllllll}\text { TALLDAAGVASLLTTAEVVVTEIPK } & 1.00 & 34.93 & 16.90 & 22.29 & 3 & 2769.5995 & 2769.5983 & 924.2067 & 0.0012 & 0.4328 & 5.228\end{array}$

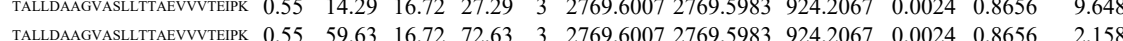

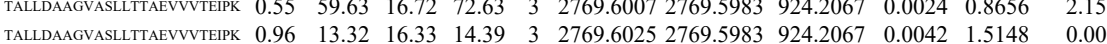
$\begin{array}{lllllllllllll}\text { TALLDAAGVASLITTAEVVVTEIPK } & 1.00 & 39.47 & 16.33 & 17.72 & 3 & 2769.6043 & 2769.5983 & 924.2067 & 0.0060 & 2.1640 & 7.560\end{array}$ $\begin{array}{llllllllllll}\text { GVMLAVDAVIAELK } & 0.97 & 21.87 & 23.14 & 20.86 & 3 & 1716.0106 & 1716.0099 & 573.0106 & 0.0007 & 0.4072 & 252.745\end{array}$ $\begin{array}{lllllllllllll}\text { GVMLAVDAVIAELK } & 1.00 & 27.68 & 23.07 & 16.83 & 3 & 1716.0115 & 1716.0099 & 573.0106 & 0.0016 & 0.9308 & 277.077\end{array}$

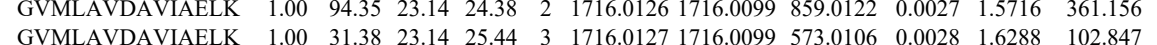
$\begin{array}{llllllllllll}\text { GVMLAVDAVIAELK } & 1.00 & 31.38 & 23.14 & 25.44 & 3 & 1716.0127 & 1716.0099 & 573.0106 & 0.0028 & 1.6288 & 102.847\end{array}$ $\begin{array}{llllllllllll}\text { GVMLAVDAVIAELK } & 0.99 & 24.49 & 23.34 & 19.18 & 3 & 1716.0133 & 1716.0099 & 573.0106 & 0.0034 & 1.9779 & 211.671 \\ \text { GVMLAVDAVIAELK } & 1.00 & 84.80 & 23.46 & 24.44 & 2 & 1716.0136 & 1716.0099 & 859.0122 & 0.0037 & 2.1536 & 590.406\end{array}$ $\begin{array}{llllllllllll}\text { GVMLAVDAVIAELK } & 1.00 & 84.80 & 23.46 & 24.44 & 2 & 1716.0136 & 1716.0099 & 859.0122 & 0.0037 & 2.1536 & 590.406\end{array}$

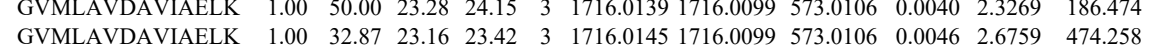

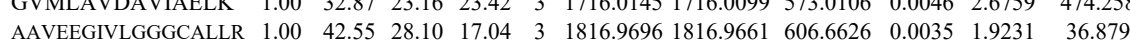
$\begin{array}{lllllllllllll}\text { TALLDAAGVASLLTTAEVVVTEIPK } & 1.00 & 56.10 & 16.81 & 18.03 & 3 & 2769.5998 & 2769.5983 & 924.2067 & 0.0015 & 0.5410 & 2.231\end{array}$ $\begin{array}{lllllllllllll}\text { TALLDAAGVASLLTTAEVVVTEIPK } & 0.55 & 22.74 & 16.81 & 35.74 & 3 & 2769.6001 & 2769.5983 & 924.2067 & 0.0018 & 0.6492 & 2.192\end{array}$ $\begin{array}{llllllllllllll}\text { TALLDAGGVASLITAEVVVTEIPKK } & 1.00 & 27.04 & 16.72 & 14.98 & 3 & 2769.6007 & 2769.5983 & 924.2067 & 0.0024 & 0.8656 & 4.696\end{array}$ $\begin{array}{llllllllllll}\text { TALLDAGVASLLTTAEVVVTEIPK } & 0.53 & 47.75 & 16.72 & 60.75 & 3 & 2769.6010 & 2769.5983 & 924.2067 & 0.0027 & 0.9738 & 0.000\end{array}$

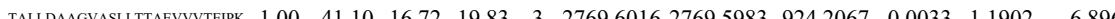
$\begin{array}{llllllllllllll}\text { TALLDAGYASUTTAEYYYTEPK } & 0.53 & 32.84 & 16.72 & 45.84 & 3 & 2769.6016 & 2769.5983 & 924.2067 & 0.0033 & 1.1902 & 0.000\end{array}$

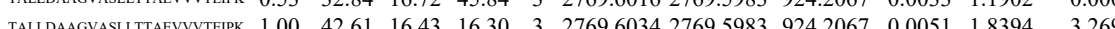
$\begin{array}{lllllllllllll}\text { TALLDAAGVASLITAEVYVTEIPK } & 1.00 & \text { \#\#\#\#\# } & 16.43 & 21.22 & 3 & 2769.6034 & 2769.5983 & 9242067 & 0.0051 & 1.8394 & 1.521\end{array}$ $\begin{array}{lllllllllllll}\text { TALLDAAGVASLTTAEVVVTEIPK } & 0.95 & 3.85 & 16.33 & 16.85 & 4 & 2769.6045 & 2769.5983 & 693.4069 & 0.0062 & 2.2353 & 176.294\end{array}$ $\begin{array}{lllllllllllll}\text { GVMLAVDAVIAELK } & 100 & 56.96 & 23.42 & 22.94 & 3 & 1716.0130 & 1716.0099 & 573.0106 & 0.0031 & 1.8033 & 241.603\end{array}$ $\begin{array}{llllllllllll}\text { GVMLAVDAVIAELK } & 1.00 & 65.14 & 23.34 & 24.50 & 3 & 1716.0133 & 1716.0099 & 573.0106 & 0.0034 & 1.9779 & 153.264\end{array}$ $\begin{array}{lllllllllllll}\text { GVMLAVDAVIAELK } & 1.00 & \text { \#\#\#\#\# } 23.26 & 25.75 & 2 & 1716.0140 & 1716.0099 & 859.0122 & 0.0041 & 2.3865 & 132.244\end{array}$ $\begin{array}{lllllllllllll}\text { AAVEEGIVLGGGCALLR } & 0.92 & 22.42 & 28.08 & 15.54 & 3 & 1816.9705 & 1816.9661 & 606.6626 & 0.0044 & 2.4176 & 10.641\end{array}$ $\begin{array}{lllllllllllll}\text { TALLDAGGVASLTTAEVVVTEPKK } & 1.00 & 97.10 & 16.72 & 21.87 & 3 & 2769.6010 & 2769.5983 & 924.2067 & 0.0027 & 0.9738 & 3.06\end{array}$ $\begin{array}{lllllllllllll}\text { TALLDAAGVASLLTTAEVVVTEPK } & 1.00 & 81.69 & 16.72 & 18.26 & 3 & 2769.6019 & 2769.5983 & 924.2067 & 0.0036 & 1.2984 & 8.481 \\ \end{array}$ $\begin{array}{llllllllllll}\text { TALLDAGGVASLITAEVVVTEIPK } & 1.00 & 73.23 & 16.72 & 17.75 & 3 & 2769.6019 & 2769.5983 & 924.2067 & 0.0036 & 1.2984 & 1.354\end{array}$ $\begin{array}{llllllllllll}\text { TALLDAGGVASLITAEVVVTEIPK } & 1.00 & 79.16 & 16.33 & 19.16 & 3 & 2769.6025 & 2769.5983 & 924.2067 & 0.0042 & 1.5148 & 22.516 \\ \text { TALDAAGASLTTAEVVTEIPK } & 1.00 & 70.59 & 16.33 & 19.84 & 3 & 2769.6025 & 2769.5983 & 924.2067 & 0.0042 & 1.5148 & 0.000\end{array}$ $\begin{array}{llllllllllll}\text { TALLDAAGVASLLTTAEVVVTEPKK } & 1.00 & 70.59 & 16.33 & 19.84 & 3 & 2769.6025 & 2769.5983 & 924.2067 & 0.0042 & 1.5148 & 0.000 \\ \text { TALDAAGVASLTTAEVVVTEPKK } & 1.00 & \# \# \# \# ~ & 16.13 & 23.52 & 3 & 2769.6073 & 2769.5983 & 924.2067 & 0.0090 & 3.2460 & 61.325\end{array}$ $\begin{array}{lllllllllllll}\text { TALLDAAGVASLLTAAEVVVTEIPK } & 1.00 & \text { \#\#\#\# } & 16.13 & 23.52 & 3 & 2769.6073 & 2769.5983 & 924.2067 & 0.0090 & 3.2460 & 61.325 \\ \text { GVMLAVDAVIAELK } & 1.00 & 53.62 & 23.10 & 22.87 & 3 & 1716.0112 & 1716.0099 & 573.0106 & 0.0013 & 0.7562 & 212.186\end{array}$ $\begin{array}{llllllllllll}\text { GVMLAVDAVIAELK } & 1.00 & 53.62 & 23.10 & 22.87 & 3 & 1716.0112 & 1716.0099 & 573.0106 & 0.0013 & 0.7562 & 212.186 \\ \text { GV } & 1.00 & 49.26 & 23.34 & 18.35 & 3 & 1716.0133 & 1716.0099 & 573.0106 & 0.0034 & 1.9779 & 197.458\end{array}$ $\begin{array}{lllllllllllll}\text { GVMLANAVAELK } & 1.00 & 49.26 & 23.34 & 18.35 & 3 & 1716.0133 & 1716.0099 & 573.0106 & 0.0034 & 1.9779 & 197.458\end{array}$

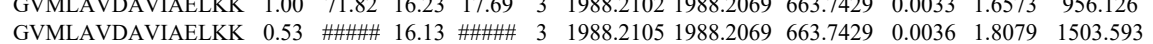

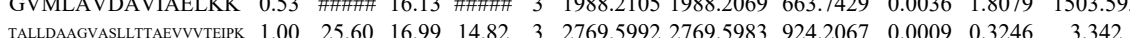
$\begin{array}{llllllllllll}\text { TALDAAGASLTTAEVVTEIPK } & 1.00 & 25.60 & 16.99 & 14.82 & 3 & 2769.5992 & 2769.5983 & 924.2067 & 0.0009 & 0.3246 & 3.342\end{array}$ $\begin{array}{lllllllllllll}\text { TALLDAGGVSLLTTAEVVVTEIPK } & 1.00 & 52.40 & 16.81 & 17.96 & 3 & 2769.6004 & 2769.5983 & 924.2067 & 0.0021 & 0.7574 & 1.291\end{array}$ $\begin{array}{lllllllllllll}\text { TALLDAGGVASLLTTAEVVVTEIPK } & 0.55 & 63.04 & 16.72 & 76.04 & 3 & 2769.6007 & 2769.5983 & 924.2067 & 0.0024 & 0.8656 & 9.571\end{array}$

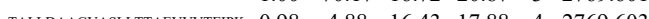

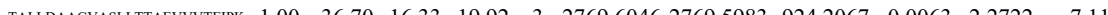


IPAMTIAK

VGLQVVAVK

\begin{tabular}{lllll}
0.99 & 44.63 & 25.49 & 27.93 & 2 \\
\hline
\end{tabular}

VGLQVVAVK

$\begin{array}{llllllllllll}1.00 & 48.45 & 24.97 & 28.22 & 2 & 1131.7006 & 1131.6929 & 566.8537 & 0.0077 & 6.7918 & 7728.439 & 6191.442 \\ 1.00 & 61.28 & 18.13 & 22.90 & 2 & 1199.7928 & 1199.7845 & 600.8995 & 0.0083 & 6.9063 & 20197.136 & 21122.847\end{array}$

$\begin{array}{ll}15.533 & 9.656 \\ 5.319 & 2.745\end{array}$

$\begin{array}{lllllllllllll}\text { MMLQGVDLADAVAVTMGPK } & 0.69 & 60.98 & 23.60 & 17.56 & 3 & 2400.3391 & 2400.3364 & 801.1194 & 0.0027 & 1.1234 & 19.751\end{array}$

$\begin{array}{lllllllllllll} & \text { ALMLQGVDLADAVAVTMGPK } & 1.00 & 60.16 & 23.48 & 19.44 & 3 & 2400.3403 & 2400.3364 & 801.1194 & 0.0039 & 1.6227 & 21.133\end{array}$ $\begin{array}{lllllllllllll} & \text { AMLQGVLLADAVAVIMGPK } & 1.00 & 96.36 & 23.38 & 23.04 & 3 & 2400.3409 & 2400.3364 & 801.1194 & 0.0045 & 1.8724 & 43.249\end{array}$

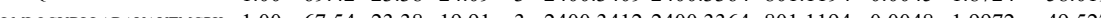
$\begin{array}{llllllll} & \end{array}$

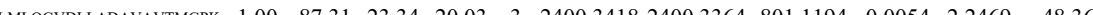

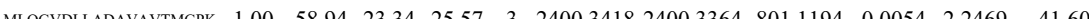
$\begin{array}{llllllllllll} & \end{array}$ $\begin{array}{llllllllllllll}\text { LMLQсVDUADAVAVTYGPK } & 1.00 & 78.85 & 23.28 & 19.09 & 3 & 2400.3424 & 24003364 & 801.1194 & 0.0060 & 2.4965 & 0.000\end{array}$

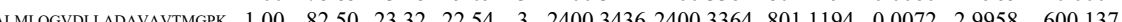
$\begin{array}{llllllllllllll} & \text { LMLOGVDLADAVAVTMGPK } & 1.00 & \text { \#\#\#\# } 23.14 & 25.47 & 2 & 2400.3454 & 2400.3364 & 1201.1755 & 0.0090 & 3.7463 & 26.526\end{array}$ $\begin{array}{lllllllllll} & \end{array}$ $\begin{array}{lllllllllll}\text { ALMLQGVDLLADANAVTMGKK } & 0.98 & 53.95 * 24.03 & 22.49 & 3 & 2416.3312 & 2416.3313 & 806.4510 & -0.0001 & -0.0413 & 5.799\end{array}$ $\begin{array}{lllllllllll}\text { ALMLOGVDLLADAVAVTMGPK } & 1.00 & 86.30 * 23.91 & 19.40 & 3 & 2416.3351 & 2416.3313 & 806.4510 & 0.0038 & 1.5707 & 3.231\end{array}$ $\begin{array}{lllllllllll}\text { ALMLQGVDLLADAVAVTMGPK } & 0.90 & 45.16 * 23.84 & 20.67 & 3 & 2416.3390 & 2416.3313 & 806.4510 & 0.0077 & 3.1827 & 63.517\end{array}$ $\begin{array}{llllllllllll}\text { TALLDAGVASLLTTAEVVVTEPK } & 1.00 & 48.04 & 16.72 & 18.26 & 3 & 2769.6019 & 2769.5983 & 924.2067 & 0.0036 & 1.2984 & 2.841\end{array}$

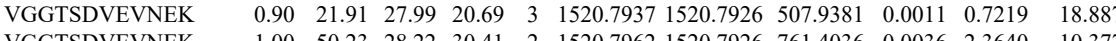
$\begin{array}{lllllllllllll}\text { VGGTSDVEVNEK } & 1.00 & 50.23 & 28.22 & 30.41 & 2 & 1520.7962 & 1520.7926 & 761.4036 & 0.0036 & 2.3640 & 10.377\end{array}$ $\begin{array}{llllllllllll}\text { ALMLQGVDLLADAVAVTMGPK } & 0.99 & 25.04 & 23.54 & 21.67 & 3 & 2400.3397 & 2400.3364 & 801.1194 & 0.0033 & 1.3731 & 22.405\end{array}$ TALLDAGVASLLTTAEVVVTEPKK $0.99 \begin{array}{llllllllllll} & 22.67 & 17.08 & 15.97 & 3 & 2769.5983 & 2769.5983 & 924.2067 & 0.0000 & 0.0000 & 1.301\end{array}$

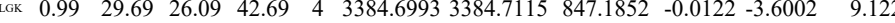
$\begin{array}{lllllllllllll} & & & \end{array}$ $\begin{array}{llllllllllll} & \end{array}$

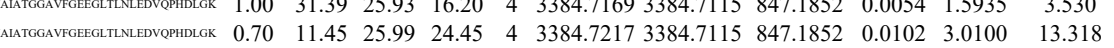
VGLQVVVAVK 

$\begin{array}{lllllllllllll}\text { ISSIQSIVPALEIANAHR } & 1.00 & 37.43 & 24.23 & 24.71 & 3 & 2062.1671 & 2062.1656 & 688.3958 & 0.0015 & 0.7263 & 71.775\end{array}$ $\begin{array}{lllllllllllll}\text { ISSIQSIVPALEIANAHR } & 1.00 & 60.01 & 24.25 & 28.18 & 3 & 2062.1674 & 2062.1656 & 688.3958 & 0.0018 & 0.8716 & 999.655 & 94\end{array}$

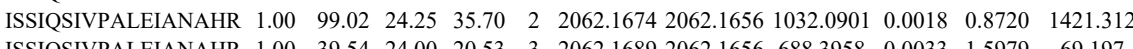
$\begin{array}{llllllllllll}\text { ISSIQSIVPALEIANAHR } & 1.00 & 39.54 & 24.00 & 20.53 & 3 & 2062.1689 & 2062.1656 & 688.3958 & 0.0033 & 1.5979 & 69.197\end{array}$

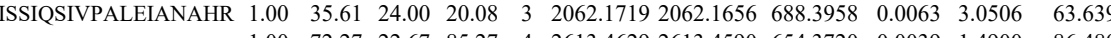
$\begin{array}{lllllllllllll} & \end{array}$ $\begin{array}{lllllllllllll} & \text { LMLQGVLLADAVAVTMGPKGR } & 1.00 & 64.90 & 22.55 & 18.10 & 4 & 2613.4637 & 2613.4590 & 654.3720 & 0.0047 & 1.7956 & 82.416\end{array}$ $\begin{array}{llllllllllll}\text { ISSIQSIVPALEIANAHR } & 1.00 & \text { \#\#\#\# } 24.25 & 36.29 & 2 & 2062.1674 & 2062.1656 & 1032.0901 & 0.0018 & 0.8720 & 972.620\end{array}$ $\begin{array}{llllllllllllll}\text { ISSIQSIVPALEIANAHR } & 1.00 & \text { \#\#\#\# } & 24.25 & 35.90 & 2 & 2062.1674 & 2062.1656 & 1032.0901 & 0.0018 & 0.8720 & 1807.146 \\ \text { ISSIQSIVPALEINAHR } & 1.00 & 62.81 & 24.07 & 28.07 & 3 & 2062.1683 & 2062.1656 & 6883958 & 0.0027 & 1.3074 & 796.794\end{array}$ $\begin{array}{lllllllllllll}\text { ISSIQSIVPALEIANAHR } & 1.00 & 62.81 & 24.07 & 28.07 & 3 & 2062.1683 & 2062.1656 & 688.3958 & 0.0027 & 1.3074 & 796.794\end{array}$ $\begin{array}{llllllllllllll}\text { ISSIQSIVPALEIANAHR } & 1.00 & 68.87 & 24.00 & 28.41 & 3 & 2062.1686 & 2062.1656 & 688.3958 & 0.0030 & 1.4527 & 1621.561 & 20 \\ \text { ISSIQSIVPALEIANAHR } & 1.00 & 98.31 & 24.25 & 35.19 & 2 & 2062.1674 & 2062.1656 & 1032.0901 & 0.0018 & 0.8720 & 500.015 & 350\end{array}$ $\begin{array}{llllllllllll}\text { ISSIQSIVPALEIANAHR } & 1.00 & 98.31 & 24.25 & 35.19 & 2 & 2062.1674 & 2062.1656 & 1032.0901 & 0.0018 & 0.8720 & 500.015 \\ \text { ISSIQSIVPALEIANAHR } & 1.00 & \# \# \# \# \frac{24.25}{37.19} & 2 & 2062.1674 & 2062.1656 & 1032.0901 & 0.0018 & 0.8720 & 554.207\end{array}$ $\begin{array}{lllllllllllll}\text { ISSIQSIVPALEIANAHR } & 1.00 & \text { \#\#\#\# } & 24.25 & 37.19 & 2 & 2062.1674 & 2062.1656 & 1032.0901 & 0.0018 & 0.8720 & 554.207 \\ \text { ISSIOSIVPALEIANAHR } & 1.00 & 64.76 & 24.12 & 31.80 & 3 & 2062.1680 & 2062.1656 & 688.3958 & 0.0024 & 1.1621 & 796.971\end{array}$ $\begin{array}{lllllllllllll}\text { ISSIQSIVPALEIANAHR } & 1.00 & 64.76 & 24.12 & 31.80 & 3 & 2062.1680 & 2062.1656 & 688.3958 & 0.0024 & 1.1621 & 796.971\end{array}$ $\begin{array}{llllllllllll}\text { ISSIQSIVPALEIANAHR } & 1.00 & 60.13 & 23.93 & 29.08 & 3 & 2062.1698 & 2062.1656 & 688.3958 & 0.0042 & 2.0337 & 1164.663 \\ \text { ISSIOSIVPALEIANAHR } & 1.00 & 73.73 & 24.23 & 28.55 & 3 & 2062.1671 & 2062.1656 & 688.3958 & 0.0015 & 0.7263 & 678.267\end{array}$ $\begin{array}{llllllllllllll}\text { ISSIQSIVPALEIANAHR } & 1.00 & 73.73 & 24.23 & 28.55 & 3 & 2062.1671 & 2062.1656 & 688.3958 & 0.0015 & 0.7263 & 678.267\end{array}$ $\begin{array}{lllllllllllll}\text { ISSIOSIVPALEIANAHR } & 1.00 & 69.90 & 24.12 & 32.56 & 3 & 2062.1680 & 2062.1656 & 688.3958 & 0.0024 & 1.1621 & 599.291\end{array}$

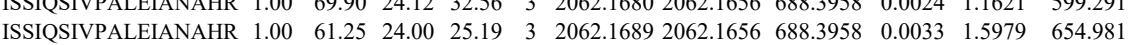
$\begin{array}{lllllllll} & \end{array}$ $\begin{array}{lllllllll} & \end{array}$ $\begin{array}{llllllllll} & \end{array}$ $\begin{array}{llllllllllll} & 0.85\end{array}$ $\begin{array}{lllllllllllll}\text { VTDALNATR } & 1.00 & 41.24 & 28.03 & 26.52 & 2 & 1103.6064 & 1103.6057 & 552.8101 & 0.0007 & 0.6331 & 116.550\end{array}$ VTDALNATR VGGTSDVEVNEK VGGTSDVEVNEK $\begin{array}{lllllllllllll}1.00 & 64.87 & 28.04 & 20.95 & 2 & 1520.7968 & 1520.7926 & 761.4036 & 0.0042 & 2.7581 & 20571.794 & 2049\end{array}$ $\begin{array}{llllllllllll} & 0.86 & 25 & 25.52 .1653 & 2062.1656 & 688.3958 & -0.0003 & -0.1453 & 8.562\end{array}$

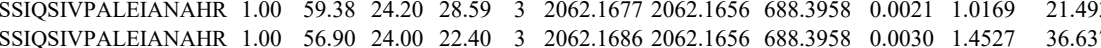

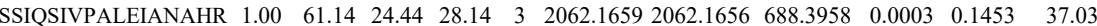
$\begin{array}{llllllllllll}\text { ISSIQSIVPALEIANAHR } & 1.00 & 62.32 & 24.28 & 30.96 & 3 & 2062.1665 & 2062.1656 & 688.3958 & 0.0009 & 0.4358 & 55.193\end{array}$ $\begin{array}{lllllllllllll}\text { ISSIQSIVPALEIANAHR } & 1.00 & 51.89 & 24.25 & 25.32 & 3 & 2062.1674 & 2062.1656 & 688.3958 & 0.0018 & 0.8716 & 7.96\end{array}$ $\begin{array}{lllllllllllll}\text { ISSIQSIVPALEIANAHR } & 1.00 & 45.78 & 24.00 & 16.72 & 3 & 2062.1689 & 2062.1656 & 688.3958 & 0.0033 & 1.5979 & 18.109\end{array}$

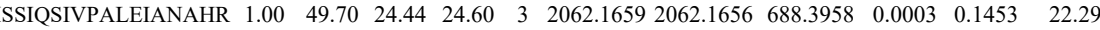

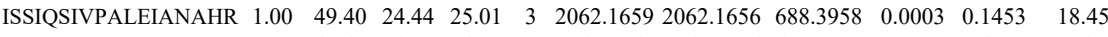
$\begin{array}{lllllllllllll} & 24.162 .45 & 2062.1665 & 2062.1656 & 688.3958 & 0.0009 & 0.4358 & 7.481\end{array}$ $\begin{array}{llllllllllllll}\text { ISSIQSIVPALEIANAHR } & 1.00 & 39.82 & 24.23 & 24.33 & 3 & 2062.1671 & 2062.1656 & 688.3958 & 0.0015 & 0.7263 & 6.536\end{array}$

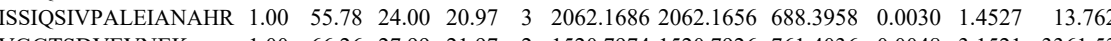
$\begin{array}{llllllllllll}66.34 & 27.99 & 23.05 & 2 & 1520.7976 & 1520.7926 & 761.4036 & 0.0050 & 3.2834 & 3217.375 & 2640.221 & 22\end{array}$ $\begin{array}{llllllllllll}1.00 & 84.88 & 27.94 & 23.19 & 2 & 1791.9564 & 1791.9532 & 896.9839 & 0.0032 & 1.7838 & 14704.811 & 13654.070\end{array}$ $\begin{array}{lllllllllllll}1.00 & 81.0 & 27.98 & 21.78 & 2 & 1791.9566 & 1791.9532 & 896.9839 & 0.0034 & 1.8952 & 8647.188 & 9759.324\end{array}$ 
53 SDIDEIVLVGGSTR SDIDEIVLVGGSTR SDIDEIVLVGGSTR SDIDEIVLVGGSTR TWNDPSVQQDIK

TWNDPSVQQDIK

NQLTSNPENTVFDAK

SDIDEIVLVGGSTR

SDIDEIVLVGGSTR

NQLTSNPENTVFDAK

NQLTSNPENTV
VYEGERPLTK

VYEGERPLTK

ELEEIVQPIISK

ELEEIVQPIISK

ELEEIVQPIISK

ELEEIVQPISK

VYEGERPLTK

VYEGERPLTK

VYEGERPLTK

NELESYAYSLK

NELESYAYSLK

ELEEIVPIISK

ELEEIVQPIISK

ELEEIVQPIISK

ELEEIVQPIISK
VYEGERPLTK

ELEEIVQPIISK

ELEEIVQPIISK

NTVVPTK

NTVVPT

NTVVPTK

NTVVPTK

NTVVPTK

NTVVPTK

NTVVPTK

NTVVPTK

STMKPVQK

STMKPVQK

FEELNMDLFR

FEELNMDLFR

ITPSYVAFTP

STMKPVQK

STMKPVQK

STELPR

FEELNMDLFR
FEELNMDLFR $\begin{array}{lllllllllll}0.53 & 18.89 & 27.23 & 17.81 & 3 & 2703.3469 & 2703.343433 & 902.1217 & 0.0036 & 1.3302 & 54.778 \\ & 1703.3433 & 902.1217 & 0.0111 & 4.1014 & 2.855\end{array}$

$\begin{array}{llllllllll} & 27.23 \\ 17.81 & 3 & 2703.3544 & 2703.3433 & 902.1217 & 0.0111 & 4.1014 & 2.855 & 4.810\end{array}$

$\begin{array}{lllllllllllll} & \end{array}$ $\begin{array}{llllllllllll}0.86 & 18.81 & 27.83 & 18.98 & 3 & 1603.8559 & 1603.8539 & 535.6252 & 0.0020 & 1.2446 & 162.676 & 201.758 \\ 1.00 & 33.98 & 27.77 & 21.00 & 3 & 1603.8562 & 1603.8539 & 535.6252 & 0.023 & 1.4313 & 131.509 & 141.083\end{array}$ $\begin{array}{llllllllllll}1.00 & 33.98 & 27.77 & 21.00 & 3 & 1603.8562 & 1603.8539 & 535.6252 & 0.0023 & 1.4313 & 131.509 & 141.083\end{array}$

$\begin{array}{llllllllllll}1.00 & 67.41 & 27.92 & 32.80 & 2 & 1717.9012 & 1717.8879 & 859.9512 & 0.0133 & 7.7329 & 2038.946 & 2156.448\end{array}$

$\begin{array}{lllllllllllll} & \end{array}$

$\begin{array}{llllllllllll}72.26 & 28.27 & 19.63 & 2 & 1965.0030 & 1965.0047 & 983.5096 & -0.0017 & -0.8643 & 542.906 & 719.136 & 797.733\end{array}$

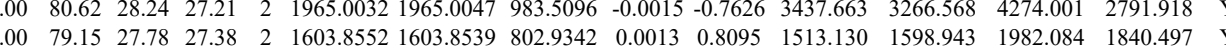

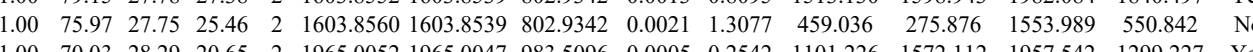

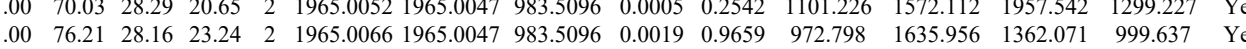
$\begin{array}{llllllllllllllll}0.98 & 26.10 & 26.87 & 20.34 & 3 & 1478.8369 & 1478.8336 & 493.9518 & 0.0033 & 2.2269 & 58360.772 & 82098.751 & 39120.541 & 11139.240 & \text { Yes }\end{array}$ $\begin{array}{lllllllllllllll}0.95 & 22.02 & 26.87 & 21.20 & 3 & 1478.8369 & 1478.8336 & 493.9518 & 0.0033 & 2.2269 & 49609.831 & 68610.289 & 30055.494 & 11592.283 & \text { Y }\end{array}$ $\begin{array}{llllllllllllllll}1.00 & 78.30 & 23.86 & 25.36 & 2 & 1684.9862 & 1684.9854 & 843.5000 & 0.0008 & 0.4742 & 318.445 & 344.190 & 1409.514 & 1152.134 & \text { Yes } \\ 1.00 & 75.96 & 23.87 & 22.32 & 2 & 1684.964 & 1684.954 & 833.5000 & 0.0010 & 0.592 & 433.904 & 590.46 & 2584.958 & 2555.865 & \text { No }\end{array}$

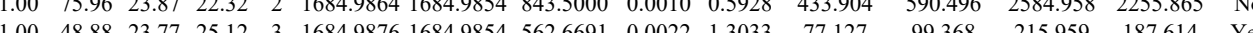

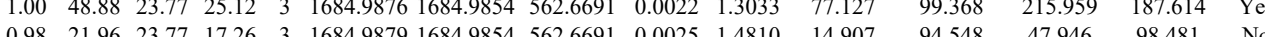

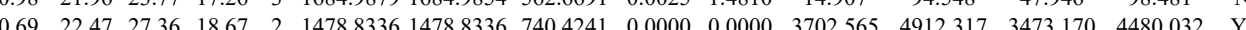

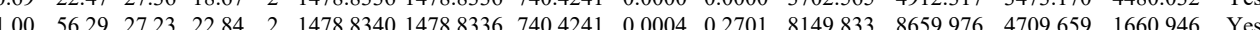
$\begin{array}{llllllllllllllll}0.98 & 25.53 & 27.23 & 23.81 & 3 & 1478.8360 & 1478.8336 & 493.9518 & 0.0024 & 1.6196 & 25687.432 & 37921.178 & 17068.517 & 6924.138 & \text { Yes }\end{array}$

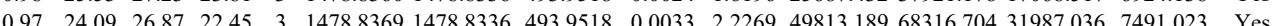

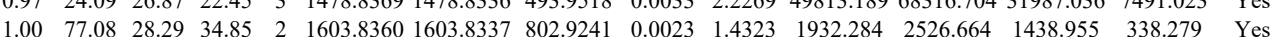
$\begin{array}{lllllllllllllll}1.00 & 47.12 & 23.89 & 27.26 & 2 & 1684.9858 & 1684.9854 & 843.5000 & 0.0004 & 0.2371 & 182.376 & 111.152 & 1201.101 & 332.671 & \text { No }\end{array}$

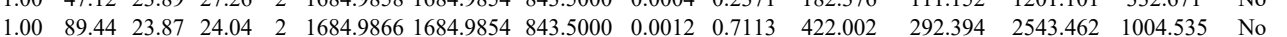
$\begin{array}{lllllllllllllll}1.00 & 39.68 & 23.89 & 19.10 & 3 & 1684.9870 & 1684.9854 & 562.6691 & 0.0016 & 0.9479 & 85.311 & 88.542 & 137.327 & 94.856 & \text { Yes }\end{array}$

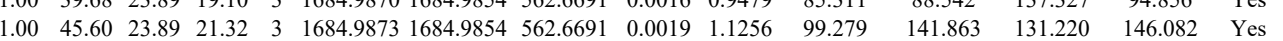
$\begin{array}{llllllllllllllll}0.94 & 28.62 & 27.37 & 20.30 & 3 & 1478.8327 & 1478.8336 & 493.9518 & -0.0009 & -0.6073 & 26623.027 & 38869.139 & 17257.446 & 3007.682 & \text { Yes }\end{array}$ $\begin{array}{llllllllllllllll}0.91 & 25.44 & 23.89 & 29.65 & 2 & 1684.9858 & 1684.9854 & 843.5000 & 0.0004 & 0.2371 & 147.078 & 281.577 & 2489.880 & 459.177 & \text { No }\end{array}$ $\begin{array}{lllllllllllllll}0.98 & 24.11 & 23.89 & 23.31 & 3 & 1684.9873 & 1684.9854 & 562.6691 & 0.0019 & 1.1256 & 98.648 & 119.635 & 171.718 & 115.458 & \text { Yes }\end{array}$

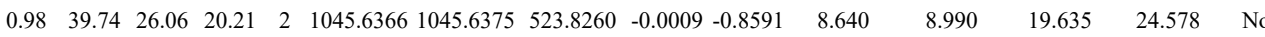

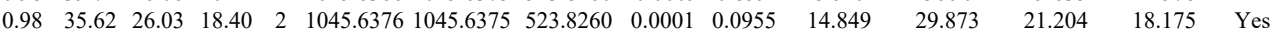

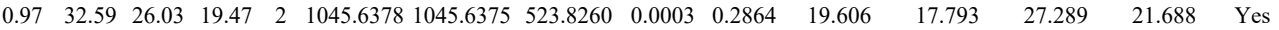

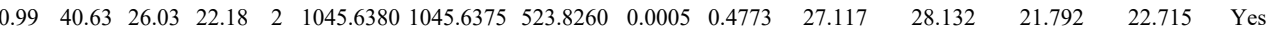

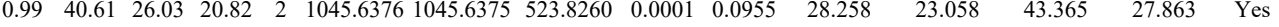

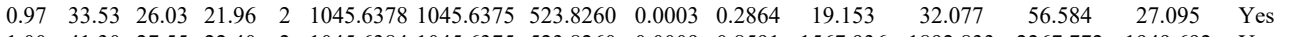

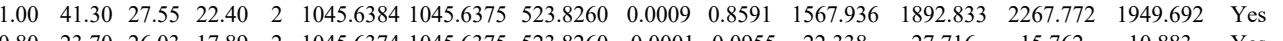

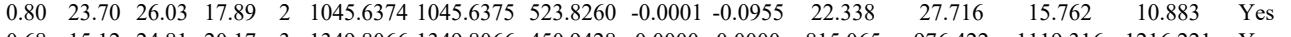

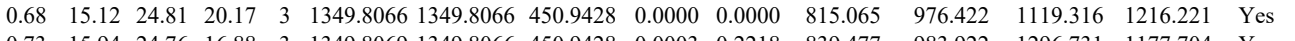

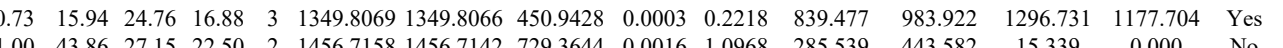
$\begin{array}{lllllllllllllll}1.00 & 43.86 & 27.15 & 22.50 & 2 & 1456.7158 & 1456.7142 & 729.3644 & 0.0016 & 1.0968 & 285.539 & 443.582 & 15.339 & 0.000 & \text { No } \\ 1.00 & 55.35 & 27.19 & 30.49 & 2 & 1456.7164 & 1456.7142 & 729.3644 & 0.0022 & 1.5082 & 296.756 & 282.924 & 18.462 & 0.000 & \text { No }\end{array}$

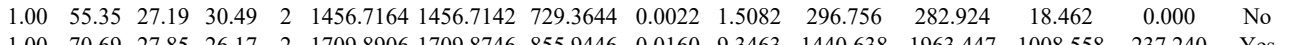
$\begin{array}{lllllllllllllll}1.00 & 70.69 & 27.85 & 26.17 & 2 & 1709.8906 & 1709.8746 & 855.9446 & 0.0160 & 9.3463 & 1440.638 & 1963.447 & 1008.558 & 237.240 & \text { Yes } \\ 0.71 & 15.53 & 24.76 & 1825 & 3 & 1349.8069 & 1349.8066 & 450.9428 & 0.0003 & 0.2218 & 693.470 & 928.172 & 1082.018 & 1065.806 & \text { Yes }\end{array}$ $\begin{array}{lllllllllllllll}0.71 & 15.53 & 24.76 & 18.25 & 3 & 1349.8069 & 1349.8066 & 450.9428 & 0.0003 & 0.2218 & 693.470 & 928.172 & 1082.018 & 1065.806 & \text { Yes } \\ 0.68 & 19.70 & 24.76 & 16.21 & 2 & 1349.8070 & 1349.8066 & 675.9106 & 0.0004 & 0.2959 & 28.545 & 46.127 & 68.921 & 45.681 & \text { Yes }\end{array}$

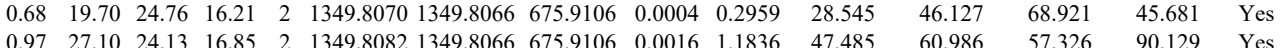

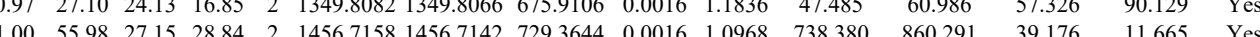

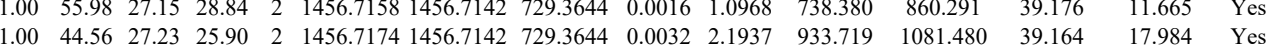

Table S-3 page 122 of 499 
$\begin{array}{llllllllllll}31.48 & 27.19 & 16.92 & 3 & 2031.0862 & 2031.0660 & 678.0293 & 0.0202 & 9.9306 & 5996.471 & 5285.816 & 263.719\end{array}$

$\begin{array}{lllllllllllll}0.80 & 0.000\end{array}$

FLPFK

$\begin{array}{llllllllllllll}0.83 & 25.86 & 20.93 & 28.88 & 2 & 938.5906 & 938.5833 & 470.2989 & 0.0073 & 7.7610 & 67121.341 & 59859.045 \\ 0.88 & 25.89 & 20.76 & 28.94 & 2 & 938.5920 & 938.583 & 470.2989 & 0.0087 & 9.2494 & 65191.771 & 58329.191\end{array}$

IEWLESHQDADIEDFK

IEWLESHQDADIEDFK

TWNDPSVQQDIK

TWNDPSVQQDIK

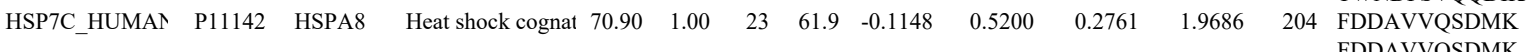

$\begin{array}{lllllllllllll}0.99 & 27.72 & 27.66 & 14.84 & 3 & 22621072 & 22621048 & 755.0422 & 0.0024 & 1.0595 & 530.169 & 595.756\end{array}$ FDDAVVQSDMK

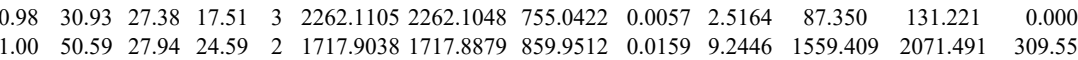

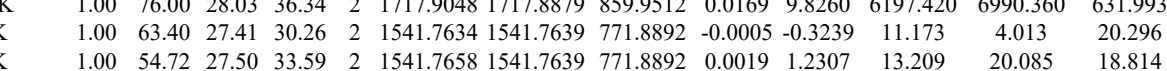
$\begin{array}{llllllllllllll} & \\ & 1.00 & 54.72 & 27.50 & 33.59 & 2 & 1541.7658 & 1541.7639 & 771.8892 & 0.0019 & 1.2307 & 13.209 & 20.085 & 18.814 \\ 15.025 & 15.02 & 28.09 & 15.25 & 3 & 1936.9951 & 1936.9920 & 646.6713 & 0.0031 & 1.5979 & 10.959 & 15.356 & 9.734\end{array}$

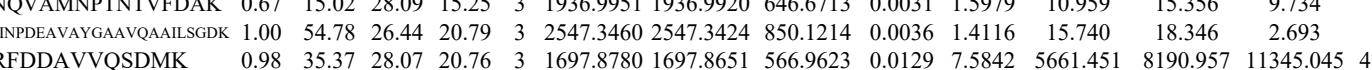
RFDDAVVQSDMK FEELNADLFR

EELNADLFR

\begin{tabular}{llllllllllll}
35.37 & 28.07 & 20.76 & 3 & 1697.8780 & 1697.8651 & 566.9623 & 0.0129 & 7.5842 & 5661.451 & 8190.957 \\
\hline 5.86 & 28.08 & 23.70 & 3 & 1697.8801 & 1697.8651 & 566.9623 & 0.0150 & 8.8189 & 6017.135 & 5325.399
\end{tabular}

(25.399 4789.584

FEELNADLFR

FEELNADLFR

FEELNADLFR

FEELNADLFR

FEELNADLFR

FEELNADLFR

FEELNADLFR

FEELNADLFR

FEELNADLFR

FEELNADLFR

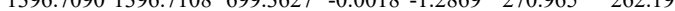

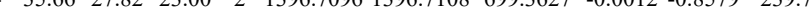

$\begin{array}{lllllllllllll} & \end{array}$

\begin{tabular}{llllllllllllll}
0.97 & 30.76 & 27.89 & 21.29 & 2 & 1396.7128 & 1396.7108 & 699.3627 & 0.0020 & 1.4299 & 243.428 & 263.100 & 60.205 \\
\hline
\end{tabular}

$\begin{array}{lllllllllllll}1.00 & 62.37 & 27.77 & 26.47 & 2 & 1396.7130 & 1396.7108 & 699.3627 & 0.0022 & 1.5729 & 21457.393 & 19743.477 & 282.307\end{array}$

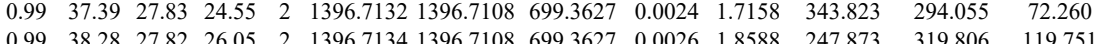

$\begin{array}{llllllllllllll}0.99 & 38.28 & 27.82 & 26.05 & 2 & 1396.7134 & 1396.7108 & 699.3627 & 0.0026 & 1.8588 & 247.873 & 319.806 & 119.751 \\ 1.08 & 61.62 & 27.8 & 27.73 & 2 & 136.7134 & 196.7108 & 699.327 & 0.002 & 1.8588 & 50195.758 & 4200.250 & 49.908\end{array}$

$\begin{array}{lllllllllllll}1.00 & 61.62 & 27.82 & 27.73 & 2 & 1396.7134 & 1396.7108 & 699.3627 & 0.0026 & 1.8588 & 50195.758 & 42020.250 & 495.908\end{array}$

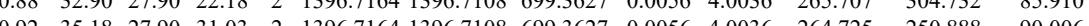

$\begin{array}{lllllllllllll}0.92 & 35.18 & 27.90 & 31.03 & 2 & 1396.7164 & 1396.7108 & 699.3627 & 0.0056 & 4.0036 & 264.725 & 250.888 & 90.006 \\ 1.00 & 64.49 & 27.69 & 27.35 & 2 & 1396.7114 & 1396.7108 & 6993627 & 0.0006 & 0.4290 & 43949.222 & 38553.073 & 699.191\end{array}$

$\begin{array}{lllllllllllll}1.00 & 64.49 & 27.69 & 27.35 & 2 & 1396.7144 & 1396.7108 & 699.3627 & 0.0006 & 0.4290 & 43949.222 & 38553.073 & 699.191\end{array}$

\title{
Q QVAMNPTNTVFDAK
}

$\begin{array}{lllllllllllll}1.00 & 51.03 & 27.89 & 25.86 & 2 & 1396.7128 & 1396.7108 & 699.3627 & 0.0020 & 1.4299 & 24968.596 & 21638.895 & 1254.165\end{array}$

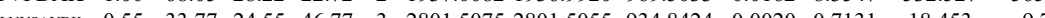

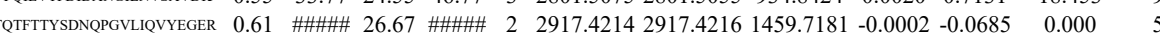

TQTFTTYSDNQPGVLLQYYEGER

9.752
5.738

FEELNADLFR

$\begin{array}{llllllllllllll}1.00 & 50.75 & 27.77 & 27.36 & 2 & 1396.7136 & 1396.7108 & 699.3627 & 0.0028 & 2.0018 & 14373.977 & 12162.195 & 1067.468\end{array}$

$\begin{array}{llllllllllllllll} & 1.00 & 58.17 & 27.71 & 26.44 & 2 & 1396.7138 & 1396.7108 & 699.3627 & 0.0030 & 2.1448 & 27137.785 & 22093.329 & 1604.553\end{array}$

NQVAMNPTNTVFDAK

FEELNADLFR
FEELNADLFR

$\begin{array}{llllllllllll}0.75 & 16.52 & 28.10 & 24.27 & 3 & 1936.9948 & 1936.9920 & 646.6713 & 0.0028 & 1.4433 & 28.365 & 40.892 \\ 1.00 & 32.73 & 24.52 & 23.87 & 3 & 3489.5962 & 3489.5939 & 1164.2052 & 0.0023 & 0.6585 & 7.922 & 12.065\end{array}$

$\begin{array}{lllllllllll} & 1396.7156 & 1396.7108 & 699.3627 & 0.0048 & 3.4317 & 3471.669 & 2874.984\end{array}$

$\begin{array}{llllllllllll}1.00 & 72.51 & 27.74 & 25.74 & 2 & 1396.7164 & 1396.7108 & 699.3627 & 0.0056 & 4.0036 & 3250.939 & 2747.156\end{array}$

$\begin{array}{lllllllllllllll} & \end{array}$

$\begin{array}{lllllllllllllll} & \text { SFYPEEVSSMVLTK } & 0.69 & 18.29 & 27.78 & 18.58 & 3 & 1903.9849 & 1903.9845 & 635.6688 & 0.0004 & 0.2098 & 80.142 & 86.042 & 37.450\end{array}$

$\begin{array}{llllllllllllll} & & 190.989 & 1903.9845 & 952.9995 & 0.0027 & 1.4166 & 4839.537 & 4376.014 & 1102.241\end{array}$

SFYPEEVSSMVLTK

$\begin{array}{llllllllllll}1.00 & 87.18 & 27.69 & 23.38 & 2 & 1903.9888 & 1903.9845 & 952.9995 & 0.0043 & 2.2560 & 10864.146 & 9772.337\end{array}$

$\begin{array}{llllllllllll}0.95 & 27.40 & 27.70 & 16.71 & 3 & 1903.9909 & 1903.9845 & 635.6688 & 0.0064 & 3.3560 & 546.139 & 254.737\end{array}$

GVPQIEVTFDIDANGILNVSAVDK

$\begin{array}{lllllllllllll}0.55 & 21.53 & 24.53 & 34.53 & 3 & 2801.5078 & 2801.5055 & 934.8424 & 0.0023 & 0.8201 & 11.575\end{array}$

$\begin{array}{llllllllllll}\text { GVPRIEVTFDIDANGILNVSAVDK } & 0.98 & 23.53 & 24.39 & 17.72 & 3 & 2801.5093 & 2801.5055 & 934.8424 & 0.0038 & 1.3550 & 11.505\end{array}$

GTLDPVEK

GTLDPVEK

FDDAVVQSDMK

$\begin{array}{llllllllllll}0.92 & 30.38 & 28.27 & 29.05 & 2 & 1145.6532 & 1145.6536 & 573.8341 & -0.0004 & -0.3485 & 33.669\end{array}$

DDAVVQSDMK

$\begin{array}{llllllllllll}0.86 & 24.48 & 28.47 & 25.71 & 2 & 1145.6554 & 1145.6536 & 573.8341 & 0.0018 & 1.5684 & 70.296 \\ 1.00 & 66.44 & 27.39 & 42.24 & 2 & 1541.7638 & 1541.7639 & 771.8892 & -0.0001 & -0.0648 & 27.740\end{array}$ $\begin{array}{llllllllllll}1.00 & 66.44 & 27.39 & 42.24 & 2 & 1541.7638 & 1541.7639 & 771.8892 & -0.0001 & -0.0648 & 27.740 \\ 1.00 & 61.36 & 27.37 & 31.90 & 2 & 1541.7650 & 1541.7639 & 771.8892 & 0.0011 & 0.7125 & 39.106\end{array}$ $\begin{array}{lllllllllllll}0.99 & 31.83 & 27.50 & 29.57 & 3 & 1541.7658 & 1541.7639 & 514.9286 & 0.0019 & 1.2299 & 13.800\end{array}$ $\begin{array}{lllllllllllll} & \text { STAGDTHLGGEDFDNR } & 1.00 & 36.23 & 23.91 & 19.29 & 3 & 1834.8220 & 1834.8204 & 612.6141 & 0.0016 & 0.8706 & 21.759\end{array}$

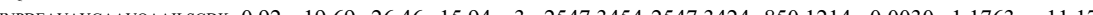

\author{
3.782
5.799
}

4.319

3.574

35.715

18.184

24.368

23.516

$\begin{array}{llllllllll} & 0.0069 & 2.7055 & 2016\end{array}$ Yes Yes
Yes Yes
Yes No 


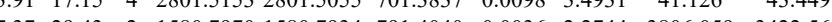

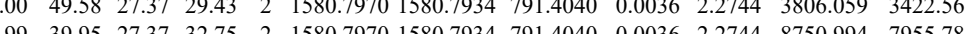
$\begin{array}{llllllllllllll} & \end{array}$

$\begin{array}{llllllllllll}\text { SWDANGAAVQAAILSGDK } & 1.00 & 80.82 & 26.24 & 20.20 & 3 & 2547.3496 & 2547.3424 & 850.1214 & 0.0072 & 2.8231 & 38.256\end{array}$

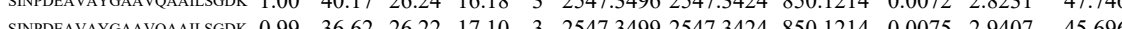
$\begin{array}{lllllllllll} & \text { G }\end{array}$

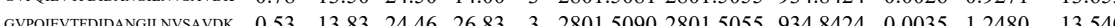
$\begin{array}{llllllllllll} & & \end{array}$ 10.377 $\begin{array}{lllllllllllll}\text { SINPDEAYAYGAAVQAAILSGDK } & 1.00 & 50.12 & 26.34 & 22.77 & 3 & 2547.3472 & 2547.3424 & 850.1214 & 0.0048 & 1.8821 & 19.571\end{array}$ $\begin{array}{llllllllllll}\text { SINPDEAVAYGAAVQAAILGDK } & 1.00 & 62.85 & 26.35 & 19.55 & 3 & 2547.3478 & 2547.3424 & 850.1214 & 0.0054 & 2.1173 & 146.080\end{array}$ $\begin{array}{llllllllllll} & \end{array}$ $\begin{array}{llllllllllllll} & \end{array}$ 3 2801.50722801 .5055 934.8424 0 
$\begin{array}{lllllllll} & \end{array}$

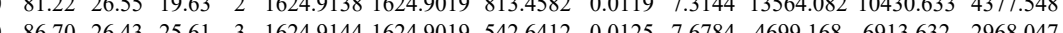

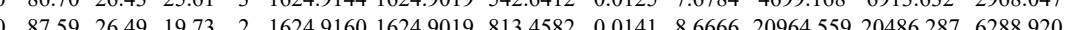

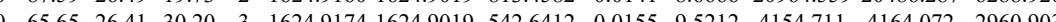

$\begin{array}{llllllllllllll}1.00 & 74.96 & 26.43 & 18.79 & 2 & 1624.9144 & 16249019 & 813.4582 & 0.0125 & 7.6832 & 9574.958 & 9961.285 & 3696.547 & 562\end{array}$

$\begin{array}{lllllllllllll} & \end{array}$

$\begin{array}{lllllllllllll}76.13 & 26.49 & 23.91 & 2 & 1624.9160 & 1624.9019 & 813.4582 & 0.0141 & 8.6666 & 14765.938 & 16386.765 & 4306.016\end{array}$

$\begin{array}{lllllllllllll}54.41 & 26.56 & 24.01 & 3 & 1624.9165 & 1624.9019 & 542.6412 & 0.0146 & 8.9684 & 3525.404 & 4702.212 & 1409.574\end{array}$

$\begin{array}{llllllllllllll}1 & 64.03 & 26.60 & 22.59 & 3 & 1624.9132 & 1624.9019 & 542.6412 & 0.0113 & 6.9413 & 3582.158 & 4257.116 & 1102.409\end{array}$ $\begin{array}{llllllllllllllll}1.00 & 67.93 & 26.43 & 25.92 & 3 & 1624.9144 & 1624.9019 & 542.6412 & 0.0125 & 7.6784 & 3329.034 & 4433.693 & 1537.341 & 457.106\end{array}$ $\begin{array}{lllllllllllllll}0.98 & 37.79 & 27.72 & 24.99 & 2 & 1220.6962 & 1220.6865 & 611.3505 & 0.0097 & 7.9332 & 80775.427 & 80193.744 & 1167.953\end{array}$

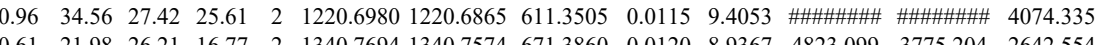

GPAVGIDLGTTYSCVGVFOH

GPAVGIDLGTTYSCVGVFOHGK

$\begin{array}{llllllllllll}\text { GPAVGIDLGTTYSCVGVFOHGK } & 1.00 & 71.38 & 27.02 & 18.71 & 3 & 2539.2844 & 2539.2807 & 847.4342 & 0.0037 & 1.4554 & 12.537\end{array}$

$\begin{array}{llllllllllllll}\text { GPAVGIDLGTTYSCVGVFOHGK } & 1.00 & 30.05 & 27.01 & 43.05 & 4 & 2539.2849 & 2539.2807 & 635.8275 & 0.0042 & 1.6514 & 80.321 & 6\end{array}$

GPAVGIDLGTTYSCVGVFPHGK

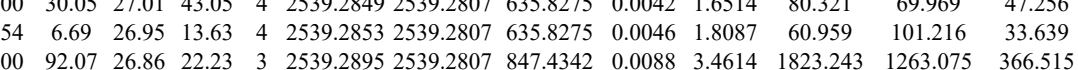

CNPIITK

6.

$\begin{array}{lc}1266.515 \\ 63.075 \\ 0.105 & 0.000\end{array}$

$\begin{array}{lllllllllllll}\text { GPAVGIDLGTTYSCVGVFOHGK } & 1.00 & 83.98 & 26.98 & 18.98 & 3 & 2539.2826 & 2539.2807 & 847.4342 & 0.0019 & 0.7474 & 24.218 & 34.192 \\ \text { GPAVGIDLGTYYSCVGVFPHGK } & 0.53 & 64.06 & 26.97 & 77.06 & 3 & 2539.2835 & 2539.2807 & 847.4342 & 0.0028 & 1.1014 & 265.284 & 262.909\end{array}$ $\begin{array}{llllllllllllll}\text { GPAVGIDLGTTYSCVGVFQHGK } & 1.00 & 88.39 & 26.95 & 21.07 & 3 & 2539.2853 & 2539.2807 & 847.4342 & 0.0046 & 1.8094 & 29.871 & 33.954 & 21.931\end{array}$

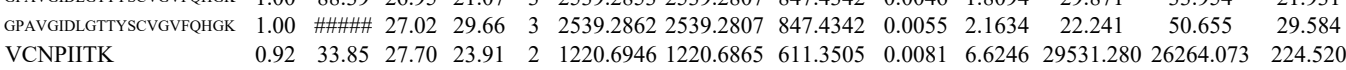

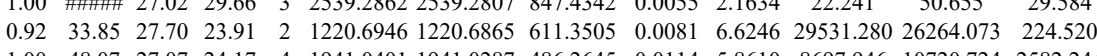

$\begin{array}{llllllllllllll}\text { HWPFMVVNDAGRPK } & 1.00 & 48.07 & 27.07 & 24.17 & 4 & 1941.0401 & 1941.0287 & 486.2645 & 0.0114 & 5.8610 & 8697.946 & 10720.724 & 2582.244\end{array}$ $\begin{array}{lllllllllllllllll}\text { HWPFMVVNDAGRPK } & 1.00 & 37.95 & 27.08 & 19.43 & 4 & 1941.0413 & 1941.0287 & 486.2645 & 0.0126 & 6.4779 & 9325.491 & 12070.373 & 1806.681 & 792.638\end{array}$

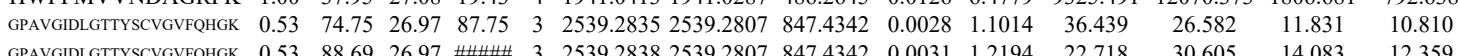

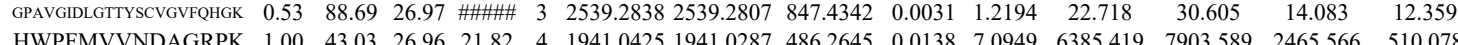

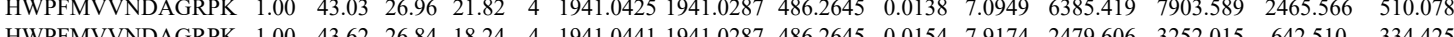
$\begin{array}{lllllllllllllll}\text { HWPFMV NDDAGRPK } & 1.00 & 43.62 & 26.84 & 18.24 & 4 & 1941.0441 & 1941.0287 & 486.2645 & 0.0154 & 7.9174 & 2479.606 & 3252.015 & 642.510 & 334.425 \\ \end{array}$ $\begin{array}{lllllllllllllllll}\text { GPAVGIDLGTTSCVGVFOHGK } & 1.00 & 50.26 & 26.44 & 16.44 & 3 & 2251.0789 & 2251.0766 & 751.3661 & 0.0023 & 1.0204 & 25.904 & 37.680 & 24.525 & 5 .\end{array}$

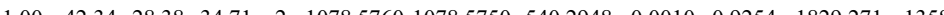


$\begin{array}{lllllllllllll}0.99 & 41.00 & 28.34 & 31.73 & 2 & 1145.6638 & 1145.6536 & 573.8341 & 0.0102 & 8.8875 & 1961.103 & 978.166 & 909.986\end{array}$ $\begin{array}{llllllllllllllll}0.99 & 40.83 & 28.34 & 31.57 & 2 & 1145.6640 & 1145.6536 & 573.8341 & 0.0104 & 9.0618 & 2350.017 & 2289.666 & 1656.655 & 1492.819 & \text { Yes }\end{array}$ $\begin{array}{llllllllllllllll} & & 1430.164 & \text { Yes }\end{array}$

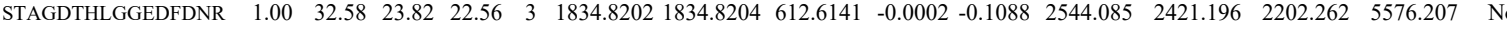

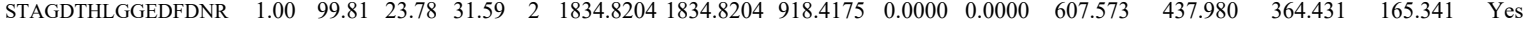

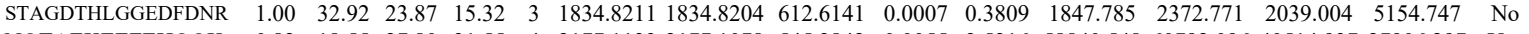

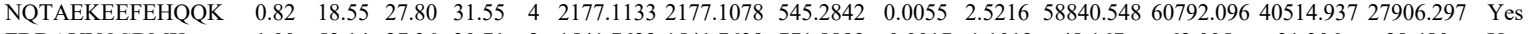
FDDAVVQSDMK FDDAVVQSDMK FDDAVVQSDMK FDDAVVQSDMK FDDAVVQSDMK FDDAVVQSDMK FDDAVVQSDMK FDDAVVQDMK FDDAVVQSDMK FDDAVVSDMK DDAVVQSDM DDAVYS FDDAVVQSDMK

FDAVVSDMK

FDDAVVQSDMK

FDDAVVQSDMK

FDDAVVQSDMK

FDDAVVQSDMK

FDDAVVQSDMK FDDAVVQSDMK FDDAVVQSDMK $\begin{array}{lllllllllll}0.63 & 25.15 & 27.37 & 30.56 & 3 & 1541.7628 & 1541.7639 & 514.9286 & -0.0011 & -0.7121 & 98.689\end{array}$

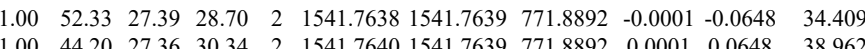
$\begin{array}{lllllllllll}1.00 & 44.20 & 27.36 & 30.34 & 2 & 1541.7640 & 1541.7639 & 771.8892 & 0.0001 & 0.0648 & 38.962 \\ 1.00 & 48.57 & 27.44 & 32.30 & 2 & 1541.7644 & 1541.7639 & 771.8892 & 0.0005 & 0.3239 & 49.581\end{array}$

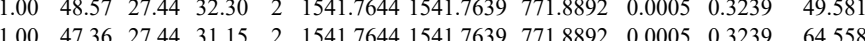
$\begin{array}{lllllllllll}1.00 & 47.36 & 27.44 & 31.15 & 2 & 1541.7644 & 1541.7639 & 771.8892 & 0.0005 & 0.3239 & 64.558 \\ 1.00 & 54.65 & 27.43 & 31.57 & 2 & 1541.7646 & 1541.7639 & 771.8892 & 0.0007 & 0.4534 & 51.526\end{array}$

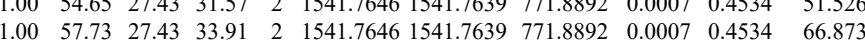
$\begin{array}{lllllllllll}1.00 & 57.73 & 27.43 & 33.91 & 2 & 1541.7646 & 541.7639 & 71.8892 & 0.0007 & 0.4534 & 66.873 \\ 1.00 & 53.21 & 27.39 & 34.49 & 2 & 1541.7648 & 1541.7639 & 771.8892 & 0.0009 & 0.5830 & 48.109\end{array}$

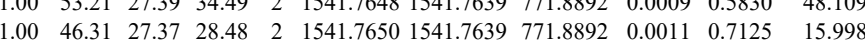
$\begin{array}{lllllllllll}1.00 & 47.43 & 27.40 & 34.10 & 2 & 1541.7652 & 1541.7639 & 771.8892 & 0.0013 & 0.8421 & 41.653\end{array}$

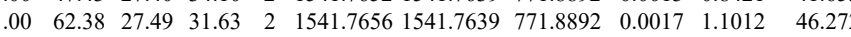
$\begin{array}{lllllllllll}00 & 52.70 & 27.50 & 33.62 & 2 & 1541.7658 & 1541.7639 & 771.8892 & 0.0019 & 1.2307 & 38.849\end{array}$ $\begin{array}{lllllllllll}1.00 & 51.51 & 27.51 & 33.53 & 2 & 1541.7660 & 1541.7639 & 771.8892 & 0.0021 & 1.3603 & 43.538\end{array}$ $\begin{array}{lllllllllllll}0.62 & 13.50 & 27.51 & 19.33 & 3 & 1541.7661 & 1541.7639 & 514.9286 & 0.0022 & 1.4241 & 78.349\end{array}$

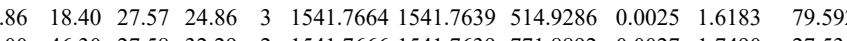
$\begin{array}{lllllllllllll}1.76 & 18.41 & 27.58 & 32.29 & 2 & 1541.7666 & 1541.7639 & 771.8892 & 0.0027 & 1.7490 & 27.535\end{array}$ $\begin{array}{llllllllllll}1.00 & 43.17 & 27.59 & 25.08 & 2 & 1541.7678 & 1541.7639 & 514.9286 & 0.0028 & 1.8125 & 47.659 \\ 0.571 .8892 & 0.0029 & 1.8785 & 16.840\end{array}$ $\begin{array}{llllllllllll}0.55 & 12.53 & 27.57 & 24.55 & 3 & 1541.7670 & 1541.7639 & 514.9286 & 0.0031 & 2.0067 & 98.022\end{array}$ $\begin{array}{llllllllllll}1.00 & 43.07 & 27.56 & 27.11 & 2 & 1541.7670 & 1541.7639 & 771.8892 & 0.0031 & 2.0081 & 21.573\end{array}$

$\begin{array}{lll}62.005 & 31.306 & 38.480 \\ 95.938 & 47.044 & 67.264\end{array}$

$\begin{array}{llllllllll}44.29 & 27.63 & 20.01 & 2 & 1557.7736 & 1557.7589 & 779.8867 & 0.0147 & 9.4244 & 317.625\end{array}$

$\begin{array}{llllllllllll} & \end{array}$

$\begin{array}{lllllllllllllll}1 & & \end{array}$ $\begin{array}{llllllllllllllll}1.00 & 63.92 & 27.76 & 24.75 & 2 & 1208.6720 & 1208.6709 & 605.3427 & 0.0011 & 0.9086 & 4905.233 & 573.122 & 749.344 & 689.243 & \text { Yes } \\ 1.06 & 63.673 .647 & 381.331 & 237.173 & \text { Yes }\end{array}$ $\begin{array}{lllllllllllllll}1.00 & 63.87 & 27.76 & 22.91 & 2 & 1208.6720 & 1208.6709 & 605.3427 & 0.0011 & 0.9086 & 4034.378 & 8326.213 & 430.753 & 203.011 & \text { Yes } \\ 1.00 & 43.97 & 25.79 & 27.81 & 2 & 1133.6938 & 1133.6930 & 567.8538 & 0.0008 & 0.7044 & 638.953 & 11539.281 & 576.922 & 85.106 & \text { Yes }\end{array}$ $\begin{array}{lllllllllllllll}1.00 & 43.97 & 25.79 & 27.81 & 2 & 1133.6938 & 1133.6930 & 567.8538 & 0.0008 & 0.7044 & 6338.953 & 11539.281 & 576.922 & 85.106 & \text { Yes } \\ 1.00 & 44.54 & 25.80 & 26.82 & 2 & 1133.6932 & 1133.6930 & 567.8538 & 0.0002 & 0.1761 & 14965.583 & 27645.404 & 926.859 & 332.988 & \text { Yes }\end{array}$

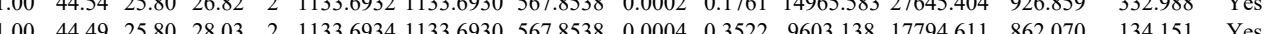




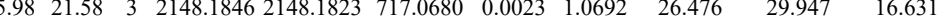

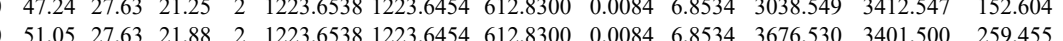

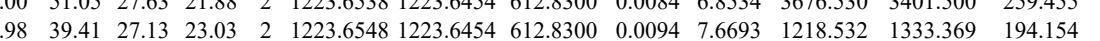
$\begin{array}{lllllllllllllll}0.90 & 30.22 & 27.28 & 21.73 & 2 & 1223.6552 & 1223.6454 & 612.8300 & 0.0098 & 7.9956 & 2164.898 & 2010.458 & 230.815 & 48.02\end{array}$ $\begin{array}{llllllllllllllll}1.00 & 36.61 & 28.36 & 22.25 & 3 & 1507.8139 & 1507.8095 & 503.6104 & 0.0044 & 2.9123 & 4584.411 & 4598.065 & 1053.857 & 713.050\end{array}$ $\begin{array}{llllllllllllll}1.00 & 39.48 & 28.14 & 21.35 & 3 & 1507.8160 & 1507.8095 & 503.6104 & 0.0065 & 4.3022 & 4639.131 & 3962.153 & 1506.869 & 738.751\end{array}$ $\begin{array}{lllllllllllllll}1.00 & 36.74 & 27.75 & 22.44 & 3 & 1626.8125 & 1626.8102 & 543.2773 & 0.0023 & 1.4112 & 992.557 & 952.648 & 1430.635 & 1322.971 & \text { Yes }\end{array}$

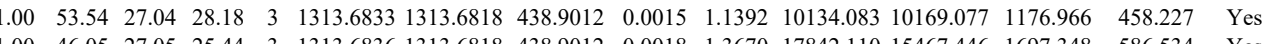
$\begin{array}{llllllllllllllll}1.00 & 46.05 & 27.05 & 25.44 & 3 & 1313.6836 & 1313.6818 & 438.9012 & 0.0018 & 1.3670 & 17842.110 & 15467.446 & 1697.348 & 586.534 & \text { Yes } \\ 1.00 & 55.54 & 27.05 & 25.05 & 2 & 1313.6836 & 1313.6818 & 657.8482 & 0.0018 & 1.3681 & 6309.447 & 5123.594 & 499.804 & 98.273 & \text { Yes }\end{array}$ $\begin{array}{lllllllllllllllll}1.00 & 55.54 & 27.05 & 25.05 & 2 & 1313.6836 & 1313.6818 & 657.8482 & 0.0018 & 1.3681 & 6309.447 & 5123.594 & 499.804 & 98.273 & \text { Yes } \\ 1.00 & 66.29 & 26.75 & 25.63 & 2 & 1313.6842 & 1313.6818 & 657.8482 & 0.0024 & 1.8241 & 5071.273 & 5177.259 & 462524 & 107.789 & \text { Yes }\end{array}$ $\begin{array}{lllllllllllllll}1.00 & 66.29 & 26.75 & 25.63 & 2 & 1313.6842 & 1313.6818 & 657.8482 & 0.0024 & 1.8241 & 5071.273 & 5177.259 & 462.524 & 107.789 & \text { Yes } \\ 1.00 & 42.16 & 26.98 & 26.28 & 3 & 1313.6824 & 1313.6818 & 438.9012 & 0.0006 & 0.4557 & 3947.178 & 3556.911 & 512.521 & 225.029 & \text { Yes }\end{array}$ $\begin{array}{lllllllllllllll}1.00 & 42.16 & 26.98 & 26.28 & 3 & 1313.6824 & 1313.6818 & 438.9012 & 0.0006 & 0.4557 & 3947.178 & 3556.911 & 512.521 & 225.029 & \text { Yes } \\ 1.00 & 62.71 & 26.89 & 30.58 & 3 & 1313.6830 & 1313.6818 & 438.9012 & 0.0012 & 0.9114 & 3188.820 & 2970.881 & 395.919 & 300.200 & \text { Yes }\end{array}$

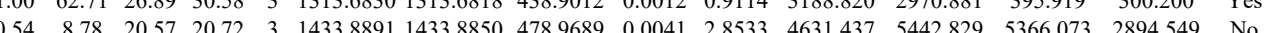

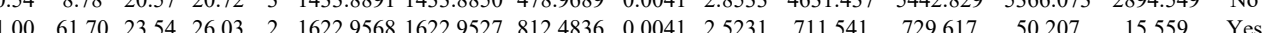




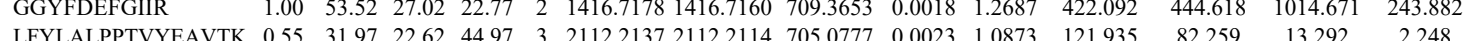

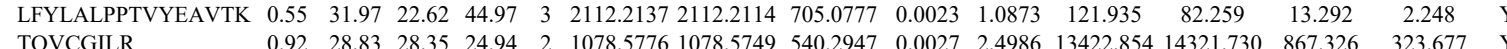

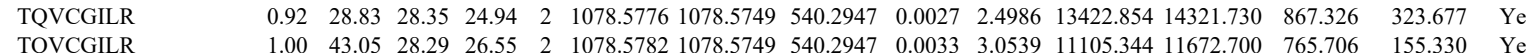

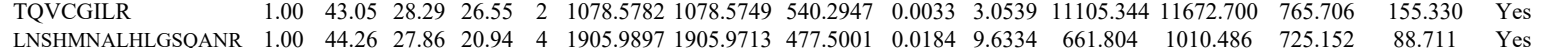

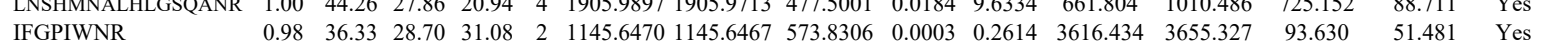

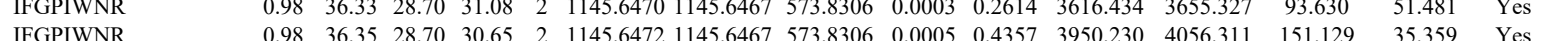
$\begin{array}{llllllllllllllll}\text { IFGPIWNR } & 0.90 & 34.39 & 28.81 & 32.41 & 2 & 1145.6462 & 1145.6467 & 573.8306 & -0.0005 & -0.4357 & 6654.511 & 6468.666 & 211.853 & 55.605 & \text { Yes }\end{array}$ IFGPIWNR IFGPIWNR
IFGPIWNR

GYLDDPTVPR

GYLDDPTVPR $\begin{array}{lllllllllllllll}0.90 & 34.39 & 28.81 & 32.41 & 2 & 1145.6462 & 1145.6467 & 573.8306 & -0.0005 & -0.4357 & 6654.511 & 6468.666 & 211.853 & 55.605 & \text { Yes } \\ 0.96 & 34.43 & 28.70 & 29.54 & 2 & 1145.6470 & 1145.6467 & 573.8306 & 0.0003 & 0.2614 & 1931.275 & 2073.984 & 119.071 & 36.313 & \text { Yes }\end{array}$ $\begin{array}{lllllllllllllllll}0.96 & 34.45 & 28.70 & 31.84 & 2 & 1145.6470 & 1145.6467 & 573.8306 & 0.0003 & 0.2614 & 2706.046 & 2947.514 & 144.000 & 49.262 & \text { Yes }\end{array}$

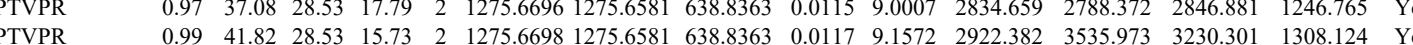
$\begin{array}{llllllllllllllll}\text { IYGADDIELLPEAQHK } & 1.00 & 37.49 & 26.96 & 16.27 & 3 & 2099.1166 & 2099.1142 & 700.7120 & 0.0024 & 1.1417 & 1112.558 & 1367.781 & 337.508 & 237.673 & \text { Yes }\end{array}$ $\begin{array}{lllllllllllllllll}\text { IYGADDIELLPEAQHK } & 1.00 & 48.30 & 27.12 & 19.32 & 3 & 2099.1175 & 2099.1142 & 700.7120 & 0.0033 & 1.5698 & 1587.674 & 1789.726 & 762.986 & 387.540 & \text { Yes }\end{array}$ TPVPSDIDISR TPVPSDIDISR

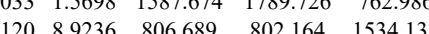

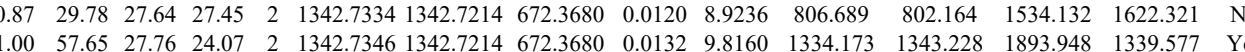
$\begin{array}{lllllllllllllllll}1.00 & 46.07 & 27.51 & 21.31 & 2 & 1342.7318 & 1342.7214 & 672.3680 & 0.0104 & 7.7338 & 1016.683 & 1034.533 & 1269.726 & 907.847 & \text { Yes } & & \end{array}$

MHGGGPTVTAGLPLPK $\begin{array}{lllllllllllllll}1.00 & 51.26 & 25.34 & 24.23 & 2 & 1344.7954 & 1344.7856 & 673.4001 & 0.0098 & 7.2765 & 9424.420 & 7838.983 & 11980.904 & 9306.682 & \text { Yes }\end{array}$ $\begin{array}{lllllllllllllll}1.00 & 52.71 & 25.68 & 22.81 & 2 & 1344.7970 & 1344.7856 & 673.4001 & 0.0114 & 8.4644 & 9202.527 & 10123.269 & 15895.026 & 10283.873 & \text { Yes }\end{array}$ $\begin{array}{lllllllllllllll}1.00 & 68.80 & 27.94 & 24.53 & 2 & 1629.8502 & 1629.8484 & 815.9315 & 0.0018 & 1.1030 & 270.331 & 339.586 & 9.290 & 12.825 & \text { Yes } \\ \end{array}$ $\begin{array}{llllllllllllllll}1.09 & 63.61 & 27.82 & 28.14 & 2 & 1629.8514 & 1629.8484 & 815.9315 & 0.0030 & 1.8384 & 202.969 & 251.174 & 34.725 & 22.016 & \text { Yes } \\ \end{array}$

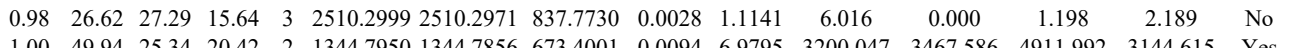

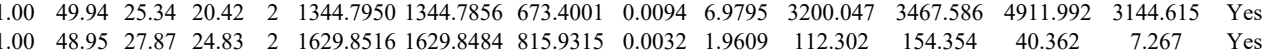

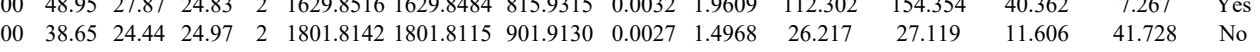
$\begin{array}{llllllllllllllll}1.00 & 53.11 & 24.41 & 28.96 & 2 & 1801.8148 & 1801.8115 & 901.9130 & 0.0033 & 1.8294 & 175.430 & 166.716 & 258.929 & 122.584 & \text { Yes }\end{array}$ $\begin{array}{lllllllllllllll}1.00 & 48.12 & 24.03 & 61.12 & 4 & 4349.2029 & 4349.1984 & 1088.3069 & 0.0045 & 1.0337 & 20.357 & 22.265 & 17.709 & 20.067 & \text { Yes } \\ 1.00 & 39.57 & 24.03 & 52.57 & 4 & 4349.2029 & 4349.1984 & 1088.3069 & 0.0045 & 1.0337 & 35.802 & 53.402 & 44.455 & 28.796 & \text { Yes }\end{array}$

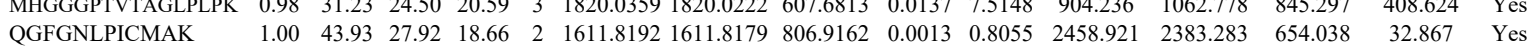

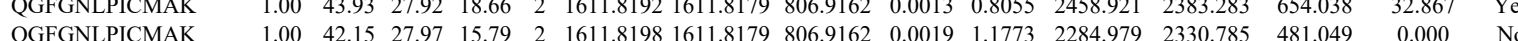




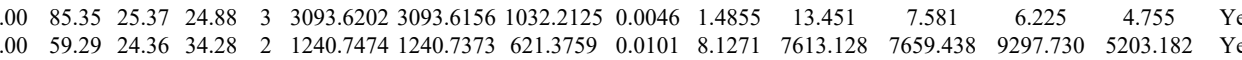

$\begin{array}{lllllllllllllll} & \end{array}$

03.182 Yes

TPPPGGYGPMTVAMLMOS 1.00

GALALAQAVQR

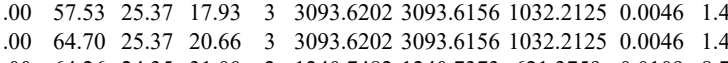

MFGIPVVVAVNAFK

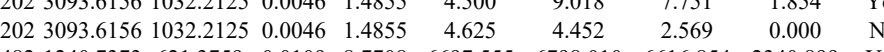
$\begin{array}{lllllllllllllllllll} & 1.00 & 55.75 & 24.41 & 31.20 & 2 & 1240.7486 & 1240.7373 & 621.3759 & 0.0113 & 9.0926 & 9598.371 & 9486.935 & 2988.037 & 1492.875 & Y e s\end{array}$ $\begin{array}{lllllllllllllll} & \end{array}$ $\begin{array}{llllllllllllllll}\text { MFGIPVVVAVNAFK } & 1.00 & 52.60 & 23.52 & 20.08 & 3 & 1779.0376 & 1779.0361 & 594.0193 & 0.0015 & 0.8417 & 311.951 & 352.233 & 51.575 & 53.057 & \text { Yes } \\ \text { MFGIPVVVAVNAFK } & 1.00 & 52.46 & 23.50 & 18.92 & 3 & 1779.0361 & 1779.0361 & 594.0193 & 0.0000 & 0.0000 & 396.328 & 332.596 & 55.103 & 61.806 & \text { Yes }\end{array}$ LAILQVGNR LAILQVGNR GAILQVGNR GVPTGFILPIR LAILQVGNR GVPTGFILPIR LAILQVGNR LAILQVGNR

GALALAQAVQR 61.806 Yes $\begin{array}{llllllllllllll}.00 & 46.52 & 23.34 & 21.96 & 3 & 1779.0388 & 1779.0361 & 594.0193 & 0.0027 & 1.5151 & 1727.331 & 1832.841 & 177.332\end{array}$

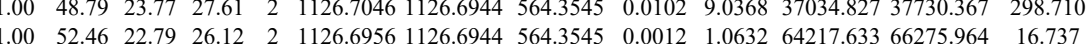
$\begin{array}{lllllllllllllll}1.00 & 39.00 & 23.60 & 25.70 & 2 & 1126.6978 & 1126.6944 & 564.3545 & 0.0034 & 3.0123 & 43778.719 & 44748.083 & 0.000\end{array}$

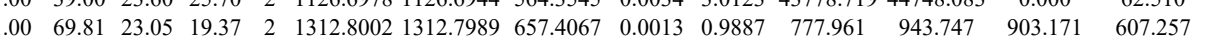
$\begin{array}{llllllllllllll}1.00 & 69.82 & 23.05 & 23.02 & 2 & 1312.8002 & 1312.7989 & 657.4067 & 0.0013 & 0.9887 & 726.503 & 1030.140 & 615.996 & 42 .\end{array}$ $\begin{array}{lllllllllllll}0.98 & 46.05 & 23.73 & 21.48 & 2 & 1126.6912 & 1126.6944 & 564.3545 & -0.0032 & -2.8351 & 7424.365 & 8949.806 & 80.781\end{array}$ $\begin{array}{llllllllllllll}1.00 & 66.90 & 23.32 & 17.61 & 2 & 1312.7992 & 1312.7989 & 657.4067 & 0.0003 & 0.2282 & 312.804 & 318.700 & 226.601\end{array}$ $\begin{array}{lllllllllllll}1.00 & 50.89 & 23.69 & 23.40 & 2 & 1126.6926 & 1126.6944 & 564.3545 & -0.0018 & -1.5947 & 1109.751 & 1204.973 & 85.995\end{array}$ $\begin{array}{lllllllllllll}1.00 & 48.31 & 23.69 & 21.51 & 2 & 1126.6926 & 1126.6944 & 564.3545 & -0.0018 & -1.5947 & 1753.927 & 2031.417 & 78.117\end{array}$

VVGDVAYDEAK

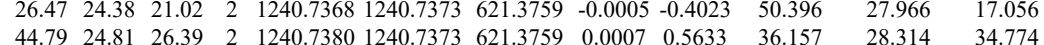

$\begin{array}{llllllllllllll} & 1.00 & 70.44 & 28.10 & 24.57 & 2 & 1452.7738 & 1452.7704 & 727.3925 & 0.0034 & 2.3371 & 573.459 & 657.006 & 120.807 \\ \text { PEAQHK } & 1.00 & 38.62 & 26.98 & 17.32 & 3 & 2099.1172 & 2099.1142 & 7007120 & 0.030 & 1.4271 & 2779.232 & 3035.024 & 318.379\end{array}$

$\begin{array}{lllllllllllll} & \end{array}$

$\begin{array}{lllllllllllllll} & 17.64 & 3 & 2099.1193 & 2099.1142 & 700.7120 & 0.0051 & 2.4261 & 2487.555 & 2856.562 & 222.262\end{array}$

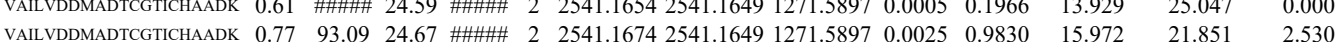

IQVIDISMILGICAAR IQVIDISMILAEAIR IQVIDISMILAEAIR $\begin{array}{llllllllllll}0.77 & 93.09 & 24.67 & \# \# \# \# & 2 & 2541.1674 & 2541.1649 & 1271.5897 & 0.0025 & 0.9830 & 15.972 & 2 \\ 1.00 & 91.35 & 23.14 & 30.43 & 2 & 1828.0614 & 1828.0614 & 915.0380 & 0.0000 & 0.0000 & 557.812 & 55\end{array}$ 551.747 QQVIDISMILAEAIR $\begin{array}{llllllllllll}1.00 & \text { \#\#\#\# 23.24 } & 28.22 & 2 & 1828.0622 & 1828.0614 & 915.0380 & 0.0008 & 0.4371 & 478.983 & 383.832 & 74.384\end{array}$ $\begin{array}{llllllllll}17.08 & 3 & 1828.0627 & 828.0614 & 615.3611 & 0.0013 & 0.7100 & 92.012 & 91.250\end{array}$ $\begin{array}{ll}15.502 \\ 76.976 & 42.127\end{array}$ GYGFVHFETQEAAER

$\begin{array}{lllllllllllll}0.94 & 29.72 & 27.32 & 24.63 & 2 & 1022.6038 & 1022.6004 & 512.3075 & 0.0034 & 3.3183 & 4084.204 & 3223.076 & 552.183 \\ 1.00 & 77.78 & 24.30 & 22.19 & 2 & 176.0098 & 1765.9930 & 884.038 & 0.0168 & 9.5021 & 956.45 & 1055.011 & 418.26\end{array}$

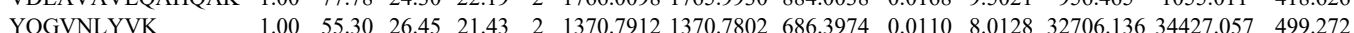
YQGVNLYVK

YQGVNLYVK QAHLTNOYMQR SGVGNIFIK GFGFVSFER QAHLTNQYMQR QAHLTNQYMQR NLDDGIDDER NLDDGIDDER NLDDGIDDER $\begin{array}{lllllllllllll}1.00 & 55.30 & 26.45 & 21.43 & 2 & 1370.7912 & 1370.7802 & 686.3974 & 0.0110 & 8.0128 & 32706.136 & 34427.057 & 499.272\end{array}$ $\begin{array}{llllllllllllll}1.00 & 41.06 & 27.60 & 19.68 & 3 & 1532.7661 & 1532.7640 & 511.9286 & 0.0021 & 1.3674 & 1070.335 & 927.031 & 425.232 & 4.6\end{array}$ $\begin{array}{lllllllllllllll}0.99 & 32.82 & 27.54 & 17.72 & 3 & 1532.7646 & 1532.7640 & 511.9286 & 0.0006 & 0.3907 & 781.575 & 788.326 & 406.589 & 29\end{array}$

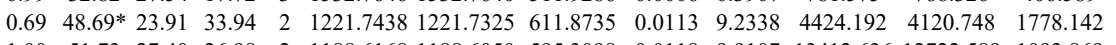
$\begin{array}{llllllllllllll}1.00 & 51.73 & 27.40 & 26.98 & 2 & 1188.6168 & 1188.6050 & 595.3098 & 0.0118 & 9.9107 & 13412.636 & 12722.589 & 1093.869\end{array}$ $\begin{array}{lllllllllllllll}1.00 & 43.06 & 27.65 & 22.30 & 3 & 1532.7652 & 1532.7640 & 511.9286 & 0.0012 & 0.7814 & 1027.773 & 616.880 & 343.308 & 10\end{array}$

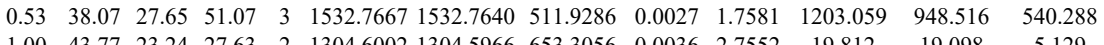

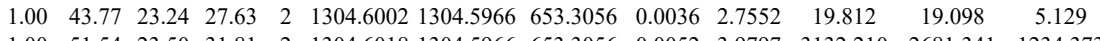
$\begin{array}{lllllllllllll}1.00 & 51.54 & 23.50 & 31.81 & 2 & 1304.6018 & 1304.5966 & 653.3056 & 0.0052 & 3.9797 & 3132.210 & 2681.341 & 1234.373\end{array}$ $\begin{array}{llllllllllllll}1.00 & 58.14 & 23.62 & 30.77 & 2 & 1304.6020 & 1304.5966 & 653.3056 & 0.0054 & 4.1328 & 4991.179 & 4588.859 & 679.015 & 11 . \\ 1.00 & 85.34 & 22.12 & 26.99 & 2 & 1924.1224 & 1924.1212 & 963.0679 & 0.0012 & 0.6230 & 2790.966 & 261.483 & 163.279 & 0\end{array}$ $\begin{array}{llllllllllllll}\text { LFPLIQAMHPTLAGK } & 1.00 & 86.19 & 22.01 & 30.39 & 2 & 1924.1230 & 1924.1212 & 963.0679 & 0.0018 & 0.9345 & 1593.544 & 1575.523 & 86.693\end{array}$ LFPLIQAMHPTLAGK LFPLIQAMHPTLAGK FSPAGPILSIR FSPAGPILSIR FSPAGPILSIR FSPAGPILSIR FSPAGPILSIR FSPAGPILSIR FSPAGPILSIR FSPAGPILSIR FSPAGPILSIR $\begin{array}{llllllllllllll}1.53 & 66.41 & 22.10 & 21.26 & 3 & 1924.1251 & 1924.1212 & 642.3810 & 0.0039 & 2.0237 & 12764.603 & 13251.768 & 1330.589\end{array}$ $\begin{array}{ccccccccccccc}0.53 & 61.75 & 23.64 & 74.75 & 3 & 1940.1193 & 1940.1162 & 647.7126 & 0.0032 & 1.6468 & 2247.906 & 2386.072 & 283.211 \\ 0.97 & 29.33 & 26.19 & 15.84 & 2 & 1300.7632 & 1300.7625 & 651.3885 & 0.0007 & 0.5373 & 54.590 & 43.446 & 5.873\end{array}$ $\begin{array}{llllllllllllll}0.99 & 36.32 & 26.00 & 22.64 & 2 & 1300.7636 & 1300.7625 & 651.3885 & 0.0011 & 0.8443 & 59.999 & 38.870 & 5.124\end{array}$ $\begin{array}{lllllllllllll}0.53 & 16.84 & 26.07 & 17.22 & 2 & 1300.7650 & 1300.7625 & 651.3885 & 0.0025 & 1.9190 & 42.769 & 23.582 & 4.588 \\ 0.76 & 22.88 & 26.26 & 24.75 & 2 & 1300.7622 & 1300.7625 & 651.3885 & -0.0003 & -0.2303 & 67.442 & 64.380 & 20.672\end{array}$

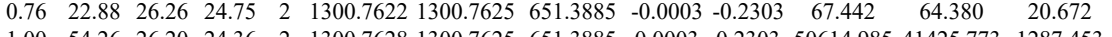
$\begin{array}{lllllllllllll}1.00 & 54.26 & 26.20 & 24.36 & 2 & 1300.7628 & 1300.7625 & 651.3885 & 0.0003 & 0.2303 & 50614.985 & 41425.773 & 1287.453\end{array}$ $\begin{array}{llllllllllllll}1.00 & 50.94 & 26.19 & 22.92 & 2 & 1300.7630 & 1300.7625 & 651.3885 & 0.0005 & 0.3838 & 17978.378 & 17899.356 & 833.342\end{array}$ $\begin{array}{lllllllllllll}0.94 & 26.28 & 26.03 & 25.71 & 2 & 1300.7634 & 1300.7625 & 651.3885 & 0.0009 & 0.6908 & 103.778 & 98.617 & 9.317\end{array}$

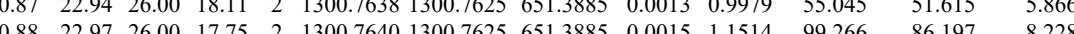

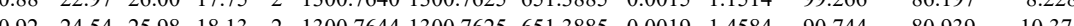

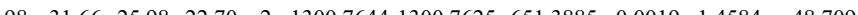
$\begin{array}{llllllllllll}0.99 & 39.07 & 26.09 & 19.07 & 2 & 1300.7654 & 1300.7625 & 651.3885 & 0.0029 & 2.2260 & 76.019 & 67.540\end{array}$

Table S-3 page 129 of 499 


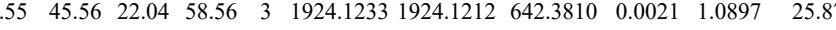

(3)

$\begin{array}{lllllllllllllll}1.00 & 60.60 & 27.84 & 25.67 & 2 & 1393.6952 & 1393.6815 & 697.8480 & 0.0137 & 9.8158 & 12407.571 & 13736.432 & 206.480 & & \\ 1.00 & 58.93 & 27.84 & 24.22 & 2 & 1393.6954 & 1393.6815 & 697.8480 & 0.0139 & 9.9591 & 8541.581 & 8418.668 & 289.577 & 3\end{array}$

$\begin{array}{llllllllllllll}1.00 & 78.80 & 27.80 & 33.88 & 2 & 1580.8544 & 1580.8402 & 791.4274 & 0.0142 & 8.9711 & 1301.388 & 1352.090 & 1003.945 & \\ 1.00 & 77.65 & 27.50 & 33.77 & 2 & 1580.8558 & 1580.8402 & 791.4274 & 0.0156 & 9.8555 & 2774.013 & 2252.518 & 1687.835 & \\ 0\end{array}$

FSASGELGNGNIK

LVQGSILK $\begin{array}{llllllllllllllll}0.81 & 39.76 & 23.42 & 43.59 & 2 & 1144.7494 & 1144.7423 & 573.3784 & 0.0071 & 6.1913 & 5765.596 & 6583.418 & 1558.862 & 53 & & \\ 0\end{array}$ $\begin{array}{llllllllllllll}0.83 & 36.19 & 23.42 & 40.16 & 2 & 1144.7502 & 1144.7423 & 573.3784 & 0.0079 & 6.8889 & 18574.731 & 24758.805 & 3278.940\end{array}$

LVQGSILK

YLNFFTK

YLNFFTK

$\begin{array}{lllllllllllll}0.90 & 39.27 & 23.42 & 41.39 & 2 & 1144.7510 & 1144.7423 & 573.3784 & 0.0087 & 7.5866 & 23029.997 & 34753.629 & 5745.511\end{array}$

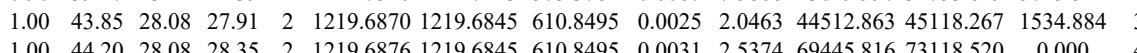

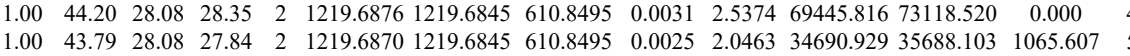

YLNFFTK

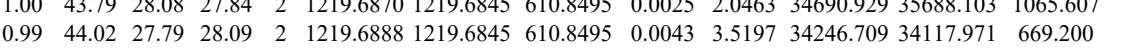
$\begin{array}{llllllllllll} & \text { YLNETK } & 1.200 & 333.736\end{array}$

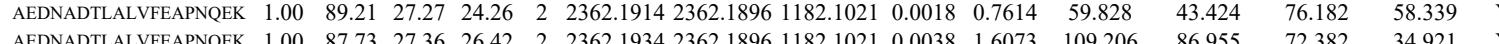

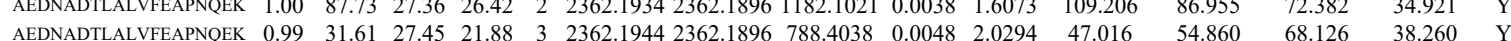

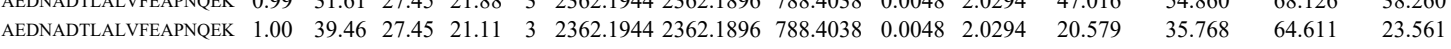

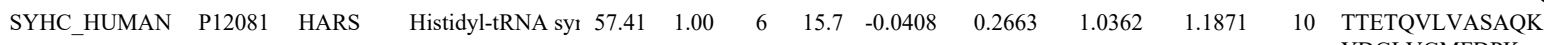
YDGLVGMFDPK

YVGELWDAGIK

LVSELWDAGIK

IGDYVQQHGGSSLVEQLLQD

LLFEYLTLFGIDDK LLFEYLTLFGIDDK ISFDLSLAR ISFDLSLAR

49 GMLPDPK GMLPDPK GMLPDPK GLGDCLVK GLGDCLVK MMMQSGR MMMQSGR MMMQSGR MMMQSGR LLLQVQHASK LLLQVQHASK LLLQVQHASK
GNLANVIR GNLANVIR GNLANVIR LLLQVQHASK LLLQVQHASK GNLANVIR LLLQVQHASK $\begin{array}{lllllllllllllll} & \text { AEN }\end{array}$

$\begin{array}{llllllllllllll}1.00 & 92.78 & 25.24 & 33.21 & 2 & 1662.9542 & 1662.9396 & 832.4771 & 0.0146 & 8.7689 & 964.984 & 1066.536 & 262.886 & 276.8 \\ 1.00 & 48.01 & 28.00 & 24.79 & 2 & 1528.7866 & 1528.7840 & 765.993 & 0.0026 & 1.6985 & 546.628 & 590.522 & 135.819 & 91.1\end{array}$

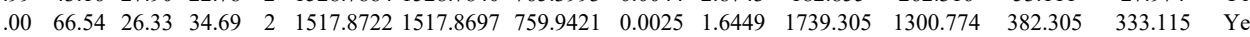
$\begin{array}{lllllllllllllll}1.00 & 57.97 & 26.14 & 28.89 & 2 & 1517.8736 & 1517.8697 & 759.9421 & 0.0039 & 2.5660 & 2055.308 & 1650.635 & 282.152 & 358.437 & \text { Yes }\end{array}$ $\begin{array}{lllllllllllllll}1.00 & 18.71 & 24.97 & 31.71 & 4 & 2710.4565 & 2710.4534 & 678.6206 & 0.0031 & 1.1420 & 193.053 & 151.929 & 247.937 & 157.207 & \text { No }\end{array}$

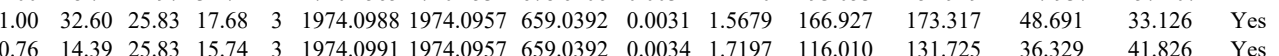
$\begin{array}{lllllllllllllll}0.97 & 27.43 & 25.51 & 20.78 & 3 & 1974.1015 & 1974.0957 & 659.0392 & 0.0058 & 2.9336 & 141.685 & 136.452 & 27.372 & 49.167 & \text { Yes }\end{array}$ $\begin{array}{llllllllllllllll}1.00 & 54.62 & 27.36 & 26.51 & 2 & 1164.6660 & 1164.6624 & 583.3385 & 0.0036 & 3.0857 & 11647.686 & 10641.180 & 130.065 & 368.044 & \text { Yes }\end{array}$ $\begin{array}{lllllllllllllll}1.00 & 54.17 & 28.14 & 29.12 & 2 & 1164.6664 & 1164.6624 & 583.3385 & 0.0040 & 3.4285 & 14090.834 & 13686.794 & 619.339 & 593.430 & \text { Yes }\end{array}$ $\begin{array}{lllllllllllllll}0.80 & 29.92 & 29.08 & 28.20 & 2 & 1044.5976 & 1044.5881 & 523.3013 & 0.0095 & 9.0769 & 17920.168 & 12844.432 & 7714.014 & 4371.269 & \text { Yes }\end{array}$ $\begin{array}{llllllllllllllll}0.57 & 26.80 & 29.04 & 29.47 & 2 & 1044.5948 & 1044.5881 & 523.3013 & 0.0067 & 6.4016 & 18874.213 & 12763.804 & 7330.098 & 4924.476 & \text { Yes }\end{array}$ $\begin{array}{llllllllllllllll}0.61 & 26.78 & 29.15 & 29.51 & 2 & 1044.5966 & 1044.5881 & 523.3013 & 0.0085 & 8.1214 & 16009.632 & 11420.385 & 6565.784 & 3953.419 & \text { Yes }\end{array}$

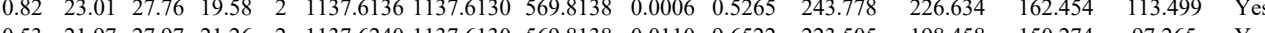

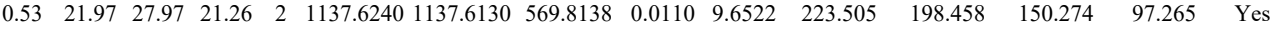
$\begin{array}{llllllllllllllll}0.98 & 28.39 & 22.88 & 22.21 & 2 & 983.4486 & 983.4473 & 492.7309 & 0.0013 & 1.3192 & 816.774 & 664.408 & 53.770 & 34.685 & \text { Yes }\end{array}$ $\begin{array}{llllllllllllllll}0.95 & 32.63 & 22.83 & 37.76 & 2 & 983.4490 & 983.4473 & 492.7309 & 0.0017 & 1.7251 & 805.520 & 701.278 & 44.411 & 33.134 & \text { Yes }\end{array}$ $\begin{array}{lllllllllllllll}0.85 & 27.03 & 22.88 & 37.86 & 2 & 983.4488 & 983.4473 & 492.7309 & 0.0015 & 1.5221 & 923.401 & 714.976 & 56.142 & 21.596 & \text { Yes }\end{array}$

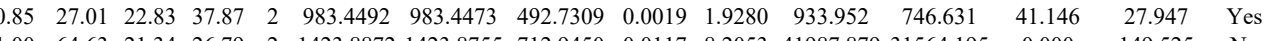

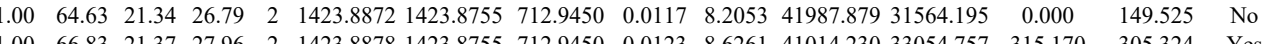

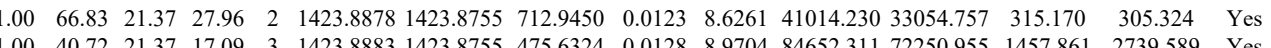

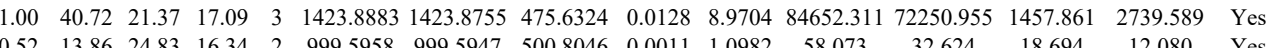
$\begin{array}{lllllllllllllll}0.52 & 13.86 & 24.83 & 16.34 & 2 & 999.5958 & 999.5947 & 500.8046 & 0.0011 & 1.0982 & 58.073 & 32.624 & 18.694 & 12.080 & \text { Yes } \\ 0.77 & 26.92 & 25.89 & 24.10 & 2 & 999.6024 & 999.5947 & 500.8046 & 0.0077 & 7.6876 & 37399.675 & 29374.849 & 17239.520 & 4264.234 & \text { Yes }\end{array}$ $\begin{array}{lllllllllllllllll}0.77 & 26.92 & 25.89 & 24.10 & 2 & 999.6024 & 999.5947 & 500.8046 & 0.0077 & 7.6876 & 37399.675 & 29374.849 & 17239.520 & 4264.234 & \text { Yes } \\ 1.00 & 41.92 & 21.21 & 24.70 & 2 & 1423.8858 & 1423.8755 & 712.9450 & 0.0103 & 7.2235 & 40846.996 & 35083.372 & 5909.834 & 588.750 & \text { Yes }\end{array}$ $\begin{array}{lllllllllllllll}1.00 & 41.92 & 21.21 & 24.70 & 2 & 1423.8858 & 1423.8755 & 712.9450 & 0.0103 & 7.2235 & 40846.996 & 35083.372 & 5909.834 & 588.750 & \text { Yes } \\ 1.00 & 57.55 & 21.34 & 25.28 & 2 & 1423.8866 & 1423.8755 & 712.9450 & 0.0111 & 7.7846 & 49516256 & 44919.804 & 3288.334 & 916.234 & \text { Yes }\end{array}$

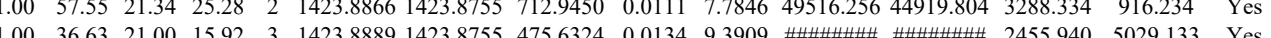

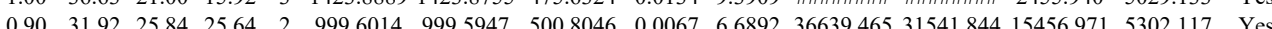
$\begin{array}{llllllllllllllll}0.90 & 66.89 & 21.14 & 25.92 & 2 & 1423.8846 & 1423.8755 & 712.9450 & 0.0091 & 6.3819 & 8929.683 & 6082.381 & 197.535 & 148.695 & \text { Yes }\end{array}$ 


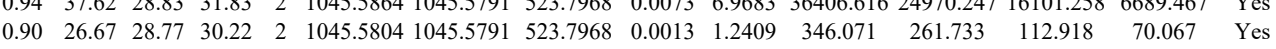

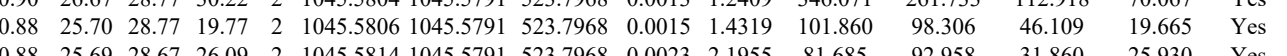
$\begin{array}{lllllllllllllll}0.88 & 25.69 & 28.67 & 26.09 & 2 & 1045.5814 & 1045.5791 & 523.7968 & 0.0023 & 2.1955 & 81.685 & 92.958 & 31.860 & 25.930 & \text { Yes } \\ 0.83 & 25.58 & 28.68 & 24.19 & 2 & 1045.5820 & 1045.5791 & 523.7968 & 0.0029 & 2.7682 & 343.388 & 285.954 & 126.515 & 89.622 & \text { Yes }\end{array}$

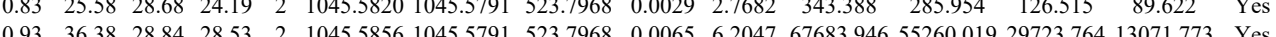
$\begin{array}{llllllllllllllll}0.93 & 36.38 & 28.84 & 28.53 & 2 & 1045.5856 & 1045.5791 & 523.7968 & 0.0065 & 6.2047 & 64683.946 & 55260.019 & 29723.764 & 13071.773 & \text { Yes } & \end{array}$

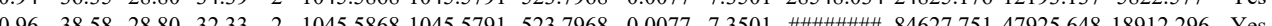

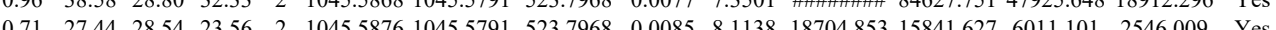
$\begin{array}{llllllllllllllll}0.96 & 39.25 & 28.82 & 30.16 & 2 & 1045.5858 & 1045.5791 & 523.7968 & 0.0067 & 6.3956 & 12927.009 & 11205.401 & 5391.796 & 1943.044 & \text { Yes }\end{array}$ $\begin{array}{llllllllllllllllll}0.96 & 39.14 & 28.85 & 33.31 & 2 & 1045.5860 & 1045.5791 & 523.7968 & 0.0069 & 6.5865 & 18520.263 & 13435.302 & 7259.061 & 3396.966 & \text { Yes }\end{array}$

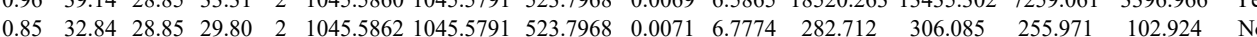
$\begin{array}{lllllllllllllll}1.00 & 78.52 & 27.82 & 26.63 & 2 & 1733.9420 & 1733.9385 & 867.9765 & 0.0035 & 2.0162 & 47114899 & 36841.280 & 0.000 & 81.500 & \text { No }\end{array}$ $\begin{array}{lllllllllllllll}1.00 & 78.69 & 27.80 & 25.90 & 2 & 1733.9430 & 1733.9385 & 867.9765 & 0.0045 & 2.5922 & 53539.737 & 41915.155 & 0.000 & 211.233 & \mathrm{No}\end{array}$ $\begin{array}{lllllllllllllll}0.51 & 14.04 & 27.81 & 16.13 & 3 & 1733.9434 & 1733.9385 & 578.9868 & 0.0049 & 2.8210 & 18125.719 & 19394.196 & 4855.143 & 570.148 & \text { Yes }\end{array}$ $\begin{array}{lllllllllllllll}0.62 & 15.75 & 27.76 & 15.02 & 3 & 1733.9440 & 1733.9385 & 578.9868 & 0.0055 & 3.1664 & 178.865 & 183.414 & 80.428 & 66.316 & \text { Yes }\end{array}$ $\begin{array}{llllllllllllllll}1.00 & 78.69 & 27.71 & 26.57 & 2 & 1733.9402 & 1733.9385 & 867.9765 & 0.0017 & 0.9793 & 41421.254 & 31237.677 & 0.000 & 210.886 & \text { No }\end{array}$ $\begin{array}{lllllllllllllll}1.00 & 65.74 & 27.72 & 26.12 & 2 & 1733.9414 & 1733.9385 & 867.9765 & 0.0029 & 1.6705 & 26055.292 & 19880.571 & 0.000 & 143.263 & \end{array}$ $\begin{array}{lllllllllllllll}1.00 & 37.49 & 27.87 & 22.72 & 3 & 1733.9419 & 1733.9385 & 578.9868 & 0.0034 & 1.9574 & 1867.743 & 2423.811 & 326.404 & 209.336 & \text { No }\end{array}$ $\begin{array}{lllllllllllllll}1.00 & 50.89 & 27.77 & 21.24 & 3 & 1733.9437 & 1733.9385 & 578.9868 & 0.0052 & 2.9937 & 1054.877 & 976.088 & 212.728 & 132.128 & \text { Yes }\end{array}$ $\begin{array}{lllllllllllllll}1.00 & 78.67 & 27.71 & 27.42 & 2 & 1733.9402 & 1733.9385 & 867.9765 & 0.0017 & 0.9793 & 28915.066 & 25884.652 & 0.000 & 187.922 & \mathrm{~N} o\end{array}$ $\begin{array}{lllllllllllllll}1.00 & 68.01 & 27.70 & 25.59 & 2 & 1733.9408 & 1733.9385 & 867.9765 & 0.0023 & 1.3249 & 30760.454 & 21223.470 & 0.000 & 128.824 & \text { No }\end{array}$ $\begin{array}{lllllllllllllll}1.00 & 39.35 & 27.86 & 20.38 & 3 & 1733.9425 & 1733.9385 & 578.9868 & 0.0040 & 2.3029 & 1318.112 & 1020.848 & 283.387 & 72.331 & \text { Yes }\end{array}$ $\begin{array}{llllllllllllllll}1.00 & 37.14 & 27.86 & 21.19 & 3 & 1733.9428 & 1733.9385 & 578.9868 & 0.0043 & 2.4756 & 1167.982 & 1704.775 & 249.871 & 131.115 & \text { No } \\ 0.96 & 24.87 & 27.86 & 1.54 & 3 & 1733.942 & 1733.938 & 57.988 & 0.004 & 2.4756 & 402.40 & 324.852 & 130.739 & 82.5 & \end{array}$

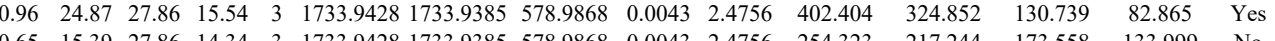
$\begin{array}{lllllllllllllll}.15 .39 & 27.86 & 14.34 & 3 & 1733.9428 & 1733.9385 & 578.9868 & 0.0043 & 2.4756 & 254.323 & 217.244 & 173.558 & 133.999 & \text { No }\end{array}$ $\begin{array}{lllllllllllllll}1.00 & 3.45 & 27.80 & 24.68 & 3 & 1733.9431 & 1733.9385 & 578.9868 & 0.0046 & 2.6483 & 497.974 & 403.490 & 79.042 & 94.007 & \text { Yes }\end{array}$

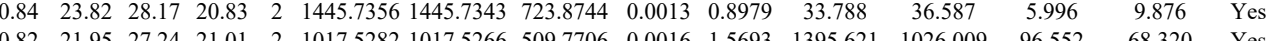

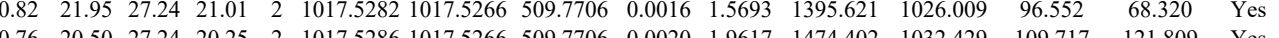

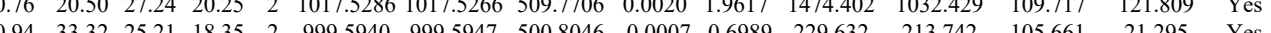

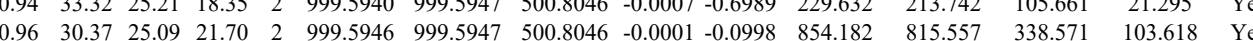

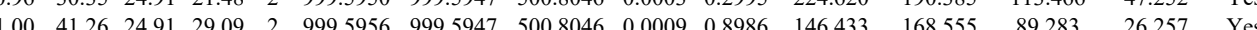

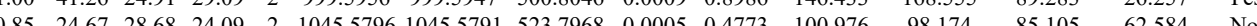
$\begin{array}{lllllllllllllllll}0.99 & 32.62 & 25.12 & 22.53 & 2 & 999.5960 & 999.5947 & 500.8046 & 0.0013 & 1.2979 & 429.528 & 407.790 & 176.582 & 47.483 & \text { Yes }\end{array}$ $\begin{array}{lllllllllllllll}1.00 & 38.53 & 24.96 & 22.90 & 2 & 999.5970 & 999.5947 & 500.8046 & 0.0023 & 2.2963 & 256.020 & 260.849 & 132.793 & 48.357 & \text { Yes } \\ 0.81 & 23.68 & 28.68 & 28.16 & 2 & 1045.5796 & 1945.5791 & 523.798 & 0.0005 & 0.4773 & 181.279 & 186.494 & 120.652 & 145.765 & \text { No }\end{array}$ $\begin{array}{llllllllllllllll}0.91 & 26.79 & 28.69 & 32.97 & 2 & 1045.5808 & 1045.5791 & 523.7968 & 0.0017 & 1.6228 & 197.465 & 227.534 & 154.513 & 203.053 & \text { No }\end{array}$ $\begin{array}{llllllllllllllllll}1.00 & 61.63 & 26.95 & 22.56 & 2 & 1445.8182 & 1445.8082 & 723.9114 & 0.0100 & 6.9069 & 10664.779 & 8956.128 & 5246.451 & 2688.430 & \text { Yes }\end{array}$ $\begin{array}{llllllllllllllll}0.96 & 30.52 & 27.31 & 22.67 & 3 & 1445.8192 & 1445.8082 & 482.9433 & 0.0110 & 7.5923 & 2004.807 & 2133.253 & 1357.343 & 1204.640 & \text { Yes }\end{array}$ $\begin{array}{llllllllllllllll}0.99 & 38.11 & 27.41 & 19.66 & 3 & 1445.8201 & 1445.8082 & 482.9433 & 0.0119 & 8.2135 & 2644.049 & 2690.770 & 1731.224 & 1368.542 & \text { Yes }\end{array}$ VAQGVSGAVQDK TSSAQVEGGVHSLHSYEK TSSAQVEGGVHSLHSYEK VAQGVSGAVQDK VAQGVSGAVQDK $\begin{array}{llllllllllllllll}\text { VAQGVSGAVQDK } & 0.98 & 34.30 & 27.35 & 19.73 & 3 & 1445.8195 & 1445.8082 & 482.9433 & 0.0113 & 7.7993 & 3156.701 & 2386.319 & 1182.335 & 830.041 & \text { Yes } \\ \text { TSSAQVEGGVHSLHSYEK } & 1.00 & 42.75 & 27.84 & 19.59 & 4 & 2203.1229 & 2203.1113 & 551.7851 & 0.0116 & 5.2556 & 6455.286 & 6867.649 & 5432.034 & 3891.821 & \text { Yes }\end{array}$ $\begin{array}{llllllllllllllll}0.99 & 36.15 & 27.29 & 22.69 & 3 & 1445.8162 & 1445.8082 & 482.9433 & 0.0080 & 5.5217 & 2231.236 & 1737.535 & 944.134 & 1188.466 & \text { Yes } \\ 1.00 & 62.10 & 27.28 & 23.93 & 2 & 1445.8168 & 1445.8082 & 723.9114 & 0.0086 & 5.9399 & 9558.634 & 8880.440 & 4211.175 & 1949.871 & \text { Yes }\end{array}$ $\begin{array}{llllllllllllllllll} & & & \end{array}$ $\begin{array}{llllllllllllllll}\text { VAQGVSGAVQDK } & 1.00 & 68.46 & 27.29 & 26.84 & 2 & 1445.8162 & 1445.8082 & 723.9114 & 0.0080 & 5.5255 & 14044.959 & 12828.945 & 7214.585 & 2493.936 & \text { Yes }\end{array}$ $\begin{array}{llllllllllllllll}\text { VAQGVSGAVQDK } & 1.00 & 71.29 & 26.95 & 28.27 & 2 & 1445.8180 & 1445.8082 & 723.9114 & 0.0098 & 6.7687 & 13846.529 & 12035.096 & 7241.607 & 2332.644 & \text { Yes }\end{array}$ $\begin{array}{llllllllllllllll}\text { LPIVNEDDELVAIIAR } & 1.00 & 91.71 & 25.05 & 21.92 & 2 & 1923.0810 & 1923.0798 & 962.5472 & 0.0012 & 0.6233 & 1231.981 & 906.047 & 853.088 & 566.150 & \text { Yes }\end{array}$ $\begin{array}{llllllllllllllll}\text { LPIVNEDDELVAIIAR } & 1.00 & 83.86 & 25.04 & 20.30 & 2 & 1923.0812 & 1923.0798 & 962.5472 & 0.0014 & 0.7272 & 2785.432 & 3520.452 & 2245.099 & 1396.939 & \text { Yes }\end{array}$ $\begin{array}{llllllllllllllll}\text { LPIVNEDDELVAIIAR } & 1.00 & 62.69 & 24.94 & 19.67 & 2 & 1923.0824 & 1923.0798 & 962.5472 & 0.0026 & 1.3506 & 26.468 & 8.997 & 13.431 & 3.165 & \text { No }\end{array}$ $\begin{array}{llllllllllllllll}\text { LPIVNEDDELVAIIAR } & 1.00 & 46.15 & 24.90 & 17.48 & 3 & 1923.0829 & 1923.0798 & 642.0339 & 0.0031 & 1.6095 & 346.610 & 391.641 & 110.487 & 96.134 & \text { Yes }\end{array}$

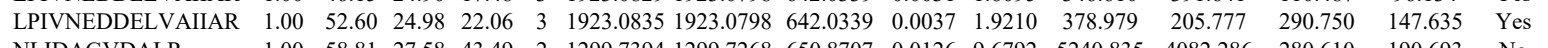
$\begin{array}{llllllllllllllll}\text { NLIDAGVDALR } & 1.00 & 58.81 & 27.58 & 43.49 & 2 & 1299.7394 & 1299.7268 & 650.8707 & 0.0126 & 9.6792 & 5240.835 & 4082.286 & 280.610 & 190.693 & \text { No }\end{array}$

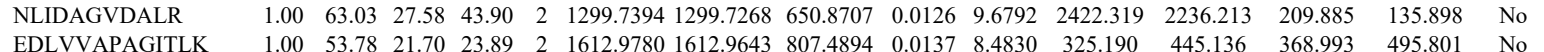
$\begin{array}{llllllllllllllll}\text { EDLVVAPAGITLK } & 1.00 & 53.78 & 21.70 & 23.89 & 2 & 1612.9780 & 1612.9643 & 807.4894 & 0.0137 & 8.4830 & 325.190 & 445.136 & 368.993 & 495.801 & \mathrm{No} \\ \text { EDLVVAPAGITLK } & 1.00 & 45.45 & 21.73 & 21.75 & 2 & 1612.9784 & 1612.9643 & 807.4894 & 0.0141 & 8.7307 & 473.062 & 572.332 & 428.207 & 595.653 & \mathrm{~N}\end{array}$ $\begin{array}{llllllllllllllll}\text { EDLVVAPAGITLK } & 1.00 & 45.45 & 21.73 & 21.75 & 2 & 1612.9784 & 1612.9643 & 807.4894 & 0.0141 & 8.7307 & 473.062 & 572.332 & 428.207 & 595.653 & \text { No } \\ \text { LPIVNEDDELVAIIAR } & 1.00 & 73.12 & 25.05 & 18.54 & 2 & 1923.0810 & 1923.0798 & 962.5472 & 0.0012 & 0.6233 & 1035.572 & 984.286 & 716.520 & 515.488 & \text { Yes }\end{array}$

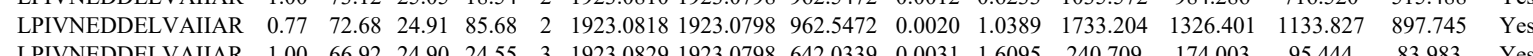

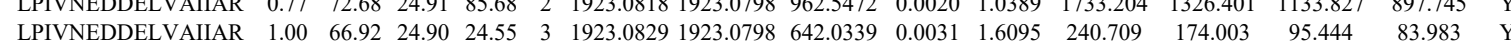

Table S-3 page 131 of 499 


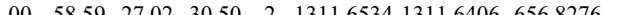

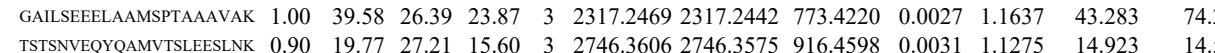
$\begin{array}{llllllllllllllll}\text { TVPSTPTLVVPHR } & 1.00 & 41.19 & 25.11 & 18.07 & 3 & 1546.9042 & 1546.8953 & 516.6390 & 0.0089 & 5.7422 & 4580.900 & 6048.723 & 2659.737 & 2083.213 & \text { Yes }\end{array}$ $\begin{array}{llllllllllllllll}\text { GQNLLLTNLQTIQGILER } & 1.00 & 93.14 & 22.70 & 22.47 & 2 & 2167.2454 & 2167.2446 & 1084.6296 & 0.0008 & 0.3688 & 91.232 & 74.141 & 101.191 & 28.649 & \text { Yes }\end{array}$

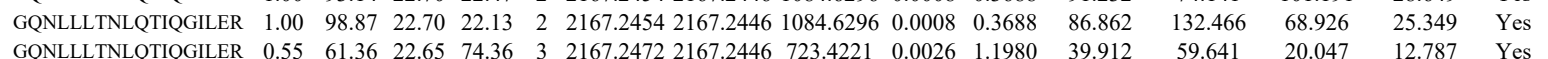

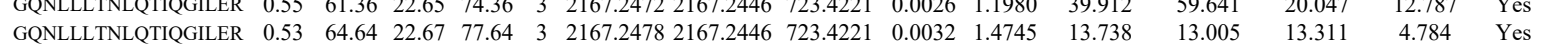

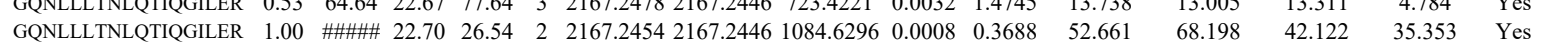

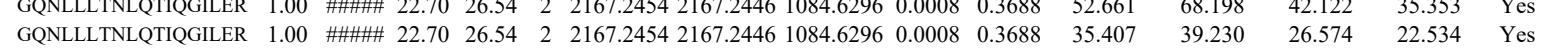

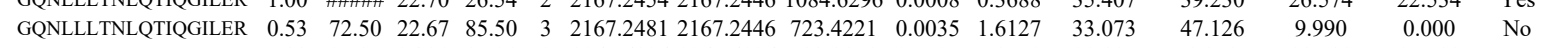
$\begin{array}{llllllllllll}\text { RPPHPLPPR } & 0.83 & 25.35 & 26.81 & 15.21 & 2 & 1065.6196 & 1065.6196 & 533.8171 & 0.0000 & 0.0000 & 11.117\end{array}$ $9.279 \quad 11.789$

$\begin{array}{llllllllllllllll}1.00 & 58.37 & 28.79 & 35.61 & 2 & 1216.6800 & 1216.6785 & 609.3465 & 0.0015 & 1.2308 & 1514.280 & 1847.282 & 1403.852 & 532.457 & \text { Yes }\end{array}$ $\begin{array}{lllllllllllllllll}\text { GIGTDEFTLNR } & 1.00 & 55.14 & 28.79 & 35.35 & 2 & 1216.6800 & 1216.6785 & 609.3465 & 0.0015 & 1.2308 & 1999.794 & 2600.090 & 2186.804 & 537.452 & \text { Yes }\end{array}$

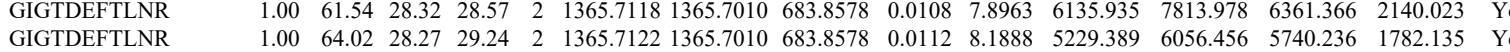

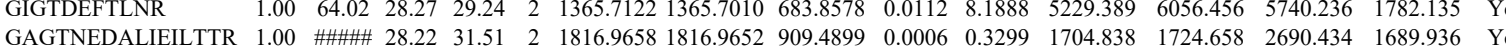
$\begin{array}{lllllllllllllll}\text { GAGTNEDALIEILTTR } & 1.00 & \text { \#\#\#\# } 28.22 & 21.51 & 2 & 1816.9658 & 1816.9652 & 909.4899 & 0.0006 & 0.3299 & 1704.838 & 1724.658 & 2690.434 & 1689.936 & \text { Yes } \\ \text { GAGTNEDALIET } & 1.00 & 186.9664 & 1816.9652 & 909.4899 & 0.0012 & 0.6597 & 705.373 & 853.431 & 1346.170 & 1022.037 & \text { Yes }\end{array}$ $\begin{array}{llllllllllllllll}\text { GIGTDEFTLNR } & 1.00 & 60.30 & 28.57 & 30.23 & 2 & 1365.7132 & 1365.7010 & 683.8578 & 0.0122 & 8.9199 & 2012.455 & 2316.551 & 2067.115 & 654.123 & \text { Yes }\end{array}$ $\begin{array}{lllllllllllllll}\text { GAGTNEDALIEILTTR } & 1.00 & \text { \#\#\# } 28.22 & 30.02 & 2 & 1816.9664 & 1816.9652 & 909.4899 & 0.0012 & 0.6597 & 789.268 & 1289.769 & 1594.876 & 1199.226 & \text { Yes }\end{array}$

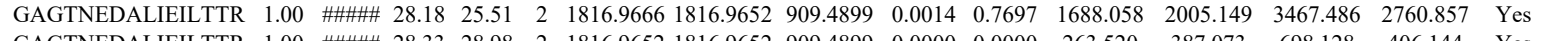

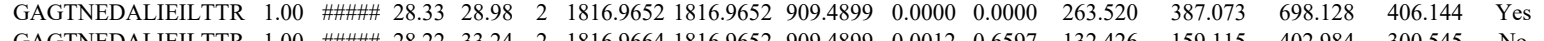

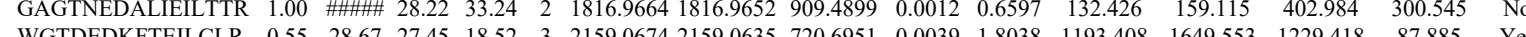

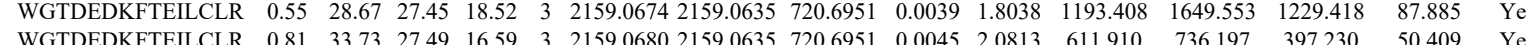
$\begin{array}{llllllllllllllll}\text { WGTDEDKFTEILCLR } & 0.81 & 33.73 & 27.49 & 16.59 & 3 & 2159.0680 & 2159.0635 & 720.6951 & 0.0045 & 2.0813 & 611.910 & 736.197 & 397.230 & 50.409 & \text { Yes } \\ \text { ALLTLADGR } & 0.99 & 39.14 & 26.70 & 27.74 & 2 & 10726464 & 1072.6362 & 537.3254 & 0.0102 & 9.4914 & 12055.583 & 14123.282 & 2695.546 & 1244.495 & \text { Yes }\end{array}$

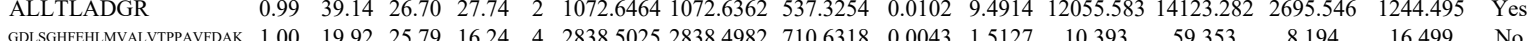

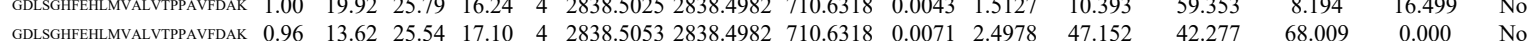

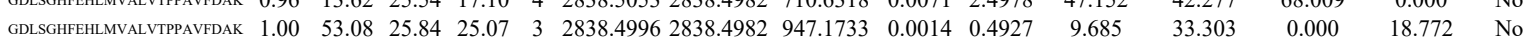

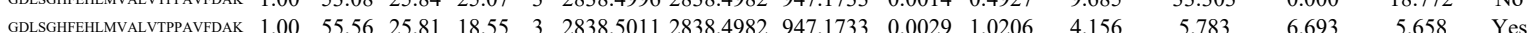

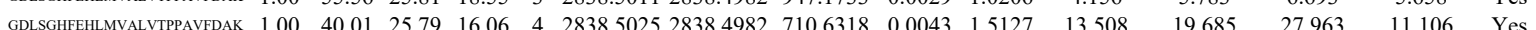

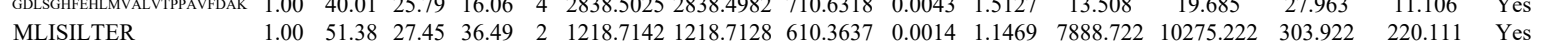

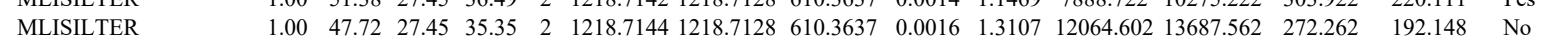

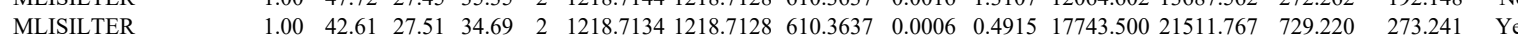

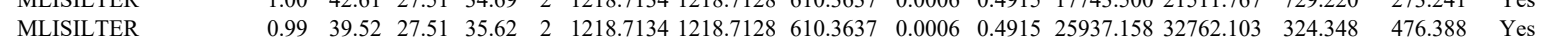

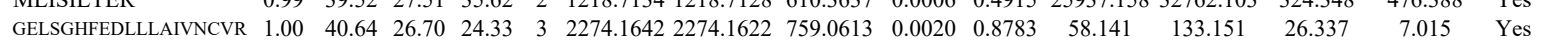

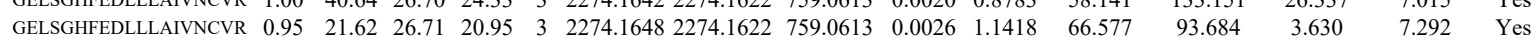

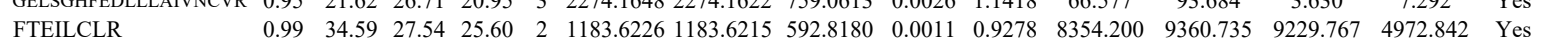
$\begin{array}{llllllllllllllll}\text { FTEILCLR } & 0.99 & 37.91 & 27.56 & 24.66 & 2 & 1183.6238 & 1183.6215 & 592.8180 & 0.0023 & 1.9399 & 6931.210 & 8577.052 & 9595.156 & 4514.014 & \text { Yes }\end{array}$ $\begin{array}{llllllllllllllll}\text { MLISILTER } & 0.99 & 46.33 & 27.45 & 45.53 & 2 & 1218.7148 & 1218.7128 & 610.3637 & 0.0020 & 1.6384 & 7213.717 & 9034.832 & 170.138 & 163.921 & \text { Yes }\end{array}$

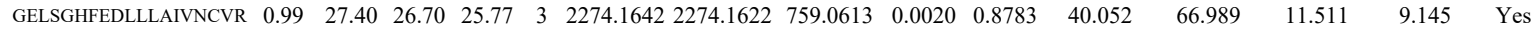

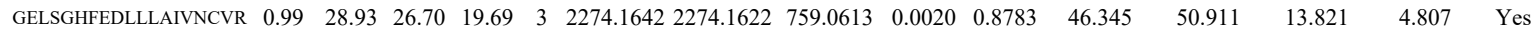
$\begin{array}{llllllllllllllll}\text { FTEILCLR } & 0.99 & 38.39 & 27.64 & 24.53 & 2 & 1183.6232 & 1183.6215 & 592.8180 & 0.0017 & 1.4338 & 5061.613 & 6055.529 & 7344.983 & 4204.121 & \text { Yes }\end{array}$

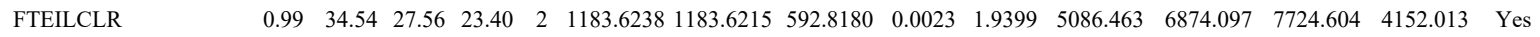
$\begin{array}{llllllllllllllll}\text { FTEILCLR } & 0.92 & 28.30 & 27.68 & 20.25 & 2 & 1183.6244 & 1183.6215 & 592.8180 & 0.0029 & 2.4459 & 130.427 & 180.144 & 139.847 & 98.528 & \text { Yes }\end{array}$

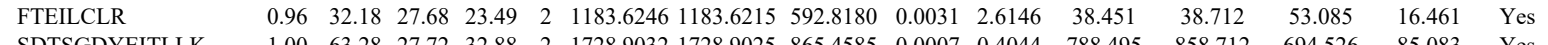

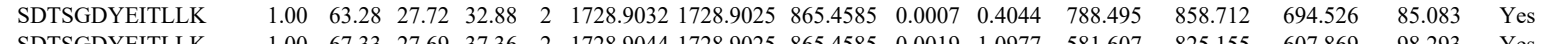

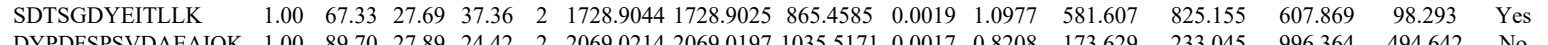
$\begin{array}{llllllllllllllll}\text { DYPDFSPSVDAEAIQK } & 1.00 & 89.70 & 27.89 & 24.42 & 2 & 2069.0214 & 2069.0197 & 1035.5171 & 0.0017 & 0.8208 & 173.629 & 233.045 & 996.364 & 494.642 & \text { No }\end{array}$ $\begin{array}{llllllllllllllll}\text { DYPDFSPSVDAEAIQK } & 1.00 & 99.45 & 27.89 & 24.15 & 2 & 2069.0214 & 2069.0197 & 035.5171 & 0.0017 & 0.8208 & 81.664 & 123.828 & 677.430 & 363.597 & \text { No }\end{array}$

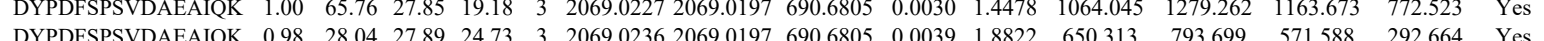

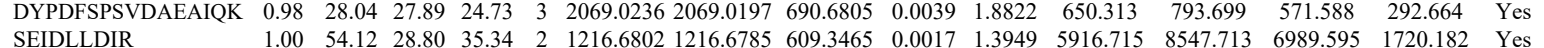
$\begin{array}{llllllllllllllll}\text { SEIDLLDIR } & 1.00 & 54.12 & 28.80 & 35.34 & 2 & 1216.6802 & 1216.6785 & 609.3465 & 0.0017 & 1.3949 & 5916.715 & 8547.713 & 6989.595 & 1720.182 & \text { Yes } \\ \text { SEIDLDIR } & 1.00 & 54.07 & 28.80 & 35.29 & 2 & 1216.6804 & 1216.6785 & 609.3465 & 0.0019 & 1.5590 & 7458.828 & 10259.839 & 8822.967 & 1986.742 & \text { Yes }\end{array}$

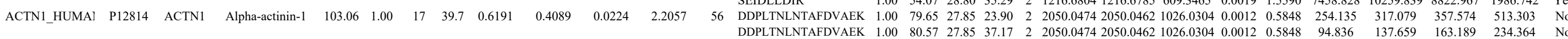




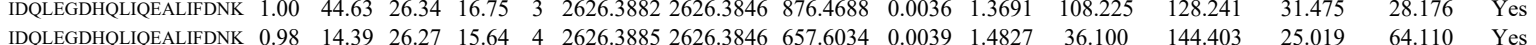
$\begin{array}{llllllllllllll} & \end{array}$

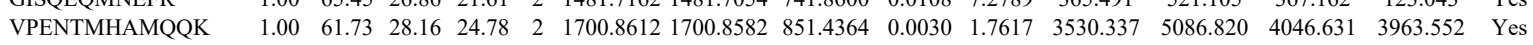
$\begin{array}{lllllllllllllllllll}\text { VPENTMHAMQQK } & 1.00 & 4879 & 28.15 & 20.54 & 3 & 1700.8624 & 1700.8582 & 567.9600 & 0.0042 & 2.7650 & 7138.440 & 11494.378 & 6448.977 & 7412.224 & \text { Yes }\end{array}$ $\begin{array}{llllllllllllllll}\text { VPENTMHAMQQK } & 1.00 & 37.74 & 28.03 & 16.68 & 3 & 1700.8633 & 1700.8582 & 567.9600 & 0.0051 & 2.4932 & 11397.971 & 21998309 & 14882086 & 12801.757 & \text { Yes }\end{array}$ $\begin{array}{lllllllllllllllllll}\text { VPENTMHAMQQK } & 100 & 62.96 & 28.07 & 24.28 & 2 & 17008594 & 17008582 & 851.4364 & 0.0012 & 0.7047 & 2580.400 & 3365094 & 2396114 & 1974.319 & \text { Yes }\end{array}$ $\begin{array}{llllllllllllllll}\text { VPENTMHAMOQK } & 1.00 & 39.60 & 28.17 & 22.49 & 3 & 1700.8600 & 1700.8582 & 567.9600 & 0.018 & 1.0564 & 10323.912 & 17866.517 & 13938.855 & 12870.814 & \text { Yes }\end{array}$ $\begin{array}{lllllllllllllllll}\text { VPENTMHAMQQK } & 1.00 & 55.15 & 28.17 & 23.61 & 2 & 1700.8600 & 1700.8582 & 851.4364 & 0.0018 & 1.0570 & 352.817 & 721.898 & 430.117 & 394.310 & \text { Yes }\end{array}$ $\begin{array}{llllllllllllllll}\text { VPENTMHAMQQK } & 1.00 & 48.86 & 28.17 & 20.85 & 3 & 1700.8606 & 1700.8582 & 567.9600 & 0.0024 & 1.4085 & 6728.680 & 10999.283 & 7962.152 & 7902.719 & \text { Yes }\end{array}$ $\begin{array}{lllllllllllllllll}\text { VPENTMHAMQQK } & 0.99 & 33.36 & 28.07 & 17.81 & 3 & 1700.8594 & 1700.8582 & 567.9600 & 0.0012 & 0.7043 & 4894.348 & 8260.275 & 6283.092 & 6000298 & \text { Yes }\end{array}$ $\begin{array}{llllllllllllllll}\text { VPENTMHAMQQK } & 1.00 & 46.09 & 28.17 & 21.02 & 3 & 1700.8600 & 1700.8582 & 567.9600 & 0.0018 & 1.0564 & 4944.118 & 8638.238 & 3818.523 & 5169.555 & \text { Yes }\end{array}$ \begin{tabular}{llllllllllllllll} 
MVSDINNAWGCLEQVEK & 0.91 & 20.56 & 26.76 & 14.67 & 3 & 2269.0828 & 2269.0785 & 757.3668 & 0.0043 & 1.8925 & 155.031 & 147.484 & 32.181 & 62.006 & Yes \\
\hline
\end{tabular} $\begin{array}{lllllllllllllllll} & & \end{array}$ $\begin{array}{lllllllllllllllll}\text { LLETIDQLYLEYAK } & 1.00 & 33.05 & 24.96 & 16.20 & 3 & 1999.1143 & 1999.1121 & 667.3780 & 0.0022 & 1.0988 & 208.147 & 269.435 & 33.546 & 51.691 & \text { Yes }\end{array}$ $\begin{array}{llllllllllllllll}\text { LLETIDQLYLEYAK } & 1.00 & 67.20 & 24.97 & 18.04 & 2 & 1999.1134 & 1999.1121 & 1000.5633 & 0.0013 & 0.6496 & 2275.233 & 4606.874 & 0.000 & 0.000 & \text { No }\end{array}$ $\begin{array}{lllllllllllllllll}\text { LLETIDQLYLEYAK } & 1.00 & 34.40 & 25.17 & 26.76 & 3 & 1999.1158 & 1999.1121 & 667.3780 & 0.0037 & 1.8480 & 1353.155 & 2366.696 & 102.619 & 0.000 & \text { No }\end{array}$ $\begin{array}{llllllllllllllll}\text { LLETIDQLYLEYAK } & 0.76 & 69.38 & 24.97 & 82.38 & 2 & 1999.1134 & 1999.1121 & 1000.5633 & 0.0013 & 0.6496 & 250.893 & 524.761 & 25.526 & 2.662 & \text { Yes }\end{array}$ $\begin{array}{llllllllllllllll}\text { LLETIDQLYLEYAK } & 1.00 & 81.62 & 24.97 & 18.61 & 2 & 1999.1134 & 1999.1121 & 1000.5633 & 0.0013 & 0.6496 & 113.991 & 244.010 & 3.566 & 14.350 & \text { Yes }\end{array}$ $\begin{array}{lllllllllllllllll}\text { LLETIDQLYLEYAK } & 1.00 & 35.00 & 25.07 & 16.81 & 3 & 1999.1146 & 1999.1121 & 667.3780 & 0.0025 & 1.2487 & 332.460 & 416.919 & 92.686 & 37.980 & \text { Yes }\end{array}$ $\begin{array}{lllllllllllllllll}\text { LLETIDQLYLEYAK } & 0.55 & 19.38 & 25.07 & 32.38 & 3 & 1999.1146 & 1999.1121 & 667.3780 & 0.0025 & 1.2487 & 240.475 & 253.083 & 119.604 & 73.293 & \text { Yes }\end{array}$ $\begin{array}{llllllllllllllll}\text { ICDQWDNLGALTQK } & 1.00 & 38.28 & 28.00 & 19.92 & 3 & 1937.9596 & 1937.9583 & 646.9934 & 0.0013 & 0.6698 & 342.485 & 383.407 & 103.715 & 27.906 & \text { Yes }\end{array}$ $\begin{array}{llllllllllllllll}\text { ICDQWDNLGALTQK } & 1.00 & 62.31 & 28.16 & 20.83 & 2 & 1937.9612 & 1937.9583 & 969.9864 & 0.0029 & 1.4949 & 1420.571 & 2087.846 & 209.910 & 33.881 & \text { Yes }\end{array}$

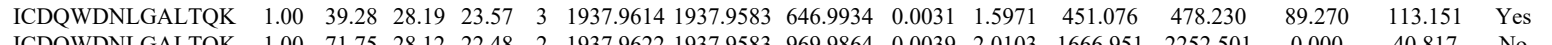

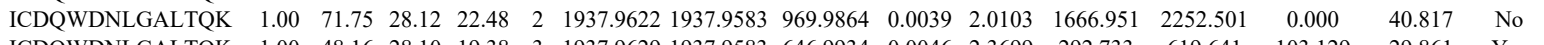

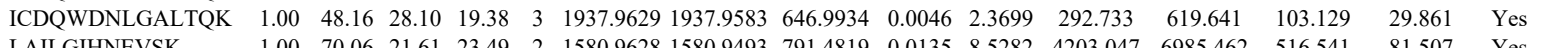

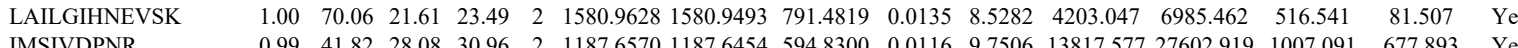

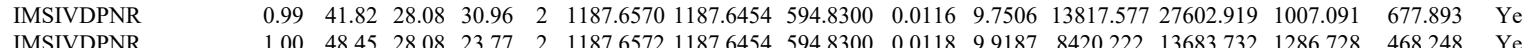

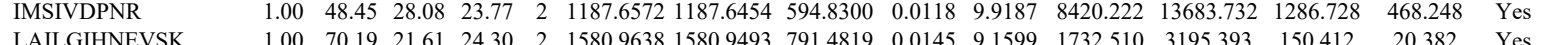

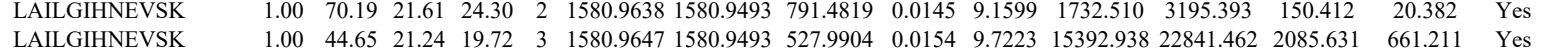

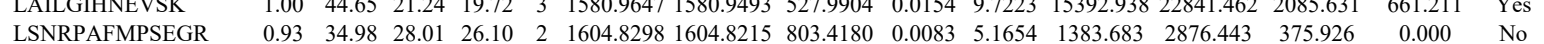

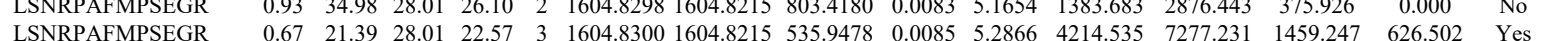

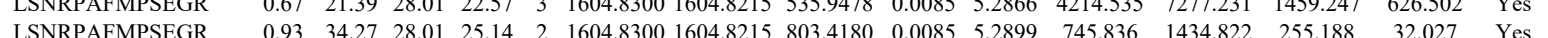

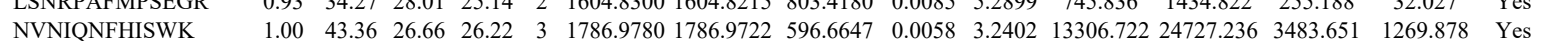

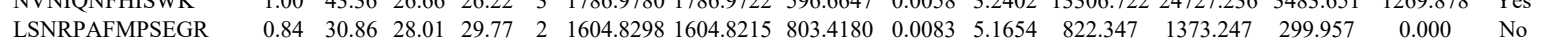

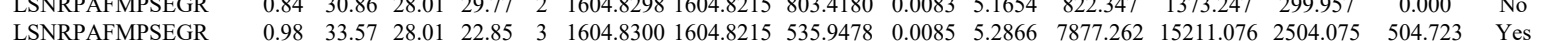
$\begin{array}{llllllllllllllll}\text { LSNRPAFMPSEGR } & 0.95 & 3043 & 28.01 & 18.65 & 3 & 1604.8306 & 16048215 & 535.9478 & 0.0091 & 5.6597 & 5634.267 & 7998.783 & 1452.058 & 192.797 & \text { Yes }\end{array}$ $\begin{array}{lllllllllllllllll}\text { NVNIONFHISWK } & 1.00 & 56.24 & 27.07 & 24.47 & 3 & 1786.9708 & 1786.9722 & 596.6647 & -0.0014 & -0.7821 & 6515.800 & 13171.006 & 1956.381 & 935.280 & \text { Yes }\end{array}$ $\begin{array}{llllllllllllllll}\text { NVNIONFHISWK } & 1.00 & 48.53 & 26.93 & 34.99 & 3 & 1786.9741 & 1786.9722 & 596.6647 & 0.0019 & 1.0615 & 8689.067 & 14147.318 & 2277.152 & 1127.579 & \text { Yes }\end{array}$ $\begin{array}{llllllllllllllll}\text { LSNRPAFMPSEGR } & 0.89 & 27.08 & 27.99 & 17.59 & 3 & 1604.8303 & 1604.8215 & 535.9478 & 0.0088 & 5.4731 & 9016.741 & 15468.641 & 2291.358 & 448.246 & \text { Yes }\end{array}$

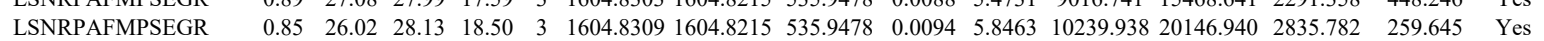

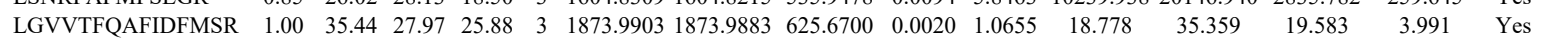
$\begin{array}{llllllllllllllll}\text { AGTQIENIEEDFR } & 1.00 & 70.05 & 26.88 & 27.90 & 2 & 1664.8126 & 1664.8127 & 833.4136 & -0.0001 & -0.0600 & 543.052 & 833.071 & 515.436 & 269.636 & \text { Yes }\end{array}$ $\begin{array}{lllllllllllllllll}\text { AGTQIENIEEDFR } & 1.00 & 71.08 & 26.90 & 27.87 & 2 & 1664.8130 & 1664.8127 & 833.4136 & 0.0003 & 0.1800 & 167.810 & 336.039 & 271.164 & 150.976 & \text { Yes }\end{array}$ $\begin{array}{llllllllllllllll}\text { AGTQIENIEEDFR } & 1.00 & 73.14 & 26.91 & 29.05 & 2 & 1664.8128 & 1664.8127 & 833.4136 & 0.0001 & 0.0600 & 189.996 & 393.010 & 205.693 & 78.804 & \text { Yes }\end{array}$ $\begin{array}{llllllllllllllll}\text { AGTQIENIEEDFR } & 1.00 & 58.96 & 26.98 & 24.89 & 2 & 1664.8142 & 1664.8127 & 833.4136 & 0.0015 & 0.8999 & 29.482 & 51.738 & 14.449 & 19.561 & \text { Yes }\end{array}$ $\begin{array}{llllllllllllllll}\text { ETADTDTADQVMASFK } & 1.00 & 87.99 & 27.15 & 22.67 & 2 & 2016.9554 & 2016.9554 & 1009.4850 & 0.0000 & 0.0000 & 172.353 & 170.767 & 480.984 & 416.097 & \text { No }\end{array}$

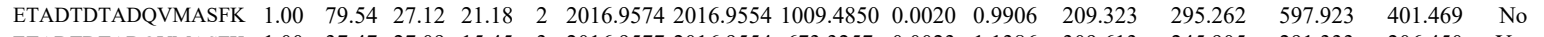

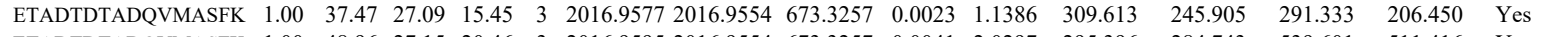
$\begin{array}{llllllllllllllll}\text { ETADTDTADQVMASFK } & 1.00 & 48.96 & 27.15 & 20.46 & 3 & 2016.9595 & 2016.9554 & 673.3257 & 0.0041 & 2.0297 & 295.396 & 284.743 & 539.601 & 511.416 & \text { Yes }\end{array}$ $\begin{array}{lllllllllllllllll}\text { MLDAEDIVGTARPDEK } & 0.99 & 31.05 & 27.51 & 16.95 & 3 & 2047.0528 & 2047.0499 & 683.3572 & 0.0029 & 1.4146 & 17346.628 & 294132.803 & 1147.374 & 467.550 & \text { Yes }\end{array}$ $\begin{array}{lllllllllllllllll}\text { MLDAEDIVGTARPDEK } & 0.53 & 37.81 & 27.49 & 50.81 & 3 & 2047.0531 & 2047.0499 & 683.3572 & 0.0032 & 1.5609 & 23607.594 & 41198.275 & 1719.486 & 436.786 & \text { Yes }\end{array}$

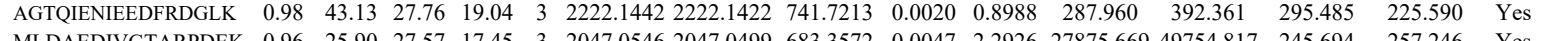
$\begin{array}{lllllllllllllllll}\text { MLDAEDIVGTARPDEK } & 0.96 & 25.90 & 27.57 & 17.45 & 3 & 2047.0546 & 2047.0499 & 683.3572 & 0.0047 & 2.2926 & 27875.669 & 49754.817 & 245.694 & 257.246 & \text { Yes }\end{array}$

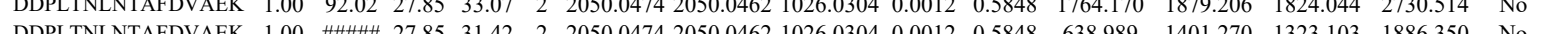

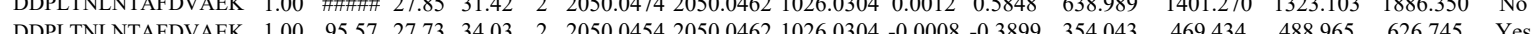

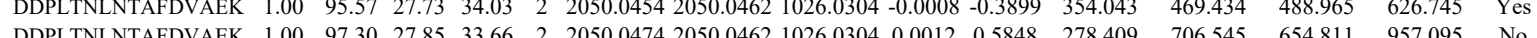
$\begin{array}{llllllllllllllll} & \end{array}$

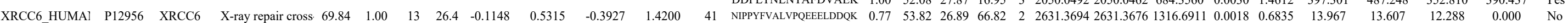

Table S-3 page 133 of 499 


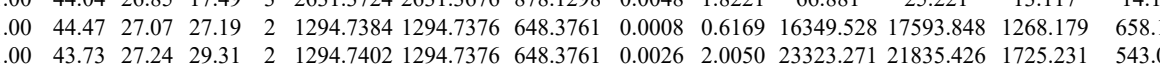

$\begin{array}{llllllllllllll}1.00 & 55.11 & 24.47 & 39.77 & 2 & 1331.7944 & 1331.7904 & 666.9025 & 0.0040 & 2.9989 & 7026.178 & 7229.896 & 11019.276 & 7167.000\end{array}$ $\begin{array}{llllllllllllllllll} & 0.99 & 40.66 & 27.36 & 20.55 & 2 & 1360.7756 & 1360.7628 & 681.3887 & 0.0128 & 9.3925 & 7835.540 & 7600.579 & 1648.094 & 957.689 & Y & Y\end{array}$ $\begin{array}{llllllllllllll} & \end{array}$

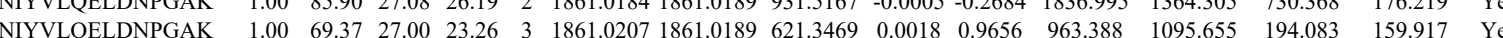
$\begin{array}{llllllllllllllll}\text { NIYVLQELDNPGAK } & 1.00 & 56.03 & 27.02 & 28.40 & 3 & 1861.0213 & 1861.0189 & 621.3469 & 0.0024 & 1.2875 & 1239.853 & 1106.516 & 270.861 & 109.558 & \text { Yes }\end{array}$

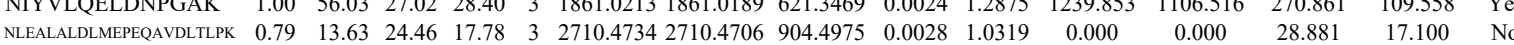
$\begin{array}{llllllllllllllll}\text { NLEALALDIMEPEOAVDLTLPK } & 1.00 & 28.43 & 24.25 & 15.38 & 4 & 2710.4773 & 2710.4706 & 678.6249 & 0.0067 & 2.4682 & 102.779 & 110.237 & 75.864 & 44.682 & \text { Yes }\end{array}$ $\begin{array}{lllllllllllllllll}\text { IMATPEQVGK } & 1.00 & 52.68 & 27.44 & 26.47 & 2 & 1360.7730 & 1360.7628 & 681.3887 & 0.0102 & 7.4847 & 20925.566 & 19784.568 & 3336.772 & 2197.770 & \text { Yes }\end{array}$ $\begin{array}{lllllllllllllllll}\text { IMATPEQVGK } & 1.00 & 52.73 & 27.78 & 26.63 & 2 & 1360.7748 & 1360.7628 & 681.3887 & 0.0120 & 8.8055 & 26716.300 & 25480.737 & 2575.650 & 1168.661 & \text { Yes }\end{array}$ $\begin{array}{llllllllllllllll}\text { NLEALALDLMEPEQAVDLTLPK } & 1.00 & 69.67 & 24.55 & 20.27 & 2 & 2710.4714 & 2710.4706 & 1356.2426 & 0.0008 & 0.2949 & 4.424 & 0.000 & 0.000 & 0.000 & \text { No } \\ \text { NLEALALDLMEPEQAVDLTLPK } & 0.99 & 14.99 & 24.42 & 16.34 & 4 & 2710.4753 & 2710.4706 & 678.6249 & 0.0047 & 1.7314 & 108.977 & 138.600 & 80.853 & 63.833 & \text { Ye }\end{array}$

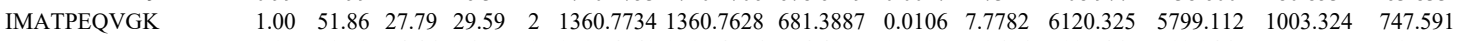
$\begin{array}{lllllllllllllll}\text { NLEALALDLEPFEAVDLTLPK } & 0.90 & 18.03 & 24.46 & 16.22 & 3 & 2710.4743 & 2710.4706 & 904.4975 & 0.0037 & 1.3636 & 18.546 & 13.046 & 0.000 & 12.055\end{array}$

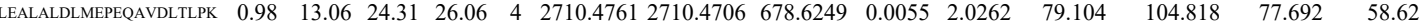
$\begin{array}{lllllllllllllllll}\text { NLEALALDLMEPEQAVDLTLPK } & 1.00 & 55.57 & 24.42 & 17.46 & 3 & 2710.4752 & 2710.4706 & 904.4975 & 0.0046 & 1.6952 & 14.195 & 15.582 & 21.222 & 11.774 & \text { Yes }\end{array}$ $\begin{array}{llllllllllllllll}\text { NLEALALDLMEPEQAVDLTLPK } & 0.93 & 23.17 & 24.30 & 15.91 & 3 & 2710.4764 & 2710.4706 & 904.4975 & 0.0058 & 2.1375 & 30.676 & 15.471 & 20.913 & 8.125 & \text { Yes }\end{array}$ $\begin{array}{llllllllllllllll}\text { ALKPPPIK } & 0.97 & 15.04 & 12.30 & 14.39 & 3 & 1294.8712 & 1294.8702 & 432.6307 & 0.0010 & 0.7705 & 38845.742 & 41600.453 & 589.852 & 535.109 & \text { Yes }\end{array}$ $\begin{array}{llllllllllllllll}\text { IQVTPPGFQLVFLPFADDK } & 1.00 & 72.60 & 23.91 & 20.40 & 2 & 2419.3414 & 2419.3395 & 1210.6770 & 0.0019 & 0.7847 & 37.796 & 20.592 & 9.880 & 0.000 & \text { No }\end{array}$

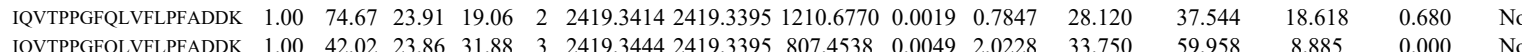

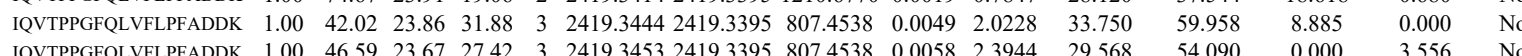
$\begin{array}{llllllllllllllll}\text { IQVTPPGFQLVFLPFADDK } & 1.00 & 46.59 & 23.67 & 27.42 & 3 & 2419.3453 & 2419.3395 & 807.4538 & 0.0058 & 2.3944 & 29.568 & 54.090 & 0.000 & 3.556 & \text { No }\end{array}$

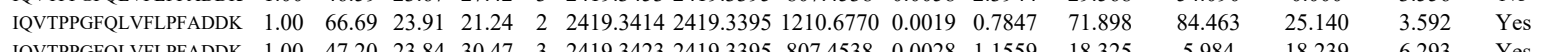

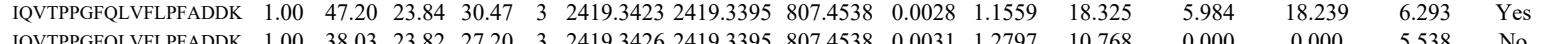

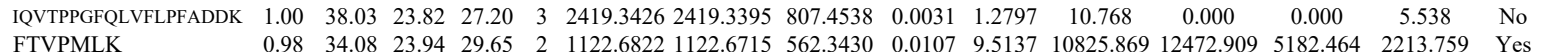

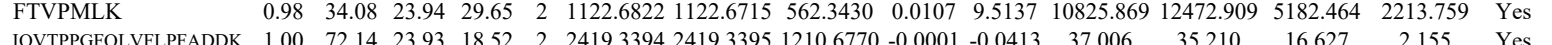

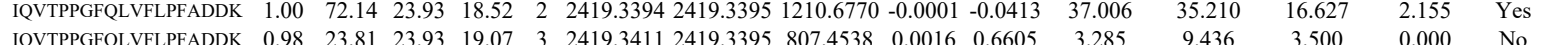

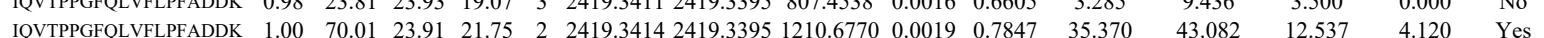

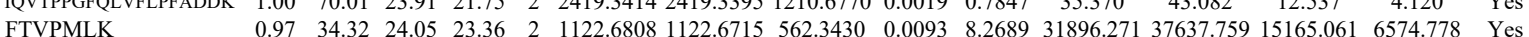

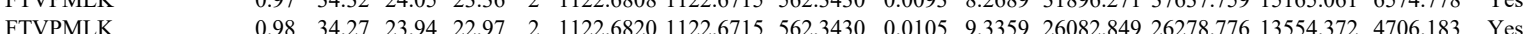
$\begin{array}{llllllllllllllll}\text { IQVTPPGFOLVFLPFADDK } & 1.00 & 33.20 & 23.93 & 23.23 & 3 & 2419.3396 & 2419.3395 & 807.4538 & 0.0001 & 0.0413 & 35.977 & 29.327 & 13.900 & 5.510 & \text { Yes }\end{array}$

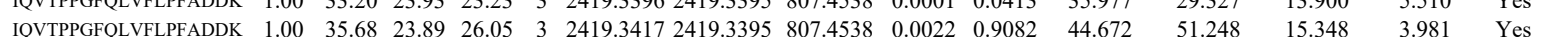

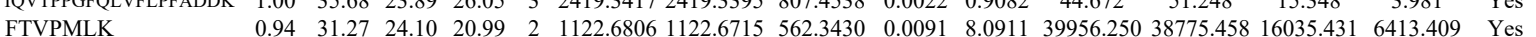
$\begin{array}{llllllllllllllll}\text { KPGGFDISLFYR } & 0.99 & 3820 & 26.70 & 24.10 & 2 & 1686.9344 & 1686.9337 & 844.4741 & 0.0007 & 0.4145 & 4470.456 & 5035.127 & 4635.458 & 1036.806 & \text { Yes }\end{array}$

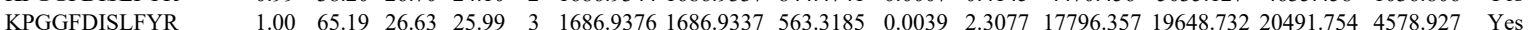
$\begin{array}{lllllllllllllllll}\text { KPGGFDISLFYR } & 100 & 58.42 & 26.54 & 23.75 & 3 & 1686.9391 & 1686.9337 & 563.3185 & 0.0054 & 31953 & 9654.070 & 11095.245 & 11685.071 & 3172.638 & \text { Yes }\end{array}$

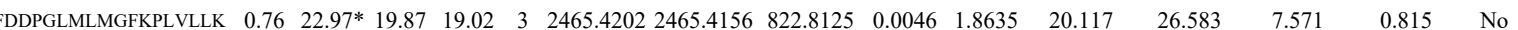
$\begin{array}{llllllllllllllll}\text { KPGGFDISLFYR } & 1.00 & 44.83 & 26.70 & 19.39 & 2 & 1686.9346 & 1686.9337 & 844.4741 & 0.0009 & 0.5329 & 2921.346 & 2802.996 & 2502.210 & 523.096 & \text { Yes }\end{array}$

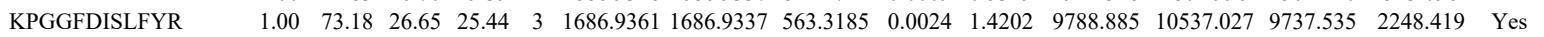
$\begin{array}{llllllllllllllll}\text { IQVTPPGFQLVFLPFADDKR } & 0.55 & 54.65 & 22.28 & 67.65 & 3 & 2575.4428 & 2575.4406 & 859.4875 & 0.0022 & 0.8532 & 1305.532 & 1308.343 & 517.048 & 43.839 & \text { Yes }\end{array}$ $\begin{array}{lllllllllllllllll}\text { IQVTPPGFQLVFLPFADDKR } & 0.53 & 54.41 & 22.30 & 67.41 & 3 & 2575.4437 & 2575.4406 & 859.4875 & 0.0031 & 1.2023 & 1138.762 & 1308.652 & 416.878 & 58.852 & \text { Yes }\end{array}$ $\begin{array}{llllllllllllllll}\text { DIISIAEDEDLR } & 1.00 & 70.21 & 28.18 & 27.10 & 2 & 1531.7868 & 1531.7851 & 766.8998 & 0.0017 & 1.1084 & 90.078 & 150.107 & 153.934 & 57.874 & \text { Yes }\end{array}$

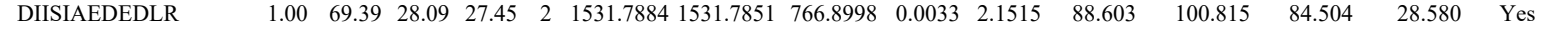

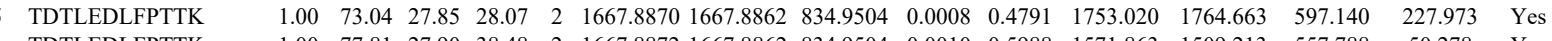
$\begin{array}{llllllllllllllll}\text { TDTLEDLFPTTK } & 1.00 & 77.81 & 27.90 & 38.48 & 2 & 1667.8872 & 1667.8862 & 834.9504 & 0.0010 & 0.5988 & 1571.863 & 1509.213 & 557.788 & 50.278 & \text { Yes }\end{array}$ $\begin{array}{llllllllllllllll}\text { TDTLEDLFPTTK } & 0.94 & 22.23 & 27.90 & 25.02 & 3 & 1667.8888 & 1667.8862 & 556.9693 & 0.0026 & 1.5560 & 101.101 & 98.341 & 54.522 & 29.463 & \text { Yes }\end{array}$ $\begin{array}{llllllllllllllll}\text { TDTLEDLFPTTK } & 0.96 & 25.30 & 27.80 & 25.65 & 3 & 1667.8900 & 1667.8862 & 556.9693 & 0.0038 & 2.2742 & 99.996 & 132.358 & 70.902 & 61.079 & \text { Yes }\end{array}$

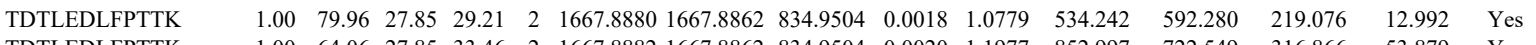

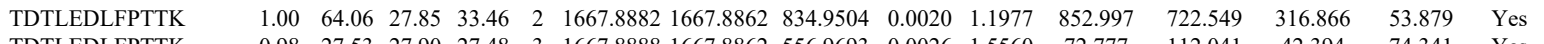

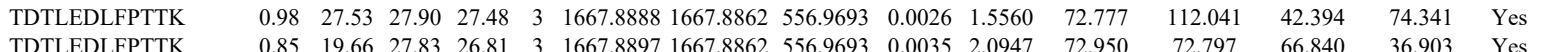

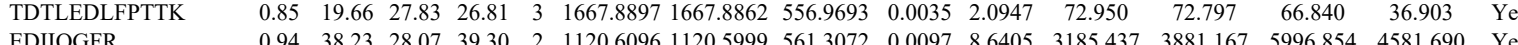

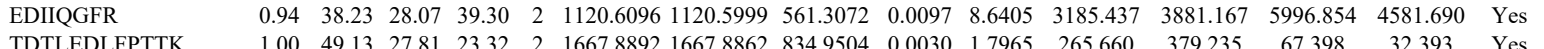
$\begin{array}{llllllllllllllll}\text { TDTLEDLFPTTK } & 1.00 & 49.13 & 27.81 & 23.32 & 2 & 1667.8892 & 1667.8862 & 834.9504 & 0.0030 & 1.7965 & 265.660 & 379.235 & 67.398 & 32.393 & \text { Yes } \\ \text { TDTLEDLFPTTK } & 1.00 & 52.60 & 27.86 & 28.33 & 2 & 1667.8894 & 1667.8862 & 834.9504 & 0.0032 & 1.9163 & 213.533 & 233.819 & 101.827 & 19.580 & \text { Yes }\end{array}$

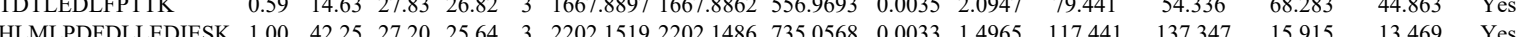

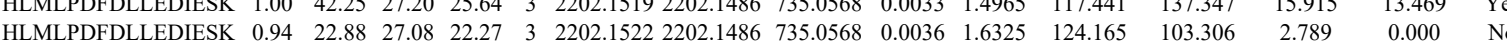

Table S-3 page 134 of 499 
YAPTEAQLNAVDALISYSIN $\begin{array}{llllllllll}0.99 & 66.81 * 26.17 & 20.83 & 3 & 2808.3723 & 2682.4817 & 961.8345 & 0.0024 & 0.8317 & 18.873 \\ & 26.3661 & 870.4626 & 0.0062 & 2.3742 & 27.737\end{array}$ $\begin{array}{llllllllllll}\text { VMFINLNADALDSMSLAK } & 1.00 & 113.64 * 26.37 & 22.78 & 2 & 2608.3674 & 2608.3661 & 1305.1903 & 0.0013 & 0.4980 & 42.247\end{array}$ $\begin{array}{lllllllllllll}\text { YAPTEAQLNAVDALIDSMSLAK } & 1.00 & 85.89 * 26.30 & 19.79 & 2 & 2608.3694 & 2608.3661 & 1305.1903 & 0.0033 & 1.2642 & 12.162 \\ \text { YAPTEAQLNAVDALIDSMSLAK } & 1.00 & 59.46 * & 26.26 & 20.39 & 4 & 2608.3709 & 2608.3661 & 653.0988 & 0.0048 & 1.8374 & 121.732\end{array}$ $\begin{array}{llllllllllll}\text { YAPTEAQLNAVDALIDSMSLAK } & 1.00 & 69.46 * 26.18 & 21.67 & 3 & 2608.3717 & 2608.3661 & 870.4626 & 0.0056 & 2.1444 & 55.593\end{array}$ $\begin{array}{lllllllllllll}\text { YAPTEAQLNAVDALIDSMSLAK } & 1.00 & 78.22 * & 26.18 & 22.16 & 3 & 2608.3717 & 2608.3661 & 870.4626 & 0.0056 & 2.1444 & 40.290\end{array}$ $\begin{array}{llllllllllll}\text { YAPTEAQLNAVDALIDSMSLAK } & 0.97 & 35.22 * & 26.16 & 15.34 & 4 & 2608.3741 & 2608.3661 & 653.0988 & 0.0080 & 3.0623 & 84.877 \\ \text { DDEAAVALSSLHALDLDMVAIVR } & 1.00 & 32.97 & 26.12 & 15.46 & 4 & 2866.4921 & 2866.4868 & 717.6290 & 0.0053 & 1.8464 & 35.637\end{array}$

$\begin{array}{llllllllllll}\text { IPPSSQQADFLALIVSMDVIHETIGK } & 1.00 & 77.75 * & 24.61 & 18.21 & 3 & 3340.7632 & 3340.7581 & 1114.5933 & 0.0051 & 1.5252 & 3258.767\end{array}$

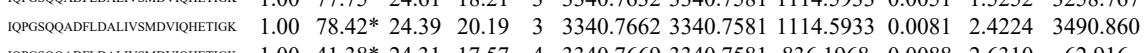

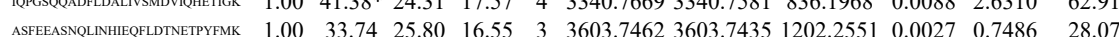
$\begin{array}{lllllllllll}1.00 & 33.74 & 25.80 & 16.55 & 3 & 3603.7462 & 3603.7435 & 1202.2551 & 0.0027 & 0.7486 & 28.071\end{array}$ $\begin{array}{llllllllllllll}\text { XSA } & 1.00 & 33.66 & 25.89 & 16.29 & 4 & 3603.7489 & 3603.7435 & 901.9432 & 0.0054 & 1.4968 & 9.390\end{array}$

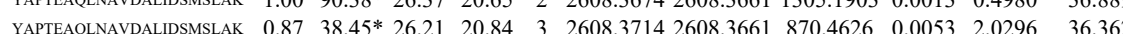

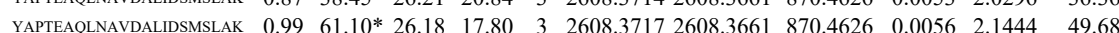
$\begin{array}{lllllllllllll}\text { IOPGSOQADELALVSMDVIOHETTIK } & 1.00 & 64.61 * & 24.62 & 77.61 & 4 & 3340.7649 & 3340.7581 & 836.1968 & 0.0068 & 2.0330 & 21.165\end{array}$ $\begin{array}{lllllllllllll}\text { IQPGSSQRADLDALIVSMDVILHETIGK } & 0.96 & 30.89 * & 24.31 & 43.89 & 4 & 3340.7669 & 3340.7581 & 836.1968 & 0.0088 & 2.6310 & 64.367\end{array}$

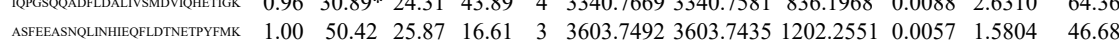
$\begin{array}{lllllllllllll}\text { ASFEASNQLLNHEEFLTTNETYYFMK } & 1.00 & 50.96 & 25.92 & 25.41 & 4 & 3603.7521 & 3603.7435 & 901.9432 & 0.0086 & 2.3837 & 124.591\end{array}$

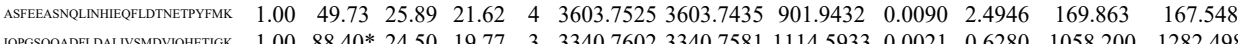

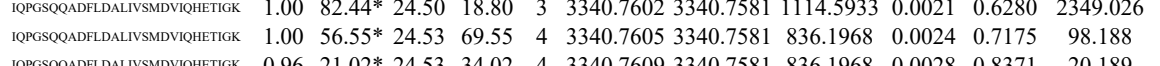

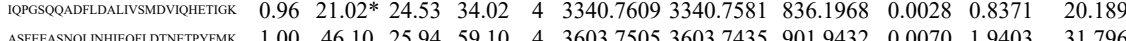

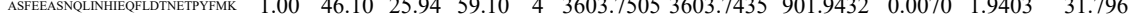

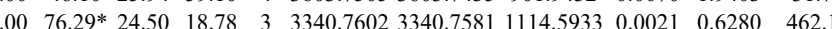

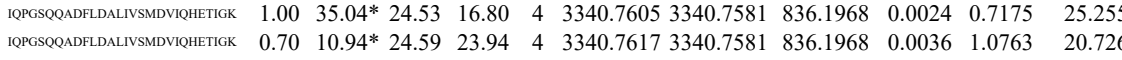

\section{ANPQVGVAFPHIK} $\begin{array}{lllllllllll}1.94 & 24.59 & 23.94 & 4 & 3340.7617 & 3340.7581 & 836.1968 & 0.0036 & 1.0763 & 20.726\end{array}$ $\begin{array}{lllllllllllll}1.00 & 30.09 & 24.01 & 43.09 & 4 & 2940.5861 & 2940.5775 & 736.1517 & 0.0086 & 2.9206 & 98.028\end{array}$ $\begin{array}{llllllllllll}0.99 & 18.92 & 23.86 & 31.92 & 4 & 2940.5877 & 2940.5775 & 736.1517 & 0.0102 & 3.4639 & 58.227 \\ 1.00 & 54.23 & 25.28 & 26.68 & 2 & 1396.8166 & 1396.8071 & 699.4108 & 0.0095 & 6.7914 & 11478.037\end{array}$

EPLPPIQQHIWNMLNP $\begin{array}{lllllllllll}18.19 & 23.86 & 15.00 & 4 & 2940.5877 & 2940.5775 & 736.1517 & 0.0102 & 3.4639 & 102.390 & 108.519\end{array}$

\section{LGGHGPSFPLK}

$\begin{array}{llllllllllll}0.92 & 28.59 & 25.20 & 25.56 & 3 & 1396.8175 & 1396.8071 & 466.6096 & 0.0104 & 7.4294 & 57345.004 & 57668\end{array}$

$\begin{array}{llllllllllllll}\text { QLNHFWEIVQDGITLITK } & 1.00 & 54.03 & 22.67 & 17.14 & 3 & 2541.4231 & 2541.4199 & 848.1472 & 0.0032 & 1.2576 & 43.376 & 54.55 \\ \text { QLNHFWEIVVQDGITLITK } & 1.00 & 63.45 & 22.67 & 18.27 & 3 & 2541.4234 & 2541.4199 & 848.1472 & 0.0035 & 1.3755 & 92.589 & 47.277\end{array}$

$\begin{array}{lllllllllllll}\text { QLNHFWEIVVQDGITLITK } & 1.00 & 31.08 & 22.60 & 15.62 & 4 & 2541.4241 & 2541.4199 & 636.3623 & 0.0042 & 1.6500 & 275.776 & 529.410\end{array}$

$\begin{array}{lllllllllllll}\text { QLNHFWEIVVQDGITLITK } & 1.00 & 30.14 & 22.60 & 43.14 & 4 & 2541.4241 & 2541.4199 & 636.3623 & 0.0042 & 1.6500 & 134.804 & 279.289\end{array}$ $\begin{array}{lllllllllllll}\text { QLNHFWEIVVQDGITLITK } & 1.00 & 40.49 & 22.48 & 53.49 & 4 & 2541.4253 & 2541.4199 & 636.3623 & 0.0054 & 2.1214 & 175.442 & 128.778\end{array}$ $\begin{array}{lllllllllllllll}\text { QLNHFWEIVVODGITLITK } & 1.00 & 56.51 & 22.48 & 17.74 & 4 & 2541.4253 & 2541.4199 & 636.3623 & 0.0054 & 2.1214 & 156.870 & 98.856 & 51.796\end{array}$ FFMGNQVLK

FFMGNQVLK $\begin{array}{llllllllllllll}1.00 & 44.76 & 26.88 & 23.21 & 2 & 1370.7744 & 1370.7624 & 686.3885 & 0.0120 & 8.7413 & 28298.484 & 29211.355 & 77.685 \\ 0.99 & 39.68 & 26.88 & 24.90 & 2 & 1370.7744 & 1370.7624 & 686.3885 & 0.0120 & 8.7413 & 27359.336 & 27733.547 & 0.000\end{array}$ $\begin{array}{lllllllllllllll}\text { OLNHFWEIVVODGITLITK } & 0.95 & 17.76 & 22.83 & 17.17 & 3 & 2541.4216 & 2541.4199 & 848.1472 & 0.0017 & 0.6681 & 5.166 & 12.722 & 14.214\end{array}$ QLNHFWEIVVQDGITLITK

FFMGNQVLK

FFMGNQVLK

FFMGNQVLK

LTIGSNLSIR

LTIGSNLSIR

LTIGSNLSIR

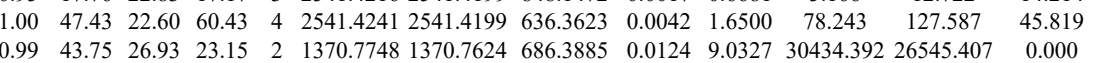
$\begin{array}{lllllllllllll}0.99 & 43.75 & 26.93 & 23.15 & 2 & 1370.7748 & 1370.7624 & 686.3885 & 0.0124 & 9.0327 & 30434.392 & 26545.407 & 0.000\end{array}$

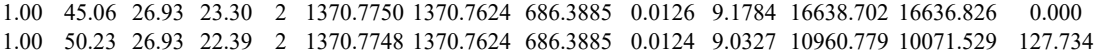
$\begin{array}{llllllllllllll}1.00 & 57.32 & 26.19 & 28.96 & 2 & 1216.7288 & 1216.7261 & 609.3703 & 0.0027 & 2.2154 & 33469.372 & 33257.930 & 7253.268 & \end{array}$

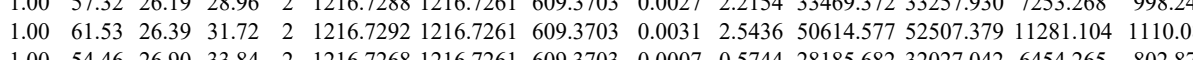
$\begin{array}{lllllllllllllll}1.00 & 54.46 & 26.90 & 33.84 & 2 & 1216.7268 & 1216.7261 & 609.3703 & 0.0007 & 0.5744 & 28185.682 & 32027.042 & 6454.265 & 802.871\end{array}$ $\begin{array}{llllllllllllll}1.00 & 59.92 & 26.67 & 29.29 & 2 & 1216.7270 & 1216.7261 & 609.3703 & 0.0009 & 0.7385 & 28243.417 & 31243.416 & 6546.029 & 452.778 \\ 1.00 & \# \# \# & 27.23 & 27.88 & 2 & 1681.8254 & 1681.8250 & 841.9198 & 0.0004 & 0.2376 & 313.659 & 323.182 & 899.042 & 741.538\end{array}$

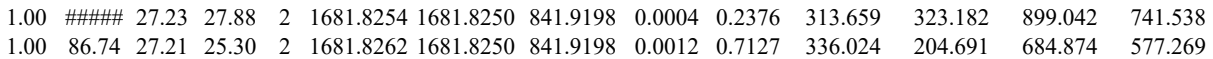
$\begin{array}{lllllllllllllll}1.00 & 86.74 & 27.21 & 25.30 & 2 & 1681.8262 & 1681.8250 & 841.9198 & 0.0012 & 0.7127 & 336.024 & 204.691 & 684.874 & 577.269 \\ 0.99 & 30.92 & 27.32 & 15.25 & 3 & 1681.8274 & 1681.8250 & 561.6156 & 0.0024 & 1.4245 & 504.060 & 620.428 & 689.378 & 524.486\end{array}$ $\begin{array}{llllllllllllll}0.99 & 30.92 & 27.32 & 15.25 & 3 & 1681.8274 & 1681.8250 & 561.6156 & 0.0024 & 1.4245 & 504.060 & 620.428 & 689.378 & 524.486 \\ 0.57 & 12.74 & 27.37 & 20.29 & 3 & 1681.8277 & 1681.8250 & 561.6156 & 0.0027 & 1.6025 & 596.047 & 519.959 & 708.141 & 655.409\end{array}$

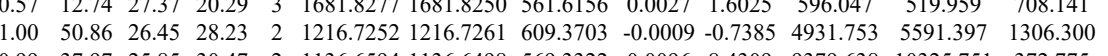
$\begin{array}{lllllllllllll}0.98 & 37.97 & 25.85 & 30.47 & 2 & 1136.6594 & 1136.6498 & 569.3322 & 0.0096 & 0.4309 & 9379.638 & 10325.751 & 372.775\end{array}$ $\begin{array}{lllllllllllll}0.99 & 39.32 & 27.53 & 19.83 & 2 & 1152.6444 & 1152.6447 & 577.3296 & -0.0003 & -0.2598 & 4614.394 & 4719.616 & 236.970\end{array}$ 


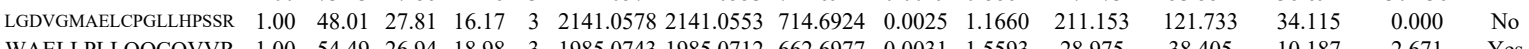

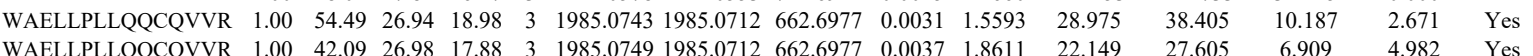

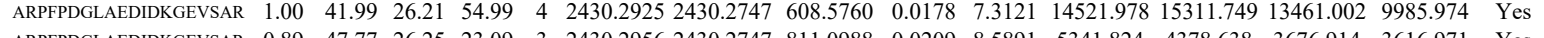
$\begin{array}{llllllllllllllll}\text { ARPFPDGLAEDIDKGEVSAR } & 0.89 & 47.77 & 26.25 & 23.09 & 3 & 2430.2956 & 2430.2747 & 811.0988 & 0.0209 & 8.5891 & 5341.824 & 4378.638 & 3676.914 & 3616.971 & \text { Yes }\end{array}$

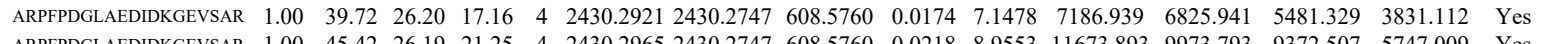

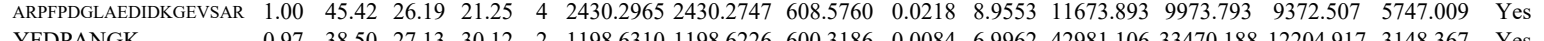
YFDPANGK $\begin{array}{llllllllllllllll}0.97 & 38.50 & 27.13 & 30.12 & 2 & 1198.6310 & 1198.6226 & 600.3186 & 0.0084 & 6.9962 & 42981.106 & 33470.188 & 12204.917 & 3148.367 & \text { Yes } \\ 0.98 & 38.45 & 27.23 & 29.04 & 2 & 1198.6328 & 1198.6226 & 6003186 & 0.0102 & 8.4954 & 54311.237 & 43990.223 & 14245616 & 2500.709 & \text { Yes }\end{array}$

GVQYLNEIK
GVQYLNEIK

QFAEMYVAK

QFAEMYVAK

EDLYLKPIQR

EDLYLKPIQR

EGIPALDNFLDKL

EGIPALDNFLDKL

EGIPALDNFLDKL

GVQYLNEIK

QFAEMYVAK

QFAEMYVAK

EGIPALDNFLDKL

EGIPALDNFLDKL

EGIPALDNFLDKL

EGIPALDNFLDK

KEDLYLKPIQR

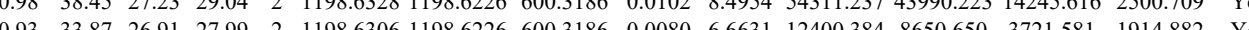

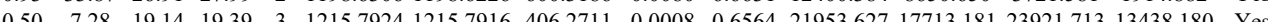

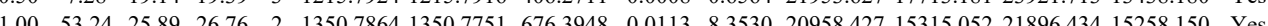
$\begin{array}{lllllllllllllll}1.00 & 60.11 & 25.89 & 26.57 & 2 & 1350.786 & 1350.7751 & 676.3948 & 0.0115 & 85009 & 11364.445 & 9544.654 & 10867.441 & 9173.191 & \text { Yes }\end{array}$ $\begin{array}{llllllllllllllll}100 & 46.75 & 27.92 & 24.01 & 2 & 1373.7384 & 1373.7257 & 687.8701 & 0.0127 & 9.2313 & 24008.790 & 19303680 & 942.876 & 782.374 & \text { Yes }\end{array}$ $\begin{array}{llllllllllllllll}1.00 & 46.65 & 28.01 & 26.72 & 2 & 1373.7388 & 1373.7257 & 687.8701 & 0.0131 & 9.5221 & 24463.821 & 19700.378 & 816.544 & 692.320 & \text { Yes }\end{array}$ $\begin{array}{llllllllllllllll}1.00 & 41.51 & 24.49 & 21.07 & 2 & 1561.9178 & 1561.9071 & 781.9608 & 0.0107 & 6.8417 & 99.217 & 90.007 & 612.568 & 547.851 & \text { No }\end{array}$

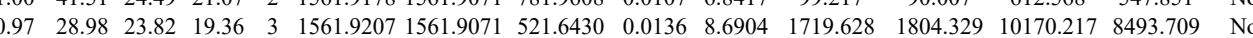

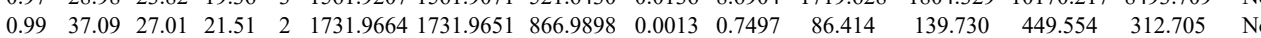
$\begin{array}{lllllllllllllllll}0.99 & 35.66 & 27.01 & 16.13 & 2 & 1731.9664 & 1731.9651 & 866.9898 & 0.0013 & 0.7497 & 40.546 & 84.251 & 424.338 & 241.258 & \text { No }\end{array}$ $\begin{array}{llllllllllllllll}1.00 & 38.33 & 27.01 & 20.99 & 3 & 1731.9667 & 1731.9651 & 578.3290 & 0.0016 & 0.9222 & 77.729 & 75.650 & 99.422 & 93.664 & \text { Yes } & \end{array}$ $\begin{array}{llllllllllllllll}1.00 & 53.26 & 25.58 & 28.76 & 2 & 1350.7876 & 1350.7751 & 676.3948 & 0.0125 & 9.2401 & 5504.574 & 4632.314 & 5456.027 & 3407.131 & \text { Yes }\end{array}$ $\begin{array}{lllllllllllllllll}0.99 & 43.84 & 27.94 & 24.63 & 2 & 1373.7386 & 1373.7257 & 687.8701 & 0.0129 & 9.3767 & 14624.493 & 11724.383 & 769.405 & 530.954 & \text { Yes }\end{array}$ $\begin{array}{lllllllllllllll}1.00 & 50.49 & 28.01 & 27.21 & 2 & 1373.7388 & 1373.7257 & 687.8701 & 0.0131 & 9.5221 & 18493.068 & 13566.561 & 837.604 & 513.523 & \text { Yes }\end{array}$ $\begin{array}{llllllllllllllllll}0.62 & 12.96 & 27.00 & 17.58 & 3 & 1731.9670 & 1731.9651 & 578.3290 & 0.0019 & 1.0951 & 141.224 & 119.969 & 103.702 & 90.423 & \text { Yes }\end{array}$ $\begin{array}{llllllllllllllll}0.79 & 15.83 & 26.88 & 17.21 & 3 & 1731.9673 & 1731.9651 & 578.3290 & 0.0022 & 1.2680 & 132.625 & 152.526 & 81.954 & 48.486 & \text { Yes }\end{array}$ $\begin{array}{lllllllllllllll}1.00 & 52.94 & 26.88 & 20.08 & 2 & 1731.9674 & 1731.9651 & 866.9898 & 0.0023 & 1.3264 & 9.134 & 66.140 & 476.516 & 287.596 & \text { No }\end{array}$ $\begin{array}{llllllllllllllll}\text { GHFEESQVAGTPMFVVK } & 0.55 & 23.34 & 27.36 & 36.34 & 3 & 2249.1775 & 2249.1758 & 750.7325 & 0.0017 & 0.7548 & 33.230 & 12.900 & 29.069 & 12.704 & \text { Yes }\end{array}$

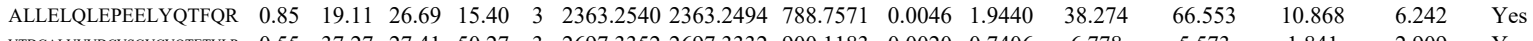

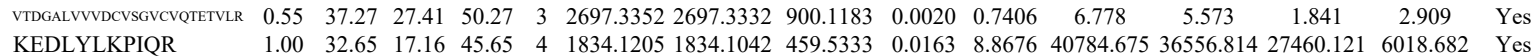

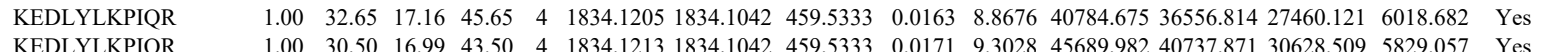

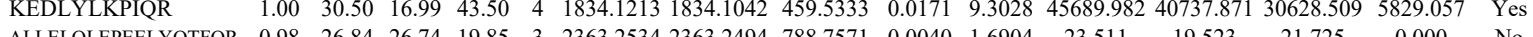

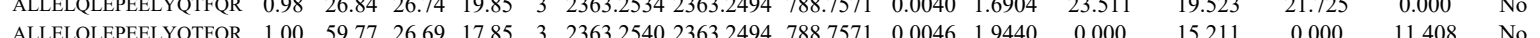
$\begin{array}{llllllllllllllll}\text { ALLELQLEPEELYQTFQR } & 1.00 & 59.77 & 26.69 & 17.85 & 3 & 2363.2540 & 2363.2494 & 788.7571 & 0.0046 & 1.9440 & 0.000 & 15.211 & 0.000 & 11.408 & \text { No } \\ \text { TGTITTFEHAHNMR } & 1.00 & 26.38 & 27.08 & 19.09 & 4 & 1758.8617 & 1758.8593 & 440.7221 & 0.0024 & 1.3614 & 5378.005 & 6411.477 & 3978.052 & 1305.231 & \text { Yes }\end{array}$ $\begin{array}{lllllllllllllllll}\text { TGTITTEHAHNMR } & 1.00 & 26.38 & 27.08 & 19.09 & 4 & 1758.8617 & 1758.8593 & 440.7221 & 0.0024 & 1.3614 & 5378.005 & 6411.477 & 3978.052 & 1305.231 & \text { Yes } \\ \text { TGTITTFEHAHNMR } & 1.00 & 27.28 & 27.18 & 40.28 & 4 & 1758.8633 & 1758.8593 & 440.7221 & 0.0040 & 22690 & 6709.111 & 7626.113 & 4042557 & 1701.172 & \text { Yes }\end{array}$ $\begin{array}{lllllllllllllllll}\text { TGTITFEHAHNMR } & 1.00 & 27.28 & 27.18 & 40.28 & 4 & 1758.8633 & 1758.853 & 40.7221 & 0.004 & 2.2690 & 679.111 & 7626.113 & 4042.55 & 1301.172 & \text { Yes }\end{array}$ $\begin{array}{lllllllllllllllll}\text { TGTITTFEHAHNMR } & 1.00 & 55.25 & 27.08 & 21.05 & 3 & 1758.8638 & 1758.8593 & 587.2937 & 0.0045 & 2.5541 & 7764.554 & 9690.347 & 5385.965 & 3699.922 & \text { Yes } \\ \text { TGTITTFEHAHNMR } & 1.00 & 39.30 & 27.16 & 22.35 & 3 & 1758.8647 & 1758.8593 & 587.2937 & 0.0054 & 3.0649 & 3184.473 & 2552.207 & 1963.738 & 1226.884 & \text { Yes }\end{array}$ 
$\begin{array}{lllllllllllll}.00 & 45.66 & 28.63 & 26.26 & 2 & 1364.7492 & 1364.7366 & 683.3756 & 0.0126 & 9.2189 & 28782.430 & 22777.802 & 221.191\end{array}$ $\begin{array}{llllllllllllll}\text { TGTITTFEHAHNMR } & 1.00 & 26.96 & 27.13 & 39.96 & 4 & 1758.8649 & 1758.8593 & 440.7221 & 0.0056 & 3.1766 & 4679.869 & 4670.166 & 2359.894\end{array}$ $\begin{array}{lllllllllllll} & \end{array}$ $\begin{array}{llllllllll} & \end{array}$ 11.314

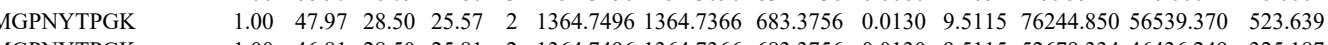
$\begin{array}{llllllllllllll}1.00 & 46.81 & 28.50 & 25.81 & 2 & 1364.7496 & 1364.7366 & 683.3756 & 0.0130 & 9.5115 & 52679.334 & 46436.249 & 325.187\end{array}$

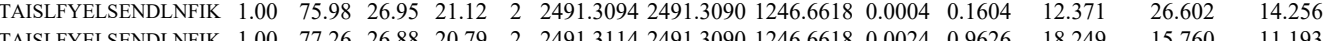
$\begin{array}{llllllllllllll}\text { STAISLFYELSENDLNFIK } & 1.00 & 47.93 & 26.86 & 19.96 & 3 & 2491.3141 & 2491.3090 & 831.4436 & 0.0051 & 2.0446 & 23.454 & 17.574 & 34.218\end{array}$ $\begin{array}{llllllllllllll}\text { STAISLFYELSENDLNFIK } & 0.94 & 25.81 & 26.73 & 17.59 & 3 & 2491.3153 & 2491.3090 & 831.4436 & 0.0063 & 2.5257 & 39.852 & 57.041 & 11.120\end{array}$ $\begin{array}{lllllllllll} & \text { MGAGFLNY }\end{array}$

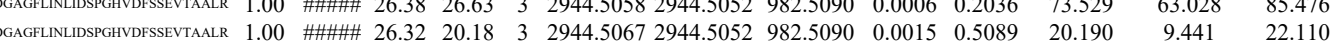
$\begin{array}{llllllllllllll}\text { DGAGELINLIDPGGHDFSSEVTAALR } & 1.00 & 72.03 & 26.38 & 24.01 & 3 & 2944.5088 & 2944.5052 & 982.5090 & 0.0036 & 1.2214 & 14.582 & 25.548 & 32.393\end{array}$ $\begin{array}{llllllllllllll}\text { DGAGFLINLISPGHVDFSSEVTAALR } & 1.00 & 73.63 & 26.36 & 19.35 & 3 & 2944.5094 & 2944.5052 & 982.5090 & 0.0042 & 1.4249 & 5.802 & 7.730 & 15.752\end{array}$ $\begin{array}{llllllllllllll}\text { DGAGLINLIDSPGHVFSSEVTAALR } & 1.00 & 88.98 & 26.38 & 19.61 & 3 & 2944.5100 & 2944.5052 & 982.5090 & 0.0048 & 1.6285 & 30.815 & 21.431 & 37.601 \\ \end{array}$ $\begin{array}{llllllllllll} & \end{array}$ $\begin{array}{llllllllllllll}\text { GGAGELINLDSPGHVDFSSEVTAALR } & 1.00 & 60.89 & 26.35 & 17.87 & 3 & 2944.5115 & 2944.5052 & 982.5090 & 0.0063 & 2.1374 & 14.893 & 25.445 & 10.196\end{array}$

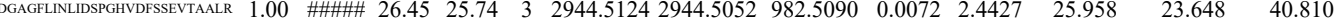

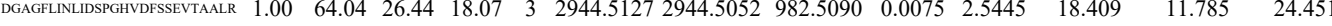

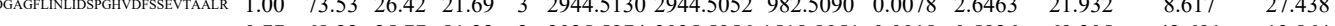

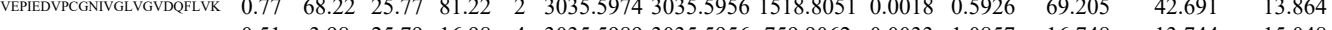

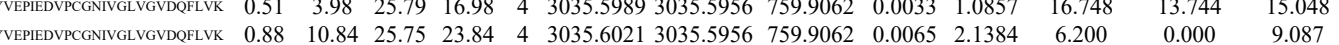
$\begin{array}{llllllllllll} & \end{array}$ $\begin{array}{lllllllllllll} & \end{array}$

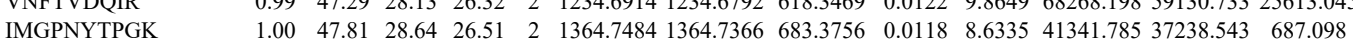
$\begin{array}{llllllllllllll} & 0.99 & 43.96 & 28.50 & 25.21 & 2 & 1364.7494 & 1364.7366 & 683.3756 & 0.0128 & 9.3652 & 29238.867 & 23564.388 & 565.607\end{array}$

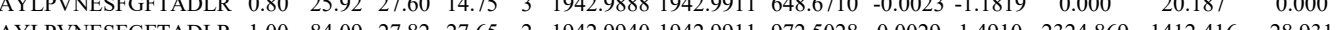

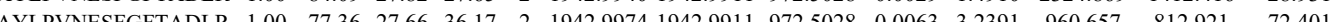

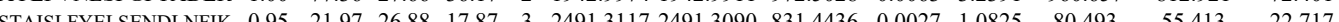

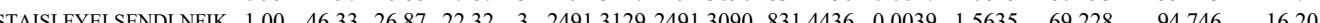
$\begin{array}{llllllllllllll} & \text { STA. }\end{array}$

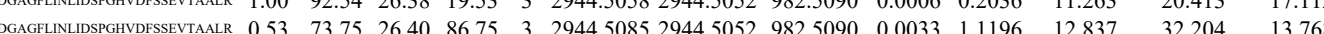

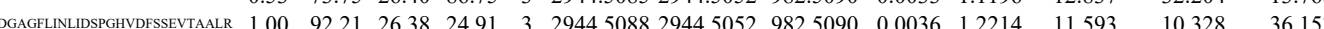

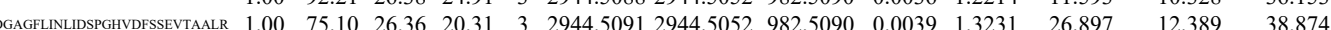
$\begin{array}{lllllllllllllll} & 20.95 & 2944.5100 & 2944.5052 & 9825090 & 0.0048 & 1.6285 & 32.911 & 19.933 & 32.342\end{array}$ $\begin{array}{lllllllllllllll}\text { GGAGLINLIDSPGHVDFSSEVTAALR } & 1.00 & 80.57 & 26.38 & 22.76 & 3 & 2944.5100 & 2944.5052 & 982.5090 & 0.0048 & 1.6285 & 30.835 & 21.891 & 36.062\end{array}$ $\begin{array}{llllllllllllll}\text { DGAGFLINLIDSPGHUDFSEVTAALR } & 1.00 & 86.10 & 26.42 & 21.43 & 3 & 2944.5118 & 2944.5052 & 982.5090 & 0.0066 & 2.2392 & 31.541 & 32.126 & 27.642\end{array}$ $\begin{array}{llllllllllllll}\text { DGAGFINLIDSPGHVDFSEVTAALR } & 1.00 & 92.13 & 26.44 & 25.06 & 3 & 2944.5121 & 2944.5052 & 982.5090 & 0.0069 & 2.3409 & 28.103 & 40.761 & 62.449\end{array}$ $\begin{array}{llllllllllllll}\text { DGAGGLILLDSPGHVDFSEVTAALR } & 1.00 & 61.19 & 26.42 & 21.35 & 3 & 2944.5130 & 2944.5052 & 982.5090 & 0.0078 & 2.6463 & 8.258 & 10.647 & 28.548 \\ \end{array}$

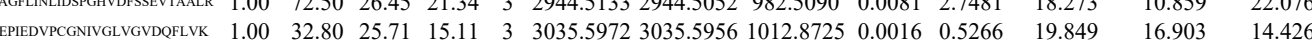

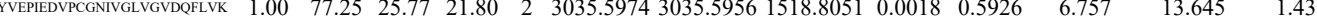

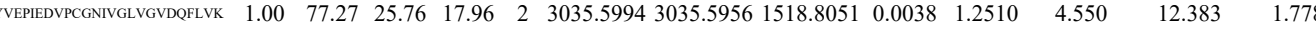
$\begin{array}{llllllllllllll}\text { WEPEDVPCGNIVGLVGVDERLVK } & 0.81 & 8.18 & 25.76 & 14.36 & 4 & 3035.5997 & 3035.5956 & 759.9062 & 0.0041 & 1.3488 & 23.645 & 33.261 & 12.173\end{array}$ $\begin{array}{llllllllllllll}0.99 & 4.96 & 28.16 & 25.38 & 2 & 1234.6896 & 1234.6792 & 618.3469 & 0.0104 & 8.4094 & 37968.786 & 32418.705 & 13958.270 & 15\end{array}$ (1) AGIIASAR VFDAIMNFK VFDAIMNFK $\begin{array}{lllllllllllll}0.86 & 19.92 & 27.37 & 2.33 & 3 & 2697.3340 & 2697.3332 & 900.1183 & 0.0008 & 0.2963 & 4.585 & 7.094 & 1.797\end{array}$ $\begin{array}{llllllllllllll}0.98 & 43.71 & 28.16 & 26.57 & 2 & 1234.6894 & 1234.6792 & 618.3469 & 0.0102 & 8.2477 & 14803.762 & 12102.944 & 5033.644 & 1.138 \\ 1.00 & 44.10 & 27.57 & 35.11 & 2 & 90.5472 & 901.5467 & 451.7806 & 0.0005 & 0.5534 & 7135.262 & 6712.546 & 2942.826 & 6.8\end{array}$ $\begin{array}{lllllllllllllll}1.00 & 44.10 & 27.57 & 35.11 & 2 & 901.5472 & 901.5467 & 451.7806 & 0.0005 & 0.5534 & 7135.262 & 6712.546 & 2942.826 \\ 0.99 & 30.70 & 27.33 & 23.27 & 3 & 1371.7492 & 1371.7464 & 458.2561 & 0.0028 & 2.0367 & 1734.190 & 1888.318 & 137.883\end{array}$ $\begin{array}{llllllllllllll}0.99 & 30.70 & 27.33 & 23.27 & 3 & 1371.7492 & 1371.7464 & 458.2561 & 0.0028 & 2.0367 & 1734.190 & 1888.318 & 137.883 \\ 1.00 & 53.96 & 27.33 & 23.70 & 2 & 1371.7492 & 1371.7464 & 686.8805 & 0.0028 & 2.0382 & 34547.762 & 34737.071 & 240.922\end{array}$ $\begin{array}{llllllllllllll}1.00 & 53.96 & 27.33 & 23.70 & 2 & 1371.7492 & 1371.7464 & 686.8805 & 0.0028 & 2.0382 & 34547.762 & 34737.071 & 240.922 \\ 1.00 & 54.00 & 27.32 & 23.45 & 2 & 1371.7494 & 1371.7464 & 686.8805 & 0.0030 & 2.1838 & 20324.508 & 24388.584 & 302.543\end{array}$ $\begin{array}{llllllllllllll}1.00 & 54.00 & 27.32 & 23.45 & 2 & 1371.7494 & 1371.7464 & 686.8805 & 0.0030 & 2.1838 & 20324.508 & 24388.584 & 302.543 \\ 0.99 & 30.68 & 27.38 & 24.21 & 3 & 1371.7504 & 1371.7464 & 458.2561 & 0.0040 & 2.9096 & 1076.272 & 1290.000 & 141.489\end{array}$ $\begin{array}{llllllllllllll}0.99 & 41.30 & 26.91 & 18.52 & 2 & 1371.7574 & 1371.7464 & 686.8805 & 0.0110 & 8.0072 & 276.600 & 269.583 & 83.761\end{array}$ $\begin{array}{lllllllllll} & \end{array}$ 
$\begin{array}{llllllllll} & \end{array}$

VFDAIMNFK

$\begin{array}{lllllllllllll} & \\ \text { VDAIMNFK } & 1.00 & 52.39 & 27.32 & 18.15 & 2 & 1371.7494 & 1371.7464 & 686.8805 & 0.0030 & 2.1838 & 33746.056 & 32917.865\end{array}$

\begin{tabular}{llllllllllll}
\hline & VIDALG
\end{tabular}

\begin{tabular}{lllllllllllll} 
& 1.90 \\
\hline
\end{tabular}

$\begin{array}{lllllllllll} & \end{array}$

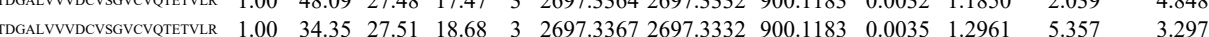

$\begin{array}{lllllllllllll}\text { VTDGALVVVDCYSGVCVOTETVLR } & 1.00 & 64.02 & 27.49 & 17.06 & 3 & 2697.3385 & 2697.3332 & 900.1183 & 0.0053 & 1.9627 & 4.524\end{array}$

$\begin{array}{llllllllllll}\text { VIDGALVWDESGGCVOTETVLR } & 0.95 & 29.89 & 27.57 & 17.77 & 3 & 2697.3439 & 2697.3332 & 900.1183 & 0.0107 & 3.9624 & 10.628\end{array}$

YEWDVAEAR
VFDAIMNFK

$\begin{array}{lllllllllll}0.95 & 29.89 & 27.57 & 17.77 & 3 & 2697.3439 & 2697.3332 & 900.1183 & 0.0107 & 3.9624 & 10.628 \\ 1.00 & 47.34 & 25.37 & 19.15 & 2 & 1281.6126 & 1281.6111 & 641.8128 & 0.0015 & 1.1686 & 47.430\end{array}$

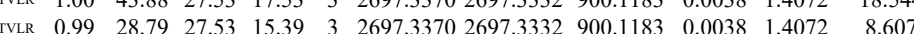
$\begin{array}{llllllllllllll}49.72 & 19.14 & 21.23 & 2 & 1504.9342 & 1504.9199 & 753.4672 & 0.0143 & 9.4894 & 47834.186 & 41269.825 & 0.000\end{array}$

IKPVLMMNK

IKPVLMMNK

IKPVLMMNK

TKPVQLILDPIFK

TFCQLILDPIFK

TFCOLILDPIFK

IKPVLMMNK

TFCQLILDPIFK

TFCQLILDPIFK

TFCQLILDPIFK

TFCQLILDPIFK

FSVSPVVVR

TFCQLILDPIFK

TFCQLILDPIFK

TFCQLILDPIFK

TFCQLILDPIFK

TFCQLILDPIFK

WLAGALQLOMTTHLPPPVAOK

TILMMGR

TILMMGR

TILMMGR

TILMMGR

TILMMG $\begin{array}{llllllllllll} & \end{array}$

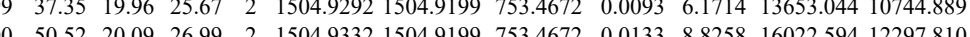
$\begin{array}{llllllllllll}98 & 29.02 & 20.09 & 20.46 & 3 & 1504.9333 & 1504.9199 & 502.6472 & 0.0134 & 8.8862 & 57570.759 & 45957.579\end{array}$ $\begin{array}{llllllllllllll}0.99 & 29.87 & 19.14 & 20.27 & 3 & 1504.9342 & 1504.9199 & 502.6472 & 0.0143 & 9.4830 & 51340.898 & 44103.952\end{array}$ $\begin{array}{lllllllllllll}1.00 & 58.76 & 27.17 & 25.37 & 2 & 1770.9682 & 1770.9656 & 886.4901 & 0.0026 & 1.4665 & 12984.727 & 13417.279\end{array}$ $\begin{array}{llllllllllll}1.00 & 64.89 & 27.28 & 31.25 & 2 & 1770.9690 & 1770.9656 & 886.4901 & 0.0034 & 1.9177 & 11107.002 & 11736.481\end{array}$ $\begin{array}{lllllllllllll}1.00 & 37.34 & 27.29 & 22.46 & 3 & 1770.9697 & 1770.9656 & 591.3291 & 0.0041 & 2.3112 & 244.228 & 275.627\end{array}$ $\begin{array}{llllllllllll}1.00 & 65.51 & 25.88 & 24.29 & 3 & 3121.6162 & 3121.6136 & 1041.5451 & 0.0026 & 0.8321 & 3.747 & 2.574 \\ 1.00 & 4.73 & 19.03 & 20.98 & 2 & 150.9346 & 1504.9199 & 753.4672 & 0.0147 & 9.7548 & 2284.765 & 1933.293\end{array}$ $\begin{array}{llllllllllllll}1.00 & 47.73 & 19.03 & 20.98 & 2 & 1504.9346 & 1504.9199 & 753.4672 & 0.0147 & 9.7548 & 2284.765 & 1933.293 \\ 1.00 & 35.01 & 27.17 & 2237 & 3 & 1770.9682 & 1770.9656 & 591.3291 & 0.0026 & 1.4656 & 732.473 & 692368\end{array}$ $\begin{array}{lllllllllllll}1.00 & 70.45 & 27.17 & 31.24 & 2 & 1770.9684 & 1770.9656 & 886.4901 & 0.0028 & 1.5793 & 4861.502 & 4132.66\end{array}$ $\begin{array}{lllllllllllll}1.00 & 69.83 & 27.27 & 31.17 & 2 & 1770.9686 & 1770.9656 & 886.4901 & 0.0030 & 1.6921 & 8046.774 & 8457.693\end{array}$ $\begin{array}{lllllllllllll}0.98 & 33.06 & 26.92 & 23.78 & 3 & 1770.9727 & 1770.9656 & 591.3291 & 0.0071 & 4.0023 & 88.993 & 186.933\end{array}$ $\begin{array}{llllllllllll}0.54 & 23.63 & 27.21 & 17.86 & 2 & 1033.6120 & 1033.6042 & 517.8094 & 0.0078 & 7.5317 & 95178.680 & 86957.771\end{array}$ $\begin{array}{lllllllllllll}1.00 & 64.72 & 27.17 & 27.73 & 2 & 1770.9684 & 1770.9656 & 886.4901 & 0.0028 & 1.5793 & 1408.483 & 1012.206 \\ 1.00 & 73.36 & 27.28 & 29.90 & 2 & 1770.9690 & 1770.9656 & 886.4901 & 0.0034 & 1.9177 & 1964.902 & 1726.968\end{array}$ $\begin{array}{llllllllllll}1.00 & 33.78 & 27.28 & 26.07 & 3 & 1770.9691 & 1770.9656 & 591.3291 & 0.0035 & 1.9730 & 126.119 & 139.216\end{array}$ $\begin{array}{lllllllllllll}0.99 & 32.03 & 27.25 & 20.25 & 3 & 1770.9703 & 1770.9656 & 591.3291 & 0.0047 & 2.6494 & 91.480 & 109.269\end{array}$ $\begin{array}{llllllllllll}0.51 & 12.66 & 27.29 & 18.32 & 3 & 1770.9697 & 1770.9656 & 591.3291 & 0.0041 & 2.3112 & 119.430 & 123.449\end{array}$ $\begin{array}{llllllllllll}0.79 & 18.22 & 27.29 & 17.80 & 3 & 1770.9706 & 1770.9656 & 591.3291 & 0.0050 & 2.8185 & 160.203 & 172.448\end{array}$ $\begin{array}{llllllllllll}0.79 & 18.22 & 27.29 & 17.80 & 3 & 170.9706 & 1770.9656 & 591.3291 & 0.0050 & 2.8185 & 160.203 & 172.448 \\ 0.92 & 4.88 & 20.45 & 49.85 & 4 & 2903.6205 & 2903.6187 & 726.9120 & 0.0018 & 0.6191 & 195.932 & 192.518\end{array}$ $\begin{array}{llllllllllll}0.92 & 25.67 & 26.58 & 29.96 & 2 & 964.5330 & 964.5320 & 483.2733 & 0.0010 & 1.0346 & 375.113 & 328.333\end{array}$ $\begin{array}{llllllllllllll}0.94 & 27.33 & 26.58 & 28.26 & 2 & 964.5332 & 964.5320 & 483.2733 & 0.0012 & 1.2415 & 335.044 & 333.676\end{array}$ $\begin{array}{llllllllllllll}0.90 & 25.35 & 27.67 & 28.17 & 2 & 964.5338 & 964.5320 & 483.2733 & 0.0018 & 1.8623 & 187.021 & 152.782\end{array}$

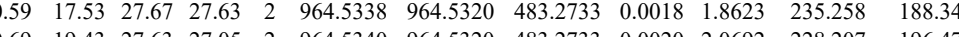
$\begin{array}{lllllllllllll}0.69 & 19.43 & 27.63 & 27.05 & 2 & 964.5340 & 964.5320 & 483.2733 & 0.0020 & 2.0692 & 228.207 & 196.474 \\ 0.69 & 19.14 & 27.40 & 23.63 & 2 & 964.5342 & 964.5320 & 483.2733 & 0.0022 & 2.2761 & 82.636 & 64.321\end{array}$

3.684

2.328




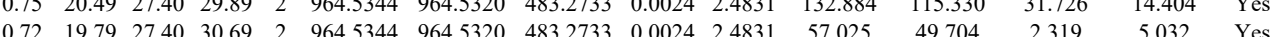
$\begin{array}{llllllllllllll}0.74 & 21.46 & 26.81 & 31.27 & 2 & 964.5354 & 964.5320 & 483.2733 & 0.0034 & 3.5177 & 155.571 & 99.211 & 15.867\end{array}$

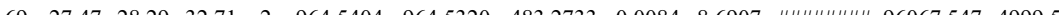

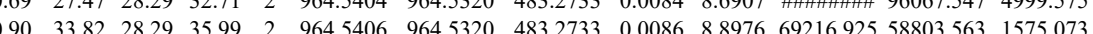

TILMMGR

TILMMGR $\begin{array}{lllllllllll}0.078 & 28.17 & 21.24 & 3 & 2887.6264 & 2887.6237 & 963.5485 & 0.0027 & 0.9340 & 197.203\end{array}$

TFCQLILDPIFK

$\begin{array}{lllllllllllll}0.87 & 32.06 & 28.29 & 34.59 & 2 & 964.5404 & 964.5320 & 483.2733 & 0.0084 & 8.6907 & 30999.071 & 28756.936 & 1146.926 \\ 0.97 & 25.84 & 27.29 & 20.86 & 3 & 1770.9697 & 1770.9656 & 5913291 & 0.0041 & 23112 & 85.568 & 84.929 & 34.445\end{array}$

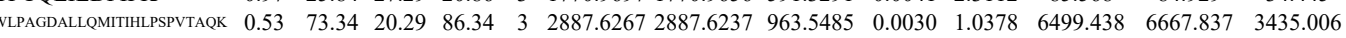

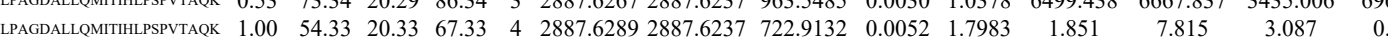

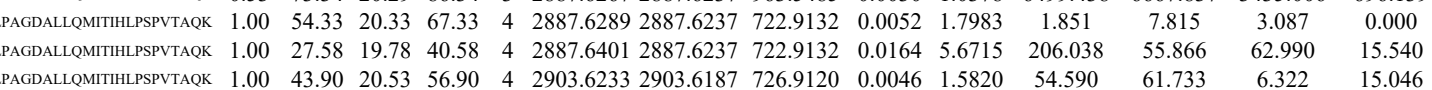

CLYASVLTAQPR

AGIIASAR

CLYASVLTAQPR

CLYASVLTAQPR

CLYASVLTAQPR

CLYASVLTAQPR

CLYASVLTAQPR

CLYASVLTAQPR

CLYASVLTAQPR

CLYASVLTAQPR

CLYASVLTAQPR

CLYASVLTAQPR

CLYASVLTAQPR

CLYASLTAQPR

CLYASVLTAQPR

CLYASVITAQPR

CLYASVLTAQPR

CLYASVLTAQPR

AGIIASAR

CLYASVLTAQPR

CLYASVLTAQPR

CLYASVLTAQPR

CLYASVLTAQPR

CLYASVLTAQPR

CLYASVLTAQPR

CLYASVLTAQPR

CLYASVLTAQPR

CLYASVLTAQPR

CLYASVLTAQPR

CLYASVLTAQPR

CLYASVLTAQPR

CLYASVLTAQPR

CLYASVLTAQPR

CLYASVLTAQPR

CLYASVLTAQPR

CLYASVLTAQPR

CLYASVLTAQPR

CLYASVLTAQPR

CLYASVLTAQPR

CLYASVLTAQPR

CLYASVLTAQPR

CLYASVLTAQPR $\begin{array}{lllllllll} & & \end{array}$ $\begin{array}{lllllllllll}64.86 & 27.92 & 77.86 & 2 & 1510.7762 & 1510.7758 & 756.3952 & 0.0004 & 0.2644 & 38.419\end{array}$ $\begin{array}{llllllllllllll}0.83 & 26.01 & 27.57 & 23.51 & 2 & 901.5470 & 901.5467 & 451.7806 & 0.0003 & 0.3320 & 566.855 & 570.839\end{array}$

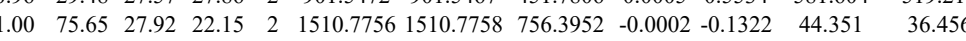
$\begin{array}{llllllllllll}1.00 & 78.48 & 27.92 & 21.21 & 2 & 1510.7758 & 1510.7758 & 756.3952 & 0.0000 & 0.0000 & 5320.642 & 4349.771 \\ 1.00 & 79.08 & 27.92 & 2.93 & 2 & 15107758 & 1510.7758 & 756.3952 & 0.0000 & 0.0000 & 13972.546 & 11566.471\end{array}$ $\begin{array}{llllllllllll}1.00 & 79.08 & 27.92 & 22.93 & 2 & 1510.7758 & 1510.7758 & 756.3952 & 0.0000 & 0.0000 & 13972.546 & 11566.471\end{array}$ $\begin{array}{lllllllllllll}1.00 & 77.18 & 27.93 & 19.23 & 2 & 1510.7760 & 1510.7758 & 756.3952 & 0.0002 & 0.1322 & 42.555 & 42.297\end{array}$ $\begin{array}{lllllllllllll}1.00 & 68.09 & 27.92 & 18.77 & 2 & 1510.7762 & 1510.7758 & 756.3952 & 0.0004 & 0.2644 & 69.684 & 59.109\end{array}$ $\begin{array}{llllllllllll}1.00 & 76.31 & 27.92 & 21.07 & 2 & 1510.7762 & 1510.7758 & 756.3952 & 0.0004 & 0.2644 & 38.621 & 50.547\end{array}$ $\begin{array}{lllllllllllll}1.00 & 59.86 & 27.92 & 18.63 & 2 & 1510.7762 & 1510.7758 & 756.3952 & 0.0004 & 0.2644 & 31.509 & 19.123\end{array}$ $\begin{array}{llllllllllll}1.00 & 66.24 & 27.90 & 17.44 & 2 & 1510.7764 & 1510.7758 & 756.3952 & 0.0006 & 0.3966 & 59.282 & 45.178\end{array}$ $\begin{array}{lllllllllllll}1.00 & 74.78 & 27.87 & 21.18 & 2 & 1510.7766 & 1510.7758 & 756.3952 & 0.0008 & 0.5288 & 41.346 & 31.519\end{array}$ $\begin{array}{llllllllllll}1.00 & 7.93 & 27.90 & 2.99 & 2 & 1510.7770 & 1510.7758 & 756.3952 & 0.0012 & 0.7932 & 71.346 & 31.519\end{array}$ $\begin{array}{lllllllllllll}1.00 & 76.08 & 27.89 & 19.63 & 2 & 1510.7772 & 1510.7758 & 756.3952 & 0.0014 & 0.9254 & 70.918 & 53.825\end{array}$

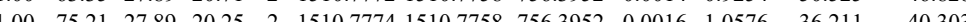
$\begin{array}{llllllllllll}1.00 & 0.0576 & 32.755 & 36.828\end{array}$ $\begin{array}{llllllllllll}1.00 & 58.45 & 27.94 & 23.95 & 2 & 1510.7776 & 1510.7758 & 756.3952 & 0.0018 & 1.1899 & 40.613 & 51.241\end{array}$

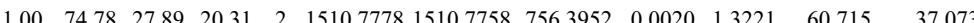
$\begin{array}{llllllllllll}0.77 & 72.56 & 27.82 & 85.56 & 2 & 1510.7780 & 1510.7758 & 7563952 & 0.0022 & 1.4543 & 37.428 & 27.613\end{array}$ $\begin{array}{lllllllllllll}0.87 & 24.21 & 27.43 & 27.00 & 2 & 901.5480 & 901.5467 & 451.7806 & 0.0013 & 1.4387 & 131.698 & 95.203\end{array}$ $\begin{array}{lllllllllllll}1.00 & 60.80 & 27.68 & 17.45 & 2 & 1510.7734 & 1510.7758 & 756.3952 & -0.0024 & -1.5865 & 28.191 & 22.966\end{array}$ $\begin{array}{llllllllllll}0.98 & 32.74 & 27.80 & 19.82 & 3 & 1510.7746 & 1510.7758 & 504.5992 & -0.0012 & -0.7927 & 536.327 & 510.820\end{array}$ $\begin{array}{llllllllllll}1.00 & 66.10 & 27.80 & 17.28 & 2 & 1510.7748 & 1510.7758 & 756.3952 & -0.0010 & -0.6610 & 41.293 & 32.667\end{array}$ $\begin{array}{llllllllllll}1.00 & 64.85 & 27.80 & 17.64 & 2 & 1510.7748 & 1510.7758 & 756.3952 & -0.0010 & -0.6610 & 26.593 & 18.607\end{array}$ $\begin{array}{llllllllllll}1.00 & 80.73 & 27.95 & 21.73 & 2 & 1510.7754 & 1510.7758 & 756.3952 & -0.0004 & -0.2644 & 8377.721 & 7543.482\end{array}$ $\begin{array}{lllllllllllll}1.00 & 62.40 & 27.95 & 19.45 & 2 & 1510.7754 & 1510.7758 & 756.3952 & -0.0004 & -0.2644 & 30.043 & 41.688\end{array}$ $\begin{array}{llllllllllll}1.00 & 64.38 & 27.95 & 19.67 & 2 & 1510.7754 & 1510.7758 & 756.3952 & -0.0004 & -0.2644 & 20.379 & 28.678\end{array}$ $\begin{array}{lllllllllllll}1.00 & 65.68 & 27.92 & 21.86 & 2 & 1510.7756 & 1510.7758 & 756.3952 & -0.0002 & -0.1322 & 23.856 & 20.179\end{array}$ $\begin{array}{llllllllllll}0.96 & 26.89 & 27.92 & 18.71 & 3 & 1510.7758 & 1510.7758 & 504.5992 & 0.0000 & 0.0000 & 163.958 & 228.471\end{array}$ $\begin{array}{lllllllllllll}0.61 & 67.87 & 27.92 & 80.87 & 2 & 1510.7758 & 1510.7758 & 756.3952 & 0.0000 & 0.0000 & 46.038 & 24.46\end{array}$ $\begin{array}{llllllllllll}1.00 & 69.41 & 27.93 & 19.99 & 2 & 1510.7760 & 1510.7758 & 756.3952 & 0.0002 & 0.1322 & 29.397 & 21.606 \\ 1.00 & 63.42 & 27.90 & 18.63 & 2 & 1510.7764 & 1510.7758 & 7563952 & 0.0006 & 0.3966 & 31.016 & 32.753\end{array}$ $\begin{array}{llllllllllll}1.00 & 63.42 & 27.90 & 18.63 & 2 & 1510.7764 & 1510.7758 & 756.3952 & 0.0006 & 0.3966 & 31.016 & 32.753 \\ 1.00 & 91.99 & 27.90 & 20.80 & 2 & 1510.7764 & 1510.7758 & 7563952 & 0.0006 & 0.3966 & 29.448 & 31.024\end{array}$

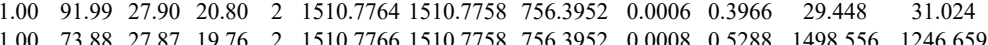

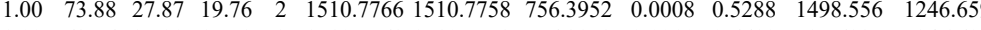

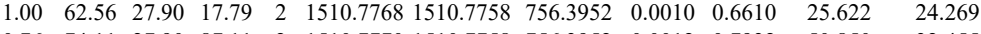
$\begin{array}{llllllllllll}0.76 & 74.11 & 27.90 & 87.11 & 2 & 1510.7770 & 1510.7758 & 756.3952 & 0.0012 & 0.7932 & 50.850\end{array}$ $\begin{array}{lllllllllll}0.76 & 61.95 & 27.90 & 74.95 & 2 & 1510.7770 & 1510.7758 & 756.3952 & 0.0012 & 0.7932 & 30.965\end{array}$ $\begin{array}{llllllllllll}0.76 & 61.93 & 27.90 & 74.93 & 2 & 1510.7770 & 1510.7758 & 756.3952 & 0.0012 & 0.7932 & 22.708\end{array}$ $\begin{array}{lllllllllll}1.00 & 63.05 & 27.89 & 20.87 & 2 & 1510.7772 & 1510.7758 & 756.3952 & 0.0014 & 0.9254 & 29.970\end{array}$

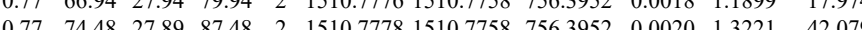
$\begin{array}{lllllllllll}0.69 & 72.01 & 28.20 & 85.01 & 2 & 1510.7784 & 1510.7758 & 756.3952 & 0.0026 & 1.7187 & 36.338\end{array}$ $\begin{array}{lllllllllllll}1.00 & 64.97 & 28.20 & 19.63 & 2 & 1510.7784 & 1510.7758 & 756.3952 & 0.0026 & 1.7187 & 24.468\end{array}$

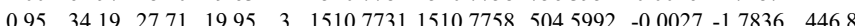
61.733 20.448

$\begin{array}{ll}6.322 & 15.046\end{array}$

$13.197 \quad 19.160$

$0.000 \quad 0.000$

$\begin{array}{ll}209.417 & 64.942 \\ 209.447 & 79.351\end{array}$

2.624

89.590

0.000

8.755

7.266
0.000

0.000
0.000

0.826

4.451

4.026
7.457
0.000

0.000

2.392
1.989

4.387
36.816

1.402

58.685

0.000

3.416
0.000

1.621

0.516

30.511

2.204
5.176

6.732

\begin{tabular}{ll}
5.571 \\
\hline
\end{tabular}

2.905

41.658 
CLYASVLTAQPR CLYASVLTAQPR CLYASVLTAQPR WLPAGDALLQMITIHLPPP CLYASVLTAQPR WLPAGDALLQMITIHLPSVVTAQK CLYASVLTAQPR CLYASVLTAQPR CLYASVLTAQPR CLYASVLTAQPR AGIIASAR AGIIASAR TILMMGR FSVSPVVR VNFTVDQIR CLYASVLTAQPR CLYASVLTAQPR TILMMGR TILMMGR VNFTVDQIR

CLYASVLTAQPR

CLYASVLTAQPR

TILMMGR

FSVSPVVR

VNFTVDQIR

VNFTVDQIR

CLYASVLTAQPR

CLYASVLTAQP

TILMMGR

TILMMGR

CLYASVLTAQPR

AGIIASAR

CLYASVLTAQPR

CLYASVLTAQPR

AGIIASAR

TILMMGR

TILMMGR

CLYASVLTAQPR

CLYASVLTAQPR

TILMMGR

CLYASVLTAQPR

CLYASVLTAQPR

FSVSPVVR

CLYASVLTAQPR

CLYASVLTAQPR

CLYASVLTAQPR
CLYASVLTAQPR

CLYASVLTAQPR

CLYASVLTAQPR

SATSPEGK

DLEEDHACIPIK

DLEEDHACIPIK

DLEEDHACIPIK

DLEEDHACIPIK

DLEEDHACIPIK

DLEEDACIPIK

CLYASLTAQR

YEWDVAEAR $\begin{array}{lllllllllll}4.93 & 27.70 & 17.93 & 2 & 1510.7738 & 1510.7758 & 756.3952 & -0.0020 & -1.3221 & 16.071 & 12.153\end{array}$ $\begin{array}{lllllllllll} & \end{array}$

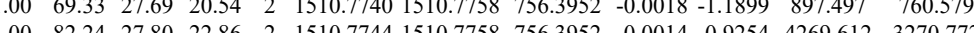

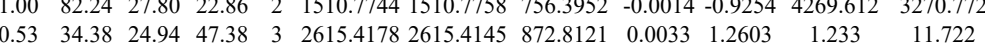

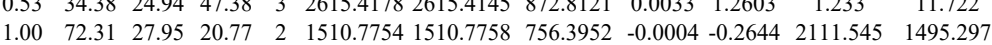

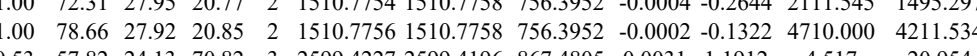
$\begin{array}{llllllllllll}0.53 & 57.82 & 24.13 & 70.82 & 3 & 2599.4227 & 2599.4196 & 867.4805 & 0.0031 & 1.1912 & 4.517 & 20.954 \\ 1.00 & 21.77 & 24.17 & 34.77 & 4 & 2599.4229 & 2599.4196 & 650.8622 & 0.0033 & 1.2675 & 19.928 & 7.293\end{array}$

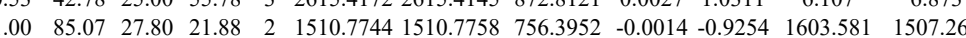
$\begin{array}{llllllllllll}.00 & 75.28 & 27.92 & 21.99 & 2 & 1510.7756 & 1510.7758 & 756.3952 & -0.0002 & -0.1322 & 1137.077 & 992.260\end{array}$ $\begin{array}{lllllllllllll}1.00 & 80.80 & 27.80 & 2.74 & 2 & 1510.7766 & 1510.7758 & 756.3952 & 0.0008 & 0.5288 & 54.456 & 567.317\end{array}$ $\begin{array}{lllllllllllllll}0.89 & 25.23 & 27.43 & 24.61 & 2 & 901.5478 & 901.5467 & 451.7806 & 0.0011 & 1.2174 & 111.413 & 69.833\end{array}$ $\begin{array}{lllllllllllll}0.78 & 21.53 & 27.43 & 27.83 & 2 & 901.5480 & 901.5467 & 451.7806 & 0.0013 & 1.4387 & 66.863 & 91.005\end{array}$ $\begin{array}{lllllllllllll}0.63 & 17.48 & 27.58 & 2.4 .45 & 2 & 964.5332 & 964.5320 & 483.2733 & 0.0012 & 1.2415 & 190.453 & 155.873\end{array}$ $\begin{array}{llllllllllllll}0.67 & 18.94 & 27.60 & 21.56 & 2 & 964.5336 & 964.5320 & 483.2733 & 0.0016 & 1.6554 & 160.390 & 113.038\end{array}$ $\begin{array}{llllllllllll} & 150.590 & 13.038\end{array}$ $\begin{array}{lllllllllllll}0.52 & 2.10 & 28.69 & 22.42 & 2 & 1234.6796 & 1234.6792 & 618.3469 & 0.0004 & 0.3234 & 93.037 & 81.161\end{array}$ $\begin{array}{llllllllllllll}1.00 & 78.43 & 27.89 & 20.66 & 2 & 1510.7772 & 1510.7758 & 756.3952 & 0.0014 & 0.9254 & 101.065 & 51.649\end{array}$ $\begin{array}{lllllllllllll}1.00 & 65.07 & 27.89 & 20.70 & 2 & 1510.7778 & 1510.7758 & 756.3952 & 0.0020 & 1.3221 & 90.146 & 72.184\end{array}$ $\begin{array}{lllllllllllll}0.65 & 17.86 & 26.58 & 24.27 & 2 & 964.5334 & 964.5320 & 483.2733 & 0.0014 & 1.4485 & 306.411 & 280.435\end{array}$ $\begin{array}{llllllllllllll}0.76 & 21.00 & 27.67 & 24.23 & 2 & 964.5338 & 964.5320 & 483.2733 & 0.0018 & 1.8623 & 352.547 & 252.948\end{array}$ $\begin{array}{llllllllllll}0.76 & 21.00 & 27.67 & 24.23 & 2 & 964.5338 & 964.5320 & 483.2733 & 0.0018 & 1.8623 & 32.547\end{array}$ $\begin{array}{llllllllllll}1.00 & 60.47 & 27.90 & 18.66 & 2 & 1510.7770 & 1510.7758 & 756.3952 & 0.0012 & 0.7932 & 134.169\end{array}$ $\begin{array}{llllllllllll}1.00 & 58.78 & 27.89 & 17.86 & 2 & 1510.7772 & 1510.7758 & 756.3952 & 0.0014 & 0.9254 & 90.172 & \\ 0.81 & 2.36 & 26.58 & 30.97 & 2 & 964.5334 & 964.5320 & 43.2733 & 0.004 & 1.485 & 282.272 & 2\end{array}$ $\begin{array}{llllllllllll}0.81 & 21.36 & 26.58 & 30.97 & 2 & 964.5334 & 964.5320 & 483.2733 & 0.0014 & 1.4485 & 282.272 & \\ 0.72 & 20.46 & 27.62 & 26.51 & 2 & 1033.6050 & 1033.6042 & 517.8094 & 0.0008 & 0.7725 & 186.769\end{array}$ $\begin{array}{llllllllllll}0.723 .671 & 28.86 & 21.65 & 2 & 1234.6792 & 1234.6792 & 618.3469 & 0.0000 & 0.0000 & 87.214 & 78.240\end{array}$ $\begin{array}{lllllllllllll}0.92 & 34.60 & 28.69 & 24.89 & 2 & 1234.6794 & 1234.6792 & 618.3469 & 0.0002 & 0.1617 & 134.981 & 144.157\end{array}$ $\begin{array}{llllllllllll}1.00 & 62.74 & 27.90 & 19.41 & 2 & 1510.7770 & 1510.7758 & 756.3952 & 0.0012 & 0.7932 & 119.715\end{array}$ $\begin{array}{llllllllllllll}1.00 & 74.66 & 27.89 & 20.74 & 2 & 1510.7772 & 1510.7758 & 756.3952 & 0.0014 & 0.9254 & 123.088\end{array}$ $\begin{array}{lllllllllllll}0.76 & 20.28 & 26.58 & 22.89 & 2 & 964.5330 & 964.5320 & 483.2733 & 0.0010 & 1.0346 & 347.704\end{array}$ $\begin{array}{lllllllllllll}0.94 & 28.44 & 27.96 & 30.77 & 2 & 1033.6052 & 1033.6042 & 517.8094 & 0.0010 & 0.9656 & 246.647 & 187.207\end{array}$

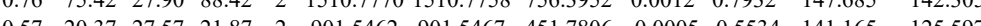

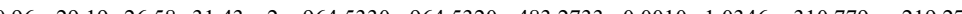
$\begin{array}{lllllllllllll}0.76 & 80.46 & 27.89 & 93.46 & 2 & 1510.7772 & 1510.7758 & 756.3952 & 0.0014 & 0.9254 & 164.637 & 142.130\end{array}$ $\begin{array}{lllllllllllll}0.88 & 24.42 & 27.89 & 2.52 & 2 & 150.7744 & 1510.7758 & 756.3952 & 0.0016 & 1.0576 & 182.235 & 14.543\end{array}$ $\begin{array}{llllllllllll}0.97 & 29.53 & 26.58 & 32.16 & 2 & 964.5328 & 964.5320 & 483.2733 & 0.0008 & 0.8277 & 3807.312 & 3018.472\end{array}$ $\begin{array}{llllllllllllll}0.83 & 23.33 & 26.58 & 34.49 & 2 & 964.5332 & 964.5320 & 483.2733 & 0.0012 & 1.2415 & 1620.758 & 1542.755\end{array}$ $\begin{array}{lllllllllllll}0.59 & 35.00 * & 27.28 & 23.35 & 2 & 980.5280 & 980.5269 & 491.2707 & 0.0011 & 1.1195 & 754.115 & 634.149\end{array}$ $\begin{array}{llllllllllll}0.77 & 73.34 & 27.89 & 86.34 & 2 & 1510.7774 & 1510.7758 & 7563952 & 0.0016 & 1.1195 & 754.115 & 634.149 \\ 1.00 & 76.50 & 27.89 & 21.55 & 2 & 1510.774 & 261.110\end{array}$ $\begin{array}{lllllllllllll}1.00 & 76.50 & 27.89 & 21.55 & 2 & 1510.7774 & 1510.7758 & 756.3952 & 0.0016 & 1.0576 & 230.555 & 151.076\end{array}$ $\begin{array}{lllllllllllllll}0.94 & 27.44 & 26.58 & 29.68 & 2 & 964.5332 & 964.5320 & 483.2733 & 0.0012 & 1.2415 & 539.844 & 502.003\end{array}$ $\begin{array}{lllllllllllll}0.87 & 24.67 & 27.92 & 24.28 & 2 & 1033.6056 & 1033.6042 & 517.8094 & 0.0014 & 1.3518 & 324.417 & 284.784\end{array}$ $\begin{array}{lllllllllllll}1.00 & 63.51 & 27.87 & 19.51 & 2 & 1510.7766 & 1510.7758 & 756.3952 & 0.0008 & 0.5288 & 245.387 & 169.683\end{array}$ $\begin{array}{llllllllllllll}1.00 & 72.38 & 27.89 & 21.97 & 2 & 1510.7772 & 1510.7758 & 756.3952 & 0.0014 & 0.9254 & 191.064 & 152.713\end{array}$

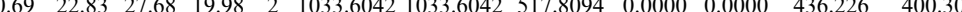
$\begin{array}{lllllllllllll}0.79 & 72.83 & 27.68 & 19.98 & 2 & 103.6042 & 1033.6042 & 517.804 & 0.0000 & 0.090 & 436.226 & 400.300 \\ 0.76 & 7.10 & 27.89 & 87.17 & 2 & 1510.7772 & 1510.7758 & 756.3952 & 0.0014 & 0.9254 & 232.699 & 219.187\end{array}$ $\begin{array}{llllllllllllll}0.76 & 79.10 & 27.89 & 92.10 & 2 & 1510.7772 & 1510.7758 & 756.3952 & 0.0014 & 0.9254 & 236.669 & 219.237\end{array}$ $\begin{array}{llllllllllll}0.88 & 19.38 & 27.88 & 17.58 & 3 & 1510.7779 & 1510.7758 & 504.5992 & 0.0021 & 1.3872 & 31.941 & 33.539\end{array}$ $\begin{array}{llllllllllll}0.88 & 19.55 & 27.94 & 20.71 & 3 & 1510.7776 & 1510.7758 & 504.5992 & 0.0018 & 1.1891 & 38.637 & 23.104\end{array}$ $\begin{array}{llllllllllll}1.00 & 75.39 & 27.89 & 19.72 & 2 & 1510.7772 & 1510.7758 & 756.3952 & 0.0014 & 0.9254 & 184.157 & 172.202\end{array}$ $\begin{array}{llllllllllll}1.00 & 77.16 & 28.03 & 19.96 & 2 & 1510.7792 & 1510.7758 & 756.3952 & 0.0034 & 2.2475 & 157.776 & 119.463\end{array}$ $\begin{array}{lllllllllllll}1.00 & 77.16 & 28.03 & 19.96 & 2 & 1510.7792 & 1510.7758 & 756.3952 & 0.0034 & 2.2475 & 157.776 & 1\end{array}$ $\begin{array}{llllllllllll}1.00 & 80.11 & 28.05 & 28.86 & 2 & 1715.8482 & 1715.8466 & 858.9306 & 0.0016 & 0.9314 & 402.448 & 39\end{array}$ $\begin{array}{llllllllllllll}1.00 & 37.64 & 28.01 & 21.84 & 3 & 1715.8498 & 1715.8466 & 572.9561 & 0.0032 & 1.8617 & 4361.656 & 3153.205\end{array}$

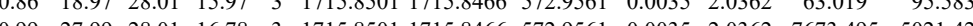

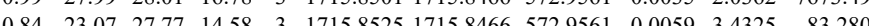
$\begin{array}{llllllllllll}0.84 & 23.07 & 27.77 & 14.58 & 3 & 1715.8525 & 1715.8466 & 572.9561 & 0.0059 & 3.4325 & 83.280\end{array}$

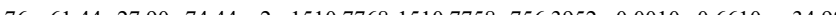
$\begin{array}{llllll} & 0.474\end{array}$ $\begin{array}{lllllllllllll}0.98 & 34.30 & 25.44 & 16.61 & 2 & 1281.6108 & 1281.6111 & 641.8128 & -0.0003 & 0.2337 & 170.838\end{array}$ 


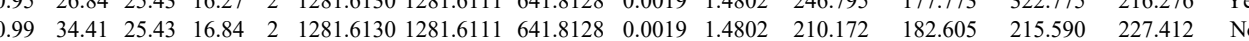

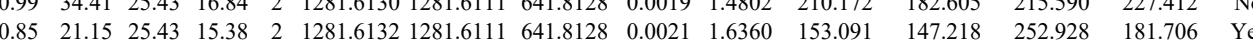

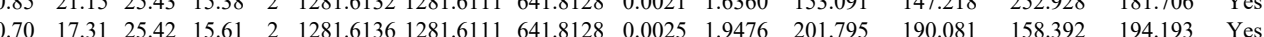
$\begin{array}{lllllllllllllll}1.00 & 3738 & 25.42 & 18.19 & 2 & 1281.6136 & 1281.6111 & 6418128 & 0.0025 & 1.9476 & 289.996 & 258.007 & 317.305 & 154.563 & \text { Yes }\end{array}$ $\begin{array}{lllllllllllllll} & 197.811 & \text { Y }\end{array}$ $\begin{array}{llllllllllllll}36.83 & 25.53 & 16.24 & 2 & 1281.6146 & 1281.6111 & 641.8128 & 0.0035 & 2.7266 & 142.250 & 150.910 & 190.374 & 93.301 & \text { Yes }\end{array}$ $\begin{array}{llllllllllllllll}00 & 37.10 & 27.92 & 24.02 & 3 & 1715.8519 & 1715.8466 & 572.9561 & 0.0053 & 3.0834 & 998.558 & 688.180 & 1920.828 & 917.176 & \text { No }\end{array}$ $\begin{array}{lllllllllllllll}0.97 & 31.96 & 27.81 & 28.29 & 2 & 1830.9728 & 1830.9719 & 916.4932 & 0.0009 & 0.4910 & 558.238 & 455.831 & 788.049 & 681.885 & \mathrm{No}\end{array}$ $\begin{array}{lllllllllllllll}1.00 & 46.48 & 27.83 & 29.80 & 2 & 1830.9730 & 1830.9719 & 916.4932 & 0.0011 & 0.6001 & 289.495 & 232.105 & 231.235 & 270.449 & \text { Yes }\end{array}$ $\begin{array}{lllllllllllllll}00 & 47.75 & 27.83 & 29.90 & 3 & 1830.9748 & 1830.9719 & 611.3312 & 0.0029 & 1.5812 & 3639.725 & 3187.813 & 4292.656 & 3183.637 & \text { Yes }\end{array}$ $\begin{array}{lllllllllllllll}1.00 & 44.66 & 27.67 & 32.72 & 3 & 1830.9751 & 1830.9719 & 611.3312 & 0.0032 & 1.7448 & 3047.360 & 2661.913 & 3314.364 & 1990.938 & \text { Yes }\end{array}$ $\begin{array}{lllllllllllllll}1.00 & 81.46 & 27.53 & 30.79 & 2 & 1870.9262 & 1870.9260 & 936.4703 & 0.0002 & 0.1068 & 106.906 & 53.283 & 681.154 & 407.715 & \mathrm{No}\end{array}$ $\begin{array}{lllllllllllllll}1.00 & 65.05 & 27.52 & 23.68 & 2 & 1870.9274 & 1870.9260 & 936.4703 & 0.0014 & 0.7475 & 81.757 & 59.101 & 167.628 & 164.715 & \text { No }\end{array}$ $\begin{array}{llllllllllllllll}1.00 & 56.98 & 27.69 & 29.53 & 2 & 1337.6770 & 1337.6697 & 669.8421 & 0.0073 & 5.4490 & 5746.599 & 9312.829 & 5633.560 & 1504.083 & \text { Yes }\end{array}$ $\begin{array}{llllllllllllllll}1.00 & 58.44 & 27.68 & 29.26 & 2 & 1337.6774 & 1337.6697 & 669.8421 & 0.0077 & 5.7476 & 6234.659 & 9696.757 & 5511.821 & 2108.405 & \text { Yes }\end{array}$ YEELQQTAGR LAELEEALQK LAELEEALQK LAELEEALQK

LAELEEALQK

LAELEEALQK

NLDLDSIIAEVK

NLDLDSIIAEVK

NLDLDSIIAEVK

NLDLDSIIAEVK

NLDLDSIIAEVK

NLDLDSIIAEVK

NLDLDSIIAEVK

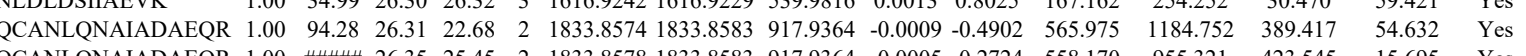

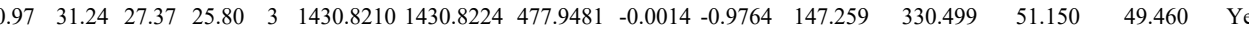

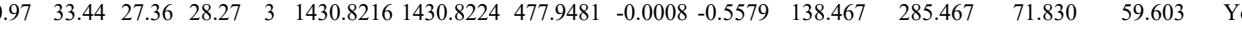
$\begin{array}{lllllllllllllll} & \end{array}$

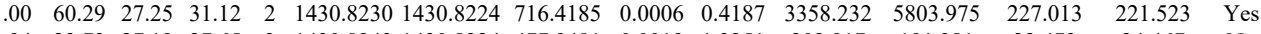
$\begin{array}{lllllllllllllll}0.94 & 23.73 & 27.19 & 27.65 & 3 & 1430.8243 & 1430.8224 & 477.9481 & 0.0019 & 1.3251 & 202.917 & 191.381 & 22.473 & 24.467 & \text { No }\end{array}$

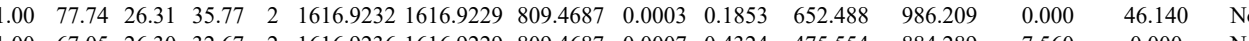
$\begin{array}{llllllllllllllll}1.00 & 67.05 & 26.30 & 32.67 & 2 & 1616.9236 & 1616.9229 & 809.4687 & 0.0007 & 0.4324 & 475.554 & 884.289 & 7.560 & 0.000 & \text { No }\end{array}$ $\begin{array}{lllllllllllllll}0.99 & 35.29 & 26.38 & 31.20 & 3 & 1616.9245 & 1616.9229 & 539.9816 & 0.0016 & 0.9877 & 111.222 & 237.587 & 55.838 & 28.935 & \text { Yes }\end{array}$ $\begin{array}{llllllllllllllll}1.00 & 45.73 & 26.38 & 27.12 & 3 & 1616.9245 & 1616.9229 & 539.9816 & 0.0016 & 0.9877 & 119.479 & 177.375 & 55.311 & 22.064 & \text { Yes }\end{array}$ $\begin{array}{llllllllllllllll}1.00 & 77.48 & 26.30 & 34.76 & 2 & 1616.9236 & 1616.9229 & 809.4687 & 0.0007 & 0.4324 & 141.966 & 383.799 & 36.727 & 12.438 & \text { No }\end{array}$

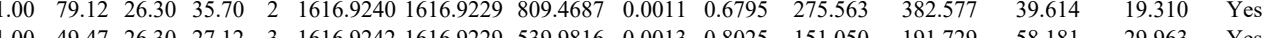
$\begin{array}{lllllllllllllll}1.00 & 49.47 & 26.30 & 27.12 & 3 & 1616.9242 & 1616.9229 & 539.9816 & 0.0013 & 0.8025 & 151.050 & 191.729 & 58.181 & 29.963 & \text { Yes } \\ 1.00 & 34.99 & 2630 & 26.32 & 3 & 1616.9242 & 1616.9229 & 539.9816 & 0.0013 & 0.8025 & 167.162 & 254.252 & 30.470 & 59.421 & \text { Yes }\end{array}$

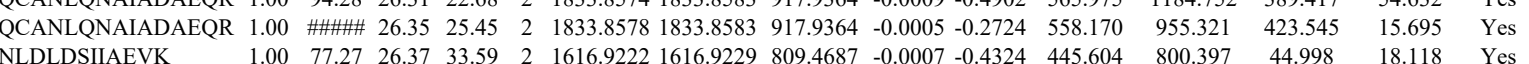
$\begin{array}{llllllllllllllll}\text { VDALMDEINFMK } & 1.00 & 55.28 & 27.90 & 16.56 & 2 & 1712.8744 & 1712.8721 & 857.4433 & 0.0023 & 1.3412 & 1493.546 & 1598.238 & 76.795 & 99.941 & N o\end{array}$

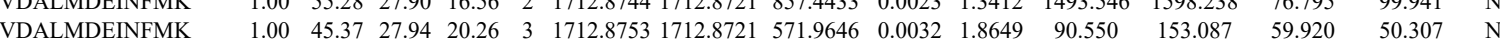
WTLLQEQGTK WTLLQEQGTK

FVSTTSSSR
FVSTTSSSR

FVSTTSSSR

FVSTTSSSR SFSTASAITPSVSR ISISTSGGSFR ISISTSGGSFR SISTSGGSFR

ISISTSGGSFR $\begin{array}{lllllllllllllll}1.00 & 48.78 & 27.38 & 25.13 & 2 & 1490.8442 & 1490.8337 & 746.4241 & 0.0105 & 7.0335 & 1609.525 & 2421.777 & 1379.187 & 300.239 & \text { Yes }\end{array}$

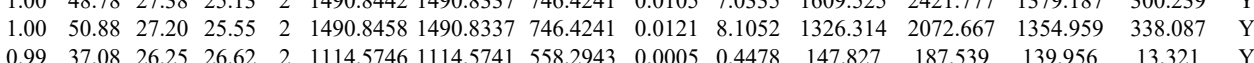
$\begin{array}{lllllllllllllll}0.99 & 37.08 & 26.25 & 26.62 & 2 & 1114.5746 & 1114.5741 & 558.2943 & 0.0005 & 0.4478 & 147.827 & 187.539 & 139.956 & 13.321 & \text { Yes } \\ 0.94 & 6.43 & 26.29 & 24.76 & 2 & 111.5764 & 111.5741 & 558.2943 & 0.0023 & 2.0598 & 64.036 & 103.134 & 55.790 & 16.783 & \text { Yes }\end{array}$

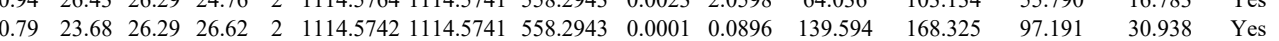
$\begin{array}{llllllllllllllll}0.87 & 23.11 & 26.25 & 24.26 & 2 & 1114.5746 & 1114.5741 & 558.2943 & 0.0005 & 0.4478 & 147.910 & 184.531 & 103.422 & 34.328 & \text { Yes }\end{array}$ $\begin{array}{llllllllllllll}1.00 & \# \# \# 27.69 & 28.84 & 2 & 1553.8260 & 1553.8171 & 777.9158 & 0.0089 & 5.7204 & 8187.126 & 13721.312 & 6834.923 & 254.977 & \text { Yes }\end{array}$ $\begin{array}{lllllllllllllllll}1.00 & 57.44 & 27.24 & 25.80 & 2 & 1254.6750 & 1254.6690 & 628.3418 & 0.0060 & 4.7744 & 12519.016 & 21524.790 & 4905.214 & 330.966 & \text { Yes }\end{array}$ $\begin{array}{llllllllllllllll}1.00 & 51.10 & 27.42 & 25.34 & 2 & 1254.6752 & 1254.6690 & 628.3418 & 0.0062 & 4.9336 & 15411.866 & 25984.200 & 5691.277 & 326.891 & \text { Yes }\end{array}$

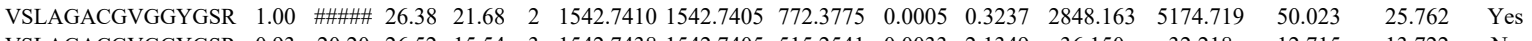
$\begin{array}{llllllllllllllll}\text { VSLAGACGVGGYGSR } & 0.93 & 20.20 & 26.52 & 15.54 & 3 & 1542.7438 & 1542.7405 & 515.2541 & 0.0033 & 2.1349 & 36.150 & 32.218 & 12.715 & 13.722 & \text { No }\end{array}$

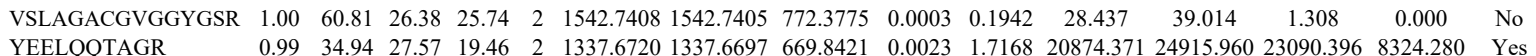
$\begin{array}{lllllllllllllll} & & & \end{array}$

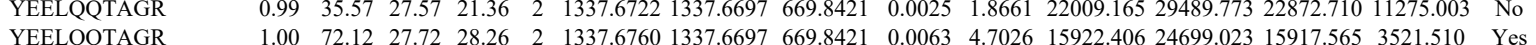

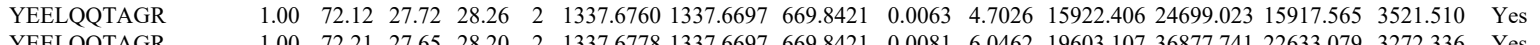
$\begin{array}{llllllllllllllll}\text { YEELQQTAGR } & 1.00 & 72.21 & 27.65 & 28.20 & 2 & 1337.6778 & 1337.6697 & 669.8421 & 0.0081 & 6.0462 & 19603.107 & 36877.741 & 22633.079 & 3272.336 & \text { Yes }\end{array}$

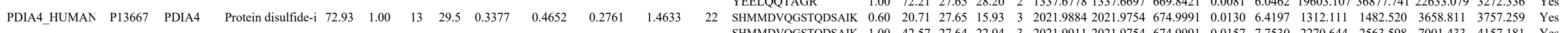
$\begin{array}{llllllllllllllll}\text { SHMMDVQGSTQDSAIK } & 1.00 & 42.57 & 27.64 & 22.94 & 3 & 2021.9911 & 2021.9754 & 674.9991 & 0.0157 & 7.7530 & 2270.644 & 2563.598 & 7001.433 & 4157.181 & \text { Yes }\end{array}$ $\begin{array}{llllllllllllllll}\text { GESDPAYQQYQDAANNLR } & 1.00 & 85.29 & 25.61 & 23.82 & 2 & 2182.9974 & 2183.0001 & 1092.5073 & -0.0027 & -1.2357 & 37.217 & 99.004 & 175.333 & 181.887 & \text { Yes } \\ \text { DGDDVIIIGVFK } & 1.00 & 95.16 & 26.10 & 29.43 & 2 & 1577.8932 & 1577.8909 & 789.9527 & 0.0023 & 1.4558 & 161.361 & 108.521 & 559.691 & 528.118 & \text { Yes }\end{array}$

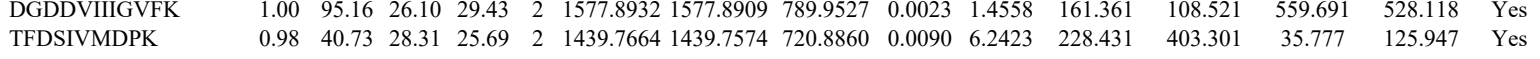
$\begin{array}{llllllllllllllll}0 & 1.00 & 54.31 & 28.17 & 33.51 & 2 & 1439.7682 & 1439.7574 & 720.8860 & 0.0108 & 7.4907 & 346.214 & 384.391 & 89.734 & 59.558 & \text { Yes }\end{array}$ 


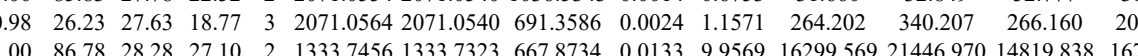

IDATSASVLASR

$\begin{array}{cccccccccccccccc}1.00 & 80.50 & 28.02 & 25.50 & 2 & 1109.7162 & 1109.7052 & 555.8599 & 0.0110 & 9.8945 & 5741.577 & 5447.766 & 4216.292 & 3602.499 & \text { Yes } & \\ & 1333.7323 & 667.8734 & 0.0093 & 6.9623 & 5756.703 & 7457.662 & 5142.116 & 913.297 & \text { Yes } & \end{array}$

VDATAETDLAK $\begin{array}{lllllllllllllll}1.00 & 40.41 & 27.59 & 18.46 & 3 & 2406.2047 & 2406.2005 & 803.0741 & 0.0042 & 1.7433 & 12.549 & 29.436 & 26.867 & 5.582 & \text { Yes }\end{array}$

VDATAETDLAK

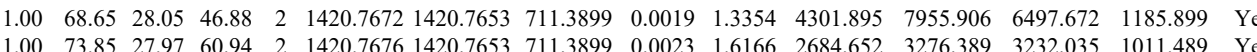

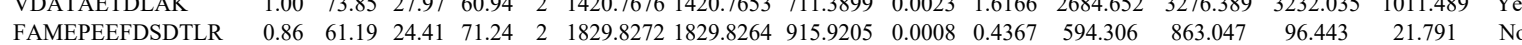

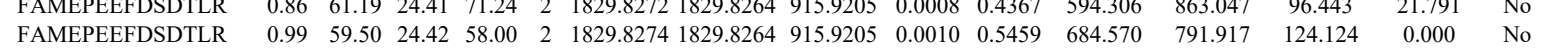

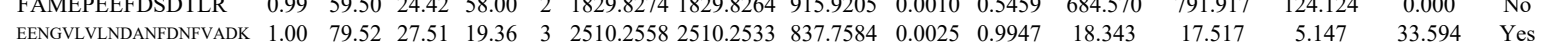

TF HUMAN P13726 F3

Tissue factor $\begin{array}{llllllllll}33.07 & 1.00 & 2 & 8.5 & 0.8152 & 0.2703 & 0.1799 & 1.5827 & 4 & \text { STDSPVECMGQEK } \\ & & & & & & & & & \text { STDSPVEMGQEK }\end{array}$ STDSPVECMGQEK TNTNEFLIDVDK

IDINMSGFNETDDLK

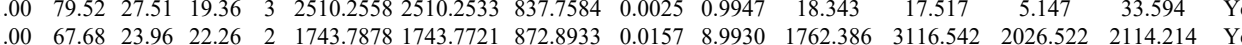

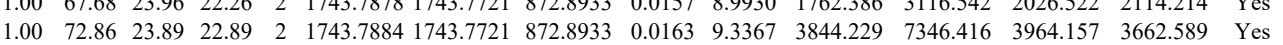
$\begin{array}{lllllllllllllll}1.00 & 78.15 & 27.75 & 29.40 & 2 & 1695.8932 & 1695.8923 & 848.9534 & 0.0009 & 0.5301 & 335.531 & 747.504 & 149.967 & 63.207 & \text { Yes }\end{array}$ $\begin{array}{lllllllllllllll}1.00 & 54.79 & 27.69 & 24.74 & 2 & 1695.8938 & 1695.8923 & 848.9534 & 0.0015 & 0.8834 & 242.872 & 345.022 & 119.231 & 34.178 & \text { Yes }\end{array}$ $\begin{array}{cccccccccccccccc}\text { YTILNVLEDLGDGQK } & 1.00 & 69.39 & 27.67 & 34.88 & 2 & 1998.9814 & 1998.9812 & 1000.4979 & 0.0002 & 0.1000 & 70.220 & 51.303 & 57.100 & 7.508 & \text { Yes } \\ \text { YTL } & 1.00 & 77.60 & 31.61 & 2 & 1851.9840 & 1851.9822 & 926.9984 & 0.0018 & 0.9709 & 399.492 & 492.200 & 793.104 & 875.639 & \text { Yes }\end{array}$ $\begin{array}{llllllllllllllll}\text { YTLNVLEDLGDGQK } & 1.00 & 74.27 & 27.69 & 30.26 & 2 & 1851.9828 & 1851.9822 & 926.9984 & 0.0006 & 0.3236 & 296.312 & 390.123 & 746.526 & 631.422 & \text { Yes }\end{array}$

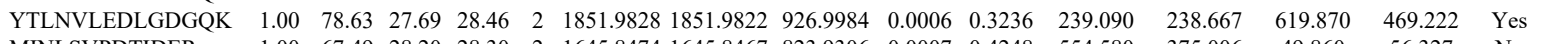
$\begin{array}{llllllllllllllll}\text { MINLSVPDTIDER } & 1.00 & 67.49 & 28.20 & 28.30 & 2 & 1645.8474 & 1645.8467 & 823.9306 & 0.0007 & 0.4248 & 554.580 & 375.006 & 49.860 & 56.327 & \text { No }\end{array}$ $\begin{array}{llllllllllllllll}\text { MINLSVPDTIDER } & 1.00 & 69.47 & 28.27 & 32.61 & 2 & 1645.8488 & 1645.8467 & 823.9306 & 0.0021 & 1.2744 & 307.335 & 495.864 & 64.657 & 45.519 & \text { No }\end{array}$

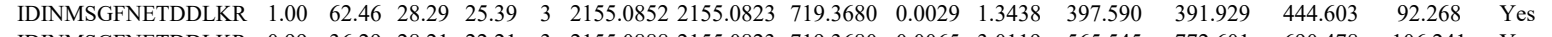

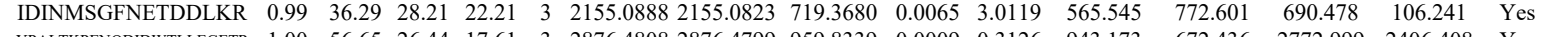
$\begin{array}{llllllllllllllll}\text { YPALTKPENODIDWTLLEGETR } & 1.00 & 56.65 & 26.44 & 17.61 & 3 & 2876.4808 & 2876.4799 & 959.8339 & 0.0009 & 0.3126 & 943.173 & 672.436 & 2772.999 & 2406.408 & \text { Yes }\end{array}$ $\begin{array}{llllllllllllllll}\text { VYALPEDLVEVKPK } & 0.84 & 51.10 * & 20.29 & 33.27 & 3 & 2031.2005 & 2031.1981 & 678.0733 & 0.0024 & 1.1798 & 3962.145 & 4323.005 & 5263.080 & 919.500 & \text { Yes }\end{array}$

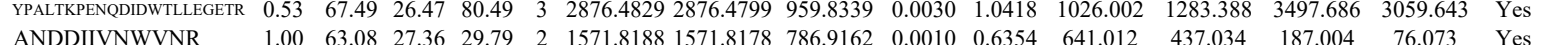

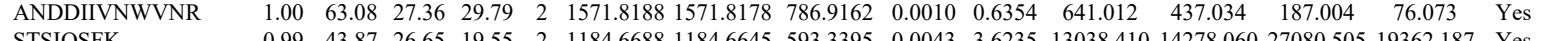
STSIQSFK

ISFDEFVYIFQEVK

ISFDEFVYIFQEVK

ISFDEFVYFQEVK

LNLAFVANLFN

LNLAFVANLFNK

LNLAFVANLFNK

LNLAFVANLFNK

LNLAFVANLFNK

DGETLEELMK

DGETLEELMK

MVMTVFACLMGR

MVMTVFACLMGR

MVMTVFACLMGR

MVMTVFACLMGR

AESMLQQADK

AESMLQQADK

AESMLQQADK

AESMLQQADK

$\begin{array}{llllllllllllllllllll}0.99 & 43.87 & 6.65 & 19.55 & 2 & 1184.6688 & 1184.6645 & 5933395 & 0.0043 & 3.6235 & 13038.410 & 14278.060 & 27080.505 & 19362.187 & \text { Yes }\end{array}$ $\begin{array}{lllllllllllllllll}1.00 & 46.78 & 26.65 & 21.89 & 2 & 1184.6688 & 1184.6645 & 593.3395 & 0.0043 & 3.6235 & 12694.432 & 13712.997 & 23819.616 & 14431.945 & \text { Yes }\end{array}$

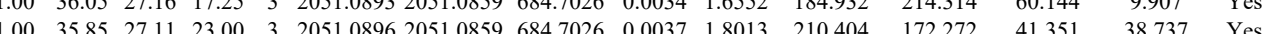

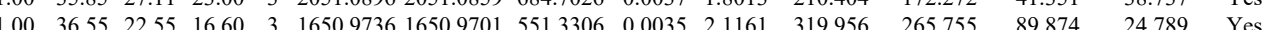

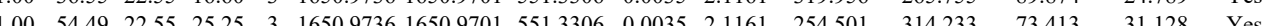

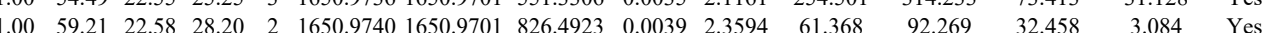

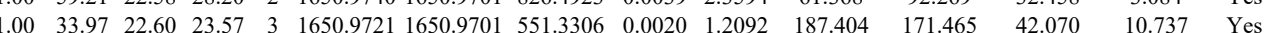

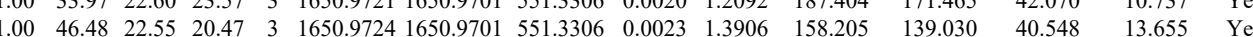

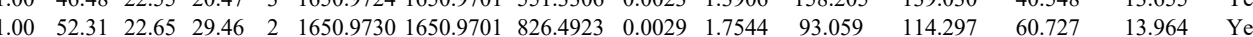
$\begin{array}{lllllllllllllll}1.00 & 57.54 & 27.69 & 23.91 & 2 & 1451.7444 & 1451.7421 & 726.8783 & 0.0023 & 1.5821 & 25.795 & 30.782 & 145.820 & 180.516 & \text { No }\end{array}$ $\begin{array}{lllllllllllllll}1.00 & 66.13 & 27.69 & 31.27 & 2 & 1451.7450 & 1451.7421 & 726.8783 & 0.0029 & 1.9948 & 43.142 & 19.851 & 235.299 & 165.371 & \text { Yes }\end{array}$

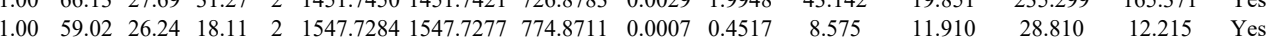
$\begin{array}{lllllllllllllll}0.61 & 24.30 & 24.62 & 37.30 & 2 & 1579.7176 & 1579.7175 & 790.8660 & 0.0001 & 0.0632 & 14.730 & 27.782 & 22.697 & 37.531 & \text { Yes }\end{array}$

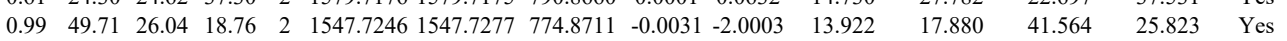

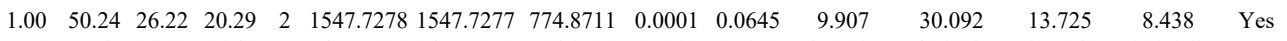
$\begin{array}{llllllllllllllll}1.00 & 57.65 & 28.20 & 26.43 & 2 & 1407.7392 & 1407.7271 & 704.8708 & 0.0121 & 8.5831 & 479.087 & 416.960 & 625.248 & 308.863 & \text { Yes }\end{array}$ $\begin{array}{lllllllllllllll}1.00 & 54.73 & 28.20 & 24.24 & 2 & 1407.7394 & 1407.7271 & 704.8708 & 0.0123 & 8.7249 & 1489.888 & 1092.981 & 2215.845 & 914.564 & \text { Yes }\end{array}$ $\begin{array}{lllllllllllllll}1.00 & 59.76 & 28.07 & 24.88 & 2 & 1407.7372 & 1407.7271 & 704.8708 & 0.0101 & 7.1644 & 650.003 & 547.771 & 930.639 & 492.994 & \text { Yes }\end{array}$ $\begin{array}{lllllllllllllll}1.00 & 51.85 & 28.14 & 26.11 & 2 & 1407.7380 & 1407.7271 & 704.8708 & 0.0109 & 7.7319 & 861.183 & 725.495 & 1224.717 & 376.075 & \text { Yes }\end{array}$

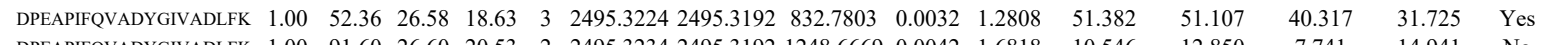

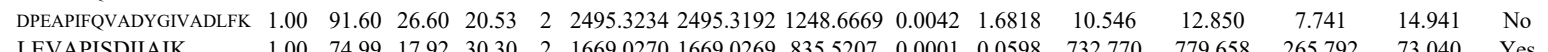

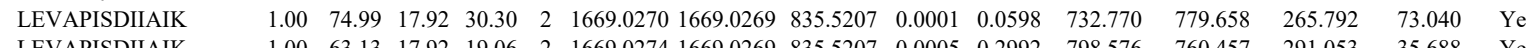

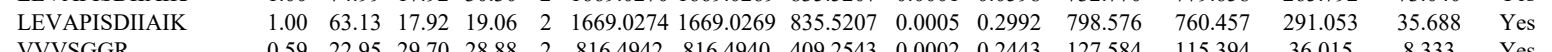

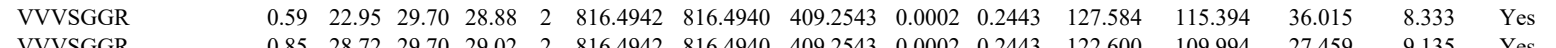

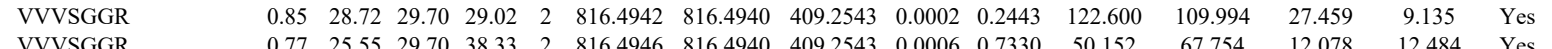

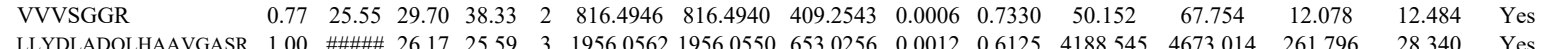

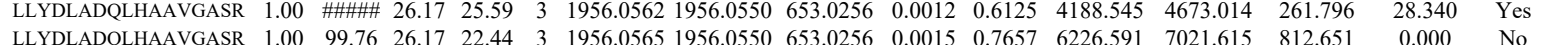

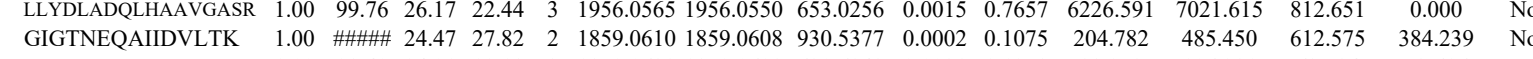

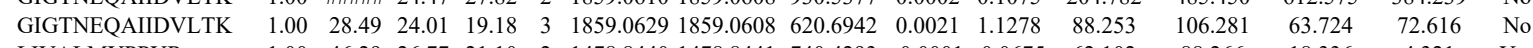

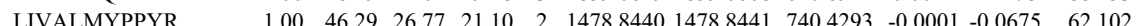



$\begin{array}{lllllllllllll}1.00 & 45.36 & 26.81 & 20.98 & 2 & 1478.8452 & 1478.8441 & 740.4293 & 0.0011 & 0.7428 & 30.980 & 103.280 & 15.940 \\ 0.97 & 33.91 & 27.72 & 23.49 & 2 & 1155.6262 & 1155.6266 & 578.8206 & -0.0004 & -0.3455 & 419.349 & 1112.600 & 138.787\end{array}$ $\begin{array}{lllllllllllll}0.97 & 33.91 & 27.72 & 23.49 & 2 & 1155.6262 & 1155.6266 & 578.8206 & -0.0004 & -0.3455 & 419.349 & 1112.600 & 138.787\end{array}$

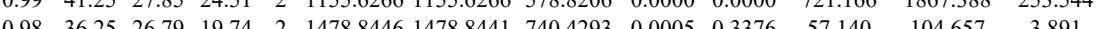

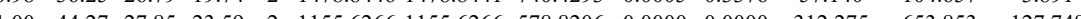
$\begin{array}{lllllllllllll}0.98 & 36.75 & 27.85 & 22.83 & 2 & 1155.6266 & 1155.6266 & 578.8206 & 0.0000 & 0.0000 & 468.785 & 1157.956 & 150.280\end{array}$

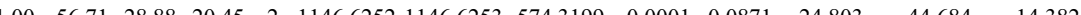

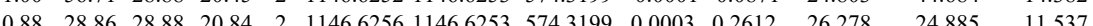

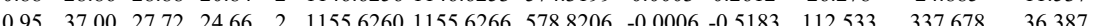
$\begin{array}{lllllllllllll}0.99 & 41.85 & 27.86 & 24.17 & 2 & 1155.6264 & 1155.6266 & 578.8206 & -0.0002 & -0.1728 & 136.647 & 244.111 & 42.539\end{array}$ $\begin{array}{lllllllllllll}0.51 & 18.51 & 26.80 & 25.59 & 2 & 1478.8444 & 1478.8441 & 740.4293 & 0.0003 & 0.2026 & 72.179 & 137.746 & 6.998\end{array}$ $\begin{array}{llllllllllllll}0.81 & 21.63 & 26.66 & 28.45 & 2 & 1478.8454 & 1478.8441 & 740.4293 & 0.0013 & 0.8779 & 155.392 & 122.732 & 2.335\end{array}$ $\begin{array}{llllllllllllll}0.90 & 28.94 & 27.86 & 24.63 & 2 & 1155.6264 & 1155.6266 & 578.8206 & -0.0002 & -0.1728 & 151.174 & 289.884 & 60.387\end{array}$ $\begin{array}{lllllllllllll}0.96 & 32.78 & 27.86 & 24.21 & 2 & 1155.6268 & 1155.6266 & 578.8206 & 0.0002 & 0.1728 & 146.802 & 383.850 & 39.468\end{array}$ $\begin{array}{lllllllllllllll}0.95 & 31.53 & 26.77 & 21.84 & 2 & 1478.8442 & 1478.8441 & 740.4293 & 0.0001 & 0.0675 & 71.765 & 70.085 & 7.491 \\ 0.92 & 29.72 & 27.72 & 25.86 & 2 & 1155.6262 & 155.6266 & 578.8206 & 0.0004 & -0.355 & 40.829 & 148.617 & 18.039\end{array}$ $\begin{array}{lllllllllllll}0.92 & 29.72 & 27.72 & 25.86 & 2 & 1155.6262 & 1155.6266 & 578.8206 & -0.0004 & -0.3455 & 40.829 & 148.617 & 18.039\end{array}$ $\begin{array}{llllllllllllll}0.59 & 21.09 & 27.85 & 24.67 & 2 & 1155.6266 & 1155.6266 & 578.8206 & 0.0000 & 0.0000 & 58.835 & 110.104 & 14.312\end{array}$ $\begin{array}{lllllllllllllll}1.00 & 40.99 & 28.20 & 19.30 & 2 & 1290.7280 & 1290.7274 & 646.3710 & 0.0006 & 0.4641 & 51.223 & 98.392 & 19.679\end{array}$

LVGDVDFEGVR

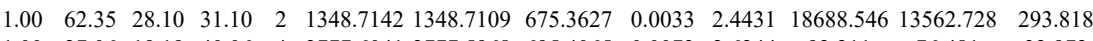
$\begin{array}{llllllllllllllll} & \text { HILADIVISAAGIPNLITADMIK } & 1.00 & 27.06 & 19.19 & 40.06 & 4 & 2777.6041 & 2777.5968 & 695.4065 & 0.0073 & 2.6244 & 92.211 & 76.481 & 32.972\end{array}$

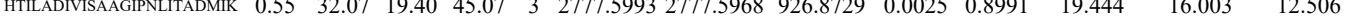
$\begin{array}{llllllllllllll}\text { HILADIVISAGGIPNLITADMIK } & 0.99 & 24.95 & 19.24 & 19.06 & 3 & 2777.6008 & 2777.5968 & 926.8729 & 0.0040 & 1.4385 & 27.050 & 22.065 & 12.482\end{array}$ $\begin{array}{lllllllllllllll}\text { HTLADIVISAAGIPNLITADMIK } & 1.00 & 40.54 & 19.24 & 53.54 & 4 & 2777.6013 & 2777.5968 & 695.4065 & 0.0045 & 1.6178 & 63.197 & 49.131 & 21.500\end{array}$ $\begin{array}{lllllllllllllll}\text { QEVEEWVASGNK } & 1.00 & 73.75 & 27.95 & 29.31 & 2 & 1662.8538 & 1662.8457 & 832.4301 & 0.0081 & 4.8652 & 527.254 & 310.104 & 135.698\end{array}$ 39 IGGAQNR

LLCGLLAER LLCGLLAER LLCGLLAER LLCGLLAER PMFIVNTNVPR PMFIVNTNVPR LLCGLLAER

LLCGLAER

LLCGLLAER

LLCGLLAER

LLCGLLAER

LLCGGLAER

LLCGGLLAER

LLCGLLAER

LLCGLLAER

LLCGLLAER

LLCGLLAER

LLCGLLAER

LLCGLLAER

PMFIVNTNVPR

PMFIVNTNVPR

PMFIVNTNVPR

PMFIVNTNVPR

LLCGLLAER

PMFIVNTNVPR

PMFIVNTNVPR

PMFIVNTNVPR

PMFIVNTNVPR

PMFIVNTNVPR

PMFIVNTNVPR $\begin{array}{lllllllllllll}0.99 & 36.33 & 28.45 & 32.71 & 2 & 1176.6490 & 1176.6480 & 589.3313 & 0.0010 & 0.8484 & 29569.345 & 39131.948 & 1133.861 \\ 0.93 & 28.04 & 28.88 & 26.00 & 2 & 1176.6494 & 1176.6480 & 589.3313 & 0.0014 & 1.1878 & 116.138 & 148.968 & 42.462\end{array}$ $\begin{array}{llllllllllllll}0.93 & 28.04 & 28.28 & 26.00 & 2 & 1176.6494 & 1176.6480 & 589.3313 & 0.0014 & 1.1878 & 116.138 & 148.968 & 42.462 \\ 0.99 & 37.4 & 28.33 & 34.25 & 2 & 1176.6506 & 1176.6480 & 589.3313 & 0.0026 & 22059 & 51147.923 & 64633.267 & 1297.933\end{array}$ $\begin{array}{lllllllllllll}0.99 & 37.40 & 28.33 & 34.25 & 2 & 1176.6506 & 1176.6480 & 589.3313 & 0.0026 & 2.2059 & 51147.923 & 64633.267 & 1297.937\end{array}$ $\begin{array}{llllllllllllll}1.00 & 5.28 & 28.85 & 18.52 & 2 & 1446.7876 & 1446.7775 & 724.3960 & 0.0101 & 6.9713 & 7364.821 & 8898.095 & 2965.067\end{array}$ $\begin{array}{lllllllllllll}0.99 & 45.99 & 28.83 & 1.5 .93 & 2 & 1466.7916 & 1466.7775 & 724.3960 & 0.0141 & 9.7322 & 3462.533 & 7987.164 & 2546.942\end{array}$

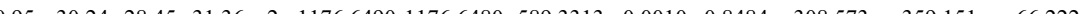

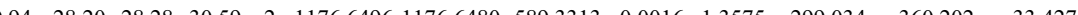

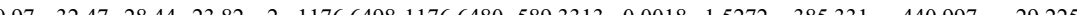
$\begin{array}{lllllllllllll}0.96 & 32.60 & 28.44 & 23.18 & 2 & 1176.6498 & 1176.6480 & 589.3313 & 0.0018 & 1.5272 & 303.796 & 466317 & 61.723\end{array}$ $\begin{array}{lllllllllllll}0.89 & 25.74 & 28.33 & 23.48 & 2 & 1176.6500 & 1176.6480 & 589.3313 & 0.0020 & 1.6968 & 365.269 & 453.253 & 53.359\end{array}$ $\begin{array}{llllllllllllll}0.93 & 28.07 & 28.33 & 24.12 & 2 & 1176.6504 & 1176.6480 & 589.3313 & 0.0024 & 2.0362 & 298.112 & 346.024 & 56.943\end{array}$

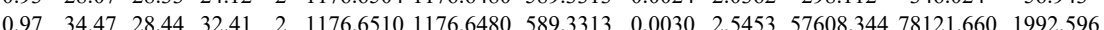
$\begin{array}{lllllllllll}0.95 & 35.12 & 28.43 & 31.91 & 2 & 1176.6522 & 1176.6480 & 589.3313 & 0.0042 & 3.5633 & \text { \#\#\#\#\#\# \#\#\#\#\# } 9133.923\end{array}$

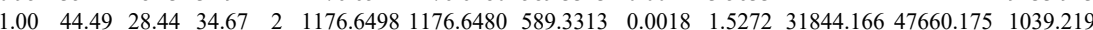

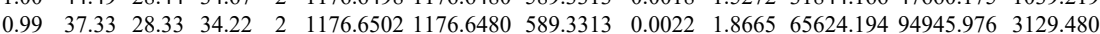
$\begin{array}{llllllllllllll}0.98 & 37.58 & 28.42 & 34.34 & 2 & 1176.6482 & 1176.6480 & 589.3313 & 0.0002 & 0.1697 & 20142.869 & 26903.529 & 783.334\end{array}$ $\begin{array}{llllllllllllll}1.00 & 41.72 & 28.28 & 34.54 & 2 & 1176.6494 & 1176.6480 & 589.3313 & 0.0014 & 1.1878 & 23874.143 & 29537.678 & 247.443\end{array}$ $\begin{array}{lllllllllllllll}1.98 & 33.01 & 28.44 & 32.13 & 2 & 1176.6498 & 1176.6480 & 589.3313 & 0.0018 & 1.5272 & 5805.353 & 7439.976 & 229.979\end{array}$ $\begin{array}{lllllllllllllll}0.99 & 40.84 & 27.70 & 19.87 & 2 & 1430.7832 & 1430.7826 & 716.3986 & 0.0006 & 0.4188 & 55.780 & 66.595 & 8.873\end{array}$ $\begin{array}{llllllllllllll}0.93 & 30.94 & 27.70 & 16.87 & 2 & 1430.7834 & 1430.7826 & 716.3986 & 0.0008 & 0.5583 & 16.206 & 24.445 & 6.329\end{array}$ $\begin{array}{lllllllllllll}0.95 & 32.58 & 27.70 & 22.76 & 2 & 1430.7836 & 1430.7826 & 716.3986 & 0.0010 & 0.6979 & 82.464 & 90.409 & 13.793\end{array}$ $\begin{array}{lllllllllllll}0.85 & 27.32 & 27.75 & 14.89 & 2 & 1430.7838 & 1430.7826 & 716.3986 & 0.0012 & 0.8375 & 69.393 & 82.499 & 11.240\end{array}$

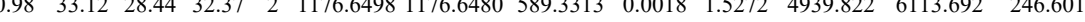
$\begin{array}{lllllllllllll}0.99 & 45.32 & 27.59 & 16.91 & 2 & 1430.7822 & 1430.7826 & 716.3986 & -0.0004 & -0.2792 & 21092.041 & 28663.896 & 1188.761\end{array}$

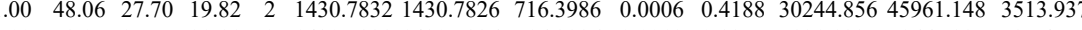

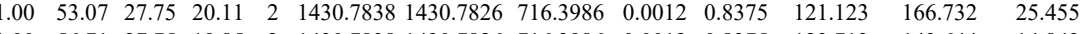
$\begin{array}{lllllllllllll}1.00 & 53.07 & 27.75 & 20.11 & 2 & 1430.7838 & 1430.782 & 716.3986 & 0.0012 & 0.8375 & 121.123 & 166.732 & 25.45 \\ 1.00 & 56.71 & 27.75 & 19.85 & 2 & 1430.7838 & 1430.7826 & 716.3986 & 0.0012 & 0.8375 & 123.713 & 143.644 & 14.842\end{array}$

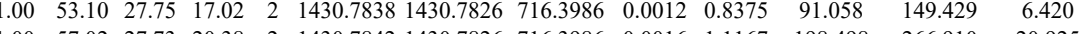

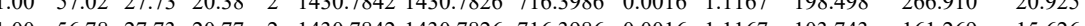

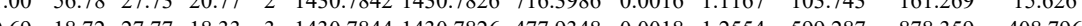

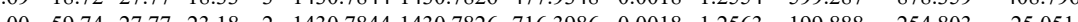

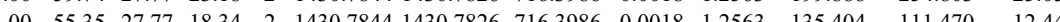


$\begin{array}{lllllllllllll}0.99 & 35.27 & 28.44 & 32.59 & 2 & 1176.6498 & 1176.6480 & 589.3313 & 0.0018 & 1.5272 & 713.356 & 1052.722 & 46.994\end{array}$

$\begin{array}{lllllllllllll}1.00 & 62.21 & 27.69 & 21.01 & 2 & 1430.7924 & 1430.7826 & 716.3986 & 0.0098 & 6.8397 & 11573.136 & 15819.309 & 1010.562\end{array}$ $\begin{array}{llllllllllllll}1.00 & 54.21 & 27.44 & 22.05 & 2 & 1430.7936 & 1430.7826 & 716.3986 & 0.0110 & 7.6772 & 8349.450 & 10722.739 & 655.022\end{array}$

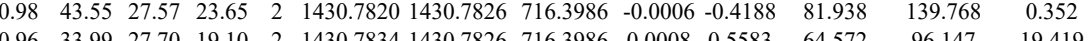

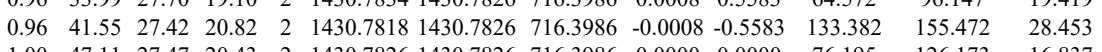
PMFIVNTNVPR

PMFIVNTNVPR

PMFIVNTNYPR

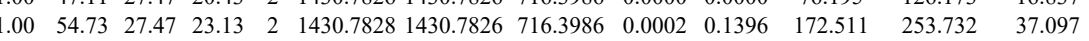
LLCGLLAER

$\begin{array}{llllllllllll} & 27.75 & 24.78 & 2 & 1430.7838 & 1430.7826 & 716.3986 & 0.0012 & 0.8375 & 227.927 & 242.603 & 17.383\end{array}$

$\begin{array}{llllllllllllll}0.66 & 19.56 & 28.33 & 21.54 & 2 & 1176.6504 & 1176.6480 & 589.3313 & 0.0024 & 2.0362 & 87.913 & 85.440 & 11.900\end{array}$

MPPYDEQTQAFIDAQQE

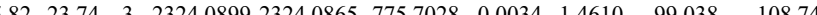

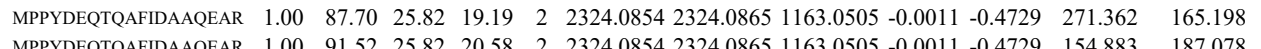

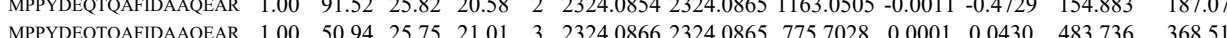
$\begin{array}{lllllllllllllll}\text { MPPYDEOTQAFIDACAR } & 1.00 & 51.96 & 25.77 & 26.97 & 3 & 2324.0881 & 2324.0865 & 775.7028 & 0.0016 & 0.6875 & 612.065 & 696.273 & 246.278\end{array}$ $\begin{array}{lllllllllllllll}\text { MPPYDEQTQAFIDAAQEAR } & 0.80 & 16.68 & 25.79 & 17.49 & 3 & 2324.0875 & 2324.0865 & 775.7028 & 0.0010 & 0.4297 & 604.806 & 410.388 & 299.617\end{array}$ $\begin{array}{llllllllllllll}\text { MPPYDEQTQAFIDAAQEAR } & 1.00 & 56.32 & 25.80 & 20.20 & 3 & 2324.0893 & 2324.0865 & 775.7028 & 0.0028 & 1.2032 & 221.201 & 224.460 & 122.522\end{array}$ ILIEDWK

LCPFK

SLEDQVEMLR

$\begin{array}{lllllllllllll}\text { FPPS_HUMAN } & \text { P14324 } & \text { FDPS } & \text { Farnesyl pyrophos } 48.28 & 1.00 & 5 & 14.3 & 0.7162 & 0.1901 & 0.2527 & 1.3153 & 13 & \text { ATPEQYQILK }\end{array}$

$\begin{array}{lllllllllll} & \end{array}$ $\begin{array}{lllllllllllll}0.99 & 41.53 & 26.23 & 30.15 & 2 & 1203.7216 & 1203.7107 & 602.8626 & 0.0109 & 9.0401 & 8187.661 & 7931.667 & 447.004\end{array}$

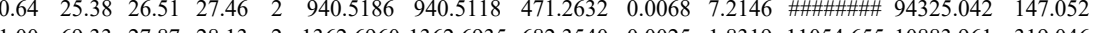
ATPEQYQILK QDFVQHFSQIVR QDFVQHFSQIVR CSWLVVQCLQR CSWLVVQCLQR CSWLVVQCLQR CSWLVVQCLQR CSWLVVQCLQR
IGTDIQDNK IGTDIQDNK

$\begin{array}{llllllllllllll} & \end{array}$ $\begin{array}{llllllllllllllll}1.00 & 54.89 & 26.42 & 25.03 & 2 & 1477.8492 & 1477.8384 & 739.9265 & 0.0108 & 7.2980 & 2010.498 & 2984.162 & 2141.698 & 17 & & \\ \end{array}$ $\begin{array}{lllllllllllllll}1.00 & 64.86 & 26.30 & 26.91 & 2 & 1477.8502 & 1477.8384 & 739.9265 & 0.0118 & 7.9737 & 1792.753 & 3200.102 & 2112.451 & 1621 & \\ 1.00 & 53.76 & 27.25 & 2.19 & 3 & 1646801 & 1646.8651 & 549.9623 & 0.0150 & 9.0914 & 5694.681 & 9487.669 & 1437.355 & 551 . & \end{array}$

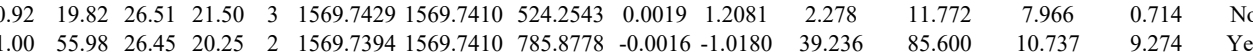

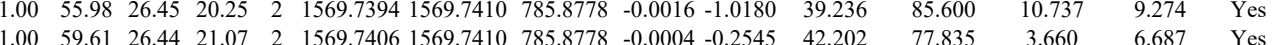
$\begin{array}{llllllllllllllllll}0.82 & 31.66 & 28.65 & 27.65 & 2 & 1290.7074 & 1290.7023 & 646.3584 & 0.0051 & 3.9452 & 8703.448 & 13165.260 & 8275.194 & 6187.448 & \text { Yes } \\ & 1.0 & 5853 & 27.78 & 17.82 & 3 & 20960338 & 2096.0330 & 699.6849 & 0.0008 & 0.3811 & 4573.350 & 9014.452 & 2423.116 & 857.725 & \text { Yes }\end{array}$

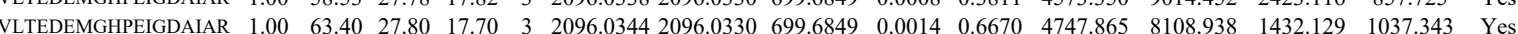

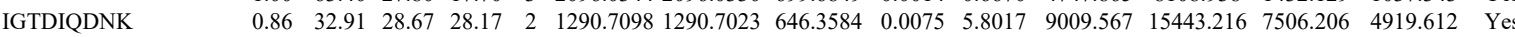

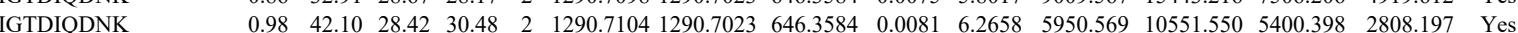

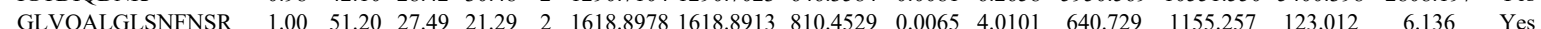

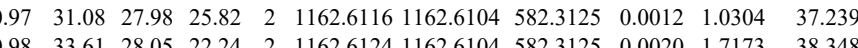
$\begin{array}{lllllllllll}0.80 & 28.10 & 28.09 & 37.04 & 2 & 1162.6124 & 1162.6104 & 582.3125 & 0.0020 & 1.7173 & 38.348 \\ 0.97 & 51.51 & 27.13 & 27.01 & 2 & 1428.8032 & 1277.7071 & 639.8608 & 0.0003 & 0.2344 & 9.706\end{array}$ $\begin{array}{lllllllllll}0.97 & 51.51 & 27.13 & 27.01 & 2 & 1428.8032 & 1428.8068 & 715.4107 & -0.0036 & -2.5160 & 39.058 \\ 1.00 & 57.50 & 27.13 & 28.49 & 2 & 1428.8038 & 1428.8068 & 715.4107 & -0.0030 & -2.0967 & 38.298\end{array}$ DPVQEAWAEDVDL $\begin{array}{llllllllllllll} & \end{array}$ $\begin{array}{llllllllllll} & \end{array}$ $\begin{array}{llllllllllllll} & 1.00\end{array}$ $\begin{array}{llllllllllll}\text { AEGSDVANAVLDGADCIMLSGETAK } & 1.00 & 87.89 & 25.98 & 21.55 & 3 & 2770.3087 & 2770.3067 & 924.4428 & 0.0020 & 0.7212 & 7.424\end{array}$

\section{GDYPLEAVR}

GDYPLEAVR GDLGIEIPAEK $\begin{array}{llllllllllll}1.00 & 82.96 & 26.03 & 18.70 & 3 & 2770.3111 & 2770.3067 & 924.4428 & 0.0044 & 1.5865 & 3.217 & \end{array}$ \begin{tabular}{llll}
1 & -1.136 & Yes \\
\hline & 20.949 & 14.859 & Yes
\end{tabular} $\begin{array}{lllllllllllllllll}\text { GADFLVTEVENGGSLGSK } & 1.00 & 98.50 & 27.62 & 20.90 & 2 & 2067.0714 & 2067.0728 & 1034.5437 & -0.0014 & -0.6766 & 283.132 & 626.028 & 1171.376 & 1070.894 & \text { Yes }\end{array}$

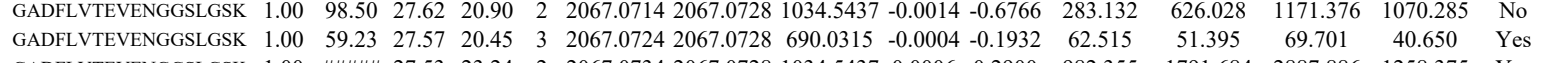
$\begin{array}{llllllllllllll} & 27.53 & 23.24 & 2 & 2067.0734 & 2067.0728 & 1034.5437 & 0.0006 & 0.2900 & 982.355 & 1791.684 & 2887.886 & 1258.375 & \text { Yes }\end{array}$

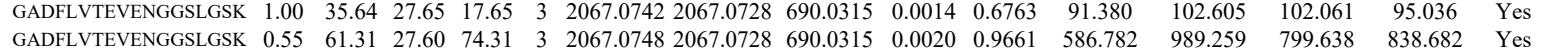
$\begin{array}{llllllllllllllll}\text { GADFLVTEVENGGSLGSK } & 0.79 & 16.58 & 27.60 & 15.41 & 3 & 2067.0751 & 2067.0728 & 690.0315 & 0.0023 & 1.1111 & 129.523 & 135.257 & 129.413 & 145.067 & \text { Yes }\end{array}$ $\begin{array}{llllllllllllllll}\text { GADFLVTEVENGGSLGSK } & 1.00 & 41.07 & 27.60 & 16.72 & 3 & 2067.0751 & 2067.0728 & 690.0315 & 0.0023 & 1.1111 & 802.737 & 800.858 & 476.848 & 281.122 & \text { Yes }\end{array}$ 

$\begin{array}{lllllllllllll}\text { AEGSDVANAVIDGADCIMLSGETAK } & 1.00 & 36.44 & 25.99 & 15.99 & 3 & 2770.3093 & 2770.3067 & 924.4428 & 0.0026 & 0.9375 & 51.508\end{array}$ $\begin{array}{llllllllllll}\text { EGSDVANAVLDGADCIMLLGEETAK } & 0.95 & 21.27 & 26.00 & 15.05 & 3 & 2770.3096 & 2770.3067 & 924.4428 & 0.0029 & 1.0457 & 56.081\end{array}$ $\begin{array}{lllllllllllll} & \end{array}$

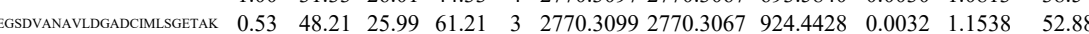

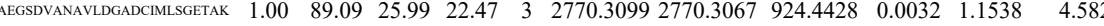

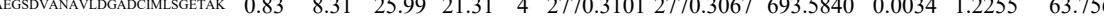
$\begin{array}{lllllllllllll}\text { EEGSDVANAVLDGADCIMLLGGEAK } & 1.00 & 18.40 & 25.99 & 31.40 & 4 & 2770.3101 & 2770.3067 & 693.5840 & 0.0034 & 1.2255 & 57.520\end{array}$ $\begin{array}{lllllllllllll}\text { AEGSDVANAVLDGADCIMLSGIAN } & 0.77 & 7.49 & 25.99 & 20.49 & 4 & 2770.3101 & 2770.3067 & 693.5840 & 0.0034 & 1.2255 & 52.127\end{array}$

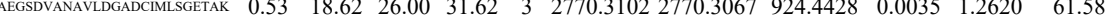

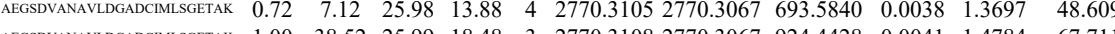
$\begin{array}{lllllllllllll}\text { AEGSDVANAVIDGADCMLLSGETAK } & 1.00 & 38.52 & 25.99 & 18.48 & 3 & 2770.3108 & 2770.3067 & 924.4428 & 0.0041 & 1.4784 & 67.711\end{array}$ $\begin{array}{llllllllllllll}\text { AEGSDVANAVLDGADCMLSGETAK } & 1.00 & 20.27 & 26.02 & 16.29 & 4 & 2770.3113 & 2770.3067 & 693.5840 & 0.0046 & 1.6581 & 80.520\end{array}$ $\begin{array}{llllllllllll}\text { GSDVANAVLGGADCIMLSGeTAK } & 1.00 & 25.82 & 26.07 & 17.41 & 4 & 2770.3165 & 2770.3067 & 693.5840 & 0.0098 & 3.5324 & 49.590\end{array}$ $\begin{array}{llllllllllll} & 27.53 & 26.03 & 2 & 2067.0734 & 2067.0728 & 1034.5437 & 0.0006 & 0.2900 & 118.968\end{array}$

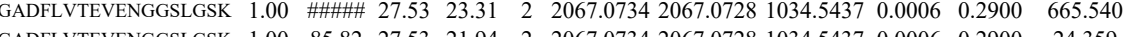

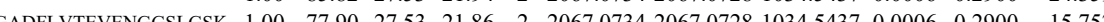

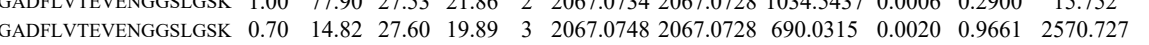

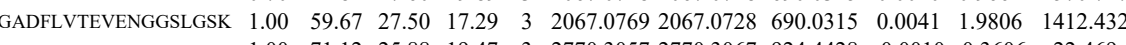
$\begin{array}{lllllllllllll} & \text { GSDVANAVLDGADCMMSGETAK } & 1.00 & 71.12 & 25.88 & 19.47 & 3 & 2770.3057 & 2770.3067 & 924.4428 & -0.0010 & -0.3606 & 22.469\end{array}$

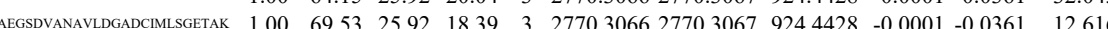
$\begin{array}{lllllllllllll}\text { AEGSDVANAVLDGADCIMILGETAK } & 1.00 & 63.96 & 25.91 & 18.29 & 3 & 2770.3069 & 2770.3067 & 924.4428 & 0.0002 & 0.0721 & 13.523\end{array}$ $\begin{array}{llllllllllll}\text { AEGSDVANAVLDGADCMLISGETAK } & 1.00 & 76.16 & 25.91 & 20.41 & 3 & 2770.3072 & 2770.3067 & 924.4428 & 0.0005 & 0.1803 & 21.542\end{array}$

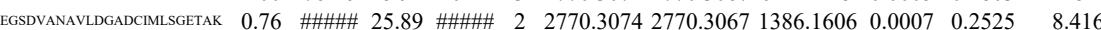

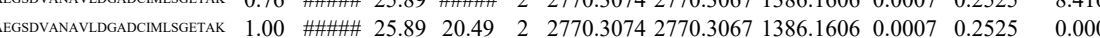
$\begin{array}{lllllllllllll}\text { AEGSDVANAVLDGADCIMLSGETAK } & 1.00 & 70.08 & 25.89 & 17.47 & 3 & 2770.3075 & 2770.3067 & 924.4428 & 0.0008 & 0.2885 & 16.835\end{array}$ $\begin{array}{llllllllllll}\text { AEGSDVANAVLDGADCIMLSGETAK } & 1.00 & 44.67 & 25.93 & 18.02 & 4 & 2770.3077 & 2770.3067 & 693.5840 & 0.0010 & 0.3604 & 101.249\end{array}$ $\begin{array}{lllllllllllll} & \text { EGSDVANAVLDGADCIMLSGETAK } & 1.00 & 79.83 & 25.97 & 18.71 & 3 & 2770.3078 & 2770.3067 & 924.4428 & 0.0011 & 0.3966 & 6.906\end{array}$ $\begin{array}{lllllllllllll} & \text { AEGSDVANAVLDGADCIMLSGETAK } & 1.00 & 79.79 & 25.97 & 25.44 & 3 & 2770.3078 & 2770.3067 & 924.4428 & 0.0011 & 0.3966 & 26.154\end{array}$ $\begin{array}{llllllllllll}\text { AEGSDVANAVLDGADCIMLLGETAK } & 1.00 & 70.86 & 25.94 & 18.18 & 3 & 2770.3081 & 2770.3067 & 924.4428 & 0.0014 & 0.5048 & 38.487\end{array}$ $\begin{array}{lllllllllllll} & 1.00 & 59.28 & 25.94 & 16.78 & 3 & 2770.3081 & 2770.3067 & 924.4428 & 0.0014 & 0.5048 & 44.865\end{array}$ $\begin{array}{llllllllllll} & 53.28 & 25.94 & 16.49 & 3 & 2770.3081 & 2770.3067 & 924.4428 & 0.0014 & 0.5048 & 6.342\end{array}$ $\begin{array}{llllllllllll}\text { AEGSDVANAVLDGADCIMLSGETAK } & 1.00 & 33.24 & 25.94 & 46.24 & 4 & 2770.3081 & 2770.3067 & 693.5840 & 0.0014 & 0.5046 & 105.875 \\ \text { AEGSDVANAVIDGADCIMLSGETAK } & 1.00 & 64.04 & 25.93 & 20.77 & 3 & 2770.3084 & 2770.3067 & 924.4428 & 0.0017 & 0.6130 & 26.723\end{array}$

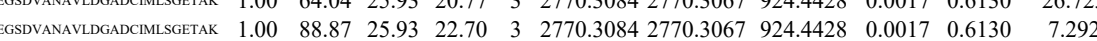

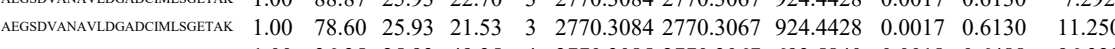
$\begin{array}{llllllllllll}\text { AEGSDVANAVDGGADCMLLSGEEAK } & 1.00 & 36.35 & 25.93 & 49.35 & 4 & 2770.3085 & 2770.3067 & 693.5840 & 0.0018 & 0.6488 & 96.328\end{array}$

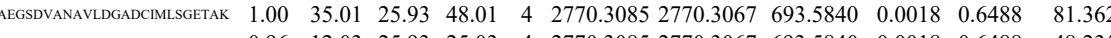

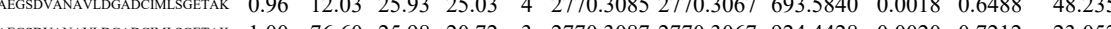

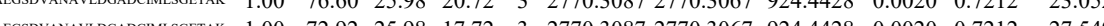
$\begin{array}{lllllllllll}1.00 & 72.92 & 25.98 & 17.72 & 3 & 2770.3087 & 2770.3067 & 924.4428 & 0.0020 & 0.7212 & 27.549\end{array}$

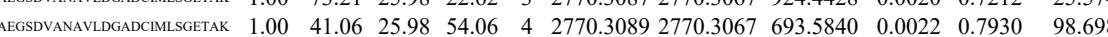

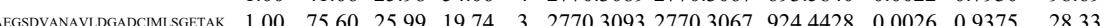


$\begin{array}{lllllllll} & \\ & \end{array}$

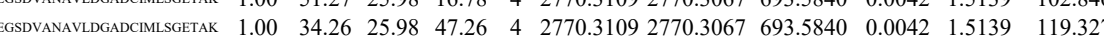

$\begin{array}{lllllllllllll} & \text { FDEILEASDGIMVAR } & 1.00 & 72.98 & 27.71 & 24.35 & 2 & 1808.9068 & 1808.9100 & 905.4623 & -0.0032 & -1.7671 & 17.855\end{array}$ $\begin{array}{lllllllllllll}\text { FDEILEASDGIMVAR } & 1.00 & \# \# \# \# & 27.68 & 30.25 & 2 & 1808.9078 & 1808.9100 & 905.4623 & -0.0022 & -1.2149 & 2.286 \\ \text { FDEILEASDGIMVAR } & 1.00 & 84.94 & 27.69 & 24.85 & 2 & 1808.9102 & 1808.9100 & 905.4623 & 0.0002 & 0.1104 & 17.50\end{array}$ $\begin{array}{lllllllllllll}\text { FDEILEASDGIMVAR } & 1.00 & 77.93 & 27.63 & 26.15 & 2 & 1808.9114 & 1808.9100 & 905.4623 & 0.0014 & 0.7731 & 23.218\end{array}$ $\begin{array}{llllllllllllll}\text { FDEILEASDGIMVAR } & 1.00 & 95.68 & 27.59 & 32.64 & 2 & 1808.9118 & 1808.9100 & 905.4623 & 0.0018 & 0.9940 & 83.407\end{array}$ $\begin{array}{llllllllllll}27.59 & 31.72 & 2 & 1808.9118 & 1808.9100 & 905.4623 & 0.0018 & 0.9940 & 70.212\end{array}$

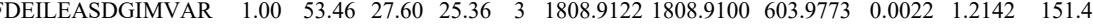
$\begin{array}{lllllllllllll} & \text { FDEILEASDGIMVAR } & 1.00 & 56.89 & 27.63 & 20.57 & 3 & 1808.9125 & 1808.9100 & 603.9773 & 0.0025 & 1.3797 & 26.655\end{array}$ \begin{tabular}{lllllllllllll} 
FDEILEASDGIMVAR & 1.00 & 74.46 & 27.64 & 18.53 & 3 & 1808.9131 & 1808.9100 & 603.9773 & 0.0031 & 1.7109 & 95.912 \\
\hline
\end{tabular} $\begin{array}{lllllllllllll}\text { FDEILEASDGIMVAR } & 1.00 & 46.28 & 27.70 & 16.83 & 3 & 1808.9152 & 1808.9100 & 603.9773 & 0.0052 & 2.8699 & 32.399 \\ \text { FDEILEASDGIMVAR } & 1.00 & 78.44 & 27.80 & 22.10 & 2 & 1808.9180 & 1808.9100 & 905.4623 & 0.0080 & 4.4176 & 22.970\end{array}$ $\begin{array}{llllllllllll}\text { FDEILEASDGIMVAR } & 1.00 & 78.44 & 27.80 & 22.10 & 2 & 1808.9180 & 1808.9100 & 905.4623 & 0.0080 & 4.4176 & 22.970 \\ \text { GADFLVTEVENGGSLGSK } & 1.00 & 98.60 & 27.53 & 26.88 & 2 & 2067.0734 & 2067.0728 & 1034.5437 & 0.0006 & 0.2900 & 20.422\end{array}$ $\begin{array}{lllllllllllll}\text { GADFLVTEVENGGSLGSK } & 1.00 & 98.60 & 27.53 & 26.88 & 2 & 2067.0734 & 2067.0728 & 1034.5437 & 0.0006 & 0.2900 & 20.422 \\ \text { GADFLVTEVENGGSLGSK } & 0.53 & 50.52 & 27.62 & 63.52 & 3 & 2067.0754 & 2067.0728 & 690.0315 & 0.0026 & 1.2560 & 600.729\end{array}$

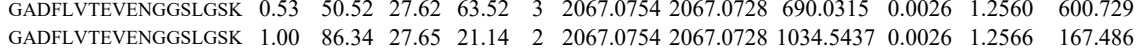
$\begin{array}{llllllllllll}\text { GADFLVTEVENGGSLGSK } & 1.00 & 86.34 & 27.65 & 21.14 & 2 & 2067.0754 & 2067.0728 & 1034.5437 & 0.0026 & 1.2566 & 167.486 \\ \text { GADFLVTEVENGGSLGSK } & 0.96 & 23.42 & 27.51 & 25.52 & 3 & 2067.0763 & 2067.0728 & 690.0315 & 0.0035 & 1.6907 & 688.492\end{array}$

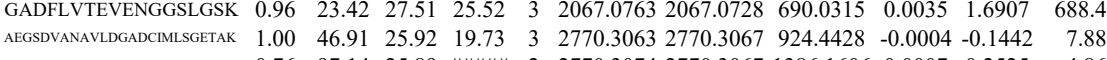
$\begin{array}{lllllllllllll}\text { AEGSDVANAVLDGADCIMLSGETAK } & 0.76 & 97.14 & 25.89 & \text { \#\#\#\# } & 2 & 2770.3074 & 2770.3067 & 1386.1606 & 0.0007 & 0.2525 & 4.867\end{array}$ $\begin{array}{lllllllllllll}\text { AEGSDVANAVIDGADCMMLSGETAK } & 1.00 & 69.02 & 25.89 & 23.95 & 3 & 2770.3075 & 2770.3067 & 924.4428 & 0.0008 & 0.2885 & 19.649 \\ \text { AESDVANAVLDGADCIMLSGETAK } & 1.00 & 40.52 & 25.94 & 16.41 & 3 & 2770.3081 & 2770.3067 & 924.4428 & 0.0014 & 0.5048 & 19.590\end{array}$ $\begin{array}{lllllllllllll}\text { AEGSDVANAVLDGADCIMLSGETAK } & 1.00 & 45.61 & 25.94 & 17.11 & 3 & 2770.3081 & 2770.3067 & 924.4428 & 0.0014 & 0.5048 & 26.542\end{array}$ $\begin{array}{lllllllllllll}\text { AFGSDVANAVLDGADCIMLSGETAK } & 1.00 & 60.46 & 25.98 & 17.90 & 3 & 2770.3087 & 2770.3067 & 924.4428 & 0.0020 & 0.7212 & 36.958\end{array}$ $\begin{array}{llllllllllllll}\text { AEGSDVANAVLDGADCMLSGETAK } & 1.00 & 39.56 & 25.98 & 17.07 & 3 & 2770.3087 & 2770.3067 & 924.4428 & 0.0020 & 0.7212 & 26.474\end{array}$ $\begin{array}{lllllllllllll}\text { AEGSDVANAVLDGADCIMLSGETAK } & 1.00 & 48.92 & 25.98 & 16.78 & 3 & 2770.3087 & 2770.3067 & 924.4428 & 0.0020 & 0.7212 & 36.901\end{array}$ $\begin{array}{lllllllllllll}\text { AEGSDVANAVLDGADCIMLSGETAK } & 0.96 & 21.88 & 25.98 & 14.76 & 3 & 2770.3087 & 2770.3067 & 924.4428 & 0.0020 & 0.7212 & 12.891\end{array}$ $\begin{array}{lllllllllllll}\text { AEGSDVANAVLDGADCIMLSGETAK } & 0.55 & 83.37 & 25.98 & 96.37 & 3 & 2770.3087 & 2770.3067 & 924.4428 & 0.0020 & 0.7212 & 7.739\end{array}$ $\begin{array}{llllllllllll}\text { AEGSDVANAVLDGADCIMLSGETAK } & 0.81 & 8.11 & 25.98 & 21.11 & 4 & 2770.3089 & 2770.3067 & 693.5840 & 0.0022 & 0.7930 & 127.184\end{array}$

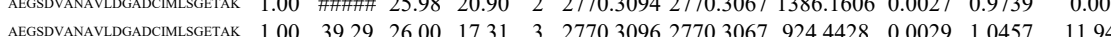
$\begin{array}{lllllllllllll}\text { AEGSDVANAVLDGADCIMLSGETAK } & 0.97 & 12.69 & 26.01 & 25.69 & 4 & 2770.3097 & 2770.3067 & 693.5840 & 0.0030 & 1.0813 & 97.004\end{array}$ $\begin{array}{llllllllllll}\text { AEGSDVANAVLDGADCIMLSGETAK } & 1.00 & 57.02 & 26.00 & 19.72 & 3 & 2770.3102 & 2770.3067 & 924.4428 & 0.0035 & 1.2620 & 36.599\end{array}$ $\begin{array}{lllllllllllll}\text { AEGSDVANAVLDGADCIMLSGETAK } & 0.69 & 14.31 & 25.99 & 14.04 & 3 & 2770.3108 & 2770.3067 & 924.4428 & 0.0041 & 1.4784 & 24.732 \\ & & \end{array}$

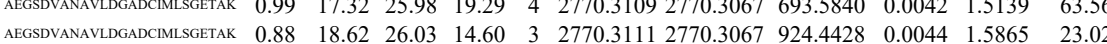

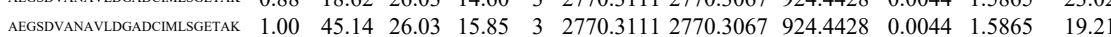

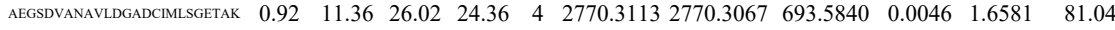
$\begin{array}{lllllllllllll}\text { AEGSDVANAVLDGADCIMLSGETAK } & 1.00 & 82.76 & 26.02 & 20.08 & 3 & 2770.3114 & 2770.3067 & 924.4428 & 0.0047 & 1.6947 & 35.37\end{array}$

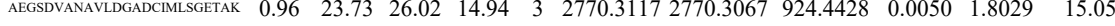
$\begin{array}{llllllllllll}\text { AEGSDVANAVLDGADCIMLSGETAK } & 1.00 & \text { \#\#\#\# } 26.02 & 21.26 & 3 & 2770.3117 & 2770.3067 & 924.4428 & 0.0050 & 1.8029 & 67.56\end{array}$

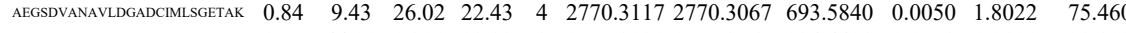
$\begin{array}{llllllllllll}\text { AEGSDVANAVLDGADCIMLSGETAK } & 1.00 & 44.22 & 26.01 & 22.32 & 3 & 2770.3120 & 2770.3067 & 924.4428 & 0.0053 & 1.9111 & 22.893\end{array}$ $\begin{array}{llllllllllll}\text { AEGSDVANAVDDGADCMLSGETAK } & 0.89 & 11.82 & 25.98 & 24.82 & 4 & 2770.3133 & 2770.3067 & 693.5840 & 0.0066 & 2.3789 & 89.20\end{array}$ $\begin{array}{llllllllllll}\text { AEGSDVANAVLGADCMLSGETAK } & 0.85 & 13.05 & 26.05 & 14.45 & 4 & 2770.3145 & 2770.3067 & 693.5840 & 0.0078 & 2.8115 & 103.982\end{array}$ $\begin{array}{llllllllllll}0.98 & 44.33 & 25.37 & 36.03 & 2 & 911.5050 & 911.5059 & 456.7602 & -0.0009 & -0.9852 & 16.670\end{array}$ 
$\begin{array}{llllllllllll}1.00 & 91.06 & 27.59 & 26.03 & 2 & 1808.9118 & 1808.9100 & 905.4623 & 0.0018 & 0.9940 & 23.223\end{array}$

$\begin{array}{llllllllllll}\text { FDEILEASDGIMVAR } & 1.00 & \text { \#\#\#\# } 27.60 & 25.40 & 2 & 1808.9120 & 1808.9100 & 905.4623 & 0.0020 & 1.1044 & 32.042\end{array}$

$\begin{array}{llllllllllll}\text { FDEILEASDGIMVAR } & 0.55 & 16.04 & 27.60 & 29.04 & 3 & 1808.9122 & 1808.9100 & 603.9773 & 0.0022 & 1.2142 & 267.091\end{array}$

$\begin{array}{llllllllllll}\text { FDEILEASDGIMVAR } & 0.82 & 17.40 & 27.60 & 15.41 & 3 & 1808.9122 & 1808.9100 & 603.9773 & 0.0022 & 1.2142 & 215.673\end{array}$

$\begin{array}{lllllllllllll} & \end{array}$

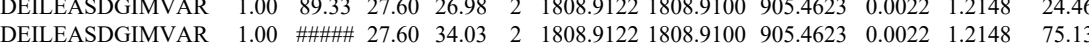

DEILEASDGIMVAR

FDEILEASDGIMVAR

FDEILEASDGIMVAR

$\begin{array}{lllllllllllll}\text { FDEILEASDGIMVAR } & 1.00 & 90.04 & 27.62 & 30.21 & 2 & 1808.9126 & 1808.9100 & 905.4623 & 0.0026 & 1.4357 & 25.467 \\ \text { FDEILEASDGIMVAR } & 0.53 & 19.11 & 27.66 & 32.11 & 3 & 1808.9128 & 1808.9100 & 603.9773 & 0.0028 & 1.5453 & 165.820\end{array}$

$\begin{array}{lllllllllllll}0.94 & 22.06 & 27.63 & 18.27 & 3 & 1808.9125 & 1808.9100 & 603.9773 & 0.0025 & 1.3797 & 221.379 & 21 \\ 1.00 & 88.06 & 27.63 & 28.42 & 3 & 1808.9125 & 1808.9100 & 603.9773 & 0.0025 & 1.3797 & 246.486 & 39 \\ 1.00 & & 14 & 27.62 & 28.73 & 2 & 1808.9126 & 1808.9100 & 905.4623 & 0.0026 & 1.4357 & 30.572 & 3\end{array}$

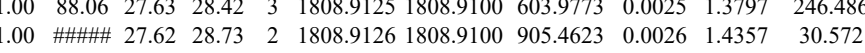

$\begin{array}{lllllllllllll} & \end{array}$

DEILEASDGIMVAR

ITLDNAYMEK

$\begin{array}{lllllllllll}1.00 & 54.06 & 27.64 & 20.02 & 3 & 1808.9131 & 1808.9100 & 603.9773 & 0.0031 & 1.7109 & 28.058\end{array}$

TLDNAYMEK

$\begin{array}{llllllllll}1.00 & 41.24 & 25.99 & 20.50 & 3 & 2770.3108 & 2770.3067 & 924.4428 & 0.0041 & 1.4784\end{array}$

$\begin{array}{llllllllllll}1.00 & 60.23 & 27.94 & 30.61 & 2 & 1484.7900 & 14847788 & 743.3967 & 0.0112 & 7.5329 & 71.61 .077\end{array}$

CDENILWLDYK

$\begin{array}{llllllllllll}65.58 & 26.97 & 23.36 & 2 & 1744.8424 & 1744.8408 & 873.4277 & 0.0016 & 0.9159 & 6349.264 & 9770.092\end{array}$

CDENILWLDYK

162.916

FDEILEASDGIMVAR

FEILEASDGIMVAR

FDEILEASDGIMVAR

FDELLEASDGIMVAR

\begin{tabular}{lllllllllll}
1.00 & \#\#\#\# 27.59 & 30.69 & 2 & 1808.9110 & 1808.9100 & 905.4623 & 0.0010 & 0.5522 & 343.336 \\
\hline
\end{tabular}

$\begin{array}{cc}15117.106 & 148.630 \\ 525.052 & 1109.223\end{array}$

$\begin{array}{llllllllllll}1.00 & 45.10 & 27.60 & 21.77 & 3 & 1808.9122 & 1808.9100 & 603.9773 & 0.0022 & 1.2142 & 81.617\end{array}$

$\begin{array}{llllllllllllll} & \end{array}$

$\begin{array}{llllllllllllll} & \text { EAEAAIYHLQLFEELR } & 1.00 & 52.42 & 28.10 & 21.26 & 3 & 2075.0824 & 2075.0809 & 692.7009 & 0.0015 & 0.7218 & 250.694\end{array}$

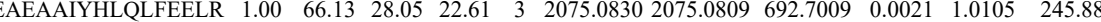

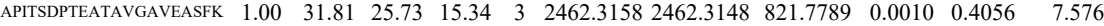

LAPITSDPTEATAVGAVEASFK

LDIDSPPITAR

LDIDSPPITAR

ITLDNAYMEK

ITLDNAYMEK

CDENILWLDYK

CDENILWLDYK

CDENILWLDYK

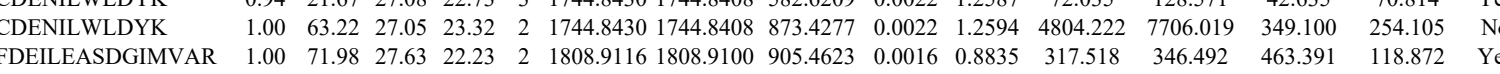

$\begin{array}{llllllllll}2.11 & 25.72 & 15.29 & 3 & 2462.3167 & 2462.3148 & 821.7789 & 0.0019 & 0.7707 & 597.150\end{array}$

$\begin{array}{llllllllllllll} & \end{array}$

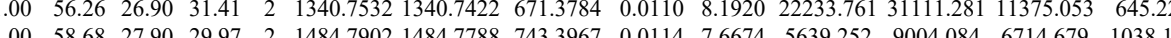

$\begin{array}{lllllllllllllllll}1.00 & 58.68 & 27.90 & 29.97 & 2 & 1484.7902 & 1484.7788 & 743.3967 & 0.0114 & 7.6674 & 5639.252 & 9004.084 & 6714.679 & 1038.115 & \text { Yes } & \\ 1.00 & 60.97 & 27.84 & 30.73 & 2 & 1484.7906 & 1484.7788 & 743.3967 & 0.0118 & 7.9365 & 4621.024 & 6864.814 & 5223.634 & 1155.695 & \text { Yes } & \end{array}$

$\begin{array}{lllllllllllllll}1.00 & 65.43 & 27.00 & 25.25 & 2 & 1744.8420 & 1744.8408 & 873.4277 & 0.0012 & 0.6869 & 3422.584 & 4939.857 & 79.614 & 149.631 & \text { No }\end{array}$ $\begin{array}{lllllllllllllllll} & \end{array}$

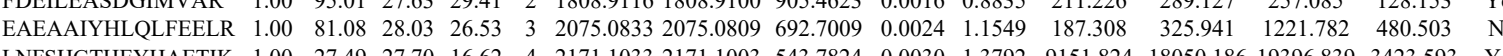

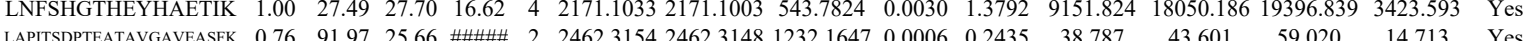
$\begin{array}{llllllllllll}1 & & \end{array}$ 

$\begin{array}{lllllllllllll}\text { LAPITSDPTEATAVGAVEASFK } & 0.53 & 39.81 & 25.61 & 52.81 & 3 & 2462.3176 & 2462.3148 & 821.7789 & 0.0028 & 1.1357 & 150.505\end{array}$ $\begin{array}{lllllllllllll}\text { LAPISDPTEATAVGAVEASFK } & 0.53 & 63.73 & 25.56 & 76.73 & 3 & 2462.3179 & 2462.3148 & 821.7789 & 0.0031 & 1.2574 & 27.408\end{array}$

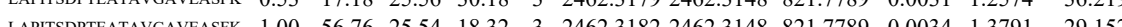

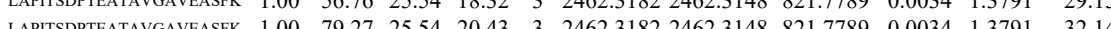

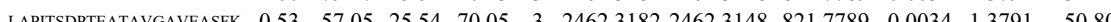
$\begin{array}{lllllllllllll}\text { LAPITSDPTEATAVGAVEASFK } & 0.97 & 12.57 & 25.53 & 25.57 & 4 & 2462.3185 & 2462.3148 & 616.5860 & 0.0037 & 1.5002 & 28.527\end{array}$ $\begin{array}{lllllllllllll}\text { SGMNVAR } & 0.60 & 20.91 & 27.49 & 30.64 & 2 & 877.4558 & 877.4562 & 439.7354 & -0.0004 & -0.4548 & 109.510\end{array}$ $\begin{array}{lllllllllllll}\text { SGMNVAR } & 0.97 & 37.17 & 27.49 & 37.16 & 2 & 877.4562 & 877.4562 & 439.7354 & 0.0000 & 0.0000 & 310.196\end{array}$ $\begin{array}{llllllllllll}\text { GVNLPGAAVDLPAVSEK } & 0.91 & 25.89 & 24.00 & 18.34 & 3 & 1924.1050 & 1924.0873 & 642.3697 & 0.0177 & 9.1847 & 533.617 \\ \text { GVNLPGAAVDLPAVSEK } & 1.00 & \# \# \# \text { 23.98 } & 25.76 & 2 & 1924.1056 & 1924.0873 & 963.0509 & 0.0183 & 9.5010 & 889.525\end{array}$ $\begin{array}{llllllllllll}\text { RFDEILEASDGIMVAR } & 0.90 & 37.16 & 28.25 & 19.31 & 3 & 1965.0061 & 1965.0111 & 656.0110 & -0.0050 & -2.5406 & 162.767\end{array}$ $\begin{array}{llllllllllll}\text { RFDEILEASDGIMVAR } & 1.00 & 41.40 & 28.26 & 25.34 & 3 & 1965.0118 & 1965.0111 & 656.0110 & 0.0007 & 0.3557 & 86.684\end{array}$ $\begin{array}{lllllllllllll}\text { RFDEILEASDGIMVAR } & 1.00 & 50.69 & 28.22 & 25.73 & 3 & 1965.0127 & 1965.0111 & 656.0110 & 0.0016 & 0.8130 & 68.265\end{array}$ $\begin{array}{lllllllllllll}\text { RFDEILEASDGIMVAR } & 1.00 & 56.47 & 28.22 & 23.40 & 3 & 1965.0130 & 1965.0111 & 656.0110 & 0.0019 & 0.9654 & 9100.517\end{array}$ $\begin{array}{lllllllllllll}\text { RFDEILEASDGIMVAR } & 1.00 & 62.61 & 28.22 & 23.86 & 3 & 1965.0130 & 1965.0111 & 656.0110 & 0.0019 & 0.9654 & 8873.045 & 8391.111\end{array}$ $\begin{array}{llllllllllllll}\text { EAEAAIYHLQLFEELR } & 1.00 & 55.00 & 28.06 & 18.00 & 3 & 2075.0857 & 2075.0809 & 692.7009 & 0.0048 & 2.3098 & 241.783 & 354.593\end{array}$ $\begin{array}{llllllllllllll}\text { EAEAAIYHLQLFEELR } & 1.00 & 80.50 & 28.10 & 26.76 & 3 & 2075.0866 & 2075.0809 & 692.7009 & 0.0057 & 2.7429 & 207.616 & 393.237\end{array}$

$\begin{array}{llllllllll} & \end{array}$ $\begin{array}{llllllllllllllllll} & \end{array}$

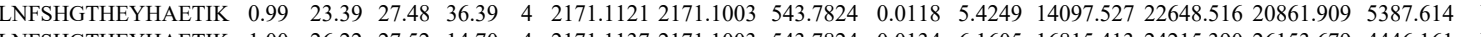
$\begin{array}{lllllllllllllll} & & \end{array}$

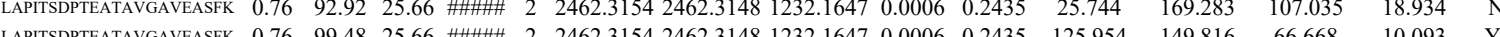

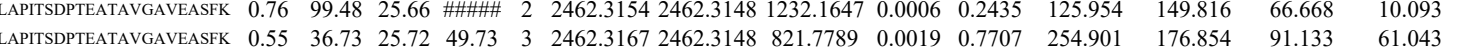

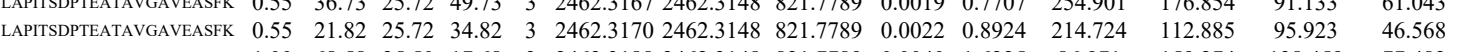

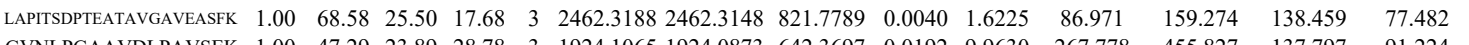
$\begin{array}{lllllllllllllll}\text { GVNLPGAAVDLPAVSEK } & 1.00 & 47.29 & 23.89 & 28.78 & 3 & 1924.1065 & 1924.0873 & 642.3697 & 0.0192 & 9.9630 & 267.778 & 455.827 & 137.797 & 91.224 \\ \text { RFDEILEASDGIMVAR } & 1.00 & 58.00 & 28.32 & 24.91 & 3 & 1965.0103 & 1965.0111 & 656.0110 & -0.0008 & -0.4065 & 58.963 & 39.880 & 23.990 & 14.043\end{array}$

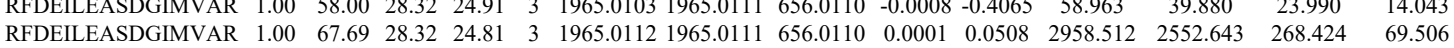

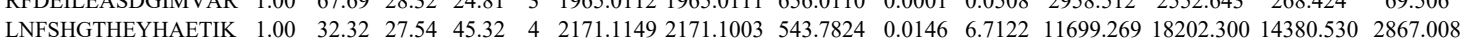

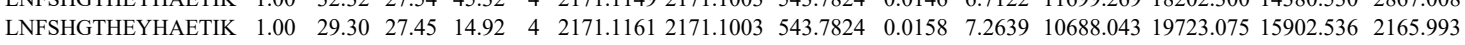

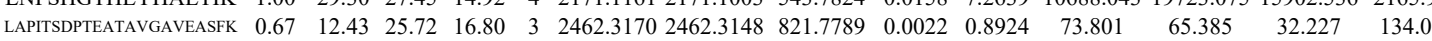

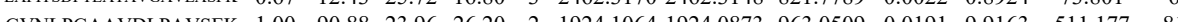

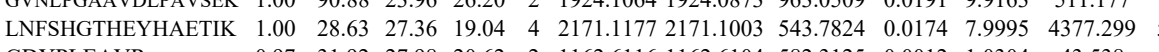
GDYPLEAVR

GSGTAEVELK GSGTAEVELK GDLGIEIPAEK GDLGIEIPAEK GDLGIEIPAEK $\begin{array}{lllllllllll}0.93 & 27.82 & 28.05 & 22.67 & 2 & 1162.6122 & 1162.6104 & 582.3125 & 0.0018 & 1.5456 & 55.538\end{array}$

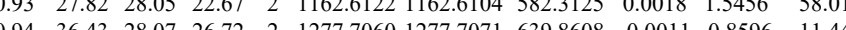
$\begin{array}{lllllllllllll}1.00 & 39.93 & 28.08 & 30.66 & 2 & 1277.7076 & 1277.7071 & 639.8608 & 0.0005 & 0.3907 & 4.648\end{array}$ $\begin{array}{lllllllllll}0.97 & 53.10 & 27.04 & 24.66 & 2 & 1428.8016 & 1428.8068 & 715.4107 & -0.0052 & -3.6343 & 55.374\end{array}$ $\begin{array}{llllllllllll}0.74 & 16.88 & 27.30 & 15.98 & 3 & 1428.8074 & 1428.8068 & 477.2762 & 0.0006 & 0.5376 & 42.129 \\ 1 & 1.00 & 7.07 & 2.83 & 23.36 & 2 & 1785.8658 & 1785.8655 & 893.9400 & 0.0003 & 0.1678 & 8.536\end{array}$

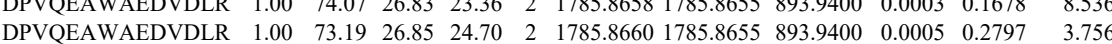
$\begin{array}{llllllllllllll}\text { DPVQEAWAEDVDLR } & 0.83 & 16.83 & 26.83 & 15.77 & 3 & 1785.8674 & 1785.8655 & 596.2958 & 0.0019 & 1.0621 & 23.855\end{array}$ $\begin{array}{llllllllllll} & 26.00 & 23.81 & 3 & 2770.3096 & 2770.3067 & 924.4428 & 0.0029 & 1.0457 & 1.036\end{array}$ $\begin{array}{llllllllllll} & \end{array}$ $\begin{array}{llllllllllll} & 1.00 & 37.57 & 25.98 & 50.57 & 4 & 2770.3109 & 2777.067 & 63.5840 & 0.042 & 1.5139 & 15.79\end{array}$ $\begin{array}{llllllllllllllll} & \end{array}$

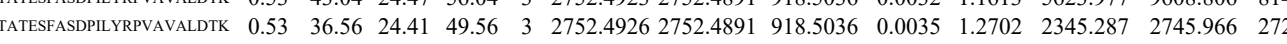
$\begin{array}{llllllllllllll}\text { IATESFASDPILYRPVAVALDTK } & 0.55 & 43.67 & 24.55 & 56.67 & 3 & 2752.4911 & 2752.4891 & 918.5036 & 0.0020 & 0.7258 & 3478.758 & 52\end{array}$ $88.522 \quad 887.809$

$\begin{array}{lllllllllll} & \end{array}$ 4258.470
7.415

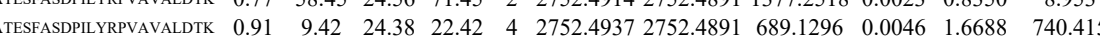
$\begin{array}{lllllllllllll}\text { TATESFASDPILYRPVAVALDTK } & 1.00 & 38.28 & 24.31 & 51.28 & 4 & 2752.4957 & 2752.4891 & 689.1296 & 0.0066 & 2.3943 & 808.0\end{array}$ $\begin{array}{llllllllllll}\text { FGVEQDVDMVFASFIR } & 0.98 & 49.00 & 27.89 & 17.02 & 2 & 2002.9914 & 2002.9945 & 1002.5045 & -0.0031 & -1.5461 & 12.331\end{array}$ $\begin{array}{lllllllllllll}\text { FGVEQDVDMVFASFIR } & 0.98 & 27.48 & 27.89 & 17.67 & 3 & 2002.9951 & 2002.9945 & 668.6721 & 0.0006 & 0.2991 & 165.940 & 1 \\ \text { FGVEQDVDMVFASFIR } & 0.76 & 87.40 & 27.89 & \# \# \# \# & 2 & 2002.9954 & 2002.9945 & 1002.5045 & 0.0009 & 0.4489 & 19.918\end{array}$ $\begin{array}{lllllllllllll} & \text { FGVEDVDMVAFIR } & 0.76 & 87.40 & 27.89 & 20 & 2002.9954 & 2002.9945 & 1002.5045 & 0.0009 & 0.4489 & 19.918 & \\ \text { FGVEODVDMVFASFIR } & 1.00 & 83.38 & 27.89 & 20.81 & 2 & 2002.9954 & 2002.9945 & 1002.5045 & 0.0009 & 0.4489 & 595.113 & \end{array}$ $\begin{array}{lllllllllllll}\text { FGVEDDVMVASFR } & 1.00 & 83.38 & 27.89 & 20.81 & 2 & 2002.9954 & 2002.9945 & 102.5045 & 0.0009 & 0.4489 & 595.113 \\ \text { FGVEDVDMVFASFIR } & 0.55 & 43.49 & 27.99 & 56.49 & 3 & 2002.9969 & 2002.9945 & 668.6721 & 0.0024 & 1.1964 & 102.876\end{array}$ $\begin{array}{lllllllllllll}\text { FGVEDDVDMVFASFIR } & 1.00 & 37.34 & 28.00 & 20.73 & 3 & 2002.9972 & 2002.9945 & 668.6721 & 0.0027 & 1.3459 & 158.258\end{array}$

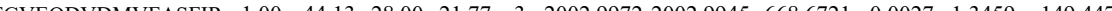
$\begin{array}{lllllllllllll}\text { FGVEQDVDMVFASFIR } & 0.69 & 82.22 & 28.01 & 95.22 & 2 & 2002.9974 & 2002.9945 & 1002.5045 & 0.0029 & 1.4464 & 463.515 & 952.726\end{array}$

(17.283 

$\begin{array}{lllllllllllll}\text { FGVEQDVDMVFASFIR } & 1.00 & 68.31 & 27.95 & 19.59 & 2 & 2003.0114 & 2002.9945 & 1002.5045 & 0.0169 & 8.4288 & 8.626\end{array}$ $\begin{array}{llllllllllll}\text { FGVEQDVDMVFASFIR } & 0.99 & 48.48 & 27.57 & 17.59 & 2 & 2018.9874 & 2018.9894 & 1010.5020 & -0.0020 & -0.9896 & 13.739\end{array}$ $\begin{array}{lllllllllll} & \end{array}$ $\begin{array}{llllllllllll} & \end{array}$ $\begin{array}{llllllllllll} & \text { L }\end{array}$

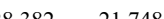
$\begin{array}{llllllllllllll}0.80 & 26.27 & 27.90 & 19.50 & 3 & 202.9924 & 2002.9945 & 68.6721 & -0.0021 & -1.0469 & 226.301\end{array}$

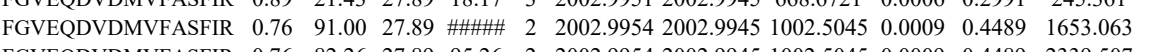
$\begin{array}{ll}37.780 & 29.323 \\ 41.432 & 31.356\end{array}$ $89.042 \quad 35.525$ 75.936 $\begin{array}{llllllllllllll} & 0.76 & 82.26 & 27.89 & 95.26 & 2 & 2002.9954 & 2002.9945 & 1002.5045 & 0.0009 & 0.4489 & 2339.507 & 3513.641 & 1744.899\end{array}$

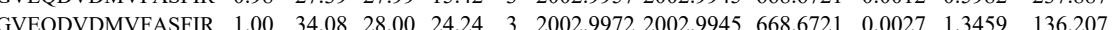
$\begin{array}{lllllllllllllll}\text { FGVEQDVDMVFASFIR } & 0.53 & 42.78 & 28.00 & 55.78 & 3 & 2002.9978 & 2002.9945 & 668.6721 & 0.0033 & 1.6450 & 173.393\end{array}$

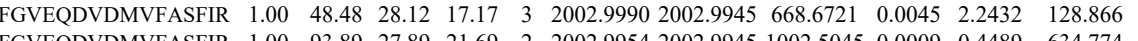

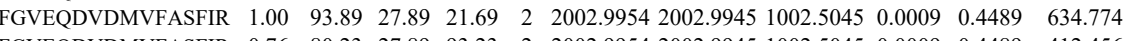
$\begin{array}{llllllllllll}\text { FGVEQDVDMVFASFIR } & 0.76 & 80.23 & 27.89 & 93.23 & 2 & 2002.9954 & 2002.9945 & 1002.5045 & 0.0009 & 0.4489 & 412.456\end{array}$

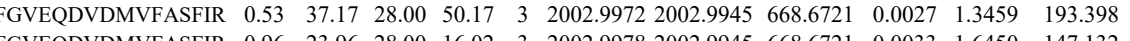
$\begin{array}{lllllllllllll}\text { VNFAMNVGK } & 0.96 & 32.96 & 28.00 & 16.02 & 3 & 2002.9978 & 2002.9945 & 668.6721 & 0.0033 & 1.6450 & 147.132 \\ \text { VIn } & 0.95 & 2 & 1266.6982 & 1266.6998 & 634.3572 & -0.0016 & -1.2611 & 29.791\end{array}$

VNFAMNVGK

VNFAMNVGK

VNFAMNVGK

VNFAMNVGK

VNFAMNVGK

GDYPLEAVR

GDYPLEAVR

GDLGIEIPAEK

$\begin{array}{lllllllllll} & \end{array}$

-1
0

$\begin{array}{lllllllllllll}51.46 & 27.32 & 24.08 & 2 & 1266.7084 & 1266.6998 & 634.3572 & 0.0086 & 6.7785 & 49844.006 & 77553.452 & 19594.906\end{array}$

$\begin{array}{lllllllllllllll}1.0 & 58.89 & 27.27 & 21.66 & 2 & 1266.7096 & 1266.6998 & 634.3572 & 0.0098 & 7.7243 & 31281.441 & 48751.668 & 9873.938 & 1230.258 & \end{array}$

$\begin{array}{lllllllllllllll}1.00 & 58.81 & 27.47 & 23.51 & 2 & 1266.7060 & 1266.6998 & 634.3572 & 0.0062 & 4.8868 & 19003.030 & 30504.017 & 7013.391 & 1015.618 & \end{array}$ $\begin{array}{lllllllllllllll}1.00 & 61.45 & 27.47 & 24.04 & 2 & 1266.7060 & 1266.6998 & 634.3572 & 0.0062 & 4.8868 & 18158.161 & 28900.091 & 5467.537 & 842.563\end{array}$ $\begin{array}{llllllllllll}0.98 & 33.41 & 28.08 & 22.15 & 2 & 1162.6114 & 1162.6104 & 582.3125 & 0.0010 & 0.8586 & 46.225\end{array}$ GDLGIEIPAEK

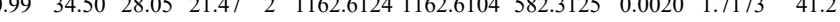
DLGIEIPAEK $\begin{array}{llllllllllll}1.00 & 60.44 & 27.19 & 25.90 & 2 & 1428.8064 & 1428.8068 & 715.4107 & -0.0004 & -0.2796 & 51.773\end{array}$

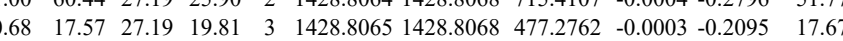
$\begin{array}{lllllllllllll}\text { DPVQEAWAEDVDLR } & 0.67 & 21.49 & 26.82 & 16.10 & 2 & 1785.8652 & 1785.8655 & 893.9400 & -0.0003 & -0.1678 & 8.970\end{array}$ $\begin{array}{lllllllllllll}\text { DPVQEAWAEDVDLR } & 1.00 & 70.00 & 26.83 & 23.27 & 2 & 17855.8658 & 1785.8655 & 893.9400 & 0.0003 & 0.1678 & 13.704\end{array}$

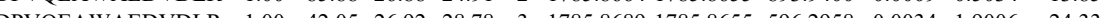
$\begin{array}{llllllllll} & \end{array}$

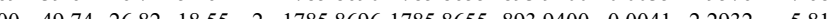

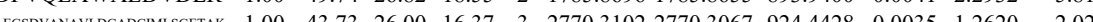
$\begin{array}{llllllll} & \end{array}$

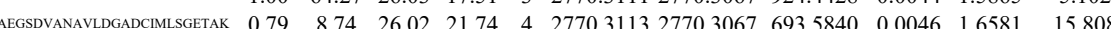
$\begin{array}{lllllllllllll}\text { GIFPVLCK } & 0.73 & 19.87 & 26.97 & 20.76 & 2 & 1209.6864 & 1209.6857 & 605.8501 & 0.0007 & 0.5777 & 256.153\end{array}$ $\begin{array}{lllllllllll}1.00 & 42.38 & 27.08 & 22.01 & 2 & 1209.6874 & 1209.6857 & 605.8501 & 0.0017 & 1.4030 & 282.742\end{array}$ $\begin{array}{llllllllllll}\text { AGKPVICATQMLESMIK } & 1.00 & 67.94 & 25.99 & 18.12 & 2 & 2297.2354 & 2297.2345 & 1149.6245 & 0.0009 & 0.3914 & 460.348\end{array}$ $\begin{array}{llllllllllll}\text { AGKPVICATQMLESMIK } & 1.00 & 67.22 & 25.99 & 21.13 & 2 & 2297.2354 & 2297.2345 & 1149.6245 & 0.0009 & 0.3914 & 166.360\end{array}$ $\begin{array}{lllllllll}24.67 & 3 & 2297.2375 & 2297.2345 & 766.7521 & 0.0030 & 1.3042 & 3694\end{array}$ $\begin{array}{llllllllllllllll} & \end{array}$ $\begin{array}{llllllllllllll}0.94 & 22.99 & 19.29 & 17.60 & 2 & 983.6250 & 983.6249 & 492.8197 & 0.0001 & 0.1015 & 255.750 & 26 & \\ 0.97 & 26.18 & 19.29 & 16.48 & 2 & 983.6250 & 983.6249 & 492.8197 & 0.0001 & 0.1015 & 161.394 & 18\end{array}$ $\begin{array}{lllllllllllll}0.97 & 26.18 & 19.29 & 16.48 & 2 & 983.6250 & 983.6249 & 492.8197 & 0.0001 & 0.1015 & 161.394 & 18 \\ 0.96 & 2.81 & 19.29 & 19.29 & 2 & 983.6254 & 983.6249 & 42.8197 & 0.005 & 0.5073 & 178.826 & 15\end{array}$ $\begin{array}{llllllllllllll}0.96 & 24.81 & 19.29 & 19.29 & 2 & 983.6254 & 983.6249 & 492.8197 & 0.0005 & 0.5073 & 178.826 & 159 . \\ 0.61 & 16.81 & 19.29 & 29.81 & 2 & 983.6254 & 983.6249 & 492.8197 & 0.0005 & 0.5073 & 159.714 & 161 . & \\ 0.96 & 21.76 & 19.29 & 15.02 & 2 & 983.6256 & 983.6249 & 492.8197 & 0.0007 & 0.7102 & 215.834 & 210 .\end{array}$ $\begin{array}{lllllllllllll}0.61 & 16.81 & 19.29 & 29.81 & 2 & 983.6254 & 983.6249 & 492.8197 & 0.0005 & 0.5073 & 159.714 & 16 \\ 0.96 & 21.76 & 19.29 & 15.02 & 2 & 983.6256 & 983.6249 & 4928197 & 0.0007 & 0.7102 & 215.834\end{array}$ $\begin{array}{llllllllllll}0.98 & 23.77 & 19.14 & 19.06 & 2 & 983.6258 & 983.6249 & 492.8197 & 0.0009 & 0.9131 & 195.448 & 21\end{array}$ $\begin{array}{lllllllllllll}0.99 & 29.45 & 19.14 & 16.55 & 2 & 983.6258 & 983.6249 & 492.8197 & 0.0009 & 0.9131 & 75.277\end{array}$ $\begin{array}{rrrrrrrrrrrrrr}0.92 & 18.04 & 19.14 & 14.68 & 2 & 983.6258 & 983.6249 & 492.8197 & 0.0009 & 0.9131 & 73.661 & 105.786 & 57.171 \\ 0.96 & 21.53 & 18.63 & 16.95 & 2 & 983.6262 & 983.6249 & 492.8197 & 0.0013 & 1.3189 & 170.498 & 232.664 & 118.05\end{array}$ $\begin{array}{lllllllllllllll}0.67 & 2.10 & 20.76 & 19.22 & 2 & 983.6298 & 983.6249 & 492.8197 & 0.0049 & 4.9714 & 656.422 & 929.118 & 716.590\end{array}$

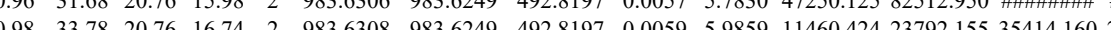

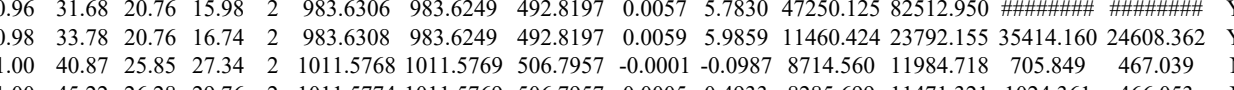

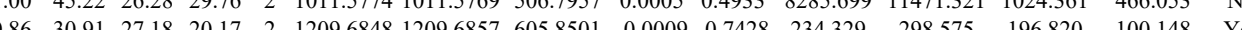




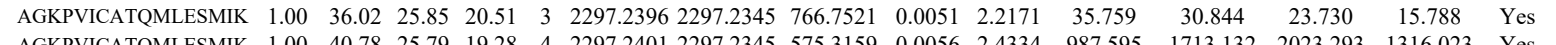

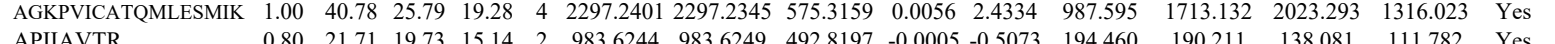

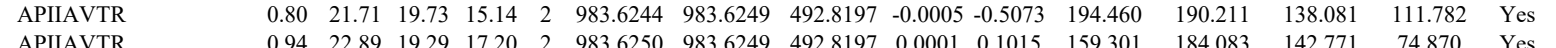
$\begin{array}{lllllllllllllll}0.94 & 22.89 & 19.29 & 17.20 & 2 & 983.6250 & 983.6249 & 492.8197 & 0.0001 & 0.1015 & 159.301 & 184.083 & 142.771 & 74.870 & \\ \end{array}$ $\begin{array}{lllllllllllllll}0.61 & 17.85 & 19.29 & 30.85 & 2 & 983.6252 & 983.6249 & 492.8197 & 0.0003 & 0.3044 & 137.181 & 200.663 & 111.644 & 64.486 & \text { Yes } \\ 0.97 & 25.57 & 19.29 & 19.57 & 2 & 933.6252 & 983.6249 & 492.8197 & 0.0003 & 0.3044 & 10232 & 177.22 & 145.043 & 82.631 & \text { Yes }\end{array}$

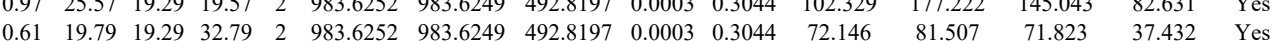
$\begin{array}{lllllllllllllll}0.61 & 19.79 & 19.29 & 32.79 & 2 & 983.6252 & 983.6249 & 492.8197 & 0.0003 & 0.3044 & 72.146 & 81.507 & 71.823 & 37.432 & \text { Yes } \\ 0.92 & 21.67 & 19.29 & 17.25 & 2 & 983.6254 & 983.6249 & 4928197 & 0.0005 & 0.5073 & 178.107 & 179.135 & 143.977 & 111.741 & \text { Yes }\end{array}$ $\begin{array}{llllllllllllllll}0.98 & 23.94 & 19.29 & 14.57 & 2 & 983.6256 & 983.6249 & 492.8197 & 0.00007 & 0.7102 & 148.091 & 197.630 & 130.736 & 113.975 & \text { Yes } \\ \end{array}$

$\begin{array}{lllllllllllllll}0.95 & 29.83 & 20.76 & 14.93 & 2 & 983.6300 & 983.6249 & 492.8197 & 0.0051 & 5.1743 & 32044.780 & 59443.592 & 87393.807 & 69711.460 & \text { Yes }\end{array}$ $\begin{array}{lllllllllllllll}0.98 & 33.74 & 20.76 & 19.22 & 2 & 983.6300 & 983.6249 & 492.8197 & 0.0051 & 5.1743 & 6719.881 & 8592.557 & 8712.197 & 5247.784 & \text { Yes }\end{array}$ \begin{tabular}{llllllllllllllll}
0.98 & 34.45 & 20.76 & 18.11 & 2 & 983.6302 & 983.6249 & 492.8197 & 0.0053 & 5.3772 & 6199.100 & 7488.265 & 7806.330 & 5022.349 & Yes \\
\hline
\end{tabular} GIFPVLCK GIFPVLCK GIFPVLCK

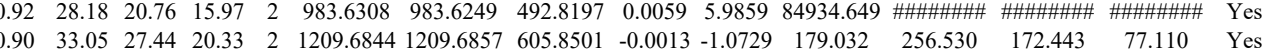

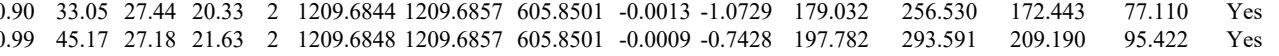
$\begin{array}{lllllllllllllll}0.77 & 28.42 & 27.16 & 18.65 & 2 & 1209.6852 & 1209.6857 & 605.8501 & -0.0005 & -0.4126 & 84.333 & 87.943 & 91.766 & 14.933 & \text { Yes }\end{array}$

GPPLC

GIFPVLCK

GIFPVLCK

GIFPVLCK

GIFPVLCK

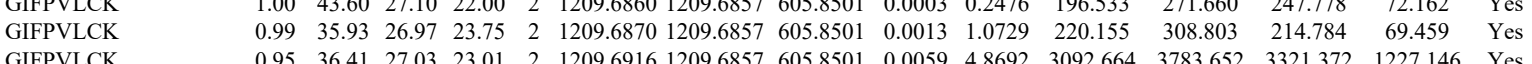
$\begin{array}{lllllllllll}0.95 & 31.23 & 27.17 & 19.19 & 2 & 1209.6854 & 1209.6857 & 605.8501 & -0.0003 & -0.2476 & 199.486\end{array}$ $\begin{array}{llllllllllll}0.99 & 37.01 & 27.10 & 23.43 & 2 & 1209.6858 & 1209.6857 & 605.8501 & 0.0001 & 0.0825 & 287.017 & 39\end{array}$ $\begin{array}{lllllll} & \end{array}$

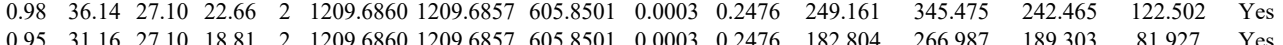

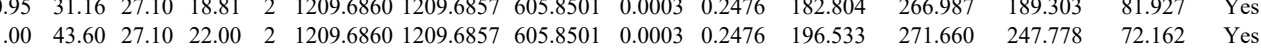
\begin{tabular}{llllllllllllllll} 
& 0.95 & 36.41 & 27.03 & 23.01 & 2 & 1209.6916 & 1209.6857 & 605.8501 & 0.0059 & 4.8692 & 3092.664 & 3783.652 & 3321.372 & 1227.146 & Yes \\
\hline AGKPVICATQMLESMIK & 1.00 & 50.46 & 26.19 & 16.31 & 2 & 2297.2334 & 2297.2345 & 149.6245 & -0.0011 & 0.4784 & 240.190 & 300.724 & 420.821 & 185.646 & Yes
\end{tabular} $\begin{array}{llllllllllllllll} & \end{array}$ $\begin{array}{lllllllllllllll} & \end{array}$

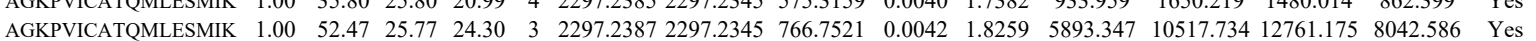

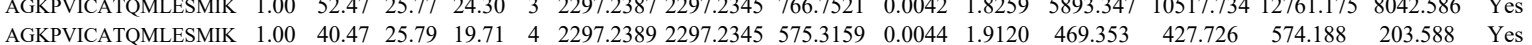
$\begin{array}{llllllllllllllll}\text { APIIAVTR } & 0.93 & 22.16 & 19.29 & 14.50 & 2 & 983.6254 & 983.6249 & 492.8197 & 0.0005 & 0.5073 & 56.788 & 67.720 & 32.714 & 22.482 & \text { Yes }\end{array}$

APIIAVTR

GIFPVLCK

GIFPVLLCK

GIFPVLCK

GIFPVLCK
GIFPVLCK

GIFPVLCK

GIFPVLCK

GIFPVLCK

GIFPVLCK

GIFPVLCK

GIFPVLCK

GIFPVLCK
GIFPVLCK

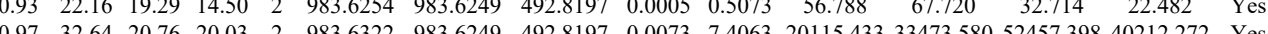

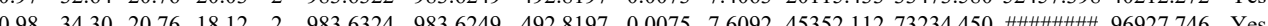
$\begin{array}{lllllllllllllll}0.97 & 34.08 & 27.12 & 22.81 & 2 & 123096856 & 1209.6857 & 605.8501 & -0.001 & 0.0825 & 359.985 & 482.609 & 449.488 & 203.525 & \text { Yes }\end{array}$ $\begin{array}{lllllllllllllll}1.00 & 45.96 & 27.10 & 23.44 & 2 & 1209.6860 & 1209.6857 & 605.8501 & 0.0003 & 0.2476 & 275.815 & 464.231 & 427.756 & 182.687 & \text { Yes }\end{array}$

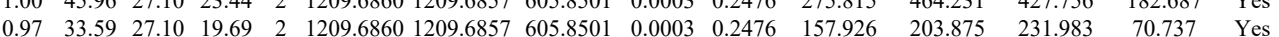

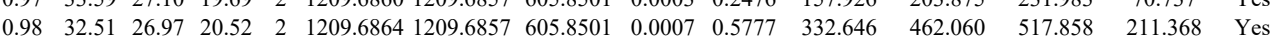
$\begin{array}{lllllllllllllll}0.99 & 36.39 & 26.97 & 23.51 & 2 & 1209.6864 & 1209.6857 & 605.8501 & 0.0007 & 0.5777 & 231.593 & 445.297 & 374.305 & 129.510 & \text { Yes }\end{array}$ $\begin{array}{lllllllllllllll}0.99 & 36.46 & 26.97 & 22.70 & 2 & 1209.6864 & 1209.6857 & 605.8501 & 0.0007 & 0.5777 & 294.367 & 403.173 & 404.148 & 186.832 & \text { Yes }\end{array}$ $\begin{array}{lllllllllllllll}1.00 & 43.04 & 26.97 & 20.86 & 2 & 1209.6864 & 1209.6857 & 605.8501 & 0.0007 & 0.5777 & 67075.841 & \# \# \# \# \# \# \# \# \# \text { \#4070.644 } & \text { Yes }\end{array}$ $\begin{array}{lllllllllllllll}0.99 & 37.97 & 26.97 & 24.48 & 2 & 1209.6864 & 1209.6857 & 605.8501 & 0.0007 & 0.5777 & 31325.208 & 54230.127 & 58301.451 & 22904.724 & \text { Yes }\end{array}$ $\begin{array}{lllllllllllllllll}0.98 & 32.63 & 26.97 & 20.10 & 2 & 1209.6866 & 1209.6857 & 605.8501 & 0.0009 & 0.7428 & 386.140 & 508.064 & 466.076 & 176.553 & \text { Yes }\end{array}$ $\begin{array}{llllllllllllllll}0.99 & 36.48 & 26.97 & 22.60 & 2 & 1209.6866 & 1209.6857 & 605.8501 & 0.0009 & 0.7428 & 370.999 & 587.907 & 462.785 & 192.483 & \text { Yes }\end{array}$ $\begin{array}{lllllllllllllll}0.98 & 31.99 & 26.97 & 19.48 & 2 & 1209.6868 & 1209.6857 & 605.8501 & 0.0011 & 0.9078 & 126.544 & 199.955 & 170.567 & 78.655 & \text { Yes }\end{array}$ $\begin{array}{lllllllllllllllll}\text { AGKPVICATQMLESMIK } & 1.00 & 60.45 & 25.95 & 23.64 & 3 & 2297.2363 & 2297.2345 & 766.7521 & 0.0018 & 0.7825 & 27.575 & 39.071 & 10.813 & 5.931 & \text { Yes }\end{array}$

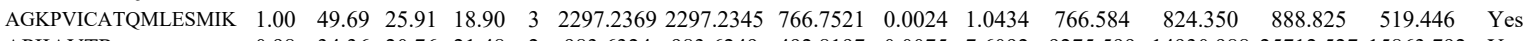

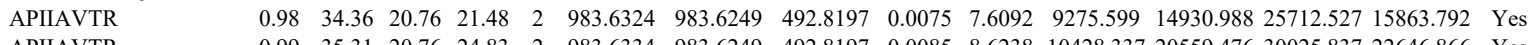
APIIAVTR GIFPVLCK GIFPVLCK GIFPVLCK GIFPVLCK GIFPVLCK GIFPVLCK $\begin{array}{llllllllllllllllll}0.99 & 35.31 & 20.76 & 24.83 & 2 & 983.6334 & 983.6249 & 4928197 & 0.0085 & 8.6238 & 10428.337 & 20559.476 & 30025.837 & 22646.866 & \text { Y }\end{array}$ $\begin{array}{llllllllllllllll}1.00 & 43.04 & 27.10 & 19.91 & 2 & 1209.6860 & 1209.6857 & 605.8501 & 0.0003 & 0.2476 & 159.030 & 242.976 & 205.815 & 101.682 & \text { Yes }\end{array}$

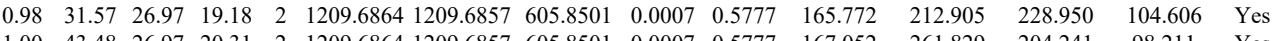
$\begin{array}{lllllllllllllll}1.00 & 43.48 & 26.97 & 20.31 & 2 & 1209.6864 & 1209.6857 & 605.8501 & 0.0007 & 0.5777 & 167.052 & 261.829 & 204.241 & 98.211 & \text { Yes } \\ 0.98 & 33.53 & 26.97 & 20.31 & 2 & 1209.6866 & 1209.6857 & 605.8501 & 0.0009 & 0.7428 & 226.992 & 317.276 & 307.927 & 149.018 & \text { Ys }\end{array}$

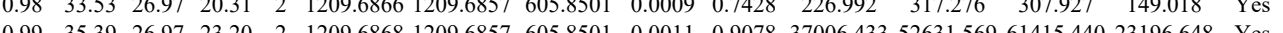
$\begin{array}{lllllllllllllllll}0.99 & 35.39 & 26.97 & 23.20 & 2 & 1209.6868 & 1209.6857 & 605.8501 & 0.0011 & 0.9078 & 37006.433 & 52631.569 & 61415.440 & 23196.648 & \text { Yes } \\ 0.98 & 32.04 & 27.08 & 19.59 & 2 & 1209.6872 & 1209.6857 & 605.8501 & 0.0015 & 1.2379 & 178.235 & 324.488 & 270.069 & 103.891 & \text { Yes }\end{array}$

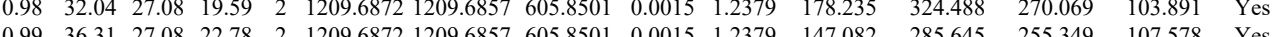

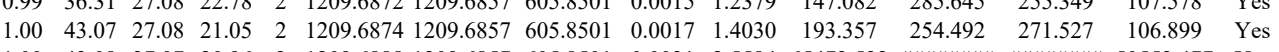

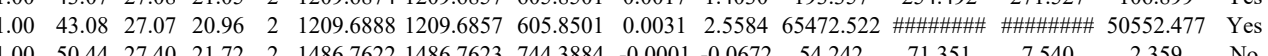

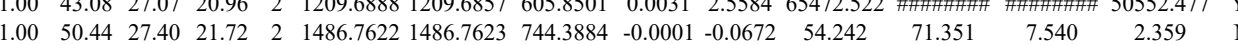

Table S-3 page 150 of 499 
$\begin{array}{llllllllllllllll}0.98 & 34.87 & 20.76 & 23.68 & 2 & 983.6332 & 983.6249 & 492.8197 & 0.0083 & 8.4209 & 10261.478 & 12583.419 & 14113.471 & 9730.512 & \text { Yes }\end{array}$

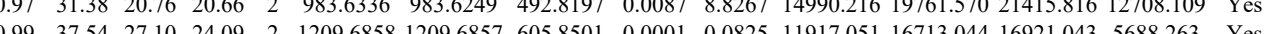
$\begin{array}{llllllllllllllllllll}0.99 & 36.59 & 27.107 & 24.09 & 2 & 1209.6858 & 1209.6857 & 605.8501 & 0.0001 & 0.0825 & 1 & 1917.051 & 16713.044 & 16921.043 & 5688.263 & \text { Yes }\end{array}$

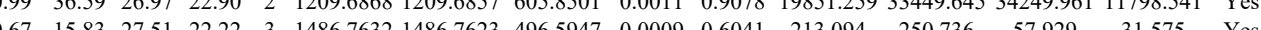
$\begin{array}{llllllllllllllll}1.00 & 55.21 & 27.45 & 24.26 & 2 & 1486.7626 & 1486.7623 & 744.3884 & 0.0003 & 0.2015 & 1553.019 & 2442.333 & 653.922 & 133.074 & \text { Yes }\end{array}$ $\begin{array}{llllllllllllllll}1.00 & 78.52 & 28.38 & 27.34 & 2 & 1491.7662 & 1491.7659 & 746.8902 & 0.0003 & 0.2008 & 6095.960 & 11179.522 & 4634.148 & 277.124 & \text { Yes }\end{array}$

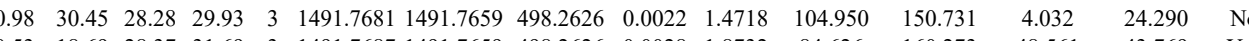
$\begin{array}{lllllllllllllll}0.53 & 18.69 & 28.37 & 31.69 & 3 & 1491.7687 & 1491.7659 & 498.2626 & 0.0028 & 1.8732 & 84.626 & 160.273 & 48.561 & 43.769 & \text { Yes }\end{array}$

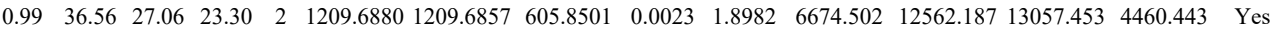
$\begin{array}{llllllllllllllll}0.99 & 36.94 & 27.06 & 23.85 & 2 & 1209.6882 & 1209.6857 & 605.8501 & 0.0025 & 2.0632 & 5306.568 & 8969.865 & 9222.989 & 3008.091 & \text { Yes }\end{array}$ $\begin{array}{lllllllllllllll}1.00 & 48.58 & 27.44 & 26.70 & 2 & 1486.7624 & 1486.7623 & 744.3884 & 0.0001 & 0.0672 & 967.307 & 1353.889 & 299.358 & 109.916 & \text { Yes }\end{array}$ $\begin{array}{lllllllllllllll}1.00 & 62.31 & 27.51 & 26.78 & 2 & 1486.7632 & 1486.7623 & 744.3884 & 0.0009 & 0.6045 & 563.970 & 904.536 & 254.987 & 108.834 & \text { Yes }\end{array}$ $\begin{array}{lllllllllllllll}1.00 & 71.17 & 28.41 & 45.54 & 2 & 1491.7654 & 1491.7659 & 746.8902 & -0.0005 & -0.3347 & 15005.189 & 22016.049 & 8095.178 & 117.926 & \text { Yes }\end{array}$ $\begin{array}{lllllllllllllll}1.00 & 73.42 & 28.33 & 24.47 & 2 & 1491.7676 & 1491.7659 & 746.8902 & 0.0017 & 1.1381 & 30079.373 & 44316.606 & 20451.918 & 1501.030 & \text { Yes } \\ 0.94 & 2.8 & 28.48 & 19.47 & 3 & 1491.7690 & 1491.765 & 49.262 & 0.031 & 2.0739 & 155.416 & 181.456 & 151.550 & 144.738 & \end{array}$ $\begin{array}{ccccccccccccccc}1.00 & 34.17 & 28.62 & 22.98 & 3 & 1491.7699 & 1491.7659 & 498.2626 & 0.0040 & 2.6760 & 101.374 & 84.140 & 262.986 & 29.791 & \text { No }\end{array}$ $\begin{array}{llllllllllllllll} & \end{array}$ $\begin{array}{llllllllllllllll} & \end{array}$ $\begin{array}{llllllllllllll} & \end{array}$

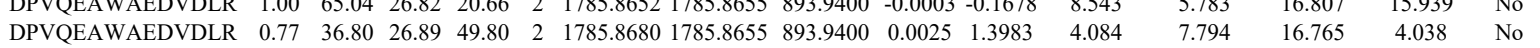

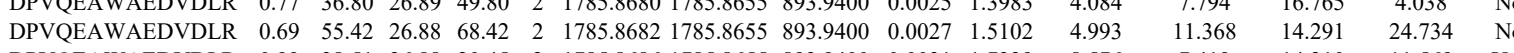

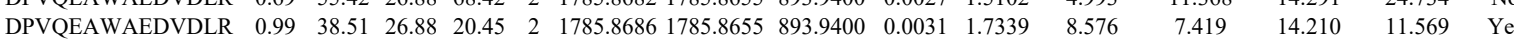

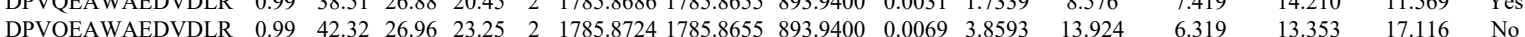

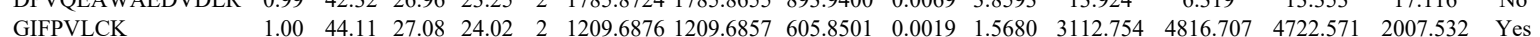
$\begin{array}{llllllllllllllll}\text { NTGIICTIGPASR } & 1.00 & 62.08 & 28.41 & 29.18 & 2 & 1491.7660 & 14917659 & 746.8902 & 0.0001 & 0.0669 & 10676.217 & 17013.518 & 57311810 & 2071.892 & \text { Yes }\end{array}$ NTGIICTIGPASR APIIAVTR
APIIAVTR APIIAVTR GIFPVLCK GIFPVLCK APIIAVTR APIIAVTR APIIAVTR $\begin{array}{lllllllllllllllll}\text { APIIAVTR } & 0.99 & 34.17 & 19.73 & 18.82 & 2 & 983.6246 & 983.6249 & 492.8197 & -0.0003 & -0.3044 & 312.090 & 297.170 & 393.392 & 288.375 & \text { Yes } \\ \text { APIIAVTR } & 0.99 & 30.72 & 19.29 & 18.90 & 2 & 983.6250 & 983.6249 & 492.8197 & 0.0001 & 0.1015 & 440.688 & 414.474 & 374.692 & 306.059 & \text { Yes }\end{array}$ $\begin{array}{llllllllllllllll}1.00 & 62.08 & 28.41 & 29.18 & 2 & 1491.7660 & 1491.7659 & 746.8902 & 0.0001 & 0.0669 & 10676.217 & 17013.518 & 5731.810 & 271.892 & \text { Yes } & \\ 1.00 & 78.46 & 28.37 & 27.36 & 2 & 1491.7666 & 1491.7659 & 746.8902 & 0.0007 & 0.4686 & 16789.261 & 24050.468 & 8051.317 & 221.881 & \text { Yes }\end{array}$ $\begin{array}{llllllllllllllll}0.94 & 32.97 & 20.49 & 18.30 & 2 & 983.6228 & 983.6249 & 492.8197 & -0.0021 & -2.1306 & 892.887 & 1048.826 & 1411.013 & 1101.561 & \text { Yes }\end{array}$ $\begin{array}{lllllllllllllll}0.98 & 37.21 & 20.49 & 16.80 & 2 & 983.6234 & 983.6249 & 4928197 & -0.0015 & -1.5219 & 678.839 & 878.824 & 1250.834 & 876.843 & \text { Yes }\end{array}$ $\begin{array}{lllllllllllllll}1.00 & 46.03 & 26.97 & 23.87 & 2 & 1209.6866 & 1209.6857 & 605.8501 & 0.0009 & 0.7428 & 474.585 & 839.694 & 650.142 & 221.391 & \text { Y }\end{array}$ $\begin{array}{lllllllllllllll}1.00 & 44.00 & 26.97 & 23.18 & 2 & 1209.6870 & 1209.6857 & 605.8501 & 0.0013 & 1.0729 & 545.584 & 755.824 & 897.948 & 299.968 & \text { Yes }\end{array}$ $\begin{array}{lllllllllllllll}0.99 & 37.46 & 19.73 & 19.70 & 2 & 983.6244 & 983.6249 & 492.8197 & -0.0005 & -0.5073 & 372.825 & 519.323 & 794.551 & 490.486 & \text { Yes }\end{array}$ $\begin{array}{llllllllllllllllll}0.99 & 31.37 & 19.73 & 18.83 & 2 & 983.6246 & 983.6249 & 492.8197 & -0.0003 & -0.3044 & 457.581 & 586.364 & 848.313 & 535.223 & \text { Yes }\end{array}$ $\begin{array}{lllllllllllllllll}0.99 & 32.73 & 19.29 & 18.71 & 2 & 983.6250 & 983.6249 & 492.8197 & 0.0001 & 0.1015 & 384.761 & 415.012 & 513.723 & 374.099 & \text { Yes }\end{array}$ $\begin{array}{lllllllllllllllll}0.99 & 32.33 & 19.29 & 24.56 & 2 & 983.6252 & 983.6249 & 492.8197 & 0.0003 & 0.3044 & 330.740 & 354.363 & 398.548 & 305.549 & \text { Yes }\end{array}$

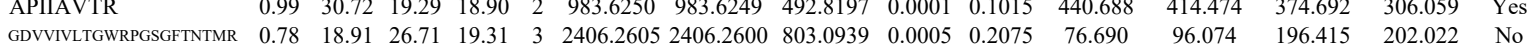
$\begin{array}{llllllllllllllll}\text { GDWNULTGWRPGSGFTNTMR } & 0.99 & 39.44 & 26.58 & 15.78 & 2 & 2406.2634 & 2406.2600 & 1204.1373 & 0.0034 & 1.4118 & 0.000 & 3.338 & 1.482 & 3.006 & \text { No }\end{array}$ $\begin{array}{llllllllllllllll}\text { GDVVIVLTGWRPGSGFTNTMR } & 0.77 & 19.09 & 27.13 & 15.28 & 3 & 2422.2550 & 2422.2549 & 808.4256 & 0.0001 & 0.0412 & 128.438 & 130.301 & 220.962 & 213.102 & \text { Yes }\end{array}$ $\begin{array}{llllllllllllllll}\text { GDVVIVLTGWRPGSGFTNTMR } & 0.98 & 27.29 & 27.13 & 16.79 & 3 & 2422.2556 & 2422.2549 & 808.4256 & 0.0007 & 0.2886 & 77.485 & 130.319 & 220.329 & 275.845 & \text { No } \\ \text { APIIAVTR } & 0.98 & 28.67 & 19.29 & 18.36 & 2 & 983.6250 & 983.6249 & 492.8197 & 0.0001 & 0.1015 & 331.223 & 406.536 & 517.041 & 401.439 & \text { Yes }\end{array}$ APIIAVTR $\begin{array}{lllllllllllllll} & 0.97 & 26.24 & 19.29 & 18.25 & 2 & 983.6252 & 983.6249 & 492.8197 & 0.0003 & 0.3044 & 229.786\end{array}$

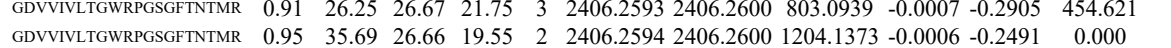

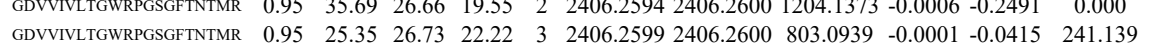

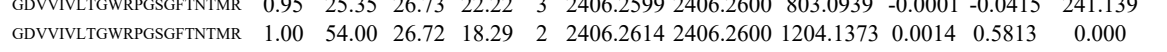
$\begin{array}{llllllllllll}\text { GDVVIVLTGWRPGSGFTNTMR } & 0.97 & 24.07 & 26.61 & 20.79 & 3 & 2406.2629 & 2406.2600 & 803.0939 & 0.0029 & 1.2037 & 17.270\end{array}$

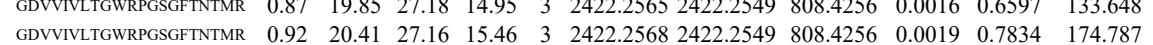
$\begin{array}{lllllllllllll}\text { APIIAVTR } & 0.99 & 30.21 & 19.73 & 19.23 & 2 & 983.6248 & 983.6249 & 492.8197 & -0.0001 & -0.1015 & 288.809 & \end{array}$ 

$\begin{array}{llllllllllll}\text { KGDVVIVLTGWRPGSGFTNTMR } & 0.53 & 13.22 & 24.00 & 26.22 & 3 & 2678.4601 & 2678.4570 & 893.8263 & 0.0031 & 1.1561 & 31.413\end{array}$

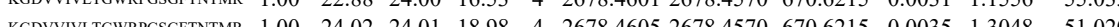

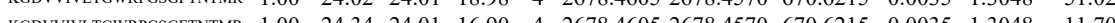
KCDVIVITGWPPGG

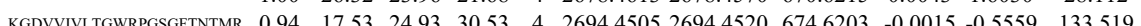
$\begin{array}{llllllllllll}\text { KGDVVIVITGWRPGSGTNTMR } & 1.00 & 21.33 & 24.87 & 34.33 & 4 & 2694.4521 & 2694.4520 & 674.6203 & 0.0001 & 0.0371 & 120.166\end{array}$

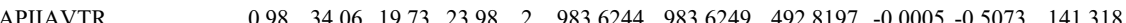
APIIAVTR $\begin{array}{llllllllllll}\text { DPVQEAWAEDVDLR } & 1.00 & 90.18 & 26.83 & 25.36 & 2 & 1785.8656 & 1785.8655 & 893.9400 & 0.0001 & 0.0559 & 12.801\end{array}$ $\begin{array}{lllllllllllll}\text { DPVQEAWAEDVDLR } & 1.00 & 83.62 & 26.83 & 25.48 & 2 & 1785.8656 & 1785.8655 & 893.9400 & 0.0001 & 0.0559 & 18.124\end{array}$ $\begin{array}{llllllllllll}\text { DPVQEAWAEDVDLR } & 1.00 & 79.62 & 26.83 & 27.74 & 2 & 1785.8658 & 1785.8655 & 893.9400 & 0.0003 & 0.1678 & 97.656\end{array}$ $\begin{array}{lllllllllllll}\text { DPVQEAWAEDVDLR } & 1.00 & 68.92 & 26.83 & 22.47 & 2 & 1785.8658 & 1785.8655 & 893.9400 & 0.0003 & 0.1678 & 23.327\end{array}$ $\begin{array}{lllllllllllll}\text { DPVQEAWAEDVDLR } & 1.00 & 83.83 & 26.87 & 23.80 & 2 & 1785.8662 & 1785.8655 & 893.9400 & 0.0007 & 0.3915 & 23.344\end{array}$ $\begin{array}{llllllllllllll}\text { DPVQEAWAEDVDLR } & 1.00 & 63.07 & 26.81 & 21.07 & 2 & 1785.8666 & 1785.8655 & 893.9400 & 0.0011 & 0.6153 & 13.576\end{array}$ $\begin{array}{llllllllllll}\text { DPVQEAWAEDVDLR } & 1.00 & 70.48 & 26.77 & 20.65 & 2 & 1785.8668 & 1785.8655 & 893.9400 & 0.0013 & 0.7271 & 21.28\end{array}$ $\begin{array}{llllllllllllll}\text { DPVQEAWAEDVDLR } & 1.00 & 87.29 & 26.77 & 23.51 & 2 & 1785.8668 & 1785.8655 & 893.9400 & 0.0013 & 0.7271 & 40.233\end{array}$ $\begin{array}{llllllllllll}\text { DPVQEAWAEDVDLR } & 1.00 & 90.98 & 26.77 & 25.64 & 2 & 1785.8668 & 1785.8655 & 893.9400 & 0.0013 & 0.7271 & 12.132 \\ \text { DPVQEAWAEDVDLR } & 1.00 & 72.14 & 26.77 & 25.18 & 2 & 1785.8668 & 1785.8655 & 893.9400 & 0.0013 & 0.7271 & 5.038\end{array}$ $\begin{array}{llllllllllll}\text { DPVQEAWAEDVDLR } & 1.00 & 72.14 & 26.77 & 25.18 & 2 & 1785.8668 & 1785.8655 & 893.9400 & 0.0013 & 0.7271 & 5.038 \\ \text { DPVQEAWAEDVDLR } & 1.00 & 75.44 & 26.78 & 24.65 & 2 & 1785.8670 & 1785.8655 & 893.9400 & 0.0015 & 0.8390 & 25.140\end{array}$ $\begin{array}{lllllllllllll}\text { DPVQEAWAEDVDLR } & 1.00 & 75.44 & 26.78 & 24.65 & 2 & 1785.8670 & 1785.8655 & 893.9400 & 0.0015 & 0.8390 & 25.140 \\ \text { DPVQEAWAEDVDLR } & 1.00 & 70.39 & 26.78 & 25.37 & 2 & 1785.8670 & 1785.8655 & 893.9400 & 0.0015 & 0.8390 & 23.144\end{array}$ $\begin{array}{llllllllllll}\text { DPVQEAWAEDVDLR } & 1.00 & 70.39 & 26.78 & 25.37 & 2 & 1785.8670 & 1785.8655 & 893.9400 & 0.0015 & 0.8390 & 23.144 \\ \text { DPVQEAWAEDVDLR } & 1.00 & 83.37 & 26.78 & 23.50 & 2 & 1785.8670 & 1785.8655 & 893.9400 & 0.0015 & 0.8390 & 818.603\end{array}$ $\begin{array}{llllllllllll}\text { DPVQEAWAEDVDLR } & 1.00 & 83.37 & 26.78 & 23.50 & 2 & 1785.8670 & 1785.8655 & 893.9400 & 0.0015 & 0.8390 & 818.603 \\ \text { DPVQEAWAEDVDLR } & 1.00 & 88.87 & 26.78 & 23.98 & 2 & 1785.8670 & 1785.8655 & 893.9400 & 0.0015 & 0.8390 & 9.153\end{array}$ $\begin{array}{llllllllllll}\text { DPVQEAWAEDVDLR } & 1.00 & 88.87 & 26.78 & 23.98 & 2 & 1785.8670 & 1785.8655 & 893.9400 & 0.0015 & 0.8390 & 9.153 \\ \text { DPVQEAWAEDVDLR } & 1.00 & 88.29 & 26.83 & 24.07 & 2 & 1785.8672 & 1785.8655 & 893.9400 & 0.0017 & 0.9508 & 18.737\end{array}$ $\begin{array}{llllllllllllll}\text { DPVQEAWAEDVDLR } & 1.00 & 70.03 & 26.83 & 22.23 & 2 & 1785.8672 & 1785.8655 & 893.9400 & 0.0017 & 0.9508 & 155.067 \\ \text { DPVQEAWAEDVDLR R } & 1.00 & 75.39 & 26.83 & 23.95 & 2 & 1785.8672 & 1785.8655 & 893.9400 & 0.0017 & 0.9508 & 17.176\end{array}$ $\begin{array}{lllllllllllll} & 0.9308\end{array}$ $\begin{array}{llllllllllll}\text { DPVQEAWAEDVDLR } & 0.99 & 28.60 & 26.83 & 18.63 & 3 & 1785.8674 & 1785.8655 & 596.2958 & 0.0019 & 1.0621 & 64.041\end{array}$ $\begin{array}{lllllllllllll}\text { DPVQEAWAEDVDLR } & 1.00 & 81.89 & 26.84 & 22.74 & 2 & 1785.8674 & 1785.8655 & 893.9400 & 0.0019 & 1.0627 & 14.506\end{array}$ $\begin{array}{lllllllllllll}\text { DPVQEAWAEDVDLR } & 1.00 & 67.23 & 26.84 & 25.36 & 2 & 1785.8674 & 1785.8655 & 893.9400 & 0.0019 & 1.0627 & 26.657 \\ \text { DPVQEAWAEDVDLR } & 1.00 & 75.78 & 26.84 & 23.38 & 2 & 1785.8674 & 1785.8655 & 893.9400 & 0.0019 & 1.0627 & 169.973\end{array}$ $\begin{array}{llllllllllllll}\text { DPVQEAWAEDVDLR } & 1.00 & 75.78 & 26.84 & 23.38 & 2 & 1785.8674 & 1785.8655 & 893.9400 & 0.0019 & 1.0627 & 169.973\end{array}$ $\begin{array}{lllllllllllll}\text { DPVQEAWAEDVDLR } & 1.00 & 85.58 & 26.84 & 23.50 & 2 & 1785.8674 & 1785.8655 & 893.9400 & 0.0019 & 1.0627 & 10.406\end{array}$ $\begin{array}{lllllllllllll}\text { DPVQEAWAEDVDLR } & 1.00 & 84.50 & 26.84 & 23.37 & 2 & 1785.8674 & 1785.8655 & 893.9400 & 0.0019 & 1.0627 & 21.969\end{array}$ $\begin{array}{lllllllllllll}\text { DPVQEAWAEDVDLR } & 1.00 & 65.78 & 26.87 & 23.91 & 2 & 1785.8676 & 1785.8655 & 893.9400 & 0.0021 & 1.1746 & 20.043\end{array}$ $\begin{array}{llllllllllll}\text { DPVQEAWAEDVDLR } & 1.00 & 97.34 & 26.87 & 27.31 & 2 & 1785.8676 & 1785.8655 & 893.9400 & 0.0021 & 1.1746 & 18.719\end{array}$

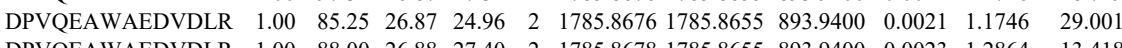
$\begin{array}{llllllllllll}\text { DPVQEAWAEDVDLR } & 1.00 & 88.00 & 26.88 & 27.40 & 2 & 1785.8678 & 1785.8655 & 893.9400 & 0.0023 & 1.2864 & 13.418\end{array}$ $\begin{array}{llllllllllll}\text { DPVQEAWAEDVDLR } & 1.00 & 69.81 & 26.88 & 22.05 & 2 & 1785.8678 & 1785.8655 & 893.9400 & 0.0023 & 1.2864 & 23.007 \\ \text { DPVQEAWAEDVDLR } & 0.65 & 13.31 & 26.89 & 16.19 & 3 & 1785.860 & 1785.865 & 596.2958 & 0.0025 & 1.395 & 132.193\end{array}$ $\begin{array}{llllllllllll}\text { DPVQEAWAEDVDLR } & 0.65 & 13.31 & 26.89 & 16.19 & 3 & 1785.8680 & 1785.8655 & 596.2958 & 0.0025 & 1.3975 & 132.193 \\ \text { DPVQEAWAEDVDLR } & 1.00 & 73.32 & 2689 & 27.56 & 2 & 1755.8680 & 1755.8655 & 893.9400 & 0.0025 & 1.3983 & 16.827\end{array}$ $\begin{array}{llllllllllllll}\text { DPVQEAWAEDVDLR } & 1.00 & 73.32 & 26.89 & 27.56 & 2 & 1785.8680 & 1785.8655 & 893.9400 & 0.0025 & 1.3983 & 16.827\end{array}$ $\begin{array}{lllllllllllll}\text { DPVQEAWAEDVDLR } & 1.00 & 86.33 & 26.89 & 24.67 & 2 & 1785.8680 & 1785.8655 & 893.9400 & 0.0025 & 1.3983 & 14.262 \\ \text { DPVQEAWAEDVDLR } & 1.00 & 87.71 & 26.89 & 25.88 & 2 & 1785.8680 & 1785.8655 & 893.9400 & 0.0025 & 1.3983 & 33.543\end{array}$ $\begin{array}{lllllllllllll}\text { DPVQEAWAEDVDLR } & 1.00 & 87.71 & 26.89 & 25.88 & 2 & 1785.8680 & 1785.8655 & 893.9400 & 0.0025 & 1.3983 & 33.543 \\ \text { DPVQEAWAEDVDLR } & 1.00 & 85.05 & 26.89 & 24.64 & 2 & 1785.8680 & 1785.8655 & 893.9400 & 0.0025 & 1.3983 & 7.195\end{array}$ $\begin{array}{llllllllllll}\text { DPVQEAWAEDVDLR } & 1.00 & 85.05 & 26.89 & 24.64 & 2 & 1785.8680 & 1785.8655 & 893.9400 & 0.0025 & 1.3983 & 7.195 \\ \text { DPVQEAWAEDVDLR } & 0.81 & 16.59 & 26.88 & 16.32 & 3 & 1785.8683 & 1785.8655 & 596.2958 & 0.0028 & 1.5652 & 156.346\end{array}$ $\begin{array}{llllllllllllll}\text { DPVQEAWAEDVDLR } & 1.00 & 55.14 & 26.88 & 17.04 & 3 & 1785.8683 & 1785.8655 & 596.2958 & 0.0028 & 1.5652 & 54.210\end{array}$ $\begin{array}{lllllllllllll}\text { DPVQEAWAEDVDLR } & 1.00 & 71.53 & 26.88 & 25.65 & 2 & 1785.8684 & 1785.8655 & 893.9400 & 0.0029 & 1.6220 & 15.145 \\ \text { DPVQEAWAEDVDLR } & 1.00 & 83.69 & 26.91 & 29.62 & 2 & 1785.8688 & 1785.8655 & 893.9400 & 0.0033 & 1.8458 & 18.597\end{array}$ $\begin{array}{llllllllllll}\text { DPVQEAWAEDVDLR } & 1.00 & 83.69 & 26.91 & 29.62 & 2 & 1785.8688 & 1785.8655 & 893.9400 & 0.0033 & 1.8458 & 18.597\end{array}$ $\begin{array}{llllllllllll}\text { DPVQEAWAEDVDLR } & 1.00 & 50.94 & 26.72 & 23.15 & 3 & 1785.8692 & 1785.8655 & 596.2958 & 0.0037 & 2.0683 & 41.595\end{array}$ $\begin{array}{llllllllllll}\text { DPVQEAWAEDVDLR } & 0.60 & 13.59 & 26.88 & 15.08 & 3 & 1785.8698 & 1785.8655 & 596.2958 & 0.0043 & 2.4037 & 114.962\end{array}$

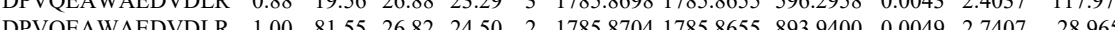
$\begin{array}{llllllllllll}\text { DPVQEAWAEDVDLR } & 0.98 & 28.37 & 26.87 & 19.17 & 3 & 1785.8707 & 1785.8655 & 596.2958 & 0.0052 & 2.9068 & 104.190\end{array}$

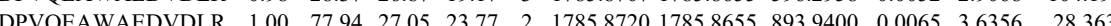
$\begin{array}{lllllllllllll}\text { APIILVTR } & 1.00 & 35.98 & 19.73 & 19.56 & 2 & 983.6248 & 983.6249 & 492.8197 & -0.0001 & -0.1015 & 154.195\end{array}$ 
APIIAVTR GDYPLEAVR APIAVTR

GDYPLEAVR

NTGIICTIGPASR NTGIICTIGPASR
APIIAVTR

NTGIICTIGPASR NTGIICTIGPASR APIIAVTR

NCSGAIVLTK

NTGIICTIGPASR

APIIAVTR

APIIAVTR

GIFPVLCK

CCSGAIIVLTK

NTGIICTIGPASR

NTGIICTIGPASR

APIIAVTR

GIFPVLCK

GIFPVLCK

CCSGAIIVLTK

CCSGAIIVLTK

NTGIICTIGPASR

NTGIICTIGPASR

GIFPVLCK

CCSGAIIVLTK

CCSGAIIVLTK

NTGIICTIGPASR
NTGIICTIGPASR

APIIAVTR

GIFPVLCK

GIFPVCK

CCSGAIIVLTK

CESAIIVLTK

NTGICTIGPASR

APIIAVTR
APIIAVTR

GIFPVLCK

GIFPVLCK

CCSGAIIVLTK

CCSGAIIVLTK

NTGIICTIGPASR

NTGIICTIGPASR

GSGTAEVELK

GSGTAEVELK

GSGTAEVELK

DPVQEAWAEDVDLR

APIIAVTR

APIIAVTR

CCSGAIIVLTK

NTGIICTIGPASR

GSGTAEVELK

GSGTAEVELK

GDLGIEIPAEK

GDLGIEIPAEK

NPQTAR

GDYPLEAVR

GDYPLEAVR

GDYLEAVR

GDYPLEAVR $\begin{array}{llllllllllll}0.99 & 33.86 & 19.29 & 19.38 & 2 & 983.6252 & 983.6249 & 492.8197 & 0.0003 & 0.3044 & 122.979\end{array}$

$\begin{array}{lllllllllll}.00 & 36.14 & 19.73 & 19.47 & 2 & 983.6246 & 983.6249 & 492.8197 & -0.0003 & -0.3044 & 124.817\end{array}$

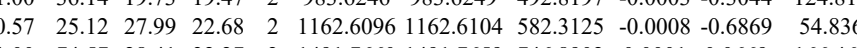
$\begin{array}{lllllllllll}1.00 & 74.57 & 28.41 & 32.27 & 2 & 1491.7660 & 1491.7659 & 746.8902 & 0.0001 & 0.0669 & 166.469\end{array}$ $\begin{array}{llllllllllll}1.00 & 83.09 & 28.38 & 23.40 & 2 & 1491.7662 & 1491.7659 & 746.8902 & 0.0003 & 0.2008 & 140.302\end{array}$ $\begin{array}{llllllllllll}1.00 & 34.27 & 19.14 & 23.78 & 2 & 983.6258 & 983.6249 & 492.8197 & 0.0009 & 0.9131 & 186.080\end{array}$ $\begin{array}{llllllllllll}1.00 & 34.27 & 19.14 & 23.78 & 2 & 983.6258 & 983.6249 & 492.8197 & 0.0009 & 0.9131 & 186.080\end{array}$ $\begin{array}{llllllllllll}1.00 & 81.20 & 28.41 & 38.58 & 2 & 1491.7660 & 983.6249 & 492.8197 & 0.0009 & 0.9131 & 157.613\end{array}$

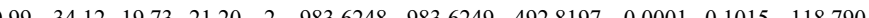
$\begin{array}{lllllllllll}0.99 & 32.18 & 19.29 & 22.75 & 2 & 983.6252 & 983.6249 & 492.8197 & 0.0003 & 0.3044 & 131.949\end{array}$ $\begin{array}{lllllllllllll}0.81 & 25.21 & 27.44 & 17.76 & 2 & 14867624 & 1486.7623 & 744.3884 & 0.0001 & 0.0672 & 126.059\end{array}$ $\begin{array}{lllllllllll}1.00 & 88.11 & 28.41 & 37.02 & 2 & 1491.7656 & 1491.7659 & 746.8902 & -0.0003 & -0.2008 & 98.655\end{array}$ $\begin{array}{lllllllllll}1.00 & 76.64 & 28.37 & 29.00 & 2 & 1491.7666 & 1491.7659 & 746.8902 & 0.0007 & 0.4686 & 152.885\end{array}$ $\begin{array}{llllllllllllll}0.99 & 31.93 & 19.73 & 18.33 & 2 & 983.6248 & 983.6249 & 492.8197 & -0.0001 & -0.1015 & 249.510\end{array}$ $\begin{array}{lllllllllll}0.97 & 46.04 & 27.06 & 22.37 & 2 & 1209.6832 & 1209.6857 & 605.8501 & -0.0025 & -2.0632 & 214.334\end{array}$ $\begin{array}{lllllllllll}0.99 & 39.01 & 27.17 & 23.90 & 2 & 1209.6854 & 1209.6857 & 605.8501 & -0.0003 & -0.2476 & 296.312\end{array}$ $\begin{array}{lllllllllll}0.99 & 37.99 & 27.45 & 19.52 & 2 & 1486.7620 & 1486.7623 & 744.3884 & -0.0003 & -0.2015 & 205.158\end{array}$ $\begin{array}{llllllllllll}1.00 & 74.63 & 28.38 & 25.53 & 2 & 1491.7662 & 1491.7659 & 746.8902 & 0.0003 & 0.2008 & 219.276\end{array}$ $\begin{array}{lllllllllll}1.00 & 67.38 & 28.37 & 23.49 & 2 & 1491.7666 & 1491.7659 & 746.8902 & 0.0007 & 0.4686 & 352.926\end{array}$ $\begin{array}{llllllllllll}0.99 & 32.56 & 19.73 & 23.46 & 2 & 983.6246 & 983.6249 & 492.8197 & -0.0003 & -0.3044 & 194.231\end{array}$ $\begin{array}{lllllllllll}0.94 & 35.38 & 27.16 & 23.33 & 2 & 1209.6852 & 1209.6857 & 605.8501 & -0.0005 & -0.4126 & 121.513\end{array}$ $\begin{array}{lllllllllll}0.97 & 33.55 & 27.10 & 20.51 & 2 & 1209.6858 & 1209.6857 & 605.8501 & 0.0001 & 0.0825 & 103.902 \\ 0.99 & 40.90 & 27.45 & 23.69 & 2 & 1486.7628 & 1486.7623 & 744.3884 & 0.0005 & 0.3358 & 87.522 \\ 1.00 & 45.62 & 27.43 & 23.59 & 2 & 148.7638 & 146.7623 & 74.384 & 0.005 & 1.0075 & 52.012\end{array}$ $\begin{array}{lllllllllll}1.00 & 45.62 & 27.43 & 23.59 & 2 & 1486.7638 & 1486.7623 & 744.3884 & 0.0015 & 1.0075 & 52.012\end{array}$ $\begin{array}{lllllllllll}1.00 & 93.15 & 28.38 & 26.01 & 2 & 1491.7662 & 1491.7659 & 746.8902 & 0.0003 & 0.2008 & 211.322\end{array}$ $\begin{array}{lllllllllll}1.00 & 80.57 & 28.38 & 23.81 & 2 & 1491.7662 & 1491.7659 & 746.8902 & 0.0003 & 0.2008 & 267.031\end{array}$ $\begin{array}{llllllllllll}0.98 & 35.24 & 27.10 & 21.20 & 2 & 1209.6858 & 1209.6857 & 605.8501 & 0.0001 & 0.0825 & 110.131\end{array}$ $\begin{array}{llllllllllll}1.00 & 54.24 & 27.40 & 23.83 & 2 & 1486.7618 & 1486.7623 & 744.3884 & -0.0005 & -0.3358 & 85.647 \\ 1.00 & 53.16 & 27.44 & 28.59 & 2 & 1486.7624 & 1486.7623 & 744.3884 & 0.0001 & 0.0672 & 73.853\end{array}$ $\begin{array}{llllllllllll}1.00 & 53.16 & 27.44 & 28.59 & 2 & 1486.7624 & 1486.7623 & 744.3884 & 0.0001 & 0.0672 & 73.853 \\ 1.00 & 73.98 & 28.41 & 43.64 & 2 & 1491.7660 & 1491.7659 & 746.8902 & 0.0001 & 0.0669 & 224.220\end{array}$ $\begin{array}{llllllllllll}1.00 & 73.98 & 28.41 & 43.64 & 2 & 1491.7660 & 1491.7659 & 746.8902 & 0.0001 & 0.0669 & 224.220 \\ 1.00 & 78.98 & 28.37 & 25.41 & 2 & 1491.7664 & 1491.7659 & 746.8902 & 0.0005 & 0.3347 & 262.593\end{array}$ $\begin{array}{llllllllllll}1.00 & 78.98 & 28.37 & 25.41 & 2 & 1491.7664 & 4491.7659 & 746.8902 & 0.0005 & 0.3347 & 262.593 \\ 1.00 & 34.92 & 19.29 & 18.76 & 2 & 983.6250 & 983.6249 & 492.8197 & 0.0001 & 0.1015 & 146.052\end{array}$ $\begin{array}{llllllllllll}1.00 & 34.92 & 19.29 & 18.76 & 2 & 983.6250 & 983.6249 & 492.8197 & 0.0001 & 0.1015 & 146.052 \\ 0.52 & 30.47 & 26.77 & 17.90 & 2 & 1209.6826 & 1209.6857 & 605.8501 & -0.0031 & -2.5584 & 40.864 \\ 0.95 & 3.8 & 27.17 & 18.82 & 2 & 209.6854 & 1209.6857 & 65.8501 & -0.0003 & -0.2276 & 59.174\end{array}$ $\begin{array}{lllllllllll}0.52 & 30.47 & 26.77 & 17.90 & 2 & 1209.6826 & 1209.6857 & 605.8501 & -0.0031 & -2.5584 & 40.864 \\ 0.95 & 31.08 & 27.17 & 18.82 & 2 & 1209.6854 & 1209.6857 & 605.8501 & -0.0003 & -0.2476 & 59.174\end{array}$ $\begin{array}{lllllllllll}0.95 & 1.08 & 27.17 & 18.82 & 2 & 1209.6854 & 1209.6857 & 655.8501 & -0.0003 & -0.2476 & 59.174 \\ 1.00 & 67.21 & 27.45 & 24.56 & 2 & 1486.7628 & 1486.7623 & 744.3884 & 0.0005 & 0.3358 & 48.438\end{array}$ $\begin{array}{llllllllllll}00 & 52.84 & 27.40 & 22.64 & 2 & 1486.7640 & 1486.7623 & 744.3884 & 0.0017 & 1.1419 & 21.788\end{array}$ $\begin{array}{llllllllll}1.00 & 1491.7662 & 1491.7659 & 746.8902 & 0.0003 & 0.2008 & 205.455\end{array}$ $\begin{array}{lllllllllllllllll}0.95 & 33.20 & 20.49 & 23.07 & 2 & 983.6234 & 983.6249 & 492.8197 & -0.0015 & 1.5219 & 206.888 & 3\end{array}$ $\begin{array}{llllllllllllll}1.00 & 35.05 & 19.73 & 23.94 & 2 & 983.6246 & 983.6249 & 492.8197 & -0.0003 & -0.3044 & 142.167\end{array}$ $\begin{array}{lllllllllll}0.98 & 36.64 & 27.12 & 21.15 & 2 & 1209.6856 & 1209.6857 & 605.8501 & -0.0001 & -0.0825 & 27.005\end{array}$ $\begin{array}{llllllllllll}0.97 & 33.35 & 27.10 & 19.56 & 2 & 1209.6860 & 1209.6857 & 605.8501 & 0.0003 & 0.2476 & 60.981\end{array}$ $\begin{array}{llllllllllll}1.00 & 52.16 & 27.26 & 22.20 & 2 & 1486.7612 & 1486.7623 & 744.3884 & -0.0011 & -0.7389 & 76.031\end{array}$ $\begin{array}{lllllllllll}1.00 & 48.26 & 27.51 & 19.72 & 2 & 1486.7632 & 1486.7623 & 744.3884 & 0.0009 & 0.6045 & 40.440\end{array}$ $\begin{array}{llllllllllll}1.00 & 75.88 & 28.37 & 23.51 & 2 & 1491.7664 & 1491.7659 & 746.8902 & 0.0005 & 0.3347 & 253.894\end{array}$ $\begin{array}{lllllllllll}1.00 & 78.68 & 28.33 & 26.98 & 2 & 1491.7670 & 1491.7659 & 746.8902 & 0.0011 & 0.7364 & 181.053\end{array}$ $\begin{array}{lllllllllllll}0.99 & 52.00 & 28.06 & 31.43 & 2 & 1277.7040 & 1277.7071 & 639.8608 & -0.0031 & -2.4224 & 4528.267 & 7042.0\end{array}$ $\begin{array}{llllllllllllllll}1.00 & 55.07 & 28.19 & 36.42 & 2 & 1277.7092 & 1277.7071 & 639.8608 & 0.0021 & 1.6410 & 12005.038 & 18659.160 & 31855.051 & 29388.360 & \text { Yes }\end{array}$ $\begin{array}{lllllllllll}1.00 & 65.88 & 26.88 & 22.25 & 2 & 1785.8678 & 1785.8655 & 893.9400 & 0.0023 & 1.2864 & 1.028\end{array}$ $\begin{array}{llllllllllll}0.61 & 20.69 & 19.73 & 33.69 & 2 & 983.6248 & 983.6249 & 492.8197 & -0.0001 & -0.1015 & 36.334\end{array}$ $\begin{array}{llllllllllll}1.00 & 51.40 & 27.43 & 20.77 & 2 & 1486.7638 & 1486.7623 & 744.3884 & 0.0015 & 1.0075 & 10.301\end{array}$

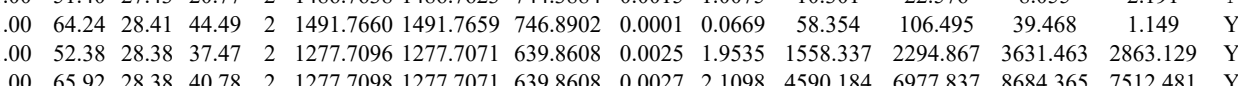
22.576 $\begin{array}{lllllllllllllll}1.00 & 88.35 & 27.38 & 32.10 & 2 & 1428.8078 & 1428.8068 & 715.4107 & 0.0010 & 0.6989 & 3919.273 & 5737.969 & 86818.776 & 5642.532 & \text { Yes }\end{array}$ $\begin{array}{lllllllllllllll}1.00 & 66.40 & 27.25 & 27.14 & 2 & 1428.8080 & 1428.8068 & 715.4107 & 0.0012 & 0.8387 & 881.681 & 904.918 & 1914.459 & 1473.614 & \text { Yes }\end{array}$ $\begin{array}{lllllllllllllllll}0.85 & 26.02 & 26.95 & 32.52 & 2 & 829.4526 & 829.4528 & 415.7337 & -0.0002 & -0.2405 & 107.031 & 145.439 & 200.052 & 185.756 & \text { Yes } \\ 0.58 & 21.12 & 28.10 & 19.07 & 2 & 1162.6100 & 1162.6104 & 582.3125 & -0.0004 & -0.345 & 114.520 & 146.349 & 199.232 & 175.498 & \text { Yes }\end{array}$ $\begin{array}{lllllllllllllll}0.58 & 21.12 & 28.10 & 19.07 & 2 & 1162.6100 & 1162.6104 & 582.3125 & -0.0004 & -0.3435 & 114.520 & 146.349 & 199.232 & 175.498 & \text { Yes } \\ 0.84 & 23.84 & 28.09 & 20.95 & 2 & 1162.6118 & 11626104 & 582.3125 & 0.0014 & 1.2021 & 190.045 & 257.405 & 309.892 & 234.484 & \text { Yes }\end{array}$

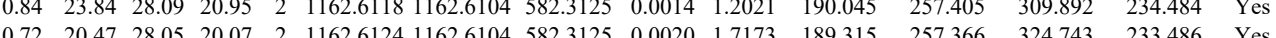
$\begin{array}{llllllllllllllll}0.82 & 28.27 & 28.16 & 22.92 & 2 & 1162.6204 & 1162.6104 & 582.3125 & 0.0100 & 8.5864 & 2453.3127 & 3926.239 & 5860.899 & 6988.824 & \text { No }\end{array}$

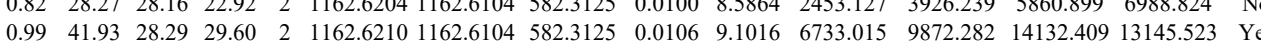


GDYPLEAVR GDLGIEIPAEK

GDLGIEIPAEK

GDLGIEIPAEK

GDLGIEIPAEK

GDLGIEIPAEK

GDLGIEIPAEK

GDYPLEAVR

GDYPLEAVR

GDYPEAVR

GDYPLEAVR

GDLGIEIPAEK

72 GLFDEYGSK

GVVDSDDLPLNVSR

LISLTDENALSGNEELTYK

LISLTDENALSGNEELTVK

LISLTDENALSGNEELTVK

LISLTDENALS
AQAYQTGK

AQAYQTGK

SGTSEFLNK

SGTSEFLNK

SGTSEFLNK

DISTNYYASQK

DISTNYYASQK

GVVDSDDLPLNVSR

GVVDSDDLPLNVSR

LISLTDENALSGNEEL
LSLNIDPDAK

LSLNIDPDAK

DISTNYYASQK

DISTNYYASQ

AQAYQTGK

SGYLLPDTK
SGYLLPDTK

SGYLLPDTK

LSLNIDPDAK

SGYLLPDTK

SGYLLPDTK

EDEDDKTVLDLAVVLFE

VFITDDFHDMMPK

FITDDFHDMMPK

EDEDDKTVLDLAVVLFETATLR

EDEDDKTVLDLAVVLFETATL
VFITDDFHDMMPK

VFITDDFHDMMPK

VFITDDFHDMMPK

VFITDDFHDMMPK

EDEDDKTVLDLAVVLFETAT

EDEDDKTVLDLAVVLFETATLR

EDEDDKTVLDLAVVLFETATLR
EDEDDKTVLDLAVVLFETATLR

EDEDDKTVLDLAV

NLLHVTDTGVGMT

NLLHVTDTGVGMTR

NLLHVTDTGVGMTR
NLLHVTDTGVGMTR

NLLHVTDTGVGMTR
LTESPCALVASQYGWSGNMER

LIINSLYK

LIINSLY

LIINSLYK

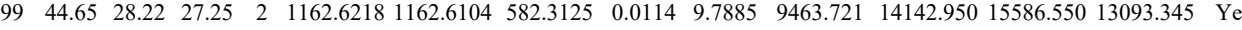

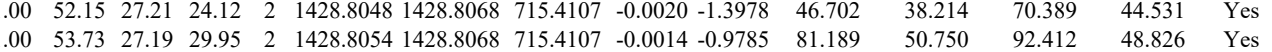
$\begin{array}{lllllllllllllllll}0.95 & 23.93 & 27.28 & 20.69 & 3 & 1428.8080 & 1428.8068 & 477.2762 & 0.0012 & 0.8381 & 43.807 & 83.913 & 143.769 & 188.569 & \text { No }\end{array}$ $\begin{array}{lllllllllllllll}1.00 & 65.03 & 27.19 & 24.65 & 2 & 1428.8082 & 1428.8068 & 715.4107 & 0.0014 & 0.9785 & 17518.275 & 33285.765 & 47756.300 & 180838.017 & \text { Yes }\end{array}$

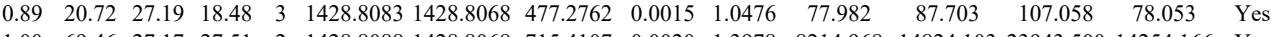
$\begin{array}{llllllllllllllll}1.00 & 69.46 & 27.17 & 27.51 & 2 & 1428.8088 & 1428.8068 & 715.4107 & 0.0020 & 1.3978 & 8214.968 & 14824.103 & 23943.500 & 14254.166 & \text { Yes }\end{array}$ \begin{tabular}{lllllllllllllll}
0.65 & 30.26 & 27.63 & 21.60 & 2 & 1162.6084 & 1162.6104 & 582.3125 & -0.0020 & -1.7173 & 126.214 & 167.613 & 156.971 & 165.021 & Yes \\
\hline .89 & 25.84 & 28.08 & 20.91 & 2 & 1162.6112 & 1162.6104 & 582.3125 & 0.0008 & 0.6869 & 96.677 & 85.616 & 114768 & 126.070 & Yes
\end{tabular}

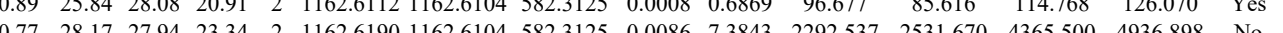

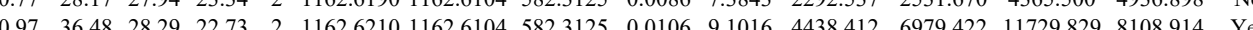

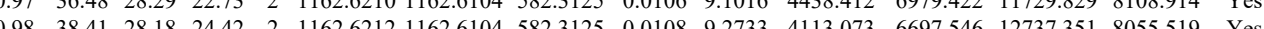

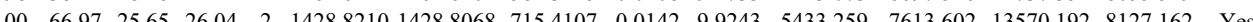

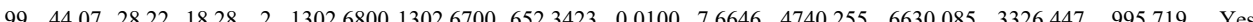
$\begin{array}{lllllllllllllll}1.00 & 89.62 & 27.85 & 33.94 & 2 & 1628.8634 & 1628.8492 & 815.4319 & 0.0142 & 87070 & 2504.637 & 2873.133 & 4885087 & 2932.748 & \text { Yes }\end{array}$ $\begin{array}{lllllllllllllll}100 & \# \# \# \# 27.95 & 33.43 & 2 & 1628.8638 & 1628.8492 & 815.4319 & 0.0146 & 8.9522 & 3108.924 & 5241.271 & 6728.437 & 5746.361 & \text { Yes }\end{array}$ $\begin{array}{llllllllllllllll}100 & \# \# \# \#+27.80 & 33.28 & 2 & 1628.8614 & 1628.8492 & 815.4319 & 0.0122 & 7.4806 & 1560.190 & 2121.732 & 2456.494 & 1799.966 & \text { Yes }\end{array}$ $\begin{array}{lllllllllllllll}1.00 & 84.50 & 26.05 & 23.06 & 2 & 2333.2554 & 2333.2569 & 1167.6357 & -0.0015 & -0.6423 & 7.928 & 8.303 & 0.489 & 4.122 & \text { No }\end{array}$ $\begin{array}{lllllllllllllll}1.00 & 70.96 & 25.83 & 39.16 & 2 & 2333.2594 & 2333.2569 & 1167.6357 & 0.0025 & 1.0705 & 5.636 & 13.134 & 7.684 & 0.000 & \text { No }\end{array}$

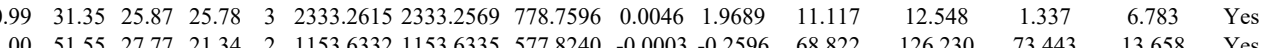

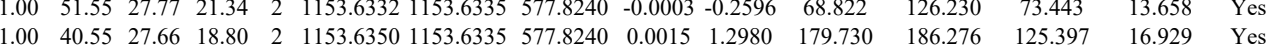

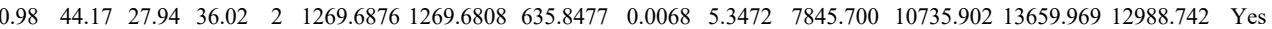
$\begin{array}{llllllllllllllll}0.97 & 39.94 & 27.94 & 32.15 & 2 & 1269.6876 & 1269.6808 & 635.8477 & 0.0068 & 5.3472 & 10966.042 & 13007.750 & 17791.290 & 17210.175 & \text { Yes }\end{array}$ $\begin{array}{lllllllllllllll}0.83 & 29.40 & 27.51 & 28.64 & 2 & 1269.6894 & 1269.6808 & 635.8477 & 0.0086 & 6.7626 & 20574.433 & 22541.572 & 24059.177 & 18237.094 & \text { Yes }\end{array}$ $\begin{array}{lllllllllllllll}1.00 & 78.36 & 27.47 & 31.76 & 2 & 1576.8048 & 1576.7977 & 789.4061 & 0.0071 & 4.4970 & 3048.910 & 2988.014 & 11080.255 & 10274.546 & \text { No }\end{array}$

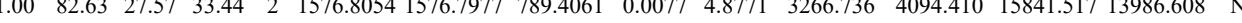

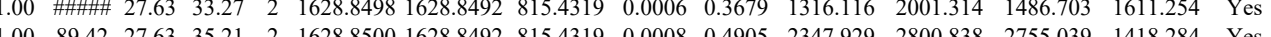

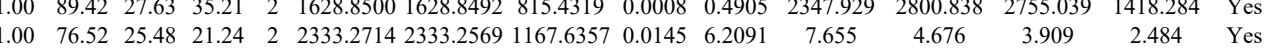

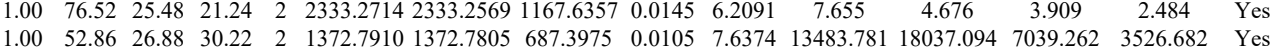
$\begin{array}{llllllllllllllllll}1.00 & 56.22 & 26.78 & 27.02 & 2 & 1372.7920 & 1372.7805 & 687.3975 & 0.0115 & 8.3648 & 12090.007 & 16200.500 & 6364.934 & 2523.402 & \text { Yes }\end{array}$ $\begin{array}{lllllllllllllll}1.00 & 65.79 & 27.59 & 32.53 & 2 & 1576.8032 & 1576.7977 & 789.4061 & 0.0055 & 3.4836 & 1178.065 & 992.730 & 4143.759 & 3367.760 & \text { No }\end{array}$ $\begin{array}{lllllllllllllll}1.00 & 61.46 & 27.63 & 24.52 & 2 & 1576.8042 & 1576.7977 & 789.4061 & 0.0065 & 4.1170 & 1253.638 & 1063.111 & 5442.344 & 4064.662 & \text { No }\end{array}$

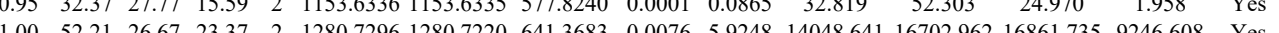
$\begin{array}{llllllllllllllllll}1.00 & 52.21 & 26.67 & 23.37 & 2 & 1280.7296 & 1280.7220 & 641.3683 & 0.0076 & 5.9248 & 14048.641 & 16702.962 & 16861.735 & 9246.608 & \text { Yes } \\ 1.00 & 59.80 & 26.76 & 26.28 & 2 & 1280.7312 & 1280.7220 & 641.3683 & 0.0092 & 7.1721 & 9931.545 & 14525.869 & 16708.879 & 10303.613 & \text { Yes }\end{array}$ $\begin{array}{llllllllllllllllll}1.00 & 45.52 & 26.89 & 24.40 & 2 & 1872.7914 & 1372.7805 & 687.3875 & 0.0109 & 7.9284 & 14145.143 & 17784.186 & 5321.421 & 1793.793 & \text { Yes }\end{array}$

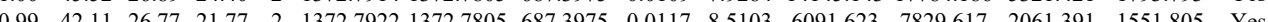
$\begin{array}{llllllllllllllll} & \end{array}$

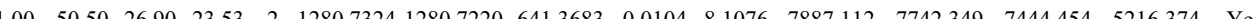
\begin{tabular}{llllllllllllll}
\hline & 02.805 & Yes
\end{tabular} $\begin{array}{lllllllllllllll}100 & 56.83 & 27.20 & 25.49 & 2 & 18829226 & 1882.9201 & 942.4673 & 0.0025 & 1.3263 & 480.366 & 578.889 & 167.549 & 24.294 & \text { Yes }\end{array}$ $\begin{array}{lllllllllllllll}0.99 & 39.21 & 27.35 & 21.68 & 3 & 1882.9384 & 1882.9201 & 628.6473 & 0.0183 & 9.7033 & 8518.768 & 10457.094 & 174.633 & 400.858 & \text { Yes }\end{array}$ $\begin{array}{lllllllllllllll}0.99 & 21.44 & 25.13 & 14.58 & 4 & 2779.4761 & 2779.4735 & 695.8757 & 0.0026 & 0.9341 & 120.312 & 123.938 & 111.524 & 72.126 & \text { Yes }\end{array}$ \begin{tabular}{lllllllllllllll}
1.00 & 62.36 & 25.09 & 18.61 & 3 & 2779.4767 & 2779.4735 & 927.4984 & 0.0032 & 1.1500 & 8.807 & 12.519 & 18.828 & 12.903 & Yes \\
\hline
\end{tabular} $\begin{array}{lllllllllllllll}1.00 & 33.34 & 25.00 & 16.52 & 4 & 2779.4781 & 2779.4735 & 695.8757 & 0.0046 & 1.6526 & 105.153 & 135.361 & 94.236 & 78.487 & \text { Yes }\end{array}$ $\begin{array}{llllllllllllllll}1.00 & 40.17 & 27.19 & 21.81 & 3 & 1882.9219 & 1882.9201 & 628.6473 & 0.0018 & 0.9544 & 6647.343 & 8431.883 & 10.386 & 210.326 & \text { Yes }\end{array}$ $\begin{array}{llllllllllllllll}1.00 & 67.57 & 27.19 & 29.17 & 2 & 1882.9220 & 1882.9201 & 942.4673 & 0.0019 & 1.0080 & 357.399 & 516.606 & 50.628 & 17.356 & \text { Yes }\end{array}$ $\begin{array}{lllllllllllllll}1.00 & 33.32 & 27.20 & 21.15 & 3 & 1882.9225 & 1882.9201 & 628.6473 & 0.0024 & 1.2726 & 5710.440 & 7195.763 & 0.000 & 142.020 & \mathrm{No}\end{array}$ $\begin{array}{lllllllllllllll}.00 & 57.83 & 27.08 & 25.25 & 2 & 1882.9242 & 1882.9201 & 942.4673 & 0.0041 & 2.1751 & 206.314 & 277.212 & 56.361 & 26.462 & \text { Yes }\end{array}$ $\begin{array}{llllllllllllll}48.38 & 25.13 & 16.65 & 4 & 2779.4761 & 2779.4735 & 695.8757 & 0.0026 & 0.9341 & 74.416 & 67.066 & 69.264 & 94.810 & \text { Yes }\end{array}$ $\begin{array}{lllllllllllll} & \end{array}$

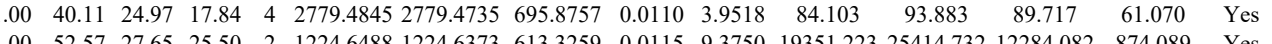
$\begin{array}{lllllllllllllll}1.00 & 67.98 & 27.53 & 26.34 & 2 & 1224.6488 & 1224.6373 & 613.3259 & 0.0115 & 9.3750 & 19351.223 & 25414.732 & 12284.082 & 874.089 & \text { Yes } \\ & 1656.8739 & 829.4442 & 0.0149 & 8.9818 & 1440.565 & 2323.721 & 40.605 & 25.710 & \text { Yes }\end{array}$ $\begin{array}{lllllllllllllll} & 1.1 .94 & 2 & 1656.8890 & 1656.8739 & 829.4442 & 0.0151 & 9.1024 & 2437.444 & 3488.647 & 207.113 & 25.286 & \text { Yes }\end{array}$ $\begin{array}{lllllllllllllllll}1.00 & 58.43 & 27.60 & 20.17 & 3 & 1656.8893 & 1656.8739 & 553.2986 & 0.0154 & 9.2776 & 9667.529 & 10834.292 & 1483.893 & 585.197 & \text { Yes }\end{array}$ $\begin{array}{llllllllllllllll}1.00 & 43.92 & 27.72 & 19.64 & 3 & 1656.8905 & 1656.8739 & 553.2986 & 0.0166 & \text { \#\#\#\#\# } 5532.924 & 6832.637 & 2076.427 & 4403.827 & \text { Yes }\end{array}$

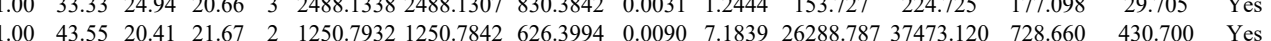
$\begin{array}{lllllllllllllll}00 & 50.69 & 20.45 & 21.90 & 2 & 1250.7944 & 1250.7842 & 6263994 & 0.0102 & 8.1417 & 38160.225 & 55131.934 & 0.000 & 628.884 & N\end{array}$

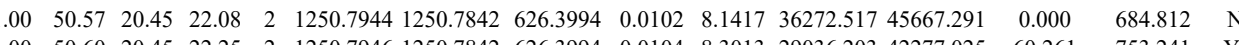

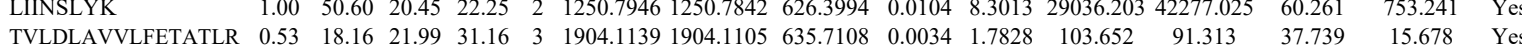

Table S-3 page 154 of 499 
$\begin{array}{lllllllllllll}\text { TVLDLAVVLFETATLR } & 1.00 & 91.38 & 22.17 & 27.67 & 2 & 1904.1128 & 1904.1105 & 953.0625 & 0.0023 & 1.2066 & 13.949 & 21.631\end{array}$

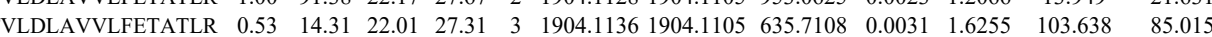

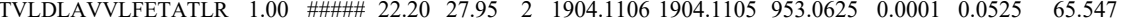
$\begin{array}{lllllllllll}\text { TVLDLAVVLFETATLR } & 1.00 & \text { \#2.20 } & 29.04 & 2 & 1904.1132 & 1904.1105 & 953.0625 & 0.0027 & 1.4165 & 83.399\end{array}$ $\begin{array}{lllllllllllll}\text { TVLDLAVVLFETATLR } & 0.53 & 31.30 & 22.20 & 44.30 & 3 & 1904.1133 & 1904.1105 & 635.7108 & 0.0028 & 1.4682 & 76.863 \\ \text { TVLDLAVVLFETATLR } & 0.53 & 25.79 & 21.99 & 38.79 & 3 & 1904.1139 & 1904.1105 & 635.7108 & 0.0034 & 1.7828 & 130.916\end{array}$ $\begin{array}{llllllllllll}\text { TVLDLAVVLFETATLR } & 0.53 & 25.79 & 21.99 & 38.79 & 3 & 1904.1139 & 1904.1105 & 635.7108 & 0.0034 & 1.7828 & 130.916 \\ \text { TVLDLAVVLFETATLR } & 1.00 & 39.45 & 21.82 & 16.32 & 3 & 1904.1145 & 1904.1105 & 635.7108 & 0.0040 & 2.0974 & 93.212\end{array}$

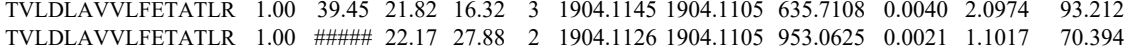
$\begin{array}{lllllllllll}\text { TVLDLAVVLFETATLR } & 1.00 & \text { \#\#\# 22.17 } & 27.88 & 2 & 1904.1126 & 1904.1105 & 953.0625 & 0.0021 & 1.1017 & 70.394 \\ \text { TVLDLAVVLFETATLR } & 1.00 & \text { \#\#\#\# } 22.17 & 28.23 & 2 & 1904.1126 & 1904.1105 & 953.0625 & 0.0021 & 1.1017 & 42.984\end{array}$

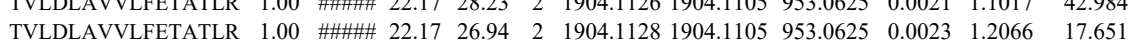
$\begin{array}{llllllllllll}\text { TVLDLAVVLFETATLR } & 0.53 & 19.39 & 22.20 & 32.39 & 3 & 1904.1133 & 1904.1105 & 635.7108 & 0.0028 & 1.4682 & 69.955\end{array}$ $\begin{array}{lllllllllllll}\text { TVLDLAVVLFETATLR } & 0.53 & 30.54 & 21.99 & 43.54 & 3 & 1904.1139 & 1904.1105 & 635.7108 & 0.0034 & 1.7828 & 42.032\end{array}$ $\begin{array}{lllllllllllll}\text { TVLDLAVVLFETATLR } & 1.00 & 67.59 & 21.73 & 30.36 & 2 & 1904.1146 & 1904.1105 & 953.0625 & 0.0041 & 2.1510 & 17.488\end{array}$ $\begin{array}{lllllllllllll}\text { TVLDLAVVLFETATLR } & 1.00 & 86.51 & 21.88 & 18.74 & 2 & 1904.1148 & 1904.1105 & 953.0625 & 0.0043 & 2.2559 & 25.335\end{array}$ $\begin{array}{lllllllllllll}\text { TVLDLAVVLFETATLR } & 1.00 & 61.62 & 21.30 & 20.22 & 2 & 1904.1184 & 1904.1105 & 953.0625 & 0.0079 & 4.1445 & 16.844\end{array}$ $\begin{array}{llllllllllll}\text { TVLDLAVVLFETATLR } & 1.00 & \text { \#\#\#\# } 22.12 & 28.54 & 2 & 1904.1112 & 1904.1105 & 953.0625 & 0.0007 & 0.3672 & 26.748\end{array}$ $\begin{array}{llllllllllll}\text { TVLDLAVVLFETATLR } & 0.55 & 16.87 & 22.23 & 29.87 & 3 & 1904.1124 & 1904.1105 & 635.7108 & 0.0019 & 0.9963 & 43.680\end{array}$ $\begin{array}{llllllllllllll}\text { TVLDLAVVLFETATLR } & 0.55 & 31.10 & 22.17 & 44.10 & 3 & 1904.1127 & 1904.1105 & 635.7108 & 0.0022 & 1.1536 & 27.964\end{array}$ $\begin{array}{lllllllllllll}\text { YSQFINFPIYVWSSK } & 0.85 & 17.79 & 27.13 & 17.57 & 3 & 2166.1414 & 2166.1393 & 723.0537 & 0.0021 & 0.9681 & 8.155\end{array}$ $\begin{array}{lllllllllllll}\text { YSOFINFPIYVWSSK } & 0.69 & 14.39 & 27.10 & 18.30 & 3 & 2166.1420 & 2166.1393 & 723.0537 & 0.0027 & 1.2447 & 18.498\end{array}$ EVEEDEYK EVEEDEYK SILFVPTSAPR $\begin{array}{lllllllllll}1.00 & 43.23 & 26.80 & 25.50 & 2 & 1327.6396 & 1327.6387 & 664.8266 & 0.0009 & 0.6769 & 980.701\end{array}$ $\begin{array}{llllllllllllll} & \end{array}$

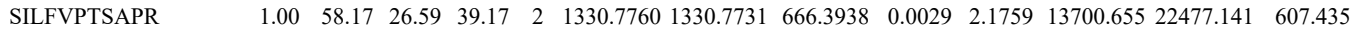
$\begin{array}{llllllllllllll}\text { TVLDLAVVLFETATLR } & 0.98 & 20.23 & 22.17 & 17.17 & 3 & 1904.1127 & 1904.1105 & 635.7108 & 0.0022 & 1.1536 & 36.508 & 32.161 & 7.324 \\ \text { YSQFINFPIYVWSSK } & 0.53 & 29.43 & 27.10 & 42.43 & 3 & 2166.1426 & 2166.1393 & 723.0537 & 0.0033 & 1.5213 & 45.009 & 54.311 & 55.567\end{array}$

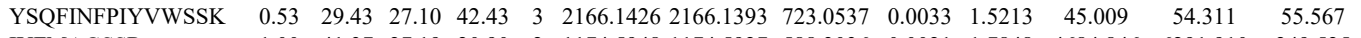
IYFMAGSSR IYFMAGSSR $\begin{array}{llllllllllllll}\text { EEASDYLELDTIK } & 1.00 & 79.27 & 27.68 & 23.90 & 2 & 1812.9256 & 1812.9236 & 907.4691 & 0.0020 & 1.1020 & 41.607 & 55.048 & 124.027 \\ \text { EEEAIQLDGLNASQIR } & 1.00 & 89.30 & 27.93 & 25.83 & 2 & 1928.9940 & 1928.9925 & 965.5035 & 0.0015 & 0.7768 & 704.147 & 912.500 & 1964.325\end{array}$ $\begin{array}{lllllllllllll}1.00 & 41.37 & 27.19 & 20.90 & 2 & 1174.5948 & 1174.5927 & 588.3036 & 0.0021 & 1.7848 & 4684.846 & 6291.910 & 249.525\end{array}$ $\begin{array}{llllllllllllll} & \end{array}$ GLFDEYGSK $\begin{array}{lllllllllllll}1.00 & \text { \#\#\#\# } 27.96 & 29.41 & 2 & 1928.9942 & 1928.9925 & 965.5035 & 0.0017 & 0.8804 & 2450.883 & 2509.836 & 5088.893\end{array}$ $\begin{array}{llllllllllllll}0.99 & 41.47 & 28.37 & 18.33 & 2 & 1302.6816 & 1302.6700 & 652.3423 & 0.0116 & 8.8910 & 10045.979 & 15209.342 & 7648.954 & 130 \\ 1.00 & \# \# \# \# 26.93 & 39.54 & 2 & 1841.9944 & 1841.9801 & 921.9973 & 0.0143 & 7.7548 & 1223.869 & 1144.451 & 684.607 & & \\ 1\end{array}$ IFIGTFK

VLGLVLLR

VLGLVLLR

VLGLVLLR

VLGLVLLR

VLGLVLLR

VLGLVLLR

VLGLVLLR

VLGLVLLR
VLGLVLLR

VLGLVLLR

VLGLVLLR

VLGLVLLR

VLGLVLLR

VLGLVLLR

VLGLVLLR

VLGLVLLR

VLGLVLLR

VLGLVLLR

VLGLVLLR

VLGLVLLR

VLGLVLLR

VLGLVLLR

VLGLVLLR

VLGLVLLR
VLGLVLLR

VLGLVLLR

VLGLVLLR

VLGLVLLR

VLGLVLR

RVLGLVLLR $\begin{array}{llllllllllll}1.00 & 61.90 & 21.93 & 18.02 & 3 & 1843.7695 & 1843.7669 & 615.5962 & 0.0026 & 1.74078 & 214.485 & 126.764\end{array}$

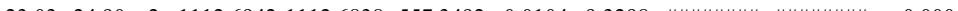

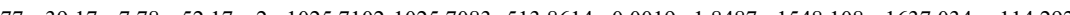
$\begin{array}{lllllllllllll}0.77 & 35.80 & 7.78 & 48.80 & 2 & 1025.7104 & 1025.7083 & 513.8614 & 0.0021 & 2.0433 & 1386.293 & 1715.715 & 98.622\end{array}$ $\begin{array}{lllllllllllllll}0.61 & 12.53 & 7.78 & 25.53 & 2 & 1025.7080 & 1025.7083 & 513.8614 & -0.0003 & -0.2919 & 25.742 & 38.970 & 0.208\end{array}$ $\begin{array}{lllllllllllllll}0.61 & 16.62 & 7.78 & 29.62 & 2 & 1025.7084 & 1025.7083 & 513.8614 & 0.0001 & 0.0973 & 62.413 & 50.628\end{array}$ $\begin{array}{lllllllllllll}0.61 & 17.35 & 7.78 & 30.35 & 2 & 1025.7084 & 1025.7083 & 513.8614 & 0.0001 & 0.0973 & 25.192 & 24.335\end{array}$ $\begin{array}{llllllllllllll}0.76 & 18.79 & 7.78 & 31.79 & 2 & 1025.7090 & 1025.7083 & 513.8614 & 0.0007 & 0.6811 & 32.679 & 14.633 \\ 0.76 & 31.46 & 7.78 & 44.46 & 2 & 1052.7096 & 1025.7083 & 513.8614 & 0.0013 & 1.2649 & 3145.226 & 3573.159\end{array}$ $\begin{array}{llllllllllll}0.76 & 31.46 & 7.78 & 44.46 & 2 & 1025.7096 & 1025.7083 & 513.8614 & 0.0013 & 1.2649 & 3145.226 & 3573.159 \\ 0.77 & 32.52 & 7.78 & 45.52 & 2 & 1025.7908 & 1025.7083 & 513.8614 & 0.0015 & 1.4595 & 6119.855 & 7305.964\end{array}$ $\begin{array}{lllllllllllllll}0.77 & 26.03 & 7.78 & 39.03 & 2 & 1025.7104 & 1025.7083 & 513.8614 & 0.0021 & 2.0433 & 16.541 & 38.191 & 0.000\end{array}$ $\begin{array}{llllllllllllll}0.61 & 40.04 & 6.02 & 53.04 & 2 & 881.6064 & 881.6062 & 441.8104 & 0.0002 & 0.2263 & 21.381 & 16.295 & 3.620\end{array}$ $\begin{array}{lllllllllllllll}0.61 & 38.15 & 6.02 & 51.15 & 2 & 881.6066 & 881.6062 & 441.8104 & 0.0004 & 0.4527 & 17.432 & 29.490\end{array}$ $\begin{array}{lllllllllllll}0.76 & 36.25 & 7.78 & 49.25 & 2 & 1025.7094 & 1025.7083 & 513.8614 & 0.0011 & 1.0703 & 1940.173 & 2160.200\end{array}$ $\begin{array}{lllllllllllll}0.76 & 34.16 & 7.78 & 47.16 & 2 & 1025.7096 & 1025.7083 & 513.8614 & 0.0013 & 1.2649 & 859.770 & 947.157\end{array}$ $\begin{array}{lllllllllllllll}0.61 & 40.26 & 6.02 & 53.26 & 2 & 881.6062 & 881.6062 & 441.8104 & 0.0000 & 0.0000 & 0.000 & 36.698\end{array}$ $\begin{array}{llllllllllll}0.61 & 34.23 & 6.02 & 47.23 & 2 & 881.6064 & 881.6062 & 441.8104 & 0.0002 & 0.2263 & 9.908 & 19.747\end{array}$ $\begin{array}{lllllllllllll}0.76 & 38.96 & 7.78 & 51.96 & 2 & 1025.7092 & 1025.7083 & 513.8614 & 0.0009 & 0.8757 & 410.926 & 592.560 \\ 0.76 & 34.57 & 7.78 & 47.57 & 2 & 1025.7092 & 1025.7083 & 513.8614 & 0.009 & 0.8757 & 786.871 & 912.619\end{array}$ $\begin{array}{llllllllllllll}0.76 & 34.57 & 7.78 & 47.57 & 2 & 1025.7092 & 1025.7083 & 513.8614 & 0.0009 & 0.8757 & 786.871 & 912.619 \\ 0.76 & 36.36 & 7.78 & 49.36 & 2 & 1025.7094 & 1025.7083 & 513.8614 & 0.0011 & 1.0703 & 298.731 & 309.225\end{array}$ $\begin{array}{llllllllllll}0.76 & 36.36 & 7.78 & 49.36 & 2 & 1025.7094 & 1025.7083 & 513.8614 & 0.0011 & 1.0703 & 298.731 & 309.225 \\ 0.76 & 34.35 & 7.78 & 47.35 & 2 & 1025.7096 & 1025.7083 & 513.8614 & 0.0013 & 1.2649 & 454.532 & 562.441\end{array}$ $\begin{array}{lllllllllllll}0.76 & 34.35 & 7.78 & 47.35 & 2 & 1025.7096 & 1025.7083 & 513.8614 & 0.0013 & 1.2649 & 454.532 & 562.441 \\ 0.76 & 32.91 & 7.78 & 45.91 & 2 & 1025.7096 & 1025.7083 & 513.8614 & 0.0013 & 1.2649 & 403.922 & 461.839 \\ 0.76 & 39.41 & 7.78 & 52.41 & 2 & 1025.796 & 1025.708 & 513.8614 & 0.001 & 1.269 & 636.792 & 7\end{array}$ $\begin{array}{lllllllllllll}0.76 & 32.91 & 7.78 & 45.91 & 2 & 1025.7096 & 1025.7083 & 513.8614 & 0.0013 & 1.2649 & 403.922 & 461.839 \\ 0.76 & 39.41 & 7.78 & 52.41 & 2 & 1025.7096 & 1025.7083 & 513.8614 & 0.0013 & 1.2649 & 636.792 & 776.813\end{array}$ $\begin{array}{lllllllllllllll}0.76 & 39.41 & 7.78 & 52.41 & 2 & 1025.7096 & 1025.7083 & 513.8614 & 0.0013 & 1.2649 & 636.792 & 776.813 \\ 0.76 & 33.07 & 7.78 & 46.07 & 2 & 1025.7092 & 1025.7083 & 513.8614 & 0.0009 & 0.8757 & 413.427 & 501.930 \\ 0.76 & 33.10 & 7.78 & 46.10 & 2 & 1025.7096 & 1025.7083 & 513.8614 & 0.0013 & 1.2649 & 382.704 & 428.234\end{array}$ $\begin{array}{lllllllllllll}0.76 & 33.07 & 7.78 & 46.07 & 2 & 1025.7092 & 1025.7083 & 513.8614 & 0.0009 & 0.8757 & 413.427 & 501.930 \\ 0.76 & 33.10 & 7.78 & 46.10 & 2 & 1025.7096 & 1025.7083 & 513.8614 & 0.0013 & 1.2649 & 382.704 & 428.234 \\ 0.76 & 39.30 & 7.78 & 52.30 & 2 & 1025.7092 & 1025.783 & 513.8614 & 0.0009 & 0.8757 & 51.283 & 585.669\end{array}$ $\begin{array}{lllllllllllll}0.76 & 33.10 & 7.78 & 46.10 & 2 & 1025.7096 & 1025.7083 & 513.8614 & 0.0013 & 1.2649 & 382.704 & 428.234 \\ 0.76 & 39.30 & 7.78 & 52.30 & 2 & 1025.7092 & 1025.7083 & 513.8614 & 0.0009 & 0.8757 & 511.283 & 585.669\end{array}$ $\begin{array}{llllllllllll}0.76 & 39.30 & 7.78 & 52.30 & 2 & 1025.7092 & 1025.7083 & 513.8614 & 0.0009 & 0.8757 & 511.283 & 585.669\end{array}$

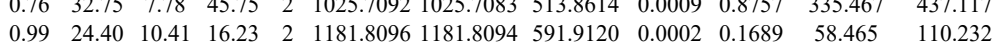
$\begin{array}{lllllllllllll}0.91 & 10.31 & 6.02 & 23.31 & 2 & 881.6066 & 881.6062 & 441.8104 & 0.0004 & 0.4527 & 20.086 & 8.939\end{array}$ $\begin{array}{ccccccccccccc}0.61 & 10.31 & 6.02 & 23.31 & 2 & 881.6066 & 881.6062 & 441.8104 & 0.0004 & 0.4527 & 2.086 & 8.939 \\ 0.76 & 26.52 & 7.78 & 39.52 & 2 & 1025.7088 & 1025.7083 & 513.8614 & 0.0005 & 0.4865 & 169.246 & 162.716\end{array}$ $\begin{array}{lllllllllllll}0.76 & 26.52 & 7.78 & 39.52 & 2 & 1025.7088 & 1025.7083 & 513.8614 & 0.0005 & 0.4865 & 169.246 & 162.716 \\ 0.76 & 38.48 & 7.78 & 51.48 & 2 & 1025.7092 & 1025.7083 & 513.8614 & 0.0009 & 0.8757 & 178.529 & 232.592\end{array}$ 
VLGLVLLR $\begin{array}{lllllllllll} & \end{array}$ $\begin{array}{lllllllllll}0.99 & 27.98 & 1.3 .30 & 18.91 & 2 & 1181.8088 & 1181.8094 & 591.9120 & -0.0006 & -0.5068 & 68.490\end{array}$ $\begin{array}{lllllllllll}0.99 & 29.20 & 10.41 & 20.97 & 2 & 1181.8092 & 1181.8094 & 591.9120 & -0.0002 & -0.5689 & 75.130\end{array}$ $\begin{array}{lllllllllll}0.76 & 25.08 & 7.78 & 38.08 & 2 & 1825.7088 & 1025.083 & 513.8614 & 0.0005 & 0.4865 & 65.865\end{array}$

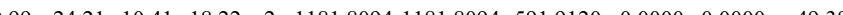

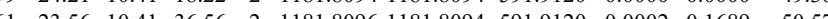
$\begin{array}{lllllllllllll}0.97 & 24.50 & 25.47 & 21.13 & 3 & 2091.1546 & 2091.1496 & 698.0571 & 0.0050 & 2.3876 & 95.320\end{array}$ $\begin{array}{lllllllllllll}0.72 & 14.15 & 25.45 & 14.73 & 3 & 2091.1537 & 2091.1496 & 698.0571 & 0.0041 & 1.9578 & 86.560\end{array}$ $\begin{array}{llllllllllllll}0.92 & 25.79 & 25.15 & 27.93 & 2 & 1187.7180 & 1187.7148 & 594.8647 & 0.0032 & 2.6897 & 3551.950 & 3395.415 & 2053.096 & 125.8\end{array}$ $\begin{array}{llllllllllllllll}0.99 & 34.68 & 25.26 & 30.80 & 2 & 1187.7160 & 1187.7148 & 594.8647 & 0.0012 & 1.0086 & 4091.494 & 39.45 & & \\ 0.99 & 33.63 & 25.26 & 27.85 & 2 & 1187.7162 & 1187.7148 & 594.8647 & 0.0014 & 1.1767 & 3716.181 & 3798.925 & 896.708 & 155.035\end{array}$ $\begin{array}{llllllllllllll}0.90 & 52.50 & 28.16 & 23.85 & 2 & 1509.7948 & 1509.7918 & 755.9032 & 0.0030 & 1.9844 & 3327.389 & 3219.582 & 1711.458 & 264.383\end{array}$ $\begin{array}{llllllllllllll}1.00 & 66.95 & 28.16 & 25.83 & 2 & 1509.7950 & 1509.7918 & 755.9032 & 0.0032 & 2.1167 & 253.175 & 221.219 & 139.314 & 29.128\end{array}$ $\begin{array}{llllllllllllllll}1.00 & 52.53 & 28.78 & 28.24 & 2 & 1265.6894 & 1265.6859 & 633.8502 & 0.0035 & 2.7609 & 47969.639 & 45156.493 & 31013.313 & 21262.573 & \text { Yes }\end{array}$ $\begin{array}{lllllllllllllll}1.00 & 52.74 & 28.74 & 29.72 & 2 & 1265.6896 & 1265.6859 & 633.8502 & 0.0037 & 2.9187 & 26037.338 & 25389.944 & 16970.951 & 11628.086 & \text { Yes }\end{array}$ $\begin{array}{lllllllllllllll}1.00 & 44.10 & 28.62 & 33.93 & 2 & 1265.6882 & 1265.6859 & 633.8502 & 0.0023 & 1.8143 & 34467.858 & 32895.312 & 23309.999 & 17419.180 & \text { Yes }\end{array}$

MAAAGGGGGGGR $\begin{array}{lllllllllllll}1.00 & 27.36 & 25.75 & 18.90 & 4 & 4072.0109 & 4072.0073 & 1019.0091 & 0.0036 & 0.8832 & 47.448 & 65.823 & 52.831\end{array}$

MGPPVGGHR MGPPVGGHR MGPPVGGHR LCFSTAQHAS LCFSTAQHAS MGPPVGGHR MGPPVGGHR TPASPVVHIR TPASPVVHIR TPASPVVHIR

LCFSTAQHAS

LCFSTAQHAS

TPASPVVHIR
TPASPVVHIR TPASPVVHIR
TPASPVVHIR TPASPVVHIR TPASPVVHIR TPASPVVHIR
TPASPVVHIR $\begin{array}{llllllllllll}1.00 & 7.19 & 2 . .83 & 85.19 & 4 & 3268.4033 & 3268.3995 & 818.1072 & 0.0038 & 1.1612 & 14.579 & 14.884\end{array}$ $\begin{array}{llllllllllll}0.99 & 36.43 & 29.12 & 27.69 & 2 & 1050.5526 & 1050.5515 & 526.2830 & 0.0011 & 1.0451 & 30.267 & 30.169\end{array}$ $\begin{array}{llllllllllllll}0.98 & 34.55 & 28.95 & 29.60 & 2 & 1050.5536 & 1050.5515 & 526.2830 & 0.0021 & 1.9951 & 28.535 & 49.705 & 14.167 & 6.447\end{array}$ $\begin{array}{ccccccccccccccc}0.98 & 34.55 & 28.95 & 29.60 & 2 & 1050.5536 & 050.5515 & 526.2830 & 0.0021 & 1.9951 & 28.535 & 49.705 & 14.167 & 6.447 & \text { Yes } \\ 0.82 & 25.87 & 24.25 & 15.00 & 2 & 1253.5748 & 1253.5655 & 627.7900 & 0.0093 & 7.4069 & 3103.206 & 3038.848 & 964.744 & 1472.775 & \text { Yes } \\ 0.70 & 21.22 & 24.23 & 14.58 & 2 & 1253.5764 & 1253.5655 & 627.7900 & 0.0109 & 8.6812 & 2505.206 & 2267.149 & 587.841 & 1028.650 & \text { Yes } \\ 1.00 & 49.01 & 29.14 & 26.06 & 2 & 1050.5524 & 1050.5515 & 526.2830 & 0.0009 & 0.8551 & 46.498 & 34.936 & 7.894 & 4.849 & \text { Yes }\end{array}$ $\begin{array}{lllllllllllllll}1.00 & 49.01 & 29.14 & 26.06 & 2 & 1050.5524 & 1050.5515 & 526.2830 & 0.0009 & 0.8551 & 46.498 & 34.936 & 7.894 & 4.849 & \text { Yes } \\ 1.00 & 49.34 & 29.12 & 29.05 & 2 & 10505526 & 1050.5515 & 5262830 & 0.0011 & 1.0451 & 22.759 & 19.326 & 8.128 & 4.026 & \text { Yes }\end{array}$

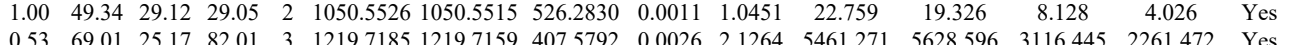
$\begin{array}{lllllllllllllll}0.53 & 69.01 & 25.17 & 82.01 & 3 & 1219.7185 & 1219.7159 & 407.5792 & 0.0026 & 2.1264 & 5461.271 & 5628.596 & 3116.445 & 2261.472 & \text { Yes } \\ 1.00 & 56.98 & 25.62 & 21.24 & 3 & 1219.7194 & 1219.7159 & 407.5792 & 0.0035 & 2.8624 & 8434.256 & 6499.974 & 5130.461 & 4388.071 & \text { Yes }\end{array}$

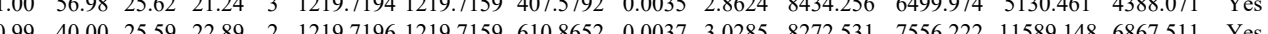
$\begin{array}{llllllllllllllll}0.99 & 39.62 & 25.52 & 22.026 & 2 & 1219.7202 & 1219.7159 & 6108652 & 0.0043 & 3.5196 & 7465.180 & 8517.817 & 20093.641 & 12279.150 & \text { No }\end{array}$ $\begin{array}{llllllllllllllll}0.97 & 33.20 & 2423 & 16.83 & 2 & 1253.5756 & 1253.5655 & 627.7900 & 0.0101 & 8.040 & 2459.334 & 2379.571 & 418.780 & 601.052 & \text { Yes }\end{array}$ $\begin{array}{lllllllllllllll}0.51 & 33.22 & 24.23 & 46.22 & 2 & 1253.5764 & 1253.5655 & 627.7900 & 0.0109 & 8.6812 & 2966.355 & 2856112 & 219.816 & 582.971 & \text { Yes }\end{array}$

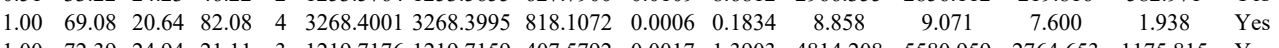
$\begin{array}{lllllllllllllll}1.00 & 72.39 & 24.94 & 21.11 & 3 & 1219.7176 & 1219.7159 & 407.5792 & 0.0017 & 1.3903 & 4814.208 & 5580.959 & 2764.653 & 1175.815 & \text { Yes } \\ 0.99 & 35.77 & 25.21 & 20.21 & 2 & 12197176 & 1219.7159 & 610.8652 & 0.0017 & 1.3915 & 9894.942 & 12343.887 & 46141.190 & 24760.648 & \text { No }\end{array}$ $\begin{array}{lllllllllllllll}0.99 & 35.77 & 25.21 & 20.21 & 2 & 1219.7176 & 1219.7159 & 670.8652 & 0.0017 & 1.3915 & 9894.942 & 12343.887 & 46141.190 & 24760.648 & N\end{array}$ $\begin{array}{llllllllllllllll}0.53 & 59.81 & 25.17 & 72.81 & 3 & 1219.7185 & 1219.7159 & 407.5792 & 0.0026 & 2.1264 & 7744.878 & 7363.848 & 6721.131 & 3116.049 & \text { Yes }\end{array}$ $\begin{array}{llllllllllllllll}100 & 74.46 & 25.22 & 18.24 & 3 & 1219.7206 & 1219.7159 & 407.5792 & 0.0047 & 3.8438 & 4236.269 & 5521.298 & 3716.538 & 1960.366 & \text { Yes }\end{array}$ $\begin{array}{lllllllllllllll}1.00 & 72.68 & 25.22 & 24.23 & 3 & 1219.7209 & 1219.7159 & 407.5792 & 0.0050 & 4.0892 & 4516.120 & 5891.711 & 2983.362 & 1533.912 & \text { Yes }\end{array}$ $\begin{array}{llllllllllllllll}1.00 & 80.33 & 27.65 & 28.91 & 2 & 1922.0212 & 1922.0076 & 962.0111 & 0.0136 & 7.0685 & 1715.921 & 1875.984 & 111.917 & 11.859 & \text { Yes }\end{array}$ $\begin{array}{lllllllllllllll}1.00 & 49.12 & 27.63 & 16.65 & 3 & 1922.0227 & 1922.0076 & 641.6765 & 0.0151 & 7.8440 & 17951.784 & 14519.770 & 680.706 & 61.250 & \text { Yes } \\ 1.00 & 76.60 & 27.66 & 31.27 & 2 & 1922.0232 & 1922.0076 & 962.0111 & 0.0156 & 8.1079 & 1644.723 & 1462.031 & 73.247 & 24.034 & \text { Yes }\end{array}$

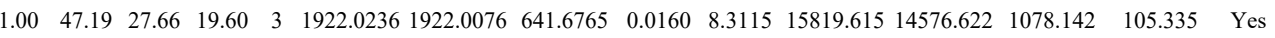

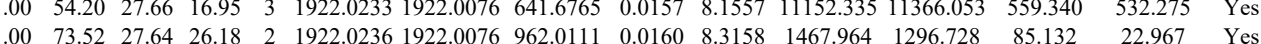
$\begin{array}{lllllllllllllll}1.00 & 52.98 & 27.41 & 16.42 & 3 & 1922.0260 & 1922.0076 & 641.6765 & 0.0184 & 9.5582 & 8907.574 & 7800.450 & 632.915 & 222.427 & \text { Yes }\end{array}$

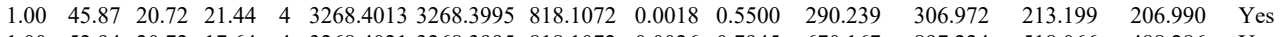

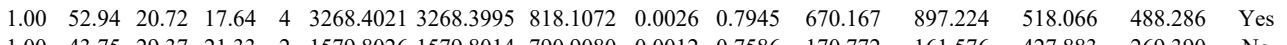
$\begin{array}{lllllllllllllll}1.00 & 43.75 & 29.37 & 21.33 & 2 & 1579.8026 & 1579.8014 & 790.9080 & 0.0012 & 0.7586 & 170.772 & 161.576 & 427.883 & 269.390 & \text { No }\end{array}$ $\begin{array}{lllllllllllllll}0.97 & 34.63 & 29.37 & 16.90 & 2 & 1579.8042 & 1579.8014 & 790.9080 & 0.0028 & 1.7701 & 102.139 & 96.216 & 217.289 & 179.770 & \text { No }\end{array}$

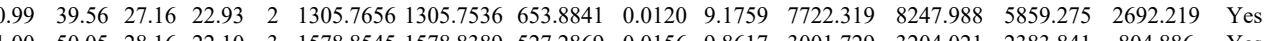

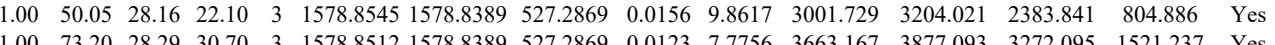

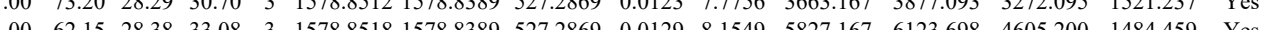

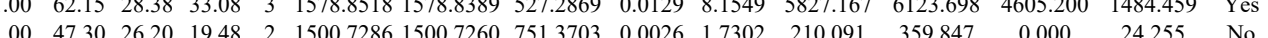

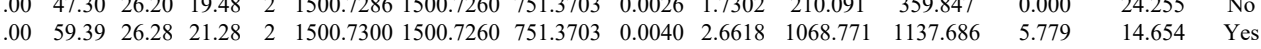
$\begin{array}{lllllllllllllll}1.00 & 56.05 & 26.98 & 25.84 & 2 & 1303.7622 & 1303.7621 & 652.8883 & 0.0001 & 0.0766 & 10793.448 & 12634.933 & 589.460 & 197.321 & \text { Yes }\end{array}$ $\begin{array}{lllllllllllllllll}1.08 & 24.52 & 26.64 & 19.36 & 2 & 1303.7632 & 1303.7621 & 652.8883 & 0.0011 & 0.8424 & 1282.550 & 1207.888 & 1173.456 & 211.279 & \text { Yes }\end{array}$ 

$\begin{array}{llllllllllllll}1.00 & 44.78 & 26.96 & 25.91 & 2 & 1164.6792 & 1164.6777 & 583.3461 & 0.0015 & 1.2857 & 5230.010 & 6035.325 & 48.732\end{array}$ $\begin{array}{lllllllllllll}1.00 & 48.77 & 27.01 & 26.67 & 2 & 1164.6782 & 1164.6777 & 583.3461 & 0.0005 & 0.4286 & 1748.224 & 1864.348 & 61.913 \\ 1.00 & 45.74 & 26.93 & 25.62 & 2 & 1164.6784 & 1164.6777 & 583.3461 & 0.0007 & 0.6000 & 3428.096 & 3701.135 & 66.326\end{array}$

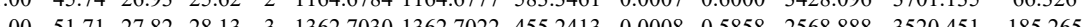

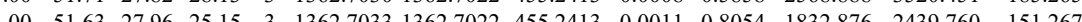
$\begin{array}{llllllllllllll}0.98 & 34.76 & 26.86 & 23.15 & 2 & 1164.6774 & 1164.6777 & 583.3461 & -0.0003 & -0.2571 & 1046.661 & 1094.292 & 73.541\end{array}$ $\begin{array}{lllllllllllllll}0.93 & 26.76 & 26.96 & 20.61 & 2 & 1164.6790 & 1164.6777 & 583.3461 & 0.0013 & 1.1143 & 927.996 & 879.114 & 92.895\end{array}$ $\begin{array}{llllllllllllll}0.88 & 24.24 & 26.91 & 23.72 & 2 & 1164.6788 & 1164.6777 & 583.3461 & 0.0011 & 0.9428 & 629.357 & 623.055 & 66.434\end{array}$ $\begin{array}{llllllllllllll}1.00 & 49.63 & 26.31 & 23.95 & 3 & 1542.8845 & 1542.8826 & 515.3015 & 0.0019 & 1.2291 & 69.141 & 88.717 & 70.949\end{array}$ $\begin{array}{llllllllllllll}1.00 & 62.42 & 26.28 & 25.05 & 3 & 1542.8848 & 1542.8826 & 515.3015 & 0.0022 & 1.4231 & 69.701 & 82.691 & 92.250\end{array}$ $\begin{array}{lllllllllllll}1.00 & 88.09 & 26.34 & 35.93 & 2 & 1542.8832 & 1542.8826 & 772.4486 & 0.0006 & 0.3884 & 207.163 & 196.833 & 99.152 \\ 1.00 & 73.45 & 26.35 & 34.85 & 2 & 1528834 & 1528826 & 77.486 & 0.001 & 0.5178 & 123.483 & 144.875 & 56.082\end{array}$ $\begin{array}{lllllllllllll}1.00 & 73.45 & 26.35 & 34.85 & 2 & 1542.8834 & 1542.8826 & 772.4486 & 0.0008 & 0.5178 & 123.483 & 144.875 & 56.082 \\ 1.00 & 57.25 & 26.31 & 27.03 & 3 & 1522.8845 & 1452.882 & 515.315 & 0.0019 & 1.2291 & 201.874 & 259.196 & 185.737\end{array}$ $\begin{array}{llllllllllllll}1.00 & 67.75 & 26.31 & 27.03 & 3 & 1542.8845 & 1542.8826 & 515.3015 & 0.0019 & 1.2291 & 201.874 & 259.196 & 185.737 \\ 1.00 & 59.29 & 6.31 & 26.64 & 3 & 1542.8845 & 1542.882 & 5153015 & 0.0019 & 1.2291 & 142.180 & 126.882 & 125.934\end{array}$ $\begin{array}{llllllllllllll}1.00 & 59.29 & 26.31 & 26.64 & 3 & 1542.8845 & 1542.8826 & 515.3015 & 0.0019 & 1.2291 & 142.180 & 126.882 & 125.934 \\ 1.00 & 74.82 & 6.45 & 17.98 & 2 & 1558.8782 & 1558.8776 & 780.441 & 0.0006 & 0.3844 & 72.466 & 68.728 & 41.154\end{array}$ $\begin{array}{llllllllllllll}1.00 & 59.39 & 26.44 & 18.57 & 3 & 1558.8787 & 1558.8776 & 520.6331 & 0.0011 & 0.7043 & 100.584 & 111.006 & 63.627\end{array}$ $\begin{array}{lllllllllllll}0.76 & 89.23 & 26.31 & \text { \#\#\# } & 2 & 1558.8788 & 1558.8776 & 780.4461 & 0.0012 & 0.7688 & 59.132 & 81.282 & 37.296\end{array}$ $\begin{array}{llllllllllllll}0.55 & 50.82 & 26.30 & 63.82 & 3 & 1558.8793 & 1558.8776 & 520.6331 & 0.0017 & 1.0884 & 113.535 & 116.866 & 86.609 \\ 1.00 & 90.26 & 26.28 & 37.40 & 2 & 15428828 & 1542.8826 & 772.4486 & 0.0002 & 0.1295 & 190.861 & 119.861 & 75.274 & 3\end{array}$ $\begin{array}{lllllllllllll}1.00 & 90.26 & 26.28 & 37.40 & 2 & 1542.8828 & 1542.8826 & 772.4486 & 0.0002 & 0.1295 & 190.861 & 119.861 & 75.274 \\ 1.00 & 74.98 & 26.35 & 36.35 & 2 & 1542.8834 & 1542.8826 & 772.4486 & 0.0008 & 0.5178 & 174.625 & 204.251 & 70.091\end{array}$ $\begin{array}{lllllllllllll}1.00 & 55.02 & 26.31 & 26.33 & 3 & 1542.8845 & 1542.8826 & 515.3015 & 0.0019 & 1.2291 & 84.218 & 148.525 & 124.198\end{array}$ $\begin{array}{lllllllllllll}1.00 & 55.32 & 26.31 & 32.06 & 3 & 1542.8845 & 1542.8826 & 515.3015 & 0.0019 & 1.2291 & 229.775 & 208.224 & 162.273\end{array}$ $\begin{array}{lllllllllllll}0.55 & 58.87 & 26.30 & 71.87 & 3 & 1558.8793 & 1558.8776 & 520.6331 & 0.0017 & 1.0884 & 80.393 & 111.020 & 38.315\end{array}$ $\begin{array}{lllllllllllll}1.00 & 70.93 & 26.35 & 26.17 & 2 & 1542.8834 & 1542.8826 & 772.4486 & 0.0008 & 0.5178 & 60.921 & 45.941 & 25.657\end{array}$

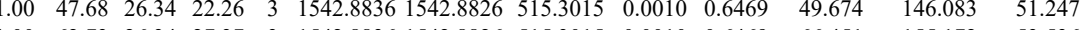
$\begin{array}{llllllllllll}1.00 & 62.73 & 26.34 & 27.37 & 3 & 1542.8836 & 1542.8826 & 515.3015 & 0.0010 & 0.6469 & 66.451\end{array}$ $\begin{array}{lllllllllll}1.00 & 73.70 & 26.31 & 23.16 & 3 & 1542.8842 & 1542.8826 & 515.3015 & 0.0016 & 1.0350 & 95.089\end{array}$ $\begin{array}{llllllllllll}1.00 & 45.49 & 26.31 & 25.41 & 3 & 1542.8845 & 1542.8826 & 515.3015 & 0.0019 & 1.2291 & 144.552 & 4\end{array}$ $\begin{array}{lllllllllll}0.95 & 22.60 & 26.27 & 19.85 & 3 & 1542.8839 & 1542.8826 & 515.3015 & 0.0013 & 0.8409 & 32.409\end{array}$ $\begin{array}{lllllllllll}.98 & 26.17 & 26.36 & 18.40 & 3 & 1542.8854 & 1542.8826 & 515.3015 & 0.0028 & 1.8112 & 37.343 \\ 1.00 & 45.88 & 26.27 & 22.98 & 3 & 1542.8839 & 1542.8826 & 515.3015 & 0.0013 & 0.8409 & 32.967\end{array}$

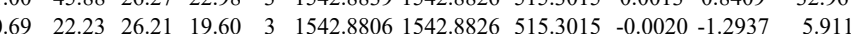
$\begin{array}{lllllllllllll}1.00 & 73.86 & 25.12 & 21.63 & 2 & 1554.9046 & 1554.9038 & 778.4592 & 0.0008 & 0.5138 & 1153.117 & 3381.885 & 791.630\end{array}$ $\begin{array}{llllllllllllll}\text { ALMGSPQLVAAVVR } & 1.00 & 75.15 & 24.81 & 19.76 & 2 & 1554.9050 & 1554.9038 & 778.4592 & 0.0012 & 0.7708 & 605.102 & 1445.482 & 309.170\end{array}$ $\begin{array}{lllllllllllllll}\text { LNTIPLFVQLLYSSVENIQR } & 1.00 & 38.38 & 22.72 & 16.01 & 3 & 2490.4006 & 2490.3968 & 831.1395 & 0.0038 & 1.5240 & 2.981 & 4.989 & 7.071\end{array}$ $\begin{array}{lllllllllllllll}\text { LNTIPLFVQLLYSSVENIQR } & 1.00 & 56.75 & 22.70 & 19.73 & 3 & 2490.3985 & 2490.3968 & 831.1395 & 0.0017 & 0.6818 & 1.740 & 5.829 & 0.000 & 0.00\end{array}$

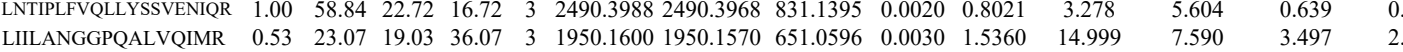
$\begin{array}{lllllllllllllll} & \text { LIILANGGPQALVQIMR } & 0.66 & 13.25 & 20.00 & 14.42 & 3 & 1950.1564 & 1950.1570 & 651.0596 & -0.0006 & -0.3072 & 25.952 & 18.371 & 3.485\end{array}$

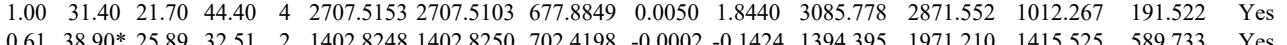

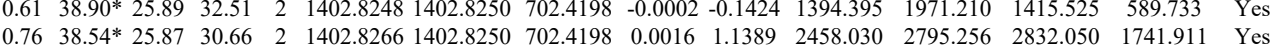

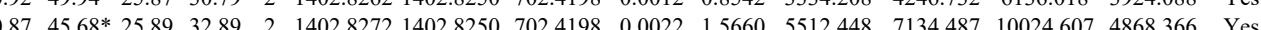

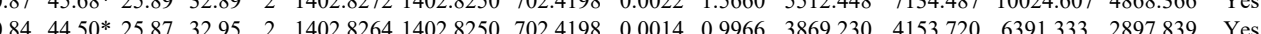
$\begin{array}{lllllllllllllll}0.84 & 43.92 * & 25.87 & 32.86 & 2 & 1402.8264 & 1402.8250 & 702.4198 & 0.0014 & 0.9966 & 3566.199 & 4276.291 & 6197.371 & 3038.039 & \text { Yes }\end{array}$ $\begin{array}{llllllllllllllll}1.00 & 42.10 & 27.08 & 27.15 & 3 & 1540.7500 & 1540.7478 & 514.5899 & 0.0022 & 1.4251 & 12510.426 & 11108.989 & 1218.598 & 422.400 & \text { Yes }\end{array}$

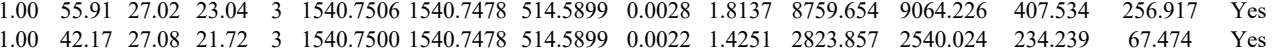


VCALLSCTSHK

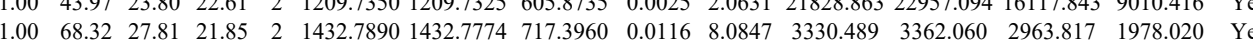

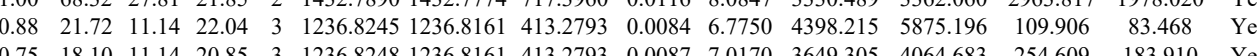
$\begin{array}{llllllllllllllll}0.75 & 18.10 & 11.14 & 20.85 & 3 & 1236.8248 & 1236.8161 & 413.2793 & 0.0087 & 7.0170 & 3649.305 & 4064.683 & 254.609 & 183.910 & \text { Yes } & \\ 0.88 & 19.97 & 11.14 & 19.64 & 3 & 1236.8257 & 1236.8161 & 413.2793 & 0.0096 & 7.7429 & 4236.616 & 4114.718 & 393.896 & 245.267 & \text { Yes }\end{array}$ $\begin{array}{lllllllllllllll}0.88 & 1.97 & 1.14 & 1.64 & 3 & 1236.8257 & 1236.8161 & 413.2793 & 0.0096 & 7.7429 & 4236.616 & 4114.718 & 393.896 & 245.267 & \text { Yes } \\ 0.87 & 22.33 & 11.14 & 22.31 & 3 & 1236.8272 & 1236.8161 & 413.2793 & 0.111 & 8.9527 & 4920.342 & 5179.647 & 201.470 & 109.691 & \text { Yes }\end{array}$

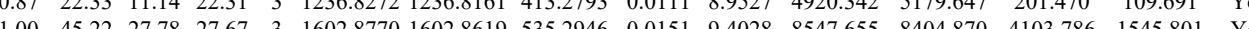

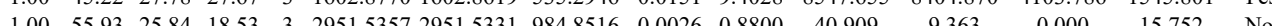
$\begin{array}{lllllllllllllll} & \end{array}$

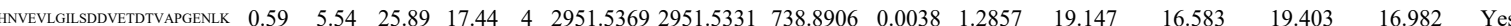
$\begin{array}{llllllllllllllll}\text { NVEVLGILSDDVETDTVAPGENLK } & 1.00 & 28.87 & 25.88 & 18.97 & 4 & 2951.5377 & 2951.5331 & 738.8906 & 0.0046 & 1.5564 & 33.298 & 35.250 & 42.968 & 28.271 & \text { Yes }\end{array}$

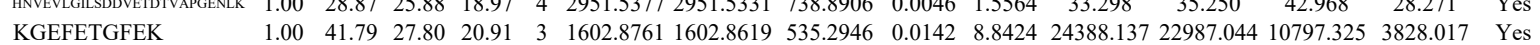

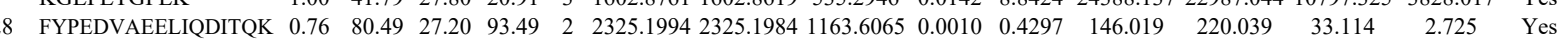

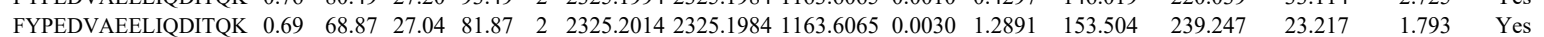

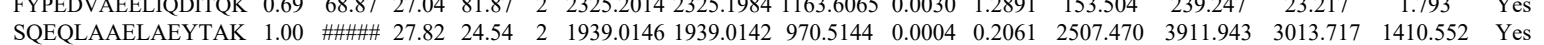
$\begin{array}{lllllllllllllllll}\text { SQEQLAAELAEYTAK } & 1.00 & 81.57 & 27.61 & 21.48 & 2 & 1939.0162 & 1939.0142 & 970.5144 & 0.0020 & 1.0304 & 960.803 & 1524.128 & 1255.778 & 846.546 & \text { Yes }\end{array}$

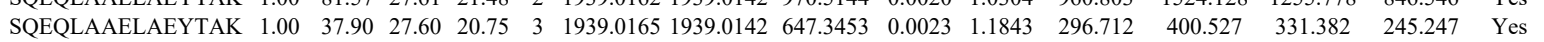
$\begin{array}{llllllllllllllll}\text { SQEQLAAELAEYTAK } & 1.00 & 46.43 & 27.69 & 18.81 & 3 & 1939.0174 & 1939.0142 & 647.3453 & 0.0032 & 1.6478 & 432.798 & 491.973 & 333.580 & 378.314 & \text { Yes }\end{array}$ $\begin{array}{lllllllllllllllll}\text { SQEQLAAELAEYTAK } & 1.00 & 80.44 & 27.82 & 21.21 & 2 & 1939.0146 & 1939.0142 & 970.5144 & 0.0004 & 0.2061 & 1023.069 & 1481.833 & 890.172 & 722.234 & \text { Yes }\end{array}$ $\begin{array}{llllllllllllllll}\text { SQEQLAAELAEYTAK } & 1.00 & 95.81 & 27.60 & 22.98 & 2 & 1939.0158 & 1939.0142 & 970.5144 & 0.0016 & 0.8243 & 893.208 & 1074.451 & 822.870 & 519.309 & \text { Yes }\end{array}$ $\begin{array}{llllllllllllllll}\text { SQEQLAAELAEYTAK } & 0.53 & 30.06 & 27.67 & 43.06 & 3 & 1939.0171 & 1939.0142 & 647.3453 & 0.0029 & 1.4933 & 661.622 & 826.140 & 855.799 & 888.834 & \text { Yes }\end{array}$

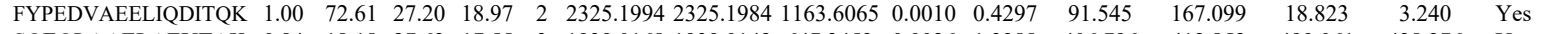
$\begin{array}{lllllllllllllllll}\text { SQEQLAAELAEYTAK } & 0.84 & 18.18 & 27.63 & 17.55 & 3 & 1939.0168 & 1939.0142 & 647.3453 & 0.0026 & 1.3388 & 406.796 & 412.852 & 499.061 & 428.376 & \text { Yes }\end{array}$ $\begin{array}{lllllllllllllll}\text { IALLEEAR } & 0.70 & 50.30 * 26.53 & 30.65 & 2 & 1057.6344 & 1057.6253 & 529.8199 & 0.0091 & 8.5877 & 17558.688 & 21993.352 & 729.379 & 193.470 & \text { Yes }\end{array}$ $\begin{array}{lllllllllllllll}\text { IALLEEAR } & 0.57 & 45.50 * 26.53 & 29.02 & 2 & 1057.6348 & 1057.6253 & 529.8199 & 0.0095 & 8.9652 & 16511.187 & 20483.633 & 534.567 & 202.812 & \text { Yes }\end{array}$

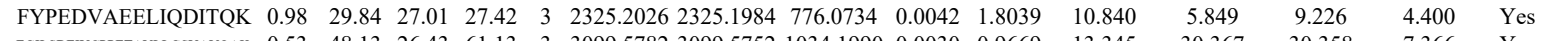

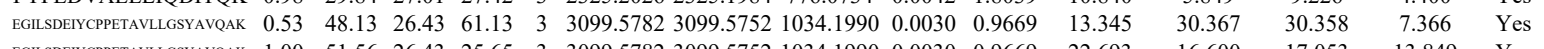

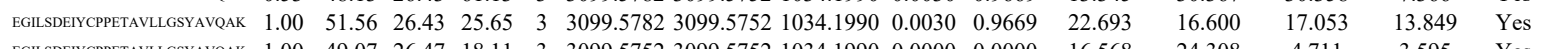

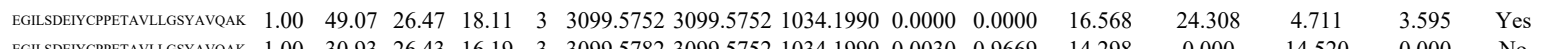

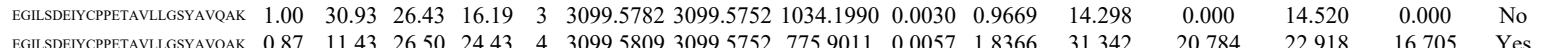

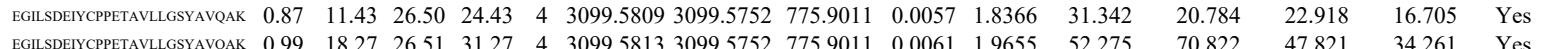
EGLLDEIYCPPETAVLGSYAVAK

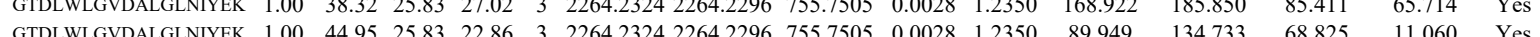

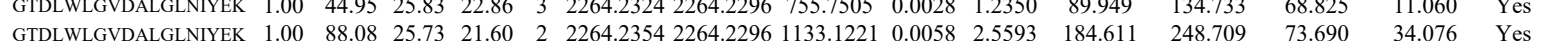

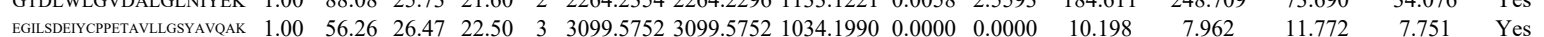

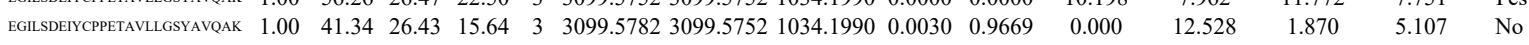
$\begin{array}{llllllllllllllll}\text { GFPTWLK } & 1.00 & 44.57 & 26.48 & 24.60 & 2 & 1135.6740 & 1135.6634 & 568.8390 & 0.0106 & 93171 & 41070.237 & 57268.636 & 20064.722 & 3500812 & \text { Yes }\end{array}$

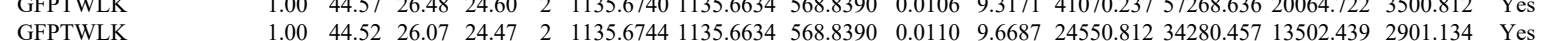

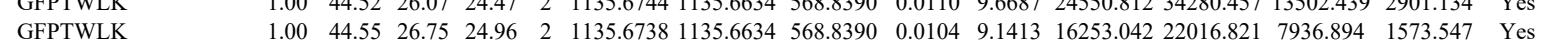

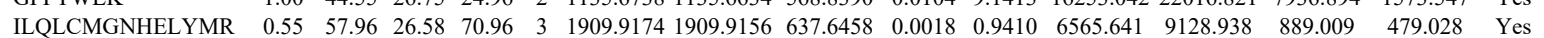
$\begin{array}{llllllllllllllll}\text { ILQLCMGNHELYMR } & 0.55 & 77.67 & 26.58 & 90.67 & 3 & 1909.9174 & 1909.9156 & 637.6458 & 0.0018 & 0.9410 & 4880.968 & 7656.241 & 837.820 & 146.902 & \text { Yes }\end{array}$ $\begin{array}{llllllllllllllll}\text { EDEVEEWQHR } & 1.00 & 43.39 & 25.26 & 25.12 & 3 & 1499.6911 & 1499.6763 & 500.8994 & 0.0148 & 9.8489 & 149.591 & 157.140 & 379.471 & 405.068 & \text { No }\end{array}$ $\begin{array}{lllllllllllllllll}\text { EDEVEEWQHR } & 1.00 & 54.89 & 24.71 & 34.45 & 3 & 1499.6791 & 1499.6763 & 500.8994 & 0.0028 & 1.8633 & 302.178 & 422.186 & 1005.537 & 1035.153 & \text { No }\end{array}$

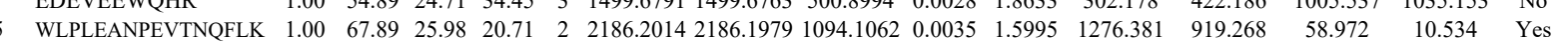
$\begin{array}{lllllllllllllllll}\text { WLPLEANPEVTNQFLK } & 1.00 & 67.37 & 25.98 & 22.47 & 2 & 2186.2014 & 2186.1979 & 1094.1062 & 0.0035 & 1.5995 & 1817.400 & 1640.272 & 12.218 & 6.139 & \text { Yes }\end{array}$ $\begin{array}{llllllllllllllll}\text { WLPLEANPEVTNQFLK } & 0.99 & 31.16 & 25.98 & 23.53 & 3 & 2186.2015 & 2186.1979 & 729.7399 & 0.0036 & 1.6444 & 292.759 & 264.848 & 117.854 & 80.613 & \text { Yes }\end{array}$ $\begin{array}{llllllllllllllll}\text { VTHETSAHEGQTEAPSIDEK } & 0.97 & 15.08 & 27.08 & 18.86 & 4 & 2453.1961 & 2453.1914 & 614.3051 & 0.0047 & 1.9127 & 3039.342 & 3104.017 & 2119.522 & 1435.149 & \text { Yes }\end{array}$ $\begin{array}{llllllllllllllllll}\text { VTHETSAHEGQTEAPSIDEK } & 1.00 & 28.88 & 27.04 & 14.91 & 4 & 2453.1969 & 2453.1914 & 614.3051 & 0.0055 & 2.2383 & 1338.012 & 1876.307 & 1968.416 & 1681.822 & \text { Yes }\end{array}$

3 GLVGEIIK

FMQASEDLLK

GLVGEIIK

GLVGEIIK

FMQASEDLLK

GLVGEIIK

GLVGEIIK

GLVGEIIK

GLVGEIIK

GLVGEIIK

GLVGEIK

GLVGEIK

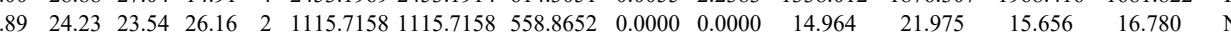

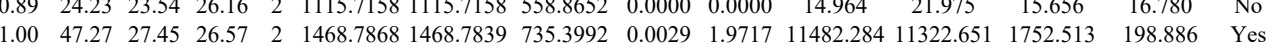
$\begin{array}{llllllllllllllll}1.00 & 47.27 & 27.72 & 24.30 & 2 & 1468.7872 & 1468.7839 & 735.3992 & 0.0033 & 2.2437 & 19633.498 & 18081.700 & 2492.473 & 178.776 & \text { Yes }\end{array}$ $\begin{array}{lllllllllllllll}1.00 & 55.58 & 22.92 & 41.39 & 2 & 1115.7262 & 1115.7158 & 558.8652 & 0.0104 & 9.3045 & 20022.354 & 19951.323 & 18056.199 & 9240.025 & \text { Yes }\end{array}$

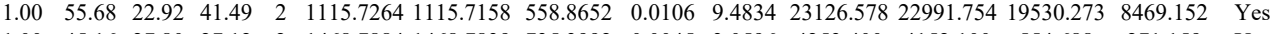

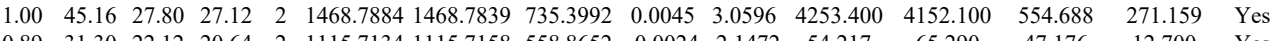

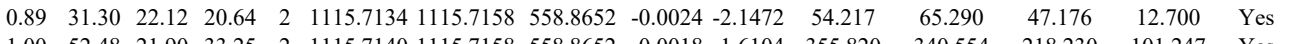

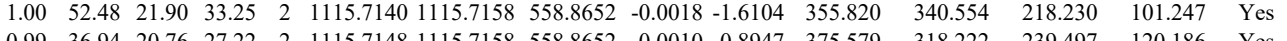
$\begin{array}{lllllllllllllll}0.99 & 36.94 & 20.76 & 27.22 & 2 & 1115.7148 & 1115.7158 & 558.8652 & -0.0010 & -0.8947 & 375.579 & 318.222 & 239.497 & 120.186 & \text { Yes } \\ 1.00 & 50.24 & 20.76 & 27.26 & 2 & 1115.7156 & 1115.7158 & 558.8652 & 0.0002 & -0.1789 & 326.834 & 358.057 & 206796 & 137.056 & \text { Yes }\end{array}$ $\begin{array}{lllllllllllllll}1.00 & 50.24 & 20.76 & 27.26 & 2 & 1115.7156 & 115.7158 & 558.8652 & -0.0002 & -0.1789 & 326.834 & 358.057 & 206.796 & 137.056 & \text { Yes } \\ 0.99 & 35.48 & 23.69 & 29.27 & 2 & 1115.7162 & 1115.7158 & 558.8652 & 0.0004 & 0.3579 & 269.947 & 293.481 & 163.029 & 6821 & \text { Yes }\end{array}$

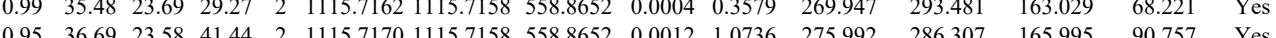

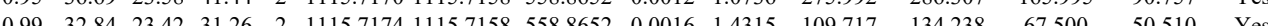

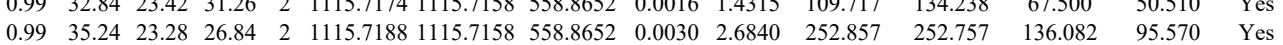



\begin{tabular}{llllllllllllllll}
0.64 & 15.18 & 25.56 & 15.96 & 3 & 1631.9608 & 1631.9603 & 544.9940 & 0.0005 & 0.3058 & 81.323 & 89.916 & 31.968 & 15.162 & Yes \\
\hline
\end{tabular} $\begin{array}{lllllllllllllll}0.59 & 10.80 & 25.11 & 15.24 & 3 & 1631.9638 & 1631.9603 & 544.9940 & 0.0035 & 2.1407 & 180.251 & 207.454 & 82.997 & 36.391 & \text { Yes } \\ 1.00 & 52.11 & 24.50 & 20.30 & 2 & 1631.9742 & 1631.9603 & 816.9874 & 0.0139 & 8.5068 & 16030.716 & 177.938 & 968.106 & 0.000 & \end{array}$ $\begin{array}{llllllllllllllll}1.00 & 52.11 & 24.50 & 20.30 & 2 & 1631.9742 & 1631.9603 & 816.9874 & 0.0139 & 8.5068 & 16630.716 & 17712.938 & 968.106 & 0.000 & \text { No }\end{array}$ $\begin{array}{llllllllllllllll}0.89 & 24.31 & 24.39 & 15.03 & 3 & 1631.9746 & 1631.9603 & 544.9940 & 0.0143 & 8.7462 & 58777.022 & 59894.546 & 5828.292 & 969.554 & \text { Yes } & \\ 1.00 & 57.18 & 24.38 & 21.58 & 2 & 1631.9748 & 1631.9603 & 816.9874 & 0.0145 & 8.8740 & 15958271 & 14190.427 & 62.656 & 68.658 & & \end{array}$ $\begin{array}{lllllllllllllll}1.00 & 57.18 & 24.58 & 21.58 & 2 & 1631.9748 & 1631.9603 & 816.9874 & 0.0145 & 8.8740 & 1598.271 & 14190.427 & 62.656 & 68.658 & \mathrm{Nos}\end{array}$

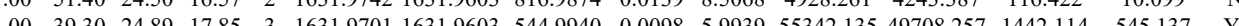

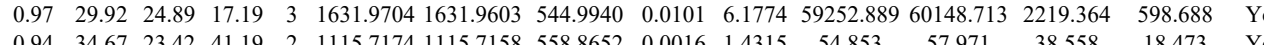
$\begin{array}{llllllllllllll} & & & \end{array}$ $\begin{array}{llllllllllllllll}\text { YMHSGPVVAMVWEGLNVYK } & 1.00 & 42.09 & 26.13 & 20.97 & 3 & 2403.2713 & 2403.2687 & 802.0968 & 0.0026 & 1.0805 & 114.234 & 279.052 & 122.094 & 58.240 & \text { Yes }\end{array}$ $\begin{array}{llllllllllllllll}\text { YMHSGPVVAMVWEGLVVVK } & 1.00 & 49.12 & 26.17 & 21.21 & 4 & 2403.2725 & 2403.2687 & 601.8245 & 0.0038 & 1.5785 & 377.535 & 509.088 & 125.750 & 46.981 & \text { Yes }\end{array}$ $\begin{array}{llllllllllllllll}\text { YMHSGPVVAMVWEGLNVVK } & 1.00 & 47.40 & 26.13 & 25.92 & 4 & 2403.2733 & 2403.2687 & 601.8245 & 0.0046 & 1.9109 & 202.333 & 245.414 & 99.711 & 30.339 & \text { Yes }\end{array}$ $\begin{array}{llllllllllllllll}\text { YMHSGPVVAMVWEGLNVVK } & 0.99 & 30.15 & 26.10 & 20.12 & 3 & 2403.2701 & 2403.2687 & 802.0968 & 0.0014 & 0.5818 & 24.610 & 67.965 & 15.428 & 27.837 & \text { No }\end{array}$

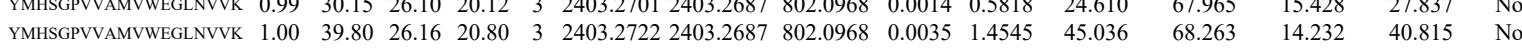
$\begin{array}{lllllllllllllllll}\text { YMHSGPVVAMVWEGLNVVK } & 1.00 & 55.05 & 26.13 & 27.44 & 4 & 2403.2733 & 2403.2687 & 601.8245 & 0.0046 & 1.9109 & 241.958 & 230.642 & 53.300 & 15.721 & \text { Yes }\end{array}$

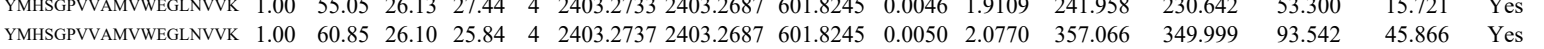
$\begin{array}{llllllllllllllll}\text { NIIHGSDSVESAEK } & 1.00 & 92.18 & 28.00 & 22.78 & 2 & 1772.9194 & 1772.9148 & 887.4647 & 0.0046 & 2.5916 & 1662.852 & 2073.221 & 1552.563 & 295.047 & \text { Yes }\end{array}$ $\begin{array}{lllllllllllllllll}\text { NIIHGSDSVESAEK } & 1.00 & 58.94 & 28.02 & 23.00 & 3 & 1772.9203 & 1772.9148 & 591.9789 & 0.0055 & 3.0969 & 3669.074 & 4085.389 & 3517.619 & 2975.835 & \text { No }\end{array}$ $\begin{array}{lllllllllllllllll}\text { NIIHGSDSVESAEK } & 1.00 & 90.25 & 27.87 & 23.80 & 2 & 1772.9210 & 1772.9148 & 887.4647 & 0.0062 & 3.4931 & 2172.887 & 2680.027 & 2057.016 & 337.345 & \text { Yes }\end{array}$ $\begin{array}{lllllllllllllllll}\text { NIIHGSDSVESAEK } & 1.00 & 68.74 & 27.97 & 23.18 & 3 & 1772.9224 & 1772.9148 & 591.9789 & 0.0076 & 4.2794 & 7698.775 & 8440.599 & 8700.564 & 2707.298 & \text { Yes }\end{array}$ $\begin{array}{lllllllllllllll}0.75 & 27.13 & 27.56 & 28.46 & 2 & 1302.7476 & 1302.7387 & 652.3766 & 0.0089 & 6.8212 & 15455.662 & 12060.582 & 11994.386 & 6954.814 & \text { Yes }\end{array}$

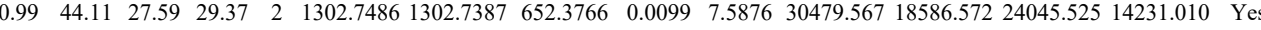
$\begin{array}{llllllllllllllll}0.98 & 35.26 & 27.89 & 25.14 & 2 & 1302.7418 & 1302.7387 & 652.3766 & 0.0031 & 2.3759 & 24150.475 & 17469.841 & 17003.896 & 9782.046 & \text { Yes }\end{array}$ $\begin{array}{lllllllllllllll}1.00 & 44.20 & 25.13 & 18.16 & 3 & 1251.7525 & 1251.7421 & 418.2546 & 0.0104 & 8.2883 & 10140.076 & 7075.723 & 2089.517 & 684.243 & \text { Yes }\end{array}$ $\begin{array}{lllllllllllllll}1.00 & 43.51 & 24.87 & 19.35 & 3 & 1251.7528 & 1251.7421 & 418.2546 & 0.0107 & 8.5274 & 5632.712 & 4459.407 & 1575.957 & 1056.816 & \text { Yes }\end{array}$ $\begin{array}{lllllllllllllll}0.98 & 31.85 & 25.44 & 24.42 & 3 & 1438.8397 & 1438.8289 & 480.6169 & 0.0108 & 7.4903 & 15414.684 & 12602.202 & 6697.222 & 748.782 & \text { Yes }\end{array}$ $\begin{array}{llllllllllllllllll}0.98 & 33.04 & 25.22 & 25.27 & 3 & 1438.8403 & 1438.8289 & 480.6169 & 0.0114 & 7.9064 & 26264.553 & 20149.296 & 9739.506 & 1366.544 & \text { Yes }\end{array}$ $\begin{array}{lllllllllllllllll}0.97 & 30.70 & 25.60 & 22.80 & 3 & 1438.8388 & 1438.8289 & 480.6169 & 0.0099 & 6.8661 & 2187.376 & 2100.537 & 1666.813 & 492.156 & \text { Yes } \\ 0.86 & 53.53 & 27.48 & 28.15 & 2 & 1764.9598 & 1764.946 & 883.4796 & 0.0152 & 8.6023 & 2376.589 & 214.834 & 1641.665 & 818.869 & \text { Yes }\end{array}$ $\begin{array}{lllllllllllllllll}0.86 & 53.53 & 27.48 & 28.15 & 2 & 1764.9598 & 1764.9446 & 883.4796 & 0.0152 & 8.6023 & 2376.589 & 2214.834 & 1641.665 & 818.869 & \text { Yes } \\ 0.51 & 35.41 & 27.50 & 21.27 & 3 & 1764.9598 & 1764.946 & 589.3221 & 0.0152 & 8.5974 & 9777.874 & 8963.437 & 5838.289 & 32.038 & \text { Yes }\end{array}$ $\begin{array}{llllllllllllllll}0.51 & 35.41 & 27.50 & 21.27 & 3 & 1764.9598 & 1764.9446 & 589.3221 & 0.0152 & 8.5974 & 9777.874 & 8963.437 & 5838.289 & 3240.038 & \text { Yes } \\ 0.98 & 35.91 & 28.63 & 16.96 & 3 & 1750.9285 & 1750.9134 & 584.6451 & 0.0151 & 8.6091 & 8884.540 & 8488.357 & 8088.931 & 5615.928 & \text { Yes }\end{array}$ $\begin{array}{llllllllllllllll}0.98 & 35.91 & 28.63 & 16.96 & 3 & 1750.9285 & 1750.9134 & 584.6451 & 0.0151 & 8.6091 & 8884.540 & 8488.357 & 8088.931 & 5615.928 & \text { Yes } \\ 1.00 & 53.13 & 28.60 & 27.32 & 2 & 1750.9286 & 1750.9134 & 876.4640 & 0.0152 & 8.6711 & 269.433 & 403.300 & 268.102 & 208.506 & \text { Yes }\end{array}$ SPYQEFTDHLVK SPYQEFTDHLVK SPYQEFTDHLVK

\section{ATFDAISK}

ATFDAISK

SPYQEFTDHLVK

ATFDAISK

ATFDAISK

SPYQEFTDHLVK

ATFDAISK

ATFDAISK

GTGIVSAPVPK

ESEIIDFFLGASLK

ESEIIDFFLGASLK

ESEIIDFFLGASLK

ESEIIDFFLGASLK

ESEIIDFFLGASLK

GTGIVSAPVPK

GTGIVSAPVPK

GTGIVSAPVPK
SLEEIYLFSLPIK

SLEEIYLFSLPIK

SLEEIYLFSLPIK

SLEEIYLFSLPIK

SLEEIYLFSLPIK

SLEEIYLFSLPIK

SLEEISLP

SLEEIYLFSLPIK
SLEEIYLFSLPIK

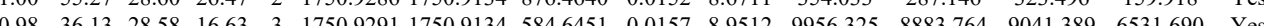

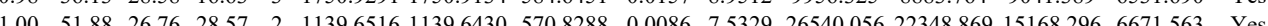
$\begin{array}{lllllllllllllll}1.00 & 54.38 & 26.75 & 29.70 & 2 & 1139.6520 & 1139.6430 & 570.8288 & 0.0090 & 7.8832 & 37246916 & 33162.391 & 20736323 & 8339.540 & \text { Yes }\end{array}$ $\begin{array}{lllllllllllllll}1.00 & 45.69 & 28.63 & 20.04 & 3 & 1750.9285 & 1750.9134 & 584.6451 & 0.0151 & 8.6091 & 8267.023 & 10309.545 & 8753.622 & 7130.693 & \text { Yes }\end{array}$ $\begin{array}{lllllllllllllll}0.98 & 37.41 & 28.46 & 20.40 & 3 & 1750.9306 & 1750.9134 & 584.6451 & 0.0172 & 9.8064 & 7531.678 & 7419.768 & 7807.964 & 5490.105 & \text { Yes }\end{array}$

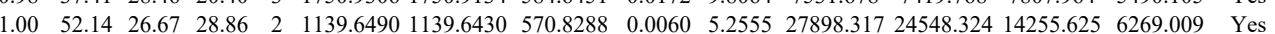
$\begin{array}{lllllllllllllllll}1.00 & 52.74 & 26.85 & 29.71 & 2 & 1139.6510 & 1139.6430 & 570.8288 & 0.0080 & 7.0073 & 35140.723 & 28970.197 & 15230.025 & 7625.206 & \text { Yes }\end{array}$ $\begin{array}{lllllllllllllllll}1.00 & 56.22 & 28.57 & 18.07 & 3 & 1750.9282 & 1750.9134 & 584.6451 & 0.0148 & 8.4381 & 3108.527 & 3924.184 & 2848.784 & 2461.861 & \text { Yes }\end{array}$ $\begin{array}{lllllllllllllll}0.99 & 38.81 & 28.63 & 18.45 & 3 & 1750.9285 & 1750.9134 & 584.6451 & 0.0151 & 8.6091 & 3750.151 & 3936.849 & 3517.863 & 2793.874 & \text { Yes }\end{array}$ $\begin{array}{lllllllllllllll}1.00 & 59.72 & 26.69 & 25.32 & 2 & 1139.6494 & 1139.6430 & 570.8288 & 0.0064 & 5.6059 & 15872.584 & 13949.632 & 9749.547 & 4344.429 & \text { Yes }\end{array}$ $\begin{array}{lllllllllllllll}1.00 & 52.61 & 26.69 & 29.48 & 2 & 1139.6494 & 1139.6430 & 570.8288 & 0.0064 & 5.6059 & 29674.922 & 26423.455 & 16535.649 & 7842.142 & \text { Yes }\end{array}$ $\begin{array}{llllllllllllllll}1.00 & 56.89 & 23.77 & 21.97 & 2 & 1312.8070 & 1312.7958 & 657.4052 & 0.0112 & 8.5183 & 6768.562 & 9263.194 & 5215.522 & 3942.737 & \text { Yes }\end{array}$

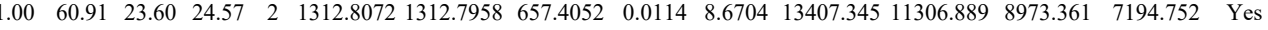
$\begin{array}{llllllllllllllll}1.00 & 44.97 & 26.22 & 28.91 & 3 & 1856.0203 & 1856.0175 & 619.6798 & 0.0028 & 1.5062 & 237.235 & 216.754 & 584.750 & 341.293 & \text { No }\end{array}$

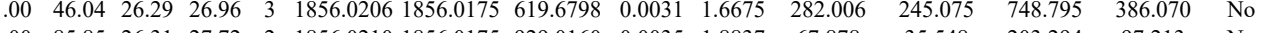
$\begin{array}{lllllllllllllll}1.00 & 85.85 & 26.31 & 27.72 & 2 & 1856.0210 & 1856.0175 & 929.0160 & 0.0035 & 1.8837 & 67.878 & 35.548 & 203.294 & 97.213 & \text { No }\end{array}$ $\begin{array}{lllllllllllllll}1.00 & 34.28 & 26.14 & 20.44 & 3 & 1856.0221 & 1856.0175 & 619.6798 & 0.0046 & 2.4744 & 188.529 & 183.204 & 332.775 & 143.718 & \text { No } \\ 0.97 & 27.03 & 6.29 & 2.44 & 3 & 1856.020 & 1856.017 & 61.6798 & 0.03 & 1.675 & 187.25 & 179.4 & 183.54 & 182.253 & \text { No }\end{array}$ $\begin{array}{lllllllllllllll}0.97 & 27.03 & 26.29 & 27.44 & 3 & 1856.0206 & 1856.0175 & 619.6798 & 0.0031 & 1.6675 & 187.251 & 179.411 & 183.545 & 182.253 & \text { No } \\ 1.00 & 50.14 & 22.65 & 17.39 & 2 & 1312.808 & 1312.7958 & 657.452 & 0.013 & 9.8873 & 864.128 & 9255.261 & 5879.201 & 452.597 & \text { Yos }\end{array}$

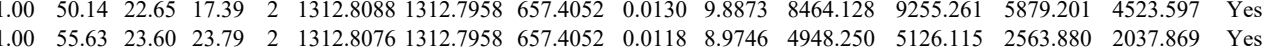

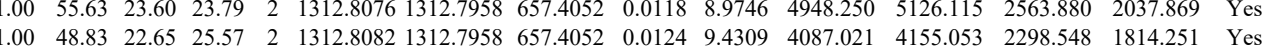

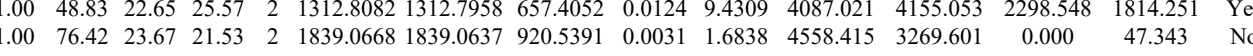
$\begin{array}{llllllllllllllll}1.00 & 81.77 & 23.42 & 25.61 & 2 & 1839.0672 & 1839.0637 & 920.5391 & 0.0035 & 1.9011 & 1940.074 & 1357.350 & 0.000 & 17.142 & \text { No } \\ 0\end{array}$ $\begin{array}{lllllllllllllll}0.99 & 28.19 & 23.52 & 19.25 & 3 & 1839.0682 & 1839.0637 & 614.0285 & 0.0045 & 2.4429 & 221.265 & 194.243 & 78.446 & 29.355 & \text { Yes } \\ 1.00 & 36.38 & 33.52 & 20.60 & 3 & 183.0682 & 1839.0637 & 614.0285 & 0.0045 & 2.4429 & 502.640 & 404.176 & 81.504 & 45.767 & \text { Yes }\end{array}$ $\begin{array}{llllllllllllllll}1.00 & 36.38 & 23.52 & 20.60 & 3 & 1839.0682 & 1839.0637 & 614.0285 & 0.0045 & 2.4429 & 502.640 & 404.176 & 81.504 & 45.767 & \text { Yes } \\ 0.98 & 22.97 & 23.38 & 19.27 & 3 & 1839.0673 & 1839.0637 & 614.0285 & 0.0036 & 1.9543 & 305.603 & 276.192 & 62.525 & 58.387 & \text { Yes }\end{array}$ $\begin{array}{lllllllllllllll}1.00 & 85.98 & 23.38 & 25.79 & 2 & 1839.0674 & 1839.0637 & 920.5391 & 0.0037 & 2.0097 & 726.278 & 650.557 & 87.759 & 12.585 & \text { Yes }\end{array}$

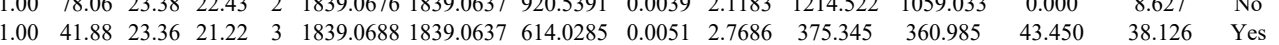

Table S-3 page 159 of 499 
$\begin{array}{lllllllllllll}0.74 & 18.59 & 25.72 & 16.21 & 3 & 1556.8957 & 1556.8896 & 519.9705 & 0.0061 & 3.9105 & 39393.710 & 42052.200 & 1281.097\end{array}$

AFVAIGDYNG $\begin{array}{lllllllllllllll}0.53 & 22.74 & 26.10 & 35.74 & 3 & 2004.1063 & 2004.1037 & 669040418 & 0.0026 & 1.2954 & 11.275 & 15.275 & 0.080 & 4.604\end{array}$

LSIVPVR

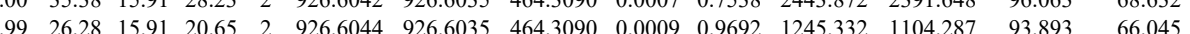

AEDKEWMPVTK

$\begin{array}{lllllllllllllll} & \end{array}$

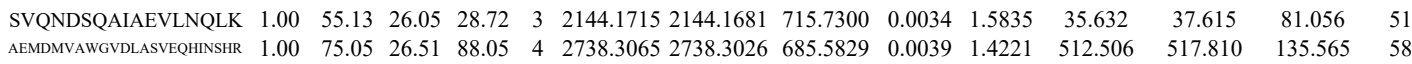
$\begin{array}{llllllllllllllll} & \text { ALLQAILQIEDMLK } & 1.00 & 33.29 & 23.54 & 20.34 & 3 & 1874.0827 & 1874.0790 & 625.7003 & 0.0037 & 1.9711 & 96.197 & 106.620 & 45.968 & 13.930\end{array}$ $\begin{array}{llllllllllllllll}\text { FLEFQYLTGGLVDPEVHGR } & 1.00 & 69.96 & 27.28 & 22.35 & 3 & 2320.1998 & 2320.1974 & 774.4064 & 0.0024 & 1.0330 & 169.855 & 220.857 & 43.556 & 50.363 & \text { Yes }\end{array}$

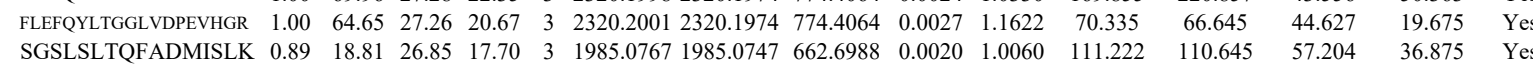

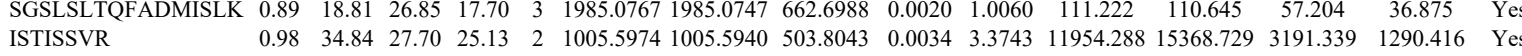
$\begin{array}{llllllllllllllll}\text { ISTISSVR } & 0.98 & 34.84 & 27.70 & 25.13 & 2 & 1005.5974 & 1005.5940 & 503.8043 & 0.0034 & 3.3743 & 11954.288 & 15368.729 & 3191.339 & 1290.416 & \text { Yses } \\ \text { SNKPIILR } & 0.89 & 13.43 & 19.34 & 18.03 & 3 & 1227.7918 & 1227.7906 & 410.2708 & 0.0012 & 0.9750 & 30929.140 & 41171.705 & 3578.450 & 1754.774 & \text { Yes }\end{array}$

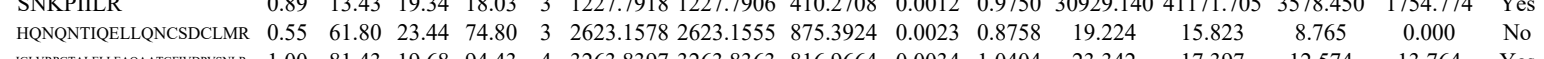
\begin{tabular}{llllllllllllllll} 
IGLVRGTALELEAQAATEFVPPSSLR & 1.00 & 81.43 & 19.68 & 94.43 & 4 & 3263.8397 & 3263.8363 & 816.9664 & 0.0034 & 1.0404 & 23.342 & 17.397 & 12.574 & 13.764 & Yes \\
\hline
\end{tabular}

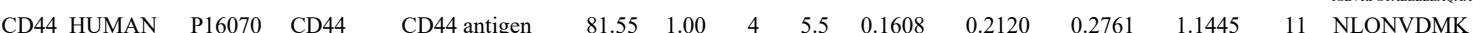
NLQNVDMK
KPSGLNGEASK KPSGLNGEASK KPSGLNGEASK SQEMVHLVNK SQEMVHLVNK SQEMVHLVNK SQEMVHLVNK YGFIEGHVVIPR YGFIEGHVVIPR

$\begin{array}{llllllllllllll}\text { H2AX_HUMAN } & \text { P16104 } & \text { H2AFX } & \text { Histone H2A.x } & 15.14 & 1.00 & 3 & 62.2 & -0.2089 & 0.3085 & 0.1293 & 1.1061 & 9 & \text { TSATVGPK }\end{array}$

$\begin{array}{ccccccccccccccc}1.00 & 84.22 & 19.96 & 20.42 & 4 & 3263.8353 & 3263.8363 & 816.9664 & -0.0010 & -0.3060 & 15.206 & 25.265 & 13.934 & 8.773 & \text { Yes } \\ 0.97 & 40.15 & 28.36 & 30.91 & 2 & 1248.6814 & 1248.6740 & 625.3443 & 0.0074 & 5.9167 & 6544.965 & 6598.947 & 6355.640 & 1659.531 & \text { Yes }\end{array}$ $\begin{array}{lllllllllllllllll}0.96 & 37.86 & 28.63 & 30.46 & 2 & 1248.6824 & 1248.6740 & 625.3443 & 0.0084 & 6.7163 & 6796.153 & 8609.814 & 8353.617 & 1990.612 & \text { Yes }\end{array}$ $\begin{array}{lllllllllllllll}1.00 & 45.49 & 25.95 & 18.19 & 3 & 1518.8743 & 1518.8731 & 507.2983 & 0.0012 & 0.7885 & 319.395 & 390.763 & 615.780 & 632.350 & \text { Yes } \\ 1\end{array}$ $\begin{array}{lllllllllllllllll}1.00 & 42.84 & 25.93 & 22.37 & 3 & 1518.8746 & 1518.8731 & 507.2983 & 0.0015 & 0.9856 & 479.686 & 501.967 & 1340.230 & 1628.374 & \text { Yes } \\ 1.00 & 38.98 & 25.91 & 21.65 & 3 & 1518.8740 & 15188731 & 507.2983 & 0.0009 & 0.5914 & 378.170 & 306.456 & 1041.465 & 929.109 & \text { Yes }\end{array}$ $\begin{array}{llllllllllllllll}0.97 & 31.32 & 27.54 & 19.14 & 3 & 1471.8142 & 1471.8061 & 491.6093 & 0.0081 & 5.4921 & 3959.993 & 5215.473 & 6221.192 & 4872109 & \text { Yes }\end{array}$ $\begin{array}{lllllllllllllll}.00 & 33.79 & 27.21 & 16.08 & 3 & 1471.8097 & 1471.8061 & 491.6093 & 0.0036 & 2.4410 & 9005.478 & 10112.415 & 17219.421 & 11123.539 & \text { Yes }\end{array}$ $\begin{array}{llllllllllllllllll}1.00 & 37.01 & 27.28 & 18.37 & 3 & 1471.8100 & 1471.8061 & 491.6093 & 0.0039 & 2.6444 & 6857.059 & 8691.828 & 15010.476 & 9579.584 & \text { Yes }\end{array}$ $\begin{array}{lllllllllllllll}0.99 & 34.88 & 27.29 & 18.97 & 3 & 1471.8154 & 1471.8061 & 491.6093 & 0.0093 & 6.3058 & 9374.644 & 11158.010 & 17689.799 & 10346.352 & \text { Yes }\end{array}$ $\begin{array}{lllllllllllllllll}0.98 & 34.67 & 27.38 & 17.40 & 3 & 1471.8157 & 1471.8061 & 491.6093 & 0.0096 & 6.5092 & 7264.412 & 9765.491 & 18031.290 & 9109.912 & \text { Yes }\end{array}$ $\begin{array}{lllllllllllllllll}1.00 & 84.18 & 26.97 & 21.91 & 2 & 1529.8618 & 1529.8476 & 765.9311 & 0.0142 & 9.2697 & 2334.683 & 2665.931 & 2950.368 & 2158.526 & \text { Yes }\end{array}$ $\begin{array}{llllllllllllllll}1.00 & 43.30 & 26.90 & 17.75 & 3 & 1529.8627 & 1529.8476 & 510.9565 & 0.0151 & 9.8507 & 29914.469 & 33856.711 & 4711.714 & 1780.547 & \text { No }\end{array}$

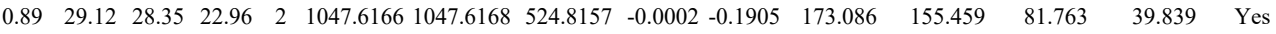
$\begin{array}{llllllllllllllll} & 1.04 & 47.36 & 28.35 & 26.68 & 2 & 1047.6166 & 1047.6168 & 524.8157 & -0.0002 & -0.1905 & 246.113 & 194.397 & 95.329 & 34.352 & \text { Yes }\end{array}$ $\begin{array}{lllllllllllllll} & & \end{array}$ $\begin{array}{llllllllllllllll}\text { LLGGVTIAQGGVLPNIQAVLLPK } & 1.00 & 40.81 & 10.00 & 53.81 & 4 & 2558.5797 & 2558.5767 & 640.6515 & 0.0030 & 1.1707 & 7.885 & 4.226 & 15.787 & 2.697 & \text { No }\end{array}$

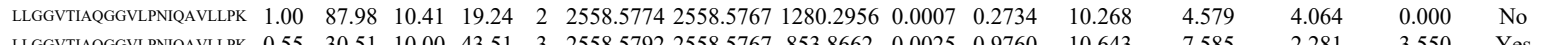

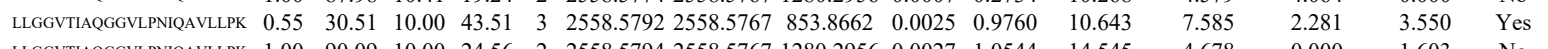

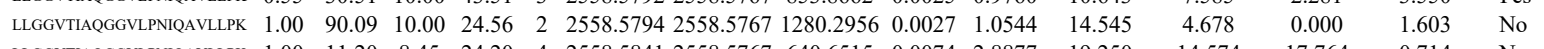

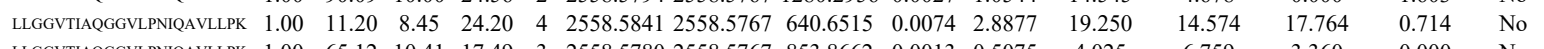

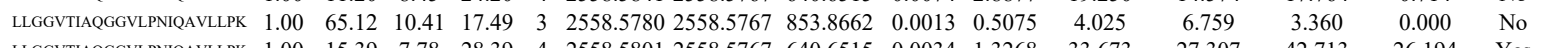

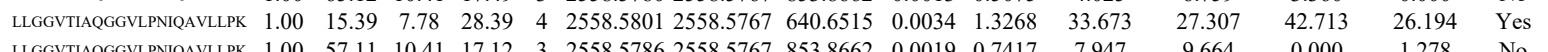

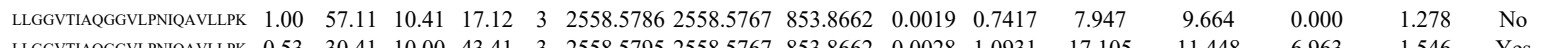

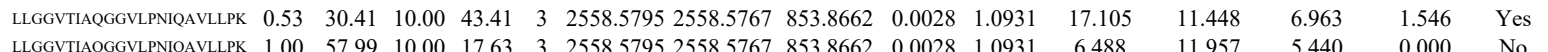

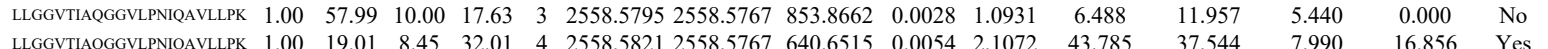

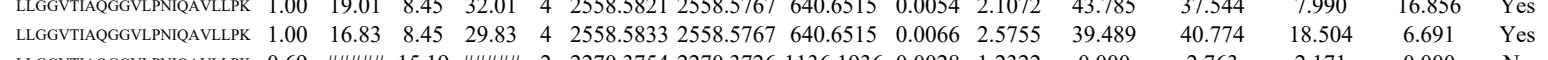

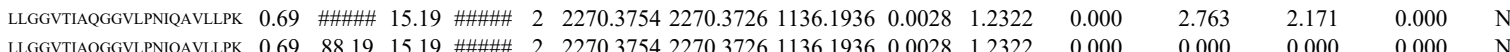


$\begin{array}{lllllllll} & 25.3724 & 803.4745 & 402.7445 & -0.0021 & -2.6071 & 167.144\end{array}$

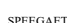

SETITEEELLVGLMNK

ALAAGGYDVEK ALAAGGYDVEK KPAGATPK KPAGATPK KPAGATPK KPAGATPK KPAGATPK KPAGATPK KPAGATPK

KPAAAGVK

KPAAAGVK

KPAGATPK

KPAGATPK

KPAGATPK

KPAGATPK

ATGPPVSELITK

ATGPPVSELITK

KPAAAGVK

KPAAAGVK

KPAAATKK

KPAGATPK

KPAAAGVK

KPAAAGVK

ALAAGGYDVEK

NGLSLAALK

NGLSLAALK

NGLSLAALK

NGLSLAALK

ALAAGGYDVEK

KPAGATPK

KPAGATPK

KPAGATPK

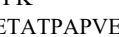

SETAPAETATPAPVEK

ALAAGGYDVEK

ALAAGGYDVEK

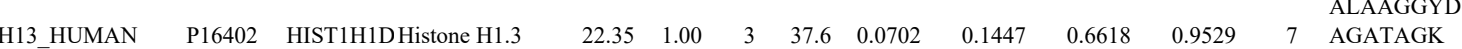

VAGAATPK

VAGAATPK

VAGAATPK

VAGAATPK

KPATAAGTK

KPATAAGTK $\begin{array}{lllllllllllll}\text { H12_HUMAN } & \text { P16403 } & \text { HIST1H1C Histone H1.2 } & 21.36 & 1.00 & 2 & 39.9 & 0.0568 & 0.3120 & 0.2527 & 1.2852 & 13 & \begin{array}{l}\text { AAGGATPK } \\ \text { AAGGATPK }\end{array} \\ & & & & & & & & & & & & \\ \text { AAGGATPK }\end{array}$

$\begin{array}{lllllllllllll}\text { H12_HUMAN } & \text { P16403 } & \text { HIST1H1C Histone H1.2 } & 21.36 & 1.00 & 2 & 39.9 & 0.0568 & 0.3120 & 0.2527 & 1.2852 & 13 & \begin{array}{l}\text { AAGGATPK } \\ \text { AAGGATPK }\end{array} \\ & & & & & & & & & & & & \\ \text { AAGGATPK }\end{array}$ $\begin{array}{llllllllllllllll}0.87 & 18.44 & 27.32 & 15.45 & 3 & 1859.9893 & 1859.9873 & 621.0030 & 0.0020 & 1.0735 & 1754.769 & 2375.648 & 6509.370 & 4826.028\end{array}$

$\begin{array}{llllllllllllll}1.00 & 53.76 & 25.87 & 25.09 & 3 & 3451.7422 & 3451.7391 & 1151.5870 & 0.0031 & 0.8973 & 17.047 & 13.738 & 63.685 & 60.059 \\ 0.61 & 5.44 & 25.90 & 16.57 & 4 & 3451.7425 & 3451.7391 & 863.9421 & 0.0034 & 0.9839 & 20.348 & 20.390 & 39.288 & 5.048\end{array}$

$\begin{array}{llllllllllllll}0.98 & 25.91 & 27.32 & 17.00 & 3 & 1980.0349 & 1980.0329 & 661.0182 & 0.0020 & 1.0085 & 193.793 & 295.703 & 307.784 & 277.662\end{array}$

$\begin{array}{llllllllllllll}1.00 & 72.61 & 27.21 & 23.65 & 2 & 1380.7568 & 1380.7493 & 691.3819 & 0.0075 & 5.4239 & 17151.506 & 15777.026 & 606.541 & 749.536\end{array}$ $\begin{array}{llllllllllllll}1.00 & 74.13 & 27.31 & 25.04 & 2 & 1380.7576 & 1380.7493 & 691.3819 & 0.0083 & 6.0024 & 10377.015 & 8670.201 & 625.993 & 614.587\end{array}$

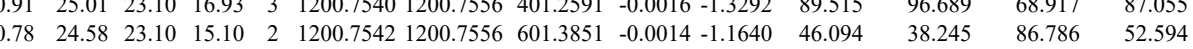
$\begin{array}{lllllllllllllll}0.85 & 20.42 & 23.10 & 14.32 & 3 & 1200.7543 & 1200.7556 & 401.2591 & -0.0013 & -1.0799 & 259.026 & 290.209 & 323.309 & 234.520 & \text { Y }\end{array}$ $\begin{array}{lllllllllllllll}0.77 & 18.35 & 23.01 & 18.04 & 3 & 1200.7546 & 1200.7556 & 401.2591 & -0.0010 & -0.8307 & 258.177 & 345.371 & 331.146 & 299.373 & Y\end{array}$

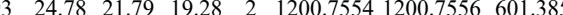

$\begin{array}{llllllllllllll}12.00 .756 & 36.66 & 22.17 & 15.61 & 3 & 1200.7561 & 1200.7556 & 401.2591 & 0.0005 & 0.4154 & 252.818 & 241.436 & 421.732\end{array}$ $\begin{array}{lllllllllllllll} & & & \end{array}$ $\begin{array}{lllllllllllllll}0.81 & 23.24 & 20.93 & 21.20 & 2 & 1172.7596 & 1172.7607 & 587.3876 & -0.0011 & 0.96364 & 47.806 & 52.564 & 113.265 & 82.605 & \text { Yes }\end{array}$

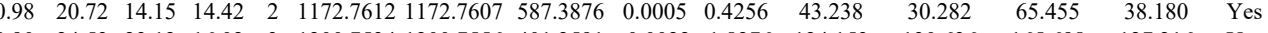

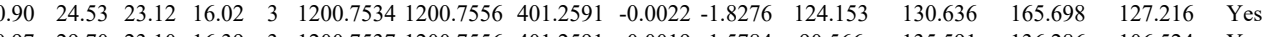
$\begin{array}{llllllllllllllll}0.97 & 29.70 & 23.10 & 16.39 & 3 & 1200.7537 & 1200.7556 & 401.2591 & -0.0019 & -1.5784 & 90.566 & 135.591 & 136.286 & 106.524 & \text { Yes }\end{array}$

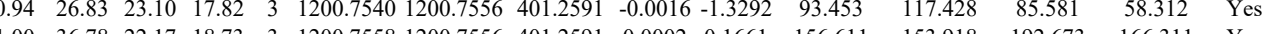
$\begin{array}{llllllllllllllll}1.00 & 36.78 & 22.17 & 18.73 & 3 & 1200.7558 & 1200.7556 & 401.2591 & 0.0002 & 0.1661 & 156.611 & 153.918 & 192.673 & 166.311 & \text { Yes } \\ 1.00 & 63.32 & 24.83 & 23.19 & 2 & 149.8934 & 1499.8803 & 750.9474 & 0.0131 & 8.7222 & 276.214 & 2827.419 & 4960.387 & 335.852 & \text { Yes }\end{array}$ $\begin{array}{lllllllllllllll}1.00 & 63.32 & 24.83 & 23.19 & 2 & 1499.8934 & 1499.8803 & 750.9474 & 0.0131 & 8.7222 & 2762.214 & 2827.419 & 4460.387 & 3375.852 & \text { Yes }\end{array}$ $\begin{array}{llllllllllllllll}1.00 & 67.26 & 24.83 & 25.36 & 2 & 149.8942 & 1499.8803 & 750.9474 & 0.0139 & 9.2549 & 7310.543 & 8050.885 & 14257.676 & 10827.172 & \text { Yes }\end{array}$

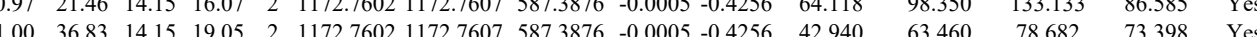

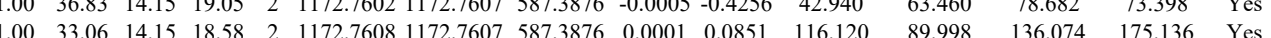

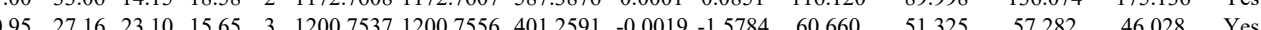

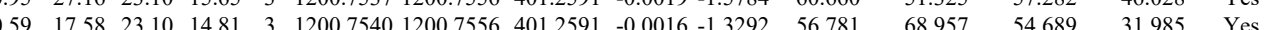

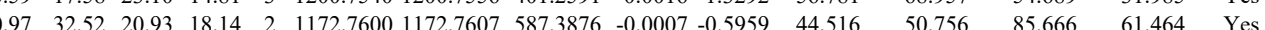
$\begin{array}{lllllllllllllll}0.99 & 28.03 & 14.15 & 20.98 & 2 & 1172.7606 & 1172.7607 & 587.3876 & -0.0001 & -0.0851 & 38.741 & 47.683 & 57.876 & 49.071 & \text { Yes }\end{array}$ $\begin{array}{lllllllllllllll}1.00 & 59.96 & 27.44 & 19.82 & 2 & 1380.7518 & 1380.7493 & 691.3819 & 0.0025 & 1.8080 & 29.310 & 20.595 & 0.851 & 2.832 & \text { No }\end{array}$ $\begin{array}{llllllllllllllll}0.99 & 41.70 & 24.90 & 28.24 & 2 & 1173.7440 & 1173.7325 & 587.8735 & 0.0115 & 9.7809 & 6735.335 & 7437.311 & 9261.257 & 2847.333 & \text { Yes }\end{array}$ $\begin{array}{llllllllllllllll}1.00 & 45.93 & 24.90 & 24.71 & 2 & 1173.7440 & 1173.7325 & 587.8735 & 0.0115 & 9.7809 & 14077.964 & 13885.415 & 16302.100 & 5256.049 & \text { Yes }\end{array}$

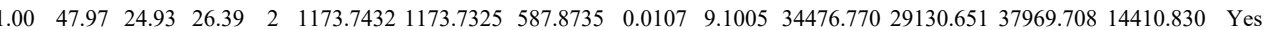
$\begin{array}{lllllllllllllllll}0 & 52.42 & 24.90 & 27.92 & 2 & 1173.7438 & 1173.7325 & 587.8735 & 0.0113 & 9.6108 & 18645.006 & 17726.039 & 19823.249 & 7498.981 & \text { Yes }\end{array}$

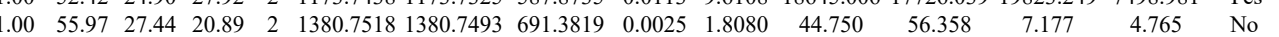
$\begin{array}{llllllllllllllll}0.58 & 19.65 & 23.12 & 18.90 & 3 & 1200.7531 & 1200.7556 & 401.2591 & -0.0025 & -2.0768 & 54.993 & 65.383 & 105.000 & 76.100 & \text { Yes }\end{array}$ $\begin{array}{llllllllllllllll}0.98 & 31.46 & 23.10 & 19.26 & 3 & 1200.7537 & 1200.7556 & 401.2591 & -0.0019 & -1.5784 & 49.447 & 63.881 & 84.386 & 74.759 & \text { Yes }\end{array}$

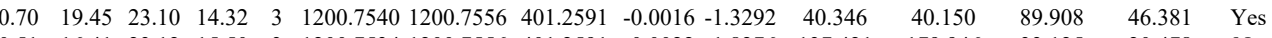
$\begin{array}{lllllllllllllll}0.51 & 16.41 & 23.12 & 15.50 & 3 & 1200.7534 & 1200.7556 & 401.2591 & -0.0022 & -1.8276 & 137.421 & 179.946 & 33.125 & 20.478 & \text { No }\end{array}$

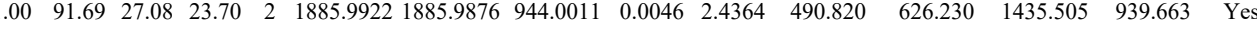

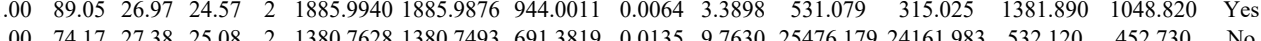
$\begin{array}{llllllllllllllll}1.00 & 74.17 & 27.38 & 25.08 & 2 & 1380.7628 & 1380.7493 & 691.3819 & 0.0135 & 9.7630 & 25476.179 & 24161.983 & 532.120 & 452.730 & \text { No }\end{array}$ \begin{tabular}{lllllllllllllll}
1.00 & 74.15 & 27.48 & 25.09 & 2 & 1380.7620 & 1380.7493 & 691.3819 & 0.0127 & 9.1844 & 49476.586 & 50565.276 & 167.194 & 561.229 & $\mathrm{No}$ \\
\hline
\end{tabular} $\begin{array}{lllllllllllllll}1.00 & 79.31 & 27.32 & 26.28 & 2 & 1380.7626 & 1380.7493 & 691.3819 & 0.0133 & 9.6183 & 53402.726 & 56876.788 & 734.276 & 685.121 & \text { No } \\ 0.70 & 23.14 & 2.98 & 25.84 & 2 & 862.512 & 862.516 & 432.231 & -0.004 & 0.4627 & 262.106 & 274.710 & 184.112 & 180.110 & \text { Yes }\end{array}$ $\begin{array}{lllllllllllllll}1.70 & 23.14 & 27.98 & 25.84 & 2 & 862.5112 & 862.5116 & 432.2631 & -0.0004 & -0.4627 & 262.106 & 274.710 & 184.112 & 180.110 & \text { Yes } \\ 0.72 & 25.62 & 25.66 & 2.08 & 2 & 1001.6106 & 1001.611 & 50.8129 & 0.0007 & -0.695 & 356.622 & 34.682 & 134.946 & 158.685 & \text { Yes }\end{array}$

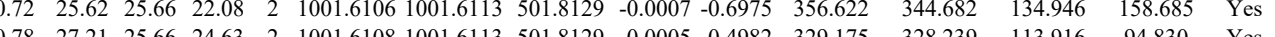

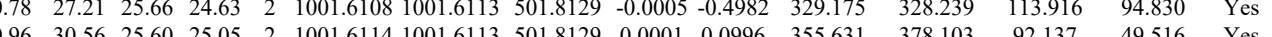
$\begin{array}{lllllllllllllll}0.64 & 18.82 & 23.52 & 15.62 & 3 & 1275.7861 & 1275.7876 & 426.2698 & -0.0015 & -1.1730 & 153.480 & 193.075 & 108.688 & 116.587 & \text { Yes }\end{array}$

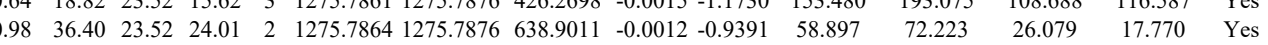
$\begin{array}{llllllllllllllll}0.55 & 16.03 & 23.52 & 20.52 & 2 & 1275.7874 & 1275.7876 & 638.9011 & -0.0002 & -0.1565 & 59.898 & 56.442 & 50.807 & 16.133 & \text { No }\end{array}$ $\begin{array}{llllllllllllllll}0.63 & 37.49 & 26.60 & 45.65 & 2 & 959.5634 & 959.5644 & 480.7895 & -0.0010 & -1.0400 & 579.055 & 565.761 & 482.721 & 119.691 & \text { Yes }\end{array}$

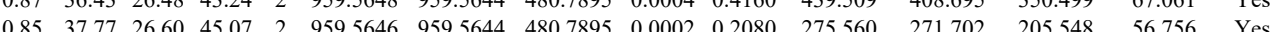


KPAAATVTK

KPAAATVTK

KPAAATVTK

KPAAATVTK

KPAAATVTK

KPAAATVTK

KPAAATVTK

PPAAATVTK

KPAAATVTK

TQNDVDIADVAYYFEK

TQNDVDIADVAYYFEK

TQNDVDIADVAYYFEK

TQNDVDIADVAYYFEK
TQNDVDIADVAYYFEK

TQNDVDIADVAYY
LAVNCFVNNNR

LAVNCFVNNNR

TDKDTEITCSER

TDKDTEITCSER

AKPEGALQNNDGLYDPDCDESGLFK

DVQNTFYDIVAELGA

-

FAVFGLGNK

IQTLTSSVR

IQTLTSSVR

GVATNWLR

FAVFGLGNK

ALVPMFVR

NPFLAAVTTNR
NPFLAAVTTNR

NPFLAAVTTN

NAENAIEALK

IGIFGQDEDVTSK

DIFGDIVIAVGDK

VGEATETALTCLVEK

VIMITGDNK

TASEMVLADDNFSTIVAAVE

IVEFLLSFDEITAMTGDGVNDAPALK

IVEFLSFDEITAMTGDGVND
ISLPVILMDETLK

ISLPVILMDETLK

ISLPVILMDETLK

ISLPVILMDETLK

ISLPVILMDETLK

ISLPVILMDETLK
GTAVAICR

GTAVAICR

CLALATHDNPLR

CLALATHDNPLR

GTAVAICR

GTAVAICR

EPLISGWLFFR

EPLISGWLFFR

CLALATHDNPLR

CLALATHDNPLR

WGSNELPAEEGK

WGSNELPAEEGK

IRDEMVATEQER

IRDEMVATEQER

IRDEMVATEQER

NAENAIEALK

DIVPGDIVEIAVGD

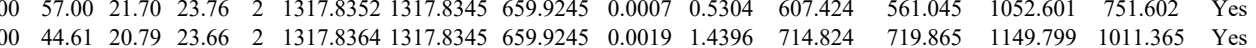
$\begin{array}{llllllllllllllll}1.00 & 40.60 & 20.83 & 16.36 & 3 & 1317.8365 & 1317.8345 & 440.2854 & 0.0020 & 1.5142 & 563.085 & 596.481 & 926.263 & 709.832 & \text { Yes }\end{array}$ $\begin{array}{lllllllllllllll}0.98 & 29.62 & 21.52 & 21.80 & 2 & 1317.8342 & 1317.8345 & 659.9245 & -0.0003 & -0.2273 & 215.188 & 215.049 & 341.354 & 307.506 & \text { Yes }\end{array}$

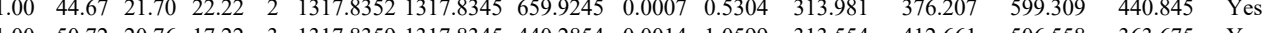
$\begin{array}{llllllllllllllll}1.00 & 50.72 & 2.0 .76 & 17.22 & 3 & 1317.8359 & 1317.8345 & 440.2854 & 0.0014 & 1.0599 & 313.554 & 412.661 & 506.558 & 363.675 & \text { Yes } \\ 1.06 & 26.61 & 2.64 & 21.40 & 2 & 1317.8344 & 1317.8345 & 559.9245 & 0.000 & -0.0758 & 21.928 & 22.254 & 369.975 & 277.285 & \text { Yes }\end{array}$ $\begin{array}{lllllllllllllll}0.96 & 26.61 & 21.64 & 21.40 & 2 & 1317.8344 & 1317.8345 & 659.9245 & -0.0001 & -0.0758 & 219.928 & 221.254 & 369.975 & 277.285 & \text { Yes } \\ 1.00 & 38.65 & 1.64 & 23.80 & 2 & 1317.8346 & 1317.8345 & 659.9245 & 0.0001 & 0.0758 & 177.187 & 154.746 & 287.747 & 252.546 & \text { Yes }\end{array}$

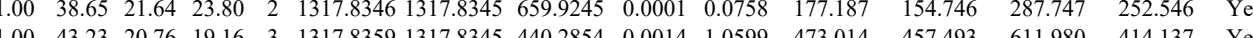

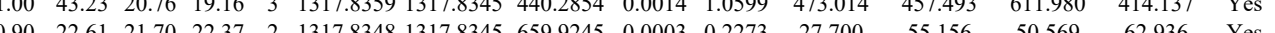

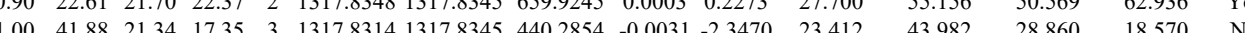

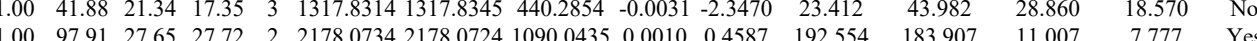
$\begin{array}{lllllllllllllll}0.97 & 24.30 & 27.59 & 20.80 & 3 & 2178.0757 & 2178.0724 & 727.0314 & 0.0033 & 1.5130 & 43.725 & 31.041 & 24.743 & 0.000 & \text { No }\end{array}$

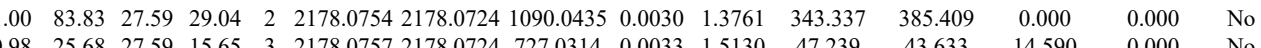
$\begin{array}{lllllllllllllll}0.99 & 28.69 & 27.50 & 16.70 & 3 & 2178.0769 & 2178.0724 & 727.0314 & 0.0045 & 2.0632 & 33.922 & 39.299 & 8.920 & 13.826 & \mathrm{~N} 0\end{array}$ $\begin{array}{llllllllllllllll}1.00 & 54.23 & 26.98 & 23.51 & 2 & 1452.7100 & 1452.7088 & 727.3617 & 0.0012 & 0.8249 & 6478.659 & 6588.023 & 0.000 & 37.149 & \text { No }\end{array}$ $\begin{array}{llllllllllllllll}1.00 & 56.14 & 26.95 & 26.26 & 2 & 1452.7104 & 1452.7088 & 727.3617 & 0.0016 & 1.0999 & 3292.079 & 3417.536 & 0.000 & 16.564 & \mathrm{No}\end{array}$ $\begin{array}{lllllllllllllll}0.99 & 79.05 & 26.12 & 24.76 & 2 & 1730.8038 & 1730.8059 & 866.4102 & -0.0021 & -1.2119 & 166.440 & 161.324 & 31.240 & 12.172 & \text { Yes }\end{array}$ $\begin{array}{llllllllllllllll}0.68 & 8.95 & 26.28 & 21.95 & 4 & 3173.5081 & 3173.5011 & 794.3826 & 0.0070 & 2.2030 & 86.681 & 17.571 & 66.715 & 23.749 & \text { No }\end{array}$

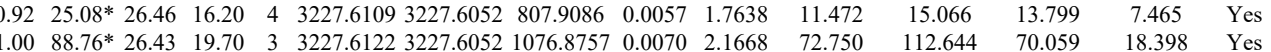
$\begin{array}{lllllllllllllllll}0.99 & 47.10 & 27.25 & 30.87 & 2 & 1147.6750 & 1147.6683 & 574.8414 & 0.0067 & 5.8277 & 11383.161 & 12348.339 & 1175.385 & 736.768 & \text { Yes }\end{array}$ $\begin{array}{lllllllllllllllll}1.00 & 50.04 & 27.25 & 22.65 & 2 & 1147.6750 & 1147.6683 & 574.8414 & 0.0067 & 5.8277 & 26368.321 & 27011.351 & 1998.611 & 719.580 & \text { Yes }\end{array}$ $\begin{array}{lllllllllllllll}0.96 & 32.99 & 24.77 & 20.72 & 2 & 1239.7338 & 1239.7219 & 620.8682 & 0.0119 & 9.5833 & 7884.133 & 8380.362 & 9833.334 & 1353.733 & \text { Yes }\end{array}$ $\begin{array}{llllllllllllllll}0.99 & 47.22 & 27.54 & 22.86 & 2 & 1147.6738 & 1147.6683 & 574.8414 & 0.0055 & 4.7839 & 5781.832 & 6551.131 & 665.170 & 185.372 & \text { Yes }\end{array}$ $\begin{array}{llllllllllllllll}1.00 & 49.01 & 27.54 & 23.78 & 2 & 1147.6738 & 1147.6683 & 574.8414 & 0.0055 & 4.7839 & 4616.002 & 5011.297 & 722.544 & 215.406 & \text { Yes }\end{array}$ $\begin{array}{lllllllllllllll}0.85 & 38.49 & 27.23 & 43.88 & 2 & 1059.6044 & 1059.5947 & 530.8046 & 0.0097 & 9.1370 & 277.077 & 256.588 & 87.214 & 37.184 & \text { Yes }\end{array}$ $\begin{array}{llllllllllllllll}0.97 & 34.08 & 24.50 & 21.59 & 2 & 1239.7336 & 1239.7219 & 620.8682 & 0.0117 & 9.4222 & 12948.435 & 11298.238 & 14291.270 & 1206.666 & \text { Yes }\end{array}$ $\begin{array}{lllllllllllllll}0.93 & 25.32 & 26.09 & 20.69 & 2 & 1075.6356 & 1075.6334 & 538.8240 & 0.0022 & 2.0415 & 6181.273 & 7023.573 & 261.743 & 119.026 & \text { Yes }\end{array}$ \begin{tabular}{llllllllllllllll}
1.00 & 55.66 & 28.02 & 34.34 & 2 & 1346.7538 & 1346.7428 & 674.3787 & 0.0110 & 8.1556 & 2008.600 & 1993.468 & 1195.529 & 1081.341 & Yes \\
\hline
\end{tabular} $\begin{array}{lllllllllllllll}1.00 & 55.40 & 28.23 & 33.39 & 2 & 1346.7550 & 1346.7428 & 674.3787 & 0.0122 & 9.0453 & 1882.796 & 2052.631 & 989.337 & 1103.827 & \text { No }\end{array}$ $\begin{array}{lllllllllllll} & \end{array}$

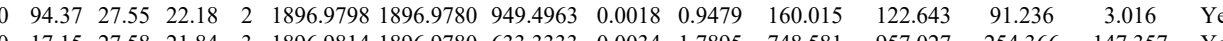
$\begin{array}{llllllllllllllll}0.65 & 26.23 & 27.82 & 24.63 & 2 & 1277.7338 & 1277.7257 & 639.8701 & 0.0081 & 63294 & 2013.889 & 2517.673 & 1100.868 & 305.550 & \text { Yes }\end{array}$

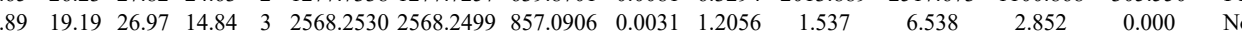
$\begin{array}{llllllllllllll}0.99 & 57.87 * 26.73 & 23.98 & 3 & 3068.5642 & 3068.5620 & 1023.8613 & 0.0022 & 0.7162 & 3.794 & 3.682 & 0.000 & 5.204 & \mathrm{~N}\end{array}$

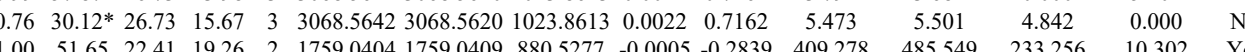

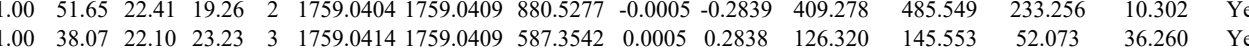

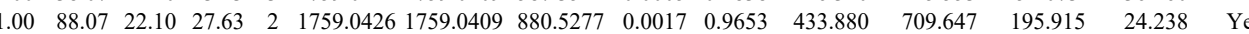
$\begin{array}{lllllllllllllll}1.00 & 54.39 & 22.12 & 16.63 & 3 & 1759.0432 & 1759.0409 & 587.3542 & 0.0023 & 1.3053 & 385.894 & 272.854 & 137.812 & 47.807 & \text { No }\end{array}$ $\begin{array}{lllllllllllllll}1.00 & 70.69 & 22.15 & 17.58 & 2 & 1759.0438 & 1759.0409 & 880.5277 & 0.0029 & 1.6467 & 543.194 & 773.981 & 129.153 & 34.965 & \text { Yes }\end{array}$ $\begin{array}{llllllllllllllll}1.00 & 49.79 & 22.15 & 22.55 & 3 & 1759.0441 & 1759.0409 & 587.3542 & 0.0032 & 1.8161 & 161.042 & 194.451 & 84.662 & 35.025 & \text { Yes }\end{array}$ $\begin{array}{lllllllllllllll}0.97 & 36.42 & 27.47 & 23.68 & 2 & 979.5102 & 979.5065 & 490.7605 & 0.0037 & 3.7696 & 8509.935 & 11852.448 & 9670.682 & 5782.868 & \text { Yes }\end{array}$ $\begin{array}{lllllllllllllllll}0.71 & 24.92 & 27.40 & 19.13 & 2 & 979.5106 & 979.5065 & 490.7605 & 0.0041 & 4.1772 & 3691.564 & 6290.416 & 5304.429 & 2580.048 & \text { Yes }\end{array}$ $\begin{array}{llllllllllllllll}1.00 & 57.52 & 27.61 & 22.32 & 3 & 1512.7747 & 1512.7663 & 505.2627 & 0.0084 & 5.5416 & 9935.517 & 12299.539 & 1140.652 & 520.951 & \text { Yes }\end{array}$ $\begin{array}{llllllllllllllll}1.00 & 61.11 & 27.58 & 21.80 & 3 & 1512.7750 & 1512.7663 & 505.2627 & 0.0087 & 5.7396 & 8722.228 & 10317.063 & 1439.160 & 644.767 & \text { Yes }\end{array}$ $\begin{array}{llllllllllllllll}0.87 & 32.43 & 27.98 & 23.10 & 2 & 979.5112 & 979.5065 & 490.7605 & 0.0047 & 4.7885 & 13333.311 & 18261.195 & 15759.680 & 6823.017 & \text { Yes }\end{array}$ $\begin{array}{lllllllllllllll}0.17 & 29.67 & 27.97 & 26.12 & 2 & 979.5114 & 979.5065 & 490.7605 & 0.0049 & 4.9922 & 14205.839 & 19828.986 & 15663.224 & 9426.044 & \text { Yes }\end{array}$

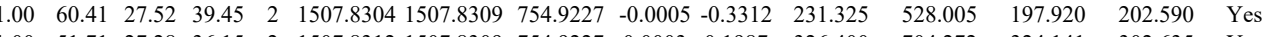

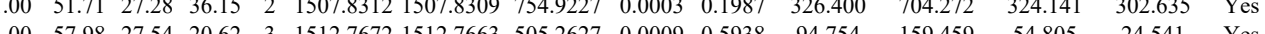
\begin{tabular}{lllllllllllllll}
1.00 & 57.98 & 27.54 & 20.62 & 3 & 1512.7672 & 1512.7663 & 505.2627 & 0.0009 & 0.5938 & 94.754 & 159.459 & 54.805 & 24.541 & Yes \\
\hline
\end{tabular}

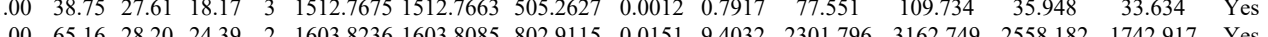
$\begin{array}{lllllllllllllll}.00 & 65.16 & 28.20 & 24.39 & 2 & 1603.8236 & 1603.8085 & 802.9115 & 0.0151 & 9.4032 & 2301.796 & 3162.749 & 2558.182 & 1742.917 & \text { Yes }\end{array}$

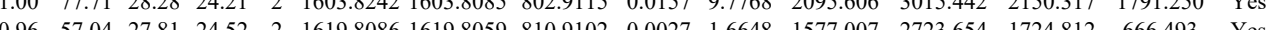

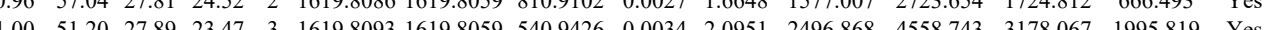
$\begin{array}{lllllllllllllll}0.99 & 67.08 & 27.89 & 26.54 & 2 & 1619.8094 & 1619.8059 & 810.9102 & 0.0035 & 2.1581 & 2075.190 & 3464.860 & 2554.934 & 1377.116 & \text { Yes }\end{array}$

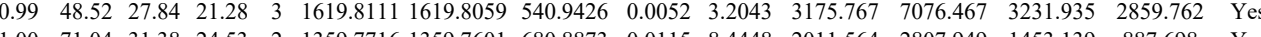
$\begin{array}{llllllllllllll}1.00 & 74.54 & 26.13 & 28.07 & 2 & 1827.0234 & 1827.0233 & 914.5189 & 0.0001 & 0.0547 & 175.506 & 169.716 & 423.830 & 296.821\end{array}$

Table S-3 page 162 of 499 
$\begin{array}{llllllllllllllll}\text { DIVPGDIVEIAVGDK } & 1.00 & 74.80 & 25.99 & 27.07 & 2 & 1827.0238 & 1827.0233 & 914.5189 & 0.0005 & 0.2734 & 136.077 & 155.531 & 220.742 & 173.685 & \text { Yes }\end{array}$ $\begin{array}{lllllllllllllllll}\text { DIVPGDIVEIAVGDK } & 0.96 & 22.35 & 25.98 & 16.93 & 3 & 1827.0250 & 1827.0233 & 610.0150 & 0.0017 & 0.9289 & 314.389 & 232.816 & 132.631 & 136.554 & \text { Yes }\end{array}$ $\begin{array}{llllllllllllllll}\text { DIVPGDIVEIAVGDK } & 0.91 & 18.66 & 25.97 & 14.96 & 3 & 1827.0259 & 1827.0233 & 610.0150 & 0.0026 & 1.4207 & 130.550 & 121.531 & 112.097 & 107.062 & \text { Yes }\end{array}$ $\begin{array}{llllllllllllllll}\text { IGIFGQDEDVTSK } & 1.00 & 68.27 & 27.55 & 22.85 & 2 & 1695.8926 & 1695.8923 & 848.9534 & 0.0003 & 0.1767 & 4885.085 & 6174.058 & 2796.783 & 285.016 & \text { Yes }\end{array}$

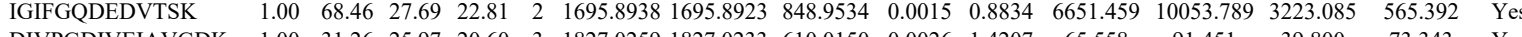

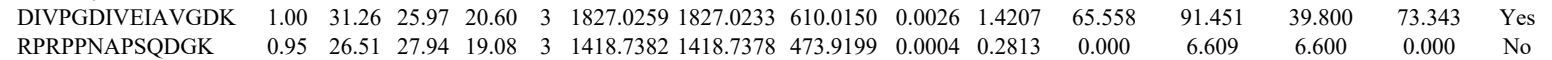
$\begin{array}{lllllllllllll}\text { DBPA HUMAN } & \text { P16989 } & \text { CSDA } & \text { DNA-binding prot } 40.09 & 1.00 & 4 & 23.9 & 0.0432 & 0.8854 & 0.7814 & 1.2013 & 12 & \text { RPRPPNAPSQDGK }\end{array}$ RPRPPNAPSQDGK IQAGEIGEMK PRPPNAPSQDGK

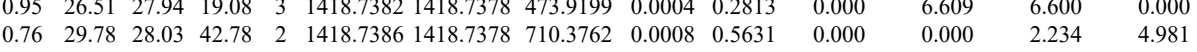
$\begin{array}{lllllllllllllll}1.00 & 55.69 & 28.07 & 24.30 & 2 & 1362.7532 & 1362.7421 & 682.3783 & 0.0111 & 8.1333 & 5018.989 & 5324.691 & 5421.137 & 2253.590 & \text { Yes }\end{array}$ $\begin{array}{llllllllllllllllll} & \end{array}$

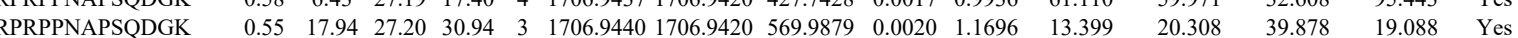
$\begin{array}{lllllllllllllllll}\text { RPRPPNAPSQDGK } & 0.51 & 11.44 & 26.98 & 24.44 & 3 & 1706.9449 & 1706.9420 & 569.9879 & 0.0029 & 1.6959 & 33.798 & 34.771 & 43.268 & 47.568 & \text { Yes }\end{array}$ $\begin{array}{llllllllllllllll}\text { RPRPPNAPSQDGK } & 0.60 & 8.18 & 27.23 & 17.69 & 4 & 1706.9429 & 1706.9420 & 427.7428 & 0.0009 & 0.5260 & 17.893 & 37.035 & 5.168 & 11.222 & \text { No }\end{array}$ $\begin{array}{lllllllllllllllll}\text { RPRPPNAPSQDGK } & 0.69 & 7.69 & 27.19 & 18.51 & 4 & 1706.9437 & 1706.9420 & 427.7428 & 0.0017 & 0.9936 & 33.002 & 21.982 & 22.485 & 14.387 & \text { Yes }\end{array}$

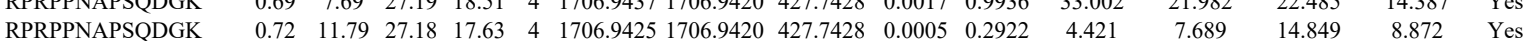

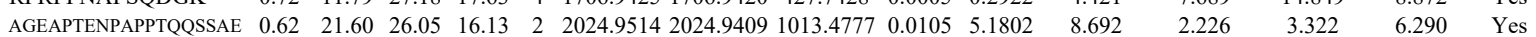

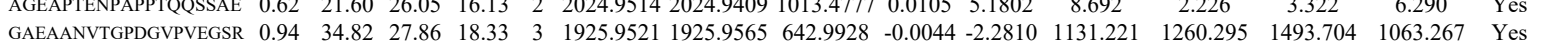

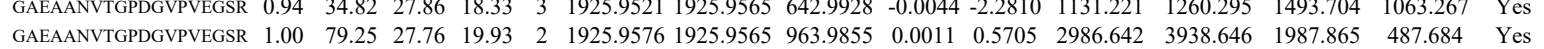
$\begin{array}{lllllllllllllllll}32 & \text { KQPPVSPGTALVGSQK } & 1.00 & 89.53 & 26.72 & 25.41 & 2 & 1592.8890 & 1592.8886 & 797.4516 & 0.0004 & 0.2508 & 3.369 & 3.676 & 0.000 & 0.000 & \text { No }\end{array}$ $\begin{array}{lllllllllllllllll}\text { KQPPVSPGTALVGSQK } & 1.00 & 50.93 & 26.91 & 21.77 & 3 & 1592.8900 & 1592.8886 & 531.9701 & 0.0014 & 0.8772 & 3.065 & 11.481 & 10.762 & 18.037 & \text { No }\end{array}$ $\begin{array}{lllllllllllllllll}\text { KQPPVSPGTALVGSQK } & 1.00 & 34.95 & 26.91 & 21.31 & 3 & 1592.8900 & 1592.8886 & 531.9701 & 0.0014 & 0.8772 & 7.079 & 15.461 & 12.318 & 6.023 & \text { Yes }\end{array}$

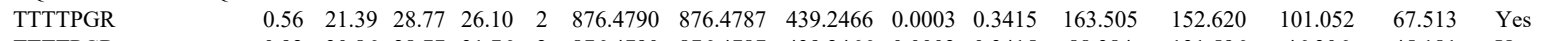
$\begin{array}{lllllllllllllllll}\text { TTTTPGR } & 0.92 & 30.86 & 28.77 & 31.76 & 2 & 876.4790 & 876.4787 & 439.2466 & 0.0003 & 0.3415 & 88.384 & 131.596 & 46.306 & 45.181 & \text { Yes }\end{array}$ $\begin{array}{llllllllllllllll}\text { SSQPLASK } & 0.97 & 31.90 & 27.81 & 32.51 & 2 & 1104.6388 & 1104.6382 & 553.3264 & 0.0006 & 0.5422 & 1149.384 & 1043.079 & 314.664 & 152.927 & \text { Yes }\end{array}$ $\begin{array}{llllllllllllllll}\text { SSQPLASK } & 1.00 & 46.63 & 27.77 & 35.41 & 2 & 1104.6396 & 1104.6382 & 553.3264 & 0.0014 & 1.2651 & 1534.709 & 1458.451 & 444.337 & 122.926 & \text { Yes }\end{array}$

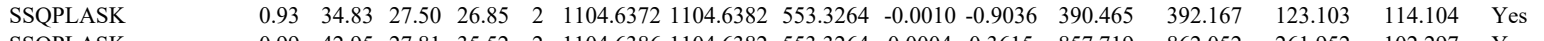

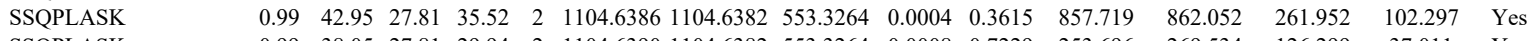

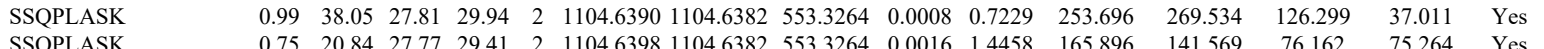

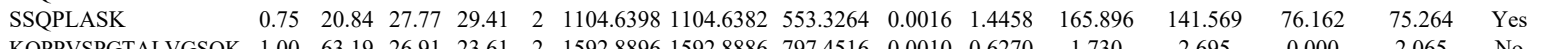

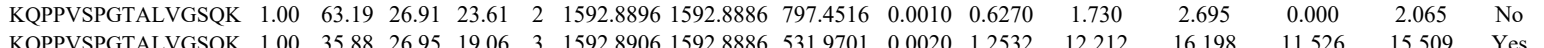

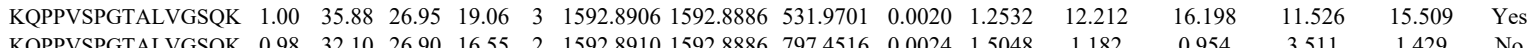

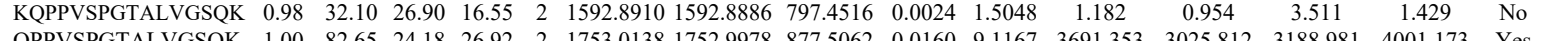
\begin{tabular}{llllllllllllllll} 
QPPVSPGTALVGSQK & 1.00 & 82.65 & 24.18 & 26.92 & 2 & 1753.0138 & 1752.9978 & 877.5062 & 0.0160 & 9.1167 & 3691.353 & 3025.812 & 3188.981 & 4001.173 & Yes \\
\hline QPPVSPTALVGSQK & 0.83 & 27.17 & 2.08 & 25.59 & 3 & 1753.0144 & 1752.9978 & 585.3399 & 0.0166 & 9.4531 & 2011.175 & 1838.565 & 1539.953 & 1270.876 & Yes
\end{tabular} $\begin{array}{lllllllllllllll} & \end{array}$

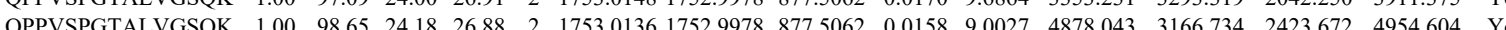

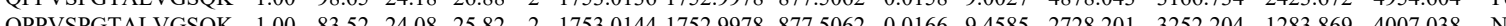

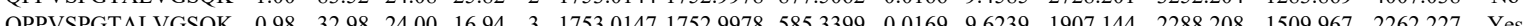

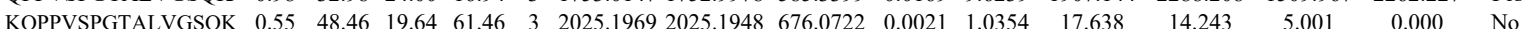

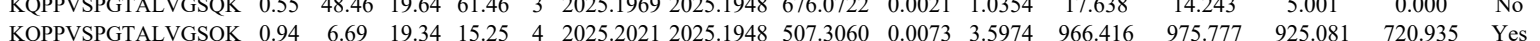
$\begin{array}{lllllllllllllllll}\text { KQPPVSPGTALVGSOK } & 1.00 & 27.83 & 17.99 & 40.83 & 4 & 2025.2117 & 2025.1948 & 507.3060 & 0.0169 & 8.3282 & 6650.352 & 6947.853 & 4702.145 & 3321.083 & \text { Yes }\end{array}$ $\begin{array}{lllllllllllllllll}\text { KOPPVSPGTALVGSQK } & 1.00 & 12.14 & 1934 & 25.14 & 4 & 2025.2001 & 2025.1948 & 507.3060 & 0.0053 & 2.6118 & 32.874 & 20.307 & 35.147 & 10.130 & \text { N }\end{array}$

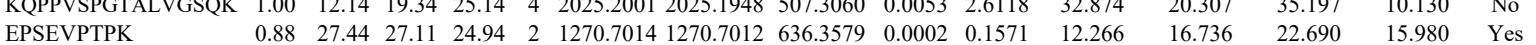

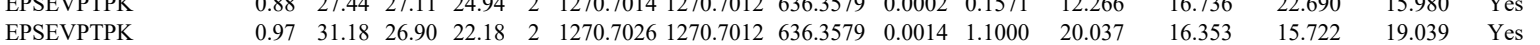

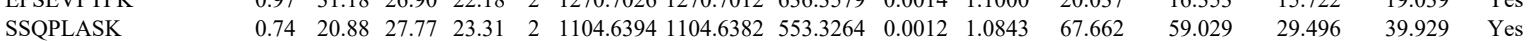

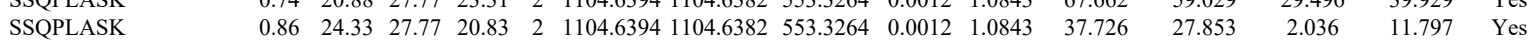

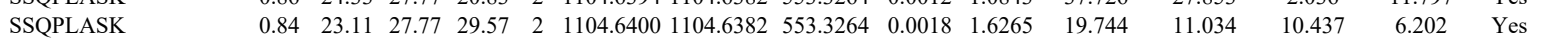

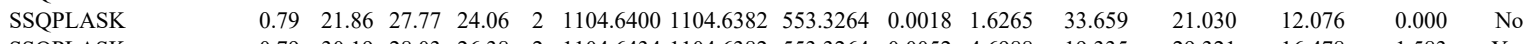

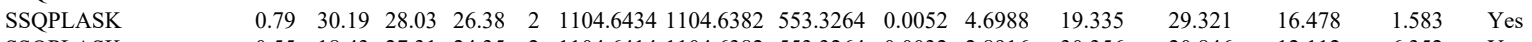

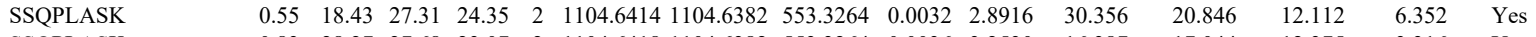

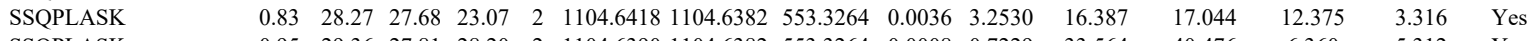
SSQPLASK SSQPLASK EPSEVPTPK EPSEVPTPK EPSEVPTPK EPSEVPTPK EPSEVPTPK $\begin{array}{lllllllllllllll}0.85 & 24.03 & 27.81 & 21.78 & 2 & 1104.6392 & 1104.6382 & 553.3264 & 0.0010 & 0.9036 & 34.137 & 29.353 & 4.288 & 4.288 & \text { Yes }\end{array}$

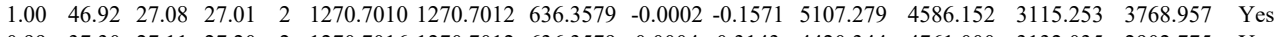

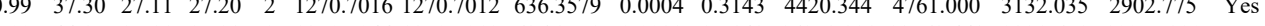
$\begin{array}{llllllllllllllll}1.00 & 44.97 & 27.11 & 25.28 & 2 & 1270.7044 & 1270.7012 & 636.3579 & 0.0032 & 2.5143 & 16258.328 & 18562.443 & 9321.671 & 10077.320 & \text { Yes }\end{array}$ $\begin{array}{llllllllllllllllllll}1.00 & 42.74 & 27.16 & 22.44 & 2 & 1270.7046 & 1270.7012 & 636.3579 & 0.0034 & 2.6714 & 14678.680 & 15680.998 & 9471.805 & 8542.950 & \text { Yes }\end{array}$ $\begin{array}{llllllllllllllll}0.98 & 38.31 & 27.09 & 23.95 & 2 & 1270.7052 & 1270.7012 & 636.3579 & 0.0040 & 3.1429 & 19207.432 & 19536.633 & 10752.456 & 11990.850 & \text { Yes }\end{array}$ $\begin{array}{lllllllllllllllll}1.00 & 77.79 & 25.01 & 24.56 & 2 & 1386.8094 & 1386.7962 & 694.4054 & 0.0132 & 9.5044 & 5897.077 & 5800.666 & 888.867 & 628.675 & \text { Yes } \\ 1.00 & 68.01 & 27.46 & 17.76 & 2 & 1918.0344 & 1918.0325 & 960.0235 & 0.0019 & 0.9896 & 34.019 & 47.599 & 30.590 & 5.958 & \text { No }\end{array}$ $\begin{array}{llllllllllllllll}1.00 & 68.01 & 27.46 & 17.76 & 2 & 1918.0344 & 1918.0325 & 960.0235 & 0.0019 & 0.9896 & 34.019 & 47.599 & 30.590 & 54.958 & \mathrm{No} & \\ 0.69 & 61.83 & 27.49 & 74.83 & 2 & 1918.0350 & 1918.0325 & 960.0235 & 0.0025 & 1.3020 & 28.086 & 36.678 & 24.389 & 35.971 & \mathrm{No}\end{array}$ $\begin{array}{lllllllllllllll}0.69 & 1.83 & 27.49 & 74.83 & 2 & 1918.0350 & 1918.0325 & 960.0235 & 0.0025 & 1.3020 & 28.086 & 36.678 & 24.389 & 35.971 & \mathrm{No}\end{array}$

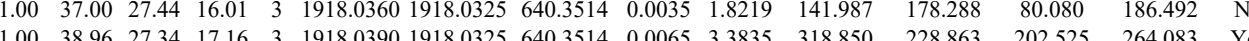
$\begin{array}{llllllllllllll}45.44 & 27.34 & 16.64 & 3 & 1918.0390 & 1918.0325 & 6403514 & 0.006 & 3.3835 & 156.004 & 133.156 & 120.692 & 62.868 & \text { Yes }\end{array}$

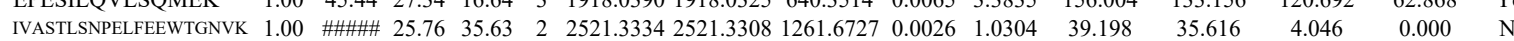

Table S-3 page 163 of 499 


\subsection{00
0.87}

VGGVQSLGGTGALR
VGGVQSLGGTGALR

VGGVQSLGGTGALR
VNLGVGAYR

VNLGVGAYR
VNLGVGAYR

VNLGVGAYR
VGGVQSLGGTGALR

VGGVQSLGGTGALR
ITWSNPPAQGAR

TPGTWNHITDQIGMFSFTGLNPK

VNLGVGAYR

VNLGVGAYR

VGGVQSLGGTGALR

ITWSNPPAQGAR

ITWSNPPAQGAR

ITWSNPPAQGAR

23 NPWGEVEWTGR

FADDQLIIDFDNFVR

FADDQLIIDFDNFVR

FADDQLIIDFDNFVR

FADDQLIIDFDNFVR

NECLEAGTLFPDPSPAAISALG

NECLEAGTLFQDPSPPAIPSALGFK

NECLEAGTLFQDPSFPAIPALGGK

KPPPNLFK

KPPPNLFK

RPTEICADPQFIIGGATR RPTEICADPQFIIGGATR

NFFLTNR

NFFLTNR

MPFLTNR

MPCQLHQVIVAR
MPCQLHQVIVAR

MPCQLHQVIVAR

MPCQLHQVIVAR

MPCQLHQVIVAR

MPCQLHQVIVAR

MPCQLHQVIVAR

19

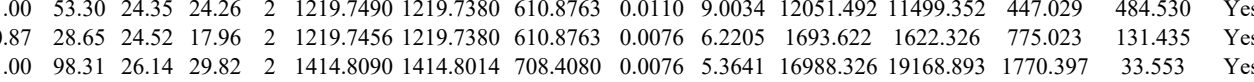
$\begin{array}{lllllllllllllll}.00 & 95.59 & 26.14 & 32.64 & 2 & 1414.8090 & 1414.8014 & 708.4080 & 0.0076 & 5.3641 & 22322.391 & 24174.219 & 1434.240 & 235.878 & \text { Yes }\end{array}$ $\begin{array}{lllllllllllllllll}1.00 & 53.89 & 28.07 & 25.71 & 2 & 1091.6260 & 1091.6209 & 546.8177 & 0.0051 & 4.6633 & 28331.327 & 28355.065 & 1584.548 & 2303.848 & \text { Yes } \\ 0.99 & 48.29 & 2.08 & 27.89 & 2 & 091.6202 & 091.620 & 54.8177 & 0.053 & 4.8462 & 4545.978 & 565.440 & 565.568 & 48.534 & \text { Yes }\end{array}$ $\begin{array}{llllllllllllllll}0.98 & 48.29 & 28.08 & 27.89 & 2 & 1091.6262 & 1091.6209 & 546.8177 & 0.0053 & 4.8462 & 14545.978 & 15695.440 & 565.668 & 4816.554 & \text { Yes } \\ 1.00 & 98.24 & 6.12 & 31.93 & 2 & 1414.8024 & 1414.8014 & 708.4080 & 0.080 & 5.6464 & 13898695 & 16138.071 & 1205.952 & 122.277 & \text { Yes }\end{array}$ $\begin{array}{lllllllllllllllll}.00 & 92.19 & 26.12 & 36.25 & 2 & 1414.8096 & 1414.8014 & 708.4080 & 0.0082 & 5.7876 & 6597.502 & 7759.044 & 413.896 & 158.636 & \text { Yes }\end{array}$ \begin{tabular}{lllllllllllll} 
& 14.24 & 2 & 1440.7680 & 1440.7595 & 721.3870 & 0.0085 & 5.8914 & 801.335 & 927.942 & 291.325 & 155.233 & Y \\
\hline
\end{tabular}

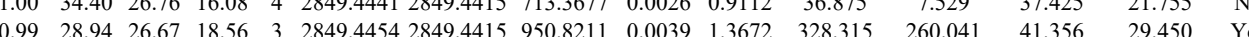

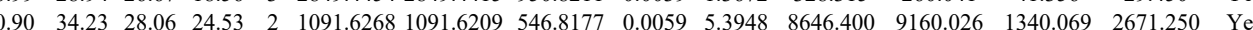
$\begin{array}{lllllllllllllll}1.00 & \# \# \# \# & 26.02 & 37.10 & 2 & 1414.8098 & 1414.8014 & 708.4080 & 0.0084 & 5.9288 & 1073.015 & 1510.732 & 55.245 & 54.078 & \text { Yes }\end{array}$ $\begin{array}{llllllllllllllll}1.00 & 70.31 & 27.90 & 28.28 & 2 & 1440.7674 & 1440.7595 & 721.3870 & 0.0079 & 5.4755 & 3368.755 & 4281.376 & 1894.816 & 763.891 & \text { Yes }\end{array}$ $\begin{array}{llllllllllllllll}1.00 & 61.81 & 27.95 & 25.88 & 2 & 1440.7682 & 1440.7595 & 721.3870 & 0.0087 & 6.0300 & 9565.937 & 10695.899 & 3607.917 & 1580.361 & \text { Yes }\end{array}$ $\begin{array}{llllllllllllllll}1.00 & 67.80 & 27.96 & 28.43 & 2 & 1440.7698 & 1440.7595 & 721.3870 & 0.0103 & 7.1390 & 2026.963 & 2181.700 & 772.134 & 481.650 & \text { Yes }\end{array}$

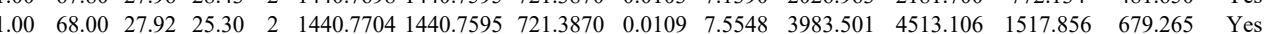

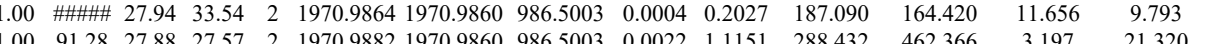
$\begin{array}{lllllllllllll} & \end{array}$

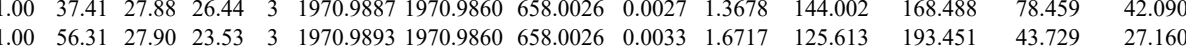
$\begin{array}{llllllllllllll}1.00 & 84.72 & 27.94 & 27.69 & 2 & 1970.9878 & 1970.9860 & 986.5003 & 0.0018 & 0.9123 & 139.115 & 108.693 & 12.278 & 6.022\end{array}$ \begin{tabular}{lllllllllllll}
1.00 & 91.00 & 27.88 & 29.01 & 2 & 1970.9884 & 1970.9860 & 986.5003 & 0.0024 & 1.2164 & 80.451 & 69.821 & 5.219 \\
\hline & 44.96 & 26.63 & 22.19 & 3 & 2985.4891 & 2985.4860 & 996.1693 & 0.0031 & 1.0373 & 23.106 & 17.217 & 12.361
\end{tabular}

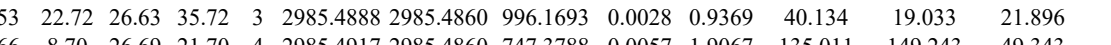

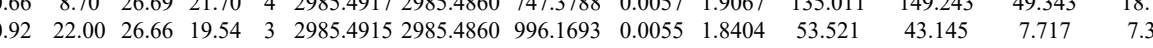
$\begin{array}{llllllllllllllll}1.00 & 28.80 & 19.29 & 18.45 & 3 & 1371.8644 & 1371.8604 & 458.2941 & 0.0040 & 2.9093 & 37561.764 & 40991.255 & 26347.618 & 14081.567 & \text { Yes }\end{array}$

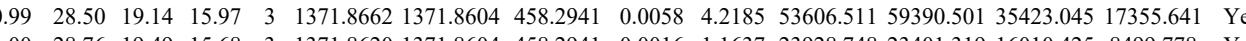
$\begin{array}{llllllllllllllll}1.00 & 28.76 & 19.49 & 15.68 & 3 & 1371.8620 & 1371.8604 & 458.2941 & 0.0016 & 1.1637 & 23928.748 & 23401.319 & 16010.425 & 8499.778 & \text { Yes }\end{array}$ $\begin{array}{lllllllllllllll}1.00 & 33.71 & 19.19 & 15.39 & 3 & 1371.8653 & 1371.8604 & 458.2941 & 0.0049 & 3.5639 & 28976.131 & 28050.548 & 18703.865 & 10401.786 & \text { Yes }\end{array}$ $\begin{array}{lllllllllllllll}0.98 & 37.74 & 26.86 & 22.79 & 2 & 1054.5780 & 1054.5682 & 528.2914 & 0.0098 & 9.2751 & 481.651 & 504.852 & 60.161 & 22.151 & \text { Yes } \\ 0.93 & 32.92 & 26.70 & 26.46 & 2 & 1054.5776 & 1054.5682 & 528.2914 & 0.0094 & 8.8965 & 6703.318 & 6677.177 & 0.000 & 12.921 & \text { No }\end{array}$

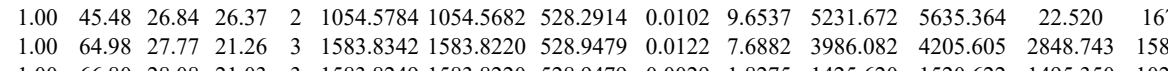
$\left.\begin{array}{llllllllllll}1.00 & 66.80 & 28.08 & 21.03 & 3 & 1583.8249 & 1583.8220 & 528.9479 & 0.0029 & 1.8275 & 1425.620\end{array}\right]$ $\begin{array}{lllllllllllllllll}100 & 62.21 & 27.94 & 21.04 & 3 & 1583.8264 & 1583.8220 & 528.9479 & 0.0044 & 2.7728 & 1719.322 & 1555.575 & 1577.490 & 877.275 & \text { Yes }\end{array}$ $\begin{array}{lllllllllllllll}1.00 & 65.20 & 27.82 & 21.47 & 2 & 1583.8270 & 1583.8220 & 792.9183 & 0.0050 & 3.1529 & 130.135 & 195.667 & 296.294 & 140.560 & \text { Yes }\end{array}$ $\begin{array}{llllllllllllllll}1.00 & 62.25 & 28.10 & 23.13 & 2 & 1583.8280 & 1583.8220 & 792.9183 & 0.0060 & 3.7835 & 149.962 & 209.906 & 250.396 & 185.344 & \text { Yes } & \\ 1.00 & 54.02 & 27.71 & 27.29 & 3 & 1599.8170 & 159.8169 & 534.2796 & 0.0001 & 0.0624 & 2522.012 & 3307.744 & 857.534 & 580.303 & \text { Yes }\end{array}$ $\begin{array}{lllllllllllllll}1.00 & 72.85 & 28.29 & 20.66 & 3 & 1583.8183 & 1583.8220 & 528.9479 & -0.0037 & -2.3317 & 299.698 & 366.666 & 163.476 & 125.016 & \text { Yes }\end{array}$ $\begin{array}{llllllllllllllll}\text { VPLLLEEQGVVDYFLR } & 1.00 & 93.61 & 25.08 & 18.96 & 2 & 2033.1334 & 2033.1319 & 1017.5732 & 0.0015 & 0.7370 & 190.015 & 178.018 & 89.165 & 50.187 & \text { Yes }\end{array}$

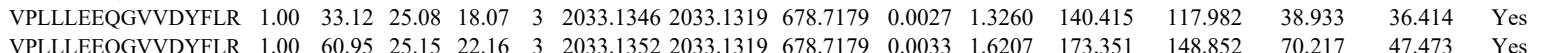
$\begin{array}{llllllllllllllll}\text { VPLLLEEQGVVDYFLR } & 0.76 & 81.42 & 25.08 & 94.42 & 2 & 2033.1334 & 2033.1319 & 1017.5732 & 0.0015 & 0.7370 & 171.677 & 189.098 & 117.382 & 92.850 & \text { Yes }\end{array}$ $\begin{array}{lllllllllllllllll}\text { VPLLLEEQGVVDYFLR } & 1.00 & 63.90 & 25.08 & 19.73 & 3 & 2033.1346 & 2033.1319 & 678.7179 & 0.0027 & 1.3260 & 122.003 & 87.557 & 83.484 & 19.340 & \text { Yes }\end{array}$

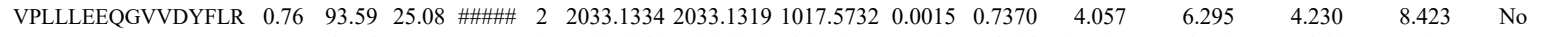
$\begin{array}{lllllllllllllllll}\text { VPLLLEEQGVVDYFLR } & 1.00 & 61.54 & 25.05 & 21.87 & 3 & 2033.1349 & 2033.1319 & 678.7179 & 0.0030 & 1.4734 & 111.807 & 160.239 & 116.611 & 51.329 & \text { Yes }\end{array}$

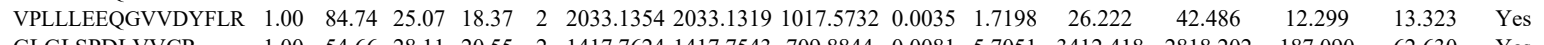
$\begin{array}{llllllllllllllll}\text { GLGLSPDLVVCR } & 1.00 & 54.66 & 28.11 & 20.55 & 2 & 1417.7624 & 1417.7543 & 709.8844 & 0.0081 & 5.7051 & 3412.418 & 2818.202 & 187.090 & 62.630 & \text { Yes }\end{array}$

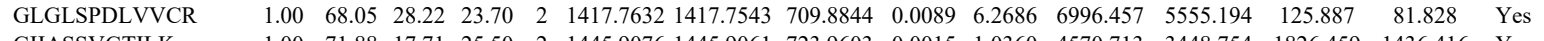
$\begin{array}{llllllllllllllll}\text { GIIASSVGTILK } & 1.00 & 71.88 & 17.71 & 25.50 & 2 & 1445.9076 & 1445.9061 & 723.9603 & 0.0015 & 1.0360 & 4570.713 & 3448.754 & 1826.459 & 1436.416 & \text { Yes }\end{array}$ \begin{tabular}{lllllllllllllllll} 
GIIASSVGTILK & 1.00 & 71.36 & 17.71 & 28.11 & 2 & 1445.9080 & 1445.9061 & 723.9603 & 0.0019 & 1.3122 & 4478.965 & 4343.584 & 1592.228 & 1063.326 & Yes \\
\hline
\end{tabular} $\begin{array}{llllllllllllllll}\text { GLGLSPDLVVCR } & 1.00 & 64.02 & 28.31 & 28.99 & 2 & 1417.7594 & 1417.7543 & 709.8844 & 0.0051 & 3.5921 & 3573.492 & 3342.358 & 225.089 & 47.595 & \text { Yes }\end{array}$ \begin{tabular}{llllllllllllllll} 
GLGLSPDLVVCR & 1.00 & 65.41 & 28.27 & 22.21 & 2 & 1417.7596 & 1417.7543 & 709.8844 & 0.0053 & 3.7330 & 3291.346 & 3651.295 & 152.626 & 131.573 & Yes \\
\hline LCSAHGVLVPGGGVR & 0.97 & 27.99 & 27.98 & 17.67 & 3 & 1757.9197 & 1757.9191 & 586.9803 & 0.0006 & 0.3407 & 521.106 & 589.400 & 124.787 & 39.839 & Yes
\end{tabular}

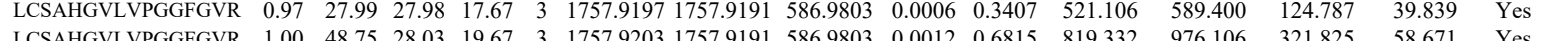
$\begin{array}{llllllllllllllll}\text { LCSAHGVLVPGGFGVR } & 1.00 & 4.7 .7 & 28.03 & 19.67 & 3 & 1757.9203 & 1757.9191 & 586.9803 & 0.0012 & 0.6815 & 819.332 & 976.106 & 321.825 & 58.671 & \text { Yes } \\ \text { LCSAHGVLVPGGFGVR } & 1.00 & 43.96 & 27.96 & 25.14 & 3 & 1757.9212 & 1757.9191 & 586.9803 & 0.0021 & 1.1925 & 735.013 & 896.439 & 371.432 & 80.551 & \text { Yes }\end{array}$ $\begin{array}{llllllllllllllll}\text { YILVTGGVISGIGK } & 0.53 & 13.64 & 19.82 & 26.64 & 3 & 1664.0152 & 1664.0116 & 555.6778 & 0.0036 & 2.1595 & 18.124 & 27.063 & 14.993 & 13.440 & \text { Yes }\end{array}$ $\begin{array}{llllllllllllllll}\text { YIDSADLEPITSQEEPVR } & 1.00 & 95.70 & 27.51 & 20.95 & 2 & 2205.0954 & 2205.0923 & 1103.5534 & 0.0031 & 1.4046 & 184.615 & 192.480 & 87.764 & 29.997 & \text { Yes }\end{array}$

Table S-3 page 164 of 499 


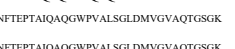

\section{QVSDLISVLR}

QVSDLISVLR

QVSDLISVLR

TLSYLLPAIVHINHOPFLE

TLSYLLPAIVHINHQPFLER
TLSYLLPAIVHINHQPFLER

LMEEIMSEK

LMEEIMSEK

TTYLVLDEADR
TTYLVLDEADR

LMEEIMSEK

LMEEIMSEK

$\begin{array}{lllllllllll}\text { PRS6A_HUMA } & \text { P17980 } & \text { PSMC3 } & \text { 26S protease regul } 49.20 & 1.00 & 6 & 20.3 & -0.2089 & 0.3445 & 0.5507 & 0.6437\end{array}$

TTYLVLDEADR

APSIFIDELDAIGTK

APSIIFIDELDAIGTK APSIIFIDELDAIGTK APSIFIDELDAIGTK

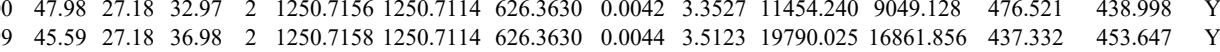
$\begin{array}{llllllllllllllll}1.00 & 52.81 & 27.53 & 19.58 & 3 & 1532.7607 & 1532.7494 & 511.9237 & 0.0113 & 7.3578 & 18714.855 & 17420.581 & 2517.120 & 4628.563 & \text { Yes }\end{array}$ $\begin{array}{llllllllllllllll}1.00 & 45.17 & 27.28 & 16.70 & 3 & 1532.7583 & 1532.7494 & 511.9237 & 0.0089 & 5.7951 & 13069.944 & 16045.306 & 1614.897 & 1824.303 & \text { Yes }\end{array}$ $\begin{array}{lllllllllllllll}0.98 & 36.05 & 28.10 & 35.18 & 2 & 1301.7252 & 1301.7223 & 651.8684 & 0.0029 & 2.2244 & 19744.557 & 16162.362 & 2144.258 & 386.047 & \text { Yes }\end{array}$ $\begin{array}{llllllllllllllll}0.94 & 37.78 & 28.03 & 38.31 & 2 & 130.7262 & 1301.7223 & 651.8684 & 0.0039 & 2.9914 & 16981.757 & 12600.721 & 2412.437 & 607.721 & \text { Yes }\end{array}$ $\begin{array}{llllllllllllllll}0.94 & 36.11 & 28.03 & 37.15 & 2 & 1301.7262 & 1301.7223 & 651.8684 & 0.0039 & 2.9914 & 13991.039 & 10926.044 & 1655.467 & 701.729 & \text { Yes }\end{array}$ $\begin{array}{llllllllllllllll}0.95 & 36.25 & 28.03 & 35.82 & 2 & 1301.7262 & 1301.7223 & 651.8684 & 0.0039 & 2.9914 & 19777.536 & 15424.171 & 2369.493 & 580.766 & \text { Yes }\end{array}$ $\begin{array}{lllllllllllllll}1.00 & 51.67 & 27.02 & 34.93 & 2 & 1370.7208 & 1370.7182 & 686.3664 & 0.0026 & 1.8940 & 14902.399 & 12536.032 & 0.000 & 70.189 & \\ 1.00 & 53.88 & 27.14 & 37.02 & 2 & 1370.7218 & 1370.7182 & 686.364 & 0.0036 & 2.6225 & 23172.573 & 20110.794 & 0.000 & 15.142 & \end{array}$

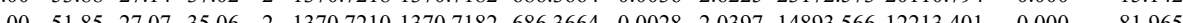
$\begin{array}{llllllllllll} & \end{array}$

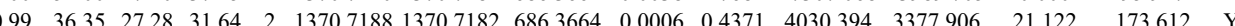

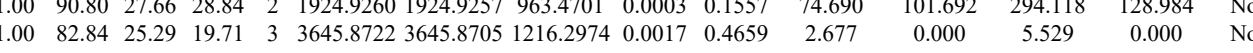
$\begin{array}{llllllllllllllll}1.00 & 26.89 & 25.28 & 16.88 & 4 & 3645.8741 & 3645.8705 & 912.4749 & 0.0036 & 0.9863 & 33.695 & 32.678 & 11.634 & 130.860 & \text { No }\end{array}$ $\begin{array}{lllllllllllllllll}0.99 & 15.98 & 25.25 & 16.10 & 4 & 3645.8749 & 3645.8705 & 912.4749 & 0.0044 & 1.2055 & 14.446 & 31.327 & 3.006 & 21.304 & \mathrm{No}\end{array}$

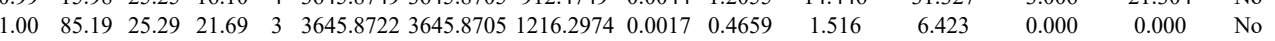
$\begin{array}{llllllllllllllll}1.00 & 57.46 & 25.47 & 34.05 & 2 & 1272.7556 & 1272.7523 & 637.3834 & 0.0033 & 2.5887 & 36954.453 & 31816.835 & 895.305 & 115.855 & \text { Yes }\end{array}$ $\begin{array}{lllllllllllllll}1.00 & 53.67 & 25.53 & 35.32 & 2 & 1272.7560 & 1272.7523 & 637.3834 & 0.0037 & 2.9025 & 23153.579 & 21302.593 & 778.057 & 374.336 & \text { Yes }\end{array}$ $\begin{array}{llllllllllllllll}1.00 & 52.76 & 25.33 & 33.74 & 2 & 1272.7578 & 1272.7523 & 637.3834 & 0.0055 & 4.3145 & 18293.888 & 15471.113 & 753.161 & 26.040 & \text { Yes }\end{array}$ $\begin{array}{llllllllllllllll}1.00 & 55.86 & 25.50 & 35.50 & 2 & 1272.7582 & 1272.7523 & 637.3834 & 0.0059 & 4.6283 & 18649.049 & 16482.072 & 164.154 & 64.050 & \text { Yes }\end{array}$ $\begin{array}{llllllllllllllll}1.00 & 63.92 & 28.06 & 25.65 & 2 & 1438.7420 & 1438.7426 & 720.3786 & -0.0006 & -0.4164 & 5217.796 & 4676.617 & 2178.251 & 3551.015 & \text { Yes }\end{array}$ $\begin{array}{lllllllllllllll}1.00 & 61.33 & 28.20 & 26.37 & 2 & 1396.7196 & 1396.7185 & 699.3665 & 0.0011 & 0.7864 & 4972.290 & 4322.658 & 0.000 & 115.001 & \text { No }\end{array}$ $\begin{array}{lllllllllllllll}1.00 & 52.23 & 28.05 & 24.49 & 2 & 1396.7214 & 1396.7185 & 699.3665 & 0.0029 & 2.0733 & 3834.158 & 3245.109 & 106.006 & 148.865 & \text { Yes } \\ 1.00 & 72.94 & 27.86 & 25.98 & 2 & 1438.7456 & 1438.7426 & 720.3786 & 0.0030 & 2.0822 & 363.093 & 308.134 & 39.914 & 60.352 & Y e s\end{array}$ $\begin{array}{lllllllllllllll}1.00 & 72.94 & 27.86 & 25.98 & 2 & 1438.7456 & 1438.7426 & 720.3786 & 0.0030 & 2.0822 & 363.093 & 308.134 & 39.914 & 60.352 & \text { Yes } \\ 1.00 & 83.29 & 25.20 & 25.39 & 2 & 1990.1256 & 1990.1230 & 996.0688 & 0.0026 & 1.3051 & 135.839 & 95.764 & 101.683 & 80.672 & \text { Yes }\end{array}$ $\begin{array}{lllllllllll} & \end{array}$

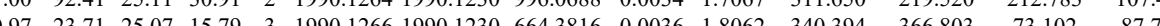

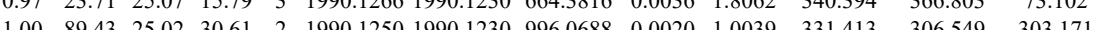

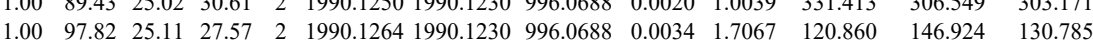
$\begin{array}{lllllllllllll}1.00 & 54.54 & 22.25 & 28.62 & 2 & 1267.7662 & 1267.7622 & 634.8884 & 0.0040 & 3.1502 & 3312.554 & 2869.789 & 234.739\end{array}$ $\begin{array}{llllllllllllllll} & \end{array}$ $\begin{array}{llllllllllllll} & \end{array}$ $\begin{array}{lllllllllllll} & \end{array}$

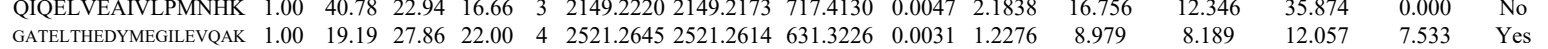

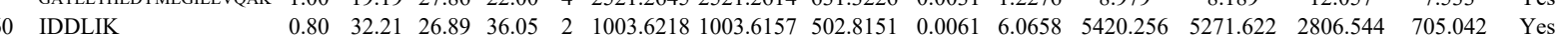
$\begin{array}{llllllllllllllll}\text { LLEVEHPAAK } & 0.95 & 27.05 & 24.36 & 17.10 & 3 & 1393.8262 & 1393.8173 & 465.6130 & 0.0089 & 6.3715 & 44167.965 & 40701.059 & 1593.035 & 2189.069 & \text { Yes }\end{array}$ $\begin{array}{llllllllllllllll}\text { LLEVEHPAAK } & 1.00 & 50.12 & 24.42 & 19.61 & 2 & 1393.8268 & 1393.8173 & 697.9159 & 0.0095 & 6.8059 & 17268.617 & 16480.354 & 4315.249 & 4473.278 & \text { Yes }\end{array}$ $\begin{array}{llllllllllllllll}\text { LLEVEHPAAK } & 0.98 & 31.28 & 24.38 & 15.06 & 3 & 1393.8274 & 1393.8173 & 465.6130 & 0.0101 & 7.2306 & 72350.260 & 65549.043 & 1097.155 & 783.098 & \text { Yes }\end{array}$ $\begin{array}{llllllllllllllll}\text { VLCELADLQDK } & 1.00 & 63.97 & 28.34 & 20.97 & 2 & 1579.8230 & 1579.8193 & 790.9169 & 0.0037 & 2.3391 & 273.079 & 306.202 & 4.558 & 0.000 & \text { No }\end{array}$ $\begin{array}{llllllllllllllll}\text { LLEVEHPAAK } & 0.99 & 34.92 & 24.33 & 21.94 & 3 & 1393.8259 & 1393.8173 & 465.6130 & 0.0086 & 6.1567 & 22823.054 & 22316.050 & 1979.301 & 1285.923 & \text { Yes }\end{array}$ $\begin{array}{llllllllllllllll}\text { LLEVEHPAAK } & 1.00 & 48.66 & 24.38 & 24.86 & 3 & 1393.8274 & 1393.8173 & 465.6130 & 0.0101 & 7.2306 & 30149.797 & 24719.236 & 907.746 & 820.016 & \text { Yes }\end{array}$

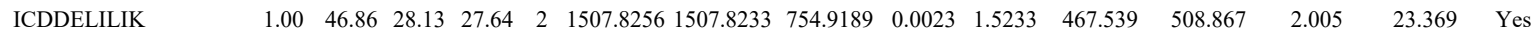
$\begin{array}{llllllllllllllll}\text { ICDDELILIK } & 1.00 & 50.11 & 28.14 & 27.13 & 2 & 1507.8264 & 1507.8233 & 754.9189 & 0.0031 & 2.0532 & 135.049 & 69.990 & 8.887 & 0.000 & \text { No }\end{array}$

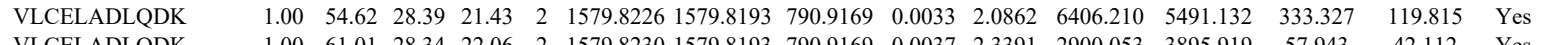
$\begin{array}{lllllllllllllllll}\text { VLCELADLQDK } & 1.00 & 61.01 & 28.34 & 22.06 & 2 & 1579.8230 & 1579.8193 & 790.9169 & 0.0037 & 2.3391 & 2900.053 & 3895.919 & 57.943 & 42.112 & \text { Yes }\end{array}$

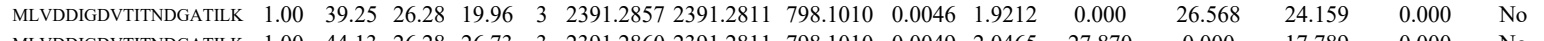

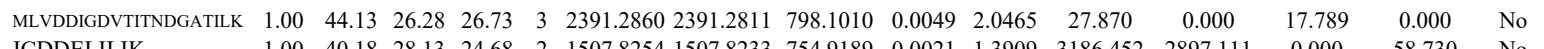

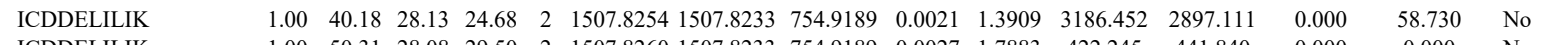

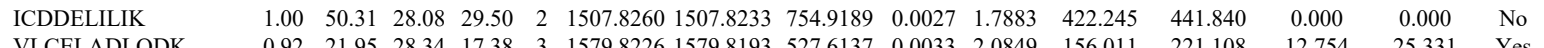

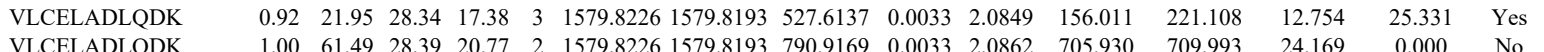

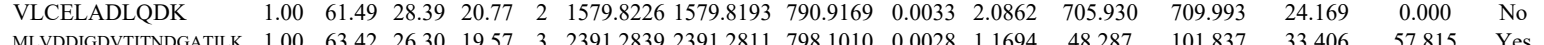

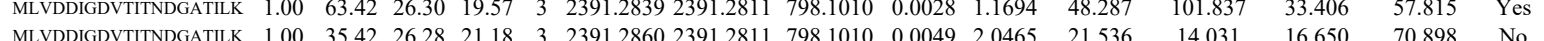

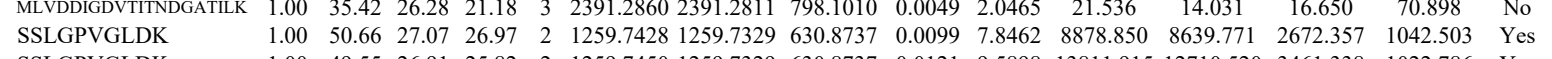

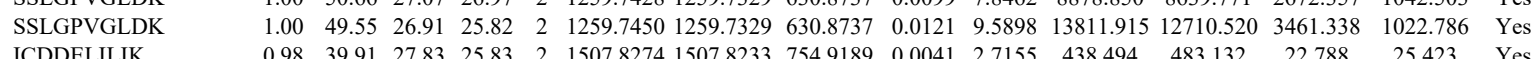

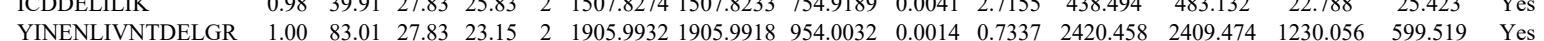



$\begin{array}{llllllllllllllllll}\text { ILATGANVILTTGGIDDMCLK } & 1.00 & 73.16 & 26.73 & 26.85 & 3 & 2452.3021 & 2452.2983 & 818.4400 & 0.0038 & 1.5477 & 81.482 & 72.360 & 35.517 & 16.627 & \text { Yes }\end{array}$ $\begin{array}{llllllllllllllllll}\text { ILATGANVILTTGGIDDMCLK } & 1.00 & 63.28 & 26.73 & 19.08 & 3 & 2452.3021 & 2452.2983 & 818.4400 & 0.0038 & 1.5477 & 46.826 & 83.789 & 37.696 & 22.820 & \text { Yes }\end{array}$ $\begin{array}{lllllllllllllllll}\text { IACLDFSLQK } & 1.00 & 48.73 & 27.24 & 21.99 & 2 & 1470.7864 & 1470.7818 & 736.3982 & 0.0046 & 3.1233 & 9257.054 & 9683.746 & 0.000 & 225.666 & \text { No }\end{array}$

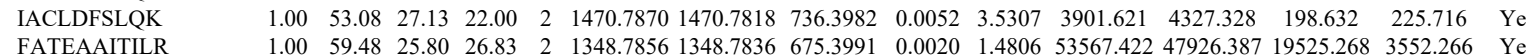
$\begin{array}{llllllllllllllll}\text { FATEAAITILR } & 1.00 & 59.48 & 25.80 & 26.83 & 2 & 1348.7856 & 1348.7836 & 675.3991 & 0.0020 & 1.4806 & 53567.422 & 47926.387 & 19525.268 & 3552.266 & \text { Yes } \\ \text { FATEAAITILR } & 1.00 & 57.06 & 26.5 & 23.22 & 2 & 1348.7858 & 1348.7836 & 675.3991 & 0.0022 & 1.6287 & 37645.166 & 40414846 & 16255.497 & 3103.538 & \text { Yes }\end{array}$ $\begin{array}{lllllllllllllllll}\text { FATEAAITILR } & 1.00 & 57.06 & 26.25 & 23.22 & 2 & 1348.7858 & 1348.7836 & 675.3991 & 0.0022 & 1.6287 & 37645.166 & 40414.846 & 16255.497 & 3103.538 & \text { Yes } \\ \text { SQNVMAAASIANIVK } & 1.00 & 86.03 & 26.23 & 29.98 & 2 & 1804.0132 & 1804.0120 & 903.0133 & 0.0012 & 0.6644 & 3250.061 & 2986.239 & 1304.756 & 737.191 & \text { Yes }\end{array}$ $\begin{array}{lllllllllllllllll}\text { SQNVMAAASIANIVK } & 1.00 & 86.03 & 26.23 & 29.98 & 2 & 1804.0132 & 1804.0120 & 903.0133 & 0.0012 & 0.6644 & 3250.061 & 2986.239 & 1304.756 & 737.191 & \text { Yes } \\ \text { SQNVMAAASIANIVK } & 1.00 & 94.72 & 26.16 & 28.26 & 2 & 1804.0136 & 1804.0120 & 903.0133 & 0.0016 & 0.8859 & 4227.400 & 3480.758 & 1787.258 & 969.293 & \text { Yes }\end{array}$ $\begin{array}{lllllllllllllllll}\text { SQNVMAAASIANIVK } & 1.00 & 94.72 & 26.16 & 28.26 & 2 & 1804.0136 & 1804.0120 & 903.0133 & 0.0016 & 0.8859 & 4227.400 & 3480.758 & 1787.258 & 969.293 & \text { Yes } \\ \text { SQNVMAAAASIANIVK } & 1.00 & 42.39 & 26.18 & 20.11 & 3 & 1804.0144 & 1804.0120 & 602.3446 & 0.0024 & 1.3281 & 669.173 & 895.094 & 694.967 & 192.117 & \text { Yes }\end{array}$ $\begin{array}{llllllllllllllll}\text { SQNVMAAASIANIVK } & 1.00 & 42.39 & 26.18 & 20.11 & 3 & 1804.0144 & 1804.0120 & 602.3446 & 0.0024 & 1.3281 & 669.173 & 895.094 & 694.967 & 192.117 & \text { Yes } \\ \text { SQNVMAAAASIANIVK } & 1.00 & 57.04 & 26.18 & 19.10 & 3 & 1804.0144 & 1804.0120 & 602.3446 & 0.0024 & 1.3281 & 1141.381 & 1139.559 & 848.055 & 551.365 & \text { Yes }\end{array}$

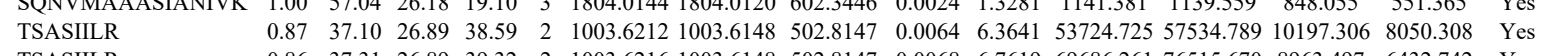

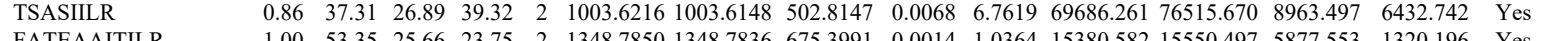
\begin{tabular}{lllllllllllllllll} 
FATEAAITILR & 1.00 & 53.35 & 25.66 & 23.75 & 2 & 1348.7850 & 1348.7836 & 675.3991 & 0.0014 & 1.0364 & 15380.582 & 15550.497 & 5877.553 & 1320.196 & Yes \\
\hline SQNVVMAAASIANIVK & 0.54 & 10.86 & 26.16 & 19.77 & 3 & 1804.0141 & 1804.0120 & 6023446 & 0.0021 & 1.1621 & 1686.941 & 1252.057 & 2911.382 & 1497.331 & No
\end{tabular} $\begin{array}{llllllllllllllll}\text { SQNVMAAASIANIVK } & 0.54 & 10.86 & 26.16 & 19.77 & 3 & 1804.0141 & 1804.0120 & 602.3446 & 0.0021 & 1.1621 & 1686.941 & 1252.057 & 2911.382 & 1497.331 & \text { No } \\ \text { syypGGaNGM }\end{array}$

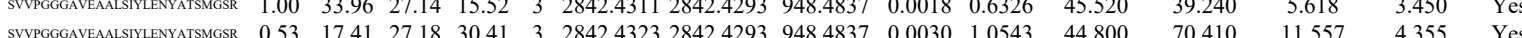

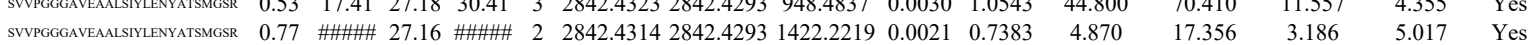

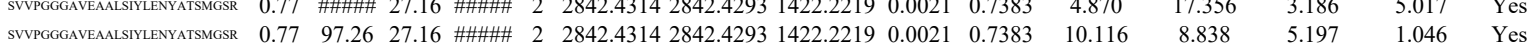

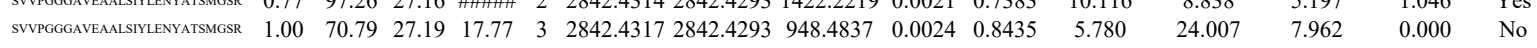

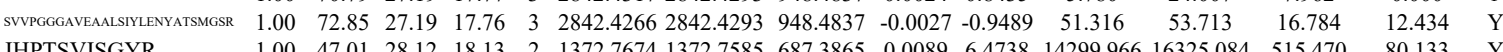
IHPTSVISGYR IHPTSVISGYR
IHPTSVISGYR IHPTSVISGYR
IHPTSVISGYR IHPTSVISGYR IHPTSVISGYR IHPTSVISGYR IHPTSVISGYR $\begin{array}{llllllllllllllll}0.99 & 45.28 & 28.14 & 24.04 & 2 & 1372.7676 & 13727585 & 6873865 & 0.0091 & 6.6192 & 11245.840 & 13576.563 & 448.765 & 49.675 & \text { Yes }\end{array}$ $\begin{array}{lllllllllllllll}1.00 & 41.29 & 28.15 & 17.79 & 3 & 1372.7680 & 1372.7585 & 458.5934 & 0.0095 & 6.9051 & 17746.597 & 20043.990 & 4816.765 & 2316.751 & \text { Yes }\end{array}$ $\begin{array}{lllllllllllllll}1.00 & 53.53 & 27.85 & 17.62 & 3 & 1372.7710 & 1372.7585 & 458.5934 & 0.0125 & 9.0857 & 18810.810 & 22718.322 & 3062.324 & 708.395 & \text { Yes }\end{array}$ $\begin{array}{lllllllllllllll}1.00 & 49.60 & 27.88 & 17.61 & 3 & 1372.7716 & 1372.7585 & 458.5934 & 0.0131 & 9.5218 & 12339.885 & 16496.447 & 1818.708 & 439.323 & \text { Yes }\end{array}$ $\begin{array}{llllllllllllllll}0.99 & 43.22 & 27.88 & 23.10 & 2 & 1372.7716 & 1372.7585 & 687.3865 & 0.0131 & 9.5288 & 7899.881 & 9039.202 & 556.149 & 22.521 & \text { Yes }\end{array}$ $\begin{array}{llllllllllllllll}1.00 & 46.03 & 27.88 & 18.12 & 2 & 1372.7720 & 1372.7585 & 687.3865 & 0.0135 & 9.8197 & 7562.159 & 9334.909 & 258.278 & 105.968 & \text { Yes }\end{array}$ $\begin{array}{lllllllllllllll}1.00 & 48.85 & 27.88 & 18.08 & 3 & 1372.7716 & 1372.7585 & 458.5934 & 0.0131 & 9.5218 & 13009.283 & 14527.178 & 1742.528 & 337.780 & \text { Yes }\end{array}$ $\begin{array}{lllllllllllllll}1.00 & 45.68 & 27.41 & 17.91 & 3 & 1372.7650 & 1372.7585 & 458.5934 & 0.0065 & 4.7246 & 6152.834 & 6500.718 & 891.536 & 459.623 & \text { Yes }\end{array}$

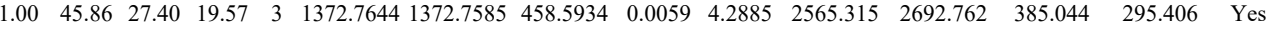

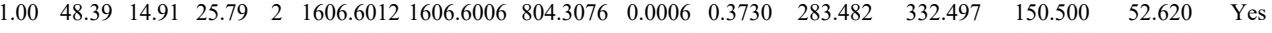
$\begin{array}{lllllllllllllll}1.00 & 49.87 & 23.93 & 19.73 & 2 & 1714.7666 & 1714.7669 & 858.3907 & -0.0003 & -0.1747 & 316.174 & 471.775 & 154.166 & 73.116 & \text { Yes } \\ 1.00 & 46.90 & 24.25 & 20.03 & 2 & 1714.7680 & 1714.7669 & 858.3907 & 0.0011 & 0.6407 & 1269.690 & 1489.784 & 562.066 & 300.280 & \text { Yes } \\ 1.00 & 35.02 & 25.56 & 18.82 & 3 & 1557.9495 & 1657.9477 & 553.6565 & 0.0018 & 1.037 & 225 & \end{array}$

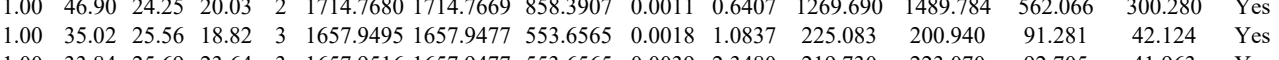

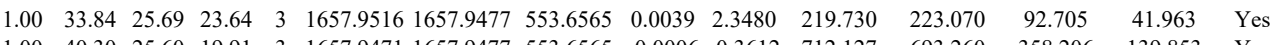

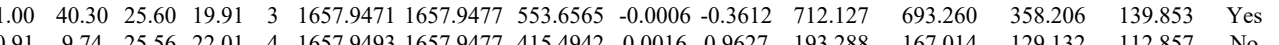
$\begin{array}{lllllllllllllll}0.91 & 9.74 & 25.56 & 22.01 & 4 & 1657.9493 & 1657.9477 & 415.4942 & 0.0016 & 0.9627 & 193.288 & 167.014 & 129.132 & 112.857 & \text { No } \\ 1.00 & 68.67 & 25.55 & 19.45 & 2 & 1657.9498 & 1657.9477 & 829.9811 & 0.0021 & 1.2651 & 61.008 & 76.560 & 22.742 & 4.945 & \text { Yes }\end{array}$

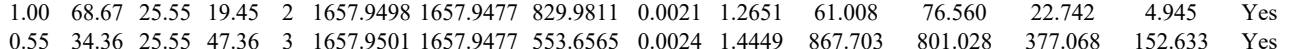

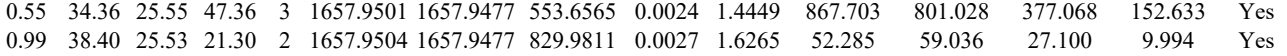
$\begin{array}{ccccccccccccccc}0.99 & 38.40 & 25.53 & 21.30 & 2 & 1657.9504 & 1657.9477 & 829.9811 & 0.0027 & 1.6265 & 52.285 & 59.036 & 27.100 & 9.994 & \text { Yes } \\ 1.00 & 34.62 & 25.58 & 15.95 & 3 & 1657.9492 & 1657.9477 & 553.6565 & 0.0015 & 0.9031 & 515.152 & 579.665 & 278.354 & 100.850 & \text { Yes }\end{array}$

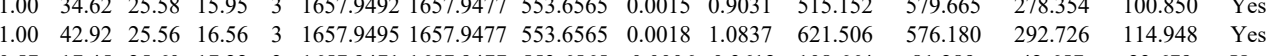
$\begin{array}{lllllllllll}0.0105 & 0.9183 & 33334.308 & 31585929 & 1429.857 & 1242.710 & \text { Yes }\end{array}$ 

$\begin{array}{lllllllllllllll}0.96 & 37.64 & 26.88 & 28.53 & 2 & 1024.5542 & 1024.5497 & 513.2821 & 0.0045 & 4.3835 & 18764.834 & 20179.114 & 834.817 & 474.191 & \text { Yes }\end{array}$ $\begin{array}{lllllllllllllll}0.96 & 37.71 & 26.87 & 23.16 & 2 & 1088.5620 & 1008.5548 & 505.2847 & 0.0072 & 7.1246 & 94980.419 & 90908.693 & 1371.797 & 259.487 & \text { Yes }\end{array}$ $\begin{array}{lllllllllllllll}0.85 & 24.55 & 26.86 & 33.16 & 2 & 108.5622 & 1008.5548 & 505.2847 & 0.0774 & 7.3226 & 61662.575 & 59985.317 & 1049.726 & 785.781 & \text { Yes }\end{array}$

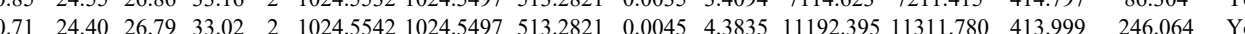

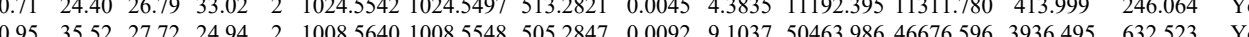
$\begin{array}{lllllllllllllllll}0.82 & 29.14 & 27.72 & 25.50 & 2 & 1008.5642 & 1008.5548 & 5052847 & 0.0094 & 0.3016 & 33928.693 & 31293.759 & 7508.661 & 1447.737 & \text { Yes } & \end{array}$ $\begin{array}{llllllllllllll} & \end{array}$

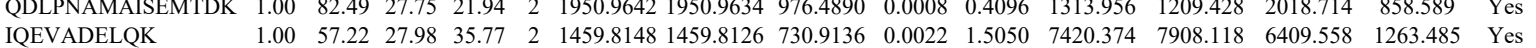

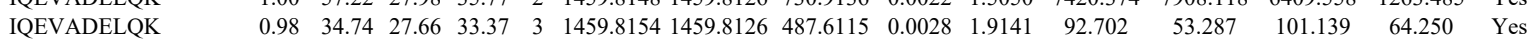

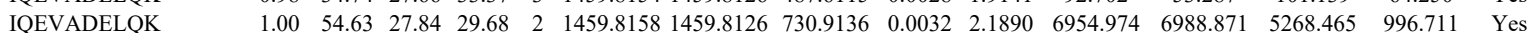

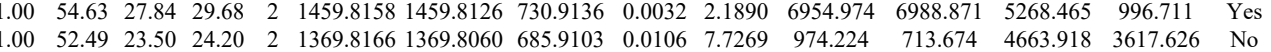

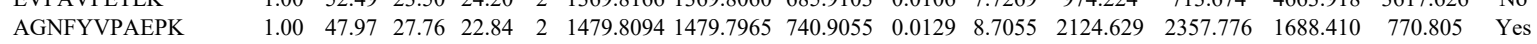

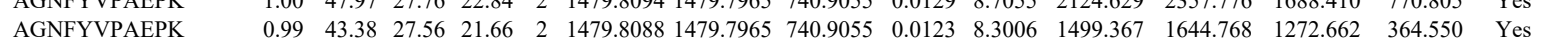
$\begin{array}{lllllllllllllllll}\text { AGNFYVPAEPK } & 1.00 & 55.19 & 27.77 & 26.33 & 2 & 1479.8102 & 1479.7965 & 740.9055 & 0.0137 & 9.2454 & 944.118 & 958.346 & 650.063 & 205.212 & \text { Yes }\end{array}$

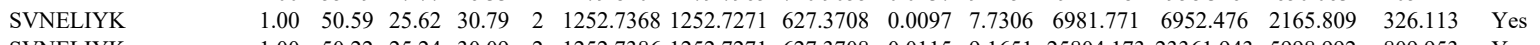
$\begin{array}{llllllllllllllll}\text { SVNELIYK } & 1.00 & 50.22 & 25.24 & 30.09 & 2 & 1252.7386 & 1252.7271 & 627.3708 & 0.0115 & 9.1651 & 25804.173 & 23361.943 & 5998.992 & 809.953 & \text { Yes }\end{array}$ $\begin{array}{llllllllllllllll}\text { GINGVSPK } & 0.97 & 30.70 & 24.73 & 23.86 & 2 & 1058.6332 & 1058.6328 & 530.3237 & 0.0004 & 0.3771 & 1746.718 & 1814.736 & 1187.626 & 972.328 & \text { Yes }\end{array}$

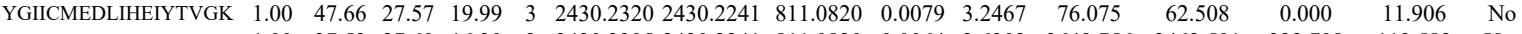

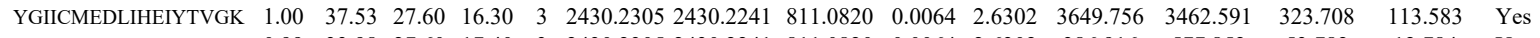

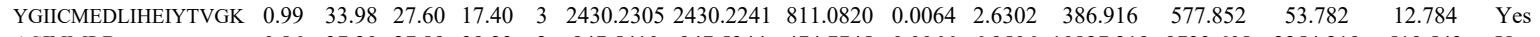
$\begin{array}{llllllllllllllll}\text { ASINMLR } & 0.86 & 37.20 & 27.89 & 39.23 & 2 & 947.5410 & 947.5344 & 474.7745 & 0.0066 & 6.9506 & 10827.219 & 9733.608 & 2254.219 & 519.543 & \text { Yes }\end{array}$

ASINMLR TTHFVEGGDAGNR LAFVIR

LAFVIR

LAFVIR

LAFVIR

LAFVIR

LAFVIR

LAFVIR $\begin{array}{llllllllllllllll}0.81 & 35.18 & 27.87 & 38.79 & 2 & 947.5416 & 947.5344 & 474.7745 & 0.0072 & 7.5825 & 10021.017 & 9857.064 & 1972.249 & 367.353 & \text { Yes }\end{array}$ $\begin{array}{lllllllllllllllll}0.56 & 23.23 & 26.44 & 27.13 & 2 & 861.5640 & 861.5558 & 431.7852 & 0.0082 & 9.4954 & 74611.069 & 73234.241 & 4480.729 & 201.158 & \text { Yes }\end{array}$ $\begin{array}{lllllllllllllll}1.00 & 33.64 & 25.59 & 18.00 & 3 & 1503.7201 & 1503.7188 & 502.2469 & 0.0013 & 0.8628 & 40.955 & 69.717 & 48.625 & 37.185 & \text { Yes }\end{array}$ $\begin{array}{llllllllllllllll}0.72 & 22.11 & 29.63 & 27.36 & 2 & 861.5574 & 861.5558 & 431.7852 & 0.0016 & 1.8528 & 13985.825 & 14798.302 & 938.853 & 109.230 & \text { Yes } \\ 0.67 & 2.98 & 29.63 & 27.79 & 2 & 861.5580 & 861.5558 & 431.7852 & 0.0022 & 2.5476 & 26253053 & 24462.04 & 134.221 & 116.025 & \text { Yes }\end{array}$

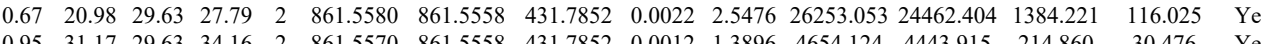
$\begin{array}{lllllllllllllllll}0.95 & 31.17 & 2.63 & 34.16 & 2 & 861.5570 & 861.5558 & 431.7852 & 0.0012 & 1.3896 & 4654.124 & 4443.915 & 214.860 & 30.476 & \text { Yes } & \\ 0.91 & 27.99 & 29.63 & 31.26 & 2 & 81.5580 & 861.5558 & 431.7852 & 0.0022 & 2.5476 & 5320.104 & 5670.216 & 143.773 & 75.059 & \text { Yes }\end{array}$ $\begin{array}{lclllllllllllllll}\text { LAFVIR } & 0.91 & 28.50 & 29.63 & 31.95 & 2 & 861.5568 & 861.5558 & 431.7852 & 0.0010 & 1.1580 & 4210.330 & 3732.512 & 172.567 & 92.625 & \text { Yes } \\ \text { LAFVIR } & 0.89 & 27.10 & 29.63 & 33.11 & 2 & 861.5566 & 861.5558 & 431.7852 & 0.0008 & 0.9264 & 1035.442 & 993.566 & 76.932 & 43.092 & \text { Yes } \\ & 0.86 & 19.15 & 26.80 & 15.15 & 4 & 2259.0813 & 2259.0750 & 565.7760 & 0.0063 & 2.7838 & 3006052 & 3166.431 & 7679.395 & 17006.579 & \text { No }\end{array}$ $\begin{array}{lllllllllllllll} & \\ & \end{array}$

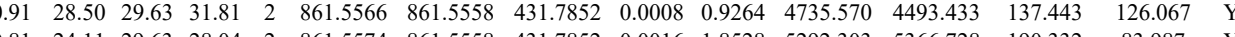
$\begin{array}{llllllllllllllll}0.84 & 25.53 & 29.63 & 32.47 & 2 & 861.5568 & 861.5558 & 431.7852 & 0.0010 & 1.1580 & 4164.268 & 4163.449 & 167.819 & 103.068 & \text { Yes } \\ 0.91 & 28.50 & 29.63 & 31.95 & 2 & 861.5568 & 861.5558 & 431.7852 & 0.0010 & 1.1580 & 4210.330 & 3732.512 & 172.567 & 92.625 & \text { Yes }\end{array}$ $\begin{array}{llllllllllllllll}\text { TTHFVEGGDAGNREDQINR } & 0.96 & 21.38 & 26.68 & 34.38 & 4 & 2259.0801 & 22590750 & 565.7760 & 0.0051 & 2.2535 & 7953.427 & 10668.702 & 4634.763 & 602.679 & \text { Yes }\end{array}$

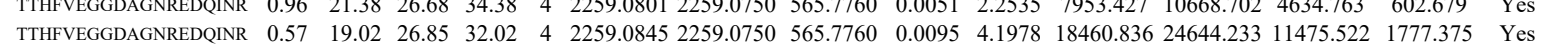

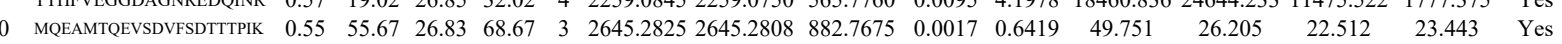

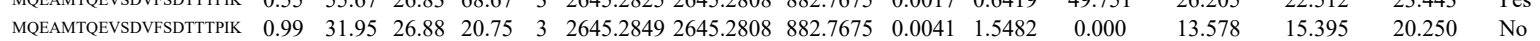

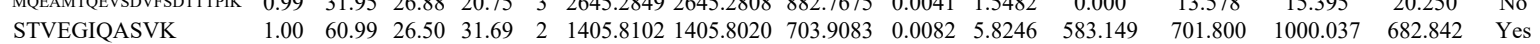
$\begin{array}{lllllllllllllllll}\text { STVEGIQASVK } & 1.00 & 59.87 & 26.41 & 29.06 & 2 & 1405.8110 & 1405.8020 & 703.9083 & 0.0090 & 6.3928 & 634.994 & 802.456 & 1167.577 & 1178.899 & \text { No }\end{array}$ $\begin{array}{lllllllllllllllll}\text { MQEAMTOEVSDVFSDTTTPIK } & 0.99 & 28.78 & 26.82 & 16.84 & 3 & 2645.2843 & 2645.2808 & 882.7675 & 0.0035 & 1.3216 & 33.847 & 64.945 & 52.919 & 35.082 & \text { Yes }\end{array}$ $\begin{array}{lllllllllllllllll}\text { STVEGIQASVK } & 1.00 & 66.55 & 26.73 & 27.53 & 2 & 1405.8086 & 1405.8020 & 703.9083 & 0.0066 & 4.6881 & 573.792 & 717.422 & 950.361 & 690.195 & \text { Yes }\end{array}$ $\begin{array}{llllllllllllllll}\text { STVEGIQASVK } & 1.00 & 68.94 & 26.70 & 28.19 & 2 & 1405.8092 & 1405.8020 & 703.9083 & 0.0072 & 5.1143 & 1808.786 & 2008.662 & 2082.085 & 2608.036 & \text { No }\end{array}$ $\begin{array}{lllllllllllllllll}\text { AVAGNISDPGLQK } & 1.00 & 73.80 & 26.28 & 26.15 & 2 & 1556.8880 & 1556.8766 & 779.4456 & 0.0114 & 7.3128 & 971.136 & 1063.620 & 1090.620 & 469.948 & \text { Yes }\end{array}$ $\begin{array}{llllllllllllllll}\text { AVAGNISDPGLQK } & 1.00 & 76.77 & 26.29 & 27.99 & 2 & 1556.8882 & 1556.8766 & 779.4456 & 0.0116 & 7.4411 & 2941.031 & 3775.357 & 3480.992 & 1354.576 & \text { Yes }\end{array}$

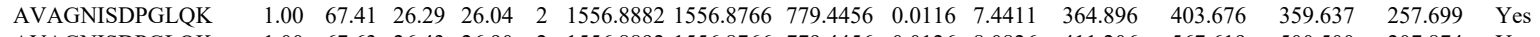
$\begin{array}{lllllllllllllllll}\text { AVAGNISDPGLQK } & 1.00 & 67.63 & 26.43 & 26.90 & 2 & 1556.8892 & 1556.8766 & 779.4456 & 0.0126 & 8.0826 & 411.206 & 567.619 & 500.500 & 207.874 & \text { Yes }\end{array}$ $\begin{array}{llllllllllllllll}\text { GILSGTSDLLLTFDEAEVR } & 1.00 & \text { \#\#\#\# } 27.02 & 26.29 & 2 & 2179.1514 & 2179.1494 & 1090.5820 & 0.0020 & 0.9169 & 76.405 & 116.781 & 102.004 & 22.905 & \text { Yes }\end{array}$

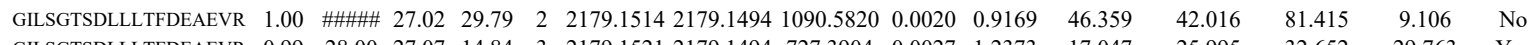

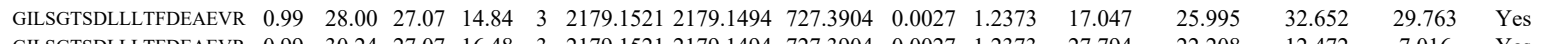

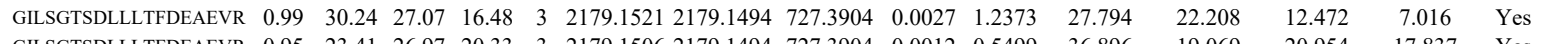

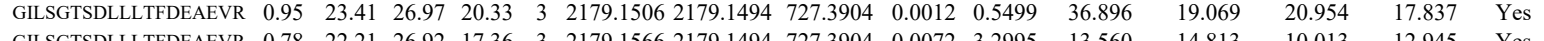

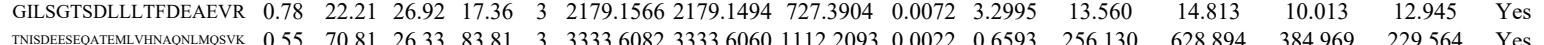

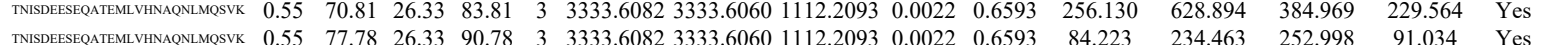

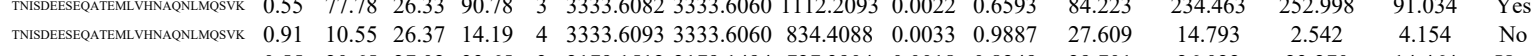
$\begin{array}{llllllllllllll}\text { GILSGTSDLLLTFDEAEVR } & 0.55 & 20.65 & 27.02 & 33.65 & 3 & 2179.1512 & 2179.1494 & 727.3904 & 0.0018 & 0.8249 & 29.701\end{array}$

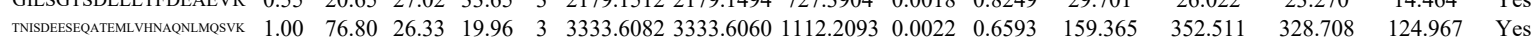


$\begin{array}{llllllllllll} & 1627.9038 & 1627.9015 & 814.9580 & 0.0023 & 1.4111 & 2453.386 & 2897.918 & 643.459\end{array}$

$\begin{array}{llllllllllllll}1.00 & 56.23 & 23.44 & 26.02 & 2 & 1287.8108 & 1287.8006 & 644.9076 & 0.0102 & 7.9080 & 6114.391 & 6341.454 & 7143.945\end{array}$

$\begin{array}{llllllllllllll}.00 & 56.06 & 23.71 & 29.29 & 2 & 1287.8116 & 1287.8006 & 644.9076 & 0.0110 & 8.5283 & 5130.509 & 5880.582 & 6694.829 & 51\end{array}$

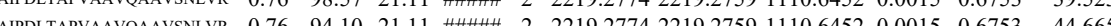

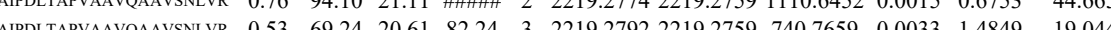

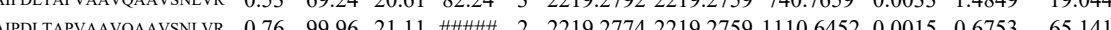

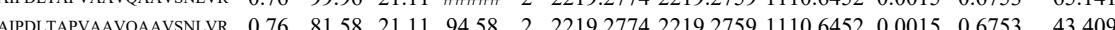

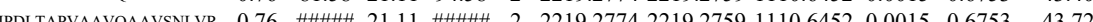
$\begin{array}{llllllllllll} & \end{array}$ $\begin{array}{lllllllllll} & 0.55\end{array}$ $\begin{array}{lllllllllllll} & 0.02\end{array}$

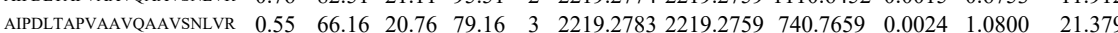

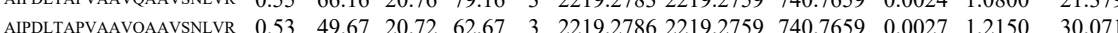
$\begin{array}{lllllllllllll}\text { DPSASPGDAGEQAIR } & 1.00 & 69.51 & 26.50 & 22.02 & 2 & 1613.7790 & 1613.7767 & 807.8956 & 0.0023 & 1.4234 & 5276.550 & 7396.95\end{array}$

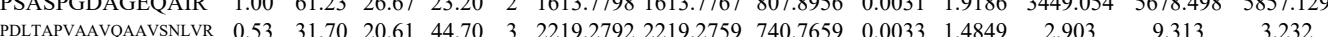
SLLDASEEAIK

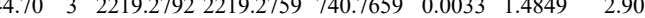

YSLDPENPTK

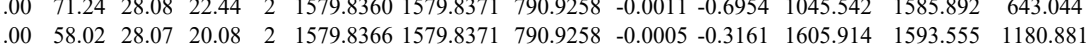
$\begin{array}{llllllllllllll}0.98 & 25.54 & 27.69 & 16.66 & 3 & 1579.8391 & 1579.8371 & 527.6196 & 0.0020 & 1.2635 & 77.793 & 144.782 & 147.385\end{array}$

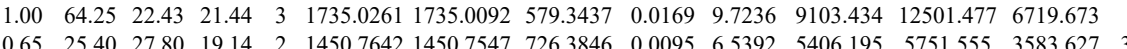

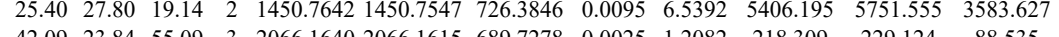
$\begin{array}{lllllllllllllll} & \end{array}$ $\begin{array}{llllllllllllllll}\text { GLDVDSLVIEHIQVNKK } & 0.55 & 44.94 & 23.84 & 57.94 & 3 & 2066.1640 & 2066.1615 & 689.7278 & 0.0025 & 1.2082 & 156.349 & 126.387 & 85.9 & \end{array}$ $\begin{array}{lllllllllllllll}\text { GLDVDSLVIEHIQVNK } & 0.55 & 36.01 & 23.84 & 49.01 & 3 & 2066.1640 & 2066.1615 & 689.7278 & 0.0025 & 1.2082 & 161.454 & 137.636 & 97.2\end{array}$ $\begin{array}{lllllllllllllll}\text { GLDVDSLVIEHIQVNK } & 0.53 & 46.57 & 23.69 & 59.57 & 3 & 2066.1649 & 2066.1615 & 689.7278 & 0.0034 & 1.6432 & 140.002 & 123.812 & 82.527 \\ \text { GLDVDSLVIEHIQVNK } & 0.97 & 38.44 & 24.81 & 17.62 & 3 & 2066.1553 & 2066.1615 & 689.7278 & -0.0062 & -2.9964 & 923.252 & 876.651 & 894.31\end{array}$ $\begin{array}{llllllllllllll}\text { GLDVDSLVIEHIQVNK } & 0.97 & 38.44 & 24.81 & 17.62 & 3 & 2066.1553 & 2066.1615 & 689.7278 & -0.0062 & -2.9964 & 923.252 & 876.651 & 894.314 \\ \text { GLDVDSLVIEHIQVNK } & 1.00 & 31.29 & 24.01 & 15.63 & 4 & 2066.1625 & 2066.1615 & 517.5477 & 0.0010 & 0.4830 & 41.339 & 57.199 & 17.429\end{array}$ $\begin{array}{lllllllllllllll}\text { GLDVDSLVIEHIQVNK } & 1.00 & 52.12 & 23.98 & 21.64 & 3 & 2066.1634 & 2066.1615 & 689.7278 & 0.0019 & 0.9182 & 1402.815 & 1392.076 & 972.69 & \end{array}$ $\begin{array}{llllllllllllllll}\text { GLDVDSLVIEHIQVNK } & 1.00 & 42.02 & 23.98 & 18.14 & 3 & 2066.1634 & 2066.1615 & 689.7278 & 0.0019 & 0.9182 & 125.139 & 116.550 & 77.823 & 45.76\end{array}$ $\begin{array}{llllllllllllll}\text { GLDVDSLVIEHIQVNK } & 1.00 & 51.40 & 23.80 & 19.46 & 3 & 2066.1637 & 2066.1615 & 689.7278 & 0.0022 & 1.0632 & 196.731 & 200.433 & 143.544 \\ \text { GLDVDSLVIEHLVNK } & 0.55 & 46.03 & 23.80 & 59.03 & 3 & 20661637 & 2066.1615 & 689.7278 & 0.0022 & 1.0632 & 3369.685 & 3194.131 & 1623.389\end{array}$

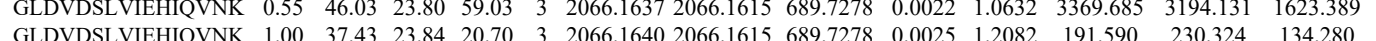

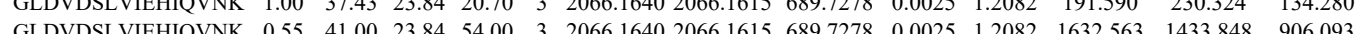
$\begin{array}{llllllllllllll}\text { GLDVDSLVIEHPVNK } & 0.55 & 48.63 & 23.84 & 61.63 & 3 & 2066.1640 & 20661615 & 689.7278 & 0.0025 & 1.2082 & 146.553 & 126.019 & 67.425\end{array}$

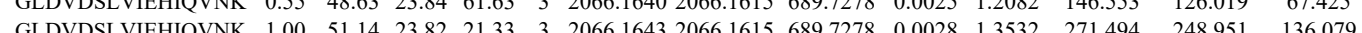



$\begin{array}{lllllllllllllll}0.99 & 37.69 & 27.22 & 19.75 & 3 & 1475.8483 & 1475.8414 & 492.9544 & 0.0069 & 4.6657 & 27846.289 & 33823.932 & 2873.955 & 482.024\end{array}$ $\begin{array}{llllllllllllll}.00 & 44.99 & 27.15 & 17.18 & 3 & 1475.8477 & 1475.8414 & 492.9544 & 0.0063 & 4.2600 & 8059.636 & 9504.944 & 1061.259 & 54.304 \\ 0.98 & 32.19 & 27.22 & 17.95 & 3 & 1475.8486 & 1475.8414 & 492.9544 & 0.0072 & 4.8686 & 9972.762 & 10575.776 & 1138.013 & 180.257\end{array}$

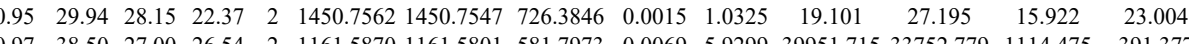
$\begin{array}{llllllllllllll}0.97 & 38.50 & 27.00 & 26.54 & 2 & 1161.5870 & 1161.5801 & 581.7973 & 0.0069 & 5.9299 & 39951.715 & 33752.779 & 1114.475 & 391.377\end{array}$ $\begin{array}{llllllllllllll}0.98 & 42.06 & 26.95 & 33.36 & 2 & 1161.5876 & 1161.5801 & 581.7973 & 0.0075 & 6.4455 & 53222.557 & 42834.483 & 1234.116 & 448.712\end{array}$ $\begin{array}{llllllllllllll}0.98 & 40.30 & 26.95 & 30.82 & 2 & 1161.5876 & 1161.5801 & 581.7973 & 0.0075 & 6.4455 & 24260.639 & 22803.557 & 301.665 & 189.172\end{array}$ $\begin{array}{cccccccccccccc}0.98 & 40.46 & 26.95 & 31.47 & 2 & 1161.5878 & 1161.5801 & 581.7973 & 0.0077 & 6.6174 & 32409.409 & 27354.439 & 0.000 & 72.471 \\ 1.00 & 37.38 & 23.50 & 16.18 & 3 & 2055.1666 & 2055.1577 & 686.0598 & 0.0089 & 43242 & 13473.295 & 9208.624 & 21663.178 & 21127.554\end{array}$ $\begin{array}{llllllllllllll}1.00 & 37.38 & 23.50 & 16.18 & 3 & 2055.1666 & 2055.1577 & 686.0598 & 0.0089 & 4.3242 & 13473.295 & 9208.624 & 21663.178 & 21127.554 \\ 0.94 & 13.41 & 23.48 & 26.41 & 4 & 2055.1673 & 2055.1577 & 514.7967 & 0.0096 & 4.6620 & 339.324 & 296.270 & 549.419 & 541.534\end{array}$

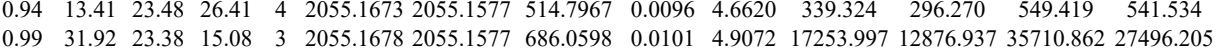
$\begin{array}{lllllllllllllllll}1.00 & 50.65 & 27.98 & 24.04 & 2 & 1450.7678 & 1450.7547 & 726.3846 & 0.0131 & 9.0172 & 4009.819 & 3290.866 & 3406.763 & 1623.068 & \text { Yes } & \end{array}$ FSGWYDADLSPAGHEE AMEAVAAQGK $\begin{array}{llllllllllllll}0.55 & 46.88 & 26.35 & 59.88 & 3 & 2267.0758 & 2267.0738 & 756.6985 & 0.0020 & 0.8810 & 4833.797 & 6135.443 & 3067.329 & 577.885\end{array}$ $\begin{array}{lllllllllllllll}\text { AMEAVAAQGK } & 1.00 & 71.86 & 28.10 & 31.75 & 2 & 1262.6936 & 1262.6896 & 632.3521 & 0.0040 & 3.1628 & 22499.288 & 21659.695 & 6414.023 & 947.207 \\ \text { YADLTEDQLPSCESLK } & 1.00 & 83.80 & 26.61 & 24.95 & 2 & 2145.0214 & 2145.0213 & 1073.5179 & 0.0001 & 0.0466 & 459.681 & 544.370 & 490.014 & 90.313\end{array}$ $\left.\begin{array}{llllllllllllll}0.99 & 29.92 & 28.12 & 19.76 & 3 & 1262.6926 & 1262.6896 & 421.9038 & 0.0030 & 2.3702 & 1375.013 & 1444.308 & 934.715 & 1472.357\end{array}\right)$

$\begin{array}{llllllllllllll} & \end{array}$ AMEAVAAQGK

MEAVAAQGK $\begin{array}{llllllllllllllll} & \end{array}$ $\begin{array}{lllllllllllllllll}\text { YADLTEDQLPSCESLK } & 1.00 & 83.54 & 26.67 & 28.671 & 2 & 2145.0234 & 2145.0213 & 1073.5179 & 0.0021 & 0.9781 & 1953.490 & 2039.376 & 2006725 & 316.309 & \text { Yes }\end{array}$ $\begin{array}{llllllllllllllll}\text { YADLTEDQLPSCESLK } & 100 & 65.37 & 26.61 & 23.34 & 2 & 2145.0214 & 2145.0213 & 1073.5179 & 0.0001 & 0.0466 & 953207 & 1240.844 & 818.248 & 191.450 & \text { Yes }\end{array}$ $\begin{array}{llllllllllllllll}\text { YADLTEDQL PSCESLK } & 100 & 78.63 & 26.61 & 24.14 & 2 & 2145.0214 & 2145.0213 & 1073.5179 & 0.0001 & 0.0466 & 789.506 & 1233.481 & 990.538 & 188.472 & \text { Yes }\end{array}$

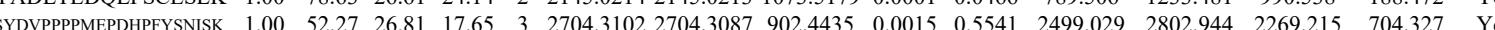
$\begin{array}{lllllllllllllllll}\text { SYDVPPPMEPDHPFYSNISK } & 1.00 & 49.88 & 27.02 & 16.85 & 3 & 2704.3300 & 2704.3087 & 902.4435 & 0.0213 & 7.8675 & 2593.976 & 4003.377 & 2495.463 & 399.716 & \text { Yes }\end{array}$ $\begin{array}{lllllllllllllllll}\text { SYDVPPPPMPPDHPYSNISK } & 1.00 & 45.00 & 27.22 & 16.65 & 3 & 2704.3315 & 2704.3087 & 902.4435 & 0.0228 & 8.4215 & 4339.277 & 5890.745 & 3179.586 & 246.412 & \text { Yes }\end{array}$ $\begin{array}{lllllllllllllllllll}\text { SYDVPPPPMEPDHPFYSNISK } & 1.00 & 47.37 & 26.99 & 16.59 & 3 & 2704.3351 & 2704.3087 & 902.4435 & 0.0264 & 9.7512 & 2762.090 & 3154.413 & 1895.990 & 313.320 & Y & \text { Yes }\end{array}$ $\begin{array}{lllllllllllllll}\text { HLEGLSEAMELNLPGIPIYYELRK } & 0.55 & 45.20 & 24.12 & 58.20 & 3 & 3310.7632 & 3310.7614 & 1104.5944 & 0.0018 & 0.5432 & 18.476 & 26.314 & 34.456 & 16.178\end{array}$

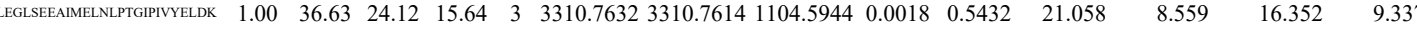
$\begin{array}{lllllllllllllll} & \end{array}$ ALPFWNEEIVPQIK ALPFWNEEIVPQIK ALPFWNEEIVPQIK ALPFWNEEIVPQIK ALPFWNEEIVPQIK ALPFWNEEIVPQIK ALPFWNEEIVPQIK ALPFWNEEIVPQIK ALPFWNEEIVPQIK VLIAAHGNSLR VLIAAHGNSLR VLIAAHGNSLR

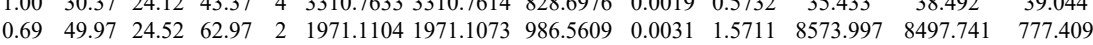
$\begin{array}{lllllllllllll}0.53 & 17.78 & 24.52 & 30.78 & 3 & 1971.1105 & 1971.1073 & 658.0430 & 0.0032 & 1.6210 & 176.863 & 249.969 & 59.968\end{array}$ $\begin{array}{lllllllllllll}1.00 & 51.23 & 24.25 & 16.86 & 2 & 1971.1108 & 1971.1073 & 986.5609 & 0.0035 & 1.7738 & 11131.374 & 12667.446 & 703.619\end{array}$ $\begin{array}{llllllllllllll}0.92 & 18.71 & 24.25 & 16.26 & 3 & 1971.1111 & 1971.1073 & 658.0430 & 0.0038 & 1.9249 & 326.910 & 297.760 & 109.676\end{array}$ $\begin{array}{llllllllllllll}1.00 & 59.22 & 24.55 & 23.67 & 2 & 1971.1094 & 1971.1073 & 986.5609 & 0.0021 & 1.0643 & 10253.006 & 13250.870 & 400.634\end{array}$ $\begin{array}{lllllllllllll}1.00 & 33.92 & 24.22 & 16.10 & 3 & 1971.1132 & 1971.1073 & 658.0430 & 0.0059 & 2.9887 & 405.803 & 445.842 & 40.589\end{array}$ $\begin{array}{llllllllllllllll}1.00 & 74.60 & 24.25 & 23.76 & 2 & 1971.1134 & 1971.1073 & 986.5609 & 0.0061 & 3.0915 & 6150.793 & 5939.675 & 152.004 & 95.357 & \end{array}$ $\begin{array}{lllllllllllllll}0.65 & 11.12 & 24.50 & 14.47 & 3 & 1971.1099 & 1971.1073 & 658.0430 & 0.0026 & 1.3170 & 219.508 & 336.091 & 144.157 & 131.6\end{array}$ $\begin{array}{lllllllllllllll}1.00 & 60.75 & 24.25 & 16.81 & 2 & 1971.1108 & 1971.1073 & 986.5609 & 0.0035 & 1.7738 & 3460.207 & 3601.362 & 225.617 & 142.544\end{array}$

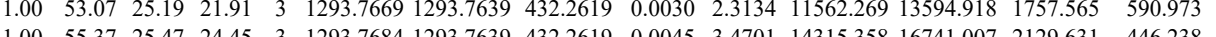

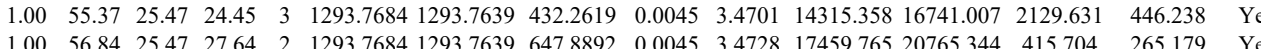
$\begin{array}{lllllllllllllll}1.00 & 56.84 & 25.47 & 27.64 & 2 & 1293.7684 & 1293.7639 & 647.8892 & 0.0045 & 3.4728 & 17459.765 & 20765.344 & 415.704 & 265.179 & \text { Yes } \\ 1.00 & 60.61 & 25.45 & 29.59 & 2 & 1293.7688 & 1293.7639 & 647.8892 & 0.0049 & 3.7815 & 7739.492 & 8247.812 & 342.071 & 169.315 & \text { Yes }\end{array}$ $\begin{array}{lllllllllllllllllll}1.00 & 56.62 & 25.48 & 23.04 & 3 & 1293.7693 & 1293.7639 & 432.2619 & 0.0054 & 4.1641 & 10925.505 & 12723.628 & 976.783 & 355.853 & \text { Yes }\end{array}$

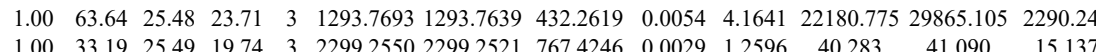




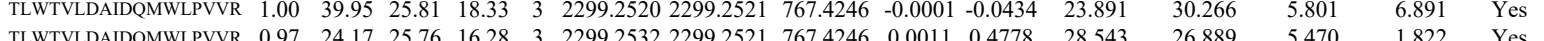

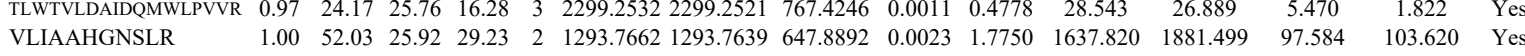
$\begin{array}{llllllllllllllll} & \\ \text { VLIAAHGNSLR } & 1.00 & 52.34 & 25.92 & 29.09 & 3 & 1293.7663 & 1293.7639 & 432.2619 & 0.0024 & 1.8507 & 10219.115 & 13471.552 & 1158.025 & 610.606 & \text { Yes }\end{array}$ \begin{tabular}{llllllllllllllll} 
& \\
VLIAAHGNSLR & 1.00 & 49.09 & 25.31 & 26.01 & 3 & 1293.7666 & 1293.7639 & 432.2619 & 0.0027 & 2.0821 & 13269.864 & 16345.757 & 1663.670 & 814.097 & Yes \\
\hline & 0.91 & 30.10 & 28.63 & 15.95 & 3 & 1293.7663 & 1293.7639 & 432.9619 & 0.0024 & 1.8507 & 5067.624 & 6100.541 & 1552.937 & 1032.051 & Yes
\end{tabular} $\begin{array}{llllllllllllllll} & \\ \text { AETAAK } & 0.91 & 30.10 & 28.63 & 25.94 & 2 & 877.5112 & 877.5112 & 439.7629 & 0.0024 & 0.0000 & 342.678 & 388.641 & 397.692 & 267.385 & \text { No }\end{array}$

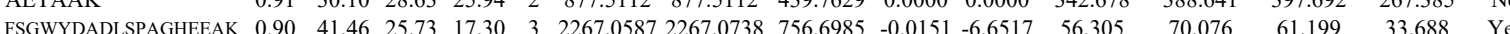

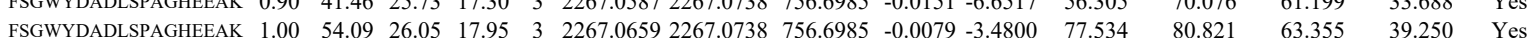

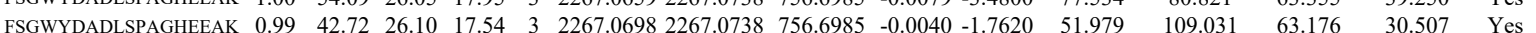
$\begin{array}{llllllllllllllll}\text { FSGWYDADLSPAGHEEAK } & 1.00 & 40.72 & 26.36 & 17.84 & 3 & 2267.0749 & 2267.0738 & 756.6985 & 0.0011 & 0.4846 & 64.550 & 48.617 & 36.672 & 42.439 & \text { No }\end{array}$

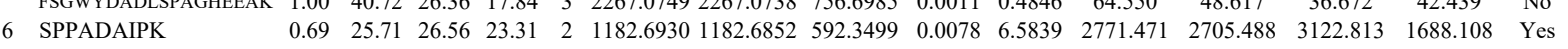

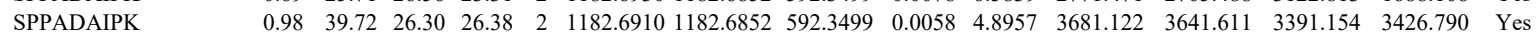
$\begin{array}{lllllllllllllllll}\text { SPPADAIPK } & 0.97 & 38.47 & 26.21 & 24.43 & 2 & 1182.6916 & 1182.6852 & 592.3499 & 0.0064 & 5.4022 & 3560.581 & 3173.115 & 4047.386 & 2904.168 & \text { Yes }\end{array}$ $\begin{array}{llllllllllllllll}\text { SPALSIPEDVVAAEGGMHTVCLSK } & 1.00 & 34.43 & 25.04 & 16.66 & 4 & 3156.6773 & 3156.6711 & 790.1751 & 0.0062 & 1.9616 & 26.706 & 43.531 & 79.348 & 44.077 & \text { Yes }\end{array}$

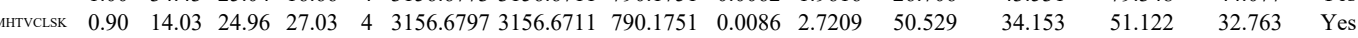

VPELFANR

VPELFANR

VPELFANR

SMVPVQVQLI
SIPTLISR

VFLWGSFR

VFLWGSFR

VFLWGSFR

VFLWGSFR

VFLWGSFR

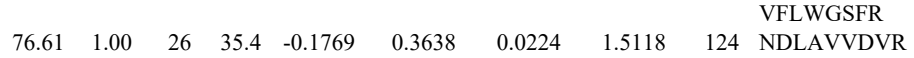

NUCL_HUMAN P19338 NCL Nucleolin

GATPGK

NDLAVVDVR

AAATPAK

AAATPAK

VPQNQNGK

TVTPAK

TVTPAK

VPQNQNGK

TVTPAK

AAVTPGK

AAVTPGK

AVTTPGK

GYAFIEFASFEDAK

GAAIPAK

AAVTPGK

AAVTPGK

AVTTPGK

GYAFIEFASFEDAK

GYAFIEFASFEDAK

GYAFIEFASFEDAK

GYAFIEFASFEDAK

GYAFIEFASFEDAK

GYAFIEFASFEDAK

GYAFIEFASFEDAK

GYAFIEFASFEDAK

GYAFIEFASFEDAK

GYAFIEFASFEDAK

GYAFIEFASFEDAK

GAAIPAK

GAAIPAK

GAAIPAK $\begin{array}{lllllllllllllll}0.88 & 30.69 & 28.84 & 26.28 & 2 & 1088.6206 & 1088.6100 & 545.3123 & 0.0106 & 9.7191 & 4106.738 & 3365.524 & 2749.391 & 2254.112 & \text { Yes }\end{array}$

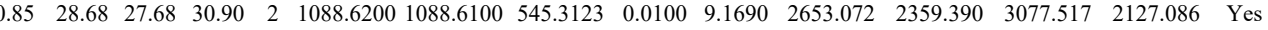
$\begin{array}{llllllllllllllll}0.94 & 34.50 & 28.84 & 31.33 & 2 & 1088.6208 & 1088.6100 & 545.3123 & 0.0108 & 9.9025 & 2407.542 & 2186.251 & 3147.018 & 2001.034 & \text { Yes }\end{array}$

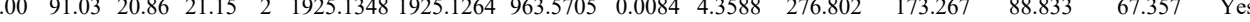
$\begin{array}{lllllllllllllll}0.73 & 27.11 & 27.22 & 30.07 & 2 & 1029.6386 & 1029.6304 & 515.8225 & 0.0082 & 7.9484 & 17992.843 & 15656.325 & 5546.483 & 933.345 & \text { Yes }\end{array}$ $\begin{array}{lllllllllllllll}1.00 & 42.77 & 26.68 & 24.48 & 2 & 1154.6378 & 1154.6359 & 578.3252 & 0.0019 & 1.6427 & 1411.992 & 1220.533 & 24.956 & 11.767 & \text { Yes } \\ 1.00 & 45.76 & 26.68 & 21.77 & 2 & 1154.6380 & 1154.6359 & 578.3252 & 0.0021 & 1.8156 & 3857.741 & 2912.903 & 91.237 & 8.599 & \text { Yes }\end{array}$

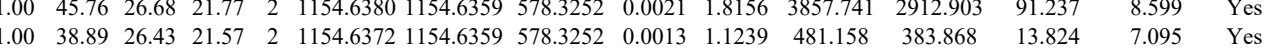

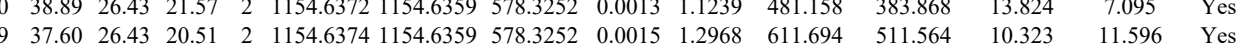

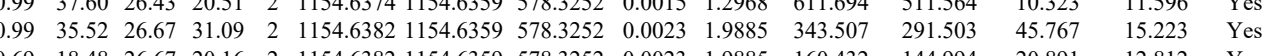
$\begin{array}{lllllllllllllll}0.69 & 18.48 & 26.67 & 20.16 & 2 & 1154.6382 & 1154.6359 & 578.3252 & 0.0023 & 1.9885 & 160.432 & 144.994 & 20.891 & 12.812 & \text { Yes } \\ 0.94 & 28.19 & 27.80 & 25.24 & 2 & 1143.6388 & 1143.6370 & 572.8258 & 0.0018 & 1.5712 & 37.965 & 44.484 & 25.322 & 7.192 & \text { Yes }\end{array}$ \begin{tabular}{llllllllllllllll}
0.94 & 28.19 & 27.80 & 25.24 & 2 & 1143.6388 & 1143.6370 & 572.8258 & 0.0018 & 1.5712 & 37.965 & 44.484 & 25.322 & 7.192 & Yes \\
\hline
\end{tabular} $\begin{array}{lllllllllllllll}0.62 & 22.14 & 25.94 & 35.06 & 2 & 817.4902 & 817.4901 & 409.7523 & 0.0001 & 0.1220 & 784.275 & 688.865 & 469.871 & 399.594 & \text { Yes } \\ 1.00 & 51.73 & 27.64 & 25.72 & 2 & 1143.6478 & 1143.6370 & 572.8258 & 0.0108 & 9.4269 & 12901.231 & 10147.681 & 2694.768 & 2337.587 & \text { Yes }\end{array}$ $\begin{array}{ccccccccccccccc}1.00 & 51.73 & 27.64 & 25.72 & 2 & 1143.6478 & 1143.6370 & 572.8258 & 0.0108 & 9.4269 & 12901.231 & 10147.681 & 2694.768 & 2337.587 & \text { Yes }\end{array}$ $\begin{array}{lllllllllllllll}0.89 & 24.11 & 26.33 & 22.14 & 2 & 916.560 & 916.5585 & 459.2865 & 0.0015 & 1.6330 & 1010.339 & 821.976 & 171.389 & 41.999 & \text { Yes } \\ 0.91 & 24.94 & 26.33 & 25.95 & 2 & 916.5600 & 916.5585 & 459.2865 & 0.0015 & 1.6330 & 1138299 & 1017.938 & 173.069 & 49.802 & \text { Yes }\end{array}$

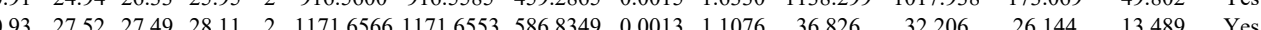

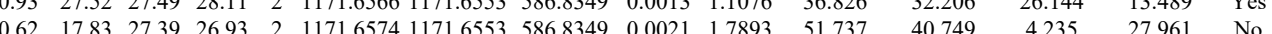
$\begin{array}{lllllllllllllll}0.85 & 23.17 & 26.95 & 27.59 & 2 & 903.5642 & 903.5633 & 452.7889 & 0.0009 & 0.9938 & 1176474 & 1062.935 & 437.211 & 258.810 & \text { Y }\end{array}$

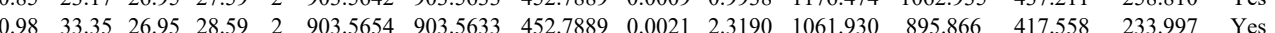
$\begin{array}{llllllllllllllll}0.79 & 23.33 & 27.36 & 19.72 & 2 & 1171.6580 & 1171.6553 & 586.8349 & 0.0027 & 23005 & 12.192 & 36.584 & 14.539 & 13.699 & \text { No }\end{array}$ $\begin{array}{lllllllllllllll}0.87 & 23.63 & 26.95 & 17.74 & 2 & 903.5650 & 903.5633 & 452.7889 & 0.0017 & 1.8773 & 284.668 & 246.273 & 140.258 & 89.952 & \text { Yes }\end{array}$ $\begin{array}{lllllllllllllll}0.96 & 37.48 & 25.13 & 38.42 & 2 & 930.5738 & 930.5742 & 4662944 & 0.0004 & 0.4289 & 668.768 & 633.418 & 191.733 & 67.858 & \text { Yes }\end{array}$ $\begin{array}{llllllllllllllll}0.98 & 37.96 & 25.00 & 38.70 & 2 & 930.5748 & 930.5742 & 4662944 & 0.0006 & 0.6434 & 1036.065 & 861.974 & 203.277 & 67.559 & \text { Yes }\end{array}$ $\begin{array}{lllllllllllllllll}0.99 & 33.33 & 26.36 & 24.81 & 2 & 960.5860 & 960.5848 & 481.2997 & 0.0012 & 1.2466 & 510.247 & 432.757 & 265.070 & 149.534 & \text { Yes }\end{array}$ $\begin{array}{lllllllllllllll}0.91 & 21.76 & 27.27 & 16.23 & 3 & 1881.9439 & 1881.9392 & 628.3203 & 0.0047 & 2.4934 & 31.698 & 43.477 & 15.812 & 13.331 & \text { Yes }\end{array}$ $\begin{array}{llllllllllllllll}0.98 & 28.38 & 23.78 & 23.89 & 2 & 914.5802 & 914.5793 & 458.2969 & 0.0009 & 0.9819 & 2353.463 & 1935.657 & 844.673 & 305.180 & \text { Yes }\end{array}$ $\begin{array}{llllllllllllllll}0.85 & 19.90 & 23.75 & 16.72 & 2 & 914.5806 & 914.5793 & 458.2969 & 0.0013 & 1.4183 & 2030.867 & 1726.486 & 2310.939 & 1093.026 & \text { No }\end{array}$ $\begin{array}{llllllllllllllll}0.98 & 37.63 & 25.00 & 38.53 & 2 & 930.5748 & 930.5742 & 466.2944 & 0.0006 & 0.6434 & 350.121 & 335.226 & 92.759 & 34.985 & \text { Yes }\end{array}$ $\begin{array}{lllllllllllllll}0.89 & 37.39 & 25.71 & 38.30 & 2 & 930.5794 & 930.5742 & 466.2944 & 0.0052 & 5.5758 & 315.661 & 263.213 & 78.649 & 20.784 & \text { Yes }\end{array}$ $\begin{array}{lllllllllllllll}0.97 & 33.43 & 26.67 & 24.77 & 2 & 960.5846 & 960.5848 & 481.2997 & -0.0002 & -0.2078 & 513.507 & 423.022 & 201.907 & 127.387 & \text { Yes }\end{array}$ $\begin{array}{lllllllllllllll}0.92 & 26.92 & 27.13 & 16.35 & 3 & 1881.9379 & 1881.9392 & 628.3203 & -0.0013 & -0.6897 & 146.862 & 156.324 & 84.657 & 79.753 & \text { Yes }\end{array}$

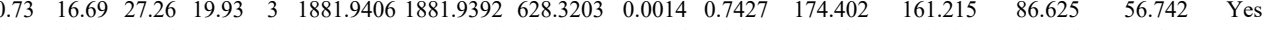

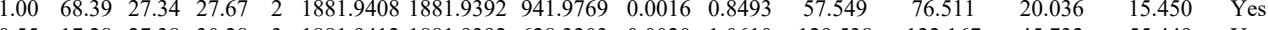
$\begin{array}{lllllllllllllll}0.55 & 17.28 & 27.38 & 30.28 & 3 & 1881.9412 & 1881.9392 & 628.3203 & 0.0020 & 1.0610 & 129.538 & 122.167 & 45.732 & 55.449 & \text { Yes }\end{array}$

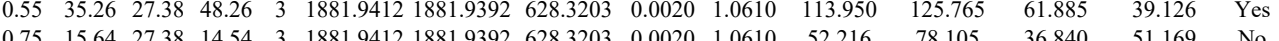
$\begin{array}{lllllllllllllll}1.00 & 7.64 & 27.38 & 14.54 & 3 & 1881.9412 & 1881.9392 & 628.3203 & 0.0020 & 1.0610 & 52.216 & 78.105 & 36.840 & 51.169 & \text { No }\end{array}$

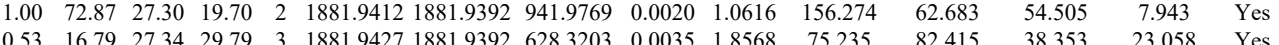

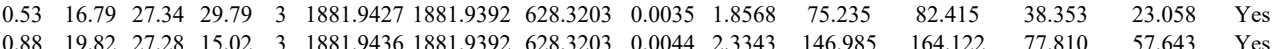

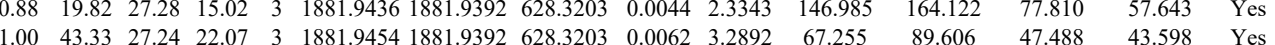

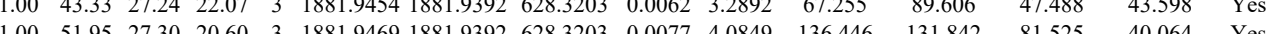
$\begin{array}{lllllllllllllll}0.98 & 28.29 & 23.78 & 24.70 & 2 & 914.5802 & 914.5793 & 458.2969 & 0.0009 & 0.9819 & 2611.066 & 2604.340 & 877.844 & 275.361 & \text { Yes }\end{array}$

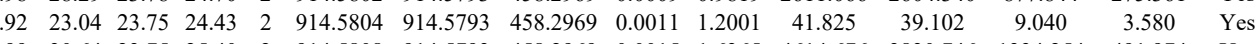
$\begin{array}{lllllllllllllllll}0.99 & 30.64 & 23.75 & 25.40 & 2 & 914.5808 & 914.5793 & 458.2969 & 0.0015 & 1.6365 & 4614.676 & 3830.746 & 1334.254 & 491.974 & \text { Yes }\end{array}$ 
$\begin{array}{llllllllllllllll}0.99 & 30.74 & 23.78 & 24.09 & 2 & 914.5800 & 914.5793 & 458.2969 & 0.0007 & 0.7637 & 2867.912 & 2347.620 & 926.889\end{array}$ $\begin{array}{lllllllllllll}0.92 & 26.28 & 27.26 & 31.40 & 2 & 927.5470 & 927.5455 & 464.7800 & 0.0015 & 1.6137 & 8833.666 & 7342.287\end{array}$

TGISDVFAK $\begin{array}{llllllllllllll}0.92 & 25.08 & 26.43 & 26.18 & 2 & 927.5478 & 927.5455 & 464.7800 & 0.0023 & 2.4743 & 522.001 & 366.175 & 0.000 \\ 0.87 & 22.81 & 26.43 & 24.69 & 2 & 927.5480 & 927.5455 & 464.7800 & 0.0025 & 2.6894 & 462.507 & 402.150 & 0.324\end{array}$

MLLSNLSYSATEET $\begin{array}{llllllllllll}0.76 & 25.62 & 27.00 & 24.24 & 2 & 1224.6998 & 1224.6958 & 6133552 & 0.0040 & 3.2607 & 264.051 & 245.38\end{array}$

GIAYIEFK

NDLAVVDVR $\begin{array}{lllllllllllll}0.97 & 3.18 & 26.05 & 31.91 & 2 & 1227.7102 & 1227.7107 & 614.8626 & -0.0005 & -0.4066 & 297.953 & 224\end{array}$ $\begin{array}{lllllllllll}1.00 & 43.48 & 25.93 & 33.74 & 2 & 1227.7134 & 1227.7107 & 614.8626 & 0.0027 & 2.1956 & 301.823\end{array}$

NDLAVVDVR

VAVATPAK

VAVATPAK $\begin{array}{llllllllllllll}1.00 & 44.24 & 25.94 & 31.85 & 2 & 1227.7138 & 1227.7107 & 614.8626 & 0.0031 & 2.5209 & 289.896 & 21 & \\ 1.66 & 27.80 & 25.69 & 2 & 1143.6392 & 1143.6370 & 572.8258 & 0.0022 & 1.9203 & 58.376 & 4\end{array}$

VAVATPAK

VTLDWAKPK

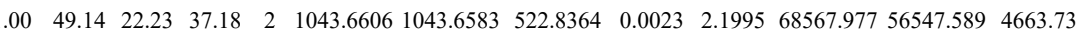

VEGTEPTTAFNLFVGNLNF

$\begin{array}{lllllllllllll}.00 & 45.67 & 22.43 & 30.68 & 2 & 1043.6620 & 1043.6583 & 522.8364 & 0.0037 & 3.5384 & 49423.587 & 42442.936 & 3082.779\end{array}$ $\begin{array}{llllllllllllll}1.00 & 48.95 & 22.28 & 37.01 & 2 & 1043.6600 & 1043.6583 & 522.8364 & 0.0017 & 1.6257 & 15845.603 & 12557.406 & 1142.384 \\ 0.96 & 29.80 & 21.40 & 23.68 & 3 & 1488.9172 & 1488.9030 & 497.3083 & 0.0142 & 9.5178 & 26616.588 & 27317.048 & 2916.239\end{array}$ $\begin{array}{llllllllllllll}\text { VEGTEPTTAFNLFVGNLNFNK } & 1.00 & 82.48 & 26.50 & 19.51 & 2 & 2599.3554 & 2599.3526 & 1300.6836 & 0.0028 & 1.0764 & 266.009 & 184.609 & 130.686\end{array}$

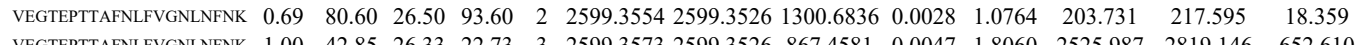
$\begin{array}{llllllllllllll}\text { VEGTEPTTAFNLFVGNLNFNK } & 1.00 & 42.85 & 26.33 & 22.73 & 3 & 2599.3573 & 2599.3526 & 867.4581 & 0.0047 & 1.8060 & 2525.987 & 2819.146 & 652.610\end{array}$

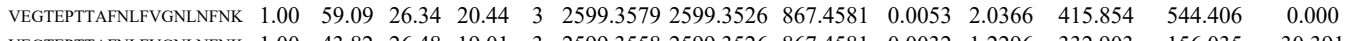
NDLAVVDVR NDLAVVDVR

TEADAEK

EAMEDGEIDGNK

EAMEDGEIDGNK

EAMEDGEIDGNK

EAMEDGEIDGNK

EAMEDGEIDGNK

EAMEDGEIDGNK

AVTTPGK
GAAIPAK

AVTTPGK

AVTTPGK

QGTEIDGR

GLSEDTTEETLK

GAAIPAK

AVTTPGK

AAPEAK

FGYVDFESAEDLEK

NSTWSGESK

GFGFVDFNSEEDAK

GFGFVDFNSEEDAK
GFGFVDFNSEEDAK

GFGFVDFNSEEDAK

GFGFVDFNSEEDAK

GFGFVDFNSEEDAK

GFGFVDFNSEEDAK

GFGFVDFNSEEDAK

GFGVDFNSEEDAK $\begin{array}{lllllllll} & 0.0032 & 1.2296 & 332.903\end{array}$ $\begin{array}{llllllllllll}0.99 & 34.67 & 27.82 & 26.75 & 2 & 1143.6394 & 1143.6370 & 572.8258 & 0.0024 & 2.0949 & 44.262\end{array}$

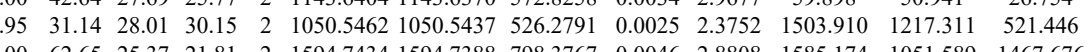

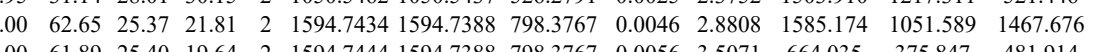
$\begin{array}{llllllllllll}0.99 & 34.24 & 25.67 & 25.85 & 3 & 1594.7464 & 1594.7388 & 532.5869 & 0.0076 & 4.7566 & 363.091\end{array}$ $\begin{array}{lllllllllllll}0.76 & 47.61 & 24.76 & 60.61 & 2 & 1610.7352 & 1610.7337 & 806.3741 & 0.0015 & 0.9301 & 383.703\end{array}$ $\begin{array}{lllllllllllll}0.77 & 54.63 & 24.87 & 67.63 & 2 & 1610.7354 & 1610.7337 & 806.3741 & 0.0017 & 1.0541 & 248.208\end{array}$

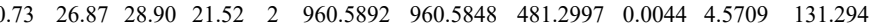
$\begin{array}{llllllllllll}0.52 & 15.80 & 23.89 & 25.26 & 2 & 914.5790 & 914.5793 & 458.2969 & -0.0003 & -0.3273 & 108.436\end{array}$ $\begin{array}{lllllllllllll}0.93 & 36.44 & 28.90 & 25.99 & 2 & 960.5908 & 960.5848 & 481.2997 & 0.0060 & 6.2331 & 24.185 \\ 0\end{array}$ $\begin{array}{lllllllllllll}.69 & 28.74 & 28.90 & 31.40 & 2 & 960.5904 & 960.5848 & 481.2997 & 0.0056 & 5.8175 & 36.054 \\ 0.98 & 32.56 & 26.48 & 29.57 & 2 & 1018.5174 & 1018.5165 & 510.2655 & 0.0009 & 0.8819 & 436.245\end{array}$

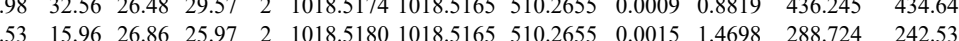
$\begin{array}{llllllllllll}0.00 & 58.96 & 28.46 & 28.29 & 2 & 1609.8448 & 1609.8290 & 805.9218 & 0.0158 & 9.8023 & 1279.283 & 1027.852\end{array}$ $\begin{array}{llllllllllll}0.89 & 20.92 & 23.75 & 26.09 & 2 & 914.5810 & 914.5793 & 458.2969 & 0.0017 & 1.8547 & 72.084\end{array}$ $\begin{array}{lllllllllllll}0.71 & 29.19 & 28.95 & 25.84 & 2 & 960.5918 & 960.5848 & 481.2997 & 0.0070 & 7.2719 & 29.923\end{array}$ $\begin{array}{llllllllllllll}0.77 & 31.38 & 27.85 & 28.40 & 2 & 873.5170 & 873.5163 & 437.7654 & 0.0007 & 0.7995 & 1729.996\end{array}$ $\begin{array}{llllllllllll}1.00 & 43.84 & 27.19 & 18.06 & 3 & 1935.9406 & 1935.9346 & 646.3188 & 0.0060 & 3.0944 & 57.308\end{array}$ $\begin{array}{llllllllllll}1.00 & 47.14 & 27.06 & 26.96 & 2 & 1282.6412 & 1282.6397 & 642.3271 & 0.0015 & 1.1676 & 1147.042 \\ 0.98 & 39.31 & 26.72 & 17.79 & 2 & 1848.8766 & 1848.8774 & 925.4460 & -0.0008 & -0.4322 & 57.278\end{array}$ $\begin{array}{lllllllllll}1.00 & 63.45 & 26.69 & 17.92 & 2 & 1848.8776 & 1848.8774 & 925.4460 & 0.0002 & 0.1081 & 43.241\end{array}$ $\begin{array}{llllllllllll}1.00 & 53.61 & 26.76 & 21.45 & 2 & 1848.8780 & 1848.8774 & 925.4460 & 0.0006 & 0.3242 & 48.683\end{array}$ $\begin{array}{llllllllllll}1.00 & 62.51 & 26.76 & 22.14 & 2 & 1848.8780 & 1848.8774 & 925.4460 & 0.0006 & 0.3242 & 65.245\end{array}$ $\begin{array}{lllllllllll}1.00 & 46.64 & 26.79 & 18.08 & 2 & 1848.8790 & 1848.8774 & 925.4460 & 0.0016 & 0.8644 & 38.600\end{array}$ $\begin{array}{lllllllllll}1.00 & 42.57 & 26.78 & 18.75 & 2 & 1848.8794 & 1848.8774 & 925.4460 & 0.0020 & 1.0806 & 49.636\end{array}$ $\begin{array}{llllllllllll}0.69 & 56.04 & 27.19 & 69.04 & 2 & 1848.8802 & 1848.8774 & 925.4460 & 0.0028 & 1.5128 & 50.474\end{array}$ $\begin{array}{lllllllllll}56.54 & 27.22 & 18.10 & 2 & 1848.8804 & 1848.8774 & 925.4460 & 0.0030 & 1.6208 & 50.591\end{array}$ $\begin{array}{lllllllllll}1.00 & 48.06 & 27.22 & 21.09 & 2 & 1848.8804 & 1848.8774 & 925.4460 & 0.0030 & 1.6208 & 64.442\end{array}$

$$
4.06 \quad 27.22
$$

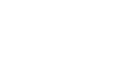$$
1848.8804
$$

$$
848.87 / 4925.4940
$$


$\begin{array}{lllllllllll}1.00 & 59.98 & 27.13 & 22.28 & 2 & 1935.9352 & 1935.9346 & 968.9746 & 0.0006 & 0.3096 & 35.650\end{array}$ $\begin{array}{llllllllllll}1.00 & 53.78 & 27.23 & 21.86 & 2 & 1935.9356 & 1935.9346 & 968.9746 & 0.0010 & 0.5160 & 31.024\end{array}$ $\begin{array}{llllllllllllll}1.00 & 79.40 & 27.23 & 28.03 & 2 & 1935.9356 & 1935.9346 & 968.9746 & 0.0010 & 0.5160 & 3988.547 & 33 \\ 0.67 & 15.48 & 27.19 & 23.71 & 3 & 1935.9361 & 1935.9346 & 64.3188 & 0.0015 & 0.7736 & 132.917 & 12\end{array}$

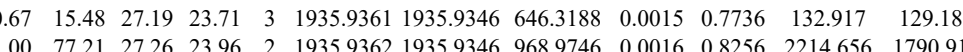

$\begin{array}{lllllllllllll}1.00 & 89.48 & 27.23 & 25.09 & 2 & 1935.9366 & 1935.9346 & 968.9746 & 0.0020 & 1.0320 & 116.497 & 89.535\end{array}$ $\begin{array}{lllllllllllll}1.00 & 35.37 & 27.23 & 26.23 & 3 & 1935.9367 & 1935.9346 & 646.3188 & 0.0021 & 1.0831 & 124.390 & 14 \\ 1.00 & 55.33 & 27.23 & 22.34 & 3 & 1935.9367 & 1935.9346 & 6463188 & 0.0021 & 1.0831 & 539.706 & 62\end{array}$ $\begin{array}{lllllllllll}1.00 & 61.72 & 27.21 & 27.17 & 2 & 1935.9368 & 1935.9346 & 646.3188 & 0.0021 & 1.0831 & 539.706 \\ 1.9746 & 0.0022 & 1.1352 & 43.950\end{array}$ $\begin{array}{llllllllllllll}1.00 & 61.64 & 27.24 & 18.62 & 2 & 1935.9370 & 1935.9346 & 968.9746 & 0.0024 & 1.2384 & 24.369\end{array}$ $\begin{array}{lllllllllllll}0.89 & 19.29 & 27.28 & 18.24 & 3 & 1935.9373 & 1935.9346 & 646.3188 & 0.0027 & 1.3925 & 144.977 & 1\end{array}$ $\begin{array}{lllllllllllll}0.99 & 27.88 & 27.28 & 18.02 & 3 & 1935.9376 & 1935.9346 & 646.3188 & 0.0030 & 1.5472 & 152.536\end{array}$ $\begin{array}{llllllllllll}0.57 & 12.65 & 27.28 & 16.31 & 3 & 1935.9376 & 1935.9346 & 646.3188 & 0.0030 & 1.5472 & 80.870 \\ 0.99 & 29.72 & 27.28 & 18.04 & 3 & 1935.9376 & 1935.9346 & 646.3188 & 0.0030 & 1.5472 & 37.425\end{array}$ $\begin{array}{llllllllllll}0.88 & 19.05 & 27.28 & 18.04 & 3 & 1935.9376 & 1935.4346 & 646.3188 & 0.0030 & 1.5472 & 37.425 \\ 0.9 & 1935.9379 & 1935.9346 & 6463188 & 0.0033 & 1.7019 & 117.032 & \end{array}$ $\begin{array}{lllllllllll}0.88 & 19.05 & 27.28 & 17.41 & 3 & 1935.9379 & 1935.9346 & 646.3188 & 0.0033 & 1.7019 & 117.032 \\ 0.99 & 34.48 & 27.28 & 28.90 & 3 & 1935.9382 & 1935.9346 & 646.3188 & 0.0036 & 1.8567 & 122.864\end{array}$ $\begin{array}{lllllllllll}0.95 & 19.11 & 27.28 & 18.04 & 3 & 1935.9382 & 1935.9346 & 646.3188 & 0.0036 & 1.8567 & 83.690\end{array}$ $\begin{array}{lllllllllllll}1.00 & 57.11 & 27.28 & 25.90 & 3 & 1935.9385 & 1935.9346 & 646.3188 & 0.0039 & 2.0114 & 970.312 & \end{array}$ $\begin{array}{lllllllllllll}1.00 & 59.14 & 27.24 & 24.82 & 2 & 1935.9388 & 1935.9346 & 968.9746 & 0.0042 & 2.1672 & 22.097\end{array}$

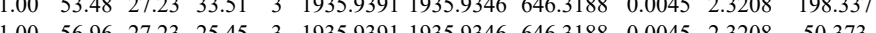

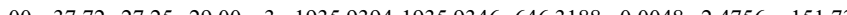
$\begin{array}{lllllllllllll}1.00 & 36.19 & 27.19 & 26.29 & 3 & 1935.9397 & 1935.9346 & 646.3188 & 0.0051 & 2.6303 & 128.970 & 188\end{array}$ $\begin{array}{llllllllllll}0.66 & 15.70 & 27.19 & 17.29 & 3 & 1935.9397 & 1935.9346 & 646.3188 & 0.0051 & 2.6303 & 96.332\end{array}$ $\begin{array}{lllllllllll}1.00 & 51.65 & 27.19 & 23.34 & 2 & 1935.9398 & 1935.9346 & 968.9746 & 0.0052 & 2.6832 & 20.372\end{array}$ $\begin{array}{llllllllllll}0.91 & 21.89 & 27.18 & 21.13 & 3 & 1935.9400 & 1935.9346 & 646.3188 & 0.0054 & 2.7850 & 123.314\end{array}$ $\begin{array}{llllllllllll}0.99 & 35.26 & 27.19 & 20.75 & 3 & 1935.9403 & 1935.9346 & 646.3188 & 0.0057 & 2.9397 & 104.813\end{array}$ $\begin{array}{llllllllllll}0.81 & 30.01 & 27.21 & 21.10 & 2 & 1935.9420 & 1935.9346 & 968.9746 & 0.0074 & 3.8185 & 29.736\end{array}$ $\begin{array}{llllllllllllll}1.00 & 81.72 & 27.22 & 27.78 & 2 & 1935.9442 & 1935.9346 & 968.9746 & 0.0096 & 4.9537 & 38.689 & 51.732\end{array}$ $\begin{array}{lllllllllllll}1.00 & 65.96 & 27.22 & 22.47 & 2 & 1848.8804 & 1848.8774 & 925.4460 & 0.0030 & 1.6208 & 1997.073 & 1907.507\end{array}$ $\begin{array}{lllllllllllll}1.00 & 75.76 & 27.09 & 23.73 & 2 & 1848.8806 & 1848.8774 & 925.4460 & 0.0032 & 1.7289 & 2430.584 & 1786.522\end{array}$ $\begin{array}{lllllllllllll}1.00 & 75.39 & 27.26 & 26.00 & 2 & 1935.9362 & 1935.9346 & 968.9746 & 0.0016 & 0.8256 & 498.600 & 429.618 \\ 1.00 & 81.16 & 27.26 & 26.84 & 2 & 1935.9362 & 1935.9346 & 968.9746 & 0.0016 & 0.8256 & 481.004 & 412.140\end{array}$ $\begin{array}{lllllllllllllll}0.94 & 29.61 & 28.81 & 22.35 & 2 & 906.5392 & 906.5378 & 454.2762 & 0.0014 & 1.5409 & 1098.833 & 997.786\end{array}$ $\begin{array}{llllllllllll}1.00 & 66.93 & 28.06 & 27.52 & 2 & 1497.8042 & 1497.7919 & 749.9032 & 0.0123 & 8.2010 & 726.719 & 627.263\end{array}$ $\begin{array}{lllllllllllll}1.00 & 68.31 & 28.06 & 28.96 & 2 & 1497.8044 & 1497.7919 & 749.9032 & 0.0125 & 8.3343 & 236.825 & 339.590\end{array}$ $\begin{array}{llllllllllllll}1.00 & 76.23 & 28.43 & 26.48 & 2 & 1549.8162 & 1549.8143 & 775.9144 & 0.0019 & 1.2244 & 543.444 & 681.219\end{array}$ $\begin{array}{lllllllllllll}1.00 & 76.10 & 28.31 & 26.84 & 2 & 1549.8174 & 1549.8143 & 775.9144 & 0.0031 & 1.9976 & 677.465 & 646 & \\ \end{array}$ $\begin{array}{llllllllllll}1.00 & 86.21 & 28.46 & 32.07 & 2 & 1549.8160 & 1549.8143 & 775.9144 & 0.0017 & 1.0955 & 776.810 & 969.087\end{array}$ $\begin{array}{llllllllllll}0.97 & 36.02 & 25.55 & 29.87 & 2 & 1085.6658 & 1085.6566 & 543.8356 & 0.0092 & 8.4584 & 6144.366 & 6197.695\end{array}$ $\begin{array}{lllllllllllll}0.95 & 32.30 & 25.35 & 23.27 & 2 & 1085.6666 & 1085.6566 & 543.8356 & 0.0100 & 9.1939 & 5709.628 & 7043.170 & 40\end{array}$ $\begin{array}{llllllllllll}\text { GAALITAVGVR } & 1.00 & 52.34 & 24.10 & 27.99 & 2 & 1170.7308 & 1170.7206 & 586.3676 & 0.0102 & 8.6975 & 4782.786 \\ \text { LPVGFTFSFPCQQSK } & 0.60 & 14.38 & 27.65 & 15.85 & 3 & 2019.0241 & 2019.0202 & 674.0140 & 0.0039 & 1.9287 & 95.148\end{array}$ $\begin{array}{llllllllllll}1.00 & 59.26 & 24.10 & 29.63 & 2 & 1170.7302 & 1170.7206 & 586.3676 & 0.0096 & 8.1859 & 8239.363\end{array}$

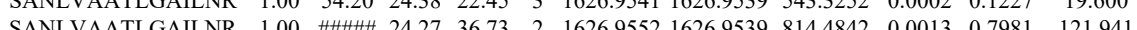
$\begin{array}{llllllllllll}\text { SANLVAATLGAILNR } & 1.00 & 98.91 & 24.27 & 31.99 & 2 & 1626.9552 & 1626.9539 & 814.4842 & 0.0013 & 0.7981 & 61.835\end{array}$ $\begin{array}{lllllllllllll} & \text { SANLVAATLGAINNR } & 1.00 & 67.63 & 24.27 & 25.33 & 3 & 1626.9553 & 1626.9539 & 543.3252 & 0.0014 & 0.8589 & 9.966\end{array}$ 

$\begin{array}{llllllllllll}\text { SANLVAATLGAILNR } & 1.00 & 78.44 & 24.31 & 25.44 & 2 & 1626.9526 & 1626.9539 & 814.4842 & -0.0013 & -0.7981 & 13.409\end{array}$

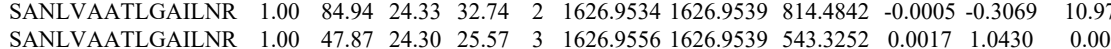
$\begin{array}{llllllllllll}\text { SANLVAATLGAILNR } & 1.00 & 51.81 & 24.28 & 21.25 & 3 & 1626.9550 & 1626.9539 & 543.3252 & 0.0011 & 0.6749 & 0.000\end{array}$ $\begin{array}{lllllllllllll}\text { SANLVAATLGAILNR } & 1.00 & 34.18 & 24.30 & 27.21 & 3 & 1626.9556 & 1626.9539 & 543.3252 & 0.0017 & 1.0430 & 6.738\end{array}$ $\begin{array}{llllllllllll}\text { SANLVAATLGAILNR } & 1.00 & 83.06 & 24.25 & 24.53 & 2 & 1626.9564 & 1626.9539 & 814.4842 & 0.0025 & 1.5347 & 13.091\end{array}$

$\begin{array}{lllllllllll}\text { E2AK2_HUMAI } & \text { P19525 } & \text { EIF2AK2 } & \text { Interferon-inducec } 62.09 & 1.00 & 3 & 6.9 & 0.2222 & 0.2261 & 0.6257 & 0.3026\end{array}$

$\begin{array}{llllllllll}\text { CSK22_HUMAR P19784 } & \text { CSNK2A2 Casein kinase II sı 41.21 } & 1.00 & 3 & 11.7 & -0.0123 & 0.2912 & -0.1235 & 2.2345\end{array}$

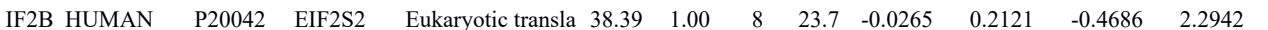

SANLVAATLGAILN
YQELPNGGPHDR

YQELPNSGPPHDR

YQELPNSGPPHDR

KPEDRPNTSEILR

KPEDRPNTSEILR

KPEDRPNTSEILR

KPEDRPNTSEILR

VLALELFEQITK

VLALELFEITK

DVKPHNVMIDHQQK

QLYQILTDFDIR

SPDTILQK

SPDTILQK

TSFVNFTDICK

TSFVNFTDICK

TSFVNFTDICK

TSFVNFTDICK

QIENVLR

VFNIMR

FVMKPPQVVR

FVMKPPQVVR

FVMKPPQVVR

FVMKPPQVVR

FVMKPPQVVR

FVMKPPQVVR

FVMKPPQVVR

FPDEDEILEK

FPDEDEILEK

IFDIDEAEEGVK

IFDIDEAEEGVK

$\begin{array}{llllllllllllll} \\ \text { DASDDLDDLNFFNQK } & 1.00 & 83.06 & 26.47 & 34.52 & 2 & 2043.9654 & 2043.9629 & 1022.9887 & 0.0025 & 1.2219 & 800.879 & 653.109 & 664.654 \\ \text { DASDDLDDLNFFNQK } & 1.00 & 84.36 & 26.47 & 30.02 & 2 & 2043.9654 & 2043.9629 & 1022.9887 & 0.0025 & 1.2219 & 512.596 & 427.647 & 390.700\end{array}$

$\begin{array}{llllllllllllll}\text { DASDDLDDLNFFNQK } & 1.00 & 54.20 & 26.57 & 23.02 & 3 & 2043.9676 & 2043.9629 & 682.3282 & 0.0047 & 2.2961 & 347.093 & 506.629 & 388.391\end{array}$

$\begin{array}{cccccccccccccc}1.00 & 63.04 & 24.25 & 22.51 & 2 & 1626.9564 & 1626.9539 & 814.4842 & 0.0025 & 1.5347 & 8.491 & 12.602 & 1.470 & 1.935 \\ 1.00 & 43.30 & 27.61 & 24.63 & 3 & 1652.8108 & 1652.8029 & 551.9416 & 0.0079 & 4.7710 & 2608.611 & 3810.271 & 2421.410 & 2512.359 \\ 1.00 & 48.25 & 27.68 & 17.88 & 3 & 1652.8120 & 1652.8029 & 551.9416 & 0.0091 & 5.4957 & 1970.323 & 1926.743 & 1959.207 & 1120.202\end{array}$

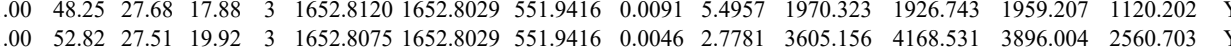

$\begin{array}{lllllllllllllllll}1.00 & 28.15 & 25.62 & 27.96 & 4 & 1842.0225 & 1842.0203 & 461.5124 & 0.0022 & 1.1917 & 9831.161 & 12681.604 & 9275.607 & 8200.602 & \text { Yes }\end{array}$

$\begin{array}{lllllllllllllll}1.00 & 27.34 & 25.49 & 24.90 & 4 & 1842.0229 & 1842.0203 & 461.5124 & 0.0026 & 1.4084 & 13316.344 & 13080.045 & 12469.530 & 10019.193 & \text { Yes }\end{array}$ $\begin{array}{llllllllllllll}15.84 & 22.28 & 23.03 & 3 & 1691.0128 & 1691.0113 & 564.6777 & 0.0015 & 0.8855 & 216.081 & 280.238 & 19.521 & 20.705 & \\ 1.00 & 30.55 & 22 & 20.95 & 3 & 1691.0131 & 1691.0113 & 564.6777 & 0.0018 & 1.0626 & 97.026 & 80.368 & 26.369 & 11.016\end{array}$

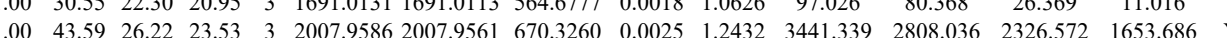
$\begin{array}{llllllllllllllll}.00 & 20.15 & 26.03 & 19.59 & 4 & 2120.1549 & 2120.1526 & 531.0454 & 0.0023 & 1.0828 & 1972.943 & 2393.845 & 4380.399 & 2029.239 & \text { Yes }\end{array}$

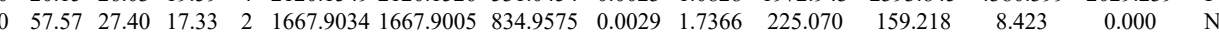

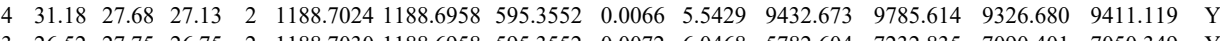
$\begin{array}{lllllllllllllll}0.63 & 2.52 & 27.75 & 26.75 & 2 & 1188.7030 & 1188.6958 & 595.3552 & 0.0072 & 6.0468 & 5782.604 & 7232.835 & 7090.401 & 7050.349 & \text { Yes } \\ 1.00 & 55.11 & 27.73 & 18.66 & 2 & 1607.7970 & 1607.7931 & 804.9038 & 0.0039 & 2.4226 & 4703.817 & 4531.790 & 4.635 & 28.729 & \text { Yes }\end{array}$ $\begin{array}{lllllllllllllll}1.00 & 55.53 & 27.73 & 17.15 & 2 & 1607.7970 & 1607.7931 & 804.9038 & 0.0039 & 2.4226 & 2515.455 & 2260.011 & 51.813 & 57.018 & \text { Yes }\end{array}$ $\begin{array}{llllllllllllllll}1.00 & 61.82 & 28.05 & 18.97 & 2 & 1607.8028 & 1607.7931 & 804.9038 & 0.0097 & 6.0255 & 12864.625 & 11014.487 & 0.000 & 198.212 & \text { No }\end{array}$ $\begin{array}{lllllllllllllll}1.00 & 51.41 & 28.02 & 16.32 & 2 & 1607.8036 & 1607.7931 & 804.9038 & 0.0105 & 6.5225 & 6167.312 & 6196.978 & 53.779 & 80.349 & \text { Yes }\end{array}$ $\begin{array}{lllllllllllllll}0.84 & 24.56 & 26.97 & 33.60 & 2 & 1014.5978 & 1014.5944 & 508.3045 & 0.0034 & 3.3444 & 154.125 & 200.496 & 129.678 & 51.077 & \text { Yes }\end{array}$ $\begin{array}{lllllllllllllll}0.50 & 23.14 & 27.38 & 20.58 & 2 & 922.5260 & 922.5180 & 462.2663 & 0.0080 & 8.6529 & 42599.568 & 41135.690 & 1108.581 & 281.127 & \text { Yes }\end{array}$ $\begin{array}{lllllllllllllll}0.51 & 23.31 & 27.38 & 20.70 & 2 & 922.5262 & 922.5180 & 462.2663 & 0.0082 & 8.8693 & 43674.841 & 44794.069 & 1552.919 & 564.225 & \text { Yes }\end{array}$ $\begin{array}{llllllllllllllll}0.58 & 17.49 & 22.83 & 22.27 & 3 & 1487.9032 & 1487.8890 & 496.9703 & 0.0142 & 9.5243 & 22036.638 & 24026.127 & 3435.620 & 356.720 & \text { Yes }\end{array}$ $\begin{array}{lllllllllllllll}0.61 & 16.63 & 22.83 & 20.25 & 3 & 1487.9035 & 1487.8890 & 496.9703 & 0.0145 & 9.7255 & 36654.868 & 36911.581 & 4139.592 & 330.897 & \text { Yes }\end{array}$ $\begin{array}{lllllllllllllll}0.89 & 17.82 & 24.68 & 22.27 & 3 & 1487.8927 & 1487.8890 & 496.9703 & 0.0037 & 2.4817 & 11737.966 & 11704.550 & 1193.759 & 618.264 & \text { Yes }\end{array}$

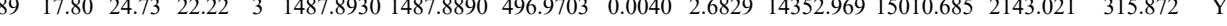
$\begin{array}{llllllllllllllll}0.76 & 16.26 & 24.49 & 21.08 & 3 & 1487.8894 & 1487.8890 & 496.9703 & 0.0004 & 0.2683 & 8584.111 & 8536.177 & 1278.260 & 239.627 & \text { Yes }\end{array}$ $\begin{array}{llllllllllllllll}.91 & 2.66 & 24.49 & 22.57 & 3 & 1487.8894 & 1487.8890 & 496.9703 & 0.0004 & 0.2683 & 8822.945 & 8275.744 & 1165.991 & 245.376 & \text { Yes }\end{array}$

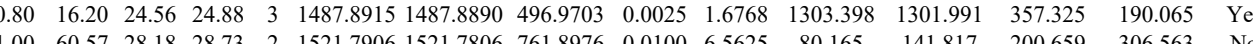
$\begin{array}{lllllllllllllll}1.00 & 60.57 & 28.18 & 28.73 & 2 & 1521.7906 & 1521.7806 & 761.8976 & 0.0100 & 6.5625 & 80.165 & 141.817 & 200.659 & 306.563 & \text { No }\end{array}$ $\begin{array}{lllllllllllllll}1.00 & 56.73 & 28.43 & 26.37 & 2 & 1521.7916 & 1521.7806 & 761.8976 & 0.0110 & 7.2188 & 147.794 & 97.871 & 264.532 & 161.257 & \text { No }\end{array}$ $\begin{array}{lllllllllllllll}1.00 & 89.20 & 28.17 & 32.71 & 2 & 1651.8580 & 1651.8548 & 826.9347 & 0.0032 & 1.9349 & 900.299 & 1042.310 & 0.095 & 35.763 & \text { No }\end{array}$ $\begin{array}{lllllllllllll} & & \end{array}$ $\begin{array}{llllllllllll}\text { ANXA7 HUMA } & \text { P20073 } & \text { ANXA7 } & \text { Annexin A7 } & 52.74 & 1.00 & 5 & 12.1 & 0.1857 & 0.1628 & 0.1799 & 1.7597\end{array}$ 
$\begin{array}{llllllllllll}75.28 & 27.99 & 29.10 & 2 & 1794.9304 & 1794.9168 & 898.4657 & 0.0136 & 7.5684 & 637.530 & 660.51\end{array}$ $\begin{array}{lllllllllllllll} & \end{array}$ $\begin{array}{lllllllllllll} & \end{array}$ $\begin{array}{lllllllllllllllll}\text { AGGSASAMLOPLDNOVGFK } & 1.00 & 95.75 & 26.31 & 19.69 & 2 & 2291.2274 & 2291.2187 & 1146.6166 & 0.0087 & 3.7938 & 177.548 & 80.714 & 80.805 & 110.018 & \text { Y }\end{array}$ $\begin{array}{llllllllllllllll}\text { AGGSASAMLQPLLDNOVGFK } & 1.00 & 76.07 & 26.31 & 18.40 & 2 & 2291.2274 & 2291.2187 & 1146.6166 & 0.0087 & 3.7938 & 153.593 & 111.360 & 111.804 & 64.006 & \text { Yes }\end{array}$ ICIVTK $\quad \begin{array}{lllllllllllllllll}0.55 & 22.93 & 25.62 & 24.54 & 2 & 1009.5966 & 1009.5908 & 505.8027 & 0.0058 & 5.7334 & 65864.603 & 69936.163 & 2917.177 & 3363.523 & \text { Yes }\end{array}$

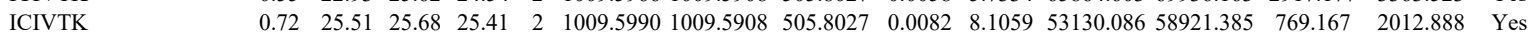

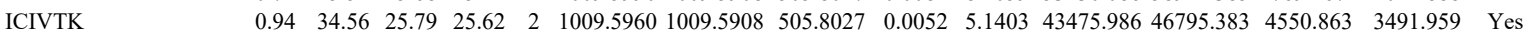
$\begin{array}{llllllllllllllll}\text { AMTTGAIAAMLSTILYSR } & 1.00 & 32.50 & 26.65 & 17.55 & 3 & 2014.0723 & 2014.0713 & 672.3644 & 0.0010 & 0.4958 & 2.998 & 6.408 & 1.162 & 1.092 & \text { Yes }\end{array}$ $\begin{array}{lllllllllllllllll}\text { AMTTGAIAAMLSTILYSR } & 1.00 & 31.75 & 26.54 & 16.04 & 3 & 2014.0729 & 2014.0713 & 672.3644 & 0.0016 & 0.7932 & 5.623 & 5.925 & 5.104 & 0.000 & \text { No }\end{array}$ $\begin{array}{llllllllllllllll}\text { AMTTGAIAAMLSTILYSR } & 0.79 & 35.73 * & 27.23 & 17.77 & 3 & 2030.0668 & 2030.0662 & 677.6960 & 0.0006 & 0.2951 & 14.041 & 9.294 & 6.474 & 11.809 & \text { No }\end{array}$ $\begin{array}{llllllllllllllll}\text { AMTTGAIAAMLSTILYSR } & 0.59 & 21.16 & 26.64 & 17.03 & 3 & 2014.0696 & 2014.0713 & 672.3644 & -0.0017 & -0.8428 & 19.987 & 6.593 & 6.188 & 2.153 & \text { No }\end{array}$ $\begin{array}{lllllllllllllllll}11 & \text { DQMQQQLNDYEQLLDVK } & 1.00 & 68.88 & 27.12 & 20.39 & 3 & 2395.1956 & 2395.1933 & 799.4050 & 0.0023 & 0.9590 & 14.187 & 23.080 & 34.128 & 6.979 & \text { No }\end{array}$ $\begin{array}{llllllllllllllll}\text { CQSLTEDLEFR } & 1.00 & 56.08 & 25.05 & 22.37 & 2 & 1529.7002 & 1529.6976 & 765.8561 & 0.0026 & 1.6974 & 640.938 & 564.564 & 0.000 & 0.000 & \text { No }\end{array}$ $\begin{array}{llllllllllllllll}\text { IGDTSVSYK } & 1.00 & 61.65 & 27.19 & 29.25 & 2 & 1256.6878 & 1256.6856 & 629.3501 & 0.0022 & 1.7478 & 22851.763 & 23702.561 & 10822.851 & 5728.388 & \text { Yes }\end{array}$ $\begin{array}{llllllllllllllll}\text { CQSLTEDLEFR } & 1.00 & 52.45 & 24.81 & 19.83 & 2 & 1529.6996 & 1529.6976 & 765.8561 & 0.0020 & 1.3057 & 327.403 & 376.767 & 9.271 & 7.741 & \text { Yes }\end{array}$ $\begin{array}{lllllllllllllll}\text { IQELEDLLAK } & 0.79 & 51.44 * 26.31 & 38.31 & 2 & 1458.8560 & 1458.8537 & 730.4341 & 0.0023 & 1.5744 & 1353.989 & 1507.292 & 380.489 & 56.257 & \text { Yes }\end{array}$ $\begin{array}{lllllllllllllllll}\text { LSSEMNTSTVNSAR } & 1.00 & 98.58 & 27.35 & 28.08 & 2 & 1639.8056 & 1639.7957 & 820.9051 & 0.0099 & 6.0299 & 2176.812 & 2232.424 & 667.067 & 379.321 & \text { Yes }\end{array}$ $\begin{array}{lllllllllllllllll}\text { SLEGDLEDLKDPIAQLEASLAAAK } & 1.00 & 59.39 & 23.18 & 19.49 & 3 & 2959.6105 & 2959.6079 & 987.5432 & 0.0026 & 0.8776 & 105.198 & 194.175 & 39.622 & 9.486 & \text { Yes }\end{array}$

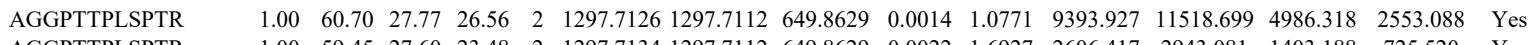
$\begin{array}{llllllllllllllll}\text { AGGPTTPLSPTR } & 1.00 & 59.45 & 27.60 & 23.48 & 2 & 1297.7134 & 1297.7112 & 649.8629 & 0.0022 & 1.6927 & 2606.417 & 2943.081 & 1403.188 & 725.520 & \text { Yes }\end{array}$

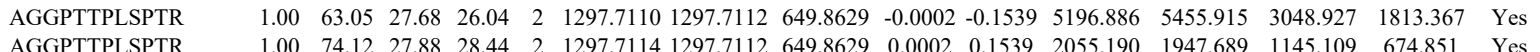
\begin{tabular}{llllllllllllllll} 
AGGPTTPLSPTR & 1.00 & 74.12 & 27.88 & 28.44 & 2 & 1297.7114 & 1297.7112 & 649.8629 & 0.0002 & 0.1539 & 2055.190 & 1947.689 & 1145.109 & 674.851 & Yes \\
\hline
\end{tabular}

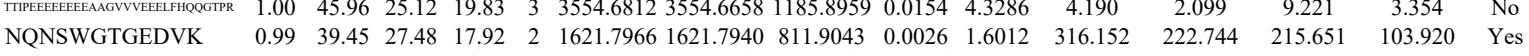
$\begin{array}{llllllllllllllll} & \end{array}$ $\begin{array}{llllllllllllllll}\text { GTVPDDAVEALADSLGK } & 1.00 & 86.48 & 27.53 & 19.42 & 2 & 1945.0262 & 1945.0248 & 973.5197 & 0.0014 & 0.7190 & 167.771 & 229.593 & 239.829 & 147.660 & \text { Yes }\end{array}$

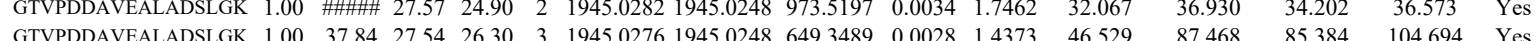


$\begin{array}{lllllllllll}\text { IMDH1_HUMAI P20839 } & \text { IMPDH1 } & \text { Inosine-5'-monopl } & 55.41 & 1.00 & 3 & 11.9 & 0.1227 & 0.2631 & 0.2046 & 0.4550\end{array}$

$\begin{array}{llllllllll}\text { VATB2_HUMAl } & \text { P21281 } & \text { ATP6V1B2V-type proton AT. } 56.50 & 1.00 & 4 & 15.3 & 0.1608 & 0.4220 & -0.5906 & 2.3736\end{array}$

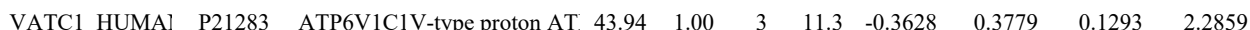
$\begin{array}{llllllllllll}\text { FVPYLIAGIQHGCQDIGAR } & 1.00 & 73.23 & 27.62 & 22.93 & 3 & 2247.1435 & 2247.1414 & 750.0544 & 0.0021 & 0.9333 & 263.362\end{array}$

$\begin{array}{llllllllllllll}\text { GPVVLAEDFLDIMGQPINPQCR } & 1.00 & 32.95 & 26.87 & 19.71 & 3 & 2601.2914 & 2601.2875 & 868.1031 & 0.0039 & 1.4975 & 13.002\end{array}$ $\begin{array}{llllllllllllll}\text { GPVVLAEDFLDIMGQPINPQCR } & 0.61 & 56.39 & 26.85 & 69.39 & 2 & 2601.2874 & 2601.2875 & 1301.6510 & -0.0001 & -0.0384 & 9.130\end{array}$ $\begin{array}{llllllllllllll}\text { GPVVLAEDFLDIMGQPINPQCR } & 0.94 & 21.02 & 26.91 & 16.97 & 3 & 2601.2893 & 2601.2875 & 868.1031 & 0.0018 & 0.6912 & 11.079\end{array}$ $\begin{array}{llllllllllllll}\text { GPVVLAEDFLDIMGQPINPQCR } & 1.00 & 55.93 & 26.89 & 18.62 & 3 & 2601.2926 & 2601.2875 & 868.1031 & 0.0051 & 1.9583 & 10.696\end{array}$ $\begin{array}{lllllllllllll}\text { GPVVLAEDFLDIMGQPINPQCR } & 1.00 & 63.37 & 26.89 & 17.27 & 3 & 2601.2890 & 2601.2875 & 868.1031 & 0.0015 & 0.5760 & 11.741 \\ \text { GPVYLAEDFDIMGOPINPQCR } & 1.00 & 44.99 & 26.91 & 16.65 & 3 & 2601.2899 & 2601.2875 & 868.1031 & 0.0024 & 0.9215 & 5.559\end{array}$ $\begin{array}{lllllllllllll}\text { GPVVLAEDFLDIMGQPINPQCR } & 1.00 & 44.99 & 26.91 & 16.65 & 3 & 2601.2899 & 2601.2875 & 868.1031 & 0.0024 & 0.9215 & 5.559 \\ \text { IYPEEMIQTGISAIDGMNSIAR } & 1.00 & 80.50 & 26.99 & 22.41 & 2 & 25522734 & 25522736 & 1277.1441 & -0.0002 & -0.0783 & 36.457\end{array}$ $\begin{array}{llllllllllll}\text { IYPEEMIQTGISAIDGMNSIAR } & 1.00 & 80.50 & 26.99 & 22.41 & 2 & 2552.2734 & 2552.2736 & 1277.1441 & -0.0002 & -0.0783 & 36.457 \\ \text { IYPEEMIQTGISAIDGMNSAR } & 1.00 & \# \# \#+26.91 & 22.97 & 2 & 2552.2754 & 2552.2736 & 1277.1441 & 0.0018 & 0.7047 & 35.177\end{array}$ $\begin{array}{llllllllllll}\text { IYPEEMIQTGISAIDGMNSIAR } & 1.00 & \text { \#\#\#\# } 26.91 & 22.97 & 2 & 2552.2754 & 2552.2736 & 1277.1441 & 0.0018 & 0.7047 & 35.177 \\ \text { IYPEEMIQTGISAIDGMNSIAR } & 1.00 & 36.37 & 26.96 & 29.96 & 3 & 2552.2765 & 2552.2736 & 851.7651 & 0.0029 & 1.1349 & 17.150\end{array}$ $\begin{array}{llllllllllll}\text { IYPEEMIQTGISAIDGMNSIAR } & 1.00 & 36.37 & 26.96 & 29.96 & 3 & 2552.2765 & 2552.2736 & 851.7651 & 0.0029 & 1.1349 & 17.150 \\ \text { IYPEEMIQTGISAIDGMNSIAR } & 1.00 & 38.36 & 26.98 & 30.39 & 3 & 2552.2771 & 2552.2736 & 851.7651 & 0.0035 & 1.3697 & 21.062\end{array}$

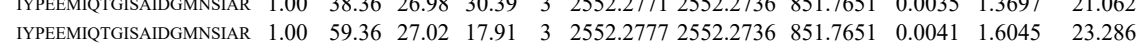

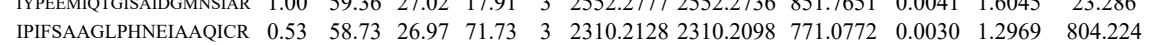

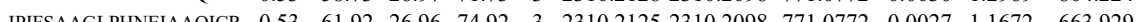
$\begin{array}{llllllllllll}\text { QIYPPINVLPSLSR } & 1.00 & 54.41 & 23.56 & 20.54 & 2 & 1740.0066 & 1740.0056 & 871.0101 & 0.0010 & 0.5740 & 922.767\end{array}$ $\begin{array}{lllllllllllll}\text { QIYPPINVLPSLSR } & 1.00 & 67.36 & 23.58 & 24.15 & 2 & 1740.0064 & 1740.0056 & 871.0101 & 0.0008 & 0.4592 & 187.197\end{array}$ $\begin{array}{llllllllllllll} & 1.00 & 47.86 & 23.48 & 17.72 & 2 & 1740.0072 & 1740.0056 & 871.0101 & 0.0016 & 0.9185 & 195.749\end{array}$

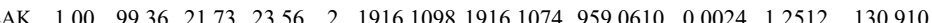
$\begin{array}{lllllllllllllll}\text { VGTLDVLVGLSDELAK } & 1.00 & 93.72 & 21.82 & 20.77 & 3 & 1916.1112 & 1916.1074 & 639.7097 & 0.0038 & 1.9801 & 90.283\end{array}$ $\begin{array}{lllllllllllll}\text { VGTLDVLVGLSDELAK } & 1.00 & 93.47 & 21.82 & 23.50 & 2 & 1916.1120 & 1916.1074 & 959.0610 & 0.0046 & 2.3982 & 120.478\end{array}$ $\begin{array}{lllllllllllll}\text { VGTLDVLVGLSDELAK } & 1.00 & 29.16 & 21.82 & 17.00 & 3 & 1916.1115 & 1916.1074 & 639.7097 & 0.0041 & 2.1364 & 121.069\end{array}$ $\begin{array}{llllllllllll}\text { VGTLDVLVGLSDELAK } & 1.00 & 29.26 & 21.82 & 17.98 & 3 & 1916.1124 & 1916.1074 & 639.7097 & 0.0050 & 2.6053 & 86.303\end{array}$ IDCNLLEFK IDCNLLEFK $\begin{array}{lllllllllllll}0.99 & 48.79 & 28.05 & 37.10 & 2 & 1427.7444 & 1427.7396 & 714.8771 & 0.0048 & 3.3572 & 1525.870 & 838.441\end{array}$ $\begin{array}{lllllllllllll}1.00 & 44.73 & 27.68 & 30.73 & 2 & 1427.7424 & 1427.7396 & 714.8771 & 0.0028 & 1.9584 & 580.355 & 604.324\end{array}$ $\begin{array}{llllllllllllll} & \text { GDLVTYITR } & 1.00 & 51.35 & 25.66 & 18.55 & 3 & 2161.1899 & 2161.1865 & 721.4028 & 0.0034 & 1.5710 & 9.993 & 25.581 \\ \text { A VDLVTYITR } & 0.53 & 60.07 & 25.66 & 73.07 & 3 & 2161.1899 & 2161.1865 & 721.4028 & 0.0034 & 1.5710 & 11.129 & 14.661\end{array}$

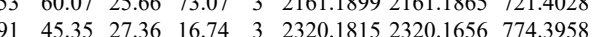
$\begin{array}{llllllllllllllll} & \end{array}$ $\begin{array}{lllllllllllllllll}\text { GYGYGQGAGTLSTDK } & 1.00 & 87.34 & 27.63 & 37.19 & 2 & 1761.8834 & 1761.8777 & 881.9461 & 0.0057 & 3.2315 & 3287.343 & 10472.039 & 2259.050 & 1189\end{array}$ $\begin{array}{lllllllllllllllll}\text { GYGYGQGAGTLSTDK } & 1.00 & 92.58 & 27.58 & 36.34 & 2 & 1761.8846 & 1761.8777 & 881.9461 & 0.0069 & 3.9118 & 4454.010 & 10199.957 & 1507.769 & 8 \\ \text { CSQAVYAAEK } & 1.00 & 77.91 & 26.14 & 2288 & 2 & 1402.676 & 1402.628 & 702.3487 & 0.0048 & 3.4171 & 2708.774 & 6445294 & 468.477 & 3\end{array}$ CSQAVYAAEK GLESTTLADK GLESTTLADK $\begin{array}{llllllllllllllll}1.00 & 61.85 & 27.72 & 27.36 & 2 & 1321.7440 & 1321.7333 & 661.8739 & 0.0107 & 8.0830 & 5242.488 & 9732.876 & 4473.574 & 4128.571 & \text { Yes }\end{array}$

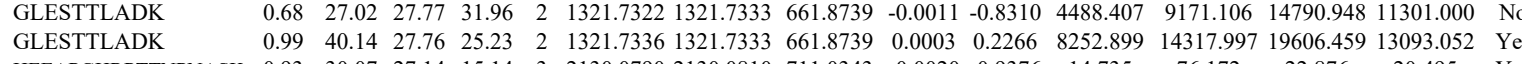
HEEAPGHRPTTNPNASK \begin{tabular}{lllllllllllllll}
0.93 & 40.14 & 27.76 & 25.23 & 2 & 1321.7336 & 1321.7333 & 661.8739 & 0.0003 & 0.2266 & 8252.899 & 14317.997 & 19606.459 & 13093.052 & Yes \\
\hline
\end{tabular} \begin{tabular}{llllllllllllllll} 
HEEAPGHRPTTNPNASK & 0.95 & 16.48 & 27.21 & 14.58 & 4 & 2130.0809 & 2130.0810 & 533.5275 & -0.0001 & -0.0469 & 90.004 & 187.099 & 65.890 & 59.421 & Yes \\
\hline
\end{tabular}

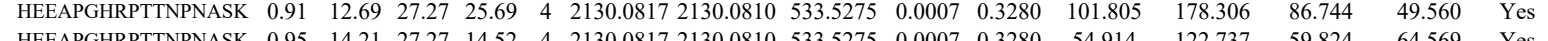

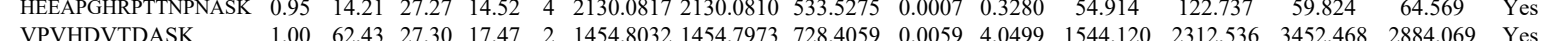
$\begin{array}{lllllllllllllll}\text { FLNA HUMAN } & \text { P21333 } & \text { FLNA } & \text { Filamin-A } & 280.74 & 1.00 & 44 & 26.9 & 0.4952 & 0.4488 & -0.5081 & 1.9286 & 149 & \text { VPVHDVTDASK }\end{array}$ $\begin{array}{lllllllllllllll}1.00 & 62.43 & 27.30 & 17.47 & 2 & 1454.8032 & 1454.7973 & 728.4059 & 0.0059 & 4.0499 & 1544.120 & 2312.536 & 3452.468 & 2884.069 & \text { Yes }\end{array}$ $\begin{array}{lllllllllllllll}1.00 & 65.77 & 27.08 & 18.07 & 2 & 1454.8040 & 1454.7973 & 728.4059 & 0.0067 & 4.5991 & 1683.033 & 1979.488 & 4833.765 & 3661.811 & \text { Yes }\end{array}$ $\begin{array}{lllllllllllllll}1.00 & 63.63 & 27.07 & 17.63 & 3 & 1454.8051 & 1454.7973 & 485.9397 & 0.0078 & 5.3504 & 5243.143 & 6848.376 & 11626.129 & 9328.831 & \text { Yes }\end{array}$ 


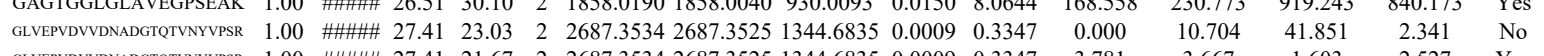

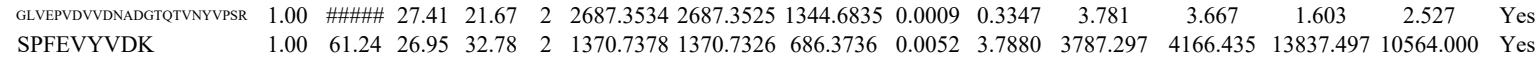

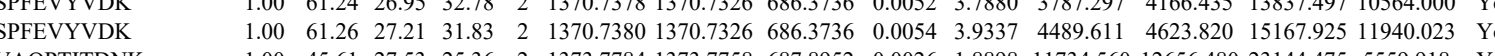

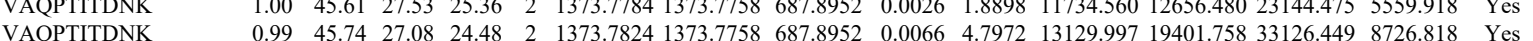

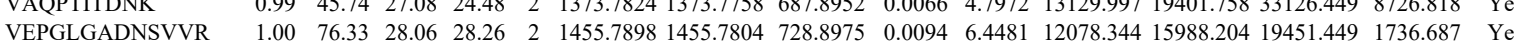

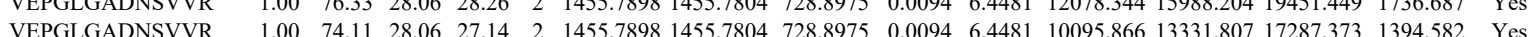

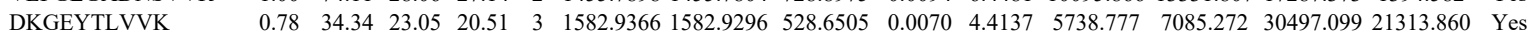

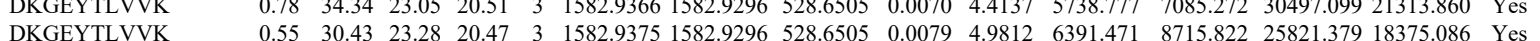

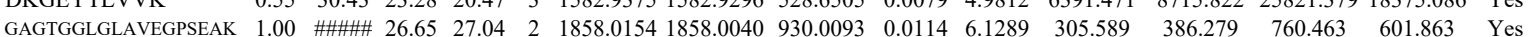
$\begin{array}{llllllllllllllll}\text { VQVODNEGCPVEALVK } & 1.00 & 94.09 & 27.87 & 27.95 & 2 & 2061.0494 & 2061.0478 & 1031.5312 & 0.0016 & 0.7755 & 202.103 & 297.952 & 489.435 & 106.285 & \text { Yes }\end{array}$

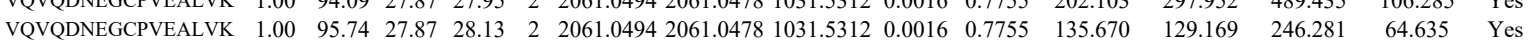

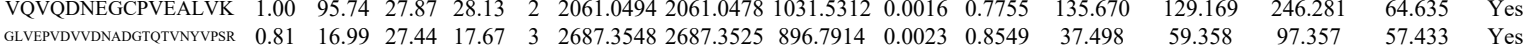

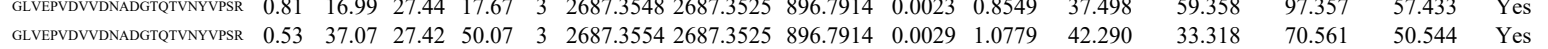

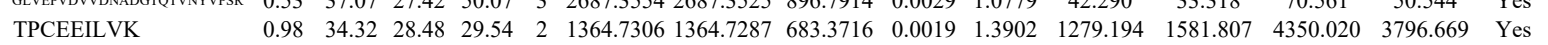
$\begin{array}{lllllllllllllllll}\text { TPCEEILVK } & 0.99 & 35.04 & 28.32 & 28.10 & 2 & 1364.7308 & 1364.7287 & 683.3716 & 0.0021 & 1.5365 & 1667.055 & 2005.054 & 6054.918 & 4645.514 & \text { Yes }\end{array}$ $\begin{array}{llllllllllllllll}\text { VAQPTITDNK } & 1.00 & 53.40 & 28.02 & 25.08 & 2 & 1373.7766 & 1373.7758 & 687.8952 & 0.0008 & 0.5815 & 9537.781 & 13729.685 & 23282.883 & 5976.721 & \text { Yes }\end{array}$

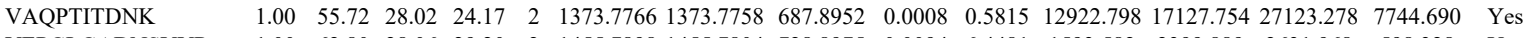
$\begin{array}{llllllllllllllll}\text { VEPGLGADNSVVR } & 1.00 & 62.80 & 28.06 & 29.20 & 2 & 1455.7898 & 1455.7804 & 728.8975 & 0.0094 & 6.4481 & 1593.582 & 2399.889 & 2631.968 & 598.328 & \text { Yes }\end{array}$

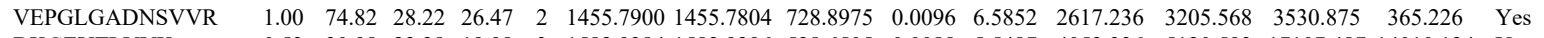
$\begin{array}{llllllllllllllll}\text { DKGEYTLVVK } & 0.53 & 30.98 & 23.38 & 19.98 & 3 & 1582.9384 & 1582.9296 & 528.6505 & 0.0088 & 5.5487 & 4052.336 & 5120.593 & 17107.487 & 14010.124 & \text { Yes }\end{array}$ \begin{tabular}{lllllllllllllllll} 
VQVQDNEGCPVEALVK & 1.00 & 79.69 & 27.77 & 23.99 & 2 & 2061.0474 & 2061.0478 & 1031.5312 & -0.0004 & -0.1939 & 318.862 & 505.360 & 936.367 & 138.514 & Yes \\
\hline
\end{tabular} $\begin{array}{lllllllllllllll}\text { VQVQDNEGCPVEALVK } & 1.00 & \text { \#\#\# } 27.87 & 29.32 & 2 & 2061.0494 & 2061.0478 & 1031.5312 & 0.0016 & 0.7755 & 220.919 & 256.002 & 519.885 & 111.856 & \text { Yes }\end{array}$ $\begin{array}{llllllllllllllll}\text { ATCAPQHGAPGPGPADASK } & 1.00 & 65.00 & 26.81 & 17.83 & 3 & 2065.9930 & 2065.9917 & 689.6712 & 0.0013 & 0.6283 & 1369.498 & 3548.550 & 5260.060 & 3560.669 & \text { Yes }\end{array}$

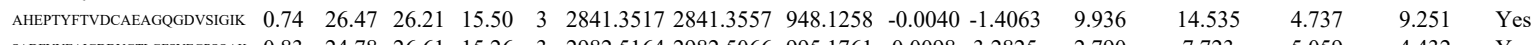

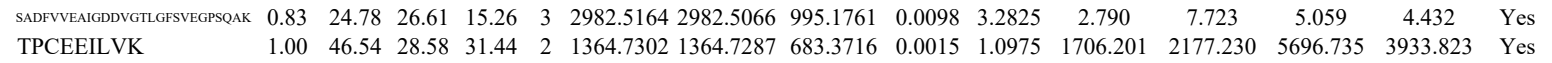
$\begin{array}{llllllllllllllllll}\text { TPCEEILVK } & 0.96 & 30.34 & 28.33 & 28.53 & 2 & 1364.7312 & 1364.7287 & 683.3716 & 0.0025 & 1.8292 & 1389.714 & 1852.704 & 4770.587 & 3709.413 & \text { Yes }\end{array}$

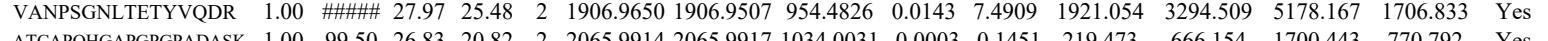
$\begin{array}{llllllllllllllll}\text { ATCAPQHGAPGPGPADASK } & 1.00 & 99.50 & 26.83 & 20.82 & 2 & 2065.9914 & 2065.9917 & 1034.0031 & -0.0003 & -0.1451 & 219.473 & 666.154 & 1700.443 & 770.792 & \text { Yes }\end{array}$

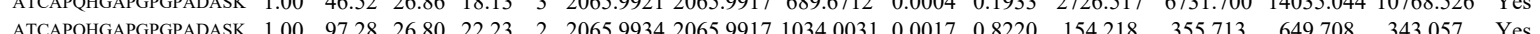

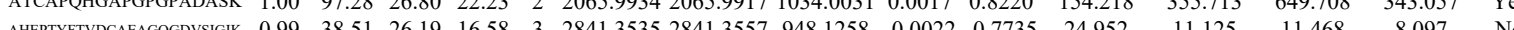

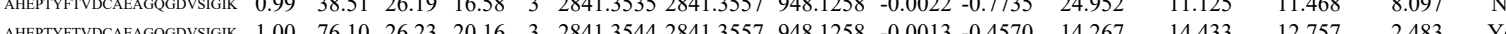

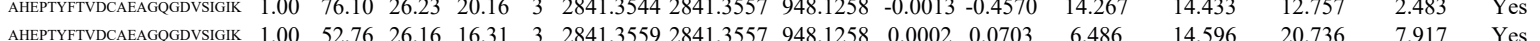

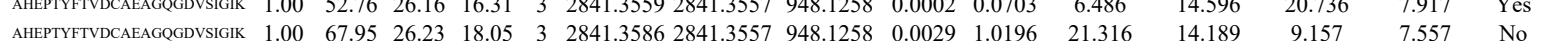

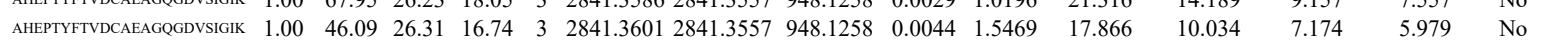

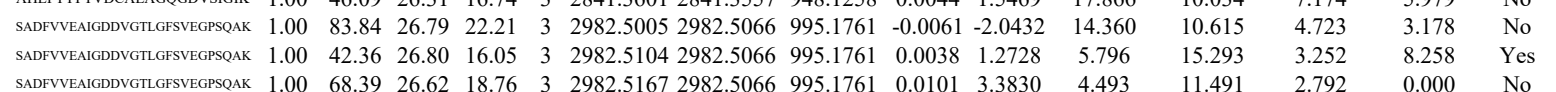

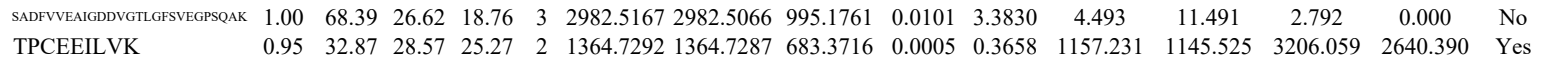

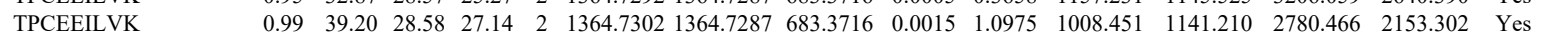

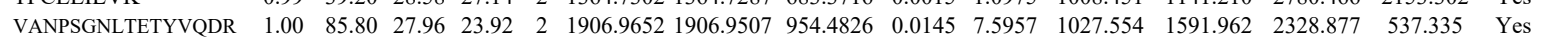
$\begin{array}{lllllllllllllllll}\text { TGVAVNKPAEFTVDAK } & 1.00 & 74.30 & 22.94 & 18.10 & 2 & 2078.1894 & 2078.1737 & 1040.0941 & 0.0157 & 7.5473 & 115.395 & 333.731 & 614.871 & 376.766 & \text { Yes }\end{array}$ $\begin{array}{lllllllllllllllll}\text { FNEEHIPDSPVVPVASPSGDAR } & 0.55 & 17.63 & 27.25 & 30.63 & 3 & 2610.2860 & 2610.2836 & 871.1018 & 0.0024 & 0.9184 & 74.062 & 85.909 & 41.410 & 30.505 & \text { Yes }\end{array}$ $\begin{array}{llllllllllllllll}\text { FNEEHIPDSPFVVPVASPSGDAR } & 1.00 & 53.28 & 27.24 & 20.42 & 3 & 2610.2872 & 2610.2836 & 871.1018 & 0.0036 & 1.3776 & 86.245 & 166.370 & 130.414 & 67.905 & \text { Yes } \\ \text { VTAQGPGPSA } & \end{array}$ \begin{tabular}{llllllllllllllll} 
VTAQGPGLEPSGNIANK & 1.00 & 91.00 & 26.24 & 23.17 & 2 & 1940.0710 & 1940.0571 & 971.0358 & 0.0139 & 7.1573 & 294.861 & 505.299 & 1434.949 & 914.560 & Yes \\
\hline
\end{tabular} $\begin{array}{llllllllllllllll}\text { ATCAPQHGAPGPGPADASK } & 1.00 & 51.82 & 26.85 & 17.77 & 3 & 2065.9918 & 2065.9917 & 689.6712 & 0.0001 & 0.0483 & 2543.812 & 4025.682 & 7444.053 & 5528.225 & \text { Yes } \\ \text { ATCAPOHGAPGGPADAK } & 1.00 & 72.30 & 26.86 & 19.90 & 3 & 2065.9921 & 2065.9917 & 689.6712 & 0.0004 & 0.1933 & 2039.773 & 4570.010 & 6920246 & 4709.265 & \text { Yes }\end{array}$ $\begin{array}{lllllllllllllllll}\text { ATCAPOHGAPGGGPADASK } & 1.00 & 72.30 & 26.86 & 19.90 & 3 & 2065.9921 & 2065.9917 & 689.6712 & 0.0004 & 0.1933 & 2039.773 & 4570.010 & 6920.246 & 4709.265 & \text { Yes } \\ \text { FNEEHIPDSPFVYVYASPSGDAR } & 0.93 & 36.87 & 27.42 & 16.60 & 3 & 2610.3073 & 2610.2836 & 871.1018 & 0.0237 & 9.0689 & 407.363 & 283.716 & 287.237 & 97.652 & \text { Yes }\end{array}$ $\begin{array}{llllllllllllllll}\text { VNVGAGSHPNK } & 1.00 & 48.75 & 27.65 & 16.97 & 3 & 1366.7563 & 1366.7561 & 456.5926 & 0.0002 & 0.1460 & 398.713 & 500.548 & 659.054 & 165.576 & \text { Yes }\end{array}$ VNVGAGSHPNK $\begin{array}{llllllllllll}1.00 & 52.35 & 27.96 & 20.52 & 3 & 1366.7566 & 1366.7561 & 456.5926 & 0.0005 & 0.3650 & 506.304\end{array}$ $\begin{array}{llllllllllllll}\text { VINQGDGLESGNIANK } & 1.00 & 99.02 & 26.18 & 23.11 & 2 & 1940.0714 & 1940.0571 & 971.0358 & 0.0143 & 7.3632 & 317.264\end{array}$ $\begin{array}{llllllllllllllll}\text { VTAQGPGLEPSGNIANK } & 1.00 & 99.02 & 26.18 & 23.11 & 2 & 1940.0714 & 1940.0571 & 971.0358 & 0.0143 & 7.3632 & 317.264 & 565.372 & 1132.035 & 789.153 & \text { Yes } \\ \text { VTAQGPGLEPSGNIANK K } & 1.00 & 85.18 & 25.89 & 21.32 & 2 & 1940.0734 & 1940.0571 & 971.0358 & 0.0163 & 8.3930 & 101.997 & 139.635 & 312.258 & 261.061 & \text { Yes }\end{array}$ TGVAVNKPAEFTVDAK $\begin{array}{lllllllllllll}1.00 & 50.38 & 27.64 & 21.16 & 2 & 1366.7560 & 1366.7561 & 684.3853 & -0.0001 & -0.0731 & 94.949 & 17 & \\ 1.00 & 43.70 & 27.65 & 17.43 & 3 & 1366.7563 & 1367561 & 456.5926 & 0.002 & 0.1460 & 73.834 & 99 & \end{array}$ 261.061 Yes $\begin{array}{llllllllllllllll} & & & \\ & 1.00 & 43.70 & 27.65 & 17.43 & 3 & 1366.7563 & 1366.7561 & 456.5926 & 0.0002 & 0.1460 & 733.834 & 992.002 & 1709.630 & 411.206 & \text { Yes } \\ \end{array}$

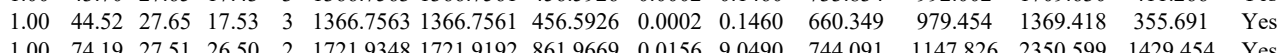

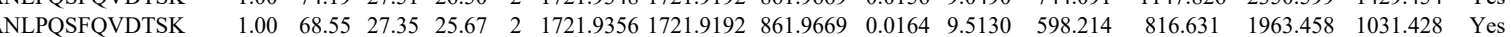


$\begin{array}{llllllllllllllll} & 0.51 .31 .36 & 8.65 & 24.25 & 21.65 & 3 & 2629.4242 & 2629.4207 & 877.4808 & 0.0035 & 1.3296 & 141.893 & 182.756 & 78.488 & 46.393\end{array}$

$\begin{array}{lllllllllllllll}1.00 & 39.90 & 21.21 & 16.53 & 2 & 1169.7416 & 1169.7376 & 585.8761 & 0.0040 & 3.4137 & 8472.357 & 9461.536 & 13819.942 & 4461.955 & \text { Yes }\end{array}$

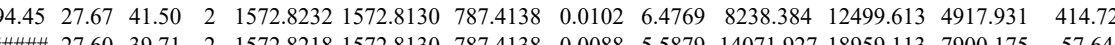

AFGPGLQGGSAGSPA

VTVLFAGQHIAK

VTVLFAGQHIAK

$\begin{array}{lllllllllllll} & \end{array}$

$\begin{array}{llllllllllllll}1.00 & 96.89 & 27.54 & 38.79 & 2 & 1572.8214 & 1572.8130 & 787.4138 & 0.0084 & 5.3339 & 4618.148 & 7321.432 & 3052.596 & 123.264\end{array}$

$\begin{array}{lllllllllllllll}1.00 & 97.98 & 27.52 & 39.09 & 2 & 1572.8220 & 1572.8130 & 787.4138 & 0.0090 & 5.7149 & 5997.877 & 8787.491 & 3400.458 & 189.916\end{array}$

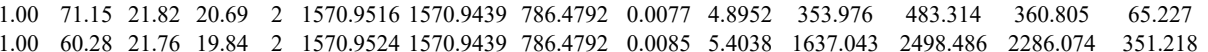

$\begin{array}{llllllllllllll}1.00 & 60.28 & 21.76 & 19.84 & 2 & 1570.9524 & 1570.9439 & 786.4792 & 0.0085 & 5.4038 & 1637.043 & 2498.486 & 2286.074 & 351.218\end{array}$

TTVLFAQHIAK

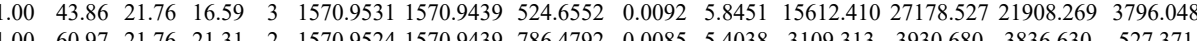

VTVLFAGQHIAK

$\begin{array}{llllllllllllll}1.00 & 60.97 & 21.76 & 21.31 & 2 & 1570.9524 & 1570.9439 & 786.4792 & 0.0085 & 5.4038 & 3109.313 & 3930.680 & 3836.630 & 5\end{array}$

527.371

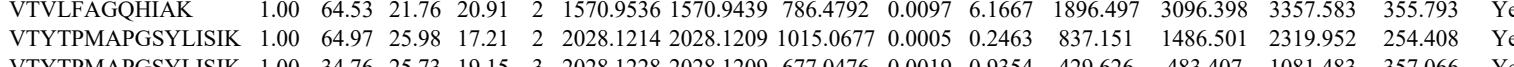
$\begin{array}{lllllllllllllll} & \end{array}$

$\begin{array}{lllllllllllllllll}\text { CSGPGLSPGMVR } & 1.00 & 48.76 & 25.92 & 23.65 & 2 & 1349.6474 & 1349.6376 & 675.8261 & 0.0098 & 7.2503 & 8547.554 & 13059.836 & 596.508 & 169.206 & \text { No }\end{array}$

$\begin{array}{llllllllllllllllll}\text { VTVLFAGQHIAK } & 1.00 & 51.68 & 20.64 & 16.87 & 3 & 1570.9582 & 1570.9439 & 524.6552 & 0.0143 & 9.0852 & 4023.750 & 5605.756 & 6106.960 & 576.894 & \text { Yes }\end{array}$

$\begin{array}{lllllllllllllllll}\text { VTYTPMAPGSYLISIK } & 1.00 & 60.62 & 25.45 & 20.85 & 2 & 2028.1274 & 2028.1209 & 1015.0677 & 0.0065 & 3.2017 & 1808.051 & 2557.119 & 4355.824 & 289.837 & \text { Yes }\end{array}$

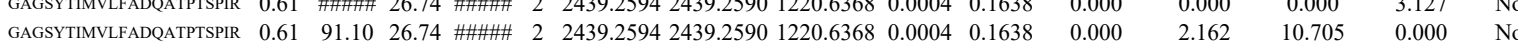
$\begin{array}{llllllllllllllll}\text { GAGSYTIMVLFADQATPTSPIR } & 0.53 & 21.88 & 26.67 & 34.88 & 3 & 2439.2623 & 2439.2590 & 814.0936 & 0.0033 & 1.3512 & 12.101 & 22.678 & 19.162 & 10.954 & \text { Yes }\end{array}$ $\begin{array}{lllllllllllllllll}\text { GAGSYTIMVLFADQATPTSPIR } & 1.00 & 34.78 & 26.70 & 21.84 & 3 & 2439.2629 & 2439.2590 & 814.0936 & 0.0039 & 1.5969 & 161.779 & 131.283 & 111.280 & 34.810 & \text { Yes }\end{array}$ $\begin{array}{llllllllllllllll}\text { CSGPGLSPGMVR } & 1.00 & 61.65 & 25.93 & 32.47 & 2 & 1349.6476 & 1349.6376 & 675.8261 & 0.0100 & 7.3983 & 2174.045 & 3500.089 & 150.977 & 62.703 & \text { No }\end{array}$ $\begin{array}{lllllllllllllllll}\text { CSGPGLSPGMVR } & 1.00 & 64.19 & 26.13 & 25.11 & 2 & 1349.6484 & 1349.6376 & 675.8261 & 0.0108 & 7.9902 & 1773.235 & 2512.281 & 191.550 & 58.568 & N 0.045 & \text { Nos }\end{array}$ $\begin{array}{lllllllllllllllll}\text { GAGSYTIMVLFADQATPTSPIR } & 0.99 & 29.46 & 26.75 & 20.70 & 3 & 2439.2599 & 2439.2590 & 814.0936 & 0.0009 & 0.3685 & 57.402 & 53.507 & 25.695 & 16.044 & \text { Yes }\end{array}$ $\begin{array}{llllllllllllllllll}\text { CSYQPTMEGVHTVHVTFAGVPIPR } & 1.00 & 22.47 & 26.73 & 14.80 & 4 & 2815.3745 & 2815.3730 & 704.8505 & 0.0015 & 0.5320 & 480.812 & 280.479 & 364.893 & 123.057 & \text { Yes }\end{array}$

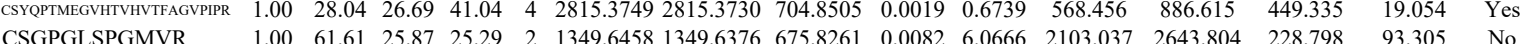

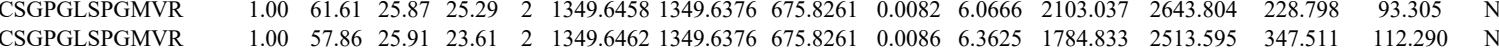
$\begin{array}{lllllllllllllllll} & \end{array}$

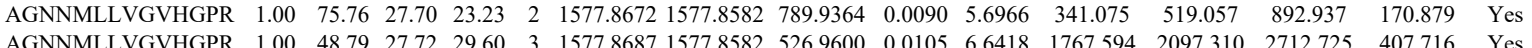
$\begin{array}{llllllllllllllll}\text { AGNNMLLVGVHGPR } & 1.00 & 48.79 & 27.72 & 29.60 & 3 & 1577.8687 & 1577.8582 & 526.9600 & 0.0105 & 6.6418 & 1767.594 & 2097.310 & 2712.725 & 407.716 & \text { Yes }\end{array}$ $\begin{array}{lllllllllllllll} & \end{array}$ $\begin{array}{lllllllllllllll} & \end{array}$ $\begin{array}{lllllllllllllll} & \end{array}$

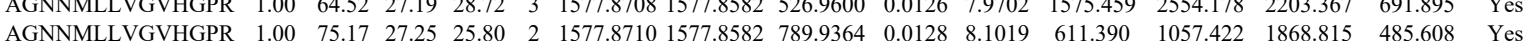
$\begin{array}{llllllllllllllll}\text { AGNNMLLVACNPACR } & 1.00 & \text { \#\#\#\# } 22.53 & 21.71 & 2 & 1988.8694 & 1988.8698 & 995.4422 & -0.0004 & -0.2009 & 94.529 & 252.606 & 538.343 & 534.153 & \text { Yes } \\ \text { SPYTVTVGQACS }\end{array}$

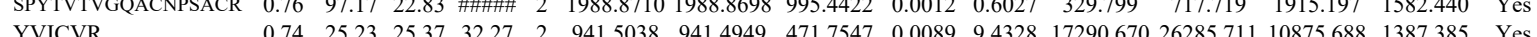
$\begin{array}{llllllllllllll} & & & \end{array}$ 

$\begin{array}{llllllllllllll}N & 0.85 & 28.04 & 26.01 & 35.32 & 2 & 1083.6030 & 1083.6029 & 542.8087 & 0.0001 & 0.0921 & 41.087 & 4\end{array}$ $\begin{array}{llllllllllll} & \end{array}$

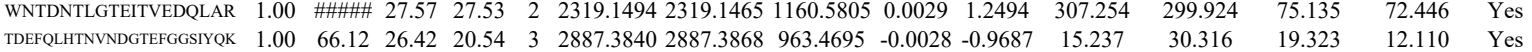

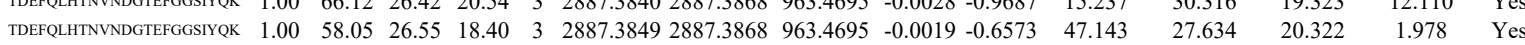
$\begin{array}{llllllllllllllll}\text { TDEFOLHTNYNDGTEFGGSYOK } & 1.00 & 57.49 & 26.54 & 22.11 & 3 & 2887.3858 & 2887.3868 & 963.4695 & 0.0010 & 0.3460 & 65.103 & 53.204 & 12.073 & 4246 & \text { Yes }\end{array}$

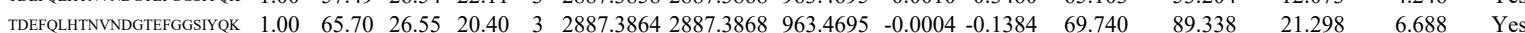

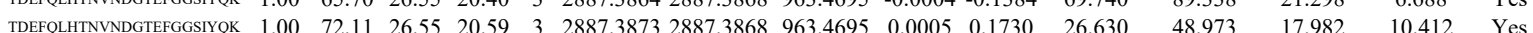

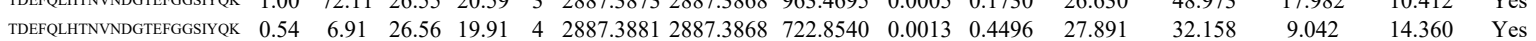

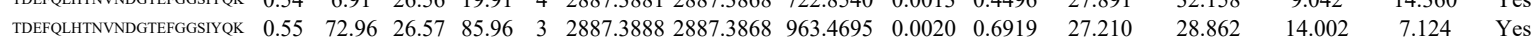
$\begin{array}{llllllllllllllll}\text { TDEFLLHTNNNDGTEFGGSIYYK } & 0.55 & 72.59 & 26.58 & 85.59 & 3 & 2887.3894 & 2887.3868 & 963.4695 & 0.0026 & 0.8995 & 35.535 & 60.347 & 2.232 & 7.562 & \text { Yes }\end{array}$

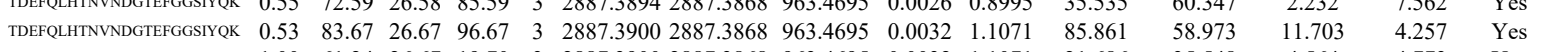
$\begin{array}{lllllllllllllllll}\text { TDEFPLHTNVNDGTEFGGSIYQK } & 1.00 & 61.24 & 26.67 & 19.70 & 3 & 2887.3900 & 2887.3868 & 963.4695 & 0.0032 & 1.1071 & 21.686 & 35.548 & 4.564 & 4.773 & \text { Yes }\end{array}$

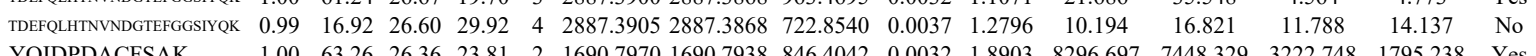
$\begin{array}{llllllllllllllll}\text { YQIDPDACFSAK } & 1.00 & 63.26 & 26.36 & 23.81 & 2 & 1690.7970 & 1690.7938 & 846.4042 & 0.0032 & 1.8903 & 8296.697 & 7448.329 & 3222.748 & 1795.238 & \text { Yes } \\ \text { YQDDPDACFSAK } & 1.0 & 6.89 & 26.39 & 3.76 & & \end{array}$

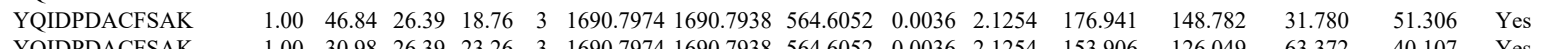
$\begin{array}{llllllllllllllll}\text { YQIDPDACFSAK } & 1.00 & 30.98 & 26.39 & 23.26 & 3 & 1690.7974 & 1690.7938 & 564.6052 & 0.0036 & 2.1254 & 153.906 & 126.049 & 63.372 & 40.107 & \text { Yes }\end{array}$

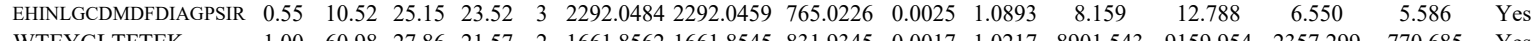

WTEYGLTFTEK

YQIDPDACFSAK $\begin{array}{llllllllllllllll}\text { VTQSNFAVGYK } & 1.00 & 65.47 & 27.23 & 28.15 & 2 & 1500.8304 & 1500.8180 & 751.4163 & 0.0124 & 8.2510 & 21280.681 & 21316.339 & 4133.728 & 613.186 & \text { Yes } \\ \text { VTQSNFAVGYK } & 1.00 & 62.45 & 27.29 & 23.34 & 2 & 1500.8312 & 1500.8180 & 751.4163 & 0.0132 & 8.7833 & 3755.244 & 3222.907 & 886.497 & 133.467 & \text { Yes } \\ \text { VTQSNFAVGYK } & 1.00 & 63.36 & 27.29 & 21.79 & 2 & 1500.8314 & 1500.8180 & 751.463 & 0.0134 & 8.9164 & 3410.406 & 3243.630 & 656.804 & 207.633 & \text { Yes }\end{array}$ $\begin{array}{lllllllllllllllll}1.00 & 60.98 & 27.86 & 21.57 & 2 & 1661.8562 & 1661.8545 & 831.9345 & 0.0017 & 1.0217 & 8901.543 & 9159.954 & 2357.299 & 770.685 & \text { Yes }\end{array}$ $\begin{array}{lllllllllllllll}0.97 & 25.23 & 27.87 & 17.75 & 3 & 1661.8576 & 1661.8545 & 554.9588 & 0.0031 & 1.8620 & 316.956 & 245.459 & 271.832 & 239.922 & \text { No }\end{array}$ $\begin{array}{llllllllllllllll}1.00 & 61.54 & 26.25 & 22.44 & 2 & 1690.7984 & 1690.7938 & 846.4042 & 0.0046 & 2.7174 & 5669.333 & 6178.989 & 2187.288 & 1307.182 & \text { Yes }\end{array}$ $\begin{array}{llllllllllllllll}1.00 & 63.13 & 26.10 & 23.47 & 2 & 1690.7986 & 1690.7938 & 846.4042 & 0.0048 & 2.8355 & 5155.948 & 4988.114 & 1741.168 & 1208.048 & \text { Yes }\end{array}$ $\begin{array}{llllllllllllllll}1.00 & 56.11 & 27.85 & 16.80 & 2 & 1661.8550 & 1661.8545 & 831.9345 & 0.0005 & 0.3005 & 2796.864 & 2567.671 & 682.666 & 292.425 & \text { Yes }\end{array}$ $\begin{array}{lllllllllllllll}1.00 & 52.30 & 26.38 & 18.10 & 2 & 1690.7948 & 1690.7938 & 846.4042 & 0.0010 & 0.5907 & 316.466 & 294.540 & 104.361 & 76.653 & \text { Yes }\end{array}$

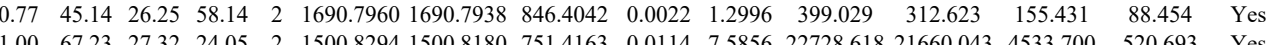
$\begin{array}{lllllllllllllllll}1.00 & 67.23 & 27.32 & 24.05 & 2 & 1500.8294 & 1500.8180 & 751.4163 & 0.0114 & 7.5856 & 22728.618 & 21660.043 & 4533.700 & 520.693 & \text { Yes } \\ 1.00 & 66.04 & 27.23 & 27.18 & 2 & 1500.8308 & 1500.8180 & 751.4163 & 0.0128 & 8.5172 & 21678.728 & 20441.675 & 4105.775 & 635.295 & \text { Yes }\end{array}$ $\begin{array}{llllllllllllllll}1.00 & 66.04 & 27.23 & 27.18 & 2 & 1500.8308 & 1500.8180 & 751.4163 & 0.0128 & 8.5172 & 21678.728 & 20441.675 & 4105.775 & 635.295 & \text { Yes } \\ 1.00 & 65.00 & 27.19 & 25.19 & 2 & 1500.8300 & 1500.8180 & 751.4163 & 0.0120 & 7.9849 & 22543.497 & 20743.241 & 3767.606 & 510.337 & \text { Yes }\end{array}$ $\begin{array}{llllllllllllllll} & \end{array}$ $\begin{array}{lllllllllllllll}\text { LETAVNLAWTAGNSNTR } & 1.00 & \# \# \# \# 27.93 & 25.92 & 2 & 1961.0098 & 1961.0088 & 981.5117 & 0.0010 & 0.5094 & 522.438 & 408.940 & 225.823 & 9.196 & \text { Yes }\end{array}$

Table S-3 page 178 of 499 

$\begin{array}{lllllllllllllll}\text { KLETAVNLAWTAGNSNTR } & 1.00 & 54.78 & 25.56 & 20.07 & 3 & 2233.2208 & 2233.2058 & 745.4092 & 0.0150 & 6.7077 & 1703.195 & 1416.729 & 427.151\end{array}$ $\begin{array}{lllllllllllllll}\text { KLETAVNLAWTAGNSNTR } & 1.00 & 65.53 & 25.40 & 20.01 & 3 & 2233.2223 & 2233.2058 & 745.4092 & 0.0165 & 7.3784 & 1703.481 & 1886.205 & 259.761\end{array}$

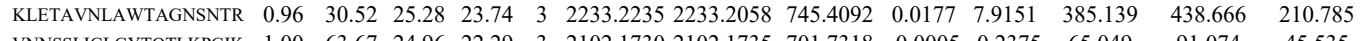

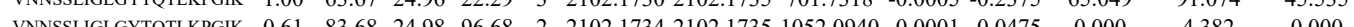
$\begin{array}{llllllllllll}\text { VNNSSUG } & 0.000\end{array}$

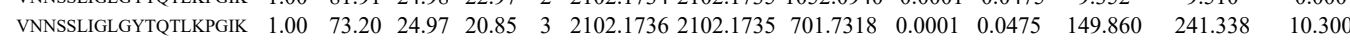
$\begin{array}{lllllllllllllll}\text { VNNSSUGCYTOTLVGK } & 1.00 & 51.79 & 24.91 & 22.09 & 3 & 2102.1739 & 21021735 & 701.7318 & 0.0004 & 0.1900 & 55.537 & 184.658 & 50.199\end{array}$

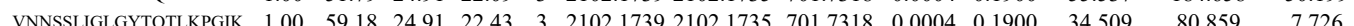
$\begin{array}{lllllllllllllll}\text { VNNSSLIGLGYTOTLKPGIK } & 1.00 & 51.86 & 24.90 & 1824 & 3 & 21021745 & 21021735 & 701.7318 & 0.0010 & 0.4750 & 35.537 & 73.194 & 13.396\end{array}$

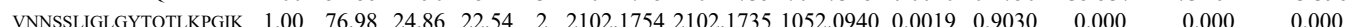
$\begin{array}{llllllllllllll}\text { VNNSSLIGLGYTQTLKPGIK } & 1.00 & 36.17 & 24.90 & 17.23 & 3 & 2102.1760 & 2102.1735 & 701.7318 & 0.0025 & 1.1875 & 31.927 & 40.653 & 8.315\end{array}$

$\begin{array}{llllllllllllll}\text { YDVDTLDMVFLDHWK } & 1.00 & 47.03 & 28.90 & 25.97 & 3 & 2184.0829 & 2184.0805 & 729.0341 & 0.0024 & 1.0973 & 425.356 & 489.749 & 151.530\end{array}$ $\begin{array}{llllllllllllll}\text { YDVDTLDMVFLDHWK } & 1.00 & 46.19 & 28.84 & 29.38 & 3 & 2184.0847 & 2184.0805 & 729.0341 & 0.0042 & 1.9203 & 431.038 & 374.712 & 248.134\end{array}$ $\begin{array}{llllllllllllll}\text { YLPDTLLLEECGLLR } & 1.00 & 63.06 & 28.12 & 20.60 & 2 & 1937.0140 & 1937.0124 & 969.5135 & 0.0016 & 0.8252 & 451.152 & 705.455 & 9.929\end{array}$ $\begin{array}{lllllllllllllll}\text { YLPDTLLLEECGLLR } & 1.00 & 50.20 & 28.09 & 22.63 & 2 & 1937.0146 & 1937.0124 & 969.5135 & 0.0022 & 1.1346 & 248.676 & 426.578 & 0.000\end{array}$

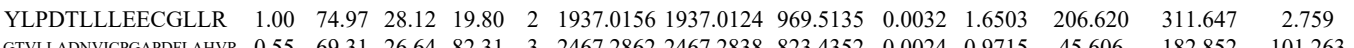
\begin{tabular}{llllllllllllllll} 
GTVLLADNVICPGAPDFLAHVR & 0.55 & 69.31 & 26.64 & 82.31 & 3 & 2467.2862 & 2467.2838 & 823.4352 & 0.0024 & 0.9715 & 45.606 & 182.852 & 101.263 \\
\hline
\end{tabular} \begin{tabular}{llllllllllllll} 
GTVLLADNVICPGAPDFLAHVR & 0.96 & 12.91 & 26.65 & 14.96 & 4 & 2467.2865 & 2467.2838 & 617.8282 & 0.0027 & 1.0925 & 126.457 & 133.753 & 58.625 \\
\hline GTVLUDVICPGAPDFLHV & 1.00 & 21.68 & 26.64 & 15.28 & 4 & 2467.2873 & 2467.2838 & 617.8282 & 0.0035 & 1.4162 & 130.140 & 124.748 & 11.199
\end{tabular} \begin{tabular}{llllllllllllll} 
GTVLLADNVIIPGAPDFLAHVR & 1.00 & 21.68 & 26.64 & 15.28 & 4 & 2467.2873 & 2467.2838 & 617.8282 & 0.0035 & 1.4162 & 130.140 & 124.748 & 11.199 \\
\hline
\end{tabular} $\begin{array}{llllllllllllll}\text { GTVLLADNVICPGAPDFLAHVR } & 1.00 & 64.65 & 26.70 & 17.81 & 3 & 2467.2853 & 2467.2838 & 823.4352 & 0.0015 & 0.6072 & 60.910 & 49.5\end{array}$

5 LVVNFESDK $\begin{array}{llllllllllllll}0.95 & 28.59 & 27.15 & 24.96 & 2 & 1337.7446 & 1337.7435 & 669.8790 & 0.0011 & 0.8210 & 4059.087 & 3429.145 & 4659.237 & 1227.899\end{array}$ $\begin{array}{llllllllllllllll} & & 3351.6322 & 3351.6292 & 1118.2170 & 0.0030 & 0.8943 & 20.910 & 20.767 & 3.180 & 2.774\end{array}$ $\begin{array}{llllllllllllll}1.00 & 63.11 & 26.16 & 20.51 & 3 & 3351.6262 & 3351.6292 & 1118.2170 & -0.0030 & -0.8943 & 38.579 & 27.180 & 8.412 & 7.029\end{array}$

YDAPFVAEVNADVDDWQQDDCSYHKK
YLLNLNLEPFSEK

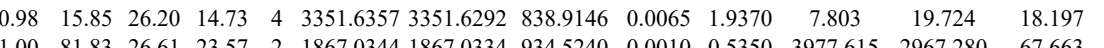
SVLNLNLER SVPLCILYEK $\begin{array}{lllllllllllll}1.00 & 81.83 & 26.61 & 23.57 & 2 & 1867.0344 & 1867.0334 & 934.5240 & 0.0010 & 0.5350 & 3977.615 & 2967.280 & 67.663 \\ 1.00 & 47.02 & 28.01 & 18.55 & 2 & 1497.8182 & 1497.8179 & 749.9162 & 0.0003 & 0.2000 & 16799.965 & 15195.837 & 3668.471\end{array}$ $\begin{array}{lllllllllllll}0.92 & 21.22 & 27.80 & 26.10 & 3 & 1497.8209 & 1497.8179 & 500.2799 & 0.0030 & 1.9989 & 83.520 & 80.571 & 34.404\end{array}$

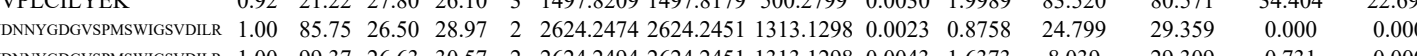
$\begin{array}{lllllllllllll} & 0.731 & 0.6\end{array}$ $\begin{array}{llllllllllllll}\text { ALLVEPVINSYLLAER } & 1.00 & 71.59 & 23.30 & 18.03 & 2 & 1943.1224 & 1943.1213 & 972.5679 & 0.0011 & 0.5655 & 1016.719 & 881.827 & 63.067\end{array}$

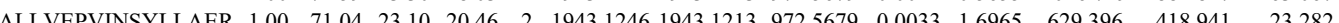

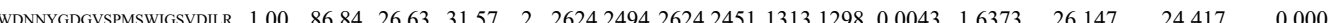
$\begin{array}{llllllllllllll}\text { ALLVPYINSYLLAER } & 0.69 & 54.31 & 23.01 & 67.31 & 2 & 1943.1240 & 1943.1213 & 972.5679 & 0.0027 & 1.3881 & 88.646 & 146.864 & 0.531\end{array}$

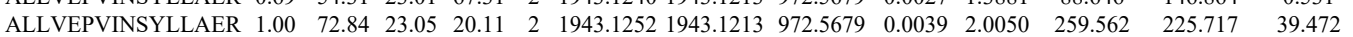
$\begin{array}{lllllllllllllll}\text { GQPFWLTLHFEGR } & 1.00 & 62.17 & 27.77 & 27.31 & 3 & 1730.9032 & 1730.9015 & 577.9744 & 0.0017 & 0.9804 & 3888.436 & 3257.717 & 769.839\end{array}$ GQPFWLTLHFEGR GQPFWLTLHFEGR GQPFWLTLHFEGR CLGIPTR CLGIPTR CLGIPTR CLGIPTR LLLCAR

LLLCAR

LLLCAR

LLLCAR

LLLCAR

LLLCAR

LLLCAR

LLLCAR

LLLCAR

LLLCAR

LLLCAR

LLLCAR

LLLCAR

LLLCAR

LLLCAR $\begin{array}{llllllllllll}1.00 & 52.17 & 27.747 .31 & 3 & 1730.0032 & 1730.9015 & 577.9744 & 0.0017 & 0.9804 & 3888.436 & 3257.717 & 769.839\end{array}$ $\begin{array}{llllllllllllllll}1.00 & 58.63 & 27.69 & 22.87 & 3 & 1730.9053 & 17309015 & 577.9744 & 0.0038 & 2.1916 & 2001.809 & 1696.634 & 403.426 & 149.741\end{array}$ $\begin{array}{llllllllllllllll}1.00 & 73.02 & 27.77 & 30.13 & 3 & 1730.9059 & 1730.9015 & 577.9744 & 0.0044 & 2.5376 & 2311.900 & 1963.335 & 553.951 & 114.379\end{array}$ $\begin{array}{llllllllllllll}0.67 & 27.78 & 29.03 & 27.62 & 2 & 948.5090 & 948.5007 & 475.2576 & 0.0083 & 8.7320 & 58152.178 & 46166.524 & 1488.852 & 729.468\end{array}$ $\begin{array}{llllllllllllllll}0.72 & 27.59 & 28.59 & 27.46 & 2 & 948.5096 & 948.5007 & 475.2576 & 0.0089 & 9.3633 & 51286.635 & 38335.157 & 1835.376 & 804.037\end{array}$ $\begin{array}{llllllllllllll}0.72 & 27.61 & 28.56 & 27.51 & 2 & 948.5094 & 948.5007 & 475.2576 & 0.0087 & 9.1528 & 41028.992 & 39347.497 & 1230.446 & 605.152\end{array}$ $\begin{array}{lllllllllllllll}0.72 & 27.79 & 28.56 & 27.67 & 2 & 948.5094 & 948.5007 & 475.2576 & 0.0087 & 9.1528 & 59565.770 & 46550.333 & 814.044 & 2\end{array}$ $\begin{array}{lllllllllllllll}0.69 & 18.93 & 26.81 & 28.56 & 2 & 877.5006 & 877.4999 & 439.7572 & 0.0007 & 0.7959 & 11516.659 & 10937.380 & 1715.080 & 852\end{array}$ $\begin{array}{llllllllllllll}0.83 & 20.77 & 25.77 & 28.71 & 2 & 877.5016 & 877.4999 & 439.7572 & 0.0017 & 1.9329 & 26028.148 & 22765.533 & 2422.054 & 643.604\end{array}$ $\begin{array}{llllllllllllll}0.65 & 16.79 & 25.77 & 28.03 & 2 & 877.5016 & 877.4999 & 439.7572 & 0.0017 & 1.9329 & 23.663 & 52.870 & 7.041 & 3.370 \\ 0.53 & 1.41 & 25.67 & 2.54 & 2 & 877.5022 & 877.499 & 439.7572 & 0.0023 & 2.615 & 33.160 & 60.488 & 0.000 & 1.604\end{array}$ $\begin{array}{llllllllllllll}0.53 & 14.41 & 25.67 & 25.34 & 2 & 877.5022 & 877.4999 & 439.7572 & 0.0023 & 2.6151 & 33.160 & 60.488 & 0.000 & 1.60 \\ 0.54 & 1.16 & 26.81 & 28.4 & 2 & 877.4998 & 877.4999 & 439.7572 & 0.000 & 0.1137 & 3631.341 & 3358.193 & 1136.422 & 55.6\end{array}$ $\begin{array}{lllllllllllllll}0.54 & 19.16 & 26.81 & 28.40 & 2 & 877.4998 & 877.4999 & 439.7572 & -0.0001 & -0.1137 & 3631.341 & 3358.193 & 1136.422 & 55.6 .6 \\ 0.82 & 21.96 & 26.87 & 28.36 & 2 & 877.5008 & 877.4999 & 439.7572 & 0.0009 & 1.0233 & 5921.510 & 5724.778 & 688.890 & \text {. }\end{array}$ $\begin{array}{lllllllllllllll}0.82 & 21.96 & 26.87 & 28.36 & 2 & 877.5008 & 877.4999 & 439.7572 & 0.0009 & 1.0233 & 5921.510 & 5724.778 & 688.890 \\ 0.78 & 21.03 & 26.87 & 28.07 & 2 & 877.5012 & 877.4999 & 439.7572 & 0.0013 & 1.4781 & 4598.130 & 3580.015 & 241.442\end{array}$ $\begin{array}{lllllllllllllll}0.78 & 21.03 & 26.87 & 28.07 & 2 & 877.5012 & 877.4999 & 439.7572 & 0.0013 & 1.4781 & 4598.130 & 3580.015 & 241.442 \\ 0.84 & 21.18 & 25.77 & 28.04 & 2 & 877.5018 & 877.4999 & 439.7572 & 0.0019 & 2.1603 & 5993.240 & 4544.878 & 197.449\end{array}$ $\begin{array}{lllllllllllll}0.84 & 21.18 & 25.77 & 28.04 & 2 & 877.5018 & 877.4999 & 439.7572 & 0.0019 & 2.1603 & 5993.240 & 4544.878 & 197.449 \\ 0.67 & 21.43 & 26.81 & 28.59 & 2 & 877.5004 & 877.4999 & 439.7572 & 0.0005 & 0.5685 & 4326.944 & 4597.076 & 296.654\end{array}$ $\begin{array}{lllllllllllllll}0.67 & 21.43 & 26.81 & 28.59 & 2 & 877.5004 & 877.4999 & 439.7572 & 0.0005 & 0.5685 & 4326.944 & 4597.076 & 296.654 \\ 0.94 & 25.94 & 25.49 & 29.05 & 2 & 877.5014 & 877.4999 & 439.7572 & 0.0015 & 1.7055 & 4168.912 & 4630.274 & 354.206\end{array}$ $\begin{array}{llllllllllllll}0.94 & 25.94 & 25.49 & 29.05 & 2 & 877.5014 & 877.4999 & 439.7572 & 0.0015 & 1.7055 & 4168.912 & 4630.274 & 354.206 \\ 0.96 & 29.17 & 26.81 & 28.98 & 2 & 877.5006 & 877.4999 & 439.7572 & 0.0007 & 0.7959 & 3201.248 & 3224.831 & 165.705\end{array}$ $\begin{array}{lllllllllllllll}0.72 & 19.67 & 26.87 & 28.95 & 2 & 877.5010 & 877.4999 & 439.7572 & 0.0011 & 1.2507 & 3305.460 & 3110.596 & 203.737\end{array}$ $\begin{array}{lllllllllllllllll}0.73 & 18.48 & 25.77 & 27.94 & 2 & 877.5016 & 877.4999 & 439.7572 & 0.0017 & 1.9329 & 8793.152 & 7517.860 & 496.434\end{array}$

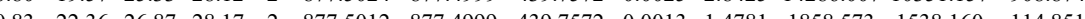

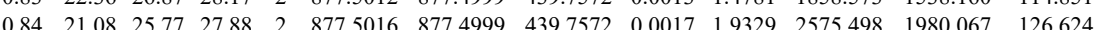


$\begin{array}{llllllllll} & \end{array}$ $\begin{array}{lllllllllllllllll} & \end{array}$

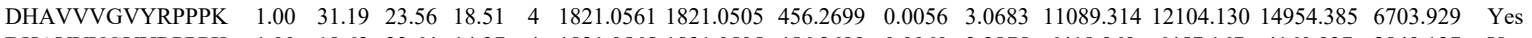
$\begin{array}{lllllllllllllllll}\text { DHAVVVGVYRPPPK } & 1.00 & 18.63 & 23.64 & 14.37 & 4 & 1821.0565 & 1821.0505 & 456.2699 & 0.0060 & 3.2875 & 6418.969 & 6457.167 & 4160.937 & 2849.127 & \text { Yes }\end{array}$ $\begin{array}{lllllllllllllllll} & \text { MLIAMVDVIFADVAQPDQTR } & 0.55 & 37.90 & 26.95 & 50.90 & 3 & 2376.2326 & 2376.2303 & 793.0840 & 0.0023 & 0.9667 & 7.966 & 6.605 & 3.412 & 4.406 & \text { Yes }\end{array}$

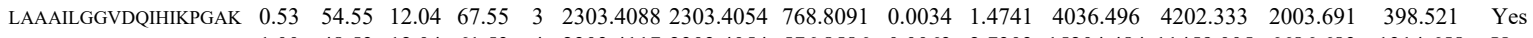
$\begin{array}{lllllllllllllllll}\text { LAAALGGVDQIHIKPGAK } & 1.00 & 48.53 & 12.04 & 61.53 & 4 & 2303.4117 & 2303.4054 & 576.8586 & 0.0063 & 2.7303 & 15204.484 & 11459.005 & 6686.683 & 1314.658 & \text { Yes }\end{array}$

IVALNAHTFLR IVALNAHTFLR IVALNAHTFLR NLVPGESVYGEK $\begin{array}{llllllllllllllll}1.00 & 49.45 & 24.35 & 19.84 & 3 & 1397.8264 & 1397.8265 & 466.9494 & -0.0001 & -0.0714 & 3070.876 & 3170.344 & 512.429 & 232.271 & \text { Yes } \\ 1\end{array}$ $\begin{array}{llllllllllllllll}1.00 & 54.14 & 27.64 & 22.11 & 2 & 1578.8650 & 1578.8497 & 790.4321 & 0.0153 & 9.6782 & 1450.914 & 1343.209 & 603.189 & 349.261 & \text { Yes } \\ 1.00 & 58.70 & 28.35 & 24.57 & 3 & 1578.8464 & 1578.8432 & 527.2883 & 0.0032 & 2.0229 & 17414.225 & 17426.037 & 4870.936 & 2256.667 & \text { Yes }\end{array}$ $\begin{array}{lllllllllllllll}1.00 & 58.70 & 28.35 & 24.57 & 3 & 1578.8464 & 1578.8432 & 527.2883 & 0.0032 & 2.0229 & 17414.225 & 13426.037 & 4870.936 & 2256.667 & \text { Yes } \\ 1.00 & 52.08 & 28.28 & 22.89 & 3 & 1578.8476 & 1578.8432 & 527.2883 & 0.0044 & 2.7815 & 21325.950 & 21488.305 & 7940.177 & 4454.373 & \text { Yes }\end{array}$ $\begin{array}{llllllllllllllllll}1.00 & 52.08 & 28.28 & 22.89 & 3 & 1578.8476 & 1578.8432 & 527.2883 & 0.0044 & 2.781 & 21325.950 & 21488.305 & 7940.177 & 4454.373 & \text { Yes } & \\ 1.00 & 33.03 & 28.23 & 25.92 & 3 & 1578.8449 & 1578.8432 & 527.2883 & 0.0017 & 1.0747 & 10333.982 & 10079.552 & 8600.711 & 13540.680 & \text { No }\end{array}$ $\begin{array}{llllllllllllllll}\text { SAGVQCFGPTAEAAQLESSK } & 1.00 & 85.16 & 26.77 & 21.18 & 2 & 2314.1194 & 2314.1177 & 1158.0661 & 0.0017 & 0.7340 & 281.733 & 335.836 & 116.771 & 78.652 & \text { Yes }\end{array}$

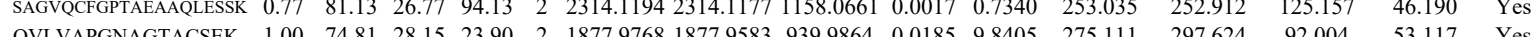

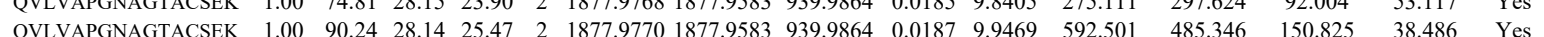

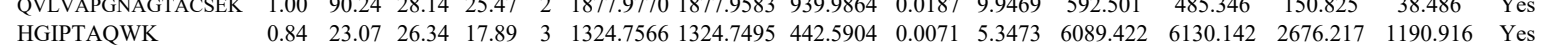

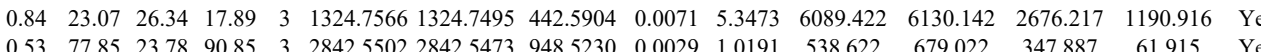

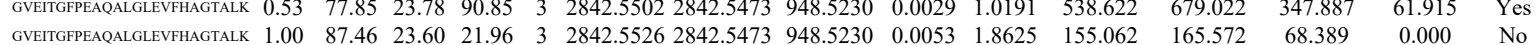
$\begin{array}{llllllllllllllll}\text { HGIPTAQWK } & 0.90 & 20.58 & 26.39 & 17.33 & 3 & 1324.7545 & 1324.7495 & 442.5904 & 0.0050 & 3.7657 & 5497.684 & 6435.744 & 1620.755 & 599.222 & \text { Yes }\end{array}$ $\begin{array}{llllllllllllllll}\text { HGIPTAQWK } & 0.90 & 20.54 & 26.39 & 14.41 & 3 & 1324.7545 & 1324.7495 & 442.5904 & 0.0050 & 3.7657 & 10952.396 & 11485.212 & 1837.956 & 571.925 & \text { Yes }\end{array}$ $\begin{array}{llllllllllllllll}\text { FGDPECQVILPLLK } & 1.00 & 46.99 & 27.37 & 34.59 & 2 & 1905.0356 & 1905.0347 & 953.5246 & 0.0009 & 0.4719 & 1365.550 & 1379.685 & 682.595 & 363.239 & \text { Yes }\end{array}$ $\begin{array}{llllllllllllllll}\text { FGDPECQVILPLLK } & 1.00 & 51.39 & 27.43 & 34.99 & 2 & 1905.0366 & 1905.0347 & 953.5246 & 0.0019 & 0.9963 & 593.661 & 469.505 & 241.600 & 101.371 & \text { Yes }\end{array}$ $\begin{array}{lllllllllllllllll}\text { FGDPECQVILPLLK } & 0.91 & 39.60 & 27.23 & 44.03 & 3 & 1905.0385 & 1905.0347 & 636.0188 & 0.0038 & 1.9916 & 599.940 & 652.299 & 444.942 & 131.900 & \text { Yes }\end{array}$ $\begin{array}{lllllllllllllllll}\text { FGDPECQVILPLLK } & 0.92 & 37.81 & 27.23 & 41.41 & 3 & 1905.0388 & 1905.0347 & 636.0188 & 0.0041 & 2.1488 & 223.216 & 159.393 & 102.782 & 71.820 & \text { Yes }\end{array}$ $\begin{array}{lllllllllllllllll}\text { GVEITGPEAQALGLEVFHAGTALK } & 1.00 & 67.15 & 23.82 & 20.00 & 3 & 2842.5505 & 2842.5473 & 948.5230 & 0.0032 & 1.1246 & 129.887 & 105.412 & 34.489 & 0.000 & \text { No }\end{array}$ $\begin{array}{llllllllllllllll}\text { FGDPECQVILPLLK } & 1.00 & 56.04 & 27.36 & 32.66 & 2 & 1905.0344 & 1905.0347 & 953.5246 & -0.0003 & -0.1573 & 125.778 & 123.999 & 59.322 & 34.585 & \text { Yes }\end{array}$ $\begin{array}{llllllllllllllll}\text { FGDPECQVILPLLK } & 1.00 & 53.55 & 27.30 & 33.26 & 2 & 1905.0378 & 1905.0347 & 953.5246 & 0.0031 & 1.6255 & 267.004 & 308.184 & 184.102 & 47.440 & \text { Yes }\end{array}$ $\begin{array}{lllllllllllllllll}\text { FGDPECQVILPLLK } & 0.99 & 49.03 & 27.23 & 43.15 & 3 & 1905.0385 & 1905.0347 & 636.0188 & 0.0038 & 1.9916 & 236.056 & 221.957 & 103.429 & 34.827 & \text { Yes }\end{array}$ $\begin{array}{llllllllllllllll}\text { GEVR } & 282.5493 & 2842.5473 & 948.5230 & 0.0020 & 0.7028 & 149.625 & 81.271 & 32.451 & 18.913 & \text { Yes }\end{array}$

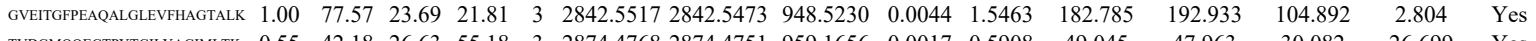

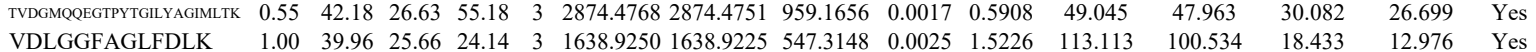

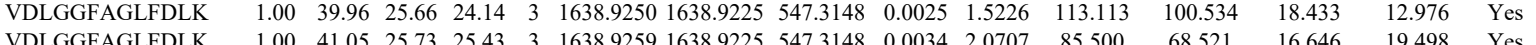

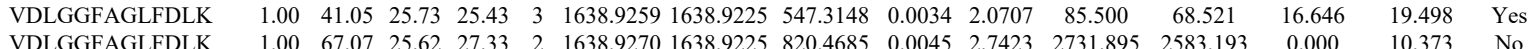

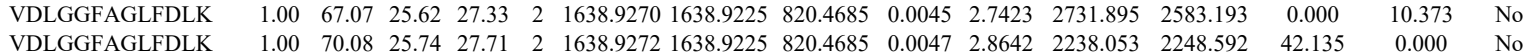

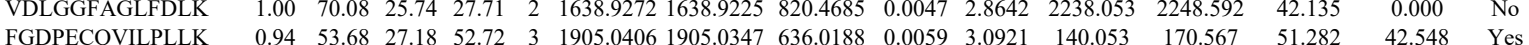

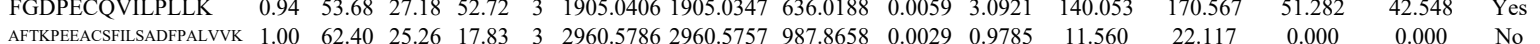
\begin{tabular}{llllllllllllllll} 
AFTKPEEACSFISADPFALVVK K & 1.00 & 67.58 & 25.15 & 24.94 & 3 & 2960.5786 & 2960.5757 & 987.8658 & 0.0029 & 0.9785 & 11.560 & 22.117 & 0.000 & 0.000 & No \\
\hline
\end{tabular} $\begin{array}{lllllllllllll} & \text { AFTE }\end{array}$

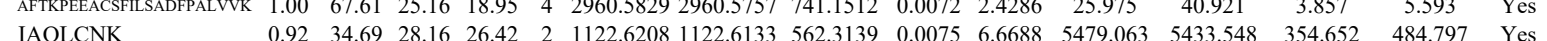




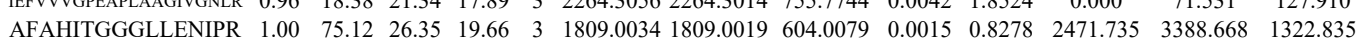

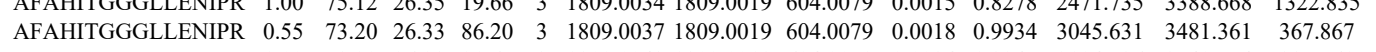

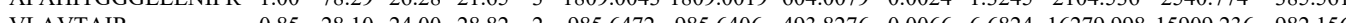

$\begin{array}{llllllllllllllll}0.85 & 28.10 & 24.00 & 28.82 & 2 & 985.6472 & 985.6406 & 493.8276 & 0.0066 & 6.6824 & 16279.998 & 15909.236 & 982.156\end{array}$

$\begin{array}{lllllllllllllll} & \text { MLNIHPSLLPSF } & 1.00 & 36.65 & 23.44 & 23.12 & 3 & 1784.0287 & 1784.0262 & 595.6827 & 0.0025 & 1.3990 & 10105.419 & 11138.078 & 473.517\end{array}$

$\begin{array}{lllllllllllll}1.00 & 50.74 & 24.39 & 18.01 & 3 & 21582097 & 21582079 & 720.4099 & 0.0018 & 0.8329 & 42.129 & 44390 & 22.845\end{array}$

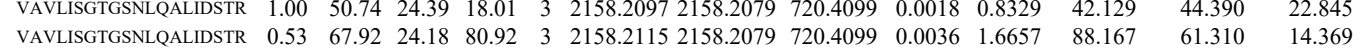

$\begin{array}{lllllllllllllll}\text { MLNIHPSLLPSFK } & 0.99 & 26.36 & 23.36 & 23.56 & 3 & 1784.0290 & 1784.0262 & 595.6827 & 0.0028 & 1.5668 & 7331.365 & 8993.440 & 808.684\end{array}$

$\begin{array}{lllllllllllllll}\text { MLNIHPSLLPSFK } & 1.00 & 30.21 & 23.38 & 20.84 & 3 & 1784.0302 & 1784.0262 & 595.6827 & 0.0040 & 2.2383 & 3283.323 & 3872.425 & 545.136\end{array}$

$\begin{array}{lllllllllllllll}\text { VAVLISGTGSNLAALDSTR } & 1.00 & \# \# \# \# & 24.65 & 25.51 & 2 & 2158.2074 & 2158.2079 & 1080.1112 & -0.0005 & -0.2315 & 205.259 & 218.631 & 18.853\end{array}$

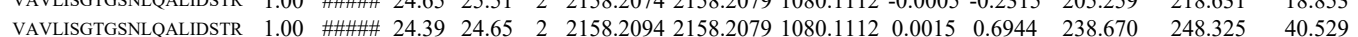

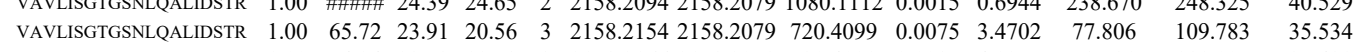

$\begin{array}{llllllllllllll}\text { VAVLIGGTGSNLQALIDSTR } & 1.00 & 74.24 & 23.73 & 19.58 & 3 & 2158.2166 & 2158.2079 & 720.4099 & 0.0087 & 4.0255 & 58.581 & 111.005 & 25.429\end{array}$

VLIIGSGGR
VLIIGSGGR

AIAFLQQPR

AIAFLQQPR

AIAFLQQPR

IYSHSLLPVLR

IYSHSLLPVLR

VLAVTAIR

VLIIGSGGR

VLIIGSGGR

AIAFLQQPR

AIAFLQQPR

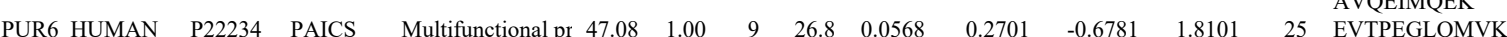

$\begin{array}{lllllllllllll}0.90 & 32.28 & 26.11 & 28.36 & 2 & 1014.6356 & 1014.6308 & 508.3227 & 0.0048 & 4.7214 & 9895.586 & 10399.862 & 171.783 \\ 0.96 & 36.26 & 26.19 & 28.56 & 2 & 1014.6360 & 1014.6308 & 508.3227 & 0.0052 & 5.1148 & 21698.583 & 23665.325 & 582.331\end{array}$ $\begin{array}{llllllllllllll}1.00 & 51.63 & 26.70 & 33.03 & 2 & 1186.7048 & 1186.6944 & 594.3545 & 0.0104 & 8.7489 & 26463.027 & 26662.951 & 27.176\end{array}$ $\begin{array}{lllllllllllll}1.00 & 47.60 & 26.66 & 26.61 & 2 & 1186.7050 & 1186.6944 & 594.3545 & 0.0106 & 8.9172 & 37866.900 & 38453.723 & 0.000\end{array}$ $\begin{array}{llllllllllllll}1.00 & 49.81 & 26.70 & 26.66 & 2 & 1186.7048 & 1186.6944 & 594.3545 & 0.0104 & 8.7489 & 17745.524 & 18629.313 & 0.000 & 2 \\ 0.93 & 4.60 & 24.15 & 15.99 & 3 & 1460.8566 & 1440.8575 & 48.2931 & 0.0009 & -0.6233 & 5659.865 & 5771.231 & 500.834 & 1\end{array}$ $\begin{array}{llllllllllllll}0.93 & 24.60 & 24.15 & 15.99 & 3 & 1440.8566 & 1440.8575 & 481.2931 & -0.0009 & -0.6233 & 5659.865 & 5771.231 & 500.834 & 1 \\ 0.91 & 18.02 & 23.60 & 18.31 & 3 & 1440.8590 & 1440.8575 & 481.2931 & 0.0015 & 1.0389 & 3211.786 & 3142.811 & 416.064 & \end{array}$ $\begin{array}{llllllllllllll}0.91 & 18.02 & 23.60 & 18.31 & 3 & 1440.8590 & 1440.8575 & 481.2931 & 0.0015 & 1.0389 & 3211.786 & 3142.811 & 416.064 \\ 0.95 & 30.39 & 23.20 & 35.87 & 2 & 985.6416 & 985.6406 & 493.8276 & 0.0010 & 1.0125 & 771.713 & 873.140 & 90.959\end{array}$

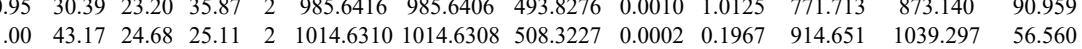
$\begin{array}{lllllllllllll}0.98 & 29.99 & 25.26 & 29.29 & 2 & 1014.6320 & 1014.6308 & 5083227 & 0.0012 & 1.1804 & 82.1086 & 734.801 & 84.590\end{array}$ $\begin{array}{llllllllllllll}1.00 & 45.81 & 26.72 & 23.48 & 2 & 1186.6958 & 1186.6944 & 594.3545 & 0.0014 & 1.1777 & 579.189 & 660.344 & 39.666\end{array}$

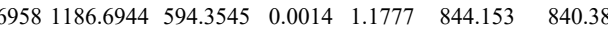
$\begin{array}{llllllllllll} & \end{array}$ EVTPEGLQMVK $\begin{array}{lllllllllllll}1.00 & 45.58 & 26.89 & 25.64 & 2 & 1517.8486 & 1517.8367 & 759.9256 & 0.0119 & 7.8297 & 19.208 & 51.194 & 334.529\end{array}$ EVTPEGLQMVK $\begin{array}{lllllllllllll}1.00 & 53.28 & 26.95 & 24.54 & 2 & 1517.8490 & 1517.8367 & 759.9256 & 0.0123 & 8.0928 & 122.558 & 42.039 & 1715.905 \\ 0.85 & 30.61 & 27.49 & 22.56 & 2 & 1193.6028 & 1193.5951 & 597.8048 & 0.0077 & 6.4402 & 13976.092 & 13353.647 & 1439042\end{array}$ $\begin{array}{lllllllllllll}0.85 & 30.61 & 27.49 & 22.56 & 2 & 1193.6028 & 1193.5951 & 597.8048 & 0.0077 & 6.4402 & 13976.092 & 13353.647 & 1439.042 \\ 1.00 & 60.93 & 28.28 & 22.23 & 2 & 1994.0256 & 1994.0231 & 998.0188 & 0.0025 & 1.2525 & 500.299 & 733.203 & 1000.506\end{array}$

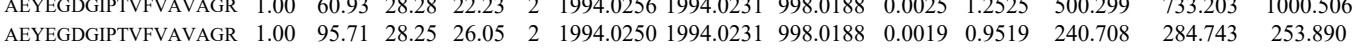
$\begin{array}{lllllllllllllll}\text { AEYEGDGIPTVFVAVAGR } & 1.00 & 95.38 & 28.27 & 26.71 & 2 & 1994.0254 & 1994.0231 & 998.0188 & 0.0023 & 1.1523 & 802.421 & 753.913 & 647.367\end{array}$

SWLPQNCTLVDMK

IATGSFLK

SWLPQNCTLVDMK SWLPQNCTLVDMK ACGNFGIPCELR ACGNFGIPCELR ACGNFGIPCELR ACGNFGIPCELR ACGNFGIPCELR ACGNFGIPCELR

ASILNTWISLK

ASILNTWISLK

ASILNTWISLK

ASILNTWISLK

ASILNTWISLK

ASILNTWISLK

ASILNTWISLK

ITSCIFQLLQEAGIK $\begin{array}{lllllllllllll}1.00 & 44.41 & 21.88 & 21.47 & 2 & 1514.6636 & 1514.6624 & 758.3385 & 0.0012 & 0.7912 & 8090.808 & 7348.632 & 300.126\end{array}$ $\begin{array}{lllllllllllllll}1.00 & 45.46 & 22.01 & 20.57 & 2 & 1514.6646 & 1514.6624 & 758.3385 & 0.0022 & 1.4505 & 4208.426 & 3069.124 & 299.189\end{array}$ $\begin{array}{lllllllllllllll}0.77 & 47.52 & 22.15 & 60.52 & 2 & 1514.6642 & 1514.6624 & 758.3385 & 0.0018 & 1.1868 & 5597.211 & 6331.631 & 75.924\end{array}$

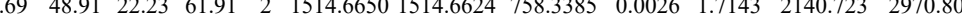

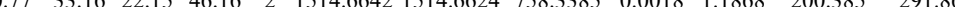
$\begin{array}{llllllllllllllll}1.00 & 67.44 & 22.07 & 24.38 & 2 & 1532.9202 & 1532.9170 & 767.4658 & 0.0032 & 2.0848 & 9837.530 & 8276.442 & 1772.296 & 283.030 & \text { Yes } \\ 1.00 & 42.86 & 22.12 & 22.58 & 3 & 1532.9215 & 1532.9170 & 511.9796 & 0.0045 & 2.9298 & 131.146 & 218.776 & 30.538 & 9.576 & \text { Yes }\end{array}$

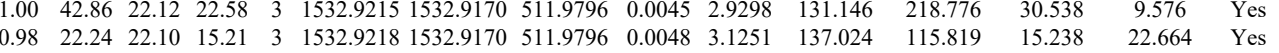
$\begin{array}{lllllllllllllll}1.00 & 63.71 & 22.07 & 23.05 & 2 & 1532.9202 & 1532.9170 & 767.4658 & 0.0032 & 2.0848 & 7459.941 & 9888.889 & 2251.245 & 161.519 & \text { Yes }\end{array}$

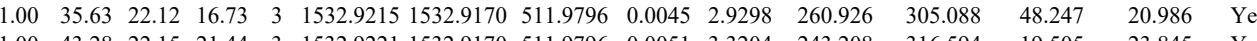
$\begin{array}{lllllllllllllll}1.00 & 43.28 & 22.15 & 21.44 & 3 & 1532.9221 & 1532.9170 & 511.9796 & 0.0051 & 3.3204 & 243.208 & 316.594 & 19.505 & 23.845 & \text { Yes } \\ \end{array}$ $\begin{array}{lllllllllllllll}1.00 & 45.73 & 26.57 & 21.60 & 3 & 1997.0965 & 1997.0933 & 666.7050 & 0.0032 & 1.5999 & 133.950 & 153.603 & 88.135 & 36.049 & \text { Yes } \\ \end{array}$

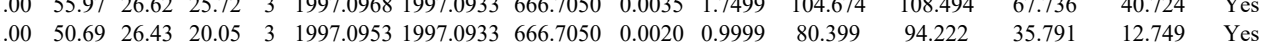

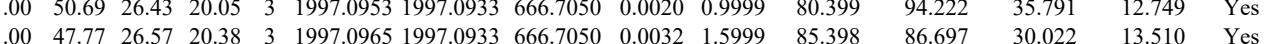
$\begin{array}{lllllllllllllll}1.00 & 80.22 & 27.37 & 18.12 & 2 & 2331.1234 & 2331.1222 & 1166.5684 & 0.0012 & 0.5143 & 85.398 & 86.697 & 30.022 & 13.510 & \text { Yes } \\ & 57.324 & 147.518 & 178.367 & \text { No }\end{array}$

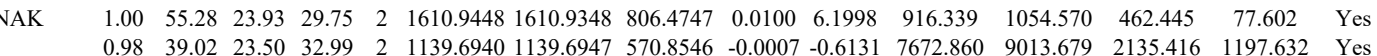



$\begin{array}{llllllllllllllll}\text { ATLPSPDK } & 0.96 & 33.96 & 28.48 & 29.86 & 2 & 1115.6432 & 1115.6430 & 558.8288 & 0.0002 & 0.1789 & 12605.063 & 9809.381 & 5672.041 & 7536.014 & \text { Yes }\end{array}$

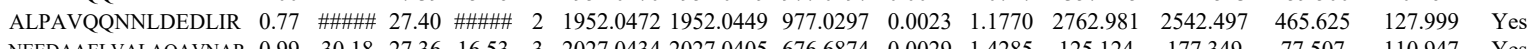
$\begin{array}{lllllllllllllllll}\text { NEEDAAELVALAQAVNAR } & 0.99 & 30.18 & 27.36 & 16.53 & 3 & 2027.0434 & 2027.0405 & 676.6874 & 0.0029 & 1.4285 & 125.124 & 177.349 & 77.507 & 110.947 & \text { Yes }\end{array}$

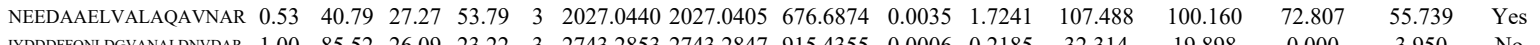
$\begin{array}{llllllllllllllll} & 274.2853 & 2743.2847 & 915.4355 & 0.0006 & 0.2185 & 32.314 & 19.898 & 0.000 & 3.950 & \text { No }\end{array}$ $\begin{array}{llllllllllllllll}\text { FEVQGLQPNGEEMTLK } & 1.00 & 64.60 & 28.12 & 30.39 & 2 & 2107.0874 & 2107.0863 & 1054.5504 & 0.0011 & 0.5215 & 643.491 & 877.108 & 572.799 & 460.596 & \text { Yes } \\ \text { FEVQGLQ }\end{array}$

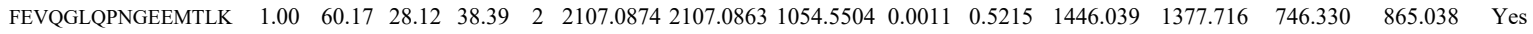
$\begin{array}{llllllllllllllllll} & \end{array}$ $\begin{array}{lllllllllllllllll} & & & \end{array}$ GLGVELAKAALDNDA

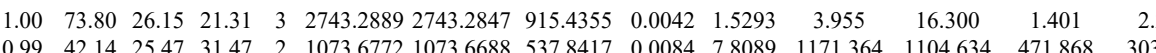

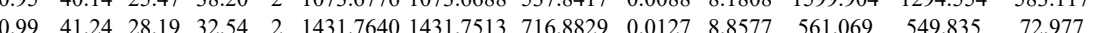

\section{GLGVEIAK}

LDQPMTEIVSR

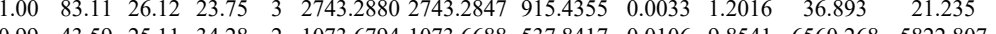

$\begin{array}{lllllllllllllll}1.00 & 70.39 & 28.12 & 31.45 & 2 & 1431.7624 & 1431.7513 & 716.8829 & 0.0111 & 7.7418 & 8365.237 & 6694.153 & 1591.467\end{array}$ $\begin{array}{llllllllllllllll}\text { LDQPMTEIVSR } & 1.00 & 70.39 & 28.12 & 31.45 & 2 & 1431.7624 & 1431.7513 & 716.8829 & 0.0111 & 7.7418 & 8365.237 & 6694.153 & 1591.467 & 298.610 & \text { Yes } \\ \text { LDQPMTEIVSR } & 1.00 & 69.05 & 28.06 & 30.09 & 2 & 1431.7632 & 1431.7513 & 716.8829 & 0.0119 & 8.2998 & 10669.475 & 8980.048 & 1586.990 & 665.010 & \text { Yes } \\ \text { SLVASLAEPDFVVDDFAK } & 1.00 & 86.40 & 25.59 & 19.49 & 2 & 2196.1954 & 2196.1922 & 1099.1034 & 0.0032 & 1.4557 & 346.480 & 329.312 & 40.624 & 6.309 & \text { Yes } \\ \text { SLVALLAEPDFVVDDFAK } & 1.00 & 77.30 & 25.59 & 20.68 & 2 & 2196.1954 & 2196.1922 & 1099.1034 & 0.0032 & 1.4557 & 467.219 & 551.629 & 12.826 & 0.000 & \text { No } \\ \text { SLVASAPPDVVDDAK } & 1.00 & 55.94 & 25.62 & 20.30 & 3 & 2196.1969 & 2196.1922 & 733.0713 & 0.0047 & 2.1371 & 94.118 & 65.718 & 15.988 & 35.820 & \text { Yes }\end{array}$ $\begin{array}{llllllllllllllll} & \end{array}$

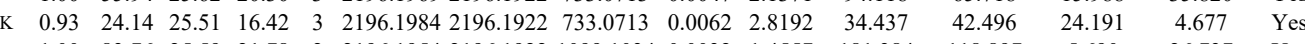
$\begin{array}{llllllllllllllll} & \end{array}$ $\begin{array}{lllllllllllllll} & & & \end{array}$

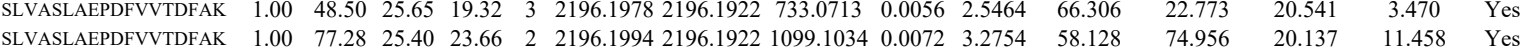

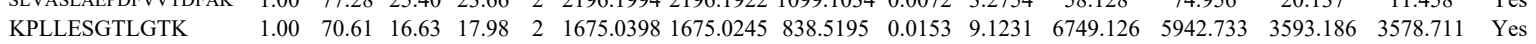
$\begin{array}{lllllllllllllllll}\text { KPLLESGTLGTK } & 1.00 & 72.71 & 16.63 & 19.27 & 2 & 1675.0398 & 1675.0245 & 838.5195 & 0.0153 & 9.1231 & 4115.931 & 3137.487 & 1594.544 & 1437.148 & \text { Yes }\end{array}$ $\begin{array}{llllllllllllllll}\text { KPLLESGTLGTK } & 1.00 & 68.15 & 16.63 & 19.26 & 2 & 1675.0396 & 1675.0245 & 838.5195 & 0.0151 & 9.0039 & 5684.490 & 4311.388 & 3195.457 & 2936.034 & \text { Yes }\end{array}$ NIILGGVK NIILGGVK NIILGGVK $\left.\begin{array}{llllllllllllllll}0.94 & 38.16 & 21.27 & 37.40 & 2 & 1100.7254 & 1100.7161 & 551.3653 & 0.0093 & 8.4335 & 9999.777 & 8807.478 & 530.944 & 361.047\end{array}\right)$ $\begin{array}{llllllllllllllll}0.93 & 38.59 & 21.27 & 40.22 & 2 & 1100.7258 & 1100.7161 & 551.3653 & 0.0097 & 8.7963 & 20045.868 & 18571.223 & 768.353 & 716.053 & \text { Yes }\end{array}$

SIPICTLK $\begin{array}{llllllllllllll}0.92 & 34.07 & 21.21 & 36.25 & 2 & 1100.7270 & 1100.7161 & 551.3653 & 0.0109 & 9.8845 & 1673.320 & 1845.884 & 676.598\end{array}$ $\begin{array}{lllllllllllllllll}\text { SIPICTLK } & 1.00 & 52.38 & 27.29 & 31.86 & 2 & 1207.6936 & 1207.6912 & 604.8529 & 0.0024 & 1.9839 & 35356.085 & 32684.474 & 1439.297 & 109.356 & \text { Yes } \\ \text { NFPNAIEHTLQWAR } & 1.00 & 72.23 & 27.73 & 26.60 & 2 & 1839.9546 & 1839.9502 & 920.9824 & 0.0044 & 2.3887 & 3643.466 & 3232.617 & 128.101 & 49.467 & \text { Yes }\end{array}$ $\begin{array}{lllllllllllllllll}\text { SIPICTLK } & 1.00 & 52.38 & 27.29 & 31.86 & 2 & 1207.6936 & 1207.6912 & 604.8529 & 0.0024 & 1.9839 & 35356.085 & 32684.474 & 1439.297 & 109.356 & \text { Yes } \\ \text { NFPNAIEHTLQWAR } & 1.00 & 72.23 & 27.73 & 26.60 & 2 & 1839.9546 & 1839.9502 & 920.9824 & 0.0044 & 2.3887 & 3643.466 & 3232.617 & 128.101 & 49.467 & \text { Yes } \\ \text { NFPNAIEHTLQWAR } & 1.00 & 70.72 & 27.75 & 22.88 & 2 & 1839.9550 & 1839.9502 & 920.9824 & 0.0048 & 2.6059 & 5433.634 & 4496.017 & 114.178 & 19.310 & \text { Yes }\end{array}$ $\begin{array}{llllllllllllllll} & \end{array}$ $\begin{array}{llllllllllllllll}\text { NFPNAIEHTLQWAR } & 1.00 & 72.14 & 27.73 & 29.58 & 3 & 1839.9559 & 1839.9502 & 614.3240 & 0.0057 & 3.0928 & 22208.089 & 21714.601 & 1694.894 & 610.856 & \text { Yes }\end{array}$

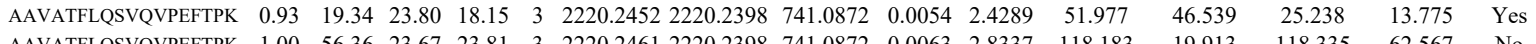

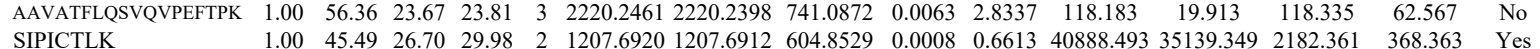

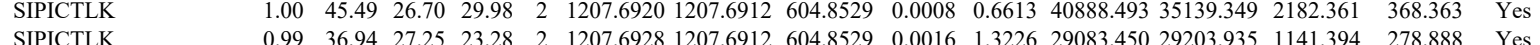

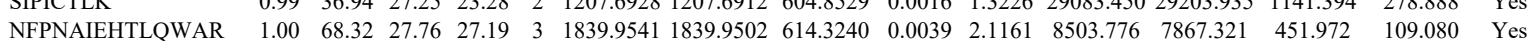

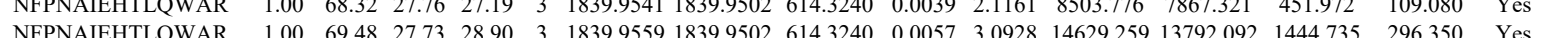
YFLVGAGAICCELK

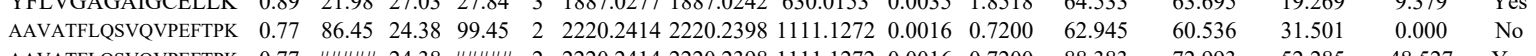
$\begin{array}{lllllllllllllll} & \text { A }\end{array}$ 
$\begin{array}{lllllllllll}0.96 & 30.49 & 25.20 & 23.55 & 2 & 1668.7716 & 1668.7713 & 835.3929 & 0.0003 & 0.1796 & 103.311\end{array}$

$\begin{array}{ll}1.000 & 1.856\end{array}$

0.000
9.900
10.162

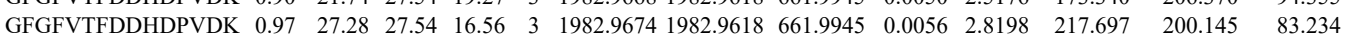
$\begin{array}{lllllllllllllll}\text { GFGFVTFDDHDPVDK } & 0.93 & 26.11 & 27.54 & 22.94 & 3 & 1982.9680 & 1982.9618 & 661.9945 & 0.0062 & 3.1219 & 173.671 & 165.538 & 80.521\end{array}$ $\begin{array}{llllllllllllll}\text { GFGFVTFDDHDPVDK } & 0.93 & 27.80 & 27.60 & 18.77 & 3 & 1982.9698 & 1982.9618 & 661.9945 & 0.0080 & 4.0282 & 208.936 & 235.731 & 89.082\end{array}$ $\begin{array}{llllllllllllll}\text { GFGFVTFDDHDPVDK } & 0.92 & 28.14 & 27.65 & 18.45 & 3 & 1982.9710 & 1982.9618 & 661.9945 & 0.0092 & 4.6324 & 196.562 & 178.144 & 99.087\end{array}$

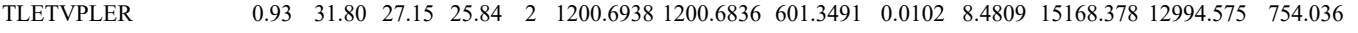

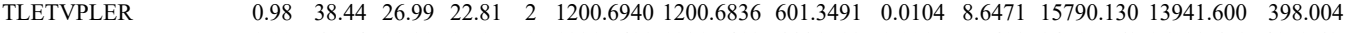

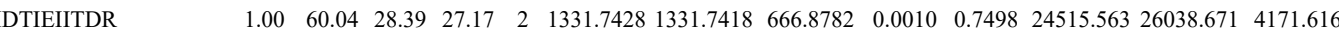

IDTIEIITD

$\begin{array}{lllllllllllll}1.00 & 53.69 & 28.25 & 24.23 & 2 & 1331.7434 & 1331.7418 & 666.8782 & 0.0016 & 1.1996 & 17039.913 & 15663.487 & 2934.445\end{array}$

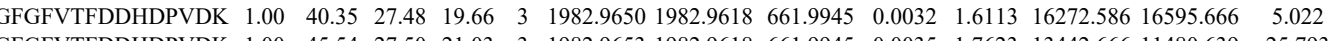

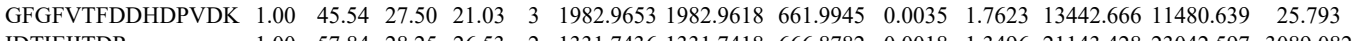
IDTIEIITDR 
$\begin{array}{lllllllllllll} & \end{array}$ $\begin{array}{llllllllllllllllll} & \end{array}$ $\begin{array}{lllllllllllll} & \end{array}$

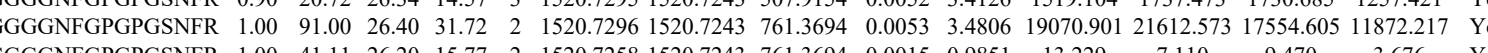
$\begin{array}{llllllllllll} & \end{array}$

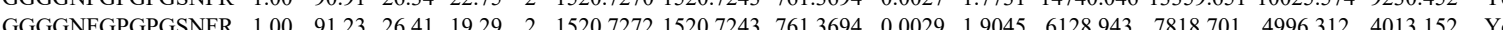

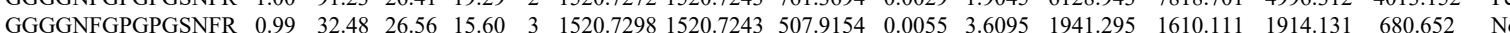
$\begin{array}{llllllllllllllll}\text { GGGGNFGPGPGSNFR } & 1.00 & \# \# \# \# 26.55 & 30.92 & 2 & 1520.7306 & 1520.7243 & 761.3694 & 0.0063 & 4.1373 & 9601.094 & 11637.320 & 7084.540 & 6436266 & \text { Yes }\end{array}$ $\begin{array}{lllllllllllllllllll}\text { GGGGNFGPGPGSNFR } & 1.00 & 88.35 & 26.53 & 29.22 & 2 & 1520.7308 & 1520.7243 & 761.3694 & 0.0065 & 4.2686 & 17155.180 & 14907.454 & 10815.633 & 8175.708 & \text { Yes }\end{array}$ $\begin{array}{llllllllllllllll}\text { GGGGNFGPGPGSNFR } & 1.00 & 89.44 & 26.40 & 29.56 & 2 & 1520.7292 & 1520.7243 & 761.3694 & 0.0049 & 3.2179 & 6356.598 & 5539.995 & 4572.409 & 3469.668 & \text { Yes }\end{array}$ $\begin{array}{lllllllllllllllll}\text { GGGGNFGPGPGSNFR } & 1.00 & 97.77 & 26.40 & 30.13 & 2 & 1520.7296 & 1520.7243 & 761.3694 & 0.0053 & 3.4806 & 9637.889 & 9798.364 & 7098.408 & 5115.956 & \text { Yes }\end{array}$ $\begin{array}{lllllllllllllllll}\text { GGGGNFGPGPGSNFR } & 1.00 & 85.85 & 26.85 & 29.60 & 2 & 1520.7344 & 1520.7243 & 761.3694 & 0.0101 & 6.6327 & 1378.817 & 1078.368 & 948.020 & 927.716 & \text { Yes }\end{array}$

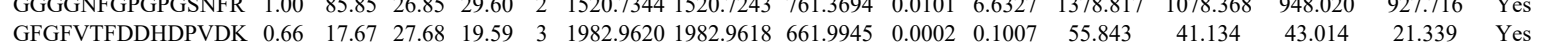

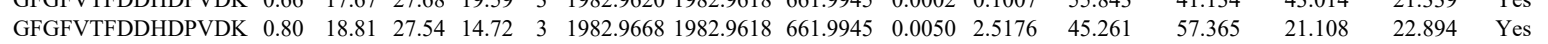
$\begin{array}{llllllllllllllll}\text { GFGFVTFDDHDPVDK } & 0.99 & 31.98 & 27.55 & 21.83 & 3 & 1982.9671 & 1982.9618 & 661.9945 & 0.0053 & 2.6687 & 49.609 & 43.431 & 31.204 & 29.982 & \text { Yes }\end{array}$ $\begin{array}{llllllllllllllll}\text { EESGKPGAHVTVK } & 0.78 & 21.42 & 26.03 & 18.24 & 3 & 1769.9995 & 1770.0001 & 591.0073 & -0.0006 & -0.3384 & 199.901 & 180.413 & 214.108 & 206.751 & \text { No }\end{array}$

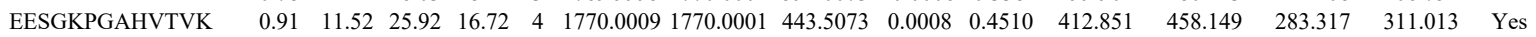
$\begin{array}{llllllllllllllll}\text { GFGFVTFDDHDPVDK } & 0.51 & 12.88 & 27.53 & 16.57 & 3 & 1982.9662 & 1982.9618 & 661.9945 & 0.0044 & 2.2155 & 66.924 & 66.744 & 27.605 & 36.205 & \text { Yes }\end{array}$

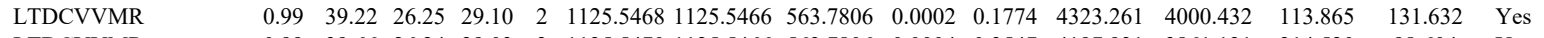

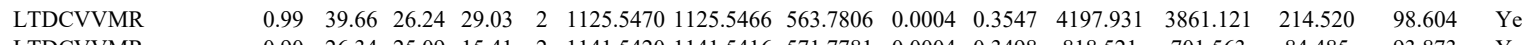
$\begin{array}{llllllllllllllll}\text { LTDCVVMR } & 0.90 & 26.34 & 25.09 & 15.41 & 2 & 1141.5420 & 1141.5416 & 571.7781 & 0.0004 & 0.3498 & 818.521 & 701.563 & 84.485 & 93.873 & \text { Yes }\end{array}$

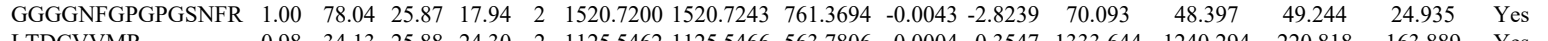

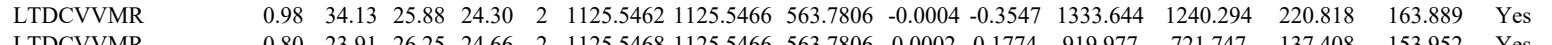
\begin{tabular}{llllllllllllllll} 
LTDCVVMR & 0.80 & 23.91 & 26.25 & 24.66 & 2 & 1125.5468 & 1125.5466 & 563.7806 & 0.0002 & 0.1774 & 919.977 & 721.747 & 137.408 & 153.952 & Yes \\
\hline
\end{tabular} $\begin{array}{llllllllllllllll}\text { QEMQEVQSSR } & 1.00 & 49.64 & 25.95 & 20.43 & 2 & 1364.6488 & 1364.6476 & 683.3311 & 0.0012 & 0.8781 & 650.254 & 576.798 & 252.986 & 108.486 & \text { Yes }\end{array}$ $\begin{array}{llllllllllllllll}\text { GFGFVTFDDHDPVDK } & 0.82 & 17.50 & 27.49 & 17.03 & 3 & 1982.9647 & 1982.9618 & 661.9945 & 0.0029 & 1.4602 & 81.279 & 104.554 & 42.449 & 37.101 & \text { Yes }\end{array}$

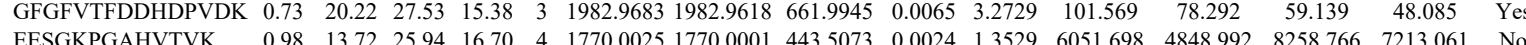
$\begin{array}{llllllllllllllll}\text { EESGKPGAHVTVK } & 0.98 & 13.72 & 25.94 & 16.70 & 4 & 1770.0025 & 1770.0001 & 443.5073 & 0.0024 & 1.3529 & 6051.698 & 4848.992 & 8258.766 & 7213.061 & \text { No } \\ \text { GFGFVTFDDHDPVDK } & 0.83 & 17.83 & 27.49 & 19.37 & 3 & 1982.9647 & 1982.9618 & 661.9945 & 0.0029 & 1.4602 & 135.694 & 167.187 & 112.689 & 67.667 & \text { Y }\end{array}$

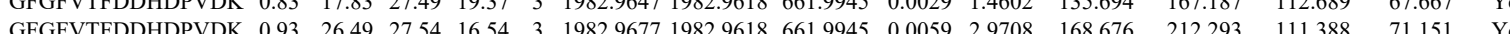

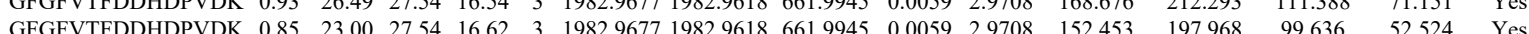

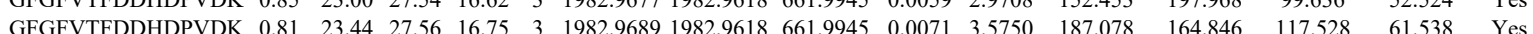

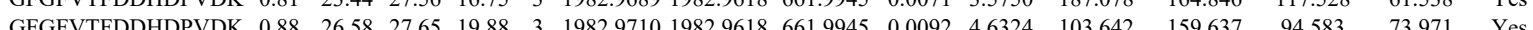

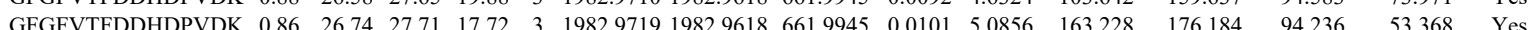

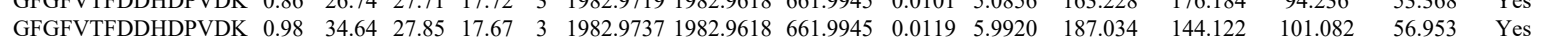
$\begin{array}{llllllllllllllll}\text { EESGKPGAHVTVK } & 0.55 & 20.36 & 26.00 & 33.36 & 3 & 17700022 & 17700001 & 591.0073 & 0.0021 & 1.1844 & 7177.969 & 6883.119 & 8715.218 & 7774.976 & \text { No }\end{array}$ $\begin{array}{llllllllllllllll}\text { EESGKPGAHVTVK } & 0.98 & 14.24 & 25.91 & 19.30 & 4 & 1770.0033 & 1770.0001 & 443.5073 & 0.0032 & 1.8038 & 24668.416 & 23581.961 & 35623.795 & 32186.179 & \text { No }\end{array}$ $\begin{array}{lllllllllllllllll}\text { EESGKPGAHVTVK } & 0.94 & 11.25 & 25.91 & 17.22 & 4 & 1770.0037 & 1770.0001 & 4435073 & 0.0036 & 2.0293 & 28469.064 & 29784.145 & 36335.524 & 38403.207 & \text { No }\end{array}$ $\begin{array}{llllllllllllllll}\text { GFGFVTFDDHDPVDK } & 0.99 & 29.04 & 27.57 & 22.04 & 3 & 1982.9632 & 1982.9618 & 661.9945 & 0.0014 & 0.7049 & 278.424 & 237.877 & 85.628 & 72.892 & \text { Yes }\end{array}$

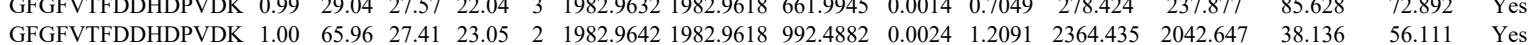
$\begin{array}{lllllllllllllllll}\text { GFGFVTFDDHDPVDK } & 1.00 & 32.29 & 27.41 & 19.48 & 3 & 1982.9644 & 1982.9618 & 661.9945 & 0.0026 & 1.3092 & 331.229 & 286.029 & 82.766 & 64.262 & \text { Yes }\end{array}$ $\begin{array}{lllllllllllllllll}\text { GFGFVTFDDHDPVDK } & 1.00 & 35.24 & 27.41 & 19.81 & 3 & 1982.9644 & 1982.9618 & 661.9945 & 0.0026 & 1.3092 & 231.214 & 224.743 & 79.819 & 43.176 & \text { Yes }\end{array}$ $\begin{array}{lllllllllllllllll}\text { GFGFVTFDDHDPVDK } & 1.00 & 69.31 & 27.49 & 26.35 & 2 & 1982.9646 & 1982.9618 & 992.4882 & 0.0028 & 1.4106 & 1488.288 & 1443.182 & 156.364 & 155.250 & \text { Yes }\end{array}$ $\begin{array}{llllllllllllllll}\text { GFGFVTFDDHDPVDK } & 1.00 & 32.49 & 27.49 & 19.28 & 3 & 1982.9647 & 1982.9618 & 661.9945 & 0.0029 & 1.4602 & 233.603 & 281.905 & 55.285 & 57.906 & \text { Yes }\end{array}$ $\begin{array}{lllllllllllllllll}\text { GFGFVTFDDHDPVDK } & 1.00 & 41.34 & 27.49 & 18.32 & 3 & 1982.9647 & 1982.9618 & 661.9945 & 0.0029 & 1.4602 & 274.394 & 257.626 & 107.300 & 42.196 & \text { Yes }\end{array}$ $\begin{array}{llllllllllllllll}\text { GFGFVTFDDHDPVDK } & 0.97 & 24.50 & 27.50 & 17.76 & 3 & 1982.9653 & 1982.9618 & 661.9945 & 0.0035 & 1.7623 & 282.074 & 270.549 & 78.570 & 38.043 & \text { Yes }\end{array}$ $\begin{array}{llllllllllllllllll}\text { GFGFVTFDDHDPVDK } & 0.98 & 28.35 & 27.57 & 18.64 & 3 & 1982.9656 & 1982.9618 & 661.9945 & 0.0038 & 1.9134 & 326.120 & 362.179 & 83.517 & 52.284 & \text { Yes }\end{array}$ $\begin{array}{lllllllllllllllll}\text { GFGFVTFDDHDPVDK } & 1.00 & 38.25 & 27.57 & 19.58 & 3 & 1982.9656 & 1982.9618 & 661.9945 & 0.0038 & 1.9134 & 320.831 & 271.114 & 98.031 & 77.638 & \text { Yes }\end{array}$ $\begin{array}{lllllllllllllllll}\text { GFGFVTFDDHDPVDK } & 1.00 & 36.75 & 27.57 & 21.38 & 3 & 1982.9656 & 1982.9618 & 661.9945 & 0.0038 & 1.9134 & 231.490 & 220.882 & 107.714 & 73.804 & \text { Yes }\end{array}$ $\begin{array}{lllllllllllllllll}\text { GFGFVTFDDHDPVDK } & 0.99 & 31.11 & 27.50 & 17.51 & 3 & 1982.9659 & 1982.9618 & 661.9945 & 0.0041 & 2.0645 & 352.194 & 348.049 & 77.430 & 75.929 & \text { Yes }\end{array}$

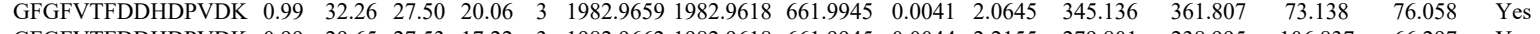

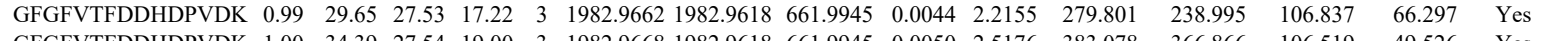
$\begin{array}{llllllllllllllll}\text { GFGFVIFDDHDPVDK } & 1.00 & 34.39 & 27.54 & 17.00 & 3 & 1982.9668 & 1982.9618 & 661.9945 & 0.0050 & 2.5176 & 383.078 & 366.866 & 106.519 & 49.526 & \text { Yes }\end{array}$

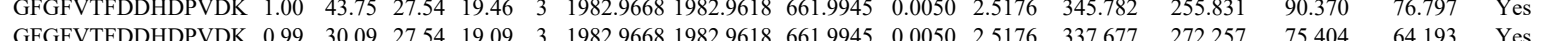

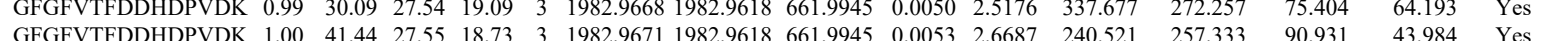
$\begin{array}{llllllllllllllll}\text { GFGFVTFDDHDPVDK } & 1.00 & 41.44 & 27.55 & 18.73 & 3 & 1982.967 & 1982.9618 & 6661.9945 & 0.0053 & 2.6687 & 240.521 & 257.333 & 90.931 & 43.984 & \text { Yes } \\ \text { GFGFVTFDDHDPVDK } & 1.00 & 39.72 & 27.55 & 21.30 & 3 & 1982.9671 & 1982.9618 & 661.9945 & 0.0053 & 2.6687 & 237.938 & 206.890 & 68.252 & 71.035 & \text { Yes }\end{array}$ $\begin{array}{lllllllllllllllll}\text { GFGFVTFDDHDPVDK } & 0.99 & 33.35 & 27.54 & 17.75 & 3 & 1982.9674 & 1982.9618 & 661.9945 & 0.0056 & 2.8198 & 42795.019 & 35636.060 & 1458.494 & 290.795 & \text { Yes }\end{array}$

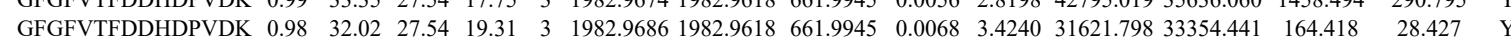

Table S-3 page 184 of 499 


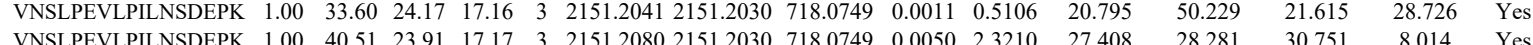

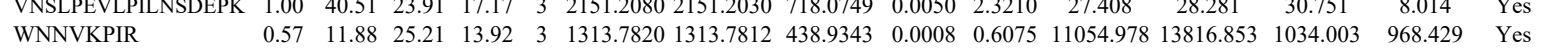

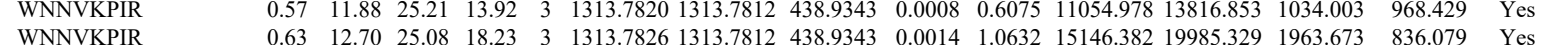
$\begin{array}{lllllllllllllllll} & \\ \text { LLLVGAPR } & 0.99 & 43.92 & 17.40 & 33.13 & 2 & 981.6520 & 981.6457 & 491.8301 & 0.0063 & 6.4046 & 4228.327 & 6032.010 & 449.414 & 282290 & \text { Yes }\end{array}$

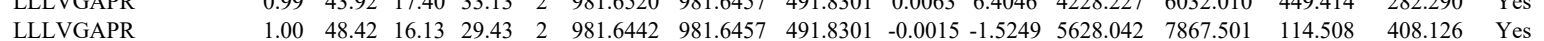

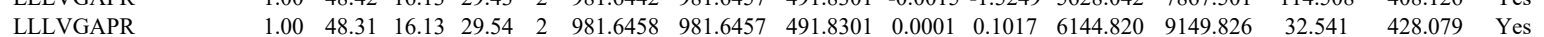

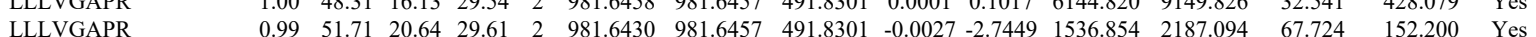

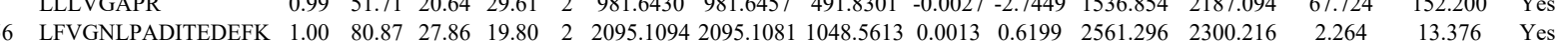

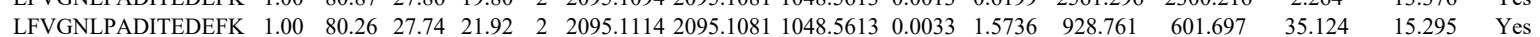

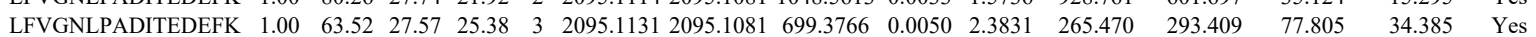

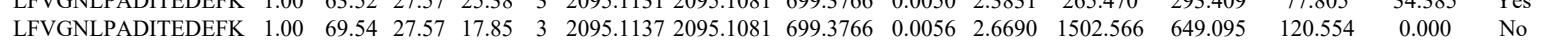
$\begin{array}{llllllllllllllll}\text { LFVGNLPADITEDEFK } & 1.00 & 44.48 & 27.72 & 18.88 & 3 & 2095.1107 & 2095.1081 & 699.3766 & 0.0026 & 1.2392 & 183.484 & 218.702 & 354.100 & 313.821 & \text { No }\end{array}$ $\begin{array}{llllllllllllllll}\text { LFVGNLPADITEDEFK } & 1.00 & 70.03 & 27.74 & 21.67 & 2 & 2095.1114 & 2095.1081 & 1048.5613 & 0.0033 & 1.5736 & 1671.517 & 1360.184 & 0.664 & 16.643 & \text { No }\end{array}$ $\begin{array}{lllllllllllllllll}\text { LFVGNLPADITEDEFK } & 1.00 & 67.87 & 27.57 & 24.19 & 3 & 2095.1131 & 2095.1081 & 699.3766 & 0.0050 & 2.3831 & 287.268 & 247.099 & 113.901 & 136.100 & \text { Yes }\end{array}$ $\begin{array}{llllllllllllllll}26.03 & 34.76 & 2 & 2058.9354 & 2058.9165 & 1030.4655 & 0.0189 & 9.1705 & 309.939 & 302.825 & 136.673 & 65.311 & \text { Yes }\end{array}$ $\begin{array}{llllllllllllllll}\text { LFVGNLPADITEDEFRR } & 1.00 & 38.22 & 26.43 & 17.43 & 3 & 2251.2142 & 2251.2092 & 751.4103 & 0.0050 & 2.2180 & 7903.615 & 9016.083 & 992.981 & 1832.709 & \text { Yes } \\ \text { GMGPGTPAGY }\end{array}$ $\begin{array}{lllllllllllllllll}\text { GMGPGTPAGYGR } & 1.00 & 72.35 & 26.67 & 28.70 & 2 & 1263.6154 & 1263.6152 & 632.8149 & 0.0002 & 0.1580 & 4970.710 & 4053.507 & 1004.044 & 680.016 & \text { Yes }\end{array}$ $\begin{array}{llllllllllllllllll}\text { GMGPGTPAGYGR } & 1.00 & 77.95 & 26.82 & 31.17 & 2 & 1263.6156 & 1263.6152 & 632.8149 & 0.0004 & 0.3160 & 11567.374 & 9329.748 & 1982.736 & 680.362 & \text { Yes }\end{array}$ $\begin{array}{llllllllllllllll}\text { GMGPGTPAGYGR } & 1.00 & 69.71 & 26.82 & 36.29 & 2 & 1263.6156 & 1263.6152 & 632.8149 & 0.0004 & 0.3160 & 11087.472 & 9622.021 & 1702.092 & 173.500 & \text { Yes } \\ \text { GMGPGTPAGYGR } & 1.00 & 68.36 & 26.81 & 32.00 & 2 & 1263.6162 & 1263.6152 & 6328149 & 0.0010 & 0.7901 & 4933.339 & 3838.946 & 664249 & 165.149 & \text { Yes }\end{array}$ $\begin{array}{llllllllllllllll} & & \end{array}$

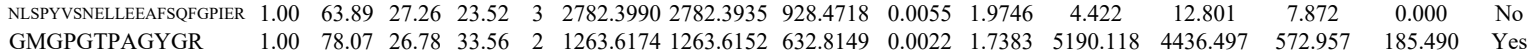

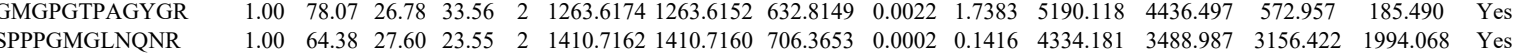
$\begin{array}{llllllllllllllll} & \end{array}$ $\begin{array}{llllllllllllllllll}\text { SPPPGMGLNQNR } & 1.00 & 36.73 & 27.54 & 29.58 & 3 & 1410.7177 & 1410.7160 & 471.2459 & 0.0017 & 1.2025 & 1905.928 & 2394.796 & 3337.375 & 3283.370 & \text { No }\end{array}$ \begin{tabular}{lllllllllllllllll} 
& \\
SPPGMGLNQNR & 1.00 & 63.31 & 27.51 & 25.56 & 2 & 1410.7154 & 1410.7160 & 7063653 & -0.0006 & -0.4247 & 4227.172 & 3520.609 & 2891.947 & 2289.024 & Yes \\
\hline
\end{tabular} $\begin{array}{lllllllllllllllll} & \\ \text { SPPGMGLNQNR } & 1.00 & 43.04 & 27.40 & 22.18 & 2 & 1410.7156 & 1410.7160 & 706.3653 & -0.0004 & -0.2831 & 10604.640 & 9785.327 & 8226.892 & 5936340 & Y & \text { Yes }\end{array}$

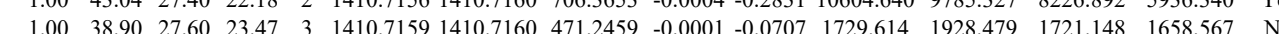

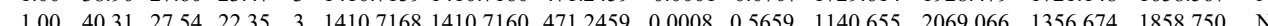
$\begin{array}{lllllllllllllll} & & & \end{array}$

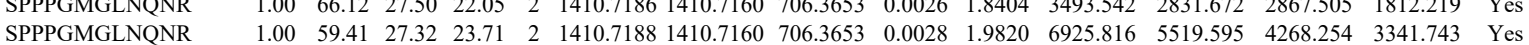
$\begin{array}{llllllllllllllll}\text { SPPPGMGLNONR } & 0.53 & 26.78 & 27.40 & 39.78 & 3 & 1410.7195 & 1410.7160 & 471.2459 & 0.0035 & 2.4757 & 2681.568 & 2722.581 & 1299.470 & 1102.163 & \text { Yes }\end{array}$ $\begin{array}{llllllllllllllll} & \end{array}$ $\begin{array}{lllllllllllllllll}\text { FGQGGAGPVGGQGPR } & 1.00 & 84.00 & 27.80 & 26.77 & 2 & 1484.7638 & 1484.7607 & 743.3876 & 0.0031 & 2.0850 & 40478.382 & 28819.101 & 9557.955 & 2322.821 & \text { Yes }\end{array}$ $\begin{array}{lllllllllllllllll}\text { FGQGGAGPVGGQGPR } & 0.95 & 23.93 & 27.85 & 14.87 & 3 & 1484.7643 & 1484.7607 & 495.9275 & 0.0036 & 2.4197 & 3046.467 & 2164.045 & 1158.810 & 1012.237 & \text { Yes }\end{array}$ $\begin{array}{lllllllllllllllll}\text { GMGPGTPAGYGR } & 1.00 & 74.08 & 26.78 & 34.55 & 2 & 1263.6174 & 1263.6152 & 632.8149 & 0.0022 & 1.7383 & 2067.849 & 1414.700 & 160.169 & 58.995 & \text { Yes }\end{array}$ $\begin{array}{lllllllllllllllll}\text { SPPPGMGLNQNR } & 1.00 & 54.18 & 27.54 & 24.76 & 2 & 1410.7170 & 1410.7160 & 706.3653 & 0.0010 & 0.7078 & 279.410 & 248.243 & 235.438 & 154.513 & \text { Yes }\end{array}$

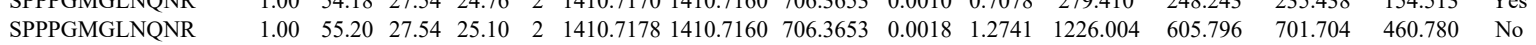

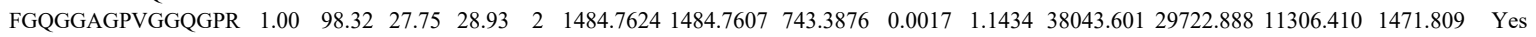

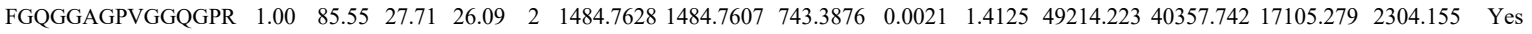
$\begin{array}{lllllllllllllllll}\text { FGQGGAGPVGGQGPR } & 0.99 & 31.79 & 27.87 & 16.90 & 3 & 1484.7637 & 1484.7607 & 495.9275 & 0.0030 & 2.0164 & 2080.026 & 2576.045 & 1488.504 & 866.943 & \text { Yes }\end{array}$ $\begin{array}{llllllllllllllll}\text { FGQGGAGPVGGQGPR } & 1.00 & 34.51 & 27.87 & 20.07 & 3 & 1484.7637 & 1484.7607 & 495.9275 & 0.0030 & 2.0164 & 1648.420 & 1267.707 & 618.143 & 604.464 & \text { Yes }\end{array}$ $\begin{array}{lllllllllllllllll}\text { FGQGGAGPVGGQGPR } & 1.00 & 96.06 & 27.86 & 33.51 & 2 & 1484.7650 & 1484.7607 & 743.3876 & 0.0043 & 2.8922 & 19170.705 & 14098.180 & 6250.777 & 729.522 & \text { Yes }\end{array}$

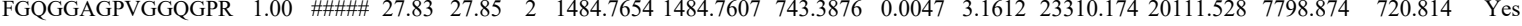
$\begin{array}{llllllllllllllll}\text { FGQGGAGPVGGQGPR } & 0.89 & 21.74 & 27.80 & 19.61 & 3 & 1484.7661 & 1484.7607 & 495.9275 & 0.0054 & 3.6295 & 3224.713 & 4103.160 & 1356.506 & 1179.232 & \text { Yes }\end{array}$ $\begin{array}{llllllllllllllll}\text { FGQGGAGPVGGQGPR } & 1.00 & 94.10 & 27.80 & 28.19 & 2 & 1484.7656 & 1484.7607 & 743.3876 & 0.0049 & 3.2957 & 3706.804 & 3284.509 & 1492.646 & 274.104 & \text { Yes }\end{array}$ $\begin{array}{llllllllllllllll}\text { ANLSLLR } & 0.79 & 29.71 & 27.60 & 30.62 & 2 & 929.5838 & 929.5780 & 465.7963 & 0.0058 & 6.2259 & 23398.710 & 19759.995 & 10321.327 & 4501.029 & \text { Yes }\end{array}$ $\begin{array}{llllllllllllllll}\text { ANLSLLR } & 0.91 & 33.98 & 27.60 & 32.51 & 2 & 929.5838 & 929.5780 & 465.7963 & 0.0058 & 6.2259 & 47050.334 & 42685.495 & 9462.560 & 3323.666 & \text { Yes }\end{array}$

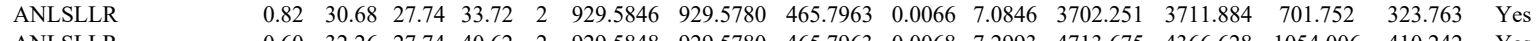
ANLSLLR $\begin{array}{lllllllllllllll}0.60 & 32.26 & 27.74 & 40.62 & 2 & 929.5848 & 929.5780 & 465.7963 & 0.0068 & 7.2993 & 4713.675 & 4366.628 & 1054.006 & 410.242 & \text { Yes }\end{array}$ $\begin{array}{llllllllllllllll}0.87 & 33.20 & 27.81 & 35.53 & 2 & 929.5864 & 929.5780 & 465.7963 & 0.0084 & 9.0167 & 3673.854 & 3281.357 & 677.313 & 234.720 & \text { Yes } \\ 0.92 & 38.32 & 27.81 & 39.40 & 2 & 929.5872 & 929.5780 & 465.7963 & 0.0092 & 9.8755 & 3354.663 & 3312349 & 635371 & 231.540 & \text { Yes }\end{array}$ $\begin{array}{lllllllllllllll}0.92 & 38.32 & 27.81 & 39.40 & 2 & 929.5872 & 929.5780 & 465.7963 & 0.0092 & 9.8755 & 3354.663 & 3312.349 & 635.371 & 231.540 & \text { Yes } \\ 0.68 & 27.62 & 27.60 & 34.44 & 2 & 929.5838 & 929.5780 & 465.7963 & 0.0058 & 6259 & 78809.099 & 82211.495 & 13356.089 & 2178.640 & \text { Yes }\end{array}$

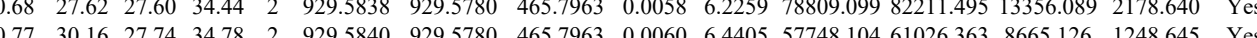
$\begin{array}{llllllllllllllll}1.00 & 76.53 & 27.44 & 35.15 & 2 & 1286.7260 & 1286.7217 & 644.3681 & 0.0043 & 3.3366 & 25989.948 & 19677.802 & 94.591 & 620.075 & \text { Yes }\end{array}$ $\begin{array}{lllllllllllllllll}1.00 & 62.41 & 27.51 & 25.57 & 3 & 1286.7262 & 1286.7217 & 429.9145 & 0.0045 & 3.4891 & 15180.402 & 19406.721 & 11610.870 & 6760.314 & \text { Yes }\end{array}$ 
FATHAAALSVR FATHAAALSVR FATHAAALSVR FATHAAALSVR FATHAAALSVR FATHAAALSVR FATHAAALSVR FATHAAALSVR MEELHNQEMQK MEELHNQEMQK MELINQEMQK MELHNQMQ ISDSEGFK

ISDSEGFK

FPDENFK

VLEGMEVVR

VLEGMEVVR

VLEGMEVVR

VLEGMEVVR

TVDNFVALATGEK

TVDNFVALATGEK TVDNFVALATGEK VIFGLFGK

VIFGLFGK

VIFGLFGK

VIFGLFGK

FPDENFK

FPDENFK

FPDENFK

FPDENFK

IETQDIQALR

ILGLGDLGVYGMGIPV

GKPLMLNPR

GKPLMLNPR

GKPLMLNPR

GKPLMLNPR

3 GIFGFTDSDCIGK

GIFGFTDSDCIGK
GIFGFTDSDCIGK

GIFGFTDSDCIGK

GIFGFTDSDCIGK

ALIEVLQPLIAEHQAR

PNSEPASLLELFNSIATRGELVR

PNSEPASLLELFNSIATQGeLVR PNSEPASLLELFNSIATQGELV GIFFSHR

GIFFSHR

GIFFSHR

ISFPAIQAAPSFSNSFPQIIR

ISFPAIQAAPSFSNSFPQIF

ISFPAIQAAPSFSNSFPQII

ISSPARAAAPSFSNSFPQ
ISFPAIQAAPSFSNSFPQ

ISFPAIQAAPSFSNSFPQIF

ISFPAIQAAPSFSNSFPQRR

RS3_HUMAN P23396 RPS3

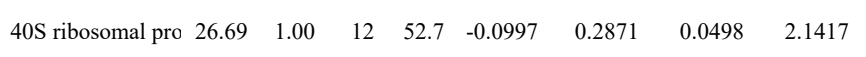

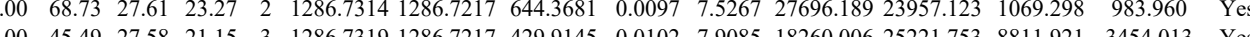

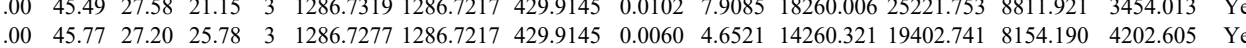
$\begin{array}{lllllllllllllll}1.00 & 45.77 & 27.20 & 25.78 & 3 & 1286.7277 & 1286.7217 & 429.9145 & 0.0060 & 4.6521 & 14260.321 & 19402.741 & 8154.190 & 4202.605 & \text { Yes } \\ 1.00 & 58.34 & 27.20 & 23.55 & 3 & 1286.7277 & 1286.7217 & 429.9145 & 0.0060 & 4.6521 & 14742.640 & 18037.610 & 6300.051 & 2857.464 & \text { Yes }\end{array}$ \begin{tabular}{lllllllllllllll}
1.00 & 71.75 & 27.16 & 23.33 & 2 & 1286.7278 & 1286.7217 & 644.3681 & 0.0061 & 4.7333 & 16782.144 & 15156.165 & 939.579 & 583.797 & Yes \\
\hline
\end{tabular} $\begin{array}{llllllllllllllll}.00 & 53.48 & 27.47 & 21.32 & 3 & 1286.7265 & 1286.7217 & 429.9145 & 0.0048 & 3.7217 & 14560.573 & 14989.723 & 3489.407 & 1088.790 & \text { Yes }\end{array}$ $\begin{array}{lllllllllllllll}1.00 & 37.15 & 27.36 & 25.34 & 3 & 1286.7244 & 1286.7217 & 429.9145 & 0.0027 & 2.0934 & 4349.774 & 4223.025 & 1110.894 & 698.137 & \text { Yes }\end{array}$ $\begin{array}{lllllllllllllll}1.00 & 40.47 & 27.42 & 25.17 & 3 & 1286.7250 & 1286.7217 & 429.9145 & 0.0033 & 2.5586 & 1608.983 & 1957.594 & 971.585 & 560.808 & \text { Yes } \\ 1.00 & 52.37 & 27.17 & 33.43 & 2 & 1703.8368 & 1703.8214 & 852.9180 & 0.0154 & 9.0278 & 2887.155 & 2131.724 & 635.132 & 74.04 & \text { Yes }\end{array}$ $\begin{array}{lllllllllllllll}1.00 & 52.37 & 27.17 & 33.43 & 2 & 1703.8368 & 1703.8214 & 852.9180 & 0.0154 & 9.0278 & 2887.155 & 2131.724 & 635.132 & 74.404 & \text { Yes } \\ 1.00 & 51.21 & 27.10 & 31.72 & 2 & 1703.8378 & 1703.8214 & 8529180 & 0.0164 & 9.6140 & 2117.110 & 1817.740 & 587.328 & 85.636 & \text { Yes }\end{array}$

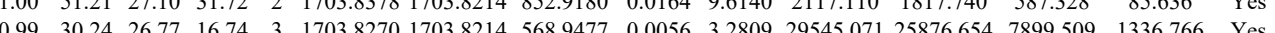
$\begin{array}{llllllllllllll}1.00 & 51.21 & 27.10 & 31.72 & 2 & 1703.8378 & 1703.8214 & 852.9180 & 0.0164 & 9.6140 & 2117.110 & 1817.740 & 587.328 & 85.636\end{array}$

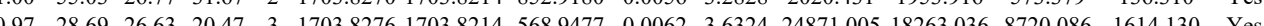

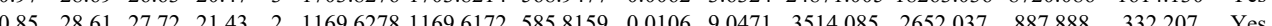
$\begin{array}{llllllllllllllll}0.91 & 32.60 & 27.63 & 25.79 & 2 & 1183.6212 & 1183.6117 & 592.8131 & 0.0095 & 8.0126 & 2572.461 & 4568.383 & 5813.869 & 5823.301 & \text { Yes }\end{array}$

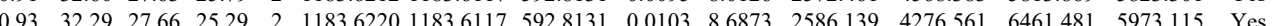
$\begin{array}{llllllllllllllll}0.99 & 46.51 & 28.13 & 36.58 & 2 & 1174.6570 & 1174.6502 & 588.3324 & 0.0068 & 5.7790 & 16908.988 & 32783.882 & 981.883 & 1270.089 & \text { Yes }\end{array}$ $\begin{array}{lllllllllllllllll}1.00 & 48.23 & 27.95 & 32.73 & 2 & 1174.6588 & 1174.6502 & 588.3324 & 0.0086 & 7.3087 & 13525.729 & 24666.168 & 887.430 & 1056.258 & \text { Yes } \\ 0.99 & 44.91 & 27.95 & 29.37 & 2 & 1174.656 & 1174.652 & 588.3324 & 0.0084 & 7.1388 & 289.553 & 47276.100 & 11.518 & 161.929 & \text { Yes }\end{array}$ $\begin{array}{llllllllllllllll}0.99 & 44.91 & 27.95 & 29.37 & 2 & 1174.6586 & 1174.6502 & 588.3324 & 0.0084 & 7.1388 & 9289.553 & 17276.100 & 1151.518 & 761.929 & \text { Yes } \\ 1\end{array}$ $\begin{array}{lllllllllllllll}1.00 & 49.72 & 27.95 & 32.74 & 2 & 1174.6590 & 1174.6502 & 588.3324 & 0.0088 & 7.4787 & 7823.722 & 14658.677 & 705.235 & 628.771 & \text { Yes }\end{array}$ $\begin{array}{llllllllllllllll}1.00 & 84.81 & 27.60 & 29.23 & 2 & 1651.9036 & 1651.9025 & 826.9585 & 0.0011 & 0.6651 & 941.870 & 2148.494 & 668.717 & 48.237 & \text { Yes } \\ 0.98 & 26.37 & 27.33 & 17.91 & 3 & 1651.9057 & 1651.9025 & 551.644 & 0.003 & 1.9336 & 234.85 & 284.042 & 157.578 & 68.72 & \text { Yes }\end{array}$ $\begin{array}{lllllllllllllll}0.98 & 26.37 & 27.33 & 17.91 & 3 & 1651.9057 & 1651.9025 & 551.6414 & 0.0032 & 1.9336 & 234.855 & 284.042 & 157.578 & 68.721 & \text { Yes }\end{array}$ $\begin{array}{lllllllllllllllll}0.66 & 14.06 & 27.28 & 16.09 & 3 & 1651.9060 & 1651.9025 & 551.6414 & 0.0035 & 2.1149 & 398.048 & 466.791 & 99.604 & 46.207 & \text { Yes }\end{array}$ $\begin{array}{lllllllllllllll}1.00 & 87.99 & 27.33 & 26.00 & 2 & 1651.9056 & 1651.9025 & 826.9585 & 0.0031 & 1.8743 & 373.827 & 549.465 & 333.318 & 56.778 & \text { Yes }\end{array}$ $\begin{array}{lllllllllllllll}1.00 & 46.91 & 21.96 & 20.65 & 2 & 1167.7262 & 1167.7260 & 584.8703 & 0.0002 & 0.1710 & 12806.260 & 27355.624 & 0.000 & 193.871 & \text { No }\end{array}$ $\begin{array}{lllllllllllllll}1.00 & 37.27 & 21.96 & 23.05 & 2 & 1167.7262 & 1167.7260 & 584.8703 & 0.0002 & 0.1710 & 22600.994 & 42963.409 & 0.000 & 470.871 & \text { No }\end{array}$ $\begin{array}{lllllllllllllll}0.96 & 37.32 & 22.79 & 19.27 & 2 & 1167.7244 & 1167.7260 & 584.8703 & -0.0016 & -1.3678 & 1689.185 & 3502.782 & 0.000 & 21.442 & \mathrm{~N} o\end{array}$

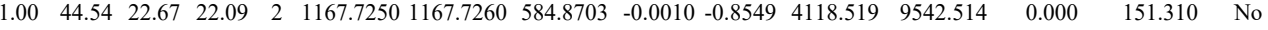
$\begin{array}{llllllllllllllll}0.93 & 32.59 & 27.66 & 28.34 & 2 & 1183.6224 & 1183.6117 & 592.8131 & 0.0107 & 9.0247 & 5342.587 & 9382.165 & 12426.779 & 12995.361 & \text { Yes }\end{array}$ $\begin{array}{lllllllllllllllll}0.96 & 35.61 & 27.64 & 33.36 & 2 & 1183.6234 & 1183.6117 & 592.8131 & 0.0117 & 9.8681 & 5285.466 & 11401.902 & 15571.230 & 15352.871 & \text { Yes }\end{array}$

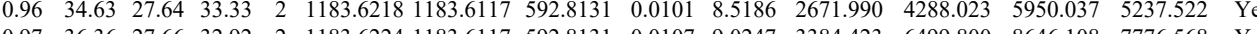

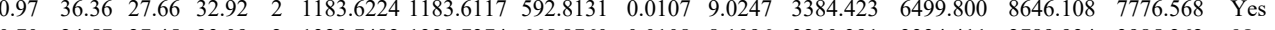

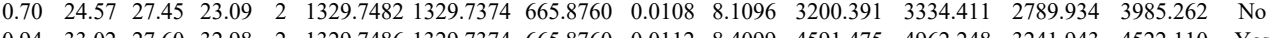

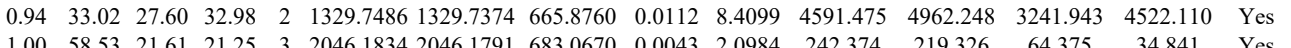

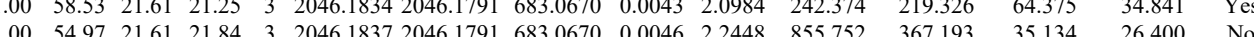

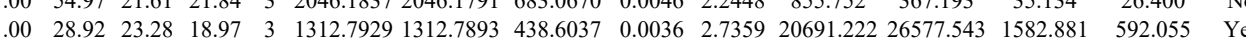

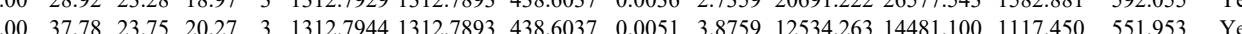
$\begin{array}{lllllllllllllllll} & \end{array}$ $\begin{array}{llllllllllllll} & \end{array}$ $\begin{array}{lllllllllllllllll} & 27.53 & 23.28 & 15.41 & 3 & 1312.7229 & 13127893 & 438.6037 & 0.0036 & 27359 & 7140.873 & 8090.545 & 1624861 & 1172.928 & \text { Yes }\end{array}$ $\begin{array}{lllllllllllllll}1 & 7.35 & 27.28 & 20.69 & 2 & 16928106 & 1692.8095 & 847.4120 & 0.0011 & 0.6490 & 621.027 & 832.988 & 351.301 & 182.550 & \text { Yes }\end{array}$

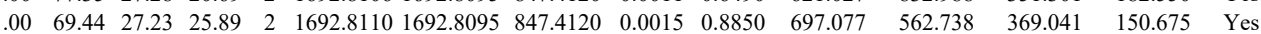
$\begin{array}{lllllllllllllll}1.00 & 72.45 & 27.27 & 23.88 & 2 & 1692.8108 & 1692.8095 & 847.4120 & 0.0013 & 0.7670 & 791.480 & 711.553 & 325.300 & 118.105 & \text { Yes }\end{array}$ $\begin{array}{llllllllllllllll}00 & 68.80 & 27.48 & 21.97 & 2 & 1692.8128 & 1692.8095 & 847.4120 & 0.0033 & 1.9471 & 991.955 & 854.607 & 497.906 & 220.895 & \text { Yes }\end{array}$ $\begin{array}{llllllllllllllll}1.00 & 63.91 & 23.07 & 17.51 & 3 & 1944.1351 & 1944.1278 & 649.0499 & 0.0073 & 3.7491 & 2751.256 & 3055.788 & 456.616 & 111.893 & \text { Yes }\end{array}$ $\begin{array}{lllllllllllllll}1.00 & 36.66 & 26.27 & 20.10 & 3 & 2628.3910 & 2628.3880 & 877.1366 & 0.0030 & 1.1401 & 10.028 & 3.495 & 8.296 & 3.294 & \text { Yes } \\ 1.00 & 52.54 & 26.29 & 9.21 & 3 & 2628395 & 2628.380 & 87.1366 & 0.05 & 0.570 & 20.361 & 39.744 & 8.555 & 1.122 & \text { Yes }\end{array}$ $\begin{array}{lllllllllllllll}1.00 & 52.54 & 26.29 & 19.21 & 3 & 2628.3895 & 2628.3880 & 877.1366 & 0.0015 & 0.5700 & 20.361 & 39.744 & 8.555 & 11.132 & \text { Yes }\end{array}$

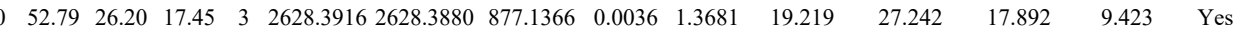
$\begin{array}{lllllllllllllll}0.99 & 40.40 & 29.72 & 25.78 & 2 & 1006.5502 & 1006.5470 & 504.2808 & 0.0032 & 3.1728 & 8264.470 & 10422.762 & 1856.329 & 368.495 & \text { Yes } \\ 0.98 & 40.41 & 29.72 & 25.78 & 2 & 10065508 & 1006.5470 & 504.2808 & 0.0038 & 3.7677 & 10430.682 & 12661.238 & 2329.683 & 493.609 & \text { Yes }\end{array}$ $\begin{array}{lllllllllllllll}0.94 & 35.12 & 29.72 & 26.42 & 2 & 1006.5508 & 1006.5470 & 504.2808 & 0.0038 & 3.7677 & 6997.672 & 8119.841 & 1458.342 & 337.590 & \text { Yes }\end{array}$

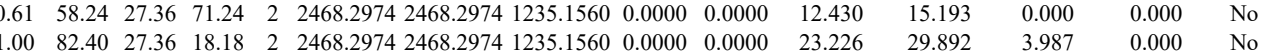

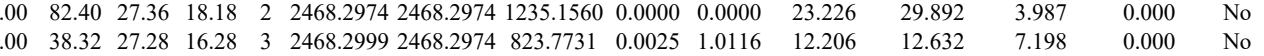

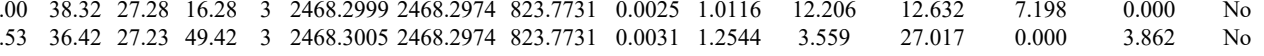

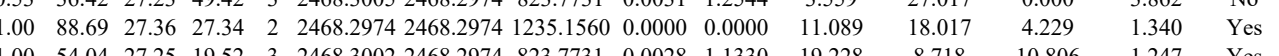

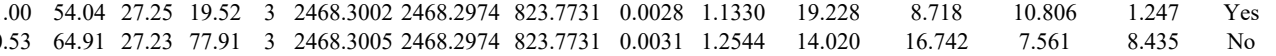
$\begin{array}{rlllllllllllllll}0.99 & 40.60 & 25.67 & 27.73 & 2 & 1174.7244 & 1174.7165 & 588.3655 & 0.0079 & 6.7135 & 14759.288 & 12911.567 & 8116.321 & 2497.531 & \text { Yes }\end{array}$ $\begin{array}{llllllllllllllll}\text { ELTAVVQK } & 0.98 & 39.62 & 25.67 & 26.93 & 2 & 1174.7246 & 1174.7165 & 588.3655 & 0.0081 & 6.8834 & 11727.515 & 8278.346 & 7341.321 & 2197.806 & \text { Yes } \\ \text { FGFPEGSVELYAEK } & 1.00 & 35.72 & 28.16 & 18.05 & 3 & 1859.9581 & 1859.9549 & 620.9922 & 0.0032 & 1.7177 & 152.661 & 142.860 & 130.704 & 73.507 & \text { Yes }\end{array}$

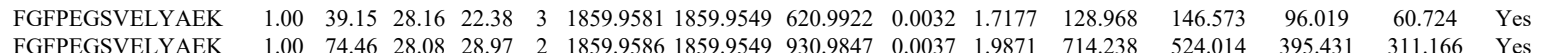
$\begin{array}{llllllllllllllll}\text { FGFPEGSVELYAEK } & 1.00 & 74.46 & 28.08 & 28.97 & 2 & 1859.9586 & 1859.9549 & 930.9847 & 0.0037 & 1.9871 & 714.238 & 524.014 & 395.431 & 311.166 & \text { Yes } \\ \text { FGFPEGSVELYAEK } & 1.00 & 75.59 & 28.10 & 23.68 & 2 & 1859.9596 & 1859.9549 & 930.9847 & 0.0047 & 2.5242 & 491.321 & 488.065 & 425.043 & 206.642 & \text { Yes }\end{array}$

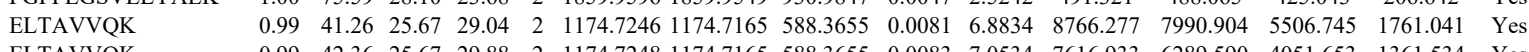
ELTAVVQK 
$\begin{array}{lllllllllllllll}1.00 & 52.24 & 27.90 & 32.38 & 2 & 1210.6400 & 1210.6294 & 606.3220 & 0.0106 & 8.7412 & 12921.132 & 11965.020 & 7453.304 & 4035.320 & \text { Yes }\end{array}$ $\begin{array}{lllllllllllllllll} & \end{array}$ $\begin{array}{lllllllllllllllll} & \end{array}$ $\begin{array}{llllllllllllll} & \end{array}$

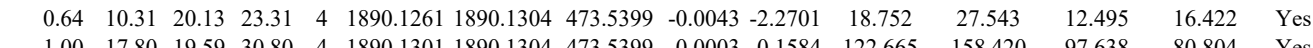

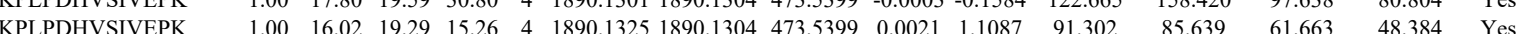
$\begin{array}{lllllllllllllllll}\text { KPLPDHVSIVEPK } & 1.00 & 19.54 & 19.49 & 17.05 & 4 & 1890.1353 & 1890.1304 & 473.5399 & 0.0049 & 25869 & 65.780 & 62.967 & 39.297 & 36292 & \text { Yes }\end{array}$ $\begin{array}{llllllllllllllll}\text { KPLPDHVSIVEPK } & 1.00 & 46.21 & 19.19 & 20.05 & 2 & 1890.1444 & 1890.1304 & 946.0725 & 0.0140 & 7.3890 & 1837.372 & 1874.520 & 1420.632 & 1276663 & \text { Yes }\end{array}$

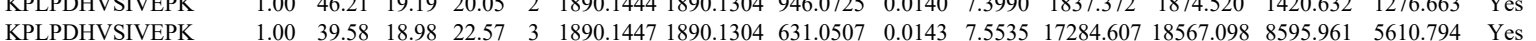

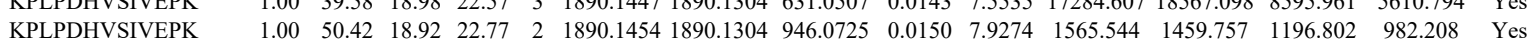
$\begin{array}{llllllllllllllll}\text { KPLPDHVSIVEPK } & 1.00 & 30.34 & 18.92 & 18.32 & 4 & 1890.1461 & 1890.1304 & 473.5399 & 0.0157 & 8.2886 & 10299.532 & 10348.044 & 8220.495 & 8633.059 & \text { Yes }\end{array}$ $\begin{array}{lllllllllllllllll}\text { KPLPDHVSIVEPK } & 1.00 & 32.16 & 18.86 & 21.81 & 4 & 1890.1469 & 1890.1304 & 473.5399 & 0.0165 & 8.7109 & 9241.237 & 9613.513 & 7528.475 & 7081.304 & \text { Yes }\end{array}$ $\begin{array}{lllllllllllllll}1.00 & 69.18 & 28.04 & 34.86 & 2 & 1210.6368 & 1210.6294 & 606.3220 & 0.0074 & 6.1023 & 5991.878 & 5859.739 & 4066.089 & 1918.889 & \text { Yes }\end{array}$

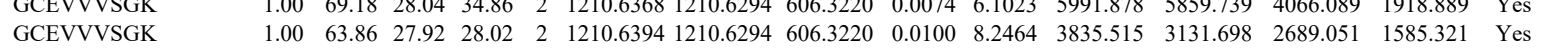

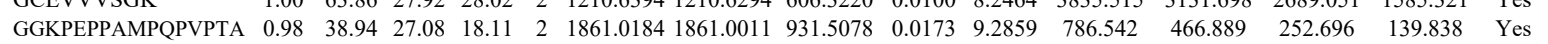
$\begin{array}{llllllllllllllllll}\text { GGKPEPPAMPQPVPTA } & 0.85 & 32.73 & 27.06 & 16.29 & 2 & 1861.0188 & 1861.0011 & 931.5078 & 0.0177 & 9.5006 & 274.748 & 379.173 & 140.046 & 120.407 & \text { Yes }\end{array}$

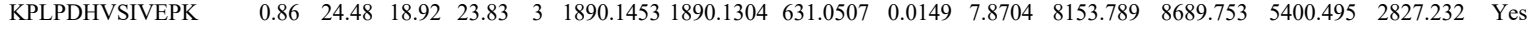
$\begin{array}{lllllllllllllllll}\text { KPLPDHVSIVEPK } & 0.98 & 32.43 & 18.92 & 23.15 & 3 & 1890.1462 & 1890.1304 & 631.0507 & 0.0158 & 8.3458 & 11805.960 & 11432.220 & 8422.949 & 4456.039 & \text { Yes }\end{array}$ $\begin{array}{llllllllllllllll}\text { KPLPDHVSIVEPK } & 1.00 & 29.06 & 18.86 & 15.05 & 4 & 1890.1465 & 1890.1304 & 473.5399 & 0.0161 & 8.4997 & 5260.295 & 6577.430 & 4650.893 & 4872.503 & \text { Yes }\end{array}$ $\begin{array}{lllllllllllllllll}\text { KPLPDHVSIVEPK } & 1.00 & 25.45 & 18.92 & 15.92 & 4 & 1890.1473 & 1890.1304 & 473.5399 & 0.0169 & 8.9221 & 6838.792 & 6670.345 & 5794.407 & 5183.664 & \text { Yes }\end{array}$ $\begin{array}{lllllllllllllllll}\text { GGKPEPPAMPQPVPTA } & 0.93 & 33.09 & 27.02 & 17.23 & 2 & 1861.0174 & 1861.0011 & 931.5078 & 0.0163 & 8.7492 & 196.960 & 207.194 & 89.024 & 138.791 & \text { Yes }\end{array}$

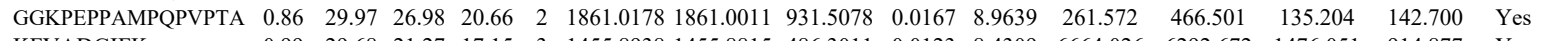

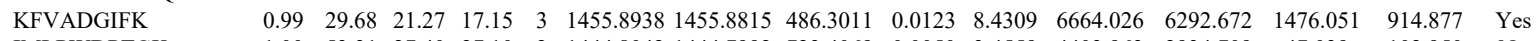
IMLPWDPTGK IMLPWDPTGK GLCAIAQAESLR IMLPWDPTGK IMLPWDPTGK GLCAIAQAESLR
DEILPTTPISEQK DEILPTTISEQK $\begin{array}{lllllllllllllll}0.90 & 33.32 & 27.36 & 17.37 & 2 & 1444.8064 & 1444.7992 & 723.4069 & 0.0072 & 4.9764 & 453.132 & 375.300 & 144.484 & 1.232 & \text { Yes } \\ 0.98 & 4.38 & 27.36 & 21.59 & 2 & 1444.8064 & 1444.7992 & 723.4069 & 0.0072 & 4.9764 & 288.460 & 204.320 & 57.382 & 26.214 & \text { Yes }\end{array}$ $\begin{array}{lllllllllllllll}0.98 & 42.38 & 27.36 & 21.59 & 2 & 1444.8064 & 1444.7992 & 723.4069 & 0.0072 & 4.9764 & 288.460 & 204.320 & 57.382 & 26.214 & \text { Yes } \\ 1.00 & 74.79 & 28.46 & 21.13 & 2 & 1420.7322 & 1420.7288 & 711.3717 & 0.0034 & 2.3897 & 1312.848 & 1861.142 & 804.959 & 279.553 & \text { Yes }\end{array}$

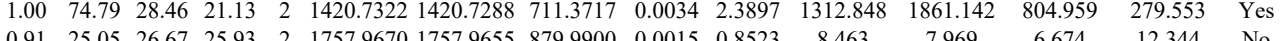
$\begin{array}{lllllllllllllll}0.87 & 31.18 & 26.45 & 24.80 & 2 & 970.4910 & 970.4850 & 486.2498 & 0.0060 & 6.1696 & 49377.265 & 46420.449 & 2131.512 & 995.728 & \text { Y }\end{array}$

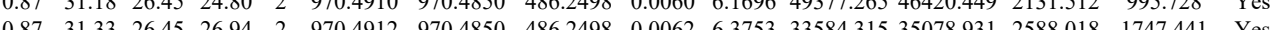

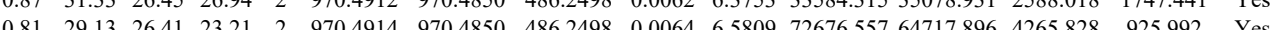
$\begin{array}{lllllllllllllllll}0.93 & 34.34 & 26.28 & 23.98 & 2 & 970.4918 & 970.4850 & 4862498 & 0.0068 & 6.9922 & 7592407067538.256 & 4088.440 & 716.238 & \text { Yes }\end{array}$ $\begin{array}{llllllllllllllllll}0.61 & 23.42 & 26.62 & 31.03 & 2 & 970.4938 & 970.4850 & 486.2498 & 0.0088 & 9.0488 & 16710.222 & 16137.314 & 693.247 & 248.886 & \text { Yes }\end{array}$ $\begin{array}{llllllllllllllllll}0.94 & 35.24 & 26.45 & 25.75 & 2 & 970.4912 & 970.4850 & 486.2498 & 0.0062 & 6.04753 & 33974.312 & 32015732 & 1818.664 & 628.335 & \text { Yes }\end{array}$ $\begin{array}{llllllllllllllll}0.88 & 31.54 & 26.48 & 24.52 & 2 & 970.4920 & 970.4850 & 4862498 & 0.0070 & 7.1979 & 25921.211 & 26722.735 & 829.674 & 480.793 & \text { Yes }\end{array}$ $\begin{array}{llllllllllllllll}0.60 & 24.75 & 26.47 & 31.45 & 2 & 970.4924 & 970.4850 & 486.2498 & 0.0074 & 7.6092 & 7349.257 & 6374.202 & 502.827 & 173.983 & \text { Yes }\end{array}$ $\begin{array}{lllllllllllllllll}0.70 & 25.37 & 26.67 & 31.55 & 2 & 970.4936 & 970.4850 & 486.2498 & 0.0086 & 8.8431 & 6595.662 & 5858.493 & 249.643 & 181.046 & \text { Yes }\end{array}$ $\begin{array}{lllllllllllllll}0.71 & 10.24 & 17.71 & 16.24 & 2 & 941.6150 & 941.6144 & 471.8145 & 0.0006 & 0.6358 & 49.324 & 29.822 & 0.775 & 1.986 & \text { No }\end{array}$ $\begin{array}{llllllllllllllll}0.88 & 14.54 & 17.48 & 19.65 & 2 & 941.6158 & 941.6144 & 471.8145 & 0.0014 & 1.4836 & 43.283 & 47.376 & 12.894 & 4.915 & \text { Yes }\end{array}$ $\begin{array}{lllllllllllllllll}0.99 & 28.66 & 19.96 & 27.76 & 2 & 941.6164 & 941.6144 & 471.8145 & 0.0020 & 2.1195 & 5484.833 & 4544.027 & 1123.139 & 617.585 & \text { Yes }\end{array}$ $\begin{array}{lllllllllllllll}0.99 & 27.55 & 17.56 & 26.95 & 2 & 941.6156 & 941.6144 & 471.8145 & 0.0012 & 1.2717 & 60.859 & 49.293 & 1.304 & 0.000 & \text { No }\end{array}$ $\begin{array}{llllllllllllllll}1.00 & 35.73 & 17.56 & 28.60 & 2 & 941.6156 & 941.6144 & 471.8145 & 0.0012 & 1.2717 & 52.348 & 48.529 & 0.000 & 6.669 & \text { No }\end{array}$ $\begin{array}{llllllllllllllll}0.61 & 8.14 & 17.48 & 21.14 & 2 & 941.6158 & 941.6144 & 471.8145 & 0.0014 & 1.4836 & 24.016 & 38.211 & 5.704 & 6.037 & \text { Yes }\end{array}$ $\begin{array}{llllllllllllllll}0.97 & 33.16 & 20.53 & 29.09 & 2 & 941.6222 & 941.6144 & 471.8145 & 0.0078 & 8.2659 & 27729.115 & 26918.095 & 1420.110 & 1102.059 & \text { Yes }\end{array}$ $\begin{array}{lllllllllllllll}1.00 & 38.02 & 20.21 & 29.81 & 2 & 941.6172 & 941.6144 & 471.8145 & 0.0028 & 2.9673 & 19595.938 & 15226.618 & 939.015 & 182.234 & \text { Yes }\end{array}$ $\begin{array}{llllllllllllllll}0.99 & 31.01 & 20.21 & 28.47 & 2 & 941.6172 & 941.6144 & 471.8145 & 0.0028 & 2.9673 & 23178.906 & 21763.383 & 1002.835 & 176.341 & \text { Yes }\end{array}$ $\begin{array}{llllllllllllllll}1.00 & 38.15 & 17.71 & 29.87 & 2 & 941.6152 & 941.6144 & 471.8145 & 0.0008 & 0.8478 & 3810.950 & 3436.530 & 209.043 & 112.948 & \text { Yes }\end{array}$ $\begin{array}{llllllllllllllll}0.96 & 20.56 & 17.71 & 18.42 & 2 & 941.6150 & 941.6144 & 471.8145 & 0.0006 & 0.6358 & 310.574 & 267.410 & 9.593 & 20.564 & \text { Yes }\end{array}$ $\begin{array}{llllllllllllllll}0.91 & 16.09 & 17.71 & 17.26 & 2 & 941.6152 & 941.6144 & 471.8145 & 0.0008 & 0.8478 & 286.098 & 272.316 & 17.351 & 18.785 & \text { Yes }\end{array}$

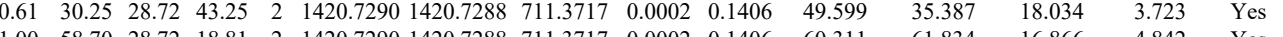

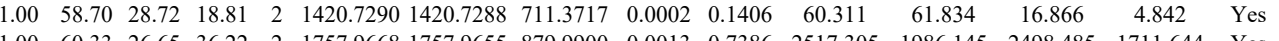
$\begin{array}{llllllllllllllll}1.00 & 60.33 & 26.65 & 36.22 & 2 & 1757.9668 & 1757.9655 & 879.9900 & 0.0013 & 0.7386 & 2517.305 & 1986.145 & 2498.485 & 1711.644 & \text { Yes } \\ 1.00 & 62.78 & 26.49 & 30.76 & 2 & 1757.9684 & 1757.965 & 879.9900 & 0.0029 & 1.6477 & 3562.726 & 3318.021 & 3670.657 & 3453.226 & \text { No }\end{array}$ $\begin{array}{lllllllllllllll}1.00 & 62.78 & 26.49 & 30.76 & 2 & 1757.9684 & 1757.9655 & 879.9900 & 0.0029 & 1.6477 & 3562.726 & 3318.021 & 3670.657 & 3453.226 & \text { No } \\ 1.00 & 33.95 & 26.40 & 22.29 & 3 & 1757.9695 & 1757.9655 & 586.9958 & 0.0040 & 2.2714 & 357.583 & 507.569 & 597.543 & 346.748 & \text { No }\end{array}$

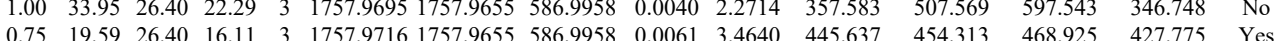

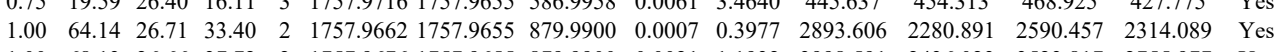

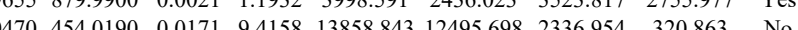




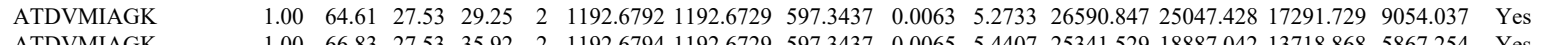

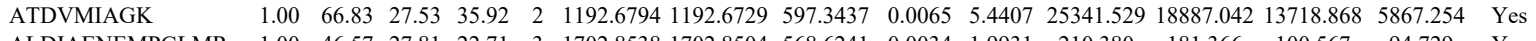

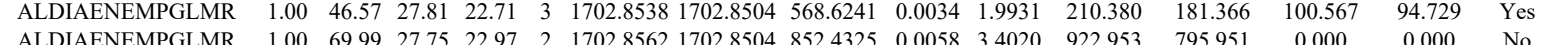

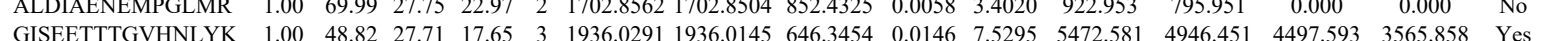

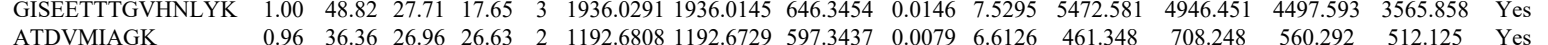

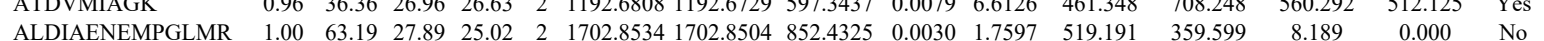

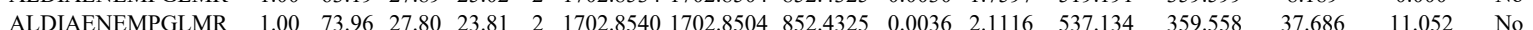

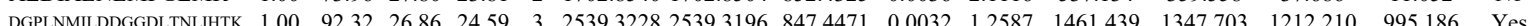
$\begin{array}{llllllllllllllll}\text { DGPLNMLDDGCDLTNLHTK } & 1.00 & 84.6 & 26.79 & 18.92 & 3 & 25393234 & 2539.3196 & 847.4471 & 0.0038 & 1.4947 & 2059.825 & 1292.597 & 1922.945 & 1133.745 & \text { Yes }\end{array}$

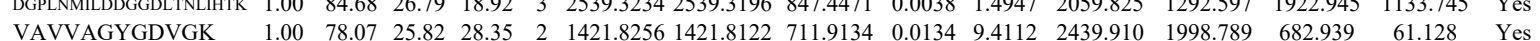

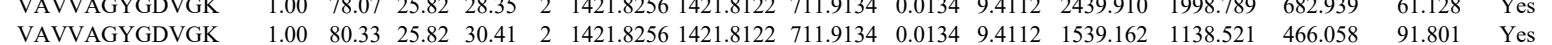

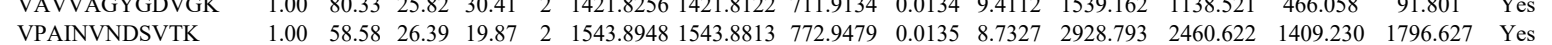
$\begin{array}{llllllllllllllll}\text { VPAINVNDSVTK } & 1.00 & 52.38 & 26.13 & 18.48 & 2 & 1543.8960 & 1543.8813 & 772.9479 & 0.0147 & 9.5090 & 1385.588 & 874.989 & 850.753 & 663.299 & \text { Yes }\end{array}$ $\begin{array}{lllllllllllllllll}\text { DGPLNMILDDGGDLTNLHHTK } & 1.00 & 76.88 & 26.79 & 18.23 & 3 & 2539.3231 & 2539.3196 & 847.4471 & 0.0035 & 1.3767 & 1627.837 & 1214.037 & 1533.063 & 1585.951 & \text { No }\end{array}$

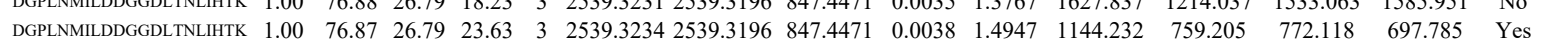

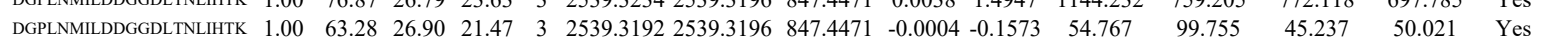
\begin{tabular}{llllllllllllllll} 
DGPLNMILDDGGDLTNLHHTK & 1.00 & 73.09 & 26.79 & 17.64 & 3 & 2539.3234 & 2539.3196 & 847.4471 & 0.0038 & 1.4947 & 662.436 & 594.118 & 678.857 & 465.006 & Yes \\
\hline
\end{tabular} $\begin{array}{lllllllllllllllll}\text { VADIGLAAWGR } & 1.00 & 63.09 & 27.34 & 32.73 & 2 & 1271.7120 & 1271.7108 & 636.8627 & 0.0012 & 0.9421 & 11428.896 & 9030.644 & 394.356 & 248.470 & \text { No }\end{array}$ $\begin{array}{lllllllllllllllll}\text { VADIGLAAWGR } & 1.00 & 73.16 & 27.22 & 32.28 & 2 & 1271.7126 & 1271.7108 & 636.8627 & 0.0018 & 1.4132 & 6645.174 & 5014.033 & 451.077 & 344.591 & \text { No }\end{array}$

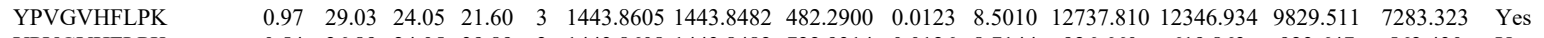
$\begin{array}{llllllllllllllllll}\text { YPVGVHFLPK } & 0.54 & 26.89 & 24.05 & 39.89 & 2 & 1443.8608 & 1443.8482 & 722.9314 & 0.0126 & 8.7144 & 926.660 & 619.863 & 923.647 & 562.430 & \text { Yes }\end{array}$ $\begin{array}{llllllllllllllll}\text { YPVGVHFLPK } & 0.88 & 23.55 & 24.07 & 17.18 & 3 & 1443.8626 & 1443.8482 & 482.2900 & 0.0144 & 9.9524 & 13547.133 & 11856.090 & 11889.071 & 9537.285 & \text { Yes }\end{array}$ YPVGVHFLPK YPVGVHFLPK YPVGVHFLPK YPVGVHFLPK YPVGVHFLPK YPVGVHFLPK YPVGVHFLPK YPVGVHFLPK YPQLLPGIR YPQLLPGIR
YPQLLPGIR YPQLLPGIR YPQLLPGIR YPQLLPGIR YPQLLPGIR
YPQLLPGIR YPQLLPGIR
YPQLLPGIR YPQLLPGIR YPQLLPGIR YPQLLPGIR $\begin{array}{llllllllllllllll}0.98 & 34.44 & 24.33 & 20.66 & 2 & 1443.8588 & 1443.8482 & 722.9314 & 0.0106 & 7.3312 & 751.245 & 582.145 & 728.514 & 480.236 & \text { Yes }\end{array}$ $\begin{array}{lllllllllllllll}0.93 & 26.23 & 24.33 & 19.45 & 3 & 1443.8587 & 1443.8482 & 482.2900 & 0.0105 & 7.2570 & 5286.111 & 4576.097 & 3941.659 & 2636.284 & \text { Yes }\end{array}$

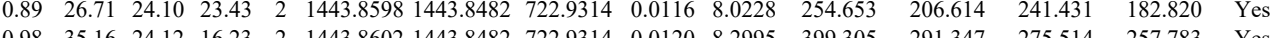
$\begin{array}{lllllllllllllll}0.98 & 35.16 & 24.12 & 16.23 & 2 & 1443.8602 & 1443.8482 & 722.9314 & 0.0120 & 8.2995 & 399.305 & 291.347 & 275.514 & 257.783 & \text { Yes } \\ 0.96 & 27.32 & 24.00 & 19.49 & 3 & 1443.8611 & 1443.8482 & 482.2900 & 0.0129 & 8.9157 & 8300.111 & 7827.310 & 7001.430 & 4714.615 & \text { Yes }\end{array}$ $\begin{array}{lllllllllllllll}0.96 & 27.32 & 24.00 & 19.49 & 3 & 1443.8611 & 1443.8482 & 482.2900 & 0.0129 & 8.9157 & 8300.111 & 7827.310 & 7001.430 & 4714.615 & \text { Yes }\end{array}$

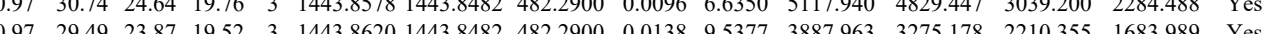
$\begin{array}{lllllllllllllll}100 & 49.51 & 25.83 & 17.88 & 2 & 1199.7162 & 1199.7148 & 600.8647 & 0.0014 & 11650 & 1744.583 & 1763.614 & 1580.495 & 1000.525 & \text { Yes }\end{array}$ $\begin{array}{llllllllllllllllll}1.00 & 49.54 & 25.61 & 17.95 & 2 & 1199.7164 & 1199.7148 & 600.8647 & 0.0016 & 1.3314 & 2688.104 & 2771.527 & 2217.612 & 1594.354 & \text { Yes }\end{array}$ $\begin{array}{lllllllllllllll}0.99 & 35.38 & 25.61 & 17.40 & 2 & 1199.7164 & 1199.7148 & 600.8647 & 0.0016 & 1.3314 & 5150.755 & 4729.832 & 3697.330 & 2850.577 & \text { Yes }\end{array}$ $\begin{array}{lllllllllllllll}0.76 & 20.38 & 25.55 & 33.38 & 2 & 1199.7156 & 1199.7148 & 600.8647 & 0.0008 & 0.6657 & 4706.642 & 5335.029 & 10252.426 & 45269.928 & \text { No }\end{array}$ $\begin{array}{lllllllllllllll}0.99 & 34.27 & 25.63 & 16.54 & 2 & 1199.7158 & 1199.7148 & 600.8647 & 0.0010 & 0.8321 & 141.273 & 149.742 & 107.273 & 55.284 & \text { Yes }\end{array}$

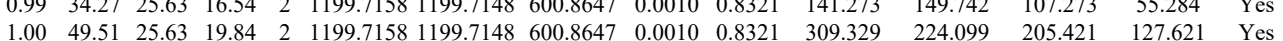

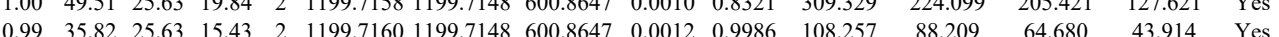
$\begin{array}{lllllllllllllll}1.00 & 40.84 & 25.61 & 17.21 & 2 & 1199.7164 & 1199.7148 & 600.8647 & 0.0016 & 1.3314 & 93.809 & 76.929 & 61.805 & 56.887 & \text { Yes }\end{array}$

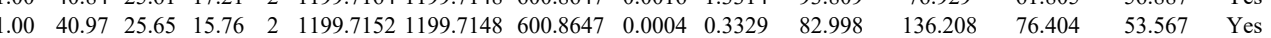

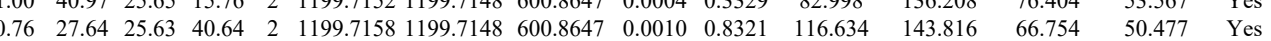

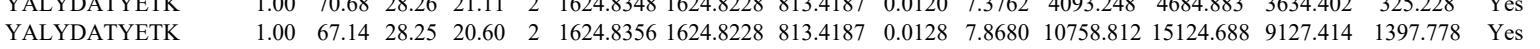
$\begin{array}{lllllllllllllllll}\text { EILVGDVGQTVDDPYATFVK } & 1.00 & 96.01 & 26.62 & 19.65 & 2 & 2453.2934 & 2453.2934 & 1227.6540 & 0.0000 & 0.0000 & 101.431 & 74.448 & 357.632 & 106.205 & \text { Yes }\end{array}$ $\begin{array}{llllllllllllllll}\text { ELVGDVGQTVDDPYATFVK } & 1.00 & 76.62 & 26.63 & 19.80 & 2 & 2453.2954 & 2453.2934 & 1227.6540 & 0.0020 & 0.8146 & 121.224 & 205.771 & 232.509 & 98.866 & \text { Yes }\end{array}$ $\begin{array}{llllllllllllllll}\text { EILVGDVGQTVDDPYATFVK } & 1.00 & 41.02 & 26.62 & 18.41 & 3 & 2453.2960 & 2453.2934 & 818.7717 & 0.0026 & 1.0585 & 132.138 & 98.928 & 75.932 & 90.543 & \text { Yes }\end{array}$ $\begin{array}{llllllllllllllll}\text { EILVGDVGQTVDDPYATFVK } & 1.00 & 69.98 & 26.56 & 20.02 & 3 & 2453.2966 & 2453.2934 & 818.7717 & 0.0032 & 1.3028 & 192.877 & 173.737 & 294.350 & 186.425 & \text { Yes }\end{array}$

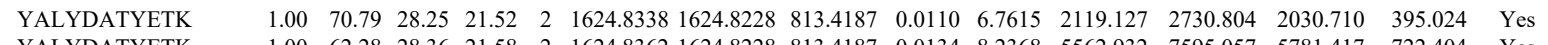
$\begin{array}{llllllllllllllll}\text { YALYDATYETK } & 1.00 & 62.28 & 28.36 & 21.58 & 2 & 1624.8362 & 1624.8228 & 813.4187 & 0.0134 & 8.2368 & 5562.932 & 7595.057 & 5781.417 & 722.404 & \text { Yes }\end{array}$ $\begin{array}{llllllllllllllll}\text { EILVGDVGQTVDDPYATFVK } & 1.00 & 39.87 & 26.65 & 17.47 & 3 & 2453.2933 & 2453.2934 & 818.7717 & -0.0001 & -0.0407 & 105.906 & 228.101 & 48.414 & 54.326 & \text { Yes }\end{array}$ $\begin{array}{llllllllllllllll}\text { EILVGDVGQTVDDPYATFVK } & 1.00 & 84.38 & 26.63 & 18.54 & 2 & 2453.2954 & 2453.2934 & 1227.6540 & 0.0020 & 0.8146 & 140.781 & 49.852 & 219.387 & 49.462 & \text { Yes }\end{array}$

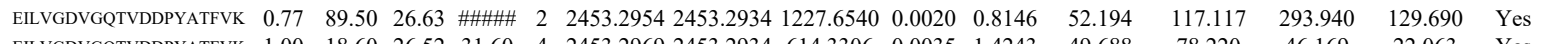

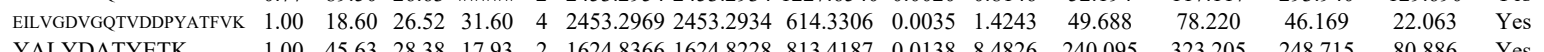
$\begin{array}{llllllllllllllll}\text { YALYDATYETK } & 1.00 & 45.63 & 28.38 & 17.93 & 2 & 1624.8366 & 1624.8228 & 813.4187 & 0.0138 & 8.4826 & 240.095 & 323.205 & 248.715 & 80.886 & \text { Yes } \\ \text { YALYDATYETK } & 1.00 & 60.64 & 28.33 & 70.82 & 2 & 1624.8386 & 1624.8228 & 813.4187 & 0.0158 & 9.7120 & 608.030 & 956.332 & 575.864 & 69.140 & \text { Yes }\end{array}$ $\begin{array}{lllllllllllllllll}\text { YALYDATYETK } & 1.00 & 60.64 & 28.33 & 20.82 & 2 & 1624.8386 & 1624.8228 & 813.4187 & 0.0158 & 9.7120 & 608.030 & 956.332 & 575.864 & 69.140 & \text { Yes }\end{array}$

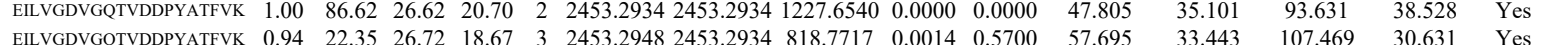

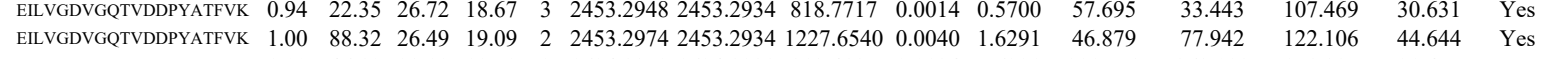
$\begin{array}{lccccccccccccccc}\text { YALYDATYETK } & 1.00 & 46.19 & 28.19 & 19.59 & 2 & 1624.8352 & 1624.8228 & 813.4187 & 0.0124 & 7.6221 & 229.553 & 363.022 & 151.897 & 21.455 & \text { Yes } \\ \text { EILVGDVGQTVDDPYATFVK } & 1.00 & 80.99 & 26.62 & 20.11 & 2 & 2453.2934 & 2453.2934 & 1227.6540 & 0.0000 & 0.0000 & 13.080 & 11.217 & 42.920 & 14.305 & \text { Yes }\end{array}$

Table S-3 page 188 of 499 

$\begin{array}{lllllllllllllll} & \end{array}$ $\begin{array}{llllllllllllllll} & \end{array}$

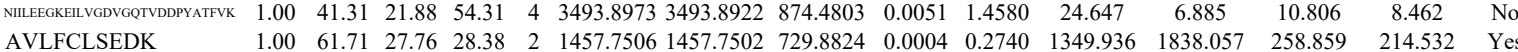
$\begin{array}{lllllllllllllll} & \end{array}$

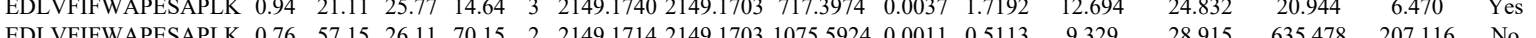
$\begin{array}{lllllllllllllll} & \end{array}$

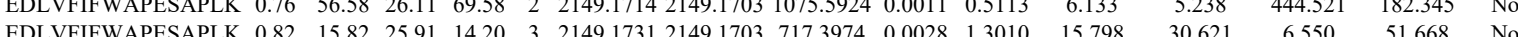
$\begin{array}{llllllllllllllll} & 6.62 .612 & 156.597 & \text { No }\end{array}$

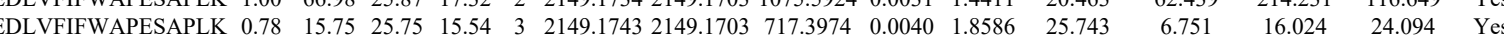

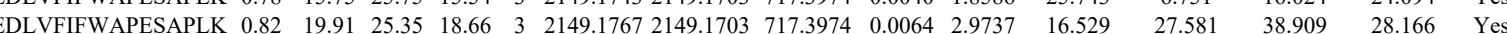
$\begin{array}{llllllllllllllll}0.98 & 25.57 & 21.17 & 22.67 & 3 & 1627.9804 & 1627.9752 & 543.6657 & 0.0052 & 3.1882 & 39.811 & 43.855 & 32.992 & 10.024 & \text { Yes }\end{array}$ $\begin{array}{llllllllllllll} & \end{array}$

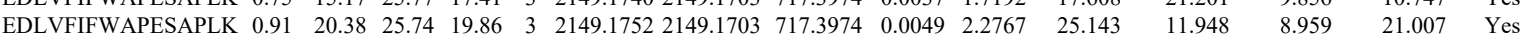
$\begin{array}{lllllllllllllllll}\text { KEDLVFIFWAPESAPLK } & 1.00 & 70.15 & 22.20 & 18.86 & 2 & 2421.3674 & 2421.3673 & 1211.6909 & 0.0001 & 0.0413 & 22.228 & 84.842 & 50.459 & 11.446 & \text { Yes }\end{array}$ $\begin{array}{lllllllllllllllll}\text { KEDLVFIFWAPESAPLK } & 1.00 & 46.49 & 22.04 & 17.00 & 3 & 2421.3697 & 2421.3673 & 808.1297 & 0.0024 & 0.9899 & 603.010 & 875.655 & 253.301 & 6.894 & \text { Yes }\end{array}$ $\begin{array}{lllllllllllllllll}\text { KEDLVFIFWAPESAPLK } & 1.00 & 39.03 & 22.04 & 19.37 & 4 & 2421.3697 & 2421.3673 & 606.3491 & 0.0024 & 0.9895 & 191.234 & 285.870 & 110.481 & 20.788 & \text { Yes }\end{array}$ $\begin{array}{lllllllllllllllll}\text { KEDLVFIFWAPESAPLK } & 1.00 & 40.82 & 22.17 & 23.42 & 4 & 2421.3709 & 2421.3673 & 606.3491 & 0.0036 & 1.4843 & 220.828 & 220.159 & 101.445 & 3.964 & \text { Yes }\end{array}$ $\begin{array}{lllllllllllllllll}\text { KEDLVFIFWAPESAPLK } & 1.00 & 65.24 & 22.20 & 26.60 & 2 & 2421.3654 & 2421.3673 & 1211.6909 & -0.0019 & -0.7840 & 60.893 & 87.032 & 41.883 & 6.693 & \text { Yes }\end{array}$ $\begin{array}{llllllllllllllll}\text { KEDLVFIFWAPESAPLK } & 1.00 & 37.14 & 22.15 & 22.44 & 4 & 2421.3701 & 2421.3673 & 606.3491 & 0.0028 & 1.1544 & 145.431 & 98.341 & 120.436 & 3.721 & \text { Yes }\end{array}$ $\begin{array}{llllllllllllllll}\text { KEDLVFIFWAPESAPLK } & 1.00 & 37.94 & 22.20 & 21.78 & 3 & 2421.3706 & 2421.3673 & 808.1297 & 0.0033 & 1.3612 & 1256.270 & 1254.529 & 676.412 & 187.873 & \text { Yes } \\ \text { KEDLVIFWAPESAPLK } & 1.00 & 36.39 & 22.20 & 21.64 & 3 & 2421.3712 & 2421.3673 & 808.1297 & 0.0039 & 1.6087 & 1164.679 & 1656.833 & 774.176 & 63.198 & \text { Yes }\end{array}$ $\begin{array}{llllllllllllllll}-1.00 & 36.18 & 22.23 & 26.64 & 4 & 2421.37132421 .3673 & 606.3491 & 0.0040 & 1.6492 & 176.802 & 159.226 & 202.085 & 36.413 & \text { Yes }\end{array}$ $\begin{array}{llllllllllllllll}\text { SSTPEEVK } & 0.97 & 35.12 & 28.56 & 26.47 & 2 & 1163.6278 & 1163.6277 & 582.8211 & 0.0001 & 0.0858 & 606.164 & 851.676 & 1188.661 & 1195.497 & \text { Yes }\end{array}$

SSTPEEVK

SSTPEEVKK

NIILEEGK

NIILEEGK

NIILEEGK

NIILEEGK

NILEEGK

$\begin{array}{llllllllllllll} & & & \end{array}$ $\begin{array}{lllllllllllllll}0.99 & 38.50 & 28.27 & 28.78 & 2 & 1163.6288 & 1163.6277 & 582.8211 & 0.0011 & 0.9437 & 510.228 & 677.032 & 1033.868 & 974.673 & \text { Yes }\end{array}$ $\begin{array}{lllllllllllllll}0.99 & 30.62 & 26.39 & 18.98 & 3 & 1435.8253 & 1435.8248 & 479.6155 & 0.0005 & 0.3475 & 674.728 & 845.396 & 1631.337 & 1357.996 & \text { Yes }\end{array}$ $\begin{array}{lllllllllllllll}0.53 & 27.53 & 27.04 & 31.24 & 2 & 1202.7090 & 1202.7114 & 602.3630 & -0.0024 & -1.9922 & 196.107 & 188.307 & 140.593 & 105.721 & \text { Yes }\end{array}$ $\begin{array}{lllllllllllllll}0.87 & 27.87 & 28.10 & 31.67 & 2 & 1202.7110 & 1202.7114 & 602.3630 & -0.0004 & -0.3320 & 265.598 & 285.079 & 161.032 & 82.576 & \text { Yes }\end{array}$ $\begin{array}{lllllllllllllll}0.96 & 29.56 & 27.44 & 33.06 & 2 & 1202.7126 & 1202.7114 & 602.3630 & 0.0012 & 0.9961 & 216.773 & 189.974 & 148.476 & 104.364 & \text { Yes }\end{array}$ $\begin{array}{lllllllllllllll}0.91 & 31.21 & 27.33 & 26.99 & 2 & 1202.7154 & 1202.7114 & 602.3630 & 0.0040 & 3.3202 & 7013.873 & 6593.745 & 3512.879 & 2113.723 & \text { Yes }\end{array}$ \begin{tabular}{lllllllllllllll}
0.69 & 27.81 & 27.27 & 34.36 & 2 & 1202.7162 & 1202.7114 & 602.3630 & 0.0048 & 3.9843 & 180.229 & 232.907 & 155.167 & 97.458 & Yes \\
\hline .82 & 31.51 & 27.27 & 34.95 & 2 & 1202.7164 & 1202.7114 & 602.3630 & 0.0050 & 4.1503 & 256.132 & 328.297 & 173.384 & 128.695 & Yes
\end{tabular}

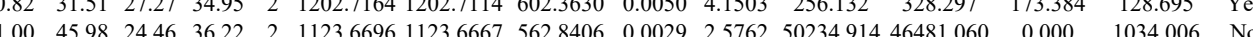
$\begin{array}{llllllllllllllll}1.00 & 45.98 & 24.46 & 36.22 & 2 & 1123.6696 & 1123.6667 & 562.8406 & 0.0029 & 2.5762 & 50234.914 & 46481.060 & 0.000 & 1034.006 & \text { No } \\ 1.00 & 45.80 & 24.46 & 36.06 & 2 & 1123.6700 & 1123.6667 & 5628406 & 0.0033 & 2.9315 & 30574.490 & 30308.221 & 441.030 & 1421.230 & \text { Yes }\end{array}$

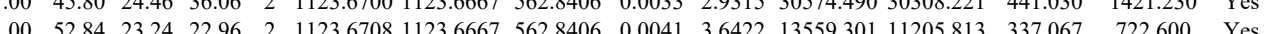
VMPAPPPK GLNISAVR

GLNISAVR

SILPTAPR

GLNISAVR

GLNISAVR

SILPTAPR

SILPTAPR

SILPTAPR

SILPTAPR

SILPTAPR

LNLKPR

LNLKPR

LNLKPR

LNLKPR

EDDSSASTSQSTR

KPEENPASK

KPEENPASK

VAPAQPSEEGPGR

VAPAQPSEEGPGR

$\begin{array}{lllllllllll}\text { RIR1_HUMAN } & \text { P23921 } & \text { RRM1 } & \text { Ribonucleoside-di } 90.07 & 1.00 & 3 & 4.7 & -0.1301 & 0.1754 & -0.5488 & 1.6552\end{array}$

TRPAANPIQFTLNK

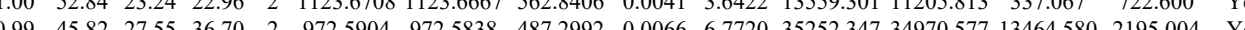

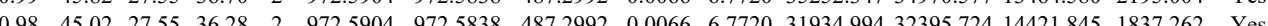

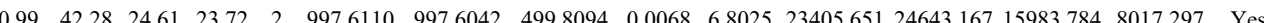
$\begin{array}{llllllllllllllllll}0.92 & 31.52 & 24.6 & 22.98 & 2 & 997.6112 & 997.6042 & 499.8094 & 0.0070 & 7.0026 & 28293.880 & 27885.664 & 17474.359 & 7623.106 & \text { Yes }\end{array}$ $\begin{array}{llllllllllllllll}0.82 & 30.76 & 27.57 & 28.66 & 2 & 972.5896 & 972.5838 & 487.2992 & 0.0058 & 5.9511 & 21577.834 & 23717.006 & 8178.666 & 2042883 & \text { Yes }\end{array}$ $\begin{array}{lllllllllllllll}0.93 & 35.58 & 27.54 & 29.88 & 2 & 972.5900 & 972.5838 & 487.2992 & 0.0062 & 63616 & 21707.079 & 21917.832 & 7523.121 & 1853.508 & \text { Yes }\end{array}$ $\begin{array}{lllllllllllllll}0.99 & 39.89 & 24.58 & 24.24 & 2 & 997.6100 & 997.6042 & 499.8094 & 0.0058 & 5.8022 & 22577.470 & 26148705 & 14327.072 & 6345.656 & \text { Yes }\end{array}$ $\begin{array}{lllllllllllllllll}0.96 & 35.68 & 24.58 & 23.83 & 2 & 997.6100 & 997.6042 & 499.8094 & 0.0058 & 5.8022 & 11308.846 & 10348.325 & 9224.803 & 4762.446 & \text { Yes }\end{array}$ $\begin{array}{lllllllllllllll}0.88 & 29.64 & 24.58 & 22.38 & 2 & 997.6100 & 997.6042 & 499.8094 & 0.0058 & 5.8022 & 18041.107 & 20781.985 & 19597.320 & 11665.599 & \text { Yes }\end{array}$ $\begin{array}{lllllllllllllllll}0.52 & 13.76 & 25.12 & 18.17 & 2 & 997.6064 & 997.6042 & 499.8094 & 0.0022 & 2.2008 & 2491.431 & 2965.463 & 3197.561 & 2219.665 & \text { Yes }\end{array}$ $\begin{array}{lllllllllllllllll}0.61 & 17.27 & 25.12 & 18.81 & 2 & 997.6068 & 997.6042 & 499.8094 & 0.0026 & 2.6010 & 2976.039 & 3370.078 & 2827.923 & 2320.167 & \text { Yes }\end{array}$ $\begin{array}{lllllllllllllll}0.97 & 31.05 & 17.16 & 34.64 & 2 & 1027.6764 & 1027.6746 & 514.8446 & 0.0018 & 1.7481 & 2215.411 & 2030.717 & 102.569 & 131.973 & \text { Yes }\end{array}$ $\begin{array}{llllllllllllllll}0.96 & 26.22 & 17.16 & 30.60 & 2 & 1027.6758 & 1027.6746 & 514.8446 & 0.0012 & 1.1654 & 4394.812 & 4011.915 & 14.666 & 91.015 & \text { Yes }\end{array}$ $\begin{array}{lllllllllllllll}0.98 & 29.12 & 17.16 & 30.34 & 2 & 1027.6760 & 1027.6746 & 514.8446 & 0.0014 & 1.3596 & 5340.238 & 4997.561 & 47.457 & 80.202 & \text { Yes }\end{array}$ $\begin{array}{lllllllllllllllll}0.88 & 21.12 & 21.34 & 28.96 & 2 & 1027.6774 & 1027.6746 & 514.8446 & 0.0028 & 2.7193 & 2183.967 & 2088.471 & 96.473 & 104.747 & \text { Yes }\end{array}$

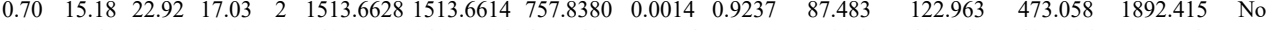

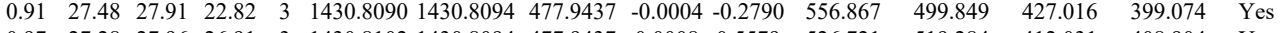
$\begin{array}{lllllllllllllll}0.97 & 27.28 & 27.96 & 26.91 & 3 & 1430.8102 & 1430.8094 & 477.9437 & 0.0008 & 0.5579 & 526.721 & 519.284 & 412.031 & 408.904 & \text { Yes }\end{array}$

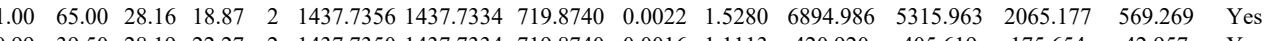
$\begin{array}{lllllllllllllll}0.99 & 39.50 & 28.19 & 22.27 & 2 & 1437.7350 & 1437.7334 & 719.8740 & 0.0016 & 1.1113 & 420.920 & 405.619 & 175.654 & 42.957 & \text { Yes }\end{array}$

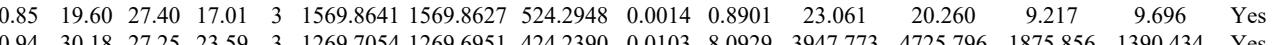

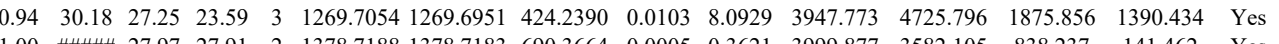

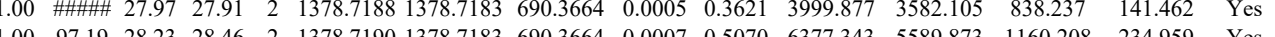
$\begin{array}{lllllllllllllllll}1.00 & 97.19 & 28.23 & 28.46 & 2 & 1378.7190 & 1378.7183 & 690.3664 & 0.0007 & 0.5070 & 6377.343 & 5589.873 & 1160.208 & 234.959 & \text { Yes } \\ 1.00 & 95.81 & 27.91 & 28.69 & 2 & 1378.7186 & 1378.7183 & 690.3664 & 0.0003 & 0.2173 & 3187.564 & 2828.062 & 658.951 & 127.470 & \text { Yes }\end{array}$ $\begin{array}{lllllllllllllll}1.00 & 95.81 & 27.91 & 28.69 & 2 & 1378.7186 & 1378.7183 & 690.3664 & 0.0003 & 0.2173 & 3187.564 & 2828.062 & 658.951 & 127.470 & \text { Yes } \\ 1\end{array}$ $\begin{array}{llllllllllllllll}\text { SSILLDVKPWDDETDMAK } & 1.00 & 39.64 & 26.79 & 18.10 & 3 & 2494.3030 & 2494.2991 & 832.4403 & 0.0039 & 1.5617 & 15610.738 & 13919.555 & 4262.630 & 286.270 & \text { Yes }\end{array}$

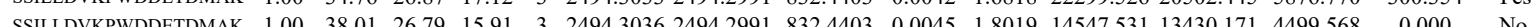




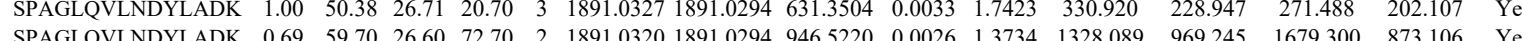
$\begin{array}{llllllllllllllll}\text { SPAGLQVLNDYLADK } & 0.69 & 59.70 & 26.60 & 72.70 & 2 & 1891.0320 & 1891.0294 & 946.5220 & 0.0026 & 1.3734 & 1328.089 & 969.245 & 1679.300 & 873.106 & \text { Yes } \\ \text { SPAGLQVLNDYLADK } & 1.00 & 69.22 & 26.60 & 23.58 & 2 & 1891.0320 & 1891.0294 & 946.5220 & 0.0026 & 1.3734 & 1466.115 & 989.427 & 933.284 & 728.821 & \text { Yes }\end{array}$

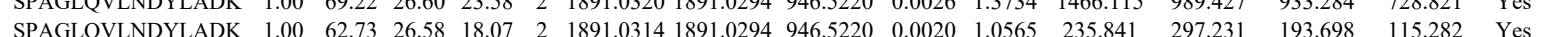
$\begin{array}{llllllllllllllll} & \\ \text { LVAGVGYGIK } & 1.00 & 55.99 & 21.93 & 28.26 & 2 & 1232.7850 & 1232.7736 & 617.3941 & 0.0114 & 9.2323 & 15178.470 & 14144.204 & 283.002 & 115.282 & \text { Yes } \\ \text { LVP.712 } & \text { Yes }\end{array}$

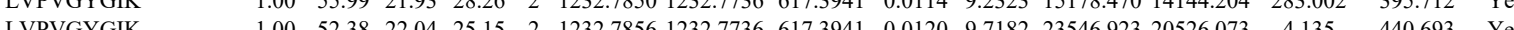

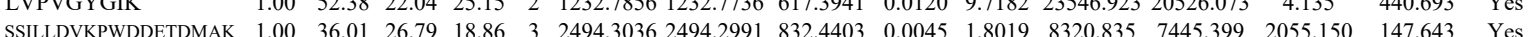

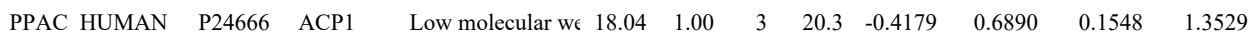

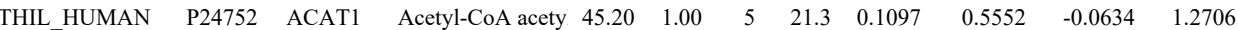

$\begin{array}{lllllllllll}\text { RPB1_HUMAN } & \text { P24928 } & \text { POLR2A } & \text { DNA-directed RN } 217.18 & 1.00 & 4 & 2.7 & 0.0568 & 0.1446 & -0.1235 & 1.1961\end{array}$

\section{IELLGSYDPQK}

SPIAEAVFR

SVLFVCLGNICR

SVLFVCLGNICR

$\begin{array}{llllllllllllll} & \end{array}$

$\begin{array}{lllllllllllll}1.00 & 65.51 & 27.09 & 21.52 & 2 & 1558.7606 & 1558.7614 & 780.3880 & -0.0008 & -0.5126 & 28.889 & 10.052 & 14.217\end{array}$

$\begin{array}{llllllllllll}1.00 & 58.07 & 27.13 & 23.40 & 2 & 1558.7624 & 1558.7614 & 780.3880 & 0.0010 & 0.6407 & 25.920\end{array}$

$\begin{array}{llllllllllll}1.00 & 48.50 & 27.18 & 21.60 & 2 & 1558.7628 & 1558.7614 & 780.3880 & 0.0014 & 0.8970 & 49.008\end{array}$

18 INAFADAAVEPIDFPIAPVYAASMY

\section{LNVTPLAR}

LNVTPLAR

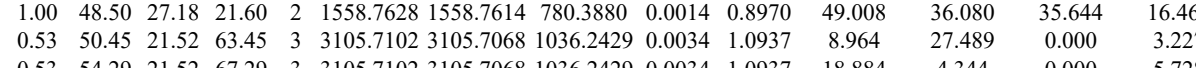

30.100

$\begin{array}{cc}30.100 & 17.255 \\ 36.080 & 35.644 \\ 27.489 & 0.000\end{array}$

\begin{tabular}{rr}
.217 & 8.936 \\
\hline .255 & 19.951 \\
\hline & 16.465
\end{tabular}

$\begin{array}{llllllllllllll}0.82 & 27.42 & 24.28 & 26.75 & 2 & 1026.6380 & 1026.6308 & 514.3227 & 0.0072 & 6.9994 & 15848.047 & 16370.090 & 2017.330 \\ 0.84 & 27.12 & 24.28 & 28.27 & 2 & 1026.6384 & 1026.6308 & 514.3227 & 0.0076 & 7.3883 & 12949.155 & 11136.090 & 705.184 & 29\end{array}$ $\begin{array}{lllllllllllllll}\text { QAVLGAGLPSTPCTTINK } & 0.99 & 30.84 & 25.85 & 15.98 & 3 & 2217.2116 & 2217.2105 & 740.0774 & 0.0011 & 0.4954 & 122.356 & 1030.494 & 60.170\end{array}$ $\begin{array}{llllllllllllll}\text { VNINGGAVSLGHPIGMSGAR } & 1.00 & 89.05 & 27.50 & 19.60 & 3 & 2050.0879 & 2050.0864 & 684.3694 & 0.0015 & 0.7306 & 669.976 & 759.222 & 329.242\end{array}$

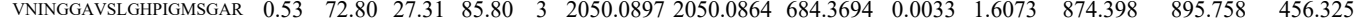
$\begin{array}{llllllllllllll}\text { VNINGGAVSLGHPIGMSGAR } & 1.00 & 79.19 & 27.30 & 18.56 & 3 & 2050.0894 & 2050.0864 & 684.3694 & 0.0030 & 1.4612 & 815.468 & 845.523 & 328.130\end{array}$ TPIGSFLGSLSLLPATK

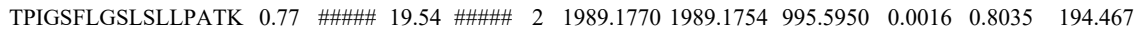
$\begin{array}{lllllllllllll}\text { TPIGSFLGSLSLLPATK } & 0.53 & 38.07 & 19.40 & 51.07 & 3 & 1989.1786 & 1989.1754 & 664.0657 & 0.0032 & 1.6063 & 40.011\end{array}$ $\begin{array}{lllllllllll}\text { TPIGSFLGSLSLLPATK } & 1.00 & \# \text { \#\#\# } 19.49 & 22.79 & 2 & 1989.1754 & 1989.1754 & 995.5950 & 0.0000 & 0.0000 & 60.507\end{array}$ $\begin{array}{lllllllllll}\text { TPIGSFLGSLSLLPATK } & 1.00 & \text { \#\#\#\# } 19.54 & 20.78 & 2 & 1989.1770 & 1989.1754 & 995.5950 & 0.0016 & 0.8035 & 63.577\end{array}$ $\begin{array}{llllllllllll}\text { TPIGSFLGSLSLLPATK } & 0.53 & 55.48 & 19.49 & 68.48 & 3 & 1989.1783 & 1989.1754 & 664.0657 & 0.0029 & 1.4557 & 43.953\end{array}$ $\begin{array}{llllllllllll}\text { TPIGSFLGSLSLLPATK } & 0.53 & 50.37 & 19.49 & 63.37 & 3 & 1989.1783 & 1989.1754 & 664.0657 & 0.0029 & 1.4557 & 55.121\end{array}$ $\begin{array}{llllllllllll}\text { TPIGSLGSLSLLPATK } & 0.55 & 56.04 & 19.44 & 69.04 & 3 & 1989.1777 & 1989.1754 & 664.0657 & 0.0023 & 1.1545 & 10.321\end{array}$ $\begin{array}{llllllllllll}\text { TPIGSFGSLSLLPATK } & 0.53 & 39.05 & 19.49 & 52.05 & 3 & 1989.1783 & 1989.1754 & 664.0657 & 0.029 & 1.4557 & 12.442\end{array}$

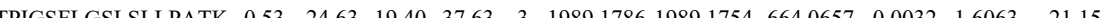

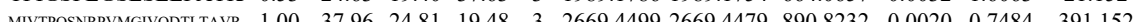

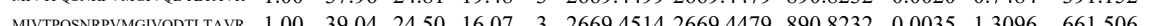
$\begin{array}{lllllllllllll}\text { MIVTPOSNRPVMGIVDDTLTAVR } & 1.00 & 38.95 & 24.59 & 17.60 & 3 & 2669.4508 & 2669.4479 & 890.8232 & 0.0029 & 1.0851 & 225.127 & 280.828\end{array}$ $\begin{array}{lllllllllllll}\text { MIITPOSNRPYMGIODTIAVR } & 0.53 & 39.95 & 24.50 & 52.95 & 3 & 2669.4514 & 2669.4479 & 890.8232 & 0.0035 & 13096 & 155.070 & 151.959\end{array}$ $\begin{array}{llllllllllll}\text { ISPWLLR } & 0.85 & 24.06 & 25.07 & 26.13 & 2 & 1027.6298 & 1027.6300 & 514.8223 & -0.0002 & -0.1942 & 1399.203\end{array}$

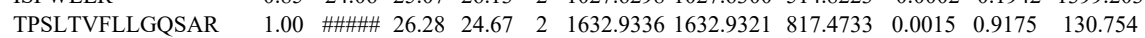

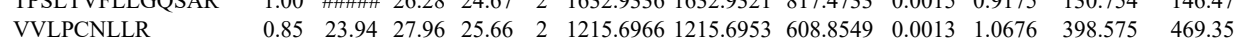

TPMENIGLQDS

$\begin{array}{llllllllllllll} & \end{array}$ $\begin{array}{lllllllllllll}\text { TPMENIGLQDSLLSR } & 1.00 & 74.60 & 28.34 & 37.01 & 2 & 1816.9524 & 1816.9475 & 909.4810 & 0.0049 & 2.6938 & 928.065 & 1082.521\end{array}$ $\begin{array}{lllllllllllllll}\text { LLNNAFEELVAFQR } & 1.00 & 96.97 & 26.98 & 20.79 & 2 & 1806.9768 & 1806.9750 & 904.4948 & 0.0018 & 0.9950 & 590.752 & 697.299 & 35.221 \\ \text { LLNNAFEELVAFQR } & 1.00 & 98.01 & 26.98 & 22.47 & 2 & 1806.9768 & 18069750 & 904.4948 & 0.0018 & 0.9950 & 828.860 & 895.107 & 14.974\end{array}$ $\begin{array}{llllllllllllll}0.99 & 36.68 & 27.36 & 29.65 & 2 & 1064.6130 & 1064.6100 & 533.3123 & 0.0030 & 2.8126 & 16318.874 & 18235.795 & 1203.641 & 22 \\ 0.99 & 40.47 & 27.36 & 33.40 & 2 & 10646140 & 10646100 & 533.3123 & 0.0040 & 3.7501 & 33186.434 & 37508.977 & 1082.785 & 975\end{array}$ $\begin{array}{llllllllllllll}0.99 & 43.10 & 27.36 & 33.40 & 2 & 1064.6140 & 1064.6100 & 533.3123 & 0.0040 & 3.7501 & 33186.434 & 37508.977 & 082.785 \\ & 27.89 & 1064.6148 & 1064.6100 & 533.3123 & 0.0048 & 4.5002 & 7577.729 & 7970.471 & 598.553\end{array}$ $\begin{array}{lllllllllllll}1.00 & 41.97 & 26.79 & 22.22 & 2 & 1075.6530 & 1075.6512 & 538.8329 & 0.0018 & 1.6703 & 20659.013 & 20052.631 & 830.901\end{array}$ $\begin{array}{lllllllllllll}1.00 & 43.73 & 26.79 & 20.62 & 2 & 1075.6532 & 1075.6512 & 538.8329 & 0.0020 & 1.8559 & 20632.360 & 22786.818 & 415.174\end{array}$ $\begin{array}{lllllllllllll}0.96 & 34.40 & 26.65 & 27.13 & 2 & 1111.5742 & 1111.5640 & 556.7893 & 0.0102 & 9.1596 & 18158.427 & 19850.316 & 3491.037\end{array}$ $\begin{array}{llllllllllllll}0.96 & 36.23 & 26.88 & 23.37 & 2 & 1111.5732 & 1111.5640 & 556.7893 & 0.0092 & 8.2616 & 15594.915 & 17987.899 & 2337.837 & 362.338\end{array}$ $\begin{array}{llllllllllllll}1.00 & 64.50 & 27.14 & 27.86 & 2 & 1445.8230 & 1445.8220 & 723.9183 & 0.0010 & 0.6907 & 164.069 & 186.673 & 52.936 & 31.323\end{array}$ $\begin{array}{llllllllllll}1.00 & 54.72 & 27.13 & 26.86 & 2 & 1445.8240 & 1445.8220 & 723.9183 & 0.0020 & 1.3814 & 262.976 & 306\end{array}$ $\begin{array}{llllllllllll}1.00 & 60.65 & 27.13 & 26.81 & 2 & 1445.8226 & 1445.8220 & 723.9183 & 0.0006 & 0.4144 & 183.033\end{array}$ $\begin{array}{llllllllllll}0.96 & 25.10 & 27.13 & 21.14 & 3 & 1445.8234 & 1445.8220 & 482.9479 & 0.0014 & 0.9663 & 75.049\end{array}$ $\begin{array}{lllllllllll}1.00 & 34.31 & 27.13 & 20.93 & 3 & 1445.8234 & 1445.8220 & 482.9479 & 0.0014 & 0.9663 & 96.671\end{array}$ $\begin{array}{lllllllllll}1.00 & 48.00 & 27.14 & 24.28 & 2 & 1445.8230 & 1445.8220 & 723.9183 & 0.0010 & 0.6907 & 12.192\end{array}$ $\begin{array}{lllllllllll}1.00 & 48.00 & 27.14 & 24.28 & 2 & 1445.8230 & 1445.8220 & 723.9183 & 0.0010 & 0.6907 & 12.192 \\ 1.00 & 43.70 & 23.20 & 19.36 & 4 & 4496.0709 & 4496.0693 & 1125.0246 & 0.0016 & 0.3555 & 3.582\end{array}$

$\begin{array}{lllllllllllll}\text { AGQPLQLLDASWYLPK } & 1.00 & 53.76 & 25.01 & 21.55 & 3 & 2087.1685 & 2087.1659 & 696.7292 & 0.0026 & 1.2439 & 264.733\end{array}$ $\begin{array}{llllllllllllllll} & \end{array}$

306.457 


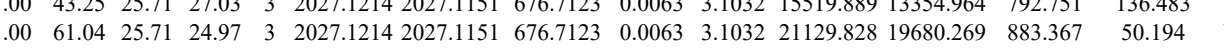
$\begin{array}{lllllllllllllll}1.00 & 72.80 & 25.90 & 29.01 & 2 & 2027.1174 & 2027.1151 & 1014.5648 & 0.0023 & 1.1335 & 3359.217 & 3029.322 & 21.973 & 35.720 & \text { Y }\end{array}$

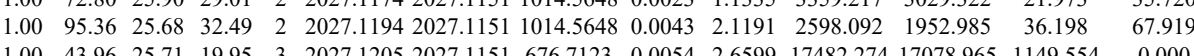

$\begin{array}{llllllllllllll}1.00 & 43.96 & 25.71 & 19.95 & 3 & 2027.1205 & 2027.1151 & 676.7123 & 0.0054 & 2.6599 & 17482.274 & 17078.965 & 1149.554 & 0 \\ 1.00 & 43.27 & 25.74 & 20.53 & 3 & 2027.1217 & 2027.1151 & 676.7123 & 0.0066 & 3.2510 & 40664.063 & 34226.695 & 1837.016 & 83\end{array}$ LGEWVGLCK

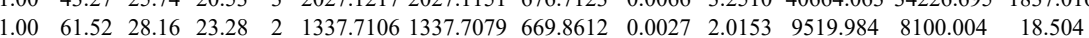
$\begin{array}{lllllllllllll}.00 & 61.52 & 28.16 & 23.28 & 2 & 1337.7106 & 1337.7079 & 669.8612 & 0.0027 & 2.0153 & 9519.984 & 8100.004 & 18.504\end{array}$ $\begin{array}{lllllllllllllll}1.00 & 54.48 & 26.71 & 26.47 & 3 & 1209.6940 & 1209.6951 & 404.2390 & -0.0011 & -0.9071 & 355.555 & 277.434 & 55.425 & 15.297\end{array}$

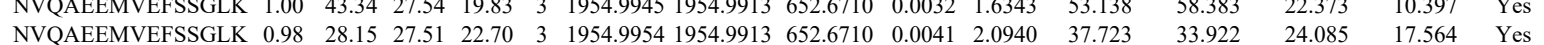

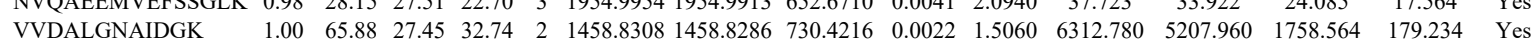

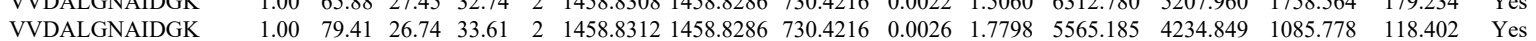

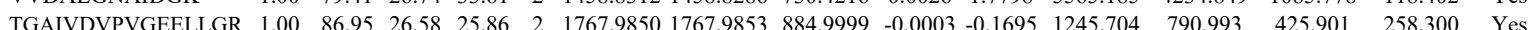

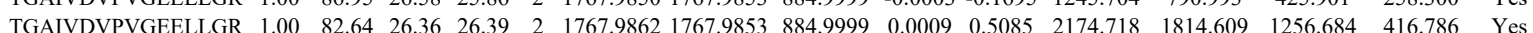
$\begin{array}{llllllllllllllll}\text { TGAIVDVPVGEELLGR } & 1.00 & 45.06 & 26.30 & 19.63 & 2 & 1767.9868 & 1767.9853 & 884.9999 & 0.0015 & 0.8475 & 828.119 & 913.915 & 594.263 & 521.019 & \text { Yes }\end{array}$

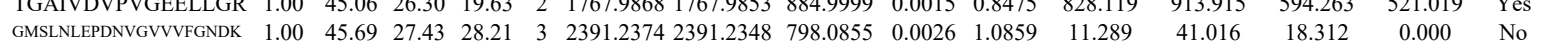

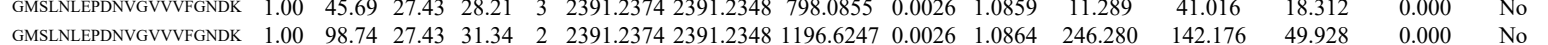

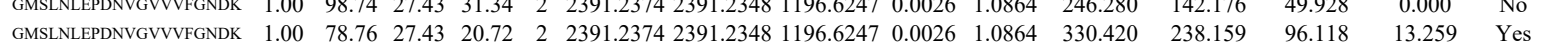
$\begin{array}{llllllllllllllll}\text { GMSLNLEPDNVGVVVFGNDK } & 1.00 & 52.83 & 27.38 & 17.74 & 3 & 2391.2380 & 2391.2348 & 798.0855 & 0.0032 & 1.3365 & 74.245 & 36.816 & 40.843 & 51.874 & \text { No }\end{array}$ \begin{tabular}{llllllllllllllll} 
GMSLNLEPDNVGVVVFGNDK & 0.82 & 19.03 & 27.28 & 14.87 & 3 & 2391.2398 & 2391.2348 & 798.0855 & 0.0050 & 2.0883 & 304.570 & 253.918 & 126.950 & 108.994 & Yes \\
\hline
\end{tabular}

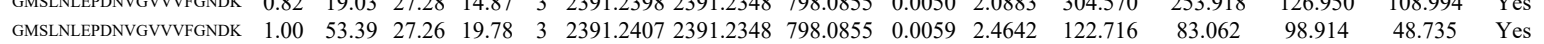
\begin{tabular}{lllllllllllllllll} 
GMSLNLEPDNVGVVVFGNDK & 1.00 & 76.46 & 27.25 & 22.70 & 2 & 2391.2414 & 2391.2348 & 1196.6247 & 0.0066 & 2.7577 & 58.142 & 43.216 & 12.702 & 10.884 & Yes \\
\hline
\end{tabular} $\begin{array}{lllllllllllllllll}\text { AVDSLVPIGR } & 0.99 & 37.75 & 24.27 & 19.40 & 2 & 1169.7002 & 1169.6890 & 585.8518 & 0.0112 & 9.5586 & 23896.705 & 17376.766 & 1952.377 & 1845.972 & \text { Yes }\end{array}$ $\begin{array}{lllllllllllllllll}\text { QGQYSPMAIEEQVAVIYAGVR } & 0.53 & 42.55 & 27.02 & 55.55 & 3 & 2452.2571 & 2452.2542 & 818.4253 & 0.0029 & 1.1811 & 225.765 & 218.936 & 136.878 & 78.566 & \text { Yes }\end{array}$ $\begin{array}{llllllllllllllll}\text { EVAAFAQFGSDLDAATQQLLSR } & 1.00 & 99.50 & 27.41 & 23.14 & 3 & 2481.2674 & 2481.2621 & 828.0946 & 0.0053 & 2.1334 & 20.823 & 21.163 & 11.577 & 0.000 & \text { No }\end{array}$

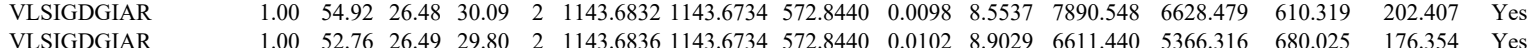
$\begin{array}{llllllllllllllll}\text { EVAAFAQFGSDLDAATQQLLSR } & 1.00 & 52.76 & 26.49 & 29.80 & 2 & 1143.6836 & 1143.6734 & 572.8440 & 0.0102 & 8.9029 & 6611.440 & 5366.316 & 680.025 & 176.354 & \text { Yes } \\ & 1.00 & 27.47 & 24.57 & 3 & 2481.2665 & 2481.2621 & 828.0946 & 0.0044 & 1.7711 & 18.713 & 57.617 & 19.940 & 11.472 & \text { No }\end{array}$

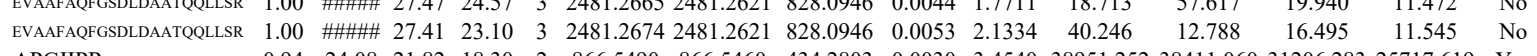

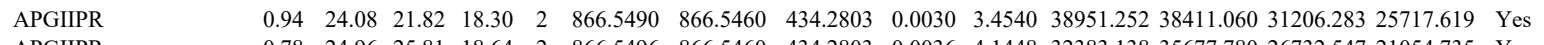

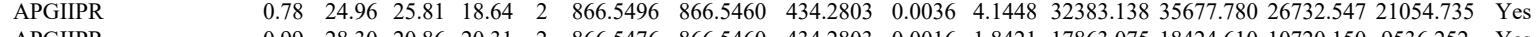

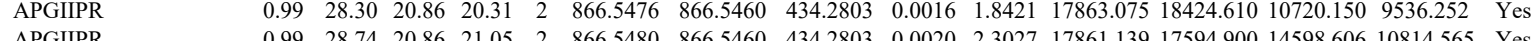

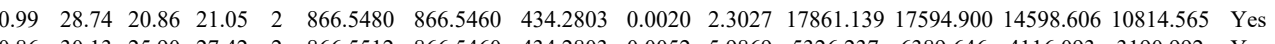
$\begin{array}{lllllllllllllll}0.87 & 30.82 & 25.90 & 25.88 & 2 & 866.5524 & 866.5460 & 434.2803 & 0.0064 & 7.3685 & 7154.874 & 6258.904 & 4531.760 & 2924.258 & \text { Yes } \\ 0.79 & 29.57 & 27.90 & 28.78 & 2 & 1003.5962 & 1003.5970 & 502.8058 & 0.0008 & -0.7955 & 38930.650 & 35393.877 & 5810.23 & 1209.413 & \text { Yes }\end{array}$

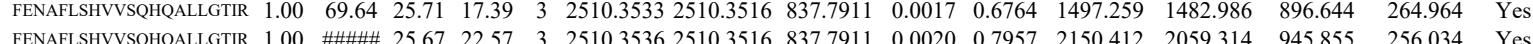


$\begin{array}{lllllllllllll}1.00 & 62.36 & 26.85 & 25.70 & 2 & 1566.7706 & 1566.7681 & 784.3913 & 0.0025 & 1.5936 & 5038.426 & 4321.248 & 1199.218\end{array}$ TGTAEMSSILEER

$\begin{array}{lllllllllllll}\text { PSA1_HUMAN } & \text { P25786 } & \text { PSMA1 } & \text { Proteasome subun } 29.56 & 1.00 & 9 & 28.5 & 0.0835 & 0.2582 & 0.0768 & 1.8919 & 32 & \text { TQIPTQR }\end{array}$ $\left.\begin{array}{lllllllllllllll}1.00 & 68.63 & 26.88 & 25.31 & 2 & 1566.7708 & 1566.7681 & 784.3913 & 0.0027 & 1.7211 & 12816.797 & 10459.085 & 2623.360 & 241.463\end{array}\right)$

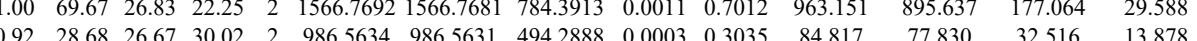

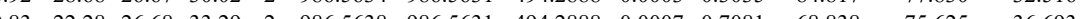

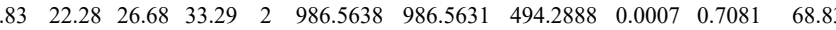

$\begin{array}{llllllllllllllll}0.83 & 22.28 & 26.68 & 33.29 & 2 & 986.5638 & 986.5631 & 494.2888 & 0.0007 & 0.7081 & 68.838 & 75.625 & 36.693 & 12.135 & \text { Y S } & \\ 1.00 & 42.96 & 24.94 & 21.74 & 2 & 1173.7422 & 1173.7325 & 587.8735 & 0.0097 & 8.2500 & 20925.147 & 21265.644 & 8221.295 & 5513.178 & \text { Y s } & \\ 0.96 & 33.03 & 24.93 & 19.63 & 2 & 1173.7428 & 1173.7325 & 587.8735 & 0.0103 & 8.7603 & 9069.840 & 9197.093 & 5192.434 & 3660.788 & \text { Yes }\end{array}$ 2.135 Yes

NVSIGIVGK

NVSIGIVGK

THAVLVALK

THAVLVALK

THAVLVALK
THAVLVALK

THAVLVALK
LVSLIGSK

LVSLIGSK

LVSLIGSK

AQSELAAHQK

FVPDRPLPVSR

FVFDRPLPVSR

FVFDRPLPVSR

FVFDRPLPVSR
FVFDRPLPVSR

LLCNFMR

LLCNFMR

LLCNFMR

LLCNFMR

LLCNFMR

LLCNFMR

LLCNFMR

LLCNFMR $\begin{array}{llllllllllllllll}\text { LLCNFMR } & 0.98 & 29.81 & 24.81 & 19.95 & 2 & 1101.5268 & 1101.5255 & 551.7700 & 0.0013 & 1.1780 & 543.178 & 532.061 & 39.706 & 22.266 & \text { Yes } \\ \text { AQPAQPADEPAEK } & 1.00 & 41.35 & 27.72 & 17.42 & 2 & 1638.8466 & 1638.8457 & 820.4301 & 0.0009 & 0.5485 & 119.347 & 105.808 & 95.049 & 39.145 & \text { Yes } \\ \text { AQPAQPADEPAEK } & 0.69 & 14.65 & 27.47 & 23.40 & 3 & 1638.8479 & 1638.8457 & 547.2892 & 0.0022 & 1.3399 & 394.754 & 377.043 & 416.405 & 363.580 & \text { No }\end{array}$

$\begin{array}{lllllllllllllll}1.00 & 65.40 & 24.94 & 27.03 & 2 & 1137.7424 & 1173.7325 & 587.8735 & 0.0099 & 8.401 & 6877.895 & 7870.248 & 2907.644 & 1896.267 & \text { Yes }\end{array}$

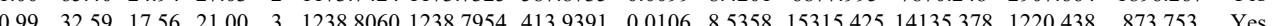
$\begin{array}{llllllllllllllllll}1.00 & 37.98 & 17.56 & 20.81 & 3 & 1238 & 8063 & 1238 & 7954 & 413.9391 & 0.0109 & 8.7774 & 10694.397 & 9348.222 & 1786.394 & 876.506 & \text { Yes }\end{array}$ $\begin{array}{lllllllllllllll}0.99 & 31.20 & 17.56 & 20.34 & 3 & 1238.8054 & 1238.7954 & 413.9391 & 0.0100 & 8.0526 & 13267.634 & 14772.458 & 1282.969 & 1174.641 & \text { Yes }\end{array}$ $\begin{array}{lllllllllllllllll}0.99 & 28.98 & 17.56 & 18.79 & 3 & 1238.8057 & 1238.7954 & 413.9391 & 0.0103 & 8.2942 & 17460.185 & 15273.931 & 902.952 & 596.572 & \text { Yes }\end{array}$ $\begin{array}{lllllllllllllll}0.92 & 46.15 & 21.73 & 46.44 & 2 & 1103.7234 & 1103.7158 & 552.8652 & 0.0076 & 6.8732 & 58699.793 & 59743.104 & 1087.783 & 1154.979 & \text { Yes }\end{array}$

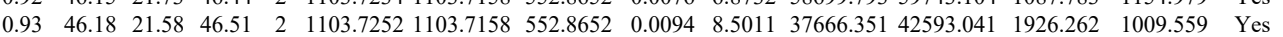
$\begin{array}{lllllllllllllll}0.91 & 46.04 & 21.73 & 46.40 & 2 & 1103.7236 & 1103.7158 & 552.8652 & 0.0078 & 7.0541 & 37731.265 & 41562893 & 219.988 & 616.216 & \text { Yes }\end{array}$ $\begin{array}{lllllllllllllll}0.59 & 16.26 & 27.39 & 15.80 & 3 & 1369.7560 & 1369.7557 & 457.5925 & 0.0003 & 0.2185 & 51.962 & 55.439 & 34.720 & 21.684 & \text { Yes }\end{array}$

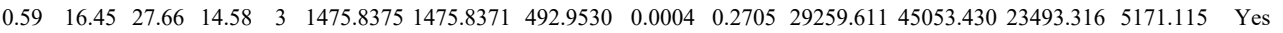
$\begin{array}{lllllllllllllll}0.78 & 16.37 & 27.52 & 14.20 & 3 & 1475.8387 & 1475.8371 & 492.9530 & 0.0016 & 1.0819 & 12984.194 & 19782.548 & 9911.418 & 1612.920 & \text { Yes }\end{array}$ $\begin{array}{lllllllllllllll}0.71 & 15.02 & 27.54 & 22.51 & 3 & 1475.8390 & 1475.8371 & 492.9530 & 0.0019 & 1.2848 & 56.191 & 106.186 & 30.564 & 23.166 & \text { Yes }\end{array}$ $\begin{array}{lllllllllllllll}0.69 & 21.36 & 27.22 & 14.68 & 3 & 1475.8483 & 1475.8371 & 492.9530 & 0.0112 & 7.5733 & 4519.271 & 6446.681 & 2827.740 & 543.450 & \text { Yes }\end{array}$ $\begin{array}{lllllllllllllll}0.58 & 19.93 & 26.59 & 14.71 & 3 & 1475.8516 & 1475.8371 & 492.9530 & 0.0145 & 9.8048 & 2997.443 & 3668.465 & 1709.916 & 579.087 & \text { Yes }\end{array}$ $\begin{array}{lllllllllllllll}0.91 & 23.95 & 25.28 & 23.96 & 2 & 1085.5312 & 1085.5306 & 543.7726 & 0.0006 & 0.5517 & 2879.230 & 3441.106 & 126.570 & 50.812 & \text { Yes }\end{array}$ $\begin{array}{lllllllllllllll}0.93 & 25.25 & 25.33 & 21.95 & 2 & 1085.5320 & 1085.5306 & 543.7726 & 0.0014 & 1.2873 & 3198.379 & 3344.904 & 168.955 & 51.099 & \text { Yes }\end{array}$ $\begin{array}{llllllllllllllll}0.82 & 20.48 & 25.33 & 23.81 & 2 & 1085.5320 & 1085.5306 & 543.7726 & 0.0014 & 1.2873 & 1812.061 & 2060.270 & 111.912 & 7.754 & \text { Yes }\end{array}$ $\begin{array}{lllllllllllllll}1.00 & 41.04 & 24.76 & 26.74 & 2 & 1101.5262 & 1101.5255 & 551.7700 & 0.0007 & 0.6343 & 1241.094 & 1209.873 & 50.048 & 31.446 & \text { Yes }\end{array}$

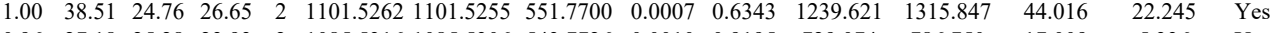
\begin{tabular}{lllllllllllllll}
0.96 & 27.18 & 25.28 & 23.93 & 2 & 1085.53161085 .5306 & 543.7726 & 0.0010 & 0.9195 & 729.074 & 786.750 & 17.009 & 5.336 & Yes \\
\hline
\end{tabular} \begin{tabular}{lllllllllllllll}
0.99 & 32.72 & 25.33 & 24.70 & 2 & 1085.5320 & 1085.5306 & 543.7726 & 0.0014 & 1.2873 & 579.863 & 663.430 & 16.880 & 7.820 & Yes \\
\hline
\end{tabular}

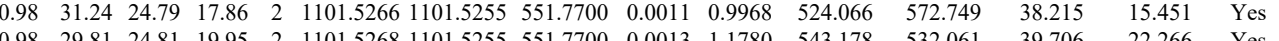

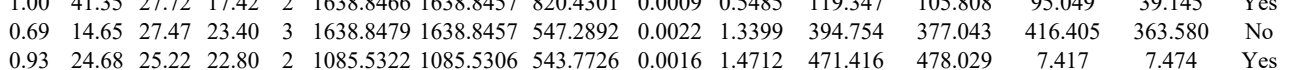
LLCNFMR

LLCNFMR

LLCNFMR

KAQPAQPADEPAEK

AQSELAAHQK
AQSELAAHQK

18 AANGVVLATEK

AANGVVLATEK $\begin{array}{llllllllllll}0.54 & 14.74 & 25.33 & 14.29 & 2 & 1085.5320 & 1085.5306 & 543.7726 & 0.0014 & 1.2873 & 161.713 & 171.931\end{array}$

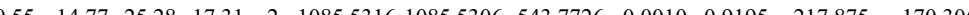
$\begin{array}{lllllllllllll}0.65 & 16.61 & 25.33 & 18.77 & 2 & 1085.5320 & 1085.5306 & 543.7726 & 0.0014 & 1.2873 & 146757 & 163.563\end{array}$ $\begin{array}{llllllllllll}1.00 & 51.97 & 26.48 & 17.76 & 3 & 1911.0436 & 1911.0427 & 638.0215 & 0.0009 & 0.4702 & 406.375 & 588.262\end{array}$ $\begin{array}{lllllllllllll}0.97 & 25.44 & 27.28 & 22.58 & 3 & 1369.7566 & 1369.7557 & 457.5925 & 0.0009 & 0.6556 & 334.432 & 44.8172\end{array}$ AANGVVLATEK $\begin{array}{llllllllllll} & & \end{array}$ $\begin{array}{llllllllllllllll}1.00 & 68.59 & 25.72 & 33.13 & 2 & 1359.8046 & 1359.7965 & 680.9055 & 0.0081 & 5.9479 & 7928.353 & 8294.345 & 11012.776 & 4705.040 & Y c 5 & \end{array}$ $\begin{array}{lllllllllllllllll}1.00 & 69.97 & 25.68 & 31.24 & 2 & 1359.8052 & 1359.7965 & 680.9055 & 0.0087 & 6.3885 & 7905.171 & 7385.452 & 9696.820 & 4107.068 & \text { Yes }\end{array}$ $\begin{array}{lllllllllllllllll}1.00 & 75.59 & 25.85 & 39.31 & 2 & 1359.8026 & 1359.7965 & 680.9055 & 0.0061 & 4.4793 & 5699.274 & 6139.080 & 4604.657 & 2454.649 & \text { Yes } & \end{array}$ \begin{tabular}{llllllllllllllll} 
YNEDLELEDAIHTAILTLK & 1.00 & 70.98 & 25.69 & 20.05 & 3 & 2488.3375 & 2488.3304 & 830.4507 & 0.0071 & 2.8498 & 111.327 & 118.078 & 92.186 & 30.603 & Yes \\
\hline
\end{tabular}

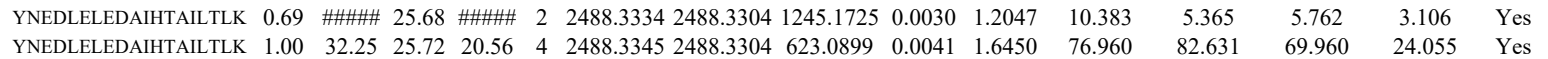
$\begin{array}{llllllllllllllll}\text { YNEDLELEDAIHTAILTLK } & 1.00 & 64.27 & 25.71 & 24.69 & 3 & 2488.3351 & 2488.3304 & 830.4507 & 0.0047 & 1.8865 & 58.816 & 157.740 & 83.283 & 16.325 & \text { Yes }\end{array}$ $\begin{array}{llllllllllllllll}\text { YNEDLELEDAIHTAILTLK } & 1.00 & 42.35 & 25.72 & 15.84 & 4 & 2488.3361 & 2488.3304 & 623.0899 & 0.0057 & 2.2870 & 74.759 & 67.157 & 87.334 & 54.966 & \text { Yes }\end{array}$ $\begin{array}{llllllllllllllll}\text { YNEDLELEDAIHTAILTLK } & 1.00 & 59.86 & 25.72 & 17.62 & 3 & 2488.3345 & 2488.3304 & 830.4507 & 0.0041 & 1.6457 & 93.502 & 156.375 & 127.820 & 35.724 & \text { Yes }\end{array}$ $\begin{array}{llllllllllllllll}\text { YNEDLELEDAIHTAILTLK } & 1.00 & 29.06 & 25.72 & 16.04 & 4 & 2488.3361 & 2488.3304 & 623.0899 & 0.0057 & 2.2870 & 77.537 & 91.362 & 74.047 & 49.405 & \text { Yes }\end{array}$ $\begin{array}{lllllllllllllllll}\text { GYSFSLTTFSPSGK } & 1.00 & 90.04 & 28.29 & 21.78 & 2 & 1765.9150 & 1765.9131 & 883.9638 & 0.0019 & 1.0747 & 1609.493 & 1767.755 & 1238.043 & 364.599 & \text { Yes }\end{array}$

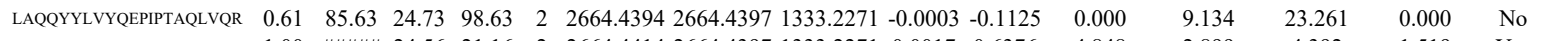

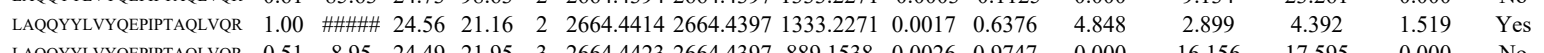

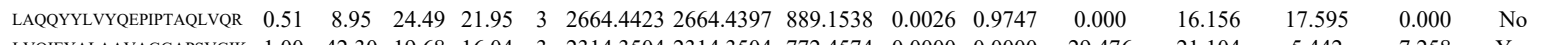

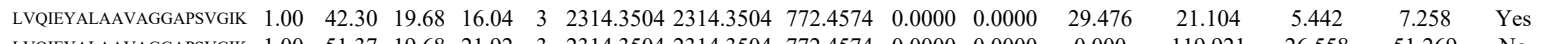

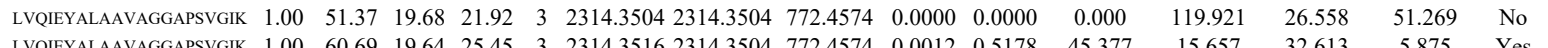

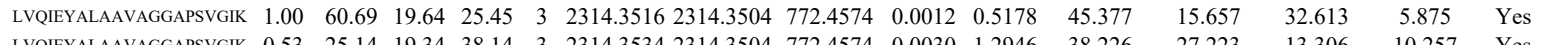

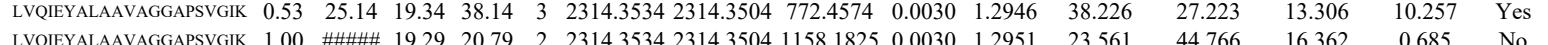

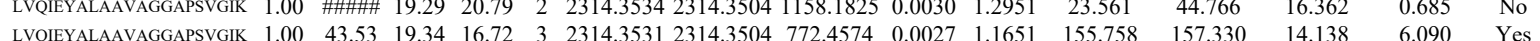
\begin{tabular}{llllllllllllllll} 
LVQIEYALAAVAGGAPSVGIK & 1.00 & 49.91 & 19.34 & 19.66 & 3 & 2314.3531 & 2314.3504 & 772.4574 & 0.0027 & 1.1651 & 157.284 & 147.690 & 46.770 & 32.012 & Yes \\
\hline
\end{tabular} $\begin{array}{llllllllllllllll}\text { LVIEYALAAVAGGAPSVGIK } & 1.00 & 59.97 & 19.64 & 18.13 & 3 & 2314.3513 & 2314.3504 & 772.4574 & 0.0009 & 0.3884 & 97.423 & 58.354 & 17.392 & 4.378 & \text { Yes }\end{array}$ $\begin{array}{llllllllllllll}\text { LVQIEYALAAVAGGAPSVGIK } & 1.00 & 59.97 & 19.64 & 18.13 & 3 & 2314.3513 & 2314.3504 & 772.4574 & 0.0009 & 0.3884 & 97.423 & 58.354 & 17\end{array}$

Table S-3 page 192 of 499 
$\begin{array}{lllllllllllll}\text { PSA3_HUMAN } & \text { P25788 } & \text { PSMA3 } & \text { Proteasome subun } 28.43 & 1.00 & 2 & 8.6 & 0.1857 & 0.1323 & -0.3205 & 0.8801 & 6 & \text { IIYIVHDEVK }\end{array}$ IIYIVHDEVK AVENSSTAIGIR AVENSSTAIGIR AVENSSTAIGIR AVENSSTAIGIR

$\begin{array}{lllllllllllll}\text { PSA4 HUMAN } & \text { P25789 } & \text { PSMA4 } & \text { Proteasome subun } 29.48 & 1.00 & 5 & 25.3 & 0.0835 & 0.0704 & -0.7239 & 1.0820 & 8 & \text { LLDEVFFSEK }\end{array}$ LLDEVFFSEK

LNEDMACSVAGI

EIATLTR

SALALAIK

ATCIGNNSAAAVSML

ATCIGNNSAAAVSMLK

ATCIGNSAANSMLK

VLVCAHR

YLLLAGAPR YLLLAGAPR
QPOQVIHGEK

YLLLAGAPR

YLLLAGAPR

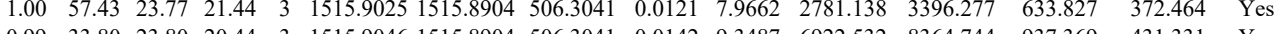
$\begin{array}{lllllllllllllll}.93 .80 & 23.80 & 20.44 & 3 & 1515.9046 & 1515.8904 & 506.3041 & 0.0142 & 9.3487 & 6922.532 & 8364.744 & 937.369 & 431.331 & \text { Yes } \\ 1.00 & 69.93 & 28.08 & 26.86 & 2 & 1360.7448 & 1360.7432 & 681.3789 & 0.0016 & 1.1741 & 14220.788 & 15133.160 & 11289.791 & 3862.881 & \text { Yes }\end{array}$ $\begin{array}{lllllllllllllll}1.00 & 69.93 & 28.08 & 26.86 & 2 & 1360.7448 & 1360.7432 & 681.3789 & 0.0016 & 1.1741 & 14220.788 & 15133.160 & 11289.791 & 3862.881 & \text { Yes } \\ 1.00 & 69.24 & 28.24 & 28.11 & 2 & 1360.7452 & 1360.7432 & 681.3789 & 0.0020 & 1.4676 & 21695.395 & 26120.633 & 17064.685 & 6654.727 & \text { Yes }\end{array}$ $\begin{array}{llllllllllllllll}.00 & 69.24 & 28.24 & 28.11 & 2 & 1360.7452 & 1360.7432 & 681.3789 & 0.0020 & 1.4676 & 21695.395 & 26120.633 & 17064.685 & 6654.727 & \text { Yes } \\ 1.00 & 62.68 & 28.07 & 32.74 & 2 & 13607444 & 1367.7432 & 681.3789 & 0.0012 & 0.8806 & 7044.954 & 7200.508 & 4157.250 & 1858.035 & \text { Yes }\end{array}$

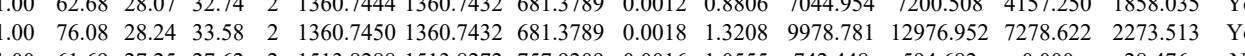

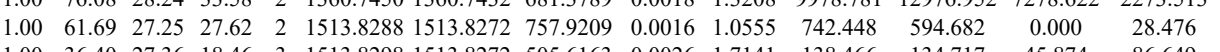
$\begin{array}{llllllllllllll}1.00 & 36.40 & 27.36 & 18.46 & 3 & 1513.8298 & 1513.8272 & 505.6163 & 0.0026 & 1.7141 & 138.466 & 134.717 & 45.874 & 86.649 \\ 1.00 & 5.53 & 27.36 & 88.27 & 2 & 1513.8298 & 1513.8272 & 757.9209 & 0.026 & 1.7152 & 3761.255 & 3900.474 & 0.000 & 31.348\end{array}$

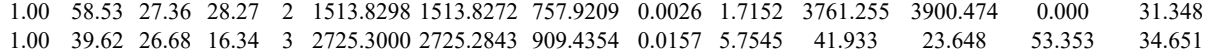
$\begin{array}{llllllllllllll}0.98 & 40.99 & 27.40 & 32.12 & 2 & 1045.6338 & 1045.6253 & 523.8199 & 0.0085 & 8.1134 & 17157.793 & 18432.750 & 2927.511 & 584.532\end{array}$ $\begin{array}{lllllllllllllll}0.97 & 36.00 & 27.22 & 26.90 & 2 & 1045.6352 & 1045.6253 & 523.8199 & 0.0099 & 9.4497 & 18345.896 & 20755.386 & 2855.824 & 863.970 & \text { Y ses }\end{array}$

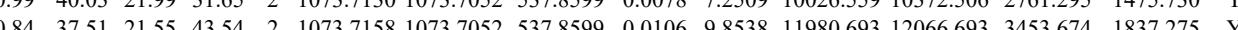

$\begin{array}{llllllllllllllll} & 1837.275 & \text { Yes }\end{array}$

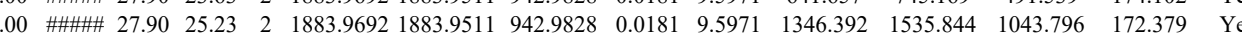
$\begin{array}{llllllllllllll}1.00 & \text { \#\#\#\# } 27.94 & 27.03 & 2 & 1883.9696 & 1883.9511 & 942.9828 & 0.0185 & 9.8092 & 1958.088 & 2131.688 & 1390.968 & 404.342 & \text { Yes }\end{array}$ $\begin{array}{llllllllllllllll}0.97 & 30.19 & 26.74 & 30.17 & 2 & 986.5292 & 986.5276 & 494.2711 & 0.0016 & 1.6185 & 5935.802 & 9433.736 & 542.515 & 352.334 & \text { Yes }\end{array}$ $\begin{array}{llllllllllllllll}0.99 & 52.21 & 24.62 & 40.52 & 2 & 1116.6858 & 1116.6777 & 559.3461 & 0.0081 & 7.2405 & 6007.277 & 11567.466 & 203.592 & 181.454 & \text { Yes }\end{array}$ $\begin{array}{lllllllllllllll}0.98 & 39.08 & 24.62 & 32.88 & 2 & 1116.6860 & 1116.6777 & 559.3461 & 0.0083 & 7.4193 & 9630.779 & 17983.446 & 462.562 & 140.053 & \text { Yes }\end{array}$ $\begin{array}{lllllllllllllll}0.68 & 20.24 & 26.71 & 15.45 & 3 & 1450.8127 & 1450.8136 & 484.6118 & -0.0009 & -0.6191 & 108.421 & 109.575 & 144.851 & 69.843 & \text { No }\end{array}$ $\begin{array}{llllllllllllllll}1.00 & 52.12 & 24.62 & 33.45 & 2 & 1116.6860 & 1116.6777 & 559.3461 & 0.0083 & 7.4193 & 2630.036 & 4175.589 & 51.257 & 161.640 & \text { Yes }\end{array}$ $\begin{array}{llllllllllllllll}1.00 & 52.15 & 24.76 & 34.99 & 2 & 1116.6870 & 1116.6777 & 559.3461 & 0.0093 & 8.3132 & 2876.392 & 4481.150 & 105.148 & 83.978 & \text { Yes }\end{array}$

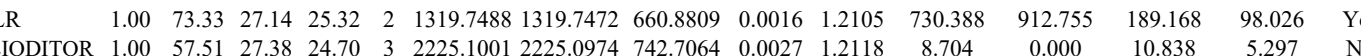

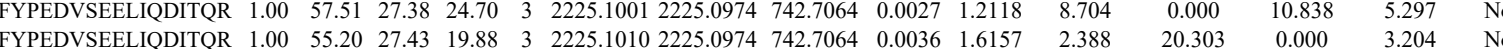

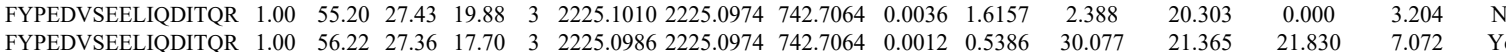
$\begin{array}{lllllllllllllll} & \end{array}$

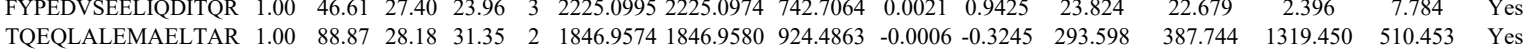

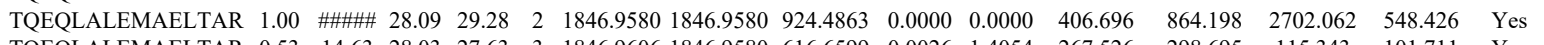

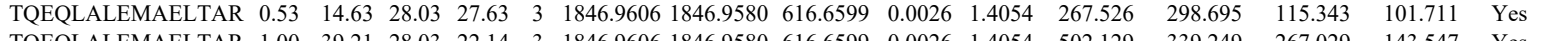

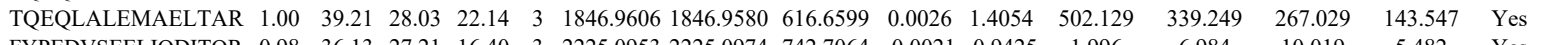

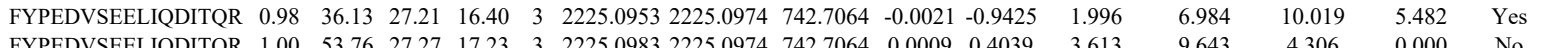

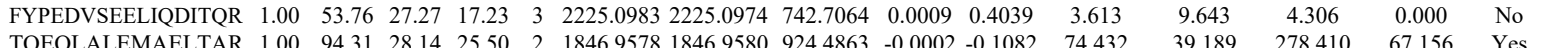

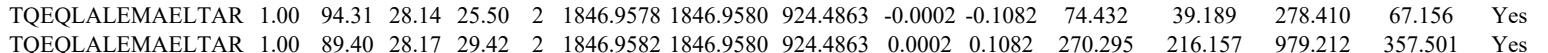

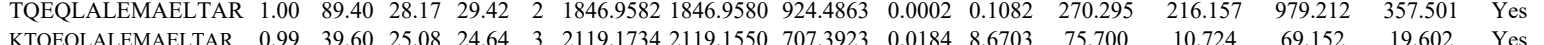

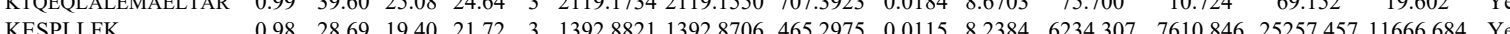

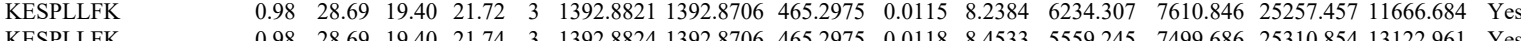

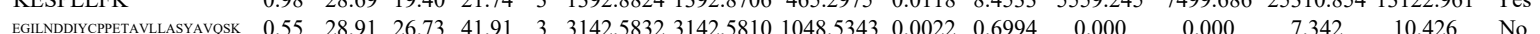

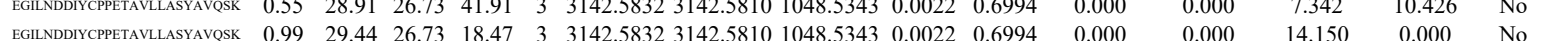

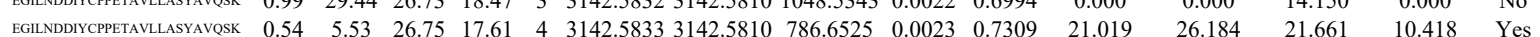

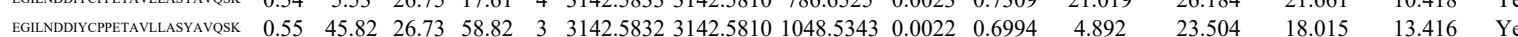

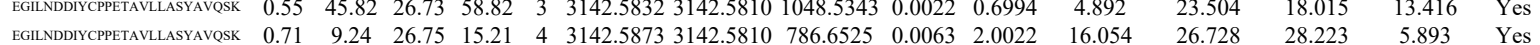

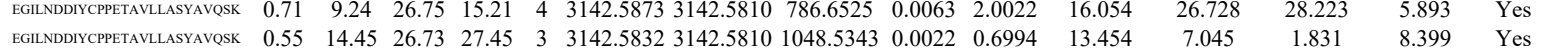

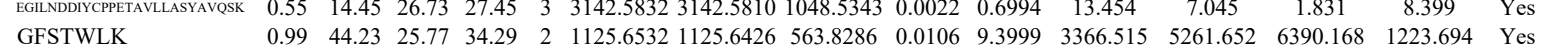

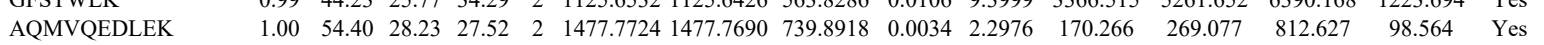

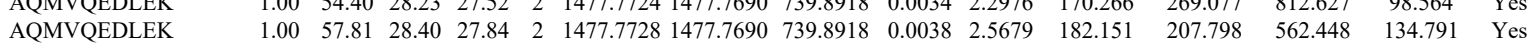
EDAVLEYLK EDAVLEYLK VMATTGGTNLR SGAYLIPLLER SGAYLIPLLER NLVCTDLFTR VHCLNTLFSR VHCLNTLFSR GNEFEDYCLK LNLLHEFLQTEIK LNLLHEFLQTEIK FFLLENVR LAGVTLGQR LAGVTLGQR LAGVTLGQR LAGVTLGQR

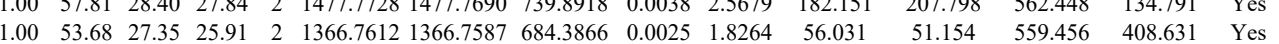

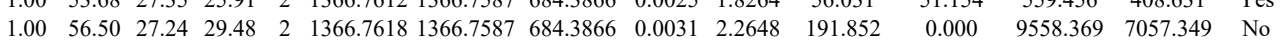
$\begin{array}{llllllllllllllll}1.00 & 65.95 & 28.39 & 32.05 & 2 & 1263.6738 & 1263.6727 & 632.8436 & 0.0011 & 0.8691 & 24537.743 & 26516.073 & 27.767 & 254.761 & \text { Yes }\end{array}$ $\begin{array}{lllllllllllllll}1.00 & 61.53 & 28.13 & 33.00 & 2 & 1263.6762 & 1263.6727 & 632.8436 & 0.0035 & 2.7653 & 10628.911 & 11128.445 & 56.199 & 241.734 & \text { Yes }\end{array}$ $\begin{array}{llllllllllllllll}1.00 & 43.42 & 27.02 & 24.25 & 2 & 1374.7998 & 1374.7993 & 688.4069 & 0.0005 & 0.3632 & 2810.416 & 4194.060 & 956.048 & 203.130 & \text { Yes }\end{array}$ $\begin{array}{lllllllllllllll}1.00 & 42.79 & 26.88 & 24.43 & 2 & 1374.8006 & 1374.7993 & 688.4069 & 0.0013 & 0.9442 & 2676.473 & 3360.440 & 1113.831 & 203.914 & \text { Yes }\end{array}$ $\begin{array}{llllllllllllllll}0.99 & 36.77 & 26.80 & 21.89 & 2 & 1370.6822 & 1370.6808 & 686.3477 & 0.0014 & 1.0199 & 3907.730 & 4207.933 & 165.018 & 248.739 & \text { Yes }\end{array}$ $\begin{array}{lllllllllllllll}1.00 & 51.04 & 27.61 & 23.16 & 2 & 1378.6980 & 1378.6971 & 690.3558 & 0.0009 & 0.6518 & 684.541 & 579.133 & 142.024 & 93.796 & \text { Yes }\end{array}$

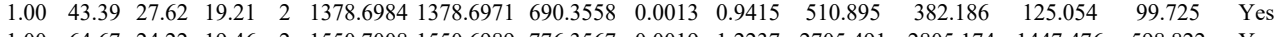

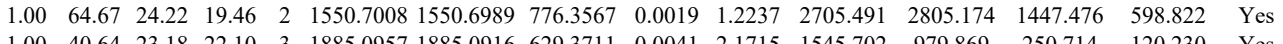
$\begin{array}{llllllllllllllll}1.00 & 40.64 & 23.18 & 22.10 & 3 & 1885.0957 & 1885.0916 & 629.3711 & 0.0041 & 2.1715 & 1545.702 & 979.869 & 250.714 & 120.230 & \text { Yes }\end{array}$ $\begin{array}{lllllllllllllll}1.00 & 34.90 & 23.18 & 20.46 & 3 & 1885.0957 & 1885.0916 & 629.3711 & 0.0041 & 2.1715 & 2747.089 & 2173.406 & 383.297 & 23.111 & \text { Yes } \\ 0.99 & 39.97 & 27.07 & 29.44 & 2 & 1180.6758 & 1180.6726 & 5913436 & 0.0032 & 2.7057 & 8192347 & 6555.745 & 121.827 & 100.477 & \text { Yes }\end{array}$

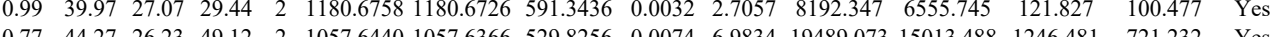
$\begin{array}{lllllllllllllllll}0.77 & 44.27 & 26.23 & 49.12 & 2 & 1857.6440 & 1057.6366 & 529.8256 & 0.0074 & 6.9834 & 19489.073 & 15013.488 & 1246.481 & 721.232 & \text { Yes } \\ 0.99 & 42.79 & 26.26 & 30.85 & 2 & 1057.6450 & 1057.6366 & 529.8256 & 0.0084 & 7.9271 & 15882.948 & 11735.703 & 669.216 & 747.056 & \text { Yes }\end{array}$ $\begin{array}{llllllllllllllll}0.99 & 42.79 & 26.26 & 30.85 & 2 & 1057.6450 & 1057.6366 & 529.8256 & 0.0084 & 7.9271 & 15882.948 & 11735.703 & 669.216 & 747.066 & \text { Yes } \\ 0.89 & 31.23 & 26.26 & 27.75 & 2 & 1057.6448 & 1057.6366 & 529.8256 & 0.0082 & 7.7383 & 7963.910 & 6633.660 & 1116.238 & 787.154 & \text { Yes }\end{array}$ \begin{tabular}{lllllllllllllll}
0.94 & 1.23 & 26.26 & 27.75 & 2 & 1057.6448 & 1057.6366 & 529.8256 & 0.0082 & 7.7883 & 793.910 & 6633.660 & 1116.238 & 787.154 & Yes \\
\hline
\end{tabular}

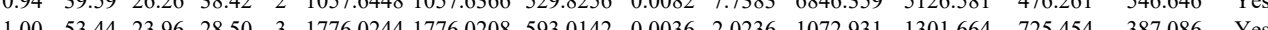
$\begin{array}{llllllllllllllll}1.00 & 67.48 & 24.01 & 34.31 & 3 & 1776.0247 & 1776.0208 & 593.0142 & 0.0039 & 2.1922 & 1821.788 & 2070.463 & 1514.435 & 442.098 & \text { Yes }\end{array}$ 

$\begin{array}{llllllllllllll}0.99 & 41.66 & 26.99 & 23.25 & 2 & 1186.6296 & 1186.6257 & 594.3201 & 0.0039 & 3.2810 & 10547.343 & 10492.784 & 355.990 & 262.005 \\ 0.98 & 39.62 & 26.94 & 19.48 & 2 & 1186.6304 & 1186.6257 & 594.3201 & 0.0047 & 3.9541 & 16816.666 & 16082.147 & 771.466 & 203.435\end{array}$ $\left.\begin{array}{llllllllllllll}0.98 & 39.62 & 6.94 & 19.48 & 2 & 1186.6304 & 1186.6257 & 594.3201 & 0.0047 & 3.9541 & 16816.266 & 16082.147 & 771.466 & 203.435 \\ 1.00 & 47.88 & 27.12 & 20.10 & 2 & 1186.6288 & 1186.6257 & 594.3201 & 0.0031 & 2.6080 & 12974.445 & 12615.023 & 187.636 & 127.057\end{array}\right)$

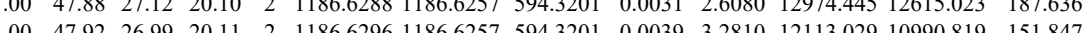

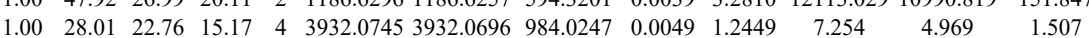

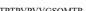

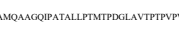

STESLQANVQR STESLQANVQR STESLQANVQR GFSLEELR GTESLQLANVQR STESLQANVQR NGMVLKPHFHK NGMVLKPHFHK LATQLTGPVMPVR LATQLTGPVMPVR VATWFNQPAR VATWFNQPAR

LATQLTGPVMPVR

LATQLTGPVMPVR

LATQLTGPVMPVR

LATQLTGPVMPVR

LATQLTGPVMPVR

LATQLTGPVMPVR

LATQLTGPVMPVR

LATQLTGPVMPVR
VATWFNQPAR

VATWFNQPAR

VATWFNQPAR

VATWFNQPAR

VATWFNQPAR

VATWFNQPAR

VATWFNQPAR

VATWFNQPAR

LATQLTGPVMPVR

LATQLTGPVMPVR

LILFPR

LILFPR

LILFPR

LILFPR

LILFPR

LILFPR

LILFPR

LILFPR

LILFPR

LILFPR

LILFPR

LILFPR

LILFPR

LILFPR

LILFPR

LILFPR
LILFPR

LILFPR

TILFR

LILFPR

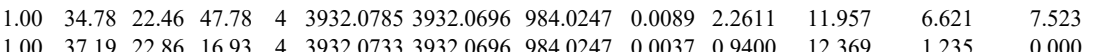

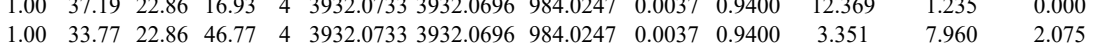

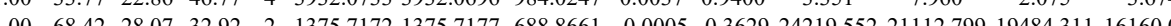
$\begin{array}{llllllllllllllll}1.00 & 65.47 & 28.07 & 30.34 & 2 & 1375.7174 & 1375.7177 & 688.8661 & -0.0003 & -0.2177 & 21153.329 & 18879.797 & 16137.488 & 12575.321\end{array}$ $\begin{array}{llllllllllllll}1.00 & 68.50 & 28.06 & 34.77 & 2 & 1375.7176 & 1375.7177 & 688.8661 & -0.0001 & -0.0726 & 18166.402 & 16082.227 & 12600.192 & 10798.143\end{array}$ $\begin{array}{lllllllllllllllll}1.00 & 66.53 & 28.08 & 30.62 & 2 & 1375.7180 & 1375.7177 & 688.8661 & 0.0003 & 0.2177 & 16958.263 & 14764.647 & 12564.749 & 10195.052 & \mathrm{No}\end{array}$ $\begin{array}{lllllllllllllll}0.99 & 43.32 & 28.34 & 29.90 & 2 & 1093.5986 & 1093.5889 & 547.8017 & 0.0097 & 8.8535 & 35408.297 & 31239.699 & 6964.589 & 572.801 & Y(x e s\end{array}$ $\begin{array}{lllllllllllllll}0.99 & 44.83 & 28.25 & 27.53 & 2 & 1093.5996 & 1093.5889 & 547.8017 & 0.0107 & 9.7662 & 28533.880 & 26808.398 & 5936.285 & 415.036 & \text { Y }\end{array}$ $\begin{array}{llllllllllllllll}1.00 & 63.79 & 28.05 & 29.60 & 2 & 1375.7190 & 1375.7177 & 688.8661 & 0.0013 & 0.9436 & 2347.227 & 2083.831 & 1714.076 & 1376.736 & \text { No }\end{array}$ $\begin{array}{lllllllllllllll}1.00 & 64.55 & 28.25 & 31.05 & 2 & 1375.7196 & 1375.7177 & 688.8661 & 0.0019 & 1.3791 & 6390.883 & 6279.538 & 4795.890 & 3845.894 & \text { No }\end{array}$ $\begin{array}{llllllllllllllll}0.99 & 14.53 & 23.48 & 19.21 & 4 & 1739.0097 & 1739.0030 & 435.7580 & 0.0067 & 3.8439 & 40739.434 & 38736.881 & 3784.374 & 1165.776 & \text { Yes }\end{array}$ $\begin{array}{lllllllllllllll}0.99 & 16.52 & 23.48 & 18.09 & 4 & 1739.0097 & 1739.0030 & 435.7580 & 0.0067 & 3.8439 & 38775.147 & 34493.927 & 4002.654 & 741.809 & \text { Yes }\end{array}$ $\begin{array}{lllllllllllllll}1.00 & 73.07 & 25.17 & 24.78 & 2 & 1525.8752 & 1525.8772 & 763.9459 & -0.0020 & -1.3090 & 5537.995 & 5383.202 & 1081.901 & 0.000 & \text { No }\end{array}$ $\begin{array}{llllllllllllllll}0.53 & 35.30 & 24.62 & 48.30 & 3 & 1525.8802 & 1525.8772 & 509.6330 & 0.0030 & 1.9622 & 350.844 & 299.735 & 119.603 & 5.478 & \text { Yes }\end{array}$ $\begin{array}{llllllllllllllllll}0.99 & 44.94 & 27.88 & 21.22 & 2 & 1332.7176 & 1332.7061 & 667.3603 & 0.0115 & 8.6160 & 13543.303 & 13662.061 & 123.865 & 22.908 & \text { Yes }\end{array}$ $\begin{array}{llllllllllllllll}1.00 & 46.15 & 27.88 & 21.85 & 2 & 1332.7176 & 1332.7061 & 667.3603 & 0.0115 & 8.6160 & 17575.250 & 17422.030 & 97.151 & 68.386 & \text { Yes }\end{array}$

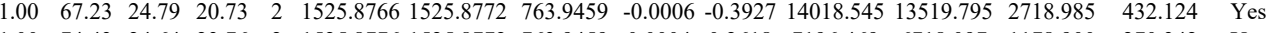
$\begin{array}{lllllllllllllll}1.00 & 74.43 & 24.64 & 23.76 & 2 & 1525.8776 & 1525.8772 & 763.9459 & 0.0004 & 0.2618 & 7196.469 & 6718.097 & 1178.900 & 270.342 & \text { Yes }\end{array}$

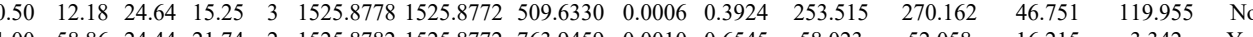
\begin{tabular}{lllllllllllllll}
1.00 & 58.86 & 24.44 & 21.74 & 2 & 1525.8782 & 1525.8772 & 763.9459 & 0.0010 & 0.6545 & 58.023 & 52.058 & 16.215 & 3.342 & Yes \\
\hline
\end{tabular} $\begin{array}{lllllllllllllll}1.00 & 72.11 & 24.44 & 20.63 & 2 & 1525.8782 & 1525.8772 & 763.9459 & 0.0010 & 0.6545 & 52.920 & 78.155 & 28.675 & 5.874 & \text { No }\end{array}$ \begin{tabular}{lllllllllllllll}
1.00 & 48.56 & 24.42 & 21.89 & 2 & 1525.8786 & 1525.8772 & 763.9459 & 0.0014 & 0.9163 & 71.696 & 54.926 & 3.094 & 9.255 & Yes \\
\hline
\end{tabular}

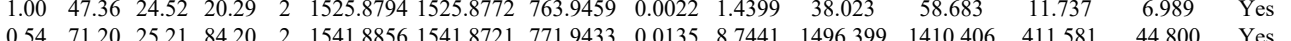

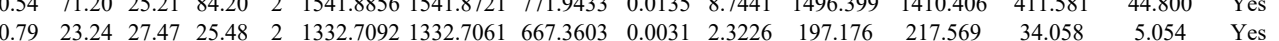

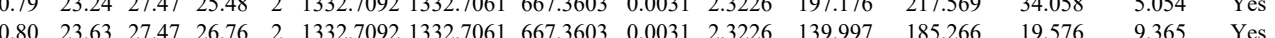
$\begin{array}{llllllllllllllll}0.63 & 23.52 & 27.45 & 27.89 & 2 & 1332.7096 & 1332.7061 & 667.3603 & 0.0035 & 2.3223 & 263.590 & 262.387 & 32.286 & 14.981 & \text { Yes }\end{array}$

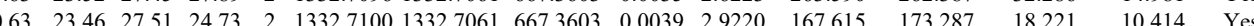

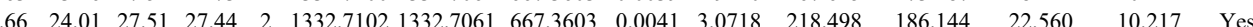
$\begin{array}{lllllllllllllllll}0.65 & 26.72 & 27.63 & 27.56 & 2 & 1332.7108 & 13327061 & 667.3603 & 0.0047 & 3.5213 & 302.879 & 313.321 & 31.198 & 13.825 & \text { Yes }\end{array}$ $\begin{array}{lllllllllllllll}1.00 & 46.55 & 28.03 & 23.90 & 2 & 132.7186 & 1332.7061 & 667.3603 & 0.0125 & 9.3652 & 49471.444 & 44473.100 & 0.000 & 54.073 & \text { No }\end{array}$ $\begin{array}{lllllllllllllllll}1.00 & 46.33 & 28.03 & 22.00 & 2 & 1332.7190 & 1332.7061 & 667.3603 & 0.0129 & 9.6649 & 13101.925 & 14284.265 & 0.000 & 50.747 & \text { No }\end{array}$ $\begin{array}{lllllllllllllll}1.00 & 74.45 & 24.46 & 24.20 & 2 & 1525.8784 & 1525.8772 & 763.9459 & 0.0012 & 0.7854 & 8696.348 & 8696.952 & 1900.234 & 14.875 & \text { Yes }\end{array}$

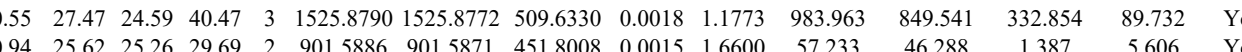
$\begin{array}{llllllllllllllll}0.94 & 25.62 & 25.26 & 29.69 & 2 & 901.5886 & 901.5871 & 451.8008 & 0.0015 & 1.6600 & 57.233 & 46.288 & 1.387 & 5.606 & \text { Yes } \\ 0.76 & 25.27 & 24.23 & 28.14 & 2 & 901.5856 & 901.5871 & 451.8008 & 0.0015 & -1.6600 & 4262.834 & 4149.544 & 468.085 & 65.270 & \text { Yes }\end{array}$ $\begin{array}{lllllllllllllll}0.93 & 25.08 & 25.26 & 27.97 & 2 & 901.5882 & 901.5871 & 451.8008 & 0.0011 & 1.2173 & 5376.902 & 5447.408 & 511.147 & 97.652 & \text { Yes }\end{array}$ \begin{tabular}{llllllllllllllll}
0.81 & 19.84 & 25.26 & 27.27 & 2 & 901.5892 & 901.5871 & 451.8008 & 0.0021 & 2.3240 & 133.051 & 114.739 & 5.337 & 11.132 & Yes \\
\hline
\end{tabular} $\begin{array}{lllllllllllllll}0.78 & 22.26 & 25.28 & 28.91 & 2 & 901.5866 & 901.5871 & 451.8008 & -0.0005 & -0.5533 & 117.870 & 131.574 & 7.466 & 4.988 & \text { Yes }\end{array}$ $\begin{array}{lllllllllllllllll}0.82 & 26.54 & 25.28 & 34.82 & 2 & 901.5868 & 901.5871 & 451.8008 & -0.0003 & -0.3320 & 48083.366 & 62909.120 & 2280.565 & 677.841 & \text { Yes }\end{array}$

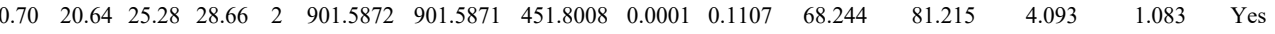
$\begin{array}{llllllllllllllll}0.57 & 18.01 & 25.26 & 28.64 & 2 & 901.5874 & 901.5871 & 451.8008 & 0.0003 & 0.3320 & 107.172 & 118.059 & 8.818 & 5.401 & \text { Yes }\end{array}$ $\begin{array}{lllllllllllllllll}0.93 & 25.31 & 25.26 & 29.32 & 2 & 901.5876 & 901.5871 & 451.8008 & 0.0005 & 0.5533 & 200.838 & 222.206 & 0.106 & 9.356 & \text { No }\end{array}$ $\begin{array}{llllllllllllllll}0.67 & 17.08 & 25.26 & 24.06 & 2 & 901.5878 & 901.5871 & 451.8008 & 0.0007 & 0.7747 & 199.567 & 229.452 & 17.291 & 16.942 & \text { Yes }\end{array}$

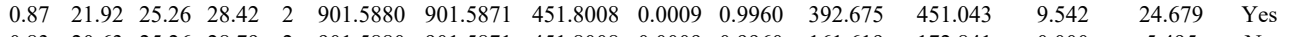

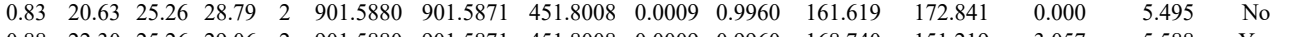

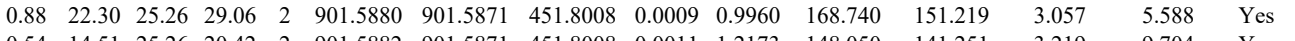

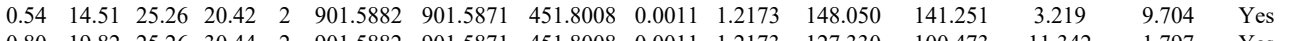
$\begin{array}{lllllllllllllll}0.80 & 19.82 & 25.26 & 30.44 & 2 & 901.5882 & 901.5871 & 451.8008 & 0.0011 & 1.2173 & 127.330 & 100.473 & 11.342 & 1.797 & \text { Yes } \\ 0.51 & 1.00 & 25.26 & 25.38 & 2 & 90.5884 & 901.5871 & 45.8008 & 0.0013 & 1.4387 & 40.513 & 365.301 & 32.822 & 1.548 & \text { Yes }\end{array}$ $\begin{array}{lllllllllllllll}0.51 & 14.00 & 25.26 & 25.38 & 2 & 901.5884 & 901.5871 & 451.8008 & 0.0013 & 1.4387 & 409.513 & 365.301 & 32.822 & 31.848 & \text { Yes } \\ 0.83 & 20.61 & 25.26 & 28.57 & 2 & 901.5884 & 901.5871 & 451.8008 & 0.0013 & 1.4387 & 411.594 & 502.334 & 43.427 & 21.506 & \text { Yes }\end{array}$ $\begin{array}{llllllllllllllll}0.83 & 20.61 & 25.26 & 28.57 & 2 & 901.5884 & 901.5871 & 451.8008 & 0.0013 & 1.4387 & 411.594 & 502.334 & 43.427 & 21.506 & \text { Yes } \\ 0.62 & 15.96 & 25.26 & 23.44 & 2 & 901.5884 & 901.5871 & 451.8008 & 0.0013 & 1.4387 & 199.488 & 200.711 & 19.456 & 4.100 & \text { Yes }\end{array}$ $\begin{array}{lllllllllllllll}0.62 & 15.96 & 25.26 & 23.44 & 2 & 901.5884 & 901.5871 & 451.8008 & 0.0013 & 1.4387 & 199.488 & 200.711 & 19.456 & 4.100 & \text { Yes } \\ 0.88 & 22.34 & 25.26 & 28.99 & 2 & 901.5884 & 901.5871 & 451.8008 & 0.0013 & 1.4387 & 251.925 & 221.847 & 7.602 & 18.558 & \text { Yes }\end{array}$ $\begin{array}{lllllllllllllll}0.88 & 22.34 & 25.26 & 28.99 & 2 & 901.5884 & 901.5871 & 451.8008 & 0.0013 & 1.4387 & 251.925 & 221.847 & 7.602 & 18.558 & \text { Yes } \\ 0.85 & 20.88 & 25.26 & 28.93 & 2 & 901.5886 & 901.5871 & 451.8008 & 0.0015 & 1.6600 & 377.306 & 398.220 & 15.935 & 22.145 & \text { Yes }\end{array}$

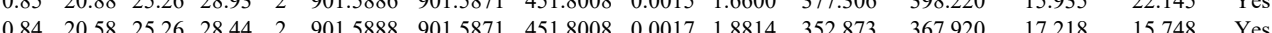
$\begin{array}{llllllllllll}0.79 & 2.58 & 25.26 & 26.44 & 2 & 901.5888 & 901.5871 & 451.8008 & 0.0017 & 1.8814 & 352.873 & 367.920\end{array}$

Table S-3 page 194 of 499 

$\begin{array}{lllllllllllllll}0.75 & 18.63 & 25.26 & 30.51 & 2 & 901.5884 & 901.5871 & 451.8008 & 0.0013 & 1.4387 & 110.330 & 116.508 & 14.345\end{array}$

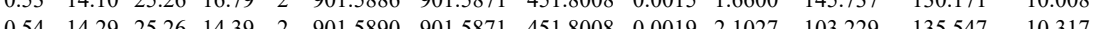

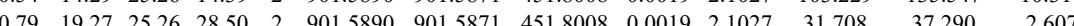
$\begin{array}{lllllllllllll}0.58 & 20.27 & 25.26 & 28.50 & 2 & 01.5890 & 01.5871 & 41.8008 & 0.0019 & 2.1027 & 31.708 & 37.290 & 2.607\end{array}$ $\begin{array}{lllllllllllll}0.71 & 21.86 & 25.28 & 32.87 & 2 & 901.5870 & 901.5871 & 451.8008 & -0.0001 & -0.1107 & 18951.137 & 25220.246 & 690.346\end{array}$ $\begin{array}{llllllllllllll}0.95 & 33.50 & 25.26 & 35.66 & 2 & 901.5874 & 901.5871 & 451.8008 & 0.0003 & 0.3320 & 2121.687 & 2358.775 & 102.255\end{array}$ $\begin{array}{llllllllllllllll}0.98 & 33.26 & 25.26 & 35.13 & 2 & 901.5876 & 901.5871 & 451.8008 & 0.0005 & 0.5533 & 2996.784 & 2913.925 & 115.984\end{array}$ $\begin{array}{lllllllllllll}0.94 & 25.47 & 25.26 & 31.62 & 2 & 901.5880 & 901.5871 & 451.8008 & 0.0009 & 0.9960 & 508.569 & 533.128 & 13.934\end{array}$

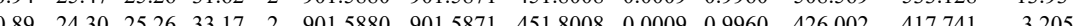
$\begin{array}{llllllllllllll}1.00 & 52.98 & 28.30 & 30.63 & 2 & 1375.7192 & 1375.7177 & 688.8661 & 0.0015 & 1.0887 & 19.593 & 10.102 & 9.580\end{array}$ $\begin{array}{llllllllllllll}1.00 & 38.71 & 27.62 & 24.08 & 3 & 1494.8263 & 1494.8255 & 499.2824 & 0.0008 & 0.5341 & 3335.846 & 2519.811 & 2037.133\end{array}$ $\begin{array}{lllllllllllll}1.00 & 67.46 & 24.64 & 25.13 & 2 & 1525.8774 & 1525.8772 & 763.9459 & 0.0002 & 0.1309 & 543.464 & 481.526 & 137.243\end{array}$ $\begin{array}{lllllllllllll}1.00 & 70.59 & 24.44 & 24.91 & 2 & 1525.8782 & 1525.8772 & 763.9459 & 0.0010 & 0.6545 & 562.818 & 536.199 & 157.952\end{array}$

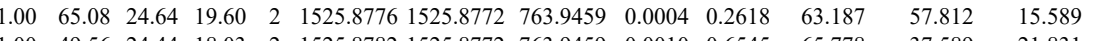
$\begin{array}{lllllllllllll}1.00 & 49.56 & 24.44 & 18.03 & 2 & 1525.8782 & 1525.8772 & 763.9459 & 0.0010 & 0.6545 & 65.778 & 37.589 & 21.831 \\ 1.00 & 57.18 & 27.53 & 18.78 & 3 & 1598.8639 & 1598.8508 & 533.9575 & 0.0131 & 8.1779 & 9014.036 & 8693.440 & 4961.594\end{array}$ LGEMWSEQSAK LGEMWSEQSAK KHPDSSVNFAEFSK GPGRPTGSK

GPGRPTGSK

KGPGRPTGSK

GPGRPTGSK

GPGRPTGSK

KGPGRPTGSK

KGPGRPTGSK

GPGRPTGSK

GPGRPTTCSK

KGPBRPTGSK

KGPGRPTGSK

KEPRET

SEHPGLSIGDTAK

SEHPGLSIGDTAK

SEHPGLSIGDTAK

SEHPGLSIGDTAK

SEHPGLSIGDTAK

$\begin{array}{lllllllllllll}\text { PTBP1 HUMAN } & \text { P26599 } & \text { PTBP1 } & \text { Polypyrimidine tr، 57.22 } & 1.00 & 13 & 37.9 & -0.1928 & 0.8393 & 0.2761 & 1.7143 & 60 & \text { SAGVPS }\end{array}$

SAGVPSR

$\begin{array}{lllllllllllllll}.00 & 53.91 & 28.08 & 30.57 & 2 & 1552.7936 & 1552.7799 & 777.3972 & 0.0137 & 8.8114 & 1244.880 & 1339.564 & 267.505 & 35.958 & Y\end{array}$ $\begin{array}{llllllllllllllll}0.97 & 74.55 * 27.10 & 30.80 & 3 & 2024.0836 & 2024.0693 & 675.6970 & 0.0143 & 7.0544 & 4191.726 & 4944.804 & 2833.973 & 1110.757 & \text { Yes } & \end{array}$ $\begin{array}{llllllllllllllll}0.85 & 25.60 & 26.45 & 25.71 & 2 & 999.5588 & 999.5583 & 500.7864 & 0.0005 & 0.4992 & 365.597 & 467.260 & 1.282 & 0.000 & \text { No } \\ 0.95 & 30.89 & 26.45 & 30.24 & 2 & 999.5588 & 999.5583 & 500.7864 & 0.0005 & 0.4992 & 210.536 & 249.667 & 0.000 & 0.000 & \text { No }\end{array}$ $\begin{array}{llllllllllllllll}0.99 & 31.66 & 24.33 & 21.11 & 2 & 1415.8590 & 1415.8574 & 708.9360 & 0.0016 & 1.1285 & 1234.353 & 1333.711 & 0.000 & 3.538 & \text { No }\end{array}$ $\begin{array}{llllllllllllllll}0.81 & 24.33 & 26.45 & 1.98 & 2 & 999.5588 & 999.5583 & 500.7864 & 0.0005 & 0.4992 & 256.980 & 324.373 & 8.762 & 2.567 & \text { Yes } \\ 0.85 & 2.69 & 26.40 & 3.56 & 2 & 99.5590 & 99.5583 & 50.7864 & 0.0007 & 0.6989 & 27.457 & 381706 & 0.000 & 0.000 & \end{array}$ $\begin{array}{llllllllllllllll}0.85 & 22.60 & 26.40 & 32.56 & 2 & 999.5590 & 999.5583 & 500.7864 & 0.0007 & 0.6989 & 279.457 & 381.706 & 0.000 & 0.000 & \text { No } \\ 0.92 & 26 & 24.22 & 18.47 & 2 & 1415.8576 & 1415.8574 & 708.9360 & 0.0002 & 0.1411 & 263.367 & 289.951 & 7.633 & 0.000 & \text { No }\end{array}$ $\begin{array}{lllllllllllllll}0.92 & 26.29 & 24.22 & 18.47 & 2 & 1415.8576 & 1415.8574 & 708.9360 & 0.0002 & 0.1411 & 263.367 & 289.951 & 7.633 & 0.000 & \mathrm{No} \\ 0.54 & 12.33 & 24.18 & 14.69 & 3 & 1415.8579 & 1415.8574 & 472.9597 & 0.0005 & 0.3524 & 567.228 & 750.033 & 0.000 & 4.186 & \mathrm{No}\end{array}$

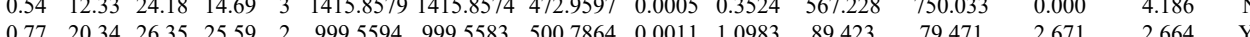

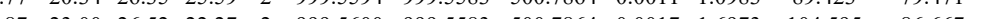

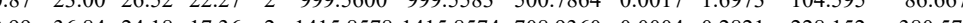
$\begin{array}{llllllllllll}0.68 & 12.75 & 24.33 & 16.28 & 3 & 1415.8588 & 1415.8574 & 472.9597 & 0.0014 & 0.9867 & 630.101 & 779.292\end{array}$ $\begin{array}{lllllllllllllll}1.00 & 61.11 & 27.57 & 23.17 & 2 & 1598.8606 & 1598.8508 & 800.4327 & 0.0098 & 6.1217 & 4803.099 & 5333.647 & 1756.426 & 1254.679 & \text { Yes }\end{array}$ $\begin{array}{llllllllllllllll}1.00 & 63.84 & 27.69 & 22.37 & 2 & 1598.8608 & 1598.8508 & 800.4327 & 0.0100 & 6.2466 & 7995.810 & 9245.906 & 4277.567 & 1967.963 & \text { Yes }\end{array}$ $\begin{array}{llllllllllllllll}1.00 & 59.16 & 27.45 & 19.00 & 3 & 1598.8621 & 1598.8508 & 533.9575 & 0.0113 & 7.0542 & 11397.942 & 13519.790 & 5677.110 & 3116.718 & \text { Yes }\end{array}$ $\begin{array}{llllllllllllllll}1.00 & 54.59 & 27.44 & 18.29 & 3 & 1598.8627 & 1598.8508 & 533.9575 & 0.0119 & 7.4288 & 20721.675 & 24200.835 & 10576.555 & 5157.098 & \text { Yes } \\ 0.58 & 20.84 & 27.86 & 28.23 & 2 & 816.4574 & 816.4575 & 409.2360 & 0.0001 & -0.1222 & 128.970 & 138.261 & 31.797 & 7.239 & \text { Yes }\end{array}$ $\begin{array}{llllllllllllllll}0.58 & 20.84 & 27.86 & 28.23 & 2 & 816.4574 & 816.4575 & 409.2360 & -0.0001 & -0.1222 & 128.670 & 138.261 & 31.797 & 7.239 & \text { Yes } \\ 0.66 & 22.11 & 27.56 & 30.29 & 2 & 816.4576 & 816.4575 & 409.2360 & 0.0001 & 0.1222 & 151.356 & 142.144 & 28.202 & 2.211 & \text { Yes }\end{array}$

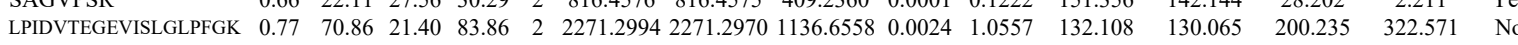

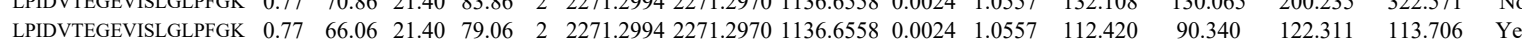

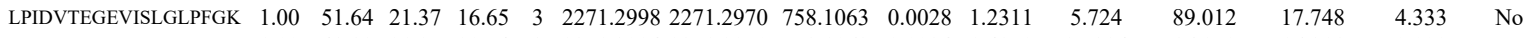

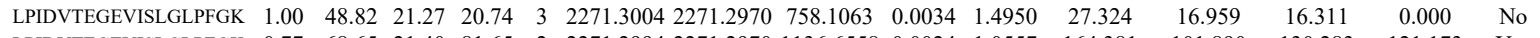
$\begin{array}{llllllllllllllll}\text { LPIDVTEGEVISLGLPFGK } & 0.77 & 68.65 & 21.40 & 81.65 & 2 & 2271.2994 & 2271.2970 & 1136.6558 & 0.0024 & 1.0557 & 164.381 & 101.890 & 130.283 & 121.173 & \text { Yes }\end{array}$

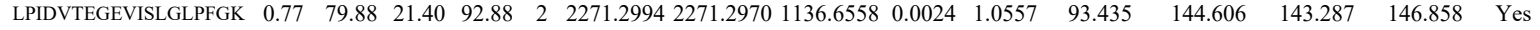

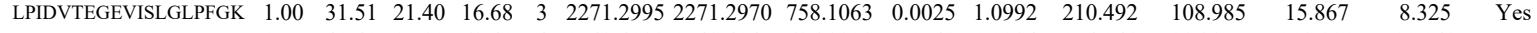
$\begin{array}{llllllllllllllll}\text { KLPIDVTEGEVISLGLPFGK } & 1.00 & 49.41 & 15.80 & 62.41 & 4 & 2543.4989 & 2543.4940 & 636.8808 & 0.0049 & 1.9234 & 274.941 & 386.375 & 213.391 & 10.043 & \text { Yes }\end{array}$

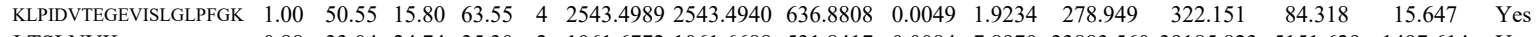

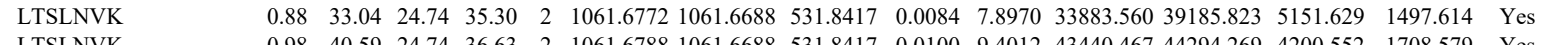
$\begin{array}{llllllllllllllll}\text { LTSLNVK } & 0.98 & 40.59 & 24.74 & 36.63 & 2 & 1061.6788 & 1061.6688 & 531.8417 & 0.0100 & 9.4012 & 43440.467 & 44294.269 & 4200.552 & 1708.579 & \text { Yes }\end{array}$

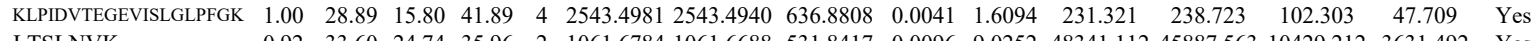

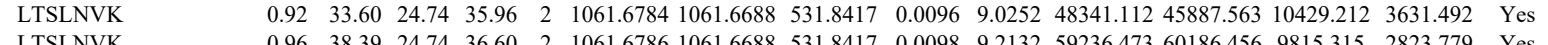
$\begin{array}{llllllllllllllll}\text { LTSLNVK } & 0.96 & 38.39 & 24.74 & 36.60 & 2 & 1061.6786 & 1061.6688 & 531.8417 & 0.0098 & 9.2132 & 59236.473 & 60186.456 & 9815.315 & 2823.779 & \text { Yes }\end{array}$ $\begin{array}{llllllllllllllll}\text { NNQFPALLQYADPVSAQHAK } & 1.00 & 29.14 & 26.61 & 42.14 & 4 & 2530.3261 & 2530.3172 & 633.5866 & 0.0089 & 3.5117 & 1448.433 & 1868.732 & 339.820 & 143.824 & \text { Yes } \\ \text { VLFSSNGGVVK } & 1.00 & 58.63 & 24.70 & 33.05 & 2 & 1393.8292 & 1393.8173 & 697.9159 & 0.019 & 85253 & 7059.859 & 6113.046 & 268.194 & 239.412 & \text { Yes }\end{array}$ $\begin{array}{llllllllllllllll}\text { VLFSSNGGVVK } & 1.00 & 58.63 & 24.70 & 33.05 & 2 & 1393.8292 & 1393.8173 & 697.9159 & 0.0119 & 8.5253 & 7059.859 & 6113.046 & 268.194 & 239.412 & \text { Yes } \\ \text { VLFSSNGGVVK } & 1 & 58.00 & 54.68 & 34.88 & 2 & 1393.8294 & 1393.8173 & 697.9159 & 0.0121 & 86686 & 9258.726 & 8590.225 & 463.528 & 203.286 & \text { Yes }\end{array}$ $\begin{array}{lccccccccccccccc}\text { VLFSSNGGVVK } & 1.00 & 58.39 & 24.68 & 34.88 & 2 & 1393.8294 & 1393.8173 & 697.9159 & 0.0121 & 8.6686 & 9258.726 & 8590.225 & 463.528 & 203.286 & \text { Yes } \\ \text { ILFNK } & 0.59 & 24.06 & 26.79 & 28.71 & 2 & 921.5970 & 921.5891 & 461.8018 & 0.0079 & 8.5534 & 75723.686 & 74881.490 & 1485.315 & 1539.063 & \text { Yes }\end{array}$

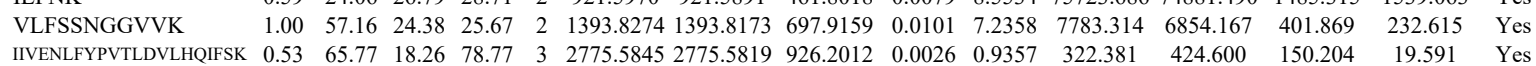

Table S-3 page 195 of 499 

$\begin{array}{lllllllllll}1.00 & 27.26 & 24.55 & 40.26 & 4 & 3823.9789 & 3823.9794 & 957.0021 & -0.0005 & -0.1306 & 13.600\end{array}$ $\begin{array}{llllllllllll}1.00 & 31.18 & 24.53 & 16.21 & 4 & 3823.9809 & 3823.9794 & 957.0021 & 0.0015 & 0.3918 & 9.731\end{array}$

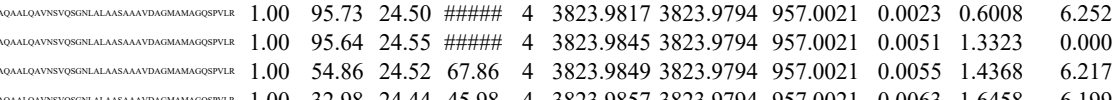

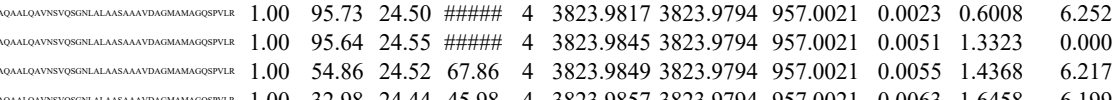
$\begin{array}{lllllllllll}1.00 & 32.98 & 24.44 & 45.98 & 4 & 3823.9857 & 3823.9794 & 957.0021 & 0.0063 & 1.6458 & 6.199\end{array}$ $\begin{array}{llllllllllll}1.00 & 30.52 & 24.38 & 43.52 & 4 & 3823.9865 & 3823.9794 & 957.0021 & 0.0071 & 1.8547 & 11.087\end{array}$

$\begin{array}{llllllllllll} & \end{array}$ $\begin{array}{llllllllllll}1.00 & 59.28 & 21.55 & 16.79 & 2 & 2418.3734 & 2418.3716 & 1210.1931 & 0.0018 & 0.7437 & 20.020\end{array}$

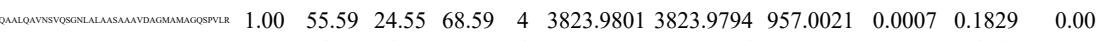

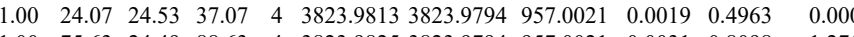
$\begin{array}{lllllllllll}1.00 & 75.63 & 24.49 & 88.63 & 4 & 3823.9825 & 3823.9794 & 957.0021 & 0.0031 & 0.8098 & 1.275\end{array}$

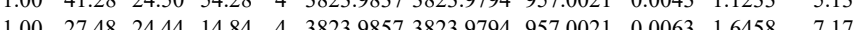

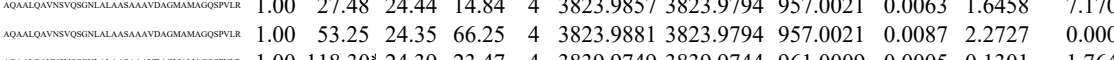

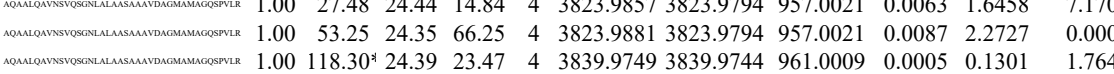

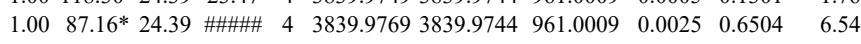

$\begin{array}{llllllllllll}\text { VPQSLFILFGVYGDVQR } & 1.00 & 67.25 & 25.91 & 21.23 & 3 & 2182.1932 & 2182.1909 & 728.4042 & 0.0023 & 1.0525 & 2.981 \\ \end{array}$

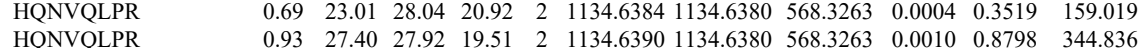

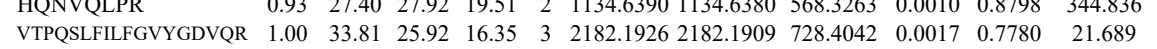
$\begin{array}{lllllllllllll}\text { VTPQSLFILFGVYGDVQR } & 1.00 & 57.86 & 25.84 & 20.33 & 3 & 2182.1938 & 2182.1909 & 728.4042 & 0.0029 & 1.3271 & 6.853\end{array}$

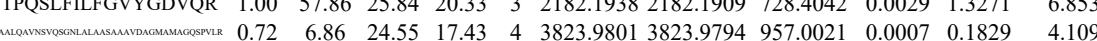

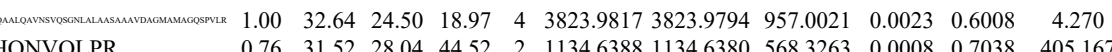
HQNVQLPR $\begin{array}{llllllllllll}0.76 & 31.52 & 28.04 & 44.52 & 2 & 1134.6388 & 1134.6380 & 568.3263 & 0.0008 & 0.7038 & 405.167\end{array}$

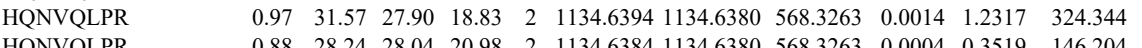
$\begin{array}{lllllllllllll} & 0.88 & 28.24 & 28.04 & 20.98 & 2 & 1134.6384 & 1134.6380 & 568.3263 & 0.0004 & 0.3519 & 146.204\end{array}$ $\begin{array}{lllllllllllll} & 0.78 & 21.58 & 27.94 & 18.08 & 2 & 1134.6396 & 1134.6380 & 568.3263 & 0.0016 & 1.4076 & 115.392\end{array}$ $\begin{array}{lllllllllllll} & \end{array}$

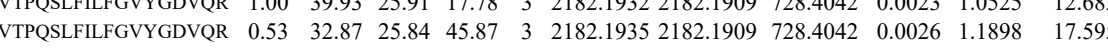
$\begin{array}{llllllllllll}\text { VTPQSLFILFGVYGDVQR } & 0.53 & 40.44 & 25.84 & 53.44 & 3 & 2182.1938 & 2182.1909 & 728.4042 & 0.0029 & 1.3271 & 15.979\end{array}$ $\begin{array}{lllllllllll}1.00 & 58.22 & 24.44 & 71.22 & 4 & 3823.9857 & 3823.9794 & 957.0021 & 0.0063 & 1.6458 & 1.172\end{array}$ $\begin{array}{lllllllllll}1.00 & 44.83 & 24.53 & 57.83 & 4 & 3823.9813 & 3823.9794 & 957.0021 & 0.0019 & 0.4963 & 0.000\end{array}$ $\begin{array}{llllllllllll}1.00 & 41.18 & 24.41 & 54.18 & 4 & 3823.9869 & 3823.9794 & 957.0021 & 0.0075 & 1.9592 & 1.828\end{array}$ $\begin{array}{lllllllllllll}\text { AAAPGLAGAGAGNSVLLVSNLNPER } & 1.00 & 34.16 & 21.58 & 15.41 & 3 & 2418.3739 & 2418.3716 & 807.1311 & 0.0023 & 0.9499 & 3.082\end{array}$

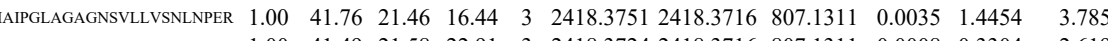

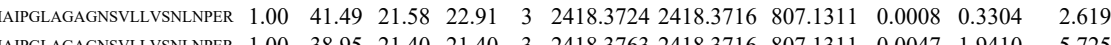
$\begin{array}{lllllllllllll}\text { IAIPGLAGAGNSVLLVSNLNPER } & 1.00 & 38.95 & 21.40 & 21.40 & 3 & 2418.3763 & 2418.3716 & 807.1311 & 0.0047 & 1.9410 & 5.725 \\ \text { HIPGLAGAGNSVLLVSNLNPER } & 1.00 & 44.62 & 21.61 & 17.26 & 3 & 2418.3721 & 2418.3716 & 807.1311 & 0.0005 & 0.2065 & 8.726\end{array}$ 

$\begin{array}{llllllllllllllll}\text { FMADIDLDPGCTLNK } & 1.00 & 67.94 & 26.79 & 26.55 & 2 & 1985.9518 & 1985.9504 & 993.9825 & 0.0014 & 0.7042 & 1285.986 & 1321.804 & 25.268 & 75.452 & N o \\ \text { QVMVVPVGPTCDEYAQK } & 1.00 & 82.86 & 27.42 & 26.27 & 2 & 2197.0814 & 2197.0825 & 1099.5485 & -0.0011 & -0.5002 & 160.441 & 227.023 & 27.089 & 11.036 & Y\end{array}$ $\begin{array}{llllllllllllllll}\text { QVMVVPVGPTCDEYAQK } & 1.00 & 82.86 & 27.42 & 26.27 & 2 & 2197.0814 & 2197.0825 & 1099.5485 & -0.0011 & -0.5002 & 160.441 & 227.023 & 27.089 & 11.036 & Y \\ \text { QVMVYPVGPTCDEYAQK } & 1.00 & 41.15 & 27.26 & 17.53 & 3 & 2197.0825 & 2197.0825 & 733.3681 & 0.0000 & 0.0000 & 206.475 & 244.416 & 185.886 & 32.051 & \text { N }\end{array}$ $\left.\begin{array}{lllllllllllllll}\text { QVMVVPVGPTCDEYAQK } & 1.00 & 41.15 & 27.26 & 17.53 & 3 & 2197.0825 & 2197.0825 & 733.3681 & 0.0000 & 0.0000 & 206.475 & 244.416 & 185.886 & 32.051 \\ \text { FMADIDLDPGCTLNK } & 1.00 & 42.65 & 26.79 & 22.87 & 2 & 1985.9520 & 1985.9504 & 993.9825 & 0.0016 & 0.8048 & 158.070 & 244.371 & 29.942 & 25.743\end{array}\right)$

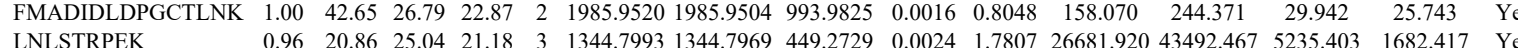

\section{LNLSTRPEK}

LNLSTRE

LNLSTRPEK

LNLSTRPEK

VNTPTTTVYR

VNTPTTTVYR

VNTPTTTVYR

VNTPTTTVYR

VNTPTTTVYR

VNTPTTTVYR

LADFGVLHR

KETLLAMFK

ISGTVNIR

GCLDFLR

GCLDFLR

TTPYQIACGISQGLADNTVIAK

GCLDFLR

GCLDFLR

TTPYQIACGISQGLADNTVIAK

CGPLIDLCR

CGPLIDLCR

CGPLIDLCR

GAYIYNALIEFIR

GAYIYNALIEFIR

GAYIYNALIEFIR

GAYIYNALIEFIR

GAYIYNALIEFIR

GAYIYNALIEFIR

GAYIYNALIEFIR

GAYIYNALIEFIR

GAYIYNALIEFIR

GAYIYNALI
WPFWLSPR

WPFWLSPR

WPFWLSPR

MGGEEKPIGAGEEK MGGEEKPIGAGEEK

WPFWLSPR

WPFWLSPR

WPFWLSPR

WPFWLSPR

WPFWLSPR

WPFWLSPR

WPFWLSPR

WPFWLSPR

QLENSLNEFGEK

QLENSLNEFGEK

FLGDIEVWDQAEK

FLGDIEVWDQAEK

FLGDIEVWDQAEK

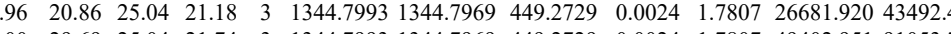

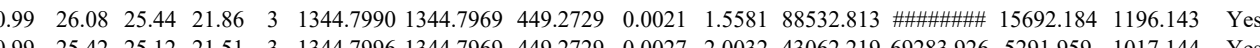

$\begin{array}{lllllllllllllll}1.00 & 59.03 & 28.26 & 23.51 & 2 & 1294.7010 & 1294.7003 & 648.3574 & 0.0007 & 0.5398 & 33847.654 & 57877.500 & 52263.959 & 1017.144 & \text { Yes } \\ 1.635 .701 & \text { Yes }\end{array}$

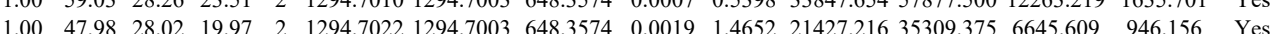

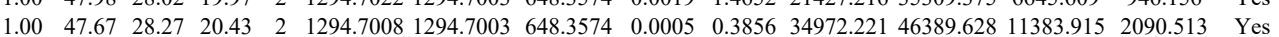

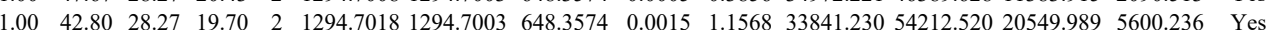
$\begin{array}{llllllllllllllll}0.86 & 27.53 & 28.27 & 22.61 & 2 & 1294.7004 & 1294.7003 & 648.3574 & 0.0001 & 0.0771 & 6353.712 & 10349.336 & 7222.062 & 3259.644 & \text { Yes }\end{array}$ $\begin{array}{lllllllllllllll}0.96 & 33.67 & 28.27 & 19.95 & 2 & 1294.7006 & 1294.7003 & 648.3574 & 0.0003 & 0.2314 & 12339.231 & 20516964 & 7566.630 & 3793.384 & \text { Yes }\end{array}$ $\begin{array}{llllllllllllllll}1.00 & 49.35 & 26.11 & 21.85 & 2 & 1170.6730 & 1170.6631 & 586.3388 & 0.0099 & 8.4421 & 12479.990 & 15835.041 & 949.315 & 758.197 & \text { Yes }\end{array}$ $\begin{array}{llllllllllllllll}1.00 & 45.71 & 26.11 & 24.48 & 2 & 1170.6736 & 1170.6631 & 586.3388 & 0.0105 & 8.9538 & 14464.236 & 20916.595 & 1118.458 & 873.676 & \text { Yes }\end{array}$

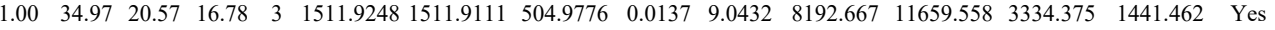
$\begin{array}{lllllllllllllll}0.97 & 49.99 & 27.81 & 44.71 & 2 & 1002.6014 & 1002.5944 & 502.3045 & 0.0070 & 6.9678 & 38464.402 & 64002.607 & 2690.078 & 6809.506 & \text { Yes }\end{array}$

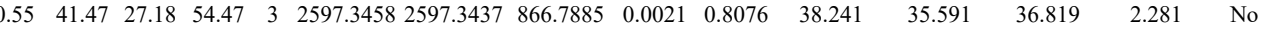
$\begin{array}{lllllllllllllll}0.99 & 37.32 & 26.12 & 23.44 & 2 & 1012.4964 & 012.4956 & 507.2551 & 0.0008 & 0.7886 & 18864.938 & 40242.470 & 6834.447 & 770.535 & \text { Yes }\end{array}$

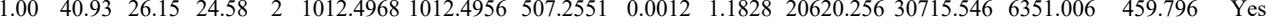
\begin{tabular}{lllllllllllllll}
0.55 & 15.43 & 27.19 & 16.43 & 3 & 2597.3437 & 2597.3437 & 866.7885 & 0.0000 & 0.0000 & 78.209 & 118.946 & 87.798 & 42.705 & Yes \\
\hline
\end{tabular} $\begin{array}{llllllllllllllll}1.00 & 40.95 & 25.81 & 25.14 & 2 & 1012.4952 & 1012.4956 & 507.255 & -0.0004 & -0.3943 & 6144.703 & 11297.134 & 1944.326 & 210.366 & \text { Yes } \\ 0.99 & 37.19 & 26.11 & 23.29 & 2 & 1012.4960 & 1012.4956 & 507.255 & 0.004 & 0.3943 & 13740.48 & 23512.877 & 4547.267 & 436.321 & \text { Yes }\end{array}$

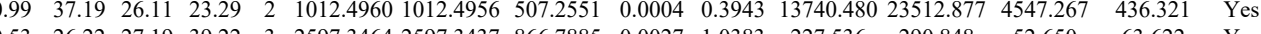

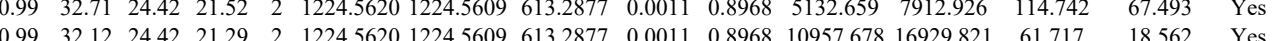
$\begin{array}{lllllllllllllllll}0 & 0.07 .562 & \text { Yes }\end{array}$

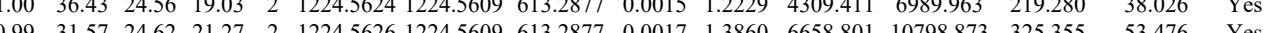
$\begin{array}{lllllllllllllll}1.00 & 66.35 & 26.85 & 24.79 & 2 & 1685.9270 & 1685.9262 & 843.9704 & 0.0008 & 0.4740 & 1650.823 & 3623.467 & 616.034 & 224.908 & \text { Yes }\end{array}$

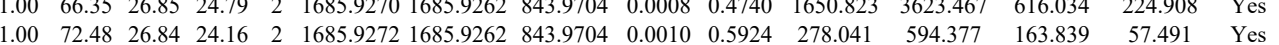

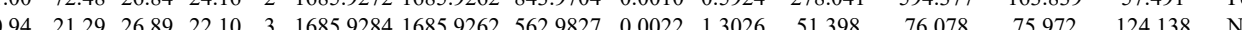

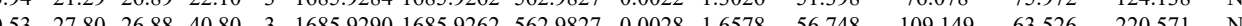

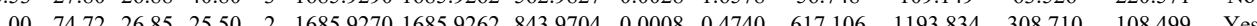

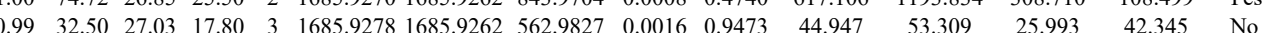

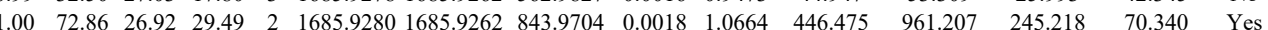
$\begin{array}{lllllllllllllll}1.00 & 33.06 & 26.88 & 21.13 & 3 & 1685.9290 & 1685.9262 & 5629827 & 0.0028 & 1.6578 & 47.120 & 49.943 & 34.433 & 37.922 & \text { Yes }\end{array}$ $\begin{array}{lllllllllllllll}10 & 50.74 & 27.01 & 20.07 & 2 & 1655.9268 & 1685.9262 & 843.9704 & 0.0006 & 0.3555 & 173.698 & 375.900 & 79.695 & 57.509 & \text { Yes }\end{array}$ $\begin{array}{llllllllllllllll}1.00 & 59.99 & 26.89 & 22.31 & 2 & 1685.9274 & 1685.9262 & 843.9704 & 0.0012 & 0.7109 & 255.485 & 414.339 & 140.557 & 79.771 & \text { Yes }\end{array}$ $\begin{array}{llllllllllllllll}0.72 & 28.39 & 28.34 & 33.81 & 2 & 1231.6610 & 1231.6624 & 616.8385 & -0.0014 & -1.1348 & 251.004 & 429.613 & 222.106 & 179.436 & \text { Yes }\end{array}$ $\begin{array}{lllllllllllllll}0.68 & 27.62 & 28.39 & 30.30 & 2 & 1231.6616 & 1231.6624 & 616.8385 & -0.0008 & -0.6485 & 248.988 & 503.526 & 279.842 & 217.915 & \text { Yes }\end{array}$ $\begin{array}{llllllllllllllll}0.94 & 31.50 & 28.33 & 26.85 & 2 & 1231.6620 & 1231.6624 & 616.8385 & -0.0004 & -0.3242 & 151.868 & 251.142 & 140.772 & 148.078 & \text { Yes }\end{array}$

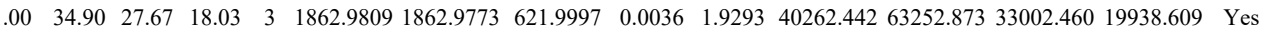

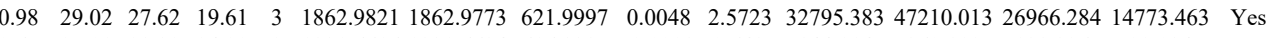

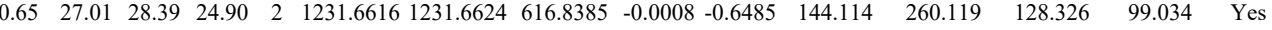

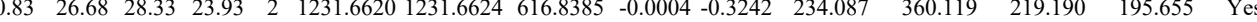
\begin{tabular}{llllllllllllllll}
0.83 & 26.68 & 28.33 & 23.93 & 2 & 1231.6620 & 1231.624 & 66.8385 & -0.004 & -0.3242 & 234.087 & 36.119 & 219.190 & 195.651 & Yes \\
\hline & 30.76 & 28.39 & 26.44 & 2 & 1231.6616 & 1231.6624 & 616.8385 & -0.0008 & -0.6485 & 124.904 & 194.081 & 82.231 & 87.371 & Yes
\end{tabular} $\begin{array}{lllllllllllllll}0.58 & 25.77 & 28.39 & 24.22 & 2 & 1231.6618 & 1231.6624 & 616.8385 & -0.0006 & -0.4864 & 122.553 & 220.590 & 124.397 & 132.411 & \text { Yes }\end{array}$ $\begin{array}{lllllllllllllll}0.52 & 24.71 & 28.39 & 24.34 & 2 & 1231.6618 & 1231.6624 & 616.8385 & -0.0006 & -0.4864 & 129.664 & 224.616 & 109.157 & 111.276 & \text { Yes }\end{array}$ $\begin{array}{lllllllllllllll}0.74 & 24.47 & 28.33 & 21.35 & 2 & 1231.6622 & 1231.6624 & 616.8385 & -0.0002 & -0.1621 & 226.042 & 346.723 & 181.273 & 198.688 & \text { Yes }\end{array}$

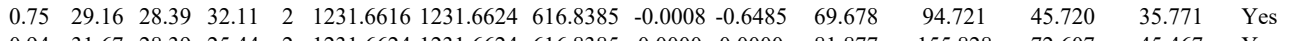

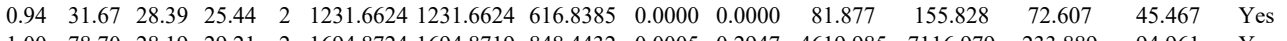
$\begin{array}{llllllllllllllll}1.00 & 78.70 & 28.19 & 29.21 & 2 & 1694.8724 & 1694.8719 & 848.4432 & 0.0005 & 0.2947 & 4619.985 & 7116.979 & 233.889 & 94.961 & \text { Yes }\end{array}$

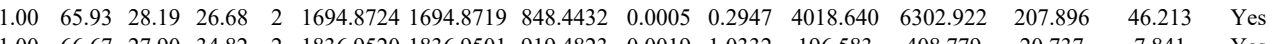
$\begin{array}{lllllllllllllll}1.00 & 66.67 & 27.90 & 34.82 & 2 & 1836.9520 & 1836.9501 & 919.4823 & 0.0019 & 1.0332 & 196.583 & 408.779 & 20.737 & 7.841 & \text { Yes } \\ 0.80 & 17.23 & 27.85 & 17.31 & 3 & 1836.9523 & 1836.9501 & 613.3240 & 0.0022 & 1.1957 & 291.840 & 331.983 & 92.758 & 45.672 & \text { Yes }\end{array}$

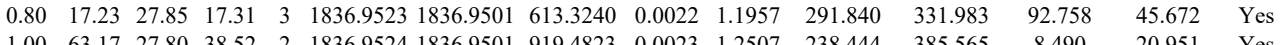
$\begin{array}{lllllllllllllll}1.00 & 63.17 & 27.80 & 38.52 & 2 & 1836.9524 & 1836.9501 & 919.4823 & 0.0023 & 1.2507 & 238.444 & 385.565 & 8.490 & 20.951 & \text { Yes } \\ 0.99 & 31.43 & 27.81 & 18.95 & 3 & 1836.9526 & 1836.9501 & 613.3240 & 0.0025 & 1.3587 & 246.295 & 261.009 & 53.784 & 67.244 & \text { Yes }\end{array}$

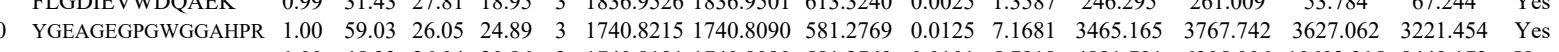
$\begin{array}{lllllllllllll} & \end{array}$ $\begin{array}{llllllllllllllllll}\text { YGEAGEGPGWGGAHPR } & 1.00 & 44.67 & 26.12 & 22.40 & 3 & 1740.8227 & 1740.8090 & 581.2769 & 0.0137 & 7.8562 & 5904.188 & 5871.854 & 11780.250 & 9737.144 & \text { Yes }\end{array}$ 

$\begin{array}{lllllllllll}1.00 & 35.02 & 21.93 & 48.02 & 4 & 4191.2349 & 4191.2307 & 1048.8150 & 0.0042 & 1.0011 & 19.926\end{array}$ $\begin{array}{lllllllllllll}0.99 & 43.52 & 27.54 & 33.44 & 2 & 1300.6872 & 1300.6753 & 651.3449 & 0.0119 & 9.1349 & 3242.186 & 3 \\ 0.99 & 43.46 & 27.53 & 28.73 & 2 & 1300.6870 & 1300.6753 & 651.3449 & 0.0117 & 8.9813 & 6198.441 & 6070 .\end{array}$

$\begin{array}{llllllllllll}.00 & 45.63 & 20.93 & 19.26 & 3 & 1704.0241 & 1704.0208 & 569.0142 & 0.0033 & 1.9332 & 54.203\end{array}$

$\begin{array}{lllllllllllll}1.00 & 48.43 & 21.34 & 22.39 & 2 & 1704.0216 & 1704.0208 & 853.0177 & 0.0008 & 0.4689 & 35.610 & 62.755\end{array}$

$\begin{array}{lllllllllllll}1.00 & 67.52 & 25.97 & 19.83 & 3 & 1860.0331 & 1860.0196 & 621.0138 & 0.0135 & 7.2462 & 8343.716 & 786 \\ 1.00 & 57.52 & 28.01 & 22.23 & 2 & 1372.7494 & 1372.7482 & 687.3814 & 0.0012 & 0.8729 & 5428.969 & 55\end{array}$

STFVLDEFK

STFVLDEFK

DPFAHLPK

DPFAHLPK

DPFAHLPK

DPFAHLPK

DPFAHLPK

DPFAHLPK

DPFAHLPK

DPFAHLPK

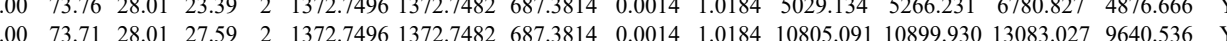
$\begin{array}{lllllllllllllll}1.00 & 73.54 & 27.95 & 24.71 & 2 & 1372.7488 & 1372.7482 & 687.3814 & 0.0006 & 0.4364 & 3303.832 & 2810.305 & 3704.194 & 2741.725 & \text { Yes }\end{array}$

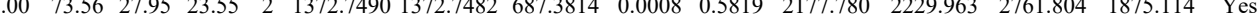
$\begin{array}{lllllllllllllll}0.66 & 16.08 & 2.05 & 15.14 & 3 & 1211.6911 & 1211.6906 & 404.9041 & 0.0005 & 0.4116 & 109.383 & 137.706 & 67.972 & 51.938 & \text { Yes }\end{array}$

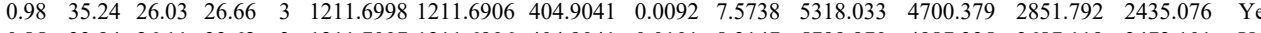

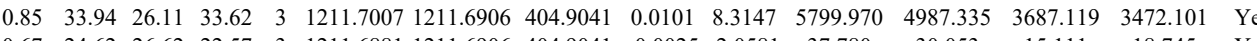

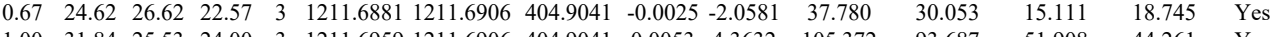

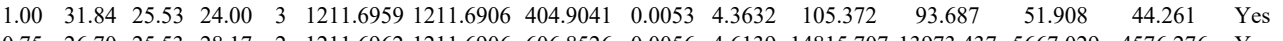

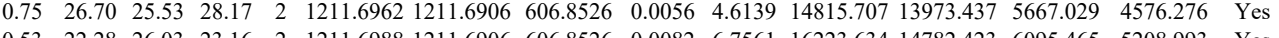
$\begin{array}{lllllllllllllllll}0.53 & 22.28 & 26.03 & 23.16 & 2 & 1211.6988 & 1211.6906 & 606.8526 & 0.0082 & 6.7561 & 16223.634 & 14782.423 & 6095.465 & 5208.993 & \text { Yes }\end{array}$ $\begin{array}{lllllllllllllllll} & \end{array}$ $\begin{array}{lllllllllllllllll}\text { VSNEDTLSVALPYFWEHFDK } & 1.00 & 71.83 & 26.69 & 19.76 & 3 & 2748.3337 & 2748.3315 & 917.1178 & 0.0022 & 0.7996 & 496.313 & 827.428 & 104.489 & 70.013 & \text { Yes }\end{array}$ $\begin{array}{lllllllllllll}0.71 & 20.50 & 28.02 & 18.76 & 2 & 1090.5648 & 1090.5641 & 546.2893 & 0.0007 & 0.6407 & 724.463 & 679.674 & 41.038\end{array}$

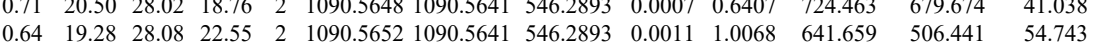

GQELAFPLSPDWQVDYESYTWR

QELAEPLSPDWOVDYESYT R

QAFPNTNR

QAFPNTNR

QAFPNTNR

LDPGSEETQTLVR

ILGLLDAYLK

ILGLLDAYLK

ILGLLDAYLK

ILGLLDAYLK

LGLLDAYLK

LGLLDAYLK

ILGLLDAYLK

ILGLLDAYLK

ILGLLDAYLK

ILGLLDAYLK

ILGLLDAYLK

ALIAAQYSGAQVR

ALIAAQYSGAQVR

ALIAAQYSGAQVR

ALIAAQYSGAQVR

ALIAAQYSGAQVR

ALIAAQYSGAQVR

ALIAAQYSGAQVR

ALIAAQYSGAQRR

ALIAAQYSGAQVR $\begin{array}{llllllllllllll}88.71 & 25.90 & 18.70 & 2 & 2830.3394 & 2830.3360 & 1416.1753 & 0.0034 & 1.2004 & 14.344 & 14.040 & 0.992 & 0.000 & \text { No }\end{array}$

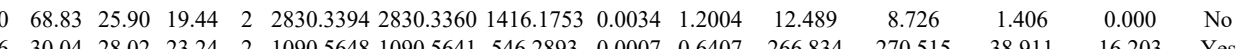

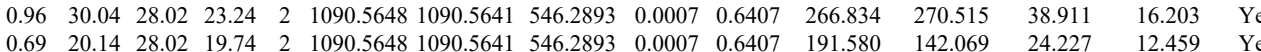

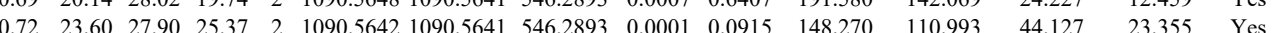

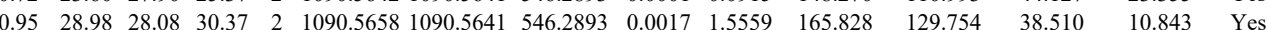
$\begin{array}{lllllllllllll}0.99 & 35.14 & 27.82 & 25.32 & 2 & 1587.8246 & 1587.8226 & 794.9186 & 0.0020 & 1.2580 & 19.551 & 25.155 & 23.015\end{array}$ $\begin{array}{lllllllllllll}1.00 & 57.26 & 17.99 & 24.70 & 2 & 1405.8808 & 1405.8788 & 703.9467 & 0.0020 & 1.4206 & 12851.577 & 12661.400 & 0.000\end{array}$ $\begin{array}{lllllllllllllll}0.99 & 22.02 & 17.99 & 17.05 & 3 & 1405.8814 & 1405.8788 & 469.6335 & 0.0026 & 1.8454 & 896.379 & 680.519 & 0.000\end{array}$ $\begin{array}{llllllllllllll}1.00 & 57.65 & 17.92 & 24.93 & 2 & 1405.8822 & 1405.8788 & 703.9467 & 0.0034 & 2.4149 & 26679.032 & 22856.880 & 0.000\end{array}$ $\begin{array}{lllllllllllllll}0.99 & 18.94 & 17.99 & 16.92 & 3 & 1405.8808 & 1405.8788 & 469.6335 & 0.0020 & 1.4195 & 366.053 & 380.108 & 54.825\end{array}$ $\begin{array}{llllllllllllll}1.00 & 57.35 & 17.99 & 25.50 & 2 & 1405.8812 & 1405.8788 & 703.9467 & 0.0024 & 1.7047 & 20719.450 & 18787.510 & 102.984\end{array}$ $\begin{array}{lllllllllllllll}0.91 & 16.59 & 17.99 & 21.71 & 3 & 1405.8814 & 1405.8788 & 469.6335 & 0.0026 & 1.8454 & 679.420 & 308.028 & 90.048\end{array}$ $\begin{array}{llllllllllllll}1.00 & 63.20 & 17.99 & 25.56 & 2 & 1405.8816 & 1405.8788 & 703.9467 & 0.0028 & 1.9888 & 29630.556 & 27045.439 & 0.000\end{array}$ $\begin{array}{lllllllllllll}1.00 & 48.35 & 18.51 & 20.16 & 2 & 1405.8806 & 1405.8788 & 703.9467 & 0.0018 & 1.2785 & 1842.863 & 1484.559 & 33.961\end{array}$ $\begin{array}{llllllllllllll}0.77 & 40.73 & 17.99 & 53.73 & 2 & 1405.8810 & 1405.8788 & 703.9467 & 0.0022 & 1.5626 & 784.308 & 720.420 & 28.544\end{array}$ $\begin{array}{lllllllllllll}0.55 & 7.30 & 17.99 & 20.30 & 3 & 1405.8811 & 1405.8788 & 469.6335 & 0.0023 & 1.6325 & 165.383 & 132.816 & 35.254\end{array}$ $\begin{array}{llllllllllllll}0.63 & 4.28 & 17.99 & 15.08 & 3 & 1405.8817 & 1405.8788 & 469.6335 & 0.0029 & 2.0583 & 199.099 & 145.966 & 47.840\end{array}$ $\begin{array}{llllllllllllll}1.00 & 70.21 & 26.82 & 24.86 & 2 & 1490.8408 & 1490.8327 & 746.4236 & 0.0081 & 5.4258 & 23256.676 & 20578.839 & 931.736\end{array}$ $\begin{array}{lllllllllllll}1.00 & 67.70 & 26.82 & 23.69 & 2 & 1490.8410 & 490.8327 & 746.4236 & 0.0083 & 5.5598 & 13302.114 & 14946.762 & 333.732\end{array}$ $\begin{array}{lllllllllllllll}1.00 & 47.56 & 26.90 & 23.60 & 3 & 1490.8420 & 1490.8327 & 497.9515 & 0.0093 & 6.2255 & 2406.575 & 2917.800 & 1554.92 \\ 1.00 & 76.08 & 2.87 & 24.05 & 2 & 140.8406 & 140.8327 & 74.4236 & 0.0079 & 5.2919 & 1268517 & 1189.325 & 5511.238\end{array}$ $\begin{array}{llllllllllllll}1.00 & 7.568 & 26.87 & 24.05 & 2 & 1490.8406 & 1490.8327 & 746.4236 & 0.0079 & 5.2919 & 12618.517 & 11899.325 & 551.186\end{array}$

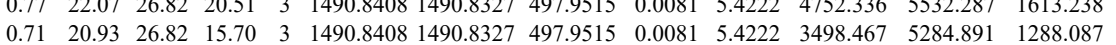
$\begin{array}{lllllllllllll}0.71 & 20.93 & 26.82 & 15.70 & 3 & 1490.8408 & 1490.8327 & 497.9515 & 0.0081 & 5.4222 & 3498.467 & 5284.891 & 1288.087 \\ 1.00 & 72.80 & 26.82 & 23.93 & 2 & 1490.8412 & 1490.8327 & 746.4236 & 0.0085 & 5.6938 & 3626.602 & 3739.831 & 143.418\end{array}$

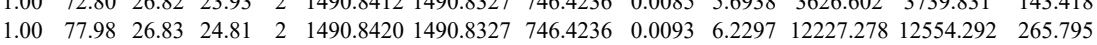
$\begin{array}{lllllllllllll}1.00 & 77.98 & 26.83 & 24.81 & 2 & 140.8420 & 1490.8327 & 44.4236 & 0.009 & 6.2297 & 2227.278 & 254.292 & 265.795 \\ 1.00 & 70.41 & 26.84 & 25.63 & 2 & 1490.8418 & 1490.8327 & 746.4236 & 0.0091 & 6.0957 & 2277.657 & 2206.682 & 119.335\end{array}$ $\begin{array}{lllllllllllll}1.00 & 72.14 & 26.83 & 23.96 & 2 & 1490.8424 & 1490.8327 & 746.4236 & 0.0097 & 6.4976 & 1713.659 & 1556.395 & 105.025\end{array}$ 


\section{DPFAHLPK}

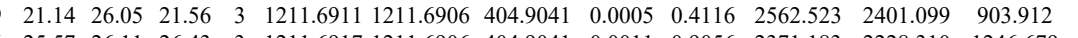

TLLWLYKQVLEPSF DPFAHLPK

WFLTCINQPQFR

WFLTCINQPQFR

WFLTCINQPOFR

WFLTCINQPQFR

WFLTCINQPQFR

WFLTCINQPQFR

WFLTCINQPQFR

LDPGSEETQTLVR

LDPGSEETQTLVR

LDPGSEETQTLVR

LDPGSEETQTLVR

KLDPGSEETQTLVR

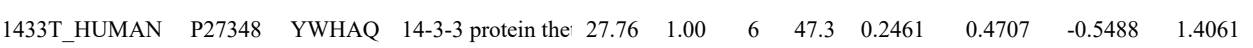

KLDPGSEETQTLVR

YLAEVACGDDR
YLAEVACGDDR

$\begin{array}{lllllllllllllll}0.96 & 25.57 & 26.11 & 26.43 & 3 & 1211.6917 & 1211.6906 & 404.9041 & 0.0011 & 0.9056 & 2371.183 & 2228.310 & 1246.679 & 768.955\end{array}$

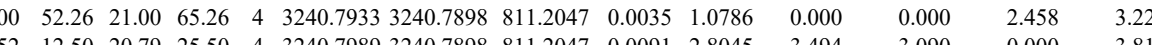

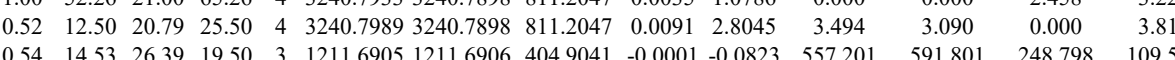
$\begin{array}{cccccccccccccc}0.54 & 14.53 & 26.39 & 19.50 & 3 & 1211.6905 & 1211.6906 & 404.9041 & -0.0001 & -0.0823 & 557.201 & 591.801 & 248.798 & 109.574 \\ 1.00 & 94.86 & 27.37 & 29.72 & 2 & 1741.8568 & 1741.8554 & 871.9350 & 0.0014 & 0.8028 & 518.010 & 453.932 & 9.308 & 10.725\end{array}$

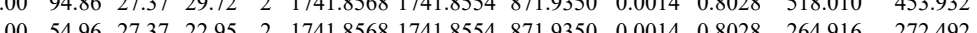

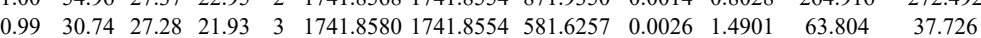
$\begin{array}{lllllllllllll}0.53 & 25.44 & 27.29 & 38.44 & 3 & 1741.8586 & 1741.8554 & 581.6257 & 0.0032 & 1.8339 & 65.803 & 82.721\end{array}$ $\begin{array}{llllllllllll}1.00 & 73.87 & 27.39 & 24.18 & 2 & 1741.8570 & 1741.8554 & 871.9350 & 0.0016 & 0.9175 & 365.405 & 391.326\end{array}$ $\begin{array}{lllllllllllll}1.00 & 63.88 & 27.38 & 19.57 & 2 & 1741.8572 & 1741.8554 & 871.9350 & 0.0018 & 1.0322 & 507.613 & 454.648\end{array}$

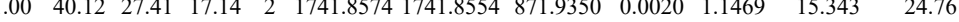

$\begin{array}{llllllllllllll}1.04 & \end{array}$

$\begin{array}{llllllllllllll}1.00 & 71.89 & 28.06 & 26.79 & 2 & 1587.8376 & 1587.8226 & 794.9186 & 0.0150 & 9.4348 & 6398.669 & 3833.994 & 4259.964 & 4\end{array}$

$\begin{array}{lllllllllllllll}1.00 & 76.79 & 28.06 & 27.30 & 2 & 1587.8380 & 1587.8226 & 794.9186 & 0.0154 & 9.6864 & 2068.832 & 2128.737 & 1480.246 & 237 . & \\ 1.00 & 54.39 & 25.80 & 19.79 & 3 & 1860.0361 & 1860.0196 & 621.0138 & 0.0165 & 8.8564 & 8306.065 & 9610.596 & 5413.987 & 31906\end{array}$

$\begin{array}{lllllllllllllll}1.00 & 54.39 & 25.80 & 19.79 & 3 & 1860.0361 & 1860.0196 & 621.0138 & 0.0165 & 8.8564 & 8306.065 & 9610.596 & 5413.987 & 319 \\ 1.00 & 55.35 & 25.75 & 19.76 & 3 & 1860.0373 & 1860.0196 & 621.0138 & 0.0177 & 9.5005 & 6139.117 & 5801.157 & 5011.221 & 366\end{array}$ $\begin{array}{llllllllllllll}1.00 & 75.87 & 22.99 & 25.59 & 2 & 1400.6188 & 1400.6186 & 701.3166 & 0.0002 & 0.1426 & 7401.829 & 9018.321 & 533.649 \\ 1.00 & 70.97 & 23.12 & 19.81 & 2 & 140.6212 & 1400.6186 & 701.316 & 0.0026 & 1.8537 & 7658.773 & 7500.580 & 5962.53 & 2\end{array}$ $\begin{array}{llllllllllllll}1.00 & 70.97 & 23.12 & 19.81 & 2 & 1400.6212 & 1400.6186 & 701.3166 & 0.0026 & 1.8537 & 7658.773 & 7500.580 & 596.861 \\ 1.00 & & 27.65 & 30.15 & 2 & 2302.1514 & 2302.1321 & 1152.0733 & 0.0193 & 8.3761 & 424.794 & 492.587 & 562.531\end{array}$

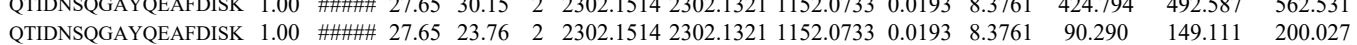

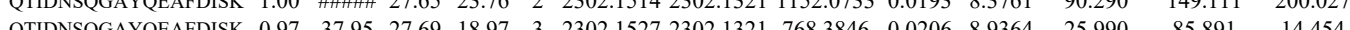

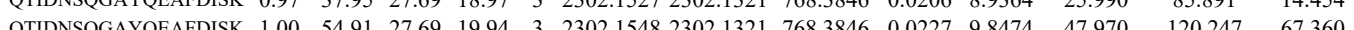
$\begin{array}{llllllllllllll}\text { YDDMATCMK } & 1.00 & 58.64 & 20.93 & 19.77 & 2 & 1410.5912 & 1410.5895 & 7063020 & 0.0227 & 1.8374 & 47.970 & 120.247 & 67.560\end{array}$ YDDMATCMK

QTIDNSQGAYQEAFDISK

YDDMATCMK

YDDMATCMK

YLIANATNPESK

YLIANATNPESK

YLIANATNPESK

YLIANATNPESK

SICTTVLELLDK

SICTTVLELLDK

SICTTVLELLDK

SICTTVLELLDK

SICTTVLELLDK

SICTTVLELLDK

SICTTVLELLDK

SICTTVLELLDK

SICTTVLELLDK

SICTTVLELLDK

AVTEQGAELSNEER

AVTEQGAELSNEER AVTEQGAELSNEER
AVTEQGAELSNEER AVTEQGAELSNE
YLAEVACGDDR YLAEVACGDDR

$\begin{array}{lllllllllllll}\text { RL10 HUMAN } & \text { P27635 } & \text { RPL10 } & 60 \text { S ribosomal pro } 24.60 & 1.00 & 6 & 27.6 & -0.0700 & 0.2328 & 0.0498 & 1.8179 & 58 & \text { MLSCAGADR }\end{array}$

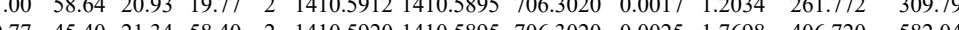
$\begin{array}{llllllllllllll} & \end{array}$ $\begin{array}{llllllllllllll}0 & \end{array}$ $\begin{array}{llllllllllllll}1.00 & 35.19 & 26.93 & 26.51 & 3 & 1667.9125 & 1667.9081 & 556.9766 & 0.0044 & 2.6333 & 97.844 & 112.804 & 108.319 & 6\end{array}$ $\begin{array}{lllllllllllll}1.00 & 76.95 & 27.07 & 24.88 & 2 & 1667.9100 & 1667.9081 & 834.9613 & 0.0019 & 1.1378 & 6011.261 & 6714.971 & 3622.452\end{array}$ $\begin{array}{llllllllllllll}1.00 & 75.06 & 27.03 & 25.00 & 2 & 1667.9104 & 1667.9081 & 834.9613 & 0.0023 & 1.3773 & 5378.961 & 5446.958 & 3571.017 & 700 \\ 0.98 & 26.02 & 27.08 & 24.72 & 3 & 1679.9113 & 1667.9081 & 556.9766 & 0.032 & 1.9151 & 70.870 & 51.439 & 49.379 & 259\end{array}$

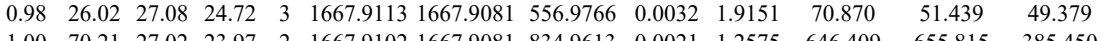
$\begin{array}{llllllllllllll}1.00 & 70.21 & 27.02 & 23.97 & 2 & 1667.9102 & 1667.9081 & 834.9613 & 0.0021 & 1.2575 & 646.409 & 655.815 & 385.450 \\ 1.00 & 75.98 & 27.09 & 23.67 & 2 & 1667.9106 & 1667.9081 & 834.9613 & 0.0025 & 1.4971 & 227.505 & 253.541 & 150.003\end{array}$ $\begin{array}{lllllllllllll}1.00 & 75.98 & 27.09 & 23.67 & 2 & 1667.9106 & 1667.9081 & 834.9613 & 0.0025 & 1.4971 & 227.505 & 253.541 & 150.003\end{array}$ $\begin{array}{llllllllllllll}0.95 & 22.72 & 27.08 & 24.35 & 3 & 1667.9113 & 1667.9081 & 556.9766 & 0.0032 & 1.9151 & 153.005 & 233.206 & 128.151\end{array}$ $\begin{array}{cccccccccccccc}0.88 & 18.46 & 27.09 & 19.66 & 3 & 1667.9107 & 1667.9081 & 556.9766 & 0.0026 & 1.5560 & 121.034 & 102.853 & 53.045 & \\ 1.00 & 87.96 & 27.11 & 33.95 & 2 & 1675.8202 & 1675.8135 & 838.9140 & 0.0067 & 3.9932 & 647.174 & 747.515 & 304.815\end{array}$ $\begin{array}{llllllllllllll}1.00 & 87.96 & 27.11 & 33.95 & 2 & 1675.8202 & 1675.8135 & 838.9140 & 0.0067 & 3.9932 & 647.174 & 747.515 & 304.815 & \\ 1.00 & 84.77 & 27.40 & 27.99 & 2 & 1675.8300 & 1675.8135 & 838.9140 & 0.0165 & 9.8340 & 995.836 & 1287.284 & 487.024 & 84\end{array}$ $\begin{array}{llllllllllllll}1.00 & 84.77 & 27.40 & 27.99 & 2 & 1675.8300 & 1675.8135 & 838.9140 & 0.0165 & 9.8340 & 995.836 & 1287.284 & 487.024 \\ 1.00 & 88.67 & 27.01 & 33.54 & 2 & 1675.8180 & 1675.8135 & 838.9140 & 0.0045 & 2.6820 & 13878.901 & 16847.652 & 6936.641\end{array}$ $\begin{array}{lllllllllllll}1.00 & 88.93 & 27.01 & 35.90 & 2 & 1675.8180 & 1675.8135 & 838.9140 & 0.0045 & 2.6820 & 9789.879 & 13577.396 & 5342.827\end{array}$ $\begin{array}{llllllllllllll}1.00 & 70.99 & 23.10 & 19.36 & 2 & 1400.6214 & 1400.6186 & 701.3166 & 0.0028 & 1.9962 & 7784.054 & 8200.648 & 727.839 \\ 1.00 & 68.57 & 23.10 & 19.67 & 2 & 1400.6216 & 1400.6186 & 701.3166 & 0.0030 & 2.1388 & 10423.881 & 11400.983 & 816.105\end{array}$ $\begin{array}{lllllllllllll}1.00 & 68.57 & 23.10 & 19.67 & 2 & 1400.6216 & 1400.6186 & 701.3166 & 0.0030 & 2.1388 & 10423.881 & 11400.983 & 816.105 \\ 1.00 & 43.59 & 23.34 & 30.63 & 2 & 1112.5006 & 1112.4898 & 557.2522 & 0.0108 & 9.6903 & 12801.562 & 11511.140 & 1774.601\end{array}$ $\begin{array}{llllllllllllll}1.00 & 43.59 & 23.34 & 30.63 & 2 & 1112.5006 & 1112.4898 & 557.2522 & 0.0108 & 9.6903 & 12801.562 & 11511.140 & 1774.601 \\ 0.56 & 24.50 & 27.75 & 28.29 & 2 & 863.5070 & 863.4987 & 432.7566 & 0.0083 & 9.5896 & 7906.744 & 7178.477 & 350.598\end{array}$ $\begin{array}{llllllllllllll}0.72 & 27.54 & 27.75 & 30.18 & 2 & 863.5066 & 863.4987 & 432.7566 & 0.0079 & 9.1274 & 20497935 & 17693201 & 778.851\end{array}$ $\begin{array}{llllllllllllll}0.63 & 25.72 & 27.75 & 28.74 & 2 & 863.5068 & 863.4987 & 432.7566 & 0.0081 & 9.3585 & 19725.530 & 15626.485 & 596.655\end{array}$ 


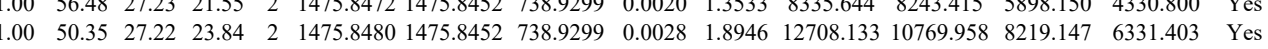
$\begin{array}{lllllllllllllllll}0.99 & 28.61 & 27.22 & 21.85 & 3 & 1475.8486 & 1475.8452 & 492.9557 & 0.0034 & 2.2991 & 60759.618 & 68024.727 & 53562.582 & 38897.120 & \text { Yes }\end{array}$ $\begin{array}{lllllllllllllllll}0.98 & 26.23 & 27.22 & 26.40 & 3 & 1475.8486 & 1475.8452 & 492.9557 & 0.0034 & 2.2991 & 19721.449 & 20512.511 & 12063.873 & 10365.822 & \text { Yes }\end{array}$ $\begin{array}{llllllllllllllll}1.00 & 52.30 & 27.32 & 22.18 & 2 & 1475.8458 & 1475.8452 & 738.9299 & 0.0006 & 0.4060 & 4226.309 & 4756.517 & 3229.645 & 2145.911 & \text { Yes } \\ 0.98 & 26.93 & 27.21 & 19.80 & 3 & 1475.8468 & 1475.8452 & 492.9557 & 0.0016 & 1.0819 & 23599.410 & 25772.835 & 16314.682 & 12811.171 & \text { Yes }\end{array}$

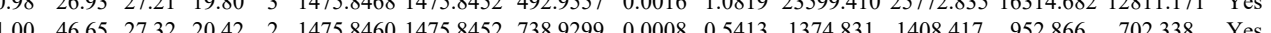
$\begin{array}{lllllllllllllll}100 & 33.15 & 27.32 & 18.14 & 3 & 1475.8462 & 1475.8452 & 4929557 & 0.0010 & 0.6762 & 15048.66416987 .286 & 11376.320 & 8372.177 & \text { Yes }\end{array}$

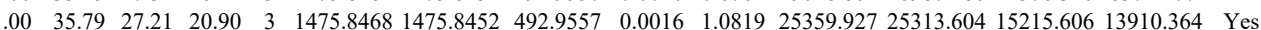

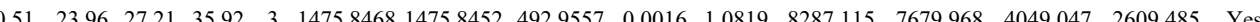
$\begin{array}{lllllllllllllllll}0.87 & 19.99 & 27.32 & 23.44 & 3 & 1475.8459 & 1475.8452 & 492.9557 & 0.0007 & 0.4733 & 2654.807 & 2550.293 & 1267.299 & 923.205 & \text { Yes }\end{array}$ $\begin{array}{lllllllllllllllll}0.94 & 25.09 & 27.23 & 27.32 & 3 & 1475.8465 & 1475.8452 & 492.9557 & 0.0013 & 0.8791 & 5159.815 & 4487.521 & 2594.557 & 1627.586 & \text { Yes }\end{array}$ $\begin{array}{lllllllllllllll}0.86 & 31.13 & 27.32 & 23.77 & 2 & 1161.6880 & 1161.6893 & 581.8519 & -0.0013 & -1.1171 & 2182.825 & 1996.986 & 161.603 & 105.508 & \text { Yes }\end{array}$ \begin{tabular}{llllllllllllllll}
0.92 & 33.77 & 27.32 & 29.84 & 2 & 1161.6882 & 1161.6893 & 581.8519 & -0.0011 & -0.9453 & 2855.581 & 2866.098 & 281.200 & 96.946 & Yes \\
\hline
\end{tabular}

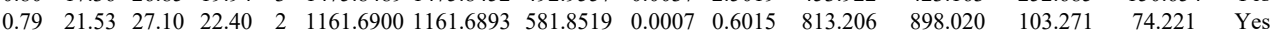
$\begin{array}{llllllllllllllll}1.00 & 66.55 & 24.71 & 18.82 & 2 & 1395.8152 & 1395.8142 & 698.9144 & 0.0010 & 0.7154 & 4797.456 & 3987.771 & 576.463 & 335.317 & \text { Yes }\end{array}$ $\begin{array}{llllllllllllllll}0.55 & 52.93 & 24.70 & 65.93 & 3 & 1395.8161 & 1395.8142 & 466.2787 & 0.0019 & 1.3583 & 3039.880 & 2928.958 & 690.791 & 77.739 & \text { Yes }\end{array}$

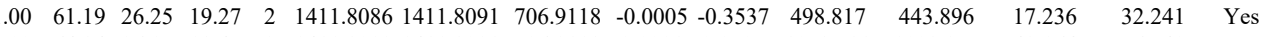
$\begin{array}{lllllllllllllll}.00 & 64.84 & 26.17 & 18.45 & 2 & 1411.8092 & 1411.8091 & 706.9118 & 0.0001 & 0.0707 & 1073.538 & 1003.275 & 49.164 & 56.740 & \text { Yes }\end{array}$ $\begin{array}{lllllllllllllll}1.00 & 39.45 & 26.15 & 24.37 & 3 & 1411.8094 & 1411.8091 & 471.6103 & 0.0003 & 0.2120 & 1976.592 & 2013.152 & 291.785 & 77.114 & \text { Yes }\end{array}$

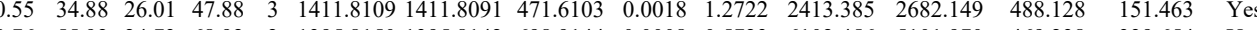
$\begin{array}{lllllllllllllll}0.76 & 55.92 & 24.73 & 68.92 & 2 & 1395.8150 & 1395.8142 & 698.9144 & 0.0008 & 0.5723 & 6102.456 & 5101.970 & 469.238 & 339.654 & \text { Yes }\end{array}$ $\begin{array}{lllllllllllllllll}0.76 & 57.02 & 24.73 & 70.02 & 2 & 1395.8150 & 1395.8142 & 698.9144 & 0.0008 & 0.5723 & 8913.983 & 6982.426 & 620.695 & 356.576 & \text { Yes }\end{array}$ $\begin{array}{lllllllllllllll}1.0 & 53.53 & 24.71 & 17.44 & 3 & 1395.8155 & 1395.8142 & 466.2787 & 0.0013 & 0.9293 & 2495.559 & 2423.025 & 676.646 & 294.001 & \text { Yes }\end{array}$

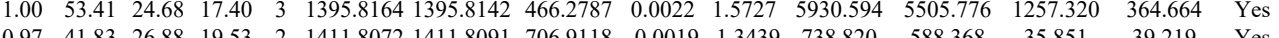

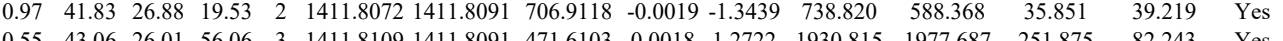
$\begin{array}{lllllllllllllll}0.55 & 43.06 & 26.01 & 56.06 & 3 & 1411.8109 & 1411.8091 & 471.6103 & 0.0018 & 1.2722 & 1930.815 & 1977.687 & 251.875 & 82.243 & \text { Yes } \\ 1.00 & 44.46 & 25.95 & 18.83 & 3 & 1411.8112 & 1411.8091 & 471.6103 & 0.0021 & 1.4843 & 1875.889 & 1836.984 & 321.980 & 126.67 & \text { Yes }\end{array}$ $\begin{array}{lllllllllllllll}1.00 & 44.46 & 25.95 & 18.83 & 3 & 1411.8112 & 1411.8091 & 471.6103 & 0.0021 & 1.4843 & 1875.889 & 1836.984 & 321.980 & 126.607 & \text { Yes } \\ 1.00 & 62.52 & 24.71 & 17.17 & 2 & 1395.8154 & 1395.8142 & 698.9144 & 0.0012 & 0.8585 & 2688.728 & 2406.961 & 283.755 & 196.520 & \text { Yes }\end{array}$

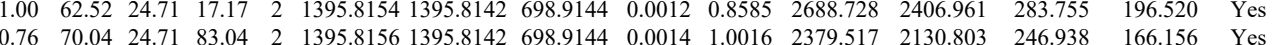
$\begin{array}{lllllllllllllll}1.00 & 51.69 & 24.71 & 17.11 & 3 & 1395.8167 & 1395.8142 & 466.2787 & 0.0025 & 1.7872 & 1542.656 & 2093.366 & 445.546 & 162.156 & \text { Yes }\end{array}$

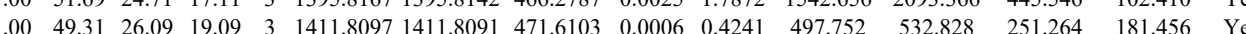
$\begin{array}{llllllllllllllll}1.00 & 38.45 & 24.71 & 17.49 & 3 & 1395.8155 & 1395.8142 & 466.2787 & 0.0013 & 0.9293 & 263.048 & 234.490 & 69.118 & 25.269 & \text { Y ses }\end{array}$ $\begin{array}{lllllllllllllllll}0.55 & 40.23 & 24.70 & 53.23 & 3 & 1395.8161 & 1395.8142 & 466.2787 & 0.0019 & 1.3583 & 260.145 & 297.190 & 25.168 & 34.616 & \text { Yes }\end{array}$

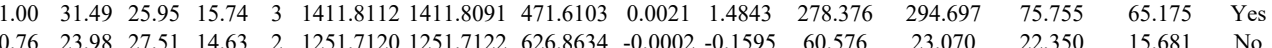

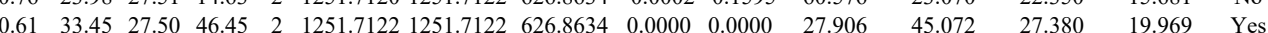

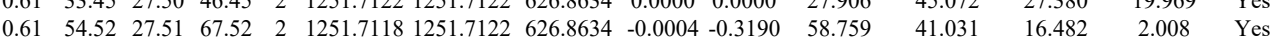

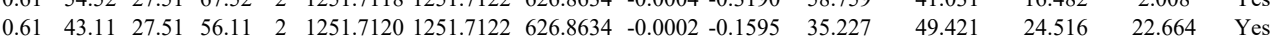

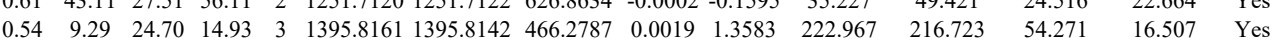
$\begin{array}{lllllllllllllll}0.71 & 22.91 & 27.50 & 14.80 & 2 & 1251.7124 & 1251.7122 & 626.8634 & 0.0002 & 0.1595 & 39.140 & 89.660 & 18.338 & 11.880 & \text { No }\end{array}$ $\begin{array}{lllllllllllllll}1.00 & 32.97 & 24.64 & 16.14 & 3 & 1395.8170 & 1395.8142 & 466.2787 & 0.0028 & 2.0017 & 133.971 & 95.436 & 44.236 & 10.942 & \text { Yes }\end{array}$

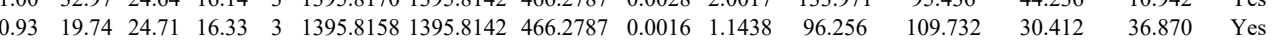

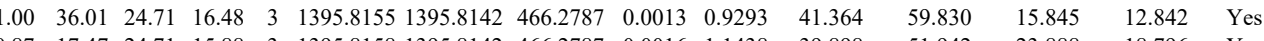
$\begin{array}{lllllllllllllll}0.87 & 17.47 & 24.71 & 15.88 & 3 & 1395.8158 & 1395.8142 & 466.2787 & 0.0016 & 1.1438 & 39.898 & 51.942 & 23.888 & 18.796 & \text { Yes }\end{array}$

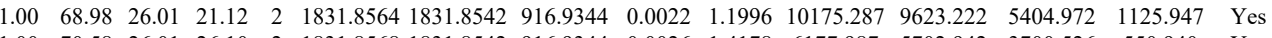

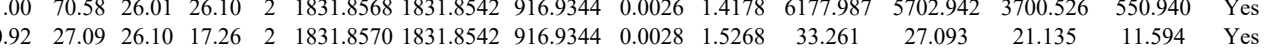

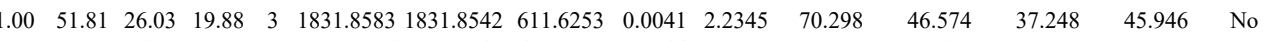
$\begin{array}{lllllllllllllll}0.98 & 25.95 & 26.01 & 15.29 & 3 & 1831.8586 & 1831.8542 & 611.6253 & 0.0044 & 2.3980 & 202.961 & 37.625 & 13.521 & 23.105 & \text { No }\end{array}$

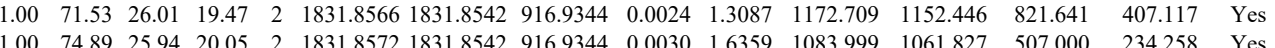

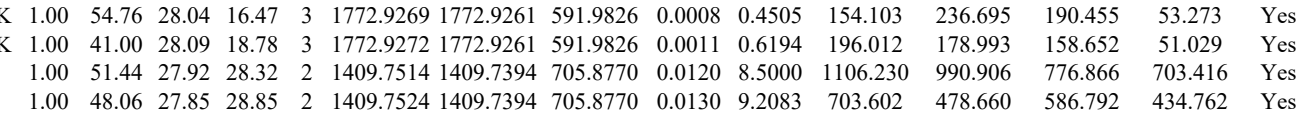
$\begin{array}{lllllllllllllllll} & 1.00 & 48.06 & 27.85 & 28.85 & 2 & 1409.7524 & 1409.7394 & 705.8770 & 0.0130 & 9.2083 & 703.602 & 478.660 & 586.792 & 703.416 & \text { Yes } \\ \end{array}$ $\begin{array}{lllllllllllllllll} & \end{array}$

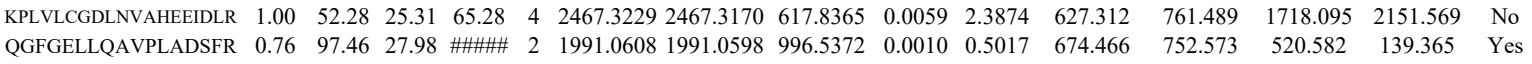

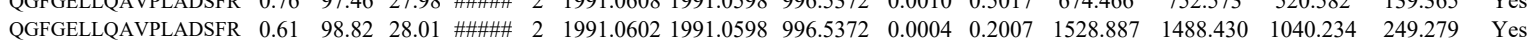

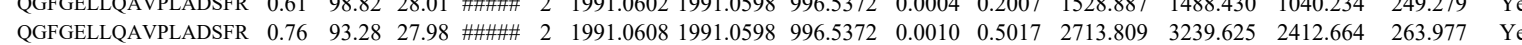


512.975

$\begin{array}{llllllllllll} & \end{array}$

$\begin{array}{lllllllllllll}1.00 & 60.94 & 27.90 & 33.60 & 2 & 1147.6224 & 1147.6141 & 574.8143 & 0.0083 & 7.2197 & 7222.160 & 5738.177 & 2\end{array}$

424.343 Yes

LLSSAAAVSK

TSSSFAAAMAR

$\begin{array}{lllllllllllll}1 & 1267.740 & 1267.7380 & 634.8763 & 0.0110 & 8.6630 & 11306.902 & 7726.336 & 405.566\end{array}$

TSSSFAAAMAR

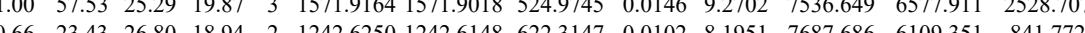

VFNTGGAPR

$\begin{array}{llllllllllllll}0.60 & 22.96 & 25.58 & 15.01 & 2 & 1045.6124 & 1045.6042 & 523.8094 & 0.0082 & 7.8272 & 24447.837 & 20169.571 & 2319.131\end{array}$

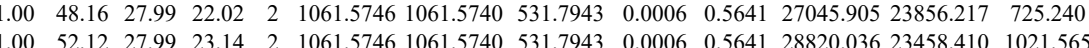
$\begin{array}{llllllllllllll}1.00 & 55.63 & 27.97 & 25.05 & 2 & 1061.5752 & 1061.5740 & 531.7943 & 0.0012 & 1.1283 & 14004.476 & 11288.610 & 816.139\end{array}$

G

LDDTIGISQPQWR

NILLTIGSYK

LLDTIGISQPQWR

LALGIPLPELR

SVHICHVAR

SVHICHVAR

LALGIPLPELR

LALGIPLPEL

VPQFSFSR

$\begin{array}{lllllllllllll}1.00 & 19.85 & 23.42 & 32.85 & 4 & 2832.5401 & 2832.5368 & 709.1415 & 0.0033 & 1.1634 & 30.041 & 32.219 & 40.732 \\ 1.00 & 65.33 & 23.30 & 78.33 & 4 & 28325405 & 28325368 & 709.1415 & 0.0037 & 1.3044 & 291.228 & 238.026 & 817.441\end{array}$

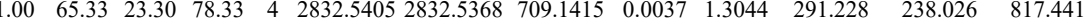

$\begin{array}{lllllllllllll}.00 & 7.83 & 26.78 & 24.37 & 2 & 1669.9288 & 1669.9273 & 835.9709 & 0.0015 & 0.8972 & 1152.412 & 1040.862\end{array}$

$\begin{array}{lllllllllllll}1.00 & 72.97 & 26.70 & 22.20 & 2 & 1669.9302 & 1669.9273 & 835.9709 & 0.0029 & 1.7345 & 1253.844 & 1218.010 & 0.00\end{array}$

$\begin{array}{lllllllllllll}1.00 & 62.62 & 21.82 & 42.56 & 2 & 1408.8580 & 408.8533 & 705.4339 & 0.0047 & 3.3313 & 742.586 & 675.555 & 47.951\end{array}$

$\begin{array}{lllllllllllll}.00 & 60.83 & 26.94 & 24.58 & 2 & 1669.9282 & 1669.9273 & 835.9709 & 0.0009 & 0.5383 & 1095.182 & 889.467 & 0.000 \\ 1.00 & 50.92 & 18.98 & 23.15 & 2 & 1334.8430 & 1334.8407 & 668.4276 & 0.0023 & 1.7205 & 15161.937 & 12661.527 & 367.475\end{array}$

$\begin{array}{llllllllllllll}1.00 & 41.56 & 27.69 & 24.89 & 3 & 1210.6183 & 1210.6185 & 404.5468 & -0.0002 & -0.1648 & 2743.590 & 3030.229 & 641.295\end{array}$ $\begin{array}{lllllllllllll}1.00 & 36.57 & 27.92 & 27.57 & 3 & 1210.6198 & 1210.6185 & 404.5468 & 0.0013 & 1.0712 & 2210.741 & 2546.334 & 675.065\end{array}$

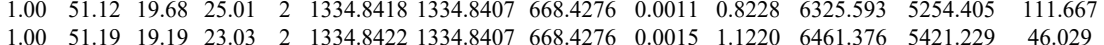
$\begin{array}{lllllllllllll}1.00 & 51.19 & 19.19 & 23.03 & 2 & 1334.842 & 1334.8407 & 688.4276 & .0015 & 1.1220 & 6461.376 & 5421.229 & 46.029 \\ 0.87 & 27.44 & 27.54 & 24.75 & 2 & 1110.5948 & 1110.5944 & 556.3045 & 0.0004 & 0.3595 & 2866.180 & 3609.120 & 2231.658\end{array}$

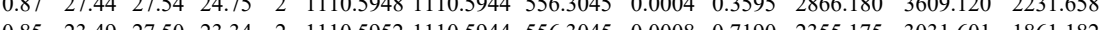

$\begin{array}{lllllllllllll}1.00 & 42.98 & 27.64 & 25.83 & 3 & 1240.6480 & 1240.6365 & 414.5528 & 0.0115 & 9.2468 & 28284.815 & 22956.609 & 1732.029\end{array}$

MVVMHPMP

GSGFA

AAFALGGLGSGFAS

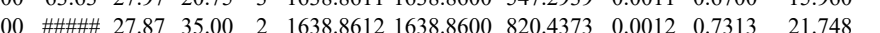

AAFALGGLGSGFASNR

LCPPGIPTPGSGLPPP

LCPPGIPTPGSGLPPPR

CGSPPPGFGGLTMLPLLTA

ASDPGLPAEEPK

MALLATVLGR

MALLATVLGR

MALLATVLGR

MALLATVLGR

MALLATVLGR

MALLATVLGR

MALLATVLGR

MALLATVLGR

MALLATVLGR

MALLATVLGR

MALLATVLGR

MALLATVLGR

MALLATVLGR

MALLATVLGR

MALLATVLGR

MALLATVLGR

MALLATVLGR

MALLATVLGR

VLGTSPEAIDSAEN

$\begin{array}{lllllllllllll}1.00 & 72.47 & 27.84 & 28.41 & 2 & 1844.9768 & 1844.9763 & 923.4954 & 0.0005 & 0.2707 & 474.768 & 454\end{array}$

$\begin{array}{llllllllllll} & 0.0011 & 0.5956 & 449.741\end{array}$

$\begin{array}{cccccccccccc}1.00 & 58.12 & 28.01 & 24.62 & 2 & 1497.7934 & 1497.7918 & 749.9032 & 0.0016 & 1.0668 & 184.936\end{array}$

$\begin{array}{lllllllllll}1.00 & 55.01 & 27.98 & 26.98 & 2 & 1497.7938 & 1497.7918 & 749.9032 & 0.0020 & 1.3335 & 155.687\end{array}$

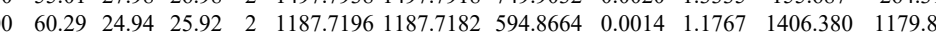

$\begin{array}{llllllllllll}1.00 & 54.77 & 24.94 & 25.79 & 2 & 1187.7196 & 1187.7182 & 594.8664 & 0.0014 & 1.1767 & 2945.172 & 2977.572\end{array}$

$\begin{array}{llllllllllll}.00 & 53.86 & 27.17 & 24.80 & 2 & 1203.7130 & 1203.7131 & 602.8638 & -0.0001 & -0.0829 & 88.433 & 68.671\end{array}$

$\begin{array}{lllllllllllll}1.00 & 54.12 & 27.03 & 31.54 & 2 & 1203.7142 & 1203.7131 & 602.8638 & 0.0011 & 0.9123 & 527.950 & 438.483 \\ .00 & 60.29 & 27.02 & 36.64 & 2 & 1203.7146 & 1203.7131 & 602.8638 & 0.0015 & 1.2441 & 779.642 & 789.471\end{array}$

$\begin{array}{lllllllllllll}1.00 & 52.63 & 24.93 & 24.21 & 2 & 1187.7192 & 1187.7182 & 594.8664 & 0.0010 & 0.8405 & 1545.434 & 1395.864\end{array}$

$\begin{array}{lllllllllllll}1.00 & 55.93 & 24.94 & 24.97 & 2 & 1187.7196 & 1187.7182 & 594.8664 & 0.0014 & 1.1767 & 959.769 & 807.657\end{array}$

$\begin{array}{llllllllllll}1.00 & 52.27 & 27.02 & 35.30 & 2 & 1203.7146 & 1203.7131 & 602.8638 & 0.0015 & 1.2441 & 854.803 & 725.105 \\ 1.00 & 62.50 & 27.02 & 32.53 & 2 & 1203.7146 & 1203.7131 & 602.8638 & 0.0015 & 1.2441 & 513.558 & 395.277\end{array}$

$\begin{array}{llllllllllll}1.00 & 62.50 & 27.02 & 32.53 & 2 & 1203.7146 & 1203.7131 & 602.8638 & 0.0015 & 1.2441 & 513.558 & 395.277 \\ 1.00 & 63.71 & 24.94 & 25.26 & 2 & 1187.7198 & 1187.7182 & 594.8664 & 0.0016 & 1.3448 & 759.051 & 740.562\end{array}$

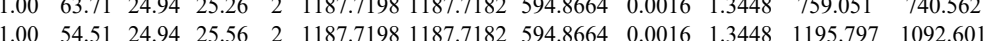

$\begin{array}{lllllllllllll}1.00 & 54.51 & 24.94 & 25.56 & 2 & 1187.7198 & 1187.7182 & 594.8664 & 0.0016 & 1.3448 & 1195.797 & 1092.601 \\ 1.00 & 54.72 & 27.02 & 29.28 & 2 & 1203.7146 & 1203.7131 & 602.8638 & 0.0015 & 1.2441 & 393.823 & 308.297\end{array}$ $\begin{array}{lllllllllllll}1.00 & 52.02 & 27.02 & 33.85 & 2 & 1203.7148 & 1203.7131 & 602.8638 & 0.0017 & 1.4099 & 242.046 & 256.394\end{array}$ $\begin{array}{llllllllllll}1.00 & 53.94 & 24.93 & 24.45 & 2 & 1203.7148 & 1203.7131 & 602.8638 & 0.0017 & 1.4099 & 242.046 & 256.394 \\ 1 & 4.7187 .7182 & 594.8664 & 0.0010 & 0.8405 & 364.771 & 306.88\end{array}$ $\begin{array}{llllllllllll}1.00 & 56.12 & 24.94 & 24.59 & 2 & 1187.7198 & 1187.7182 & 594.8664 & 0.0016 & 1.3448 & 574.637 & 529.434\end{array}$ $\begin{array}{llllllllllllll}1.00 & 58.41 & 24.94 & 25.80 & 2 & 1187.7196 & 1187.7182 & 594.8664 & 0.0014 & 1.1767 & 671.755 & 621.117\end{array}$ $\begin{array}{llllllllllllll}1.00 & 59.24 & 24.94 & 24.93 & 2 & 1187.7198 & 1187.7182 & 594.8664 & 0.0016 & 1.3448 & 594.559 & 609.704\end{array}$

$\begin{array}{lllll} & 187.7182 & 94.864 & 0.016 & 1.3478\end{array}$ 

$\begin{array}{lllllllllllllll}1.00 & 67.78 & 26.15 & 21.99 & 2 & 1752.8270 & 1752.8167 & 877.4156 & 0.0103 & 5.8695 & 5234.619 & 3891.134 & 4729.964 & 1494.946 & \text { Yes } \\ 1.00 & 66.49 & 26.17 & 23.41 & 2 & 1752.8274 & 1752.8167 & 877.4156 & 0.0107 & 6.0974 & 4955.049 & 4608.010 & 5204.123 & 2311.977 & \text { Yes } \\ 0.99 & 36.20 & 6.17 & 16.88 & 3 & 1752.829 & 1752.8167 & 585.2795 & 0.0132 & 7.5177 & 2590.575 & 2912.524 & 3046.300 & 153.545 & \text { Yes }\end{array}$ $\begin{array}{lllllllllllllll}0.99 & 36.20 & 26.17 & 16.88 & 3 & 1752.8299 & 1752.8167 & 585.2795 & 0.0132 & 7.5177 & 2790.575 & 2912.524 & 3086.600 & 1573.545 & \text { Yes }\end{array}$

SGTFPNEUTNDEAYAEFGNETWGG $\begin{array}{llllllllllll}1.00 & 30.03 & 25.92 & 43.03 & 4 & 3555.6953 & 3555.6926 & 889.9304 & 0.0027 & 0.7585\end{array}$

DDEFTHLYTLIVRPDNTY

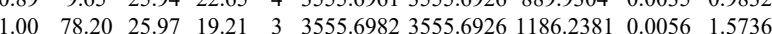
$\begin{array}{llllllllllllllll} & \end{array}$ $\begin{array}{llllllllllllllll} & \end{array}$ $\begin{array}{llllllllllllllll} & \end{array}$

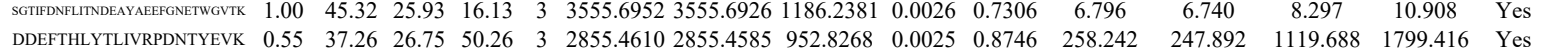
$\begin{array}{llllllllllllllll}\text { DDEFTHLYTLVRPDNTYEVK } & 0.95 & 12.45 & 26.71 & 25.45 & 4 & 2855.4625 & 2855.4585 & 714.8719 & 0.0040 & 1.3989 & 127.280 & 73.140 & 718.742 & 1509.873 & \text { No }\end{array}$ $\begin{array}{llllllllllllllll}\text { DDEFTHLYTLVRPDNTYEVK } & 0.98 & 15.00 & 26.65 & 16.06 & 4 & 2855.4637 & 2855.4585 & 714.8719 & 0.0052 & 1.8185 & 286.715 & 515.215 & 2194.334 & 5085.169 & \text { No }\end{array}$ $\begin{array}{llllllllllllllll}\text { DDEFTHLYTLIVRPDNTYEVK } & 0.98 & 14.73 & 26.69 & 21.00 & 4 & 2855.4617 & 2855.4585 & 714.8719 & 0.0032 & 1.1191 & 193.866 & 145.336 & 380.060 & 708.502 & \text { Yes } \\ \text { DEF } & & \end{array}$

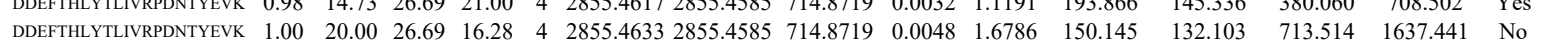
\begin{tabular}{llllllllllllllll} 
CKDDEFTHLYTLIVRPDNTYVVK & 0.99 & 24.33 & 26.43 & 15.30 & 4 & 3276.6573 & 3276.6524 & 820.1704 & 0.0049 & 1.4936 & 4589.413 & 5881.415 & 3571.120 & 791.103 & Yes \\
\hline
\end{tabular} $\begin{array}{lllllllllllllllll}\text { CKDDEFTHLYTLIVRPNTYEVK } & 0.99 & 25.59 & 26.38 & 16.46 & 4 & 3276.6581 & 3276.6524 & 820.1704 & 0.0057 & 1.7374 & 5663.153 & 4975.801 & 3949.382 & 760.059 & \text { Yes }\end{array}$ \begin{tabular}{lllllllllllllllll} 
CKDDEFTHLYTLIVRPDNTYEVK & 0.98 & 22.81 & 26.38 & 20.42 & 4 & 3276.6569 & 3276.6524 & 820.1704 & 0.0045 & 1.3717 & 3316.851 & 2747.525 & 3155.062 & 603.361 & Yes \\
\hline
\end{tabular} $\begin{array}{llllllllllllllll}\text { CKDDEFTHLYTLIVRPDNTYEVK } & 0.93 & 19.75 & 26.43 & 19.97 & 4 & 3276.6577 & 3276.6524 & 820.1704 & 0.0053 & 1.6155 & 3440.254 & 3104.857 & 2591.872 & 635.630 & \text { Yes } \\ \text { FVLSSGK } & 0.99 & 34.38 & 25.81 & 25.72 & 2 & 1024.6186 & 1024.6161 & 513.3153 & 0.0025 & 2.4351 & 25532.698 & 25188.840 & 28476.812 & 21408.458 & \text { Yes }\end{array}$ FVLSSGK

FVLSSGK

FVLSSGK

FVLSSGK

FYALSASFEPFSNK

FYALSASFEPFSNK

FYALSASFEPFSNK

QDEEQR

VHVIFNYK

VHVIFNYK

VHVIFNYK

VHVIFNYK $\begin{array}{lllllllllllllllll}\text { VHVIFNYK } & 0.98 & 32.39 & 25.47 & 15.83 & 3 & 1306.7743 & 1306.7641 & 436.5953 & 0.0102 & 7.7875 & 12306.359 & 12317.271 & 882.148 & 581.496 & \text { N } \\ \text { DPDASKPEDWDER } & 0.60 & 11.31 & 25.79 & 19.01 & 3 & 1846.8598 & 1846.8577 & 616.6265 & 0.0021 & 1.1352 & 2600.781 & 3268.613 & 4812.660 & 7710.570 & \text { Yes }\end{array}$

$\begin{array}{llllllllllllllll}0.99 & 37.94 & 25.79 & 29.75 & 2 & 1024.6190 & 1024.6161 & 513.3153 & 0.0029 & 2.8248 & 37324.905 & 35477.382 & 45228.880 & 31779.762 & \text { Yes }\end{array}$

$\begin{array}{lllllllllllllll}0.99 & 32.64 & 25.85 & 27.65 & 2 & 1024.6178 & 1024.6161 & 513.3153 & 0.0017 & 1.6559 & 8987.998 & 8985.707 & 9078.669 & 6845.192 & \text { Yes }\end{array}$

$\begin{array}{llllllllllllllll}0.91 & 32.59 & 25.94 & 28.25 & 2 & 1024.6212 & 1024.6161 & 513.3153 & 0.0051 & 4.9677 & 18979.179 & 18382.998 & 19386.843 & 16129.387 & \text { Yes }\end{array}$

$\begin{array}{lllllllllllllll}0.93 & 32.67 & 26.15 & 28.52 & 2 & 1024.6248 & 1024.6161 & 513.3153 & 0.0087 & 8.4743 & 20589.172 & 19044.908 & 23644.008 & 17439.182 & \text { Yes }\end{array}$

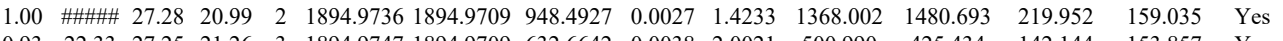

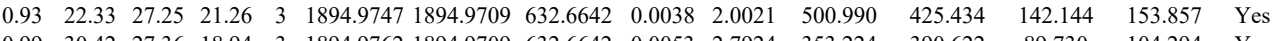
$\begin{array}{lllllllllllllll}0.99 & 30.42 & 27.36 & 18.94 & 3 & 1894.9762 & 1894.9709 & 632.6642 & 0.0053 & 2.7924 & 353.224 & 390.622 & 89.730 & 104.294 & \text { Yes }\end{array}$ $\begin{array}{lllllllllllllll}0.81 & 21.47 & 23.62 & 24.41 & 2 & 947.4432 & 947.4430 & 474.7288 & 0.0002 & 0.2106 & 17.584 & 20.473 & 12.719 & 28.784 & \text { Yes } \\ 1.00 & 46.90 & 25.94 & 22.83 & 2 & 1306.773 & 1306.7641 & 65.3893 & 0.0089 & 6.8002 & 25433.866 & 22236.228 & 1557.358 & 10.276 & \text { No }\end{array}$ $\begin{array}{lllllllllllllllll}1.00 & 46.90 & 25.94 & 22.83 & 2 & 1306.7730 & 1306.7641 & 654.3893 & 0.0089 & 6.8002 & 25433.866 & 22236.228 & 1557.358 & 1010.276 & \text { No } \\ 1.00 & 47.08 & 25.69 & 22.66 & 2 & 1306.7734 & 1306.7641 & 654.3893 & 0.0093 & 7.1058 & 20145.081 & 16064.004 & 1200.244 & 729.194 & \end{array}$ $\begin{array}{llllllllllllllll}1.00 & 47.08 & 25.69 & 22.66 & 2 & 1306.7734 & 1306.7641 & 654.3893 & 0.0093 & 7.1058 & 20145.081 & 16064.004 & 1200.244 & 729.194 & \mathrm{No}\end{array}$

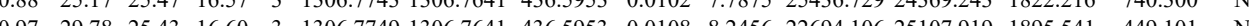

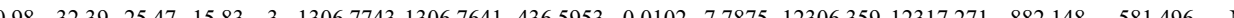
$\begin{array}{llllllllllllllllll}\text { DPDASKPEDWDER } & 0.54 & 10.70 & 25.89 & 15.10 & 3 & 1846.8610 & 1846.8577 & 616.62653 & 0.033 & 1.7839 & 3249.484 & 3245.137 & 6198.733 & 11745.484 & \text { Yes }\end{array}$ $\begin{array}{lllllllllllllll} & \end{array}$ $\begin{array}{llllllllllllll} & \end{array}$ $\begin{array}{llllllllllllllll}\text { KPEDWDEFMDGFWEPPYONPPYY } & 1.00 & 43.26 & 25.26 & 1825 & 3 & 3391.6042 & 3391.5920 & 1131.5379 & 0.0122 & 3.5939 & 14.250 & 34.961 & 43.358 & 68.555 & \text { Yes }\end{array}$

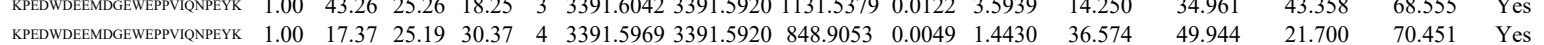

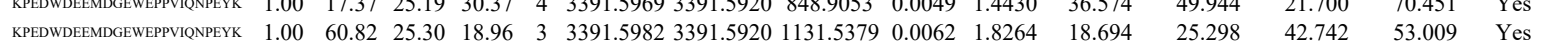
$\begin{array}{llllllllllllllll}\text { KPEDWDEEMDGEWEPVYQNPEYK } & 1.00 & 60.82 & 25.30 & 18.96 & 3 & 3391.5982 & 3391.5920 & 1131.5379 & 0.0062 & 1.8264 & 18.694 & 25.298 & 42.742 & 53.009 & \text { Yes } \\ \text { KPEDWDEEMDGEWEPYIQNPEYK } & 0.99 & 33.32 & 25.30 & 15.26 & 3 & 3391.6012 & 3391.5920 & 1131.5379 & 0.0092 & 2.7102 & 47.939 & 12.315 & 65.211 & 37.951 & \text { Yes }\end{array}$ GLQTSQDAR

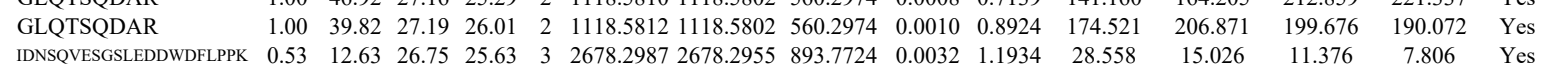
$\begin{array}{lllllllllllllll}1.00 & 46.92 & 27.16 & 25.29 & 2 & 1118.5810 & 1118.5802 & 560.2974 & 0.0008 & 0.7139 & 141.160 & 164.205 & 212.859 & 221.337 & \text { Yes }\end{array}$

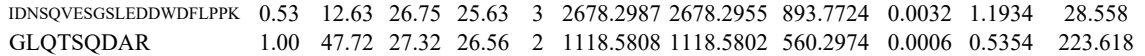
GLQTSQDAR $\begin{array}{lllllllllll}1.00 & 47.72 & 27.32 & 26.56 & 2 & 1118.5808 & 1118.5802 & 560.2974 & 0.0006 & 0.5354 & 223.618\end{array}$ $\begin{array}{lllllllllllll} & \end{array}$ \begin{tabular}{llllllllllllll} 
DDNSQVESGSLEDDWDFLPPKK & 0.97 & 15.30 & 26.43 & 28.30 & 4 & 2950.5001 & 2950.4926 & 738.6304 & 0.0075 & 2.5385 & 20.375 \\
\hline DNSOVESGSEDWDFPPKK & 1.00 & 30.64 & 26.40 & 43.64 & 4 & 2950.5009 & 2950.4926 & 738.6304 & 0.0083 & 28092 & 34.501
\end{tabular} 


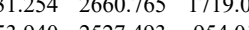

KPTSAKPSSTTP

KPTSAKPS

KPTSAKPSSTTPR $\begin{array}{lllllllllllll}0.96 & 14.31 & 23.56 & 27.31 & 4 & 1789.0417 & 1789.0423 & 448.2679 & -0.0006 & -0.3346 & 53.659\end{array}$

1949.291 65.876 $\begin{array}{lllllllllllll}0.96 & 13.34 & 23.58 & 14.34 & 4 & 1789.0421 & 789.0423 & 48.2679 & 0.0006 & 0.3346 & 19.909\end{array}$

$\begin{array}{llllllllll} & 3.48 & 25.31 & 4 & 1789.0425 & 789.0423 & 448.2679 & 0.0002 & 0.115 & 86.518 \\ & 26.43 & 2 & 1707.9192 & 1707.9174 & 854.9660 & 0.0018 & 1.0527 & 227.648 \\ \end{array}$

TPELNLDQFHDK

TPELNLDQFHDK

TPELNLDQFHDK

TPELNLDQFHDK

TPELNLDQFHDK

TPELNLDQFHDK

TPELNLDQFHDK

TPELNLDQFHDK

TPELNLDQFHDK

TPELNLDQFHDK

TPELNLDQFHDK

TPELNLDQFHDK

IVDDWANDGWGLK

$\begin{array}{llllllllllll}0.55 & 28.38 & 25.49 & 41.38 & 3 & 1980.1048 & 1980.1023 & 661.0414 & 0.0025 & 1.2606 & 556.698\end{array}$

516.64

203.591
39.014

37.907

\begin{tabular}{ll}
73.048 & 52.292 \\
\hline 01.466 & 63.567
\end{tabular}

269.332

$\begin{array}{llllllllllllllll}.55 & 28.38 & 25.49 & 41.38 & 3 & 1980.1048 & 1980.1023 & 661.0414 & 0.0025 & 1.2606 & 556.698 & 513.251 & 1062.630 & 747.504 \\ 1.00 & 53.62 & 27.50 & 23.63 & 2 & 1743.9040 & 1743.9035 & 872.9590 & 0.0005 & 0.2864 & 1432.955 & 1484.276 & 1759.469 & 1683.68 \\ 1.00 & 61.93 & 27.50 & 24.85 & 2 & 1743.9048 & 1743.9035 & 872.9590 & 0.0013 & 0.7446 & 897.871 & 977.571 & 883.346 & 957.033\end{array}$

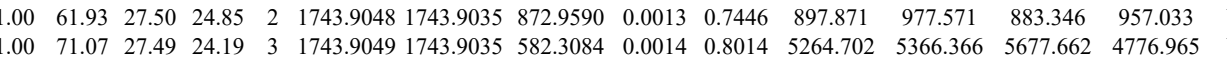
$\begin{array}{llllllllllllll}0.83 & 23.99 & 27.49 & 15.03 & 3 & 1743.9109 & 1743.9035 & 582.3084 & 0.0074 & 4.2360 & 165.307\end{array}$ $\begin{array}{llllllllllll}0.72 & 21.68 & 27.50 & 15.11 & 3 & 1743.9112 & 1743.9035 & 582.3084 & 0.0077 & 4.4077 & 152.852\end{array}$ $\begin{array}{lllllllllllll}0.79 & 23.70 & 27.54 & 17.63 & 3 & 1743.9145 & 1743.9035 & 582.3084 & 0.0110 & 6.2967 & 98.050\end{array}$ $\begin{array}{lllllllllll}1.00 & 56.14 & 27.50 & 23.81 & 2 & 1743.9058 & 1743.9035 & 872.9590 & 0.0023 & 1.3174 & 737.530\end{array}$ $\begin{array}{lllllllllllll}1.00 & 54.95 & 27.42 & 20.53 & 2 & 1743.9070 & 1743.9035 & 872.9590 & 0.0035 & 2.0047 & 636.750 & 868.0 \\ 1.00 & 75.55 & 27.51 & 21.83 & 3 & 1743.9076 & 1743.9035 & 582.3084 & 0.0041 & 23470 & 4326.973 & 5361 .\end{array}$ $\begin{array}{lllllllllllll}1.00 & 58.13 & 27.57 & 24.25 & 3 & 1743.9082 & 1743.9035 & 582.3084 & 0.0047 & 2.6904 & 6047.591 & 8357 . \\ 0.99 & 30.03 & 27.57 & 17.93 & 3 & 1743.9088 & 1743.9035 & 582.3084 & 0.0053 & 3.0339 & 427.021 & 458.6\end{array}$

57.130

IVDDWANDGWGLK

$\begin{array}{lllllllllllll}1.00 & 71.70 & 27.45 & 24.83 & 3 & 1743.9103 & 1743.9035 & 582.3084 & 0.0068 & 3.8925 & 2047.535 & 2445.312 & 2\end{array}$

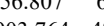

IVDDWANDGWGLK

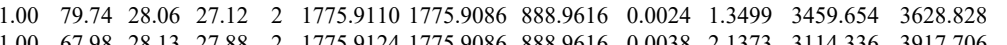

8.293

DDDWANDGWGLK $\begin{array}{llllllllllll}1.00 & 38.49 & 28.13 & 22.67 & 3 & 1775.9125 & 175.9086 & 592.9768 & 0.0039 & 2.1373 & 215.150 & 185.5\end{array}$ $\begin{array}{lll}85.505 & 102.467 \\ 165.359 & 138.911\end{array}$

APVPTGEVYFADSFDR

IVDDWANDGWGLK IPNPDFFEDLEPFR IPNPDFFEDLEPFR IPNPDFFEDLEPFR $\begin{array}{lllllllllllll}0.77 & 89.29 & 26.84 & \# \# \# \# \quad 2 & 1913.9302 & 1913.9281 & 957.9713 & 0.0021 & 1.0961 & 2827.767 & 2412 .\end{array}$

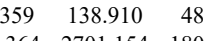

$\begin{array}{llllllllllllll}0.69 & 95.18 & 27.02 & \text { \#\#\#\# } & 2 & 1913.9314 & 1913.9281 & 957.9713 & 0.0033 & 1.7224 & 2052.423 & 2300.700 & 3469.091 & 3220.551\end{array}$

$\begin{array}{llllllllllllll}1.00 & 77.05 & 28.06 & 28.72 & 2 & 1775.9118 & 1775.9086 & 888.9616 & 0.0032 & 1.7998 & 2408.347 & 2846.358 & 3.047 & 61.081 \\ 1.00 & 68.96 & 28.13 & 30.61 & 2 & 1775.9120 & 1775.9086 & 888.9616 & 0.0034 & 1.9123 & 7946.785 & 6831.006 & 0.000 & 247.786\end{array}$

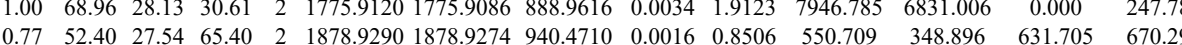
IPNPDFFEDLEPFR $\begin{array}{llllllllllllll}0.77 & 52.40 & 27.54 & 65.40 & 2 & 1878.9290 & 1878.9274 & 940.4710 & 0.0016 & 0.8506 & 550.709 \\ 3\end{array}$ $\begin{array}{lllllllllll}1.00 & 60.79 & 27.54 & 18.99 & 2 & 1878.9290 & 1878.9274 & 940.4710 & 0.0016 & 0.8506 & 339.972 \\ 0.97 & 24.52 & 27.67 & 16.96 & 3 & 1878.9301 & 1878.9274 & 627.3164 & 0.0027 & 1.4347 & 55.481\end{array}$

$\begin{array}{lllllllllllllll} & \end{array}$

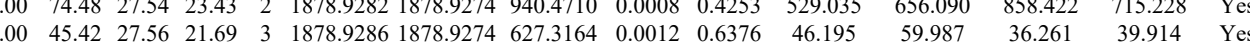
$\begin{array}{lllllllllllllll}1.00 & 42.36 & 27.58 & 23.48 & 3 & 1878.9292 & 1878.9274 & 627.3164 & 0.0018 & 0.9565 & 38.564 & 107.170 & 52.579 & 27.594 & \text { Yes }\end{array}$

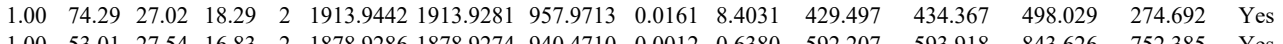
\begin{tabular}{llllllllllllllll}
1.00 & 53.01 & 27.54 & 16.83 & 2 & 1878.9286 & 1878.9274 & 940.4710 & 0.0012 & 0.6380 & 592.207 & 593.918 & 843.626 & 752.385 & Yes \\
\hline
\end{tabular}

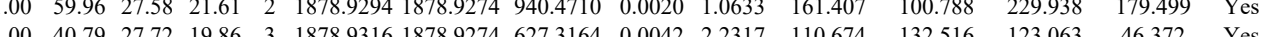

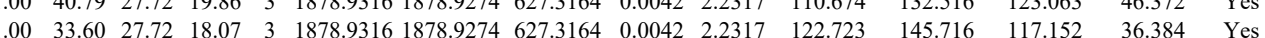

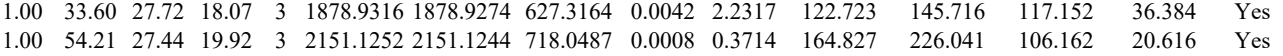

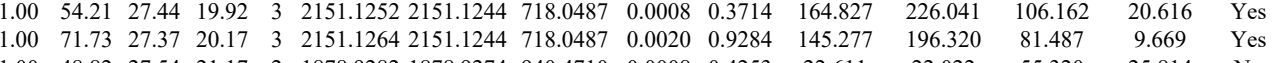

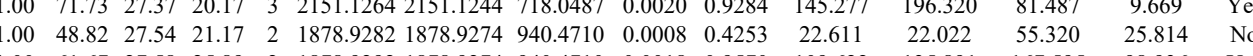
$\begin{array}{llllllllllllll}1.00 & 51.39 & 27.39 & 19.75 & 3 & 2151.1282 & 2151.1244 & 718.0487 & 0.0038 & 1.7640 & 1161.081 & 1380.649 & 465.710\end{array}$ 

$\begin{array}{llllllllllllllllll}1.00 & 58.73 & 25.43 & 47.86 & 2 & 1348.7966 & 1348.7958 & 67.4052 & 0.0008 & 0.5922 & 15515.048 & 18118.565 & 14762.017 & 13045.579 & \text { Yes }\end{array}$ $\begin{array}{llllllllllllllllll}1.00 & 60.36 & 25.43 & 49.03 & 2 & 1348.7968 & 1348.7958 & 675.4052 & 0.0010 & 0.7403 & 16927.656 & 19135.164 & 16098.054 & 13680.083 & \text { Yes } \\ 1.00 & 57.34 & 24.93 & 45.25 & 2 & 1348.7982 & 1348.7958 & 675.4052 & 0.024 & 1.7767 & 22295.860 & 26007.946 & 20365.671 & 18750.095 & \text { Yes }\end{array}$ $\begin{array}{llllllllllllllll}1.00 & 59.22 & 25.42 & 43.09 & 2 & 1348.7964 & 1348.7958 & 675.4052 & 0.0006 & 0.4442 & 8172.628 & 8720.793 & 7123.801 & 6214.807 & \text { Yes }\end{array}$ $\begin{array}{lllllllllllllllll} & \end{array}$

GLVLMSR

WKPPMIDNPSYQGIWKPR

GLVLMSR

GLVLMSR
GLVLMSR

GLVLMSR

DDTDDEIAK

KDDTDDEIAK

KDDTDDEIAK

$\begin{array}{lllllllllllllllll}0.69 & 27.74 & 28.00 & 31.87 & 2 & 918.5488 & 918.5443 & 460.2794 & 0.0045 & 4.8883 & 33574.282 & 36722.550 & 13055.095 & 8418.368 & \text { Yes }\end{array}$

$\begin{array}{llllllllllllllll}0.72 & 28.46 & 27.74 & 34.33 & 2 & 918.5498 & 918.5443 & 460.2794 & 0.0055 & 5.9746 & 41292.420 & 44032.198 & 14058.495 & 10624.468 & \text { Yes }\end{array}$

SDAEEDGGTVSQEEEDR SDAEEDGGTVSQEEEDR

LHFIFR

$\begin{array}{llllllllllllllll}0.72 & 44.43 & 24.42 & 57.43 & 4 & 2644.4393 & 2644.4313 & 662.1151 & 0.0080 & 3.0206 & 11484.636 & 12975.363 & 5511.849 & 689.078 & \text { Yes }\end{array}$

WEVEEMK

$\begin{array}{lllllllllllllllll}0.70 & 30.44 & 27.16 & 36.80 & 2 & 918.5514 & 918.5443 & 460.2794 & 0.0071 & 7.7126 & 47644.377 & 60062.038 & 11054.478 & 6642.244 & \text { Yes } \\ 0.81 & 29.76 & 27.16 & 34.22 & 2 & 918.5518 & 9185443 & 4602794 & 0.0075 & 8.1472 & 24191.561 & 32348.252 & 8041.352 & 4102.821 & \text { Yes }\end{array}$

$\begin{array}{llllllllllllllll}0.81 & 29.59 & 27.16 & 34.09 & 2 & 918.5524 & 918.5443 & 460.2794 & 0.0081 & 8.7989 & 19990.445 & 24890.428 & 5802.414 & 4044.918 & \text { Yes }\end{array}$

$\begin{array}{llllllllllllllll}1.00 & 38.42 & 26.43 & 24.32 & 2 & 1308.6306 & 1308.6289 & 655.3217 & 0.0017 & 1.2971 & 545.364 & 589.808 & 1148.691 & 1038.159 & \text { Yes }\end{array}$

$\begin{array}{lllllllllllllll}1.00 & 41.31 & 28.07 & 21.17 & 3 & 1580.8267 & 1580.8259 & 527.9492 & 0.0008 & 0.5051 & 2958.204 & 2808.263 & 1731.819 & 800.531 & \text { Yes }\end{array}$ $\begin{array}{llllllllllllllll}1.00 & 46.08 & 28.30 & 21.85 & 3 & 1580.8291 & 1580.8259 & 527.9492 & 0.0032 & 2.0204 & 3386.065 & 3376.710 & 1818.735 & 1143.755 & \text { Yes }\end{array}$

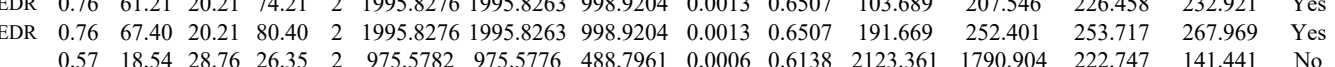
$\begin{array}{llllllllllllllllll}0.99 & 37.50 & 27.40 & 19.59 & 2 & 1237.6274 & 1237.6256 & 619.8201 & 0.0018 & 1.4520 & 116.377 & 111.021 & 97.858 & 69.989 & \text { Yes } \\ 1\end{array}$ $\begin{array}{llllllllllllllll} & & & \end{array}$ $\begin{array}{lllllllllllllllll} & \text { DPPEAVKPDDEDAPAK } & 0.99 & 28.29 & 26.97 & 15.12 & 3 & 2539.2838 & 2539.2808 & 847.4342 & 0.0030 & 1.1800 & 4534.152 & 8453.103 & 13869.398 & 16568.694 & \text { No }\end{array}$ $\begin{array}{lllllllllllllllll} & \end{array}$

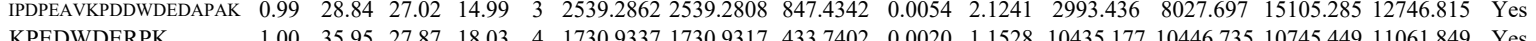

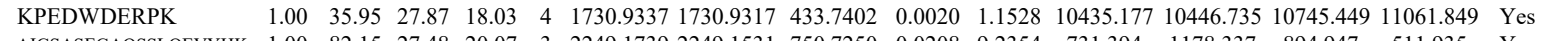
$\begin{array}{lllllllllllllllll}\text { AIGSASEGAQSSLQEVYHK } & 1.00 & 82.15 & 27.48 & 20.07 & 3 & 2249.1739 & 2249.1531 & 750.7250 & 0.0208 & 9.2354 & 731.394 & 1178.337 & 894.947 & 511.935 & \text { Yes }\end{array}$

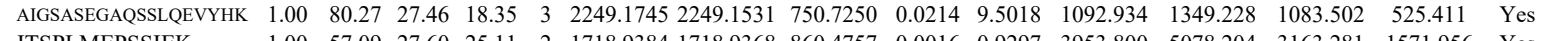

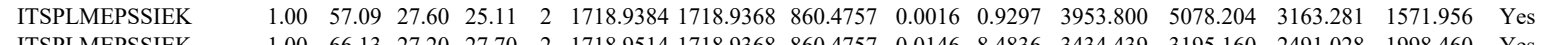

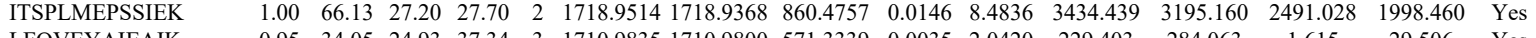

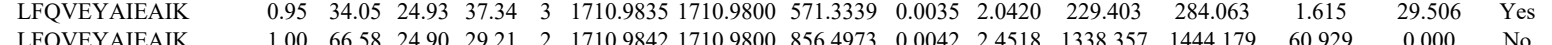

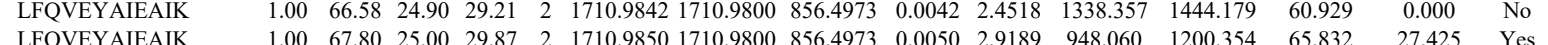

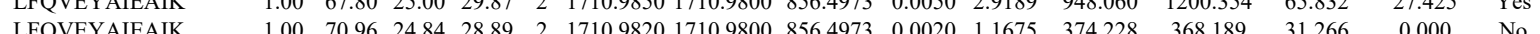

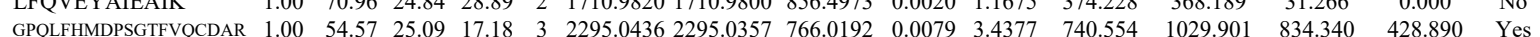
$\begin{array}{llllllllllllll} & \end{array}$

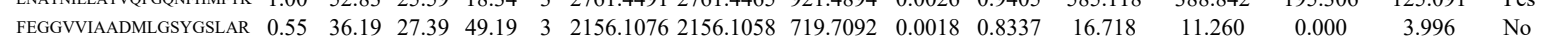
$\begin{array}{llllllllllllllll}\text { FEGGVVIAADMLGSYGSLAR } & 1.00 & 61.12 & 27.40 & 24.39 & 3 & 2156.1085 & 2156.1058 & 719.7092 & 0.0027 & 1.2505 & 56.666 & 69.352 & 53.839 & 9.457 & \text { No }\end{array}$

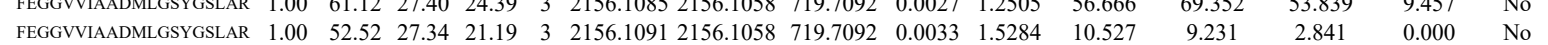

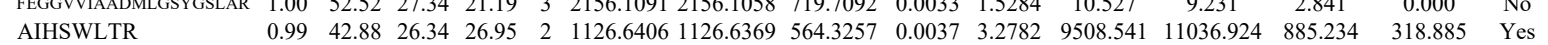
AIHSWLTR
AIHSWLTR AIHSWLTR AIHSWLTR
AIHSWLTR

10 LAAIAESGVER LAAIAESGVER LAAIAESGVER LAAIAESGVER TTTGSYIANR $\begin{array}{lllllllllllllll}0.99 & 42.88 & 26.34 & 26.95 & 2 & 1126.6406 & 1126.6369 & 564.3257 & 0.0037 & 3.2782 & 9508.541 & 11036.924 & 885.234 & 318.885 & \text { Yes } \\ 0.99 & 42.21 & 26.14 & 24.37 & 2 & 1126.6416 & 1126.6369 & 564.3257 & 0.0047 & 4.1642 & 13463.423 & 20949.200 & 946.084 & 463.509 & \text { Yes }\end{array}$ $\begin{array}{lllllllllllllll}0.99 & 41.34 & 26.14 & 26.90 & 2 & 1126.6418 & 1126.6369 & 564.3257 & 0.0049 & 4.3414 & 5505.015 & 6717.233 & 303.298 & 137.278 & \text { Yes }\end{array}$ $\begin{array}{llllllllllllllll}0.98 & 41.25 & 26.26 & 26.81 & 2 & 1126.6426 & 1126.6369 & 564.3257 & 0.0057 & 5.0502 & 6811.528 & 7970.934 & 374.509 & 320.085 & \text { Yes }\end{array}$ $\begin{array}{lllllllllllllllll}1.00 & 59.10 & 27.36 & 35.82 & 2 & 1258.7108 & 1258.7003 & 630.3574 & 0.0105 & 8.3285 & 12930.164 & 14669.936 & 1162.730 & 892.638 & \text { Yes }\end{array}$ $\begin{array}{lllllllllllllllll}1.00 & 57.09 & 27.54 & 40.04 & 2 & 1258.7118 & 1258.7003 & 630.3574 & 0.0115 & 9.1217 & 10427.053 & 13153.903 & 1551.269 & 541.770 & \text { Yes }\end{array}$ $\begin{array}{lllllllllllllllll}1.00 & 51.88 & 27.30 & 39.75 & 2 & 1258.7100 & 1258.7003 & 630.3574 & 0.0097 & 7.6940 & 5931.604 & 6151.342 & 773.885 & 676.503 & \text { Yes }\end{array}$ $\begin{array}{llllllllllllllllll}0.99 & 41.07 & 27.36 & 26.31 & 2 & 1258.7106 & 1258.7003 & 630.3574 & 0.0103 & 8.1699 & 863.936 & 981.795 & 331.205 & 202.912 & \text { Yes }\end{array}$ TTTGSYIANR

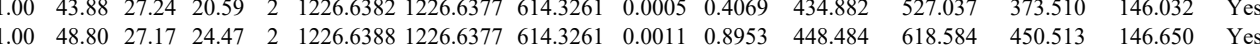
$\begin{array}{lllllllllllllll} & & & \end{array}$ GPGLYYVDSEGNR VSSDNVADLHEK VSSDNVADLHEK VSSDNVADLHEK

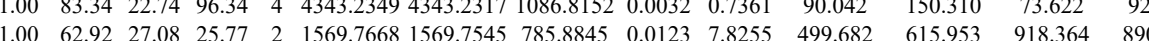

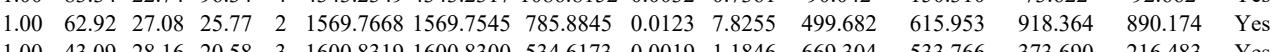
$\begin{array}{lllllllllllllll}1.00 & 43.09 & 28.16 & 20.58 & 3 & 1600.8319 & 1600.8300 & 534.6173 & 0.0019 & 1.1846 & 669.304 & 533.766 & 373.690 & 216.483 & \text { Yes }\end{array}$ $\begin{array}{lllllllllllllll}1.00 & 45.69 & 28.17 & 22.53 & 3 & 1600.8331 & 1600.8300 & 534.6173 & 0.0031 & 1.9328 & 410.275 & 297.247 & 290.859 & 133.744 & \text { Yes }\end{array}$

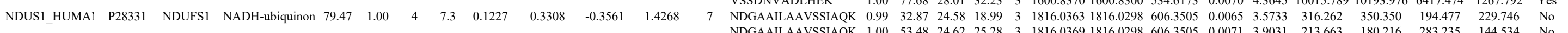

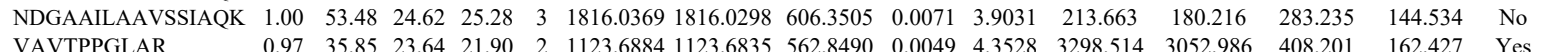

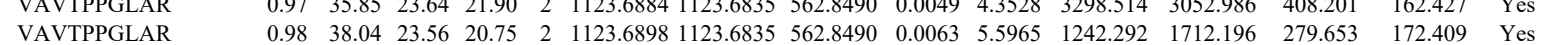

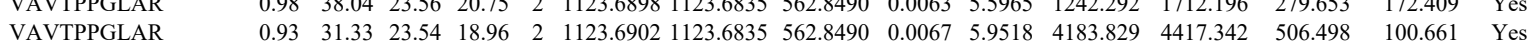


VAVTPPGLAR

VLFLLGADGGCIT

VLFLLGADGGCITR

KPMVVLGSSALQR

ITVALPR

VQMDMLQVLLR

GLLPQILENLLSAR

GLLPQILENLLSAR

VTGVPLSYLLSR

LALTLRPCAPILGAK

LALTLRPCAPILGAK

ADMGGAATICSAIVSAAK

TLIEFLLR

GVLFASGQNLAR

GVLFASGQNLAR

TLIEFLLR
TLIEFLLR

ELPSFVGEK

VDEEGLK

VDEEGLK

SILTDNPTWIIDPIDGTTNFVH

SILTDNPTWIIPPID

LFCIPVHGIR

LFCIPVHGIR

LFCIPVHGIR
LFCIPVHGIR

LFCIPVHGIR
LFCIPVHGIR

LFCIPVHGIR

LFCIPVHGIR

LTCIP HHG

$\begin{array}{llllllllllll}\text { TKT_HUMAN } & \text { P29401 } & \text { TKT } & \text { Transketolase } & 67.88 & 1.00 & 18 & 40 & -0.0408 & 0.3181 & -0.0342 & 1.5871\end{array}$
LALTLRPCAPILGAK

LALTLRPCAPILGAK

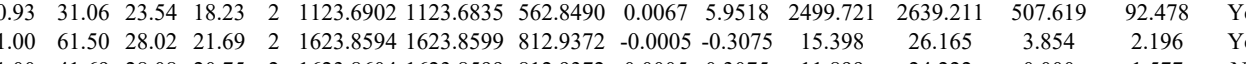

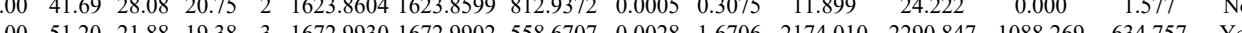

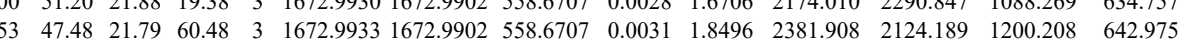
$\begin{array}{lllllllllllllllll}0.91 & 31.93 & 20.00 & 32.34 & 2 & 912.5958 & 912.5878 & 457.3012 & 0.0080 & 8.7469 & 1291.190 & 1630.916 & 518.720 & 256.351 & \text { Yes }\end{array}$ $\begin{array}{lllllllllllllllll}0.86 & 27.17 & 19.59 & 29.98 & 2 & 912.5962 & 912.5878 & 457.3012 & 0.0084 & 9.1842 & 4340.692 & 5108.151 & 1411.065 & 987.492 & \text { Yes }\end{array}$ $\begin{array}{lllllllllllllll}1.00 & 52.64 & 27.57 & 25.14 & 2 & 1488.8292 & 1488.8278 & 745.4212 & 0.0014 & 0.9391 & 884.740 & 1193.242 & 89.079 & 38.505 & \text { Yes } \\ 1.00 & 88.60 & 20.90 & 31.77 & 2 & 1680.0066 & 1680.0056 & 841.0101 & 0.0010 & 0.5945 & 115.561 & 132.363 & 43.146 & 11.102 & \text { Yes }\end{array}$

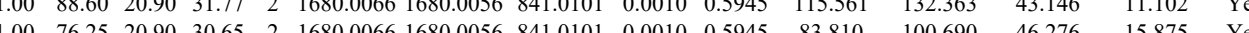

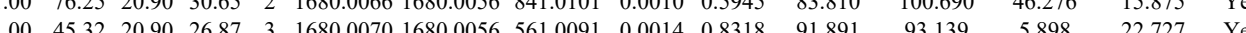
$\begin{array}{llllllllllllll} & \end{array}$ $\begin{array}{lllllllllllll} & 3 . .670 & \text { Yes }\end{array}$ $\begin{array}{lllllllllllll}1 & 151.9112 & 1581.9098 & 528.3105 & 0.0014 & 0.8833 & 5.005 & 17.224 & 0.321 & 3.242 & \text { No }\end{array}$

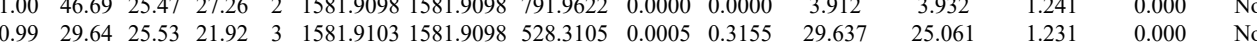
\begin{tabular}{lllllllllllllll}
1.00 & 36.46 & 27.64 & 15.71 & 3 & 1969.9903 & 1969.9879 & 657.6699 & 0.0024 & 1.2164 & 288.155 & 248.533 & 93.284 & 44.247 & Yes \\
\hline
\end{tabular}

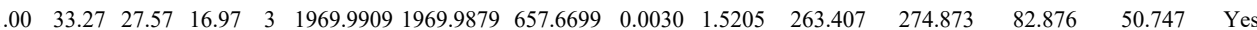
$\begin{array}{llllllllllllllll}1.00 & 39.58 & 24.61 & 34.36 & 2 & 1147.7102 & 1147.7087 & 574.8616 & 0.0015 & 1.3047 & 4298.150 & 4998.991 & 177.821 & 30.357 & \text { Yes }\end{array}$ $\begin{array}{lllllllllllllll}1.00 & 41.08 & 23.64 & 34.47 & 2 & 1147.7108 & 1147.7087 & 574.8616 & 0.0021 & 1.8265 & 4574.238 & 5293.295 & 191.750 & 18.293 & \text { Yes }\end{array}$ $\begin{array}{lllllllllllllll}1.00 & 52.56 & 27.81 & 26.01 & 2 & 1375.7806 & 1375.7694 & 688.8920 & 0.0112 & 8.1289 & 2931.612 & 3802.013 & 5263.565 & 782.210 & \text { No }\end{array}$ $\begin{array}{lllllllllllllll}1.00 & 51.79 & 27.36 & 30.83 & 2 & 1292.7322 & 1292.7220 & 647.3683 & 0.0102 & 7.8780 & 2539.293 & 1856.562 & 18564.131 & 1140.812 & \text { Yes }\end{array}$

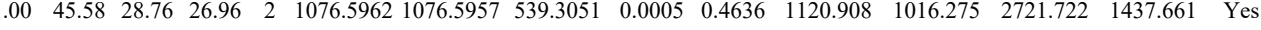
$\begin{array}{llllllllllllllll}0.99 & 40.01 & 28.76 & 27.73 & 2 & 1076.5962 & 1076.5957 & 539.3051 & 0.0005 & 0.4636 & 1474.453 & 1436.695 & 4140.853 & 2005.978 & \text { Yes }\end{array}$ \begin{tabular}{lllllllllllllll}
1.00 & 35.71 & 26.67 & 17.66 & 3 & 2768.4262 & 2768.4256 & 923.8158 & 0.0006 & 0.2165 & 35.722 & 20.362 & 22.863 & 69.424 & $\mathrm{No}$ \\
\hline
\end{tabular} $\begin{array}{lllllllllllllll}0.53 & 43.87 & 26.58 & 56.87 & 3 & 2768.4286 & 2768.4256 & 923.8158 & 0.0030 & 1.0825 & 46.849 & 45.721 & 0.000 & 74.010 & \text { No } \\ 1.00 & 54.37 & 27.66 & 24.00 & 3 & 1343.7340 & 1343.7328 & 448.9182 & 0.0012 & 0.8910 & 124.151 & 13.356 & 3.752 & 2.16 & \text { Yes }\end{array}$ $\begin{array}{llllllllllllll}1 & 1343.7340 & 1343.7328 & 448.9182 & 0.0012 & 0.8910 & 124.151 & 133.356 & 3.752 & 12.616 & \text { Yes } \\ \end{array}$

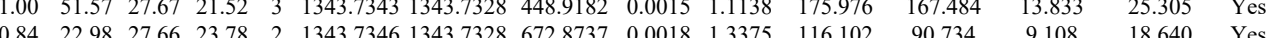
\begin{tabular}{lllllllllllllll}
0.84 & 22.98 & 27.66 & 23.78 & 2 & 1343.7346 & 1343.7328 & 672.8737 & 0.0018 & 1.3375 & 116.102 & 90.734 & 9.108 & 18.640 & Yes \\
\hline 0.85 & 23.3 & 27.68 & 2.48 & 2 & 1343.735 & 343.732 & 672837 & 0.002 & 1.783 & 96.935 & 88.547 & 1.251 & 1.042 & Yes
\end{tabular} \begin{tabular}{llllllllllllllll}
0.85 & 23.39 & 27.68 & 23.48 & 2 & 1343.7352 & 1343.7328 & 672.8737 & 0.0024 & 1.7834 & 96.935 & 88.547 & 14.251 & 11.042 & Yes \\
\hline .68 & 24.44 & 27.54 & 18.64 & 2 & 1343.7364 & 1343.7328 & 6728737 & 0.0036 & 2.6751 & 118.081 & 124.075 & 11.072 & 7.319 & Yes
\end{tabular} $\begin{array}{llllllllllllllll}0.68 & 24.44 & 27.54 & 18.64 & 2 & 1343.7364 & 1343.7328 & 672.8737 & 0.0036 & 2.6751 & 118.081 & 124.075 & 11.072 & 7.319 & \text { Yes } \\ 1.00 & 48.91 & 27.64 & 19.37 & 3 & 1343.7337 & 1343.7328 & 448.9182 & 0.009 & 0.6683 & 159.874 & 162.822 & 18.301 & 31.407 & \text { Yes }\end{array}$ \begin{tabular}{llllllllllllllll} 
& 0.00 & 24.44 & 27.54 & 18.64 & 2 & 1343.7364 & 1343.7328 & 672.8737 & 0.0036 & 2.6751 & 118.081 & 124.075 & 11.072 & 7.319 & Yes \\
\hline
\end{tabular}

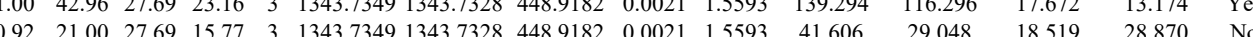

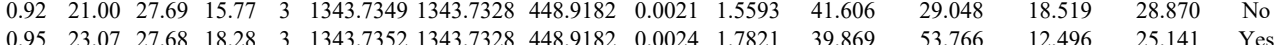

IALDGDTK

IIALDGDTK

IIALDGDTK

IIALDGDTK

ISSDLDGHPVPK

ISSDLDGHPVPK

ISSDLDGHPVPK

ISSDLDGHPVPK

ISSDLDGHPVPK

ISSDLDGHPVPK

KISSDLDGHPVPK

KISSDLDGHPVPK

ISSDLDGHPVPK

ISSDLDGHPVPK

KISSDLDGHPVPK 53.766

4.400

$\begin{array}{llllllllll}0.98 & 50.86 & 27.28 & 47.39 & 2 & 1232.7324 & 1232.7220 & 617.3683 & 0.0104 & 8.842\end{array}$

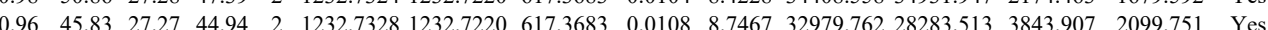
$\begin{array}{llllllllllllllll}0.99 & 57.28 & 27.28 & 48.05 & 2 & 1232.7330 & 1232.7220 & 617.3683 & 0.0110 & 8.9087 & 15247.347 & 14959.988 & 1481.152 & 1056.484 & \text { Yes }\end{array}$ $\begin{array}{lllllllllllllll}0.95 & 63.45 & 27.29 & 62.75 & 2 & 1232.7336 & 1232.7220 & 617.3683 & 0.0116 & 9.3946 & 29636.493 & 25048.878 & 901.509 & 1040.372 & \text { Yes }\end{array}$ $\begin{array}{llllllllllllllll}1.00 & 65.97 & 27.02 & 40.22 & 2 & 1551.8584 & 1551.8501 & 776.9323 & 0.0083 & 5.3415 & 4925.804 & 5475.649 & 2447.805 & 1265.262 & \text { Yes }\end{array}$ $\begin{array}{llllllllllllllll}.00 & 50.38 & 27.25 & 31.66 & 2 & 1551.8598 & 1551.8501 & 776.9323 & 0.0097 & 6.2425 & 2548.429 & 2270.207 & 1493.091 & 1711.424 & \text { Yes } & \\ 0\end{array}$ $\begin{array}{lllllllllllllllll}1.00 & 42.20 & 27.15 & 26.63 & 3 & 1551.8617 & 1551.8501 & 518.2906 & 0.0116 & 7.4604 & 14840.349 & 18583.477 & 8335.975 & 3049.239 & \text { Yes } \\ 0.99 & 37.50 & 27.23 & 20.48 & 3 & 155.820 & 1551.8501 & 58.290 & 0.019 & 7.653 & 29132.924 & 27627.660 & 12586.123 & 4790.358 & \text { Yes }\end{array}$ $\begin{array}{lllllllllllllllll}1.00 & 53.51 & 27.02 & 20.48 & 3 & 1551.8620 & 1551.8501 & 518.2906 & 0.0119 & 7.6533 & 29132.924 & 27627.660 & 12586.123 & 4790.558 & \text { Yes } \\ & 2751.8586 & 1551.8501 & 776.9323 & 0.0085 & 5.4702 & 5087.060 & 4696.353 & 3010.049 & 2039.697 & \text { Yes }\end{array}$ $\begin{array}{lllllllllllllll}0.99 & 38.51 & 27.13 & 20.87 & 3 & 1551.8608 & 1551.8501 & 518.2906 & 0.0107 & 6.8815 & 17695.274 & 22403.133 & 11398.559 & 4352.135 & \text { Yes }\end{array}$ $\begin{array}{lllllllllllllllll}0.99 & 42.73 & 27.13 & 36.89 & 2 & 1551.8610 & 1551.8501 & 776.9323 & 0.0109 & 7.0147 & 9486.906 & 7144.899 & 2747.207 & 1386.259 & \text { Yes }\end{array}$ $\begin{array}{lllllllllllllllll}1.00 & 29.91 & 23.01 & 42.91 & 4 & 1824.0557 & 1824.0471 & 457.0191 & 0.0086 & 4.7044 & 9213.706 & 9940.818 & 4363.397 & 2280.469 & \text { Yes }\end{array}$ $\begin{array}{lllllllllllllll}1.00 & 30.32 & 22.90 & 43.32 & 4 & 1824.0569 & 1824.0471 & 457.0191 & 0.0098 & 5.3608 & 7357.480 & 7696.159 & 3424.259 & 1980.803 & \text { Yes }\end{array}$ $\begin{array}{lllllllllllllll}0.79 & 24.23 & 27.22 & 24.34 & 3 & 1551.8638 & 1551.8501 & 518.2906 & 0.0137 & 8.8109 & 6919.700 & 7705.899 & 3501.483 & 2652.881 & \text { Yes }\end{array}$ $\begin{array}{llllllllllllllll}0.99 & 38.73 & 27.08 & 22.39 & 3 & 1551.8647 & 1551.8501 & 518.2906 & 0.0146 & 9.3898 & 11294.030 & 10818.549 & 5652.899 & 3156.037 & \text { Yes }\end{array}$ $\begin{array}{lllllllllllllllll}\text { SVPTSTVFYPSDGVATEK } & 1.00 & 89.54 & 27.32 & 19.48 & 2 & 2172.1374 & 2172.1194 & 1087.0670 & 0.0180 & 8.2791 & 1493.886 & 1084.608 & 649.974 & 714.389 & \text { Yes }\end{array}$ $\begin{array}{llllllllllllllll}\text { TSRPENAIIYNNNEDFQVGQAK } & 1.00 & 69.06 & 26.34 & 17.96 & 3 & 2795.4286 & 2795.4082 & 932.8100 & 0.0204 & 7.2897 & 2118.248 & 1068.245 & 1174.138 & 679.505 & \text { Yes }\end{array}$

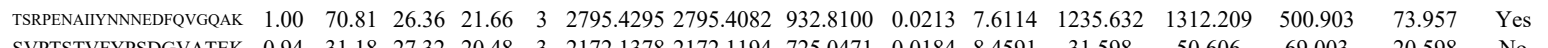

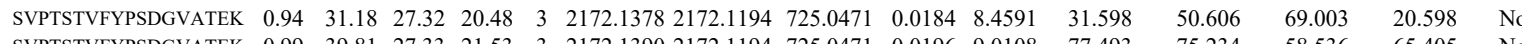
$\begin{array}{llllllllllllllll}\text { SVPTSTVFYPSDGVATEK } & 0.99 & 39.81 & 27.33 & 21.53 & 3 & 2172.1390 & 2172.1194 & 725.0471 & 0.0196 & 9.0108 & 77.493 & 75.234 & 58.536 & 65.405 & \text { No }\end{array}$

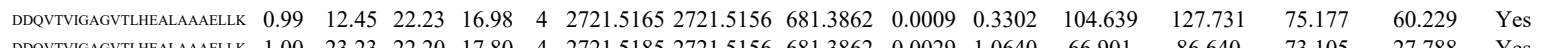
$\begin{array}{lllllllllllllll}\text { DDQVTVG } & \end{array}$

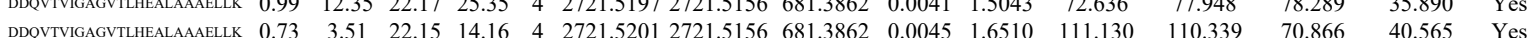
$\begin{array}{llllllllllllllll}\text { DDQVTVIGAGVTLHEALAAAELLK } & 1.00 & 30.36 & 21.96 & 17.58 & 4 & 2721.5217 & 2721.5156 & 681.3862 & 0.0061 & 2.2381 & 82.220 & 86.896 & 81.675 & 49.995 & \text { Yes }\end{array}$

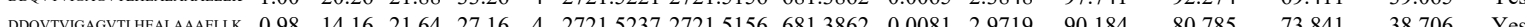

Table S-3 page 205 of 499 


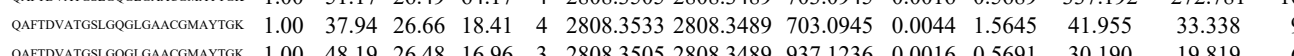
$\begin{array}{lllllllllllll}0.72 & 18.88 & 26.13 & 16.39 & 2 & 897.4692 & 897.4686 & 449.7416 & 0.0006 & 0.6670 & 38.130\end{array}$

GICFIR

GICFIR

GICFIR

KLILDSAR

KLILDSAR

GICFIR

GICFIR

GICFIR

GICFIR HQPTAIIAK $\begin{array}{llllllllllll}0.52 & 14.92 & 26.04 & 19.23 & 2 & 897.4694 & 897.4686 & 449.7416 & 0.0008 & 0.8894 & 39.797\end{array}$ $\begin{array}{llllllllllll}0.56 & 15.69 & 26.04 & 16.88 & 2 & 897.4694 & 897.4686 & 449.7416 & 0.0008 & 0.8894 & 42.060 \\ 0.57 & 15.92 & 26.02 & 20.86 & 2 & 897.4698 & 897.4686 & 49.7416 & 0.0012 & 1.3341 & 43.113\end{array}$ $\begin{array}{lllllllllllll}0.57 & 15.92 & 26.02 & 20.86 & 2 & 897.4698 & 897.4686 & 449.7416 & 0.0012 & 1.3341 & 43.113\end{array}$ $\begin{array}{lllllllllllll}0.57 & 15.92 & 26.02 & 2.86 & 2 & 897.4698 & 897.4686 & 449.7416 & 0.0012 & 1.3341 & 43.113\end{array}$ $\begin{array}{lllllllllllll}0.58 & 16.09 & 26.02 & 15.34 & 2 & 897.4698 & 897.4686 & 449.7416 & 0.0012 & 1.3341 & 143.479 & 158 & \\ 1.00 & 33.12 & 24.15 & 16.54 & 3 & 12027586 & 1202.7590 & 401.9269 & -0.0004 & -0.3317 & 855.582 & 112\end{array}$ $\begin{array}{llllllllllll}1.00 & 33.12 & 24.15 & 16.54 & 3 & 1202.7586 & 1202.7590 & 401.9269 & -0.0004 & -0.3317 & 855.582\end{array}$ $\begin{array}{lllllllllllllll}0.63 & 17.05 & 26.13 & 29.05 & 2 & 897.4692 & 897.4686 & 449.7416 & 0.0006 & 0.6670 & 7432.537 & 8266.490 & 1169.594\end{array}$ 
VGTDLLEETTKFEHVQSVDIAAFNK GVVQELQQAISK

ATAPQTQHVSPMR

ATAPQTQHVSPMR GVVQELQQAISK GVVQELQQAISK GVVQELQQAISK GVVQELQQAISK ATAPQTQHVSPMR ATAPQTQHVSPMR ATAPQRQNSTR ATAPQTQHVSPMR ATAPQTOHVSPMR ATAPQRQHVSPMR ATAPQTQHVSPMR
ATAPQTQHVSPMR ATAPQTQHY
LVPVGYGIR LVPVGYGIR LVPVGYGIR LVPVGYGIR VGTDLLEEEITK VGTDLLEEEITK ATAPQTQHVSPMR ATAPQTQHVSPMR
ATAPQTQHVSPMR

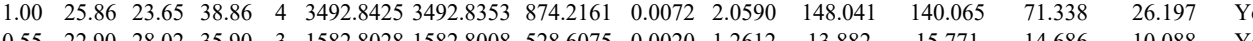

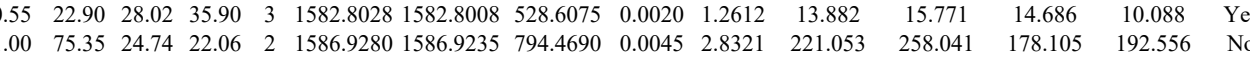
$\begin{array}{lllllllllllllll}1.00 & 36.53 & 27.90 & 17.70 & 3 & 1582.8016 & 1582.8008 & 528.6075 & 0.0008 & 0.5045 & 19.000 & 23.726 & 14.311 & 6.784 & \text { Yes }\end{array}$

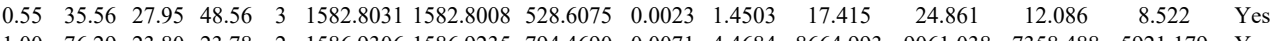

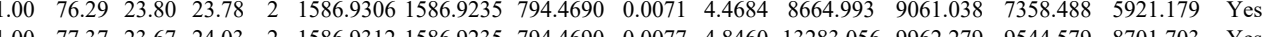
$\begin{array}{llllllllllllllllll}1.00 & 77.37 & 2.67 & 24.03 & 2 & 1586.9312 & 1586.9235 & 794.4690 & 0.0077 & 4.8460 & 13283.056 & 9962.279 & 9544.579 & 8701.703 & \text { Yes }\end{array}$

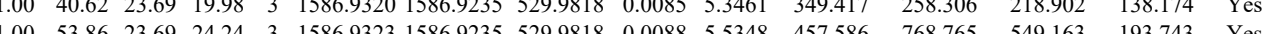

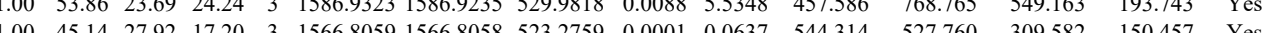

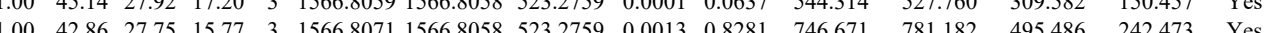

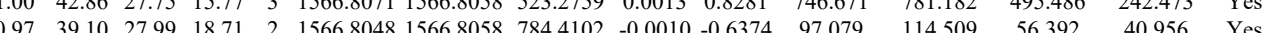

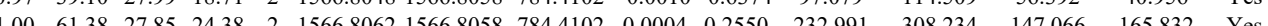
$\begin{array}{lllllllllllllll}1.00 & 6 . .11 & 27.89 & 18.23 & 3 & 1566.8024 & 1566.8058 & 523.2759 & 0.0016 & 1.0192 & 694.417 & 910.588 & 561.371 & 335.353 & \text { Yes }\end{array}$

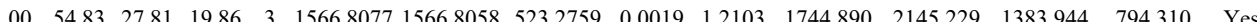
$\begin{array}{lllllllllllllll}1.00 & 52.42 & 27.85 & 17.00 & 3 & 1566.8062 & 1566.8058 & 523.2759 & 0.0004 & 0.2548 & 746.969 & 971.173 & 574.224 & 292.310 & \text { Yes }\end{array}$ $\begin{array}{lllllllllllllll}1.00 & 60.68 & 27.85 & 17.40 & 3 & 15668065 & 15668058 & 522.2759 & 0.0007 & 0.4459 & 1302861 & 1563.547 & 964.690 & 483.161 & \text { Yes }\end{array}$ $\begin{array}{lllllllllllllll}1.00 & 51.51 & 27.92 & 17.56 & 3 & 1566.8059 & 1566.8058 & 523.2759 & 0.0001 & 0.0637 & 266.006 & 307.082 & 134.613 & 99.019 & \text { Yes }\end{array}$ $\begin{array}{lllllllllllllll}1.00 & 47.57 & 27.85 & 16.52 & 3 & 1566.8062 & 1566.8058 & 523.2759 & 0.0004 & 0.2548 & 374.182 & 370.179 & 204.825 & 124.199 & \text { Yes } \\ 0.84 & 25.71 & 25.02 & 20.99 & 2 & 1166.686 & 1116.677 & 559.3461 & 0.009 & 8.8495 & 2501.230 & 22.684 & 536.202 & 339.659 & \text { Yes }\end{array}$ $\begin{array}{llllllllllllllll}0.84 & 25.71 & 25.02 & 20.99 & 2 & 1116.6876 & 1116.6777 & 559.3461 & 0.0099 & 8.8495 & 25081.230 & 22268.401 & 536.202 & 339.659 & \text { Yes }\end{array}$ $\begin{array}{llllllllllllllll}0.77 & 23.64 & 24.68 & 22.93 & 2 & 1116.6874 & 1116.6777 & 559.3461 & 0.0097 & 8.6708 & 14638.764 & 12408.062 & 294.526 & 210.513 & \text { Yes }\end{array}$ $\begin{array}{llllllllllllllll}0.61 & 16.98 & 26.42 & 23.64 & 2 & 1116.6792 & 1116.6777 & 559.3461 & 0.0015 & 1.3408 & 1777.968 & 1518.519 & 104.919 & 66.801 & \text { Yes }\end{array}$ $\begin{array}{lllllllllllllll}0.56 & 15.76 & 26.36 & 23.48 & 2 & 1116.6800 & 1116.6777 & 559.3461 & 0.0023 & 2.0560 & 1860.739 & 1591.335 & 79.775 & 58.928 & \text { Yes }\end{array}$ $\begin{array}{llllllllllllllll}1.00 & 61.87 & 27.73 & 32.04 & 2 & 1633.9046 & 1633.9018 & 817.9582 & 0.0028 & 1.7116 & 4254.207 & 3138.325 & 3041.629 & 1224.759 & \text { Yes }\end{array}$ $\begin{array}{lllllllllllllll}1.00 & 64.66 & 27.72 & 30.91 & 2 & 1633.9048 & 1633.9018 & 817.9582 & 0.0030 & 1.8338 & 5739.335 & 4744.464 & 4548.230 & 1562.475 & \text { Yes }\end{array}$

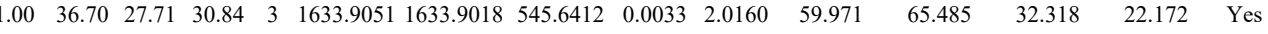
$\begin{array}{llllllllllllllll}\text { GEPAAAAAPEAGASPVEK } & 0.68 & 16.18 & 27.77 & 17.28 & 3 & 1909.9999 & 1909.9989 & 637.6736 & 0.0010 & 0.5227 & 15.221 & 16.397 & 5.242 & 2.323 & \text { No }\end{array}$ $\begin{array}{lllllllllllllllll}\text { GEPAAAAAPEAGASPVEK } & 1.00 & 49.75 & 27.77 & 16.50 & 3 & 1909.9945 & 1909.9989 & 637.6736 & -0.0044 & -2.3000 & 10.938 & 14.493 & 5.954 & 8.808 & \text { Yes }\end{array}$ $\begin{array}{llllllllllllllll}\text { AAEEPSKVEEK } & 0.83 & 32.93 & 27.40 & 21.13 & 3 & 1647.9061 & 1647.9044 & 550.3087 & 0.0017 & 1.0297 & 2450.281 & 3233.983 & 3101.469 & 1655.001 & \text { Yes }\end{array}$

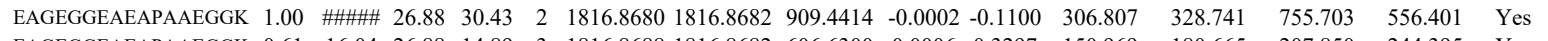

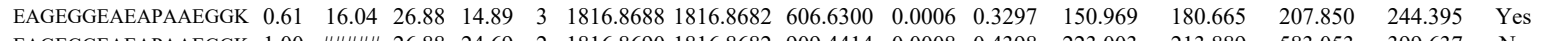
$\begin{array}{lllllllllllllll}\text { EAGEGGEAEAPAAEGGK } & 1.00 & 26.88 & 24.69 & 2 & 1816.8690 & 1816.8682 & 909.4414 & 0.0008 & 0.4398 & 223.003 & 213.889 & 583.053 & 399.637 & \text { No }\end{array}$

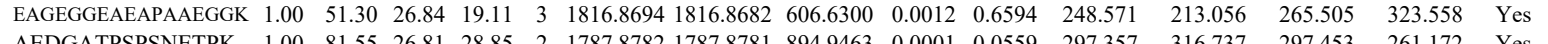

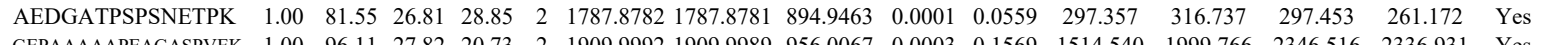

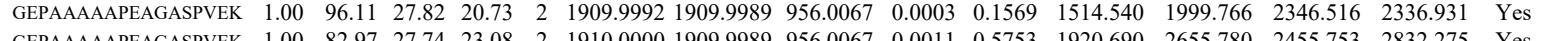
\begin{tabular}{llllllllllllllll} 
& GEPAAAPAASPVE \\
\hline
\end{tabular}

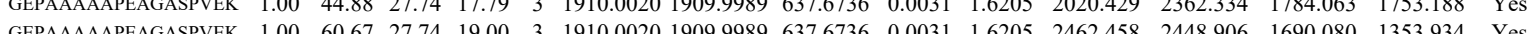
$\begin{array}{lllllllllllllllll}\text { GEPAAAAAPEAGAPVEK } & 1.00 & 89.82 & 27.44 & 22.74 & 2 & 1910.0152 & 1909.9989 & 9560067 & 0.0163 & 8.5250 & 259.491 & 274.479 & 331.282 & 276.195 & \text { Yes }\end{array}$

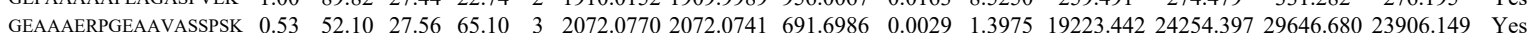

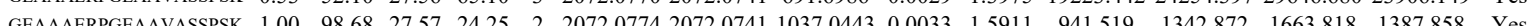
$\begin{array}{lllllllllllllllll}\text { GEAAAERPGEAAVASSPSK } & 1.00 & 41.53 & 27.60 & 18.29 & 4 & 20720777 & 20720741 & 519.0258 & 0.0036 & 1.7340 & 8463.285 & 8817.379 & 13076.896 & 9527.064 & \text { Yes }\end{array}$ $\begin{array}{lllllllllllllllll}\text { GEAAAERPGEAAVASSPSK } & 1.00 & 47.10 & 27.60 & 20.67 & 4 & 20720837 & 2072.0741 & 519.0258 & 0.0096 & 4.6240 & 369.276 & 509.362 & 764.884 & 1001.243 & \text { Yes }\end{array}$ $\begin{array}{llllllllllllllll}\text { GEAAAERPGEAAVASSPSK } & 1.00 & 44.83 & 27.56 & 19.96 & 3 & 2072.0770 & 2072.0741 & 691.6986 & 0.0029 & 1.3975 & 2001.003 & 1903.645 & 1577.244 & 1153.118 & \text { Yes }\end{array}$ $\begin{array}{lllllllllllllllll}\text { GEAAAERPGEAAVASSPSK } & 1.00 & 66.07 & 27.56 & 22.56 & 3 & 2072.0770 & 20720741 & 691.6986 & 0.0029 & 1.3975 & 12662.360 & 18452.232 & 21262.110 & 15598.429 & \text { Yes }\end{array}$

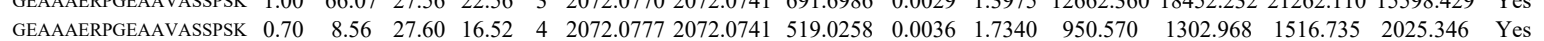
$\begin{array}{lllllllllllllllll}6 & \text { FDTQYPYGEK } & 1.00 & 51.81 & 27.47 & 24.04 & 2 & 1534.7658 & 1534.7547 & 768.3846 & 0.0111 & 7.2229 & 406.535 & 628.810 & 509.680 & 288.511 & \text { No }\end{array}$

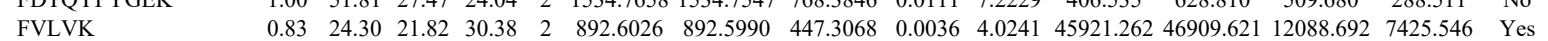

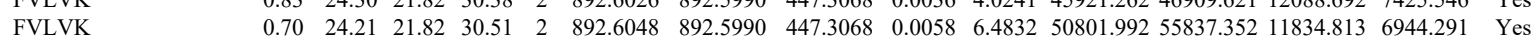
$\begin{array}{llllllllllllllll}\text { FVLVK } & 0.95 & 27.33 & 21.82 & 30.93 & 2 & 892.6024 & 892.5990 & 447.3068 & 0.0034 & 3.8005 & 53119.077 & 59729.154 & 11688.722 & 8063.913 & \text { Yes }\end{array}$

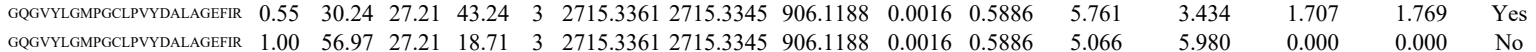
$\begin{array}{lllllllllllllllll}\text { ILDQGEDFPASEMTR } & 1.00 & 87.33 & 27.43 & 22.03 & 2 & 1851.8796 & 1851.8795 & 926.9470 & 0.0001 & 0.0539 & 1285.582 & 1490.117 & 23.107 & 121.833 & \text { Yes }\end{array}$ $\begin{array}{llllllllllllllllll}\text { ILDQGEDFPASEMTR } & 1.00 & 91.15 & 27.43 & 24.75 & 2 & 1851.8818 & 1851.8795 & 926.9470 & 0.0023 & 1.2406 & 908.657 & 1127.865 & 97.492 & 39.265 & \text { Yes }\end{array}$

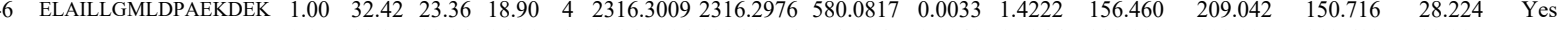
$\begin{array}{lllllllllllllllll}\text { ELAILLGMLDPAEKDEK } & 0.97 & 38.35 & 23.24 & 16.91 & 3 & 2316.3016 & 2316.2976 & 773.1065 & 0.0040 & 1.7246 & 332.117 & 308.097 & 212.619 & 32.285 & \text { Yes }\end{array}$ $\begin{array}{llllllllllllllll}\text { ELAILLGMLDPAEKDEK } & 1.00 & 30.73 & 23.18 & 43.73 & 4 & 2316.3025 & 2316.2976 & 580.0817 & 0.0049 & 2.1118 & 127.197 & 156.454 & 130.892 & 35.030 & \text { Yes }\end{array}$ $\begin{array}{llllllllllllllll}\text { NFDEILR } & 0.99 & 45.27 & 28.32 & 22.30 & 2 & 1049.5706 & 1049.5627 & 525.7886 & 0.0079 & 7.5125 & 19962.441 & 29125.749 & 1118.493 & 289.822 & \text { Yes }\end{array}$ $\begin{array}{llllllllllllllll}\text { NFDEILR } & 0.99 & 43.11 & 28.39 & 21.74 & 2 & 1049.5708 & 1049.5627 & 525.7886 & 0.0081 & 7.7027 & 21698.104 & 30010.502 & 1155.558 & 481.558 & \text { Yes }\end{array}$

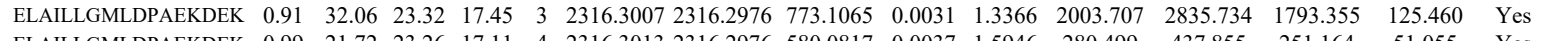

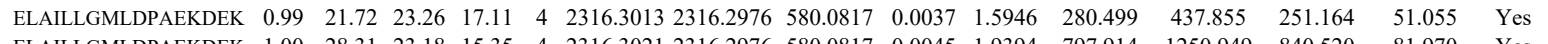
$\begin{array}{llllllllllllllll}\text { ELAILLGMLDPAEKDEK } & 1.00 & 28.31 & 23.18 & 15.35 & 4 & 2316.3021 & 2316.2976 & 580.0817 & 0.0045 & 1.9394 & 797.914 & 1250.949 & 840.520 & 81.970 & \text { Yes }\end{array}$

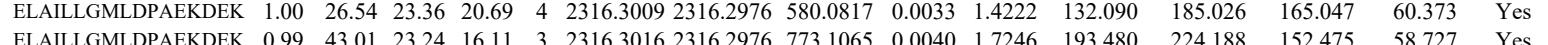

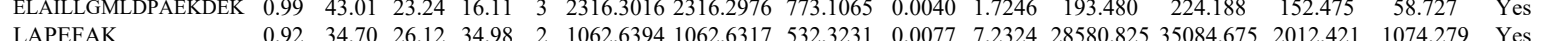
$\begin{array}{llllllllllllllll}\text { LAPEFAK } & 0.92 & 34.70 & 26.12 & 34.98 & 2 & 1062.6394 & 1062.6317 & 532.3231 & 0.0077 & 7.2324 & 28580.825 & 35084.675 & 2012.421 & 1074.279 & \text { Yes } \\ \text { LAPEFAK } & 0.91 & 34.69 & 26.11 & 35.11 & 2 & 10626400 & 1062.6317 & 532.3231 & 0.0083 & 7.7960 & 21483.757 & 33430.922 & 1948.721 & 1095.510 & \text { Yes }\end{array}$

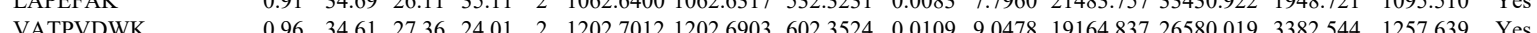
$\begin{array}{llllllllllllllll}\text { VATPVDWK } & 0.96 & 34.61 & 27.36 & 24.01 & 2 & 1202.7012 & 1202.6903 & 602.3524 & 0.0109 & 9.0478 & 19164.837 & 26580.019 & 3382.544 & 1257.639 & \text { Yes } \\ \text { VATPVDWK } & 0.91 & 30.91 & 27.16 & 25.03 & 2 & 1202.7020 & 1202.6903 & 602.3524 & 0.0117 & 9.7118 & 13606.162 & 19418.324 & 2675.641 & 1143.254 & \text { Yes }\end{array}$ 
$\begin{array}{lllllllll} & \end{array}$

$$
\begin{array}{cccccc}
0.81 & 17.34 & 27.64 & 20.94 & 3 & 217 \\
0.99 & 61.95 * & 27.60 & 21.87 & 3 & 2117
\end{array}
$$

$\begin{array}{lllll}08362117.0806 & 7067008 & 0.0030 & 1.4150 & 71.792\end{array}$

000

LPGFVEQAEALK

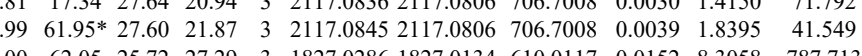

$\begin{array}{lllllllllllll}\text { ETDLLDDSLVSIFGNR } & 1.00 & 50.41 & 27.72 & 18.64 & 3 & 2050.0729 & 2050.0704 & 684.3641 & 0.0025 & 1.2177 & 99.983\end{array}$

$\begin{array}{lllllllllllll}\text { ETDLLLDDSLVSIFGNR } & 1.00 & 48.36 & 27.72 & 21.77 & 3 & 2050.0729 & 2050.0704 & 684.3641 & 0.0025 & 1.2177 & 92.936\end{array}$

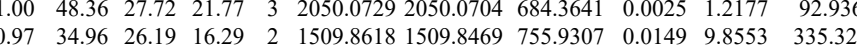

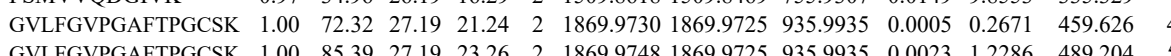

$\begin{array}{llllllllllllll}\text { GVLFGVPGAFTPGCSK } & 1.00 & 85.39 & 27.19 & 23.26 & 2 & 1869.9748 & 1869.9725 & 935.9935 & 0.0023 & 1.2286 & 489.204 & 573.173 & 569\end{array}$

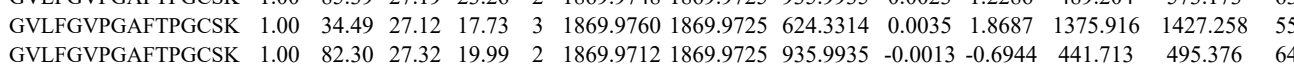
$\begin{array}{llllllllllllllll}\text { GVLFGVPGAFPGCSK } & 1.00 & 82.30 & 27.32 & 19.99 & 2 & 1869.9712 & 1869.9725 & 935.9935 & -0.0013 & -0.6944 & 441.713 & 495.376 & 648.225 \\ \text { GVLFGVPGAFTPGCSK } & 1.00 & 94.83 & 27.32 & 22.80 & 2 & 1869.9712 & 1869.9725 & 935.9935 & -0.0013 & -0.6944 & 243.477 & 298.188 & 309.760\end{array}$

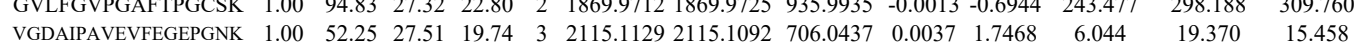
$\begin{array}{llllllllllllll}\text { VGDAIPAVEVFEGEPGNK } & 1.00 & 77.71 & 27.54 & 27.27 & 2 & 2115.1094 & 2115.1092 & 1058.5619 & 0.0002 & 0.0945 & 141.534 & 184.975 & 269.159\end{array}$

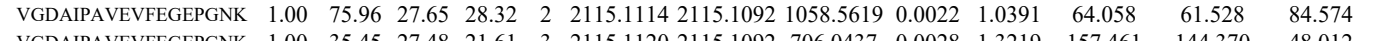
$\begin{array}{lllllllllllllll}\text { VGDAIPAVEVFEGEPGNK } & 1.00 & 35.45 & 27.48 & 21.61 & 3 & 2115.1120 & 2115.1092 & 706.0437 & 0.0028 & 1.3219 & 157.461 & 144.370 & 48.012 \\ \text { VGAPAVE }\end{array}$ $\begin{array}{lllllllllllllll}\text { VGDAIPAVEVFEGEANK } & 1.00 & 36.99 & 27.51 & 20.36 & 3 & 2115.1129 & 2115.1092 & 706.0437 & 0.0037 & 1.7468 & 104.137 & 103.930 & 48.670 & 51\end{array}$ $\begin{array}{llllllllllllll}1.00 & 49.78 & 27.33 & 27.44 & 2 & 1308.7358 & 1308.7281 & 655.3713 & 0.0077 & 5.8745 & 5360.875 & 4719.901 & 3269.783 & 2589.722\end{array}$ 

$\begin{array}{llllllllllllllll}\text { AQFAQPELIGTIPGAGGTQR } & 0.69 & 14.39 & 25.67 & 14.98 & 3 & 2268.2359 & 2268.2348 & 757.0855 & 0.0011 & 0.4843 & 515.136 & 740.830 & 207.086 & 74.519 & \text { Yes }\end{array}$ $\begin{array}{lllllllllllllllll}\text { AQPAQPEILIGTIPGAGGTQR } & 0.81 & 15.36 & 25.71 & 14.49 & 3 & 2268.2380 & 2268.2348 & 757.0855 & 0.0032 & 1.4089 & 292.499 & 264.448 & 274.959 & 47.082 & \text { No }\end{array}$ $\begin{array}{lllllllllllllllll}\text { AQFAQPEILIGTIPGAGGTQR } & 0.79 & 15.03 & 25.80 & 14.34 & 3 & 2268.2374 & 2268.2348 & 757.0855 & 0.0026 & 1.1447 & 235.142 & 170.016 & 59.679 & 34.942 & \text { Yes } \\ \text { AQFAQPELIGTIPGAGGTQR } & 0.96 & 24.01 & 25.63 & 16.46 & 3 & 2268.2395 & 2268.2348 & 757.0855 & 0.0047 & 2.0693 & 238.977 & 246.709 & 131.004 & 48.529 & \text { Yes }\end{array}$ $\begin{array}{llllllllllllllllll}\text { NNTVGLIQLNRPK } & 1.00 & 55.83 & 20.57 & 19.12 & 3 & 1754.0527 & 1754.0406 & 585.6875 & 0.0121 & 6.8864 & 27925.032 & 29599.100 & 3833.582 & 526.385 & \text { Yes }\end{array}$ $\begin{array}{llllllllllllllll}\text { NNTVGLIQLNRPK } & 1.00 & 35.71 & 20.57 & 20.49 & 3 & 1754.0527 & 1754.0406 & 585.6875 & 0.0121 & 6.8864 & 30240.739 & 33910.756 & 5131.216 & 1016.738 & \text { Yes }\end{array}$

PEBP1_HUMAN P30086 PEBP1

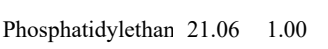

6 NQDNLQGWNK

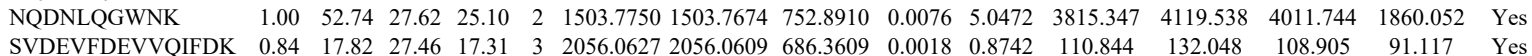

$\begin{array}{lllllllllllllllll}1.00 & 48.82 & 27.72 & 26.74 & 2 & 1503.7734 & 1503.7674 & 752.8910 & 0.0060 & 3.9846 & 2590.626 & 2303.957 & 3008.622 & 1655.639 & \text { Yes } & \end{array}$ $\begin{array}{llllllllllllllll} & \\ \text { SVDEFDEVVQIFDK } & 0.84 & 17.82 & 27.46 & 17.31 & 3 & 2056.0627 & 2056.0609 & 686.3609 & 0.0018 & 0.8742 & 110.844 & 132.048 & 108.905 & 91.117 & \text { Yes }\end{array}$

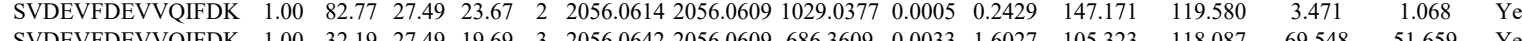
$\begin{array}{llllllllllllll} & \text { Yes }\end{array}$

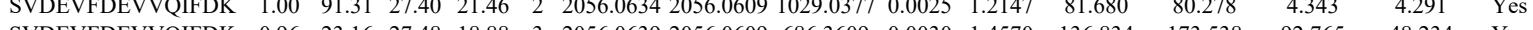

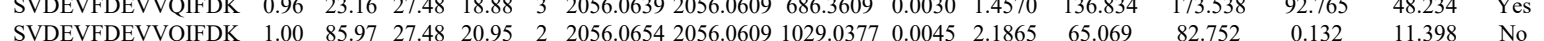

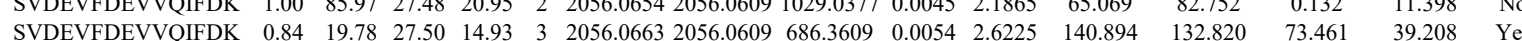

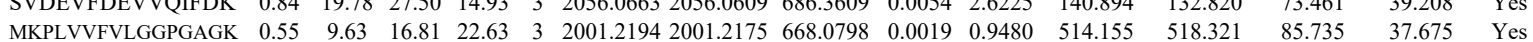
$\begin{array}{llllllllllllllll}\text { MKPLVVFVLGGPGAGK } & 1.00 & 37.78 & 16.33 & 15.56 & 4 & 2001.2217 & 20012175 & 5013117 & 0.0042 & 2.0945 & 38.391 & 41.640 & 44.409 & 16.674 & \text { Yes }\end{array}$

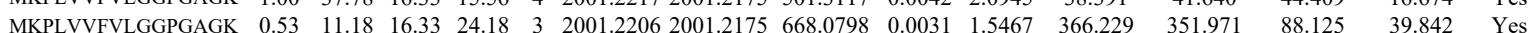

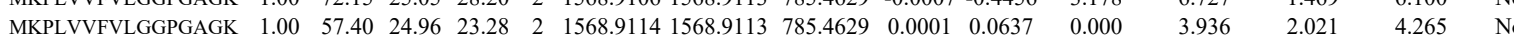

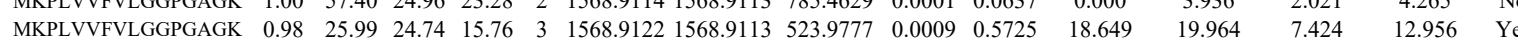

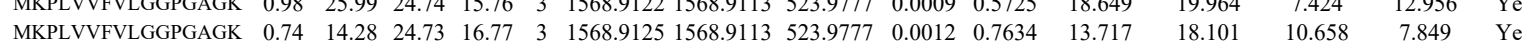

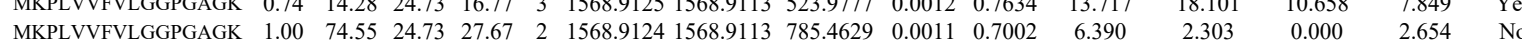

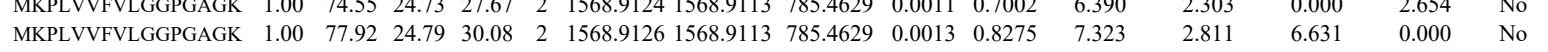
\begin{tabular}{llllllllllllllll} 
MKPLVVFVLGGPGAGK & 1.00 & 33.62 & 24.79 & 20.97 & 3 & 1568.9131 & 1568.9113 & 523.9777 & 0.0018 & 1.1451 & 23.869 & 22.716 & 6.295 & 5.250 & Yes \\
\hline
\end{tabular} $\begin{array}{lllllllllllllllll}\text { KNPDSQYGELIEK } & 1.00 & 53.03 & 26.24 & 28.48 & 3 & 1952.0749 & 1952.0580 & 651.6933 & 0.0169 & 8.6441 & 4067.121 & 3792.674 & 3142.008 & 2228.653 & \text { Yes }\end{array}$ $\begin{array}{lllllllllllllllll}\text { CDEPILSNR } & 0.59 & 20.92 & 25.90 & 23.99 & 2 & 1235.5872 & 1235.5760 & 618.7953 & 0.0112 & 9.0498 & 10375.085 & 9541.321 & 914.803 & 924.417 & \text { No }\end{array}$

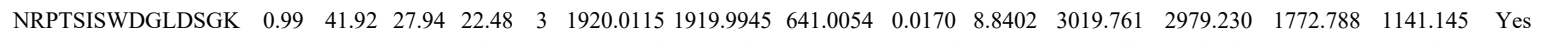
$\begin{array}{lllllllllllllll}\text { GNDISSGTVLSDYVGSGPPK } & 1.00 & \text { \#\#\#\# } 27.81 & 24.82 & 2 & 2237.1594 & 2237.1420 & 1119.5783 & 0.0174 & 7.7707 & 257.864 & 126.763 & 210.883 & 232.622 & \text { Yes }\end{array}$

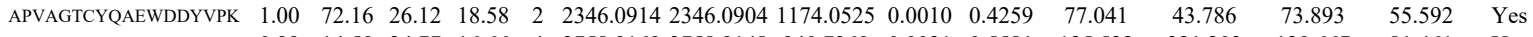
$\begin{array}{llllllllllllllll} & 0.99 & 14.50 & 24.77 & 16.66 & 4 & 3758.9169 & 3758.9148 & 940.7360 & 0.0021 & 0.5581 & 125.522 & 321.203 & 120.667 & 81.461 & \text { Yes } \\ \end{array}$

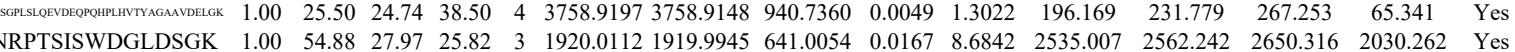

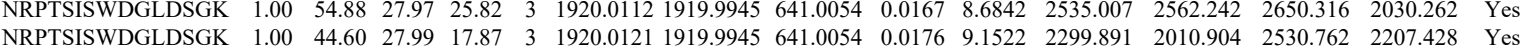

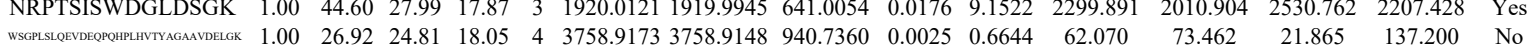

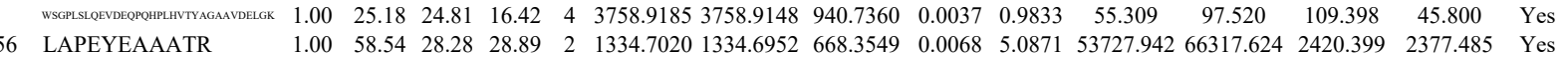

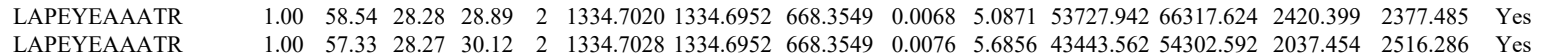

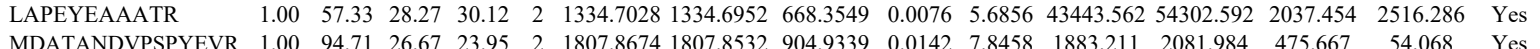

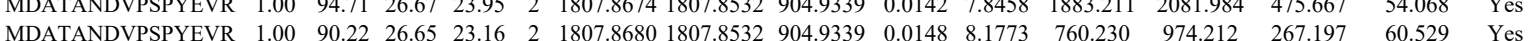

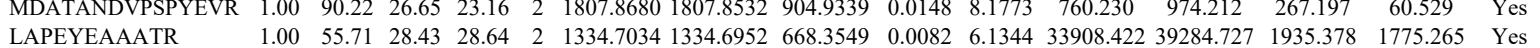

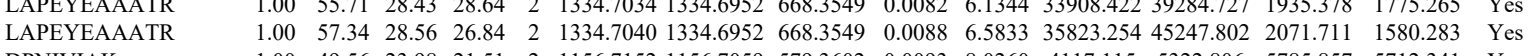

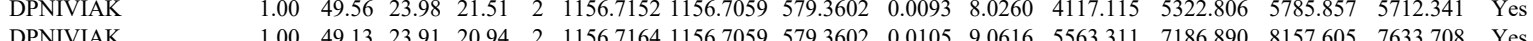
$\begin{array}{lllllllllllllllll}\text { DPNIVIAK } & & 1.00 & 49.13 & 23.91 & 20.94 & 2 & 156.7164 & 1156.7059 & 579.3602 & 0.0103 & 9.0616 & 5563.311 & 7186.890 & 8157.605 & 7633.708 & \text { Yes }\end{array}$ 


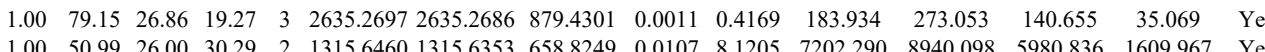

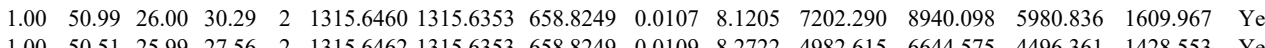
$\begin{array}{llllllllllllllll}1.00 & 50.51 & 25.99 & 27.56 & 2 & 1315.6462 & 1315.6353 & 658.8249 & 0.0109 & 8.2722 & 4982.615 & 6644.575 & 4496.361 & 1428.553 & \text { Yes } \\ 1.00 & 66.27 & 25.63 & 28.56 & 2 & 1327.7760 & 1327.7703 & 6648924 & 0.0057 & 4.2864 & 6354.003 & 7609.751 & 2395.787 & 608.891 & \text { Yes }\end{array}$ $\begin{array}{lllllllllllllll}1.00 & 66.27 & 25.63 & 28.56 & 2 & 1327.7760 & 1327.7703 & 664.8924 & 0.0057 & 4.2864 & 6354.003 & 7609.751 & 2395.787 & 608.891 & \text { Yes } \\ 1.00 & 61.09 & 25.62 & 25.17 & 3 & 1327.7764 & 1327.7703 & 443.5974 & 0.0061 & 4.5837 & 21542.191 & 28235.038 & 7940.280 & 198319 & \text { Yes }\end{array}$ $\begin{array}{llllllllllllllll}1.00 & 73.96 & 27.67 & 21.50 & 2 & 1628.8826 & 1628.8806 & 815.4476 & 0.0020 & 1.2263 & 5187.106 & 8616.544 & 5229.436 & 950.446 & \text { Yes } \\ 0.98 & 26.86 & 27.65 & 18.85 & 3 & 1628.8840 & 1628.8806 & 543.9675 & 0.0034 & 2.0835 & 660.001 & 510367 & 209.200 & 85.646 & \text { Yes }\end{array}$ $\begin{array}{lllllllllllllll}0.98 & 26.86 & 27.65 & 18.85 & 3 & 1628.8840 & 1628.8806 & 543.9675 & 0.0034 & 2.0835 & 660.001 & 510.367 & 209.200 & 85.646 & \text { Yes } \\ 1.00 & 49.11 & 27.13 & 27.85 & 2 & 1020.5910 & 1020.5838 & 5112992 & 0.0072 & 7.0408 & 25445282 & 35367.195 & 954.589 & 810.916 & \text { Y }\end{array}$ $\begin{array}{llllllllllllllll}1.00 & 49.11 & 27.13 & 27.85 & 2 & 1020.5910 & 1020.5838 & 511.2992 & 0.0072 & 7.0408 & 25445.282 & 35367.195 & 954.589 & 810.916 & \text { Yes } & \\ 1.00 & 50.12 & 27.09 & 27.15 & 2 & 1020.5920 & 1020.5838 & 511.2992 & 0.0082 & 8.0187 & 36047.284 & 47243.442 & 2404.455 & 825.252 & \text { Yes }\end{array}$ $\begin{array}{llllllllllllllll}1.00 & 48.54 & 27.11 & 28.81 & 2 & 1020.5928 & 1020.5838 & 511.2992 & 0.0090 & 8.8010 & 31979.272 & 40590.569 & 1924.899 & 657.030 & \text { Yes } \\ 1.00 & 46.60 & 27.11 & 23.98 & 2 & 1020.5930 & 10205838 & 511.2992 & 0.0092 & 8.9966 & 34183.767 & 39574.338 & 2378.953 & 427.248 & \text { Yes }\end{array}$ $\begin{array}{lllllllllllllll} & & 1 & \end{array}$

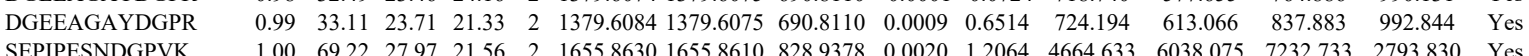
$\begin{array}{llllllllllllllll} & \\ \text { SEPIPESNDGPVK } & 1.00 & 69.22 & 27.97 & 21.56 & 2 & 1655.8630 & 1655.8610 & 828.9378 & 0.0020 & 1.2064 & 4664.633 & 6038.075 & 7232.733 & 2793.830 & \text { Yes } \\ & 1.00 & 73.07 & 27.93 & 20.87 & 2 & 1655.8636 & 1655.8610 & 828.9378 & 0.0026 & 1.5683 & 7697.541 & 7364.184 & 8542.797 & 4990301 & \text { Yes }\end{array}$

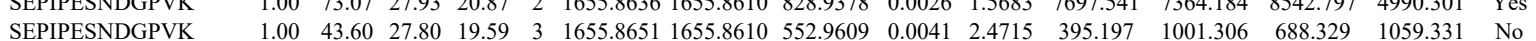
$\begin{array}{llllllllllllllll}\text { LNFAVASR } & 0.99 & 41.75 & 27.80 & 25.62 & 2 & 1020.5834 & 1020.5838 & 511.2992 & -0.0004 & -0.3912 & 582.422 & 754.989 & 97.529 & 30.295 & \text { Yes }\end{array}$ $\begin{array}{llllllllllllllll}\text { EATNPPVIQEEKPK } & 1.00 & 39.72 & 24.71 & 17.23 & 3 & 2011.1371 & 2011.1315 & 671.3844 & 0.0056 & 2.7803 & 5878.009 & 4588.881 & 15989.876 & 17805.958 & \text { No }\end{array}$ $\begin{array}{llllllllllllllll}\text { EATNPPVIQEEKPK } & 1.00 & 31.89 & 24.49 & 23.99 & 4 & 2011.1393 & 2011.1315 & 503.7902 & 0.0078 & 3.8706 & 940.259 & 1091.869 & 1764.000 & 2326.547 & \text { No }\end{array}$ $\begin{array}{llllllllllllllll}\text { EATNPPVIQEEKPK } & 1.00 & 29.86 & 24.49 & 27.15 & 4 & 2011.1393 & 2011.1315 & 503.7902 & 0.0078 & 3.8706 & 864.512 & 1128.208 & 2628.647 & 2809.351 & \text { No }\end{array}$ $\begin{array}{llllllllllllllll}\text { EATNPPVIQEEKPK } & 1.00 & 41.03 & 23.54 & 19.85 & 3 & 2011.1485 & 2011.1315 & 671.3844 & 0.0170 & 8.4402 & 4451.727 & 4438.889 & 16484.457 & 15096.217 & \text { No }\end{array}$

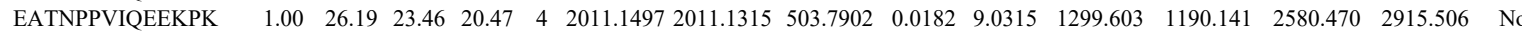
$\begin{array}{lllllllllllllllll}\text { EATNPPVIQEEKPK } & 1.00 & 30.97 & 23.54 & 20.99 & 4 & 2011.1505 & 2011.1315 & 503.7902 & 0.0190 & 9.4284 & 1209.498 & 1117.565 & 2908.982 & 2315.098 & \text { No }\end{array}$ $\begin{array}{lllllllllllllllll}\text { VVVAENFDEIVNNENK } & 1.00 & 99.41 & 27.76 & 27.21 & 2 & 2120.1014 & 2120.0993 & 1061.0569 & 0.0021 & 0.9896 & 289.325 & 307.346 & 177.439 & 72.832 & \text { Yes }\end{array}$ $\begin{array}{llllllllllllllll}\text { LAPEYEAAATR } & 0.99 & 43.42 & 28.48 & 22.54 & 2 & 1334.7052 & 1334.6952 & 668.3549 & 0.0100 & 7.4810 & 17421.005 & 23383.032 & 3156.346 & 6429.292 & \text { Yes }\end{array}$ $\begin{array}{lllllllllllllllll}\text { MDATANDVPSPYEVR } & 1.00 & 94.47 & 26.81 & 22.45 & 2 & 1807.8706 & 1807.8532 & 904.9339 & 0.0174 & 9.6139 & 2929.833 & 3284.364 & 699.980 & 127.395 & \text { Yes }\end{array}$

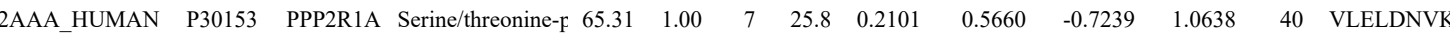
$\begin{array}{lllllllllllllllll}1.00 & 44.23 & 25.68 & 31.61 & 2 & 1216.7372 & 1216.7271 & 609.3708 & 0.0101 & 8.2872 & 4341.006 & 5044.039 & 972.786 & 481.796 & \text { Yes }\end{array}$ $\begin{array}{lllllllllllllllll}\text { VLELDNVK } & 0.92 & 29.78 & 25.98 & 28.34 & 2 & 1216.7380 & 1216.7271 & 609.3708 & 0.0109 & 8.9436 & 3971.480 & 4005.657 & 766.816 & 363.520 & \text { Yes }\end{array}$ $\begin{array}{llllllllllllllll}\text { MAGDPVANVR } & 0.98 & 33.54 & 27.04 & 27.10 & 2 & 1172.6120 & 1172.6094 & 587.3120 & 0.0026 & 2.2135 & 10250.954 & 13044.405 & 1363.310 & 1487.562 & \text { Yes }\end{array}$ $\begin{array}{llllllllllllllll}\text { MAGDPVANVR } & 0.57 & 22.04 & 27.06 & 23.19 & 2 & 1172.6130 & 1172.6094 & 587.3120 & 0.0036 & 3.0648 & 5620.744 & 6027.891 & 2011.475 & 1967.039 & \text { Yes }\end{array}$ $\begin{array}{lllllllllllllllll}\text { IGPILDNSTLQSEVKPILEK } & 1.00 & 51.30 & 16.33 & 19.46 & 3 & 2625.5359 & 2625.5318 & 876.1845 & 0.0041 & 1.5598 & 5409.317 & 6019.451 & 3545.108 & 2468.080 & \text { Yes }\end{array}$

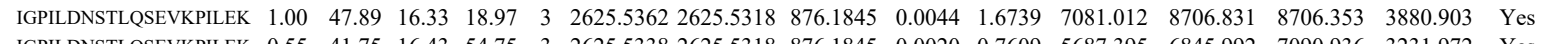

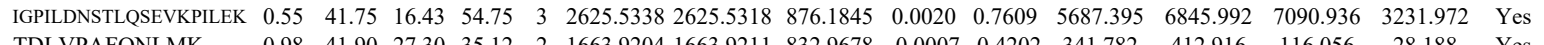
\begin{tabular}{llllllllllllllll} 
TDLVPAFQNLMK & 0.98 & 41.90 & 27.30 & 35.12 & 2 & 1663.9204 & 1663.9211 & 832.9678 & -0.0007 & -0.4202 & 341.782 & 412.916 & 116.056 & 28.188 & Yes \\
\hline
\end{tabular} $\begin{array}{lllllllllllllllll}\text { TDLVPAFQNLMK } & 1.00 & 37.75 & 27.30 & 17.47 & 3 & 1663.9231 & 1663.9211 & 555.6476 & 0.0020 & 1.1998 & 227.365 & 228.898 & 84.197 & 40.744 & \text { Yes } \\ \text { TDLVPAFQNLMK } & 1.00 & 34.23 & 27.20 & 16.36 & 3 & 1663.9249 & 1663.9211 & 555.6476 & 0.0038 & 2.2796 & 203204 & 221.632 & 89.358 & 41.160 & \text { Yes }\end{array}$ $\begin{array}{llllllllllllllll}\text { TDLVPAFQNLMK } & 1.00 & 34.23 & 27.20 & 16.36 & 3 & 1663.9249 & 16633.9211 & 555.6476 & 0.0038 & 2.2796 & 203.204 & 221.632 & 89.358 & 41.160 & \text { Yes } \\ \text { DNTIEHLLPLFLAQLK } & 0.53 & 34.34 & 21.37 & 47.34 & 3 & 2152.2532 & 2152.2499 & 718.4239 & 0.0033 & 1.5311 & 13.842 & 32.593 & 54.554 & 28.122 & \text { No }\end{array}$ $\begin{array}{llllllllllllll} & \text { DNA }\end{array}$ 

$\begin{array}{lllllllllllll}\text { SALASVIMGLSPILGK } & 1.00 & 62.10 & 19.68 & 20.79 & 3 & 1844.1061 & 1844.1049 & 615.7089 & 0.0012 & 0.6497 & 45.466\end{array}$

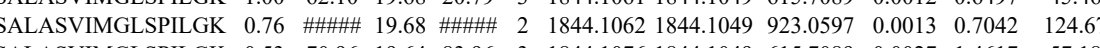

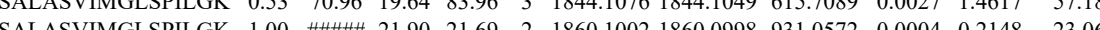

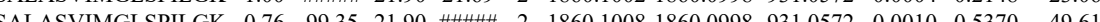

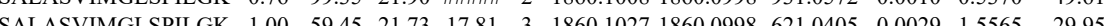

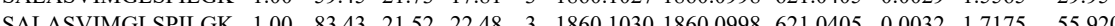
$\begin{array}{lllllllllllll}\text { SALASVIMGLSPILGK } & 0.76 & 74.78 & 1.578 & 87.78 & 2 & 1844.1060 & 1844.1049 & 923.0597 & 0.0011 & 0.5958 & 11.948\end{array}$ $\begin{array}{lllllllllllll}\text { SALASVIMGLSPILGK } & 1.00 & 79.12 & 19.87 & 23.47 & 3 & 1844.1067 & 1844.1049 & 615.7089 & 0.0018 & 0.9745 & 49.985\end{array}$ $\begin{array}{lllllllllllll}\text { SALASVIMGLSPILGK } & 0.55 & 53.91 & 21.88 & 66.91 & 3 & 1860.1015 & 1860.0998 & 621.0405 & 0.0017 & 0.9124 & 28.485\end{array}$ $\begin{array}{llllllllllll}\text { SALASVIMGLSPIGK } & 0.77 & 89.92 & 21.79 & \# \# \# \# & 2 & 1860.1020 & 1860.0998 & 931.0572 & 0.0022 & 1.1815 & 13.093\end{array}$

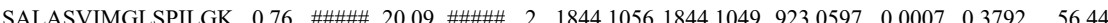
$\begin{array}{lllllllllllll}\text { SALASVIMGLSPILGK } & 1.00 & \# \# \# \# 19.82 & 21.09 & 2 & 1844.1064 & 1844.1049 & 923.0597 & 0.0015 & 0.8125 & 47.241\end{array}$ $\begin{array}{llllllllllllll}\text { SALASVIMGLSPILGK } & 1.00 & 63.20 & 19.87 & 21.68 & 3 & 1844.1067 & 1844.1049 & 615.7089 & 0.0018 & 0.9745 & 63.748\end{array}$ $\begin{array}{llllllllllllll}\text { SALASVIMGLSPILGK } & 1.00 & 67.83 & 19.64 & 18.90 & 3 & 1844.1076 & 1844.1049 & 615.7089 & 0.0027 & 1.4617 & 64.89\end{array}$ $\begin{array}{lllllllllllll}\text { SALASVIMGLSPILGK } & 1.00 & 99.70 & 22.10 & 19.55 & 2 & 1860.0996 & 1860.0998 & 931.0572 & -0.0002 & -0.1074 & 17.750\end{array}$ $\begin{array}{llllllllllllll}\text { SALASVIMGLSPILGK } & 1.00 & 51.31 & 21.88 & 18.59 & 3 & 1860.1018 & 1860.0998 & 621.0405 & 0.0020 & 1.0735 & 73.738\end{array}$ $\begin{array}{lllllllllllll}\text { SALASVIMGLSPILGK } & 0.61 & 80.50 & 20.04 & 93.50 & 2 & 1844.1048 & 1844.1049 & 923.0597 & -0.0001 & -0.0542 & 31.78\end{array}$

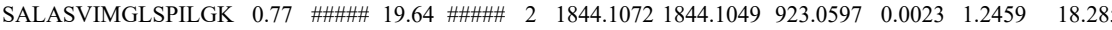
$\begin{array}{lllllllllllll}\text { SALASVIMGLSPILGK } & 0.53 & 63.47 & 19.64 & 76.47 & 3 & 1844.1076 & 1844.1049 & 615.7089 & 0.0027 & 1.4617 & 33.037\end{array}$

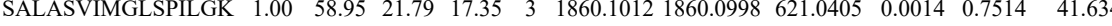

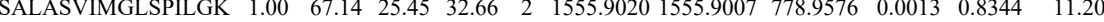
$\begin{array}{lllllllllllll}\text { SALASVIMGLSPILGK } & 1.00 & 46.24 & 25.74 & 20.67 & 2 & 1555.9026 & 1555.9007 & 778.9576 & 0.0019 & 1.2196 & 2.198\end{array}$

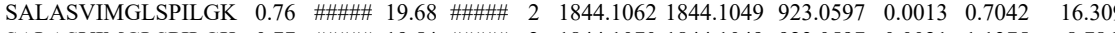

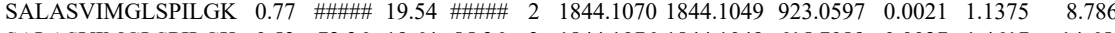
$\begin{array}{llllllllllll}\text { SALASVIMGLSPILGK } & 0.53 & 72.36 & 19.64 & 85.36 & 3 & 1844.1076 & 1844.1049 & 615.7089 & 0.0027 & 1.4617 & 14.650\end{array}$

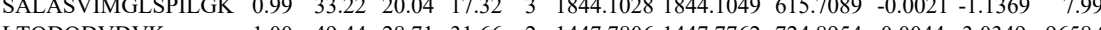
LTQDQDVDVK

$\begin{array}{llllllllllll}1.00 & 49.44 & 28.71 & 31.66 & 2 & 1447.7806 & 1447.7762 & 724.8954 & 0.0044 & 3.0349 & 9658.940 & 1046 \\ 1.00 & 54.08 & 28.66 & 39.27 & 2 & 1447.7810 & 1447.7762 & 724.8954 & 0.0048 & 3.3108 & 14522.009 & 1552\end{array}$ LTQDQDVDVK

$\begin{array}{llllllllllll}1.00 & 54.08 & 28.66 & 39.27 & 2 & 1447.7810 & 1447.7762 & 724.8954 & 0.0048 & 3.3108 & 14522.009\end{array}$ $\begin{array}{lllllllllllll}\text { ITLNDLIPAFQNLLK } & 1.00 & 39.17 & 18.45 & 19.25 & 3 & 2000.1961 & 2000.1914 & 667.7377 & 0.0047 & 2.3462 & 80.65\end{array}$ $\begin{array}{llllllllllll}\text { TLNDLIPAFQNLLK } & 1.00 & 70.38 & 18.39 & 36.96 & 2 & 2000.1934 & 2000.1914 & 1001.1030 & 0.0020 & 0.9989 & 88.172\end{array}$ $\begin{array}{lllllllllllll}\text { ITLNDLIPAFQNLLK } & 1.00 & 42.26 & 18.45 & 22.69 & 3 & 2000.1952 & 2000.1914 & 667.7377 & 0.0038 & 1.8969 & 71.442\end{array}$ $\begin{array}{llllllllllllll}\text { ITLNDLIPAFQNLLK } & 1.00 & 41.71 & 18.26 & 20.11 & 3 & 2000.1964 & 2000.1914 & 667.7377 & 0.0050 & 2.4960 & 69.632\end{array}$ $\begin{array}{llllllllllll}\text { SALASVIMGLSTILGK } & 0.76 & 58.01 & 21.07 & 71.01 & 2 & 1848.1006 & 1848.0998 & 925.0572 & 0.0008 & 0.4324 & 12.127\end{array}$ $\begin{array}{lllllllllllll}\text { SALASVIMGLSTILGK } & 0.55 & 50.83 & 20.53 & 63.83 & 3 & 1848.1021 & 1848.0998 & 617.0405 & 0.0023 & 1.2425 & 37.816\end{array}$ $\begin{array}{llllllllllll}\text { SALASVIMGLSTILGK } & 0.55 & 36.40 & 20.53 & 49.40 & 3 & 1848.1021 & 1848.0998 & 617.0405 & 0.0023 & 1.2425 & 61.537\end{array}$ $\begin{array}{lllllllllllll}\text { SALASVIMGLSTILGK } & 0.55 & 40.17 & 21.49 & 53.17 & 3 & 1864.0972 & 1864.0947 & 622.3722 & 0.0025 & 1.3390 & 60.203\end{array}$ $\begin{array}{llllllllllllll}\text { SALASVIMGLSTILGK } & 1.00 & 70.26 & 21.55 & 21.76 & 3 & 1864.0978 & 1864.0947 & 622.3722 & 0.0031 & 1.6603 & 45.272\end{array}$ $\begin{array}{lllllllllllll}\text { SALASVIMGLSTILGK } & 1.00 & \text { \#\#\#\# } 20.83 & 23.32 & 2 & 1848.1012 & 1848.0998 & 925.0572 & 0.0014 & 0.7567 & 58.468\end{array}$

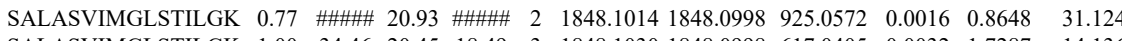
$\begin{array}{llllllllllllll}\text { SALASVIMGLSTILGK } & 1.00 & 34.46 & 20.45 & 18.49 & 3 & 1848.1030 & 1848.0998 & 617.0405 & 0.0032 & 1.7287 & 14.136\end{array}$ $\begin{array}{lllllllllllll}\text { SALASVIMGLSTILGK } & 1.00 & 91.63 & 21.61 & 23.08 & 2 & 1864.0942 & 1864.0947 & 933.0546 & -0.0005 & -0.2679 & 15.187\end{array}$ $\begin{array}{lllllllllllll}\text { SALASVIMGLSTILGK } & 1.00 & 40.68 & 21.61 & 17.40 & 3 & 1864.0999 & 1864.0947 & 622.3722 & 0.0052 & 2.7850 & 42.733\end{array}$ $\begin{array}{llllllllllllll}\text { SALASVIMGLSTILGK } & 0.76 & 90.38 & 20.83 & \text { \#\#\#\# } 2 & 1848.1010 & 1848.0998 & 925.0572 & 0.0012 & 0.6486 & 8.037\end{array}$

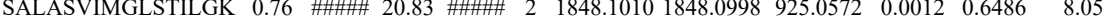
$\begin{array}{lllllllllllll}\text { SALASVIMGLSTILGK } & 1.00 & 51.31 & 20.61 & 16.36 & 3 & 1848.1024 & 1848.0998 & 617.0405 & 0.0026 & 1.4046 & 8.795\end{array}$ $\begin{array}{llllllllllll}\text { SALASVIMGLSTILGK } & 1.00 & 47.94 & 20.61 & 17.38 & 3 & 1848.1024 & 1848.0998 & 617.0405 & 0.0026 & 1.4046 & 6.285\end{array}$ $\begin{array}{lllllllllllll}\text { SALASVIMGLSTILGK } & 1.00 & 63.71 & 21.64 & 19.38 & 2 & 1864.0948 & 1864.0947 & 933.0546 & 0.0001 & 0.0536 & 3.247 \\ \text { SALASVIMGLSTIGK } & 1.00 & 70.56 & 21.58 & 21.33 & 3 & 1864.0969 & 1864.0947 & 622.3722 & 0.0022 & 1.1783 & 15.614\end{array}$ $\begin{array}{llllllllllll}\text { SALASVIMGLSTILGK } & 1.00 & 70.56 & 21.58 & 21.33 & 3 & 1864.0969 & 1864.0947 & 622.3722 & 0.0022 & 1.1783 & 15.614 \\ \text { SALASVIMGLSTILGK } & 1.00 & 49.81 & 21.46 & 17.11 & 3 & 1864.0990 & 1864.0947 & 622.3722 & 0.0043 & 2.3030 & 16.469\end{array}$ $\begin{array}{llllllllllll}\text { SALASVIMGLSTILGK } & 1.00 & 49.81 & 21.46 & 17.11 & 3 & 1864.0990 & 1864.0947 & 622.3722 & 0.0043 & 2.3030 & 16.469 \\ \text { FIEDELQIPVK } & 1.00 & 51.30 & 26.13 & 29.62 & 2 & 1617.9232 & 1617.9221 & 809.9683 & 0.0011 & 0.6790 & 131.396 \\ \text { VGIGAFPTEODNEIGELOTR } & 1.00 & 86.27 & 27.05 & 19.76 & 2 & 2430.2534 & 2430.2513 & 1216.1329 & 0.0021 & 0.8634 & 56.281\end{array}$ FIEDELQIPVK $\begin{array}{llllllllllll}\text { VGIGAFPTEQDNEIGELLQTR } & 1.00 & 86.27 & 27.05 & 19.76 & 2 & 2430.2534 & 2430.2513 & 1216.1329 & 0.0021 & 0.8634 & 56.281 \\ \text { VGIGAFPTEODNEIGELLOTR } & 0.53 & 13.76 & 26.95 & 26.76 & 3 & 2430.2548 & 2430.2513 & 811.0910 & 0.0035 & 1.4384 & 113.257\end{array}$ $\begin{array}{llllllllllll}\text { VGIGAFPTEQDNEIGELLQTR } & 0.53 & 13.76 & 26.95 & 26.76 & 3 & 2430.2548 & 2430.2513 & 811.0910 & 0.0035 & 1.4384 & 113.257 \\ \text { VVDLLAQDADIVCR } & 1.00 & 65.03 & 27.92 & 20.84 & 2 & 1718.8846 & 1718.8817 & 860.4481 & 0.0029 & 1.6852 & 75.532\end{array}$

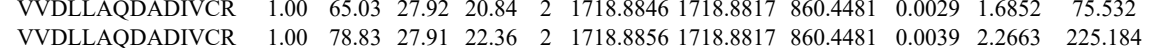

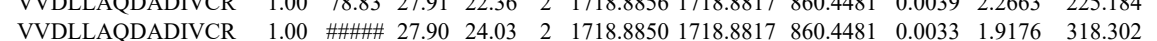
$\begin{array}{llllllllllll}\text { VVDLLAQDADIVCR } & 1.00 & 27.90 & 24.03 & 2 & 1718.8850 & 1718.8817 & 860.4481 & 0.0033 & 1.9176 & 318.302 \\ \text { VVDLLAQDADIVCR } & 1.00 & 94.31 & 27.94 & 25.58 & 2 & 1718.8866 & 1718.8817 & 860.4481 & 0.0049 & 2.8473 & 427.920\end{array}$ $\begin{array}{lllllllllllll}\text { LDILDMFTEIK } & 1.00 & 56.58 & 26.92 & 32.25 & 2 & 1624.9010 & 1624.8990 & 813.4568 & 0.0020 & 1.2293 & 279.432\end{array}$

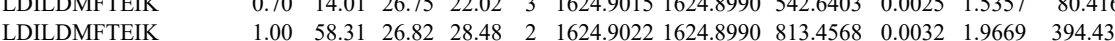


CGWLDLVLLK CGWLDLVLLK LSPQAVNSIAK LSPQAVNSIAK LSPQAVNSIAK ALTTMGFR ALTTMGFR SGTVDPQELQK

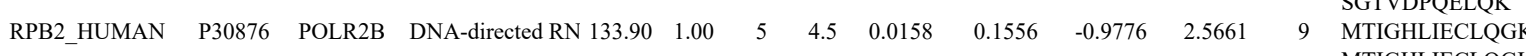
GPIQILNR

LTFASTLSHLR

LLLAALGR

LLLAALGR

LLLAALGR

LDLAGPLLAFLFR

LDLAGPLLAFLFR LGANSLLDLVVFGR LGANSLLDLVVFGR LGANSLLDLVVFGR TGHSLLHTLYGR TGHSLLHTLYGR

LGANSLLDLVVFGR

LGANSLLDLVVFGR LGANSLLDLVVFGR
GEGGILINSQGER

$\begin{array}{lllllllllll}\text { GDIA_HUMAN } & \text { P31150 } & \text { GDI1 } & \text { Rab GDP dissocia } 50.58 & 1.00 & 4 & 26.2 & 0.3377 & 0.5116 & -0.0342 & 2.5133\end{array}$

IICILSHPIK

VEPALELLEPIDQK
LGANSLLDLVVFGR

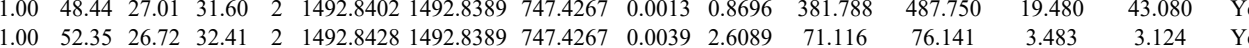

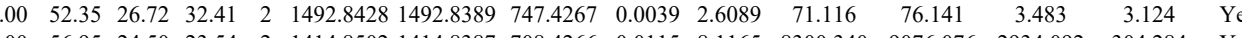

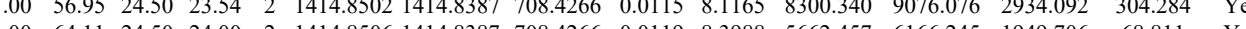

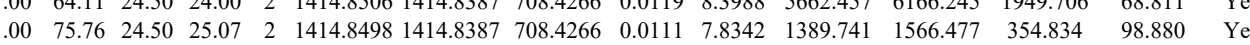

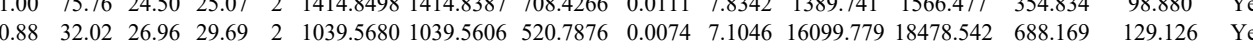

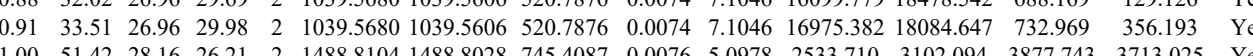
$\begin{array}{lllllllllllllllll}1.00 & 51.42 & 28.16 & 26.21 & 2 & 1488.8104 & 1488.8028 & 745.4087 & 0.0076 & 5.0978 & 2533.710 & 3102.094 & 3877.743 & 3713.025 & \text { Yes } \\ 0.99 & 47.22 & 28.10 & 27.22 & 2 & 1488.8112 & 1488.8028 & 745.4087 & 0.0084 & 5.6345 & 1630.126 & 2417.416 & 2728.755 & 2613.043 & \text { Yes }\end{array}$ $\begin{array}{lllllllllllllll}0.90 & 4.22 & 28.10 & 27.22 & 2 & 1488.8112 & 1488.8028 & 745.4087 & 0.0084 & 5.6345 & 1630.126 & 2417.416 & 2728.755 & 2613.043 & \text { Yes } \\ 1.00 & 38.4 & 28.20 & 16.36 & 3 & 1775.9377 & 1775.9340 & 592.9853 & 0.0037 & 2.0799 & 683.919 & 665.603 & 648.931 & 242.838 & \text { Yes }\end{array}$

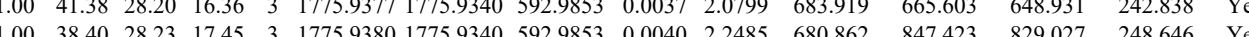

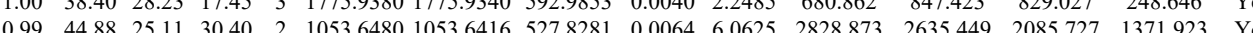
$\begin{array}{lllllllllllllll}0.73 & 24.29 & 25.08 & 28.34 & 2 & 1053.6506 & 1053.6416 & 527.8281 & 0.0090 & 8.0254 & 28.875 & 20.787 & 14.804 & 21.266 & \text { No }\end{array}$

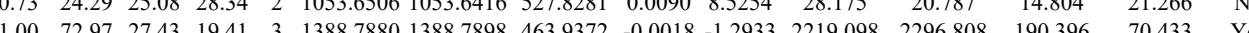
$\begin{array}{lllllllllllllll}0.99 & 44.93 & 16.72 & 44.05 & 2 & 969.6470 & 969.6457 & 485.8301 & 0.0013 & 1.3379 & 3952.620 & 3792.210 & 353.786 & 43.683 & \text { Yes }\end{array}$ $\begin{array}{llllllllllllllllll}0.94 & 46.73 & 16.72 & 45.33 & 2 & 969.644 & 969.6457 & 485.8301 & -0.0013 & -1.3379 & 10546.912 & 11698.039 & 717.782 & 94.319 & \text { Yes }\end{array}$ $\begin{array}{llllllllllllllllll}0.96 & 39.93 & 16.72 & 41.34 & 2 & 969.6452 & 969.6457 & 485.8301 & 0.0005 & -0.5146 & 9289.960 & 10210.720 & 448.241 & 54.426 & \text { Y }\end{array}$

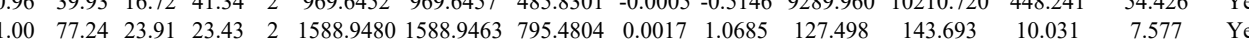
$\begin{array}{lllllllllllllll}1.00 & 67.94 & 23.91 & 22.61 & 2 & 1588.9482 & 1588.9463 & 795.4804 & 0.0019 & 1.1942 & 212.596 & 189.186 & 16.432 & 2.274 & \text { Yes }\end{array}$

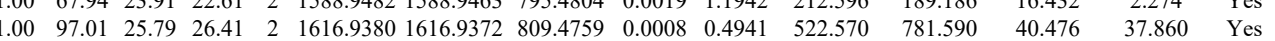

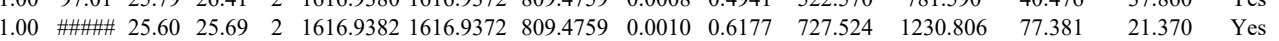
$\begin{array}{llllllllllllllll}1.00 & 99.91 & 25.60 & 26.79 & 2 & 1616.9382 & 1616.9372 & 809.4759 & 0.0010 & 0.6177 & 3716.188 & 6674.179 & 296.023 & 156.602 & \text { Yes }\end{array}$ $\begin{array}{lllllllllllllll}1.00 & \text { \#\#\#\# } 25.61 & 28.78 & 2 & 1616.9386 & 1616.9372 & 809.4759 & 0.0014 & 0.8648 & 2125.740 & 3237.805 & 171.799 & 80.189 & \text { Yes }\end{array}$

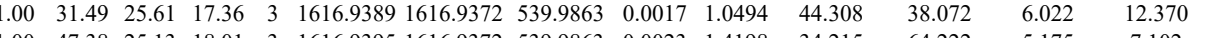

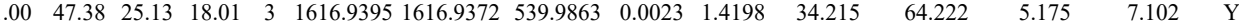

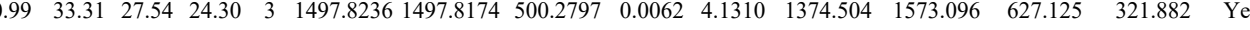
$\begin{array}{lllllllllllllll}1.00 & 51.34 & 27.57 & 20.73 & 3 & 1497.8248 & 1497.8174 & 500.2797 & 0.0074 & 4.9306 & 1731.562 & 2672.458 & 647.632 & 292.593 & \text { Yes }\end{array}$ \begin{tabular}{llllllllllllllll}
1.00 & 99.58 & 25.61 & 30.40 & 2 & 1616.9386 & 1616.9372 & 809.4759 & 0.0014 & 0.8648 & 1679.624 & 3179.687 & 144.743 & 57.391 & Yes \\
\hline
\end{tabular}

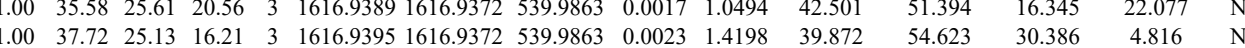

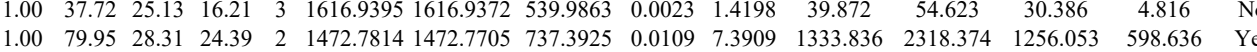
$\begin{array}{lllllllllllllll}1.00 & 79.95 & 28.31 & 24.39 & 2 & 1472.7814 & 1472.7705 & 737.3925 & 0.0109 & 7.3909 & 1333.836 & 2318.374 & 1256.053 & 598.636 & \text { Yes }\end{array}$

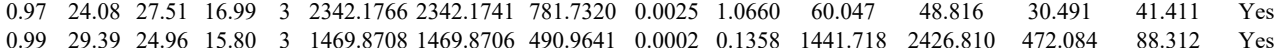

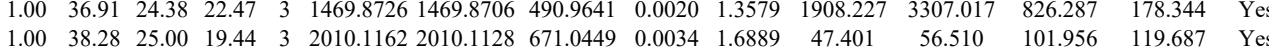

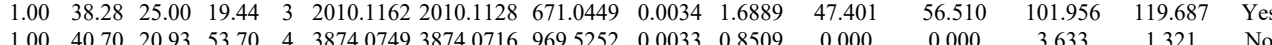

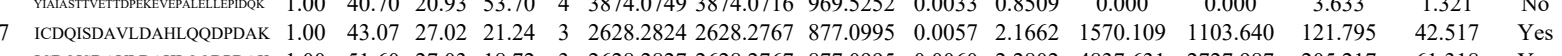

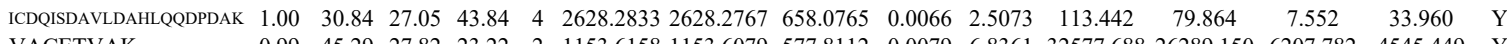

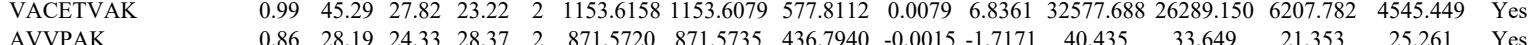

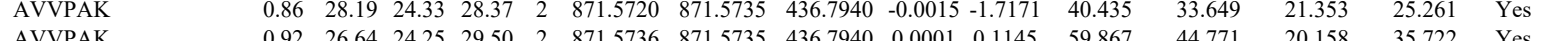

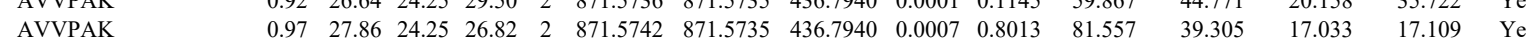

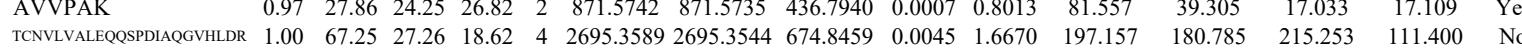

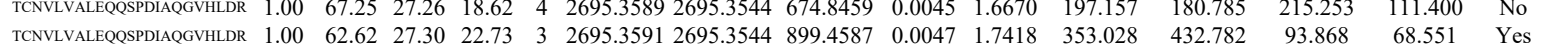
$\begin{array}{llllllllllllllll}\text { TCNVLVALEQSPPIAQGVHLDR } & 1.00 & 60.08 & 27.31 & 26.67 & 4 & 2695.3597 & 2695.3544 & 674.8459 & 0.0053 & 1.9634 & 134.110 & 95.639 & 190.630 & 146.139 & \text { No }\end{array}$ \begin{tabular}{lllllllllllllllll} 
TCNVLVALEQQSPDIAQGVHLDR & 1.00 & 73.74 & 27.29 & 25.66 & 3 & 2695.3609 & 2695.3544 & 899.4587 & 0.0065 & 2.4089 & 748.634 & 553.188 & 142.754 & 44.127 & Yes \\
\hline
\end{tabular}

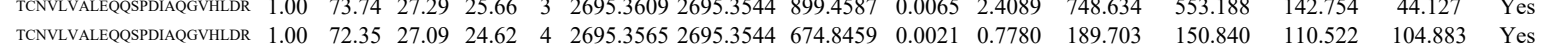

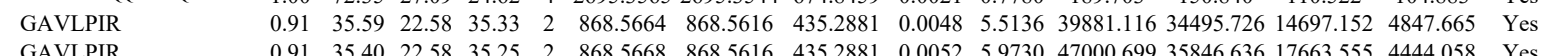

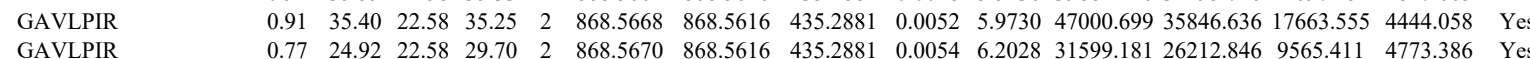
$\begin{array}{lllllllllllllllll}\text { GAVLPIR } & 0.77 & 24.92 & 22.58 & 29.70 & 2 & 868.5670 & 868.5616 & 435.2881 & 0.0054 & 6.2028 & 31599.181 & 26212.846 & 9565.411 & 4773.386 & \text { Yes } \\ \text { GAVLPIR } & 0.77 & 2431 & 22.58 & 28.65 & & 868.5678 & 86.5616 & 435.288 & 0.062 & 7.1217 & 30315.856 & 26922.710 & 9921.255 & 4456.035 & \text { Yes }\end{array}$ $\begin{array}{llllllllllllllll}\text { NFDLRPGVIVR } & 0.97 & 32.14 & 22.58 & 28.65 & 2 & 868.5678 & 868.5616 & 435.2881 & 0.0062 & 7.1217 & 30315.856 & 26922.710 & 9921.255 & 56.867 & \text { Yes }\end{array}$ $\begin{array}{llllllllllllllll}\text { NFDLRPGVIVR } & 0.98 & 24.72 & 25.09 & 19.96 & 3 & 1428.8329 & 1428.8323 & 477.2847 & 0.0006 & 0.4190 & 14033.054 & 14451.742 & 2032.507 & 587.557 & \text { Yes }\end{array}$ $\begin{array}{lllllllllllllll}0.94 & 19.28 & 24.94 & 21.64 & 3 & 1428.8341 & 1428.8323 & 477.2847 & 0.0018 & 1.2571 & 19470.537 & 14563.909 & 2604.843 & 1441.496 & \text { Yes }\end{array}$

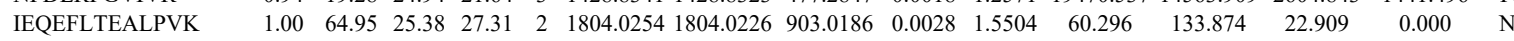
$\begin{array}{llllllllllllllll}\text { IEQEFLTEALPVK } & 1.00 & 34.03 & 25.30 & 26.52 & 3 & 1804.0267 & 1804.0226 & 602.3481 & 0.0041 & 2.2689 & 259.340 & 172.850 & 48.781 & 66.314 & \text { Yes }\end{array}$ $\begin{array}{llllllllllllllll}\text { IEQEFLTEALPVK } & 0.73 & 21.71 & 25.25 & 29.85 & 3 & 1804.0273 & 1804.0226 & 602.3481 & 0.0047 & 2.6009 & 145.392 & 166.796 & 77.142 & 89.556 & \text { Yes }\end{array}$ $\begin{array}{llllllllllllllll}\text { VENPFDFMENISLEGK } & 1.00 & 72.92 & 27.52 & 17.76 & 2 & 2156.0714 & 2156.0703 & 1079.0424 & 0.0011 & 0.5097 & 587.341 & 549.192 & 32.284 & 30.508 & \text { Yes }\end{array}$

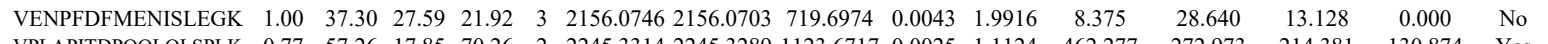

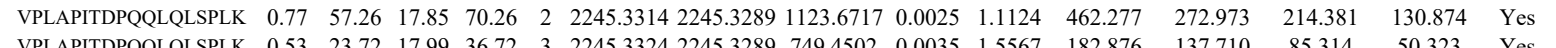

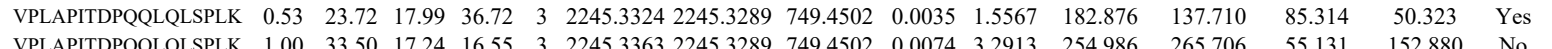
$\begin{array}{llllllllllllllll}\text { VPLAPITDPQLQLSPLK } & 1.00 & 33.50 & 17.24 & 16.55 & 3 & 2245.3363 & 2245.3289 & 749.4502 & 0.0074 & 3.2913 & 254.986 & 265.706 & 55.131 & 152.880 & \text { No } \\ \text { GLMPGLTFSNELSR } & 1.00 & 66.40 & 28.19 & 19.16 & 2 & 1777.9520 & 1777.9518 & 889.9832 & 0.0002 & 0.1124 & 909.058 & 956.769 & 291.921 & 9484 & \text { Yes }\end{array}$ $\begin{array}{llllllllllllllll}\text { GLMPGLTFSNELISR } & 1.00 & 66.40 & 28.19 & 19.16 & 2 & 1777.9520 & 1777.9518 & 889.9832 & 0.0002 & 0.1124 & 909.058 & 956.769 & 291.921 & 94.848 & \text { Yes } \\ \text { GLMPGLTFSNELISR } & 1.00 & 67.81 & 28.12 & 20.75 & 2 & 1777.9526 & 1777.9518 & 889.9832 & 0.0008 & 0.4494 & 2434.799 & 2244.666 & 1009.328 & 303.000 & \text { Yes }\end{array}$ $\begin{array}{llllllllllllllll}\text { GLMPGLTSNELSR } & 1.00 & 67.81 & 28.12 & 20.75 & 2 & 1777.9526 & 1777.9518 & 888.9832 & 0.008 & 0.4494 & 2434.799 & 2244.666 & 1009.328 & 303.000 & \text { Yes } \\ \text { GLMPGLTFSNELISR } & 1.00 & 71.47 & 28.20 & 19.19 & 2 & 1777.9534 & 1777.9518 & 889.9832 & 0.0016 & 0.8989 & 747.487 & 617.754 & 216.909 & 66.159 & \text { Yes }\end{array}$

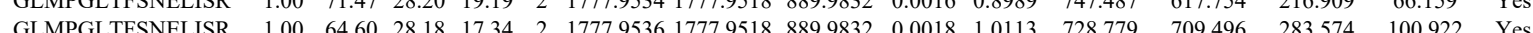

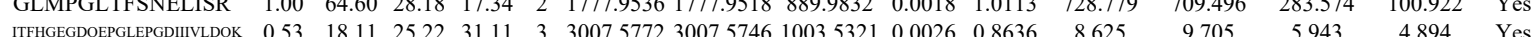



TIVITSHPGQIVK

$\begin{array}{lllllllllll}\text { QCR1_HUMAN } & \text { P31930 } & \text { UQCRC1 } & \text { Cytochrome b-c1 } 1,52.65 & 1.00 & 3 & 7.5 & -0.3809 & 0.4922 & 0.4305 & 2.5812\end{array}$

$\begin{array}{lllllllllll}\text { PUR9_HUMAN } & \text { P31939 } & \text { ATIC } & \text { Bifunctional purin 64.62 } & 1.00 & 11 & 28.5 & -0.0123 & 0.3041 & -0.5488 & 2.3630\end{array}$
YCTSATESEVAR IAEVDASVVR SNNVEMDWVLK

\section{ITFHGEGDQEPGLEPGDIIIVLDOK} QISQAYEVLSDAK QISQAYEVLSDAK TIVTTSHPQIVK TIVITSHPGQIVK YHPDKNPNEGEK

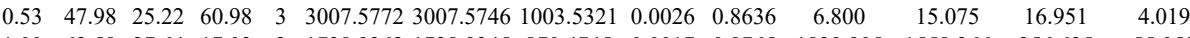
$\begin{array}{llllllllllllll}1.00 & 62.58 & 27.64 & 17.03 & 2 & 1738.9362 & 1738.9345 & 870.4745 & 0.0017 & 0.9765 & 1839.905 & 1558.366 & 356.635 & 55.058\end{array}$ $\begin{array}{lllllllllllllllll}0.69 & 61.06 & 27.38 & 74.06 & 2 & 1738.9378 & 1738.9345 & 870.4745 & 0.0033 & 1.8955 & 405.386 & 366.648 & 68.347 & 28.096\end{array}$ $\begin{array}{llllllllllllll}1.00 & 4.43 & 18.69 & 19.98 & 3 & 1680.0319 & 1680.0178 & 561.0132 & 0.0141 & 8.3776 & 25327.952 & 19404.006 & 3790.113 & 808.042\end{array}$

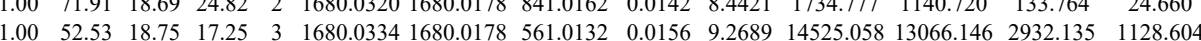

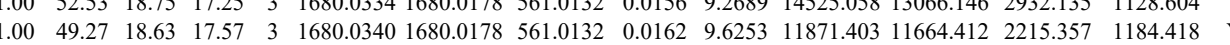
$\begin{array}{llllllllllllll}1.82 & 17.35 & 27.47 & 16.63 & 4 & 1858.9569 & 1858.9539 & 465.7458 & 0.0030 & 1.6103 & 481.649 & 533.341 & 248.191 & 230.637\end{array}$ $\left.\begin{array}{llllllllllllll}0.99 & 40.52 & 26.16 & 17.01 & 2 & 1455.6930 & 1455.6819 & 728.8482 & 0.0111 & 7.6147 & 590.971 & 642.883 & 406.926 & 718.422\end{array}\right)$

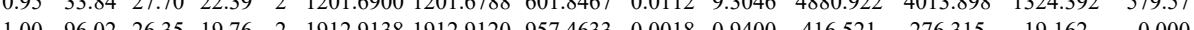
$\begin{array}{lllllllllllllll} & \end{array}$ $\begin{array}{lllllllllllll} & 27.986\end{array}$ $\begin{array}{llllllllllllll} & \end{array}$ $\begin{array}{llllllllllllll}\text { EVSDGUAPGYEEDALTLSK } & 1.00 & 67.96 & 25.79 & 19.61 & 2 & 25213434 & 2521.3407 & 1261.6776 & 0.0027 & 1.0700 & 6.003\end{array}$ $\begin{array}{lllllllllllllll}\text { EVSDGIAPGYEFEALTISK } & 1.00 & 36.96 & 25.76 & 17.30 & 3 & 2521.3447 & 2521.3407 & 841.4542 & 0.0040 & 1.5846 & 27.292 & 23.552 & 11.232\end{array}$ $\begin{array}{lllllllllllllll}\text { EVSDGIIAPGYEFEALTLSK } & 0.53 & 23.18 & 25.82 & 36.18 & 3 & 2521.3438 & 2521.3407 & 841.4542 & 0.0031 & 1.2280 & 5.652 & 26.529 & 56.232\end{array}$

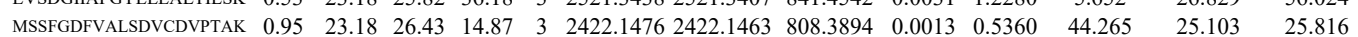
$\begin{array}{lllllllllllllll}\text { SLFSNVVTK } & 1.00 & 46.55 & 25.07 & 21.06 & 2 & 1281.7646 & 1281.7536 & 641.8841 & 0.0110 & 8.5685 & 17486.701 & 18121.502 & 1363.191\end{array}$ SLFSNVVTK NGQVIGIGAGQQSR VVIEACDELGILAHTNLR LDFNLIR LDFNLIR LDFNLIR LDFNLIR LDFNLIR LDFNLIR TLTPISAAYAR TLTPISAAYAR TLTPISAAYAR TLTPISAAYAR NLTALGLNLVASGGTAK TLHPAVHAGILAR TLHPAVHAGILAR TLHPAVHAGILAR TLHPAVHAGILAR TLHPAVHAGLAR TLHPAVHAGILAR

TLHPAVHAGILAR $\begin{array}{llllllllllllll}1.00 & 46.55 & 25.07 & 21.06 & 2 & 1281.7646 & 1281.7536 & 641.8841 & 0.0110 & 8.5685 & 17486.701 & 18121.502 & 1363.191 \\ 1.00 & 48.07 & 24.76 & 24.09 & 2 & 1281.7656 & 1281.7536 & 641.8841 & 0.0120 & 9.3474 & 15634.904 & 15681.293 & 1273.893\end{array}$ $\begin{array}{lllllllllllllll}1.00 & 48.07 & 24.76 & 24.09 & 2 & 1281.7656 & 1281.7536 & 641.8841 & 0.0120 & 9.3474 & 15634.904 & 15681.293 & 1273.893 & 289.148 \\ 1.00 & 78.66 & 27.42 & 28.03 & 2 & 1527.8238 & 1527.8239 & 764.9192 & 0.0001 & -0.0654 & 1143.265 & 1044.260 & 726.413 & 173.767\end{array}$ $\begin{array}{llllllllllllll}1.00 & 58.93 & 26.47 & 19.29 & 3 & 2268.2143 & 2268.2092 & 757.0770 & 0.0051 & 2.2455 & 504.967 & 616.699 & 0.000 & 17.676\end{array}$ $\begin{array}{llllllllllllll}0.93 & 30.53 & 27.68 & 25.55 & 2 & 1033.6042 & 1033.6042 & 517.8094 & 0.0000 & 0.0000 & 29487.973 & 32861.492 & 3205.308 & 469.044\end{array}$ $\begin{array}{lllllllllllllll}0.96 & 30.09 & 27.62 & 28.53 & 2 & 1033.6050 & 1033.6042 & 517.8094 & 0.0008 & 0.7725 & 27416.682 & 25702.857 & 2289.289\end{array}$ $\begin{array}{lllllllllllllll}0.97 & 31.82 & 27.62 & 27.52 & 2 & 1033.6050 & 1033.6042 & 517.8094 & 0.0008 & 0.7725 & 21229.641 & 24209.249 & 2021.280\end{array}$ $\begin{array}{llllllllllllll}0.96 & 30.25 & 27.62 & 23.03 & 2 & 1033.6050 & 1033.6042 & 517.8094 & 0.0008 & 0.7725 & 20858.088 & 21341.710 & 1882.548 & 298.292\end{array}$ $\begin{array}{lllllllllllllll}0.78 & 21.64 & 27.87 & 26.94 & 2 & 1033.6058 & 1033.6042 & 517.8094 & 0.0016 & 1.5450 & 946.073 & 1720.091 & 41767.696 & 6074.509\end{array}$ $\begin{array}{lllllllllllllll}0.66 & 19.41 & 28.21 & 26.24 & 2 & 1033.6064 & 1033.6042 & 517.8094 & 0.0022 & 2.1243 & 384.320 & 1194.813 & 27549.581 & 4277.308\end{array}$ $\begin{array}{lllllllllllllll}0.98 & 33.56 & 27.54 & 25.41 & 2 & 1306.7374 & 1306.7367 & 654.3756 & 0.0007 & 0.5349 & 32624.735 & 30185.076 & 2002.494 & 1269.778\end{array}$ $\begin{array}{llllllllllllll}0.91 & 33.76 & 27.28 & 31.40 & 2 & 1306.7430 & 1306.7367 & 654.3756 & 0.0063 & 4.8137 & 38273.646 & 41451.136 & 992.407\end{array}$ $\begin{array}{llllllllllllll}0.99 & 58.03 & 27.17 & 48.47 & 2 & 1306.7444 & 1306.7367 & 654.3756 & 0.0077 & 5.8834 & 20315.982 & 20786.532 & 528.432\end{array}$ $\begin{array}{llllllllllllll}1.00 & 59.69 & 27.17 & 32.28 & 2 & 1306.7444 & 1306.7367 & 654.3756 & 0.0077 & 5.8834 & 24368.144 & 25799.617 & 265.215\end{array}$ $\begin{array}{lllllllllll}1.00 & \text { \#\#\#\# 22.90 } 22.58 & 2 & 1887.1038 & 1887.1033 & 944.5589 & 0.0005 & 0.2647 & 223.254 & 212.288 & 66.966\end{array}$ $\begin{array}{lllllllllllll}1.00 & 60.56 & 23.82 & 18.68 & 2 & 1498.8916 & 1498.8854 & 750.4500 & 0.0062 & 4.1308 & 4379.919 & 3991.959 & 28.767 \\ 1.00 & 53.62 & 24.00 & 18.71 & 2 & 1498.8928 & 1498.8854 & 750.4500 & 0.0074 & 4.9304 & 2184.321 & 2169.131 & 80.449\end{array}$ $\begin{array}{llllllllllllll}1.00 & 53.62 & 24.00 & 18.71 & 2 & 1498.8928 & 1498.8854 & 750.4500 & 0.0074 & 4.9304 & 2184.321 & 2169.131 & 80.449\end{array}$

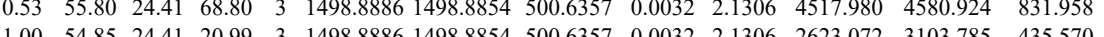
$\begin{array}{lllllllllllll}1.00 & 54.85 & 24.41 & 20.99 & 3 & 1498.8886 & 1498.8854 & 50.6357 & 0.0032 & 2.1306 & 2623.072 & 3103.785 & 435.570\end{array}$

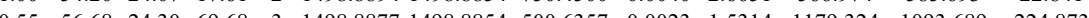

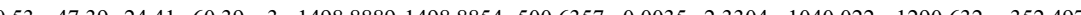

ALFEEVPELLTEA

ALFEEVPELLTEAEK AEISNAIDQYVTGTIGEDEDLIK AEISNAIDQYVTGTIGEDEDLIK AEISNAIDQYVTGTIGEDEDLIK

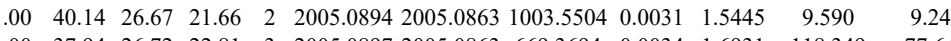
$\begin{array}{lllllllllllll}1.00 & 60.13 & 26.70 & 21.52 & 3 & 2005.0906 & 2005.0863 & 699.3694 & 0.0043 & 2.1413 & 115.073 & 139.167\end{array}$ $\begin{array}{llllllllllllll}1.53 & 11.07 & 26.61 & 16.06 & 3 & 2781.4189 & 2781.4164 & 928.1461 & 0.0025 & 0.8978 & 3.836 & 11.690\end{array}$ $\begin{array}{lllllllllll}5 & 1.07 & 26.61 & 16.06 & 3 & 2781.4189 & 2781.4164 & 928.1461 & 0.0025 & 0.8978 & 3.836\end{array}$

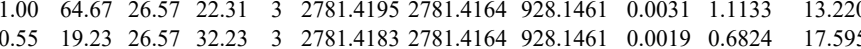

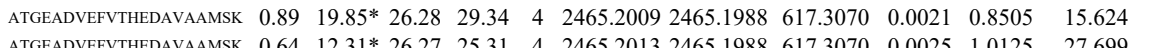

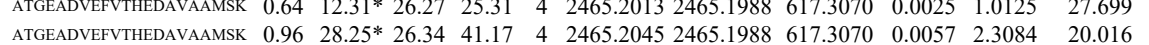
$\begin{array}{lllllllllll} & \end{array}$

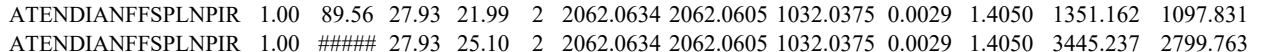
$\begin{array}{lllllllllllllll}\text { ATENDIANFFSPLNPIR } & 1.00 & 74.36 & 27.91 & 19.21 & 3 & 2062.0648 & 2062.0605 & 688.3608 & 0.0043 & 2.0822 & 167.339 & 189.672\end{array}$ $\begin{array}{lllllllllllll}\text { ATENDIANFFSPLNPIR } & 1.00 & 84.08 & 28.06 & 28.71 & 2 & 2062.0614 & 2062.0605 & 1032.0375 & 0.0009 & 0.4360 & 1186.756 & 944.262\end{array}$ $\begin{array}{llllllllllllll}\text { ATENDIANFFSPLNPIR } & 1.00 & 82.44 & 28.06 & 21.70 & 2 & 2062.0614 & 2062.0605 & 1032.0375 & 0.0009 & 0.4360 & 602.578\end{array}$

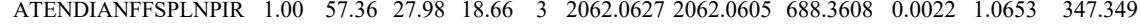
$\begin{array}{lllllllllllll}\text { ATENDIANFFSPLNPIR } & 1.00 & 48.27 & 27.88 & 21.00 & 3 & 2062.0639 & 2062.0605 & 688.3608 & 0.0034 & 1.6464 & 343.499 & \end{array}$ $\begin{array}{lllllllllllll}\text { ATENDIANFFSPLNPIR } & 1.00 & 78.19 & 27.93 & 21.69 & 2 & 2062.0634 & 2062.0605 & 1032.0375 & 0.0029 & 1.4050 & 287.928 & 17\end{array}$

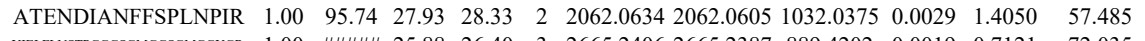
$\begin{array}{llllllllllllll}\text { YIELELNSTPGGGSGMGGSGMGGYGR } & 1.00 & \text { \#\#\#\# } 25.88 & 26.40 & 3 & 2665.2406 & 2665.2387 & 889.4202 & 0.0019 & 0.7121 & 72.035\end{array}$ $\begin{array}{llllllllllll}\text { ATGEADVEFVTHEDAVAAMSK } & 0.93 & 22.97 * & 26.32 & 35.86 & 4 & 2465.2025 & 2465.1988 & 617.3070 & 0.0037 & 1.4984 & 48.496\end{array}$ $\begin{array}{llllllllllll}\text { ATGEADVEFVTHEDAVAAMSK } & 0.62 & 11.94 * & 26.31 & 17.94 & 4 & 2465.2021 & 2465.1988 & 617.3070 & 0.0033 & 1.3364 & 87.095\end{array}$

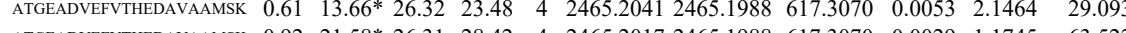
SNNVEMDWVLK SNNVEMDWVLK

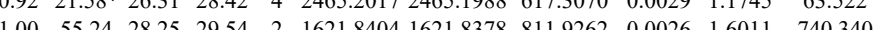
$\begin{array}{lllllllllll}1.00 & 55.24 & 28.25 & 29.54 & 2 & 1621.8404 & 1621.8378 & 811.9262 & 0.0026 & 1.6011 & 740.340\end{array}$ $\begin{array}{lllllllllll}1.00 & 50.86 & 28.18 & 30.63 & 2 & 1621.8410 & 1621.8378 & 811.9262 & 0.0032 & 1.9706 & 462.835\end{array}$

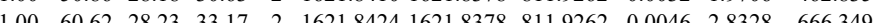

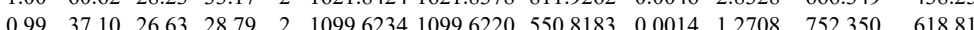




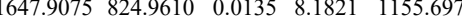
$\begin{array}{llllllllllll}\text { VETELQGVCDTVLGLLDSHLIK } & 1.00 & 88.64 & 24.91 & 25.46 & 3 & 2715.4471 & 2715.4431 & 906.1550 & 0.0040 & 1.4714 & 22.468\end{array}$ $\begin{array}{lllllllllllll}\text { VETELQGVCDTVLGLLDSHLIK } & 1.00 & 75.76 & 24.89 & 26.19 & 3 & 2715.4474 & 2715.4431 & 906.1550 & 0.0043 & 1.5818 & 114.782 \\ \text { VI. }\end{array}$ $\begin{array}{llllllllllll}\text { VETELQGVCDTVLGLDSHLIK } & 1.00 & 80.11 & 24.89 & 24.75 & 3 & 2715.4474 & 2715.4431 & 906.1550 & 0.0043 & 1.5818 & 27.218 \\ \text { VETELQGVCDTVLGLDSHUK } & 1.00 & 50.46 & 24.93 & 19.47 & 4 & 2715.4481 & 2715.4431 & 679.8681 & 0.0050 & 1.8386 & 86.074\end{array}$ $\begin{array}{llllllllllllll}\text { VETELQGVCDTVLGLLDSHLIK } & 1.00 & 86.74 & 24.91 & 27.85 & 3 & 2715.4486 & 2715.4431 & 906.1550 & 0.0055 & 2.0232 & 2382.885\end{array}$

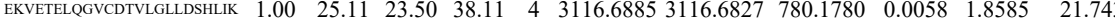
$\begin{array}{llllllllllll}\text { EKVETELQGVCDTVLGLLDSHLIK } & 1.00 & 40.04 & 23.58 & 53.04 & 4 & 3116.6893 & 3116.6827 & 780.1780 & 0.0066 & 2.1149 & 7.930 \\ \text { VETELOGGCDVLGLDSHKK } & 1.00 & 82.99 & 24.90 & 25.50 & 2 & 2715.4454 & 2715.4431 & 1358.7288 & 0.0023 & 0.8464 & 1.279\end{array}$ $\begin{array}{cccccccccccc}\text { VETELQGVCDTVLGLLDSHLIK } & 1.00 & 82.99 & 24.90 & 25.50 & 2 & 2715.4454 & 2715.4431 & 1358.7288 & 0.0023 & 0.8464 & 1.279 \\ \text { VETELQGVCDTVLGLDSHIK } & 1.00 & 67.67 & 24.90 & 23.46 & 3 & 2715.4459 & 2715.4431 & 906.1550 & 0.0028 & 1.0300 & 307.039\end{array}$ $\begin{array}{llllllllllll}\text { VETELQGVCDTVLGLLDSHLIK } & 1.00 & 67.67 & 24.90 & 23.46 & 3 & 2715.4459 & 2715.4431 & 906.1550 & 0.0028 & 1.0300 & 307.039 \\ \text { VETELOGVCDTVLGLLSSHIK } & 1.00 & 30.31 & 24.89 & 21.36 & 4 & 2715.4473 & 2715.4431 & 679.8681 & 0.0042 & 1.5444 & 120.993\end{array}$ $\begin{array}{llllllllllll}\text { VETELQGVCDTVLGLLDSHLIK } & 1.00 & 30.31 & 24.89 & 21.36 & 4 & 2715.4473 & 2715.4431 & 679.8681 & 0.0042 & 1.5444 & 120.993 \\ \text { VETELOGVCDTVLGLDSHLIK } & 1.00 & 76.06 & 24.89 & 25.18 & 3 & 2715.4474 & 2715.4431 & 906.1550 & 0.0043 & 1.5818 & 1134.945\end{array}$ $\begin{array}{llllllllllll}\text { VETELQGVCDTVLGLLDSHLIK } & 1.00 & 76.06 & 24.89 & 25.18 & 3 & 2715.4474 & 2715.4431 & 906.1550 & 0.0043 & 1.5818 & 1134.945 \\ \text { VETELQGVCDTVLGLLSHLIK } & 1.00 & 39.92 & 24.91 & 18.37 & 4 & 2715.4493 & 2715.4431 & 679.8681 & 0.0062 & 2.2798 & 121.347\end{array}$ $\begin{array}{llllllllllll}\text { VETELQGVCDTVLGLLDSHLIK } & 1.00 & 39.92 & 24.91 & 18.37 & 4 & 2715.4493 & 2715.4431 & 679.8681 & 0.0062 & 2.2798 & 121.347 \\ \text { VETELQGVCDTVLGLLDSHIK } & 1.00 & 95.93 & 24.93 & 27.41 & 3 & 2715.4465 & 2715.4431 & 906.1550 & 0.0034 & 1.2507 & 743.634\end{array}$ $\begin{array}{llllllllllll}\text { VETELQGVCDTVLGLLDSHLIK } & 1.00 & 88.20 & 24.89 & 24.28 & 3 & 2715.4474 & 2715.4431 & 906.1550 & 0.0043 & 1.5818 & 172.020\end{array}$ $\begin{array}{lllllllllllll}\text { VETELQGVCDTVLGLLDSHLIK } & 1.00 & 86.27 & 24.87 & 29.72 & 3 & 2715.4453 & 2715.4431 & 906.1550 & 0.0022 & 0.8093 & 139.933\end{array}$ $\begin{array}{llllllllllll}\text { VETELQGVCDTVLGLLDSHLIK } & 1.00 & 91.91 & 24.89 & 27.36 & 3 & 2715.4474 & 2715.4431 & 906.1550 & 0.0043 & 1.5818 & 125.798\end{array}$ 

$\begin{array}{lllllllllllllllll}\text { SAYYEAMDISK } & 1.00 & 61.36 & 27.83 & 26.49 & 2 & 1529.7788 & 1529.7639 & 765.8892 & 0.0149 & 9.7272 & 7887.451 & 10149.013 & 13424.371 & 3014.051 & \text { Yes } \\ \text { SAYQEAMDISK } & 1.00 & 66.96 & 27.83 & 29.98 & 2 & 1529.7788 & 1529.7639 & 765.8892 & 0.0149 & 9.7272 & 8704749 & 10180.635 & 15831.092 & 3564.882 & \text { Yes }\end{array}$ $\begin{array}{lllllllllllllllll}1.00 & 66.96 & 27.83 & 29.98 & 2 & 1529.7788 & 1529.7639 & 765.8892 & 0.0149 & 9.7272 & 8704.749 & 10180.635 & 15831.092 & 3564.882 & \text { Yes }\end{array}$

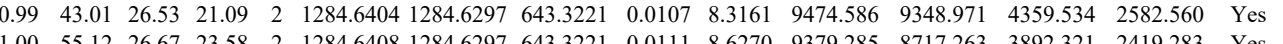
LDLDSSCK $\begin{array}{llllllllllllllll}1.00 & 55.12 & 26.67 & 23.58 & 2 & 1284.6408 & 1284.6297 & 643.3221 & 0.0111 & 8.6270 & 9379.285 & 8717.263 & 3892.321 & 2419.283 & \text { Yes } & \\ 1.00 & 57.36 & 26.67 & 23.10 & 2 & 1284.6410 & 1284.6297 & 643.3221 & 0.0113 & 8.7825 & 6141.402 & 5429.168 & 300.525 & 601.793 & \text { Yes }\end{array}$ $\begin{array}{lllllllllllllll}1.00 & 57.36 & 26.67 & 23.10 & 2 & 1284.6410 & 1284.6297 & 643.3221 & 0.0113 & 8.7825 & 6141.402 & 5429.168 & 300.525 & 601.793 & \text { Yes } \\ 1.00 & 55.72 & 26.78 & 27.17 & 2 & 1284.6418 & 1284.6297 & 643.3221 & 0.0121 & 9.4042 & 4572.400 & 4259.090 & 372.341 & 445.667 & \text { Yes }\end{array}$ DPQALSEHLK

DPQALSEHLK

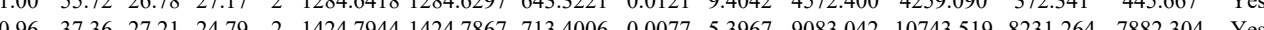
DPQALSEHLK

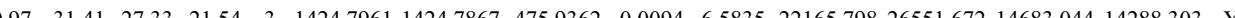

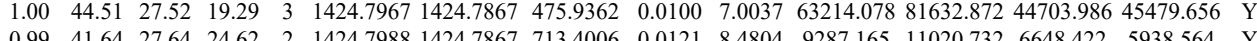
$\begin{array}{llllllllllllllll}\text { AMADPEVQQIMSDPAMR } & 1.00 & 85.38 & 25.75 & 21.39 & 2 & 2032.9514 & 2032.9502 & 1017.4824 & 0.0012 & 0.5897 & 841.507 & 719.146 & 158.578 & 40.451 & \text { Yes }\end{array}$

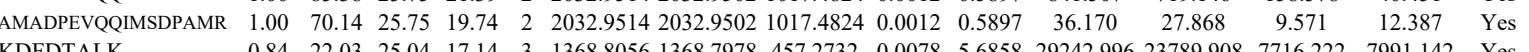
$\begin{array}{llllllllllllllll}\text { KDFDTALK } & 0.84 & 22.03 & 25.04 & 17.14 & 3 & 1368.8056 & 1368.7978 & 457.2732 & 0.0078 & 5.6858 & 29242.996 & 23789.908 & 7716.222 & 7991.142 & \text { Yes } \\ \text { NKPSDLGTK } & 0.99 & 28.44 & 25.89 & 15.38 & 3 & 1390.8160 & 1390.8145 & 464.6121 & 0.0015 & 1.0762 & 2235.544 & 1987.453 & 132.348 & 92.323 & \text { Yes }\end{array}$

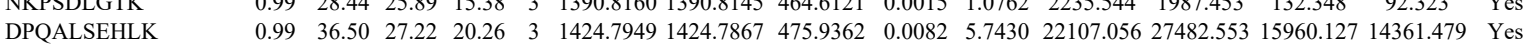

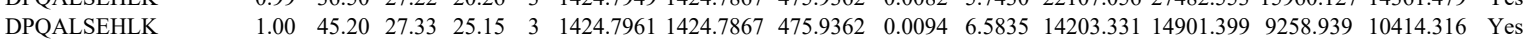
$\begin{array}{lllllllllllllllll}\text { LAYINPDLALEEK } & 1.00 & 63.11 & 26.09 & 21.80 & 2 & 1775.9944 & 1775.9912 & 889.0029 & 0.0032 & 1.7998 & 1152.765 & 1364.581 & 44.262 & 172.314 & \text { Yes }\end{array}$ $\begin{array}{lllllllllllllllll}\text { AMADPEVQQIMSDPAMR } & 1.00 & 86.78 & 25.75 & 21.02 & 2 & 2032.9514 & 2032.9502 & 1017.4824 & 0.0012 & 0.5897 & 929.666 & 726.721 & 276.831 & 77.496 & \text { Yes }\end{array}$ $\begin{array}{llllllllllllllll}\text { AMADPEVQQIMSDPAMR } & 1.00 & 80.52 & 25.75 & 20.57 & 2 & 2032.9514 & 2032.9502 & 1017.4824 & 0.0012 & 0.5897 & 773.848 & 879.353 & 263.993 & 60.961 & \text { Yes }\end{array}$

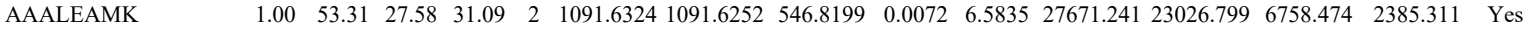

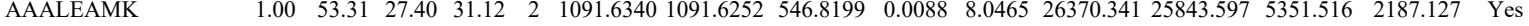

$\begin{array}{llllllllllllllll}\text { DPQALSEHLK } & 0.81 & 24.17 & 27.28 & 16.42 & 3 & 1424.7955 & 1424.7867 & 475.9362 & 0.0088 & 6.1633 & 8096.453 & 10924.586 & 5779.671 & 4715.833 & \text { Yes } \\ \text { DPQALSEHLK } & 1.00 & 39.49 & 27.28 & 17.21 & 3 & 1424.7955 & 1424.7867 & 475.9362 & 0.0088 & 6.1633 & 8701.262 & 9465.148 & 4298.584 & 4568.468 & \text { Yes }\end{array}$

DPQALSEHLK

LAYINPDLALEEK

LAYINPDLALEEK

AAALEAMK

AAALEAMK LAYINPDLALEEK

TVDLKPDWGK

TVDLKPDWGK

TVDLKPDW

NPVIAQK

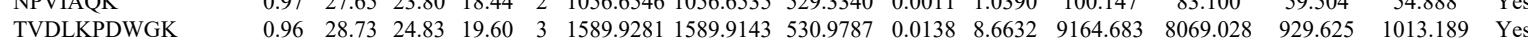

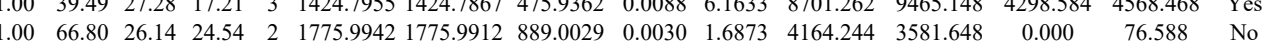
$\begin{array}{llllllllllllllll}1.00 & 68.75 & 26.15 & 24.78 & 2 & 1775.9948 & 1775.9912 & 889.0029 & 0.0036 & 2.0247 & 1908.440 & 1962.001 & 61.182 & 86.754 & \text { Yes }\end{array}$ $\begin{array}{lllllllllllllll}1.00 & 53.21 & 27.29 & 30.86 & 2 & 1091.6306 & 1091.6252 & 546.8199 & 0.0054 & 4.9376 & 27642.640 & 23972.507 & 6249.349 & 1560.373 & \text { Yes }\end{array}$

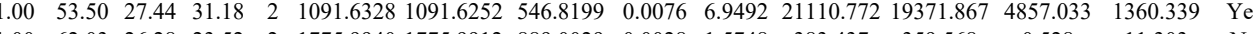

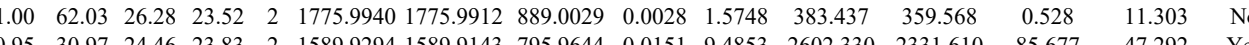
$\begin{array}{lllllllllllllll}0.95 & 30.97 & 24.46 & 23.83 & 2 & 1589.9294 & 7589.9143 & 795.9644 & 0.0151 & 9.4853 & 2602.330 & 2331.610 & 85.677 & 47.292 & \text { Yes } \\ \end{array}$

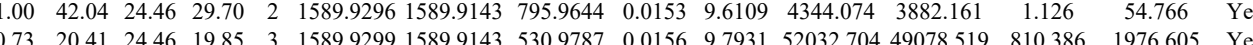
$\begin{array}{lllllllllllllll}0.73 & 2.41 & 24.46 & 19.85 & 3 & 1589.9299 & 1589.9143 & 530.9787 & 0.0156 & 9.7931 & 52032.704 & 49078.519 & 810.386 & 1976.605 & \text { Yes } \\ 0.61 & 26.26 & 23.40 & 39.26 & 2 & 1056.6532 & 1056.6535 & 529.3340 & 0.0003 & 0.2834 & 77.637 & 74.379 & 57.647 & 57.860 & \text { Yes }\end{array}$

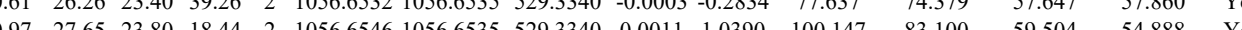

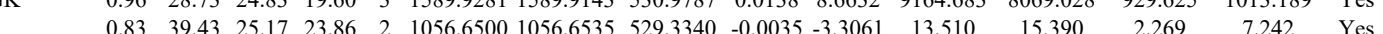

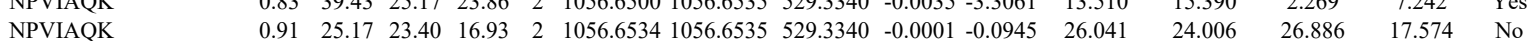
$\begin{array}{lllllllllllllll}\text { ALSVGNIDDALQCYSEAIK } & 1.00 & \text { \#\#\#\# } 28.67 & 34.42 & 2 & 2343.1714 & 2343.1694 & 1172.5920 & 0.0020 & 0.8528 & 127.230 & 147.689 & 26.475 & 20.158 & \text { Yes }\end{array}$

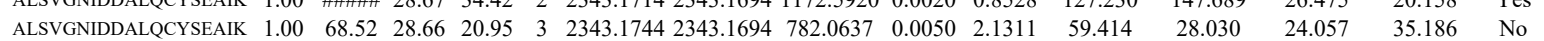

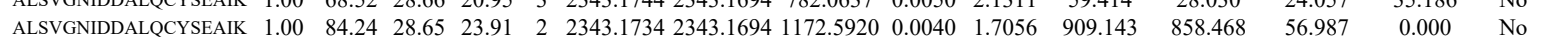
$\begin{array}{llllllllllllllll}\text { ALSVGNIDDALOCYSEAIK } & 0.96 & 26.98 & 28.66 & 23.41 & 3 & 2343.1744 & 2343.1694 & 782.0637 & 0.0050 & 2.1311 & 97.355 & 91.664 & 22.437 & 0.000 & \text { No }\end{array}$ $\begin{array}{llllllllllllllll}\text { ALSVGNIDDALOCYSEAIK } & 1.00 & 61.24 & 28.73 & 29.36 & 3 & 2343.1753 & 2343.1694 & 782.0637 & 0.0059 & 2.5147 & 97.760 & 182.994 & 170.888 & 32.985 & \text { No }\end{array}$

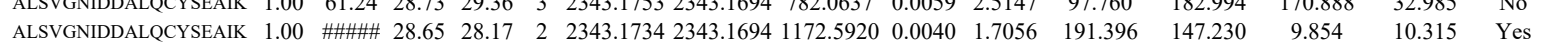

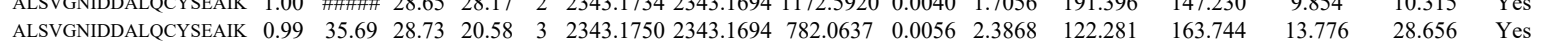

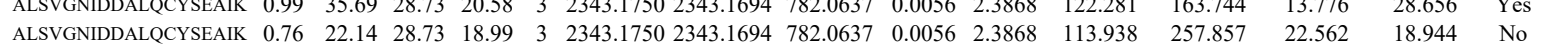

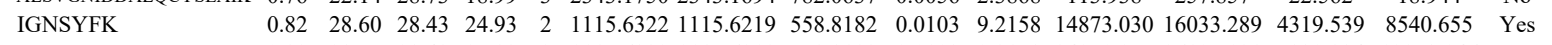

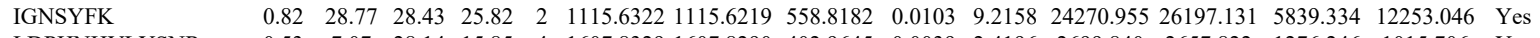
$\begin{array}{lllllllllllllllll}\text { LDPHNHVLYSNR } & 0.53 & 7.07 & 28.14 & 15.85 & 4 & 1607.8329 & 1607.8290 & 402.9645 & 0.0039 & 2.4196 & 2699.840 & 2657.822 & 1276.246 & 1015.706 & \text { Yes }\end{array}$ $\begin{array}{llllllllllllllll}0.67 & 25.34 & 26.65 & 23.32 & 2 & 1115.6302 & 1115.6219 & 558.8182 & 0.0083 & 7.4263 & 11050.727 & 10310.861 & 2689.701 & 2067.268 & \text { Yes }\end{array}$

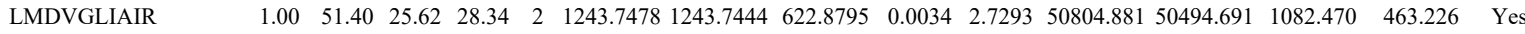
$\begin{array}{lllllllllllllllll}\text { LMDVGLIAIR } & 1.00 & 51.34 & 25.79 & 25.23 & 2 & 1243.7480 & 1243.7444 & 622.8795 & 0.0036 & 2.8898 & 24722.719 & 23912.158 & 506.194 & 879.580 & \text { Yes }\end{array}$

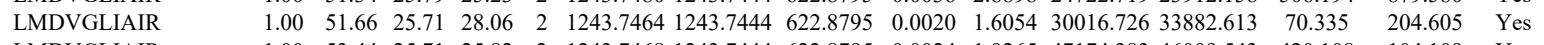
$\begin{array}{llllllllllllllll}\text { LMDVGLIAIR } & 1.00 & 53.44 & 25.71 & 25.82 & 2 & 1243.7468 & 1243.7444 & 622.8795 & 0.0024 & 1.9265 & 47174.383 & 46009.543 & 420.108 & 104.109 & \text { Yes }\end{array}$ $\begin{array}{llllllllllllllll}\text { LMDVGLIAIR } & 1.00 & 51.52 & 25.21 & 27.91 & 2 & 1243.7508 & 1243.7444 & 622.8795 & 0.0064 & 5.1374 & 11435.445 & 10058.887 & 119.371 & 21.086 & \text { Yes }\end{array}$ $\begin{array}{llllllllllllllll}\text { LMDVGLIAIR } & 1.00 & 51.40 & 25.24 & 25.17 & 2 & 1243.7510 & 1243.7444 & 622.8795 & 0.0066 & 5.2979 & 8431.867 & 9338.690 & 221.339 & 67.900 & \text { Yes }\end{array}$ $\begin{array}{llllllllllllllll}\text { CMMAQYNR } & 0.99 & 35.34 & 19.68 & 18.72 & 2 & 1205.5012 & 1205.4935 & 603.7540 & 0.0077 & 6.3767 & 9344.505 & 8688.621 & 124.446 & 105.707 & \text { Yes } \\ \text { CMMAQYNR } & 0.99 & 33.49 & 19.87 & 17.87 & 2 & 1205.5022 & 1205.4935 & 03.7540 & 0.0087 & 7.2049 & 8779.574 & 8073.957 & 148.335 & 89.23 & \text { Yes }\end{array}$

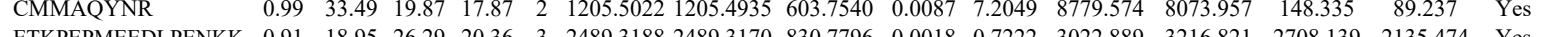
\begin{tabular}{lllllllllllllllll} 
ETKPEPMEEDLPENKK & 0.91 & 18.95 & 26.29 & 20.36 & 3 & 2489.3188 & 2489.3170 & 830.7796 & 0.0018 & 0.7222 & 3022.889 & 3216.821 & 2708.139 & 2135.474 & Yes \\
\hline
\end{tabular}

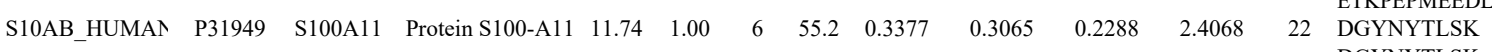
DGYNYTLSK

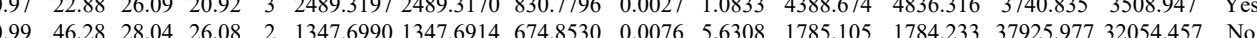

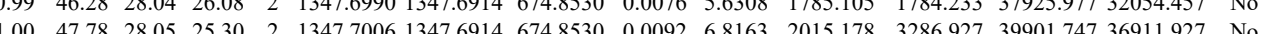
$\begin{array}{llllllllllllllll}0.61 & 24.54 & 26.63 & 27.36 & 2 & 916.5578 & 916.5585 & 459.2865 & -0.0007 & 0.7621 & 272.756 & 338.708 & 481.910 & 29.916 & \text { Y }\end{array}$ $\begin{array}{lllllllllllllll}0.69 & 28.29 & 26.43 & 39.89 & 2 & 916.5588 & 916.5585 & 459.2865 & 0.0003 & 0.3266 & 449.525 & 618.192 & 1065.095 & 565.714 & \text { Yes }\end{array}$ 


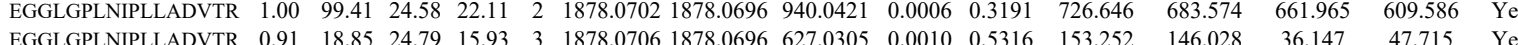

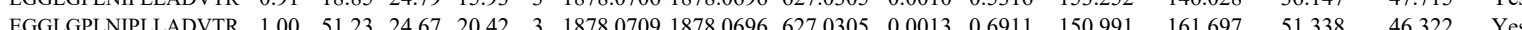

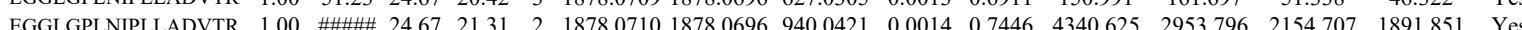
$\begin{array}{lllllllllllllll}\text { EGGLGPLNIPLLADVTR } & 1.00 & \text { \#\#\#\# } 24.50 & 20.71 & 2 & 1878.0718 & 1878.0696 & 940.0421 & 0.0022 & 1.1702 & 3281.569 & 3505.078 & 1933.990 & 2092.078 & \text { Yes }\end{array}$ $\begin{array}{llllllllllllllll}\text { EGGLGPLNIPLLADVTR } & 1.00 & 40.04 & 24.49 & 16.20 & 3 & 1878.0727 & 1878.0696 & 627.0305 & 0.0031 & 1.6480 & 159.614 & 151.948 & 64.583 & 87.728 & \text { Yes }\end{array}$

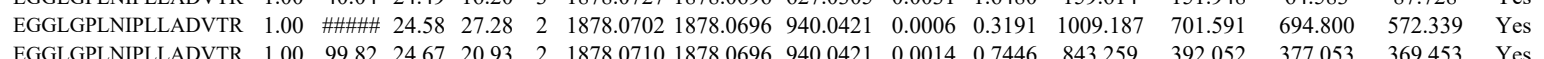

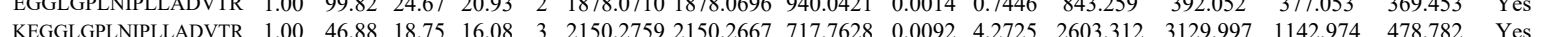

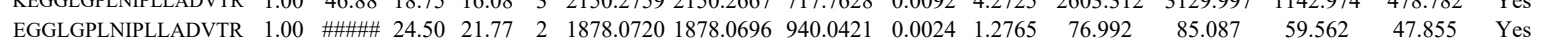

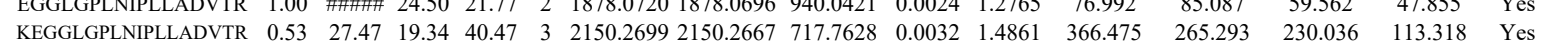

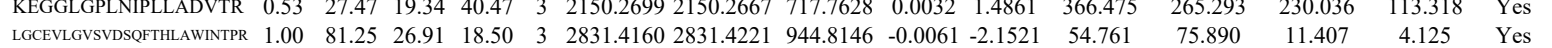

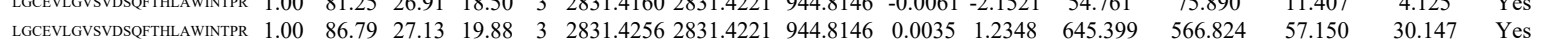

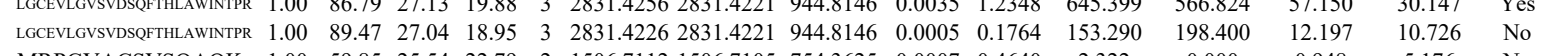

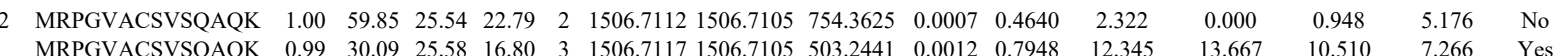

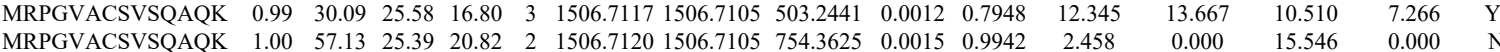

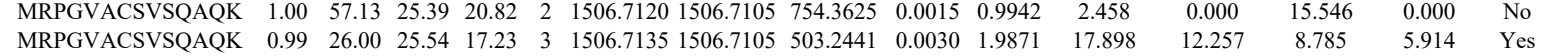
$\begin{array}{llllllllllllllll}\text { FLDGIYVSEK } & 1.00 & 50.40 & 27.54 & 21.60 & 2 & 1457.8134 & 1457.8010 & 729.9078 & 0.0124 & 8.4942 & 9103.646 & 6836.067 & 389.074 & 482.034 & \text { Yes }\end{array}$ $\begin{array}{llllllllllllllll}\text { FLDGIYVSEK } & 1.00 & 55.62 & 27.46 & 22.95 & 2 & 1457.8136 & 1457.8010 & 729.9078 & 0.0126 & 8.6312 & 12403.047 & 11188.974 & 453.345 & 238.988 & \text { Yes }\end{array}$ $\begin{array}{llllllllllllllll}\text { TILSNQTVDIPENVDITLK } & 1.00 & 88.94 & 23.93 & 23.46 & 2 & 2400.3354 & 2400.3355 & 1201.1750 & -0.0001 & -0.0416 & 220.255 & 225.528 & 43.637 & 21.039 & \text { Yes }\end{array}$ $\begin{array}{llllllllllllllll}\text { TILSNQTVDIPENVDITLK } & 1.00 & 91.08 & 23.67 & 20.72 & 2 & 2400.3374 & 2400.3355 & 1201.1750 & 0.0019 & 0.7909 & 149.417 & 197.216 & 67.296 & 15.843 & \text { Yes }\end{array}$

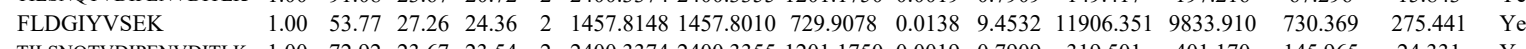

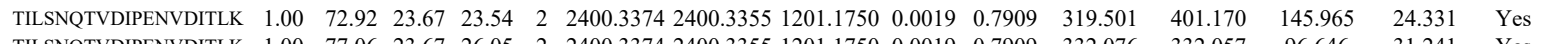

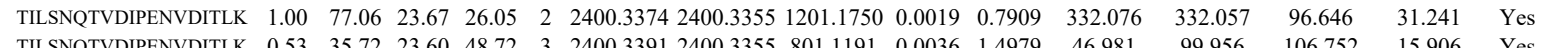

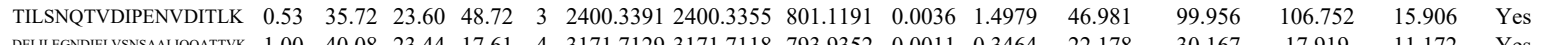

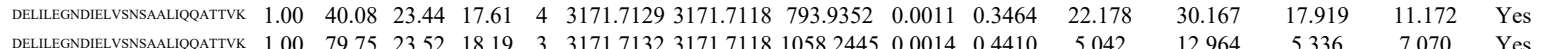

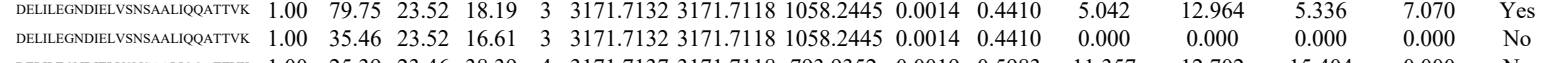
$\begin{array}{llllllllllllllll}\text { DELLEGNDELVSNSALLQQATTVK } & 1.00 & 25.39 & 23.46 & 38.39 & 4 & 3171.7137 & 3171.7118 & 793.9352 & 0.0019 & 0.5983 & 11.357 & 12.702 & 15.404 & 0.000 & \text { No }\end{array}$

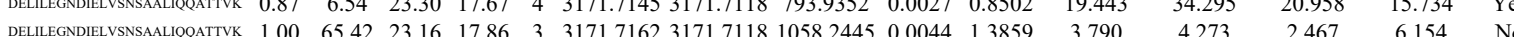




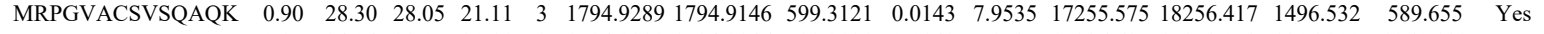
$\begin{array}{llllllllllllllll}\text { MRPGVACSVSQAQK } & 0.97 & 34.04 & 28.05 & 20.11 & 3 & 1794.9289 & 1794.9146 & 599.3121 & 0.0143 & 7.9535 & 17386.685 & 15878.973 & 1306.309 & 1260.182 & \text { Yes }\end{array}$ $\begin{array}{llllllllllllllll}\text { MRPGVACSVSQAQK } & 0.98 & 31.58 & 27.69 & 17.50 & 3 & 1810.9159 & 1810.9096 & 604.6438 & 0.0063 & 3.4731 & 3325.537 & 3063.391 & 456.746 & 272.650 & \text { Yes }\end{array}$

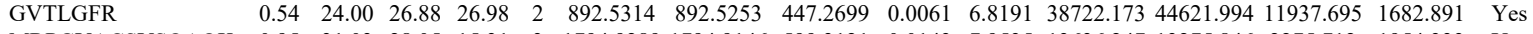

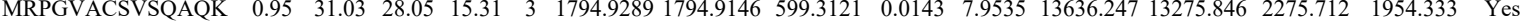

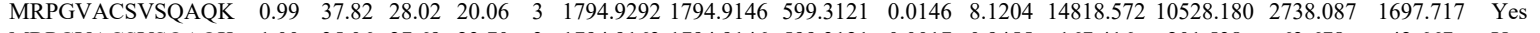

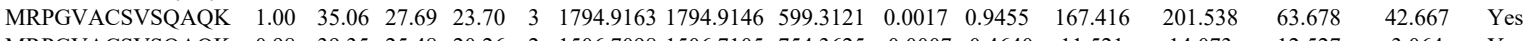
$\begin{array}{llllllllllllllll}\text { MRPGVACSVSQAQK } & 0.98 & 39.35 & 25.48 & 20.26 & 2 & 1506.7098 & 1506.7105 & 754.3625 & -0.0007 & -0.4640 & 11.521 & 14.073 & 12.527 & 3.064 & \text { Yes }\end{array}$

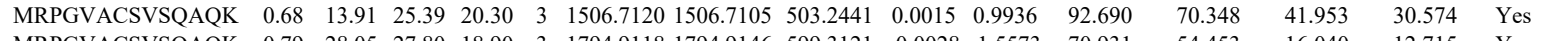

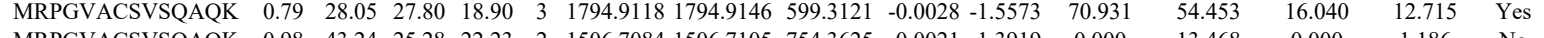

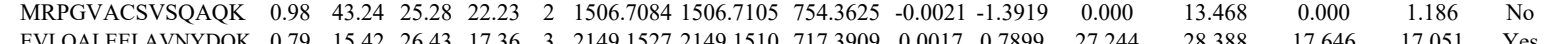

$\begin{array}{llllllllllll}\text { KINH_HUMAN } & \text { P33176 } & \text { KIF5B } & \text { Kinesin-1 } & & & & & \end{array}$ DUT HUMAN $\quad$ P33316 DUT

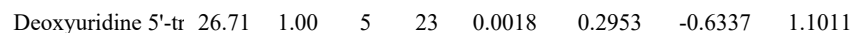

EVLQALEELAVNYDQK

FRPLNESEVNR

\section{QLEESVDALSEELVQ}

QLEESVDALSEELVQL

GSGGFGSTGK

LSEHATAPTR

ARPAEVGGMQLR

ARPAEVGGMQLR

ARPAEVGGMQLR

ARPAEVGGMQLR

ARPAEVGGMQLR

ARPAEVGGMQLR

TDIQIALPSGCYGR

TDIQIALPSGCYGR

TDIQIALPSGCYGR

TDIQIALPSGCYGR

GNVGVVLFNFGK

GNVGVVLFNFGK

GNVGVVLFNFGK

GNVGVVLFNFGK

ALADDDFLTVTGK

ALADDDFLTVTGK

ATPAQTPR

NLNPEDIDQLITISGMVIR 0.7

VNVTGIYR

VNVTGIYR

VNVTGIYR

TGIVDISILTTGM

$\begin{array}{lllllllll} & \end{array}$

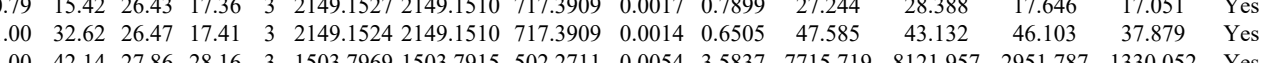

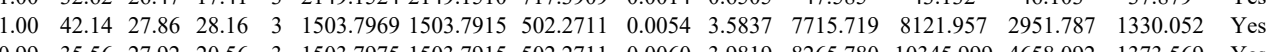
$\begin{array}{llllllllllllllll}14.39 & 27.20 & 27.39 & 3 & 2101.1044 & 2101.1024 & 701.3747 & 0.0020 & 0.9505 & 80.019 & 116.515 & 89.909 & 76.771 & \text { Yes }\end{array}$ $\begin{array}{llllllllll} & 2101.1059 & 2101.1024 & 701.3747 & 0.0035 & 1.6634 & 86.960\end{array}$ $\begin{array}{llllllllllllllll}1.00 & 52.68 & 27.02 & 24.13 & 2 & 1141.5962 & 1141.5972 & 571.8059 & -0.0010 & -0.8744 & 251.193 & 244.919 & 104.343 & 80.574 & \text { No } \\ 0.72 & 16.70 & 27.53 & 16.59 & 3 & 1225.6543 & 1225.6537 & 409.5585 & 0.0006 & 0.4883 & 280.244 & 323.871 & 129.014 & 79.580 & \text { Yes }\end{array}$ $\begin{array}{llllllllllllllll}0.96 & 25.17 & 27.71 & 21.30 & 3 & 1225.6546 & 1225.6537 & 409.5585 & 0.0009 & 0.7325 & 278.311 & 246.228 & 149.618 & 106.820 & \text { No }\end{array}$ $\begin{array}{llllllllllllllll}1.00 & 58.77 & 26.79 & 24.79 & 3 & 1427.7802 & 1427.7789 & 476.9336 & 0.0013 & 0.9086 & 11261501 & 11951.063 & 3198204 & 909.947 & \text { Yes }\end{array}$ $\begin{array}{llllllllllllllll}1.00 & 46.97 & 26.73 & 21.36 & 3 & 1427.7805 & 1427.7789 & 476.9336 & 0.0016 & 1.1183 & 16353.150 & 23573.626 & 4106.878 & 736.566 & \text { Yes }\end{array}$ $\begin{array}{llllllllllllllll}1.00 & 52.43 & 26.69 & 22.97 & 3 & 1427.7841 & 1427.7789 & 476.9336 & 0.0052 & 3.6343 & 10996.551 & 13061.614 & 2524.412 & 464.758 & \text { Yes }\end{array}$ $\begin{array}{lllllllllllllllll}1.00 & 54.33 & 26.82 & 23.08 & 3 & 1427.7853 & 1427.7789 & 476.9336 & 0.0064 & 4.4730 & 14046.130 & 17258.943 & 2162.475 & 192.900 & \text { Yes }\end{array}$ $\begin{array}{llllllllllllllll}1.00 & 51.30 & 26.39 & 20.93 & 3 & 1427.7832 & 1427.7789 & 476.9336 & 0.0043 & 3.0053 & 4926.794 & 5836.795 & 1373.954 & 339.792 & \text { Yes }\end{array}$ $\begin{array}{lllllllllllllll}1.00 & 33.85 & 26.69 & 18.33 & 3 & 1427.7841 & 1427.7789 & 476.9336 & 0.0052 & 3.6343 & 794.790 & 836.833 & 286.449 & 114.344 & \text { Yes }\end{array}$ $\begin{array}{llllllllllllllll}1.00 & 64.94 & 27.60 & 27.30 & 2 & 1682.8254 & 1682.8242 & 842.4194 & 0.0012 & 0.7122 & 2045.636 & 2214.124 & 268.275 & 99.605 & \text { Yes }\end{array}$ $\begin{array}{lllllllllllllll}1.00 & 55.78 & 27.47 & 27.14 & 2 & 1682.8264 & 1682.8242 & 842.4194 & 0.0022 & 1.3058 & 3186.837 & 3131.156 & 194.896 & 112.096 & \text { Yes }\end{array}$ $\begin{array}{llllllllllllllll}1.00 & 58.58 & 27.43 & 26.79 & 2 & 1682.8270 & 1682.8242 & 842.4194 & 0.0028 & 1.6619 & 4940.845 & 4629.458 & 490.510 & 234.387 & \text { Yes }\end{array}$ $\begin{array}{lllllllllllllll}1.00 & 62.13 & 27.37 & 27.66 & 2 & 1682.8276 & 1682.8242 & 842.4194 & 0.0034 & 2.0180 & 4272.210 & 4292.844 & 230.919 & 224.106 & \text { Yes } \\ 1.00 & 76.97 & 25.22 & 25.84 & 2 & 1537.8888 & 1537.8861 & 769.9503 & 0.0027 & 1.7534 & 11768.556 & 7810.919 & 5043.089 & 1519.423 & \text { Yes } \\ 1.00 & 38.51 & 25.24 & 17.93 & 3 & 1537.8892 & 537.8861 & 513.630 & 0.0031 & 2.018 & 622.452 & 655.283 & 225.643 & 75.922 & \end{array}$ $\begin{array}{lllllllllllllll}1.00 & 38.51 & 25.24 & 17.93 & 3 & 1537.8892 & 1537.8861 & 513.6360 & 0.0031 & 2.0118 & 622.452 & 655.283 & 225.643 & 75.922 & \text { Yes }\end{array}$ $\begin{array}{lllllllllllllll}1.00 & 78.87 & 24.46 & 24.63 & 2 & 1537.8906 & 1537.8861 & 769.9503 & 0.0045 & 2.9223 & 13187.959 & 9362.320 & 4970.321 & 1806.110 & \text { Yes }\end{array}$

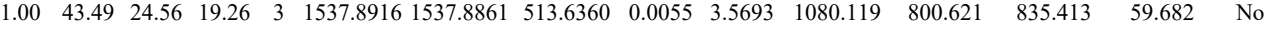

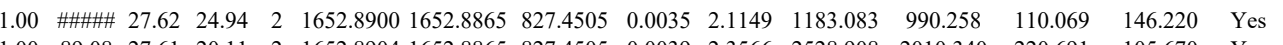
$\begin{array}{lllllllllllllll}1.00 & 89.08 & 27.61 & 20.11 & 2 & 1652.8904 & 1652.8865 & 827.4505 & 0.0039 & 2.3566 & 2528.908 & 2010.340 & 220.691 & 105.670 & \text { Yes }\end{array}$ $\begin{array}{lllllllllllllll}0.70 & 21.36 & 26.15 & 24.13 & 2 & 984.5478 & 984.5474 & 493.2810 & 0.0004 & 0.4054 & 26.490 & 28.085 & 4.599 & 5.187 & \text { Yes } \\ 0.98 & 32.69 & 26.78 & 16.95 & 3 & 3015.5242 & 3015.5174 & 1006.1797 & 0.008 & 2.2527 & 4.952 & 6.753 & 3.853 & 0.000 & \text { No }\end{array}$

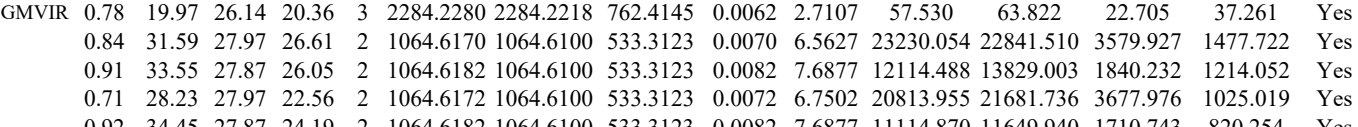

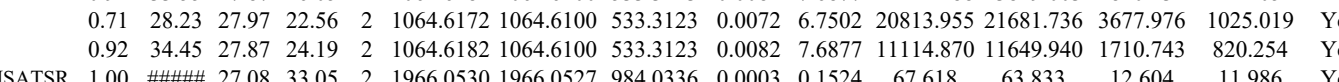
$\begin{array}{llllllllllllll} & \end{array}$

Table S-3 page 217 of 499 


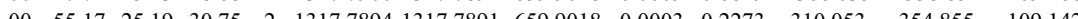

$\begin{array}{llllllllllll}1.00 & \text { \#\#\#\# } 27.65 & 26.14 & 2 & 1831.9454 & 1831.9438 & 916.9792 & 0.0016 & 0.8724 & 822.034 & 110 & \end{array}$

$\begin{array}{lllllllllllll}\text { LQPFATEADVEEALR } & 1.00 & \text { \#\#\#\# } 27.66 & 26.92 & 2 & 1831.9450 & 1831.9438 & 9169792 & 0.0012 & 0.6543 & 397.276 & 469 .\end{array}$

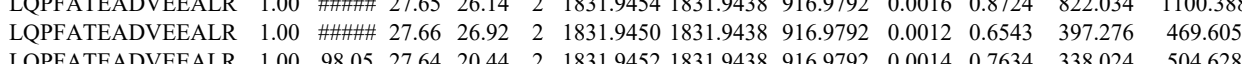

GEDNIDFMPTILSR

FDMIFIVK

CSPIGVYTSGK

LAALPNVYEVISK

LAALPNVYEVISK

GAALPNGYGEVISK

SSIPITVR

GSSAAGLTASVMR

GSSAAGLTASVMR

FGLTTSR

FGLTTSR

FGLTTSR

VLQLMLR

VLQLMLR

VLQLMLR

VLQLMLR

IPGIIIAASAVR

IPGIIIAASAVR

IPGIIIAASAVR

CSVLAAANSVFG

CSVLAAANSVFGR

\begin{tabular}{|llllllllllll}
27.64 & 20.44 & 2 & 1831.9452 & 1831.9438 & 916.9792 & 0.0014 & 0.7634 & 338.024 & 504.628 & 16.928
\end{tabular} $\begin{array}{lllllllllllllll}1.00 & 77.16 & 26.95 & 27.15 & 2 & 1750.8688 & 1750.8682 & 876.4414 & 0.0006 & 0.3423 & 139.459 & 155.164 & 53.052\end{array}$

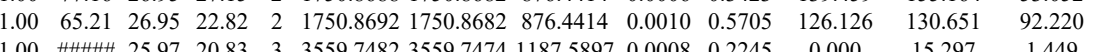

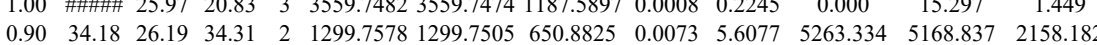

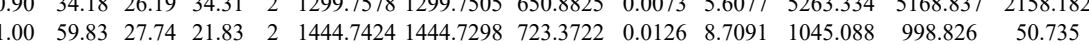
$\begin{array}{llllllllllllll}1.00 & 68.02 & 22.25 & 37.08 & 2 & 1744.0118 & 1704.0065 & 853.0105 & 0.0053 & 3.1066 & 827.316 & 1002.784 & 135.898 \\ 1 & 6.83 & 22.30 & 38.60 & 2 & 1704.0134 & 1704.0065 & 853.0105 & 0.009 & 4.0445 & 462.463 & 652.567 & 72.860\end{array}$ $\begin{array}{lllllllllllll}1.00 & 61.83 & 22.30 & 38.60 & 2 & 1704.0134 & 1704.0065 & 853.0105 & 0.0069 & 4.0445 & 462.463 & 652.567 & 72.860\end{array}$ $\begin{array}{lllllllllllllll}0.73 & 17.06 & 21.93 & 19.56 & 3 & 1704.0157 & 1704.0065 & 569.0094 & 0.0092 & 5.3895 & 297.381 & 317.704 & 108.663\end{array}$ $\begin{array}{lllllllllllllll} & 13.00 & 81.90 & 28.59 & 27.88 & 2 & 1350.7138 & 1350.7047 & 676.3596 & 0.0091 & 6.7271 & 5215.320 & 6349.392 & 2800.323 & 1495.327\end{array}$ $\begin{array}{llllllllllllllll}0.69 & 27.48 & 27.61 & 27.73 & 2 & 1015.6206 & 1015.6148 & 508.8147 & 0.0058 & 5.6995 & 27612.351 & 30838.318 & 13113.941 & 2858.252 & \text { Yes }\end{array}$ $\begin{array}{llllllllllllllllll}0.69 & 27.45 & 27.61 & 26.70 & 2 & 1015.6206 & 1015.6148 & 508.8147 & 0.0058 & 5.6995 & 27449.247 & 29160.776 & 13425.534 & 4464.097 & \text { Yes }\end{array}$ $\begin{array}{llllllllllllllll}1.00 & 89.05 & 28.64 & 29.69 & 2 & 1350.7130 & 1350.7047 & 676.3596 & 0.0083 & 6.1358 & 9108.222 & 10805.816 & 4348.725 & 790.582 & \text { Yes } \\ 1.00 & 86.84 & 28.59 & 27.00 & 2 & 1350.7136 & 1350.7047 & 676.3596 & 0.089 & 6.5793 & 3766.666 & 4146331 & 2071.362 & 1454.427 & \text { Yes }\end{array}$ $\begin{array}{lllllllllllllllll}1.00 & 86.84 & 28.59 & 27.00 & 2 & 1350.7136 & 1350.7047 & 676.3596 & 0.0089 & 6.5793 & 3766.666 & 4146.331 & 2071.362 & 1454.427 & \text { Yes } \\ 0.84 & 21.95 & 26.01 & 23.39 & 2 & 924.5164 & 924.5151 & 463.2648 & 0.0013 & 1.4031 & 28850.007 & 31899.291 & 16825.686 & 6067.039 & \text { Yes }\end{array}$ $\begin{array}{llllllllllllllll}0.84 & 21.95 & 26.01 & 23.39 & 2 & 924.5164 & 924.5151 & 463.2648 & 0.0013 & 1.4031 & 28850.007 & 31899.291 & 16825.686 & 6067.039 & \text { Yes } \\ 0.62 & 16.38 & 25.90 & 23.04 & 2 & 924.5168 & 924.5151 & 463.2648 & 0.0017 & 1.8348 & 29994.975 & 33711.653 & 17102.958 & 6090.565 & \text { Yes } \\ 0.81 & 23.09 & 26.63 & 24.75 & 2 & 924.5182 & 924.5151 & 463.2648 & 0.0031 & 3.348 & 88384.086 & 20799.191 & 1209.898 & 3533.871 & \text { Yes }\end{array}$

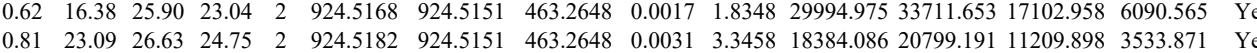

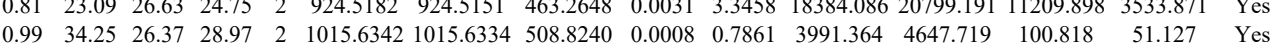

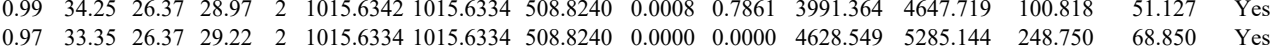
$\begin{array}{llllllllllllllll}0.98 & 34.12 & 26.37 & 29.08 & 2 & 1015.6336 & 1015.6334 & 508.8240 & 0.0002 & 0.1965 & 3516.722 & 3813.283 & 168.227 & 79.618 & \text { Yes }\end{array}$ $\begin{array}{lllllllllllllll}0.99 & 35.36 & 28.18 & 26.91 & 2 & 1031.6296 & 1031.6283 & 516.8214 & 0.0013 & 1.2577 & 1252.057 & 1301.173 & 57.252 & 98.952 & \text { Yes }\end{array}$ $\begin{array}{llllllllllllllll}1.00 & 70.11 & 18.86 & 18.02 & 2 & 1323.8374 & 1323.8360 & 662.9253 & 0.0014 & 1.0559 & 818.687 & 1019.200 & 520.297 & 366.031 & \text { Yes } \\ 0.55 & 35.89 & 18.86 & 48.89 & 3 & 1323.8377 & 1323.8360 & 442.2859 & 0.0017 & 1.2812 & 57.007 & 131.204 & 38.760 & 8.412 & \text { Yes }\end{array}$

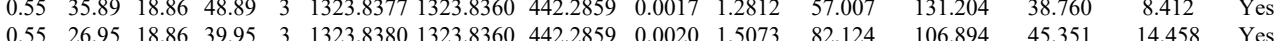

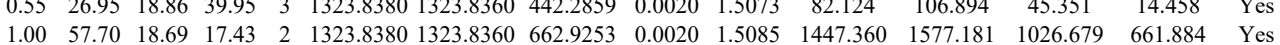

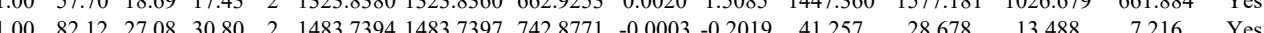

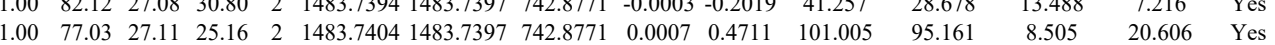

Table S-3 page 218 of 499 
IPGIIIAASAVR IPGIIIAASAVR CSVLAAANSVFGR CSVLAAANSVFGR CSVLAAANSVFGR CSVLAAANSVFGR IPGIIIAASAVR IPGIIIAASAVR CSVLAAANSVFGR CSVLAAANSVFGR CSVLAAANSVF AIACLLFGGSR

AIACLLFGGSR

AIACLLFGGSR

AIACLLFGGSR

AIACLLFGGSR

AIACLLFGGSR

KAIACLLFGGSR

AIACLLFGGSR

AIACLLFGGSR

KAIACLLFGGSR

AIACLLFGGSR

AIACLLFGGSR

IPGIIIAASAVR

AIACLLFGGSR

AIACLLFGGSR

AIACLLFGGSR

AIACLLFGGSR

IPGIIIAASAVR

AIACLLFGGSR

QPPSQFEPLDMK QPMVPESLADYITAAYV QPMVPESLADYITAAYVEM SLEQNIQLPAALLSR FDLLWLIQDRPDR FDLLWLIQDRPDR

LSTALAR

SLEQNIQLPAALLSR

SLEQNIQLPAALIS

SLEQNIQLPAALLSR

FDLLWLIQDRPDR

GSSGVGLTAAVLR

GSSGVGLTAAVLR

SLEQNIQLPAALLSR

FDLLWLIODRPDR

GSSGVGLTAAVLR

GSSGVGLTAAVLR

LAQHITYVHQHSR

\section{AGILTTLNAR}

IAQPGDHVSVTGIFLPILR 0.5

IAQPGDHVSVTCH

AGILTTLNAR

AGILTTLNAR
SEDDESGAGELTR ALLLLLVGGVDQSPR $\begin{array}{ll}\text { ALLLLLVGGVDQSPR } & 0.77 \\ \text { ALLLLLVGGVDQSPR } & 0.53\end{array}$ ALLLLLVGGVDQSP CSILAAANPAYGR
CSILAAANPAYGR CSILAAANPAYGR ALLLLLVGGVDQSPR ALLLLLVGGVDQSPR 0.5 ALLLLLVGGVDQSPR

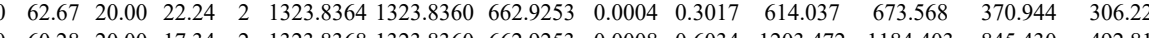
$\begin{array}{lllllllllllllll}60.28 & 20.00 & 17.34 & 2 & 1323.8368 & 1323.8360 & 62.925253 & 0.0008 & 0.6034 & 1203.472 & 1184.403 & 845.430 & 492.81\end{array}$ $\begin{array}{llllllllllllll}1.00 & 84.75 & 27.11 & 26.80 & 2 & 1483.7402 & 1483.7397 & 742.8771 & 0.0005 & 0.3365 & 705.144 & 850.194 & 23.781 \\ 1.00 & 77.86 & 27.11 & 26.08 & 2 & 1483.702 & 1483.7397 & 742.8771 & 0.005 & 0.3365 & 1414.930 & 1395.99 & 76.512\end{array}$ $\begin{array}{lllllllllllll}1.00 & 84.75 & 27.11 & 26.80 & 2 & 1483.7402 & 1483.7397 & 742.8771 & 0.0005 & 0.3365 & 705.144 & 850.194 & 23.781 \\ 1.00 & 77.86 & 27.11 & 26.08 & 2 & 148.7402 & 1483.7397 & 742.8771 & 0.0005 & 0.3365 & 1414.930 & 1395.999 & 76.512\end{array}$ $\begin{array}{lllllllllllll}1.00 & 77.86 & 27.11 & 6.08 & 2 & 1483.7402 & 1483.7397 & 742.8771 & 0.0005 & 0.3365 & 1414.930 & 1395.999 & 76.512 \\ 0.55 & 60.19 & 27.17 & 18.42 & 3 & 1483.7413 & 1483.7397 & 495.5872 & 0.0016 & 1.0762 & 57.472 & 42.322 & 17.115\end{array}$

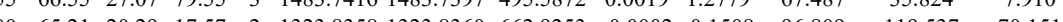
$\begin{array}{lllllllllllll}1.00 & 66.79 & 20.00 & 23.24 & 2 & 1323.8368 & 1323.8360 & 662.9253 & 0.0008 & 0.6034 & 204.327 & 251.988 & 166.174\end{array}$ $\begin{array}{llllllllllll}8.47 & 27.11 & 27.73 & 2 & 1483.7396 & 1483.7397 & 742.8771 & -0.0001 & -0.0673 & 319.796 & 357.645 & 15.366\end{array}$ $\begin{array}{lllllllllllll}81.97 & 27.11 & 23.07 & 2 & 1483.7404 & 1483.7397 & 742.8771 & 0.0007 & 0.4711 & 453.264 & 472.926 & 19.530\end{array}$ $\begin{array}{lllllllllllll}79.59 & 27.18 & 31.13 & 2 & 1483.7414 & 1483.7397 & 742.8771 & 0.0017 & 1.1442 & 83.277 & 125.122 & 0.000\end{array}$ $\begin{array}{lllllllllll}27.18 & 21.13 & 2 & 1483.7444 & 1483.7397 & 74.877 & 0.0017 & 1.1442 & 83.277 & 125.122\end{array}$

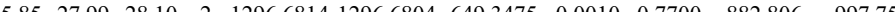
$\begin{array}{llllllllllllll} & \end{array}$ $\begin{array}{llllllllllllll}1.00 & 47.47 & 28.25 & 28.33 & 2 & 1296.6810 & 1296.6804 & 649.3475 & 0.0006 & 0.4620 & 537.033 & 663.747 & 161.4\end{array}$ $\begin{array}{llllllllllllll}1.00 & 61.50 & 28.25 & 22.68 & 2 & 1296.6810 & 1296.6804 & 649.3475 & 0.0006 & 0.4620 & 757.783 & 875.824 & 163.510\end{array}$ $\begin{array}{llllllllllllll}1.00 & 54.87 & 27.99 & 28.72 & 2 & 1296.6814 & 1296.6804 & 649.3475 & 0.0010 & 0.7700 & 706.506 & 816.490 & 153.773\end{array}$ $\begin{array}{lllllllllllll}.00 & 5023 & 27.99 & 2.216 & 2 & 1296.6814 & 1296.6804 & 6493475 & 0.0010 & 0.7700 & 687755 & 740.557 & 148.8\end{array}$ $\begin{array}{lllllllllllll}0.99 & 30.59 & 26.29 & 21.77 & 3 & 1568.8813 & 1568.8774 & 523.9664 & 0.0039 & 2.4811 & 74.775 & 54.504 & 1.757\end{array}$ $\begin{array}{llllllllllllll}100 & 53.65 & 28.18 & 26.35 & 2 & 1296.6808 & 1296.6804 & 649.3475 & 0.0004 & 0.3080 & 513.542 & 5\end{array}$ $\begin{array}{llllllllllll} & \end{array}$ $\begin{array}{llllllllllll}1.00 & 53.61 & 26.62 & 24.03 & 3 & 1568.8801 & 1568.8774 & 523.9664 & 0.0027 & 1.7177 & 107.540 & 78.731\end{array}$ $\begin{array}{llllllllllll}1.00 & 44.29 & 27.99 & 23.93 & 2 & 1296.6816 & 1296.6804 & 649.3475 & 0.0012 & 0.9240 & 126.601 & 129.547\end{array}$ $\begin{array}{lllllllllllll}1.00 & 45.03 & 28.08 & 24.62 & 2 & 1296.6818 & 1296.6804 & 649.3475 & 0.0014 & 1.0780 & 178.876 & 173.692\end{array}$ $\begin{array}{llllllllllll}0.76 & 14.78 & 20.00 & 27.78 & 2 & 1323.8368 & 1323.8360 & 662.9253 & 0.0008 & 0.6034 & 21.109 & 25.710\end{array}$ $\begin{array}{lllllllllllll}1.00 & 47.60 & 27.94 & 20.12 & 2 & 1296.6822 & 1296.6804 & 649.3475 & 0.0018 & 1.3860 & 70.193 & 36.686 \\ \end{array}$ $\begin{array}{llllllllllll}0.90 & 27.36 & 27.89 & 20.56 & 2 & 1296.6832 & 1296.6804 & 649.3475 & 0.0028 & 2.1560 & 42.423 & 19.452\end{array}$ $\begin{array}{llllllllllll}0.97 & 31.64 & 27.99 & 23.36 & 2 & 1296.6814 & 1296.6804 & 649.3475 & 0.0010 & 0.7700 & 8.459 & 9.123 \\ \end{array}$ $\begin{array}{lllllllllllll}0.98 & 33.62 & 27.94 & 24.26 & 2 & 1296.6822 & 1296.6804 & 649.3475 & 0.0018 & 1.3860 & 17.371 & 19.267\end{array}$ $\begin{array}{llllllllllll}0.76 & 16.39 & 20.00 & 29.39 & 2 & 1323.8370 & 1323.8360 & 662.9253 & 0.0010 & 0.7542 & 6.090 & 21.788\end{array}$ $\begin{array}{llllllllllll}0.98 & 34.52 & 27.87 & 19.84 & 2 & 1296.6830 & 1296.6804 & 649.3475 & 0.0026 & 2.0020 & 12.608 & 21.927\end{array}$ $\begin{array}{lllllllllllll}0.68 & 27.95 & 28.27 & 17.02 & 2 & 1703.8860 & 1703.8796 & 852.9471 & 0.0064 & 3.7517 & 764.042 & 768.72\end{array}$ $\begin{array}{lllllllllllll}0.55 & 43.33 & 27.28 & 56.33 & 3 & 2427.1954 & 2427.1936 & 810.0718 & 0.0018 & 0.7407 & 26.118 & 41.194\end{array}$ $\begin{array}{llllllllllll}1.00 & 69.79 & 27.21 & 19.13 & 3 & 2427.1966 & 2427.1936 & 810.0718 & 0.0030 & 1.2345 & 36.326 & 54.234 \\ 0.53 & 57.89 & 27.21 & 70.89 & 3 & 2427.1966 & 2427.1936 & 810.0718 & 0.0030 & 1.2345 & 20.795 & 26.735\end{array}$ $\begin{array}{lllllllllllll} & \end{array}$ $\begin{array}{lllllllllllll} & 26.735 & 12.690\end{array}$ $\begin{array}{llllllllllll} & \end{array}$

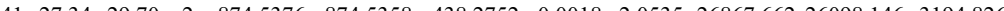

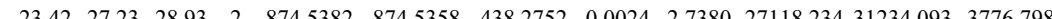
$\begin{array}{llllllllllllll}86.74 & 25.09 & 20.48 & 2 & 1796.0272 & 1796.0277 & 899.0211 & -0.0005 & -0.2781 & 4043.443 & 4946.579 & 1202.484\end{array}$ $\begin{array}{llllllllllllll}0.98 & 26.55 & 27.04 & 18.97 & 3 & 1796.0278 & 1796.027 & 89.0211 & 0.0005 & 0.2781 & 4043.443 & 4946.579 & 1202.484\end{array}$

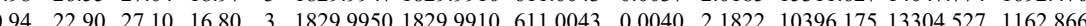

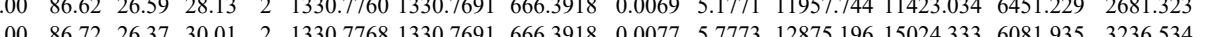
$\begin{array}{lllllllllllllll}1.00 & 98.68 & 25.08 & 22.52 & 2 & 1796.0288 & 1796.0277 & 899.0211 & 0.0011 & 0.6118 & 1038.486 & 917.195 & 242.569 & 7.9\end{array}$ $\begin{array}{lllllllllllllll}0.60 & 13.87 & 27.04 & 19.19 & 3 & 1829.9947 & 1829.9910 & 611.0043 & 0.0037 & 2.0185 & 6209.564 & 7583.464 & 888.738\end{array}$ $\begin{array}{lllllllllllllll}100 & 81.27 & 26.37 & 31.62 & 2 & 1330.7768 & 1330.7691 & 6663918 & 0.0077 & 5.7773 & 6437.950 & 7258.614 & 4105.741\end{array}$ $\begin{array}{llllllllllllll}1.00 & 87.35 & 26.37 & 29.95 & 2 & 1330.7770 & 1330.7691 & 666.3918 & 0.0079 & 5.9274 & 13039.015 & 15910.701 & 7078.012\end{array}$ $\begin{array}{llllllllllllll}0.99 & 21.67 & 27.64 & 16.36 & 4 & 1732.9241 & 1732.9243 & 434.2384 & -0.0002 & -0.1151 & 529.665 & 601.431 & 327.140 \\ 0.55 & 34.94 & 21.99 & 47.94 & 3 & 2176.2511 & 2176.2490 & 726.4236 & 0.0021 & 0.9636 & 1269.182 & 1129.055 & 291.573\end{array}$ $\begin{array}{lllllllllllllll}1.00 & 56.85 & 24.83 & 36.79 & 2 & 1172.7112 & 1172.6999 & 587.3572 & 0.0113 & 9.6193 & 23123.573 & 27414.965 & 6902.867\end{array}$ $\begin{array}{llllllllllllll}0.53 & 55.16 & 21.85 & 68.16 & 3 & 2176.2523 & 2176.2490 & 726.4236 & 0.0033 & 1.5143 & 3283.716 & 3687.065 & 1556.202\end{array}$ $\begin{array}{llllllllllllll}1.00 & 53.31 & 24.83 & 32.24 & 2 & 1172.7110 & 1172.6999 & 587.3572 & 0.0111 & 9.4490 & 13512.520 & 14052.187 & 4884.556 & 93 \\ 1.00 & 56.63 & 24.83 & 31.28 & 2 & 1172.7110 & 1172.699 & 587.3572 & 0.0111 & 9.4490 & 12509.453 & 13928.561 & 4024.60 & 75\end{array}$

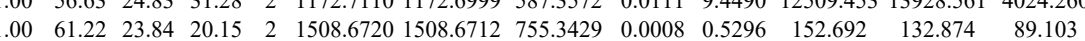
$\begin{array}{lllllllllllll}1.00 & 61.22 & 23.84 & 20.15 & 2 & 1508.6720 & 1508.6712 & 755.3429 & 0.0008 & 0.5296 & 152.692 & 132.874 & 89.103 \\ 0.77 & 98.52 & 20.90 & \# \# \# \# & 2 & 1694.0232 & 1694.0212 & 848.0179 & 0.0020 & 1.1792 & 11.164 & 18.966 & 0.056\end{array}$ $\begin{array}{llllllllll} & \end{array}$ $\begin{array}{llllllllllll}0.53 & 69.90 & 20.97 & 82.90 & 3 & 1694.0239 & 1694.0212 & 565.6810 & 0.0027 & 1.5910 & 36.416 & 71.669\end{array}$ $\begin{array}{lllllllllllll}.00 & 88.70 & 27.80 & 28.76 & 2 & 1495.7410 & 1495.7397 & 748.8771 & 0.0013 & 0.8680 & 1322.016 & 2093.459\end{array}$

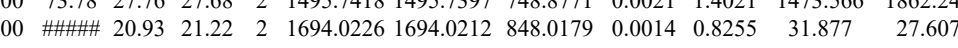
29.636 


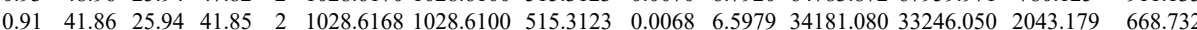
$\begin{array}{lllllllllllllll}0.94 & 44.62 & 25.94 & 42.05 & 2 & 1028.6172 & 1028.6100 & 515.3123 & 0.0072 & 6.9860 & 31994.653 & 36782.350 & 1250.031 & 706.117\end{array}$ $\begin{array}{llllllllllllllll}0.96 & 37.08 & 25.94 & 33.21 & 2 & 1028.6160 & 1028.6100 & 515.3123 & 0.0060 & 5.8217 & 4960.603 & 5449.154 & 734.278 & 356.656\end{array}$ $\begin{array}{lllllllllllllll}0.78 & 24.65 & 25.40 & 23.05 & 2 & 998.5766 & 998.5671 & 500.2908 & 0.0095 & 9.4944 & 15805.269 & 16720.495 & 6711.090 & 4533.571\end{array}$ $\begin{array}{lllllllllllllll}1.00 & 55.91 & 25.97 & 29.50 & 2 & 1278.7522 & 1278.7417 & 640.3781 & 0.0105 & 8.1982 & 9157.484 & 11151.327 & 229.552 & 391.124 & \end{array}$ $\left.\begin{array}{llllllllllllll}1.00 & 53.54 & 26.10 & 30.72 & 2 & 1278.7524 & 1278.7417 & 640.3781 & 0.0107 & 8.3544 & 8763.804 & 9474.667 & 458.028 & 266.493\end{array}\right)$ $\begin{array}{lllllllllllllll} & \end{array}$ $\begin{array}{llllllllllllllll}1.00 & 56.37 & 26.00 & 34.53 & 2 & 1278.7528 & 1278.7417 & 640.3781 & 0.0111 & 8.6667 & 12247.699 & 12857.523 & 953.771 & 1\end{array}$ $\begin{array}{lllllllll}.00 & 55.67 & 25.97 & 25.64 & 3 & 1582.8985 & 1582.8922 & 528.6380 & 0.0\end{array}$

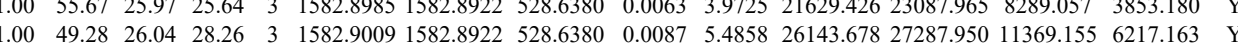
$\begin{array}{lllllllllllllllllll}0.96 & 37.26 & 26.99 & 23.60 & 2 & 1122.6574 & 1122.6528 & 562.3337 & 0.0046 & 4.0901 & 12113.858 & 10977.136 & 3634.063 & 2784.042 & \text { Yes }\end{array}$ $\begin{array}{lllllllllllllllll}1.00 & 52.73 & 27.13 & 24.01 & 2 & 1404.8000 & 1404.7890 & 703.4018 & 0.0110 & 7.8191 & 9703.990 & 9421.892 & 3005.587 & 931.323 & \text { Yes } & \\ \end{array}$ $\begin{array}{lllllllllllllll}1.00 & 49.44 & 27.09 & 24.80 & 2 & 1404.8010 & 1404.7890 & 703.4018 & 0.0120 & 8.5299 & 10596.649 & 10591.537 & 2938.622 & 512.156 & \text { Yes }\end{array}$ $\begin{array}{lllllllllllllll}1.00 & 66.67 & 25.55 & 24.16 & 2 & 1741.8086 & 1741.8007 & 871.9076 & 0.0079 & 4.5303 & 1458.001 & 1457.526 & 647.506 & 705.026 & \text { No }\end{array}$ $\begin{array}{lllllllllllllll}0.99 & 47.18 & 28.36 & 25.44 & 2 & 1133.6636 & 1133.6648 & 567.8397 & -0.0012 & -1.0566 & 516.412 & 517.829 & 164.502 & 66.429 & \text { Yes }\end{array}$ $\begin{array}{llllllllllllllll}0.99 & 39.91 & 27.09 & 25.56 & 2 & 1404.8010 & 1404.7890 & 703.4018 & 0.0120 & 8.5299 & 5893.116 & 5838.947 & 1693.593 & 957.440 & \text { Yes }\end{array}$

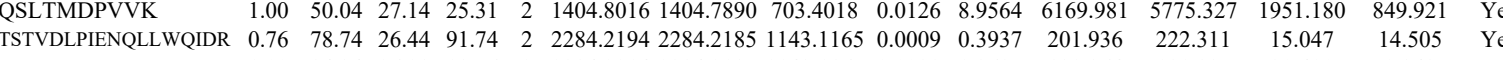
$\begin{array}{lllllllllllllllll} & & \end{array}$ $\begin{array}{lllllllllllllllll} & \end{array}$

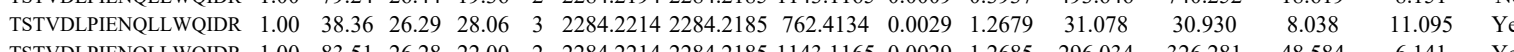

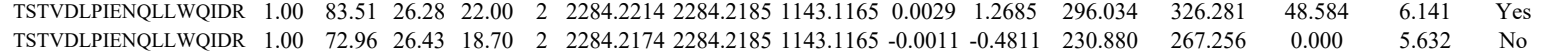

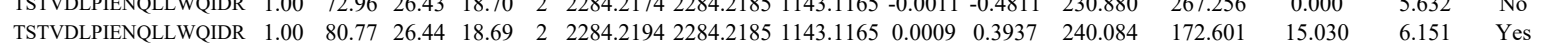

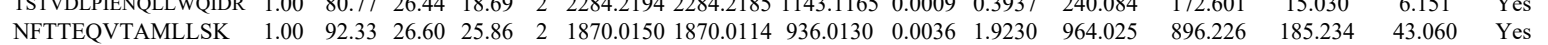

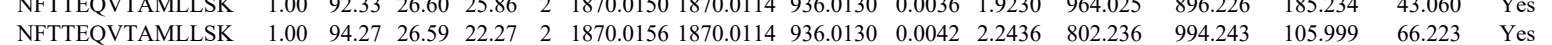
$\begin{array}{llllllllllllllll}\text { NFTTEQVTAMLLSK } & 0.96 & 27.95 & 26.62 & 15.26 & 3 & 1870.0171 & 1870.0114 & 624.3444 & 0.0057 & 3.0432 & 228.250 & 163.995 & 104.206 & 54.586 & \text { Yes }\end{array}$

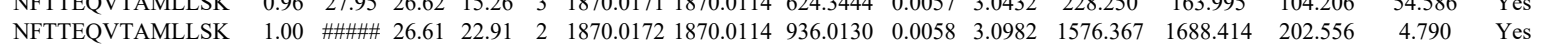

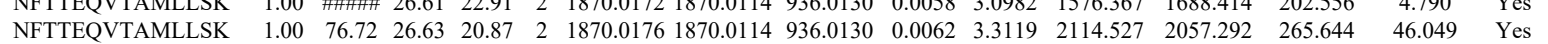
$\begin{array}{llllllllllllllll}\text { NFTTEQVTAMLLSK } & 0.87 & 24.24 & 26.58 & 20.93 & 3 & 1870.0192 & 1870.0114 & 624.3444 & 0.0078 & 4.1644 & 213.837 & 281.056 & 99.215 & 33.723 & \text { Yes }\end{array}$ $\begin{array}{llllllllllllllllll}\text { NFTTEQVTAMLLSK } & 0.97 & 31.00 & 26.58 & 19.09 & 3 & 1870.0192 & 1870.0114 & 624.3444 & 0.0078 & 4.1644 & 180.793 & 205.657 & 124.616 & 109.654 & \text { No }\end{array}$ $\begin{array}{llllllllllllllll}\text { SNLAYDIVQLPTGLTGIK } & 0.69 & 95.05 & 21.70 & \# \# \# \# \quad 2 \quad 2190.2534 & 2190.2504 & 1096.1325 & 0.0030 & 1.3684 & 947.705 & 553.591 & 320.967 & 185.258 & \text { No }\end{array}$ $\begin{array}{llllllllllllllll}\text { SNLAYDIVQLPTGLTGIK } & 0.69 & 85.83 & 21.70 & 98.83 & 2 & 2190.2534 & 2190.2504 & 1096.1325 & 0.0030 & 1.3684 & 608.739 & 602.192 & 157.525 & 108.393 & \text { Yes }\end{array}$ $\begin{array}{lllllllllllllllll}\text { SNLAYDIVQLPTGLTGIK } & 0.99 & 23.95 & 21.64 & 19.82 & 3 & 2190.2542 & 2190.2504 & 731.0907 & 0.0038 & 1.7326 & 172.970 & 178.842 & 49.555 & 176.278 & \text { No }\end{array}$ $\begin{array}{llllllllllllllll}\text { VLATAFDTTLGGR } & 1.00 & 80.05 & 27.97 & 37.22 & 2 & 1464.8064 & 1464.8058 & 733.4102 & 0.0006 & 0.4090 & 15724.214 & 15794.458 & 103.077 & 137.885 & \text { Yes }\end{array}$ $\begin{array}{lllllllllllllllll}\text { VLATAFDTTLGGR } & 1.00 & 84.22 & 28.03 & 37.58 & 2 & 1464.8076 & 1464.8058 & 733.4102 & 0.0018 & 1.2271 & 20944.063 & 21584.509 & 0.000 & 273.618 & \text { No }\end{array}$

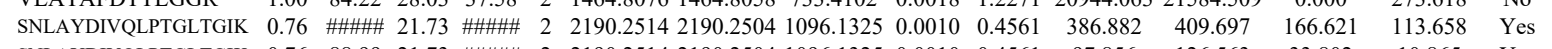

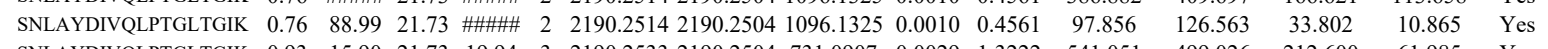

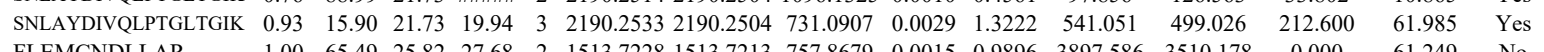

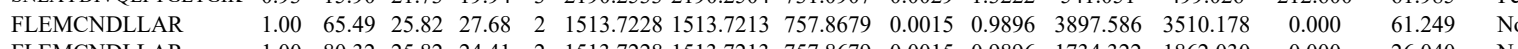

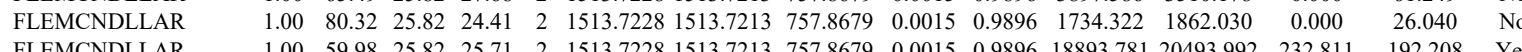

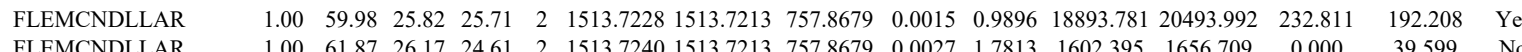

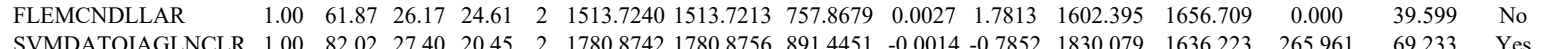
$\begin{array}{llllllllllllllll}\text { SVMDATQIAGLNCLR } & 1.00 & 82.02 & 27.40 & 20.45 & 2 & 1780.8742 & 1780.8756 & 891.4451 & -0.0014 & -0.7852 & 1830.079 & 1636.223 & 265.961 & 69.233 & \text { Yes } \\ \text { SVMDATQIAGLNCLR } & 1.00 & 88.09 & 27.38 & 25.31 & 2 & 1780.8760 & 1780.8756 & 891.4451 & 0.0004 & 0.2244 & 971.721 & 1156.775 & 204.893 & 71.097 & \text { Yes }\end{array}$ $\begin{array}{llllllllllllllll}\text { SVMDATQIAGLNCLR } & 1.00 & 88.09 & 27.38 & 25.31 & 2 & 1780.8760 & 1780.8756 & 891.4451 & 0.0004 & 0.2244 & 971.721 & 1156.775 & 204.893 & 71.097 & \text { Yes } \\ \text { FLEMCNDLLAR } & 1.00 & 58.92 & 26.01 & 25.18 & 2 & 1513.7232 & 1513.7213 & 757.8679 & 0.0019 & 1.2535 & 5409.493 & 5218.516 & 99.061 & 12.991 & \text { Yes }\end{array}$ $\begin{array}{lrllllllllllllll}\text { FLENCNLLAR } & 1.00 & 8.76 & 25.90 & 34.17 & 2 & 1513.7236 & 1513.713 & 57.867 & 0.0023 & 1.5174 & 824.471 & 672.777 & 0.000 & 17.081 & \text { No }\end{array}$ 

SVMDATQIAGLNCL FLEMCNDLLAR $\begin{array}{lllllllllllll}1.00 & 89.14 & 27.47 & 26.62 & 2 & 1780.8774 & 1780.8756 & 891.4451 & 0.0018 & 1.0096 & 3331.842 & 379.394 & 471.469\end{array}$ LEMCNDLLAR $\begin{array}{llllllllllllll}1.00 & 62.38 & 25.69 & 25.47 & 2 & 1513.7218 & 1513.7213 & 757.8679 & 0.0005 & 0.3299 & 1182.837 & 1137.224 & 7.150 \\ 1.00 & 61.50 & 25.85 & 26.74 & 2 & 1513.7224 & 1513.7213 & 757.8679 & 0.0011 & 0.7257 & 636.021 & 538.217 & 14555 & 0 \\ 1.00 & & 26.13 & 21.07 & 2 & 1770.8202 & 1770.8185 & 886.4165 & 0.0017 & 0.9589 & 443.461 & 363.428 & 232.833 & 17\end{array}$ AESEEMETSQAGSK AESEEMETSQAGSK VLTFYR

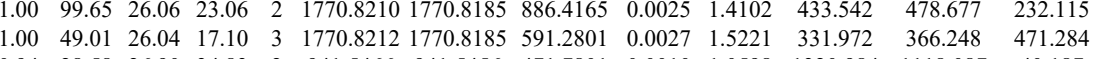
$\begin{array}{lllllllllllll}0.94 & 28.58 & 26.90 & 34.83 & 2 & 941.5466 & 941.5456 & 471.7801 & 0.0010 & 1.0598 & 1320.984 & 1118.087 & 40.187\end{array}$ $\begin{array}{llllllllllllll}0.54 & 23.09 & 28.65 & 21.01 & 2 & 1247.6794 & 1247.6675 & 624.8410 & 0.0119 & 9.5223 & 4951.237 & 5693.468 & 622.384\end{array}$

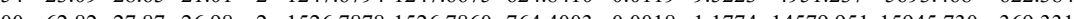

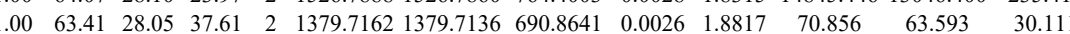

QDLPALEEKPR

SQGGEPTYNVAVGR $\begin{array}{lllllllllllll}1.03 .06 & 28.03 & 37.85 & 2 & 1577.7992 & 1577.7920 & 789.9033 & 0.0072 & 4.5575 & 6544.508 & 5904.849 & 9402.632 & 4462.277\end{array}$ SOGGEPTYNVAVGR $\begin{array}{lllllllllllllll}1.00 & 82.66 & 27.28 & 31.99 & 2 & 1577.7928 & 1577.7920 & 789.9033 & 0.0008 & 0.5064 & 4756.966 & 5369.496 & 8508.169 & 4065.908 & \\ 1.00 & 90.05 & 27.36 & 30.19 & 2 & 1577.7942 & 1577.7920 & 789.9033 & 0.0022 & 1.3926 & 3836.724 & 4099.338 & 6848.067 & 3645.580 & \end{array}$ VLVFVMGK VLVFVMGK

21 ALKPEVDK $\begin{array}{lllllllllllllll}1.00 & 49.28 & 23.07 & 26.57 & 2 & 1179.7318 & 1179.7293 & 590.8719 & 0.0025 & 2.1155 & 15853.323 & 11679.311 & 465.809 & 578.497 & Y\end{array}$ $\begin{array}{llllllllllllllll}1.00 & 48.81 & 23.07 & 26.50 & 2 & 1179.7326 & 1179.7293 & 590.8719 & 0.0033 & 2.7925 & 4907.793 & 4068.754 & 383.996 & 704.237 & \text { Yes }\end{array}$

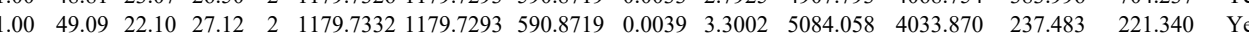
$\begin{array}{lllllllllllllll}0.86 & 13.56 & 22.65 & 20.01 & 3 & 1330.8202 & 1330.8186 & 444.6135 & 0.0016 & 1.1995 & 7581.009 & 9559.405 & 5050.721 & 1040.892 & \text { Yes }\end{array}$ NTSDVISAAK

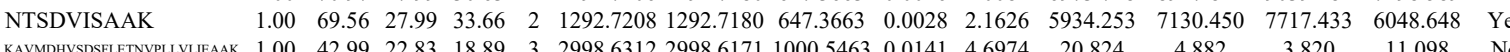
$\begin{array}{llllllllllll} & \end{array}$

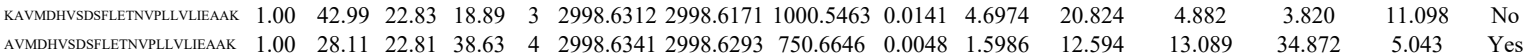

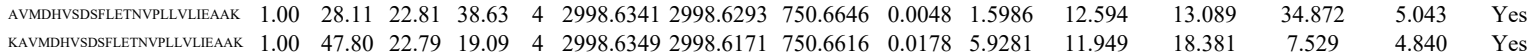

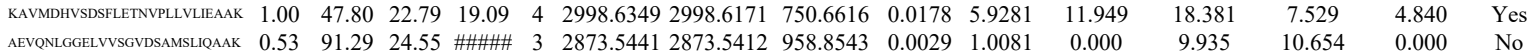

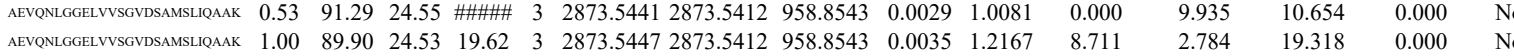

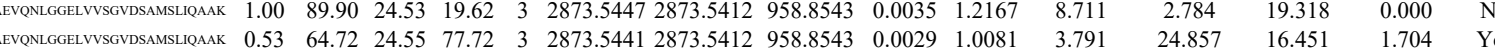

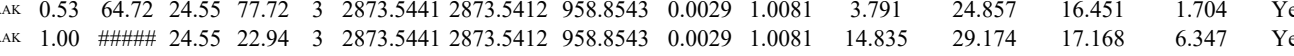
$\begin{array}{lllllllllllllll} & \end{array}$

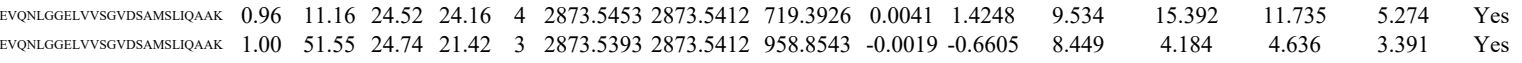
$\begin{array}{llllllllllllllll} & \end{array}$

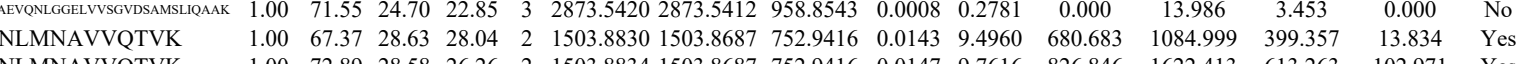
$\begin{array}{llllllllllllllllll} & \\ \text { NLMNAVVQTVK } & 1.00 & 72.89 & 28.58 & 26.26 & 2 & 1503.8834 & 1503.8687 & 752.9416 & 0.0147 & 9.7616 & 826.846 & 1622.413 & 613.263 & 102.971 & \text { Yes }\end{array}$ $\begin{array}{llllllllllllllll}\text { NLMNAVVQMADS } & 1.00 & 7.89 & 28.58 & 26.26 & 2 & 1503.8834 & 1503.8687 & 752.9416 & 0.0147 & 9.7616 & 826.846 & 1622.413 & 613.263 & 102.971 & \text { Ye } \\ \text { LESIISGAALMADSCTR } & 0.66 & 14.19 & 27.40 & 23.15 & 3 & 2013.9685 & 2013.9655 & 672.3291 & 0.0030 & 1.4874 & 37.373 & 72.810 & 121.210 & 56.624 & \text { Yes } \\ \text { ALLSAVTR } & 0.96 & 40.00 & 26.29 & 35.37 & 2 & 973.6102 & 973.6042 & 487.8094 & 0.0060 & 6.1499 & 14066.729 & 19908.717 & 2024.129 & 1005.613 & \text { Yes } \\ \text { AVLMIR } & 0.76 & 23.37 & 24.77 & 21.61 & 2 & 845.5322 & 845.5279 & 423.7712 & 0.0043 & 5.0735 & 19957.177 & 28592.078 & 3521.080 & 1419.927 & \text { Yes }\end{array}$

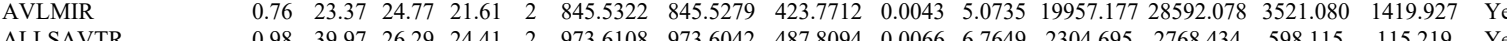

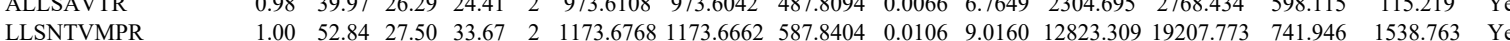

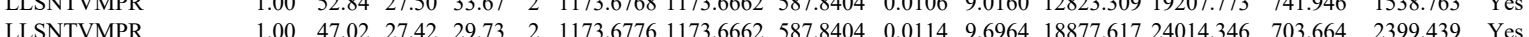

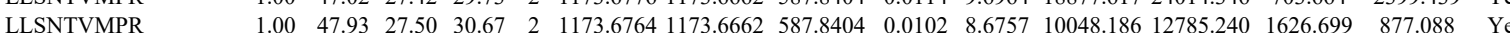

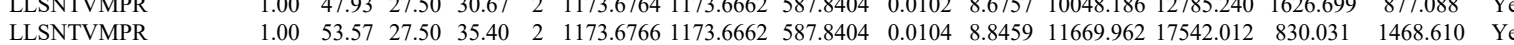
$\begin{array}{lllllllllllllll}\text { TSVQTEDDQLIAGQSAR } & 1.00 & \text { \#\#\#\# } 27.63 & 34.46 & 2 & 1961.9844 & 1961.9776 & 981.9961 & 0.0068 & 3.4623 & 74.083 & 98.804 & 51.155 & 5.549 & \text { Yes }\end{array}$

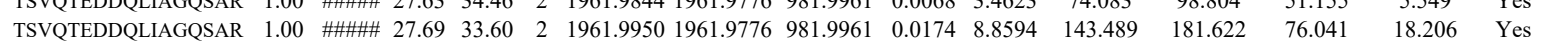

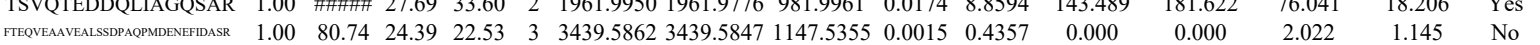

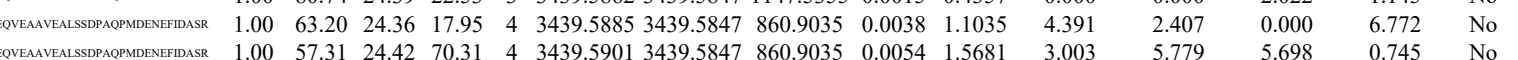

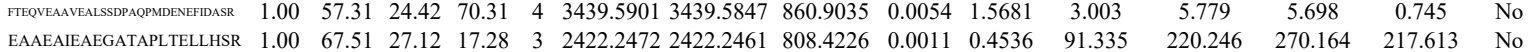
$\begin{array}{llllllllllllllll}\text { EAAEAiEAEGATAPLtELLHSR } & 1.00 & 64.28 & 27.19 & 19.72 & 3 & 2422.2532 & 2422.2461 & 808.4226 & 0.0071 & 2.9275 & 68.637 & 77.418 & 139.384 & 119.049 & \text { No }\end{array}$ $\begin{array}{lllllllllllllllll}\text { AAVMVHQLSK } & 0.93 & 19.03 & 25.53 & 16.95 & 3 & 1370.7970 & 1370.7948 & 457.9389 & 0.0022 & 1.6014 & 14934.626 & 18109.911 & 7869.132 & 1209.013 & \text { Yes }\end{array}$ $\begin{array}{llllllllllllllll}\text { LHYGLPVVVK } & 0.56 & 13.46 & 19.03 & 19.44 & 3 & 1411.8907 & 1411.8795 & 471.6338 & 0.0112 & 7.9157 & 14231.484 & 11688.437 & 2961.087 & 1730.468 & \text { Yes }\end{array}$

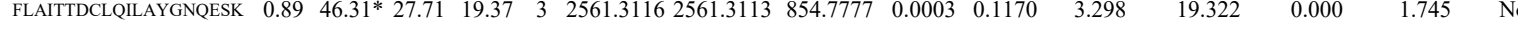
$\begin{array}{llllllllllllllll}\text { SPQMVSAIVR } & 1.00 & 59.26 & 28.41 & 29.54 & 2 & 1230.6938 & 1230.6876 & 616.3511 & 0.0062 & 5.0296 & 8654.127 & 9618.265 & 15650.829 & 8923.047 & \text { No }\end{array}$ $\begin{array}{llllllllllllllll}\text { SPQMVSAIVR } & 1.00 & 52.82 & 28.41 & 33.21 & 2 & 1230.6946 & 1230.6876 & 616.3511 & 0.0070 & 5.6785 & 6816.610 & 9441.679 & 9789.720 & 7075.238 & \text { Yes }\end{array}$ $\begin{array}{llllllllllllllll}\text { CTAGTLHNLSHHR } & 1.00 & 44.95 & 26.43 & 30.05 & 4 & 1635.7817 & 1635.7844 & 409.9534 & -0.0027 & -1.6465 & 4256.845 & 5380.802 & 1281.363 & 851.939 & \text { Yes }\end{array}$ LLHPPSHWPLIK LLHPPSHWPLIK

LVQLLVR LVQLLVR
LVQLLVR $\begin{array}{lllllllllllllll}1.00 & 24.19 & 20.79 & 27.02 & 4 & 1725.0337 & 1725.0334 & 432.2656 & 0.0003 & 0.1735 & 3168.154 & 5303.553 & 56.686 & 93.314\end{array}$ $\begin{array}{ccccccccccccccc}1.00 & 28.10 & 20.64 & 15.76 & 4 & 1725.0345 & 1725.0334 & 432.2656 & 0.0011 & 0.6362 & 3513.818 & 5291.967 & 0.000 & 93.925 & \mathrm{No} \\ 0.98 & 32.90 & 14.91 & 26.69 & 2 & 983.6602 & 983.6613 & 492.8379 & -0.0011 & -1.1160 & 7226.712 & 11395.272 & 428.776 & 228.888 & \mathrm{Y}\end{array}$ $\begin{array}{llllllllllllllll}1.00 & 33.69 & 14.91 & 27.94 & 2 & 983.6620 & 983.6613 & 492.8379 & 0.0007 & 0.7102 & 11723.148 & 17475.492 & 697.447 & 542.861 & \text { Yes } \\ 0.54 & 4.24 & 14.91 & 16.84 & 2 & 983.6620 & 983.6613 & 492.8379 & 0.0007 & 0.7102 & 43.449 & 35.487 & 34.397 & 2.844 & \text { Yes }\end{array}$

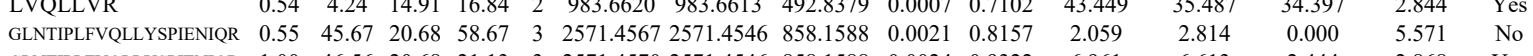

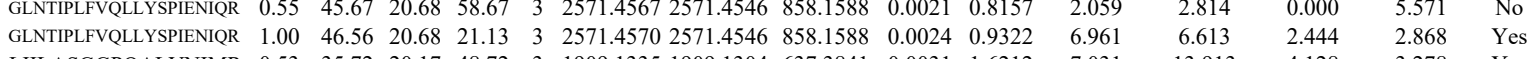

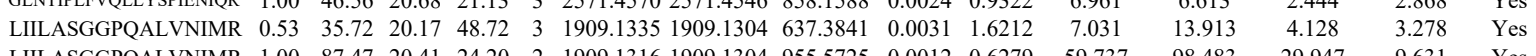

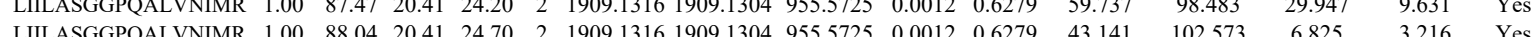

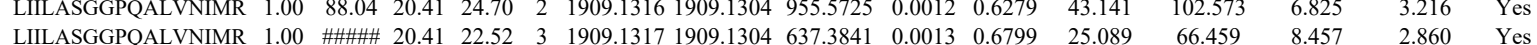

Table S-3 page 221 of 499 
$\begin{array}{llllll}1254 & 642.7157 & 0.0008 & 0.4149 & 31.574 & 57.162\end{array}$

$\begin{array}{llllll} & \\ 0\end{array}$

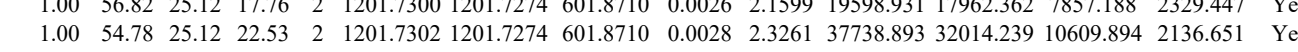
$\begin{array}{lllllllllllllll} & \end{array}$ $\begin{array}{llllllllllll} & \end{array}$ $\begin{array}{lllllllll} & \text { A A }\end{array}$

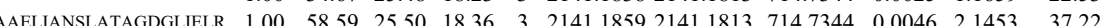
$\begin{array}{llllllllllll}\text { VLPSITTEILK } & 1.00 & 59.88 & 17.71 & 31.74 & 2 & 1500.9412 & 1500.9371 & 751.4758 & 0.0041 & 2.7280 & 822.383\end{array}$ VLPSITTEILK $\begin{array}{llllllllllll}1.00 & 59.88 & 17.71 & 31.74 & 2 & 1500.9412 & 1500.9371 & 751.4758 & 0.0041 & 2.7280 & 822.383\end{array}$ $\begin{array}{llllllllllllll}\text { AAELIANSLATAGDGLIELR } & 1.00 & 30.31 & 25.48 & 16.33 & 3 & 2141.1838 & 2141.1813 & 714.7344 & 0.0025 & 1.1659 & 37.649\end{array}$

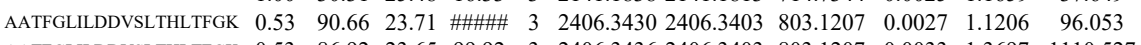
$\begin{array}{lllllllllllll}\text { AATFGLILDDVSLTHLTFGK } & 0.53 & 86.92 & 23.65 & 99.92 & 3 & 2406.3436 & 2406.3403 & 803.1207 & 0.0033 & 1.3697 & 1110.527 & 89\end{array}$ $\begin{array}{lllllllllllll}\text { AATFGLLLDVVSLTHLTFGK } & 1.00 & 75.06 & 23.67 & 23.60 & 3 & 2406.3439 & 2406.3403 & 803.1207 & 0.0036 & 1.4942 & 80.504\end{array}$ $\begin{array}{llllllllllllll}\text { AATFGLILDDVSLTHLTFGK } & 1.00 & 92.74 & 23.69 & 20.81 & 3 & 2406.3448 & 2406.3403 & 803.1207 & 0.0045 & 1.8677 & 533.666\end{array}$ $\begin{array}{lllllllllllll}\text { NITYLPAGQSVLLQLPQ } & 0.77 & 21.86 & 24.71 & 34.86 & 2 & 1998.1294 & 1998.1272 & 1000.0709 & 0.0022 & 1.0999 & 97.036\end{array}$ $\begin{array}{llllllllllllll} & \text { NQDINGEGTHFLIPWVOKPIFPCR } & 1.00 & 44.07 & 23.48 & 19.18 & 4 & 3399.8113 & 3399.8080 & 850.9593 & 0.0033 & 0.9695 & 107.125\end{array}$

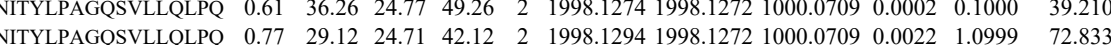
$\begin{array}{llllllllllll}\text { GVQDIVGEGTHFLLPWVQKPIIFCR } & 1.00 & 45.51 & 23.28 & 17.58 & 4 & 3399.8129 & 3399.8080 & 850.9593 & 0.0049 & 1.4395 & 239.896\end{array}$

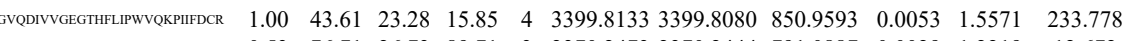

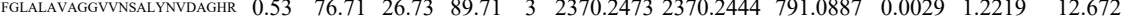

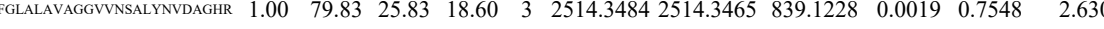

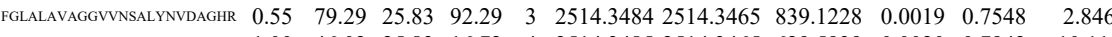
$\begin{array}{llllllllllll}\text { FGLALAVAGGVVNSALYNVDAGHR } & 1.00 & 46.02 & 25.83 & 16.72 & 4 & 2514.3485 & 2514.3465 & 629.5939 & 0.0020 & 0.7942 & 10.119 \\ \text { FGLALAVAGGVVNSALYNVDAGHR } & 1.00 & 76.37 & 25.75 & 18.25 & 4 & 2514.3493 & 2514.3465 & 629.5939 & 0.0028 & 1.1118 & 15.850\end{array}$

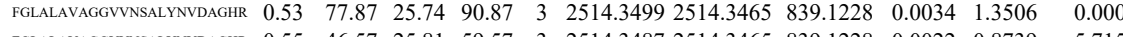

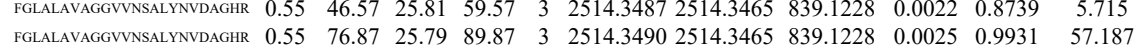

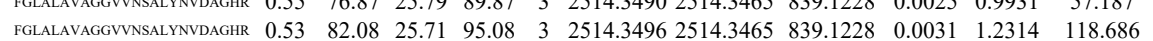

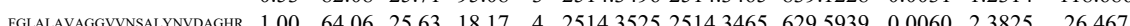

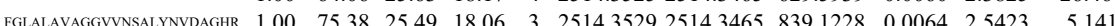

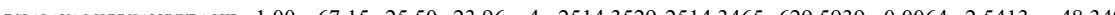
$\begin{array}{lllllllllllll}\text { FGLALAVAGGVVNSALYNVDAGHR } & 1.00 & 74.40 & 25.24 & 25.21 & 3 & 2514.3574 & 2514.3465 & 839.1228 & 0.0109 & 4.3299 & 6.695\end{array}$ $\begin{array}{llllllllllll}\text { FGLALAVAGGVNSALYYNVAGGHR } & 0.99 & 42.19 & 25.15 & 32.24 & 3 & 2514.3586 & 2514.3465 & 839.1228 & 0.0121 & 4.8066 & 3.695\end{array}$ $\begin{array}{llllllllllll}\text { FGLALAVAGGVNSALYNVDAGHR } & 1.00 & 59.23 & 25.16 & 22.13 & 3 & 2514.3595 & 2514.3465 & 839.1228 & 0.0130 & 5.1641 & 39.230\end{array}$ $\begin{array}{llllllllllll}\text { FGLALAVAGGVVNSALYNVDAGHR } & 1.00 & 59.73 & 25.02 & 41.15 & 3 & 2514.3607 & 2514.3465 & 839.1228 & 0.0142 & 5.6408 & 18.380\end{array}$

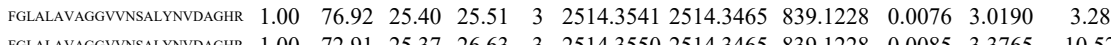

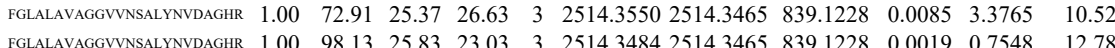
$\begin{array}{llllllllllllll}\text { FGLALAVAGGVVNSALYNVDAGHR } & 1.00 & 98.13 & 25.83 & 23.03 & 3 & 2514.3484 & 2514.3465 & 839.1228 & 0.0019 & 0.7548 & 10.783 \\ \text { FGLLLAGGG }\end{array}$

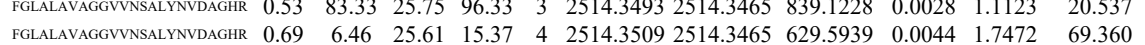
$\begin{array}{llllllllllll}\text { FGLALAVAGGVVNSALYNVDAGHR } & 0.53 & 61.92 & 25.75 & 74.92 & 3 & 2514.3493 & 2514.3465 & 839.1228 & 0.0028 & 1.1123 & 30.122\end{array}$ $\begin{array}{lllllllllllll}\text { FGLALAVAGGVNSALYNVDAGHR } & 0.53 & 98.32 & 25.75 & \text { \#\#\#\# } & 2514.3493 & 2514.3465 & 839.1228 & 0.0028 & 1.1123 & 11.939\end{array}$ $\begin{array}{lllllllllllll}\text { FOLALAVAGGVNSALYNVDAGHR } & 1.00 & 59.53 & 25.33 & 26.55 & 3 & 2514.3559 & 2514.3465 & 839.1228 & 0.0094 & 3.7340 & 7.843 \\ \text { ILFRPVASQLPR } & 0.7 & 23.56 & 24.61 & 2.84 & 3 & 1395.834 & 1395.835 & 466.2856 & -0.0003 & -0.245 & 12.032\end{array}$ $\begin{array}{llllllllllll} & \end{array}$ FTSIGEDYDER

$\begin{array}{llllllllllll}1.00 & 70.95 & 25.83 & 22.43 & 2 & 1587.7560 & 1587.7538 & 794.8842 & 0.0022 & 1.3838 & 1481.084 & \end{array}$

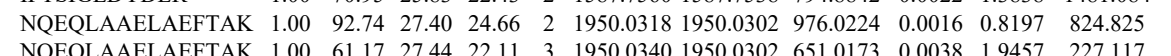
$\begin{array}{llllllllllll}\text { NQEQLAAELAEFTAK } & 1.00 & 61.17 & 27.44 & 22.11 & 3 & 1950.0340 & 1950.0302 & 651.0173 & 0.0038 & 1.9457 & 227.117 \\ \text { NQEQLAAELAEFTAK } & 1.00 & 65.74 & 27.44 & 20.44 & 3 & 1950.0340 & 1950.0302 & 651.0173 & 0.0038 & 1.9457 & 202.678\end{array}$ $\begin{array}{lllllllllllll}\text { NQEQLAAELAEFTAK } & 0.80 & 16.72 & 27.36 & 17.63 & 3 & 1950.0325 & 1950.0302 & 651.0173 & 0.0023 & 1.1776 & 341.334\end{array}$ $\begin{array}{llllllllllll}\text { NQEQLAAELAEFTAK } & 0.53 & 40.98 & 27.40 & 53.98 & 3 & 1950.0334 & 1950.0302 & 651.0173 & 0.0032 & 1.6385 & 263.308 \\ \text { FFPEDVSEELIEEITQR } & 1.00 & 93.37 & 27.80 & 26.46 & 2 & 2223.1234 & 2223.1181 & 11125663 & 0.0053 & 2.3819 & 111.102\end{array}$ $\begin{array}{lllllllllllll}\text { FFPEDVSEELIQEITQR } & 1.00 & 93.37 & 27.80 & 26.46 & 2 & 2223.1234 & 2223.1181 & 1112.5663 & 0.0053 & 2.3819 & 111.102 \\ \text { AFAAQEDLEK } & 1.00 & 66.69 & 28.63 & 26.13 & 2 & 1408.7490 & 1408.7442 & 705.3794 & 0.0048 & 3.4024 & 630.382\end{array}$ AFAAQEDLEK

$\begin{array}{lllllllllllll}1.00 & 66.69 & 28.63 & 26.13 & 2 & 1408.7490 & 1408.7442 & 705.3794 & 0.0048 & 3.4024 & 630.382 & 66.165\end{array}$

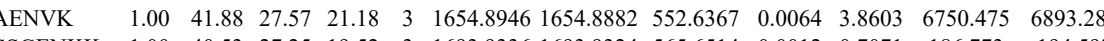

NFAQLTVSGSR

NFAQLTVSGSR $\begin{array}{llllllllllll}1.00 & 54.83 & 25.67 & 18.55 & 4 & 3373.7405 & 3373.7357 & 844.4412 & 0.0048 & 1.4211 & 47.170\end{array}$ 
VPYTDDGLEAIFTAQGD $\begin{array}{lllllllllll}0.77 & 78.09 & 28.12 & 91.09 & 2 & 2355.1554 & 2355.1539 & 1178.5842 & 0.0015 & 0.6364 & 55.989\end{array}$ $\begin{array}{llllllllllll}\text { VPYTDDGLEAIFTAQGDMR } & 1.00 & 35.73 & 28.05 & 16.24 & 3 & 2355.1561 & 2355.1539 & 786.0586 & 0.0022 & 0.9329 & 47.995 \\ \text { VPYTDDGLEAIFTAQGDMR } & 1.00 & 40.56 & 28.08 & 16.91 & 3 & 2355.1576 & 2355.1539 & 786.0586 & 0.0037 & 1.5690 & 61.164\end{array}$ $\begin{array}{lllllllllllll}\text { NPYTDDGLEAIIFTAQGDMR } & 1.00 & 40.56 & 28.08 & 16.91 & 3 & 2355.1576 & 2355.1539 & 786.0586 & 0.0037 & 1.5690 & 61.164\end{array}$ $\begin{array}{llllllllllll}\text { IAEGVNSLLQMAGLLAR } & 1.00 & 71.02 & 25.98 & 28.90 & 2 & 1915.0692 & 1915.0682 & 958.5414 & 0.0010 & 0.5216 & 9.410 \\ \text { IAEGVNSLLOMAGLLAR } & 1.00 & \text { \#\#\#\# } & 25.04 & 32.49 & 2 & 1899.0744 & 1899.0733 & 950.5439 & 0.0011 & 0.5786 & 88.290\end{array}$ $\begin{array}{llllllllllll}\text { IAEGVNSLLQMAGLLAR } & 1.00 & \text { malm } & 25.04 & 32.49 & 2 & 1899.0744 & 1899.0733 & 950.5439 & 0.0011 & 0.5786 & 88.290 \\ \text { IAEGVNSLLMAGLLAR } & 1.00 & 96.93 & 25.04 & 27.81 & 2 & 1899.0744 & 1899.0733 & 950.5439 & 0.0011 & 0.5786 & 148.695\end{array}$ $\begin{array}{llllllllllllll} & \text { IAEGNSLQMALAR } & 1.00 & 6.93 & 25.04 & 27.81 & 2 & 1899.0744 & 1899.0733 & 950.5439 & 0.0011 & 0.5786 & 148.695\end{array}$

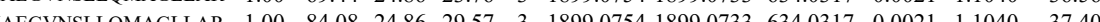
$\begin{array}{llllllllllll}\text { IAEGVNSLLQMAGLLAR } & 1.00 & 52.22 & 24.80 & 22.58 & 3 & 1899.0763 & 1899.0733 & 634.0317 & 0.0030 & 1.5772 & 32.263\end{array}$ $\begin{array}{llllllllllll}\text { AEGVNSLLQMAGLLAR } & 1.00 & 61.79 & 24.79 & 29.12 & 3 & 1899.0766 & 1899.0733 & 634.0317 & 0.0033 & 1.7349 & 23.722\end{array}$ $\begin{array}{lllllllllllll}\text { VPADLGaEAgLQQLLGalr } & 1.00 & 59.95 & 23.46 & 17.02 & 3 & 2035.1566 & 2035.1548 & 679.3922 & 0.0018 & 0.8831 & 115.768\end{array}$ $\begin{array}{lllllllllllll}\text { VPADLGAEAGLQQLLGALR } & 0.55 & 69.11 & 23.42 & 82.11 & 3 & 2035.1569 & 2035.1548 & 679.3922 & 0.0021 & 1.0303 & 136.948\end{array}$

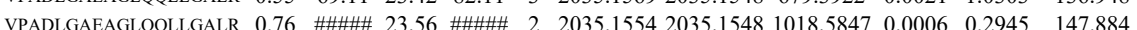
$\begin{array}{lllllllllll}\text { VPADLGAEAGLQQLLGALR } & 0.69 & \# \# \# \# \text { 23.36 \#\#\#\# } 202035.15742035 .1548 & 1018.5847 & 0.0026 & 1.2763 & 307.138\end{array}$ $\begin{array}{llllllllllll}\text { VPADLGAEAGLQQLLGALR } & 0.53 & 67.66 & 23.36 & 80.66 & 3 & 2035.1575 & 2035.1548 & 679.3922 & 0.0027 & 1.3247 & 108.843\end{array}$ $\begin{array}{lllllllllllll}\text { VPADLGAEAGLQQLLGALR } & 1.00 & 28.43 & 23.32 & 18.09 & 3 & 2035.1581 & 2035.1548 & 679.3922 & 0.0033 & 1.6191 & 84.199\end{array}$

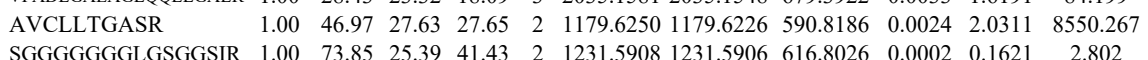
$\begin{array}{lllllllllllll}\text { SGGGGGGGLGSGGSIR } & 1.00 & 69.70 & 25.44 & 29.68 & 2 & 1231.5912 & 1231.5906 & 616.8026 & 0.0006 & 0.4864 & 6.918\end{array}$

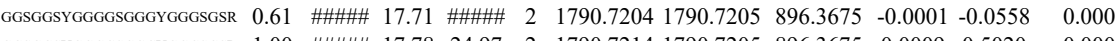
$\begin{array}{llllllllllll}\text { GGSGGSYGGGGSGGGYGGGSGSR } & 1.00 & \text { \#\#\#\# } 17.78 & 24.97 & 2 & 1790.7214 & 1790.7205 & 896.3675 & 0.0009 & 0.5020 & 0.000\end{array}$ $\begin{array}{lllllllllllllll}\text { SGGGGGGGLGSGGSIR } & 1.00 & 57.55 & 25.12 & 24.37 & 2 & 1231.5902 & 1231.5906 & 616.8026 & -0.0004 & -0.3243 & 4.503\end{array}$ $\begin{array}{llllllllllllll}\text { SGGGGGGGLGSGGSIR } & 1.00 & 59.96 & 25.39 & 23.08 & 2 & 1231.5908 & 1231.5906 & 616.8026 & 0.0002 & 0.1621 & 0.000\end{array}$ $\begin{array}{lllllllllllll}\text { SGGGGGGGLGSGGSIR } & 1.00 & 64.14 & 25.21 & 31.01 & 2 & 1231.5898 & 1231.5906 & 616.8026 & -0.0008 & -0.6485 & 5.25\end{array}$ \begin{tabular}{lllllllllllll}
\hline SGGGGGGGLGSGGSRR & 1.00 & 74.73 & 25.39 & 28.73 & 2 & 1231.5908 & 231.5906 & 616.8026 & 0.0002 & 0.1621 & 1.886
\end{tabular} $\begin{array}{llllllllllllll}\text { GGSGGSYGGGGSGGGYGGGSGSR } & 0.61 & \text { \#\#\#\# } 17.71 \quad \text { \#\#\#\# } 2 & 1790.7206 & 1790.7205 & 896.3675 & 0.0001 & 0.0558 & 0.000\end{array}$

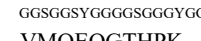

VMQEQGTHPK VMQEQGTHPK KEEELQAALAR KEEELQAALAR KEEELQAALAR KEEELQAALAR KQELEEICHDLEAR KQELEEICHDLEAR LQQELDDLLVDLDHQR LQQELDDLLVDLDHQR

HSQAVEELAEQEQTK DFSALESQLQDTQELLQEENR VMQEQGTHPK VMQEQGTHPK KEEELQAALAR KEEELQAALAR KEEELQAALAR LKDVLLQVDDER LKDVLLQVDDER

LQQELDDLLVDLDHQR KLEMDLK

KLEMDLK

KEEELQAALAR NLPIYSEEIVEMYK NLPIYSEEIVEMYK NLPIYSEEIVEMYK SGFEPASLK SGFEPASLK
VEAQLQELQVK VEAQLQELQVK
VEAQLQELQVK VEAQLQELQVK VEAQLQELQVK

NLPIYSEEIVEMYK NLPIYSEEIVEMYK $\begin{array}{cccccccccccc}0.61 & \# \# \# \# & 17.71 & \# \# \# \# & 2 & 1790.7206 & 1790.7205 & 896.3675 & 0.0001 & 0.0558 & 0.000 & 3.329 \\ 1.00 & \# \# \# 17.78 & 25.99 & 2 & 1790.7208 & 1790.7205 & 896.3675 & 0.0003 & 0.1673 & 0.000 & 5.301 \\ 1.00 & 44.04 & 27.55 & 17.72 & 3 & 1441.7599 & 1441.7591 & 481.5936 & 0.0008 & 0.5537 & 1179.120 & 1465.237\end{array}$ $\begin{array}{llllllll} & \end{array}$

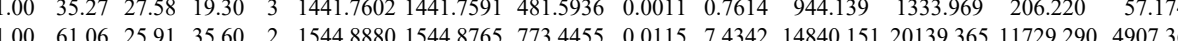

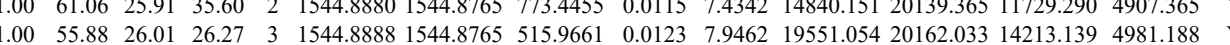
$\begin{array}{lllllllllllllllll}1.00 & 65.74 & 26.01 & 33.01 & 2 & 1544.8888 & 1544.8765 & 773.4455 & 0.0123 & 7.9514 & 19395.089 & 25008.520 & 11800.209 & 5309.857 & \text { Yes }\end{array}$ $\begin{array}{lllllllllllllllll}1.00 & 52.81 & 26.14 & 30.56 & 3 & 1544.8897 & 1544.8765 & 515.9661 & 0.0132 & 8.5276 & 22842.464 & 27659.542 & 16500.892 & 5238.549 & \text { Yes }\end{array}$ $\begin{array}{llllllllllllllll}1.00 & 53.16 & 27.00 & 18.00 & 4 & 2046.0141 & 2046.0117 & 512.5102 & 0.0024 & 1.1707 & 3768.785 & 5758.749 & 723.813 & 13.407 & \text { Yes } \\ 1.00 & 70.43 & 26.98 & 22.67 & 3 & 2046.0142 & 2046.0117 & 683.0112 & 0.0025 & 1.2201 & 2207.739 & 3415.125 & 492.344 & 20.420 & \text { Yes }\end{array}$

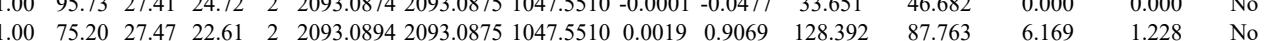
$\begin{array}{lllllllllllllll}1.00 & 78.79 & 27.40 & 24.21 & 3 & 2093.0908 & 2093.0875 & 698.7031 & 0.0033 & 1.5743 & 875.716 & 1534.900 & 69.145 & 0.000 & \text { No }\end{array}$

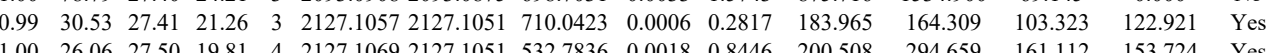
$\begin{array}{lllllllllllllll}1.00 & 79.02 & 26.99 & 21.75 & 3 & 2636.2705 & 2636.2687 & 879.7635 & 0.0018 & 0.6820 & 37.845 & 39.586 & 26.781 & 23.544 & \text { Yes }\end{array}$

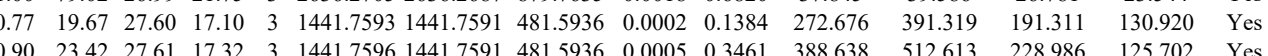
$\begin{array}{lllllllllllllll}0.90 & 23.42 & 27.61 & 17.32 & 3 & 1441.7596 & 1441.7591 & 481.5936 & 0.0005 & 0.3461 & 388.638 & 512.613 & 228.986 & 125.702 & \text { Yes } \\ 1.00 & 66.02 & 25.93 & 34.53 & 2 & 1544.884 & 1544.875 & 773.4455 & 0.019 & 7.6928 & 10174.125 & 13451.175 & 10168.837 & 3152.249 & \text { Yes }\end{array}$

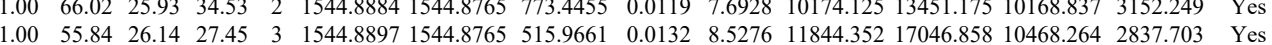
$\begin{array}{lllllllllllllllll}1.00 & 55.51 & 26.11 & 27.35 & 3 & 1544.8915 & 1544.8765 & 515.9661 & 0.0150 & 9.6905 & 12981.642 & 18675.920 & 11392.809 & 5221.210 & \text { Yes }\end{array}$ $\begin{array}{lllllllllllllll}1.00 & 53.97 & 26.17 & 29.57 & 3 & 1729.9840 & 1729.9818 & 577.6679 & 0.0022 & 1.2695 & 347.459 & 545.070 & 462.891 & 140.656 & \text { Yes }\end{array}$ $\begin{array}{llllllllllllllll}0.99 & 56.11 & 26.17 & 34.51 & 3 & 1729.9840 & 1729.9818 & 577.6679 & 0.0022 & 1.2695 & 1267.995 & 2338.353 & 1477.846 & 292.423 & \text { Yes }\end{array}$ \begin{tabular}{lllllllllllllll}
1.00 & 73.70 & 27.52 & 22.72 & 3 & 2093.0902 & 2093.0875 & 698.7031 & 0.0027 & 1.2881 & 593.047 & 477.880 & 50.510 & 27.855 & No \\
\hline
\end{tabular} $\begin{array}{llllllllllllll} & \end{array}$ $\begin{array}{lllllllllllllll}0.79 & 31.28 & 23.30 & 38.69 & 3 & 1307.7862 & 1307.7848 & 436.9355 & 0.0014 & 1.0680 & 37109.030 & 52190.275 & 461.377 & 646.838 & \text { Yes } \\ 0.94 & 32.83 & 23.32 & 36.48 & 3 & 1307.78711 & 1307.7848 & 436.9355 & 0.0023 & 1.7546 & 42667.389 & 56077.554 & 1282.568 & 403.730 & \text { Yes }\end{array}$ $\begin{array}{llllllllllllllllll}1.00 & 42.71 & 25.91 & 21.37 & 3 & 1544.8882 & 1544.8765 & 515.9661 & 0.0117 & 7.5586 & 1750.959 & 2340.723 & 1809.687 & 738.263 & \text { Yes }\end{array}$ $\begin{array}{lllllllllllllll}0.76 & 68.01 & 27.05 & 81.01 & 2 & 2015.0534 & 2015.0529 & 1008.5337 & 0.0005 & 0.2479 & 917.795 & 1174.972 & 38.063 & 12.734 & \text { Yes }\end{array}$ $\begin{array}{lllllllllllllll}1.00 & 56.04 & 27.04 & 19.97 & 3 & 2015.0554 & 2015.0529 & 672.6916 & 0.0025 & 1.2388 & 336.108 & 693.874 & 32.657 & 53.241 & \text { Yes }\end{array}$

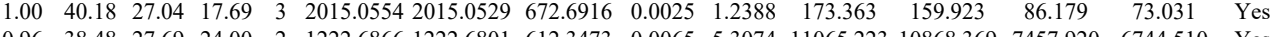

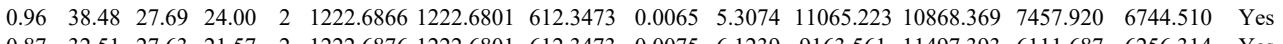
$\begin{array}{llllllllllllllll}0.87 & 32.51 & 27.63 & 21.57 & 2 & 1222.6876 & 1222.6801 & 612.3473 & 0.0075 & 6.1239 & 9163.561 & 11497.393 & 6111.687 & 6256.314 & \text { Yes } \\ 1.00 & 68.31 & 25.9 & 30.70 & 2 & 1571.9252 & 1571.9126 & 786.9636 & 0.0126 & 8.0054 & 5745.020 & 8851.095 & 5545.284 & 2667.592 & \text { Yes }\end{array}$ $\begin{array}{llllllllllllllll}1.00 & 68.31 & 25.19 & 30.70 & 2 & 1571.9252 & 1571.9126 & 786.9636 & 0.0126 & 8.0054 & 5745.020 & 8851.095 & 5545.284 & 2667.592 & \text { Yes }\end{array}$

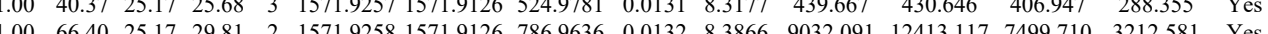

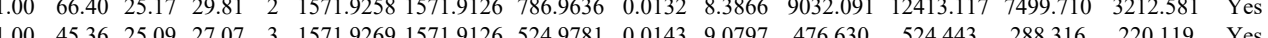

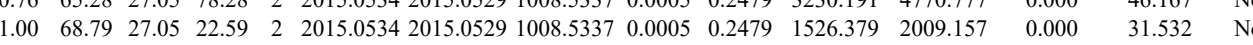

Table S-3 page 223 of 499 

$\begin{array}{lllllllllllllllll}\text { ANLQIDQINTDLNLER } & 0.92 & 32.21 & 27.04 & 22.40 & 3 & 2013.0811 & 2013.0612 & 672.0277 & 0.0199 & 9.8705 & 2054.755 & 1583.588 & 397.010 & 230.133 & \text { No }\end{array}$ $\begin{array}{lllllllllllllllll}\text { LTEMETLQSQLMAEK } & 1.00 & 96.18 & 27.53 & 24.82 & 2 & 2039.0514 & 2039.0522 & 1020.5334 & -0.0008 & -0.3920 & 89.577 & 91.650 & 38.227 & 13.845 & \text { Yes }\end{array}$ $\begin{array}{llllllllllllllll}\text { LTEMETLQSQLMAEK } & 1.00 & 99.44 & 27.59 & 27.75 & 2 & 2039.0534 & 2039.0522 & 1020.5334 & 0.0012 & 0.5879 & 374.855 & 463.029 & 285.991 & 63.134 & \text { Yes }\end{array}$ $\begin{array}{llllllllllllllll}\text { LTEMETLQSQLMAEK } & 1.00 & 32.29 & 27.38 & 19.91 & 3 & 2039.0554 & 2039.0522 & 680.6913 & 0.0032 & 1.5670 & 541.899 & 437.846 & 179.067 & 237.959 & \text { Yes }\end{array}$ $\begin{array}{llllllllllllllll}\text { LTEMETLQSQLMAEK } & 1.00 & 49.49 & 27.38 & 21.77 & 3 & 2039.0554 & 2039.0522 & 680.6913 & 0.0032 & 1.5670 & 639.176 & 562.114 & 391.595 & 157.913 & \text { Yes }\end{array}$ $\begin{array}{llllllllllllllll}\text { NMDPLNDNIATLLHQSSDK } & 1.00 & 52.97 & 27.74 & 16.75 & 3 & 2413.2202 & 2413.2151 & 805.4123 & 0.0051 & 2.1107 & 7193.226 & 12450.496 & 5139.561 & 1169.029 & \text { Yes }\end{array}$

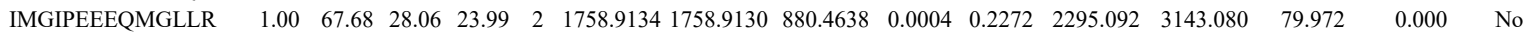
$\begin{array}{lllllllllllllllll}\text { IMGIPEEEQMGLLR } & 1.00 & 78.87 & 28.12 & 27.99 & 2 & 1758.9144 & 1758.9130 & 880.4638 & 0.0014 & 0.7950 & 7296.380 & 8448.978 & 198.918 & 0.000 & \text { No }\end{array}$

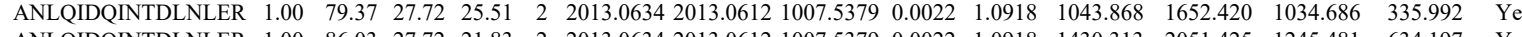
$\begin{array}{lllllllllllllllll}\text { ANLQIDQINTDLNLER } & 1.00 & 86.03 & 27.72 & 21.83 & 2 & 2013.0634 & 2013.0612 & 1007.5379 & 0.0022 & 1.0918 & 1430.313 & 2051.425 & 1245.481 & 634.197 & \text { Yes }\end{array}$

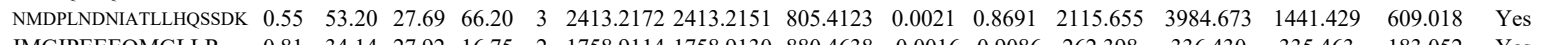

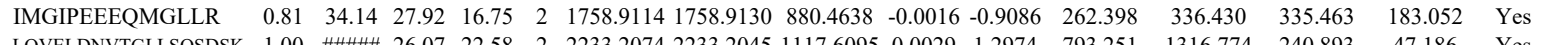

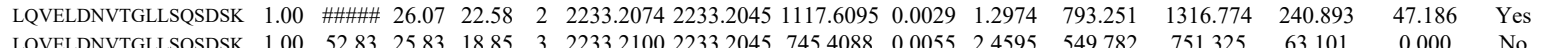

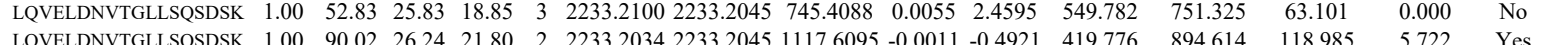

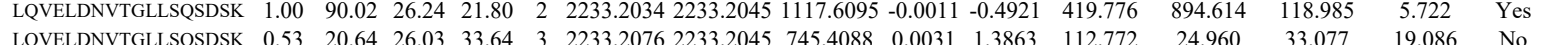
\begin{tabular}{lllllllllllllll} 
& 118.985 & 5.722 & Yes \\
\hline
\end{tabular}

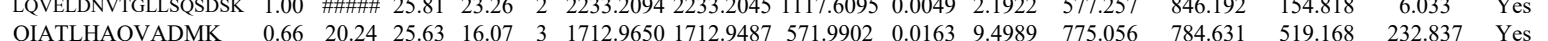

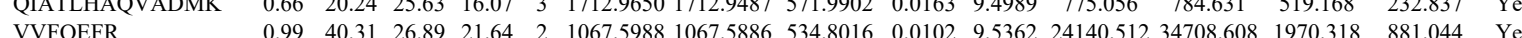

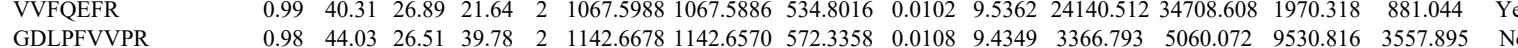

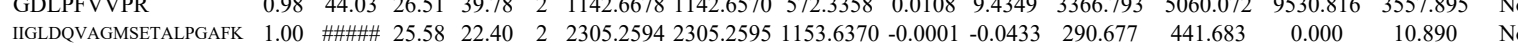

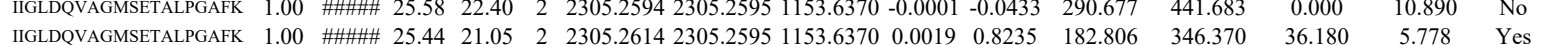

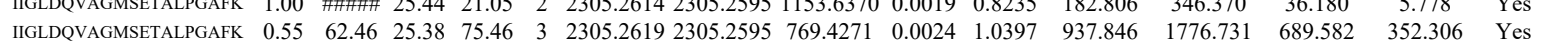

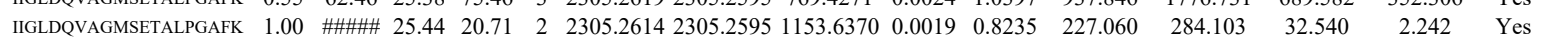
$\begin{array}{llllllllllllllll}\text { IIGLDQVAGMSETALPGAFK } & 1.00 & 67.62 & 25.02 & 17.61 & 3 & 2305.2649 & 2305.2595 & 769.4271 & 0.0054 & 2.3394 & 146.664 & 88.167 & 37.902 & 12.729 & \text { No }\end{array}$

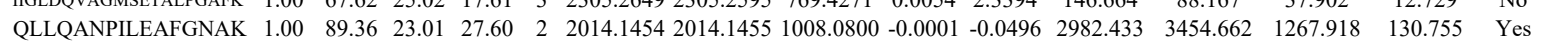
$\begin{array}{llllllllllllllll}\text { QLLQANPILEAFGNAK } & 0.53 & 33.15 & 23.18 & 46.15 & 3 & 2014.1485 & 2014.1455 & 672.3891 & 0.0030 & 1.4872 & 1426.052 & 1521.581 & 412.045 & 189.936 & \text { Yes }\end{array}$

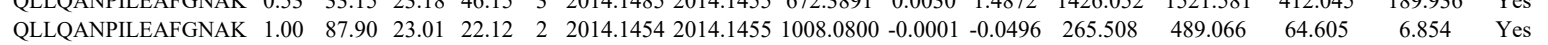
$\begin{array}{llllllllllllllll}\text { QLLQANPILEAFGNAK } & 1.00 & 89.23 & 23.18 & 22.30 & 2 & 2014.1474 & 2014.1455 & 1008.0800 & 0.0019 & 0.9424 & 1383.281 & 1831.841 & 632.720 & 39.173 & \text { Yes }\end{array}$

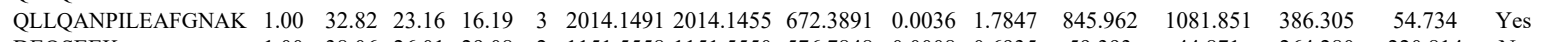

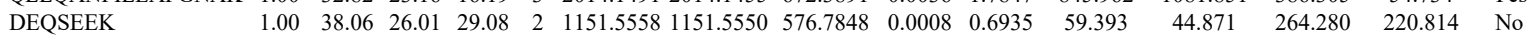

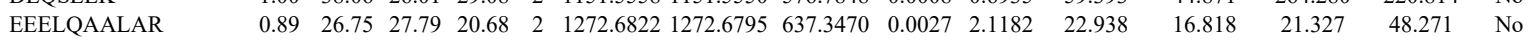

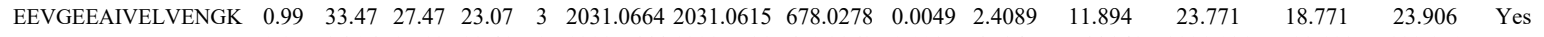
$\begin{array}{llllllllllllllll}\text { RGDLPFVVPR } & 0.97 & 36.06 & 25.13 & 23.41 & 2 & 1298.7666 & 1298.7581 & 650.3863 & 0.0085 & 6.5345 & 5766.349 & 8821.031 & 798.193 & 189.150 & \text { Yes }\end{array}$ RGDLPFVVPR RGDLPFVVPR RGDLPFVVPR RGDLPFVVPR RGDLPFVVPR RGDLPFVVPR RGDLPFVVPR $\begin{array}{lllllllllllllll}0.98 & 37.74 & 25.09 & 24.79 & 2 & 1298.7674 & 1298.7581 & 650.3863 & 0.0093 & 7.1495 & 4861.013 & 8583.879 & 649.571 & 191.504 & \text { Yes }\end{array}$ $\begin{array}{lllllllllllllll}1.00 & 46.94 & 24.74 & 26.45 & 3 & 1298.7685 & 1298.7581 & 433.9266 & 0.0104 & 7.9890 & 4620.241 & 10021.598 & 2376.115 & 587.960 & \text { Yes }\end{array}$ $\begin{array}{llllllllllllllll}1.00 & 41.69 & 24.74 & 22.63 & 3 & 1298.7685 & 1298.7581 & 433.9266 & 0.0104 & 7.9890 & 3429.921 & 5804.404 & 1712.084 & 100.355 & \text { Yes }\end{array}$ $\begin{array}{lllllllllllllll}0.81 & 25.17 & 25.11 & 21.57 & 2 & 1298.7678 & 1298.7581 & 650.3863 & 0.0097 & 7.4571 & 506.438 & 837.975 & 223.839 & 90.879 & \text { Yes } \\ 1.00 & 44.76 & 24.61 & 27.57 & 3 & 1298.7688 & 1298.7581 & 433.9266 & 0.0107 & 8.2194 & 2050.878 & 4835.055 & 810.844 & 94.196 & \text { Yes }\end{array}$

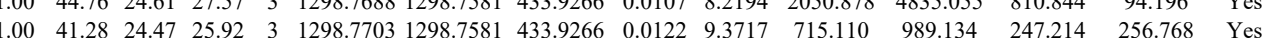

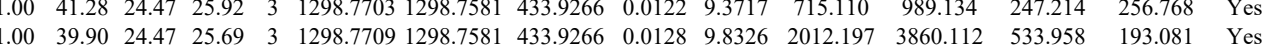

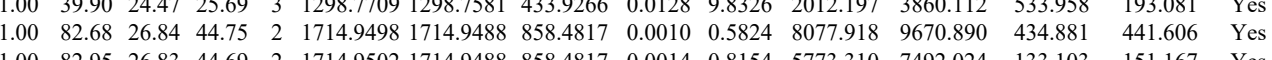
$\begin{array}{lllllllllllllll}1.00 & 82.95 & 26.83 & 44.69 & 2 & 1714.9502 & 1714.9488 & 858.4817 & 0.0014 & 0.8154 & 5773.310 & 7492.024 & 133.103 & 151.167 & \text { Yes } \\ 1.00 & 58.20 & 26.62 & 24.92 & 3 & 1714.9510 & 1714.9488 & 572.6569 & 0.0022 & 1.2806 & 2549.528 & 4139.653 & 540.584 & 184.151 & \text { Yes }\end{array}$ $\begin{array}{llllllllllllllll}1.00 & 65.46 & 26.63 & 25.81 & 3 & 1714.9522 & 1714.9488 & 572.6569 & 0.0034 & 1.9791 & 4518.001 & 7423.608 & 1478.484 & 2585.970 & \text { Yes }\end{array}$ 

\begin{tabular}{llllllllllllllll}
\hline & 26.84 & 40.82 & 2 & 1714.9498 & 1714.9488 & 858.4817 & 0.0010 & 0.5824 & 1149.770 & 1609.848 & 90.429 & 46.646 & Yes \\
1.00 & 70.13 & 26.66 & 21.76 & 3 & 1714.9516 & 1714.9488 & 572.6569 & 0.0028 & 1.6298 & 2695.826 & 3658.467 & 587.024 & 110.856 & Yes
\end{tabular} $\begin{array}{lllllllllllllllll}1.00 & 55.22 & 26.62 & 19.03 & 3 & 1714.9519 & 1714.9488 & 572.6569 & 0.0031 & 1.8045 & 3190.088 & 4097.541 & 765.018 & 359.474 & \text { Yes } \\ 1.00 & 49.84 & 26.84 & 20.92 & 3 & 1714.9498 & 1714.9488 & 572.569 & 0.001 & 0.5821 & 736.307 & 1075.394 & 184.179 & 183.471 & \text { Yes }\end{array}$

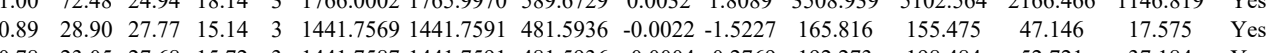
$\begin{array}{llllllllllllllll}1.00 & 60.18 & 25.01 & 17.31 & 3 & 1765.9987 & 1765.9970 & 589.6729 & 0.0017 & 0.9610 & 941.228 & 1277.820 & 447.122 & 198.960 & \text { Yes } \\ 1.00 & 58.24 & 25.07 & 17.51 & 3 & 1765.9990 & 1765.9970 & 589.6729 & 0.0020 & 1.1306 & 88.443 & 1360.040 & 552.477 & 2.713 & \text { Yes }\end{array}$ $\begin{array}{lllllllllllllll}1.00 & 85.58 & 18.33 & 20.61 & 2 & 1774.0976 & 1774.0960 & 888.0553 & 0.0016 & 0.9008 & 577.755 & 989.260 & 74.492 & 296.713 & \text { Yes } \\ 12.402 & \text { Yes }\end{array}$ 12.402 Yes $0.000 \quad$ No Yes 80.411 Yes $\begin{array}{ll}267.458 & \text { Yes } \\ 1281.161 & \text { Yes }\end{array}$ Yes 271.848 Yes 98.218 Yes 2.868 No 0.000 No 0.000 No $\begin{array}{ll}23.766 & \text { Yes } \\ 15.796 & \text { Yes } \\ 70.114 & \text { Yes }\end{array}$ 70.114 Yes 17.269 Yes 18.243 Yes 147.362 Yes 1156.192 No $\begin{array}{lll}8.327 & \text { Yes } \\ 0.000 & & \end{array}$ $\begin{array}{lll} & \\ 1.074 & 0.000 & \text { No } \\ 3.503 & 28.318 & \text { Yes }\end{array}$ $\begin{array}{lll} & \\ 1.503 & 28.318 & \text { Yes } \\ 8.81 & 14.157 & \text { Yes }\end{array}$ $\begin{array}{lllll}63.290 & 88.891 & 85.499 & \text { Yes }\end{array}$ $\begin{array}{llll}6.316 & 60.917 & 72.141 & \text { No }\end{array}$ $\begin{array}{llll}4.796 & 77.819 & 63.123 & \text { Yes } \\ 50.597 & 85184 & 6.96 & Y e s\end{array}$ \begin{tabular}{llll}
50.106 & 85.184 & 69.960 & Yes \\
\hline & 70.226 & 58.704 & Yes
\end{tabular} $\begin{array}{llll}39.306 & 66.753 & 82.532 & \text { No }\end{array}$

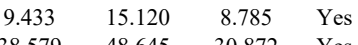
$\begin{array}{llll}38.579 & 48.645 & 30.872 & \text { Yes } \\ 53.432 & 120.168 & 88.72 & \text { Yes }\end{array}$ $\begin{array}{llll}53.432 & 120.168 & 88.779 & \text { Yes } \\ 25.029 & 26.814 & 12.040 & \text { Yes } \\ 64.217 & 55.238 & 77.38 & \text { Yes }\end{array}$ 

$\begin{array}{lllllllllllllll} & \text { Yes }\end{array}$

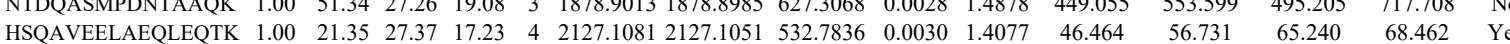

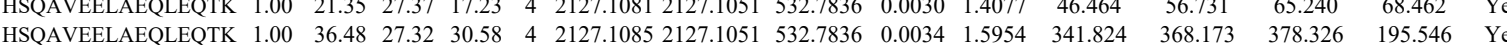

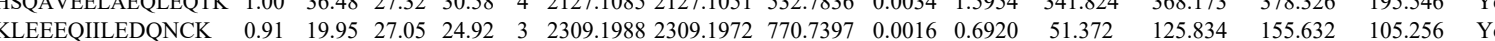
$\begin{array}{lllllllllllllllll} & \text { LQEMEGTVK } & 0.98 & 47.15 & 28.20 & 41.66 & 2 & 1321.7268 & 1321.7155 & 661.8650 & 0.0113 & 8.5364 & 24167.123 & 31813.813 & 13075.511 & 26568297 & \text { Yes }\end{array}$

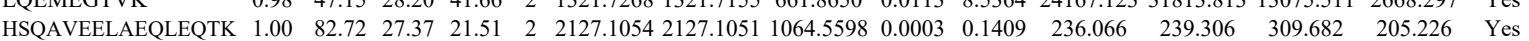

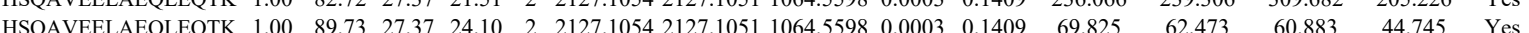
$\begin{array}{llllllllllllllll}\text { HSQAVEELAEQLEQTK } & 1.00 & 28.73 & 27.41 & 19.44 & 4 & 2127.1057 & 2127.1051 & 532.7836 & 0.0006 & 0.2815 & 1029.693 & 1008.781 & 373.343 & 426.172 & \text { Yes }\end{array}$

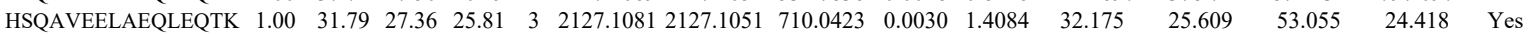

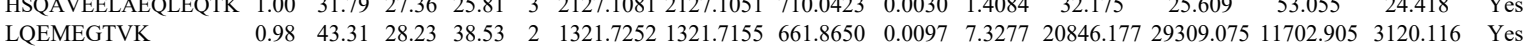

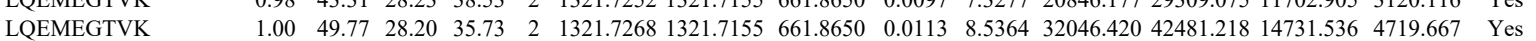

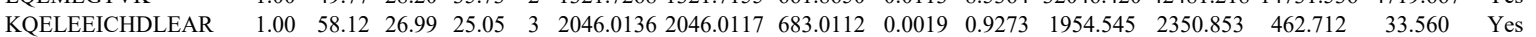
$\begin{array}{llllllllllllllllll}\text { KQELEEICHDLEAR } & 1.00 & 49.55 & 27.00 & 16.23 & 4 & 2046.0141 & 2046.0117 & 512.5102 & 0.0024 & 1.1707 & 5734.408 & 8399.434 & 1069.000 & 5.214 & \text { Yes }\end{array}$

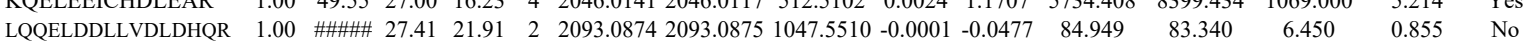
$\begin{array}{llllllllllllllll}\text { LQQELDDLLVDLDHQR } & 0.55 & 68.73 & 27.47 & 81.73 & 3 & 2093.0899 & 2093.0875 & 698.7031 & 0.0024 & 1.1450 & 369.872 & 468.615 & 58.726 & 17.331 & \text { Yes }\end{array}$ $\begin{array}{lllllllllllllllll}\text { LQQELDDLLVDLDHQR } & 1.00 & 61.30 & 27.43 & 20.20 & 3 & 2093.0911 & 2093.0875 & 698.7031 & 0.0036 & 1.7175 & 2817.360 & 3279.637 & 187.814 & 0.000 & \text { No }\end{array}$

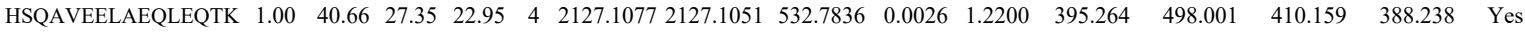
$\begin{array}{llllllllllllllll}\text { HSQAVEELAEQLEQTK } & 0.54 & 12.23 & 27.33 & 18.01 & 3 & 2127.1084 & 2127.1051 & 710.0423 & 0.0033 & 1.5492 & 59.865 & 129.273 & 156.790 & 82.354 & \text { Yes }\end{array}$ $\begin{array}{llllllllllllllll}\text { HSQAVEELAEQLEQTK } & 1.00 & 29.01 & 27.32 & 27.35 & 4 & 2127.1089 & 2127.1051 & 532.7836 & 0.0038 & 1.7831 & 371.665 & 441.576 & 240.406 & 207.769 & \text { Yes }\end{array}$

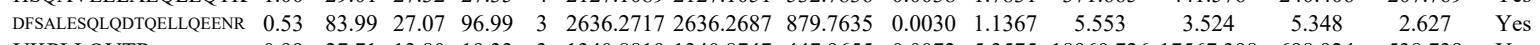




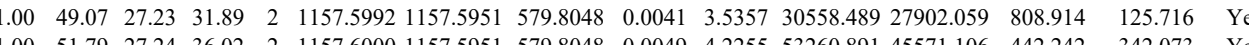
$\begin{array}{llllllllllllllll}1.00 & 51.79 & 27.24 & 36.02 & 2 & 1157.6000 & 1157.5951 & 579.8048 & 0.0049 & 4.2255 & 53260.891 & 45571.106 & 442.242 & 342.073 & \text { Yes } & \\ 1.00 & 48.97 & 27.11 & 35.74 & 2 & 115.5990 & 115.5951 & 579.8048 & 0.039 & 3.3632 & 2309.547 & 20064.641 & 50.832 & 104.428 & \text { Yes }\end{array}$ FFVSSSQGR $\begin{array}{lllllllllllll}1.00 & 48.97 & 27.11 & 35.74 & 2 & 1157.5990 & 1157.5951 & 579.8048 & 0.0039 & 3.3632 & 23309.547 & 20064.641 & 509.832 \\ 1.00 & 51.23 & 27.23 & 35.92 & 2 & 1157.5992 & 1157.5951 & 579.8048 & 0.0041 & 3.5357 & 11339.144 & 9626.373 & 210.920 \\ 0.99 & 51.06 & 27.11 & 37.43 & 2 & 1157.5942 & 1157.5951 & 579.8048 & -0.0009 & -0.7761 & 775.738 & 720.421 & 53.067\end{array}$

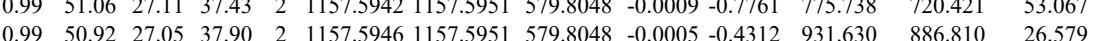
$\begin{array}{llllllllllllll} & \end{array}$ $\begin{array}{llllllllll} & 0.056\end{array}$ $\begin{array}{lllllllllllllll}\text { SSEHINEGETAMLVCK } & 0.53 & 67.52 & 26.31 & 80.52 & 3 & 2080.9867 & 2080.9835 & 694.6684 & 0.0032 & 1.5355 & 61.052 & 45.601 & 40.003 & 17.245\end{array}$ $\begin{array}{lllllllllllllll}\text { APKPDGPGGGGGSHMGGNYGDDR } & 0.53 & \text { \#\#\#\# } 25.69 & \text { \#\#\#\# } 3 & 2540.1739 & 2540.1707 & 847.7308 & 0.0032 & 1.2583 & 3580.974 & 3728.762 & 3970.647 & 3131.868 & \text { Yes }\end{array}$

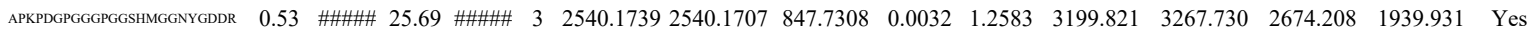
$\begin{array}{lllllllllllllllll}\text { APRPDGPGGGPGGSHMGGNYGDDR } & 1.00 & 51.41 & 25.71 & 64.41 & 4 & 2540.1753 & 2540.1707 & 636.0500 & 0.0046 & 1.8080 & 8274.980 & 9937.801 & 12197.328 & 8455.497 & \text { Yes }\end{array}$

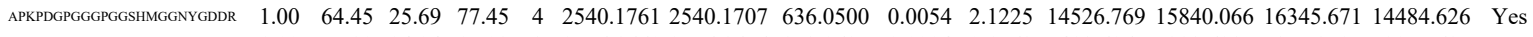

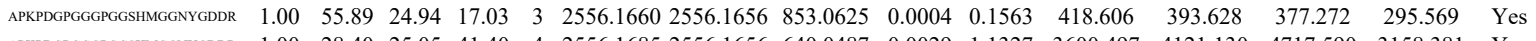
$\begin{array}{llllllllllllllll}\text { APRPDGGGGGGGHMGGNYGDDR } & 1.00 & 28.40 & 25.05 & 41.40 & 4 & 2556.1685 & 2556.1656 & 640.0487 & 0.0029 & 1.1327 & 3600.497 & 4121.130 & 4717.590 & 3158.381 & \text { Yes }\end{array}$

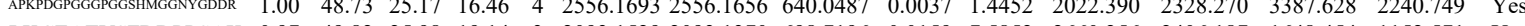
$\begin{array}{lllllllllllllllll}\text { LKGEATVSFDDPPSAK } & 0.97 & 49.82 & 25.98 & 19.14 & 3 & 2093.1529 & 2093.1370 & 698.7196 & 0.0159 & 7.5852 & 2660.256 & 2406.187 & 1648.454 & 1152.571 & \text { Yes }\end{array}$ $\begin{array}{llllllllllllllllll}\text { R. } & 1.00 & 58.31 & 25.72 & 71.31 & 4 & 2540.1741 & 2540.1707 & 636.0500 & 0.0034 & 1.3364 & 8787.828 & 9464.014 & 7849.496 & 6556.575 & \text { Yes }\end{array}$ $\begin{array}{llllllllllllllll} & \end{array}$ $\begin{array}{llllllllllllllll}\text { ARKDGFGGGGGSHMGGNYGDDR } & 1.00 & 35.84 & 25.05 & 48.84 & 4 & 2556.1673 & 2556.1656 & 640.0487 & 0.0017 & 0.6640 & 496.948 & 662.460 & 716.518 & 658.055 & \text { Yes }\end{array}$ $\begin{array}{lllllllllllllllllll} & \end{array}$ $\begin{array}{lllllllllllllllll}\text { APKRD } & & \end{array}$ $\begin{array}{llllllllllllllll}\text { APKPDCPGG } & 28.19 & 24.83 & 41.19 & 4 & 2556.1645 & 2556.1656 & 640.0487 & -0.0011 & -0.4297 & 233.242 & 249.252 & 279.703 & 209.548 & \text { Yes }\end{array}$

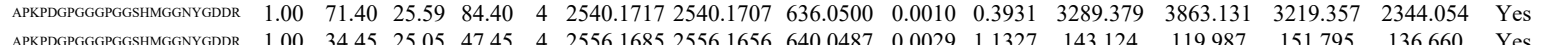

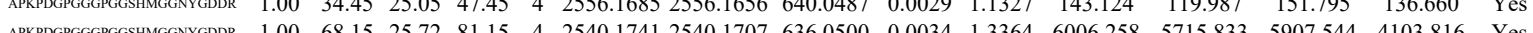

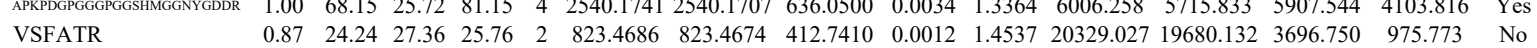
$\begin{array}{llllllllllllllll}\text { VSFATR } & 0.61 & 17.86 & 27.36 & 23.35 & 2 & 823.4686 & 823.4674 & 412.7410 & 0.0012 & 1.4537 & 25580.887 & 27926.206 & 4438.220 & 1182.314 & \text { No }\end{array}$

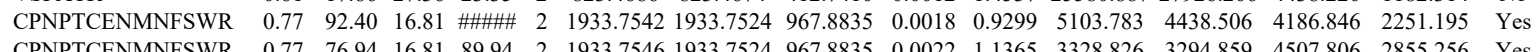
$\begin{array}{llllllllllllllll}\text { CPNPCENMNSR } & 0.77 & 76.94 & 16.81 & 89.94 & 2 & 1933.7546 & 1933.7524 & 967.8835 & 0.0022 & 1.1365 & 3328.826 & 3294.859 & 4507.806 & 2855.256 & \text { Yes } \\ \text { CPNPTCENMNFSWR } & 0.53 & 26.71 & 16.90 & 39.71 & 3 & 1933.7551 & 1933.7524 & 645.5914 & 0.0027 & 1.3941 & 647.950 & 886.173 & 9944.329 & 551.843 & \text { No }\end{array}$ $\begin{array}{llllllllllllllllll}\text { CPNPTCENMNFSWR } & 0.61 & 73.17 & 16.33 & 86.17 & 2 & 1933.7526 & 1933.7524 & 967.8835 & 0.0002 & 0.1033 & 84.919 .48 & 707.299 & 737.890 & 485.751 & \text { Yes }\end{array}$ $\begin{array}{lllllllllllllllll}\text { CPNPCENASW } & 0.61 & 73.17 & 16.33 & 86.17 & 2 & 1933.7526 & 1933.7524 & 967.883 & 0.0002 & 0.1033 & 819.483 & 707.299 & 737.890 & 485.751 & \text { Yes } \\ \text { GEATVSFDDPPSAK } & 1.00 & 80.24 & 27.92 & 22.47 & 2 & 1707.8712 & 1707.8559 & 854.9352 & 0.0153 & 8.9480 & 315.965 & 294.259 & 240.310 & 251.098 & \text { Yes }\end{array}$ $\begin{array}{llllllllllllllll}\text { GEATVSFDDPPSAK } & 1.00 & 80.24 & 27.92 & 22.47 & 2 & 1707.8712 & 1707.8559 & 854.9352 & 0.0153 & 8.9480 & 315.965 & 294.259 & 240.310 & 251.098 & \text { Yes } \\ \text { GEATVSFDDPPSAK } & 1.00 & 69.69 & 27.99 & 23.29 & 2 & 1707.8720 & 1707.8559 & 854.9352 & 0.0161 & 9.4158 & 281.600 & 284.694 & 213.918 & 271.109 & \text { Yes }\end{array}$

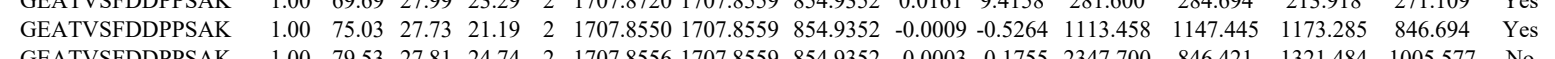
$\begin{array}{llllllllllllllllll}\text { GEATVSFDDPPSAK } & 1.00 & 79.53 & 27.81 & 24.74 & 2 & 1707.8556 & 1707.8559 & 854.9352 & -0.0003 & -0.1755 & 2347.700 & 846.421 & 1321.484 & 1005.577 & \text { No }\end{array}$

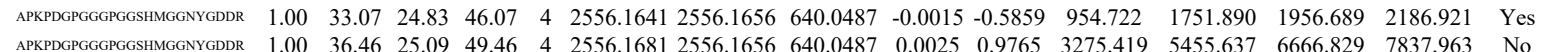
$\begin{array}{llllllllllllllll}\text { APRPDGPGGGGGGSHMGGNYGDDR } & 1.00 & 36.46 & 25.09 & 49.46 & 4 & 2556.1681 & 2556.1656 & 640.0487 & 0.0025 & 0.9765 & 3275.419 & 5455.637 & 6666.829 & 7837.963 & \text { No } \\ & 0.53 & 25.04 & 66.49 & 3 & 2556.1684 & 2556.1656 & 853.0625 & 0.0028 & 1.0941 & 383.278 & 594.695 & 636.146 & 694.413 & \text { Yes }\end{array}$

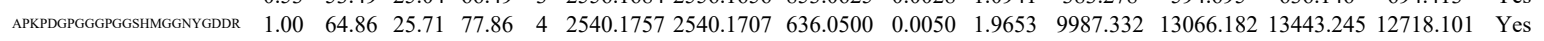

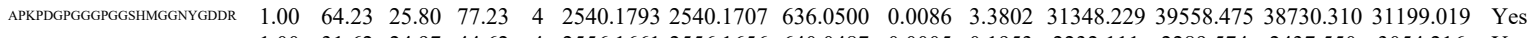
$\begin{array}{llllllllllllllllll}\text { APKPDGPGGGPGGSHGGNYGDDR } & 1.00 & 31.62 & 24.97 & 44.62 & 4 & 2556.1661 & 2556.1656 & 640.0487 & 0.0005 & 0.1953 & 2232.111 & 2289.574 & 2437.550 & 3054.216 & \text { Yes }\end{array}$

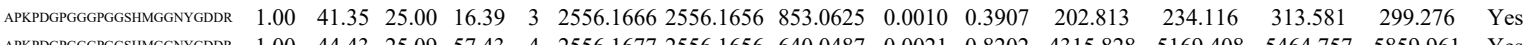

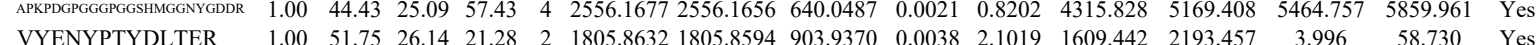

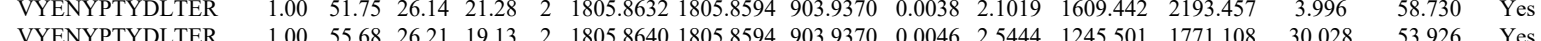

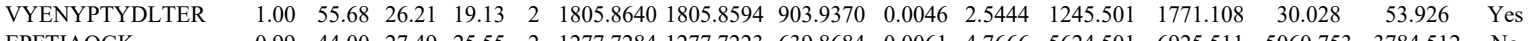
EPFTIAQGK EPFTIAQGK SICEVLDLER SICEVLDLER SICEVLDLER SICEVLDLER
LLASANLEEVTMK LLASANL $\begin{array}{llllllllllllllll}0.99 & 44.00 & 27.49 & 25.55 & 2 & 1277.7284 & 1277.7223 & 639.8684 & 0.0061 & 4.7666 & 5624.501 & 6925.511 & 5060.753 & 3784.512 & \text { No }\end{array}$ $\begin{array}{lllllllllllllllll}0.98 & 40.34 & 27.36 & 25.99 & 2 & 1277.7296 & 1277.7223 & 639.8684 & 0.0073 & 5.7043 & 4078.278 & 5697.139 & 3480.496 & 2578.306 & \text { No }\end{array}$ $\begin{array}{lllllllllllllll}1.00 & 59.50 & 27.35 & 25.42 & 2 & 1365.6758 & 1365.6754 & 683.8450 & 0.0004 & 0.2925 & 8574.874 & 12109.522 & 0.000 & 41.601 & \text { No }\end{array}$

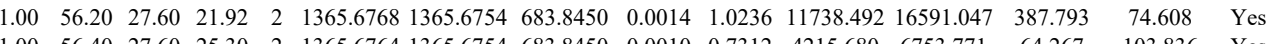
$\begin{array}{llllllllllllllll}1.00 & 56.40 & 27.60 & 25.30 & 2 & 1365.6764 & 1365.6754 & 683.8450 & 0.0010 & 0.7312 & 4215.680 & 6753.771 & 64.267 & 103.836 & \text { Yes }\end{array}$ $\begin{array}{lllllllllllllll}1.00 & 67.74 & 27.60 & 26.03 & 2 & 1365.6766 & 1365.6754 & 683.8450 & 0.0012 & 0.8774 & 6227.990 & 9776.470 & 14.626 & 44.799 & \text { Yes } \\ 1.00 & 81.40 & 25.93 & 28.10 & 2 & 1705.9688 & 1705.9528 & 853.9837 & 0.0160 & 9.3678 & 1193.028 & 1205.694 & 252.704 & 42.562 & \text { Yes }\end{array}$

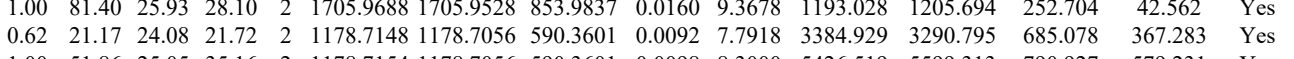


IHFFLSK

IHFFLSK

LTMQVSSLQR

LTMQVSSLQR

LTMQVSSLQR

LTMQVSSLQR

LLYNRPGTVSSLK

LLYNRPGTVSSLK

LLYNRPGTVSSLK

LLYNRPGTVSSLK

LLYNRPGTVSSLK

QTLQSEQPLQVAR

ACLIFFDEIDAIGGAR

TMLELINQLDGFDPR

TMLELINQLDGFDPR

TMLELINQLDGFDPR

TMLELINQLDGFD

SVCTEAGMFAIR

GVLLFGPPGTGK

FDDGAGGDNEVQR

FDDGAGGDNEVQR

GVLLFGPPGTGK

IINADSEDPK

ALDEGDIALLK

QVEDDIQQLLK

QVEDDIQQLLK

QVEDDIQQLLK

ALDEGDIALLK

QVEDDIQQLLK

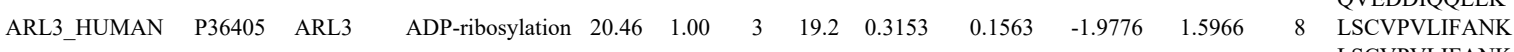

LSCVPVLIFANK

GLLSILR

LSCVPVLIFANK

LSCVPVLIFANK

GLLSILR

FELTGRQELAELLEEEK

FEETGQELAELLEEEK

SEVATLTAAGK

GLCGAIHS

GALFGANAN

GALFGANANR

GALFGANANR

GALFGANANR

IQMSNLMNQAR

IQMSNLMNQAR

IQMSNLMNQAR

DDLITDLLNEAK

DDLITDLLNEAK

NPHAPTIHFNYR

NPHAPTIHFNYR

FVQSCAR

IESILMSLPLTAR

IESILMSLPLTA

FGLFTPGSR

FGLFTPGS
KPAPEK

GPCIIYNEDNGIIK

GPCIIYNEDNGIIK

GPCIYNEDNGIK

GPCIIYNEDNGIIK $\begin{array}{lllllllllllllll}1.00 & 48.72 & 25.19 & 25.16 & 2 & 1178.7070 & 1178.7056 & 590.3601 & 0.0014 & 1.1857 & 11864.534 & 11879.796 & 1235.009 & 1095.451 & \text { Yes } \\ 1.00 & 48.67 & 25.19 & 25.26 & 2 & 1178.7080 & 1178.7056 & 590.3601 & 0.0024 & 2.0327 & 11272.983 & 1228.035 & 1218.396 & 1074.614 & \text { Yes }\end{array}$ $\begin{array}{llllllllllllllll}1.00 & 48.67 & 25.19 & 25.26 & 2 & 1178.7080 & 1178.7056 & 590.3601 & 0.0024 & 2.0327 & 11272.983 & 12228.035 & 1218.396 & 1074.614 & \text { Yes } \\ 1.06 & 67.75 & 28.18 & 28.07 & 2 & 1305.7284 & 1305.7197 & 653.8671 & 0.0087 & 6.6527 & 7978.061 & 10742.701 & 1572.361 & 251.724 & \text { Yes }\end{array}$ $\begin{array}{llllllllllllllll}1.00 & 63.78 & 28.18 & 28.60 & 2 & 1305.7286 & 1305.7197 & 653.8671 & 0.0089 & 6.8056 & 4382.361 & 6222.910 & 677.135 & 103.199 & \text { Yes }\end{array}$ $\begin{array}{llllllllllllllll}1.00 & 59.04 & 28.17 & 26.81 & 2 & 1305.7292 & 1305.7197 & 653.8671 & 0.0095 & 7.2644 & 3698.994 & 5115.838 & 545.401 & 179.470 & \text { Yes }\end{array}$ $\begin{array}{lllllllllllllll}1.00 & 61.95 & 28.05 & 24.17 & 2 & 1305.7302 & 1305.7197 & 653.8671 & 0.0105 & 8.0291 & 5370.956 & 7544.607 & 759.596 & 191.571 & \text { Yes }\end{array}$ $\begin{array}{lllllllllllllll}0.97 & 25.97 & 20.97 & 15.70 & 3 & 1735.0393 & 1735.0236 & 579.3485 & 0.0157 & 9.0331 & 27250.956 & 39552.085 & 279.105 & 358.364 & \text { Yes }\end{array}$ $\begin{array}{lllllllllllllll}1.00 & 56.82 & 21.04 & 25.90 & 2 & 1735.0398 & 1735.0236 & 868.5191 & 0.0162 & 9.3261 & 1342.860 & 1855.976 & 0.000 & 0.000 & \text { No }\end{array}$

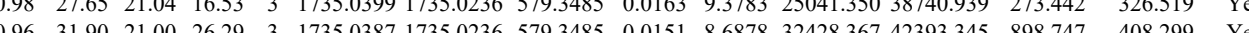

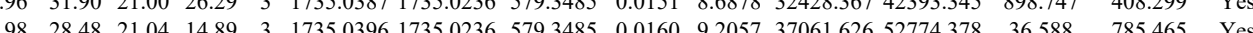
$\begin{array}{llllllllllll} & \end{array}$

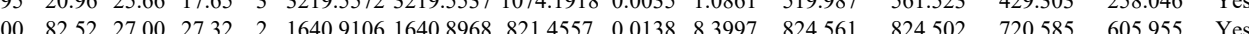
$\begin{array}{lllllllllllllll} & \end{array}$

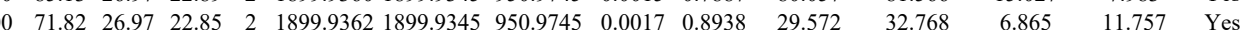

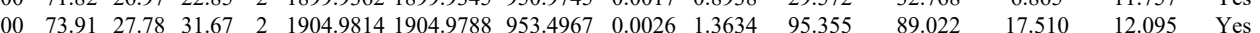
$\begin{array}{llllllllllllllll}1.00 & 57.98 & 27.86 & 23.80 & 3 & 1904.9821 & 1904.9788 & 636.0002 & 0.0033 & 1.7296 & 195.502 & 200.427 & 110.023 & 73.678 & \text { Yes }\end{array}$ $\begin{array}{lllllllllllllll}1.00 & 71.74 & 24.93 & 25.27 & 2 & 1473.6942 & 1473.6900 & 737.8523 & 0.0042 & 2.8461 & 877.131 & 787.579 & 179.588 & 48.870 & \text { Yes }\end{array}$ $\begin{array}{lllllllllllllll}1.00 & 65.68 & 23.12 & 34.54 & 2 & 1429.8650 & 1429.8537 & 715.9341 & 0.0113 & 7.8917 & 3261.129 & 4688.493 & 2143.740 & 522.495 & \text { Yes }\end{array}$ \begin{tabular}{lllllllllllllll}
1.00 & 67.76 & 22.92 & 38.13 & 2 & 1429.8662 & 1429.8537 & 715.9341 & 0.0125 & 8.7298 & 438.274 & 472.612 & 278.291 & 81.447 & Yes \\
\hline
\end{tabular}

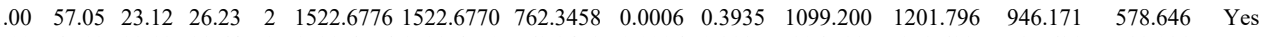

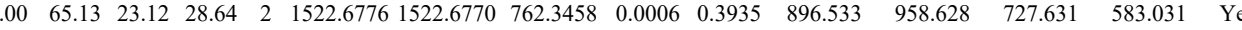

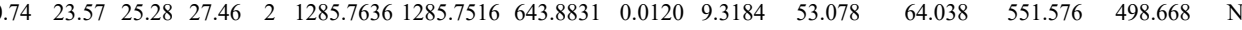

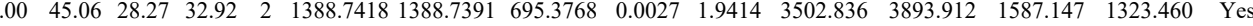
$\begin{array}{llllllllllllllll}1.00 & 50.80 & 28.27 & 33.11 & 2 & 1388.7418 & 1388.7391 & 695.3768 & 0.0027 & 1.9414 & 5356.770 & 5334.469 & 1712.548 & 1421.650 & \text { Yes }\end{array}$ $\begin{array}{llllllllllllllll}1.00 & 65.78 & 26.11 & 32.62 & 2 & 1444.8406 & 1444.8381 & 723.4263 & 0.0025 & 1.7279 & 15456.426 & 15108.624 & 2058.358 & 991.110 & \text { Yes }\end{array}$ \begin{tabular}{lllllllllllllll}
1.00 & 64.07 & 26.63 & 33.03 & 2 & 1615.9056 & 1615.9025 & 808.9585 & 0.0031 & 1.9160 & 541.170 & 667.578 & 188.302 & 10.635 & Yes \\
\hline
\end{tabular}

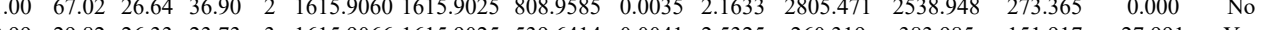
$\begin{array}{lllllllllllllll}0.96 & 29.82 & 26.33 & 23.73 & 3 & 1615.9066 & 1615.9025 & 539.6414 & 0.0041 & 2.5325 & 260.319 & 383.985 & 151.917 & 27.991 & \text { Yes } \\ 0\end{array}$

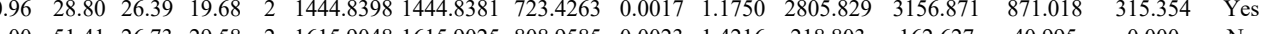
$\begin{array}{lllllllllllllll}1.00 & 1.41 & 26.73 & 29.58 & 2 & 1615.9048 & 1615.9025 & 808.9585 & 0.0023 & 1.4216 & 218.803 & 162.627 & 40.995 & 0.000 & \text { No }\end{array}$ $\begin{array}{lllllllllllllll}0.83 & 17.62 & 25.53 & 20.11 & 3 & 1636.9315 & 1636.9288 & 546.6502 & 0.0027 & 1.6464 & 101.544 & 109.340 & 37.355 & 6.960 & \text { Yes } \\ 0.83 & 18.62 & 25.53 & 26.46 & 3 & 1636.9321 & 1636.9288 & 546.6502 & 0.0033 & 2.0123 & 93.226 & 139.394 & 19.412 & 15.389 & \text { Yes }\end{array}$

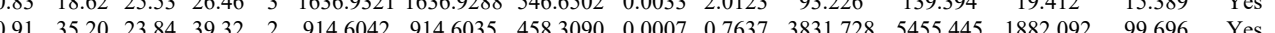

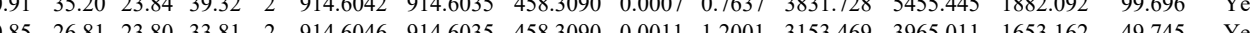

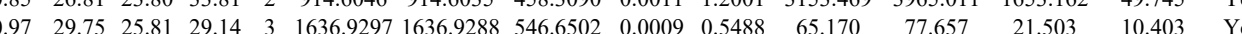

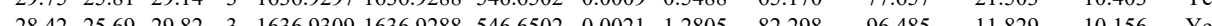

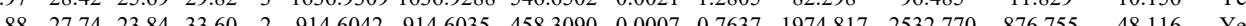
$\begin{array}{lllllllllllllll}0.86 & 27.78 & 23.84 & 34.42 & 2 & 914.642 & 914.6035 & 4583090 & 0.0007 & 0.7637 & 1583.137 & 2154.130 & 783.282 & 15.541 & \text { Yes }\end{array}$

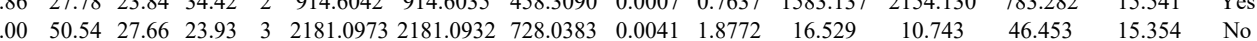
$\begin{array}{lllllllllllllll}1.00 & 55.06 & 27.66 & 25.94 & 3 & 2181.0985 & 2181.0932 & 728.0383 & 0.0053 & 2.4266 & 6.745 & 9.813 & 31.163 & 14.894 & \text { No }\end{array}$ $\begin{array}{lllllllllllllll}1.00 & 74.64 & 26.69 & 28.44 & 2 & 1334.7728 & 1334.7649 & 668.3897 & 0.0079 & 5.9097 & 6611.390 & 5738.923 & 4598.059 & 3121.008 & \text { Yes } \\ 0.93 & 29.08 & 28.36 & 17.09 & 3 & 1489.8097 & 1489.7989 & 497.6069 & 0.0108 & 7.2346 & 17372.386 & 17376.901 & 6900.760 & 1214.727 & \text { Yes }\end{array}$ $\begin{array}{llllllllllllllll}0.90 & 31.90 & 27.61 & 27.46 & 2 & 1007.5974 & 1007.5886 & 504.8016 & 0.0088 & 8.7162 & 18405.320 & 16569.966 & 1002.093 & 1480.551 & \text { Yes }\end{array}$

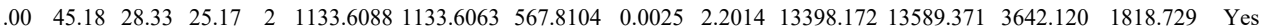
$\begin{array}{lllllllllllllll}1.00 & 43.98 & 28.65 & 24.77 & 2 & 1133.6092 & 1133.6063 & 567.8104 & 0.0029 & 2.5537 & 12306.930 & 13860.142 & 3663.716 & 1981.080 & \text { Yes }\end{array}$ $\begin{array}{llllllllllllllllll}1.00 & 52.10 & 28.65 & 27.22 & 2 & 1133.6094 & 1133.6063 & 567.8104 & 0.0031 & 2.7298 & 9095.391 & 9479.311 & 2934.131 & 1007.471 & \text { Yes }\end{array}$ $\begin{array}{lllllllllllllll}1.00 & 48.40 & 28.65 & 29.14 & 2 & 1133.6094 & 1133.6063 & 567.8104 & 0.0031 & 2.7298 & 10081.736 & 11765.868 & 4380.942 & 1326.279 & \text { Yes }\end{array}$ $\begin{array}{llllllllllllllll}1.00 & 52.51 & 27.94 & 43.33 & 2 & 1448.7352 & 1448.7350 & 725.3748 & 0.0002 & 0.1379 & 2845.147 & 3712.428 & 230.009 & 74.791 & \text { Yes }\end{array}$ $\begin{array}{llllllllllllllll}1.00 & 55.04 & 28.36 & 27.98 & 2 & 1448.7488 & 1448.7350 & 725.3748 & 0.0138 & 9.5122 & 1474.353 & 1513.871 & 73.802 & 21.827 & \text { Yes }\end{array}$ $\begin{array}{lllllllllllllll}1.00 & 52.91 & 28.35 & 26.70 & 2 & 1448.7492 & 1448.7350 & 725.3748 & 0.0142 & 9.7879 & 1538.481 & 1626.561 & 124.869 & 57.161 & \text { Yes }\end{array}$ $\begin{array}{llllllllllllllll}0.55 & 12.42 & 27.54 & 19.73 & 3 & 1646.8990 & 1646.8970 & 549.9729 & 0.0020 & 1.2122 & 82.820 & 79.024 & 57.484 & 35.416 & \text { Yes }\end{array}$

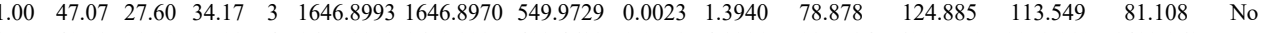

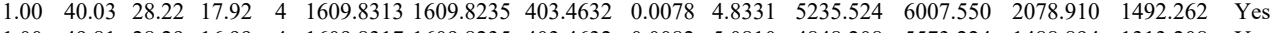
$\begin{array}{llllllllllllllll}1.00 & 49.81 & 28.29 & 16.99 & 4 & 1609.8317 & 1609.8235 & 403.4632 & 0.0082 & 5.0810 & 4848.208 & 5573.224 & 1488.894 & 1313.208 & \text { Yes }\end{array}$ $\begin{array}{llllllllllllllll}0.97 & 31.66 & 25.90 & 24.85 & 2 & 999.4778 & 999.4752 & 500.7449 & 0.0026 & 2.5961 & 3113.622 & 3431.235 & 728.548 & 262.623 & \text { Yes }\end{array}$ $\begin{array}{lllllllllllllll}1.00 & 66.14 & 25.12 & 36.29 & 2 & 1586.9200 & 1586.9187 & 794.4666 & 0.0013 & 0.8182 & 117.738 & 193.553 & 0.000 & 19.413 & \text { No }\end{array}$

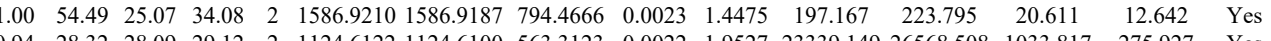

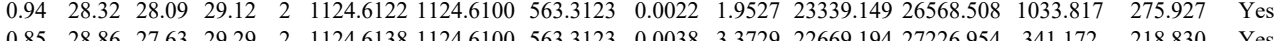
$\begin{array}{lllllllllllllll}0.85 & 28.86 & 27.63 & 29.29 & 2 & 1124.6138 & 1124.6100 & 563.3123 & 0.0038 & 3.3729 & 22669.194 & 27226.954 & 341.172 & 218.830 & \text { Yes } \\ 0.55 & 22.66 & 2.90 & 26.59 & 2 & 1100.6898 & 1100.6919 & 551.3532 & 0.0021 & -1.9044 & 272.049 & 273.861 & 269.848 & 204.547 & \text { Yes }\end{array}$

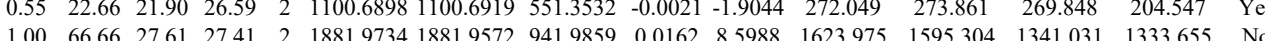
$\begin{array}{lllllllllllllll}1.00 & 66.66 & 27.61 & 27.41 & 2 & 1881.9734 & 1881.9572 & 941.9859 & 0.0162 & 8.5988 & 1623.975 & 1595.304 & 1341.031 & 1333.655 & \mathrm{No} \\ 1.00 & 65.61 & 27.60 & 31.23 & 2 & 1881.9736 & 1881.9572 & 941.9859 & 0.0164 & 8.7049 & 2236.971 & 2089.017 & 2140.613 & 1873.204 & \text { No }\end{array}$

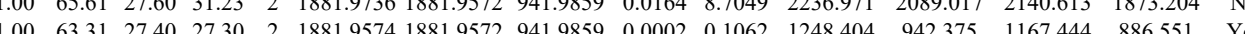

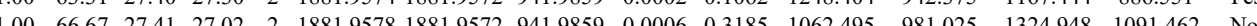

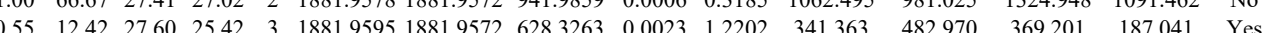




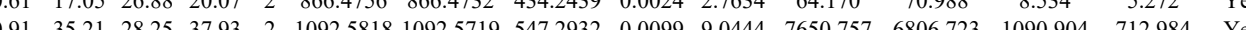

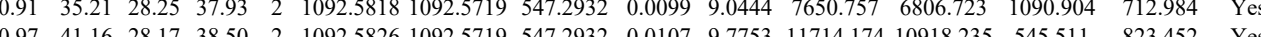
$\begin{array}{llllllllllllllll}0.97 & 41.16 & 28.17 & 38.50 & 2 & 1022.5826 & 1092.5719 & 547.2932 & 0.0107 & 9.7753 & 11714.174 & 10918.235 & 545.511 & 823.452 & \text { Yes }\end{array}$ $\begin{array}{lllllllllllllll}0.96 & 38.53 & 28.22 & 22.79 & 2 & 130.7316 & 130.7271 & 69.3708 & 0.004 & 3.2310 & 12068.33 & 1390.212 & 22800.598 & 7636.218 & \text { No }\end{array}$ $\begin{array}{lllllllllllllll}0.96 & 3.20 & 28.34 & 25.04 & 2 & 1390.7322 & 1390.727 & 696.3708 & 0.0051 & 3.6618 & 1703.109 & 16253.025 & 18702.123 & 5407.528 & \text { No } \\ 1.00 & 36.07 & 28.31 & 22.75 & 3 & 1390.7323 & 1390.7271 & 464.583 & 0.052 & 3.7309 & 31565.447 & 34195.176 & 28253.709 & 12578.421 & \text { Yes }\end{array}$ $\begin{array}{lllllllllllllll}1.00 & 43.11 & 27.97 & 22.45 & 3 & 1390.7290 & 1390.7271 & 464.5830 & 0.0019 & 1.3632 & 32494.494 & 32596.836 & 25977.938 & 13379.636 & \text { Yes }\end{array}$ $\begin{array}{lllllllllllllll}1.00 & 33.74 & 28.00 & 20.39 & 3 & 1390.7293 & 1390.7271 & 464.5830 & 0.0022 & 1.5785 & 45076.47742827 .725 & 41708.840 & 17656.999 & \text { Yes }\end{array}$ $\begin{array}{lllllllllllllll}0.96 & 30.27 & 28.00 & 21.18 & 2 & 1390.7294 & 1390.7271 & 696.3708 & 0.0023 & 1.6514 & 10247.374 & 10189.408 & 12434.466 & 5146.112 & \text { No }\end{array}$ $\begin{array}{lllllllllllllll}0.97 & 24.31 & 25.42 & 19.04 & 3 & 1243.7530 & 1243.7492 & 415.5903 & 0.0038 & 3.0479 & 3501.745 & 3780.267 & 366.738 & 741.347 & \text { Yes }\end{array}$

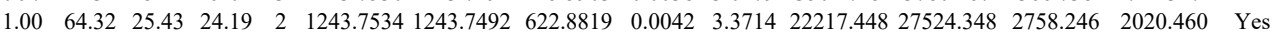
$\begin{array}{llllllllllllllll}0.99 & 27.68 & 24.94 & 20.19 & 3 & 1243.7539 & 1243.7492 & 415.5903 & 0.0047 & 3.7697 & 4481.724 & 5280.201 & 731.946 & 308.380 & \text { Yes }\end{array}$ $\begin{array}{lllllllllllllll}1.00 & 64.98 & 24.94 & 23.72 & 2 & 1243.7540 & 1243.7492 & 622.8819 & 0.0048 & 3.8530 & 45161.081 & 42949.604 & 3332.886 & 505.594 & \text { Yes }\end{array}$

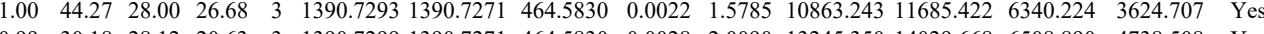
$\begin{array}{lllllllllllllllll}0.99 & 30.18 & 28.12 & 20.63 & 3 & 1390.7299 & 1390.7271 & 464.5830 & 0.0028 & 2.0090 & 13245.350 & 44029.668 & 6508.890 & 4738.508 & \text { Yes }\end{array}$ $\begin{array}{llllllllllllllll}1.00 & 78.31 & 24.94 & 23.22 & 2 & 1243.7536 & 1243.7492 & 622.8819 & 0.0044 & 3.5320 & 15245.640 & 15792.004 & 1982.538 & 1082.749 & \text { Yes } \\ 1.00 & 78.40 & 24.87 & 23.32 & 2 & 1243.7546 & 1243.7492 & 622.8819 & 0.0054 & 4.3347 & 22114.789 & 20724.500 & 993.046 & 1009.462 & \text { Yes }\end{array}$ $\begin{array}{lllllllllllllll}1.00 & 78.40 & 24.87 & 23.32 & 2 & 1243.7546 & 1243.7492 & 622.8819 & 0.0054 & 4.3347 & 22114.789 & 20724.500 & 993.046 & 1009.462 & \text { Yes } \\ 0.98 & 28.55 & 24.89 & 20.34 & 3 & 1243.7551 & 1243.7492 & 415.5903 & 0.0059 & 4.7322 & 3590.262 & 3385.376 & 1320.792 & 1268.853 & \text { Yes }\end{array}$

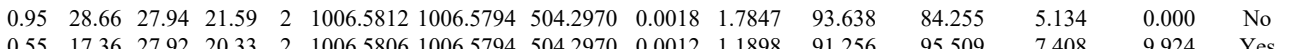

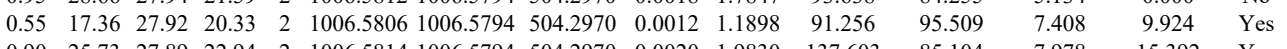

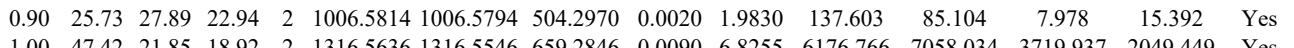

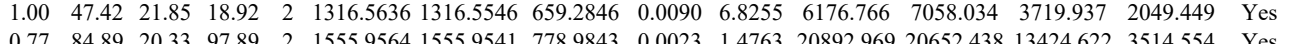
$\begin{array}{lllllllllllllllll}0.77 & 84.89 & 20.33 & 97.89 & 2 & 1555.9564 & 1555.9541 & 778.9843 & 0.0023 & 1.4763 & 20892.969 & 20652.438 & 13424.622 & 3514.554 & \text { Yes } \\ 1.00 & 8.04 & 20.33 & 21.11 & 2 & 1555.9564 & 1555.9541 & 778.9843 & 0.0023 & 1.4763 & 13797.585 & 13139.889 & 8905.256 & 2586.690 & \text { Yes }\end{array}$

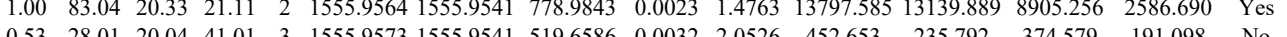

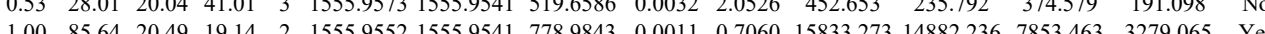

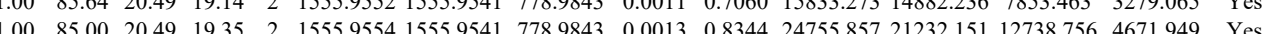
$\begin{array}{llllllllllllllll}1.00 & 35.45 & 20.29 & 16.51 & 3 & 1555.9561 & 1555.9541 & 519.6586 & 0.0020 & 1.8329 & 302.259 & 633.184 & 218.019 & 110.569 & \text { Yes }\end{array}$

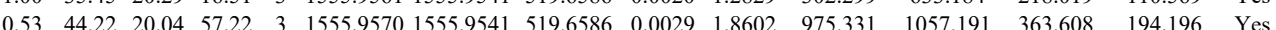

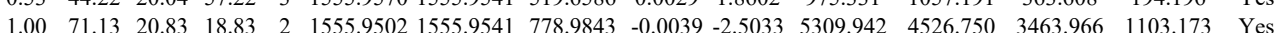

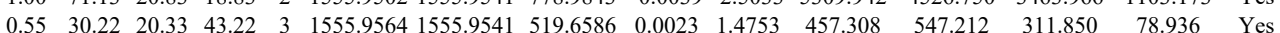

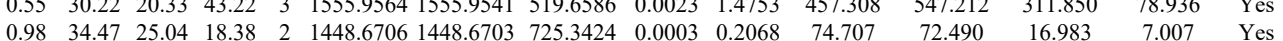

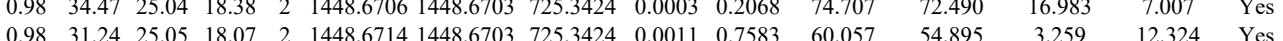

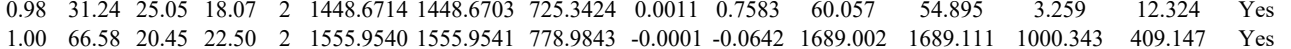
$\begin{array}{lllllllllllllll}1.00 & 66.58 & 20.45 & 22.50 & 2 & 1555.9544 & 155.9541 & 77.9843 & -0.0001 & -0.0642 & 1689.002 & 1689.111 & 1000.343 & 409.147 & \text { Yes } \\ 1.00 & 80.76 & 20.49 & 19.75 & 2 & 1555.9548 & 1555.9541 & 778.9843 & 0.0007 & 0.4493 & 2497.704 & 2243.038 & 1483.724 & 578.404 & \text { Yes }\end{array}$

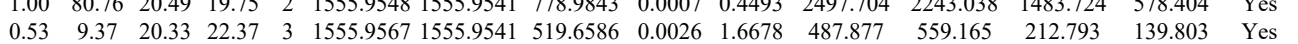
$\begin{array}{lllllllllllllll}1.00 & 43.92 & 25.00 & 20.61 & 2 & 1448.6710 & 1448.6703 & 725.3424 & 0.0007 & 0.4825 & 19413.567 & 16297.817 & 0.000 & 52.099 & \text { No }\end{array}$

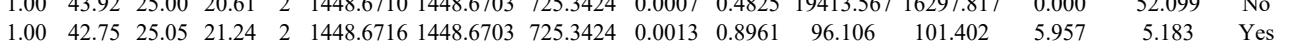

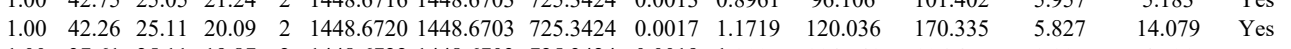
\begin{tabular}{lllllllllllllll}
1.00 & 37.61 & 25.11 & 19.87 & 2 & 1448.6722 & 1448.6703 & 725.3424 & 0.0019 & 1.3097 & 114.541 & 106.455 & 8.807 & 4.591 & Yes \\
\hline
\end{tabular} $\begin{array}{lllllllllllllll}0.99 & 38.08 & 25.26 & 17.51 & 2 & 1448.6730 & 1448.6703 & 725.3424 & 0.0027 & 1.8612 & 139.341 & 105.322 & 18.329 & 7.090 & \text { Yes }\end{array}$ $\begin{array}{lllllllllllllll}0.99 & 42.53 & 25.33 & 21.00 & 2 & 1448.6742 & 1448.6703 & 725.3424 & 0.0039 & 2.6884 & 10488.768 & 10594.475 & 394.437 & 201.359 & \text { Yes }\end{array}$

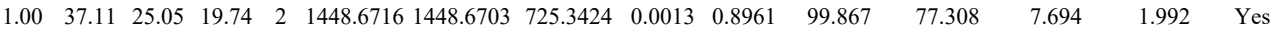
$\begin{array}{lllllllllllllll}0.99 & 33.59 & 25.01 & 16.15 & 2 & 1448.6718 & 1448.6703 & 725.3424 & 0.0015 & 1.0340 & 72.039 & 70.049 & 6.123 & 7.148 & \text { Yes }\end{array}$

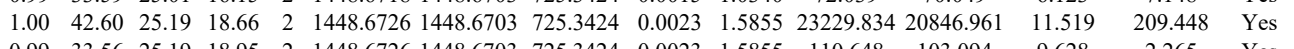

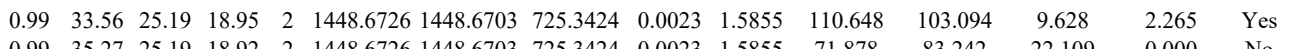

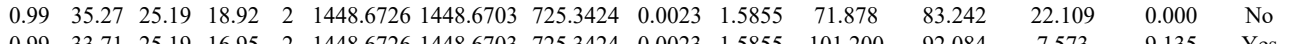

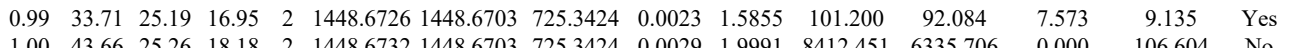

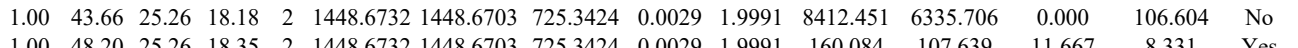

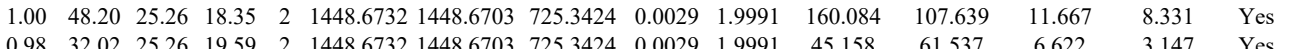

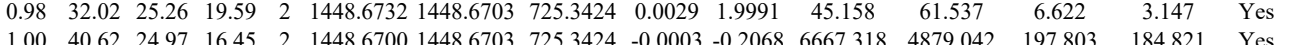
$\begin{array}{llllllllllllllll}1.00 & 40.62 & 24.97 & 16.45 & 2 & 1448.6700 & 1448.6703 & 725.3424 & -0.0003 & -0.2068 & 6667.318 & 4879.042 & 197.803 & 184.821 & \text { Yes } \\ 1.00 & 41.02 & 25.04 & 17.81 & 2 & 1448.6712 & 1448.6703 & 7253424 & 0.0009 & 0.6204 & 9920.943 & 8468.239 & 305.633 & 0.000 & \text { No }\end{array}$ $\begin{array}{llllllllllllllll}.00 & 41.02 & 25.04 & 17.81 & 2 & 1448.6712 & 1448.6703 & 725.3424 & 0.0009 & 0.6204 & 9920.943 & 8468.239 & 305.633 & 0.000 & \text { No } \\ 1.00 & 87.39 & 20.33 & 19.16 & 2 & 1555.9562 & 1555.9541 & 778.9843 & 0.0021 & 1.3479 & 209.511 & 132.416 & 97.055 & 47.158 & \text { Yes }\end{array}$ 

$\begin{array}{lllllllllllll}\text { APIRPDIVNFVHTNLR } & 1.00 & 29.70 & 23.77 & 42.70 & 4 & 2005.1353 & 2005.1343 & 502.2909 & 0.0010 & 0.4977 & 22.923\end{array}$ $\begin{array}{llllllllllll}\text { APIRPDIVNFVHTNLR } & 1.00 & 22.79 & 23.77 & 35.79 & 4 & 2005.1353 & 2005.1343 & 502.2909 & 0.0010 & 0.4977 & 13.989\end{array}$

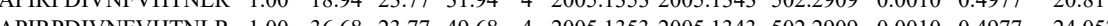

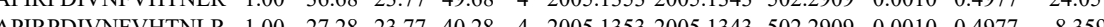
$\begin{array}{lllllllllll} & \end{array}$ $\begin{array}{llllllllll} & \end{array}$

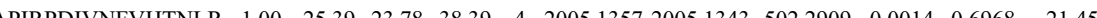
$\begin{array}{llllllllllllll} & \text { APIRPDIVNFVHTNLR } & 1.00 & 23.75 & 23.78 & 36.75 & 4 & 2005.1357 & 2005.1343 & 502.2909 & 0.0014 & 0.6968 & 21.830\end{array}$ $\begin{array}{lllllllllllllll} & \text { APIRPDIVNFVHTNLR } & 0.99 & 15.34 & 23.78 & 15.72 & 4 & 2005.1357 & 2005.1343 & 5022909 & 0.0014 & 0.6968 & 21.233\end{array}$ $\begin{array}{lllllllllllllll}\text { APIRPDIVNFVHTNLR } & 1.00 & 23.31 & 23.78 & 36.31 & 4 & 2005.1357 & 2005.1343 & 502.2909 & 0.0014 & 0.6968 & 9.060\end{array}$

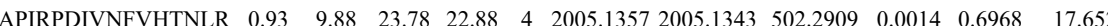
$\begin{array}{lllllllllllll}\text { APIRPDIVNFVHTNLR } & 0.55 & 41.58 & 23.78 & 54.58 & 3 & 2005.1359 & 2005.1343 & 669.3854 & 0.0016 & 0.7968 & 48.155\end{array}$ $\begin{array}{llllllllllllll}\text { APIRPDIVNFVHTNLR } & 0.55 & 14.69 & 23.78 & 27.69 & 3 & 2005.1359 & 2005.1343 & 669.3854 & 0.0016 & 0.7968 & 19.770\end{array}$

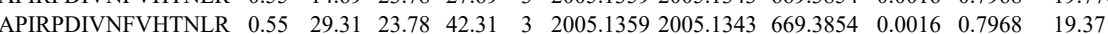
$\begin{array}{llllllllllllll}\text { APIRPDIVNFVHTNLR } & 1.00 & 16.04 & 23.75 & 29.04 & 4 & 2005.1361 & 2005.1343 & 502.2909 & 0.0018 & 0.8959 & 28.830\end{array}$ $\begin{array}{lllllllllllllll}\text { APIRPDIVNFVHTNLR } & 1.00 & 27.66 & 23.75 & 40.66 & 4 & 2005.1361 & 2005.1343 & 502.2909 & 0.0018 & 0.8959 & 9.632\end{array}$ $\begin{array}{lllllllllllll}\text { APIRPDIVNFVHTNLR } & 1.00 & 17.31 & 23.75 & 30.31 & 4 & 2005.1361 & 2005.1343 & 502.2909 & 0.0018 & 0.8959 & 22.274\end{array}$ $\begin{array}{llllllllllllll}\text { APIRPDIVNFVHTNLR } & 0.99 & 14.38 & 23.75 & 27.38 & 4 & 2005.1361 & 2005.1343 & 502.2909 & 0.0018 & 0.8959 & 17.83\end{array}$ $\begin{array}{lllllllllllll}\text { APIRPDIVNFVHTNLR } & 0.55 & 14.80 & 23.75 & 27.80 & 3 & 2005.1362 & 2005.1343 & 669.3854 & 0.0019 & 0.9461 & 22.768\end{array}$

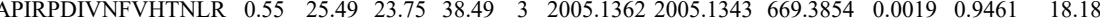

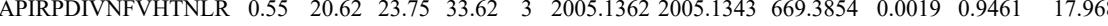

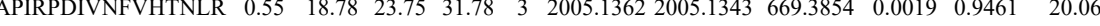

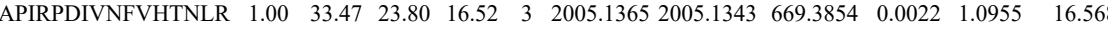

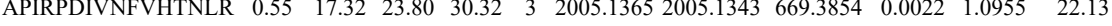

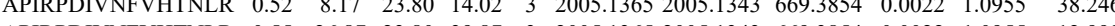
$\begin{array}{llllllllllll}\text { APIRPDIVNFVHTNLR } & 0.55 & 26.87 & 23.80 & 39.87 & 3 & 2005.1365 & 2005.1343 & 669.3854 & 0.0022 & 1.0955 & 12.999\end{array}$ $\begin{array}{lllllllllllll} & \text { APIRPDVNFVHTNLR } & 0.55 & 15.32 & 23.80 & 28.32 & 3 & 2005.1365 & 2005.1343 & 669.3854 & 0.0022 & 1.0955 & 21.481\end{array}$

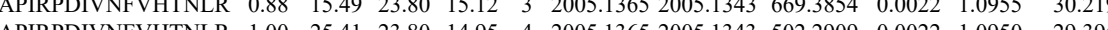

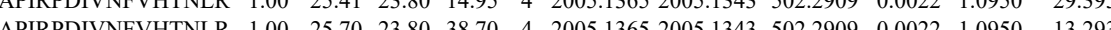

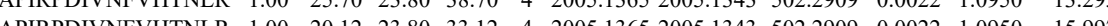
$\begin{array}{lllllllllll} & \end{array}$ $\begin{array}{llllllll} & \end{array}$ $\begin{array}{lllllllll} & \end{array}$

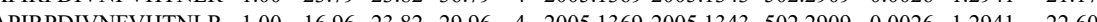

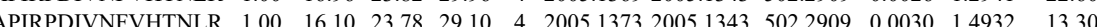
$\begin{array}{lllllllllllll}\text { APIRPDIVNFVHTNLR } & 0.53 & 21.97 & 23.78 & 34.97 & 3 & 2005.1377 & 2005.1343 & 669.3854 & 0.0034 & 1.6931 & 24.943\end{array}$ $\begin{array}{lllllllllllllll}\text { APIRPDIVNFVHTNLR } & 0.53 & 23.54 & 23.78 & 36.54 & 3 & 2005.1377 & 2005.1343 & 669.3854 & 0.0034 & 1.6931 & 4.750\end{array}$ $\begin{array}{lllllllllllll}\text { APIRPDIVNFVHTNLR } & 1.00 & 25.37 & 23.69 & 38.37 & 4 & 2005.1389 & 2005.1343 & 502 & 2909 & 0.0046 & 2.2895 & 27.082\end{array}$ $\begin{array}{llllllllllll}\text { APIRPDIVNFVHTNLR } & 1.00 & 20.50 & 23.56 & 33.50 & 4 & 2005.1401 & 2005.1343 & 502.2909 & 0.0058 & 2.8868 & 13.263\end{array}$ $\begin{array}{llllllllllll}\text { APIRPDIVNFVHTNLR } & 1.00 & 27.62 & 24.07 & 40.62 & 4 & 2005.1341 & 2005.1343 & 502.2909 & -0.0002 & -0.0995 & 32.494\end{array}$ $\begin{array}{llllllllllllll}\text { APIRPDIVNFVHTNLR } & 1.00 & 40.28 & 23.77 & 16.83 & 4 & 2005.1353 & 2005.1343 & 502.2909 & 0.0010 & 0.4977 & 50.284\end{array}$ $\begin{array}{lllllllllllll}\text { APIRPDIVNFVHTNLR } & 1.00 & 21.43 & 23.77 & 14.45 & 4 & 2005.1353 & 2005.1343 & 502.2909 & 0.0010 & 0.4977 & 60.125\end{array}$ $\begin{array}{lllllllllllll}\text { APIRPDIVNFVHTNLR } & 0.76 & 47.64 & 23.78 & 60.64 & 2 & 2005.1354 & 2005.1343 & 1003.5744 & 0.0011 & 0.5480 & 93.083\end{array}$

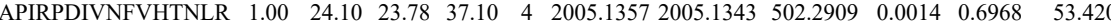
$\begin{array}{lllllllllllll}\text { APIRPDIVNFVHTNLR } & 0.55 & 22.62 & 23.78 & 35.62 & 3 & 2005.1359 & 2005.1343 & 669.3854 & 0.0016 & 0.7968 & 59.805\end{array}$

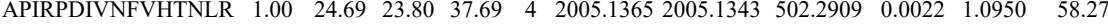

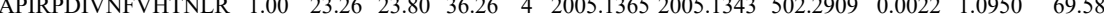

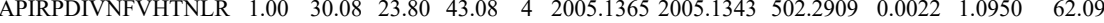
$\begin{array}{lllllllllllll}\text { APIRPDIVNFVHTNLR } & 1.00 & 22.48 & 23.80 & 35.48 & 4 & 2005.1365 & 2005.1343 & 502.2909 & 0.0022 & 1.0950 & 57.34\end{array}$ $\begin{array}{lllllllllllll}\text { APIRPDIVNFVHTNLR } & 0.55 & 21.70 & 23.82 & 34.70 & 3 & 2005.1368 & 2005.1343 & 669.3854 & 0.0025 & 1.2449 & 61.544\end{array}$

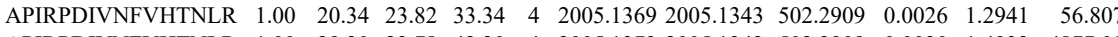

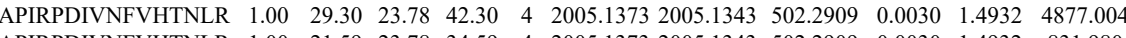
$\begin{array}{llllllllllll}\text { APIRPDIVNFVHTNLR } & 1.00 & 21.59 & 23.78 & 34.59 & 4 & 2005.1373 & 2005.1343 & 502.2909 & 0.0030 & 1.4932 & 831.980\end{array}$ $\begin{array}{lllllllllllll}\text { APIRPDIVNFVHTNLR } & 1.00 & 24.25 & 23.78 & 37.25 & 4 & 2005.1373 & 2005.1343 & 502.2909 & 0.0030 & 1.4932 & 39.317\end{array}$ $\begin{array}{lllllllllllll}\text { APIRPDIVNFVHTNLR } & 1.00 & 30.01 & 23.78 & 43.01 & 4 & 2005.1373 & 2005.1343 & 502.2909 & 0.0030 & 1.4932 & 22.954 \\ \text { APIRPDIVNFVHTNLR } & 0.53 & 21.29 & 23.80 & 34.29 & 3 & 2005.1374 & 2005.1343 & 669.3854 & 0.0031 & 1.5437 & 61.321\end{array}$ $\begin{array}{llllllllllll}\text { APPPDIVNFVHTNLR } & 1.00 & 30.54 & 23.78 & 43.54 & 4 & 2005.1377 & 2005.1343 & 502.2909 & 0.0034 & 1.6922 & 34.318\end{array}$

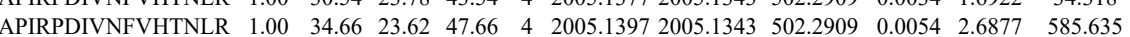
$\begin{array}{llllllllllll}\text { APIRPDIVNFVHTNLR } & 1.00 & 27.82 & 24.07 & 40.82 & 4 & 2005.1333 & 2005.1343 & 502.2909 & 0.0010 & 0.6977 & 1679.309\end{array}$ $\begin{array}{lllllllllllll}\text { APIRPDIVNFVHTNLR } & 0.99 & 12.98 & 23.75 & 16.30 & 4 & 2005.1361 & 2005.1343 & 502.2909 & 0.0018 & 0.8959 & 26.600\end{array}$

\subsection{3}




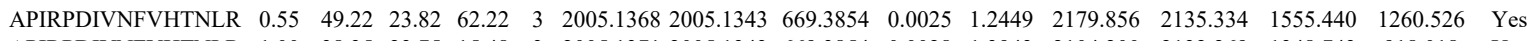
$\begin{array}{lllllllllllllll} & \end{array}$ $\begin{array}{llllllllllllllll}\text { APIRPDIVNFVHTNLR } & 1.00 & 15.24 & 23.78 & 22.51 & 4 & 2005.1381 & 2005.1343 & 502.2909 & 0.0038 & 1.8913 & 23.863 & 46.052 & 7.985 & 10.328 & \text { Yes }\end{array}$ $\begin{array}{llllllllllllllll}\text { APIRPDIVNFVHTNLR } & 1.00 & 26.95 & 23.58 & 16.82 & 4 & 2005.1405 & 2005.1343 & 502.2909 & 0.0062 & 3.0859 & 3132.100 & 4409.685 & 2927.192 & 2090.925 & \text { Yes }\end{array}$

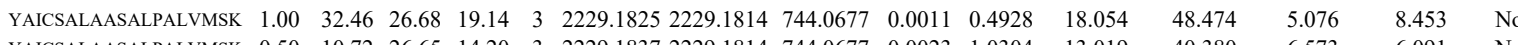

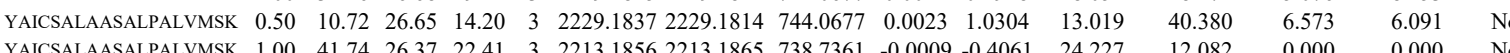

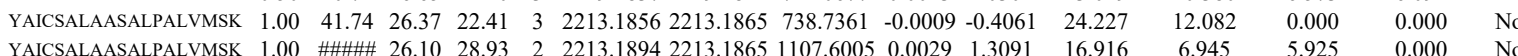

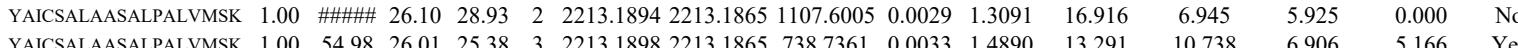

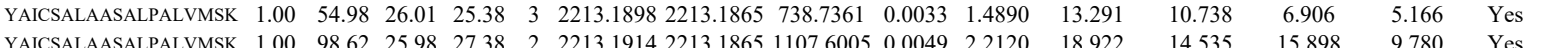
$\begin{array}{lllllllllllllll} & \end{array}$

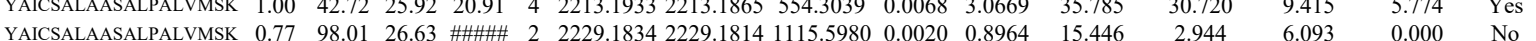

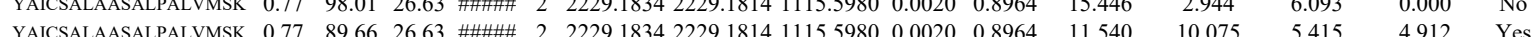
\begin{tabular}{lllllllllll} 
& YAISALASALALVMSK \\
\hline
\end{tabular}

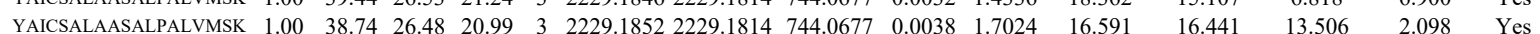

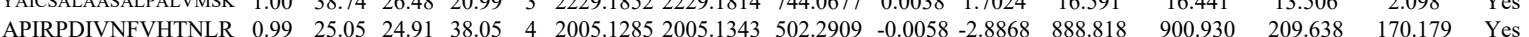

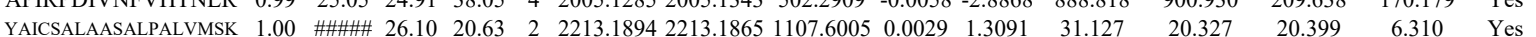

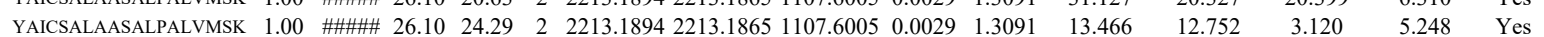

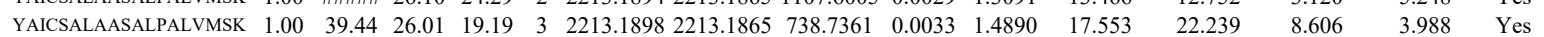
$\begin{array}{llllllllllllllll}\text { YAICSALAASALPALVMSK } & 1.00 & 48.47 & 26.03 & 17.01 & 4 & 2213.1905 & 2213.1865 & 554.3039 & 0.0040 & 1.8041 & 53.050 & 50.186 & 19.729 & 10.050 & \text { Yes }\end{array}$

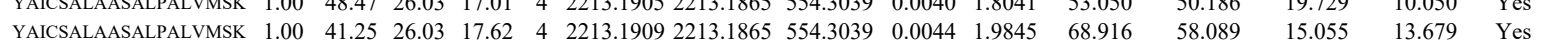
$\begin{array}{llllllllllllllll}\text { YAICSALAASALPALVMSK } & 1.00 & 36.80 & 26.02 & 19.63 & 3 & 2213.1910 & 2213.1865 & 738.7361 & 0.0045 & 2.0305 & 71.616 & 67.938 & 19.463 & 21.787 & \text { Yes }\end{array}$ $\begin{array}{lllllllllllllllllllllll}\text { YAICSALAASALPALVMSK } & 0.77 & 87.93 & 26.63 & 2229.1834 & 2229.1814 & 1115.5980 & 0.0020 & 0.8964 & 8.292\end{array}$ $\begin{array}{lllllllllllll}\text { YAICSALAASALPALVMSK } & 1.00 & 66.09 & 26.51 & 19.24 & 3 & 2229.1849 & 2229.1814 & 744.0677 & 0.0035 & 1.5680 & 12.190\end{array}$ $\begin{array}{llllllllllllll}\text { YAICSALAASALPALVMSK } & 1.00 & \text { \#\#\#\#\# } 26.29 & 25.98 & 2 & 2213.1874 & 2213.1865 & 1107.6005 & 0.0009 & 0.4063 & 14.837\end{array}$ $\begin{array}{lllllllllllll}\text { YAICSALAASALPALVMSK } & 1.00 & 36.31 & 26.20 & 15.82 & 3 & 2213.1886 & 2213.1865 & 738.7361 & 0.0021 & 0.9476 & 25.143\end{array}$ $\begin{array}{llllllllllllll}\text { YAICSALAASALPALVMSK } & 1.00 & 33.01 & 26.20 & 16.70 & 3 & 2213.1886 & 2213.1865 & 738.7361 & 0.0021 & 0.9476 & 17.317\end{array}$ $\begin{array}{llllllllllll}\text { YAICSALAASALPALVMSK } & 1.00 & \text { \#\#\#\# } & 26.10 & 26.96 & 2 & 2213.1894 & 2213.1865 & 1107.6005 & 0.0029 & 1.3091 & 18.378 \\ \text { YAICSALAASALPALVMSK } & 0.93 & 20.11 & 26.65 & 14.50 & 3 & 2229.1837 & 2229.1814 & 744.0677 & 0.0023 & 1.0304 & 13.757\end{array}$ $\begin{array}{llllllllllll}\text { YAICSALAASALPALVMSK } & 0.93 & 20.11 & 26.65 & 14.50 & 3 & 2229.1837 & 2229.1814 & 744.0677 & 0.0023 & 1.0304 & 13.757 \\ \text { YAICSALASALPAVMMSK } & 0.93 & 21.53 & 26.50 & 17.93 & 3 & 2229.1858 & 2229.1814 & 744.0677 & 0.0044 & 1.9711 & 24.15\end{array}$ $\begin{array}{lllllllllllll}\text { YAICSALAASALPALVMSK } & 0.93 & 21.53 & 26.50 & 17.93 & 3 & 2229.1858 & 2229.1814 & 744.0677 & 0.0044 & 1.9711 & 24.154 \\ \text { YAICSALASALPALVMSK } & 1.00 & 46.47 & 26.10 & 23.25 & 3 & 2213.1895 & 2213.1865 & 738.7361 & 0.0030 & 1.3537 & 12.737\end{array}$ $\begin{array}{lllllllllllll}\text { YAICSALAASALPALVMSK } & 1.00 & 51.04 & 26.03 & 22.62 & 3 & 2213.1913 & 2213.1865 & 738.7361 & 0.0048 & 2.1659 & 8.769\end{array}$ $\begin{array}{llllllllllll}\text { YAICSALAASALPALVMSK } & 0.77 & 71.32 & 27.83 & 84.32 & 2 & 1924.9848 & 1924.9824 & 963.4985 & 0.0024 & 1.2455 & 1.186\end{array}$ $\begin{array}{llllllllllll}\text { YAICSALAASALPALVMSK } & 1.00 & 89.69 & 27.79 & 30.76 & 2 & 1924.9836 & 1924.9824 & 963.4985 & 0.0012 & 0.6227 & 0.000 \\ \text { APIRPDIVNFVHTNLR } & 1.00 & 19.02 & 24.07 & 32.02 & 4 & 2005.1341 & 2005.1343 & 502.2909 & -0.0002 & -0.0995 & 32.884\end{array}$ $\begin{array}{lllllllllllll}\text { APIRPDIVNFVHTNLR R } & 1.00 & 29.78 & 24.00 & 42.78 & 4 & 2005.1349 & 2005.1343 & 502.2909 & 0.0006 & 0.2986 & 68.817\end{array}$ $\begin{array}{llllllllll} & 0.817\end{array}$ $\begin{array}{llllllllll} & 0.221\end{array}$ $\begin{array}{lllllllllll} & 0.003\end{array}$

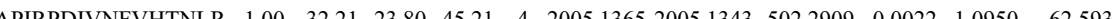
$\begin{array}{llllllllll} & 0.002 & 1.0950\end{array}$ $\begin{array}{llllllllllllll}\text { APIRPDIVNFVHTNLR } & 1.00 & 21.98 & 23.77 & 34.98 & 4 & 2005.1353 & 2005.1343 & 5022909 & 0.0010 & 0.4977 & 4.7749\end{array}$ $\begin{array}{llllllllllll}\text { KPTTEEK } & 0.91 & 26.47 & 27.10 & 17.84 & 3 & 1263.7393 & 1263.7400 & 422.2539 & -0.0007 & -0.5526 & 767.01\end{array}$

$\begin{array}{lllllllllllll}\text { KPTTEEK } & 0.91 & 26.47 & 27.10 & 17.84 & 3 & 1263.7393 & 1263.7400 & 422.2539 & -0.0007 & -0.5526 & 767.011 & 651.5 \\ \text { IEEVPELPLVVEDK } & 1.00 & 73.73 & 24.36 & 23.67 & 2 & 1896.0730 & 1896.0699 & 949.0422 & 0.0031 & 1.6332 & 3800.282 & 3353 .\end{array}$ $\begin{array}{lllllllllllllll}\text { IEEVPELPLVVEDK } & 1.00 & 63.90 & 24.46 & 21.27 & 2 & 1896.0736 & 1896.0699 & 949.0422 & 0.0037 & 1.9493 & 3821.023 & 3203.849\end{array}$ $\begin{array}{llllllllllllll}\text { IEEVPELPLVVEDK } & 1.00 & 49.66 & 24.46 & 26.00 & 3 & 1896.0745 & 1896.0699 & 633.0306 & 0.0046 & 2.4222 & 903.945 & 742.314\end{array}$ $\begin{array}{llllllllllllll}\text { IEEVPELPLVVEDK } & 1.00 & 46.60 & 24.39 & 18.51 & 3 & 1896.0751 & 1896.0699 & 633.0306 & 0.0052 & 2.7381 & 817.503 & 959.917\end{array}$ $\begin{array}{lllllllllllll}\text { IEEVPELPLVVEDK } & 1.00 & 61.55 & 24.33 & 20.82 & 2 & 1896.0732 & 1896.0699 & 949.0422 & 0.0033 & 1.7386 & 3118.670 & 2531.724\end{array}$

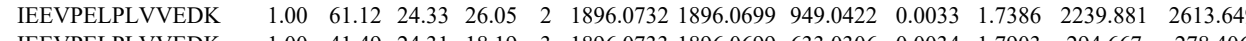
$\begin{array}{lllllllllllll}\text { IEEVPELPLVVEDK } & 1.00 & 41.49 & 24.31 & 18.19 & 3 & 1896.0733 & 1896.0699 & 633.0306 & 0.0034 & 1.7903 & 294.667 & 278.406\end{array}$ $\begin{array}{lllllllllllll}\text { IEEVPELPLVVEDK } & 1.00 & 48.98 & 24.46 & 17.09 & 3 & 1896.0745 & 1896.0699 & 633.0306 & 0.0046 & 2.4222 & 2091.627 & 1921.073\end{array}$ $\begin{array}{lllllllllllll}\text { IEEVPELPLVVEDK } & 1.00 & 59.60 & 24.33 & 19.71 & 2 & 1896.0722 & 1896.0699 & 949.0422 & 0.0023 & 1.2117 & 542.570 & 542.906\end{array}$

$\begin{array}{lllllllllllll}\text { IEEVPELPLVVEDK } & 1.00 & 54.45 & 24.42 & 20.20 & 2 & 1896.0724 & 1896.0699 & 949.0422 & 0.0025 & 1.3171 & 470.434 & 406.322 \\ \text { IEEVPELPLVVEDK } & 1.00 & 31.48 & 24.49 & 17.35 & 3 & 1896.0748 & 1896.0699 & 633.0306 & 0.0049 & 2.5802 & 223.456 & 345.032\end{array}$ IEEVPELPLVVEDK $\begin{array}{llllllllllll}\text { TQAYQDQKPGTSGLR } & 0.65 & 20.86 & 27.85 & 19.07 & 3 & 1937.0206 & 1937.0210 & 646.6809 & -0.0004 & -0.2062 & 1683.866\end{array}$ $\begin{array}{lllllllllllllll}\text { INQDPQVMLAPLISIALK } & 1.00 & 84.39 & 17.85 & 19.44 & 2 & 2251.3234 & 2251.3217 & 1126.6681 & 0.0017 & 0.7544 & 67.161 & \\ \text { INQDPQVMLAPLISIALK } & 0.55 & 6.15 & 17.71 & 18.90 & 3 & 2251.3243 & 2251.3217 & 751.4478 & 0.0026 & 1.1533 & 14.444 & 0\end{array}$ $\begin{array}{lllllllllllll}\text { INQDPQVMLAPLISIALK } & 0.55 & 6.15 & 17.71 & 18.90 & 3 & 2251.3243 & 2251.3217 & 751.4478 & 0.0026 & 1.1533 & 14.444 \\ \text { INODPOVMLAPLISIALK } & 0.72 & 5.00 & 17.24 & 14.28 & 3 & 2251.3249 & 2251.3217 & 751.4478 & 0.0032 & 1.4195 & 17.867\end{array}$ $\begin{array}{llllllllllll}\text { INQDPQVMLAPLISIALK } & 0.72 & 5.00 & 17.24 & 14.28 & 3 & 2251.3249 & 2251.3217 & 751.4478 & 0.0032 & 1.4195 & 17.867 \\ \text { VFQSSANYAEFIOSISTVEPAOR } & 1.00 & 41.84 & 26.29 & 19.41 & 3 & 2942.4922 & 2942.4896 & 981.8371 & 0.0026 & 0.8827 & 7.460\end{array}$ $\begin{array}{llllllllllll}\text { VFQSSANYAENFIQSIISTVEPAQR } & 1.00 & 41.84 & 26.29 & 19.41 & 3 & 2942.4922 & 2942.4896 & 981.8371 & 0.0026 & 0.8827 & 7.460 \\ \text { VFOSSANYAENFIOSISTYEPAOR } & 1.00 & 57.85 & 26.26 & 24.62 & 3 & 2942.4940 & 2942.4896 & 981.8371 & 0.0044 & 1.4938 & 3.680\end{array}$ $\begin{array}{llllllllllllll}\text { VFESSANYAENFIQSIISTEPAQR } & 1.00 & 57.85 & 26.26 & 24.62 & 3 & 2942.4940 & 2942.4896 & 981.8371 & 0.0044 & 1.4938 & 3.680 \\ \text { VFOSSANYAENFIOSISTVEPAOR } & 0.55 & 38.12 & 26.30 & 51.12 & 3 & 2942.4916 & 2942.4896 & 981.8371 & 0.0020 & 0.6790 & 7.056\end{array}$ $\begin{array}{llllllllllll}\text { VFPSSANYAENFILSIISTVEPAQR } & 0.55 & 38.12 & 26.30 & 51.12 & 3 & 2942.4916 & 2942.4896 & 981.8371 & 0.0020 & 0.6790 & 7.056 \\ \text { VFQSANYNAENFILSIISTVEPAQR } & 1.00 & 41.42 & 26.30 & 20.22 & 3 & 2942.4916 & 2942.4896 & 981.8371 & 0.0020 & 0.6790 & 3.475\end{array}$

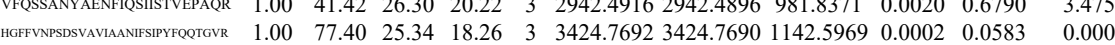

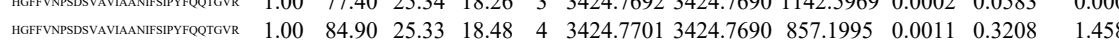

8.381

10.460

(3..696

25.019

15.464

0.403

0.000

47.150

78.250

0.770

7.371
80.838

8.838
57.160

(

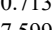




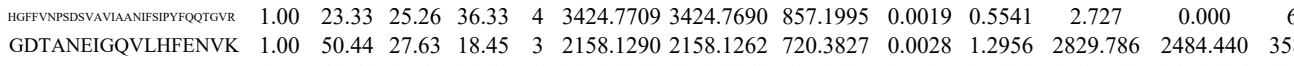

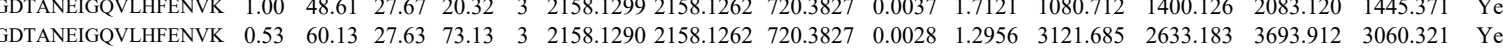

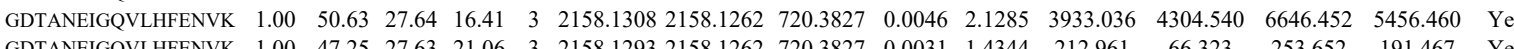

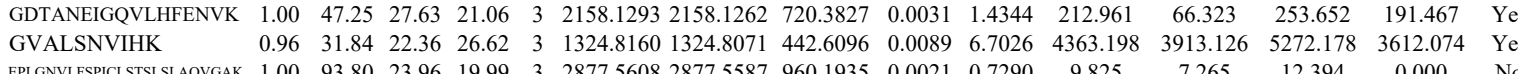

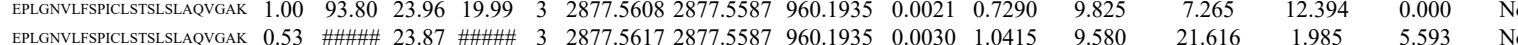

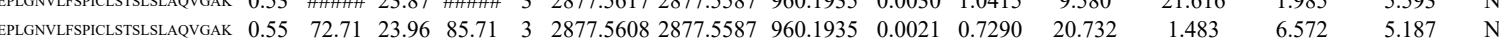

$\begin{array}{llllllllll}\text { ODO2 HUMAN P36957 DLST Dihydrolipoyllysii } & 48.73 & 1.00 & 5 & 15 & -0.0553 & 0.6593 & -0.9232 & 2.1918\end{array}$

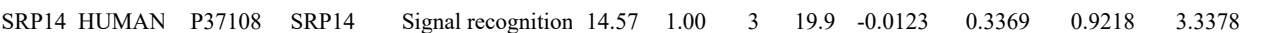

$\begin{array}{lllllllllll}\text { FDFT_HUMAN } & \text { P37268 } & \text { FDFT1 } & \text { Squalene synthase 48.12 } & 1.00 & 3 & 7.9 & 0.9664 & 0.1764 & -1.6781 & 0.8607\end{array}$ $\begin{array}{llllllll}22.39 & 1.00 & 9 & 59.3 & 0.5345 & 0.5981 & -0.8707 & 2.1550\end{array}$
10 NVEAMNFADIER

AKPAEAPAAAAPK

AKPAEAPAAAAPK

AKPAEAPAAAAPK

ASAFALQEQPVVNAVIDDTTK

ASAFALQEQP

GLVVPVIR

GLVVPVIR

TPAFAESVTEGDVR

TPAFAESVTEGDVR

VLLESEQFLTELTR

VLLESEQFLTELTR

VLLESEQFLTELTR

VLLESEQFLTELTR

GTVEGFEPADNK

GTVEGFEPADNK

KGTVEGFEPADNK
KGTVEGFEPADNK

KGTVEGFEPADNK

MGIGMAEFLDK

YQTVIADICR

TQNLPNCQLISR

TQNLPNCQLISR

TQNLPNCQLISR

DDGLFSGDPNWF

DDGLFSGDPNWFPK

DDGLFSGDPNWFPK
DDGLFGDPNWFP

DDGLFSGDPNWFPK

DDGLFSGDPNWFPK

YGINTTDIFQTVDLWEGK$$
\text { YGINTTDIFQTVDLWEGK }
$$
\begin{tabular}{llllllllllllllll}
0.53 & 33.71 & 22.53 & 46.71 & 3 & 1623.9703 & 1623.9673 & 542.3297 & 0.0030 & 1.8439 & 7628.973 & 7491.202 & 4340.527 & 492.944 & Yes \\
\hline
\end{tabular} $\begin{array}{ccccccccccccccc}1.00 & 20.52 & 22.50 & 20.93 & 4 & 1623.9677 & 1623.9673 & 406.9991 & 0.0004 & 0.2457 & 401.359 & 486.374 & 397.163 & 259.795 & \text { Yes }\end{array}$

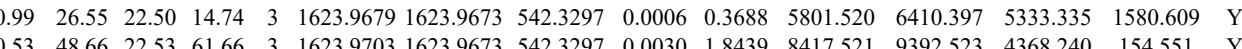
$\begin{array}{llllllllllllllll}0.53 & 48.66 & 22.53 & 61.66 & 3 & 1623.9703 & 1623.9673 & 542.3297 & 0.0030 & 1.8439 & 8417.521 & 9392.523 & 4368.240 & 154.551 & \text { Y }\end{array}$ $\begin{array}{ccccccccccccccc}0.53 & 28.36 & 26.24 & 14.92 & 3 & 2504.3398 & 2504.3366 & 835.7861 & 0.0032 & 1.2762 & 84.656 & 28.863 & 77.059 & 28.225 & \text { Yes } \\ 0.53 & 40.02 & 26.22 & 53.02 & 3 & 25043401 & 25043366 & 835.7861 & 0.0035 & 1.3959 & 36.425 & 144.370 & 41.269 & 4.683 & \mathrm{No}\end{array}$ $\begin{array}{llllllllllllllllll}0.99 & 40.67 & 11.76 & 33.16 & 2 & 995.6710 & 995.6613 & 498.8379 & 0.0097 & 9.7225 & 5244.862 & 5659.444 & 1060.732 & 79.442 & \text { Yes }\end{array}$ $\begin{array}{lllllllllllllllll}0.92 & 21.11 & 12.30 & 28.65 & 2 & 995.6620 & 995.6613 & 498.8379 & 0.0007 & 0.7016 & 542.977 & 465.570 & 130.351 & 32.118 & \text { Yes } \\ 0.97 & 25.02 & 12.30 & 27.99 & 2 & 995.6620 & 995.6613 & 498.8379 & 0.0007 & 0.7016 & 76.837 & 739.442 & 133.647 & 39.125 & Y(s)\end{array}$ $\begin{array}{lllllllllllllll}1.00 & 61.07 & 28.37 & 29.29 & 2 & 1621.8194 & 1621.8070 & 811.9108 & 0.0124 & 7.6362 & 970.405 & 1428.632 & 1435.910 & 1374.845 & \text { No }\end{array}$

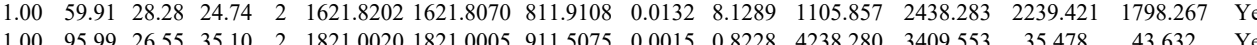
$\begin{array}{lllllllllllll} & \end{array}$

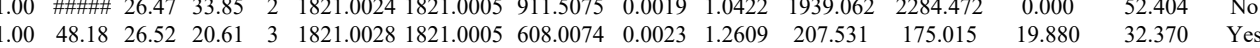

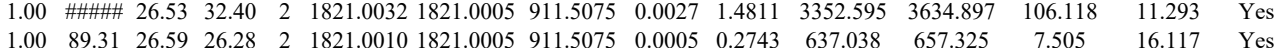
$\begin{array}{lllllllllllllll}0.99 & 46.81 & 27.77 & 27.62 & 2 & 1550.7872 & 1550.7820 & 776.3983 & 0.0052 & 3.3488 & 133.666 & 219.912 & 236.273 & 293.733 & \text { Yes }\end{array}$ $\begin{array}{lllllllllllllll}1.00 & 60.58 & 27.77 & 23.46 & 2 & 1550.7872 & 1550.7820 & 776.3983 & 0.0052 & 3.3488 & 270.030 & 201.674 & 186.517 & 360.570 & \text { Yes }\end{array}$ $\begin{array}{lllllllllllllll}1.00 & 39.42 & 27.85 & 21.55 & 3 & 1822.9870 & 1822.9790 & 608.6669 & 0.0080 & 4.3811 & 7548.952 & 8486.492 & 6387.973 & 5846.364 & \text { Yes }\end{array}$ $\begin{array}{lllllllllllllll}0.99 & 4.07 & 27.84 & 23.80 & 2 & 1822.9878 & 1822.9790 & 912.4968 & 0.0088 & 4.8219 & 1787.865 & 1951.430 & 915.230 & 873.804 & \text { Yes } \\ \end{array}$ $\begin{array}{lllllllllllllll}1.00 & 57.95 & 27.73 & 22.39 & 3 & 1822.9879 & 1822.9790 & 608.6669 & 0.0089 & 4.8740 & 9090.566 & 9131.261 & 7335.135 & 5771.493 & \text { Yes }\end{array}$ $\begin{array}{llllllllllllll} & \end{array}$ $\begin{array}{llllllllllllllll}1.00 & 57.38 & 27.46 & 29.83 & 2 & 1575.7982 & 1575.7983 & 788.9064 & -0.0001 & -0.0634 & 1709.923 & 3554.536 & 311.937 & 120.852 & \text { Yes }\end{array}$ $\begin{array}{lllllllllllllll}1.00 & 66.29 & 27.49 & 31.82 & 2 & 1575.7988 & 1575.7983 & 788.9064 & 0.0005 & 0.3169 & 2340.125 & 5185.809 & 543.171 & 49.859 & \text { Yes }\end{array}$ $\begin{array}{llllllllllllllll}1.00 & 57.22 & 27.73 & 28.91 & 2 & 1575.7996 & 1575.7983 & 788.9064 & 0.0013 & 0.8239 & 2915.454 & 5933.890 & 629.427 & 68.928 & \text { Yes }\end{array}$

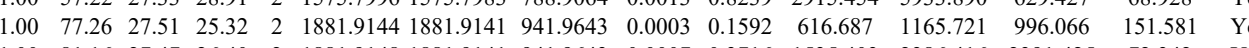
$\begin{array}{lllllllllllllll}1.00 & 81.16 & 27.47 & 26.40 & 2 & 1881.9148 & 1881.9141 & 941.9643 & 0.0007 & 0.3716 & 1535.403 & 2386.416 & 2391.425 & 72.342 & \text { Yes } \\ 1.00 & 74.96 & 27.47 & 22.21 & 2 & 1581.9148 & 1581.914 & 941.963 & 0.0007 & 0.3716 & 909.558 & 158.773 & 164.305 & 51.80 & \text { Yes }\end{array}$ $\begin{array}{llllllllllllllll}1.00 & 74.96 & 27.47 & 22.21 & 2 & 1881.9148 & 1881.9141 & 941.9643 & 0.0007 & 0.3716 & 909.558 & 1598.773 & 1654.305 & 51.803 & \text { Yes } \\ 1.00 & 78.41 & 27.47 & 24.61 & 2 & 1881.948 & 1881.914 & 91.643 & 0.000 & 0.3716 & 526.120 & 856.253 & 867.398 & 180.585 & \text { Yes }\end{array}$

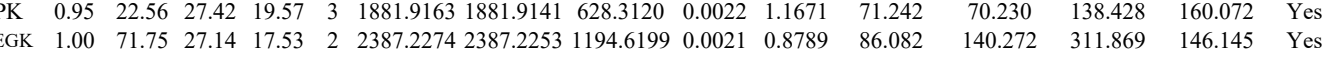

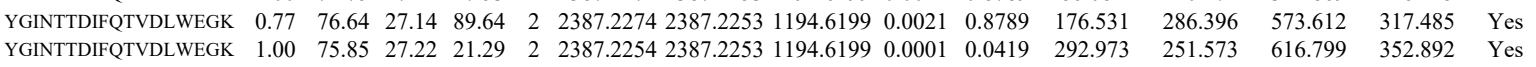
$\begin{array}{llllllllllllllllll}\text { YGINTIDIFOTVDLWEGK } & 1.00 & 81.57 & 27.22 & 22.93 & 2 & 2387.2254 & 2387.2253 & 1194.6199 & 0.0001 & 0.0419 & 214.588 & 531.068 & 1238.522 & 353.484 & \text { Yes } \\ \text { Yes } & & & \end{array}$

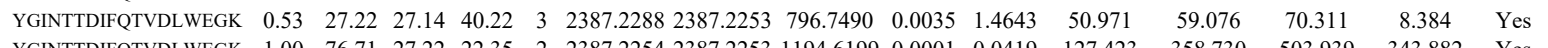
$\begin{array}{llllllllllllllll}\text { YGINTTDIFQTVDLWEGK } & 1.00 & 76.71 & 27.22 & 22.35 & 2 & 2387.2254 & 2387.2253 & 1194.6199 & 0.0001 & 0.0419 & 127.423 & 358.730 & 503.939 & 343.882 & \text { Yes }\end{array}$

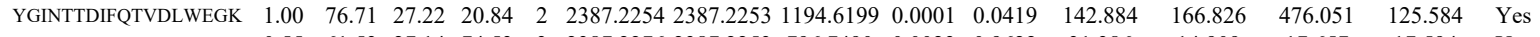

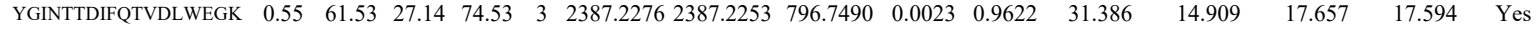
$\begin{array}{llllllllllllllll}\text { YGINTTDIFQTVDLWEGK } & 1.00 & 43.17 & 27.14 & 19.89 & 3 & 2387.2294 & 2387.2253 & 796.7490 & 0.0041 & 1.7153 & 52.438 & 16.903 & 73.233 & 0.000 & \text { No }\end{array}$ $\begin{array}{lllllllllllllllll}\text { YGINTIDIFQTVDLWEGK } & 1.00 & 77.65 & 27.22 & 27.62 & 2 & 2387.2254 & 2387.2253 & 1194.6199 & 0.0001 & 0.0419 & 21.354 & 32.011 & 50.193 & 25.675 & \text { Yes }\end{array}$

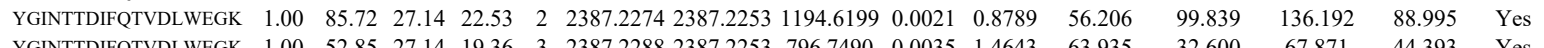

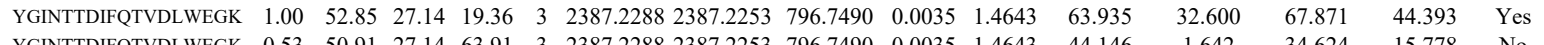

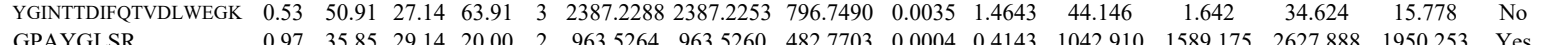
$\begin{array}{llllllllllllllll} & 0.97 & 35.85 & 29.14 & 20.00 & 2 & 963.5264 & 963.5260 & 482.7703 & 0.0004 & 0.4143 & 1042.910 & 1589.175 & 2627.888 & 1950.253 & \text { Yes }\end{array}$ $\begin{array}{llllllllllllllll}\text { GASQAGMTGYGMPR } & 1.00 & 96.91 & 25.47 & 40.08 & 2 & 1526.7134 & 1526.7092 & 764.3619 & 0.0042 & 2.7474 & 2599.833 & 5494.724 & 6678.846 & 4156.332 & \text { Yes }\end{array}$

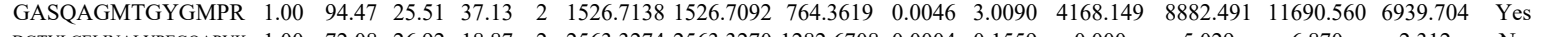

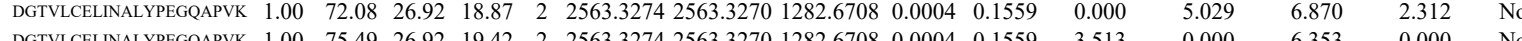

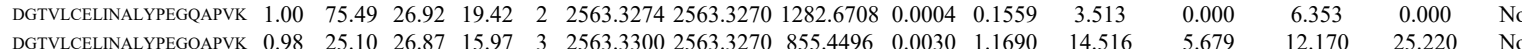

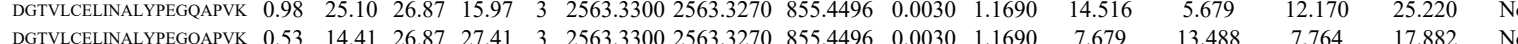

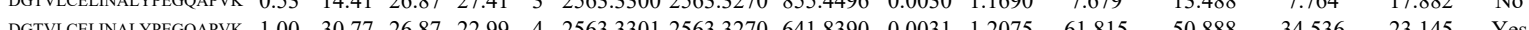

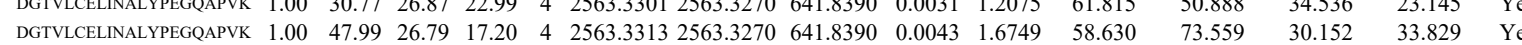




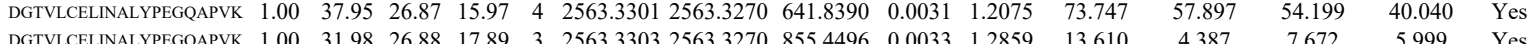

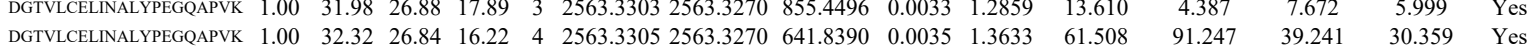

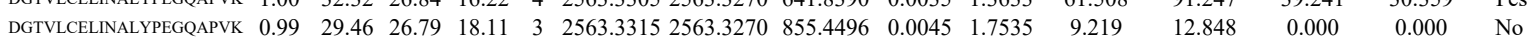

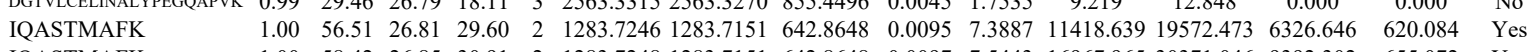

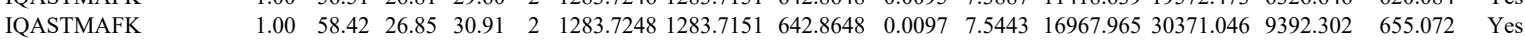

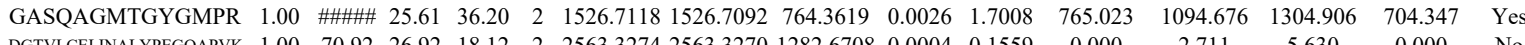

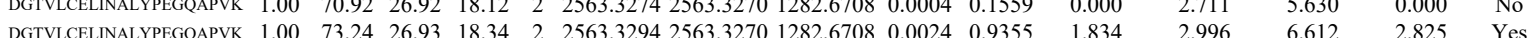

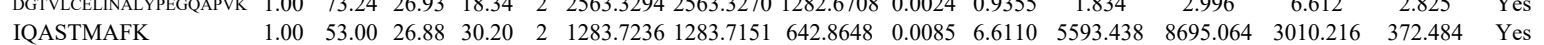
IQASTMAFK

NVIGLQMGTNR

NVIGLQMGTNR

NVIGLQMGGTNR

NVIGLQMGTNR

NVIGLQMGTNR

NVIGLQMGTNR

NVIGLQMGTNR

TLMNLGGLAVAR

TLMNLGGLAVAR

TLMNLGGLAVAR

TLMNLGGLAVAR

TLMNLGGLAVAR

TLMNLGGLAVAR

TLMNLGGLAVAR

TLMNLGGLAVAR

TLMNLGGLAVAR

NFSDNQLQEGK

NFSDNQLQEGK

NFSDNQLQEGK

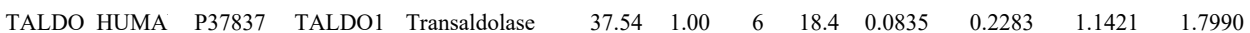

14 LLGELLQDNAK

LLGELLDNAK

LVPVLSAK

LVPVLSAK

LVPVLSAK

LFVLFGAEILK

LFVLFGAEILKK

LFVLFGAEILK
LFVLFGAEILK

LFVLFGAEILK

TIVMGASFR

TIVMGASFR

SYEPLEDPGVK

SYEPLEDPGVK

WLHNEDQMAVE

WLHNEDQMAVEK

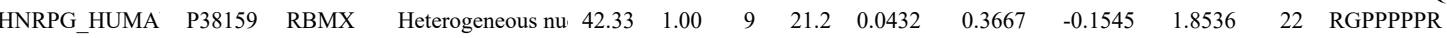

\section{RGPPPPR}

SSSGMGGR

VEQATKPSFESGR

VEQATKPSFESGR

VEQATKPSFESGR

VEQATKPSFESGR

VEQATKPSFESGR

VEQATKPSFESG

SAPSGPVR
VEQATKPSFESGR

LFIGGLNTETNEK

LFIGGLNTETNEK

GPPPPPR $\begin{array}{lllllllllllllll}1.00 & 50.91 & 26.88 & 29.11 & 2 & 1283.7242 & 1283.7151 & 642.8648 & 0.0005 & 6.6110 & 5593.438 & 8695.064 & 3010.216 & 372.484 & \text { Yes } \\ 1.0776 & 5792.085 & 10096.234 & 3288.422 & 467.321 & \text { Yes }\end{array}$

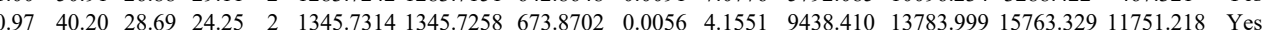
$\begin{array}{lllllllllllllll}1.00 & 53.23 & 28.73 & 25.46 & 2 & 1345.7334 & 1345.7258 & 673.8702 & 0.0076 & 5.6390 & 12891.571 & 24232.542 & 19948.685 & 8746.132 & \text { Yes }\end{array}$

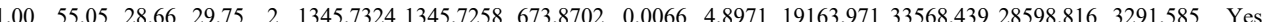
$\begin{array}{lllllllllllllll}0.99 & 45.64 & 28.72 & 28.75 & 2 & 1345.7332 & 1345.7258 & 673.8702 & 0.0074 & 5.4906 & 31832.992 & 59227.316 & 55375.371 & 3692.210 & \text { Yes }\end{array}$ $\begin{array}{llllllllllllllll}0.99 & 39.86 & 28.62 & 24.69 & 3 & 1345.7341 & 1345.7258 & 449.5825 & 0.0083 & 6.1538 & 1777.083 & 2188.340 & 1044.261 & 227.761 & \text { Yes }\end{array}$ $\begin{array}{llllllllllllllll}1.00 & 55.24 & 28.69 & 26.21 & 2 & 1345.7314 & 1345.7258 & 673.8702 & 0.0056 & 4.1551 & 6976.962 & 13539.645 & 12984.818 & 503.772 & \text { Yes }\end{array}$ $\begin{array}{lllllllllllllllll}1.00 & 59.30 & 28.67 & 27.15 & 2 & 1345.7336 & 1345.7258 & 673.8702 & 0.0078 & 5.7874 & 16738.850 & 27457.850 & 24913.103 & 965.096 & \text { Yes }\end{array}$

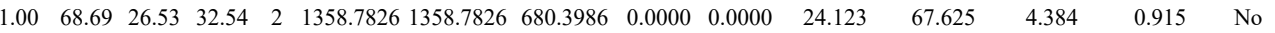
$\begin{array}{lllllllllllllll}1.00 & 81.03 & 26.61 & 33.12 & 2 & 1358.7822 & 1358.7826 & 680.3986 & -0.0004 & -0.2939 & 10346.638 & 17976.631 & 211.463 & 189.908 & \text { Yes }\end{array}$

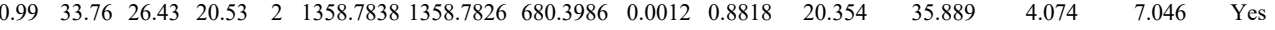

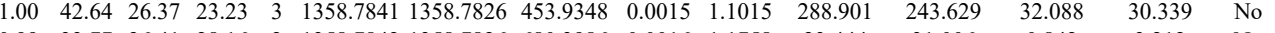

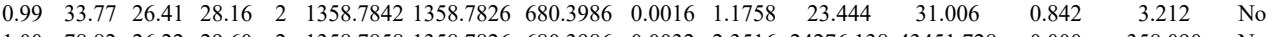
$\begin{array}{lllllllllllllll}1.00 & 78.82 & 26.22 & 29.60 & 2 & 1358.7858 & 1358.7826 & 680.3986 & 0.0032 & 2.3516 & 24276.138 & 43451.728 & 0.000 & 358.090 & \text { No }\end{array}$

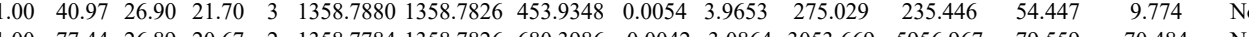

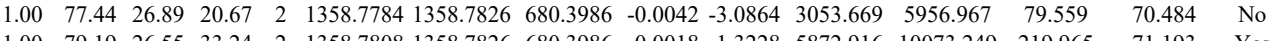
$\begin{array}{llllllllllllllll}1.00 & 79.19 & 26.55 & 33.24 & 2 & 1358.7808 & 1358.7826 & 680.3986 & -0.0018 & -1.3228 & 5872.916 & 10073.249 & 219.965 & 71.193 & \text { Yes } \\ 1.00 & 46.97 & 27.82 & 22.87 & 2 & 15667904 & 1566.7882 & 784.4014 & 0.0022 & 1.4023 & 3413.158 & 7056.054 & 4035.237 & 8.024 & \text { Yes }\end{array}$ $\begin{array}{lllllllllllllll}1.00 & 46.97 & 27.82 & 22.87 & 2 & 1566.7904 & 1566.7882 & 784.4014 & 0.0022 & 1.4023 & 3413.158 & 7056.054 & 4035.237 & 84.024 & \text { Yes } \\ 1.00 & 48.30 & 27.80 & 22.11 & 2 & 1566.7908 & 1566.7882 & 784.4014 & 0.0026 & 1.6573 & 6263.227 & 11234.718 & 5603.792 & 414.541 & \text { Yes }\end{array}$

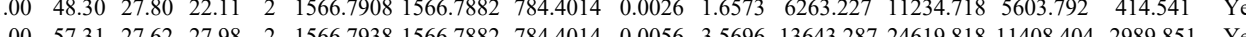
$\begin{array}{llllllllllllllllll}1.00 & 57.31 & 27.62 & 27.98 & 2 & 1566.7938 & 1566.7882 & 784.4014 & 0.0056 & 3.5696 & 13643.287 & 24619.818 & 11408.404 & 2989.851 & \text { Yes }\end{array}$ $\begin{array}{llllllllllllllll}1.00 & 57.39 & 24.56 & 43.18 & 2 & 1500.8900 & 1500.8755 & 751.440 & 0.0145 & 9.6480 & 744.954 & 907.684 & 15.407 & 6.645 & \text { Yes }\end{array}$

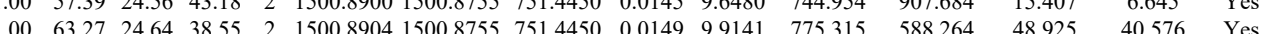
$\begin{array}{lllllllllllllll}1.00 & 44.83 & 18.51 & 24.72 & 2 & 1113.7446 & 1113.7365 & 557.8755 & 0.0081 & 7.2596 & 31085.62135836 .469 & 254.444 & 1113.010 & \text { Yes }\end{array}$ $\begin{array}{lllllllllllllllll}1.00 & 44.65 & 18.51 & 24.41 & 2 & 1113.7456 & 1113.7365 & 557.8755 & 0.0091 & 8.21559 & 28245.00833762 .719 & 266.112 & 174.2398 & \text { Yes }\end{array}$ $\begin{array}{llllllllllllllll}0.99 & 36.99 & 18.51 & 21.61 & 2 & 1113.7442 & 1113.7365 & 557.8755 & 0.0077 & 6.9011 & 26644.694 & 31736.121 & 6.322 & 816.123 & \text { Yes }\end{array}$

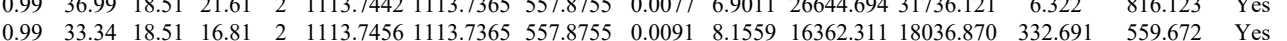
$\begin{array}{lllllllllllllll}.90 & 73.98 & 18.81 & 26.15 & 2 & 1536.9530 & 1536.9523 & 769.4834 & 0.0007 & 0.4549 & 554.349 & 731.199 & 50.661 & 30.781 & \text { Yes } \\ 1.00 & 28.69 & 8.57 & 15.84 & 3 & 1536.9538 & 1536.952 & 513.347 & 0.005 & 0.9740 & 36.67 & 3.49 & 1.13 & 3.943 & \text { Yes }\end{array}$

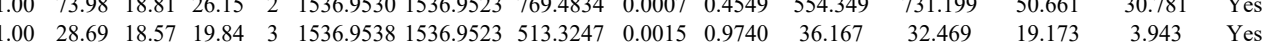

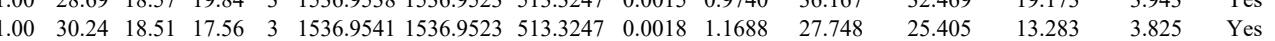
$\begin{array}{lllllllllllllll}1.00 & 66.35 & 18.45 & 22.17 & 2 & 1536.9548 & 1536.9523 & 769.4834 & 0.0025 & 1.6245 & 352.899 & 387.485 & 13.304 & 5.297 & \text { Yes }\end{array}$ $\begin{array}{llllllllllllllll}0.94 & 41.29 & 27.34 & 39.43 & 2 & 1124.6206 & 1124.6134 & 563.3140 & 0.0072 & 6.3907 & 5494.805 & 7113.011 & 236.386 & 156.508 & \text { Yes }\end{array}$ $\begin{array}{llllllllllllllll}0.94 & 40.78 & 27.38 & 39.09 & 2 & 1124.6216 & 1124.6134 & 563.3140 & 0.0082 & 7.2783 & 1699.192 & 2681.282 & 0.000 & 87.772 & \text { No }\end{array}$ $\begin{array}{lllllllllllllll}0.99 & 41.84 & 27.87 & 19.57 & 2 & 1520.8106 & 1520.7966 & 761.4056 & 0.0140 & 9.1934 & 2008.514 & 2516.327 & 1681.279 & 854.430 & \text { Yes }\end{array}$ $\begin{array}{lllllllllllllll}0.98 & 37.39 & 27.64 & 18.51 & 2 & 1520.8110 & 1520.7966 & 761.4056 & 0.0144 & 9.4561 & 831.239 & 911.301 & 555.291 & 374.794 & \text { Yes }\end{array}$ $\begin{array}{lllllllllllllll}0.99 & 38.99 & 28.01 & 26.96 & 3 & 1786.9090 & 1786.8916 & 596.6378 & 0.0174 & 9.7210 & 5585.067 & 5541.038 & 3538.560 & 2632.882 & \text { Yes }\end{array}$

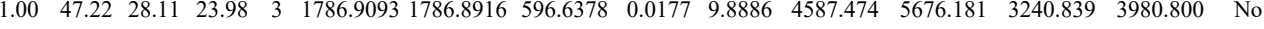
$\begin{array}{llllllllllllllll}0.94 & 29.63 & 26.39 & 17.74 & 2 & 872.4982 & 872.4981 & 437.2563 & 0.0001 & 0.1143 & 8.108 & 15.253 & 3.341 & 4.724 & \text { Yes } \\ \end{array}$ $\begin{array}{lllllllllllllll}0.93 & 26.39 & 26.39 & 17.86 & 2 & 872.4986 & 872.4981 & 437.2563 & 0.0005 & 0.5717 & 9.881 & 4.657 & 5.978 & 2.230 & \text { Yes }\end{array}$

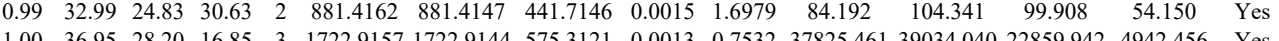
$\begin{array}{llllllllllllllll}1.00 & 36.95 & 28.20 & 16.85 & 3 & 1722.9157 & 1722.9144 & 575.3121 & 0.0013 & 0.7532 & 37825.461 & 39034.040 & 22859.942 & 4942.456 & \text { Yes }\end{array}$

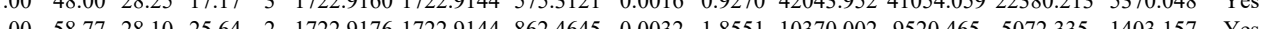
$\begin{array}{lllllllllllllllll}1.00 & 58.77 & 28.10 & 25.64 & 2 & 1722.9176 & 1722.9144 & 862.4645 & 0.0032 & 1.8551 & 10370.002 & 9520.465 & 5072.335 & 1403.157 & \text { Yes }\end{array}$ $\begin{array}{llllllllllllllll}1.00 & 47.59 & 28.10 & 23.52 & 3 & 1722.9178 & 1722.9144 & 575.3121 & 0.0034 & 1.9699 & 52092.276 & 53895.196 & 34361.611 & 12818.183 & \text { Yes } \\ 1.00 & 73.58 & 28.10 & 26.83 & 2 & 1722.9192 & 1722.9144 & 862.4645 & 0.0048 & 2.7827 & 3118525 & 3366.252 & 2214503 & 176.122 & \text { Yes }\end{array}$

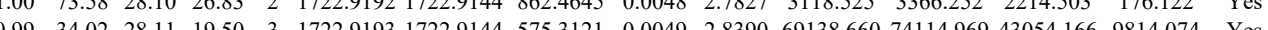
$\begin{array}{llllllllllllllll}0.74 & 18.54 & 2.531 & 28.53 & 2 & 913.5114 & 913.5103 & 457.7624 & 0.0011 & 1.2915 & 98.254 & 111.883 & 14.606 & 14.797 & \text { Yes }\end{array}$

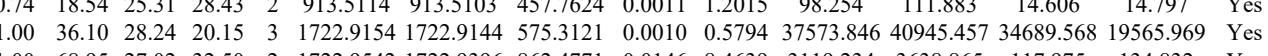

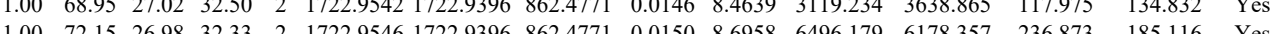

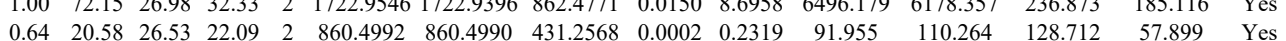

Table S-3 page 233 of 499 
$\begin{array}{lllllllllllll}1.00 & 46.84 & 22.01 & 22.96 & 2 & 1231.7844 & 1231.7817 & 6168981 & 0.0027 & 2.1884 & 14657.597 & 158900 & 122.684\end{array}$

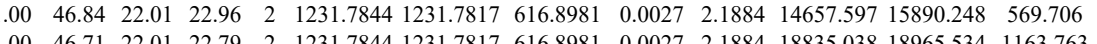

GVYVSALS

$\begin{array}{llllllllllllll}1.00 & 48.62 & 27.11 & 25.74 & 2 & 1045.6042 & 1045.6002 & 523.8074 & 0.0040 & 3.8182 & 22598.780 & 22555.429 & 11343.903 & 785\end{array}$

TALVANTSNMPVAAR
LPANHPLLTGQR

LPANHPLLTGQR

LPANHPLLTGQR

LPANHPLLTGQR

$\begin{array}{llllllllllllll}1.00 & 50.02 & 26.11 & 17.03 & 3 & 1459.8445 & 1459.8381 & 487.6200 & 0.0064 & 4.3750 & 4441.833 & 5644.647 & 3286.763\end{array}$

LPANHPLLTGQR

LPANHPLLTGQR

LPANHPLLTGQR

ITWSIIR

ITWSIIR

ITWSIIR

FTMVQVWPVR

FTMVQVWPVR
FTMVQVWPVR

$\begin{array}{llllllllllllll}1.00 & 51.23 & 26.11 & 16.99 & 3 & 1459.8445 & 1459.8381 & 487.6200 & 0.0064 & 4.3750 & 3759.052 & 4246.697 & 3565.255 \\ 1.00 & 54.63 & 26.26 & 21.37 & 2 & 1459.8508 & 1459.8381 & 730.9263 & 0.0127 & 8.6875 & 678.362 & 720.454 & 565.122\end{array}$

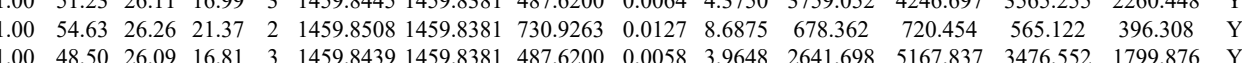
$\begin{array}{lllllllllllllll} & 1459.8439 & 1459.8381 & 487.6200 & 0.0058 & 3.9648 & 2641.698 & 5167.837 & 3476.552 & 1799.876 & \text { Yes } & \\ 1.00 & 52.98 & 26.11 & 20.48 & 2 & 1459.8442 & 459.8381 & 730.9263 & 0.0061 & 4.1728 & 457.406 & 502.488 & 426.757 & 204159 & \text { Yes }\end{array}$ $\begin{array}{llllllllllllllll}1.00 & 63.47 & 25.79 & 18.15 & 3 & 1459.8451 & 1459.8381 & 487.6200 & 0.0070 & 4.7851 & 1932.731 & 3539.998 & 2622.292 & 1459.392 & \text { Yes }\end{array}$ $\begin{array}{llllllllllllllll}1.00 & 48.83 & 26.12 & 16.78 & 3 & 1459.8427 & 1459.8381 & 487.6200 & 0.0046 & 3.1445 & 2865.421 & 3093.238 & 2138.396 & 993.953 & \text { Yes }\end{array}$ $\begin{array}{lllllllllllllll}1.00 & 84.19 & 26.12 & 20.26 & 3 & 1459.8430 & 1459.8381 & 487.6200 & 0.0049 & 3.3496 & 3534.700 & 3930.231 & 2331.180 & 1173.159 & \text { Yes }\end{array}$ $\begin{array}{lllllllllllllll}0.89 & 34.04 & 27.99 & 39.73 & 2 & 1031.6246 & 1031.6249 & 516.8197 & -0.0003 & -0.2902 & 16637.127 & 19867.722 & 8478.401 & 1930.838 & \text { Yes }\end{array}$ $\begin{array}{llllllllllllllll}0.89 & 34.18 & 28.02 & 39.88 & 2 & 1031.6252 & 1031.6249 & 516.8197 & 0.0003 & 0.2902 & 5219.426 & 5648.801 & 2356.228 & 531.600 & \text { Yes } & \\ \end{array}$ $\begin{array}{llllllllllllllll}0.93 & 38.68 & 28.02 & 42.15 & 2 & 1031.6252 & 1031.6249 & 516.8197 & 0.0003 & 0.2902 & 18930.861 & 26072.809 & 7107.418 & 1016.892 & \text { Yes }\end{array}$ FTMVQVWPVR $\begin{array}{lllllllllllllll}1.00 & 60.36 & 28.44 & 21.64 & 2 & 1405.7672 & 1405.7662 & 703.8904 & 0.0010 & 0.7103 & 2846.562 & 3464.807 & 1056.373 & 249.697 & \text { Yes } \\ 1.00 & 59.04 & 28.43 & 22.14 & 2 & 1405.7674 & 1405.7662 & 703.8904 & 0.0012 & 0.8524 & 2219.412 & 2736.332 & 782.476 & 146.612 & \text { Yes }\end{array}$ $\begin{array}{lllllllllllllll} & & \end{array}$

QEEEDLAEIVQLVGK

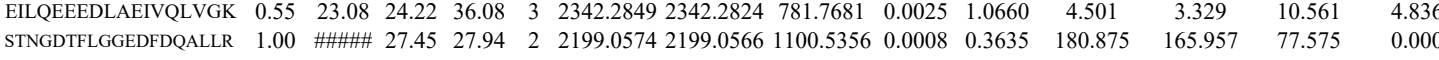

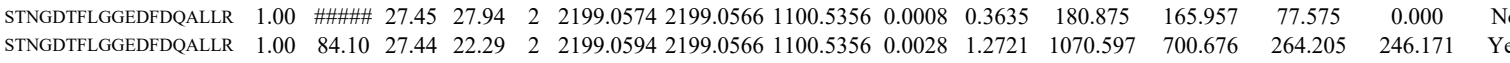

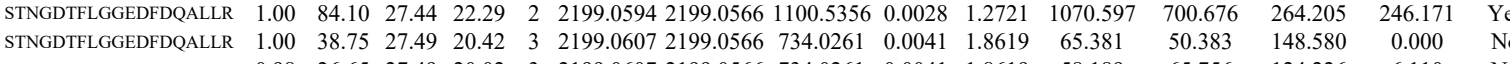

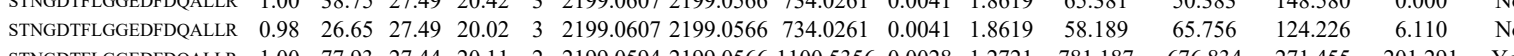

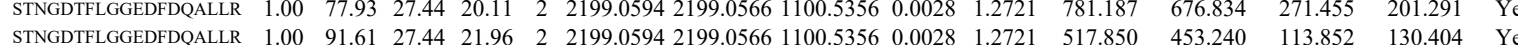

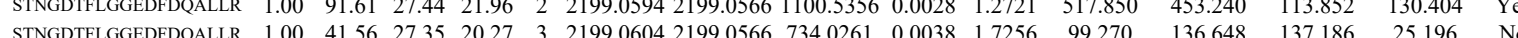

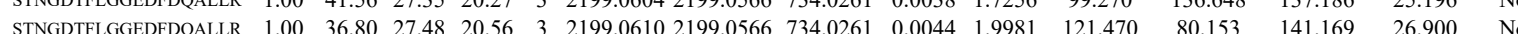

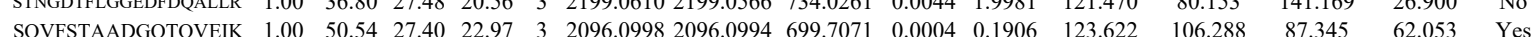

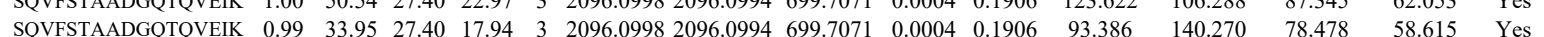

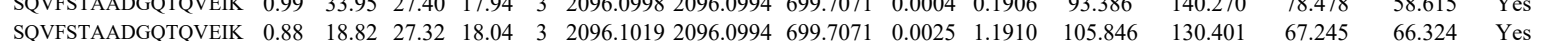

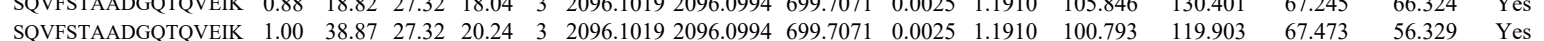

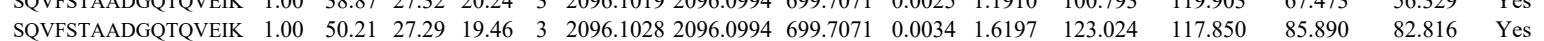
$\begin{array}{llllllllllllllll}\text { SQVFSTAADGQTOVEIK } & 1.00 & 38.94 & 27.29 & 20.74 & 3 & 2096.1028 & 2096.0994 & 699.7071 & 0.0034 & 1.6197 & 116.066 & 111.702 & 73.526 & 77.327 & \text { No }\end{array}$

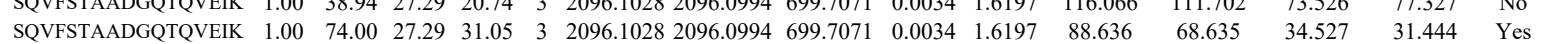

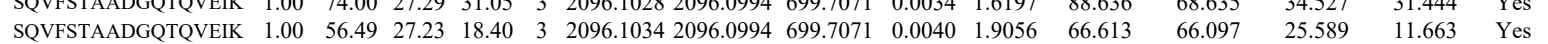

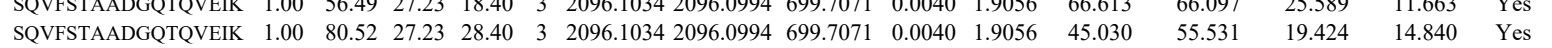
$\begin{array}{llllllllllllllll}\text { SQVFSTAADGQTQVEIK } & 0.99 & 42.41 & 27.23 & 25.32 & 2 & 2096.1034 & 2096.0994 & 1049.0570 & 0.0040 & 1.9065 & 4.718 & 14.168 & 7.128 & 2.987 & \text { Yes }\end{array}$

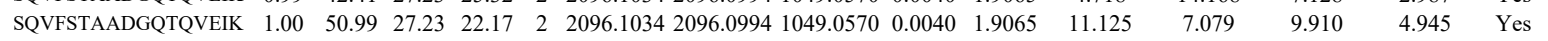
$\begin{array}{llllllllllllllllll}\text { SQVFSTAADGQTQVEIK } & 1.00 & 42.51 & 27.25 & 17.09 & 3 & 2096.1040 & 2096.0994 & 699.7071 & 0.0046 & 2.1914 & 101.311 & 98.248 & 77.052 & 63.170 & \text { Yes }\end{array}$ $\begin{array}{llllllllllllllllll}\text { SQVFSTAADGQTQVEIK } & 1.00 & 68.78 & 27.25 & 23.29 & 3 & 2096.1040 & 2096.0994 & 699.7071 & 0.0046 & 2.1914 & 65.580 & 77.692 & 36.486 & 28.831 & \text { Yes }\end{array}$

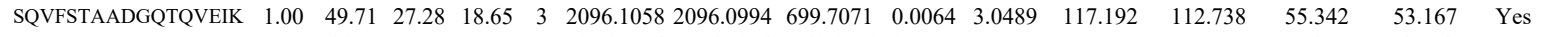
$\begin{array}{llllllllllllllll}\text { SQVFSTAADGQTQVEIK } & 1.00 & 66.53 & 27.32 & 22.08 & 2 & 2096.1074 & 2096.0994 & 1049.0570 & 0.0080 & 3.8129 & 10.278 & 13.891 & 7.611 & 4.804 & \text { Yes }\end{array}$

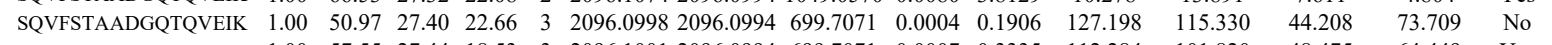

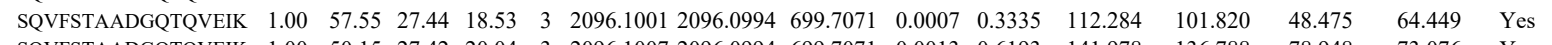
$\begin{array}{llllllllllllllll}\text { SQVFSTAADGQTQVEIK } & 1.00 & 50.15 & 27.42 & 20.04 & 3 & 2096.1007 & 2096.0994 & 699.7071 & 0.0013 & 0.6193 & 141.978 & 136.788 & 78.948 & 73.076 & \text { Yes }\end{array}$ $\begin{array}{llllllllllllllll}\text { SQVFSTAADGQTQVEIK } & 0.72 & 16.58 & 27.42 & 19.07 & 3 & 2096.1007 & 2096.0994 & 699.7071 & 0.0013 & 0.6193 & 101.675 & 132.014 & 55.416 & 58.825 & \text { Yes }\end{array}$

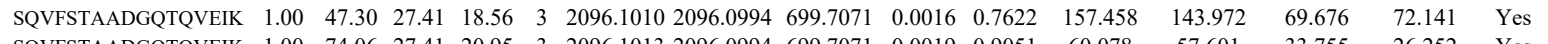

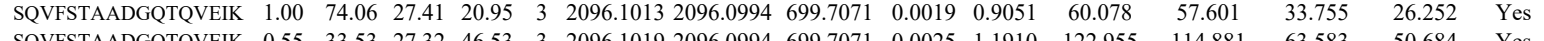

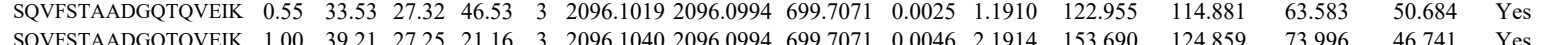

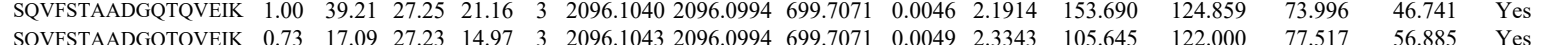

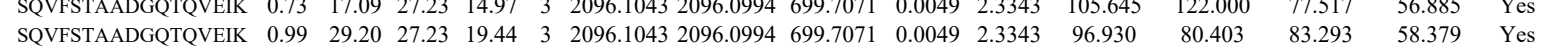

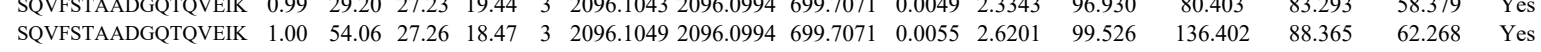

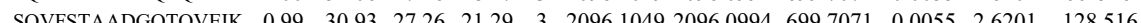


\begin{tabular}{lllllllllllll|l}
.00 & 69.47 & 25.94 & 26.44 & 2 & 1518.8662 & 1518.8609 & 760.4377 & 0.0053 & 3.4848 & 29954.034 & 22144.123 & 1428.471
\end{tabular} 125.469 Yes

$\begin{array}{lllllllllllll}1.00 & 41.43 & 27.18 & 30.95 & 3 & 1504.8397 & 1504.8371 & 502.6196 & 0.002 & 1.7243 & 74.906 & 49.223 & 37.021 \\ 1.00 & 61.97 & 27.19 & 26.68 & 2 & 1504.8398 & 1504.8371 & 753.4258 & 0.0027 & 1.7918 & 5929.565 & 4537.507 & 238.038\end{array}$ QFEGIVTDLI $\begin{array}{lllllllllllll}1.00 & 63.83 & 27.05 & 22.76 & 2 & 1504.8402 & 1504.8371 & 753.4258 & 0.0031 & 2.0573 & 19795.262 & 14174.569 & 354.075\end{array}$ $\begin{array}{llllllllllll}1.00 & 42.15 & 18.57 & 17.42 & 3 & 1736.0503 & 1736.0471 & 579.6896 & 0.0032 & 1.8401 & 16.316 & 25.027\end{array}$ $\begin{array}{llllllllllll}0.98 & 18.57 & 18.45 & 14.61 & 3 & 1736.0509 & 1736.0471 & 579.6896 & 0.0038 & 2.1851 & 28.874 & 34.892\end{array}$ $\begin{array}{lllllllllllll}1.00 & 89.16 & 19.24 & 18.85 & 2 & 1736.0484 & 1736.0471 & 869.0308 & 0.0013 & 0.7480 & 213.736 & 152.625\end{array}$ $\begin{array}{llllllllllll}1.00 & 91.42 & 19.24 & 19.85 & 2 & 1736.0486 & 1736.0471 & 869.0308 & 0.0015 & 0.8630 & 177.323 & 151.241 \\ 1.00 & 35.99 & 19.14 & 16.95 & 3 & 1736.0494 & 1736.0471 & 579.689 & 0.0023 & 1.3225 & 16.609 & 20.489\end{array}$

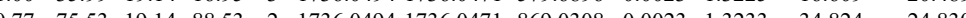
$\begin{array}{lllllllllllll}1.00 & 41.36 & 19.14 & 16.36 & 3 & 1736.0497 & 1736.0471 & 579.6896 & 0.0026 & 1.4951 & 15.396 & 8.505\end{array}$ $\begin{array}{llllllllllll}1 & 176.040 & 1736.0471 & 579.6896 & 0.0029 & 1.6676 & 1.981 & 11.108\end{array}$ $\begin{array}{lllllllllllll}1.00 & 93.18 & 19.19 & 16.72 & 3 & 1736.0500 & 1736.0471 & 579.6896 & 0.0029 & 1.6676 & 7.523 & 8.136 \\ 0.69 & 93.76 & 19.14 & \# \# \# & 2 & 1736.0500 & 1736.0471 & 869.0308 & 0.0029 & 1.6685 & 55.463 & 42.760\end{array}$

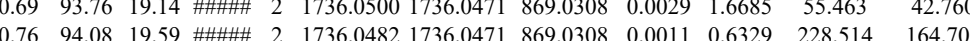
$\begin{array}{llllllllllll}0.76 & 93.04 & 19.59 & \text { \#\#\#\# } & 2 & 1736.0482 & 1736.0471 & 8690.0308 & 0.0011 & 0.6329 & 121.986 & 104.432\end{array}$ $\begin{array}{lllllllllllll}0.55 & 30.30 & 19.24 & 43.30 & 3 & 1736.0488 & 1736.0471 & 579.6896 & 0.0017 & 0.9775 & 63.848 & 105.785\end{array}$ $\begin{array}{lllllllllllll}1.00 & 45.92 & 19.14 & 17.49 & 3 & 1736.0494 & 1736.0471 & 579.6896 & 0.0023 & 1.3225 & 12.722 & 17.716\end{array}$ $\begin{array}{llllllllllll}0.55 & 19.85 & 19.14 & 32.85 & 3 & 1736.0494 & 1736.0471 & 579.6896 & 0.0023 & 1.3225 & 4.046 & 28.811\end{array}$ $\begin{array}{llllllllllllll}0.88 & 10.78 & 19.14 & 13.97 & 3 & 1736.0497 & 1736.0471 & 579.6896 & 0.0026 & 1.4951 & 64.074 & 110.182\end{array}$ $\begin{array}{llllllllllllll}1.00 & 93.04 & 19.64 & 20.85 & 2 & 1736.0480 & 1736.0471 & 869.0308 & 0.0009 & 0.5178 & 83.278 & 76.094\end{array}$ $\begin{array}{llllllllllll}0.76 & 86.03 & 19.59 & 99.03 & 2 & 1736.0482 & 1736.0471 & 869.0308 & 0.0011 & 0.6329 & 77.217 & 61.032 \\ 0.77 & 65.64 & 19.24 & 78.64 & 2 & 1736.0490 & 1736.0471 & 86.0308 & 0.0019 & 1.0932 & 62.341 & 50.666\end{array}$ $\begin{array}{lllllllllllll}0.77 & 65.64 & 19.24 & 78.64 & 2 & 1736.0490 & 1736.0471 & 869.0308 & 0.0019 & 1.0932 & 62.341 & 50.666 \\ \end{array}$ $\begin{array}{lllllllllllll}1.00 & 63.61 & 19.24 & 19.00 & 2 & 1736.0484 & 1736.0471 & 869.0308 & 0.0013 & 0.7480 & 33.434 & 28.843 \\ \end{array}$ $\begin{array}{llllllllllllll}0.77 & 67.86 & 19.24 & 80.86 & 2 & 1736.0486 & 1736.0471 & 869.0308 & 0.0015 & 0.8630 & 30.929 & 36.677\end{array}$ $\begin{array}{llllllllllll}1.00 & 27.86 & 19.14 & 17.95 & 3 & 1736.0494 & 1736.0471 & 579.6896 & 0.0023 & 1.3225 & 37.379 & 59.704 \\ 0.55 & 14.45 & 19.24 & 27.45 & 3 & 1736.0491 & 1736.0471 & 579.6896 & 0.0020 & 1.1500 & 9.244 & 3.405\end{array}$ ASNGDAWVEAHGK

$\begin{array}{llllllllllll}1.00 & 6.82 & 27.26 & 28.07 & 4 & 2429.2533 & 2429.2464 & 608.3189 & 0.0069 & 2.8357 & 71.318 & 36.514 \\ 1.00 & 0.10 & 27.75 & 23.90 & 3 & 1628.8198 & 1628.8150 & 543.9456 & 0.0048 & 2.9415 & 11819.108 & 7256.668\end{array}$ $\begin{array}{llllllllll} & \end{array}$ $\begin{array}{llllllllllll}.00 & 80.59 & 27.92 & 31.95 & 3 & 1628.8204 & 1628.8150 & 815.4148 & 0.0054 & 3.3112 & 846.765 & 687.562 \\ 1628.8150 & 543.9456 & 0.0066 & 4.0445 & 16647.926 & 15050.788\end{array}$ $\begin{array}{lllllllllllll}1.00 & 56.59 & 27.40 & 27.27 & 3 & 2144.1067 & 2144.1027 & 715.7082 & 0.0040 & 1.8630 & 7292.271 & 5677.145\end{array}$ 
$\begin{array}{llllllllllllllll}1.00 & 53.29 & 22.62 & 21.84 & 2 & 1134.7116 & 1134.7005 & 568.3575 & 0.0111 & 9.7649 & 11364.816 & 11694.123 & 9744.807 & 4758.023 & \text { Yes } & \end{array}$ $\begin{array}{llllllllllllllll}1.00 & 53.61 & 22.62 & 20.57 & 2 & 1134.7114 & 1134.7005 & 568.3575 & 0.0109 & 9.5889 & 21775.374 & 18238.089 & 16797.944 & 7406.775 & \text { Yes } & \\ \end{array}$ VLISTDVWAR $\begin{array}{lllllllllllllll}1.00 & 43.61 & 27.68 & 29.02 & 2 & 1302.7428 & 1302.7418 & 652.3782 & 0.0010 & 0.7664 & 15148.066 & 14660.378 & 200.683 & 223.683 & \text { Yes }\end{array}$

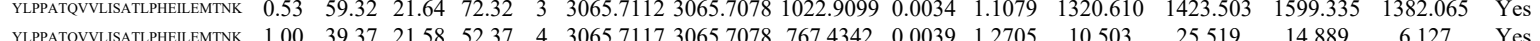

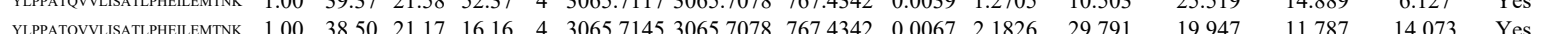

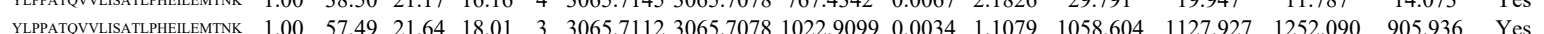
$\begin{array}{llllllllllllllllll}\text { YLPPATQVVUSATLPHELEMTNK } & 1.00 & 30.34 & 21.40 & 43.34 & 4 & 3065.7129 & 3065.7078 & 767.4342 & 0.0051 & 1.6614 & 0.000 & 38.079 & 0.000 & 14.597 & \text { No }\end{array}$

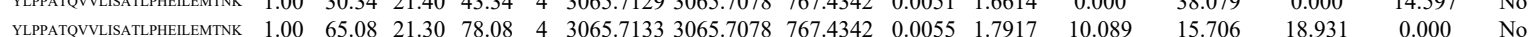

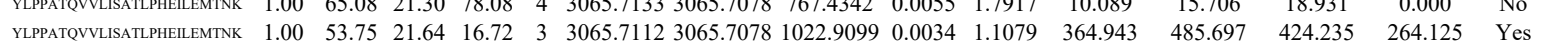
$\begin{array}{llllllllllllllll}\text { YLPATQVVUSATPHEIEMTNK } & 1.00 & 48.93 & 21.17 & 18.85 & 4 & 3065.7145 & 3065.7078 & 767.4342 & 0.0067 & 2.1826 & 13.422 & 33.734 & 3.826 & 16.138 & \text { Yes }\end{array}$ $\begin{array}{llllllllllllllll}\text { YLPPATQVLLSATLPHELIEMTNK } & 1.00 & 51.63 & 21.46 & 64.63 & 4 & 3065.7125 & 3065.7078 & 767.4342 & 0.0047 & 1.5311 & 20.986 & 14.926 & 5.371 & 10.344 & \text { Yes }\end{array}$

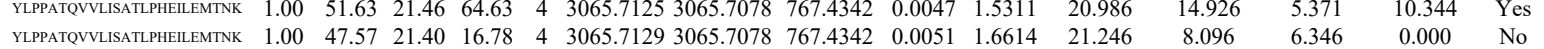

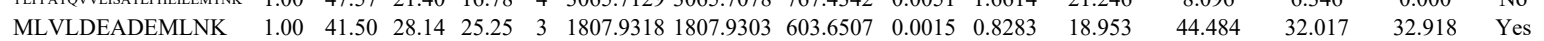

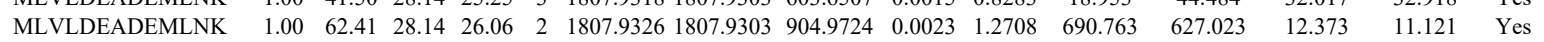
$\begin{array}{lllllllllllllllll}\text { MLVLDEADEMLNK } & 1.00 & 67.00 & 28.11 & 27.01 & 2 & 1807.9332 & 1807.9303 & 904.9724 & 0.0029 & 1.6023 & 670.074 & 526.564 & 0.000 & 7.896 & \text { No }\end{array}$

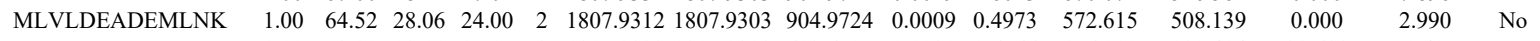

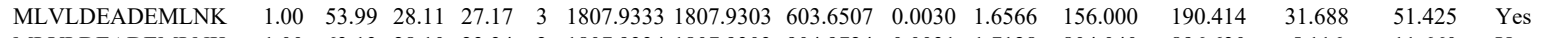

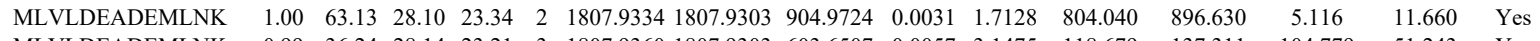
$\begin{array}{llllllllllllllll}\text { MLVLDEADEMLNK } & 0.99 & 36.24 & 28.14 & 23.21 & 3 & 1807.9360 & 1807.9303 & 603.6507 & 0.0057 & 3.1475 & 118.679 & 137.311 & 104.779 & 51.243 & \text { Yes }\end{array}$

9 VPEWVDTVK VPEWVDTVK VPEWVDTVK VPEWVDTVK VPEWVDTVK VPEWVDTVK VPEWVDTVK GGAGVGSMTK GGAGVGSMTK GGAGVGSMTK GGAGVGSMTK GGAGVGSMTK GGAGVSMTK

GGAGVGSMTK

IAGQVAAANK

IAGQVAAANK

IAGQVAAANK
LTPQGQR

LTPQGQR

ALAAFLK $\begin{array}{lllllllllllllll}1.00 & 50.66 & 31.30 & 25.44 & 2 & 1359.7764 & 1359.7642 & 680.8894 & 0.0122 & 8.9588 & 6157.202 & 5161.140 & 5308.575 & 5718.985 & \text { Yes }\end{array}$ $\begin{array}{lllllllllllllllll}0.99 & 46.91 & 31.27 & 22.32 & 2 & 1359.7762 & 1359.7642 & 680.8894 & 0.0120 & 8.8119 & 1721.932 & 1467.131 & 1073.811 & 1029.822 & \text { Yes } \\ 1.06 & 50.40 & 31.12 & 23.83 & 2 & 1359772 & 1359.762 & 60.8894 & 0.030 & 9.5462 & 1617.708 & 1383.557 & 1243.908 & 1078.594 & \text { Yes }\end{array}$ $\begin{array}{lllllllllllllll}1.00 & 50.40 & 31.12 & 23.83 & 2 & 1359.7772 & 1359.7642 & 680.8894 & 0.0130 & 9.5462 & 1617.708 & 1383.557 & 1243.908 & 1078.594 & \text { Yes }\end{array}$ $\begin{array}{lllllllllllllll}1.00 & 60.47 & 27.63 & 26.78 & 2 & 1151.6222 & 1151.6212 & 576.8179 & 0.0010 & 0.8668 & 122.111 & 100.770 & 95.537 & 75.275 & \text { Yes } \\ 1.00 & 59.15 & 27.63 & 33.04 & 2 & 1151.6222 & 1151.6212 & 576.8179 & 0.0010 & 0.8668 & 145.096 & 112.010 & 92.611 & 83.061 & \text { Yes }\end{array}$

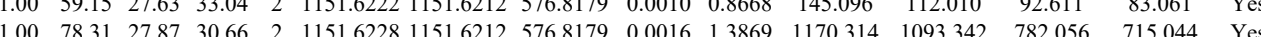
$\begin{array}{lllllllllllllll}1.00 & 78.31 & 27.87 & 30.66 & 2 & 151.6228 & 151.6212 & 576.8179 & 0.0016 & 1.3869 & 1170.314 & 1093.342 & 782.056 & 715.044 & \text { Yes } \\ 1.00 & 67.03 & 27.87 & 31.41 & 2 & 1151.6228 & 1151.6212 & 576.8179 & 0.0016 & 1.3869 & 2161.500 & 1799.054 & 1509.469 & 1386.840 & \text { Yes }\end{array}$

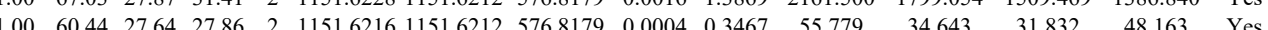

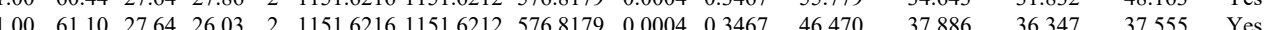
$\begin{array}{lllllllllllllll}1.00 & 66.81 & 27.63 & 29.60 & 2 & 1151.6222 & 1151.6212 & 5768179 & 0.0010 & 0.8668 & 1106.609 & 905.807 & 813.397 & 660.516 & \text { Yes }\end{array}$ $\begin{array}{lllllllllllllll}1.00 & 45.98 & 27.73 & 26.00 & 2 & 1151.6224 & 1151.6212 & 576.8179 & 0.0012 & 1.0402 & 819.176 & 634.164 & 507.643 & 418.481 & \text { Yes }\end{array}$ $\begin{array}{lllllllllllllll}1.00 & 53.66 & 25.31 & 23.56 & 2 & 1229.7360 & 1229.7335 & 615.8740 & 0.0025 & 2.0296 & 14244.021 & 13327.040 & 4681.799 & 871.455 & \text { Yes }\end{array}$ $\begin{array}{lllllllllllllll}1.00 & 65.45 & 25.63 & 24.43 & 2 & 1229.7366 & 1229.7335 & 615.8740 & 0.0031 & 25167 & 7878.680 & 7459.379 & 2823.600 & 772.446 & \text { Yes }\end{array}$ $\begin{array}{lllllllllllllll}0.96 & 28.21 & 26.17 & 29.77 & 2 & 942.5376 & 942.5369 & 472.2757 & 0.0007 & 0.7411 & 67.115 & 47.054 & 47.014 & 4.979 & \text { Yes }\end{array}$ $\begin{array}{lllllllllllllll}0.78 & 20.28 & 26.17 & 24.72 & 2 & 942.5378 & 942.5369 & 472.2757 & 0.0009 & 0.9528 & 42.187 & 38.469 & 30.526 & 4.384 & \text { Yes }\end{array}$ $\begin{array}{llllllllllllllll}0.99 & 41.32 & 24.17 & 23.57 & 2 & 1020.6646 & 1020.6575 & 511.3360 & 0.0071 & 6.9425 & 41367.129 & 36343.179 & 1269.585 & 822.375 & \text { No }\end{array}$ $\begin{array}{llllllllllllllll}0.96 & 33.42 & 24.17 & 18.53 & 2 & 1020.6664 & 1020.6575 & 511.3360 & 0.0089 & 8.7026 & 41468.282 & 42351.079 & 2732.252 & 1430.786 & \text { No }\end{array}$ ALAAFLK $\begin{array}{lllllllllllllll}1.00 & 58.30 & 26.26 & 19.98 & 3 & 1711.8175 & 1711.8153 & 571.6124 & 0.0022 & 1.2829 & 4930.372 & 5226.291 & 1041.340 & 902.051\end{array}$ $\begin{array}{lllllllllllllll} & 2473.5729 & 2973.5725 & 744.4004 & 0.0004 & 0.1343 & 54.031 & 67.990 & 35.433 & 28.487 & Y\end{array}$ $\begin{array}{llllllllllllllll}\text { LEQQVPNOVFGQDEMIDVIGVTK } & 1.00 & 87.65 & 25.04 & 20.54 & 2 & 2973.5754 & 2973.5725 & 1487.7935 & 0.0029 & 0.9746 & 4.029 & 3.098 & 4.085 & 0.000 & \text { No }\end{array}$

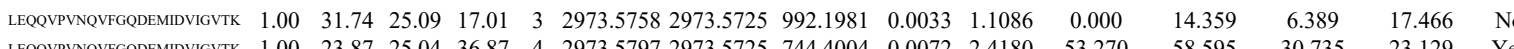

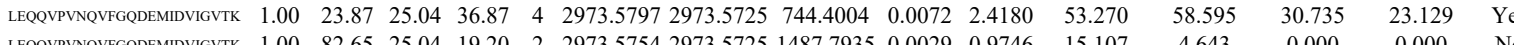
$\begin{array}{llllllllllllllll}\text { LEQQVPVNQVFGQDEMIDVIGVTK } & 1.00 & 82.65 & 25.04 & 19.20 & 2 & 2973.5754 & 2973.5725 & 1487.7935 & 0.0029 & 0.9746 & 15.107 & 4.643 & 0.000 & 0.000 & \text { No }\end{array}$ $\begin{array}{lllllllllllllllll}\text { LEQQVPNQVFGQDEMIDVIGVTK } & 1.00 & 67.94 & 25.02 & 20.04 & 3 & 2973.5764 & 2973.5725 & 992.1981 & 0.0039 & 1.3102 & 58.679 & 16.949 & 17.701 & 0.000 & \text { No }\end{array}$ $\begin{array}{llllllllllllllll}\text { LEQQVPVNQVFGQDEMIDVIGVTKK } & 0.98 & 24.40 & 25.00 & 16.80 & 3 & 2973.5770 & 2973.5725 & 992.1981 & 0.0045 & 1.5118 & 22.278 & 2.861 & 5.130 & 21.253 & \text { No }\end{array}$

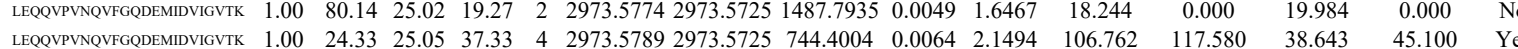
$\begin{array}{lllllllllllllllll}\text { LEQQPNQVFGQDEMIDVGVTK } & 1.00 & 24.33 & 25.05 & 37.33 & 4 & 2973.5789 & 2973.5725 & 744.4004 & 0.0064 & 2.1494 & 106.762 & 117.580 & 38.643 & 45.100 & \text { Yes }\end{array}$

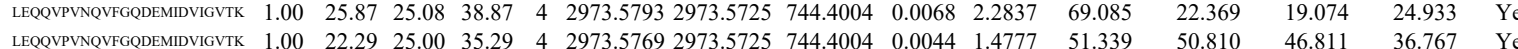
$\begin{array}{llllllllllllll} & \end{array}$ $\begin{array}{llllllllllllllll} & \end{array}$

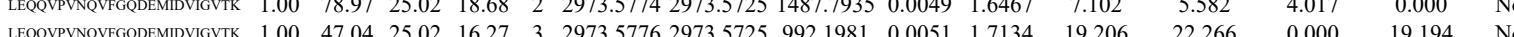

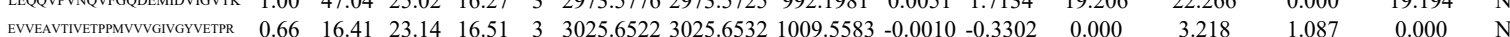
$\begin{array}{lllllllllll} & 0\end{array}$

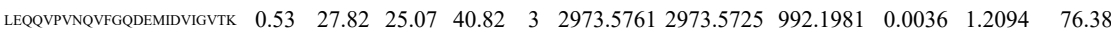
$\begin{array}{lllllllllllll} & \end{array}$ $\begin{array}{lllllllllllll}\text { EVVEAVTIVETPPMVVGGIGGVETPR } & 0.55 & 12.18 & 22.92 & 25.18 & 3 & 3025.6552 & 3025.6532 & 1009.5583 & 0.0020 & 0.6604 & 2.366\end{array}$ 


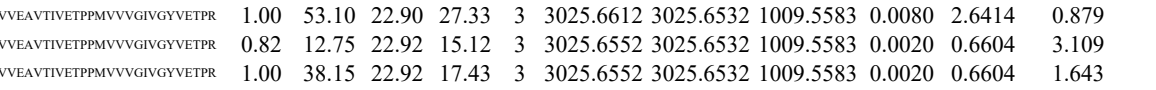

ENVEAVTIVETPMMVVVGIVGYVETP

$\begin{array}{llllllllllll} & 1.02 .946 & \text { Yes }\end{array}$ $\begin{array}{lllllllllllllllll}\text { GEGFUYGEVTNDFYMLK } & 0.93 & 13.43 & 26.28 & 14.75 & 4 & 2724.4261 & 2724.4189 & 682.1120 & 0.0072 & 2.6389 & 373.391 & 292.053 & 122.982 & 116.478 & \text { Yes }\end{array}$

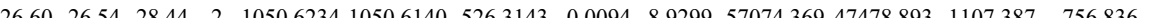
$\begin{array}{llllllllllllll} & \end{array}$

GQGYLIK $\begin{array}{llllllllllllllll}0.93 & 39.98 & 24.03 & 41.58 & 2 & 1178.7370 & 1178.7267 & 590.3706 & 0.0103 & 8.7233 & 87052.797 & 91198.183 & 19468.408 & 1764.545 & \text { Y } & \end{array}$ $\begin{array}{llllllllllllllll}0.92 & 35.08 & 24.01 & 37.74 & 2 & 1178.7376 & 1178.7267 & 590.3706 & 0.0109 & 9.2314 & 44202.430 & 44118.057 & 9549.154 & 1559.373 & \text { Yes } & \end{array}$

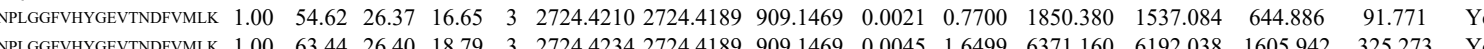

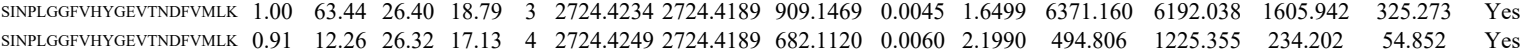

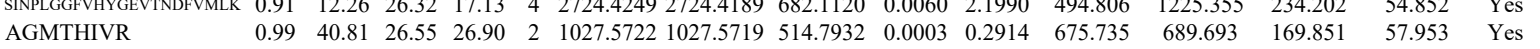
AGMTHIVR IGQGYLIK IGQGYLIK

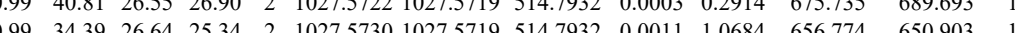
$\begin{array}{lllllllllllll}0.92 & 36.02 & 24.15 & 38.09 & 2 & 1178.7362 & 1178.7267 & 590.3706 & 0.0095 & 8.0457 & 28602.863 & 24603.461 & 7088.790\end{array}$ $\begin{array}{lllllllllllllll}0.99 & 38.12 & 26.57 & 34.05 & 2 & 1098.6112 & 1098.6090 & 550.3118 & 0.0022 & 1.9989 & 82.079 & 58.648 & 13.129 & 19.597 & \text { Yes }\end{array}$

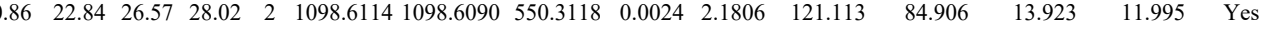
$\begin{array}{lllllllllllllll}0.99 & 38.67 & 26.52 & 33.94 & 2 & 1098.6098 & 1098.6090 & 550.3118 & 0.0008 & 0.7269 & 257.723 & 218.533 & 22.117 & 19.281 & \text { Yes }\end{array}$

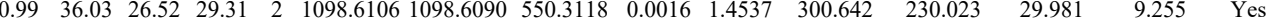

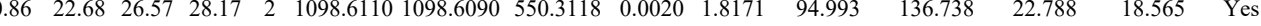

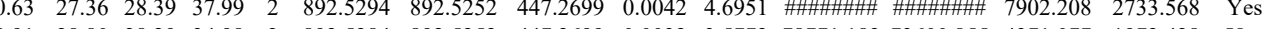
$\begin{array}{lllllllllllllll}0.91 & 28.80 & 28.29 & 34.98 & 2 & 892.5284 & 892.5252 & 447.2699 & 0.0032 & 3.5772 & 78771.182 & 73600.855 & 4371.077 & 1972.428 & \text { Yes }\end{array}$ $\begin{array}{lllllllllllllllll}0.72 & 26.15 & 28.43 & 28.07 & 2 & 892.5288 & 892.5252 & 447.2699 & 0.0036 & 4.0244 & \text { \#冊册册 } 98104.915 & 4975.148 & 1412.127 & \text { Yes }\end{array}$ $\begin{array}{lllllllllllllll}0.91 & 32.33 & 25.82 & 15.14 & 2 & 1126.6442 & 1126.6369 & 564.3257 & 0.0073 & 6.4679 & 24279.096 & 29639.527 & 332.609 & 464.657 & \text { Yes }\end{array}$ $\begin{array}{lllllllllllllll}0.93 & 32.75 & 25.80 & 16.02 & 2 & 1126.6448 & 1126.6369 & 564.3257 & 0.0079 & 6.9995 & 12285.964 & 14926.316 & 47.167 & 306.332 & \text { Yes }\end{array}$ $\begin{array}{lllllllllllllll}0.91 & 31.10 & 25.49 & 16.19 & 2 & 1126.6454 & 1126.6369 & 564.3257 & 0.0085 & 7.5311 & 4987.663 & 5264.323 & 137.657 & 115.073 & \text { Yes }\end{array}$ $\begin{array}{lllllllllllllll}0.92 & 31.14 & 25.49 & 16.06 & 2 & 1126.6460 & 1126.6369 & 564.3257 & 0.0091 & 8.0627 & 3754.485 & 4597.591 & 133.227 & 126.386 & \text { Yes }\end{array}$

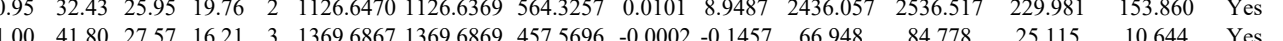

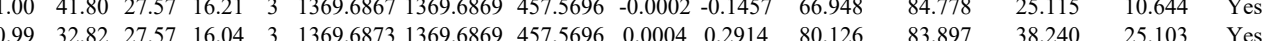

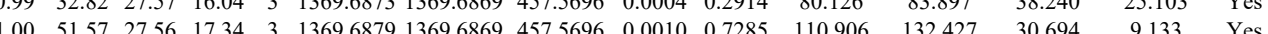

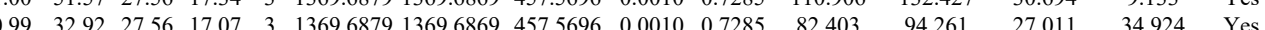

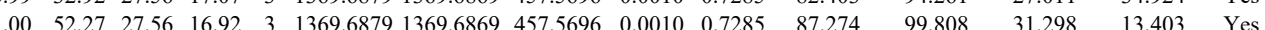
$\begin{array}{lllllllllllllll}1.00 & 36.18 & 27.56 & 15.91 & 3 & 1369.6879 & 1369.6869 & 457.5696 & 0.0010 & 0.7285 & 91.110 & 77.808 & 11.2913 & 15.333 & \text { Yes }\end{array}$

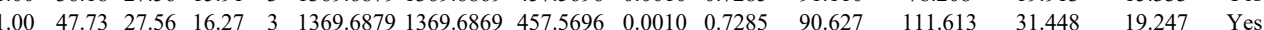

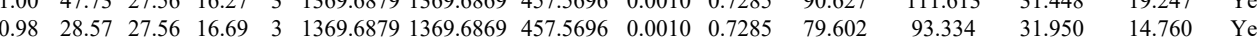

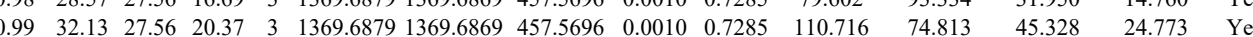

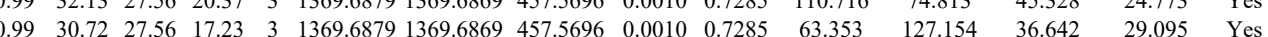
$\begin{array}{lllllllllllllll}00 & 64.93 & 27.57 & 19.29 & 2 & 1369.6880 & 1369.6869 & 685.8507 & 0.0011 & 0.8019 & 6658.068 & 5759.952 & 23.649 & 131.799 & \text { Yes }\end{array}$

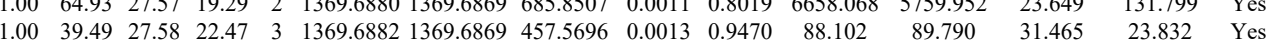

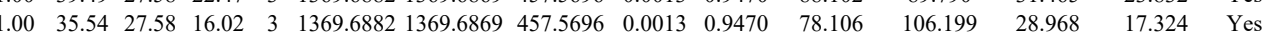
$\begin{array}{lllllllllllllll}1.00 & 49.97 & 27.58 & 16.64 & 3 & 1369.6882 & 1369.6869 & 457.5696 & 0.0013 & 0.9470 & 52.083 & 95.906 & 21.936 & 19.243 & \text { Yes }\end{array}$ $\begin{array}{llllllllllllll}1.00 & 37.22 & 27.58 & 15.81 & 3 & 1369.6882 & 1369.6869 & 457.5696 & 0.0013 & 0.9470 & 38.943 & 53.563 & 14.504\end{array}$ $\begin{array}{llllllllllllll}0.76 & 57.85 & 27.58 & 70.85 & 2 & 1369.6882 & 1369.6869 & 685.8507 & 0.0013 & 0.9477 & 11250.468 & 9686.415 & 260.283\end{array}$ \begin{tabular}{lllllllllllll}
0.76 & 57.85 & 27.58 & 70.85 & 2 & 1369.6882 & 1369.6869 & 685.8507 & 0.0013 & 0.9477 & 11250.468 & 9686.415 & 260.283 \\
\hline
\end{tabular}

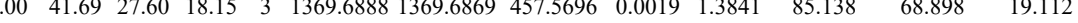
$\begin{array}{lllllllllllll}1.00 & 49.05 & 27.56 & 18.52 & 3 & 1369.6891 & 1369.6869 & 457.5696 & 0.0022 & 1.6027 & 17293.615 & 16053.015 & 2070.786 \\ 1.00 & 52.46 & 27.56 & 17.57 & 3 & 1369.6891 & 1369.6869 & 457.5696 & 0.0022 & 1.6027 & 82.184 & 109.818 & 55.300\end{array}$ $\begin{array}{llllllllllllll}0.55 & 33.47 & 27.56 & 46.47 & 3 & 1369.6891 & 1369.6869 & 457.5696 & 0.0022 & 1.6027 & 104.675 & 117.444 & 45.132\end{array}$

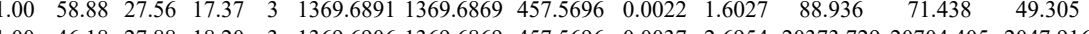
$\begin{array}{lllllllllllll}1.00 & 46.18 & 27.88 & 18.20 & 3 & 1369.6906 & 1369.6869 & 457.5696 & 0.0037 & 2.6954 & 20373.729 & 20704.405 & 2047.916\end{array}$ $\begin{array}{lllllllllllllll}1.00 & 44.42 & 27.29 & 20.27 & 4 & 1641.8865 & 1641.8839 & 411.4783 & 0.0026 & 1.5797 & 2357.107 & 1709.182 & 832.683\end{array}$

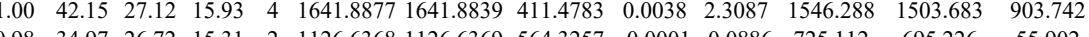

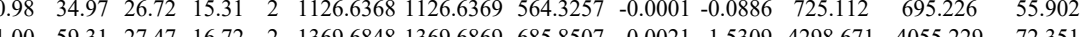

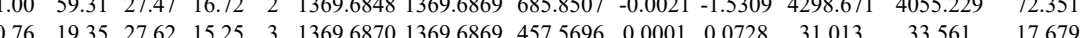

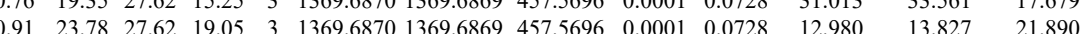
$\begin{array}{lllllllllllll}1.00 & 42.18 & 27.57 & 18.14 & 3 & 1369.6873 & 1369.6869 & 457.5696 & 0.0004 & 0.2914 & 3665.327 & 3356.249 & 499.612\end{array}$ 

$\begin{array}{llllllllllll}0.55 & 30.88 & 27.56 & 43.88 & 3 & 1369.6891 & 1369.6869 & 457.5696 & 0.0022 & 1.6027 & 36.930\end{array}$ $\begin{array}{lllllllllllll}0.96 & 23.71 & 27.56 & 15.51 & 3 & 1369.6891 & 1369.6869 & 457.5696 & 0.0022 & 1.6027 & 26.824\end{array}$

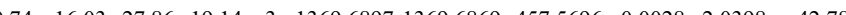

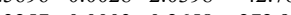

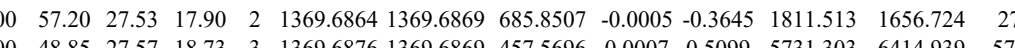
$\begin{array}{llllllllllllll}0.52 & 12.41 & 27.85 & 17.21 & 3 & 1369.6903 & 1369.6869 & 457.5696 & 0.0034 & 2.4768 & 18.806 & 20.465 & 14.281\end{array}$ $\begin{array}{llllllllllllll}0.63 & 24.73 & 2.54 & 17.68 & 2 & 1126.6362 & 1126.6369 & 564.3257 & 0.0007 & -0.6202 & 365.589 & 502.135 & 99.846\end{array}$

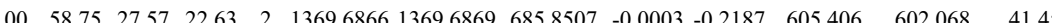
$\begin{array}{llllllllllllll}1.00 & 72.28 & 27.62 & 23.98 & 2 & 1369.6870 & 1369.6869 & 685.8507 & 0.0001 & 0.0729 & 769.334 & 719.168 & 25.441\end{array}$ $\begin{array}{llllllllllllll}1.00 & 48.80 & 27.57 & 18.53 & 3 & 1369.6873 & 1369.6869 & 457.5696 & 0.0004 & 0.2914 & 2704.445 & 3412.540 & 311.745\end{array}$ $\begin{array}{llllllllllllll}1.00 & 49.03 & 27.56 & 16.39 & 3 & 1369.6879 & 1369.6869 & 457.5696 & 0.0010 & 0.7285 & 5039.653 & 3381.253 & 478.354\end{array}$ $\begin{array}{lllllllllllll}1.00 & 72.08 & 27.57 & 22.12 & 2 & 1369.6880 & 1369.6869 & 685.8507 & 0.0011 & 0.8019 & 499.802 & 512.791 & 38.270\end{array}$

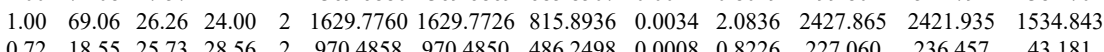
$\begin{array}{llllllllllllllll}0.72 & 18.55 & 25.73 & 28.56 & 2 & 970.4858 & 970.4850 & 486.2498 & 0.0008 & 0.8226 & 227.060 & 236.457 & 43.181 \\ 0.73 & 18.48 & 25.80 & 27.76 & 2 & 970.4868 & 970.4850 & 486248 & 0.0018 & 1.8509 & 231315 & 238.164 & 21.460\end{array}$ $\begin{array}{llllllllllllll}0.73 & 18.48 & 25.80 & 27.76 & 2 & 970.4868 & 970.4850 & 486.2498 & 0.0018 & 1.8509 & 231.315 & 238.164 & 21.460 \\ 1.00 & 40.28 & 27.62 & 19.88 & 3 & 1369.6870 & 1369.6869 & 457.5696 & 0.0001 & 0.0728 & 91.553 & 92.545 & 31.24\end{array}$ $\begin{array}{lllllllllllll}1.00 & 37.55 & 27.58 & 15.89 & 3 & 1369.6882 & 1369.6869 & 457.5696 & 0.0013 & 0.9470 & 79.894 & 80.441 & 13.953\end{array}$ $\begin{array}{lllllllllllll}0.86 & 23.62 & 26.16 & 15.48 & 3 & 1711.8139 & 1711.8153 & 571.6124 & -0.0014 & -0.8164 & 212.973 & 225.372 & 93.017\end{array}$

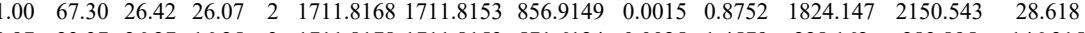
$\begin{array}{lllllllllllll}0.97 & 23.37 & 26.27 & 16.25 & 3 & 1711.8178 & 1711.8153 & 571.6124 & 0.0025 & 1.4579 & 228.162 & 283.895 & 146.215\end{array}$

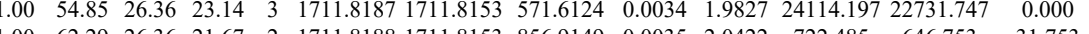
$\begin{array}{lllllllllllll}1.00 & 62.29 & 26.36 & 21.67 & 2 & 1711.8188 & 1711.8153 & 856.9149 & 0.0035 & 2.0422 & 722.485 & 646.753 & 31.753\end{array}$ $\begin{array}{lllllllllllll}0.97 & 25.14 & 26.52 & 16.68 & 3 & 1711.8202 & 1711.8153 & 571.6124 & 0.0049 & 2.8574 & 279.226 & 293.196 & 143.892\end{array}$ $\begin{array}{lllllllllllll}0.77 & 22.27 & 26.73 & 17.16 & 3 & 1711.8259 & 1711.8153 & 571.6124 & 0.0106 & 6.1813 & 277.783 & 280.084 & 153.520\end{array}$

$\begin{array}{lllllllllllll}1.00 & 57.40 & 27.69 & 27.64 & 2 & 1446.8174 & 1446.8173 & 724.4159 & 0.0001 & 0.0690 & 2438.056 & 2376.504 & 714.041 \\ 1.00 & 56.17 & 27.69 & 28.16 & 2 & 1446.8176 & 1446.8173 & 724.4159 & 0.0003 & 0.2071 & 572.403 & 562.295 & 115.478\end{array}$ TADDPSLSLIK

WVPFDGDDIQLEFV WVPFDGDDIQLE

LPDVYGVFQFK

LPDVYGVFQFK

LPDVYGVFQFK

TLVLLDNLNVR

TLVLLDNLNVR

TLVLLDNLNVR

SSLNPILFR

SSLNPILFR

SSLNPILFR

NTLLIAGLQAR

NTLLIAGLQAR

NTLLIAGLQAR

NTLLIAGLQAR

NTLLIAGLQAR

NTLLIAGLQAR

SSLNPILFR

NTLLIAGLQAR 
$\begin{array}{llllllllllllllll}\text { VLAQNSGFDLETLVK } & 1.00 & 94.36 & 25.79 & 23.31 & 2 & 2049.1394 & 2049.1350 & 1025.5748 & 0.0044 & 2.1451 & 279.846 & 230.230\end{array}$ $\begin{array}{llllllllllllll}\text { NAIDDGCVVPGGGAVEVAMAEALIK } & 1.00 & 61.02 & 26.99 & 19.81 & 3 & 2746.4017 & 2746.3947 & 916.4722 & 0.0070 & 2.5460 & 27.006\end{array}$

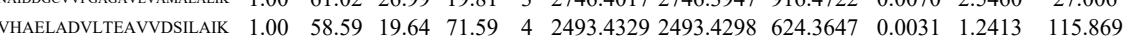
$\begin{array}{lllllllllllllll}\text { VHAELADVLTEAVVDSILAIK } & 1.00 & 51.85 & 19.40 & 64.85 & 4 & 2493.4341 & 2493.4298 & 624.3647 & 0.0043 & 1.7217 & 139.351 & 204.184\end{array}$ $\begin{array}{llllllllllllll}\text { VHAELADVLTEAVVDSILAIK } & 1.00 & 73.75 & 19.40 & 18.68 & 3 & 2493.4342 & 2493.4298 & 832.1505 & 0.0044 & 1.7625 & 28.916 & 28.170\end{array}$ $\begin{array}{llllllllllllll}\text { VHAELADVLTEAVVDSLAIK } & 1.00 & 53.06 & 19.34 & 21.12 & 4 & 2493.4349 & 2493.4298 & 624.3647 & 0.0051 & 2.0421 & 154.243 & 185.764\end{array}$ $\begin{array}{lllllllllllll}\text { VHAELADVLTEAVVDSILAIK } & 1.00 & 52.70 & 19.64 & 17.87 & 4 & 2493.4321 & 2493.4298 & 624.3647 & 0.0023 & 0.9209 & 186.155 & 137.860\end{array}$ $\begin{array}{llllllllllllll}\text { VHAELADVLTEAVVDSILAIK } & 1.00 & 56.43 & 19.40 & 23.57 & 3 & 2493.4342 & 2493.4298 & 832.1505 & 0.0044 & 1.7625 & 10.578 & 163.086\end{array}$ $\begin{array}{lllllllllllll}\text { VHAELADVLTEAVVDSILAIK } & 1.00 & 59.01 & 19.34 & 72.01 & 4 & 2493.4349 & 2493.4298 & 624.3647 & 0.0051 & 2.0421 & 119.740 & 176.584\end{array}$

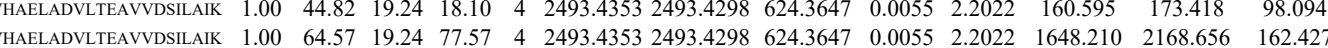
$\begin{array}{llllllllllllll}\text { VHAELADVLTEAVVDSILAIK } & 1.00 & 86.96 & 19.24 & 18.62 & 2 & 2493.4354 & 2493.4298 & 1247.7222 & 0.0056 & 2.2441 & 10.701 & 9.938 & 6.995\end{array}$

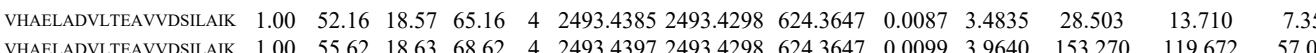
$\begin{array}{lllllllllllllll}\text { VHAELADVLTEAVVDSILAIK } & 1.00 & 55.62 & 18.63 & 68.62 & 4 & 2493.4397 & 2493.4298 & 624.3647 & 0.0099 & 3.9640 & 153.270 & 119.672 & 57.051\end{array}$ $\begin{array}{lllllllllllllll}\text { VHAELADVLTEAVVDSILAIK } & 1.00 & 69.45 & 17.99 & 82.45 & 4 & 2493.4441 & 2493.4298 & 624.3647 & 0.0143 & 5.7258 & 6866.493 & 8372.963 & 396.311 & 245.15\end{array}$ $\begin{array}{lllllllllllllll}\text { GFVVINQK } & 0.99 & 39.69 & 23.84 & 22.19 & 2 & 1191.7312 & 1191.7219 & 596.8682 & 0.0093 & 7.7906 & 22544.943 & 22851.795 & 13053.338 & 4806.56 \\ \text { GFVVINQK } & 0.99 & 37.01 & 23.80 & 20.25 & 2 & 1191.7324 & 1191.7219 & 596.8682 & 0.0105 & 8.7958 & 31863.438 & 28897.444 & 14254.424 & 5486.108\end{array}$ $\begin{array}{lllllllllllll}\text { VHAELADVLTEAVVDSILAIK } & 1.00 & \text { \#\#\#\# } 19.59 & 20.27 & 2 & 2493.4334 & 2493.4298 & 1247.7222 & 0.0036 & 1.4426 & 10.062 & 15.398 & 0.000\end{array}$

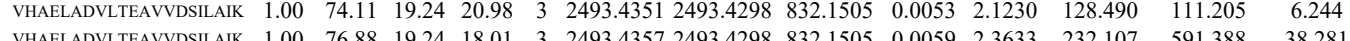
$\begin{array}{llllllllllllll}\text { VHAELADVLTEAVVDSILAIK } & 1.00 & 58.99 & 19.03 & 71.99 & 4 & 2493.4361 & 2493.4298 & 624.3647 & 0.0063 & 2.5226 & 1095.074 & 1008.766 & 181.458\end{array}$ $\begin{array}{llllllllllllllll}\text { VHAELADVLTEAVVDSILAIK } & 1.00 & 70.85 & 18.63 & 83.85 & 4 & 2493.4397 & 2493.4298 & 624.3647 & 0.0099 & 3.9640 & 3118.507 & 3374.437 & 51.325\end{array}$ $\begin{array}{lllllllllllllll}\text { VHAELADVLTEAVVDSILAIK } & 1.00 & 74.54 & 19.59 & 26.34 & 3 & 2493.4336 & 2493.4298 & 832.1505 & 0.0038 & 1.5222 & 83.084 & 15.537 & 18.890\end{array}$ $\begin{array}{llllllllllllllll}\text { VHAELADVLTEAVVDSILAIK } & 1.00 & 52.33 & 19.24 & 16.84 & 4 & 2493.4353 & 2493.4298 & 624.3647 & 0.0055 & 2.2022 & 335.829 & 444.814 & 64.322\end{array}$ $\begin{array}{llllllllllllllll}\text { VHAELADVLTEAVVDSLAIK } & 1.00 & 47.95 & 19.03 & 60.95 & 4 & 2493.4361 & 2493.4298 & 624.3647 & 0.0063 & 2.5226 & 819.081 & 975.160 & 240.822\end{array}$ $\begin{array}{lllllllllllllll}\text { VHAELADVITEAVVDSLATK } & 0.53 & 81.20 & 19.59 & 94.20 & 3 & 2493.4333 & 2493.4298 & 832.1505 & 0.0035 & 1.4020 & 22.853 & 12\end{array}$

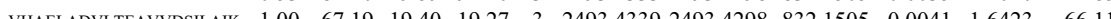
$\begin{array}{lllllllllllll}\text { VHAELADVLTEAVVDSILAIK } & 1.00 & 40.56 & 19.34 & 15.74 & 4 & 2493.4349 & 2493.4298 & 624.3647 & 0.0051 & 2.0421 & 295.134 & 24\end{array}$ $\begin{array}{lllllllllllllll}\text { VHAELADVLTEAYDSILAIK } & 1.00 & 49.95 & 18.69 & 62.95 & 4 & 2493.4381 & 2493.4298 & 624.3647 & 0.0083 & 3.3234 & 155.893 & 149.5\end{array}$ $\begin{array}{llllllllllllll}0.93 & 48.45 & 15.05 & 47.51 & 2 & 1060.7184 & 1060.7100 & 531.3623 & 0.0084 & 7.9041 & 15026.198 & 12404.578 & 2793.219 \\ 0.75 & 48.84 & 9.03 & 56.92 & 2 & 1060.7202 & 1060.7100 & 531.3623 & 0.0102 & 9.5979 & 18488.357 & 19442.714 & 3376.311 \\ 0.90 & 48.27 & 15.05 & 49.28 & 2 & 1060.7184 & 1060.7100 & 531.3623 & 0.0084 & 7.9041 & 18791.502 & 15855.020 & 3519.313\end{array}$ $\begin{array}{llllllllllllllll} & & 0.758 .235 & 2055.2336 & 686.0851 & 0.0023 & 1.1174 & 44.447 & 14.825 & 15.119\end{array}$ $\begin{array}{lllllllllllllll} & 17.16 & 65.64 & 3 & 2055.235 & 20555.236 & 68.0851 & 0.023 & 1.1174 & 44.447 & 14.825 & 15.119 \\ \end{array}$ $\begin{array}{llllllllllllll} & \end{array}$ $\begin{array}{lllllllllllll} & \end{array}$ $\begin{array}{lllllllllllllll} & \text { AQLGVQAFADALLIIPK } & 0.53 & 54.27 & 16.81 & 67.27 & 3 & 2055.2365 & 2055.2336 & 686.0851 & 0.0029 & 1.4090 & 199.773 & 207.333\end{array}$ $\begin{array}{lllllllllllllll} & \end{array}$ $\begin{array}{lllllllllllll}\text { AQAALAVNISAAR } & 1.00 & 54.08 & 26.30 & 21.87 & 2 & 1398.8086 & 1398.8065 & 700.4105 & 0.0021 & 1.4991 & 52.047\end{array}$ $\begin{array}{llllllllllllll}\text { AQAALAVNISAAR } & 1.00 & 69.17 & 26.14 & 22.65 & 2 & 1398.8096 & 1398.8065 & 700.4105 & 0.0031 & 2.2130 & 78.589 \\ \text { AQLGVQAFADALLIIPK } & 0.61 & 78.95 & 16.90 & 91.95 & 2 & 2055.2334 & 2055.2336 & 1028.6241 & -0.0002 & -0.0972 & 22.006\end{array}$ $\begin{array}{lllllllllllll}\text { AQLGVQAFADALLIIPK } & 0.61 & 78.95 & 16.90 & 91.95 & 2 & 2055.2334 & 2055.2336 & 1028.6241 & -0.0002 & -0.0972 & 22.006\end{array}$ $\begin{array}{llllllllllll}\text { AQLGVQAFADALLIIIPK } & 1.00 & 88.64 & 16.90 & 19.06 & 2 & 2055.2334 & 2055.2336 & 1028.6241 & -0.0002 & -0.0972 & 19.827\end{array}$ $\begin{array}{llllllllllll}\text { AQLGVQAFADALLIIPK } & 1.00 & 76.07 & 16.90 & 21.88 & 2 & 2055.2334 & 2055.2336 & 1028.6241 & -0.0002 & -0.0972 & 13.011\end{array}$

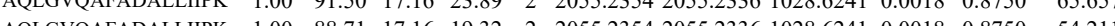

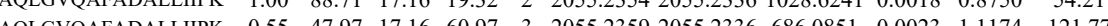
$\begin{array}{lllllllllll} & \end{array}$ $\begin{array}{llllllllllll}\text { AQLGVQAFADALLIPK } & 0.53 & 65.26 & 16.81 & 78.26 & 3 & 2055.2365 & 2055.2336 & 686.0851 & 0.0029 & 1.4090 & 111.271\end{array}$ $\begin{array}{llllllllllll}\text { AQLGVQAFADALLIIPK } & 0.53 & 69.37 & 16.81 & 82.37 & 3 & 2055.2365 & 2055.2336 & 686.0851 & 0.0029 & 1.4090 & 23.879\end{array}$ 

$\begin{array}{llllllllllll}0.96 & 26.15 & 22.70 & 15.64 & 2 & 1767.0322 & 1767.0294 & 884.5220 & 0.0028 & 1.5828 & 18.703\end{array}$ $\begin{array}{lllllllllll}1.00 & 53.70 & 23.18 & 18.80 & 2 & 1767.0300 & 1767.0294 & 884.5220 & 0.0006 & 0.3392 & 8.717\end{array}$ $\begin{array}{lllllllllllll}0.92 & 49.46 & 24.42 & 48.63 & 2 & 1056.6580 & 1056.6525 & 529.3335 & 0.0055 & 5.1952 & 950.265\end{array}$ $\begin{array}{lllllllllll}1.00 & 86.68 & 26.33 & 20.18 & 2 & 1398.8066 & 1398.8065 & 700.4105 & 0.0001 & 0.0714 & 308.663\end{array}$ $\begin{array}{lllllllllll}.00 & 89.00 & 26.33 & 21.02 & 2 & 1398.8066 & 1398.8065 & 700.4105 & 0.0001 & 0.0714 & 330.848\end{array}$ $\begin{array}{llllllllllll}0.92 & 31.29 & 24.41 & 33.24 & 2 & 1056.6570 & 1056.6525 & 529.3335 & 0.0045 & 4.2506 & 92.555 \\ 0.97 & 35.95 & 24.56 & 31.04 & 2 & 10566574 & 10566525 & 529.3335 & 0.0049 & 4.6284 & 43.057\end{array}$ $\begin{array}{lllllllllll}0.97 & 35.95 & 24.56 & 31.04 & 2 & 1056.6574 & 1056.6525 & 529.3335 & 0.0049 & 4.6284 & 43.057 \\ 0.94 & 35.01 & 24.42 & 32.79 & 2 & 1056.6580 & 10566525 & 529.3335 & 0.0055 & 5.1952 & 73.531\end{array}$ $\begin{array}{llllllllllll}0.90 & 31.93 & 24.42 & 32.46 & 2 & 1056.6582 & 1056.6525 & 529.3335 & 0.0057 & 5.3841 & 52.695\end{array}$ $\begin{array}{lllllllllllll}0.92 & 49.01 & 24.36 & 48.19 & 2 & 1056.6584 & 1056.6525 & 529.3335 & 0.0059 & 5.5730 & 4957.222 & 4950.562\end{array}$ $\begin{array}{lllllllllllll}0.92 & 49.03 & 24.36 & 48.19 & 2 & 1056.6584 & 1056.6525 & 529.3335 & 0.0059 & 5.5730 & 6974.723 & 7276.276\end{array}$ $\begin{array}{lllllllllllll}0.58 & 43.34 & 24.56 & 52.09 & 2 & 1056.6574 & 1056.6525 & 529.3335 & 0.0049 & 4.6284 & 3981.844 & 4310.820\end{array}$ $\begin{array}{llllllllllll}0.58 & 43.34 & 24.56 & 5.09 & 2 & 1056.6574 & 1056.6525 & 529.3335 & 0.0049 & 4.6284 & 3981.844 & 4310.820\end{array}$ $\begin{array}{llllllllllll}0.96 & 49.50 & 24.41 & 48.69 & 2 & 1056.6564 & 1056.6525 & 529.3335 & 0.0039 & 3.6839 & 767.169 & 845.822\end{array}$ $\begin{array}{llllllllllll}1.00 & 69.94 & 26.12 & 25.79 & 2 & 1398.8062 & 1398.8065 & 700.4105 & -0.0003 & -0.2142 & 79.386 & 58.393 \\ 1.00 & 93.74 & 26.33 & 27.99 & 2 & 1398.8064 & 1398.8065 & 700.4105 & -0.0001 & -0.0714 & 41.711 & 58.864\end{array}$

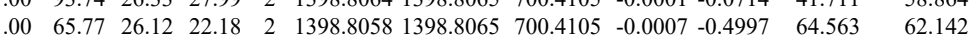
$\begin{array}{lllllllll} & \end{array}$

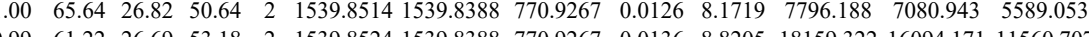

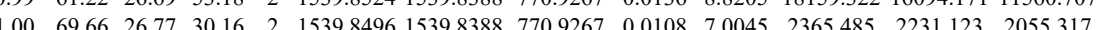
$\begin{array}{llllllllllllllll}100 & 57.38 & 26.89 & 26.92 & 2 & 1539.8506 & 1539.8388 & 770.9267 & 0.0118 & 7.6531 & 716.000 & 747.281 & 618.742 & 2 & & \end{array}$ $\begin{array}{lllllllllllllll}0.86 & 25.07 & 26.82 & 15.24 & 3 & 1539.8515 & 15398388 & 5142869 & 0.0127 & 8.2314 & 89.215 & 114.078 & 161.460 & 20 & 20\end{array}$

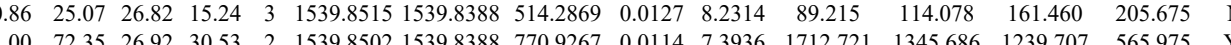
$\begin{array}{lllllllllllllll}1.00 & 72.21 & 26.74 & 37.42 & 2 & 1539.8520 & 1539.8388 & 770.9267 & 0.0132 & 8.5611 & 4326.594 & 4436.917 & 2364.025 & 1563.945 & \text { Yes }\end{array}$

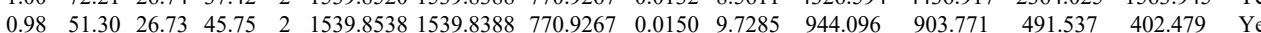
$\begin{array}{lllllllllllllll}1.00 & 46.76 & 27.80 & 25.39 & 2 & 1534.8284 & 1534.8275 & 7684210 & 0.0009 & 0.5856 & 3441.358 & 3163.189 & 396.480 & 461.848 & \text { Yes }\end{array}$ $\begin{array}{lllllllllllllll}0.00 & 46.69 & 27.46 & 28.88 & 2 & 1534.8400 & 1534.8275 & 768.4210 & 0.0125 & 8.1335 & 4846.453 & 4629.366 & 376.369 & 554.098 & \text { Yes }\end{array}$ $\begin{array}{lllllllllllllll}0.99 & 41.21 & 27.51 & 20.57 & 2 & 1534.8408 & 1534.8275 & 768.4210 & 0.0133 & 8.6540 & 367.769 & 354.454 & 28.536 & 32.011 & \text { Yes }\end{array}$ $\begin{array}{lllllllllllllll}0.87 & 28.47 & 27.46 & 19.56 & 2 & 1534.8410 & 1534.8275 & 768.4210 & 0.0135 & 8.7842 & 395.340 & 481.841 & 6.303 & 0.000 & \text { No }\end{array}$ $\begin{array}{lllllllllllllllll}0.86 & 23.81 & 27.30 & 25.97 & 2 & 962.4736 & 962.4725 & 482.2435 & 0.0011 & 1.1405 & 26.980 & 50.934 & 23.046 & 9.617 & \text { Yes }\end{array}$

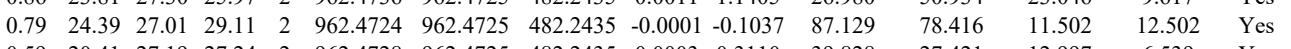
$\begin{array}{lllllllllllllll}0.59 & 20.41 & 27.19 & 27.24 & 2 & 962.4728 & 962.4725 & 482.2435 & 0.0003 & 0.3110 & 39.828 & 27.421 & 12.997 & 6.539 & \text { Yes }\end{array}$

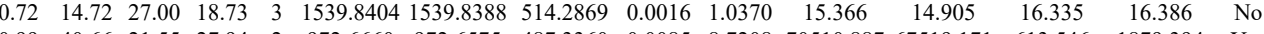
$\begin{array}{llllllllllllllll}0.99 & 40.66 & 21.55 & 27.94 & 2 & 972.6660 & 972.6575 & 487.3360 & 0.0085 & 8.7208 & 70510.887 & 67519.171 & 613.546 & 1879.394 & \text { Yes }\end{array}$ $\begin{array}{lllllllllllllll}0.93 & 22.72 & 19.24 & 29.43 & 2 & 1100.7284 & 1100.7273 & 551.3709 & 0.0011 & 0.9975 & 1456.662 & 1687.867 & 480.337 & 181.584 & \text { Yes }\end{array}$ $\begin{array}{llllllllllllllll}0.99 & 38.07 & 22.97 & 21.04 & 2 & 1115.7086 & 1115.6980 & 558.8563 & 0.0106 & 9.4836 & 34388.915 & 36986.078 & 2702.639 & 1523.588 & \text { Yes }\end{array}$

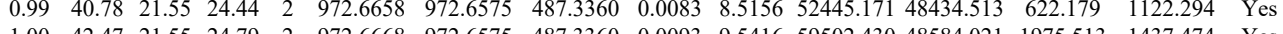
\begin{tabular}{llllllllllllllll}
1.00 & 42.47 & 21.55 & 24.79 & 2 & 972.6668 & 972.6575 & 487.3360 & 0.0093 & 9.5416 & 59502.430 & 48584.021 & 1975.513 & 1437.474 & Yes \\
\hline
\end{tabular} $\begin{array}{lllllllllllllll}0.99 & 36.62 & 23.10 & 16.35 & 2 & 1115.7074 & 1115.6980 & 558.8563 & 0.0094 & 8.4100 & 40150.294 & 40512.417 & 1027.858 & 877.112 & \text { Yes } \\ 0.99 & 37.40 & 23.26 & 21.77 & 2 & 115.7080 & 115.6980 & 558.8563 & 0.0100 & 8.9468 & 54526.108 & 48251.576 & 1457.800 & 530.367 & \text { Yes }\end{array}$ $\begin{array}{lllllllllllllll}0.99 & 37.40 & 23.26 & 21.77 & 2 & 1115.7080 & 1115.6980 & 558.8563 & 0.0100 & 8.9468 & 54526.108 & 48251.576 & 1457.800 & 530.367 & \text { Yes } \\ 0.98 & 33.03 & 22.97 & 2.13 & 2 & 1115.708 & 115.698 & 558.8563 & 0.0104 & 9.3046 & 2019.066 & 17751.04 & 2267.013 & 431.43 & \text { Yes }\end{array}$ $\begin{array}{lllllllllllllllll}0.98 & 33.03 & 22.97 & 20.13 & 2 & 1115.7084 & 1115.6980 & 558.8563 & 0.0104 & 9.3046 & 20194.066 & 17751.104 & 2267.013 & 431.431 & \text { Yes }\end{array}$ $\begin{array}{lllllllllllllll}1.00 & 57.50 & 25.08 & 23.24 & 2 & 1561.7294 & 1561.7139 & 781.8642 & 0.0155 & 9.9121 & 13384.532 & 14101.924 & 358.308 & 168.767 & \text { Yes } \\ 0.79 & 17.60 & 27.08 & 16.27 & 3 & 1539.8401 & 1539.8388 & 514.2869 & 0.0013 & 0.8426 & 25.933 & 12.082 & 16.686 & 1.334 & \text { No }\end{array}$

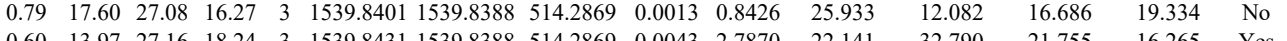

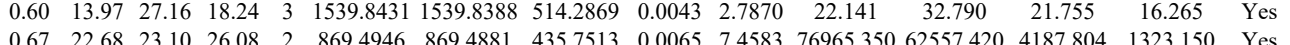

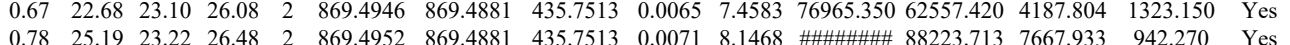
$\begin{array}{llllllllllllllll}0.78 & 25.19 & 23.22 & 26.48 & 2 & 869.4952 & 869.4881 & 435.7513 & 0.0071 & 8.1468 & \text { \#冊册册 } 88223.713 & 7667.933 & 942.270 & \text { Yes } \\ 0.70 & 22.48 & 23.05 & 27.59 & 2 & 869.4962 & 869.4881 & 435.7513 & 0.0081 & 9.2942 & 42453.832 & 38078.108 & 2881.115 & 1027.090 & \text { Yes }\end{array}$ $\begin{array}{lllllllllllllll}0.74 & 22.48 & 23.05 & 27.59 & 2 & 869.4962 & 869.4881 & 435.7513 & 0.0081 & 9.2942 & 42453.832 & 38078.108 & 2881.115 & 1027.090 & \text { Yes } \\ 0.94 & 27.77 & 27.04 & 32.57 & 2 & 925.5518 & 925.5507 & 463.7826 & 0.0011 & 1.1859 & 6837.067 & 5578.416 & 81.714 & 25.482 & \text { Yes }\end{array}$ $\begin{array}{llllllllllllllll}0.94 & 27.77 & 27.04 & 32.57 & 2 & 925.5518 & 925.5507 & 463.7826 & 0.0011 & 1.1859 & 6837.067 & 5578.416 & 81.714 & 25.482 & \text { Yes } \\ 0.95 & 27.82 & 27.01 & 24.39 & 2 & 925.5526 & 925.5507 & 463.7826 & 0.0019 & 2.0484 & 10708.716 & 8781.323 & 324.665 & 18.771 & \text { Yes }\end{array}$ 
AILVVFANK

AILVVFANK

AILVVFANK

AILVVFANK

AILVVFANK

AILVVFANK

AILVVFANK

AILVVFANK

AILVVFANK

AILVVFANK

AILVVFANK

SELVAMLEEEELR

AILVVFANK

AILVVFANK

AILVVFANK

AILVVFANK

AILVVFANK

SELVAMLEEEELRK

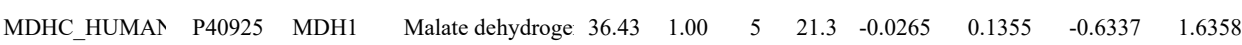

10 LGVTANDVK

LGVTANDVK

LGVTANDVK

LGVTANDVK

GEFVTVQR

GEFVTTVQQR

IVVGNPANTNCLTAS

VIVVGNPANTNCLTASK

IVVGNPANTNCLTASK

6 MISDAIPELK

MISDAIPELK

ANTFVAELK

MISDAIPELK

ANTFVAELK

GYLGPEQLPDCLK

GYLGPEQLPDCLK

GYLGPEQLPDCLK

GYLGPEQLPDCLK

GYLGPEQLPDCLK

GYLGPEQLPDCLK

LTLYDIAHTPGVAADLSHETK $\begin{array}{lllllllllllllllll}\text { LTLYDIAHTPGVAADLSHIETK K } & 1.00 & 50.44 & 24.38 & 63.44 & 4 & 2652.4429 & 2652.4366 & 664.1164 & 0.0063 & 2.3716 & 7004.054 & 8042.917 & 2493.121 & 552.161 & \text { Yes } \\ \text { NSPLVSR } & 0.85 & 22.44 & 26.29 & 28.64 & 2 & 915.5266 & 915.5260 & 458.7703 & 0.0006 & 0.6539 & 196.357 & 134.220 & 27.606 & 8.398 & \text { Yes }\end{array}$

$\begin{array}{lllllllllllll}0.55 & 31.01 & 20.68 & 44.01 & 3 & 1261.8025 & 1261.8002 & 421.6073 & 0.0023 & 1.8184 & 2608.328 & 2759.425 & 481.065\end{array}$ $\begin{array}{llllllllllllll}0.53 & 30.95 & 20.68 & 43.95 & 3 & 1261.8028 & 1261.8002 & 421.6073 & 0.0026 & 2.0556 & 2294.095 & 2980.898 & 504.107 & 314\end{array}$

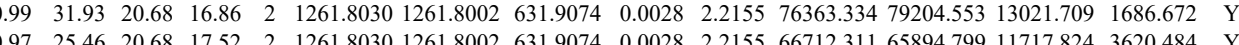

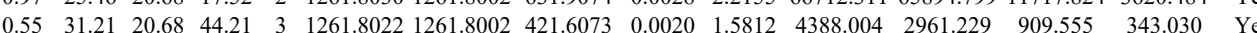
$\begin{array}{lllllllllllllll}0.96 & 30.37 & 21.14 & 18.95 & 2 & 1261.8082 & 1261.8002 & 631.9074 & 0.0080 & 6.3300 & 46671.561 & 43005.528 & 6491.181 & 1469.859 & \text { Yes }\end{array}$ $\begin{array}{lllllllllllllll}0.94 & 27.92 & 21.24 & 16.93 & 2 & 1261.8088 & 1261.8002 & 631.9074 & 0.0086 & 6.8047 & 62175.279 & 58092.441 & 10372.623 & 2526.535 & \text { Yes }\end{array}$ $\begin{array}{llllllllllllllll}0.55 & 15.89 & 20.68 & 28.89 & 3 & 1261.8019 & 1261.8002 & 421.6073 & 0.0017 & 1.3441 & 1422.192 & 1462.817 & 519.321 & 109.637 & \text { Yes } \\ \end{array}$ $\begin{array}{lllllllllllllllll}0.99 & 28.46 & 20.68 & 17.40 & 2 & 1261.8022 & 1261.8002 & 631.9074 & 0.0020 & 1.5825 & 27028.954 & 26279.962 & 4536.481 & 606.742 & \text { Yes }\end{array}$

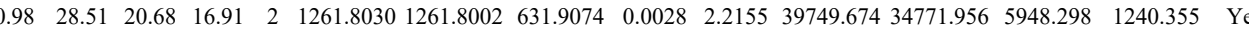
$\begin{array}{lllllllllllllll}0.99 & 29.17 & 20.79 & 20.69 & 2 & 1261.8014 & 1261.8002 & 631.9074 & 0.0012 & 0.9495 & 8526.752 & 7015.701 & 1169.496 & 403.985 & \text { Yes ses }\end{array}$ $\begin{array}{lllllllllllllll}1.00 & 32.26 & 20.68 & 19.82 & 2 & 1261.8018 & 1261.8002 & 631.9074 & 0.0016 & 1.2660 & 4269.155 & 3756.958 & 774.149 & 251.351 & \text { Yes }\end{array}$

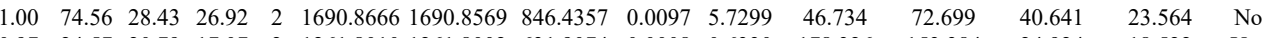

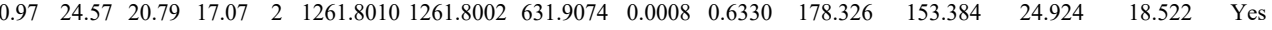

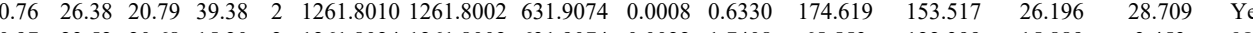

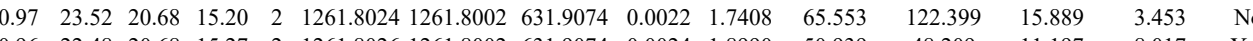

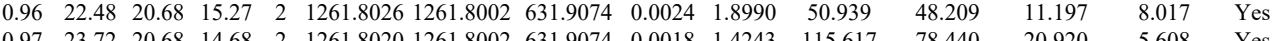
$\begin{array}{llllllllllllllll}0.97 & 23.72 & 20.68 & 14.68 & 2 & 1261.8020 & 1261.8002 & 631.9074 & 0.0018 & 1.4243 & 115.617 & 78.440 & 20.920 & 5.608 & \text { Yes }\end{array}$ $\begin{array}{lllllllllllllll}1.00 & 49.77 & 26.98 & 18.59 & 3 & 1963.0570 & 1963.0539 & 655.3586 & 0.0031 & 1.5767 & 1066.323 & 1097.244 & 1074.911 & 292.208 & \text { No }\end{array}$

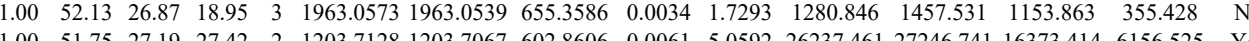

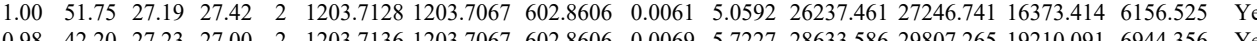
$\begin{array}{lllllllllllllll} & 0.98 & 42.20 & 27.23 & 27.00 & 2 & 1203.7136 & 1203.7067 & 602.8606 & 0.0069 & 5.7227 & 28633.586 & 29807.26519210 .091 & 6944.356 & \text { Yes }\end{array}$ $\begin{array}{llllllllllllllll}0.92 & 31.26 & 27.29 & 29.01 & 2 & 1203.7102 & 1203.7067 & 602.8606 & 0.0035 & 2.9028 & 52962.272 & 55371.884 & 16417.400 & 3394.680 & \text { Yes } \\ 0.99 & 43.82 & 27.29 & 30.51 & 2 & 1203.7102 & 1203.7067 & 602.8606 & 0.0035 & 2.9028 & 35188.533 & 36379.922 & 15115.877 & 3810.598 & \text { Yes }\end{array}$ $\begin{array}{lllllllllllllll}1.00 & 57.91 & 28.42 & 28.25 & 2 & 1307.6958 & 1307.6956 & 654.8551 & 0.0002 & 0.1527 & 16778047 & 19161.469 & 18179.070 & 10497.982 & \text { Yes }\end{array}$ $\begin{array}{llllllllllll} & \end{array}$ $\begin{array}{llllllllllllllll}0 & 58.41 & 27.56 & 22.66 & 2 & 11526456 & 1152.6416 & 577.3281 & 0.0040 & 3.4642 & 5858.669 & 4793.914 & 761.309 & 859.041 & \text { Yes }\end{array}$ $\begin{array}{llllllllllllll}1.00 & \# \# \# \# \text { 27.81 } & 24.75 & 2 & 2034.0854 & 2034.0845 & 1018.0495 & 0.0009 & 0.4420 & 1121.659 & 1153.644 & 509.375 & 90.691 & \text { Yes }\end{array}$ $\begin{array}{lllllllllllll} & \end{array}$ $\begin{array}{lllllllllllllllll}1.00 & 58.47 & 27.22 & 35.05 & 2 & 1403.7964 & 1403.7937 & 702.9041 & 0.0027 & 1.9206 & 17821.665 & 14099.804 & 0.000 & 298.783 & \text { No }\end{array}$ $\begin{array}{lllllllllllllll}1.00 & 53.59 & 27.24 & 28.08 & 2 & 1403.7970 & 1403.7937 & 702.9041 & 0.0033 & 2.3474 & 16511.404 & 17477.570 & 0.000 & 438.505 & \mathrm{No}\end{array}$ $\begin{array}{lllllllllllllll}1.00 & 46.89 & 26.73 & 22.50 & 2 & 1279.7484 & 1279.7380 & 640.8763 & 0.0104 & 8.1138 & 16715.439 & 17344.619 & 7080.893 & 3113.791 & \text { Yes }\end{array}$ $\begin{array}{lllllllllllllll}1.00 & 55.26 & 26.30 & 32.58 & 2 & 1403.8062 & 1403.7937 & 702.9041 & 0.0125 & 8.8916 & 5466244 & 5378.648 & 400.880 & 390.367 & \text { Y }\end{array}$ $\begin{array}{lllllllllllllll}1.00 & 57.37 & 26.27 & 28.85 & 2 & 1403.8066 & 1403.7937 & 702.9041 & 0.0129 & 9.1761 & 4862.666 & 4372.547 & 200.762 & 304.166 & \text { Yes }\end{array}$

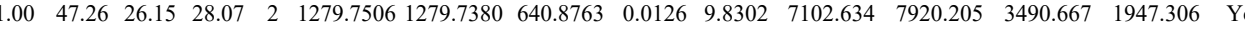
$\begin{array}{rllllllllllllll}1.00 & 70.24 & 27.99 & 37.22 & 2 & 1765.9008 & 1765.8986 & 883.9566 & 0.0022 & 1.2444 & 5114.351 & 4117.737 & 689.476 & 21.479 & \text { Yes } \\ 1 & 73.06 & 28.11 & 37.45 & 2 & 1765.9012 & 1765.8986 & 883.9566 & 0.0026 & 1.4707 & 2933.371 & 3078.203 & 655.454 & 1.17 & \text { Yes }\end{array}$ $\begin{array}{lllllllllllllll}1.00 & 73.69 & 28.10 & 36.37 & 2 & 1765.8978 & 1765.8986 & 883.9566 & -0.0008 & -0.4525 & 2716.449 & 2485.316 & 627.745 & 73.382 & \text { Yes }\end{array}$ $\begin{array}{lllllllllllllll}1.00 & 62.07 & 28.10 & 32.26 & 2 & 1765.8982 & 1765.8986 & 883.9566 & -0.0004 & -0.2263 & 5852.928 & 5378.604 & 1136.768 & 108.746 & \text { Yes } \\ 1.00 & 61.39 & 28.12 & 29.67 & 2 & 1765.9016 & 17658986 & 883.9566 & 0.0030 & 1.6969 & 1853.991 & 1807.169 & 488.817 & 54.427 & \text { Yes }\end{array}$ $\begin{array}{lllllllllllllll}1.00 & 59.32 & 28.12 & 28.38 & 2 & 1765.9016 & 1765.8986 & 883.9566 & 0.0030 & 1.6969 & 1066.069 & 1179.386 & 369.920 & 47.905 & \text { Yes }\end{array}$

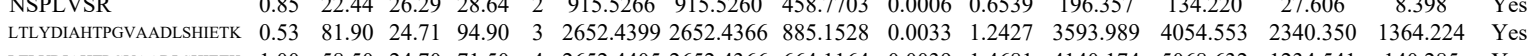
\begin{tabular}{llllllllllllllll} 
LTLYDIAHTPGVADSHIETK & 1.00 & 58.50 & 24.70 & 71.50 & 4 & 2652.4405 & 2652.4366 & 664.1164 & 0.0039 & 1.4681 & 4140.174 & 5068.632 & 1234.541 & 140.285 & Yes \\
\hline
\end{tabular} \begin{tabular}{llllllllllllllll} 
& NSPLVSR \\
NSPLER K & 1.00 & 51.65 & 24.58 & 64.65 & 4 & 2652.4413 & 2652.4366 & 664.1164 & 0.0047 & 1.7693 & 7237.771 & 9321.583 & 2292.282 & 358.825 & Yes \\
\hline
\end{tabular}

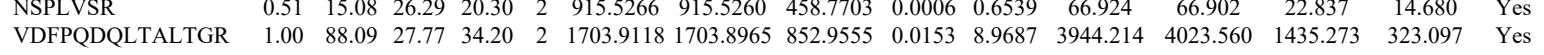

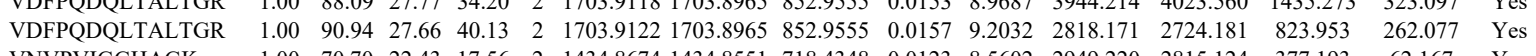

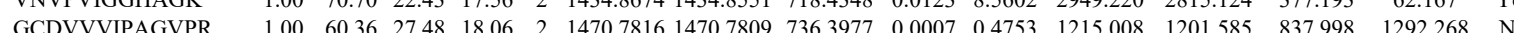




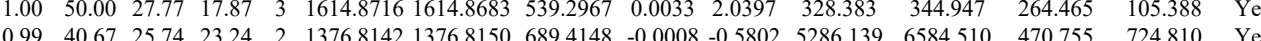

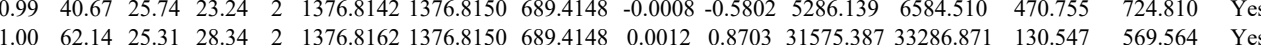
$\begin{array}{lllllllllllllll}1.00 & 62.14 & 25.31 & 28.34 & 2 & 1376.8162 & 1376.8150 & 689.4148 & 0.0012 & 0.8703 & 31575.387 & 33286.871 & 130.547 & 569.564 & \text { Yes } \\ 1.00 & 63.93 & 25.26 & 28.18 & 2 & 1376.8166 & 1376.8150 & 689.4148 & 0.0016 & 1.1604 & 45211.678 & 50696807 & 41.222 & 218.52 & \text { Yes }\end{array}$ $\begin{array}{llllllllllllllll}1.00 & 63.93 & 25.26 & 28.18 & 2 & 1376.8166 & 1376.8150 & 689.4148 & 0.0016 & 1.1604 & 45211.678 & 50696.807 & 41.222 & 218.252 & \text { Yes } \\ 1.00 & 62.77 & 25.24 & 28.05 & 2 & 1376.8216 & 1376.8150 & 689.4148 & 0.0066 & 4.7866 & 22693.957 & 24376.722 & 140.478 & 107.284 & \text { Yes }\end{array}$ $\begin{array}{lllllllllllllll}1.00 & 62.77 & 25.24 & 28.05 & 2 & 1376.8216 & 1376.8150 & 689.4148 & 0.0066 & 4.7866 & 22693.957 & 24376.722 & 140.478 & 107.284 & \text { Yes } \\ 1.00 & 60.28 & 25.24 & 27.02 & 2 & 1376.8216 & 13768150 & 689.4148 & 0.0066 & 4.7866 & 36483.181 & 38113291 & 499.922 & 120.704 & \text { Yes }\end{array}$ $\begin{array}{lllllllllllll}1.00 & 50.75 & 25.56 & 25.60 & 2 & 1376.8156 & 1376.8150 & 689.4148 & 0.0006 & 0.4352 & 7772.607 & 7666.568 & 368.997\end{array}$

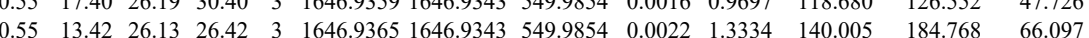
$\begin{array}{llllllllllllll} & 7.78 & 16.09 & 3 & 2080.2880 & 2080.2863 & 694.4360 & 0.0017 & 0.8160 & 129.591 & 164.470 & 67.219 \\ \end{array}$ $\begin{array}{lllllllllllllll}\text { VAVLGASGGIGQPISLLKK } & 0.55 & 81.50 & 7.78 & 94.50 & 3 & 2080.2883 & 2080.2863 & 694.4360 & 0.0020 & 0.9600 & 1761.042 & 2710.510 & 426.886\end{array}$ $\begin{array}{llllllllllllllll}\text { VAVLGASGGIGOPLSLLLK } & 0.69 & \text { \#\#\#\# } 7.78 \text { \#\#\# } 2 & 2080.2894 & 2080.2863 & 1041.1504 & 0.0031 & 1.4887 & 2644.661 & 2640.139 & 569.704\end{array}$ $\begin{array}{llllllllllllll}\text { VAVLGASGGIGQPLSLLLK } & 0.53 & 29.22 & 7.78 & 42.22 & 3 & 2080.2895 & 2080.2863 & 694.4360 & 0.0032 & 1.5360 & 40.840 & 47.081 & 15.073\end{array}$ $\begin{array}{lllllllllllllll}\text { VAVLGASGGIGQPLSLLLK } & 0.53 & 5.56 & 7.78 & 18.56 & 3 & 2080.2898 & 2080.2863 & 694.4360 & 0.0035 & 1.6800 & 30.493 & 41.739 & 26.485\end{array}$

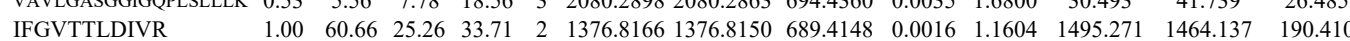
$\begin{array}{llllllllllllllll}\text { IFGVTTLDIVR } & 1.00 & 46.44 & 25.51 & 32.31 & 2 & 1376.8174 & 1376.8150 & 689.4148 & 0.0024 & 1.7406 & 842.188 & 821.393 & 298.327\end{array}$ $\begin{array}{lllllllllllllll}\text { VAVLGASGGIGQPLSLLLK } & 0.76 & \text { \#\#\# } & 9.03 & \text { \#\#\#\# } 2 & 2080.2874 & 2080.2863 & 1041.1504 & 0.0011 & 0.5283 & 1579.069 & 1285.017 & 220.104\end{array}$ $\begin{array}{lllllllllllllll}\text { VAVLGASGGIGQPLSLLLK } & 0.55 & 92.13 & 7.78 & \# \# \# & 3 & 2080.2889 & 2080.2863 & 694.4360 & 0.0026 & 1.2480 & 1006.893 & 1545.106 & 228.700\end{array}$ $\begin{array}{lllllllllllll}\text { VAVLGASGGIGQPLSLLLK } & 0.69 & \text { \#\#\#\# } & 7.78 & \text { \#\#\#\# } 2 & 2080.2894 & 2080.2863 & 1041.1504 & 0.0031 & 1.4887 & 37.443 & 34.131 & 12.309\end{array}$ $\begin{array}{llllllllllllll}\text { VAVLGASGGIGQPLSLLLK } & 0.55 & 47.84 & 7.78 & 60.84 & 3 & 2080.2880 & 2080.2863 & 694.4360 & 0.0017 & 0.8160 & 30.973 & 28.900 & 11.692\end{array}$ $\begin{array}{lllllllllllll}\text { VAVLGASGGIGQPLSLLLK } & 0.55 & 35.35 & 7.78 & 48.35 & 3 & 2080.2880 & 2080.2863 & 694.4360 & 0.0017 & 0.8160 & 15.019 & 41.383\end{array}$

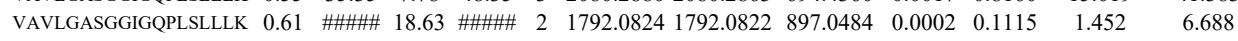
$\begin{array}{llllllllllllll}\text { VAVLGASGGIGQPLSLLLK } & 0.61 & \text { \#\#\#\# } 18.63 & \text { \#\#\#\# } 2 & 2 & 1792.0824 & 1792.0822 & 897.0484 & 0.0002 & 0.1115 & 0.000 & 7.719\end{array}$

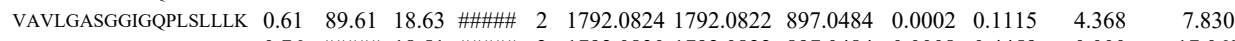
$\begin{array}{lllllllllllll}\text { VAVLGASGGIGQPLSLLLK } & 0.76 & 18.51 & 2 & 1792.0830 & 1792.0822 & 897.0484 & 0.0008 & 0.4459 & 0.000 & 17.068\end{array}$ $\begin{array}{lllllllllllllll}\text { IFGVTTLDIVR } & 1.00 & 78.22 & 25.34 & 23.69 & 2 & 1376.8164 & 1376.8150 & 689.4148 & 0.0014 & 1.0154 & 150.567 & 188.150\end{array}$ $\begin{array}{lllllllllllllll}\text { AGAGSATLSMAYAGAR } & 1.00 & 90.51 & 27.13 & 23.19 & 2 & 1597.8008 & 1597.8004 & 799.9075 & 0.0004 & 0.2500 & 35.825 & 32.953\end{array}$

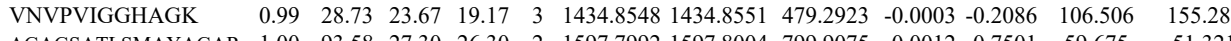

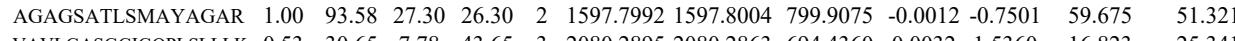
$\begin{array}{lllllllllllll}\text { VAVLGASGGIGQPLSLLLK } & 0.53 & 30.65 & 7.78 & 43.65 & 3 & 2080.2895 & 2080.2863 & 694.4360 & 0.0032 & 1.5360 & 16.823 & 25.34 \\ \text { VAVLGASGGIGQPLSLLLK } & 0.55 & 6.47 & 7.78 & 19.47 & 3 & 2080.2883 & 2080.2863 & 694.4360 & 0.0020 & 0.9600 & 2.364 & 6.337\end{array}$ $\begin{array}{lllllllllllll}\text { AGAGASATLSMAYAGAR } & 1.00 & \# \# \# \# 27.23 & 27.39 & 2 & 1597.8046 & 1597.8004 & 799.9075 & 0.0042 & 2.6253 & 96.130 & 78.715\end{array}$

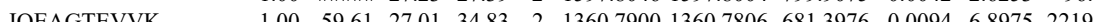
IQEAGTEVVK

IQEAGTEVVK

IQEAGTEVVK

IQEAGTEVVK

(1)

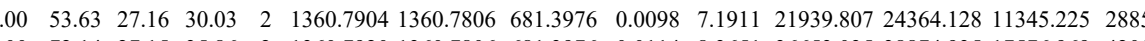

$\begin{array}{lllllllllllllll}1.00 & 72.14 & 27.15 & 35.86 & 2 & 1360.7920 & 1360.7806 & 681.3976 & 0.0114 & 8.3651 & 36653.035 & 38874.935 & 17576.969 & 4205.275 & Y \text { Ys }\end{array}$ $\begin{array}{lllllllllllll}\text { LVILDEADAMTODAQNALR } & 1.00 & 75.95 & 27.73 & 26.47 & 3 & 2230.1422 & 2230.1385 & 744.3868 & 0.0037 & 1.6568 & 53.067\end{array}$

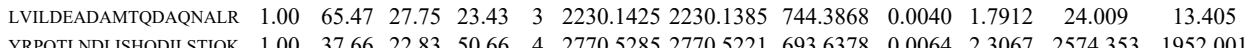
$\begin{array}{lllllllllllll}\text { YRPQTLNDLISHQDILSTIQK } & 1.00 & 40.22 & 22.81 & 53.22 & 4 & 2770.5301 & 2770.5221 & 693.6378 & 0.0080 & 2.8833 & 2152.548 & 1904.54\end{array}$ $\begin{array}{lllllllllllll}\text { YRPQTLNDLISHQDILSTIQK } & 1.00 & 29.02 & 23.28 & 42.02 & 4 & 2770.5233 & 2770.5221 & 693.6378 & 0.0012 & 0.4325 & 1076.282 & 1282.305\end{array}$ YRPQTLNDLISHQDILSTIQK

FGPLTPELMVPR

FGPLTPELMVPR

FGPLTPELMVPR

FGPLTPELMVPR LPHLLLYGPPGTGK IIPALQSR GPILSFAST IIPALQSR FCLICNYLSK FCLICNYLSK FCLICNYLSK FCLICNYLSK \begin{tabular}{lllllllllllllll}
\hline & 1.01 & &
\end{tabular} $\begin{array}{lllllllllllllll}1.00 & 47.77 & 26.53 & 22.89 & 2 & 1582.7638 & 1582.7623 & 792.3884 & 0.0015 & 0.9465 & 279.912 & 249.443 & 126.004 & 62.295 & \text { Yes } \\ 1.00 & 47.28 & 26.53 & 25.95 & 2 & 1582.7640 & 1582.7623 & 7923884 & 0.0017 & 1.0727 & 289.305 & 293.612 & 128.359 & 51.653 & \text { Yes }\end{array}$ $\begin{array}{lllllllllllllll}1.00 & 47.28 & 26.53 & 25.95 & 2 & 1582.7640 & 1582.7623 & 792.3884 & 0.0017 & 1.0727 & 289.305 & 293.612 & 128.359 & 51.653 & \text { Yes } \\ 1.00 & 46.10 & 26.44 & 23.79 & 2 & 1582.7644 & 1582.7623 & 792.3884 & 0.0021 & 1.3251 & 87.198 & 130.056 & 36.952 & 25.527 & \text { Yes }\end{array}$ $\begin{array}{lllllllllllll}1.00 & 46.10 & 26.44 & 23.79 & 2 & 1582.7644 & 1582.7623 & 792.3884 & 0.0021 & 1.3251 & 87.198 & 130.056\end{array}$

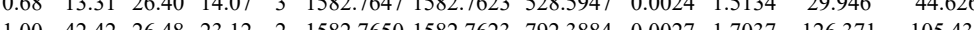
$\begin{array}{lllllllllllll}1.00 & 47.53 & 23.44 & 23.52 & 3 & 1689.9910 & 1689.9899 & 5643372 & 0.0011 & 0.6497 & 8.526 & 18.480\end{array}$ 
$\begin{array}{llllllllll}4 & 290.1470 & 2290.1437 & 764.3885 & 0.0033 & 1.4391 & 193.246\end{array}$

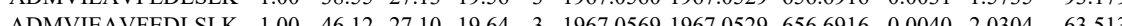

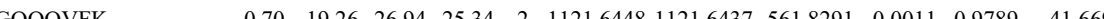
$\begin{array}{lllllllllll} & \end{array}$ $\begin{array}{lllllllllllllll} & \text { TLOEVTQLSQEAQR } & 1.00 & 72.13 & 27.69 & 28.80 & 2 & 1773.9474 & 1773.9343 & 887.9744 & 0.0131 & 7.3763 & 399.923\end{array}$ $\begin{array}{lllllllllllll} & \text { ADMVIEAVFEDLSLK } & 0.97 & 24.45 & 27.05 & 19.29 & 3 & 1967.0548 & 1967.0529 & 656.6916 & 0.0019 & 0.9644 & 86.090\end{array}$ $\begin{array}{llllllllllll}\text { ADMVIEAVFEDLSLK } & 0.99 & 29.05 & 27.05 & 17.63 & 3 & 1967.0548 & 1967.0529 & 656.6916 & 0.0019 & 0.9644 & 116.351\end{array}$ $\begin{array}{lllllllllllll}\text { TIEYLEEVAITFAK } & 0.96 & 21.77 & 26.14 & 19.18 & 3 & 1914.0619 & 1914.0593 & 639.0270 & 0.0026 & 1.3562 & 85.096\end{array}$ $\begin{array}{llllllllllll}\text { TIEYLEEVAITFAK } & 0.96 & 21.77 & 26.14 & 19.18 & 3 & 1914.0619 & 1914.0593 & 639.0270 & 0.0026 & 1.3562 & 85.096 \\ \text { KMGLVDQLVEPLGPGLPPEER } & 0.92 & 54.74 & 23.94 & 18.94 & 3 & 2561.4178 & 2561.4009 & 854.8076 & 0.0169 & 6.5901 & 109.727\end{array}$ $\begin{array}{llllllllllllll}\text { KMGLVDQLVEPLGPGLKPPEER } & 1.00 & 53.19 & 23.93 & 17.67 & 3 & 2561.4199 & 2561.4009 & 854.8076 & 0.0190 & 7.4090 & 16.458\end{array}$

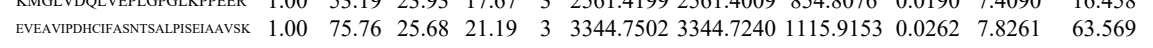
$\begin{array}{llllllllllllll}\text { TVLGTPEVLLGALPGAGGTQR } & 1.00 & 97.92 & 23.62 & 23.51 & 2 & 2150.2174 & 2150.2181 & 1076.1163 & -0.0007 & -0.3252 & 222.115\end{array}$ $\begin{array}{lllllllllllll}\text { TVLGTPEVLLGALPGAGGTQR } & 1.00 & 44.87 & 23.60 & 18.68 & 3 & 2150.2180 & 2150.2181 & 717.7466 & -0.0001 & -0.0464 & 19.428\end{array}$ $\begin{array}{llllllllllll}\text { MVGVPAALDMMLTGR } & 1.00 & 80.06 & 28.01 & 19.70 & 2 & 1704.8862 & 1704.8847 & 853.4496 & 0.0015 & 0.8788 & 853.171\end{array}$ $\begin{array}{llllllllllll}\text { MVGVPAALDMMLTGR } & 0.55 & 12.77 & 27.93 & 14.18 & 3 & 1704.8872 & 1704.8847 & 569.3022 & 0.0025 & 1.4638 & 68.951\end{array}$ $\begin{array}{llllllllllll}\text { TVLGTPEVLLGALPGAGGTQR } & 1.00 & 47.43 & 23.38 & 17.83 & 3 & 2150.2201 & 2150.2181 & 717.7466 & 0.0020 & 0.9288 & 37.964 \\ \end{array}$ $\begin{array}{llllllllllll}\text { TVLGTPEVLLGALPGAGGTQR } & 1.00 & 52.68 & 23.30 & 20.71 & 3 & 2150.2219 & 2150.2181 & 717.7466 & 0.0038 & 1.7648 & 63.175\end{array}$ $\begin{array}{lllllllllllll}\text { MVGVPAALDMMLTGR } & 0.98 & 35.10 & 27.93 & 15.65 & 2 & 1704.8874 & 1704.8847 & 853.4496 & 0.0027 & 1.5818 & 27.091\end{array}$ $\begin{array}{llllllllllllllll}\text { SFDVNKPGCEVDDLKK } & 0.84 & 18.40 & 27.97 & 14.40 & 3 & 2143.0690 & 2143.0655 & 715.3624 & 0.0035 & 1.6309 & 2537.537 & 2596.486 & 1156.137 & 388.611 & \text { Yes }\end{array}$

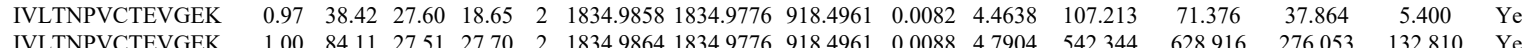

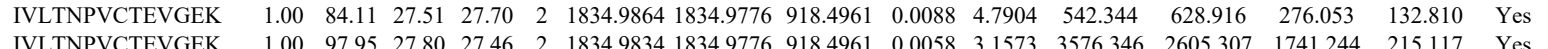

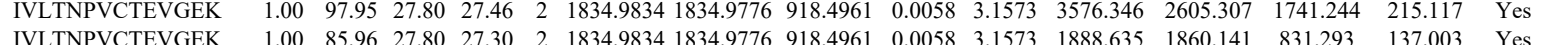

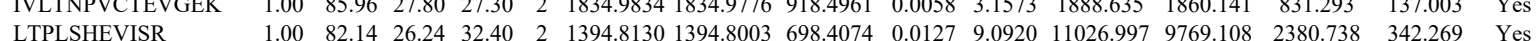

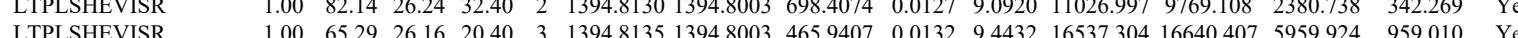
$\begin{array}{lllllllllllllllll} & \text { LTPLSHEVISR } & 1.00 & 52.65 & 26.23 & 17.54 & 3 & 1394.8126 & 1394.8003 & 465.9407 & 0.0123 & 87993 & 14852.292 & 16021.944 & 4421.616 & 1530.511 & \text { Yes }\end{array}$

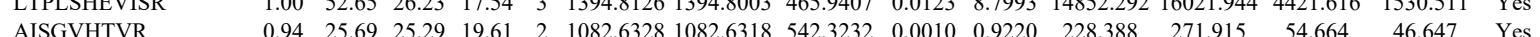

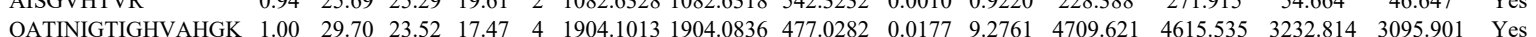
$\begin{array}{lllllllllllllllll}\text { HILILQNK } & 0.97 & 28.63 & 17.92 & 22.41 & 3 & 1265.8180 & 1265.8063 & 422.9427 & 0.0117 & 92210 & 13572301 & 12659.381 & 1580.340 & 910.800 & \text { Yes }\end{array}$

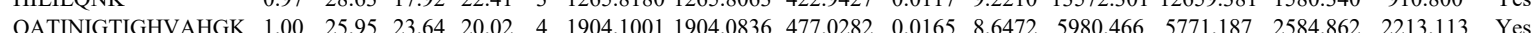

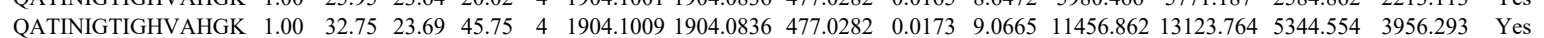
$\begin{array}{llllllllllllllll}\text { RIILILQNK } & 0.87 & 19.71 & 17.48 & 18.73 & 3 & 1265.8165 & 1265.8063 & 422.9427 & 0.0102 & 8.0388 & 20361.627 & 20758.191 & 1758.154 & 901.590 & \text { Yes }\end{array}$

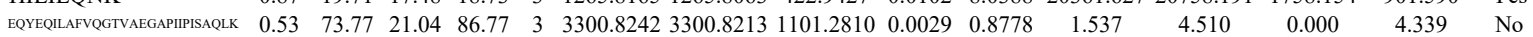

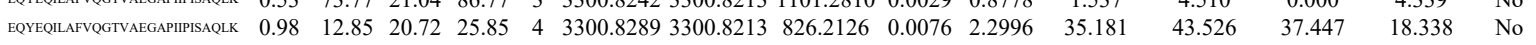

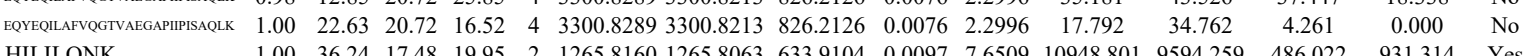

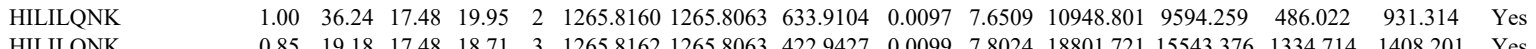
$\begin{array}{lllllllllllllll} & & 1265.8162 & 1265.8063 & 422.9427 & 0.0099 & 7.8024 & 18801.721 & 15543.376 & 1334.714 & 1408.201 & \text { Yes }\end{array}$ $\begin{array}{llllllllllllllllll}\text { NEVLMVNIGSLSTGGR } & 1.00 & 92.98 & 27.79 & 27.04 & 2 & 1789.9510 & 1789.9478 & 895.9812 & 0.0032 & 1.7857 & 1953.627 & 1672.359 & 872.959 & 195.107 & \text { Yes }\end{array}$ $\begin{array}{llllllllllllllll}\text { NEVLMVNIGSLSTGGR } & 1.00 & 99.20 & 27.83 & 28.73 & 2 & 1789.9518 & 1789.9478 & 895.9812 & 0.0040 & 2.2322 & 2233.919 & 2668.264 & 1242.677 & 429.420 & \text { Yes }\end{array}$

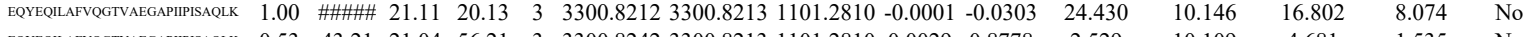

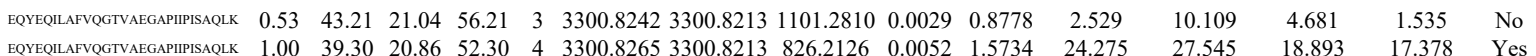

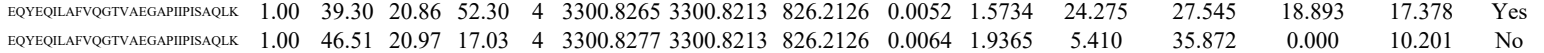

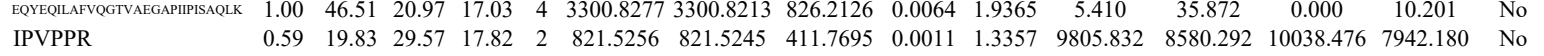
$\begin{array}{lllllllllllllllll}\text { IPVPPR } & 0.97 & 32.90 & 29.57 & 19.00 & 2 & 821.5258 & 821.5245 & 411.7695 & 0.0013 & 1.5786 & 10043.572 & 8245.914 & 7085.762 & 7607.176 & \text { No }\end{array}$

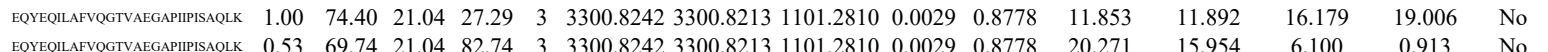

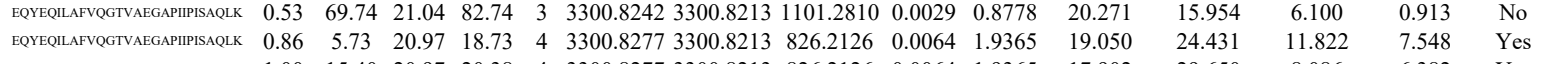

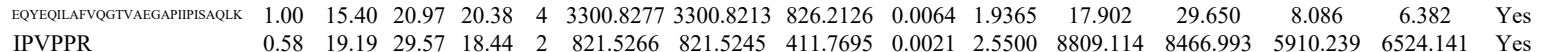

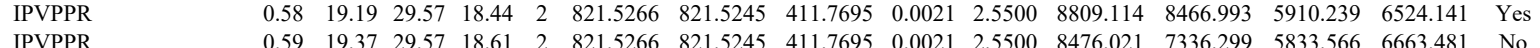

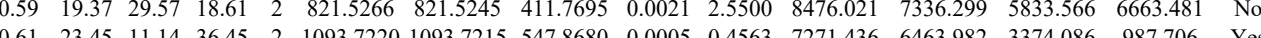
$\begin{array}{lllllllllllllllll}0.90 & 19.15 & 26.76 & 18.79 & 3 & 1543.8688 & 1543.8654 & 515.6291 & 0.0034 & 2.1980 & 21255.210 & 20740.033 & 385.676 & 259.156 & \text { Yes }\end{array}$ 

$\begin{array}{lllllllllllll}0.85 & 22.32 & 26.11 & 27.61 & 2 & 1085.6478 & 1085.6467 & 543.8306 & 0.0011 & 1.0113 & 175.687 & 237.550\end{array}$ $\begin{array}{lllllllllll} & \end{array}$

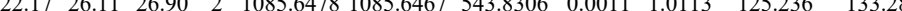
$\begin{array}{lllllllllllll} & 105.648 & 1085.6467 & 543.8366 & 0.001 & 1.013 & 125.436 & 13.286\end{array}$ $\begin{array}{llllllllllll}0.86 & 22.38 & 26.09 & 27.96 & 2 & 1085.6484 & 1085.6467 & 543.8306 & 0.0017 & 1.5630 & 115.819 & 122.019\end{array}$ $\begin{array}{lllllllllllll}0.86 & 22.38 & 26.09 & 27.96 & 2 & 1085.6484 & 085.6467 & 543.8306 & 0.0017 & 1.5630 & 15.819 & 122.019\end{array}$ $\begin{array}{lllllllllllll}0.84 & 21.71 & 26.11 & 23.94 & 2 & 1085.6490 & 1085.6467 & 543.8306 & 0.0023 & 2.1146 & 115.511 & 115.771\end{array}$ $\begin{array}{lllllllllllll}0.78 & 1.782 & 26.11 & 22.76 & 2 & 1085.6492 & 1085.6467 & 543.8306 & 0.0025 & 2.2985 & 152.799 & 146.570\end{array}$ $\begin{array}{llllllllllll}0.92 & 27.93 & 26.07 & 23.07 & 2 & 1085.6466 & 1085.6467 & 543.8306 & -0.0001 & -0.0919 & 67.219 & 94.365\end{array}$

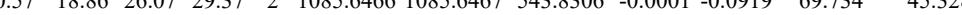
$\begin{array}{lllllllllllll}0.98 & 38.68 & 26.09 & 31.97 & 2 & 1085.6484 & 1085.6467 & 543.8306 & 0.0017 & 1.5630 & 58.332 & 45.095\end{array}$ $\begin{array}{lllllllllllll}0.94 & 26.71 & 26.11 & 28.79 & 2 & 1085.6478 & 1085.6467 & 543.8306 & 0.0011 & 1.0113 & 6528.564 & 5382.684 & 209.000\end{array}$ $\begin{array}{lllllllllllllll}0.97 & 32.42 & 28.92 & 25.91 & 2 & 1446.7826 & 1446.7810 & 724.3978 & 0.0016 & 1.1044 & 7265.741 & 6882.141 & 6476.014 & 5913.963\end{array}$ APPDGWELIEPTLDELD

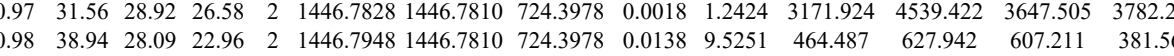
$\begin{array}{lllllllllllllll} & 52.65 & 25.71 & 17.82 & 4 & 2725.4561 & 2725.4540 & 682.3708 & 0.0021 & 0.7694 & 135.019 & 162.477 & 111.956 & 36.017\end{array}$ $\begin{array}{lllllllllllll} & \text { KA }\end{array}$ $\begin{array}{lllllllllllll} & \end{array}$

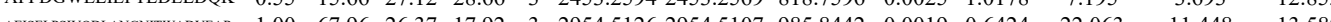

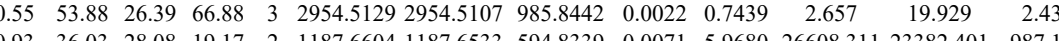

NNIIQTWR

NNIIQTWR

IYLYLTK

$\begin{array}{llllllllllll}0.94 & 36.14 & 28.08 & 21.57 & 2 & 1187.6608 & 1187.6533 & 594.8339 & 0.0075 & 6.3042 & 32269217331380.837 & 1542.058\end{array}$

TFFSFPAVVAPFK

TFFSFPAVVAPFK

TFFSFPAVVAPFK

TFFSFPAVVAPFK

TFFSFPAVVAPFK

TFFSFPAVVAPFK

TFFSFPAVVAPFK

TFFSFPAVVAPFK

LPFAAAQIGNSFF

LPFAAAQIGNSFR

LPFAAAQIGNSFR

LPFAAAQIGNSFR

LPFAAAQIGNSFR

LPFAAAQIGNSFR

LPFAAAQIGNSFR

LPFAAAQIGNS

GEFTIETEGK

$\begin{array}{llllllllllllll}0.94 & 35.69 & 27.93 & 20.49 & 2 & 1187.6616 & 1187.6533 & 594.8339 & 0.0083 & 6.9767 & 11026.168 & 10584.016 & 460.784\end{array}$

$\begin{array}{lllllllllllllll}0.83 & 40.66 & 24.22 & 43.93 & 2 & 1200.7416 & 1200.7362 & 601.3754 & 0.0054 & 4.4897 & 11806.173 & 11177.089 & 75.722\end{array}$ $\begin{array}{lllllllllllll}0.92 & 17.53 & 25.07 & 30.53 & 4 & 3112.6365 & 3112.6412 & 779.1676 & -0.0047 & -1.5080 & 51.282 & 89.140 & 18.828\end{array}$

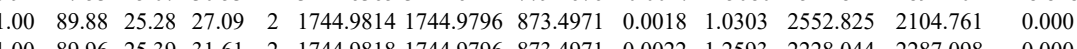
$\begin{array}{lllllllllllll}1.00 & 89.96 & 25.39 & 31.61 & 2 & 1744.9818 & 1744.9796 & 873.4971 & 0.0022 & 1.2593 & 2228.044 & 2287.098 & 0.000\end{array}$

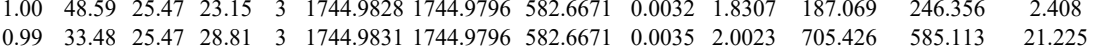
$\begin{array}{lllllllllllll}1.00 & 83.46 & 25.28 & 23.23 & 2 & 1744.9814 & 1744.9796 & 873.4971 & 0.0018 & 1.0303 & 1177.194 & 1111.425 & 0.000\end{array}$ $\begin{array}{lllllllllllll}1.00 & 71.63 & 25.28 & 24.66 & 2 & 1744.9814 & 1744.9796 & 873.4971 & 0.0018 & 1.0303 & 1277.104 & 1137.393 & 0.000\end{array}$ $\begin{array}{llllllllllllll}0.99 & 28.72 & 25.50 & 23.35 & 3 & 1744.9840 & 1744.9796 & 582.6671 & 0.0044 & 2.5172 & 340.855 & 300.462 & 23.423\end{array}$ $\begin{array}{lllllllllllll}1.00 & 31.83 & 25.50 & 21.64 & 3 & 1744.9840 & 1744.9796 & 582.6671 & 0.0044 & 2.5172 & 453.347 & 444.263 & 44.206\end{array}$ $\begin{array}{lllllllllllll}1.00 & 69.69 & 27.50 & 21.84 & 2 & 1534.8396 & 1534.8378 & 768.4262 & 0.0018 & 1.1712 & 472.333 & 436.645 & 181.203\end{array}$ $\begin{array}{lllllllllllll}1.00 & 66.51 & 27.46 & 20.88 & 2 & 1534.8400 & 1534.8378 & 768.4262 & 0.0022 & 1.4315 & 494.940 & 576.258 & 115.722\end{array}$

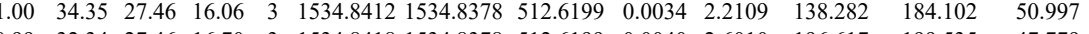
$\begin{array}{lllllllllllll}0.99 & 32.34 & 27.46 & 16.70 & 3 & 1534.8418 & 1534.8378 & 512.6199 & 0.0040 & 2.6010 & 196.617 & 199.535 & 47.779\end{array}$ $\begin{array}{lllllllllllll}1.00 & 81.45 & 27.87 & 22.24 & 2 & 1534.8372 & 1534.8378 & 768.4262 & -0.0006 & -0.3904 & 291.505 & 447.160 & 106.388\end{array}$ $\begin{array}{lllllllllllll}1.00 & 70.96 & 27.54 & 21.54 & 2 & 1534.8388 & 1534.8378 & 768.4262 & 0.0010 & 0.6507 & 511.589 & 588.545 & 170.152\end{array}$ $\begin{array}{lllllllllllll}0.55 & 36.15 & 27.50 & 49.15 & 3 & 1534.8397 & 1534.8378 & 512.6199 & 0.0019 & 1.2355 & 100.375 & 109.576 & 42.381 \\ 1.00 & 34.08 & 27.46 & 15.86 & 3 & 1534.8403 & 1534.8378 & 5126199 & 0.0025 & 1.6256 & 152.976 & 143.268 & 42.222\end{array}$

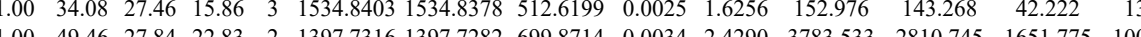
$\begin{array}{lllllllllllllll}1.00 & 49.46 & 27.84 & 22.83 & 2 & 1397.7316 & 1397.7282 & 699.8714 & 0.0034 & 2.4290 & 3783.533 & 2810.745 & 1651.775 & 1002.568 & \text { Yes }\end{array}$ $\begin{array}{llllllllllllllll}\text { LFLNETQTOEITEDIPVK } & 0.98 & 29.77 & 25.40 & 15.19 & 3 & 24052990 & 2405.293 & 8027717 & 0.0057 & 2.3668 & 27.313 & 40.067 & 35.778 & 48.465 & \text { Yes }\end{array}$

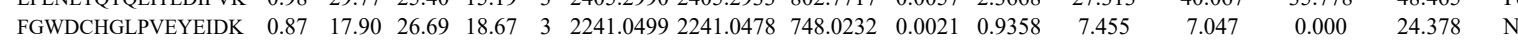
$\begin{array}{llllllllllllllll}\text { APLKPYNVPSDK } & 0.78 & 19.19 & 22.33 & 14.31 & 3 & 1830.0766 & 1830.0616 & 611.0278 & 0.0150 & 8.1829 & 10018.246 & 11018.083 & 8942.662 & 7584.763 & \text { Yes }\end{array}$ 

$\begin{array}{lllllllllllllllll}0.99 & 38.84 & 26.18 & 18.92 & 2 & 1299.6288 & 1299.6259 & 650.8202 & 0.0029 & 2.2280 & 3713.559 & 3978.268 & 188.615 & 49.281 & \text { Yes }\end{array}$ $\begin{array}{llllllllllllll}1.00 & 60.80 & 27.23 & 26.18 & 2 & 1568.8480 & 1568.8473 & 785.4309 & 0.0007 & 0.4456 & 399.662 & 442.790 & 1.941 & 17.730 \\ 1.00 & 63.03 & 27.19 & 24.57 & 2 & 1568.8484 & 1568.8473 & 785.4309 & 0.0011 & 0.7003 & 1205.728 & 1054.205 & 0.000 & 11.146\end{array}$

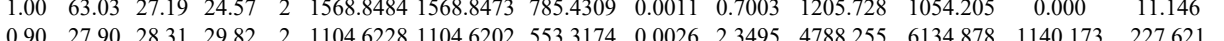

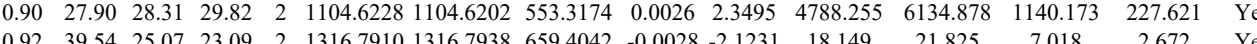

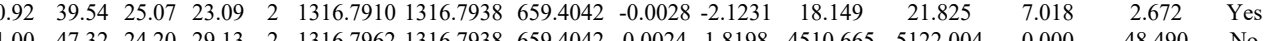
$\begin{array}{lllllllllllllll}0.99 & 36.66 & 24.07 & 28.84 & 2 & 13167074 & 13167938 & 695.4042 & 0.003 & 2.7297 & 5464.642 & 6150.226 & 32.388 & 09.236 & \text { Yes }\end{array}$ $\begin{array}{lllllllllllllll}0.91 & 30.93 & 26.24 & 38.62 & 2 & 1145.7052 & 1145.7043 & 573.8594 & 0.0009 & 0.7842 & 15163.484 & 16865.142 & 267.978 & 32.286 & \text { Yes }\end{array}$ $\begin{array}{llllllllllllllllll}0.94 & 32.51 & 26.34 & 38.80 & 2 & 1145.7062 & 1145.7043 & 573.8594 & 0.0019 & 1.6555 & 17129.001 & 20216288 & 522.592 & 87.961 & \text { Yes }\end{array}$

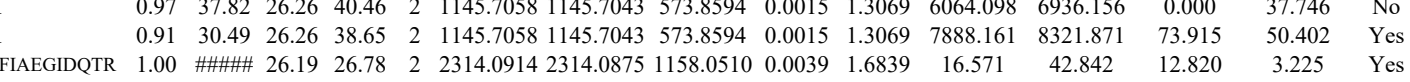
$\begin{array}{lllllllllllllllll}\text { GDDLLPAGTEDYIHIR } & 1.00 & 70.08 & 27.94 & 21.71 & 3 & 1927.9783 & 1927.9761 & 643.6660 & 0.0022 & 1.1393 & 510.358 & 678.565 & 1018.800 & 497.457 & \text { No }\end{array}$ $\begin{array}{llllllllllllllll}\text { GDDLLPAGTEDYIHIR } & 1.00 & 92.71 & 27.96 & 28.29 & 3 & 1927.9795 & 1927.9761 & 643.6660 & 0.0034 & 1.7607 & 870.728 & 601.171 & 513.541 & 234.277 & \text { Yes }\end{array}$

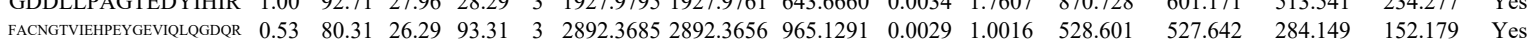

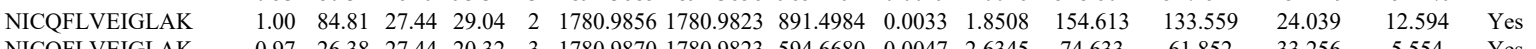

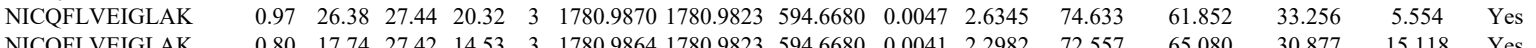

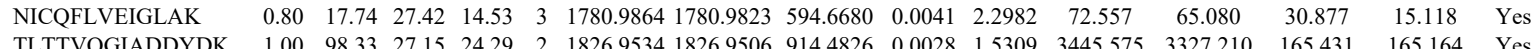
$\begin{array}{llllllllllllllll}\text { TLTIVQGIADDYDK } & 1.00 & 98.33 & 27.15 & 24.29 & 2 & 1826.9534 & 1826.9506 & 914.4826 & 0.0028 & 1.5309 & 3445.575 & 3327.210 & 165.431 & 165.164 & \text { Yes }\end{array}$ $\begin{array}{lllllllllllllll}\text { ILTTVGIADDYDK } & 1.00 & \text { \#\#\#\# } 27.20 & 25.83 & 2 & 1826.9538 & 1826.9506 & 914.4826 & 0.0032 & 1.7496 & 1795.651 & 1426.180 & 21.878 & 88.552 & \text { Yes }\end{array}$ \begin{tabular}{lllllllllllllllll} 
TLTTVQGIADDYDK & 1.00 & 83.85 & 27.23 & 26.01 & 2 & 1826.9516 & 1826.9506 & 914.4826 & 0.0010 & 0.5468 & 2843.288 & 2590.486 & 61.346 & 86.943 & Yes \\
\hline
\end{tabular} TLTTVQGIADDYDK

PEFLEDPSVLTK PEFLEDPSVLTK PEFLEDPSVLTK $\begin{array}{llllllllllllll}1.09 & 79.24 & 27.16 & 24.34 & 2 & 1826.9536 & 1826.9506 & 914.4826 & 0.0030 & 1.6403 & 212.442 & 150.588 & 66.648\end{array}$ $\begin{array}{lllllllllllll}0.99 & 39.77 & 27.50 & 24.81 & 2 & 1661.9134 & 1661.9120 & 831.9633 & 0.0014 & 0.8414 & 1291.091 & 1526.452 & 255.875\end{array}$ $\begin{array}{lllllllllllllllll} & \text { SELVANNVTLPAGEQR } & 1.00 & 75.76 & 27.06 & 30.16 & 2 & 1840.9908 & 1840.9765 & 921.4955 & 0.0143 & 7.7591 & 429.018 & 449.206 & 290.639 & 23 & \end{array}$ $\begin{array}{llllllllllllll}\text { SELVANNVTLPAGEQR } & 1.00 & 73.37 & 27.00 & 24.88 & 2 & 1840.9922 & 1840.9765 & 921.4955 & 0.0157 & 8.5187 & 289.180 & 233.764 & 216.128 \\ \text { SEIVANVLP }\end{array}$ $\begin{array}{lllllllllllllll}\text { SELVANNVTLPAGEQR } & 1.00 & 94.52 & 27.10 & 35.79 & 2 & 1840.9904 & 1840.9765 & 921.4955 & 0.0139 & 7.5420 & 513.193 & 690.068 & 318.810 & 20 . \\ \text { SELVANNVTLPAGEQR } & 1.00 & 87.39 & 26.95 & 33.12 & 2 & 1840.9912 & 1840.9765 & 921.4955 & 0.0147 & 7.9761 & 256.672 & 332.751 & 274.100 & 19\end{array}$ $\begin{array}{llllllllllllll}\text { SELVANNVTLPAGEQR } & 1.00 & 87.39 & 26.95 & 33.12 & 2 & 1840.9912 & 1840.9765 & 921.4955 & 0.0147 & 7.9761 & 256.672 & 332.751 & 27.100 \\ \text { NRPPLPAGTNSK } & 1.00 & 35.09 & 25.87 & 22.54 & 3 & 1538.8783 & 1538.8772 & 513.9663 & 0.0011 & 0.7134 & 1290.903 & 1431.310 & 114.564\end{array}$ NRPPLPAGTNSK RPPATS NRPPLPAGTNSK NRPPLPAGTNSK

NRPPLPAGTNSK

YGVNPGPIVGTTR

YGVNPGPIVGTTR

YGVNPGPIVGTTR

YGVNPGPIVGTTR

YGVNPGPIVGTTR

YGVNPGPIVGTTR

GGPLQALTR

GGPLQALTR

GGPLQALTR

GGPLQALTR

$\begin{array}{llllllllllllll}1.00 & 35.09 & 25.87 & 22.54 & 3 & 1538.8783 & 1538.8772 & 513.9663 & 0.0011 & 0.7134 & 1290.903 & 1431.310 & 114.564 & \\ 1.00 & 35.39 & 26.03 & 21.81 & 3 & 1538.8789 & 1538.8772 & 513.9663 & 0.0017 & 1.1025 & 5210.884 & 5741.572 & 242.665 & \end{array}$ $\begin{array}{llllllllllllll}1.00 & 39.15 & 26.03 & 22.35 & 3 & 1538.8792 & 1538.8772 & 513.9663 & 0.0020 & 1.2971 & 2541.721 & 3017.033 & 224.700\end{array}$

$\begin{array}{lllllllllllll}1.00 & 35.35 & 26.03 & 22.88 & 3 & 1538.8801 & 1538.8772 & 513.9663 & 0.0029 & 1.8808 & 2780.416 & 3369.692 & 129.155\end{array}$

$\begin{array}{lllllllllllllll}1.00 & 40.21 & 26.03 & 22.12 & 3 & 1538.8792 & 1538.8772 & 513.9663 & 0.0020 & 1.2971 & 518.620 & 646.134 & 48.787 & 29.463 & \text { Y } \\ 1.00 & 43.00 & 65.00 & 23.36 & 3 & 1538.8798 & 1538.8772 & 513.9663 & 0.0026 & 1.682 & 1143.853 & 1239.286 & 52.935 & 21.531 & \text { Y }\end{array}$ $\begin{array}{lllllllllllllll}1.00 & 61.58 & 27.82 & 21.89 & 2 & 1473.8160 & 1473.8062 & 737.9104 & 0.0098 & 6.6403 & 12005.121 & 14565.263 & 7186.242 & 2305.851 & \text { Yes }\end{array}$ $\begin{array}{lllllllllllllll}1.00 & 53.07 & 27.89 & 22.44 & 2 & 1473.8174 & 1473.8062 & 737.9104 & 0.0112 & 7.5889 & 5695.804 & 7222.918 & 3383.711 & 1315.504 & \text { Yes }\end{array}$ $\begin{array}{lllllllllllllll}1.00 & 49.96 & 27.77 & 18.47 & 2 & 1473.8148 & 14738062 & 737.9104 & 0.0086 & 5.8272 & 18266386 & 19038659 & 9699.730 & 3421.005 & \text { Yes }\end{array}$ $\begin{array}{llllllllllllllll}100 & 52.53 & 27.77 & 20.09 & 2 & 1473.8148 & 1473.8062 & 737.9104 & 0.0086 & 5.8272 & 17278.103 & 22420.470 & 7344.709 & 4369.104 & \text { Yes }\end{array}$

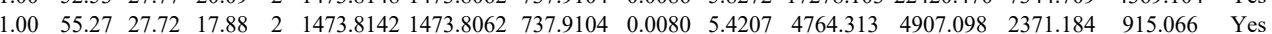
$\begin{array}{llllllllllllllll}1.00 & 55.36 & 27.67 & 18.87 & 2 & 1473.8146 & 1473.8062 & 737.9104 & 0.0084 & 5.6917 & 6365.850 & 8974.699 & 3984.819 & 1367.165 & \text { Yes }\end{array}$ $\begin{array}{llllllllllllllll}1.00 & 65.94 & 26.18 & 31.84 & 2 & 1055.6262 & 1055.6209 & 528.8177 & 0.0053 & 5.0112 & 9926.637 & 13287.271 & 5846.857 & 3054.323 & \text { Yes }\end{array}$ $\begin{array}{lllllllllllllll}1.00 & 57.67 & 26.18 & 27.00 & 2 & 1055.6268 & 1055.6209 & 528.8177 & 0.0059 & 5.5785 & 18203.441 & 25046.944 & 12184.129 & 6297.598 & \text { Yes }\end{array}$ $\begin{array}{llllllllllllllll}.00 & 63.60 & 26.18 & 28.27 & 2 & 1055.6264 & 1055.6209 & 528.8177 & 0.0055 & 5.2003 & 14761.025 & 22735.016 & 10178.671 & 5880.528 & \text { Yes }\end{array}$ $\begin{array}{llllllllllllllll}\text { QEDKDDLDVTELTNEDLDQLVK } & 1.00 & 49.58 & 26.42 & 18.13 & 3 & 3119.6122 & 3119.6087 & 1040.8768 & 0.0035 & 1.1208 & 3.967 & 5.128 & 3.729 & 0.000 & \text { No }\end{array}$ $\begin{array}{llllllllllllllll}\text { QEDKDDLDVTELTNEDLLDQLVK } & 1.00 & 38.13 & 26.41 & 16.93 & 4 & 3119.6141 & 3119.6087 & 780.9095 & 0.0054 & 1.7288 & 10.179 & 16.016 & 13.140 & 9.666 & \text { No }\end{array}$

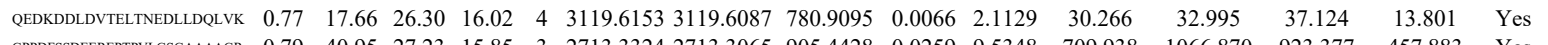
$\begin{array}{llllllllllllllll}\text { GPPDESDEEREPTPVLGSGAAAAGR } & 0.79 & 40.95 & 27.23 & 15.85 & 3 & 2713.3324 & 2713.3065 & 905.4428 & 0.0259 & 9.5348 & 709.938 & 1066.870 & 923.377 & 457.883 & \text { Yes }\end{array}$

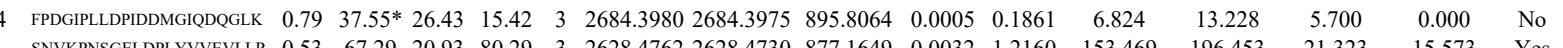

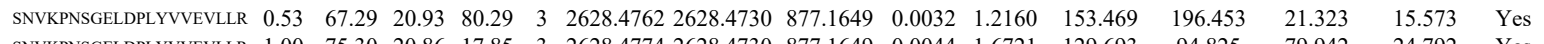

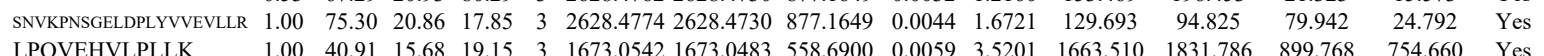

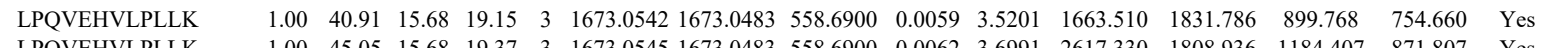
LPQVEHVLPLLK $\begin{array}{llllllllllllllll}1.00 & 45.05 & 15.68 & 19.37 & 3 & 1673.0545 & 1673.0483 & 558.6900 & 0.0062 & 3.6991 & 2617.330 & 1808.936 & 1184.407 & 871.807 & \text { Yes } \\ 0.99 & 45.05 & 27.87 & 27.01 & 2 & 1064.6190 & 1064.6100 & 533.3123 & 0.0090 & 8.4378 & 17102.055 & 14515506 & 502.512 & 316.887 & \text { Ys }\end{array}$ $\begin{array}{lllllllllllllllll}\text { GIGHCLPLK } & 1.00 & 2.54 & 13.98 & 18.56 & 4 & 1712.0861 & 1712.0705 & 429.0249 & 0.0156 & 9.0903 & 1845.658 & 1676.733 & 1044.420 & 272.258 & \text { Yes } \\ \text { GIGIHGGLPILK } & 1.00 & 30.92 & 13.98 & 20.72 & 3 & 1712.0740 & 1712.0705 & 571.6974 & 0.0035 & 2.0407 & 4151.063 & 3126.610 & 2040.089 & 1157.559 & \text { Yes }\end{array}$ $\begin{array}{lllllllllllllllll}\text { GIGIHHGGLLPILK } & 1.00 & 30.92 & 13.98 & 20.72 & 3 & 1712.0740 & 1712.0705 & 571.6974 & 0.0035 & 2.0407 & 4151.063 & 3126.610 & 2040.089 & 1157.559 & \text { Yes } \\ \text { GIGIHHGGLLPILK } & 1.00 & 24.69 & 13.98 & 26.63 & 4 & 1712.0741 & 1712.0705 & 429.0249 & 0.0036 & 2.0978 & 950.328 & 1143.028 & 366.274 & 156.670 & \text { Yes }\end{array}$ 
$\begin{array}{llllllllllllll}\text { GEMQVVPVLVHLLSAISSVR } & 0.55 & 69.70 & 22.01 & 82.70 & 3 & 2277.3025 & 2277.3001 & 760.1073 & 0.0024 & 1.0525 & 17.400 & 17.042 & 7.334\end{array}$

$\begin{array}{llllllllllllll}1.00 & 52.18 & 26.55 & 25.80 & 2 & 1240.7002 & 1240.6897 & 621.3521 & 0.0105 & 8.4492 & 9147.779 & 8563.755 & 2304.844 & 5\end{array}$ $\begin{array}{llllllll} & \end{array}$

$\begin{array}{lllllllllll} & \end{array}$ $\begin{array}{lllllllllllllll}\text { AGDMENAENIITVMR } & 1.00 & 91.75 & 27.57 & 22.60 & 2 & 1806.8744 & 1806.8726 & 904.4436 & 0.0018 & 0.9951 & 455.161 & 375.735 & 200.55\end{array}$ $\begin{array}{llllllllllllll} & 16.735 & 200.556\end{array}$

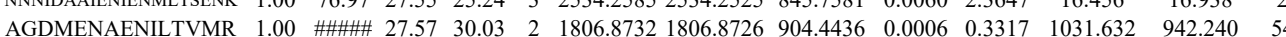

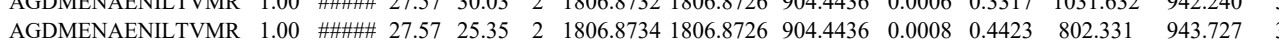

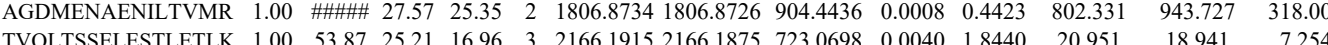
$\begin{array}{llllllllllllll}\text { NNNIDAAIENIENMLTSENK } & 1.00 & 73.92 & 27.55 & 17.71 & 3 & 2534.2585 & 2534.2525 & 845.7581 & 0.0060 & 2.3647 & 39.585 & 2.953 & 22.045\end{array}$

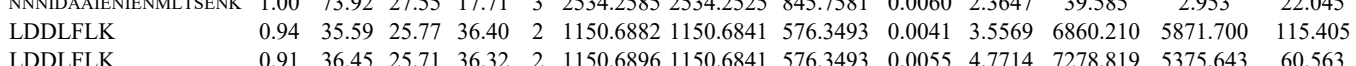
$\begin{array}{llllllllllll}0.94 & 35.59 & 25.77 & 36.40 & 2 & 1150.6882 & 1150.6841 & 576.3493 & 0.0041 & 3.5569 & 6860.210 & 5871.700\end{array}$ $\begin{array}{llllllllllll}1.00 & 64.22 & 23.96 & 18.78 & 2 & 1670.9718 & 1670.9698 & 836.4922 & 0.0020 & 1.1955 & 268.721 & 373.864\end{array}$ SVLELIPELNEK

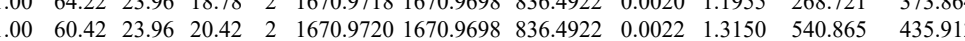
SVLELIPELNEK $\begin{array}{lllllllllll}1.00 & 42.66 & 23.50 & 20.84 & 3 & 1670.9737 & 1670.9698 & 557.9972 & 0.0039 & 2.3298 & 53.419\end{array}$

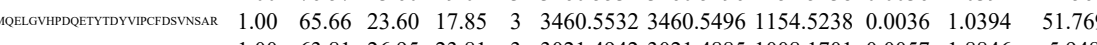

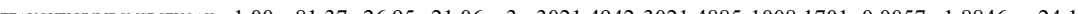

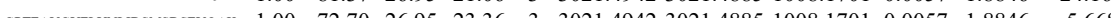

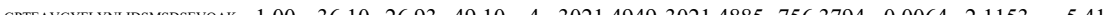
$\begin{array}{lllllllllll} & 0\end{array}$

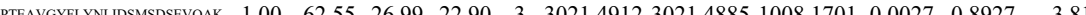

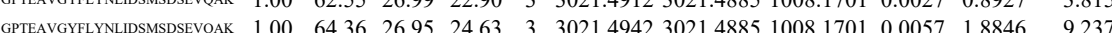
$\begin{array}{lllllllllllll}\text { GPTEAVGYFLYNLIDSMSDSEVQAK } & 1.00 & 61.84 & 26.95 & 74.84 & 4 & 3021.4961 & 3021.4885 & 756.3794 & 0.0076 & 2.5120 & 2.311\end{array}$ $\begin{array}{llllllllllll}\text { GPTEAVGYLYNLIDSMSDSEVQAK } & 1.00 & 24.62 & 26.89 & 37.62 & 4 & 3021.4977 & 3021.4885 & 756.3794 & 0.0092 & 3.0408 & 10.609\end{array}$ $\begin{array}{llllllllllll}\text { SEAANGNLDFVLSFLK } & 1.00 & 65.00 & 26.49 & 20.69 & 3 & 2012.0878 & 2012.0822 & 671.7013 & 0.0056 & 2.7790 & 440.324 \\ \text { SMNINLWSEITELLYK } & 0.99 & 28.69 & 25.61 & 15.83 & 3 & 2241.2014 & 2241.1958 & 748.0725 & 0.0056 & 2.4953 & 14.520\end{array}$ 49.042 2.029

VIQALAMK

VIQALAMK

LLAEILR

VIQALAMK

YVGLVR

LLAEILR

ISNQFDWALMR

ISNQFDWALMR LEDVALQILLACPVS LQWFCDR LQWFCDR $\begin{array}{lllllllllllll}1.00 & 48.40 & 22.79 & 22.03 & 2 & 1160.7306 & 1160.7195 & 581.3670 & 0.0111 & 9.5464 & 5147.336 & 4229.53\end{array}$ $\begin{array}{lllllllllllll}.00 & 42.37 & 22.74 & 24.44 & 2 & 1160.7308 & 1160.7195 & 581.3670 & 0.0113 & 9.7184 & 4061.558 & 3780.703\end{array}$ $\begin{array}{llllllllllllll}0.96 & 38.20 & 21.64 & 42.62 & 2 & 970.6316 & 970.6297 & 486.3221 & 0.0019 & 1.9534 & 22312.771 & 15995.003 & 549.869\end{array}$ $\begin{array}{lllllllllllllll}0.98 & 41.90 & 21.64 & 42.78 & 2 & 970.6318 & 970.6297 & 486.3221 & 0.0021 & 2.1591 & 28503.953 & 24588.521 & 651.180\end{array}$ $\begin{array}{lllllllllllll}1.00 & 42.95 & 22.79 & 18.78 & 2 & 1160.7304 & 1160.7195 & 581.3670 & 0.0109 & 9.3744 & 710.128 & 618.744 & 193.682\end{array}$ $\begin{array}{lllllllllllll}0.53 & 21.69 & 24.65 & 28.34 & 2 & 849.5250 & 849.5194 & 425.7670 & 0.0056 & 6.5763 & 26512.196 & 22490.438 & 2178.731\end{array}$ $\begin{array}{lllllllllllllll}0.85 & 32.77 & 21.64 & 43.39 & 2 & 970.6316 & 970.6297 & 486.3221 & 0.0019 & 1.9534 & 13800.189 & 12453.137 & 183.434\end{array}$ $\begin{array}{llllllllllllll}1.00 & 58.70 & 27.86 & 20.84 & 2 & 1523.7710 & 1523.7677 & 762.8911 & 0.0033 & 2.1628 & 5209.087 & 4482.965 & 253.056\end{array}$ SNQFDWALMR LEDVALQILLACPVSK YIPDAMNLILLLVT

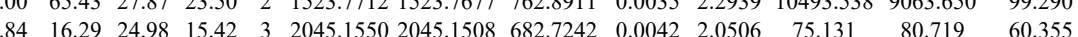
$\begin{array}{ccccccccccccc}0.84 & 16.29 & 24.98 & 15.42 & 3 & 2045.1550 & 2045.1508 & 682.7242 & 0.0042 & 2.0506 & 75.131 & 80.719 & 60.355 \\ 0.99 & 35.12 & 24.08 & 27.67 & 2 & 1156.5314 & 1156.5280 & 579.2713 & 0.0034 & 2.9347 & 17753.784 & 14822.887 & 568.386\end{array}$ $\begin{array}{lllllllllllll}0.97 & 29.55 & 24.08 & 25.61 & 2 & 1156.5314 & 1156.5280 & 579.2713 & 0.0034 & 2.9347 & 20718.060 & 18110.142 & 158.540\end{array}$

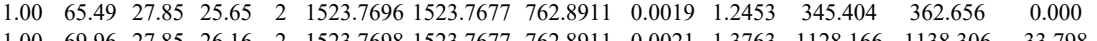
$\begin{array}{llllllllllll} & \end{array}$ 
SNTLPISLQSIR

MVFINNIALAQIK

MVFINNIALAQIK

LIITQVR

SNTLPISLQSIR

SNTLPISLQSIR

MVFINNIALAQIK

MVFINNIALAQIK

VIEPQYFGLAYLFR

VIEPQYFGLAYLFR

VIEPQYFGLAYLFR

IEPQYR

SGGLGGSHALLLLR

SGGLGGSHALLLLR

SSLLLGFR

CGAIAEQTPILLLFLLR $\begin{array}{lllllllllllll}0 & \end{array}$ $\begin{array}{llllllllllllll}\text { CGAIAEOTPILLLFLLR } & 1.00 & 99.24 & 23.48 & 21.36 & 2 & 2060.1674 & 2060.1648 & 1031.0897 & 0.0026 & 1.2608 & 43.452 & 72.741 & 22.874\end{array}$ $\begin{array}{llllllllllllll}\text { CGAIAEQTPILLLFLLR } & 1.00 & 77.40 & 23.48 & 25.64 & 2 & 2060.1674 & 2060.1648 & 1031.0897 & 0.0026 & 1.2608 & 55.773 & 33.563 & 11.046\end{array}$ $\begin{array}{lllllllllllllll}\text { CGAIAEQTPILLLFLLR } & 1.00 & 57.45 & 23.28 & 19.19 & 3 & 2060.1700 & 2060.1648 & 687.7289 & 0.0052 & 2.5204 & 14.180 & 14.731 & 12.895\end{array}$ $\begin{array}{lllllllllllllll} & \text { GAIAEQTPILLLFLLR } & 1.00 & 57.34 & 23.32 & 21.19 & 3 & 2060.1703 & 2060.1648 & 687.7289 & 0.0055 & 2.6658 & 0.000 & 13.385 & 4.307\end{array}$

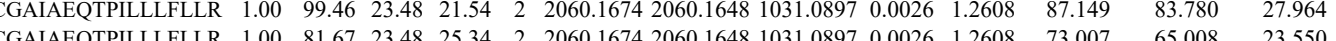

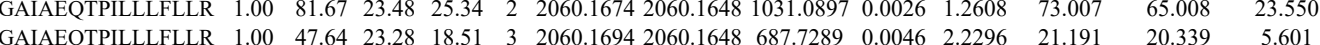
$\begin{array}{llllllllllllll}\text { CGAIAEQTPILLLFLLR } & 1.00 & 75.66 & 23.38 & 19.14 & 2 & 2060.1654 & 2060.1648 & 1031.0897 & 0.0006 & 0.2910 & 25.867 & 25.492 & 6.742\end{array}$ $\begin{array}{lllllllllllllll}\text { CGAIAEQTPILLLFLLR } & 1.00 & 63.74 & 23.38 & 23.70 & 2 & 2060.1654 & 2060.1648 & 1031.0897 & 0.0006 & 0.2910 & 25.993 & 23.436 & 21.491\end{array}$ $\begin{array}{lllllllllllllll}\text { CGAIAEQTPILLLFLLR } & 0.55 & 54.42 & 23.48 & 67.42 & 3 & 2060.1673 & 2060.1648 & 687.7289 & 0.0025 & 1.2117 & 11.681 & 4.787 & 8.722\end{array}$ $\begin{array}{llllllllllllll}\text { CGAIAEQTPILLLFLLR } & 0.53 & 68.28 & 23.34 & 81.28 & 3 & 2060.1679 & 2060.1648 & 687.7289 & 0.0031 & 1.5025 & 10.592 & 22.857 & 10.252\end{array}$ LITTQVR

2 VTGGAASK VTGGAASK VTGGAASK VTGGAASK VLTVINQTQK VLTVINQTQK
YKPLDLRPK YKPLDLRK

YKPLDLRPK

VLTVINQTQK

YKPLDLRPK

YKPLDLRPK

YKPLDLRPK

VLTVINQTOK

VLTVINQTOK

YKPLDLRPK

YKPLDLRPK

TAPYVVTGSVDQTVK TAPYVVTGSVDQTV

48 SQAFIEMETR GPSLNPVLDYDHGS NTHCSSLPHYQK

NTHCSSLPHYQK

NTHCSSLPHYQK

SFQQSSLSR

GDADQASNILASFGLSAR

GDADQASNILASFGLSAR

$\begin{array}{cccccccccc} & \end{array}$

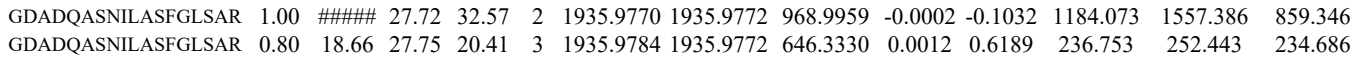
GDADQASNILASFGLSAR

VVHIMDFQR

$\begin{array}{lllllllllllll}0.56 & 30.54 & 23.20 & 31.69 & 2 & 985.6410 & 985.6406 & 493.8276 & 0.0004 & 0.4050 & 1131.467 & 1028.645\end{array}$ $\begin{array}{lllllllllllll}0.86 & 27.31 & 28.02 & 26.36 & 2 & 977.5752 & 977.5749 & 489.7947 & 0.0003 & 0.3063 & 107.885 & 117.288\end{array}$ $\begin{array}{lllllllllllll}0.99 & 38.97 & 28.02 & 28.70 & 2 & 977.5754 & 977.5749 & 489.7947 & 0.0005 & 0.5104 & 251.706 & 225.357 & \end{array}$ $\begin{array}{llllllllllll}0.97 & 3.19 & 28.16 & 28.51 & 2 & 977.544 & 97.5749 & 489.7947 & 0.0005 & 0.5104 & 251.706 & 225.37\end{array}$ $\begin{array}{llllllllllll} & 0.03\end{array}$ $\begin{array}{lllllllllllll}1.00 & 54.78 & 22.17 & 30.06 & 2 & 1430.8818 & 1430.871 & 716.4423 & 0.0117 & 8.1653 & 16081.404 & 12672.170 & 1183.413\end{array}$ $\begin{array}{lllllllllllllll}1.00 & 56.00 & 22.25 & 30.26 & 2 & 1430.8826 & 1430.8701 & 716.4423 & 0.0125 & 8.7236 & 11962.749 & 1017.375 & 686.783\end{array}$

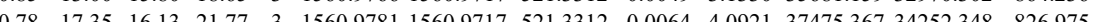
$\begin{array}{llllllllllllll}1.00 & 55.16 & 22.17 & 32.19 & 2 & 1430.8828 & 1430.8701 & 7164423 & 0.0127 & 8.8632 & 20712.354 & 15520.837 & 824.402\end{array}$ $\begin{array}{llllllllllllll}.00 & 55.19 & 22.30 & 31.76 & 2 & 1430.8838 & 1430.8701 & 716.4423 & 0.0137 & 9.5610 & 14023.290 & 11767.505 & 591.014\end{array}$ $\begin{array}{lllllllllllllll}0.90 & 22.34 & 16.13 & 15.64 & 2 & 1560.9780 & 1560.9717 & 781.4931 & 0.0063 & 4.0307 & 6077.401 & 6140.816 & 0.000\end{array}$ $\begin{array}{llllllllllllll}0.66 & 11.79 & 15.68 & 16.77 & 3 & 1560.9793 & 1560.9717 & 521.3312 & 0.0076 & 4.8593 & 41181.057 & 39100.581 & 257.660\end{array}$ $\begin{array}{lllllllllllllll}0.80 & 14.97 & 16.23 & 15.89 & 3 & 1560.9817 & 1560.9717 & 521.3312 & 0.0100 & 6.3938 & 45407.436 & 47421.507 & 0.000 & 19\end{array}$ $\begin{array}{lllllllllllll}1.00 & 55.13 & 21.70 & 22.11 & 2 & 1430.8798 & 1430.8701 & 716.4423 & 0.0097 & 6.7695 & 8261.068 & 6967.527 & 619.536\end{array}$

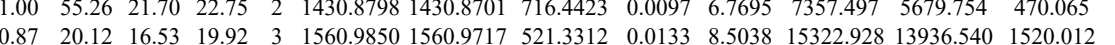
$\begin{array}{lllllllllllll}0.97 & 25.43 & 16.53 & 15.57 & 2 & 1560.9852 & 1560.9717 & 781.4931 & 0.0135 & 8.6372 & 4591.181 & 4372.339 & 24.470\end{array}$

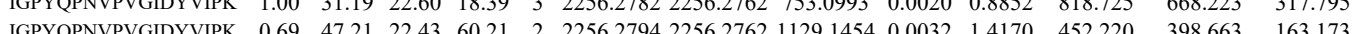

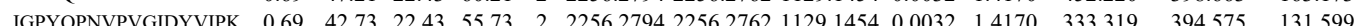

VVHIMDFQR

$\begin{array}{llllllllllllll}1.00 & 44.36 & 28.31 & 22.45 & 3 & 1287.6967 & 1287.6880 & 4302366 & 0.0087 & 6.7404 & 4344.280 & 5016.071 & 628.510\end{array}$

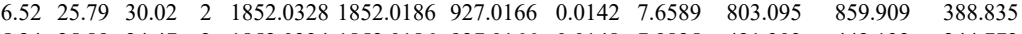
$\begin{array}{llllllllllllllll}0.99 & 40.54 & 27.08 & 22.11 & 2 & 1354.6786 & 1354.6673 & 678.3409 & 0.0113 & 8.3291 & 3926.776 & 3661.791 & 998.399 & 10 & \\ 1.00 & 48.32 & 28.83 & 19.12 & 3 & 1769.8972 & 1769.8819 & 590.9679 & 0.0153 & 8.6298 & 2708.299 & 3026.660 & 2092.646 & 14\end{array}$ $\begin{array}{lllllllllll}2.08 & 22.11 & 1354.6786 & 1394.6673 & 678.3469 & 0.013 & 8.3291 & 926.776 & 361.791 & 998.399 & 1034\end{array}$ $\begin{array}{llllllllllllll} & \end{array}$ $\begin{array}{lllllllllllllll} & 1.00 \\ 1.00 & 23.26 & 26.40 & 16.27 & 4 & 1747.8397 & 1747.8378 & 437.9667 & 0.0019 & 1.0846 & 7317.305 & 10146.033 & 7957.008 & 2528.282 & \text { Yes } \\ \end{array}$

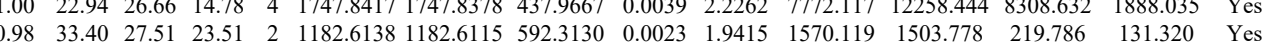

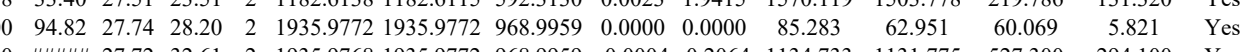
65.992 Yes 140.837 Yes 581.474 Yes 66.175 Yes 75.253 Ye

Table S-3 page 247 of 499 


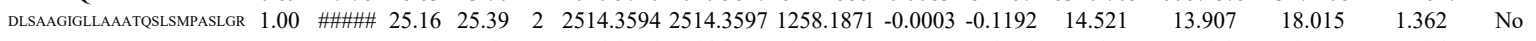

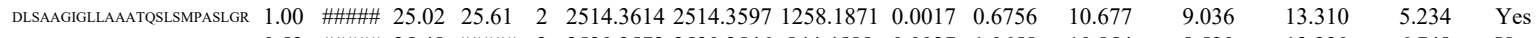
$\begin{array}{llllllllllllll}\text { DLSAAGIGLLAAATSLSSMPALLG } & 0.53 & \text { \#\#\#\# } 25.48 & \text { \#\#\#\# } 3 & 2530.3573 & 2530.3546 & 844.4588 & 0.0027 & 1.0658 & 10.854 & 8.520 & 12.230 & 6.748 & \text { Yes }\end{array}$

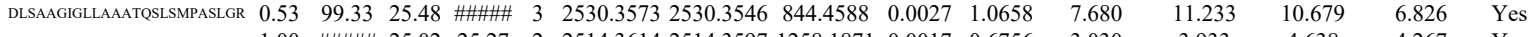

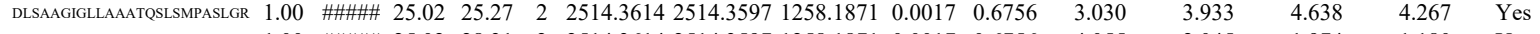

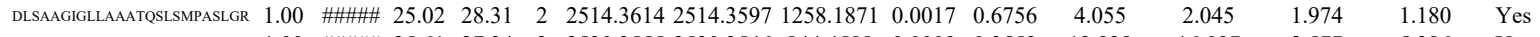

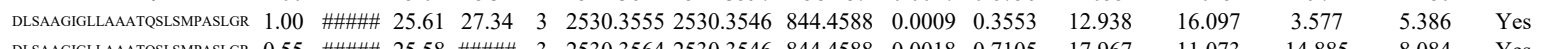

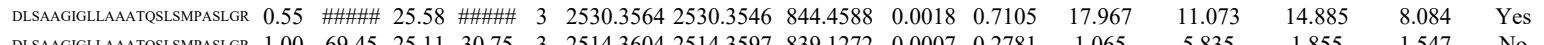

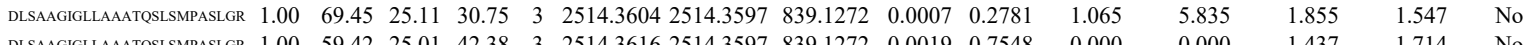

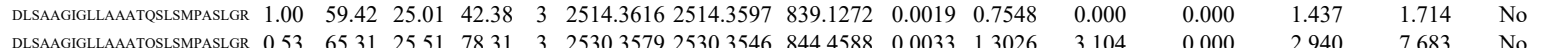

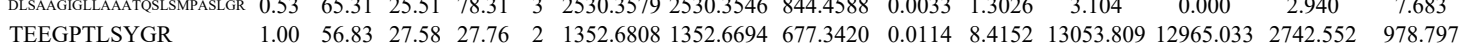
$\begin{array}{lllllllllllll}1.00 & 97.00 & 27.75 & 22.70 & 2 & 1760.9434 & 1760.9430 & 881.4788 & 0.0004 & 0.2269 & 127.273 & 282.429 & 42.380\end{array}$ $\begin{array}{lllllllllllll} & \\ \end{array}$ $\begin{array}{lllllllllllll} & \\ \end{array}$ $\begin{array}{lllllllllllllll} & \end{array}$ $\begin{array}{lllllllllllll} & \end{array}$ LNLVEAFVEDAELR LNLVEAFVEDAELR LNLVEAFVEDAELR NLQSVVLSK $\begin{array}{llllllllllll}0.83 & 18.57 & 27.51 & 25.50 & 3 & 1760.9470 & 1760.9430 & 587.9883 & 0.0040 & 2.2676 & 84.733 & 115.825\end{array}$ $\begin{array}{lllllllllllll}0.63 & 16.76 & 27.69 & 28.43 & 3 & 1760.9452 & 1760.9430 & 587.9883 & 0.0022 & 1.2472 & 115.161 & 125.691\end{array}$ NLQSVVLSK MQSTLISAAR MQSTLISAAR MQSTLISAAR $\begin{array}{lllllllllll} & 1760.9455 & 1760.9430 & 587.9883 & 0.0025 & 1.4173 & 100.583 & 131.239\end{array}$

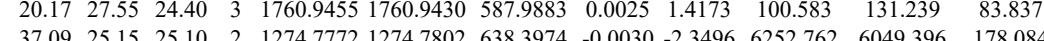
MQSTLISAAR $\begin{array}{llllllllllllll}0.95 & 29.78 & 27.35 & 17.58 & 3 & 1926.0409 & 1926.0277 & 643.0165 & 0.0132 & 6.8427 & 6639.445 & 6365.763 & 822.238\end{array}$ $\begin{array}{lllllllllllll}1.00 & 58.47 & 28.34 & 32.73 & 2 & 1220.6736 & 1220.6669 & 611.3407 & 0.0067 & 5.4797 & 14243.844 & 12289.669 & 690.088\end{array}$ $\begin{array}{lllllllllllllll}1.00 & 59.66 & 28.41 & 32.74 & 2 & 1220.6738 & 1220.6669 & 611.3407 & 0.0069 & 5.6433 & 9318.140 & 9232.370 & 398.515 \\ 1.00 & 5.63 & 28.41 & 30.69 & 2 & 122.6738 & 1220.669 & 6113407 & 0.069 & 5.6433 & 415.143 & 4342327 & 50.519\end{array}$ LLLAVFVTPLTDLR $\begin{array}{lllllllllllll}1.00 & 61.39 & 28.46 & 33.38 & 2 & 1220.6744 & 1220.6669 & 611.3407 & 0.0075 & 6.1340 & 9300.874 & 8022.339 & 137.172\end{array}$ LLLAVFVTPLTDLR LLLAVFVTPLTDLR LLLAVFVTPLTDLR LLLAVFVTPLTDLR LLLAVFVTPLTDLR \begin{tabular}{lllllllllllll}
1.00 & 72.00 & 18.57 & 21.34 & 2 & 1714.0526 & 1714.0515 & 858.0330 & 0.0011 & 0.6410 & 116.805 & 109.512 & 18.888 \\
\hline
\end{tabular} $\begin{array}{llllllllllllll}1.00 & 53.42 & 18.57 & 28.35 & 3 & 1714.0531 & 1714.0515 & 572.3578 & 0.0016 & 0.9318 & 66.532 & 48.066 & 5.913 \\ 1.00 & 83.50 & 18.45 & 22.79 & 2 & 1714.0536 & 1714.0515 & 858.0330 & 0.0021 & 1.2237 & 76.724 & 79.163 & 14.480\end{array}$ $\begin{array}{llllllllllllll}1.00 & 60.90 & 18.45 & 20.31 & 3 & 1714.0537 & 1714.0515 & 572.3578 & 0.0022 & 1.2812 & 75.978 & 79.064 & 5.236\end{array}$

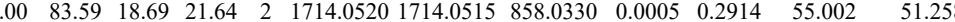
LAILMK $\begin{array}{lllllllllll}1.09 & 33.88 & 18.45 & 15.60 & 3 & 1714.0540 & 1714.0515 & 572.3578 & 0.0025 & 1.4560 & 27.929 \\ 0.99 & 26.52 & 26.66 & 14.81 & 3 & 2349.2629 & 2349.2606 & 784.0941 & 0.0023 & 0.9778 & 46.877\end{array}$

LAILMK LAILMK

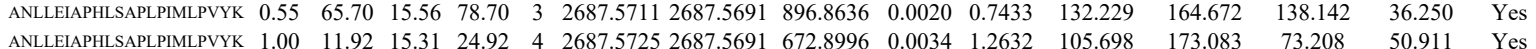

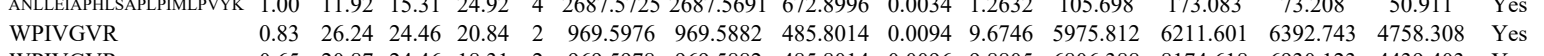

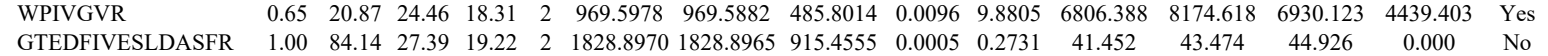




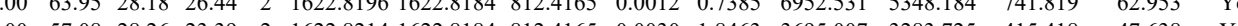

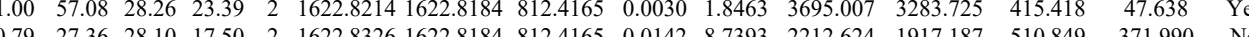

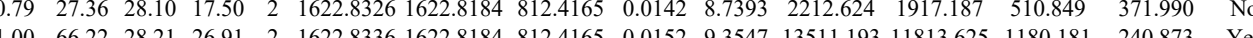

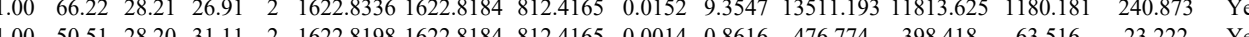

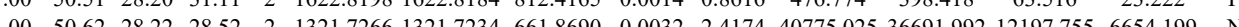

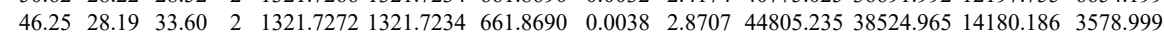
NVWNTHADFADECPKPELL $\begin{array}{llllllllllllll}49.23 & 28.20 & 32.40 & 2 & 1321.7268 & 1321.7234 & 661.8690 & 0.0034 & 2.5685 & 55348.075 & 47627.550 & 7927.368 & 3058.009 & \text { Yes }\end{array}$ $\begin{array}{llllllllllllll} & \end{array}$

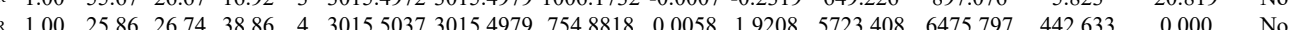
$\begin{array}{llllllllllllllllll}\text { AWVWNTHADFADECPKPELLAIR } & 1.00 & 33.19 & 26.72 & 46.19 & 4 & 3015.5033 & 3015.4979 & 754.8818 & 0.0054 & 1.7884 & 4871.400 & 3224.862 & 139.104 & 120.908 & \text { No }\end{array}$ $\begin{array}{lllllllllllllllll}\text { TLEEDEEELFK } & 1.00 & 64.46 & 27.93 & 27.78 & 2 & 1668.8358 & 1668.8338 & 835.4242 & 0.0020 & 1.1970 & 1880.186 & 1663.699 & 0.000 & 30.112 & \text { No }\end{array}$ TLEEDEEELFK TLEEDEEELFK $\begin{array}{lllllllllllllll}1.00 & 51.88 & 27.80 & 25.17 & 2 & 1668.8376 & 1668.8338 & 835.4242 & 0.0038 & 2.2743 & 1602.551 & 1666.616 & 4.398 & 36.585 & \text { Yes }\end{array}$

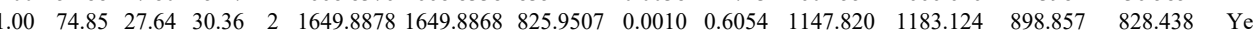
$\begin{array}{llllllllllllllll}1.00 & 74.42 & 27.60 & 25.69 & 2 & 1649.8882 & 1649.8868 & 825.9507 & 0.0014 & 0.8475 & 896.905 & 970.158 & 1035.977 & 662.386 & \text { No }\end{array}$ $\begin{array}{lllllllllllllll}1.00 & 74.91 & 27.47 & 26.44 & 2 & 1649.8898 & 1649.8868 & 825.9507 & 0.0030 & 1.8161 & 470.717 & 643.860 & 431.456 & 458.608 & \text { Yes }\end{array}$ $\begin{array}{llllllllllllllll}1.00 & 92.15 & 27.40 & 28.32 & 2 & 1649.8902 & 1649.8868 & 825.9507 & 0.0034 & 2.0582 & 676.669 & 635.666 & 453.017 & 476.816 & \text { Yes }\end{array}$ $\begin{array}{lllllllllllllll}0.97 & 40.42 & 27.76 & 27.48 & 2 & 1208.6718 & 1208.6645 & 605.3395 & 0.0073 & 6.0296 & 1957.595 & 2578.813 & 4262.786 & 7638.381 & \text { No }\end{array}$ $\begin{array}{lllllllllllllll}0.99 & 46.15 & 27.76 & 23.66 & 2 & 1208.6720 & 1208.6645 & 605.3395 & 0.0075 & 6.1948 & 2004.747 & 2262.698 & 4143.173 & 6678.063 & \text { No }\end{array}$ $\begin{array}{lllllllllllllll} & & & \end{array}$ $\begin{array}{llllllllllllll} & & \end{array}$

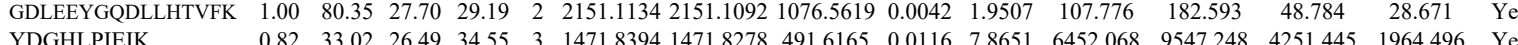

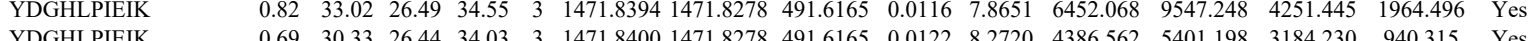

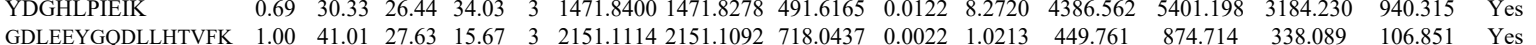
$\begin{array}{llllllllllllllll}\text { GDLEEYGQDLLHTVFK } & 1.00 & 41.01 & 27.63 & 15.67 & 3 & 2151.1114 & 2151.1092 & 718.0437 & 0.0022 & 1.0213 & 449.761 & 874.714 & 338.089 & 106.851 & \text { Yes } \\ \text { GDLES } & 92.62 & 29.58 & 2 & 2151.1114 & 2151.1092 & 1076.5619 & 0.0022 & 1.0218 & 95.589 & 93.508 & 45.288 & 24.161 & \text { Yes }\end{array}$

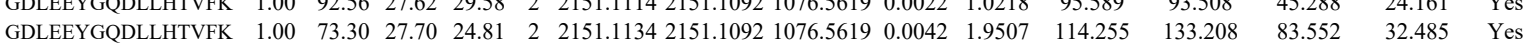

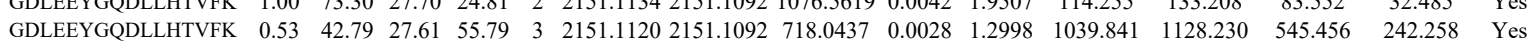

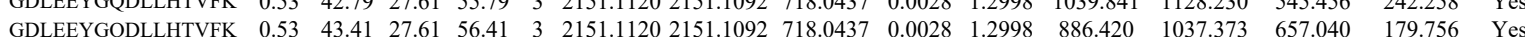

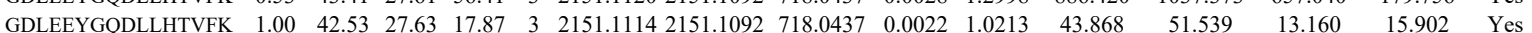

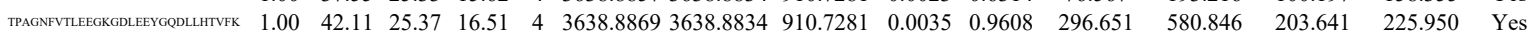

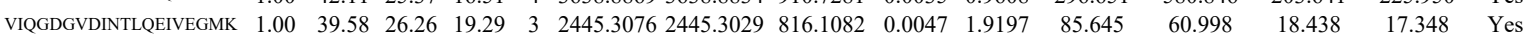

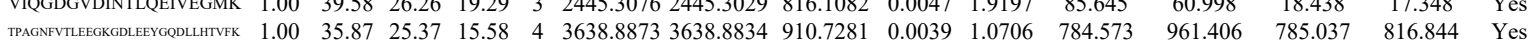

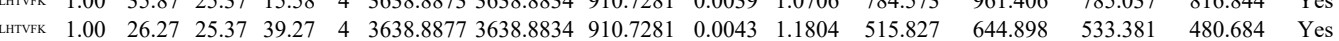
$\begin{array}{lllllllllllllllll}\text { VIQGDGVDINTLOEIVEGMK } & 1.00 & 36.52 & 26.24 & 24.81 & 3 & 2445.3031 & 2445.3029 & 816.1082 & 0.0002 & 0.0817 & 76.091 & 43.581 & 23.350 & 14.744 & \text { Yes }\end{array}$

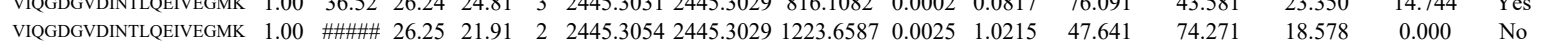

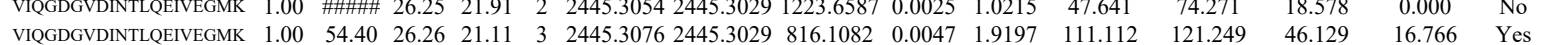

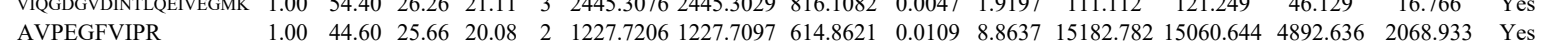

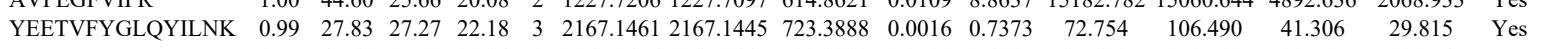
$\begin{array}{llllllllllllllll}\text { YEETVFYGLQYILNK } & 1.00 & 47.61 & 27.19 & 20.84 & 3 & 2167.1476 & 2167.1445 & 723.3888 & 0.0031 & 1.4285 & 85.602 & 159.719 & 22.715 & 12.254 & \text { Yes }\end{array}$ $\begin{array}{llllllllllllllll}\text { MWSIENIAFGSGGGLLQK } & 1.00 & 86.60 & 26.64 & 24.37 & 2 & 2195.1674 & 2195.1652 & 1098.5899 & 0.0022 & 1.0013 & 581.862 & 616.463 & 33.477 & 0.000 & \text { No }\end{array}$

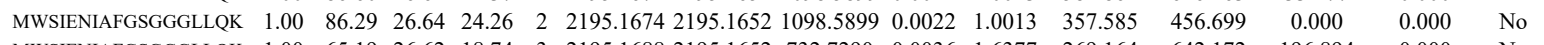
$\begin{array}{llllllllllllllll}\text { MWSIENIAFGSGGGLLQK } & 1.00 & 65.19 & 26.62 & 18.74 & 3 & 2195.1688 & 2195.1652 & 732.7290 & 0.0036 & 1.6377 & 269.164 & 642.172 & 196.894 & 0.000 & \text { No }\end{array}$

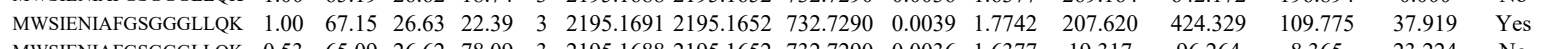

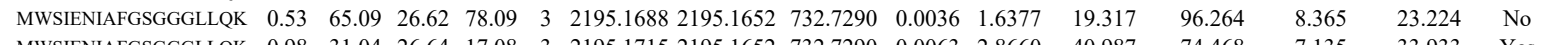

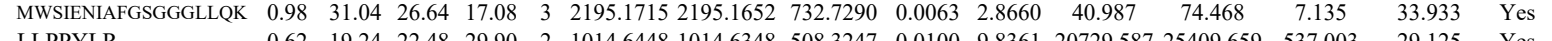
$\begin{array}{lllllllllllllllll}\text { LLPPYLR } & 0.62 & 19.24 & 22.48 & 29.90 & 2 & 1014.6448 & 1014.6348 & 508.3247 & 0.0100 & 9.8361 & 20729.587 & 25409.659 & 537.003 & 29.125 & \text { Yes }\end{array}$

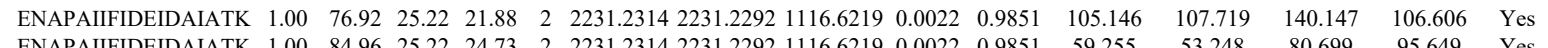

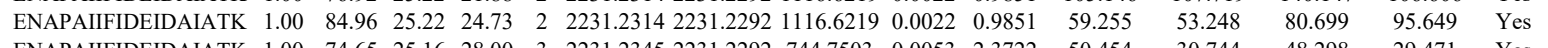

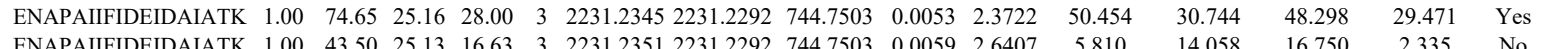

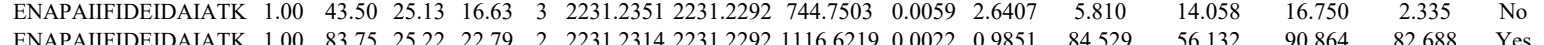

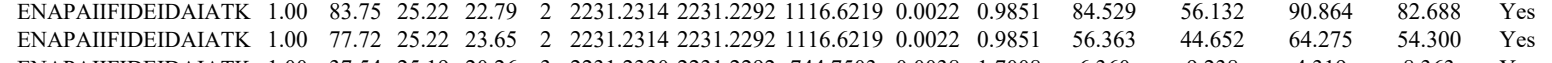

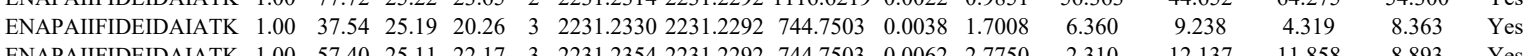

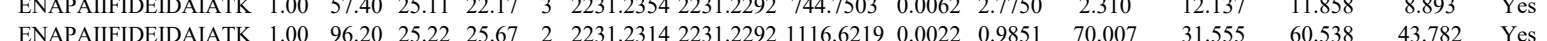

Table S-3 page 249 of 499 


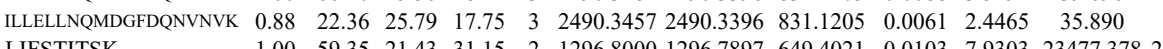

$\begin{array}{lllllllllllll}1.00 & 59.35 & 21.43 & 31.15 & 2 & 1296.8000 & 1296.7897 & 649.4021 & 0.0103 & 7.9303 & 23477.378 & 24239.184 & 891.417\end{array}$

$\begin{array}{lllllllllllllll}0.81 & 18.22 & 27.11 & 14.30 & 3 & 1437.7978 & 1437.7963 & 480.2727 & 0.0015 & 1.0411 & 1145.811 & 1213.509 & 585.344\end{array}$

$\begin{array}{lllllllllllll}1.00 & 55.74 & 21.43 & 29.27 & 2 & 1296.7948 & 1296.7897 & 649.4021 & 0.0051 & 3.9267 & 13214.517 & 13511.167 & 707.703 \\ 1.00 & 55.85 & 21.04 & 29.67 & 2 & 1296.7976 & 1296.7897 & 649.4021 & 0.0079 & 6.0825 & 10809.254 & 10399.818 & 179.164\end{array}$

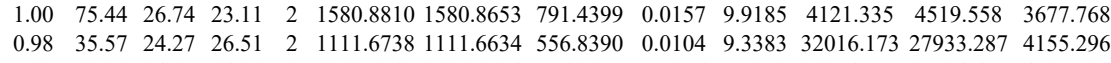
$\begin{array}{lllllllllllll}0.98 & 33.86 & 24.27 & 24.89 & 2 & 1111.6740 & 1111.6634 & 556.8390 & 0.0106 & 9.5179 & 33854.059 & 35024.670 & 4395.082\end{array}$ $\begin{array}{llllllllllllll} & & & \end{array}$ $\begin{array}{llllllllllllll}\text { NNSSLIGVGYTQTLRPGVK } & 1.00 & 92.69 & 25.80 & 20.17 & 2 & 2102.1474 & 2102.1484 & 1052.0815 & -0.0010 & -0.4752 & 0.000 & 0.000 & 0.000\end{array}$

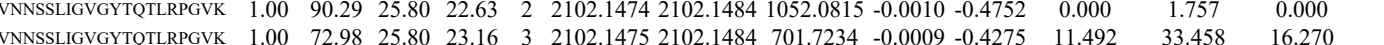

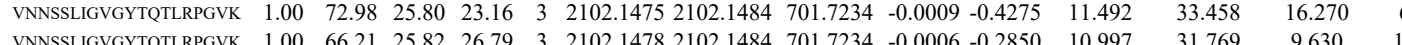
$\begin{array}{llllllllllllll}\text { VNNSSLIGVGYTQTLRPGVK } & 1.00 & 66.21 & 25.82 & 26.79 & 3 & 2102.1478 & 2102.1484 & 701.7234 & -0.0006 & -0.2850 & 10.997 & 31.769\end{array}$ $\begin{array}{llllllllllllll} & \text { RASSIGVGYQILRPGKK } & 1.00 & 59.46 & 25.82 & 21.81 & 3 & 2102.1478 & 2102.1484 & 701.7234 & -0.0006 & -0.2850 & 5.399 & 12.816\end{array}$

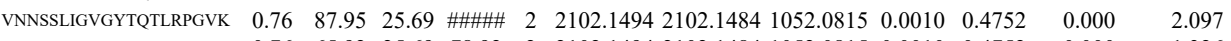
$\begin{array}{llllllllllllll}\text { VNNSSLIGVGYTQTLRPGVK } & 0.76 & 65.92 & 25.69 & 78.92 & 2 & 2102.1494 & 2102.1484 & 1052.0815 & 0.0010 & 0.4752 & 0.000 & 1.326\end{array}$

$\begin{array}{lllllllllllll}\text { VNNSSLIGVGYTQTLRPGVK } & 1.00 & 64.53 & 25.73 & 22.99 & 3 & 2102.1490 & 2102.1484 & 701.7234 & 0.0006 & 0.2850 & 16.475 & 19.809\end{array}$

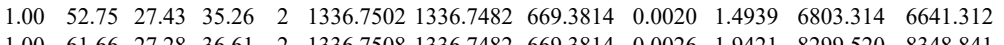
SGASEANLIVAK LDLTENLTGSK $\begin{array}{llllllllll} & \end{array}$ LDPAASVTGSK $\begin{array}{llllllllll} & 0\end{array}$ $\begin{array}{lllllllllllll}0.99 & 44.15 & 26.29 & 22.45 & 2 & 1446.8368 & 1446.8286 & 724.4216 & 0.0082 & 5.6597 & 386.206 & 459.594\end{array}$

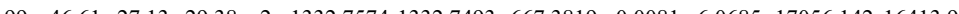
LDPAASVTGSK

AQALEDLAGFK TPVQYSQQQNSPQK

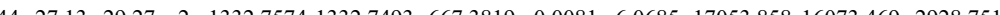
$\begin{array}{llllllllllll} & \\ \end{array}$ $\begin{array}{llllllllllllll}1.00 & 61.82 & 27.90 & 23.20 & 3 & 1919.9962 & 1919.9945 & 641.0054 & 0.0017 & 0.8840 & 1402.677 & 1514.590 & 800.409 & 91\end{array}$

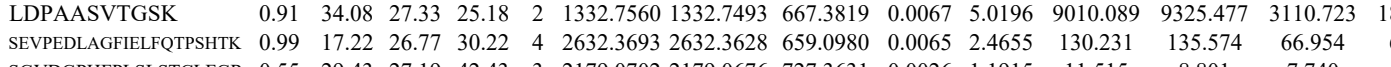
$\begin{array}{lllllllllllllll}\text { SGVDGPHFPLSLSTCLFGR } & 0.55 & 29.43 & 27.19 & 42.43 & 3 & 2179.0702 & 2179.0676 & 727.3631 & 0.0026 & 1.1915 & 11.515 & 8.801 & 7.740 & 2.454\end{array}$ $\begin{array}{lllllllllllllll}\text { SGVDGPHFPLSLSTCLFGR } & 0.55 & 45.17 & 27.19 & 58.17 & 3 & 2179.0702 & 2179.0676 & 727.3631 & 0.0026 & 1.1915 & 23.345 & 9.166 & 4.121 & 0.000\end{array}$ $\begin{array}{lllllllllllllll}\text { SGVDGPHFPLSLSTCLFGR } & 0.99 & 27.77 & 27.23 & 17.55 & 3 & 2179.0705 & 2179.0676 & 727.3631 & 0.0029 & 1.3290 & 8.245 & 0.000 & 0.000 & 0.000\end{array}$ $\begin{array}{lllllllllllllllll}\text { ADVEEEFLALR } & 1.00 & 54.19 & 28.69 & 28.70 & 2 & 1434.7500 & 1434.7476 & 718.3811 & 0.0024 & 1.6704 & 619.476 & 692.530 & 885.609 & 241.940 & N o\end{array}$

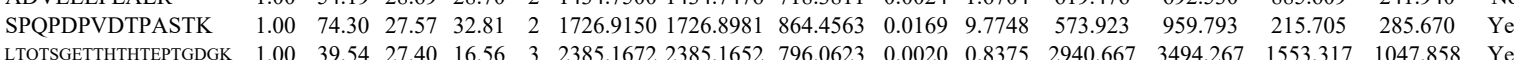

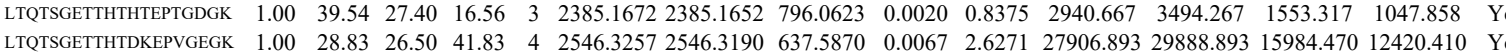

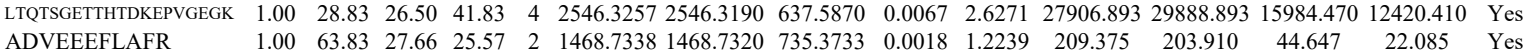

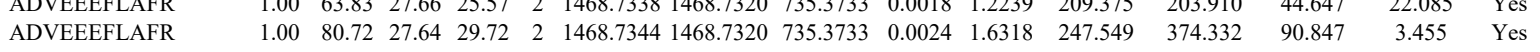

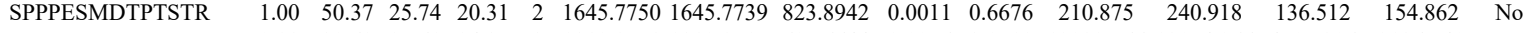

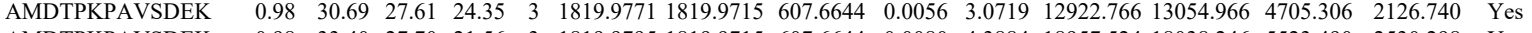

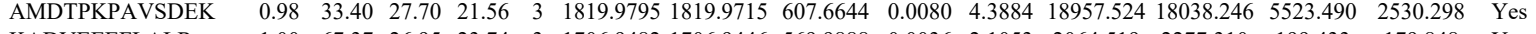
$\begin{array}{llllllllllllllll}\text { KADVEEEFLALR } & 1.00 & 67.37 & 26.95 & 23.74 & 3 & 1706.9482 & 1706.9446 & 569.9888 & 0.0036 & 2.1053 & 2064.519 & 2277.310 & 199.433 & 179.848 & \text { Yes }\end{array}$ $\begin{array}{lllllllllllllllll}1.00 & 75.89 & 28.78 & 28.63 & 2 & 1358.7396 & 1358.7276 & 680.3711 & 0.0120 & 8.8186 & 25065.900 & 24789.004 & 3285.554 & 1335.342 & \text { Yes }\end{array}$ $\begin{array}{lllllllllllllll}1.00 & 52.97 & 27.13 & 25.57 & 2 & 1277.7356 & 1277.7257 & 639.8701 & 0.0099 & 7.7359 & 4943.432 & 4797.885 & 2577.055 & 1675.748 & \text { Yes }\end{array}$

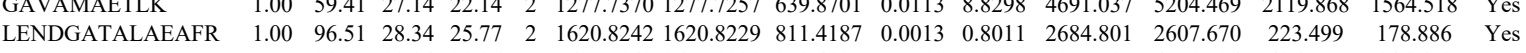
\begin{tabular}{llllllllllllllll} 
& \\
LENDGATALAEAFR & 1.00 & 82.85 & 28.34 & 22.36 & 2 & 1620.8242 & 1620.8229 & 811.4187 & 0.0013 & 0.8011 & 5157.585 & 4091.524 & 426.957 & 146.658 & Yes \\
\hline
\end{tabular} GAVAMAETLK

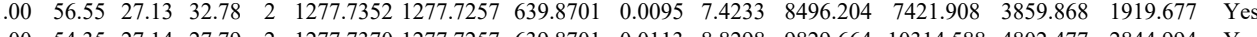


MAVQDAVDALMQK PPNTGEAPVILSPPADVSTFLAPSP LNNCGMGIGGGK ILAAALTECHR ILAAALTECHR ILAAALTECHR ILAAALTECHR LLVHMGLLK LLVHMGLLK

LLVHMGLLK

.

AFNSSSFNSNTFLTR

AFNSSSFNSNTFLTR

AFNSSSFNSNTFLTR

ALAPLLLAFVTKPNSALESCSFAR ALAPLLLAFVTKPNSALESC EIEDFDSLEALR

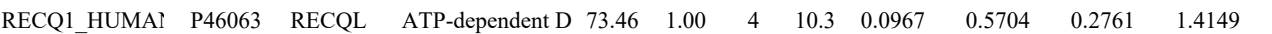

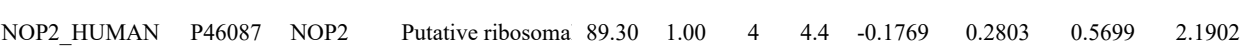

$\begin{array}{lllllllllll}\text { BAT3_HUMAN } & \text { P46379 } & \text { BAT3 } & \text { Large proline-rich 119.41 } & 1.00 & 2 & 2.7 & -0.0700 & 0.1711 & -0.7712 & 1.5031\end{array}$

$\begin{array}{lllllllllll}\text { MP2K3 HUMAI } & \text { P46734 } & \text { MAP2K3 } & \text { Dual specificity m } 39.32 & 1.00 & 3 & 13 & 0.0158 & 0.4925 & 0.3443 & 1.9771\end{array}$

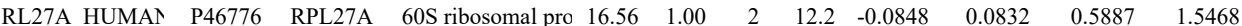

RL5_HUMAN P46777 RPL5

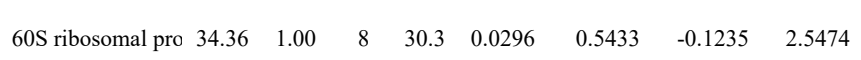

FRPLQLETINVTMAGK KGPQSLFNAPR

KGPQSLFNAPR TQASSSFQDSSQPAGK IQDIVGILR IQDIVGILR IQDIVGILR IQDIVGILR GPQSLFNAPR GPQSLFNAPR LLGNTFVALSDLR

DLKPSNVLINK YHPGYFGK YHPGYFGK
YHPGYFGK YHPGYFGK YHPGYFGK YHPGYFGK LWTLVSEQTR LWTLVSEQTR LWTLVSEQTR LWTLVSEQTR LWTLVSEQTR LWTLVSEQTR LWTLVSEQTR RFPGYDSESK $\begin{array}{llllllllllll}0.77 & 82.49 & 28.23 & 95.49 & 2 & 1706.8956 & 1706.8939 & 854.4542 & 0.0017 & 0.9948 & 76.680 & 109.9926\end{array}$ $\begin{array}{lllllllllll}24.01 & 26.25 & 4 & 3577.8821 & 3577.8800 & 895.4773 & 0.0021 & 0.5863 & 87.273 & 70.386 & 65.780\end{array}$

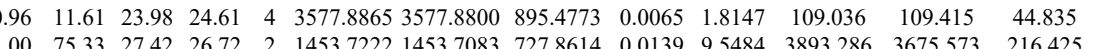
$\begin{array}{llllllllllllll}1 & 0.07 .3 & 27.42 & 26.72 & 2 & 1453.7222 & 1453.7083 & 727.8614 & 0.0139 & 9.5484 & 3893.286 & 3675.573 & 216.425\end{array}$ $\begin{array}{lllllllllllll}1.00 & 75.33 & 27.42 & 26.72 & 2 & 1453.722 & 1453.7083 & 727.8614 & 0.0139 & 9.5484 & 3893.286 & 3675.573 & 216.425 \\ 1.00 & 57.68 & 26.96 & 25.58 & 2 & 1386.7222 & 1386.7233 & 694.3689 & -0.0011 & -0.7921 & 5764.304 & 5353.534 & 230.099\end{array}$ $\begin{array}{llllllllllllll}1.00 & 80.48 & 26.96 & 25.58 & 2 & 1386.7222 & 1386.723 & 694.3689 & 0.0011 & 0.7921 & 5764.304 & 5353.534 & 230.099\end{array}$ $\begin{array}{llllllllllllll} & \end{array}$ $\begin{array}{llllllllllllll}1.00 & 43.12 & 18.39 & 18.26 & 2 & 1310.8364 & 1310.8352 & 656.4249 & 0.0012 & 0.9140 & 1899.739 & 2655.057 & 141.541\end{array}$ $\begin{array}{llllllllllll} & \end{array}$ $\begin{array}{lllllllllll}1 & 0\end{array}$

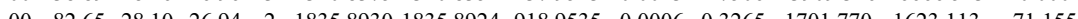
$\begin{array}{lllllllllllll}0.99 & 28.41 & 28.12 & 15.71 & 3 & 1835.8951 & 1835.8924 & 612.9714 & 0.0027 & 1.4683 & 389.238 & 348.300 & 427.978\end{array}$ $\begin{array}{llllllllllll}1 & 0.0010 & 0.5441 & 1811.930 & 1785.291 & 43.427\end{array}$ $\begin{array}{lllllllllllll}1.00 & 97.87 & 28.16 & 27.54 & 2 & 1835.8940 & 1835.8924 & 918.9535 & 0.0016 & 0.8706 & 2289.319 & 1935.279 & 13.768 \\ 1.00 & 51.91 & 23.71 & 17.22 & 3 & 28525561 & 2852.5536 & 951.8585 & 0.0025 & 0.8755 & 248.387 & 199.480 & 138.137\end{array}$

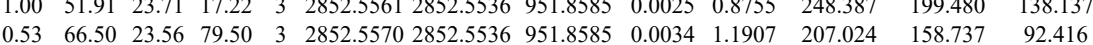

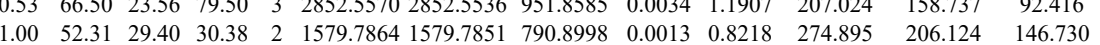

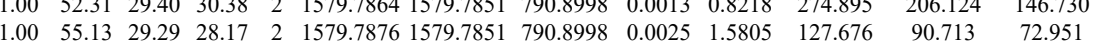

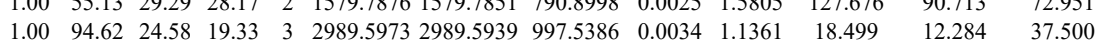
$\begin{array}{lllllllllllllll}\text { VAGVVAPTLPR } & 1.00 & 45.69 & 22.07 & 28.16 & 2 & 1222.7620 & 1222.7520 & 612.3833 & 0.0100 & 8.1648 & 9597.890 & 13371.216 & 990.125 & 356.64 \\ \text { FRPLQLETINVTMAGK } & 1.00 & 53.04 & 23.75 & 21.72 & 3 & 2105.1919 & 2105.1911 & 702.7376 & 0.0008 & 0.3795 & 1673.629 & 1790.314 & 1936.327 & 877.44\end{array}$ $\begin{array}{lllllllllllll}.00 & 39.94 & 23.71 & 18.43 & 3 & 2105.1928 & 2105.1911 & 702.7376 & 0.0017 & 0.8064 & 4578.179 & 3906.349 & 3411.141\end{array}$ $\begin{array}{llllllllllllllll}\text { QKPSNTEDFIEDIVK } & 1.00 & 39.22 & 26.37 & 20.91 & 3 & 2194.1857 & 2194.1847 & 732.4022 & 0.0010 & 0.4551 & 546.308 & 932.282 & 1553.404 & 1851.453 & \text { Yese. }\end{array}$ $\begin{array}{lllllllllllllllll}\text { QKPSNTEDFIEDIVK } & 1.00 & 38.91 & 26.37 & 19.14 & 3 & 2194.1857 & 2194.1847 & 732.4022 & 0.0010 & 0.4551 & 690.020 & 1060.859 & 1905.945 & 1467.424 & \text { Yes }\end{array}$

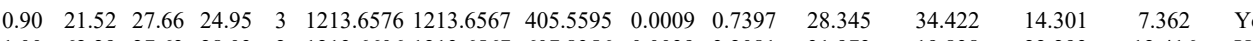

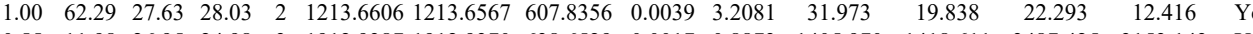

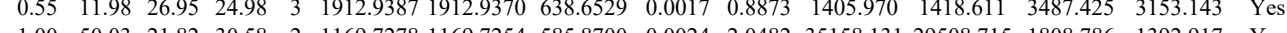
$\begin{array}{lllllllllllllll}1.00 & 50.03 & 21.82 & 30.58 & 2 & 1169.7278 & 1169.7254 & 585.8700 & 0.0024 & 2.0482 & 35158.131 & 29508.715 & 1808.786 & 1392.917 & \text { Yes }\end{array}$ $\begin{array}{lllllllllllllll}1.00 & 45.47 & 21.55 & 27.08 & 2 & 1169.7282 & 1169.7254 & 585.8700 & 0.0028 & 2.3896 & 31544.891 & 27838.190 & 1988.036 & 800.062 & \text { Yes }\end{array}$ $\begin{array}{lllllllllllllll}1.00 & 50.10 & 21.61 & 28.74 & 2 & 1169.7292 & 1169.7254 & 585.8700 & 0.0038 & 3.2430 & 7585.233 & 5901.736 & 386.146 & 426.168 & \text { Yes }\end{array}$

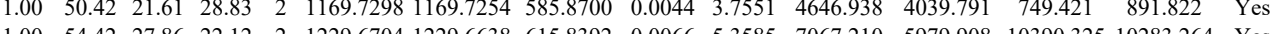
$\begin{array}{llllllllllllllll}1.00 & 54.42 & 27.86 & 22.12 & 2 & 1229.6704 & 1229.6638 & 615.8392 & 0.0066 & 5.3585 & 7067.210 & 5979.908 & 10390.325 & 10283.264 & \text { Yes } \\ 0.99 & 4.89 & 27.86 & 2.18 & 2 & 1229.6710 & 1229.6638 & 615.8392 & 0.0072 & 5.8456 & 8706.455 & 10393.16 & 12010.861 & 1675.526 & \text { Yes }\end{array}$ $\begin{array}{llllllllllllllll} & \end{array}$ $\begin{array}{llllllllllllllll}\text { TQASSSFQDSSQPAGK } & 1.00 & 36.45 & 27.03 & 19.01 & 3 & 1912.9399 & 1912.9370 & 638.6529 & 0.0029 & 1.5136 & 1350.412 & 1428.262 & 1339.748 & 1094.087 & \text { Yes }\end{array}$

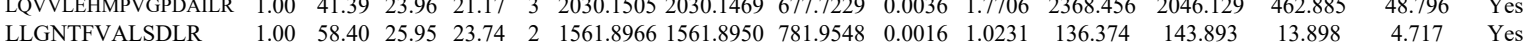

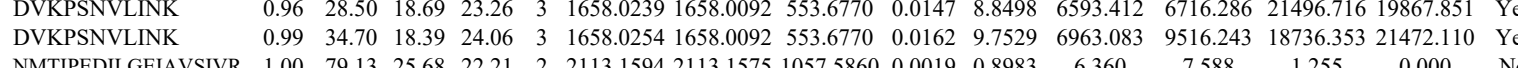

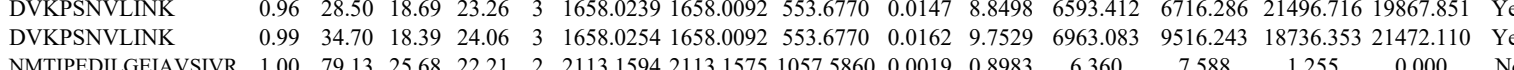

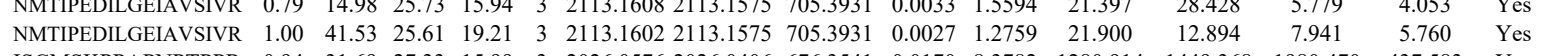

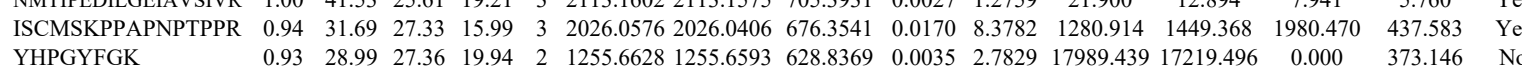
RFPGYDSESK RFPGYDSESK $\begin{array}{lll}0 & 0 \\ 0 & 0\end{array}$ $\begin{array}{lllllllllllllll}0.53 & 29.67 & 27.39 & 42.67 & 3 & 1255.6621 & 1255.6593 & 419.5604 & 0.0028 & 2.2245 & 37634.031 & 41664.398 & 4041.609 & 2546.483\end{array}$ $\begin{array}{llllllllllllllllll}0.96 & 31.08 & 27.36 & 16.98 & 2 & 1255.6626 & 1255.6593 & 628.8369 & 0.0033 & 2.6239 & 12777.291 & 12537.054 & 0.000 & 416.630 & \text { No }\end{array}$ $\begin{array}{lllllllllllllllll}0.98 & 27.23 & 27.55 & 16.00 & 3 & 1255.6630 & 1255.6593 & 419.5604 & 0.0037 & 2.9396 & 49060.103 & 48488.521 & 2490.971 & 945.139 & \text { Yes }\end{array}$ $\begin{array}{lllllllllllllllll}0.55 & 21.78 & 27.32 & 34.78 & 3 & 1255.6612 & 1255.6593 & 419.5604 & 0.0019 & 1.5095 & 9817.710 & 8949.919 & 4539.337 & 3690.241 & \text { No }\end{array}$ $\begin{array}{llllllllllllllll}0.53 & 24.68 & 27.36 & 37.68 & 3 & 1255.6627 & 1255.6593 & 419.5604 & 0.0034 & 2.7012 & 26007.230 & 24706.841 & 3997.509 & 2842.936 & \text { Yes }\end{array}$ $\begin{array}{lllllllllllllllll}0.99 & 30.25 & 27.32 & 15.01 & 3 & 1255.6612 & 1255.6593 & 419.5604 & 0.0019 & 1.5095 & 23795.513 & 21088.323 & 1558.182 & 1483.282 & \text { Yes }\end{array}$ $\begin{array}{llllllllllllllll}1.00 & 57.78 & 28.12 & 28.48 & 2 & 1375.7604 & 1375.7581 & 688.8863 & 0.0023 & 1.6694 & 42256.806 & 42849.116 & 760.264 & 450.522 & \text { Yes }\end{array}$ $\begin{array}{lllllllllllllll}1.00 & 61.17 & 28.08 & 23.91 & 2 & 1375.7612 & 1375.7581 & 688.8863 & 0.0031 & 2.2500 & 68837.791 & 63998.169 & 1401.765 & 181.160 & \text { Yes }\end{array}$ $\begin{array}{llllllllllllllll}1.00 & 57.85 & 27.92 & 23.95 & 2 & 1375.7598 & 1375.7581 & 688.8863 & 0.0017 & 1.2339 & 40817.340 & 40253.368 & 441.792 & 903.092 & \text { Yes }\end{array}$ $\begin{array}{lllllllllllllll}1.00 & 51.06 & 28.12 & 21.42 & 2 & 1375.7600 & 1375.7581 & 688.8863 & 0.0019 & 1.3790 & 31413.387 & 29882.023 & 1076.552 & 990.874 & \text { Yes }\end{array}$

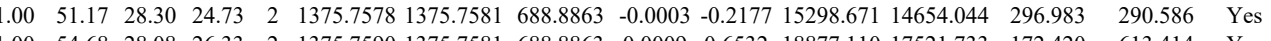
$\begin{array}{lllllllllllllllll}1.00 & 54.68 & 28.08 & 26.33 & 2 & 1375.7590 & 1375.7581 & 688.8863 & 0.0009 & 0.6532 & 18877.110 & 17521.733 & 172.420 & 613.414 & \text { Yes }\end{array}$ $\begin{array}{lllllllllllllll}1.00 & 52.80 & 28.21 & 29.21 & 2 & 1375.7588 & 1375.7581 & 688.8863 & 0.0007 & 0.5081 & 1555.920 & 1477.100 & 210.760 & 137.269 & \text { Yes } \\ 0.99 & 39.31 & 27.32 & 22.55 & 2 & 1472.7538 & 1772.7503 & 737.3824 & 0.0035 & 2.3733 & 2688.822 & 2393.474 & 448.308 & 273.075 & \text { Yes }\end{array}$ $\begin{array}{lllllllllllllll}0.99 & 39.31 & 27.32 & 22.55 & 2 & 1472.7538 & 1472.7503 & 737.3824 & 0.0035 & 2.3733 & 2648.822 & 2393.474 & 448.308 & 273.075 & \text { Yes } \\ 1.00 & 33.80 & 27.36 & 24.43 & 3 & 1472.7547 & 1472.7503 & 491.9240 & 0.0044 & 2.9815 & 30195.461 & 27936.461 & 2942.975 & 713.205 & \text { Yes }\end{array}$ $\begin{array}{lllllllllllllll}1.00 & 33.80 & 27.36 & 24.43 & 3 & 1472.7547 & 1472.7503 & 491.9240 & 0.0044 & 2.9815 & 30195.461 & 27936.461 & 2942.975 & 713.205 & \text { Yes } \\ 0.99 & 28.62 & 27.41 & 2.27 & 3 & 1472.7520 & 1472.7503 & 491.9240 & 0.0017 & 1.1519 & 10833.970 & 7933.719 & 2943.098 & 1573.415 & \text { Yes }\end{array}$

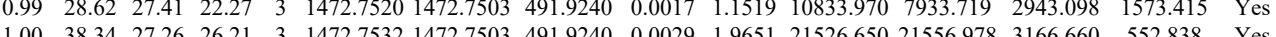
$\begin{array}{llllllllllllllll}1.00 & 38.34 & 27.26 & 26.21 & 3 & 1472.7532 & 1472.7503 & 491.9240 & 0.0029 & 1.9651 & 21526.650 & 21556.978 & 3166.660 & 552.838 & \text { Yes } \\ 1.00 & 97.79 & 26.78 & 29.48 & 2 & 1625.9056 & 1625.8981 & 813.9563 & 0.0075 & 4.6071 & 2112.457 & 2223.020 & 1605.082 & 1361.921 & \text { Yes }\end{array}$

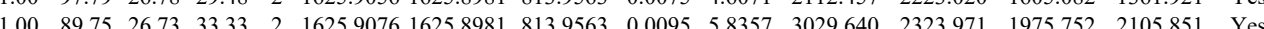
$\begin{array}{llllllllllllllll}1.00 & 46.79 & 26.79 & 20.23 & 3 & 1625.9083 & 1625.8981 & 542.9733 & 0.0102 & 6.2618 & 9193.419 & 8400.726 & 8441.694 & 7836.544 & \text { Yes }\end{array}$ 


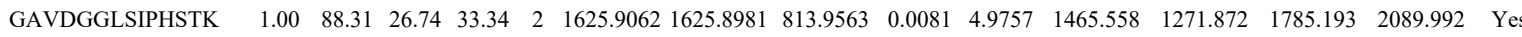
$\begin{array}{lllllllllllllllll}\text { GAVDGGLSIPHSTK } & 1.00 & 88.43 & 26.78 & 36.87 & 2 & 1625.9072 & 1625.8981 & 813.9563 & 0.0091 & 5.5899 & 2103.964 & 2638.387 & 2090.598 & 2670.778 & \text { Yes }\end{array}$

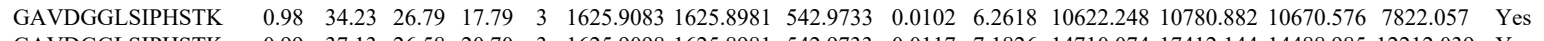

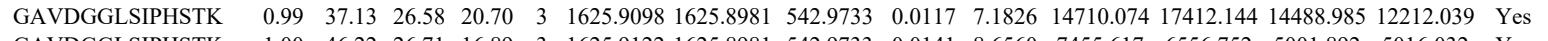

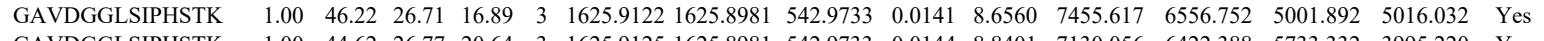
$\begin{array}{lllllllllllllllll}\text { GAVDGGLSIPHSTK } & 1.00 & 44.62 & 26.77 & 20.64 & 3 & 1625.9125 & 1625.8981 & 542.9733 & 0.0144 & 8.8401 & 7130.056 & 6422.388 & 5733.332 & 3995.220 & \text { Yes }\end{array}$

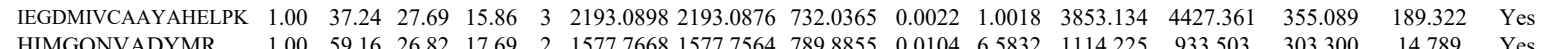

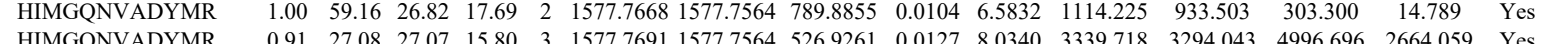
$\begin{array}{llllllllllllllll}\text { HIMGQNVADYMR } & 0.91 & 27.08 & 27.07 & 15.80 & 3 & 1577.7691 & 1577.7564 & 526.9261 & 0.0127 & 8.0340 & 3339.718 & 3294.043 & 4996.696 & 2664.059 & \text { Yes } \\ \text { HIMGQNVADYMR } & 1.00 & 41.66 & 27.14 & 16.51 & 3 & 1577.7703 & 1577.7564 & 526.9261 & 0.0139 & 8.7931 & 3783.267 & 3085.777 & 2787.906 & 1725.091 & \text { Yes }\end{array}$

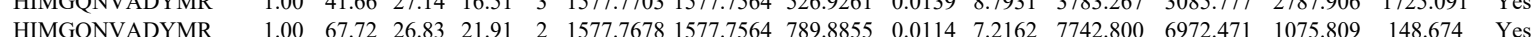

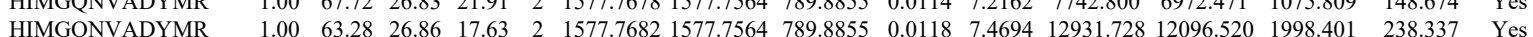

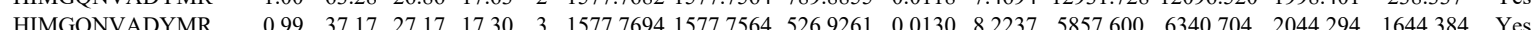

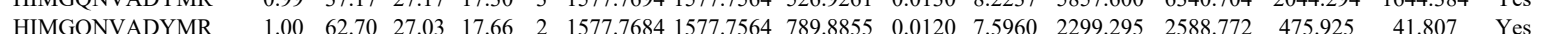
\begin{tabular}{lllllllllllllllllll}
\hline HIMGQNVADYMR & 1.00 & 46.86 & 27.07 & 19.19 & 3 & 1577.7691 & 1577.7564 & 526.9261 & 0.0127 & 8.0340 & 5532.143 & 5144.991 & 11132.19 & 624.096 & Yes
\end{tabular} VFGALK

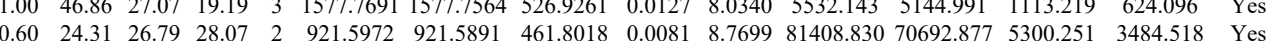
$\begin{array}{llllllllllllllll}\text { VGLTNYAAAYCTGLLLAR } & 1.00 & 34.05 & 27.59 & 26.17 & 3 & 2059.0750 & 2059.0716 & 687.3645 & 0.0034 & 1.6488 & 3.380 & 10.498 & 7.043 & 3.721 & \text { Yes }\end{array}$

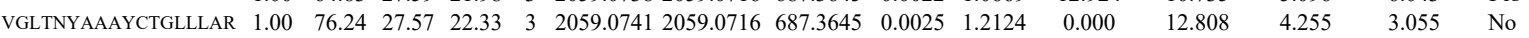
$\begin{array}{llllllllllllllll}\text { VGLTNYAAAYCTGLLLAR } & 0.63 & 17.07 & 27.61 & 16.86 & 3 & 2059.0720 & 2059.0716 & 687.3645 & 0.0004 & 0.1940 & 5.869 & 14.148 & 6.543 & 9.808 & \text { Yes }\end{array}$ $\begin{array}{llllllllllllllll}\text { VGLTNYAAAYCTGLLLAR } & 1.00 & 52.42 & 27.70 & 19.31 & 3 & 2059.0705 & 2059.0716 & 687.3645 & -0.0011 & -0.5334 & 1.781 & 7.545 & 2.699 & 2.134 & \text { Yes }\end{array}$

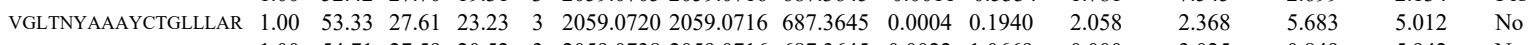

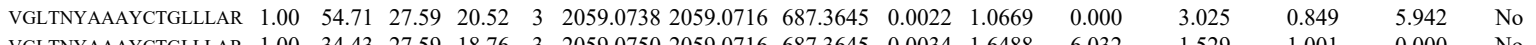

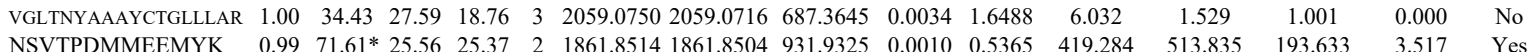

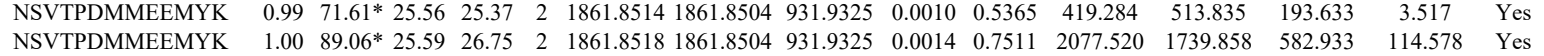

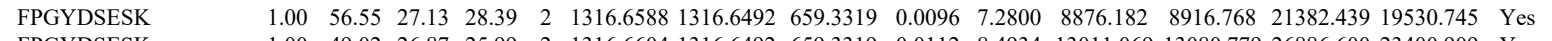

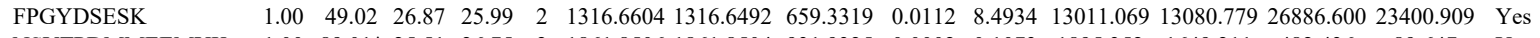

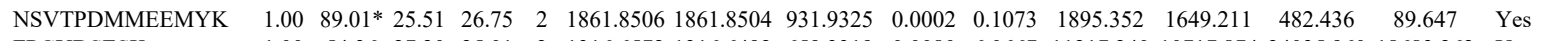

$\begin{array}{llllllllllllllll}\text { FPGYDSESK } & 1.00 & 54.36 & 27.20 & 25.01 & 2 & 1316.6572 & 1316.6492 & 659.3319 & 0.0080 & 6.0667 & 11217.240 & 10717.874 & 24035.960 & 18683.262 & \text { Yes } \\ \text { FPGYDSESK } & 1.00 & 58.11 & 27.16 & 24.89 & 2 & 1316.6578 & 1316.6492 & 659.3319 & 0.0086 & 6.5217 & 9772.343 & 8363.188 & 18083.436 & 15205.251 & \text { Yes }\end{array}$ FPGYDSESK

$\begin{array}{lllllllllllll}\text { RL21_HUMAN } & \text { P46778 } & \text { RPL21 } & \text { 60S ribosomal pro } 18.56 & 1.00 & 6 & 38.8 & -0.0997 & 0.1355 & -0.8201 & 1.1698 & 28 & \text { KGDIVDIK }\end{array}$ KGDIVDIK EPELLEPIPYEFMA KGDIVDIK KGDIVDIK KGDIVDIK KGDIVDIK

KGDIVDIK

KGDIVDIK

KGDIVDIK

GMGTVQK

GMGTVQK

GTWVQLK

GTWVQLK

GTWVQLK

GTWVQLK

GTWVQLK $\begin{array}{lllllllllllllllllll}0.86 & 24.03 & 20.90 & 24.25 & 3 & 1318.8280 & 1318.8186 & 440.6135 & 0.0094 & 7.1112 & 40042.821 & 35387.981 & 18442.434 & 3647.349 & \text { Yes }\end{array}$ $\begin{array}{llllllllllllllllll}0.98 & 32.76 & 21.04 & 25.81 & 3 & 1318.8295 & 1318.8186 & 440.6135 & 0.0109 & 8.2460 & 35278.944 & 30348.175 & 15737.798 & 2764.329 & \text { Yes }\end{array}$

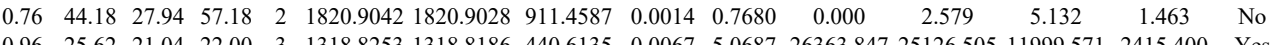

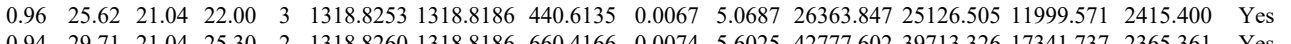
$\begin{array}{llllllllllllllll}0.94 & 29.71 & 21.04 & 25.30 & 2 & 1318.8260 & 1318.8186 & 660.4166 & 0.0074 & 5.6025 & 42777.602 & 39713.326 & 17341.737 & 2365.361 & \text { Yes } \\ 0.99 & 37.53 & 21.04 & 27.52 & 2 & 1318.8264 & 1318.8186 & 660.4166 & 0.0078 & 5.9053 & 31815.626 & 31805.416 & 15408.685 & 3049.778 & \text { Yes }\end{array}$

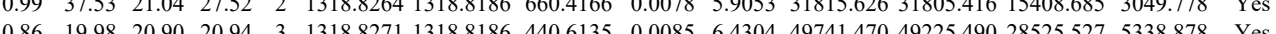

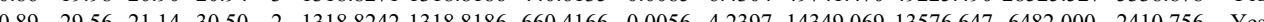

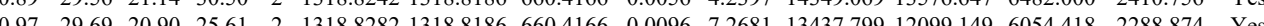

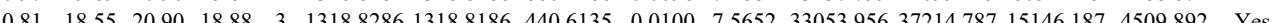
$\begin{array}{llllllllllllllll}0.94 & 22.67 & 21.04 & 19.66 & 3 & 1318.8292 & 1318.8186 & 440.6135 & 0.0106 & 8.0191 & 27112852 & 25133.666 & 14671.537 & 4879.573 & \text { Yes } & \end{array}$ $\begin{array}{lllllllllllllllll}0.91 & 26.52 & 27.70 & 21.59 & 2 & 1007.5690 & 1007.5677 & 504.7911 & 0.0013 & 1.2877 & 1374.086 & 1092.728 & 484.626 & 171.034 & \text { Yes }\end{array}$ $\begin{array}{lllllllllllllllll}0.93 & 27.75 & 27.70 & 25.90 & 2 & 1007.5690 & 1007.5677 & 504.7911 & 0.0013 & 1.2877 & 1345.479 & 1152.400 & 532.673 & 159.075 & \text { Yes }\end{array}$

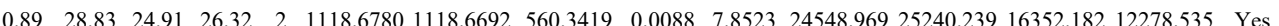
$\begin{array}{llllllllllllll}0.88 & 27.02 & 24.74 & 26.70 & 2 & 1118.6788 & 1118.6692 & 560.3419 & 0.0096 & 85661 & 27207.011 & 27833657 & 22056.95613789 .652 & \text { Yes }\end{array}$ $\begin{array}{llllllllllllllll}0.78 & 25.41 & 24.91 & 28.23 & 2 & 118.6788 & 118.662 & 560.34118 & 0.0086 & 7.6738 & 22084.649 & 21189.106 & 17591.565 & 9101.833 & \text { Yes }\end{array}$ $\begin{array}{llllllllllllllll}0.97 & 35.93 & 25.12 & 27.61 & 2 & 1118.6772 & 1118.6692 & 560.3419 & 0.0080 & 7.1384 & 10549.439 & 11557.324 & 6218.447 & 4504.282 & \text { Yes }\end{array}$

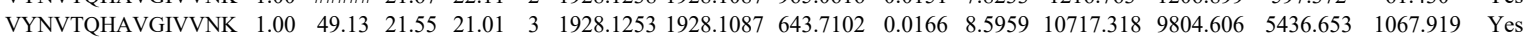

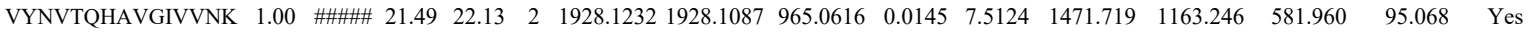
$\begin{array}{lllllllllllllllll}\text { VYNVTQHAVGIVVNK } & 1.00 & 45.59 & 21.49 & 18.62 & 3 & 1928.1235 & 1928.1087 & 643.7102 & 0.0148 & 7.6638 & 14058.308 & 12454.597 & 6829.145 & 1123.489 & \text { Yes }\end{array}$ $\begin{array}{llllllllllllllll}\text { VYNVTQHAVGIVVNK } & 1.00 & 58.53 & 21.55 & 17.90 & 3 & 1928.1250 & 1928.1087 & 643.7102 & 0.0163 & 8.4406 & 3780.273 & 3913.537 & 1698.211 & 459.938 & \text { Yes }\end{array}$

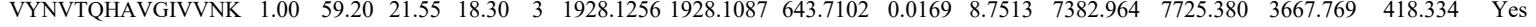
$\begin{array}{llllllllllllllll}\text { HGVVPLATYMR } & 0.98 & 32.20 & 27.63 & 18.66 & 3 & 1386.7636 & 1386.7564 & 463.2594 & 0.0072 & 5.1807 & 11483.613 & 12006.793 & 5214.222 & 3829.333 & \text { Yes }\end{array}$ $\begin{array}{llllllllllllllllllll}\text { HGVVPLATYMR } & 0.99 & 39.98 & 27.44 & 27.67 & 2 & 1386.7678 & 1386.7564 & 694.3855 & 0.0114 & 8.2086 & 3962.813 & 4601.098 & 492.592 & 143.915 & \text { Yes }\end{array}$ $\begin{array}{lllllllllllllllll}\text { HGVVPLATYMR } & 0.98 & 39.04 & 27.37 & 27.87 & 2 & 1386.7684 & 1386.7564 & 694.3855 & 0.0120 & 8.6407 & 3710.215 & 3667.188 & 337.790 & 98.011 & \text { Yes }\end{array}$ $\begin{array}{llllllllllllllll}\text { HGVVPLATYMR } & 0.99 & 41.20 & 27.45 & 30.33 & 2 & 1386.7696 & 1386.7564 & 694.3855 & 0.0132 & 9.5047 & 2546.084 & 2472.861 & 332.363 & 163.528 & \text { Yes }\end{array}$ $\begin{array}{llllllllllllllll}\text { HGVVPLATYMR } & 0.98 & 38.72 & 27.47 & 30.80 & 2 & 1386.7700 & 1386.7564 & 694.3855 & 0.0136 & 9.7927 & 2590.347 & 2669.084 & 211.716 & 114.857 & \text { Yes }\end{array}$

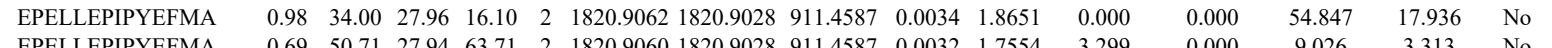

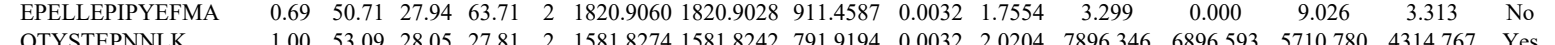
QTYSTEPNNLK QTYSTEPNNLK

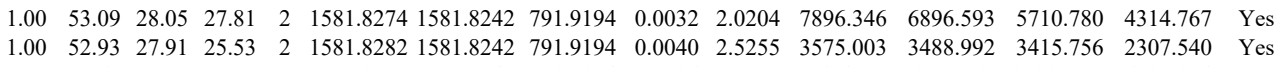
$\begin{array}{lllllllllllllll}1.00 & 52.93 & 27.91 & 25.53 & 2 & 1581.8282 & 1581.8242 & 791.9194 & 0.0040 & 2.5255 & 3575.003 & 3488.992 & 3415.756 & 2307.540 & \text { Yes } \\ 1.00 & 53.61 & 27.99 & 27.27 & 2 & 1581.8278 & 1581.8242 & 791.9194 & 0.0036 & 2.2730 & 13604.909 & 12708.720 & 10315.500 & 6228.854 & \text { Yes }\end{array}$ $\begin{array}{llllllllllllllll}1.00 & 53.91 & 27.90 & 26.18 & 2 & 1581.8286 & 1581.8242 & 791.9194 & 0.0044 & 2.7781 & 13691.267 & 12236.210 & 12064.803 & 8428.881 & \text { Yes }\end{array}$ $\begin{array}{lllllllllllllll}0.96 & 23.47 & 22.86 & 18.44 & 3 & 1347.8332 & 1347.8274 & 4502831 & 0.0058 & 4.2936 & 44384.416 & 13216.924 & 126.047 & 118.800 & \end{array}$ 

$\begin{array}{llllllllllllll} & \end{array}$

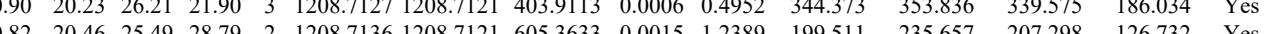

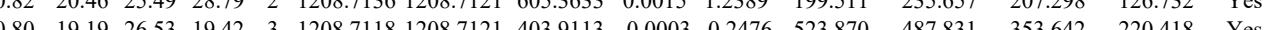

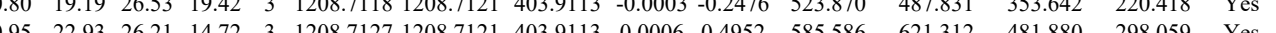

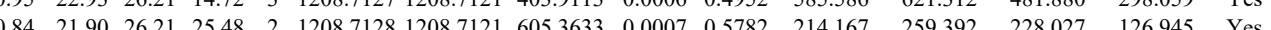

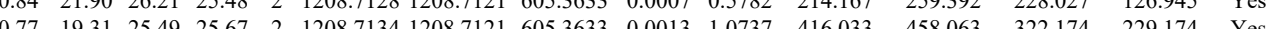

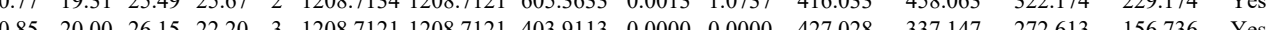

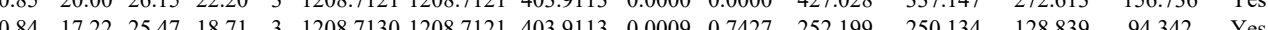
$\begin{array}{lllllllllllllll}0.87 & 18.20 & 25.51 & 15.39 & 3 & 1208.7133 & 1208.7121 & 403.9113 & 0.0012 & 0.9903 & 526.13 & 444.896 & 309.915 & 203.102 & \text { Yes }\end{array}$

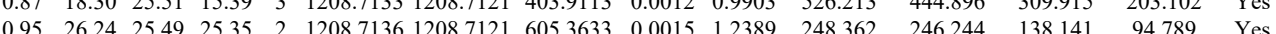

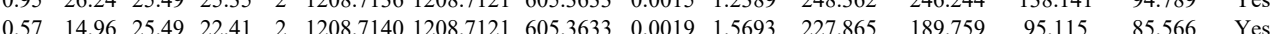
$\begin{array}{lllllllllllllll}0.85 & 17.46 & 25.47 & 15.05 & 3 & 1208.7130 & 1208.7121 & 403.9113 & 0.0009 & 0.7427 & 804.314 & 676.814 & 510.567 & 338.038 & \text { Yes }\end{array}$

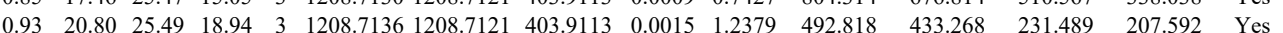

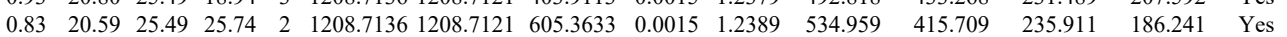
$\begin{array}{llllllllllllllll}0.74 & 18.42 & 25.49 & 27.10 & 2 & 1208.7142 & 1208.7121 & 605.3633 & 0.0021 & 1.7345 & 565.700 & 469.925 & 302.137 & 200.257 & \text { Yes }\end{array}$ $\begin{array}{lllllllllllllll}0.95 & 21.74 & 25.47 & 20.82 & 3 & 1208.7130 & 1208.7121 & 403.9113 & 0.0009 & 0.7427 & 586.930 & 494.684 & 293.262 & 232.526 & \text { Yes }\end{array}$ $\begin{array}{lllllllllllllll}0.95 & 22.39 & 25.47 & 23.01 & 3 & 1208.7130 & 1208.7121 & 403.9113 & 0.0009 & 0.7427 & 363.456 & 363.207 & 235.497 & 157.259 & \text { Yes }\end{array}$ $\begin{array}{lllllllllllllll}0.65 & 16.67 & 25.47 & 26.49 & 3 & 1208.7130 & 1208.7121 & 403.9113 & 0.0009 & 0.7427 & 127.972 & 145.775 & 101.844 & 68.860 & \text { Yes }\end{array}$ $\begin{array}{lllllllllllllll}0.80 & 16.26 & 25.47 & 19.75 & 3 & 1208.7130 & 1208.7121 & 403.9113 & 0.0009 & 0.7427 & 70.543 & 73.852 & 35.943 & 22.512 & \text { Yes }\end{array}$ $\begin{array}{lllllllllllllll}0.58 & 12.42 & 25.90 & 19.25 & 3 & 1208.7160 & 1208.7121 & 403.9113 & 0.0039 & 3.2185 & 37.294 & 54.492 & 34.024 & 26.007 & \text { Yes }\end{array}$

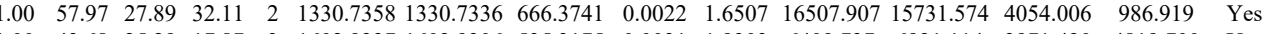
$\begin{array}{lllllllllllllllll}1.00 & 43.68 & 25.29 & 17.87 & 3 & 1602.9337 & 1602.9306 & 535.3175 & 0.0031 & 1.9303 & 6409.737 & 6921.114 & 3971.420 & 4819.700 & \text { Yes }\end{array}$ $\begin{array}{lllllllllllllll}0.66 & 19.29 & 27.84 & 20.69 & 2 & 1117.6598 & 1117.6587 & 559.8366 & 0.0011 & 0.9824 & 22.080 & 32.442 & 25.822 & 18.175 & \text { No }\end{array}$

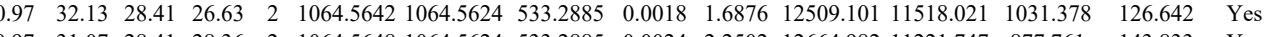
$\begin{array}{lllllllllllllll}0.97 & 31.07 & 28.41 & 28.36 & 2 & 1064.5648 & 1064.5624 & 533.2885 & 0.0024 & 2.2502 & 12664.982 & 11221.747 & 877.761 & 143.833 & \text { Yes }\end{array}$ $\begin{array}{lllllllllllllllll}0.99 & 41.01 & 27.50 & 29.12 & 2 & 1063.6244 & 1063.6148 & 532.8147 & 0.0096 & 9.0087 & 26384.134 & 23506.729 & 1150.238 & 287.899 & \text { Yes }\end{array}$ \begin{tabular}{lllllllllllllllll}
0.96 & 35.68 & 27.65 & 21.84 & 2 & 1063.6248 & 1063.6148 & 532.8147 & 0.0100 & 9.3840 & 30838.322 & 26152.821 & 908.061 & 563.186 & Yes \\
\hline .98 & 35.50 & 23.94 & 23.72 & 2 & 1 & 150.7400 & 150.6954 & 5763550 & 0.0106 & 9.1956 & 25015.062 & 21738.671 & 1315.905 & 699.383 & Yes
\end{tabular} $\begin{array}{llllllllllllllll}0.98 & 35.50 & 23.94 & 23.72 & 2 & 1150.7060 & 1150.6954 & 576.3550 & 0.0106 & 9.1956 & 25015.062 & 21738.671 & 1315.905 & 699.383 & \text { Yes }\end{array}$ $\begin{array}{lllllllllllllll}1.00 & 50.73 & 20.83 & 27.30 & 2 & 1221.7628 & 1221.7576 & 611.8861 & 0.0052 & 4.2491 & 29018.821 & 26404.810 & 1150.004 & 311.515 & \text { Yes } \\ 1.00 & 50.70 & 20.83 & 24.98 & 2 & 1221.7638 & 1221.7576 & 611.8861 & 0.006 & 5.0663 & 27418.063 & 21611.376 & 1476.893 & 227.847 & \text { Yes }\end{array}$ \begin{tabular}{lllllllllllllll}
1.00 & 0.70 & 20.83 & 24.98 & 2 & 1221.7638 & 1221.7576 & 61.8861 & 0.0062 & 5.0663 & 27418.063 & 2161.376 & 1406.893 & 227.847 & Yes \\
\hline .61 & 9.03 & 23.05 & 13.95 & 3 & 1306.7995 & 1306.7965 & 436.6061 & 0.0030 & 22904 & 8420.340 & 7061.692 & 3406.160 & 1797.157 & Yes
\end{tabular}

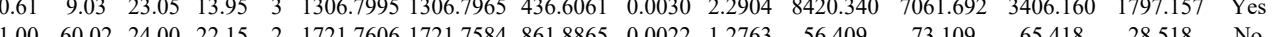
$\begin{array}{llllllllllllllll}1.00 & 53.85 & 24.49 & 28.60 & 2 & 1414.8432 & 14148418 & 708.4282 & 0.0014 & 0.9881 & 9241.697 & 8673.942 & 1286.055 & 753.902 & \text { Yes }\end{array}$

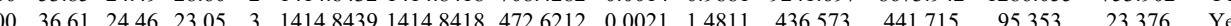
$\begin{array}{llllllllllllllll}0.99 & 28.21 & 24.46 & 18.26 & 3 & 1414.8442 & 1414.8418 & 472.6212 & 0.0024 & 1.6927 & 306.295 & 351.332 & 75.388 & 5.063 & \text { Yes }\end{array}$ $\begin{array}{lllllllllllllll}1.00 & 53.99 & 24.46 & 28.78 & 2 & 1414.8446 & 1414.8418 & 708.4282 & 0.0028 & 1.9762 & 30533.977 & 25089.679 & 3048.563 & 1445.514 & \text { Yes }\end{array}$ $\begin{array}{llllllllllllllll}1.00 & 49.92 & 24.35 & 28.38 & 2 & 1414.8430 & 1414.8418 & 708.4282 & 0.0012 & 0.8469 & 3185.638 & 2863.812 & 441.049 & 236.383 & \text { Yes } \\ 1.00 & 50.03 & 24.49 & 27.32 & 2 & 1414.8434 & 1414.8418 & 708.4282 & 0.0016 & 1.1293 & 5176.070 & 4199.586 & 503.697 & 155.904 & \text { Yes } \\ 0.87 & 15.82 & 2.3 & 16.82 & 3 & 144.8451 & 144.8418 & 472.621 & 0.013 & 2.327 & 98.32 & 89.530 & 26.748 & 12.923 & \text { Yes }\end{array}$

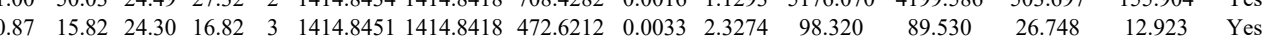
$\begin{array}{llllllllllllllll}0.99 & 38.27 & 27.96 & 23.64 & 2 & 1175.6806 & 1175.6784 & 588.8465 & 0.0022 & 1.8681 & 5792.709 & 5019.261 & 186.707 & 63.573 & \text { Yes }\end{array}$ $\begin{array}{lllllllllllllll}1.00 & 37.98 & 24.46 & 29.55 & 2 & 1414.8426 & 1414.8418 & 708.4282 & 0.0008 & 0.5646 & 1187.942 & 1136.699 & 90.460 & 56.739 & \text { Yes }\end{array}$ $\begin{array}{lllllllllllllll}1.00 & 37.66 & 24.49 & 26.37 & 2 & 1414.8434 & 1414.8418 & 708.4282 & 0.0016 & 1.1293 & 1449.615 & 1347.330 & 51.361 & 50.906 & \text { Yes }\end{array}$ $\begin{array}{lllllllllllllll}1.00 & 30.45 & 19.40 & 18.09 & 3 & 1687.0414 & 1687.0388 & 563.3535 & 0.0026 & 1.5384 & 1025.279 & 1086.601 & 569.588 & 322.977 & \text { Yes }\end{array}$ $\begin{array}{lllllllllllllll}0.57 & 33.65 & 25.31 & 22.20 & 2 & 1414.8378 & 1414.8418 & 708.4282 & -0.0040 & -2.8232 & 38.288 & 52.694 & 1.497 & 14.066 & \text { Yes }\end{array}$

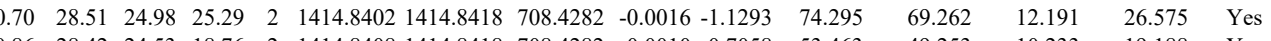

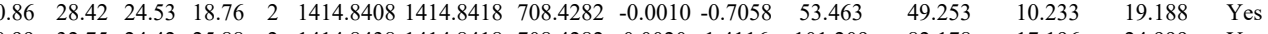

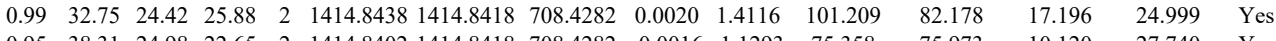

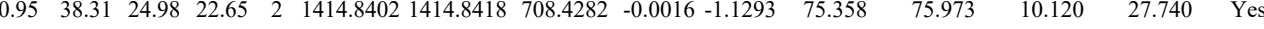

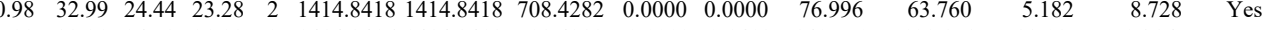

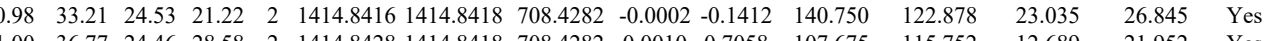

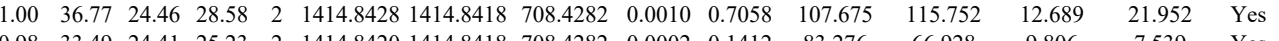

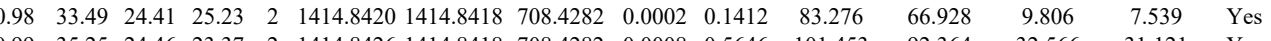
$\begin{array}{lllllllllllllll}0.99 & 35.25 & 24.46 & 23.37 & 2 & 1414.8426 & 1414.8418 & 708.4282 & 0.0008 & 0.5646 & 101.453 & 92.364 & 32.566 & 31.121 & \text { Yes }\end{array}$

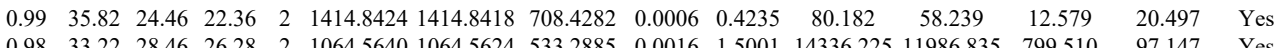

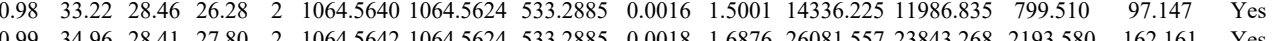
$\begin{array}{llllllllllllllll}0.99 & 34.96 & 28.41 & 27.80 & 2 & 1064.5642 & 1064.5624 & 533.2885 & 0.0018 & 1.6876 & 26081.557 & 23843.268 & 2193.580 & 162.161 & \text { Yes } \\ 0.98 & 37.08 & 27.49 & 29.53 & 2 & 1117.6694 & 1117.6587 & 559.8366 & 0.0107 & 9.5563 & 36291.445 & 36548.661 & 19344.665 & 11356.030 & \text { Yes }\end{array}$ $\begin{array}{lllllllllllllll}0.98 & 37.08 & 27.49 & 29.53 & 2 & 1117.6694 & 1117.6587 & 559.8366 & 0.0107 & 9.5563 & 36291.445 & 36548.661 & 19344.665 & 11356.030 & \text { Yes } \\ 0.98 & 32.87 & 28.41 & 26.17 & 2 & 1064.5642 & 1064.5624 & 5332885 & 0.0018 & 1.6876 & 26969.029 & 22705.434 & 1985.600 & 52.624 & \text { Yes }\end{array}$ $\begin{array}{llllllllllllllll}0.98 & 32.87 & 28.41 & 26.17 & 2 & 1064.5642 & 1064.5624 & 533.2885 & 0.0018 & 1.6876 & 26969.029 & 22705.434 & 1985.600 & 52.624 & \text { Yes } \\ 0.98 & 33.99 & 28.41 & 34.59 & 2 & 1064.5642 & 1064.5624 & 533.2885 & 0.0018 & 1.6876 & 46689.790 & 40538.217 & 3712.660 & 127.486 & \text { Yes }\end{array}$

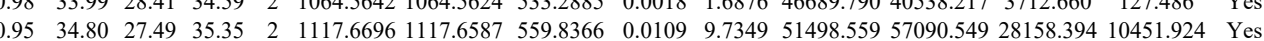

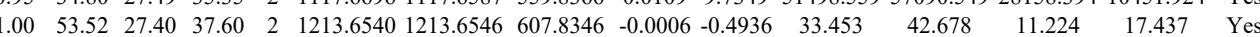
GSSNSYAIK 


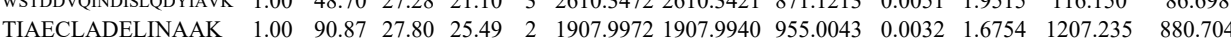

$\begin{array}{llllllllllllll} & & & \end{array}$

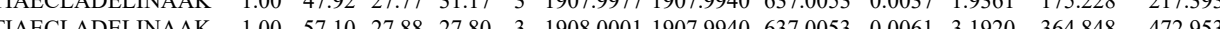

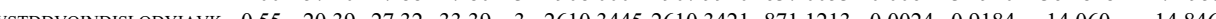

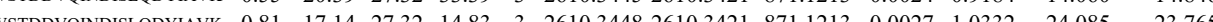

\begin{tabular}{llllllllllllll}
\hline & 1.00 & 50.12 & 27.39 & 23.58 & 3 & 2610.3451 & 26103421 & 871.1213 & 0.0030 & 1.1479 & 89.176 & 51.060
\end{tabular}

$\begin{array}{lllllllllllllll}\text { WSTDDVQNDISLQDYIAYK } & 1.00 & 59.63 & 27.36 & 19.03 & 3 & 2610.3457 & 2610.3421 & 871.1213 & 0.0036 & 1.3775 & 68.119 & 120.957\end{array}$

$\begin{array}{llllllllllllll}\text { WSTDDVONDISLODYIAVK } & 1.00 & 45.64 & 27.36 & 16.46 & 3 & 2610.3463 & 2610.3421 & 871.1213 & 0.0042 & 1.6071 & 18.830 & 15.999\end{array}$

$\begin{array}{llllllllllllll}\text { TIAECLADELINAAK } & 1.00 & 91.93 & 27.77 & 25.57 & 2 & 1907.9976 & 1907.9940 & 955.0043 & 0.0036 & 1.8848 & 792.293 & 665.334\end{array}$

TIAECLADELINAAK

TIAECLADELINAAK

$\begin{array}{lllllllllllll}1.00 & 91.93 & 27.77 & 25.57 & 2 & 1907.9976 & 1907.9940 & 955.0043 & 0.0036 & 1.8848 & 792.293 & 665.334 \\ 1.00 & 64 & 27.77 & 29.81 & 3 & 1907.9980 & 1907.9940 & 637.0053 & 0.0040 & 20931 & 242509 & 184.103\end{array}$

TIAECLADELINAAK

$\begin{array}{llllllllllll}.00 & 41.01 & 27.79 & 26.85 & 2 & 1907.9984 & 1907.9940 & 955.0043 & 0.0044 & 2.3036 & 424.513 & 228.924\end{array}$

AQCPIVER

$\begin{array}{llllllllllll}0.90 & 29.99 & 26.97 & 23.57 & 2 & 1104.5650 & 1104.5542 & 553.2844 & 0.0108 & 9.7598 & 20679.451 & 20057.350\end{array}$

TIAECLADELINAAK

TIAECLADELINAAK

YLPHSAGR

YLPHSAGR

YLPHSAGR

LTNSMMMHGR

LTNSMMMHGR

LTNSMMMHGR

LTNSMMMHGR

LTNSMMMHGR

VNQAIWLLCTGAR

VNQAIWLLCTGAR

VAILLCAR

WAIWLCTGAR

QATWLCTGAR

VNQAIWLLCTGAR

VNQAIWLLCTGAR

VNQAIWLLCTGAR

VNQAIWLLCTGAR

VNQAIWLLCTGAR

VNQAIWLLCTGAR

VNQAIWLLCTGAR

VNQAIWLLCTGAR

VNQAIWLLCTGAR

VNQAIWLLCTGAR

VNQAIWLLCTGAR

VNQAIWLLCTGAR

VNQAIWLLCTGAR

VNQAIWLLCTGAR

VNQAIWLLCTGAR

VNQAIWLLCTGAR

VNQAIWLLCTGAR 
NVPNLHVMK NVPNLHVMK NVPNLHVMK NVPNLHVMK IAIYELLFK IAIYELLFK IAIYELLFK IAIYELLFK IAIYELLFK IAIYELLFK

\section{HFYWYLTNEGI}

NVPNLHVMK

TVFVCDEDATLELK

TFNMDEYVGLPR VPTMALTVGVGTVMDAR YFTLGLPTGSTPLGCYK

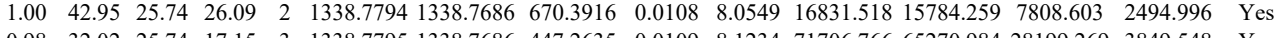
$\begin{array}{llllllllllllllll}0.98 & 32.02 & 25.74 & 17.15 & 3 & 1338.7795 & 1338.7686 & 447.2635 & 0.0109 & 8.1234 & 71706.766 & 65270.984 & 28199.269 & 3849.548 & \text { Yes } \\ 1.00 & 41.71 & 25.88 & 18.61 & 3 & 1338.7786 & 1338.7686 & 447.2635 & 0.0100 & 7.4527 & 31923299 & 27813.470 & 17385.036 & 6176.044 & \text { Yes }\end{array}$ $\begin{array}{lllllllllllllllll}1.00 & 41.71 & 25.88 & 18.61 & 3 & 1338.7786 & 1338.7686 & 447.2635 & 0.0100 & 7.4527 & 31923.299 & 27813.470 & 17385.036 & 6176.044 & \text { Yes } \\ 1.00 & 45.55 & 25.73 & 18.56 & 3 & 1338.7798 & 1338.7686 & 447.2635 & 0.0112 & 83470 & 28356.728 & 27122.539 & 17929.385 & 4693.116 & \text { Yes }\end{array}$

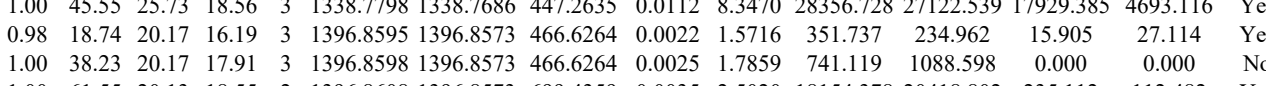
$\begin{array}{ccccccccccccccc}1.00 & 38.23 & 20.17 & 17.91 & 3 & 1396.8598 & 1396.8573 & 466.6264 & 0.0025 & 1.7859 & 741.119 & 1088.598 & 0.000 & 0.000 & \text { No } \\ 1.00 & 61.55 & 20.13 & 18.55 & 2 & 1396.8608 & 1396.8573 & 699.4359 & 0.0035 & 2.5020 & 18154.378 & 20418.802 & 235.112 & 112.482 & \text { Yes }\end{array}$ $\begin{array}{llllllllllllllll}1.00 & 61.55 & 20.13 & 18.55 & 2 & 1396.8608 & 1396.8573 & 699.4359 & 0.0035 & 2.5020 & 18154.378 & 20418.802 & 235.112 & 112.482 & \text { Yes } \\ 1.00 & 57.18 & 20.13 & 17.90 & 2 & 1396.8608 & 1396.8573 & 699.4359 & 0.0035 & 2.5020 & 61974.459 & 59439.277 & 0.000 & 411.875 & \text { No }\end{array}$ $\begin{array}{lllllllllllllll}0.55 & 25.52 & 20.17 & 38.52 & 3 & 1396.8592 & 1396.8573 & 466.6264 & 0.0019 & 1.3573 & 93.621 & 142.408 & 0.811 & 8.836 & \text { No }\end{array}$ $\begin{array}{lllllllllllllll}0.99 & 23.30 & 20.17 & 14.56 & 3 & 1396.8595 & 1396.8573 & 466.6264 & 0.0022 & 1.5716 & 136.379 & 232.752 & 23.232 & 15.183 & \text { Yes } \\ 1.00 & 61.48 & 20.17 & 18.37 & 2 & 13968602 & 13968573 & 699.4359 & 0.0029 & 2.0731 & 20414.924 & 19561.245 & 0.000 & 208.442 & \text { No }\end{array}$

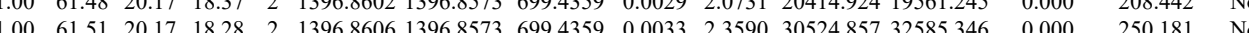
$\begin{array}{lllllllllllllll}1.00 & 57.93 & 20.17 & 17.86 & 2 & 1396.8600 & 13968573 & 699.4359 & 0.0027 & 1.9301 & 21137.474 & 20884947 & 0.000 & 101.317 & N\end{array}$ $\begin{array}{llllllllllllll}1.00 & 61.48 & 20.17 & 21.00 & 2 & 1396.8600 & 1396.8573 & 699.4359 & 0.0027 & 1.9301 & 22352.181 & 21584.013 & 0.000 & 130.627\end{array}$

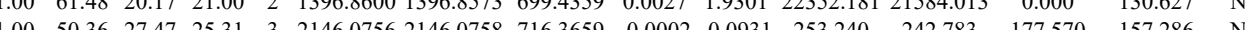
$\begin{array}{lllllllllllllll}0.98 & 27.94 & 26.09 & 14.97 & 3 & 1338.7684 & 1338.7686 & 447.2635 & -0.0002 & -0.1491 & 631.513 & 596.430 & 130.921 & 44.132 & \text { Yes }\end{array}$ $\begin{array}{llllllllllllllll}0.99 & 36.79 & 26.83 & 31.35 & 2 & 1128.6398 & 1128.6383 & 565.3264 & 0.0015 & 1.3267 & 566.794 & 426.480 & 431.864 & 357.569 & \mathrm{No}\end{array}$

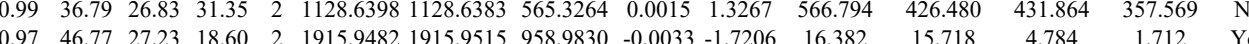
$\begin{array}{llllllllllllll}1.00 & 62.60 & 26.89 & 26.30 & 2 & 1584.7776 & 1584.7728 & 793.3937 & 0.0048 & 3.0250 & 1087.420 & 784.416 & 38.684 & 27.609\end{array}$

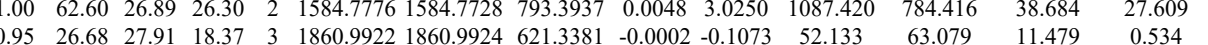

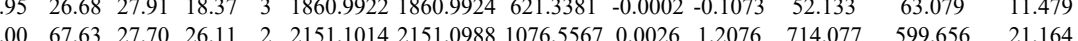

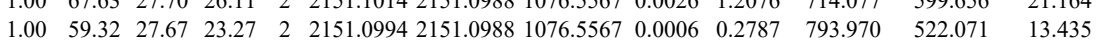

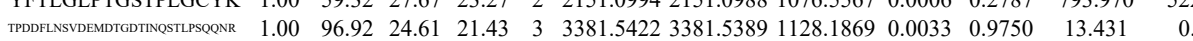

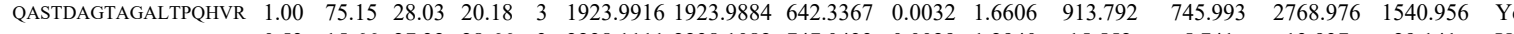
$\begin{array}{llllllllllllllll}\text { GDSETDLEALFNAVMNPK } & 0.53 & 15.66 & 27.32 & 28.66 & 3 & 2238.1111 & 2238.1082 & 747.0433 & 0.0029 & 1.2940 & 15.552 & 5.741 & 13.937 & 29.141 & \text { Yes }\end{array}$ $\begin{array}{llllllllllllllll}\text { QASTDAGTAGALTPQHVR } & 1.00 & 68.09 & 28.01 & 18.38 & 3 & 1923.9874 & 1923.9884 & 642.3367 & -0.0010 & -0.5189 & 1313.496 & 1113.110 & 4931.828 & 2058.674 & \text { Yes }\end{array}$ $\begin{array}{llllllllllllllllll}\text { QASTDAGTAGALTPQHVR } & 1.00 & 51.79 & 28.02 & 18.57 & 3 & 1923.9880 & 1923.9884 & 642.3367 & -0.0004 & -0.2076 & 1051.399 & 1109.247 & 1430.874 & 876.905 & \text { Yes }\end{array}$

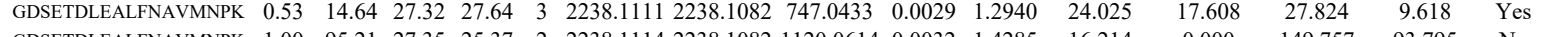

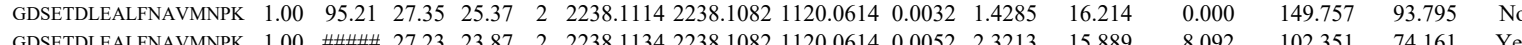

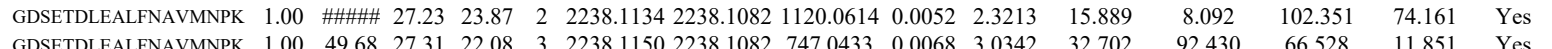

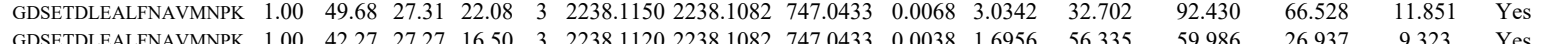
\begin{tabular}{llllllllllllllll} 
GDSEDLEALNAVMNPK & 1.00 & 42.27 & 27.27 & 16.50 & 3 & 2238.1120 & 2238.1082 & 747.0433 & 0.0038 & 1.6956 & 56.335 & 59.986 & 26.937 & 9.323 & Yes \\
\hline
\end{tabular}

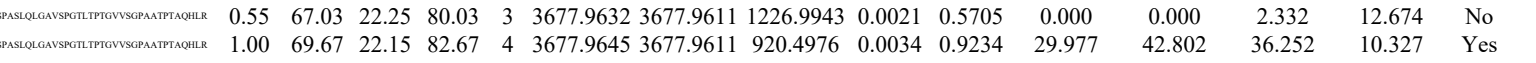

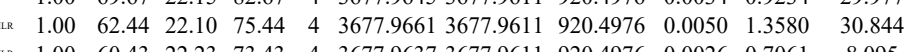
$\begin{array}{lllllllllll}1.00 & 60.43 & 22.23 & 73.43 & 4 & 3677.9637 & 3677.9611 & 920.4976 & 0.0026 & 0.7061 & 8.095\end{array}$ $\begin{array}{lllllllllllllll}1.00 & 13.34 & 22.23 & 13.88 & 4 & 3677.9637 & 3677.9611 & 920.4976 & 0.0026 & 0.7061 & 2.286 & 5.528 & 6.103 & 4.139 & \text { Yes } \\ 1.00 & 35.40 & 22.30 & 48.40 & 4 & 3677.9617 & 3677.9611 & 920.4976 & 0.0006 & 0.1630 & 15.056 & 12.260 & 14.345 & 7.382 & \text { Yes }\end{array}$ $\begin{array}{lllllllllllllllll} & & & \end{array}$

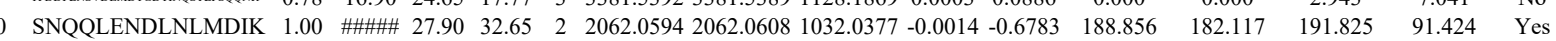
$\begin{array}{llllllllllllllll}\text { SNQQLENDLNLMDIK } & 1.00 & 91.58 & 28.06 & 29.36 & 2 & 2062.0614 & 2062.0608 & 1032.0377 & 0.0006 & 0.2907 & 289.577 & 538.801 & 560.140 & 416.381 & \text { Yes }\end{array}$ \begin{tabular}{llllllllllllllll} 
LNYDVTPEQALAHEEVK & 0.96 & 29.64 & 26.47 & 15.95 & 3 & 2226.1858 & 2226.1776 & 743.0665 & 0.0082 & 3.6784 & 4536.446 & 5780.169 & 2618.551 & 2347.414 & Yes \\
\hline
\end{tabular}

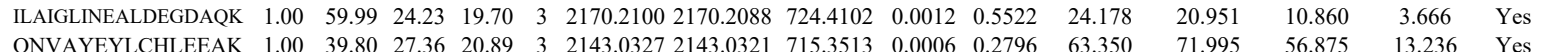

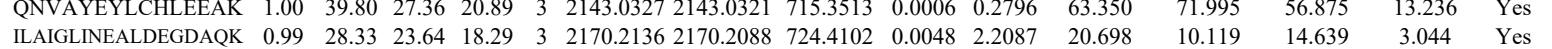

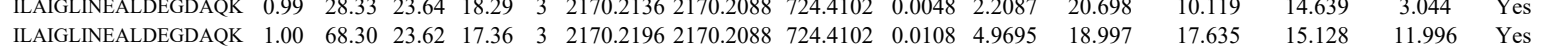

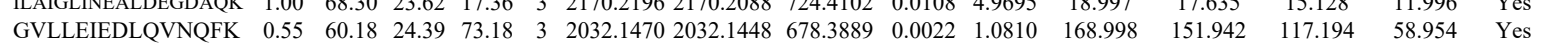

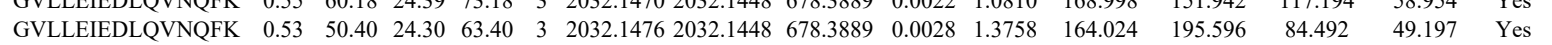

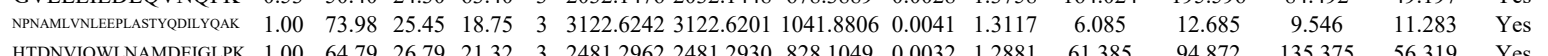
\begin{tabular}{llllllllllllllll} 
HTDNVIQWLNAMDEIGLPK & 1.00 & 64.79 & 26.79 & 21.32 & 3 & 2481.2962 & 2481.2930 & 828.1049 & 0.0032 & 1.2881 & 61.385 & 94.872 & 135.375 & 56.319 & Yes \\
\hline
\end{tabular} $\begin{array}{lllllllllllllllll}\text { HTDNVIQWLNAMDEIGLPK } & 1.00 & 49.92 & 26.73 & 20.35 & 3 & 2481.2989 & 2481.2930 & 828.1049 & 0.0059 & 2.3749 & 67.804 & 67.856 & 150.983 & 26.463 & \text { No }\end{array}$ $\begin{array}{llllllllllllllll}\text { TGGLANELSVEAALHAAVANNEADR } & 0.96 & 13.58 & 23.56 & 14.83 & 4 & 3101.6841 & 3101.6842 & 776.4283 & -0.0001 & -0.0322 & 14.191 & 11.211 & 6.414 & 6.075 & \text { Yes } \\ \end{array}$

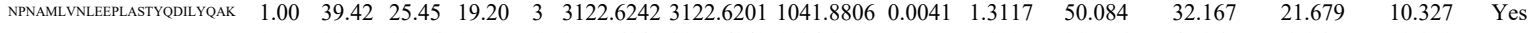
$\begin{array}{lllllllllllllllll}\text { TGGLANELSVEAALHAAVININEAIDR } & 1.00 & 89.85 & 23.56 & 20.75 & 3 & 3101.6842 & 3101.6842 & 1034.9020 & 0.0000 & 0.0000 & 28.506 & 45.360 & 2.367 & 13.910 & \text { Yes }\end{array}$

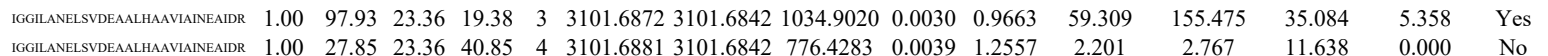
$\begin{array}{lllllllllllllll} & & \end{array}$

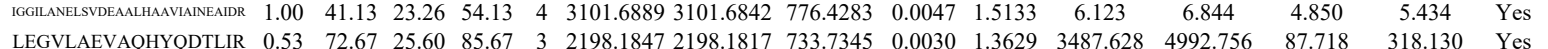

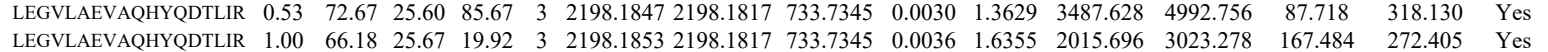
$\begin{array}{llllllllllllllll} & \end{array}$

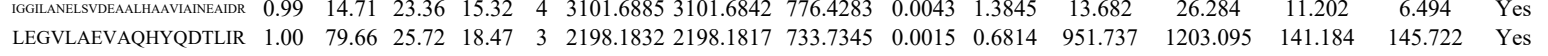
$\begin{array}{lllllllllllllll} & \end{array}$

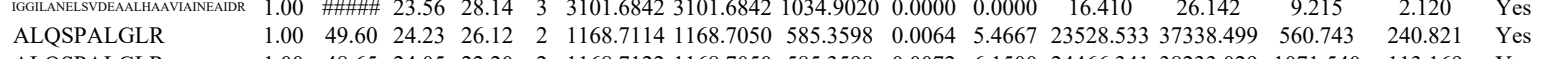

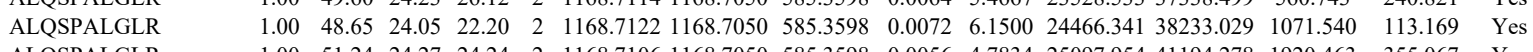

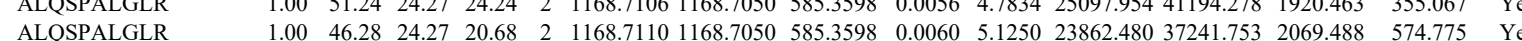


$\begin{array}{llllllllllll}1.00 & 81.14 & 26.38 & 20.77 & 3 & 2984.4502 & 2984.4485 & 995.8234 & 0.0017 & 0.5690 & 37.024\end{array}$

$\begin{array}{llllllllllllll}0.56 & 17.83 & 26.98 & 30.62 & 3 & 1344.7621 & 1344.7605 & 449.2608 & 0.0016 & 1.1871 & 27759.434 & 31344.737 & 3432.013 & 10 \\ 0.91 & 22.06 & 27.04 & 26.56 & 3 & 1344.7645 & 1344.7605 & 449.2608 & 0.0040 & 2.9678 & 34698.579 & 39301.157 & 3156.510\end{array}$

FLWMVR

FLWMVR

FLWMVR

FLWMVR

FLWMVR

FLWMVR

FLWMVR

FLWMVR

FLWMVR

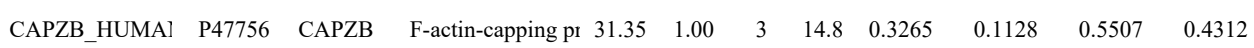

LEVEANNAP

GGSTMNLGSLTR SGSGTMNLGGSLTR SGSGTMNLGGSLTR

SGSGTMNLGGSLTR

YDPLEDGAMPSAR

ECGVGVIVTPEQIEEAVEAAI

\section{ECGVGVIVTPEOIEE,}

GFHQVPFAPIVFIER GFHQVPFAPIVFIER ANNGICFLR LAWGQPVGLR LAWGQPVGLR ATGILLYGLASR ILQLVATGAVR ILQLVATGAVR ATGILLYGLASR ATGILLYGLASR LFTLTALR LFTLTALR ILQLVATGAVR ILQLVATGAVR ILQLVATGAVR
ATGILLYGLASR ATGILLYGLASR LFTLTALR LFTLTALR ILQLVATGAVR LFTLTALR $\begin{array}{lllllllllll}45.50 & 25.00 & 23.49 & 3 & 2159.1910 & 2159.1894 & 720.7371 & 0.0016 & 0.7400 & 20.7\end{array}$ $\begin{array}{llllllllllll}1.00 & 45.10 & 25.00 & 18.71 & 3 & 2159.1913 & 2159.1894 & 720.7371 & 0.0019 & 0.8787 & 8.921 & \end{array}$ $\begin{array}{lllllllllll}2.13 & 30.95 & 2 & 994.5566 & 994.5544 & 498.2845 & 0.0022 & 2.2076 & 3412.209 & 3779.941 & 136.660\end{array}$ $\begin{array}{llllllllllllll}0.92 & 25.86 & 27.13 & 31.14 & 2 & 994.5566 & 994.5544 & 498.2845 & 0.0022 & 2.2076 & 2665.922 & 3355.742 & 145.257 & 2\end{array}$ $\begin{array}{llllllllllllll}0.76 & 19.64 & 26.33 & 15.86 & 2 & 1010.5510 & 1010.5493 & 506.2819 & 0.0017 & 1.6789 & 793.023 & 922.896 & 48.955\end{array}$ $\begin{array}{llllllllllllll}0.91 & 25.41 & 27.01 & 30.69 & 2 & 994.5558 & 994.5544 & 498.2845 & 0.0014 & 1.4048 & 808.855 & 834.108 & 35.797\end{array}$ $\begin{array}{llllllllllllllll}0.91 & 25.41 & 27.13 & 30.69 & 2 & 994.5560 & 994.5544 & 498.2845 & 0.0016 & 1.6055 & 539.791 & 584.037 & 37.350\end{array}$ $\begin{array}{llllllllllllll}0.86 & 22.41 & 26.29 & 15.32 & 2 & 1010.5514 & 1010.5493 & 506.2819 & 0.0021 & 2.0739 & 353.928 & 392.265 & 49.880\end{array}$ $\begin{array}{llllllllllllll}0.89 & 24.66 & 27.14 & 29.95 & 2 & 994.5556 & 994.5544 & 498.2845 & 0.0012 & 1.2041 & 328.299 & 433.485 & 18.612 \\ 0.88 & 23.67 & 27.14 & 29.18 & 2 & 994.556 & 994.554 & 498.245 & 0.002 & 1.204 & 19.57 & 23.447 & 14.219\end{array}$ $\begin{array}{lllllllllllllll}0.86 & 23.67 & 27.14 & 29.18 & 2 & 994.5556 & 994.5544 & 498.2845 & 0.0012 & 1.2041 & 197.657 & 239.447 & 14.219\end{array}$

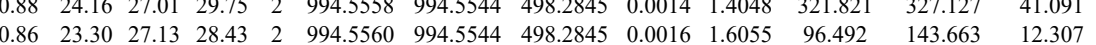

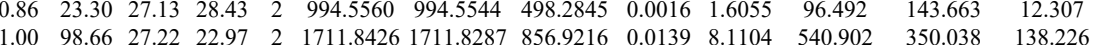

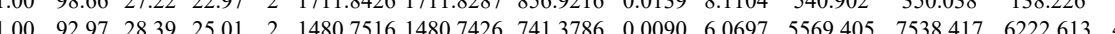

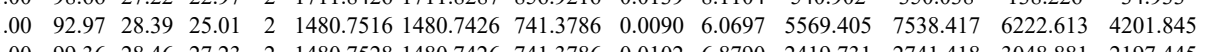

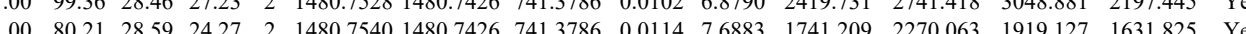

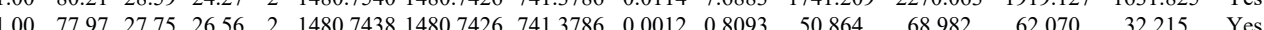
$\begin{array}{lllllllllllllll}0.96 & 33.26 & 27.36 & 23.59 & 2 & 1496.7374 & 1496.7375 & 749.3760 & -0.0001 & -0.0667 & 3.008 & 9.292 & 1.238 & 4.119 & \text { No }\end{array}$ $\begin{array}{lllllllllllllll}1.00 & 67.28 & 26.67 & 27.64 & 2 & 1661.8000 & 1661.7841 & 831.8993 & 0.0159 & 9.5564 & 3842.620 & 4745.291 & 4867.319 & 5378.930 & \text { Yes }\end{array}$ $\begin{array}{lllllllllllllll}0.98 & 39.66 & 26.67 & 25.69 & 2 & 1661.8000 & 1661.7841 & 831.8993 & 0.0159 & 9.5564 & 679.338 & 952.400 & 1126.125 & 851.828 & \text { Yes }\end{array}$

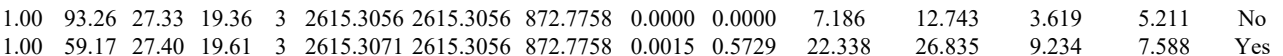

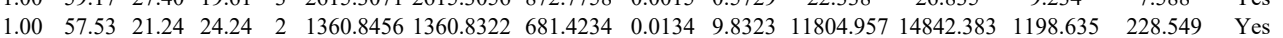
$\begin{array}{lllllllllllllll}1.00 & 33.17 & 26.11 & 19.62 & 3 & 1900.0504 & 1900.0481 & 634.3566 & 0.0023 & 1.2086 & 772.632 & 762.193 & 313.201 & 70.051 & \text { Yes }\end{array}$ $\begin{array}{lllllllllllllll}1.00 & 30.95 & 26.17 & 17.69 & 3 & 1900.0507 & 1900.0481 & 634.3566 & 0.0026 & 1.3662 & 649.753 & 737.499 & 270.061 & 103.548 & \text { Yes }\end{array}$ $\begin{array}{lllllllllllllll}1.00 & 49.66 & 27.21 & 27.59 & 2 & 1196.5934 & 1196.5916 & 599.3031 & 0.0018 & 1.5017 & 2455.384 & 2881.432 & 409.599 & 147.814 & \text { Yes }\end{array}$ $\begin{array}{llllllllllllllll}1.00 & 45.59 & 26.12 & 20.31 & 2 & 1239.7220 & 1239.7210 & 620.8678 & 0.0010 & 0.8053 & 20743.975 & 23596.029 & 337.060 & 219.812 & \text { Yes }\end{array}$ $\begin{array}{lllllllllllllll}1.00 & 40.83 & 25.90 & 20.51 & 2 & 1239.7230 & 1239.7210 & 620.8678 & 0.0020 & 1.6106 & 12184.249 & 12513.275 & 139.584 & 141.478 & \text { Yes }\end{array}$ $\begin{array}{lllllllllllllllll}1.00 & 69.83 & 25.91 & 30.29 & 2 & 1377.8116 & 1377.8102 & 689.9124 & 0.0014 & 1.0146 & 1670.905 & 1929.152 & 261.633 & 47.746 & \text { Yes }\end{array}$ $\begin{array}{lllllllllllllll}1.00 & 58.16 & 22.01 & 30.39 & 2 & 1283.8062 & 1283.8047 & 642.9096 & 0.0015 & 1.1666 & 1138.636 & 1239.166 & 20.032 & 13.879 & \text { Yes }\end{array}$ $\begin{array}{lllllllllllllll}1.00 & 57.89 & 21.21 & 31.60 & 2 & 1283.8066 & 1283.8047 & 642.9096 & 0.0019 & 1.4777 & 678.616 & 752.867 & 4.649 & 18.019 & \text { Yes }\end{array}$ $\begin{array}{lllllllllllllll}1.00 & 78.69 & 26.22 & 32.70 & 2 & 1377.8102 & 1377.8102 & 689.9124 & 0.0000 & 0.0000 & 1571.482 & 1877.427 & 157.962 & 50.519 & \text { Yes }\end{array}$

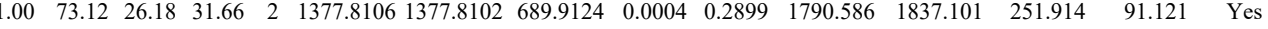
$\begin{array}{lllllllllllllll}1.00 & 44.48 & 26.44 & 28.96 & 2 & 1077.6676 & 1077.6668 & 539.8407 & 0.0008 & 0.7410 & 2960.982 & 3607.427 & 100.350 & 3.053 & \text { Yes }\end{array}$ $\begin{array}{lllllllllllllll}1.00 & 42.26 & 26.02 & 23.98 & 2 & 1077.6680 & 1077.6668 & 539.8407 & 0.0012 & 1.1114 & 3245.499 & 3652.386 & 120.610 & 10.329 & \text { Yes }\end{array}$ $\begin{array}{lllllllllllllll}1.00 & 55.99 & 22.17 & 30.38 & 2 & 1283.8050 & 1283.8047 & 642.9096 & 0.0003 & 0.2333 & 5125.161 & 6645.621 & 122.847 & 42.837 & \text { Yes }\end{array}$ $\begin{array}{llllllllllllllll}1.00 & 59.99 & 22.10 & 27.63 & 2 & 1283.8054 & 1283.8047 & 642.9096 & 0.0007 & 0.5444 & 3438.149 & 3577.287 & 35.890 & 25.284 & \text { Yes }\end{array}$

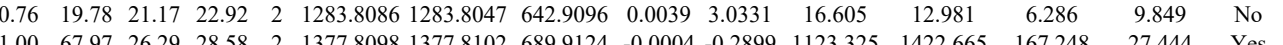

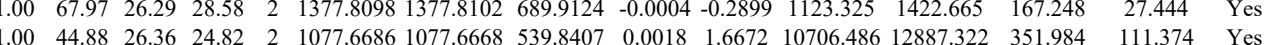
$\begin{array}{llllllllllllllll}1.00 & 44.88 & 26.36 & 24.82 & 2 & 1077.6686 & 1077.6668 & 539.8407 & 0.0018 & 1.6672 & 10706.486 & 12887.322 & 351.984 & 111.374 & \text { Yes } \\ 1.00 & 38.50 & 26.34 & 23.01 & 2 & 1077.6692 & 1077.6668 & 539.8407 & 0.0024 & 2.2229 & 21146.729 & 26120.784 & 543.069 & 75.373 & \text { Yes }\end{array}$ $\begin{array}{llllllllllllllll}1.00 & 38.50 & 26.34 & 23.01 & 2 & 1077.6692 & 1077.6668 & 539.8407 & 0.0024 & 2.2229 & 21146.729 & 26120.784 & 543.069 & 75.373 & \text { Yes } \\ 1.00 & 61.57 & 22.04 & 26.69 & 2 & 1283.8040 & 1283.8047 & 642.9096 & -0.0007 & -0.5444 & 3769.008 & 4228.767 & 79.363 & 0.009 & \text { No }\end{array}$ $\begin{array}{lllllllllllllll}1.00 & 61.57 & 22.04 & 26.69 & 2 & 1283.8040 & 1283.8047 & 642.9096 & -0.0007 & -0.5444 & 3769.008 & 4228.767 & 79.363 & 0.000 & \text { No } \\ 1.00 & 55.93 & 22.10 & 29.08 & 2 & 1283.8044 & 1283.8047 & 642.9096 & -0.0003 & -0.2333 & 2921.561 & 3574.750 & 57.072 & 97.592 & \text { Yes } \\ 1.00\end{array}$

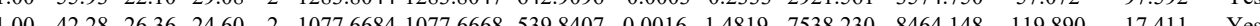
$\begin{array}{lllllllllllll}1.00 & 43.15 & 26.36 & 24.44 & 2 & 1077.6684 & 1077.6668 & 539.8407 & 0.0016 & 1.4819 & 6006.001 & 7561.836 & 207.183\end{array}$ 


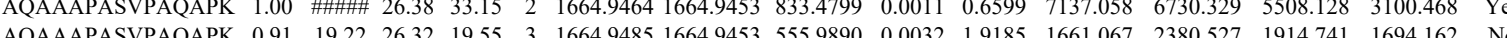

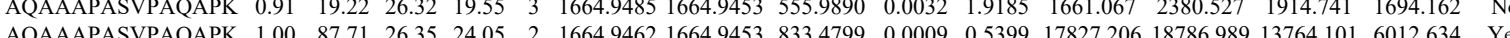
$\begin{array}{llllllllllllllll}\text { AQAAAPASPQAPK } & 1.00 & 87.71 & 26.35 & 24.05 & 2 & 1664.9462 & 1664.9453 & 833.4799 & 0.0009 & 0.5399 & 17827.206 & 18786.989 & 13764.101 & 6012.634 & \text { Yes }\end{array}$

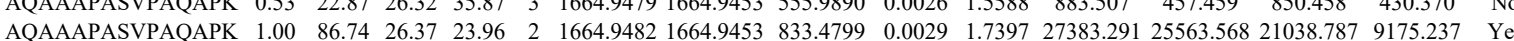
$\begin{array}{llllllllllllllll}\text { AQAAAPASVPAQAPK } & 1.00 & 48.67 & 26.18 & 27.97 & 3 & 1664.9494 & 1664.9453 & 555.9890 & 0.0041 & 2.4581 & 926.107 & 752.124 & 438.327 & 238.112 & \text { Y }\end{array}$

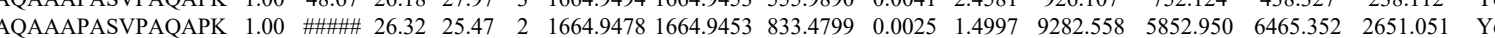

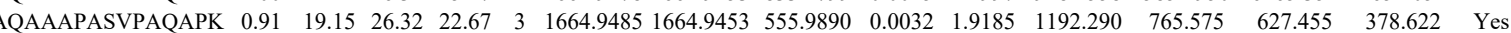
$\begin{array}{lllllllllllllll} & \end{array}$ $\begin{array}{llllllllllllllllll}\text { AQAAAPASVPAQAPK } & 1.00 & 37.62 & 26.18 & 19.45 & 3 & 1664.9497 & 1664.9453 & 555.9890 & 0.0044 & 2.6379 & 806.670 & 806.009 & 445.875 & 449.268 & \text { Yes }\end{array}$

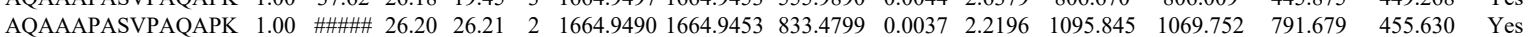

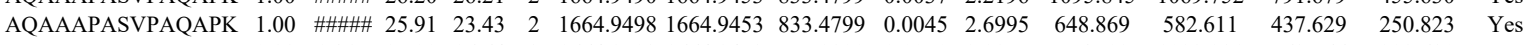
$\begin{array}{lllllllllllllllll}\text { AQAAAPASVPAQAPK } & 0.98 & 26.85 & 25.90 & 16.64 & 3 & 1664.9503 & 1664.9453 & 555.9890 & 0.0050 & 2.9977 & 756.702 & 1022.231 & 563.766 & 292.680 & \text { Yes }\end{array}$ $\begin{array}{lllllllllllllllll}\text { LAYIAHPK } & 0.84 & 20.20 & 23.60 & 21.66 & 3 & 1199.7343 & 1199.7270 & 400.9163 & 0.0073 & 6.0694 & 8400.106 & 7361.444 & 917.343 & 1208.043 & \text { No }\end{array}$

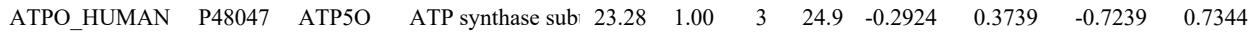

PPCE_HUMAN P48147 PREP

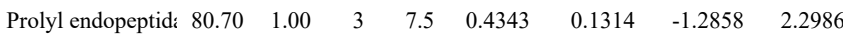

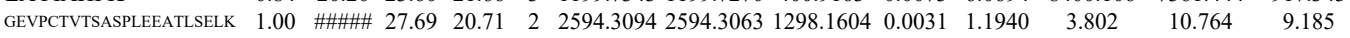
$\begin{array}{llllllllllllll}\text { GEVPCTVTSASPLEEATLSELK } & 1.00 & 63.49 & 27.64 & 17.04 & 3 & 2594.3113 & 2594.3063 & 865.7760 & 0.0050 & 1.9251 & 25.712 & 4.109 & 0.000\end{array}$ $\begin{array}{lllllllllllllll}\text { GEVPCTVTSASPLEEATLSELK } & 0.99 & 31.82 & 27.65 & 18.49 & 3 & 2594.3077 & 2594.3063 & 865.7760 & 0.0014 & 0.5390 & 50.087 & 57.914 & 43.107 \\ \text { LVRPPVQVYGIEGR } & 0.55 & 34.76 & 23.60 & 47.76 & 3 & 1726.0030 & 1726.0012 & 576.3410 & 0.0018 & 1.0410 & 2220.157 & 2660.366 & 809.274 & \end{array}$

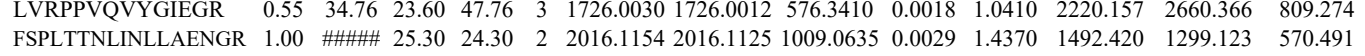
$\begin{array}{llllllllllllll}\text { FSPLTTNLINLLAENGR } & 1.00 & \text { \#\#\#\# } 25.30 & 23.42 & 2 & 2016.1154 & 2016.1125 & 1009.0635 & 0.0029 & 1.4370 & 1494.905 & 1038.357 & 679.101\end{array}$

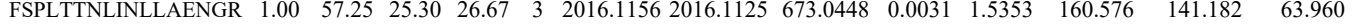
$\begin{array}{lllllllllllllll}\text { FSPLTTNLINLLAENGR } & 1.00 & 46.31 & 25.39 & 20.35 & 3 & 2016.1171 & 2016.1125 & 673.0448 & 0.0046 & 2.2782 & 160.333 & 164.379 & 48.007\end{array}$

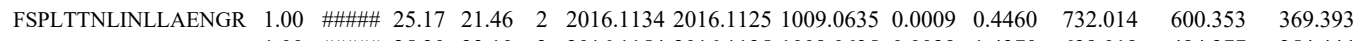

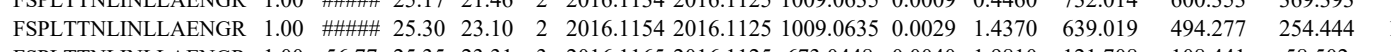

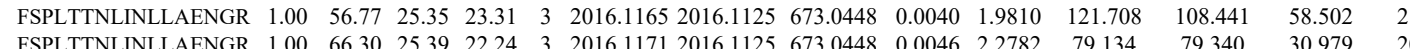

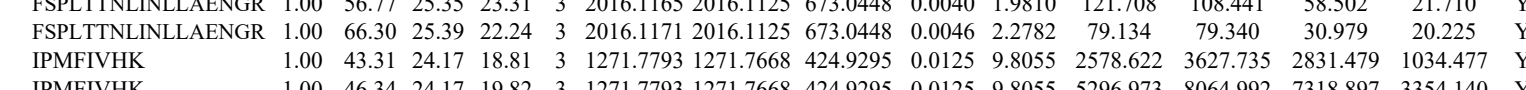
IPMFIVHK IPMFIVHK

IPMFIVHK

ITVPFLEQCPIR

ITVPFLQPCPR

ITVPFELCPIR

ITVPELCTR

ITVPFLEQCPIR

FIATLQYIVGR

FIATLOYIVGR

NSNILEDLETLR

NSNILEDLETLR

NSNILEDLETLR

NSNILEDLETLR

GVQLQTHPNVDK

GVQLQTHPNVDK

GVQLQTHPNVDK

VAPAPARPSGPSK

VAPAPARPSGPSK

VAPAPARPSGPSK

VAPAPARPSGPSK

VAPAPARPSGPSK

VAPAPARPSGPSK

VAPAPARPSGPSK

IEGLLAAFPK

IEGLLAAFPK

IEGLLAAFPK

LFTAESLIGLK

VAPAPARPSGPSK

VAPAPARPSGPSK

VAPAPARPSGPSK

VAPAPARPSGPSK

VLLAAAVCTK $\begin{array}{llllllllllllllllll}1.00 & 43.31 & 24.17 & 18.81 & 3 & 1271.7793 & 1271.7668 & 424.9295 & 0.0125 & 9.8055 & 2578.622 & 3627.735 & 2831.479 & 1034.477 & \text { Yes } & \\ 1.00 & 43.31 & 24.23 & 17.98 & 3 & 1271.7793 & 1271.7668 & 424.9295 & 0.0125 & 9.855 & 529.973 & 8064.992 & 7318.897 & 3354.140 & \text { Yes }\end{array}$

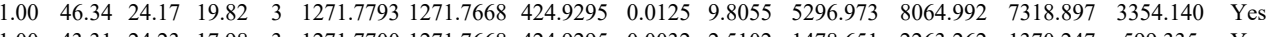
$\begin{array}{llllllllllllllll}1.00 & 43.31 & 24.23 & 17.98 & 3 & 1271.7700 & 1271.7668 & 424.9295 & 0.0032 & 2.5102 & 1478.651 & 2263.262 & 1370.247 & 599.335 & \text { Yes } \\ 1.00 & 49.77 & 24.23 & 19.40 & 3 & 1271.7703 & 1271.7668 & 42.9295 & 0.0035 & 2.7455 & 3008.806 & 3893.418 & 3417.374 & 1049.164 & \text { Yes }\end{array}$

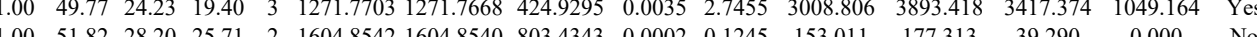

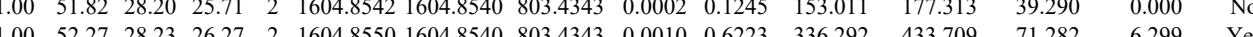

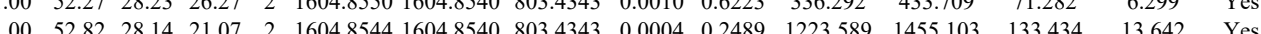
$\begin{array}{llllllllllllll}13.642 & \text { Yes }\end{array}$

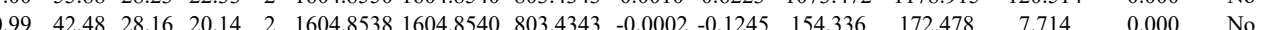

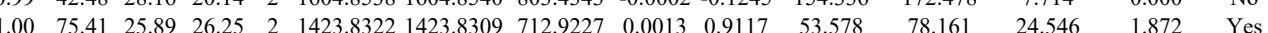

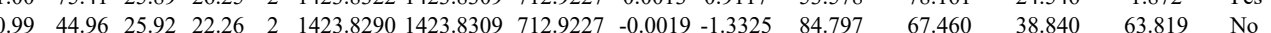

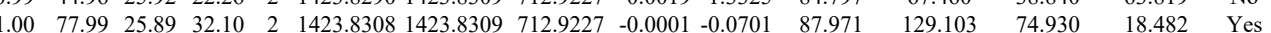
$\begin{array}{lllllllllllllll}1.00 & 70.68 & 27.92 & 28.18 & 2 & 1559.8292 & 1559.8277 & 780.9211 & 0.0015 & 0.9604 & 334.021 & 454.402 & 49.784 & 17.332 & \text { Yes }\end{array}$ $\begin{array}{lllllllllllllll}1.00 & 71.18 & 27.85 & 28.44 & 2 & 1559.8300 & 1559.8277 & 780.9211 & 0.0023 & 1.4726 & 351.088 & 346.457 & 55.527 & 17.828 & \text { Yes }\end{array}$ $\begin{array}{lllllllllllllll}1.00 & 62.82 & 27.90 & 26.74 & 2 & 1559.8290 & 1559.8277 & 780.9211 & 0.0013 & 0.8323 & 629.959 & 817.121 & 63.199 & 52.624 & \text { Yes }\end{array}$

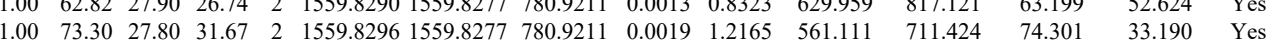
$\begin{array}{lllllllllllllll}0.99 & 30.93 & 27.24 & 19.94 & 3 & 1622.9014 & 1622.8984 & 541.9734 & 0.0030 & 1.8451 & 9775.403 & 11598.930 & 9452.738 & 9915.328 & \text { No }\end{array}$ $\begin{array}{lllllllllllllll}0.95 & 23.81 & 27.23 & 16.79 & 3 & 1622.9023 & 1622.8984 & 541.9734 & 0.0039 & 2.3986 & 14181.464 & 14980.149 & 12770.980 & 9449.651 & \text { No }\end{array}$ $\begin{array}{lllllllllllllll}0.99 & 29.95 & 27.24 & 21.24 & 3 & 1622.9017 & 1622.8984 & 541.9734 & 0.0033 & 2.0296 & 8921.948 & 8345.239 & 6510.322 & 5766.598 & \text { No }\end{array}$

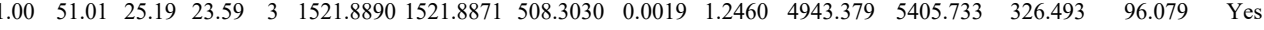
$\begin{array}{lllllllllllllll}.99 & 34.19 & 25.28 & 28.71 & 2 & 1521.8896 & 1521.8871 & 761.9508 & 0.0025 & 1.6405 & 794.289 & 788.194 & 49.141 & 22.231 & \text { Yes }\end{array}$

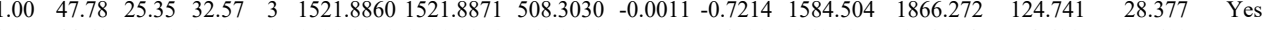

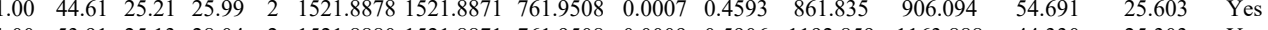

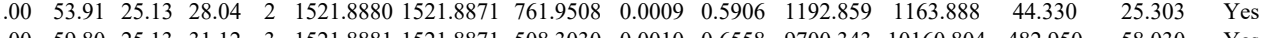
$\begin{array}{lllllllllllllll}1.00 & 59.80 & 25.13 & 31.12 & 3 & 1521.8881 & 1521.8871 & 508.3030 & 0.0010 & 0.6558 & 9700.343 & 10160.804 & 482.950 & 58.030 & \text { Yes }\end{array}$ \begin{tabular}{llllllllllllllll}
1.00 & 60.21 & 23.82 & 27.82 & 2 & 1345.8242 & 1345.8213 & 673.9179 & 0.0029 & 2.1516 & 6028.431 & 5814.286 & 319.927 & 75.833 & Yes \\
\hline
\end{tabular}

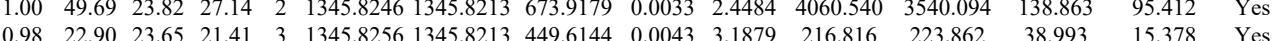
$\begin{array}{llllllllllllllll}.00 & 4.4 & 23.65 & 21.41 & 3 & 1345.8256 & 1345.8213 & 449.6144 & 0.0043 & 3.1879 & 216.816 & 223.862 & 38.993 & 15.378 & \text { Yes }\end{array}$ $\begin{array}{lllllllllllllll}1.00 & 47.27 & 25.40 & 31.53 & 2 & 1478.928 & 1478.8952 & 740.4549 & 0.0076 & 5.1320 & 7241.739 & 7105.328 & 1165.977 & 3837.704 & \text { No }\end{array}$

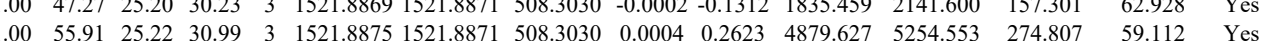

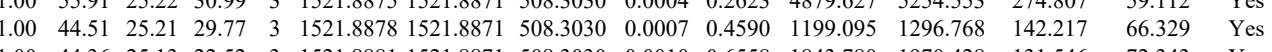

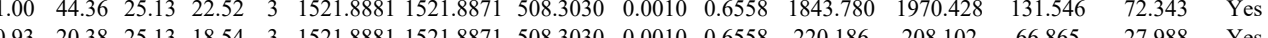

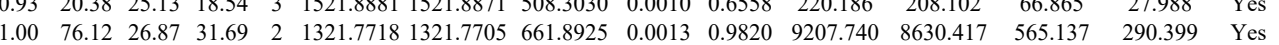

Table S-3 page 257 of 499 


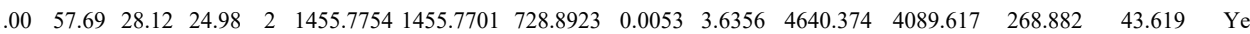
$\begin{array}{lllllllllllllll}1.00 & 49.74 & 27.75 & 34.94 & 2 & 1211.6718 & 1211.6641 & 606.8393 & 0.0077 & 6.3443 & 9549.592 & 9450.337 & 3057.960 & 1213.615 & \text { Ye }\end{array}$

VAIEHLDK

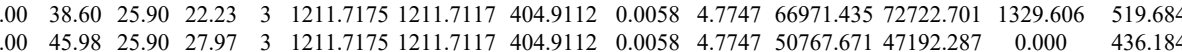

VAIEHLDK $\begin{array}{lllllllllllllll}1.00 & 49.87 & 25.83 & 30.09 & 2 & 1211.7182 & 1211.7117 & 606.8631 & 0.0065 & 5.3554 & 26745.111 & 31974.347 & 686.292 & 1453.311 & \text { Yes } \\ 1.00 & 49.76 & 25.83 & 30.05 & 2 & 1211.7182 & 1211.7117 & 606.8631 & 0.0065 & 5.3554 & 33017.132 & 33817.705 & 614.567 & 2375.198 & \text { Y }\end{array}$

VAIEHLDK

TSLGPNGLDK

TSLGPNGLDK

TSLGPNGLDK

TSLGPNGLDK

DFSHPQMPK

ISDSVLVDIK

ISDSVLVDIK

DFSHPQMPK

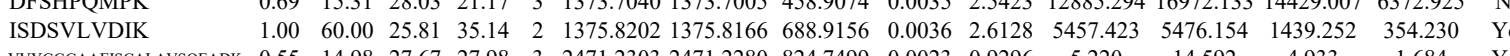

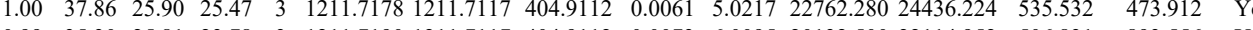
$\begin{array}{lllllllllllllll}0.99 & 35.30 & 25.81 & 23.78 & 3 & 1211.7190 & 1211.7117 & 404.9112 & 0.0073 & 6.0095 & 20132.500 & 22114.952 & 506.831 & 893.556 & \text { Yes }\end{array}$ $\begin{array}{llllllllllllllll}1.00 & 59.37 & 27.40 & 33.03 & 2 & 1288.7326 & 1288.7231 & 645.3688 & 0.0095 & 7.3601 & 48615.300 & 43804.696 & 7493.308 & 3062.827 & \text { Yes } & \\ \end{array}$

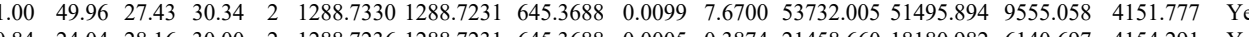
$\begin{array}{llllllllllllllll}0.84 & 24.04 & 28.16 & 30.00 & 2 & 1288.7236 & 1288.7231 & 645.3688 & 0.0005 & 0.3874 & 21458.660 & 18180.982 & 6140.697 & 4154.291 & \text { Yes }\end{array}$ $\begin{array}{llllllllllllllll}0.94 & 32.99 & 27.64 & 23.82 & 2 & 1288.7274 & 1288.7231 & 645.3688 & 0.0043 & 3.3314 & 27192.287 & 24159.642 & 9213.429 & 3866.903 & \text { Yes }\end{array}$

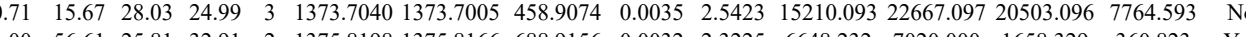
$\begin{array}{lllllllllllllll}1.00 & 56.61 & 25.81 & 32.91 & 2 & 1375.8198 & 1375.8166 & 688.9156 & 0.0032 & 2.3225 & 6648.232 & 7020.000 & 1658.329 & 360.823 & \text { Yes }\end{array}$ $\begin{array}{llllllllllllllll}0.91 & 20.97 & 27.97 & 21.11 & 3 & 1373.7034 & 1373.7005 & 458.9074 & 0.0029 & 2.1064 & 14924.937 & 17857.116 & 14664.087 & 8492.260 & \text { No }\end{array}$ $\begin{array}{lllllllllllllll} & 247.2303 & 2471.2280 & 824.7499 & 0.0023 & 0.9296 & 5.220 & 14.592 & 4.933 & 1.684 & \text { Yes }\end{array}$ $\begin{array}{lllllllllll} & \end{array}$ $\begin{array}{llllllllllllll} & \end{array}$

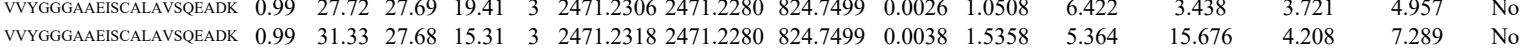

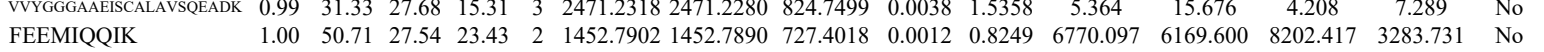

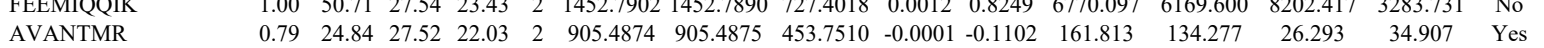
$\begin{array}{llllllllllllllll}\text { AVANTMR } & 0.52 & 19.54 & 27.52 & 19.92 & 2 & 905.4878 & 905.4875 & 453.7510 & 0.0003 & 0.3306 & 134.095 & 157.751 & 35.463 & 17.526 & \text { Yes }\end{array}$

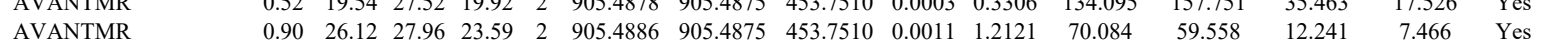
$\begin{array}{llllllllllllllll}\text { QMAEIAVNAVLTVADMER } & 0.93 & 23.39 & 27.94 & 15.20 & 3 & 2104.0792 & 2104.0778 & 702.3665 & 0.0014 & 0.6644 & 58.489 & 68.164 & 65.472 & 34.203 & \text { No }\end{array}$

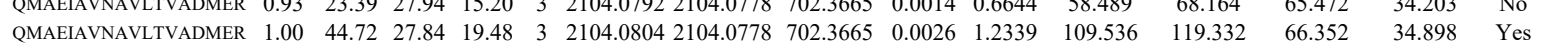
$\begin{array}{llllllllllllllll}\text { QMAEIAVNAVLTVADMER } & 1.00 & 32.67 & 27.84 & 15.42 & 3 & 2104.0807 & 2104.0778 & 702.3665 & 0.0029 & 1.3763 & 83.558 & 93.600 & 51.313 & 13.836 & \text { Yes }\end{array}$ $\begin{array}{lllllllllllllllll}\text { QMAEIAVNAVLTVADMER } & 0.58 & 14.27 & 27.77 & 19.69 & 3 & 2104.0819 & 2104.0778 & 702.3665 & 0.0041 & 1.9458 & 75.391 & 82.712 & 77.681 & 33.834 & \text { No }\end{array}$ $\begin{array}{lllllllllllllllll}\text { QMAEIAVNAVLTVADMER } & 0.99 & 33.87 & 27.73 & 19.41 & 3 & 2104.0831 & 2104.0778 & 702.3665 & 0.0053 & 2.5153 & 103.987 & 120.848 & 78.422 & 46.740 & \text { Yes }\end{array}$ $\begin{array}{llllllllllllllll}\text { QMAEIAVNAVLTVADMER } & 1.00 & 40.92 & 27.73 & 18.35 & 3 & 2104.0831 & 2104.0778 & 702.3665 & 0.0053 & 2.5153 & 96.713 & 98.962 & 76.367 & 33.720 & \text { Yes }\end{array}$ \begin{tabular}{llllllllllllllll}
\hline QMAEIAVNAVLTVADMER & 0.55 & 14.17 & 27.94 & 27.17 & 3 & 2104.0795 & 2104.0778 & 702.3665 & 0.0017 & 0.8068 & 92.512 & 107.624 & 67.372 & 38.981 & Yes
\end{tabular}

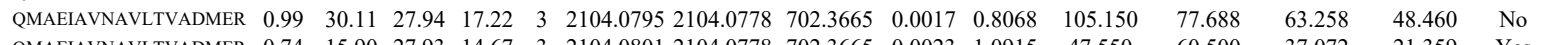

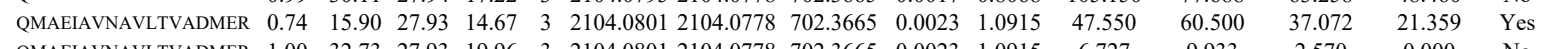
$\begin{array}{llllllllllllllll}\text { QMAEIAVNAVLTVADMER } & 1.00 & 32.73 & 27.93 & 19.96 & 3 & 2104.0801 & 2104.0778 & 702.3665 & 0.0023 & 1.0915 & 6.727 & 9.933 & 2.570 & 0.000 & \text { No }\end{array}$

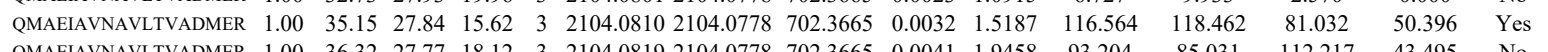

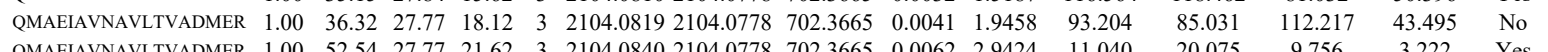

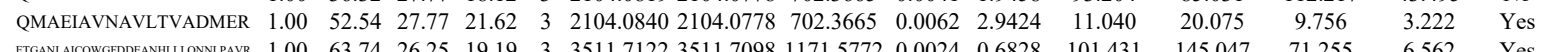

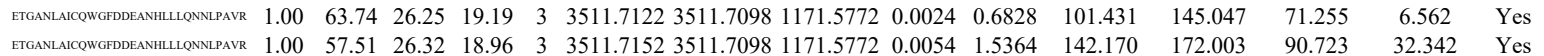

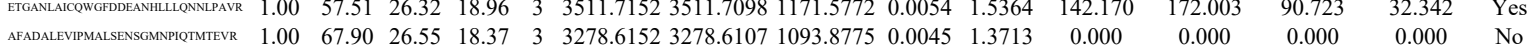
$\begin{array}{llllllllllllllll}\text { ETGANLACQNGFDERANHLLONLPAVR } & 1.00 & 67.04 & 26.25 & 19.47 & 3 & 3511.7122 & 3511.7098 & 1171.5772 & 0.0024 & 0.6828 & 419.059 & 332.880 & 259.241 & 52.697 & \text { Yo }\end{array}$ $\begin{array}{llllllllllllllll}\text { ETGANLACOGGFDENANLLONNLPAVR } & 1.00 & 22.91 & 26.30 & 35.91 & 4 & 3511.7149 & 3511.7098 & 878.9347 & 0.0051 & 1.4506 & 103.606 & 66.850 & 56.787 & 59.540 & \text { No }\end{array}$ 


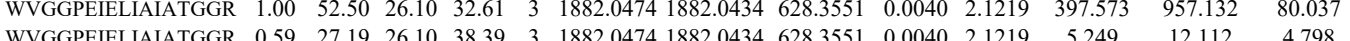

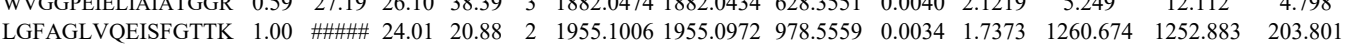

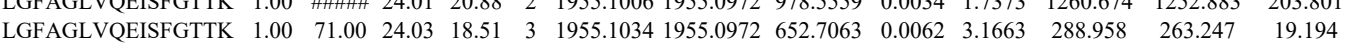

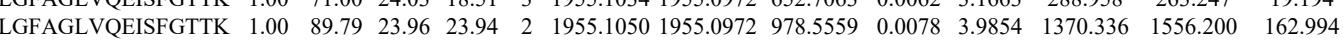
$\begin{array}{llllllllllllll}\text { LGFAGLVQEISFGTTK } & 1.00 & 52.40 & 23.93 & 18.72 & 3 & 1955.1058 & 1955.0972 & 652.7063 & 0.0086 & 4.3920 & 233.007 & 350.333 & 82.611\end{array}$ $\begin{array}{llllllllllllll}\text { WVGGPEIELIAIATGGR } & 1.00 & \text { \#\#\#\# } 26.00 & 24.68 & 2 & 1882.0450 & 1882.0434 & 942.0290 & 0.0016 & 0.8492 & 17393.534 & 20298.834 & 362.218\end{array}$ $\begin{array}{llllllllllllll}\text { WVGGPEIELIAIATGGR } & 1.00 & \text { \#\#\# } 25.91 & 24.84 & 2 & 1882.0454 & 1882.0434 & 942.0290 & 0.0020 & 1.0615 & 9363.248 & 10100.106 & 140.643\end{array}$

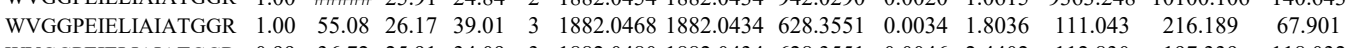

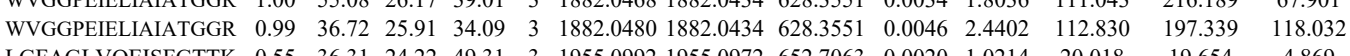
$\begin{array}{llllllllllllll}\text { LGFAGLVQEISFGTTK } & 0.55 & 36.31 & 24.22 & 49.31 & 3 & 1955.0992 & 1955.0972 & 652.7063 & 0.0020 & 1.0214 & 20.018 & 19.654 & 4.869\end{array}$ $\begin{array}{lllllllllllllll}\text { LGFAGLVQEISFGTTK } & 0.55 & 31.95 & 24.22 & 44.95 & 3 & 1955.0995 & 1955.0972 & 652.7063 & 0.0023 & 1.1746 & 81.191 & 79.323 & 19.842\end{array}$ $\begin{array}{lllllllllllllll}\text { LGFAGLVQEISFGTTK } & 1.00 & 93.47 & 24.18 & 24.61 & 2 & 1955.1004 & 1955.0972 & 978.5559 & 0.0032 & 1.6351 & 5287.985 & 5723.289 & 611.382\end{array}$ $\begin{array}{llllllllllllll}\text { LGFAGLVQEISFGTTK } & 1.00 & 88.99 & 24.01 & 19.65 & 2 & 1955.1006 & 1955.0972 & 978.5559 & 0.0034 & 1.7373 & 3550.919 & 3635.468 & 574.382\end{array}$ $\begin{array}{llllllllllllllll}\text { LGFAGLVQEISFGTTK } & 1.00 & 49.65 & 24.03 & 17.40 & 3 & 1955.1028 & 1955.0972 & 652.7063 & 0.0056 & 2.8599 & 280.948 & 193.538 & 79.650\end{array}$

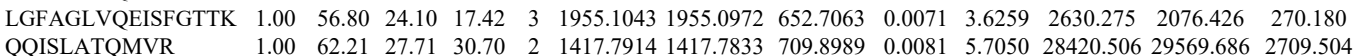
QQISLATQMVR $\begin{array}{llllllllllllll}1.00 & 62.21 & 27.71 & 30.70 & 2 & 1417.7914 & 1417.7833 & 709.8989 & 0.008 & 5.7050 & 28420.506 & 29569.686 & 270.504 & \\ 1.00 & 61.42 & 27.70 & 29.18 & 2 & 1417.7918 & 1417.7833 & 709.8989 & 0.0085 & 5.9867 & 36470.446 & 33325.090 & 3650.745 & 4\end{array}$

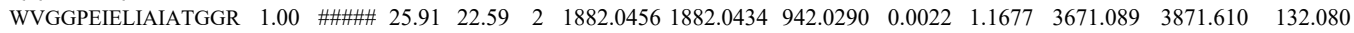
$\begin{array}{lllllllllllll}\text { WVGGPEIELIAIATGGR } & 1.00 & \text { \#\#\#\# 26.10 } & 27.43 & 2 & 1882.0476 & 1882.0434 & 942.0290 & 0.0042 & 2.2292 & 3718.122 & 4144.537 & 39.065\end{array}$ $\begin{array}{llllllllllllll}\text { LGFAGLVQEISFGTTK } & 1.00 & 86.12 & 24.22 & 18.53 & 2 & 1955.0992 & 1955.0972 & 978.5559 & 0.0020 & 1.0219 & 1360.657 & 1816.043 & 247.334\end{array}$ $\begin{array}{llllllllllllll}\text { LGFAGLVQEISFGTTK } & 1.00 & 50.85 & 24.01 & 18.68 & 3 & 1955.1007 & 1955.0972 & 652.7063 & 0.0035 & 1.7874 & 505.700 & 442.756 & 128.985 \\ \text { LGFAGLVQESFGTTK } & 1.00 & 59.18 & 23.96 & 19.15 & 3 & 1955.1016 & 1955.0972 & 652.7063 & 0.0044 & 2.2470 & 270.121 & 595.639 & 30.767\end{array}$

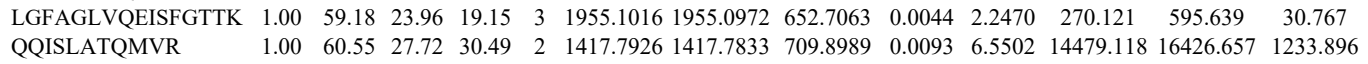
QQISLATQMVR IAILTCPFEPPKPK IAILTCPFEPPKPK IAILTCPFEPPKPK IAILTCPFEPPKPK IAILTCPFEPPKPK IAILTCPFEPPKPK

AALTCP

IAILTCPFEPRPK

QQISLATQMVR

QQISLATQMVR

AVTIFIR

MIIEEAKR

MIIEEAKR

MIIEEAKR

MIIEEAKR

MIIEEAKR

MIIEEAKR

MIIEEAKR

MIIEEAKR

MIIEEAKR

MIIEEAKR

MIIEEAKR

MIIEEAKR

MIIEEAKR

MIIEEAKR

MIIEEAKR

MIIEEAKR

MIIEEAKR

MIIEEAKR

MIIEEAKR

MIIEEAKR

MIEEAKR

MIEEAKR

$\begin{array}{llllllllllllll}1.00 & 60.55 & 27.72 & 30.49 & 2 & 1417.7926 & 1417.7833 & 709.8989 & 0.0093 & 6.5502 & 14479.118 & 16426.657 & 1233.896\end{array}$ $\begin{array}{lllllllllllll}1.00 & 61.97 & 27.69 & 30.38 & 2 & 1417.7950 & 1417.7833 & 709.8989 & 0.0117 & 8.2405 & 31481.118 & 29600.609 & 3352.332\end{array}$

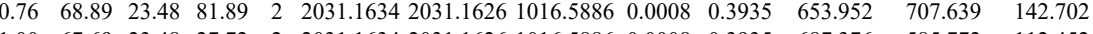
$\begin{array}{llllllllllllll}1.00 & 67.69 & 23.48 & 27.72 & 2 & 2031.1634 & 2031.1626 & 1016.5886 & 0.0008 & 0.3935 & 687.376 & 585.772 & 112.452\end{array}$ $\begin{array}{lllllllllllll}1.00 & 18.11 & 23.62 & 16.73 & 4 & 2031.1657 & 2031.1626 & 508.7979 & 0.0031 & 1.5232 & 258.060 & 127.561 & 39.712 \\ 1.00 & 32.03 & 23.4 & 15.68 & 4 & 2031.1669 & 2031.1626 & 508.7979 & 0.0043 & 2.1128 & 39.846 & 69.616 & 16.41\end{array}$ $\begin{array}{lllllllllllll}1.00 & 32.03 & 23.44 & 15.68 & 4 & 2031.1669 & 2031.1626 & 508.7979 & 0.0043 & 2.1128 & 396.846 & 699.616 & 11.4 .491 \\ 1.00 & 46.70 & 23.38 & 24.54 & 3 & 2031.1681 & 2031.1626 & 678.0615 & 0.0055 & 2.7038 & 7540.499 & 8202.474 & 2154.118\end{array}$ $\begin{array}{llllllllllllll}1.00 & 46.70 & 23.38 & 24.54 & 3 & 2031.1681 & 2031.1626 & 678.0615 & 0.0055 & 2.7038 & 7540.499 & 8202.474 & 2154.118 \\ 1.00 & 63.07 & 27.51 & 27.64 & 2 & 1417.7958 & 1417.7833 & 709.8989 & 0.0125 & 8.8040 & 7707.705 & 7164.652 & 574.518\end{array}$ $\begin{array}{lllllllllllllll}1.00 & 36.16 & 23.50 & 17.18 & 3 & 2031.1660 & 2031.1626 & 678.8015 & 0.0034 & 1.6714 & 2990.394 & 3289.182 & 763.066\end{array}$ $\begin{array}{llllllllllllllll}1.00 & 1626 & 23.32 & 16.58 & 4 & 2031.1673 & 2031 & 2031.162 & 508.7979 & 0.0047 & 2.3094 & 22.775 & 94.487 & 54.436\end{array}$ $\begin{array}{lllllllllllll}1.00 & 28.82 & 23.38 & 41.82 & 4 & 2031.1681 & 2031.1626 & 508.7979 & 0.0055 & 2.7024 & 2115.437 & 2949.160 & 685.325\end{array}$

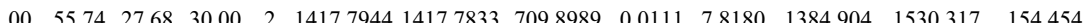
$\begin{array}{llllllllllllll}1.00 & 71.58 & 27.68 & 31.42 & 2 & 1417.7944 & 1417.7833 & 709.8989 & 0.0111 & 7.8180 & 948.160 & 916.412 & 100.135\end{array}$ $\begin{array}{lllllllllllllll}0.93 & 29.50 & 2230 & 27.45 & 2 & 962.6114 & 962.6035 & 4823090 & 0.0079 & 8.1897 & 23466.671 & 26956.318 & 2092105\end{array}$ $\begin{array}{lllllllllllll}0.92 & 27.44 & 22.12 & 7.22 & 2 & 962.6128 & 962.6035 & 482.3090 & 0.0093 & 9.6410 & 32324.548 & 38381.277 & 3576.1263\end{array}$ $\begin{array}{llllllllllllll}0.57 & 20.34 & 27.51 & 29.73 & 2 & 1292.7368 & 1292.7366 & 647.3756 & 0.0002 & 0.1545 & 30.790 & 73.260 & 7.747 & 10.2\end{array}$ $\begin{array}{lllllllllllllll}0.91 & 30.24 & 27.30 & 38.33 & 2 & 1292.7374 & 1292.7366 & 647.3756 & 0.0008 & 0.6179 & 50.133 & 43.263 & 7.195\end{array}$ $\begin{array}{lllllllllllll}0.95 & 30.29 & 27.07 & 26.04 & 2 & 1292.7394 & 1292.7366 & 647.3756 & 0.0028 & 2.1626 & 4038.061 & 5169.147 & 918.561\end{array}$

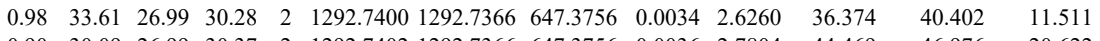
$\begin{array}{lllllllllllllll}0.90 & 30.09 & 26.99 & 30.37 & 2 & 1292.7402 & 1292.7366 & 647.3756 & 0.0036 & 2.7804 & 44.469 & 46.976 & 20.622\end{array}$ $\begin{array}{llllllllllllll}0.95 & 32.94 & 26.89 & 26.96 & 2 & 1292.7406 & 1292.7366 & 647.3756 & 0.0040 & 3.0894 & 43.579 & 40.009 & 12.969\end{array}$ $\begin{array}{llllllllllllll}0.86 & 28.22 & 26.89 & 29.87 & 2 & 1292.7408 & 1292.7366 & 647.3756 & 0.0042 & 3.2439 & 36.024 & 36.529 & 3.501\end{array}$ $\begin{array}{llllllllllllll}0.95 & 36.08 & 26.89 & 29.91 & 2 & 1292.7412 & 1292.7366 & 647.3756 & 0.0046 & 3.5528 & 8709.465 & 11061.760 & 1228.805\end{array}$ $\begin{array}{llllllllllllll}0.81 & 29.64 & 26.89 & 28.79 & 2 & 1292.7412 & 1292.7366 & 647.3756 & 0.0046 & 3.5528 & 29.671 & 39.759 & 6.097\end{array}$ $\begin{array}{llllllllllllll}0.82 & 29.98 & 26.91 & 26.72 & 2 & 1292.7414 & 1292.7366 & 647.3756 & 0.0048 & 3.7073 & 53.102 & 68.811 & 9.591\end{array}$ $\begin{array}{lllllllllllll}0.82 & 29.98 & 26.91 & 26.72 & 2 & 1292.7414 & 1292.7366 & 647.3756 & 0.0048 & 3.7073 & 53.102 & 68.811\end{array}$ $\begin{array}{llllllllllll}0.59 & 24.90 & 26.91 & 25.33 & 2 & 1292.7416 & 1292.7366 & 647.3756 & 0.0050 & 3.8617 & 17.850 & 31.090\end{array}$ $\begin{array}{lllllllllllllll}0.91 & 33.64 & 26.90 & 29.96 & 2 & 1292.7418 & 1292.7366 & 647.3756 & 0.0052 & 4.0162 & 47.776 & 78.179\end{array}$ $\begin{array}{llllllllllll}0.83 & 30.00 & 26.90 & 29.27 & 2 & 1292.7420 & 1292.7366 & 647.3756 & 0.0054 & 4.1707 & 40.102 & 32.638 \\ 0.84 & 23.19 & 27.30 & 24.42 & 2 & 12927374 & 1292.7366 & 647.3756 & 0.0008 & 0.6179 & 19.915 & 36.350\end{array}$ $\begin{array}{llllllllllllll}0.84 & 23.19 & 27.30 & 24.42 & 2 & 1292.7374 & 1292.7366 & 647.3756 & 0.0008 & 0.6179 & 19.915 & 36.350 & 19.498\end{array}$ $\begin{array}{llllllllllllll}0.97 & 31.05 & 27.30 & 30.64 & 2 & 1292.7376 & 1292.7366 & 647.3756 & 0.0010 & 0.7723 & 8363.685 & 10800.774 & 1106.005\end{array}$ $\begin{array}{lllllllllllll}0.99 & 33.79 & 27.08 & 30.88 & 2 & 1292.7390 & 1292.7366 & 647.3756 & 0.0024 & 1.8536 & 4282.907 & 5107.869 & 582.789 \\ 0\end{array}$ $\begin{array}{llllllllllllll}0.97 & 30.98 & 27.28 & 31.52 & 2 & 1292.7382 & 1292.7366 & 647.3756 & 0.0016 & 1.2358 & 8809.577 & 11537.569 & 925.823\end{array}$

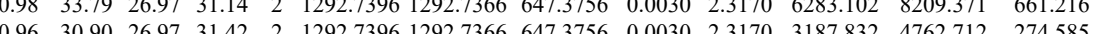

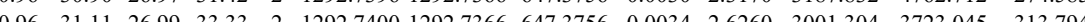
$\begin{array}{llllllllllllll}0.97 & 32.84 & 2.99 & 31.68 & 2 & 1292.7400 & 1292.7366 & 647.3756 & 0.0034 & 2.6260 & 837.885 & 989.479 & 119.794\end{array}$

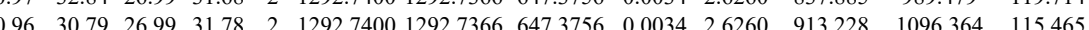




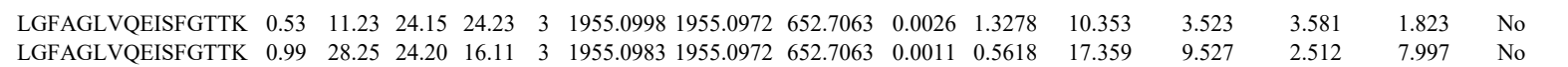

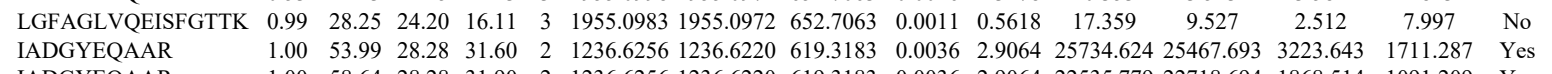
\begin{tabular}{llllllllllllllll} 
& \\
IADGYEQAAR & 1.00 & 53.99 & 28.28 & 31.60 & 2 & 1236.6256 & 1236.6220 & 619.3183 & 0.0036 & 2.9064 & 2534.624 & 25467.693 & 3223.643 & 171.287 & Yes \\
\hline & 1.00 & 58.64 & 28.28 & 31.90 & 2 & 1236.6256 & 1236.6220 & 619.3183 & 0.0036 & 2.9064 & 22535.779 & 22718.694 & 1868.514 & 1091.209 & Yes
\end{tabular} $\begin{array}{llllllllllllllll}\text { LDVTSVEDYK } & 0.99 & 44.25 & 28.01 & 21.90 & 2 & 1455.7694 & 1455.7701 & 728.8923 & -0.0007 & -0.4802 & 7084.312 & 6467.165 & 1050.629 & 697.065 & \text { Yes }\end{array}$ LDVTSVEDYK FSELTAEK FSELTAEK

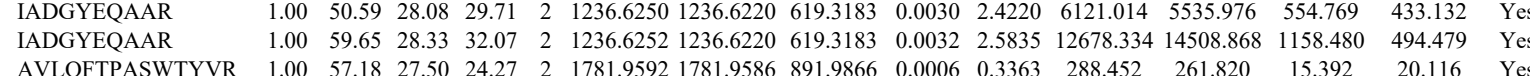
$\begin{array}{llllllllllllllll}1.00 & 60.00 & 28.10 & 33.29 & 2 & 1455.7710 & 1455.7701 & 728.8923 & 0.0009 & 0.6174 & 12679.513 & 11641.569 & 1953.129 & 342.175 & \text { Yes } \\ 0.99 & 44.54 & 27.58 & 27.78 & 2 & 1211.6750 & 1211.6641 & 606.8393 & 0.0109 & 8.9809 & 42960.478 & 38993.112 & 19582.415 & 6976.443 & \text { Yes }\end{array}$ $\begin{array}{lllllllllllllllll}0.98 & 37.63 & 27.66 & 33.44 & 2 & 1211.6752 & 1211.6641 & 606.8393 & 0.0111 & 9.1457 & 46089.069 & 44095.381 & 21769.331 & 6709.522 & \text { Yes } \\ 1.00 & 50.59 & 28.08 & 29.71 & 2 & 1236.6250 & 1236.6220 & 6193183 & 0.0030 & 2.4220 & 6121.014 & 5535.976 & 554.769 & 433.132 & \text { Yes }\end{array}$ $\begin{array}{llllllllllllll} & \end{array}$ $\begin{array}{lllllllllllll} & \end{array}$

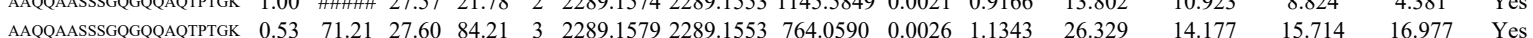

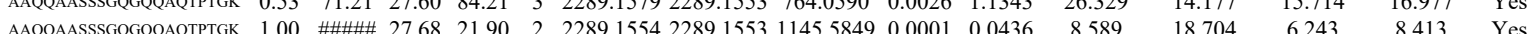

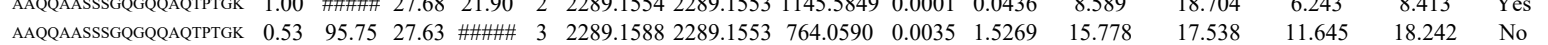

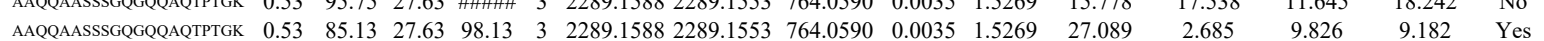
$\begin{array}{llllllllllllllll}\text { AAQQAASSGGQGQQAQTPTGK } & 1.00 & 90.58 & 27.68 & 18.92 & 3 & 2289.1561 & 2289.1553 & 764.0590 & 0.0008 & 0.3490 & 5.333 & 3.670 & 14.884 & 0.000 & \text { No }\end{array}$

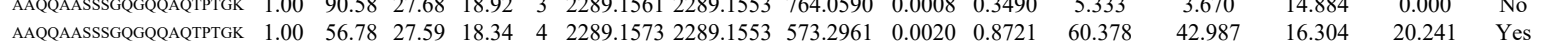

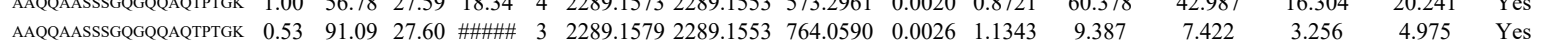

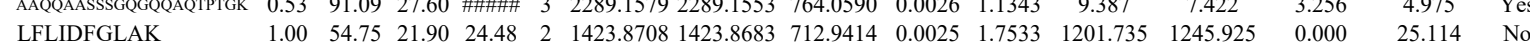

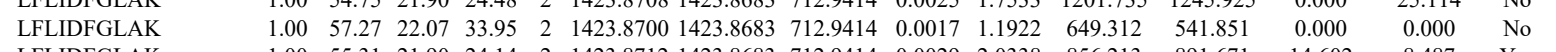

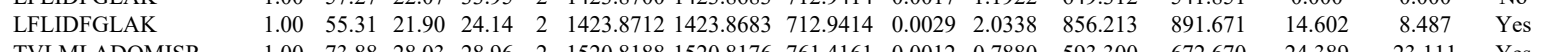

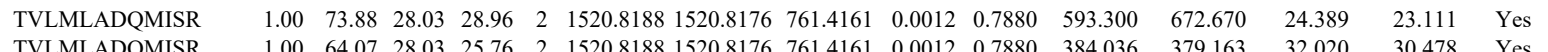
$\begin{array}{llllllllllllllll}\text { TVLMLADQMISR } & 1.00 & 64.07 & 28.03 & 25.76 & 2 & 1520.8188 & 1520.8176 & 761.4161 & 0.0012 & 0.7880 & 384.036 & 379.163 & 32.020 & 30.478 & \text { Yes }\end{array}$ $\begin{array}{llllllllllllllll}\text { ILQGGVGIPHIR } & 0.55 & 41.99 & 22.79 & 54.99 & 3 & 1402.8550 & 1402.8531 & 468.6250 & 0.0019 & 1.3515 & 1155.486 & 1592.235 & 190.408 & 124.346 & \text { Yes }\end{array}$ $\begin{array}{llllllllllllllllll}\text { ILQGGVGIPHIR } & 0.55 & 47.41 & 22.79 & 60.41 & 3 & 1402.8550 & 1402.8531 & 468.6250 & 0.0019 & 1.3515 & 1997.696 & 2170.138 & 258.738 & 136.674 & \text { Yes }\end{array}$

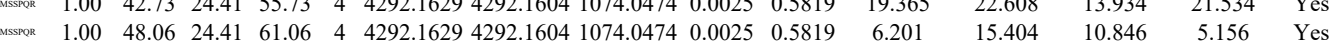
$\begin{array}{llllllllllllllll}\text { LGVATVAK } & 1.57 & 21.05 & 26.22 & 30.47 & 2 & 1045.6782 & 1045.6739 & 523.8442 & 0.0043 & 4.1043 & 15217.218 & 12878.381 & 3578.701 & 1012.997 & \text { Yes }\end{array}$

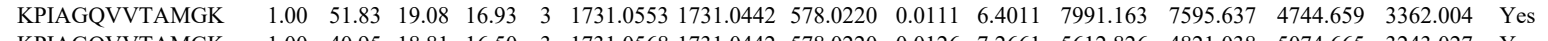

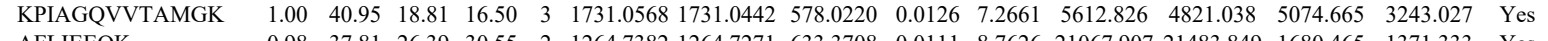

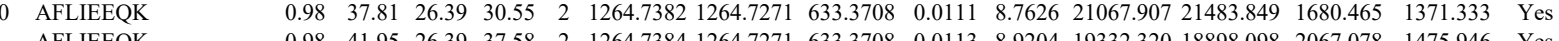
$\begin{array}{llllllllllllllll}\text { AFLIEEQK } & 0.98 & 41.95 & 26.39 & 37.58 & 2 & 1264.7384 & 1264.7271 & 633.3708 & 0.0113 & 8.9204 & 19332.320 & 18898.098 & 2067.078 & 1475.946 & \text { Yes } \\ \text { LSYNTASNK } & 1.00 & 50.35 & 27.65 & 32.88 & 2 & 1284.6924 & 1284.6917 & 643.3531 & 0.0007 & 0.5440 & 14288.858 & 13263.847 & 804.027 & 256.868 & \text { Yes }\end{array}$

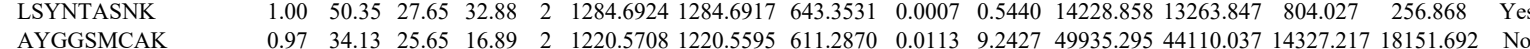

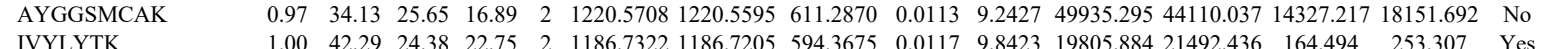
IVYLYTK IVYLYTK

SACGVCPGR

SACGVCPGR

SACGVCPGR

SACGVCPGR

AQAQSOK

10 NMPSNEKPK

NMPSNEKPK

YVSSLTEEISK

YVSSLTEEISK $\begin{array}{lccccccccccccccc}\text { GAGMPGQHGQITQQELDTVVK } & 1.00 & 51.05 & 26.18 & 18.36 & 3 & 2497.3042 & 2497.2839 & 833.4352 & 0.0203 & 8.1189 & 729.311 & 597.940 & 1303.659 & 1010.355 & \text { Yes } \\ \text { YVSSLTEEISK } & 1.00 & 6.0 .45 & 27.31 & 26.19 & 2 & 1542.8396 & 1542.8385 & 772.4265 & 0.0011 & 0.7120 & 503.772 & 655.360 & 787.278 & 582.850 & \text { Yes } \\ \text { VAPSLK } & 0.62 & 18.01 & 24.36 & 26.47 & 2 & 901.5838 & 901.5840 & 451.7993 & -0.0002 & -0.2213 & 3790.204 & 4465.761 & 10311.512 & 5640.907 & \text { Yes }\end{array}$ $\begin{array}{llllllllllllllll}\text { GAGMPGQHGQITQQELDTVVK } & 1.00 & 51.05 & 26.18 & 18.36 & 3 & 2497.3042 & 2497.2839 & 833.4352 & 0.0203 & 8.1189 & 729.311 & 597.940 & 1303.659 & 1010.355 & \text { Yes } \\ \text { YVSSLTEISK } & 1.00 & 60.45 & 27.31 & 26.19 & 2 & 1542.8396 & 1542.8385 & 772.4265 & 0.0011 & 0.7120 & 503.772 & 655.360 & 787.278 & 582.850 & \text { Yes } \\ \text { VAPSLK } & 0.62 & 18.01 & 24.36 & 26.47 & 2 & 901.5838 & 901.5840 & 451.7993 & -0.0002 & -0.2213 & 3790.204 & 4465.761 & 10311.512 & 5640.907 & \text { Yes } \\ \text { YQEEFEHFQQELDK } & 0.87 & 29.93 & 27.14 & 18.19 & 3 & 2157.0460 & 2157.0258 & 720.0159 & 0.0202 & 9.3516 & 346.734 & 310.511 & 638.124 & 417.834 & \text { Yes }\end{array}$ $\begin{array}{lllllllllllllllll}1.00 & 48.85 & 24.27 & 27.71 & 2 & 1186.7306 & 1186.7205 & 594.3675 & 0.0101 & 8.4964 & 26245.816 & 25641.497 & 384.972 & 405.300 & \text { Yes }\end{array}$ $\begin{array}{llllllllllllllllll}1.00 & 41.99 & 24.18 & 24.44 & 2 & 1186.7318 & 1186.7205 & 594.3675 & 0.0113 & 9.5058 & 21527.313 & 20164.831 & 226.378 & 332.766 & \text { Yes }\end{array}$ $\begin{array}{llllllllllllllll}1.00 & 47.89 & 17.48 & 23.15 & 2 & 1084.4468 & 1084.4408 & 543.2277 & 0.0060 & 5.5225 & 40928.716 & 40637.179 & 7812.148 & 715.281 & \text { Yes }\end{array}$ $\begin{array}{lllllllllllllllll}1.00 & 46.90 & 17.48 & 16.45 & 2 & 1084.4476 & 1084.4408 & 543.2277 & 0.0068 & 6.2588 & 20819.216 & 22772.556 & 6753.077 & 715.281 & \text { Yes }\end{array}$ $\begin{array}{llllllllllllllll}1.00 & 47.11 & 17.71 & 16.58 & 2 & 1084.4476 & 1084.4408 & 543.2277 & 0.0068 & 6.52588 & 17489.946 & 15503.587 & 2966.343 & 758.432 & \text { Yes }\end{array}$ $\begin{array}{llllllllllllllll}0.99 & 39.38 & 28.01 & 31.72 & 2 & 1047.5926 & 1047.5916 & 524.8031 & 0.0010 & 0.9527 & 44.421 & 36.447 & 25.204 & 15.302 & \text { No }\end{array}$

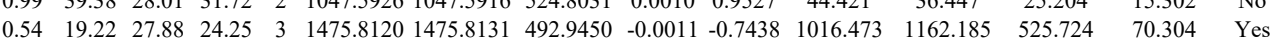

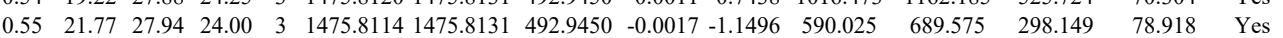
$\begin{array}{lllllllllllllll}1.00 & 66.70 & 27.35 & 36.64 & 2 & 1542.8506 & 1542.8385 & 772.4265 & 0.0121 & 7.8324 & 733.623 & 907.274 & 779.392 & 501.214 & \text { Yes }\end{array}$ $\begin{array}{lllllllllllllll}1.00 & 62.47 & 27.35 & 28.03 & 2 & 1542.8506 & 1542.8385 & 772.4265 & 0.0121 & 7.8324 & 603.333 & 706.248 & 1097.412 & 569.778 & \text { Yes }\end{array}$ $\begin{array}{lllllllllllllllll}\text { GHPDLQGQPAEEIFESVGDR } & 1.00 & 49.47 & 26.21 & 18.61 & 3 & 2324.1175 & 2324.1155 & 775.7124 & 0.0020 & 0.8594 & 40.387 & 80.518 & 167.658 & 238.474 & \text { Yes }\end{array}$ $\begin{array}{llllllllllllllll}\text { GHPLQGPPAETLSVGR } & 1.00 & 52.77 & 26.26 & 17.15 & 3 & 2324.1181 & 2324.1155 & 775.7124 & 0.0026 & 1.1173 & 108.955 & 121.097 & 169.028 & 262.548 & \text { Yes }\end{array}$

LLGLGQK

LLGLGQK

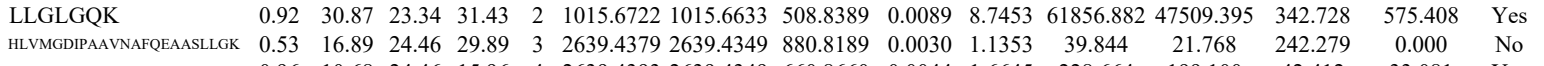
$\begin{array}{lllllllllllllll}0.99 & 43.37 & 26.79 & 27.66 & 2 & 1318.7646 & 1318.7522 & 660.3834 & 0.0124 & 9.3884 & 4103.691 & 3505.984 & 1365.030 & 1250.279 & \text { Yes } \\ 0.85 & 28.05 & 23.30 & 31.87 & 2 & 1015.6728 & 1015.6633 & 508.8389 & 0.099 & 9.3349 & 1068.866 & 163.231 & 201.415 & 224.211 & \text { Y }\end{array}$ $\begin{array}{lllllllllllllll}0.88 & 29.53 & 23.34 & 32.25 & 2 & 1015.6720 & 1015.6633 & 508.8389 & 0.0087 & 8.5488 & 26741.952 & 24344.011 & 649.951 & 939.878 & \text { Yes }\end{array}$ $\begin{array}{lllllllllllllllllll} & 0.44 & 15.96 & 4 & 2639.4393 & 2639.4349 & 660.8660 & 0.0044 & 1.6645 & 228.664 & 199.100 & 42.412 & 33.081 & \text { Yes }\end{array}$

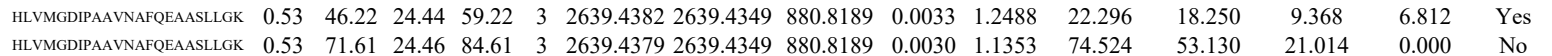
HLVMGDIPAAVNAFEFASLOK

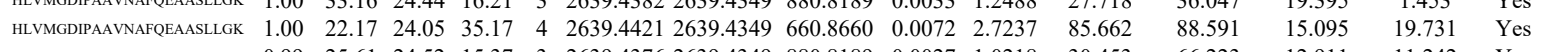

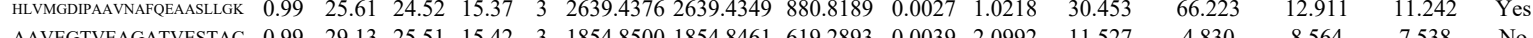

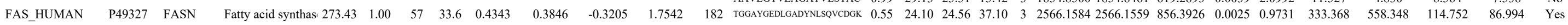


VVVQVLAEEPEAVLK $\begin{array}{lllllllllll}0.76 & 69.35 & 19.64 & 82.35 & 2 & 1910.1340 & 1910.1332 & 956.0739 & 0.0008 & 0.4184 & 3.48\end{array}$

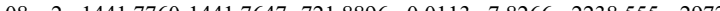
$\begin{array}{lllllllllllllllll} & 0.95 & 26.20 & 23.54 & 21.71 & 3 & 1621.9531 & 1621.9405 & 541.6541 & 0.0126 & 7.7540 & 6899.643 & 8635.468 & 2613.466 & & \\ \end{array}$ $\begin{array}{llllllllllllll} & \end{array}$ EQGVTFPSGDIQEQLIR

\section{VFTTVGSAEK}

$$
1.00
$$

$\begin{array}{ll}\text { EQGVTFPSGDIQEQLIR } & 1.00 \\ \text { DGLLENQTPEFFQDVCKRK } & 0.55\end{array}$

SLYQSAGVAPESFEYIEAHGTGTK

LPESENLLEFWDNLLGGDMVTDDDRR

$\begin{array}{lllllllllllll}5.10 & 26.80 & 22.88 & 2 & 1325.7514 & 1325.7435 & 663.8790 & 0.0079 & 5.9498 & 6014.108 & 9709.319 & 3660.645\end{array}$

VFTTVGSAEK

VFTTVGSAEK

$\begin{array}{llllllllllllll} & \end{array}$

\begin{tabular}{lllllllllllll}
0 & 2829.4099 & 2829.4065 & 944.1428 & 0.0034 & 1.2004 & 1689.257 & 2704.659 & 674.728 \\
\hline
\end{tabular}

$\begin{array}{lllllllllllll}1.00 & 69.60 & 25.35 & 18.29 & 3 & 3306.5602 & 3306.5585 & 1103.1934 & 0.0017 & 0.5137 & 74.249 & 119.875 & 58.331 \\ 1.00 & 53.82 & 25.35 & 20.91 & 3 & 3306.5602 & 3306.5585 & 1103.1934 & 0.0017 & 0.5137 & 35.493 & 81.484 & 50.283 \\ 0.93 & 11.95 & 25.43 & 16.64 & 4 & 3306.5641 & 3306.5585 & 827.6469 & 0.0056 & 1.6915 & 27.760 & 36.479 & 18.117\end{array}$

GILADEDSSRPVWL $\begin{array}{llllllllllllll}1.00 & 62.63 & 27.27 & 22.12 & 2 & 1325.7490 & 1325.7435 & 663.8790 & 0.0055 & 4.1423 & 12351.892 & 18376.520 & 3845.743 \\ 1.00 & 58.49 & 27.09 & 22.30 & 2 & 1325.7500 & 1325.7435 & 663.8790 & 0.0065 & 4.8954 & 15654.705 & 22283.150 & 3692.778\end{array}$ LPESNOEFWDNLGGDDMVDDDRR

LPESENLEEFWDNLGGVDMVTDDDRR

LSPDAIPGK 1.0078 .2 25.35 18.81 $\left.\begin{array}{llllllllllll}0.99 & 42.01 & 25.45 & 17.72 & 4 & 3306.5633 & 3306.5585 & 827.6469 & 0.0048 & 1.448\end{array}\right]$ $\begin{array}{ll}403.811 & 203.471 \\ 307.215 & 218.009\end{array}$ .7.009

YSGTLNLDR

$\begin{array}{lllllllllll}1.00 & 78.87 & 25.48 & 19.39 & 3 & 3306.5632 & 3306.5585 & 1103.1934 & 0.0047 & 1.4201 & 48.886\end{array}$

74.041

59.902

YSGTLNLDR

$\begin{array}{llllllllllllll}1.00 & 49.81 & 27.44 & 25.69 & 2 & 1181.6260 & 1181.6162 & 591.8154 & 0.0098 & 8.2795 & 15990.436 & 23690.223 & 4649.018 & 12 \\ 1.00 & 45.39 & 27.75 & 25.38 & 2 & 1181.6270 & 1181.6162 & 591.8154 & 0.0108 & 9.1244 & 17767.278 & 26503.298 & 4727.899 & 12\end{array}$

$\begin{array}{lllllllllllll}1.00 & 44.30 & 23.73 & 26.05 & 2 & 1184.7124 & 1184.7009 & 593.3577 & 0.0115 & 9.6905 & 11365.100 & 16828.247 & 2787.406\end{array}$

AQVADVVVS

$\begin{array}{lllllllllllllll}0.99 & 39.92 & 23.73 & 24.94 & 2 & 1184.7124 & 1184.7009 & 593.3577 & 0.0115 & 9.6905 & 14478.713 & 22432.115 & 3695.312 & 569.508 & \text { Yes } \\ 1.00 & 58.68 & 27.05 & 29.98 & 2 & 1186.6874 & 1186.6792 & 594.3469 & 0.0082 & 6.8983 & 19761.561 & 35539.046 & 9317.997 & 1658.413 & \text { Yes }\end{array}$

AQVADVVVSR

$\begin{array}{lllllllllllll}1.00 & 49.89 & 27.05 & 28.19 & 2 & 1186.6874 & 1186.6792 & 594.3469 & 0.0082 & 6.8983 & 20549.042 & 35978.535 & 7682.198\end{array}$

LPEDPLLSGLLDSPALK

LPEDPLLSGLLDSPALK

LPEDPLLSGLLDSPALK

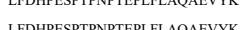

LFDHPESTPNPTEPLFLAQAEVIK

ACLDTAVENMPSLK
ACLDTAVENMPSLK

$\begin{array}{lllllllllll} & \end{array}$

$\begin{array}{llllllllllll}.00 & 34.93 & 21.21 & 21.87 & 3 & 2065.1938 & 2065.1914 & 689.4044 & 0.0024 & 1.1604 & 346.691 & 28\end{array}$

$\begin{array}{lllllllllll}1.00 & 33.91 & 21.27 & 19.87 & 3 & 2065.1953 & 2065.1914 & 689.4044 & 0.0039 & 1.8857 & 359.109\end{array}$

$\begin{array}{lllllllllll}0.55 & 56.78 & 25.95 & 69.78 & 3 & 3127.6132 & 3127.6110 & 1043.5443 & 0.0022 & 0.7027 & 278.682 \\ 1.00 & 30.02 & 25.85 & 15.15 & 4 & 3127.6145 & 3127.6110 & 782.9100 & 0.0035 & 1.1176 & 63.928\end{array}$

$\begin{array}{llllllllllllll}\text { PEDDPLSGLLDSPALK } & 1.00 & 74.48 & 21.07 & 21.04 & 2 & 2065.1914 & 2065.1914 & 1033.6030 & 0.0000 & 0.0000 & 725.487\end{array}$

$\begin{array}{llllllllllll} & \end{array}$

$\begin{array}{llllllllllll}\text { LPEDPLLSGLLDSPALK } & 0.99 & 27.66 & 21.27 & 21.08 & 3 & 2065.1950 & 2065.1914 & 689.4044 & 0.0036 & 1.7406 & 370.94\end{array}$

$417.146 \quad 1132.419$ Yes

$\begin{array}{lllll}438.711 & 269.713 & 221.058 & \text { Yes }\end{array}$

$\begin{array}{lll}287.150 & 232.776 \\ 396.482 & 287.494\end{array}$

$396.482 \quad 287.494$

$325.621 \quad 85.475$

$\begin{array}{ll}1.490 & 32.530 \\ 24.706 & 20.695\end{array}$

$\begin{array}{ll}356.178 & 40.200 \\ 547.694 & 69.434\end{array}$

$547.694 \quad 69.434$

714.187 


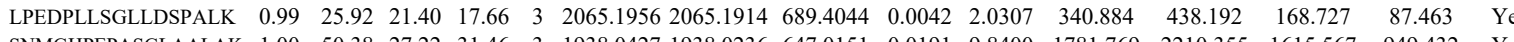
$\begin{array}{llllllllllllllll}\text { SNMGHPEPASGLAALAK } & 1.00 & 50.38 & 27.22 & 31.46 & 3 & 1938.0427 & 1938.0236 & 647.0151 & 0.0191 & 9.8400 & 1781.769 & 2210.355 & 1615.567 & 949.432 & \text { Yes }\end{array}$

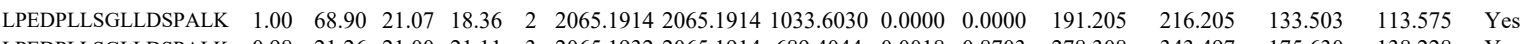
$\begin{array}{llllllllllllllll}\text { LPEDPLLSGLLDSPALK } & 0.98 & 21.26 & 21.00 & 21.11 & 3 & 2065.1932 & 2065.1914 & 689.4044 & 0.0018 & 0.8703 & 278.308 & 343.497 & 175.630 & 138.228 & \text { Yes } \\ \text { LPEDPLLSGLDSPALK } & 0.97 & 19.08 & 21.27 & 18.93 & 3 & 2065.1947 & 2065.1914 & 689.4044 & 0.0033 & 1.5956 & 113.064 & 144.781 & 112.858 & 25.516 & \text { Yes }\end{array}$ $\begin{array}{llllllllllllllll}\text { LPEDPLLSGLLDSPALK } & 0.97 & 19.08 & 21.27 & 18.93 & 3 & 2065.1947 & 2065.1914 & 689.4044 & 0.0033 & 1.5956 & 113.064 & 144.781 & 112.858 & 25.516 & \text { Yes } \\ \text { RPTPQDSPFPVDDTSR } & 1.00 & 39.64 & 26.86 & 19.81 & 3 & 2331.2020 & 2331.1981 & 778.0733 & 0.0039 & 1.6708 & 512.141 & 1132.396 & 462.332 & 45.761 & \text { Yes }\end{array}$ $\begin{array}{lllllllllllllllll}\text { RPTPQDSPIFLPVDDTSFR } & 1.00 & 39.64 & 26.86 & 19.81 & 3 & 2331.2020 & 2331.1981 & 778.0733 & 0.0039 & 1.6708 & 512.141 & 1132.396 & 462.332 & 45.761 & Y \\ \text { RPTPQDSPIFLPVDDTSFR } & 1.00 & 46.63 & 26.79 & 18.19 & 3 & 233.2041 & 2331.1981 & 778.0733 & 0.0060 & 2.5704 & 264.928 & 292.809 & 630.061 & 376.603 & \mathrm{~N}\end{array}$

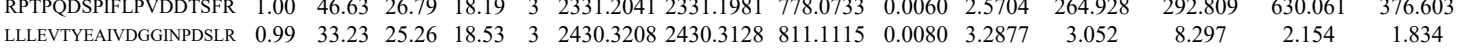
$\begin{array}{lllllllllllllll}\text { LLLEVTYEAIVDGGINPDSLR } & 0.99 & 33.23 & 25.26 & 18.53 & 3 & 2430.3208 & 2430.3128 & 811.1115 & 0.0080 & 3.2877 & 3.052 & 8.297 & 2.154 & 1.834 \\ \text { LLLEVTYEAIVDGGINPDSLR } & 1.00 & 44.67 & 24.97 & 16.03 & 3 & 2430.3259 & 2430.3128 & 811.1115 & 0.0131 & 5.3835 & 8.373 & 12.181 & 8.576 & 12.247\end{array}$

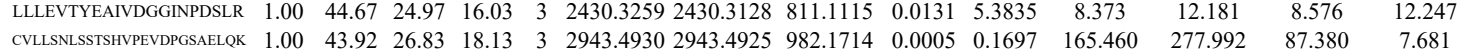
$\begin{array}{lllllllllllllllll}\text { LPEDPLLSGLLDSPALK } & 1.00 & 59.17 & 21.00 & 23.86 & 3 & 2065.1932 & 2065.1914 & 689.4044 & 0.0018 & 0.8703 & 105.637 & 109.944 & 51.298 & 32.539 & \text { Yes }\end{array}$ $\begin{array}{llllllllllllllll}\text { LPEDPLLSGLLDSPALK } & 1.00 & 50.75 & 21.21 & 21.95 & 3 & 2065.1938 & 2065.1914 & 689.4044 & 0.0024 & 1.1604 & 107.724 & 157.363 & 67.772 & 66.534 & \text { Yes }\end{array}$

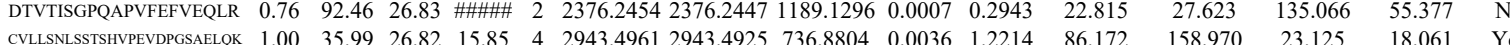
$\begin{array}{lllllllllllllllll}\text { VTAIHIDPATHR } & 0.99 & 30.78 & 27.55 & 18.92 & 3 & 1473.8218 & 1473.8174 & 492.2797 & 0.0044 & 2.9793 & 9906.339 & 14956.741 & 2095.250 & 843.595 & \text { Yes }\end{array}$ \begin{tabular}{lllllllllllllllll} 
VTAIHIDPATHR & 1.00 & 38.30 & 27.47 & 16.06 & 3 & 1473.8224 & 1473.8174 & 492.2797 & 0.0050 & 3.3856 & 7504.599 & 9463.976 & 1877.283 & 1288.253 & Yes \\
\hline
\end{tabular} AYLQAR SEGVVAVLLTK VTAIHIDPATHR VTAIHIDPATHR GLVQALQTK GLVQALQTK LMSAISK LMSAISK GLVQALQTK
GLVQALQTK $\begin{array}{lllllllllllllll}0.51 & 19.56 & 27.72 & 27.87 & 2 & 864.4940 & 864.4939 & 433.2542 & 0.0001 & 0.1154 & 320.945 & 407.051 & 79.016 & 47.218\end{array}$ $\begin{array}{lllllllllllllll}0.81 & 37.54 & 21.73 & 22.49 & 2 & 1402.8590 & 1402.8639 & 702.4392 & -0.0049 & -3.4879 & 1394.928 & 2202.899 & 5920.789 & 6663.615 & \text { No }\end{array}$ $\begin{array}{lllllllllllllll}0.92 & 35.84 & 21.46 & 22.31 & 2 & 1402.8606 & 1402.8639 & 702.4392 & -0.0033 & -2.3490 & 2036.999 & 3194.473 & 10444.367 & 9513.059 & \text { No }\end{array}$ $\begin{array}{lllllllllllllll}1.00 & 35.94 & 27.55 & 16.11 & 3 & 1473.8215 & 1473.8174 & 492.2797 & 0.0041 & 2.7762 & 7102.796 & 7242.185 & 2109.516 & 1289.677 & \text { Yes }\end{array}$ $\begin{array}{lllllllllllllll}0.99 & 29.68 & 27.47 & 15.37 & 3 & 1473.8221 & 1473.8174 & 492.2797 & 0.0047 & 3.1825 & 9059.061 & 12279.539 & 1405.418 & 851.271 & \text { Yes }\end{array}$

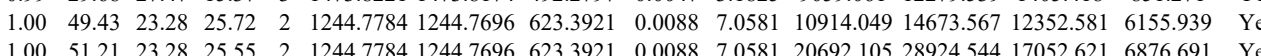
$\begin{array}{lllllllllllllllll}1.00 & 51.21 & 23.28 & 25.55 & 2 & 1244.7784 & 1244.7696 & 623.3921 & 0.0088 & 7.0581 & 20692.105 & 28924.544 & 17052.621 & 6876.691 & \text { Yes } \\ 0.89 & 29.08 & 25.12 & 30.42 & 2 & 1036.6280 & 1036.6194 & 519.3170 & 0.0086 & 8.2800 & 24469.220 & 33953.427 & 14217.767 & 3245.991 & \text { Yes } \\ 0.92 & 30.99 & 25.17 & 26.49 & 2 & 1036.6282 & 1036.6194 & 519.3170 & 0.0088 & 8.4726 & 33464.042 & 47878.970 & 27733.757 & 6789.632 & \text { Yes }\end{array}$ $\begin{array}{lllllllllllllllll}0.92 & 30.99 & 25.17 & 26.49 & 2 & 1036.6282 & 1036.6194 & 519.3170 & 0.0088 & 8.4726 & 33464.042 & 47878.970 & 27733.757 & 6789.632 & \text { Yes } & \\ 1.00 & 53.81 & 23.28 & 29.00 & 2 & 1244.7776 & 1244.7696 & 623.3921 & 0.0080 & 6.4165 & 5252.594 & 7464.281 & 3715.290 & 1617.438 & \text { Yes }\end{array}$ $\begin{array}{lllllllllllllll}1.00 & 53.81 & 23.28 & 29.00 & 2 & 1244.7776 & 1244.7696 & 623.3921 & 0.0080 & 6.4165 & 5252.594 & 7464.281 & 3715.290 & 1617.438 & \text { Yes } \\ 1.00 & 47.70 & 23.28 & 25.57 & 2 & 1244.7778 & 1244.7696 & 623.392 & 0.0082 & 6.5769 & 11841.279 & 15086.441 & 8564.467 & 3227.784 & \text { Yes }\end{array}$

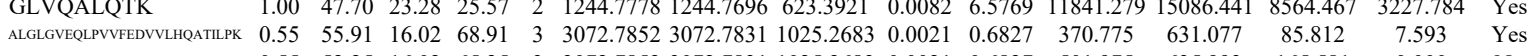

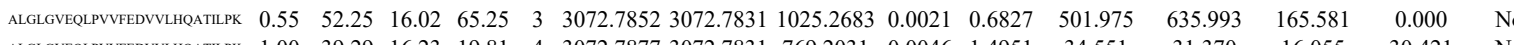
$\begin{array}{llllllllllllllll}\text { ALGLGVELLPVVFEVVLHQATLPK } & 1.00 & 39.29 & 16.23 & 19.81 & 4 & 3072.7877 & 3072.7831 & 769.2031 & 0.0046 & 1.4951 & 34.551 & 31.370 & 16.055 & 30.421 & \text { No }\end{array}$

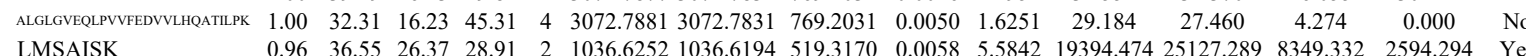

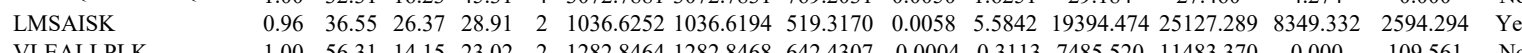

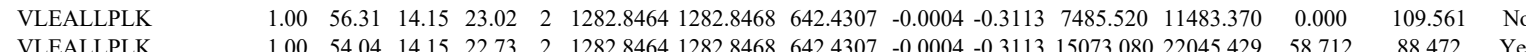

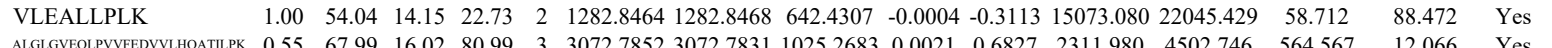

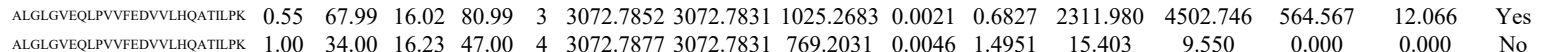

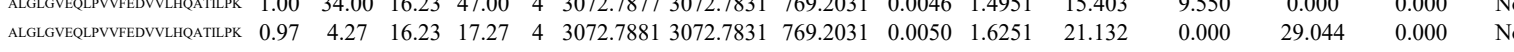

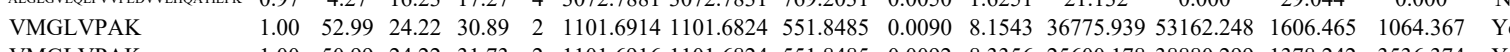
$\begin{array}{llllllllllllllll}\text { VMGLVPAK } & 1.00 & 50.99 & 24.22 & 31.73 & 2 & 1101.6916 & 1101.6824 & 551.8485 & 0.0092 & 8.3356 & 25600.17838880 .299 & 1378.242 & 3536.374 & \text { Yes }\end{array}$

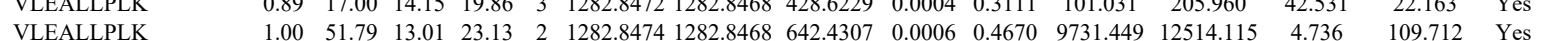
$\begin{array}{llllllllllllllll}\text { VLEALLPLK } & 1.00 & 51.79 & 13.01 & 23.13 & 2 & 1282.8474 & 1282.8468 & 642.4307 & 0.006 & 0.4670 & 9731.449 & 12514.115 & 4.736 & 109.712 & \text { Yes } \\ \text { ALGLGVELPYVEDVLLHQATILKK } & 0.55 & 56.22 & 16.02 & 69.22 & 3 & 3072.7852 & 3072.7831 & 10252683 & 0.0021 & 0.6827 & 969.302 & 1197.377 & 307.139 & 3.327 & \text { Yes }\end{array}$

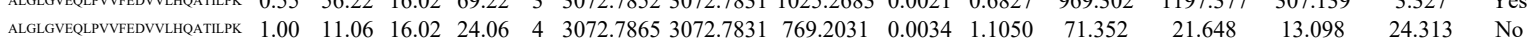
$\begin{array}{llllllllllllllll}\text { ALGLGVELLPVVFEVVLHQATLPK } & 0.99 & 8.08 & 16.02 & 21.08 & 4 & 3072.7889 & 3072.7831 & 769.2031 & 0.0058 & 1.8851 & 19.699 & 13.841 & 0.000 & 14.392 & \text { No }\end{array}$

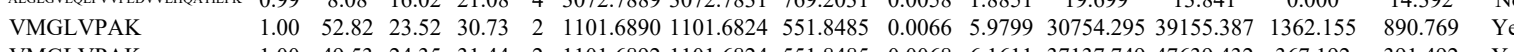
$\begin{array}{llllllllllllllll}\text { VMGLVPA } & 1.00 & 49.53 & 24.35 & 31.44 & 2 & 1101.6892 & 1101.6824 & 551.8485 & 0.0068 & 6.1611 & 37137.749 & 47639.432 & 367.192 & 391.492 & \text { Yes }\end{array}$ $\begin{array}{llllllllllllllll}\text { VLEALLPLK } & 1.00 & 53.72 & 13.01 & 27.59 & 2 & 1282.8474 & 1282.8468 & 642.4307 & 0.0006 & 0.4670 & 15039.995 & 19690.770 & 110.708 & 196.056 & \text { Yes }\end{array}$

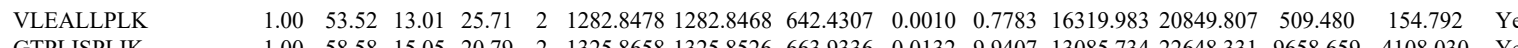

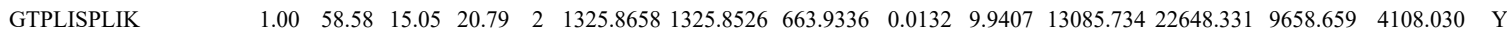
$\begin{array}{llllllllllllllll}\text { MVVPGLDGAQIPR } & 1.00 & 49.87 & 25.89 & 28.11 & 2 & 1495.8442 & 1495.8303 & 748.9224 & 0.0139 & 9.2799 & 6133.323 & 11044.331 & 1265.555 & 160.686 & \text { Yes }\end{array}$ $\begin{array}{llllllllllllllll}\text { MVVPGLDGAQIPR } & 1.00 & 60.60 & 26.05 & 28.81 & 2 & 1495.8448 & 1495.8303 & 748.9224 & 0.0145 & 9.6805 & 8172.567 & 11128.664 & 1832.373 & 68.986 & \text { Yes }\end{array}$

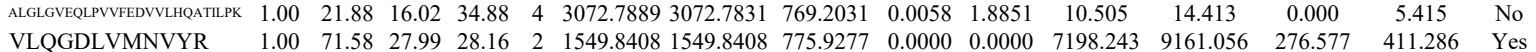
$\begin{array}{llllllllllllllllll}\text { VLQGDLVMNVYR } & 1.00 & 74.20 & 28.01 & 29.15 & 2 & 1549.8412 & 1549.8408 & 775.9277 & 0.0004 & 0.2578 & 4107.532 & 6448.430 & 196.310 & 242.262 & \text { Yes }\end{array}$ $\begin{array}{llllllllllllllll}\text { VVEVLAGHGHLYSR } & 1.00 & 53.69 & 26.83 & 18.81 & 3 & 1679.9335 & 1679.9229 & 560.9816 & 0.0106 & 6.2984 & 14170.554 & 14905.287 & 1488.825 & 919.143 & \text { Yes }\end{array}$ $\begin{array}{lllllllllllllllll}\text { VVEVLAGHGHLYSR } & 1.00 & 81.03 & 26.94 & 20.39 & 3 & 1679.9350 & 1679.9229 & 560.9816 & 0.0121 & 7.1897 & 11520.339 & 20737.428 & 2067.656 & 899.741 & \text { Yes }\end{array}$ $\begin{array}{llllllllllllllll}\text { CPPGVVPACHNSK } & 0.97 & 30.87 & 26.18 & 16.70 & 3 & 1687.8004 & 1687.7910 & 563.6043 & 0.0094 & 5.5594 & 20313.914 & 21473.118 & 6217.114 & 1937.628 & \text { Yes }\end{array}$ $\begin{array}{lllllllllllllllll}\text { CPPGVVPACHNSK } & 1.00 & 64.95 & 26.26 & 17.74 & 3 & 1687.8013 & 1687.7910 & 563.6043 & 0.0103 & 6.0917 & 7590.257 & 10161.456 & 4346.472 & 2290.961 & \text { Yes }\end{array}$

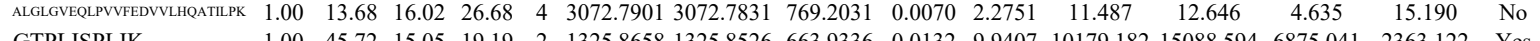

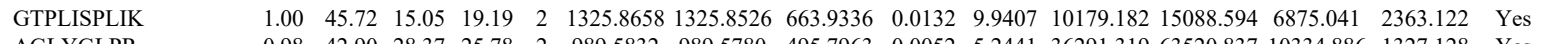

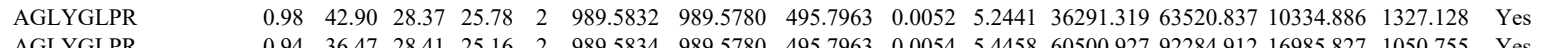

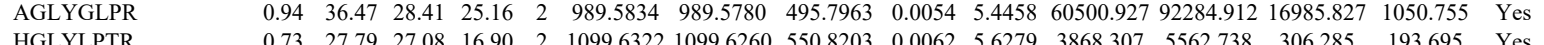
\begin{tabular}{llllllllllllllll} 
HGLYLPTR & 0.73 & 27.79 & 27.08 & 16.90 & 2 & 1099.6322 & 1099.6260 & 550.8203 & 0.0062 & 5.6279 & 3868.307 & 5562.738 & 306.285 & 193.695 & Yes \\
\hline
\end{tabular}

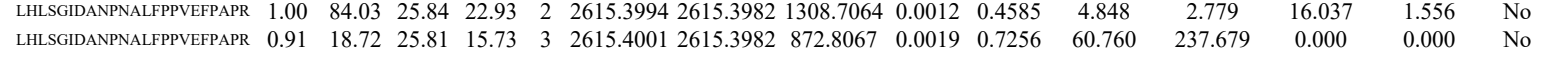

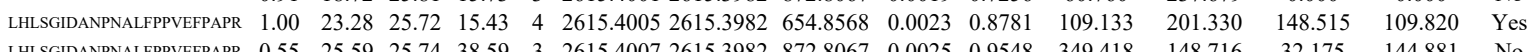
$\begin{array}{llllllllllllllll}\text { LHLSGIDANPNALFPPVEFAPR } & 1.00 & 27.45 & 25.75 & 16.72 & 4 & 2615.4009 & 2615.3982 & 654.8568 & 0.0027 & 1.0308 & 119.616 & 274.958 & 156.085 & 138.843 & \text { Y }\end{array}$

Table S-3 page 262 of 499 
$\begin{array}{lllllllllllll} & \end{array}$ $\begin{array}{lllllllllll} & \\ 1\end{array}$ $\begin{array}{lllllllllllll}1.00 & 34.10 & 23.24 & 47.10 & 4 & 3485.8641 & 3485.8694 & 872.4746 & -0.0053 & -1.5187 & 32.794 & 93.573 & 46.813\end{array}$

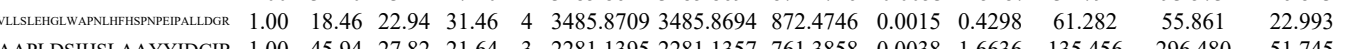
$\begin{array}{llllllllllllll}\text { AAPLDSIHSLAAYYIDCIR } & 1.00 & 45.94 & 27.82 & 21.64 & 3 & 2281.1395 & 2281.1357 & 761.3858 & 0.0038 & 1.6636 & 135.456 & 296.480 & 51.745\end{array}$

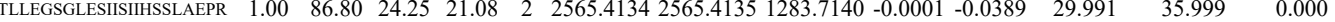
$\begin{array}{lllllllllllllll}\text { TLLEGSGLESIISIIHSSLAEPR } & 0.77 & 86.85 & 24.01 & 99.85 & 2 & 2565.4154 & 2565.4135 & 1283.7140 & 0.0019 & 0.7400 & 23.856 & 27.042 & 6.041\end{array}$

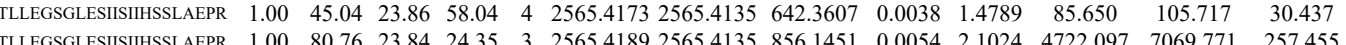
$\begin{array}{llllllllllllll}\text { TLLEGSGLESIISIHSSLAEPR } & 1.00 & 80.76 & 23.84 & 24.35 & 3 & 2565.4189 & 2565.4135 & 856.1451 & 0.0054 & 2.1024 & 4722.097 & 7069.771 & 257.455\end{array}$

$\begin{array}{lllllllllllll} & \end{array}$

$\begin{array}{lllllllllllllll} & \text { YHGNVMLLR } & 0.93 & 28.50 & 27.81 & 24.89 & 3 & 1245.6856 & 1245.6774 & 416.2331 & 0.0082 & 6.5668 & 18214.036 & 18451.603 & 2976.243\end{array}$ $\begin{array}{llllllllllll} & \end{array}$

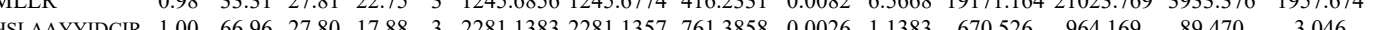
$\begin{array}{lllllllllllllll} & \end{array}$ $\begin{array}{llllllllllllllll} & \end{array}$ $\begin{array}{llllllllllllllll}\text { EGGFLLLHTLLR } & 1.00 & 57.09 & 23.46 & 25.03 & 3 & 1511.8966 & 1511.8946 & 504.9721 & 0.0020 & 1.3202 & 3276.553 & 4897.900 & 4226.523 & 831.969 & \text { Yes }\end{array}$ $\begin{array}{lllllllllllllllll}\text { EGGFLLLHTLL } & 1.00 & 57.09 & 23.46 & 25.03 & 3 & 1511.8966 & 1511.8946 & 504.9721 & 0.0020 & 1.3202 & 3276.553 & 4897.900 & 4226.523 & 831.969 & \text { Yes } \\ \text { EGGFLLLHTLLR } & 1.00 & 54.08 & 23.36 & 19.89 & 3 & 1511.8975 & 1511.8946 & 504.9721 & 0.0029 & 1.9143 & 1605.904 & 2292.572 & 1969.275 & 691.332 & \text { Yes }\end{array}$ $\begin{array}{lllllllllll} & \end{array}$ $\begin{array}{llllllllllllll}1.00 & 48.49 & 23.36 & 30.08 & 3 & 1511.8957 & 1511.8946 & 504.9721 & 0.0011 & 0.7261 & 4272.975 & 6238.487 & 6080.230 & 15\end{array}$ $\begin{array}{lllllllllllll} & \end{array}$

LSFFFDR $\begin{array}{lllllllllllll}25.76 & 29.31 & 21.62 & 2 & 922.4940 & 922.4850 & 462.2498 & 0.0090 & 9.7349 & 34655.920 & 37117.708 & 1769.758\end{array}$ $\begin{array}{lllllllllllll}0.89 & 25.84 & 28.14 & 18.38 & 2 & 1221.6310 & 1221.6304 & 611.8225 & 0.0006 & 0.4903 & 1631.738 & 2305.660 & 379.096\end{array}$

LSIPTYGLQCTR $\begin{array}{lllllllllllll}0.75 & 21.57 & 28.14 & 19.03 & 2 & 1221.6312 & 1221.6304 & 611.8225 & 0.0008 & 0.6538 & 1716.469 & 2894.077 & 453.516 \\ 0.73 & 23.74 & 25.88 & 22.88 & 2 & 1039.5160 & 1039.5065 & 520.765 & 0.005 & 9.1212 & 36896.459 & 47350.249 & 356.150\end{array}$

LSIPTYGLQCTR $\begin{array}{lllllllllllll}0.73 & 23.74 & 25.88 & 22.88 & 2 & 1039.5160 & 1039.5065 & 520.7605 & 0.0095 & 9.1212 & 36896.459 & 47350.249 & 356.150\end{array}$

LSIPTYGLQCTR $\begin{array}{llllllllllllll}.00 & 69.35 & 27.57 & 25.43 & 2 & 1540.7866 & 1540.7863 & 771.4004 & 0.0003 & 0.1945 & 6763.672 & 12697.731 & 0.000\end{array}$

LSIPTYGLQCTR

$\begin{array}{llllllllllllll}1.00 & 53.83 & 27.53 & 19.79 & 2 & 1540.7872 & 1540.7863 & 771.4004 & 0.0009 & 0.5834 & 1057.454 & 1804.848 & 73.861\end{array}$ $\begin{array}{lllllllllllll}1.00 & 31.62 & 27.51 & 20.07 & 3 & 1540.7881 & 1540.7863 & 514.6027 & 0.0018 & 1.1659 & 188.861 & 158.684 & 61.707\end{array}$

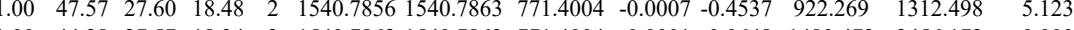
$\begin{array}{lllllllllllll}1.00 & 44.28 & 27.57 & 18.34 & 2 & 1540.7862 & 1540.7863 & 771.4004 & -0.0001 & -0.0648 & 1480.472 & 2456.172 & 0.000\end{array}$ $\begin{array}{lllllllllllll}0.76 & 53.98 & 26.97 & 66.98 & 2 & 1482.7128 & 1482.7121 & 742.3633 & 0.0007 & 0.4715 & 595.799 & 951.143\end{array}$ $\begin{array}{llllllllllll}0.76 & 60.62 & 26.96 & 73.62 & 2 & 1482.7132 & 1482.7121 & 742.3633 & 0.0011 & 0.7409 & 814.203 & 1236.327 \\ 0.95 & 28.38 & 26.97 & 17.54 & 2 & 1482.7136 & 1482.7121 & 742.363 & 0.0015 & 1.0103 & 588.63 & 92.65\end{array}$ SFYGSTLFLC $\begin{array}{lllllllllllll}0.95 & 28.38 & 26.97 & 17.54 & 2 & 1482.7136 & 1482.7121 & 742.3633 & 0.0015 & 1.0103 & 588.163 & 920.605\end{array}$ 30.254 SFYGSTLFLCR $\begin{array}{lllllllllll}0.95 & 28.29 & 26.97 & 19.51 & 2 & 1482.7136 & 1482.7121 & 742.3633 & 0.0015 & 1.0103 & 450.528\end{array}$

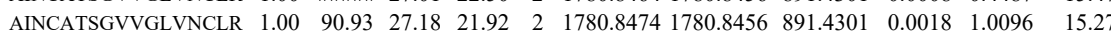
$\begin{array}{llllllllllll} & \end{array}$ $\begin{array}{llllllllllllll}\text { ANCATSGVVGLVNCLR } & 1.00 & 51.23 & 27.97 & 17.50 & 3 & 1924.9495 & 1924.9477 & 642.6565 & 0.0018 & 0.9336 & 23.303\end{array}$ 

$\begin{array}{lllllllllllll}\text { AINCATSGVVGLVNCLR } & 1.00 & 66.63 & 27.98 & 19.14 & 3 & 1924.9498 & 1924.9477 & 642.6565 & 0.0021 & 1.0892 & 34.780\end{array}$ $\begin{array}{lllllllllllll}\text { AINCATSGVVGLVNCLR } & 1.00 & 52.01 & 28.00 & 18.70 & 3 & 1924.9501 & 1924.9477 & 642.6565 & 0.0024 & 1.2448 & 25.172 \\ \text { AINCATSGVVGLVNCLR } & 1.00 & \# \# \# \# \frac{27.88}{22.54} & 2 & 1924.9484 & 1924.9477 & 963.4811 & 0.0007 & 0.3633 & 146.640\end{array}$

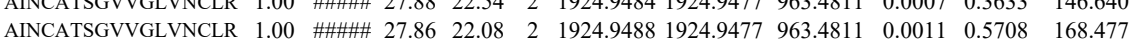
$\begin{array}{llllllllllll}\text { AINCATSGVVGLVNCLR } & 1.00 & 60.89 & 27.98 & 17.70 & 3 & 1924.9498 & 1924.9477 & 642.6565 & 0.0021 & 1.0892 & 19.673\end{array}$ $\begin{array}{lllllllllllll}\text { AINCATSGVVGLVNCLR } & 1.00 & 91.32 & 28.06 & 22.54 & 3 & 1924.9504 & 1924.9477 & 642.6565 & 0.0027 & 1.4004 & 22.759\end{array}$ $\begin{array}{llllllllllllll}\text { QGVQVQVSTSNISLEGAR } & 0.80 & 18.38 & 27.51 & 16.81 & 3 & 2103.1048 & 2103.1042 & 702.0420 & 0.0006 & 0.2849 & 18.777\end{array}$ $\begin{array}{llllllllllll}\text { QGVQVQVSTSNISSLEGAR } & 1.00 & 55.61 & 27.40 & 22.58 & 3 & 2103.1051 & 2103.1042 & 702.0420 & 0.0009 & 0.4273 & 16.685\end{array}$ $\begin{array}{lllllllllllll}\text { QGVQVQVSTSNISSLEGAR } & 1.00 & 90.19 & 27.40 & 26.21 & 3 & 2103.1051 & 2103.1042 & 702.0420 & 0.0009 & 0.4273 & 3.954\end{array}$ $\begin{array}{lllllllllllll}\text { LLSAACR } & 0.75 & 24.30 & 27.89 & 26.03 & 2 & 922.4854 & 922.4850 & 462.2498 & 0.0004 & 0.4327 & 900.491\end{array}$ $\begin{array}{lllllllllllll}\text { LLSAACR } & 0.55 & 20.30 & 27.89 & 22.00 & 2 & 922.4854 & 922.4850 & 462.2498 & 0.0004 & 0.4327 & 630.549\end{array}$ $\begin{array}{lllllllllllll}\text { AINCATSGVVGLVNCLR } & 1.00 & 51.64 & 27.84 & 18.03 & 3 & 1924.9471 & 1924.9477 & 642.6565 & -0.0006 & -0.3112 & 8.724\end{array}$ $\begin{array}{lllllllllllll}\text { AINCATSGVVGLVNCLR } & 1.00 & 48.74 & 28.00 & 16.97 & 3 & 1924.9501 & 1924.9477 & 642.6565 & 0.0024 & 1.2448 & 0.000 \\ \text { AINCATSGVVGLVNCLR } & 1.00 & 86.32 & 27.85 & 23.12 & 2 & 1924.9464 & 1924.9477 & 963.4811 & -0.0013 & -0.6746 & 8.964\end{array}$ $\begin{array}{lllllllllllll}\text { AINCATSGVVGLVNCLR } & 1.00 & 45.95 & 27.98 & 18.12 & 3 & 1924.9498 & 1924.9477 & 642.6565 & 0.0021 & 1.0892 & 3.082\end{array}$ $\begin{array}{lllllllllllll}\text { ADEASELACPTPK } & 1.00 & 77.84 & 27.04 & 27.69 & 2 & 1664.8152 & 1664.7993 & 833.4069 & 0.0159 & 9.5391 & 602.908 & 1.62 .3\end{array}$ $\begin{array}{lllllllllllllll}\text { ADEASELACPTPK } & 1.00 & 94.20 & 27.08 & 32.30 & 2 & 1664.8156 & 1664.7993 & 833.4069 & 0.0163 & 9.7790 & 577.225 & 902.325 & 425.713\end{array}$

$\begin{array}{lllllllllllllll}\text { ADEASELACPTK } & 1.00 & 94.20 & 27.08 & 32.30 & 2 & 1664.8156 & 1664.7993 & 833.4069 & 0.0163 & 9.7790 & 577.225 & 902.325 & 425.713 \\ \text { QQEQQVPILEK } & 1.00 & 63.10 & 25.54 & 30.51 & 2 & 1626.9336 & 1626.9184 & 814.4665 & 0.0152 & 9.3312 & 1091.883 & 1663.421 & 1246.788\end{array}$ QQEQQVPILEK

$\begin{array}{lllllllllllll}1.00 & 65.60 & 25.29 & 26.61 & 2 & 1626.9338 & 1626.9184 & 814.4665 & 0.0154 & 9.4540 & 1617.596 & 2488.288 & 1649.956\end{array}$ QQEQQVPILEK

$\begin{array}{lllllllllllll}\text { TCPG_HUMAN } & \text { P49368 } & \text { CCT3 } & \text { T-complex proteir } 60.53 & 1.00 & 18 & 40.6 & 0.0158 & 0.3030 & -0.1545 & 1.8353 & 74 & \text { IDDIVSGHK }\end{array}$ IDDIVSGHK IDDIVSGHK IDDIVSGHK $\begin{array}{llllllllllllll}1 & \end{array}$ $\begin{array}{lllllllllllllll}1.00 & 56.74 & 26.44 & 28.25 & 3 & 1270.7215 & 1270.7125 & 424.5781 & 0.0090 & 7.0658 & 17308.208 & 19395.643 & 7617.604 & 27\end{array}$ $\begin{array}{llllllllllllll}1.00 & 50.11 & 26.48 & 26.61 & 3 & 1270.7200 & 1270.7125 & 424.5781 & 0.0075 & 5.8882 & 23402.241 & 24374.533 & 8327.703 & 3\end{array}$ $\begin{array}{rllllllllllllll}1.00 & 59.18 & 26.58 & 44.29 & 2 & 1270.7226 & 1270.7125 & 636.3635 & 0.0101 & 7.9357 & 10150.699 & 11873.322 & 8320.317 & 5462.220 & \text { Yss }\end{array}$ $\begin{array}{llllllllllllllll} & \end{array}$ \begin{tabular}{llllllllllllllll} 
IVSRPEELREDDVGGGALLEIK & 1.00 & 25.30 & 22.60 & 38.30 & 4 & 2783.5345 & 2783.5272 & 696.8891 & 0.0073 & 2.6188 & 1495.484 & 1234.310 & 404.534 & 211.411 & Yes \\
\hline
\end{tabular}

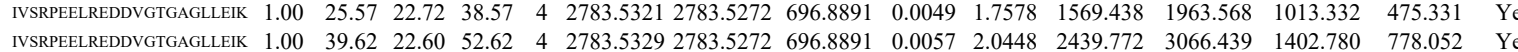

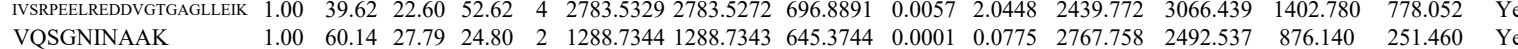

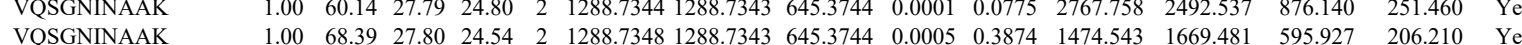

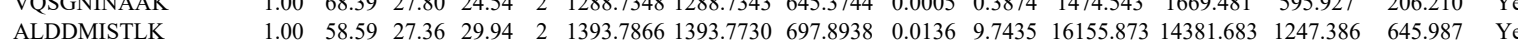
ALDDMISTLK

ALDDMISTLK

ALDDMISTLK

KVQSGNINAAK

KVQSGNINAAK

IVLLDSSLEYK IGDEYFTFITDCK IGDEYFTFITDCK IGDEYFTFITDCK $\begin{array}{lllllllllllllll}1.00 & 58.59 & 27.36 & 29.94 & 2 & 1393.7866 & 1393.7730 & 697.8938 & 0.0136 & 9.7435 & 16155.873 & 14381.683 & 1247.386 & 645.987 & \text { Yes } \\ 1.00 & 56.64 & 27.19 & 29.13 & 2 & 1393.7868 & 1393.7730 & 697.8938 & 0.0138 & 9.8868 & 14392.424 & 13269.169 & 1202.117 & 1615.846 & \text { Yes }\end{array}$

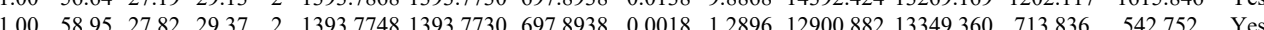
$\begin{array}{lllllllllllllll}1.00 & 70.47 & 27.84 & 30.91 & 2 & 1393.7754 & 1393.7730 & 697.8938 & 0.0024 & 1.7195 & 19984.378 & 19705849 & 682.378 & 476.931 & \text { Yes }\end{array}$

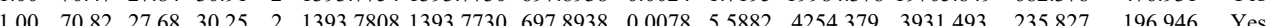

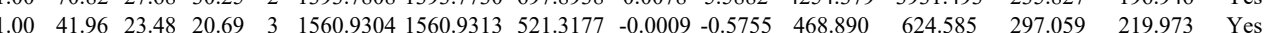

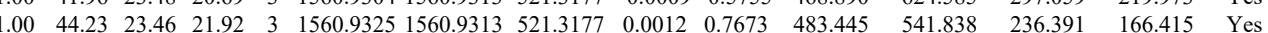
$\begin{array}{llllllllllllllll}1.00 & 84.33 & 24.13 & 21.78 & 2 & 1566.9168 & 1566.9112 & 784.4629 & 0.0056 & 3.5693 & 2659.763 & 2651.504 & 57.047 & 57.678 & \text { Y ses }\end{array}$ $\begin{array}{lllllllllllllll}100 & 69.69 & 26.27 & 17.55 & 2 & 1884.8902 & 1884.8882 & 943.4514 & 0.0020 & 1.0599 & 1461.275 & 1490.769 & 94.673 & 27.314 & \text { Yes }\end{array}$ IGDEYFTFITDCK $\begin{array}{lllllllllllllllll}0.69 & 61.29 & 26.29 & 74.29 & 2 & 1884.8908 & 1884.8882 & 943.4514 & 0.0026 & 1.3779 & 1696.838 & 1584.614 & 58.882 & 45.691 & \text { Yes } & \\ \end{array}$ $\begin{array}{llllllllllllllll} & \\ \text { IGDEYFTFITDCK } & 0.97 & 24.89 & 26.31 & 14.92 & 3 & 1884.8920 & 1884.8882 & 629.3033 & 0.0038 & 2.0128 & 136.047 & 166.064 & 59.488 & 34.442 & \text { Yes } \\ & 1.00 & 38.25 & 26.30 & 25.08 & 3 & 1884.8923 & 1884.8882 & 629.3033 & 0.0041 & 2.1717 & 179.773 & 170.294 & 97.666 & 50.453 & \text { Yes }\end{array}$ $\begin{array}{lllllllllllllllll}\text { NVLLPPLLPGGGASEMAVAHALTEK } & 1.00 & 71.03 & 24.20 & 17.77 & 3 & 2904.5692 & 2904.5623 & 969.1947 & 0.0069 & 2.3731 & 1289.850 & 1441.781 & 782.822 & 172.345 & \text { Yes }\end{array}$ $\begin{array}{lllllllllllllllll} & 24 . D P P L L G G G A A E M A V A H A L T E K & 0.55 & 41.43 & 24.30 & 54.43 & 3 & 2904.5647 & 2904.5623 & 969.1947 & 0.0024 & 0.8254 & 155.126 & 233.780 & 180.438 & 41.355 & \text { No }\end{array}$ $\begin{array}{lllllllllllllllll} & \text { ISIPDISDSDMMLNIINSSITTK } & 1.00 & 61.69 & 25.42 & 44.14 & 3 & 2894.5258 & 2894.5224 & 965.8481 & 0.0034 & 1.1734 & 104.621 & 31.631 & 0.000 & 16.407 & \text { No }\end{array}$ $\begin{array}{llllllllllllllll}\text { ISPRDISDSDMMLNIINSSITTK } & 0.99 & 38.67 & 25.38 & 32.33 & 3 & 2894.5273 & 2894.5224 & 965.8481 & 0.0049 & 1.6911 & 72.683 & 10.430 & 0.000 & 0.000 & \text { No }\end{array}$

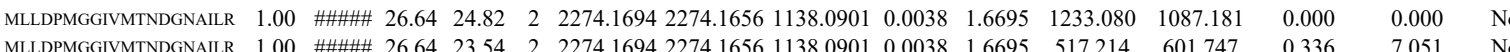

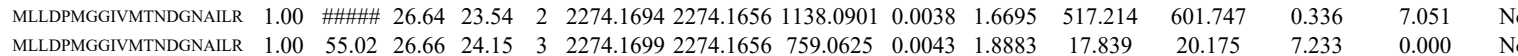

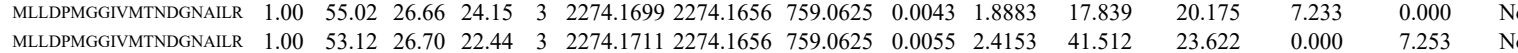

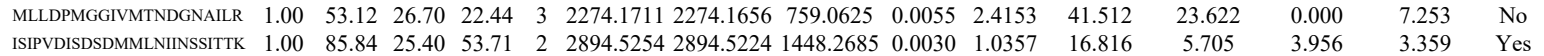
$\begin{array}{ccccccccccccc}\text { MLLDPU } & \text { Yes }\end{array}$

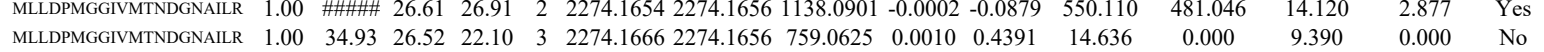

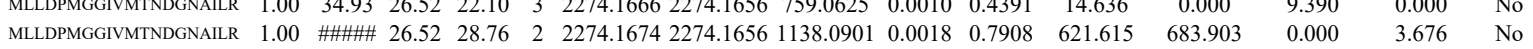

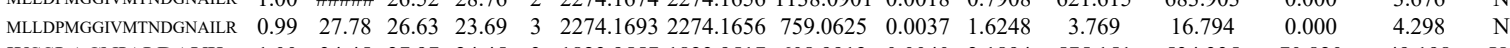

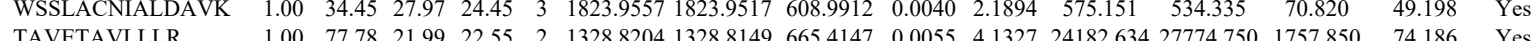

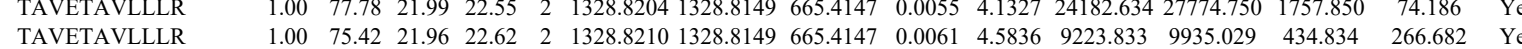


TAVETAVLLLR GISDLAQHYLMR GISDLAQHYLMR TAVETAVLLLR TAVETAVLLLR TLIQNCGASTIR TLIQNCGASTIR TLIQNCGAS
LLTSLR

TLIQNCGASTIR

TLIQNCGASTIR

ACTILLR

ACTILLR

ACTILLR
ACTILLR

ACTILLR

ACTILLR

ACTILLR

ACTILLR
ACTILLR

ACTILLR
ACTILLR

ACTILLR
ACTILLR

ACTILLR

ACTILLR

ACTILLR

ACTILLR

ACTILLR

ACTILLR

ACTILLR

ACTILLR

ACTILLR

ACTILLR

ACTILLR

ACTILLR

ACTILLR

ACTILLR

ACTILLR

ACTILLR

ACTILLR

ACTILLR

ACTILLR

ACTILLR

ACTILLR

EDDVGTGAGLLEIK

EDDVGTGAGLLEIK

EDDVGTGAGLLEIK EDDVGTGAGLLEIK KGESQTDIEITR
KGESQTDIEITR KGESQTDIEITR KGESQTDIEITR

$\begin{array}{llllllllllll} & \text { EFTU HUMAN P49411 TUFM Elongation factor' } 49.54 & 1.00 & 11 & 33.6 & -0.0123 & 0.1797 & -0.5488 & 1.8119 & 24 & \text { AEAGDNLGALVR }\end{array}$

AEAGDNLGALVR

AEAGDNLGALVR

AEAGDNLGALVR

TIGTGLVTNTLAMTEEEK

TIGTGLVTNTLAMTEEEK

TIGTGLVTNTLAMTEEEK
DKPHVNVGTIGHVDHGK

DKPHVNVGTIGHVDHGK
DKPHVNVGTIGHVDHGK

DKPHVNVGTIGHVDHGK
GEETPVIVGSALCALEGR GEETPVIVGSALCALEGR TTLTAAITK TTLTAAITK
TTLTAAITK

DLEKPFLLPVEAVYSYPGR

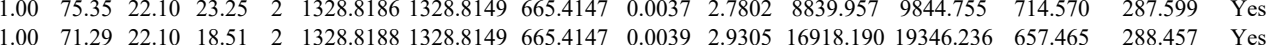
$\begin{array}{llllllllllllllll}0 & 65.70 & 27.89 & 28.74 & 3 & 1328.8188 & 1328.8149 & 665.4147 & 0.0039 & 2.9305 & 16918.190 & 19346.236 & 657.465 & 288.457 & \text { Yes } \\ 1.00 & 64.67546 .8048 & 516.6089 & 0.0025 & 1.6131 & 5693.156 & 7473.128 & 2036.773 & 443.764 & \text { Y }\end{array}$ \begin{tabular}{lllllllllllllllll}
1.00 & 64.67 & 27.89 & 22.45 & 3 & 1546.8076 & 1546.8048 & 516.6089 & 0.0028 & 1.8067 & 5259.941 & 7022.969 & 922.275 & 238.822 & Yes \\
\hline
\end{tabular} $\begin{array}{llllllllllllllll}1.00 & 75.15 & 22.72 & 19.74 & 2 & 1328.8156 & 1328.8149 & 665.4147 & 0.0007 & 0.5260 & 9390.061 & 11260.088 & 1121.043 & 455.826 & \text { Yes } & \\ \end{array}$ $\begin{array}{llllllllllllllll}1.00 & 75.13 & 22.36 & 21.46 & 2 & 1328.8170 & 1328.8149 & 665.4147 & 0.0021 & 1.5780 & 11160.613 & 10729.275 & 77.444 & 305.698 & \text { Yes } & \\ 1.00 & 67.76 & 27.84 & 24.60 & 2 & 1465.7646 & 145.7503 & 733.8824 & 0.0243 & 9.7426 & 20766.793 & 22910.829 & 772.940 & 142.138 & \text { Yes }\end{array}$ $\begin{array}{llllllllllllllll}1.00 & 67.76 & 27.84 & 24.60 & 2 & 1465.7646 & 1465.7503 & 733.8824 & 0.0143 & 9.7426 & 20766.793 & 22910.829 & 772.940 & 142.138 & \text { Yes } \\ 1.00 & 63.20 & 28.46 & 25.86 & 2 & 1455.7512 & 145.7503 & 733.8824 & 0.0009 & 0.6132 & 13495.726 & 12443.295 & 134.936 & 11.157 & \text { Yes }\end{array}$

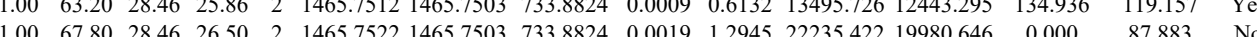
$\begin{array}{lllllllllllllll}1.00 & 67.80 & 28.46 & 26.50 & 2 & 1465.7522 & 465.7503 & 733.8824 & 0.0019 & 1.2945 & 22235.422 & 19980.646 & 0.000 & 87.883 & \text { No } \\ 0.81 & 29.13 & 26.04 & 33.68 & 2 & 845.5532 & 845.5456 & 423.7801 & 0.0076 & 8.9668 & 13800.142 & 13269.628 & 1165.555 & 1007.915 & \text { Yes }\end{array}$

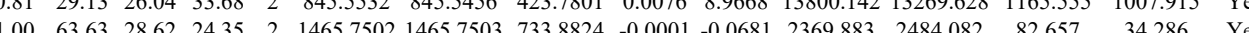

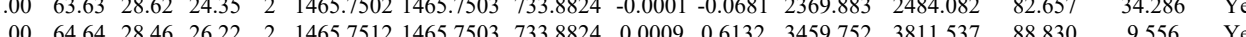
$\begin{array}{llllllllllllllll}0.53 & 19.99 & 27.78 & 17.82 & 2 & 978.5480 & 978.5476 & 490.2811 & 0.0004 & 0.4079 & 29.397 & 45.083 & 0.000 & 2.936 & \text { No }\end{array}$

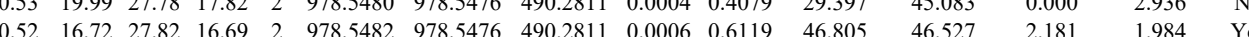
$\begin{array}{lllllllllllllll}0.83 & 23.30 & 27.82 & 22.01 & 2 & 978.5482 & 978.5476 & 490.2811 & 0.0006 & 0.6119 & 39.883 & 22.559 & 5.471 & 0.981 & \text { No } \\ 0.97 & 1.56 & 27.51 & 20.28 & 2 & 978.5486 & 98.5476 & 49.2811 & 0.000 & 1.0198 & 34.371 & 45.935 & 8.857 & 13.13 & \text { Yes }\end{array}$ $\begin{array}{lllllllllllllllll}0.97 & 31.66 & 27.51 & 20.28 & 2 & 978.5486 & 978.5476 & 490.2811 & 0.0010 & 1.0198 & 34.371 & 45.935 & 8.457 & 13.130 & \text { Y }\end{array}$ $\begin{array}{llllllllllllllll}0.94 & 28.17 & 27.51 & 20.10 & 2 & 978.5486 & 978.5476 & 490.2811 & 0.0010 & 1.0198 & 62.654 & 79.819 & 0.000 & 0.000 & \mathrm{No}\end{array}$ $\begin{array}{llllllllllllllll}0.69 & 19.60 & 27.51 & 17.88 & 2 & 978.5488 & 978.5476 & 490.2811 & 0.0012 & 1.2238 & 37.542 & 64.867 & 9.031 & 0.000 & \mathrm{~N} 0\end{array}$ $\begin{array}{lllllllllllllll}0.98 & 32.80 & 27.51 & 18.99 & 2 & 978.5488 & 978.5476 & 490.2811 & 0.0012 & 1.2238 & 45.251 & 40.233 & 3.580 & 1.730 & \text { Yes }\end{array}$ $\begin{array}{llllllllllllllll}0.71 & 20.01 & 27.54 & 21.64 & 2 & 978.5490 & 978.5476 & 490.2811 & 0.0014 & 1.4278 & 36.835 & 50.376 & 5.810 & 6.703 & \text { Yes }\end{array}$ $\begin{array}{llllllllllllllll}0.66 & 22.25 & 27.78 & 23.42 & 2 & 978.5480 & 978.5476 & 490.2811 & 0.0004 & 0.4079 & 86.138 & 103.368 & 14.421 & 11.250 & \text { Yes }\end{array}$ $\begin{array}{lllllllllllllll}0.63 & 18.69 & 27.82 & 16.89 & 2 & 978.5482 & 978.5476 & 490.2811 & 0.0006 & 0.6119 & 103.714 & 136.053 & 32.434 & 16.736 & \text { Yes }\end{array}$ $\begin{array}{lllllllllllllllll}0.70 & 19.82 & 27.51 & 17.43 & 2 & 978.5484 & 978.5476 & 490.2811 & 0.0008 & 0.8159 & 65.863 & 86.323 & 20.121 & 12.972 & \text { Yes }\end{array}$ $\begin{array}{llllllllllllllll}0.77 & 21.42 & 27.51 & 20.93 & 2 & 978.5486 & 978.5476 & 490.2811 & 0.0010 & 1.0198 & 76.789 & 82.471 & 14.945 & 7.964 & \text { Yes }\end{array}$ $\begin{array}{lllllllllllllll}0.74 & 21.30 & 28.44 & 19.61 & 2 & 978.5494 & 978.5476 & 490.2811 & 0.0018 & 1.8357 & 121.736 & 137.773 & 22.417 & 12.657 & \text { Yes }\end{array}$ \begin{tabular}{llllllllllllllll}
0.73 & 21.12 & 28.43 & 16.69 & 2 & 978.5498 & 978.5476 & 490.2811 & 0.0022 & 2.2436 & 80.271 & 78.144 & 16.801 & 12.054 & Yes \\
\hline
\end{tabular} $\begin{array}{llllllllllllllll}0.92 & 28.94 & 28.18 & 17.15 & 2 & 978.5502 & 978.5476 & 490.2811 & 0.0026 & 2.6515 & 71.034 & 74.270 & 7.766 & 4.072 & \text { Yes }\end{array}$ $\begin{array}{llllllllllllllll}0.86 & 31.14 & 28.31 & 27.33 & 2 & 978.5568 & 978.5476 & 490.2811 & 0.0092 & 9.3823 & 14999.896 & 18127.143 & 1121.463 & 90.412 & \text { Yes }\end{array}$ $\begin{array}{lllllllllllllll}0.71 & 27.70 & 27.94 & 16.75 & 2 & 978.5468 & 978.5476 & 490.2811 & -0.0008 & -0.8159 & 52.703 & 80.432 & 8.763 & 1.013 & \text { Yes }\end{array}$

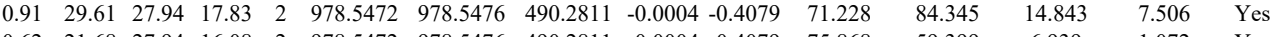

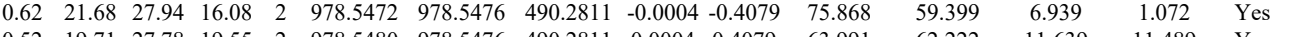
\begin{tabular}{lllllllllllllll}
0.52 & 19.71 & 27.78 & 19.55 & 2 & 978.5480 & 978.5476 & 490.2811 & 0.0004 & 0.4079 & 63.991 & 62.222 & 11.639 & 11.489 & Yes \\
\hline .02 & 27.24 & 27.82 & 6.33 & 2 & 978.5482 & 978.5476 & 40.2811 & 0.006 & 0.6119 & 99.152 & 87.806 & 11.297 & 6.413 & Yes
\end{tabular} $\begin{array}{llllllllllllllll}0.92 & 27.24 & 27.82 & 16.33 & 2 & 978.5482 & 978.5476 & 490.2811 & 0.0006 & 0.6119 & 99.152 & 87.806 & 10.297 & 6.413 & \text { Yes } \\ 0.77 & 21.4 & 27.51 & 19.77 & 2 & 978.5484 & 9785476 & 49.2811 & 0.0008 & 0.8159 & 104704 & 92.657 & 24764 & 10.108 & \text { Yes }\end{array}$ $\begin{array}{lllllllllllllll}0.77 & 21.49 & 27.51 & 19.77 & 2 & 978.5484 & 978.5476 & 490.2811 & 0.0008 & 0.8159 & 104.704 & 92.657 & 24.764 & 10.108 & \text { Yes } \\ 0.96 & 30.01 & 27.51 & 24.19 & 2 & 978.5486 & 978.5476 & 490.2811 & 0.0010 & 1.0198 & 68.658 & 61.587 & 13.423 & 5.402 & \text { Yes }\end{array}$ $\begin{array}{lllllllllllllll}0.96 & 30.01 & 27.51 & 24.19 & 2 & 978.5486 & 978.5476 & 490.2811 & 0.0010 & 1.0198 & 68.658 & 61.587 & 13.423 & 5.402 & \text { Yes } \\ 0.99 & 36.75 & 28.43 & 23.17 & 2 & 978.5498 & 978.5476 & 490.2811 & 0.0022 & 2.436 & 57.664 & 64.996 & 14.721 & 3.545 & \text { Yes }\end{array}$

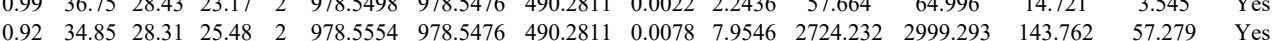
$\begin{array}{lllllllllllllll}0.92 & 44.85 & 28.31 & 25.48 & 2 & 978.5554 & 978.5476 & 490.2811 & 0.0078 & 7.9546 & 2724.232 & 2999.293 & 143.762 & 57.279 & \text { Yes } \\ 0.90 & 33.64 & 28.52 & 27.64 & 2 & 978.556 & 978.5476 & 490.2811 & 0.0080 & 8.1585 & 7391.869 & 9583.489 & 388.317 & 159.486 & \text { Yes }\end{array}$ $\begin{array}{llllllllllllllll}0.99 & 34.58 & 27.51 & 22.31 & 2 & 978.5488 & 978.5476 & 490.2811 & 0.0012 & 1.2238 & 6434.942 & 6725.476 & 382539 & 73.419 & \text { Yes }\end{array}$

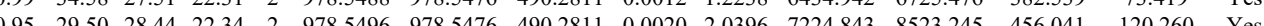
$\begin{array}{llllllllllllllll}0.67 & 19.35 & 27.54 & 18.21 & 2 & 978.5490 & 978.5476 & 4902811 & 0.0014 & 1.4278 & 1275.440 & 1270.518 & 504.190 & 585.239 & \text { Yes }\end{array}$ $\begin{array}{lllllllllllllll}0.91 & 28.15 & 2.819 & 21.94 & 2 & 978.5506 & 978.5476 & 490.2811 & 0.0030 & 3.0595 & 2171.008 & 2675.100 & 308.919 & 106.063 & \text { Yes }\end{array}$ $\begin{array}{lllllllllllllll}0.94 & 28.16 & 27.51 & 21.85 & 2 & 978.5488 & 9785476 & 4902811 & 0.0012 & 1.2238 & 1657.676 & 1672.745 & 147.120 & 40.677 & \text { Yes }\end{array}$ $\begin{array}{llllllllllllllll}0.94 & 27.88 & 27.54 & 21.72 & 2 & 978.5490 & 978.5476 & 490.2811 & 0.0014 & 1.4278 & 954.939 & 974.018 & 94.484 & 106.613 & \text { Yes }\end{array}$ $\begin{array}{lllllllllllllll}1.00 & 77.87 & 27.70 & 26.97 & 2 & 1703.9202 & 17039185 & 8529665 & 0.0017 & 0.9965 & 1674.636 & 1774.211 & 1883.223 & 1674.360 & \text { No }\end{array}$

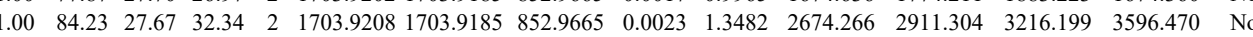
$\begin{array}{lllllllllllllll}1.00 & 63.63 & 27.52 & 29.32 & 3 & 1703.9221 & 1703.9185 & 568.9801 & 0.0036 & 2.1090 & 263.380 & 413.032 & 276.295 & 472.048 & \mathrm{No}\end{array}$ $\begin{array}{lllllllllllllll}1.00 & 71.98 & 27.54 & 34.56 & 3 & 1703.9224 & 1703.9185 & 568.9801 & 0.0039 & 2.2848 & 272.042 & 316.469 & 329.966 & 197.341 & \text { No }\end{array}$

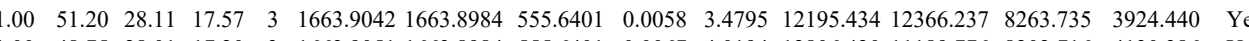
$\begin{array}{lllllllllllllll}1.00 & 48.75 & 28.01 & 17.20 & 3 & 1663.9051 & 1663.8984 & 555.6401 & 0.0067 & 4.0194 & 12806.420 & 11189.776 & 8202.716 & 4130.386 & \text { Yes }\end{array}$ $\begin{array}{llllllllllllllll}1.00 & 56.15 & 28.09 & 22.69 & 3 & 1663.9018 & 1663.8984 & 555.6401 & 0.0034 & 2.0397 & 12342.374 & 15341.068 & 8154.059 & 4202.799 & \text { Yes }\end{array}$ $\begin{array}{lllllllllllllll}.00 & 51.36 & 28.12 & 21.84 & 3 & 1663.9027 & 1663.8984 & 555.6401 & 0.0043 & 2.5796 & 5814.690 & 6856.473 & 3282.639 & 1888.061 & \text { Yes }\end{array}$

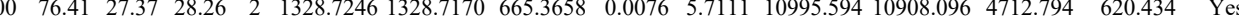
$\begin{array}{lllllllllllllll}1.00 & 80.11 & 27.28 & 28.41 & 2 & 1328.7250 & 1328.7170 & 665.3658 & 0.0080 & 6.0117 & 7888.313 & 7957.301 & 3271.521 & 731.851 & \text { Yes }\end{array}$ $\begin{array}{llllllllllllllll}1.00 & 75.15 & 27.17 & 27.36 & 2 & 1328.7256 & 1328.7170 & 665.3658 & 0.0086 & 6.4626 & 10312.504 & 8443.320 & 3621.932 & 795.612 & \text { Yes }\end{array}$ $\begin{array}{lllllllllllllll}.00 & 84.76 & 27.46 & 28.72 & 2 & 1328.7280 & 1328.7170 & 665.3658 & 0.0110 & 8.2661 & 3767.329 & 3160.718 & 1362.062 & 338.368 & \text { Yes }\end{array}$

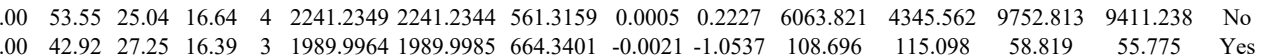

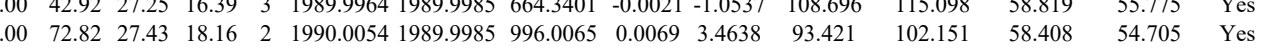

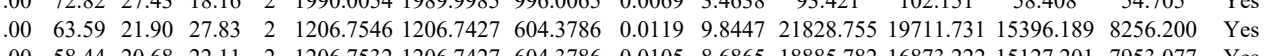




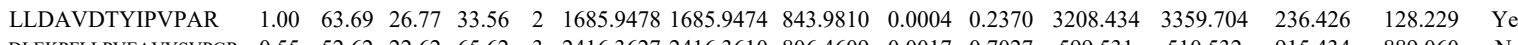

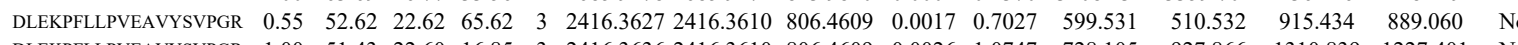
$\begin{array}{llllllllllllllll}\text { DLEKPFLLPVEAVYSVPGR } & 1.00 & 51.43 & 22.60 & 16.85 & 3 & 2416.3636 & 2416.3610 & 806.4609 & 0.0026 & 1.0747 & 728.105 & 927.866 & 1310.839 & 1227.401 & \text { No }\end{array}$ $\begin{array}{llllllllllllllll}\text { LLDAVDTYIPVPAR } & 1.00 & 69.23 & 26.57 & 24.47 & 2 & 1685.9520 & 1685.9474 & 843.9810 & 0.0046 & 2.7252 & 716.936 & 818.150 & 0.000 & 30.138 & \text { No } \\ \text { LLDAVDTYIPVPAR } & 1.00 & 81.83 & 26.50 & 23.44 & 2 & 1685.9526 & 1685.9474 & 843.9810 & 0.0052 & 3.0806 & 409.802 & 593.485 & 0.000 & 0.000 & \text { No }\end{array}$

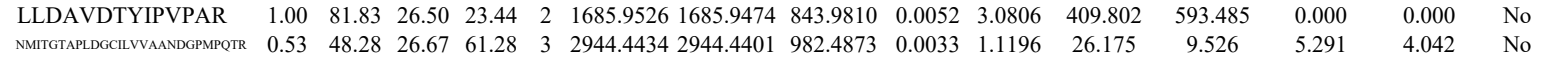

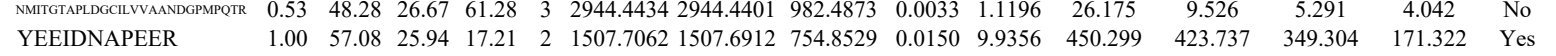

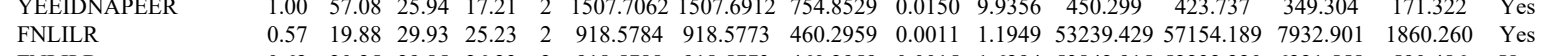

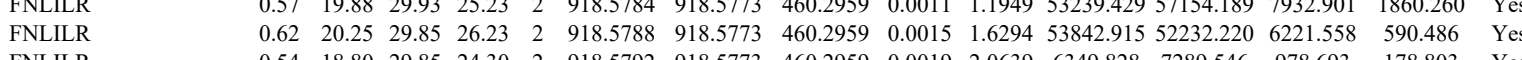
FNLILR

FNLILR

FNLILR

FNLILR

FNLILR

FNLILR

KYEEIDNAPEER

PQYQTWEEFSR

PQYQTWEEFSR VTDDLVCLVYK VTDDLVCLVYK VTDDLVCLVYK $\begin{array}{lllllllllllllllll}0.54 & 18.80 & 29.85 & 24.30 & 2 & 918.5792 & 918.5773 & 460.2959 & 0.0019 & 2.0639 & 6349.828 & 7289.546 & 978.693 & 178.803 & \text { Yes } & \\ 0.65 & 24.06 & 29.85 & 28.12 & 2 & 918.572 & 918.5773 & 460.295 & 0.0019 & 2.039 & 8047.532 & 7873.275 & 1074.822 & 225308 & \text { Yes }\end{array}$ $\begin{array}{lllllllllllllll}0.65 & 20.91 & 29.96 & 26.87 & 2 & 918.5794 & 918.5773 & 46.2959 & 0.0021 & 2.06311 & 32.532 & 387.275 & 3074.822 & 225.308 & \text { Yes }\end{array}$ $\begin{array}{lllllllllllllll}0.53 & 18.77 & 29.96 & 24.31 & 2 & 918.5794 & 918.5773 & 4602959 & 0.0021 & 22811 & 6238.539 & 6805.127 & 1478.440 & 365.340 & \text { Yes }\end{array}$ $\begin{array}{lllllllllllllll}0.66 & 21.38 & 29.92 & 26.66 & 2 & 918.5782 & 918.5773 & 4602959 & 0.0009 & 0.9776 & 5958.757 & 6178.967 & 601.155 & 143.463 & \text { Yes }\end{array}$ $\begin{array}{llllllllllllllll}0.53 & 22.02 & 29.88 & 26.34 & 2 & 9185776 & 9185773 & 4602959 & 0.0003 & 0.3259 & 830.132 & 944.141 & 121.441 & 52.073 & \text { Yes }\end{array}$ $\begin{array}{llllllllllllllll}0.72 & 22.56 & 29.92 & 28.11 & 2 & 918.5782 & 918.5773 & 460.2959 & 0.0009 & 0.9776 & 1225.002 & 1298.348 & 129.795 & 47.839 & \text { Yes }\end{array}$ $\begin{array}{llllllllllllllll}1.00 & 51.21 & 27.89 & 26.16 & 3 & 1779.8923 & 1779.8882 & 594.3033 & 0.0041 & 2.2996 & 6721.658 & 7436.084 & 2064.589 & 1365.625 & \text { Yes }\end{array}$ $\begin{array}{lllllllllllllll}0.99 & 53.64 & 26.46 & 40.15 & 2 & 1613.7728 & 1613.7596 & 807.8871 & 0.0132 & 8.1694 & 2117.883 & 1854.044 & 61.691 & 52.718 & \text { Yes }\end{array}$ $\begin{array}{llllllllllllllll}1.00 & 52.51 & 26.44 & 30.63 & 2 & 1613.7732 & 1613.7596 & 807.8871 & 0.0136 & 8.4169 & 590.237 & 688.905 & 0.000 & 28.662 & \text { No }\end{array}$

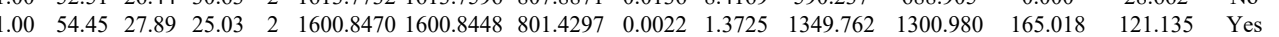
$\begin{array}{llllllllllllllll}1.00 & 59.44 & 27.85 & 23.33 & 2 & 1600.8484 & 1600.8448 & 801.4297 & 0.0036 & 2.2460 & 1086.898 & 927.558 & 99.228 & 117.148 & \text { Yes }\end{array}$ $\begin{array}{llllllllllllllll}0.95 & 25.17 & 27.81 & 16.19 & 3 & 1600.8496 & 1600.8448 & 534.6222 & 0.0048 & 2.9928 & 82.904 & 97.666 & 42.507 & 45.227 & \text { Yes }\end{array}$ $\begin{array}{llllllllllllllll}1.00 & 53.78 & 24.77 & 23.81 & 2 & 1373.8206 & 1373.8122 & 687.9134 & 0.0084 & 6.1054 & 10830.904 & 9931.060 & 10322.170 & 6427.842 & \text { Yes }\end{array}$ $\begin{array}{lllllllllllllllll}1.00 & 58.28 & 24.77 & 29.19 & 2 & 1373.8208 & 1373.8122 & 687.9134 & 0.0086 & 6.2507 & 10808.619 & 12499.069 & 9188.791 & 3039.530 & \text { Yes }\end{array}$ $\begin{array}{lllllllllllllllll}\text { TITVALADGGRPDNTGR } & 1.00 & 41.21 & 27.03 & 24.81 & 3 & 1857.0004 & 1856.9826 & 620.0015 & 0.0178 & 9.5698 & 3469.128 & 3582.270 & 1578.704 & 611.446 & \text { Yes }\end{array}$

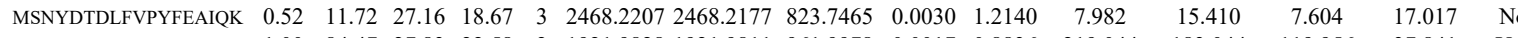
$\begin{array}{lllllllllllllllll}\text { ASEWVQQVSGLMDGK } & 1.00 & 84.47 & 27.83 & 22.58 & 2 & 1921.9828 & 1921.9811 & 961.9978 & 0.0017 & 0.8836 & 219.044 & 183.044 & 119.956 & 37.841 & \text { Yes }\end{array}$ $\begin{array}{llllllllllllllll}\text { EIADLGEALATAVIPQWQK } & 1.00 & 45.80 & 23.80 & 23.09 & 3 & 2340.2971 & 2340.2933 & 781.1050 & 0.0038 & 1.6216 & 63.560 & 48.243 & 45.498 & 11.221 & \text { Yes }\end{array}$

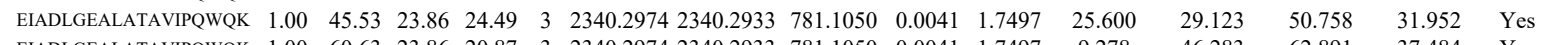

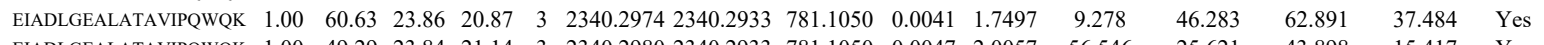

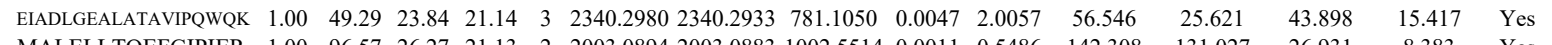

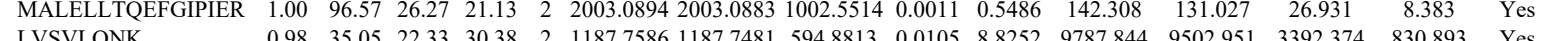

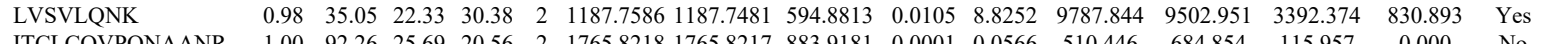

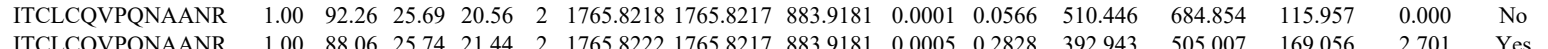

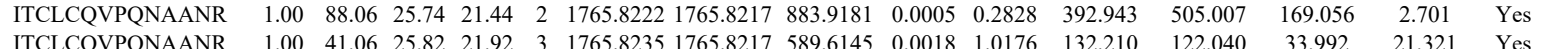

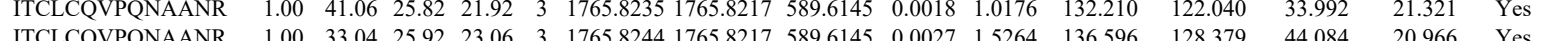
$\begin{array}{lllllllllllllll} & \end{array}$ $\begin{array}{lllllllllllll} & \end{array}$

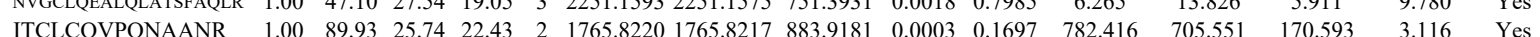

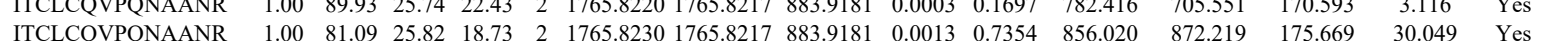

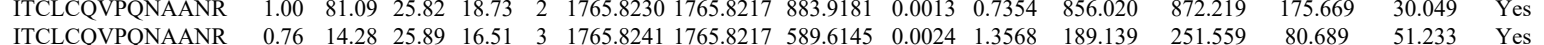

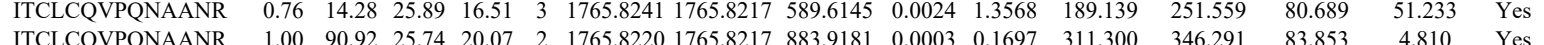

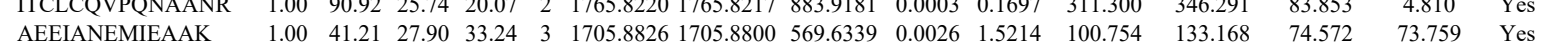

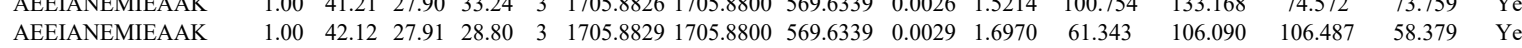

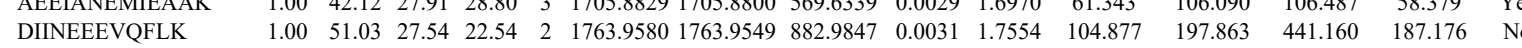

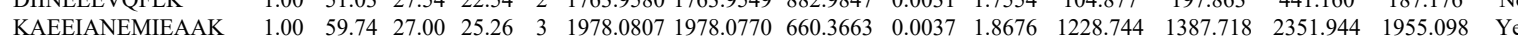
$\begin{array}{llllllllllllllll}\text { KAEEIANEMIEAAK } & 1.00 & 50.17 & 27.01 & 22.20 & 3 & 1978.0813 & 1978.0770 & 660.3663 & 0.0043 & 2.1705 & 627.083 & 645.931 & 1632.320 & 1895.603 & \text { No }\end{array}$ 6 LLIDEAILK VLIDEAILK VLDLDLFR $\begin{array}{lllllllllllllllll}1.00 & 65.04 & 19.87 & 39.39 & 2 & 1314.8374 & 1314.8366 & 658.4256 & 0.0008 & 0.6075 & 4882.650 & 4389.356 & 26.292 & 61.608\end{array}$ $\begin{array}{llllllllllllllll}1.00 & 62.70 & 18.39 & 38.20 & 2 & 1314.8408 & 1314.8366 & 658.4256 & 0.0042 & 3.1894 & 7040.433 & 6906.758 & 0.000 & 63.416\end{array}$ $\begin{array}{llllllllllll}0.99 & 40.52 & 28.06 & 25.27 & 2 & 1133.6600 & 1133.6566 & 567.8356 & 0.0034 & 2.9938 & 6774.571 & 6750.512\end{array}$

LDLEAWFPGSGAFR

YAGLSTCFR
YAGLSTCFR

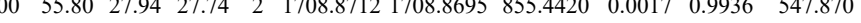
YAGLSTCF

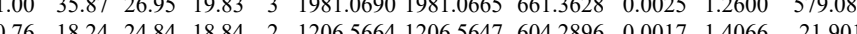
$\begin{array}{llllllllllllll} & \end{array}$

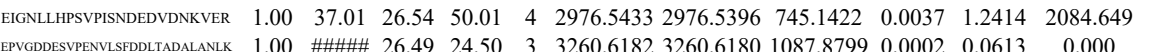

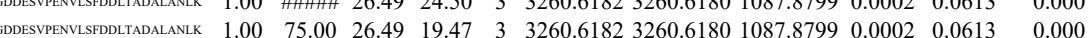

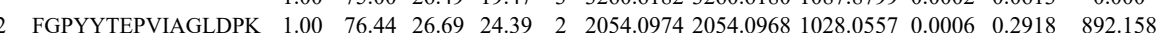

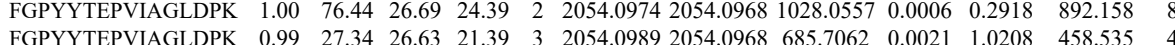

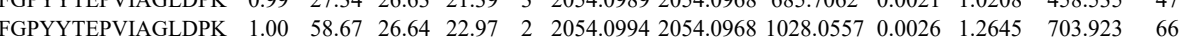
$\begin{array}{lllllllllllll} & \text { GPYYTEPVIAGLDPK } & 0.98 & 26.60 & 26.67 & 20.15 & 3 & 2054.1007 & 2054.0968 & 685.7062 & 0.0039 & 1.8959 & 525.766 \\ \text { FGPYYTEPVIAGLDPK } & 1.00 & 83.37 & 26.64 & 25.73 & 2 & 2054.0994 & 2054.0968 & 1028.0557 & 0.0026 & 1.2645 & 232.560 & 365.4\end{array}$ $\begin{array}{llll}0.470 & 40.740 & 21.203 & \text { Yes }\end{array}$ $\begin{array}{lllllllllll}\text { PSB3_HUMAN } & \text { P49720 } & \text { PSMB3 } & \text { Proteasome subun } 22.95 & 1.00 & 2 & 16.6 & 0.2342 & 0.3957 & -0.7239 & 2.1820\end{array}$ 000 (2.34.334 (.9.754 884.753 661.293 529.64

Table S-3 page 266 of 499 
$\begin{array}{llllllllllllll}0.51 & 22.92 & 27.85 & 16.87 & 2 & 1195.6272 & 1195.6184 & 598.8165 & 0.0088 & 7.3478 & 402.684 & 421.764 & 75.022\end{array}$

$\begin{array}{lllllllllllll}0.67 & 26.28 & 28.22 & 19.80 & 2 & 1195.6276 & 1195.6184 & 598.8165 & 0.0092 & 7.6818 & 165.048 & 245.977 & 10.690\end{array}$

VAASNIVQMK

VAASNIVMK

VAASNIVQMK

FILNLPTFSVR

FILNLPTFSVR

FILNLPTFSVR

FILNLPTFSVR

FILNLPTFSVR

FILNLPTFSVR

FILNLPTFSVR

FILNLPTFSVR

FILNLPTFSVR

FILNLPTFSVR

FILNLPTFSVR

FILNLPTFSVR

FILNLPTFSVR

FILNLPTFSVR

FILNLPTFSVR

GVCLIDEFDK

GVCLIDEFDK

GLALALFGGEPK

AGIVTSLQAR

AGIVTSLQAR

AGITSLAR

AGIVISLQAR

FDILCVVR

QLHLNQLIR

QLHLNQLIR
QLHLNQLIR

QLHLNQLIR
QLHLNQLIR

$\begin{array}{lllllllllllll}1.00 & 59.06 & 26.29 & 31.40 & 2 & 1347.7916 & 1347.7788 & 674.8967 & 0.0128 & 9.4828 & 17020.978 & 20384.752 & 3902.848 \\ 1.00 & 68.84 & 26.29 & 28.25 & 2 & 1347.7916 & 1347.7788 & 674.8967 & 0.0128 & 9.4828 & 22401.912 & 24832.686 & 3593.976\end{array}$ $\begin{array}{lllllllllllll}1.00 & 66.43 & 26.05 & 26.87 & 2 & 1347.7902 & 1347.7788 & 674.8967 & 0.0114 & 8.4457 & 9213.120 & 10257.502 & 1799.437\end{array}$ $\begin{array}{lllllllllllll}1.00 & 71.84 & 26.28 & 28.69 & 2 & 1347.7910 & 1347.7788 & 674.8967 & 0.0122 & 9.0383 & 10190.440 & 10569.016 & 1645.061\end{array}$ $\begin{array}{llllllllllllll}0.86 & 33.75 & 25.00 & 44.29 & 2 & 1449.8484 & 1449.8466 & 725.9306 & 0.0018 & 1.2398 & 261.586 & 205.083 & 35.172\end{array}$ $\begin{array}{lllllllllllll}1.00 & 48.97 & 25.08 & 41.25 & 2 & 1449.8480 & 1449.8466 & 725.9306 & 0.0014 & 0.9643 & 359.422 & 343.878 & 39.440\end{array}$ $\begin{array}{llllllllllllll}1.00 & 47.29 & 24.98 & 39.71 & 2 & 1449.8482 & 1449.8466 & 725.9306 & 0.0016 & 1.1020 & 468.498 & 592.506 & 58.591\end{array}$

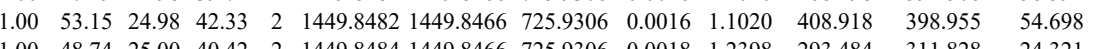

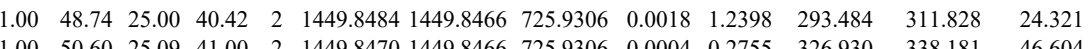
$\begin{array}{lllllllllllll}1.00 & 50.60 & 25.09 & 41.00 & 2 & 1449.8470 & 1449.8466 & 725.9306 & 0.0004 & 0.2755 & 326.930 & 338.181 & 46.604 \\ 0 & 5.939 & \end{array}$ $\begin{array}{lllllllllllll}1.00 & 51.99 & 25.04 & 41.26 & 2 & 1449.8474 & 1449.8466 & 725.9306 & 0.0008 & 0.5510 & 392.999 & 377.176 & 61.148 \\ \end{array}$ $\begin{array}{llllllllllllll}0.99 & 45.51 & 25.09 & 36.85 & 2 & 1449.8470 & 1449.8466 & 725.9306 & 0.0004 & 0.2755 & 307.566 & 257.159 & 43.388 \\ & 1.00 & 52.05 & 25.09 & 41.52 & 2 & 149.8470 & 1449.8466 & 725.9306 & 0.0004 & 0.2755 & 271.274 & 294.661 & 33.934\end{array}$ $\begin{array}{llllllllllllll}1.00 & 52.05 & 25.09 & 41.52 & 2 & 1449.8470 & 1449.8466 & 725.9306 & 0.0004 & 0.2755 & 271.274 & 294.661 & 33.934 \\ 1.00 & 49.10 & 25.08 & 38.19 & 2 & 1449.8476 & 14498466 & 725.9306 & 0.0010 & 0.6888 & 213.555 & 189.157 & 33.658\end{array}$

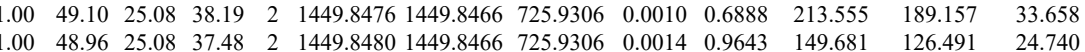
$\begin{array}{llllllllllllll}0.99 & 37.64 & 25.08 & 34.16 & 2 & 1449.8476 & 1449.8466 & 725.9306 & 0.0010 & 0.6888 & 115.505 & 117.195 & 13.359\end{array}$

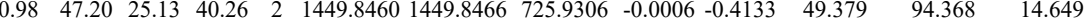
$\begin{array}{llllllllllllll}0.99 & 36.71 & 25.08 & 35.32 & 2 & 1449.8480 & 1449.8466 & 725.9306 & 0.0014 & 0.9643 & 51.117 & 73.362 & 20.357\end{array}$ $\begin{array}{lllllllllllll}0.93 & 29.11 & 24.91 & 33.97 & 2 & 1449.8496 & 1449.8466 & 725.9306 & 0.0030 & 2.0663 & 24.331 & 23.178 & 11.435\end{array}$ $\begin{array}{lllllllllllll}0.80 & 19.25 & 25.00 & 28.85 & 2 & 1449.8484 & 1449.8466 & 725.9306 & 0.0018 & 1.2398 & 14.101 & 14.778 & 11.719\end{array}$

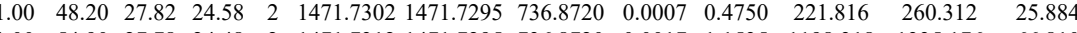

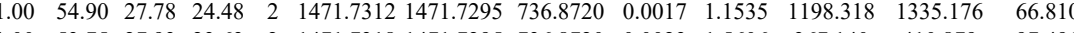
$\begin{array}{lllllllllllll}1.00 & 53.75 & 27.93 & 23.63 & 2 & 1471.7318 & 1471.7295 & 736.8720 & 0.0023 & 1.5606 & 367.140 & 410.879 & 97.491\end{array}$ $\begin{array}{llllllllllllll}1.00 & 43.00 & 27.93 & 22.17 & 2 & 1471.7318 & 1471.7295 & 736.8720 & 0.0023 & 1.5606 & 159.273 & 93.159 & 20.159\end{array}$ $\begin{array}{lllllllllllll}1.00 & 48.66 & 23.89 & 18.22 & 2 & 1459.8706 & 1459.8642 & 730.9394 & 0.0064 & 4.3779 & 402.454 & 544.327 & 1040.346\end{array}$ $\begin{array}{llllllllllllll}1.00 & 54.48 & 26.49 & 25.35 & 2 & 1158.6910 & 1158.6843 & 580.3494 & 0.0067 & 5.7724 & 23395.556 & 30366.531 & 8843.109 & 23 \\ 1.00 & 56.24 & 26.42 & 24.15 & 2 & 1158.6912 & 1158.6843 & 580.3494 & 0.009 & 5.9447 & 20814389 & 22728.944 & 791.685\end{array}$ $\begin{array}{lllllllllllll}1.00 & 56.24 & 26.42 & 24.15 & 2 & 158.6912 & 158.6843 & 580.3494 & 0.0069 & 5.9447 & 20814.389 & 22728.944 & 7910.685\end{array}$

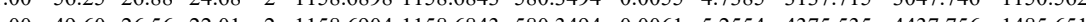

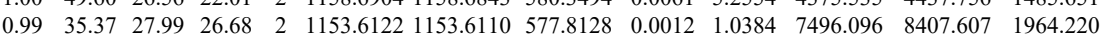
$\begin{array}{llllllllllllll}0.99 & 35.39 & 28.08 & 26.72 & 2 & 1153.6128 & 1153.6110 & 577.8128 & 0.0018 & 1.5576 & 8153.417 & 9296.481 & 2374.206\end{array}$ $\begin{array}{llllllllllllll}0.97 & 28.45 & 23.64 & 17.63 & 3 & 1277.7781 & 1277.7690 & 426.9303 & 0.0091 & 7.1049 & 2301.205 & 2599.988 & 576.743\end{array}$ $\begin{array}{lllllllllllll}0.96 & 28.32 & 24.68 & 17.21 & 3 & 1277.7796 & 1277.7690 & 426.9303 & 0.0106 & 8.2761 & 5953.887 & 5468.294 & 785.002\end{array}$ $\begin{array}{lllllllllllll}0.94 & 25.88 & 24.15 & 16.02 & 3 & 1277.7802 & 1277.7690 & 426.9303 & 0.0112 & 8.7445 & 6538.723 & 6252.998 & 824.749\end{array}$ $\begin{array}{lllllllllllllll}\text { AIFTTGGASAVGLTAYVQR } & 1.00 & 37.49 & 26.55 & 19.67 & 3 & 2154.1561 & 2154.1555 & 719.0591 & 0.0006 & 0.2781 & 56.917 & 37 .\end{array}$ $\begin{array}{llllllllllll}\text { AIFTTGQGASAVGLTAYVQR } & 0.55 & 50.53 & 26.49 & 63.53 & 3 & 2154.1576 & 2154.1555 & 719.0591 & 0.0021 & 0.9735 & 19.262\end{array}$ NDALEMVEETTWQGLK TPVTDPATGAVK TPVTDPATGAVK GFGGITHGPPEK $\begin{array}{llllllllllll}6.55 & 19.67 & 3 & 2154.1561 & 2154.1555 & 719.0591 & 0.0006 & 0.2781 & 56.917 & 37.159 & 31.896 & 25.69 \\ 26.49 & 63.53 & 3 & 2154.1576 & 2154.1555 & 719.0591 & 0.0021 & 0.9735 & 19.262 & 42.932 & 16.286 & 13.08 \\ 27.85 & 20.30 & 3 & 2151.0784 & 2151.0761 & 718.0326 & 0.0023 & 1.0677 & 41.135 & 63.125 & 48.280 & 43.73\end{array}$ FGMAAALAGTMR $\begin{array}{rllllllllllll}1.00 & 44.67 & 27.87 & 20.27 & 3 & 2151.0787 & 2151.0761 & 718.0326 & 0.0026 & 1.2070 & 50.861 & 47.332 & 60.325\end{array}$

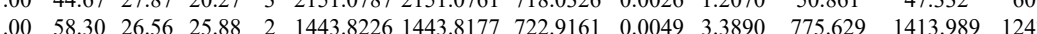
$\begin{array}{llllllllllllllll}1.00 & 58.35 & 26.50 & 26.71 & 2 & 1443.8230 & 1443.8177 & 722.9161 & 0.0053 & 3.6657 & 1226.928 & 2536.650 & 4372.987 & 4284.886 & \text { Yes } \\ 0.96 & 28.69 & 27.71 & 31.26 & 3 & 1483.8046 & 1483.8027 & 495.6082 & 0.0019 & 1.2779 & 3511.120 & 4289.494 & 5333.945 & 2473.596 & \text { Yes }\end{array}$ $\begin{array}{llllllllllllllll}1.00 & 57.74 & 27.90 & 29.91 & 2 & 1339.6842 & 1339.6862 & 670.8504 & -0.0020 & -1.4906 & 1476.169 & 2845.672 & 368.030 & 271.510 & \mathrm{No}\end{array}$

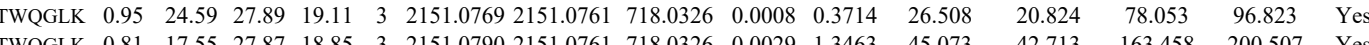

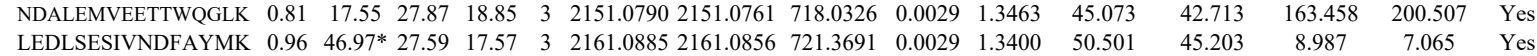
$\begin{array}{llllllllllllll} & \end{array}$

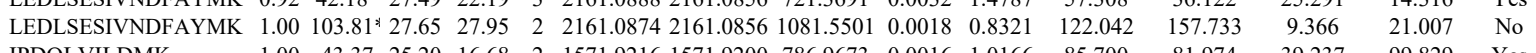
$\begin{array}{lllllllllllll}\text { IPDQLVILDMK } & 1.00 & 43.37 & 25.20 & 16.68 & 2 & 1571.9216 & 1571.9200 & 786.9673 & 0.0016 & 1.0166 & 85.700\end{array}$ IPDQLVILDMK IPDQLVILDMK IPDQLVILDMK IPDQLVILDMK IPDQLVILDMK $\begin{array}{lllllllllll}1.00 & 57.81 & 25.17 & 17.63 & 2 & 1571.9222 & 1571.9200 & 786.9673 & 0.0022 & 1.3978 & 663.454\end{array}$ $\begin{array}{lllllllllll}1.00 & 37.29 & 25.09 & 18.22 & 3 & 1571.9233 & 1571.9200 & 524.9806 & 0.0033 & 2.0953 & 37.297\end{array}$ $\begin{array}{lllllllllll}1.00 & 71.21 & 25.00 & 22.40 & 2 & 1571.9210 & 1571.9200 & 786.9673 & 0.0010 & 0.6354 & 473.668\end{array}$ $\begin{array}{lllllllllll}1.00 & 68.00 & 25.00 & 19.93 & 2 & 1571.9210 & 1571.9200 & 786.9673 & 0.0010 & 0.6354 & 193.180 \\ 0.99 & 27.50 & 25.26 & 14.84 & 3 & 1571.9215 & 1571.9200 & 524.9806 & 0.0015 & 0.9524 & 84.663\end{array}$ $\begin{array}{lllllllllll}0.99 & 27.50 & 25.26 & 14.84 & 3 & 1571.9215 & 1571.9200 & 524.9806 & 0.0015 & 0.9524 & 84.663 \\ 1.00 & 32.93 & 25.26 & 19.40 & 3 & 1571.9215 & 1571.9200 & 524.9806 & 0.0015 & 0.9524 & 88.265\end{array}$ $\begin{array}{lllllllllll}1.00 & 32.93 & 25.26 & 19.40 & 3 & 1571.9215 & 1571.9200 & 524.9806 & 0.0015 & 0.9524 & 88.265 \\ 1.00 & 56.10 & 16.81 & 18.56 & 2 & 1856.1430 & 1856.1419 & 929.0782 & 0.0011 & 0.5920 & 330.221\end{array}$ $\begin{array}{llllllllllll}0.77 & 50.76 & 16.33 & 63.76 & 2 & 1856.1436 & 1856.1419 & 929.0782 & 0.0017 & 0.9149 & 400.028\end{array}$ 
ISQMPVILTPLL

KPHTLLQR

VVYIFGPPVK

VVYIFGPPVK

VVYIFGPPVK

VVYIFGPPVK

KPHTLLQR

KPHTLLQR

KPHTLLQR

KPHTLLQR

VVYIFGPPVK

KPHTLLR

ISQMPVILTPLHFDR

ISQMPVILTPLHFDR

KPHTLLQR

KPHTLLQR

KPHTLLQR

HPFPGPGLAIR

HPFGGGLAIR

HPFPGPGLAIR

HPFPGPGLAIR

ISQMPVILTPLHFDR

KPHTLLQR

HPFPGPGLAIR

HPFPGPGLAIR

KPHTLLQR

TLNMTTSPEEK

$\begin{array}{llllllllllll}1.00 & 30.78 & 21.49 & 15.10 & 4 & 2635.4805 & 2635.4763 & 659.8764 & 0.0042 & 1.5912 & 4709.090 & 5368 . \\ 0.99 & 35.74 & 21.43 & 28.19 & 2 & 1279.7972 & 1279.7968 & 640.9057 & 0.0004 & 0.3121 & 288.493 & 273.5\end{array}$

$\begin{array}{lllllllllllllllll}0.99 & 35.74 & 21.43 & 28.19 & 2 & 1279.7972 & 1279.7968 & 640.9057 & 0.0004 & 0.3121 & 288.493 & 273.529 & 171.83\end{array}$

$\begin{array}{lllllllllllll}.96 & 18.41 & 20.68 & 16.32 & 3 & 1279.7977 & 1279.9968 & 427.6062 & 0.000 & 0.7016 & 428.429 & 507.696 & 218.869\end{array}$

$\begin{array}{lllllllllllllll}1.00 & 67.33 & 23.52 & 23.81 & 2 & 1405.8598 & 1405.8577 & 703.9361 & 0.0021 & 1.4916 & 4962.312 & 4146.276 & 517.807\end{array}$

$\begin{array}{llllllllllllll}1.00 & 65.72 & 23.50 & 23.25 & 2 & 1405.8602 & 1405.8577 & 703.9361 & 0.0025 & 1.7757 & 4008.173 & 4869.956 & 441.245\end{array}$

\begin{tabular}{llllllllllllll}
\hline & 14.83 & 23.50 & 19.96 & 3 & 1405.8604 & 1405.8577 & 469.6265 & 0.0027 & 1.9164 & 1496.477 & 1656.273
\end{tabular}

$\begin{array}{lllllllllllllll}0.65 & 10.07 & 23.50 & 20.75 & 3 & 1405.8604 & 1405.8577 & 469.6265 & 0.0027 & 1.9164 & 1242.792 & 1017.986 & 351.295\end{array}$

$\begin{array}{lllllllllllll}0.97 & 22.36 & 21.37 & 18.58 & 3 & 1279.7965 & 1279.7968 & 427.6062 & -0.0003 & -0.2339 & 772.153 & 732.599 & 298.645 \\ 0.89 & 22.94 & 21.43 & 28.89 & 2 & 1279.7972 & 1279.7968 & 640.9057 & 0.0004 & 0.3121 & 294.487 & 341.615 & 145.535\end{array}$

$\begin{array}{llllllllllll}0.89 & 22.94 & 21.43 & 28.89 & 2 & 1279.7972 & 1279.7968 & 640.9057 & 0.0004 & 0.3121 & 294.487 & 341.615 \\ 0 & 22.85 & 21.43 & 17.57 & 3 & 1279.7974 & 1279.7968 & 427.6062 & 0.0006 & 0.4677 & 553.592 & 512.447\end{array}$

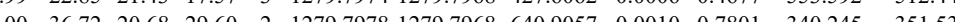

$\begin{array}{lllllllllll} & 0\end{array}$

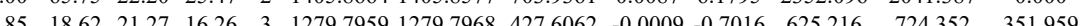

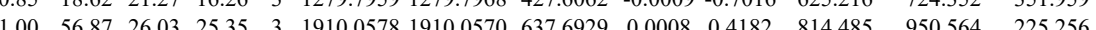

$\begin{array}{llllllllllllll}1.00 & 42.82 & 26.09 & 17.64 & 3 & 1910.0599 & 1910.0570 & 637.6929 & 0.0029 & 1.5159 & 1301.009 & 1279.878 & 389.992\end{array}$

$\begin{array}{llllllllllllll}0.77 & 13.43 & 21.37 & 13.89 & 3 & 1279.7968 & 12797968 & 427.6062 & 0.0000 & 0.0000 & 469.684 & 521.902 & 241.506 & 18\end{array}$

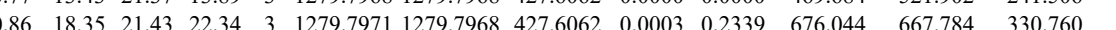

$\begin{array}{lllllllllllllll}0.99 & 35.87 & 21.43 & 22.81 & 2 & 1279.7972 & 1279.7968 & 640.9057 & 0.0004 & 0.3121 & 220.763 & 203.372 & 97.615 & 67.7 .\end{array}$

$\begin{array}{llllllllllllllll}0.81 & 27.23 & 27.28 & 18.07 & 2 & 1304.7574 & 1304.7475 & 653.3810 & 0.0099 & 7.5759 & 5639.211 & 4638.487 & 2497.514 & 1760.285 & \text { Yse } & \end{array}$

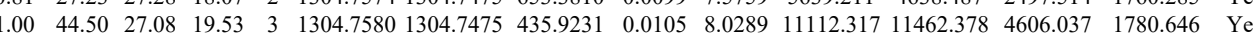
$\begin{array}{llllllllllllllll}0.51 & 22.54 & 26.80 & 35.54 & 2 & 1304.7584 & 1304.7475 & 653.3810 & 0.0109 & 8.3412 & 2705.359 & 2356.043 & 1092.375 & 1038.196 & \text { Yes }\end{array}$ $\begin{array}{lllllllllllllll}0.87 & 24.05 & 26.16 & 16.76 & 3 & 1910.0560 & 1910.0570 & 637.6929 & -0.0010 & -0.5227 & 741.404 & 801.071 & 959.401 & 1404.103 & \text { No }\end{array}$ $\begin{array}{llllllllllllllll}0.83 & 14.73 & 21.37 & 15.79 & 3 & 1279.7965 & 1279.7968 & 427.6062 & -0.0003 & -0.2339 & 533.299 & 596.270 & 287.443 & 225.562 & \text { Yes } & \end{array}$ $\begin{array}{llllllllllllllllll}1.00 & 48.87 & 27.04 & 22.85 & 3 & 1304.7601 & 1304.7475 & 435.9231 & 0.0126 & 9.6346 & 5877.820 & 6867.582 & 2849.422 & 990.837 & \text { Yes } & \\ \end{array}$ $\begin{array}{llllllllllllllll}1.00 & 56.61 & 27.04 & 26.36 & 3 & 1304.7604 & 1304.7475 & 435.9231 & 0.0129 & 9.8640 & 6407.761 & 6969.142 & 2876.384 & 1180.473 & \text { Yes } & \\ \end{array}$

$\begin{array}{lllllllllllllll}0.61 & 10.53 & 21.43 & 13.68 & 3 & 1279.7971 & 1279.7968 & 427.6062 & 0.0003 & 0.2339 & 358.508 & 384.354 & 185.763 & 110.606 & \text { Yes } \\ 1.00 & 71.40 & 27.75 & 43.84 & 2 & 1537.8026 & 1537.7901 & 769.9023 & 0.0125 & 8.1178 & 3088.885 & 2882.352 & 141.378 & 136.275 & \text { Yes }\end{array}$ $\begin{array}{llllllllllllllll}1.00 & 71.51 & 27.74 & 41.55 & 2 & 1537.8036 & 1537.7901 & 769.9023 & 0.0135 & 8.7673 & 3808.252 & 4210.158 & 130.779 & 146.767 & \text { Yes }\end{array}$ $\begin{array}{llllllllllllllll} & \end{array}$

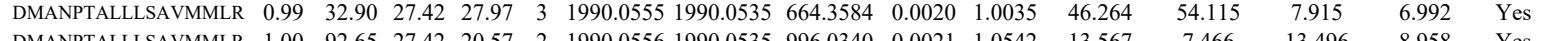

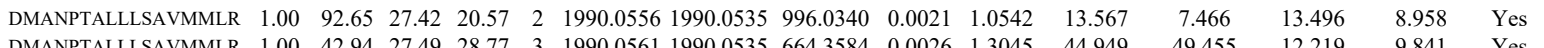

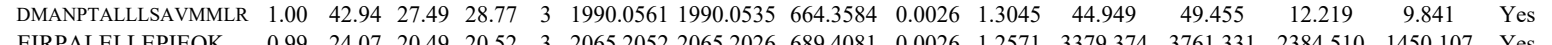

$\begin{array}{lllllllllllllll}0.99 & 24.07 & 20.49 & 20.52 & 3 & 2065.2052 & 2065.2026 & 689.4081 & 0.0026 & 1.2571 & 3379.374 & 3761.331 & 2384.510 & 1450.107 & \text { Yes }\end{array}$

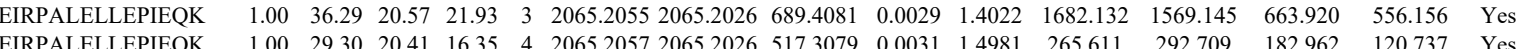

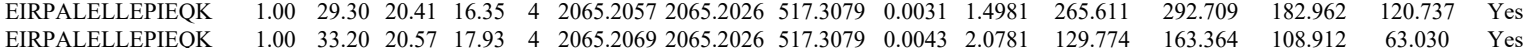
$\begin{array}{llllllllllllllll}\text { NPYGGESASITPLEDLYK } & 1.00 & 73.20 & 20.57 & 17.93 & 4 & 2065.2069 & 2065.2026 & 517.3079 & 0.0043 & 2.0781 & 129.774 & 163.364 & 108.912 & 63.030 & \text { Yes } \\ \text { NY. } & 27.63 & 2 & 2404.2054 & 2404.2042 & 1203.1094 & 0.0012 & 0.4987 & 301.419 & 367.772 & 88.098 & 106.753 & \text { Yes }\end{array}$

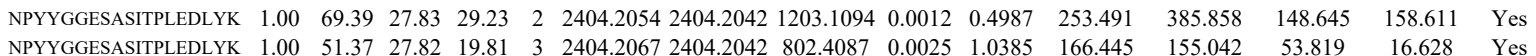

Table S-3 page 268 of 499 

$\begin{array}{lllllllllllll}0.69 & 27.16 & 27.13 & 24.40 & 2 & 1270.6522 & 1270.6461 & 636.3303 & 0.0061 & 4.7931 & 8414.823 & 8876.534 & 5407.785 \\ 0.92 & 34.30 & 27.15 & 22.74 & 2 & 1270.6532 & 1270.6461 & 636.3303 & 0.0071 & 5.5788 & 13226.859 & 12069.918 & 5498.904\end{array}$ \begin{tabular}{cccccccccccccc} 
& 1.0 .45 & 24.49 & 15.84 & 3 & 1455.8572 & 1455.8549 & 486.2922 & 0.0023 & 1.5766 & 18317.743 & 19959.038 & 142.135 \\
\hline
\end{tabular}

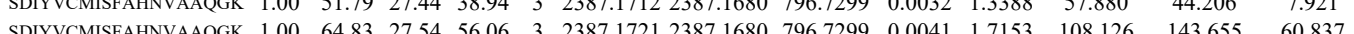

VICILSHPIK

VICILSHPIK

VICILSHPIK $\begin{array}{llllllllll} & 0.837\end{array}$

KSDIYVCMISFA
VICILSHPIK

VICILSHPIK
VICILSHPIK

VICILSHPIK

VICILSHPIK

MTGSEFDFEEMK

MTGSEFDFEEMK

$\begin{array}{llllllllllllll}1 & 49.50 & 24.41 & 23.59 & 2 & 1455.8564 & 1455.8549 & 728.9347 & 0.0015 & 1.0289 & 8553.015 & 9736.454 & 0.000\end{array}$

$\begin{array}{lllllllllllllll}1.00 & 34.48 & 24.23 & 16.18 & 3 & 1455.8587 & 1455.8549 & 4862922 & 0.0038 & 2.6047 & 57661.016 & 69073.215 & 1959.635 & & \end{array}$

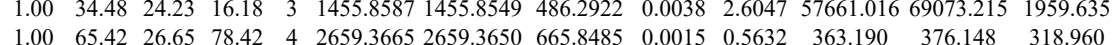

TFEGIDPK

$\begin{array}{lllllllllllll}0.99 & 37.05 & 25.13 & 20.71 & 2 & 1455.8552 & 1455.8549 & 728.9347 & 0.0003 & 0.2058 & 492.711 & 561.491 & 20.166\end{array}$

$\begin{array}{lllllllllllllll}1.00 & 34.51 & 24.97 & 24.45 & 3 & 1455.8563 & 1455.8549 & 486.2922 & 0.0014 & 0.9596 & 25531.780 & 32610.809 & 0.000 & \end{array}$

$\begin{array}{llllllllllll}1.00 & 44.91 & 24.49 & 19.12 & 2 & 1455.8572 & 1455.8549 & 728.9347 & 0.0023 & 1.5776 & 317.123 & 399.584\end{array}$

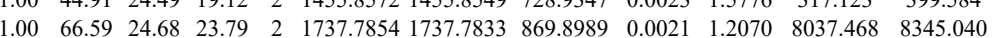

$\begin{array}{llllllllllll}1.00 & 52.27 & 24.68 & 17.21 & 2 & 1737.7856 & 1737.7833 & 869.8989 & 0.0023 & 1.3220 & 4400.544 & 4847.391\end{array}$ $\begin{array}{llllllllllllll}\text { MTGSEFDFEEMK } & 1.00 & 55.36 & 24.46 & 22.54 & 2 & 1737.7838 & 1737.7833 & 869.8989 & 0.0005 & 0.2874 & 1572.133 & 1679.854 & 0.000 \\ \text { TDDYLDQPCYETINR } & 0.76 & 98.87 & 22.17 & \# \# \# \# & 2 & 2034.8794 & 2034.8785 & 1018.4465 & 0.0009 & 0.4418 & 793.828 & 848.153 & 0.000\end{array}$ $\begin{array}{lllllllllllll}0.64 .58 & 22.33 & 67.58 & 2 & 2034.8814 & 2034.8785 & 1018.4465 & 0.0029 & 1.4237 & 129.944 & 130.687 & 23.204 \\ 0.69 & 24.56 & 27.69 & 21.69 & 2 & 1193.6646 & 1193.6536 & 597.8341 & 0.0110 & 9.1998 & 4878.127 & 4874.121 & 1616.692\end{array}$

$\begin{array}{lllllllllllll}0.51 & 21.45 & 27.73 & 22.84 & 2 & 1193.6648 & 1193.6536 & 597.8341 & 0.0112 & 9.3671 & 5454.235 & 5104.702 & 1333.300\end{array}$

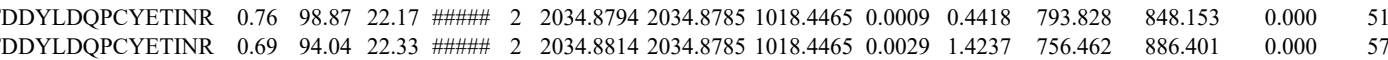
$\begin{array}{lllllllllllllll} & \text { Th }\end{array}$ $\begin{array}{llllllllllllllll} & \end{array}$ $\begin{array}{lllllllllllllll}1.00 & 40.73 & 27.23 & 18.13 & 3 & 1539.8335 & 1539.8280 & 514.2833 & 0.0055 & 3.5648 & 4546.183 & 6251.428 & 3357.216 & 1213.431 & \text { Yes } \\ 1.00 & 39.15 & 27.50 & 1.43 & 3 & 1539.8347 & 1539.8280 & 5142833 & 0.0067 & 4.3426 & 643757 & 750.750 & 382.072 & 208.582 & \text { Yes }\end{array}$

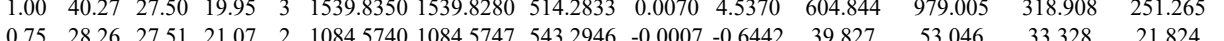
$\begin{array}{llllllllllllll}0.95 & 36.07 & 27.46 & 17.34 & 2 & 1084.5742 & 1084.5747 & 543.2946 & -0.0005 & -0.4602 & 46.413 & 124.594 & 72.776 & 38.184 \\ 0.85 & 26.18 & 27.16 & 20.14 & 2 & 1084.5746 & 1084.5747 & 5432946 & -0.0001 & -0.0920 & 55.423 & 49.481 & 32.510 & 38.182\end{array}$ 
GVVEVTHDLQK GVVEVTHDLQK GVVEVTHDLQK KPAAAAAPGTAEK KPAAAAAPGTAEK AVLSAEQLR AVLSAEQL AVAISLPK

AVAISLPK LSSLIILMPHHVEPLER DQAVNILUST WASSLGLVSLGO

DQAVENILVSPVVVASSLGLLVSLG

DQAVENILVSPVVVASSLGLLVSL

LFYADHPFIFLVR

LFYADHPFIFLVR

4 CVDLVIQELINTVR CVDLVIQELINTVR CVDLVIQELINTVR CVDLVIQELINTVR CVDLVIQELINTVR CVDLVIQELINTVR GISPVPINLR

GISPVPINLR

FFLSHPAYR

FFLSHPAYR

FFLSHPAYR

FFLSHPAYR

FFLSHPAYR

FFLSHPAYR

RPLILQLIFSK

RPLILQLIFSK

RPLILQLIFSK

ALDQASEEIWNDFR

ALDQASEEIWNDFR

NFDVGHVPIR

NLCDLGIVDPYPPLC

NLCDLGIVDPYPPLCD

NLCDLGIVDPYPPLCD

NLCDLGIVDPYPPLCD

DEDDEDGDGDGDGATC

DEDDEDGDGDGDGATG DEDDEDGDGDGDGATGK GPSAAGEQEPDKESGASVDEVA ALDQASEEIWNDFR ALDQASEEIWNDFR

FPHSAHQK

ALVDGPCTQVR

VAYVSFGPHAGK

VAYVSFGPHAGK

VAYVSFGPHAGK

CMQLTDFILK

CMQLTDFILK

CMQLTDFILK

CMQLTDFILK

CMQLTDFILK

CMQLTDFILK

CMQLTDFILK

CMQLTDFILK

CMQLTDLK

CMQLTDFILK

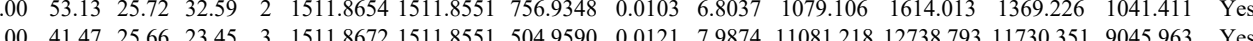
$\begin{array}{lllllllllllllll}0.99 & 46.56 & 25.69 & 35.40 & 3 & 1511.8672 & 1511.8551 & 504.9590 & 0.0121 & 7.9874 & 11081.218 & 12738.793 & 11730.351 & 9045.963 & \text { Yes } \\ \end{array}$ \begin{tabular}{llllllllllllllll}
1.00 & 38.89 & 24.08 & 24.13 & 3 & 1613.9473 & 1613.9466 & 538.9895 & 0.0007 & 0.4329 & 304.374 & 297.392 & 161.976 & 136.663 & Yes \\
\hline
\end{tabular} $\begin{array}{lllllllllllllll}1.00 & 47.78 & 24.17 & 22.66 & 3 & 1613.9482 & 1613.9466 & 538.9895 & 0.0016 & 0.9895 & 323.939 & 439.769 & 222.203 & 100.092 & \text { Yes }\end{array}$ $\begin{array}{lllllllllllllll}.94 & 34.31 & 27.36 & 27.14 & 2 & 1129.6664 & 1129.6577 & 565.8361 & 0.0087 & 7.6877 & 14551.301 & 45213.035 & 5512.688 & 2012.674 & \text { Yes } \\ 1.97 & 3.92 & 27.35 & 33.03 & 2 & 1129.6676 & 129.6577 & 565.836 & 0.009 & 8.748 & 5399.670 & 6313.725 & 2117.095 & 1108.494 & \text { Yes }\end{array}$

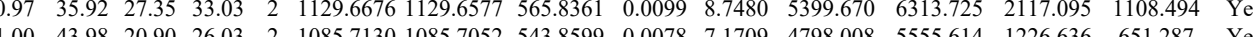

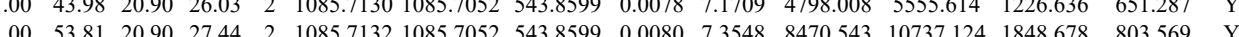

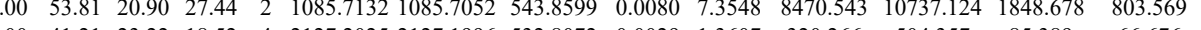
$\begin{array}{llllllllll} & 0.35\end{array}$ $\begin{array}{lllllllllllll} & \end{array}$

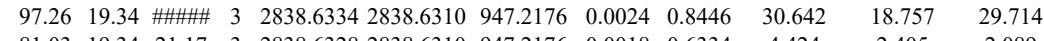

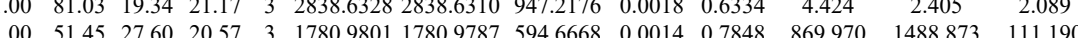
$\begin{array}{llllllllllllll}1.00 & 44.58 & 27.60 & 21.22 & 3 & 1780.9837 & 1780.9787 & 594.6668 & 0.0050 & 2.8027 & 649.480 & 1047.060 & 38.535\end{array}$

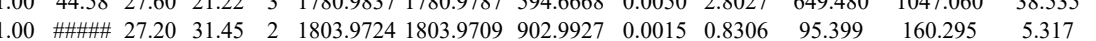

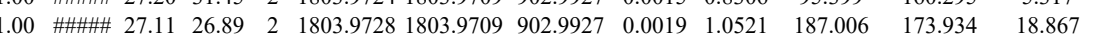
$\begin{array}{llllllllllllll}0.99 & 28.00 & 27.05 & 23.05 & 3 & 1803.9736 & 1803.9709 & 602.3309 & 0.0027 & 1.4942 & 94.872 & 113.911 & 44.359\end{array}$ $\begin{array}{lllllllllllll}1.00 & 39.56 & 27.05 & 18.01 & 3 & 1803.9736 & 1803.9709 & 602.3309 & 0.0027 & 1.4942 & 110.474 & 136.771 & 52.704\end{array}$ $\begin{array}{llllllllllll}1.00 & \# \# \# \# 27.20 & 26.13 & 2 & 1803.9724 & 1803.9709 & 902.9927 & 0.0015 & 0.8306 & 55.425 & 75.083 & 20.325\end{array}$ $\begin{array}{lllllllllllll}1.00 & \# \# \# \text { 27.11 } & 30.90 & 2 & 1803.9728 & 1803.9709 & 902.9927 & 0.0019 & 1.0521 & 71.594 & 56.118 & 0.000\end{array}$ $\begin{array}{lllllllllllll}1.00 & 82.40 & 27.20 & 21.36 & 2 & 1803.9724 & 1803.9709 & 902.9927 & 0.0015 & 0.8306 & 22.841 & 39.280 & 11.917\end{array}$ $\begin{array}{lllllllllllllll}1.00 & 60.37 & 25.09 & 32.13 & 2 & 1208.7382 & 1208.7363 & 605.3754 & 0.0019 & 1.5693 & 6589.348 & 8104.177 & 8404.244 & 3674.036 & \text { Yes }\end{array}$ $\begin{array}{lllllllllllllll}1.00 & 36.84 & 28.36 & 15.96 & 3 & 1280.6809 & 1280.6788 & 427.9002 & 0.0021 & 1.6359 & 4953.446 & 5098.418 & 418.432 & 138.968 & \text { Yes }\end{array}$ $\begin{array}{lllllllllllllll}0.99 & 32.27 & 28.39 & 19.62 & 3 & 1280.6821 & 1280.6788 & 427.9002 & 0.0033 & 2.5707 & 4510.877 & 5783.833 & 670.006 & 89.452 & \text { Yes }\end{array}$ $\begin{array}{llllllllllllllll}1.00 & 36.29 & 28.29 & 20.23 & 3 & 1280.6800 & 1280.6788 & 427.9002 & 0.0012 & 0.9348 & 2926.949 & 2643.209 & 258.584 & 78.487 & \text { Yes }\end{array}$ $\begin{array}{llllllllllllllll}1.00 & 36.51 & 28.29 & 17.52 & 3 & 1280.6800 & 1280.6788 & 427.9002 & 0.0012 & 0.9348 & 2120.512 & 2107.485 & 140.408 & 68.052 & \text { Yes }\end{array}$ $\begin{array}{lllllllllllllll}1.00 & 37.69 & 28.48 & 24.04 & 3 & 1280.6797 & 1280.6788 & 427.9002 & 0.0009 & 0.7011 & 887.934 & 964.872 & 139.736 & 65.824 & \text { Yes }\end{array}$ $\begin{array}{lllllllllllllll}0.98 & 28.08 & 28.29 & 15.22 & 3 & 1280.6800 & 1280.6788 & 427.9002 & 0.0012 & 0.9348 & 1017.634 & 954.023 & 130.089 & 48.525 & \text { Yes }\end{array}$

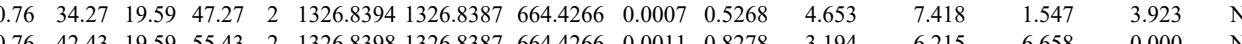
$\begin{array}{lllllllllllll}0.76 & 34.27 & 19.59 & 47.27 & 2 & 1326.8394 & 13268387 & 664.4266 & 0.0007 & 0.5268 & 4.653 & 7.418 & 1.547\end{array}$

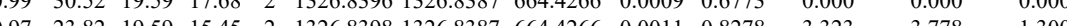

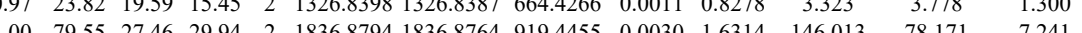
$\begin{array}{llllllllllll} & \end{array}$

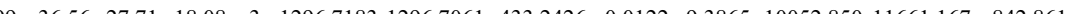
$\begin{array}{llllllllllllll}0.98 & 33.60 & 27.70 & 18.86 & 3 & 1296.7189 & 1296.7061 & 433.2426 & 0.0122 & 9.3865 & 10052.850 & 11661.167 & 842.861 & 5\end{array}$ \begin{tabular}{lllllllllllll} 
& \\
\hline
\end{tabular} $\begin{array}{lllllllllll} & \end{array}$

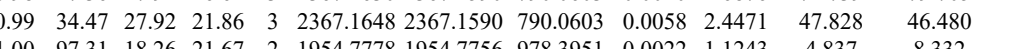
$\begin{array}{llllllllllll}0.53 & 93.74 & 18.20 & \# \# \# \# \quad 3 & 1954.7782 & 1954.7756 & 652.5991 & 0.0026 & 1.3280 & 29.266 & 12.849\end{array}$ $\begin{array}{lllllllllll}1.00 & \# 18.20 & 22.49 & 2 & 1954.7786 & 1954.7756 & 978.3951 & 0.0030 & 1.5331 & 75.042 & 50.029\end{array}$ $\begin{array}{llllllllll}18.20 & 21.93 & 3 & 1954.7788 & 1954.7756 & 652.5991 & 0.0032 & 1.6345 & 33.515\end{array}$ $\begin{array}{lllllllllllll}1.00 & 55.58 & 27.19 & 18.29 & 3 & 2573.2501 & 2573.2449 & 858.7556 & 0.0052 & 2.0184 & 4168.016 & 3553.852\end{array}$ $\begin{array}{llllllllllllll}1.00 & 79.71 & 27.63 & 24.58 & 2 & 1836.8778 & 1836.8764 & 919.4455 & 0.0014 & 0.7613 & 640.766 & 718.683\end{array}$ $\begin{array}{llllllllllllll}0.79 & 16.66 & 27.60 & 16.61 & 3 & 1836.8782 & 1836.8764 & 613.2994 & 0.0018 & 0.9783 & 167.388 & 152.28 \\ 1.00 & 78.24 & 27.61 & 27.84 & 2 & 1836.8788 & 1836.8764 & 919.4455 & 0.0024 & 13051 & 743.299 & 661.152\end{array}$ $\begin{array}{lllllllllllll}1.00 & 78.24 & 27.61 & 27.84 & 2 & 1836.8788 & 1836.8764 & 919.455 & 0.0024 & 1.3051 & 743.299 & 661.152\end{array}$

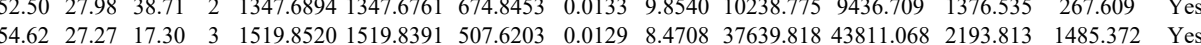
$\begin{array}{llllllllllllllll}1.00 & 69.63 & 27.27 & 17.86 & 3 & 1519.8520 & 1519.8391 & 507.6203 & 0.0129 & 8.4708 & 32077.480 & 32243.670 & 1348.222 & 941.694 & \text { Yes }\end{array}$ $\begin{array}{lllllllllllllll}1.00 & 80.34 & 27.26 & 27.21 & 3 & 1519.8511 & 1519.8391 & 507.6203 & 0.0120 & 7.8798 & 20861.066 & 21171.956 & 1756.842 & 1152.653 & \text { Yes }\end{array}$ $\begin{array}{llllllllllllllll}1.00 & 46.07 & 28.03 & 38.71 & 2 & 1544.8032 & 1544.8008 & 773.4077 & 0.0024 & 1.5516 & 16577.258 & 14935.029 & 0.000 & 192.479 & \text { No }\end{array}$ $\begin{array}{lllllllllllllll}1.00 & 51.45 & 28.18 & 32.81 & 2 & 1544.8044 & 1544.8008 & 773.4077 & 0.0036 & 2.3274 & 27394.787 & 28622.600 & 0.000 & 110.548 & \text { No }\end{array}$

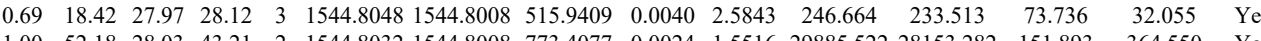

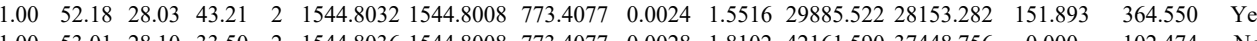
$\begin{array}{lllllllllllllll}1.00 & 53.01 & 28.10 & 33.50 & 2 & 1544.8036 & 1544.8008 & 73.4077 & 0.028 & 1.85102 & 42161.590 & 37448.756 & 0.000 & 102.474 & \text { No }\end{array}$

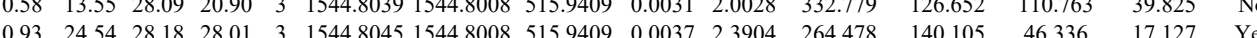

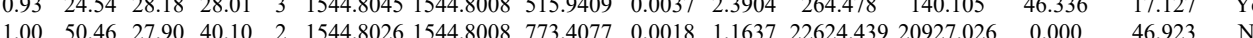

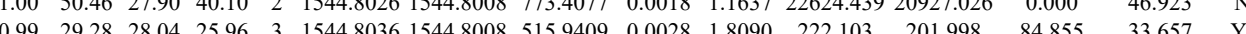

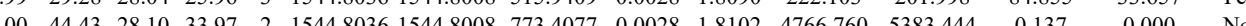




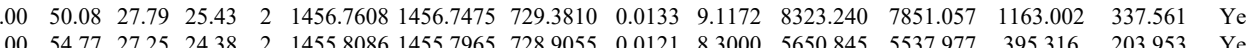

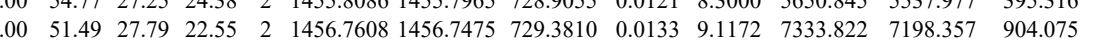
$\begin{array}{llllllllllllllll} & 1.00 & 57.04 & 27.82 & 25.16 & 2 & 1456.7610 & 1456.7475 & 729.3810 & 0.0135 & 9.2543 & 8151.515 & 6908.372 & 1112.585 & 98.589 & \text { Yes }\end{array}$ $\begin{array}{lllllllllllll} & \end{array}$ $\begin{array}{llllllllllllllllll} & \text { LVPGGGATEIELAK } & 0.67 & 11.53 & 24.62 & 18.60 & 3 & 1641.9577 & 1641.9545 & 548.3254 & 0.0032 & 1.9453 & 1588.738 & 1477.599 & 308.563 & 312.491 & Y^{2}\end{array}$

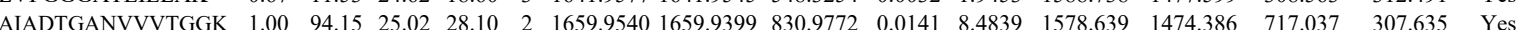
$\begin{array}{llllllllllllllll}\text { AIADTGANVVVTGGK } & 1.00 & 93.98 & 25.02 & 26.95 & 2 & 1659.9540 & 1659.9399 & 830.9772 & 0.0141 & 8.4839 & 2110.913 & 2009.131 & 1264.374 & 455.794 & \text { Yes }\end{array}$ $\begin{array}{llllllllllllllll}\text { QYGNEVFLAK } & 0.99 & 43.11 & 27.14 & 22.63 & 2 & 1455.8096 & 1455.7965 & 728.9055 & 0.0131 & 8.9860 & 2119.945 & 2112.356 & 116.238 & 256.954 & \text { Yes }\end{array}$ $\begin{array}{llllllllllllllllll}\text { LVPGGGATEIELAK } & 1.00 & 76.87 & 23.60 & 26.19 & 2 & 1651.9686 & 1641.9545 & 821.9845 & 0.0141 & 8.5767 & 10595.927 & 10530.354 & 5100.462 & 1819.137 & \text { Yes }\end{array}$ $\begin{array}{llllllllllllllll}\text { LVPGGGATEIELAK } & 1.00 & 95.85 & 23.60 & 28.33 & 2 & 1641.9686 & 1641.9545 & 821.9845 & 0.0141 & 8.5767 & 7068.491 & 6674.290 & 4268.590 & 962.529 & \text { Yes }\end{array}$ $\begin{array}{llllllllllllllll}\text { AIADTGANVVVTGGK } & 1.00 & 97.92 & 25.01 & 27.76 & 2 & 1659.9524 & 1659.9399 & 830.9772 & 0.0125 & 7.5212 & 2491.866 & 2293.595 & 1387.147 & 566.470 & \text { Yes }\end{array}$ $\begin{array}{llllllllllllllll}\text { AIADTGANVVVTGGK } & 1.00 & 98.17 & 25.05 & 24.55 & 2 & 1659.9534 & 1659.9399 & 830.9772 & 0.0135 & 8.1229 & 2435.437 & 3017.552 & 1257.866 & 473.996 & \text { Yes }\end{array}$ $\begin{array}{llllllllllllllll}\text { QITSYGETCPGLEQYAIK } & 0.99 & 31.35 & 27.28 & 16.21 & 3 & 2334.1522 & 2334.1479 & 779.0566 & 0.0043 & 1.8398 & 359.788 & 287.577 & 184.294 & 211.965 & \text { No }\end{array}$ $\begin{array}{llllllllllllllll}\text { IGLSVSEVIEGYEIACR } & 1.00 & 79.15 & 27.19 & 25.69 & 2 & 2027.0194 & 2027.0189 & 1014.5167 & 0.0005 & 0.2464 & 30.058 & 16.612 & 4.586 & 2.156 & \text { No }\end{array}$ $\begin{array}{llllllllllllllll}\text { LFVTNDAATILR } & 0.98 & 53.33 & 26.64 & 25.47 & 2 & 1476.8368 & 1476.8422 & 739.4284 & -0.0054 & -3.6515 & 25348.875 & 24852.642 & 8049.309 & 3931.096 & \text { Yes }\end{array}$

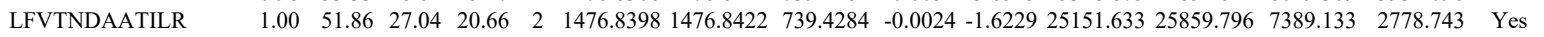

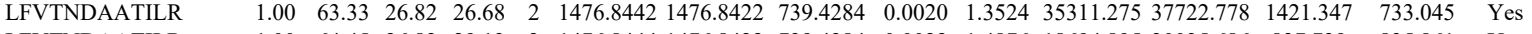
$\begin{array}{llllllllllllllllll}\text { LFVTNDAATILR } & 1.00 & 64.45 & 26.82 & 29.13 & 2 & 1476.8444 & 1476.8422 & 739.4284 & 0.0022 & 1.4876 & 18694.895 & 20035.686 & 837.739 & 835.861 & \text { Yes }\end{array}$

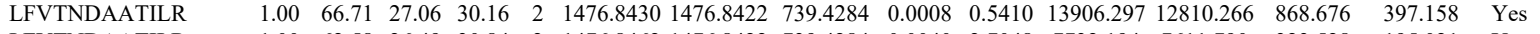
$\begin{array}{llllllllllllllll}\text { LFVTNDAATILR } & 1.00 & 62.58 & 26.49 & 30.84 & 2 & 1476.8462 & 1476.8422 & 739.4284 & 0.0040 & 2.7048 & 7732.194 & 7611.790 & 323.528 & 195.021 & \text { Yes }\end{array}$

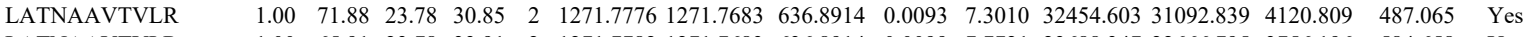
$\begin{array}{llllllllllllllll}\text { LATNAAVTVLR } & 1.00 & 65.91 & 23.78 & 33.91 & 2 & 1271.7782 & 1271.7683 & 636.8914 & 0.0099 & 7.7721 & 23688.347 & 22666.795 & 3756.196 & 584.658 & \text { Yes }\end{array}$

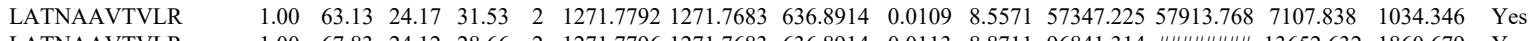
$\begin{array}{llllllllllllllll} & \text { LATNAAVTVLR } & 1.00 & 67.83 & 24.12 & 28.66 & 2 & 1271.7796 & 1271.7683 & 636.8914 & 0.0113 & 8.8711 & 96841.314 & \text { \#\#\#\#\#\# } 13652.632 & 1860.679 & \text { Yes }\end{array}$

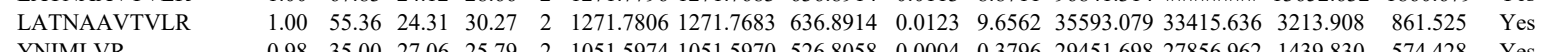

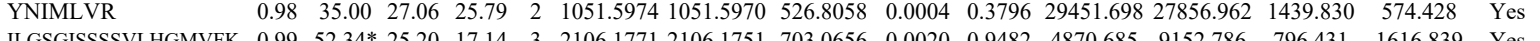

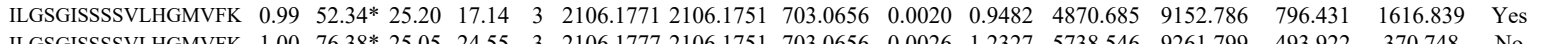

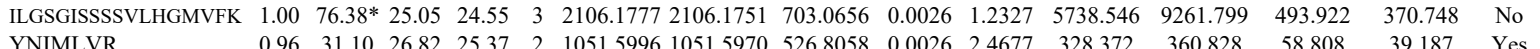

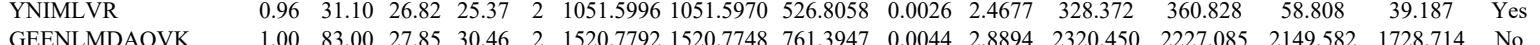
$\begin{array}{llllllllllllllll} & \end{array}$

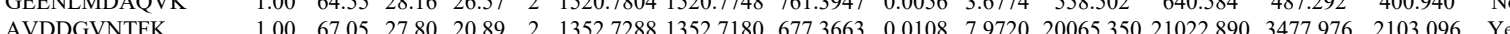
$\begin{array}{llllllllllllllll}\text { AVDDGVNTFK } & 1.00 & 55.69 & 27.84 & 2.81 & 2 & 1352.7302 & 1352.7180 & 677.3663 & 0.0122 & 9.0054 & 16508.781 & 18376.478 & 3379.565 & 1461.300 & \text { Yes }\end{array}$

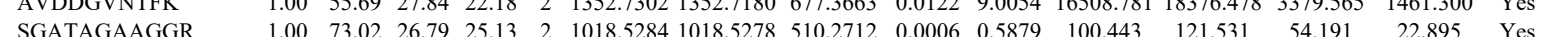

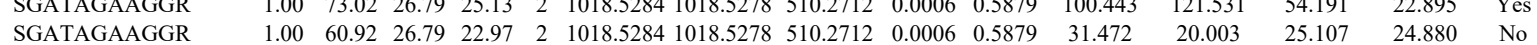

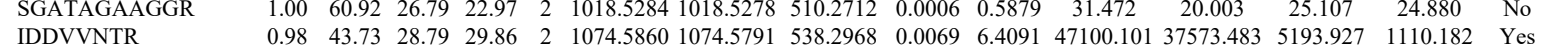
SGATAGAAGGR

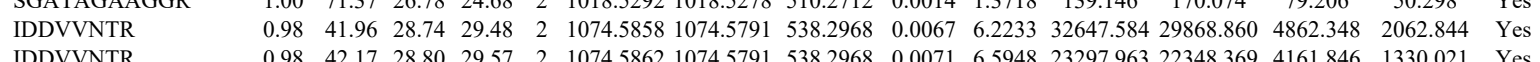

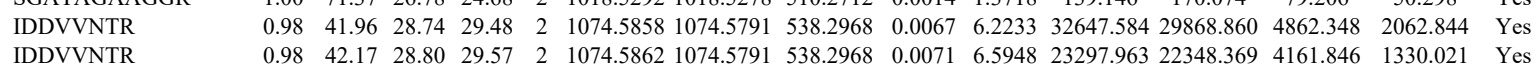
$\begin{array}{llllllllllllllll} & 0.98 & 42.17 & 28.80 & 29.57 & 2 & 1074.5862 & 1074.5791 & 538.2968 & 0.0071 & 6.5948 & 23297.963 & 22348.369 & 4161.846 & 1330.021 & \text { Yes }\end{array}$ $\begin{array}{lllllllllllllllll}\text { GDVTINDGATILK } & 1.00 & 83.45 & 26.43 & 23.35 & 2 & 1704.9532 & 1704.9502 & 853.4824 & 0.0030 & 1.7575 & 1716.439 & 1916.000 & 794.285 & 989.088 & \text { Yes }\end{array}$ GDVTITNDGATILK GDVIITNDGATILK GDVTITNDGATILK GDVTITNDGATILK VIDPATATSVDLR VIDPATATSVDLR LGGTIDDCELVEGLVLTQK

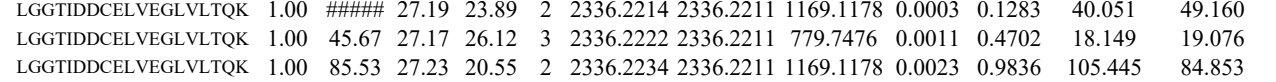
$\begin{array}{lllllllllllllll}\text { LGGTIDDCELVEGLVLTQK } & 1.00 & 35.53 & 27.23 & 20.55 & 2 & 2336.2234 & 2336.2211 & 1169.1178 & 0.0023 & 0.9836 & 105.445 & 84.853 & 0.0 & \\ & 25.16 & 25 & 2336.2261 & 2336.2211 & 779.7476 & 0.0050 & 2.1374 & 25.255 & 14.036 & 4.5\end{array}$

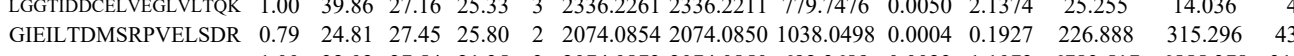
$\begin{array}{lllllllllllllll}1.00 & 32.02 & 27.54 & 21.35 & 3 & 2074.0873 & 2074.0850 & 6923689 & 0.0023 & 1.1073 & 6783.517 & 6555.378 & 3156253 & 729.089 & \text { No }\end{array}$ $\begin{array}{lllllllllllllllll}\text { GLILTDMSRPVELSDR } & 0.98 & 26.85 & 27.59 & 14.78 & 3 & 2074.0876 & 2074.0850 & 692.3689 & 0.0026 & 1.2517 & 9407.993 & 9875.094 & 3795.198 & 1227.816 & \text { Yes }\end{array}$

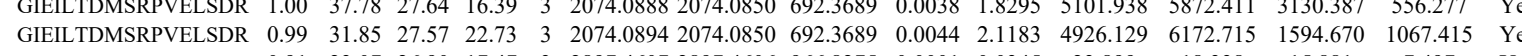

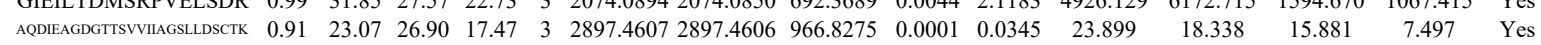

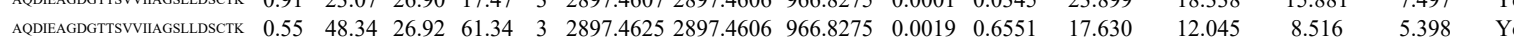

Table S-3 page 271 of 499 
ALIAGGGAPEIELALR 0 $\begin{array}{lllllllllllll}0.59 & 17.37 & 27.51 & 25.52 & 2 & 9765440 & 976.5423 & 489.2784 & 0.0017 & 1.7372 & 177.403\end{array}$

AQDIFAGDGTTSVVIAGSLDSCCK

TAGINVR

FSNISAAK

FSNISAAK

ITGCASPGK 0.55

TGCASPGK

ITGCASPGK $\begin{array}{llllllllllll}0.55 & 38.59 & 26.90 & 51.59 & 3 & 2897.4631 & 2897.4606 & 966.8275 & 0.0025 & 0.8619 & 55.728\end{array}$ $\begin{array}{llllllllll} & \end{array}$ $\begin{array}{lllllllllllll}0.59 & 19.70 & 27.85 & 24.94 & 2 & 873.5170 & 873.5154 & 437.7650 & 0.0016 & 1.8275 & 855.776 \\ 0.73 & 20.57 & 27.85 & 25.60 & 2 & 873.517 & 873.54 & 437.760 & 0.0020 & 2.843 & 883.429 & 863.03\end{array}$

ADAMEVIPSTLAENAGLNPISTVT $\begin{array}{lllllllllll} & \end{array}$

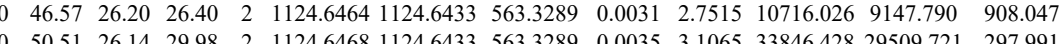
$\begin{array}{lllllllllllll}1.00 & 47.68 & 27.84 & 24.49 & 2 & 1166.6068 & 1166.6031 & 584.3088 & 0.0037 & 3.1661 & 19655.481 & 20482.440 & 2995.990\end{array}$ $\begin{array}{llllllllllllll}1.00 & 53.22 & 27.84 & 27.34 & 2 & 1166.6070 & 1166.6031 & 584.3088 & 0.0039 & 3.3373 & 27668.768 & 28177.999 & 3600.912\end{array}$

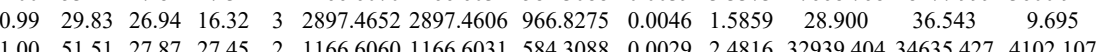
$\begin{array}{lllllllllllll}1.00 & 55.43 & 27.82 & 27.82 & 2 & 1166.6080 & 1166.6031 & 584.3088 & 0.0049 & 4.1930 & 43705.423 & 43887.269 & 6363.722\end{array}$

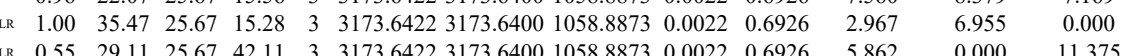

$\begin{array}{llllllllllllll}\text { LR } & 0.55 & 29.11 & 25.67 & 42.11 & 3 & 3173.6422 & 3173.6400 & 1058.8873 & 0.0022 & 0.6926 & 5.862 & 0.000 & 11.375 \\ & 19.41 & 25.67 & 32.41 & 3 & 3173.6422 & 3173.6400 & 1058.8873 & 0.0022 & 0.6926 & 0.000 & 4.765 & 3.701\end{array}$

$\begin{array}{llllllllllllll} & \end{array}$ $\begin{array}{lllllllllllll}\text { STVTER } & 1.00 & 19.64 & 25.59 & 17.43 & 4 & 3173.6461 & 3173.6400 & 794.4173 & 0.0061 & 1.9196 & 30.770 \\ \end{array}$

MDP

QMQVLHPAAR QMQVLHPAAR QMQVLHPAAR

QMQVLHPAAR

TVTIVVR

QMQVLHPAAR

QMQVLHPAAR

SIHDALCVIR

SIHDALCVIR

SIHDALCVIR

SIHDALCVIR

TGCNVLLIQK

TGCNVLLIQK

AYILNLVK

AYILNLVK

TGCNVLLIQK

TGCNVLLIQK

VVQYSSLLSPMSVNAVMK

IGLIQFCLSAPK

IGLIQFCLSAPK

IGLIQFCLSAPK

IGLIQFCLSAPK

IGLIQFCLSAPK

IGLIQFCLSAPK

IGLIQFCLSAPK

IGLIQFCLSAPK

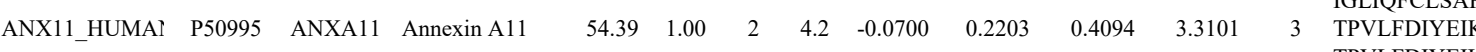

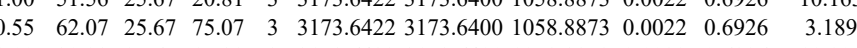

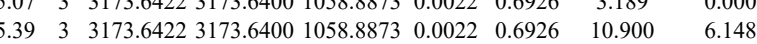
$\begin{array}{llllllllllllllll}0.66 & 14.36 & 27.80 & 18.07 & 3 & 1293.7120 & 1293.7097 & 432.2438 & 0.0023 & 1.7737 & 6679.430 & 5346.778 & 1491.001 & 97.2\end{array}$ $\begin{array}{lllllllllllllll}1 & 123.7123 & 1293.7097 & 432.2438 & 0.0026 & 2.0050 & 19202.123 & 15315.752 & 2794.487 & 1501.245\end{array}$

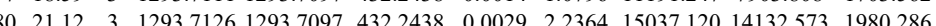

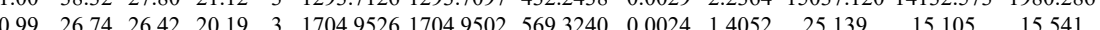

$\begin{array}{lllllllllllll}0.92 & 33.39 & 25.45 & 32.75 & 2 & 930.6032 & 930.5984 & 466.3065 & 0.0048 & 5.1468 & 47296.362 & 44684.228 & 4944.559\end{array}$ $\begin{array}{lllllllllllllll}35.83 & 27.88 & 24.88 & 3 & 1293.7093 & 1293.7097 & 432.2438 & -0.0004 & -0.3085 & 12497.466 & 12129.582 & 1460.701\end{array}$ $\begin{array}{llllllllllllll}1.00 & 48.82 & 27.81 & 23.35 & 3 & 1293.7105 & 1293.7097 & 432.2438 & 0.0008 & 0.6169 & 14994.993 & 16324.434 & 1813.078 & 28\end{array}$ $\begin{array}{llllllllllll}0.69 & 52.45 * 27.69 & 33.28 & 2 & 1315.6932 & 1315.6862 & 658.8504 & 0.0070 & 5.3123 & 10783.945 & 11922.294 & 402.727\end{array}$ $\begin{array}{lllllllllllll}0.53 & 37.74 * 27.72 & 20.84 & 3 & 1315.6948 & 1315.6862 & 439.5693 & 0.0086 & 6.5215 & 3715.731 & 4432.291 & 750.323 & 141\end{array}$ $\begin{array}{lllllllllllll}0.86 & 51.91 * 27.83 & 22.26 & 3 & 1315.6951 & 1315.6862 & 439.5693 & 0.0089 & 6.7490 & 3184.875 & 3710.703 & 595.327\end{array}$ $\begin{array}{llllllllllllll}1.00 & 49.29 & 27.02 & 27.44 & 2 & 1421.8102 & 1421.7978 & 711.9062 & 0.0124 & 8.7089 & 6085.348 & 6739.405 & 1504.208 & 29\end{array}$ $\begin{array}{llllllllllllll}0.99 & 43.33 & 27.14 & 26.32 & 2 & 1421.8110 & 1421.7978 & 711.9062 & 0.0132 & 9.2708 & 14962.336 & 12432.426 & 3743.448\end{array}$ $\begin{array}{llllllllllllll}1.00 & 43.14 & 20.61 & 21.87 & 2 & 1220.7758 & 1220.7736 & 611.3941 & 0.0022 & 1.7992 & 49854.515 & 48229.892 & 666.935\end{array}$ $\begin{array}{llllllllllllll}1.00 & 39.61 & 20.04 & 26.52 & 2 & 1220.7762 & 1220.7736 & 611.3941 & 0.0026 & 2.1263 & 70810.423 & 75509.863 & 170.694\end{array}$ $\begin{array}{lllllllllllll}1.00 & 60.45 & 26.76 & 29.34 & 2 & 1421.8072 & 1421.7978 & 711.9062 & 0.0094 & 6.6019 & 2789.488 & 2930.481 & 657.210\end{array}$ $\begin{array}{llllllllllllll}1.00 & 47.28 & 27.02 & 27.04 & 2 & 1421.8102 & 1421.7978 & 711.9062 & 0.0124 & 8.7089 & 3356.086 & 3025.883 & 1074.835\end{array}$ $\begin{array}{llllllllllllll}0.92 & 20.08 & 26.72 & 18.83 & 3 & 2327.2498 & 2327.2473 & 776.7564 & 0.0025 & 1.0728 & 71.814 & 43.044 & 27.684\end{array}$ $\begin{array}{lllllllllllll}1.00 & 38.79 & 26.71 & 16.49 & 3 & 2327.2501 & 2327.2473 & 776.7564 & 0.0028 & 1.2016 & 45.988 & 30.676 & 23.167\end{array}$ $\begin{array}{llllllllllll}1.00 & 62.10 & 26.36 & 29.19 & 2 & 1622.9144 & 1622.9132 & 812.4639 & 0.0012 & 0.7385 & 120.095 & 106.885\end{array}$ $\begin{array}{lllllllllllll}1.00 & 84.73 & 26.28 & 27.13 & 2 & 1622.9154 & 1622.9132 & 812.4639 & 0.0022 & 1.3539 & 112.887 & 106.241\end{array}$ $\begin{array}{lllllllllllll}1.00 & 37.08 & 26.28 & 20.09 & 3 & 1622.9155 & 1622.9132 & 541.9783 & 0.0023 & 1.4146 & 68.441 & 31.660\end{array}$ $\begin{array}{llllllllllllll}1.00 & 37.31 & 26.23 & 24.45 & 3 & 1622.9158 & 1622.9132 & 541.9783 & 0.0026 & 1.5991 & 89.268 & 70.837\end{array}$ $\begin{array}{llllllllllll}0.89 & 19.67 & 26.36 & 15.04 & 3 & 1622.9146 & 1622.9132 & 541.9783 & 0.0014 & 0.8610 & 20.675\end{array}$ $\begin{array}{llllllllllll}0.96 & 22.60 & 26.23 & 18.53 & 3 & 1622.9161 & 1622.9132 & 541.9783 & 0.0029 & 1.7836 & 22.387\end{array}$

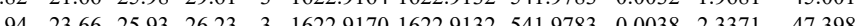

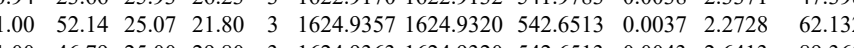

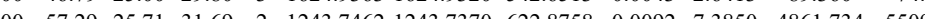
$\begin{array}{lllllllllllllllll}0.51 & 30.98 & 25.11 & 43.98 & 2 & 1335.6396 & 1335.6285 & 668.8215 & 0.011 & 8.2981 & 2488.035 & 2691.131\end{array}$ 
$\begin{array}{llllllllllll}0.53 & 50.39 & 27.70 & 63.39 & 3 & 1838.9719 & 1838.9689 & 613.9969 & 0.0030 & 1.6287 & 187.398\end{array}$ $\begin{array}{lllllllllll}1.00 & 80.45 & 27.71 & 26.29 & 2 & 1838.9708 & 1838.9689 & 920.4917 & 0.0019 & 1.0321 & 221.363\end{array}$ $\begin{array}{llllllllllll}1.00 & 86.72 & 27.72 & 29.35 & 2 & 1838.9710 & 1838.9689 & 920.4917 & 0.0021 & 1.1407 & 666.643 \\ 1.00 & 38.30 & 27.67 & 16.19 & 3 & 1838.9722 & 1838.9689 & 613.9969 & 0.0033 & 1.7915 & 114.179\end{array}$ $\begin{array}{lllllllllll}1.00 & 38.30 & 27.67 & 16.19 & 3 & 1838.9722 & 1838.9689 & 613.9969 & 0.0033 & 1.7915 & 114.179\end{array}$

$\begin{array}{llllllllllllll}0 & \end{array}$

VTMAVPEDLR

LLLMSR

LLLMSR

TKPSEDSLSGQK
TKPSEDSLSGQK

TKPSEDSLSGQK

NEPQNATGAPGR

GVDLOENNPASR GVDLQENNPASR GVDLQENNPASR GVDLQENNPASR

2 NNIPYFETSAK

\section{NNIPYFETSAK}

DPENFPFVVLGNK

DPENFPFVVLGNK

DPENFPFVVLGNK

DPENFPFVVLGNK

DPENFPFVVLGNK

DPENFPFVVLGNK

ATIGADFLTK

TSLMNQYVNK
TSLMNQYVNK

TSLMNQYVNK

$\begin{array}{lllllllllllll}\text { SMCA4_HUMA } & \text { P51532 } & \text { SMARCA4Transcription actir } 184.65 & 1.00 & 2 & 1.1 & -0.0408 & 0.1539 & 0.9658 & 1.4034 & 6 & \text { ITPIQKPR }\end{array}$

ITPIQKPR

ITPIQKP

TLMNTIMQL

TLMNTIMQLR

- 2 LAAVDGPMDK

LQAAVDGPMDK

LKDELASTK

LKDELASTK

AENQVLAMR

AENQVLAMR

KYDDVTEK

LDVGNAEVK

LDVGNAEVK

LDVGNAEVK

LQAAVDGPMDK

LQAAVDGPMDK

YIAPTVLTDVDPK

YIAPTVLTDVDPK

EKDILTAIAADLCK

EKDILTAIAADLCK

EKDILTAIAADLCK

DILTAIAADLCK

$\begin{array}{llllllllllll}\text { DHB4_HUMAN } & \text { P51659 } & \text { HSD17B4 Peroxisomal multi } 79.69 & 1.00 & 2 & 5.3 & 0.3706 & 0.5729 & -0.3927 & 0.7759 & 3 & \begin{array}{l}\text { DILTAIAADLCCK } \\ \text { IDVVVNAGILR }\end{array} \\ & & & & & & & & & & & \end{array}$

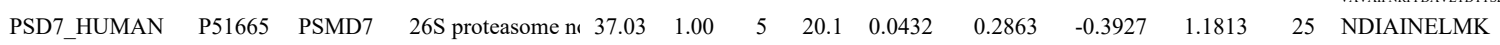

SVVALHNLINNK

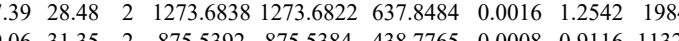
$\begin{array}{llllllllllllllll}32.90 & 29.06 & 31.35 & 2 & 875.5392 & 875.5384 & 438.7765 & 0.0008 & 0.9116 & 11321.484 & 9568.897 & 497.473 & 21.216 & \text { Yes } & \\ \end{array}$ $\begin{array}{lllllllllllllllll}0 & 0.07\end{array}$

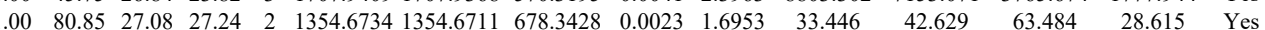
$\begin{array}{lllllllllllllll}1.00 & 64.15 & 27.32 & 38.27 & 2 & 1442.7282 & 1442.7235 & 722.3690 & 0.0047 & 3.2532 & 5591.122 & 6499.196 & 6526.419 & 3598.064 & \text { Yes }\end{array}$ $\begin{array}{llllllllllllllll}1.00 & 68.94 & 27.36 & 31.28 & 2 & 1442.7284 & 1442.7235 & 722.3690 & 0.0049 & 3.3916 & 6618.510 & 9873.882 & 9259.785 & 4452.903 & \text { Yes }\end{array}$ $\begin{array}{lllllllllllllll}1.00 & 62.41 & 27.28 & 27.12 & 2 & 1442.7318 & 1442.7235 & 722.3690 & 0.0083 & 5.7450 & 507.971 & 458.917 & 630.272 & 286.345 & \text { Yes }\end{array}$ $\begin{array}{lllllllllllllll}0.99 & 43.63 & 27.28 & 26.34 & 2 & 1442.7318 & 1442.7235 & 722.3690 & 0.0083 & 5.7450 & 0.000 & 12.758 & 17.417 & 96.587 & \text { No }\end{array}$

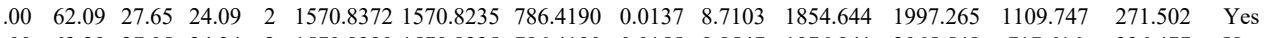
$\begin{array}{lllllllllllllll}1.00 & 62.29 & 27.05 & 24.34 & 2 & 1570.8390 & 1570.8235 & 786.4190 & 0.0155 & 9.8547 & 1976.941 & 2065.548 & 717.616 & 236.477 & \text { Yes }\end{array}$

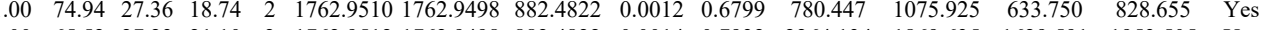
$\begin{array}{lllllllllllllllll}1.00 & 65.52 & 27.23 & 21.10 & 2 & 1762.9512 & 1762.9498 & 882.4822 & 0.0014 & 0.7932 & 2264.134 & 1869.635 & 1629.591 & 1953.505 & \text { Yes }\end{array}$ $\begin{array}{lllllllllllllll}0.53 & 26.54 & 27.40 & 39.54 & 3 & 1762.9525 & 1762.9498 & 588.6572 & 0.0027 & 1.5289 & 287.435 & 251.546 & 381.597 & 290.665 & \text { Yes } \\ 1.00 & 38.13 & 27.29 & 6.81 & 3 & 176.9531 & 1762.9498 & 588.652 & 0.023 & 1.8687 & 12.260 & 195.667 & 14.463 & 157.74 & \text { Yes }\end{array}$ \begin{tabular}{lllllllllllllll}
1.00 & 38.13 & 27.29 & 26.81 & 3 & 1762.9531 & 1762.9498 & 588.6572 & 0.0033 & 1.8687 & 120.260 & 195.667 & 144.463 & 157.743 & Yes \\
\hline
\end{tabular} $\begin{array}{lllllllllllllll}1 & 17.19 & 27.29 & 19.33 & 2 & 1762.9506 & 1762.9498 & 882.4822 & 0.0008 & 0.4533 & 1110.655 & 1279.213 & 619.044 & 733.163 & \text { Yes }\end{array}$

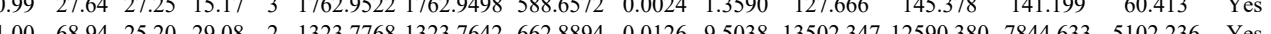
$\begin{array}{lllllllllllllll}1.00 & 54.18 & 27.80 & 25.40 & 2 & 1484.8036 & 1484.7901 & 743.4023 & 0.0135 & 9.0798 & 4532.500 & 4068.935 & 751.645 & 186.198 & \text { Yes } \\ 1.00 & 27.03 & 23.67 & 2 & 1484.8036 & 1484.7901 & 743.4023 & 0.0135 & 9.0798 & 2685.472 & 2246.174 & 565.266 & 21.108 & \text { Yes }\end{array}$

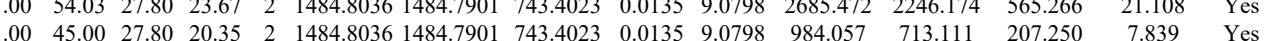

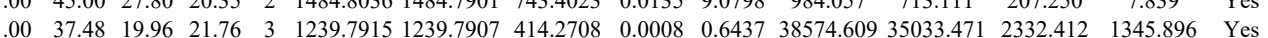

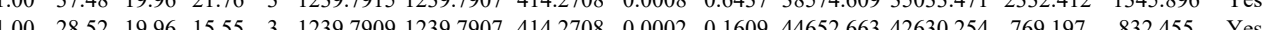
$\begin{array}{llllllllllllllll}1.00 & 28.71 & 19.96 & 20.44 & 3 & 1239.7918 & 1239.7907 & 414.2708 & 0.0011 & 0.8851 & 29186.737 & 30671.103 & 505.739 & 658.800 & \text { Yes }\end{array}$ $\begin{array}{llllllllllllllll}1.96 & 29.36 & 19.24 & 22.42 & 2 & 1239.7954 & 1239.7907 & 620.9026 & 0.0047 & 3.7848 & 2522.137 & 2218.143 & 95.645 & 143.090 & \text { Yes }\end{array}$ $\begin{array}{lllllllllllllllll}1.00 & 54.73 & 28.48 & 31.84 & 2 & 1363.7448 & 1363.7437 & 682.8791 & 0.0011 & 0.8054 & 2573.681 & 2762.206 & 36.014 & 26.220 & \text { Yes }\end{array}$

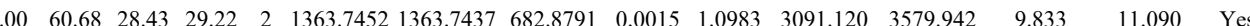
$\begin{array}{lllllllllllllll}1.00 & 54.28 & 28.54 & 25.49 & 2 & 1431.7740 & 1431.7635 & 716.8890 & 0.0105 & 73233 & 857.044 & 958.754 & 954.340 & 290.568 & \text { Yes }\end{array}$ $\begin{array}{lllllllllllllll}1.00 & 57.50 & 28.56 & 2.770 & 2 & 1431.7748 & 1431.7635 & 7168890 & 0.0113 & 7.8812 & 2193.399 & 3021.175 & 2470.519 & 531.665 & \text { Yes }\end{array}$ $\begin{array}{llllllllllllllll}0.79 & 50.07 & 23.56 & 25.51 & 2 & 1435.8660 & 1435.8611 & 718.9378 & 0.0049 & 3.4078 & 19682.545 & 29773.885 & 7866.299 & 1479.880 & \text { No }\end{array}$ $\begin{array}{lllllllllllllll}0.52 & 43.57 & 23.10 & 23.48 & 2 & 1435.8668 & 1435.8611 & 718.9378 & 0.0057 & 3.9642 & 25442.725 & 32604.936 & 7316.426 & 2237.012 & \text { Yes }\end{array}$ $\begin{array}{llllllllllllllll}1.00 & 57.38 & 28.14 & 32.56 & 2 & 1174.6300 & 1174.6250 & 588.3198 & 0.0050 & 4.2494 & 12374.180 & 15620.512 & 12213.734 & 4066.833 & \text { Yes }\end{array}$ $\begin{array}{llllllllllllllll}1.00 & 50.78 & 28.15 & 29.74 & 2 & 1174.6302 & 1174.6250 & 588.3198 & 0.0052 & 4.4193 & 10174.298 & 13481.101 & 9592.956 & 3279.023 & \text { Yes }\end{array}$ $\begin{array}{lllllllllllllll}0.51 & 32.13 * & 27.72 & 23.80 & 2 & 1284.6826 & 1284.6805 & 643.3475 & 0.0021 & 1.6321 & 17.575 & 29.087 & 37.049 & 26.208 & \text { No }\end{array}$ $\begin{array}{llllllllllllllll}0.95 & 34.45 & 27.97 & 30.92 & 2 & 1231.7126 & 1231.7016 & 616.8581 & 0.0110 & 8.9161 & 19841.555 & 26552.679 & 18023.341 & 8184.229 & \text { Yes }\end{array}$ $\begin{array}{lllllllllllllll}0.99 & 43.63 & 27.97 & 36.92 & 2 & 1231.7126 & 1231.7016 & 616.8581 & 0.0110 & 8.9161 & 22614.698 & 24784.102 & 18059.824 & 6944.121 & \text { Yes }\end{array}$ $\begin{array}{lllllllllllllll}0.99 & 40.54 & 27.80 & 32.41 & 2 & 1231.7114 & 1231.7016 & 616.8581 & 0.0098 & 7.9434 & 26474.106 & 33758.048 & 23960.303 & 5959.101 & \text { Yes }\end{array}$ $\begin{array}{lllllllllllllll}1.00 & 46.28 & 28.01 & 29.78 & 2 & 1231.7120 & 1231.7016 & 616.8581 & 0.0104 & 8.4297 & 26202.377 & 31060.934 & 23142.922 & 5135.550 & \text { Yes }\end{array}$

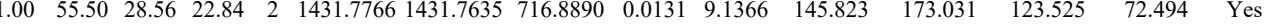

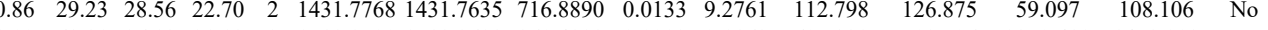
$\begin{array}{lllllllllllllll}1.00 & 68.91 & 26.13 & 21.13 & 2 & 1718.9700 & 1718.9698 & 860.4922 & 0.0002 & 0.1162 & 605.329 & 502.706 & 2270.482 & 1478.903 & \text { Yes }\end{array}$ $\begin{array}{llllllllllllllll}0.86 & 16.71 & 25.98 & 15.74 & 3 & 1718.9719 & 1718.9698 & 573.9972 & 0.0021 & 1.2195 & 185.284 & 236.174 & 307.573 & 275.874 & \text { Yes }\end{array}$ $\begin{array}{lllllllllllllll}1.00 & 56.34 & 25.74 & 20.76 & 3 & 1981.0996 & 1981.0953 & 661.3724 & 0.0043 & 2.1672 & 112.544 & 116.390 & 327.801 & 230.353 & \text { Yes }\end{array}$

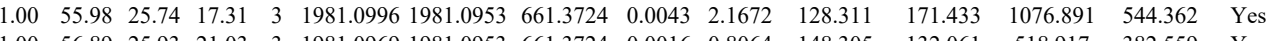

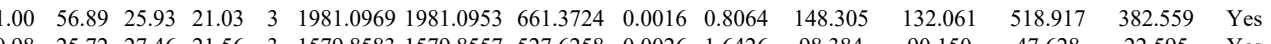

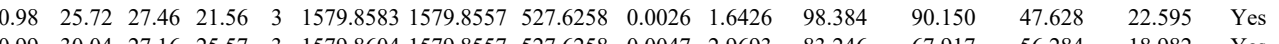
$\begin{array}{lllllllllllllll}0.99 & 5.04 & 27.16 & 25.57 & 3 & 1579.8604 & 1579.8557 & 527.6258 & 0.0047 & 2.9693 & 83.246 & 67.917 & 56.284 & 18.982 & \text { Yes } \\ 1.00 & 55.6 & 24.64 & 31.09 & 2 & 1425.8434 & 1425.8425 & 713.9285 & 0.0009 & 0.6303 & 527.033 & 891.437 & 478.661 & 155.852 & \text { Yes }\end{array}$

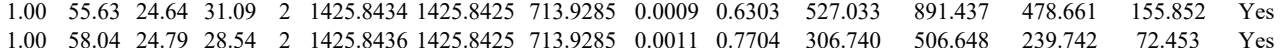
$\begin{array}{lllllllllllllll}1.00 & 58.04 & 24.79 & 28.54 & 2 & 1425.8436 & 1425.8425 & 713.9285 & 0.0011 & 0.7704 & 306.740 & 506.648 & 239.742 & 72.453 & \text { Yes } \\ 1.00 & 54.61 & 21.85 & 19.03 & 3 & 3009.6412 & 3009.6369 & 1004.2196 & 0.0043 & 1.4273 & 330.194 & 277.509 & 373.048 & 216.998 & \text { Yes }\end{array}$ \begin{tabular}{lllllllllllllll}
1.00 & 45.60 & 27.87 & 24.79 & 2 & 1447.8058 & 1447.7948 & 724.9047 & 0.0110 & 7.5871 & 519.446 & 408.537 & 244.248 & 20.364 & Yes \\
\hline
\end{tabular}

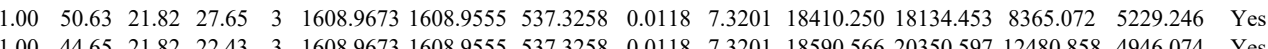


$\begin{array}{llllllllllll} & \end{array}$

$\begin{array}{lllllllllllll} & 26.59 & 32.94 & 2 & 1930.0470 & 1930.0468 & 966.0307 & 0.0002 & 0.1035 & 98.820 & 13 & \\ \text { LGMPQFLSPEAQSLLR } & 1.00 & 66.06 & 26.50 & 21.96 & 2 & 1930.0478 & 1930.0468 & 966.0307 & 0.0010 & 0.5176 & 141.913 & 169\end{array}$ $\begin{array}{llllllllllllll} & \end{array}$ $\begin{array}{llllllllllllll} & \end{array}$ $\begin{array}{lllllllllll}72 & 28.16 & 3 & 2107.0876 & 2107.0829 & 703.3682 & 0.0047 & 2.2274 & 340.308 & 365.669\end{array}$ $\begin{array}{llllllllllllll} & \end{array}$ $\begin{array}{lllllllllllllll}0.93 & 28.52 & 23.84 & 19.83 & 2 & 1171.7164 & 1171.7056 & 586.8601 & 0.0108 & 9.2014 & 5364.864 & 7390.214 & 1440.138 & 1593.263\end{array}$ $\begin{array}{llllllllllllllll}\text { GFAFVTFDDHDTVDK } & 0.96 & 24.80 & 27.23 & 17.98 & 3 & 2000.9734 & 2000.9724 & 667.9981 & 0.0010 & 0.4990 & 128.043 & 156.580 & 87.299 & 59.569 & Y\end{array}$ $\begin{array}{llllllllllllllll}\text { GFAFVTFDDHDTVDK } & 1.00 & 66.54 & 27.19 & 20.50 & 3 & 2000.9737 & 2000.9724 & 667.9981 & 0.0013 & 0.6487 & 3392.271 & 3053.721 & 729.727 & 270.849 & \text { Yes }\end{array}$ $\begin{array}{llllllllllllllllll}\text { GFAFVTFDDHDTVDK } & 0.95 & 22.02 & 27.28 & 21.53 & 3 & 2000.9746 & 2000.9724 & 667.9981 & 0.0022 & 1.0978 & 112.343 & 159.255 & 93.048 & 60.023 & \text { Yes }\end{array}$

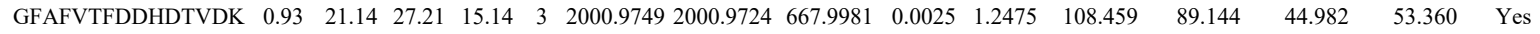

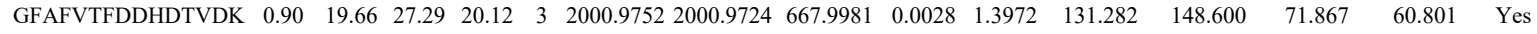

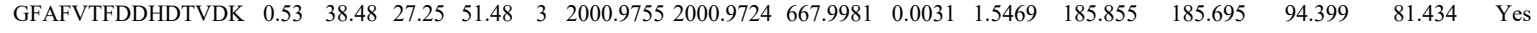

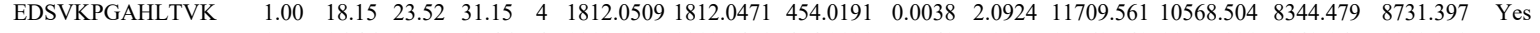
$\begin{array}{llllllllllllllllll}\text { EDSVKPGAHLTVK } & 1.00 & 16.46 & 23.50 & 29.46 & 4 & 1812.0513 & 1812.0471 & 454.0191 & 0.0042 & 2.3127 & 10768.542 & 11525.831 & 9243.165 & 9833.273 & \text { Yes }\end{array}$

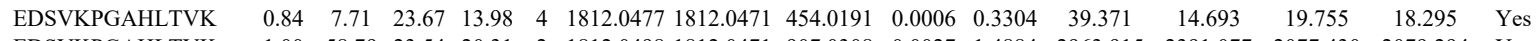
$\begin{array}{lllllllllllllllll}\text { EDSVKPGAHLTVK } & 1.00 & 58.79 & 23.54 & 20.31 & 2 & 1812.0498 & 1812.0471 & 907.0308 & 0.0027 & 1.4884 & 2963.915 & 2391.077 & 2077.430 & 2079.294 & \text { Yes }\end{array}$

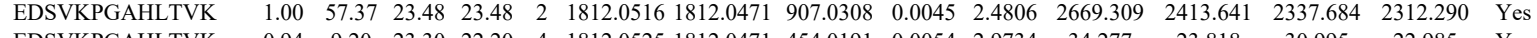

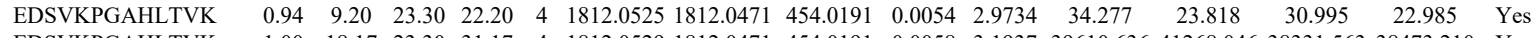

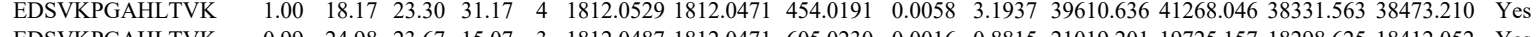

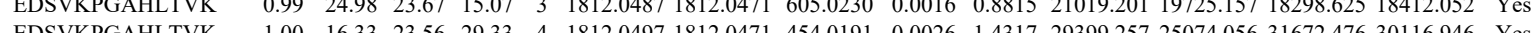
$\begin{array}{lllllllllllllllllll}\text { EDSVKPGAHLTVK } & 1.00 & 16.33 & 23.56 & 29.33 & 4 & 1812.0497 & 1812.0471 & 454.0191 & 0.0026 & 1.4317 & 29399.257 & 25074.056 & 31672.476 & 30116.946 & \text { Yes }\end{array}$ $\begin{array}{lllllllllllllllllllll}\text { EDSVKPGAHLTVK } & 1.00 & 18.61 & 23.56 & 16.35 & 4 & 1812.0497 & 1812.0471 & 454.0191 & 0.0026 & 1.4317 & 22285.661 & 20252.382 & 19385.043 & 18895.087 & \text { Yes } \\ \text { EDSVKPGAHLTVK } & 1.00 & 20.82 & 23.54 & 14.75 & 4 & 1812.0489 & 1812.0471 & 454.0191 & 0.0018 & 0.9911 & 17209.604 & 18496.877 & 14943.673 & 13956.222 & \text { Yes }\end{array}$ $\begin{array}{lllllllllllllllllll}\text { EDSVKPGAHLTVK } & 1.00 & 20.82 & 23.54 & 14.75 & 4 & 1812.0489 & 1812.0471 & 454.0191 & 0.0018 & 0.9911 & 17209.604 & 18496.877 & 14943.673 & 13956.222 & \text { Yes } \\ \text { EDSVKPGAHLTVK } & 1.00 & 17.47 & 23.58 & 30.47 & 4 & 1812.0493 & 1812.0471 & 454.0191 & 0.0022 & 1.2114 & 7449.232 & 8194.010 & 7128.387 & 6495.137 & \text { Yes }\end{array}$ $\begin{array}{llllllllllllllll}\text { ESGSPYGGGYGSGGGGGYGSR } & 1.00 & 56.06 & 22.12 & 17.39 & 3 & 2103.8829 & 2053.8848 & 685.6355 & -0.0019 & -0.9237 & 314.781 & 308.439 & 240.051 & 205.054 & \text { Yes }\end{array}$ $\begin{array}{lllllllllllllllll}\text { YHTINGHNCEVK } & 1.00 & 23.42 & 26.62 & 36.42 & 4 & 1747.8421 & 1747.8378 & 437.9667 & 0.0043 & 2.4545 & 6474.575 & 5601.981 & 2956.965 & 1426.769 & \text { Yes }\end{array}$ 
GFAFVTFDDHDTVDK

$\begin{array}{lllllllllllll}.00 & 54.44 & 25.71 & 23.13 & 2 & 1469.6960 & 1469.6951 & 735.8548 & 0.0009 & 0.6115 & 380.439 & 391.54\end{array}$

$\begin{array}{lllllllllllllllll} & 55.80 & 27.73 & 28.18 & 2 & 1377.6956 & 1377.6931 & 689.8538 & 0.0025 & 1.8120 & 6379.713 & 5529.690 & 115.413 & 175.796 \\ & 1.00 & 31.31 & 27.28 & 17.31 & 3 & 2000.9668 & 2000.9724 & 667.9981 & -0.0056 & -2.7944 & 173.857 & 179.316 & 120.165 & 92.753\end{array}$

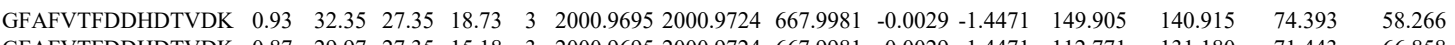

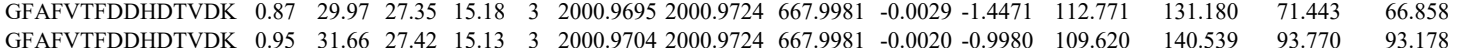
$\begin{array}{llllllllllllllll}\text { GFAFVTFDDHDTVDK } & 0.95 & 31.66 & 27.42 & 15.13 & 3 & 2000.9704 & 2000.9724 & 667.9981 & -0.0020 & -0.9980 & 109.620 & 140.539 & 93.770 & 93.178 & \text { Yes } \\ \text { GF.39 } & 15.89 & 3 & 2000.9713 & 2000.9724 & 667.9981 & -0.0011 & -0.5489 & 156.546 & 170.984 & 78.638 & 80.148 & \text { Yes }\end{array}$ $\begin{array}{lllllllllllllll}\text { GFAFVTFDDHDTVDK } & 0.91 & 23.17 & 27.29 & 16.17 & 3 & 2000.9722 & 2000.9724 & 667.9981 & -0.0002 & -0.0998 & 158.892 & 150.991 & 108.061 & 112.666\end{array}$ $\begin{array}{lllllllllllllll}\text { GFAFVTFDDHDTVDK } & 0.81 & 20.10 & 27.21 & 15.85 & 3 & 2000.9725 & 2000.9724 & 667.9981 & 0.0001 & 0.0499 & 155.707 & 141.071 & 103.414 & 96.500\end{array}$

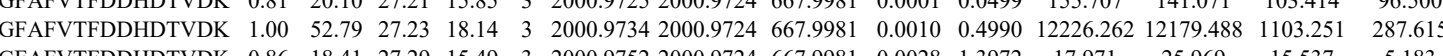
$\begin{array}{lllllllllllllll} & \end{array}$ $\begin{array}{lllllllll} & \end{array}$ $\begin{array}{lllllllllllllllll} & \end{array}$ \begin{tabular}{cccccccccccccccc} 
VGGEPCCDWVGDEGAGHFVK & 0.55 & 40.61 & 22.70 & 53.61 & 3 & 2542.1011 & 2542.0993 & 848.3737 & 0.0018 & 0.7072 & 557.290 & 715.280 & 415.358 & 104.939 & Yes \\
\hline
\end{tabular} $\begin{array}{lllllllllllllll} & \end{array}$ $\begin{array}{lllllllllllllll}\text { LVPLLDTGDIIIGGGNSEYR } & 1.00 & \text { \#\#\#\# } 27.01 & 22.28 & 2 & 2303.2134 & 2303.2131 & 1152.6138 & 0.0003 & 0.1301 & 339.521 & 303.374 & 32.250 & 12.395 & \text { Yes }\end{array}$

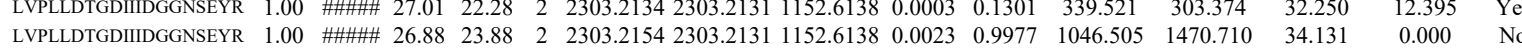

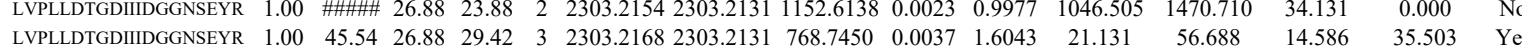

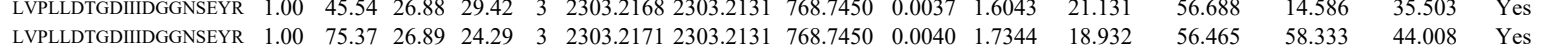

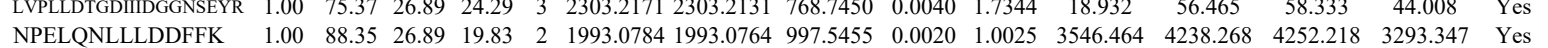
$\begin{array}{llllllllllllllllll}\text { NPELQNLLLDDFFK } & 1.00 & 86.33 & 26.88 & 21.21 & 2 & 1993.0786 & 1993.0764 & 997.5455 & 0.0022 & 1.1027 & 2522.601 & 3391.337 & 3128.704 & 2712.385 & \text { Yes }\end{array}$ $\begin{array}{llllllllllllllll}\text { NPELQNLLLDDFFK } & 0.80 & 17.93 & 26.77 & 15.81 & 3 & 1993.0813 & 1993.0764 & 665.3661 & 0.0049 & 2.4548 & 102.195 & 212.659 & 155.208 & 111.569 & \text { Yes }\end{array}$

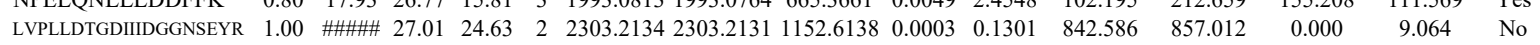
$\begin{array}{lllllllllllllll}\text { LVPLLDTGDIIIDGGNSEYR } & 1.00 & \text { \#\#\#\# 27.01 } & 24.30 & 2 & 2303.2134 & 2303.2131 & 1152.6138 & 0.0003 & 0.1301 & 956.538 & 1116.275 & 0.000 & 0.000 & \text { No }\end{array}$ $\begin{array}{llllllllllllllll}\text { LVPLLDTGDIIIDGGNSEYR } & 0.99 & 47.00 & 26.88 & 41.60 & 3 & 2303.2162 & 2303.2131 & 768.7450 & 0.0031 & 1.3442 & 36.797 & 31.874 & 11.258 & 12.252 & \text { Yes }\end{array}$ $\begin{array}{llllllllllllllll}\text { GILFVGSGVSGGEEGAR } & 1.00 & \text { \#\#\#\# } 28.05 & 28.89 & 2 & 1734.9186 & 1734.9023 & 868.4584 & 0.0163 & 9.3844 & 341.589 & 355.418 & 181.336 & 61.799 & \text { Yes }\end{array}$ $\begin{array}{lllllllllllllllll}\text { GILFVGSGVSGGEEGAR } & 1.00 & 83.52 & 28.12 & 27.57 & 2 & 1734.9192 & 1734.9023 & 868.4584 & 0.0169 & 9.7298 & 156.175 & 197.126 & 65.297 & 41.461 & \text { Yes }\end{array}$ $\begin{array}{lllllllllllllllll}\text { NPELQNLLLDDFFK } & 1.00 & 85.87 & 26.88 & 24.20 & 2 & 1993.0788 & 1993.0764 & 997.5455 & 0.0024 & 1.2030 & 617.844 & 711.920 & 484.903 & 599.331 & \text { Yes }\end{array}$ $\begin{array}{llllllllllllllll}\text { NPELQNLLLDDFFK } & 0.90 & 20.27 & 26.93 & 14.45 & 3 & 1993.0801 & 1993.0764 & 665.3661 & 0.0037 & 1.8536 & 161.432 & 129.715 & 152.049 & 108.736 & \text { Yes }\end{array}$ $\begin{array}{lllllllllllllllll}\text { NPELQNLLLDDFFK } & 1.00 & 86.89 & 26.75 & 20.74 & 2 & 1993.0818 & 1993.0764 & 997.5455 & 0.0054 & 2.7066 & 367.460 & 522.765 & 300.196 & 350.886 & \text { Yes }\end{array}$ $\begin{array}{lllllllllllllll}\text { LVPLLDTGDIIIDGGNSEYR } & 1.00 & \text { 27.01 } & 22.51 & 2 & 2303.2134 & 2303.2131 & 1152.6138 & 0.0003 & 0.1301 & 397.501 & 405.389 & 8.950 & 2.527 & \text { Yes }\end{array}$

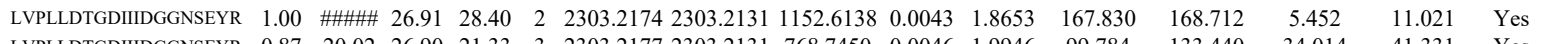

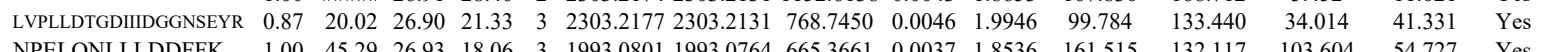

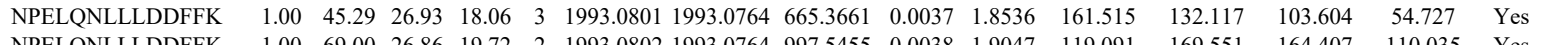
$\begin{array}{llllllllllllllll}\text { NPELQNLLLDDFFK } & 1.00 & 69.00 & 26.86 & 19.72 & 2 & 1993.0802 & 1993.0764 & 997.5455 & 0.0038 & 1.9047 & 119.091 & 169.551 & 164.407 & 110.035 & \text { Yes } \\ \text { NPELQNLLLDDFFK } & 1.00 & 78.21 & 26.77 & 23.28 & 2 & 1993.0812 & 1993.0764 & 997.5455 & 0.0048 & 2.4059 & 161.529 & 165.591 & 104.117 & 124.484 & \text { Yes }\end{array}$ $\begin{array}{lllllllllllllllll}\text { NPELQNLLLDDFFK } & 1.00 & 78.21 & 26.77 & 23.28 & 2 & 1993.0812 & 1993.0764 & 997.5455 & 0.0048 & 2.4059 & 161.529 & 165.591 & 104.117 & 124.484 & \text { Yes } \\ \text { NPELQNLLLDDFFK } & 1.00 & 42.03 & 26.77 & 18.73 & 3 & 1993.0813 & 1993.0764 & 665.3661 & 0.0049 & 2.4548 & 147.375 & 199.269 & 132.541 & 104.155 & \text { Yes }\end{array}$ $\begin{array}{llllllllllllllll}\text { NPELQNLLLDDFFK } & 1.00 & 42.03 & 26.77 & 18.73 & 3 & 1993.0813 & 1993.0764 & 665.3661 & 0.0049 & 2.4548 & 147.375 & 199.269 & 132.541 & 104.155 & \text { Yes } \\ \text { YGPSLMPGGNK } & 1.00 & 63.06 & 28.18 & 25.74 & 2 & 1407.7548 & 1407.7424 & 704.8785 & 0.0124 & 8.7958 & 656.602 & 896.156 & 16.147 & 10.403 & \text { Yes }\end{array}$ $\begin{array}{llllllllllllllllll}1.00 & 70.12 & 28.19 & 24.50 & 2 & 1407.7560 & 1407.7424 & 704.8785 & 0.0136 & 9.6470 & 2225.367 & 2687.967 & 80.437 & 53.863 & \text { Yes }\end{array}$ 


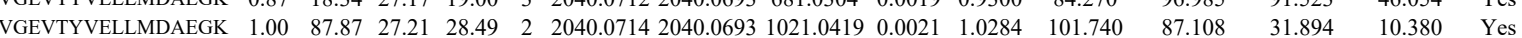

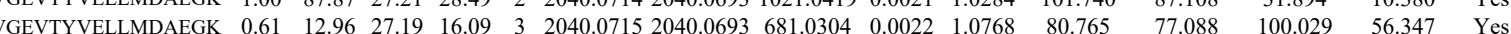
$\begin{array}{llllllllllllllll}\text { VGEVTYVELLMDAEGK } & 1.00 & 33.59 & 27.14 & 19.64 & 3 & 2040.0724 & 2040.0693 & 681.0304 & 0.0031 & 1.5173 & 68.195 & 75.795 & 53.058 & 56294 & \text { Yes }\end{array}$

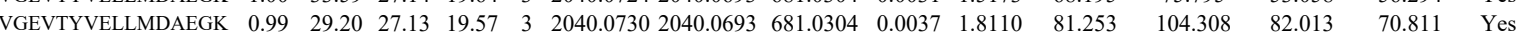

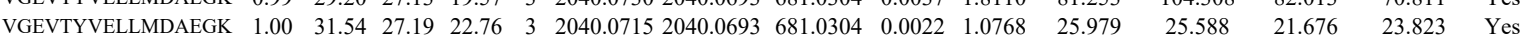

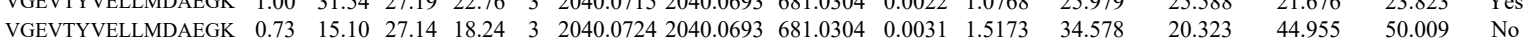
$\begin{array}{lllllllllllllllll}\text { VGEVTYVELLMDAEGK } & 0.87 & 19.39 & 27.13 & 19.57 & 3 & 2040.0730 & 2040.0693 & 681.0304 & 0.0037 & 1.8110 & 77.253 & 68.771 & 97.481 & 51.228 & \text { Yes }\end{array}$ $\begin{array}{llllllllllllllll}\text { VGEVTYVELLMDAEGK } & 1.00 & 77.89 & 27.03 & 25.42 & 2 & 2040.0734 & 2040.0693 & 1021.0419 & 0.0041 & 2.0077 & 91.220 & 127.719 & 30.907 & 1.508 & \text { No }\end{array}$ $\begin{array}{llllllllllllllll}\text { VGEVTYVELLMDAEGK } & 0.99 & 32.04 & 26.94 & 20.77 & 3 & 2040.0742 & 2040.0693 & 681.0304 & 0.0049 & 2.3983 & 35.891 & 33.901 & 25.790 & 9.373 & \text { Yes }\end{array}$ $\begin{array}{llllllllllllllll}\text { VGEVTYVELLMDAEGK } & 0.56 & 14.02 & 27.02 & 15.72 & 3 & 2040.0745 & 2040.0693 & 681.0304 & 0.0052 & 2.5452 & 77.228 & 122.455 & 88.639 & 82.431 & \text { Yes }\end{array}$ $\begin{array}{lllllllllllllllll}\text { VGEVTYVELLMDAEGK } & 0.51 & 17.83 & 26.91 & 22.84 & 3 & 2040.0769 & 2040.0693 & 681.0304 & 0.0076 & 3.7198 & 74.690 & 98.189 & 101.279 & 70.776 & \text { Yes }\end{array}$

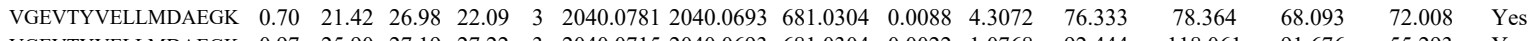

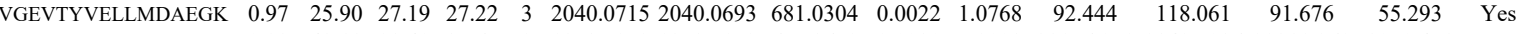

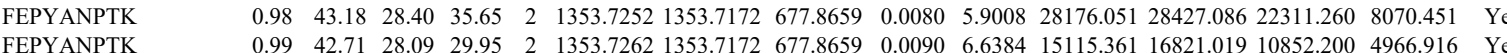

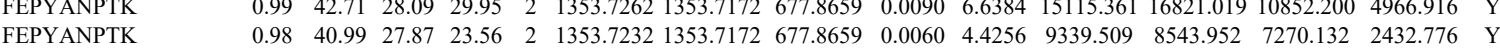

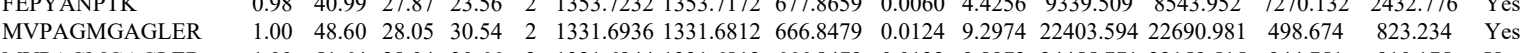
$\begin{array}{llllllllllllllll}\text { MVPAGMGAGLER } & 1.00 & 51.64 & 28.04 & 30.66 & 2 & 1331.6944 & 1331.6812 & 666.8479 & 0.0132 & 9.8972 & 24455.771 & 22159.515 & 944.751 & 910.175 & \text { Yes }\end{array}$ NLPFDFTWK AFITNIPFDVK AFITNIPFDVK NLPFDFTWK NLPFDFTWK
NLPFDFTWK $\begin{array}{lllllllllllllllll}1.00 & 55.15 & 27.33 & 22.66 & 2 & 1454.7864 & 1454.7802 & 728.3974 & 0.0062 & 4.2559 & 1689.469 & 1402.112 & 29.435 & 26.838 & \text { No }\end{array}$ $\begin{array}{llllllllllllllll}1.00 & 66.17 & 25.22 & 24.55 & 2 & 1551.8974 & 1551.8905 & 776.9525 & 0.0069 & 4.4404 & 16977.913 & 17815.311 & 181.094 & 445.252 & \text { Yes }\end{array}$ NLPFDFTWK

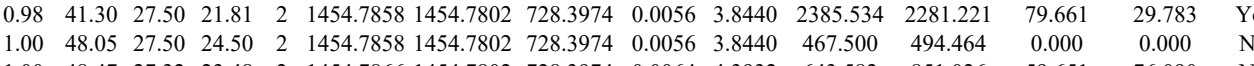
$\begin{array}{llllllllllllllllll}1.00 & 48.47 & 27.32 & 23.48 & 2 & 1454.7866 & 1454.7802 & 728.3974 & 0.0064 & 4.3932 & 643.582 & 851.026 & 59.651 & 76.090 & \text { No }\end{array}$ $\begin{array}{llllllllllllll}17.62 & 3 & 2465.2588 & 2465.2473 & 822.7564 & 0.0115 & 4.6591 & 233.298 & 176.558 & 107.762 & 32.915 & \text { Yes }\end{array}$

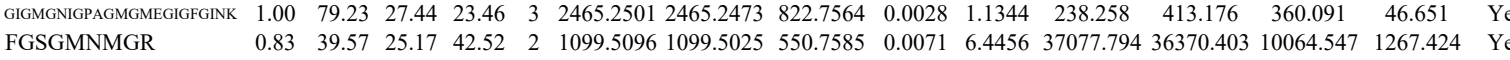

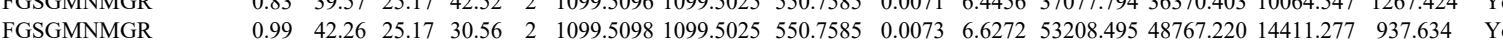

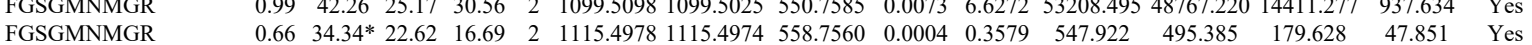

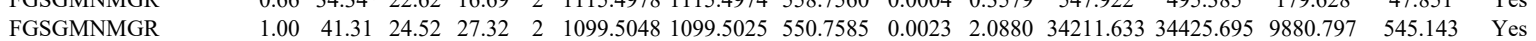

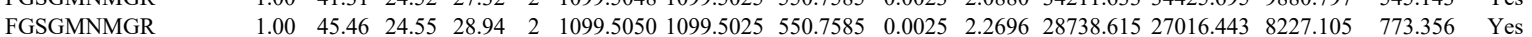
$\begin{array}{llllllllllllllll}\text { FGSGMNMGR } & 1.00 & 52.64 & 24.39 & 32.89 & 2 & 1099.5044 & 1099.5025 & 550.7585 & 0.0019 & 1.7249 & 10710.264 & 10083.784 & 2544.686 & 186.140 & \text { Yes }\end{array}$ $\begin{array}{llllllllllllllll}\text { FGSGMNMGR } & 1.00 & 41.58 & 24.55 & 30.59 & 2 & 1099.5050 & 1099.5025 & 550.7585 & 0.0025 & 2.2696 & 10926.814 & 11310.846 & 2998.521 & 116.850 & \text { Yes }\end{array}$ $\begin{array}{llllllllllllllll}\text { FGSGMNMGR } & 1.00 & 43.85 & 24.61 & 31.31 & 2 & 1099.5058 & 1099.5025 & 550.7585 & 0.0033 & 2.9959 & 2907.355 & 2843.823 & 668.728 & 134.348 & \text { Yes }\end{array}$

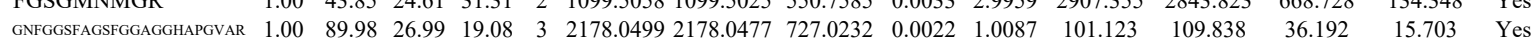
$\begin{array}{llllllllllllllll}\text { GNFGGSFAGSFGGAGGHAPGVAR } & 1.00 & 89.83 & 26.95 & 21.38 & 3 & 2178.0505 & 2178.0477 & 727.0232 & 0.0028 & 1.2838 & 131.100 & 95.599 & 45.429 & 28.777 & \text { Yes }\end{array}$

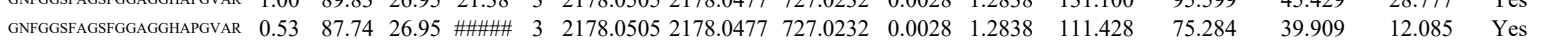

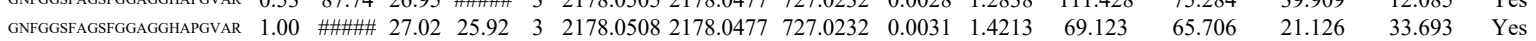

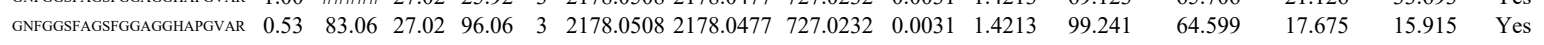

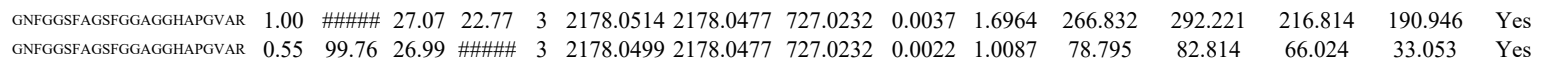
$\begin{array}{llllllllllllllll}\text { GNFGGSFAGSFGGAGGHAPGVAR } & 0.53 & 66.13 & 26.95 & 79.13 & 3 & 2178.0505 & 2178.0477 & 727.0232 & 0.0028 & 1.2838 & 16.741 & 13.117 & 11.678 & 3.236 & \text { Yes }\end{array}$ $\begin{array}{lllllllllllllllll}\text { GEGERPAQNEK } & 0.97 & 25.70 & 27.54 & 20.79 & 3 & 1501.7740 & 1501.7728 & 501.5982 & 0.0012 & 0.7975 & 260.989 & 278.877 & 172.715 & 159.756 & \text { Yes }\end{array}$ $\begin{array}{lllllllllllllllll}\text { ACQIFVR } & 0.87 & 29.98 & 26.93 & 24.21 & 2 & 1025.5366 & 1025.5272 & 513.7709 & 0.0094 & 9.1480 & 16907.420 & 18218.267 & 991.042 & 163.953 & \text { Yes }\end{array}$

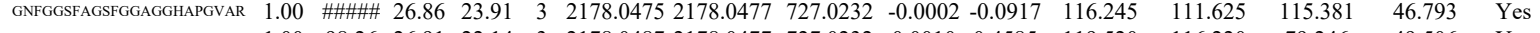

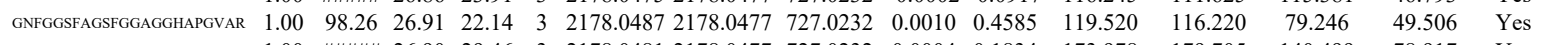

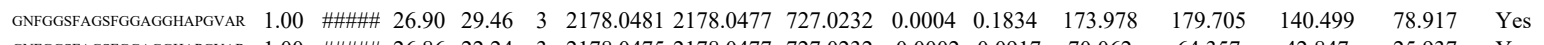

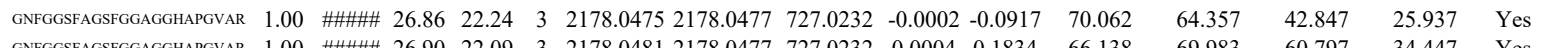

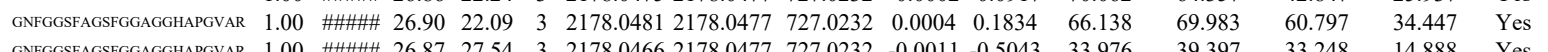

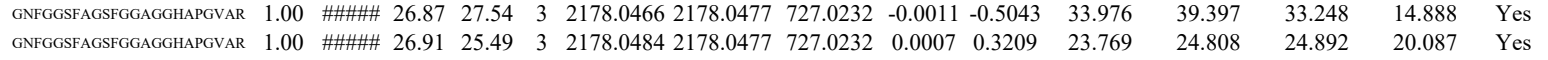

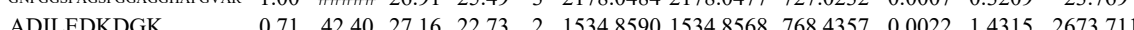

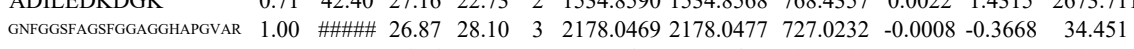
$\begin{array}{lllllllllll}\text { GNFGGSAGSFGGAGGHAPGVAR } & 1.00 & \text { \#\#\#\# } 26.86 & 29.13 & 3 & 2178.0475 & 2178.0477 & 727.0232 & -0.0002 & -0.0917 & 32.213\end{array}$

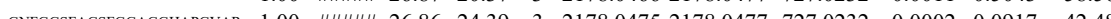

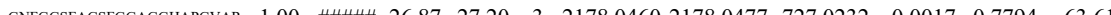




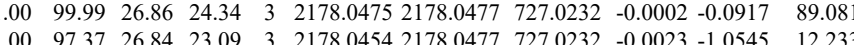

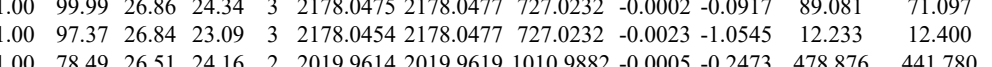

$\begin{array}{llllllllllllll}0.99 & 36.69 & 21.61 & 26.26 & 2 & 1227.7904 & 1227.7795 & 614.8970 & 0.0109 & 8.8632 & 20594.965 & 15645.782 & 5760.143\end{array}$

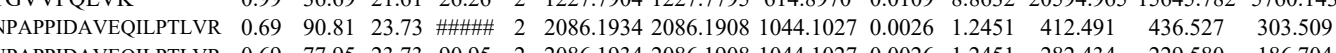
$\begin{array}{lllllllllllllll}\text { NPAPPIDAVEOILPTLVR } & 0.53 & 33.34 & 23.65 & 46.34 & 3 & 2086.1941 & 2086.1908 & 696.4042 & 0.0033 & 1.5795 & 382.897 & 402\end{array}$ $\begin{array}{lllllllllllll}\text { NPAPPIDAVEOILPTLVR } & 0.90 & 20.89 & 23.46 & 15.82 & 3 & 20861965 & 2086.1908 & 696.4042 & 0.0057 & 2.7283 & 318.379 & 256\end{array}$ $\begin{array}{llllllllllllll} & 20.09 & 50.83 & 4 & 3640.0025 & 3639.9967 & 911.0065 & 0.0058 & 1.5916 & 80.969 & 56.864 & 22.260\end{array}$

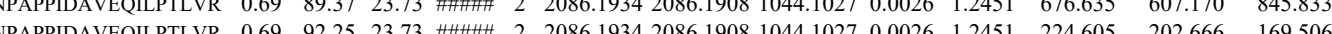

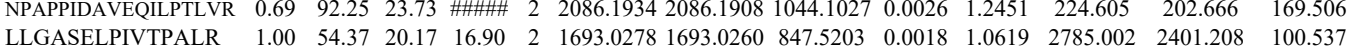
$\begin{array}{lllllllllllllll}\text { LLGASELPIVTPALR } & 1.00 & 48.31 & 20.13 & 18.89 & 2 & 1693.0284 & 1693.0260 & 847.5203 & 0.0024 & 1.4159 & 1975.064 & 1865.693 & 117.489\end{array}$ $\begin{array}{llllllllllllll}\text { LLGASELPIVTPALR } & 0.53 & 31.27 & 20.13 & 44.27 & 3 & 1693.0288 & 1693.0260 & 565.3493 & 0.0028 & 1.6509 & 401.501 & 558.152 & 83.239\end{array}$ LLGASELPIVTPALR $\begin{array}{llllllllllllll}0.53 & 31.27 & 20.13 & 44.27 & 3 & 1693.0288 & 1693.0260 & 565.3493 & 0.0028 & 1.6509 & 401.501 & 558.152 & 83.239\end{array}$ $\begin{array}{lllllllllllllll} & & \end{array}$ $\begin{array}{lllllllllllllll} & \text { LLGASELPIVTPALR } & 0.53 & 45.53 & 19.78 & 58.53 & 3 & 1693.0291 & 1693.0260 & 565.3493 & 0.0031 & 1.8278 & 249.997 & 261.291 & 68.058\end{array}$ LLGASELPIVTPALR

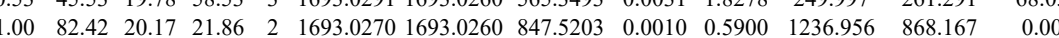
LLGASELPIVTPALR FVSFLGR
FVSFLGR

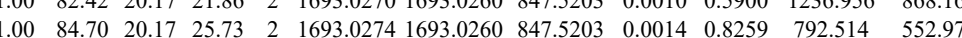
$\begin{array}{llllllllllllll}0.98 & 31.02 & 26.52 & 23.13 & 2 & 968.5572 & 968.5565 & 485.2855 & 0.0007 & 0.7212 & 3637.012 & 2523.697 & 250.628\end{array}$

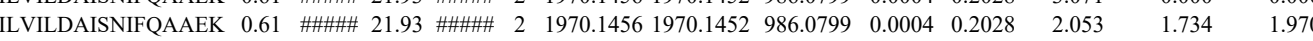
$\begin{array}{lllllllllllllll}\text { IILVILDAISNIFQAAEK } & 0.55 & 39.53 & 22.10 & 52.53 & 3 & 1970.1472 & 1970.1452 & 657.7223 & 0.0020 & 1.0136 & 19.390 & 8.881 & 6.435\end{array}$ $\begin{array}{llllllllllll} & \end{array}$ $\begin{array}{llllllllllllll}\text { IEALQNHENESVYK } & 0.69 & 25.32 & 27.98 & 16.03 & 3 & 1961.0293 & 1961.0097 & 654.6772 & 0.0196 & 9.9794 & 4769.719 & 48\end{array}$

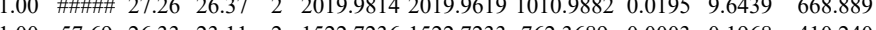

$\begin{array}{llllllllllll} & \end{array}$ \begin{tabular}{cccccccccccccc} 
& \\
\hline
\end{tabular} $\begin{array}{lllllllllllll} & \text { TES }\end{array}$ $\begin{array}{lllllllllllllll}\text { ITGEAFVQFASQELAEK } & 0.63 & 13.18 & 27.13 & 19.49 & 3 & 2155.1422 & 2155.1405 & 719.3874 & 0.0017 & 0.7877 & 10.230 & 15.696\end{array}$ $\begin{array}{lllllllllllll}\text { TGEAFVQFASQELAEK } & 1.00 & 68.94 & 27.10 & 24.59 & 3 & 2155.1440 & 2155.1405 & 719.3874 & 0.0035 & 1.6217 & 83.905\end{array}$

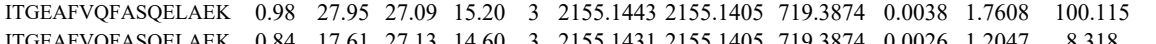
\begin{tabular}{llllllllllllll} 
ITGEAFVQFASQELAEK & 0.84 & 17.61 & 27.13 & 14.60 & 3 & 2155.1431 & 2155.1405 & 719.3874 & 0.0026 & 1.2047 & 8.318 \\
\hline
\end{tabular} $\begin{array}{llllllllllllll}\text { ITGEAFVQFASQELAEK } & 1.00 & 35.83 & 27.09 & 21.77 & 3 & 2155.1437 & 2155.1405 & 719.3874 & 0.0032 & 1.4827 & 57.355 \\ \end{array}$ $\begin{array}{lllllllllllll}\text { ITGEAFVQFASQELAEK } & 1.00 & 51.13 & 27.09 & 19.11 & 3 & 2155.1437 & 2155.1405 & 719.3874 & 0.0032 & 1.4827 & 40.288 \\ \text { ITGEAFVQFASQELAEK } & 1.00 & 56.07 & 27.13 & 17.21 & 3 & 2155.1431 & 2155.1405 & 719.3874 & 0.0026 & 1.2047 & 46.222\end{array}$ $\begin{array}{lllllllllllll}\text { ITGEAFVQFASQELAEK } & 1.00 & 56.07 & 27.13 & 17.21 & 3 & 2155.1431 & 2155.1405 & 719.3874 & 0.0026 & 1.2047 & 46.222 \\ \text { ITGEAFVQFASQELAEK } & 1.00 & 65.18 & 27.09 & 26.64 & 3 & 2155.1437 & 2155.1405 & 719.3874 & 0.0032 & 1.4827 & 63.248\end{array}$ $\begin{array}{lllllllllllll}\text { ITGEAFVQFASQELAEK } & 1.00 & 65.18 & 27.09 & 26.64 & 3 & 2155.1437 & 2155.1405 & 719.3874 & 0.0032 & 1.4827 & 63.248 \\ \text { VTGEADVEFATHEAVAMMSK } & 1.00 & 48.34 & 26.92 & 17.89 & 3 & 2479.2166 & 2479.2144 & 827.4121 & 0.0022 & 0.8863 & 18.381\end{array}$ $\begin{array}{llllllllllll}\text { VTGEADVEFATHEEAVAAMSK } & 1.00 & 48.34 & 26.92 & 17.89 & 3 & 2479.2166 & 2479.2144 & 827.4121 & 0.0022 & 0.8863 & 18.38\end{array}$ $\begin{array}{llllllllllll}\text { VTGEADVEFATHEEAVAAMSK } & 0.98 & 39.37 & 26.80 & 15.65 & 3 & 2479.2106 & 2479.2144 & 827.4121 & -0.0038 & -1.5309 & 28.794\end{array}$

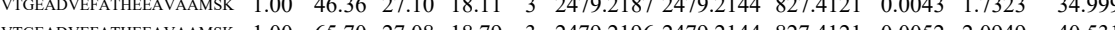

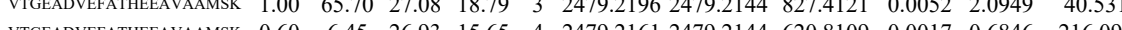

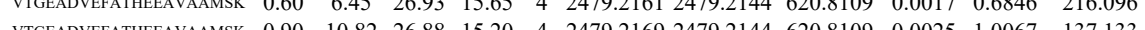

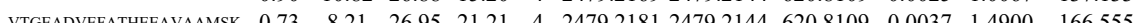
$\begin{array}{llllllllllll}\text { VTGEADVEFATHEFAVAAMSK } & 0.95 & 12.94 & 26.95 & 14.47 & 4 & 2479.2181 & 2479.2144 & 620.8109 & 0.0037 & 1.4900 & 79.549\end{array}$ 

$\begin{array}{llllllllllll}\text { VTGEADVEFATHEEANAAMSK K } & 1.00 & 53.39 & 26.79 & 18.75 & 3 & 2479.2151 & 2479.2144 & 827.4121 & 0.0007 & 0.2820 & 65.879\end{array}$

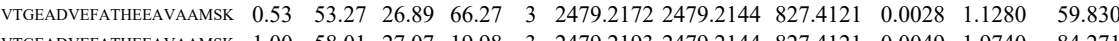
$\begin{array}{lllllllllllll}\text { VTGEADVEFATHEEAVAAMSK } & 1.00 & 58.01 & 27.07 & 19.98 & 3 & 2479.2193 & 2479.2144 & 827.4121 & 0.0049 & 1.9740 & 84.271\end{array}$

TCGDVLDNLK

$\begin{array}{llllllllllll}1.00 & 61.68 & 27.60 & 24.57 & 2 & 1410.7130 & 1410.7091 & 706.3618 & 0.0039 & 2.7606 & 1268.196 & 83\end{array}$ $\begin{array}{llllllllllll}\text { TCGDVLDNLK } & 1.00 & 55.16 & 27.56 & 25.15 & 2 & 1410.7136 & 1410.7091 & 706.3618 & 0.0045 & 3.1853 & 952.126 \\ \text { GDCYQVLIEDCIPVLK } & 1.00 & 68.54 & 28.02 & 19.80 & 2 & 2187.0694 & 2187.0692 & 1094.5419 & 0.0002 & 0.0914 & 19.773\end{array}$ $\begin{array}{llllllllllll}\text { GDCYQVLIEDCIPVLK } & 1.00 & 68.54 & 28.02 & 19.80 & 2 & 2187.0694 & 2187.0692 & 1094.5419 & 0.0002 & 0.0914 & 19.773 \\ \text { GDCYQVLIEDCIPVLK } & 1.00 & \text { \#\#\#\# } 27.36 & 23.51 & 2 & 2187.0714 & 2187.0692 & 1094.5419 & 0.0022 & 1.0050 & 62.335\end{array}$

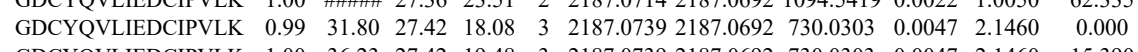

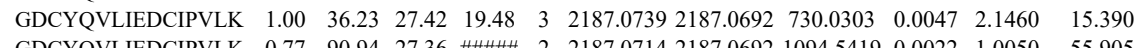
\begin{tabular}{llllllllllll} 
GDCYQVLIEDCIPVLK & 0.77 & 90.94 & 27.36 & \#\#\#\# & 2 & 2187.0714 & 2187.0692 & 1094.5419 & 0.0022 & 1.0050 & 55.905 \\
\hline
\end{tabular} $\begin{array}{lllllllllllll}\text { GDCYQVLIEDCIPVLK } & 1.00 & 36.88 & 27.42 & 15.44 & 3 & 2187.0739 & 2187.0692 & 730.0303 & 0.0047 & 2.1460 & 19.002\end{array}$

RLPPIVR

RLPPIVR

RLPPIVR

RLPPIVR

RLPPIVR

RLPPIVR

RLPPIVR

EEIDSILNK $\begin{array}{llllllllllll}0.86 & 22.28 & 22.83 & 17.26 & 2 & 849.5550 & 849.5548 & 425.7847 & 0.0002 & 0.2349 & 409.692\end{array}$ $\begin{array}{llllllllllll}0.86 & 22.27 & 22.83 & 15.10 & 2 & 849.5550 & 849.5548 & 425.7847 & 0.0002 & 0.2349 & 375.981\end{array}$ $\begin{array}{llllllllllllll}0.61 & 22.44 & 22.83 & 35.44 & 2 & 849.5550 & 849.5548 & 425.7847 & 0.0002 & 0.2349 & 255.645 \\ 0.61 & 24.38 & 22.83 & 37.38 & 2 & 849.5550 & 849.5548 & 425.7847 & 0.0002 & 0.2349 & 289.742 & 4\end{array}$ $\begin{array}{lllllllllllll}0.61 & 24.38 & 22.83 & 37.38 & 2 & 849.5550 & 849.5548 & 425.7847 & 0.0002 & 0.2349 & 289.742 & 482 & \\ 0.94 & 25.95 & 22.83 & 17.84 & 2 & 849.5548 & 849.5548 & 425.7847 & 0.0000 & 0.000 & 197.154 & 231 & \end{array}$ $\begin{array}{llllllllllll}0.94 & 25.95 & 22.83 & 17.84 & 2 & 849.5548 & 849.5548 & 425.7847 & 0.0000 & 0.0000 & 197.154 \\ 0.82 & 20.89 & 22.83 & 15.16 & 2 & 849.5548 & 849548 & 425.7847 & 0.0000 & 0.0000 & 186.554\end{array}$ EEIDSILNK $\begin{array}{llllllllllll} & 1.00 & 82.56 & 27.51 & 28.09 & 2 & 2094.0274 & 2094.0247 & 1048.0196 & 0.0027 & 1.2881 & 236.821\end{array}$ $\begin{array}{lllllllllllll} & \end{array}$ $\begin{array}{lllllllllllll} & & & \end{array}$ $\begin{array}{llllllllllllll}\text { GAALITAVACR } & 1.00 & 46.41 & 28.84 & 28.92 & 2 & 1234.6662 & 1234.6648 & 618.3397 & 0.0014 & 1.1321 & 21.246 & 21.366\end{array}$

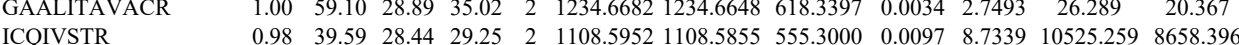



$\begin{array}{llllllllllllllll}\text { SASLCAATLAAVLQR } & 0.53 & 25.97 & 27.98 & 38.97 & 3 & 1663.8904 & 1663.8871 & 555.6363 & 0.0033 & 1.9797 & 4.692 & 8.016 & 6.274 & 4.793 & \text { Yes }\end{array}$

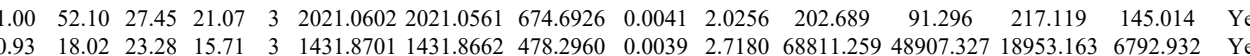

PAAAQEAvEEDPPAK

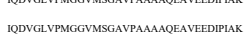

LTEAKPVDK $\begin{array}{lllllllllllllllll}0.97 & 35.52 & 23.16 & 26.73 & 2 & 1431.8708 & 1431.8662 & 716.9404 & 0.0046 & 3.2081 & 7514.217 & 6125.218 & 3989.880 & 6792.932 & \text { Yes }\end{array}$ $\begin{array}{lllllllllllllll}0.99 & 25.98 & 22.60 & 17.64 & 3 & 1431.8716 & 1431.8662 & 478.2960 & 0.0054 & 3.7633 & 48620.967 & 38778.073 & 16684.273 & 4909.291 & \text { Yes }\end{array}$ $\begin{array}{lllllllllllllll}1.00 & 50.86 & 22.38 & 22.08 & 2 & 1442.8726 & 1442.8588 & 722.4367 & 0.0138 & 9.5509 & 638.887 & 445.610 & 307.227 & 193.311 & \text { Yes }\end{array}$ $\begin{array}{lllllllllllllll}1.00 & 46.16 & 22.36 & 22.90 & 2 & 1442.8730 & 1442.8588 & 722.4367 & 0.0142 & 9.8278 & 1912.355 & 1320.842 & 495.329 & 230.970 & \text { Yes }\end{array}$

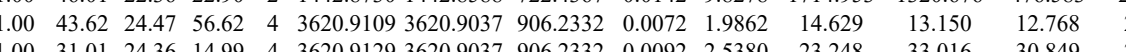
$\begin{array}{llllllllll} & \end{array}$

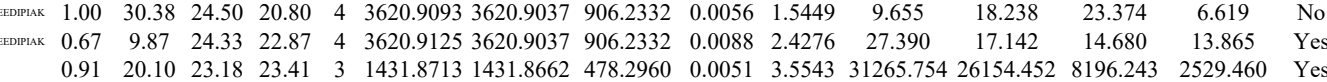
$\begin{array}{llllllllllllllll} & 0.12 & 25.18 & 23.41 & 3 & 1431.873 & 1431.8662 & 478.2960 & 0.0051 & 3.5543 & 27.355 .754 & 26154.452 & 8196.243 & 2529.460 & \text { Yes }\end{array}$ $\begin{array}{llllllllllllll} & \end{array}$ $\begin{array}{llllllllllllllll} & \end{array}$

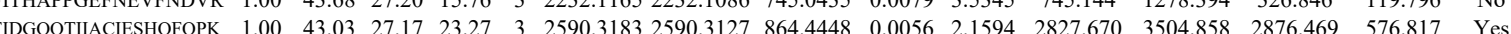
$\begin{array}{llllllllllllllllll}\text { TIDGOQTIIACIESHOFOPK } & 1.00 & 51.14 & 27.11 & 23.46 & 3 & 2590.3192 & 2590.3127 & 864.4448 & 0.0065 & 25064 & 4803.584 & 6303.508 & 4499.350 & 1079.786 & \text { Yes }\end{array}$ $\begin{array}{llllllllllllllllll}\text { TIDGQQTIIACIESHOFOPK } & 1.00 & 50.03 & 27.14 & 16.21 & 3 & 2590.3141 & 2590.3127 & 864.4448 & 0.0014 & 0.5398 & 1595.556 & 2300.776 & 1392.008 & 445.404 & \text { Yes }\end{array}$ $\begin{array}{lllllllllllllllll}\text { TIDGQQTIIACIESHOFOPK } & 1.00 & 53.68 & 27.14 & 16.64 & 3 & 2590.3162 & 2590.3127 & 864.4448 & 0.0035 & 1.3496 & 2215.222 & 3120.051 & 2043.157 & 589.997 & \text { Yes }\end{array}$ $\begin{array}{lllllllllllllllll}\text { FTITPPTAQVVGVLK } & 1.00 & 54.78 & 18.33 & 16.77 & 3 & 1858.1242 & 1858.1172 & 620.3797 & 0.0070 & 3.7611 & 1417.948 & 1614.171 & 1578.834 & 1366.242 & \text { Yes }\end{array}$ $\begin{array}{llllllllllllllll}\text { FTITPPTAQVVGVLK } & 1.00 & 51.16 & 20.04 & 19.23 & 3 & 1858.1143 & 1858.1172 & 620.3797 & -0.0029 & -1.5582 & 336.760 & 440.697 & 308.890 & 282.070 & \text { Yes } \\ \text { FTITPPTAQVVGVLK } & 1.00 & 54.21 & 20.00 & 16.86 & 3 & 1858.1152 & 1858.1172 & 620.3797 & -0.020 & -1.0746 & 154.212 & 2525.957 & 2102.161 & 1818349 & \text { Yes }\end{array}$ \begin{tabular}{lllllllllllllllll} 
& \\
FTITPPTAQVVGVLK & 1.00 & 54.21 & 20.00 & 16.86 & 3 & 1858.1152 & 1858.1172 & 620.3797 & -0.0020 & -1.0746 & 1544.212 & 2525.957 & 2102.161 & 1818.349 & Yes \\
\hline
\end{tabular}

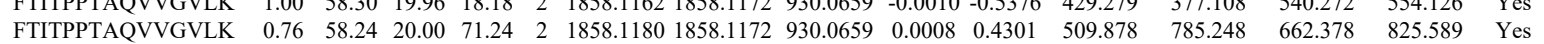

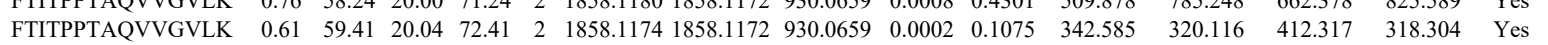
$\begin{array}{lllllllllllllllll}\text { FTITPPTAQVVGVLK } & 1.00 & 54.38 & 19.82 & 18.43 & 3 & 1858.1194 & 1858.1172 & 620.3797 & 0.0022 & 1.1821 & 1089.037 & 1249.006 & 937.171 & 533.517 & \text { Yes }\end{array}$ $\begin{array}{lllllllllllllllll}\text { FTITPPTAQVVGVLK } & 1.00 & 45.80 & 19.73 & 21.94 & 3 & 1858.1200 & 1858.1172 & 620.3797 & 0.0028 & 1.5045 & 973.012 & 1492.309 & 742.959 & 570.543 & \text { Yes }\end{array}$ $\begin{array}{llllllllllllllll}\text { EASDPQPEEADGGLK } & 1.00 & 69.81 & 27.02 & 25.51 & 2 & 1829.8934 & 1829.8887 & 915.9516 & 0.0047 & 2.5656 & 73.323 & 88.016 & 199.868 & 169.730 & \text { Yes }\end{array}$ $\begin{array}{llllllllllllllll}\text { EASDPQPEEADGGLK } & 1.00 & 68.56 & 27.01 & 25.47 & 2 & 1829.8944 & 1829.8887 & 915.9516 & 0.0057 & 3.1115 & 81.560 & 134.340 & 274.576 & 195.780 & \text { Yes }\end{array}$

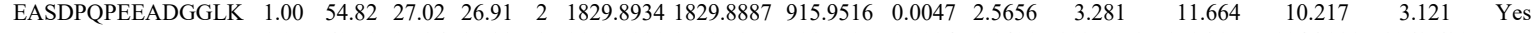

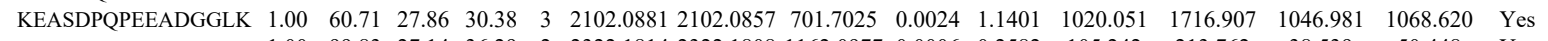

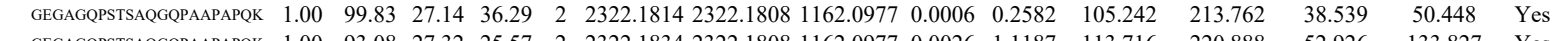
$\begin{array}{llllllllllllllll}\text { GEGAGQPSTSAQGQPAAPAPQK } & 1.00 & 93.08 & 27.32 & 25.57 & 2 & 2322.1834 & 2322.1808 & 1162.0977 & 0.0026 & 1.1187 & 113.716 & 220.888 & 52.926 & 133.827 & \text { Yes }\end{array}$

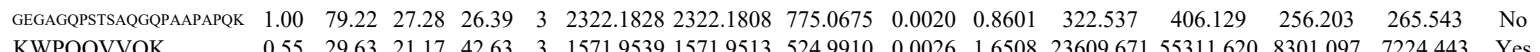

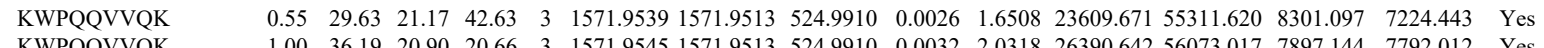

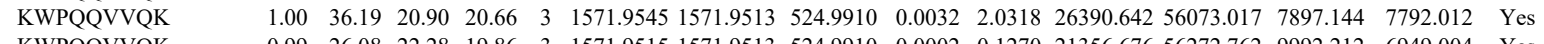

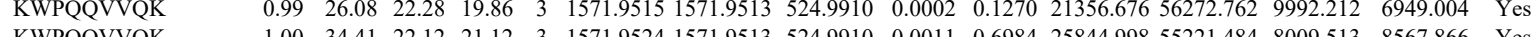

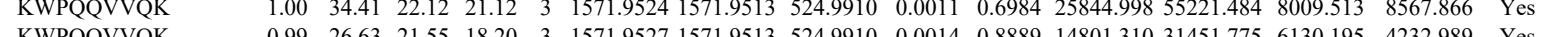

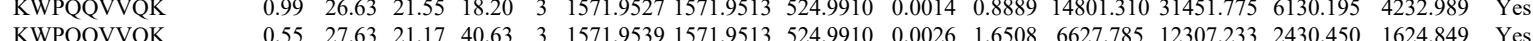

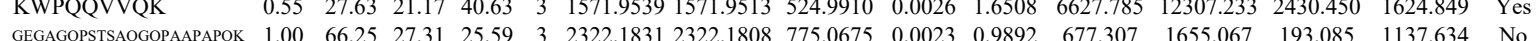
$\begin{array}{lllllllllllllllll} & \text { GEGAGNAQGPAPAPKK } & 1.00 & 66.25 & 27.31 & 25.59 & 3 & 2322.1831 & 2322.1808 & 75.0675 & 0.023 & 0.982 & 67.307 & 1655.067 & 193.085 & 1137.634 & \text { No }\end{array}$

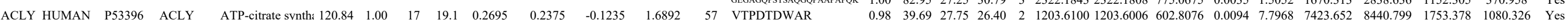



\begin{tabular}{lllllllllllllll} 
& 1.00 \\
\hline
\end{tabular}

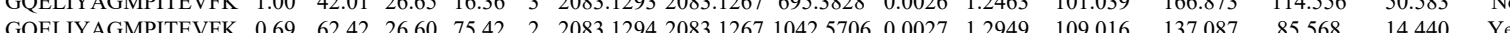
\begin{tabular}{llllllllllllllll} 
& 85.568 & 14.440 & Yes \\
\hline
\end{tabular} $\begin{array}{lllllllllllllll} & \end{array}$

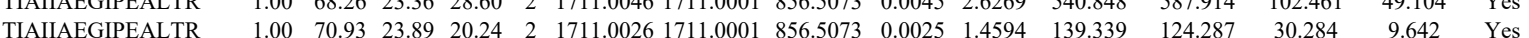

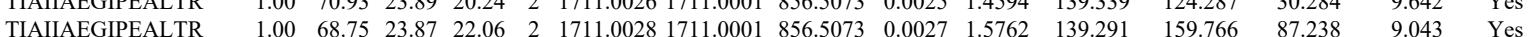

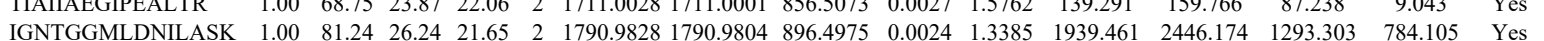

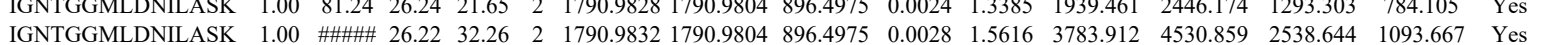

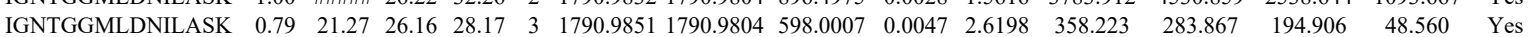

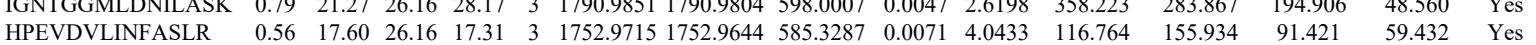
$\begin{array}{llllllllllllllll}\text { LGLVGVNLTLDGVK } & 1.00 & 76.65 & 19.87 & 22.58 & 2 & 1685.0350 & 1685.0331 & 843.5238 & 0.0019 & 1.1262 & 2017.191 & 2370.427 & 540.312 & 174.721 & \text { Yes }\end{array}$ $\begin{array}{llllllllllllllll} & & & \end{array}$ LTLLNPK $\begin{array}{lllllllllllllll}0.71 & 29.70 & 20.90 & 35.75 & 2 & 1085.7112 & 1085.7052 & 543.8599 & 0.0060 & 5.5161 & 43025.303 & 42188.826 & 6139.955 & 2199.542 & \text { Yes } \\ 0.72 & 30.05 & 20.90 & 36.06 & 2 & 1085.7120 & 1085.7052 & 543.8599 & 0.0068 & 6.2516 & 40794.418 & 44771.565 & 7450.219 & 2137.572 & \text { Yes }\end{array}$ $\begin{array}{lllllllllllllllll}\text { YPGSTFMDHVLR } & 1.00 & 66.77 & 28.11 & 25.46 & 3 & 1565.7931 & 1565.7782 & 522.9333 & 0.0149 & 9.4976 & 1876.848 & 2595.602 & 1588.560 & 686.341 & \text { Yes }\end{array}$ $\begin{array}{llllllllllllllll}\text { YPGSTFMDHVLR } & 1.00 & 56.96 & 28.22 & 19.50 & 2 & 1555.7938 & 1565.7782 & 783.8964 & 0.0156 & 9.9502 & 130.689 & 146.516 & 105.038 & 70.000 & \text { No }\end{array}$ $\begin{array}{lllllllllllllllll}\text { YPGSTFMDHVLR } & 1.00 & 64.09 & 27.70 & 22.01 & 3 & 1565.7799 & 1565.7782 & 522.9333 & 0.0017 & 1.0836 & 1858.023 & 2122.078 & 1152.502 & 816.187 & \text { Yes }\end{array}$ $\begin{array}{lllllllllllllllll}\text { YPGSTFMDHVLR } & 1.00 & 67.00 & 27.83 & 24.31 & 3 & 1565.7805 & 1565.7782 & 522.9333 & 0.0023 & 1.4661 & 1954.293 & 2737.951 & 1366.201 & 999.912 & \text { No }\end{array}$ $\begin{array}{llllllllllllllll}\text { GVTIIGPATVGGIKPGCFK } & 1.00 & 51.41 & 21.67 & 23.34 & 3 & 2292.3088 & 2292.3064 & 765.1094 & 0.0024 & 1.0456 & 6983.044 & 9387.310 & 3334.984 & 1568.227 & \text { Yes }\end{array}$

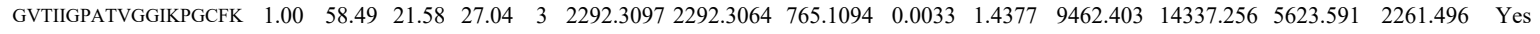
$\begin{array}{lllllllllllllllll}\text { GVTIIGPATVGGIKPGCFK } & 1.00 & 20.54 & 21.49 & 15.47 & 4 & 2292.3113 & 2292.3064 & 574.0839 & 0.0049 & 2.1338 & 1895.902 & 2003.160 & 711.833 & 638.433 & \text { Yes }\end{array}$ $\begin{array}{llllllllllllllll}\text { GVTIIGPATVGGIKPGCFK } & 1.00 & 32.36 & 21.49 & 45.36 & 4 & 2292.3113 & 2292.3064 & 574.0839 & 0.0049 & 2.1338 & 2021.967 & 1902.680 & 1011.130 & 333.158 & \text { Yes }\end{array}$ $\begin{array}{llllllllllllllll}\text { GVTIIGPATVGGIKPGCFK } & 1.00 & 56.28 & 21.90 & 23.06 & 3 & 2292.3070 & 2292.3064 & 765.1094 & 0.0006 & 0.2614 & 3279.143 & 3809.568 & 2661.490 & 736.033 & \text { Yes }\end{array}$

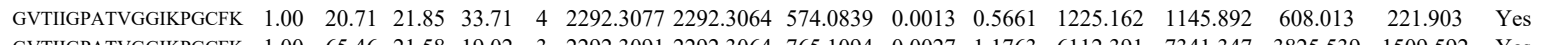
$\begin{array}{llllllllllllllll}\text { GVTIIGPATVGGIKPGCFK } & 1.00 & 65.46 & 21.58 & 19.02 & 3 & 2292.3091 & 2292.3064 & 765.1094 & 0.0027 & 1.1763 & 6112.391 & 7341.347 & 3825.539 & 1509.592 & \text { Yes }\end{array}$

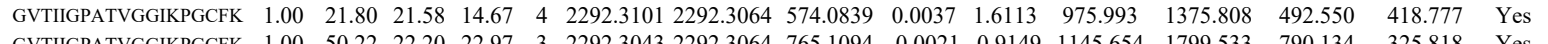

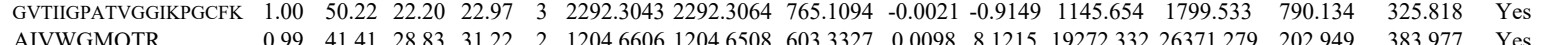

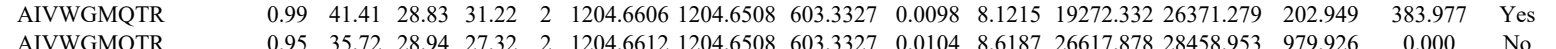
AIVWGMQTR LIMGIGHR

LIMGIGHR

AIVWGMQTR

LIMGIGHR

LICTTSATQNR

FICTTSAIQN
TILSLMTR

TILSLMTR

TILSLMTR

FICTTSAIQNR FICTTSAIQNR

TILSLMTR

TILSLMTR

TILSLMTR
TILSLMTR

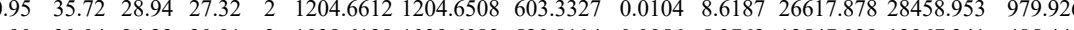

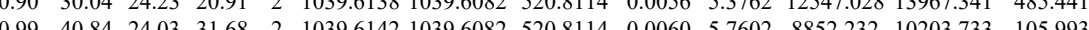

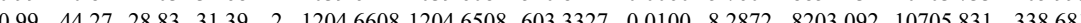
$\begin{array}{llllllllllllll}0.99 & 41.43 & 28.83 & 31.21 & 2 & 1204.6608 & 1204.6508 & 6033327 & 0.0100 & 8.2872 & 7904.905 & 9973.857 & 191.958 & 1\end{array}$ $\begin{array}{lllllllllllll}0.99 & 36.95 & 25.55 & 28.46 & 2 & 1039.6084 & 1039.6082 & 520.8114 & 0.0002 & 0.1920 & 3230.390 & 3835.704 & 491.131\end{array}$ $\begin{array}{lllllllllllll}1.00 & 69.06 & 27.46 & 28.16 & 2 & 1442.7256 & 1442.7132 & 722.3639 & 0.0124 & 8.5829 & 16938.173 & 19356.807 & 2457.882\end{array}$ $\begin{array}{llllllllllllll}0.92 & 43.02 & 27.99 & 48.83 & 2 & 1077.6372 & 1077.6338 & 539.8242 & 0.0034 & 3.1492 & 7407.925 & 9492.421 & 109.965 & 97.87\end{array}$

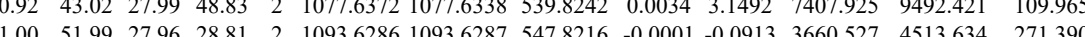
$\begin{array}{llllllllllllll}1.00 & 54.42 & 27.96 & 29.12 & 2 & 1093.6286 & 1093.6287 & 547.8216 & -0.0001 & -0.0913 & 6420.502 & 7471.104 & 721.325 & 613 .\end{array}$ $\begin{array}{llllllllllllll}1.00 & 70.97 & 26.78 & 26.30 & 2 & 1442.7148 & 1442.7132 & 722.3639 & 0.0016 & 1.1075 & 4388.514 & 5431.727 & 622.603\end{array}$ $\begin{array}{llllllllllllll}1.00 & 58.67 & 26.53 & 26.70 & 2 & 1442.7164 & 1442.7132 & 722.3639 & 0.0032 & 2.2149 & 4456.739 & 5754.304 & 1063.517 \\ 0.98 & 39.11 & 27.6 & 38.90 & 2 & 1077.6348 & 1077.6338 & 539.8242 & 0.0010 & 0.9262 & 3274.693 & 436.799 & 130.310\end{array}$ $\begin{array}{llllllllllllll}0.96 & 41.89 & 27.72 & 45.65 & 2 & 1077.6350 & 1077.6338 & 539.8242 & 0.0012 & 1.1115 & 5235.698 & 6476.099 & 151.906\end{array}$ $\begin{array}{lllllllllllll}1.00 & 43.73 & 27.96 & 25.31 & 2 & 1093.6286 & 1093.6287 & 547.8216 & -0.0001 & -0.0913 & 1579.273 & 2036.185 & 57.937\end{array}$

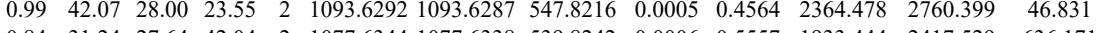
$\begin{array}{lllllllllllllll}\text { GVHIIPATVGGIKPGCFK } & 1.00 & 62.10 & 27.26 & 23.22 & 2 & 1860.0000 & 1860.0002 & 931.0074 & -0.0002 & -0.1074 & 5.086 & 3.362 & 0.000\end{array}$

GIVWGMQTR

LYRPGSVAYVSR

LYRPGSVAYVSR
LYRPGSVAYVSR

LYRPGSVAYVSR

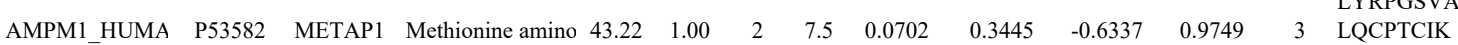

\author{
LVQTTYECLMQAIDAVKPGVR
}

LVQTTYECLMQAIDAVKPGVR

SLGEIPIVESEIK

SLGEIPIVESEIK $\begin{array}{lllllllllllll}0.99 & 29.06 & 27.36 & 20.91 & 3 & 1860.0016 & 1860.0002 & 621.0073 & 0.0014 & 0.7515 & 70.859 & 95.613 & 30.743\end{array}$

$\begin{array}{llllllllllllll}0.97 & 32.39 & 28.35 & 23.60 & 2 & 1204.6520 & 1204.6508 & 603.3327 & 0.0012 & 0.9945 & 366.368 & 481.188 & 31.999\end{array}$

$\begin{array}{lllllllllllll}0.99 & 43.88 & 28.20 & 19.38 & 3 & 1510.8349 & 1510.8378 & 504.6199 & -0.0029 & -1.9156 & 694.575 & 1105.181 & 82.364\end{array}$

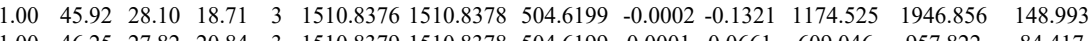

$\begin{array}{lllllllllllll}1.00 & 46.25 & 27.82 & 20.84 & 3 & 1510.8379 & 1510.8378 & 504.6199 & 0.0001 & 0.0661 & 609.046 & 957.822 & 84.417 \\ 1.00 & 36.12 & 27.83 & 20.61 & 3 & 1510.8382 & 1510.8378 & 504.6199 & 0.0004 & 0.2642 & 759.862 & 1237.472 & 78.687\end{array}$

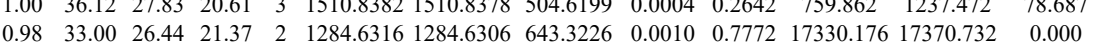

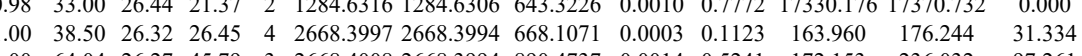

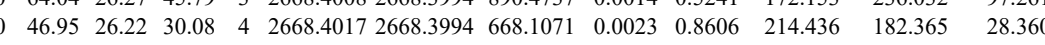

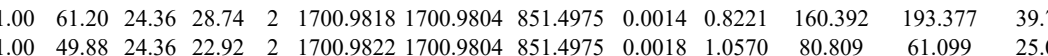


$\begin{array}{llllllllllll}1.00 & 77.53 & 26.02 & 33.79 & 2 & 1457.8414 & 1457.8398 & 729.9272 & 0.0016 & 1.0960 & 5132.805 & 5977.61\end{array}$

$\begin{array}{llllllllllll}1.00 & 83.44 & 26.02 & 36.95 & 2 & 1457.8416 & 1457.8398 & 729.9272 & 0.0018 & 1.2330 & 1846.254 & 2214.060\end{array}$

$\begin{array}{llllllllllll}1.00 & 74.88 & 26.02 & 31.30 & 2 & 1457.8418 & 1457.8398 & 729.9272 & 0.0020 & 1.3700 & 1124.952 & 1142.175 \\ 1.00 & 76.81 & 26.03 & 33.95 & 2 & 1457.8420 & 1457.8398 & 79.9272 & 0.0022 & 1.5070 & 827.764 & 907.423\end{array}$ $\begin{array}{llllllllllll}1.00 & 39.44 & 20.29 & 22.85 & 2 & 1269.7972 & 1269.7964 & 635.9055 & 0.0008 & 0.6290 & 76.795\end{array}$ $\begin{array}{llllllllllll}1.00 & 45.72 & 20.29 & 21.79 & 2 & 1269.7976 & 1269.7964 & 635.9055 & 0.0012 & 0.9435 & 100.407\end{array}$ 


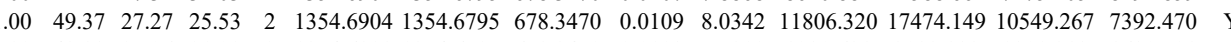
$\begin{array}{llllllllllllllll}0.99 & 43.88 & 27.06 & 21.09 & 2 & 1354.6898 & 1354.6795 & 678.3470 & 0.0103 & 7.5919 & 1980.621 & 3083.832 & 1801.213 & 1680.701 & \text { Yes } & \\ \end{array}$ $\begin{array}{lllllllllllllll}1.00 & 49.32 & 27.06 & 23.41 & 2 & 1354.6898 & 1354.6795 & 678.3470 & 0.0103 & 7.5919 & 1977.275 & 2922.995 & 1706.742 & 1673.680 & \text { Yes }\end{array}$ $\begin{array}{lllllllllllllll}1.00 & 81.65 & 26.42 & 23.84 & 2 & 1786.9810 & 1786.9821 & 894.4983 & -0.0011 & -0.6149 & 913.921 & 1457.312 & 251.287 & 137.337 & \text { Yes } \\ 1.00 & 77.88 & 26.44 & 24.38 & 2 & 1786.9828 & 1786.9821 & 894.4983 & 0.0007 & 0.3913 & 2080.119 & 2907.540 & 1071253 & 253.561 & \text { Yes }\end{array}$ $\begin{array}{llllllllllllll}0.54 & 12.33 & 26.52 & 17.60 & 3 & 17869864 & 1786.9821 & 596.6680 & 0.0043 & 2.4022 & 63.846 & 50.185 & 28.083 & 20.030\end{array}$

LMDLLGEGLK $\begin{array}{lllllllllllllllll}1.00 & 56.73 & 24.65 & 24.27 & 3 & 2439.3310 & 2439.3253 & 814.1157 & 0.0057 & 2.3338 & 121.351 & 97.567 & 90.388 & 32.452 & \text { No }\end{array}$ $\begin{array}{llllllllllllllll}1.00 & 59.75 & 26.67 & 32.57 & 2 & 1375.8008 & 1375.7988 & 688.9067 & 0.0020 & 1.4516 & 7580.495 & 5734.946 & 145.966 & 168.925 & \text { Yes }\end{array}$

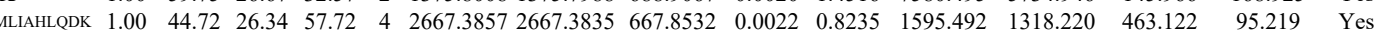
$\begin{array}{llllllllllllllll}\text { NHVGDWGTPFGMLIAHLQDK } & 1.00 & 58.92 & 26.33 & 71.92 & 4 & 2667.3877 & 2667.3835 & 667.8532 & 0.0042 & 1.5722 & 2260.658 & 2333.580 & 371.278 & 188.303 & \text { Yes }\end{array}$

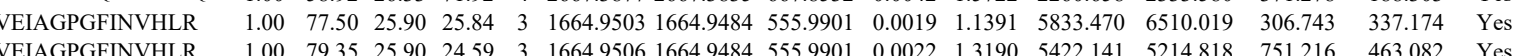
$\begin{array}{llllllllllllllll}\text { VEIAGPGFINVHLR } & 1.00 & 79.35 & 25.90 & 24.59 & 3 & 1664.9506 & 1664.9484 & 555.9901 & 0.0022 & 1.3190 & 5422.141 & 5214.818 & 751.216 & 463.082 & \text { Yes } \\ \text { AYQCVVLLQGK } & 1.00 & 60.04 & 27.37 & 25.55 & 2 & 1554.8528 & 1554.8506 & 778.4326 & 0.0022 & 1.4131 & 2250.842 & 1997.060 & 367.046 & 152.753 & \text { Yes }\end{array}$ AYQCVVLLQGK AYQCVVLLQGK AYQCVVLLQGK NMINIISR $\begin{array}{lllllllllllllll}1.00 & 59.20 & 27.08 & 25.65 & 2 & 1554.8540 & 1554.8506 & 778.4326 & 0.0034 & 2.1839 & 779.958 & 755.387 & 160.979 & 64.936 & \text { Yes }\end{array}$ $\begin{array}{lllllllllllllll}0.83 & 18.15 & 27.02 & 17.90 & 3 & 1554.8545 & 1554.8506 & 519.2908 & 0.0039 & 2.5034 & 930.332 & 931.965 & 344.661 & 164.149 & \text { Yes }\end{array}$ $\begin{array}{lllllllllllllllll}0.89 & 21.00 & 26.99 & 23.14 & 3 & 1554.8554 & 1554.8506 & 519.2908 & 0.0048 & 3.0811 & 663.656 & 695.263 & 223.117 & 103.060 & \text { Yes }\end{array}$ $\begin{array}{llllllllllllllll}0.96 & 37.41 & 28.68 & 32.16 & 2 & 1103.6328 & 1103.6243 & 552.8194 & 0.0085 & 7.6878 & 17750.836 & 17235.168 & 583.429 & 89.446 & \text { Yes }\end{array}$ $\begin{array}{lclllllllllllllll} & 0.99 & 42.33 & 28.55 & 36.09 & 2 & 1103.6340 & 1103.6243 & 552.8194 & 0.0097 & 8.7731 & 23049.984 & 18523.934 & 645.089 & 351.447 & \text { Yes } \\ \text { MLLCEAVAAVMAK } & 0.93 & 21.90 & 27.96 & 20.27 & 3 & 1682.8867 & 1682.8835 & 561.9684 & 0.0032 & 1.8981 & 82.230 & 95.447 & 21.263 & 14.052 & \text { Yes }\end{array}$ $\begin{array}{llllllllllllllll}\text { MLLCEAVAAVMAK } & 1.00 & 64.78 & 27.90 & 25.22 & 2 & 1682.8870 & 1682.8835 & 842.4490 & 0.0035 & 2.0773 & 18.815 & 51.446 & 0.000 & 0.052 & \text { Yes }\end{array}$ $\begin{array}{llllllllllllllll}\text { MLLCEAVAAVMAK } & 1.00 & 75.40 & 27.90 & 25.91 & 2 & 1682.8872 & 1682.8835 & 842.4490 & 0.0037 & 2.1960 & 198.263 & 190.197 & 8.145 & 3.000 & \text { No }\end{array}$

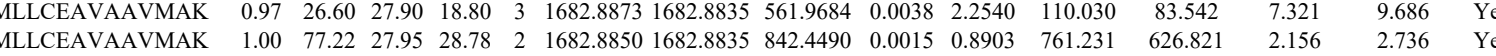
$\begin{array}{llllllllllllll}\text { MLLCEAVAAVMAK } & 1.00 & 84.21 & 27.90 & 29.63 & 2 & 1682.8856 & 1682.8835 & 842.4490 & 0.0021 & 1.2464 & 692.055 & 490.705 & 0.00\end{array}$ $\begin{array}{llllllllllllll}\text { MLLCEAVAAVMAK } & 1.00 & 34.84 & 27.96 & 21.33 & 3 & 1682.8864 & 1682.8835 & 561.9684 & 0.0029 & 1.7201 & 23.183 & 28.435\end{array}$ MLLCEAVAAVMAK MLLCEAVAAVMAK MLLCEAVAAVI $\begin{array}{llllllllllll}0.99 & 29.59 & 27.96 & 17.34 & 3 & 1682.8867 & 1682.8835 & 561.9684 & 0.0032 & 1.8981 & 57.982\end{array}$ $\begin{array}{lllllllllllll}0.99 & 31.21 & 27.90 & 19.71 & 3 & 1682.8873 & 1682.8835 & 561.9684 & 0.0038 & 2.2540 & 45.266\end{array}$ $\begin{array}{llllllllllll}0.98 & 27.91 & 27.91 & 18.58 & 3 & 1682.8876 & 1682.8835 & 561.9684 & 0.0041 & 2.4319 & 34.224 & 35.328\end{array}$ $\begin{array}{llllllllllllll}0.76 & 27.34 & 28.66 & 26.09 & 2 & 1103.6346 & 1103.6243 & 552.8194 & 0.0103 & 9.3158 & 1942.459 & 1986.580\end{array}$ $\begin{array}{llllllllllll}1.00 & 33.38 & 27.91 & 20.02 & 3 & 1682.8855 & 1682.8835 & 561.9684 & 0.0020 & 1.1863 & 89.513 \\ 1.00 & 75.82 & 27.90 & 23.84 & 2 & 16828856 & 1682.8835 & 842.490 & 0.0021 & 1.2464 & 94.814\end{array}$ ILCEAVAAVMAK $\begin{array}{llllllllllll}1.00 & 75.82 & 27.90 & 23.84 & 2 & 1682.8856 & 1682.8835 & 842.4490 & 0.0021 & 1.2464 & 94.814 \\ 1.00 & 36.49 & 27.96 & 20.77 & 3 & 1682.8864 & 1682.8835 & 561.9684 & 0.0029 & 1.7201 & 67.981\end{array}$ MLLCAVAAVMAK $\begin{array}{lllllllllll}1.00 & 36.49 & 27.96 & 20.77 & 3 & 1682.8864 & 1682.8835 & 561.9684 & 0.0029 & 1.7201 & 67.981\end{array}$ A $\begin{array}{lllllllllll}0.87 & 19.29 & 27.96 & 15.60 & 3 & 1682.884 & 1682.8835 & 561.9684 & 0.0038 & 2.2540 & 42.619\end{array}$ $\begin{array}{lllllllllll}1.00 & 72.04 & 21.88 & 21.97 & 2 & 1919.1252 & 1919.1232 & 960.5689 & 0.0020 & 1.0410 & 439.945\end{array}$ IVFVPGCSIPLTIVK

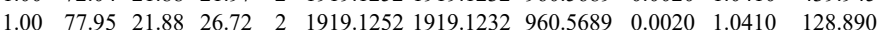
IVFVPGCSPIPLTIVK IVFVPGCSIPLTIVK IVFVPGCSIPLTIVK IVFVPGCSIPLTIVK GNTAAYLLYAFTR GNTAAYLLYAFTR GNTAAYLLYAFTR

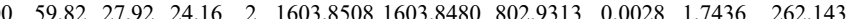
$\begin{array}{llllllllllll}1.00 & 61.10 & 27.94 & 26.96 & 2 & 1603.8510 & 1603.8480 & 802.9313 & 0.0030 & 1.8682 & 226.510\end{array}$

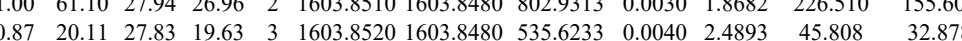
$\begin{array}{lllllllllllll} & \end{array}$ $\begin{array}{lllllllllllll}1.00 & 45.10 & 26.56 & 32.81 & 2 & 1269.7224 & 1269.7203 & 635.8674 & 0.0021 & 1.6513 & 1194.424 & 1128.775\end{array}$

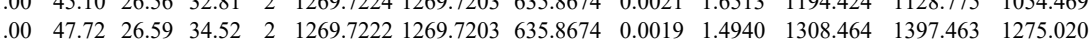
$\begin{array}{llllllllllllll}1.00 & 45.10 & 26.52 & 32.83 & 2 & 1269.7234 & 1269.7203 & 635.8674 & 0.0031 & 2.4376 & 530.416 & 483.959 & 428.782\end{array}$ $\begin{array}{lllllllllllll}1.00 & 70.58 & 21.79 & 23.08 & 2 & 1560.9496 & 1560.9483 & 781.4814 & 0.0013 & 0.8318 & 186.560 & 272.138 & 59.183 \\ 1.00 & 73.89 & 20.76 & 27.02 & 2 & 1560.9520 & 1560.9483 & 781.4814 & 0.0037 & 23673 & 564.365 & 522.854 & 207.122\end{array}$

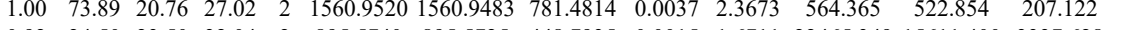
$\begin{array}{lllllllllllllllll}0.92 & 24.50 & 23.50 & 32.04 & 2 & 895.5740 & 895.5725 & 448.7935 & 0.0015 & 1.6711 & 22465.349 & 15611.400 & 3337.628 & 2064.850 & \text { Y Ss } \\ 0.60 & 13.90 & 23.50 & 26.23 & 2 & 895.5740 & 895.5725 & 448.7935 & 0.0015 & 1.6711 & 14064.866 & 11957.177 & 2096.194 & 1207.880 & \text { Y ss }\end{array}$

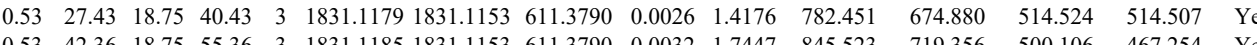

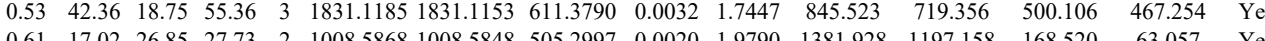

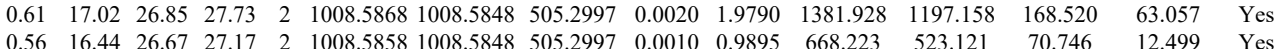

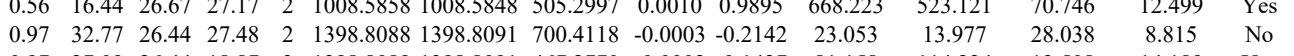

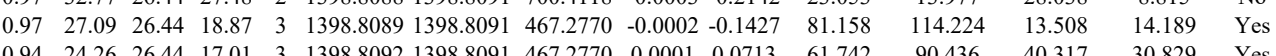

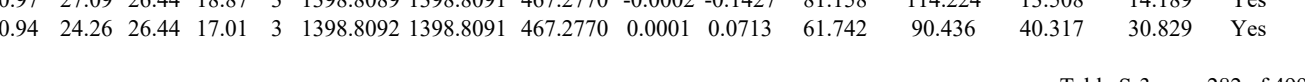



AQLFALTGVQPAR AQLFALTGVQPAR LPAYLTIQMVR LPAYLTIQMVR LPAYLTIQMVR

LPAYLTIQMVR IIGLKPEGVPR

LFIYNPTTGELGR

LFIYNPTTGEFLGR

LFIYNPTTGEFLGR

LFIYNPTTGEFLGR

6 ILNDDTAL

ILNDDTALK

AVEYLLMGIPGDR

AVEYLLMGIPGDR

AVEYLLMGIPGDR

AVEYLLMGIPGDR

QIIQQNPSLLPALLQQIG

QIIQQNPSLLPALLQQIGR

QIIQQNPSLLPALLQIIG QIIQQNPSLLPALLQQIGR QIIQQNPSLLPALLQQIG QIIQQNPSLLPALLQQIG QIIQQNPSLLPALLQQIGR
QIIQQNPSLLPALLQQIGR QIIQQNPSLLPALLQQIGR
OIIQQNPSLLPALLOIGR QIIQQNPSLLPALLQQ
NFVVVMVTKPK NFVVVMVTKPK
NFVVVMVTKPK NFVVVMVTKPK

NFVVVMVTKPK LVSDEMVVELIEK QAEMLDDLMEK

QAEMLDDLMEK

LIEK

$\begin{array}{llllllllll}\text { P5CS_HUMAN } & \text { P54886 } & \text { ALDH18A Delta-1-pyrroline- } 87.30 & 1.00 & 9 & 15.6 & -0.1148 & 0.3222 & 0.2527 & 2.1151\end{array}$
P55010 EIF5 $\begin{array}{lllllllllllllll}0.53 & 13.08 & 26.26 & 26.08 & 3 & 1514.8723 & 1514.8691 & 505.9636 & 0.0032 & 2.1082 & 925.609 & 1090.985 & 610.032 & 279.609 & \text { Yes }\end{array}$

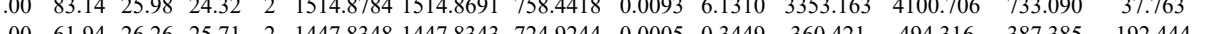

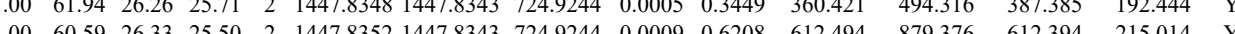

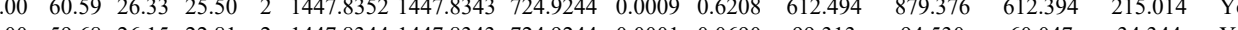

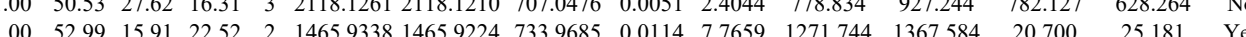
$\begin{array}{llllllllllllllll}1.00 & 70.16 & 27.52 & 18.70 & 2 & 1770.9438 & 1770.9427 & 8864786 & 0.001 & 0.6204 & 6746.714 & 6373.370 & 67.500 & 5.679 & \text { Yes }\end{array}$ $\begin{array}{lllllllllllll} & \end{array}$ $\begin{array}{llllllllllllll} & \end{array}$ $\begin{array}{llllllllllllllll}1.00 & 75.19 & 27.53 & 19.33 & 2 & 1770.9440 & 1770.9427 & 886.4786 & 0.0013 & 0.7332 & 3390.687 & 2971.850 & 0.000 & 23.789 & \text { No }\end{array}$ $\begin{array}{lllllllllllllll}1.00 & 73.22 & 27.52 & 25.03 & 2 & 1770.9438 & 1770.9427 & 886.4786 & 0.0011 & 0.6204 & 624.102 & 620.131 & 0.000 & 16.115 & N \text { N }\end{array}$ $\begin{array}{lllllllllllllll}1.00 & 56.77 & 27.49 & 31.29 & 2 & 1289.7538 & 1289.7434 & 645.8790 & 0.0104 & 8.0510 & 13785.734 & 16071.843 & 2471.914 & 3818.476 & \text { Yes }\end{array}$ $\begin{array}{lllllllllllllllll}1.00 & 54.01 & 27.72 & 30.69 & 2 & 1289.7550 & 1289.7434 & 645.8790 & 0.0116 & 8.9799 & 12441.989 & 13093.125 & 3479.424 & 4602.197 & \text { Yes }\end{array}$ $\begin{array}{lllllllllllllllll}1.00 & 74.49 & 28.58 & 26.06 & 2 & 1576.8420 & 1576.8405 & 789.4275 & 0.0015 & 0.9501 & 1835.509 & 1907.914 & 283.107 & 135.873 & \text { Yes }\end{array}$ $\begin{array}{llllllllllllllll}0 & 87.84 & 28.27 & 25.97 & 2 & 1576.8442 & 1576.8405 & 789.4275 & 0.0037 & 2.3435 & 1979.588 & 2431.127 & 298.168 & 132.006 & \text { Yes }\end{array}$

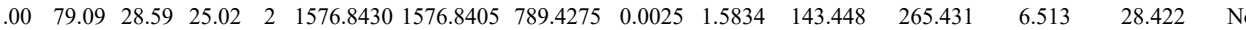
$\begin{array}{lllllllllllllll}1.00 & 87.88 & 18.75 & 27.48 & 2 & 2273.3354 & 2273.3341 & 1137.6743 & 0.0013 & 0.5713 & 7.137 & 6.936 & 14.306 & 2.622 & \text { Yes } \\ 1.00 & 78.85 & 18.75 & 22.51 & 2 & 2273.3354 & 2273.3341 & 1137.6743 & 0.0013 & 0.5713 & 1.582 & 13.670 & 9.638 & 3.18 & \text { Yes }\end{array}$

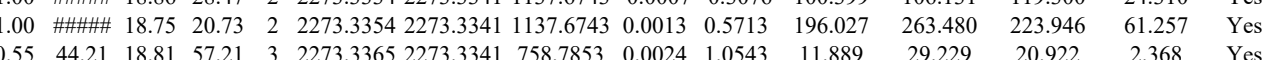

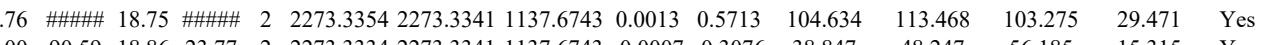

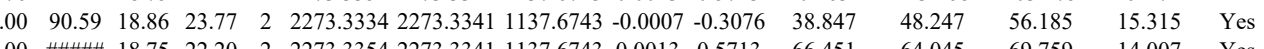
\begin{tabular}{lllllllllllll}
18.75 & 22.20 & 2 & 2273.3354 & 2273.3341 & 1137.6743 & 0.0013 & 0.5713 & 66.451 & 64.045 & 69.759 & 14.007 & Yes \\
\hline
\end{tabular}

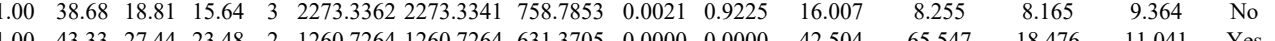

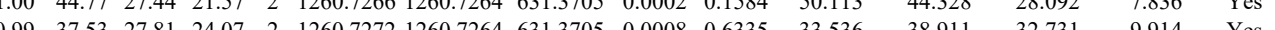

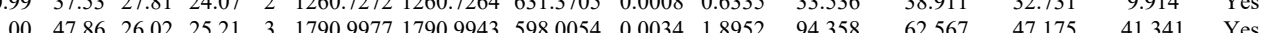

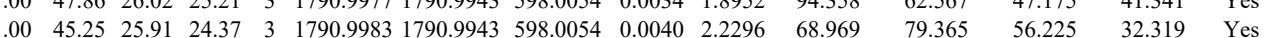

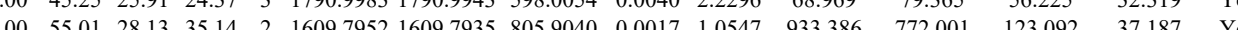
$\begin{array}{lllllllllll} & \end{array}$

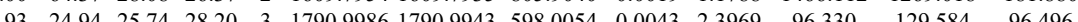

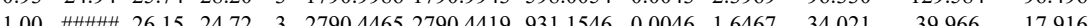
$\begin{array}{lllllllllllll}1.00 & 59.77 & 26.25 & 20.03 & 3 & 2790.4453 & 2790.4419 & 931.1546 & 0.0034 & 1.2171 & 18.314 & 21.252 & 11.962\end{array}$ $\begin{array}{lllllllllllll}1.00 & 51.88 & 25.07 & 26.36 & 2 & 1113.6726 & 1113.6702 & 557.8424 & 0.0024 & 2.1511 & 7379.207 & 6427.213 & 203.497\end{array}$ MIDLIIPR MIDLIIPR MIDLIIPR

TPLFDQIIDMLR

TPLFDQIIDMLR $\begin{array}{lllllllllllllll}\text { TPLFDQIIDMLR } & 0.98 & 26.83 & 28.01 & 20.10 & 3 & 1604.8741 & 1604.8718 & 535.9645 & 0.0023 & 1.4304 & 98.310 & 126.860 & 40.4 \\ \text { ILHLLTQEALSIHGVK } & 0.55 & 58.50 & 15.91 & 71.50 & 3 & 2059.2421 & 2059.2397 & 687.4205 & 0.0024 & 1.1638 & 5535.031 & 5548.558 & 4\end{array}$ $\begin{array}{lllllllllllll}\text { CEYPAACNALETLLIHR } & 1.00 & 69.91 & 26.45 & 21.20 & 3 & 2152.0093 & 2152.0059 & 718.3426 & 0.0034 & 1.5777 & 173.145 & 246.249\end{array}$ $\begin{array}{lllllllllllllll}\text { CEYPAACNALETLLIHR } & 1.00 & 77.20 & 26.44 & 18.84 & 3 & 2152.0084 & 2152.0059 & 718.3426 & 0.0025 & 1.1601 & 10.696 & 35.994 & 1.937\end{array}$ $\begin{array}{llllllllllllll}\text { TPLFDQIIDMLR } & 1.00 & 67.28 & 28.15 & 28.38 & 2 & 1604.8752 & 1604.8718 & 803.4432 & 0.0034 & 2.1159 & 184.873 & 157.209 & 84.413\end{array}$ $\begin{array}{lllllllllllllll}\text { LASIVEQVSVLQNQGR } & 1.00 & 58.35 & 25.00 & 30.71 & 3 & 1884.0562 & 1884.0551 & 629.0256 & 0.0011 & 0.5829 & 593.959 & 777.793 & 369.932\end{array}$ $\begin{array}{llllllllllllllll}\text { LASIVEQVSVLQNQGR } & 1.00 & 38.18 & 25.00 & 21.72 & 3 & 1884.0565 & 1884.0551 & 629.0256 & 0.0014 & 0.7419 & 511.537 & 444.107 & 279.448\end{array}$ LNSLAIGLP LNSLAIGLR SWSNIPFITVPLSR SWSNIPFITVPLS DEILLANK

$\begin{array}{llllllllllllll}1.00 & 52.70 & 24.41 & 29.64 & 2 & 1099.6848 & 1099.6835 & 550.8490 & 0.0013 & 1.1800 & 8432.088 & 7267.885 & 259.648 & 21 \\ 1.00 & 48.42 & 24.50 & 37.50 & 2 & 1099.6864 & 10996835 & 550.8490 & 0.0029 & 2.6323 & 15716.557 & 11364.385 & 513.575 & 19\end{array}$

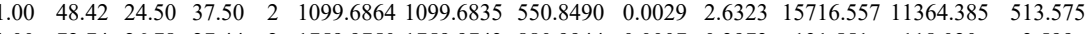
$\begin{array}{lllllllllllll}1.00 & 72.74 & 26.78 & 27.44 & 2 & 1759.9750 & 1759.9743 & 880.9944 & 0.0007 & 0.3973 & 131.551 & 118.020 & 3.599\end{array}$ $\begin{array}{lllllllllllll}1.00 & 68.59 & 26.74 & 23.31 & 2 & 1759.9754 & 1759.9743 & 880.9944 & 0.0011 & 0.6243 & 266.500 & 167.719 & 5.763\end{array}$

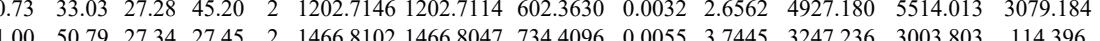

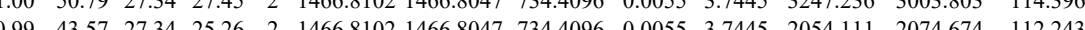
LQDMLDGFIK

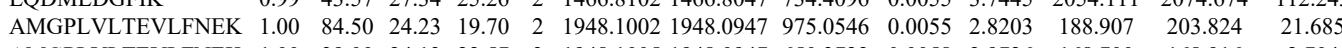

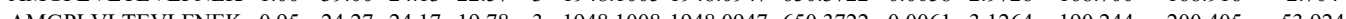

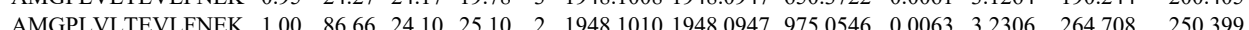




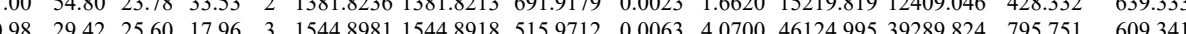
$\begin{array}{llllllllllllllll}\text { YGALALQEIFDGIQPK } & 1.00 & 42.67 & 25.22 & 20.11 & 3 & 2050.1386 & 2050.1342 & 684.3853 & 0.0044 & 2.1430 & 146.366 & 164.834 & 49.671 & 70.636 & \text { Yes }\end{array}$

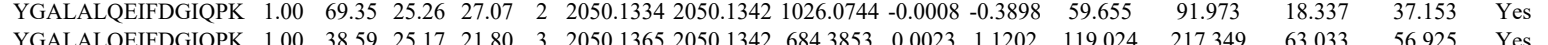

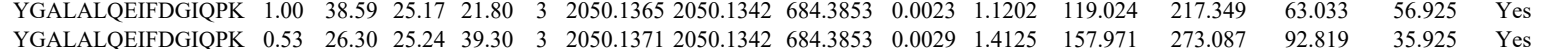

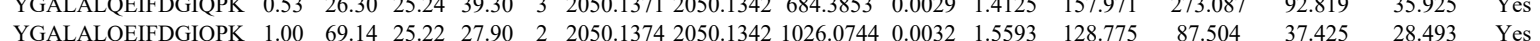

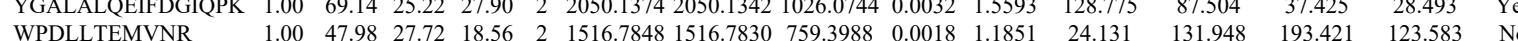

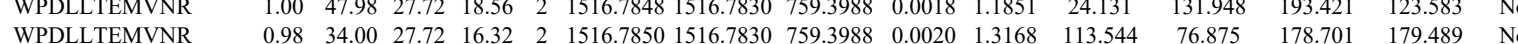

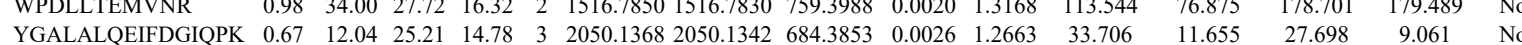

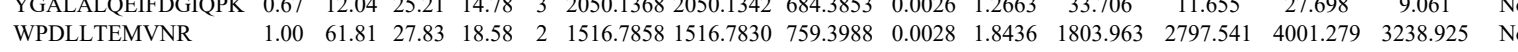

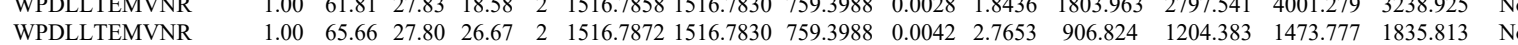
$\begin{array}{llllllllllllllll}\text { WPDLLTEMVNR } & 1.00 & 60.41 & 27.78 & 26.23 & 2 & 15167860 & 15167830 & 759.3988 & 0.0030 & 1.9752 & 226.663 & 214.003 & 361.006 & 208.250 & \text { No }\end{array}$

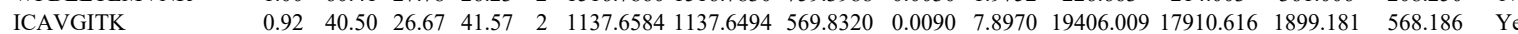

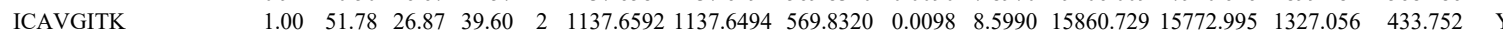
$\begin{array}{llllllllllllllll}\text { VCASVTFK } & 0.99 & 43.98 & 28.14 & 24.96 & 2 & 1187.6386 & 1187.6286 & 594.8216 & 0.0100 & 8.4058 & 25849.034 & 26836.093 & 1307.052 & 851.044 & \text { Y }\end{array}$

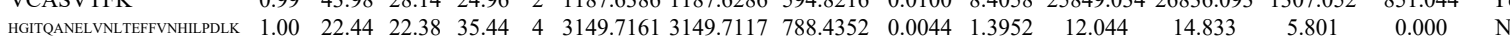
$\begin{array}{llllllllllllllll}\text { HGITQANELVNLTEFFVNHLPDLK } & 0.99 & 15.33 & 22.36 & 28.33 & 4 & 3149.7189 & 3149.7117 & 788.4352 & 0.0072 & 2.2830 & 14.212 & 0.000 & 0.000 & 3.076 & \text { No }\end{array}$

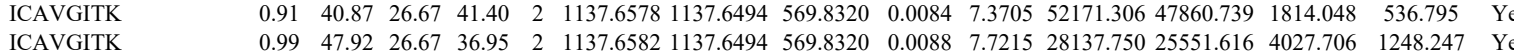
$\begin{array}{llllllllllllllll} & 0.99 & 47.92 & 26.67 & 36.95 & 2 & 1137.6582 & 1137.6494 & 569.8320 & 0.0088 & 7.7215 & 28137.750 & 25551.616 & 4027.706 & 1248.247 & \text { Yes }\end{array}$

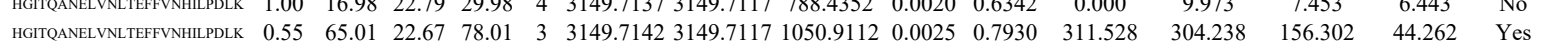

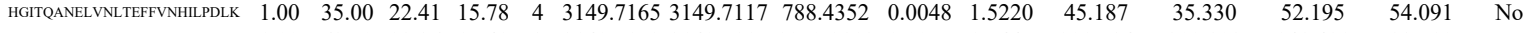
$\begin{array}{llllllllllllllll}\text { HGITQANELVNLTEFFVNHILPDLK } & 1.00 & 63.50 & 22.36 & 17.49 & 3 & 3149.7172 & 3149.7117 & 1050.9112 & 0.0055 & 1.7445 & 299.584 & 309.803 & 141.491 & 88.510 & \text { Yes }\end{array}$

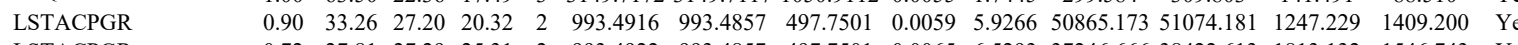

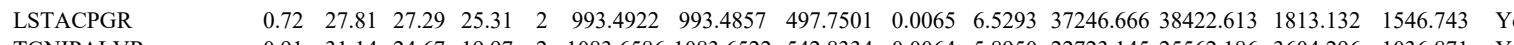

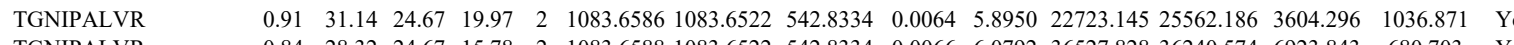
$\begin{array}{llllllllllllllll}\text { TGNIPALVR } & 0.84 & 28.32 & 24.67 & 15.78 & 2 & 1083.6588 & 1083.6522 & 542.8334 & 0.0066 & 6.0792 & 36527.828 & 36240.574 & 6923.843 & 680.703 & \text { Yes }\end{array}$

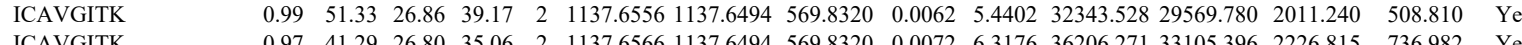

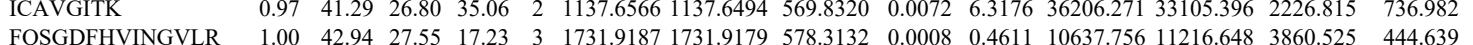
\begin{tabular}{llllllllllllllll} 
FQSGDFHVINGVLR & 1.00 & 42.94 & 27.55 & 17.23 & 3 & 1731.9187 & 1731.9179 & 578.3132 & 0.0008 & 0.4611 & 10637.756 & 11216.648 & 3860.525 & 444.639 & $Y$ \\
\hline
\end{tabular} $\begin{array}{llllllllllllll} & \end{array}$

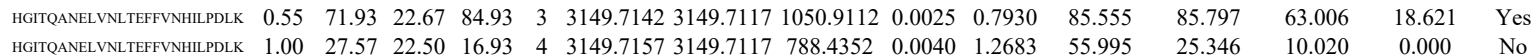
$\begin{array}{llllllllllllllll} & \end{array}$ 
IPGLLGVFQK

$\begin{array}{lllllllllll}.00 & 58.86 & 22.01 & 19.57 & 3 & 2206.2640 & 2206.2605 & 736.4274 & 0.0035 & 1.5842 \\ 1.006 .2605 & 736.4274 & 0.0065 & 2.942\end{array}$

$\begin{array}{lr}194.587 & 83.435 \\ 132.550 & 136.844\end{array}$

PGLLGVFQK

$\begin{array}{lllllllllllll}1.00 & 69.88 & 20.17 & 46.75 & 2 & 1358.8536 & 1358.8530 & 680.4338 & 0.0006 & 0.4409 & 1987.571 & 23 & \\ 0.99 & 22.27 & 20.21 & 14.57 & 3 & 1358.8540 & 1358.530 & 453.9583 & 0.0010 & 0.734 & 52.90 & 49 & \end{array}$

132.550 13.8454

IPGLLGVFQK

$\begin{array}{llllllllllll}1.00 & 64.76 & 19.59 & 22.72 & 2 & 1358.8546 & 1358.8530 & 680.4338 & 0.0016 & 1.1757 & 1467.049 & 17\end{array}$

$\begin{array}{cc}2340.133 & 1860.154 \\ 497.163 & 342.650 \\ 176.710\end{array}$

(P)

$\begin{array}{lllllllllll}1.00 & 24.08 & 19.59 & 18.34 & 3 & 1358.8549 & 1358.8530 & 453.9583 & 0.0019 & 1.3951 & 561.225\end{array}$

$\begin{array}{llllllllllll} & 22.04 & 24.86 & 2 & 2206.2634 & 2206.2605 & 1104.1375 & 0.0029 & 1.3132 & 22.576\end{array}$

$\begin{array}{llllllllllll} & \end{array}$

$\begin{array}{llllllllllll} & \end{array}$

$\begin{array}{lllllllllll}1.00 & 54.24 & 24.13 & 24.38 & 2 & 2030.8974 & 2030.8826 & 1016.4486 & 0.0148 & 7.2802 & 10.302\end{array}$

$\begin{array}{lllllllllllll}0.58 & 14.13 & 24.41 & 21.00 & 2 & 826.4508 & 826.4493 & 414.2319 & 0.0015 & 1.8106 & 7817.374 & 678 \\ 1.00 & 64.92 & 20.21 & 35.59 & 2 & 1358.8540 & 1358.8530 & 680.4338 & 0.0010 & 0.7348 & 806.179 & 80\end{array}$

LFSSLILISK

ILFSSLII

YIMIFR

YIMIFR

YIMIFR
YIMIFR

YIMIFR

YIMIFR

YIMIFR
YIMIFR

YIMIFR $\begin{array}{llllllllllll}0.53 & 31.40 & 22.04 & 44.40 & 3 & 2206.2634 & 2206.2605 & 736.4274 & 0.0029 & 1.3126 & 10.05\end{array}$

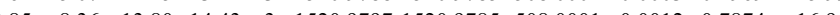
$\begin{array}{llllllllllllllllll}0.93 & 26.04 & 26.92 & 23.22 & 2 & 985.5558 & 985.5541 & 493.7843 & 0.0017 & 1.7214 & 832.418 & & & & \end{array}$ $\begin{array}{llllllllllllll}0.84 & 22.76 & 27.00 & 23.79 & 2 & 985.5548 & 985.5541 & 493.7843 & 0.0007 & 0.7088 & 1352.512 & 1444.920\end{array}$

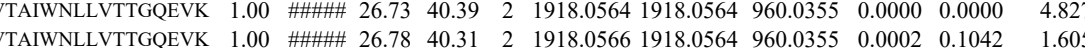
$\begin{array}{llllllllllllll} & & & \end{array}$

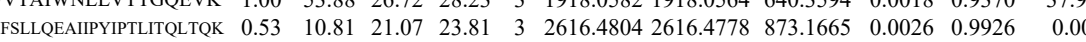
FSLLQEAIPYIPTLITQLTQK $\begin{array}{llllllllllll}1.00 & 46.07 & 24.01 & 25.75 & 2 & 1320.8048 & 1320.8040 & 661.4093 & 0.0008 & 0.6048 & 653.686\end{array}$ $\begin{array}{lllllllllll}0.88 & 21.13 & 23.96 & 21.03 & 2 & 1320.8054 & 1320.8040 & 661.4093 & 0.0014 & 1.0583 & 10.437\end{array}$ $\begin{array}{lllllllllll}0.98 & 23.47 & 23.96 & 18.22 & 3 & 1320.8056 & 1320.8040 & 441.2753 & 0.0016 & 1.2086 & 4.892\end{array}$ $\begin{array}{lllllllllll}1.00 & 47.21 & 23.96 & 27.02 & 2 & 1320.8056 & 1320.8040 & 661.4093 & 0.0016 & 1.2095 & 1087.500\end{array}$ $\begin{array}{llllllllllll}1.00 & 47.06 & 23.96 & 26.63 & 2 & 1320.8056 & 1320.8040 & 661.4093 & 0.0016 & 1.2095 & 857.861 \\ 1.00 & 38.67 & 23.96 & 24.57 & 2 & 1320.8058 & 1320.8040 & 661.4093 & 0.0018 & 1.3607 & 1680.875 & 1524\end{array}$ $\begin{array}{llllllllllll}1.00 & 38.67 & 23.96 & 24.57 & 2 & 1320.8058 & 1320.8040 & 661.4093 & 0.0018 & 1.3607 & 1680.875 & 1524.767\end{array}$ $\begin{array}{lllllllllllll}1.00 & 35.93 & 23.94 & 24.50 & 2 & 1320.8052 & 1320.8040 & 661.4093 & 0.0012 & 0.9072 & 535.026 & 4 \\ 1.00 & 46.90 & 23.96 & 28.24 & 2 & 1320.8054 & 1320.8040 & 661.4093 & 0.0014 & 1.0583 & 650.502 & 652 \\ 1.00 & 43.68 & 4.01 & 2.63 & 2 & & \end{array}$ $\begin{array}{llllllllllll}1.00 & 46.90 & 23.96 & 28.24 & 2 & 1320.8054 & 1320.8040 & 661.4093 & 0.0014 & 1.0583 & 650.502 & 65\end{array}$ $\begin{array}{llllllllllll}1.00 & 43.68 & 24.01 & 26.63 & 2 & 1320.8048 & 1320.8040 & 661.4093 & 0.0008 & 0.6048 & 275.969\end{array}$ $\begin{array}{llllllllllll}1.00 & 45.40 & 23.96 & 26.44 & 2 & 1320.8056 & 1320.8040 & 661.4093 & 0.0016 & 1.2095 & 204.956 \\ 1.00 & 34.61 & 15.19 & 19.61 & 3 & 1593.0031 & 1593.0010 & 532.0076 & 0.0021 & 1.3158 & 49.914\end{array}$ $\begin{array}{lllllllllllll}1.00 & 45.23 & 24.01 & 29.23 & 2 & 1320.8046 & 1320.8040 & 661.4093 & 0.0006 & 0.4536 & 61.742\end{array}$ 


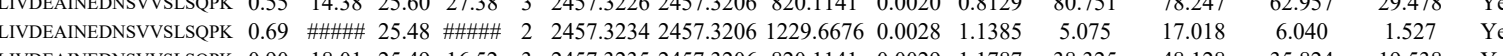
$\begin{array}{llllllllllllllll} & 16.52 & 3 & 2457.3235 & 2457.3206 & 820.1141 & 0.0029 & 1.1787 & 38.325 & 48.128 & 35.824 & 19.538 & \text { Yes }\end{array}$ $\begin{array}{llllllllllllllll}0.77 & 94.03 & 25.68 & \# \# \# \text { 2 } & 2629.3754 & 2629.3731 & 1315.6938 & 0.0023 & 0.8741 & 1.891 & 13.771 & 7.565 & 3.528 & \text { No }\end{array}$

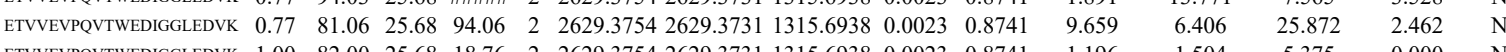
\begin{tabular}{llllllllllllllll}
\hline & 1.00 & 82.00 & 25.68 & 18.76 & 2 & 2629.3754 & 2629.3731 & 1315.6938 & 0.0023 & 0.8741 & 1.196 & 1.504 & 5.375 & 0.000 & No
\end{tabular} $\begin{array}{llllllllllllllll} & \end{array}$

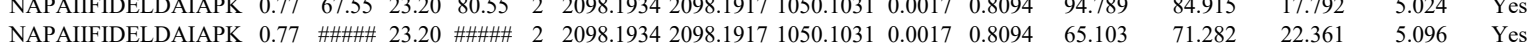

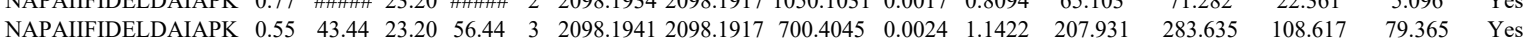

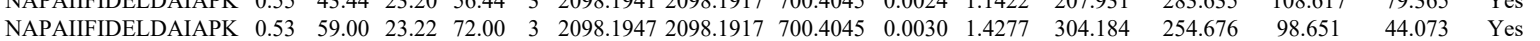
$\begin{array}{llllllllllllllll}\text { NAPAIIFIDELDAIAPK } & 1.00 & 65.67 & 23.16 & 17.38 & 3 & 2098.1926 & 2098.1917 & 700.4045 & 0.0009 & 0.4283 & 157.574 & 128.647 & 67.050 & 39.737 & \text { Yes }\end{array}$

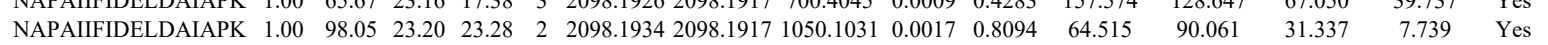

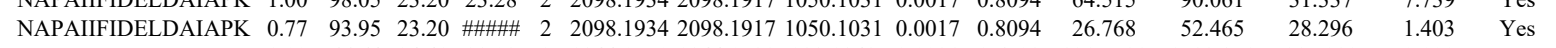
$\begin{array}{lllllllllllllllll}\text { LDQLIYIPLPDEK } & 1.00 & 66.64 & 24.49 & 28.03 & 2 & 1844.0570 & 1844.0539 & 923.0342 & 0.0031 & 1.6792 & 1215.529 & 1782.359 & 117.092 & 0.000 & \text { No }\end{array}$ $\begin{array}{llllllllllllllll}\text { LDQLIYIPLPDEK } & 0.99 & 33.69 & 24.25 & 29.94 & 3 & 1844.0575 & 1844.0539 & 615.6919 & 0.0036 & 1.9490 & 151.964 & 136.620 & 63.777 & 26.526 & \text { Yes }\end{array}$

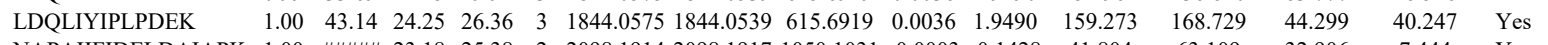

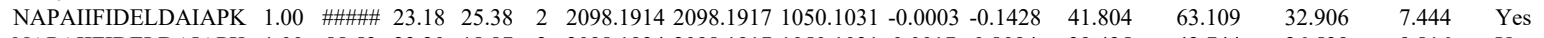

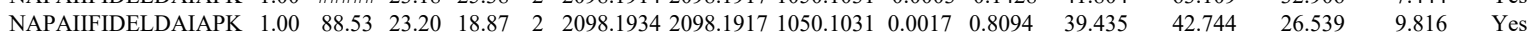
$\begin{array}{lllllllllllll}0.99 & 40.77 & 27.61 & 33.69 & 2 & 1194.6216 & 1194.6189 & 598.3167 & 0.0027 & 2.2563 & 9975.561 & 10738.447 & 388.320\end{array}$ MDELQLFR LDQLIYIPLPDEK LDQLIYIPLPDEK LDQLIYIPLPDEK
LDQLIYIPLPDEK $\begin{array}{lllllllllllllll}0.99 & 40.77 & 27.61 & 33.69 & 2 & 1194.6216 & 1194.6189 & 598.3167 & 0.0027 & 2.2563 & 9975.561 & 10738.447 & 388.320 & 23 & \\ 0.98 & 35.24 & 27.61 & 30.41 & 2 & 1194.6216 & 1194.6189 & 598.3167 & 0.0027 & 2.2563 & 11075.498 & 11502.104 & 217.174 & 17 & \end{array}$ $\begin{array}{llllllllllllll}1.00 & 62.36 & 24.49 & 27.07 & 2 & 1844.0570 & 1844.0539 & 923.0342 & 0.0031 & 1.6792 & 80.610 & 121.248 & 6.385\end{array}$ $\begin{array}{llllllllllllll}1.00 & 66.55 & 24.22 & 37.82 & 2 & 1844.0576 & 1844.0539 & 923.0342 & 0.0037 & 2.0043 & 152.460 & 189.784 & 6.691\end{array}$

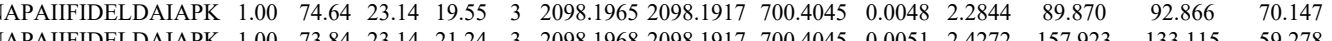
$\begin{array}{llllllllllllll}\text { QAAPCVLFFDELDSIAK } & 1.00 & 42.77 & 27.66 & 18.19 & 3 & 2200.1194 & 2200.1152 & 734.3790 & 0.0042 & 1.9064 & 26.975 & 43.170 & 4.059\end{array}$

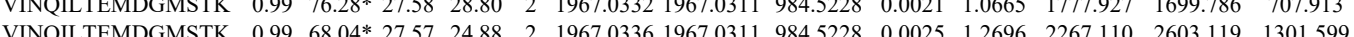

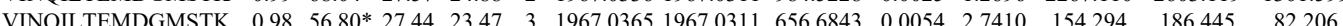
$\begin{array}{lllllllllllll} & \text { Q }\end{array}$

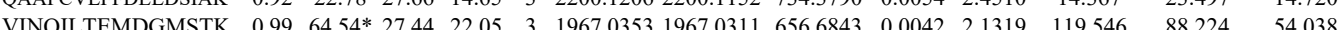
$\begin{array}{llllllllllllll}\text { VINQILTEMDGMSTKK } & 0.90 & 60.80 * 27.46 & 19.54 & 2 & 1967.0356 & 1967.0311 & 984.5228 & 0.0045 & 2.2854 & 115.158 & 136.539 & 38.174\end{array}$

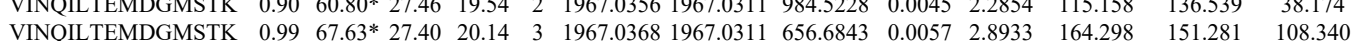
$\begin{array}{llllllllllllll}\text { GPELLTMWFGESEANVR } & 0.69 & 35.03 & 27.00 & 48.03 & 2 & 2095.0194 & 2095.0166 & 1048.5156 & 0.0028 & 1.3352 & 42.404 & 28.061 & 43.333\end{array}$ $\begin{array}{llllllllllllll}\text { GPELLTMWFGESEANVR } & 0.93 & 34.89 & 27.02 & 18.31 & 2 & 2095.0214 & 2095.0166 & 1048.5156 & 0.0048 & 2.2889 & 10.575 & 5.560 & 27.042\end{array}$ GILLYGPPGTGK GILLYGPPGTGK GILLYGPPGTGK KYEMFAQTLQQSR KYEMFAQTLQQSR KYEMFAQTLQQSR KYEMFAQTLQQSR GVLFYGPPGCGK GVLFYGPPGCGK GVLFYGPPGCGK GVLFYGPPGCGK GVLFYGPPGCGK GVLFYGPPGCGK IVSQLLTLMDGLK IVSQLLTLMDGLK IVSQLLTLMDGLK IVSQLLTLMDGLK IVSLLTLMDGLK IVSQLLTLMDGLK $\begin{array}{lllllllllllll}0.96 & 61.12 * 23.48 & 23.69 & 2 & 1459.8782 & 1459.8642 & 730.9394 & 0.0140 & 9.5766 & 4332.947 & 5069.596 & 3109.744\end{array}$ $\begin{array}{lllllllllllll}0.97 & 64.01 * 23.26 & 21.44 & 2 & 1459.8788 & 1459.8642 & 730.9394 & 0.0146 & 9.9870 & 2508.685 & 3223.401 & 2351.841\end{array}$ $\begin{array}{llllllllllllll}1.00 & 70.50 & 27.57 & 27.54 & 3 & 1917.0160 & 1917.0022 & 640.0080 & 0.0138 & 7.1874 & 2992.307 & 3573.765 & 901.259\end{array}$ $\begin{array}{lllllllllllllll}100 & 64.86 & 27.45 & 21.91 & 3 & 1917.0199 & 1917.0022 & 640.0080 & 0.0177 & 9.2185 & 3392.891 & 4467.245 & 1221.43 & 256.505\end{array}$ $\begin{array}{lllllllllllll}1.00 & 63.04 & 27.57 & 26.18 & 3 & 1917.0151 & 1917.0022 & 640.0080 & 0.0129 & 6.7186 & 3121.456 & 3417.966 & 1216.238\end{array}$ $\begin{array}{llllllllllllll}1.00 & 64.14 & 27.56 & 26.51 & 3 & 1917.0184 & 1917.0022 & 640.0080 & 0.0162 & 8.4373 & 2799.241 & 3311.090 & 1133.938 \\ 1.00 & 60.98 & 27.71 & 1.15 & 2 & 1527.7832 & 1527.7822 & 764.898 & 0.0010 & 0.6537 & 7430.295 & 7281.297 & 2000.264 & 13\end{array}$ $\begin{array}{llllllllllllll}1.00 & 60.98 & 27.71 & 31.15 & 2 & 1527.7832 & 1527.7822 & 764.8984 & 0.0010 & 0.6537 & 7430.295 & 7281.297 & 2000.264 & 1\end{array}$ $\begin{array}{lllllllllllllll}1.00 & 65.89 & 27.66 & 31.43 & 2 & 1527.7834 & 1527.7822 & 764.8984 & 0.0012 & 0.7844 & 6825.700 & 7671.390 & 1404.801 & 16 \\ 1.00 & 52.65 & 27.71 & 2.50 & 2 & 1527.7832 & 1527.7822 & 764.8984 & 0.0010 & 0.5537 & 7496.812 & 8763.707 & 2270.199 & 73\end{array}$ $\begin{array}{lllllllllllllll}1.00 & 52.65 & 27.71 & 25.50 & 2 & 1527.7832 & 1527.7822 & 764.8984 & 0.0010 & 0.6537 & 7496.812 & 8463.707 & 2270.199 & \\ 1.00 & 61.11 & 27.66 & 31.19 & 2 & 1527.7834 & 1527.7822 & 764.8984 & 0.0012 & 0.7844 & 8354.168 & 8092.060 & 2403.305 & 423 .\end{array}$ $\begin{array}{llllllllllllll}1.00 & 61.11 & 27.66 & 31.19 & 2 & 1527.7834 & 1527.7822 & 764.8984 & 0.0012 & 0.7844 & 8354.168 & 8092.060 & 2403.305 & 423 . \\ 1.00 & 56.81 & 27.73 & 29.48 & 2 & 1527.7812 & 1527.7822 & 764.8984 & -0.0010 & -0.6537 & 866.337 & 1167.518 & 380.535 & \end{array}$ $\begin{array}{llllllllllllll}1.00 & 53.98 & 27.72 & 21.38 & 2 & 1527.7818 & 1527.7822 & 764.8984 & -0.0004 & -0.2615 & 1781.340 & 1423.558 & 706.276\end{array}$ $\begin{array}{llllllllllllll}1.00 & 67.01 & 21.79 & 30.69 & 2 & 1718.0274 & 1718.0256 & 860.0201 & 0.0018 & 1.0465 & 683.650 & 977.295 & 172.988\end{array}$

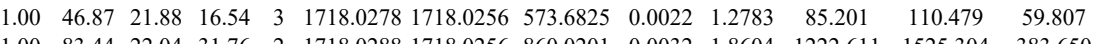

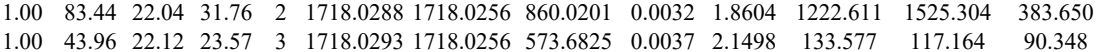

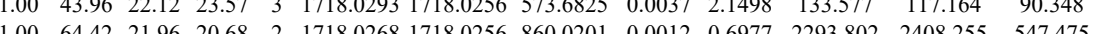
$\begin{array}{lllllllllllllll}1.00 & 64.42 & 21.96 & 20.68 & 2 & 1718.0268 & 1718.0256 & 860.0201 & 0.0012 & 0.6977 & 2293.802 & 2408.255 & 547.475 & 0 \\ 1.00 & 76.19 & 22.01 & 33.23 & 2 & 1718.0270 & 1718.0256 & 860.0201 & 0.0014 & 0.8139 & 3353.210 & 3938.058 & 1011.752 & 0\end{array}$

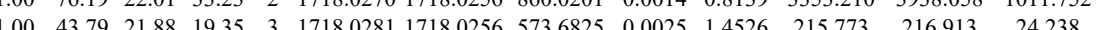
$\begin{array}{lllllllllllllll}0 & 33.01 & 21.88 & 18.01 & 3 & 1718.0284 & 1718.0256 & 573.6825 & 0.0028 & 1.6269 & 70.170 & 93.656 & 47.118\end{array}$ $\begin{array}{lllllllllllll}1.00 & 66.93 & 27.94 & 26.56 & 2 & 1472.7974 & 1472.7857 & 737.4001 & 0.0117 & 7.9332 & 8179.503 & 9367.042 & 267.999\end{array}$ 
$\begin{array}{lllllllllllll}1.00 & 60.47 & 26.56 & 28.98 & 2 & 1512.7234 & 1512.7196 & 757.3671 & 0.0038 & 2.5087 & 1159.683 & 1217.683 & 33.459\end{array}$

$\begin{array}{lllllllllllll}1.00 & 63.84 & 26.07 & 50.62 & 2 & 1418.8252 & 1418.8224 & 710.4185 & 0.0028 & 1.9707 & 1176.771 & 1168.530 & 275.394\end{array}$

$\begin{array}{lllllllllllll}1.00 & 55.40 & 25.07 & 17.44 & 2 & 1623.9294 & 1623.9268 & 812.9707 & 0.0026 & 1.5991 & 3102.632 & 3937.503 & 3284.913 \\ 1.00 & 55.45 & 55.07 & 18.38 & 2 & 1623.9294 & 1623.9268 & 12.9707 & 0.0026 & 1.5991 & 5269.650 & 6799.910 & 5384.342\end{array}$

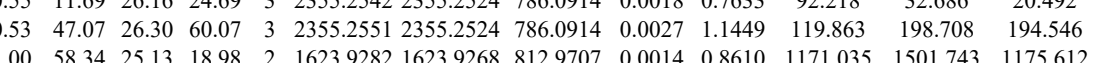
GIPEFWLTVFK

$\begin{array}{lllllllllllll}0.99 & 28.02 & 25.01 & 20.98 & 3 & 1623.9298 & 1623.9268 & 542.3162 & 0.0030 & 1.8439 & 274.257 & 343.754 & 137.448 \\ 1.00 & 33.66 & 25.00 & 18.55 & 3 & 1623.9310 & 1623.9268 & 542.3162 & 0.0042 & 2.5815 & 61.472 & 130.594 & 30.955\end{array}$ $\begin{array}{lllllllllllll}\text { QLTVQMMQNPQILAALQER } & 1.00 & \text { \#\#\#\# } 26.31 & 23.46 & 2 & 2355.2554 & 2355.2524 & 1178.6335 & 0.0030 & 1.2727 & 65.167 & 85.516 & 47.642\end{array}$ GIPEFWLTVFK

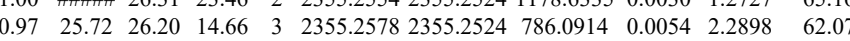

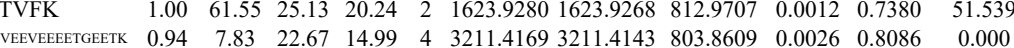
$\begin{array}{lllllllllllll}\text { NVDLLSDMVQEHDEPILK } & 1.00 & 44.90 & 27.01 & 16.70 & 3 & 2382.2371 & 2382.2344 & 795.0854 & 0.0027 & 1.1320 & 2301.028\end{array}$ $\begin{array}{lllllllllllll}\text { NVDLLSDMVQEHDEPILK } & 1.00 & 25.63 & 27.01 & 21.01 & 4 & 2382.2393 & 2382.2344 & 596.5659 & 0.0049 & 2.0534 & 107.507\end{array}$ $\begin{array}{lllllllllllll}\text { NVDLLSDMVQEHDEPILK } & 1.00 & 42.29 & 27.01 & 19.42 & 4 & 2382.2393 & 2382.2344 & 596.5659 & 0.0049 & 2.0534 & 360.549 & \\ \text { NVDLLSDMYQEHDEPIL } & 1.00 & 32.49 & 27.01 & 18.94 & 4 & 2382.2389 & 2382.2344 & 596.5659 & 0.0045 & 1.8858 & 213.418 & 171\end{array}$ $\begin{array}{lllllllllllll}\text { NVDLLSDMVQEHDEPILK } & 1.00 & 32.49 & 27.01 & 18.94 & 4 & 2382.2389 & 2382.2344 & 596.5659 & 0.0045 & 1.8858 & 213.418 \\ \text { NVDLLSDMVQEHDEPLK } & 1.00 & 31.75 & 27.01 & 21.32 & 4 & 2382.2393 & 2382.2344 & 596.5659 & 0.0049 & 2.0534 & 168.364\end{array}$ $\begin{array}{lllllllllllll}\text { NVDLLSDMVQEHDEPILK } & 1.00 & 31.75 & 27.01 & 21.32 & 4 & 2382.2393 & 2382.2344 & 596.5659 & 0.0049 & 2.0534 & 168.364 & \\ \text { YSLKPNDQILAEDK } & 0.91 & 26.76 & 23.71 & 21.46 & 3 & 2065.1608 & 2065.1421 & 689.3880 & 0.0187 & 9.0418 & 3787.245 & 4012\end{array}$ 
VAQWMIQQPHK VAQWMLQPHK VAQWMIQQPHK SLIANLAAANCYK IVIFTQGR

IVIFTQGR

IVIFTQGR

IVIFTQGR

VIFTQG

DDTIMATESEVTAFAVLDQDOK

DTIMATESEVTAFAVLDQDOK

DTIMATESEVTAFAVLDQDQK

\section{SPVTTLLECMHK}

YLNTNPVGGLLEYAR

TLPLTGSTFHDQIAMLSHR

TLPLTGSTFHDQIAMLSHR

NIFLLFK

CFNTLTNSFQPSLLGR CFNTLTNSFQPSLLGR CFNTLTNSFQPSLLGR CFNTLTNSFQPSLLGR CFNTLTNSFQPSLLGR

LVDQSGPPHEPK

LVDQSGPPHEPK

AYPLADAHLTK

AYPLADAHLTK

QQIQSIQQSIER
QQIQSIQQSIER

QQIQSIQQSIER

NVPYVFVR
NVPYVFVR

NVYYNQW

LGLQNDLFSLAR

LGLQNDLFSLAR

VILSFPSTLQTGTGTLK

KPYPDDENLVEVK

KPYPDDENLVEVK

YMTISDEWDIPEK

QVPVDVVEMK

QVPVDVVEMK

MTLDTLSIYETPSMG MTLDTLSIYETPSMGLLDK

MTLDTLSIYETPSMGLLDK MTLDTLSIYETPS

FAVLHGEAPR

FAVLHGEAPR

FAVLHGEAPR

FAVLHGEAPR

FAVLHGEAPR

GTQGVVTNFEIFR

GTQGVVTNFEIF

ISVSFYHVK

GTYLATFHQR

GTYLATFHQR

GTYLATFHQR

GTYLATFHQR

GTYLATFHQR

GTYLATFHQR

GTYLATFHOR

VDNAYWLWTFQGR

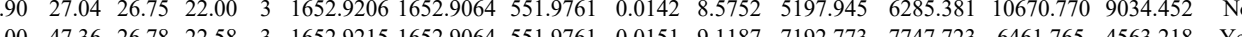

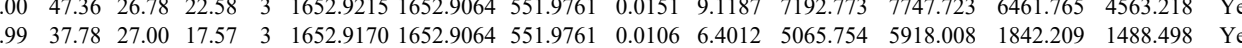
$\begin{array}{lllllllllllllll}0.79 & 23.02 & 27.63 & 18.00 & 3 & 1684.8952 & 1684.8884 & 562.6367 & 0.0068 & 4.0286 & 454.634 & 471.375 & 230.703 & 107.040 & \text { Yes }\end{array}$

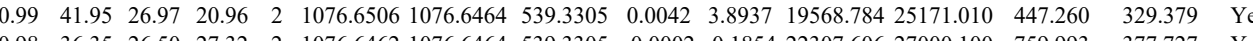
$\begin{array}{llllllllllllllll}0.98 & 36.35 & 26.50 & 27.32 & 2 & 1076.6462 & 1076.6464 & 339.3305 & -0.0002 & -0.1854 & 22307.606 & 27000.100 & 759.993 & 377.727 & \text { Yes }\end{array}$

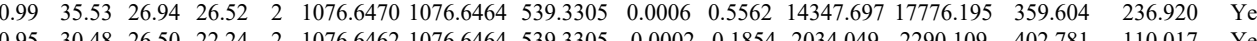
$\begin{array}{lllllllllllllll}0.95 & 30.48 & 26.50 & 22.24 & 2 & 1076.6462 & 1076.6464 & 539.3305 & -0.0002 & -0.1854 & 2034.049 & 2290.109 & 402.781 & 110.017 & \text { Yes } \\ 0.97 & 33.33 & 26.58 & 22.83 & 2 & 1076.6468 & 1076.6464 & 539.3305 & 0.004 & 0.3708 & 2810.652 & 2998.931 & 471.431 & 110.111 & \text { Yes }\end{array}$

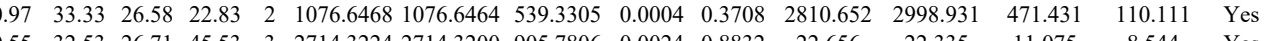
\begin{tabular}{lllllllllllllll}
0.99 & 28.73 & 26.83 & 15.83 & 3 & 2714.3239 & 2714.3200 & 905.7806 & 0.0039 & 1.4352 & 33.817 & 37.859 & 6.061 & 7.625 & Yes \\
\hline
\end{tabular} $\begin{array}{llllllllll}287.42 & 26.84 & 15.35 & 3 & 2714.3245 & 2714.3200 & 905.7806 & 0.0045 & 1.6560 & 27.676\end{array}$ $\begin{array}{lllllllllll}0.53 & 68.46 & 24.79 & 81.46 & 3 & 3779.7532 & 3779.7504 & 1260.9241 & 0.0028 & 0.7402 & 1.694\end{array}$

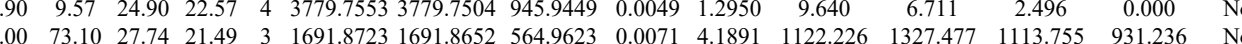
$\begin{array}{lllllllllllllll}1.00 & 88.76 & 27.90 & 25.35 & 2 & 1822.9714 & 1822.9699 & 912.4922 & 0.0015 & 0.8219 & 537.135 & 552.944 & 162.942 & 25.037 & \text { Yes }\end{array}$

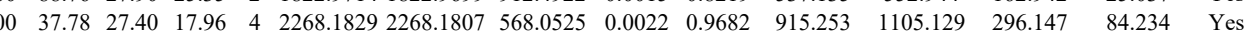
$\begin{array}{llllllllllllll}56.07 & 27.43 & 20.98 & 4 & 2268.1837 & 2268.1807 & 568.0525 & 0.0030 & 1.3203 & 1769.382 & 2355.350 & 732.966 & 291.777 & \text { Yes }\end{array}$

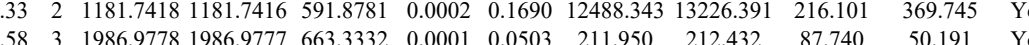

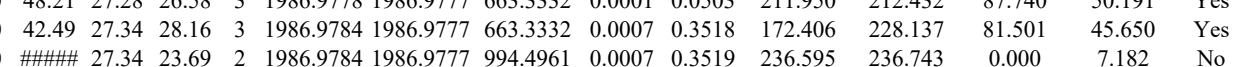

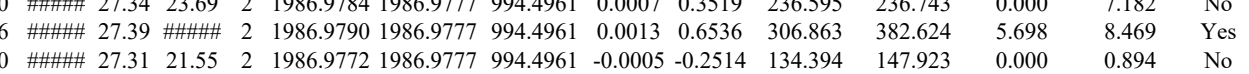

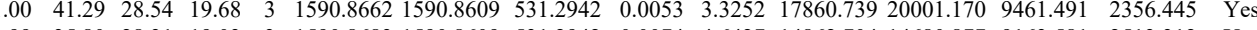
$\begin{array}{lllllllllllllll}.99 & 35.80 & 28.31 & 19.03 & 3 & 1590.8683 & 1590.8609 & 531.2942 & 0.0074 & 4.6427 & 14862.704 & 14680.877 & 9163.581 & 2513.312 & \text { Yes }\end{array}$ $\begin{array}{lllllllllllllllll}1.00 & 52.89 & 26.55 & 21.58 & 3 & 1486.8505 & 1486.8387 & 496.6202 & 0.0118 & 7.9201 & 10747.509 & 9700.458 & 3165.750 & 722.751 & \text { Yes } \\ 1.00 & 57.44 & 26.50 & 18.05 & 3 & 1486.8529 & 1486838 & 496.6202 & 0.012 & 9.5310 & 801.207 & 7897.633 & 4189.530 & 984.43 & \text { Yes }\end{array}$ $\begin{array}{llllllllllllllll}1.00 & 52.8 & 26.55 & 21.58 & 3 & 1486.8505 & 1486.8387 & 496.6202 & 0.018 & 7.9201 & 0747.509 & 9700.458 & 3165.750 & 722.751 & \text { Yes } \\ 1.0 & 57.44 & 26.50 & 18.05 & 3 & 1486.8529 & 1486.8387 & 496.6202 & 0.0142 & 9.5310 & 8801.207 & 7897.633 & 4189.530 & 984.431 & \text { Yes }\end{array}$ $\begin{array}{llllllllllllllll}1.00 & 57.44 & 26.50 & 18.05 & 3 & 1486.8529 & 1486.8387 & 496.6202 & 0.042 & 9.5310 & 8801.207 & 7897.633 & 4189.530 & 984.431 & \text { Yes } \\ 1.00 & 64.65 & 27.48 & 23.04 & 2 & 1600.8788 & 1600.8654 & 801.4400 & 0.0134 & 8.3599 & 1767.776 & 1525.249 & 1036.586 & 154.704 & \text { Yes }\end{array}$ $\begin{array}{llllllllllllllll}1.00 & 63.65 & 27.46 & 26.20 & 2 & 1600.8794 & 1600.8654 & 801.4400 & 0.0140 & 8.7342 & 1082.015 & 977.479 & 603.541 & 189.649 & \text { Yes }\end{array}$ $\begin{array}{lllllllllllllll}0.56 & 28.24 & 27.32 & 20.38 & 2 & 1136.6440 & 1136.6464 & 569.3305 & -0.0024 & -2.1077 & 8766.557 & 8194.498 & 610.564 & 358.270 & \text { Yes } \\ 0.89 & 28.07 & 27.69 & 20.80 & 2 & 1136.6466 & 1136.6464 & 569.3305 & 0.0002 & 0.1756 & 12686.664 & 12047.069 & 368.949 & 503.383 & \text { Yes }\end{array}$ \begin{tabular}{lllllllllllllll}
0.89 & 28.07 & 27.69 & 20.80 & 2 & 1136.6466 & 1136.6464 & 569.3305 & 0.0002 & 0.1756 & 12686.664 & 12047.069 & 368.949 & 503.383 & Yes \\
\hline
\end{tabular}

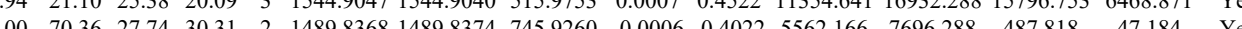

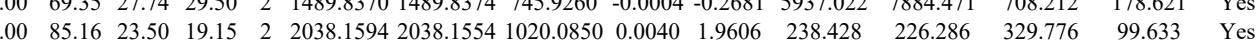
$\begin{array}{lllllllllllllll}24.80 & 23.54 & 37.80 & 3 & 2038.1575 & 2038.1554 & 680.3924 & 0.0021 & 1.0288 & 594.153 & 480.885 & 368.914 & 257.171 & \text { Yes }\end{array}$ $\begin{array}{lllllllllllllll}1.99 & 36.67 & 25.94 & 18.41 & 3 & 1977.0874 & 1977.0784 & 6600.0334 & 0.0090 & 4.5452 & 1914.982 & 2783.822 & 5041.837 & 2707.295 & \text { Yes }\end{array}$ $\begin{array}{lllllllllllllllll}0.98 & 33.64 & 28.18 & 28.60 & 2 & 1436.7772 & 14367755 & 719.3950 & 0.0017 & 1.1815 & 561.866 & 586.942 & 362.383 & 111.585 & \text { Yes }\end{array}$ $\begin{array}{lllllllllllllll}1.00 & 41.47 & 27.22 & 20.72 & 2 & 1913.9344 & 1913.9324 & 957.9735 & 0.0020 & 1.0439 & 66.010 & 77.859 & 4.924 & 9.095 & \text { Yes }\end{array}$ $\begin{array}{llllllllllllllll}1.00 & 57.12 & 27.29 & 21.56 & 2 & 1913.9350 & 1913.9324 & 957.9735 & 0.0026 & 1.3570 & 48.225 & 96.559 & 0.823 & 17.676 & \text { No }\end{array}$

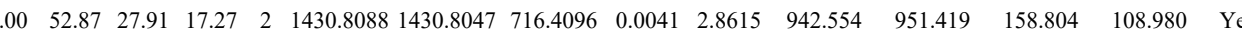

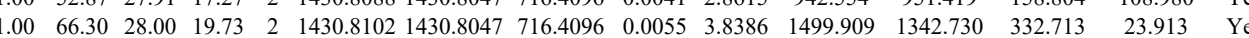

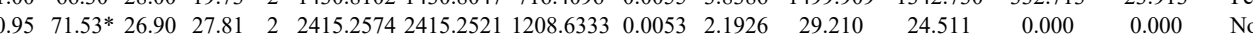

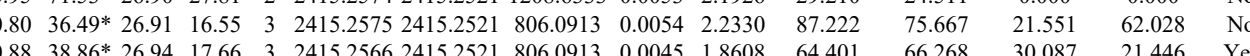

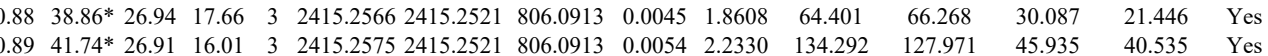
$\begin{array}{lllllllllllllll}1.00 & 44.57 & 27.18 & 24.80 & 3 & 1239.6889 & 1239.6846 & 414.2355 & 0.0043 & 3.4602 & 17796.490 & 17603.620 & 3879.827 & 2178.429 & \text { Yes }\end{array}$ $\begin{array}{lllllllllllllll}1.00 & 40.21 & 26.64 & 17.84 & 3 & 1239.6892 & 1239.6846 & 414.2355 & 0.0046 & 3.7016 & 27734.328 & 29518.354 & 5976.620 & 4594.764 & \text { Yes }\end{array}$ $\begin{array}{lllllllllllllll}0.99 & 44.27 & 26.66 & 21.27 & 2 & 1239.6898 & 1239.6846 & 620.8496 & 0.0052 & 4.1878 & 4920.258 & 4603.869 & 884.333 & 560.801 & \text { Yes }\end{array}$

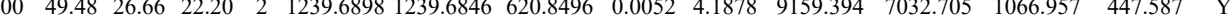
$\begin{array}{llllllllllllllll}1.00 & 41.58 & 27.10 & 19.18 & 3 & 1239.6877 & 1239.6846 & 414.2355 & 0.0031 & 2.4945 & 11505.889 & 11592.904 & 3051.377 & 2963.346 & \text { Yes }\end{array}$ $\begin{array}{llllllllllllllll}1.00 & 39.92 & 27.10 & 18.76 & 3 & 1239.6883 & 1239.6846 & 414.2355 & 0.0037 & 2.9774 & 10587.302 & 9129.796 & 6236.407 & 6686.848 & \mathrm{No} & \end{array}$ $\begin{array}{lllllllllllllll}1.00 & 79.50 & 28.08 & 26.86 & 2 & 1610.8534 & 1610.8539 & 806.4342 & -0.0005 & -0.3100 & 4711.999 & 4699.453 & 2577.497 & 2174.849 & \text { Yes }\end{array}$

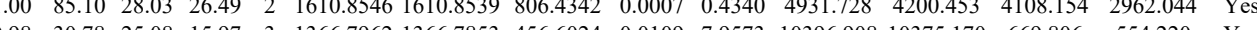

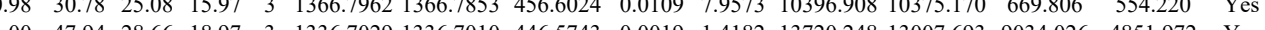
$\begin{array}{lllllllllllllllll}1.00 & 4.94 & 28.66 & 18.97 & 3 & 1336.7029 & 1336.7010 & 446.5743 & 0.0019 & 1.4182 & 13720.248 & 13007.693 & 9034.026 & 4851.972 & \text { Yes }\end{array}$ $\begin{array}{llllllllllllllll}1.00 & 48.28 & 28.66 & 21.36 & 3 & 1336.7029 & 1336.7010 & 446.5743 & 0.0019 & 1.4182 & 17861.194 & 18700.974 & 6880.587 & 3950.941 & \text { Yes }\end{array}$

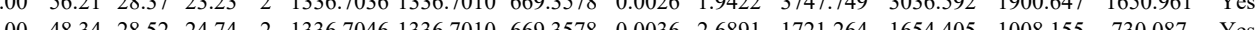

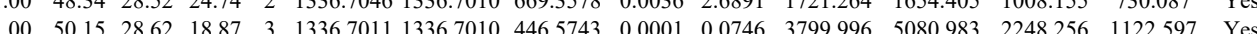

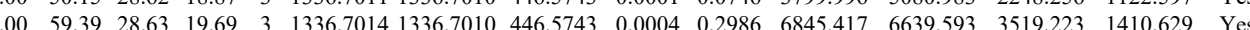
$\begin{array}{llllllllllllllll}.00 & 48.92 & 28.63 & 24.48 & 2 & 1336.7026 & 1336.7010 & 669.3578 & 0.0016 & 1.1952 & 1658.912 & 1770.656 & 1056.573 & 653.158 & \text { Yes }\end{array}$ 
VDNAYWLWTFQGR GTYLATFHQR GTYLATFHQR GTYLATFHQR VTLMQLPTR VTLMQLPTR FAVLHGEAPR $\begin{array}{lllllllllllllll}1.00 & 61.73 & 27.35 & 22.82 & 2 & 1798.8932 & 1798.8913 & 900.4529 & 0.0019 & 1.0550 & 3043.727 & 2950.283 & 72.292 & 60.579 & \text { Yes }\end{array}$ $\begin{array}{llllllllllllllll}1.00 & 44.32 & 28.47 & 19.37 & 3 & 1336.7044 & 1336.7010 & 446.5743 & 0.0034 & 2.5378 & 4459.118 & 4536.753 & 1379.737 & 586.498 & \text { Yes } \\ 1.00 & 43.20 & 28.47 & 26.29 & 3 & 1336.7044 & 1336.7010 & 446.5743 & 0.0034 & 2.5378 & 3154.848 & 3214.409 & 915.288 & 509.726 & \text { Yes }\end{array}$ $\begin{array}{llllllllllllll} & \end{array}$ $\begin{array}{lllllllllllllllll}0.90 & 22.02 & 28.52 & 14.83 & 3 & 1336.7047 & 1336.7010 & 446.5743 & 0.0037 & 2.7618 & 11936.666 & 9438.032 & 1365.684 & 444.252 & \text { Yes }\end{array}$ \begin{tabular}{llllllllllllllll}
1.00 & 40.26 & 26.90 & 28.06 & 2 & 1201.6996 & 1201.6975 & 601.8560 & 0.0021 & 1.7446 & 18708.946 & 17971.845 & 1710.447 & 76.207 & Yes \\
\hline
\end{tabular}

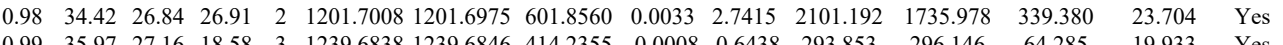

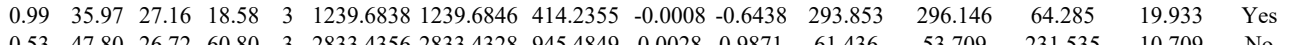

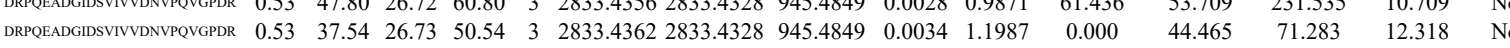
$\begin{array}{lllllllllllllllll}\text { VIIVDNVPQVGPRR } & 1.00 & 74.87 & 26.72 & 18.52 & 3 & 2833.4356 & 2833.4328 & 945.4849 & 0.0028 & 0.9871 & 175.150 & 143.034 & 266.043 & 177.727 & \text { No }\end{array}$ $\begin{array}{lllllllllllllllll} & \end{array}$

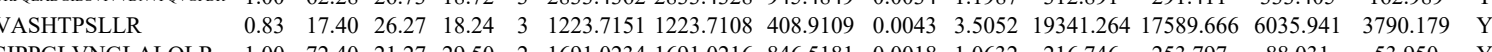

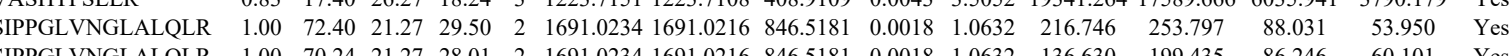
$\begin{array}{llllllllllllllll} & \end{array}$ $\begin{array}{llllllllllllllll} & 15.0234 & 1691.0216 & 564.6811 & 0.0026 & 1.5348 & 105.581 & 114.333 & 17.323 & 9.516 & \text { Yes }\end{array}$

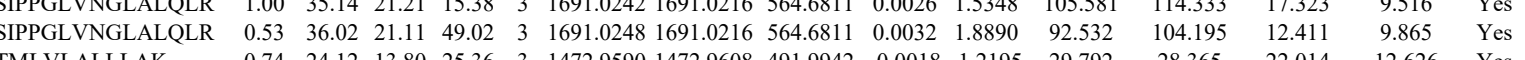
\begin{tabular}{lllllllllllllllll} 
TMLVLALLLAK & 0.74 & 24.12 & 13.80 & 25.36 & 3 & 1472.9590 & 1472.9608 & 491.9942 & -0.0018 & -1.2195 & 29.792 & 28.365 & 22.014 & 12.626 & Yes \\
\hline
\end{tabular} \begin{tabular}{llllllllllllllll} 
TMLVLALLLAK & 0.98 & 22.98 & 13.98 & 21.75 & 3 & 1472.9629 & 1472.9608 & 491.9942 & 0.0021 & 1.4228 & 16.719 & 27.724 & 8.351 & 14.246 & Yes \\
\hline
\end{tabular}

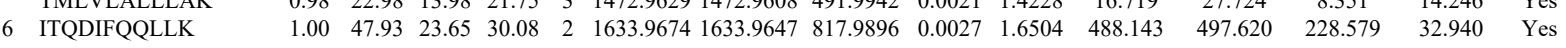
$\begin{array}{llllllllllllllll}\text { ITQDIFQQLLK } & 1.00 & 61.00 & 23.28 & 35.04 & 2 & 1633.9700 & 1633.9647 & 817.9896 & 0.0053 & 3.2396 & 1313.130 & 1137.295 & 695.112 & 75.835 & \text { Yes }\end{array}$

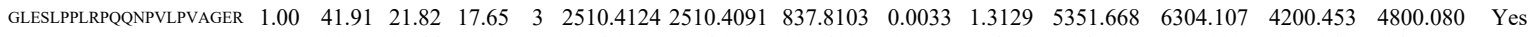

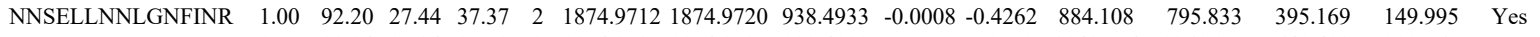
$\begin{array}{llllllllllllllll}\text { NNSELLNNLGNFINR } & 1.00 & 83.94 & 27.34 & 35.53 & 2 & 1874.9720 & 1874.9720 & 938.4933 & 0.0000 & 0.0000 & 1141.074 & 1261.205 & 649.493 & 229.960 & \text { Yes }\end{array}$

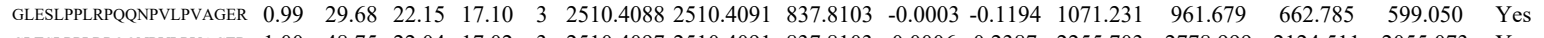
$\begin{array}{llllllllllllllll}\text { GLESLPLRPQQNPVLPVAGER } & 1.00 & 48.75 & 22.04 & 17.02 & 3 & 2510.4097 & 2510.4091 & 837.8103 & 0.0006 & 0.2387 & 2255.703 & 2778.999 & 2124.511 & 2055.073 & \text { Yes }\end{array}$ $\begin{array}{llllllllllllllll}\text { LFVSDGVPGCLPVLAAAGR } & 1.00 & 76.69 & 27.18 & 28.66 & 2 & 2031.0774 & 2031.0767 & 1016.5456 & 0.0007 & 0.3443 & 483.139 & 554.027 & 40.492 & 9.098 & \text { Yes }\end{array}$ $\begin{array}{llllllllllllllll}\text { LFVSDGVPGCLPVLAAAGR } & 1.00 & 74.26 & 27.23 & 29.96 & 2 & 2031.0794 & 2031.0767 & 1016.5456 & 0.0027 & 1.3280 & 232.478 & 424.132 & 8.068 & 27.513 & \text { No }\end{array}$ $\begin{array}{llllllllllllll} & \text { Y }\end{array}$

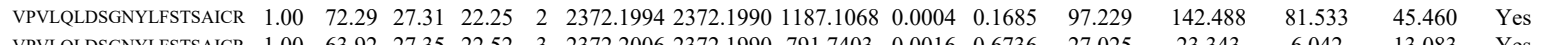

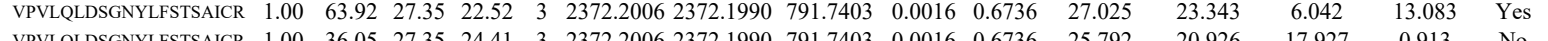
$\begin{array}{lllllllllllllll}\text { LFVSDGSG } & \text { No }\end{array}$

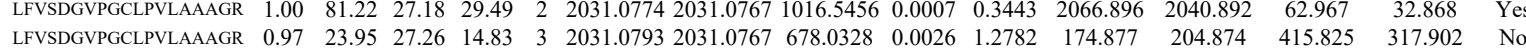

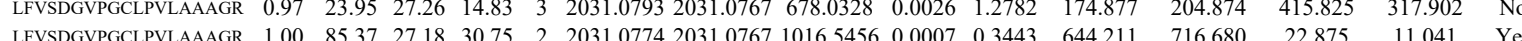

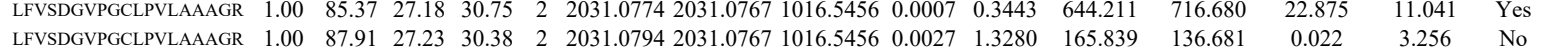

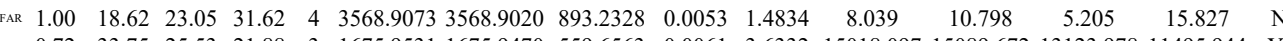

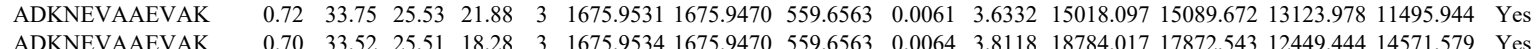

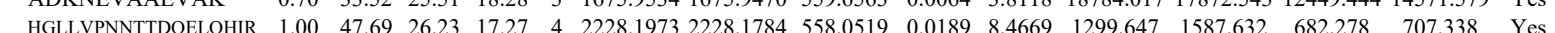
$\begin{array}{lllllllllllllllllll}\text { HGLLVPNNTTDQELOHIR } & 1.00 & 42.59 & 26.14 & 55.59 & 4 & 2228.1981 & 2228.1784 & 558.0519 & 0.0197 & 8.8253 & 713.138 & 652.902 & 868.732 & 416.504 & \text { Yes }\end{array}$

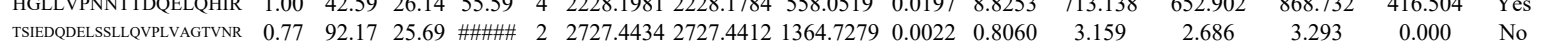

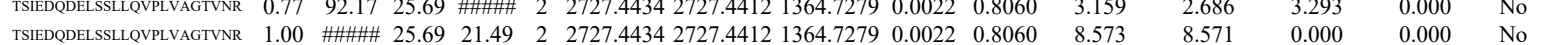

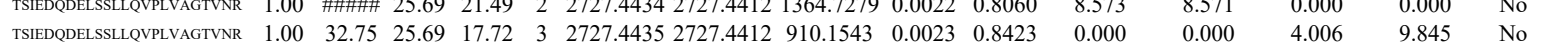

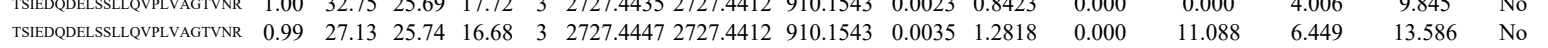
$\begin{array}{llllllllllllllll}\text { TIEDQDELSSLLQVPLVAGTVNR } & 0.99 & 27.78 & 25.55 & 15.47 & 3 & 2727.4459 & 2727.4412 & 910.1543 & 0.0047 & 1.7213 & 7.055 & 46.941 & 45.668 & 45.772 & \text { Yes }\end{array}$ $\begin{array}{lllllllllllllllll}\text { TSEDQDELSSLLQVPLVAGTVNR } & 1.00 & 32.61 & 25.55 & 17.98 & 3 & 2727.4459 & 2727.4412 & 910.1543 & 0.0047 & 1.7213 & 44.990 & 31.610 & 35.562 & 21.586 & \text { Yes }\end{array}$

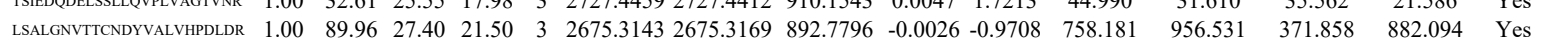

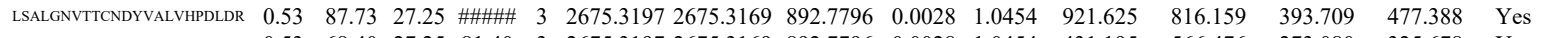
$\begin{array}{llllllllllllllll}\text { LSALGNVITCNDYVALVHPLDR } & 0.53 & 68.40 & 27.25 & 81.40 & 3 & 2675.3197 & 2675.3169 & 892.7796 & 0.0028 & 1.0454 & 431.195 & 566.476 & 273.080 & 325.678 & \text { Yes } \\ \text { ETEEIADVILS }\end{array}$

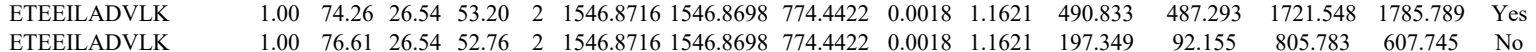
$\begin{array}{llllllllllllllll} & \\ \text { ETEEILADVLK } & 1.00 & 76.61 & 26.54 & 52.76 & 2 & 1546.8716 & 1546.8698 & 774.4422 & 0.0018 & 1.1621 & 197.349 & 92.155 & 805.783 & 607.745 & \text { No }\end{array}$ \begin{tabular}{llllllllllllllll} 
& 0.94 \\
ETEEILADVLK & 0.94 .86 & 26.56 & 31.63 & 3 & 1546.8718 & 1546.8698 & 516.6305 & 0.0020 & 1.2904 & 36.606 & 22.237 & 76.339 & 110.342 & Yes \\
\hline
\end{tabular}

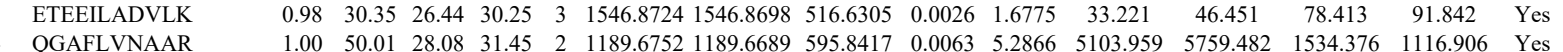

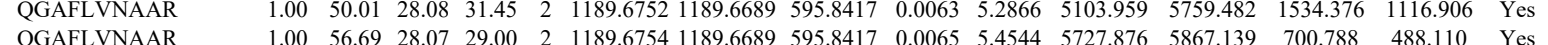
$\begin{array}{lllllllllllllllll}\text { QGAFLVNAAR } & 1.00 & 56.69 & 28.07 & 29.00 & 2 & 1189.6754 & 1189.6689 & 595.8417 & 0.0065 & 5.4544 & 5727.876 & 5867.139 & 700.788 & 488.110 & \text { Yes } \\ \text { NTWLYQALR } & 0.99 & 40.57 & 27.56 & 23.31 & 2 & 1307.7134 & 1307.7108 & 654.8627 & 0.0026 & 1.9851 & 6766.749 & 5969.831 & 2837.387 & 34.412 & \text { Yes }\end{array}$ $\begin{array}{lllllllllllllllll} & \text { NTWLYQALR } & 0.99 & 40.57 & 27.56 & 23.31 & 2 & 1307.7134 & 1307.7108 & 654.8627 & 0.0026 & 1.9851 & 6766.749 & 5969.831 & 2837.387 & 340.412 & \text { Yes } \\ \text { NTWLYQALR } & 1.00 & 44.11 & 27.60 & 2828 & 2 & 1307.7140 & 1307.7108 & 654.8627 & 0.0032 & 2.4433 & 2395.049 & 2660.572 & 873.447 & 138.721 & \text { Yes }\end{array}$

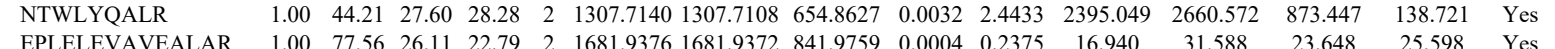

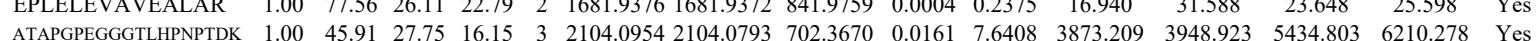
\begin{tabular}{llllllllllllllll} 
ATAPGPGGGGTLPPNPTDK & 1.00 & 45.91 & 27.75 & 16.15 & 3 & 2104.0954 & 2104.0793 & 702.3670 & 0.0161 & 7.6408 & 3873.209 & 3948.923 & 5434.803 & 6210.278 & Yes \\
\hline
\end{tabular}

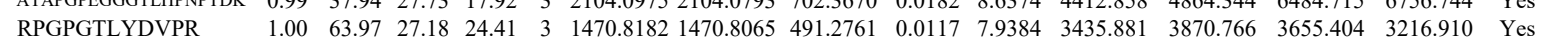
RPGPTLYDVR

GSNSLPLLR

GSNSLPLLR

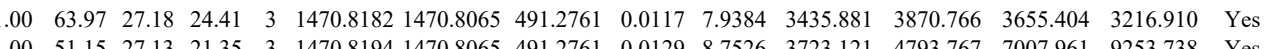

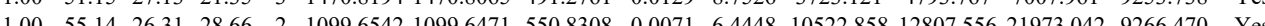
$\begin{array}{lllllllllllllllll}0.99 & 44.41 & 26.44 & 29.79 & 2 & 1099.6550 & 1099.6471 & 550.8308 & 0.0079 & 7.1709 & 10198.279 & 9818.337 & 18509.228 & 6946.164 & \text { Yes }\end{array}$ 

$\begin{array}{lllllllllllllll}1.00 & 72.12 & 23.62 & 26.85 & 2 & 1356.8226 & 1356.8210 & 679.4178 & 0.0016 & 1.1775 & 1749.213 & 1787.408 & 150.904 & 68.024 & \text { Yes } \\ 1.00 & 67.39 & 28.43 & 31.66 & 2 & 1439.7754 & 1439.7750 & 720.8948 & 0.0004 & 0.2774 & 133.282 & 125.394 & 34.851 & 22.348 & \text { Yes }\end{array}$

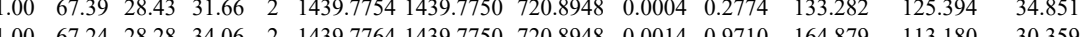

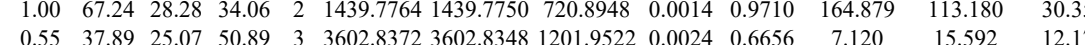

$\begin{array}{llllllllll}34.90 & 25.29 & 47.90 & 4 & 3602.8425 & 3602.8348 & 901.7160 & 0.0077 & 2.1348\end{array}$ $\begin{array}{lllllllllllllll}\text { ALEDITASIAMAVIQQK } & 0.96 & 27.91 & 24.76 & 18.16 & 3 & 2089.1782 & 2089.1696 & 697.3971 & 0.0086 & 4.1105 & 80.123 & 38.748 & 26.613\end{array}$

$\begin{array}{llllllllllll}1.00 & 50.39 & 27.03 & 17.63 & 3 & 2100.1096 & 2100.1057 & 701.0425 & 0.0039 & 1.8544 & 79.881 & 89.473\end{array}$

\section{YLFTLIR}

EPIPL_HUMAN P58107 EPPK1 Epiplakin

$\begin{array}{llllllll}553.09 & 1.00 & 10 & 12.8 & 0.8622 & 0.4739 & 0.4717 & 1.4144\end{array}$
GSAVHQLSEELR

\section{GSAVHQLSEELR}

GFFDPNTHENLTYVQLLR

\begin{tabular}{llllllllllllll}
\hline & 0.00 & 82.23 & 27.76 & 29.48 & 2 & 1829.9820 & 1829.9798 & 915.9972 & 0.0022 & 1.2009 & 136.166 & 209.256 & 25.698
\end{tabular} $\begin{array}{llllllllllllll}0.98 & 34.83 & 28.13 & 27.01 & 2 & 1205.6898 & 1205.6890 & 603.8518 & 0.0008 & 0.6624 & 8451.043 & 7083.707 & 756.080\end{array}$ $\begin{array}{lllllllllllllll}0.98 .01 & 28.22 & 27.81 & 2 & 1205.6900 & 1205.6890 & 603.8518 & 0.0010 & 0.8280 & 14820.037 & 13583.246 & 855.064\end{array}$ $\begin{array}{lllllllllllll}0.98 & 29.26 & 23.89 & 22.29 & 2 & 1068.6476 & 1068.6453 & 535.3299 & 0.0023 & 2.1482 & 6419.763 & 7428.706 & 280.495 \\ 0.93 & 23.80 & 24.22 & 23.88 & 2 & 1068.6462 & 1068.6453 & 535.3299 & 0.0009 & 0.8406 & 1209.385 & 1087.921 & 14.280\end{array}$ $\begin{array}{llllllllllllll}0.93 & 23.80 & 24.22 & 23.88 & 2 & 1068.6462 & 1068.6453 & 535.3299 & 0.0009 & 0.8406 & 1209.385 & 1087.921 & 14.280 \\ 0.98 & 34.86 & 27.59 & 17.75 & 3 & 1468.7857 & 1468.7756 & 490.5991 & 0.0101 & 6.8623 & 390.219 & 646.900 & 425.253\end{array}$ $\begin{array}{lllllllllllll}0.98 & 34.86 & 27.59 & 17.75 & 3 & 1468.7857 & 1468.7756 & 490.5991 & 0.0101 & 6.8623 & 390.219 & 646.900 & 425.253 \\ 1.00 & 40.44 & 27.77 & 16.82 & 3 & 1468.7875 & 1468.7756 & 490.5991 & 0.0119 & 8.0853 & 497.791 & 1165.470 & 344.508\end{array}$

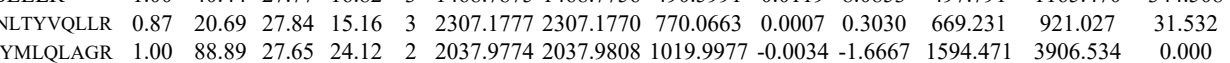

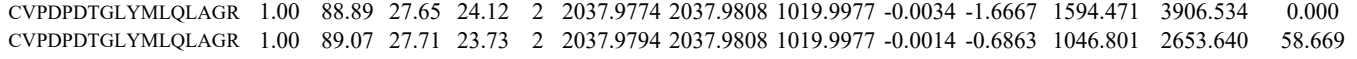

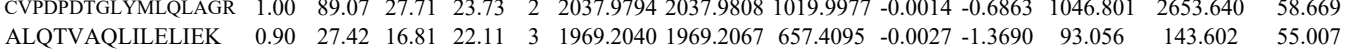

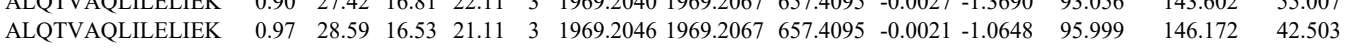

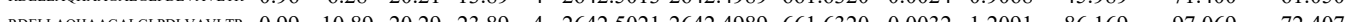
$\begin{array}{llllllllllll} & \end{array}$

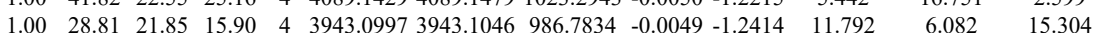
$\begin{array}{llllllllllllll}\text { AVPVWDVLASGYVSGAAR } & 0.55 & 31.29 & 27.47 & 44.29 & 3 & 1961.0512 & 1961.0493 & 654.6904 & 0.0019 & 0.9674 & 26.785 & 38.184 & 14.762\end{array}$ $\begin{array}{llllllllllllll}\text { AGTLTVELGATLTSLAQAQAQAR } & 1.00 & 82.94 & 23.98 & 24.77 & 3 & 2656.4551 & 2656.4517 & 886.4912 & 0.0034 & 1.2784 & 7.818 & 29.545 & 10.279\end{array}$ $\begin{array}{llllllllllllll}\text { AGILVFELGATLSLAQAAAQAR } & 1.00 & 93.45 & 23.89 & 25.14 & 3 & 2656.4560 & 2656.4517 & 886.4912 & 0.0043 & 1.6169 & 0.000 & 45.614 & 33.032\end{array}$ $\begin{array}{llllllllllll}\text { AGTLIVELLGATLSSLAQAQAQAR } & 1.00 & 75.51 & 24.20 & 24.42 & 3 & 2656.4506 & 2656.4517 & 886.4912 & -0.0011 & -0.4136 & 21.259\end{array}$ AGTLTVEELGATLTSLAQAQAQAR TTVPQLLASVQR

3 VLIEGSINSVR

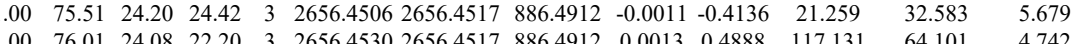

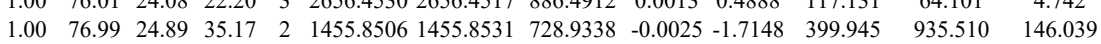

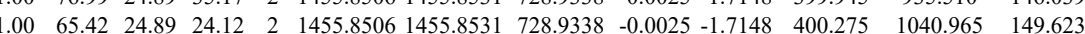
$\begin{array}{llllllllllllllll} & 1.0 & 57.85 & 26.50 & 19.00 & 4 & 3091.6073 & 3091.6054 & 773.9086 & 0.0019 & 0.6138 & 102.644 & 150.414 & 208.175 & 1\end{array}$ $\begin{array}{llllllllllllll}\text { ATLQAALCLENFSSQVVER } & 1.00 & 47.23 & 27.57 & 27.91 & 3 & 2268.1387 & 2268.1364 & 757.0527 & 0.0023 & 1.0127 & 47.107 & 37.738 & 34.880\end{array}$ $\begin{array}{lllllllllllll}1.00 & 60.55 & 27.69 & 28.52 & 2 & 1377.6982 & 1377.6970 & 689.8558 & 0.0012 & 0.8697 & 23.005 & 17.895 & 24.391\end{array}$ SNVSDAVAQSTR SNVSDAVAQSTR SNVSDAVAQSTR SNVSDAVAQSTR SNVSDAVAQSTR $\begin{array}{lllll}0.0016 & 1.1597 & 18.120 & 21.872 & 30.009\end{array}$ 0.000 No

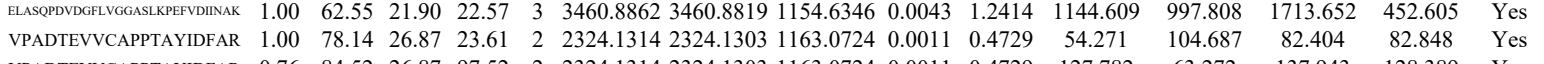
\begin{tabular}{cccccccccccccccc} 
VPADTEVVCAPPTAYIDFAR & 0.76 & 84.52 & 26.87 & 97.52 & 2 & 2324.1314 & 2324.1303 & 1163.0724 & 0.0011 & 0.4729 & 127.782 & 63.272 & 137.943 & 128.389 & Yes \\
\hline
\end{tabular} $\begin{array}{lllllllllllllll} & \end{array}$

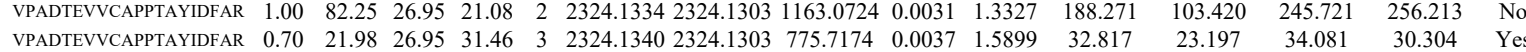
\begin{tabular}{lllllllllllllllll} 
VPADTEVVCAPPTAYIDFAR & 0.51 & 69.64 & 26.99 & 82.64 & 2 & 2324.1414 & 2324.1303 & 1163.0724 & 0.0111 & 4.7718 & 106.977 & 112.692 & 199.731 & 72.264 & Yes \\
\hline
\end{tabular} $\begin{array}{lllllllllllllllll}\text { IAVAAQNCYK } & 1.00 & 52.11 & 27.64 & 23.98 & 2 & 1413.7456 & 1413.7352 & 707.8749 & 0.0104 & 7.3459 & 5431.345 & 4487.837 & 748.841 & 167.389 & \text { Yes } \\ \text { IAVAAQNCYK } & 1.00 & 55.25 & 27.86 & 27.25 & 2 & 1413.7474 & 1413.7352 & 707.8749 & 0.0122 & 8.6173 & 19249.149 & 19843.577 & 1663.993 & 681.323 & \text { Yes }\end{array}$ 
$\begin{array}{llllllllllllll}1.00 & 69.44 & 27.83 & 24.12 & 2 & 1413.7468 & 1413.7352 & 707.8749 & 0.0116 & 8.1935 & 4321.449 & 4275.749 & 493.017\end{array}$

$\begin{array}{llllllllllllll}1.00 & 68.63 & 27.72 & 26.55 & 2 & 1413.7488 & 1413.7352 & 707.8749 & 0.0136 & 9.6061 & 3857.513 & 4234.107 & 519.640 & 11\end{array}$

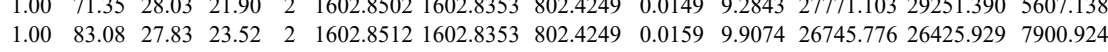

112.363

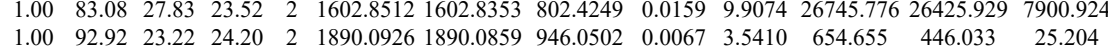

4.346

$\begin{array}{lllllllllllllll}\text { VVLAYEPVWAIGTGK } & 1.00 & 83.88 & 23.05 & 26.30 & 2 & 1890.0938 & 1890.0859 & 946.0502 & 0.0079 & 4.1752 & 12204.185 & 11543.051 & 0.000\end{array}$

$\begin{array}{llllllllllllll}\text { VVLAYEPVWAIGTGK } & 1.00 & 64.55 & 23.05 & 22.50 & 3 & 1890.0940 & 1890.0859 & 631.0359 & 0.0081 & 4.257 & 161.183 & 913.352 & 035.288\end{array}$

VALAYLAEGGVIATIGKK

IAVAAQNCYK

IIYGGSVTGATCK

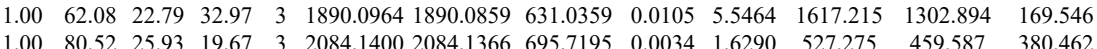

$\begin{array}{lllllllllllll}1.00 & 55.49 & 27.51 & 24.86 & 2 & 1413.7452 & 1413.7352 & 707.8749 & 0.0100 & 7.0633 & 1297.062 & 1271.064 & 147.199\end{array}$

$\begin{array}{llllllllllllll}.00 & 82.93 & 28.06 & 23.32 & 2 & 1602.8486 & 1602.8353 & 802.4249 & 0.0133 & 8.2873 & 35368.877 & 34667.383 & 9117.063 & 16\end{array}$

$\begin{array}{llllllllllllll}.00 & 74.33 & 28.01 & 20.28 & 2 & 1602.8500 & 1602.8353 & 802.4249 & 0.0147 & 9.1597 & 26456.168 & 28507.735 & 6802.704 & 1\end{array}$

$\begin{array}{lllllllllllllll} & & \end{array}$

$\begin{array}{lllllllllllllll}\text { VVLAYEPVWAIGTGK } & 1.00 & 47.07 & 23.38 & 23.08 & 3 & 1890.0913 & 1890.0859 & 631.0359 & 0.0054 & 2.8524 & 705.067 & 531.947 & 103.470 & 100\end{array}$

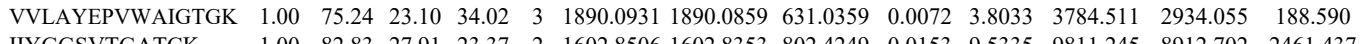

IIYGGSVTGATCK

TATPQQAQEVHEK $\begin{array}{lllllllllllll}1.00 & 54.02 & 27.99 & 19.48 & 3 & 1753.9210 & 1753.9202 & 585.6473 & 0.0008 & 0.4553 & 28.632 & 44.720\end{array}$

VLAYEPVWAIGTGK

$\begin{array}{llllllllllll}0.95 & 20.70 & 23.38 & 17.00 & 3 & 1890.0913 & 1890.0859 & 631.0359 & 0.0054 & 2.8524 & 407.588 & 224.111\end{array}$

TATPQQAQEVHEK

TATPQQAQEVHEK

TATPQQAQEVHEK

TATPQQAQEVHEK

TATPQQAQEVH

FFVGGNWK

TATPQQAQEVHEK

FFVGGNWK

TATPQQAQEVHEK

TATQQAQE

FFVGGNWK

TATPQQAQEVHEK

TATPQQAQEVHEK

TATPQQAQEVHEK

TATPQQAQEVHEK

TATPQQAQEVHEK

TATPQQAQEVHEK

TATPQQAQEVHEK

SNVSDAVAQSTR

TATPQQAQEVHEK

SNVSDAVAQSTR

SNVSDAVAQSTR

SNVSDAVAQSTR

SNVSDAVAQSTR

TATPQQAQEVHEK

SNVSDAVAQSTR

SNVSDAVAQSTR

TATPQQAQEVHEK

TATPQQAQEVHEK

TATPQQAQEVHEK

TATPQQAQEVHEK

HVFGESDELIGQK

HVFGESDELIGQK

HVFGESDELIGQK

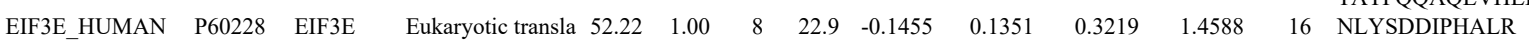

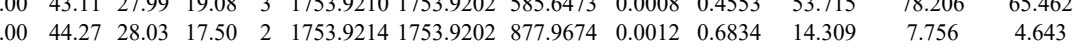

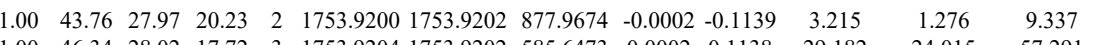

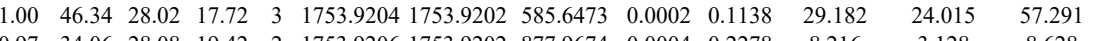

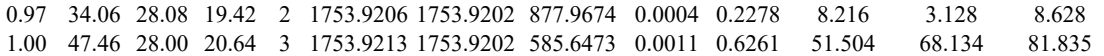

$\begin{array}{lllllllllllll}1.00 & 47.46 & 28.00 & 20.64 & 3 & 1753.9213 & 1753.9202 & 585.6473 & 0.0011 & 0.6261 & 51.504 & 68.134 & 81.835 \\ 0.92 & 30.14 & 26.23 & 20.97 & 2 & 1241.6908 & 1241.6801 & 621.8473 & 0.0107 & 8.6033 & 62144.961 & 54252.893 & 0.000 \\ 1.00 & 48.72 & 27.87 & 9.38 & 3 & 1753.9219 & 1753.9202 & 585.643 & 0.007 & 0.9676 & 31.68 & 34.672 & 22.22\end{array}$

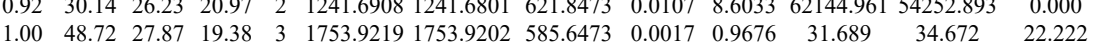

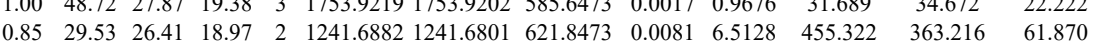

$\begin{array}{lllllllllllll}1.00 & 51.30 & 27.99 & 19.42 & 3 & 1753.9210 & 1753.9202 & 585.6473 & 0.0008 & 0.4553 & 51.341 & 47.263 & 30.871\end{array}$

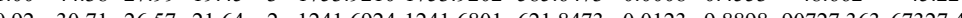

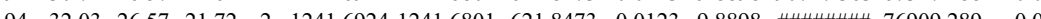

$\begin{array}{llllllllllllll}0.9 & 0.000\end{array}$

$\begin{array}{lllllllllllll}1.00 & 65.97 & 28.03 & 20.38 & 3 & 1753.9216 & 1753.9202 & 585.6473 & 0.0014 & 0.7968 & 30.646 & 33.378 & 23.850\end{array}$

$\begin{array}{lllllllllllll}1.00 & 42.30 & 28.08 & 22.07 & 3 & 1753.9207 & 1753.9202 & 585.6473 & 0.0005 & 0.2846 & 19.201 & 36.149 & 31.806\end{array}$

$\begin{array}{lllllllllllll}100 & 54.61 & 28.00 & 18.60 & 3 & 1753.9213 & 1753.9202 & 585.6473 & 0.0011 & 0.6261 & 52.387 & 54.007 & 48.468\end{array}$

$\begin{array}{lllllllllllll}1.00 & 32.93 & 27.96 & 15.68 & 3 & 1753.9225 & 1753.9202 & 585.6473 & 0.0023 & 1.3091 & 15.339 & 22.109 & 18.142\end{array}$

$\begin{array}{llllllllllll}1.00 & 45.46 & 28.03 & 19.54 & 3 & 1753.9216 & 1753.9202 & 585.6473 & 0.0014 & 0.7968 & 37.321\end{array}$

$\begin{array}{lllllllllll}0.55 & 30.76 & 27.96 & 43.76 & 3 & 1753.9225 & 1753.9202 & 585.6473 & 0.0023 & 1.3091 & 24.505\end{array}$

$\begin{array}{llllllllllll}1.00 & 52.52 & 27.55 & 22.75 & 2 & 1377.6970 & 1377.6970 & 689.8558 & 0.0000 & 0.0000 & 45.039\end{array}$

$\begin{array}{lllllllllll}0.99 & 28.05 & 27.96 & 17.40 & 3 & 1753.9225 & 1753.9202 & 585.6473 & 0.0023 & 1.3091 & 17.408\end{array}$

$\begin{array}{lllllllllll}.00 & 55.57 & 27.60 & 23.86 & 2 & 1377.6976 & 1377.6970 & 689.8558 & 0.0006 & 0.4349 & 30.664\end{array}$

$\begin{array}{lllllllllll}.00 & 52.84 & 27.57 & 24.97 & 2 & 1377.6974 & 1377.6970 & 689.8558 & 0.0004 & 0.2899 & 19.633\end{array}$

$\begin{array}{lllllllllll}1.00 & 43.26 & 27.57 & 25.24 & 2 & 1377.6974 & 1377.6970 & 689.8558 & 0.0004 & 0.2899 & 8.422\end{array}$

$\begin{array}{lllllllllll}0.89 & 19.72 & 27.87 & 16.37 & 3 & 1753.9219 & 1753.9202 & 585.6473 & 0.0017 & 0.9676 & 11.223\end{array}$

$\begin{array}{lllllllllll}1.00 & 66.38 & 27.60 & 21.37 & 2 & 1377.6976 & 1377.6970 & 689.8558 & 0.0006 & 0.4349 & 26.267\end{array}$

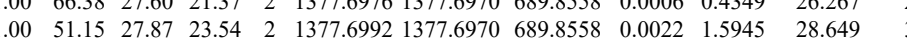

$\begin{array}{lllllllll} & \end{array}$

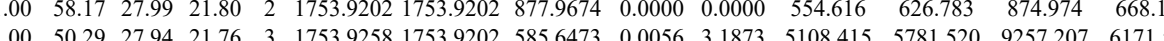

$\begin{array}{lllllllllllllll}1.00 & 5.29 & 27.94 & 21.76 & 3 & 1753.9258 & 1753.9202 & 585.6473 & 0.0056 & 3.1873 & 5108.415 & 5781.520 & 9257.207 & 6171.546 & \text { Yes }\end{array}$

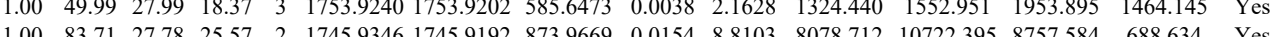
$\begin{array}{lllllllllllllll}1.00 & 84.31 & 27.78 & 25.57 & 2 & 1745.9346 & 1745.9192 & 873.9669 & 0.0154 & 8.8103 & 8078.712 & 10722.395 & 8737.584 & 688.634 & \text { Yes }\end{array}$ $\begin{array}{llllllllllllllll}1.00 & 65.01 & 27.87 & 27.84 & 2 & 1745.9352 & 1745.9192 & 873.9669 & 0.0160 & 9.1536 & 11786.127 & 14847.465 & 11916.567 & 1665.772 & \text { Yes } \\ 1.00 & 48.12 & 27.99 & 19.40 & 3 & 1753.920 & 1745.9192 & 873.969 & 0.0168 & 9.6113 & 1168.759 & 1424.841 & 1195.338 & 161.867 & \text { Yes }\end{array}$ $\begin{array}{lllllllllllllll}1.00 & 48.12 & 27.99 & 19.40 & 3 & 1753.9240 & 1753.9202 & 585.6473 & 0.0038 & 2.1628 & 894.447 & 1022.782 & 1023.792 & 1004.547 & \text { Yes }\end{array}$

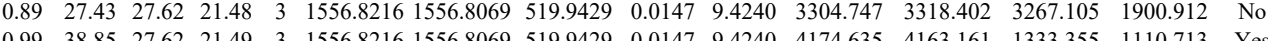


$\begin{array}{lllllllllllllll}\text { VAPEEHPVLLTEAPLNPK } & 0.93 & 17.21 * 23.48 & 24.97 & 4 & 2241.2657 & 2241.2612 & 561.3226 & 0.0045 & 2.0042 & 192.440 & 210.581 & 149.930 & 147.718 & \text { Yes }\end{array}$

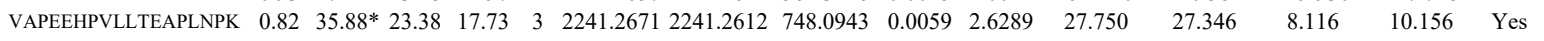
$\begin{array}{lllllllllllllllll}\text { LCYVALDFEQEMATAASSSLEKK } & 0.94 & 33.64 & 26.36 & 17.84 & 3 & 2826.3325 & 2826.3369 & 943.1196 & -0.0044 & -1.5551 & 24.599 & 15.397 & 18.548 & 8.965 & \text { Yes }\end{array}$

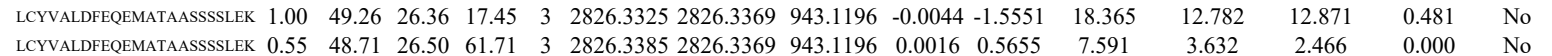

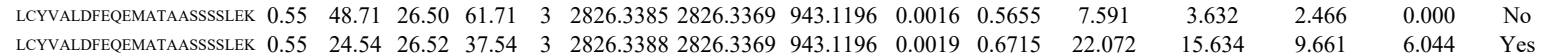

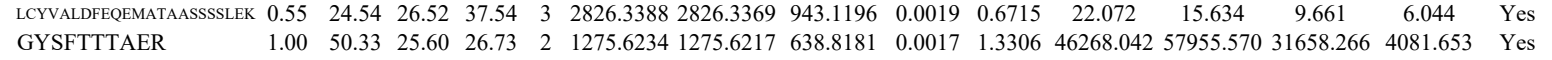

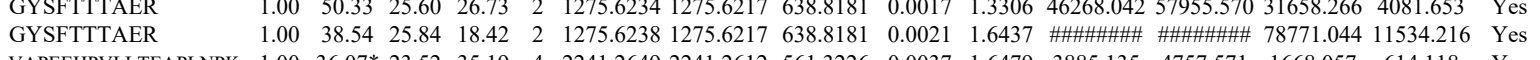
$\begin{array}{lllllllllllllll}\text { VAPEEHPVLLTEAPLNPK } & 1.00 & 36.07 * 23.52 & 35.19 & 4 & 2241.2649 & 2241.2612 & 561.3226 & 0.0037 & 1.6479 & 3885.135 & 4757.571 & 1668.057 & 614.118 & \text { Yes } \\ \text { VAPE } & & \end{array}$

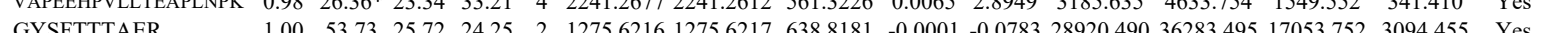

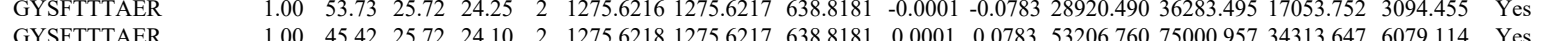

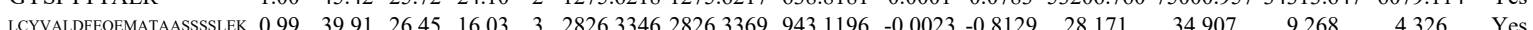

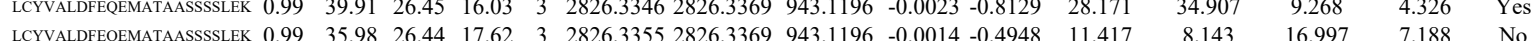

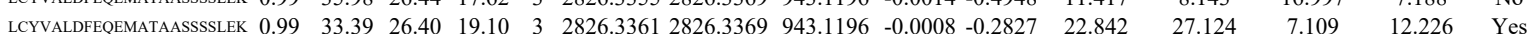

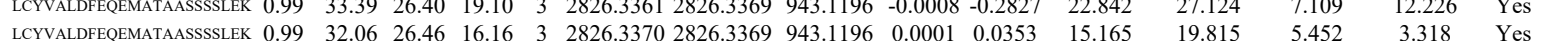

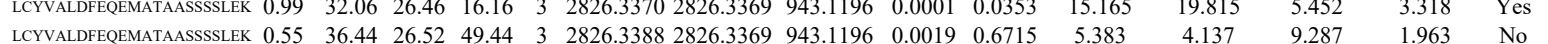

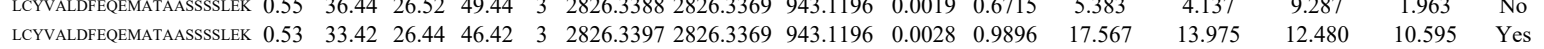

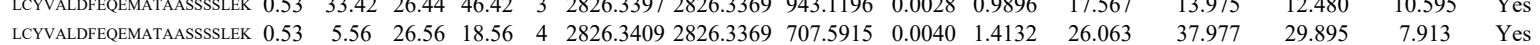

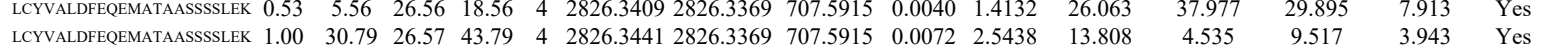

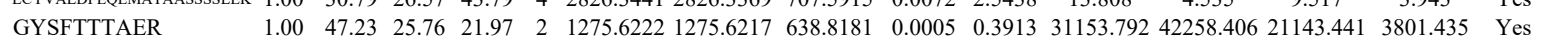
$\begin{array}{llllllllllllllll}\text { GYSFTTTAER } & 1.00 & 48.16 & 25.69 & 22.00 & 2 & 1275.6230 & 1275.6217 & 638.8181 & 0.0013 & 1.0175 & 45830.592 & 54886.143 & 27802.262 & 5109.621 & \text { Yes }\end{array}$ $\begin{array}{llllllllllllllll}\text { LCYVALDFEQEMATAASSSSLEK } & 0.99 & 42.30 & 26.39 & 16.13 & 3 & 2826.3331 & 2826.3369 & 943.1196 & -0.0038 & -1.3431 & 2.360 & 5.617 & 1.731 & 0.000 & \text { No }\end{array}$

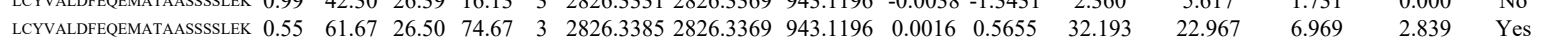

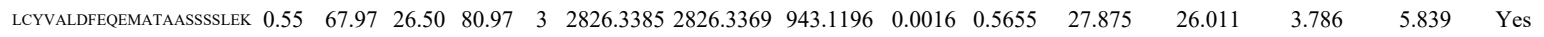
$\begin{array}{lllllllllllllllll}\text { LCYVALDFEQEMATAASSSLEK } & 0.55 & 55.97 & 26.52 & 68.97 & 3 & 2826.3388 & 2826.3369 & 943.1196 & 0.0019 & 0.6715 & 12.078 & 26.217 & 8.866 & 6.165 & \text { Yes }\end{array}$

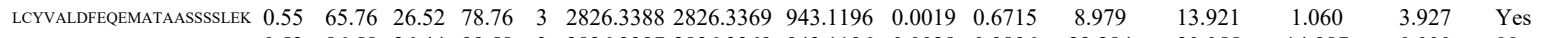

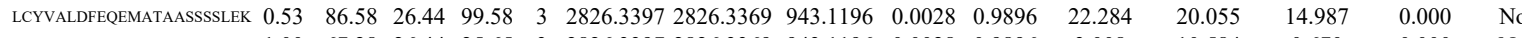
$\begin{array}{llllllllllllllll}\text { LCYVALDFEQEMATAASSSSLEK } & 1.00 & 67.28 & 26.44 & 25.65 & 3 & 2826.3397 & 2826.3369 & 943.1196 & 0.0028 & 0.9896 & 3.008 & 10.584 & 0.670 & 0.000 & \text { No }\end{array}$ $\begin{array}{lllllllllllllllll}\text { LCYVALDFEQEMATAASSSSLEK } & 1.00 & 42.23 & 26.44 & 17.28 & 4 & 2826.3397 & 2826.3369 & 707.5915 & 0.0028 & 0.9893 & 28.481 & 36.767 & 9.249 & 10.835 & \text { Yes }\end{array}$ $\begin{array}{llllllllllllllll}\text { LCYVALDFEQEMATAASSSSLEK } & 1.00 & 31.80 & 26.55 & 16.01 & 4 & 2826.3401 & 2826.3369 & 707.5915 & 0.0032 & 1.1306 & 11.869 & 9.652 & 13.717 & 3.244 & \text { Yes }\end{array}$ $\begin{array}{lllllllllllllllll}\text { LCYVALDFEQEMATAASSSSLEK } & 1.00 & 40.89 & 26.55 & 20.30 & 4 & 2826.3401 & 2826.3369 & 707.5915 & 0.0032 & 1.1306 & 11.027 & 23.493 & 7.250 & 6.466 & \text { Yes }\end{array}$

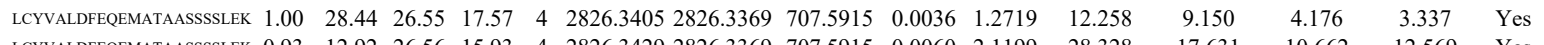

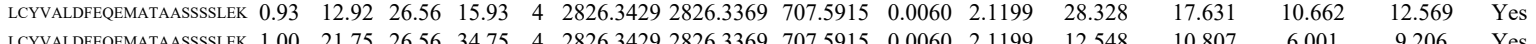
$\begin{array}{lllllllllllllll} & \end{array}$

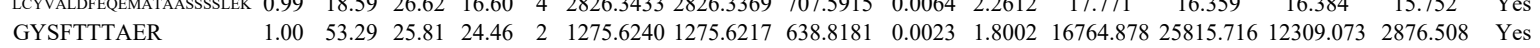

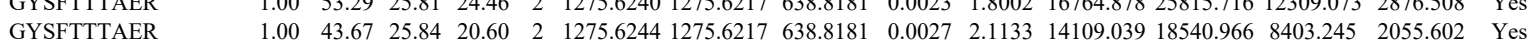

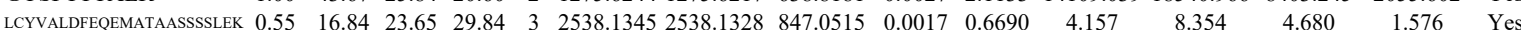

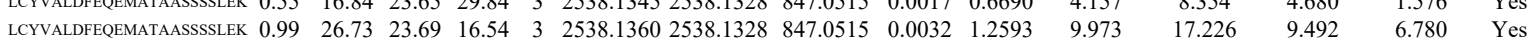

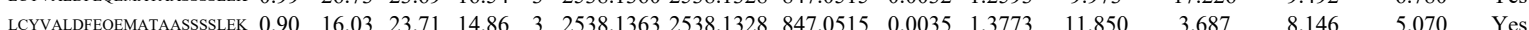

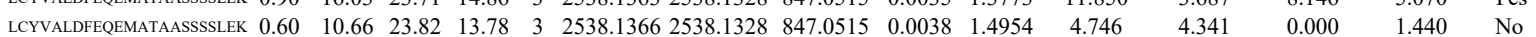
$\begin{array}{lllllllllllllllll}\text { LCYVALDFEOFMATAASSSSIEK } & 1.00 & 33.59 & 26.56 & 20.24 & 4 & 2826.3409 & 2826.3369 & 707.5915 & 0.0040 & 1.4132 & 29.666 & 17.978 & 10.212 & 0.976 & \text { No }\end{array}$

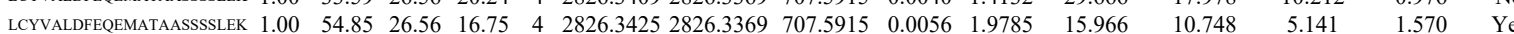
$\begin{array}{llllllllllllllll}\text { LCYVALDFEQEMATAASSSSLEK } & 1.00 & 31.09 & 26.56 & 16.11 & 4 & 2826.3429 & 2826.3369 & 707.5915 & 0.0060 & 2.1199 & 27.864 & 56.125 & 0.198 & 7.532 & \text { No }\end{array}$ $\begin{array}{llllllllllllllll}\text { LCYVALDFEOEMATAASSSSLEK } & 1.00 & 39.79 & 26.62 & 52.79 & 4 & 2826.3433 & 2826.3369 & 707.5915 & 0.0064 & 2.2612 & 22.523 & 15.601 & 13.043 & 5.102 & \text { Yes }\end{array}$

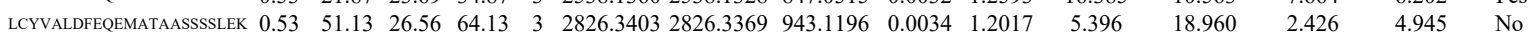
$\begin{array}{llllllllllllllll}\text { LCYVALDFEQEMATAASSSSLEK } & 1.00 & 44.80 & 26.57 & 21.02 & 4 & 2826.3421 & 2826.3369 & 707.5915 & 0.0052 & 1.8372 & 44.010 & 58.038 & 4.323 & 6.210 & \text { Yes }\end{array}$

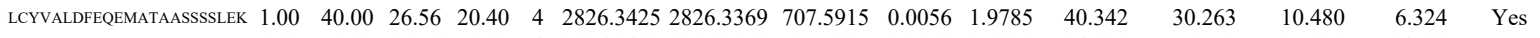
$\begin{array}{llllllllllllll}\text { GYSFTTTAER } & 0.89 & 23.12 & 25.84 & 19.31 & 2 & 1275.6238 & 1275.6217 & 638.8181 & 0.0021 & 1.6437 & 22.124 & 38.59\end{array}$ $\begin{array}{lllllllllllll}\text { VAPEEHPVLLTEAPLNPK } & 1.00 & 55.55 * & 23.48 & 59.07 & 4 & 2241.2641 & 2241.2612 & 561.3226 & 0.0029 & 1.2916 & 46.782 & 43.918\end{array}$ GYSFTTTAER $\begin{array}{lllllllllllll}\text { GYSFTTTAER } & 1.00 & 49.72 & 25.87 & 18.92 & 2 & 1275.6262 & 1275.6217 & 638.8181 & 0.0045 & 3.5221 & 27987.898 & 28936.2\end{array}$

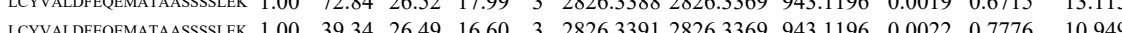

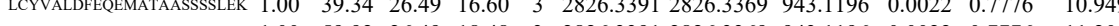
$\begin{array}{lllllllllllll}\text { LCYVALDFEQEMATAASSSSLEK } & 1.00 & 59.92 & 26.49 & 18.48 & 3 & 2826.3391 & 2826.3369 & 943.1196 & 0.0022 & 0.7776 & 11.203\end{array}$ $\begin{array}{lllllllllllll}\text { LCYVALDFEQEMATAASSSSLEK } & 1.00 & 64.27 & 26.49 & 19.78 & 3 & 2826.3391 & 2826.3369 & 943.1196 & 0.0022 & 0.7776 & 8.436\end{array}$ $\begin{array}{llllllllllll}\text { LCYVALDFEQEMATAASSSSLEK } & 0.53 & 41.45 & 26.44 & 54.45 & 3 & 2826.3397 & 2826.3369 & 943.1196 & 0.0028 & 0.9896 & 4.257 \\ \text { LCYVALDFEOEMATAASSSLEK } & 0.53 & 61.05 & 26.56 & 74.05 & 3 & 2826.3403 & 2826.3369 & 943.1196 & 0.0034 & 1.2017 & 7.779\end{array}$

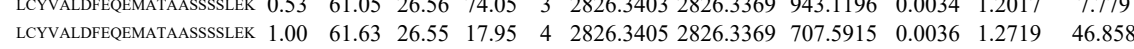
$\begin{array}{llllllllllll}\text { LCYVALDFEQEMATAASSSSLEK } & 1.00 & 62.29 & 26.55 & 75.29 & 4 & 2826.3405 & 2826.3369 & 707.5915 & 0.0036 & 1.2719 & 22.30\end{array}$

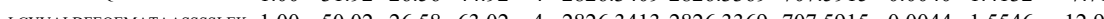
LCYvald 

$\begin{array}{llllllllllll}\text { CPEALFPPFLLMEESGIHETTFNSIMK } & 1.00 & 43.94 & 23.69 & 18.09 & 3 & 3496.5952 & 3496.5911 & 1166.5376 & 0.0041 & 1.1716 & 40.014\end{array}$

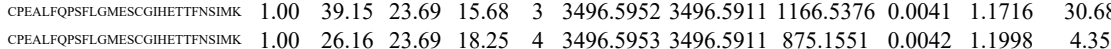
$\begin{array}{lllllllllllll}\text { CPEALFPSFLGMESCGIHETTNNSIMK } & 1.00 & 19.69 & 23.75 & 17.26 & 4 & 3496.5957 & 3496.5911 & 875.1551 & 0.0046 & 1.3141 & 5.452\end{array}$

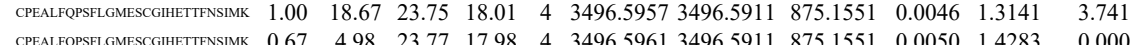
$\begin{array}{lllllllllllll}\text { CPEALFPPSELGMESCGIHETTFNIMK } & 0.67 & 4.98 & 23.77 & 17.98 & 4 & 3496.5961 & 3496.5911 & 875.1551 & 0.0050 & 1.4283 & 0.000\end{array}$ $\begin{array}{lllllllllllll}\text { CPEALFPPSELGMESCGHETTFNSIMK } & 1.00 & 22.35 & 23.73 & 35.35 & 4 & 3496.5965 & 3496.5911 & 875.1551 & 0.0054 & 1.5426 & 146.684\end{array}$

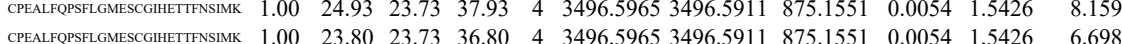
$\begin{array}{llllllllllll}\text { CPALLFPSELGMESCGIHETTRNSIMK } & 1.00 & 23.80 & 23.73 & 36.80 & 4 & 3496.5965 & 3496.5911 & 875.1551 & 0.0054 & 1.5426 & 6.698 \\ \text { CPEALFPSELGMESGIHETTNNSIMK } & 1.00 & 20.89 & 23.87 & 14.51 & 4 & 3496.5973 & 3496.5911 & 875.1551 & 0.0062 & 1.7711 & 5.385\end{array}$ \begin{tabular}{lllllllllllll} 
CPANFPPSLGMESCGHETTFNIMK & 1.00 & 20.89 & 23.87 & 14.51 & 4 & 3496.5973 & 3496.5911 & 875.1551 & 0.0062 & 1.7711 & 5.385 \\
\hline
\end{tabular}

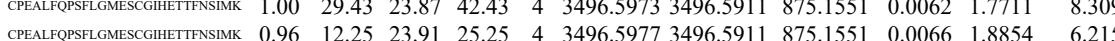

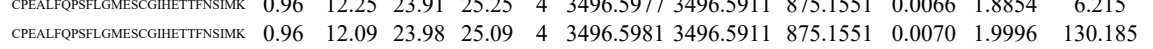
$\begin{array}{lllllllllllll}\text { CPEALFPPSLLGMESCGHETTFNSIMK } & 0.99 & 32.19 & 23.98 & 15.15 & 3 & 3496.5982 & 3496.5911 & 1166.5376 & 0.0071 & 2.0288 & 954.475\end{array}$ $\begin{array}{lllllllllllll}\text { CPEALFPPSELGMESCGHETTPNSIMK } & 0.97 & 13.11 & 23.98 & 26.11 & 4 & 3496.5985 & 3496.5911 & 875.1551 & 0.0074 & 2.1139 & 98.33\end{array}$

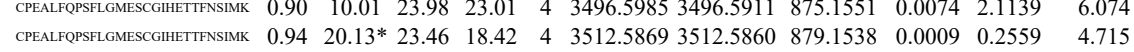

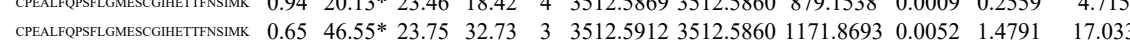

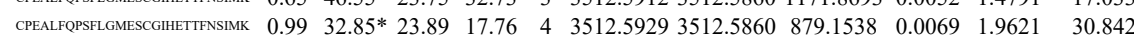

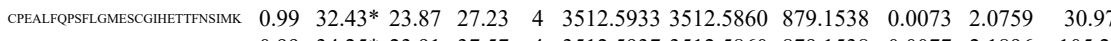

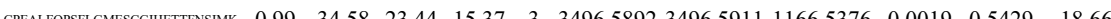

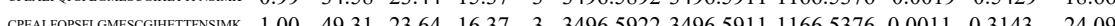

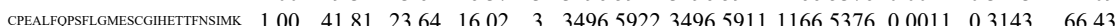

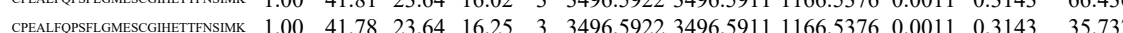
$\begin{array}{lllllllllllll}\text { CPEA FFPSFLCMEGGIHETTPSIMK } & 1.00 & 30.04 & 23.64 & 15.91 & 3 & 3496.5922 & 3496.5911 & 1166.5376 & 0.0011 & 0.3143 & 23.086\end{array}$ $\begin{array}{llllllllllllll}\text { CPEALFPPSELGMESCGHETTFNSIMK } & 1.00 & 41.07 & 23.64 & 17.22 & 3 & 3496.5922 & 3496.5911 & 1166.5376 & 0.0011 & 0.3143 & 14.076\end{array}$ $\begin{array}{llllllllllllll}\text { CPEALFOPSELGMESCGHETTPNSIMK } & 0.96 & 9.85 & 23.58 & 14.34 & 4 & 3496.5933 & 3496.5911 & 875.1551 & 0.0022 & 0.6285 & 18.409\end{array}$ $\begin{array}{llllllllllll}\text { CPEALFPPSELGMESCGHETTFNSIMK } & 0.99 & 29.36 * & 23.58 & 15.58 & 4 & 3496.5933 & 3496.5911 & 875.1551 & 0.0022 & 0.6285 & 8.020\end{array}$ $\begin{array}{lllllllllllll}\text { CPEALFPPSELGMESCGHETTFNIMK } & 0.99 & 13.58 & 23.58 & 26.58 & 4 & 3496.5937 & 3496.5911 & 875.1551 & 0.0026 & 0.7427 & 11.463\end{array}$ $\begin{array}{lllllllllllll}\text { CPEALFPSFLGMESGGHETTPNSIMK } & 1.00 & 16.07 & 23.64 & 29.07 & 4 & 3496.5945 & 3496.5911 & 875.1551 & 0.0034 & 0.9713 & 4.545\end{array}$ $\begin{array}{llllllllllll}\text { CPEALFPSFLGMESGGHETTFNIMK } & 0.98 & 24.60 * & 23.69 & 16.89 & 4 & 3496.5949 & 3496.5911 & 875.1551 & 0.0038 & 1.0855 & 4.537\end{array}$ $\begin{array}{llllllllllll}\text { CPEALFPSFLGMESGGHETTFNIMK } & 0.99 & 14.28 & 23.69 & 27.28 & 4 & 3496.5949 & 3496.5911 & 875.1551 & 0.0038 & 1.0855 & 6.636\end{array}$ $\begin{array}{llllllllllll}\text { CPEALFPPELGMESCGIHETTNNSIMK } & 1.00 & 48.88 & 23.69 & 17.04 & 3 & 3496.5952 & 3496.5911 & 1166.5376 & 0.0041 & 1.1716 & 9.698\end{array}$ $\begin{array}{lllllllllllll}\text { CPEALFPSFLGMESCGIHETTFNSIMK } & 0.93 & 8.76 & 23.69 & 15.94 & 4 & 3496.5953 & 3496.5911 & 875.1551 & 0.0042 & 1.1998 & 12.890\end{array}$ $\begin{array}{llllllllllll}\text { CPEALFPPSELGMESCGIHETTFNSIMK } & 1.00 & 18.65 & 23.77 & 31.65 & 4 & 3496.5961 & 3496.5911 & 875.1551 & 0.0050 & 1.4283 & 18.188\end{array}$

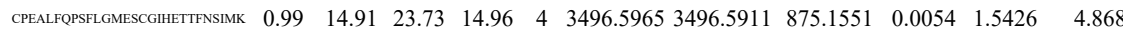
$\begin{array}{lllllllllllll}\text { CPEALFPPSLLGMESGIHETTFNSIMK } & 1.00 & 23.67 & 23.91 & 36.67 & 4 & 3496.5977 & 3496.5911 & 875.1551 & 0.0066 & 1.8854 & 1.158\end{array}$ $\begin{array}{llllllllllll}\text { CPEALFPPELGMESCGHETTPNSIMK } & 1.00 & 43.97 & 23.98 & 16.40 & 3 & 3496.5982 & 3496.5911 & 1166.5376 & 0.0071 & 2.0288 & 675.607\end{array}$

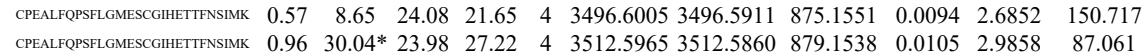
$\begin{array}{llllllllllll}\text { CPEALFPPSELGMESCGHETTFNSIMK } & 0.96 & 30.04 * & 23.98 & 27.22 & 4 & 3512.5965 & 3512.5860 & 879.1538 & 0.0105 & 2.9858 & 87.061 \\ \text { VAPEFHPVLLTEAPLNPK } & 0.99 & 27.67 * & 23.48 & 32.41 & 4 & 2241.2641 & 2241.2612 & 561.3226 & 0.0029 & 1.2916 & 25.122\end{array}$

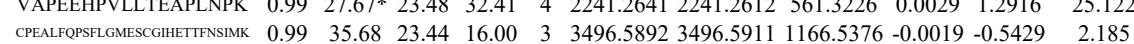

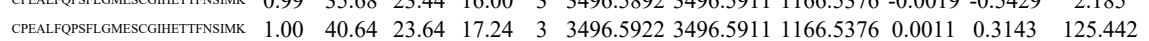
$\begin{array}{llllllllllll}\text { CPEALFPSFLGMESGGHETTFNSIMK } & 1.00 & 30.26 & 23.64 & 17.35 & 3 & 3496.5922 & 3496.5911 & 1166.5376 & 0.0011 & 0.3143 & 5.463\end{array}$

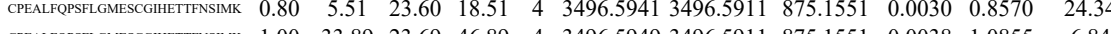




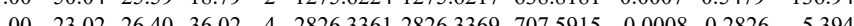
$\begin{array}{rrrrrrrrrrr}1.00 & 50.90 & 25.59 & 23.10 & 2 & 1275.6224 & 1275.6217 & 638.8181 & 0.0007 & 0.5479 & 172.256\end{array}$

$\begin{array}{llllllllllll}1.00 & 46.33 & 25.71 & 21.32 & 2 & 1275.6228 & 1275.6217 & 638.8181 & 0.0011 & 0.8610 & 156.639 & 244 \\ 1.00 & 48.35 & 25.77 & 21.84 & 2 & 1275.6220 & 1275.6217 & 638.8181 & 0.0003 & 0.2348 & 395.260 & 456\end{array}$ $\begin{array}{lllllllllll}44.69 & 25.77 & 22.09 & 2 & 1275.6220 & 1275.6217 & 638.8181 & 0.0003 & 0.2348 & 141.160 & 1\end{array}$ $\begin{array}{lllllllllllll}1.00 & 45.09 & 25.59 & 27.15 & 2 & 1275.6224 & 1275.6217 & 638.8181 & 0.0007 & 0.5479 & 341.776 & 398 . \\ 1.00 & 46.74 & 25.59 & 16.09 & 2 & 1275.6224 & 1275.6217 & 638.8181 & 0.0007 & 0.5479 & 249.219 & 388 .\end{array}$

\section{GYSFTTTAER} $\begin{array}{llllllllllll}0.78 & 18.76 & 28.31 & 15.74 & 3 & 2358.1660 & 2358.1647 & 787.0622 & 0.0013 & 0.5506 & 6.660\end{array}$

GYYSFTTTAER

DLYANTVLSGGTTM

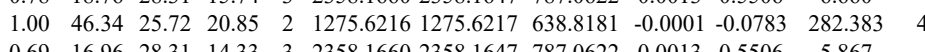

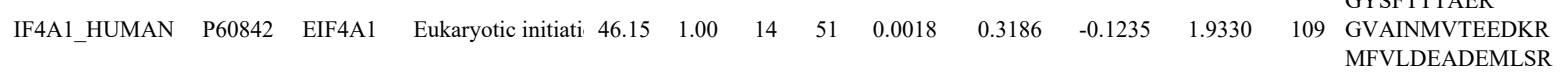
MFVLDEADEMLSR
GVAINMVTEEDKR GVAINMVTEEDKR GVAINMVTEEDKR GVAINMVTEEDKR GVAINMVTEEDKR GVAINMVTEEDKR GVAINMVTEEDKR GVAINMVTEEDKR GVAINMVTEEDKR GVAINMVTEEDKR GVAINMVTEEDKR GVAINMVTEEDKR ELAQQIQK ELAQQIQK KEELTLEGIR KEELTLEGIR

KEELTLEGIR

KEELTLEGIR

MFVLDEADEMLSR MFVLDEADEMLSR MFVLDEADEMLSR MFVLDEADEMLSR MFVLDEADEMLSR MFVLDEADEMLSR MFVLDEADEMLSR MFVLDEADEMLSR GVAINMVTEEDKR GVAINMVTEEDKR $\begin{array}{lllllllllllll}0.99 & 39.43 & 25.72 & 20.52 & 2 & 1275.6218 & 1275.6217 & 638.8181 & 0.0001 & 0.0783 & 208.764\end{array}$ $\begin{array}{lllllllllllll}0.99 & 39.43 & 25.72 & 20.52 & 2 & 1275.6218 & 1275.6217 & 638.8181 & 0.0001 & 0.0783 & 208.764 & 285.338 & 142.84 \\ 0.95 & 26.70 & 28.33 & 15.38 & 3 & 2358.1648 & 2358.1647 & 787.0622 & 0.0001 & 0.0424 & 7.839 & 19.415 & 6.347 \\ 1.00 & 39.64 & 25.69 & 17.82 & 2 & 1275.6230 & 1275.6217 & 638.8181 & 0.0013 & 1.0175 & 60.508 & 97.773 & 64.933\end{array}$ $\begin{array}{llllllllllllll}1.00 & 32.86 & 27.79 & 24.64 & 3 & 1748.9359 & 1748.9334 & 583.9851 & 0.0025 & 1.4270 & 23.041 & 19.903 & 8.512\end{array}$ $\begin{array}{lllllllllllll}1.00 & 71.74 & 26.41 & 25.59 & 2 & 1698.8098 & 1698.8079 & 850.4112 & 0.0019 & 1.1171 & 973.387 & 944.714 & 15.231\end{array}$ $\begin{array}{lllllllllllll}1.00 & 79.26 & 26.32 & 32.36 & 2 & 1698.8110 & 1698.8079 & 850.4112 & 0.0031 & 1.8226 & 11607.836 & 10461.375 & 0.000 \\ 0.84 & 24.80 & 27.80 & 17.67 & 3 & 1748.9329 & 1748.9334 & 583.9851 & -0.0005 & -02854 & 99.060 & 102.417 & 66.385\end{array}$

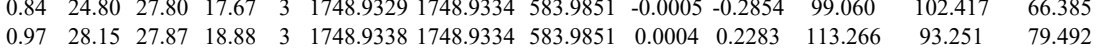

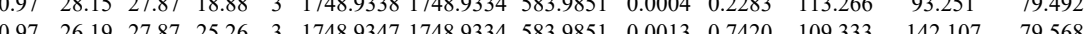

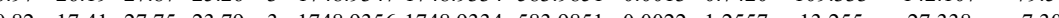

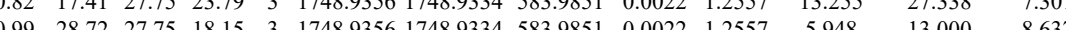
$\begin{array}{lllllllllllll}0.95 & 22.78 & 27.66 & 21.84 & 3 & 1748.9365 & 1748.9334 & 583.9851 & 0.0031 & 1.7694 & 117.770 & 109.426 & 80.150\end{array}$ $\begin{array}{llllllllllllll}0.84 & 19.31 & 27.78 & 21.95 & 3 & 1748.9371 & 1748.9334 & 583.9851 & 0.0037 & 2.1119 & 97.325 & 94.502 & 80.1505\end{array}$ $\begin{array}{llllllllllllll}0.79 & 23.10 & 27.61 & 23.34 & 3 & 1748.9404 & 1748.9334 & 583.9851 & 0.0070 & 3.9955 & 144.788 & 145.777 & 115.498 & 92.04\end{array}$

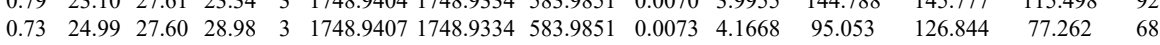
$\begin{array}{lllllllllllllll}1.00 & 80.41 & 27.53 & 31.25 & 2 & 1748.9466 & 1748.9334 & 875.4740 & 0.0132 & 7.5387 & 1312.673 & 1027.092 & 685.457 & 461.616\end{array}$ $\begin{array}{llllllllllllllll}1.00 & 78.61 & 27.40 & 30.05 & 2 & 1748.9484 & 1748.9334 & 875.4740 & 0.0150 & 8.5667 & 656.732 & 654.274 & 320.100 & 301.360 & Y e s\end{array}$ $\begin{array}{lllllllllllllll}1.00 & 59.74 & 27.38 & 26.52 & 3 & 1748.9488 & 1748.9334 & 583.9851 & 0.0154 & 8.7901 & 13633.525 & 13608.819 & 9321.210 & 7961.717 & \text { Yes }\end{array}$

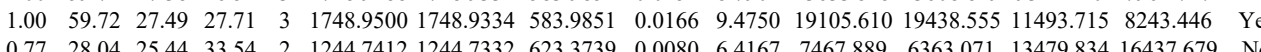
$\begin{array}{llllllllllllllll}0.77 & 28.04 & 25.44 & 33.54 & 2 & 1244.7412 & 1244.7332 & 623.3739 & 0.0080 & 6.4167 & 7467.889 & 6363.071 & 13479.834 & 16437.679 & \text { No } \\ 0.56 & 2.63 & 25.42 & 33.18 & 2 & 1244.7422 & 1244.7332 & 623.3739 & 0.0090 & 7.2187 & 14095.065 & 10991.336 & 22145.806 & 23194.424 & \text { No }\end{array}$ $\begin{array}{llllllllllllllll}0.56 & 22.63 & 25.42 & 33.18 & 2 & 1244.7422 & 1244.7332 & 623.3739 & 0.0090 & 7.2187 & 14095.065 & 10991.336 & 22145.806 & 23194.424 & \text { No } \\ 0.87 & 23.33 & 25.25 & 18.80 & 3 & 1474.8706 & 1474.8598 & 492.6272 & 0.0108 & 7.3077 & 100.865 & 116.179 & 105.602 & 117.533 & \text { No }\end{array}$ $\begin{array}{lllllllllllllll}1.00 & 49.26 & 25.45 & 24.06 & 2 & 1474.8724 & 1474.8598 & 738.4372 & 0.0126 & 8.5315 & 11663.512 & 11444.228 & 1822.387 & 160.778 & \text { Yes }\end{array}$ $\begin{array}{lllllllllllllll}1.00 & 46.54 & 25.45 & 26.35 & 2 & 1474.8724 & 1474.8598 & 738.4372 & 0.0126 & 8.5315 & 4329.138 & 4772.852 & 679.333 & 108.262 & \text { Yes }\end{array}$ $\begin{array}{lllllllllllllll}1.00 & 50.27 & 25.59 & 30.27 & 3 & 1474.8736 & 1474.8598 & 492.6272 & 0.0138 & 9.3376 & 27210.124 & 26844.114 & 4710.517 & 423.095 & \text { Yes }\end{array}$

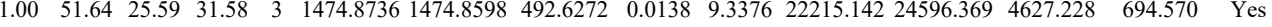

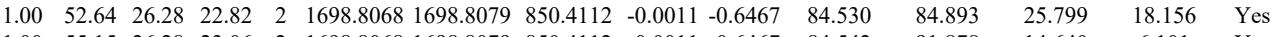

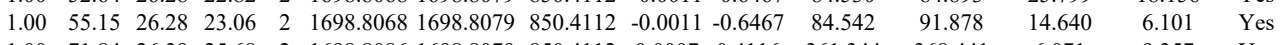

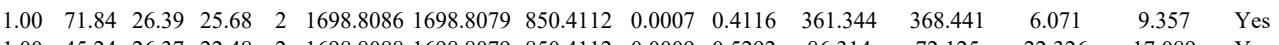

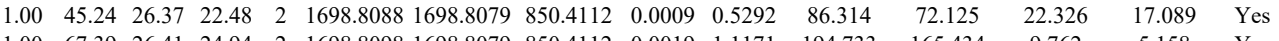

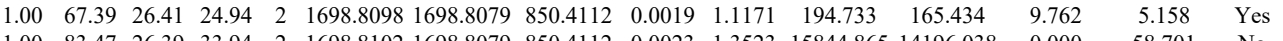

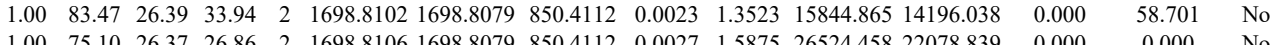

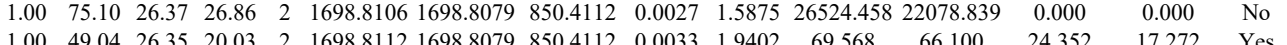
$\begin{array}{lllllllllllllll}1.00 & 49.04 & 26.35 & 20.03 & 2 & 1698.8112 & 1698.8079 & 850.4112 & 0.0033 & 1.9402 & 69.568 & 66.100 & 24.352 & 17.272 & \text { Yes } \\ 1.00 & 66.14 & 27.38 & 29.93 & 3 & 1748.9485 & 1748.9334 & 583.9851 & 0.0151 & 8.6189 & 10645.173 & 9779.471 & 4989.938 & 3911.264 & \text { Yes }\end{array}$ $\begin{array}{llllllllllllllll}1.00 & 66.14 & 27.38 & 29.93 & 3 & 1748.9485 & 1748.9334 & 583.9851 & 0.0151 & 8.6189 & 10645.173 & 9779.471 & 4989.938 & 3911.264 & \text { Yes } \\ 1.00 & 61.11 & 27.38 & 27.90 & 3 & 1748.9488 & 1748.9334 & 583.9851 & 0.0154 & 8.7901 & 10224.417 & 11655.740 & 5837.841 & 5471.701 & \text { Yes }\end{array}$

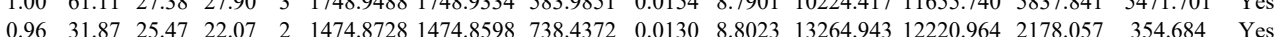

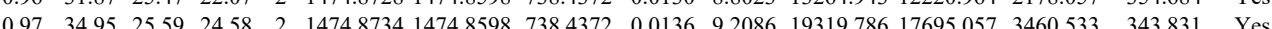
$\begin{array}{llllllllllllllll}1.00 & 46.50 & 25.59 & 31.49 & 3 & 1474.8736 & 1474.8598 & 492.6272 & 0.0138 & 9.3376 & 21074.239 & 24065.275 & 3191.983 & 378.770 & \text { Yes }\end{array}$ 
$\begin{array}{llllllllllllll}1.00 & 88.02 & 27.33 & 30.58 & 2 & 1681.9020 & 1681.8879 & 841.9512 & 0.0141 & 8.3733 & 2150.587 & 2350.445 & 1445.306\end{array}$

$\begin{array}{llllllllllllllll}0 & \end{array}$

$\begin{array}{llllllllllllllll} & \end{array}$

$\begin{array}{lllllllllllllll} & \end{array}$

GVAINMVTEEDKR $\begin{array}{llllllllllll}0.59 & 14.37 & 27.78 & 22.25 & 3 & 1748.9371 & 1748.9334 & 583.9851 & 0.0037 & 2.1119 & 16.23\end{array}$

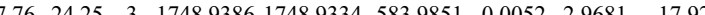

$\begin{array}{llllllllllll}\text { LNSNTQVVLLSATMPSDVLEVTK } & 0.99 & 60.13 * 24.20 & 20.35 & 3 & 2746.5079 & 2746.5030 & 916.5083 & 0.0049 & 1.7821 & 16.532\end{array}$

$\begin{array}{llllllllllll}\text { GIDVQQVSLVINYDLPTNR } & 0.54 & 10.86 & 26.19 & 23.86 & 3 & 2287.2316 & 2287.2294 & 763.4171 & 0.0022 & 0.9606 & 30.268\end{array}$ $\begin{array}{llllllllllll}\text { GIDVQQVSLVINYDLPTNR } & 1.00 & 84.53 & 26.07 & 21.14 & 2 & 2287.2334 & 2287.2294 & 1144.6220 & 0.0040 & 1.7473 & 188.953\end{array}$ $\begin{array}{llllllllllllll}\text { GIDVQQVSLVINYDLPTNR } & 1.00 & 93.60 & 26.07 & 18.91 & 2 & 2287.2334 & 2287.2294 & 1144.6220 & 0.0040 & 1.7473 & 264.388 & 24 & \end{array}$ $\begin{array}{lllllllllllll}\text { GIDVQQVSLVINYDLPTNR } & 0.93 & 24.89 & 26.03 & 15.27 & 3 & 2287.2352 & 2287.2294 & 763.4171 & 0.0058 & 2.5325 & 40.000\end{array}$ $\begin{array}{lllllllllllll}\text { GIDVQQVSLVINYDLPTNR } & 0.91 & 23.53 & 25.95 & 19.48 & 3 & 2287.2355 & 2287.2294 & 763.4171 & 0.0061 & 2.6635 & 28.552\end{array}$ $\begin{array}{lllllllllllll}\text { GIDVQQVSLVINYDLPTNR } & 1.00 & 49.67 & 26.07 & 18.89 & 3 & 2287.2334 & 2287.2294 & 763.4171 & 0.0040 & 1.7465 & 8.111\end{array}$

$\begin{array}{ll}11.432 & 23.287 \\ 14.257 & 25.024\end{array}$

$\begin{array}{ll}14.257 & 25.024 \\ 0.000 & 17.827 \\ 0.00 & 37.099\end{array}$

$\begin{array}{ll}0.000 \\ 0.000 & 37.099\end{array}$

$28.679 \quad 8.570$

$\begin{array}{rr}28.679 \\ 256.096 & 8.570 \\ 24.394\end{array}$

$244.346 \quad 110.201$

$45.145 \quad 11.729$ $\begin{array}{llllllllllll}\text { LQMEAPHIIVGTPGR } & 0.98 & 26.98 & 27.52 & 18.23 & 3 & 1761.9709 & 1761.9682 & 588.3300 & 0.0027 & 1.5298 & 49.214\end{array}$

$\begin{array}{lllllllllllllll} & \end{array}$

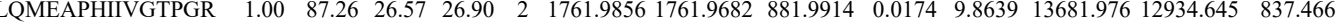

$\begin{array}{llllllllllllll} & 177.936 & 1777.9631 & 593.6616 & 0.0101 & 5.6710 & 928.910 & 1025.700 & 874.342\end{array}$

$\begin{array}{lllllllllllllll}\text { LQMEAPHIIVGTPGR } & 0.57 & 20.37 & 27.13 & 14.44 & 3 & 1777.9771 & 1777.9631 & 593.6616 & 0.0140 & 7.8608 & 251.028 & 288.804 & 211.206\end{array}$

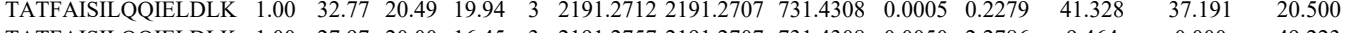

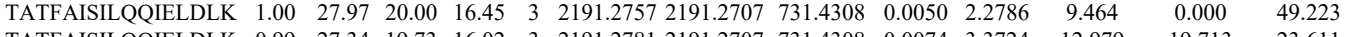

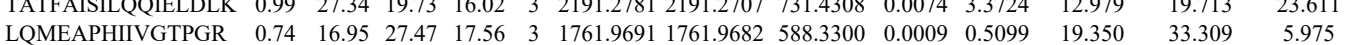

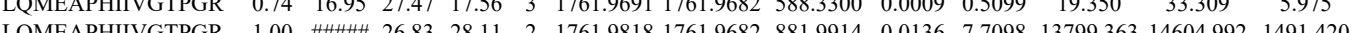

LQMEAPHIIVGTPGR

VLITTDLLAR

$\begin{array}{lllllllllllll}1.00 & \# \# \# 26.83 & 28.11 & 2 & 1761.9818 & 1761.9682 & 881.9914 & 0.0136 & 7.7098 & 13799.363 & 14604.992 & 1491.420 \\ 1.00 & 89.70 & 26.54 & 27.13 & 2 & 1761.9850 & 1761.9682 & 881.9914 & 0.0168 & 9.5238 & 12280.700 & 9500.198 & 1078.705\end{array}$

$\begin{array}{lllllllllllll}1.00 & 89.70 & 26.54 & 27.13 & 2 & 1761.9850 & 1761.9682 & 881.9914 & 0.0168 & 9.5238 & 12280.700 & 9500.198 & 1078.705 \\ 0.92 & 37.58 & 23.26 & 45.37 & 2 & 1257.7794 & 1257.7778 & 629.8962 & 0.0016 & 1.2700 & 275.670 & 294.612 & 20.389\end{array}$

VLITTDLLAR

$\begin{array}{lllllllllllllll}1.00 & 57.02 & 23.26 & 49.38 & 2 & 1257.7794 & 1257.7778 & 629.8962 & 0.0016 & 1.2700 & 31072.722 & 25932.565 & 968.826\end{array}$

VLITTLLAR

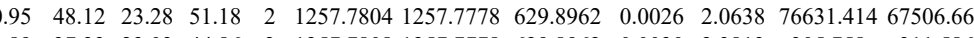

$\begin{array}{llllllllllllll} & \end{array}$

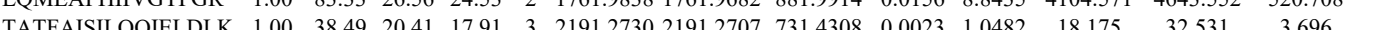

$\begin{array}{lllllllllllllll}\text { VLITTDLLAR } & 0.99 & 53.98 & 23.28 & 49.03 & 2 & 1257.7804 & 1257.7778 & 629.8962 & 0.0026 & 2.0638 & 65361.458 & 54785.893 & 3017.053 & 321.8\end{array}$

VLITTDLLAR

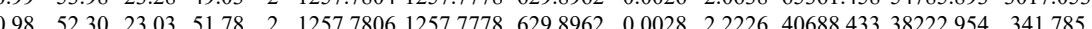

LQMEAPHIIVGTPGR

VLITTDLLAR

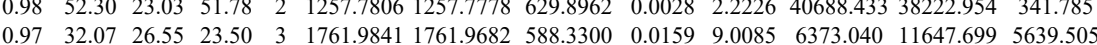

9.183
9.962
16.322

28.215

$\begin{array}{llllllllllllll}100 & 65.28 & 23.36 & 20.47 & 2 & 1283.7748 & 1283.7683 & 642.8914 & 0.0065 & 5.0553 & 40247.923 & 41528.145 & 17073.091 & 6699.392\end{array}$

ATQALVLAPTR

ATQALVLAPTR

ATQALVLAPTR

ATQALVLAPTR

ATQALVLAPTR

ATQALVLAPTR

ATQALVLAPTR

ATQALVLAPTR VFDMLNR

$\begin{array}{lllllllllllllll}1.00 & 60.58 & 23.32 & 25.51 & 2 & 1283.7754 & 1283.7683 & 642.8914 & 0.0071 & 5.5219 & 9272.312 & 9204.103 & 3209.016 & 1392.306 & \text { Yes }\end{array}$ $\begin{array}{llllllllllllllll}0.97 & 27.30 & 23.28 & 19.39 & 3 & 1283.7763 & 1283.7683 & 428.9300 & 0.0080 & 6.2170 & 2155.888 & 2173.970 & 796.222 & 534.528 & \text { Yes }\end{array}$

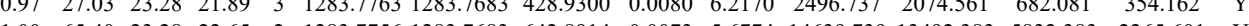
$\begin{array}{llllllllllllllllll}1.00 & 65.40 & 23.28 & 22.65 & 2 & 1283.7756 & 1283.7683 & 642.8914 & 0.0073 & 5.6774 & 14639.739 & 13492.383 & 5832.383 & 2265.601 & \text { Yes } \\ 1.00 & 65.50 & 3.2 & 26.06 & 2 & 128.7756 & 283.7883 & 42.8914 & 0.073 & 5.6774 & 3286.967 & 28737.122 & 1341.64 & 394.067 & \text { Yes }\end{array}$ $\begin{array}{lllllllllllllllll}1.00 & 65.50 & 23.28 & 26.06 & 2 & 1283.7756 & 1283.7683 & 642.8914 & 0.0073 & 5.6774 & 32286.967 & 28737.122 & 13411.764 & 3984.067 & \text { Yes } \\ 1.00 & 65.68 & 23.28 & 20.54 & 2 & 1283.7762 & 1283.763 & 642.8914 & 0.079 & 6.144 & 25390.095 & 2303.833 & 11850391 & 3457.66 & \text { Yes }\end{array}$ $\begin{array}{lllllllllllllll}1.00 & 65.68 & 23.28 & 20.54 & 2 & 1283.7762 & 1283.7683 & 642.8914 & 0.0079 & 6.1441 & 25390.095 & 23003.833 & 11850.391 & 3457.969 & \text { Yes }\end{array}$ $\begin{array}{llllllllllllllll}1.00 & 64.13 & 23.28 & 20.68 & 2 & 1283.7762 & 1283.7683 & 642.8914 & 0.0079 & 6.1441 & 36122.950 & 35889.435 & 12990.636 & 5475.649 & \text { Yes }\end{array}$ $\begin{array}{llllllllllllllll}1.00 & 58.74 & 23.12 & 21.23 & 2 & 1283.7770 & 1283.7683 & 642.8914 & 0.0087 & 6.7663 & 12840.317 & 12426.590 & 6397.234 & 1773.557 & \text { Yes } \\ 1\end{array}$

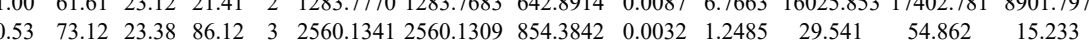



$\begin{array}{lllllllllll}1.00 & 5.578 & 24.08 & 22.22 & 2 & 1283.7688 & 1283.7683 & 642.8914 & 0.0005 & 0.3889 & 187.623\end{array}$ $\begin{array}{lllllllllllll} & \end{array}$

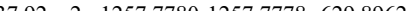
$\begin{array}{lllllllllll}1.00 & 57.51 & 27.47 & 17.26 & 3 & 1761.9691 & 1761.9682 & 588.3300 & 0.0009 & 0.5099 & 55.023 \\ 1.00 & 50.56 & 27.56 & 17.71 & 3 & 176.9685 & 1761.9682 & 588.3300 & 0.0003 & 0.1700 & 77.647\end{array}$

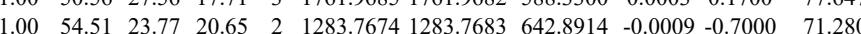
$\begin{array}{lllllllllll}1.00 & 50.39 & 23.98 & 20.56 & 2 & 1283.7676 & 1283.7683 & 642.8914 & -0.0007 & -0.5444 & 129.357\end{array}$ $\begin{array}{lllllllllll}1.00 & 61.01 & 23.98 & 21.99 & 2 & 1283.7676 & 1283.7683 & 642.8914 & -0.0007 & -0.5444 & 305.872\end{array}$ $\begin{array}{lllllllllllll}0.99 & 40.90 & 24.35 & 18.44 & 2 & 1283.7678 & 1283.7683 & 642.8914 & -0.0005 & -0.3889 & 151.096 \\ 1.00 & 58.49 & 27.59 & 20.63 & 3 & 1761.9694 & 1761.9682 & 588.3300 & 0.0012 & 0.6799 & 98.307\end{array}$ $\begin{array}{lllllllllll}1.00 & 55.34 & 23.65 & 20.21 & 2 & 1283.7728 & 1283.7683 & 642.8914 & 0.0045 & 3.4998 & 116.591\end{array}$ $\begin{array}{lllllllllll}1.00 & 58.49 & 24.08 & 22.61 & 2 & 1283.7686 & 1283.7683 & 642.8914 & 0.0003 & 0.2333 & 43.908\end{array}$ $\begin{array}{llllllllllll}1.00 & 49.79 & 28.10 & 41.07 & 2 & 1202.6636 & 1202.6628 & 602.3387 & 0.0008 & 0.6641 & 843.328\end{array}$ $\begin{array}{cccccccccccc}0.99 & 70.34 * 26.05 & 21.70 & 2 & 1714.8050 & 1714.8028 & 858.4087 & 0.0022 & 1.2814 & 244.525 & 244 \\ 0.78 & 17.68 & 27.80 & 21.35 & 3 & 1748.9380 & 1748.9334 & 583.9851 & 0.0046 & 2.6256 & 9.679 & 16 .\end{array}$ $\begin{array}{llllllllllll}0.78 & 17.68 & 27.80 & 21.35 & 3 & 1748.9380 & 1748.9334 & 583.9851 & 0.0046 & 2.6256 & 9.679\end{array}$ \begin{tabular}{lllllllllllllll}
1.00 & 78.00 & 27.40 & 28.86 & 2 & 1748.9484 & 1748.9334 & 875.4740 & 0.0150 & 8.5667 & 575.761 & 420.774 & 15.1 \\
\hline
\end{tabular}

YGYEIPVDMLCK

YGYEIPVDMLCK

YGYEIPVDMLCK

YGYEIPVDMLCK

YGYEIPVDM

HITIFSPEGR
LLDSSTVTHLFK

ALDSSTVTHLFK

AINQGGLTSVAVR

AINQGGLTSVAVR

AINQGGLTSVAVR

AINOGGLTSVAVR

QTESTSFLEK

QTESTSFLEK

QTESTSFLEK $\begin{array}{lllllllllllllll} & \end{array}$ $\begin{array}{lllllllllllllll}0.77 & 46.34 & 27.35 & 59.34 & 2 & 1763.8564 & 1763.8540 & 882.9343 & 0.0024 & 1.3591 & 2491.704 & 2823.117 & 1820.619 & 921.374 & \text { Yes } \\ 0.99 & 31.62 & 27.40 & 17.90 & 3 & 1763.8576 & 1763.8540 & 588.9586 & 0.026 & 2.0975 & 304.530 & 333.651 & 288.125 & 121.63 & \text { Yes }\end{array}$

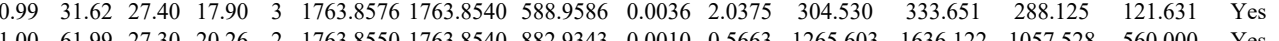
$\begin{array}{lllllllllllllll}1.00 & 61.99 & 27.30 & 20.26 & 2 & 1763.8550 & 1763.8540 & 882.9343 & 0.0010 & 0.5663 & 1265.603 & 1636.122 & 1057.528 & 560.000 & \text { Yes } \\ 1.00 & 62.62 & 27.30 & 20.01 & 2 & 1763.8558 & 1763.8540 & 882.9343 & 0.0018 & 1.0193 & 1688.811 & 1592.711 & 1049.058 & 781.156 & \text { Yes }\end{array}$

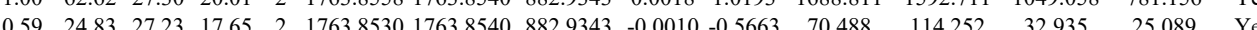

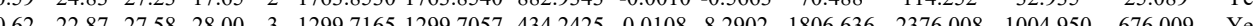
$\begin{array}{lllllllllllllll}0.55 & 30.62 & 25.87 & 43.62 & 3 & 1647.9463 & 1647.9440 & 550.3219 & 0.0023 & 13931 & 14518.774 & 14669042 & 903.323 & 257.574 & \text { No }\end{array}$ $\begin{array}{lllllllllllllll}100 & 79.53 & 25.15 & 24.98 & 2 & 1428.8260 & 1428.8171 & 715.4158 & 0.0089 & 6.2201 & 18953.388 & 22370.650 & 12076.836 & 2035.945 & \text { Yes }\end{array}$ $\begin{array}{lllllllllllllllll}1.00 & 83.92 & 25.09 & 27.19 & 2 & 1428.8274 & 1428.8171 & 715.4158 & 0.0103 & 7.1986 & 16514.143 & 19044.075 & 8779.719 & 1902.439 & \text { Yes }\end{array}$ $\begin{array}{lllllllllllllllll}1.00 & 83.60 & 25.35 & 25.16 & 2 & 1428.8252 & 1428.8171 & 715.4158 & 0.0081 & 5.6610 & 19203.658 & 21768.001 & 13907.986 & 1799.954 & \text { Yes }\end{array}$ $\begin{array}{lllllllllllllll}1.00 & 76.89 & 25.20 & 26.50 & 2 & 1428.8262 & 1428.8171 & 715.4158 & 0.0091 & 6.3599 & 33361.834 & 40238.942 & 21161.379 & 4547.167 & \text { Yes }\end{array}$ $\begin{array}{lllllllllllllll}1.00 & 88.19 & 25.40 & 28.91 & 2 & 1428.8244 & 1428.8171 & 715.4158 & 0.0073 & 5.1019 & 13700.525 & 18532.778 & 11126.350 & 2261.939 & \text { Yes }\end{array}$ $\begin{array}{llllllllllllllll}1.00 & 81.24 & 25.39 & 26.98 & 2 & 1428.8246 & 1428.8171 & 715.4158 & 0.0075 & 5.2417 & 16687.170 & 19378.851 & 10377.802 & 2371.147 & \text { Yes }\end{array}$

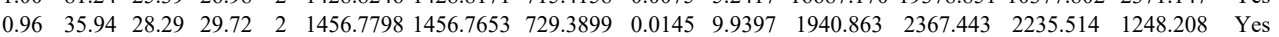
$\begin{array}{lllllllllllllll}1.00 & 50.73 & 28.27 & 26.90 & 2 & 1456.7776 & 1456.7653 & 729.3899 & 0.0123 & 8.4316 & 1648.272 & 1955.040 & 1503.431 & 1235.931 & \text { Yes }\end{array}$ $\begin{array}{lllllllllllllll}1.00 & 51.94 & 28.29 & 37.87 & 2 & 1456.7798 & 1456.7653 & 729.3899 & 0.0145 & 9.9397 & 1517.016 & 1924.213 & 1738.514 & 1170.981 & \text { Yes }\end{array}$ $\begin{array}{lllllllllllllll}0.55 & 46.32 & 24.55 & 59.32 & 3 & 1672.9747 & 1672.9725 & 558.6648 & 0.0022 & 1.3127 & 11282.529 & 13076.539 & 8081.447 & 4711.752 & \text { Yes }\end{array}$

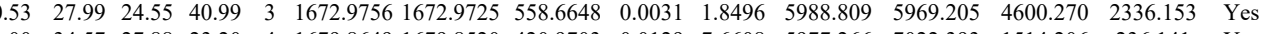
$\begin{array}{lllllllllllllll}1.00 & 34.57 & 27.88 & 23.20 & 4 & 1679.8649 & 1679.8520 & 420.9703 & 0.0129 & 7.6608 & 5977.266 & 7022.393 & 1514.206 & 236.141 & \text { Yes } \\ 0.86 & 26.96 & 28.03 & 22.12 & 3 & 1679.8669 & 1679.8520 & 560.9579 & 0.0149 & 8.8538 & 8992.132 & 11514389 & 3961.646 & 1393.725 & \text { Yes }\end{array}$ $\begin{array}{lllllllllllllll}0.86 & 26.96 & 28.03 & 22.12 & 3 & 1679.8669 & 1679.8520 & 560.9579 & 0.0149 & 8.8538 & 8992.132 & 11514.389 & 3961.646 & 1393.725 & \text { Yes } \\ 1.00 & 42.85 & 28.03 & 29.29 & 4 & 1679.8669 & 1679.8520 & 420.9703 & 0.0149 & 8.8485 & 6370.550 & 7238.075 & 1543.319 & 146.300 & \text { Yes }\end{array}$

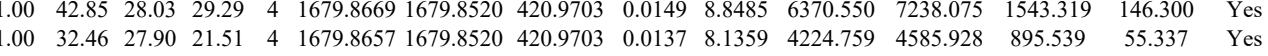
$\begin{array}{lllllllllllllll}1.00 & 34.88 & 28.01 & 24.91 & 4 & 1679.8661 & 1679.8520 & 420.9703 & 0.0137 & 8.1359 & 4224.759 & 4585.928 & 8957.539 & 53.337 & \text { Yes } \\ & 0.0141 & 8.3734 & 3353.370 & 3759.029 & 957.154 & 91.795 & \text { Yes }\end{array}$ $\begin{array}{lllllllllllllll}1.00 & 49.21 & 24.05 & 24.40 & 2 & 1615.9430 & 1615.9419 & 808.9782 & 0.0011 & 0.6799 & 59.694 & 111.970 & 64.135 & 15.426 & \text { Yes }\end{array}$

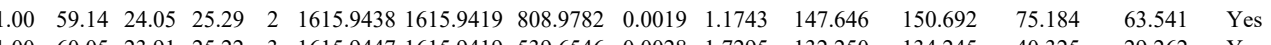

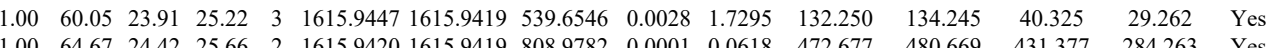

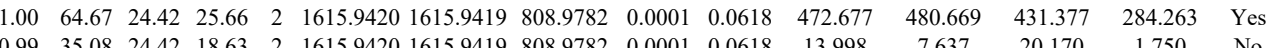
$\begin{array}{lllllllllllllll}0.99 & 35.08 & 24.42 & 18.63 & 2 & 1615.9420 & 1615.9419 & 808.9782 & 0.0001 & 0.0618 & 13.998 & 7.637 & 20.170 & 1.750 & \text { No } \\ 1.00 & 56.93 & 24.05 & 22.61 & 3 & 1615.9432 & 1615.9419 & 539.6546 & 0.0013 & 0.8030 & 131.320 & 149.396 & 39.953 & 19.83 & \text { Yes }\end{array}$

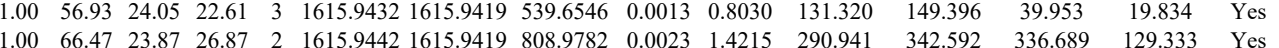
$\begin{array}{lllllllllllllll}1.00 & 66.47 & 23.87 & 26.87 & 2 & 1615.9442 & 1615.9419 & 808.9782 & 0.0023 & 1.4215 & 290.941 & 342.592 & 336.689 & 129.333 & \text { Yes } \\ 1.00 & 48.50 & 23.91 & 18.97 & 3 & 1615.9444 & 1615.9419 & 539.6546 & 0.0025 & 1.5442 & 196.868 & 148.049 & 54.568 & 37.207 & \text { Yes }\end{array}$

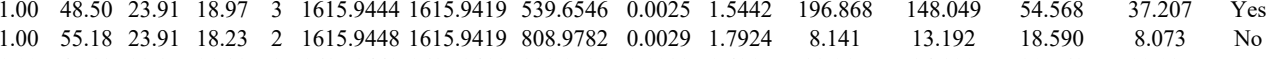


QKPITPETAEK QKPITPETAEK

QKPITPETAEK

CSTPEEIKK LGGSLIVAFEGCPV HECQANGPEDLNR

CSTPEEIK

CSTPEEIK

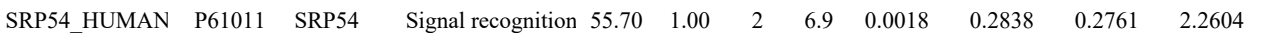

$\begin{array}{lllllllllll}\text { UBC12_HUMAP } & \text { P61081 } & \text { UBE2M } & \text { NEDD8-conjugati 20.90 } & 1.00 & 4 & 24 & -0.1769 & 0.1896 & -0.5081 & 2.4982\end{array}$

IPFYGSYTEMDPVIIASEG

LLGMGDIEGLIDK

LLGMGDIEGLIDK
LLGMGDIEGLIDK

LLGMGDIEGLIDK

IPFYGSYTEMDPVIIASEGV

VGQGYPHDPPK

VGQGYPHDPPK

VGQGYPHDPPK

TCDISFSDPDDLLNFK

LVICPDEGFYK

LVICPDEGFYK

FVFSFK

FVFSFK

FVFSFK

$\begin{array}{llllllllllll}\text { UBE2K_HUMAl } & \text { P61086 } & \text { UBE2K } & \text { Ubiquitin-conjuga } 22.41 & 1.00 & 3 & 25.5 & -0.1148 & 0.2899 & -0.3205 & 1.9432 & 5\end{array}$

TVLLLLALLAAAPDDPDDAVY

IENLCAMGFDR

IENLCAMGFDR

VDLVDENFTELR
VDLVDENFTELR

LELFLPEEYPMAAPK LELFLPEEYPMAAPK

LELFLPEEYPMAAPK

TVLLIIQALLSAPNPDDPLANDVAEQW

TYLSIQALLAPNPD

TNEAQAIETAR

TNEAQAIETAR

5 GAAGALMVYDITR

TGENVEDAFLEAAK

TGENVEDAFLEAAK

12 AEPEDHYFLLTEPPLNTPEN

TLTGTVIDSGDGVVTHVVIPVAFGYYVIGSCIK

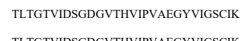

TLTGTVIDSGDGVTHVIIVAEGYVIGSCCK
TLTGTVIISGDGVTHVIPVAEGYVIGSSKK

LPACVVDCGTGYTK

LPACVVDCGTGYTK

LGYAGNTEPQFIIPSCIAIK

NIVLSGGSTMFR

NIVLSGGSTMFR

NISGGTMR

NIVLSGGSTMFR $\begin{array}{llllllllllllll}36.86 & 24.55 & 49.86 & 3 & 1672.9756 & 1672.9725 & 558.6648 & 0.0031 & 1.8496 & 24002.437 & 28042.133 & 20217.807 & 8146.389 & \text { Yes }\end{array}$ $\begin{array}{lllllllllllllll} & \\ 0.53 & 35.91 & 24.65 & 18.99 & 2 & 1672.9742 & 1672.9725 & 837.4935 & 0.0017 & 1.0149 & 3485.515 & 3772.064 & 2770.526 & 1015.794 & \text { Yes } \\ \end{array}$ $\begin{array}{lllllllllllllll}0.92 & 33.55 & 27.34 & 22.31 & 2 & 1223.6576 & 1223.6497 & 612.8321 & 0.0079 & 6.4454 & 5461.569 & 7427.649 & 2381.588 & 4513.599 & \text { Yes }\end{array}$

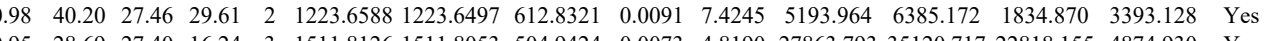
$\begin{array}{lllllllllllllllll}0.95 & 28.69 & 27.40 & 16.24 & 3 & 1511.8126 & 1511.8053 & 504.9424 & 0.0073 & 4.8190 & 27863.793 & 35120.717 & 22818.155 & 4874.930 & \text { Yes }\end{array}$ $\begin{array}{lllllllllllllll}0.96 & 34.99 & 27.00 & 22.27 & 2 & 1344.7584 & 1344.7468 & 673.3807 & 0.0116 & 8.6132 & 8117.771 & 10252.146 & 2036.283 & 2508.874 & \text { Yes }\end{array}$ \begin{tabular}{lllllllllllllll}
0.98 & 38.18 & 28.18 & 24.45 & 2 & 1550.8000 & 1550.7959 & 776.4052 & 0.0041 & 2.6404 & 57.200 & 48.962 & 26.703 & 8.438 & Yes \\
\hline
\end{tabular} $\begin{array}{llllllllllllllll}40.78 & 21.96 & 16.47 & 3 & 1671.7237 & 1671.7215 & 558.2478 & 0.0022 & 1.3136 & 3623.090 & 4921.551 & 8022.356 & 8573.871 & \text { No } \\ 1.00 & 55.63 & 22.12 & 19.30 & 2 & 1671.7246 & 1671.715 & 836.8680 & 0.0031 & 1.8521 & 1424.202 & 1874.492 & 1857.560 & 530.506 & \text { Yes }\end{array}$ $\begin{array}{llllllllllllllll}0.53 & 22.65 & 27.11 & 20.65 & 2 & 1239.6172 & 1239.6083 & 620.8114 & 0.0089 & 7.1680 & 30998.897 & 33710.681 & 18208.937 & 3213.551 & \text { Yes }\end{array}$ $\begin{array}{lllllllllllllll}0.59 & 22.46 & 27.10 & 20.67 & 2 & 1239.6204 & 1239.6083 & 620.8114 & 0.0121 & 9.7452 & 31225316 & 39321.740 & 13353.180 & 3217.875 & \text { Yes }\end{array}$

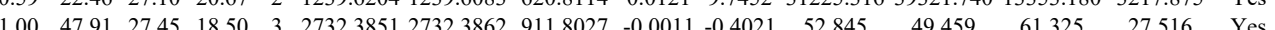

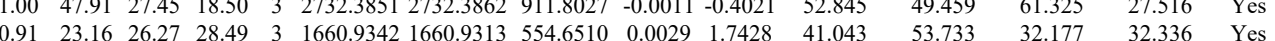
$\begin{array}{lllllllllllllll}0.60 & 12.16 & 26.28 & 17.87 & 3 & 1660.9345 & 1660.9313 & 554.6510 & 0.0032 & 1.9231 & 36.637 & 49.478 & 59.071 & 14.335 & \text { Yes }\end{array}$ $\begin{array}{llllllllllllllll}1.00 & 81.47 & 26.29 & 37.99 & 2 & 1660.9356 & 1660.9313 & 831.4729 & 0.0043 & 2.5858 & 2575.540 & 2597.067 & 0.000 & 85.955 & \text { No }\end{array}$ $\begin{array}{llllllllllllllll}1.00 & 83.22 & 26.21 & 37.85 & 2 & 1660.9360 & 1660.9313 & 831.4729 & 0.0047 & 2.8263 & 2549.718 & 2246.164 & 69.146 & 39.780 & \text { Yes }\end{array}$

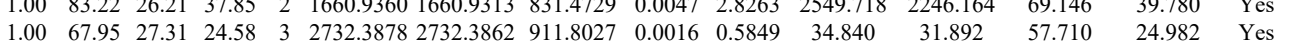
$\begin{array}{llllllllllllllll}1.00 & 86.42 & 26.20 & 37.98 & 2 & 1660.9368 & 1660.9313 & 831.4729 & 0.0055 & 3.3074 & 877.898 & 799.617 & 31.482 & 65.254 & \text { Yes }\end{array}$ $\begin{array}{llllllllllllllll}0.96 & 24.20 & 28.20 & 23.29 & 3 & 1481.7895 & 1481.7871 & 494.9363 & 0.0024 & 1.6164 & 6188.111 & 5218.668 & 5691.920 & 3539.033 & \text { Yes }\end{array}$ $\begin{array}{llllllllllllllllll}0.98 & 26.11 & 28.25 & 24.81 & 3 & 1481.7892 & 1481.7871 & 494.9363 & 0.0021 & 1.4143 & 9823.996 & 9843.437 & 8896.498 & 5966.976 & \text { Yes }\end{array}$

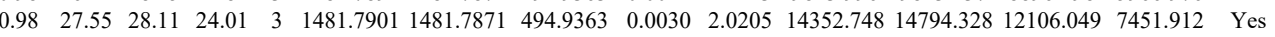

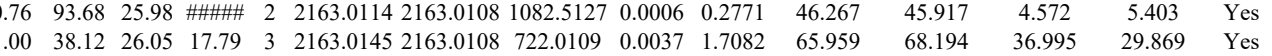

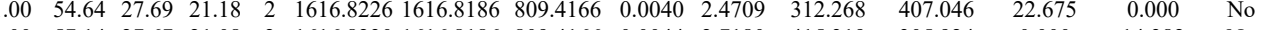

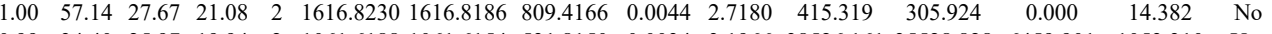
$\begin{array}{lllllllllllllll}0.99 & 34.40 & 25.97 & 19.94 & 2 & 1061.6188 & 1061.6154 & 531.8150 & 0.0034 & 3.1966 & 38526.161 & 35528.828 & 6459.901 & 1053.310 & \text { Yes }\end{array}$

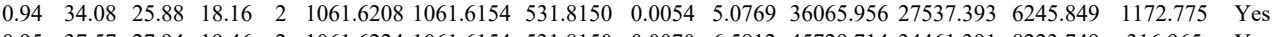
$\begin{array}{lllllllllllllll}0.95 & 37.57 & 27.94 & 19.46 & 2 & 1061.6224 & 1061.6154 & 531.8150 & 0.0070 & 6.5812 & 45729.714 & 34461.391 & 8223.749 & 316.965 & \text { Yes }\end{array}$ $\begin{array}{lllllllllllllll}1.00 & 77.32 & 23.01 & 18.51 & 3 & 3240.7522 & 3240.7485 & 1081.2568 & 0.0037 & 1.1406 & 7.659 & 13.262 & 4.595 & 7.954 & \text { No }\end{array}$

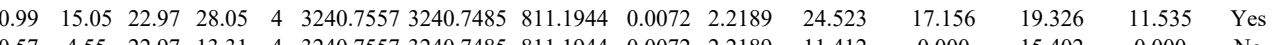

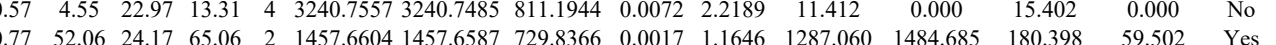
$\begin{array}{llllllllllll} & \end{array}$ $\begin{array}{llllllllllllllll}1.00 & 80.05 & 28.06 & 24.27 & 2 & 15928184 & 15928168 & 797.4157 & 0.0016 & 1.0032 & 4867.516 & 42.669 & 16.903 & 42.560 & \text { Yes }\end{array}$ $\begin{array}{llllllllllllll}0 & \end{array}$ $\begin{array}{llllllllllllllll}0.98 & 25.63 & 26.44 & 19.50 & 3 & 2035.0987 & 2035.0943 & 679.3720 & 0.0044 & 2.1589 & 159.189 & 115.394 & 152.745 & 134.319 & \text { No }\end{array}$

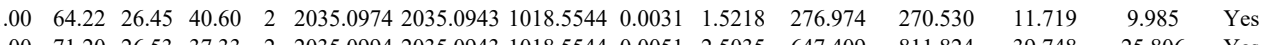

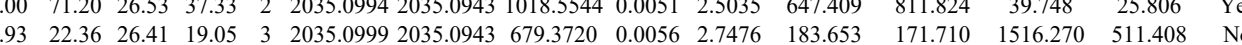
$\begin{array}{llllllllllllll}0.55 & 93.57 & 22.90 & \# \# \# \# \quad 3 & 3305.7772 & 3305.7751 & 1102.9323 & 0.0021 & 0.6347 & 20.264 & 8.527 & 10.153 & 2.244 & \text { Y }\end{array}$ $\begin{array}{llllllllllllllll}1.00 & 85.52 & 22.65 & 21.91 & 3 & 3305.7802 & 3305.7751 & 1102.9323 & 0.0051 & 1.5413 & 0.000 & 22.614 & 2.708 & 3.298 & \text { No }\end{array}$

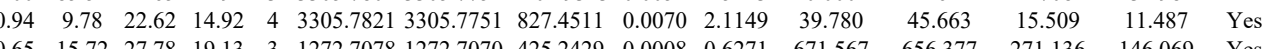
\begin{tabular}{lllllllllllllll}
0.65 & 15.72 & 27.78 & 19.13 & 3 & 1272.7078 & 1272.7070 & 425.2429 & 0.0008 & 0.6271 & 671.567 & 656.377 & 271.136 & 146.069 & Yes \\
\hline
\end{tabular} $\begin{array}{llllllllllllllll}1.00 & 72.74 & 28.12 & 27.00 & 2 & 1346.6942 & 1346.6912 & 674.3529 & 0.0030 & 2.2243 & 19957.053 & 27448.956 & 11542.327 & 3989.180 & \text { Yes } \\ 1.00 & 84.6 & 2.0 & 28.92 & 2 & 1346.6946 & 1346.6912 & 674.3529 & 0.0034 & 2.5209 & 23183.568 & 28449.313 & 11764.451 & 2770.833 & \text { Yes }\end{array}$

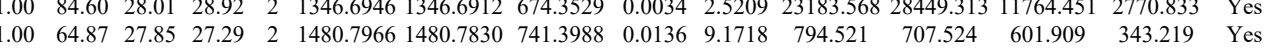
$\begin{array}{llllllllllllllll}1.00 & 67.83 & 28.22 & 22.16 & 2 & 1780.9108 & 1780.9087 & 891.4616 & 0.0021 & 1.1778 & 1247.531 & 1106.709 & 726.247 & 78.759 & \text { Yes } \\ 1.00 & 43.49 & 28.16 & 30.23 & 3 & 1780.9117 & 1780.9087 & 594.6435 & 0.0030 & 1.6817 & 47.505 & 60.937 & 64.210 & 18.366 & \text { Yes }\end{array}$ $\begin{array}{lllllllllllllll}1.00 & 43.49 & 28.16 & 30.23 & 3 & 1780.9117 & 1780.9087 & 594.6435 & 0.0030 & 1.6817 & 47.505 & 60.937 & 64.210 & 18.366 & \text { Yes } \\ 1.00 & 42.40 & 28.12 & 23.91 & 3 & 1780.9120 & 1780.9087 & 594.6435 & 0.0033 & 1.8498 & 64.905 & 30.310 & 95.725 & 35.458 & \text { Yes }\end{array}$

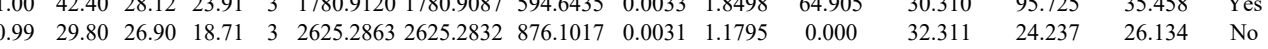

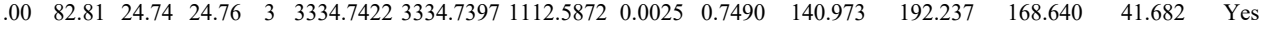

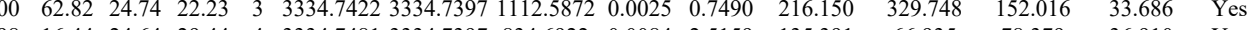
$\begin{array}{lllllllllllllll} & 16.44 & 24.64 & 29.44 & 4 & 3334.7481 & 3334.7397 & 834.6922 & 0.0084 & 2.5159 & 135.391 & 66.935 & 78.379 & 36.910 & \text { Yes }\end{array}$

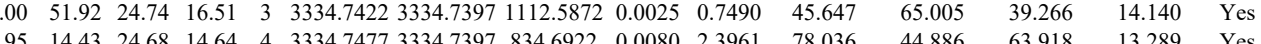
\begin{tabular}{lllllllllllllll}
14.43 & 24.68 & 14.64 & 4 & 3334.7477 & 3334.7397 & 834.6922 & 0.0080 & 2.3961 & 78.036 & 44.886 & 63.918 & 13.289 & Yes \\
\hline
\end{tabular} $\begin{array}{llllllllllllll} & \end{array}$ \begin{tabular}{lllllllllllllll}
0.75 & 15.16 & 26.87 & 21.36 & 3 & 2468.3068 & 2468.3051 & 823.7756 & 0.0017 & 0.6879 & 25.852 & 45.416 & 37.195 & 17.176 & Yes \\
\hline
\end{tabular} $\begin{array}{lllllllllllllll}1.00 & 57.27 & 27.36 & 24.79 & 2 & 1424.7580 & 1424.7568 & 713.3857 & 0.0012 & 0.8411 & 660.300 & 764.531 & 39.262 & 18.650 & \text { Yes } \\ 1.00 & 74.92 & 27.45 & 29.23 & 2 & 14247584 & 1424.758 & 713.3857 & 0.0016 & 1.1214 & 1475.347 & 1560.711 & 0.000 & 39.470 & \text { No }\end{array}$ $\begin{array}{lllllllllllllll}1.00 & 74.92 & 27.45 & 29.23 & 2 & 1424.7584 & 1424.7568 & 713.3857 & 0.0016 & 1.1214 & 1475.347 & 1560.711 & 0.000 & 39.470 & \mathrm{~N} \\ 1.00 & 67.45 & 27.47 & 20.65 & 2 & 1424.7594 & 1424.7568 & 713.3857 & 0.0026 & 1.8223 & 7949.197 & 13380.138 & 0.000 & 232.695 & \mathrm{~N} 0\end{array}$ $\begin{array}{lllllllllllllll}1.00 & 62.52 & 26.99 & 21.72 & 2 & 1424.7600 & 1424.7568 & 713.3857 & 0.0032 & 2.2428 & 4101.095 & 5342.114 & 72.174 & 11.406 & \text { Y }\end{array}$ $\begin{array}{lllllllllllllll}1.00 & 67.14 & 27.68 & 28.54 & 2 & 1424.7564 & 1424.7568 & 713.3857 & -0.0004 & -0.2804 & 5112.544 & 6889.384\end{array}$ 

$\begin{array}{llllllllllllllll}\text { QDLPNAMNAAEITDK } & 1.00 & 95.82 & 28.01 & 24.43 & 2 & 1917.9730 & 1917.9709 & 959.9927 & 0.0043 & 2.2396 & 6234.908 & 4917.094 & 3775.923 & 2599.279 & \text { Yes }\end{array}$ $\begin{array}{lllllllllllllllll}\text { QDLPNAMNAAEITDK } & 1.00 & \text { \#\#\#\# } 28.10 & 31.51 & 2 & 1917.9888 & 1917.9709 & 959.9927 & 0.0179 & 9.3229 & 3818.278 & 3688.037 & 3044.311 & 2449.303 & \text { No }\end{array}$

$\begin{array}{llllllllllllllll}\text { ADIFMFDEPSSYLDVK } & 1.00 & 49.66 & 27.60 & 31.54 & 3 & 2164.0696 & 2164.0642 & 722.3620 & 0.0054 & 2.4918 & 48.897 & 32.944 & 14.447 & 18.076 & \text { Yes }\end{array}$ $\begin{array}{lllllllllllllllll}\text { ADIFMFDEPSSYLDVK } & 1.00 & 63.26 & 27.60 & 24.42 & 3 & 2164.0708 & 2164.0642 & 722.3620 & 0.0066 & 3.0456 & 59.354 & 94.277 & 26.242 & 14.843 & \text { Yes }\end{array}$

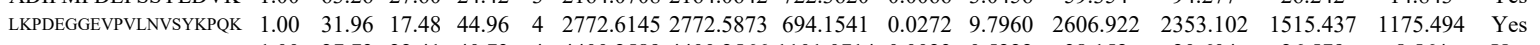

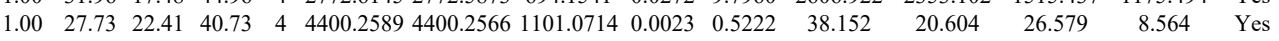

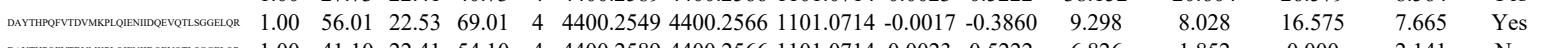

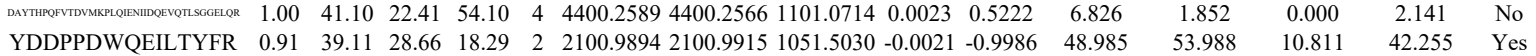

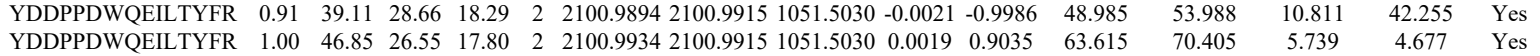

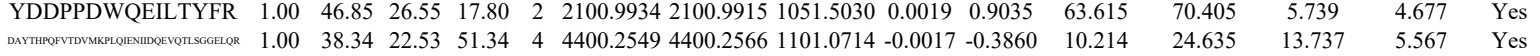

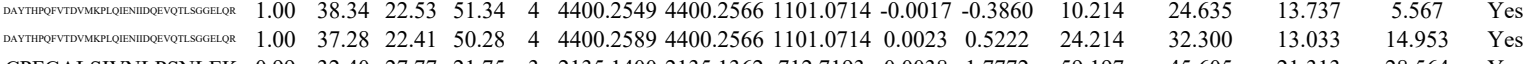

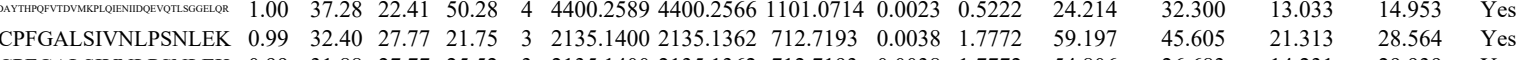

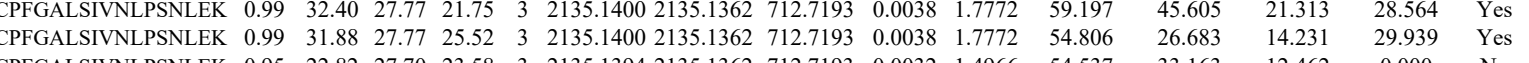
$\begin{array}{llllllllllllllll}\text { CPFGALSIVNLPSNLEK } & 0.95 & 22.82 & 27.70 & 23.58 & 3 & 2135.1394 & 2135.1362 & 712.7193 & 0.0032 & 1.4966 & 54.537 & 33.163 & 12.462 & 0.000 & \text { No }\end{array}$

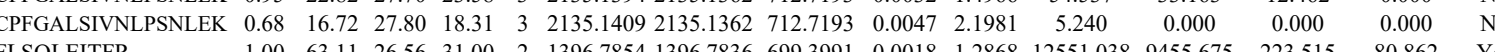

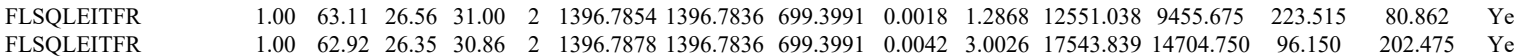

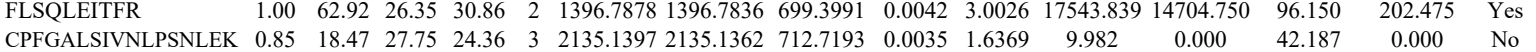

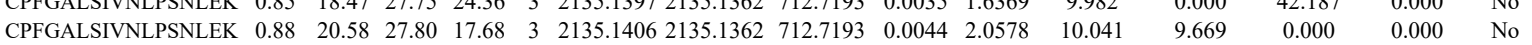

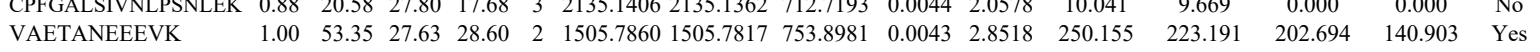

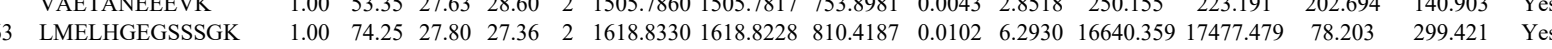

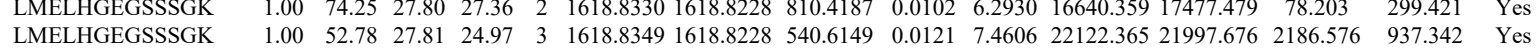

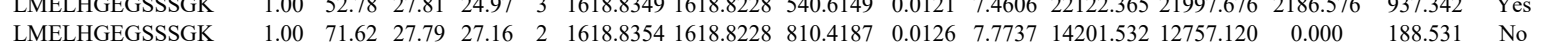
$\begin{array}{llllllllllllllll}\text { LMELHGEGSSSGK } & 1.00 & 55.39 & 27.77 & 22.07 & 3 & 1618.8376 & 1618.8228 & 540.6149 & 0.0148 & 9.1253 & 43937.474 & 44218.588 & 2275.511 & 1326.258 & \text { Yes }\end{array}$ $\begin{array}{lllllllllllllllll}\text { LMELHGEGSSSGK } & 1.00 & 52.03 & 27.78 & 22.45 & 3 & 1618.8352 & 1618.8228 & 540.6149 & 0.0124 & 7.6456 & 25026.176 & 22539.292 & 2157.065 & 1830.042 & \text { Yes }\end{array}$

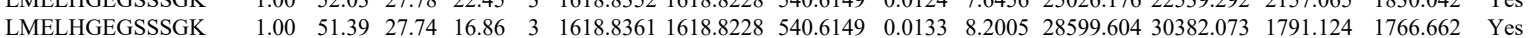
$\begin{array}{llllllllllllllll}\text { KDWYDVK } & 0.93 & 27.76 & 26.77 & 24.86 & 3 & 1384.7803 & 1384.7716 & 462.5978 & 0.0087 & 6.2689 & 34895.355 & 32952.051 & 12146.978 & 1672.964 & \text { Yes }\end{array}$ $\begin{array}{llllllllllllllll}\text { KDWYDVK } & 0.99 & 34.49 & 26.68 & 20.67 & 3 & 1384.7812 & 1384.7716 & 462.5978 & 0.0096 & 6.9174 & 31969.052 & 32362.756 & 11469.122 & 1604.109 & \text { Yes }\end{array}$ $\begin{array}{llllllllllllllll}\text { LMELHGEGSSSGK } & 1.00 & 58.17 & 27.81 & 16.93 & 3 & 1618.8349 & 1618.8228 & 540.6149 & 0.0121 & 7.4606 & 12348.448 & 10500.214 & 2845.683 & 2143.748 & \text { Yes }\end{array}$ $\begin{array}{llllllllllllllll}\text { KDWYDVK } & 0.93 & 27.53 & 26.82 & 19.67 & 3 & 1384.7797 & 1384.7716 & 462.5978 & 0.0081 & 5.8366 & 18932.402 & 18189.336 & 6094.380 & 1673.248 & \text { Yes }\end{array}$

VVDPFSK

TSYPFSK $\begin{array}{lllllllllllllllll}0.99 & 39.40 & 26.22 & 30.75 & 2 & 1078.6368 & 1078.6266 & 540.3206 & 0.0102 & 9.4388 & 13512.363 & 13315.409 & 1901.565 & 841.272 & \text { Yes }\end{array}$ TSYAQHQQVR $\begin{array}{ccccccccccccccc}0.97 & 34.78 & 26.26 & 30.17 & 2 & 1078.6370 & 1078.6266 & 540.3206 & 0.0104 & 9.6238 & 18332.499 & 16762.930 & 2001.991 & 991.603 & \text { Yes } \\ 0.79 & 20.15 & 27.81 & 17.46 & 3 & 1360.6969 & 1360.6969 & 454.5729 & 0.0000 & 0.0000 & 59.690 & 66.487 & 37.513 & 21.117 & \text { Yes }\end{array}$ $\begin{array}{llllllllllllll} & 27.71 & 25.43 & 2 & 2095.0674 & 2095.0708 & 1048.5427 & -0.0034 & -1.6213 & 34.395 & 39.870 & 10.339 & 5.012 & \text { Yes }\end{array}$

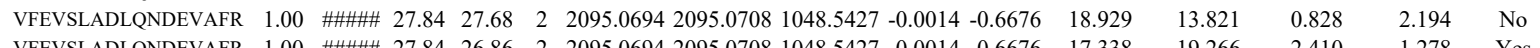

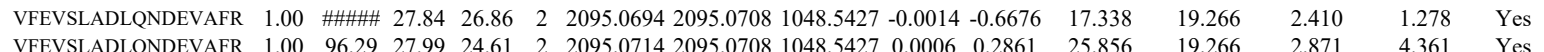

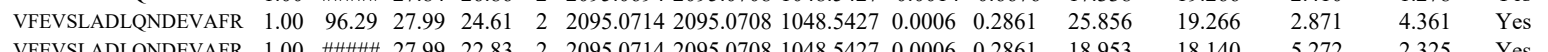

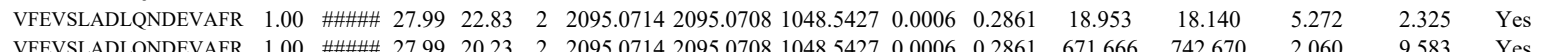

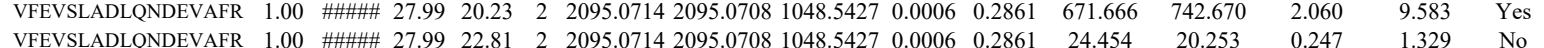

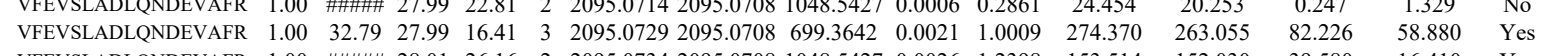

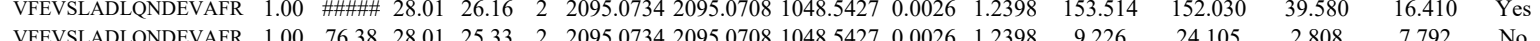

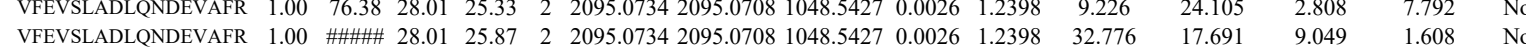


MMEIMTR

$\begin{array}{lllllllllllll}1.00 & 48.45 & 26.20 & 26.40 & 2 & 1054.5188 & 1054.5095 & 528.2620 & 0.0093 & 8.8024 & 14121.810 & 13349.734 & 4534.007\end{array}$

DGYEPPVQESV

NCLTNFHGMDLTR

$\begin{array}{lllllllllllll}0.51 & 13.86 & 25.40 & 18.11 & 2 & 1433.6812 & 1433.6796 & 717.8471 & 0.0016 & 1.1144 & 20.125 & 26.280\end{array}$

NCLTNFHGMDLTR

$\begin{array}{lllllllllll}2.93 & 21.84 & 3 & 1710.7783 & 1710.7762 & 571.2660 & 0.0021 & 1.2253 & 10846.724 & 8658.867\end{array}$

ACOSIYPLHDVFVR

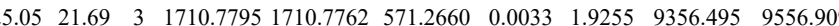

$\begin{array}{llllllllll}28.10 & 21.34 & 3 & 1836.9184 & 1836.9137 & 613.3118 & 0.0047 & 2.5544 & 3116.015 & 3966.120\end{array}$

ACQSIYPLHDVFVR

ACQSIYPLHDVFVR

$\begin{array}{lllllllllllll}0.97 & 24.95 & 28.34 & 17.84 & 3 & 1836.9154 & 1836.9137 & 613.3118 & 0.0017 & 0.9239 & 249.037 & 281.417 & 86.491\end{array}$

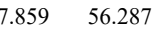

ACQSIYPLHDVFVR

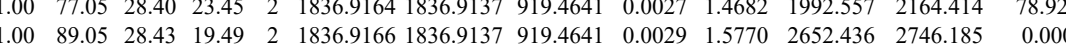

ACQSIYPLHDVFVR

$\begin{array}{lllllllllllll}1.00 & 52.86 & 28.08 & 21.63 & 3 & 1836.9178 & 1836.9137 & 613.3118 & 0.0041 & 2.2283 & 5665.707 & 7337.939 & 747.107 \\ 1.00 & 39.2 & 28.09 & 23.39 & 3 & 1869.9181 & 1836.9137 & 613.318 & 0.0044 & 2.3914 & 15050.645 & 11677.891 & 1997.353\end{array}$

$\begin{array}{llllllllllllll}1.00 & 53.96 & 28.09 & 23.39 & 3 & 1836.9181 & 1836.9137 & 613.3118 & 0.0044 & 2.3914 & 15050.645 & 11677.891 & 1997.353 \\ 1.00 & 89.23 & 28.37 & 19.71 & 2 & 1836.9138 & 1836.9137 & 919.4641 & 0.0001 & 0.0544 & 1386.942 & 1639.325 & 153.919\end{array}$

ACQSIYPLHDVFVR

APAMFNIR

APAMFNIR

$\begin{array}{llllllllllllll}0.53 & 60.70 & 28.13 & 73.70 & 3 & 1836.9172 & 1836.9137 & 613.3118 & 0.0035 & 1.9022 & 6350.738 & 6384.817 & 356.752\end{array}$

$\begin{array}{llllllllllllll}0.53 & 47.78 & 28.34 & 60.78 & 3 & 1836.9163 & 1836.9137 & 613.3118 & 0.0026 & 1.4131 & 2805.026 & 3137.485 & 892.925\end{array}$

$\begin{array}{lllllllllllll}1.00 & 47.56 & 28.12 & 17.48 & 3 & 1836.9169 & 1836.9137 & 613.3118 & 0.0032 & 1.7392 & 3059.080 & 2545.001 & 554.796\end{array}$

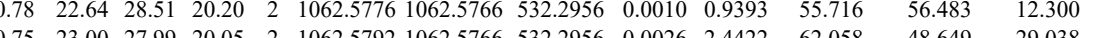
$\begin{array}{lllllllllllll}0.75 & 23.00 & 27.99 & 20.05 & 2 & 1062.5792 & 1062.5766 & 532.2956 & 0.0026 & 2.4422 & 62.058 & 48.649 & 29.038\end{array}$ ACQSTYPLHDV APAMFNIR

APCMGFTK

LFCVGFTK $\begin{array}{lllllllllllll}0.93 & 33.69 & 28.54 & 37.20 & 2 & 1062.5766 & 1062.5766 & 532.2956 & 0.0000 & 0.0000 & 12514.673 & 12090.223 & 9134.580\end{array}$ $\begin{array}{lllllllllllll}0.96 & 3.71 & 28.56 & 37.22 & 2 & 1062.5774 & 1062.5766 & 532.2936 & 0.0008 & 0.7515 & 25287.530 & 23193.831 & 19239.690\end{array}$

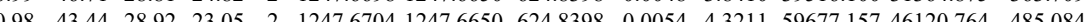

ACQSIYPLHDVFVR

LFCVGFTK

ACQSIYPLHDVFVR

LFCVGFTK

$\begin{array}{lllllllllllllll}00 & 39.37 & 28.34 & 15.89 & 3 & 1836.9163 & 1836.9137 & 613.3118 & 0.0026 & 1.4131 & 1249.103 & 1403.588 & 915.945\end{array}$

$\begin{array}{lllllllllllll}0.99 & 45.33 & 28.84 & 23.52 & 2 & 1247.6688 & 1247.6650 & 624.8398 & 0.0038 & 3.0408 & 26567.225 & 25477.786 & 776.053\end{array}$

$\begin{array}{lllllllllllll}1.00 & 47.02 & 28.83 & 25.16 & 2 & 1247.6694 & 1247.6650 & 624.8398 & 0.0044 & 3.5209 & 45156.254 & 38817.475 & 579.870\end{array}$

LFCVGFTK
LFCVGFTK

$\begin{array}{lllllllllllll}1.00 & 43.33 & 28.81 & 22.15 & 2 & 1247.6680 & 1247.6650 & 624.8398 & 0.0030 & 2.4006 & 8080.278 & 6764.244 & 178.325 \\ 0\end{array}$

ACQSIYPLHDVFVR

ACQSIYPLHDV

$\begin{array}{llllllllllllll}0.99 & 41.27 & 28.85 & 21.83 & 2 & 1247.6686 & 1247.6650 & 624.8398 & 0.0036 & 2.8807 & 5917.259 & 5416.759 & 120.595\end{array}$

LFCVGFTK

$\begin{array}{lllllllllllllll}0.55 & 58.21 & 28.34 & 71.21 & 3 & 1836.9154 & 1836.9137 & 613.3118 & 0.0017 & 0.9239 & 686.439 & 767.430 & 107.817\end{array}$

$\begin{array}{lllllllllllll}45.64 & 28.34 & 58.64 & 3 & 1836.9160 & 1836.9137 & 613.3118 & 0.0023 & 1.2500 & 887.067 & 1165.044 & 181.803\end{array}$

ACQSIYPLHDVFVR

$\begin{array}{lllllllllllll}0.55 & 44.71 & 28.34 & 57.71 & 3 & 1836.9160 & 1836.9137 & 613.3118 & 0.0023 & 1.2500 & 841.862 & 954.452 & 203.525\end{array}$

ACQSIYPLHDVFVR

$\begin{array}{llllllllllllll}1.00 & 52.16 & 28.12 & 22.04 & 3 & 1836.9169 & 1836.9137 & 613.3118 & 0.0032 & 1.7392 & 886.684 & 751.912 & 158.237\end{array}$

ACQSTYPLHDVFVR

NCLTNFHGMDLTR

NCLTNFHGMDLTR

TSYAQHQQVR

LITEDVQGK

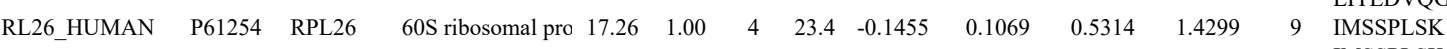

IMSSPLSK

IMSSPLSK

HFNAPSHIR

HFNAPSHIR

HFNAPSHIR

FNPFVTSDR

$\begin{array}{lllllllllllll}.96 & 26.15 & 28.34 & 18.85 & 3 & 1836.9151 & 1836.9137 & 613.3118 & 0.0014 & 0.7609 & 72.366 & 55.413 & 10.787\end{array}$

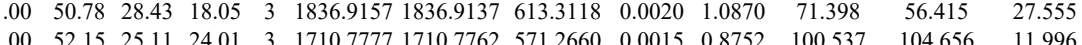

$\begin{array}{lllllllllllll}1.00 & 52.15 & 25.11 & 24.01 & 3 & 1710.7777 & 1710.7762 & 571.2660 & 0.0015 & 0.8752 & 100.537 & 104.656 & 11.996 \\ 1.00 & 52.75 & 24.96 & 22.95 & 3 & 1710.7789 & 1710.7762 & 571.2660 & 0.0027 & 1.5754 & 105.446 & 83.774 & 8.678\end{array}$

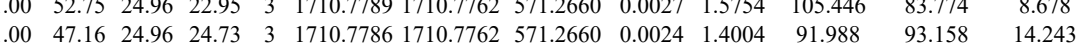

$\begin{array}{llllllllllllll}0.67 & 15.98 & 27.70 & 24.55 & 3 & 1360.6984 & 1360.6969 & 454.5729 & 0.0015 & 1.0999 & 8.545 & 22.214 & 11.711\end{array}$

$\begin{array}{lllllllllllll}1.00 & 57.65 & 27.58 & 28.89 & 2 & 1289.7562 & 1289.7435 & 645.8790 & 0.0127 & 9.8315 & 27801.392 & 25952.818 & 3778.398\end{array}$

$\begin{array}{ccccccccccccc}0.59 & 44.56 * 27.19 & 28.22 & 2 & 1149.6780 & 1149.6671 & 575.8408 & 0.0109 & 9.4643 & 60749.829 & 55026.140 & 1400.945 & 806 \\ 0.61 & 4.98 * 27.19 & 30.23 & 2 & 1149.6780 & 1149.6671 & 575.8408 & 0.0109 & 9.4643 & 90611.049 & 81159.409 & 0.000 & 707\end{array}$

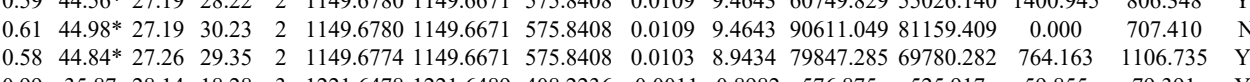

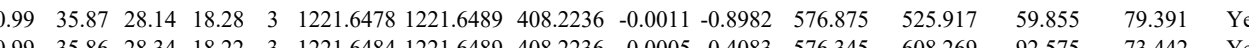

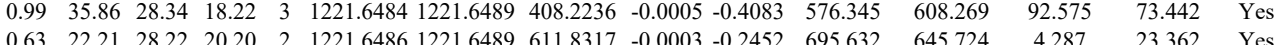

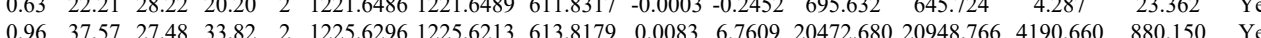

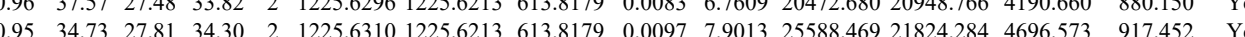

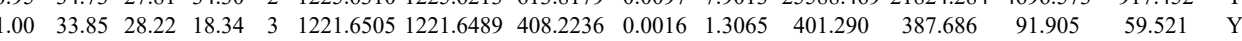

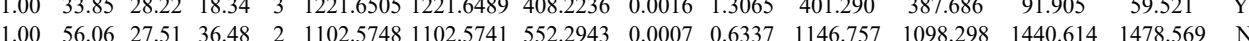


23 SNQQLVDIIEK

SNQQLVDIIEK

TVESEAASYLDQISR

TVESEAASYLDQISR

TVESEAASYLDQISR

TVESEAASYLDQISR
ITSEAEDLVANFFPK

ITSEAEDLVANFFPK
ITSEAEDLVANFFK ITSEAEDLVANFFPK

ITEAEDLVAN

ITSEAEDLVANFFPK

ITSEAEDLVANFFPK

LLELDSFLK

MWVQLLIPR

MWVQLLIPR

MWVQLLIPR

MWVQLLIPR

MWVQLLIPR

MWVQLLIPR

MWVQLLIPR

MWVQLLIPR

MWVQLLIPR

MWVQLLIPR

MWVQLLIPR

MWVQLLIPR

MWVQLLIPR

MWVQLLIPR

MWVQLLIPR
LDECEEAFQGTK

LDECEEAFQGTK

$\begin{array}{lllllllllllll}\text { RL15_HUMAN } & \text { P61313 } & \text { RPL15 } & \text { 60S ribosomal pro } 24.15 & 1.00 & 6 & 27.5 & -0.1769 & 0.2458 & 0.6970 & 1.7923 & 17 & \text { VLNSYWVGEDSTYK }\end{array}$ GLTSAGR

GLTSAGR

GLTSAGR

NTLQLHR

(1)

FFEVILIDPFHK

FFEVILIDPFHK

FFEVILIDPFHK

FFEVILIDPFHK

FFEVILIDPFHK

FFEVILIDPFHK

FFEVILIDPFHK

YIQELWR

FFEVILIDPFHK

FFEVILIDPFHK

FHHTIGGSR

FHHTIGGSR

FHHTIGGSR

FHHTIGGSR

FGHEFLEFEFRPDG

IGSLIDVNQSK

IGSLIDVNQSK

CLVFSLIGLHFK

CLVFSLIGLHFK

IIDDSEITKEDD

YSVDIPLDK

YSVDIPLDK

YSVDIPLDK

YSVDIPLDK

VTAIMK

VTAAMGK
VTAAMGK $\begin{array}{lllllllllllllll}1.00 & 35.50 & 28.25 & 15.81 & 3 & 1221.6499 & 1221.6489 & 408.2236 & 0.0010 & 0.8165 & 365.965 & 317.309 & 104.093 & 52.717 & \text { Y }\end{array}$

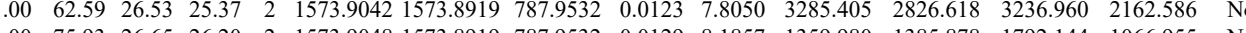

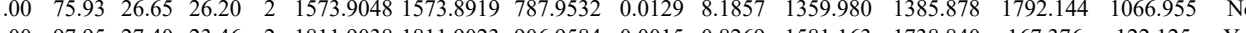

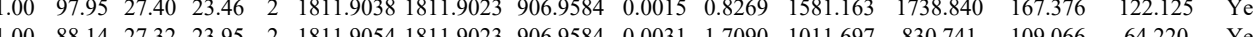
$\begin{array}{llllllllllll} & \end{array}$

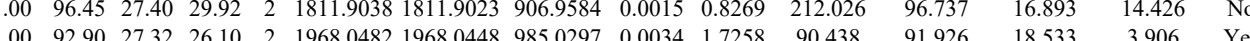

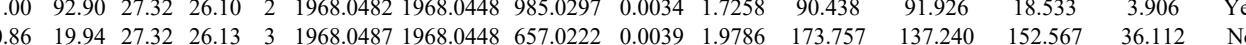

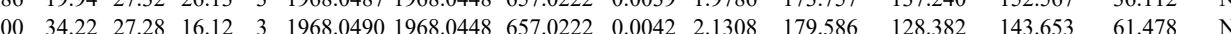
$\begin{array}{llllllllllllll} & 0.86\end{array}$

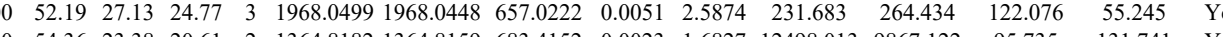

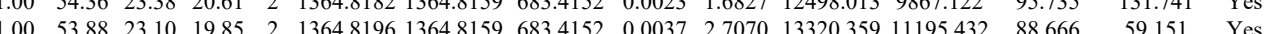
$\begin{array}{llllllllllllllll}1.00 & 50.50 & 25.13 & 17.84 & 2 & 1298.7666 & 1298.7655 & 6503900 & 0.0011 & 0.8456 & 677.469 & 659.697 & 24.188 & 10.496 & \text { Yes }\end{array}$ $\begin{array}{lllllllllllllllll}1.00 & 47.31 & 25.13 & 18.54 & 2 & 1298.7668 & 1298.7655 & 6503900 & 0.0013 & 0.9994 & 1035.548 & 890.091 & 33.486 & 5.203 & \text { Yes }\end{array}$

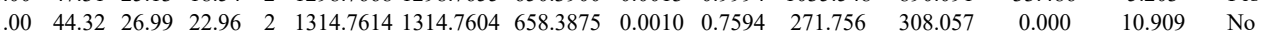
$\begin{array}{lllllllllllllll}1.00 & 47.71 & 26.97 & 27.66 & 2 & 1314.7616 & 1314.7604 & 658.3875 & 0.0012 & 0.9113 & 582.566 & 571.742 & 14.112 & 10.128 & \text { Yes }\end{array}$ $\begin{array}{lllllllllllllll}1.00 & 54.30 & 25.13 & 22.05 & 2 & 1298.7668 & 1298.7655 & 650.3900 & 0.0013 & 0.9994 & 1387.164 & 1300.253 & 74.067 & 46.735 & \text { Yes }\end{array}$ $\begin{array}{lllllllllllllll}1.00 & 50.42 & 25.09 & 20.97 & 2 & 1298.7674 & 1298.7655 & 650.3900 & 0.0019 & 1.4607 & 1478.626 & 1283.805 & 32.009 & 13.702 & \text { Yes }\end{array}$ $\begin{array}{lllllllllllllll}1.00 & 45.94 & 26.97 & 21.86 & 2 & 1314.7616 & 1314.7604 & 658.3875 & 0.0012 & 0.9113 & 408.735 & 410.830 & 14.039 & 15.821 & \text { Yes }\end{array}$

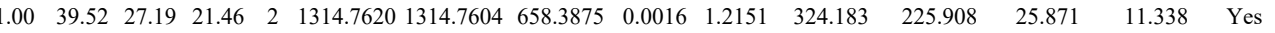
$\begin{array}{lllllllllllllll}.00 & 48.69 & 24.94 & 16.83 & 2 & 1298.7670 & 1298.7655 & 650.3900 & 0.0015 & 1.1532 & 926.065 & 955.952 & 108.190 & 215.487 & \text { Yes }\end{array}$ $\begin{array}{llllllllllllllll}1.00 & 47.68 & 25.09 & 17.53 & 2 & 1298.7672 & 1298.7655 & 650.3900 & 0.0017 & 1.3069 & 928.944 & 884.011 & 74.146 & 123.470 & \text { Yes }\end{array}$ $\begin{array}{llllllllllllllll}0.99 & 34.77 & 27.19 & 21.49 & 2 & 1314.7620 & 1314.7604 & 658.3875 & 0.0016 & 1.2151 & 296.898 & 293.644 & 48.037 & 18.264 & \text { Yes }\end{array}$

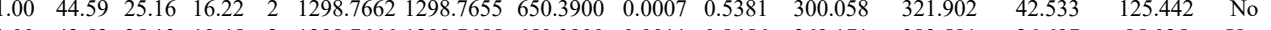
$\begin{array}{llllllllllllllll}1.00 & 42.52 & 25.13 & 19.45 & 2 & 1298.7666 & 1298.7655 & 650.3900 & 0.0011 & 0.8456 & 369.171 & 383.581 & 26.697 & 85.025 & \text { Yes }\end{array}$

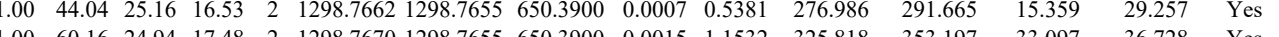

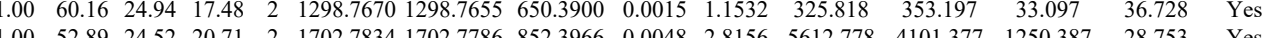

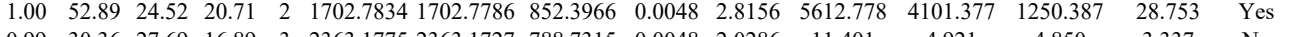

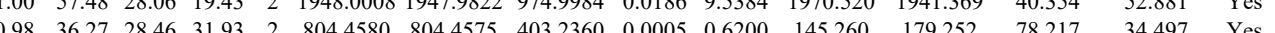
$\begin{array}{lllllllllllllll}0.87 & 26.62 & 28.46 & 36.19 & 2 & 804.4584 & 804.4575 & 403.2360 & 0.0009 & 1.1160 & 185.301 & 152.893 & 65.360 & 32.834 & \text { Yes }\end{array}$ $\begin{array}{lllllllllllllll}0.65 & 22.66 & 28.46 & 32.64 & 2 & 804.4580 & 804.4575 & 403.2360 & 0.0005 & 0.6200 & 44.098 & 76.335 & 28.647 & 1.1291 & \text { No }\end{array}$

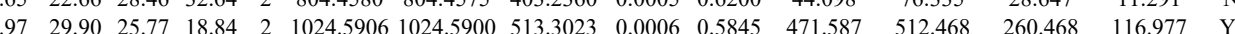
$\begin{array}{llllllllllllll}0.99 & 32.59 & 25.77 & 21.80 & 2 & 1024.5908 & 1024.5900 & 513.3023 & 0.0008 & 0.7793 & 415.539 & 397.433 & 357.423 & 141.036\end{array}$ $\begin{array}{lllllllllllllll} & 56.55 & 25.15 & 22.91 & 2 & 1792.0176 & 1792.0167 & 897.0156 & 0.0009 & 0.5017 & 879.352 & 673.196 & 12.997 & 51.218 & \text { Yes }\end{array}$ $\begin{array}{lllllllllllll} & 22.173 & \text { Yes }\end{array}$ $\begin{array}{llllllllllllllll}0.53 & 43.46 & 24.71 & 56.46 & 3 & 17920198 & 1792.0167 & 598.3462 & 0.0031 & 1.7270 & 16956.466 & 15645.838 & 177.342 & 257.894 & \text { Yes }\end{array}$ $\begin{array}{llllllllllllllll}00 & 45.50 & 24.53 & 18.05 & 3 & 1792.0213 & 1792.0167 & 598.3462 & 0.0046 & 2.5626 & 7406.142 & 6359.520 & 200.990 & 170.944 & \text { Yes }\end{array}$ $\begin{array}{lllllllllllllll}1.00 & 66.08 & 24.91 & 22.91 & 2 & 1792.0184 & 1792.0167 & 897.0156 & 0.0017 & 0.9476 & 549.874 & 622.026 & 1.514 & 24.596 & \text { Yes }\end{array}$ $\begin{array}{llllllllllllllll}1.00 & 61.16 & 24.74 & 20.66 & 2 & 1792.0200 & 1792.0167 & 897.0156 & 0.0033 & 1.8394 & 340.484 & 312.021 & 43.755 & 37.531 & \text { Yes }\end{array}$ $\begin{array}{lllllllllllllll}1.00 & 30.75 & 24.74 & 15.61 & 3 & 1792.0207 & 1792.0167 & 598.3462 & 0.0040 & 2.2284 & 10223.190 & 10253.787 & 659.444 & 26.080 & \text { Yes }\end{array}$ $\begin{array}{lllllllllllllll}0.00 & 60.36 & 24.62 & 23.38 & 3 & 1792.0210 & 1792.0167 & 598.3462 & 0.0043 & 2.3955 & 4074.174 & 4408.720 & 109.275 & 64.234 & \text { Yes }\end{array}$ $\begin{array}{llllllllllllllll}0.96 & 35.62 & 28.70 & 30.00 & 2 & 1150.6368 & 1150.6257 & 576.3201 & 0.0111 & 9.6300 & 5947.861 & 5043.140 & 876.013 & 222.105 & \text { Yes }\end{array}$

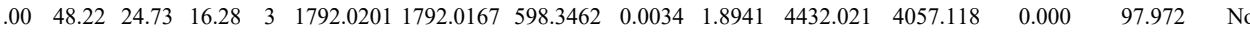
$\begin{array}{lllllllllllllll}1.00 & 52.68 & 24.58 & 25.37 & 3 & 1792.0216 & 1792.0167 & 598.3462 & 0.0049 & 2.7297 & 3487.111 & 3382.797 & 39.577 & 69.543 & \text { Yes }\end{array}$

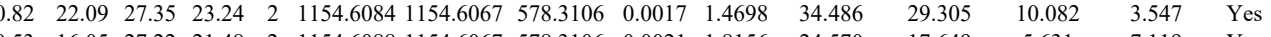

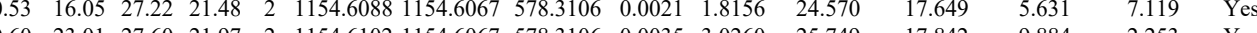

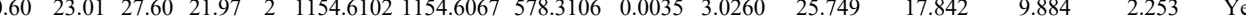

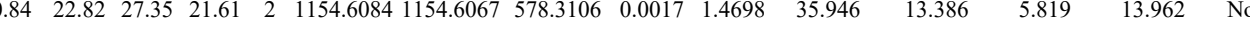
$\begin{array}{lllllllllllllll}1.00 & 21.20 & 27.78 & 34.20 & 4 & 2142.0829 & 2142.0778 & 536.5267 & 0.0051 & 2.3764 & 3920.219 & 2990.930 & 1797.242 & 648.208 & \text { Yes }\end{array}$ \begin{tabular}{llllllllllllllll}
1.00 & 57.11 & 26.06 & 33.02 & 2 & 1460.8570 & 1460.8442 & 731.4294 & 0.0128 & 8.7499 & 2271.073 & 1628.439 & 1140.474 & 230.929 & Yes \\
\hline
\end{tabular} \begin{tabular}{lllllllllllllll}
1.00 & 59.59 & 26.04 & 28.27 & 2 & 1460.8576 & 1460.8442 & 731.4294 & 0.0134 & 9.1601 & 2864.247 & 1886.332 & 1266.617 & 333.505 & Yes \\
\hline
\end{tabular}

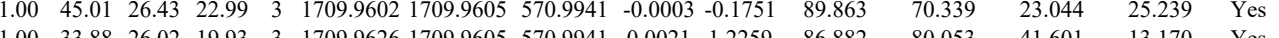

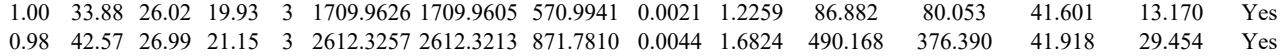

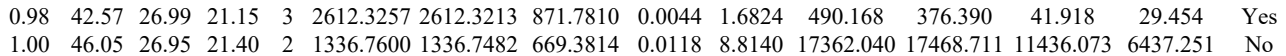

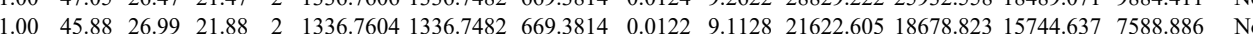

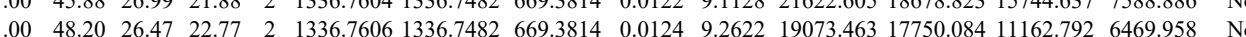

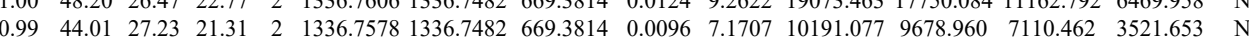
$\begin{array}{lllllllllllllllll}1.00 & 44.16 & 26.47 & 22.81 & 2 & 1336.7606 & 1336.7482 & 669.3814 & 0.0124 & 9.2622 & 13618.794 & 12936598 & 7482.025 & 4162.444 & \text { No }\end{array}$ $\begin{array}{lllllllllllllll}0.50 & 26.05 & 26.05 & 20.96 & 2 & 964.5600 & 9645619 & 483.2882 & -0.0019 & -1.9657 & 35.927 & 35.388 & 43.559 & 16.096 & N o\end{array}$

Table S-3 page 301 of 499 

$\begin{array}{llllllllllllllll}0.95 & 28.13 & 26.50 & 20.63 & 2 & 964.5634 & 964.5619 & 483.2882 & 0.0015 & 1.5519 & 3534.215 & 2632.719 & 1393.237 & 634.071 & \text { Yes } \\ 0.99 & 36.76 & 27.82 & 16.41 & 3 & 1550.7868 & 1550.7785 & 517.9334 & 0.0083 & 5.3417 & 7358.579 & 9043.279 & 2984.775 & 1104.173 & \text { Yes }\end{array}$ $\begin{array}{lllllllllllllllll}0.99 & 42.14 & 27.77 & 26.39 & 2 & 1550.7872 & 1550.7785 & 776.3965 & 0.0087 & 5.6028 & 2945.180 & 3510.437 & 146.299 & 26.605 & \text { Yes }\end{array}$ $\begin{array}{lllllllllllllll}1.00 & 41.96 & 27.77 & 21.74 & 3 & 1550.7874 & 1550.7785 & 517.9334 & 0.0089 & 5.7279 & 10711.570 & 12034.588 & 2406.175 & 925.835 & \text { Yes }\end{array}$ $\begin{array}{llllllllllllllll}1.00 & 43.15 & 27.99 & 17.95 & 3 & 1550.7883 & 1550.7785 & 517.9334 & 0.0098 & 6.3071 & 34163.530 & 34099.941 & 3016.933 & 562.783 & \text { Yes }\end{array}$ $\begin{array}{lllllllllllllll}1.00 & 53.30 & 27.96 & 27.33 & 2 & 1550.7884 & 1550.7785 & 776.3965 & 0.0099 & 6.3756 & 2618.551 & 3226.208 & 126.993 & 67.527 & \text { Yes }\end{array}$

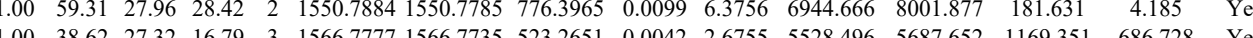

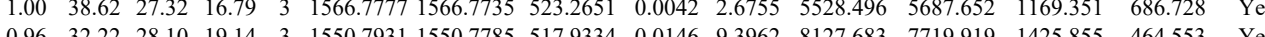

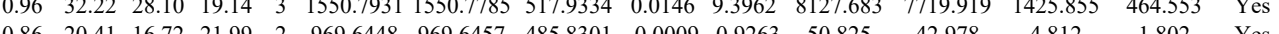

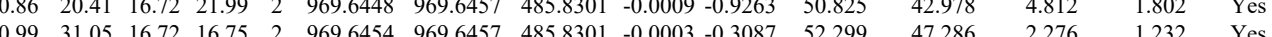

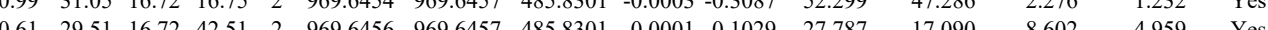

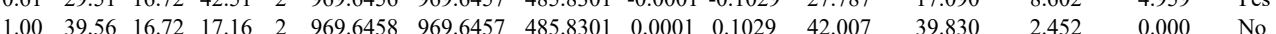
$\begin{array}{llllllllllllllll}0.99 & 27.35 & 16.72 & 20.43 & 2 & 969.6460 & 969.6457 & 485.8301 & 0.0003 & 0.3087 & 44.075 & 27.236 & 13.650 & 6.337 & \text { Yes }\end{array}$ $\begin{array}{llllllllllllllll}0.96 & 1.34 .64 & 16.72 & 30.64 & 2 & 969.6464 & 969.6457 & 485.8301 & 0.0007 & 0.7204 & 50.987 & 31.820 & 9.469 & 2.018 & \text { Yes }\end{array}$

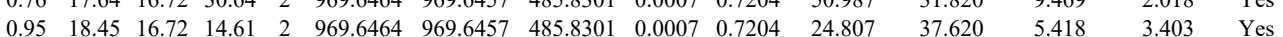
$\begin{array}{llllllllllllllll}1.00 & 36.55 & 16.72 & 19.35 & 2 & 969.6464 & 969.6457 & 485.8301 & 0.0007 & 0.7204 & 52.474 & 59.498 & 2.077 & 1.255 & \text { Yes }\end{array}$ $\begin{array}{llllllllllllllll}0.99 & 24.08 & 16.72 & 14.75 & 2 & 969.6466 & 969.6457 & 485.8301 & 0.0009 & 0.9262 & 42.987 & 35.339 & 12.974 & 3.279 & \text { Yes }\end{array}$ $\begin{array}{lllllllllllllll}0.92 & 16.06 & 16.72 & 15.12 & 2 & 969.6466 & 969.6457 & 485.8301 & 0.0009 & 0.9262 & 32.171 & 28.218 & 2.931 & 0.870 & \text { No }\end{array}$ $\begin{array}{llllllllllllllll}0.76 & 16.70 & 16.72 & 29.70 & 2 & 969.6468 & 969.6457 & 485.8301 & 0.0011 & 1.1321 & 45.290 & 60.942 & 0.988 & 4.736 & \text { No }\end{array}$ $\begin{array}{llllllllllllllll}0.99 & 24.12 & 16.72 & 16.07 & 2 & 969.6468 & 969.6457 & 485.8301 & 0.0011 & 1.1321 & 34.755 & 39.538 & 0.000 & 3.138 & \text { No }\end{array}$ $\begin{array}{lllllllllllllllll}0.99 & 25.97 & 16.72 & 15.31 & 2 & 969.6470 & 969.6457 & 485.8301 & 0.0013 & 1.3379 & 36.341 & 40.169 & 1.347 & 6.372 & \text { Yes }\end{array}$ $\begin{array}{lllllllllllllll}1.00 & 35.78 & 16.72 & 18.21 & 2 & 969.6470 & 969.6457 & 485.8301 & 0.0013 & 1.3379 & 68.610 & 53.594 & 0.000 & 3.167 & \text { No }\end{array}$ $\begin{array}{llllllllllllllll}0.99 & 28.25 & 17.85 & 24.62 & 2 & 969.6474 & 969.6457 & 485.8301 & 0.0017 & 1.7496 & 47.803 & 22.383 & 9.519 & 4.917 & \text { No }\end{array}$

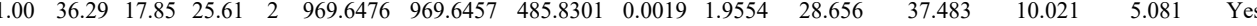
$\begin{array}{lllllllllllllll}0.61 & 22.37 & 16.72 & 35.37 & 2 & 969.6452 & 969.6457 & 485.8301 & -0.0005 & -0.5146 & 40.136 & 37.429 & 10.561 & 1.743 & \text { Yes }\end{array}$ \begin{tabular}{lllllllllllllll}
0.94 & 20.57 & 16.72 & 14.31 & 2 & 969.6456 & 969.6457 & 485.8301 & -0.0001 & -0.1029 & 102.748 & 88.289 & 8.794 & 7.290 & Yes \\
\hline
\end{tabular} $\begin{array}{llllllllllllllll}0.98 & 26.23 & 16.72 & 16.15 & 2 & 969.6458 & 969.6457 & 485.8301 & 0.0001 & 0.1029 & 124.187 & 140.002 & 13.809 & 5.152 & \text { Yes } \\ 0.98 & 26.50 & 16.7 & 15.70 & 2 & 969.640 & 969.657 & 485.831 & 0.0003 & 0.087 & 143.538 & 142.659 & 26.512 & 133 & \text { Yes }\end{array}$

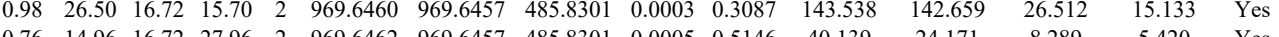
$\begin{array}{lllllllllllllllll}0.76 & 14.96 & 16.72 & 27.96 & 2 & 969.6462 & 969.6457 & 485.8301 & 0.0005 & 0.5146 & 40.139 & 24.171 & 8.289 & 5.420 & \text { Yes }\end{array}$ $\begin{array}{llllllllllllllll}0.99 & 26.51 & 16.72 & 20.63 & 2 & 969.6464 & 969.6457 & 485.8301 & 0.0007 & 0.7204 & 128.402 & 189.655 & 23.285 & 10.247 & \text { Yes }\end{array}$ $\begin{array}{llllllllllllllll}1.00 & 28.51 & 16.72 & 15.92 & 2 & 969.6466 & 969.6457 & 485.8301 & 0.0009 & 0.9262 & 116.449 & 148.433 & 20.160 & 8.438 & \text { Yes } \\ 0 & 27.99 & 16.72 & 18.01 & 2 & 96968 & 969.657 & 485.8301 & 0.001 & 1.1321 & 94.941 & 146.756 & 6.054 & 8.206 & \text { Yes }\end{array}$ $\begin{array}{llllllllllllllll}0.99 & 27.39 & 16.72 & 18.01 & 2 & 969.6468 & 969.6457 & 485.8301 & 0.0011 & 1.1321 & 94.941 & 146.756 & 6.054 & 8.206 & \text { Yes } \\ 1.00 & 33.21 & 17.85 & 25.82 & 2 & 969.6472 & 969.6457 & 485.8301 & 0.0015 & 1.5437 & 88.562 & 96.111 & 13.592 & 8.246 & \text { Yes }\end{array}$ $\begin{array}{lllllllllllllll}1.00 & 33.21 & 17.85 & 25.82 & 2 & 969.6472 & 969.6457 & 485.8301 & 0.0015 & 1.5437 & 88.562 & 96.111 & 13.592 & 8.246 & \text { Yes } \\ 0.99 & 28.81 & 17.85 & 26.48 & 2 & 969.6472 & 969.6457 & 485.8301 & 0.0015 & 1.5437 & 80.947 & 93.385 & 9.336 & 9.373 & \text { Yes }\end{array}$

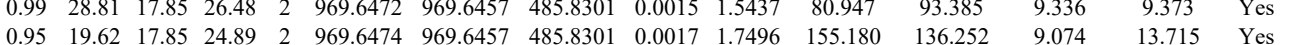

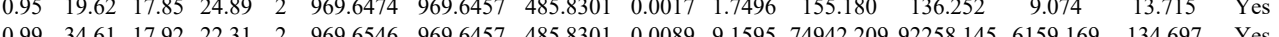
$\begin{array}{lllllllllllllll}0.90 & 34.61 & 17.92 & 22.31 & 2 & 96.6546 & 96.6457 & 485.8301 & 0.0089 & 9.157 & 74942.209 & 92258.145 & 6159.169 & 134.697 & \text { Yes } \\ 1.00 & 42.79 & 17.92 & 23.28 & 2 & 969.6552 & 969.6457 & 485.8301 & 0.0095 & 9.7770 & 32538.730 & 37415.834 & 1622.425 & 299.105 & \text { Yes }\end{array}$ $\begin{array}{lllllllllllllllll}1.00 & 32.93 & 16.72 & 18.16 & 2 & 969.6462 & 969.6457 & 485.8301 & 0.0005 & 0.5146 & 47105.495 & 45951.903 & 998.228 & 49.378 & \text { Yes }\end{array}$ $\begin{array}{lllllllllllllll}1.00 & 32.02 & 16.72 & 19.33 & 2 & 969.6468 & 969.6457 & 485.8301 & 0.0011 & 1.51321 & 88358.731 & 99504.541 & 6135.213 & 236.521 & \text { Yes }\end{array}$ $\begin{array}{lllllllllllllllll}1.00 & 37.14 & 16.72 & 21.12 & 2 & 969.6460 & 969.6457 & 485.8301 & 0.0003 & 0.3087 & 5429.003 & 6502.471 & 296.410 & 53.883 & \text { Yes }\end{array}$ $\begin{array}{llllllllllllllll}1.00 & 38.84 & 16.72 & 20.58 & 2 & 969.6462 & 969.6457 & 485.8301 & 0.0005 & 0.5146 & 15029.631 & 16892.058 & 739.018 & 206.737 & \text { Yes }\end{array}$ $\begin{array}{lllllllllllllll}1.00 & 35.87 & 16.72 & 20.24 & 2 & 969.6462 & 969.6457 & 485.8301 & 0.0005 & 0.5146 & 2753.207 & 2840.319 & 120.587 & 97.629 & \text { Yes }\end{array}$ $\begin{array}{lllllllllllllll}1.00 & 37.84 & 16.72 & 21.08 & 2 & 969.6462 & 969.6457 & 485.8301 & 0.0005 & 0.5146 & 6456.082 & 6775.153 & 223.864 & 80.271 & \text { Yes }\end{array}$ $\begin{array}{llllllllllllllll}1.00 & 41.37 & 16.72 & 20.92 & 2 & 969.6460 & 969.6457 & 485.8301 & 0.0003 & 0.3087 & 2673.287 & 2942.909 & 116.083 & 130.586 & \text { Yes }\end{array}$ $\begin{array}{lllllllllllllllll}0.99 & 27.43 & 16.72 & 19.83 & 2 & 969.6460 & 969.6457 & 485.8301 & 0.0003 & 0.3087 & 717.731 & 753.426 & 213.904 & 122.854 & \text { Yes }\end{array}$ $\begin{array}{llllllllllllllll}1.00 & 41.41 & 16.72 & 20.20 & 2 & 969.6468 & 969.6457 & 485.8301 & 0.0011 & 1.1321 & 1726.552 & 2048.555 & 120.381 & 123.287 & \text { Yes }\end{array}$ $\begin{array}{llllllllllllllll}1.00 & 32.26 & 16.72 & 15.58 & 2 & 969.6466 & 969.6457 & 485.8301 & 0.0009 & 0.9262 & 761.177 & 695.210 & 53.438 & 18.225 & \text { Yes }\end{array}$ $\begin{array}{lllllllllllllll}1.00 & 33.83 & 16.72 & 19.12 & 2 & 969.6466 & 969.6457 & 485.8301 & 0.0009 & 0.9262 & 736.310 & 835.946 & 46.000 & 47.739 & \text { Yes }\end{array}$ $\begin{array}{llllllllllllllll}0.98 & 22.85 & 16.72 & 23.29 & 2 & 969.6462 & 969.6457 & 485.8301 & 0.0005 & 0.5146 & 174.218 & 182.642 & 25.038 & 15.652 & \text { Yes }\end{array}$ $\begin{array}{lllllllllllllll}0.99 & 27.74 & 16.72 & 16.24 & 2 & 969.6468 & 969.6457 & 485.8301 & 0.0011 & 1.1321 & 224.783 & 189.454 & 44.304 & 26.701 & \text { Yes }\end{array}$ $\begin{array}{lllllllllllllll}0.99 & 26.97 & 16.72 & 15.67 & 2 & 969.6464 & 969.6457 & 485.8301 & 0.0007 & 0.7204 & 193.266 & 227.959 & 29.748 & 22.195 & \text { Yes }\end{array}$ $\begin{array}{llllllllllllllll}1.00 & 31.36 & 16.72 & 17.25 & 2 & 969.6464 & 969.6457 & 485.8301 & 0.0007 & 0.7204 & 231.547 & 209.432 & 33.348 & 14.974 & \text { Yes }\end{array}$ $\begin{array}{llllllllllllllll}1.00 & 31.14 & 16.72 & 16.90 & 2 & 969.6468 & 969.6457 & 485.8301 & 0.0011 & 1.1321 & 165.846 & 178.508 & 23.170 & 18.993 & \text { Yes }\end{array}$ $\begin{array}{lllllllllllllll}0.99 & 25.86 & 16.72 & 24.02 & 2 & 969.6464 & 969.6457 & 485.8301 & 0.0007 & 0.7204 & 308.448 & 318.658 & 16.477 & 15.569 & \text { Yes }\end{array}$

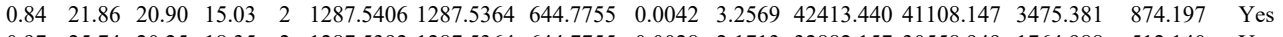

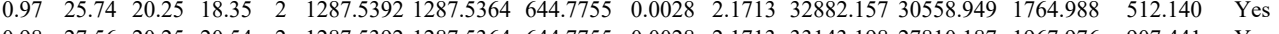
$\begin{array}{lllllllllllllll}0.98 & 27.56 & 20.25 & 20.54 & 2 & 1287.5392 & 1287.5364 & 644.7755 & 0.0028 & 2.1713 & 33143.198 & 27810.187 & 1967.976 & 907.441 & \text { Yes }\end{array}$ $\begin{array}{llllllllllllllll}0.99 & 33.82 & 24.38 & 15.19 & 3 & 1670.7556 & 1670.7467 & 557.9228 & 0.0089 & 5.3173 & 9218.916 & 10291.464 & 1187.337 & 772.814 & \text { Yes }\end{array}$ $\begin{array}{llllllllllllllll}1.00 & 37.05 & 24.20 & 21.43 & 3 & 1670.7508 & 1670.7467 & 557.9228 & 0.0041 & 2.4496 & 17559.735 & 16392.867 & 947.346 & 468.676 & \text { Yes } \\ 0.99 & 27.67 & 24.22 & 20.94 & 3 & 1670.7511 & 1670.7467 & 557.9228 & 0.0044 & 2.6288 & 14728.63 & 12435.967 & 954.476 & 810.388 & \text { Yes }\end{array}$ $\begin{array}{lllllllllllllll}0.99 & 27.67 & 24.22 & 20.94 & 3 & 1670.7511 & 1670.7467 & 557.9228 & 0.0044 & 2.6288 & 14728.623 & 12435.967 & 954.476 & 810.388 & \text { Yes } \\ 0.98 & 23.97 & 24.15 & 20.74 & 3 & 1670.7478 & 1670.7467 & 557.9228 & 0.0011 & 0.6572 & 4473.203 & 3749.075 & 618.323 & 245.606 & \text { Yes }\end{array}$

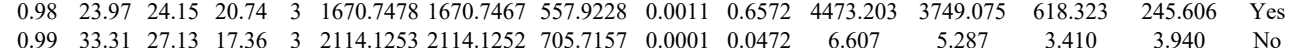

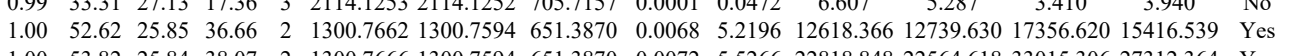
$\begin{array}{lllllllllllllll}1.00 & 53.82 & 25.84 & 38.07 & 2 & 1300.7666 & 1300.7594 & 651.3870 & 0.0072 & 5.5266 & 22818.848 & 22564.618 & 33015.306 & 27312.364 & \text { Yes } \\ 0.99 & 52.63 & 26.07 & 38.46 & 2 & 1300.7650 & 1300.7594 & 651.3870 & 0.0056 & 4.2985 & 14169.158 & 12954.099 & 17196.474 & 17683.238 & \text { No }\end{array}$ $\begin{array}{lllllllllllllllll}0.97 & 37.08 & 27.07 & 38.46 & 2 & 1300.7650 & 1300.7594 & 651.3870 & 0.0056 & 4.2985 & 14169.158 & 12954.099 & 17196.474 & 17683.238 & \text { No }\end{array}$ 

$\begin{array}{llllllllllllllll}0.64 & 19.07 & 28.33 & 31.47 & 2 & 1050.6006 & 1050.5984 & 526.3065 & 0.0022 & 2.0900 & 537.038 & 437.038 & 84.220 & 37.422 & \text { Yes }\end{array}$ $\begin{array}{llllllllllllllll}0.73 & 22.84 & 28.31 & 32.22 & 2 & 1050.6010 & 1050.5984 & 526.3065 & 0.0026 & 2.4700 & \# \# \# \# \# \text { \#\#\#\#\# } 10379.503 & 2295.983 & \text { Yes }\end{array}$ $\begin{array}{llllllllllllllll}0.88 & 27.06 & 28.31 & 32.80 & 2 & 1050.6012 & 1050.5984 & 526.3065 & 0.0028 & 2.6600 & 99752.740 & 80157.329 & 5391.170 & 870.207 & \text { Yes }\end{array}$

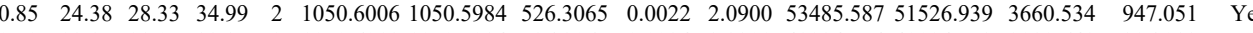

IIEVGDTPK

GQYNTYPIK

AFSPTTVNTGR

AFSPTTVNTGR

AFSPTTVNTGR
AFSPTTVNTGR

AFSPTTVNTGR
AFSPTTVNTGR

AFSPTTVNTGR

$\begin{array}{llllllllllllll}0.79 & 23.87 & 28.07 & 33.35 & 2 & 1050.6018 & 1050.5984 & 526.3065 & 0.0034 & 3.2300 & 49224.754 & 40024.753 & 2089.648 & 326.083\end{array}$

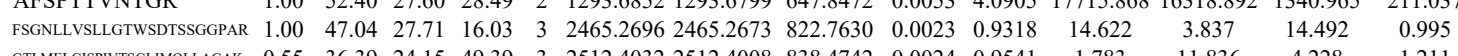

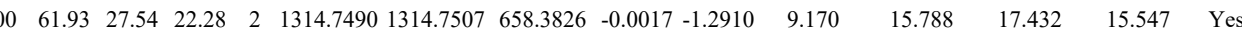

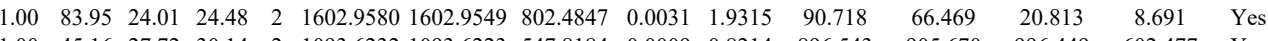

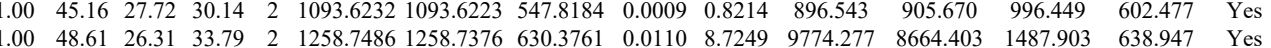
$\begin{array}{lllllllllllllllll}1.00 & 48.61 & 26.31 & 33.79 & 2 & 1258.7486 & 1258.7376 & 630.3761 & 0.0110 & 8.7249 & 9774.277 & 8664.403 & 1487.903 & 638.947 & \text { Yes } \\ 1.00 & 62.92 & 26.31 & 34.10 & 2 & 12587488 & 12587376 & 630.3761 & 0.0112 & 8.8835 & 11875.534 & 10411.622 & 1991.431 & 520.694 & \text { Yes }\end{array}$ $\begin{array}{llllllllllllllll}0.99 & 38.81 & 27.40 & 26.51 & 2 & 1370.7472 & 1370.7438 & 686.3792 & 0.0034 & 2.4768 & 17741.594 & 15726.250 & 14251.946 & 13588.266 & \text { No } & \end{array}$ $\begin{array}{lllllllllllllll}0.98 & 42.57 & 27.75 & 25.47 & 2 & 1293.6856 & 1293.6799 & 647.8472 & 0.0057 & 4.3992 & 9139.071 & 10613.093 & 1122.085 & 737.976 & \text { Yes }\end{array}$ $\begin{array}{llllllllllllllll}0.99 & 44.56 & 27.75 & 27.76 & 2 & 1293.6858 & 1293.6799 & 647.8472 & 0.0059 & 4.5535 & 23944.429 & 20567.495 & 1736.504 & 752.526 & \text { Yes }\end{array}$ $\begin{array}{lllllllllllllll}1.00 & 57.53 & 27.61 & 27.67 & 2 & 1293.6822 & 1293.6799 & 647.8472 & 0.0023 & 1.7751 & 43553.587 & 42552.071 & 1104.806 & 306.846 & \text { Yes }\end{array}$ $\begin{array}{lllllllllllllll}1.00 & 54.29 & 27.92 & 30.40 & 2 & 1293.6832 & 1293.6799 & 647.8472 & 0.0033 & 2.5469 & 37088.509 & 37972.158 & 1739.412 & 365.554 & \text { Yes } \\ 1.00 & 51.79 & 27.99 & 26.95 & 2 & 1293.6846 & 1293.6799 & 647.8472 & 0.0047 & 3.6274 & 12264.180 & 10545.707 & 70.638 & 198.50 & \text { Yes }\end{array}$ $\begin{array}{llllllllllllllll}1.00 & 51.79 & 27.99 & 26.95 & 2 & 1293.6846 & 1293.6799 & 647.8472 & 0.0047 & 3.6274 & 12264.180 & 10545.707 & 700.638 & 198.250 & \text { Yes } & \\ 1.00 & 52.40 & 27.60 & 28.49 & 2 & 1293.6852 & 1293.6799 & 647.8472 & 0.0053 & 4.0905 & 17715.868 & 16318.892 & 1340.965 & 211.037 & \text { Yes }\end{array}$ $\begin{array}{llllllllllllll} & 0.5\end{array}$ \begin{tabular}{lllllllllllllll}
0.99 & 41.99 & 27.94 & 27.10 & 2 & 1292.6922 & 1292.6824 & 647.3485 & 0.0098 & 7.5693 & 13000.334 & 15562.179 & 6004.685 & 3276.815 & Yes \\
\hline
\end{tabular} $\begin{array}{lllllllllllllll}0.99 & 43.43 & 27.92 & 28.28 & 2 & 1292.6932 & 1292.6824 & 647.3485 & 0.0108 & 8.3417 & 8309.065 & 10680.130 & 3677.917 & 2188.896 & \text { Yes }\end{array}$

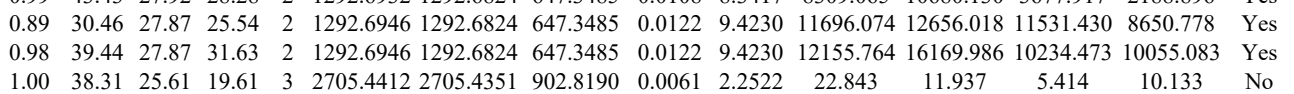
SGINCPIQK $\begin{array}{llllllllllllllll}\text { AVVHGLMGVPVPFPPEPDGCK } & 1.00 & 38.31 & 25.61 & 19.61 & 3 & 2705.4412 & 2705.4351 & 902.8190 & 0.0061 & 2.2522 & 22.843 & 11.937 & 5.414 & 10.133 & \text { No } \\ \text { AVVHGIMGVPVPFPPFPDGCK } & 1.00 & 43.22 & 25.79 & 17.40 & 3 & 2705.4376 & 2705.4351 & 902.8190 & 0.0025 & 0.9230 & 177.203 & 264.670 & 61.105 & 9.492 & \text { Yes }\end{array}$ $\begin{array}{lllllllllllllllll}\text { AVVHGILMGVVVPFIPFPDGCK } & 0.55 & 30.84 & 25.79 & 43.84 & 3 & 2705.4376 & 2705.4351 & 902.8190 & 0.0025 & 0.9230 & 87.450 & 190.523 & 34.608 & 48.272 & \text { Yes }\end{array}$

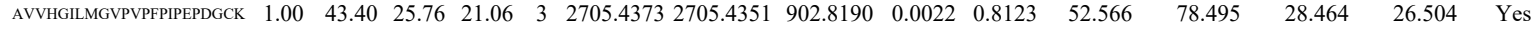

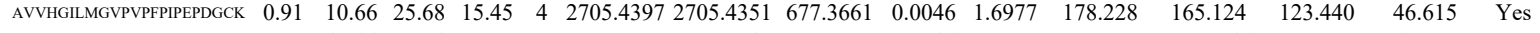
$\begin{array}{llllllllllllllll}\text { ADEDPIMGFHQMFLLK } & 1.00 & 43.44 & 27.14 & 15.82 & 3 & 2179.1095 & 2179.1049 & 727.3756 & 0.0046 & 2.1080 & 1112.993 & 1020.146 & 378.558 & 69.097 & \text { Yes }\end{array}$

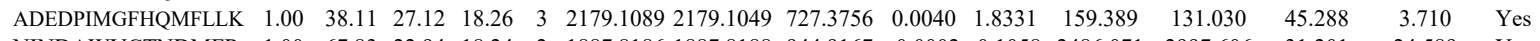

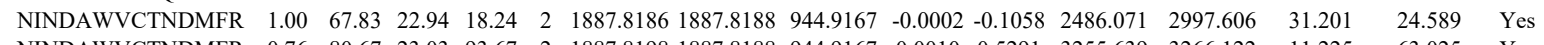
$\begin{array}{llllllllllllllll}\text { NINDAWVCTNDMFR } & 0.76 & 80.67 & 23.03 & 93.67 & 2 & 1887.8198 & 1887.8188 & 944.9167 & 0.0010 & 0.5291 & 3255.639 & 3266.122 & 11.225 & 63.025 & \text { Yes }\end{array}$

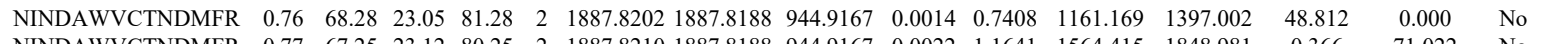

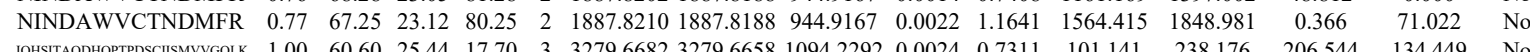

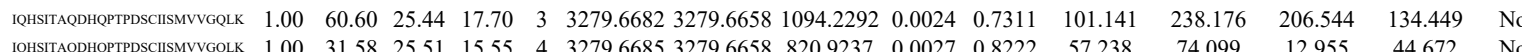
$\begin{array}{llllllllllllllll}\text { IQHSITAQDHPPTPSCIISMVVGGLK } & 1.00 & 31.58 & 25.51 & 15.55 & 4 & 3279.6685 & 3279.6658 & 820.9237 & 0.0027 & 0.8222 & 57.238 & 74.099 & 12.955 & 44.672 & \text { No }\end{array}$ $\begin{array}{llllllllllllllll}\text { IRHSITAQDHQPTPSCCIISMVGGQLK K } & 0.71 & 6.55 & 25.47 & 19.55 & 4 & 3279.6697 & 3279.6658 & 820.9237 & 0.0039 & 1.1877 & 99.330 & 182.005 & 79.738 & 90.096 & \text { Yes } \\ \text { LSSLPFQK } & 0.96 & 36.63 & 26.22 & 27.15 & 2 & 1206.7278 & 1206.7216 & 604.3681 & 0.0062 & 5.1293 & 4243.634 & 4265.626 & 206.380 & 175.364 & \text { Yes } \\ \text { LSSLPFQK } & 0.84 & 28.99 & 26.17 & 25.37 & 2 & 1206.7292 & 1206.7216 & 6043681 & 0.0076 & 6.2875 & 4336.420 & 5190.956 & 77.122 & 159.555 & \text { Yes }\end{array}$

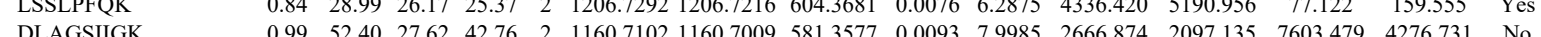
$\begin{array}{lllllllllllllllll}\text { DLAGSIIGK } & 0.99 & 48.40 & 27.62 & 40.56 & 2 & 1160.7102 & 1160.7009 & 581.3577 & 0.0093 & 7.9985 & 2596.177 & 2215.859 & 7540.000 & 3950.191 & \text { No }\end{array}$ 
IILDLISESPIK

VVLIGGKPDR
VVLIGGKPDR

VVLIGGKPDR
VVLIGGKPDR

VVLIGGKPDR
VVLIGGKPDR

VVLIGGKPDR

VVLIGGKPDR

VVLIGGKPDR

VVLIGGKPDR

VVLIGGKPDR

VVLIGGKPDR

VVLIGGKPDR

VVLIGGKPDR

GSDFDCELR

NTDEMVELR

IDEPLEGSEDR
IDEPLEGSEDR

IDEPLEGSEDR

RPAEDMEEEQAFK

RPAEDMEEEQAFK

RPAEDMEEEQAFK

RPAEDMEEEQAFK

RPAEDMEEEQAFK

RPAEDMEEEQAFK

NLPLPPPPPPR

$\begin{array}{lllllllllll}1.00 & 35.94 & 2.64 & 20.93 & 3 & 2002.1824 & 2002.1805 & 668.4008 & 0.0019 & 0.9475 & 21.048\end{array}$

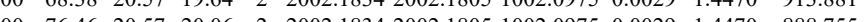

$\begin{array}{lllllllllll}1.00 & 48.46 & 20.57 & 17.68 & 3 & 2002.1845 & 2002.1805 & 668.4008 & 0.0040 & 1.9948 & 182.795\end{array}$

$\begin{array}{llllllllllll}0.81 & 11.28 & 20.57 & 14.84 & 3 & 2002.1848 & 2002.1805 & 668.4008 & 0.0043 & 2.1444 & 232.090\end{array}$

$\begin{array}{llllllllll} & \end{array}$

$\begin{array}{llllllllll} & 06.174\end{array}$

$\begin{array}{lllllllll} & 0.031 .278\end{array}$

$\begin{array}{lllllllllllll}1.00 & 33.58 & 20.53 & 20.62 & 3 & 2002.1857 & 2002.1805 & 668.4008 & 0.0052 & 2.5932 & 197.253 & 195.961\end{array}$

$\begin{array}{llllllllllll}1.00 & 69.58 & 19.40 & 27.47 & 2 & 1628.0016 & 1628.0004 & 815.0075 & 0.0012 & 0.7362 & 1095.468 & 1135.147\end{array}$

$\begin{array}{lllllllllllll}1.00 & 49.84 & 18.92 & 16.44 & 3 & 1628.0032 & 1628.0004 & 543.6741 & 0.0028 & 1.7167 & 293.852 & 238.670 \\ 1.00 & 73.13 & 18.92 & 30.26 & 2 & 1628.0034 & 1628.0004 & 815.0075 & 0.0030 & 1.8405 & 1374.342 & 1392.679\end{array}$

$\begin{array}{lllllllllllll}1.00 & 41.98 & 18.86 & 18.88 & 3 & 1628.0044 & 1628.0004 & 543.6741 & 0.0040 & 2.4524 & 205.492 & 206.985\end{array}$

$\begin{array}{lllllllllllll}1.00 & 90.51 & 20.64 & 21.32 & 2 & 2002.1814 & 2002.1805 & 1002.0975 & 0.0009 & 0.4491 & 181.627 & 280.556\end{array}$

$\begin{array}{llllllllllll}1.00 & 34.07 & 20.64 & 15.18 & 3 & 2002.1824 & 2002.1805 & 668.4008 & 0.0019 & 0.9475 & 225.617\end{array}$

$\begin{array}{llllllllllll}.00 & 35.10 & 20.57 & 22.70 & 3 & 2002.1833 & 2002.1805 & 668.4008 & 0.0028 & 1.3964 & 138.058\end{array}$

$\begin{array}{llllllllllll}1.00 & 36.01 & 20.57 & 19.02 & 3 & 2002.1833 & 2002.1805 & 668.4008 & 0.0028 & 1.3964 & 203.877\end{array}$

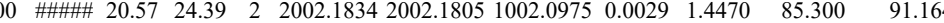

$\begin{array}{llllllllllll}0.67 & 7.49 & 20.57 & 14.97 & 3 & 2002.1836 & 2002.1805 & 668.4008 & 0.0031 & 1.5460 & 146.366 & 156.912\end{array}$

$\begin{array}{lllllllllllll}0.67 & 7.4 & 14.57 & 14.97 & 3 & 202.1836 & 202.180 & 668.408 & 0.0031 & 1.6460 & 146.364 & 156.912 \\ 0.99 & 22.62 & 20.57 & 20.80 & 3 & 2002.1839 & 2002.1805 & 668.4008 & 0.0034 & 1.6956 & 177.742 & 209.016\end{array}$

$\begin{array}{llllllllllllll}0.53 & 22.46 & 20.57 & 35.46 & 3 & 2002.1839 & 2002.1805 & 668.4008 & 0.0034 & 1.6956 & 159.552 & 163.898\end{array}$

$\begin{array}{llllllllllllll}0.5 & 6.49 & 20.53 & 13.72 & 3 & 2002.1842 & 2002.1805 & 668.4008 & 0.0037 & 1.8452 & 180.670 & 163.140 \\ 0.76 & 10.19 & 20.57 & 15.91 & 3 & 2002.1845 & 2002.1805 & 668.4008 & 0.0040 & 1.9948 & 191.190 & 174.566\end{array}$

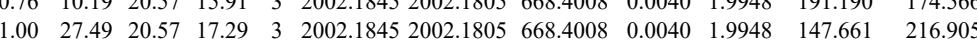

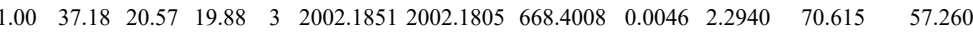

$\begin{array}{lllllllllllll}0.98 & 21.92 & 20.57 & 15.06 & 3 & 2002.1851 & 2002.1805 & 668.4008 & 0.0046 & 2.2940 & 378.500 & 345.509 \\ 1.00 & 90.06 & 18.92 & 32.33 & 2 & 1628.0028 & 1628.0004 & 815.0075 & 0.0024 & 1.4724 & 3681.834 & 3519.529\end{array}$

$\begin{array}{llllllllllll}1.05 & 0.06 & 18.92 & 32.33 & 2 & 1628.0028 & 1628.0004 & 815.0075 & 0.0024 & 1.4724 & 3681.834 & 3519.529 \\ 0.53 & 43.54 & 18.86 & 56.54 & 3 & 1628.0038 & 1628.0004 & 543.6741 & 0.0034 & 2.0846 & 278.660 & 348.565\end{array}$

$\begin{array}{llllllllllll}0.56 & 43.54 & 8.86 & 56.54 & 3 & 1628.0038 & 1628.0004 & 543.6741 & 0.0034 & 2.0846 & 278.660 & 348.565 \\ 18.00 & 62.47 & 18.86 & 18.81 & 3 & 1628.0041 & 1628.0004 & 543.6741 & 0.0037 & 2.2685 & 1708.969 & 1911.627\end{array}$

$\begin{array}{llllllllllll}0 & 44.43 & 20.57 & 18.51 & 3 & 2002.1848 & 2002.1805 & 668.4008 & 0.0043 & 2.1444 & 116.653 & 241.28\end{array}$

$\begin{array}{lllllllllllll}1.00 & 77.55 & 18.92 & 30.02 & 2 & 1628.0034 & 1628.0004 & 815.0075 & 0.0030 & 1.8405 & 759.309 & 793.516\end{array}$ $\begin{array}{llllllllllll}0.53 & 38.36 & 18.92 & 51.36 & 3 & 1628.0035 & 1628.0004 & 543.6741 & 0.0031 & 1.9006 & 491.660 & 380.452\end{array}$ $\begin{array}{lllllllllllll}0.53 & 38.36 & 18.92 & 51.36 & 3 & 1628.0035 & 1628.004 & 543.6741 & 0.0031 & 1.9006 & 491.660 & 380.452\end{array}$ $\begin{array}{lllllllllllll}0.53 & 25.10 & 18.86 & 38.10 & 3 & 1628.0038 & 1628.0004 & 543.6741 & 0.0034 & 2.0846 & 474.858 & 464.823\end{array}$ $\begin{array}{lllllllllllll}0.65 & 4.73 & 24.35 & 13.64 & 4 & 4331.1989 & 4331.1949 & 1083.8060 & 0.0040 & 0.9227 & 11.142 & 10.326\end{array}$

$\begin{array}{lllllllllllll}1 & 0.00\end{array}$

$\begin{array}{lllllllllllllll}1.00 & 32.15 & 19.19 & 16.28 & 3 & 1340.8432 & 1340.8384 & 447.9534 & 0.0048 & 3.5718 & 90031.661 & 96364.184 & 7636.973 & 443.288\end{array}$ $\begin{array}{llllllllllllllll}0.81 & 10.45 & 24.67 & 23.45 & 4 & 4331.1949 & 4331.1949 & 1083.8060 & 0.0000 & 0.0000 & 22.889 & 17.128 & 8.239 & 2.757 & \text { Yes }\end{array}$ $\begin{array}{lllllllllllllllll}1.00 & 43.73 & 19.49 & 26.85 & 2 & 1340.8414 & 1340.8384 & 671.4265 & 0.0030 & 2.2340 & 39294.094 & 42893.365 & 1542.077 & 337.335 & \text { Yes }\end{array}$

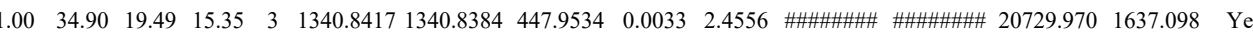
$\begin{array}{lllllllllllllll}.00 & 37.28 & 19.49 & 15.72 & 3 & 1340.8417 & 1340.8384 & 447.9534 & 0.0033 & 2.4556 & 76801.213 & 84322.406 & 9802.676 & 548.757 & \text { Yes }\end{array}$ $\begin{array}{lllllllllllllll}1.00 & 45.09 & 19.49 & 26.97 & 2 & 1340.8418 & 1340.8384 & 671.4265 & 0.0034 & 2.5319 & 42066.057 & 45940.944 & 2220.809 & 676.749 & \text { Yes }\end{array}$

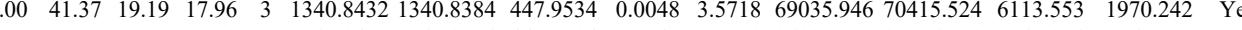
$\begin{array}{llllllllllllllll}1.00 & 33.07 & 19.19 & 15.12 & 3 & 1340.8432 & 1340.8384 & 447.9534 & 0.0048 & 3.5718 & 86335.702 & 81596.111 & 8842.254 & 1061.109 & \text { Yes }\end{array}$ $\begin{array}{lllllllllllllll}1.00 & 47.36 & 19.03 & 24.98 & 2 & 1340.8448 & 1340.8384 & 671.4265 & 0.0064 & 4.7659 & 9667.865 & 8168.607 & 773.496 & 867.347 & \text { Yes }\end{array}$ $\begin{array}{lllllllllllllll}1.00 & 38.67 & 19.19 & 21.11 & 3 & 1340.8435 & 1340.8384 & 447.9534 & 0.0051 & 3.7950 & 27056.695 & 28592.299 & 3085.576 & 2849.724 & \text { Yes }\end{array}$ $\begin{array}{lllllllllllllll}0.77 & 18.02 & 20.93 & 31.02 & 2 & 1230.5152 & 1230.5131 & 616.2638 & 0.0021 & 1.7038 & 37.265 & 33.833 & 32.861 & 15.557 & \text { Yes }\end{array}$ $\begin{array}{llllllllllllllll}0.53 & 18.89 & 26.70 & 24.90 & 2 & 1249.6094 & 1249.6094 & 625.8120 & 0.0000 & 0.0000 & 31.830 & 39.030 & 88.688 & 20.754 & \text { No }\end{array}$ $\begin{array}{lllllllllllllll}1.00 & 47.73 & 26.05 & 23.96 & 2 & 1402.6690 & 1402.6698 & 702.3422 & -0.0008 & -0.5695 & 53.651 & 64.600 & 11.984 & 4.403 & \text { Yes }\end{array}$

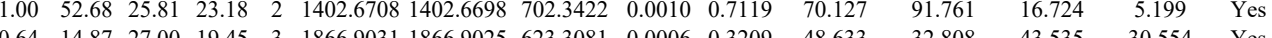

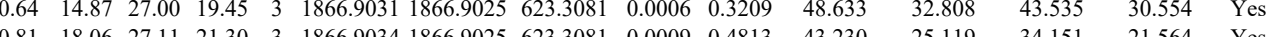

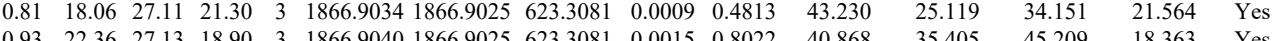
$\begin{array}{lllllllllllllll}0.93 & 22.36 & 27.13 & 18.90 & 3 & 1866.9040 & 1866.9025 & 623.3081 & 0.0015 & 0.8022 & 40.868 & 35.405 & 45.209 & 18.363 & \text { Yes } \\ 0.97 & 24.43 & 27.07 & 21.40 & 3 & 18669046 & 1866.9025 & 232.3081 & 0.021 & 1.1230 & 24.254 & 47.200 & 32.731 & 32.84 & \text { Yes }\end{array}$

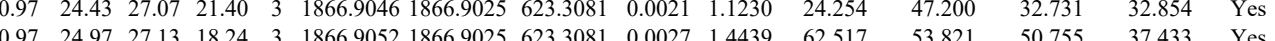

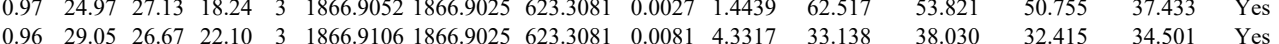

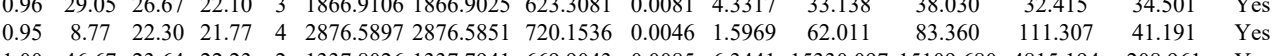
$\begin{array}{lllllllllllllll}1.00 & 46.67 & 23.64 & 22.23 & 2 & 1337.8026 & 1337.7941 & 669.9043 & 0.0085 & 6.3441 & 15330.097 & 15109.680 & 4815.194 & 208.961 & \text { Yes } \\ 1.00 & 45.07 & 23.62 & 17.53 & 2 & 1337.8036 & 1337.7941 & 669.9043 & 0.0095 & 7.0905 & 14273.094 & 13439.830 & 3772.924 & 118.879 & \text { Yes }\end{array}$

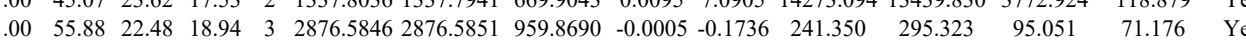

Table S-3 page 304 of 499 

$\begin{array}{lllllllllllllll} & \end{array}$ $\begin{array}{lllllllllllllllll}0.98 & 32.3 & 23.77 & 19.85 & & 1337.8021 & 1337.7941 & 446.9386 & 0.008 & 5.9665 & 3846.229 & 4053.022 & 1594.016 & 491.912 & \text { Yes } \\ 0.99 & 4.16 & 23.64 & 17.18 & 2 & 1337.8026 & 1337.7941 & 669.9043 & 0.0085 & 6.3441 & 26584.939 & 2437.458 & 7258.548 & 693.437 & \text { Yes }\end{array}$ \begin{tabular}{lllllllllllllllll}
0.90 & 40.16 & 24.13 & 17.65 & 2 & 1337.8028 & 1337.7941 & 669.9043 & 0.0087 & 6.4934 & 16358.938 & 17402.798 & 3974.924 & 423.374 & Yes \\
\hline
\end{tabular} \begin{tabular}{lllllllllllllllll}
1.07 & 45.38 & 23.77 & 18.32 & 2 & 1337.8020 & 1337.7941 & 669.9043 & 0.0079 & 5.8963 & 4854.675 & 4948.570 & 1450.710 & 134.344 & Yes \\
\hline
\end{tabular} $\begin{array}{llllllllllllllll}0.75 & 18.38 & 23.64 & 1.3 .18 & 3 & 1337.8027 & 1337.7941 & 446.9386 & 0.0086 & 6.4140 & 10363.845 & 12662.900 & 4090.897 & 1354.068 & \text { Yes }\end{array}$

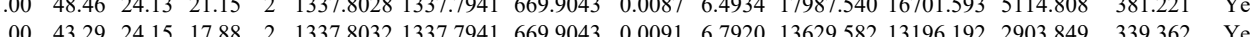

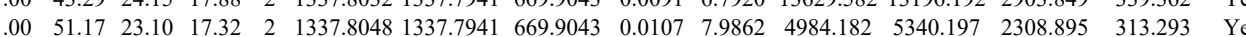
$\begin{array}{llllllllllllllll}1.00 & 41.62 & 23.10 & 19.19 & 2 & 1337 & 13048 & 1337.7941 & 669.9043 & 0.0107 & 7.9862 & 1787.834 & 2074.374 & 534.389 & 71.905 & \text { Yes }\end{array}$

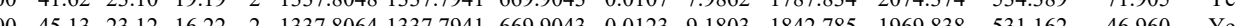
$\begin{array}{lllllllllllll} & \end{array}$ $\begin{array}{lllllllllllllll}1.00 & 56.56 & 15.05 & 17.21 & 3 & 1806.1345 & 1806.1335 & 6030518 & 0.0010 & 0.5527 & 2760.656 & 4743.240 & 758.318 & 109.560 & \text { No }\end{array}$ $\begin{array}{lllllllllllllll}.00 & 35.53 & 14.91 & 15.92 & 4 & 1806.1349 & 1806.1335 & 452.5407 & 0.0014 & 0.7734 & 55.263 & 49.496 & 12.227 & 8.631 & \text { Yes }\end{array}$ $\begin{array}{lllllllllllllll}1.00 & 46.65 & 14.91 & 18.87 & 3 & 1806.1357 & 1806.1335 & 603.0518 & 0.0022 & 1.2160 & 147.770 & 198.572 & 53.524 & 18.311 & \text { Yes } \\ 0.55 & 22.40 & 14.91 & 35.40 & 3 & 1806.1357 & 1806.1335 & 603.0518 & 0.0022 & 1.2160 & 191.837 & 198.715 & 148.270 & 53.432 & \text { Yes }\end{array}$

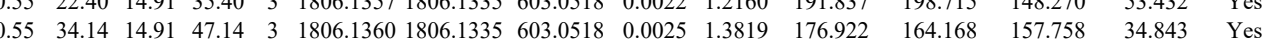
$\begin{array}{llllllllllllllll}0.53 & 21.60 & 14.91 & 34.60 & 3 & 1806.1363 & 1806.1335 & 603.0518 & 0.0028 & 1.5477 & 217.916 & 282.602 & 204.109 & 68.362 & \text { Yes }\end{array}$ $\begin{array}{llllllllllllllllll}0.53 & 22.75 & 14.91 & 35.75 & 3 & 1806.1363 & 1806.1335 & 603.0518 & 0.0028 & 1.5477 & 163.462 & 158.965 & 160.135 & 39.964 & \text { Yes }\end{array}$ \begin{tabular}{llllllllllllllll}
0.53 & 29.03 & 14.91 & 42.03 & 3 & 1806.1369 & 1806.1335 & 603.0518 & 0.0034 & 1.8793 & 190.122 & 269.916 & 226.051 & 60.815 & Yes \\
\hline
\end{tabular} \begin{tabular}{llllllllllllllll}
0.53 & 39.74 & 14.91 & 52.74 & 3 & 1806.1369 & 1806.1335 & 603.0518 & 0.0034 & 1.8793 & 109.669 & 147.051 & 177.721 & 48.626 & Yes \\
\hline
\end{tabular} $\begin{array}{lllllllllllllll}0.61 & 99.33 & 15.05 & \# \# \# & 2 & 1806.1330 & 1806.1335 & 904.0740 & -0.0005 & -0.2765 & 1136.881 & 1621.587 & 101.251 & 30.430 & \text { Yes }\end{array}$ \begin{tabular}{llllllllllllllll}
0.95 & 1.80 & 15.05 & 14.80 & 4 & 1806.1341 & 1806.1335 & 452.5407 & 0.0006 & 0.3315 & 546.168 & 477.431 & 44.368 & 32.004 & Yes \\
\hline
\end{tabular} $\begin{array}{llllllllllllllll}1.00 & 51.67 & 15.05 & 17.35 & 3 & 1806.1345 & 1806.1335 & 603.0518 & 0.0010 & 0.5527 & 6966.374 & 9185.910 & 1208.294 & 45.479 & \text { Yes } \\ 0.55 & 66.01 & 14.91 & 79.01 & 3 & 1806.1351 & 1806.1335 & 603.0518 & 0.0016 & 0.8844 & 7552.506 & 7871.675 & 703.597 & 180.020 & \text { Yes }\end{array}$

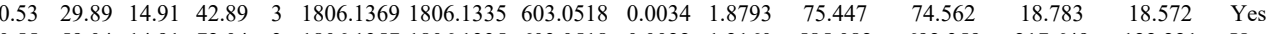
$\begin{array}{lllllllllllllll}0.55 & 59.04 & 14.91 & 72.04 & 3 & 1806.1357 & 1806.1335 & 603.0518 & 0.0022 & 1.2160 & 585.082 & 692.359 & 217.649 & 122.221 & \text { Yes }\end{array}$ $\begin{array}{llllllllllllllll}0.53 & 42.84 & 14.91 & 55.84 & 3 & 1806.1363 & 1806.1335 & 603.0518 & 0.0028 & 1.5477 & 1124.641 & 1625.545 & 315.387 & 133.516 & \text { Yes } \\ 0.99 & 30.9 & 26.95 & 19.02 & 3 & 186.928 & 1866.925 & 63.308 & 0.023 & 0.004 & 56.889 & 63.022 & 54.269 & 6.28 & \text { No }\end{array}$ $\begin{array}{lllllllllllllll}0.99 & 3.96 & 26.95 & 19.02 & 3 & 1866.9028 & 1866.9025 & 623.3081 & 0.0003 & 0.1604 & 56.889 & 63.022 & 54.269 & 66.881 & \text { No }\end{array}$

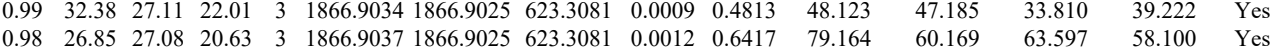

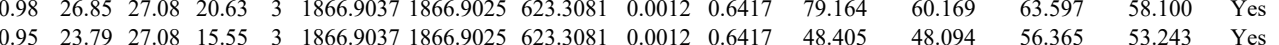

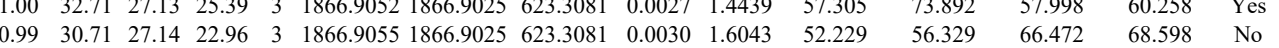

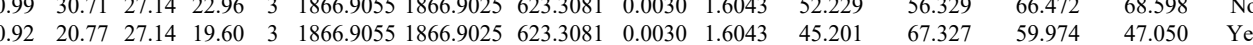

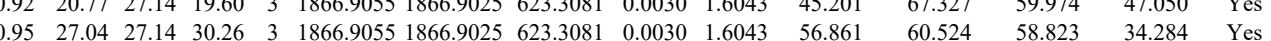
$\begin{array}{lllllllllllllllll}0.98 & 26.30 & 27.18 & 20.57 & 3 & 1866.9058 & 1866.9025 & 623.3081 & 0.0033 & 1.7648 & 57.640 & 70.524 & 58.823 & 34.284 & \text { Yes } \\ 0.989 & 52.125 & \text { Yes }\end{array}$ $\begin{array}{llllllllllllllll} & 0.99 & 30.85 & 27.15 & 21.42 & 3 & 1866.9061 & 1866.9025 & 623.3081 & 0.0036 & 1.9252 & 71.761 & 78.598 & 69.021 & 57.596 & \text { Yes }\end{array}$ $\begin{array}{lllllllllllllll}0.95 & 24.42 & 27.10 & 21.74 & 3 & 1866.9076 & 18669025 & 623.3081 & 0.0051 & 2.7274 & 59.473 & 53.685 & 60.521 & 75.254 & \text { No }\end{array}$

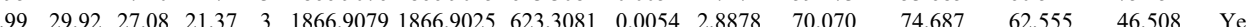
\begin{tabular}{lllllllllllllll}
0.64 & 19.49 & 26.71 & 24.51 & 3 & 1866.9103 & 1866.9025 & 623.3081 & 0.0078 & 4.1713 & 67.681 & 79.003 & 64.432 & 44.366 & Yes \\
\hline
\end{tabular}

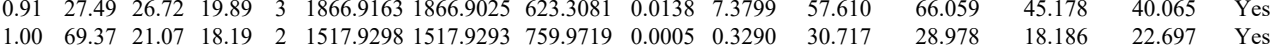
$\begin{array}{lllllllllllllll}0.93 & 22.39 & 27.08 & 23.27 & 3 & 1866.9037 & 18669025 & 623.3081 & 0.0012 & 0.6417 & 79.691 & 92.275 & 81.991 & 74.866 & \text { Yes }\end{array}$

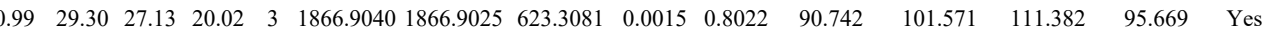

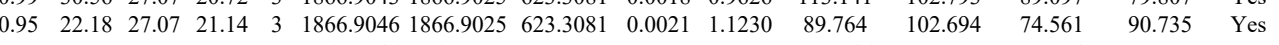
\begin{tabular}{llllllllllllllll}
0.99 & 30.50 & 27.07 & 25.33 & 3 & 1866.9046 & 1866.9025 & 623.3081 & 0.0021 & 1.1230 & 115.346 & 77.072 & 58.254 & 88.928 & Yes \\
\hline
\end{tabular} $\begin{array}{lllllllllllllll}0.98 & 25.17 & 27.07 & 21.19 & 3 & 1866.9046 & 1866.9025 & 623.3081 & 0.0021 & 1.1230 & 72.793 & 97.729 & 92.446 & 73.134 & \text { Yes }\end{array}$ $\begin{array}{lllllllllllllll}1.00 & 36.22 & 27.13 & 22.81 & 3 & 1866.9052 & 1866.9025 & 623.3081 & 0.0027 & 1.4439 & 67.057 & 70.645 & 69.359 & 59.403 & \text { Yes }\end{array}$

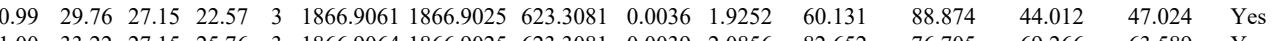

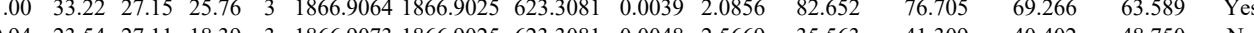

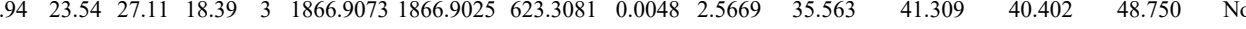

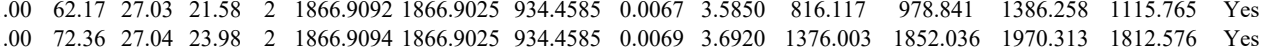
$\begin{array}{lllllllllllllll}1.00 & 72.36 & 27.04 & 23.98 & 2 & 1866.9094 & 1866.9025 & 934.4585 & 0.0069 & 3.6920 & 1376.003 & 1852.036 & 1970.313 & 1812.576 & \text { Yes } \\ 0.99 & 37.06 & 26.72 & 20.18 & 3 & 1866.9115 & 1866.9025 & 623.308 & 0.0090 & 4.8130 & 545.844 & 3946885 & 5364.304 & 5134.341 & \text { Yes }\end{array}$ $\begin{array}{llllllllllllllll}0.95 & 26.06 & 26.72 & 20.18 & 3 & 1866.9115 & 1866.9025 & 623.3081 & 0.0090 & 4.8130 & 5455.844 & 3946.885 & 5364.304 & 5134.341 & \text { Yes } \\ 0.95 & 29.29 & 26.71 & 19.46 & 3 & 1866.9139 & 1866.9025 & 623.3081 & 0.0114 & 6.0965 & 15759.489 & 15702.748 & 14591.107 & 11195.688 & \text { Yes }\end{array}$

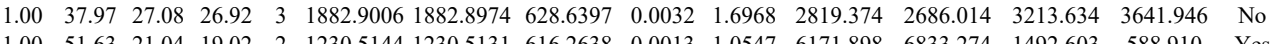
$\begin{array}{lllllllllllllll}1.00 & 51.63 & 21.04 & 19.02 & 2 & 1230.5144 & 1230.5131 & 616.2638 & 0.0013 & 1.0547 & 6171.898 & 6833.274 & 1492.603 & 588.910 & \text { Yes }\end{array}$

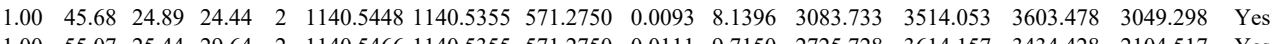

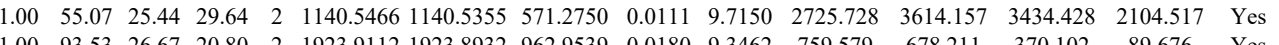
$\begin{array}{lllllllllllllll}1.00 & 94.64 & 26.67 & 20.61 & 2 & 1923.9112 & 1923.8932 & 962.9539 & 0.0180 & 9.3462 & 910.119 & 651.461 & 510.235 & 51.502 & \text { Yes }\end{array}$ $\begin{array}{lllllllllllllll}1.00 & 47.96 & 24.91 & 25.43 & 2 & 1140.5444 & 1140.5355 & 571.2750 & 0.0089 & 7.7895 & 4337.569 & 4913.069 & 6244.011 & 3395.766 & \text { Yes } \\ 0.97 & 38.73 & 27.34 & 2.40 & 2 & 1146.6932 & 1146.6852 & 5744349 & 0.0080 & 6.9643 & 21861.170 & 16995.388 & 35275.437 & 4889.792 & \text { No }\end{array}$

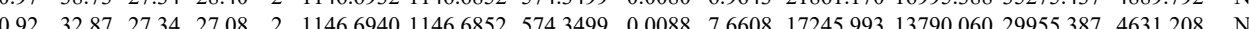
$\begin{array}{lllllllllllllllll}0.92 & 32.87 & 27.34 & 27.08 & 2 & 1 & 146.6940 & 146.6852 & 574.3499 & 0088 & 6.6608 & 17245.993 & 13790.060 & 29955.387 & 4631.208 & \text { No }\end{array}$ 

$\begin{array}{lllllllllllllll}0.95 & 16.16 & 15.56 & 15.29 & 2 & 1111.7338 & 1111.7321 & 556.8733 & 0.0017 & 1.5264 & 78173.651 & 77188.083 & 0.000\end{array}$ $\begin{array}{lllllllllllll}0.97 & 29.08 & 25.55 & 23.97 & 2 & 1112.6594 & 1112.6577 & 557.3361 & 0.0017 & 1.5251 & 19768.471 & 17837.339 & 1223.261\end{array}$

ILPKPTR

HVVFIAQR

ILPKPTR

ILPKPTR

AIIIFVPVPQLK

AIIIFVPVPQLK

AIIIFVPVPQLK

AIIIFVPVPQLK

AIIIFVPVPQLK

AIIIFVPVPQLK

ILPKPTR

AIIIFVPVPQLK

$\begin{array}{lllllllllllll}0.99 & 34.75 & 25.67 & 24.33 & 2 & 1112.6602 & 1112.6577 & 557.3361 & 0.0025 & 2.2428 & 22441.958 & 20144.956 & 507.524\end{array}$

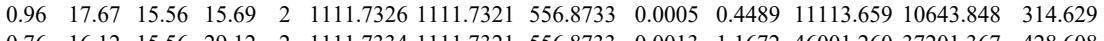
$\begin{array}{lllllllllllll}0.76 & 16.12 & 15.56 & 29.12 & 2 & 1111.7334 & 1111.7321 & 556.8733 & 0.0013 & 1.1672 & 46001.260 & 37201.367 & 428.608\end{array}$ $\begin{array}{llllllllllllll}0.98 & 30.44 & 25.43 & 24.39 & 2 & 1112.6582 & 1112.6577 & 557.3361 & 0.0005 & 0.4486 & 744.679 & 546.160 & 134.103\end{array}$ $\begin{array}{llllllllllllll}0.77 & 19.04 & 15.56 & 32.04 & 2 & 1111.7336 & 1111.7321 & 556.8733 & 0.0015 & 1.3468 & 6018.164 & 5565.716 & 60.598\end{array}$ $\begin{array}{llllllllllllll}0.94 & 18.97 & 16.81 & 25.67 & 2 & 1111.7344 & 1111.7321 & 556.8733 & 0.0023 & 2.0651 & 4997.436 & 4749.328 & 74.101\end{array}$ $\begin{array}{lllllllllllll}1.00 & 65.78 & 13.42 & 22.21 & 2 & 1625.0536 & 1625.0524 & 813.5335 & 0.0012 & 0.7375 & 1853.095 & 2403.519 & 493.507 \\ 1.00 & 56.83 & 13.4 & 20.59 & 2 & 1625.0544 & 1625.0524 & 8135335 & 0.0020 & 12292 & 2743.64 & 2316375 & 505.826\end{array}$ $\begin{array}{lllllllllllll}1.00 & 56.83 & 13.42 & 20.59 & 2 & 1625.0544 & 1625.0524 & 813.5335 & 0.0020 & 1.2292 & 2743.684 & 2316.375 & 505.826\end{array}$ $\begin{array}{lllllllllllll}0.90 & 11.25 & 13.42 & 16.85 & 3 & 1625.0551 & 1625.0524 & 542.6914 & 0.0027 & 1.6584 & 46.307 & 75.153 & 24.809\end{array}$ $\begin{array}{llllllllllllll}1.00 & 34.04 & 13.62 & 18.96 & 3 & 1625.0563 & 1625.0524 & 542.6914 & 0.0039 & 2.3955 & 66.273 & 157.302 & 44.719\end{array}$

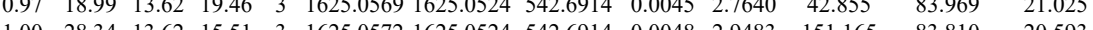

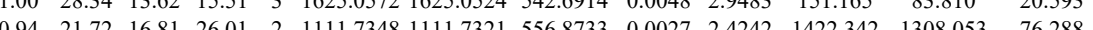
$\begin{array}{lllllllllllll}0.94 & 21.72 & 16.81 & 26.01 & 2 & 1111.7348 & 1111.7321 & 556.8733 & 0.0027 & 2.4242 & 1422.342 & 1308.053 & 76.288 \\ 0.74 & 15.33 & 16.81 & 27.25 & 2 & 111.7352 & 1111.7321 & 5568733 & 0.0031 & 2.7834 & 2193.370 & 1839.999 & 53.855\end{array}$

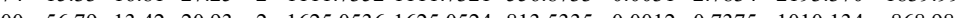

AIIIFVPVPQLK

AIIIFVPVPQLK

AIIIFVPVPQLK
AIIIFVPVPQLK

AIIIFVPVPQLK

AIIIFVPVPQLK

AIIIFVPVPQLK

KAIIIFVPVPQLK

HVVFIAQR

HVVFIAQR

AIIIFVPVPQLK

AIIIFVPVPQLK

AIIIFVPVPQLK

HVVFIAQR

AIIIFVPVPQLK

AIIIFVPVPQLK

HVVFIAQR

ILPKPTR

ILPKPTR

ILPKPTR

AIIIFVPVPQLK

AIIIFVPVPQLK

AIIIFVPVPQLK
AIIIFVPVPQLK $\begin{array}{lllllllllllll}0.91 & 31.62 & 25.59 & 23.98 & 2 & 1112.6568 & 1112.6577 & 557.3361 & -0.0009 & -0.8074 & 1033.605 & 965.664\end{array}$ $\begin{array}{llllllllllll}0.97 & 31.72 & 25.43 & 24.09 & 2 & 1112.6580 & 1112.6577 & 557.3361 & 0.0003 & 0.2691 & 1327.167 & 1216.091\end{array}$ $\begin{array}{llllllllllll}0.77 & 61.16 & 13.42 & 74.16 & 2 & 1625.0544 & 1625.0524 & 813.5335 & 0.0020 & 1.2292 & 90.869 & 78.887\end{array}$ $\begin{array}{lllllllllllllll}0.77 & 57.38 & 13.42 & 70.38 & 2 & 1625.0548 & 1625.0524 & 813.5335 & 0.0024 & 1.4750 & 48.895 & 95.360\end{array}$ $\begin{array}{lllllllllllll}0.66 & 8.24 & 13.62 & 18.35 & 3 & 1625.0560 & 1625.0524 & 542.6914 & 0.0036 & 2.2112 & 46.351 & 75.684\end{array}$ $\begin{array}{llllllllllllll}1.00 & 42.59 & 25.43 & 25.32 & 2 & 1112.6584 & 1112.6577 & 557.3361 & 0.0007 & 0.6280 & 1017.351 & 918.841\end{array}$ $\begin{array}{llllllllllllll}0.97 & 13.39 & 13.42 & 13.89 & 3 & 1625.0551 & 1625.0524 & 542.6914 & 0.0027 & 1.6584 & 69.568 & 67.032 \\ 0.53 & 18.07 & 13.42 & 31.07 & 3 & 1625.0554 & 1625.0524 & 542.6914 & 0.0030 & 1.8427 & 50.004 & 81.242\end{array}$ $\begin{array}{lllllllllllll}0.53 & 18.07 & 13.42 & 31.07 & 3 & 1625.0554 & 1625.0524 & 542.6914 & 0.0030 & 1.8427 & 50.004 & 81.242 \\ 0.97 & 29.33 & 25.55 & 20.23 & 2 & 1112.6594 & 1112.6577 & 557.3361 & 0.0017 & 1.5251 & 515.105 & 592.293\end{array}$

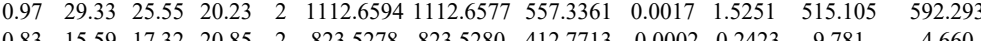
$\begin{array}{lllllllllllll}0.83 & 15.59 & 17.32 & 20.85 & 2 & 823.5278 & 823.5280 & 412.7713 & -0.0002 & -0.2423 & 9.781 & 4.660 \\ 0.58 & 10.37 & 17.32 & 15.43 & 2 & 823.5276 & 823.5280 & 412.7713 & -0.0004 & -0.4845 & 2.404 & 11.151\end{array}$ $\begin{array}{lllllllllllll}0.58 & 10.37 & 17.32 & 15.43 & 2 & 823.5276 & 823.5280 & 412.7713 & -0.0004 & -0.4845 & 2.404 & 11.151 \\ 0.75 & 13.62 & 17.32 & 22.21 & 2 & 823.5278 & 823.5280 & 412.7713 & -0.0002 & -0.2423 & 5.829 & 13.262\end{array}$ $\begin{array}{lllllllllllll}0.75 & 13.62 & 17.32 & 22.21 & 2 & 823.5278 & 823.5280 & 412.7713 & -0.0002 & -0.2423 & 5.829 & 13.262 \\ 0.76 & 42.10 & 13.42 & 55.10 & 2 & 1625.0538 & 1625.0524 & 813.5335 & 0.0014 & 0.8604 & 8.730 & 7.928\end{array}$ $\begin{array}{lllllllllll}0.99 & 20.20 & 13.62 & 17.12 & 3 & 1625.0557 & 1625.0524 & 542.6914 & 0.0033 & 2.0269 & 11.418\end{array}$ $\begin{array}{llllllllllll}0.55 & 7.20 & 13.42 & 20.20 & 3 & 1625.0542 & 1625.0524 & 542.6914 & 0.0018 & 1.1056 & 6.981\end{array}$ 


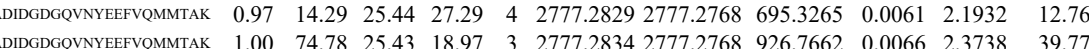

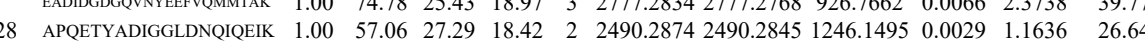

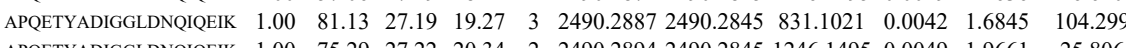

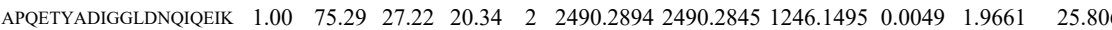

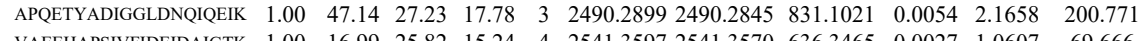
\begin{tabular}{llllllllllll} 
VAEEHAPSIVFIDEIDAIGTK & 1.00 & 16.99 & 25.82 & 15.24 & 4 & 2541.3597 & 2541.3570 & 636.3465 & 0.0027 & 1.0607 & 69.666 \\
\hline
\end{tabular} $\begin{array}{llllllllllllll}\text { APQETYADIGGLDNQIQEIK } & 1.00 & 41.25 & 27.18 & 15.69 & 3 & 2490.2929 & 2490.2845 & 831.1021 & 0.0084 & 3.3690 & 129.154 \\ \text { ESVII }\end{array}$ $\begin{array}{llllllllllll}\text { ESVELPLTHPEYYEEMGIKPPK } & 1.00 & 22.66 & 25.34 & 35.66 & 4 & 3017.5829 & 3017.5785 & 755.4019 & 0.0044 & 1.4562 & 153.172\end{array}$ $\begin{array}{llllllllllll}\text { MTLADDVTLDDLIMAK } & 1.00 & 94.48 & 27.90 & 29.05 & 2 & 2052.0734 & 2052.0726 & 1027.0436 & 0.0008 & 0.3895 & 586.509\end{array}$ $\begin{array}{llllllllllll}\text { MTLADDVTLDDLIMAK } & 1.00 & 72.35 & 27.90 & 29.07 & 2 & 2052.0734 & 2052.0726 & 1027.0436 & 0.0008 & 0.3895 & 65.972\end{array}$ $\begin{array}{lllllllllllll}\text { MTLADDVTLDDLIMAK } & 1.00 & 46.48 & 27.84 & 25.07 & 3 & 2052.0769 & 2052.0726 & 685.0315 & 0.0043 & 2.0924 & 188.059\end{array}$ YEPPVPTR $\begin{array}{lllllllllllll}\text { IKDYLLMEEEFIR } & 0.96 & 29.97 & 27.41 & 23.09 & 2 & 1101.5952 & 1101.5940 & 551.8043 & 0.0012 & 1.0873 & 14007.953 & 15688.9\end{array}$ KYEPPVPTR $\begin{array}{lllllllllll} & \end{array}$ $\begin{array}{llllllllllllllllll} & 0.94 & 39.76 & 26.54 & 28.08 & 3 & 1986.0772 & 1986.0739 & 663.0319 & 0.0033 & 1.6590 & 1070.812 & 1296.482 & 337.361 & 102.822 \\ 0 & 0.55 & 28.34 & 26.23 & 41.34 & 3 & 1373.7928 & 1373.7911 & 458.9376 & 0.0017 & 1.2347 & 19527.744 & 19283.315 & 3663.625 & 1941.620\end{array}$ $\begin{array}{lllllllllllllllllll} & \end{array}$ $\begin{array}{llllllllllllllllll} & 1489.95 & 1894.9580 & 948.4863 & 0.0010 & 0.5272 & 417.007 & 484.269 & 58.744 & 10.226 & \text { Yes }\end{array}$

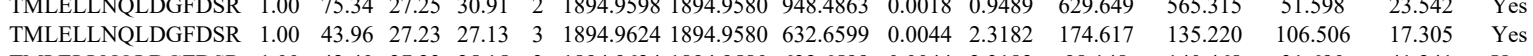

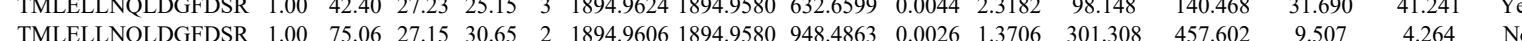


$\begin{array}{llllllllllllll}1.00 & 69.12 & 27.61 & 20.60 & 2 & 1421.7838 & 1421.7749 & 711.8947 & 0.0089 & 6.2509 & 1201.714 & 1194.158 & 345.119\end{array}$

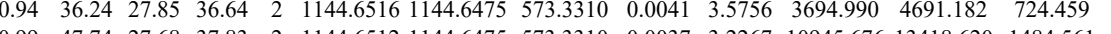
$80.794 \quad$ Ye

NQEQMKPLEEK

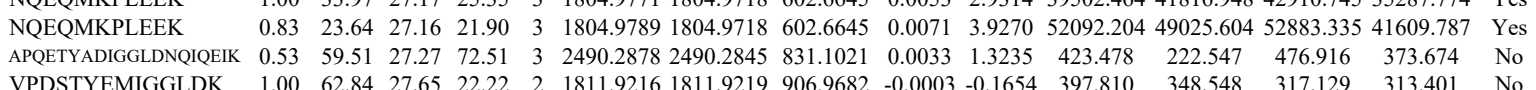

$\begin{array}{llllllllllllllll}1.00 & 41.74 & 27.20 & 25.46 & 2 & 1804.9752 & 1804.9718 & 903.4932 & 0.0034 & 1.8816 & 2621.747 & 2393.071 & 2344.925 & 1429.418 & \text { Yes } & \end{array}$

$\begin{array}{lllllllllllll}1.00 & 59.90 & 27.61 & 18.53 & 2 & 1811.9240 & 1811.9219 & 906.9682 & 0.0021 & 1.1577 & 80.942 & 73.725 & 51.666\end{array}$

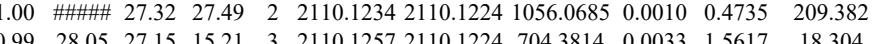

TMLELLNQLDGFEATK

$\begin{array}{lllllllllll} & \end{array}$

$53.918 \quad 21.521$

IDILDSALLRPGR

$\begin{array}{llllllllllll}0.99 & 30.12 & 26.61 & 23.96 & 3 & 1647.9220 & 1647.9183 & 550.3134 & 0.0037 & 2.2411 & 89.116\end{array}$

$\begin{array}{ll}38.225 & 10.455 \\ 136.447 & 77.389\end{array}$

IDILDSALLRPGR
IDILDSALLRPGR

$\begin{array}{lllllllllllll}39.72 & 23.52 & 52.72 & 3 & 1581.9352 & 1581.9324 & 528.3181 & 0.0028 & 1.7666 & 11387.953 & 13554.095 & 1699.37\end{array}$

$\begin{array}{lllllllllllllll}0.00 & 41.90 & 23.22 & 16.61 & 3 & 1581.9367 & 1581.9324 & 528.3181 & 0.0043 & 2.7130 & 14656.320 & 19503.230 & 2678.160 & 1\end{array}$

$\begin{array}{lllllllllllllll}1.00 & 35.29 & 23.52 & 17.17 & 3 & 1581.9352 & 1581.9324 & 528.3181 & 0.0028 & 1.7666 & 12351.577 & 12549.766 & 1390.065\end{array}$

ISSLLEQRQQT

ISSLLEQPQQK

ISSLLEEQFQQGK

ISSLLEEQFQQGK

ISSLLEFQFQQGK

$\begin{array}{llllllllllllll}1.00 & 45.15 & 27.03 & 21.25 & 3 & 1793.9788 & 1793.9767 & 598.9995 & 0.0021 & 1.1686 & 919.033 & 834.615 & 382.419 & 139\end{array}$

$\begin{array}{llllllllllllllll}1.00 & 40.11 & 27.00 & 21.47 & 3 & 1793.9797 & 1793.9767 & 598.9995 & 0.0030 & 1.6694 & 1194.226 & 832.779 & 450.745 & 235.021\end{array}$

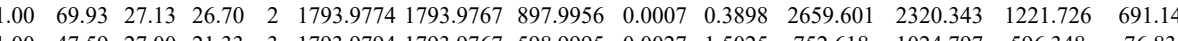

$\begin{array}{llllllllllllll}1.00 & 47.59 & 27.00 & 21.33 & 3 & 1793.9794 & 1793.9767 & 598.9995 & 0.0027 & 1.5025 & 752.618 & 1024.797 & 596.348 & 76.836\end{array}$

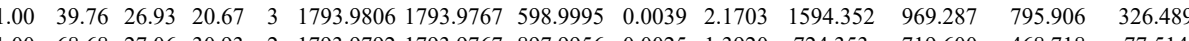

ISSLLEQFQQGK

$\begin{array}{lllllllllllll}1.00 & 68.68 & 27.06 & 30.93 & 2 & 1793.9792 & 1793.9767 & 897.9956 & 0.0025 & 1.3920 & 724.353 & 719.600 & 468.718\end{array}$

$\begin{array}{lllllllllllllll} & 1.00 & 67.29 & 26.99 & 29.77 & 2 & 1793.9796 & 1793.9767 & 897.9956 & 0.0029 & 1.6147 & 950.650 & 797.484 & 411.723 & 108\end{array}$

$\begin{array}{llllllllllllll} & \text { L }\end{array}$

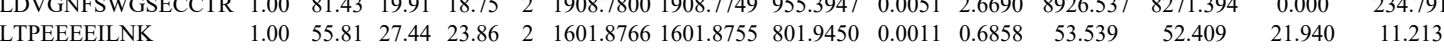

NCIVLIDSTPYR

ADGYVLEGK

$\begin{array}{lllll}1.8299 & 562.503 & 708.501 & 70.096\end{array}$

GVLEGK $\begin{array}{llllllllllllllll}0.54 & 28.19 & 28.64 & 37.62 & 2 & 874.4864 & 874.4817 & 438.2481 & 0.0047 & 5.3622 & 15512.486 & 14833.050 & 1146.955 & 811.499 & \text { Yes }\end{array}$ $\begin{array}{llllllllllllllll}0.78 & 33.89 & 27.77 & 41.13 & 2 & 920.4734 & 920.4694 & 461.2420 & 0.0040 & 4.3361 & 12089.177 & 10704.990 & 988.095 & 766.872 & \text { Yes }\end{array}$ $\begin{array}{lllllllllllllll}1.00 & 44.25 & 26.47 & 22.99 & 2 & 1156.6622 & 1156.6592 & 579.3369 & 0.0030 & 2.5892 & 22760.723 & 23765.688 & 1014.803 & 473.682 & \text { Yes }\end{array}$ $\begin{array}{llllllllllllllll}0.60 & 26.09 & 27.69 & 37.14 & 2 & 920.4730 & 920.4694 & 461.2420 & 0.0036 & 3.9025 & 26791.188 & 24918.913 & 1585.630 & 512.533 & \text { Yes }\end{array}$ $\begin{array}{lllllllllllllll}0.72 & 27.52 & 27.77 & 36.31 & 2 & 920.4732 & 920.4694 & 461.2420 & 0.0038 & 4.1193 & 59760.396 & 54939.992 & 1507.110 & 402.674 & \text { Yes s }\end{array}$ $\begin{array}{llllllllllllllll}0.85 & 27.17 & 28.00 & 35.88 & 2 & 920.4728 & 920.4694 & 461.2420 & 0.0034 & 3.6857 & 23535.355 & 23615.902 & 1698.317 & 512.115 & \text { Yes }\end{array}$ $\begin{array}{lllllllllllllll}0.99 & 43.12 & 27.01 & 29.38 & 2 & 1270.7020 & 1270.6904 & 636.3525 & 0.0116 & 9.1144 & 62276.327 & 56877.661 & 1886.024 & 44.485 & \text { Yes }\end{array}$ $\begin{array}{lllllllllllllll}1.00 & 60.60 & 27.01 & 31.86 & 2 & 1270.7020 & 1270.6904 & 636.3525 & 0.0116 & 9.1144 & 48405.935 & 43077.118 & 1848.820 & 664.669 & \text { Yes }\end{array}$ $\begin{array}{llllllllllllllll}0.53 & 15.06 & 26.35 & 17.07 & 2 & 886.5096 & 886.5075 & 444.2610 & 0.0021 & 2.3635 & 171.842 & 115.405 & 9.677 & 4.048 & \text { No }\end{array}$

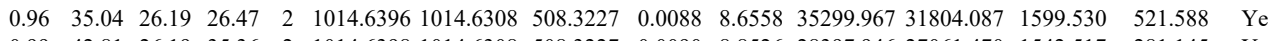
$\begin{array}{lllllllllllllll}0.99 & 42.81 & 26.19 & 35.36 & 2 & 1014.6398 & 1014.6308 & 508.3227 & 0.0090 & 8.8526 & 28397.946 & 27061.470 & 1542.517 & 281.145 & \text { Yes }\end{array}$ $\begin{array}{llllllllllllllll}0.96 & 34.50 & 26.95 & 30.49 & 2 & 1270.7024 & 1270.6904 & 636.3525 & 0.0120 & 9.4286 & 30648.169 & 27741.479 & 477.935 & 322.017 & \text { Yes }\end{array}$ $\begin{array}{lllllllllllllll}0.50 & 14.66 & 26.39 & 16.88 & 2 & 886.5094 & 886.5075 & 444.2610 & 0.0019 & 2.1384 & 131.103 & 107.210 & 18.956 & 12.032 & \text { Yes }\end{array}$

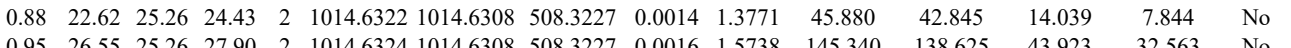
$\begin{array}{lllllllllllllll}0.95 & 26.55 & 25.26 & 27.90 & 2 & 1014.6324 & 1014.6308 & 508.3227 & 0.0016 & 1.5738 & 145.340 & 138.625 & 43.923 & 32.563 & \text { No } \\ 0.89 & 22.77 & 25.26 & 24.19 & 2 & 1014.6324 & 1014.6308 & 508.3227 & 0.0016 & 1.5738 & 106.468 & 127.306 & 23.803 & 12.425 & \text { Y }\end{array}$

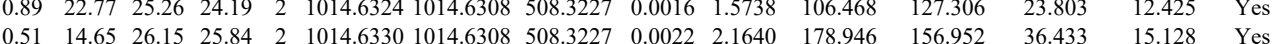

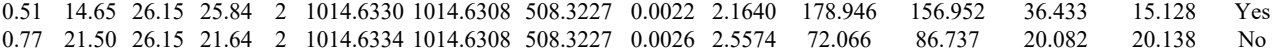

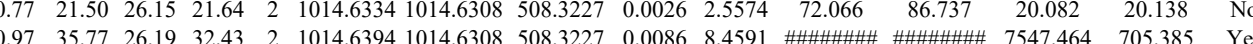




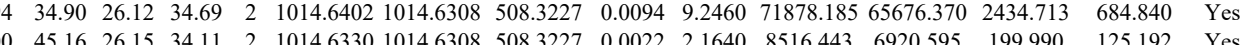

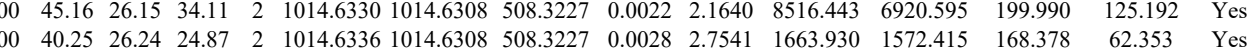

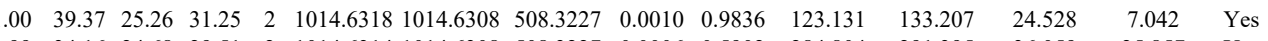

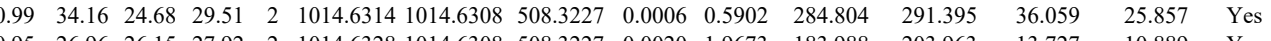
$\begin{array}{lllllllllllllll}0.95 & 26.96 & 26.15 & 27.92 & 2 & 1014.6328 & 1014.6308 & 508.3227 & 0.0020 & 1.9673 & 183.988 & 203.963 & 13.727 & 10.889 & \text { Yes }\end{array}$ $\begin{array}{lllllllllllllll}1.00 & 39.62 & 24.68 & 25.20 & 2 & 1014.6316 & 1014.6308 & 508.3227 & 0.0008 & 0.7869 & 194.180 & 243.900 & 31.545 & 11.730 & \text { Yes }\end{array}$ $\begin{array}{lllllllllllllll}0.99 & 35.18 & 24.68 & 22.53 & 2 & 1014.6314 & 1014.6308 & 508.3227 & 0.0006 & 0.5902 & 229.603 & 205.341 & 25.219 & 10.539 & \text { Yes } \\ 0.99 & 39.95 & 2.84 & 30.57 & 2 & 1027.6240 & 1027.6148 & 514.8147 & 0.0092 & 8.9352 & 9737.132 & 9608.625 & 1170.897 & 288.899 & \text { Yes }\end{array}$ $\begin{array}{lllllllllllllll}0.99 & 39.95 & 24.84 & 30.57 & 2 & 1027.6240 & 1027.6148 & 514.8147 & 0.0092 & 8.9352 & 9737.132 & 9608.625 & 1170.897 & 288.899 & \text { Yes } \\ 0.98 & 40.09 & 24.38 & 36.02 & 2 & 1027.6244 & 1027.6148 & 514.8147 & 0.0096 & 9.3237 & 11726.680 & 12163358 & 344.307 & 856.320 & \text { No }\end{array}$

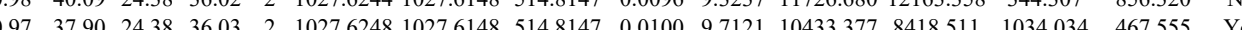

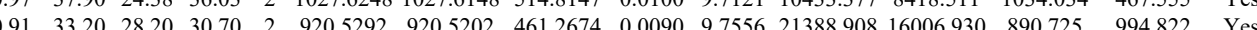
$\begin{array}{lllllllllllllll}0.99 & 39.93 & 23.65 & 31.24 & 2 & 1027.6250 & 1027.5148 & 514.8147 & 0.0102 & 9.9064 & 7189.980 & 6073.134 & 1246.862 & 712.768 & \text { Yes }\end{array}$

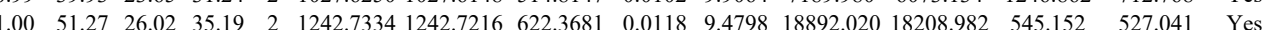
$\begin{array}{lllllllllllllll}0.84 & 23.56 & 24.91 & 26.09 & 2 & 804.4368 & 804.4364 & 4033255 & 0.0004 & 0.4960 & 104.865 & 95.031 & 44.566 & 7.418 & \text { Yes }\end{array}$

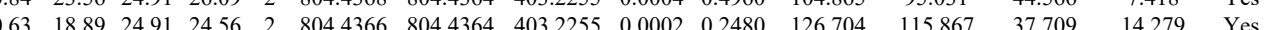
$\begin{array}{llllllllllllllll}1.00 & 69.68 & 12.30 & 21.70 & 2 & 1381.9200 & 1381.9152 & 691.9649 & 0.0048 & 3.4684 & 33717.801 & 31118.951 & 0.000 & 426.770 & \text { No }\end{array}$

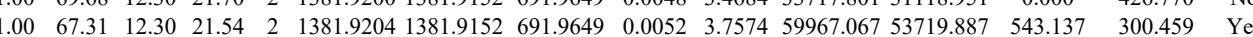
$\begin{array}{lllllllllllllll}1.00 & 67.93 & 12.55 & 21.42 & 2 & 1381.9198 & 1381.9152 & 691.9649 & 0.0046 & 3.3239 & 26834.053 & 24413.473 & 0.000 & 106.086 & \mathrm{No}\end{array}$ $\begin{array}{llllllllllllllll}1.00 & 67.83 & 12.30 & 21.32 & 2 & 1381.9204 & 1381.9152 & 691.9649 & 0.0052 & 3.7574 & 42203.084 & 34099.230 & 329.700 & 103.743 & \text { No }\end{array}$ $\begin{array}{llllllllllllllll}1.00 & 70.44 & 26.50 & 26.20 & 2 & 1384.7774 & 1384.7697 & 693.3921 & 0.0077 & 5.5524 & 7094.225 & 7369.818 & 5702.217 & 3143.862 & \text { Yes }\end{array}$

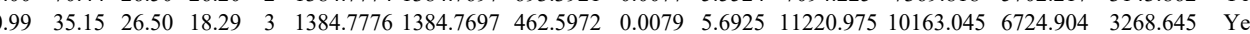
$\begin{array}{lllllllllllllll}1.00 & 77.50 & 26.50 & 25.87 & 2 & 1384.7778 & 1384.7697 & 693.3921 & 0.0081 & 5.8408 & 7492.056 & 7881.886 & 6476.036 & 4264.833 & \text { Yes }\end{array}$ $\begin{array}{llllllllllllllll}1.00 & 69.89 & 26.53 & 26.25 & 2 & 1384.7772 & 1384.7697 & 693.3921 & 0.0075 & 5.4082 & 7744.286 & 7162.542 & 8462.841 & 3226.313 & \text { Yes }\end{array}$

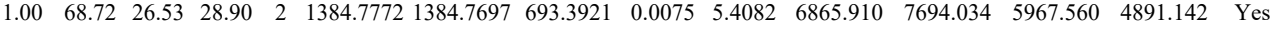

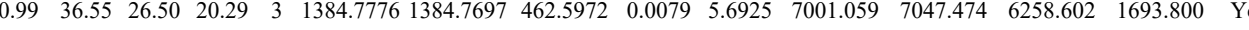

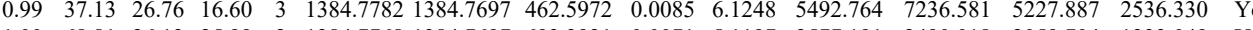
$\begin{array}{llllllllllllllll}1.00 & 68.81 & 26.13 & 25.99 & 2 & 1384.7768 & 1384.7697 & 693.3921 & 0.0071 & 5.1197 & 2577.191 & 2490.018 & 2059.704 & 1333.049 & \text { Yes }\end{array}$ $\begin{array}{llllllllllllllll}1.00 & 37.47 & 26.33 & 18.28 & 3 & 1384.7770 & 1384.7697 & 462.5972 & 0.0073 & 5.2601 & 5348.163 & 6768.668 & 10293.167 & 2307.198 & \text { No }\end{array}$ \begin{tabular}{lllllllllllllll}
1.00 & 66.99 & 26.50 & 25.94 & 2 & 1384.7776 & 1384.7697 & 693.3921 & 0.0079 & 5.6966 & 1886.662 & 1907.162 & 1429.996 & 1062.327 & Yes \\
\hline
\end{tabular} $\begin{array}{lllllllllllllll}.00 & 40.44 & 26.50 & 21.25 & 3 & 1384.7779 & 1384.7697 & 462.5972 & 0.0082 & 5.9086 & 7605.728 & 8475.148 & 11409.475 & 1407.671 & \text { No }\end{array}$ \begin{tabular}{llllllllllllllll}
1.00 & 67.30 & 27.79 & 22.96 & 2 & 1330.7494 & 1330.7479 & 666.3812 & 0.0015 & 1.1255 & 3288.715 & 3364.466 & 2744.298 & 1736.255 & Yes \\
\hline
\end{tabular} $\begin{array}{lllllllllllllll}1.00 & 62.62 & 27.79 & 28.11 & 2 & 1330.7494 & 1330.7479 & 666.3812 & 0.0015 & 1.1255 & 3609.676 & 3630.845 & 2380.554 & 1908.567 & \text { Yes } \\ 1.00 & 64.07 & 27.68 & 31.01 & 2 & 1330.7512 & 1330.7479 & 666.3812 & 0.0033 & 2.4761 & 2574.156 & 3273.410 & 2382.289 & 1558.879 & \text { Yes }\end{array}$

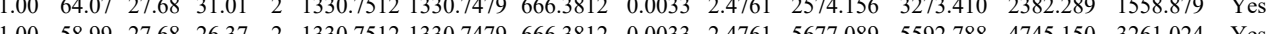

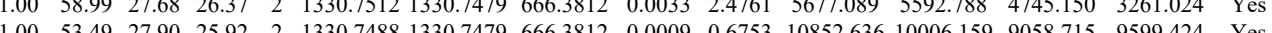

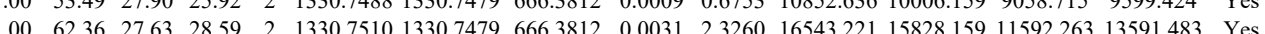

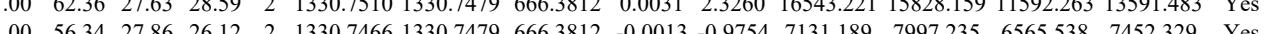

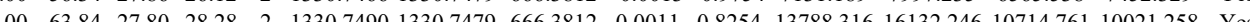
$\begin{array}{llllllllllllllll}10 & 61.38 & 27.85 & 27.71 & 2 & 1330.7484 & 1330.7479 & 6663812 & 0.0005 & 0.3752 & 6064.382 & 5376.496 & 4249.015 & 3568.603 & \text { Yes }\end{array}$ $\begin{array}{llllllllllllllll}1.00 & 61.43 & 27.79 & 31.12 & 2 & 1330.7494 & 1330.7479 & 666.3812 & 0.0015 & 1.1255 & 3998.614 & 3854.478 & 3159.706 & 2987.874 & \text { Yes }\end{array}$

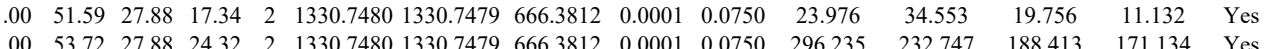
$\begin{array}{lllllllllllllll}1.00 & 53.72 & 27.88 & 24.32 & 2 & 1330.7480 & 1330.7479 & 666.3812 & 0.0001 & 0.0750 & 296.235 & 232.747 & 188.413 & 171.134 & \text { Yes } \\ 1.00 & 60.64 & 27.85 & 24.43 & 2 & 1330.7484 & 1330.7479 & 666.3812 & 0.0005 & 0.3752 & 413.082 & 404.500 & 256.065 & 275.103 & \text { Yes }\end{array}$

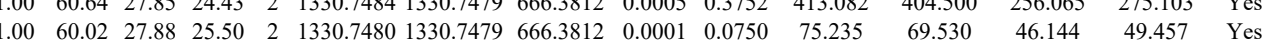
$\begin{array}{lllllllllllllll}1.00 & 64.40 & 27.88 & 30.64 & 2 & 1330.7482 & 1330.7479 & 666.3812 & 0.0003 & 0.2251 & 147.116 & 120.462 & 81.205 & 86.326 & \text { Yes } \\ 0.96 & 35.38 & 25.49 & 20.89 & 2 & & \end{array}$

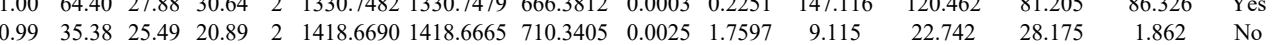

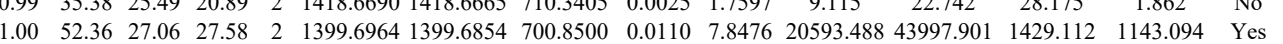

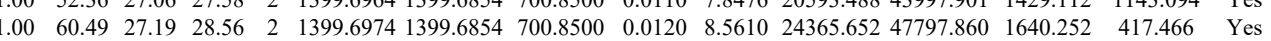
$\begin{array}{llllllllllllllll}1.00 & 47.59 & 27.19 & 29.45 & 2 & 1399.6968 & 1399.6854 & 700.8500 & 0.0114 & 8.1329 & 12609.189 & 23990.582 & 555.672 & 681.357 & \text { Yes }\end{array}$ $\begin{array}{lllllllllllllll}1.00 & 50.51 & 27.19 & 27.58 & 2 & 1399.6968 & 1399.6854 & 700.8500 & 0.0114 & 8.1329 & 14766.315 & 26420.907 & 701.498 & 398.281 & \text { Yes }\end{array}$ $\begin{array}{lllllllllllllll}1.00 & 51.54 & 27.21 & 20.29 & 3 & 1963.0510 & 1963.0319 & 655.3512 & 0.0191 & 9.7148 & 481.737 & 806.437 & 1429.099 & 794.765 & \text { Yes } \\ 0.72 & 36.92 & 25.65 & 19.13 & 2 & 1418.6674 & 1418.6665 & 7103405 & 0.000 & 0.6335 & 12.430 & 17.620 & 22.023 & 1.353 & \text { Yes }\end{array}$

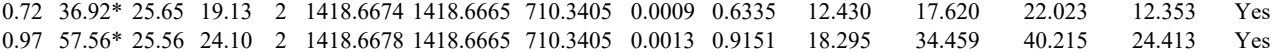
\begin{tabular}{lllllllllllllll}
1.00 & 69.59 & 27.04 & 50.18 & 2 & 1741.8732 & 1741.8730 & 871.9438 & 0.0002 & 0.1147 & 5383.804 & 8483.221 & 92.336 & 3.930 & Yes \\
\hline
\end{tabular} $\begin{array}{lllllllllllllll}1.00 & 72.84 & 27.05 & 50.51 & 2 & 1741.8734 & 1741.8730 & 871.9438 & 0.0004 & 0.2294 & 2137.260 & 3676.775 & 25.689 & 24.220 & \text { Yes }\end{array}$

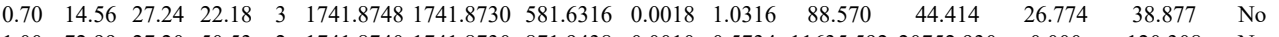

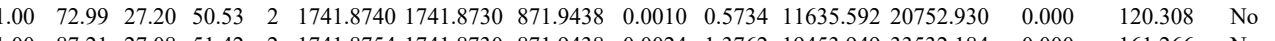
$\begin{array}{lllllllllllllll}.00 & 87.21 & 27.08 & 51.42 & 2 & 1741.8754 & 1741.8730 & 871.9438 & 0.0024 & 1.3762 & 19453.949 & 33532.184 & 0.000 & 161.266 & \text { No }\end{array}$

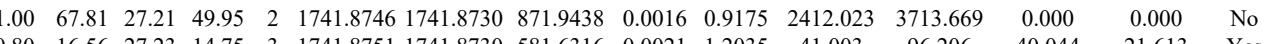

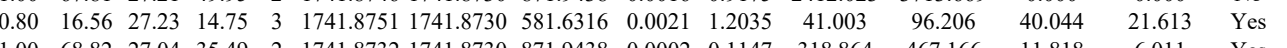
$\begin{array}{llllllllllllllll}1.00 & 68.82 & 27.04 & 35.49 & 2 & 1741.8732 & 1741.8730 & 871.9438 & 0.0002 & 0.1147 & 318.864 & 467.166 & 11.818 & 6.011 & \text { Yes } \\ 1.00 & 66.65 & 27.16 & 37.52 & 2 & 1741.8744 & 1741.8730 & 871.9438 & 0.0014 & 0.8028 & 83.552 & 1241.237 & 0.000 & 15.289 & \text { No }\end{array}$ $\begin{array}{lllllllllllllll}1.00 & 66.65 & 27.16 & 37.52 & 2 & 1741.8744 & 1741.8730 & 871.9438 & 0.0014 & 0.8028 & 831.552 & 1241.237 & 0.000 & 15.289 & \text { No } \\ 0.98 & 31.50 & 27.16 & 29.75 & 3 & 1741.8745 & 1741.8730 & 581.6316 & 0.0015 & 0.8596 & 76.234 & 101.799 & 23.507 & 12.872 & \text { Yos }\end{array}$ $\begin{array}{lllllllllllllll}0.98 & 31.50 & 27.16 & 29.75 & 3 & 1741.8745 & 1741.8730 & 581.6316 & 0.0015 & 0.8596 & 76.234 & 101.799 & 23.507 & 12.872 & \text { Yes } \\ 1.00 & 63.87 & 27.11 & 37.07 & 2 & 1741.8736 & 1741.8730 & 871.9438 & 0.0006 & 0.3441 & 128.114 & 207.829 & 1.069 & 3.461 & \text { Yes }\end{array}$

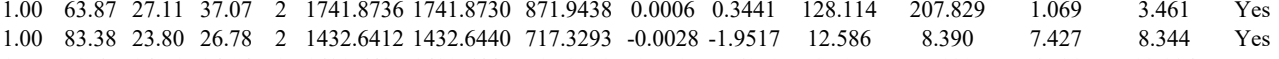

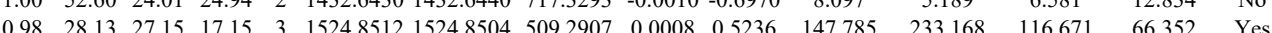




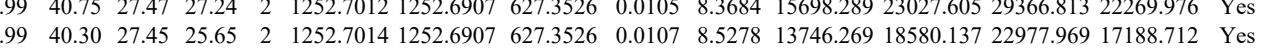

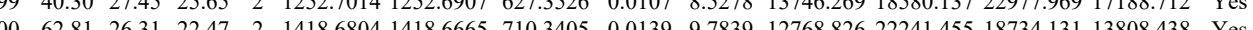
$\begin{array}{llllllllllllllll}0.9302 .798 & \text { Yes }\end{array}$

VAGMDVELTVEER

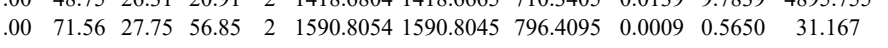
$\begin{array}{lllllllllll}1.00 & 82.09 & 27.71 & 58.84 & 2 & 1590.8060 & 1500.8045 & 796.405 & 0.0015 & 0.9417 & 49.204\end{array}$

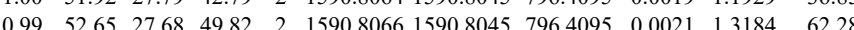
$\begin{array}{lllllllllllll}1.00 & 56.25 & 27.82 & 48.87 & 2 & 1590.8072 & 15908045 & 796.4095 & 0.0027 & 1.6951 & 57.601\end{array}$

VAGMDVELTVERR $\begin{array}{lllllllllll}1.00 & 53.19 & 27.85 & 42.27 & 2 & 1590.8080 & 1590.8045 & 796.4095 & 0.0035 & 2.1974 & 46.184\end{array}$

VAGMDVELTVEER

VAGMDVELTVEER

VAGMDVELTVEER

VAGMDVELTVEER

VAGMDVELTVEER

YDEMVESMK

YDEMVESMK

YDEMVESMK

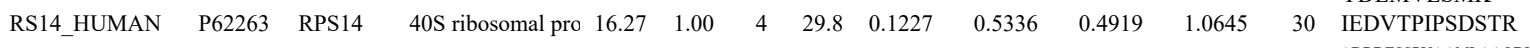

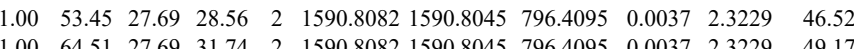

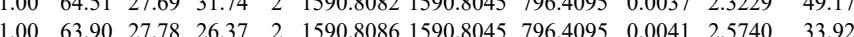

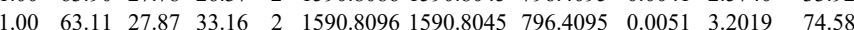

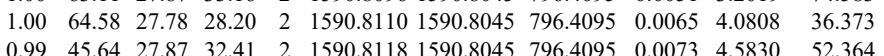
$\begin{array}{llllllllllllllll}.00 & 62.85 & 26.04 & 23.38 & 2 & 1418.6798 & 1418.6665 & 710.3405 & 0.0133 & 9.3616 & 8053.358 & 12618.284 & 12047.822 & 9065.874 & \text { Yes } & \\ \end{array}$ $\begin{array}{lllllllllllllll}1.00 & 44.11 & 26.15 & 25.78 & 2 & 1418.6796 & 1418.6665 & 710.3405 & 0.0131 & 9.2208 & 715.566 & 900.645 & 717.220 & 485.426 & \text { Yes }\end{array}$

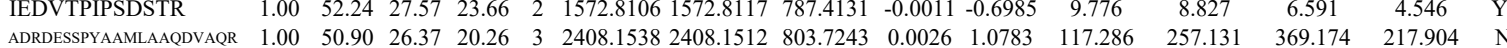
$\begin{array}{llllllllllllllllll}\text { ADRDESSPYAAMLAAQDVAQR } & 0.98 & 42.05 & 26.39 & 18.78 & 3 & 2408.1541 & 2408.1512 & 803.7243 & 0.0029 & 1.2027 & 297.007 & 475.651 & 297.256 & 269.253 & \text { Yes }\end{array}$ $\begin{array}{lllllllllllllll}\text { DESSPYAAMLAAQDVAQR } & 1.00 & \text { \#\#\# } 26.64 & 24.86 & 2 & 2065.9874 & 2065.9860 & 1034.0003 & 0.0014 & 0.6770 & 499.082 & 318.882 & 708.511 & 458.087 & \text { Yes }\end{array}$

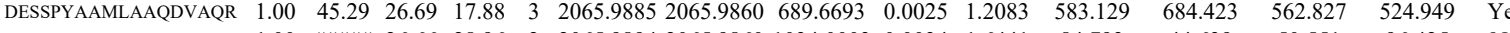

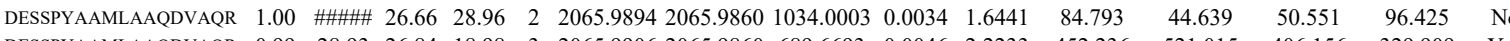
$\begin{array}{llllllllllllllll}\text { DESSPYAAMLAAQDVAQR } & 0.99 & 28.93 & 26.84 & 18.98 & 3 & 2065.9906 & 2065.9860 & 689.6693 & 0.0046 & 2.2233 & 452.236 & 521.015 & 406.156 & 329.909 & \text { Yes }\end{array}$ $\begin{array}{lllllllllllllllll}\text { ADRDESSPYAAMLAAQDVAQR } & 1.00 & 53.53 & 26.33 & 22.44 & 3 & 2408.1529 & 2408.1512 & 803.7243 & 0.0017 & 0.7051 & 686.834 & 1358.579 & 828.484 & 869.657 & \text { Yes }\end{array}$

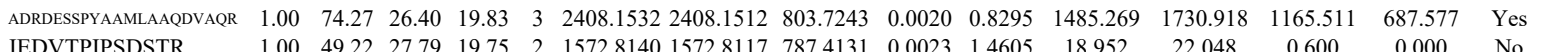

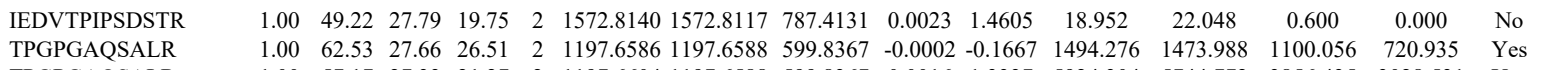
TPGPGAQSALR TPGPGAQSALR TPGPAQSALR TPGTARS

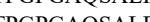

TPGPGAQSALR

TPGPGAQSALR

TPGPGAQSALR

TPGPGAQSALR

TPGPGAQSALR

TPGPGAQSALR

TPGPGAQSALR

TPGPGAQSALR

TPGPGAQSALR

TPGPGAQSALR

TPGPGAQSALR

PPGGAQSALR

TPGPGAQSALR

TPGPGAQSALR

TPGPGAQSALR

IEDVTPIPSDSTR

IEDVTPIPSDSTR

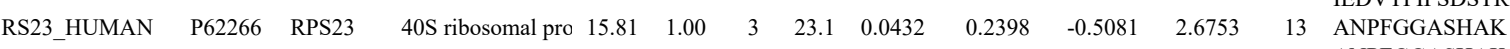

ANPFGGASHAK

ANPFGGASHAK

VANVSLLALYK

VANVSLLALYK

VANVSLLALYK

VANVSLLALYK

VANVSLLALYK

GHAVGDIPGVR $\begin{array}{lllllllllllllll}1.00 & 62.53 & 27.66 & 26.51 & 2 & 1197.6586 & 1197.6588 & 599.8367 & -0.0002 & -0.1667 & 1494.276 & 1473.988 & 1100.056 & 720.935 & \text { Yes }\end{array}$ $\begin{array}{lllllllllllllll}1.00 & 57.17 & 27.33 & 21.27 & 2 & 1197.6604 & 1197.6588 & 599.8367 & 0.0016 & 1.3337 & 5924.304 & 5744.772 & 3856.435 & 3028.531 & \text { Yes } \\ 1.00 & 54.06 & 27.77 & 25.75 & 2 & 1197.6590 & 1197.6588 & 599.8367 & 0.002 & 0.1667 & 2703.597 & 2543.521 & 1822.192 & 1598.906 & \text { Yes }\end{array}$ $\begin{array}{lllllllllllllll}1.00 & 54.06 & 27.77 & 25.75 & 2 & 197.6590 & 197.6588 & 599.8367 & 0.0016 & 1.3337 & 5924.304 & 5744.772 & 3856.435 & 3028.531 & \text { Yes } \\ 1.00 & 54.46 & 27.76 & 27.54 & 2 & 1197.6594 & 1197.6588 & 599.837 & 0.0002 & 0.1667 & 2703.597 & 2543.521 & 1822.192 & 1598.906 & \text { Yes }\end{array}$

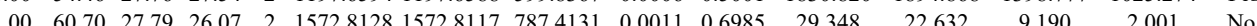

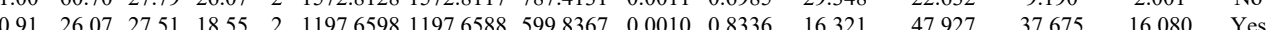

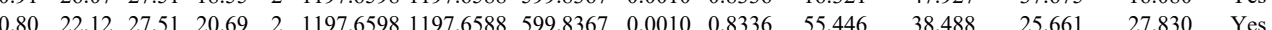

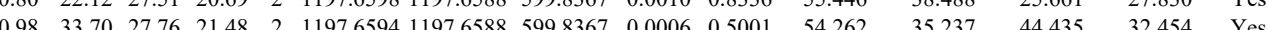

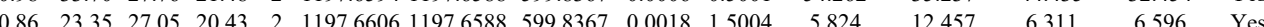

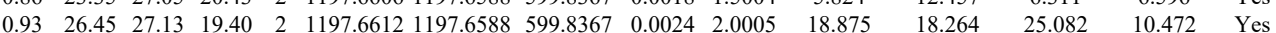

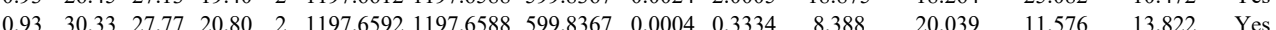

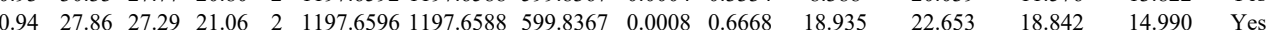

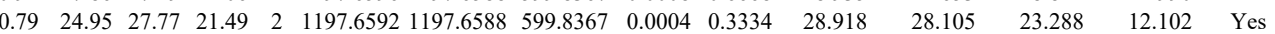
$\begin{array}{lllllllllllllll}0.96 & 29.89 & 27.54 & 21.80 & 2 & 1197.6600 & 1197.6588 & 599.8367 & 0.0012 & 1.0003 & 26.851 & 28.008 & 29.466 & 13.816 & \text { Yes }\end{array}$ $\begin{array}{lllllllllllllll}0.96 & 33.01 & 27.77 & 22.81 & 2 & 1197.6590 & 1197.6588 & 599.8367 & 0.0002 & 0.1667 & 21.197 & 23.595 & 13.907 & 5.757 & \text { Yes }\end{array}$ \begin{tabular}{llllllllllllllll}
0.98 & 32.34 & 27.54 & 26.30 & 2 & 1197.6600 & 1197.6588 & 599.8367 & 0.0012 & 1.0003 & 15.730 & 22.300 & 23.250 & 10.838 & Yes \\
\hline
\end{tabular}

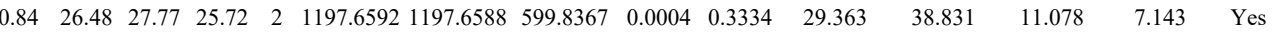

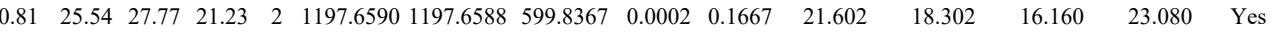

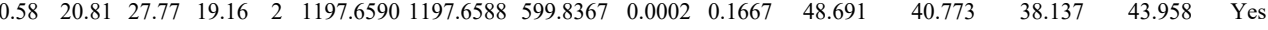

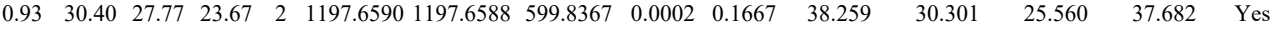

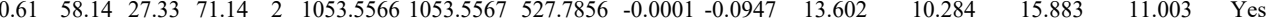

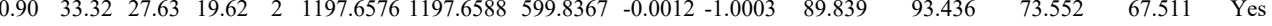
$\begin{array}{lllllllllllllll}0.95 & 34.71 & 27.75 & 27.13 & 2 & 1572.8264 & 1572.8117 & 787.4131 & 0.0147 & 9.3343 & 644.858 & 885.327 & 564.482 & 823.046 & \text { Yes }\end{array}$ $\begin{array}{lllllllllllllll}1.00 & 72.08 & 27.77 & 27.07 & 2 & 1572.8268 & 1572.8117 & 787.4131 & 0.0151 & 9.5883 & 9429.208 & 9581.902 & 2674.535 & 253.666 & \text { Yes }\end{array}$ $\begin{array}{llllllllllllllllll}1.00 & 52.01 & 27.64 & 27.86 & 3 & 1343.7214 & 1343.7190 & 448.9136 & 0.0024 & 1.7821 & 13897.134 & 11888.103 & 3263.560 & 377.927 & \text { Yes }\end{array}$ $\begin{array}{lllllllllllllllll}1.00 & 55.22 & 27.87 & 28.29 & 3 & 1343.7220 & 1343.7190 & 448.9136 & 0.0030 & 2.2276 & 17473.797 & 15566.272 & 3468.849 & 505.020 & \text { Yes }\end{array}$ $\begin{array}{lllllllllllllll}1.00 & 46.14 & 27.72 & 29.82 & 3 & 1343.7196 & 1343.7190 & 448.9136 & 0.0006 & 0.4455 & 10402.241 & 10112.887 & 2120.285 & 374.605 & \text { Yes }\end{array}$ $\begin{array}{llllllllllllllll}1.00 & 54.7 & 2.00 & 18.45 & 2 & 1477.9144 & 1477.9112 & 739.9629 & 0.0032 & 2.1623 & 3194.551 & 3245.479 & 109.221 & 10.177 & \text { Yes }\end{array}$

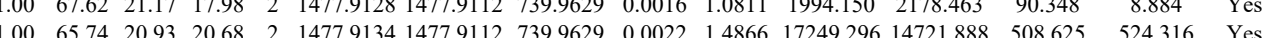

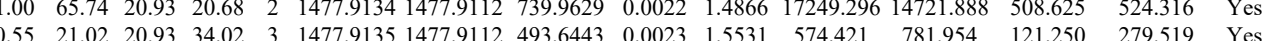

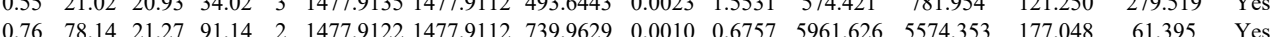

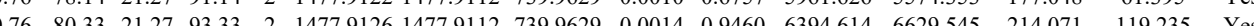
$\begin{array}{lllllllllllllll}0.76 & 80.33 & 21.27 & 93.33 & 2 & 1477.9126 & 1477.9112 & 739.9629 & 0.0014 & 0.9460 & 6394.614 & 6629.545 & 214.071 & 119.235 & \text { Yes } \\ 0.96 & 27.94 & 28.06 & 29.10 & 3 & 1220.6758 & 1220.6748 & 407.8989 & 0.0010 & 0.8172 & 111.892 & 135.841 & 76.840 & 52.482 & \text { Yes }\end{array}$ 
GHAVGDIPGVR GHAVGDIPGVR GHAVGDIPGVR

61 KADIDLTK KADIDLTK KADIDLTK KADIDLTK KADIDLTK KADIDLTK YSQVLANGLDNK YSQVLANGLDNK AGLTEDER AGELTEDEVER AGELTEDEVER YAHVVLR YAHVVLR
IPDWFLNR IPDWFLNR IPDWFLNR
IPDWFLNR IPDWFLNR IPDWFLNR IPDWFLNR IPDWFLNR IPDWFLNR IPDWFLNR IPDWFLNR IPDWFLNR IPDWFLNR IPDWFLNR IPDWFLNR IAFAITAIK IAFAITAIK IAFAITAIK YAHVVLR
YAHVVLR FQHILR

YAHVVLR

VITIMQNPR

VITIMQNPR
VITIMQNPR

VITIMQNPR

VITIMQNPR

FQHILR

FQHILR

VITIMQNPR

VITIMQNPR

VITIMQNPR

VITIMQNPR

FQHILR

FQHILR

VITIMQNPR

VITIMQNPR

FQHILR

FQHILR

VITIMQNPR

VITIMQNPR

IPDWFLNR

IPDWFLNR

IPDWFLNR

IPDWFLNR

AGELTEDEVER

AGELTEDEVER

IPDWFLNR

IPDWFLNR

VITIMQNPR
VITIMQNPR

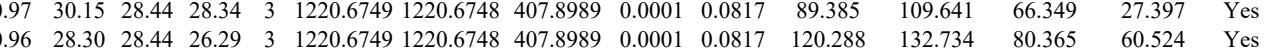

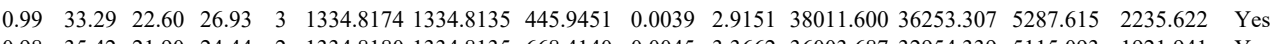

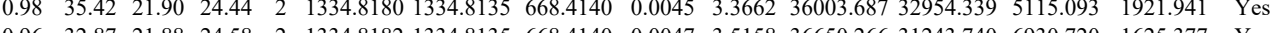
\begin{tabular}{lllllllllllllllll}
0.96 & 32.87 & 21.88 & 24.58 & 2 & 1334.8182 & 1334.8135 & 668.4140 & 0.0047 & 3.5158 & 36650.266 & 31243.740 & 6930.720 & 1625.377 & Yes \\
\hline
\end{tabular} $\begin{array}{llllllllllllllll}0.99 & 29.69 & 21.88 & 24.89 & 3 & 1334.8183 & 1334.8135 & 445.9451 & 0.0048 & 3.5879 & 56850.695 & 54483.963 & 6256.375 & 1862.002 & \text { Yes } \\ 0.97 & 2.11 & 22.07 & 25.24 & 3 & 1334.8198 & 1334.8135 & 445.9451 & 0.0063 & 4.7091 & 28017.323 & 2297.341 & 2710.271 & 614.940 & \text { Yes }\end{array}$

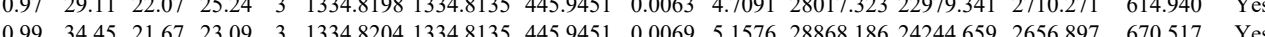
$\begin{array}{lllllllllllllll}0.99 & 34.45 & 21.67 & 23.09 & 3 & 1334.8204 & 1334.8135 & 445.9451 & 0.0069 & 5.1576 & 28868.186 & 24244.659 & 2656.897 & 670.517 & \text { Yes } \\ 1.00 & 6.53 & 27.19 & 27.85 & 2 & 1608.8866 & 1608.8715 & 805.4430 & 0.0151 & 9.3736 & 3531.769 & 3142.054 & 1692.198 & 333.270 & \text { Yes }\end{array}$ $\begin{array}{lllllllllllllll}1.00 & 62.53 & 27.19 & 27.85 & 2 & 1608.8866 & 1608.875 & 80.4430 & 0.0151 & 9.3736 & 3531.769 & 3142.054 & 1692.198 & 333.270 & \text { Yes } \\ 1.00 & 56.78 & 27.32 & 28.46 & 2 & 1608.8874 & 1608.8715 & 805.4430 & 0.0159 & 9.8702 & 10037215 & 8292.905 & 5018.312 & 576.645 & \text { Yes }\end{array}$

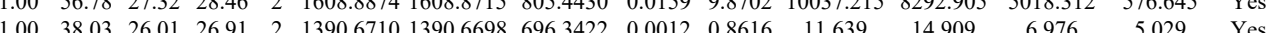

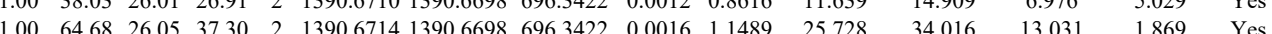

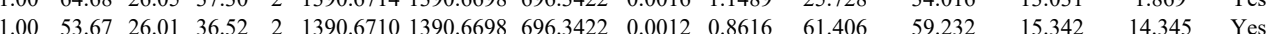

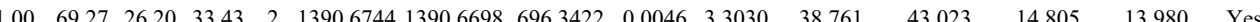
$\begin{array}{llllllllllllllll}0.99 & 34.40 & 26.63 & 28.92 & 2 & 1000.5954 & 1000.5940 & 5013043 & 0.0014 & 13964 & 18073.510 & 17785363 & 1259.568 & 755.909 & \text { Yes }\end{array}$ $\begin{array}{lllllllllllllll}0.98 & 34.70 & 26.43 & 26.59 & 2 & 1000.5966 & 1000.5940 & 5013043 & 0.0026 & 25932 & 18505.906 & 17876111 & 1262.298 & 714.530 & \text { Yes }\end{array}$ $\begin{array}{lllllllllllllll}0.69 & 20.83 & 28.62 & 20.41 & 2 & 1203.6528 & 1203.6522 & 602.8334 & 0.0006 & 0.4976 & 192.319 & 191.265 & 103.165 & 134.319 & \text { No }\end{array}$

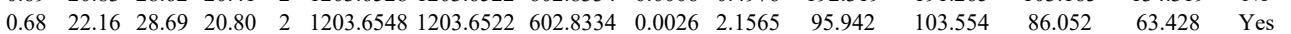
$\begin{array}{lllllllllllllll}0.93 & 29.92 & 28.69 & 25.30 & 2 & 1203.6548 & 1203.6522 & 602.8334 & 0.0026 & 2.1565 & 7795.846 & 5866.141 & 5409.622 & 3050.544 & \text { Yes }\end{array}$ $\begin{array}{lllllllllllllll}0.99 & 42.97 & 28.63 & 25.67 & 2 & 1203.6560 & 1203.6522 & 602.8334 & 0.0038 & 3.1518 & 5780.576 & 5172.242 & 4104.064 & 2623.415 & \text { Yes }\end{array}$ $\begin{array}{llllllllllllllll}1.00 & 40.95 & 26.43 & 26.70 & 2 & 1000.5962 & 1000.5940 & 501.3043 & 0.0022 & 2.1943 & 14893.055 & 14956.917 & 1035.705 & 557.006 & \text { Yes }\end{array}$ $\begin{array}{lllllllllllllll}0.98 & 33.14 & 28.62 & 23.00 & 2 & 1203.6528 & 1203.6522 & 602.8334 & 0.0006 & 0.4976 & 290.782 & 285.933 & 166.378 & 109.980 & \text { Yes }\end{array}$ $\begin{array}{llllllllllllllll}0.76 & 22.09 & 28.56 & 21.77 & 2 & 1203.6532 & 1203.6522 & 602.8334 & 0.0010 & 0.8294 & 228.241 & 223.082 & 89.832 & 94.778 & \text { Yes }\end{array}$ $\begin{array}{lllllllllllllll}0.75 & 23.66 & 28.69 & 22.58 & 2 & 1203.6548 & 1203.6522 & 602.8334 & 0.0026 & 2.1565 & 337.120 & 270.178 & 147.099 & 125.160 & \text { Yes }\end{array}$ $\begin{array}{lllllllllllllll}0.99 & 40.29 & 28.69 & 22.89 & 2 & 1203.6548 & 1203.6522 & 602.8334 & 0.0026 & 2.1565 & 7310.045 & 8306.257 & 8109.392 & 4777.656 & \text { Yes }\end{array}$ $\begin{array}{llllllllllllllll}0.96 & 32.94 & 28.62 & 16.95 & 2 & 1203.6554 & 1203.6522 & 602.8334 & 0.0032 & 2.6541 & 17072.010 & 18141.567 & 16075.578 & 8352.228 & \text { Yes }\end{array}$ $\begin{array}{lllllllllllllll}0.99 & 40.15 & 28.56 & 23.99 & 2 & 1203.6532 & 1203.6522 & 602.8334 & 0.0010 & 0.8294 & 6209.082 & 6704.336 & 6125.013 & 2108.406 & \text { Yes }\end{array}$ $\begin{array}{lllllllllllllll}0.98 & 34.77 & 28.56 & 23.12 & 2 & 1203.6532 & 1203.6522 & 602.8334 & 0.0010 & 0.8294 & 17577.325 & 15952.805 & 14810.913 & 7145.500 & \text { Yes }\end{array}$

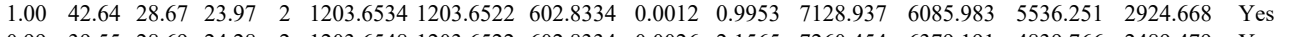
$\begin{array}{llllllllllllllll}0.99 & 39.55 & 28.69 & 24.28 & 2 & 1203.6548 & 1203.6522 & 602.8334 & 0.0026 & 2.1565 & 7260.454 & 6379.191 & 4839.766 & 2489.479 & \text { Yes }\end{array}$ $\begin{array}{llllllllllllllll}1.00 & 54.92 & 19.91 & 30.50 & 2 & 1234.7910 & 1234.7893 & 618.4019 & 0.0017 & 1.3745 & 38334.163 & 40349.478 & 7184.196 & 2710.753 & \text { Yes }\end{array}$ $\begin{array}{llllllllllllllll}1.00 & 50.56 & 19.91 & 29.10 & 2 & 1234.7916 & 1234.7893 & 618.4019 & 0.0023 & 1.8596 & 21007.404 & 20705.097 & 2775.607 & 793.705 & \text { Yes }\end{array}$ $\begin{array}{lllllllllllllll}1.00 & 50.64 & 19.82 & 28.91 & 2 & 1234.7918 & 1234.7893 & 618.4019 & 0.0025 & 2.0213 & 40729.413 & 39837.565 & 3866.222 & 1761.803 & \text { Yes } \\ 0.99 & 35.63 & 26.63 & 2.90 & 2 & 1000.5958 & 1000.5940 & 501.3043 & 0.0018 & 1.7953 & 8231.722 & 6665.638 & 220.257 & 331.334 & \text { Yes }\end{array}$ $\begin{array}{llllllllllllllll}0.99 & 35.63 & 26.63 & 26.90 & 2 & 1000.5958 & 1000.5940 & 501.3043 & 0.0018 & 1.7953 & 8231.722 & 6665.638 & 220.257 & 331.334 & \text { Yes } \\ 0.99 & 34.81 & 26.43 & 26.42 & 2 & 1000.5964 & 1000.5940 & 501.3043 & 0.0024 & 23938 & 10412.045 & 8662.473 & 515.675 & 352.289 & \text { Yes }\end{array}$ $\begin{array}{lllllllllllllll}0.9 & 34.81 & 26.43 & 26.42 & 2 & 100.564 & 00.5940 & 501.3043 & 0.024 & 2.3938 & 10412.045 & 8662.473 & 515.675 & 352.289 & \text { Yes } \\ 0.87 & 24.76 & 26.53 & 25.65 & 2 & 956.5712 & 9565678 & 479.2912 & 0.0034 & 3.5469 & 14660.868 & 14364.699 & 346.824 & 417.998 & \text { Yes }\end{array}$ $\begin{array}{lllllllllllllll}0.87 & 24.76 & 26.53 & 25.65 & 2 & 956.5712 & 956.5678 & 479.2912 & 0.0034 & 3.5469 & 14660.868 & 14364.699 & 346.824 & 417.998 & \text { Yes } \\ 0.85 & 24.21 & 26.53 & 32.32 & 2 & 956.5712 & 956.5678 & 479.2912 & 0.0034 & 3.5469 & 26042.878 & 27357.434 & 1542.352 & 642.017 & \text { Yes }\end{array}$ $\begin{array}{llllllllllllllll}1.00 & 41.33 & 26.63 & 32.23 & 2 & 1000.5956 & 1000.5940 & 501.3043 & 0.0016 & 1.5958 & 4819.215 & 3987.973 & 362.833 & 345.912 & \text { Yes }\end{array}$

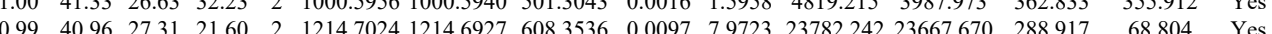
$\begin{array}{llllllllllllllll}0.99 & 40.84 & 27.30 & 22.71 & 2 & 1214.7026 & 1214.6927 & 6083536 & 0.0099 & 81366 & 44060825 & 43932.763 & 0.000 & 64.377 & \text { No }\end{array}$

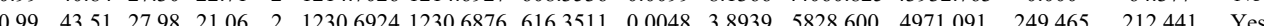
$\begin{array}{llllllllllllllll}1.00 & 51.48 & 27.98 & 21.24 & 2 & 1230.6924 & 1230.6876 & 616.3511 & 0.0048 & 3.8939 & 16393.379 & 14211.271 & 307.165 & 2.63 .162 & \text { Yes }\end{array}$ $\begin{array}{lllllllllllllll}1.00 & 51.92 & 28.08 & 25.35 & 2 & 1230.6970 & 1230.6876 & 6163511 & 0.0094 & 7.6255 & 4569.843 & 4809.878 & 423.766 & 225.567 & \text { Yes }\end{array}$ $\begin{array}{llllllllllllllll}0.93 & 25.58 & 26.45 & 30.11 & 2 & 956.5702 & 956.5678 & 479.2912 & 0.0024 & 25037 & 60756139 & 55806.303 & 2431.683 & 960.346 & \text { Yes }\end{array}$ $\begin{array}{llllllllllllllll}0.86 & 24.56 & 26.46 & 30.00 & 2 & 956.5708 & 956.5678 & 479.2912 & 0.0030 & 3.1296 & 79167.893 & 72922.554 & 2696.057 & 974.158 & \text { Yes }\end{array}$ $\begin{array}{lllllllllllllllll}0.98 & 39.29 & 27.33 & 21.17 & 2 & 1214.7044 & 1214.6927 & 608.3536 & 0.0117 & 9.6160 & 52776.865 & 48963.158 & 0.000 & 185.169 & \text { No }\end{array}$ $\begin{array}{lllllllllllllll}1.00 & 42.43 & 27.99 & 21.13 & 2 & 1230.6904 & 1230.6876 & 616.3511 & 0.0028 & 2.2714 & 4905.902 & 4567.327 & 93.704 & 46.228 & \text { Yes }\end{array}$ $\begin{array}{llllllllllllllll}0.97 & 32.58 & 28.02 & 28.43 & 2 & 1230.6906 & 1230.6876 & 616.3511 & 0.0030 & 2.4337 & 17171.909 & 14425.443 & 52.851 & 190.852 & \text { Yes }\end{array}$ $\begin{array}{lllllllllllllllll}0.97 & 37.42 & 28.15 & 26.04 & 2 & 1230.6994 & 1230.6876 & 616.3511 & 0.0118 & 9.5724 & 2021.494 & 1807.184 & 291.003 & 56.491 & \text { Yes }\end{array}$ $\begin{array}{llllllllllllllllll}0.95 & 27.12 & 26.45 & 28.74 & 2 & 956.5698 & 956.5678 & 479.2912 & 0.0020 & 2.0864 & 39490.914 & 34784.590 & 1865.370 & 1098.397 & \text { Yes }\end{array}$ $\begin{array}{llllllllllllllll}0.91 & 24.47 & 26.45 & 26.03 & 2 & 956.5698 & 956.5678 & 479.2912 & 0.0020 & 2.0864 & 50104.017 & 48794.460 & 2033.690 & 1380.033 & \text { Yes }\end{array}$ $\begin{array}{lllllllllllllll}0.99 & 40.76 & 27.30 & 21.17 & 2 & 1214.7026 & 1214.6927 & 608.3536 & 0.0099 & 8.1366 & 18045.840 & 17213.145 & 250.345 & 84.434 & \text { Yes }\end{array}$ $\begin{array}{llllllllllllllll}0.99 & 40.48 & 27.22 & 25.62 & 2 & 1214.7048 & 1214.6927 & 608.3536 & 0.0121 & 9.9448 & 42179.552 & 37173.371 & 161.773 & 130.011 & \text { Yes }\end{array}$ $\begin{array}{lllllllllllllllll}0.93 & 25.68 & 26.45 & 28.89 & 2 & 956.5698 & 956.5678 & 479.2912 & 0.0020 & 2.0864 & 9516.557 & 9004.525 & 573.197 & 362.917 & \text { Yes }\end{array}$ $\begin{array}{lllllllllllllllll}0.95 & 27.25 & 26.45 & 28.72 & 2 & 956.5702 & 956.5678 & 479.2912 & 0.0024 & 2.5037 & 10134.063 & 8583.705 & 638.026 & 349.264 & \text { Yes }\end{array}$ $\begin{array}{llllllllllllllll}0.99 & 40.76 & 27.30 & 25.07 & 2 & 1214.7026 & 1214.6927 & 608.3536 & 0.0099 & 8.1366 & 11105.091 & 9270.488 & 278.520 & 130.905 & \text { Yes }\end{array}$ $\begin{array}{llllllllllllllll}0.98 & 38.89 & 27.30 & 23.09 & 2 & 1214.7032 & 1214.6927 & 608.3536 & 0.0105 & 8.6298 & 20004.198 & 18482.989 & 0.000 & 51.804 & \text { No }\end{array}$ $\begin{array}{lllllllllllllll}0.91 & 27.07 & 28.57 & 33.69 & 2 & 1203.6530 & 1203.6522 & 602.8334 & 0.0008 & 0.6635 & 267.648 & 304.863 & 355.619 & 154.221 & \text { No }\end{array}$ $\begin{array}{lllllllllllllll}0.91 & 27.11 & 28.57 & 27.16 & 2 & 1203.6530 & 1203.6522 & 602.8334 & 0.0008 & 0.6635 & 316.414 & 309.790 & 296.708 & 151.321 & \text { Yes }\end{array}$

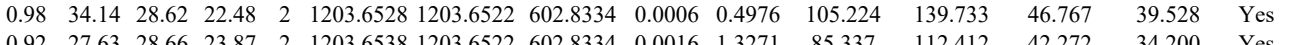
$\begin{array}{lllllllllllllll}0.92 & 27.63 & 28.66 & 23.87 & 2 & 1203.6538 & 1203.6522 & 602.8334 & 0.0016 & 1.3271 & 85.337 & 112.412 & 42.272 & 34.200 & \text { Yes } \\ 1.00 & 67.37 & 6.05 & 33.04 & 2 & 1390.6714 & 1390.6698 & 6963422 & 0.0016 & 1.1489 & 2594.631 & 2407.288 & 1374.580 & 905.685 & \text { Yes }\end{array}$

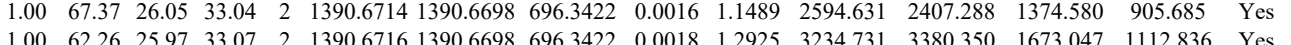

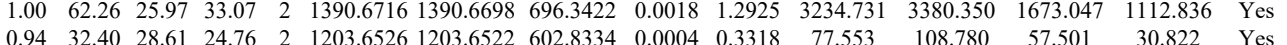

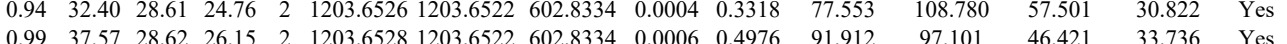

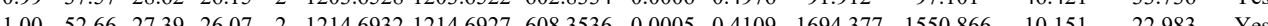
$\begin{array}{lllllllllllllll}1.09 & 52.66 & 27.39 & 26.07 & 2 & 1214.6932 & 1214.6927 & 608.3536 & 0.0005 & 0.4109 & 1694.377 & 1550.866 & 10.151 & 22.983 & \text { Yes } \\ 0.99 & 3936 & 27.39 & 21.89 & 2 & 1214.6932 & 1214.6927 & 608.3536 & 0.0005 & 0.4109 & 1822.410 & 1473.054 & 31.473 & 15.301 & \text { Yes }\end{array}$

Table S-3 page 311 of 499 

$\begin{array}{lllllllllllllll}1.00 & 64.32 & 27.88 & 25.71 & 2 & 1551.7824 & 1551.7817 & 776.8981 & 0.0007 & 0.4505 & 958.264 & 990.979 & 473.852 & 128.717 & \text { Yes }\end{array}$ $\begin{array}{lllllllllllllll}1.00 & 63.05 & 27.91 & 23.58 & 2 & 1551.7826 & 1551.7817 & 776.8981 & 0.0009 & 0.5792 & 1269.723 & 1608.572 & 644.670 & 216.527 & \text { Yes } \\ 1.00 & 38.55 & 27.94 & 18.87 & 3 & 1551.7831 & 151.7817 & 518.2678 & 0.0014 & 0.904 & 2490.225 & 2323.906 & 891.305 & 56.115 & \text { Yes }\end{array}$ $\begin{array}{lllllllllllllll}1.00 & 38.60 & 27.94 & 18.87 & 3 & 1551.7831 & 1551.7817 & 518.2678 & 0.0014 & 0.9004 & 2400.225 & 2323.906 & 891.305 & 518.115 & \text { Yes } \\ 1.00 & 58.55 & 27.94 & 21.73 & 3 & 1551.7834 & 1551.7817 & 518.2678 & 0.0017 & 1.0934 & 2226.813 & 2401.801 & 984.706 & 363.692 & \text { Yes }\end{array}$

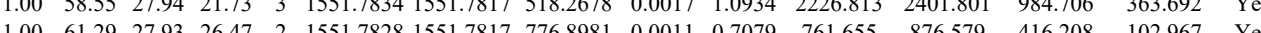

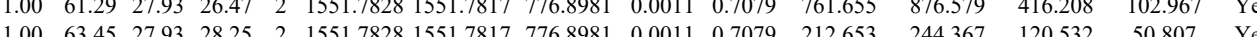

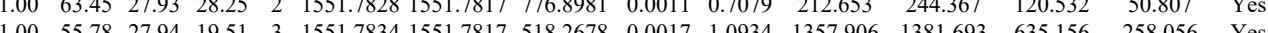
$\begin{array}{lllllllllllllll}1.00 & 36.62 & 28.00 & 18.89 & 3 & 1551.7837 & 1551.7817 & 518.2678 & 0.0020 & 1.2863 & 1992.433 & 2033.902 & 8313.449 & 253.835 & \text { Yes }\end{array}$ $\begin{array}{llllllllllllllll}0.99 & 37.91 & 27.91 & 17.12 & 3 & 1551.7828 & 1551.7817 & 518.2678 & 0.0011 & 0.7005 & 127.1742 & 1179.686 & 488.340 & 353.8302 & \text { Yes }\end{array}$ $\begin{array}{lllllllllllllll}0.96 & 27.01 & 21.11 & 15.74 & 2 & 1045.4632 & 1045.4629 & 523.7387 & 0.0003 & 0.2864 & 38616260 & 40128.074 & 9054.306 & 1564.960 & \text { No }\end{array}$ $\begin{array}{llllllllllllllll}\text { GLAPDLPEDLYHLIK } & 1.00 & 67.76 & 25.30 & 17.61 & 3 & 1981.1164 & 1981.1128 & 661.3782 & 0.0036 & 1.8144 & 10718.904 & 11626.953 & 2192.470 & 0.000 & \text { No }\end{array}$

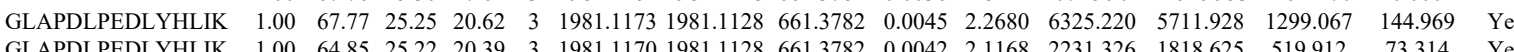

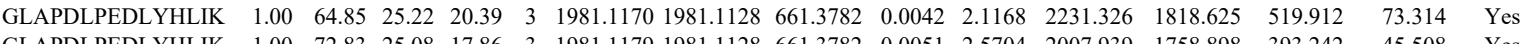
LILIESR

LILIESR

LILIESR
LILIESR

SVPTWLK

SVPTWLK

VLPPNWK

VLPPNWK

GLSQSALPYR

GLSQSALPYR

VLPPNWK

GLSQSALPYR

GLSQSALPYR

GLSQALPY

GLSBAPYR

GLSQSALPYR

GLSQSALPYR

GLTPSQIGVILR

GLTPSQIGVILR

GLTPSQIGVILR

GLTPSQIGVILR

GLTPSQIGVILR

GLTPSQIGVILR

GLTPSQIGVILR

GLTPSQIGVILR

GLTPSQIGVILR

GLTPSQIGVIL

GLTPSQIGVILR

GLTPSQIGVILR

GLTPSQIGVILR

GLTPSQIGVILR

GLTPSQIGVILR

GLTPSQIGVILR

GLTPSQIGVILR

GLTPSQIGVILR

GLTPSQIGVILR

GLTPSQIGVILR

GLTPSQIGVILR

$\begin{array}{lllllllllllllllll}1.00 & 72.83 & 25.08 & 17.86 & 3 & 1981.1179 & 1981.1128 & 661.3782 & 0.0051 & 2.5704 & 2007.939 & 1758.898 & 393.242 & 45.508 & \text { Yes }\end{array}$ $\begin{array}{lllllllllllllllll}0.96 & 40.96 & 25.59 & 38.32 & 2 & 986.6340 & 986.6246 & 494.3196 & 0.0094 & 9.5079 & 20683.883 & 19531.995 & 2086.082 & 739.390 & \text { Yes } \\ 0.99 & 40.90 & 25.47 & 32.20 & 2 & 986.6344 & 986.6246 & 494.3196 & 0.0098 & 9.9125 & 15816.221 & 16151.300 & 1726.434 & 599.694 & \text { Yes }\end{array}$ $\begin{array}{lllllllllllllllll}0.96 & 41.07 & 25.59 & 38.45 & 2 & 986.6332 & 986.6246 & 494.3196 & 0.0086 & 8.6988 & 19227.476 & 18536.910 & 2617.350 & 767.173 & \text { Yes }\end{array}$ $\begin{array}{lllllllllllllllll}0.99 & 40.99 & 25.59 & 32.48 & 2 & 986.6338 & 986.6246 & 494.3196 & 0.0092 & 9.3056 & 14790.699 & 14610.052 & 2111.509 & 447.799 & \text { Yes }\end{array}$ $\begin{array}{lllllllllllllll}0.92 & 29.94 & 24.30 & 26.13 & 2 & 1117.6832 & 1117.6739 & 559.8442 & 0.0093 & 8.3058 & 41944.348 & 36245.674 & 9998.307 & 1911.290 & \text { Yes }\end{array}$ $\begin{array}{lllllllllllllllll}0.96 & 31.93 & 24.30 & 26.20 & 2 & 1117.6836 & 1117.6739 & 559.8442 & 0.0097 & 8.6630 & 37556.903 & 37716.534 & 12205.487 & 1926.548 & \text { Yes }\end{array}$ \begin{tabular}{llllllllllllllll}
1.00 & 45.76 & 22.99 & 26.34 & 2 & 1140.6970 & 1140.6899 & 571.3522 & 0.0071 & 6.2133 & 24435.035 & 20953.366 & 257.315 & 258.597 & Yes \\
\hline
\end{tabular} $\begin{array}{llllllllllllllll}1.00 & 45.57 & 22.17 & 27.72 & 2 & 1140.6974 & 1140.6899 & 571.3522 & 0.0075 & 6.5633 & 34021.387 & 31166.711 & 202.446 & 367.131 & \text { Yes } \\ 1.00 & 47.41 & 2.10 & 29.01 & 2 & 123.682 & 1234.6792 & 618346 & 0.090 & 7.2774 & 5827.369 & 59244.182 & 15059.387 & 110.588 & \text { Yes }\end{array}$ \begin{tabular}{llllllllllllllll}
1.00 & 47.41 & 28.10 & 29.01 & 2 & 1234.6882 & 1234.6792 & 618.3469 & 0.0090 & 7.2774 & 58927.369 & 59244.182 & 15059.387 & 1110.588 & Yes \\
\hline
\end{tabular} $\begin{array}{lllllllllllllll}1.00 & 49.12 & 27.84 & 29.16 & 2 & 1234.6888 & 1234.6792 & 618.3469 & 0.0096 & 7.7626 & 37097.779 & 32977.197 & 10824.321 & 1531.273 & \text { Yes } \\ 0.99 & 37.83 & 22.8 & 28.72 & 2 & 1140.6996 & 1140.6899 & 571.3522 & 0.0097 & 8.4886 & 23367.573 & 23461.888 & 329.130 & 594.384 & \text { Yes }\end{array}$

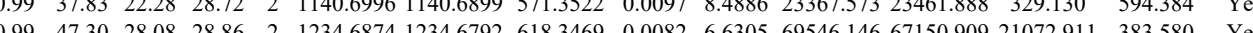
\begin{tabular}{llllllllllllllll}
0.99 & 47.30 & 28.08 & 28.86 & 2 & 1434.6874 & 1234.6792 & 618.3469 & 0.0082 & 6.6305 & 69546.146 & 67150.909 & 21072.911 & 383.580 & Yes \\
\hline
\end{tabular}

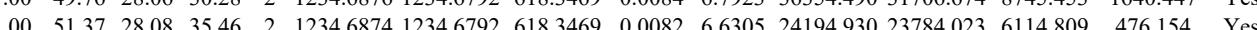
$\begin{array}{llllllllllllllll}1.00 & 48.01 & 28.03 & 30.06 & 2 & 1234.6878 & 1234.6792 & 6183469 & 0.0086 & 6.9540 & 3003.690 & 29918237 & 6773.574 & 1364.080 & \text { Yes }\end{array}$ $\begin{array}{llllllllllllllll}0.99 & 47.56 & 28.08 & 30.66 & 2 & 1234.6860 & 1234.6792 & 6183469 & 0.0068 & 5.4985 & 7416.474 & 6776.231 & 2388.869 & 452.218 & \text { Yes }\end{array}$ $\begin{array}{lllllllllllllll}1.00 & 49.61 & 28.08 & 30.03 & 2 & 1234.6860 & 1234.6792 & 6183469 & 0.0068 & 5.4985 & 7007.303 & 6576.560 & 1816.194 & 401.554 & \text { Yes }\end{array}$ $\begin{array}{lllllllllllllll}0.97 & 25.96 & 22.30 & 15.65 & 3 & 13968517 & 13968524 & 4666247 & -0.0007 & -0.5000 & 403.186 & 454.211 & 1184.148 & 1451.934 & \text { No }\end{array}$ $\begin{array}{lllllllllllllll}0.91 & 18.39 & 22.28 & 15.58 & 3 & 1396.8526 & 1396.8524 & 466.6247 & 0.0002 & 0.1429 & 468.984 & 465.662 & 918.216 & 1110.741 & \text { No }\end{array}$ $\begin{array}{lllllllllllllllll}0.76 & 58.77 & 22.23 & 71.77 & 2 & 1396.8530 & 1396.8524 & 699.4335 & 0.0006 & 0.4289 & 4638.067 & 3959.915 & 2247.324 & 590.716 & \text { Yes }\end{array}$ $\begin{array}{lllllllllllllllll}1.00 & 67.06 & 22.23 & 17.76 & 2 & 1396.8530 & 1396.8524 & 699.4335 & 0.0006 & 0.4289 & 14390.336 & 14361.432 & 8467.958 & 1463.753 & \text { Yes }\end{array}$ $\begin{array}{lllllllllllllll}1.00 & 41.41 & 22.23 & 17.43 & 2 & 1396.8528 & 1396.8524 & 699.4335 & 0.0004 & 0.2859 & 101.314 & 70.471 & 45.414 & 10.337 & \text { Yes }\end{array}$

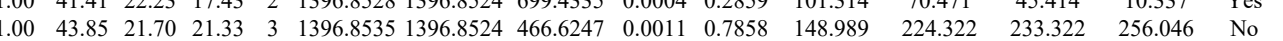
$\begin{array}{lllllllllllllll}0.76 & 26.36 & 21.76 & 39.36 & 2 & 1396.8536 & 1396.8524 & 699.4335 & 0.0012 & 0.8578 & 24.205 & 34.122 & 14.519 & 5.410 & \text { Yes }\end{array}$ $\begin{array}{llllllllllllllll}1.00 & 47.48 & 21.88 & 20.49 & 3 & 1396.8538 & 1396.8524 & 466.6247 & 0.0014 & 1.0001 & 200.867 & 168.743 & 369.551 & 233.030 & \text { No }\end{array}$

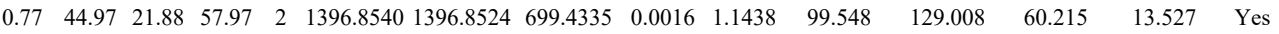

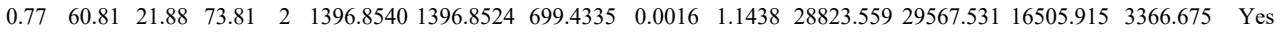
$\begin{array}{lllllllllllllll}0.77 & 57.27 & 21.88 & 70.27 & 2 & 1396.8540 & 1396.8524 & 699.4335 & 0.0016 & 1.1438 & 9878.480 & 8342.774 & 5497.676 & 996.363 & \text { Yes }\end{array}$ $\begin{array}{lllllllllllllll}0.77 & 15.37 & 21.88 & 28.37 & 2 & 1396.8540 & 1396.8524 & 699.4335 & 0.0016 & 1.1438 & 8.552 & 20.358 & 7.260 & 6.966 & \text { Yes }\end{array}$

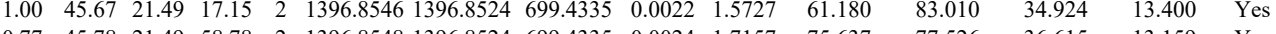

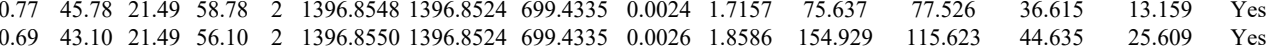
$\begin{array}{lllllllllllllll}0.69 & 43.10 & 21.49 & 56.10 & 2 & 1396.8550 & 1396.8524 & 699.4335 & 0.0026 & 1.8586 & 154.929 & 115.623 & 44.635 & 25.609 & \text { Yes } \\ 0.69 & 48.22 & 21.49 & 61.22 & 2 & 1396.8550 & 1396.8524 & 699.4335 & 0.0026 & 1.8586 & 93.972 & 92.235 & 37.046 & 16.148 & \text { Yes } \\ 1.00 & 62.54 & 22.23 & 17.16 & 2 & 1396.8532 & 1396.8524 & 699.435 & 0.0008 & 0.579 & 225.63 & 0337.968 & 580.898 & 1479.860 & Y \text { es }\end{array}$

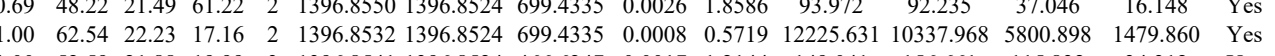
$\begin{array}{llllllllllllllll}1.00 & 52.59 & 21.88 & 19.99 & 3 & 1396.8541 & 1396.8524 & 466.6247 & 0.0017 & 1.2144 & 149.041 & 156.661 & 115.832 & 34.312 & \text { Yes }\end{array}$

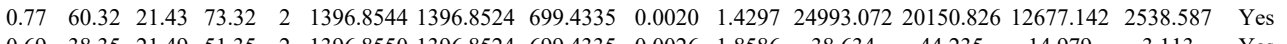

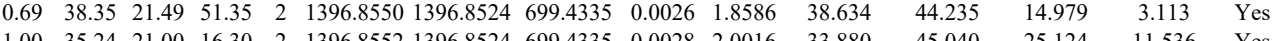

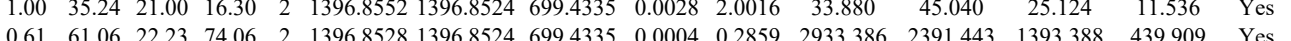
$\begin{array}{lllllllllllllll}0.61 & 61.06 & 22.23 & 74.06 & 2 & 1396.8528 & 1396.8524 & 699.4335 & 0.0004 & 0.2859 & 2933.386 & 2391.443 & 1393.388 & 439.909 & \text { Yes } \\ 0.76 & 62.01 & 22.23 & 75.01 & 2 & 1396.8530 & 1396.8524 & 699.4335 & 0.0006 & 0.4289 & 2345.834 & 2389.924 & 1151.185 & 266.610 & \text { Yes }\end{array}$

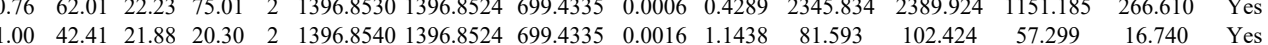

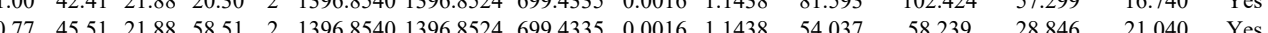

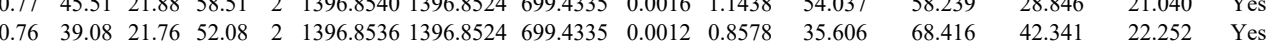

Table S-3 page 312 of 499 

$\begin{array}{lllllllllllllll}1.00 & 61.63 & 22.28 & 18.14 & 2 & 1396.8524 & 1396.8524 & 699.4335 & 0.0000 & 0.0000 & 204.329 & 142.634 & 111.687 & 10.610 & \text { Yes } \\ 0.95 & 34.19 & 27.23 & 20.66 & 2 & 1262.7328 & 1262.7227 & 6323686 & 0.0101 & 7.9858 & 23721.418 & 23961.600 & 17594.794 & 13549.363 & \text { Yes }\end{array}$ $\begin{array}{llllllllllllllll}0.95 & 34.19 & 27.23 & 20.66 & 2 & 1262.7328 & 1262.7227 & 632.3686 & 0.0101 & 7.9858 & 23721.418 & 23961.600 & 17594.794 & 13549.363 & \text { Yes } \\ 0.98 & 37.25 & 27.23 & 21.24 & 2 & 1262.7334 & 1262.7227 & 6323686 & 0.0107 & 8.4602 & 33074.811 & 29175.105 & 27915.219 & 20699.300 & \text { Yes }\end{array}$ $\begin{array}{lllllllllllllll}0.98 & 37.25 & 27.23 & 21.24 & 2 & 1262.7334 & 1262.7227 & 632.3686 & 0.0107 & 8.4602 & 33074.811 & 29175.105 & 27915.219 & 20699.300 & \text { Yes } \\ 0.97 & 35.93 & 27.54 & 21.96 & 2 & 12627270 & 12627227 & 633.3686 & 0.0043 & 3.3999 & 11455.379 & 10628.472 & 9214.600 & 7654.374 & \text { Yes }\end{array}$

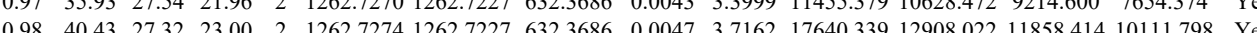
$\begin{array}{lllllllllllllllllll}0.97 & 35.97 & 27.78 & 24.02 & 2 & 1262.7264 & 1262.7227 & 6323686 & 0.0037 & 2.9255 & 8271.064 & 7862.732 & 7169.272 & 5429.752 & \text { Yes }\end{array}$ $\begin{array}{lllllllllllllll}0.98 & 39.60 & 27.54 & 29.47 & 2 & 1262.7268 & 1262.7227 & 6323686 & 0.0041 & 32418 & 7142.561 & 6360.637 & 5831.502 & 4426.864 & \text { Yes }\end{array}$ $\begin{array}{lllllllllllllll}0.97 & 32.60 & 23.93 & 26.65 & 2 & 10356416 & 1035.6320 & 518.8233 & 0.0096 & 9.2516 & 33082015 & 28186.676 & 5988.864 & 4089.709 & \text { Yes }\end{array}$ $\begin{array}{llllllllllllllll}0.57 & 18.92 & 23.93 & 26.00 & 2 & 1035.6416 & 1035.6320 & 518.8233 & 0.0096 & 9.2516 & 28019.739 & 25097.274 & 6473.820 & 3702.811 & \text { Yes }\end{array}$ $\begin{array}{lllllllllllllll}0.77 & 25.45 & 24.55 & 27.43 & 2 & 1035.6398 & 1035.6320 & 518.8233 & 0.0078 & 7.5170 & 45418.412 & 37861.272 & 7077.296 & 4816.097 & \text { Yes }\end{array}$

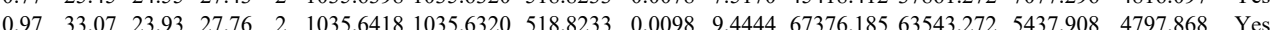
$\begin{array}{lllllllllllllll}0.79 & 23.37 & 23.93 & 23.53 & 2 & 1035.6420 & 1035.6320 & 518.8233 & 0.0100 & 9.6371 & 37175.943 & 27469.536 & 4622.379 & 1687.953 & \text { Yes }\end{array}$ $\begin{array}{lllllllllllllllll}0.91 & 46.10 & 21.73 & 46.55 & 2 & 1103.7242 & 1103.7158 & 552.8652 & 0.0084 & 7.5967 & 60038.323 & 49041.769 & 1410.772 & 697.862 & \text { Yes }\end{array}$

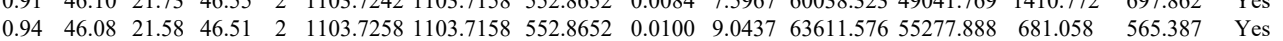

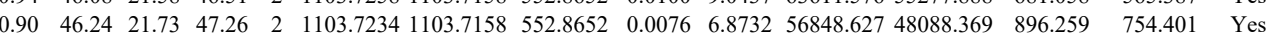
$\begin{array}{llllllllllllllll}0.92 & 49.67 & 21.73 & 49.97 & 2 & 1103.7238 & 1103.7158 & 552.8652 & 0.0080 & 7.2350 & 51210.571 & 44667.496 & 561.427 & 1019.381 & \text { Yes }\end{array}$ $\begin{array}{llllllllllllllll}0.70 & 21.15 & 21.73 & 28.26 & 2 & 1103.7240 & 1103.7158 & 552.8652 & 0.0082 & 7.4159 & 16777.551 & 19494.176 & 1865.584 & 2092.699 & \text { Yes }\end{array}$ $\begin{array}{llllllllllllllll}1.00 & 46.32 & 26.40 & 26.05 & 2 & 1282.6294 & 1282.6284 & 642.3215 & 0.0010 & 0.7784 & 11945.962 & 9514.868 & 8390.580 & 5250.551 & \text { Yes }\end{array}$ $\begin{array}{lllllllllllllll}1.00 & 55.85 & 26.51 & 27.52 & 2 & 1282.6306 & 1282.6284 & 642.3215 & 0.0022 & 1.7125 & 15810.729 & 15553.531 & 12113.670 & 9566.567 & \text { Yes }\end{array}$ $\begin{array}{lllllllllllllllll}0.56 & 16.01 & 26.40 & 18.31 & 2 & 1282.6292 & 1282.6284 & 642.3215 & 0.0008 & 0.6227 & 106.248 & 118.910 & 56.718 & 45.938 & \text { Yes }\end{array}$ $\begin{array}{lllllllllllllll}0.58 & 16.42 & 26.40 & 17.42 & 2 & 1282.6296 & 1282.6284 & 642.3215 & 0.0012 & 0.9341 & 120.372 & 101.771 & 52.288 & 29.190 & \text { Yes }\end{array}$ $\begin{array}{lllllllllllllll}0.54 & 15.80 & 26.39 & 14.85 & 2 & 1282.6298 & 1282.6284 & 642.3215 & 0.0014 & 1.0898 & 87.852 & 99.716 & 50.277 & 35.839 & \text { Yes }\end{array}$ $\begin{array}{lllllllllllllll}0.57 & 16.25 & 26.39 & 14.10 & 2 & 1282.6298 & 1282.6284 & 642.3215 & 0.0014 & 1.0898 & 103.173 & 112.964 & 49.871 & 41.206 & \text { Yes }\end{array}$ $\begin{array}{lllllllllllllll}0.50 & 14.75 & 26.49 & 27.75 & 2 & 1282.6304 & 1282.6284 & 642.3215 & 0.0020 & 1.5569 & 144.389 & 135.229 & 81.024 & 41.802 & \text { Yes }\end{array}$ $\begin{array}{lllllllllllllllll}0.99 & 36.37 & 26.51 & 21.83 & 2 & 1282.6306 & 1282.6284 & 642.3215 & 0.0022 & 1.7125 & 11153.308 & 9675.265 & 11009.119 & 6329.148 & \text { Yes }\end{array}$ $\begin{array}{lllllllllllllll}0.93 & 28.17 & 26.51 & 21.75 & 2 & 1282.6310 & 1282.6284 & 642.3215 & 0.0026 & 2.0239 & 4354.771 & 5282.015 & 6639.596 & 3442.483 & \text { Yes }\end{array}$

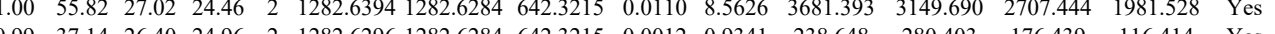

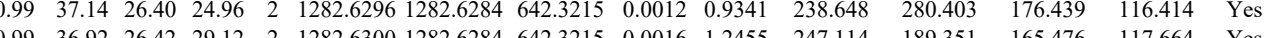
$\begin{array}{lllllllllllllll}0.99 & 36.92 & 26.42 & 29.12 & 2 & 1282.6300 & 1282.6284 & 642.3215 & 0.0016 & 1.2455 & 247.114 & 189.351 & 165.476 & 117.664 & \text { Yes } \\ 0.85 & 22.32 & 26.42 & 21.51 & 2 & 1282.6300 & 1282.6284 & 642.3215 & 0.0016 & 1.2455 & 69.360 & 57.114 & 62.145 & 2.257 & \text { Yes }\end{array}$

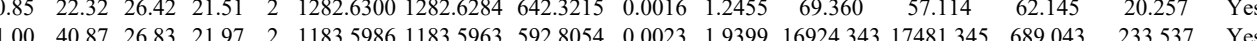
$\begin{array}{lllllllllllllll}1.00 & 40.87 & 26.83 & 21.97 & 2 & 1183.5986 & 1183.5963 & 592.8054 & 0.0023 & 1.9399 & 16924.343 & 17481.345 & 689.043 & 233.537 & \text { Yes } \\ 1.00 & 41.23 & 26.98 & 24.77 & 2 & 1183.5990 & 1183.5963 & 5928054 & 0.0027 & 2.2773 & 28862211 & 26285.663 & 2284.244 & 257.341 & \text { Yes }\end{array}$

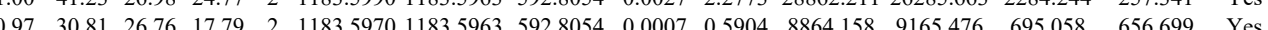
$\begin{array}{lllllllllllllll}0.60 & 22.34 & 27.14 & 21.67 & 2 & 1833.6074 & 1183.5963 & 592.8054 & 0.0111 & 9.3622 & 814.701 & 748.049 & 153.324 & 110.433 & \text { Yes }\end{array}$

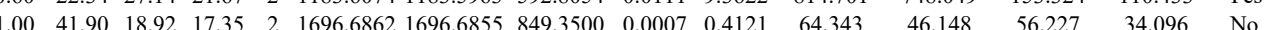
$\begin{array}{lllllllllllllll}0.76 & 64.15 & 19.08 & 77.15 & 2 & 1696.6866 & 16966855 & 849.3500 & 0.0011 & 0.6476 & 25.760 & 63.628 & 30.304 & 45.809 & \mathrm{No}\end{array}$ $\begin{array}{lllllllllllllll}0.98 & 32.85 & 26.78 & 20.34 & 2 & 1183.5978 & 1183.5963 & 5928054 & 0.0015 & 1.2652 & 428.448 & 442.988 & 69.085 & 28.139 & \text { Yes }\end{array}$ $\begin{array}{llllllllllllllll}0.97 & 30.89 & 26.84 & 23.66 & 2 & 11835980 & 1183.5963 & 5928054 & 0.0017 & 1.4339 & 556257 & 538.747 & 82.123 & 34.054 & \text { Yes }\end{array}$ $\begin{array}{lllllllllllllll}1.00 & 60.34 & 26.90 & 33.16 & 2 & 1427.8136 & 1427.8106 & 714.9126 & 0.0030 & 2.0982 & 198.887 & 212.208 & 124.427 & 274.830 & \text { Yes }\end{array}$

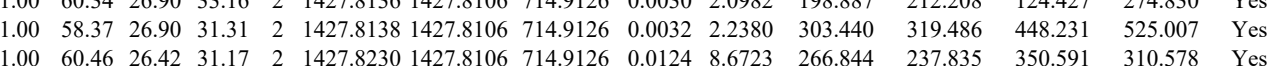

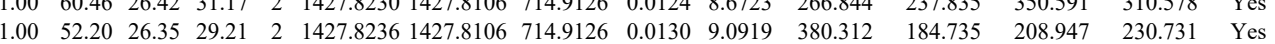
$\begin{array}{lllllllllllllll}\text { YFILPDSLPLDTLLVDVEPK } & 1.00 & 54.12 & 21.82 & 16.71 & 3 & 2574.4489 & 2574.4440 & 859.1553 & 0.0049 & 1.9011 & 135.345 & 209.453 & 32.421 & 9.381\end{array}$ $\begin{array}{llllllllllllllll}\text { YFILPDSLPLDTLLVDVEPK } & 1.00 & 35.21 & 21.85 & 15.42 & 3 & 2574.4492 & 2574.4440 & 859.1553 & 0.0052 & 2.0175 & 206.283 & 125.701 & 36.735 & 0.000\end{array}$ $\begin{array}{lllllllllllllllll}\text { YFLPDSLPLDILLVDVEPK } & 1.00 & 66.84 & 22.04 & 17.27 & 2 & 2574.4454 & 2574.4440 & 1288.2293 & 0.0014 & 0.5434 & 18.522 & 22.285 & 0.615 & 2.738 & \text { No }\end{array}$

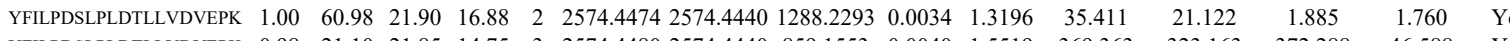
$\begin{array}{llllllllllllllll}\text { YFILPDSLPLDTLLVDVEPK } & 0.98 & 21.10 & 21.85 & 14.75 & 3 & 2574.4480 & 2574.4440 & 859.1553 & 0.0040 & 1.5519 & 369.363 & 323.163 & 372.288 & 46.588 & \text { Yes }\end{array}$ $\begin{array}{llllllllllllllll}\text { YFILPDSLPLDTLLVDVEPK } & 1.00 & 30.80 & 21.82 & 18.09 & 3 & 2574.4489 & 2574.4440 & 859.1553 & 0.0049 & 1.9011 & 552.573 & 449.071 & 151.458 & 79.555 & \text { Yes } \\ \text { YFILPDSLPLDTLLVDVEPK } & 1.00 & 63.00 & 21.79 & 18.27 & 2 & 2574.4494 & 2574.4440 & 1288.2293 & 0.0054 & 2.0959 & 17.459 & 8.934 & 0.000 & 0.000 & \text { No }\end{array}$

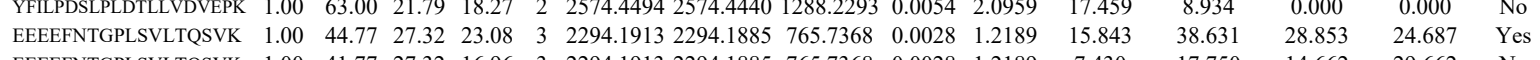

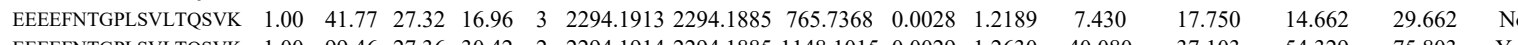

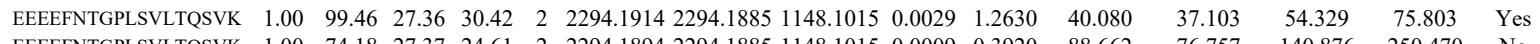

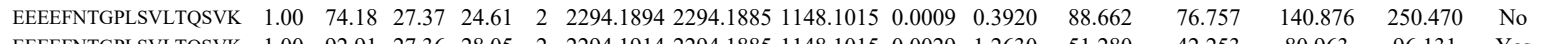

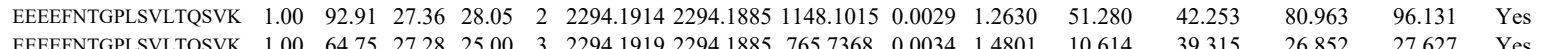
$\begin{array}{lllllllllllllll} & \end{array}$

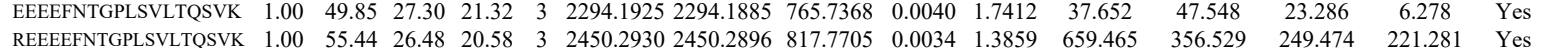
$\begin{array}{llllllllllllllll}\text { REEEEFNTGPLSVLTQSVK } & 1.00 & 55.44 & 26.48 & 20.58 & 3 & 2450.2930 & 2450.2896 & 817.7705 & 0.0034 & 1.3859 & 659.465 & 356.529 & 249.474 & 221.281 & \text { Yes } \\ \text { REEEEFNTGPLSVLTQSVK } & 1.00 & 38.19 & 26.47 & 18.01 & 3 & 2450.2933 & 24502896 & 817.7705 & 0.0037 & 1.5082 & 11.499 & 81.666 & 11.620 & 11.537 & \text { No }\end{array}$

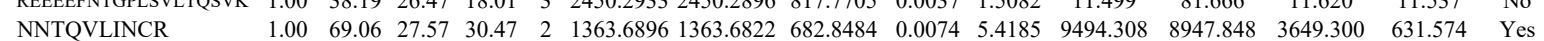
$\begin{array}{llllllllllllllll}\text { NNTQVLINCR } & 1.00 & 66.48 & 27.50 & 36.08 & 2 & 1363.6902 & 1363.6822 & 682.8484 & 0.0080 & 5.8578 & 21744.830 & 22995.754 & 8547.835 & 839.883 & \text { Yes }\end{array}$ 


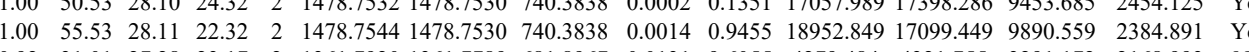
$\begin{array}{lllllllllllllllll}0.92 & 31.01 & 27.28 & 23.17 & 2 & 1361.7920 & 1361.7789 & 681.8967 & 0.0131 & 9.6055 & 4279.484 & 4321.755 & 3291.172 & 2168.993 & \text { No }\end{array}$ $\begin{array}{llllllllllllllll}0.99 & 42.97 & 27.21 & 20.23 & 2 & 1361.7910 & 1361.7789 & 681.8967 & 0.0121 & 8.8722 & 19814.062 & 19838.643 & 4333.329 & 2589.994 & \text { Yes } & \\ 0.98 & 26.33 & 24.20 & 25.82 & 3 & 1376.8363 & 1376.8345 & 459.9521 & 0.0018 & 1.3045 & 364.945 & 327.839 & 42.619 & 7.688 & \text { Yes }\end{array}$ $\begin{array}{llllllllllllllll}0.98 & 26.33 & 24.20 & 25.82 & 3 & 136.8363 & 1376.8345 & 459.9521 & 0.0018 & 1.3045 & 364.945 & 327.839 & 42.619 & 7.688 & \text { Yes } \\ 0.98 & 41.55 & 24.10 & 41.82 & 2 & 1376.8370 & 1376.8345 & 689.4245 & 0.0025 & 1.8131 & 34379.690 & 30119.391 & 55.787 & 442.769 & \text { Yes }\end{array}$

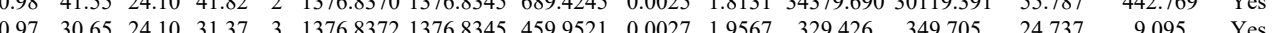

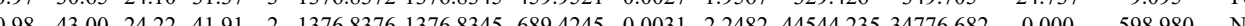

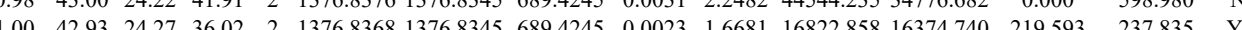
$\begin{array}{lllllllllllllll}0.98 & 23.45 & 24.12 & 23.81 & 3 & 1376.8369 & 1376.8345 & 459.9521 & 0.0024 & 1.7393 & 186.579 & 210.894 & 12.840 & 6.520 & \text { Yes }\end{array}$ $\begin{array}{lllllllllllllll}0.93 & 17.85 & 24.17 & 21.49 & 3 & 1376.8378 & 1376.8345 & 459.9521 & 0.0033 & 23915 & 213.006 & 220.712 & 33.367 & 7.739 & \text { Yes }\end{array}$ $\begin{array}{lllllllllllllll}0.98 & 43.34 & 24.08 & 43.35 & 2 & 1376.8374 & 1376.8345 & 689.4245 & 0.0029 & 21032 & 5323.911 & 4781.420 & 166.412 & 73.988 & \text { Yes }\end{array}$ $\begin{array}{llllllllllllllll}0.93 & 30.90 & 28.08 & 19.01 & 2 & 1361.7792 & 1361.7789 & 681.8967 & 0.0003 & 0.2200 & 285.352 & 234.895 & 206.528 & 217.648 & \mathrm{~N} o & \\ \end{array}$ $\begin{array}{llllllllllllllll} & \\ \text { GVIVLK } & 1.00 & 96.97 & 20.25 & 24.90 & 2 & 1728.0408 & 1728.0389 & 865.0267 & 0.0019 & 1.0982 & 1771.759 & 1853.942 & 770.152 & 94.002 & \text { Yes }\end{array}$ $\begin{array}{lllllllllllllllll}\text { ALQSVGQIVGEVLK } & 1.00 & 86.51 & 20.25 & 25.31 & 2 & 1728.0410 & 1728.0389 & 865.0267 & 0.0021 & 1.2138 & 1989.877 & 1995.671 & 762.339 & 87.189 & \text { Yes }\end{array}$ $\begin{array}{llllllllllllllll}\text { ALQSVGQIVGEVLK } & 1.00 & 52.13 & 20.21 & 25.26 & 3 & 1728.0418 & 1728.0389 & 577.0202 & 0.0029 & 1.6753 & 100.792 & 144.601 & 90.768 & 66.703 & \text { No }\end{array}$ $\begin{array}{lllllllllllllllll}\text { ALQSVGQIVGEVLK } & 1.00 & 37.38 & 20.21 & 17.88 & 3 & 1728.0430 & 1728.0389 & 577.0202 & 0.0041 & 2.3685 & 217.690 & 152.071 & 48.641 & 23.573 & \text { Yes }\end{array}$ $\begin{array}{lllllllllllllllll}\text { TLMELLNQMDGFDTLHR } & 1.00 & 53.89 & 27.90 & 18.55 & 3 & 2177.0743 & 2177.0731 & 726.6983 & 0.0012 & 0.5504 & 205.415 & 271.192 & 5.068 & 0.000 & \text { No }\end{array}$ $\begin{array}{llllllllllllllll}\text { TLMELLNQMDGFDTLHR } & 1.00 & 67.98 & 27.91 & 21.44 & 3 & 2177.0746 & 2177.0731 & 726.6983 & 0.0015 & 0.6880 & 386.774 & 473.413 & 15.638 & 20.191 & \text { Yes }\end{array}$ \begin{tabular}{llllllllllllllll} 
ALQSVGQIVGEVLK & 1.00 & 84.98 & 20.13 & 24.19 & 2 & 1728.0394 & 1728.0389 & 865.0267 & 0.0005 & 0.2890 & 907.968 & 832.021 & 328.387 & 61.775 & Yes \\
\hline
\end{tabular}

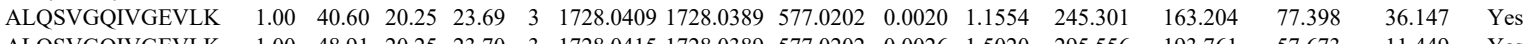

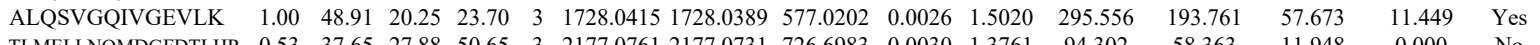
$\begin{array}{llllllllllllllll}\text { TLMELLNQMDGFDTLHR } & 0.53 & 37.65 & 27.88 & 50.65 & 3 & 2177.0761 & 2177.0731 & 726.6983 & 0.0030 & 1.3761 & 94.302 & 58.363 & 11.948 & 0.000 & \text { No }\end{array}$ VALDMTTLTIMR VALDMTTLTIMR VALDMTTLTIMR $\begin{array}{llllllllllllll}1.00 & 64.43 & 28.09 & 24.33 & 2 & 1507.8258 & 1507.8224 & 754.9185 & 0.0034 & 2.2519 & 261.896 & 300.401 & 27.951 & 5.915\end{array}$

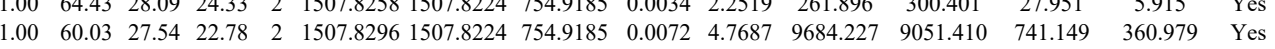
$\begin{array}{llllllllllllllll} & \text { MANA }\end{array}$ $\begin{array}{llllllllllllllllll} & \end{array}$

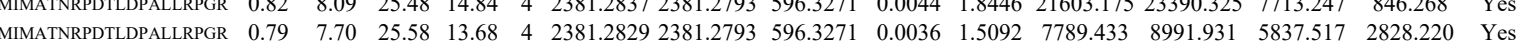
$\begin{array}{llllllllllllllllll} & \text { MIMATNRPDTLDPLLRPG } & 0.79 & 7.70 & 25.58 & 13.68 & 4 & 2381.2829 & 2381.2793 & 596.3271 & 0.0036 & 1.5092 & 7789.433 & 8991.931 & 5837.517 & 2828.220 & \text { YeS }\end{array}$ $\begin{array}{lllllllllllllllll}1.00 & 46.73 & 28.26 & 23.00 & 2 & 1503.8414 & 1503.8289 & 752.9217 & 0.0125 & 8.3009 & 15111.801 & 13889.617 & 201.048 & 521.446 & \text { Yes } & \end{array}$

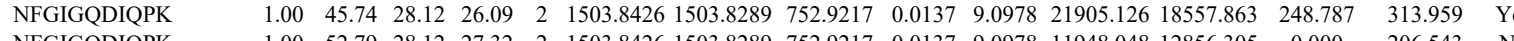

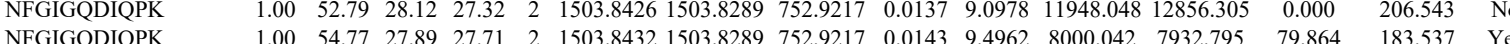

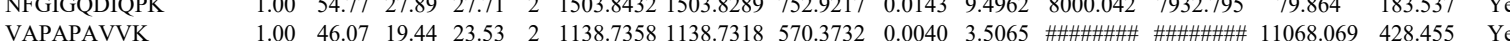
VAPAPAVVK
VAPAPAVVK VAPAPAVVK
VAPAPAVVK VAPAPAVVK KVVNPLFEK KVVNPLFEK KVVNPLFEK HWGGNVLGPK HWGGNVLGPK HWGGNVLGPK HWGGNVLGPK VPPAINQFTQALDR VPPAINQFTQALDR VPPAINQFTQALDR VPPAINQFTQALDR VPPAINQFTQALDR VPPAINQFTQALDR VPPAINQFTQALDR VPPAINQFTQALDR

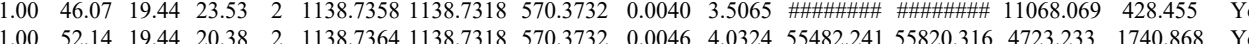
$\begin{array}{lllllllllllllll}1.00 & 52.14 & 19.44 & 20.38 & 2 & 1138.7364 & 1138.7318 & 570.3732 & 0.0046 & 4.0324 & 55482.241 & 55820.316 & 4723.233 & 1740.868 & \text { Yes } \\ 1.00 & 52.17 & 19.73 & 2.93 & 2 & 1138.7348 & 1138.7318 & 5703732 & 0.0030 & 2.6299 & 42687.862 & 37098.030 & 3025.330 & 1017.381 & \text { Yes }\end{array}$

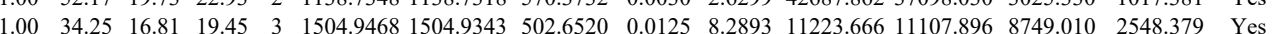
$\begin{array}{llllllllllllllllll}1.00 & 56.30 & 16.81 & 21.19 & 2 & 1504.9476 & 1504.9343 & 753.4744 & 0.0133 & 8.8257 & 4863.682 & 5279.205 & 3377.928 & 1480.138 & \text { Yes }\end{array}$ $\begin{array}{lllllllllllllllll}1.00 & 46.62 & 16.81 & 19.06 & 2 & 1504.9474 & 1504.9343 & 753.4744 & 0.0131 & 8.6930 & 4160.601 & 4575.585 & 2930.020 & 951.992 & \text { Yes }\end{array}$ $\begin{array}{llllllllllllllll}1.00 & 51.08 & 16.43 & 19.12 & 2 & 1504.9484 & 1504.9343 & 753.4744 & 0.0141 & 9.3566 & 1464.166 & 1712.187 & 1158.398 & 379.765 & \text { Yes }\end{array}$ $\begin{array}{lllllllllllllll}0.53 & 29.16 & 27.02 & 42.16 & 3 & 1351.7638 & 1351.7605 & 451.5941 & 0.0033 & 2.4358 & 14956.085 & 15085.548 & 20261.521 & 3491.229 & \text { Yes }\end{array}$ $\begin{array}{lllllllllllllll}0.95 & 22.60 & 27.02 & 19.96 & 3 & 1351.7638 & 1351.7605 & 451.5941 & 0.0033 & 2.4358 & 13047.842 & 15751.988 & 5941.611 & 2075.455 & \text { Yes }\end{array}$ $\begin{array}{llllllllllllllll}0.94 & 22.36 & 27.07 & 15.10 & 3 & 1351.7644 & 1351.7605 & 451.5941 & 0.0039 & 2.8787 & 13323.744 & 15431.352 & 6635.535 & 2227.415 & \text { Yes }\end{array}$ $\begin{array}{llllllllllllllll}0.81 & 17.57 & 27.03 & 21.41 & 3 & 1351.7647 & 1351.7605 & 451.5941 & 0.0042 & 3.1001 & 13868.258 & 11828.144 & 17084.997 & 2360.610 & \text { Yes }\end{array}$ $\begin{array}{lllllllllllllll}1.00 & 74.33 & 27.51 & 22.49 & 2 & 1712.9326 & 1712.9332 & 857.4739 & -0.0006 & -0.3499 & 1265.621 & 1407.755 & 1484.607 & 601.323 & \text { Yes } \\ 1.00 & 72.51 & 27.53 & 27.73 & 2 & 1712.9330 & 1712.9332 & 857.4739 & -0.0002 & -0.1166 & 1441.179 & 1310.876 & 728.951 & 499.172 & \text { Yes }\end{array}$ $\begin{array}{ccccccccccccccc}1.00 & 72.51 & 27.53 & 27.73 & 2 & 1712.9330 & 1712.9332 & 857.4739 & -0.0002 & -0.1166 & 1441.179 & 1310.876 & 728.951 & 499.172 & \text { Yes } \\ 1.00 & 33.96 & 27.29 & 20.03 & 3 & 1712.9353 & 1712.9332 & 571.9850 & 0.0021 & 1.2238 & 350.253 & 297.313 & 162.925 & 98.930 & \text { Yes }\end{array}$

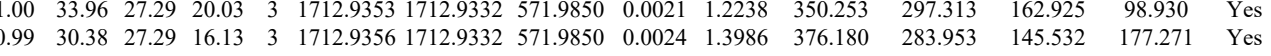
$\begin{array}{llllllllllllllll}0.98 & 26.96 & 27.41 & 20.54 & 3 & 1712.9347 & 1712.9332 & 571.9850 & 0.0015 & 0.8741 & 134.008 & 205.908 & 87.358 & 47.656 & \text { Yes }\end{array}$

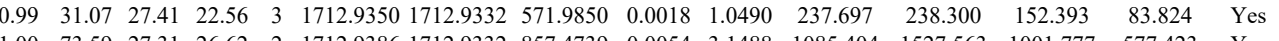
$\begin{array}{lllllllllllllll}1.00 & 73.59 & 27.31 & 26.62 & 2 & 1712.9386 & 1712.9332 & 857.4739 & 0.0054 & 3.1488 & 1085.404 & 1527.563 & 1001.777 & 577.423 & \text { Yes }\end{array}$ $\begin{array}{llllllllllllllllll}1.00 & 59.20 & 27.32 & 30.19 & 2 & 1712.9374 & 1712.9332 & 857.4739 & 0.0042 & 2.4490 & 709.911 & 655.606 & 965.992 & 445.269 & \text { Yes } & \end{array}$

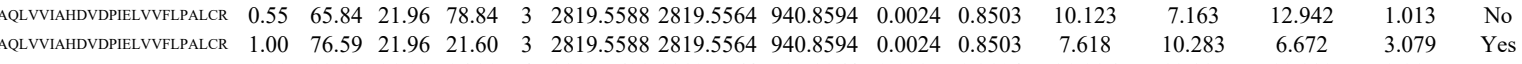

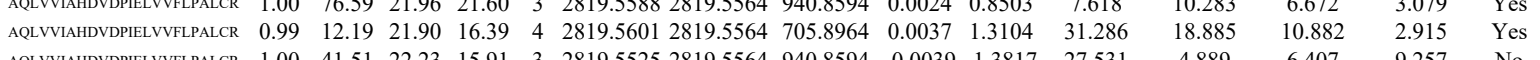
$\begin{array}{lllllllllllll}\text { AQL } & \end{array}$

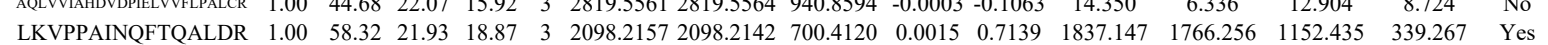




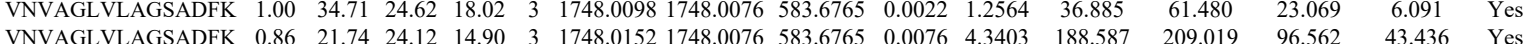

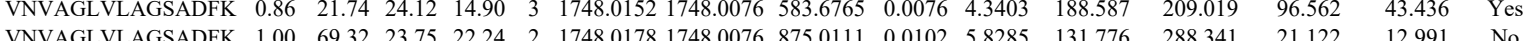

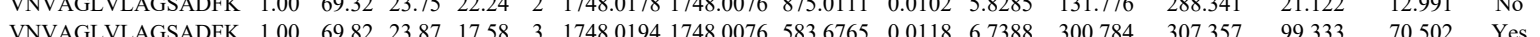

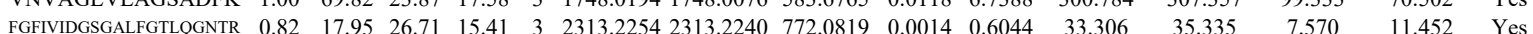

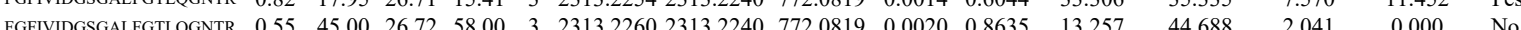
$\begin{array}{llllllllllllllll}\text { FGFIIDGSGALFGTLGNTR } & 0.55 & 24.61 & 26.73 & 37.61 & 3 & 2313.2263 & 2313.2240 & 772.0819 & 0.0023 & 0.9930 & 20.877 & 37.114 & 16.410 & 6.861 & \text { Y }\end{array}$

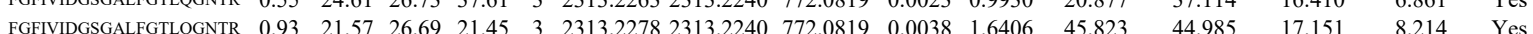

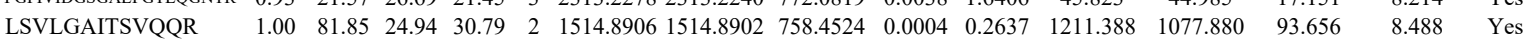
$\begin{array}{llllllllllllllll}\text { LSVLGAITSVQQR } & 0.84 & 15.38 & 24.87 & 17.21 & 3 & 1514.8933 & 1514.8902 & 505.9707 & 0.0031 & 2.0423 & 533.492 & 672.035 & 4537.929 & 1177.237 & \text { No- }\end{array}$ $\begin{array}{lllllllllllllllll}\text { LSVLGAITSVQQR } & 1.00 & 82.36 & 24.94 & 29.76 & 2 & 1514.8904 & 1514.8902 & 758.4524 & 0.0002 & 0.1318 & 3064.857 & 2445.558 & 157.734 & 4.741 & \text { Yes }\end{array}$ $\begin{array}{lllllllllllllllll}\text { LSVLGAITSVQQR } & 1.00 & 86.73 & 25.01 & 31.03 & 2 & 1514.8918 & 1514.8902 & 758.4524 & 0.0016 & 1.0548 & 9518.966 & 7582.498 & 501.550 & 24.771 & \text { Yes }\end{array}$ $\begin{array}{lllllllllllllllll}\text { LSVLGAITSVQQR } & 1.00 & 30.68 & 24.87 & 15.39 & 3 & 1514.8933 & 1514.8902 & 505.9707 & 0.0031 & 2.0423 & 942.593 & 859.812 & 5465.888 & 1142.647 & \text { No }\end{array}$ $\begin{array}{llllllllllllllll}\text { LSVLGAITSVQQR } & 1.00 & 78.77 & 24.94 & 30.40 & 2 & 1514.8904 & 1514.8902 & 758.4524 & 0.0002 & 0.1318 & 3757.820 & 2694.845 & 66.502 & 5.653 & \text { Yes }\end{array}$ $\begin{array}{lllllllllllllllll}\text { LSVLGAITSVQQR } & 1.00 & 80.64 & 25.15 & 30.37 & 2 & 1514.8914 & 1514.8902 & 758.4524 & 0.0012 & 0.7911 & 4637.968 & 4336.542 & 152.449 & 43.854 & \text { Yes }\end{array}$ $\begin{array}{llllllllllllllll}\text { LSVLGAITSVQQR } & 0.99 & 27.11 & 24.87 & 16.47 & 3 & 1514.8933 & 1514.8902 & 505.9707 & 0.0031 & 2.0423 & 1058.660 & 994.161 & 562.774 & 218.982 & \text { Yes }\end{array}$

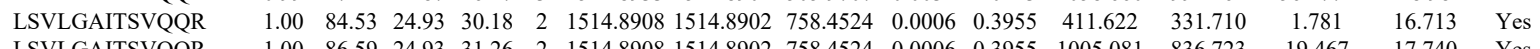

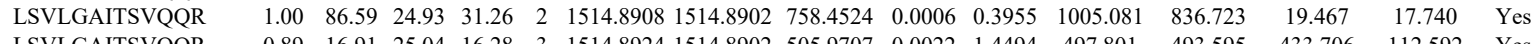
\begin{tabular}{llllllllllllllll} 
LSVLGAITSVQQR & 0.89 & 16.91 & 25.04 & 16.28 & 3 & 1514.8924 & 1514.8902 & 505.9707 & 0.0022 & 1.4494 & 497.801 & 493.595 & 433.706 & 112.592 & Yes \\
\hline
\end{tabular} $\begin{array}{llllllllllllllll}\text { LSVLGAITSVQQR } & 0.89 & 16.88 & 24.77 & 15.12 & 3 & 1514.8936 & 1514.8902 & 505.9707 & 0.0034 & 2.2399 & 580.040 & 530.295 & 406.891 & 143.993 & \text { Yes }\end{array}$ $\begin{array}{llllllllllllllll}\text { LSVLGAITSVQQR } & 0.54 & 12.99 & 24.84 & 18.30 & 3 & 1514.8900 & 1514.8902 & 505.9707 & -0.0002 & -0.1318 & 201.616 & 240.108 & 649.402 & 132.753 & \text { No }\end{array}$

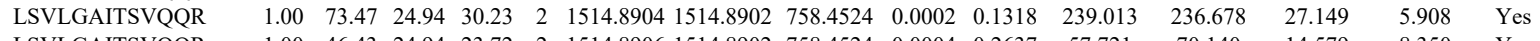

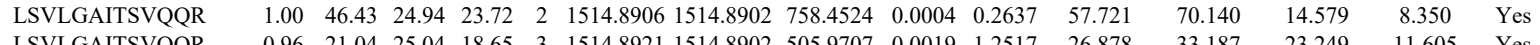

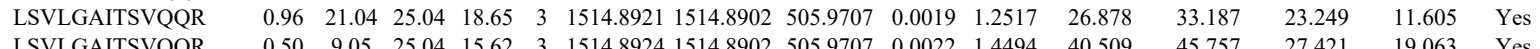
\begin{tabular}{llllllllllllllll} 
LSVLGAITSVQQR & 0.50 & 9.05 & 25.04 & 15.62 & 3 & 1514.8924 & 1514.8902 & 505.9707 & 0.0022 & 1.4494 & 40.509 & 45.757 & 27.421 & 19.063 & Yes \\
\hline LSVLGAITSVQQR & 0.74 & 13.93 & 24.83 & 16.09 & 3 & 1514.8939 & 1514.8902 & 505.9707 & 0.0037 & .4376 & 27.947 & 6.489 & 1.894 & 2.65 & Nes
\end{tabular} LSVLGAITSVQQR LSTGATSRQR GFGGIGGILR LSVLGAITSVQQ $\begin{array}{lllllllllllllll}1.00 & 45.44 & 27.81 & 33.14 & 2 & 1089.6442 & 1089.6417 & 545.8281 & 0.0025 & 2.2901 & 381.388 & 386.339 & 49.794 & 24.460 & \text { Yes } \\ 1.00 & 54.20 & 24.94 & 28.72 & 2 & 1514.8904 & 1514.8902 & 758.4524 & 0.0002 & 0.1318 & 46.851 & 41.324 & 6.079 & 8.652 & \text { Yes }\end{array}$

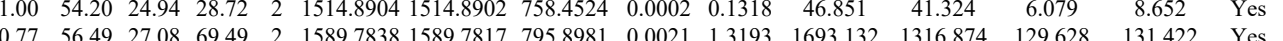
GNKPWISLPR

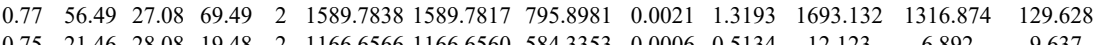
VNDTIQIDLETGK VNDTIDLETGK VNDTIQIDLETGK YPDPLIK

YPDPLIK

YPDPLIK

YPDPLIK

YPDPLIK
YPDPLIK

YPDPLIK

YPDPLIK

HPGSFDVVHVK

HPGSFDVVHVK

$\begin{array}{lllllllllllll}0.77 & 5.46 & 27.08 & 0.468 & 19.48 & 2 & 1166.6566 & 1166.6560 & 584.3353 & 0.0006 & 0.5134 & 12.123 & 6.892\end{array}$

9.637 .

$\begin{array}{llllllllllllllll}1.00 & 88.63 & 27.11 & 26.50 & 2 & 1732.9478 & 1732.9451 & 867.4798 & 0.0027 & 1.5562 & 459.399 & 368.532 & 135.853 & 129\end{array}$

17.525 $\begin{array}{lllllllllllllll} & \end{array}$ $\begin{array}{llllllllllllllll}0.75 & 25.65 & 26.02 & 22.94 & 2 & 1132.6830 & 1132.6736 & 567.3441 & 0.0094 & 8.2841 & 14697.664 & 14646122 & 21904.413 & 11896.471 & \text { No }\end{array}$ $\begin{array}{lllllllllllllll}0.85 & 26.23 & 25.42 & 23.30 & 2 & 11326842 & 1132.6736 & 567.3441 & 0.0106 & 9.3417 & 21642024 & 22317.319 & 23533.050 & 15683.234 & \text { Y }\end{array}$ $\begin{array}{lllllllllllllll}0.92 & 28.34 & 27.36 & 27.77 & 2 & 1132.6766 & 1132.6736 & 567.3441 & 0.0030 & 2.6439 & 284.404 & 294.444 & 187.612 & 140.585 & \text { Yes }\end{array}$

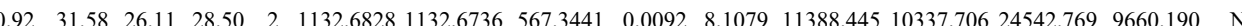
$\begin{array}{llllllllllllllllll}0.86 & 27.61 & 26.02 & 27.98 & 2 & 1132.6832 & 1132.6736 & 567.3441 & 0.0096 & 8.4604 & 17231.049 & 18956.530 & 37590.376 & 14689.433 & \text { No }\end{array}$ $\begin{array}{llllllllllllllll}0.96 & 35.53 & 25.94 & 29.44 & 2 & 1132.6820 & 1132.6736 & 567.3441 & 0.0084 & 7.4029 & 3066.475 & 2552.085 & 3451.953 & 2207.518 & \text { Y }\end{array}$ $\begin{array}{lllllllllllllll}0.96 & 33.75 & 26.15 & 24.35 & 2 & 1132.6838 & 1132.6736 & 567.3441 & 0.0102 & 8.9892 & 3690.573 & 3634.833 & 3828.857 & 2423.148 & \text { Yes }\end{array}$ $\begin{array}{lllllllllllllll}0.77 & 45.91 & 27.77 & 58.91 & 2 & 1508.8356 & 27.608 .8344 & 755.4245 & 0.0012 & 0.7943 & 4648.049 & 6110.054 & 5146.596 & 3689.551 & \text { Yes } \\ 0.77 & 46 & 1508.8362 & 1508.8344 & 755.4245 & 0.0018 & 1.1914 & 5235.039 & 4849.758 & 6305.649 & 4460.864 & \text { Yes }\end{array}$ $\begin{array}{llllllllllllllll} & & & \\ \text { HPGSFDVVHVK } & 0.53 & 52.88 & 27.65 & 65.88 & 3 & 1508.8372 & 1508.8344 & 503.9521 & 0.0028 & 1.8520 & 9398.015 & 8296.732 & 10989.936 & 8478.758 & \text { No }\end{array}$

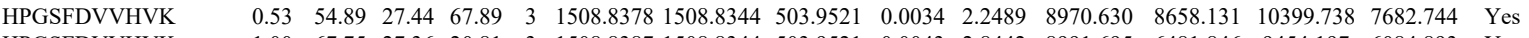
$\begin{array}{lllllllllllllllll}\text { HPGSFDVVHVK } & 1.00 & 67.75 & 27.36 & 20.81 & 3 & 1508.8387 & 1508.8344 & 503.9521 & 0.0043 & 2.8442 & 8991.695 & 6481.846 & 9454.197 & 6084.893 & \text { Yes }\end{array}$

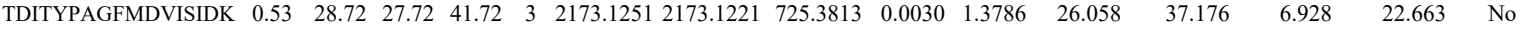
$\begin{array}{llllllllllllllll}\text { TDITYPAGFMDVISIDK } & 1.00 & 94.70 & 27.76 & 30.48 & 2 & 2173.1254 & 2173.1221 & 1087.5683 & 0.0033 & 1.5171 & 487.302 & 361.012 & 6.679 & 0.000 & \text { No }\end{array}$

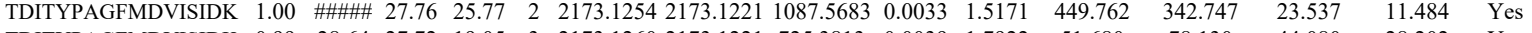

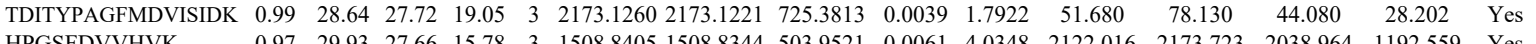

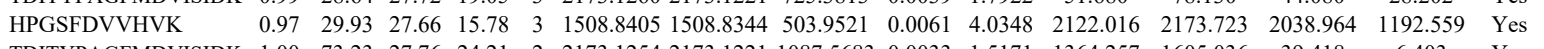
$\begin{array}{llllllllllllllll}\text { TDITYPAGFMDVISIDK } & 1.00 & 73.23 & 27.76 & 24.21 & 2 & 2173.1254 & 2173.1221 & 1087.5683 & 0.0033 & 1.5171 & 1364.257 & 1605.036 & 39.418 & 6.403 & \text { Yes }\end{array}$

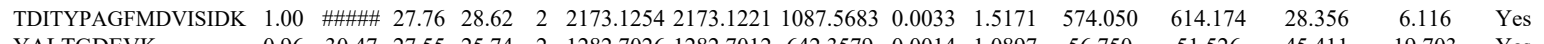

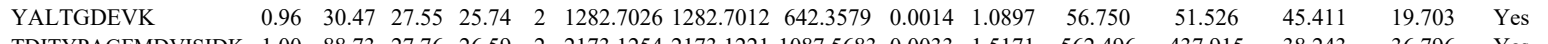

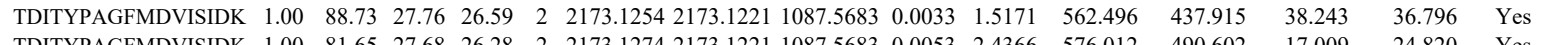

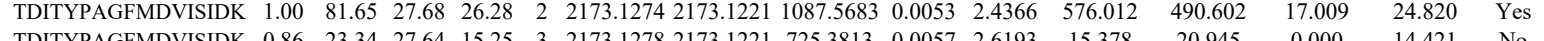

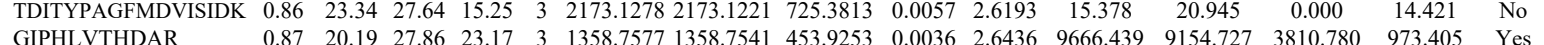

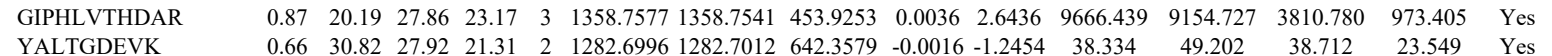

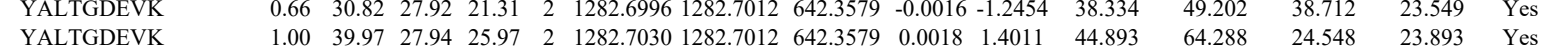




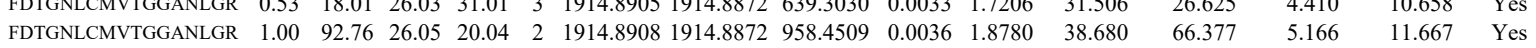

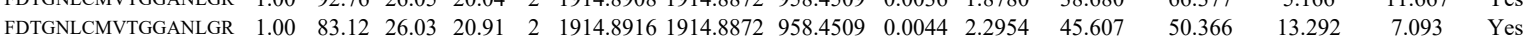

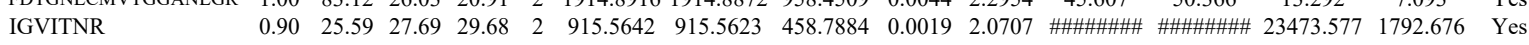

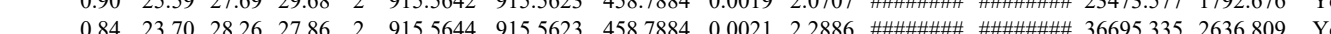

LSNIFVIGK $\begin{array}{llllllllllllllll}1.00 & 46.51 & 22.90 & 18.58 & 2 & 1277.7962 & 1277.7951 & 639.9048 & 0.0011 & 0.8595 & 59508.015 & 53460.883 & 0.000 & 390.152 & \text { No }\end{array}$ $\begin{array}{llllllllllllllll} & 1.00 & 44.70 & 22.90 & 19.26 & 2 & 1277.7964 & 1277.7951 & 639.9048 & 0.0013 & 1.0158 & 29479.752 & 28949.794 & 0.000 & 359.303 & \text { No }\end{array}$

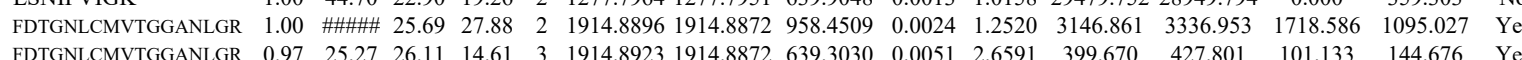
IGVITNR IGVITNR LSNIFVIGK LSNIFVIGK
IGVITNR LSNIFVIGK

LSNIFVIGK

LSNIFVIGK

LSNIFVIGK

LSNIFVIGK

LSNIFVIGK

GIPHLVTHDAR

GNKPWISLPR

ECLPLIIFLR

ECLPLIIFLR

LSNIFVIGK

GNKPWISLPR

GNKPWISLPR

GNKPWISLPR

GNKPWISLP

LSNIFVIGK

ECLPLIFLR

ECLPLIIFLR
ECLPLIIFLR

ECLPLIIFLR

GNKPWISLPR

GNKPWISLPR

LSNIFVIGK

LSNIFVIGK

GNKPWISLPR

GNKPWISLPR

FDTGNLCMV

LSNIFVIGK

$\left.\begin{array}{llllllllllllllll}.97 & 25.27 & 26.11 & 14.61 & 3 & 1914.8923 & 1914.8872 & 639.3030 & 0.0051 & 2.6591 & 399.670 & 427.801 & 101.133 & 144.676\end{array}\right)$

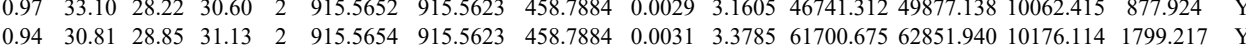

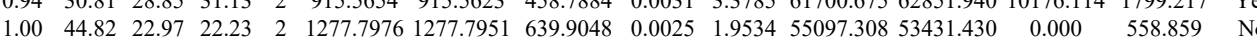
$\begin{array}{llllllllllllllll}1.00 & 41.99 & 23.01 & 21.46 & 2 & 1277.7978 & 1277.7951 & 639.9048 & 0.0027 & 2.1097 & 22428.040 & 21991.423 & 0.000 & 889.518 & \text { No }\end{array}$ $\begin{array}{lllllllllllllllll}0.94 & 31.19 & 27.69 & 37.52 & 2 & 915.5642 & 915.5623 & 458.7884 & 0.0019 & 2.0707 & 13469.653 & 13457.277 & 3238.640 & 788.827 & \text { Yes }\end{array}$ $\begin{array}{lllllllllllllllll}1.00 & 57.91 & 22.97 & 23.42 & 2 & 1277.7976 & 1277.7951 & 639.9048 & 0.0025 & 1.9534 & 38539.149 & 34534.699 & 694.615 & 787.154 & \text { Yes }\end{array}$ $\begin{array}{llllllllllllllllll}1.00 & 44.86 & 22.99 & 22.54 & 2 & 1277.7982 & 1277.7951 & 639.9048 & 0.0031 & 2.4222 & 30111.020 & 26924.879 & 86.742 & 795.644 & \text { Yes }\end{array}$ $\begin{array}{llllllllllllllll}1.00 & 45.75 & 22.92 & 19.80 & 2 & 1277.7972 & 1277.7951 & 639.9048 & 0.0021 & 1.6409 & 7285.117 & 6444.144 & 374.383 & 373.773 & \text { Yes }\end{array}$ $\begin{array}{lllllllllllllllll}1.00 & 57.62 & 22.99 & 22.87 & 2 & 1277.7980 & 1277.7951 & 639.9048 & 0.0029 & 2.2660 & 8817.928 & 7318.437 & 554.378 & 491.219 & \text { Yes }\end{array}$ $\begin{array}{lllllllllllllll}1.00 & 45.14 & 22.90 & 20.03 & 2 & 1277.7960 & 1277.7951 & 639.9048 & 0.0009 & 0.7032 & 7594.772 & 6362.294 & 293.016 & 130.072 & \text { Yes }\end{array}$ $\begin{array}{lllllllllllllll}1.00 & 45.09 & 22.90 & 17.64 & 2 & 1277.7960 & 1277.7951 & 639.9048 & 0.0009 & 0.7032 & 7081.854 & 6537.087 & 205.906 & 195.825 & \text { Yes }\end{array}$ $\begin{array}{lllllllllllllll}0.99 & 35.42 & 28.27 & 18.56 & 3 & 1358.7544 & 1358.7541 & 453.9253 & 0.0003 & 0.2203 & 5575.182 & 5288.725 & 2092.285 & 927.065 & \text { Yes }\end{array}$ $\begin{array}{llllllllllllllll}0.79 & 20.35 & 23.14 & 14.39 & 3 & 1454.8747 & 1454.8601 & 485.9606 & 0.0146 & \text { \#\#\#\#\# } 25447.949 & 23751.413 & 2338.293 & 651.397 & \text { Yes }\end{array}$ $\begin{array}{lllllllllllllll}0.77 & 36.12 & 28.27 & 49.12 & 2 & 1261.6942 & 1261.6926 & 631.8536 & 0.0016 & 1.2661 & 18.609 & 37.651 & 14.117 & 9.665 & \text { Yes }\end{array}$ $\begin{array}{lllllllllllllll}0.85 & 24.09 & 28.23 & 22.75 & 2 & 1261.6946 & 1261.6926 & 631.8536 & 0.0020 & 1.5826 & 36.906 & 37.341 & 23.897 & 7.080 & \text { Yes }\end{array}$

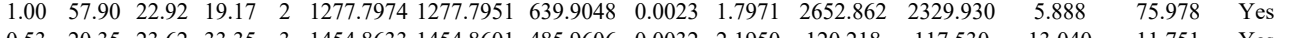

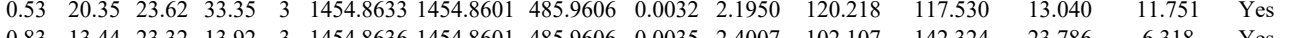
$\begin{array}{lllllllllllllll}0.83 & 13.44 & 23.32 & 13.92 & 3 & 1454.8636 & 454.8601 & 485.9606 & 0.0035 & 2.4007 & 102.107 & 142.324 & 23.786 & 6.318 & \text { Yes } \\ 0.64 & 11.41 & 23.18 & 13.83 & 3 & 1454.8657 & 1454.8601 & 485.9606 & 0.0056 & 3.8412 & 169.190 & 163.178 & 16.985 & 8.226 & \text { Yes }\end{array}$

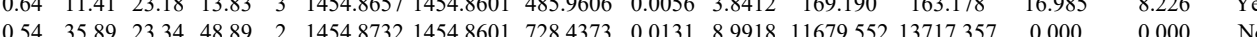
$\begin{array}{llllllllllllllll}0.54 & 35.89 & 23.34 & 48.89 & 2 & 1454.8732 & 1454.8601 & 728.4373 & 0.0131 & 8.9918 & 11679.552 & 13717.357 & 0.000 & 0.000 & \text { No } \\ 1.00 & 44.36 & 22.99 & 21.28 & 2 & 1277.7980 & 1277.7951 & 639.9048 & 0.0029 & 2.2660 & 2472.538 & 2176.181 & 40.090 & 178.881 & \text { Yes }\end{array}$

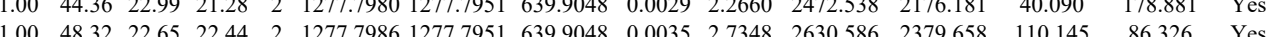
$\begin{array}{lllllllllllllll}1.00 & 43.74 & 27.51 & 26.63 & 2 & 1405.7972 & 1405.7947 & 703.9046 & 0.0025 & 1.7758 & 992.380 & 853.116 & 1308.501 & 574.394 & \text { No }\end{array}$

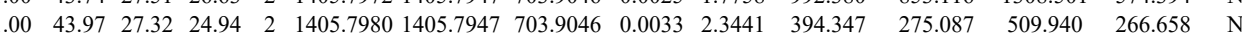
$\begin{array}{llllllllllllllll}0.81 & 15.32 & 24.15 & 15.83 & 3 & 1454.8612 & 1454.8601 & 485.9606 & 0.0011 & 0.7545 & 66.698 & 83.293 & 0.000 & 10.661 & \mathrm{~N} 0\end{array}$ $\begin{array}{llllllllllllllll}0.79 & 17.14 & 23.14 & 18.19 & 3 & 1454.8660 & 1454.8601 & 485.9606 & 0.0059 & 4.0470 & 18281.736 & 17492.694 & 457.643 & 408.967 & \text { Y }\end{array}$ $\begin{array}{lllllllllllllllll}0.95 & 26.99 & 26.07 & 19.08 & 2 & 1195.5718 & 1195.5703 & 598.7924 & 0.0015 & 1.2525 & 6.049 & 7.499 & 9.773 & 6.083 & \text { Yes }\end{array}$

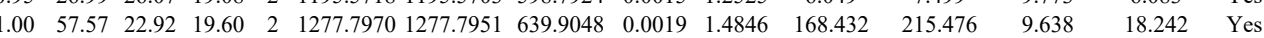

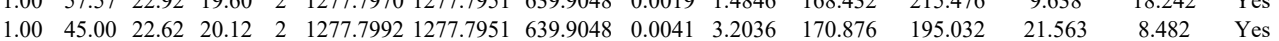
$\begin{array}{lllllllllllllll}0.97 & 20.77 & 23.91 & 16.64 & 3 & 1454.8624 & 1454.8601 & 485.9606 & 0.0023 & 1.5776 & 1255.001 & 1127.422 & 91.554 & 32.778 & \text { Yes }\end{array}$ $\begin{array}{llllllllllllllll}0.55 & 19.25 & 23.62 & 32.25 & 3 & 1454.8627 & 1454.8601 & 485.9606 & 0.0026 & 1.7834 & 1419.552 & 1447.271 & 75.621 & 26.540 & \text { Yes }\end{array}$

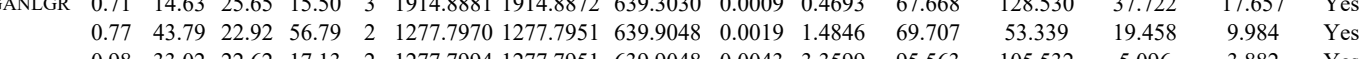
$\begin{array}{llllllllllllllll}\text { FDTGNLCMVTGGANLGR } & 1.00 & \text { \#\#\#\# } 26.05 & 30.86 & 2 & 1914.8910 & 1914.8872 & 958.4509 & 0.0038 & 1.9824 & 16.482 & 17.027 & 14.883 & 2.814 & \text { Yes }\end{array}$ $\begin{array}{llllllllllllllll}\text { FDTGNLCMVTGGANLGR } & 1.00 & 85.08 & 25.66 & 26.00 & 2 & 1914.8858 & 1914.8872 & 958.4509 & -0.0014 & -0.7303 & 24.896 & 7.519 & 14.159 & 4.722 & \text { No }\end{array}$

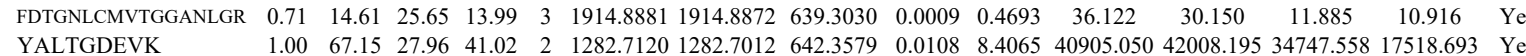

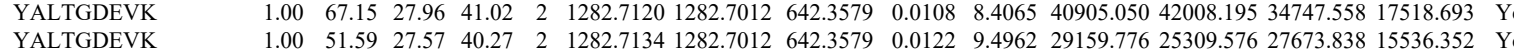

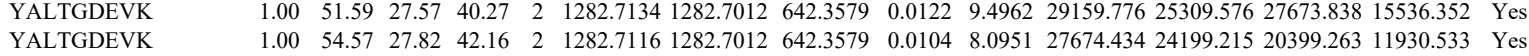

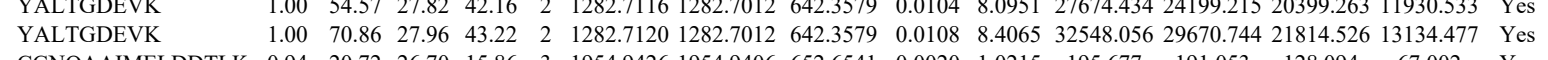

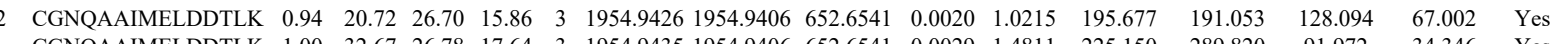
$\begin{array}{llllllllllllllll}\text { CGNQAAIMELDDTLK } & 1.00 & 32.67 & 26.78 & 17.64 & 3 & 1954.9435 & 1954.9406 & 652.6541 & 0.0029 & 1.4811 & 225.150 & 289.820 & 91.972 & 34.346 & \text { Yes }\end{array}$

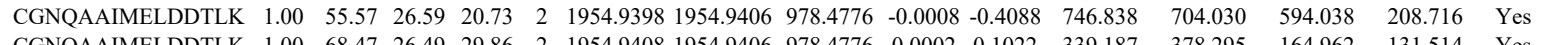

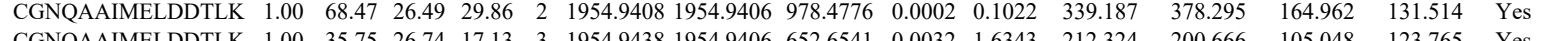

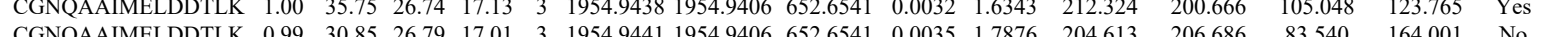

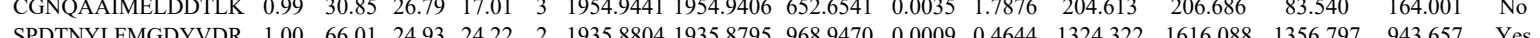

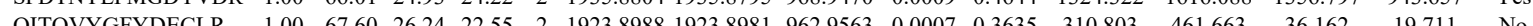

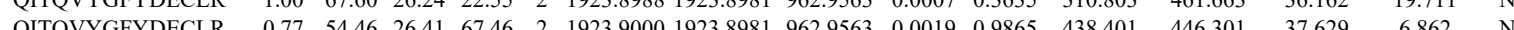

Table S-3 page 316 of 499 
$\begin{array}{llllllllllllllll}1.0 & 51.83 & 27.49 & 26.70 & 2 & 972.5328 & 972.5263 & 487.2704 & 0.0065 & 6.6698 & 15388.248 & 16161.863 & 12816.272 & 8983.996 & \text { Yes } \\ 1.00 & 83.75 & 28.18 & 28.16 & 2 & 1691.8988 & 1691.8974 & 846.9560 & 0.0014 & 0.8265 & 38609.689 & 31095.402 & 340.613 & 242.674 & \text { Yes }\end{array}$ $\begin{array}{lllllllllllllll}1.00 & 83.75 & 28.18 & 28.16 & 2 & 1691.8988 & 1691.8974 & 846.9560 & 0.0014 & 0.8265 & 38609.689 & 31095.402 & 340.613 & 242.674 & \text { Yes }\end{array}$ $\begin{array}{llllllllllllllll}1.00 & 46.50 & 28.06 & 39.92 & 3 & 1691.9002 & 1691.8974 & 564.9731 & 0.0028 & 1.6520 & 871.454 & 885.137 & 132.773 & 43.411 & \text { Yes } \\ 1.00 & 74.96 & 28.00 & 26.65 & 2 & 1691.9004 & 1691.8974 & 846.9560 & 0.0030 & 1.7710 & 21193.064 & 18624.552 & 203.072 & 2.2045 & \text { Yes }\end{array}$ LAPDYDALDVANK

$\begin{array}{llllllllllllll}1.00 & 42.73 & 25.71 & 32.84 & 2 & 1528.8838 & 1528.8817 & 765.4481 & 0.0021 & 1.3717 & 22491.431 & 21955.025 & 9388.119 & 1141.036\end{array}$

VNTLIRPDGEK

$\begin{array}{lllllllllllllllllll}1.00 & 44.88 & 25.74 & 29.82 & 2 & 1528.8844 & 1528.8817 & 765.4481 & 0.0027 & 1.7637 & 14028.941 & 13644.412 & 5265.472 & 613.363 & \text { Yes }\end{array}$

$\begin{array}{lllllllllllll}0.76 & 15.50 & 25.05 & 20.63 & 3 & 1528.8865 & 1528.8817 & 510.6345 & 0.0048 & 3.1333 & \text { \#\#\#\#\#\#\#\#\# } 48736.519 & 7726.878 & \text { Yes }\end{array}$

VNTLIRPDGEK

VNTLIRPDGEK

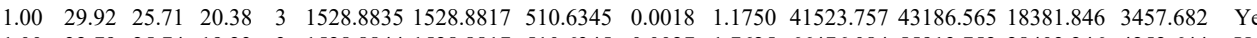

VNTLIRPDGEK

$\begin{array}{lllllllllllllll}1.00 & 32.79 & 25.74 & 19.23 & 3 & 1528.8844 & 1528.8817 & 510.6345 & 0.0027 & 1.7625 & 66476.084 & 55913.752 & 28403.246 & 4252.644 & \text { Yes }\end{array}$ $\begin{array}{llllllllllllllll}0.88 & 18.46 & 25.05 & 15.13 & 3 & 1528.8865 & 1528.8817 & 510.6345 & 0.0048 & 3.1333 & 23237.285 & 25038.436 & 20371.305 & 8629.037 & \text { Yes }\end{array}$ $\begin{array}{llllllllllllllll}0.90 & 19.06 & 25.01 & 15.61 & 3 & 1528.8871 & 1528.8817 & 510.6345 & 0.0054 & 3.5250 & 15266.926 & 17196.628 & 5828.646 & 1436.753 & \text { Yes }\end{array}$ $\begin{array}{lllllllllllllll}1.00 & 52.21 & 26.88 & 31.85 & 2 & 1427.7866 & 1427.7742 & 714.8944 & 0.0124 & 8.6725 & 11403.105 & 8268.607 & 15291.971 & 12210.793 & \text { No }\end{array}$ $\begin{array}{lllllllllllllll}1.00 & 67.30 & 26.80 & 37.32 & 2 & 1427.7868 & 1427.7742 & 714.8944 & 0.0126 & 8.8124 & 8997.772 & 6540.231 & 12828.100 & 9457.048 & \text { No }\end{array}$

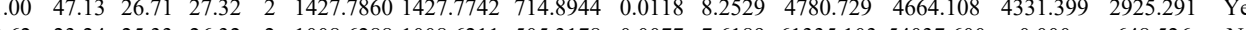
$\begin{array}{lllllllllllllll}0.62 & 23.24 & 25.33 & 26.32 & 2 & 1008.6288 & 1008.6211 & 505.3178 & 0.0077 & 7.6189 & 61335.103 & 54037.600 & 0.000 & 648.526 & \text { No }\end{array}$

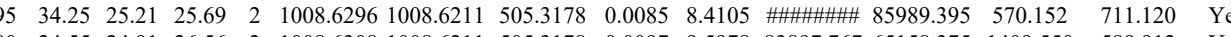
DIPGLTDTTVP DIPGIDTTVR LFNLSK

LFNLSK

LFNLSK

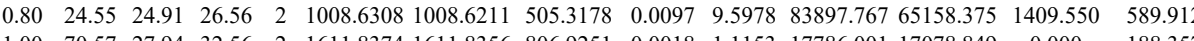

LNISFPATGCQK

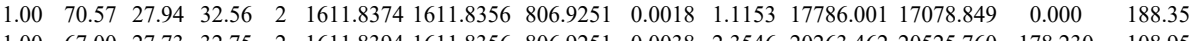

LNISFPATGCQK

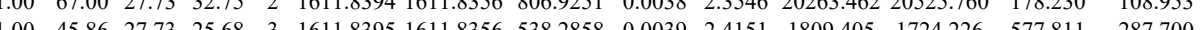

$\begin{array}{lcccccccccccc} & \end{array}$

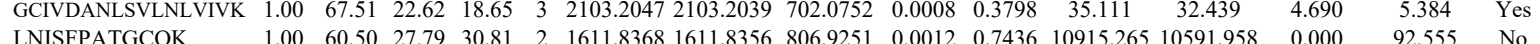

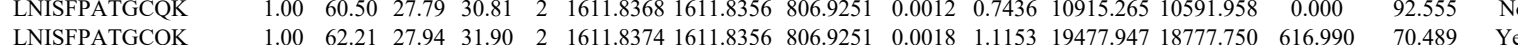

$\begin{array}{llllllllllllllll}\text { LNISFPATGCQK } & 1.00 & 62.21 & 27.94 & 31.90 & 2 & 1611.8374 & 1611.8356 & 806.9251 & 0.0018 & 1.1153 & 19477.947 & 18777.750 & 616.990 & 70.489 & \text { Yes } \\ \text { LNISFPATGCQK } & 1.00 & 44.84 & 27.85 & 20.94 & 3 & 1611.8380 & 1611.8356 & 538.2858 & 0.0024 & 1.4862 & 2061.687 & 1476.831 & 551.061 & 162.220 & \text { Yes }\end{array}$

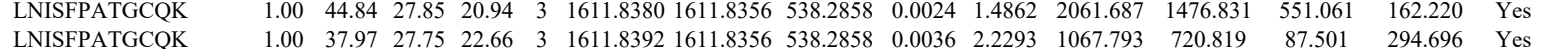

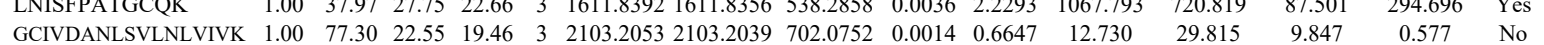

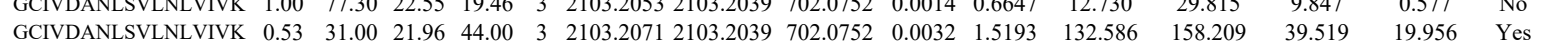

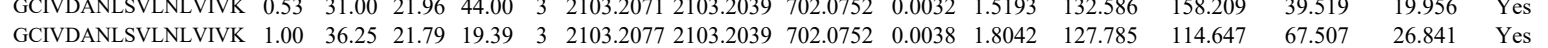

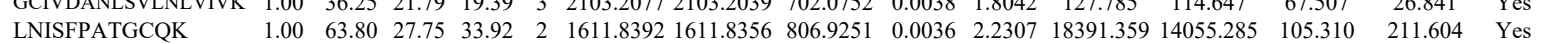
$\begin{array}{lllllllllllllllll}\text { LNISFPATGCQK } & 1.00 & 59.36 & 27.54 & 30.45 & 2 & 1611.8398 & 1611.8356 & 806.9251 & 0.0042 & 2.6025 & 9317.197 & 9966.326 & 135.712 & 36.286 & \text { Yes }\end{array}$ $\begin{array}{lllllllllllllllll}\text { LNISFPATGCQK } & 0.78 & 18.39 & 27.63 & 17.34 & 3 & 1611.8407 & 1611.8356 & 538.2858 & 0.0051 & 3.1582 & 2504.334 & 2143.721 & 3139.258 & 333.550 & \text { No }\end{array}$ $\begin{array}{lllllllllllllllll}\text { LNISFPATGCQK } & 0.78 & 21.39 & 27.66 & 16.74 & 3 & 1611.8419 & 1611.8356 & 538.2858 & 0.0063 & 3.9013 & 2342.928 & 2078.819 & 1917.641 & 339.369 & \text { Yes }\end{array}$ $\begin{array}{llllllllllllllll}\text { GCIVDANLSVLNLVIVK } & 1.00 & 55.91 & 22.55 & 17.09 & 3 & 2103.2053 & 2103.2039 & 702.0752 & 0.0014 & 0.6647 & 41.163 & 38.452 & 21.332 & 8.347 & \text { Yes }\end{array}$

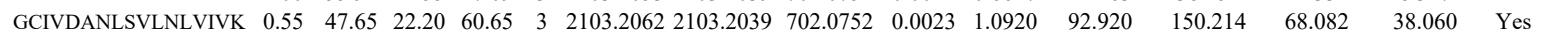

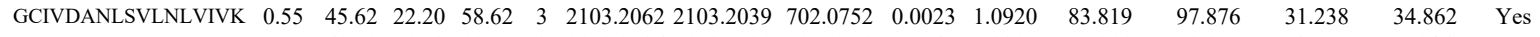
$\begin{array}{llllllllllllllll}\text { GCIVDANLSVLNLVIVK } & 1.00 & 61.59 & 21.73 & 18.77 & 3 & 2103.2086 & 2103.2039 & 702.0752 & 0.0047 & 2.2315 & 25.311 & 28.829 & 6.097 & 1.946 & \text { Yes }\end{array}$ $\begin{array}{llllllllllllllll}\text { GCIVDANLSVLNLVIVK } & 1.00 & 48.92 & 21.64 & 20.68 & 3 & 2103.2092 & 2103.2039 & 702.0752 & 0.0053 & 2.5163 & 95.710 & 93.024 & 40.805 & 12.666 & \text { Yes }\end{array}$

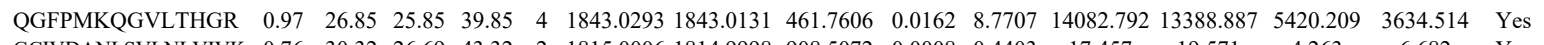

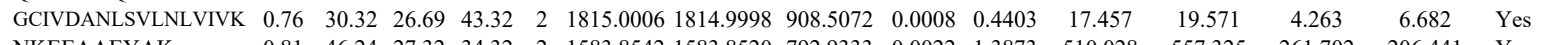
$\begin{array}{llllllllllllllll}\text { NKEEAAEYAK } & 0.81 & 46.24 & 27.32 & 34.32 & 2 & 1583.8542 & 1583.8520 & 792.9333 & 0.0022 & 1.3873 & 510.028 & 557.325 & 261.702 & 206.441 & \text { Yes }\end{array}$

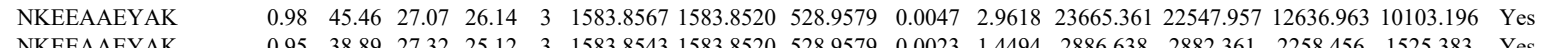
$\begin{array}{llllllllllllllllll}\text { NKEEAAEYAK } & 0.95 & 38.89 & 27.32 & 25.12 & 3 & 1583.8543 & 1583.8520 & 528.9579 & 0.0023 & 1.4494 & 2886.638 & 2882.361 & 2258.456 & 1525.383 & \text { Yes }\end{array}$

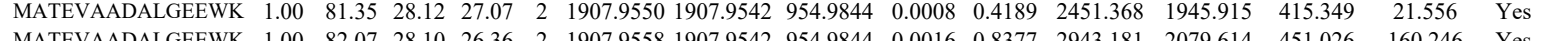
\begin{tabular}{lllllllllllllllll} 
MATEVAADALGEEWK & 1.00 & 82.07 & 28.10 & 26.36 & 2 & 1907.9558 & 1907.9542 & 954.9844 & 0.0016 & 0.8377 & 2943.181 & 2079.614 & 451.026 & 160.246 & Yes \\
\hline
\end{tabular} $\begin{array}{llllllllllllllll}\text { MATEVAADALGEEWK } & 0.82 & 18.97 & 28.18 & 16.94 & 3 & 1907.9581 & 1907.9552 & 636.9920 & 0.0039 & 2.0408 & 52.358 & 84.617 & 13.168 & 73.121 & \text { No } \\ \text { MATEVAADALGEWWK } & 1.00 & 40.99 & 28.23 & 33.39 & 3 & 1907.9593 & 1907.9542 & 636.9920 & 0.0051 & 2.6688 & 197.636 & 199.847 & 78.488 & 88.815 & \text { Yes }\end{array}$ $\begin{array}{llllllllllllllll}\text { MATEVAADALGEEWK } & 1.00 & 79.59 & 28.12 & 25.46 & 2 & 1907.9552 & 1907.9542 & 954.9844 & 0.0010 & 0.5236 & 2669.296 & 2822.698 & 309.472 & 142.373 & \text { Yes }\end{array}$ $\begin{array}{llllllllllllllll}\text { MATEVAADALGEEWK } & 1.00 & 85.80 & 28.29 & 29.10 & 2 & 1907.9570 & 1907.9542 & 954.9844 & 0.0028 & 1.4660 & 3454.875 & 2731.165 & 87.395 & 124.117 & \text { Y }\end{array}$ 


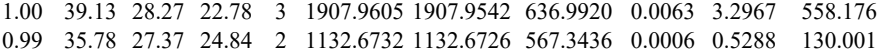
$\begin{array}{llllllllllll}0.99 & 35.23 & 27.37 & 26.84 & 2 & 1132.6732 & 1132.6726 & 567.3436 & 0.0006 & 0.5288 & 130.001\end{array}$ $\begin{array}{lllllllllll}1.08 .40 & 27.85 & 28.74 & 2 & 1323.7174 & 1323.7156 & 662.8651 & 0.0018 & 1.3577 & 154.763\end{array}$

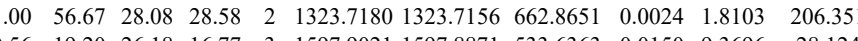
$\begin{array}{llllllllllll}0.58 & 17.55 & 27.85 & 21.70 & 2 & 1323.7174 & 1323.7156 & 662.8651 & 0.0018 & 1.3577 & 212.295\end{array}$

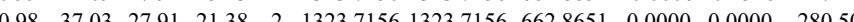

ISGLIYEETR

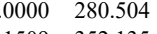

ISGLIYEETR $\begin{array}{llllllllllllll}0.90 & 29.03 & 27.89 & 28.64 & 2 & 1323.7158 & 1323.7156 & 662.8651 & 0.0002 & 0.1509 & 352.135 \\ 0.95 & 29.28 & 27.85 & 33.02 & 2 & 1323.7174 & 1323.7156 & 662.8651 & 0.0018 & 1.3577 & 324.399\end{array}$ $\begin{array}{llllllllllll}0.95 & 29.28 & 27.85 & 33.02 & 2 & 1323.7174 & 32323.7156 & 662.8651 & 0.002 & 0.1509 & 352.135 & 324.399 \\ 0.93 & 27.28 & 27.91 & 28.06 & 2 & 1323.7176 & 1323.7156 & 662.8651 & 0.020 & 1.5086 & 384.248\end{array}$

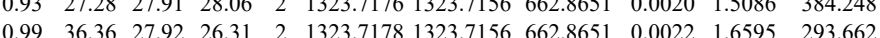
$\begin{array}{lllllllllll}0.99 & 36.36 & 27.92 & 26.31 & 2 & 1323.7178 & 323.7156 & 662.8651 & 0.0022 & 1.6595 & 293.662 \\ 1.00 & 49.76 & 27.75 & 23.08 & 2 & 1323.7192 & 1323.7156 & 662.8651 & 0.0036 & 2.7155 & 300.809\end{array}$ $\begin{array}{llllllllllll}1.00 & 58.25 & 27.66 & 27.00 & 2 & 1323.7272 & 1323.7156 & 662.8651 & 0.0116 & 8.7498 & 8293.509\end{array}$ $\begin{array}{llllllllllll}1.00 & 54.91 & 27.82 & 28.99 & 2 & 1323.7160 & 1323.7156 & 662.8651 & 0.0004 & 0.3017 & 245.379 \\ 1.00 & 50.63 & 27.83 & 30.64 & 2 & 1323.7164 & 1323.7156 & 62.8651 & 0.0008 & 0.6034 & 695.448\end{array}$

ISGLIYEETR $\begin{array}{llllllllllll}1.00 & 54.60 & 27.83 & 24.30 & 2 & 1323.7164 & 1323.7156 & 662.8651 & 0.00008 & 0.6034 & 695.448 & 307.171\end{array}$ $\begin{array}{lllllllllll}1.00 & 56.19 & 27.85 & 30.64 & 2 & 1323.7170 & 1323.7156 & 662.8651 & 0.0014 & 1.0560 & 634.151 \\ 1.00 & 55.41 & 27.85 & 27.56 & 2 & 1323.7174 & 1323.7156 & 662.8651 & 0.0018 & 1.3577 & 620.582\end{array}$ $\begin{array}{lllllllllllll}1.00 & 44.11 & 28.08 & 28.12 & 2 & 1323.7180 & 1323.7156 & 662.8651 & 0.0024 & 1.8103 & 304.226 & 34 \\ 1.00 & 59.36 & 28.08 & 29.53 & 2 & 1323.7182 & 1323.7156 & 662.8651 & 0.0026 & 1.9612 & 579.962 & 63\end{array}$ $\begin{array}{lllllllllll}1.00 & 59.36 & 28.08 & 29.53 & 2 & 1323.7182 & 1323.7156 & 662.8651 & 0.0026 & 1.9612 & 579.962\end{array}$ $\begin{array}{llllllllllll}1.00 & 55.21 & 28.08 & 27.54 & 2 & 1323.7182 & 1323.7156 & 662.8651 & 0.0026 & 1.9612 & 604.203 \\ 1.0 & 56.10 & 28.08 & 25.89 & 2 & 1323.7184 & 1323.7156 & 662.8651 & 0.028 & 2.1120 & 587.637\end{array}$ $\begin{array}{llllllllllll}1.00 & 56.10 & 28.08 & 25.89 & 2 & 1323.7184 & 1323.7156 & 662.8651 & 0.0028 & 2.1120 & 587.637\end{array}$ $\begin{array}{llllllllllll}1.00 & 59.24 & 28.08 & 29.47 & 2 & 1323.7184 & 1323.7156 & 662.8651 & 0.0028 & 2.1120 & 193.647 \\ 1.00 & 59.75 & 28.07 & 31.34 & 2 & 1323.7186 & 1323.7156 & 6628651 & 0.0030 & 2.2629 & 730.923\end{array}$ $\begin{array}{llllllllllll}1.00 & 59.75 & 28.07 & 31.34 & 2 & 1323.7186 & 1323.7156 & 662.8651 & 0.0030 & 2.2629 & 730.923 & 83 \\ 1.00 & 55.43 & 28.07 & 25.43 & 2 & 1323.7186 & 1323.7156 & 662.8651 & 0.0030 & 2.2629 & 693.741 & 69\end{array}$ $\begin{array}{lllllllllllll}1.00 & 55.43 & 28.07 & 25.43 & 2 & 1323.7186 & 1323.7156 & 662.8651 & 0.0030 & 2.2629 & 693.741 & 69 \\ 1.00 & 59.56 & 28.07 & 31.45 & 2 & 1323.7186 & 1323.7156 & 662.8651 & 0.0030 & 2.2629 & 718.122 & 71\end{array}$ $\begin{array}{llllllllllll}1.00 & 59.56 & 28.07 & 31.45 & 2 & 1323.7186 & 1323.7156 & 662.8651 & 0.0030 & 2.2629 & 718.122 \\ 1.00 & 56.08 & 28.07 & 31.03 & 2 & 1323.7186 & 1323.7156 & 662.8651 & 0.0030 & 2.2629 & 646.820\end{array}$ $\begin{array}{llllllllllll}1.00 & 56.08 & 28.07 & 31.03 & 2 & 1323.7186 & 1323.7156 & 662.8651 & 0.0030 & 2.2629 & 646.820 & 63 \\ 1.00 & 61.26 & 28.07 & 29.72 & 2 & 1323.7186 & 1323.7156 & 662.8651 & 0.0030 & 2.2629 & 603.962 & 61\end{array}$ $\begin{array}{lllllllllll}1.00 & 61.26 & 28.07 & 29.72 & 2 & 1323.7186 & 1323.7156 & 662.8651 & 0.0030 & 2.2629 & 603.962 \\ 1.00 & 58.82 & 28.08 & 27.92 & 2 & 1323.7188 & 1323.7156 & 662.8651 & 0.0032 & 2.4138 & 736.675\end{array}$ $\begin{array}{llllllllllll}1.00 & 58.82 & 28.08 & 27.92 & 2 & 1323.7188 & 1323.7156 & 662.8651 & 0.0032 & 2.4138 & 736.675 & 862 \\ 1.00 & 54.84 & 28.08 & 27.00 & 2 & 1323.7188 & 1323.7156 & 662.8651 & 0.0032 & 2.4138 & 666.764 & \end{array}$ $\begin{array}{llllllllllll}1.00 & 54.84 & 28.08 & 27.00 & 2 & 1323.7188 & 1323.7156 & 662.8651 & 0.0032 & 2.4138 & 666.764 & 661.4 \\ 1.00 & 49.19 & 27.90 & 30.40 & 2 & 1323.7190 & 1323.7156 & 662.8651 & 0.0034 & 2.5646 & 631.731 & 608.6\end{array}$

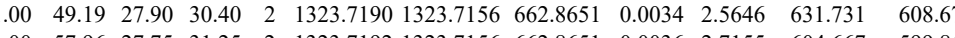
$\begin{array}{llllllllllll}1.031 .731 & 608.672\end{array}$

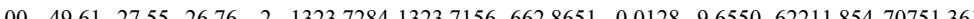

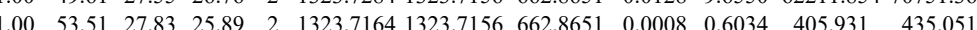

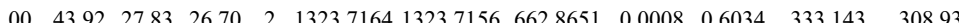
$\begin{array}{lllllllllllll}0.99 & 37.41 & 27.83 & 28.13 & 2 & 1323.7164 & 1323.7156 & 662.8651 & 0.0008 & 0.6034 & 192.594 & 154.528\end{array}$ $\begin{array}{llllllllllll}1.00 & 51.67 & 27.85 & 25.91 & 2 & 1323.7170 & 1323.7156 & 662.8651 & 0.0014 & 1.0560 & 421.680 & 405.945\end{array}$ $\begin{array}{llllllllllll}1.00 & 52.10 & 27.85 & 24.91 & 2 & 1323.7174 & 1323.7156 & 662.8651 & 0.0018 & 1.3577 & 349.311 & 339.212\end{array}$ $\begin{array}{llllllllllll}0.95 & 28.69 & 27.85 & 33.98 & 2 & 1323.7174 & 1323.7156 & 662.8651 & 0.0018 & 1.3577 & 187.250 & 188.523\end{array}$ $\begin{array}{lllllllllllll}1.00 & 44.54 & 27.91 & 25.50 & 2 & 1323.7176 & 1323.7156 & 6628651 & 0.0020 & 1.5086 & 454.937 & 3\end{array}$ $\begin{array}{lllllllllll}1.00 & 53.22 & 28.08 & 25.52 & 2 & 1323.7182 & 1323.7156 & 6628651 & 0.0026 & 1.9612 & 364.895\end{array}$ $\begin{array}{lllllllllll}1.00 & 53.92 & 28.08 & 28.22 & 2 & 1323.7182 & 1323.7156 & 662.8651 & 0.0026 & 1.9612 & 381.445\end{array}$ $\begin{array}{lllllllllllll}1.00 & 49.40 & 28.08 & 29.14 & 2 & 1323.7184 & 1323.7156 & 662.8651 & 0.0028 & 2.1120 & 304.554 & 314.377 \\ 1.723 & 1323.7156 & 662.8651 & 0.0028 & 2.1120 & 329.808 & 384.111\end{array}$ $\begin{array}{lllllllllllll}1.00 & 41.63 & 28.08 & 26.71 & 2 & 1323.7188 & 1323.7156 & 662.8651 & 0.0032 & 2.4138 & 298.860 & 345.646\end{array}$

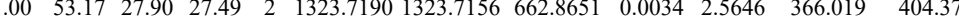
$\begin{array}{llllllllllll}1.00 & 48.99 & 27.66 & 27.52 & 2 & 1323.7198 & 1323.7156 & 662.8651 & 0.0042 & 3.1681 & 426.070 & 438.891\end{array}$

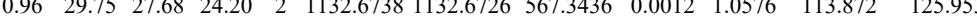
$\begin{array}{llllllllllll}0.99 & 36.71 & 27.68 & 26.81 & 2 & 132.6740 & 1132.6726 & 567.3436 & 0.0014 & 1.2338 & 111.277 & 142.065\end{array}$ $\begin{array}{llllllllllll}1.00 & 55.00 & 27.80 & 27.02 & 2 & 1323.7168 & 1323.7156 & 662.8651 & 0.0012 & 0.9052 & 214.864 & 224.586\end{array}$ $\begin{array}{llllllllllll}1.00 & 51.99 & 27.85 & 28.08 & 2 & 1323.7174 & 1323.7156 & 62.8651 & 0.0018 & 1.3577 & 213.958 & 193.380\end{array}$

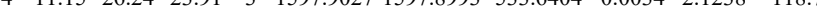
$\begin{array}{lllllllllll} & \end{array}$

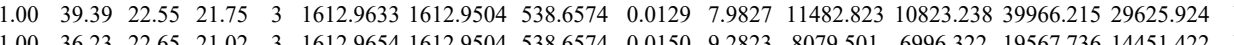

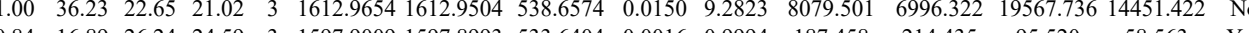

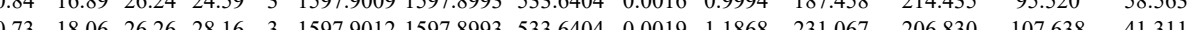
$\begin{array}{lllllllllllll}0.73 & 18.06 & 26.26 & 28.16 & 3 & 1597.9001 & 1597.8993 & 533.6404 & 0.0016 & 0.9994 & 187.458 & 214.435 \\ 1.00 & 73.67 & 26.26 & 41.00 & 2 & 1597.9012 & 1597.89993 & 533.6404 & 0.0019 & 1.1868 & 231.067 & 206.830\end{array}$ $\begin{array}{lllllllllll}1.00 & 73.67 & 26.26 & 41.00 & 2 & 1597.9012 & 1597.8993 & 799.9569 & 0.0019 & 1.1876 & 96.706\end{array}$

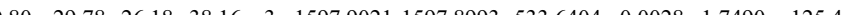
$\begin{array}{lllllllllllll}0.86 & 23.10 & 26.13 & 30.08 & 3 & 1597.9024 & 1597.8993 & 533.6404 & 0.0031 & 1.9364 & 219.024 & 202.906\end{array}$ 

$\begin{array}{lllllllllllll}1.00 & 61.13 & 26.24 & 21.26 & 2 & 1597.9038 & 1597.893 & 79.9569 & 0.0045 & 2.8126 & 89.561 & 100.356\end{array}$

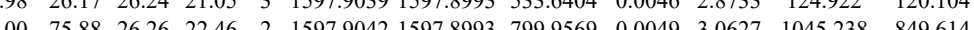
$\begin{array}{lllllllllll} & \end{array}$

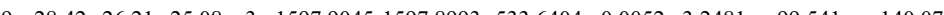
$\begin{array}{lllllllllllll}0.77 & 21.32 & 27.70 & 21.26 & 2 & 1132.6742 & 1132.6726 & 567.3436 & 0.0016 & 1.4101 & 167.821 & 147.130 & 30.372\end{array}$

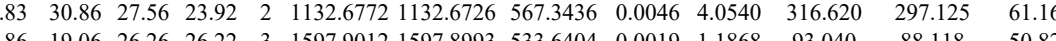

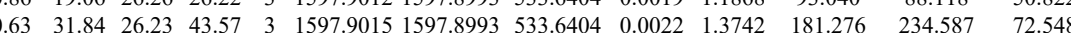
$\begin{array}{lllllllllllllll}0.91 & 21.97 & 26.23 & 27.55 & 3 & 1597.9015 & 1597.8993 & 533.6404 & 0.0022 & 1.3742 & 156.990 & 193.493 & 90.626\end{array}$ $\begin{array}{llllllllllllll}1.00 & 64.68 & 26.19 & 37.82 & 2 & 1597.9020 & 1597.8993 & 799.9569 & 0.0027 & 1.6876 & 26490.384 & 27024.722 & 3518.265\end{array}$ $\begin{array}{llllllllllllll}0.60 & 15.56 & 26.18 & 27.51 & 3 & 1597.9021 & 1597.8993 & 533.6404 & 0.0028 & 1.7490 & 128.067 & 120.106 & 65.606\end{array}$ $\begin{array}{llllllllllllll}1.00 & 62.86 & 26.24 & 34.85 & 2 & 1597.9026 & 1597.8993 & 799.9569 & 0.0033 & 2.0626 & 48.773 & 74.137 & 18.473\end{array}$

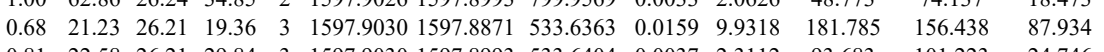
$\begin{array}{llllllllllllll}0.81 & 22.58 & 26.21 & 29.84 & 3 & 1597.9030 & 1597.8993 & 533.6404 & 0.0037 & 2.3112 & 93.683 & 101.223 & 24.746 \\ 0.89 & 19.10 & 26.21 & 24.23 & 3 & 1597.9030 & 1597.8993 & 533.6404 & 0.0037 & 23112 & 91.135 & 113.390 & 55.770\end{array}$ $\begin{array}{lllllllllllll}0.99 & 35.59 & 26.21 & 30.53 & 3 & 1597.9030 & 1597.8993 & 533.6404 & 0.0037 & 2.3112 & 1780.437 & 1755.195 & 141.288\end{array}$ $\begin{array}{llllllllllllll}0.91 & 20.03 & 26.23 & 22.49 & 3 & 1597.9033 & 1597.8993 & 533.6404 & 0.0040 & 2.4986 & 194.420 & 167.628 & 84.738\end{array}$

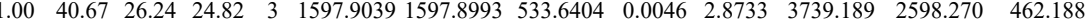

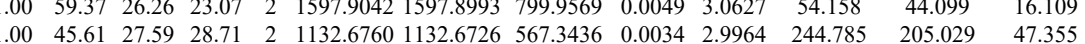
$\begin{array}{lllllllllllll}0.99 & 65.85 & 26.70 & 40.06 & 2 & 1597.8954 & 1597.8993 & 799.9569 & -0.0039 & -2.4376 & 17782.222 & 17737.327 & 8241.242\end{array}$ $\begin{array}{llllllllllllll}0.59 & 15.14 & 26.27 & 22.65 & 3 & 1597.8997 & 1597.8993 & 533.6404 & 0.0004 & 0.2499 & 196.206 & 236.229 & 105.412\end{array}$ $\begin{array}{ccccccccccccc}0.85 & 32.83 & 26.24 & 40.28 & 3 & 1597.9009 & 1597.8993 & 533.6404 & 0.0016 & 0.9994 & 187.984 & 150.754 & 92.216 \\ 1.00 & 66.68 & 26.26 & 40.36 & 2 & 1597.9012 & 1597.8993 & 799.9569 & 0.0019 & 1.1876 & 28531.641 & 26594.190 & 9174.835\end{array}$ $\begin{array}{llllllllllllll}1.00 & 66.68 & 26.26 & 40.36 & 2 & 1597.9012 & 1597.8993 & 799.9569 & 0.0019 & 1.1876 & 28531.641 & 26594.190 & 9174.835 \\ 0.81 & 41.72 & 26.23 & 50.24 & 3 & 1597.9015 & 1597.8993 & 533.6404 & 0.0022 & 1.3742 & 252.986 & 327.238 & 178.078\end{array}$ $\begin{array}{lllllllllllll}0.81 & 41.72 & 26.23 & 50.24 & 3 & 1597.9015 & 1597.8993 & 533.6404 & 0.0022 & 1.3742 & 252.986 & 327.238 & 178.078\end{array}$ $\begin{array}{llllllllllllll}0.89 & 24.76 & 26.31 & 24.74 & 3 & 1597.9069 & 1597.8993 & 533.6404 & 0.0076 & 4.7472 & 241.226 & 241.479 & 98.390\end{array}$ $\begin{array}{lllllllllllll}0.99 & 38.10 & 27.70 & 28.15 & 2 & 1132.6742 & 1132.6726 & 567.3436 & 0.0016 & 1.4101 & 792.629 & 845.173 & 48.968 \\ 0.99 & 38.00 & 27.63 & 28.24 & 2 & 1132.6744 & 1132.6726 & 567.3436 & 0.0018 & 1.5863 & 946.225 & 891.178 & 51.602 \\ 1.00 & 39.95 & 27.63 & 28.54 & 2 & 1132.6748 & 1132.6726 & 567.3436 & 0.002 & 1.9389 & 172.082 & 121.024 & 48.268\end{array}$

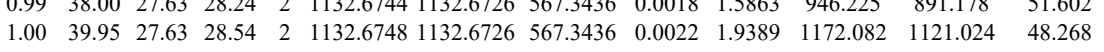
$\begin{array}{lllllllllllll}1.00 & 39.89 & 27.63 & 27.68 & 2 & 1132.6748 & 1132.6726 & 567.3436 & 0.0022 & 1.9389 & 1262.950 & 1259.219 & 59.371\end{array}$

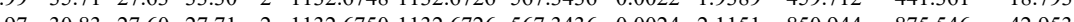
$\begin{array}{lllllllllllll}0.99 & 39.90 & 27.58 & 28.40 & 2 & 1132.6752 & 1132.6726 & 5673436 & 0.002 & 22914 & 945.552 & 857.254 & 49.185\end{array}$ $\begin{array}{lllllllllllll}0.99 & 3828 & 27.58 & 29.21 & 2 & 1132.6752 & 1132.6726 & 5673436 & 0.0026 & 22914 & 933.309 & 977.414 & 36.066\end{array}$ $\begin{array}{lllllllllllll}0.99 & 38.12 & 27.58 & 31.20 & 2 & 1132.6752 & 1132.6726 & 567.3436 & 0.0026 & 22914 & 895.308 & 918.725 & 59.467\end{array}$ $\begin{array}{lllllllllllll}1.00 & 48.81 & 27.58 & 28.90 & 2 & 1132.6756 & 1132.6726 & 567.3436 & 0.0030 & 2.6439 & 934.548 & 925.537 & 36.63\end{array}$ $\begin{array}{lllllllllllllll}0.98 & 33.62 & 27.57 & 27.56 & 2 & 1132.6758 & 1132.6726 & 567.3436 & 0.0032 & 2.8202 & 438.276 & 443.793 & 41.887\end{array}$

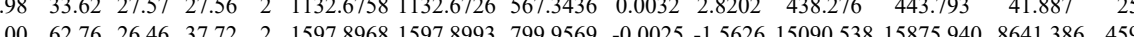
$\begin{array}{lllllllllllllll}1.00 & 60.20 & 26.26 & 38.00 & 2 & 1597.9012 & 1597.8993 & 799.9569 & 0.0019 & 1.1876 & 15857.910 & 16095.055 & 8034.164 & 2132.849 & \text { Yes }\end{array}$ $\begin{array}{lllllllllllllll}0.59 & 13.64 & 26.26 & 19.63 & 3 & 1597.9042 & 1597.8993 & 533.6404 & 0.0049 & 3.0607 & 224.473 & 179.010 & 236.215 & 183.658\end{array}$ $\begin{array}{llllllllllllll}0.86 & 19.00 & 26.21 & 20.60 & 3 & 1597.9045 & 1597.8993 & 533.6404 & 0.0052 & 3.2481 & 191.051 & 111.690 & 178.067 & 104.701 \\ 1.00 & 39.86 & 27.68 & 28.46 & 2 & 1132.6738 & 1132.6726 & 567.3436 & 0.0012 & 1.0576 & 1217.187 & 1206.671 & 34.524 & 23.195\end{array}$ $\begin{array}{lllllllllllllll}1.00 & 51.09 & 27.68 & 26.81 & 2 & 1132.6738 & 1132.6726 & 567.3436 & 0.0012 & 1.0576 & 937.566 & 828.794 & 34.914\end{array}$ $\begin{array}{lllllllllllll}1.00 & 39.76 & 27.63 & 28.41 & 2 & 1132.6744 & 1132.6726 & 567.3436 & 0.0018 & 1.5863 & 977.745 & 1000.753 & 44.006\end{array}$ $\begin{array}{llllllllllllll}1.00 & 51.12 & 27.63 & 29.17 & 2 & 1132.6744 & 1132.6726 & 567.3436 & 0.0018 & 1.5863 & 1215.303 & 1401.861 & 12.837\end{array}$ $\begin{array}{lllllllllllll}0.99 & 35.10 & 27.63 & 28.29 & 2 & 1132.6746 & 1132.6726 & 567.3436 & 0.0020 & 1.7626 & 1356.795 & 1406.979 & 41.630\end{array}$ $\begin{array}{lllllllllllll}1.00 & 51.04 & 27.63 & 25.82 & 2 & 1132.6746 & 1132.6726 & 567.3436 & 0.0020 & 1.7626 & 894.036 & 885.848 & 32.557\end{array}$ $\begin{array}{lllllllllllll}1.00 & 51.31 & 27.63 & 29.35 & 2 & 1132.6748 & 1132.6726 & 567.3436 & 0.0022 & 1.9389 & 1127.544 & 1160.665 & 70.645\end{array}$ $\begin{array}{llllllllllllll}.00 & 51.08 & 27.60 & 25.91 & 2 & 1132.6750 & 1132.6726 & 567.3436 & 0.0024 & 2.1151 & 1151.490 & 1140.729 & 21.996\end{array}$ $\begin{array}{lllllllllllll}1.00 & 48.82 & 27.60 & 29.07 & 2 & 1132.6750 & 1132.6726 & 567.3436 & 0.0024 & 2.1151 & 1174.118 & 1270.919 & 50.886\end{array}$ $\begin{array}{lllllllllllll}1.00 & 50.95 & 27.60 & 26.60 & 2 & 1132.6750 & 1132.6726 & 567.3436 & 0.0024 & 2.1151 & 972.032 & 939.395 & 41.120\end{array}$

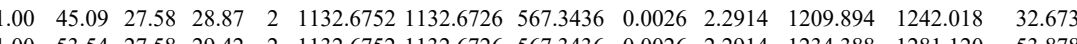
$\begin{array}{lllllllllllll}1.00 & 53.54 & 27.58 & 29.42 & 2 & 1132.6752 & 1132.6726 & 567.3436 & 0.0026 & 2.2914 & 1234.388 & 1281.120 & 53.878\end{array}$ $\begin{array}{lllllllllllll}1.00 & 48.40 & 27.59 & 28.53 & 2 & 1132.6788 & 1132.6726 & 567.3436 & 0.0062 & 5.4640 & 329.143 & 313.111 & 13.957\end{array}$ $\begin{array}{lllllllllllll} & \end{array}$ $\begin{array}{lllllllllllllll}1.00 & 68.26 & 26.23 & 46.30 & 2 & 1597.8982 & 1597.8993 & 799.9569 & -0.0011 & -0.6875 & 10204.436 & 9746.090 & 3880.208 & 1573.876 & \text { Yes } \\ 0.88 & 31.17 & 6.13 & 37.45 & 3 & 1597.9024 & 1597.8993 & 533.6404 & 0.0031 & 1.9364 & 203.070 & 186.322 & 138.603 & 80.225 & \text { Yes }\end{array}$

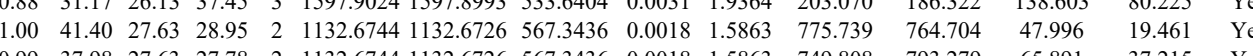
$\begin{array}{llllllllllllllll}0.99 & 37.98 & 27.63 & 27.78 & 2 & 1132.6744 & 1132.6726 & 567.3436 & 0.0018 & 1.5863 & 749.808 & 793.279 & 65.891 & 37.215 & \text { Y } \\ 0.96 & 29.97 & 27.63 & 30.15 & 2 & 1132.6744 & 1132.6726 & 567.3436 & 0.0018 & 1.5863 & 614.412 & 548.664 & 45.410 & 35.989 & \text { Y S }\end{array}$

Table S-3 page 319 of 499 


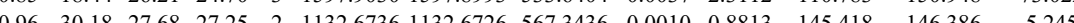



$\begin{array}{llllllllllll}1.00 & 72.75 & 26.24 & 37.52 & 2 & 1597.9018 & 1597.893 & 79.9569 & 0.0025 & 1.5626 & 84.039 & 84.627\end{array}$ $\begin{array}{lllllllllllll}1.00 & 39.61 & 27.68 & 25.06 & 2 & 1132.6736 & 1132.6726 & 567.3436 & 0.0010 & 0.8813 & 628.941 & 604.254 \\ 1.00 & 55.30 & 27.80 & 29.45 & 2 & 1323.7168 & 1323.7156 & 662.8651 & 0.0012 & 0.9052 & 394.119 & 44654\end{array}$ $\begin{array}{lllllllllllll}1.00 & 55.30 & 27.80 & 29.45 & 2 & 1323.7168 & 1323.7156 & 662.8651 & 0.0012 & 0.9052 & 394.119 & 446.544 \\ 1.00 & 54.71 & 27.85 & 25.20 & 2 & 1323.7170 & 1323.7156 & 662.8651 & 0.0014 & 1.0560 & 295.091 & 249.958\end{array}$ $\begin{array}{lllllllllllll}1.00 & 54.71 & 27.85 & 25.20 & 2 & 1323.7170 & 1323.7156 & 662.8651 & 0.0014 & 1.0560 & 295.091 & 249.958 \\ 1.00 & 78.25 & 6.11 & 46.67 & 2 & 1597.9000 & 1597.8993 & 799.9569 & 0.0007 & 0.4375 & 157.082 & 126.836\end{array}$ $\begin{array}{lllllllllllll}1.00 & 75.59 & 26.33 & 38.02 & 2 & 1597.9002 & 1597.8993 & 799.9569 & 0.0009 & 0.5625 & 130.172 & 141.18\end{array}$ $\begin{array}{llllllllllllll}1.00 & 50.79 & 27.37 & 25.63 & 2 & 1132.6734 & 1132.6726 & 567.3436 & 0.0008 & 0.7050 & 575.405 & 634.691\end{array}$ $\begin{array}{lllllllllllll}1.00 & 51.13 & 27.68 & 29.98 & 2 & 1132.6738 & 1132.6726 & 567.3436 & 0.0012 & 1.0576 & 59.801 & 863.116\end{array}$

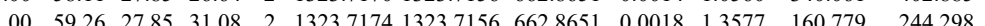
$\begin{array}{lllllllllllll}1.00 & 65.04 & 26.20 & 34.23 & 2 & 1597.8988 & 1597.8993 & 799.9569 & -0.0005 & -0.3125 & 67.244 & 42.430\end{array}$ $\begin{array}{llllllllllllll}0.58 & 34.10 & 26.24 & 46.61 & 3 & 1597.9009 & 15978993 & 533.6404 & 0.0016 & 0.9994 & 10.059 & 14.444\end{array}$ $\begin{array}{lllllllllllll}1.00 & 62.74 & 26.19 & 36.35 & 2 & 1597.9014 & 1597.8993 & 799.9569 & 0.0021 & 13126 & 67.979 & 90.361\end{array}$ $\begin{array}{llllllllllllll}0.60 & 37.05 & 26.24 & 49.24 & 3 & 1597.9018 & 1597.8993 & 533.6404 & 0.0025 & 1.5616 & 17.731 & 17.723\end{array}$ $\begin{array}{lllllllllllll}100 & 51.12 & 27.37 & 25.94 & 2 & 1132.6730 & 1132.6726 & 567.3436 & 0.0004 & 0.3525 & 946.260 & 946.169\end{array}$ $\begin{array}{llllllllllll}1.00 & 39.94 & 27.37 & 28.58 & 2 & 1132.6732 & 1132.6726 & 567.3436 & 0.0006 & 0.5288 & 1014.193 & 991.584\end{array}$ $\begin{array}{lllllllllllll}0.74 & 20.31 & 27.20 & 18.10 & 2 & 1309.6958 & 1309.6952 & 655.8549 & 0.0006 & 0.4574 & 4.049 & 22.782\end{array}$ $\begin{array}{llllllllllllll}1.00 & 66.97 & 26.24 & 46.41 & 2 & 1597.9018 & 1597.8993 & 799.9569 & 0.0025 & 1.5626 & 48.789 & 59.098\end{array}$ $\begin{array}{lllllllllllll}0.57 & 31.43 & 26.13 & 43.86 & 3 & 1597.9024 & 1597.8993 & 533.6404 & 0.0031 & 1.9364 & 19.204 & 12.986\end{array}$ $\begin{array}{lllllllllllll}1.00 & 69.96 & 26.21 & 38.44 & 2 & 1597.9028 & 1597.8993 & 799.9569 & 0.0035 & 2.1876 & 58.035 & 68.452\end{array}$ $\begin{array}{lllllllllllllll}1.96 .61 & 26.23 & 16.60 & 3 & 1597.9033 & 1597.8993 & 533.6404 & 0.0040 & 2.4986 & 6.278 & 15.638 \\ 0.83 & 27.15 & 28.78 & 30.04 & 2 & 98.5706 & 98.5706 & 495.2926 & 0.000 & 0.0000 & 9.927 & 10.267\end{array}$ $\begin{array}{lllllllllllll}0.83 & 27.15 & 28.78 & 30.04 & 2 & 988.5706 & 988.5706 & 495.2926 & 0.0000 & 0.0000 & 9.927 & 10.267 \\ 0.96 & 3.22 & 28.60 & 6.31 & 2 & 988.5710 & 988.5706 & 495.2926 & 0.0004 & 0.4038 & 2.557 & 10.902\end{array}$ $\begin{array}{llllllllllllll}0.96 & 34.22 & 28.60 & 26.31 & 2 & 988.5710 & 988.5706 & 495.2926 & 0.0004 & 0.4038 & 2.557 & 10.902 \\ 0.94 & 27.68 & 27.63 & 22.92 & 2 & 1132.6744 & 1132.6726 & 567.3436 & 0.0018 & 1.5863 & 260.987 & 290.742\end{array}$ $\begin{array}{lllllllllllll}0.94 & 27.68 & 27.63 & 22.92 & 2 & 1132.6744 & 1132.6726 & 567.3436 & 0.0018 & 1.5863 & 260.987 & 290.742 \\ 0.99 & 34.66 & 27.63 & 24.93 & 2 & 1132.6748 & 1132.6726 & 567.3436 & 0.0022 & 1.9389 & 276.723 & 293.355\end{array}$ $\begin{array}{llllllllllll}0.99 & 34.66 & 27.63 & 24.93 & 2 & 1132.6748 & 1132.6726 & 567.3436 & 0.0022 & 1.9389 & 276.723 & 293.355\end{array}$ $\begin{array}{lllllllllllll}1.00 & 50.71 & 27.17 & 21.51 & 2 & 1309.6954 & 1309.6952 & 655.8549 & 0.0002 & 0.1525 & 7.664 & 6.838 \\ 1.00 & 62.94 & 27.54 & 19.55 & 2 & 1309.6966 & 1309.6952 & 655.8549 & 0.0014 & 1.0673 & 0.000 & 8.393\end{array}$ $\begin{array}{lllllllllllll}1.00 & 62.94 & 27.54 & 19.55 & 2 & 1309.6966 & 1309.6952 & 655.8549 & 0.0014 & 1.0673 & 0.000 & 8.393 \\ 0.93 & 20.22 & 26.26 & 17.61 & 3 & 1597.9012 & 1597.8993 & 533.6404 & 0.0019 & 1.1868 & 5.103 & 4.041 \\ 1.00 & 36.06 & 27.87 & 19.59 & 3 & 1581.8047 & 1581.803 & 528.2750 & 0.016 & 1.096 & 12.799 & 79.54\end{array}$

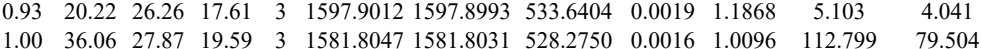

$\begin{array}{cccccccccccc}1.00 & 36.06 & 27.87 & 19.59 & 3 & 1581.8047 & 1581.8031 & 528.2750 & 0.0016 & 1.0096 & 112.799 & 79.504 \\ 0.77 & 17.73 & 27.87 & 15.92 & 3 & 1581.8068 & 1581.8031 & 528.2750 & 0.0037 & 2.3346 & 106.160 & 118.110\end{array}$ FNVWDTAGQEK FNVWDTAGQEK FNOWTAGQK FNVWDTAGQEK FNVWDTAGQK

FNWDTAGQEK

N

FNVWDTAGQEK

FNVWDTAGQEK

ENVWDTAGQEK

NLQYYDISAK

FNVWDTAGQEK

FNVWDTAGQEK

LVLVGDGGTGK

LVLVGDGGTGK

LVLVGDGGTGK

LVLVGDGGTGK

LVLVGDGGTGK

LVLVGDGGTGK

NVPNWHR

NVPNWHR

NVPNWHR

VCENIPIVLCGNK

VCENIPIVLCGNK

VCENIPIVLCGNK

VCENIPIVLCGNK

VCENIPIVLCGNK

VCENIPIVLCGNK

VCENIPIVLCGNK

SIVENRI

VCENIPIVLCGNK

VCENIPIVLCGNK $\begin{array}{lllllllllll}1.00 & 35.68 & 27.86 & 22.08 & 3 & 1581.8077 & 1581.8031 & 528.2750 & 0.0046 & 2.9025 & 115.794\end{array}$

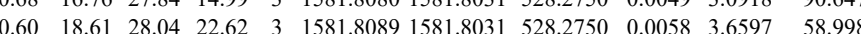
$\begin{array}{llllllllllllll} & \end{array}$ $\begin{array}{llllllllllllll}41.36 & 27.82 & 19.62 & 3 & 1581.8185 & 1581.8031 & 528.2750 & 0.0154 & 9.7171 & 2207.366 & 2014.865 & 1089.869\end{array}$ $\begin{array}{lllllllllllllll}1.00 & 55.36 & 28.04 & 29.25 & 2 & 1581.8164 & 1581.8031 & 791.9088 & 0.0133 & 8.3974 & 24212.679 & 13328.776 & 8556.427 & 4680.365 & \text { Yes }\end{array}$ $\begin{array}{lllllllllllllll}1.00 & 51.81 & 27.55 & 19.92 & 2 & 1501.8166 & 15018020 & 751.9083 & 0.0146 & 9.5085 & 372.15 .973 & 23695.536 & 907.028 & 460.296 & \text { Y }\end{array}$ $\begin{array}{lllllllllllllll}1.00 & 59.31 & 27.91 & 32.06 & 2 & 1581.8166 & 1581.8031 & 791.9088 & 0.0135 & 8.5236 & 2874.479 & 1610.500 & 1722.689 & 1122.447 & \mathrm{No}\end{array}$ $\begin{array}{lllllllllllllll}1.00 & 57.73 & 27.87 & 29.33 & 2 & 1581.8170 & 1581.8031 & 791.9088 & 0.0139 & 8.7762 & 4551.548 & 3207.242 & 3009.628 & 1585.748 & \text { No }\end{array}$

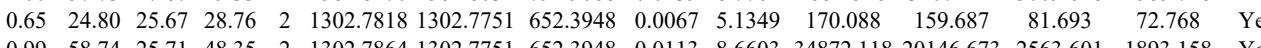
$\begin{array}{lllllllllllllll}0.99 & 58.74 & 25.71 & 48.35 & 2 & 1302.7864 & 1302.7751 & 652.3948 & 0.0113 & 8.6603 & 34872.118 & 20146.673 & 2563.601 & 1893.158 & \text { Yes }\end{array}$ $\begin{array}{llllllllllllllll}0.98 & 54.21 & 25.71 & 49.24 & 2 & 1302.7866 & 1302.7751 & 652.3948 & 0.0115 & 8.8136 & 46748.170 & 32706.096 & 3769.527 & 1306.641 & \text { Yes }\end{array}$ $\begin{array}{lllllllllllllll}0.78 & 34.39 & 25.53 & 35.44 & 2 & 1302.7730 & 1302.7751 & 652.3948 & -0.0021 & -1.6095 & 201.740 & 194.202 & 132.071 & 105.157 & \text { No } \\ 0.78 & 20.01 & 25.88 & 31.22 & 2 & 13027760 & 1302.7751 & 652.3948 & 0.0009 & 0.6898 & 24.982 & 19.469 & 4.406 & 16.226 & \text { No } \\ 0.98 & 52.02 & 25.67 & 47.72 & 2 & 1302.7878 & 1302.751 & 652.3948 & 0.017 & 9.7333 & 3889.037 & 8372.53 & 2560.508 & 6.305 & \text { Yes }\end{array}$ $\begin{array}{lllllllllllllll}0.98 & 52.02 & 25.67 & 47.72 & 2 & 1302.7878 & 1302.7751 & 652.3948 & 0.0127 & 9.7333 & 38893.037 & 28372.537 & 2560.508 & 665.305 & \text { Yes }\end{array}$ $\begin{array}{llllllllllllllll}0.86 & 24.31 & 27.80 & 15.94 & 2 & 1065.5600 & 1065.5590 & 533.7868 & 0.0010 & 0.9367 & 6013.492 & 4020.576 & 786.411 & 186.617 & \text { Yes }\end{array}$ $\begin{array}{lllllllllllllll}0.69 & 28.34 & 27.46 & 41.34 & 2 & 1065.5616 & 1065.5590 & 533.7868 & 0.0026 & 2.4354 & 2124.717 & 1515.388 & 339.741 & 151.360 & \text { Yes }\end{array}$ $\begin{array}{lllllllllllllll}0.70 & 25.21 & 27.94 & 16.68 & 2 & 1065.5630 & 1065.5590 & 533.7868 & 0.0040 & 3.7468 & 3134.833 & 1959.766 & 474.000 & 156.813 & \text { Yes }\end{array}$ $\begin{array}{llllllllllllllll}1.00 & 46.56 & 28.20 & 22.29 & 3 & 1780.8985 & 1780.8951 & 594.6390 & 0.0034 & 1.9059 & 2957.103 & 1860.240 & 16.624 & 99.748 & \text { Yes }\end{array}$

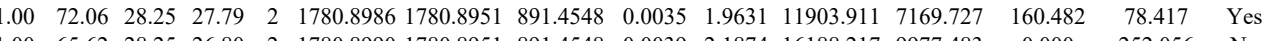
$\begin{array}{llllllllllllllll}1.00 & 65.62 & 28.25 & 26.80 & 2 & 1780.8990 & 1780.8951 & 891.4548 & 0.0039 & 2.1874 & 16188.217 & 9977.483 & 0.000 & 252.056 & \text { No }\end{array}$ $\begin{array}{lllllllllllllll}1.00 & 40.18 & 28.25 & 18.84 & 3 & 1780.8994 & 1780.8951 & 594.6390 & 0.0043 & 2.4104 & 2423.705 & 1076.967 & 68.547 & 0.000 & \text { No }\end{array}$ $\begin{array}{llllllllllllllll}1.00 & 65.53 & 27.98 & 26.93 & 2 & 1780.8972 & 1780.8951 & 891.4548 & 0.0021 & 1.1778 & 9142.721 & 6053.283 & 215.373 & 98.135 & \text { Yes } \\ 1.53 & 40.62 & 28.18 & 53.62 & 3 & 17808982 & 1780.8951 & 594.6390 & 0.0031 & 1.7377 & 1011.055 & 930.418 & 145.795 & 0.000 & \text { No }\end{array}$ $\begin{array}{llllllllllllllll}0.53 & 40.62 & 28.18 & 53.62 & 3 & 1780.8982 & 1780.8951 & 594.6390 & 0.0031 & 1.7377 & 1.11 .055 & 930.418 & 145.795 & 0.000 & \text { No } \\ 1.00 & 78.16 & 28.20 & 28.93 & 2 & 1780.8984 & 1780.8951 & 891.4548 & 0.0033 & 1.8509 & 15017.582 & 9576.041 & 0.000 & 0.000 & \text { No }\end{array}$ $\begin{array}{ccccccccccccccc}1.00 & 78.16 & 28.20 & 28.93 & 2 & 1780.8984 & 1780.8951 & 891.4548 & 0.0033 & 1.8509 & 15017.582 & 9576.041 & 0.000 & 0.000 & \text { No } \\ 1.00 & 60.32 & 28.08 & 28.14 & 3 & 1780.9000 & 1780.8951 & 594.6390 & 0.0049 & 2.7468 & 2997.816 & 1973.942 & 177.999 & 76.017 & \text { Yes }\end{array}$ $\begin{array}{lllllllllllllllll}1.00 & 60.32 & 28.08 & 28.14 & 3 & 1780.9000 & 1780.8951 & 594.6390 & 0.0049 & 2.7468 & 2997.816 & 1973.942 & 177.999 & 76.017 & \text { Yes } \\ 0.62 & 23.74 & 25.92 & 36.67 & 2 & 901.5260 & 901.5256 & 451.7701 & 0.0004 & 0.4427 & 3003.082 & 2970.806 & 519.861 & 443.532 & \text { Yes }\end{array}$

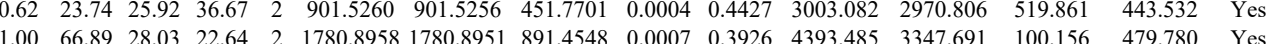

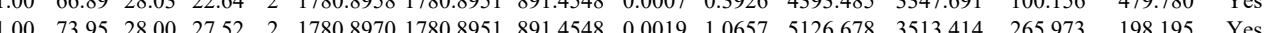
$\begin{array}{lllllllllllllll}1.00 & 33.31 & 28.20 & 20.75 & 3 & 1780.8985 & 1780.8951 & 594.6390 & 0.0034 & 1.9059 & 911.886 & 550.087 & 49.430 & 49.928 & \text { Yes }\end{array}$

Table S-3 page 321 of 499 

$\begin{array}{llllllllllllllll}\text { YVATLGVEVHPLVFHTNR } & 1.00 & 55.58 & 25.21 & 29.88 & 4 & 2195.2093 & 2195.1973 & 549.8066 & 0.0120 & 5.4564 & 9923.120 & 7235.915 & 2915.269 & 763.311 & \text { Yes }\end{array}$

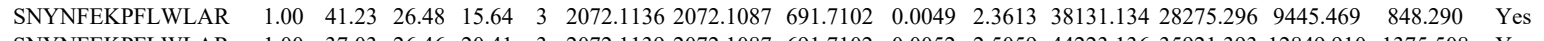
$\begin{array}{llllllllllllllll}\text { SNYNFEKPFLWLAR } & 1.00 & 37.03 & 26.46 & 20.41 & 3 & 2072.1139 & 2072.1087 & 691.7102 & 0.0052 & 2.5059 & 44223.136 & 35921.393 & 12849.910 & 1375.508 & \text { Yes }\end{array}$ $\begin{array}{llllllllllllllllll}\text { YVATLGVEVHPLVFHTNR } & 1.00 & 54.79 & 25.58 & 24.91 & 4 & 2195.2041 & 2195.1973 & 549.8066 & 0.0068 & 3.0920 & 7651.478 & 5473.093 & 2479.439 & 471.609 & \text { Yes }\end{array}$ $\begin{array}{lllllllllllllllll}\text { YVATLGVEVHPLVFHTNR } & 1.00 & 61.42 & 25.56 & 25.36 & 4 & 2195.2045 & 2195.1973 & 549.8066 & 0.0072 & 3.2739 & 6834.926 & 4089.392 & 2246.423 & 1485.358 & \text { Yes }\end{array}$ $\begin{array}{llllllllllllllll}\text { YVATLGVEVHPLVFHTNR } & 1.00 & 41.65 & 26.12 & 22.52 & 4 & 2195.2001 & 2195.1973 & 549.8066 & 0.0028 & 1.2732 & 1251.772 & 1221.384 & 875.173 & 408.964 & \text { Yes }\end{array}$ $\begin{array}{lllllllllllllllll}\text { YVATLGVEHPLVFHTNR } & 1.00 & 47.72 & 26.16 & 23.92 & 4 & 2195.1985 & 2195.1973 & 549.8066 & 0.0012 & 0.5456 & 696.793 & 496.136 & 170.201 & 10.363 & \text { Yes }\end{array}$

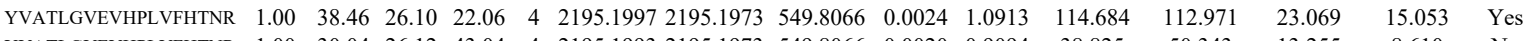
$\begin{array}{llllllllllllllll}\text { YVATLGVEVHPLVFHTNR } & 1.00 & 30.04 & 26.12 & 43.04 & 4 & 2195.1993 & 2195.1973 & 549.8066 & 0.0020 & 0.9094 & 38.825 & 50.343 & 13.255 & 8.610 & \text { No } \\ \text { YVATLG }\end{array}$

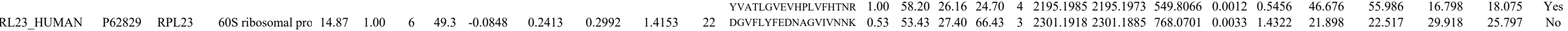

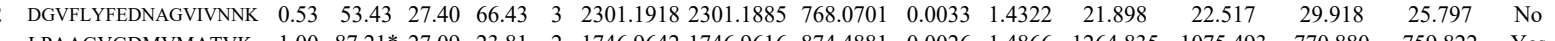
$\begin{array}{lllllllllllllll}\text { LPAAGVGDMVMATVK } & 1.00 & 87.21 * 27.09 & 23.81 & 2 & 1746.9642 & 1746.9616 & 874.4881 & 0.0026 & 1.4866 & 1264.835 & 1075.493 & 770.880 & 759.822 & \text { Yes }\end{array}$

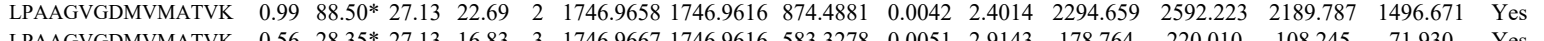

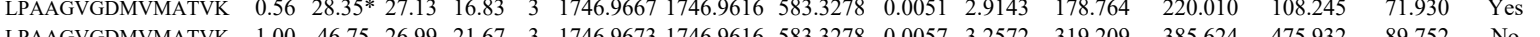

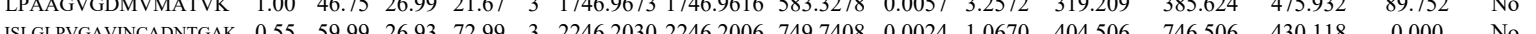
$\begin{array}{llllllllllllll} & \end{array}$ $\begin{array}{llllllllllllll} & \end{array}$ $\begin{array}{llllllllllllll} & 13.94\end{array}$

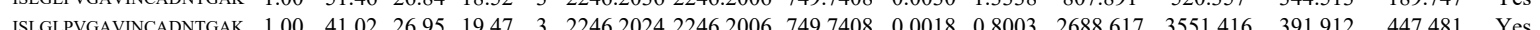
$\begin{array}{llllllllllllllll} & \text { ISLGLVANA }\end{array}$ $\begin{array}{llllllllllllllll}\text { ISGLVGAVINCADNTGAK } & 1.00 & 68.73 & 26.71 & 20.09 & 3 & 2246.2045 & 2246.2006 & 749.7408 & 0.0039 & 1.7339 & 2778.449 & 2249.162 & 506.460 & 246.9265 & \text { Yes }\end{array}$

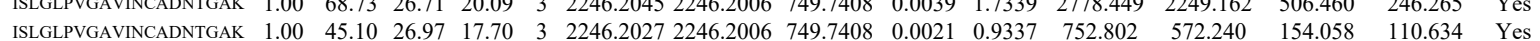

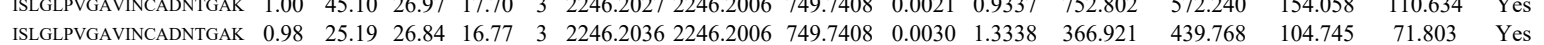

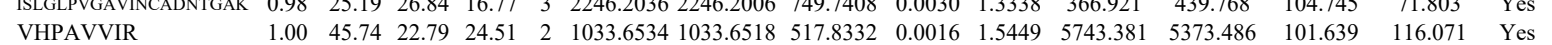
$\begin{array}{llllllllllllllll}\text { VHPAVVIR } & 1.00 & 39.82 & 22.86 & 20.03 & 2 & 1033.6540 & 1033.6518 & 517.8332 & 0.0022 & 2.1242 & 8160.569 & 7674.224 & 434.066 & 291.153 & \text { Yes }\end{array}$

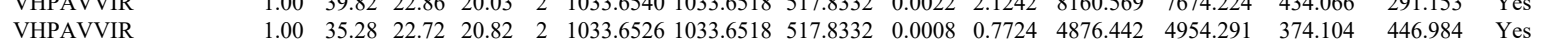

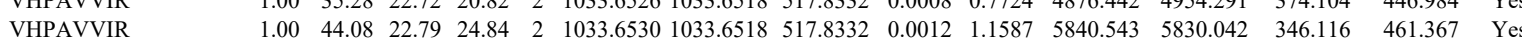
$\begin{array}{lllllllllllllllll}\text { VHPAVVIR } & 1.00 & 45.80 & 22.79 & 23.17 & 2 & 1033.6536 & 1033.6518 & 517.8332 & 0.0018 & 1.7380 & 2399.690 & 2448.462 & 194.032 & 123.824 & \text { Yes }\end{array}$ $\begin{array}{lllllllllllllllll}\text { VHPAVVIR } & 1.00 & 35.66 & 22.86 & 21.86 & 2 & 1033.6542 & 1033.6518 & 517.8332 & 0.0024 & 2.3173 & 2311.298 & 1965.075 & 183.168 & 177.604 & \text { Yes }\end{array}$ $\begin{array}{llllllllllllllll}\text { VHPAVVIR } & 0.98 & 28.99 & 22.79 & 19.60 & 2 & 1033.6528 & 1033.6518 & 517.8332 & 0.0010 & 0.9656 & 1455.638 & 1376.663 & 269.817 & 246.169 & \text { Yes }\end{array}$ $\begin{array}{llllllllllllllll}\text { KVHPAVVIR } & 0.61 & 24.58 & 15.44 & 37.58 & 2 & 1305.8484 & 1305.8489 & 653.9317 & -0.0005 & -0.3823 & 2663.400 & 2497.951 & 665.153 & 243.438 & \text { Yes }\end{array}$ KVHPAVVIR GGSSGAK

GGSSGAK $\begin{array}{lllllllllllllllll}0.77 & 23.89 & 14.31 & 36.89 & 2 & 1305.8508 & 1305.8489 & 653.9317 & 0.0019 & 1.4527 & 1778.375 & 1587.967 & 354.994 & 111.138 & \text { Yes }\end{array}$

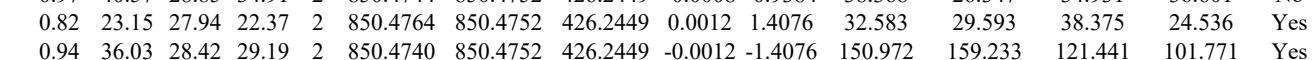
\begin{tabular}{llllllllllllllll} 
& \\
\hline
\end{tabular} $\begin{array}{llllllllllllllll} & \end{array}$

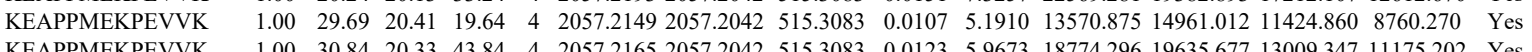

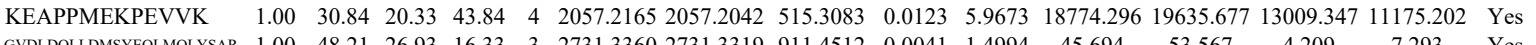

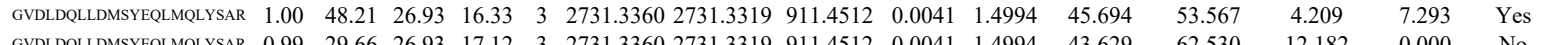

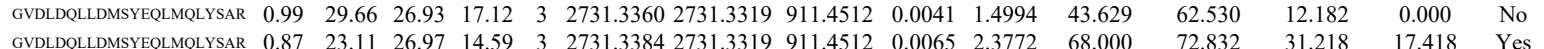

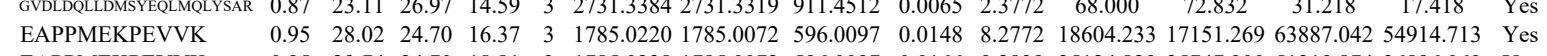
$\begin{array}{llllllllllllllll} & \end{array}$ $\begin{array}{lllllllllllll}\text { RS24 HUMAN } & \text { P62847 } & \text { RPS24 } & \text { 40S ribosomal pro } & 15.42 & 1.00 & 3 & 25.6 & 0.1227 & 0.4577 & -0.2186 & 1.7661 & 18\end{array}$ 


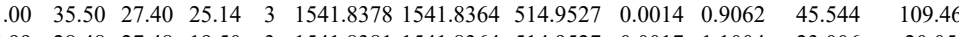
$\begin{array}{llllllllllll}1.00 & 28.48 & 27.48 & 19.50 & 3 & 1541.8381 & 1541.8364 & 514.9527 & 0.0017 & 1.1004 & 23.006 & 20.058\end{array}$ $\begin{array}{llllllllll}1.04 & 0.513 & 166.365\end{array}$

TTPDVIFVFGFR

TTPDVIFVFGFR

TTPDVIFVFGFR

TTPDVIFVFGFR

TTPDVIFVFGFR

TTPDVIFVFGFR

TTPDVIFVFGFR

TGSQGQCTQVR

TGSQGQCTQVR TGSQGQCTQVR TGSQGQCTQVR TGSQGQCTQVR TGSQGQCTQVR TGSQGQCTQVR

EGDVLTLLESER

EGDVLTLLESER

EGDVLTLLESER

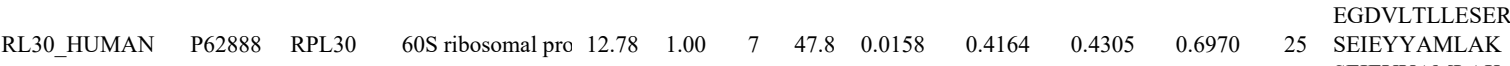

SEIEYYAMLAK

KSEIEYYAMLAK

VCTLAIIDPGDSDIIR VCTLAIIDPGDSDIIR CTLAIDPGDSDIR VCTL AIDPGDSDIIR VCTLAIIDPGDSDIIR VCTLAIIDPGDSDIR YVLGYK

YVLGYK
YVLGYK

YVLGYK

LVILANNCPALR

LVILANNCPALR

LVILANNCPALR

LVILANNCPALR

LVILANNCPALR

LVILANNCPALR

LVILANNCPALR

LVILANNCPALR

LVILANNCPALR

LVILANNCPALR

SMPEQTGEK

LVILANNCPALR

LVILANNCPALR

LVILANNCPALR

LVILANNCPALR

LVILANNCPALR

SMPEQTGEK

$\begin{array}{lllllllllllll}\text { RL31_HUMAN } & \text { P62899 } & \text { RPL31 } & \text { 60S ribosomal pro } 14.46 & 1.00 & 4 & 32.8 & -0.3448 & 0.4899 & 0.4919 & 2.9700 & 9 & \text { EYTINIHK }\end{array}$

$\begin{array}{llllllllllll} & 0\end{array}$ $\begin{array}{lllllllllllll} & 0\end{array}$ $\begin{array}{llllllllllll} & \end{array}$

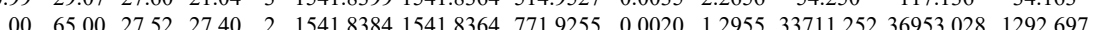
$\begin{array}{lllllllllllll}0.99 & 28.49 & 27.55 & 19.31 & 3 & 1541.8390 & 1541.8364 & 514.9527 & 0.0026 & 1.6830 & 72.965 & 104.892 & 25.886\end{array}$ $\begin{array}{llllllllllllll}1.00 & 32.56 & 27.55 & 22.36 & 3 & 1541.8390 & 1541.8364 & 514.9527 & 0.0026 & 1.6830 & 59.563 & 77.402 & 20.910 & 0.0\end{array}$ $\begin{array}{lllllllllllll}1.00 & 54.23 & 27.55 & 24.88 & 2 & 1541.8392 & 1541.8364 & 771.9255 & 0.0028 & 1.8136 & 19331.458 & 17729.337 & 1938.133\end{array}$ $\begin{array}{lllllllllllll}0.97 & 36.29 & 27.67 & 20.23 & 2 & 1541.8402 & 1541.8364 & 771.9255 & 0.0038 & 2.4614 & 23.576 & 16.376 & 0.860\end{array}$ $\begin{array}{llllllllllllll}1.00 & 73.18 & 25.04 & 39.08 & 2 & 1353.6264 & 1353.6251 & 677.8198 & 0.0013 & 0.9590 & 1269.393 & 1113.091 & 628.394\end{array}$ $\begin{array}{lllllllllllll}1.00 & 71.48 & 24.98 & 47.61 & 2 & 1353.6266 & 1353.6251 & 677.8198 & 0.0015 & 1.1065 & 681.860 & 684.864 & 413.727\end{array}$ $\begin{array}{llllllllllll}0.80 & 21.21 & 25.02 & 26.47 & 2 & 1353.6286 & 1353.6251 & 677.8198 & 0.0035 & 2.5818 & 4.751 & 10.550\end{array}$ $\begin{array}{llllllllllll}1.00 & 44.61 & 24.68 & 30.51 & 2 & 1353.6246 & 1353.6251 & 677.8198 & -0.0005 & -0.3688 & 65.889\end{array}$ $\begin{array}{lllllllllll}0.98 & 39.09 & 24.68 & 30.72 & 2 & 1353.6246 & 1353.6251 & 677.8198 & -0.0005 & -0.3688 & 84.612\end{array}$ $\begin{array}{llllllllllll}0.92 & 31.45 & 24.81 & 29.70 & 2 & 1353.6238 & 1353.6251 & 677.8198 & -0.0013 & -0.9590 & 35.845\end{array}$ $\begin{array}{lllllllllllll}0.96 & 27.03 & 25.05 & 30.30 & 2 & 1353.6262 & 1353.6251 & 677.8198 & 0.0011 & 0.8114 & 20.668\end{array}$ $\begin{array}{lllllllllllll}0.97 & 25.42 & 27.90 & 20.58 & 3 & 1503.7921 & 1503.7902 & 502.2707 & 0.0019 & 1.2609 & 22.967\end{array}$ $\begin{array}{llllllllllll}1.00 & 63.38 & 27.93 & 44.14 & 2 & 1503.7928 & 1503.7902 & 752.9024 & 0.0026 & 1.7266 & 653.383\end{array}$ $\begin{array}{llllllllllll}1.00 & 64.03 & 27.93 & 42.17 & 2 & 1503.7928 & 1503.7902 & 752.9024 & 0.0026 & 1.7266 & 59.091 & 81.033 \\ 1.00 & 65.81 & 27.87 & 41.46 & 2 & 1503.7924 & 1503.7902 & 752.9024 & 0.0022 & 1.4610 & 465.511 & 839.331\end{array}$ $\begin{array}{llllllllllll}1.00 & 70.36 & 27.87 & 44.40 & 2 & 1503.7924 & 1503.7902 & 752.9024 & 0.0022 & 1.4610 & 146.564 & 141.632\end{array}$

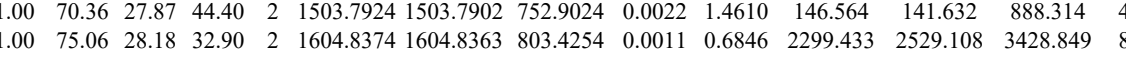
$\begin{array}{lllllllllllllll}1.00 & 69.74 & 28.05 & 28.64 & 2 & 1604.8376 & 1604.8363 & 803.4254 & 0.0013 & 0.8090 & 4139.437 & 3234.555 & 4640.573 & 1806.283\end{array}$ $\begin{array}{lllllllllllllll}1.00 & 63.20 & 25.61 & 28.76 & 2 & 1877.0510 & 1877.0333 & 939.5239 & 0.0177 & 9.4196 & 2626.412 & 2702.693 & 301.376 & 136.442\end{array}$

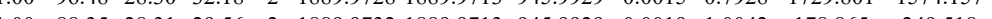

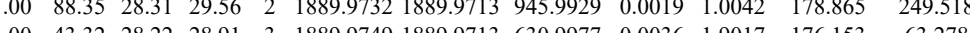

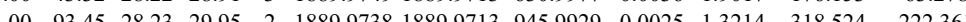

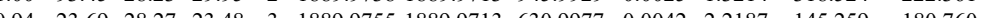
$\begin{array}{lllllllllllllll}1.00 & 53.87 & 28.28 & 27.32 & 2 & 18899.9720 & 1889.9713 & 94559929 & 0.0007 & 0.3700 & 314.901 & 435.687 & 38\end{array}$ $\begin{array}{lllllllllllll}1.00 & 74.16 & 28.22 & 25.69 & 2 & 1889.9746 & 1889.9713 & 945.9929 & 0.0033 & 1.7442 & 259.242 & 374.677 & 76\end{array}$ $\left.\begin{array}{llllllllllllllll}0.79 & 26.16 & 24.76 & 25.67 & 2 & 1029.6184 & 1029.6102 & 515.8124 & 0.0082 & 7.9486 & 26617.107 & 25055005 & 15972.524 & 6130.053\end{array}\right)$

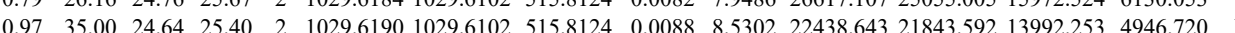

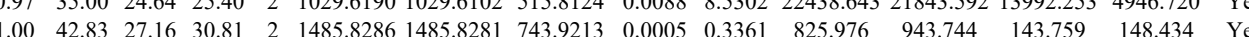
$\begin{array}{lllllllllllllll}0.98 & 33.94 & 27.19 & 20.55 & 2 & 1485.8296 & 1485.8281 & 743.9213 & 0.0015 & 1.0082 & 362.948 & 373.955 & 86.307 & 89.950 & \text { Yes }\end{array}$ $\begin{array}{lllllllllllllll}1.00 & 67.58 & 27.04 & 23.86 & 3 & 1485.8302 & 1485.8281 & 496.2833 & 0.0021 & 1.4105 & 45.249 & 46.789 & 13.365 & 0.000 & \text { No }\end{array}$ $\begin{array}{lllllllllllllll}1.00 & 34.46 & 26.97 & 19.60 & 3 & 1485.8311 & 1485.8281 & 496.2833 & 0.0030 & 2.0150 & 17.554 & 24.500 & 18.089 & 3.916 & \text { Yes }\end{array}$ $\begin{array}{lllllllllllllll}1.00 & 57.61 & 27.18 & 25.00 & 2 & 1485.8298 & 1485.8281 & 743.9213 & 0.0017 & 1.1426 & 1555.169 & 1420.670 & 224.289 & 240.574 & \text { Yes }\end{array}$ $\begin{array}{lllllllllllllll}1.00 & 49.59 & 27.02 & 26.39 & 2 & 1485.8300 & 1485.8281 & 743.9213 & 0.0019 & 1.2770 & 743.041 & 810.233 & 66.979 & 106.862 & \text { Yes }\end{array}$ $\begin{array}{lllllllllllllll}0.75 & 15.44 & 27.06 & 15.67 & 3 & 1485.8308 & 1485.8281 & 496.2833 & 0.0027 & 1.8135 & 26.834 & 30.168 & 9.571 & 3.431 & \text { Yes }\end{array}$ $\begin{array}{lllllllllllllll}0.53 & 22.03 & 26.97 & 35.03 & 3 & 1485.8311 & 1485.8281 & 496.2833 & 0.0030 & 2.0150 & 31.495 & 36.223 & 5.127 & 0.000 & \text { No }\end{array}$

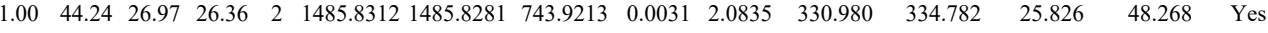
$\begin{array}{lllllllllllllll}.00 & 46.13 & 26.73 & 25.90 & 2 & 1485.8326 & 1485.8281 & 743.9213 & 0.0045 & 3.0245 & 386.058 & 390.348 & 42.685 & 34.354 & \text { Yes }\end{array}$ $\begin{array}{llllllllllllllll}1.00 & 57.66 & 27.74 & 23.74 & 2 & 1293.6542 & 1293.6478 & 647.8312 & 0.0064 & 4.9395 & 626.662 & 515.651 & 298.020 & 88.951 & \text { Yes }\end{array}$ $\begin{array}{llllllllllllllll}0.99 & 36.37 & 27.06 & 27.36 & 2 & 1485.8306 & 1485.8281 & 743.9213 & 0.0025 & 1.6803 & 94.849 & 97.727 & 47.493 & 24.947 & \text { Yes }\end{array}$

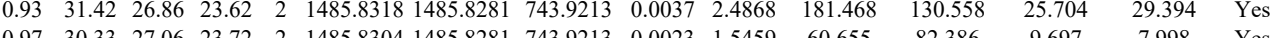

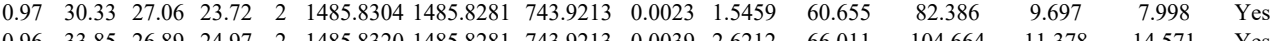

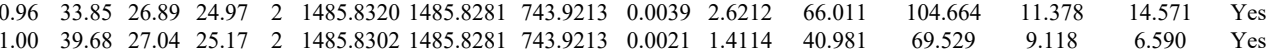

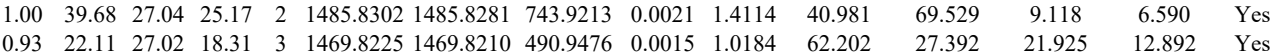

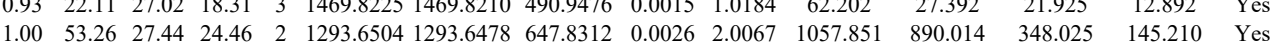

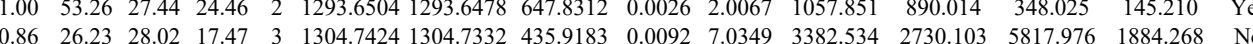

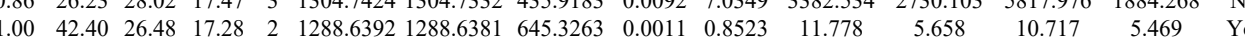

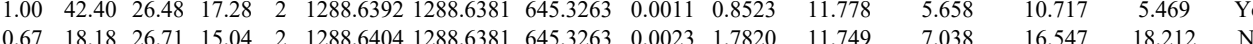

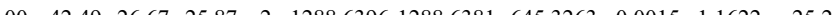


$\begin{array}{lllllllllllll} & \end{array}$ $\begin{array}{llllllllllllllll}0.99 & 35.49 & 27.29 & 30.22 & 3 & 1643.9029 & 1643.9014 & 548.9744 & 0.0015 & 0.9108 & 106.413 & 104.468 & 59.201 & 80.425\end{array}$ $\begin{array}{llllllllllllll}1.00 & 75.76 & 27.13 & 24.36 & 2 & 1643.9042 & 1643.9014 & 822.9580 & 0.0028 & 1.7012 & 438.597 & 522.642 & 611.486 & 71.503\end{array}$ $\begin{array}{lllllllllllllll}1.00 & 43.74 & 27.30 & 26.52 & 3 & 1643.9056 & 1643.9014 & 548.9744 & 0.0042 & 2.5502 & 63.585 & 65.537 & 81.476 & 31.433\end{array}$ $\begin{array}{lllllllllllllll}0.99 & 29.12 & 27.19 & 26.90 & 3 & 1643.9044 & 1643.9014 & 548.9744 & 0.0030 & 1.8216 & 106.298 & 87.952 & 53.008 & 56.587\end{array}$ $\begin{array}{llllllllllllll}1.00 & 70.83 & 27.19 & 26.68 & 2 & 1643.9046 & 1643.9014 & 822.9580 & 0.0032 & 1.9442 & 362.114 & 306.844 & 320.633 & 41.154\end{array}$

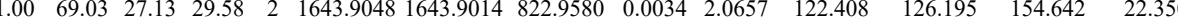
$\begin{array}{llllllllllllll}0.91 & 16.32 & 22.50 & 14.95 & 3 & 1707.0100 & 1707.0062 & 570.0093 & 0.0038 & 2.2222 & 137.735 & 142.420 & 78.346 & 72.752\end{array}$ $\begin{array}{lllllllllllllll}0.65 & 20.05 & 28.63 & 30.25 & 2 & 809.4528 & 809.4518 & 405.7332 & 0.0010 & 1.2323 & 1005.767 & 933.962 & 88.552 & 48.300 & \text { Yes }\end{array}$ $\begin{array}{lllllllllllllll}1.00 & 52.27 & 21.00 & 33.97 & 2 & 1098.7100 & 1098.7005 & 550.3575 & 0.0095 & 8.6307 & \text { \#\#\#\#\#\#\# } 0.000 & 637.146 & \text { No }\end{array}$ $\begin{array}{lllllllllllllll}1.00 & 48.68 & 19.14 & 31.93 & 2 & 1098.7106 & 1098.7005 & 550.3575 & 0.0101 & 9.1758 & 71506.004 & 63316.798 & 0.000 & 914.277 & \text { No }\end{array}$ $\begin{array}{llllllllllllllll}0.99 & 39.99 & 21.00 & 31.19 & 2 & 1098.7096 & 1098.7005 & 550.3575 & 0.0091 & 8.2673 & 73745.176 & 58545.689 & 0.000 & 836.502 & \text { No }\end{array}$

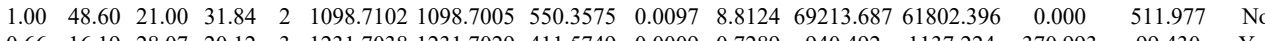

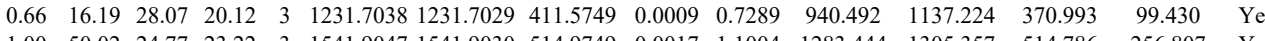
$\begin{array}{lllllllllllllll}1.00 & 50.02 & 24.77 & 23.22 & 3 & 1541.9047 & 1541.9030 & 514.9749 & 0.0017 & 1.1004 & 1283.444 & 1305.357 & 514.786 & 256.807 & \text { Yes }\end{array}$ $\begin{array}{lllllllllllllll}1.00 & 56.79 & 24.03 & 21.75 & 3 & 1541.9056 & 1541.9030 & 514.9749 & 0.0026 & 1.6829 & 1527.075 & 1500.760 & 638.925 & 221.587 & \text { Yes } \\ 1.00 & 46.70 & 2.777 & 15.97 & 3 & 1514.9047 & 151.9030 & 514.9749 & 0.0017 & 1.104 & 778.849 & 843.475 & 312.833 & 91.910 & \text { Yes }\end{array}$ $\begin{array}{lllllllllllllll}1.00 & 46.70 & 24.77 & 15.97 & 3 & 1541.9047 & 1541.9030 & 514.9749 & 0.0017 & 1.1004 & 778.849 & 843.475 & 312.833 & 91.910 & \text { Yes } \\ 1.00 & 48.61 & 24.03 & 16.23 & 3 & 1541.9056 & 1541.9030 & 514.9749 & 0.0026 & 1.6829 & 572.840 & 519.491 & 163.825 & 134.901 & \text { Yes }\end{array}$ $\begin{array}{llllllllllllllll}0.83 & 28.14 & 26.31 & 36.25 & 2 & 914.5060 & 914.5056 & 458.2601 & 0.0004 & 0.4364 & 89.944 & 62.447 & 47.903 & 31.81 & \text { Yo }\end{array}$ $\begin{array}{lllllllllllllllll}0.96 & 35.23 & 25.24 & 28.50 & 2 & 1143.7070 & 1143.7008 & 572.8577 & 0.0062 & 5.4114 & 7769.027 & 5998.884 & 974.125 & 518.259 & \text { Yes }\end{array}$

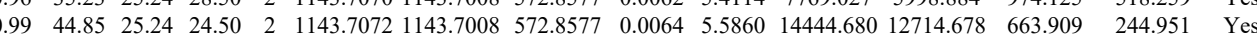
$\begin{array}{lllllllllllllll}0.92 & 25.56 & 27.00 & 16.39 & 2 & 1087.5736 & 1087.5719 & 5447932 & 0.0017 & 15602 & 37192877 & 34514.889 & 1051.653 & 103.132 & \text { Yes }\end{array}$ $\begin{array}{lllllllllllllll}0.94 & 27.30 & 26.76 & 16.36 & 2 & 1087.5742 & 1087.5719 & 544.7932 & 0.0023 & 21109 & 23180358 & 21052.912 & 558.754 & 145.035 & \text { Yes }\end{array}$ $\begin{array}{llllllllllllllll}0.91 & 30.79 & 27.28 & 22.41 & 2 & 1087.5754 & 1087.5719 & 544.7932 & 0.0035 & 3.2122 & 23358.740 & 23567.788 & 1186.517 & 468.135 & \text { Yes }\end{array}$

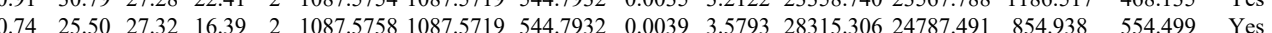
$\begin{array}{lllllllllllllll}0.86 & 25.28 & 27.31 & 16.15 & 2 & 1087.5752 & 1087.5719 & 544.7932 & 0.0033 & 3.0287 & 6516.228 & 6281.334 & 2434.807 & 994.487 & \text { Yes }\end{array}$ $\begin{array}{lllllllllllllllll}0.83 & 27.66 & 27.28 & 16.25 & 2 & 1087.5754 & 1087.5719 & 544.7932 & 0.0035 & 3.2122 & 9369.473 & 9370.127 & 2529.690 & 1157.638 & \text { Yes }\end{array}$ $\begin{array}{lllllllllllllllll}0.92 & 28.14 & 27.31 & 19.54 & 2 & 1087.5752 & 1087.5719 & 544.7932 & 0.0033 & 3.0287 & 4537.375 & 4268.976 & 299.828 & 365.964 & \text { Yes }\end{array}$ $\begin{array}{lllllllllllllllll}0.87 & 25.63 & 27.31 & 16.50 & 2 & 1087.5752 & 1087.5719 & 544.7932 & 0.0033 & 3.0287 & 4437.522 & 4008.857 & 529.991 & 460.014 & \text { Yes }\end{array}$ $\begin{array}{llllllllllllllll}0.87 & 25.60 & 27.36 & 16.45 & 2 & 1087.5748 & 1087.5719 & 544.7932 & 0.0029 & 2.6616 & 3687.254 & 3586.093 & 258.033 & 375.664 & \text { Yes }\end{array}$ $\begin{array}{llllllllllllllll}0.92 & 25.59 & 26.76 & 16.41 & 2 & 1087.5740 & 1087.5719 & 544.7932 & 0.0021 & 1.9273 & 3986.383 & 3720.589 & 167.472 & 229.273 & \text { Yes }\end{array}$

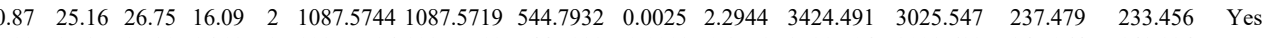

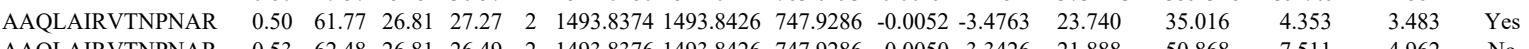
$\begin{array}{lllllllllllllllll} & \\ \text { ASGNYATVISHNPETK } & 1.00 & 60.69 & 27.34 & 19.05 & 3 & 1976.0347 & 1976.0207 & 659.6808 & 0.0140 & 7.0741 & 2251.264 & 2309.504 & 1823.703 & 1079.112 & \text { Yes } \\ \text { IDKPILK } & 0.74 & 13.4 & 12.79 & 22.30 & 3 & 1257.8431 & 1257.8386 & 420.586 & 0.0045 & 3.5690 & 62552.652 & 56436.461 & 44794.796 & 30285.237 & \text { Yes }\end{array}$

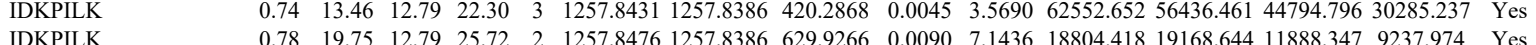
$\begin{array}{lllllllllllllll}0.78 & 19.75 & 12.79 & 25.72 & 2 & 1257.8476 & 1257.8386 & 629.9266 & 0.0090 & 7.1436 & 18804.418 & 19168.644 & 11888.347 & 9237.974 & \text { Yes }\end{array}$ $\begin{array}{lllllllllllllllll}0.89 & 32.02 & 12.79 & 35.55 & 2 & 1257.8486 & 1257.8386 & 629.9266 & 0.0100 & 7.9374 & 18174.948 & 15998.777 & 11295.596 & 7203.981 & \text { Yes }\end{array}$ $\begin{array}{lllllllllllllll}0.86 & 30.77 & 12.79 & 34.57 & 2 & 1257.8476 & 1257.8386 & 629.9266 & 0.0090 & 7.1436 & 51680.509 & 53054.107 & 38825.669 & 26796.832 & \text { Yes } \\ 0.89 & 25.91 & 12.79 & 29.51 & 2 & 1257.8486 & 1257.8386 & 629.9266 & 0.0100 & 7.9374 & 55094772 & 59199.268 & 44440.441 & 29797.516 & \text { Yes }\end{array}$ $\begin{array}{llllllllllllllll}0.89 & 25.91 & 12.79 & 29.51 & 2 & 1257.8486 & 1257.8386 & 629.9266 & 0.0100 & 7.9374 & 55094.772 & 59199.268 & 44440.441 & 29797.516 & \text { Yes } \\ 0.97 & 25.54 & 13.62 & 29.17 & 2 & 1257.8406 & 1257.8386 & 629.9266 & 0.0020 & 1.5875 & 18625.766 & 21696.643 & 14252.932 & 7277.895 & \text { Yes }\end{array}$

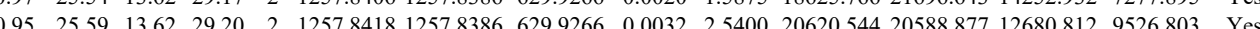

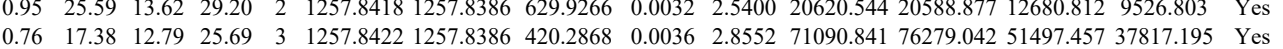




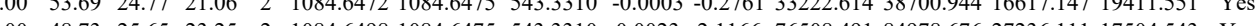
$\begin{array}{lllllllllllllll}1.00 & 48.73 & 25.65 & 23.25 & 2 & 1084.6498 & 1084.6475 & 543.3310 & 0.0023 & 2.1166 & 76508.491 & 84978.676 & 27236.111 & 17504.543 & \text { Yes }\end{array}$ $\begin{array}{lllllllllllllll}1.00 & 52.72 & 25.00 & 24.65 & 2 & 1084.6490 & 1084.6475 & 543.3310 & 0.0015 & 1.3804 & 39002.200 & 48552.761 & 16727.304 & 17937.615 & \text { Yes }\end{array}$

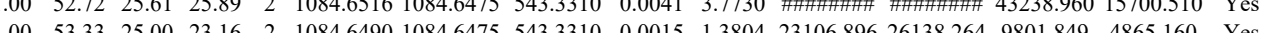

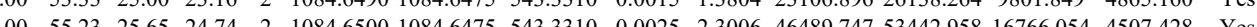
$\begin{array}{llllllllllllllll}1.00 & 53.42 & 25.00 & 23.03 & 2 & 1084.6492 & 1084.6475 & 543.3310 & 0.0017 & 1.5644 & 12834.062 & 14117.945 & 4497.854 & 1389.555 & \text { Yes }\end{array}$

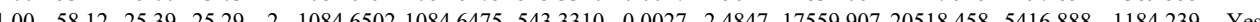

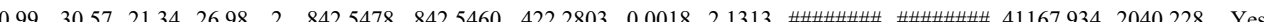
$\begin{array}{llllllllllllllll}1.00 & 39.77 & 21.34 & 28.85 & 2 & 842.5486 & 842.5460 & 422.2803 & 0.0026 & 3.0785 & 83642.195 & 88276.183 & 19034.869 & 882.338 & \text { Yes }\end{array}$ $\begin{array}{lllllllllllllll}1.00 & 40.13 & 21.34 & 30.31 & 2 & 842.5474 & 8425460 & 4222803 & 0.0014 & 1.6577 & 71779.712 & 69572.612 & 16817.374 & 1941329 & \text { Yes }\end{array}$

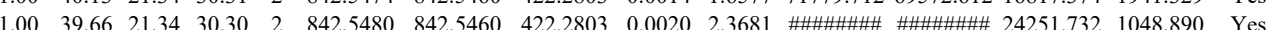

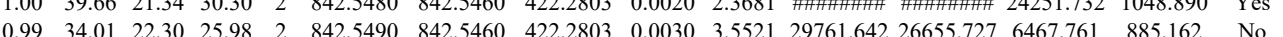
$\begin{array}{llllllllllllllll}0.99 & 35.64 & 22 & 30 & 27.98 & 2 & 842.5492 & 842.5460 & 422.2803 & 0.0032 & 3.7889 & 37034.666 & 32025.564 & 7150.881 & 798.365 & \text { No }\end{array}$

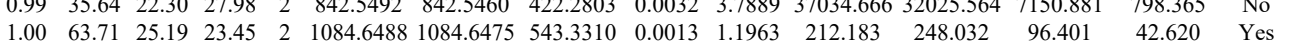

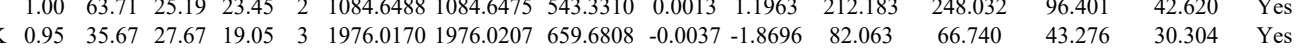
$\begin{array}{llllllllllllllll}1.00 & 41.23 & 25.80 & 17.38 & 2 & 1084.6506 & 1084.6475 & 543.3310 & 0.0031 & 2.8528 & 243.760 & 232.622 & 71.487 & 29.583 & \text { Yes }\end{array}$ $\begin{array}{lllllllllllllll}0.88 & 30.57 & 28.47 & 21.42 & 2 & 1135.6158 & 1135.6117 & 568.8131 & 0.0041 & 3.6040 & 52.191 & 54.511 & 23.645 & 5.288 & \text { Yes }\end{array}$ $\begin{array}{lllllllllllllll}1.00 & 55.54 & 27.52 & 32.36 & 2 & 1441.7708 & 1441.7697 & 721.8921 & 0.0011 & 0.7619 & 135.178 & 129.464 & 50.616 & 12.011 & \text { Yes }\end{array}$

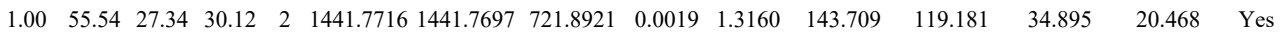
$\begin{array}{lllllllllllllll}0.93 & 33.61 & 28.39 & 25.02 & 2 & 1135.6218 & 1135.6117 & 568.8131 & 0.0101 & 8.8781 & 9543.898 & 10562.193 & 1391.101 & 776.435 & \text { Yes }\end{array}$

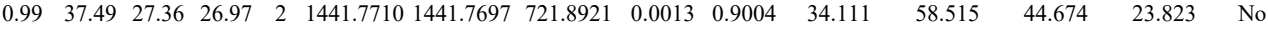

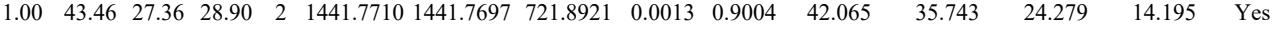

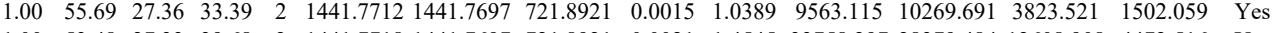

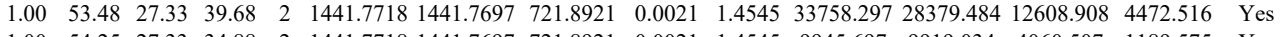

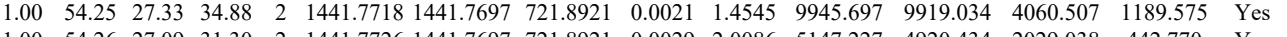

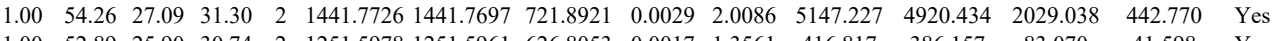
$\begin{array}{lllllllllllllll}1.00 & 52.89 & 25.90 & 30.74 & 2 & 1251.5978 & 1251.5961 & 626.8053 & 0.0017 & 1.3561 & 416.817 & 386.157 & 83.070 & 41.598 & \text { Yes }\end{array}$ $\begin{array}{lllllllllllllll}1.00 & 57.15 & 25.02 & 25.77 & 2 & 1251.5980 & 1251.5961 & 626.8053 & 0.0019 & 1.5156 & 1036.003 & 1050.104 & 93.930 & 55.172 & \text { Yes } \\ 1.00 & 5.87 & 25.95 & 29.57 & 2 & 125.5974 & 1251.596 & 62.8053 & 0.0013 & 1.0370 & 274.470 & 274.594 & 221.740 & 167.82 & \text { Yes }\end{array}$

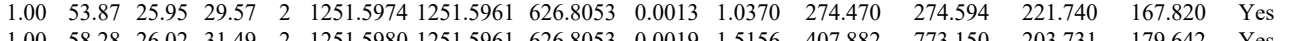

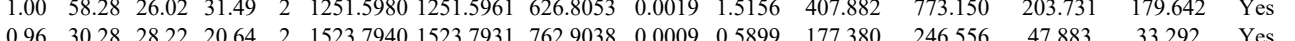

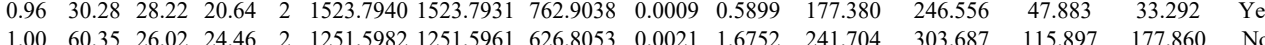

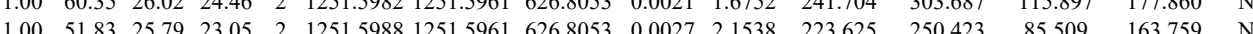

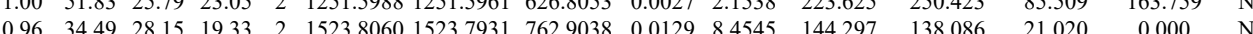

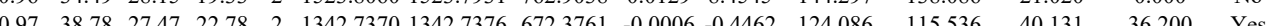

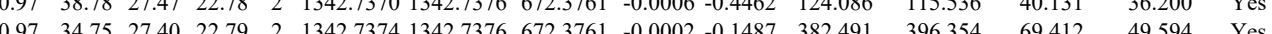

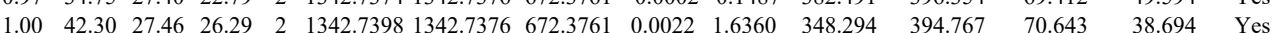

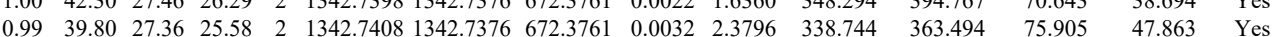

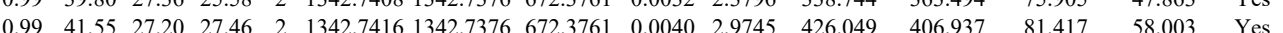

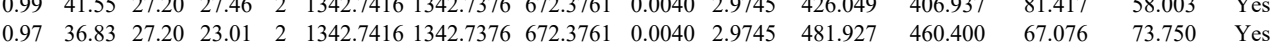
$\begin{array}{lllllllllllllll}1.00 & 49.51 & 27.20 & 24.79 & 2 & 1342.7416 & 1342.7376 & 672.3761 & 0.0040 & 2.9745 & 5286.347 & 5115.202 & 35.487 & 87.979 & \text { Yes }\end{array}$

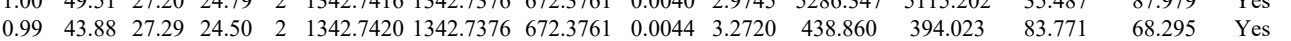
$\begin{array}{lllllllllllllll}1.00 & 52.95 & 27.27 & 27.72 & 2 & 1342.7424 & 1342.7376 & 672.3761 & 0.0048 & 3.5694 & 422.744 & 433.508 & 87.184 & 68.377 & \text { Yes }\end{array}$ $\begin{array}{lllllllllllllll}1.00 & 49.62 & 27.27 & 27.88 & 2 & 1342.7424 & 1342.7376 & 672.3761 & 0.0048 & 3.5694 & 59138.716 & 52066.243 & 0.000 & 0.000 & \text { No }\end{array}$ $\begin{array}{lllllllllllllll}0.99 & 45.38 & 27.27 & 27.59 & 2 & 1342.7424 & 1342.7376 & 672.3761 & 0.0048 & 3.5694 & 44971.205 & 45739.687 & 0.000 & 34.723 & \text { No }\end{array}$

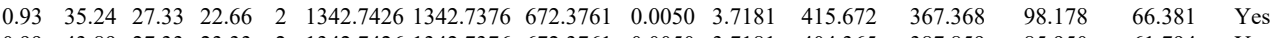
$\begin{array}{lllllllllllllll}0.99 & 43.89 & 27.33 & 23.33 & 2 & 1342.7426 & 1342.7376 & 672.3761 & 0.0050 & 3.7181 & 404.365 & 387.859 & 85.950 & 61.794 & \text { Yes }\end{array}$

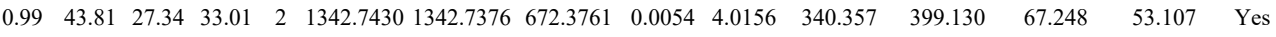
$\begin{array}{lllllllllllllll}0.99 & 46.19 & 27.34 & 27.32 & 2 & 1342.7432 & 1342.7376 & 672.3761 & 0.0056 & 4.1643 & 5446.313 & 5174.277 & 14.975 & 126.601 & \text { Yes }\end{array}$ $\begin{array}{lllllllllllllll}0.89 & 32.55 & 27.73 & 22.52 & 2 & 1342.7454 & 1342.7376 & 672.3761 & 0.0078 & 5.8003 & 405.946 & 369.272 & 82.492 & 65.451 & \text { Yes }\end{array}$ $\begin{array}{lllllllllllllll}0.92 & 34.04 & 27.73 & 23.49 & 2 & 1342.7456 & 1342.7376 & 672.3761 & 0.0080 & 5.9490 & 169.410 & 153.992 & 21.728 & 32.745 & \text { Yes }\end{array}$

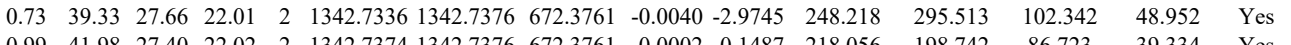

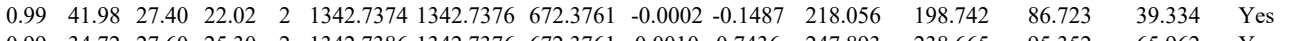

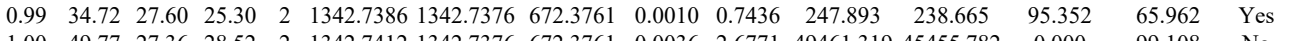
$\begin{array}{lllllllllllllll}1.00 & 49.77 & 27.36 & 28.52 & 2 & 1342.7412 & 1342.7376 & 672.3761 & 0.0036 & 2.6771 & 49461.319 & 45455.782 & 0.000 & 99.108 & \text { No }\end{array}$ $\begin{array}{lllllllllllllll}1.00 & 49.48 & 27.36 & 27.91 & 2 & 1342.7412 & 1342.7376 & 672.3761 & 0.0036 & 2.6771 & 35221.939 & 37706.563 & 0.000 & 221.911 & \text { No } \\ 1.00 & 57.49 & 27.36 & 31.56 & 2 & 1441.7710 & 1441.7697 & 721.8921 & 0.0013 & 0.9004 & 172.313 & 185.277 & 62.731 & 35.340 & \text { Y }\end{array}$

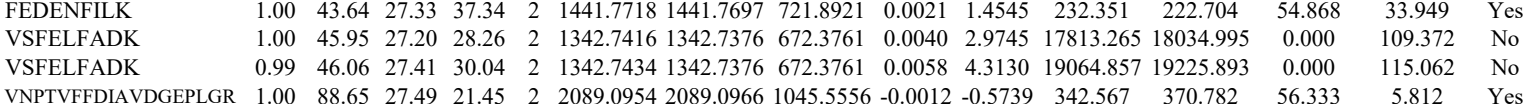

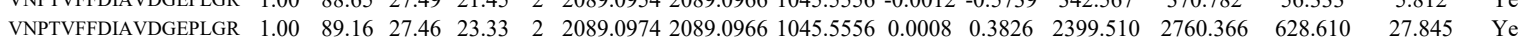


$\begin{array}{llllllllllllll}\text { VNPTVFFDIAVDGEPLGR } & 0.58 & 88.17 & 27.46 & \# \# \# \text { 2 } & 2089.0974 & 2089.0966 & 1045.5556 & 0.0008 & 0.3826 & 162.017 & 223.469\end{array}$ $\begin{array}{lllllllllllll}\text { VNPTVFFDIAVDGEPLGR } & 1.00 & 90.35 & 27.46 & 22.64 & 2 & 2089.0974 & 2089.0966 & 1045.5556 & 0.0008 & 0.38826 & 568.450 & 448.699\end{array}$ $\begin{array}{llllllllllllll}\text { VNPTVFFDIAVDGEPLGR } & 0.82 & 22.76 & 27.47 & 18.07 & 3 & 2089.0978 & 2089.0966 & 697.3728 & 0.0012 & 0.5736 & 333.796 & 418.602\end{array}$ $\begin{array}{llllllllllllll}\text { VNPTVFFDIAVDGEPLGR } & 0.93 & 24.90 & 27.43 & 17.90 & 3 & 2089.0984 & 2089.0966 & 697.3728 & 0.0018 & 0.8604 & 126.353 & 93.544 & 59 . \\ \text { VNPTVFFDIAVDGEPLGR } & 0.99 & 32.21 & 27.44 & 24.87 & 3 & 2089.0987 & 2089.0966 & 697.3728 & 0.0021 & 1.0038 & 153.483 & 150.487 & 74 .\end{array}$ $\begin{array}{lllllllllllll}\text { VNPTVFFDIAVDGEPLGR } & 0.99 & 32.21 & 27.44 & 24.87 & 3 & 2089.0987 & 2089.0966 & 697.3728 & 0.0021 & 1.0038 & 153.483 & 150.487\end{array}$ $\begin{array}{lllllllllllll}\text { VNPTVFFDIAVDGEPLGR } & 0.92 & 24.52 & 27.40 & 15.33 & 3 & 2089.0990 & 2089.0966 & 697.3728 & 0.0024 & 1.1472 & 143.451 & 154.535 \\ \text { VNPTVFFDIAVDGEPLGR } & 1.00 & 91.68 & 27.42 & 20.47 & 2 & 2089.0994 & 2089.0966 & 1045.5556 & 0.0028 & 1.3390 & 172.810 & 149.722\end{array}$ $\begin{array}{lllllllllllll}\text { VNPTVFFDIAVDGEPLGR } & 1.00 & 91.68 & 27.42 & 20.47 & 2 & 2089.0994 & 2089.0966 & 1045.5556 & 0.0028 & 1.3390 & 172.810 & 149.722 \\ \text { VNPTVFFDIAVDGEPLGR } & 1.00 & 41.31 & 27.38 & 15.71 & 3 & 2089.1008 & 2089.0966 & 697.3728 & 0.0042 & 2.0075 & 162.645 & 163.468\end{array}$ $\begin{array}{lllllllllllllll}\text { VNPTVFFDIAVDGEPLGR } & 1.00 & 41.31 & 27.38 & 15.71 & 3 & 2089.1008 & 2089.0966 & 697.3728 & 0.0042 & 2.0075 & 162.645 & 163.468\end{array}$ $\begin{array}{lllllllllllll}\text { NNPVFIAVDGLLGR } & 1.00 & 43.32 & 27.42 & 16.20 & 3 & 2089.1014 & 2089.0966 & 697.3728 & 0.0048 & 2.2943 & 83.645 & 120.953\end{array}$

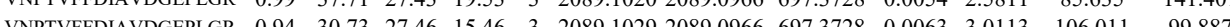

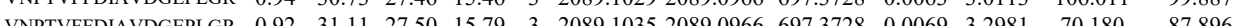

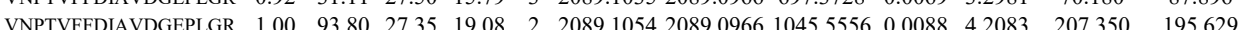

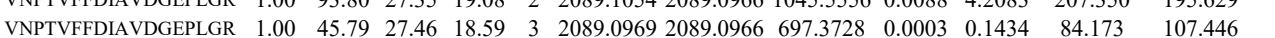

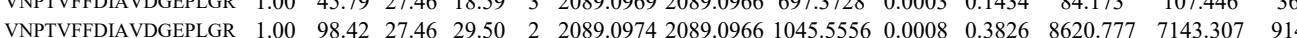

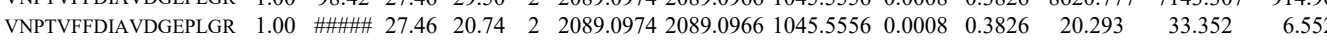

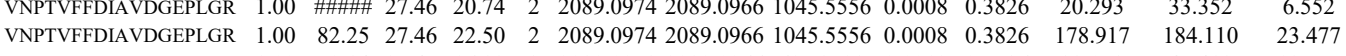
$\begin{array}{llllllllllllll}\text { VNPTVFFDIAVDGEPLGR } & 1.00 & 50.14 & 27.47 & 16.82 & 3 & 2089.0978 & 2089.0966 & 697.3728 & 0.0012 & 0.5736 & 33.058 & 47.418 & 18.757\end{array}$ $\begin{array}{llllllllllllll}\text { VNPTVFFDIAVDGEPLGR } & 0.89 & 23.33 & 27.40 & 18.75 & 3 & 2089.0990 & 2089.0966 & 697.3728 & 0.0024 & 1.1472 & 131.064 & 143.445 & 58.852\end{array}$ $\begin{array}{llllllllllllll}\text { VNPTVFFDIAVDGEPLGR } & 1.00 & 93.48 & 27.42 & 24.69 & 2 & 2089.0994 & 2089.0966 & 1045.5556 & 0.0028 & 1.3390 & 219.503 & 237.373 & 20.877\end{array}$

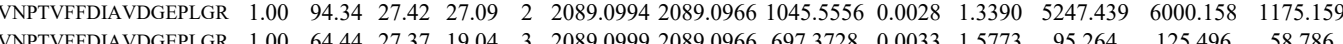

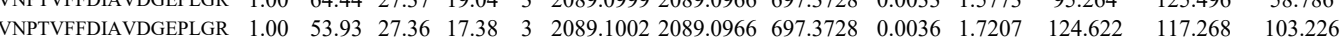
$\begin{array}{lllllllllllllll}\text { VNPTVFFDIAVDGEPLGR } & 0.92 & 25.46 & 27.36 & 19.77 & 3 & 2089.1002 & 2089.0966 & 697.3728 & 0.0036 & 1.7207 & 351.631 & 471.445 & 105.137\end{array}$ $\begin{array}{lllllllllllllll}\text { VNPTVFFDIAVDGEPLGR } & 1.00 & 38.99 & 27.38 & 18.08 & 3 & 2089.1008 & 2089.0966 & 697.3728 & 0.0042 & 2.0075 & 121.500 & 98.893 & 69.542\end{array}$ $\begin{array}{llllllllllllll}\text { VNPTVFFDIAVDGEPLGR } & 1.00 & 57.24 & 27.38 & 17.89 & 3 & 2089.1008 & 2089.0966 & 697.3728 & 0.0042 & 2.0075 & 14.109 & 27.205 & 6.800\end{array}$

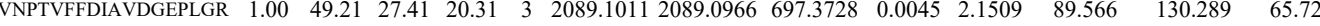
$\begin{array}{lllllllllllll}\text { MVNPTVFFDIAVDGEPLGR } & 0.55 & 32.45 & 27.80 & 45.45 & 3 & 2220.1396 & 2220.1371 & 741.0530 & 0.0025 & 1.1245 & 18.236 & 19.627\end{array}$ $\begin{array}{lllllllllllll}\text { VNPTVFFDIAVDGEPLGR } & 1.00 & 89.13 & 27.46 & 21.68 & 2 & 2089.0974 & 2089.0966 & 1045.5556 & 0.0008 & 0.3826 & 2599.171 & 2318.213\end{array}$ $\begin{array}{lllllllllllll}\text { VNPTVFFDIAVDGEPLGR } & 1.00 & 94.33 & 27.46 & 20.65 & 2 & 2089.0974 & 2089.0966 & 1045.5556 & 0.0008 & 0.3826 & 752.629 & 512.852\end{array}$ GSCFHR GSCFHR GSCFHR FEDENFILK FEDENFILK FEDENFILK $\begin{array}{lllllllllllll}0.74 & 14.13 & 20.97 & 19.60 & 2 & 895.3920 & 895.3915 & 448.7030 & 0.0005 & 0.5572 & 178.006 & 174.089 \\ 0.57 & 10.96 & 21.07 & 19.08 & 2 & 895.3922 & 895.3915 & 448.7030 & 0.0007 & 0.7800 & 281.146 & 323.708\end{array}$ $\begin{array}{lllllllllllll}0.82 & 17.52 & 22.36 & 16.86 & 2 & 895.3924 & 895.3915 & 448.7030 & 0.0009 & 1.0029 & 281.306 & 386.223\end{array}$ FEDENFILK

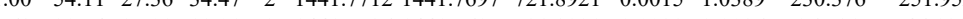
$\begin{array}{lllllllllllll} & \end{array}$

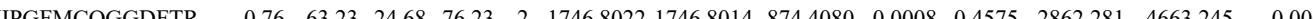
$\begin{array}{llllllllllllll}\text { IIPGFMCQGGDFTR } & 1.00 & 65.51 & 24.77 & 17.33 & 2 & 1746.8032 & 1746.8014 & 8744080 & 0.0018 & 1.0293 & 4097.026 & 5181.326\end{array}$

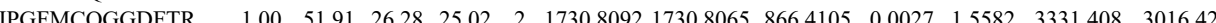
IIPGFMCQGGDFTR IIPGFMCQGGDFTR IIPGFMCQGGDFTR IIPGFMCQGGDFTR IIPGFMCQGGDFTR IIPGFMCQGGDFTR IIPGFMCQGGDFTR IIPGFMCQGGDFTR IPGFMCQGGDFTR MGFMCQGGDFR IIPGFMCQGGDFTR IPGFMCQGGDFTR IIPGFMCQGGDFTR IIPGFMCQGGDFTR IIPGFMCQGGDFTR IIPGFMCQGGDFTR IIPGFMCQGGDFTR
IIPGFMCQGGDFTR

(1)

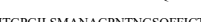

IIPGFMCQGGDFTR

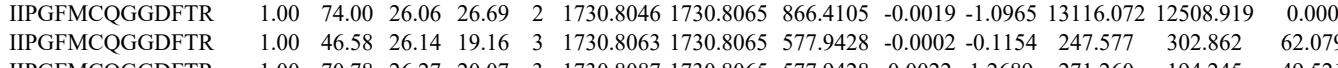
$\begin{array}{llllllllllll}1.00 & 55.51 & 24.77 & 17.33 & 2 & 1746.8032 & 1746.8014 & 874.4080 & 0.0018 & 1.0293 & 4097.026 & 5181.326 \\ 1.00 & 49.23 & 26.28 & 25.02 & 2 & 1730.8092 & 1730.8065 & 866.4105 & 0.0027 & 1.5582 & 3331.408 & 3016.420\end{array}$ $\begin{array}{lllllllllllll}0.53 & 19.19 & 26.30 & 32.19 & 3 & 1730.8093 & 1730.8065 & 577.9428 & 0.0028 & 1.6149 & 17.740 & 37.241\end{array}$ $\begin{array}{llllllllllll}0.92 & 37.06 & 26.05 & 23.09 & 2 & 1730.8042 & 1730.8065 & 866.4105 & -0.0023 & -1.3273 & 238.908 & 298.434\end{array}$ $\begin{array}{llllllllllll}0.94 & 38.62 & 26.05 & 25.84 & 2 & 1730.8044 & 1730.8065 & 866.4105 & -0.0021 & -1.2119 & 209.973 & 262.943\end{array}$ $\begin{array}{llllllllllll}0.99 & 47.67 & 26.06 & 23.52 & 2 & 1730.8048 & 1730.8065 & 866.4105 & -0.0017 & -0.9811 & 301.408 & 305.226\end{array}$ $\begin{array}{llllllllllll}0.83 & 32.96 & 26.06 & 22.34 & 2 & 1730.8048 & 1730.8065 & 866.4105 & -0.0017 & -0.9811 & 270.532 & 347.176\end{array}$ $\begin{array}{llllllllllll}0.88 & 30.61 & 26.03 & 21.97 & 2 & 1730.8052 & 1730.8065 & 866.4105 & -0.0013 & -0.7502 & 246.195 & 278.338\end{array}$ $\begin{array}{llllllllllll}0.99 & 45.77 & 26.03 & 23.30 & 2 & 1730.8052 & 1730.8065 & 866.4105 & -0.0013 & -0.7502 & 225.610 & 222.053\end{array}$ $\begin{array}{lllllllllllll}0.95 & 34.78 & 26.00 & 23.34 & 2 & 1730.8054 & 1730.8065 & 866.4105 & -0.0011 & -0.6348 & 227.919 & 234.445\end{array}$ $\begin{array}{lllllllllllll}.70 & 25.66 & 26.03 & 20.90 & 2 & 1730.8058 & 1730.8065 & 866.4105 & -0.0007 & -0.4040 & 244.006 & 208.614\end{array}$ $\begin{array}{lllllllllllll}1.00 & 62.60 & 26.24 & 22.63 & 3 & 1730.8084 & 1730.8065 & 577.9428 & 0.0019 & 1.0958 & 564.652 & 731.878\end{array}$ $\begin{array}{lllllllllllll}.01 .27 & 26.30 & 18.90 & 2 & 1730.8084 & 1730.8065 & 866.4105 & 0.0019 & 1.0965 & 21984.635 & 25600.361 \\ 0.55 & 28.85 & 26.27 & 41.85 & 3 & 1730.8087 & 1730.8065 & 577.9428 & 0.0022 & 12689 & 131.695 & 152.518\end{array}$

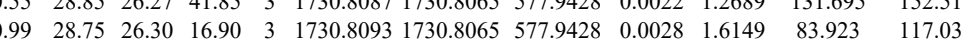
$\begin{array}{lllllllllllll}0.53 & 37.72 & 26.30 & 50.72 & 3 & 1730.8093 & 1730.8065 & 577.9428 & 0.0028 & 1.6149 & 89.710 & 99.695\end{array}$ $\begin{array}{lllllllllllll} & \end{array}$ $\begin{array}{llllllllllllll}1.00 & 69.90 & 26.36 & 19.63 & 2 & 1730.8094 & 1730.8065 & 866.4105 & 0.0029 & 1.6736 & 30917.757 & 36716.352 & 439.688\end{array}$ $\begin{array}{lllllllllllll}1.00 & 74.64 & 24.68 & 20.05 & 2 & 1746.8020 & 1746.8014 & 874.4080 & 0.0006 & 0.3431 & 11053.671 & 15122.332 & 0.000 \\ 1.00 & 74.68 & 24.19 & 19.12 & 2 & 1746.8030 & 1746.8014 & 874.4080 & 0.0016 & 0.9149 & 8568.696 & 8714.146 & 88.769\end{array}$

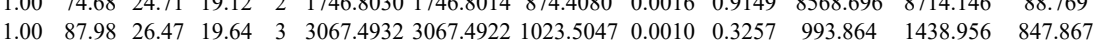
$\begin{array}{llllllllllllll}0.70 & 7.45 & 26.57 & 20.45 & 4 & 3067.4961 & 3067.4922 & 767.8803 & 0.0039 & 1.2697 & 82.522 & 113.766 & 44.653\end{array}$

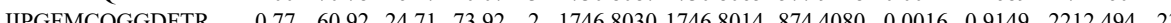

Table S-3 page 326 of 499 
$\begin{array}{llllllllllll}1.00 & 67.79 & 26.22 & 27.96 & 2 & 1730.8070 & 1730.8065 & 866.405 & 0.0005 & 0.2885 & 2591.215 & 2214.693\end{array}$

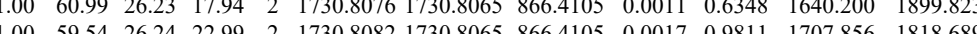
$\begin{array}{lllllllllllll}1.00 & 60.9 & 26.23 & 17.94 & 2 & 1730.8076 & 1730.8065 & 866.4105 & 0.0011 & 0.6348 & 1640.200 & 189.823 \\ 1.00 & 94.11 & 26.24 & 22.99 & 2 & 1730.8082 & 1730.8065 & 866.4105 & 0.0017 & 0.9811 & 1707.856 & 1818.689\end{array}$

IPGFMCQGGDFTR $\begin{array}{llllllllllll} & 23.84 & 3 & 3067.4932 & 3067.4922 & 1023.5047 & 0.0010 & 0.3257 & 67.021\end{array}$

IPGFMCQGGDFTR $\begin{array}{lllllllllll}32.09 & 26.14 & 23.78 & 2 & 1730.8060 & 1730.8065 & 866.4105 & -0.0005 & -0.2885 & 76.224\end{array}$

IIPGFMCQGGDFTR $\begin{array}{llllllllllll}0.55 & 18.21 & 27.43 & 19.54 & 3 & 20891020 & 20890966 & 69.3728 & 0.0054 & 2.5811 & 5.847\end{array}$

TEWLDGK

TEWLDGK

TEWLDGK

TEWLDGK

TEWLDGK

TEWLDGK

TEWLDGK

TEWLDGK

TEWLDGK

TEWLDGK

TEWLDGK

TEWLDGK

TEWLDGK

TEWLDGK

EGMNIVEAMER

EGMNIVEAM 

$\begin{array}{lllllllllll}1.00 & 53.53 & 27.34 & 33.59 & 2 & 1441.7716 & 1441.7697 & 721.8921 & 0.0019 & 1.3160 & 222.971 \\ 1.00 & 55.36 & 27.34 & 31.37 & 2 & 1441.7716 & 1441.7697 & 721.8921 & 0.0019 & 1.3160 & 244.768\end{array}$ $\begin{array}{lllllllllll}1.00 & 55.36 & 27.34 & 31.37 & 2 & 1441.7716 & 1441.7697 & 721.8921 & 0.0019 & 1.3160 & 244.768 \\ 1.00 & 57.50 & 27.34 & 33.44 & 2 & 1441.7716 & 1441.7697 & 721.8921 & 0.0019 & 1.3160 & 209.643\end{array}$ $\begin{array}{lllllllllll}1.00 & 57.50 & 27.34 & 33.44 & 2 & 1441.7716 & 1441.7697 & 721.8921 & 0.0019 & 1.3160 & 209.643 \\ 1.00 & 54.84 & 27.34 & 35.80 & 2 & 1441.7716 & 1441.7697 & 721.8921 & 0.0019 & 1.3160 & 249.537\end{array}$ $\begin{array}{lllllllllll}1.00 & 55.78 & 27.33 & 32.20 & 2 & 1441.7718 & 1441.7697 & 721.8921 & 0.0021 & 1.4545 & 237.961\end{array}$ $\begin{array}{llllllllllll}.00 & 54.03 & 27.33 & 30.09 & 2 & 1441.7718 & 1441.7697 & 721.8921 & 0.0021 & 1.4545 & 240.516\end{array}$

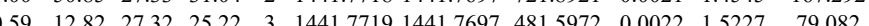
$\begin{array}{llllllllllll}1.00 & 5411 & 27.32 & 34.27 & 2 & 1441.7722 & 1441.7697 & 721.8921 & 0.0025 & 1.7316 & 251.732\end{array}$ $\begin{array}{lllllllllllll}1.00 & 48.00 & 27.23 & 35.51 & 2 & 1441.7722 & 1441.7697 & 721.8921 & 0.0025 & 1.7316 & 227.603\end{array}$ $\begin{array}{lllllllllllll}0.50 & 11.51 & 27.22 & 18.05 & 3 & 1441.7725 & 1441.7697 & 481.5972 & 0.0028 & 1.9380 & 75.176\end{array}$ $\begin{array}{llllllllllll}1.00 & 53.26 & 27.09 & 31.84 & 2 & 1441.7726 & 1441.7697 & 721.8921 & 0.0029 & 2.0086 & 257.236\end{array}$ $\begin{array}{llllllllllll}0.99 & 38.06 & 27.10 & 31.82 & 2 & 1441.7728 & 1441.7697 & 721.8921 & 0.0031 & 2.1471 & 33111.147 & 32\end{array}$ $\begin{array}{llllllllllll}1.00 & 53.57 & 27.10 & 34.22 & 2 & 1441.7728 & 1441.7697 & 721.8921 & 0.0031 & 2.1471 & 294.403\end{array}$ $\begin{array}{lllllllllll}1.00 & 53.78 & 27.10 & 31.87 & 2 & 1441.7728 & 1441.7697 & 721.8921 & 0.0031 & 2.1471 & 210.501\end{array}$ $\begin{array}{lllllllllll}1.00 & 54.55 & 27.10 & 33.00 & 2 & 1441.7728 & 1441.7697 & 721.8921 & 0.0031 & 2.1471 & 212.067\end{array}$ $\begin{array}{lllllllllll}0.69 & 21.01 & 27.32 & 21.79 & 2 & 1441.7730 & 1441.7697 & 721.8921 & 0.0033 & 2.2857 & 25.832\end{array}$

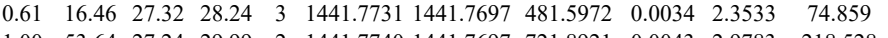
$\begin{array}{lllllllllll}1.00 & 53.64 & 27.24 & 29.99 & 2 & 1441.7740 & 1441.7697 & 721.8921 & 0.0043 & 2.9783 & 218.528 \\ 0.99 & 43.08 & 27.24 & 24.05 & 2 & 1441.7744 & 1441.7697 & 721.8921 & 0.0047 & 3.2553 & 105.997\end{array}$ $\begin{array}{lllllllllll}0.99 & 43.08 & 27.24 & 24.05 & 2 & 1441.7744 & 1441.7697 & 721.8921 & 0.0047 & 3.2553 & 105.997 \\ 1.00 & 50.51 & 27.28 & 33.09 & 2 & 1441.7752 & 1441.7697 & 721.8921 & 0.0055 & 3.8094 & 134.874\end{array}$ $\begin{array}{llllllllllll}0.95 & 37.63 & 28.89 & 24.57 & 2 & 1135.6108 & 1135.6117 & 568.8131 & -0.0009 & -0.7911 & 322.903\end{array}$ $\begin{array}{llllllllllll}0.97 & 35.97 & 28.67 & 24.98 & 2 & 1135.6116 & 1135.6117 & 568.8131 & -0.0001 & -0.0879 & 269.620 \\ 0.93 & 31.17 & 28.65 & 23.37 & 2 & 1135.6122 & 1135.6117 & 568.8131 & 0.0005 & 0.4395 & 259.750 & 265\end{array}$ $\begin{array}{lllllllllll}0.93 & 31.17 & 28.65 & 23.37 & 2 & 1135.6122 & 1135.6117 & 568.8131 & 0.0005 & 0.4395 & 259.750\end{array}$ $\begin{array}{lllllllllll}0.99 & 38.56 & 28.83 & 25.32 & 2 & 1135.6128 & 1135.6117 & 568.8131 & 0.0011 & 0.9669 & 283.559\end{array}$ $\begin{array}{llllllllllll}0.99 & 36.53 & 28.83 & 27.59 & 2 & 1135.6128 & 1135.6117 & 568.8131 & 0.0011 & 0.9669 & 204.765 & 2\end{array}$ $\begin{array}{llllllllllll}0.98 & 34.29 & 28.15 & 24.57 & 2 & 1135.6148 & 1135.6117 & 568.8131 & 0.0031 & 2.7250 & 293.988\end{array}$

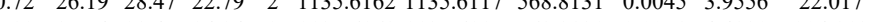

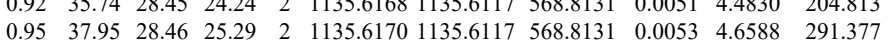

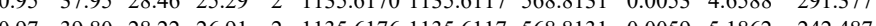
$\begin{array}{llllllllllll}0.97 & 39.80 & 28.22 & 25.91 & 2 & 1135.6176 & 135.617 & 568.8131 & 0.0059 & 5.1862 & 242.487 & 31\end{array}$

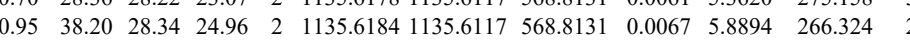
$\begin{array}{llllllllllll}0.96 & 38.20 & 28.34 & 23.97 & 2 & 135.6178 & 1135.6117 & 568.8131 & 0.0061 & 5.3620 & 275.158 & 309.41\end{array}$

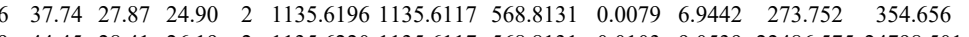

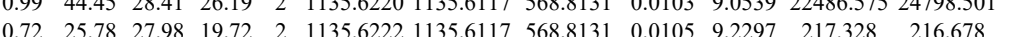
$\begin{array}{llllllllllllllll}0.99 & 44.06 & 28.14 & 26.86 & 2 & 1135.6228 & 1135.6117 & 568.8131 & 0.0111 & 9.7571 & 27314.753 & 27846.211 & 2804.833 & 1498.418 & \text { Yes }\end{array}$

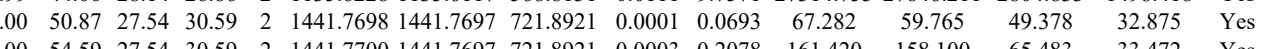

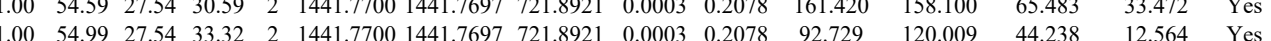
$\begin{array}{llllllllllllllll}0.76 & 17.52 & 27.50 & 24.25 & 3 & 1441.7704 & 1441.7697 & 481.5972 & 0.0007 & 0.4845 & 90.315 & 75.433 & 75.419 & 60.376 & \text { No }\end{array}$

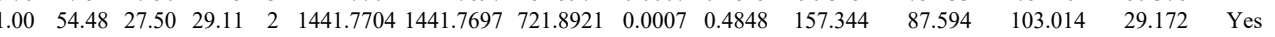

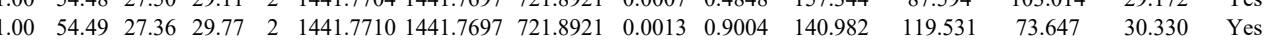

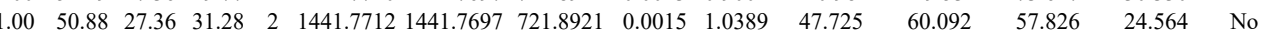

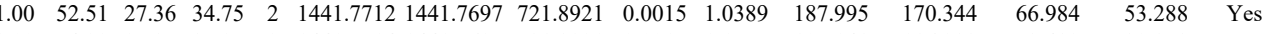

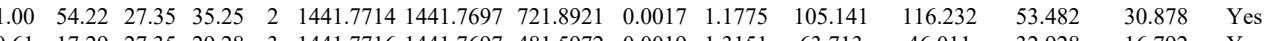

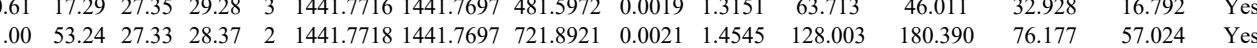
$\begin{array}{lllllllllllllll}1.00 & 58.37 & 27.33 & 31.69 & 2 & 1441.7718 & 1441.7697 & 721.8921 & 0.0021 & 1.4545 & 156.772 & 125.596 & 56.266 & 47.174 & \text { Yes }\end{array}$

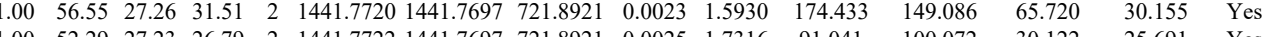

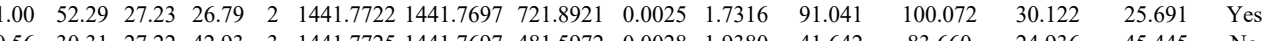

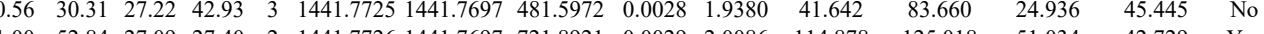

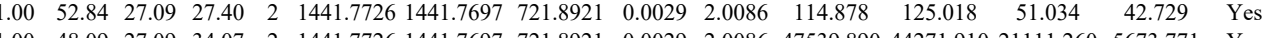
$\begin{array}{lllllllllllllll}1.00 & 48.09 & 27.09 & 34.07 & 2 & 1441.7726 & 1441.7697 & 721.8921 & 0.0029 & 2.0086 & 47539.890 & 44271.910 & 21111.260 & 5673.771 & \text { Yes }\end{array}$

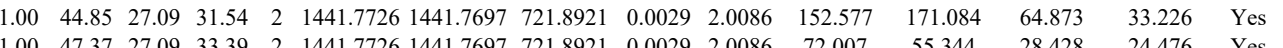

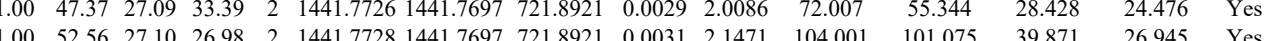

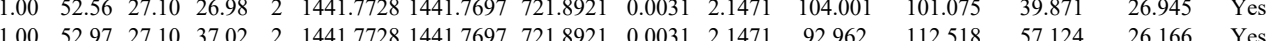

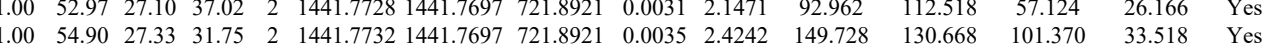

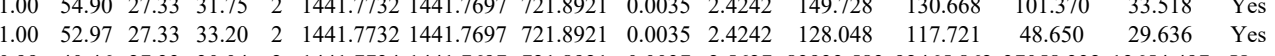

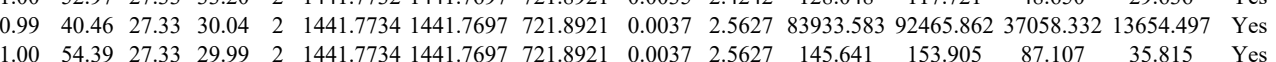

Table S-3 page 328 of 499 
IIEPSLR

IIEPSLR

CGHTNNLRPK

CGHTNNLRPK

CGHTNNLRPK

CGHTNNLRPK

CGHTNNLRPK

CGHTNNLRPK

CGHTNNLRPK

CGHN

GGHTNNLRPK

CGHTNNLRPK

CGHTNNLRPK

CGHTNNLRPK

CGHTNNLRPK

CGHTNNLRPK

CGHTNNLRPK

CGHTNNLRPK

CGHTNNLRPK

CGHTNNLRPK

CGHTNNLRPK

CGHTNNLRPK

CGHTNNLRPK

66 TITLEVEPSDTIENVK

TLSDYNIQK

TLSDYNIQK

TLSDYNIQK

TLSDYNIQK

TLSDYNIQK

TLSDYNIQK

TLSDYNIQK

LSDYNIQK

TITLEVEPSDTIENVK

ESTLHLVLR

ESTLHLVLR

TLSDYNIQK

ESTLHLVLR

ESTLHLVLR

SIFAGK

LIFAGK

MQIFVK

MQIFVK

MQIFVK

LIFAGK

LIFAGK

LIFAGK

MQIFVK

MQIFVK

MQIFVK

MQIFVK

MQIFVK

MQIFVK

LIFAGK

LIFAGK

MQIFVK

TITLEVEPSDTIENV

TITLEVEPSDTIENVK

LIFAGK

LIFAGK

IQDKEGIPPDQQR

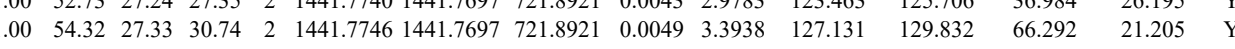
$\begin{array}{llllllllllllllll}0.59 & 23.10 & 23.64 & 33.11 & 2 & 970.6022 & 970.5933 & 486.3039 & 0.0089 & 9.1506 & 25459.037 & 27824.489 & 2013.359 & 1440.579 & \text { No }\end{array}$ $\begin{array}{lllllllllllllll}0.62 & 23.87 & 23.64 & 33.33 & 2 & 970.6026 & 970.5933 & 486.3039 & 0.0093 & 9.5618 & 35614.084 & 31895.971 & 3829.411 & 1062.875 & \text { Yes }\end{array}$ $\begin{array}{lllllllllllllll}1.00 & 59.92 & 27.54 & 22.01 & 2 & 1426.7732 & 1426.7707 & 714.3926 & 0.0025 & 1.7497 & 81.860 & 54.947 & 8.749 & 10.691 & \text { Yes }\end{array}$

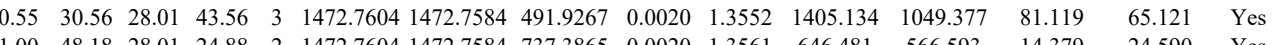

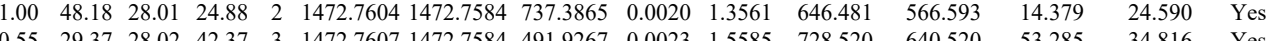

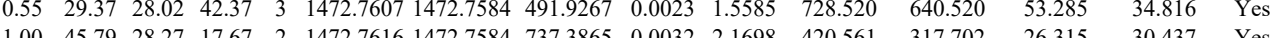

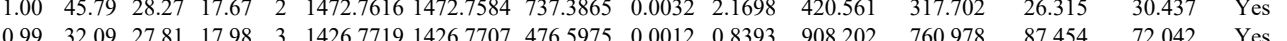

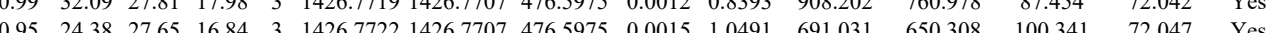

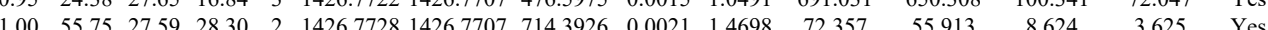

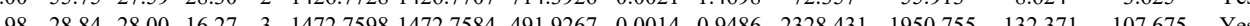
$\begin{array}{lllllllllllllll}1.00 & 46.99 & 28.01 & 25.48 & 2 & 1472.7604 & 1472.7584 & 737.3865 & 0.0020 & 1.3561 & 1060.958 & 797.723 & 20.216 & 48.276 & \text { Yes }\end{array}$ $\begin{array}{lllllllllllllll}100 & 34.41 & 28.02 & 16.40 & 3 & 14727607 & 14727584 & 491.9267 & 0.0023 & 1.5585 & 1062.911 & 824342 & 69.531 & 82.073 & \text { Yes }\end{array}$

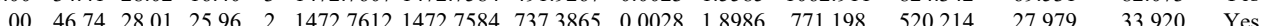

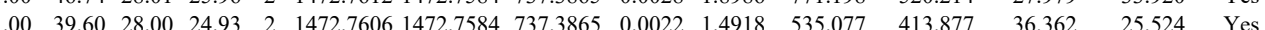

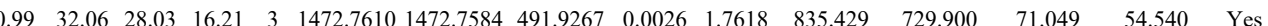
$\begin{array}{lllllllllllllll}0.99 & 42.75 & 28.21 & 19.59 & 2 & 1472.7622 & 1472.7584 & 737.3865 & 0.0038 & 25767 & 330.767 & 257.319 & 28.266 & 18.361 & \text { Yes }\end{array}$ $\begin{array}{lllllllllllllll}0.79 & 23.46 & 27.69 & 21.86 & 3 & 1472.7574 & 1472.7584 & 491.9267 & -0.0010 & -0.6776 & 144.482 & 123.867 & 33.096 & 15.848 & \text { Yes }\end{array}$ $\begin{array}{lllllllllllllll}0.71 & 16.91 & 27.84 & 15.24 & 3 & 1472.7595 & 1472.7584 & 491.9267 & 0.0011 & 0.7454 & 378.369 & 334.309 & 55.596 & 40.429 & \text { Yes }\end{array}$ $\begin{array}{lllllllllllllll}0.97 & 25.53 & 28.02 & 23.95 & 3 & 1472.7607 & 1472.7584 & 491.9267 & 0.0023 & 1.5585 & 254.567 & 195.403 & 68.469 & 29.553 & \text { No }\end{array}$ $\begin{array}{lllllllllllllllll}0.53 & 18.45 & 28.03 & 31.45 & 3 & 1472.7610 & 1472.7584 & 491.9267 & 0.0026 & 1.7618 & 358.396 & 263.842 & 65.606 & 20.292 & \text { Yes }\end{array}$ $\begin{array}{lllllllllllllll}0.94 & 24.25 & 28.25 & 16.14 & 3 & 1472.7637 & 1472.7584 & 491.9267 & 0.0053 & 3.5913 & 291.614 & 268.077 & 49.016 & 27.725 & \text { Yes }\end{array}$ $\begin{array}{lllllllllllllll}0.82 & 18.99 & 28.18 & 22.38 & 3 & 1472.7628 & 1472.7584 & 491.9267 & 0.0044 & 2.9815 & 301.489 & 266.538 & 80.980 & 47.194 & \mathrm{~N} 0\end{array}$

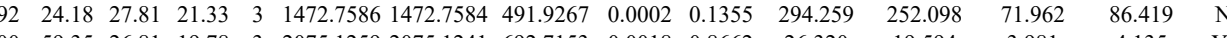

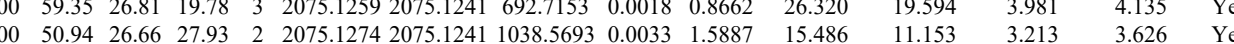

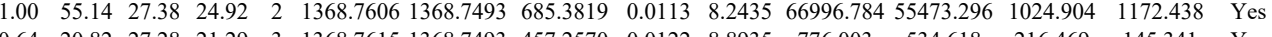
$\begin{array}{llllllllllllllll}0.64 & 20.82 & 27.28 & 21.29 & 3 & 1368.7615 & 1368.7493 & 457.2570 & 0.0122 & 8.8935 & 776.003 & 534.618 & 216.469 & 145.341 & \text { Yes }\end{array}$ \begin{tabular}{lllllllllllllll}
0.74 & 22.69 & 27.30 & 24.78 & 3 & 1368.7618 & 1368.7493 & 457.2570 & 0.0125 & 9.1122 & 866.629 & 656.977 & 258.372 & 148.829 & Yes \\
\hline
\end{tabular} $\begin{array}{llllllllllllllll}1.00 & 55.75 & 26.78 & 24.99 & 2 & 1368.7620 & 1368.7493 & 685.3819 & 0.0127 & 9.2648 & 34414.773 & 68800.346 & 998.755 & 603.190 & \text { Yes }\end{array}$ $\begin{array}{lllllllllllllllll}1.00 & 55.53 & 27.38 & 26.14 & 2 & 1368.7606 & 1368.7493 & 685.3819 & 0.0113 & 8.2435 & 19209.773 & 15812.038 & 1198.715 & 767.898 & \text { Yes } \\ 1.00 & 55.71 & 27.2 & 24.97 & 2 & 1368.714 & 1368.7493 & 685.3819 & 0.0121 & 8.8271 & 31827.942 & 28788.954 & 1026.198 & 437.282 & \text { Yes }\end{array}$ $\begin{array}{llllllllllllllll}1.00 & 55.71 & 27.28 & 24.97 & 2 & 1368.7614 & 1368.7493 & 685.3819 & 0.0121 & 8.8271 & 31827.942 & 28788.954 & 1026.198 & 437.282 & \text { Yes } \\ 1.00 & 53.47 & 27.23 & 23.74 & 2 & 1368.7596 & 1368.7493 & 685.3819 & 0.0103 & 7.5140 & 18162.602 & 16751.411 & 1358.366 & 530.480 & \text { Yes }\end{array}$

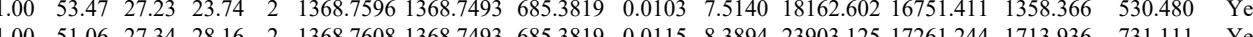
$\begin{array}{lllllllllllllll}1.00 & 51.06 & 27.34 & 28.16 & 2 & 1368.7608 & 1368.7493 & 685.3819 & 0.0115 & 8.3894 & 23903.125 & 17261.244 & 1713.936 & 731.111 & \text { Yes } \\ 1.00 & 65.78 & 26.71 & 25.32 & 3 & 2075.1262 & 2075.1241 & 692.7153 & 0.0021 & 1.0105 & 40.117 & 34.676 & 7.926 & 1.891 & \text { Yes }\end{array}$

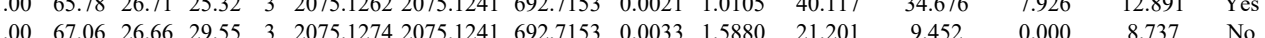

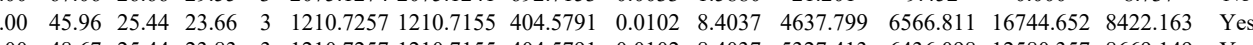
$\begin{array}{lllllllllllllll}1 & \end{array}$ $\begin{array}{lllllllllllllll}100 & 42.70 & 25.13 & 21.94 & 3 & 1210.7230 & 12107155 & 4045791 & 0.0075 & 6.1792 & 6357.239 & 6294.534 & 14532.611 & 8934.127 & \text { Yes }\end{array}$ $\begin{array}{llllllllllllllll}1.00 & 45.04 & 25.44 & 23.74 & 3 & 1210.7236 & 1210.7155 & 4045791 & 0.0081 & 6.6736 & 4931.159 & 6223.571 & 12168289 & 8296.855 & \text { Yes }\end{array}$ $\begin{array}{llllllllllllllll}1.00 & 51.79 & 25.44 & 27.67 & 2 & 1210.7244 & 1210.7155 & 6063650 & 0.0089 & 7.3388 & 2767.026 & 2784.654 & 4775.918 & 3425.422 & \text { Yes }\end{array}$ $\begin{array}{llllllllllllllll}0.89 & 32.15 & 25.09 & 33.95 & 2 & 935.6130 & 935.6048 & 468.8097 & 0.0082 & 8.3455 & \text { \#\#\#\#\#\# \#\#\#\#\#\# } 4703.321 & 3961.425 & \text { Yes }\end{array}$

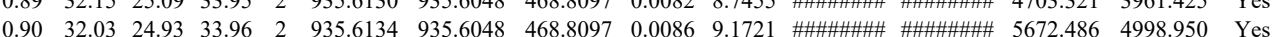

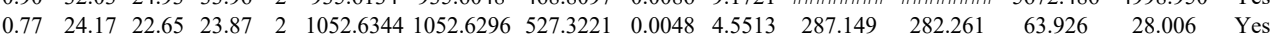

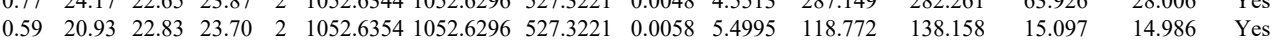
$\begin{array}{lllllllllllllll}0.96 & 36.88 & 24.41 & 35.89 & 2 & 1052.6394 & 1052.6296 & 527.3221 & 0.0098 & 9.2921 & 32964.631 & 31002.189 & 988.758 & 509.370 & \text { Yes }\end{array}$ $\begin{array}{lllllllllllllll}0.90 & 30.87 & 25.09 & 31.46 & 2 & 935.6118 & 935.6048 & 468.8097 & 0.0070 & 7.4657 & \text { \#\#\#\#\# \#\#\#\#\# } 12151.097 & 2953.138 & \text { Yes }\end{array}$ $\begin{array}{llllllllllllll}0.91 & 31.44 & 25.09 & 32.18 & 2 & 935.6126 & 935.6048 & 468.8097 & 0.0078 & 8.3189 & \text { \#\#\#\#\#\# \#\#\#\#\# } 4437.708 & 2185.012 & \text { Yes }\end{array}$ $\begin{array}{llllllllllllllll}0.86 & 29.77 & 24.93 & 33.50 & 2 & 935.6134 & 935.6048 & 468.8097 & 0.0086 & 9.1721 & 44086.281 & 40068.910 & 920.029 & 1170.447 & \text { Yes }\end{array}$

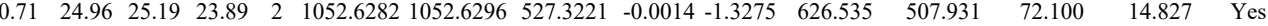

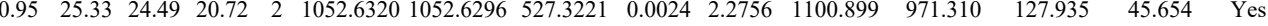
$\begin{array}{llllllllllllllll}0.95 & 25.50 & 22.92 & 23.29 & 2 & 1052.6328 & 1052.6296 & 527.3221 & 0.0032 & 3.0342 & 1125.451 & 906.999 & 125.220 & 36.173 & \text { Yes }\end{array}$ $\begin{array}{llllllllllllllll}0.73 & 23.69 & 22.83 & 25.33 & 2 & 1052.6354 & 1052.6296 & 527.3221 & 0.0058 & 5.4995 & 1091.905 & 1011.855 & 110.961 & 38.536 & \text { Yes }\end{array}$

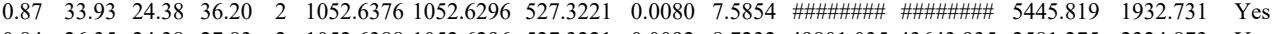
$\begin{array}{llllllllllllllll}0.84 & 26.35 & 24.38 & 27.83 & 2 & 1052.6388 & 1052.6296 & 527.3221 & 0.0092 & 8.7232 & 49801.035 & 43643.935 & 2581.275 & 2324.873 & \text { Yes }\end{array}$

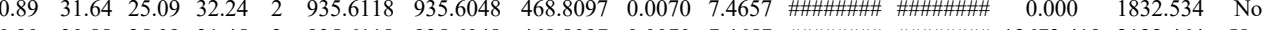
$\begin{array}{llllllllllllllll}0.90 & 30.88 & 25.09 & 31.45 & 2 & 935.6118 & 935.6048 & 468.8097 & 0.0070 & 7.4657 & \text { \#\#\#\#\#\# \#\#\#\#\# } 12673.419 & 2122.464 & \text { Yes }\end{array}$ $\begin{array}{lllllllllllllll}0.52 & 21.25 & 25.19 & 25.42 & 2 & 1068.6322 & 1068.6245 & 535.3195 & 0.0077 & 7.1919 & 2824.625 & 2773.984 & 262.277 & 162.073 & \text { Yes }\end{array}$ \begin{tabular}{lllllllllllllll}
.70 & 23.69 & 25.12 & 27.18 & 2 & 1068.6334 & 1068.6245 & 535.3195 & 0.0089 & 8.3127 & 3694.091 & 3344.410 & 460.446 & 207.217 & Yes \\
\hline
\end{tabular}

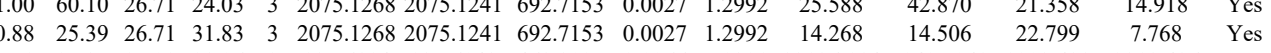

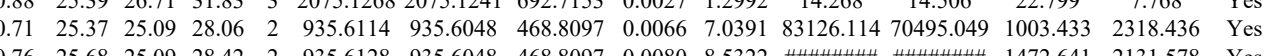

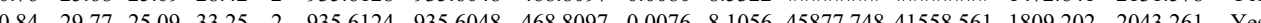
$\begin{array}{llllllllllllll}0.84 & 29.77 & 25.09 & 33.25 & 2 & 935.6124 & 935.6048 & 468.8097 & 0.0076 & 8.1056 & 45877.748 & 41558.561 & 1809.202 & 2043.261\end{array}$

Table S-3 page 329 of 499 

ULTGKTITLEVEPSDTIENVK $\begin{array}{llllllllllllll} & 0.96 & 38.40 & 26.79 & 16.88 & 3 & 2287.2175 & 2287.215 & 76.43 .4126 & 0.0016 & 0.6986 & 20.178\end{array}$ $\begin{array}{llllllllll} & 0.006\end{array}$

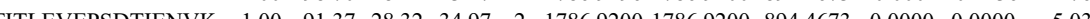

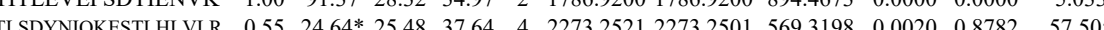

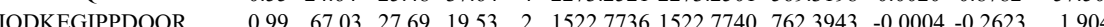
$\begin{array}{llllllllllllll}\text { IQDKEGIPDDQQR } & 0.99 & 65.08 & 27.76 & 19.61 & 2 & 1522.7740 & 1522.7740 & 762.3943 & 0.0000 & 0.0000 & 1.904\end{array}$ $\begin{array}{llllllllllll} & 0.004\end{array}$ $\begin{array}{llllllllllll}\text { TITLEVEPSDTIENVK } & 1.00 & 82.74 & 28.27 & 34.62 & 2 & 1786.9198 & 1786.9200 & 894.4673 & -0.0002 & -0.1118 & 7.591\end{array}$ $\begin{array}{lllllllllllllll}\text { IQDKEGIPPDQQR } & 0.88 & 52.31 & 27.82 & 21.61 & 2 & 1522.7744 & 1522.7740 & 762.3943 & 0.0004 & 0.2623 & 0.000\end{array}$ $\begin{array}{lllllllllllll}\text { IQDKEGIPPDQQR } & 0.88 & 52.31 & 27.82 & 21.61 & 2 & 1522.7744 & 1522.7740 & 762.3943 & 0.0004 & 0.2623 & 0.000\end{array}$ $\begin{array}{lllllllllllll}\text { IQDKEGIPPDQQR } & 0.65 & 45.43 & 27.76 & 18.92 & 2 & 1522.7740 & 1522.7740 & 762.3943 & 0.0000 & 0.0000 & 0.000\end{array}$ $\begin{array}{lllllllllllll}\text { IQDKEGIPPDQQR } & 0.99 & 64.09 & 27.82 & 20.23 & 2 & 1522.7744 & 1522.7740 & 762.3943 & 0.0004 & 0.2623 & 2.880\end{array}$

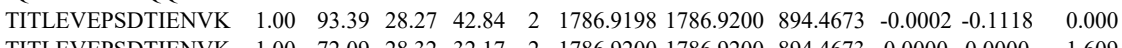
$\begin{array}{llllllllllll}\text { TITLEVEPSDTIENVK } & 1.00 & 72.09 & 28.32 & 32.17 & 2 & 1786.9200 & 1786.9200 & 894.4673 & 0.0000 & 0.0000 & 1.609\end{array}$

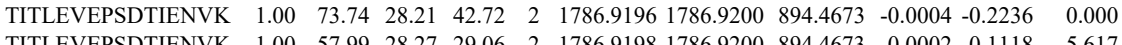

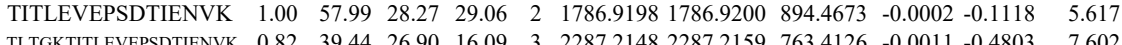
$\begin{array}{llllllllllll}\text { TLTGKTITLEVEPSDTIENVK } & 0.82 & 39.44 & 26.90 & 16.09 & 3 & 2287.2148 & 2287.2159 & 763.4126 & -0.0011 & -0.4803 & 7.602\end{array}$ \begin{tabular}{llllllllllll} 
TLTGKTITLEVEPSDTIENVK & 1.00 & 83.05 & 26.86 & 22.71 & 2 & 2287.2154 & 2287.2159 & 1144.6152 & -0.0005 & -0.2184 & 0.000 \\
\hline
\end{tabular} $\begin{array}{lrrrrrrrrrrr}\text { TLTGKTITLEVEPSDTIENVK } & 0.81 & 35.59 & 26.86 & 20.87 & 3 & 2287.2157 & 2287.2159 & 763.4126 & -0.0002 & -0.0873 & 29.123 \\ \text { IQDKEGIPPDQQR } & 0.90 & 58.14 & 27.67 & 16.69 & 2 & 1522.7734 & 1522.7740 & 762.3943 & -0.0006 & -0.3935 & 0.000\end{array}$ $\begin{array}{llllllllllll}\text { IQDKEGIPPDQQR } & 0.90 & 58.14 & 27.67 & 16.69 & 2 & 1522.7734 & 1522.7740 & 762.3943 & -0.0006 & -0.3935 & 0.000 \\ \text { IQDKEGIPPDQQR } & 0.90 & 52.92 & 27.70 & 16.83 & 2 & 1522.7738 & 1522.7740 & 762.3943 & -0.0002 & -0.1312 & 0.000\end{array}$ $\begin{array}{llllllllllll}\text { IQDKEGIPPDQQR } & 0.90 & 52.92 & 27.70 & 16.83 & 2 & 1522.7738 & 1522.7740 & 762.3943 & -0.0002 & -0.1312 & 0.000 \\ \text { TITLEVEPSDTIENVK } & 1.00 & 78.48 & 28.30 & 32.03 & 2 & 1786.9202 & 1786.9200 & 894.4673 & 0.0002 & 0.1118 & 4.701\end{array}$ $\begin{array}{llllllllllll}\text { TITLEVEPSDTIENVK } & 1.00 & 78.48 & 28.30 & 32.03 & 2 & 1786.9202 & 1786.9200 & 894.4673 & 0.0002 & 0.1118 & 4.701 \\ \text { TITLEVEPSDTIENVK } & 1.00 & 77.82 & 28.29 & 32.07 & 2 & 1786.9204 & 1786.9200 & 894.4673 & 0.0004 & 0.2236 & 8.803\end{array}$ $\begin{array}{llllllllllll}\text { TITLEVEPSDTIENVK } & 1.00 & 77.82 & 28.29 & 32.07 & 2 & 1786.9204 & 1786.9200 & 894.4673 & 0.0004 & 0.2236 & 8.803 \\ \text { TLSDYNIQKESTLHLVLR } & 0.62 & 56.67 * & 25.55 & 16.84 & 3 & 2273.2516 & 2273.2501 & 758.7573 & 0.0015 & 0.6590 & 20.273\end{array}$

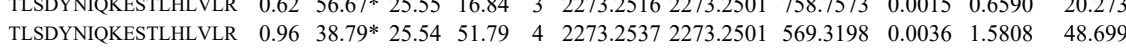
$\begin{array}{llllllllllll}\text { TLSDYNIQKESTLHLVLR } & 0.88 & 33.55 * & 25.54 & 46.55 & 4 & 2273.2537 & 2273.2501 & 569.3198 & 0.0036 & 1.5808 & 45.042\end{array}$ $\begin{array}{lllllllllllll}\text { TITLEVEPSDTIENVK } & 1.00 & \text { \#\#\#\#\# } 28.32 & 41.94 & 2 & 1786.9200 & 1786.9200 & 894.4673 & 0.0000 & 0.0000 & 0.000\end{array}$

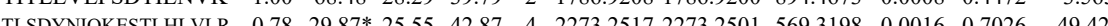
$\begin{array}{lllllllllllll}\text { TLSDYNQKESTLHLVLR } & 0.78 & 29.87 * & 25.55 & 42.87 & 4 & 2273.2517 & 2273.2501 & 569.3198 & 0.0016 & 0.7026 & 49.427 \\ \text { TLSDYNIQKESTLLVLR } & 0.74 & 28.41 * & 25.49 & 41.41 & 4 & 2273.2529 & 2273.2501 & 569.3198 & 0.0028 & 1.2295 & 47.591\end{array}$ 

$\begin{array}{llllllllllllllll}\text { TITLEVEPSDTIENVK } & 1.00 & 49.21 & 26.75 & 33.93 & 2 & 2075.1314 & 2075.1241 & 1038.5693 & 0.0073 & 3.5144 & 16.572 & 19.644 & 8.985 & 3.065 & \text { Yes }\end{array}$

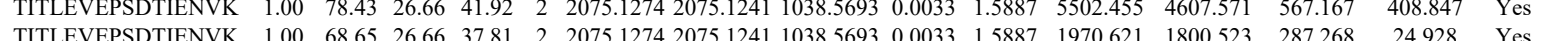

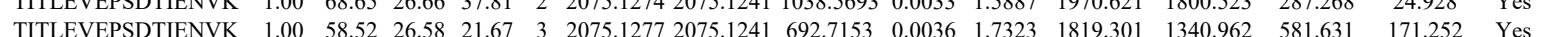

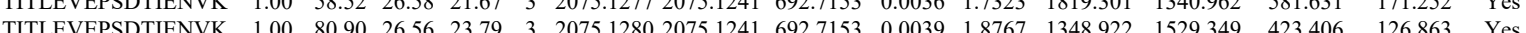

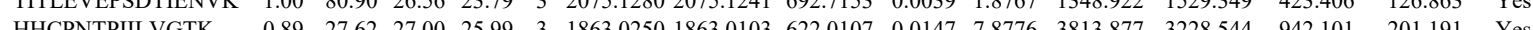
$\begin{array}{llllllllllllllll}\text { LTPITYPQGLAMAK } & 1.00 & 63.12 & 25.00 & 24.11 & 2 & 1791.0218 & 1791.0208 & 8965.5177 & 0.0010 & 0.5577 & 5758286 & 5840.420 & 1356.841 & 82.001 & \text { Yes }\end{array}$ $\begin{array}{lllllllllllllllll}\text { LTPTYPQGAMAK } & 1.00 & 63.75 & 25.05 & 23.37 & 2 & 1791.0220 & 1791.0208 & 896.5177 & 0.0012 & 0.6693 & 6590.413 & 7206.612 & 1291.624 & 129.594 & \text { Yes }\end{array}$

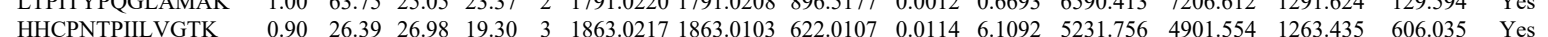
$\begin{array}{lllllllllllllllll}\text { HHCPNTPILVGTK } & 0.90 & 26.39 & 26.98 & 19.30 & 3 & 1863.0217 & 1863.0103 & 622.0107 & 0.0114 & 6.1092 & 5231.756 & 4901.554 & 1263.435 & 606.035 & \text { Yes } \\ \text { HHCPNTPILVGTK } & 0.60 & 20.06 & 27.04 & 18.15 & 3 & 1863.0235 & 1863.0103 & 62.0107 & 0.0132 & 7.0738 & 3789.839 & 3278.586 & 936.506 & 343.430 & \text { Yes }\end{array}$

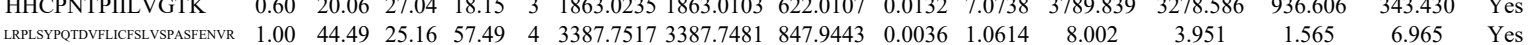

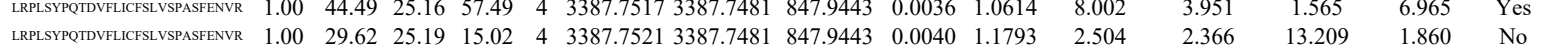

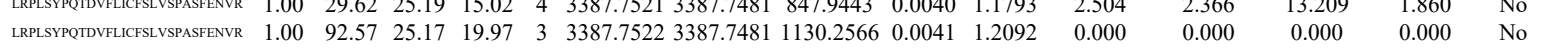

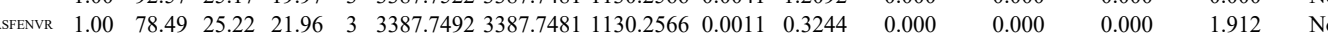
$\begin{array}{llllllllllllllll}\text { LRRLSYPQTDVFLCFSLVSPASENVRR } & 1.00 & 19.24 & 25.13 & 32.24 & 4 & 3387.7505 & 3387.7481 & 847.9443 & 0.0024 & 0.7076 & 0.000 & 10.282 & 9.601 & 1.049 & \text { No }\end{array}$ $\begin{array}{llllllllllllllll}\text { LRPLSYPTDVFLLCFLVSPASFNVR } & 1.00 & 44.04 & 24.98 & 17.28 & 4 & 3387.7553 & 3387.7481 & 847.9443 & 0.0072 & 2.1228 & 0.000 & 4.871 & 8.852 & 1.048 & \text { No }\end{array}$ $\begin{array}{llllllllllllllll}\text { KPSETTELLVQQVLLLATQDSDNPDLR } & 1.00 & \text { \#\#\#\# } 25.75 & 20.67 & 3 & 3198.6622 & 3198.6612 & 1067.2277 & 0.0010 & 0.3123 & 39.468 & 67.928 & 26.459 & 14.945 & \text { YeS }\end{array}$ $\begin{array}{llllllllllllllll}\text { RPSETRELVQVUSLATEDSDNPDLR } & 1.00 & 28.01 & 25.75 & 41.01 & 4 & 3198.6641 & 3198.6612 & 800.6726 & 0.0029 & 0.9055 & 46.597 & 28.022 & 43.699 & 98.439 & \text { No }\end{array}$ $\begin{array}{llllllllllllllll} & \end{array}$ $\begin{array}{lllllllllllllllll}\text { APEVSQYTYQVYDSILK } & 0.53 & 16.37 & 26.24 & 29.37 & 3 & 2303.2324 & 2303.2293 & 768.7504 & 0.0031 & 1.3442 & 214.573 & 338.356 & 43.044 & 43.255 & \text { Yes }\end{array}$ $\begin{array}{lllllllllllllllllll}\text { APEVSQYIYQVYDSILK } & 1.00 & 76.76 & 26.14 & 17.86 & 2 & 2303.2354 & 2303.2293 & 1152.6219 & 0.0061 & 2.6461 & 27.133 & 34.704 & 46.640 & 36.922 & \text { Yes }\end{array}$

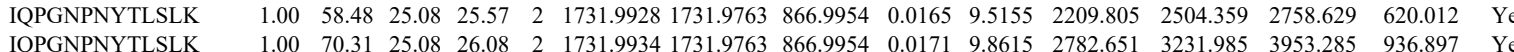
\begin{tabular}{lllllllllllllllll}
\hline QPGNPNYTLSLK & 1.00 & 70.31 & 25.08 & 26.08 & 2 & 1731.9934 & 1731.9763 & 866.9954 & 0.0171 & 9.8615 & 2782.651 & 3231.985 & 3953.285 & 936.897 & Yes
\end{tabular} $\begin{array}{llllllllllllllll}\text { LAPPLVTLLSGEPEVQYVALR } & 1.00 & 94.45 & 21.07 & 19.86 & 2 & 2408.3814 & 2408.3801 & 1205.1973 & 0.0013 & 0.5393 & 127.241 & 82.834 & 82.428 & 10.044 & \text { Yes }\end{array}$ $\begin{array}{llllllllllllllll} & 21.030 & 3 & 2408.3821 & 2408.3801 & 803.8006 & 0.0020 & 0.8294 & 10.201 & 25.036 & 19.698 & 9.444 & \text { Yes }\end{array}$

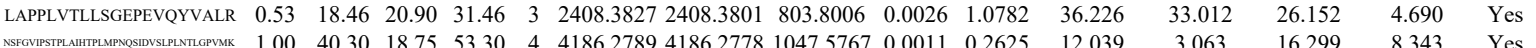
$\begin{array}{lllllllllllllll} & \end{array}$

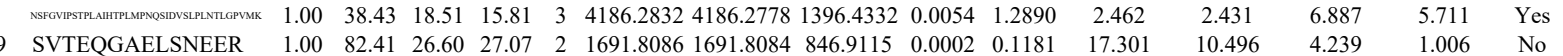

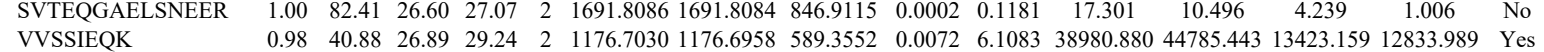

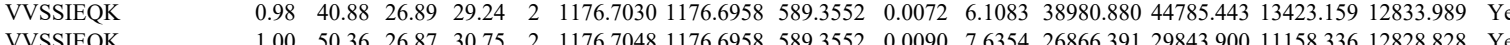

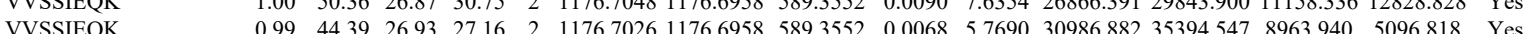

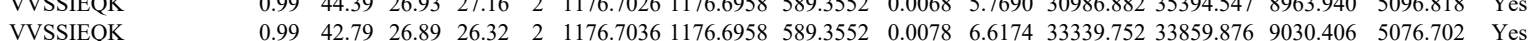

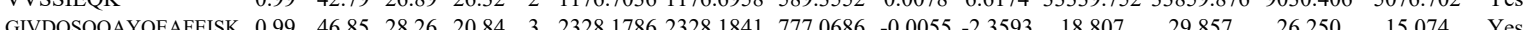

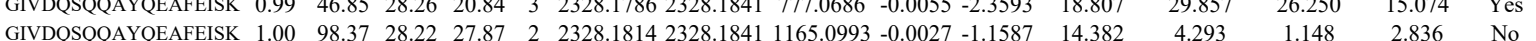

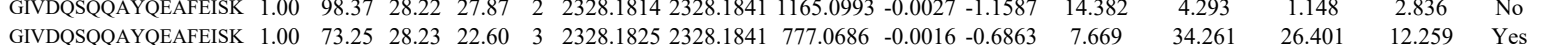

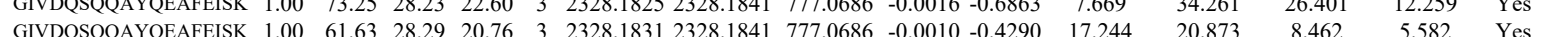

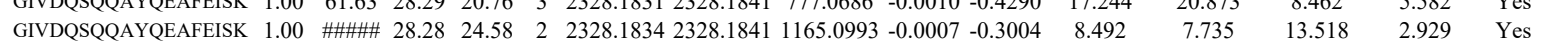

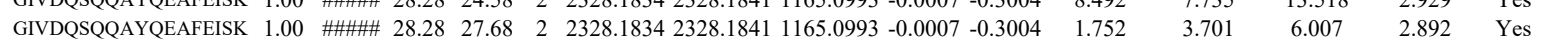

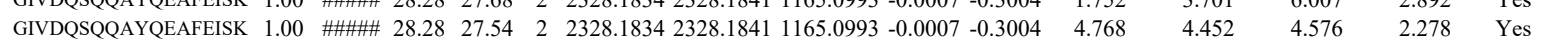

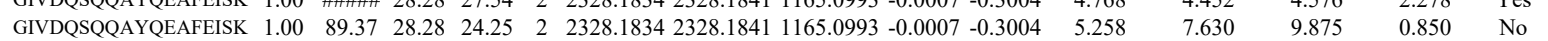
\begin{tabular}{llllllllllllllll} 
GIVDQSQQAYQEAFEISK & 1.00 & 85.61 & 28.28 & 26.10 & 2 & 2328.1834 & 2328.1841 & 1165.0993 & -0.0007 & -0.3004 & 6.260 & 7.762 & 3.392 & 1.620 & Yes \\
\hline
\end{tabular}

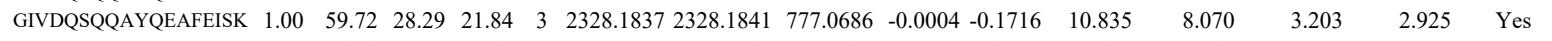
$\begin{array}{llllllllllllllll}\text { GIVDQSQQAYQEAFEISK } & 1.00 & 56.04 & 28.29 & 25.41 & 3 & 2328.1852 & 2328.1841 & 777.0686 & 0.0011 & 0.4719 & 7.131 & 20.631 & 8.220 & 9.055 & \text { Yes }\end{array}$

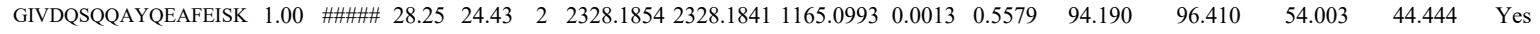

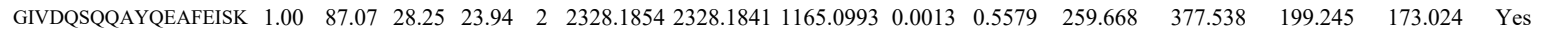

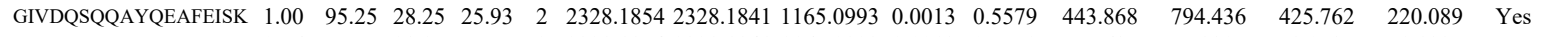

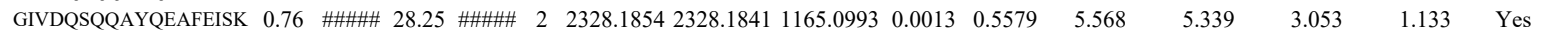

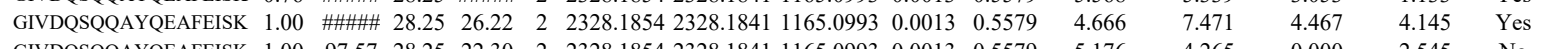

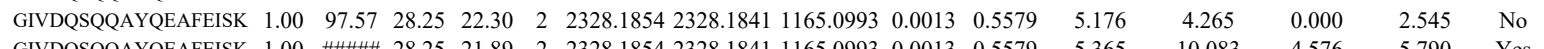

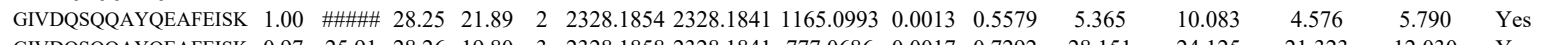

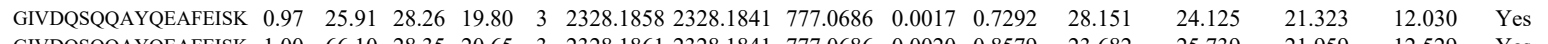

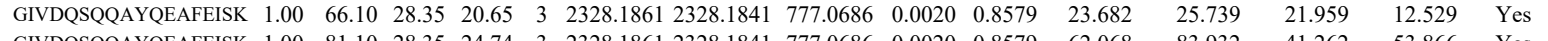

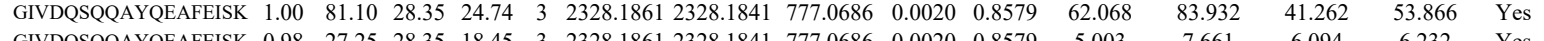

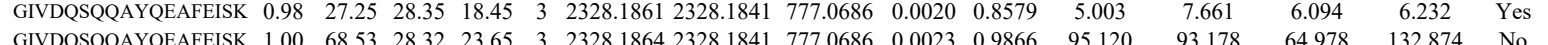

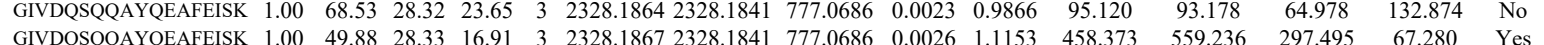

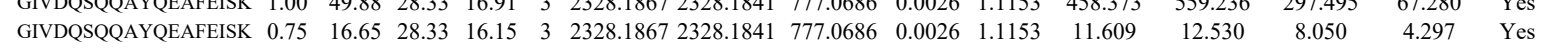
$\begin{array}{llllllllllllllll}\text { GIVDQSQQAYQEAFEISK } & 1.00 & 63.11 & 28.29 & 19.83 & 3 & 2328.1873 & 2328.1841 & 777.0686 & 0.0032 & 1.3727 & 68.359 & 68.506 & 102.928 & 83.999 & \text { Yes }\end{array}$

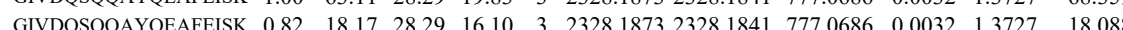



$\begin{array}{llllllllllll}\text { GIVDQSQAAYEAFEISK } & 1.00 & 59.41 & 28.23 & 18.05 & 3 & 2328.1879 & 2328.1841 & 777.0686 & 0.0038 & 1.6301 & 40.061\end{array}$ $\begin{array}{llllllllllll}\text { GIVDQSQQAYQEAFEISK } & 1.00 & 58.32 & 28.33 & 20.17 & 3 & 2328.1894 & 2328.1841 & 777.0686 & 0.0053 & 2.2735 & 56.678\end{array}$

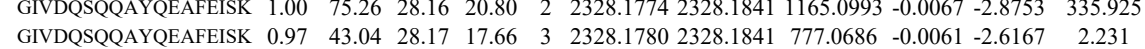

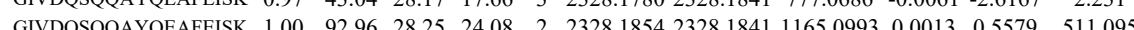
$\begin{array}{lllllllllllllll} & \text { GIVDQSQQAYQEAFESK } & 0.55 & 39.95 & 28.26 & 52.95 & 3 & 2328.1858 & 2328.1841 & 777.0686 & 0.0017 & 0.7292 & 22.742\end{array}$ $\begin{array}{llllllllllll}\text { GIVDQSQAYQEAFEISK } & 0.98 & 26.56 & 28.33 & 17.12 & 3 & 2328.1867 & 2382.1841 & 777.0686 & 0.0026 & 1.7153 & 22.742\end{array}$

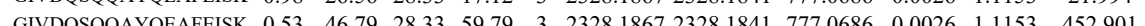

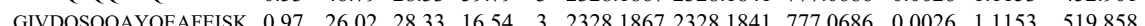

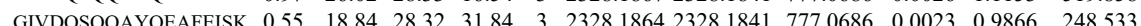
$\begin{array}{llllllllllll}\text { DICNDVLSLLEK } & 100 & 68.05 & 28.22 & 22.75 & 2 & 1694.8850 & 1694.8826 & 848.4486 & 0.0024 & 1.4143 & 84.407\end{array}$ DICNDVLSLLEK DICNDVLSLLEK $\begin{array}{llllllllllll}\text { DICNDVLSLLEK } & 1.00 & 61.17 & 28.14 & 21.19 & 2 & 1694.8862 & 1694.8826 & 848.4486 & 0.0036 & 2.1215 & 77.137\end{array}$ $\begin{array}{lllllllllllll}\text { SVTEQGAELSNEER } & 1.00 & 80.16 & 26.60 & 23.17 & 2 & 1691.8088 & 1691.8084 & 846.9115 & 0.0004 & 0.2362 & 21.293\end{array}$ SVTEQGAELSNEER DNLTLWTSDTQGDEAEAGEGG
DICNDVLSLLEK $\begin{array}{llllllllllll}1.00 & 72.90 & 26.51 & 24.45 & 2 & 1691.8094 & 1691.8084 & 846.9115 & 0.0010 & 0.5904 & 3.831 \\ 1.00 & 32.86 & 26.57 & 2.16 & 3 & 1690\end{array}$ DICNDVLSLLEK DICNDVLSLLEK DICNDVLSLLEK

DICNDVLSLLEK

DICNDVLSLLEK

DICNDVLSLLEK

SVTEQGAELSNEER

SVTEQGAELSNEER
SVTEQGAELSNEER SVTEQGAELSNEER
SVTEQGAELSNEER SVTEQGAELSNEER SVTEQGAELSNEER YLAEVAEDDDK YLAEVAAGDDKK

YLAEVAAGDDKK

YLAEVAAGDDKK

YLAEVAAGDDKK

YLAEVAAGDDKK

YLAEVAAGDDKK

YLAEVAAGDDKK

YLAEVAAGDDKK

YLAEVAAGDDKK

YLAEVAAGDDKK

TAFDEAIAELDTLSEESYK TAFDEAIAELDTLSEESY NELVQK

YLAEVAAGDDKK

YLAEVAAGDDKK

NELVQK

YLAEVAAGDDKK

YLAEVAAGDDKK

$\begin{array}{llllllllllllll}\text { RL38_HUMAN } & \text { P63173 } & \text { RPL38 } & \text { 60S ribosomal pro } & 8.22 & 1.00 & 2 & 31.4 & -0.3628 & 0.1630 & -1.2858 & 0.1383 & 7 & \text { QSLPPGLAVK }\end{array}$ QSLPPGLAVK QSLPPGLAVK QSLPPGLAVK IEEIKDFLLTAR IEEIKDFLLTAR IEEIKDFLLTAR

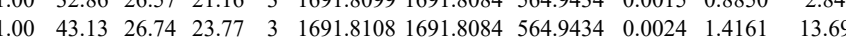
$\begin{array}{lllllllllllll}0.53 & 23.88 & 21.85 & 36.88 & 3 & 2552.0944 & 2552.0909 & 851.7042 & 0.0035 & 1.3698 & 10.346\end{array}$

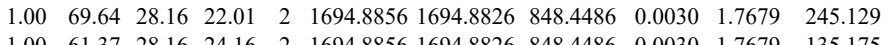
$\begin{array}{llllllllllll}1.00 & 1.37 & 28.16 & 24.16 & 2 & 1694.8856 & 1694.8826 & 848.4486 & 0.0030 & 1.7679 & 135.175 \\ 0.77 & 18.41 & 28.14 & 27.57 & 3 & 1694.8858 & 16948826 & 565.9681 & 0.0032 & 1.8847 & 50.086\end{array}$ $\begin{array}{llllllllllll}0.77 & 18.41 & 28.14 & 27.57 & 3 & 1694.8858 & 1694.8826 & 565.9681 & 0.0032 & 1.8847 & 50.086\end{array}$ $\begin{array}{lllllllllll}0.94 & 24.29 & 28.23 & 28.93 & 3 & 1694.8849 & 1694.8826 & 565.9681 & 0.0023 & 1.3546 & 38.016\end{array}$

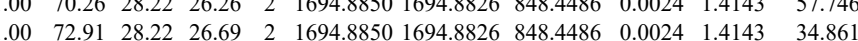
$\begin{array}{lllllllllll}0.98 & 31.54 & 28.14 & 30.16 & 3 & 1694.8858 & 1694.8826 & 565.9681 & 0.0032 & 1.8847 & 44.710\end{array}$ $\begin{array}{lllllllllll}1.00 & 89.12 & 26.82 & 29.70 & 2 & 1691.8110 & 1691.8084 & 846.9115 & 0.0026 & 1.5350 & 34.304\end{array}$

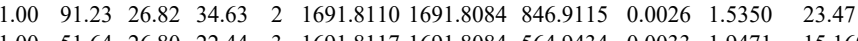
$\begin{array}{lllllllllll}1.00 & 40.60 & 26.90 & 30.75 & 3 & 1691.8120 & 1691.8084 & 564.9434 & 0.0036 & 2.1241 & 12.634\end{array}$ $\begin{array}{lllllllllll}1.00 & 40.60 & 26.90 & 30.75 & 3 & 1691.8120 & 1691.8084 & 564.9434 & 0.0036 & 2.1241 & 12.634 \\ 0.53 & 20.65 & 21.76 & 33.65 & 3 & 2552.0935 & 2552.0909 & 851.7042 & 0.0026 & 1.0176 & 24.802\end{array}$ $\begin{array}{llllllllllll}1.00 & 85.17 & 26.99 & 24.65 & 2 & 1691.8152 & 1691.8084 & 846.9115 & 0.0068 & 4.0146 & 253.750\end{array}$

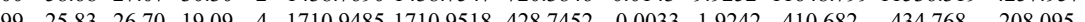
$\begin{array}{lllllllllllll}1.00 & 74.60 & 26.65 & 23.41 & 2 & 1710.9498 & 1710.9518 & 856.4832 & -0.0020 & -1.1676 & 6320.026 & 8804.764 & 3242.104\end{array}$ $\begin{array}{llllllllllllll}0.83 & 17.95 & 26.49 & 17.05 & 3 & 1710.9532 & 1710.9518 & 571.3245 & 0.0014 & 0.8168 & 22.817 & 4\end{array}$ $\begin{array}{llllllllllllll}0.55 & 24.89 & 26.35 & 37.89 & 3 & 1710.9535 & 1710.9518 & 571.3245 & 0.0017 & 0.9918 & 268.471\end{array}$ $\begin{array}{lllllllllllll}1.00 & 34.04 & 26.32 & 18.72 & 3 & 1710.9544 & 1710.9518 & 571.3245 & 0.0026 & 1.5169 & 270.094 & 3\end{array}$ $\begin{array}{lllllllllllll}1.00 & 32.09 & 26.32 & 20.66 & 3 & 1710.9544 & 1710.9518 & 571.3245 & 0.0026 & 1.5169 & 274.227\end{array}$ $\begin{array}{llllllllllll}1.00 & 35.90 & 26.23 & 17.88 & 3 & 1710.9550 & 1710.9518 & 571.3245 & 0.0032 & 1.8670 & 223.673\end{array}$ $\begin{array}{lllllllllllll}0.99 & 29.23 & 25.92 & 18.46 & 3 & 1710.9571 & 1710.9518 & 571.3245 & 0.0053 & 3.0922 & 187.560\end{array}$ $\begin{array}{llllllllll} & \end{array}$

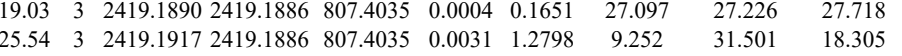
$\begin{array}{lr}15.012 & 133.929 \\ 680.665 & 3830.088 \\ 27.226 & 27.718\end{array}$ $\begin{array}{lllllllllll}0.83 & 24.69 & 26.26 & 28.35 & 2 & 1017.6058 & 1017.6062 & 509.8104 & -0.0004 & -0.3923 & 38.474\end{array}$

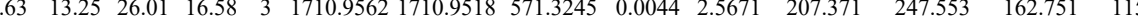

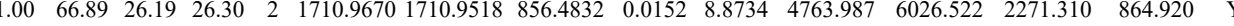

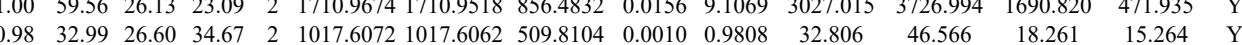

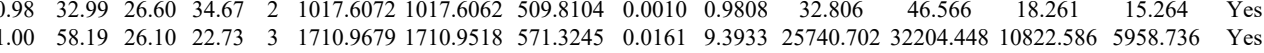

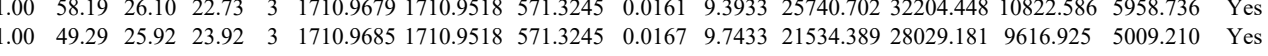

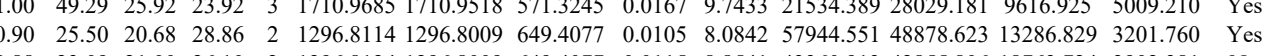
$\begin{array}{lllllllllllllllllll}0.88 & 23.09 & 21.00 & 26.10 & 2 & 1296.8124 & 1296.8009 & 649.4077 & 0.0115 & 8.8541 & 43360.913 & 42855.806 & 18763.724 & 3902.381 & \text { No }\end{array}$ $\begin{array}{llllllllllllllllll}0.85 & 22.10 & 21.00 & 24.84 & 2 & 1296.8126 & 1296.8009 & 649.4077 & 0.0117 & 9.0081 & 31999.040 & 26366.455 & 5510.944 & 1733.420 & \text { Yes }\end{array}$ $\begin{array}{llllllllllllllllll}0.98 & 36.10 & 20.64 & 31.87 & 2 & 1296.8136 & 1296.8009 & 649.4077 & 0.0127 & 9.7780 & 13506.250 & 12314.233 & 2284.144 & 817.795 & \text { Yes } \\ 0.99 & 61.18 & 23.05 & 20.01 & 2 & 1735 & 0132 & 1735.0123 & 86.5134 & 0.009 & 0.518 & 704.274 & 458.135 & 283.650 & 46.703 & \text { Yes }\end{array}$ $\begin{array}{lllllllllllllll}0.99 & 61.18 & 23.05 & 20.01 & 2 & 1735.0132 & 1735.0123 & 868.5134 & 0.0009 & 0.5181 & 704.274 & 458.135 & 283.650 & 46.703 & \text { Yes } \\ 1.00 & 50.25 & 23.01 & 23.44 & 3 & 1735.0156 & 1735.0123 & 579.3447 & 0.0033 & 1.8987 & 4322.931 & 3780.409 & 1750.518 & 257.622 & \text { Yes }\end{array}$ $\begin{array}{lllllllllllllll}1.00 & 50.25 & 23.01 & 23.44 & 3 & 1735.0156 & 1735.0123 & 579.3447 & 0.0033 & 1.8987 & 4322.931 & 3780.409 & 1750.518 & 257.622 & \text { Yes } \\ 0.99 & 44.82 & 22.65 & 20.12 & 3 & 1735.0174 & 1735.0123 & 579.3447 & 0.0051 & 2.9343 & 16763.725 & 12480.685 & 6115.110 & 907.413 & \text { Yes }\end{array}$ $\begin{array}{lllllllllllllll}0.99 & 44.82 & 22.65 & 20.12 & 3 & 1735.0174 & 1735.0123 & 59.3447 & 0.0051 & 2.9343 & 16703.725 & 12480.685 & 6115.110 & 907.413 & \text { Yes }\end{array}$

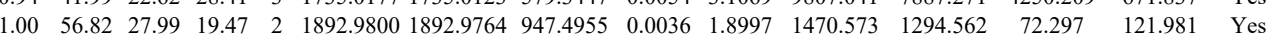




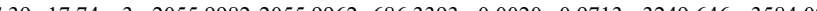

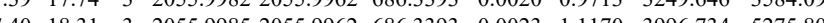

$\begin{array}{lllllllllll} & \end{array}$

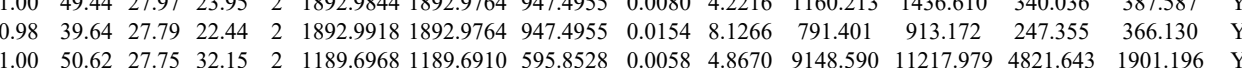

VSQAAADLK

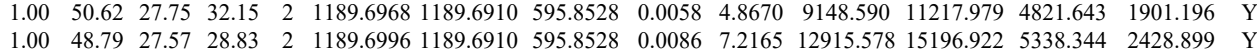

$\begin{array}{llllllllllllll}1.00 & 48.79 & 27.57 & 28.83 & 2 & 1189.6996 & 1189.6910 & 595.8528 & 0.0086 & 7.2165 & 12915.578 & 15196.922 & 5338.344 & 2428.896 \\ 1.00 & 38.66 & 26.15 & 51.66 & 4 & 3346.6793 & 3346.6794 & 837.6771 & 0.0001 & -0.0298 & 2554.482 & 2583.630 & 2102.036 & 646.750\end{array}$

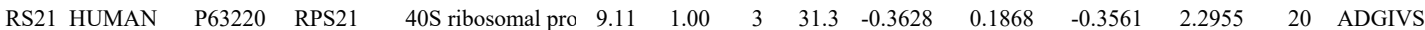

ADGIVSK

ADGIVSK

ADGIVSK

TYAICGAIR

TYAICGAIR

TYAICGAIR

TYAICGAIR

TYAICGAIR

TYAICGAIR

TYAICGAIR

TYAICGAIR

TYAICGAIR

TYAICGAIR

TYAICGAIR

TYAICGAIR

TYAICGAIR

TYAICGAIR

TYAICGAIR

TYAICGAIR

TYAICGAIR

TYAICGAIR

MGESDDSILR

TYAICGAIR

TYAICGAIR $\begin{array}{lllllllllllllllll}0.99 & 35.86 & 27.09 & 29.06 & 2 & 976.5810 & 976.5797 & 489.2971 & 0.0013 & 1.3284 & 104.248 & 78.310 & 51.157 & 10.934 & \text { No }\end{array}$ $\begin{array}{lllllllllllllll}0.95 & 28.14 & 27.09 & 29.00 & 2 & 976.5804 & 976.5797 & 489.2971 & 0.0007 & 0.7153 & 65.523 & 62.213 & 35.453 & 21.063\end{array}$

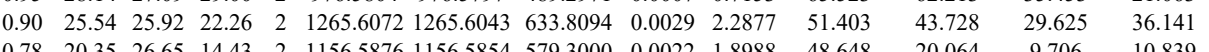
$\begin{array}{llllllllllllll}0.78 & 20.35 & 26.65 & 14.43 & 2 & 1156.5876 & 1156.5854 & 579.3000 & 0.0022 & 1.8988 & 48.648 & 20.064 & 9.706 & 10.839\end{array}$

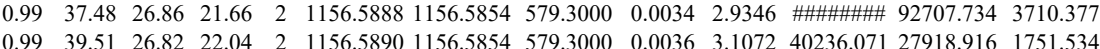
$\begin{array}{llllllllllllll}0.99 & 39.51 & 26.82 & 22.04 & 2 & 1156.5890 & 1156.5854 & 579.3000 & 0.0036 & 3.1072 & 40236.071 & 27918.916 & 1751.534\end{array}$ $\begin{array}{llllllllllllll}1.00 & 41.28 & 26.52 & 24.30 & 2 & 1156.5880 & 1156.5854 & 579.3000 & 0.0026 & 2.2441 & 77216.080 & 66188.807 & 149.674 & 15 \\ 0.99 & 38.31 & 26.52 & 24.17 & 2 & 1156.5880 & 1156.5854 & 579.3000 & 0.0026 & 2.2441 & 54558.706 & 41709.709 & 1302.689 & 58\end{array}$

$\begin{array}{llllllllllllll}1.00 & 38.00 & 26.45 & 21.33 & 2 & 1156.5872 & 1156.5854 & 579.3000 & 0.0018 & 1.5536 & 12770.357 & 11113.833 & 489.943 \\ 1.00 & 40.02 & 26.65 & 19.88 & 2 & 1156587611565854 & 579.3000 & 0.0022 & 1.8988 & 24869.133 & 22466.334 & 709.255 & 21 & \end{array}$

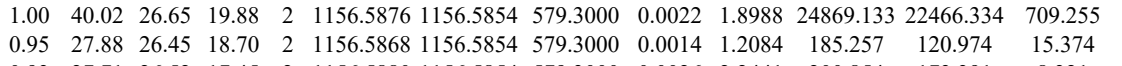

$\begin{array}{llllllllllllll}0.93 & 27.71 & 26.52 & 17.45 & 2 & 1156.5880 & 1156.5854 & 579.3000 & 0.0026 & 2.2441 & 200.854 & 173.391 & 8.321 \\ 0.99 & 35.81 & 26.49 & 19.36 & 2 & 1156.5862 & 1156.5854 & 579.3000 & 0.0008 & 0.6905 & 232.526 & 154.666 & 30.831\end{array}$ $\begin{array}{lllllllllllll}0.99 & 35.81 & 26.49 & 19.36 & 2 & 1156.5862 & 1156.5854 & 579.3000 & 0.0008 & 0.6905 & 232.526 & 154.666 & 30.831 \\ 0.77 & 31.65 & 26.65 & 44.65 & 2 & 11565876 & 1156.5854 & 579.3000 & 0.0022 & 1.8988 & 170.015 & 134.795 & 22.164 \\ 0.99 & 36.8 & 26.45 & 19.62 & 2 & 1156.5868 & 1156.5854 & 579.300 & 0.004 & 1.2084 & 219.927 & 2.386 & 0.00\end{array}$ $\begin{array}{lllllllllll}0.79 & \end{array}$ $\begin{array}{lllllllllllll}0.99 & 36.48 & 26.45 & 19.62 & 2 & 1156.5868 & 1156.5854 & 579.3000 & 0.0014 & 1.2084 & 219.927 & 209.386\end{array}$ $\begin{array}{llllllllllll}0.96 & 29.94 & 26.52 & 17.93 & 2 & 1156.5880 & 1156.5854 & 579.3000 & 0.0026 & 2.2441 & 168.826 & 139.192\end{array}$ $\begin{array}{llllllllllll}1.00 & 39.62 & 26.65 & 19.47 & 2 & 1156.5874 & 1156.5854 & 579.3000 & 0.0020 & 1.7262 & 1220.196 & 897.969\end{array}$

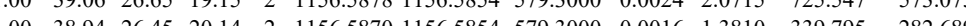

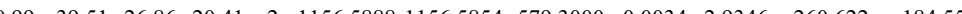

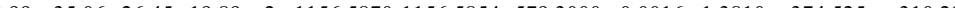
$\begin{array}{lllllllllllllllll}1.00 & 40.58 & 26.65 & 21.27 & 2 & 1156.5874 & 1156.5854 & 579.3000 & 0.0020 & 1.7262 & 442.964 & 332.706\end{array}$ $\begin{array}{lllllllllllll}0.98 & 33.37 & 25.92 & 21.17 & 2 & 1265.6074 & 1265.6043 & 633.8094 & 0.0031 & 2.4455 & 4310.008 & 3169.906\end{array}$ $\begin{array}{llllllllllll}0.95 & 27.87 & 26.45 & 16.42 & 2 & 1156.5868 & 1156.5854 & 579.3000 & 0.0014 & 1.2084 & 59.275 & 54.624\end{array}$

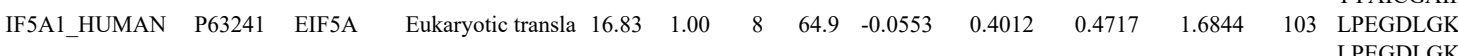

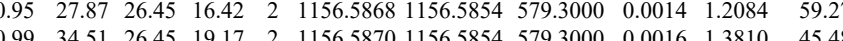

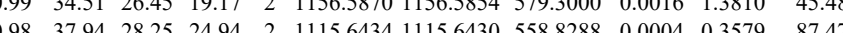

$\begin{array}{ll}54.624 & 9.700 \\ 50.400 & 1.523 \\ 82.732 & 70.466\end{array}$
\begin{tabular}{lllllllll} 
& $(15.51$ \\
\hline
\end{tabular}

LPEGDLGK

LPEGDLGK

IVEMSTSK

$\begin{array}{lllllllllll} & \end{array}$ $\begin{array}{lllllllllllllll}0.99 & 42.02 & 27.82 & 32.50 & 2 & 1181.6606 & 1181.6569 & 591.8357 & 0.0037 & 3.1259 & 30546.883 & 26550.147 & 48671.445 & 1508.441 & \text { Yes }\end{array}$

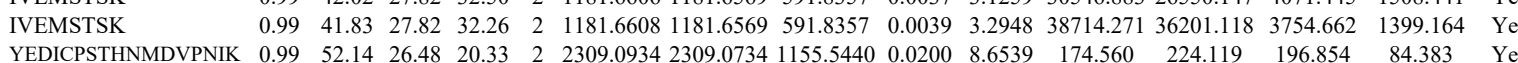
$\begin{array}{cccccccccccccccc}\text { YEDICPSTHNMDVPNIK } & 1.00 & 66.67 & 26.48 & 23.78 & 2 & 2309.0934 & 2309.0734 & 1155.5440 & 0.0200 & 8.6539 & 330.697 & 251.377 & 209.305 & 163.569 & \text { Yes }\end{array}$ $\begin{array}{lllllllllllllllll}\text { YEDICPSTHNMDVPNIK } & 0.93 & 32.58 & 26.62 & 15.53 & 3 & 2309.0947 & 2309.0734 & 770.6984 & 0.0213 & 9.2123 & 6263.270 & 6883.926 & 6910.277 & 3196.629 & \text { Yes }\end{array}$ $\begin{array}{llllllllllllllll}\text { LPEGDLGK } & 0.69 & 27.78 & 28.54 & 22.79 & 2 & 1115.6512 & 1115.6430 & 558.8288 & 0.0082 & 7.3367 & 7570.586 & 10049.734 & 3905.334 & 4987.173 & \text { Yes }\end{array}$ $\begin{array}{llllllllllllllll}\text { YEDICPSTHNMDVPNIK } & 0.93 & 32.61 & 26.62 & 15.24 & 3 & 2309.0962 & 2309.0734 & 770.6984 & 0.0228 & 9.8611 & 7427.515 & 7391.153 & 6574.595 & 3184.876 & \text { Yes }\end{array}$

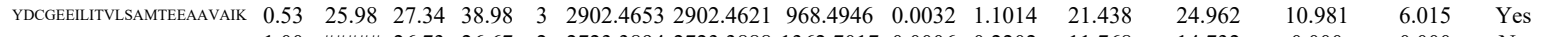

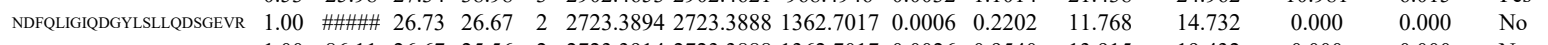

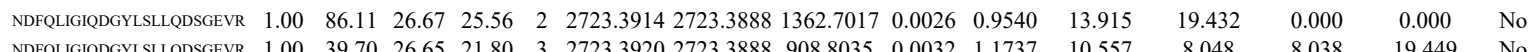

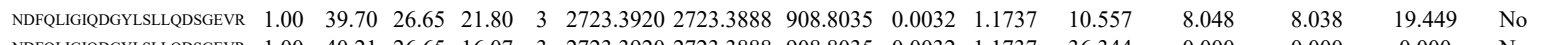

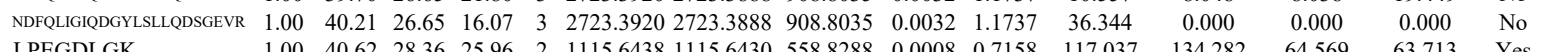

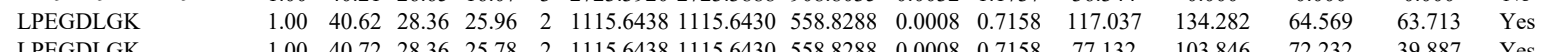
$\begin{array}{llllllllllll}\text { LPEGDLGK } & 1.00 & 40.72 & 28.36 & 25.78 & 2 & 1115.6438 & 1115.6430 & 558.8288 & 0.0008 & 0.7158 & 77.132\end{array}$

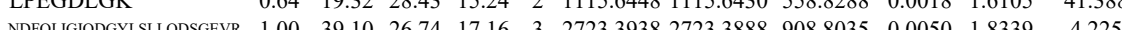

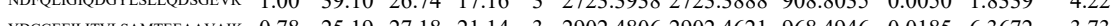

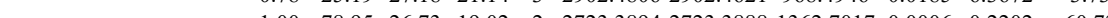

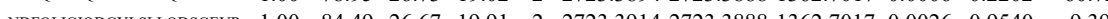



$\begin{array}{llllllllllll} & 1.00 & 81.32 & 26.54 & 21.93 & 3 & 2879.4928 & 2879.4899 & 960.8372 & 0.0029 & 1.0061 & 76.296\end{array}$ $\begin{array}{llllllllllll}1.00 & 51.66 & 23.89 & 38.49 & 2 & 1063.6732 & 1063.6634 & 532.8390 & 0.0098 & 9.1959 & 312.955 & 264.32\end{array}$ $\begin{array}{lllllllllll}0.76 & 11.77 & 23.24 & 14.56 & 3 & 1585.9471 & 1585.9436 & 529.9651 & 0.0035 & 2.2027 & 103.061\end{array}$ $199 \quad 29.797$

$\begin{array}{lllllllllllllll}0.99 & 32.51 & 23.34 & 27.23 & 3 & 1585.9456 & 1585.9436 & 529.6551 & 0.0020 & 1.2587 & 288.761 & 228 .\end{array}$

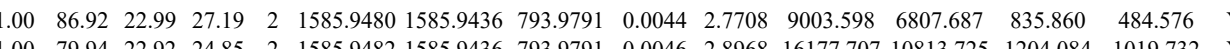

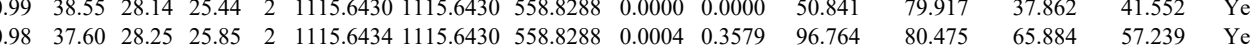

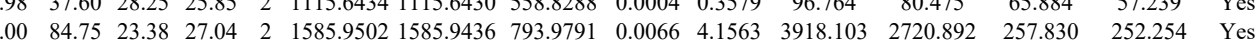
$\begin{array}{llllllllllllllll}1.00 & 76.01 & 23.38 & 24.41 & 2 & 1585.9502 & 1585.9436 & 793.9791 & 0.0066 & 4.1563 & 4909.831 & 3548.648 & 471.814 & 389.756 & \text { Y }\end{array}$ $\begin{array}{lllllllllllllllll}45.75 & 23.05 & 23.67 & 3 & 1585.9510 & 1585.9436 & 529.6551 & 0.0074 & 46571 & 9595.122 & 7343.323 & 555.097 & 71.470 & \text { Ycs }\end{array}$ $\begin{array}{lllllllllllllll}34.97 & 23.28 & 22.73 & 3 & 1585.9519 & 1585.9436 & 529.6551 & 0.0083 & 5.62235 & 13694.806 & 11616953 & 569.551 & 139.024 & \text { Yes }\end{array}$ $\begin{array}{llllllllllllllll} & 49.91 & 23.34 & 26.92 & 3 & 1585.9459 & 1585.9436 & 529.6551 & 0.0023 & 1.4475 & 2594.077 & 2003.802 & 245.936 & 80.977 & \text { Yes }\end{array}$ $\begin{array}{lllllllllllllllll}1.00 & 47.96 & 22.97 & 30.05 & 3 & 1585.9474 & 1585.9436 & 529.6551 & 0.0038 & 2.3915 & 5128.997 & 4546.712 & 186.702 & 64.958 & \text { Yes }\end{array}$ $\begin{array}{lllllllllllllll}1.00 & 38.61 & 22.92 & 21.46 & 3 & 1585.9483 & 1585.9436 & 529.6551 & 0.0047 & 2.9579 & 2208.225 & 2333.138 & 117.271 & 83.879 & \text { Yes }\end{array}$ $\begin{array}{lllllllllllllll}1.00 & 36.82 & 22.92 & 21.84 & 3 & 1585.9483 & 1585.9436 & 529.6551 & 0.0047 & 2.9579 & 2620.026 & 2161.447 & 42.931 & 31.284 & \text { Yes }\end{array}$ \begin{tabular}{lllllllllllllll}
1.00 & 37.53 & 23.22 & 21.67 & 3 & 1585.9465 & 1585.9436 & 529.6551 & 0.0029 & 1.8251 & 721.305 & 797.841 & 132.288 & 81.028 & Yes \\
\hline
\end{tabular}

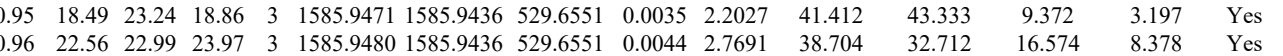

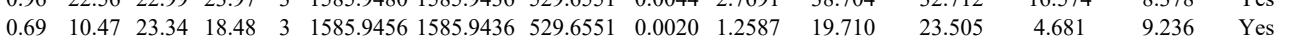
$\begin{array}{lllllllllllllll}0.96 & 34.43 & 28.48 & 19.53 & 2 & 1115.6432 & 1115.6430 & 558.8288 & 0.0002 & 0.1789 & 146.975 & 183.973 & 79.806 & 109.360 & \text { Yes }\end{array}$ $\begin{array}{lllllllllllllll}0.84 & 27.35 & 28.48 & 25.32 & 2 & 1115.6432 & 1115.6430 & 558.8288 & 0.0002 & 0.1789 & 167.540 & 164.806 & 126.218 & 95.777 & \text { Yes }\end{array}$ $\begin{array}{lllllllllllllll}0.60 & 21.56 & 28.25 & 16.79 & 2 & 1115.6434 & 1115.6430 & 558.8288 & 0.0004 & 0.3579 & 35.310 & 50.798 & 50.618 & 20.824 & \text { Yes }\end{array}$

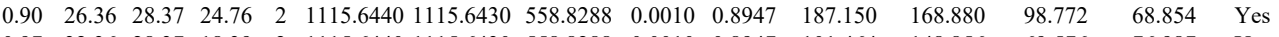

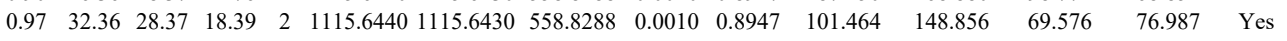

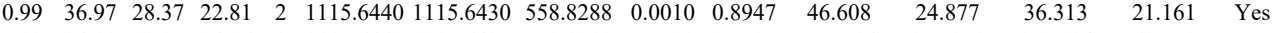

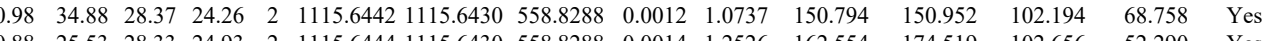
$\begin{array}{lllllllllllllll}0.88 & 25.53 & 28.33 & 24.93 & 2 & 1115.6444 & 1115.6430 & 558.8288 & 0.0014 & 1.2526 & 162.554 & 174.519 & 102.656 & 52.290 & \text { Yes }\end{array}$ $\begin{array}{lllllllllllllll}0.99 & 37.26 & 28.33 & 23.80 & 2 & 1115.6444 & 1115.6430 & 558.8288 & 0.0014 & 1.2526 & 139.714 & 173.180 & 90.421 & 81.501 & \text { Yes }\end{array}$ $\begin{array}{lllllllllllllll}0.99 & 37.21 & 28.33 & 23.79 & 2 & 1115.6446 & 1115.6430 & 558.8288 & 0.0016 & 1.4316 & 174.570 & 191.254 & 154.641 & 114.144 & \text { Yes }\end{array}$ \begin{tabular}{lllllllllllllll}
0.99 & 37.19 & 28.39 & 23.79 & 2 & 1115.6458 & 1115.6430 & 558.8288 & 0.0028 & 2.5052 & 123.122 & 105.154 & 82.300 & 63.967 & Yes \\
\hline
\end{tabular}

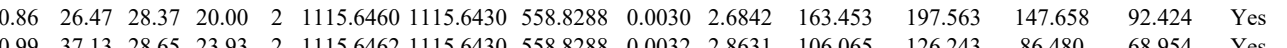

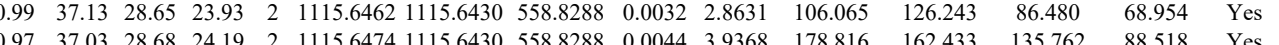

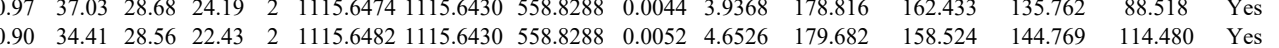

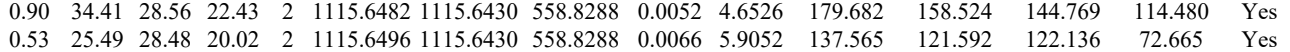

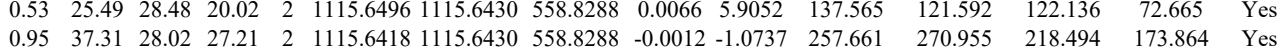

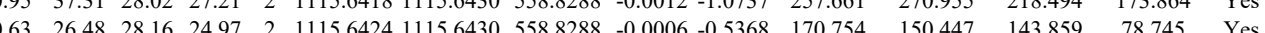

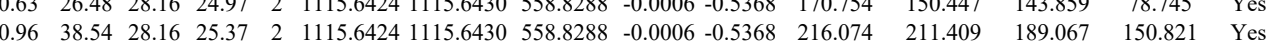

Table S-3 page 334 of 499 


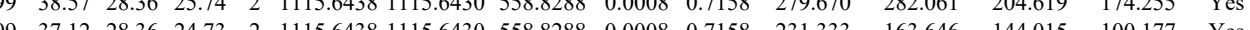
$\begin{array}{llllllllllll} & \end{array}$

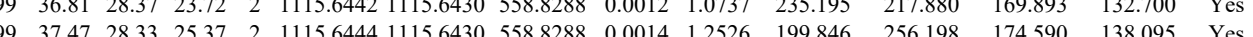
$\begin{array}{lllllllllllll} & \end{array}$ $\begin{array}{llllllllllllll}39.80 & 28.33 & 25.14 & 2 & 1115.6444 & 1115.6430 & 5588.8288 & 0.0014 & 1.2526 & 191.734 & 193.827 & 119.680 & 108.752 & \text { Yes }\end{array}$ $\begin{array}{llllllllllllll}37.47 & 28.33 & 25.04 & 2 & 1115.6444 & 1115.6430 & 5588288 & 0.0014 & 1.2526 & 205.189 & 190.621 & 138.916 & 82.018 & \text { Yes }\end{array}$

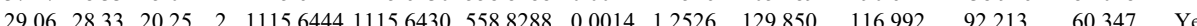

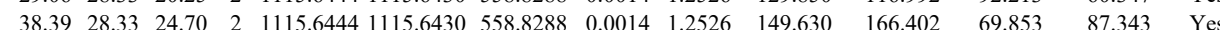
$\begin{array}{llllllllllllllll}0.98 .45 & 28.33 & 24.85 & 2 & 1115.6444 & 1115.6430 & 558.8288 & 0.0014 & 1.2526 & 183.403 & 159.851 & 127.843 & 116.400 & \text { Yes }\end{array}$ $\begin{array}{lllllllllllllll}0.99 & 36.63 & 28.33 & 24.40 & 2 & 1115.6444 & 1115.6430 & 558.8288 & 0.0014 & 1.2526 & 91.091 & 103.695 & 30.085 & 55.800 & \text { Yes }\end{array}$

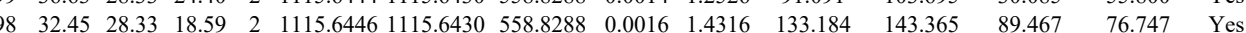
$\begin{array}{lllllllllllllll}0.89 & 25.68 & 28.39 & 24.97 & 2 & 1115.6450 & 1115.6430 & 558.8288 & 0.0020 & 1.7895 & 178.101 & 168.538 & 102.254 & 102.431 & \text { Yes }\end{array}$ $\begin{array}{lllllllllllllll}0.89 & 25.52 & 28.39 & 24.68 & 2 & 1115.6454 & 1115.6430 & 558.8288 & 0.0024 & 2.1473 & 169.488 & 193.132 & 154.921 & 93.674 & \text { Yes }\end{array}$

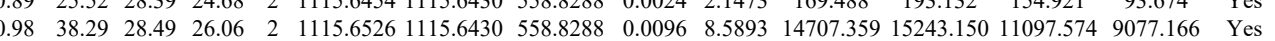
$\begin{array}{llllllllllllllll}0.99 & 42.40 & 26.53 & 26.96 & 2 & 1115.6532 & 1115.6430 & 558.8288 & 0.0102 & 9.1261 & 3957.388 & 4380.228 & 3043.866 & 2979.509 & \text { Yes }\end{array}$

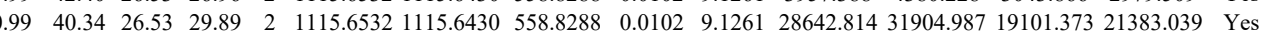

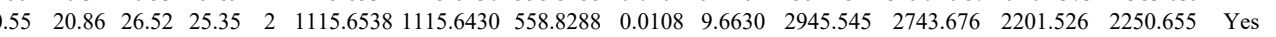
$\begin{array}{lllllllllllllll}0.84 & 26.86 & 28.14 & 30.43 & 2 & 1115.6428 & 1115.6430 & 558.8288 & -0.0002 & -0.1789 & 116.623 & 154.758 & 93.892 & 54.781 & \text { Yes }\end{array}$

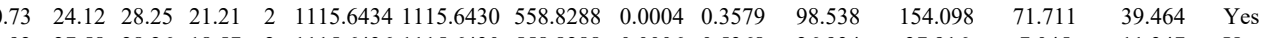
$\begin{array}{llllllllllllllll}0.92 & 27.58 & 28.26 & 18.57 & 2 & 1115.6436 & 1115.6430 & 558.8288 & 0.0006 & 0.5368 & 26.934 & 37.916 & 7.045 & 11.347 & \text { Yes }\end{array}$

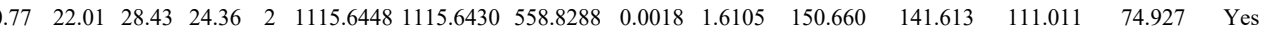

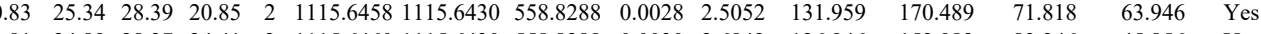
$\begin{array}{lllllllllllllll}0.81 & 24.89 & 28.37 & 24.41 & 2 & 1115.6460 & 1115.6430 & 558.8288 & 0.0030 & 2.6842 & 126.946 & 153.983 & 83.346 & 45.856 & \text { Yes }\end{array}$

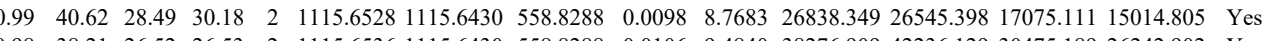
$\begin{array}{lllllllllllllll}0.98 & 38.21 & 26.52 & 26.53 & 2 & 1115.6536 & 1115.6430 & 558.8288 & 0.0106 & 9.4840 & 38276.909 & 42236.129 & 30475.189 & 26242.902 & \text { Yes }\end{array}$ $\begin{array}{lllllllllllllllll}0.98 & 52.14 & 25.31 & 43.36 & 2 & 1116.7046 & 1116.6998 & 559.3572 & 0.0048 & 4.2906 & 11392.522 & 9644.920 & 996.731 & 247.481 & \text { Yes }\end{array}$

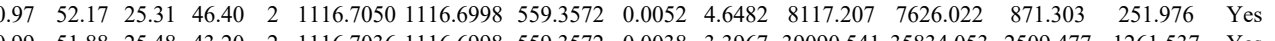
$\begin{array}{llllllllllllllll}0.99 & 51.88 & 25.48 & 43.20 & 2 & 1116.7036 & 1116.6998 & 559.3572 & 0.0038 & 3.3967 & 39090.541 & 35834.053 & 2509.477 & 1261.537 & \text { Yes }\end{array}$ $\begin{array}{llllllllllllllll}0.97 & 51.84 & 25.49 & 48.95 & 2 & 1116.7040 & 1116.6998 & 559.3572 & 0.0042 & 3.7543 & 15565.992 & 15090.510 & 1480.334 & 452.093 & \text { Yes }\end{array}$

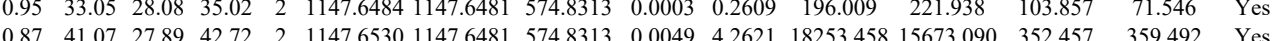
$\begin{array}{lllllllllllllll}0.87 & 41.07 & 27.89 & 42.72 & 2 & 1147.6530 & 1147.6481 & 574.8313 & 0.0049 & 4.2621 & 18253.458 & 15673.090 & 352.457 & 359.492 & \text { Yes } \\ 0.87 & 41.01 & 27.82 & 42.73 & 2 & 1147.6546 & 1147.6481 & 574.8313 & 0.0065 & 5.6538 & 15692.749 & 13758.517 & 258.159 & 532.590 & \text { Yes }\end{array}$

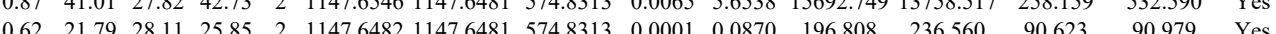

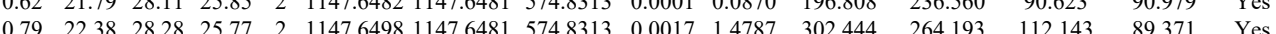
$\begin{array}{llllllllllllllll}0.50 & 22.38 & 28.28 & 25.77 & 2 & 147.6482 & 1147.6481 & 574.8313 & 0.0001 & 0.0870 & 196.808 & 236.560 & 90.623 & 90.979 & \text { Yes }\end{array}$

$\begin{array}{ccccccccccccccc}0.50 & 22.22 & 27.23 & 25.45 & 2 & 1147.6574 & 1147.6481 & 574.8313 & 0.0093 & 8.0893 & 251.483 & 233.447 & 142.753 & 102.202 & \text { Yes } \\ 0.93 & 40.88 & 27.72 & 42.49 & 2 & 1147.6592 & 1147.6481 & 574.8313 & 0.0111 & 9.6549 & 12621.634 & 11160.384 & 1427.930 & 770.185 & \text { Yes } \\ \end{array}$

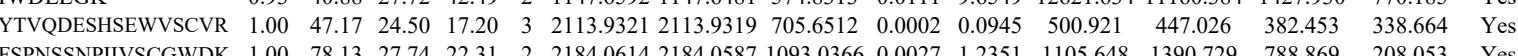

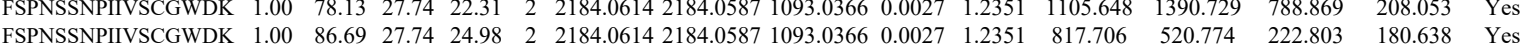

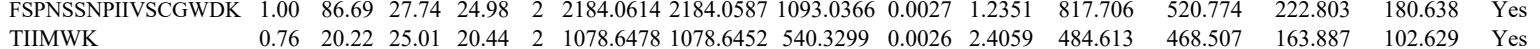

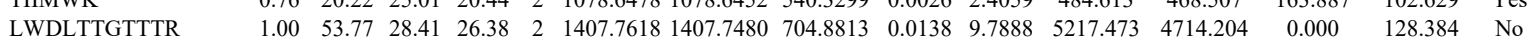

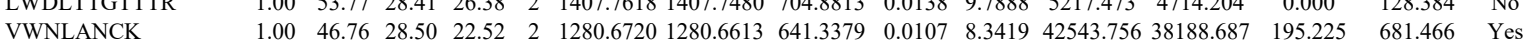

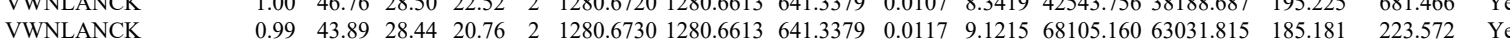

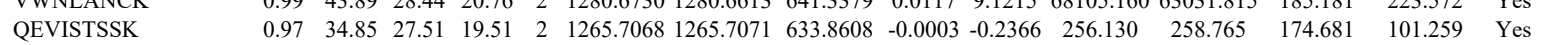

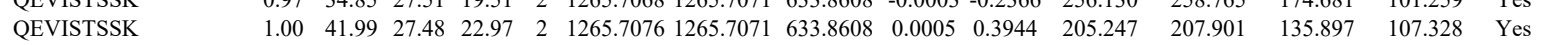
$\begin{array}{llllllllllllllll}\text { VWNLANCK } & 0.99 & 46.64 & 28.04 & 22.63 & 2 & 1280.6706 & 1280.6613 & 641.3379 & 0.0093 & 7.2504 & 32170.856 & 28372.037 & 430.466 & 390.856 & \text { Yes }\end{array}$ $\begin{array}{llllllllllllllll}\text { VWNLANCK } & 0.99 & 43.77 & 28.31 & 21.54 & 2 & 1280.6724 & 1280.6613 & 641.3379 & 0.0111 & 8.6537 & 34930.578 & 30999.281 & 1025.234 & 200.010 & \text { Yes }\end{array}$

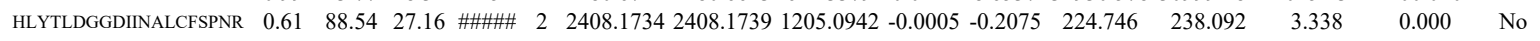
$\begin{array}{lllllllllllllllll}\text { HLYTLDGGDINALCFSPNR } & 1.00 & 48.34 & 27.25 & 20.58 & 3 & 2408.1754 & 2408.1739 & 803.7319 & 0.0015 & 0.6221 & 581.978 & 404.744 & 88.333 & 112.422 & \text { Yes }\end{array}$ $\begin{array}{llllllllllllllll}\text { HLYTLDGGDINALCFSPNR } & 0.77 & 85.85 & 27.24 & 98.85 & 2 & 2408.1754 & 2408.1739 & 1205.0942 & 0.0015 & 0.6224 & 290.425 & 233.346 & 0.000 & 4.765 & \text { No }\end{array}$

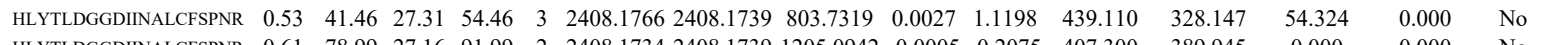

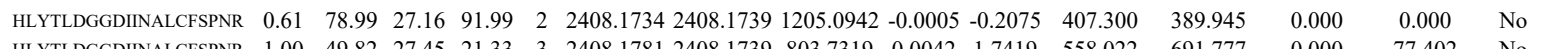

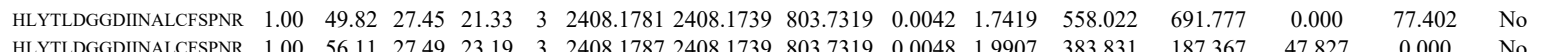
$\begin{array}{llllllllllllllll}\text { HLYTLDGGDINALCFSPNR } & 1.00 & 56.11 & 27.49 & 23.19 & 3 & 2408.1787 & 2408.1739 & 803.7319 & 0.0048 & 1.9907 & 383.831 & 187.367 & 47.827 & 0.000 & \text { No }\end{array}$

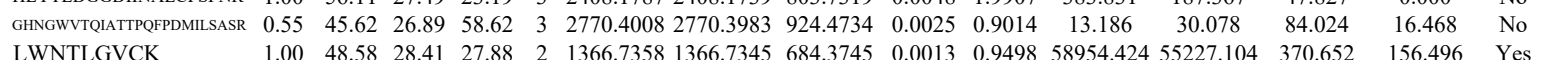

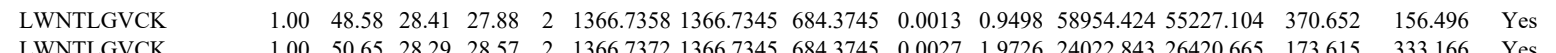

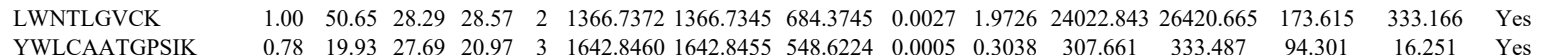
$\begin{array}{llllllllllllllll}\text { YWLCAATGPSIK } & 0.78 & 19.93 & 27.69 & 20.97 & 3 & 1642.8460 & 1642.8455 & 548.6224 & 0.0005 & 0.3038 & 307.661 & 333.487 & 94.301 & 16.251 & \text { Yes } \\ \text { YWLCAATGPSIK } & 1.00 & 67.55 & 27.61 & 33.00 & 2 & 1642.8466 & 1642.8455 & 822.4300 & 0.0011 & 0.6687 & 1027.060 & 1014.256 & 103.677 & 34.275 & \text { Yes }\end{array}$ $\begin{array}{llllllllllllllll}\text { YWLCAATGPSIK } & 1.00 & 65.68 & 27.72 & 23.60 & 2 & 1642.8488 & 1642.8455 & 822.4300 & 0.0033 & 2.0062 & 1484.650 & 1486.206 & 152.713 & 66.875 & \text { Yes } \\ \text { YWLCAATGPSIK } & 0.91 & 25.63 & 27.88 & 25.74 & 3 & 1642.8517 & 1642.8455 & 548.622 & 0.0062 & 3.7670 & 707.166 & 571.162 & 110.235 & 58.903 & \text { Yes }\end{array}$ $\begin{array}{llllllllllllllll}\text { YWLCAATGPSIK } & 0.91 & 25.63 & 27.88 & 25.74 & 3 & 1642.8517 & 1642.8455 & 548.6224 & 0.0062 & 3.7670 & 707.166 & 571.162 & 110.235 & 58.903 & \text { Yes } \\ \text { HLYTLDGGDINALCFSPNR } & 1.00 & 36.34 & 27.45 & 18.51 & 3 & 2408.1781 & 2408.1739 & 803.7319 & 0.0042 & 1.7419 & 354.926 & 290.040 & 22.483 & 21.196 & \text { Yes }\end{array}$

Table S-3 page 335 of 499 


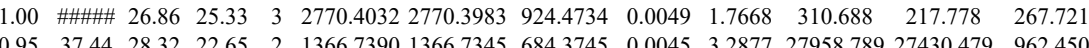

VWQVTIGTR

VWQVTIGTR $\begin{array}{llllllllll} & \end{array}$

VWQVTIGTR

VWQVTIGTR

VWQVTIGTR

VWQVTIGTR

VWQVTIGTR

LWNTLGVCK

LWNTLGVCK

VWQVTIGTR

VWQVTIGTR

VWQVTIGTR

VWQVTIGTR

VWQVTIGTR

VWQVTIGTR

VWQVTIGTR

DETNYGIPQR $\begin{array}{llllllllllllll}0.61 & 17.51 & 27.31 & 16.07 & 2 & 1202.6910 & 1202.6894 & 602.3520 & 0.0016 & 1.3281 & 24.486 & 32.706 & 6.14 \\ 0.90 & 25.24 & 27.29 & 15.64 & 2 & 1202.6912 & 1202.6894 & 602.3520 & 0.0018 & 1.4941 & 173.419 & 176.027 & 34.51\end{array}$ $\begin{array}{lllllllllllll}0.90 & 25.24 & 27.29 & 15.64 & 2 & 1202.6916 & 1202.6894 & 602.3520 & 0.0022 & 1.8262 & 217.816 & 180.503 & 38.183\end{array}$ $\begin{array}{llllllllllllll}0.99 & 42.94 & 27.56 & 22.24 & 2 & 1202.6996 & 1202.6894 & 602.3520 & 0.0102 & 8.4667 & 44316.469 & 38218.600 & 1423.358\end{array}$ $\begin{array}{llllllllllllll}0.99 & 42.90 & 27.62 & 21.55 & 2 & 1202.6998 & 1202.6894 & 602.3520 & 0.0104 & 8.6328 & 26727.662 & 22534.913 & 519.327\end{array}$ $\begin{array}{llllllllllllll}0.60 & 17.83 & 27.49 & 22.96 & 2 & 1202.6900 & 1202.6894 & 602.3520 & 0.0006 & 0.4980 & 66.543 & 39.228 & 12.985\end{array}$ $\begin{array}{llllllllllllll}0.57 & 17.22 & 27.35 & 23.08 & 2 & 1202.6906 & 1202.6894 & 602.3520 & 0.0012 & 0.996 & 56.669 & 36.626 & 9.766\end{array}$

$\begin{array}{lllllllllllll}0.99 & 42.64 & 27.10 & 21.56 & 2 & 1202.6992 & 1202.6894 & 602.3520 & 0.0098 & 8.1347 & 31369.893 & 32433.593 & 437.566\end{array}$ $\begin{array}{lllllllllllll}1.00 & 53.11 & 28.29 & 28.33 & 2 & 1366.7372 & 1366.7345 & 684.3745 & 0.0027 & 1.9726 & 2989.050 & 2632.046 & 16.859 \\ 0.99 & 41.78 & 28.40 & 22.90 & 2 & 13667378 & 1366.7345 & 684.3745 & 0.0033 & 2.4110 & 2915.282 & 2640.851 & 32.555\end{array}$ $\begin{array}{lllllllllllll}0.99 & 41.78 & 28.40 & 22.90 & 2 & 1366.7378 & 1366.7345 & 684.3745 & 0.0033 & 2.4110 & 2915.282 & 2640.851 & 32.555\end{array}$ $\begin{array}{lllllllllllll}1.00 & 45.44 & 27.28 & 20.50 & 2 & 1202.7004 & 1202.6894 & 602.3520 & 0.0110 & 9.1308 & 4091.798 & 3506.454 & 179.322\end{array}$ $\begin{array}{llllllllllllll}0.98 & 36.00 & 27.49 & 21.52 & 2 & 1202.6898 & 1202.6894 & 602.3520 & 0.0004 & 0.3320 & 131.009 & 117.366 & 7.760\end{array}$ $\begin{array}{llllllllllllll}0.97 & 30.63 & 27.32 & 22.67 & 2 & 1202.6908 & 1202.6894 & 602.3520 & 0.0014 & 1.1621 & 159.606 & 219.098 & 14.4\end{array}$

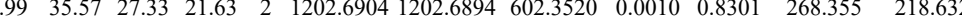

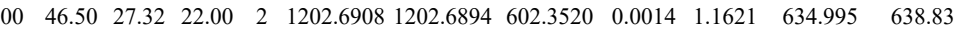
$\begin{array}{llllllllllll}0.99 & 36.94 & 27.16 & 23.81 & 2 & 1202.6902 & 1202.6894 & 602.3520 & 0.0008 & 0.6641 & 306.185 & 282.645 \\ 0.99 & 38.23 & 27.33 & 2.94 & 2 & 1202.604 & 1202.894 & 602.3520 & 0.0010 & 0.8301 & 49.017 & 30.449\end{array}$

30.449

(

$\begin{array}{lllllllllllll}.00 & 55.36 & 27.41 & 28.02 & 2 & 1335.6588 & 1335.6541 & 668.8343 & 0.0047 & 3.5136 & 8613.118 & 8067.175\end{array}$ 
$\begin{array}{lllllllllllll}\text { NYQQNYQNSESGEK } & 1.00 & 77.22 & 25.73 & 29.12 & 2 & 1975.9106 & 1975.9115 & 988.9630 & -0.0009 & -0.4550 & 2114.985 & 2011.687\end{array}$ $\begin{array}{lllllllllllll}\text { NYQQNYQNSESGEK } & 1.00 & 80.36 & 25.69 & 31.14 & 2 & 1975.9122 & 1975.9115 & 988.9630 & 0.0007 & 0.3539 & 2084.750 & 1553.547\end{array}$ $\begin{array}{lllllllllllll}\text { NYQQNYQNSESGEK } & 1.00 & 37.90 & 25.69 & 16.19 & 3 & 1975.9123 & 1975.9115 & 659.6444 & 0.0008 & 0.4043 & 51.923 & 56.815\end{array}$ $\begin{array}{lllllllllllll}\text { NYQQNYQNSESGEK } & 1.00 & 34.06 & 25.68 & 15.88 & 3 & 1975.9132 & 1975.9115 & 659.6444 & 0.0017 & 0.8590 & 95.571 & 81.058\end{array}$

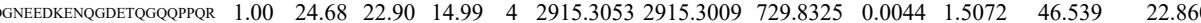

$\begin{array}{lllllllllllllll}\text { NYQQNYQNSESGEK } & 0.53 & 45.64 & 25.77 & 58.64 & 3 & 1975.9150 & 1975.9115 & 659.6444 & 0.0035 & 1.7686 & 60.975 & 59.057\end{array}$ $\begin{array}{llllllllllllll}\text { NYQQNYQNSESGEK } & 1.00 & 51.30 & 25.84 & 19.65 & 3 & 1975.9159 & 1975.9115 & 659.6444 & 0.0044 & 2.2234 & 62.188 & 74.276\end{array}$

$\begin{array}{llllllllllll}\text { EDGNEEDKENQGDETQGQQPPQR } & 1.00 & 37.47 & 22.88 & 50.47 & 4 & 2915.3041 & 2915.3009 & 729.8325 & 0.0032 & 1.0961 & 32.403 \\ \text { RPENPKPQDGK } & 0.92 & 10.86 & 25.07 & 17.64 & 4 & 1696.9601 & 1696.9586 & 425.2469 & 0.0015 & 0.8818 & 571.872\end{array}$

RPENPKPQDGK

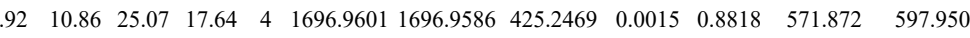

EDGNEEDKENQGDETQGeQPPO $\begin{array}{lllllllllll}0.85 & 15.48 & 25.05 & 18.37 & 3 & 1696.9606 & 1696.9586 & 566.6601 & 0.0020 & 1.1765 & 288.106\end{array}$

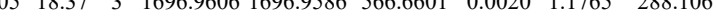
$\begin{array}{llllllllllll}1.00 & 40.05 & 22.88 & 16.73 & 4 & 2915.3041 & 2915.3009 & 729.8325 & 0.0032 & 1.0961 & 24.486\end{array}$

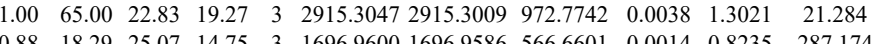

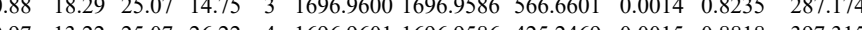

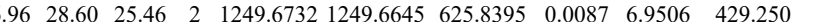

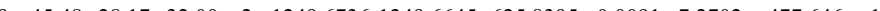

QPADEAEDR

IYHPNIDEK $\begin{array}{llll}778.758 & 1677.362 & 5470.316 & 5\end{array}$ $\begin{array}{lllllllllllllll}0.78 & 21.43 & 27.61 & 14.70 & 3 & 1415.7712 & 1415.7652 & 472.9290 & 0.0060 & 4.2289 & 28452.462 & 37183.383 & 5595.290 & 164 & \\ 0.94 & 27.49 & 27.93 & 25.37 & 3 & 1415.7715 & 1415.7652 & 472.9290 & 0.0063 & 4.4404 & 30393.513 & 43581.894 & 5211.291 & 252 .\end{array}$ $\begin{array}{lllllllllllllll}\text { TDQVIQSLIALVNDPOPEHPLR } & 1.00 & 40.81 & 24.61 & 19.95 & 4 & 2626.4233 & 2626.4200 & 657.6123 & 0.0033 & 1.2545 & 60.255 & 94.121 & 122.966\end{array}$ $\begin{array}{llllllllllllll}\text { TDQVIOSLIALVNDPQPEHPLR } & 0.53 & 65.72 & 24.59 & 78.72 & 3 & 2626.4236 & 2626.4200 & 876.4806 & 0.0036 & 1.3691 & 997.783 & 2798.533 & 555.688\end{array}$ $\begin{array}{lllllllllllllll}\text { TDQVIIQSLIALVNDPQPEHPLR } & 1.00 & 50.71 & 24.44 & 19.35 & 4 & 2626.4249 & 2626.4200 & 657.6123 & 0.0049 & 1.8628 & 169.117 & 137.726 & 226.022\end{array}$ $\begin{array}{lllllllllllllll}\text { TDQVIQSLIALVNDPQPEHPLR } & 1.00 & 61.39 & 24.62 & 18.48 & 3 & 2626.4224 & 2626.4200 & 876.4806 & 0.0024 & 0.9127 & 500.720 & 705.011 & 328.860\end{array}$ $\begin{array}{lllllllllllllll}\text { TDQVIISSLIALVNDPQPEHPLR } & 1.00 & 54.20 & 24.61 & 21.32 & 4 & 2626.4225 & 2626.4200 & 657.6123 & 0.0025 & 0.9504 & 79.092 & 76.837 & 158.494\end{array}$ $\begin{array}{llllllllllllllll}\text { TDQVIOSLIALVNDPQPEHPLR } & 1.00 & 45.73 & 24.46 & 16.68 & 4 & 2626.4253 & 2626.4200 & 657.6123 & 0.0053 & 2.0149 & 89.183 & 130.952 & 217.748 & 91.70\end{array}$ $\begin{array}{llllllllllllllll}\text { TDQVIQSLIALVNDPQPEHPLR } & 1.00 & 66.84 & 24.62 & 17.71 & 3 & 2626.4227 & 2626.4200 & 876.4806 & 0.0027 & 1.0268 & 41.513 & 40.349 & 91.802 & \end{array}$ $\begin{array}{llllllllllllll}\text { TDQVIQSLIALVNDPQPEHPLR } & 0.53 & 66.59 & 24.59 & 79.59 & 3 & 2626.4230 & 2626.4200 & 876.4806 & 0.0030 & 1.1409 & 58.501 & 78.003 & 27.558 \\ \text { TDQVIQLULN }\end{array}$

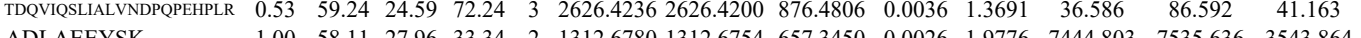
ADLAEEYSK ADLAEEYSK $\begin{array}{llllllllllllll}1.00 & 58.11 & 27.96 & 33.34 & 2 & 1312.6780 & 1312.6754 & 657.3450 & 0.0026 & 1.9776 & 7444.803 & 7535.636 & 3543.864 & 1240\end{array}$ $\begin{array}{lllllllllllll}1.00 & 52.95 & 26.89 & 21.81 & 2 & 1569.7698 & 1569.7588 & 785.8867 & 0.0110 & 6.9984 & 1229.711 & 1033.308 & 182.645\end{array}$ $\begin{array}{lllllllllllllll} & \end{array}$ YYVTIIDAPGHR YYVTIIDAPGHR YYVTIIDAPGHR YYVTIIDAPGHR YYVTIIDAPGHR

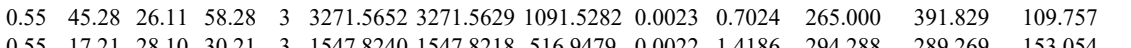
$\begin{array}{lllllllllllll}0.55 & 17.21 & 28.10 & 30.21 & 3 & 1547.8240 & 1547.8218 & 516.9479 & 0.0022 & 1.4186 & 294.288 & 289.269 & 153.054 \\ 0.66 & 14.67 & 28.10 & 16.38 & 3 & 1577.8243 & 1547.8218 & 516.979 & 0.025 & 1.612 & 188.654 & 28.490 & 108.252\end{array}$

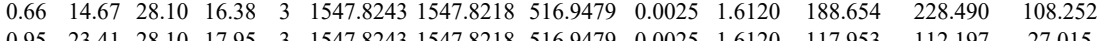

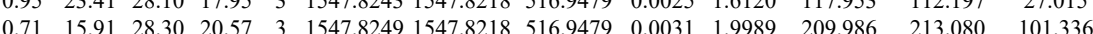
$\begin{array}{lllllllllllll}0.71 & 15.91 & 28.30 & 20.57 & 3 & 1547.8249 & 1547.8218 & 516.9479 & 0.0031 & 1.9989 & 209.986 & 213.080 & 101.336\end{array}$ $\begin{array}{lllllllllllll}0.99 & 37.66 & 28.15 & 18.66 & 3 & 1547.8363 & 1547.8218 & 516.9479 & 0.0145 & 9.3497 & 5574.658 & 6578.621 & 1724.700\end{array}$ $\begin{array}{llllllllllllll}1.00 & 69.11 & 27.92 & 18.54 & 2 & 1547.8370 & 1547.8218 & 774.9182 & 0.0152 & 9.8074 & 18551.469 & 21033.856 & 2317.808 & 231.643\end{array}$ 

$\begin{array}{llllllllll}0.62 & 11.47 * 25.77 & 17.51 & 4 & 3870.8673 & 3870.8629 & 968.7230 & 0.0044 & 1.1355 & 17.198\end{array}$ $\begin{array}{llllllllllll}0.62 & 12.92 * & 25.76 & 25.92 & 4 & 3870.8677 & 3870.8629 & 968.7230 & 0.0048 & 1.2387 & 16.825 \\ 0.96 & 53.69 * & 25.75 & 17.09 & 3 & 3870.8692 & 3870.8629 & 1291.2949 & 0.0063 & 1.6263 & 0.000\end{array}$ 
YYVTIIDAPGHR $\begin{array}{llllllllllll}1.00 & 23.0 & 25.05 & 36.05 & 4 & 3297.7325 & 3297.7305 & 825.4399 & 0.0020 & 0.6057 & 31.604\end{array}$

YYVTIIDAPGHR

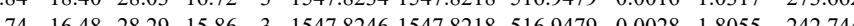
$\begin{array}{lllllllllllll}0.95 & 23.37 & 28.03 & 15.26 & 3 & 1547.8234 & 1547.8218 & 516.9479 & 0.0016 & 1.0317 & 284.931\end{array}$ $\begin{array}{lllllllllll}0.75 & 16.39 & 28.10 & 21.44 & 3 & 1547.8237 & 1547.8218 & 516.9479 & 0.0019 & 1.2251 & 364.338\end{array}$ $\begin{array}{llllllllllll}0.90 & 2028 & 28 & 10 & 17.33 & 3 & 1547.8237 & 1547.8218 & 516.9479 & 0.0019 & 12251 & 238.862\end{array}$

YYVTIIDAPGHR

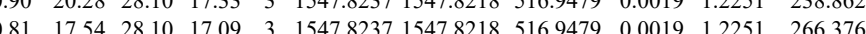

YYVTIIDAPGHR

YYVTIIDAPGHR $\begin{array}{lllllllllll}1.00 & 27.43 & 18.98 & 40.43 & 4 & 2946.6865 & 2946.6830 & 737.6780 & 0.0035 & 1.1862 & 15.791\end{array}$ $\begin{array}{llllllllllll}0.90 & 20.13 & 28.03 & 23.16 & 3 & 1547.8234 & 1547.8218 & 516.9479 & 0.0016 & 1.0317 & 525.634\end{array}$ $\begin{array}{lllllllllll}0.66 & 14.75 & 28.10 & 17.32 & 3 & 1547.8237 & 1547.8218 & 516.9479 & 0.0019 & 1.2251 & 366.900\end{array}$ YYVTIIDAPGHR $\begin{array}{lllllllllll}0.53 & 52.32 & 18.98 & 65.32 & 3 & 2946.8237 & 1547.8218 & 516.9479 & 0.0019 & 1.2251 & 280.617 \\ 0.50 & 13.77 & 28.06 & 22.91 & 3 & 1546.6830 & 983.2349 & 0.0035 & 1.1866 & 14.289\end{array}$ 304.935 $\begin{array}{lllllllllllll}0.50 & 13.77 & 28.06 & 22.91 & 3 & 1547.8231 & 1547.8218 & 516.9479 & 0.0013 & 0.8383 & 242.468\end{array}$ $\begin{array}{llllllllllllll}0.99 & 34.82 & 28.37 & 21.82 & 2 & 1034.5616 & 1034.5600 & 518.2873 & 0.0016 & 1.5435 & 1087.868 & 1014.077 & 878.140\end{array}$ $\begin{array}{lllllllllllllll}0.94 & 28.45 & 28.48 & 30.86 & 2 & 1067.6136 & 1067.6106 & 534.8126 & 0.0030 & 2.8047 & 217.659 & 1994.760 & 1125.263 & 672.594\end{array}$ $\begin{array}{llllllllllllll}0.89 & 31.43 & 26.64 & 25.29 & 2 & 1067.6182 & 1067.6106 & 534.8126 & 0.0076 & 7.1052 & 18991.585 & 19522.757 & 14979.997 & 6587.551\end{array}$ $\begin{array}{lllllllllllllll}0.89 & 31.48 & 26.64 & 31.73 & 2 & 1067.6184 & 1067.6106 & 534.8126 & 0.0078 & 7.2922 & 22063.627 & 20143.149 & 13637.596 & 7342.244\end{array}$ $\begin{array}{lllllllllllllll}0.99 & 31.50 & 25.15 & 25.08 & 3 & 1217.7352 & 1217.7345 & 406.9188 & 0.0007 & 0.5734 & 3436.842 & 3709.076 & 391.289 & 92.049\end{array}$

MDSTEPYSQK

(1)

$\begin{array}{llllllllll} & \end{array}$ $\begin{array}{lllllllllllll}1.00 & 51.51 & 27.19 & 19.04 & 2 & 1569.7650 & 1569.7588 & 785.8867 & 0.0062 & 3.9446 & 22308.180 & 21013.371 & 1560.565\end{array}$

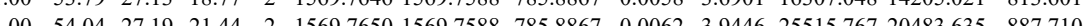

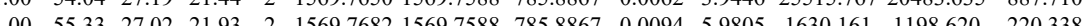

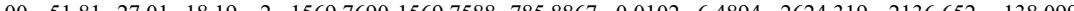

54 AVFVDLEPTVIDE

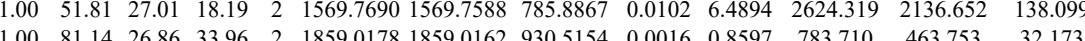

(1)

AVFVDLEPTVIDEIR AVFVDLEPTVIDEIR $\begin{array}{llllllllllllll}1.00 & 88.67 & 26.82 & 35.44 & 2 & 1859.0184 & 1859.0162 & 930.5154 & 0.0022 & 1.1821 & 723.345 & 483.405 & 65.618\end{array}$ $\begin{array}{llllllllllllll}0.98 & 29.20 & 26.76 & 28.79 & 3 & 1859.0197 & 1859.0162 & 620.6793 & 0.0035 & 1.8797 & 80.052 & 85.480 & 35.317\end{array}$ $\begin{array}{llllllllllllll}1.00 & 85.27 & 26.86 & 35.05 & 2 & 1859.0178 & 1859.0162 & 930.5154 & 0.0016 & 0.8597 & 365.443 & 367.682 & 69.951\end{array}$ $\begin{array}{llllllllllllll}1.00 & 72.82 & 26.84 & 27.69 & 2 & 1859.0182 & 1859.0162 & 930.5154 & 0.0020 & 1.0747 & 1940.280 & 1700.434 & 177.912\end{array}$ $\begin{array}{llllllllllllll}0.55 & 41.87 & 26.95 & 54.87 & 3 & 3026.4562 & 3026.4543 & 1009.8254 & 0.0019 & 0.6272 & 367.125 & 289.805 & 487.802\end{array}$ $\begin{array}{llllllllllll}0.00 & 1.87 & 6.95 & 54.87 & 3 & 3026.4562 & 3026.4543 & 1009.8254 & 0.0019 & 0.6272 & 367.125 \\ 1.00 & 41.24 & 26.95 & 20.53 & 3 & 3026.4562 & 3026.4543 & 1009.8254 & 0.0019 & 0.6272 & 146.297\end{array}$ $\begin{array}{lllllllll} & \\ 27.05 & 18.45 & 4 & 3026.462 & 3026.4543 & 1009.8254 & 0.0019 & 0.6272 & 146.297\end{array}$ $\begin{array}{llllllllllllll}\text { AYHELLSVAEITNACFEANOMVK } & 1.00 & 55.72 & 26.95 & 17.84 & 3 & 3026.4562 & 3026.4543 & 1009.8254 & 0.0019 & 0.6272 & 57.704\end{array}$ $\begin{array}{lllllllllllll}A \text { AYHEOLSVAEITACFEPANQMVK } & 0.55 & 38.59 & 26.95 & 51.59 & 3 & 3026.4562 & 3026.4543 & 1009.8254 & 0.0019 & 0.6272 & 65.225\end{array}$

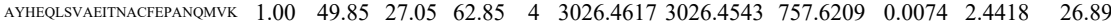

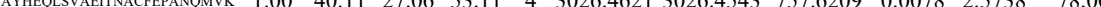

\section{STFVWCPTGK}

SIQFVDWCPTGFK

SIQFVDWCPTGFK

SIQFVDWCPTGFK

SIQFVDWCPTGFK

SIQFVDWCPTGFK

SIQFVDWCPTGFK

DIR

STR

$\begin{array}{lllllllllllll}1.00 & 61.86 & 27.13 & 26.20 & 2 & 1860.9156 & 1860.9147 & 931.4646 & 0.0009 & 0.4831 & 12709.349 & 14946.124\end{array}$

$\begin{array}{llllllllllllll}1.00 & 61.86 & 27.13 & 26.20 & 2 & 1860.9156 & 1860.9147 & 931.4646 & 0.0009 & 0.4831 & 12709.349 & 14946.124 & 28\end{array}$

$\begin{array}{lllllllllllll}1.00 & 44.50 & 27.30 & 19.68 & 3 & 1860.9172 & 1860.9147 & 621.3122 & 0.0025 & 1.3412 & 307.994 & 353.124 \\ 100 & 50.80 & 27.30 & 28.40 & 3 & 1860.9178 & 1860.9147 & 621.3122 & 0.0031 & 1.6631 & 291.514 & 485.618\end{array}$

$\begin{array}{llllllllllll}1.00 & 50.80 & 27.30 & 28.40 & 3 & 1860.9178 & 1860.9147 & 621.3122 & 0.0031 & 1.6631 & 291.514 & 485.618 \\ 1.00 & 6539 & 27.09 & 25.41 & 2 & 1860.9150 & 1860.9147 & 931.4646 & 0.0003 & 0.1610 & 6878.589 & 9179.026\end{array}$

$\begin{array}{llllllllllll}1.00 & 65.39 & 27.09 & 25.41 & 2 & 1860.9150 & 1860.9147 & 931.4646 & 0.0003 & 0.1610 & 8878.589 & 9179.026 \\ 1.00 & 36.31 & 27.23 & 24.66 & 3 & 1860.9166 & 1860.9147 & 621.3122 & 0.0019 & 1.0193 & 438.815 & 244.696\end{array}$

$\begin{array}{lllllllllllll}1.00 & 65.39 & 27.09 & 25.41 & 2 & 1860.9150 & 1860.9147 & 931.4646 & 0.0003 & 0.1610 & 6878.589 & 9179.026 & 0\end{array}$ $\begin{array}{lllllllllllll}1.00 & 36.31 & 27.23 & 24.66 & 3 & 1860.9166 & 1860.9147 & 621.3122 & 0.0019 & 1.0193 & 438.815 & 244.696\end{array}$ $\begin{array}{llllllllllllll}1.98 & 38.98 & 27.28 & 21.76 & 3 & 1860.9184 & 1860.9147 & 621.3122 & 0.0037 & 1.9850 & 2132.298 & 1887.664\end{array}$ $\begin{array}{llllllllllll}1.00 & 33.82 & 27.38 & 20.44 & 3 & 1860.9184 & 1860.9147 & 621.3122 & 0.0037 & 1.8241 & 536.984 & 602.735\end{array}$ $\begin{array}{llllllllllll}0.82 & 17.29 & 27.30 & 18.55 & 3 & 1860.9178 & 1860.9147 & 621.3122 & 0.0031 & 1.6631 & 175.944 & 99.121\end{array}$ $\begin{array}{llllllllll} & \end{array}$

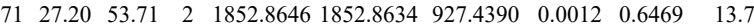
$\begin{array}{llllllllllllllll}\text { AVCMISNTTAIAEAWAR } & 1.00 & \text { \#\#\#\# } 27.99 & 28.24 & 2 & 1996.9626 & 1996.9654 & 999.4900 & -0.0028 & -1.4007 & 13.754 & 34.413\end{array}$ 

$\begin{array}{lllllllllllll}\text { AVCMLSNTTAIAEAWAR } & 1.00 & 51.02 & 27.97 & 18.41 & 3 & 1996.9675 & 1996.9654 & 666.6624 & 0.0021 & 1.0500 & 95.237\end{array}$ $\begin{array}{llllllllllllll}\text { AVCMLSNTTAIAEAWAR } & 0.55 & 44.50 & 27.97 & 57.50 & 3 & 1996.9675 & 1996.9654 & 666.6624 & 0.0021 & 1.0500 & 77.078\end{array}$ $\begin{array}{lllllllllllll}\text { AVCMLSNTTAIAEAWAR } & 0.55 & 28.06 & 27.97 & 41.06 & 3 & 1996.9675 & 1996.9654 & 666.6624 & 0.0021 & 1.0500 & 77.21\end{array}$ $\begin{array}{lllllllllllll}\text { AVCMLSNTTAIAEAWAR } & 0.55 & 22.08 & 27.97 & 35.08 & 3 & 1996.9678 & 1996.9654 & 666.6624 & 0.0024 & 1.2000 & 74.837\end{array}$

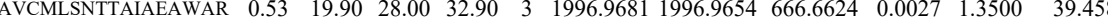

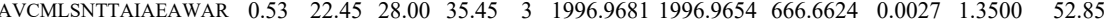

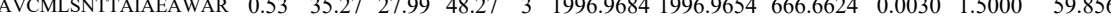
$\begin{array}{llllllllllll}\text { AVCMLSNTTAIAEAWAR } & 1.00 & 42.55 & 27.99 & 16.78 & 3 & 1996.9684 & 1996.9654 & 666.6624 & 0.0030 & 1.5000 & 220.978\end{array}$ $\begin{array}{llllllllllll}\text { AVCMLSNTTAIAEAWAR } & 0.89 & 20.04 & 27.97 & 17.20 & 3 & 1996.9687 & 1996.9654 & 666.6624 & 0.0033 & 1.6500 & 191.091 \\ \text { AVCMLNNTTAIAEAWAR } & 1.00 & \# \# \# \# & 28.10 & 33.38 & 2 & 1996.9636 & 1996.9654 & 999.4900 & -0.0018 & -0.9005 & 0.963\end{array}$ $\begin{array}{llllllllllll}\text { AVCMLSNTTAIAEAWAR } & 1.00 & \text { \#\#\#\# } 28.10 & 33.38 & 2 & 1996.9636 & 1996.9654 & 999.4900 & -0.0018 & -0.9005 & 0.963\end{array}$ $\begin{array}{llllllllllll}\text { AVCMLSNTTAIAEAWAR } & 1.00 & \text { \#\#\# } 27.99 & 29.85 & 2 & 1996.9656 & 1996.9654 & 999.4900 & 0.0002 & 0.1001 & 2398.421 \\ \text { AVCMLSNTTAIAEAWAR } & 1.00 & \text { \#\#\#\# } 27.99 & 27.05 & 2 & 1996.9658 & 1996.9654 & 999.4900 & 0.0004 & 0.2001 & 44.805\end{array}$ $\begin{array}{lllllllllll}\text { AVCMLSNTTAIAEAWAR } & 1.00 & \text { \#\#\#\# } 27.99 & 27.05 & 2 & 1996.9658 & 1996.9654 & 999.4900 & 0.0004 & 0.2001 & 44.805 \\ \text { AVCMLSNTTAIAEAWAR } & 1.00 & \text { \#\#\# } 27.99 & 27.68 & 2 & 1996.9658 & 1996.9654 & 999.4900 & 0.0004 & 0.2001 & 39.707\end{array}$ $\begin{array}{llllllllllll}\text { AVCMLSNTTAIAEAWAR } & 1.00 & \text { \#\#\#\# } 27.99 & 27.68 & 2 & 1996.9658 & 1996.9654 & 999.4900 & 0.0004 & 0.2001 & 39.707 \\ \text { AVCMLSNTTAIAEAWAR } & 1.00 & \text { \#\#\# } 28.01 & 30.23 & 2 & 1996.9664 & 1996.9654 & 999.4900 & 0.0010 & 0.5003 & 58.779\end{array}$ $\begin{array}{llllllllllllll}\text { AVCMLSNTTAIAEAWAR } & 1.00 & \text { \#\#\#\# } & 28.01 & 30.23 & 2 & 1996.9664 & 1996.9654 & 999.4900 & 0.0010 & 0.5003 & 58.779 \\ \text { AVCMLSNTTAIAEAWAR } & 1.00 & 38.54 & 28.00 & 16.48 & 3 & 1996.9666 & 1996.9654 & 666.6624 & 0.0012 & 0.6000 & 111.948\end{array}$ $\begin{array}{llllllllllll}\text { AVCMLSNTTAIAEAWAR } & 1.00 & 38.54 & 28.00 & 16.48 & 3 & 1996.9666 & 1996.9654 & 666.6624 & 0.0012 & 0.6000 & 111.948 \\ \text { AVCMLSNTTAIAEAWAR } & 1.00 & \text { \#\#\#\# } 28.01 & 27.09 & 2 & 1996.9666 & 1996.9654 & 999.4900 & 0.0012 & 0.6003 & 610.892\end{array}$ $\begin{array}{lllllllllllll} & 0.0003 & 610.892\end{array}$ $\begin{array}{llllllllllllllllll} & \end{array}$ $\begin{array}{lllllllll} & \end{array}$ $\begin{array}{lllllllllllll} & \text { AVCMLSNTTAIAEAWAR } & 1.00 & 88.53 & 27.94 & 21.75 & 2 & 1996.9672 & 1996.9654 & 999.490 & 0.0018 & 0.9005 & 934.592\end{array}$ $\begin{array}{lllllllllll} & \end{array}$

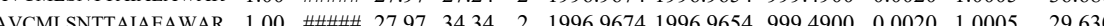
$\begin{array}{lllllllllllll}\text { AVCMLSNTTAIAEAWAR } & 0.99 & 31.49 & 27.97 & 22.94 & 3 & 1996.9675 & 19969664 & 666.6624 & 0.0021 & 1.0500 & 111.973\end{array}$ $\begin{array}{llllllllllllll}\text { AVCMLSTTAAIEAWAR } & 1.00 & 64.83 & 27.97 & 21.63 & 3 & 1996.9678 & 1996.9654 & 666.6624 & 0.0024 & 1.000 & 55.698\end{array}$ $\begin{array}{llllllllllllll}\text { AVCMLSNTTAIAEAWAR } & 1.00 & 33.56 & 28.00 & 16.75 & 3 & 1996.9681 & 19969654 & 666.6624 & 0.0027 & 13500 & 115.617\end{array}$ $\begin{array}{llllllllllllll}\text { AVCMLSNTTAIAEAWAR } & 0.99 & 30.04 & 28.00 & 16.19 & 3 & 1996.9681 & 1996.9654 & 666.6624 & 0.0027 & 1.3500 & 118.436 & 11\end{array}$ $\begin{array}{lllllllllllllll}\text { AVCMLSNTTAIAEAWAR } & 1.00 & 48.91 & 28.00 & 25.13 & 3 & 1996.9681 & 1996.9654 & 666.6624 & 0.0027 & 1.3500 & 46.054\end{array}$ $\begin{array}{llllllllllll}\text { AVCMLSNTTAIAEAWAR } & 0.53 & 27.59 & 27.97 & 40.59 & 3 & 1996.9687 & 1996.9654 & 666.6624 & 0.0033 & 1.6500 & 105.363\end{array}$ $\begin{array}{lllllllllllllll}\text { AVCMLSNTTAIAEAWAR } & 1.00 & 38.31 & 27.97 & 16.84 & 3 & 1996.9687 & 1996.9654 & 666.6624 & 0.0033 & 1.6500 & 69.983\end{array}$ $\begin{array}{lllllllllllll}\text { AVCMLSNTTAIAEAWAR } & 0.53 & 17.31 & 27.97 & 30.31 & 3 & 1996.9687 & 1996.9654 & 666.6624 & 0.0033 & 1.6500 & 71.717\end{array}$ $\begin{array}{lllllllllllll}\text { AVCMLSNTTAIAEAWAR } & 1.00 & \text { \#\#\#\# } 27.99 & 25.47 & 2 & 1996.9648 & 1996.9654 & 999.4900 & -0.0006 & -0.3002 & 20.797\end{array}$ $\begin{array}{llllllllllll}\text { AVCMLSNTTAIAEAWAR } & 1.00 & \text { \#\#\# } 27.94 & 28.91 & 2 & 1996.9668 & 1996.9654 & 999.4900 & 0.0014 & 0.7004 & 18.216\end{array}$ $\begin{array}{llllllllllll}\text { AVCMLSNTTAIAEAWAR } & 1.00 & 35.78 & 27.94 & 16.98 & 3 & 1996.9672 & 1996.9654 & 666.6624 & 0.0018 & 0.9000 & 32.540\end{array}$ $\begin{array}{llllllllllll} & \\ \text { LER } & 1.00 & 43.92 & 25.40 & 56.92 & 4 & 3259.5185 & 3259.5180 & 815.8868 & 0.0005 & 0.1532 & 422.805\end{array}$ $\begin{array}{llllllllllllll} & \end{array}$ $\begin{array}{lllllllllllllll}\text { AVLVDLEPGTMDSVR } & 1.00 & 73.54 & 27.77 & 26.97 & 2 & 1744.9172 & 1744.9151 & 873.4648 & 0.0021 & 1.2021 & 7911.784 & 7113.375 & 1658.795\end{array}$ $\begin{array}{llllllllllllll}\text { AVLVDLEPGTMDSVR } & 0.99 & 31.12 & 27.81 & 20.59 & 3 & 1744.9192 & 1744.9151 & 582.6456 & 0.0041 & 2.3456 & 153.887 & 216.125 & 63.974 \\ \text { AVLVDLEPGTMDSVR } & 1.00 & 76.85 & 27.81 & 29.19 & 2 & 1744.9192 & 1744.9151 & 873.4648 & 0.0041 & 2.3470 & 7751.911 & 9300.429 & 485.270\end{array}$ $\begin{array}{lllllllllllllll}\text { AVLVDLEPGTMDSVR } & 1.00 & 76.85 & 27.81 & 29.19 & 2 & 1744.9192 & 1744.9151 & 873.4648 & 0.0041 & 2.3470 & 7751.911 & 9300.429 & 485.270 \\ \text { FWVVISDEGDPTCTYHCDSDLLLR } & 1.00 & 28.93 & 25.33 & 41.93 & 4 & 3259.5193 & 3259.5180 & 815.8868 & 0.0013 & 0.3983 & 744.453 & 1271.239 & 41.409\end{array}$ $\begin{array}{llllllllllllll}\text { AVLVDLEPGTMDSVR } & 1.00 & 73.35 & 27.84 & 28.06 & 2 & 1744.9168 & 1744.9151 & 873.4648 & 0.0017 & 0.9731 & 5452.924 & 5340.571 & 173.356\end{array}$

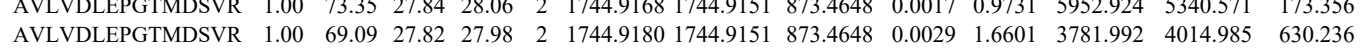

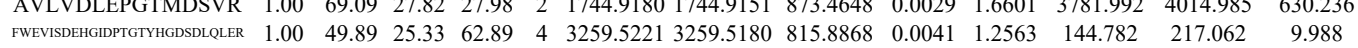

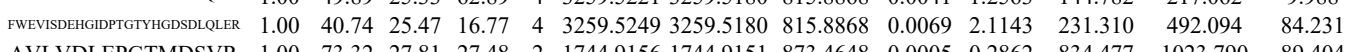

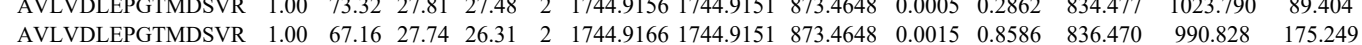

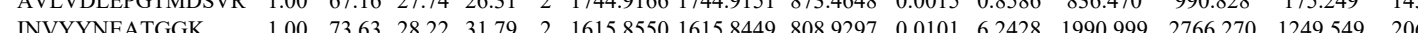
$\begin{array}{lllllllllllllll}\text { INVYYNEATGGK } & 1.00 & 73.63 & 28.22 & 31.79 & 2 & 1615.8550 & 1615.8449 & 808.9297 & 0.0101 & 6.2428 & 1990.999 & 2766.270 & 1249.5 \\ \text { IN } & 1.00 & 74.06 & 28.27 & 34.37 & 2 & 1615.8572 & 1615.8449 & 808.9297 & 0.0123 & 7.6026 & 2488.242 & 2712.654 & 1271.7\end{array}$

258.256 Yes 
$\begin{array}{llllllllllllll}1.00 & 86.30 & 27.72 & 31.46 & 2 & 1615.8590 & 1615.8449 & 808.9297 & 0.0141 & 8.7151 & 3725.516 & 4331.119 & 2069.840 & 269.661\end{array}$ $\begin{array}{lllllllllllllll}1.00 & 70.76 & 27.52 & 27.30 & 2 & 1615.8602 & 1615.8449 & 808.9297 & 0.0153 & 9.4569 & 5998.002 & 6414.112 & 3818.387 & 94.307\end{array}$ MSATFIGNSTALELFK

VLGTEDLYDYIDK VYTDVNTHRPR VYTDVNTHRPR

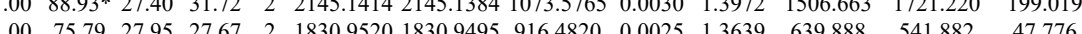

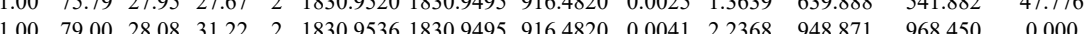

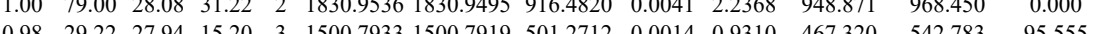

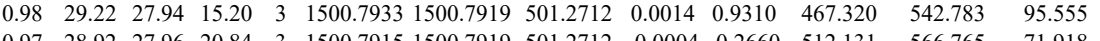
$\begin{array}{lllllllllllll}0.97 & 28.92 & 27.96 & 20.84 & 3 & 1500.7915 & 1500.7919 & 501.2712 & -0.0004 & -0.2660 & 512.131 & 566.765 & 71.918 \\ 0.93 & 2.92 & 27.88 & 18.47 & 3 & 1500.7927 & 1500.7919 & 501.2712 & 0.0008 & 0.5320 & 438.266 & 484.16 & 101891\end{array}$

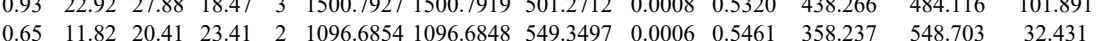
UIEICK

GQPLGPAGVQVSLR GQPLGPAGVQVSLR VSCLDTCGDLVTTOSLSR FLLFSSLVTK LIPLLLQLTSR

LIPLLLQLTSR

LDPSPQTIYK

\section{DPLGGLLDMFGQMPSGGGTTGPGVIO}

QEGIATSDNFMQAFLNVLDQCPK QEGIATSDNFMQAFLNVLDQCPK ASSLISLLK ASSLISLLK SYLAQFAAR LQPQITMIPPSAQPPR LQPQITMIPPSAQPP GLSFLFPLLK GLSFLFPLLK

GLSFLFPLLK

GLSFLFPLLK GLSFLFPLLK GLSFLFPLLK GLSFLFPLLK

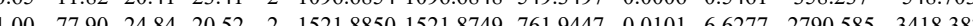
$\begin{array}{lllllllllllll}1.00 & 83.58 & 24.81 & 22.35 & 2 & 1521.8854 & 1521.8749 & 761.9447 & 0.0105 & 6.8902 & 2532.656 & 2564.967\end{array}$

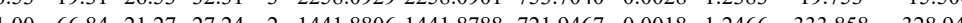
$\begin{array}{lllllllllllll}1.00 & 45.49 & 15.44 & 28.22 & 2 & 1409.9100 & 1409.9091 & 705.9618 & 0.0009 & 0.6374 & 95.059 & 85.015\end{array}$ $\begin{array}{llllllllllll}1.00 & 52.43 & 15.44 & 44.94 & 2 & 1409.9100 & 1409.9091 & 705.9618 & 0.0009 & 0.6374 & 41.334 & 46.369\end{array}$ $\begin{array}{llllllllllll}0.99 & 42.72 & 27.46 & 30.72 & 2 & 1448.8230 & 1448.8119 & 725.4132 & 0.0111 & 7.6508 & 684.705 & 562.867\end{array}$ $\begin{array}{llllllllllll}0.99 & 40.81 & 27.33 & 31.09 & 2 & 1448.8248 & 1448.8119 & 725.4132 & 0.0129 & 8.8914 & 663.261 & 756.288 \\ 1.00 & 66.96 & 27.06 & 1.90 & 3 & 2886.416 & 2886.426 & 963.148 & 0.003 & 1.3497 & 33.154 & 35.61\end{array}$ GLSFLFPLLK $\begin{array}{lllllllllllll}0.86 & 19.44 & 26.63 & 18.69 & 3 & 2902.3954 & 2902.3907 & 968.4708 & 0.0047 & 1.6177 & 13.290 & 0.949\end{array}$ $\begin{array}{llllllllllllll}0.53 & 29.43 & 26.60 & 42.43 & 3 & 2902.3939 & 2902.3907 & 968.4708 & 0.0032 & 1.1014 & 15.345 & 19.637 & 8.122 \\ 1.944\end{array}$ $\begin{array}{lllllllllllll}1.00 & 48.30 & 18.26 & 31.87 & 2 & 1218.7850 & 1218.7791 & 610.3968 & 0.0059 & 4.8329 & 1439.036 & 979.274 & 10.546 \\ 1.00 & 60.02 & 18.13 & 44.05 & 2 & 1218.7856 & 12187791 & 6103968 & 0.0065 & 5.3244 & 3438089 & 3405.000 & 64.729\end{array}$ $\begin{array}{llllllllllllll}1.00 & 46.24 & 27.39 & 32.40 & 2 & 1169.6418 & 1169.6315 & 585.8230 & 0.0103 & 8.7910 & 10425.961 & 10646.740 & 496.951\end{array}$ $\begin{array}{lllllllllllll}3.92 & 25.95 & 6.92 & 3 & 1917.0655 & 1917.0628 & 60.0282 & 0.0027 & 1.4062 & 316.085 & 209.911 & 164.57 & 1\end{array}$ $\begin{array}{llllllllllllll}0.76 & 79.14 & 19.68 & 92.14 & 2 & 1421.8898 & 1421.8890 & 711.9518 & 0.0008 & 0.5618 & 669.018 & 697.958 & 77.724\end{array}$ $\begin{array}{llllllllllllll}1.00 & 78.92 & 19.68 & 19.32 & 2 & 1421.8898 & 1421.8890 & 711.9518 & 0.0008 & 0.5618 & 1023.162 & 1169.469 & 115.548\end{array}$ $\begin{array}{llllllllllllll}1.00 & 24.35 & 19.64 & 15.32 & 3 & 1421.8909 & 1421.8890 & 474.9703 & 0.0019 & 1.3334 & 71.345 & 71.122 & 18.133 \\ 0.53 & 27.09 & 19.64 & 0.09 & 3 & 421.898 & 42.880 & 47.9703 & 0.028 & 1.965 & 57.247 & 64.398 & 32.342\end{array}$ \begin{tabular}{llllllllllllll}
1.00 & 24.35 & 19.64 & 15.32 & 3 & 1421.890 & 1421.8890 & 474.9703 & 0.00 & 1.3334 & 71.345 & 71.122 & 18.133 \\
\hline
\end{tabular} $\begin{array}{lllllllllllll}1.00 & 79.33 & 19.68 & 19.95 & 2 & 1421.8894 & 1421.8890 & 711.9518 & 0.0004 & 0.2809 & 332.813 & 406.892 & 31.208\end{array}$

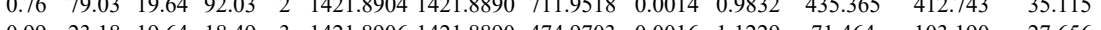
$\begin{array}{lllllllllllll}0.99 & 23.18 & 19.64 & 18.49 & 3 & 1421.8906 & 1421.8890 & 474.9703 & 0.0016 & 1.1229 & 71.464 & 103.190 & 27.656\end{array}$

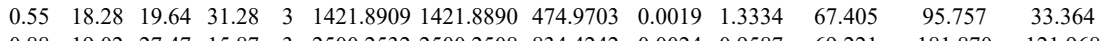

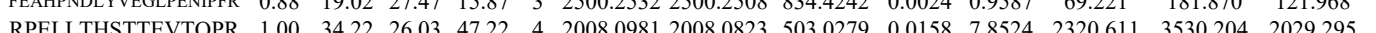

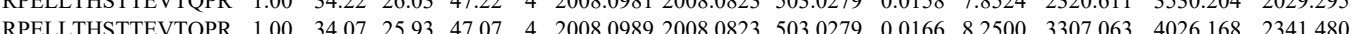
RPELLTHSTTEVTQPR

RPSTFGIPR

RPSTFGIPR

RPSTFGIPR

RPSTFGIPR

RPSTFGIPR

RPSTFGIPR

RPSTFGIPR

RPSTFGIPR

RPSTFGIPR

37 GATQQILDEAER

GATQQILDEAER

\section{NIGVDNPAAK}

NIGVDNPAAK

NIGVDNPAAK

NIGVDNPAAK

VQDDEVGDGTTSVTVLAAELLR

$\begin{array}{llllllllllllll}0.52 & 11.49 & 27.14 & 24.49 & 3 & 2431.2586 & 2431.2564 & 811.4261 & 0.0022 & 0.9038 & 8.045 & 300.144 & 9.909 & 2.80\end{array}$

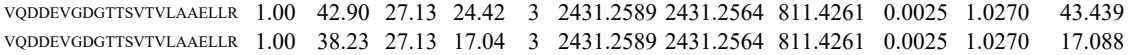

$\begin{array}{llllllllllll}\text { VQDDEVGDGTTSVTVLAAELLR } & 1.00 & 69.90 & 27.02 & 25.30 & 3 & 2431.2598 & 2431.2564 & 811.4261 & 0.0034 & 1.3967 & 24.507\end{array}$

$\begin{array}{lllllllllllll}\text { VQDDEVGDGTTSVTVAAELLR } & 1.00 & 84.94 & 27.07 & 25.64 & 3 & 2431.2604 & 2431.2564 & 811.4261 & 0.0040 & 1.6432 & 47.520\end{array}$

VQDDEVGDGTTSVTVAN

ILIANTGMDTDK

$\begin{array}{lllllllll} & \end{array}$

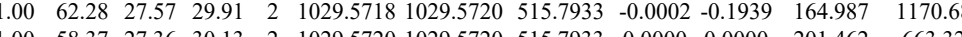

$\begin{array}{lllllllllllll}1.00 & 46.41 & 27.36 & 26.64 & 2 & 1029.5720 & 1029.5720 & 515.7933 & 0.0000 & 0.0000 & 168.067 & 958.700\end{array}$

$\begin{array}{llllllllllll}1.00 & 49.55 & 27.37 & 29.10 & 2 & 1029.5720 & 1029.5720 & 515.7933 & 0.0000 & 0.0000 & 90.424 & 378.738\end{array}$

$\begin{array}{llllllllllll}1.00 & 49.45 & 27.11 & 24.75 & 2 & 1029.5710 & 10295720 & 515.7933 & -0.0010 & -0.9694 & 110.121 & 257.031\end{array}$

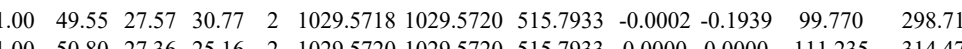

$\begin{array}{llllllllllll}1.00 & 5.80 & 27.36 & 25.16 & 2 & 1029.5720 & 1029.5720 & 515.7933 & 0.0000 & 0.0000 & 111.235 & 314.47 \\ 1.00 & 27.36 & 24.83 & 2 & 1029.5722 & 1029.5720 & 515.7933 & 0.0002 & 0.1939 & 109.976 & 335.022\end{array}$

$\begin{array}{llllllllllll}100 & 47.72 & 27.36 & 28.01 & 2 & 1029.5720 & 1029.5720 & 515.7933 & 0.0000 & 0.0000 & 171.143\end{array}$

$\begin{array}{llllllllllll}1.00 & 57.85 & 27.81 & 27.07 & 2 & 1473.7556 & 1473.7545 & 737.8845 & 0.0011 & 0.7454 & 17.916\end{array}$

259.862

$\begin{array}{lllllllllll}1.00 & 55.80 & 27.94 & 23.12 & 2 & 1473.7584 & 1473.7545 & 737.8845 & 0.0039 & 2.6427 & 18.633 \\ 1.00 & 51.29 & 26.92 & 20.43 & 3 & 2431.2610 & 2431.2564 & 811.4261 & 0.0046 & 1.8897 & 8.983\end{array}$

13.532

13.532
6.977

$\begin{array}{llll} & (1344.267 & \text { Yes } & \\ \end{array}$ ILIANTGMDTDK

$\begin{array}{lllllllllllllll}10.29 & 27.60 & 26.07 & 2 & 1578.8678 & 1578.8531 & 790.4338 & 0.0147 & 9.2986 & 4426.379 & 3990.394 & 181.323\end{array}$

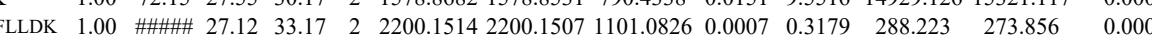
\begin{tabular}{lllllllllllll}
\hline LGGSLADSYLDGGFLLDK & 0.53 & 21.29 & 26.85 & 34.29 & 3 & 2200.1542 & 2200.1507 & 734.3908 & 0.0035 & 1.5886 & 7.105
\end{tabular} 
$\begin{array}{llllllllllll} & 0\end{array}$

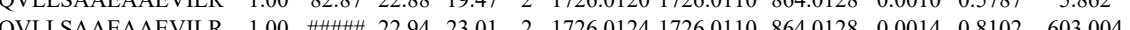
$\begin{array}{lllllllllllllllll} & 22.94 & 23.01 & 2 & 1726.0124 & 1726.0110 & 864.0128 & 0.0014 & 0.8102 & 603.004\end{array}$ \begin{tabular}{llllllllllll}
\hline QVLLSAAEAEVR & 1.00 & 80.86 & 22.94 & 23.70 & 2 & 1726.0124 & 1726.0110 & 864.0128 & 0.0014 & 0.8102 & 116.241
\end{tabular} $\begin{array}{llllllllllll}\text { QVLLSAAEAAEVILR } & 1.00 & 87.75 & 22.97 & 22.86 & 2 & 1726.0126 & 1726.0110 & 864.0128 & 0.0016 & 0.9259 & 86.171\end{array}$

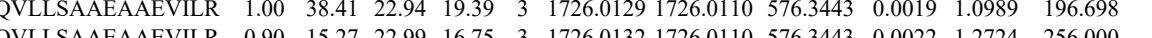
$\begin{array}{llllllllllll}\text { QVLLSAAEAAEVILR } & 0.90 & 15.27 & 22.99 & 16.75 & 3 & 1726.0132 & 1726.0110 & 576.3443 & 0.0022 & 1.2724 & 256.000 \\ \text { QVLLSAAEAAEVILR } & 0.98 & 20.83 & 22.99 & 14.98 & 3 & 1726.0132 & 1726.0110 & 5763443 & 0.0022 & 1.2724 & 276.929\end{array}$ $\begin{array}{llllllllllll}\text { QVLLSAAEAAEVILR } & 0.98 & 20.83 & 22.99 & 14.98 & 3 & 1726.0132 & 1726.0110 & 576.3443 & 0.0022 & 1.2724 & 276.929 \\ \text { QVLLSAAEAAEVILR } & 1.00 & \# \# \# \# 23.03 & 26.44 & 2 & 1726.0134 & 1726.0110 & 864.0128 & 0.0024 & 1.3889 & 81.701\end{array}$

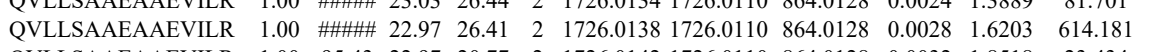
$\begin{array}{llllllllllll}\text { QVLLSAAEAAEVILR } & 1.00 & 95.43 & 22.97 & 20.77 & 2 & 1726.0142 & 1726.0110 & 864.0128 & 0.0032 & 1.8518 & 23.434\end{array}$ $\begin{array}{llllllllllll}\text { QVLLSAAEAAEVILR } & 1.00 & 32.37 & 22.97 & 17.22 & 3 & 1726.0144 & 1726.0110 & 576.3443 & 0.0034 & 1.9664 & 264.299\end{array}$ $\begin{array}{lllllllllllll}\text { QVLLSAAEAAEVILR } & 0.51 & 8.04 & 22.67 & 16.85 & 3 & 1726.0150 & 1726.0110 & 576.3443 & 0.0040 & 2.3134 & 171.599\end{array}$ $\begin{array}{lllllllllllll}\text { QVLLSAAEAAEVILR } & 1.00 & 57.67 & 22.67 & 19.07 & 2 & 1726.0150 & 1726.0110 & 864.0128 & 0.0040 & 2.3148 & 26.439\end{array}$ $\begin{array}{llllllllllll}\text { QVLLSAAEAAEVILR } & 1.00 & 30.58 & 22.55 & 17.38 & 3 & 1726.0156 & 1726.0110 & 576.3443 & 0.0046 & 2.6604 & 189.267\end{array}$ $\begin{array}{lllllllllllll}\text { QVLLSAAEAAEVILR } & 1.00 & 34.54 & 22.55 & 16.67 & 3 & 1726.0159 & 1726.0110 & 576.3443 & 0.0049 & 2.8339 & 110.384\end{array}$

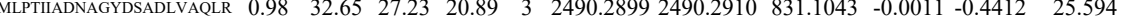

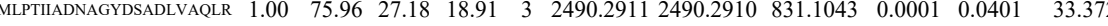

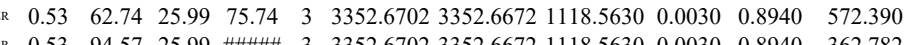

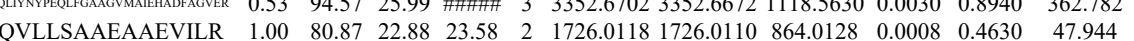
$\begin{array}{lllllllllll} & \end{array}$ $\begin{array}{llllllllllll}\text { QVLLSAAEAAEVILR } & 1.00 & 29.15 & 22.94 & 16.79 & 3 & 1726.0126 & 1726.0110 & 576.3443 & 0.0016 & 0.9254 & 218.530\end{array}$ $\begin{array}{llllllllllll}\text { QVLLSAAEAAEVILR } & 1.00 & 76.18 & 22.94 & 19.21 & 2 & 1726.0128 & 1726.0110 & 864.0128 & 0.0018 & 1.0417 & 197.439\end{array}$

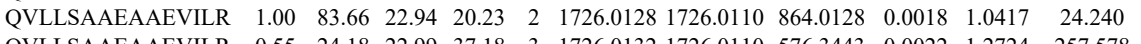
$\begin{array}{llllllllllll}\text { QVLLSAAEAAEVILR } & 0.55 & 24.18 & 22.99 & 37.18 & 3 & 1726.0132 & 1726.0110 & 576.3443 & 0.0022 & 1.2724 & 257.578 \\ \text { QVLLSAAEAAEVILR } & 1.00 & 41.58 & 22.99 & 17.51 & 3 & 1726.0132 & 1726.0110 & 576.3443 & 0.0022 & 1.2724 & 194.448\end{array}$ $\begin{array}{llllllllllll}\text { QVLLSAAEAAEVILR } & 1.00 & 41.58 & 22.99 & 17.51 & 3 & 1726.0132 & 1726.0110 & 576.3443 & 0.0022 & 1.2724 & 194.448\end{array}$ $\begin{array}{llllllllllll}\text { QVLLSAAEAAEVILR } & 1.00 & 98.05 & 22.99 & 25.49 & 2 & 1726.0132 & 1726.0110 & 864.0128 & 0.0022 & 1.2731 & 114.381 \\ \text { QVLLSAAEAAEVILR } & 1.00 & 97.10 & 23.03 & 22.10 & 2 & 1726.0134 & 1726.0110 & 864.0128 & 0.0024 & 1.3889 & 94.260\end{array}$

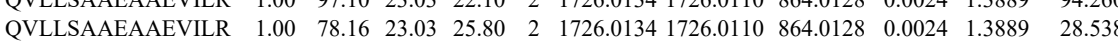

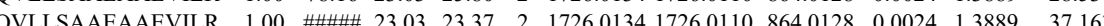

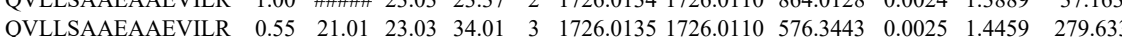




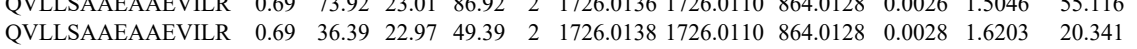

GATQQILDEAER

GATQQILDEAER

$\begin{array}{lllllllllll}1.00 & 62.01 & 27.96 & 27.41 & 2 & 1473.7554 & 1473.7545 & 737.8845 & 0.0009 & 0.6099 & 41.541 \\ 1.00 & 65.20 & 27.87 & 23.80 & 2 & 1473.7572 & 1473.7545 & 737.8845 & 0.0027 & 1.8296 & 31.617\end{array}$

LTSFIGAIAIGDLVK

LTSFIGAIAIGDLVK

$\begin{array}{llllllllll}1.00 & \# \# \# 19.19 & 26.01 & 2 & 1805.0930 & 1805.0906 & 903.5526 & 0.0024 & 1.2174 & 817.719 \\ 1.3281 & 657.715\end{array}$

LTSFAIAIGLVK

$\begin{array}{lllllllllll}1.00 & 38.11 & 18.98 & 15.89 & 3 & 1805.0947 & 1805.0906 & 602.7041 & 0.0041 & 2.2676 & 99.487\end{array}$

LTSFGATIGDLVK

$\begin{array}{llllllllllll}1.00 & 24.43 & 18.81 & 15.60 & 3 & 1805.0950 & 1805.0906 & 602.7041 & 0.0044 & 2.4335 & 197.073\end{array}$

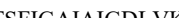

$\begin{array}{llllllllll}1.00 & \text { \#\#\#\# } 19.08 & 29.35 & 2 & 1805.0934 & 1805.0906 & 903.5526 & 0.0028 & 1.5494 & 757.451 \\ 1.00 & \text { \#\#\#\# } 19.08 & 25.69 & 2 & 1805.0936 & 1805.0906 & 903.5526 & 0.0030 & 1.6601 & 438.709\end{array}$

$\begin{array}{lllllllllllll}\mathrm{VK} & 1.00 & 35.79 & 19.14 & 16.33 & 3 & 1805.0965 & 1805.0906 & 602.7041 & 0.0059 & 3.2631 & 68.959\end{array}$

$\begin{array}{lllllllllllll} & \end{array}$

$\begin{array}{lllllllllllllll}\text { SLHDALCVLAQTVK } & 0.70 & 21.01 & 27.04 & 17.83 & 3 & 1830.9928 & 1830.9939 & 611.3386 & -0.0011 & -0.5998 & 1509.680 & 1068.695 & 442.733\end{array}$

$\begin{array}{llllllllllllllll}\text { SLHDALCVLAQTVK } & 1.00 & 74.87 & 26.85 & 26.50 & 2 & 1830.9946 & 1830.9939 & 916.5042 & 0.0007 & 0.3819 & 2690.710 & 2077.753 & 1488.308\end{array}$

$\begin{array}{lllllllllllllll}\text { LTSFIGAIAIGDLVK } & 1.00 & 40.18 & 19.24 & 15.98 & 3 & 1805.0920 & 1805.0906 & 602.7041 & 0.0014 & 0.7743 & 95.282 & 82.229 & 40.624\end{array}$

$\begin{array}{llllllllllllll}\text { LTSFIGAIAIGDLVK } & 1.00 & 50.25 & 19.14 & 17.22 & 3 & 1805.0953 & 1805.0906 & 602.7041 & 0.0047 & 2.5994 & 113.489 & 201.077 & 19.366\end{array}$

$\begin{array}{lllllllllllllll}\text { SLHDALCVLAQTVK } & 1.00 & 40.40 & 26.95 & 26.05 & 3 & 1830.9940 & 1830.9939 & 611.3386 & 0.0001 & 0.0545 & 1442.729 & 1275.271 & 333.706\end{array}$

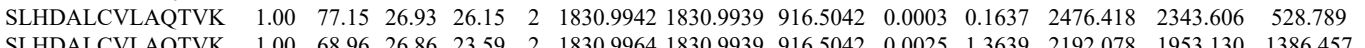

$\begin{array}{llllllllllllll}\text { SLHDALCVLAQTVK } & 1.00 & 68.96 & 26.86 & 23.59 & 2 & 1830.9964 & 1830.9939 & 916.5042 & 0.0025 & 1.3639 & 2192.078 & 1953.130 & 1386.457 \\ \text { SLHDALCVLAQTVK } & 1.00 & 40.17 & 26.48 & 25.43 & 3 & 1831.0033 & 1830.9939 & 611.3386 & 0.0094 & 5.1253 & 901.526 & 878.841 & 288.743\end{array}$

$\begin{array}{lllllllllllllll}\text { SLHDALCVLAQTVK } & 0.99 & 30.31 & 26.79 & 19.92 & 3 & 1830.9964 & 1830.9939 & 611.3386 & 0.0025 & 1.3631 & 626.372 & 391.624 & 52.018\end{array}$

$\begin{array}{lllllllllllllll}\text { SLHDALCVLAQTVK } & 0.98 & 26.35 & 26.73 & 23.87 & 3 & 1830.9970 & 1830.9939 & 611.3386 & 0.0031 & 1.6903 & 592.418 & 420.451 & 123.626\end{array}$

$\begin{array}{llllllllllll}\text { TVYGGGCSEMLMAHAVtQlanR } & 0.55 & \text { \#\#\#\# } 26.23 & \text { \#\#\#\# } 3 & 2498.1679 & 2498.1660 & 833.7293 & 0.0019 & 0.7596 & 5637.798 & 6685.792 & 795.051\end{array}$

TYGGGCSEMLMAHAVTQLANR

HGINCFINR

HGINCFINR

HGINCFINR

HGINCFINR

HGINCFINR

HGINCFINR

HGINCFINR

VPDHHPC

VPDHHPC

IHPQTIIAGWR

IHPQTIIAGWR

(T)

TQRTR $\begin{array}{lllllllllllllll}0.60 & 26.32 & 26.98 & 31.37 & 3 & 1262.6260 & 1262.6134 & 421.8784 & 0.0126 & 9.9554 & 8652.677 & 7929.896 & 1762.101\end{array}$ $\begin{array}{llllllllllllll}0.99 & 34.85 & 26.88 & 23.81 & 3 & 1262.6242 & 1262.6134 & 421.8784 & 0.0108 & 8.5332 & 12380.058 & 11502.049 & 2555.006 & \end{array}$ $\begin{array}{lllllllllllll}1.00 & 44.70 & 26.84 & 23.39 & 2 & 1262.6244 & 1262.6134 & 632.3140 & 0.0110 & 8.6981 & 9098.450 & 8212.099 & 516.004 \\ 0.99 & 37.79 & 26.90 & 24.31 & 3 & 1262.6257 & 1262.6134 & 421.8784 & 0.0123 & 9.7183 & 13903.085 & 12096290 & 2510.094\end{array}$ $\begin{array}{lllllllllllll}0.99 & 37.79 & 26.90 & 24.31 & 3 & 1262.6257 & 1262.6134 & 421.8784 & 0.0123 & 9.7183 & 13903.085 & 12096.290 & 2510.094 \\ 0.51 & 18.65 & 26.90 & 25.07 & 3 & 1262.6254 & 1262.6134 & 421.8784 & 0.0120 & 9.4813 & 15352091 & 11389.995 & 3563.710\end{array}$ $\begin{array}{lllllllllllllll}0.51 & 18.65 & 26.90 & 25.07 & 3 & 1262.6254 & 1262.6134 & 421.8784 & 0.0120 & 9.4813 & 15352.091 & 11389.995 & 3563.710 \\ 0.99 & 41.83 & 26.90 & 18.49 & 2 & 1262.6256 & 12626134 & 6323140 & 0.0122 & 9.6470 & 5122.740 & 4731.436 & 214.075\end{array}$ $\begin{array}{llllllllllllll}0.99 & 41.83 & 26.90 & 18.49 & 2 & 1262.6256 & 1262.6134 & 632.3140 & 0.0122 & 9.6470 & 5122.740 & 4731.436 & 214.075 & 19.1 \\ 0.60 & 19.84 & 26.90 & 24.18 & 3 & 1262.6257 & 1262.6134 & 421.8784 & 0.0123 & 9.7183 & 13208.402 & 10977.132 & 3329.983 & 1655\end{array}$ $\begin{array}{llllllllllllll}0.60 & 19.84 & 26.90 & 24.18 & 3 & 1262.6257 & 1262.6134 & 421.8784 & 0.0123 & 9.7183 & 13208.402 & 10977.132 & 3329.983 \\ 0.60 & 14.54 & 21.14 & 19.51 & 2 & 993.4280 & 993.4283 & 497.7214 & -0.0003 & -0.3014 & 148.407 & 177.258 & 163.491\end{array}$ $\begin{array}{llllllllllllll}0.60 & 14.54 & 21.14 & 19.51 & 2 & 993.4280 & 993.4283 & 497.7214 & -0.0003 & -0.3014 & 148.407 & 177.258 & 163.491 \\ 0.74 & 13.94 & 20.76 & 18.15 & 2 & 993.4294 & 993.4283 & 497.7214 & 0.0011 & 1.1050 & 162.102 & 167.919 & 177.856\end{array}$ $\begin{array}{lllllllllllll}0.74 & 13.94 & 20.76 & 8.15 & 2 & 993.4294 & 993.4283 & 497.7214 & 0.001 & 1.1050 & 162.102 & 167.919 & 177.856 \\ 1.00 & 48.63 & 26.89 & 18.10 & 2 & 1434.8224 & 1434.8217 & 718.4181 & 0.0007 & 0.4872 & 39.497 & 52.592 & 0.237\end{array}$

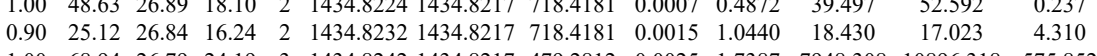

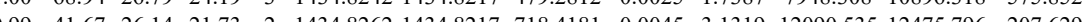
$\begin{array}{lllllllllllllll}0.99 & 41.67 & 26.14 & 21.73 & 2 & 1434.8262 & 1434.8217 & 718.4181 & 0.0045 & 3.1319 & 12090.535 & 12475.796 & 207.629 \\ 0.99 & 43.15 & 26.47 & 20.65 & 2 & 1434.8264 & 1434.8217 & 718.4181 & 0.0047 & 3.2711 & 10163.590 & 10452363 & 104.419\end{array}$ 


\section{$\begin{array}{lllllllllllll}60.75 & 26.47 & 23.42 & 3 & 1434.8269 & 1434.8217 & 479.2812 & 0.0052 & 3.6165 & 10879.007 & 11129.507 & 1512.820 & 130.888\end{array}$}

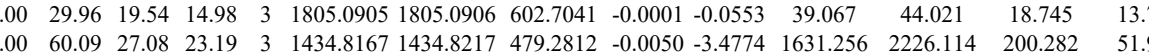

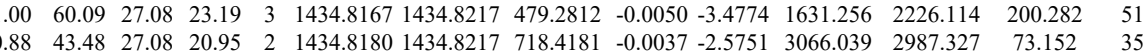

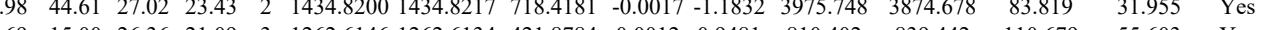

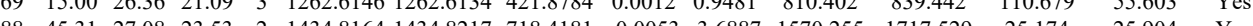

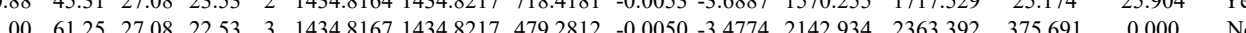

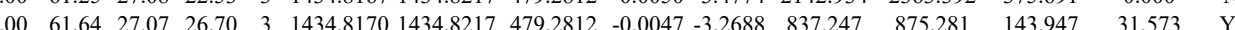

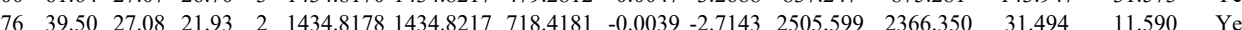
$\begin{array}{lllllllllllll} & \end{array}$ $\begin{array}{lllllllllllllll}1.99 & 50.64 & 27.08 & 22.97 & 2 & 1434.8196 & 1434.8217 & 718.4181 & -0.0021 & -1.4615 & 1307.738 & 1288.861 & 51.003 & 18.872 & \text { Yes }\end{array}$ $\begin{array}{lllllllllllllll}100 & 58.89 & 26.97 & 21.22 & 3 & 1434.8203 & 1434.8217 & 4792812 & -0.0014 & -0.9737 & 582.290 & 856.490 & 156.487 & 51.912 & \text { Yes }\end{array}$

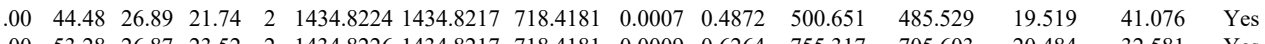

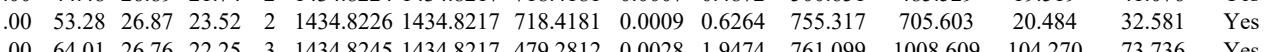

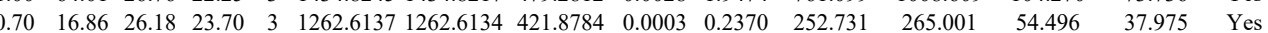
$\begin{array}{lllllllllllllll}1.00 & 65.62 & 26.81 & 22.04 & 3 & 1434.8209 & 1434.8217 & 479.2812 & -0.0008 & -0.5564 & 320.056 & 350.900 & 94.872 & 44.411 & \text { Yes } \\ 0.98 & 39.03 & 26.79 & 17.58 & 2 & 1434.8210 & 4434.8217 & 718.4181 & 0.0007 & -0.4872 & 327.575 & 313.933 & 21.75 & 10.79 & \text { Yes }\end{array}$

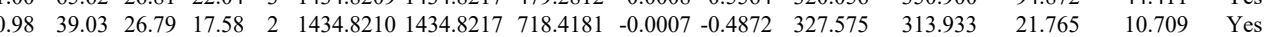

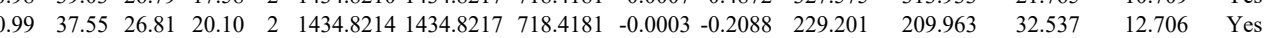
$\begin{array}{llllllllllllllll}1.00 & 59.50 & 26.89 & 24.56 & 3 & 1434.8221 & 1434.8217 & 479.2812 & 0.0004 & 0.2782 & 336.774 & 365.889 & 93.452 & 42.253 & \text { Yes }\end{array}$ $\begin{array}{lllllllllllllll}0.65 & 14.64 & 26.36 & 24.55 & 3 & 1262.6146 & 1262.6134 & 421.8784 & 0.0012 & 0.9481 & 112.223 & 96.626 & 42.944 & 42.537 & \text { Yes }\end{array}$ $\begin{array}{llllllllllllllll}0.62 & 13.82 & 26.32 & 22.95 & 3 & 1262.6140 & 1262.6134 & 421.8784 & 0.0006 & 0.4741 & 584.574 & 580.766 & 84.266 & 74.965 & \text { Yes }\end{array}$ $\begin{array}{lllllllllllllll}0.82 & 17.76 & 26.36 & 21.74 & 3 & 1262.6146 & 1262.6134 & 421.8784 & 0.0012 & 0.9481 & 384.485 & 398.322 & 63.405 & 90.927 & \text { Yes }\end{array}$ $\begin{array}{lllllllllllllll}1.00 & 74.41 & 27.92 & 27.43 & 2 & 1473.7684 & 1473.7545 & 737.8845 & 0.0139 & 9.4187 & 9086.252 & 12724.633 & 7824.436 & 3729.011 & \text { Yes } \\ 1.00 & 66.53 & 27.90 & 26.54 & 2 & 1473.7688 & 1473.7545 & 737.8845 & 0.0143 & 9.6898 & 6695.682 & 8406.739 & 4312.134 & 2862.696 & \text { Yes }\end{array}$

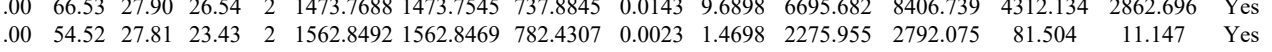

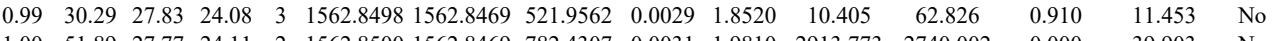
$\begin{array}{lllllllllllllll}1.00 & 51.89 & 27.77 & 24.11 & 2 & 1562.8500 & 1562.8469 & 782.4307 & 0.0031 & 1.9810 & 2913.773 & 2740.002 & 0.000 & 39.903 & \text { No }\end{array}$ $\begin{array}{lllllllllllllll}0.64 & 29.28 & 27.53 & 21.27 & 3 & 1683.9184 & 1683.9157 & 562.3125 & 0.0027 & 1.6005 & 2429.701 & 3647.406 & 4477.735 & 3803.821 & \text { Yes }\end{array}$ $\begin{array}{lllllllllllllll}0.92 & 33.98 & 27.10 & 21.64 & 2 & 1488.7378 & 1488.7308 & 745.3727 & 0.0070 & 4.6956 & 330.155 & 333.245 & 470.608 & 156.957 & \text { Yes }\end{array}$ $\begin{array}{lllllllllllllllll}0.85 & 26.06 & 27.22 & 16.15 & 3 & 1488.7408 & 1488.7308 & 497.2509 & 0.0100 & 6.7035 & 15281.684 & 19030.670 & 6839.990 & 3293.146 & \text { Yes }\end{array}$ \begin{tabular}{lllllllllllllll}
1.00 & 56.05 & 27.06 & 27.68 & 2 & 1463.7872 & 1463.7854 & 732.9000 & 0.0018 & 1.2280 & 4483.542 & 7371.055 & 5043.205 & 3129.085 & Yes \\
\hline
\end{tabular} $\begin{array}{lllllllllllllll}1.00 & 65.47 & 28.07 & 29.14 & 2 & 1463.7876 & 1463.7854 & 732.9000 & 0.0022 & 1.5009 & 5762.501 & 8120.641 & 5255.548 & 3709.558 & \text { Yes }\end{array}$ $\begin{array}{lllllllllllllll}1.00 & 69.66 & 27.93 & 28.42 & 2 & 1463.7894 & 1463.7854 & 732.9000 & 0.0040 & 2.7289 & 1576.236 & 2653.750 & 1433.118 & 890.351 & \text { Yes } \\ 1.00 & 62.34 & 27.93 & 30.22 & 2 & 1463.7896 & 1463.7854 & 732.9000 & 0.0042 & 2.8653 & 3749.884 & 4884.983 & 3882.686 & 2906.782 & \text { Yes }\end{array}$ $\begin{array}{lllllllllllllll}1.00 & 62.34 & 27.93 & 30.22 & 2 & 1463.7896 & 1463.7854 & 732.9000 & 0.0042 & 2.8653 & 3749.884 & 4884.983 & 3882.686 & 2906.782 & \text { Yes } \\ 0.65 & 17.39 & 23.71 & 21.59 & 3 & 13668295 & 13668176 & 456.131 & 0.0119 & 8.6871 & 1704.639 & 1952.283 & 1367.005 & 844.589 & \text { Yes }\end{array}$

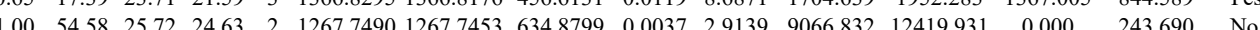

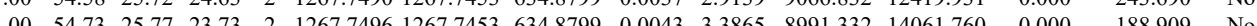
$\begin{array}{llllllllllllllll}1.00 & 58.12 & 24.97 & 22.35 & 2 & 1267.7506 & 1267.7453 & 634.8799 & 0.0053 & 4.1740 & 1721650 & 26178.137 & 101.658 & 462.811 & \text { Yes }\end{array}$ $\begin{array}{llllllllllllllll}1.00 & 54.40 & 24.79 & 21.80 & 2 & 1267.7510 & 1267.7453 & 634.8799 & 0.0057 & 4.4890 & 10151846 & 16333.099 & 0.000 & 423.634 & \text { No }\end{array}$

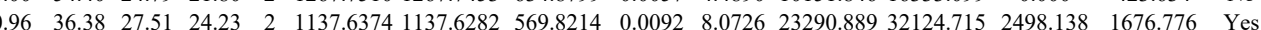

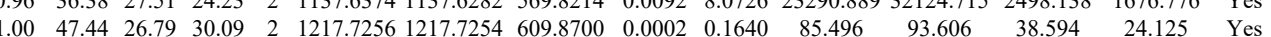

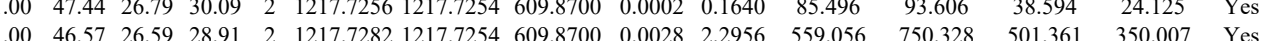

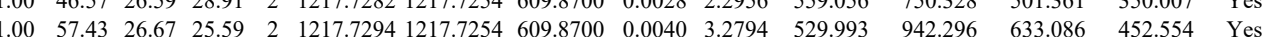
$\begin{array}{llllllllllllllll}1.00 & 52.43 & 26.79 & 22.94 & 2 & 1217.7256 & 1217.7254 & 609.8700 & 0.0002 & 0.1640 & 940.336 & 1720.669 & 1212.001 & 828.576 & \text { Yes }\end{array}$

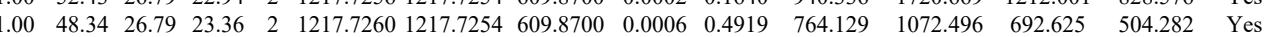
$\begin{array}{lllllllllllllll}0.99 & 35.97 & 26.79 & 21.84 & 2 & 1217.7260 & 1217.7254 & 609.8700 & 0.0006 & 0.4919 & 660.110 & 743.521 & 508.271 & 438.616 & \text { Yes }\end{array}$ $\begin{array}{lllllllllllllll}1.00 & 49.12 & 26.66 & 22.92 & 2 & 1217.7264 & 1217.7254 & 609.8700 & 0.0010 & 0.8198 & 667.800 & 835.958 & 631.523 & 520.606 & \text { Yes }\end{array}$ $\begin{array}{lllllllllllllll}0.99 & 39.07 & 26.79 & 23.59 & 2 & 1217.7258 & 1217.7254 & 609.8700 & 0.0004 & 0.3279 & 503.674 & 762.152 & 438.756 & 382.466 & \text { Yes }\end{array}$ $\begin{array}{llllllllllllllll}0.99 & 35.31 & 26.66 & 26.02 & 2 & 1217.7266 & 1217.7254 & 609.8700 & 0.0012 & 0.9838 & 527.045 & 766.446 & 394.267 & 255.709 & \text { Yes }\end{array}$ $\begin{array}{llllllllllllllll}1.00 & 52.02 & 26.79 & 23.32 & 2 & 1217.7256 & 1217.7254 & 609.8700 & 0.0002 & 0.1640 & 380.682 & 662.523 & 348.551 & 282.263 & \text { Yes }\end{array}$

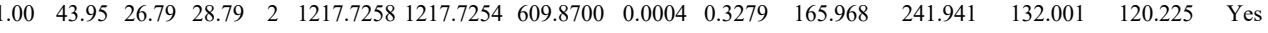
$\begin{array}{lllllllllllllll}1.00 & 54.89 & 28.25 & 29.57 & 2 & 1376.7560 & 1376.7431 & 689.3788 & 0.0129 & 9.3562 & 19278.432 & 31211.572 & 24.450 & 753.644 & \text { Yes }\end{array}$ $\begin{array}{lllllllllllllll}1.00 & 83.10 & 27.52 & 20.81 & 2 & 1676.9092 & 1676.9076 & 839.4611 & 0.0016 & 0.9530 & 3488.352 & 6129.215 & 4611.835 & 4380.992 & \text { Yes }\end{array}$ $\begin{array}{lllllllllllllll}1.00 & 86.78 & 27.55 & 27.73 & 2 & 1676.9094 & 1676.9076 & 839.4611 & 0.0018 & 1.0721 & 3657.136 & 4907.887 & 3343.260 & 2942.748 & \text { Yes }\end{array}$

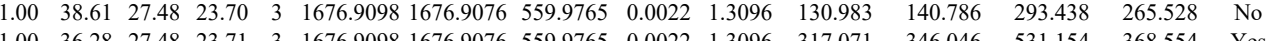

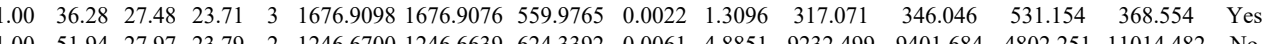

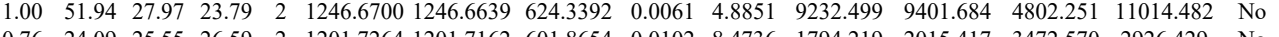
$\begin{array}{lllllllllllllll}0.76 & 24.09 & 25.55 & 26.59 & 2 & 1201.7264 & 1201.7162 & 601.8654 & 0.0102 & 8.4736 & 1794.219 & 2015.417 & 3472.570 & 2926.429 & \text { No } \\ 0.99 & 39.22 & 25.55 & 27.50 & 2 & 1201.7264 & 1201.7162 & 601.564 & 0.0102 & 8.4736 & 251.194 & 2674.700 & 262.618 & 2163.075 & \text { No }\end{array}$ $\begin{array}{llllllllllllllll}0.99 & 39.22 & 25.55 & 27.50 & 2 & 1201.7264 & 1201.7162 & 601.8654 & 0.0102 & 8.4736 & 2551.194 & 2674.700 & 2682.618 & 2163.075 & \mathrm{No} \\ 0.63 & 26.01 & 26.28 & 36.86 & 2 & 1201.7270 & 1201.7162 & 601.8654 & 0.0108 & 8.9720 & 1185.798 & 1440.633 & 1877.598 & 968.036 & \mathrm{No}\end{array}$ $\begin{array}{llllllllllllllll}0.63 & 26.01 & 26.28 & 36.86 & 2 & 1201.7270 & 1201.7162 & 601.8654 & 0.0108 & 8.9720 & 1185.798 & 1440.633 & 1877.598 & 968.036 & \text { No } \\ 0.88 & 26.11 & 18.86 & 25.53 & 3 & 1473.9220 & 1473.9132 & 492.3117 & 0.0088 & 5.9582 & 8381.664 & 8054.796 & 4020.448 & 2702.761 & \text { Yos }\end{array}$

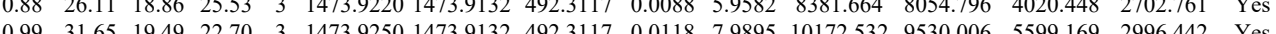
$\begin{array}{lllllllllllllll}0.99 & 31.65 & 19.49 & 22.70 & 3 & 1473.9250 & 1473.9132 & 492.3117 & 0.0118 & 7.9895 & 10172.532 & 9530.006 & 5599.169 & 2996.442 & \text { Yes } \\ 0.99 & 31.55 & 19.44 & 21.83 & 3 & 1473.9259 & 1473.9132 & 4923117 & 0.0127 & 8.5988 & 4166.456 & 3999.408 & 2402.666 & 1431.795 & \text { Yes }\end{array}$ $\begin{array}{lllllllllllllll}0.9 & 1431.795 & \text { Yes }\end{array}$ $\begin{array}{lllllllllllllll}1.00 & 58.90 & 27.93 & 22.94 & 2 & 1683.9024 & 1683.8923 & 842.9534 & 0.0101 & 5.9908 & 1710.799 & 1353.822 & 788.948 & 240.176 & \text { Yes } \\ 1.00 & 42.76 & 27.75 & 28.02 & 2 & 1598.8496 & 1598.8469 & 800.4307 & 0.0027 & 1.6866 & 139.763 & 110.928 & 53.877 & 54.500 & \text { No }\end{array}$ 
NILEESLCELVAK

NILEESLCELVAK
NILEESLCELVAK

NILEESLCELV
GIFTSEIGTK

GIFTSEIGTK

NILEESLCELVAK
NILEESLCELVAK

NILEESLCELVAK

NILEES

SDPGLLTNTMDVFVK

NLDLAVLELMQSSVDNTK
NLDLAVLELMQSSVDNTK
NLDLAVLELMQSSVDNTK

NLDLAVLELMQSSVDNTK
LAGANPAVITCDELLLGHEK

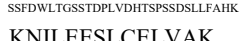

KLLQGEADQSLLTF

LLLQGEADQSLLTFIDK
NLDLAVLELMQSSVDNTK
1.00

LAGANPAVITCDELLLGHEK
MDPMNIWDDIITNR

$\begin{array}{lllllllllllllll} & \end{array}$

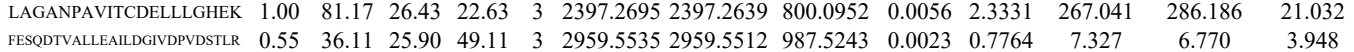

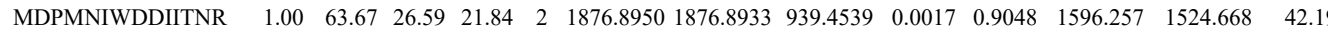

$\begin{array}{llllllllllllll}\text { MDPMNIWDDIITNR } & 1.00 & 88.11 & 26.59 & 25.40 & 2 & 1876.8954 & 1876.8933 & 939.4539 & 0.0021 & 1.1177 & 584.968 & 468.036 & 27.761\end{array}$

$\begin{array}{llllllllllllll}\text { MDPMNIWDDIITNR } & 1.00 & 36.66 & 26.66 & 17.97 & 3 & 1876.8967 & 1876.8933 & 626.6384 & 0.0034 & 1.8086 & 27.230 & 10.905 & 0.191\end{array}$

$\begin{array}{lllllllllllllll}\text { ITAQSIEELCAVNLYGPDAQVDR } & 0.99 & 34.37 & 27.42 & 16.13 & 3 & 2694.3115 & 2694.3115 & 899.1111 & 0.0000 & 0.0000 & 78.680 & 104.591 & 52.703\end{array}$

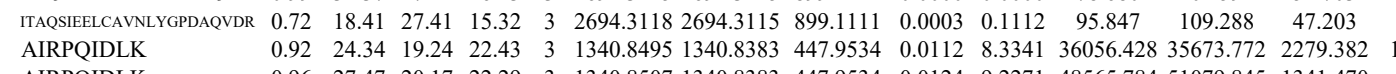

NLLIFENLIDLK

NLLIFENLIDLK

NLLIFENLIDLK

$\begin{array}{llllllllllllll}0.92 & 24.34 & 19.24 & 22.43 & 3 & 1340.8495 & 1340.8383 & 447.9534 & 0.0112 & 8.3341 & 36056.428 & 35673.772 & 2279.382 \\ 0.96 & 27.47 & 20.17 & 22.29 & 3 & 1340.8507 & 1340.8383 & 447.9534 & 0.0124 & 9.2271 & 48565.784 & 51079.845 & 1341.470 & \end{array}$

$\begin{array}{lllllllllllll}0.96 & 27.47 & 20.17 & 22.29 & 3 & 1340.8507 & 1340.8383 & 447.9534 & 0.0124 & 9.2271 & 48565.784 & 51079.845 & 1341.470 \\ 1.00 & 45.85 & 21.30 & 29.09 & 3 & 1732.0411 & 1732.0378 & 578.3532 & 0.0033 & 1.9019 & 437.941 & 696.378 & 27.493\end{array}$

$\begin{array}{lllllllllllll}1.00 & 45.85 & 21.30 & 29.09 & 3 & 1732.0411 & 1732.0378 & 578.3532 & 0.0033 & 1.9019 & 437.941 & 696.378 & 27.493 \\ 1.00 & 53.87 & 21.04 & 31.05 & 2 & 1732.0416 & 1732.0378 & 867.0262 & 0.0038 & 2.1914 & 449.118 & 236.998 & 8.281\end{array}$

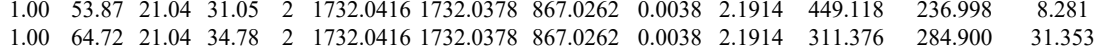

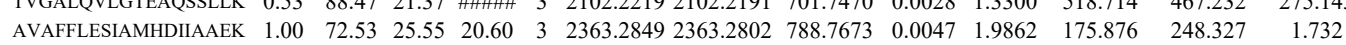

VCLDIIYK

AALSALESFLK

AALSALESFLK

QCLPSLDLSCK

NLLIFENLIDLK

NLLIFENLIDLK

TVGALOVLGTEAQSS

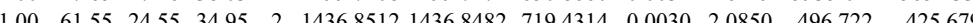

$\begin{array}{llllllllllll}1.00 & 63.16 & 24.76 & 29.65 & 2 & 1436.8526 & 14368482 & 719.4314 & 0.0044 & 3.0580 & 466.945 & 424.022\end{array}$

$\begin{array}{lllllllllllll}0.99 & 42.13 & 26.59 & 19.95 & 2 & 1585.7672 & 1585.7580 & 793.8863 & 0.0092 & 5.7942 & 370.232 & 41.2138\end{array}$

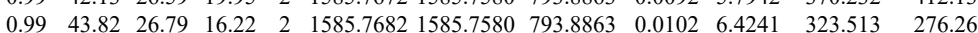

$\begin{array}{llllllllllll}1.00 & 62.62 & 21.04 & 38.77 & 2 & 1732.0414 & 1732.0378 & 867.0262 & 0.0036 & 2.0761 & 405.231 & 44.7449\end{array}$

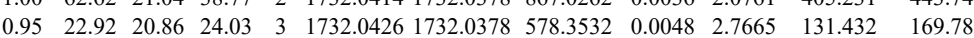
$\begin{array}{llllllllllllll}\text { TVGALQVLGTEAQSSLLK } & 1.00 & \text { \#\#\#\# } 21.00 & 23.07 & 2 & 2102.2234 & 2102.2191 & 1052.1168 & 0.0043 & 2.0435 & 633.327 & 596.694\end{array}$ $\begin{array}{llllllllllllll}\text { TVGALQVLGTEAQSSLLK } & 1.00 & 68.68 & 21.04 & 18.18 & 3 & 2102.2237 & 2102.2191 & 701.7470 & 0.0046 & 2.1850 & 1167.374 & 948.973\end{array}$

AALSALESFLK

AALSALESFLK

$\begin{array}{llllllllllll}1.00 & 61.84 & 24.58 & 35.19 & 2 & 1436.8508 & 1436.8482 & 719.4314 & 0.0026 & 1.8070 & 366.380 & 352.899\end{array}$ $\begin{array}{llllllllllll}1.00 & 61.52 & 24.56 & 29.77 & 2 & 1436.8514 & 1436.8482 & 719.4314 & 0.0032 & 2.2240 & 925.640 & 1029.558\end{array}$

$\begin{array}{lllllllllllllll}\text { LSDFNDITNMLLLK } & 1.00 & 77.65 & 26.16 & 24.56 & 2 & 1924.0618 & 1924.0583 & 963.0364 & 0.0035 & 1.8172 & 1543.126 & 1249.393 & 0.9 \\ \text { LSDFNDITNMLLLK } & 1.00 & 85.25 & 26.02 & 27.76 & 2 & 1924.0622 & 1924.0583 & 963.0364 & 0.0039 & 2.0248 & 1374.373 & 1239.045\end{array}$

$\begin{array}{llllllllllllll}\text { LDQGGVIDDFNALDQLSNPELLKK } & 1.00 & 51.65 & 23.52 & 17.56 & 3 & 3074.6572 & 3074.6532 & 1025.8917 & 0.0040 & 1.2997 & 7.985 & 11.819 & 1.9 \\ \text { LDQGGVIPDFNALDLSNPELLFK } & 1.00 & 53.22 & 23.30 & 19.55 & 3 & 3074.6632 & 3074.6532 & 1025.8917 & 0.0100 & 3.2492 & 11.734 & 20.071 & \end{array}$

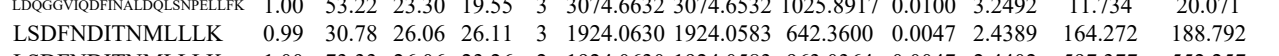

$\begin{array}{llllllllllllll}\text { LSDFNDITNMLLLK } & 1.00 & 73.33 & 26.06 & 23.26 & 2 & 1924.0630 & 1924.0583 & 963.0364 & 0.0047 & 2.4402 & 597.377 & 552.257 \\ \text { LSDFNDITNMLLLK } & 1.00 & 87.34 & 26.06 & 24.22 & 2 & 1924.0632 & 1924.0583 & 963.0364 & 0.0049 & 2.5440 & 437.667 & 394.398\end{array}$

LSDFNDITNMLLLK

YAVPSAGLR

IPALDLLIK

$\begin{array}{llllllllllllll}1.00 & 87.34 & 26.06 & 24.22 & 2 & 1924.0632 & 1924.0583 & 963.0364 & 0.0049 & 2.5440 & 437.667 & 394.398 \\ 0.99 & 32.91 & 26.07 & 26.15 & 3 & 1924.0636 & 1924.0583 & 6423600 & 0.0053 & 2.7503 & 167.992 & 177.305\end{array}$

IPALDLLIK

$\begin{array}{ccccccccccccc}0.99 & 32.91 & 26.07 & 26.15 & 3 & 1924.0636 & 1924.0583 & 642.3600 & 0.0053 & 2.7503 & 167.992 & 177.305 & 57.597 \\ 0.77 & 28.36 & 27.47 & 16.67 & 2 & 1076.6180 & 1076.6100 & 539.3123 & 0.0080 & 7.4168 & 15667.296 & 14748.508 & 2893.534\end{array}$

$\begin{array}{llllllllllllll}1.00 & 59.59 & 13.01 & 29.55 & 2 & 1282.8494 & 1282.8468 & 642.4307 & 0.0026 & 2.0236 & 2970.460 & 2697.136 & 1692.823 & 44 \\ 1.00 & 59.54 & 13.01 & 29.59 & 2 & 1282.8504 & 12828468 & 442.4307 & 0.026 & 2.8019 & 3659.640 & 3507.988 & 263.831 & 11\end{array}$

$\begin{array}{lllllllllllllll} & 0.516\end{array}$

$\begin{array}{llllllllllllll}\text { LGLIEWLENTVTLK } & 0.69 & 67.95 & 20.86 & 80.95 & 2 & 1916.1252 & 1916.1226 & 959.0686 & 0.0026 & 1.3555 & 403.024 & 308.407 & 0.000 \\ \text { LDEGGVIDFINALDQLSNPELLFK } & 1.00 & 48.27 & 23.52 & 20.53 & 3 & 3074.6572 & 3074.6532 & 1025.8917 & 0.0040 & 1.2997 & 9.296 & 8.706 & 4.892\end{array}$

YAVPSAGLR

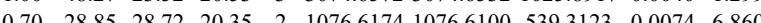


$\begin{array}{llllllll}17.85 & 3 & 2468.3800 & 2468.3770 & 823.7996 & 0.0030 & 1.2139 & 9.534\end{array}$

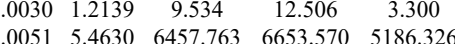

$\begin{array}{llllllllllllllll}0.74 & 29.59 & 28.61 & 29.47 & 2 & 931.5412 & 931.5361 & 466.7753 & 0.0051 & 5.4630 & 12267.538 & 11302.665 & 8000.737 & 38\end{array}$

$\begin{array}{lllllllllllllll}1.00 & 39.27 & 27.82 & 23.45 & 2 & 1345.7402 & 1345.7382 & 673.8764 & 0.0020 & 1.4839 & 10673.972 & 9574.970 & 290.602 & 18\end{array}$

AYVPALQMAFK
ICSKPVVLPK

$\begin{array}{lllllllllllll}1.00 & 45.38 & 25.93 & 17.27 & 2 & 1525.8614 & 1525.857 & 763.9358 & 0.0044 & 2.8798 & 2135.657 & 2066.893 & 23.758 \\ 1.00 & 59.74 & 25.74 & 21.64 & 2 & 1525.8628 & 1525.8570 & 763.9358 & 0.0058 & 3.7961 & 2159.958 & 1679.027 & 265.483\end{array}$

GSCVTQVGLLESVYEMFR

GFAVTLLPFTSLTTGS

CFGTGAAGNR
DFGLLVFVR

DFGLLVFVR

FLCIFLEK

FLALNSLYSP

LYSLALHPNAFK

$\begin{array}{lllllllllllll}0.69 & 81.25 & 26.91 & 94.25 & 2 & 2207.0574 & 2207.0547 & 1104.5346 & 0.0027 & 1.2222 & 163.363 & 144.937 & 32.50\end{array}$

EVYAAAAEVLGLILH

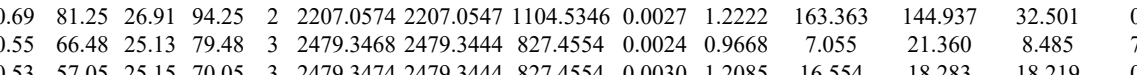

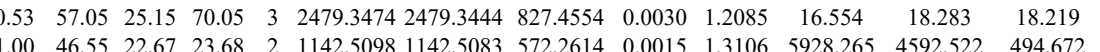

$\begin{array}{llllllllllllll}1.00 & 53.38 & 26.62 & 23.00 & 2 & 1208.7068 & 1208.7039 & 605.3592 & 0.0029 & 2.3953 & 5175.541 & 3652.229 & 825.558\end{array}$

$\begin{array}{llllllllllllll}1.00 & 53.07 & 26.69 & 21.76 & 2 & 1208.7076 & 1208.7039 & 605.3592 & 0.0037 & 3.0560 & 5703.691 & 4433.388 & 905.117 & 402\end{array}$ $\begin{array}{lllllllllllll}0.93 & 39.32 & 28.01 & 23.54 & 2 & 1345.7364 & 1345.7382 & 673.8764 & -0.0018 & -1.3356 & 5051.453 & 4223.035 & 123.263\end{array}$

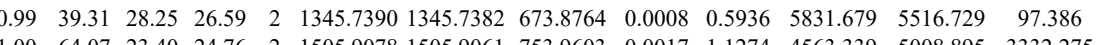
$\begin{array}{lllllllllllllll} & \end{array}$ \begin{tabular}{|lllllllllllllll} 
&
\end{tabular} $\begin{array}{lllllllllllllll}\text { EVYAAAAEVLGLILR } & 0.55 & 15.54 & 23.96 & 28.54 & 3 & 1731.0076 & 1731.0052 & 578.0090 & 0.0024 & 1.3841 & 103.144 & 106.478 & 51.584 & 22.408\end{array}$ $\begin{array}{llllllllllllllll}\text { GQAVTLLPFTSLTGGLEELR } & 0.55 & 71.27 & 25.12 & 84.27 & 3 & 2479.3462 & 2479.3444 & 827.4554 & 0.0018 & 0.7251 & 0.000 & 8.770 & 5.302 & 2.027\end{array}$

CFFLSK

CFFLSK

CFGTGAAGNR

CFGTGAAGNR

LATTILQHWK

LATTILQHWK

LLALNSLYSPK

LLALNSLYSPK

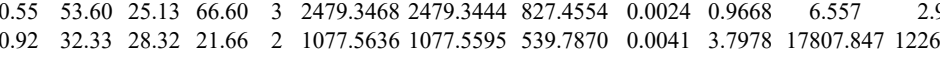

$\begin{array}{llllllllllllll}0.91 & 32.10 & 28.32 & 20.71 & 2 & 1077.5636 & 1077.5595 & 539.7870 & 0.0041 & 3.7978 & 9949.615 & 6317.355 & 189.367\end{array}$

$\begin{array}{lllllllllllll}1.00 & 39.65 & 23.18 & 19.00 & 2 & 1142.5112 & 1142.5083 & 572.2614 & 0.0029 & 2.5338 & 54347.658 & 45275.293 & 0.000 \\ 1.00 & 44.56 & 23.18 & 20.88 & 2 & 1142.5112 & 1142.5083 & 572.2614 & 0.0029 & 2.5338 & 27766.961 & 21424.843 & 439.074\end{array}$

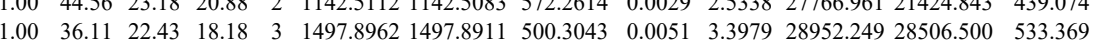

$\begin{array}{llllllllllllll}.00 & 50.78 & 22.43 & 18.86 & 3 & 1497.8962 & 1497.8911 & 500.3043 & 0.0051 & 3.3979 & 25806.880 & 26186.071 & 123.383\end{array}$

$\begin{array}{llllllllllllll}1.00 & 62.15 & 23.07 & 26.37 & 2 & 1505.9082 & 1505.9061 & 753.9603 & 0.0021 & 1.3926 & 6726.354 & 6232.917 & 482.563\end{array}$

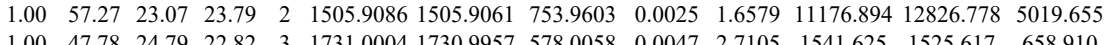

VVQMLGSLGGQINK

VEQLFQVMNGLLAQDSACSO

VEQLFQVMNGIL

VTVMASLR

VIAGLYQR

VIAGLYQR

WPVAGQIR
WPVAGQIR

CFFLSK

CFFLSK

CFGTGAAGNR

CFGTGAAGN

FIVCLNK

FIVCLNK

LPLISGFYK

LPLISGFYK

LATTILQHWK

LATTILQHWK

LLALNSLYSPK

QFINLMLPMK

QFINLMLPMK

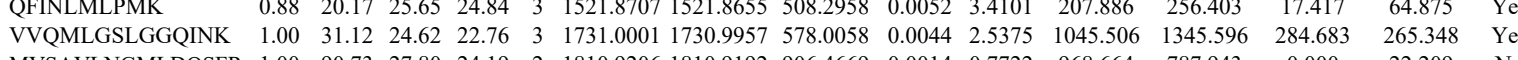

\begin{tabular}{lllllllllllll}
1.00 & 56.43 & 24.79 & 23.62 & 3 & 1731.004 & 1730.9957 & 578.0058 & 0.0047 & 2.7105 & 1541.625 & 1525.617 \\
\hline
\end{tabular}

$\begin{array}{llllll} & 0.00\end{array}$

$\begin{array}{llllllllllll}0.51 .59 & 27.05 & 94.59 & 3 & 2526.2182 & 2526.2151 & 843.0790 & 0.0031 & 1 & & \\ 1.00 & 48.03 & 27.05 & 17.13 & 3 & 2526.2182 & 2526.2151 & 843.0790 & 0.0031 & 1\end{array}$

$\begin{array}{lll}5.482 & 23.052 & 11.572\end{array}$

$\begin{array}{llllllllllllll}0.83 & 30.29 & 26.83 & 21.72 & 2 & 1019.5984 & 1019.5919 & 510.8032 & 0.0065 & 6.3625 & 1502.954 & 1525.775 & 696.783\end{array}$

$\begin{array}{llllllllllllllll} & \end{array}$

$\begin{array}{llllllllllllll}0.98 & 40.51 & 27.36 & 25.27 & 2 & 1062.6382 & 1062.6308 & 532.3227 & 0.0066 & 6.1992 & 34985.234 & 34718.810 & 2638.918 & 611.111\end{array}$

$\begin{array}{llllllllllllll}0.73 & 26.30 & 25.63 & 24.18 & 2 & 1069.6224 & 1069.6154 & 535.8150 & 0.0070 & 6.5321 & 8924.931 & 8477.766 & 5271.766 & 4130.189\end{array}$

$\begin{array}{lllllllllllllll}0.81 & 28.30 & 25.63 & 25.22 & 2 & 1069.6224 & 1069.6154 & 535.8150 & 0.0070 & 6.5321 & 8666.354 & 8128.865 & 5427.422 & 3121.442 & \text { Yes }\end{array}$ $\begin{array}{llllllllllllll}0.90 & 31.53 & 28.36 & 19.47 & 2 & 1077.5632 & 1077.5595 & 539.7870 & 0.0037 & 3.4273 & 53216.866 & 39573.851 & 0.000 & 889.067\end{array}$ $\begin{array}{llllllllllllllll}0.90 & 31.71 & 28.32 & 20.13 & 2 & 1077.5636 & 1077.5595 & 539.7870 & 0.0041 & 3.7978 & 55935.151 & 42486.338 & 47.477 & 446.449\end{array}$ $\begin{array}{lllllllllllllll}1.00 & 40.96 & 22.72 & 17.25 & 2 & 1142.5106 & 1142.5083 & 572.2614 & 0.0023 & 2.0096 & 12999.769 & 9412.999 & 282.108 & 134.258\end{array}$ $\begin{array}{lllllllllllllll}1.00 & 43.43 & 23.18 & 19.06 & 2 & 1142.5110 & 1142.5083 & 572.2614 & 0.0027 & 2.3591 & 26400.625 & 22613.965 & 337.417 & 435.932 & \text { Yes }\end{array}$ $\begin{array}{llllllllllllll}0.99 & 35.16 & 26.67 & 25.14 & 2 & 1169.6566 & 1169.6544 & 585.8345 & 0.0022 & 1.8777 & 39614.219 & 36819.506 & 1056.980 & 046\end{array}$

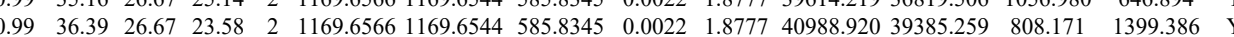
$\begin{array}{llllllllllllllll}1.00 & 64.08 & 23.18 & 23.89 & 2 & 1324.8020 & 1324.7998 & 663.4072 & 0.0022 & 1.6581 & 3507.157 & 3898.706 & 3550.175 & 1554.572 & \text { No } & \end{array}$ \begin{tabular}{lllllllllllllllll}
1.00 & 41.56 & 23.18 & 23.85 & 2 & 1324.8022 & 1324.7998 & 663.4072 & 0.0024 & 1.8088 & 4653.540 & 4685.058 & 6767.008 & 2050.482 & $\mathrm{~N} 0$ & \\
\hline
\end{tabular} $\begin{array}{lllllllllllllllll}1.00 & 32.50 & 22.38 & 15.14 & 3 & 1497.8953 & 1497.8911 & 500.3043 & 0.0042 & 2.7983 & 10099.673 & 9142.966 & 195.167 & 183.546 & \text { Yes } & & \\ \end{array}$ $\begin{array}{llllllllllllllll}1.00 & 35.31 & 22.38 & 19.94 & 3 & 1497.8953 & 1497.8911 & 500.3043 & 0.0042 & 2.7983 & 9907.388 & 11291.307 & 176.881 & 279.268 & \text { Yes } & \\ 1.00 & 53.71 & 22.81 & 2.65 & 2 & 1505.9092 & 1505.9061 & 753.903 & 0.031 & 2.058 & 3450.002 & 3266.468 & 3388377 & 477.314 & \end{array}$ $\begin{array}{llllllllllllllll}1.00 & 53.71 & 22.81 & 24.65 & 2 & 1505.9092 & 1505.9061 & 753.9603 & 0.0031 & 2.0558 & 3450.002 & 3266.468 & 3388.377 & 477.314 & \text { No } & \\ 1.00 & 48.83 & 6.30 & 32.48 & 2 & 1521.8674 & 1521.8655 & 761.940 & 0.019 & 1.248 & 3575.80 & 3517.715 & 243.978 & & \end{array}$ $\begin{array}{llllllllllllllll}1.00 & 48.83 & 26.30 & 32.48 & 2 & 1521.8674 & 1521.8655 & 761.9400 & 0.0019 & 1.2468 & 3575.808 & 3517.715 & 243.978 & 106.477 & \text { Yes } & \\ 1.00 & 39.04 & 2.13 & 33.12 & 2 & 1521.8676 & 1521.8655 & 761.940 & 0.0021 & 1.3781 & 9373.50 & 8926732 & 1097.437 & 40.329 & \text { Yes }\end{array}$ $\begin{array}{lllllllllllllll}1.00 & 39.04 & 26.13 & 33.12 & 2 & 1521.8676 & 1521.8655 & 761.9400 & 0.0021 & 1.3781 & 9373.650 & 8926.732 & 1097.437 & 401.329 & \text { Yes } \\ \end{array}$ $\begin{array}{llllllllllllll} & \end{array}$

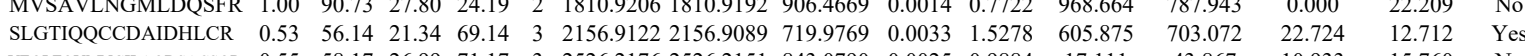
$\begin{array}{llllllllllllll} & \end{array}$

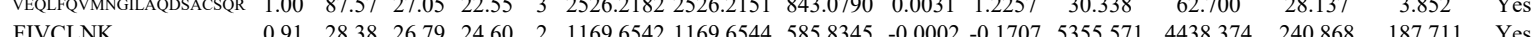

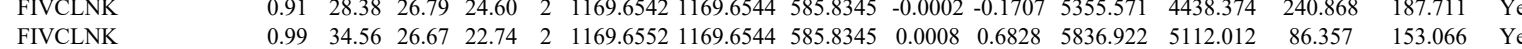


$\begin{array}{lllllllllllll}1.00 & 71.12 & 25.89 & 25.89 & 3 & 1911.0577 & 1911.0522 & 638.0247 & 0.0055 & 2.8734 & 1991.773 & 2394.799 & 189.317\end{array}$ $\begin{array}{llllllllllllll}0.85 & 23.00 & 27.30 & 16.56 & 2 & 988.6208 & 988.6191 & 495.3168 & 0.0017 & 1.7161 & 44404.937 & 39095.085 & 1082.986 \\ 0.82 & 23.85 & 7.24 & 18.04 & 2 & 988.6224 & 988.6191 & 495.3168 & 0.0033 & 3.3312 & 3968.7379 & 36578.027 & 421.670\end{array}$ $\begin{array}{llllllllllllll}0.82 & 23.85 & 27.24 & 18.04 & 2 & 988.6224 & 988.6191 & 495.3168 & 0.0033 & 3.3112 & 39687.379 & 36578.027 & 421.670 & \\ 0.99 & 41.91 & 28.19 & 26.25 & 2 & 1160.6536 & 1160.6424 & 581.3285 & 0.0112 & 9.6330 & 17511.032 & 15469.137 & 256.864 & \end{array}$

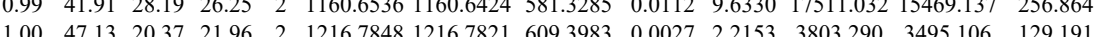
$\begin{array}{lllllllllllll}1.00 & 50.40 & 20.37 & 23.23 & 2 & 1216.7850 & 1216.7821 & 609.3983 & 0.0029 & 2.3794 & 2733.212 & 2856.331 & 100.013\end{array}$

LPVLAGCLK

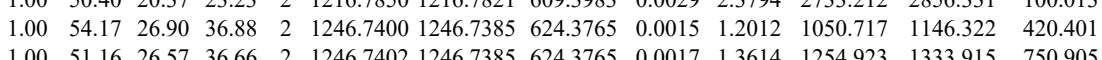

LPVLAGCLK

CGAALAGHQLIR

QLFSSLFSGILK

QLFSSLFSGILK

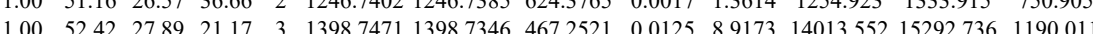

$\begin{array}{lllllllllllll}1.00 & 78.81 & 23.48 & 33.67 & 2 & 1626.9602 & 1626.9589 & 814.4867 & 0.0013 & 0.7980 & 1543.037 & 1783.999 & 0.000\end{array}$

$\begin{array}{lllllllllllll}1.00 & 75.95 & 23.42 & 30.60 & 2 & 16269604 & 1626.9589 & 814.4867 & 0.0015 & 0.9208 & 2347.803 & 2318.785 & 0.000\end{array}$

$\begin{array}{llllllllllllll}1.00 & 42.54 & 23.16 & 33.36 & 3 & 1626.9616 & 1626.9589 & 543.3269 & 0.0027 & 1.6565 & 30.231 & 46.039 & 8.147\end{array}$ $\begin{array}{lllllllllllll}1.00 & 50.78 & 26.34 & 20.89 & 3 & 1911.0556 & 1911.0522 & 638.0247 & 0.0034 & 1.7763 & 951.550 & 977.078 & 282.523\end{array}$ $\begin{array}{lllllllllllll}1.00 & 43.18 & 23.80 & 17.25 & 3 & 2635.4455 & 2635.4455 & 879.4891 & 0.0000 & 0.0000 & 185.199 & 181.410 & 115.539\end{array}$ $\begin{array}{llllllllllllll}1.00 & 64.42 & 27.49 & 37.51 & 2 & 1481.8124 & 1481.8112 & 741.9129 & 0.0012 & 0.8087 & 39.506 & 50.445 & 5.849\end{array}$ $\begin{array}{lllllllllllll}1.00 & 65.67 & 27.54 & 39.51 & 2 & 1481.8130 & 1481.8112 & 741.9129 & 0.0018 & 1.2131 & 42.369 & 46.961 & 2.006 \\ 1.06 & 63.01 & 27.60 & 34.53 & 2 & 1481.8116 & 1481.8112 & 741.9129 & 0.0004 & 0.2696 & 1485.757 & 1484.336 & 28.592\end{array}$ $\begin{array}{llllllllllllll}1.00 & 63.01 & 27.60 & 34.53 & 2 & 1481.8116 & 1481.8112 & 741.9129 & 0.0004 & 0.2696 & 1485.757 & 1484.336 & 28.592 \\ 0.96 & 29.99 & 27.98 & 26.38 & 2 & 1079.6266 & 1079.6250 & 540.8198 & 0.0016 & 1.4792 & 20700.865 & 20000.624 & 350.588\end{array}$ $\begin{array}{llllllllllllll}0.96 & 29.99 & 27.98 & 26.38 & 2 & 1079.6266 & 1079.6250 & 540.8198 & 0.0016 & 1.4792 & 20700.865 & 20000.624 & 35.52 \\ 0.99 & 38.69 & 27.98 & 25.75 & 2 & 1079.6268 & 1079.6250 & 540.8198 & 0.0018 & 1.6641 & 15143.361 & 13220.672 & 158.741\end{array}$

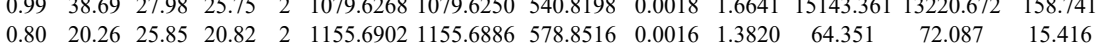
$\begin{array}{lllllllllllll}1.00 & 42.26 & 25.83 & 26.46 & 2 & 1155.6908 & 1155.6886 & 578.8516 & 0.0022 & 1.9003 & 73.695 & 62.951 & 6.766\end{array}$ $\begin{array}{lllllllllllll}0.89 & 25.05 & 25.77 & 23.52 & 2 & 1155.6914 & 1155.6886 & 578.8516 & 0.0028 & 2.4186 & 39.765 & 60.741 & 12.671\end{array}$

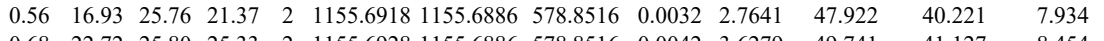
$\begin{array}{lllllllllllll}0.68 & 22.72 & 25.80 & 25.33 & 2 & 1155.6928 & 1155.6886 & 578.8516 & 0.0042 & 3.6279 & 49.741 & 41.127 & 8.454\end{array}$ $\begin{array}{lllllllllllll}1.00 & 44.78 & 25.97 & 30.38 & 2 & 1613.9264 & 1613.9247 & 807.9696 & 0.0017 & 1.0520 & 130.375 & 77.148 & 27.496 \\ 0 & 1.69 & 25.59 & 15.14 & 3 & 163.9272 & 16313.9247 & 538.922 & 0.0025 & 1.5461 & 11.490 & 128.376 & 41.819\end{array}$

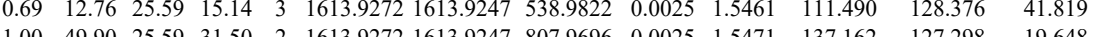

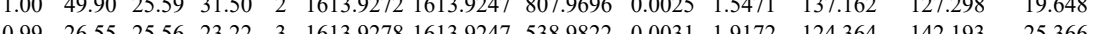
$\begin{array}{lllllllllllll}0.99 & 26.55 & 25.56 & 23.22 & 3 & 1613.9278 & 1613.9247 & 538.9822 & 0.0031 & 1.9172 & 124.364 & 142.193 & 25.366 \\ 1.00 & 43.21 & 27.92 & 27.58 & 2 & 1079.6278 & 1079.6250 & 540.8198 & 0.0028 & 2.5887 & 11296.790 & 11372.313 & 52.436\end{array}$

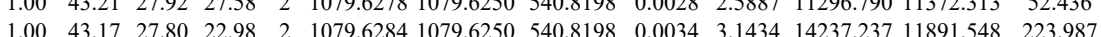

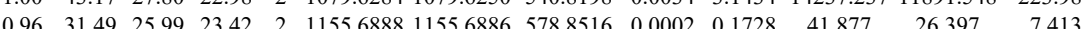
$\begin{array}{llllllllllll}0.96 & 31.49 & 25.99 & 23.42 & 2 & 1155.6888 & 1155.6886 & 578.8516 & 0.0002 & 0.1728 & 41.877 & 26.397\end{array}$ 


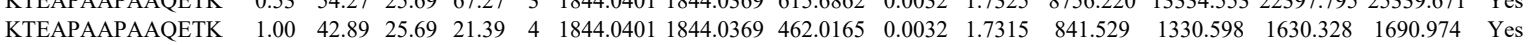

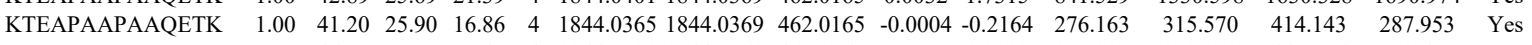
$\begin{array}{lllllllllllllllll}\text { KTEAPAAPAAQETK } & 1.00 & 46.70 & 25.77 & 20.42 & 4 & 1844.0389 & 1844.0369 & 462.0165 & 0.0020 & 1.0822 & 202.927 & 253.253 & 449.876 & 503.627 & \text { Yes }\end{array}$ $\begin{array}{llllllllllllllll}\text { KTEAPAAPAAQETK } & 0.53 & 51.81 & 25.73 & 64.81 & 3 & 1844.0404 & 1844.0369 & 615.6862 & 0.0035 & 1.8949 & 5373.077 & 7796.415 & 13240.535 & 18346.725 & \text { Yes }\end{array}$

$\begin{array}{lllllllllllll}\text { SARNP_HUMAl } & \text { P82979 } & \text { SARNP } & \text { SAP domain-cont: } 23.67 & 1.00 & 2 & 9 & -0.1148 & 0.0378 & 0.5118 & 0.5758 & 3 & \text { FGISSVPTK }\end{array}$

GISSVPTK

FGLNVSSIS

4 VFQFLNAK

VFQFLNAK

VFQFLNAK

VFQFLNAK

VFQFLNAK

VFQFLNAK

QINWTVLYR

QINWTVLYR

QINWTVLYR

QINWTVLR

QINWTVLR

$\begin{array}{llllllllllllllll}0.99 & 38.31 & 26.22 & 20.70 & 2 & 1222.7276 & 1222.7165 & 612.3655 & 0.0111 & 9.0631 & 5393.078 & 4991.916 & 667.289 & 1005.987 & \text { Yes }\end{array}$ $\begin{array}{lllllllllllllll}1.00 & 46.43 & 25.68 & 25.73 & 2 & 1222.7282 & 1222.7165 & 612.3655 & 0.0117 & 9.5530 & 8518.314 & 8178.893 & 785.267 & 1174.994 & \text { Yes }\end{array}$ $\begin{array}{llllllllllllllll}1.00 & 53.07 & 27.49 & 23.85 & 2 & 1222.6912 & 1222.6792 & 612.3469 & 0.0120 & 9.7983 & 6812.943 & 6635.098 & 3389.961 & 576.292 & \text { Yes }\end{array}$

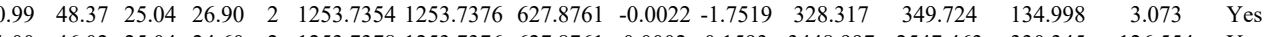

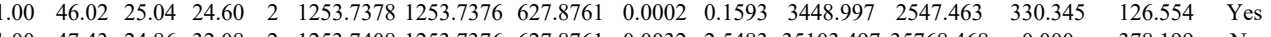
$\begin{array}{lllllllllllllll}1.00 & 47.43 & 24.86 & 32.08 & 2 & 1253.7408 & 1253.7376 & 627.8761 & 0.0032 & 2.5483 & 35103.497 & 35768.468 & 0.000 & 378.199 & \text { No }\end{array}$ $\begin{array}{lllllllllllllll}1.00 & 45.37 & 24.79 & 32.16 & 2 & 1253.7416 & 1253.7376 & 627.8761 & 0.0040 & 3.1853 & 73134.771 & 73592.447 & 0.000 & 227.478 & \text { No }\end{array}$

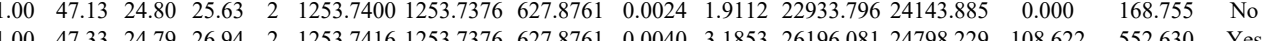
$\begin{array}{lllllllllllllll}1.00 & 47.33 & 24.79 & 26.94 & 2 & 1253.7416 & 1253.7376 & 627.8761 & 0.0040 & 3.1853 & 26196.081 & 24798.229 & 108.622 & 552.630 & \text { Yes } \\ 0.73 & 23.76 & 27.86 & 26.04 & 2 & 1335.7422 & 1335.7421 & 6688783 & 0.0001 & 0.0748 & 209.669 & 202.182 & 40.945 & 14.385 & \text { Yes }\end{array}$

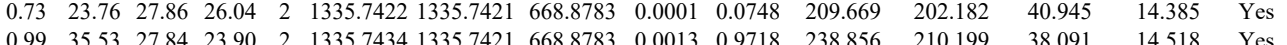

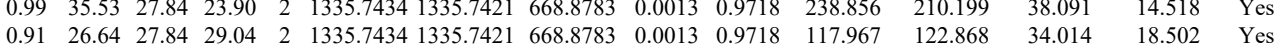

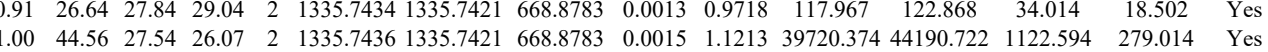

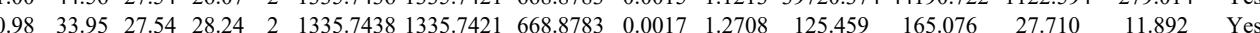
$\begin{array}{lllllllllllllll}1.00 & 46.63 & 27.54 & 26.12 & 2 & 1335.7440 & 1335.7421 & 668.8783 & 0.0019 & 1.4203 & 58342.890 & 59564.339 & 3593.102 & 1056.380 & \text { Yes }\end{array}$ 
QINWTVLYR

QINWTVLYR

QINWTVLYR

QINWTVLYR

QINWTVLYR

KGQSEEIQK

KGQSEEIQK

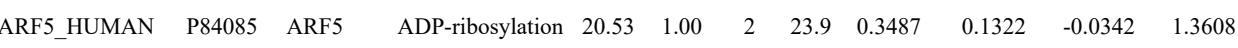

ERH HUMAN P84090 ERH

$\begin{array}{lllllllll}\text { Enhancer of rudir } & 12.26 & 1.00 & 3 & 23.1 & 0.1227 & 0.1281 & -1.3561 & 2.2092\end{array}$

LGLQHLR

LGLQHLR

LGLQHLR

QDMPNAMPVSELTDK

ADTQTYQPYNK

ADTQTYQPY
IYVLLR
IYVLLR

IYVLLR
IYVLLR

IYVLLR

IYVLLR

IYVLLR

IYVLLR
IYVLLR

IYVLLR

IYVLLR
IYVLLR

QAQQAGK

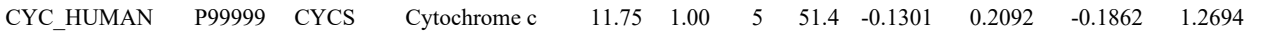

TGQAPGYSYTAANK

TGQAPGYSYTAANK

TGQAPGYSYTAANK

TGQAPGYSYTAANK

GIIWGEDTLMEYLENK

TGQAPGYSYTAANK

TGQAPGYSYTAANK GIIWGEDTLMEYLEN TGQAPGYSYTAANK TGQAPGYSYTAANK TGQAPGYSYTAANK GIIWGEDTLMEYLENPK TGQAPGYSYTAANK TGQAPGYSYTAANK

IFIMK

IFIMK

MIFVGIK

MIFVGIK

TGPNLHGLFGR

TGPNLHGLFGR

TGPNLHGLFGR

TGPNLHGLFGR

TGPNLHGLFGR

TGPNLHGLFGR

TGPNLHGLFGR

TGPNLHGLFGR

TGPNLHGLFGR

1 KPVSSYLR

KPVSSYLR

KPVSSYLR

KPVSSYLR

KPVSSYLR

KPVSSYLR

KPVSSYLR

KPVSSYLR

KPVSSYLR

SWEEQMIEVGR

SWEEQMIEVGR

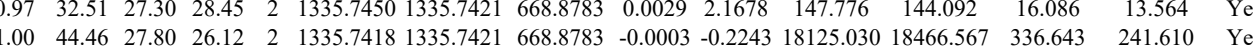

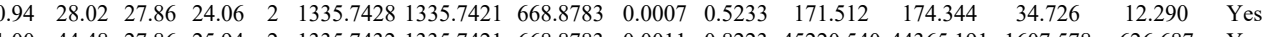
$\begin{array}{lllllllllllllll}1.00 & 44.48 & 27.86 & 25.94 & 2 & 1335.7432 & 1335.7421 & 668.8783 & 0.0011 & 0.8223 & 45220.540 & 44365.191 & 1607.578 & 626.687 & \text { Yes }\end{array}$ $\begin{array}{llllllllllllllll}0.86 & 23.76 & 27.54 & 19.62 & 2 & 1335.7438 & 1335.7421 & 668.8783 & 0.0017 & 1.2708 & 152.847 & 167.960 & 33.799 & 7.058 & \text { Yes } \\ 0.98 & 26.18 & 26.45 & 16.12 & 3 & 1477.8472 & 1477.8466 & 493.628 & 0.017 & 0.4052 & 31.162 & 298.819 & 326.79 & 292.28 & \text { No }\end{array}$

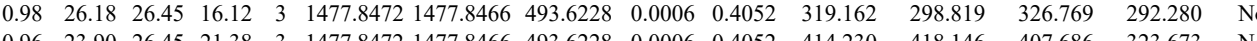

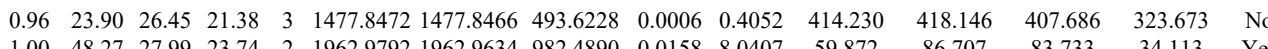
$\begin{array}{cccccccccccccccc}1.00 & 48.27 & 27.99 & 23.74 & 2 & 1962.9792 & 1962.9634 & 982.4890 & 0.0158 & 8.0407 & 59.872 & 86.707 & 83.733 & 34.113 & \text { Yes } \\ 0.66 & 17.59 & 24.50 & 22.63 & 2 & 979.6082 & 979.6049 & 490.8097 & 0.0033 & 3.3618 & 7041.409 & 9250.369 & 1345.935 & 847.457 & \text { Yes }\end{array}$ $\begin{array}{llllllllllllllll}0.60 & 19.98 & 24.50 & 26.98 & 2 & 979.6088 & 979.6049 & 490.8097 & 0.0039 & 3.9730 & 10694.993 & 14417.193 & 2311.638 & 1263.233 & \text { Y }\end{array}$ $\begin{array}{lllllllllllllll}0.63 & 20.49 & 24.50 & 25.21 & 2 & 979.6078 & 979.6049 & 490.8097 & 0.0029 & 2.9543 & 11018.787 & 12247.058 & 1659.494 & 808.514 & \text { Yes }\end{array}$

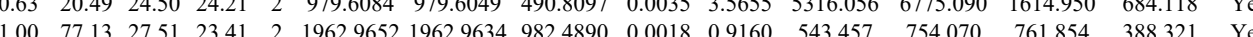
$\begin{array}{lllllllllllllll}1.00 & 48.55 & 27.56 & 24.72 & 2 & 1615.8108 & 1615.8086 & 808.9116 & 0.0022 & 1.3599 & 6549.804 & 7329.154 & 2484.626 & 1435.664 & \text { No }\end{array}$ $\begin{array}{llllllllllllllll}100 & 49.72 & 27.57 & 23.68 & 2 & 1615.8116 & 1615.8086 & 808.9116 & 0.0030 & 1.8543 & 7445.494 & 7934.054 & 2290.013 & 1157.036 & \text { Yes }\end{array}$ $\begin{array}{lllllllllllllllll}0.72 & 21.91 & 22.12 & 28.43 & 2 & 919.6056 & 919.5977 & 460.8061 & 0.0079 & 8.5719 & 39480.826 & 40156.261 & 3717.057 & 1349.827 & \text { Yes }\end{array}$ $\begin{array}{lllllllllllllll}0.75 & 21.58 & 20.90 & 25.02 & 2 & 919.5964 & 919.5977 & 460.8061 & 0.0013 & -1.4106 & 31341.502 & 39007.545 & 2056.559 & 328.820 & \text { Yes }\end{array}$ $\begin{array}{lllllllllllllllll}0.92 & 21.40 & 19.03 & 25.74 & 2 & 919.5980 & 919.5977 & 460.8061 & 0.0003 & 0.3255 & 27216.091 & 33512227 & 2749.902 & 969.777 & \text { Yes }\end{array}$ $\begin{array}{llllllllllllllll}0.81 & 23.31 & 20.90 & 27.47 & 2 & 919.5968 & 919.5977 & 460.8061 & -0.0009 & -0.9766 & 12788.874 & 14610.244 & 571.260 & 15.536 & \text { Yes }\end{array}$ $\begin{array}{llllllllllllllll}0.92 & 23.05 & 19.03 & 27.26 & 2 & 919.5980 & 919.5977 & 460.8061 & 0.0003 & 0.3255 & 13983.743 & 16930.941 & 1185.552 & 14.339 & \text { Yes }\end{array}$ $\begin{array}{lllllllllllllllll}0.93 & 21.82 & 19.03 & 28.50 & 2 & 919.5982 & 919.5977 & 460.8061 & 0.0005 & 0.5425 & 10690.192 & 10405.592 & 689.753 & 76.197 & \text { Yes }\end{array}$ $\begin{array}{lllllllllllllllll}0.93 & 21.78 & 19.03 & 28.62 & 2 & 919.5986 & 919.5977 & 460.8061 & 0.0009 & 0.9765 & 7811.065 & 8755.970 & 418.875 & 91.325 & \text { Yes }\end{array}$ $\begin{array}{llllllllllllllll}0.96 & 21.96 & 19.03 & 25.42 & 2 & 919.5986 & 919.5977 & 460.8061 & 0.0009 & 0.9765 & 7275.354 & 7142.104 & 250.712 & 252.717 & \text { Yes }\end{array}$ $\begin{array}{lllllllllllllllll}0.90 & 19.89 & 19.03 & 25.46 & 2 & 919.5980 & 919.5977 & 460.8061 & 0.0003 & 0.3255 & 1220.757 & 1445.486 & 99.051 & 38.131 & \text { Yes }\end{array}$ $\begin{array}{lllllllllllllllll}0.96 & 21.65 & 19.03 & 25.82 & 2 & 919.5984 & 919.5977 & 460.8061 & 0.0007 & 0.7595 & 1106.052 & 1267.097 & 90.179 & 46.360 & \text { Yes }\end{array}$ $\begin{array}{lllllllllllllll}0.72 & 20.62 & 27.82 & 25.29 & 2 & 1017.5818 & 1017.5811 & 509.7978 & 0.0007 & 0.6865 & 86.561 & 71.960 & 35.791 & 12.379 & \text { No }\end{array}$

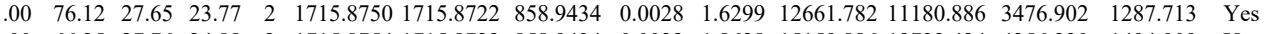
$\begin{array}{lllllllllllllll}1.00 & 66.25 & 27.76 & 24.88 & 2 & 1715.8754 & 1715.8722 & 858.9434 & 0.0032 & 1.8628 & 15159.886 & 12732.424 & 4356.230 & 1494.909 & \text { Yes }\end{array}$ $\begin{array}{llllllllllllllll}1.00 & 38.73 & 27.88 & 18.62 & 3 & 1715.8762 & 1715.8722 & 572.9647 & 0.0040 & 2.3271 & 2764.461 & 2976.081 & 1924.251 & 1179.073 & \text { No }\end{array}$

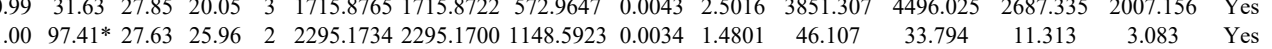
$\begin{array}{lllllllllllllll}1.00 & 79.54 & 27.86 & 25.41 & 2 & 1715.8716 & 1715.8722 & 858.9434 & -0.0006 & -0.3493 & 19641.897 & 17498.971 & 4523.100 & 3498.883 & \text { Yes }\end{array}$ $\begin{array}{lllllllllllllll}1.00 & 66.15 & 27.87 & 25.03 & 2 & 1715.8726 & 1715.8722 & 858.9434 & 0.0004 & 0.2328 & 20295.723 & 17261.300 & 6962.987 & 3223.093 & \text { Yes } \\ 0.98 & 29.02 & 27.85 & 20.21 & 3 & 1715.8735 & 1715.8722 & 5729.647 & 0.0013 & 0.7563 & 3099.298 & 2830.694 & 1022.381 & 1549.177 & \text { Ne }\end{array}$

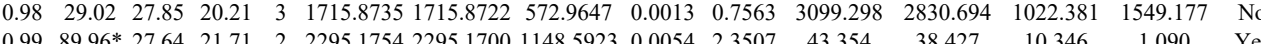

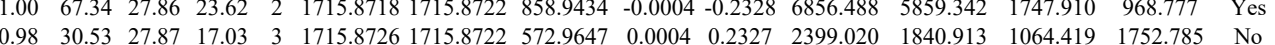

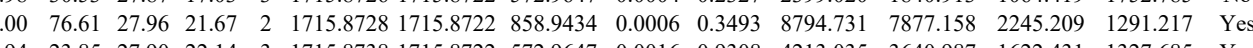

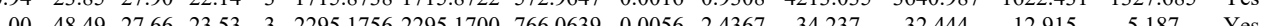

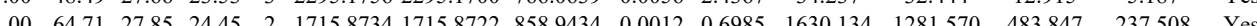
$\begin{array}{llllllllllllllll}0.87 & 20.54 & 27.90 & 17.51 & 3 & 1715.8738 & 1715.8722 & 572.9647 & 0.0016 & 0.9308 & 2816.725 & 3228.729 & 1265.480 & 1182.887 & \text { Yes }\end{array}$ $\begin{array}{llllllllllllllll}0.88 & 31.18 & 23.32 & 32.82 & 2 & 938.5852 & 938.5867 & 470.3006 & -0.0015 & -1.5947 & 20751.799 & 17098.676 & 315.228 & 1101.351 & \text { Yes }\end{array}$ $\begin{array}{lllllllllllllllll}0.84 & 25.76 & 20.76 & 28.58 & 2 & 938.5934 & 938.5867 & 470.3006 & 0.0067 & 7.1231 & 98069.822 & 85660.755 & 0.000 & 362.873 & \text { No }\end{array}$ $\begin{array}{lllllllllllllllll}0.89 & 31.73 & 21.30 & 33.41 & 2 & 938.5944 & 938.5867 & 470.3006 & 0.0077 & 8.1862 & 81042.028 & 61267.348 & 0.000 & 310.816 & \text { No }\end{array}$ $\begin{array}{lllllllllllllll}0.96 & 31.07 & 23.16 & 25.31 & 2 & 1094.6868 & 1094.6766 & 548.3456 & 0.0102 & 9.3006 & 87646.948 & 73135.461 & 0.000 & 1834.696 & \text { No }\end{array}$ $\begin{array}{lllllllllllllll}0.97 & 32.54 & 23.16 & 24.73 & 2 & 1094.6874 & 1094.6766 & 548.3456 & 0.0108 & 9.8477 & 61210.371 & 48021.823 & 0.000 & 1723.956 & \text { No }\end{array}$ $\begin{array}{lllllllllllllll}1.00 & 46.25 & 27.28 & 16.23 & 3 & 1311.7285 & 1311.7170 & 438.2463 & 0.0115 & 8.7469 & 18706.636 & 22446.517 & 9380.807 & 3531.432 & \text { Yes }\end{array}$ $\begin{array}{lllllllllllllll}1.00 & 51.80 & 27.34 & 23.18 & 2 & 1311.7292 & 1311.7170 & 656.8658 & 0.0122 & 9.72864 & 12388.153 & 10724.345 & 0.000 & 22.553 & \text { No }\end{array}$ $\begin{array}{lllllllllllllll}1.00 & 47.42 & 27.26 & 25.14 & 2 & 1311.7280 & 1311.7170 & 656.8658 & 0.0110 & 8.3730 & 19203.295 & 19134.233 & 0.000 & 89.703 & \text { No }\end{array}$

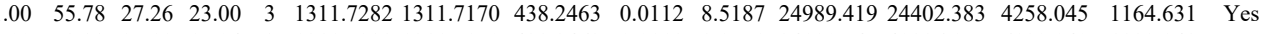
$\begin{array}{lllllllllllllll}1.00 & 52.33 & 27.19 & 17.04 & 3 & 1311.7288 & 1311.7170 & 438.2463 & 0.0118 & 8.9751 & 34190.745 & 40886.175 & 6199.040 & 1832.248 & \text { Yes }\end{array}$

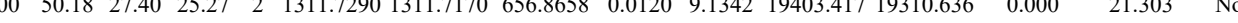

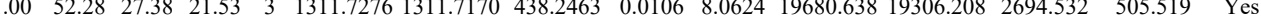

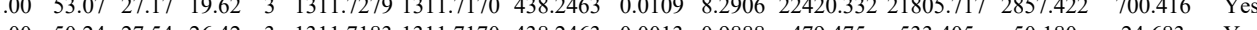

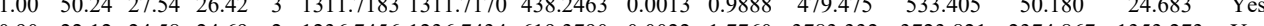
$\begin{array}{llllllllllllllll}0.90 & 22.12 & 24.58 & 24.69 & 2 & 1236.7456 & 1236.7434 & 619.3790 & 0.0022 & 1.7760 & 3783.332 & 3723.821 & 2374.867 & 1353.273 & \text { Yes } \\ 0.73 & 12.42 & 2.58 & 4.66 & 3 & 1236.7459 & 1236.7434 & 413.255 & 0.0025 & 2.65 & 1731455 & 18389.063 & 19756386 & 164.85 & \text { Yes }\end{array}$ $\begin{array}{llllllllllllllll}0.73 & 12.42 & 24.58 & 14.66 & 3 & 1236.7459 & 1236.7434 & 413.2551 & 0.0025 & 2.0165 & 17314.550 & 18389.063 & 19756.386 & 14645.851 & \text { Yes } \\ 0.87 & 2.11 & 4.58 & 32.18 & 2 & 1236.7462 & 236.743 & 61.3790 & 0.02 & 2.263 & 6733.938 & 664.172 & 3878.242 & 204.374 & \text { Yes }\end{array}$ $\begin{array}{llllllllllllllll}0.87 & 24.11 & 24.58 & 32.18 & 2 & 1236.7462 & 1236.7434 & 619.3790 & 0.0028 & 2.2603 & 6733.938 & 6664.172 & 3878.242 & 2014.374 & \text { Yes }\end{array}$

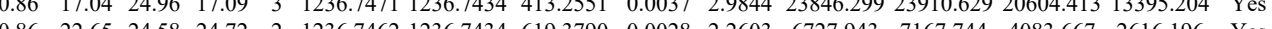

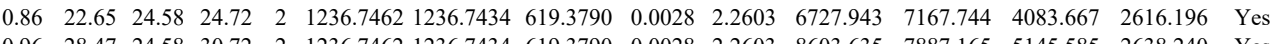
$\begin{array}{lllllllllllllll}0.96 & 28.47 & 24.58 & 30.72 & 2 & 1236.7462 & 1236.7434 & 619.3790 & 0.0028 & 2.2603 & 8603.635 & 7887.165 & 5145.585 & 2638.240 & \text { Yes }\end{array}$ $\begin{array}{lllllllllllllll}0.99 & 25.13 & 24.64 & 17.66 & 3 & 1236.7465 & 1236.7434 & 413.2551 & 0.0031 & 2.5005 & 31684.855 & 31343.424 & 18816.063 & 11542.442 & \text { Yes } \\ 0.95 & 20.23 & 24.93 & 15.21 & 3 & 1236.7468 & 1236.7434 & 413.2551 & 0.0034 & 2.7424 & 28133.231 & 30375.182 & 17328.421 & 11779.480 & \text { Yes }\end{array}$ $\begin{array}{llllllllllllllll}0.95 & 20.23 & 24.93 & 15.21 & 3 & 1236.7468 & 1236.7434 & 13.2551 & 0.0034 & 2.7424 & 28133.231 & 30375.182 & 17328.421 & 15479.480 & \text { Yes }\end{array}$

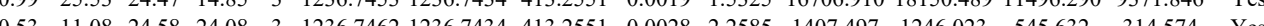
$\begin{array}{lllllllllllllll}1.00 & 59.88 & 26.22 & 21.20 & 2 & 1506.7278 & 1506.7258 & 754.3702 & 0.0020 & 1.3256 & 1507.929 & 1476.065 & 78.801 & 11.290 & \text { Ne }\end{array}$

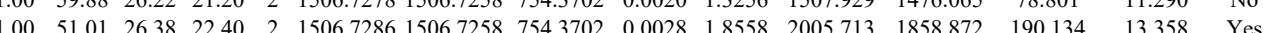




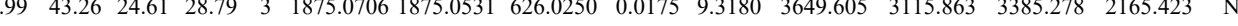
$\begin{array}{llllllllllllllll}0.93 & 35.37 & 27.91 & 18.31 & 2 & 1323.7154 & 1323.7107 & 662.8626 & 0.0047 & 3.5452 & 25843.769 & 22685.553 & 8525.671 & 1770.573 & \text { Yes }\end{array}$ $\begin{array}{llllllllllllllll}0.93 & 35.40 & 27.80 & 17.65 & 2 & 1323.7168 & 1323.7107 & 662.8626 & 0.0061 & 4.601 & 16997.271 & 16132.587 & 6089.722 & 942.914 & \text { Yes }\end{array}$ $\begin{array}{lllllllllllllll}1.00 & 54.01 & 27.88 & 31.94 & 2 & 1504.8242 & 1504.8120 & 753.4133 & 0.0122 & 8.0964 & 27139.292 & 29647.683 & 7734.551 & 416.235 & \text { Yes }\end{array}$ \begin{tabular}{lllllllllllllll}
1.00 & 54.01 & 27.88 & 31.94 & 2 & 1504.8242 & 1504.820 & 753.4133 & 0.0122 & 8.0964 & 27139.292 & 29647.683 & 7734.551 & 416.235 & Yes \\
\hline
\end{tabular}

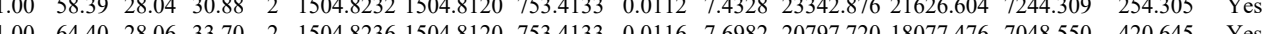
$\begin{array}{lllllllllllllll}1.09 & 44.40 & 28.06 & 33.70 & 2 & 1504.8236 & 1504.8120 & 753.4133 & 0.0116 & 7.6982 & 20797.720 & 18077.476 & 7048.550 & 420.645 & \text { Yes }\end{array}$

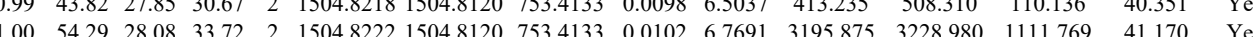

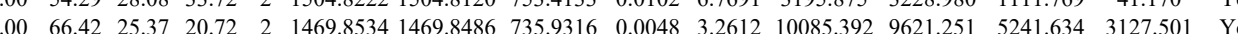

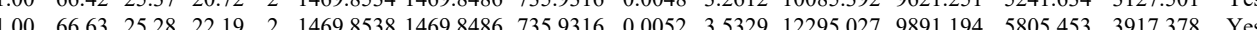
$\begin{array}{lllllllllllllll}1.00 & 50.90 & 25.87 & 23.87 & 2 & 1469.8500 & 1469.8486 & 735.9316 & 0.0014 & 0.9512 & 1785.640 & 1534.174 & 834.780 & 466.203 & \text { Yes }\end{array}$ $\begin{array}{ccccccccccccccc}0.53 & 15.38 & 27.19 & 28.38 & 3 & 2092.0222 & 2092.0188 & 698.3469 & 0.0034 & 1.6229 & 99.307 & 102.060 & 25.322 & 17.572 & \text { Yes } \\ 0.82 & 23.02 & 27.78 & 27.75 & 2 & 1072.5980 & 1072.5974 & 537.3060 & 0.0006 & 0.5583 & 672.368 & 594.952 & 235.425 & 44.805 & \text { Yes } \\ 0.90 & 27.76 & 27.7 & 36.19 & 2 & & 0.325 & & \end{array}$ $\begin{array}{lllllllllllllll} & 0.87 .76 & 27.78 & 36.19 & 2 & 1072.5980 & 1072.5974 & 537.3060 & 0.0006 & 0.5583 & 553.963 & 570.025 & 172.857 & 33.960 & \text { Yes } \\ \end{array}$ $\begin{array}{lllllllllllllllll}\text { ILEGPTEDVNVAOFOIEGMVK } & 1.00 & 49.60 & 26.81 & 18.57 & 4 & 2687.3989 & 2687.3931 & 672.8556 & 0.0058 & 2.1550 & 83.413 & 67.479 & 86.525 & 65.871 & \text { Yes }\end{array}$ $\begin{array}{llllllllllllllllll}\text { APDMSSSEEFPSFGAQVAPK } & 1.00 & 83.29 & 27.11 & 27.97 & 2 & 2369.1474 & 2369.1453 & 1185.5799 & 0.0021 & 0.8856 & 37.724 & 53.795 & 60.952 & 64.402 & \text { No }\end{array}$

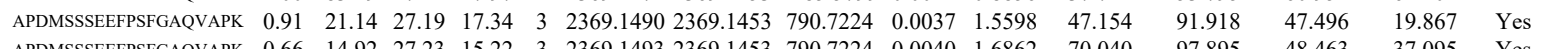

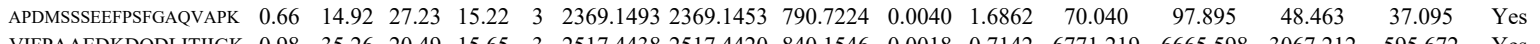

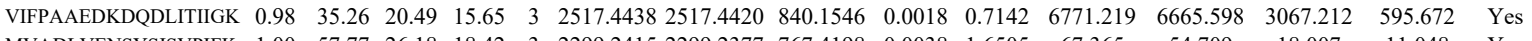
$\begin{array}{lllllllllllllllll}\text { MVADLVENSYSISVPIFK } & 1.00 & 57.77 & 26.18 & 18.42 & 3 & 2299.2415 & 2299.2377 & 767.4198 & 0.0038 & 1.6505 & 67.365 & 54.709 & 18.007 & 11.048 & \text { Yes }\end{array}$

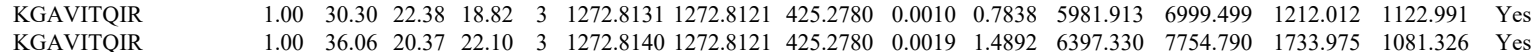
$\begin{array}{llllllllllllllll}\text { INIPPPSVNR } & 0.83 & 27.56 & 26.00 & 33.44 & 2 & 1249.7362 & 1249.7264 & 625.8705 & 0.0098 & 7.8290 & 3515.745 & 3840.394 & 621.643 & 264.228 & \text { Yes }\end{array}$ $\begin{array}{llllllllllllllll}\text { KGAVITQIR } & 1.00 & 38.09 & 22.76 & 24.00 & 3 & 1272.8134 & 1272.8121 & 425.2780 & 0.0013 & 1.0189 & 5456.421 & 6301.699 & 1101.828 & 733.557 & \text { Yes }\end{array}$ $\begin{array}{llllllllllllllll}\text { KGAVITQIR } & 1.00 & 34.41 & 20.37 & 20.14 & 3 & 1272.8140 & 1272.8121 & 425.2780 & 0.0019 & 1.4892 & 7550.885 & 8262.485 & 2024.049 & 1089.056 & \text { Yes }\end{array}$ $\begin{array}{llllllllllllllll}\text { INIPPPSVNR } & 0.97 & 40.76 & 26.13 & 35.52 & 2 & 1249.7334 & 1249.7264 & 625.8705 & 0.0070 & 5.5922 & 5952.351 & 5864.074 & 507.396 & 179.340 & \text { Yes }\end{array}$

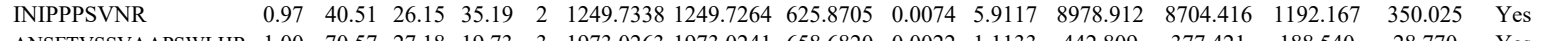

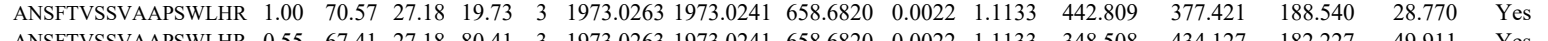
$\begin{array}{llllllllllllllll}\text { ANSFTVSSVAAPSWLHR } & 0.55 & 67.41 & 27.18 & 80.41 & 3 & 1973.0263 & 1973.0241 & 658.6820 & 0.0022 & 1.1133 & 348.508 & 434.127 & 182.227 & 49.911 & \text { Yes }\end{array}$ $\begin{array}{llllllllllllllll}\text { ANSFTVSSVAAPSWLHR } & 1.00 & 76.13 & 27.23 & 18.30 & 3 & 1973.0260 & 1973.0241 & 658.6820 & 0.0019 & 0.9615 & 373.795 & 448.011 & 114.954 & 203.020 & \text { Yes } \\ \text { ANSFTVSSVAAPSWLHR } & 0.55 & 65.25 & 27.18 & 78.25 & 3 & 1973.0263 & 1973.0241 & 658.6820 & 0.0022 & 1.1133 & 277.222 & 384.037 & 208.908 & 105.392 & \text { Yes }\end{array}$ $\begin{array}{llllllllllllllll}\text { ANSFTVSSAAPSWLHR } & 0.55 & 65.25 & 27.18 & 78.25 & 3 & 1973.0263 & 1973.0241 & 658.6820 & 0.0022 & 1.1133 & 277.222 & 384.037 & 208.908 & 105.392 & \text { Yes } \\ \text { IEGDPQGVQQAK } & 1.00 & 62.08 & 27.79 & 29.58 & 2 & 1556.8442 & 1556.8402 & 779.4274 & 0.0040 & 25660 & 7525.422 & 6887.805 & 3625.774 & 2225.874 & \text { Yes }\end{array}$

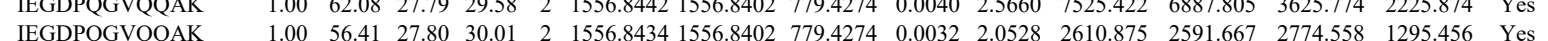
$\begin{array}{llllllllllllllll} & \\ \text { IEGDPQGVQQAK } & 0.99 & 41.43 & 27.79 & 30.45 & 2 & 15568444 & 1556.8402 & 779.4274 & 0.0042 & 2.6943 & 5430.006 & 5846.535 & 6232.934 & 5091.673 & \text { Yes }\end{array}$

$\begin{array}{llllllllll} & \\ 0.8402 & 779.4274 & 0.0042 & 2.6943 & 5430.006 & 5846.535 & 6232.934 & 5091.673 & \text { Ys }\end{array}$ $\begin{array}{llllllllllllllll}\text { IHEGCEEPATHNALAK } & 1.00 & 42.76 & 27.62 & 16.94 & 4 & 2053.0105 & 2052.9964 & 514.2564 & 0.0141 & 6.8545 & 6907.029 & 4914.218 & 6970.297 & 2381.242 & \text { Yes }\end{array}$ $\begin{array}{lllllllllllllllll}\text { IHEGCEEPATHNALAK } & 100 & 38.47 & 27.61 & 17.90 & 4 & 2053.0133 & 2052.9964 & 514.2564 & 0.0169 & 82157 & 8812.230 & 6637.875 & 8074.095 & 2441.226 & \text { Yes }\end{array}$ $\begin{array}{llllllllllllllll}\text { IHEGCEEPAENALAK } & 1.00 & 38.47 & 27.61 & 17.90 & 4 & 2053.0133 & 2052.9964 & 514.2564 & 0.0169 & 8.2157 & 8812.230 & 6637.875 & 8074.095 & 2441.226 & \text { Yes } \\ \text { IYIDSNNNPER } & 1.00 & 55.36 & 28.03 & 21.79 & 2 & 1477.7400 & 1477.7283 & 739.8714 & 0.0117 & 7.9067 & 5902.589 & 7043.514 & 336.798 & 207.692 & \text { Yes }\end{array}$ $\begin{array}{llllllllllllllll} & \\ \text { IHEGCEEPATHNALAK } & 1.00 & 38.15 & 27.57 & 17.91 & 4 & 2053.0097 & 205292964 & 514.2564 & 0.0133 & 6.4656 & 4580.900 & 4729.719 & 5037.406 & 1819.778 & \text { Yes }\end{array}$ $\begin{array}{llllllllllllllll}\text { IHEGCEEPATHNALAK } & 1.00 & 29.08 & 27.73 & 19.06 & 4 & 2053.0153 & 2052.9964 & 514.2564 & 0.0189 & 9.1879 & 4170.795 & 5519.480 & 4999.213 & 2506.612 & \text { Yes }\end{array}$ $\begin{array}{lllllllllllllllll}\text { ADDPSYYMEVYVANTSGNEEVYK } & 1.00 & 45.67 & 25.85 & 24.33 & 3 & 3027.4402 & 3027.4375 & 1010.1531 & 0.0027 & 0.8910 & 18.922 & 16223 & 9.472 & 23.674 & \text { No }\end{array}$

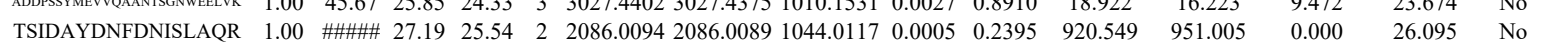
$\begin{array}{llllllllllllllll}\text { TSIDAYDNFDNISLAQR } & 0.55 & 13.79 & 27.27 & 26.79 & 3 & 2086.0111 & 2086.0089 & 696.3436 & 0.0022 & 1.0531 & 151.329 & 228.707 & 205.341 & 204.981 & \text { Yes }\end{array}$ \begin{tabular}{llllllllllllllll} 
VAANAPK & 0.65 & 27.44 & 24.91 & 30.05 & 2 & 957.5828 & 957.5851 & 479.7998 & -0.0023 & -2.3968 & 69.879 & 95.524 & 49.839 & 18.346 & Yes \\
\hline
\end{tabular} $\begin{array}{lllllllllllllllll}\text { VAANAPK } & 0.57 & 26.03 & 24.83 & 30.21 & 2 & 957.5834 & 957.5851 & 479.7998 & -0.0017 & -1.7716 & 82.820 & 136.361 & 56.212 & 23.051 & \text { Yes }\end{array}$ $\begin{array}{llllllllllllllll}\text { ALEHFTDLYDIK } & 1.00 & 46.81 & 27.72 & 19.27 & 3 & 1751.9362 & 1751.9338 & 584.9852 & 0.0024 & 1.3676 & 2017.677 & 2654.157 & 118.776 & 105.796 & \text { Yes }\end{array}$ $\begin{array}{llllllllllllllll}\text { ALEHFTDLYDIK } & 1.00 & 36.68 & 27.71 & 19.81 & 3 & 1751.9371 & 1751.9338 & 584.9852 & 0.0033 & 1.8804 & 1650.741 & 2042.759 & 137.641 & 65.317 & \text { Yes }\end{array}$ $\begin{array}{lllllllllllllllll}\text { SVNESLNNLFITEEDYQALR } & 1.00 & 44.09 & 27.72 & 19.83 & 3 & 2498.2426 & 2498.2410 & 833.7543 & 0.0016 & 0.6397 & 51.177 & 67.296 & 18.517 & 37.573 & \text { Yes }\end{array}$

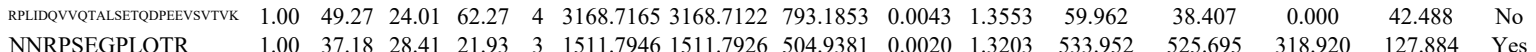
$\begin{array}{llllllllllllllll}\text { NNRPSEGPLQTR } & 1.00 & 37.18 & 28.41 & 21.93 & 3 & 1511.7946 & 1511.7926 & 504.9381 & 0.0020 & 1.3203 & 533.952 & 525.695 & 318.920 & 127.884 & \text { Yes } \\ \text { NNRPSEGLQR }\end{array}$

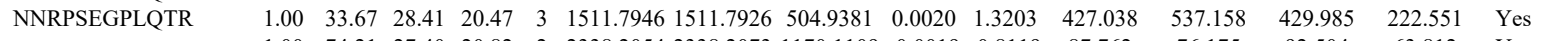
$\begin{array}{llllllllllllllll}\text { VGEQAQVVIIDMNDPSNPIR } & 1.00 & 74.21 & 27.40 & 20.82 & 2 & 2338.2054 & 2338.2073 & 1170.1109 & -0.0019 & -0.8119 & 87.762 & 76.175 & 92.504 & 63.812 & \text { Yes }\end{array}$

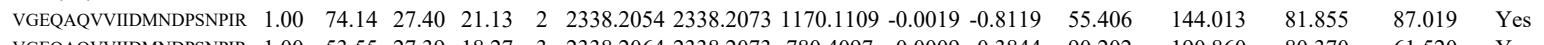
$\begin{array}{llllllllllllllll}\text { VGEQAQVVIIDMNDPSNPIR } & 1.00 & 53.55 & 27.39 & 18.27 & 3 & 2338.2064 & 2338.2073 & 780.4097 & -0.0009 & -0.3844 & 90.202 & 190.860 & 80.370 & 61.520 & \text { Yes }\end{array}$

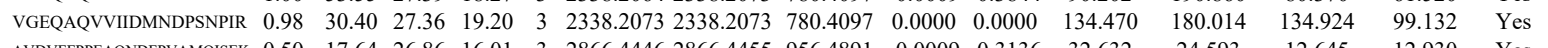

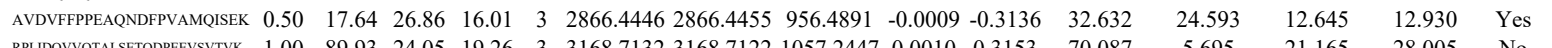

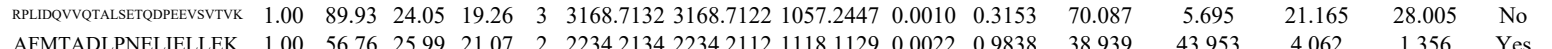

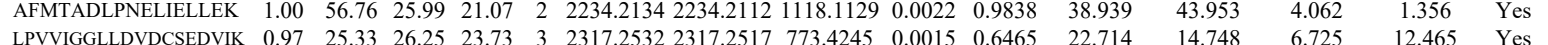

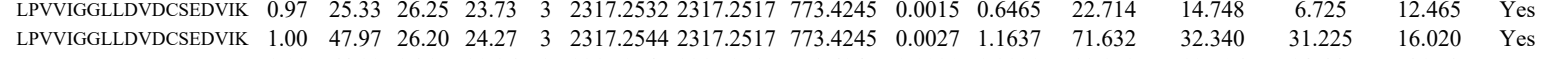

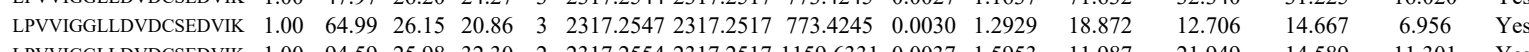

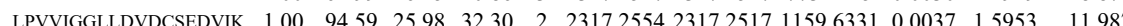



$\begin{array}{lllllllllll}1.00 & 94.03 & 25.58 & 19.55 & 3 & 3432.7612 & 3432.7591 & 1145.2603 & 0.0021 & 0.6112\end{array}$

LTDQLPLIIVCDR

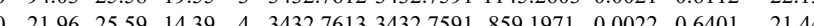

$\begin{array}{llllllllllll} & \end{array}$ $\begin{array}{llllllllllllll} & & \end{array}$ \begin{tabular}{cc}
1323.462 \\
\hline .927 & 28.789 \\
\hline &
\end{tabular} \begin{tabular}{llllllllllllll} 
LFDVNTSIVCDR & 1.00 & 41.51 & 27.66 & 23.14 & 2 & 1687.9136 & 1687.9123 & 844.9634 & 0.0013 & 0.7693 & 97.278 & 131.927 & 28.789 \\
\hline
\end{tabular} $\begin{array}{llllllllllllll}\text { DVNTSAVQVLIEHIGNLDR } & 1.00 & 53.08 & 23.01 & 24.28 & 4 & 2655.4633 & 2655.4588 & 664.8720 & 0.0045 & 1.6921 & 1001.079 & 2051.000 & 743.234 \\ \text { PVWNTAAVQVIEHIGNLDR } & 1.00 & 64.61 & 23.01 & 18.58 & 4 & 2655.4633 & 2655.4588 & 664.8720 & 0.0045 & 1.6921 & 1137.758 & 2301.147 & 585.487\end{array}$

KFVNTSAVQVIEHIGNDR

SLEMNLMAPQVADALGNQMFHHY

$\begin{array}{llllllllllll}1.00 & 60.62 & 23.10 & 18.81 & 4 & 2655.4625 & 2655.4588 & 664.8720 & 0.0037 & 1.3912 & 223.761 & 430.683\end{array}$

$\begin{array}{llllllllllll}1.00 & 61.01 & 26.54 & 17.00 & 4 & 3271.6101 & 3271.6062 & 818.9088 & 0.0039 & 1.1906 & 488.153 & 1141.191 \\ 1.00 & 61.75 & 6.55 & 74.75 & 4 & 3271.6113 & 3271.6062 & 818.9088 & 0.0051 & 1.5569 & 569.406 & 735.013\end{array}$

SVDPTLALSVYLR

$\begin{array}{llllllllllll}1.00 & 61.75 & 26.51 & 74.75 & 4 & 3271.6113 & 3271.6062 & 818.9088 & 0.0051 & 1.5569 & 589.406 & 735.013 \\ 1.00 & 59.90 & 26.27 & 20.98 & 2 & 1576.8954 & 1576.8946 & 789.4546 & 0.0008 & 0.5067 & 556.224 & 759.192\end{array}$

SVDTHLALSVYLR I

$\begin{array}{lllllllllll} & \end{array}$

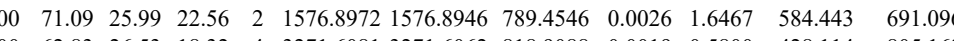

LLEMNLMHAPQVA

GYTPDWIFLLR

$\begin{array}{lllllllll} & \end{array}$

VGYTPDWIFLLR

$\begin{array}{lllllllllll}33.71 & 22.88 & 22.95 & 2 & 1112.6826 & 1112.6837 & 557.3491 & -0.0011 & -0.9868 & 4266.335 & 4944.19\end{array}$

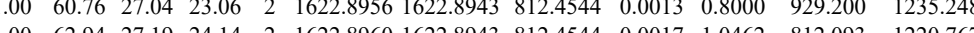
$\begin{array}{lllllllllllr}1.92 .19 & 2.84 & 21.52 & 25.88 & 4 & 3474.8797 & 3474.8755 & 869.7262 & 0.0042 & 1.2073 & 1.132 & 9.070\end{array}$ $\begin{array}{lllllllllllll}1.00 & 58.68 & 21.40 & 51.68 & 4 & 3474.8809 & 3474.8755 & 869.7262 & 0.0054 & 1.5522 & 22.317\end{array}$

\section{LLLPWLEAR}

LLLPWLEAR

VGYTPDWIFLLR

NLQNLLILTAIK

NLQNLLILTAIK

NLQNLLILTAIK

NLQNLLILTAIK

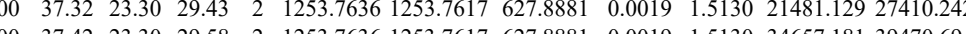

$\begin{array}{llllllllllllll}1.00 & 64.65 & 27.05 & 25.40 & 2 & 16228958 & 16228943 & 812.4544 & 0.0015 & 0.9231 & 1944.928 & 3420122 & 143.752\end{array}$

$\begin{array}{llllllllllllll}1.00 & 67.36 & 27.36 & 24.31 & 2 & 1622.8962 & 1622.8943 & 812.4544 & 0.0019 & 1.1693 & 3475.950 & 5145.598 & 43.388\end{array}$

$\begin{array}{lllllllllllll}1.00 & 67.16 & 14.47 & 17.32 & 2 & 1641.0448 & 1641.0432 & 821.5289 & 0.0016 & 0.9738 & 2771.029 & 3582.506 & 1449.837\end{array}$

$\begin{array}{llllllllllllll}0.77 & 73.63 & 14.47 & 86.63 & 2 & 1641.0450 & 1641.0432 & 821.5289 & 0.0018 & 1.0955 & 4850.261 & 5028.831 & 2330.862\end{array}$

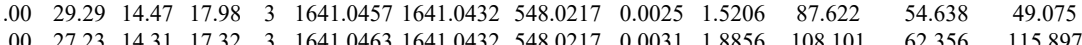
$\begin{array}{cccccccccccccc}1.00 & 27.23 & 14.31 & 17.32 & 3 & 1641.0463 & 1641.0432 & 548.0217 & 0.0031 & 1.8856 & 108.101 & 62.356 & 115.897 \\ 0.53 & 58.64 & 21.61 & 71.64 & 3 & 3474.8782 & 3474.8755 & 11592991 & 0.0027 & 0.7763 & 3.658 & 0.000 & 0.000\end{array}$

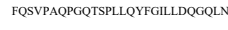

FESVAAPGQTSPLLYYGGLLDDGQLLN

LLLPWLEAR $\begin{array}{llllllllllll}.00 & 20.16 & 21.52 & 33.16 & 4 & 3474.8801 & 3474.8755 & 869.7262 & 0.0046 & 1.3223 & 1.656\end{array}$

LLYNNVSNFGR

LLYNNVSNFGR

VGYTPDWIFLLR

VGYTPDWIFLLR

NLQNLLILTAIK

NLQNLLILTAIK

NLQNLLILTAIK

NLQNLLILTAIK

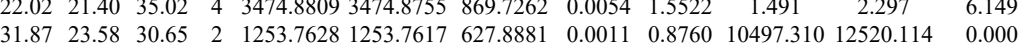

$\begin{array}{lllllllllllllll} & \end{array}$

$\begin{array}{lllllllllllll}1.00 & 59.64 & 28.18 & 21.15 & 2 & 1439.7680 & 1439.7643 & 720.8894 & 0.0037 & 2.5663 & 27634.320 & 30750.910 & 0.000\end{array}$

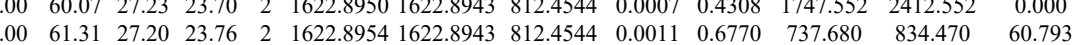

$\begin{array}{lllllllllllll}1.00 & 73.63 & 14.47 & 17.86 & 2 & 1641.0432 & 1641.0432 & 821.5289 & 0.0000 & 0.0000 & 5751.888 & 8240.426 & 3025.945\end{array}$

$\begin{array}{llllllllllllll}1.00 & 74.24 & 14.47 & 19.53 & 2 & 1641.0448 & 1641.0432 & 821.5289 & 0.0016 & 0.9738 & 13092.538 & 13976.889 & 5001.857\end{array}$ $\begin{array}{llllllllllllll}0.94 & 10.88 & 14.47 & 14.55 & 3 & 1641.0451 & 1641.0432 & 548.0217 & 0.0019 & 1.1557 & 241.162 & 121.405 & 127.918 \\ 1.00 & 27.46 & 14.31 & 17.92 & 3 & 1641.0463 & 1641.0432 & 548.0217 & 0.0031 & 1.8856 & 296.413 & 136.065 & 90.559\end{array}$

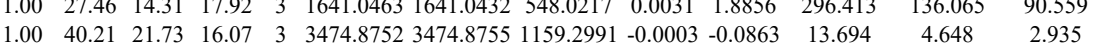

NLILVVR

NLILVVR

LLLPWLEAR

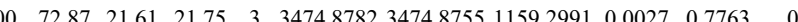

LLLPWLEAR

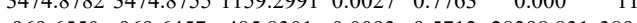

$\begin{array}{lrl}4.880 & 3.249 \\ 1182.2097 & 182.20\end{array}$ $\begin{array}{lllllllllllll}0.99 & 37.57 & 23.58 & 33.49 & 2 & 1253.7624 & 1253.7617 & 627.8881 & 0.0007 & 0.5574 & 1859.419 & 2089.069 & 4.322\end{array}$ $\begin{array}{llllllllllllll}1.00 & 58.29 & 28.22 & 27.73 & 2 & 1439.7620 & 1439.7643 & 720.8894 & -0.0023 & -1.5953 & 10117.770 & 12342.380 & 239.919\end{array}$

LLYNNVSNFGR 
NLQNLLILTAIK NLQNLLILTAIK NLQNLLILTAIK WLLLTGISAQQNR WLLLTGISAQQNR WLLLTGISAQQNR WLLLTGISAQQNR WLLLTGISAQQNR WLLLTGISAQQNR WLLLTGISAQQNR WLLTISAQQNR WLLTISAQQNR WLLLTGISAQQNR WLLLTGISAQQNR WLLLTGISAQQNR WLLLTGISAQQNR WLLLTGISAQQNR WLLLTGISAQQNR WLLLTGISAQQNR WLLLTGISAQQNR NLILVVR

NLILVVR

LLYNNVSNFGR

WLLLTGISAQQNR

WLLLTGISAQQNR

WLLLTGISAQQNR

WLLLTGISAQQNR

WLLLTGISAQQNR

WLLLTGISAQQNR

WLLLTGISAQQNR

WLLLTGISAQQNR WLLLTGISAQQNR WLLLTGISAQQNR WLLLTGISAQQNR WLLLTGISAQQNR GQFSTDELVAEVEK GQPSDELAEVEK GQPSDELVAEVEK GQFSTDELVAEVEK GQFSTDELVAEVEK GQFSTDELVAEVEK IHEGCEEPATHNALAK IHEGCEEPATHNALAK

GWDEALLTMSK GWDEALLTMSK

SEETLDEGPPK

KPMVLGHEASGTVEK

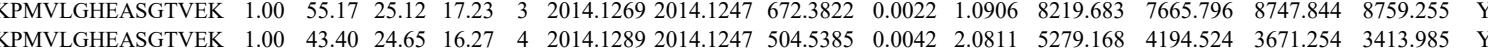

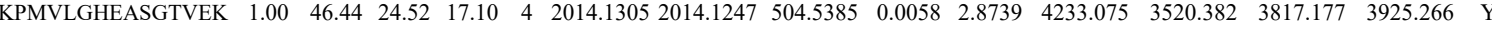
SVNVKKPLVTTHR

6 DLPEHAVLK KAEGGGGGGRPGAPANG KAEGGGGGGRPGAPAAGDGK ASYGVSK NGQDLGVAFK NGQDLGVAFK
NGQDLGVAFK NGQDLGVAFK GRLPEVAECFDEITYVELQK EKPYFPIPEEYTFIQNVPLEDR EKPYFPIPEEYTFIONYPLEDR $\begin{array}{llllllllllll}0.93 & 18.51 & 14.31 & 21.88 & 3 & 1641.0472 & 1641.0432 & 548.0217 & 0.0040 & 2.4330 & 113.355\end{array}$ $\begin{array}{llllllllllll}1.00 & 83.35 & 26.12 & 36.88 & 2 & 1642.9282 & 1642.9277 & 822.4711 & 0.0005 & 0.3040 & 512.029 & 64\end{array}$ $\begin{array}{lllllllllll}100 & 5.20 & 26.18 & 31.68 & 2 & 1642.9286 & 1642.9277 & 822.4711 & 0.0009 & 0.5471 & 572.336\end{array}$ $\begin{array}{lllllllllll}100 & 54.17 & 26.00 & 22.67 & 3 & 1642.9291 & 1642.9277 & 548.6498 & 0.0014 & 0.8506 & 70.595\end{array}$ $\begin{array}{lllllllllll}1.00 & 76.94 & 26.12 & 32.49 & 2 & 1642.9282 & 1642.9277 & 822.4711 & 0.0005 & 0.3040 & 399.231\end{array}$ $\begin{array}{lllllllllll}1.00 & 78.69 & 26.12 & 35.38 & 2 & 1642.9284 & 1642.9277 & 822.4711 & 0.0007 & 0.4255 & 494.581\end{array}$ $\begin{array}{lllllllllllll}1.00 & 51.45 & 26.17 & 19.30 & 3 & 1642.9288 & 1642.9277 & 548.6498 & 0.0011 & 0.6683 & 56.213\end{array}$ $\begin{array}{llllllllllllll}1.00 & 37.86 & 25.99 & 17.91 & 3 & 1642.9294 & 1642.9277 & 548.649 & 0.0017 & 1.0328 & 60.823\end{array}$

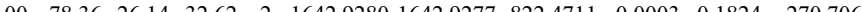
$\begin{array}{llllllllllll}.00 & 54.83 & 26.12 & 19.16 & 3 & 1642.9285 & 1642.9277 & 548.6498 & 0.0008 & 0.4860 & 44.478\end{array}$ $\begin{array}{lllllllllllll}1.00 & 50.24 & 26.00 & 19.03 & 3 & 1642.9291 & 1642.9277 & 548.6498 & 0.0014 & 0.8506 & 67.538\end{array}$ $\begin{array}{llllllllllll}1.00 & 7.79 & 26.12 & 31.54 & 2 & 1642.9282 & 1642.9277 & 822.4711 & 0.0005 & 0.3040 & 258.323 \\ 1.00 & 76.40 & 26.12 & 32.15 & 2 & 1642.9282 & 1642.9277 & 822.4711 & 0.0005 & 0.3040 & 203.499\end{array}$ $\begin{array}{llllllllllll}1.00 & 49.90 & 26.00 & 16.20 & 3 & 164.29291 & 16429277 & 5486498 & 0.0014 & 0.8506 & 39.384\end{array}$ $\begin{array}{lllllllllll}1.00 & 51.58 & 25.99 & 19.90 & 3 & 1642.9294 & 1642.9277 & 548.6498 & 0.0017 & 1.0328 & 71.226\end{array}$ $\begin{array}{lllllllllllll}1.00 & 71.51 & 26.18 & 36.17 & 2 & 1642.9286 & 1642.9277 & 822.4711 & 0.0009 & 0.5471 & 138.215\end{array}$ $\begin{array}{llllllllllll}1.00 & 70.12 & 26.06 & 32.07 & 2 & 1642.9288 & 1642.9277 & 822.4711 & 0.0011 & 0.6687 & 109.145\end{array}$ $\begin{array}{llllllllllllll}0.98 & 27.42 & 16.72 & 27.55 & 2 & 969.6462 & 969.6457 & 485.8301 & 0.0005 & 0.5146 & 297.369\end{array}$ $\begin{array}{lllllllllllll}0.91 & 20.00 & 16.72 & 27.76 & 2 & 969.6464 & 969.6457 & 485.8301 & 0.0007 & 0.7204 & 556.546 \\ 1.00 & 57.68 & 28.18 & 23.48 & 2 & 1439.7652 & 149.7643 & 720.8894 & 0.0009 & 0.6242 & 303.339 & 3.798\end{array}$ $\begin{array}{llllllllllll}1.00 & 72.75 & 26.12 & 35.48 & 2 & 1439.7652 & 1439.7643 & 720.8894 & 0.0009 & 0.6242 & 303.339\end{array}$

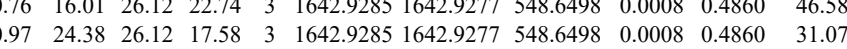
$\begin{array}{llllllllllll}1.00 & 72.35 & 25.99 & 34.27 & 2 & 1642.9292 & 1642.9277 & 822.4711 & 0.0015 & 0.9119 & 84.447\end{array}$ $\begin{array}{llllllllllll}1.00 & 65.34 & 26.06 & 32.18 & 2 & 1642.9288 & 1642.9277 & 822.4711 & 0.0011 & 0.6687 & 25.387\end{array}$ $\begin{array}{lllllllllll}1.00 & 46.86 & 25.98 & 26.10 & 2 & 1642.9294 & 1642.9277 & 822.4711 & 0.0017 & 1.0335 & 21.466\end{array}$

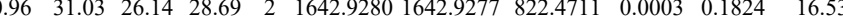

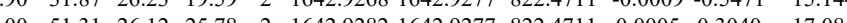

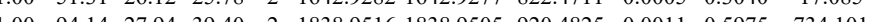
$\begin{array}{llllllllllll}1.00 & 80.09 & 27.94 & 28.81 & 2 & 1838.9518 & 1838.9505 & 920.4825 & 0.0013 & 0.7062 & 584.143 & 57\end{array}$

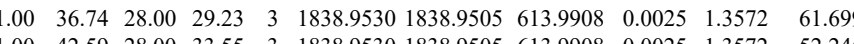

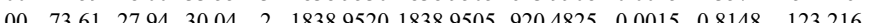
$\begin{array}{lllllllllllll}1.00 & 81.60 & 27.97 & 27.90 & 2 & 1838.9522 & 1838.9505 & 920.4825 & 0.0017 & 0.9234 & 213.582 & \end{array}$ $\begin{array}{llllllllllll} & \end{array}$ $\begin{array}{llllllllllll}.00 & 50.67 & 27.58 & 32.12 & 2 & 1537.8102 & 1537.8054 & 769.9100 & 0.0048 & 3.1172 & 572.573 & 584.1\end{array}$ $\begin{array}{lllllllllllll}1.00 & 65.50 & 27.97 & 36.30 & 2 & 1488.7584 & 1488.7551 & 745.3848 & 0.0033 & 2.2136 & 749.809 & 561.0\end{array}$ $\begin{array}{lllllllllllll}1.00 & 67.52 & 28.08 & 33.36 & 2 & 1488.7590 & 1488.7551 & 745.3848 & 0.0039 & 2.6161 & 137.781 & 158.159\end{array}$

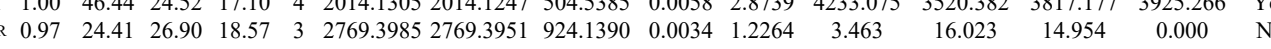

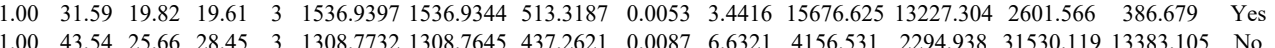
$\begin{array}{llllllllllllllll}1.00 & 43.54 & 25.66 & 28.45 & 3 & 1308.7732 & 1308.7645 & 437.2621 & 0.0087 & 6.6321 & 4156.531 & 2294.938 & 31530.119 & 13383.105 & \text { No } \\ 1.09 & 76.85 & 27.02 & 89.85 & 4 & 2098.1265 & 2098.1245 & 525.5384 & 0.0020 & 0.9514 & 505.323 & 719.342 & 495.897 & 297.299 & \text { Y s }\end{array}$

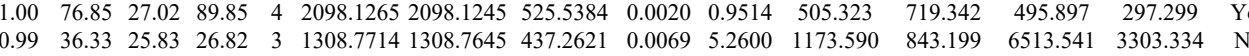

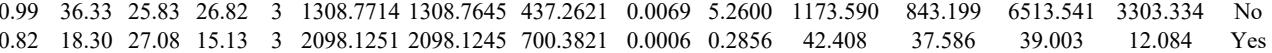

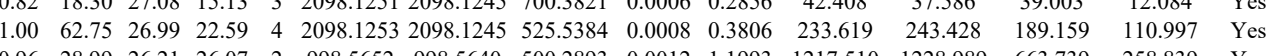
$\begin{array}{lllllllllllllll}0.96 & 28.99 & 26.21 & 26.07 & 2 & 998.5652 & 998.5640 & 500.2893 & 0.0012 & 1.1993 & 1217.510 & 1228.989 & 663.739 & 258.839 & \text { Yes }\end{array}$ $\begin{array}{lllllllllllllll}1.00 & 69.63 & 27.45 & 27.96 & 2 & 1335.7488 & 1335.7390 & 668.8768 & 0.0098 & 7.3257 & 5271.773 & 4580.957 & 3693.284 & 3195.057 & \text { Yes }\end{array}$ $\begin{array}{lllllllllllllllll}1.00 & 69.69 & 28.17 & 26.86 & 2 & 1335.7512 & 1335.7390 & 668.8768 & 0.0122 & 9.1197 & 7051.513 & 6147.171 & 4857.858 & 3659.276 & \text { Yes } \\ 0.99 & 42.57 & 27.50 & 24.82 & 2 & 1335.7494 & 1335.7390 & 668.8768 & 0.0104 & 7.7742 & 4119.159 & 4033.674 & 2165.978 & 1868.512 & \text { Yes }\end{array}$ \begin{tabular}{llllllllllllllll}
0.99 & 42.57 & 27.50 & 24.82 & 2 & 1335.7494 & 1335.7390 & 668.8768 & 0.0104 & 7.7742 & 4119.159 & 4033.674 & 2165.978 & 1868.512 & Yes \\
\hline .55 & 16.10 & 27.02 & 29.10 & 3 & 2878.4032 & 2878.4012 & 960.4743 & 0.0020 & 0.694 & 6.461 & 5.891 & 1.222 & 2.083 & Yes
\end{tabular}

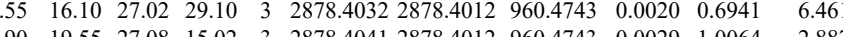

$\begin{array}{llllllllll}83.08 & 26.01 & 19.96 & 3 & 3011.5552 & 3011.5524 & 1004.8581 & 0.0028 & 0.9288 & 55.660\end{array}$ $\begin{array}{cccc}3.993 & 2.365 & 0.000 & \mathrm{~N} \\ 231.209 & 212.585 & 274.131 & \mathrm{~N} \\ 131.179 & 49.344 & 53.864 & \mathrm{Y}\end{array}$

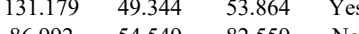
SEETLDEGPPK

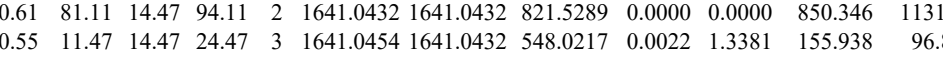
$\begin{array}{lllllllllllll}.00 & 67.62 & 26.12 & 34.31 & 2 & 1642.9282 & 1642.9277 & 822.4711 & 0.0005 & 0.3040 & 150.731 \\ 0 & 72.17 & 6.14 & 34.35 & 2 & 162.29274 & 1642.9277 & 822.4711 & -0.0003 & -0.1824 & 107.630 & 1\end{array}$ $\begin{array}{lllllllllll}1.00 & 72.17 & 26.14 & 34.35 & 2 & 1642.9274 & 1642.9277 & 822.4711 & -0.0003 & -0.1824 & 107.630\end{array}$

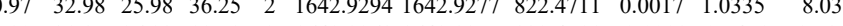
$\begin{array}{lllllllllllll}1.00 & 31.47 & 27.91 & 17.18 & 4 & 2053.0165 & 2052.9964 & 514.2564 & 0.0201 & 9.7713 & 5767.247 & 4880.869\end{array}$

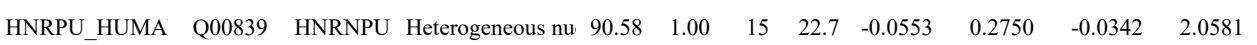

Table S-3 page 352 of 499 

$\begin{array}{lllllllllllll} & \end{array}$ $\begin{array}{lllllllllllll} & 0.07\end{array}$

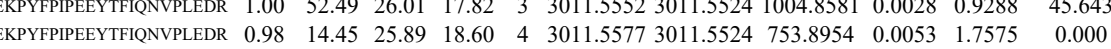

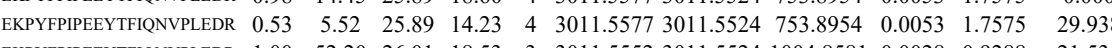

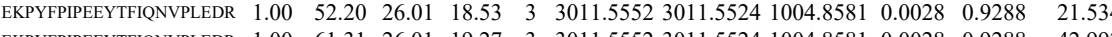
$\begin{array}{lllllllllllll} & \text { EKPYFPIPEYYTQNFLEDR } & 1.00 & 61.31 & 26.01 & 19.27 & 3 & 301.5552 & 3011.5524 & 1004.8581 & 0.0028 & 0.9288 & 42.992\end{array}$ $\begin{array}{llllllllllll}\text { KRPYFPPEEYTFQNVPLEDR } & 0.99 & 17.07 & 25.91 & 14.86 & 4 & 3011.5573 & 3011.5524 & 753.8954 & 0.0049 & 1.6249 & 47.671 \\ \text { EKPYFPPEEYTFIQNYPLEDR } & 1.00 & 26.66 & 25.97 & 39.66 & 4 & 3011.5589 & 3011.5524 & 753.8954 & 0.0065 & 2.1555 & 49.560\end{array}$

PQCLGK

APQCLGK

APQCLGK

APQCLOK

FIEIAAR

AVIAACPK

FIEIAAR

FIEIAAR

LNTLLQR

LNTLLQR

LNTLLQR

LNTLLQR

LNTLLQR

LNTLLQR

$\begin{array}{llllllllllll}0.75 & 27.36 & 28.98 & 28.44 & 2 & 1049.5642 & 1049.5605 & 525.7875 & 0.0037 & 3.5185 & 14010.735\end{array}$ $\begin{array}{llllllllllllll}26.28 & 27.41 & 2 & 962.5754 & 962.5671 & 482.2908 & 0.0083 & 8.6047 & 40921.818 & 34265.100 & 3860.251 & 273.724 & \text { Y }\end{array}$ $\begin{array}{llllllllllllllll}0.99 & 40.49 & 26.28 & 31.18 & 2 & 962.5756 & 962.5671 & 482.2908 & 0.0085 & 8.8120 & 37720.849 & 33923.104 & 4487.025 & 309.950 & \text { Yes } \\ 1.00 & 49.25 & 28.23 & 26.29 & 2 & 1048.618 & 1048.6017 & 52.5081 & 0.0101 & 9.6133 & 23972.339 & 26044.198 & 3821.748 & 1317.828 & \text { Yes }\end{array}$ $\begin{array}{lllllllllllllllll}0.95 & 35.58 & 26.32 & 29.33 & 2 & 962.5744 & 962.5671 & 4822908 & 0.0073 & 7.5680 & 30985.558 & 26830.792 & 3588.205 & 426.074 & \text { Yes }\end{array}$ $\begin{array}{lllllllllllllll}0.96 & 35.64 & 26.32 & 29.07 & 2 & 962.5750 & 962.5671 & 482.2908 & 0.0079 & 8.1900 & 27716.802 & 24699.144 & 2737.818 & 381.728 & \text { Yes }\end{array}$ $\begin{array}{llllllllllllllll}0.87 & 33.88 & 27.25 & 35.42 & 2 & 1000.6220 & 1000.6151 & 501.3148 & 0.0069 & 6.8819 & 4030.457 & 3597.850 & 563.893 & 128.707 & \text { Yes }\end{array}$ $\begin{array}{lllllllllllllllll}0.88 & 32.05 & 27.27 & 34.71 & 2 & 1000.6240 & 1000.6151 & 501.3148 & 0.0089 & 8.8766 & 4075.820 & 4023.022 & 313.220 & 80.717 & \text { Yes }\end{array}$ $\begin{array}{lllllllllllllllll}0.91 & 34.52 & 27.27 & 35.77 & 2 & 1000.6238 & 1000.6151 & 501.3148 & 0.0087 & 8.6771 & 19535.797 & 19838.401 & 1575.124 & 219.250 & \text { Yes }\end{array}$ $\begin{array}{llllllllllllllllll}0.93 & 34.19 & 27.27 & 34.53 & 2 & 1000.6242 & 1000.6151 & 501.3148 & 0.0091 & 9.0761 & 36228.690 & 33567.976 & 1758.282 & 361.191 & \text { Yes }\end{array}$ $\begin{array}{lllllllllllllll}0.88 & 31.72 & 27.25 & 33.82 & 2 & 1000.6228 & 1000.6151 & 501.3148 & 0.0077 & 7.6797 & 45003.340 & 40137.387 & 2998.055 & 119.533 & \text { Yes }\end{array}$

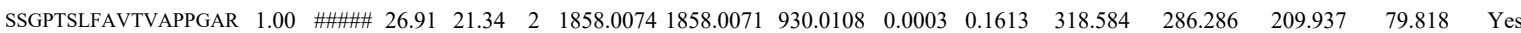

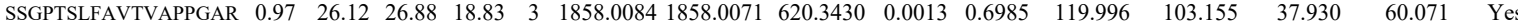

LNTLLQR

LNTLLQR $\begin{array}{llllllllllllll}0.92 & 32.79 & 27.27 & 31.15 & 2 & 1000.6238 & 1000.6151 & 501.3148 & 0.0087 & 8.6771 & 17489.587 & 15204.499 & 975.261\end{array}$

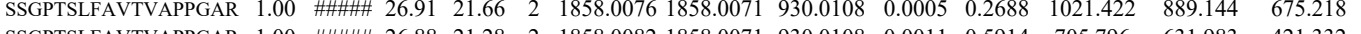

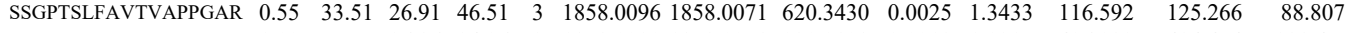
SSGPTSLFAVTVAPPGAR MCLFAGFQR

TCLFAR

MCFAGQR

MCLFAGQR

MCLFAGFQR

LNTLLQR

LNTLLQR

MCLFAGFQR

MCLFAGFQR

MCLFAGFQR

MCLFAGFQR

MCLFAGFQR

MCLFAGFQR

MCLFAGFQR

MCLFAGFQR

MCLFAGFQR

MCLFAGFQR

MCLFAGFQR

MCLFAGFQR

MCLFAGFQR

MCLFAGFQR

LNTLLQR

LNTLLQR

MCLFAGFQR SSGPTSLFAVTVAPPG . 26.8624 .96 $\begin{array}{lllllll}1858.0104 & 1858.0071 & 930.0108 & 0.0033 & 1.7742 & 487.495 & 53\end{array}$ $\begin{array}{lllllllllll}72 & 2 & 1261.5892 & 1261.5892 & 631.8019 & 0.0000 & 0.0000 & 24.039\end{array}$ $\begin{array}{lllllll}1261.5906 & 1261.5892 & 631.8019 & 0.0014 & 1.079 & 31.042\end{array}$ $\begin{array}{lllllllll} & \end{array}$ $\begin{array}{lllllllllllll}0.77 & 21.94 & 25.13 & 34.94 & 2 & 1261.5908 & 1261.5892 & 631.8019 & 0.0016 & 1.2662 & 22.571 & 6.401\end{array}$ $\begin{array}{llllllllllll}1.00 & 49.66 & 24.30 & 18.48 & 2 & 1277.5844 & 1277.5841 & 639.7993 & 0.0003 & 0.2344 & 728.393 & 65\end{array}$ $\begin{array}{llllllllllll}1.00 & 41.10 & 24.15 & 18.13 & 2 & 1277.5848 & 1277.5841 & 639.7993 & 0.0007 & 0.5470 & 714.875 & 587 .\end{array}$ $\begin{array}{llllllllllll}1.0 .88 & 24.60 & 27.34 & 30.52 & 2 & 1000.6164 & 1000.6151 & 501.3148 & 0.0013 & 1.2966 & 141.060 & 587.647\end{array}$ $\begin{array}{lllllllllllll}1.00 & 44.18 & 25.12 & 22.05 & 2 & 1261.5906 & 1261.5892 & 631.8019 & 0.0014 & 1.1079 & 757.139 & 769.095 \\ 1.00 & 38.01 & 25.13 & 21.19 & 2 & 1261.590 & 1261.582 & 631.819 & 0.001 & 1.2662 & 50641 & 392.693\end{array}$ $\begin{array}{llllllllllll}1.00 & 38.01 & 25.13 & 21.19 & 2 & 1261.5908 & 1261.5892 & 631.8019 & 0.0016 & 1.2662 & 506.471 & 392.693\end{array}$ $\begin{array}{lllllllllllll}0.97 & 30.74 & 24.30 & 15.92 & 2 & 1277.5844 & 1277.5841 & 639.7993 & 0.0003 & 0.2344 & 164.920 & 192.759\end{array}$ $\begin{array}{llllllllllllll}1.00 & 39.40 & 24.33 & 18.30 & 2 & 1277.5852 & 1277.5841 & 639.7993 & 0.0011 & 0.8596 & 417.515 & 412.142\end{array}$ $\begin{array}{llllllllllll}1.00 & 43.99 & 25.12 & 21.51 & 2 & 1261.5906 & 1261.5892 & 631.8019 & 0.0014 & 1.1079 & 598.281 & 549.240\end{array}$ $\begin{array}{llllllllllllll}0.97 & 29.20 & 25.13 & 20.01 & 2 & 1261.5908 & 1261.5892 & 631.8019 & 0.0016 & 1.2662 & 343.176 & 319.447\end{array}$

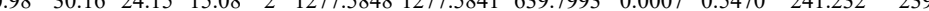
$\begin{array}{lllllllllllll}0.99 & 33.39 & 24.33 & 24.26 & 2 & 1277.5852 & 1277.5841 & 639.7993 & 0.0011 & 0.8596 & 235.720 & 198.548\end{array}$ $\begin{array}{llllllllllll}0.98 & 31.43 & 25.12 & 20.08 & 2 & 126.5906 & 1261.5892 & 631.8019 & 0.0014 & 1.1079 & 317.464 & 3\end{array}$ $\begin{array}{lllllllllll}0.98 & 31.43 & 25.12 & 20.08 & 2 & 1261.5906 & 1261.5892 & 631.8019 & 0.0014 & 1.1079 & 31.464\end{array}$ $\begin{array}{lllllllllllll}1.00 & 38.79 & 24.84 & 16.32 & 2 & 1261.5902 & 1261.5892 & 631.8019 & 0.0010 & 0.7914 & 353.083\end{array}$ $\begin{array}{llllllllllll}0.99 & 34.50 & 25.12 & 20.53 & 2 & 1261.5904 & 1261.5892 & 631.8019 & 0.0012 & 0.9497 & 400.304\end{array}$ $\begin{array}{lllllllllllll}0.76 & 28.17 & 24.84 & 41.17 & 2 & 1261.5000 & 1261.5892 & 631.8019 & 0.0008 & 0.6331 & 114.427 & 1\end{array}$ $\begin{array}{llllllllllll}0.99 & 35.67 & 25.12 & 16.28 & 2 & 1261.5906 & 1261.5892 & 631.8019 & 0.0014 & 1.1079 & 256.792 & 237 .\end{array}$ $\begin{array}{llllllllllll}0.98 & 32.81 & 26.99 & 33.24 & 2 & 100.6156 & 1000.6151 & 501.3148 & 0.0005 & 0.4987 & 1978.313 & 1780.173\end{array}$ $\begin{array}{llllllllllll}0.98 & 32.83 & 26.9 & 33.64 & 2 & 1000.6156 & 1000.6151 & 501.3148 & 0.0005 & 0.4987 & 1978.313 & 1780.173\end{array}$

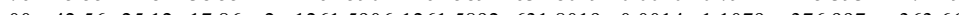
$\begin{array}{lllllllllllll} & 1.00 & 26.91 & 24.36 & 2 & 1858.0072 & 1858.0071 & 930.0108 & 0.0001 & 0.0538 & 36.031\end{array}$ $\begin{array}{lllllllllllllll}\text { SSGPTSLFAVTVAPPGAR } & 0.99 & 30.06 & 26.88 & 16.20 & 3 & 1858.0087 & 1858.0071 & 620.3430 & 0.0016 & 0.8597 & 27.298\end{array}$ 


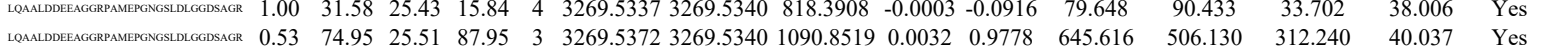

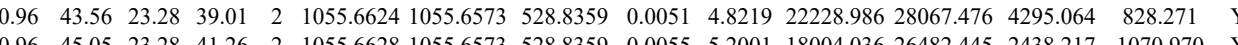
$\begin{array}{lllllllllllllll}0.96 & 45.05 & 23.28 & 41.26 & 2 & 1055.6628 & 1055.6573 & 528.8359 & 0.0055 & 5.2001 & 18004.036 & 26482.445 & 2438.217 & 1070.970 & \text { Yes } \\ 0.99 & 42.83 & 23.03 & 20.60 & 2 & 1112.6844 & 1112.6788 & 557.3467 & 0.0056 & 5.0238 & 12811.177 & 1996.031 & 2383.136 & 1195.424 & \text { Yes }\end{array}$ $\begin{array}{llllllllllllllll}0.99 & 42.83 & 23.03 & 20.60 & 2 & 11 & 11.6844 & 1112.6788 & 557.3467 & 0.0556 & 5.0238 & 12811.177 & 19996.031 & 2383.136 & 1195.424 & \text { Yes } \\ 0.99 & 42.85 & 23.05 & 26.29 & 2 & 1112.6846 & 1112.6788 & 557.3467 & 0.0058 & 5.2032 & 8543.667 & 13493.689 & 1097.260 & 737.557 & \text { Yes }\end{array}$

VAVVNQIAR $\begin{array}{llllllllllllllll} & 0.057\end{array}$ $\begin{array}{llllllllllllllll} & 0.99 & 42.00 & 23.03 & 25.90 & 2 & 1112.6840 & 1112.6788 & 557.3467 & 0.00052 & 5.9564 & 5421.794 & 7413.111 & 981.014 & 308.2445 & \text { Yes } \\ & 1.00 & 45.05 & 23.05 & 26.17 & 2 & 1112.6848 & 1112.6788 & 557.3467 & 0.0060 & 5.3826 & 7213.010 & 11001.55 & 1294.271 & 402.639 & \text { Yes } \\ \end{array}$ $\begin{array}{llllllllllllllll} & \end{array}$

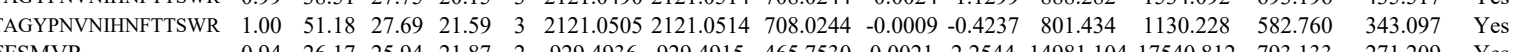

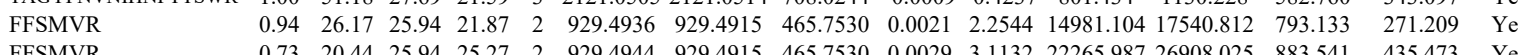
$\begin{array}{lllllllllllllllll}\text { FFSMVR } & 0.73 & 20.44 & 25.94 & 25.27 & 2 & 929.4944 & 929.4915 & 465.7530 & 0.0029 & 3.1132 & 22265.987 & 26908.025 & 883.541 & 435.473 & \text { Yes }\end{array}$

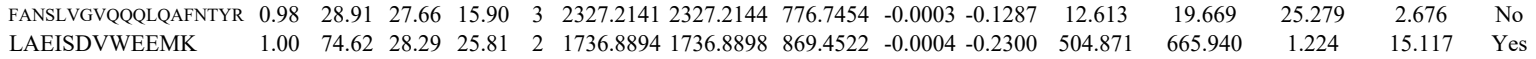

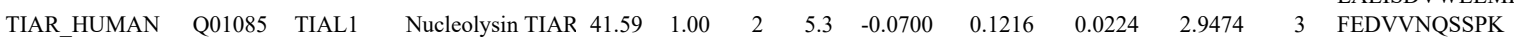
TLYVGNLSR

IDFYFDENPYFENK IDFYFDENPYFENK LNEQASEEILK

EQQEAIEHIDEVQNEIDR QPFFQK

QPFFQK

QPFFQK

QPFFQK

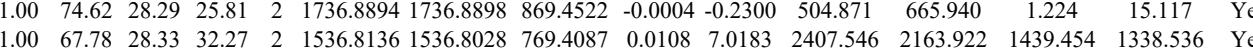
$\begin{array}{llllllllllllllll}0.98 & 41.46 & 27.65 & 27.03 & 2 & 1165.6650 & 1165.6577 & 583.8361 & 0.0073 & 6.2517 & 15783.621 & 15383.512 & 688.675 & 599.093 & \text { Yes }\end{array}$ $\begin{array}{llllllllllllllll}0.99 & 43.73 & 27.69 & 27.51 & 2 & 1165.6656 & 1165.6577 & 583.8361 & 0.0079 & 6.7656 & 21689.388 & 23074.181 & 1265.290 & 218.693 & \text { Yes }\end{array}$ $\begin{array}{lllllllllllllll}1.00 & 77.93 & 26.96 & 19.42 & 2 & 2128.0054 & 2128.0033 & 1065.0089 & 0.0021 & 0.9859 & 1151.120 & 972.612 & 24.292 & 18.880 & \text { No }\end{array}$ $\begin{array}{lllllllllllllll}1.00 & 77.84 & 26.96 & 19.70 & 2 & 2128.0054 & 2128.0033 & 1065.0089 & 0.0021 & 0.9859 & 686.897 & 547.109 & 0.000 & 0.000 & \text { No }\end{array}$ $\begin{array}{lllllllllllllll}1.00 & 46.45 & 27.41 & 25.27 & 2 & 1560.8612 & 1560.8602 & 781.4374 & 0.0010 & 0.6398 & 23.180 & 21.014 & 23.146 & 2.505 & \text { Yes }\end{array}$

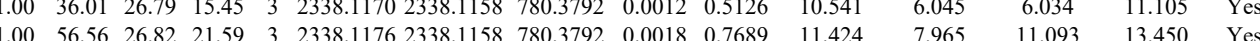

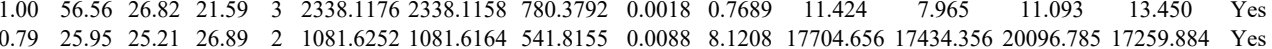
$\begin{array}{llllllllllllllll}0.79 & 25.95 & 25.21 & 26.89 & 2 & 1081.6252 & 1081.6164 & 541.8155 & 0.0088 & 8.1208 & 17704.656 & 17434.356 & 20096.785 & 17259.884 & \text { Yes } \\ 0.76 & 24.19 & 25.66 & 25.44 & 2 & 1081.6266 & 1081.6164 & 541.8155 & 0.0102 & 9.4127 & 14147.232 & 15614.407 & 18701.582 & 16048.875 & \text { Yes }\end{array}$ $\begin{array}{lllllllllllllll}0.76 & 24.19 & 25.66 & 25.44 & 2 & 1081.6266 & 1081.6164 & 541.8155 & 0.0102 & 9.4127 & 14147.232 & 15614.407 & 18701.582 & 16048.875 & \text { Yes } \\ 0.85 & 23.84 & 26.13 & 25.38 & 2 & 1081.6192 & 1081.6164 & 541.8155 & 0.0028 & 2.5839 & 712.617 & 8186.161 & 7843.770 & 7213.302 & \text { Yes }\end{array}$ $\begin{array}{lllllllllllllll}0.85 & 23.84 & 26.13 & 25.38 & 2 & 1081.6192 & 1081.6164 & 541.8155 & 0.0028 & 2.5839 & 7112.617 & 8186.161 & 7843.770 & 7213.302 & \text { Yes } \\ 0.65 & 23.09 & 24.80 & 24.85 & 2 & 1081.6244 & 1081.6164 & 541.8155 & 0.0080 & 7.3825 & 7949.685 & 9422.366 & 10451.071 & 9486.077 & \text { Yes }\end{array}$ $\begin{array}{llllllllllllllll} & 0.00 & 23.87 & 24.51 & 16.33 & 4 & 3868.9585 & 3868.9546 & 968.2459 & 0.0039 & 1.0070 & 1141.015 & 1401.961 & 1229.868 & 678.333 & \text { Yes }\end{array}$ $\begin{array}{rrrrrrrrrrrrrrr} & \end{array}$

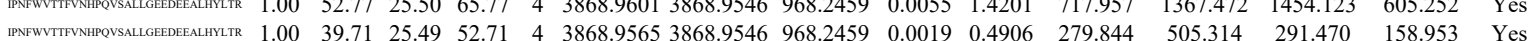
$\begin{array}{lllllllllllllllll} & \end{array}$

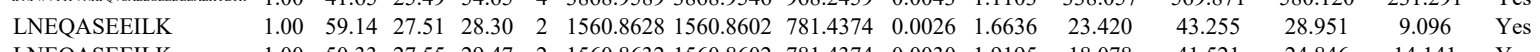

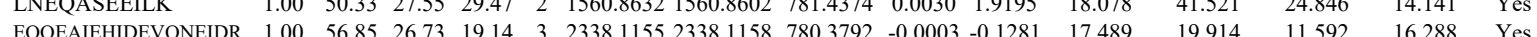


$\begin{array}{llllllllllllllll}\text { EQQEAIEHIDEVQNEIDR } & 1.00 & 50.00 & 26.95 & 18.40 & 3 & 2338.1200 & 2338.1158 & 780.3792 & 0.0042 & 1.7940 & 18.515 & 65.749 & 88.125 & 67.028 & \text { Yes } \\ \text { EQQEAEIDEVQN } & & \end{array}$ $\begin{array}{llllllllllllllll}\text { EQQEAIEHIDEVQNEIDR } & 1.00 & 42.65 & 27.02 & 16.07 & 3 & 2338.1233 & 2338.1158 & 780.3792 & 0.0075 & 3.2036 & 16.049 & 13.889 & 14.548 & 19.112 & \text { Yes } \\ \text { EQQEAIEHIDEVQNEIDR } & 1.00 & 60.28 & 26.90 & 29.76 & 3 & 2338.1197 & 2338.1158 & 780.3792 & 0.0039 & 1.6659 & 3061.530 & 2670.334 & 4170.005 & 2594.743 & \text { Yes }\end{array}$ $\begin{array}{llllllllllllllll}\text { EQQEAIEHIDEVQNEIDR } & 1.00 & 60.28 & 26.90 & 29.76 & 3 & 2338.1197 & 2338.1158 & 780.3792 & 0.0039 & 1.6659 & 3061.530 & 2670.334 & 4170.005 & 2594.743 & \text { Yes } \\ \text { EQQEAIEHIDEVQNEIDR } & 1.00 & 67.77 & 26.92 & 21.98 & 3 & 2338.1209 & 2338.1158 & 780.3792 & 0.0051 & 2.1784 & 2874.028 & 2825.400 & 3904.592 & 2192.384 & \text { Yes }\end{array}$

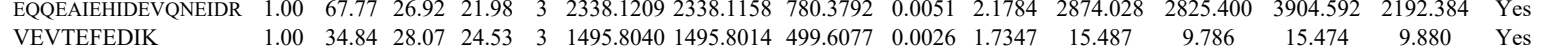

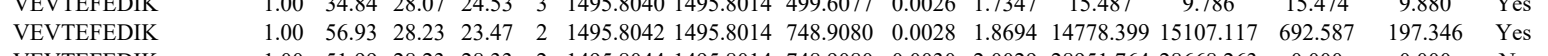

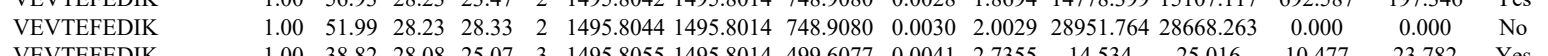
VEVTEFEDIK VEVTEFEDIK $\begin{array}{lllllllllllllll}1.00 & 38.82 & 28.08 & 25.07 & 3 & 1495.8055 & 1495.8014 & 499.6077 & 0.0041 & 2.7355 & 14.534 & 25.016 & 10.477 & 23.782 & \text { Yes }\end{array}$

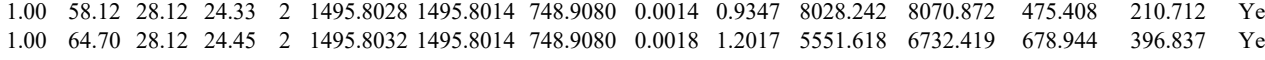
$\begin{array}{llllllllllllllll}1.00 & 58.48 & 26.73 & 27.32 & 2 & 1560.8736 & 1560.8602 & 781.4374 & 0.0134 & 8.5739 & 5838.866 & 5754.013 & 4281.213 & 2115.353 & \text { Yes }\end{array}$ $\begin{array}{rlllllllllllllll}0.86 & 19.61 & 23.18 & 28.26 & 2 & 929.4484 & 929.4477 & 465.7311 & 0.0007 & 0.7515 & 203.779 & 183.423 & 89.836 & 32.225 & \text { Yes } \\ \end{array}$

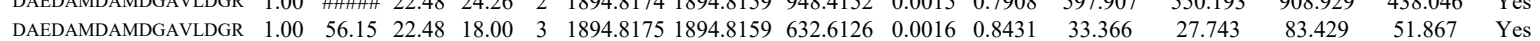

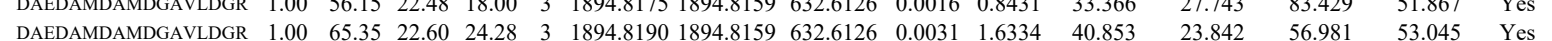

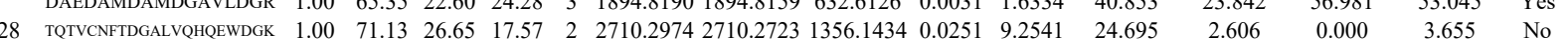

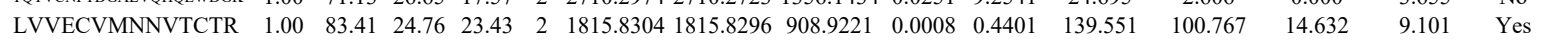

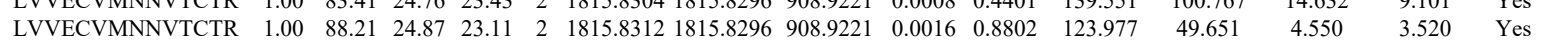

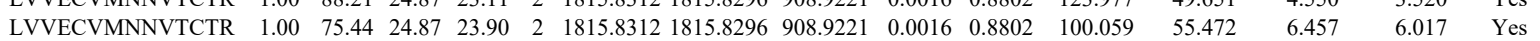

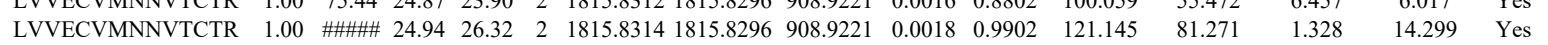

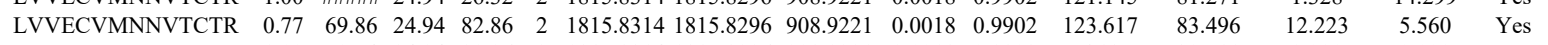
$\begin{array}{llllllllllllllll}\text { LVVECVMNNVTCTR } & 1.00 & 70.54 & 24.94 & 20.96 & 2 & 1815.8314 & 1815.8296 & 908.9221 & 0.0018 & 0.9902 & 56.137 & 39.511 & 0.000 & 0.000 & \text { No }\end{array}$

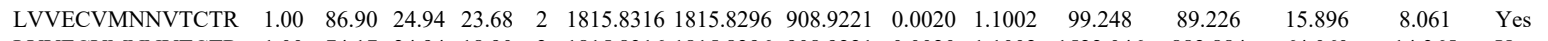

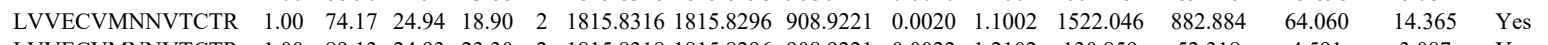
$\begin{array}{lllllllllllllllll}\text { LVVECVMNNVTCTR } & 1.00 & 89.13 & 24.93 & 23.30 & 2 & 1815.8318 & 1815.8296 & 908.9221 & 0.0022 & 1.2102 & 130.859 & 52.318 & 4.591 & 3.087 & \text { Yes }\end{array}$

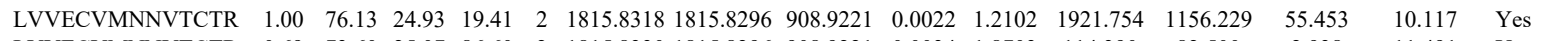
$\begin{array}{llllllllllllllll}\text { LVVECVMNNVTCTR } & 0.69 & 73.60 & 25.07 & 86.60 & 2 & 1815.8330 & 1815.8296 & 908.9221 & 0.0034 & 1.8703 & 114.390 & 82.500 & 2.938 & 11.491 & \text { Yes }\end{array}$ $\begin{array}{lllllllllllllllll}\text { LVVECVMNNVTCTR } & 0.76 & 71.13 & 24.76 & 84.13 & 2 & 1815.8302 & 1815.8296 & 908.9221 & 0.0006 & 0.3301 & 51.092 & 38.141 & 6.698 & 4.949 & \text { Yes }\end{array}$

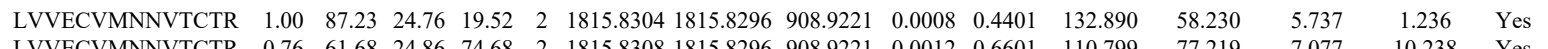

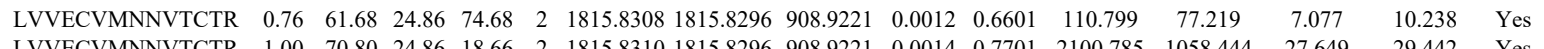

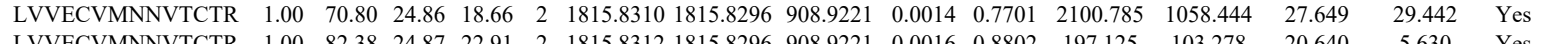

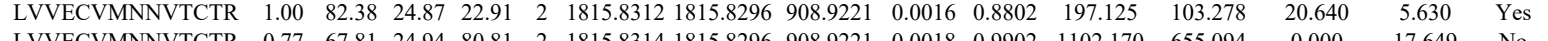

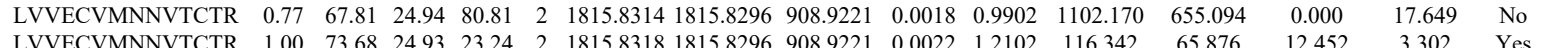
$\begin{array}{llllllllllll} & \end{array}$

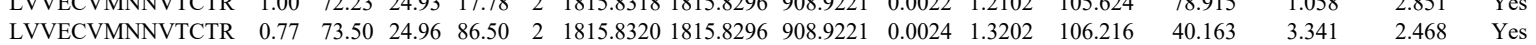

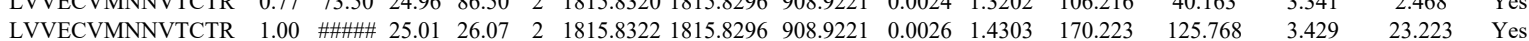

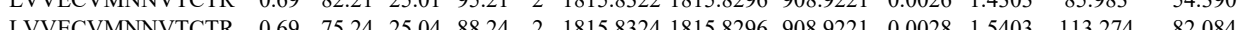

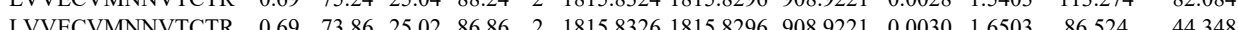

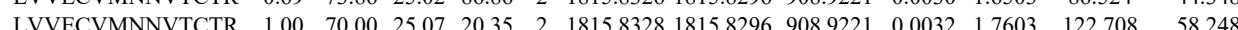
$\begin{array}{lllllllllllll}\text { LVVECVMNNVTCTR } & 0.53 & 19.95 & 25.07 & 32.95 & 3 & 1815.8329 & 1815.8296 & 6062838 & 0.0033 & 1.8143 & 589.187 & 647.131\end{array}$ $\begin{array}{llllllllllllll}\text { LVVECVMNNVTCTR } & 1.00 & 91.37 & 25.04 & 21.37 & 2 & 1815.8324 & 1815.8296 & 908.9221 & 0.0028 & 1.5403 & 62.520 & 46.531\end{array}$ $\begin{array}{lllllllllllll}\text { LVVECVMNNVTCTR } & 0.69 & 73.08 & 25.02 & 86.08 & 2 & 1815.8326 & 1815.8296 & 908.9221 & 0.0030 & 1.6503 & 297.246 & 157.842\end{array}$ $\begin{array}{llllllllllllll}\text { LVVECVMNNVTCTR } & 1.00 & 78.38 & 25.07 & 19.76 & 2 & 1815.8332 & 1815.8296 & 908.9221 & 0.0036 & 1.9804 & 65.949 & 42.187\end{array}$ $\begin{array}{lllllllllllll}\text { LVVECVMNNVTCTR } & 1.00 & 72.88 & 25.08 & 20.30 & 2 & 1815.8342 & 1815.8296 & 908.9221 & 0.0046 & 2.5305 & 60.063 & 37.452\end{array}$ $\begin{array}{llllllllllllll}\text { LVVECVMNNVTCTR } & 1.00 & 88.52 & 24.96 & 23.60 & 2 & 1815.8320 & 1815.8296 & 908.9221 & 0.0024 & 1.3202 & 8.455 & 20.747\end{array}$ $\begin{array}{lllllllllllll}\text { LVVECVMNNVTCTR } & 0.76 & 70.63 & 24.76 & 83.63 & 2 & 1815.8302 & 1815.8296 & 908.9221 & 0.0006 & 0.3301 & 41.664 & 30.484\end{array}$ $\begin{array}{lllllllllllll}\text { LVVECVMNNVTCTR } & 0.77 & 64.80 & 24.96 & 77.80 & 2 & 1815.8320 & 1815.8296 & 908.9221 & 0.0024 & 1.3202 & 50.197 & 34.172\end{array}$ $\begin{array}{lllllllllllll}\text { LVVECVMNNVTCTR } & 0.69 & 64.89 & 25.07 & 77.89 & 2 & 1815.8330 & 1815.8296 & 908.9221 & 0.0034 & 1.8703 & 38.518 & 10.830\end{array}$

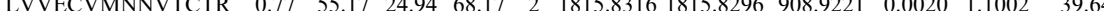

KEPAVLELEGK

KEPAVLELEGK

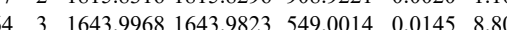
$\begin{array}{lllllllllllll}0.99 & 32.30 & 22.43 & 21.58 & 3 & 1643.9968 & 1643.9823 & 549.0014 & 0.0145 & 8.8038 & 2914.498 & 3564.989\end{array}$

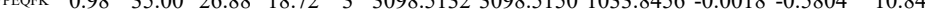
MMNVLIPTEGGDNNEFPYPEQFK LSDLLAPISEQIK LSDLLAPISEQIK LSDLLAPISEQIK LSDLLAPISEQIK LSDLLAPISEQIK LSDLLAPISEQIK LSDLLAPISEQIK

LSDLLAPISEQIK

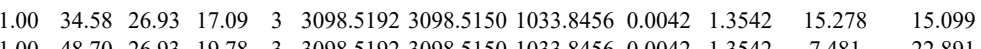

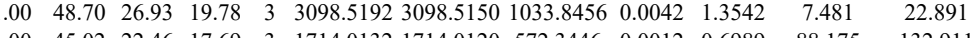

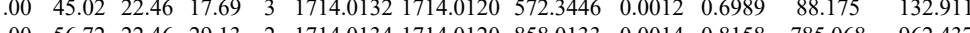
$\begin{array}{llllllllllll}1.00 & 56.72 & 22.46 & 29.13 & 2 & 1714.0134 & 1714.0120 & 858.0133 & 0.0014 & 0.8158 & 785.068 & 962.437\end{array}$ $\begin{array}{llllllllllll}1.00 & 47.86 & 22.48 & 34.65 & 2 & 174.0136 & 1714.0120 & 858.0133 & 0.0016 & 0.9324 & 500.059 & 672.639\end{array}$

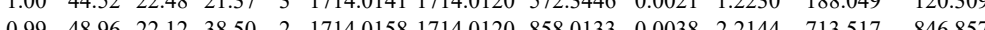

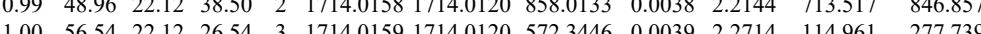

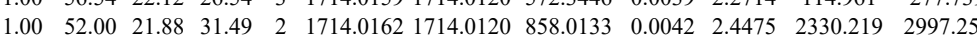
$\begin{array}{llllllllllll}1.00 & 44.31 & 21.85 & 18.72 & 3 & 1714.0174 & 17140120 & 572.3446 & 0.0054 & 3.1449 & 201.806 & 114.012\end{array}$ $\begin{array}{lllllllllllll}1.00 & 51.44 & 22.46 & 30.66 & 2 & 1714.0132 & 1714.0120 & 858.0133 & 0.0012 & 0.6993 & 290.227 & 361.702\end{array}$ 
$\begin{array}{lllllllll} & 0\end{array}$

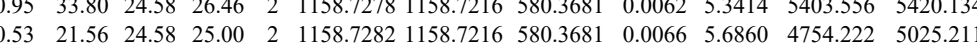

$\begin{array}{lllllllllllllll}\text { AGAAPYVQAFDSLLAGPVAEYLK } & 1.00 & 17.74 & 24.86 & 16.15 & 4 & 2638.4309 & 2638.4250 & 660.6135 & 0.0059 & 2.2328 & 142.890 & 184.676 & 66.753\end{array}$

$\begin{array}{lllllllllllll}1.00 & 44.77 & 26.86 & 26.27 & 2 & 1352.7504 & 1352.7400 & 677.3773 & 0.0104 & 7.6766 & 17844.993 & 24840.867 & 967.776\end{array}$

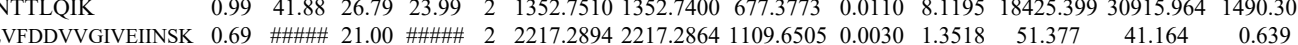
$\begin{array}{lllllllllllll} & \end{array}$

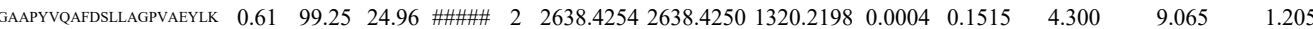

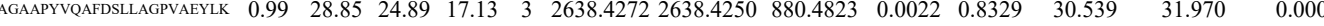
$\begin{array}{llllllllllllll}\text { AGAAPYVAADDSLLAGPVAEYLK } & 0.77 & 78.78 & 24.89 & 91.78 & 2 & 2638.4274 & 2638.4250 & 1320.2198 & 0.0024 & 0.9089 & 12.670 & 11.240 & 5.469\end{array}$

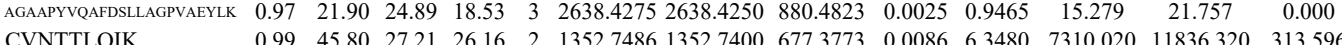

$\begin{array}{lllllllllllll} & \end{array}$

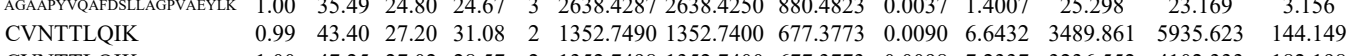

$\begin{array}{llllllllllll}0.99 & 43.40 & 27.20 & 31.08 & 2 & 1352.7490 & 1352.7400 & 677.3773 & 0.0090 & 6.6432 & 3489.861 & 5935.623 \\ 1.00 & 47.25 & 27.02 & 28.57 & 2 & 1352.7498 & 1352.7400 & 677.3773 & 0.0098 & 7.2337 & 3236.552 & 4102.33\end{array}$

$\begin{array}{llllllllllllllll}1.00 & 49.01 & 22.43 & 32.80 & 3 & 1643.9968 & 1643.9823 & 549.0014 & 0.0145 & 8.8038 & 8289.035 & 9030.710 & 6102.012 & 3563.948 & \text { Yes }\end{array}$

$\begin{array}{lllllllllllllll}1.00 & 49.79 & 22.36 & 25.62 & 3 & 1643.9971 & 1643.9823 & 549.0014 & 0.0148 & 8.9859 & 5609.684 & 8100.355 & 4614.498 & 3225.313 & \text { Yes }\end{array}$

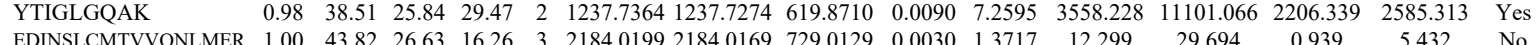

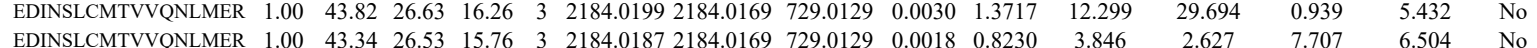
$\begin{array}{lllllllllllllll} & \end{array}$

LEVGTETIIDK

VTQDATPGSALDK

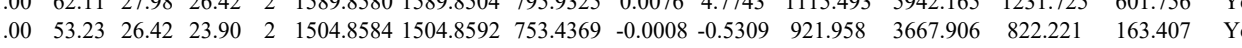
$\begin{array}{lllllllllllllll} & & & \end{array}$ $\begin{array}{llllllllllllllll}\text { GDVSNLDPNFSFEGTK } & 1.00 & 92.05 & 27.48 & 24.17 & 2 & 2013.9894 & 2013.9887 & 1008.0016 & 0.0007 & 0.3472 & 1522.239 & 1545.288 & 1490.003 & 1163.377 & \text { Yes } \\ \text { LFFVGSR } & 0.97 & 29.50 & 26.76 & 32.19 & 2 & 968.5582 & 968.5565 & 485.2855 & 0.0017 & 1.7515 & 22912.100 & 18942.346 & 599.906 & 407.892 & \text { Yes }\end{array}$

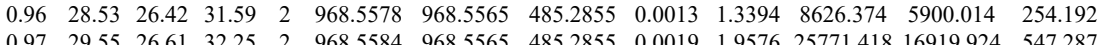
$\begin{array}{lllllllllllllll}0.97 & 29.55 & 26.61 & 32.25 & 2 & 968.5584 & 968.5565 & 485.2855 & 0.0019 & 1.9576 & 25771.418 & 16919.924 & 547.287 & 5 \\ 0.97 & 29.83 & 26.76 & 32.56 & 2 & 968.5582 & 968.5565 & 485.2855 & 0.0017 & 1.7515 & 11500.654 & 8752.507 & 381.173 & 1\end{array}$ $\begin{array}{llllllllllllll}0.96 & 28.58 & 26.61 & 31.59 & 2 & 9685588 & 968.5565 & 4852855 & 0.0023 & 2.3697 & 8624.298 & 5977.273 & 35.185 & 1.189\end{array}$ 

$\begin{array}{lllllllllllllllll}\text { IIEVVDAIMTTAQSHQR } & 1.00 & 85.33 & 27.37 & 25.52 & 3 & 2055.0946 & 2055.0905 & 686.0374 & 0.0041 & 1.9921 & 5047.977 & 5392.486 & 2851.567 & 40.446 & \text { Yes }\end{array}$

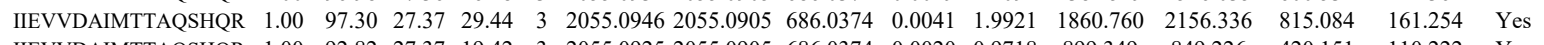
$\begin{array}{lllllllllllllll} & & \end{array}$ $\begin{array}{llllllllllllllll} & \end{array}$ $\begin{array}{lllllllllllllllll} & \text { AACNLLQR } & 0.92 & 33.93 & 28.31 & 19.25 & 2 & 1077.5638 & 1077.5545 & 539.7845 & 0.0093 & 8.6145 & 12653.297 & 13457.106 & 846.245 & 439.141 & \text { Yes }\end{array}$

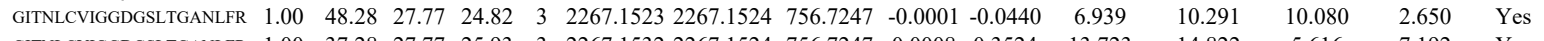

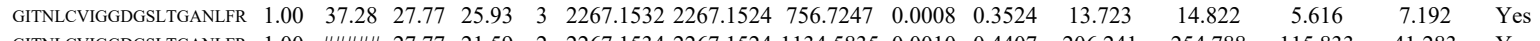

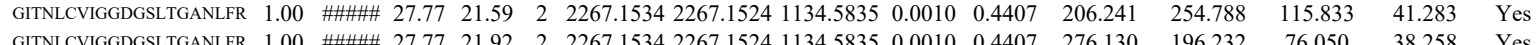

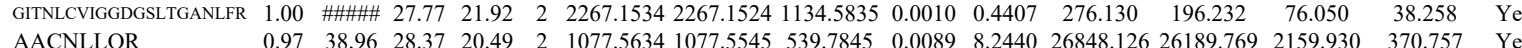

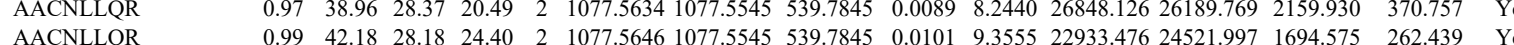

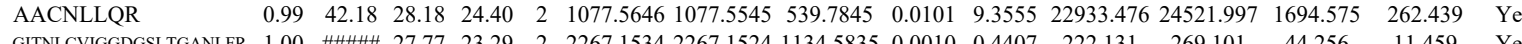

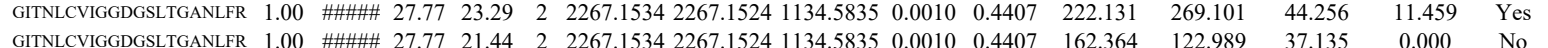

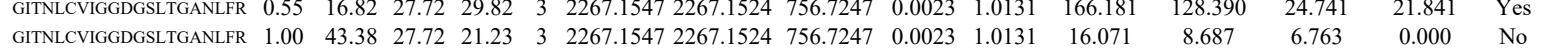

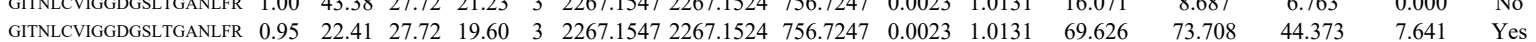

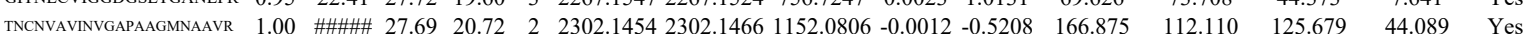

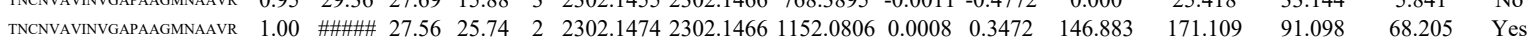

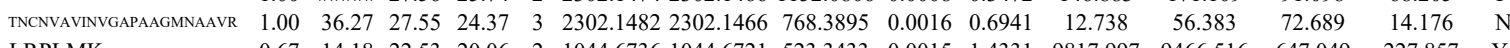

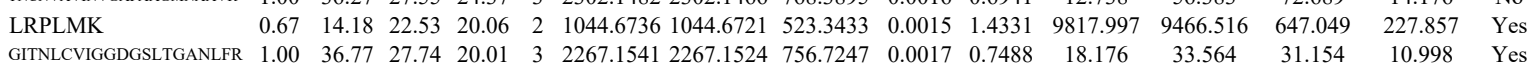

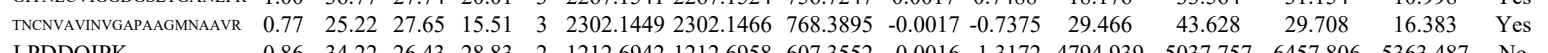

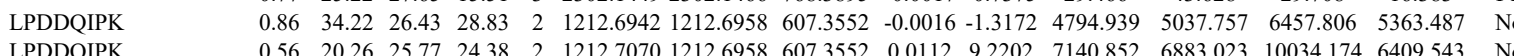
\begin{tabular}{llllllllllllllll} 
& \\
LPDDQIPK & 0.56 & 20.26 & 25.77 & 24.38 & 2 & 1212.7070 & 1212.6958 & 607.3552 & 0.0112 & 9.2202 & 7140.852 & 6883.023 & 10034.174 & 6409.543 & $\mathrm{~N}$ \\
\hline & 0.85 & 26.97 & 25.79 & 22.45 & 2 & 1212.7076 & 1212.6958 & 607.3552 & 0.0118 & 9.7142 & 8235.970 & 7615.282 & 10710.746 & 7593.350 & $\mathrm{~N}$
\end{tabular}

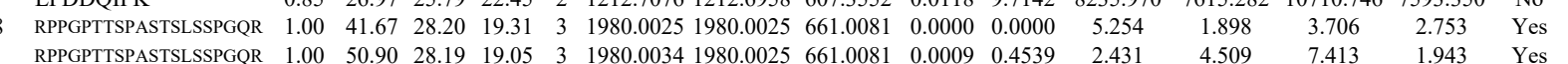

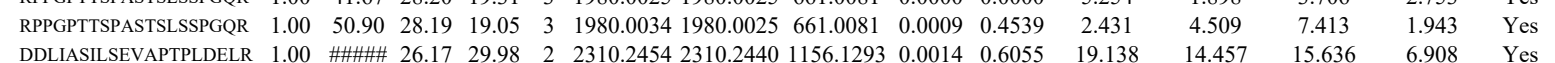

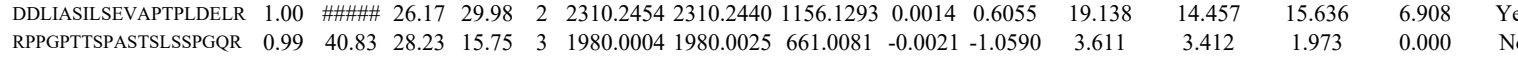
$\begin{array}{lllllllllllllllll}\text { ILPVSAIR } & 0.51 & 9.01 & 18.69 & 21.53 & 2 & 1011.6590 & 1011.6562 & 506.8354 & 0.0028 & 2.7622 & 25.516 & 27.879 & 22.012 & 4.676 & \text { Yes }\end{array}$

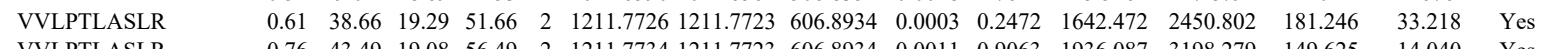
$\begin{array}{lllllllllllllllll}\text { VVLPTLASLR } & 0.76 & 43.49 & 19.08 & 56.49 & 2 & 1211.7734 & 1211.7723 & 606.8934 & 0.0011 & 0.9063 & 1936.087 & 3198.279 & 149.625 & 14.040 & \text { Yes }\end{array}$ $\begin{array}{llllllllllllllll}\text { RPPGPTTSPASTSLSSPGQR } & 0.74 & 28.17 & 27.60 & 15.11 & 2 & 2124.1034 & 2124.1045 & 1063.0595 & -0.0011 & -0.5174 & 1.066 & 0.988 & 1.164 & 0.000 & \text { No }\end{array}$ $\begin{array}{llllllllllllllll}\text { RPPGPTTSPASTSLSSPGQR } & 0.89 & 12.34 & 27.35 & 25.34 & 4 & 2124.1053 & 2124.1045 & 532.0334 & 0.0008 & 0.3759 & 74.546 & 101.281 & 107.324 & 56.871 & \text { Yes }\end{array}$ $\begin{array}{llllllllllllllll}\text { RPPGPTTSPASTSLSSPGQR } & 0.99 & 17.02 & 27.42 & 30.02 & 4 & 2124.1061 & 2124.1045 & 532.0334 & 0.0016 & 0.7518 & 75.790 & 72.856 & 78.284 & 61.056 & \text { Yes }\end{array}$

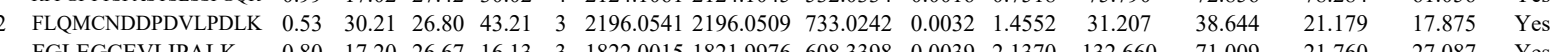

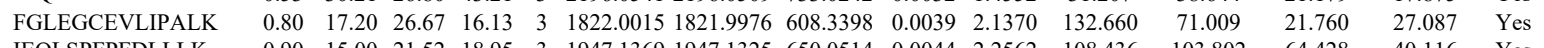

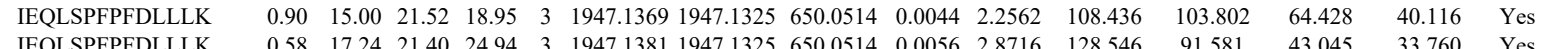

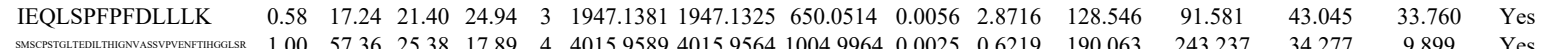

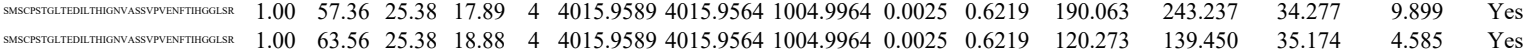
\begin{tabular}{llllllllllllllll} 
VFHLPTTTFIGGQESALPLR & 0.97 & 34.71 & 25.45 & 29.24 & 3 & 2327.2753 & 2327.2760 & 776.7659 & -0.0007 & -0.3004 & 131.253 & 78.432 & 62.021 & 45.006 & Yes \\
\hline
\end{tabular}

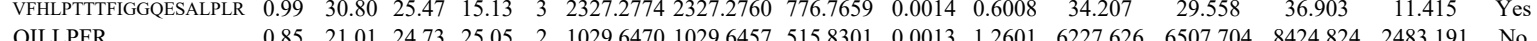

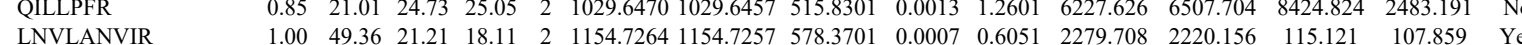



$\begin{array}{lllllllllllllll}0.87 & 30.14 & 26.46 & 19.88 & 3 & 1592.9056 & 1592.9099 & 531.9772 & -0.0043 & -2.6944 & 502.424 & 630.194 & 82.172 & 65.484 & \text { Yes } \\ 1.00 & 48.01 & 24.86 & 29.43 & 2 & 1102.7060 & 1102.6954 & 5523550 & 0.0106 & 9.5952 & 15949.724 & 19310.762 & 3105.800 & 2425.586 & \text { Yes }\end{array}$ $\begin{array}{llllllllllllllll}1.00 & 48.01 & 24.86 & 29.43 & 2 & 1102.7060 & 1102.6954 & 552.3550 & 0.0106 & 9.5952 & 50949.724 & 19310.762 & 3105.800 & 2425.586 & \text { Yes } \\ 0.97 & 37.52 & 24.90 & 32.62 & 2 & 1102.7028 & 1102.6954 & 552.3550 & 0.0074 & 6.6985 & 7731.563 & 8066.475 & 2362.967 & 2566245 & \text { Yes }\end{array}$

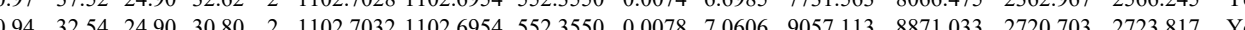

SSGETVYC
CLPTPK $\begin{array}{llllllllllllllll}0.94 & 32.54 & 24.90 & 30.80 & 2 & 1102.7032 & 1102.6954 & 552.3550 & 0.0078 & 7.0606 & 9057.113 & 8871.033 & 2720.703 & 2723.817 & \text { Yes } & \\ 0.71 & 16.95 & 27.60 & 19.61 & 3 & 1878.9154 & 1878.9099 & 627.3106 & 0.055 & 2.9225 & 57.400 & 55.920 & 40.406 & 23.116 & \text { No }\end{array}$ IFAPNHVVAK IFAPNHVVAK IFAPNHVVAK IFAPNHVVAK IFAPNHVVAK
IFAPNHVVAK IFAPNHVVAK
IFAPNHVVAK IFAPNHVVAK
IFAPNHVVAK IFAPNHVVAK IFAPNHVVAK IFAPNHVVAK $\begin{array}{lllllllllllllll}0.57 & 27.09 & 29.39 & 21.97 & 2 & 991.5508 & 991.5438 & 496.7792 & 0.0070 & 7.0453 & 40324.441 & 31430.660 & 1223.437 & 2506.801 & \text { Yes } \\ 1.00 & 58.38 & 2.62 & 18.56 & 2 & 13828396 & 1382.8278 & 692.4212 & 0.0118 & 85208 & 9170.100 & 7813.063 & 476.436 & 299.769 & \text { Yes }\end{array}$ $\begin{array}{llllllllllllllll}1.00 & 58.38 & 22.62 & 18.56 & 2 & 1382.8396 & 3882.8278 & 692.4212 & 0.018 & 8.5208 & 9170.100 & 7813.063 & 476.436 & 296.169 & \text { Yes } \\ 1.00 & 50.57 & 22.62 & 18.78 & 2 & 1382.8398 & 1382.8278 & 692.4212 & 0.0120 & 8.6652 & 20526.362 & 19178.983 & 1175.333 & 101.614 & \text { Yes }\end{array}$

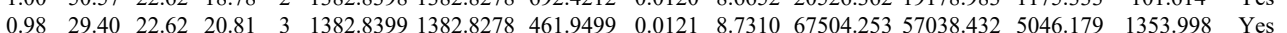
$\begin{array}{lllllllllllllll}0.98 & 16.48 & 22.52 & 20.81 & 3 & 1382.8408 & 1382.8278 & 461.9499 & 0.0130 & 9.3384 & 69784.485 & 65998.110 & 3789.365 & 999.897 & \text { Yes }\end{array}$ $\begin{array}{lllllllllllllll}1.00 & 48.23 & 23.16 & 18.03 & 2 & 1382.8382 & 1382.8278 & 692.4212 & 0.0104 & 7.5098 & 18735.595 & 17950.506 & 1137.672 & 247.297 & \text { Yes }\end{array}$

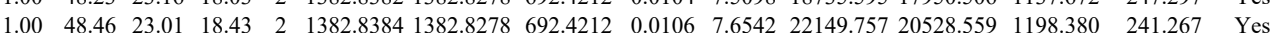
$\begin{array}{lllllllllllllll}0.88 & 23.75 & 22.79 & 23.33 & 3 & 1382.8387 & 1382.8278 & 461.9499 & 0.0109 & 7.8651 & 72642.073 & 66247.057 & 5472.086 & 761.176 & \text { Yes }\end{array}$ $\begin{array}{lllllllllllllll}0.79 & 21.71 & 22.62 & 23.48 & 3 & 1382.8396 & 1382.8278 & 461.9499 & 0.0118 & 8.5146 & 57033.934 & 56961.453 & 4818.087 & 1231.349 & \text { Yes }\end{array}$ $\begin{array}{lllllllllllllllll}0.99 & 32.14 & 23.48 & 16.24 & 3 & 1382.8375 & 1382.8278 & 461.9499 & 0.0097 & 6.9993 & 27508.246 & 22008.454 & 2928.473 & 871.813 & \text { Yes }\end{array}$ $\begin{array}{llllllllllllllll}0.99 & 34.62 & 23.20 & 17.64 & 3 & 1382.8378 & 1382.8278 & 461.9499 & 0.0100 & 7.2157 & 20447.090 & 16789.571 & 2813.380 & 1806.612 & \text { Yes }\end{array}$ $\begin{array}{lllllllllllllll}0.95 & 29.29 & 22.62 & 20.00 & 2 & 1382.8394 & 1382.8278 & 692.4212 & 0.0116 & 8.3763 & 3170.509 & 3007.081 & 703.282 & 317.377 & \text { Yes }\end{array}$ $\begin{array}{lllllllllllllll}0.82 & 21.37 & 23.48 & 19.46 & 3 & 1382.8375 & 1382.8278 & 461.9499 & 0.0097 & 6.9993 & 7040.201 & 7016.157 & 3178.775 & 1413.906 & \text { Yes }\end{array}$ $\begin{array}{llllllllllllllll}0.79 & 22.70 & 22.92 & 24.94 & 3 & 1382.8393 & 1382.8278 & 461.9499 & 0.0115 & 8.2981 & 20056.724 & 17548.248 & 5278.265 & 1476.753 & \text { Yes }\end{array}$ $\begin{array}{llllllllllllllll}0.71 & 23.65 & 26.05 & 19.78 & 2 & 1175.5746 & 1175.5701 & 588.7923 & 0.0045 & 3.8214 & 14546.701 & 5745.872 & 2729.764 & 2147.366 & \text { Yes }\end{array}$ $\begin{array}{llllllllllllllll}0.64 & 23.79 & 26.44 & 20.50 & 2 & 1175.5796 & 1175.5701 & 588.7923 & 0.0095 & 8.0673 & 20583.931 & 7942.827 & 4483.215 & 1884.605 & \text { Yes }\end{array}$ $\begin{array}{lllllllllllllllll}0.85 & 23.57 & 25.77 & 23.39 & 2 & 1175.5734 & 1175.5701 & 588.7923 & 0.0033 & 2.8023 & 6491.253 & 2814.003 & 1274.656 & 909.911 & \text { Yes }\end{array}$ $\begin{array}{lllllllllllllll}0.79 & 25.43 & 26.06 & 25.82 & 2 & 1175.5740 & 1175.5701 & 588.7923 & 0.0039 & 3.3119 & 10101.375 & 3822.295 & 2334.926 & 1212.677 & \text { No }\end{array}$ $\begin{array}{llllllllllllllll}0.89 & 22.58 & 25.15 & 22.16 & 2 & 909.5328 & 909.5307 & 455.7726 & 0.0021 & 2.3038 & 10407.050 & 9808.934 & 9347.438 & 6577.844 & \text { No }\end{array}$ $\begin{array}{llllllllllllllll}0.79 & 21.16 & 25.15 & 22.75 & 2 & 909.5334 & 909.5307 & 455.7726 & 0.0027 & 2.9620 & 10633.650 & 10313.821 & 9914.447 & 6333.135 & \text { No }\end{array}$ $\begin{array}{llllllllllllllll}0.57 & 23.72 & 26.18 & 20.01 & 2 & 1175.5752 & 1175.5701 & 588.7923 & 0.0051 & 4.3309 & 4258.711 & 1648.318 & 797.882 & 585.554 & \text { Yes }\end{array}$ $\begin{array}{lllllllllllllll}0.67 & 25.77 & 26.19 & 19.81 & 2 & 1175.5760 & 1175.5701 & 588.7923 & 0.0059 & 5.0102 & 4997.735 & 1712.915 & 967.576 & 706.952 & \text { No } \\ 0.71 & 1.15 & 24.67 & 2.09 & 2 & 970.5312 & 909.5307 & 455.7726 & 0.005 & 0.5485 & 71.869 & 54.092 & 38.514 & 23.529 & \text { Yo }\end{array}$ $\begin{array}{lllllllllllllll}0.71 & 17.15 & 24.67 & 22.09 & 2 & 909.5312 & 909.5307 & 455.7726 & 0.0005 & 0.5485 & 71.869 & 54.092 & 38.514 & 23.529 & \text { Yes } \\ 0.79 & 19.99 & 25.68 & 26.16 & 2 & 909.5318 & 909.5307 & 455.7726 & 0.0011 & 1.2067 & 38.091 & 44.341 & 38.143 & 19.495 & \text { No }\end{array}$ $\begin{array}{lllllllllllllll}0.79 & 19.99 & 25.68 & 26.16 & 2 & 909.5318 & 909.5307 & 455.7726 & 0.0011 & 1.2067 & 38.091 & 44.341 & 38.143 & 19.495 & \text { No } \\ 0.84 & 22.50 & 25.15 & 22.38 & 2 & 909.5334 & 909.5307 & 455.7726 & 0.0027 & 2.9620 & 16736.997 & 15902822 & 18671294 & 11540.582 & N\end{array}$ $\begin{array}{lllllllllllllllll}0.84 & 22.50 & 25.15 & 22.38 & 2 & 909.5334 & 909.5307 & 455.7726 & 0.0027 & 2.9620 & 16736.997 & 15902.822 & 18671.294 & 11540.582 & \mathrm{~N} 0 \\ 0.84 & 22.38 & 25.15 & 2.02 & 2 & 909.5336 & 909.5307 & 455.7726 & 0.0029 & 3.1814 & 10217.732 & 9974.536 & 9291.540 & 6490.976 & \mathrm{~N} 0\end{array}$

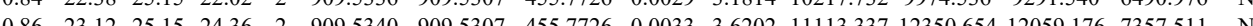

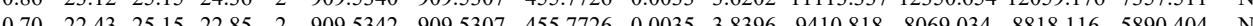

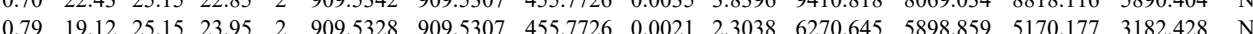
$\begin{array}{llllllllllllllll}1.00 & 56.48 & 27.50 & 25.43 & 2 & 1504.8346 & 1504.8322 & 753.4234 & 0.0024 & 1.5927 & 14897.448 & 14835.780 & 1338.602 & 447.177 & \text { Yes }\end{array}$ $\begin{array}{llllllllllllllll}0.97 & 26.17 & 27.48 & 23.85 & 3 & 1504.8364 & 1504.8322 & 502.6180 & 0.0042 & 27854 & 317.259 & 258.144 & 95.306 & 39.956 & \text { Yes }\end{array}$

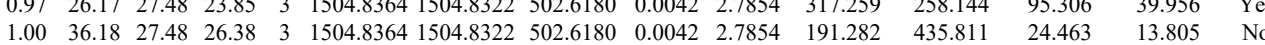

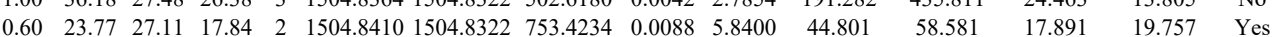

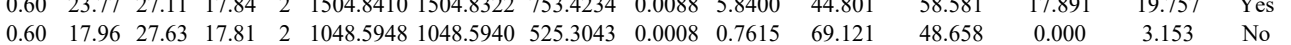
$\begin{array}{lllllllllllllll}0.69 & 19.85 & 27.63 & 18.23 & 2 & 1048.5948 & 1048.5940 & 525.3043 & 0.0008 & 0.7615 & 46.857 & 46.263 & 8.327 & 3.653 & \text { Yes }\end{array}$ $\begin{array}{lllllllllllllll}0.53 & 16.78 & 27.72 & 18.03 & 2 & 1048.5950 & 1048.5940 & 525.3043 & 0.0010 & 0.9518 & 57.547 & 53.448 & 11.486 & 14.877 & \text { Yes }\end{array}$

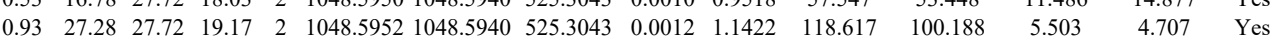

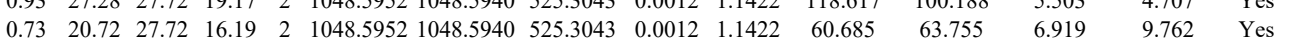

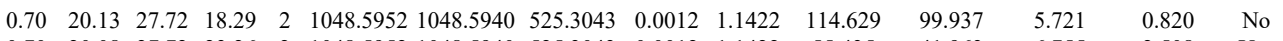

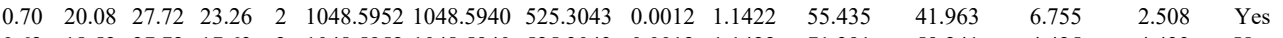

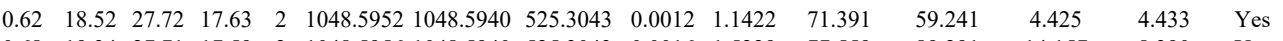
$\begin{array}{lllllllllllllll}0.68 & 19.34 & 27.71 & 17.59 & 2 & 1048.5956 & 1048.5940 & 525.3043 & 0.0016 & 1.5229 & 77.559 & 89.291 & 14.157 & 8.390 & \text { Yes }\end{array}$

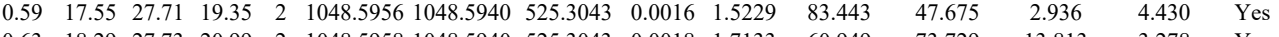

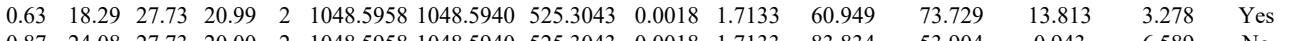

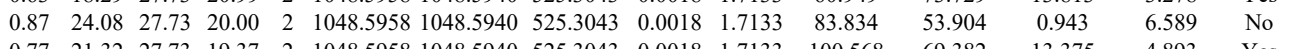

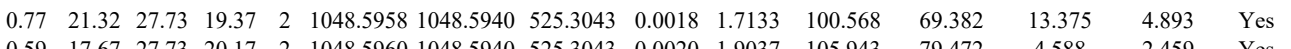

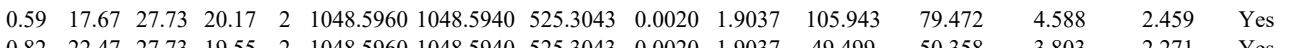

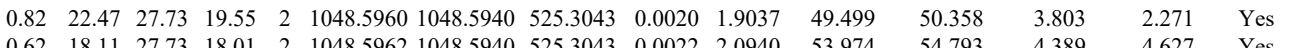

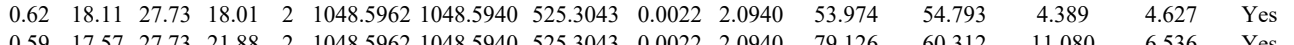

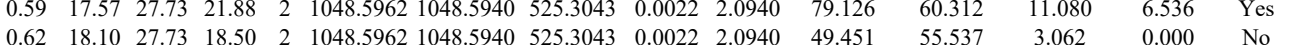

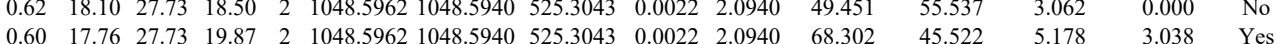

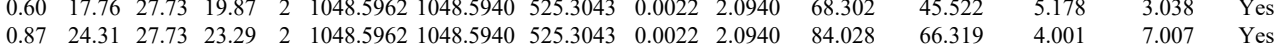

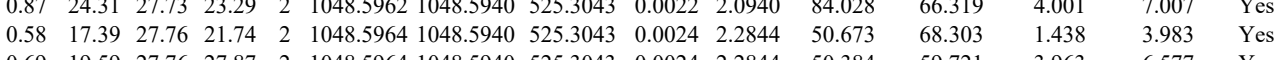

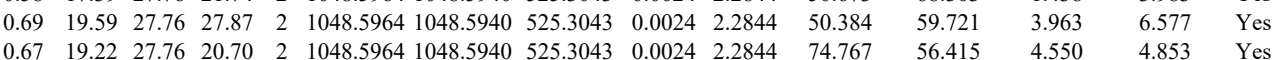

Table S-3 page 358 of 499 


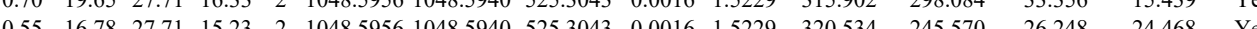

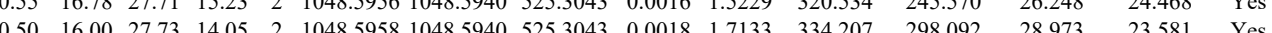

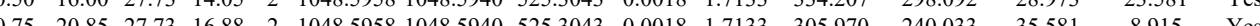
$\begin{array}{lllllllllllllll}0.78 & 21.56 & 27.73 & 17.05 & 2 & 1048.5960 & 1048.5940 & 525.3043 & 0.0020 & 1.9037 & 321.906 & 299.132 & 25.594 & 15.419 & \text { Yes }\end{array}$

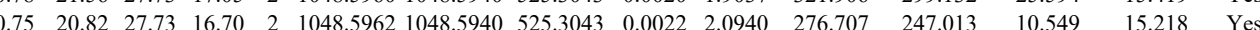
$\begin{array}{lllllllllllllll}0.59 & 19.38 & 27.59 & 22.11 & 2 & 1048.5966 & 1048.5940 & 525.3043 & 0.0026 & 2.4748 & 305.007 & 273.946 & 29.376 & 7.760 & \text { Yes }\end{array}$ $\begin{array}{lllllllllllllll}0.87 & 26.63 & 28.29 & 31.30 & 2 & 1048.5968 & 1048.5940 & 525.3043 & 0.0028 & 2.6651 & 2142.547 & 1881.947 & 39.524 & 31.986 & \text { Yes }\end{array}$

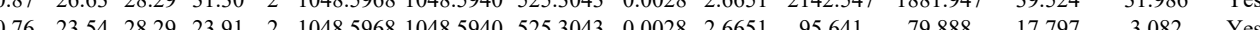
$\begin{array}{llllllllllllllll}0.52 & 23.75 & 27.44 & 19.19 & 2 & 1048.5932 & 1048.5940 & 525.3043 & -0.0008 & -0.7615 & 23651.166 & 70102.779 & 946.565 & 46.027 & \text { Yes }\end{array}$

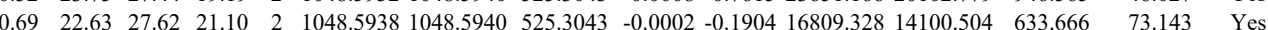
$\begin{array}{lllllllllllllll}0.52 & 19.60 & 27.62 & 17.73 & 2 & 1048.5942 & 1048.5940 & 525.3043 & 0.0002 & 0.1904 & 115.924 & 90.662 & 22.873 & 11.028 & \text { Yes }\end{array}$

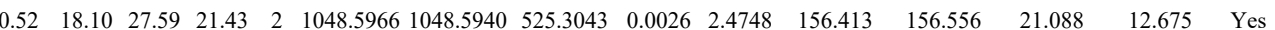
$\begin{array}{llllllllllllllll}0.62 & 22.42 & 19.24 & 18.02 & 3 & 1294.8130 & 1294.8117 & 432.6112 & 0.0013 & 1.0017 & 13556.894 & 14523.555 & 757.248 & 273.363 & \text { Yes }\end{array}$ $\begin{array}{llllllllllllllll}0.84 & 26.48 & 27.62 & 20.80 & 2 & 1048.5940 & 1048.5940 & 525.3043 & 0.0000 & 0.0000 & 2710.972 & 2379.894 & 199.845 & 92.137 & \text { Yes }\end{array}$ $\begin{array}{lllllllllllllll}0.84 & 26.33 & 27.62 & 21.60 & 2 & 1048.5944 & 1048.5940 & 525.3043 & 0.0004 & 0.3807 & 2500.083 & 2322.268 & 139.805 & 101.503 & \text { Yes }\end{array}$

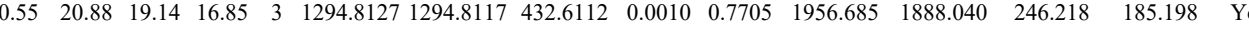

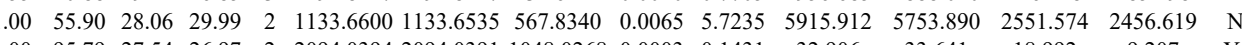

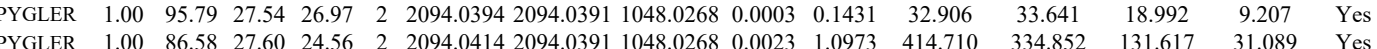
\begin{tabular}{llllllllllllllll} 
& 27.57 & 2 & 2094.0414 & 2094.0391 & 1048.0268 & 0.0023 & 1.0973 & 414.710 & 334.852 & 131.617 & 31.089 & Yes \\
\hline EIGEGENLDLPYGLER & 1.00 & 90.42 & 27.60 & 24.74 & 2 & 2094.0414 & 2094.0391 & 1048.0268 & 0.0023 & 1.0973 & 360.935 & 251.146 & 68.819 & 30.709 & Yes
\end{tabular}

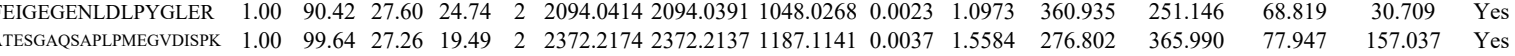

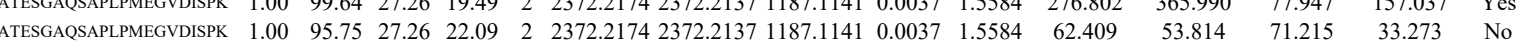
$\begin{array}{llllllllllllllll}\text { VFVHYTGWLLDGTK } & 1.00 & 34.91 & 26.81 & 16.11 & 3 & 1923.0550 & 1923.0498 & 642.0239 & 0.0052 & 2.6998 & 6816.468 & 6374.463 & 4288.082 & 3669.555 & \text { Yes }\end{array}$ $\begin{array}{llllllllllllllll}\text { VFVHYTGWLLDGTK } & 1.00 & 38.79 & 26.85 & 16.91 & 3 & 1923.0553 & 1923.0498 & 642.0239 & 0.0055 & 2.8555 & 6628.453 & 5791.177 & 4828.828 & 4496.850 & \text { Yes }\end{array}$

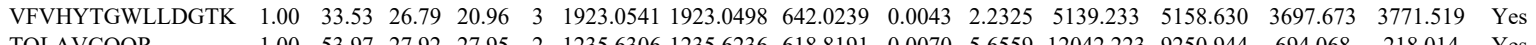
$\begin{array}{llllllllllllllll}\text { TQLAVCQQR } & 1.00 & 53.97 & 27.92 & 27.95 & 2 & 1235.6306 & 1235.6236 & 618.8191 & 0.0070 & 5.6559 & 12042.223 & 9250.944 & 694.068 & 218.014 & \text { Yes } \\ \text { TQLAVCQQR } & 1.00 & 55.62 & 27.94 & 29.71 & 2 & 1235.6310 & 1235.6236 & 618.8191 & 0.0074 & 5.9791 & 9447.497 & 7865.693 & 241.312 & 181.351 & \text { Yes }\end{array}$

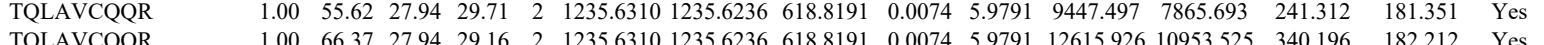

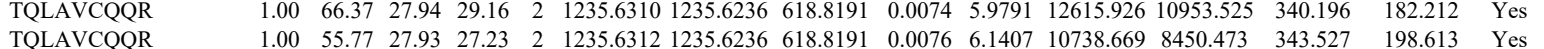

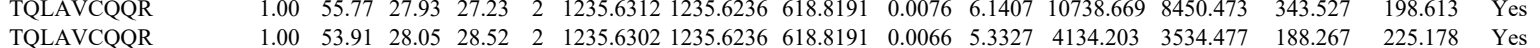
$\begin{array}{lllllllllllllll} & \end{array}$

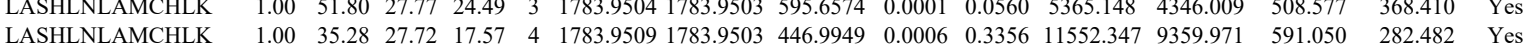
$\begin{array}{lllllllllllllllll} & \end{array}$

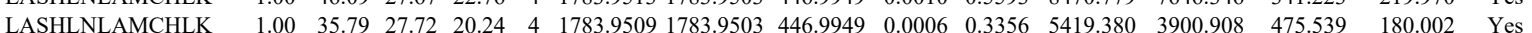
$\begin{array}{llllllllllllllll} & \\ \text { LASHLNLAMCHLK } & 1.00 & 35.79 & 27.72 & 20.24 & 4 & 1783.9509 & 1783.9503 & 446.9949 & 0.0006 & 0.3356 & 5419.380 & 3900.908 & 475.539 & 180.002 & \text { Yes } \\ \text { LASHLNLAM } & 1.00 & 38.67 & 17.65 & 4 & 1783.9513 & 1783.9503 & 446.9949 & 0.0010 & 0.5593 & 3951.848 & 3229.841 & 331.551 & 45.973 & \text { Yes }\end{array}$

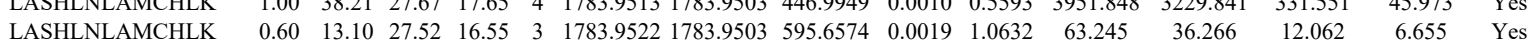

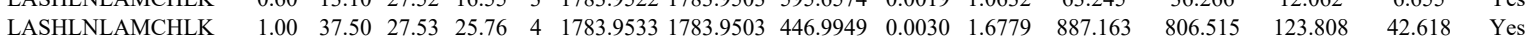

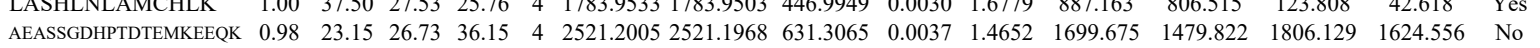

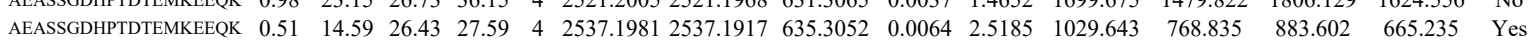
$\begin{array}{llllllllllllllll}\text { AEASSGDHPTDTEMKEEOK } & 0.99 & 25.22 & 26.79 & 38.22 & 4 & 2521.2029 & 2521.1968 & 631.3065 & 0.0061 & 2.4156 & 9923.190 & 7519.575 & 6435.696 & 4748.884 & \text { Yes }\end{array}$

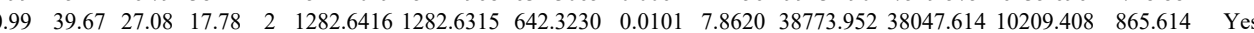
$\begin{array}{lllllllllllllll}0.99 & 42.35 & 27.03 & 19.52 & 2 & 1282.6422 & 1282.6315 & 642.3230 & 0.0107 & 8.3291 & 31947.949 & 36589.363 & 9640.161 & 942.532 & \text { Yes }\end{array}$

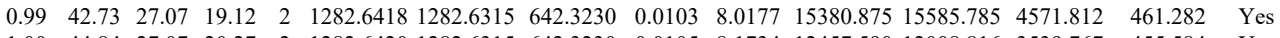
$\begin{array}{llllllllllllllll}1.00 & 44.84 & 27.07 & 20.27 & 2 & 1282.6420 & 1282.6315 & 642.3230 & 0.0105 & 8.1734 & 12457.590 & 12008.816 & 3539.767 & 455.584 & \text { Yes }\end{array}$ $\begin{array}{llllllllllllllll}1.00 & 59.43 & 24.15 & 43.24 & 2 & 1257.7624 & 1257.7536 & 629.8841 & 0.0088 & 6.9854 & 9722.113 & 10011.174 & 4929.454 & 1777.381 & \text { Yes }\end{array}$ $\begin{array}{llllllllllllllll}0.98 & 46.76 & 24.27 & 42.75 & 2 & 1257.7638 & 1257.7536 & 629.8841 & 0.0102 & 8.0967 & 15281.580 & 15587.730 & 5976.122 & 1907.048 & \text { Yes }\end{array}$ $\begin{array}{llllllllllllllll}0.97 & 44.67 & 24.12 & 42.54 & 2 & 1257.7634 & 1257.7536 & 629.8841 & 0.0098 & 7.7791 & 16182.131 & 15010.696 & 6690.749 & 1747.534 & \text { Yes }\end{array}$ $\begin{array}{lllllllllllllll}0.98 & 46.80 & 24.46 & 42.78 & 2 & 1257.7646 & 1257.7536 & 629.8841 & 0.0110 & 8.7317 & 22306.439 & 20220.473 & 7482.055 & 2292.814 & \text { Yes }\end{array}$ $\begin{array}{lllllllllllllllll}0.97 & 44.31 & 24.46 & 42.37 & 2 & 1257.7646 & 1257.7536 & 629.8841 & 0.0110 & 8.7317 & 10039.306 & 11256.089 & 5095.182 & 1652.718 & \text { Yes }\end{array}$ $\begin{array}{llllllllllllllll}1.00 & 67.74 & 17.56 & 17.74 & 2 & 1716.0670 & 1716.0511 & 859.0328 & 0.0159 & 9.2545 & 3761.760 & 3674.810 & 752.197 & 39.982 & \text { Yes }\end{array}$ $\begin{array}{llllllllllllllll}1.00 & 39.29 & 17.48 & 19.91 & 3 & 1716.0676 & 1716.0511 & 573.0243 & 0.0165 & 9.5981 & 48770.571 & 48324.533 & 8676.994 & 376.254 & \text { Yes }\end{array}$

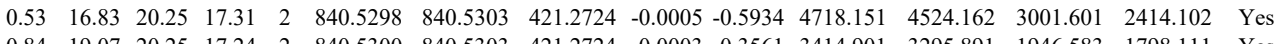
$\begin{array}{llllllllllllllll}0.84 & 19.07 & 20.25 & 17.24 & 2 & 840.5300 & 840.5303 & 421.2724 & -0.0003 & -0.3561 & 3414.901 & 3295.891 & 1946.583 & 1798.111 & \text { Yes } \\ 1.00 & 53.83 & 23.10 & 20.57 & 2 & 1153.7044 & 1153.6951 & 577.8548 & 0.0093 & 8.0469 & 47468.732 & 43677.393 & 26694.981 & 9797.742 & \text { Yes }\end{array}$ $\begin{array}{llllllllllllllll}1.00 & 53.83 & 23.10 & 20.57 & 2 & 1153.7044 & 1153.6951 & 577.8548 & 0.0093 & 8.0469 & 47468.732 & 43677.393 & 26694.981 & 9797.742 & \text { Yes } \\ 1.00 & 49.04 & 23.10 & 19.06 & 2 & 1153.7042 & 1153.6951 & 577.8548 & 0.0091 & 7.8739 & 99923.855 & 89129.894 & 57271.046 & 23508.790 & \text { Yes }\end{array}$

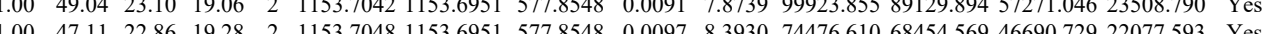
$\begin{array}{lllllllllllllll}1.00 & 47.11 & 22.86 & 19.28 & 2 & 1153.1048 & 1153.6951 & 577.8548 & 0.0097 & 8.390 & 7476.610 & 68454.569 & 46690.729 & 22077.593 & \text { Yes }\end{array}$

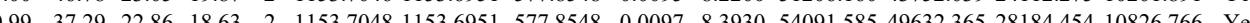

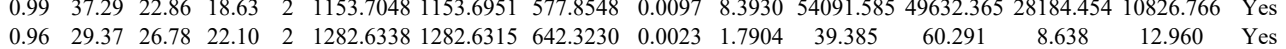



$\left.\begin{array}{lllllllllllllll}0.85 & 20.34 & 26.52 & 20.05 & 3 & 1285.7497 & 1285.7499 & 429.5906 & -0.0002 & -0.1552 & 193.534 & 198.848 & 163.179 & 78.914 \\ 0.95 & 23.08 & 26.67 & 18.08 & 3 & 1285.7506 & 1285.7499 & 229.5906 & 0.0007 & 0.5432 & 172.678 & 226.414 & 189.208 & 111.632\end{array}\right)$

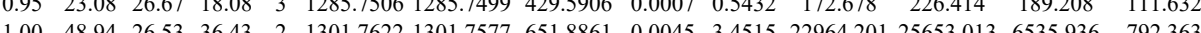
$\left.\begin{array}{llllllllllllll}.09 & 4.94 & 26.53 & 36.43 & 2 & 1301.7622 & 1301.7577 & 651.8861 & 0.0045 & 3.4515 & 22964.201 & 25653.013 & 6535.936 & 792.363\end{array}\right)$

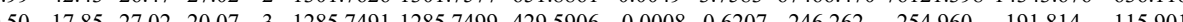

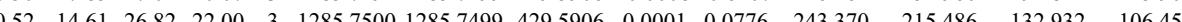

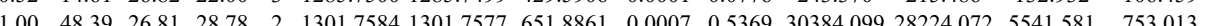
$\begin{array}{lllllllllllllll}0.99 & 30.86 & 26.69 & 19.26 & 3 & 1301.7589 & 1301.7577 & 434.9265 & 0.0012 & 0.9197 & 251.525 & 221.353 & 188.413 & 122.240 & \text { Yes }\end{array}$

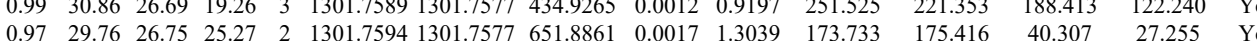
$\begin{array}{lllllllllllllll}1.00 & 47.62 & 26.75 & 27.09 & 2 & 1301.7594 & 1301.7577 & 651.8861 & 0.0017 & 1.3039 & 54257.831 & 53326.289 & 10015.420 & 705.637 & \text { Yes }\end{array}$

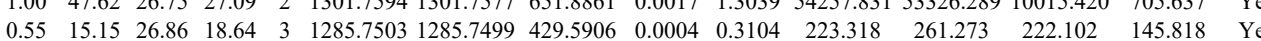

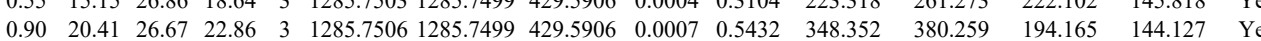
$\begin{array}{llllllllllllllll}1.00 & 50.62 & 26.81 & 25.84 & 2 & 1301.7584 & 1301.7577 & 651.8861 & 0.0007 & 0.5369 & 24437.883 & 26233.757 & 3413.041 & 571.935 & \text { Yes }\end{array}$ $\begin{array}{lllllllllllllll}1.00 & 46.17 & 26.69 & 23.02 & 2 & 1301.7590 & 1301.7577 & 651.8861 & 0.0013 & 0.9971 & 34817.645 & 32669.164 & 5262.335 & 448.453 & \text { Yes }\end{array}$ $\begin{array}{lllllllllllllll}0.94 & 21.24 & 26.75 & 21.21 & 3 & 1285.7515 & 1285.7499 & 429.5906 & 0.0016 & 1.2415 & 643.681 & 483.029 & 278.962 & 195.358 & \text { Yes }\end{array}$

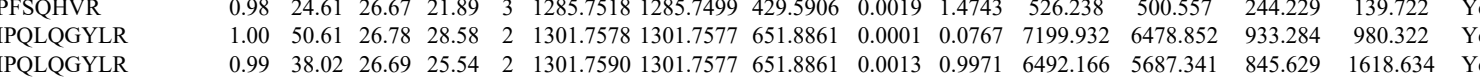
QLASGLLLVTGPLVLNR

KPFSQHVR

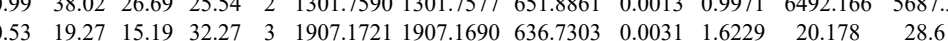

\section{KPFSQHVR} $\begin{array}{llllllllllllll}0.84 & 18.53 & 26.76 & 20.61 & 3 & 1285.7512 & 1285.7499 & 429.5906 & 0.0013 & 1.0087 & 447.606 & 335.186\end{array}$

QLASGLLLVTGPLVLNR

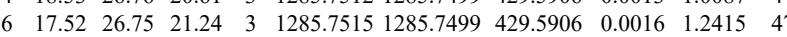

$\begin{array}{llllllllllll} & \end{array}$

$\begin{array}{lllllllllllllll} & \end{array}$ $\begin{array}{llllllllllllll}\text { QLASGLLLVTGPLVLNR } & 0.55 & 27.58 & 15.80 & 40.58 & 3 & 1907.1709 & 1907.1690 & 636.7303 & 0.0019 & 0.9947 & 34.972 & 35.645\end{array}$

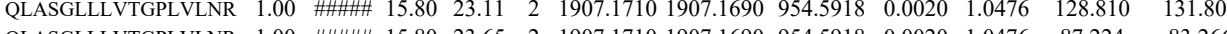

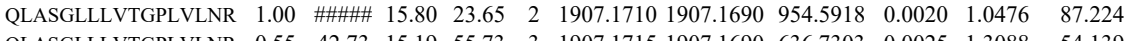
$\begin{array}{llllllllllll}\text { QLASGLLLVTGPLVLNR } & 0.55 & 42.73 & 15.19 & 55.73 & 3 & 1907.1715 & 1907.1690 & 636.7303 & 0.0025 & 1.3088 & 54.139\end{array}$

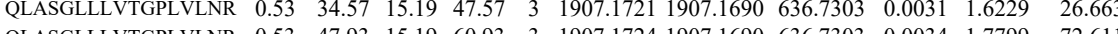
$\begin{array}{lllllllllllll} & \end{array}$ $\begin{array}{lllllllllllll}\text { ASITPGTILIILTGR } & 0.77 & 89.03 & 17.92 & \text { \#\#\# } & 2 & 1669.0276 & 1669.0260 & 835.5203 & 0.0016 & 0.9575 & 51.442 \\ \text { ASITPGTILILTGR } & 1.00 & 54.28 & 17.92 & 17.58 & 3 & 1669.0279 & 1669.0260 & 557.3493 & 0.0019 & 1.1363 & 13.388\end{array}$

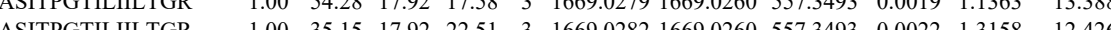

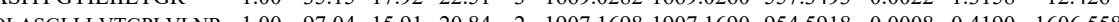

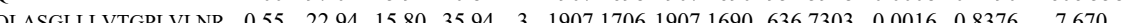
$\begin{array}{llllllllllllll} & 0.53\end{array}$

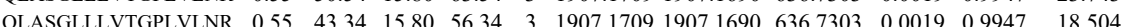
$\begin{array}{lllllllllllll}\text { QLASGLLLVTGPLVLNR } & 0.55 & 20.83 & 15.80 & 33.83 & 3 & 1907.1712 & 1907.1690 & 636.7303 & 0.0022 & 1.1517 & 25.777\end{array}$ $\begin{array}{lllllllllllll}\text { QLASGLLLVTGPLVLNR } & 0.55 & 25.81 & 15.80 & 38.81 & 3 & 1907.1712 & 1907.1690 & 636.7303 & 0.0022 & 1.1517 & 15.407\end{array}$ $\begin{array}{llllllllllll}\text { QLASGLLLVTGPLVLNR } & 0.55 & 26.30 & 15.80 & 39.30 & 3 & 1907.1712 & 1907.1690 & 636.7303 & 0.0022 & 1.1517 & 2.617\end{array}$ $\begin{array}{llllllllllll}\text { QLASGLLLVTGPLVLNR } & 1.00 & 98.42 & 15.19 & 23.23 & 2 & 1907.1714 & 1907.1690 & 954.5918 & 0.0024 & 1.2571 & 3164.976\end{array}$ $\begin{array}{lllllllllllll}\text { QLASGLLLVTGPLVLNR } & 0.55 & 23.36 & 15.19 & 36.36 & 3 & 1907.1715 & 1907.1690 & 636.7303 & 0.0025 & 1.3088 & 9.335\end{array}$ $\begin{array}{llllllllllll}\text { QLASGLLLVTGPLVLNR } & 0.53 & 73.99 & 15.19 & 86.99 & 3 & 1907.1718 & 1907.1690 & 636.7303 & 0.0028 & 1.4658 & 50.333\end{array}$ $\begin{array}{lllllllllllll}\text { QLASGLLLVTGPLVLNR } & 0.53 & 49.91 & 15.19 & 62.91 & 3 & 1907.1718 & 1907.1690 & 636.7303 & 0.0028 & 1.4658 & 19.065\end{array}$ $\begin{array}{lllllllllllll}\text { QLASGLLLVTGPLVLNR } & 0.53 & 32.74 & 15.19 & 45.74 & 3 & 1907.1718 & 1907.1690 & 636.7303 & 0.0028 & 1.4658 & 15.568\end{array}$ $\begin{array}{llllllllllllll}\text { QLASGLLLVTGPLVLNR } & 0.53 & 32.46 & 15.19 & 45.46 & 3 & 1907.1721 & 1907.1690 & 636.7303 & 0.0031 & 1.6229 & 26.460\end{array}$ $\begin{array}{llllllllllllll}\text { QLASGLLLVTGPLVLNR } & 1.00 & \text { \# } & 15.80 & 21.98 & 2 & 1907.1704 & 1907.1690 & 954.5918 & 0.0014 & 0.7333 & 68.987\end{array}$ $\begin{array}{llllllllllllll}\text { QLASGLLLVTGPLVLNR } & 0.55 & 52.75 & 15.80 & 65.75 & 3 & 1907.1709 & 1907.1690 & 636.7303 & 0.0019 & 0.9947 & 17.180\end{array}$ $\begin{array}{llllllllllllll}\text { QLASGLLLVTGPLVLNR } & 1.00 & \text { \#冊册 } 15.80 & 22.96 & 2 & 1907.1710 & 1907.1690 & 954.5918 & 0.0020 & 1.0476 & 70.694\end{array}$ $\begin{array}{lllllllllllll}\text { QLASGLLLVTGPLVLNR } & 1.00 & 54.89 & 15.19 & 20.64 & 3 & 1907.1715 & 1907.1690 & 636.7303 & 0.0025 & 1.3088 & 14.489\end{array}$ HQEGEIFDTEK ASITPGTILIILTGR ASITPGTILIILTGR ASITPGTILIILTGR $\begin{array}{llllllllllll}0.98 & 34.09 & 28.01 & 20.64 & 3 & 1619.8108 & 1619.8035 & 540.9418 & 0.0073 & 4.4983 & 1441.641 \\ 0.76 & 76.23 & 17.92 & 89.23 & 2 & 1669.0272 & 1669.0260 & 835.5203 & 0.0012 & 0.7181 & 45.869\end{array}$ ASITPGTILIILTGR

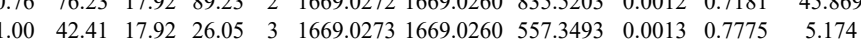
$\begin{array}{ccccccccccc}1.00 & 42.41 & 17.92 & 26.05 & 3 & 1669.0273 & 1669.0260 & 557.3493 & 0.0013 & 0.7775 & 5.174 \\ 0.76 & 94.82 & 17.92 & \# \# \# & 2 & 1669.0274 & 1669.0260 & 835.5203 & 0.0014 & 0.8378 & 129.397\end{array}$ $\begin{array}{lllllllllll}1.00 & 62.93 & 17.92 & 18.44 & 3 & 1669.0279 & 1669.0260 & 557.3493 & 0.0019 & 1.1363 & 7.149\end{array}$ $\begin{array}{lllllllllll}\text { QLASGLLLVTGPLVLNR } & 1.00 & \text { \#\#\#\# } 15.80 & 20.78 & 2 & 1907.1700 & 1907.1690 & 954.5918 & 0.0010 & 0.5238 & 51.656\end{array}$

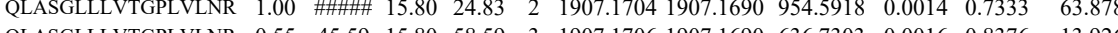

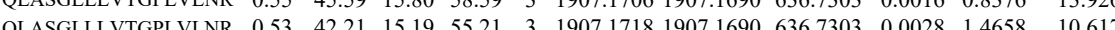

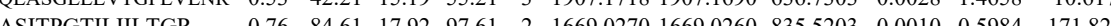
$\begin{array}{llllllllllll}\text { ASITPGTILIILTGR } & 0.76 & 85.73 & 17.92 & 98.73 & 2 & 1669.0272 & 1669.0260 & 835.5203 & 0.0012 & 0.7181 & 382.347\end{array}$ 


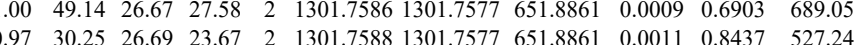

$\begin{array}{lllllllll} & & \end{array}$ $\begin{array}{lllllllllll}1.00 & 49.45 & 17.92 & 20.26 & 3 & 1669.0282 & 1669.0260 & 557.3493 & 0.0022 & 1.3158 & 3.051\end{array}$ $\begin{array}{llllllllllll}\text { QLASGLLLVTGPLVLNR } & 1.00 & \text { \#\#\#\# } 15.91 & 23.95 & 2 & 1907.1694 & 1907.1690 & 954.5918 & 0.0004 & 0.2095 & 41.485\end{array}$ $\begin{array}{lllllllllllll}\text { QLASGLLLVTGPLVLNR } & 1.00 & \text { 15.91 } & 21.47 & 2 & 1907.1698 & 1907.1690 & 954.5918 & 0.0008 & 0.4190 & 52.423\end{array}$ $\begin{array}{llllllllllll}\text { QLASGLLLVTGPLVLNR } & 0.55 & 52.87 & 15.80 & 65.87 & 3 & 1907.1706 & 1907.1690 & 636.7303 & 0.0016 & 0.8376 & 23.422\end{array}$ $\begin{array}{llllllllllllll}\text { QLASGLLLVTGPLVLNR } & 0.55 & 56.61 & 15.80 & 69.61 & 3 & 1907.1706 & 1907.1690 & 636.7303 & 0.0016 & 0.8376 & 27.962\end{array}$ $\begin{array}{llllllllllll}\text { ASITPGTILIILTGR } & 0.61 & 71.22 & 17.92 & 84.22 & 2 & 1669.0260 & 1669.0260 & 835.5203 & 0.0000 & 0.0000 & 15.778 \\ \text { ASITPGTILILLTGR } & 1.00 & 61.09 & 17.92 & 29.41 & 3 & 1669.0264 & 1669.0260 & 557.3493 & 0.0004 & 0.2392 & 0.000\end{array}$ $\begin{array}{llllllllllll}\text { ASITPGTILIILTGR } & 0.55 & 22.13 & 17.92 & 35.13 & 3 & 1669.0279 & 1669.0260 & 557.3493 & 0.0019 & 1.1363 & 0.000 \\ \text { QLASGLLVVTGPLVLNR } & 0.55 & 14.85 & 15.80 & 27.85 & 3 & 1907.1706 & 1907.1690 & 636.7303 & 0.0016 & 0.8376 & 11.465\end{array}$ $\begin{array}{lllllllllllll}\text { QLASGLLLVTGPLVLNR } & 0.55 & 14.85 & 15.80 & 27.85 & 3 & 1907.1706 & 1907.1690 & 636.7303 & 0.0016 & 0.8376 & 11.465\end{array}$ AIPQLQGYLR $\begin{array}{llllllllllll}0.89 & 27.33 & 26.81 & 23.05 & 2 & 1301.7580 & 1301.7577 & 651.8861 & 0.0003 & 0.2301 & 180.468\end{array}$ $\begin{array}{lllllllllllll}\text { ASITPGTILIILTGR } & 0.76 & 89.66 & 17.92 & \# \# \# & 2 & 1669.0270 & 1669.0260 & 835.5203 & 0.0010 & 0.5984 & 86.807 \\ \text { ASITPGTILIILTGR } & 1.00 & 38.64 & 17.92 & 23.35 & 3 & 1669.0273 & 1669.0260 & 557.3493 & 0.0013 & 0.7775 & 23.842\end{array}$ $\begin{array}{llllllllllll}\text { ASTPGTILILTGR } & 1.00 & 38.64 & 17.92 & 23.35 & 3 & 1669.0273 & 1669.0260 & 557.3493 & 0.0013 & 0.7775 & 23.842 \\ \text { ASITPGTILIILTGR } & 0.77 & 81.89 & 17.92 & 94.89 & 2 & 1669.0280 & 1669.0260 & 835.5203 & 0.0020 & 1.1969 & 50.539\end{array}$ $\begin{array}{lllllllllllll}\text { QLASGLLLVTGPLVLNR } & 0.55 & 26.90 & 15.80 & 39.90 & 3 & 1907.1706 & 1907.1690 & 636.7303 & 0.0016 & 0.8376 & 51.579\end{array}$ $\begin{array}{llllllllll} & 0.837\end{array}$

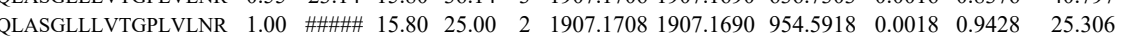
$\begin{array}{llllllllllllll}\text { ASITPGTILIILTGR } & 0.61 & 66.59 & 17.92 & 79.59 & 2 & 1669.0260 & 1669.0260 & 835.5203 & 0.0000 & 0.0000 & 37.666\end{array}$ $\begin{array}{lllllllllllll}\text { ASITPGTILIILTGR } & 0.76 & 64.88 & 17.92 & 77.88 & 2 & 1669.0266 & 1669.0260 & 835.5203 & 0.0006 & 0.3591 & 39.133\end{array}$

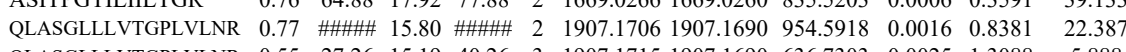
$\begin{array}{llllllllllll}\text { QLASGLLLVTGPLVLNR } & 0.55 & 27.26 & 15.19 & 40.26 & 3 & 1907.1715 & 1907.1690 & 636.7303 & 0.0025 & 1.3088 & 5.888\end{array}$ $\begin{array}{lllllllllllll}\text { QLASGLLLVTGPLVLNR } & 0.55 & 42.69 & 15.19 & 55.69 & 3 & 1907.1715 & 1907.1690 & 636.7303 & 0.0025 & 1.3088 & 9.221\end{array}$ $\begin{array}{lllllllllllll}\text { ASITPGTILIILTGR } & 1.00 & 49.20 & 17.92 & 22.58 & 3 & 1669.0270 & 1669.0260 & 557.3493 & 0.0010 & 0.5981 & 5.927\end{array}$ $\begin{array}{llllllllllll}\text { ASITPGTILIILTGR } & 0.76 & 71.76 & 17.92 & 84.76 & 2 & 1669.0274 & 1669.0260 & 835.5203 & 0.0014 & 0.8378 & 33.180\end{array}$ \begin{tabular}{llllllllllll} 
ASITPGTILIILTGR & 1.00 & 40.91 & 17.92 & 15.69 & 3 & 1669.0279 & 1669.0260 & 557.3493 & 0.0019 & 1.1363 & 3.594 \\
\hline
\end{tabular}

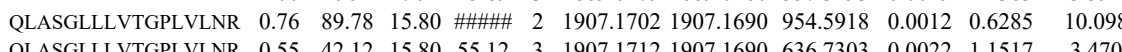
$\begin{array}{llllllllllll}\text { QLASGLLLVTGPLVLNR } & 0.55 & 42.12 & 15.80 & 55.12 & 3 & 1907.1712 & 1907.1690 & 636.7303 & 0.0022 & 1.1517 & 3.470\end{array}$

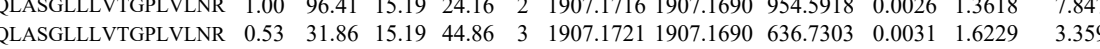
$\begin{array}{llllllllllll}\text { YYPTEDVPR } & 0.99 & 41.19 & 27.05 & 20.12 & 2 & 1282.6428 & 1282.6315 & 642.3230 & 0.0113 & 8.7961 & 7427.441\end{array}$

$\begin{array}{lllllllllllll}1.00 & 54.38 & 27.01 & 67.38 & 4 & 2328.1253 & 2328.1216 & 583.0377 & 0.0037 & 1.5865 & 7450.426 & 8427.935 & 1677.667 \\ 0.58 & 25.4273 & 2328.1216 & 583.0377 & 0.0057 & 2.4441 & 6342.880 & 8898.567 & 1922.630\end{array}$ 


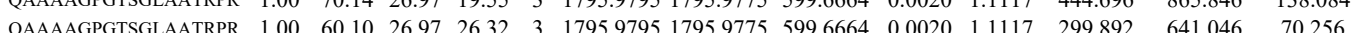

$\begin{array}{llllllllllllllll}\text { QAAAAGGPGTSGLAATRPR } & 1.00 & 65.86 & 27.13 & 19.34 & 3 & 1795.9780 & 1795.9775 & 599.6664 & 0.0005 & 0.2779 & 346.268 & 562.534 & 105.030\end{array}$ $\begin{array}{llllllllllll}\text { DVMQQQLAEPELLDVK } & 0.53 & 49.41 & 26.98 & 62.41 & 3 & 2337.2164 & 2337.2130 & 780.0783 & 0.0034 & 1.4528 & 13.952\end{array}$ $\begin{array}{lllllllllllll}\text { DVMQQQLAEYQELLDVK } & 1.00 & 53.93 & 26.99 & 19.62 & 3 & 2337.2167 & 2337.2130 & 780.0783 & 0.0037 & 1.5810 & 68.26\end{array}$ ATSSSSGSLSATGR ATSSSSGSLSATGR ATSSSSGSLSATGR ATSSSSGSLSATGR ATSSSSGSLSATGR ATSSSSGSLSATGR ATSSSSGSLSATGR ATSSSSGSLSATGR AGGPATPLSPTR AGGPATPLSPTR

ATSSSSGSLSATGR ATSSSSGSLSATGR ATSSSSGSLSATGR GLESDVAELR

$\begin{array}{lllllllllll}\text { CEBPZ_HUMAI } & \text { Q03701 } & \text { CEBPZ } & \text { CCAAT/enhancer } 120.99 & 1.00 & 2 & 3.1 & -0.1769 & 0.1208 & -1.4301 & 3.5934\end{array}$ GAIDDLQQGELEAFIQNL MLSALLTGVNR $\begin{array}{lllllllllll}1.00 & 82.52 & 27.11 & 25.93 & 2 & 1411.7032 & 1411.7025 & 706.8585 & 0.0007 & 0.4851 & 50.127\end{array}$ $\begin{array}{lllllllllll}1.00 & 85.01 & 27.23 & 28.92 & 2 & 1411.7038 & 1411.7025 & 706.8585 & 0.0013 & 0.9196 & 15.208\end{array}$

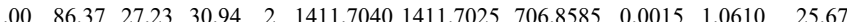
$\begin{array}{llllllllllll}1.00 & 79.08 & 27.11 & 26.73 & 2 & 1411.7032 & 1411.7025 & 706.8585 & 0.0007 & 0.4951 & 6.576\end{array}$ $\begin{array}{lllllllllll}1.00 & 69.67 & 27.11 & 31.82 & 2 & 1411.7032 & 1411.7025 & 706.8585 & 0.0007 & 0.4951 & 8.209\end{array}$

$\begin{array}{lllllllllll} & \end{array}$

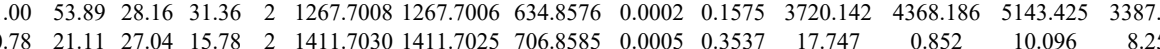

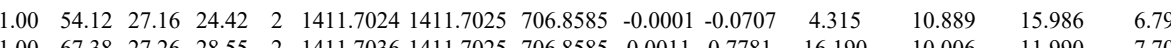

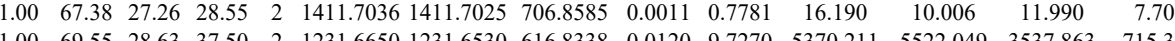

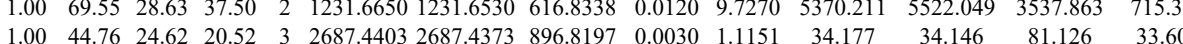
$\begin{array}{llllllllllllll}1.00 & 44.76 & 24.62 & 20.52 & 3 & 2687.4403 & 2687.4373 & 896.8197 & 0.0030 & 1.1151 & 34.177 & 34.146 & 81.126 & 33.605 \\ 1.00 & 53.53 & 27.49 & 24.78 & 2 & 1317.7566 & 1317.7560 & 659.8853 & 0.0006 & 0.4546 & 4299.100 & 3663.558 & 376.343 & 69.567\end{array}$ $\begin{array}{lllllllllllllll}1.00 & 53.53 & 27.49 & 24.78 & 2 & 1317.7566 & 1317.7560 & 659.8853 & 0.0006 & 0.4546 & 4299.100 & 3663.558 & 376.343 & 69.567\end{array}$

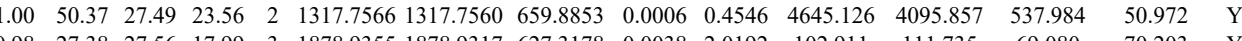

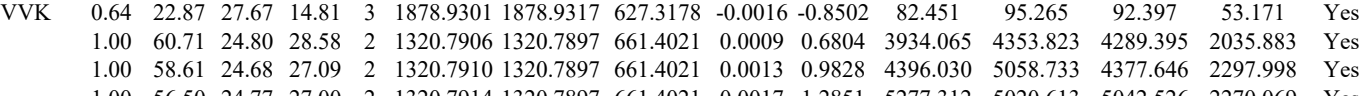
$\begin{array}{lllllllllllllllll} & \\ \text { LIFEK } & 1.00 & 56.50 & 24.77 & 27.00 & 2 & 1320.7914 & 1320.7897 & 661.4021 & 0.0017 & 1.2851 & 5277.312 & 5020.613 & 5042.526 & 2270.069 & \text { Yes } \\ & 1.00 & 58.64 & 24.77 & 27.34 & 2 & 1320.7916 & 1320.7897 & 661.4021 & 0.0019 & 1.4363 & 5913.743 & 5955.053 & 5703.794 & 2437.84 & \text { Yes }\end{array}$ $\begin{array}{lllllllllllllll} & 1.00 & 56.50 & 24.77 & 27.00 & 2 & 1320.794 & 1320.7897 & 661.4021 & 0.017 & 1.2851 & 5277.312 & 5020.613 & 5042.526 & 2270.069\end{array}$ $\begin{array}{llllllllllllllllll}\text { GLPLVDDGGWNTVPISK } & 1.00 & 68.68 & 25.93 & 27.54 & 2 & 2055.1274 & 2055.1245 & 1028.5695 & 0.0029 & 1.4097 & 445.138 & 573.522 & 398.039 & 167.128 & \text { Yes }\end{array}$ $\begin{array}{llllllllllllllll} & & & \end{array}$

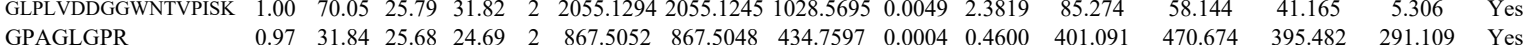

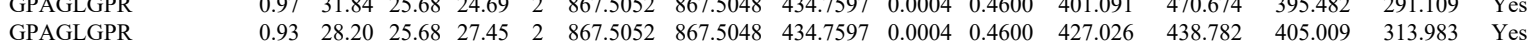
$\begin{array}{lllllllllllllllll}\text { EITKPLRPLGK } & 0.99 & 3.41 & 13.80 & 16.41 & 4 & 1683.0813 & 1683.0772 & 421.7766 & 0.0041 & 2.4302 & 26237.080 & 27011.184 & 38141.026 & 21054.178 & \text { Yes }\end{array}$

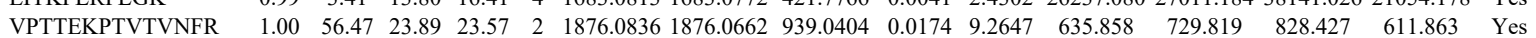
$\begin{array}{lllllllllllllllll}\text { VPTTEKPTVTVNFR } & 0.97 & 31.77 & 23.93 & 20.61 & 3 & 1876.0849 & 1876.0662 & 626.3627 & 0.0187 & 9.9515 & 7879.608 & 7245.982 & 8950.448 & 6888.010 & \text { Yes }\end{array}$

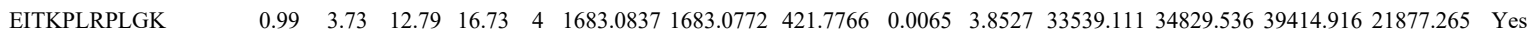

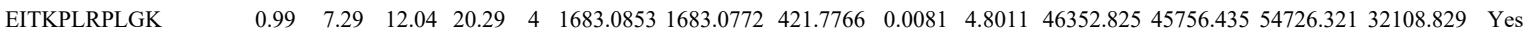
$\begin{array}{llllllllllllllll}\text { VPTTEKPTVTVNFR } & 0.97 & 29.92 & 23.94 & 16.21 & 3 & 1876.0819 & 1876.0662 & 626.3627 & 0.0157 & 8.3550 & 1019.992 & 904.089 & 1080.984 & 382.464 & \text { Yes }\end{array}$

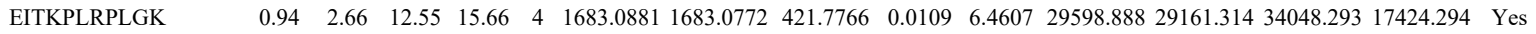
$\begin{array}{llllllllllllllll}\text { EITKPLRPLGK } & 0.92 & 4.10 & 13.42 & 17.10 & 4 & 1683.0897 & 1683.0772 & 421.7766 & 0.0125 & 7.4091 & 26542.425 & 27126.801 & 32322.179 & 18923.221 & \text { Yes }\end{array}$ $\begin{array}{llllllllllllllll}\text { ITKPGSIDSNNQLFAPGGR } & 1.00 & 57.08 & 25.80 & 19.40 & 3 & 2259.2359 & 2259.2215 & 754.0811 & 0.0144 & 6.3653 & 7210.572 & 7041.904 & 7670.216 & 4966.960 & \text { Yes }\end{array}$ $\begin{array}{lllllllllllllllll}\text { ITKPGSIDSNNQLFAPGGR } & 1.00 & 59.92 & 25.73 & 17.66 & 3 & 2259.2401 & 2259.2215 & 754.0811 & 0.0186 & 8.2219 & 3797.229 & 4905.624 & 4648.080 & 2382.865 & \text { Yes }\end{array}$ $\begin{array}{lllllllllllllllll}\text { TPLRPLDPTR } & 0.60 & 16.47 & 26.41 & 20.62 & 2 & 1308.7652 & 1308.7636 & 655.3891 & 0.0016 & 1.2206 & 2973.546 & 4709.756 & 3443.687 & 1884.349 & \text { Yes }\end{array}$ $\begin{array}{llllllllllllllll}\text { TPLRPLDPTR } & 0.51 & 10.23 & 26.07 & 14.44 & 3 & 1308.7657 & 1308.7636 & 437.2618 & 0.0021 & 1.6009 & 21244.329 & 24718.027 & 17644.122 & 11403.946 & \text { Yes }\end{array}$ $\begin{array}{llllllllllllllll}\text { CLMALK } & 0.95 & 33.51 & 26.66 & 32.12 & 2 & 1011.5620 & 1011.5523 & 506.7834 & 0.0097 & 9.5701 & 41960.560 & 34778.699 & 406.283 & 458.867 & \text { No }\end{array}$

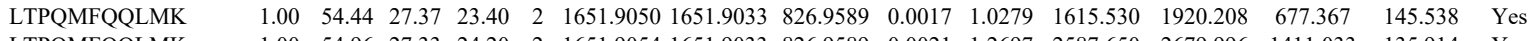
$\begin{array}{llllllllllllllll}\text { LTPQMFQQLMK } & 1.00 & 54.96 & 27.33 & 24.20 & 2 & 1651.9054 & 1651.9033 & 826.9589 & 0.0021 & 1.2697 & 2587.650 & 2679.996 & 1411.033 & 135.914 & \text { Yes }\end{array}$ $\begin{array}{llllllllllllllll}\text { LTPQMFQQLMK } & 1.00 & 32.04 & 27.28 & 23.52 & 3 & 1651.9066 & 1651.9033 & 551.6417 & 0.0033 & 1.9940 & 480.887 & 762.094 & 181.393 & 44.071 & \text { No }\end{array}$

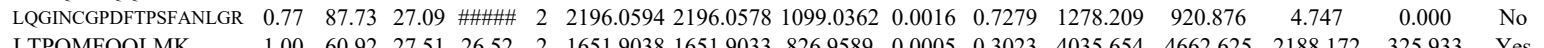

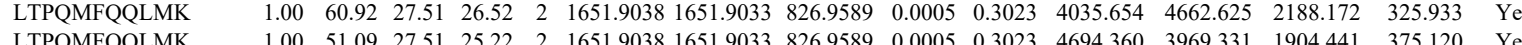
$\begin{array}{lllllllllllllll} & & & \end{array}$

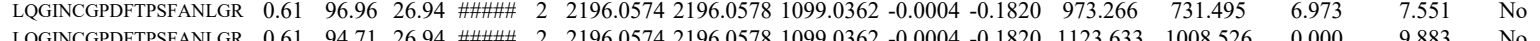

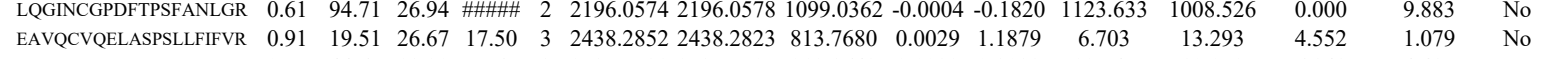

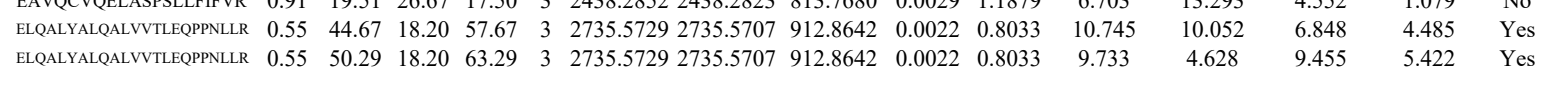




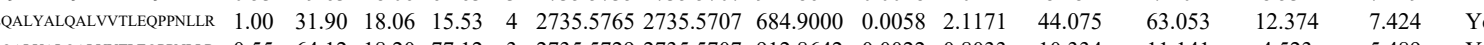
$\begin{array}{llllllllllllll} & \end{array}$ $\begin{array}{llllllllllllllll} & \end{array}$

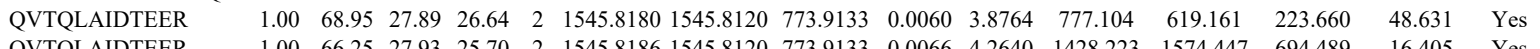

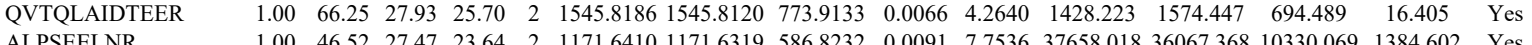

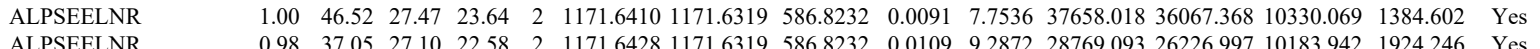
ALPSEELNR $\begin{array}{lllllllllllllll}0.98 & 37.05 & 27.10 & 22.58 & 2 & 1171.6428 & 1171.6319 & 586.8232 & 0.0109 & 9.2872 & 28769.093 & 26226.997 & 10183.942 & 1924.246 & \text { Yes }\end{array}$ $\begin{array}{llllllllllllllllll} & \end{array}$ $\begin{array}{llllllllllllllllll} & \end{array}$ QQ $\begin{array}{lllllllllllllll}0.98 & 32.48 & 28.01 & 18.77 & 3 & 1764.9409 & 1764.9362 & 589.3193 & 0.0047 & 2.6584 & 4159.900 & 3379.521 & 3929.540 & 2278.927 & Y\end{array}$

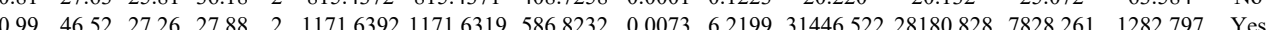

IHNAENIQPGEQK

IHNAENIQPGEQK

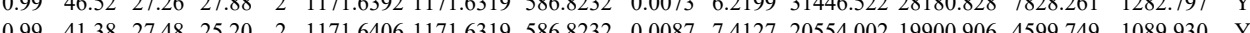
$\begin{array}{lllllllllllllll}1.00 & 3231 & 28.01 & 21.37 & 3 & 1764.9394 & 1764.9362 & 589.3193 & 0.0032 & 1.8100 & 2947.802 & 2696.083 & 2954.653 & 2451.708 & \text { Yes }\end{array}$ $\begin{array}{lllllllllllllllll}0.99 & 31.55 & 28.03 & 22.21 & 3 & 1764.9400 & 1764.9362 & 589.3193 & 0.0038 & 2.1494 & 3696.613 & 3405.867 & 3108.974 & 2025.406 & \text { Yes }\end{array}$

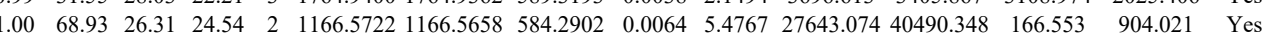
$\begin{array}{lllllllllllllll}1.00 & 71.32 & 26.45 & 21.71 & 2 & 1166.5730 & 1166.5658 & 5842902 & 0.0072 & 6.1613 & 25040.512 & 41782.903 & 704.544 & 546.981 & \text { Yes }\end{array}$ $\begin{array}{lllllllllllllll}1.00 & 56.55 & 26.19 & 22.59 & 2 & 1166.5716 & 1166.5658 & 584.2902 & 0.0058 & 4.9633 & 6576.828 & 11010.405 & 248.691 & 658.792 & \text { Yes }\end{array}$ $\begin{array}{lllllllllllllll}1.00 & 48.89 & 26.15 & 24.12 & 2 & 1166.5718 & 1166.5658 & 584.2902 & 0.0060 & 5.1344 & 14948.206 & 21363.709 & 669.299 & 1282.755 & \text { Yes }\end{array}$ $\begin{array}{lllllllllllllllll}1.00 & 66.69 & 26.12 & 21.90 & 2 & 1166.5714 & 1166.5658 & 584.2902 & 0.0056 & 4.7921 & 6222.029 & 9589.031 & 316.537 & 424.141 & \text { Yes }\end{array}$ $\begin{array}{llllllllllllllll}1.00 & 55.21 & 26.31 & 21.55 & 2 & 1166.5722 & 1166.5658 & 584.2902 & 0.0064 & 5.4767 & 6339.573 & 11019.740 & 349.091 & 310.740 & \text { Yes }\end{array}$ LSGGLGAGSC LSGGLGAGSCR LSGGLGAGSCR

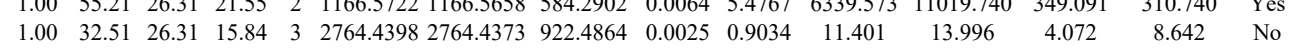

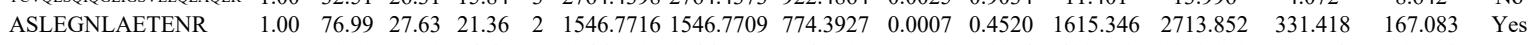
$\begin{array}{llllllllllllllll}\text { ASLEGNLAETENR } & 1.00 & 78.32 & 27.53 & 24.65 & 2 & 1546.7722 & 1546.7709 & 774.3927 & 0.0013 & 0.8394 & 482.911 & 1383.312 & 58.574 & 73.996 & \text { No }\end{array}$ $\begin{array}{llllllllllll}\text { LGUL HUMAN } & \text { Q04760 } & \text { GLO1 } & \text { Lactoylglutathion } 20.78 & 1.00 & 5 & 32.6 & 0.1608 & 0.3000 & 0.1033 & 1.5995 & 15\end{array}$

FEELGVKK $\begin{array}{llllllllllllllllll}0.98 & 38.22 & 26.66 & 27.00 & 2 & 1108.6460 & 1108.6372 & 555.3259 & 0.0088 & 7.9232 & 5376.427 & 6146.777 & 17559.845 & 10499.437 & \text { No }\end{array}$ FEELGVK $\begin{array}{lllllllllllllll}0.98 & 38.14 & 26.47 & 25.83 & 2 & 1108.6464 & 1108.6372 & 555.3259 & 0.0092 & 8.2834 & 6258.775 & 6665.085 & 20706.039 & 11439.179 & \mathrm{~N}\end{array}$ $\begin{array}{lllllllllllllllll}0.87 & 30.54 & 26.58 & 27.82 & 2 & 1108.6452 & 1108.6372 & 555.3259 & 0.0080 & 7.2029 & 3249.013 & 3916.721 & 6747.742 & 3956.870 & \text { Yes }\end{array}$ $\begin{array}{llllllllllllllll} & & & \end{array}$

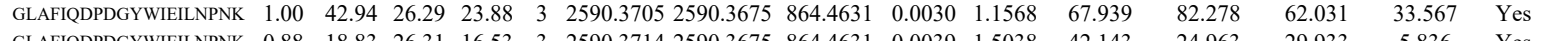

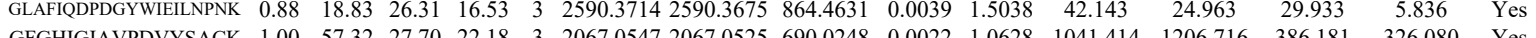

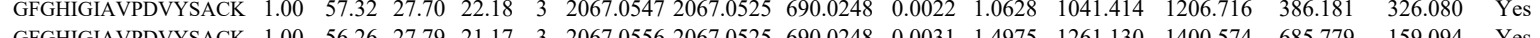
$\begin{array}{lllllllllllllllll}\text { GFGHIGIAVPDVYSACK } & 1.00 & 56.26 & 27.79 & 21.17 & 3 & 2067.0556 & 2067.0525 & 690.0248 & 0.0031 & 1.4975 & 1261.130 & 1400.574 & 685.779 & 159.094 & \text { Yes }\end{array}$ $\begin{array}{llllllllllllllll}\text { GFGHIGIAVPDVYSACK } & 1.00 & 65.32 & 27.74 & 18.52 & 3 & 2067.0565 & 2067.0525 & 690.0248 & 0.0040 & 1.9323 & 814.435 & 1269.184 & 339.280 & 259.345 & \text { Yes } \\ \text { VLGMTLQK } & 0.99 & 38.30 & 2.52 & 24.81 & 2 & 128.808 & 1289.7985 & 645.905 & 0.0095 & 7.350 & 35940.276 & 48693 & 185.684 & 119.952 & \text { Yes }\end{array}$

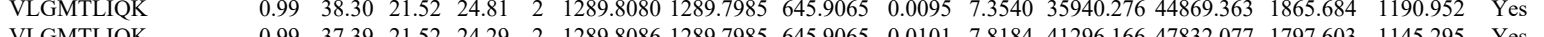

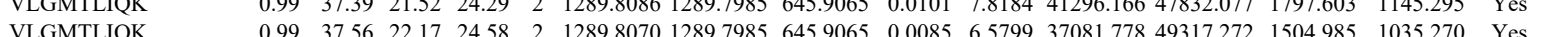

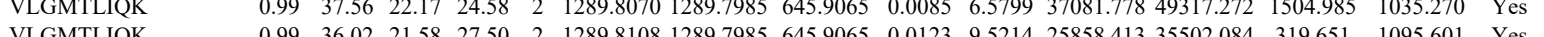
$\begin{array}{lllllllllllllllllll} & \\ \text { IAWALSR } & 0.89 & 32.70 & 27.32 & 26.51 & 2 & 959.5746 & 959.5674 & 440.7910 & 0.0072 & 7.4876 & 14208.335 & 15278.997 & 3026.842 & 1249.036 & \text { Yes }\end{array}$

IAWALSR

IAWALSR $\begin{array}{lllllllllllllll}0.89 & 32.70 & 27.32 & 26.31 & 2 & 959.5746 & 959.5674 & 480.7910 & 0.0072 & 7.4876 & 14208.335 & 15278.997 & 3026.842 & 1249.036 & \text { Yes }\end{array}$ IAWALSR
ISVFRPGLR $\begin{array}{lllllllllllllllll}0.95 & 34.79 & 27.99 & 39.72 & 2 & 959.5686 & 959.5674 & 480.7910 & 0.0012 & 1.2479 & 7858.274 & 8674.440 & 2211.387 & 822.844 & \text { Yes }\end{array}$

QVEGKNPVTIFSLATNEMWR 1.0 $\begin{array}{lllllllllllllllll}0.97 & 32.42 & 27.99 & 26.54 & 2 & 959.5688 & 959.5674 & 480.7910 & 0.0014 & 1.4559 & 11764.471 & 13107.882 & 3852.094 & 1281.584 & \text { Yes }\end{array}$

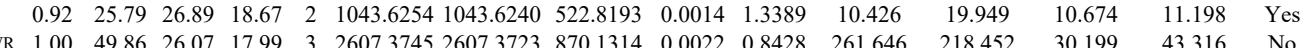
$\begin{array}{lllllllllllllllll} & \text { QVEGKNPVTIFSLATNEMWR } & 0.61 & 27.21 & 26.17 & 16.84 & 3 & 2607.3748 & 2607.3723 & 870.1314 & 0.0025 & 0.9577 & 270.031 & 233.256 & 34.714 & 68.287 & \text { No }\end{array}$ $\begin{array}{lllllllllllllllll}\text { NPVTIFSLATNEMWR } & 0.69 & 81.42 & 27.90 & 94.42 & 2 & 1921.9868 & 1921.9842 & 961.9994 & 0.0026 & 1.3514 & 322.097 & 323.059 & 72.158 & 88.056 & \text { Yes }\end{array}$ $\begin{array}{llllllllllllllll}\text { NPVTIFSLATNEMWR } & 1.00 & 51.50 & 27.84 & 24.04 & 3 & 1921.9888 & 1921.9842 & 641.6687 & 0.0046 & 2.3896 & 27.354 & 38.407 & 24.794 & 12.480 & \text { Yes }\end{array}$ $\begin{array}{llllllllllllllll}\text { NPVTIFSLATNEMWR } & 1.00 & 57.18 & 27.92 & 18.89 & 3 & 1921.9873 & 1921.9842 & 641.6687 & 0.0031 & 1.6104 & 127.416 & 180.424 & 34.663 & 9.246 & \text { Yes }\end{array}$ $\begin{array}{lllllllllllllllll}\text { VGQDPVLR } & 0.98 & 38.85 & 25.24 & 17.28 & 2 & 882.4916 & 882.4923 & 442.2534 & -0.0007 & -0.7914 & 49.234 & 89.168 & 46.528 & 47.930 & \text { Yes }\end{array}$ $\begin{array}{llllllllllllllll}\text { VGQDPVLR } & 0.99 & 39.79 & 24.98 & 23.15 & 2 & 882.4922 & 882.4923 & 442.2534 & -0.0001 & -0.1131 & 61.911 & 62.488 & 51.134 & 41.845 & \text { Yes }\end{array}$

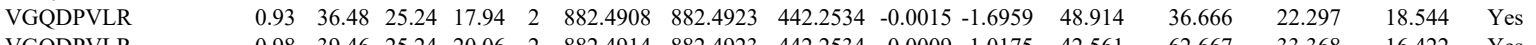
\begin{tabular}{llllllllllll} 
VGQDPVLR & 0.98 & 39.46 & 25.24 & 20.06 & 2 & 882.4914 & 882.4923 & 442.2534 & -0.0009 & -1.0175 & 42.56 \\
\hline & 0.98 & 38.87 & 25.24 & 19.18 & 2 & 882.49 & 882.423 & 42.253 & -0.000 & 0.7914 & 65.62
\end{tabular} VGQDPVLR VGQDPVLR VGQDPVLR VGQDPVLR VGQDPVLR SGDSEVYQLGDVSQK VGQDPVLR VGQDPVLR VGQDPVLR VGQDPVLR VGQDPVLR $\begin{array}{llllllllllll}0.98 & 38.87 & 25.24 & 19.18 & 2 & 882.4916 & 882.4923 & 442.2534 & -0.0007 & -0.7914 & 65.629\end{array}$ $\begin{array}{llllllllllll}0.99 & 39.04 & 25.25 & 18.71 & 2 & 882.4920 & 882.4923 & 442.2534 & -0.0003 & -0.3392 & 57.764\end{array}$ $\begin{array}{lllllllllll}0.98 & 38.82 & 25.25 & 20.49 & 2 & 882.4918 & 882.4923 & 442.2534 & -0.0005 & -0.5653 & 68.355 \\ 0.99 & 38.05 & 25.25 & 18.49 & 2 & 882.4920 & 882.4923 & 442.2534 & -0.0003 & 0.3392 & 71.142\end{array}$

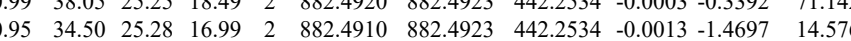
$\begin{array}{lllllllllll}0.98 & 39.45 & 25.25 & 17.17 & 2 & 882.4918 & 882.4923 & 442.2534 & -0.003 & -1.3392 & 71.142 \\ 0 & 882.4923 & 442.2534 & -0.0005 & -0.5653 & 21.133\end{array}$ $\begin{array}{llllllllllll}1.00 & 89.84 & 25.24 & 23.63 & 2 & 1610.7420 & 1610.7424 & 806.3785 & -0.0004 & -0.2480 & 4.193 \\ 0.97 & 40.74 & 25.22 & 18.59 & 2 & 882.4904 & 882.4923 & 442.2534 & -0.0019 & -2.1481 & 16.390\end{array}$ $\begin{array}{lllllllllllll}0.97 & 40.74 & 25.22 & 18.59 & 2 & 882.4904 & 882.4923 & 442.2534 & -0.0019 & -2.1481 & 16.390 \\ 0.98 & 41.74 & 25.24 & 20.69 & 2 & 882.4908 & 882.4923 & 442.2534 & -0.0015 & -1.6959 & 21.075\end{array}$ $\begin{array}{llllllllllll}0.98 & 41.74 & 25.24 & 20.69 & 2 & 882.4908 & 882.4923 & 442.2534 & -0.0015 & -1.6959 & 21.075\end{array}$ $\begin{array}{lllllllllll}0.98 & 38.41 & 25.24 & 18.20 & 2 & 882.4914 & 882.4923 & 442.2534 & -0.0009 & -1.0175 & 48.013\end{array}$ $\begin{array}{llllllllllll}0.99 & 38.74 & 24.98 & 20.89 & 2 & 882.4922 & 882.4923 & 442.2534 & 0.0001 & 0.1151 & 55.424\end{array}$

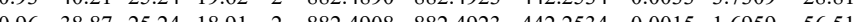

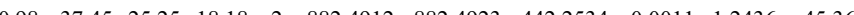

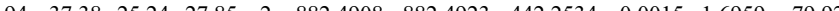
$\begin{array}{llllllllllll}0.80 & 27.24 & 25.28 & 17.68 & 2 & 882.4910 & 882.4923 & 442.2534 & -0.0013 & -1.4697 & 87.985\end{array}$ 
$\begin{array}{lllllllllll}1.00 & 46.78 & 28.42 & 19.52 & 3 & 2024.0443 & 2024.0413 & 675.6877 & 0.0030 & 1.4800 & 145.524\end{array}$

$\begin{array}{llllllllllllll}1.00 & 67.49 & 27.44 & 41.94 & 2 & 1554.8274 & 1554.8133 & 778.4139 & 0.0141 & 9.0568 & 1874.870 & 2037.063\end{array}$

$\begin{array}{llllllllllll} & \end{array}$

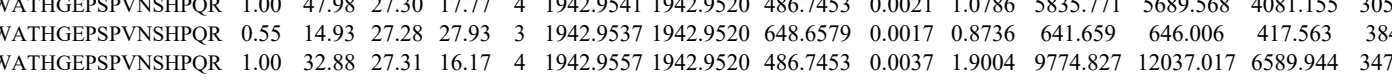

$\begin{array}{llllllllllllllllll} & \text { WATHGEPSPVNSHPQR } & 1.00 & 31.72 & 27.37 & 15.06 & 4 & 1942.9565 & 1942.9520 & 486.7453 & 0.0045 & 2.3113 & 7865.188 & 9664.519 & 6925.172 & 57777.188 & \text { Yes }\end{array}$ $\begin{array}{lllllllllllllllll} & \end{array}$ $\begin{array}{llllllllllllllll} & \end{array}$ $\begin{array}{lllllllllllllllll} & \end{array}$ $\begin{array}{llllllllllllllllll} & \end{array}$ $\begin{array}{lllllllllllllllll}1.00 & 47.18 & 27.83 & 16.84 & 3 & 1398.7573 & 1398.7490 & 467.2569 & 0.0083 & 5.9210 & 8760.987 & 13549.843 & 12246.789 & 7804.015 & \text { Yes }\end{array}$ $\begin{array}{lllllllllllllllll}1.00 & 56.13 & 27.83 & 21.77 & 3 & 1398.7573 & 1398.7490 & 467.2569 & 0.0083 & 5.9210 & 8402.504 & 12340.517 & 4112.717 & 2286.750 & \text { Yes }\end{array}$ $\begin{array}{lllllllllllllll} & & & \end{array}$ $\begin{array}{lllllllllllllllll}\text { CQNALQQVVAR } & 1.00 & 71.37 & 27.62 & 25.57 & 2 & 1418.7242 & 1418.7244 & 710.3695 & -0.0002 & -0.1408 & 20846.116 & 23661.680 & 907.711 & 119.934 & \text { Yes }\end{array}$ $\begin{array}{lllllllllllllll} & & & \end{array}$ $\begin{array}{llllllllllllll} & & & \end{array}$

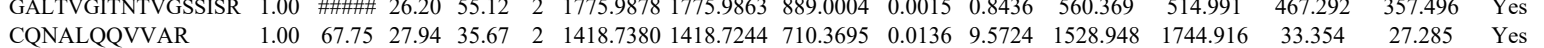

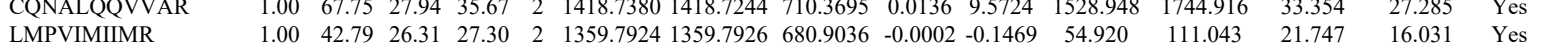

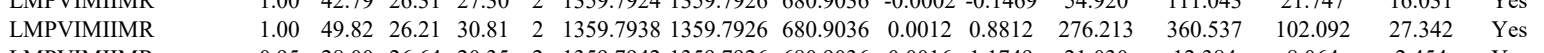

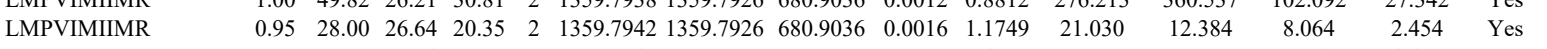

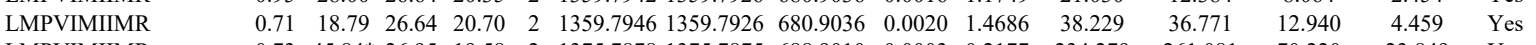
$\begin{array}{llllllllllllllll}\text { LMPVIMIIMR } & 0.73 & 45.84 * 26.95 & 19.58 & 2 & 1375.7878 & 1375.7875 & 688.9010 & 0.0003 & 0.2177 & 234.279 & 261.081 & 70.220 & 23.849 & \text { Yes }\end{array}$ $\begin{array}{llllllllllllllll}\text { LMPVIMIIMR } & 0.65 & 36.59 * & 26.95 & 23.01 & 2 & 1375.7882 & 1375.7875 & 688.9010 & 0.0007 & 0.5081 & 226.077 & 285.704 & 84.531 & 21.215 & \text { Yes }\end{array}$

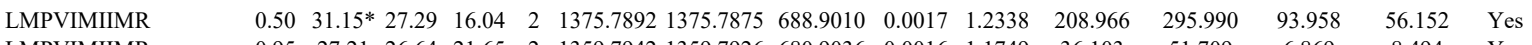

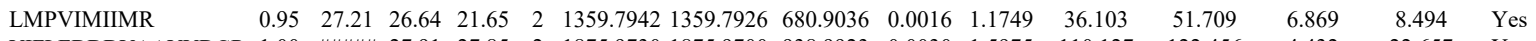

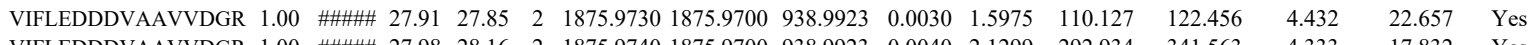

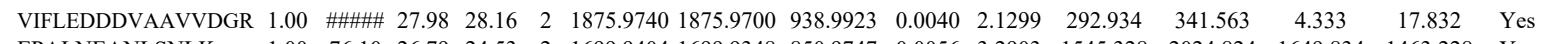

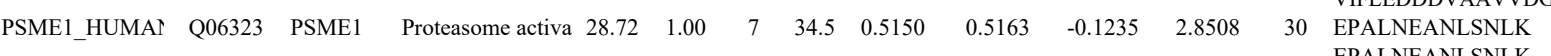
EPALNEANLSNLK APLDIPVPDPVK APLDIPVPDPVK APLDIPVPDPVK APLDIPVPDP
ISELDAFLK ISELDAFLK

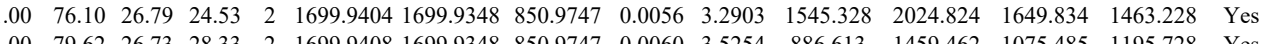
$\begin{array}{lllllllllllllll}1.00 & 7.62 & 26.73 & 28.33 & 2 & 1699.9408 & 1699.9348 & 850.9747 & 0.0060 & 3.5254 & 886.613 & 1459.462 & 1075.485 & 1195.728 & \text { Yes }\end{array}$

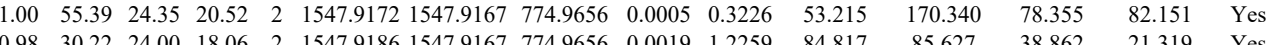

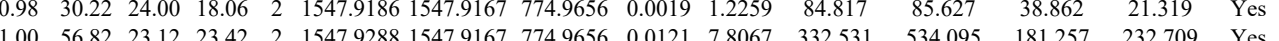
$\begin{array}{lllllllllllllll}.00 & 54.03 & 22.86 & 20.12 & 2 & 1547.9298 & 1547.9167 & 774.9656 & 0.0131 & 8.4519 & 902.465 & 978.770 & 683.797 & 573.758 & \text { Yes }\end{array}$ $\begin{array}{lllllllllllllll}0.96 & 42.11 & 26.86 & 34.50 & 2 & 1322.7672 & 1322.7689 & 662.3917 & -0.0017 & -1.2832 & 29437.129 & 36121.151 & 943.165 & 255.856 & \text { Yes }\end{array}$ $\begin{array}{lllllllllllllll}0.55 & 32.99 & 26.25 & 35.16 & 2 & 1322.7662 & 1322.7689 & 662.3917 & -0.0027 & -2.0381 & 9814.133 & 11751.816 & 236.509 & 167.710 & \text { Yes }\end{array}$ 
NAYAVLYDIILK NAYAVLYDIILK NAYAVLYDIILK

DVIEQLNLVTTWLQLO

DVIEQLNLVTTWLQLQIPR

DVIEQLNL
IVVLLQR
IVVLLQR

IVVLLQR
IVVLLQR

IVVLLQR
IVVLLQR

IVVLLQR

IVVLLQR

IVVLLQR

IVVLLQR

IVVLLQR

IVVLLQR

IVVLQR

IVVLLQR

IVVLLQR

IVVLLQR

IVVLLQR
IVVLLQR

IEDGNNFGVAVQEK

IEDGNNFGVAVQ

27 TIAQDYGVLK

TIAQDYGVLK

ATAVMPDGQFK

TIAQDYGVLK

ATAVMPDGQFK

ATAVMPDGQFK

ATAVMPDGQFK

ATAVMPDGQFK

TIAQDYGVLK
ATAVMPDGQFK

IGHPAPNFK

IGHPAPNFK

QGGLGPMNIPLVSDPK

IGHPAPNFK

IGHPAPNFK

IGHPAPNFK

IGHPAPNFK
IGHPAPNFK

IGHPAPNFK

IGHPAPNFK

IGHPAPNFK

IGHPAPNFK

IGHPAPNFK

IGHPAPNFK

IGHPAPNFK

IGHPAPNFK

IGHPAPNFK

IGHPAPNFK

48 TNRPPLSLSR

TAVVVGTITDDVR

TAVVVGTITDDVR

TAVVVGTITDDVR

TAVVVGTITDDVR

TAVVVGTITDDVR

TAVVVGTITDDV

TNRPPLSLSR

TNRPPLSLSR
TAVVVGTITDDVR

TAVVVGTITDDVR

ILTFDQLALDSPK

ILTFDLALDSF

TNSTFNQVVLK $\begin{array}{lllllllllll}1.82 & 23.24 & 24.78 & 3 & 1682.9863 & 1682.9850 & 562.0023 & 0.0013 & 0.7711 & 90.624\end{array}$

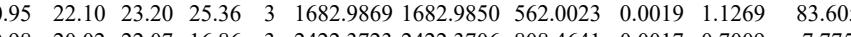

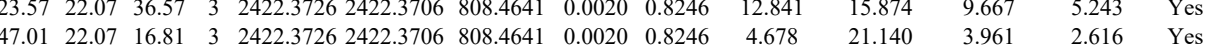
$\begin{array}{llllllllllllllll}0.79 & 12.30 & 14.91 & 20.75 & 2 & 983.6618 & 983.6613 & 492.8379 & 0.0005 & 0.5073 & 46.513 & 77.254 & 11.909 & 10.586 & \text { Yes }\end{array}$ $\begin{array}{lllllllllllllll}0.96 & 30.72 & 14.91 & 35.24 & 2 & 983.6624 & 983.6613 & 492.8379 & 0.0011 & 1.1160 & 33455.515 & 46245.619 & 1358.453 & 386.881 & \text { Yes }\end{array}$ $\begin{array}{ccccccccccccccc}0.85 & 11.03 & 14.91 & 20.64 & 2 & 983.6624 & 983.6613 & 492.8379 & 0.001 & 1.1160 & 55.461 & 62.583 & 18.506 & 6.292 & \text { Yes } \\ 0.96 & 30.57 & 14.91 & 35.04 & 2 & 983.6626 & 983.6613 & 492.8379 & 0.0013 & 1.3189 & 19785.180 & 27840.029 & 889.447 & 206.160 & \text { Yes }\end{array}$

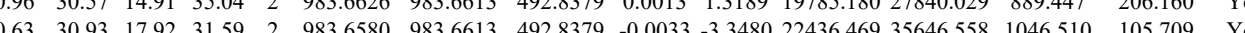

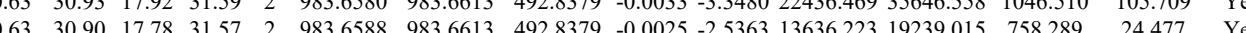

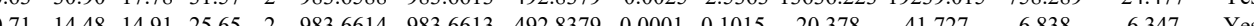
$\begin{array}{lllllllllllllll}0.72 & 10.53 & 4.91 & 21.13 & 2 & 983.6616 & 983.6613 & 4928379 & 0.0003 & 0.3044 & 43.105 & 34.697 & 5.673 & 7.190 & \text { Yes }\end{array}$ $\begin{array}{lllllllllllllllll}0.63 & 10.71 & 18.26 & 16.64 & 2 & 983.6642 & 983.6613 & 4928379 & 0.0029 & 2.9421 & 36.024 & 49.622 & 3.6264 & 12.208 & \text { Yes }\end{array}$ $\begin{array}{lllllllllllllll}0.61 & 30.80 & 17.92 & 31.75 & 2 & 983.6580 & 983.6613 & 492.8379 & -0.0033 & 3.3480 & 4115.508 & 5782.503 & 79.419 & 58.489 & \text { Yes }\end{array}$ $\begin{array}{llllllllllllllll}0.63 & 31.04 & 17.78 & 31.67 & 2 & 983.6584 & 983.6613 & 492.8379 & 0.0029 & -29422 & 4559.615 & 6442.788 & 153.889 & 18.621 & \text { Yes }\end{array}$ $\begin{array}{llllllllllllllll}0.90 & 30.08 & 14.91 & 35.29 & 2 & 983.6614 & 983.6613 & 492.8379 & 0.0001 & 0.1015 & 2370.883 & 2928.863 & 156.988 & 81.730 & \text { Y s }\end{array}$ $\begin{array}{lllllllllllllllll}0.96 & 36.24 & 14.91 & 37.73 & 2 & 983.6614 & 983.6613 & 492.8379 & 0.0001 & 0.1015 & 3143.412 & 4310.919 & 151.686 & 94.177 & \text { Yes }\end{array}$ $\begin{array}{llllllllllllllll}0.96 & 32.38 & 14.91 & 33.10 & 2 & 983.6616 & 983.6613 & 492.8379 & 0.0003 & 0.3044 & 736.395 & 997.753 & 95.341 & 50.163 & \text { Yes }\end{array}$ $\begin{array}{llllllllllllllll}0.99 & 34.04 & 14.91 & 33.15 & 2 & 983.6620 & 983.6613 & 492.8379 & 0.0007 & 0.7102 & 714.309 & 1033.967 & 97.751 & 51.766 & \text { Yes }\end{array}$

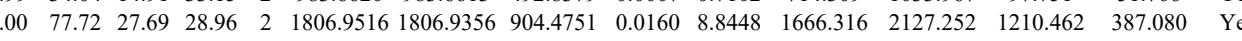
$\begin{array}{lllllllllllllll} & 76.51 & 27.57 & 30.10 & 2 & 1806.9528 & 1806.9356 & 904.4751 & 0.0172 & 9.5082 & 1510.172 & 1790.844 & 705.469 & 273.052 & \text { Y s }\end{array}$ $\begin{array}{lllllllllllllll} & \end{array}$ $\begin{array}{llllllllllllll} & \end{array}$ $\begin{array}{lllllllllllll} & \end{array}$ $\begin{array}{llllllllllllll} & \end{array}$ $\begin{array}{llllllllllllllll}1.00 & 70.53 & 26.23 & 30.61 & 2 & 1394.8126 & 1394.8013 & 698.4079 & 0.013 & 8.0888 & 17292.603 & 18746.497 & 794.182 & 639.359 & \text { Yes } & \\ 1.00 & 61.02 & 26.13 & 25.50 & 2 & 1394.8136 & 1394.8013 & 698.4079 & 0.0123 & 8.8057 & 31915.713 & 34881.255 & 1916.547 & 604.532 & \text { Yes }\end{array}$ \begin{tabular}{lllllllllllllll}
1.00 & 53.64 & 27.76 & 39.85 & 2 & 1451.7800 & 1451.7686 & 726.8916 & 0.0114 & 7.8415 & 2998.075 & 2984.162 & 2069.190 & 900.429 & Yes \\
\hline
\end{tabular}

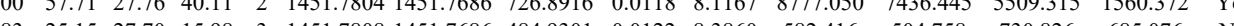
\begin{tabular}{lllllllllllllll}
1.00 & 57.71 & 27.76 & 4.11 & 2 & 1451.7804 & 1451.7686 & 726.8916 & 0.018 & 8.167 & 877.050 & 7436.445 & 5509.315 & 1560.372 & Yes \\
\hline
\end{tabular}

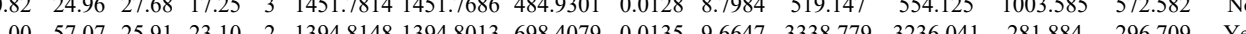

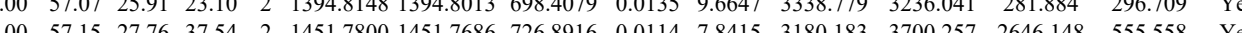
$\begin{array}{lllllllllllllll} & \end{array}$ $\begin{array}{llllllllllllllll}0.91 & 18.83 & 26.00 & 17.89 & 3 & 1267.7308 & 1267.7281 & 423.5833 & 0.0027 & 2.1247 & 18185.288 & 18628.360 & 10422.066 & 2045.626 & \text { Yes }\end{array}$ $\begin{array}{lllllllllllllll}0 & \end{array}$ $\begin{array}{lllllllllll} & \end{array}$ $\begin{array}{llllllllll} & \end{array}$

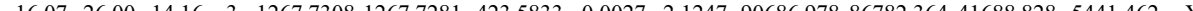
$\begin{array}{lllllllllllllll} & 18.070 & 25.07 & 14.37 & 3 & 1267.729 & 1267.7281 & 423.5833 & 0.0018 & 1.4165 & 35055.761 & 33922.583 & 16291.663 & 2337.896 & \text { Yes }\end{array}$ $\begin{array}{lllllllllllllllll}1.00 & 47.45 & 25.98 & 21.00 & 2 & 1267.7302 & 1267.7281 & 634.8713 & 0.0021 & 1.6539 & 1642.179 & 1945.680 & 955.194 & 329.175 & \text { Yes }\end{array}$ $\begin{array}{lllllllllllllll}1.00 & 63.44 & 25.95 & 22.60 & 2 & 1267.7306 & 1267.7281 & 634.8713 & 0.0025 & 1.9689 & 13635.287 & 13600.210 & 5515.102 & 1175.488 & \text { Yes }\end{array}$ $\begin{array}{llllllllllllllll}0.93 & 19.98 & 26.00 & 14.54 & 3 & 1267.7308 & 1267.7281 & 423.5833 & 0.0027 & 2.1247 & 49519.024 & 51234.510 & 24942.722 & 3378.098 & \text { Yes }\end{array}$ $\begin{array}{lllllllllllllll}0.99 & 29.11 & 25.91 & 15.53 & 3 & 1267.7326 & 1267.7281 & 423.5833 & 0.0045 & 3.5412 & 4704.980 & 4438.355 & 2798.222 & 891.339 & \text { Yes }\end{array}$ $\begin{array}{lllllllllllllll}0.97 & 23.12 & 25.97 & 19.29 & 3 & 1267.7311 & 1267.7281 & 423.5833 & 0.0030 & 2.3608 & 3938.406 & 4667.458 & 1513.109 & 725.907 & \text { Yes }\end{array}$ $\begin{array}{llllllllllllllll}0.96 & 23.61 & 26.37 & 14.49 & 3 & 1267.7293 & 1267.7281 & 423.5833 & 0.0012 & 0.9443 & 561.714 & 554.951 & 281.276 & 121.690 & \text { Yes }\end{array}$ $\begin{array}{llllllllllllllll}0.93 & 21.41 & 26.37 & 18.41 & 3 & 1267.7290 & 1267.7281 & 423.5833 & 0.0009 & 0.7082 & 320.707 & 391.758 & 172.438 & 58.867 & \text { Yes }\end{array}$

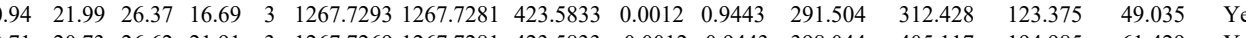
$\begin{array}{lllllllllllllll}0.71 & 20.73 & 26.62 & 21.91 & 3 & 1267.7269 & 1267.7281 & 423.5833 & -0.0012 & -0.9443 & 398.044 & 405.117 & 194.985 & 61.429 & \text { Yes }\end{array}$ $\begin{array}{llllllllllllll} & \end{array}$ $\begin{array}{llllllllllllll}32.50 & 26.63 & 15.98 & 2 & 1139.6416 & 1139.6411 & 570.8278 & 0.0005 & 0.4380 & 2.097 & 41.165 & 11.701 & 3.170 & \text { No }\end{array}$

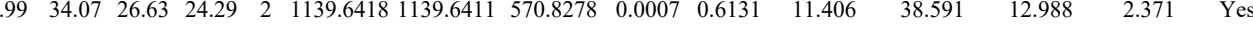
$\begin{array}{lllllllllllllll}1.00 & 68.93 & 26.99 & 29.04 & 2 & 1488.8384 & 1488.8270 & 745.4208 & 0.0114 & 7.6466 & 3375.553 & 2988.098 & 192.359 & 89.464 & \text { Yes }\end{array}$ $\begin{array}{llllllllllllllll}1.00 & 69.43 & 27.02 & 27.53 & 2 & 1488.8410 & 1488.8270 & 745.4208 & 0.0140 & 9.3906 & 3516.101 & 3749.192 & 823.873 & 287.770 & \text { Yes }\end{array}$ $\begin{array}{lllllllllllllllll}1.00 & 73.91 & 27.00 & 28.57 & 2 & 1488.8394 & 1488.8270 & 745.4208 & 0.0124 & 8.3174 & 8437.702 & 8699.304 & 1374.587 & 342.621 & \text { Yes }\end{array}$ $\begin{array}{lllllllllllllll}1.00 & 7.15 & 27.02 & 28.04 & 2 & 1488.8402 & 1488.8270 & 745.4208 & 0.0132 & 8.8540 & 4749.979 & 4896.686 & 745.067 & 503.491 & \text { Yes } \\ 1.00 & 6.06 & 27.12 & 26.62 & 2 & 188.8392 & 488.827 & 745.420 & 0.0122 & 8.1832 & 168.035 & 1579.92 & 239.345 & 44.418 & \text { Yes }\end{array}$ $\begin{array}{lllllllllllllll}1.00 & 6.06 & 27.12 & 26.62 & 2 & 1488.8392 & 1488.8270 & 745.4208 & 0.0122 & 8.1832 & 1689.035 & 1579.920 & 239.345 & 447.418 & \text { Yes }\end{array}$

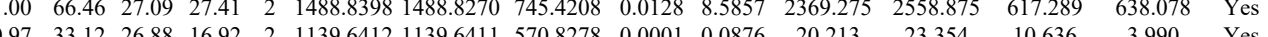

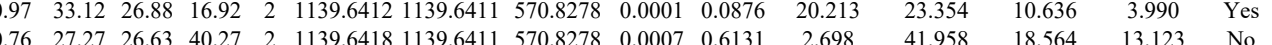

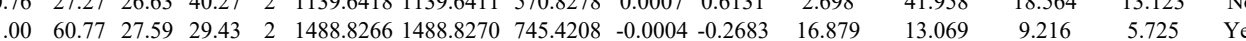

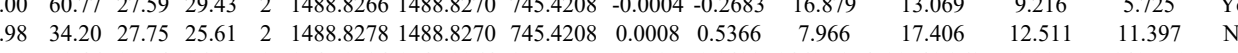

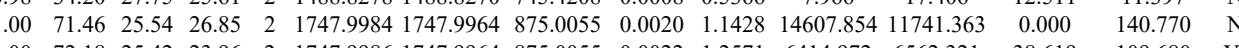

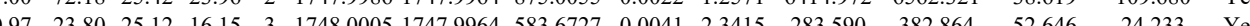

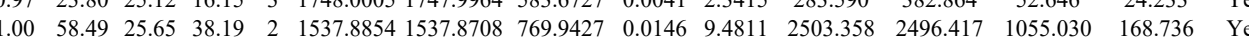

Table S-3 page 365 of 499 

$\begin{array}{lllllllllll}1.00 & 19.46 & 26.66 & 17.56 & 4 & 1835.0057 & 1835.0046 & 459.7584 & 0.0011 & 0.5981 & 21.053\end{array}$

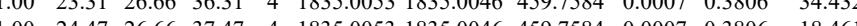
$\begin{array}{lllllllllll}1.00 & 24.47 & 26.66 & 36.31 & 4 & 1835.0053 & 1835.0046 & 459.7584 & 0.0007 & 0.3806 & 34.432\end{array}$ $\begin{array}{llllllllllll}1.00 & 30.93 & 26.66 & 16.10 & 4 & 1835.0061 & 1835.0046 & 459.7584 & 0.0015 & 0.8156 & 33.717\end{array}$

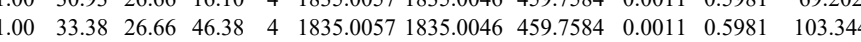
$\begin{array}{llllllllllll}0.76 & 29.72 & 26.63 & 42.72 & 2 & 1139.6416 & 1139.6411 & 570.8278 & 0.0005 & 0.4380 & 7.280\end{array}$ $\begin{array}{llllllllllll}0.84 & 22.62 & 26.83 & 17.57 & 2 & 1139.6422 & 1139.6411 & 570.8278 & 0.0011 & 0.9635 & 21.178 \\ 1.00 & 18.28 & 26.65 & 19.17 & 4 & 1835.065 & 18350.046 & 459.7584 & 0.0019 & 1.0332 & 4.478\end{array}$ $\begin{array}{lllllllllllll}0.99 & 16.22 & 26.73 & 29.22 & 4 & 1835.0069 & 1835.0046 & 459.7584 & 0.0023 & 1.2507 & 37.337\end{array}$ $\begin{array}{llllllllllll}1.00 & 34.44 & 26.65 & 47.44 & 4 & 1835.0065 & 1835.0046 & 459.7584 & 0.0019 & 1.0332 & 204.839\end{array}$ $\begin{array}{llllllllllll}0.82 & 21.87 & 26.63 & 14.39 & 2 & 1139.6418 & 1139.6411 & 570.8278 & 0.0007 & 0.6131 & 157.370\end{array}$ $\begin{array}{llllllllllll}1.00 & 23.11 & 26.66 & 22.04 & 4 & 1835.0053 & 1835.0046 & 459.7584 & 0.0007 & 0.3806 & 107.109\end{array}$ $\begin{array}{lllllllllll}1.00 & 25.16 & 26.73 & 23.08 & 4 & 1835.0069 & 1835.0046 & 459.7584 & 0.0023 & 1.2507 & 139.810\end{array}$ $\begin{array}{lllllllllll}0.86 & 23.17 & 27.06 & 16.93 & 2 & 1139.6428 & 1139.6411 & 570.8278 & 0.0017 & 1.4891 & 265.124\end{array}$ $\begin{array}{lllllllllll}1.00 & 22.55 & 26.50 & 16.90 & 4 & 1835.0081 & 1835.0046 & 459.7584 & 0.0035 & 1.9032 & 75.193\end{array}$ $\begin{array}{llllllllllll}0.95 & 27.55 & 26.63 & 15.76 & 2 & 1139.6416 & 1139.6411 & 570.8278 & 0.0005 & 0.4380 & 155.621 \\ 0.98 & 31.44 & 26.63 & 16.40 & 2 & 1139.6461139 .6411 & 570.8278 & 0.0005 & 0.4380 & 119.599\end{array}$ $\begin{array}{lllllllllllll}0.98 & 31.44 & 26.63 & 16.40 & 2 & 1139.6416 & 1139.6411 & 570.8278 & 0.0005 & 0.4380 & 119.599 \\ 0.96 & 30.01 & 27.20 & 17.53 & 2 & 1139.6420 & 1139.6411 & 570.8278 & 0.0009 & 0.7883 & 98.618\end{array}$ $\begin{array}{lllllllllllll}0.94 & 27.01 & 26.63 & 16.78 & 2 & 1139.6416 & 1139.6411 & 570.8278 & 0.0005 & 0.4380 & 57.323 \\ 0.97 & 30.08 & 26.74 & 23.20 & 2 & 1139.6424 & 1139.6411 & 570.8278 & 0.0013 & 1.1387 & 81.069\end{array}$ $\begin{array}{lllllllllll}0.97 & 30.08 & 26.74 & 23.20 & 2 & 1139.6424 & 1139.6411 & 570.8278 & 0.0013 & 1.1387 & 81.069\end{array}$ $\begin{array}{llllllllllll}0.74 & 22.99 & 26.88 & 22.41 & 2 & 1139.6412 & 1139.6411 & 570.8278 & 0.0001 & 0.0876 & 35.258\end{array}$ $\begin{array}{lllllllllllll}0.76 & 53.89 & 28.26 & 66.89 & 2 & 1248.6448 & 1248.6441 & 625.3293 & 0.0007 & 0.5597 & 83.594\end{array}$ $\begin{array}{lllllllllllll}0.88 & 23.74 & 26.63 & 23.10 & 2 & 1139.6416 & 1139.6411 & 570.8278 & 0.0005 & 0.4380 & 41.689\end{array}$ $\begin{array}{llllllllllll}0.87 & 23.59 & 26.74 & 20.80 & 2 & 1139.6424 & 1139.6411 & 570.8278 & 0.0013 & 1.1387 & 41.228\end{array}$ $\begin{array}{llllllllllll}0.76 & 56.14 & 28.33 & 69.14 & 2 & 1248.6446 & 1248.6441 & 625.3293 & 0.0005 & 0.3998 & 154.113 & \\ 1.00 & 70.43 & 28.36 & 23.44 & 2 & 1248.6452 & 1248.6441 & 625.3293 & 0.0011 & 0.8795 & 142.456\end{array}$ $\begin{array}{llllllllllll}1.00 & 70.43 & 28.36 & 23.44 & 2 & 1248.6452 & 1248.6441 & 625.3293 & 0.0011 & 0.8795 & 142.456 \\ 0.76 & 56.19 & 28.36 & 69.19 & 2 & 1248.6452 & 1248.6441 & 625.3293 & 0.0011 & 0.8795 & 108.860\end{array}$ $\begin{array}{llllllllllll}0.76 & 56.19 & 28.36 & 69.19 & 2 & 1248.6452 & 1248.6441 & 625.3293 & 0.0011 & 0.8795 & 108.860 & 11 \\ 1.00 & 60.78 & 28.45 & 19.83 & 2 & 1248.6434 & 1248.6441 & 6253293 & -0.0007 & -0.5597 & 173.128 & 21\end{array}$ $\begin{array}{lllllllllllll}1.00 & 60.78 & 28.45 & 19.83 & 2 & 1248.6434 & 1248.6441 & 625.3293 & -0.0007 & -0.5597 & 173.128\end{array}$ $\begin{array}{lllllllllllll}1.00 & 62.59 & 28.51 & 19.11 & 2 & 1248.6442 & 1248.6441 & 625.3293 & 0.0001 & 0.0800 & 178.219 & 158 \\ 1.00 & 55.65 & 28.26 & 18.84 & 2 & 1248.6448 & 1248.6441 & 625.3293 & 0.0007 & 0.5597 & 116.356\end{array}$ $\begin{array}{lllllllllll}1.00 & 55.65 & 28.26 & 18.84 & 2 & 1248.6448 & 1248.6441 & 625.3293 & 0.0007 & 0.5597 & 116.356 \\ 0.96 & 29.54 & 27.06 & 19.27 & 2 & 1139.6428 & 1139.6411 & 570.8278 & 0.0017 & 1.4891 & 2.591\end{array}$ $\begin{array}{lllllllllll}0.96 & 29.54 & 27.06 & 19.27 & 2 & 1139.6428 & 139.6411 & 57.8278 & 0.0017 & 1.4891 & 2.591\end{array}$ $\begin{array}{lllllllllll}1.00 & 61.43 & 28.26 & 21.85 & 2 & 1248.6448 & 1248.6441 & 625.3293 & 0.0007 & 0.5597 & 907.549\end{array}$

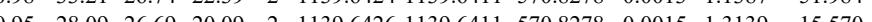
$\begin{array}{llllllllllll}1.00 & 65.25 & 28.51 & 21.96 & 2 & 1248.6440 & 1248.6441 & 625.3293 & -0.0001 & -0.0800 & 165.997 & 177\end{array}$ $\begin{array}{llllllllllll}1.00 & 62.69 & 28.26 & 19.97 & 2 & 1248.6448 & 1248.6441 & 625.3293 & 0.0007 & 0.5597 & 264.715 \\ 1.00 & 63.72 & 82.27 & 19.54 & 2 & 1284.4454 & 1248.641 & 25.3293 & 0.0013 & 1.0395 & 23.205 & 16\end{array}$

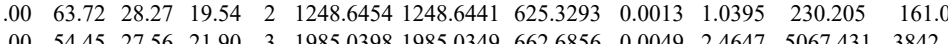
$\begin{array}{llllllllllll}1.00 & 75.32 & 25.45 & 26.95 & 2 & 2574.3694 & 2574.3672 & 1288.1909 & 0.0022 & 0.8539 & 14.435 & 27.1650\end{array}$ $\begin{array}{lllllllllll}1.00 & 53.37 & 25.58 & 19.24 & 3 & 2574.3718 & 2574.3672 & 859.1297 & 0.0046 & 1.7847 & 50.337\end{array}$ $\begin{array}{lllllllllll}1.00 & 64.99 & 27.22 & 24.62 & 2 & 1570.8518 & 1570.8486 & 786.4316 & 0.0032 & 2.0345 & 1229.641\end{array}$

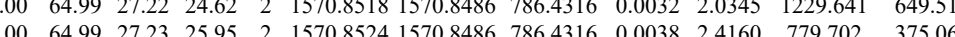
$\begin{array}{llllllllllll}0.95 & 24.14 & 27.20 & 19.92 & 3 & 1570.8535 & 1570.8486 & 524.6235 & 0.0049 & 3.1133 & 59.604 & 58.485\end{array}$ $\begin{array}{lllllllllllll}0.99 & 30.73 & 27.11 & 20.91 & 3 & 1570.8541 & 1570.8486 & 524.6235 & 0.0055 & 3.4946 & 81.315\end{array}$ $\begin{array}{llllllllllll}1.00 & 66.61 & 27.22 & 24.09 & 2 & 1570.8516 & 1570.8486 & 786.4316 & 0.0030 & 1.9073 & 2218.173 & 1502.228\end{array}$ $\begin{array}{lllllllllllll}1.00 & 52.81 & 27.22 & 23.08 & 2 & 1570.8518 & 1570.8486 & 786.4316 & 0.0032 & 2.0345 & 2792.969 & 1760.871\end{array}$ $\begin{array}{lllllllllll}0.96 & 24.13 & 27.20 & 22.20 & 3 & 1570.8523 & 1570.8486 & 524.6235 & 0.0037 & 2.3509 & 86.065\end{array}$ $\begin{array}{lllllllllllll}0.99 & 54.70 & 27.57 & 18.87 & 3 & 1985.0413 & 1985.0349 & 662.6856 & 0.0064 & 3.2192 & 11746.085 & 93\end{array}$

PELTSTPNFVVEVIK

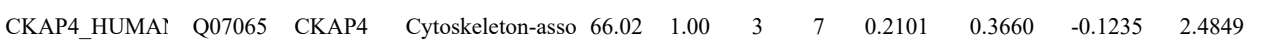
STLQTMESDIYTEV

$\begin{array}{lllllllllll}\text { ZO1_HUMAN } & \text { Q07157 } & \text { TJP1 } & \text { Tight junction pro 195.46 } & 1.00 & 3 & 1.9 & 0.0296 & 0.2552 & 0.2288 & 2.0983\end{array}$ 
APGFGFGIAISGGR

LGSWLAIR

6 SGSMDPSGAHPSVR

YLPELMAEK

YLPELMAEK

DSLDPSFTHAMQLLTAEIEK

DSLDPSFTHAMQLLTAEIIK
DSLDPSFTHAMOLLTAEI DSLDPSFTHAMQLLTAEIEK

\section{QPPLPHR}

QPPLPHR

GVPPPPTV

FNFVGK

FNFVGK

FNFVGK

DDEENYLDLFSHK

DDEENYLDLFSHK

GGPPFAFVEFEDPR

GGPPFAFVEFEDPR

GGPPFAFVEFEDPR

DIEDVFYK

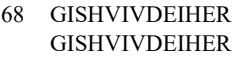

AIEPPPLDAVIEAEHTLR

YGDGPRPPK

YGDGPRPPK

AAMEALVVEVTK

QPAIISQLDPVNER
QPAIISQLDPVNER

QPAIISQLDPY
MTPSYEIR

LSMSQLNEK

MTPSYEIR

MTPSYEIR

LAQFEPSQR

LAQR

ETPFELIEALLK

TTQVPQFILDDFIQNDR

TTQVPQFILDDFIQNDR
TTQVPQFILDDFIQNDR

TTQVPQFILDDFIONDR
TTQVPQFILDDFIQNDR

ETPFELIEALLK

ETPFELIEALLK

ETPFELIEALLK

ETPFELIEALLK

TTQVPQFILDDFIQNDR TTQVPQFILDD

ETPFELIEALLK

ETPFELIEALLK

TTQVPQFILDDFIQNDR

TTQVPQFILDDFIQNDR

TTQVPQFILDDFIQNDR
TTQVPQFILDDFIQNDR

TTQVPQFILDDFIQNDR
TYPVQEYFLEDCIQMTHFVPPPK

TYPVQEYFLEDCIQMTHFVPPPK 1.00

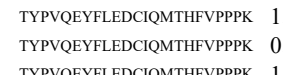

TYPVOEYFLEDC

LNQYFQK

THESLIK

LGGIGQFLAK
LGGIGQFLAK

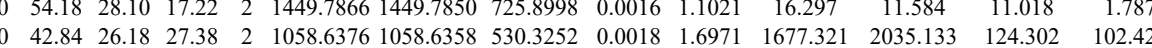
$\begin{array}{lllllllllllll} & 11.787 & & \\ 1\end{array}$ $\begin{array}{llllllllllllll}42.44 & 26.24 & 32.02 & 2 & 1058.6374 & 1058.6358 & 530.352 & 0.0016 & 1.3199 & 2689.575 & 2856.025 & 248.136 & 96.552 & \text { Yes } \\ & 2299.172 & 2893.613 & 160.133 & 59.746 & \text { Yes }\end{array}$ $\begin{array}{lllllllllllllll}1 & 15.37 .7237 & 1527.7222 & 510.2480 & 0.0015 & 0.9799 & 595.823 & 815.427 & 939.516 & 1168.889 & \text { Yes }\end{array}$ $\begin{array}{llllllllllllllll}1.00 & 47.67 & 27.32 & 24.67 & 2 & 1380.7586 & 1380.7566 & 691.3856 & 0.0020 & 1.4464 & 11829.083 & 13170.186 & 3620.125 & 4591.043 & \text { Yes }\end{array}$ $\begin{array}{lllllllllllllll}1.00 & 49.76 & 27.46 & 27.30 & 2 & 1380.7588 & 1380.7566 & 691.3856 & 0.0022 & 1.5910 & 12328.328 & 13192.338 & 3863.966 & 4921.102 & \text { Yes }\end{array}$ \begin{tabular}{llllllllllllll}
37.33 & 26.87 & 50.33 & 4 & 2533.3045 & 2533.2978 & 634.3317 & 0.0067 & 2.6406 & 92.043 & 101.871 & 191.646 & 81.748 & Yes \\
\hline
\end{tabular} $\begin{array}{lllllllll} & \\ 0\end{array}$

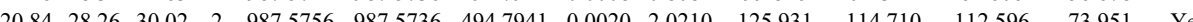
$\begin{array}{lllllllllllllll}36.38 & 27.14 & 24.99 & 2 & 1062.6316 & 1062.6308 & 532.3227 & 0.0008 & 0.7514 & 4592.967 & 4200.431 & 3206203 & 2082.634 & \text { Yes }\end{array}$ $\begin{array}{lllllllllllllllll}0.90 & 31.05 & 24.42 & 32.26 & 2 & 998.5876 & 998.5793 & 5002969 & 0.0083 & 8 & 2950 & 40539.237 & 42115.635 & 1580.862 & 644.792 & \text { Yes }\end{array}$ $\begin{array}{lllllllllllllllll}0.91 & 29.86 & 24.42 & 31.37 & 2 & 998.5882 & 998.5793 & 5002969 & 0.0089 & 8.8946 & 21300.497 & 19972.194 & 827.249 & 414.385 & \text { Yes }\end{array}$ $\begin{array}{llllllllllllllll}0.85 & 28.54 & 24.62 & 30.11 & 2 & 998.5868 & 998.5793 & 5002969 & 0.0075 & 7.4955 & 36486.890 & 32832268 & 1178.062 & 473.539 & \text { Yes }\end{array}$ $\begin{array}{llllllllllllllllll}0.88 & 28.83 & 24.58 & 30.52 & 2 & 998.5870 & 998.5793 & 5002969 & 0.0077 & 7.6954 & 19952.841 & 19972.932 & 680.048 & 388.084 & \text { Yes }\end{array}$ $\begin{array}{llllllllllllllll}100 & 61.04 & 26.98 & 23.61 & 3 & 1911.9121 & 1911.9094 & 638.3104 & 0.0027 & 1.4100 & 1204.822 & 1612.584 & 5023.963 & 3486.301 & \text { Yes }\end{array}$ $\begin{array}{lllllllllllllll}1.00 & 57.74 & 26.95 & 18.15 & 3 & 1911.9127 & 1911.9094 & 638.3104 & 0.0033 & 1.7233 & 1616.663 & 1880.245 & 4040.360 & 2222.664 & \text { Yes }\end{array}$ $\begin{array}{llllllllllllllll}0.89 & 25.17 & 27.33 & 23.15 & 2 & 1707.8392 & 1707.8379 & 854.9262 & 0.0013 & 0.7603 & 194.333 & 95.789 & 62.136 & 39.487 & \text { Yes }\end{array}$ $\begin{array}{lllllllllllllll}0.99 & 36.94 & 27.35 & 20.47 & 2 & 1707.8394 & 1707.8379 & 854.9262 & 0.0015 & 0.8773 & 73.952 & 67.669 & 34.203 & 30.641 & \text { Yes }\end{array}$ $\begin{array}{llllllllllllllll}0.97 & 30.82 & 27.40 & 18.66 & 2 & 1707.8384 & 1707.8379 & 854.9262 & 0.0005 & 0.2924 & 113.165 & 79.864 & 66.932 & 10.285 & \text { Yes }\end{array}$ $\begin{array}{lllllllllllllll}1.00 & 49.68 & 27.34 & 24.67 & 2 & 1707.8396 & 1707.8379 & 854.9262 & 0.0017 & 0.9942 & 441.561 & 378.455 & 211.266 & 130.042 & \text { Yes } \\ 1.00 & 43.20 & 27.78 & 2.83 & 2 & 1315.6916 & 1315.604 & 658.8525 & 0.012 & 0.9107 & 974.672 & 1139.755 & 2887.295 & 2484.985 & \text { Yes }\end{array}$ $\begin{array}{lllllllllllllll}1.00 & 43.20 & 27.78 & 21.83 & 2 & 1315.6916 & 1315.6904 & 658.8525 & 0.0012 & 0.9107 & 974.672 & 1139.755 & 2887.295 & 2484.985 & \text { Yes } \\ 1.00 & 47.90 & 27.60 & 17.90 & 3 & 1646.8996 & 1646.8862 & 549.9693 & 0.0134 & 8.1216 & 303542 & 322596 & 332.847 & 287.897 & \text { Yes }\end{array}$ $\begin{array}{llllllllllllllll}1.00 & 54.83 & 27.60 & 17.29 & 3 & 1646.8996 & 1646.8862 & 549.9693 & 0.0134 & 8.1216 & 549.950 & 522.681 & 366.123 & 255.723 & \text { Yes }\end{array}$ $\begin{array}{llllllllllllll} & \end{array}$

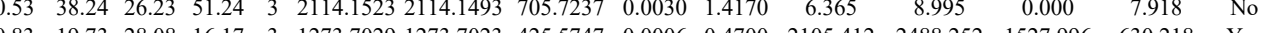
$\begin{array}{lllllllllllllll}0.83 & 1.73 & 28.08 & 16.17 & 3 & 1273.7029 & 1273.7023 & 425.5747 & 0.0006 & 0.4700 & 2105.412 & 2488.252 & 1527.996 & 630.218 & \text { Yes } \\ 1.92 & 22.88 & 28.15 & 19.05 & 3 & 1273.7035 & 1273.7023 & 425.5747 & 0.0012 & 0.9399 & 2385.590 & 2958.840 & 1494.253 & 656.210 & \text { Yes }\end{array}$

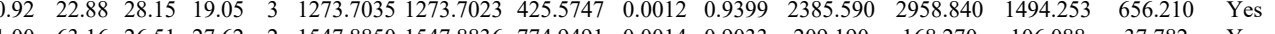
$\begin{array}{lllllllllllllll}1.00 & 63.16 & 26.51 & 27.62 & 2 & 1547.8850 & 1547.8836 & 774.9491 & 0.0014 & 0.9033 & 209.190 & 168.270 & 106.088 & 37.782 & \text { Yes }\end{array}$

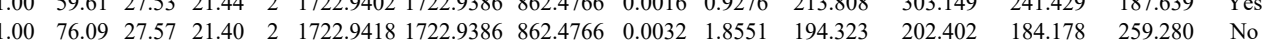

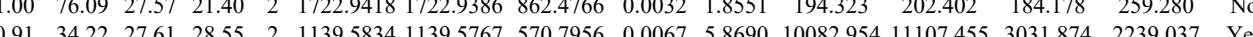
$\begin{array}{lllllllllllllll}0.91 & 34.22 & 27.61 & 28.55 & 2 & 1139.5834 & 1139.5767 & 570.7956 & 0.0067 & 5.8690 & 10082.954 & 11107.455 & 3031.874 & 2239.037 & \text { Yes } \\ 0.97 & 37.14 & 27.81 & 26.9 & 2 & 1336.7372 & 1336.7264 & 669.3705 & 0.0108 & 8.0672 & 7655.929 & 8062.865 & 1741.010 & 1020.804 & \text { Yes }\end{array}$

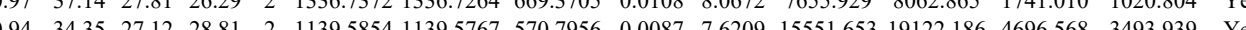

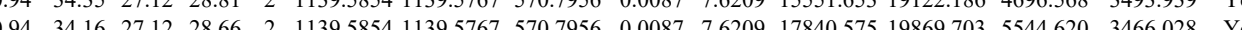
$\begin{array}{lllllllllll} & \end{array}$

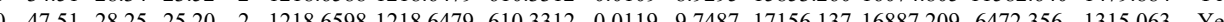

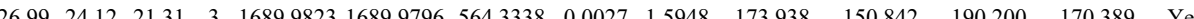

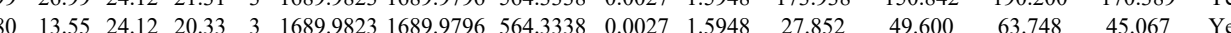

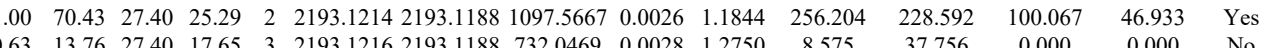

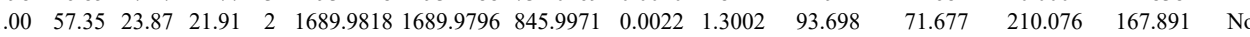

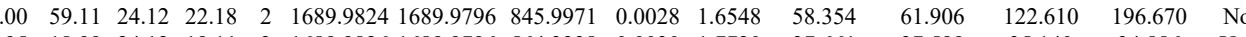
$\begin{array}{llllllllllllll} & 1689.9826 & 1689.9796 & 564.3338 & 0.0030 & 1.7720 & 37.661 & 37.599 & 35.140 & 34.886 & \text { Yes }\end{array}$

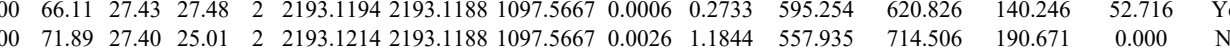
$\begin{array}{llllllllllllll}1 & \end{array}$ $\begin{array}{llllllllllllll} & \end{array}$ $\begin{array}{llllllllllllll}25.46 & 23.86 & 28.72 & 3 & 1689.9838 & 1689.9796 & 564.3338 & 0.0042 & 2.4808 & 62.642 & 84.258 & 52.309 & 34.477 & \text { Yes }\end{array}$

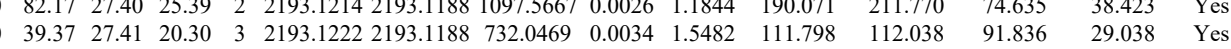

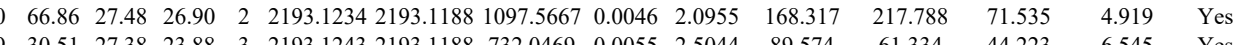

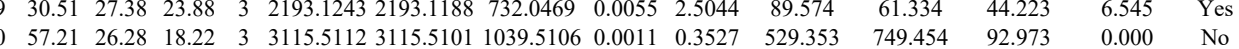
$\begin{array}{llllllllllll} & \end{array}$

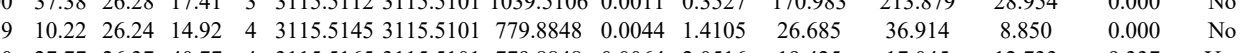

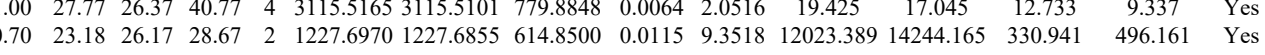
$\begin{array}{lllllllllllllll}1.00 & 36.78 & 20.41 & 15.96 & 3 & 1508.9320 & 1508.9170 & 503.9796 & 0.0150 & 9.9209 & 10107.602 & 8375.525 & 2034.185 & 887.910 & \text { Yes }\end{array}$ 
$\begin{array}{llllllllllllllll}\text { VAEAHENIIHGSGATGK } & 1.00 & 37.68 & 27.37 & 16.71 & 4 & 1978.0521 & 1978.0476 & 495.5192 & 0.0045 & 2.2703 & 10413.318 & 12154.509 & 6970.360\end{array}$ $\begin{array}{llllllllllllllll}\text { VAEAHENIIHGSGATGK } & 1.00 & 28.12 & 27.27 & 15.40 & 4 & 1978.0533 & 1978.0476 & 495.5192 & 0.0057 & 2.8758 & 5812.079 & 6106.699 & 4738.614\end{array}$ $\begin{array}{lllllllllllll}\text { KPLLPYTPGSDVAGVIEAVGDNASAFK } & 1.00 & 21.60 & 22.36 & 34.60 & 4 & 3147.7229 & 3147.7181 & 787.9368 & 0.0048 & 1.5230 & 0.000 & 9.675\end{array}$ $\begin{array}{llllllllllllll}\text { KRLLPTPGSDVAGVEAVGDNASAFK } & 0.72 & 4.90 & 22.23 & 17.90 & 4 & 3147.7237 & 3147.7181 & 787.9368 & 0.0056 & 1.7768 & 40.286 & 19.755\end{array}$ $\begin{array}{lllllllllllllll}\text { QGAAIGIPYFTAYR } & 1.00 & 59.85 & 27.75 & 28.53 & 2 & 1670.8902 & 1670.8902 & 836.4524 & 0.0000 & 0.0000 & 60.533\end{array}$

$\begin{array}{lllllllllllllll} & \text { ALEAAQIIIDVLQLPMSK } & 0.77 & \text { \#\#\#\# } 19.29 & \text { \#\#\#\# } 2 & 2240.3074 & 2240.3057 & 1121.1601 & 0.0017 & 0.7581 & 48.950 & 43.002\end{array}$

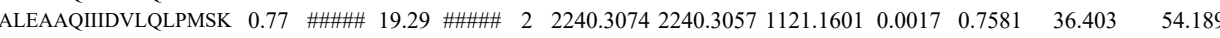
$\begin{array}{lllllllllllllll}\text { ALEAAQIIIDVLQLPMSK } & 1.00 & 53.53 & 19.29 & 17.64 & 3 & 2240.3083 & 2240.3057 & 747.7758 & 0.0026 & 1.1590 & 29.843 & 47.424\end{array}$ $\begin{array}{lllllllllllllll}\text { ALEAAQIIIDVLQLPMSK } & 0.53 & 25.79 & 19.29 & 38.79 & 3 & 2240.3089 & 2240.3057 & 747.7758 & 0.0032 & 1.4265 & 13.982 & 17.902\end{array}$ $\begin{array}{llllllllllllll}\text { LYSVVFQEICNR } & 1.00 & 38.35 & 27.08 & 15.98 & 3 & 1659.8251 & 1659.8235 & 554.2818 & 0.0016 & 0.9622 & 180.654 & 208.817\end{array}$ LYSVVFQEICNR LYSVVFQEICNR LYSVVFQEICNR LYSVVFQEICNR LYSVVFQEICNR $\begin{array}{llllllllllllll}1.00 & 40.73 & 27.08 & 21.33 & 3 & 1659.8251 & 1659.8235 & 554.2818 & 0.0016 & 0.9622 & 199.038 & 247.668\end{array}$ $\begin{array}{lllllllllllll}1.00 & 67.59 & 27.07 & 23.32 & 2 & 1659.8252 & 1659.8235 & 830.9190 & 0.0017 & 1.0230 & 1940.997 & 1983.627 \\ 1.00 & 70.43 & 27.30 & 21.22 & 2 & 1659.8272 & 1659.8235 & 830.9190 & 0.0037 & 2.2264 & 958.711 & 1080.442 & 2\end{array}$

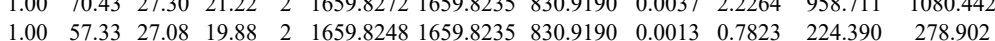
$\begin{array}{llllllllllll}1.00 & 57.33 & 27.08 & 19.88 & 2 & 1659.8248 & 1659.8235 & 830.9190 & 0.0013 & 0.7823 & 224.390 & 278.902 \\ 1.00 & 58.81 & 27.13 & 18.05 & 2 & 1659.8254 & 1659.8235 & 830.9190 & 0.0019 & 1.1433 & 71.955 & 95.523\end{array}$ LIIHLR 


\section{IYPTFLHLHGK}

IYPTFLHLHGK

IYPTFLHLHGK

IYPTFLHLHGK

IYPTFLHLHGK

YPTFLHLHGK

YPTFLHLHGK

YPTFLHLHGK

GFIYVHKPPVHIR

GFIYVHKPPVHIR

GFIYVHKPPVHIR $\begin{array}{llllllllllll}1.00 & 59.58 & 25.87 & 16.93 & 3 & 3530.7712 & 3530.7670 & 1177.9296 & 0.0042 & 1.1885 & 7.912\end{array}$ $\begin{array}{llllllllllllll}1.00 & 82.72 & 25.89 & 95.72 & 4 & 3530.7725 & 3530.7670 & 883.6990 & 0.0055 & 1.5560 & 5.731 & 0.000\end{array}$ $\begin{array}{ccccccccccccc}1.00 & 82.72 & 25.89 & 95.72 & 4 & 3530.7725 & 3530.7670 & 883.6990 & 0.0055 & 1.5560 & 5.731 & 0.000 & 43.743 \\ 1.00 & 26.15 & 24.17 & 18.72 & 4 & 1612.9445 & 1612.9333 & 404.2406 & 0.0112 & 6.9265 & 14930.014 & 17267.211 & 1791.012 \\ 0 & 22.22 & 23.89 & 18.50 & 4 & 1612.9469 & 1612.9333 & 404.2406 & 0.0136 & 8.4108 & 15148.153 & 16842.906 & 1332.292\end{array}$ $\begin{array}{llllllllllllll}1.00 & 47.70 & 23.89 & 17.49 & 3 & 1612.9471 & 1612.9333 & 538.6517 & 0.0138 & 8.5398 & 4912.026 & 4731.720 & 502.2781 & 1\end{array}$ $\begin{array}{lllllllllllll}1.00 & 45.94 & 23.96 & 16.51 & 3 & 1612.9474 & 1612.9333 & 538.6517 & 0.0141 & 8.7254 & 8059.789 & 8522.261 & 756.620\end{array}$ $\begin{array}{llllllllllllll}.00 & 59.33 & 24.93 & 24.23 & 3 & 1612.9360 & 1612.9333 & 538.6517 & 0.0027 & 1.6708 & 3188.592 & 3327.064 & 564.807 \\ 1.00 & 24.70 & 23.89 & 18.41 & 4 & 1612.9465 & 16129333 & 4042406 & 0.0132 & 8.1634 & 9675.720 & 9502.064 & 874.041 & 1\end{array}$ $\begin{array}{llllllllllllll}1.00 & 53.18 & 23.96 & 23.37 & 3 & 1612.9474 & 1612.9333 & 538.6517 & 0.0141 & 8.1734 & 9675.725 & 4463.284 & 4699.613 & 538.027\end{array}$ $\begin{array}{llllllllllllll}1.00 & 31.78 & 24.87 & 21.05 & 4 & 1612.9369 & 1612.9333 & 404.2406 & 0.0036 & 2.2264 & 2245.110 & 2111.703 & 305.014\end{array}$ $\begin{array}{lllllllllllllll}1.00 & 25.95 & 21.99 & 38.95 & 4 & 1850.0929 & 1850.0923 & 463.5304 & 0.0006 & 0.3236 & 8993.294 & 10835.003 & 2779.909 & 42\end{array}$ $\begin{array}{lllllllllllllll}1.00 & 23.14 & 21.82 & 36.14 & 4 & 1850.0933 & 1850.0923 & 463.5304 & 0.0010 & 0.5393 & 5944.621 & 7416.894 & 1302.972 & & \\ 1.00 & 39.90 & 21.27 & 15.68 & 4 & 1850.0949 & 1850.0923 & 463.5304 & 0.0026 & 1.4023 & 1564541 & 1744.418 & 523.336 & & \\ \end{array}$ $\begin{array}{llllllllllllll}\text { NEVTLEFHQNDDAEVSLMEVR } & 1.00 & 40.94 & 26.62 & 16.29 & 3 & 2618.2477 & 2618.2404 & 873.7541 & 0.0073 & 2.7849 & 17.744 & 25.965 & 14.266\end{array}$

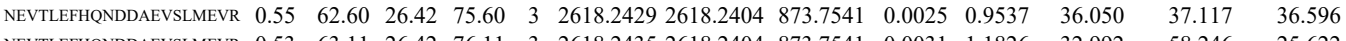
$\begin{array}{llllllllllllll}\text { NEVILEFHQNDDAEVSLMEVR } & 0.53 & 63.11 & 26.42 & 76.11 & 3 & 2618.2435 & 2618.2404 & 873.7541 & 0.0031 & 1.1826 & 32.992 & 58.246 & 25.622\end{array}$ $\begin{array}{llllllllllllll}\text { NEVILEFHQNDDAEVSLMEVR } & 1.00 & 51.95 & 26.39 & 18.80 & 3 & 2618.2441 & 2618.2404 & 873.7541 & 0.0037 & 1.4115 & 40.685 & 57.838 & 20.469\end{array}$

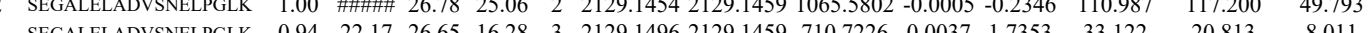

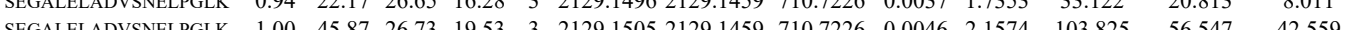

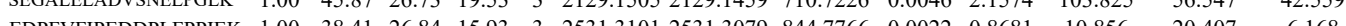
$\begin{array}{lllllllllllllll} & \text { EDAR }\end{array}$

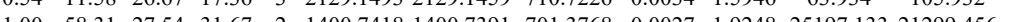

$\begin{array}{llllllllllllll}1.00 & 58.31 & 27.54 & 11.67 & 2 & 1400.7418 & 1400.7391 & 701.3768 & 0.0027 & 1.9248 & 63197.133 & 121299.456 & 3140.290 & 3\end{array}$ LSSETYSQAK

VLGEK

$\begin{array}{lllllllllllll}100 & 68.40 & 28.13 & 33.66 & 2 & 1393.7682 & 1393.7553 & 697.8849 & 0.0129 & 9.2421 & 4260.727 & 4696.704 & 396.403\end{array}$

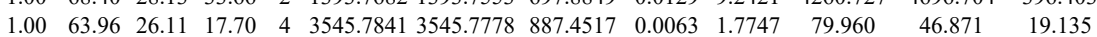

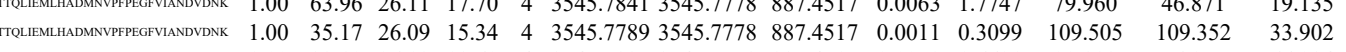

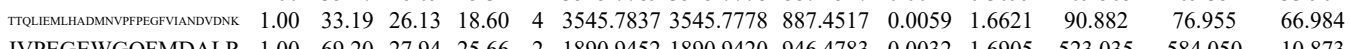

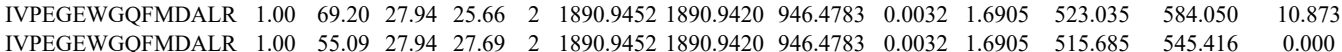

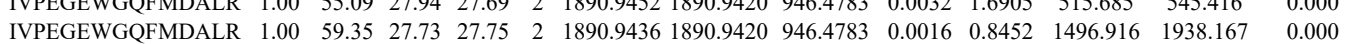

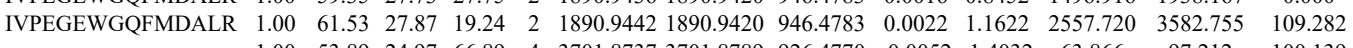

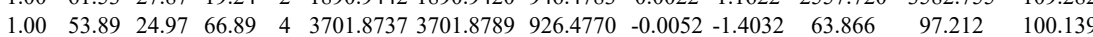

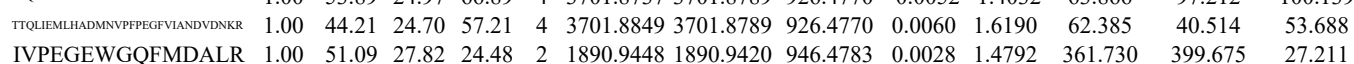

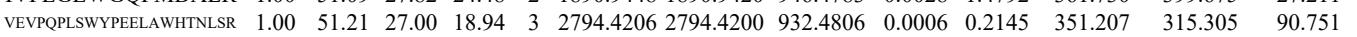
$\begin{array}{llllllllllllll}\text { CYLLVHQAK } & 0.58 & 20.77 & 28.21 & 14.59 & 3 & 1407.7705 & 1407.7610 & 470.2609 & 0.0095 & 6.7338 & 21236.674 & 23700.270 & 674.199\end{array}$ $\begin{array}{llllllllllllll}\text { WMPGITQWK } & 1.00 & 44.03 & 28.27 & 20.68 & 2 & 1433.7754 & 1433.7733 & 717.8939 & 0.0021 & 1.4626 & 2094.212 & 2620.849 & 0.000\end{array}$ $\begin{array}{llllllllllllll}\text { WMPGITQWK } & 0.99 & 46.61 & 28.53 & 22.25 & 2 & 1433.7728 & 1433.7733 & 717.8939 & -0.0005 & -0.3482 & 6936.698 & 7699.188 & 0.000\end{array}$ $\begin{array}{llllllllllllll}\text { WMPGITQWK } & 0.99 & 41.02 & 28.48 & 18.36 & 2 & 1433.7732 & 1433.7733 & 717.8939 & -0.0001 & -0.0696 & 5250.012 & 5807.328 & 0.000 \\ \text { ILLTQENPFFR } & 1.00 & 62.49 & 27.28 & 25.64 & 2 & 1520.8480 & 1520.8473 & 761.4309 & 0.0007 & 0.4597 & 5302.161 & 6911.999 & 0.000\end{array}$ ILLTQENPFR ILLTQENPFFR ILLTQENTR ILLTQENPFFR
ILLTQENPFFR $\begin{array}{lllllllllllll}1.00 & 61.67 & 27.21 & 20.88 & 2 & 1520.8486 & 1520.8473 & 761.4309 & 0.0013 & 0.8537 & 8746.568 & 10771.933 & 444.425\end{array}$ $\begin{array}{llllllllllllll}1.00 & 68.43 & 27.28 & 25.78 & 2 & 1520.8478 & 1520.8473 & 761.4309 & 0.0005 & 0.3283 & 15500.325 & 15988.440 & 392.760 & 0\end{array}$ $\begin{array}{lllllllllllll}1.00 & 66.03 & 27.25 & 23.59 & 2 & 1520.8484 & 1520.8473 & 761.4309 & 0.0011 & 0.7223 & 11744.711 & 13553.023 & 436.726\end{array}$

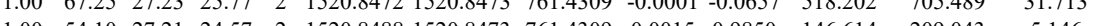
ILLTQENPFFR $\begin{array}{lllllllllllll}1.00 & 54.10 & 27.21 & 24.57 & 2 & 1520.8488 & 1520.8473 & 761.4309 & 0.0015 & 0.9850 & 146.614 & 209.043 & 5.146\end{array}$ $\begin{array}{lllllllllllllll}\text { WTTLNSLQLHGLQLR } & 1.00 & 87.03 & 24.90 & 18.74 & 3 & 1923.0829 & 1923.0812 & 642.0343 & 0.0017 & 0.8826 & 369.194 & 503.305 & 55.410 & 44.8914\end{array}$

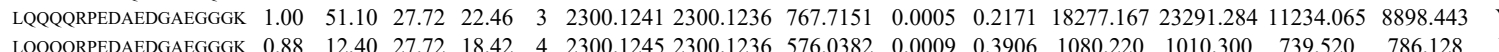

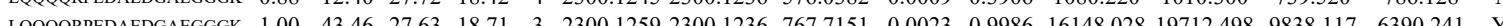
$\begin{array}{lllllllllllllllll}\text { EDPPFVIPEDDPLFPPIEK } & 1.00 & 54.73 & 26.82 & 19.15 & 2 & 2531.3114 & 2531.3079 & 1266.6612 & 0.0035 & 1.3816 & 8.597 & 4.095 & 6.001 & 0.000 & \text { No }\end{array}$ 

$\begin{array}{llllllllllll}0.61 & 13.92 & 28.02 & 24.00 & 3 & 1526.8210 & 1526.8184 & 509.9467 & 0.0026 & 1.6995 & 10.048\end{array}$

$\begin{array}{lllllllllllll}0.84 & 42.11 & 26.75 & 46.54 & 2 & 1072.6460 & 1072.6372 & 537.3259 & 0.0088 & 8.1886 & 2754.574 & 3021.714\end{array}$ $\begin{array}{lllllllllllllll}0.75 & 62.17 * 26.94 & 37.90 & 2 & 1230.7158 & 1230.7063 & 616.3604 & 0.0095 & 7.7065 & 2532.268 & 2937.858 & 3385.717 & 2895.700 & \text { Yes }\end{array}$

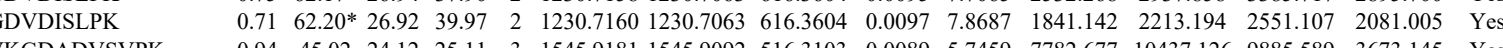

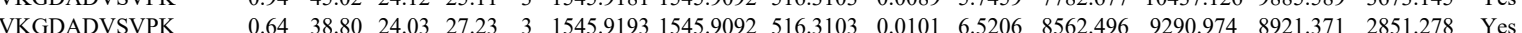

$\begin{array}{llllllllllllllll}\text { KEGDADVSVPK } & 0.64 & 38.80 & 24.03 & 27.23 & 3 & 1545.9193 & 1545.962 & 16.31 & 0.0101 & 6.5206 & 8562.496 & 9290.974 & 8921.371 & 2851.278 & \text { Yes } \\ \text { GEGPDVHMTLPK } & 1.00 & 45.25 & 27.75 & 21.45 & 3 & 1567.8397 & 1567.8272 & 523.6163 & 0.0125 & 7.9574 & 1488.194 & 1523.038 & 2632575 & 2032.862 & \text { Yes }\end{array}$

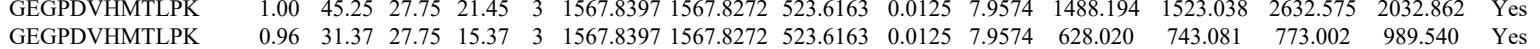

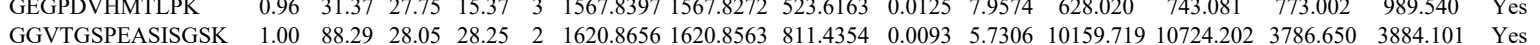

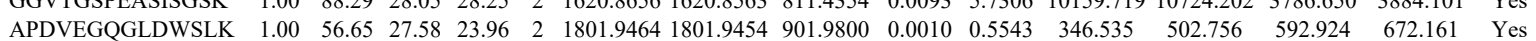
$\begin{array}{llllllllllllllll}\text { APDVEGQGLDWSLK } & 1.00 & 59.00 & 27.54 & 19.04 & 2 & 1801.9478 & 1801.9454 & 901.9800 & 0.0024 & 1.3304 & 366.960 & 422.022 & 709.432 & 506.398 & \text { Yes }\end{array}$ $\begin{array}{llllllllllllllll}\text { APDVDVNIAGPDAALK } & 0.61 & 86.33 & 27.68 & 99.33 & 2 & 1853.0140 & 1853.0138 & 927.5142 & 0.0002 & 0.1078 & 244.016 & 228.972 & 651.103 & 656.719 & \text { Yes }\end{array}$ $\begin{array}{llllllllllllllll}\text { VDIDAPDVDVHGPDWHLK } & 1.00 & 53.17 & 27.36 & 21.39 & 4 & 2315.1829 & 2315.1790 & 579.8020 & 0.0039 & 1.6816 & 6758.556 & 9507.014 & 1775.795 & 117.166 & \text { No }\end{array}$ $\begin{array}{lllllllllllllllllll}\text { VDIDAPDVDVHGPDWHLK } & 1.00 & 55.59 & 27.46 & 17.36 & 4 & 2315.1841 & 2315.1790 & 579.8020 & 0.0051 & 2.1990 & 10300.702 & 15448.833 & 682.596 & 411.813 & \text { No }\end{array}$ $\begin{array}{llllllllllllllllll}\text { AEAPLPSP } & 0.93 & 33.87 & 26.11 & 22.31 & 2 & 1196.7078 & 1196.7008 & 599.3577 & 0.0070 & 5.8396 & 5440.326 & 8404.692 & 9719.807 & 8138.181 & \text { Yes }\end{array}$ $\begin{array}{lllllllllllllllll}\text { GEGPDVHMTLPK } & 0.95 & 30.29 & 27.71 & 18.62 & 3 & 1567.8403 & 1567.8272 & 523.6163 & 0.0131 & 8.3394 & 1560.218 & 1783.869 & 2502.291 & 1935.620 & \text { Yes }\end{array}$

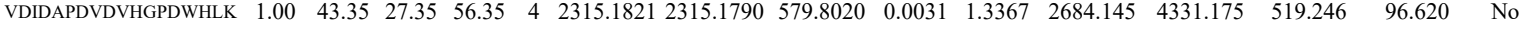
$\begin{array}{llllllllllllllll}\text { VDIDAPDVDVHGPDWHLK } & 1.00 & 36.17 & 27.34 & 16.07 & 4 & 2315.1825 & 2315.1790 & 579.8020 & 0.0035 & 1.5091 & 1884.848 & 2439.939 & 260.853 & 64.514 & \text { No }\end{array}$

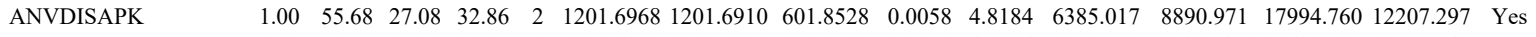

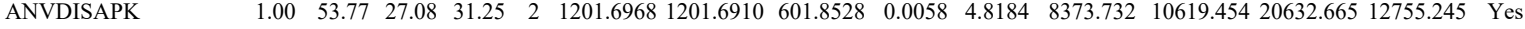
$\begin{array}{llllllllllllllll}\text { KPDIDITGPK } & 1.00 & 52.33 & 23.56 & 33.32 & 2 & 1514.9126 & 1514.9034 & 758.4590 & 0.0092 & 6.0649 & 842.736 & 1134.620 & 1899.399 & 1919.576 & \text { Yes }\end{array}$ $\begin{array}{lllllllllllllllll}\text { KPDIDITGPK } & 1.00 & 41.73 & 23.34 & 23.07 & 3 & 1514.9146 & 1514.9034 & 505.9751 & 0.0112 & 7.3784 & 6496.970 & 7128.519 & 8009.458 & 6184.558 & \text { Yes }\end{array}$

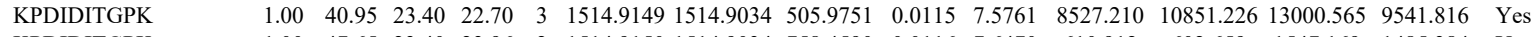

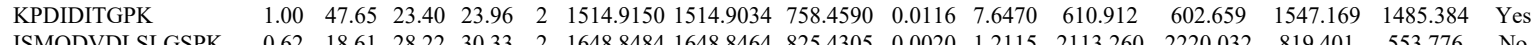
$\begin{array}{lccccccccccccccc}\text { ISMQDVDLSLGSPK } & 0.62 & 18.61 & 28.22 & 30.33 & 2 & 1648.8484 & 1648.8464 & 825.4305 & 0.0020 & 1.2115 & 2113.260 & 2220.032 & 819.401 & 553.776 & \text { No } \\ \text { VSVGAPDSLEASEGSI } & 1.00 & 94.79 & 26.31 & 24.05 & 2 & 2046.1094 & 2046.1088 & 1024.0617 & 0.0006 & 0.2930 & 44.800 & 33.125 & 118.705 & 35.275 & \text { No }\end{array}$ $\begin{array}{llllllllllllllll}\text { VSVGAPDLSLEASEGSIK } & 1.00 & 94.79 & 26.31 & 24.05 & 2 & 2046.1094 & 2046.1088 & 1024.0617 & 0.0006 & 0.2930 & 44.800 & 33.125 & 118.705 & 35.275 & \text { No } \\ \text { VSVGAPDLSLEASEGSIK } & 1.00 & 97.34 & 26.31 & 20.63 & 2 & 2046.1094 & 2046.1088 & 1024.0617 & 0.0006 & 0.2930 & 17.126 & 69.089 & 90.278 & 46.114 & \text { Yos }\end{array}$

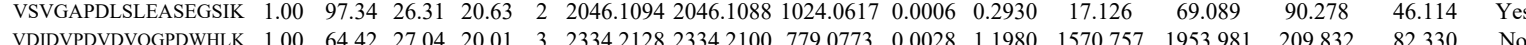

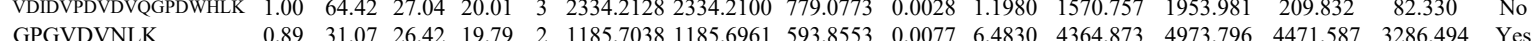
$\begin{array}{llllllllllllllll}\text { GPGVDVNLK } & 0.89 & 31.07 & 26.42 & 19.79 & 2 & 1185.7038 & 1185.6961 & 593.8553 & 0.0077 & 6.4830 & 4364.873 & 4973.796 & 4471.587 & 3286.494 & \text { Yes } \\ \text { GPGVDVNLK } & 0.84 & 27.27 & 26.37 & 18.71 & 2 & 1185.7058 & 1185.6961 & 593.8553 & 0.0097 & 8.1669 & 3273.771 & 3495.286 & 3133.174 & 2440.321 & \text { Yes }\end{array}$

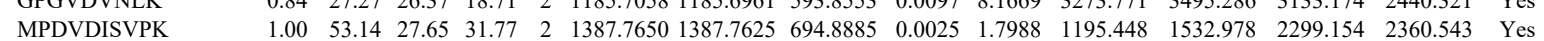

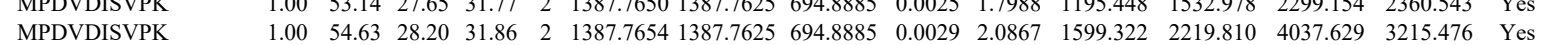




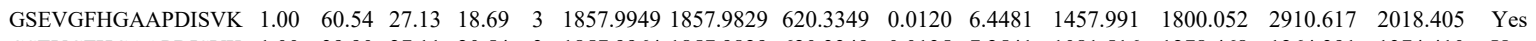
$\begin{array}{lllllllllllllllll} & \text { GSEVGFHGAAPDISVK } & 1.00 & 39.90 & 27.11 & 20.54 & 3 & 1857.9964 & 1857.9829 & 620.3349 & 0.0135 & 7.2541 & 1081.516 & 1278.468 & 1264.391 & 1374.410 & \text { Yes }\end{array}$ $\begin{array}{llllllllllllllll}\text { AGAISASGPELQGAGHSK } & 1.00 & 85.61 & 27.25 & 20.79 & 3 & 1925.0230 & 1925.0210 & 642.6809 & 0.0020 & 1.0373 & 2698.675 & 3599.931 & 8013.917 & 5360.785 & \text { Yes }\end{array}$ $\begin{array}{lllllllllllllllll}\text { AGAISASGPELQGAGHSK } & 1.00 & 91.51 & 27.22 & 23.65 & 3 & 1925.0239 & 1925.0210 & 642.6809 & 0.0029 & 1.5041 & 3026.023 & 4720.720 & 8482.418 & 4727.806 & \text { Yes }\end{array}$

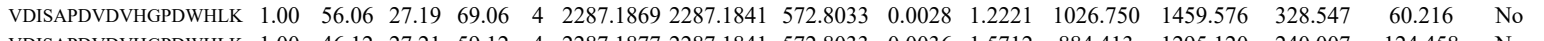

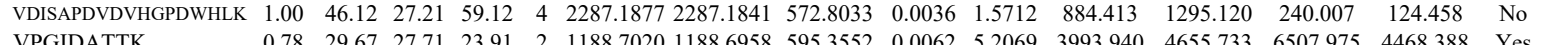
$\begin{array}{llllllllllllllll}\text { VPGIDATTK } & 0.78 & 29.67 & 27.71 & 23.91 & 2 & 1188.7020 & 1188.6958 & 595.3552 & 0.0062 & 5.2069 & 3993.940 & 4655.733 & 6507.975 & 4468.388 & \text { Yes }\end{array}$

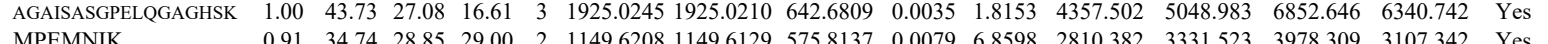

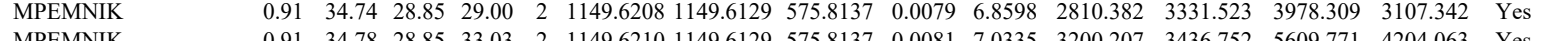
$\begin{array}{llllllllllllllll}0.91 & 34.78 & 28.85 & 33.03 & 2 & 1149.6210 & 1149.6129 & 575.8137 & 0.0081 & 7.0335 & 3200.207 & 3436.752 & 5609.771 & 4204.063 & \text { Yes }\end{array}$ $\begin{array}{lllllllllllllllll}\text { GDVVVSLPK } & 0.95 & 50.39 & 24.22 & 50.00 & 2 & 1200.7418 & 1200.7322 & 601.3734 & 0.0096 & 7.9817 & 1932.190 & 2194.395 & 1971.408 & 1718.134 & \text { Yes } \\ \text { VSAPEVSVGHK } & 0.99 & 30.96 & 26.59 & 18.03 & 3 & 13967932 & 1396.7918 & 466.6045 & 0.0014 & 1.0001 & 5496.843 & 5986.620 & 5814.885 & 1879.786 & \text { Yes }\end{array}$ $\begin{array}{lllllllllllllll} & \end{array}$

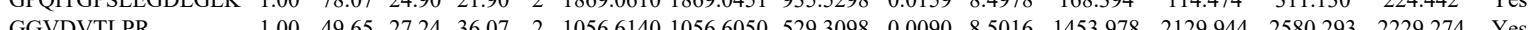

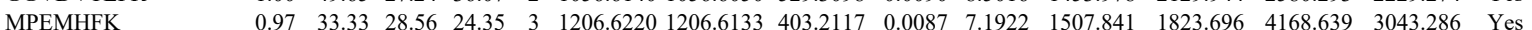

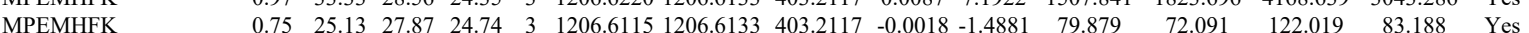

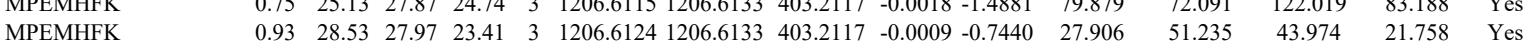

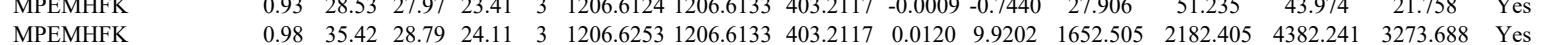

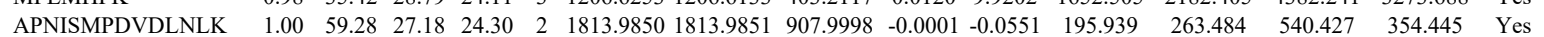

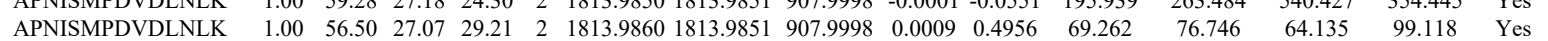

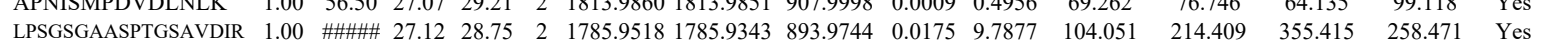
\begin{tabular}{lllllllllllllll} 
ISMPDIDLNLK & 0.80 & $35.14 * 26.79$ & 23.46 & 3 & 1545.8689 & 1545.8680 & 516.2966 & 0.0009 & 0.5811 & 102.226 & 114.753 & 67.410 & 38.513 & Yes \\
\hline
\end{tabular} $\begin{array}{llllllllllllllll}\text { ISMPDIDLNLK } & 0.98 & 62.40 * & 26.80 & 24.42 & 2 & 1545.8702 & 1545.8680 & 773.9413 & 0.0022 & 1.4213 & 646.064 & 826.324 & 279.177 & 0.000 & \text { No }\end{array}$ $\begin{array}{lllllllllllllll}\text { ISMPDIDLNLK } & 0.92 & 68.40 * 26.97 & 30.45 & 2 & 1545.8738 & 1545.8680 & 773.9413 & 0.0058 & 3.7470 & 671.143 & 1282.918 & 97.232 & 0.000 & \text { No }\end{array}$ $\begin{array}{lllllllllllllllll}\text { MPTFSTPGAK } & 0.97 & 36.86 & 27.66 & 22.32 & 2 & 1323.7196 & 1323.7101 & 662.8623 & 0.0095 & 7.1658 & 6211.399 & 7227.640 & 8479.677 & 7309.625 & \text { Yes }\end{array}$ MPTFSTPGAK $\begin{array}{llllllllllllllll}1.00 & 48.73 & 27.66 & 24.15 & 2 & 1323.7196 & 1323.7101 & 662.8623 & 0.0095 & 7.1658 & 7128.069 & 7031.790 & 9801.404 & 6343.460 & \text { Yes }\end{array}$ $\begin{array}{lllllllllllllll}1.00 & 60.62 & 24.53 & 73.62 & 4 & 4073.0829 & 4073.0772 & 1019.2766 & 0.0057 & 1.3980 & 43.133 & 62.219 & 72.792 & 42.092 & \text { Yes }\end{array}$

IGIPGVK

GPTVGGLPGIGVQGLEGLLQMP
GEGPDVDVNLPK

GEGPEVDVNLPK

FPTGGGLGGGVQ

FSMPGFK

FSMPGFK

FSMPGK

MPFLSISSPK

TTFSGR

FTFSGR

FTFSGR

GPEVDIEGPEGK

GDVDVSVPEVEGK

GEIDASVPELEGDLR

GEIDASVPELEGDLR $\begin{array}{llllllllllllll}\text { GEIDASVPELEGDLR } & 1.00 & 77.92 & 28.04 & 29.21 & 2 & 1742.8834 & 1742.8808 & 872.4477 & 0.0026 & 1.4901 & 137.279 & 121.4 \\ \text { GDVDVSLPEVEGEMK } & 1.00 & 61.58 & 27.76 & 21.80 & 2 & 1890.9498 & 1890.9488 & 946.4817 & 0.0010 & 0.5283 & 54.156 & 2.4\end{array}$ $\begin{array}{llllllllllllll}\text { GDVDVSLPEVEGEMK } & 0.97 & 24.67 & 27.73 & 23.44 & 3 & 1890.9508 & 1890.9488 & 631.3235 & 0.0020 & 1.0560 & 201.054 & 156 \\ \text { GDVDVSLPEVEGEMK } & 1.00 & 59.72 & 27.75 & 24.20 & 2 & 1890.9508 & 1890.9488 & 946.4817 & 0.0020 & 1.0565 & 2.057 & 48\end{array}$

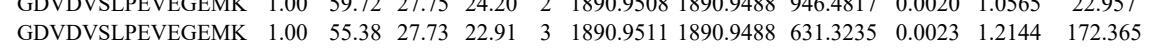
$\begin{array}{lllllllllllll}\text { VDIEGPDVNIEGPEGK } & 1.00 & 71.36 & 27.60 & 22.09 & 2 & 1955.0104 & 1955.0091 & 978.5118 & 0.0013 & 0.6643 & 257.883\end{array}$

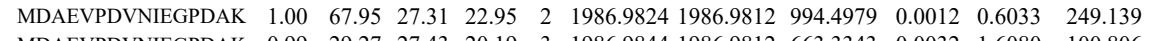
$\begin{array}{lllllllllllll}\text { MDAEVPDVNIEGPDAK } & 0.99 & 29.27 & 27.43 & 20.19 & 3 & 1986.9844 & 1986.9812 & 663.3343 & 0.0032 & 1.6080 & 100.806\end{array}$ ADIDVSGPSVDTDAPDLDIEGPEGK GDVDVSVPK GDVDVSVPK GDMDVSVPK GDMDVSVPK GEGPDVDVSLPK GEGPDVDVSLPK GEGPDVDVTLPK GEGPDVDVTLPK GEGPDVDVNLPK GEGPVDDNLK GEGPEDDNTR $\begin{array}{lllllllllllll}0.79 & 24.79 & 22.36 & 29.16 & 2 & 970.6486 & 970.6419 & 486.3282 & 0.0067 & 6.8883 & 427.982 & 77 & \\ 0.74 & 22.62 & 22.36 & 23.95 & 2 & 970.6494 & 970.6419 & 4863282 & 0.0075 & 7.7108 & 61.129 & 69 & \end{array}$ $\begin{array}{lllllllllllll}0.74 & 22.62 & 22.36 & 23.95 & 2 & 970.6494 & 970.6419 & 486.3282 & 0.0075 & 7.7108 & 611.129 & \\ 0.91 & 17.40 & 22.62 & 18.68 & 3 & 2733.5146 & 2733.5091 & 912.1770 & 0.0055 & 2.0098 & 98.827 & & \\ 0.95 & 25.02 & 27.82 & 23.34 & 3 & 1526.8237 & 1526.818 & 50.9467 & 0.053 & 3.64 & 14.28 & \end{array}$ $\begin{array}{lllllllllll}0.95 & 25.02 & 27.82 & 23.34 & 3 & 1526.8237 & 1526.8184 & 509.9467 & 0.0053 & 3.4644 & 14.128\end{array}$ $\begin{array}{llllllllllll}1.00 & 33.43 & 27.69 & 18.62 & 3 & 1540.8355 & 1540.8341 & 514.6186 & 0.0014 & 0.9068 & 19.823 \\ 1.00 & 28.47 & 22.48 & 15.14 & 3 & 2733.5137 & 2733.5091 & 912.1770 & 0.0046 & 1.6810 & 78.857\end{array}$ $\begin{array}{llllllllllll}15.14 & 3 & 2733.5137 & 2733.5091 & 912.1770 & 0.0046 & 1.6810 & 78.857 & 107.656 & 50.019 & 63.227 & \text { Yes }\end{array}$ $\begin{array}{llllllllllllllll}0.81 & 21.80 & 26.84 & 21.24 & 2 & 1100.5940 & 1100.5932 & 551.3039 & 0.0008 & 0.7256 & 465.114 & 476.828 & 72.675 & 44.688 & \text { No }\end{array}$

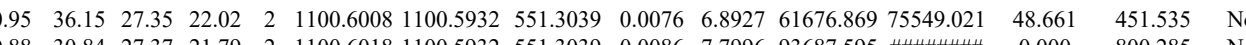

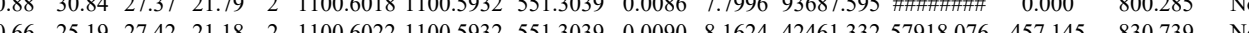

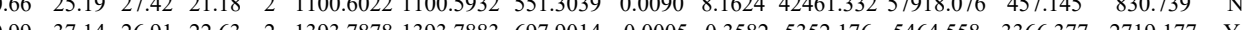
$\begin{array}{llllllllllllllll}1.00 & 63.18 & 26.78 & 22.82 & 2 & 1393.7904 & 1393.7883 & 697.9014 & 0.0021 & 1.5045 & 1867.801 & 20400.026 & 3479.550 & 2316.017 & \text { Yes }\end{array}$

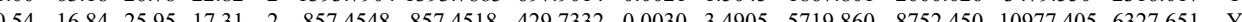
$\begin{array}{llllllllllllllll}0.79 & 21.77 & 25.95 & 20.43 & 2 & 857.4546 & 857.4518 & 429.7332 & 0.0028 & 3.4578 & 8339.742 & 11499.189 & 15588 & 221 & 11040.544 & \text { Yes }\end{array}$ $\begin{array}{lllllllllllllll}0.78 & 21.51 & 25.95 & 20.13 & 2 & 857.4546 & 857.4518 & 429.7332 & 0.0028 & 3.2578 & 10031.705 & 15083.975 & 21340.355 & 11877.057 & \text { Yes }\end{array}$

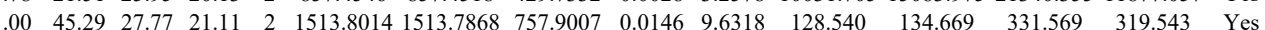

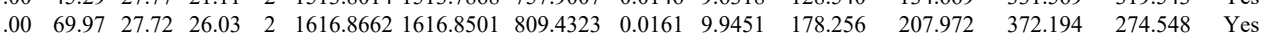
\begin{tabular}{llllllllllllllll}
1.00 & 81.26 & 28.03 & 25.77 & 2 & 1742.8820 & 1742.8808 & 872.4477 & 0.0012 & 0.6877 & 220.281 & 393.887 & 788.952 & 802.818 & Yes \\
\hline
\end{tabular} $\begin{array}{lllllllllllll}6 & \end{array}$

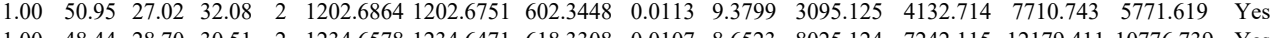

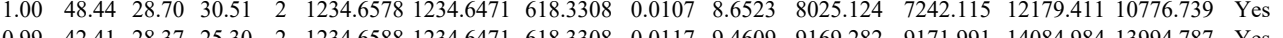
$\begin{array}{llllllllllllllll}0.99 & 42.41 & 28.37 & 25.30 & 2 & 1234.6588 & 1234.6471 & 618.3308 & 0.0117 & 9.4609 & 9169.282 & 9171.991 & 14084.984 & 13994.787 & \text { Yes }\end{array}$ $\begin{array}{llllllllllllllll}1.00 & 53.76 & 27.35 & 30.81 & 2 & 1499.8216 & 1499.8075 & 750.9110 & 0.0141 & 9.3885 & 354.371 & 375.097 & 980.920 & 550.412 & \text { Yes }\end{array}$ $\begin{array}{lllllllllllllll}1.00 & 64.54 & 27.35 & 33.30 & 2 & 1499.8216 & 1499.8075 & 750.9110 & 0.0141 & 9.3885 & 472.315 & 611.553 & 889.121 & 763.396 & \text { Yes } \\ 1.00 & 51.38 & 27.15 & 32.31 & 2 & 15138380 & 1513.8232 & 757.9189 & 0.0148 & 9.7635 & 185.68 & 270.625 & 306.604 & 424.948 & \text { Yes }\end{array}$ $\begin{array}{lllllllllllllll}1.00 & 51.38 & 27.15 & 32.31 & 2 & 1513.8380 & 1513.8232 & 757.9189 & 0.0148 & 9.7635 & 185.368 & 270.625 & 306.604 & 424.948 & \text { Yes } \\ 1.00 & 54.88 & 27.15 & 28.78 & 2 & 1513.8380 & 1513.8232 & 757.9189 & 0.0148 & 9.7635 & 102.680 & 100.727 & 547.903 & 319.785 & \text { No }\end{array}$

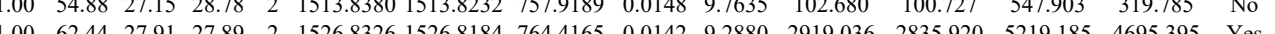
$\begin{array}{lllllllllllllll}1.00 & 62.44 & 27.91 & 27.89 & 2 & 1526.8326 & 1526.8184 & 764.4165 & 0.0142 & 9.2880 & 2919.036 & 2835.920 & 5219.185 & 4695.395 & \text { Yes } \\ 1.00 & 58.77 & 27.83 & 29.34 & 2 & 15268332 & 15268184 & 764.4165 & 0.0148 & 9.6805 & 248.040 & 179.834 & 211.584 & 239.911 & \text { Yes }\end{array}$

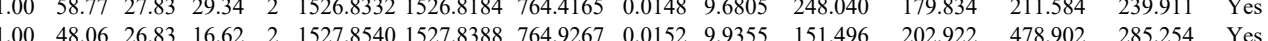
$\begin{array}{llllllllllllllll}1.00 & 75.06 & 27.83 & 30.34 & 2 & 1570.8492 & 1540.8341 & 771.4243 & 0.0151 & 9.7870 & 5117.445 & 5060363 & 11500.589 & 8915.835 & \text { Y }\end{array}$ $\begin{array}{lllllllllllllll}1.00 & 75.14 & 27.39 & 31.09 & 2 & 1540.8492 & 1540.8341 & 771.4243 & 0.0151 & 9.7870 & 4006.651 & 6822.760 & 17054.733 & 14142.343 & \text { Yes }\end{array}$ 
$\begin{array}{llllllllllll}\text { GDVPSVGLEGPDVDLQGPEAK } & 0.55 & 13.65 & 27.17 & 16.95 & 3 & 2366.2225 & 2366.2209 & 789.7476 & 0.0016 & 0.6753 & 40.095 \\ \text { VPDVDDIK } & 0.86 & 39.22 & 26.70 & 43.99 & 2 & 1072.6468 & 1072.6372 & 537.3259 & 0.0096 & 8.9330 & 2882.432\end{array}$

ADIDVSGPK

GDVDVSVPK

$\begin{array}{llllllllllll}0.86 & 39.22 & 26.70 & 43.99 & 2 & 1072.6468 & 1072.6372 & 537.3259 & 0.0096 & 8.9330 & 2882.432\end{array}$

$\begin{array}{lllllll} & \end{array}$

DVDVSLPK $\begin{array}{llllllllllll}0.97 & 43.65 & 27.62 & 39.25 & 2 & 1202.6838 & 1202.6751 & 602.3448 & 0.0087 & 7.2217 & 2417.840 & 3219.701\end{array}$ $\begin{array}{lllllllllllllll}1.00 & 53.51 & 27.95 & 32.07 & 2 & 1216.7014 & 1216.6907 & 609.3526 & 0.0107 & 8.7797 & 3211.281 & 3102.448 & 2987.258 & 2539.512 & \text { Yes }\end{array}$

GDMDVSVPK $\begin{array}{llllllllllllllll}1.00 & 53.71 & 27.95 & 26.39 & 2 & 1216.7016 & 1216.6907 & 609.3526 & 0.0109 & 8.9438 & 4489.068 & 6554.100 & 7853.209 & 6202.636 & \text { Yes } & \\ \end{array}$

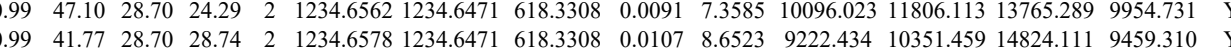

GEGPEVDVNLPK

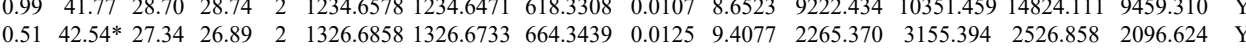

$\begin{array}{llllllllllllllll}0.92 & 40.54 & 26.61 & 42.51 & 2 & 1497.8428 & 1497.8282 & 749.9214 & 0.0146 & 9.7343 & 383.111 & 425.192 & 786.557 & 344.686 & \text { Yes } \\ 1.00 & 56.00 & 27.33 & 22.59 & 2 & 1540.8488 & 1540.8341 & 771.4243 & 0.0147 & 9.5277 & 471.636 & 845.898 & 1609.310 & 1179.954 & \text { Yes }\end{array}$

AEGPEVDVNLPK

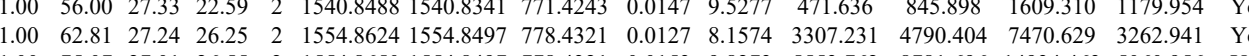
$\begin{array}{llllllllllllll} & \\ \end{array}$ $\begin{array}{lllllllllllllllll} & \end{array}$ $\begin{array}{llllllllllllllll} & \end{array}$

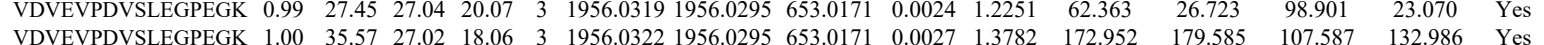

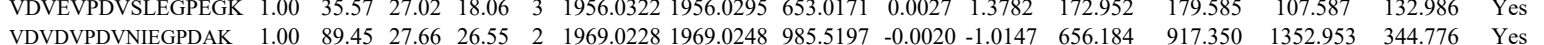

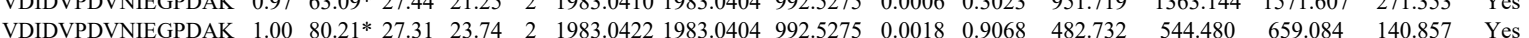

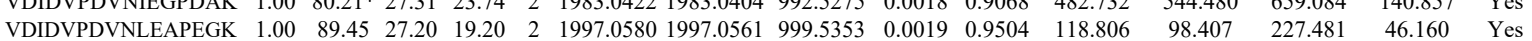

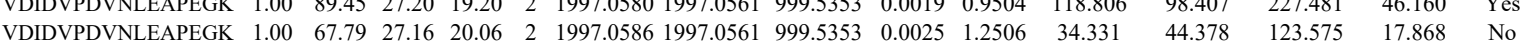

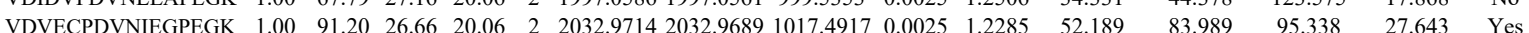

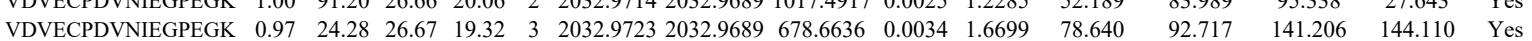
$\begin{array}{llllllllllllllll}\text { GPFVEAEVPDVDLECPDAK } & 1.00 & 63.94 & 27.05 & 18.49 & 2 & 2363.1274 & 2363.1269 & 1182.5707 & 0.0005 & 0.2114 & 7.178 & 38.477 & 72.400 & 38.492 & \text { Yes }\end{array}$ $\begin{array}{llllllllllllllll}\text { GDVDVSLPK } & 0.87 & 27.48 & 27.62 & 26.46 & 3 & 1216.7008 & 1216.6907 & 406.5708 & 0.0101 & 8.2806 & 310.632 & 362.483 & 257.351 & 168.316 & \text { Yes }\end{array}$

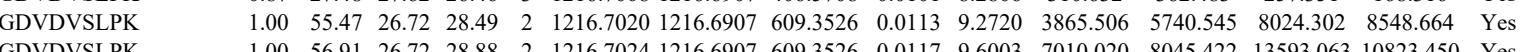

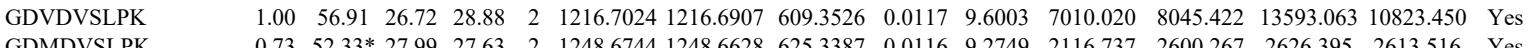
$\begin{array}{lllllllllllllll} & & & \end{array}$ $\begin{array}{lllllllllllllllll}\text { VEGPEVDVNLPK } & 1.00 & 60.20 & 27.26 & 27.20 & 2 & 1554.8642 & 1554.8497 & 778.4321 & 0.0145 & 9.3135 & 394.878 & 522.713 & 738.896 & 377.276 & \text { Yes } \\ \text { VGIDTPDIDIHGPEGK } & 0.53 & 53.23 & 27.40 & 66.23 & 3 & 1950.0334 & 1950.0302 & 651.0173 & 0.0032 & 1.6385 & 2721.849 & 4011.058 & 1865.945 & 279.478 & \text { Yes }\end{array}$ $\begin{array}{llllllllllllllll}\text { VGIDTPDIDIHGPEGK } & 1.00 & 70.56 & 27.44 & 19.16 & 3 & 1950.0340 & 1950.0302 & 651.0173 & 0.0038 & 1.9457 & 2482.933 & 3583.012 & 1473.671 & 140.572 & \text { No }\end{array}$ $\begin{array}{lllllllllllllllll}\text { VDVEVPDVSLEGPEGK } & 1.00 & 95.28 & 27.20 & 42.51 & 2 & 1956.0298 & 1956.0295 & 979.0220 & 0.0003 & 0.1532 & 74.658 & 67.257 & 139.054 & 60.442 & \text { Yes }\end{array}$ $\begin{array}{llllllllllllllllll}\text { DDGVFVQEVTQNSPAAR } & 1.00 & 74.43 & 27.79 & 27.25 & 3 & 1975.9762 & 1975.9721 & 659.6646 & 0.0041 & 2.0718 & 396.099 & 457.627 & 966.167 & 663.380 & \text { Yes }\end{array}$ $\begin{array}{llllllllllllllllll}\text { VDIDVPDVNLEAPEGK } & 1.00 & 63.13 & 27.20 & 17.68 & 2 & 1997.0566 & 1997.0561 & 999.5353 & 0.0005 & 0.2501 & 65.021 & 77.843 & 55.010 & 5.761 & \text { Yes }\end{array}$ $\begin{array}{lllllllllllllllll}\text { VDIDVPDVNLEAPEGK } & 0.53 & 34.83 & 27.15 & 47.83 & 3 & 1997.0587 & 1997.0561 & 666.6926 & 0.0026 & 1.2999 & 351.424 & 467.504 & 1105.456 & 705.833 & \text { Yes }\end{array}$ $\begin{array}{lllllllllllllllll}\text { GPFVEAEVPDVDLECPDAK } & 0.80 & 16.61 & 27.06 & 14.83 & 3 & 2363.1301 & 2363.1269 & 788.7162 & 0.0032 & 1.3524 & 41.513 & 33.677 & 32.026 & 27.634 & \text { Yes }\end{array}$ $\begin{array}{llllllllllllllll}\text { GPFVEAEVPDVDLECPDAK } & 1.00 & 49.52 & 27.08 & 16.43 & 3 & 2363.1313 & 2363.1269 & 788.7162 & 0.0044 & 1.8596 & 6.593 & 24.641 & 18.402 & 9.359 & \text { Yes }\end{array}$ FELLCSPLFNK VVLCGGSSR FTVLFPSGTPLPAR $\begin{array}{llllllllllll}1.00 & 37.51 & 28.11 & 22.27 & 3 & 1643.8699 & 1643.8659 & 548.9626 & 0.0040 & 2.4288 & 141.148\end{array}$ $\begin{array}{lllllllllllll} & \end{array}$ TTVLSTLAR

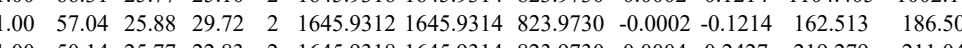
TVLFPSGTPLPAR $\begin{array}{llllllllllll}1.00 & 50.14 & 25.77 & 22.83 & 2 & 1645.9318 & 1645.9314 & 823.9730 & 0.0004 & 0.2427 & 219.279\end{array}$

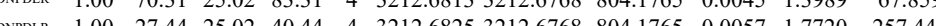

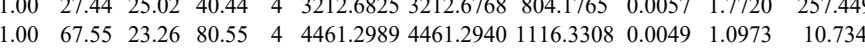

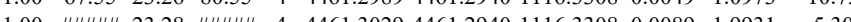



$\begin{array}{lllllllllllll}\text { GLDTVVALLADVVLQPR } & 0.53 & 63.22 & 20.04 & 76.22 & 3 & 1922.1355 & 1922.1323 & 641.7180 & 0.0032 & 1.6622 & 51.627\end{array}$ $\begin{array}{llllllllllllll}\text { GLDTVVALLADVVLOPR } & 1.00 & 80.34 & 20.53 & 24.71 & 3 & 1922.1367 & 1922.1323 & 641.7180 & 0.0044 & 2.2855 & 34.108\end{array}$ $\begin{array}{lllllllllllll}\text { GLDTVVALADVVLOPR } & 1.00 & 42.15 & 20.45 & 18.98 & 3 & 1922.1370 & 1922.1323 & 641.7180 & 0.0047 & 2.4414 & 55.231\end{array}$

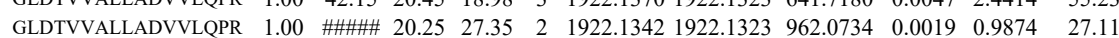
$\begin{array}{llllllllllll}\text { GLDTVVALLADVVLQPR } & 1.00 & \text { \#\#\#\# } 20.00 & 24.73 & 2 & 1922.1346 & 1922.1323 & 962.0734 & 0.0023 & 1.1953 & 45.392\end{array}$ $\begin{array}{llllllllllll}\text { GLDTVVALLADVVLQPR } & 1.00 & 43.31 & 20.04 & 24.48 & 3 & 1922.1355 & 1922.1323 & 641.7180 & 0.0032 & 1.6622 & 46.435\end{array}$ $\begin{array}{llllllllllllll}\text { GLDTVVALLADVVLQPR } & 1.00 & 46.33 & 20.13 & 23.77 & 3 & 1922.1364 & 1922.1323 & 641.7180 & 0.0041 & 2.1297 & 52.795\end{array}$ $\begin{array}{llllllllllllll}\text { GLDTVVALLADVVLOPR } & 1.00 & 48.66 & 20.45 & 17.19 & 3 & 1922.1370 & 1922.1323 & 641.7180 & 0.0047 & 2.4414 & 62.31\end{array}$

$\begin{array}{lllllllllllll}\text { LGDAVIGGTGQLFQAQQDLLHR } & 0.55 & 80.51 & 26.12 & 93.51 & 3 & 2609.3854 & 2609.3836 & 870.8018 & 0.0018 & 0.6890 & 122.787\end{array}$

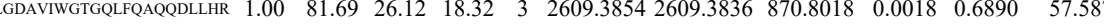
$\begin{array}{llllllllllll}\text { GFNPAQPLNIR } & 0.99 & 42.61 & 27.14 & 24.95 & 2 & 1369.7698 & 1369.7588 & 685.8867 & 0.0110 & 8.0188 & 6202.208\end{array}$ $\begin{array}{llllllllllll}\text { FVSSPQTIVELFFQEVAR } & 1.00 & 97.47 & 26.36 & 26.77 & 2 & 2240.1974 & 2240.1963 & 1121.1054 & 0.0011 & 0.4906 & 82.228 \\ \text { FVSSPQTIVELFFQEVAR } & 1.00 & 53.94 & 26.16 & 16.45 & 3 & 2240.2009 & 2240.1963 & 747.7394 & 0.0046 & 2.0506 & 6.688\end{array}$ $\begin{array}{llllllllllll}\text { FVSSPQTIVELFFQEVAR } & 1.00 & 90.16 & 26.15 & 25.41 & 2 & 2240.2014 & 2240.1963 & 1121.1054 & 0.0051 & 2.2745 & 116.851 \\ \text { FVSSPQTIVELFFOEVAR } & 0.99 & 36.29 & 26.15 & 25.87 & 3 & 2240.2021 & 2240.1963 & 747.7394 & 0.0058 & 2.5856 & 3.820\end{array}$ $\begin{array}{lllllllllllll}\text { FVSSPQTIVELFFQEVAR } & 0.99 & 36.29 & 26.15 & 25.87 & 3 & 2240.2021 & 2240.1963 & 747.7394 & 0.0058 & 2.5856 & 3.820\end{array}$ QGNCYLAALNCLR NPIHAIGLLIR NPIHAIGLLIR

LLTGWMPTAIR LLTGWMPTAIR NPIHAILLIR NPIHAIGLIR NPIHAIGLLIR

LLTGWMPTAIR LLTGWWPTAIR LLTGWMPTAIR VIILMLTNQTVHR VIILMLTNOTVHR VIILMLTNQTVHR VIILMLTNQTVHR VIILMLTNQTVHR VIILMLTNQTVHR VIILMLTNQTVHR VIILMLTNQTVHR VIILMLTNQTVHR $\begin{array}{lllllllllll}1.00 & 60.64 & 24.44 & 22.03 & 2 & 1673.7634 & 1673.7632 & 837.8889 & 0.0002 & 0.1193 & 9.454\end{array}$ $\begin{array}{lllllllllllll}1.00 & 42.27 & 21.30 & 24.37 & 3 & 1359.8476 & 1359.8472 & 454.2897 & 0.0004 & 0.2935 & 942.079 \\ 1.00 & 43.42 & 21.30 & 25.10 & 3 & 1359.8479 & 1359.8472 & 454.2897 & 0.0007 & 0.5136 & 1223.197\end{array}$ $\begin{array}{llllllllllll}1.00 & 43.42 & 21.30 & 25.10 & 3 & 1359.8479 & 1359.8472 & 454.2897 & 0.0007 & 0.5136 & 1223.197 & 1809.175\end{array}$

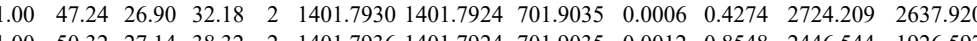

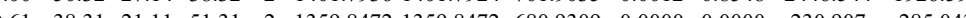
$\begin{array}{llllllllllll}1.00 & 39.37 & 21.30 & 23.33 & 3 & 1359.8476 & 13598472 & 4542897 & 0.0004 & 02935 & 230.945\end{array}$

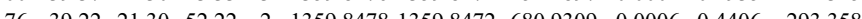
$\begin{array}{llllllllllllll}1.00 & 39.65 & 21.30 & 23.66 & 3 & 1359.8479 & 1359.8472 & 454.2897 & 0.0007 & 0.5136 & 202.298 & 3\end{array}$ $\begin{array}{lllllllllllll}1.00 & 49.54 & 27.14 & 33.93 & 2 & 1401.7938 & 1401.7924 & 701.9035 & 0.0014 & 0.9973 & 615.680\end{array}$ $\begin{array}{llllllllllll}1.00 & 48.26 & 27.19 & 35.37 & 2 & 1401.7944 & 1401.7924 & 701.9035 & 0.0020 & 1.4247 & 601.076\end{array}$ $\begin{array}{llllllllllll}1.00 & 70.09 & 22.83 & 22.10 & 2 & 1680.9840 & 1680.9831 & 841.4988 & 0.0009 & 0.5348 & 42.151\end{array}$ $\begin{array}{lllllllllll}1.00 & 74.27 & 22.83 & 19.91 & 3 & 1680.9841 & 1680.9831 & 561.3350 & 0.0010 & 0.5938 & 90.675\end{array}$ $\begin{array}{llllllllllll}1.00 & 68.69 & 22.88 & 24.73 & 3 & 1680.9853 & 1680.9831 & 561.3350 & 0.0022 & 1.3064 & 122.230\end{array}$ $\begin{array}{llllllllllll}1.00 & 34.75 & 24.65 & 26.24 & 3 & 1696.9789 & 1696.9780 & 566.6666 & 0.0009 & 0.5294 & 42.046\end{array}$ $\begin{array}{lllllllllll}1.00 & 71.24 & 22.65 & 24.86 & 2 & 1680.9838 & 1680.9831 & 841.4988 & 0.0007 & 0.4159 & 87.748\end{array}$ $\begin{array}{lllllllllllll}1.00 & 82.15 & 22.83 & 24.23 & 2 & 1680.9840 & 1680.9831 & 841.4988 & 0.0009 & 0.5348 & 99.573\end{array}$ $\begin{array}{llllllllllll}1.00 & 55.30 & 22.76 & 16.74 & 3 & 1680.9844 & 1680.9831 & 561.3350 & 0.0013 & 0.7720 & 128.054\end{array}$ $\begin{array}{lllllllllll}1.00 & 65.65 & 22.88 & 17.23 & 3 & 1680.9853 & 1680.9831 & 561.3350 & 0.0022 & 1.3064 & 154.28\end{array}$ $\begin{array}{lllllllllllll}1.00 & 37.73 & 24.65 & 20.37 & 3 & 1696.9789 & 1696.9780 & 566.6666 & 0.0009 & 0.5294 & 75.377 \\ 1.00 & 50.20 & 24.59 & 16.99 & 3 & 1696.9795 & 1696.9780 & 566.6666 & 0.0015 & 0.8824 & 77.045\end{array}$ $\begin{array}{lllllllllllll}1.00 & 50.20 & 24.59 & 16.99 & 3 & 1696.9795 & 1696.9780 & 566.6666 & 0.0015 & 0.8824 & 77.045\end{array}$

YLLSQSSPAPLTAAEEEL YLLSQSSPAPLTAAEEEIR
HQTLQGVAFPISR HQTLQGVAFPISR HQTLQGVAFPISR HQTLQGVAFPISR HQTLQGVAFPISR HQTLQGVAFPISR HQTLQGVAFPISR HQTLQGVAFPISR HQTLQGVAFPISR TQTLGVAFIS $\begin{array}{llllllllllll}1.00 & 94.88 & 27.08 & 23.26 & 2 & 2218.1634 & 2218.1603 & 1110.0874 & 0.0031 & 1.3963 & 147.395\end{array}$ $\begin{array}{lllllllllll}0.89 & 20.06 & 26.75 & 18.07 & 3 & 1596.8869 & 1596.8858 & 533.3025 & 0.0011 & 0.6875 & 1175.885 \\ 1.00 & 40.76 & 26.75 & 17.13 & 3 & 1596.8869 & 1596.8858 & 533.3025 & 0.0011 & 0.6875 & 828.538\end{array}$ $\begin{array}{lllllllllll}1.00 & 40.76 & 26.75 & 17.13 & 3 & 1596.8869 & 1596.8858 & 533.3025 & 0.0011 & 0.6875 & 828.538 \\ 0.97 & 25.84 & 26.75 & 16.54 & 3 & 1596.8869 & 1596.8858 & 533.3025 & 0.0011 & 0.6875 & 501.594\end{array}$ $\begin{array}{llllllllllllll}0.97 & 25.84 & 26.75 & 16.54 & 3 & 1596.8869 & 1596.8858 & 533.3025 & 0.0011 & 0.6875 & 501.594 \\ 0.97 & 27.53 & 26.93 & 16.74 & 3 & 1596.8860 & 1596.8858 & 533.3025 & 0.0002 & 0.1250 & 529.068\end{array}$ $\begin{array}{lllllllllllll}0.97 & 27.53 & 26.93 & 16.74 & 3 & 1596.8860 & 1596.8858 & 533.3025 & 0.0002 & 0.1250 & 529.068 \\ 0.98 & 28.77 & 26.93 & 17.06 & 3 & 1596.8860 & 1596.8858 & 533.3025 & 0.0002 & 0.1250 & 267.922\end{array}$ $\begin{array}{lllllllllllll}0.98 & 28.77 & 26.93 & 17.06 & 3 & 1596.8860 & 1596.8858 & 533.3025 & 0.0002 & 0.1250 & 267.922 \\ 0.96 & 26.19 & 26.93 & 17.98 & 3 & 1596.8860 & 1596.8858 & 533.3025 & 0.0002 & 0.1250 & 315.169\end{array}$ $\begin{array}{llllllllllll}0.96 & 26.19 & 26.93 & 17.98 & 3 & 1596.8860 & 1596.8858 & 533.3025 & 0.0002 & 0.1250 & 315.169 \\ 0.95 & 23.55 & 26.82 & 16.53 & 3 & 1596.8872 & 1596.8858 & 533.3025 & 0.0014 & 0.8750 & 126.123\end{array}$ $\begin{array}{lllllllllll}0.99 & 28.57 & 26.71 & 18.23 & 3 & 1596.8875 & 1596.8858 & 533.3025 & 0.0017 & 1.0626 & 134.106\end{array}$ $\begin{array}{lllllllllllll}1.00 & 33.90 & 26.82 & 23.07 & 3 & 1596.8872 & 1596.8858 & 533.3025 & 0.0014 & 0.8750 & 52.409\end{array}$

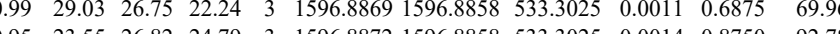
$\begin{array}{llllllllllll}0.96 & 25.42 & 26.75 & 25.95 & 3 & 1596.8869 & 1596.8858 & 533.3025 & 0.0011 & 0.6875 & 47.597\end{array}$ 
14 GAEADQIIEYLK

GAEADQIIEYLK

GAEADQIIEYLK

GAEADQIIEYLK

GAEADDQIIEYLK

QQSIAGSADSKPIDVSR

AILQATLR

AILQATLR

AILQATLR

IGCIITAR

MVILLCNLKPAK

MVILLCNLKPAK

$\begin{array}{llllllllllll}1.00 & 69.85 & 27.71 & 33.60 & 2 & 1636.8932 & 1636.8915 & 819.4530 & 0.0017 & 1.0373 & 3152.596 & 343\end{array}$

$\begin{array}{lllllllllllll}0.74 & 15.67 & 27.69 & 22.58 & 3 & 1636.8934 & 1636.8915 & 546.6378 & 0.0019 & 1.1586 & 124.753 & 140.101\end{array}$

$\begin{array}{lllllllllllll}1.00 & 91.70 & 27.69 & 29.43 & 2 & 1636.8938 & 1636.8915 & 819.4530 & 0.0023 & 1.4034 & 1038.434 & 794.853 & 371.989\end{array}$

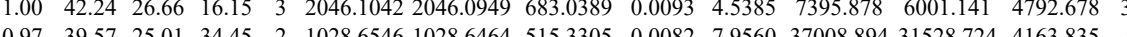

$\begin{array}{llllllllllllll}0.97 & 39.57 & 25.01 & 34.45 & 2 & 1028.6546 & 1028.6464 & 515.3305 & 0.0082 & 7.9560 & 37008.894 & 31528.724 & 4163.835 \\ 0.94 & 34.63 & 25.01 & 33.05 & 2 & 1028.6548 & 1028.6464 & 515.3305 & 0.0084 & 8.1500 & 21807.352 & 19736.472 & 2361.194 & 498\end{array}$

$\begin{array}{llllllllllllll}0.91 & 33.30 & 25.01 & 33.99 & 2 & 1028.6544 & 1028.6464 & 515.3305 & 0.0080 & 7.7619 & 25739.820 & 22872.947 & 2500.388\end{array}$

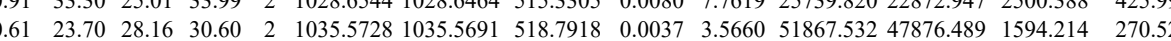
$\begin{array}{lllllllllllll}0.56 & 18.38 & 28.62 & 30.38 & 2 & 1035.5702 & 1035.5691 & 518.7918 & 0.0011 & 1.0602 & 118678.034 & 11528.971 & 281.660\end{array}$ $\begin{array}{lllllllllllll}0.99 & 38.41 & 28.02 & 25.66 & 2 & 1387.7752 & 1387.7753 & 694.8949 & -0.0001 & -0.0720 & 34.532 & 37.525 & 14.854\end{array}$

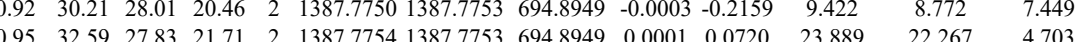

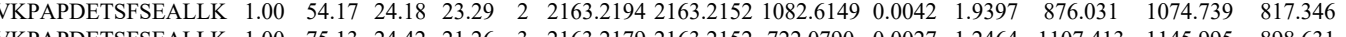
$\begin{array}{lllllllllllll} & \text { VRPAPR. }\end{array}$ $\begin{array}{lllllllll} & 0.154\end{array}$

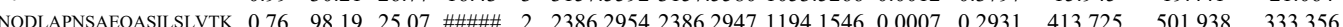

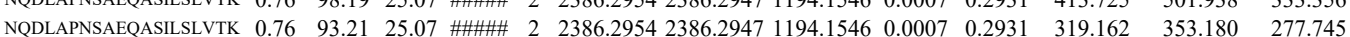

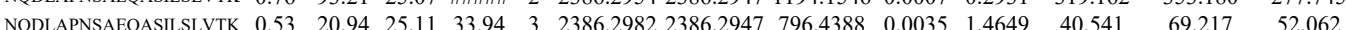
$\begin{array}{llllllllllllll}\text { NODLAPNSAEQASILSLVTK } & 1.00 & 42.58 & 25.12 & 19.54 & 3 & 2386.2985 & 2386.2947 & 796.4388 & 0.0038 & 1.5904 & 193.166 & 343.274 & 170.658\end{array}$ $\begin{array}{lllllllllllllll} & \text { N }\end{array}$

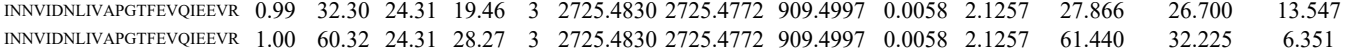

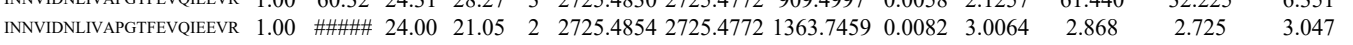
$\begin{array}{llllllllllllll}\text { ILPTLEAVAALGNK } & 1.00 & 41.66 & 19.29 & 18.47 & 3 & 1697.0350 & 1697.0331 & 566.6850 & 0.0019 & 1.1176 & 708.382 & 379.174 & 209.751\end{array}$ $\begin{array}{llllllllllllll}\text { ILPTLEAVAALGNK } & 1.00 & 87.82 & 19.29 & 27.07 & 2 & 1697.0350 & 1697.0331 & 849.5238 & 0.0019 & 1.1183 & 12349.169 & 13159.567 & 2968.480\end{array}$

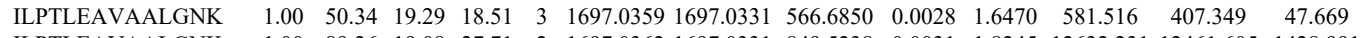
ILPTLEAVAALGNK ILPTLEAVAALGNK ILPTLEAVAALGNK ILPTLEAVAALGNK ILPTLEAVAALGNK QPLALNVAYR QPLALNVAYR QPLALNVAYR QPLALNVAYR QPLALNVAYR ILSHGGFR ILSHGGFR

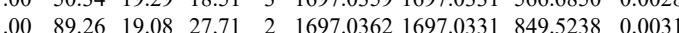
$\begin{array}{llllllllllllll}1.00 & 92.78 & 19.29 & 25.46 & 2 & 1697.0352 & 1697.0331 & 849.5238 & 0.0021 & 1.2360 & 1522.543 & 1371.467 & 229.670 & 0.0 \\ 1.00 & 4.82 & 19.29 & 22.28 & 3 & 1697.0359 & 1697.0331 & 5666850 & 0.0028 & 1.6470 & 296.583 & 282.840 & 219.163 & 95.25\end{array}$ $\begin{array}{llllllllllllll}1.00 & 48.82 & 19.29 & 22.28 & 3 & 1697.0359 & 1697.0331 & 566.6850 & 0.0028 & 1.6470 & 296.583 & 282.840 & 219.163 & 95.304 \\ 1.00 & 44.29 & 19.08 & 19.24 & 3 & 1697.0368 & 1697.0331 & 566.6850 & 0.0037 & 2.1764 & 315.548 & 339.554 & 117.615 & 47.425\end{array}$ $\left.\begin{array}{llllllllllllll}1.00 & 44.29 & 19.08 & 19.24 & 3 & 1697.0368 & 1697.0331 & 566.6850 & 0.0037 & 2.1764 & 315.548 & 339.554 & 117.615 & 47.425 \\ 1.00 & 46.61 & 26.65 & 24.09 & 2 & 1287.7502 & 1287.7421 & 644.8783 & 0.0081 & 6.2802 & 7333.188 & 7127.674 & 8900.185 & 7614.039\end{array}\right)$

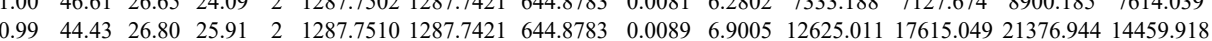

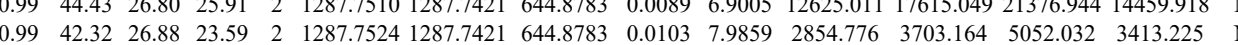

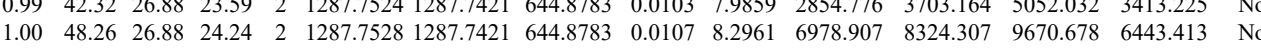
$\begin{array}{llllllllllllllll}1.00 & 5.27 & 27.10 & 28.08 & 2 & 1287.7546 & 1287.7421 & 644.8783 & 0.0125 & 9.6917 & 2005.715 & 2187.422 & 2540.919 & 1833.740 & \text { No } \\ 0.92 & 6.64 & 27.70 & 29.78 & 2 & 1029.582 & 1029.5842 & 515.7994 & 0.020 & 1.9387 & 3128.902 & 29250.767 & 546.94 & 712.015 & \text { Y }\end{array}$ $\begin{array}{lllllllllllllll}0.92 & 26.64 & 27.70 & 29.78 & 2 & 1029.5862 & 1029.5842 & 515.7994 & 0.0020 & 1.9387 & 31128.902 & 29250.767 & 546.948 & 712.015 & \text { Yes } \\ 0.88 & 26.22 & 27.52 & 29.75 & 2 & 1029.5870 & 1029.5842 & 515.7994 & 0.0028 & 2.7142 & 37557.418 & 34895.913 & 663.258 & 645.795 & \text { Yes }\end{array}$

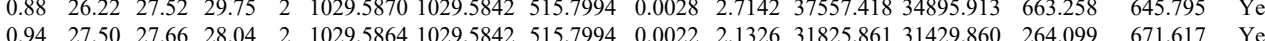
$\begin{array}{lllllllllllllll}0.94 & 27.50 & 27.66 & 28.04 & 2 & 1029.5864 & 1029.5842 & 515.7994 & 0.0022 & 2.1326 & 31825.861 & 31429.860 & 264.099 & 671.617 & \text { Yes } \\ 0.87 & 23.99 & 27.66 & 29.34 & 2 & 1029.5864 & 1029.5842 & 515.7994 & 0.0022 & 2.1326 & 28327.207 & 26535.839 & 452.714 & 526595 & \text { Yes }\end{array}$ \begin{tabular}{lllllllllllllll}
0.95 & 29.47 & 27.82 & 30.83 & 2 & 1029.5852 & 1029.5842 & 515.7994 & 0.0010 & 0.9694 & 7106.257 & 5782.832 & 4520.922 & 526.595 & Yes \\
\hline
\end{tabular} $\begin{array}{lllllllllllllll}0.90 & 57.04 & 24.47 & 28.82 & 2 & 1184.7368 & 1184.7363 & 593.3754 & 0.0005 & 0.4213 & 14600.422 & 13936.490 & 239.172 & 183.256 & \text { Yes }\end{array}$ $\begin{array}{lllllllllllllll}1.00 & 92.51 & 19.19 & 26.68 & 2 & 1697.0344 & 1697.0331 & 849.5238 & 0.0013 & 0.7651 & 2026.656 & 1738.507 & 485.203 & 36\end{array}$ 

$\begin{array}{llllllllllll} & \end{array}$

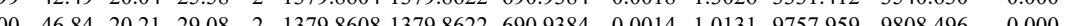
$\begin{array}{llllllllllll}1.98 .45 & 0.000\end{array}$ $\begin{array}{lllllllllllll}1.00 & 41.09 & 20.21 & 26.53 & 2 & 1379.8620 & 1379.8622 & 690.9384 & -0.0002 & -0.1447 & 2038.715 & 1998.132 & 132.113\end{array}$

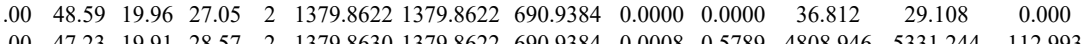
$\begin{array}{llllllllllllll}0.99 & 30.19 & 19.91 & 23.30 & 2 & 1379.8630 & 1379.8622 & 690.9384 & 0.0008 & 0.5789 & 66.048 & 48.888 & 2.509\end{array}$ $\begin{array}{lllllllllllll}0.99 & 30.37 & 19.44 & 23.40 & 2 & 1379.8634 & 1379.8622 & 690.9384 & 0.0012 & 0.5684 & 53.080 & 33.517 & 0.525\end{array}$ $\begin{array}{lllllllllllll}100 & 34.89 & 19.40 & 24.07 & 2 & 1379.8638 & 1379.8622 & 690.9384 & 0.0016 & 1.1578 & 19.969 & 35.332 & 3.418\end{array}$ $\begin{array}{lllllllllllll}1.00 & 40.78 & 19.40 & 20.88 & 2 & 1379.8638 & 1379.8622 & 690.9384 & 0.0016 & 1.1578 & 13.630 & 15.798 & 3.195\end{array}$ $\begin{array}{lllllllllllll}1.00 & 40.23 & 18.57 & 21.05 & 2 & 1379.8642 & 1379.8622 & 690.9384 & 0.0020 & 1.4473 & 24.253 & 41.860 & 16.693\end{array}$ $\begin{array}{lllllllllllll}1.00 & 38.73 & 18.57 & 23.28 & 2 & 1379.8644 & 1379.8622 & 690.9384 & 0.0022 & 1.5920 & 39.417 & 53.154 & 2.727\end{array}$

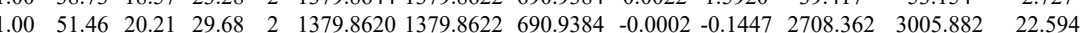
AYEKPPEK

$\begin{array}{lllllllllllll}1.00 & 50.24 & 19.44 & 29.56 & 2 & 1379.8634 & 1379.8622 & 690.9384 & 0.0012 & 0.8684 & 2460.204 & 2459.435\end{array}$ $\begin{array}{lllllllllllllll}0.86 & 19.16 & 26.67 & 17.88 & 3 & 1392.7990 & 1392.7978 & 465.2732 & 0.0012 & 0.8597 & 4549.973 & 4357.323 & 3102.057\end{array}$

\section{LQDMGLPTGAEG}

LFPDTPLALDANK
LFPDTPLALDANK

AYAALAALEK

LFPDTPLALDANK

LFPDTPLALDANK

SIGTANRPMGAGEALR SIGTANRPMGAGEALR $\begin{array}{llllllllllllll} & \end{array}$ $\begin{array}{llllllllllllll} & \end{array}$ $\begin{array}{llllllllllllllll} & & \end{array}$

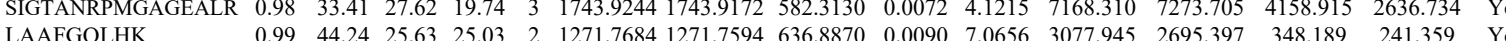
LAAFGQLHK

LAAFGQLHK

LAAFGQLHK

LAAFGQLHK

LAAFGQLHK

LAAFGQLHK

EPPLSLTIHLTSPVVR

VPTWGPLR

CLAALASLR

CLAALASLR

CLAALASLR

CLAALASLR

CLAALASLR

CLAALASLR

CLAALASLR

CLAALASLR

CLAALASLR

CLAALASLR

VPTWGPLR

VPTWGPLR

CLAALASLR

CLAALASLR

CLAALASLR

CLAALASLR

CLAALASLR

CLAALASLR

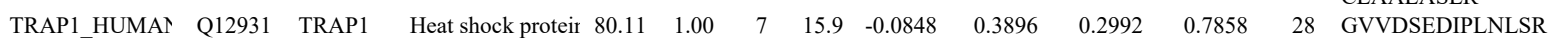
$\begin{array}{lllllllllllllll}0.99 & 44.24 & 25.63 & 25.03 & 2 & 1271.7684 & 1271.7594 & 636.8870 & 0.0090 & 7.0656 & 3077.945 & 2695.397 & 348.189 & 241.359 & \text { Yes } \\ 0.99 & 37.81 & 25.68 & 26.73 & 3 & 1271.7688 & 1271.7594 & 424.9271 & 0.0094 & 7.3738 & 67098.963 & 67633.704 & 296.499 & 251.631 & \text { Yes }\end{array}$

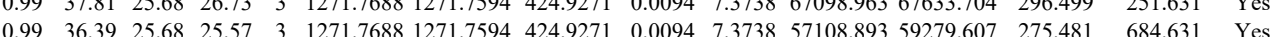
$\begin{array}{llllllllllllllll}1.00 & 48.54 & 25.51 & 28.25 & 2 & 1271.7690 & 1271.7594 & 636.8870 & 0.0096 & 7.5366 & 11955.950 & 10676.281 & 51.932 & 160.348 & \text { Yes }\end{array}$ $\begin{array}{llllllllllllllll}1.00 & 39.91 & 25.63 & 27.30 & 3 & 1271.7673 & 1271.7594 & 424.9271 & 0.0079 & 6.1971 & 36648.372 & 35839.420 & 698.549 & 315.812 & \text { Yes }\end{array}$ $\begin{array}{lllllllllllllllll}1.00 & 41.21 & 25.63 & 26.14 & 3 & 1271.7685 & 1271.7594 & 424.9271 & 0.0091 & 7.1384 & 37706.187 & 34305.667 & 28.551 & 125.040 & \text { Yes }\end{array}$

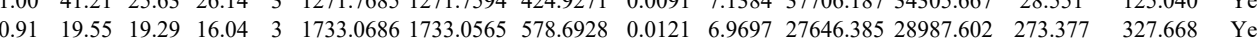
$\begin{array}{llllllllllllllll}0.53 & 62.73 & 22.70 & 75.73 & 3 & 1902.1093 & 1902.1060 & 635.0426 & 0.0033 & 1.7322 & 2564.547 & 2491.258 & 2704.908 & 2010.470 & \text { No }\end{array}$ $\begin{array}{lllllllllllllll}0.84 & 29.55 & 25.87 & 29.96 & 2 & 1068.6260 & 1068.6202 & 535.3174 & 0.0058 & 5.4173 & 31.449 & 37.761 & 21.136 & 4.772 & \text { Yes }\end{array}$ $\begin{array}{lllllllllllllll}0.99 & 37.79 & 28.33 & 24.32 & 2 & 1106.6074 & 1106.6062 & 554.3104 & 0.0012 & 1.0824 & 6194.338 & 5749.805 & 84.752 & 198.920 & \text { Yes }\end{array}$ $\begin{array}{lllllllllllllllll}1.00 & 44.93 & 28.28 & 27.16 & 2 & 1106.6080 & 1106.6062 & 554.3104 & 0.0018 & 1.6236 & 17496.989 & 15791.397 & 347.992 & 156.800 & \text { Yes }\end{array}$ $\begin{array}{lllllllllllllll}1.00 & 41.69 & 28.28 & 29.03 & 2 & 1106.6080 & 1106.6062 & 554.3104 & 0.0018 & 1.6236 & 8426.857 & 8389.280 & 34.117 & 114.669 & \text { Yes }\end{array}$ $\begin{array}{lllllllllllllll}1.00 & 42.19 & 28.28 & 29.77 & 2 & 1106.6080 & 1106.6062 & 554.3104 & 0.0018 & 1.6236 & 14130.275 & 12941.725 & 85.371 & 110.496 & \text { Yes }\end{array}$

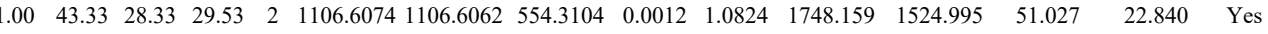

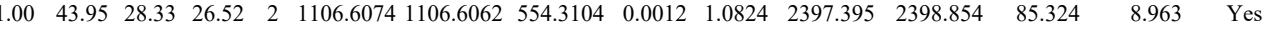

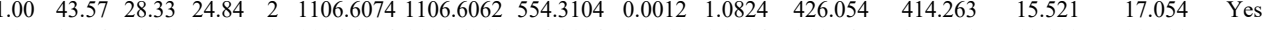
$\begin{array}{lllllllllllllll}0.99 & 37.04 & 28.33 & 27.00 & 2 & 1106.6074 & 1106.6062 & 554.3104 & 0.0012 & 1.0824 & 211.745 & 200.738 & 13.323 & 23.938 & \text { Yes }\end{array}$

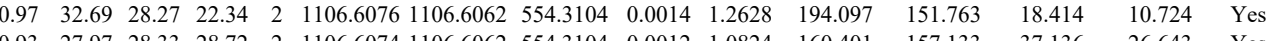
$\begin{array}{llllllllllllllll}0.93 & 27.97 & 28.33 & 28.72 & 2 & 1106.6074 & 1106.6062 & 554.3104 & 0.0012 & 1.0824 & 160.401 & 157.133 & 37.136 & 26.643 & \text { Yes }\end{array}$

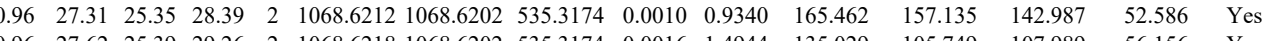

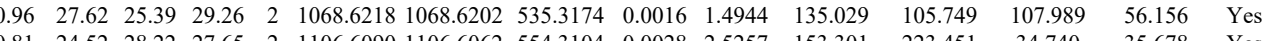
$\begin{array}{lllllllllllllll}0.81 & 24.52 & 28.22 & 27.65 & 2 & 1106.6090 & 1106.6062 & 554.3104 & 0.0028 & 2.5257 & 153.301 & 223.451 & 34.740 & 35.678 & \text { Yes } \\ 0.79 & 22.30 & 28.28 & 23.82 & 2 & 1106.6078 & 1106.6062 & 554.3104 & 0.0016 & 1.4432 & 44.389 & 74.532 & 16.719 & 6.920 & \text { Yes }\end{array}$

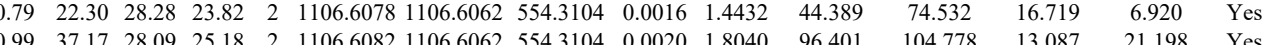

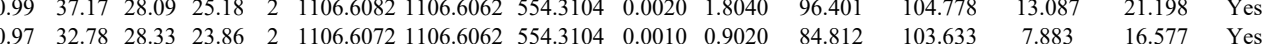

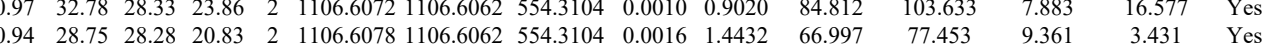

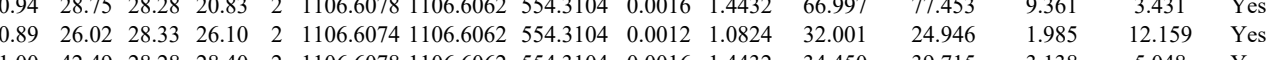

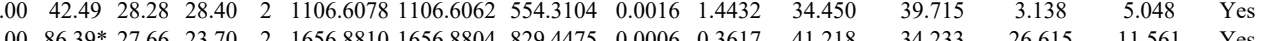


GVVDSEDIPLNLSR GVVDSEDIPLNLSR GVVDSEDIPLNLSR GVVDSEDIPLNLSR GVVDSEDIPLNLSR GVVDSEDIPLNLSR GVVDSEDIPLNLSR GVVDSEDIPLNLSR GVVDSEDIPLNLSR GVVDSEDIPLNLSR GVDSEDIPLNLSR GVVDSEDIPLNLSR

YVAQAHDKPR

YVAQAHDKPR

GVVDSEDIPLNLSR

GVVDSEDIPLNLSR

GVVDSEDIPLNLSR GVVDSEDIPLNLSR

\section{GTITIODTGGGMTPEELVSNLGTIL}

AQLLQPTLEINPR GVVDSEDIPLNLSR GVVDSEDIPLNLSR NIYYLCAPNR

GVVDSEDIPLNLSR

GVVDSEDIPLNLSR

GVVDSEDIPLNLSR

GVVDSEDIPLNLSR

SPAAECLSEK

$\begin{array}{llllllllllllll}\text { FLII_HUMAN } & \text { Q13045 } & \text { FLII } & \text { Protein flightless- } 144.75 & 1.00 & 5 & 4.7 & 0.2101 & 0.1763 & -1.7712 & 2.3644 & 6 & \begin{array}{l}\text { TGLCYLPEELAALQ } \\ \text { NQLTSLPSACK } \\ \text { VPECLYTLPLR }\end{array}\end{array}$ PECLYTLPS ADLTALFLPR ADLTALFLPR

$\begin{array}{lllllllll}90.76 * 27.69 & 23.45 & 2 & 1656.8820 & 1656.8804 & 829.4475 & 0.0016 & 0.9645 & 54 .\end{array}$ $\begin{array}{llllllllll} & \end{array}$ $\begin{array}{lllllllllll} & \\ & \end{array}$

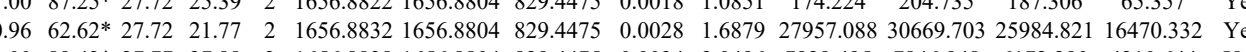
$\begin{array}{lllllllllllllll}1.00 & 89.42 * & 27.77 & 27.88 & 2 & 1656.8838 & 1656.8804 & 829.4475 & 0.0034 & 2.0496 & 7929.495 & 7846.948 & 6172.290 & 4210.644 & \text { Y }\end{array}$ $\begin{array}{lllllllllllllll}0.78 & 58.84 * & 27.60 & 29.49 & 2 & 1656.8850 & 1656.8804 & 829.4475 & 0.0046 & 2.7729 & 7.074 & 7.240 & 8.632 & 0.958 & \text { No }\end{array}$

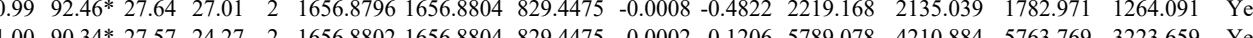

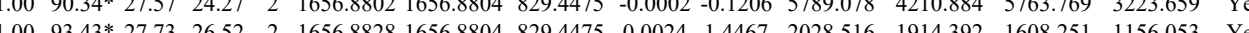

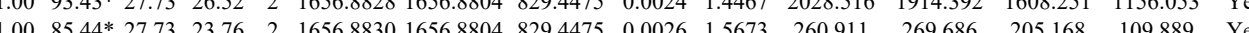
$\begin{array}{llllllllllll} & \end{array}$

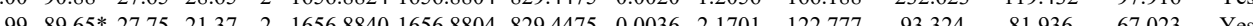
$\begin{array}{llllllllllllllll} & \end{array}$ $\begin{array}{lllllllllllllll}0.99 & 28.89 & 27.29 & 19.93 & 3 & 1471.8154 & 1471.8139 & 491.6119 & 0.0015 & 1.0171 & 201.666 & 188.690 & 111.042 & 94.913 & \text { Yes }\end{array}$ $\begin{array}{llllllllllllll}0.99 & 85.75 * 27.58 & 34.67 & 2 & 1656.8950 & 1656.8804 & 829.4475 & 0.0146 & 8.8010 & 211.352 & 155.708 & 88.063 & 71.786 & \text { Yes }\end{array}$

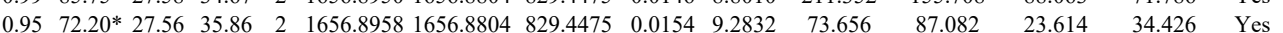
$\begin{array}{llllllllllllll}0.99 & 87.18 * 27.54 & 36.32 & 2 & 1656.8962 & 1656.8804 & 829.4475 & 0.0158 & 9.5243 & 171.209 & 76.973 & 105.768 & 80.528 & \text { Yes }\end{array}$

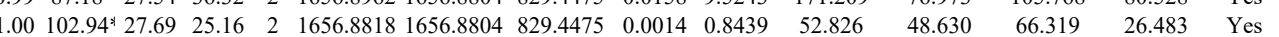

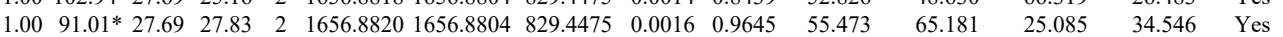

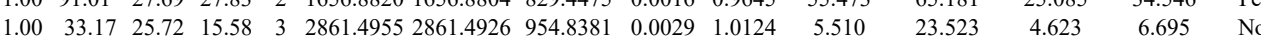

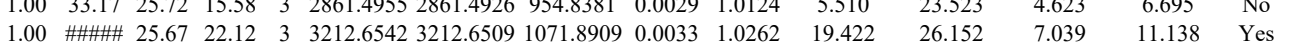
$\begin{array}{lllllllllllllll}1.00 & 55.21 & 24.01 & 17.10 & 2 & 1635.9592 & 1635.9430 & 818.9788 & 0.0162 & 9.8903 & 897.319 & 911.120 & 201.212 & 43.623 & \text { Yes }\end{array}$

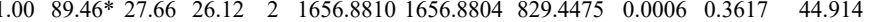

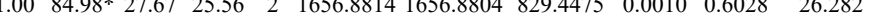
$\begin{array}{lllllllllll} & \end{array}$ $\begin{array}{lllllllllllll}.00 & 140.81 & 27.64 & 23.77 & 2 & 1656.8808 & 1656.8804 & 829.4475 & 0.0004 & 0.2411 & 24.228 & 19.432\end{array}$

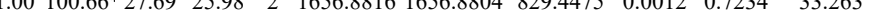
$\begin{array}{llllllllll}1.00 & 104.95 * 27.66 & 25.22 & 2 & 1656.8810 & 1656.8804 & 829.4475 & 0.0006 & 0.3617 & 54.129 \\ 1.00 & 81.89 * 27.66 & 24.49 & 2 & 16568810 & 1656.8804 & 829.4475 & 0.0006 & 0.3617 & 31.201\end{array}$

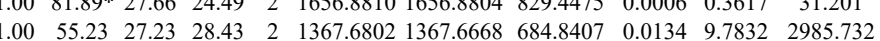

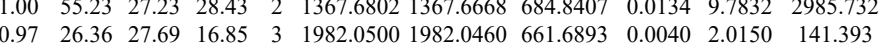
$\begin{array}{lllllllllll}1.00 & 58.56 & 27.67 & 17.28 & 2 & 1607.8630 & 1607.8618 & 804.9382 & 0.0012 & 0.7454 & 377.185\end{array}$

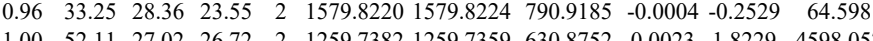

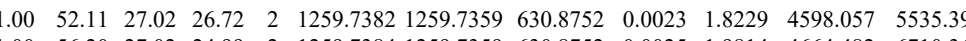
$\begin{array}{llllllllllll}1.00 & 56.20 & 27.02 & 24.99 & 2 & 1259.7384 & 1259.7559 & 630.8752 & 0.025 & 1.9814 & 4564.482 & 6710.361\end{array}$ $\begin{array}{lllllllllllll}0.94 & 34.27 & 27.69 & 30.84 & 3 & 1343.7058 & 1343.6924 & 448.9047 & 0.0134 & 9.9500 & 1813.409 & 2285.464\end{array}$

LENDLEE $\begin{array}{lllllllllll}1.00 & 32.89 & 22.36 & 18.70 & 3 & 2332.3177 & 2332.3133 & 778.4450 & 0.0044 & 1.8841 & 23.030\end{array}$ $\begin{array}{lllll}-1 & 0\end{array}$

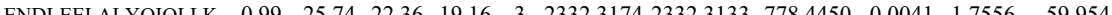

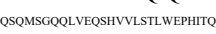
$\begin{array}{lllllllllll}1.00 & 56.51 & 24.89 & 69.51 & 4 & 3502.8125 & 3502.8113 & 876.7101 & 0.0012 & 0.3422 & 293.248 \\ 1.00 & 67.72 & 24.87 & 17.36 & 4 & 3502.8153 & 3502.8113 & 876.7101 & 0.0040 & 1.1406 & 194.399\end{array}$

LASILTSAAR $\begin{array}{llllllllllllllll}\text { SGLLVLTTPLASLAPR } & 1.00 & \# \# \# \# & 17.32 & 35.13 & 2 & 1752.0640 & 1752.0631 & 877.0388 & 0.0009 & 0.5131 & 42.257\end{array}$ $\begin{array}{lllllllllllll}\text { SGLLVLTTPLASLAPR } & 0.55 & 61.01 & 17.32 & 74.01 & 3 & 1752.0655 & 1752.0631 & 585.0283 & 0.0024 & 1.3675 & 42.113\end{array}$

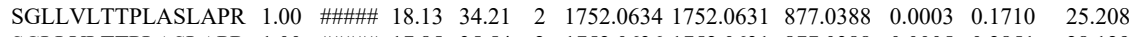
\begin{tabular}{llllllllllll} 
SGLLVLTTPLASLAPR & 1.00 & \#\#\#\# 17.85 & 35.54 & 2 & 1752.0636 & 1752.0631 & 877.0388 & 0.0005 & 0.2851 & 28.129 \\
\hline
\end{tabular} $\begin{array}{llllllllllll}\text { SGLLVLTTPLASLAPR } & 1.00 & 67.83 & 17.40 & 18.41 & 3 & 1752.0649 & 1752.0631 & 585.0283 & 0.0018 & 1.0256 & 10.457\end{array}$ $\begin{array}{lllllllllllll}\text { SGLLVLTTPLASLAPR } & 1.50 & 61.23 & 17.40 & 74.23 & 3 & 1752.0649 & 1752.0631 & 585.0283 & 0.0018 & 1.0256 & 6.450\end{array}$ $\begin{array}{lllllllllllll}\text { SGLLVLTTPLASLAPR } & 1.00 & \text { \#\#\#\# } & 18.13 & 36.29 & 2 & 1752.0632 & 1752.0631 & 877.0388 & 0.0001 & 0.0570 & 43.030\end{array}$ $\begin{array}{llllllllllllll}\text { SGLLVLTTPLASLAPR } & 0.99 & 23.36 & 17.85 & 15.15 & 3 & 1752.0637 & 1752.0631 & 585.0283 & 0.0006 & 0.3419 & 6.638\end{array}$ $\begin{array}{lllllllllllll}\text { SGLLVLTTPLASLAPR } & 1.00 & 64.18 & 18.26 & 30.70 & 2 & 1752.0628 & 1752.0631 & 877.0388 & -0.0003 & -0.1710 & 24.607\end{array}$ $\begin{array}{lllllllllllll}\text { SGLLVLTTPLASLAPR } & 1.00 & 57.60 & 17.40 & 29.48 & 2 & 1752.0646 & 1752.0631 & 877.0388 & 0.0015 & 0.8551 & 21.312\end{array}$ $\begin{array}{lllllllllllll}\text { SGLLVLTTPLASLAPR } & 0.82 & 8.72 & 17.40 & 15.51 & 3 & 1752.0646 & 1752.0631 & 585.0283 & 0.0015 & 0.8547 & 24.795\end{array}$ $\begin{array}{lllllllllllll}\text { SGLLVLTTPLASLAPR } & 0.55 & 3.56 & 17.40 & 16.56 & 3 & 1752.0649 & 1752.0631 & 585.0283 & 0.0018 & 1.0256 & 8.742\end{array}$ $\begin{array}{llllllllllllll}\text { TPTPVHYRPHGAK } & 0.99 & 19.03 & 26.64 & 32.03 & 4 & 1747.9733 & 1747.9726 & 438.0004 & 0.0007 & 0.3995 & 142.706 \\ \end{array}$ $\begin{array}{lllllllllllll}\text { IYVAELLQLQQQALSEPAVVQK } & 1.00 & 74.38 & 19.40 & 87.38 & 4 & 2883.6369 & 2883.6313 & 721.9151 & 0.0056 & 1.9393 & 26.618 \\ \text { IYVAELOQLOQOALSEPAVVOK } & 1.00 & 63.44 & 19.08 & 76.44 & 4 & 2883.6393 & 2883.6313 & 721.9151 & 0.0080 & 2.7704 & 48.508\end{array}$ $\begin{array}{lllllllllllll}\text { HVAELIQQLQQQALSEPAVVQK } & 1.00 & 63.44 & 19.08 & 76.44 & 4 & 2883.6393 & 2883.6313 & 721.9151 & 0.0080 & 2.7704 & 48.508 \\ \text { IVVAELOQLQQQALSEPAVVOK } & 1.00 & 44.21 & 19.44 & 19.60 & 4 & 2883.6365 & 2883.6313 & 721.9151 & 0.0052 & 1.8008 & 53.423\end{array}$

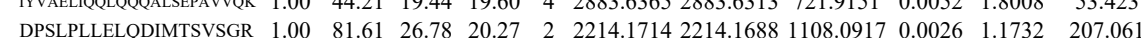

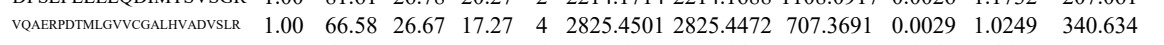
$\begin{array}{llllllllllll}\text { NLLVTMLIDQLCGR } & 0.95 & 22.95 & 28.01 & 26.28 & 3 & 1777.9393 & 1777.9374 & 593.6531 & 0.0019 & 1.0668 & 15.901\end{array}$ $\begin{array}{lllllllllllll}\text { NLLVTMLIDOLCGR } & 0.91 & 25.46 & 28.04 & 30.87 & 3 & 1777.9399 & 1777.9374 & 593.6531 & 0.0025 & 1.4037 & 25.854\end{array}$

$\begin{array}{llllllllllllll}\text { AAPTSAPPSK } & 1.00 & 61.64 & 26.99 & 21.19 & 2 & 1213.6904 & 1213.6910 & 607.8528 & -0.0006 & -0.4935 & 66.862\end{array}$ 
$\begin{array}{lllllllllllllll} & 1.00 & 48.89 & 24.17 & 33.03 & 2 & 1249.7536 & 1249.7516 & 625.8831 & 0.0020 & 1.5977 & 636.257 & 667.356 & 13 . & \\ & 1.00 & 86.08 & 27.54 & 29.06 & 2 & 2143.1294 & 2143.1283 & 10725714 & 0.0011 & 0.5128 & 127.974 & 84.920 & 2.1 .5\end{array}$

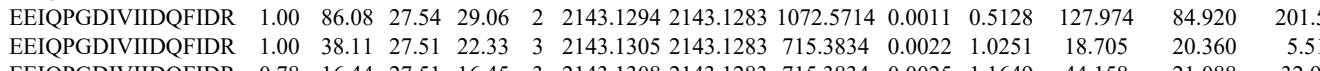
$\begin{array}{llllllllllllllll} & \end{array}$

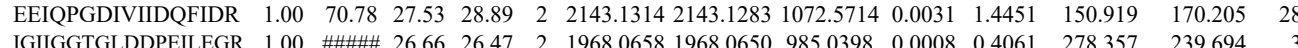

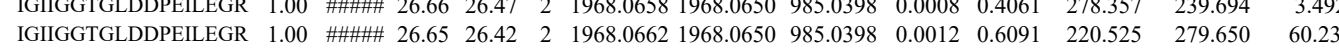
$\begin{array}{lllllllllllllllll}\text { IGIIGGTGLDDPEILEGR } & 1.00 & 70.11 & 26.66 & 18.53 & 2 & 1968.0658 & 1968.0650 & 985.0398 & 0.0008 & 0.4061 & 628.599 & 957.730 & 256.162\end{array}$

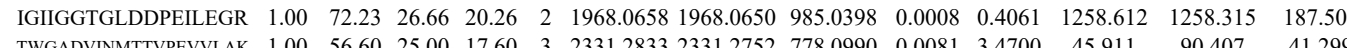

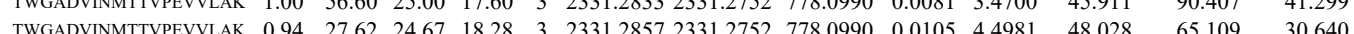

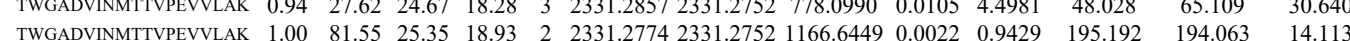
$\begin{array}{llllllllllllll}\text { TWGADVINMTTVPEVVLAK } & 1.00 & 47.13 & 25.22 & 16.09 & 3 & 2331.2812 & 2331.2752 & 778.0990 & 0.0060 & 2.5704 & 83.351 & 80.129 & 29.101\end{array}$ $\begin{array}{lllllllllllllll}\text { SLLLTTPOIGSTEWSETLHNLK } & 1.00 & 60.58 & 21.49 & 20.98 & 3 & 2868.5878 & 2868.5840 & 957.2019 & 0.0038 & 1.3233 & 703.180 & 980.634 & 256.029\end{array}$ $\begin{array}{llllllllllllllll}\text { SLLLTTPPIGSTEWSETLHNLK } & 1.00 & 64.14 & 21.49 & 18.63 & 3 & 28685881 & 28685840 & 957.2019 & 0.0041 & 1.4278 & 622.311 & 1015.570 & 44.733\end{array}$ $\begin{array}{llllllllllllllll}\text { SLLLTTPOIGSTEWSETLHNLK } & 1.00 & 66.36 & 21.85 & 1905 & 3 & 2868.5866 & 2868.5840 & 957.2019 & 0.0026 & 0.9054 & 359.305 & 572.350 & 50.533\end{array}$ $\begin{array}{lllllllllllllllll}\text { SLLLTIPPIGSTEWSETLHNLK } & 0.53 & 72.61 & 21.76 & 85.61 & 3 & 2868.5875 & 2868.5840 & 957.2019 & 0.0035 & 1.2188 & 1518.324 & 2228.697 & 281.284\end{array}$ $\begin{array}{lllllllllllllll}\text { SLLLTTIPQIGSTEWSETLHNLK } & 1.00 & 36.76 & 21.40 & 16.97 & 4 & 2868.5901 & 2868.5840 & 718.1533 & 0.0061 & 2.1235 & 13.021 & 37.811 & 12.492\end{array}$ $\begin{array}{llllllllllllllll}\text { TTMRPQSFYDGSHSCAR } & 0.99 & 22.02 & 23.54 & 35.02 & 4 & 2132.9445 & 2132.9312 & 534.2401 & 0.0133 & 6.2238 & 3521.455 & 5462.880 & 4824.752 & 1603.530\end{array}$ $\begin{array}{llllllllllllllll}\text { TTMRPQSFYDGSHSCAR } & 1.00 & 30.31 & 23.32 & 43.31 & 4 & 2132.9409 & 2132.9312 & 534.2401 & 0.0097 & 4.5391 & 1925.855 & 2307.526 & 2368.293 & 863.328\end{array}$

6 TSDLIVLGLPWK

$\begin{array}{llllllllllllllll} & \\ \text { NLGLPWK } & 1.00 & 56.50 & 22.92 & 29.42 & 2 & 1628.9768 & 1628.9745 & 815.4945 & 0.0023 & 1.4102 & 258.869 & 118.991 & 118.659\end{array}$ TSDLIVLGLPWK LVEGLLHADDAGWGNLYYVNYY NPVSQCMR NPVSQCMR NPVSQCMR NPVSQCMR NPVSQCMR $152.313 \quad 63.469 \quad \mathrm{Y}$ $\begin{array}{llllllllllllllll}0.97 & 27.31 & 23.03 & 27.05 & 3 & 1628.9785 & 1628.9745 & 543.9988 & 0.0040 & 2.4510 & 343.772 & 362.759 & 126.098 & 92.122 & \text { Yes }\end{array}$

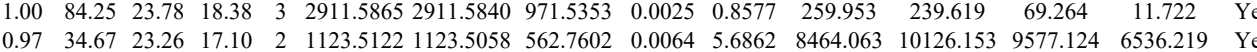
$\begin{array}{llllllllllllllll}0.98 & 38.37 & 23.64 & 20.39 & 2 & 1123.5110 & 1123.5058 & 562.7602 & 0.0052 & 4.6201 & 6065.870 & 6598.883 & 6205.013 & 4446.101 & \text { Yes } \\ 0.99 & 41.95 & 23.12 & 21.84 & 2 & 1123.5114 & 123.5058 & 562.7602 & 0.0056 & 49755 & 4162.906 & 4157.05 & 3872.88 & 3263.93 & \text { Yes }\end{array}$ \begin{tabular}{|llllllllllllllll} 
& \\
\hline & 0.53 & 20.80 & 23.73 & 17.63 & 2 & 1123.5114 & 1123.5058 & 562.7602 & 0.0056 & 4.9755 & 4162.906 & 4157.005 & 3872.289 & 3263.934 & Yes \\
\end{tabular} $\begin{array}{lllllllllllllll} & \end{array}$

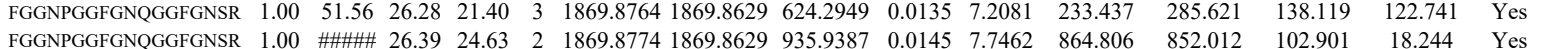

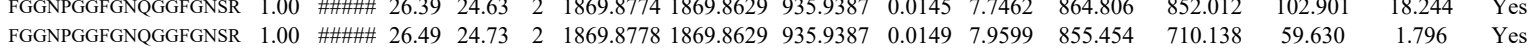

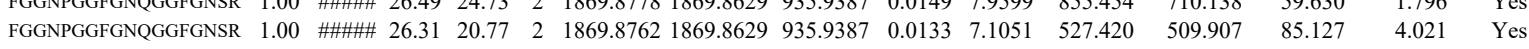

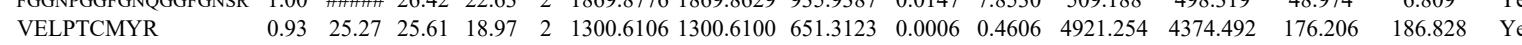

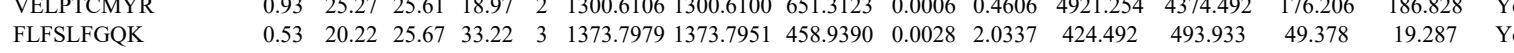

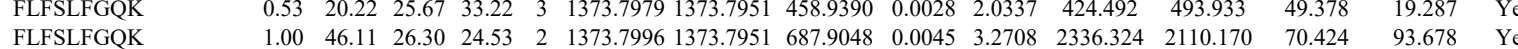
FLFSLFGQK FLFSLFGQK FLFSLFGQK FLFSLFGQK FLFSLFGQK $\begin{array}{llllllllllllllll}1.00 & 46.11 & 26.30 & 24.53 & 2 & 1373.7996 & 1373.7951 & 687.9048 & 0.0045 & 3.2708 & 2336.324 & 2110.170 & 70.424 & 93.678 & \text { Yes } \\ 0.99 & 44.01 & 26.32 & 23.57 & 2 & 1373.7998 & 1373.7951 & 687.9048 & 0.0047 & 3.4162 & 4949.984 & 4583.085 & 61.633 & 59.628 & \text { Yes }\end{array}$

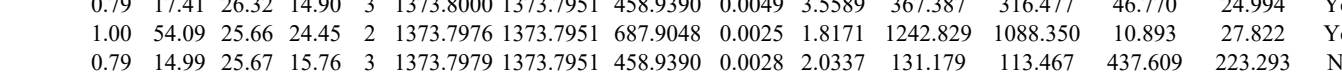
\begin{tabular}{|ccccccccccccccccc} 
& 1.00 & 54.22 & 26.33 & 23.88 & 2 & 1373.7986 & 1373.7951 & 687.9048 & 0.0035 & 2.5440 & 1404.736 & 1425.827 & 19.086 & 21.377 & Yes
\end{tabular} $\begin{array}{lllllllllllllllll}\text { DPLANHSLKPLPSVPEEK } & 1.00 & 23.07 & 22.99 & 36.07 & 4 & 2489.3977 & 2489.3855 & 623.3537 & 0.0122 & 4.8929 & 3953.147 & 4639.285 & 5490.407 & 4496.120 & \text { Yes }\end{array}$

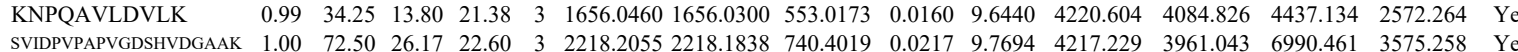

$\begin{array}{lllllllllll}\text { PAK2_HUMAN } & \text { Q13177 } & \text { PAK2 } & \text { Serine/threonine-p } 58.04 & 1.00 & 3 & 9.5 & -0.0123 & 0.1744 & 0.2761 & 0.4503\end{array}$ CBX3_HUMAN Q13185 CBX3

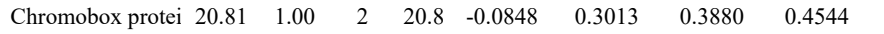
VEEAEPEEFVVEK WKDSDEADLVLAK WKDSDEADLVLAK

TLIEDEIATILK

TLIEDEIATILK

TLIEDEIATILK AIFMIPTNPPPTFR QPEEVFDVLEK $\begin{array}{llllllllllllllll}1.00 & 72.50 & 26.17 & 22.60 & 3 & 2218.2055 & 2218.1838 & 740.4019 & 0.0217 & 9.7694 & 4217.229 & 3961.043 & 6990.461 & 3575.258 & \text { Yes } & \\ & 0.98 & 53.92 & 28.08 & 25.64 & 2 & 1820.9332 & 1820.9287 & 91.476 & 0.045 & 2.685 & 25.908 & 31.807 & 16.94 & 5.543 & \text { Yes }\end{array}$

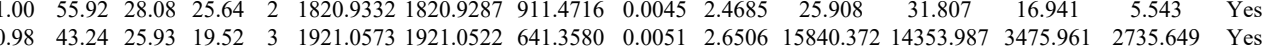
$\begin{array}{lllllllllllllll}0.94 & 42.02 & 25.92 & 22.45 & 3 & 1921.0579 & 1921.0522 & 641.3580 & 0.0057 & 2.9625 & 12676.133 & 10429.988 & 1221.198 & 1458.030 & \text { Yes }\end{array}$ $\begin{array}{lllllllllllllll}1.00 & 61.00 & 23.89 & 18.81 & 2 & 1645.9756 & 1645.9745 & 823.9945 & 0.0011 & 0.6675 & 71.648 & 96.327 & 4.622 & 0.000 & \text { No }\end{array}$ $\begin{array}{lllllllllllllll}1.00 & 72.26 & 23.89 & 21.04 & 2 & 1645.9758 & 1645.9745 & 823.9945 & 0.0013 & 0.7888 & 87.034 & 96.239 & 12.247 & 3.397 & \text { Yes }\end{array}$ $\begin{array}{llllllllllllllll}1.00 & 76.92 & 23.89 & 29.29 & 2 & 1645.9756 & 1645.9745 & 823.9945 & 0.0011 & 0.6675 & 292.206 & 333.754 & 13.629 & 20.847 & \text { Yes } & \\ 1.00 & 62.73 & 2.73 & 21.48 & 2 & 174.960 & 174.9456 & 833.480 & 0.004 & 0.229 & 83.987 & 11.64 & 20.243 & 0.910 & \end{array}$

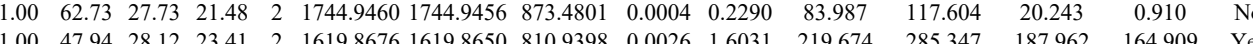
$\begin{array}{cccccccccccccccc} & 1.00 & 47.94 & 28.12 & 23.41 & 2 & 1619.8676 & 1619.8650 & 810.9398 & 0.0026 & 1.6031 & 219.674 & 285.347 & 187.962 & 164.909 & \text { Yes } \\ \text { GGDSK } & 1.00 & 70.43 & 25.54 & 27.93 & 2 & 1917.0750 & 1917.0736 & 959.5441 & 0.0014 & 0.7295 & 9.204 & 29.173 & 15.191 & 21.503 & N\end{array}$ $\begin{array}{llllllllllllll} & \end{array}$ $\begin{array}{llllllllllllllll} & \end{array}$

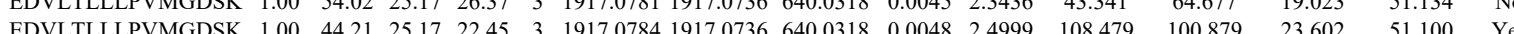

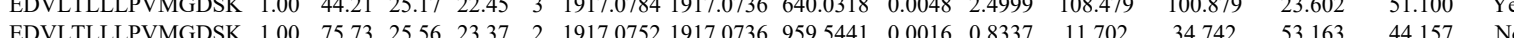

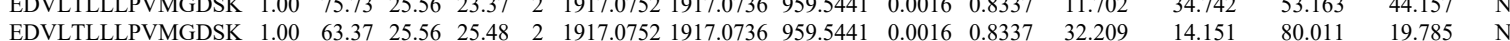
$\begin{array}{llllllllllllllll}\text { EDVLTLLLPVMGDSK } & 1.00 & 32.71 & 25.26 & 20.95 & 3 & 1917.0778 & 1917.0736 & 640.0318 & 0.0042 & 2.1874 & 149.013 & 146.995 & 142.371 & 100.967 & \text { Y }\end{array}$ $\begin{array}{llllllllllllllllll} & 0.89 & 31.24 & 28.54 & 28.84 & 2 & 1248.6530 & 1248.6407 & 625.3276 & 0.0123 & 9.8347 & 610.510 & 453.105 & 37.904 & 410.674 & \text { Yes }\end{array}$ 

$\begin{array}{llllllllllll}1.00 & \# \# \# 25.79 & 26.39 & 2 & 2157.1814 & 2157.1803 & 1079.5974 & 0.0011 & 0.5094 & 5.08\end{array}$

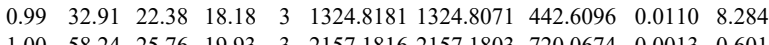

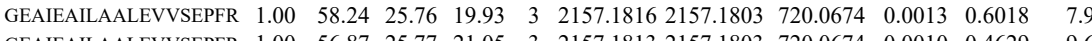
$\begin{array}{llllllllllllll}\text { EEAIEAILAALEVVSEPFR } & 1.00 & 66.16 & 25.69 & 18.11 & 3 & 2157.1828 & 2157.1803 & 720.0674 & 0.0025 & 1.1573 & 9.637 & 13.173 & 9.024\end{array}$ $\begin{array}{llllllllllllllll} & \end{array}$

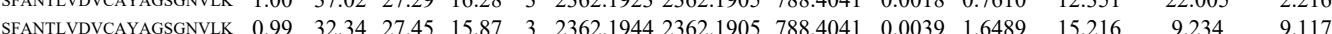

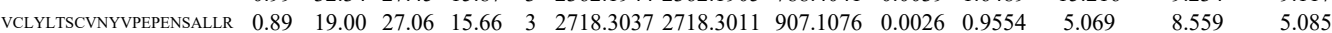
$\begin{array}{llllllllllllll}\text { MNLASSFVNGFVNAAFGQDK } & 0.55 & 46.33 & 27.77 & 59.33 & 3 & 2404.2109 & 2404.2089 & 802.4102 & 0.0020 & 0.8308 & 58.543\end{array}$ $\begin{array}{llllllllllllll}\text { MNLASSFVNGFVNAAFGQDK } & 1.00 & 41.03 & 27.76 & 19.98 & 3 & 2404.2115 & 2404.2089 & 802.4102 & 0.0026 & 1.0801 & 64.004\end{array}$ $\begin{array}{llllllllllllll}\text { FAADIISVLAMTMSGER } & 1.00 & 54.74 & 27.59 & 16.83 & 3 & 1955.0011 & 1954.9978 & 652.6732 & 0.0033 & 1.6854 & 77.959\end{array}$ $\begin{array}{lllllllllllll}\text { FAADIISVLAMTMSGER } & 0.53 & 44.37 & 27.59 & 57.37 & 3 & 1955.0011 & 1954.9978 & 652.6732 & 0.0033 & 1.6854 & 89.120\end{array}$ $\begin{array}{lllllllllllll}\text { MNLASSFVNGFVNAAFGQDK } & 1.00 & 40.80 & 27.70 & 18.99 & 3 & 2404.2121 & 2404.2089 & 802.4102 & 0.0032 & 1.3293 & 54.592\end{array}$ $\begin{array}{lllllllllllll}\text { MNLASSFVNGFVNAAFGQDK } & 1.00 & 39.65 & 27.70 & 19.51 & 3 & 2404.2121 & 2404.2089 & 802.4102 & 0.0032 & 1.3293 & 48.312\end{array}$ $\begin{array}{lllllllllllll}\text { FAADIISVLAMTMSGER } & 0.53 & 46.61 & 27.61 & 59.61 & 3 & 1955.0008 & 1954.9978 & 652.6732 & 0.0030 & 1.5322 & 190.733\end{array}$ $\begin{array}{llllllllllllll}\text { MNLASSFVNGFNARGQDK } & 0.55 & 27.03 & 27.75 & 40.03 & 3 & 2404.2106 & 2404.2089 & 802.4102 & 0.0017 & 0.7062 & 38.001\end{array}$

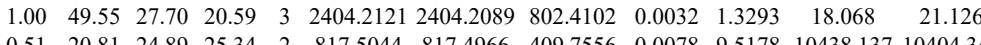

LAAMLR

FLRPHYGK

LAAMLR

LAAMLR

FLRPHYGK

FLRPHYGK

EQELSEEDK

EQELSEDK

$\begin{array}{llllllllllllll}0.51 & 20.81 & 24.89 & 25.34 & 2 & 817.5044 & 817.4966 & 409.7556 & 0.0078 & 9.5178 & 10438.137 & 10404.348 \\ 0.80 & 17.63 & 26.90 & 21.57 & 3 & 1304.7610 & 1304.7597 & 435.9272 & 0.0013 & 0.9940 & 13997.534 & 13391.238\end{array}$ $\begin{array}{lllllllllllll}0.78 & 26.85 & 24.89 & 28.94 & 2 & 817.5036 & 817.4966 & 409.7556 & 0.0070 & 8.5416 & 27709.394 & 23896.383 & 1137.065\end{array}$ $\begin{array}{llllllllllllll}0.80 & 22.89 & 2.62 & 18.76 & 2 & 1304.7630 & 1304.7597 & 653.3881 & 0.0033 & 2.5253 & 2586.581 & 2411.810 & 181.665\end{array}$ $\begin{array}{lllllllllllll}1.00 & 61.62 & 19.26 & 17.73 & 3 & 1705.0324 & 1705.0283 & 569.3500 & 0.0041 & 2.4004 & 13518.383 & 12785.343 & 13.605\end{array}$

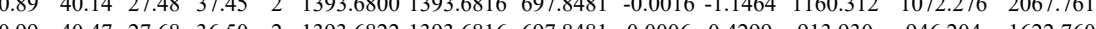

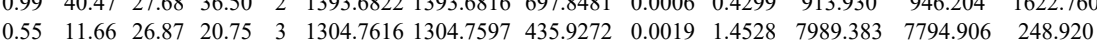

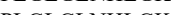

CALGVFR

CALGVF

CALGVFR $\begin{array}{llllllllllllll}0.53 & 63.63 & 19.78 & 76.63 & 3 & 1705.0318 & 1705.0283 & 569.3500 & 0.0035 & 2.0491 & 6606.467 & 6858.513 & 168.935\end{array}$

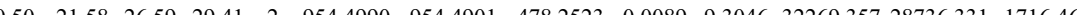
$\begin{array}{lllllllllllllll}0.50 & 21.63 & 26.59 & 2.52 & 2 & 954.4988 & 954.4901 & 478.2523 & 0.0087 & 9.0955 & 31788.659 & 30376.497 & 1250.695 & 2\end{array}$ $\begin{array}{llllllllllllll}0.50 & 21.62 & 26.59 & 29.45 & 2 & 954.4990 & 9544901 & 478.2523 & 0.0089 & 9.3046 & 37159.620 & 29147.748 & 1438.227 & 2\end{array}$ CALGVFR $\begin{array}{llllllllllllll}0.69 & 21.24 & 29.20 & 28.46 & 2 & 954.4908 & 954.4901 & 478.2523 & 0.0007 & 0.7318 & 4120.856 & 3467.595 & 83.749\end{array}$ $\begin{array}{llllllllllllll} & 0.72 & 22.11 & 29.39 & 24.65 & 2 & 954.4910 & 954.4901 & 478.2523 & 0.0009 & 0.9409 & 7541.627 & 5973.694 & 104.047\end{array}$ \begin{tabular}{llllllllllllll} 
SGALLACGIVNSGVR & 1.00 & 98.00 & 28.56 & 42.37 & 2 & 1605.8454 & 1605.8453 & 803.9299 & 0.0001 & 0.0622 & 269.426 & 361.352 & 238.081 \\
\hline
\end{tabular} $\begin{array}{llllllllllllll}\text { SGALLACGIVNSGVR } & 0.99 & 32.38 & 28.46 & 24.44 & 3 & 1605.8470 & 1605.8453 & 5362890 & 0.0017 & 1.0566 & 195.517 & 127.818 & 38.102\end{array}$ $\begin{array}{lllllllllllllll}\text { SGALLACGIVNSGVR } & 0.85 & 19.06 & 28.45 & 23.27 & 3 & 1605.8473 & 1605.8453 & 536.2890 & 0.0020 & 1.2431 & 129.497 & 190.457 & 67.873\end{array}$ $\begin{array}{lllllllllllllll}\text { SGALLACGIVNSGVR } & 1.00 & 95.50 & 28.56 & 41.99 & 2 & 1605.8454 & 1605.8453 & 803.9299 & 0.0001 & 0.0622 & 893.847 & 920.768 & 778.942\end{array}$ $\begin{array}{llllllllllllllll}\text { SGALLACGIVNSGVR } & 1.00 & 95.88 & 28.46 & 44.03 & 2 & 1605.8460 & 1605.8453 & 803.9299 & 0.0007 & 0.4354 & 698.568 & 711.964 & 534.433\end{array}$ $\begin{array}{lllllllllllllll}\text { SGALLACGIVNSGVR } & 1.00 & 58.19 & 28.54 & 30.31 & 3 & 1605.8479 & 1605.8453 & 536.2890 & 0.0026 & 1.6160 & 62.316 & 66.773 & 46.800\end{array}$

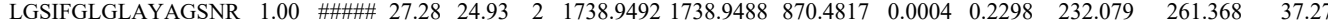
$\begin{array}{lllllllllllll}\text { LGSIFGLGLAYAGSNR } & 1.00 & \text { \#\#\#\# } 27.21 & 26.84 & 2 & 1738.9496 & 1738.9488 & 870.4817 & 0.0008 & 0.4595 & 232.365 & 240.892 & 46.500\end{array}$

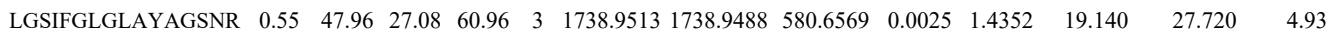
$\left.\begin{array}{llllllllllllll}\text { LGSIFGLGLAYAGSNR } & 1.00 & 43.66 & 26.78 & 25.07 & 3 & 1738.9522 & 1738.9488 & 580.6569 & 0.0034 & 1.9518 & 19.999\end{array}\right)$ $\begin{array}{lllllllllllll}\text { LGSIFGLGLAYAGSNR } & 1.00 & 88.00 & 27.28 & 23.94 & 2 & 1738.9488 & 1738.9488 & 870.4817 & 0.0000 & 0.0000 & 47.965\end{array}$ $\begin{array}{lllllllllllll}\text { LGSIFGLGLAYAGSNR } & 0.61 & 57.59 & 27.28 & 70.59 & 2 & 1738.9490 & 1738.9488 & 870.4817 & 0.0002 & 0.1149 & 46.176\end{array}$ $\begin{array}{lllllllllllll}\text { LGSIFGLGLAYAGSNR } & 1.00 & 33.09 & 27.14 & 18.36 & 3 & 1738.9507 & 1738.9488 & 580.6569 & 0.0019 & 1.0907 & 32.171 \\ \text { LGSIFGLGLAYAGSNR } & 0.55 & 36.74 & 27.14 & 49.74 & 3 & 1738.9507 & 1738.9488 & 580.6569 & 0.0019 & 1.0907 & 12.002\end{array}$ $\begin{array}{lllllllllllll}\text { LGSIFGLGLAYAGSNR } & 0.55 & 36.74 & 27.14 & 49.74 & 3 & 1738.9507 & 1738.9488 & 580.6569 & 0.0019 & 1.0907 & 12.002\end{array}$ $\begin{array}{llllllllllll}\text { AVPLALALISVSNPR } & 0.61 & 31.62 & 24.01 & 44.62 & 2 & 1519.9082 & 1519.9086 & 760.9616 & -0.0004 & -0.2628 & 8.644\end{array}$ $\begin{array}{llllllllllll}\text { AVPLALALISVSNPR } & 0.99 & 38.67 & 23.98 & 16.78 & 2 & 1519.9078 & 1519.9086 & 760.9616 & -0.0008 & -0.5257 & 8.189\end{array}$ $\begin{array}{llllllllllll}\text { AVPLALALISVSNPR } & 0.61 & 59.07 & 24.01 & 72.07 & 2 & 1519.9086 & 1519.9086 & 760.9616 & 0.0000 & 0.0000 & 14.081\end{array}$ $\begin{array}{llllllllllll}\text { SGALLACGIVNSGVR } & 1.00 & 58.91 & 28.49 & 22.52 & 2 & 1605.8452 & 1605.8453 & 803.9299 & -0.0001 & -0.0622 & 27.732\end{array}$

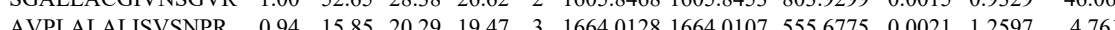
\begin{tabular}{lllllllllllll}
\hline AVPLALALISVSNPR & 0.61 & 28.02 & 24.01 & 41.02 & 2 & 1519.9084 & 1519.9086 & 760.9616 & 0.0002 & 0.1314 & 26.205
\end{tabular}

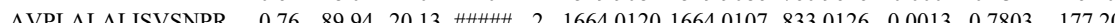



$\begin{array}{llllllllllll}\text { SGALLACGIVNSGVR } & 1.00 & 79.45 & 28.48 & 23.30 & 2 & 1605.8444 & 1605.8453 & 803.9299 & -0.0009 & -0.5598 & 41.466\end{array}$ $\begin{array}{lllllllllllll}\text { SGALLACGIVNSGVR } & 1.00 & 80.08 & 28.45 & 31.42 & 2 & 1605.8464 & 1605.8453 & 803.9299 & 0.0011 & 0.6841 & 45.540\end{array}$ $\begin{array}{lllllllllll}\text { AVPLALALISVSNPR } & 1.00 & \text { \#\#\#\# } 20.13 & 22.88 & 2 & 1664.0110 & 1664.0107 & 833.0126 & 0.0003 & 0.1801 & 139.921\end{array}$ AVPLALALISVSNPR $\quad 0.76$ \#\#\#\# 20.13 \#\#\#\# $2 \quad 1664.01161664 .0107 \quad 833.0126 \quad 0.0009 \quad 0.5402 \quad 176.762$ $\begin{array}{lllllllllllll}\text { AVPLALALISVSNPR } & 1.00 & 49.83 & 20.13 & 17.77 & 3 & 1664.0119 & 1664.0107 & 555.6775 & 0.0012 & 0.7198 & 12.700\end{array}$ $\begin{array}{llllllllllllll}\text { AVPLALALISVSNPR } & 0.96 & 16.36 & 20.13 & 17.49 & 3 & 1664.0125 & 1664.0107 & 555.6775 & 0.0018 & 1.0798 & 19.147\end{array}$ $\begin{array}{lllllllllllll}\text { AVPLALALISVSNPR } & 0.55 & 34.08 & 20.29 & 47.08 & 3 & 1664.0128 & 1664.0107 & 555.6775 & 0.0021 & 1.2597 & 13.361\end{array}$ $\begin{array}{lllllllllllll}\text { SHYVLYGLVAAMQPR } & 1.00 & 36.17 & 27.66 & 22.74 & 3 & 1847.9851 & 1847.9838 & 617.0019 & 0.0013 & 0.7023 & 43.222\end{array}$ $\begin{array}{lllllllllllll}\text { SGALLACGIVNSGVR } & 1.00 & 66.71 & 28.56 & 24.48 & 2 & 1605.8456 & 1605.8453 & 803.9299 & 0.0003 & 0.1866 & 31.647\end{array}$ $\begin{array}{llllllllllll}\text { SGALLACGIVNSGVR } & 1.00 & 73.45 & 28.45 & 31.59 & 2 & 1605.8464 & 1605.8453 & 803.9299 & 0.0011 & 0.6841 & 24.647\end{array}$ $\begin{array}{lllllllllllll}\text { AVPLALALISVSNPR } & 0.61 & 65.15 & 20.13 & 78.15 & 2 & 1664.0108 & 1664.0107 & 833.0126 & 0.0001 & 0.0600 & 22.557\end{array}$

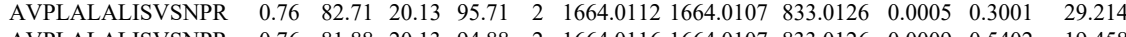

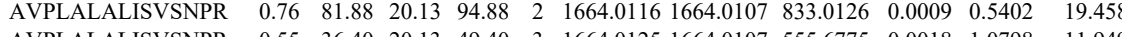
$\begin{array}{llllllllllll}\text { AVPLALALISVSNPR } & 0.55 & 36.40 & 20.13 & 49.40 & 3 & 1664.0125 & 1664.0107 & 555.6775 & 0.0018 & 1.0798 & 11.949\end{array}$ $\begin{array}{llllllllllll}\text { AVPLALALISVSNPR } & 0.55 & 16.77 & 20.29 & 29.77 & 3 & 1664.0131 & 1664.0107 & 555.6775 & 0.0024 & 1.4397 & 6.113\end{array}$ $\begin{array}{lllllllllllll}\text { SGALLACGIVNSGVR } & 1.00 & 67.49 & 28.56 & 26.78 & 2 & 1605.8456 & 1605.8453 & 803.9299 & 0.0003 & 0.1866 & 56.044\end{array}$

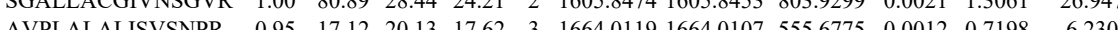

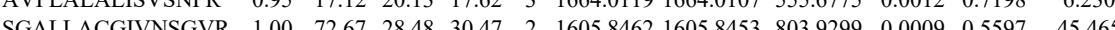

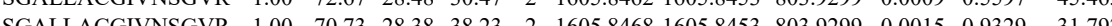

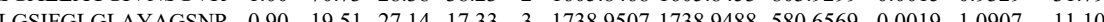

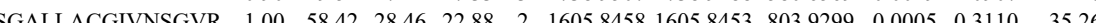

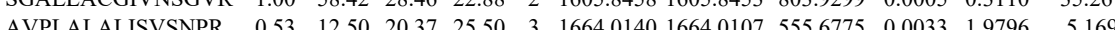
$\begin{array}{lllllllllllll}\text { SHYVLYGLVAAMQPR } & 0.98 & 28.24 & 28.15 & 17.76 & 3 & 1703.8828 & 1703.8817 & 568.9678 & 0.0011 & 0.6444 & 7.041\end{array}$ $\begin{array}{llllllllllll}\text { SHYVLYGLVAAMQPR } & 0.95 & 24.61 & 28.14 & 16.71 & 3 & 1703.8831 & 1703.8817 & 568.9678 & 0.0014 & 0.8202 & 6.103\end{array}$ $\begin{array}{llllllllllllll}\text { LGSIFGLGLAYAGSNR } & 0.55 & 12.31 & 27.08 & 25.31 & 3 & 1738.9513 & 1738.9488 & 580.6569 & 0.0025 & 1.4352 & 4.254\end{array}$ $\begin{array}{lllllllllllll}\text { SGALLACGIVNSGVR } & 1.00 & 62.24 & 28.44 & 23.52 & 2 & 1605.8474 & 1605.8453 & 803.9299 & 0.0021 & 1.3061 & 7.225\end{array}$ VPDDIYK

$\begin{array}{lllllllllllllllll}0.95 & 37.62 & 27.87 & 37.30 & 2 & 1136.6420 & 1136.6321 & 569.3233 & 0.0099 & 8.6945 & 8278.408 & 9054.842 & 7091.834 & 6280.515\end{array}$ $\begin{array}{lllllllllllllllllll} & 0.95 & & \end{array}$

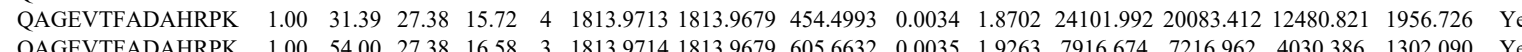
$\begin{array}{lllllllllllllllll}\text { QAGEVTFADAHRPK } & 1.00 & 54.00 & 27.38 & 16.58 & 3 & 1813.9714 & 1813.9679 & 605.6632 & 0.0035 & 1.9263 & 7916.674 & 7216.962 & 4030.386 & 1302.090 & \text { Yes } \\ \text { QAGEVTFA } & 27.36 & 18.75 & 4 & 1813.9677 & 1813.9679 & 454.4993 & -0.0002 & -0.1100 & 13752.777 & 14391.033 & 6320.682 & 2381.084 & \text { Yes }\end{array}$ $\begin{array}{llllllllllllllll}\text { QAGEVTFADAHRPK } & 1.00 & 48.69 & 27.28 & 16.79 & 4 & 1813.9697 & 1813.9679 & 454.4993 & 0.0018 & 0.9901 & 11334.517 & 12232.489 & 5929.151 & 2332.150 & \text { Yes }\end{array}$ $\begin{array}{lllllllllllllllll}\text { LIVENLSSR } & 0.99 & 41.31 & 26.67 & 27.18 & 2 & 1173.6954 & 1173.6839 & 587.8492 & 0.0115 & 9.7813 & 25704.881 & 21296.339 & 967.023 & 657.637 & \text { Yes }\end{array}$

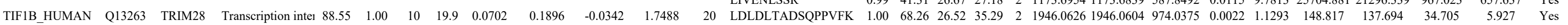
$\begin{array}{llllllllllllllllll}\text { LDLDLTADSQPPVFK } & 1.00 & 66.37 & 26.55 & 29.84 & 3 & 1946.0641 & 1946.0604 & 649.6941 & 0.0037 & 1.8983 & 415.565 & 527.579 & 150.890 & 127.688 & \text { Yes }\end{array}$ $\begin{array}{llllllllllllllll}\text { LDLDLTADSQPPVFK } & 1.00 & 47.40 & 26.57 & 28.61 & 3 & 1946.0644 & 1946.0604 & 649.6941 & 0.0040 & 2.0522 & 289.887 & 287.328 & 152.577 & 106.764 & \text { Yes }\end{array}$

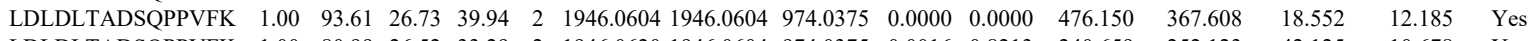

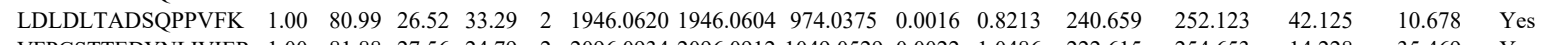

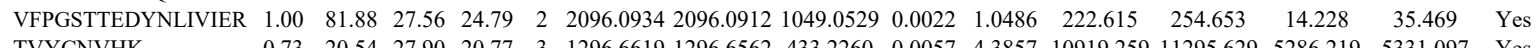

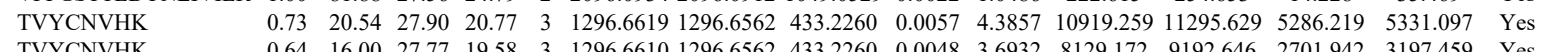

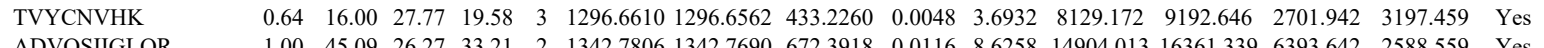
$\begin{array}{lllllllllllllllll}\text { ADVQSIIGLQR } & 1.00 & 45.09 & 26.27 & 33.21 & 2 & 1342.7806 & 1342.7690 & 672.3918 & 0.0116 & 8.6258 & 14904.013 & 16361.339 & 6393.642 & 2588.559 & \text { Yes }\end{array}$ $\begin{array}{llllllllllllllllll}\text { IVAERPGTNSTGPAPMAPPR } & 0.99 & 39.75 & 27.00 & 16.77 & 3 & 2162.1532 & 2162.1388 & 721.7202 & 0.0144 & 6.6507 & 4184.287 & 5223.163 & 1974.794 & 966.915 & \text { Yes }\end{array}$ $\begin{array}{llllllllllllllll}\text { IVAERPGTNSTGPAPMAPPR } & 1.00 & 55.74 & 26.96 & 16.74 & 3 & 2162.1547 & 2162.1388 & 721.7202 & 0.0159 & 7.3435 & 3090.149 & 3329.653 & 1379.821 & 507.361 & \text { Yes } \\ \text { IVAERPGTNSTGPAPMAPPR } & 1.00 & 51.0 & 27.07 & 19.84 & 3 & 216.1523 & 2162.1388 & 721.7202 & 0.0135 & 62351 & 7443.656 & 8236.876 & 3264.722 & 149.821 & \text { Yes }\end{array}$ $\begin{array}{llllllllllllllll}\text { IVAERPGTNSTGPAPMAPPR } & 1.00 & 51.60 & 27.07 & 19.84 & 3 & 2162.1523 & 2162.1388 & 721.7202 & 0.0135 & 6.2351 & 7443.656 & 8236.876 & 3264.722 & 1499.821 & \text { Yes } \\ \text { IVAERPGTNSTGPAPMAPPR } & 1.00 & 44.90 & 26.91 & 18.58 & 3 & 2162.1538 & 2162.1388 & 721.7202 & 0.0150 & 6.9278 & 17229.916 & 18248.689 & 8766.098 & 4033.944 & \text { Yes }\end{array}$

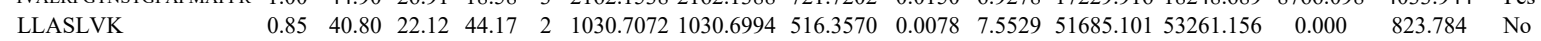

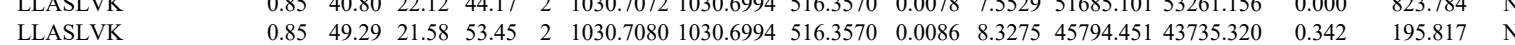



$\begin{array}{llllllllllllll}0.99 & 30.74 & 27.42 & 22.83 & 3 & 1232.7163 & 1232.7151 & 411.9123 & 0.0012 & 0.9711 & 2103.972 & 2612.464 & 182.175\end{array}$

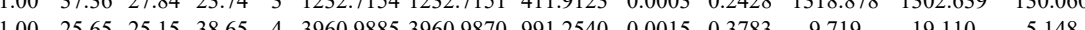

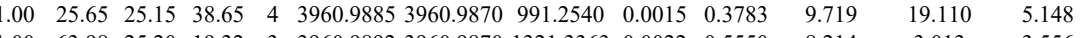

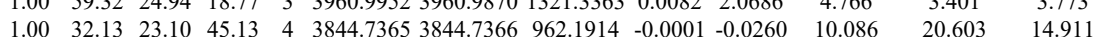

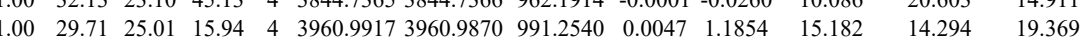

$\begin{array}{llllllllllllll} & 0.000\end{array}$

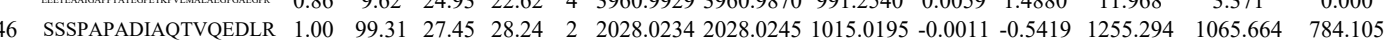

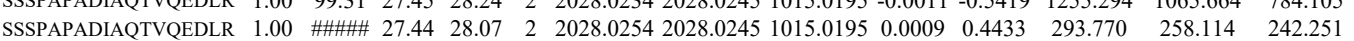
$\begin{array}{llllllllllllll}\text { SSSPAPADIAQTVQEDLR } & 1.00 & \text { \#\#\#\# } 27.44 & 23.51 & 2 & 2028.0254 & 2028.0245 & 1015.0195 & 0.0009 & 0.4433 & 110.087 & 219.975 & 80.507\end{array}$

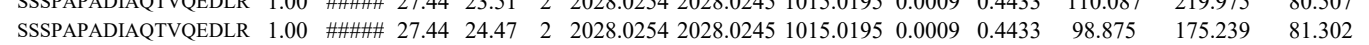
$\begin{array}{lllllllllllllll}\text { HPDSHQLFIGNLPHEVDK } & 1.00 & 34.74 & 26.43 & 47.74 & 4 & 2370.2501 & 2370.2324 & 593.5654 & 0.0177 & 7.4549 & 4017.218 & 4453.893 & 3800.806 & 610\end{array}$ $\begin{array}{llllllllllllll}\text { HPDSHQLFIGNLPHEVDK } & 1.00 & 42.18 & 26.45 & 17.51 & 4 & 2370.2521 & 2370.2324 & 593.5654 & 0.0197 & 8.2972 & 5067.410 & 3465.693 & 4158.823\end{array}$ $\begin{array}{lllllllllllllllll}\text { HPDSHQLFIGNLPHEVDK } & 0.96 & 21.08 & 26.45 & 34.08 & 4 & 2370.2521 & 2370.2324 & 593.5654 & 0.0197 & 8.2972 & 2066.240 & 2060.541 & 1592.047 & 1314.626 & \text { Yes }\end{array}$ $\begin{array}{lllllllllllllllll}\text { LPNFGFVVFDDSEPVQK } & 0.77 & 79.89 & 27.40 & 92.89 & 2 & 2225.1634 & 2225.1612 & 1113.5879 & 0.0022 & 0.9878 & 233.284 & 263.680 & 140.888 & 46.874 & \text { Yes }\end{array}$ $\begin{array}{llllllllllllllllll}\text { LPNFGFVVFDDSEPVQK } & 1.00 & 89.83 & 27.40 & 19.32 & 2 & 2225.1634 & 2225.1612 & 1113.5879 & 0.0022 & 0.9878 & 204.395 & 259.817 & 132.174 & 91.911 & \text { Yes }\end{array}$ $\begin{array}{llllllllllllllll}\text { LPNFGFVVFDDSEPVQK } & 1.00 & 45.54 & 27.46 & 20.51 & 3 & 2225.1649 & 2225.1612 & 742.7277 & 0.0037 & 1.6605 & 31.010 & 30.776 & 6.239 & 5.563 & \text { Yes }\end{array}$ $\begin{array}{llllllllllllllll}\text { LPNFGFVVFDDSEPVQK } & 0.77 & 64.96 & 27.40 & 77.96 & 2 & 2225.1634 & 2225.1612 & 1113.5879 & 0.0022 & 0.9878 & 505.081 & 492.022 & 367.183 & 73.815 & \text { Yes }\end{array}$ $\begin{array}{llllllllllllllll}\text { LPNFGFVVFDDSEPVQK } & 1.00 & 61.47 & 27.40 & 18.34 & 2 & 2225.1634 & 2225.1612 & 1113.5879 & 0.0022 & 0.9878 & 375.881 & 332.086 & 348.745 & 86.019 & \text { Yes }\end{array}$

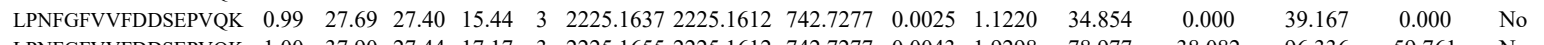

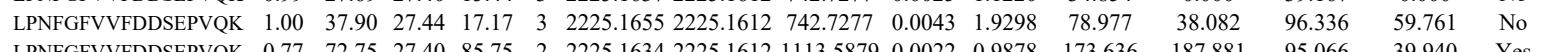

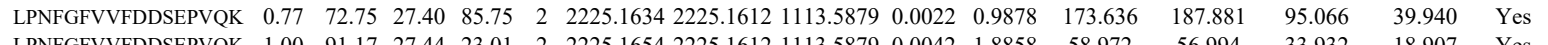

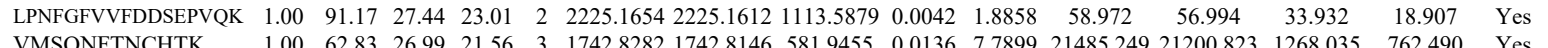
$\begin{array}{llllllllllllllll}\text { VMSQNFTNCHTK } & 1.00 & 62.83 & 26.99 & 21.56 & 3 & 1742.8282 & 1742.8146 & 581.9455 & 0.0136 & 7.7899 & 21485.249 & 21200.823 & 1268.035 & 762.490 & \text { Yes } \\ \text { VMSQNFTNCHTK } & 1.00 & 70.94 & 26.95 & 21.73 & 3 & 1742.8294 & 1742.8146 & 581.9455 & 0.0148 & 8.4772 & 9889.332 & 9109.488 & 1662060 & 750.525 & Y\end{array}$ $\begin{array}{lllllllllllllllll}\text { VMSQNFTNCHTK } & 1.00 & 70.94 & 26.95 & 21.73 & 3 & 1742.8294 & 1742.8146 & 581.9455 & 0.0148 & 8.4772 & 9889.332 & 9109.488 & 1662.060 & 750.525 & \text { Yes } \\ \text { VMSQNFTNCHTK } & 1.00 & 60.93 & 26.69 & 20.65 & 3 & 17428300 & 17428146 & 581.9455 & 0.0154 & 8.8209 & 7511.956 & 7863.209 & 816.138 & 285.430 & \text { Yes }\end{array}$

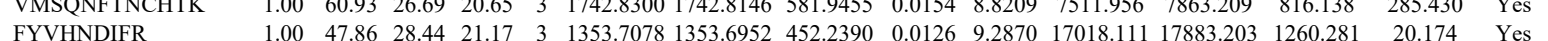

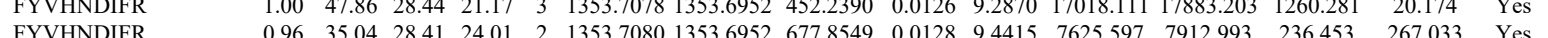

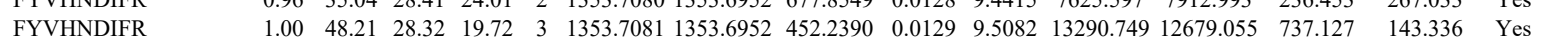

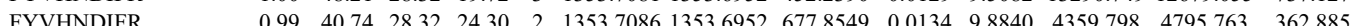
$\begin{array}{llllllllllllll}\text { QYYTLLNQAPDMLHR } & 1.00 & 42.09 & 27.73 & 16.32 & 3 & 2006.0161 & 2006.0165 & 669.6794 & -0.0004 & -0.1991 & 2636.364 & 3013.321 & 588.683\end{array}$ $\begin{array}{lllllllllllllll}\text { INIPPQR } & 0.82 & 21.98 & 25.35 & 24.22 & 2 & 980.5920 & 980.5889 & 491.3017 & 0.0031 & 3.1549 & 7666.860 & 8065.666 & 1761.364 & 1004\end{array}$ INIPPQR INIPPQR
INIPPQR $\begin{array}{lll}1004.095 & \text { Yes } \\ 417.616 & \text { Yes } & -1 \\ 735.211 & \text { Yes }\end{array}$ $\begin{array}{lllllllllllllllllll}0.90 & 22.32 & 24.70 & 23.71 & 2 & 980.5912 & 980.5889 & 491.3017 & 0.0023 & 2.3407 & 12330.352 & 13500.556 & 1079.187 & 735.211 & \text { Yes }\end{array}$ INIPPQR $\begin{array}{llllllllllllllllll}0.54 & 16.11 & 25.19 & 18.53 & 2 & 980.5918 & 980.5889 & 491.3017 & 0.0029 & 2.9513 & 12688.525 & 12432.094 & 1570.465 & 777.964 & \text { Yes }\end{array}$

gracesonved
$\begin{array}{lllllllllllll}.00 & 70.98 & 25.34 & 83.98 & 4 & 3128.6289 & 3128.6271 & 783.1641 & 0.0018 & 0.5746 & 24.449 & 49.717 & 28.906\end{array}$ HVDAHATLNDGVVVQVYMGLLSNNNQAL, $\begin{array}{lllllllllllll}1.00 & 22.17 & 25.38 & 35.17 & 4 & 3128.6277 & 3128.6271 & 783.1641 & 0.0006 & 0.1915 & 481.448 & 344.302\end{array}$ $\begin{array}{lllllllllllll}0.53 & 26.49 & 25.33 & 39.49 & 3 & 3128.6302 & 3128.6271 & 1043.8830 & 0.0031 & 0.9899 & 4.509 & 21.329\end{array}$ $\begin{array}{llllllllllll}1.00 & 20.59 & 25.21 & 33.59 & 4 & 3128.6321 & 3128.6271 & 783.1641 & 0.0050 & 1.5961 & 10.031\end{array}$ $\begin{array}{llllllllllll}0.69 & 22.06 & 28.27 & 22.59 & 3 & 1231.6852 & 1231.6859 & 411.5692 & -0.0007 & -0.5669 & 70.901 & 213 \\ 0.92 & 24.66 & 28.23 & 23.08 & 3 & 1231.6858 & 1231.6859 & 41.5692 & -0.0001 & 0.0810 & 74.148 & 40\end{array}$ $\begin{array}{llllllllllll}0.92 & 24.66 & 28.23 & 23.08 & 3 & 1231.6858 & 1231.6859 & 411.5692 & -0.0001 & -0.0810 & 74.148 \\ 0.63 & 22.29 & 28.29 & 22.91 & 2 & 1231.6858 & 1231.6859 & 616.8502 & -0.0001 & -0.0811 & 50.169\end{array}$

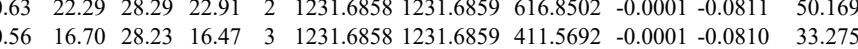

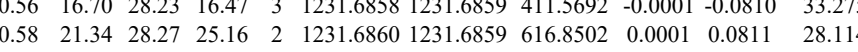
$\begin{array}{llllllllllllll}0.75 & 19.82 & 28.27 & 16.53 & 3 & 1231.6861 & 1231.6859 & 411.5692 & 0.0002 & 0.1620 & 25.228\end{array}$ $\begin{array}{llllllllllll}0.88 & 25.50 & 28.25 & 22.88 & 2 & 1231.6866 & 1231.6859 & 616.8502 & 0.0007 & 0.5674 & 114.116 \\ 0.80 & 18.35 & 28.76 & 15.59 & 3 & 1231.6894 & 1231.6859 & 411.5692 & 0.0035 & 2.8347 & 183.786\end{array}$ $\begin{array}{lllllllllll}0.80 & 18.35 & 28.76 & 15.59 & 3 & 1231.6894 & 1231.6859 & 411.5692 & 0.0035 & 2.8347 & 183.786 \\ 1.00 & 38.41 & 28.23 & 28.41 & 3 & 1231.6858 & 1231.6859 & 411.5692 & -0.0001 & -0.0810 & 16.617\end{array}$ $\begin{array}{lllllllllll}1.00 & 38.41 & 28.23 & 28.41 & 3 & 1231.6858 & 1231.6859 & 411.5692 & -0.0001 & -0.0810 & 16.617 \\ 0.63 & 22.11 & 28.27 & 23.05 & 2 & 1231.6860 & 1231.6859 & 616.8502 & 0.0001 & 0.0811 & 31.276\end{array}$ $\begin{array}{lllllllllll}0.63 & 22.11 & 28.27 & 23.05 & 2 & 1231.6860 & 1231.6859 & 616.8502 & 0.0001 & 0.0811 & 31.276 \\ 0.63 & 22.19 & 28.27 & 25.27 & 2 & 1231.6860 & 1231.6859 & 616.8502 & 0.0001 & 0.0811 & 87.849\end{array}$ $\begin{array}{llllllllllll}0.65 & 18.05 & 28.25 & 16.44 & 3 & 1231.6864 & 1231.6859 & 411.5692 & 0.0005 & 0.4050 & 0.000\end{array}$ $\begin{array}{llllllllllll}0.94 & 26.03 & 28.22 & 18.09 & 3 & 1231.6858 & 1231.6859 & 411.5692 & -0.0001 & -0.0810 & 36.636\end{array}$ $\begin{array}{llllllllllll}0.51 & 20.02 & 28.29 & 17.58 & 2 & 1231.6858 & 1231.6859 & 616.8502 & -0.0001 & -0.0811 & 28.264\end{array}$ 

$\begin{array}{llllllllllllllll}\text { IIFVGR } & 0.70 & 21.66 & 27.88 & 30.12 & 2 & 847.5434 & 847.5402 & 424.7774 & 0.0032 & 3.7667 & 28253.406 & 29833.944 & 1819.933 & 430.298 & \text { Yes } \\ \text { AGVVNGTGAPGQSPGAGR } & 1.00 & 97.32 & 28.04 & 29.07 & 2 & 1695.8790 & 1695.8775 & 848.9460 & 0.0015 & 0.8834 & 87.453 & 63.170 & 55.013 & 27.145 & \text { Yes } \\ \text { AGVVNGTGAPGQSPGAGR } & 0.74 & 1581 & 27.89 & 14.02 & 3 & 1695.8797 & 1695.8775 & 5662998 & 0.0022 & 1.2950 & 217.900 & 175.755 & 168.734 & 106.392 & \text { Yes }\end{array}$ $\begin{array}{lllllllllllllll}1.00 & 41.17 & 26.04 & 22.12 & 2 & 12867494 & 12867469 & 644.3807 & 0.0025 & 0.6983 & 25834.451 & 25962.790 & 1916.075 & 638.540 & \text { Y }\end{array}$ $\begin{array}{llllllllllllllll}0.75 & 22.74 & 27.88 & 30.40 & 2 & 847.5432 & 847.5402 & 424.7774 & 0.0030 & 3.5312 & 38062.487 & 37006.335 & 2614.859 & 583.907 & \text { Yes } \\ 0.70 & 21.66 & 27.88 & 30.12 & 2 & 847.5434 & 847.5402 & 424.7774 & 0.0032 & 3.7667 & 28253.406 & 29833.944 & 1819.933 & 430.928 & Y \text { Yes }\end{array}$ $\begin{array}{lllllllllllllll} & 27.89 & 14.02 & 3 & 1695.8797 & 1695.8775 & 566.2998 & 0.0022 & 1.2950 & 217.900 & 175.755 & 168.734 & 106.392 & \text { Yes } \\ \end{array}$

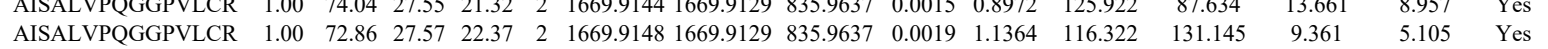

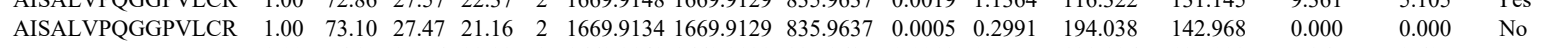

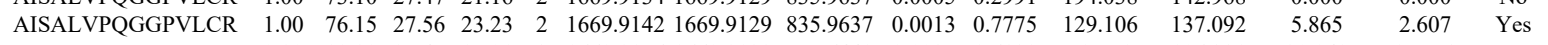
$\begin{array}{llllllllllllllll}\text { AISALVPQGGPVLCR } & 0.90 & 19.80 & 27.45 & 17.01 & 3 & 1669.9156 & 1669.9129 & 557.6449 & 0.0027 & 1.6139 & 79.751 & 106.331 & 30.942 & 15.778 & \text { Yes }\end{array}$

LFDSTTLEHQK

LFDSTTLEHQK

LFDSTTLEHQK

LFDSTTLEHQK

MKPILLQGHER

MKPILLQGHER

MKPILLQGHER

MKPILLQGHER

MKPILLQGHER

MKPILLQGHER

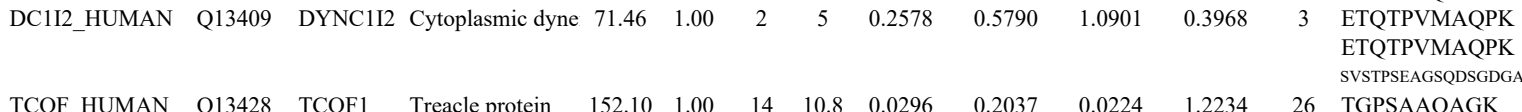

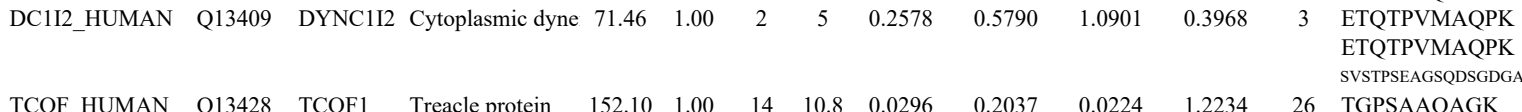

\section{LPEVQQATK}

VGDVTPQVK

TGNSMPHPATGK
GPASVPSVKK

GPASVPSVGK

TGPAAAQVQVGK

GPASVPSVGK

VGPATPSAQVGK

VGPATPSAQVGK

VGPATPSAQVGK

SPAGPAATPAQAQAASTPR

SPAGPAATPAQAQAAS
VGPATPSAQVGK

KTGPAAAQVQVGK SPAGPAATPAQAQAASTP

SPAGPAATPAQAQAA

TGLAVTVGQAK

TNVVTMPTAHPR

TNVVTMPTAHPR

TNVVTMPTAHPR

TNVVTMPTAHPR

TNVVTMPTAHPR

CFLAQPVTLLDIYTHW

KAEEDAALQAK

KAEEDAALQAK

QTGIVLNRPVLR

$\begin{array}{cccccccccccccc}1.00 & 46.18 & 28.21 & 27.78 & 3 & 1605.87371605 .8606 & 536.2941 & 0.0131 & 8.1422 & 4716.931 & 4364.381 & 1489.218 & 1094.680 & \text { Yes }\end{array}$ $\begin{array}{lllllllllllllll}0.59 & 26.14 & 28.18 & 20.54 & 2 & 1605.8678 & 1605.8606 & 803.9376 & 0.0072 & 4.4779 & 4582.220 & 6044.591 & 2152.274 & 1711.815 & \text { No }\end{array}$ $\begin{array}{llllllllllllllll}0.99 & 40.37 & 28.30 & 22.21 & 3 & 1605.8722 & 1605.8606 & 536.2941 & 0.0116 & 7.2099 & 9438.447 & 8381.298 & 1434.755 & 937.148 & \text { Yes }\end{array}$ $\begin{array}{lllllllllllllll}1.00 & 40.93 & 28.22 & 27.36 & 3 & 1605.8728 & 1605.8606 & 536.2941 & 0.0122 & 7.5828 & 10912.083 & 11834.484 & 1033.079 & 715.148 & \text { Yes }\end{array}$ $\begin{array}{lllllllllllllll}1.00 & 41.43 & 24.12 & 15.83 & 4 & 1608.9417 & 1608.9377 & 403.2417 & 0.0040 & 2.4799 & 29523.448 & 24929.335 & 6086.509 & 1863.211 & \text { Yes }\end{array}$ $\begin{array}{llllllllllllllll}1.00 & 30.68 & 24.12 & 16.28 & 4 & 1608.9445 & 1608.9377 & 403.2417 & 0.0068 & 4.2158 & 35415.965 & 35897.896 & 4830.599 & 1841.896 & \text { Yes }\end{array}$ $\begin{array}{llllllllllllllll}0.99 & 31.29 & 24.10 & 17.45 & 3 & 1608.9448 & 1608.9377 & 537.3198 & 0.0071 & 4.4046 & 7471.790 & 7356.380 & 3194.952 & 2146.786 & \text { Yes }\end{array}$ $\begin{array}{llllllllllllllll}1.00 & 37.29 & 24.10 & 15.73 & 3 & 1608.9451 & 1608.9377 & 537.3198 & 0.0074 & 4.5907 & 16344.174 & 14165.872 & 4489.790 & 2702.654 & \text { Yes }\end{array}$ $\begin{array}{llllllllllllllllllll}1.00 & 45.85 & 23.87 & 58.85 & 4 & 1608.9489 & 1608.9377 & 403.2417 & 0.0112 & 6.9437 & 15190.580 & 15217.354 & 2702.338 & 1556.484 & \text { Yes } \\ 1.00 & 58.28 & 23.38 & 6.66 & 4 & 1608.9493 & 1608.9377 & 403.2417 & 0.016 & 7.1917 & 14458.764 & 0828.103 & 235.422 & 780.775 & \text { Yes }\end{array}$ $\begin{array}{lllllllllllllllll}1.00 & 58.28 & 23.38 & 16.66 & 4 & 1608.9493 & 1608.9377 & 403.2417 & 0.0116 & 7.1917 & 14458.764 & 10828.103 & 2385.422 & 780.775 & \text { Yes } \\ 0.99 & 44.12 & 27.99 & 33.37 & 2 & 1516.8234 & 1516.8163 & 759.4154 & 0.0071 & 4.6746 & 180.924 & 294.192 & 351.502 & 533.516 & \text { Yes }\end{array}$ $\begin{array}{lllllllllllllll}0.99 & 46.86 & 27.93 & 32.35 & 2 & 1516.8240 & 1516.8163 & 759.4154 & 0.0077 & 5.0697 & 180.924 & 294.192 & 351.502 & 533.516 & \text { Yes } \\ 1\end{array}$ $\begin{array}{lllllllllllllll}0.99 & 46.86 & 27.93 & 32.35 & 2 & 1516.8240 & 1516.8163 & 759.4154 & 0.0077 & 5.0697 & 258.766 & 200.497 & 614.224 & 557.473 & \text { Yes } \\ 1.00 & 4.424 & 25.34 & 25.24 & 2 & 2093.9614 & 2093.9583 & 1047.9864 & 0.0031 & 1.4790 & 352293 & 516.281 & 632.478 & 600.490 & \text { Yes }\end{array}$

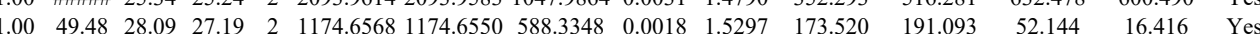

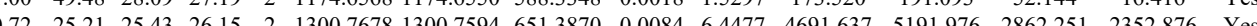

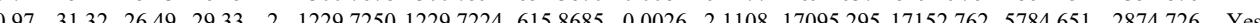
$\begin{array}{lllllllllllllll}0.98 & 29.05 & 27.87 & 17.20 & 3 & 1484.7664 & 1484.7649 & 495.9289 & 0.0015 & 1.0082 & 452.371 & 466.630 & 182.408 & 127.501 & \text { Yes }\end{array}$ $\begin{array}{lllllllllllllll}1.00 & 47.49 & 26.70 & 28.40 & 2 & 1185.6986 & 1185.6961 & 593.8553 & 0.0025 & 21049 & 11940.965 & 12273.015 & 6213.419 & 5865.196 & \text { Yes }\end{array}$ $\begin{array}{lllllllllllllllll}1.00 & 73.77 & 25.66 & 21.74 & 2 & 1413.8210 & 1413.8184 & 707.9165 & 0.0026 & 1.8364 & 13274.749 & 11467.991 & 3658.691 & 1346.424 & \text { Yes }\end{array}$ $\begin{array}{llllllllllllllll}0.58 & 12.03 & 25.53 & 16.55 & 3 & 1413.8221 & 1413.8184 & 4722801 & 0.0037 & 2.6114 & 4752.316 & 5951.606 & 2925297 & 1472.653 & \text { Yes }\end{array}$ $\begin{array}{llllllllllllllll}1.00 & 61.51 & 26.70 & 30.15 & 2 & 1185.6996 & 1185.6961 & 593.8553 & 0.0035 & 2.9468 & 6655.175 & 7641.135 & 3070.301 & 3005.993 & \text { Yes }\end{array}$ $\begin{array}{lllllllllllllllll}1.00 & 59.99 & 25.83 & 29.37 & 2 & 1398.8110 & 1398.8075 & 700.4110 & 0.0035 & 2.4985 & 26754.250 & 24889.044 & 6579.751 & 758.093 & \text { Yes }\end{array}$ $\begin{array}{llllllllllllllll}0.96 & 24.09 & 25.71 & 18.96 & 3 & 1398.8125 & 1398.8075 & 467.2764 & 0.0050 & 3.5668 & 2737.405 & 2721.379 & 1592.088 & 864.701 & \text { Yes }\end{array}$ $\begin{array}{llllllllllllllll}1.00 & 67.61 & 25.65 & 28.79 & 2 & 1398.8126 & 1398.8075 & 700.4110 & 0.0051 & 3.6407 & 22280.724 & 20536.043 & 5126.714 & 870.950 & \text { Yes }\end{array}$

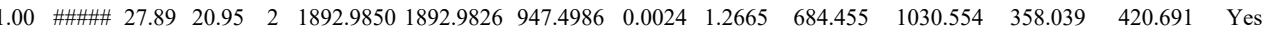

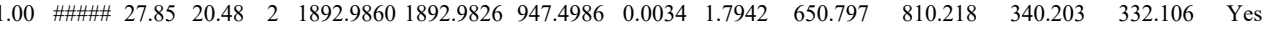
$\begin{array}{lllllllllllllll}1.00 & 66.96 & 25.82 & 26.28 & 2 & 1398.8114 & 1398.8075 & 700.4110 & 0.0039 & 2.7841 & 15142.560 & 16558.529 & 2763.529 & 489.880 & \text { Yes }\end{array}$ $\begin{array}{lllllllllllllll}0.55 & 46.93 & 21.11 & 59.93 & 3 & 1686.0178 & 1686.0154 & 563.0124 & 0.0024 & 1.4209 & 6896.399 & 7850.580 & 2590.197 & 2304.929 & \text { Yes }\end{array}$

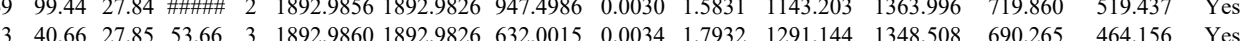
$\begin{array}{lllllllllllllll}.53 & 40.66 & 27.85 & 53.66 & 3 & 1892.9860 & 1892.9826 & 632.0015 & 0.0034 & 1.7932 & 1291.144 & 1348.508 & 690.265 & 464.156 & \text { Yes } \\ 1.00 & 75.65 & 24.15 & 30.04 & 2 & 1331.8134 & 1331.8017 & 666.9081 & 0.0117 & 8.7717 & 5485.329 & 5449.602 & 2403.767 & 1314596 & \text { Yes }\end{array}$

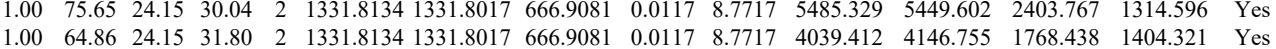
$\begin{array}{llllllllllllllll}1.00 & 4.86 & 24.15 & 31.80 & 2 & 1331.8134 & 1331.8017 & 666.9081 & 0.0177 & 8.7717 & 4039.412 & 4146.755 & 1768.438 & 1404.321 & \text { Yes } \\ 1.00 & 74.61 & 28.06 & 22.62 & 3 & 1466.7844 & 1466.7786 & 489.9335 & 0.0058 & 3.9461 & 6131.171 & 6830.204 & 2203.630 & 815.839 & \text { Yes }\end{array}$ $\begin{array}{lllllllllllllll}1.00 & 55.40 & 28.06 & 24.40 & 3 & 1466.7847 & 1466.7786 & 489.9335 & 0.0061 & 4.1502 & 8432.270 & 9884.490 & 2470.189 & 1227.432 & \text { Yes }\end{array}$ $\begin{array}{lllllllllllllll}0.99 & 28.19 & 27.99 & 15.75 & 3 & 1482.7753 & 1482.7735 & 495.2651 & 0.0018 & 1.2115 & 318.824 & 346.195 & 145.058 & 69.954 & \text { Yes }\end{array}$ $\begin{array}{lllllllllllllll}1.00 & 61.21 & 28.13 & 22.95 & 3 & 1466.7850 & 1466.7786 & 489.9335 & 0.0064 & 4.3543 & 5947.339 & 6196.226 & 2500.155 & 1285.956 & \text { Yes } \\ 1.00 & 51.89 & 28.16 & 18.30 & 3 & 1466.7859 & 1466.7786 & 489.935 & 0.0073 & 4.9666 & 9205.847 & 8884.437 & 3251.602 & 162.877 & \text { Yes }\end{array}$ $\begin{array}{lllllllllllllll}1.00 & 51.89 & 28.16 & 18.30 & 3 & 1466.7859 & 1466.7786 & 489.9335 & 0.0073 & 4.9666 & 9205.847 & 8884.437 & 3251.602 & 1624.877 & \text { Yes } \\ 1.00 & 61.69 & 26.74 & 17.56 & 3 & 3008.5012 & 3008.5010 & 1003.8409 & 0.0002 & 0.0664 & 189.780 & 155.301 & 7.028 & 14.40 & \text { No }\end{array}$

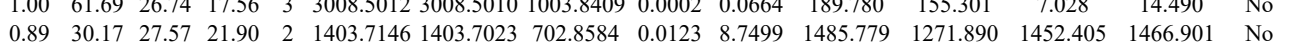

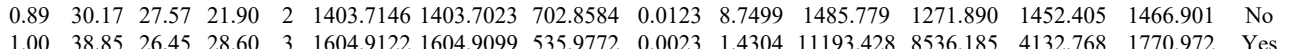
$\begin{array}{llllllllllllllll}1.00 & 53.15 & 26.50 & 31.45 & 3 & 1604.9128 & 1604.9099 & 535.9772 & 0.0029 & 1.8036 & 16489.488 & 13399.984 & 3967.094 & 2148.749 & \text { Yes }\end{array}$

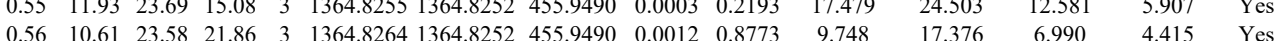



$\begin{array}{llllllllll}1.00 & \text { \#\#\#\# } 23.20 & 20.63 & 3 & 3522.8692 & 3522.8679 & 1175.2966 & 0.0013 & 0.3687 & 5.728\end{array}$ $\begin{array}{lllllllllll}1.00 & 54.37 & 23.18 & 17.57 & 4 & 3522.8709 & 3522.8679 & 881.7243 & 0.0030 & 0.8506 & 8.25\end{array}$

$\begin{array}{llllllllllll}1.00 & 27.43 & 21.82 & 15.58 & 3 & 2061.1918 & 2061.1876 & 688.0698 & 0.0042 & 2.0347 & 3686.178\end{array}$

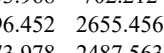

-10
0

LAEIGAPIQGNR

SLGMVGPNAHK

$\begin{array}{lllllllll} & 0\end{array}$

\begin{tabular}{lllllllllllllllll}
0.91 & 2625 & 25.69 & 15.77 & 3 & 1607.9212 & 1607.9061 & 536.9760 & 0.0151 & 9.3734 & 49751.215 & 50581.585 & 3882.104 & 825.885 & Y & & \\
\hline
\end{tabular}

$\begin{array}{lllllllllllllll}0.91 & 26.25 & 25.69 & 15.77 & 3 & 1607.9212 & 1607.9061 & 536.9760 & 0.0151 & 9.3734 & 49751.215 & 50581.585 & 3882.104 & 825.885 & \text { Yes } \\ 1.00 & 43.68 & 25.60 & 19.39 & 3 & 1607.9167 & 1607.9061 & 536.9760 & 0.0106 & 65800 & 20556.892 & 20897.306 & 4860.933 & 862.477 & Y\end{array}$

ISLGMPVGPNAHK

$\begin{array}{lllllllllllllll}1.00 & 46.29 & 25.45 & 19.65 & 3 & 1607.9179 & 1607.9061 & 536.9760 & 0.0118 & 7.3249 & 30961.098 & 26796.108 & 6301.255 & 340.046 & \text { Yes }\end{array}$

$\begin{array}{lllllllllllllllllll}\text { MGTPVPRPPODMGOIGVR } & 0.93 & 29.75 & 27.51 & 15.04 & 3 & 2079.1003 & 2079.0840 & 694.0353 & 0.0163 & 7.8286 & 11086.867 & 11095.651 & 8259.821 & 3632.711 & \text { Yes }\end{array}$

$\begin{array}{llllllllllllllll}\text { MGTPVPRPPQDMGQIGVR } & 0.64 & 21.79 & 27.51 & 14.77 & 3 & 2079.1003 & 2079.0840 & 694.0353 & 0.0163 & 7.8286 & 2613.051 & 2584.434 & 1583.812 & 894.824 & \text { Yes }\end{array}$

$\begin{array}{llllllllllllllllll}\text { VPPPWLIAMQR } & 1.00 & 46.30 & 26.75 & 25.33 & 2 & 1450.8242 & 1450.8241 & 726.4193 & 0.0001 & 0.0688 & 272.737 & 219.554 & 300.370 & 123.880 & \text { Yes }\end{array}$

VPPPWLIAMQR

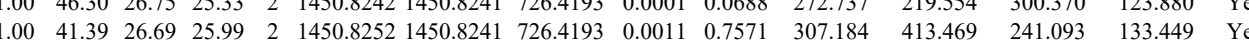

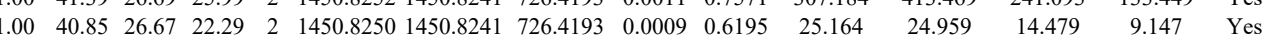
$\begin{array}{llllllllllllllll}0.99 & 34.41 & 26.69 & 22.98 & 2 & 1450.8254 & 1450.8241 & 726.4193 & 0.0013 & 0.8948 & 30.602 & 45.632 & 25.476 & 12.024 & \text { Yes }\end{array}$ $\begin{array}{lllllllllllll}0.94 & 20.99 & 21.11 & 15.76 & 2 & 1508.9288 & 1508.9273 & 755.4709 & 0.0015 & 0.9928 & 137.529 & 161.196 & 81.199\end{array}$ $\begin{array}{llll}9 & 280.737 & 265.554 & 80.720\end{array}$

QTGIVLNRPVLR
QTGIVLNRPVLR

QTGIVLNRPVLR

QTGIVLNRPVLR

GPPPPPGDENR

QTGIVLNRPVLR

$\begin{array}{llllllllllll} & \end{array}$

QTGIVLNRPVLR

KPGDLSDELR

KPGDLSDELR

KQQAQVEKEDFSDMV

KPGDLSDELR

$\begin{array}{lllllllllllll} & & & \end{array}$ GVEGLIDIENPNR TVEDLDGK

GVEGLIDIENPNR

GVTQLDIENA

MQSLSLNK

MOSLSLNK

$\begin{array}{lllllllllllllll}1.00 & 43.12 & 26.60 & 20.94 & 2 & 1275.6348 & 1275.6329 & 638.8237 & 0.0019 & 1.4871 & 447.425 & 402.134 & 235.802 & 296.643 & \text { Yes }\end{array}$

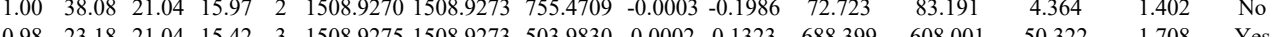
$\begin{array}{lllllllllllllll}1.00 & 49.22 & 27.39 & 24.17 & 3 & 1416.7921 & 1416.7816 & 473.2678 & 0.0105 & 7.3953 & 11176.941 & 11655.156 & 12305.141 & 9805.100 & \text { Yes } \\ 1.00 & 53.86 & 27.56 & 23.66 & 3 & 1416.7942 & 1416.7816 & 473.2678 & 0.0126 & 8.8744 & 16778.988 & 14534.646 & 17685.607 & 12020389 & \text { Yes }\end{array}$ $\begin{array}{lllllllllllllllll}1.00 & 53.86 & 27.56 & 23.66 & 3 & 1416.7942 & 1416.7816 & 473.2678 & 0.0126 & 8.8744 & 16778.988 & 14534.646 & 17685.607 & 12020.389 & \text { Yes } \\ 0.99 & 29.13 & 2.72 & 42.13 & 4 & 2821.4005 & 28213918 & 7063552 & 0.0087 & 3.0792 & 524.849 & 210.077 & 332.736 & 320.709 & \text { Yes }\end{array}$ $\begin{array}{lllllllllllllll}0.99 & 29.13 & 26.72 & 42.13 & 4 & 2821.4005 & 2821.3918 & 706.3552 & 0.0087 & 3.0792 & 524.849 & 210.077 & 332.736 & 320.709 & \text { Yes } \\ 1.00 & 43.61 & 27.51 & 22.00 & 3 & 1416.7933 & 1416.7816 & 473.2678 & 0.0117 & 8.2405 & 5350.611 & 5175.622 & 5855.681 & 512.58 & \text { Yes }\end{array}$ \begin{tabular}{lllllllllllllll}
1.00 & 43.61 & 27.51 & 22.00 & 3 & 1416.7933 & 1416.7816 & 473.2678 & 0.0117 & 8.2405 & 5350.611 & 5175.622 & 5855.681 & 5192.658 & Yes \\
\hline
\end{tabular} $\begin{array}{lllllllllllllll} & \end{array}$ $\begin{array}{lllllllllllllll}1.00 & 74.55 & 28.02 & 23.50 & 2 & 1568.8302 & 1568.8280 & 785.4213 & 0.002 & 0.6366 & 3538.407 & 3994.729 & 2343.922 & 872.224 & \text { Yes }\end{array}$ $\begin{array}{lllllllllllllll}1.00 & 74.55 & 28.02 & 24.50 & 2 & 1568.8302 & 1568.8280 & 785.4213 & 0.0022 & 1.4005 & 945.699 & 936.618 & 666.772 & 417.643 & \text { Yes } \\ 1.00 & 50.17 & 26.80 & 31.01 & 2 & 1372.7926 & 13727806 & 687.3976 & 0.0120 & 8.7285 & 2651.109 & 2014.470 & 1244.112 & 705.980 & \text { Yes }\end{array}$

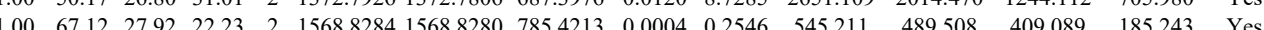

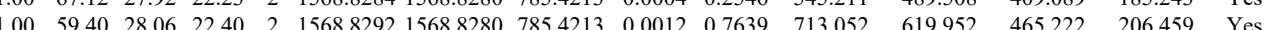
$\begin{array}{llllllllllllllll}0.97 & 35.63 & 21.96 & 29.15 & 3 & 1644.9892 & 1644.9776 & 549.3331 & 0.0116 & 7.0388 & 2515.120 & 2745.822 & 1552239 & 059.699 & \text { Yes }\end{array}$ $\begin{array}{lllllllllllllll}0.95 & 36.02 & 27.29 & 36.35 & 2 & 1207.6936 & 1207.6838 & 604.8492 & 0.0098 & 8.1011 & 19849.474 & 18850.107 & 1865.463 & 1391.205 & \text { Yes }\end{array}$ $\begin{array}{llllllllllllllll} & \\ \text { QYTSPEEIDAQLQAEK } & 1.00 & 99.86 & 27.90 & 28.03 & 2 & 2137.0794 & 2137.0782 & 1069.5464 & 0.0012 & 0.5610 & 650.588 & 527.906 & 228.129 & 84.712 & \text { Yes }\end{array}$

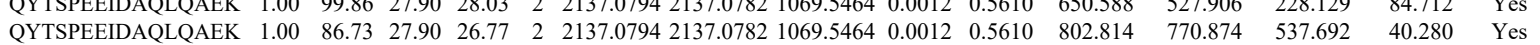

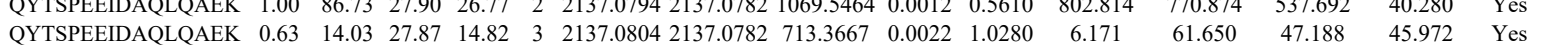

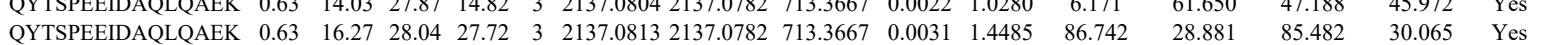

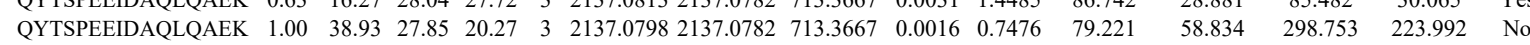

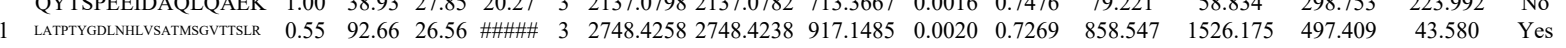
$\begin{array}{lllllllllllllllll}\text { LHFFMPGFAPLTAR } & 1.00 & 51.13 & 28.10 & 19.68 & 2 & 1747.9356 & 1747.9354 & 874.9750 & 0.0002 & 0.1143 & 96.558 & 99.136 & 19.032 & 15.443 & \text { No }\end{array}$ $\begin{array}{lllllllllllllllll}\text { LHFFMPGFAPLTAR } & 1.00 & 49.25 & 28.21 & 17.76 & 2 & 1747.9364 & 1747.9354 & 874.9750 & 0.0010 & 0.5714 & 100.516 & 158.972 & 20.511 & 16.400 & \text { Yes }\end{array}$

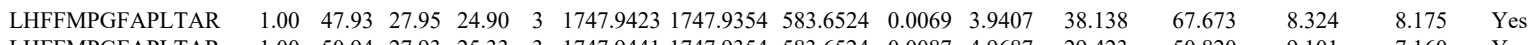
$\begin{array}{llllllllllllllll}\text { LHFFMPGFAPLTAR } & 1.00 & 50.94 & 27.93 & 25.33 & 3 & 1747.9441 & 1747.9354 & 583.6524 & 0.0087 & 4.9687 & 29.423 & 50.820 & 9.101 & 7.160 & \text { Yes }\end{array}$

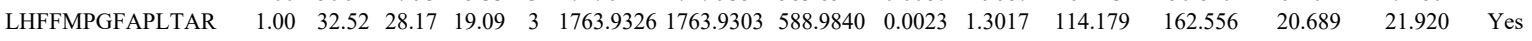
$\begin{array}{llllllllllllllll}\text { LHFFMPGFAPLTAR } & 1.00 & 33.32 & 28.05 & 17.69 & 3 & 1763.9332 & 1763.9303 & 588.9840 & 0.0029 & 1.6412 & 92.592 & 125.331 & 26.272 & 16.833 & \text { Yes }\end{array}$ $\begin{array}{llllllllllllllll}\text { LHFFMPGFAPLTAR } & 0.98 & 42.64 & 28.21 & 16.99 & 2 & 1747.9342 & 1747.9354 & 874.9750 & -0.0012 & -0.6857 & 46.150 & 64.637 & 9.832 & 6.402 & \text { Yes }\end{array}$ $\begin{array}{llllllllllllllll}\text { LHFFMPGFAPLTAR } & 0.97 & 34.83 & 28.10 & 17.69 & 2 & 1747.9356 & 1747.9354 & 874.9750 & 0.0002 & 0.1143 & 30.825 & 68.547 & 9.067 & 4.902 & \text { Yes }\end{array}$

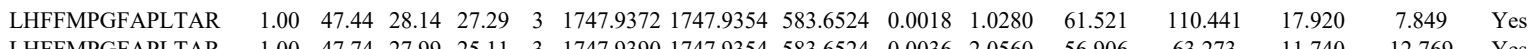

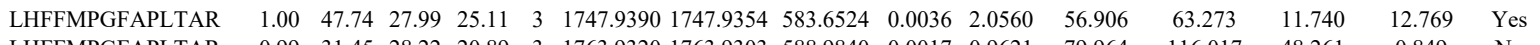

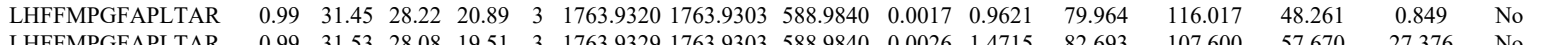

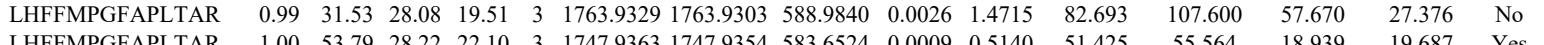

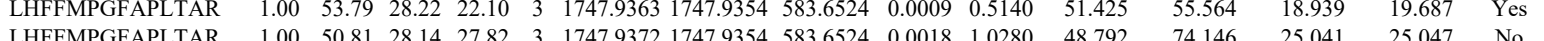

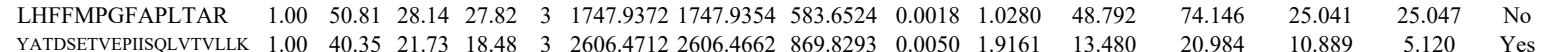

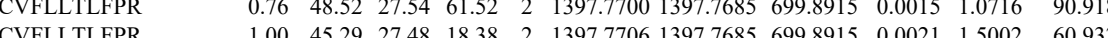
$\begin{array}{lllllllll} & 0\end{array}$ $\begin{array}{llllllllllll}\text { LLGPDAAINLTDPDGALAK } & 1.00 & 64.15 & 23.96 & 22.03 & 3 & 2152.2019 & 2152.1983 & 718.4067 & 0.0036 & 1.6704 & 118.209\end{array}$ 


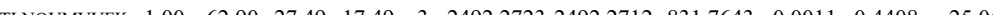
$\begin{array}{lllllllllllll}\text { YNLEELYQAVENLCSHK } & 1.00 & 74.67 & 26.79 & 22.79 & 3 & 2386.1557 & 2386.1540 & 796.3919 & 0.0017 & 0.7115 & 74.073 \\ \text { SLLGMLSDLQVYK } & 1.0 & 30.5 & 25.72 & 18.92 & 3 & 1753.9924 & 1753.9892 & 585.6703 & 0.0032 & 1.8213 & 582.411\end{array}$ SLLGMLSDLQVYK

$\begin{array}{llllllllllll}1.00 & 30.50 & 25.72 & 18.92 & 3 & 1753.9924 & 1753.9892 & 585.6703 & 0.0032 & 1.8213 & 582.441 \\ 0.82 & 20.14 & 25.56 & 19.03 & 3 & 1753.9951 & 1753.9892 & 585.6703 & 0.0059 & 3.3580 & 496.346 & \end{array}$

$\begin{array}{lllllllllllll} & \end{array}$ $\begin{array}{llllllllllll} & \end{array}$

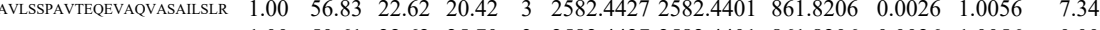
$\begin{array}{lllllllllllll}\text { AVLSSPAVTEQEVAQVASALSLR } & 1.00 & 50.61 & 22.62 & 25.70 & 3 & 2582.4427 & 2582.4401 & 861.8206 & 0.0026 & 1.0056 & 0.000\end{array}$ $\begin{array}{lllllllllll} & \end{array}$ $\begin{array}{llllllllllll}\text { AVLSSPAVTEQEVAQVASALSLR } & 0.53 & 41.12 & 22.62 & 54.12 & 3 & 2582.4430 & 2582.4401 & 861.8206 & 0.0029 & 1.1217 & 11.765 \\ \text { AVLSSPAVTEOEVAOVASAISLR } & 1.00 & 77.63 & 22.60 & 23.79 & 3 & 2582.4439 & 2582.4401 & 861.8206 & 0.0038 & 1.4698 & 22.536\end{array}$ $\begin{array}{lccccccccccc}\text { AVLSSPAVTEEEVAQVASALSLR } & 1.00 & 77.63 & 22.60 & 23.79 & 3 & 2582.4439 & 2582.4401 & 861.8206 & 0.0038 & 1.4698 & 22.536 \\ \text { AVISSPAVTFEEVAQVASAISLR } & 1.00 & \# \# \# \# \frac{22.67}{24.37} & 2 & 2582.4414 & 2582.4401 & 12922273 & 0.0013 & 0.5030 & 3.721\end{array}$

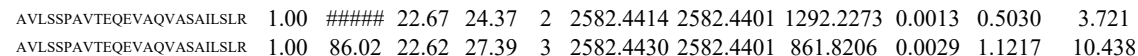
$\begin{array}{llllllllllll}\text { AVLSSPAVTEQEVAQVASALSLR } & 1.00 & 86.02 & 22.62 & 27.39 & 3 & 2582.4430 & 2582.4401 & 861.8206 & 0.0029 & 1.1217 & 10.438 \\ \text { AVLSSPAVTEOEVAQVASAILSLR } & 1.00 & 76.07 & 22.60 & 26.03 & 3 & 2582.4433 & 2582.4401 & 861.8206 & 0.0032 & 1.2377 & 16.606\end{array}$ $\begin{array}{lllllllllllll}\text { AVLSSPAVTEQEVAQVASAILSLR } & 1.00 & 76.07 & 22.60 & 26.03 & 3 & 2582.4433 & 2582.4401 & 861.8206 & 0.0032 & 1.2377 & 16.606 \\ \text { AVLSSPAVTEEEVAQVASAILLR } & 0.55 & 51.42 & 22.67 & 64.42 & 3 & 2582.4418 & 2582.4401 & 861.8206 & 0.0017 & 0.6575 & 5.982\end{array}$

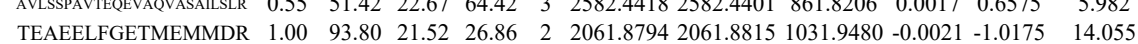
TEAFELFGETMEMMDR $1.00 \quad \# \# \# \begin{array}{lllllllll}21.99 & 21.84 & 2 & 2061.8834 & 2061.8815 & 1031.9480 & 0.0019 & 0.9206 & 8.430\end{array}$

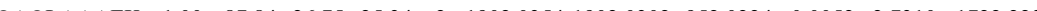

IED $\begin{array}{lllllllllllll} & \end{array}$ $\begin{array}{lllllllllllllll} & 1.002\end{array}$ $\begin{array}{lllllllllllllllll}\text { IEDLSQQAQLAAAEK } & 1.00 & 89.16 & 26.16 & 35.21 & 2 & 1902.0448 & 1902.0302 & 952.0224 & 0.0146 & 7.6678 & 3656.723 & 3128.568 & 2006.727 & 441.974\end{array}$ $\begin{array}{lllllllllllllll} & \end{array}$ $\begin{array}{lllllllllllllllll}\text { IEDLSQQAQLAAAEK } & 1.00 & 94.16 & 26.13 & 34.54 & 2 & 1902.0456 & 1902.0302 & 952.0224 & 0.0154 & 8.0880 & 2786.950 & 2485.135 & 1528.421 & 715.010 & \text { Yes }\end{array}$ $\begin{array}{lllllllllllllllll}\text { SPASDTYIVFGEAK } & 1.00 & 82.32 & 27.98 & 23.07 & 2 & 1771.9244 & 1771.9236 & 886.9691 & 0.0008 & 0.4510 & 4757.806 & 4478.368 & 3196.069 & 2135.693 & Y & \text { Yes }\end{array}$ $\begin{array}{llllllllllllllllll}\text { SPASDTYIVFGEAK } & 1.00 & 77.13 & 27.99 & 24.94 & 2 & 1771.9250 & 1771.9236 & 886.9691 & 0.0014 & 0.7892 & 6538.406 & 5801.369 & 5356.473 & 2410.191 & \text { Yes }\end{array}$ $\begin{array}{lllllllllllllllll}\text { SPASDTYIVFGEAK } & 1.00 & 40.73 & 27.87 & 17.29 & 3 & 1771.9267 & 1771.9236 & 591.6485 & 0.0031 & 1.7465 & 133.137 & 654.765 & 448.397 & 352.080 & \text { No }\end{array}$ $\begin{array}{lllllllllllllllll}\text { SPASDTYIVFGEAK } & 1.00 & 41.69 & 27.87 & 24.41 & 3 & 1771.9267 & 1771.9236 & 591.6485 & 0.0031 & 1.7465 & 379.928 & 640.120 & 503.764 & 141.442 & \text { Yes }\end{array}$ $\begin{array}{llllllllllllllll}\text { IEDLSQQAQLAAAEK } & 1.00 & 91.07 & 26.00 & 29.81 & 2 & 1902.0458 & 1902.0302 & 952.0224 & 0.0156 & 8.1930 & 172.712 & 227.178 & 160.678 & 69.974 & \text { Yes }\end{array}$ $\begin{array}{llllllllllllllllll}\text { IEDLSQQAQLAAAEK } & 1.00 & 87.37 & 25.92 & 31.92 & 2 & 1902.0470 & 1902.0302 & 952.0224 & 0.0168 & 8.8232 & 550.652 & 955.804 & 309.955 & 91.143 & \text { Yes }\end{array}$ $\begin{array}{llllllllllllllllll}\text { IEDLSQQAQLAAAEK } & 0.87 & 26.45 & 26.03 & 24.28 & 3 & 1902.0481 & 1902.0302 & 635.0173 & 0.0179 & 9.3960 & 819.031 & 949.226 & 758.801 & 425.011 & \text { Yes }\end{array}$ $\begin{array}{lllllllllllllllll}\text { SPASDTYIVFGEAK } & 1.00 & 79.89 & 28.02 & 24.74 & 2 & 1771.9236 & 1771.9236 & 886.9691 & 0.0000 & 0.0000 & 654.074 & 772.977 & 768.521 & 342.008 & \text { Yes }\end{array}$ $\begin{array}{lllllllllllllllll}\text { SPASDTYIVFGEAK } & 1.00 & 79.28 & 28.01 & 26.59 & 2 & 1771.9248 & 1771.9236 & 886.9691 & 0.0012 & 0.6765 & 561.824 & 567.114 & 527.653 & 320.694 & \text { Yes }\end{array}$ $\begin{array}{lllllllllllllllll}\text { SPASDTYIVFGEAK } & 1.00 & 37.82 & 27.94 & 20.12 & 3 & 1771.9258 & 1771.9236 & 591.6485 & 0.0022 & 1.2395 & 501.717 & 423.972 & 433.609 & 252.230 & \text { Yes }\end{array}$ $\begin{array}{lllllllllllllllll}\text { SPASDTYIVFGEAK } & 1.00 & 35.96 & 27.90 & 19.39 & 3 & 1771.9288 & 1771.9236 & 591.6485 & 0.0052 & 2.9297 & 441.817 & 593.032 & 492.241 & 253.761 & \text { Yes }\end{array}$ $\begin{array}{lllllllllllllll}\text { IEDLSQQAQLAAAEK } & 1.00 & \text { \#\#\# } 27.14 & 27.96 & 2 & 1902.0304 & 1902.0302 & 952.0224 & 0.0002 & 0.1050 & 51.957 & 52.910 & 18.846 & 30.080 & \text { Yes }\end{array}$ $\begin{array}{llllllllllllllll}\text { IEDLSQQAQLAAAEK } & 0.94 & 33.13 & 26.81 & 36.89 & 3 & 1902.0325 & 1902.0302 & 635.0173 & 0.0023 & 1.2073 & 16.673 & 28.679 & 8.940 & 18.512 & \text { No }\end{array}$

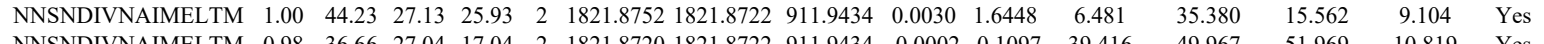

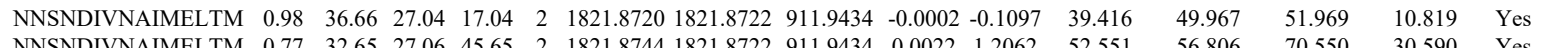

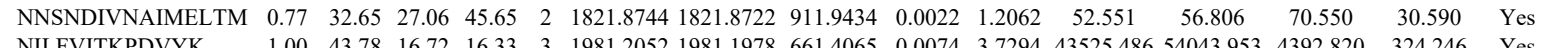

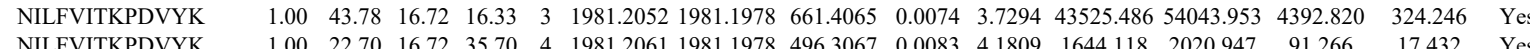

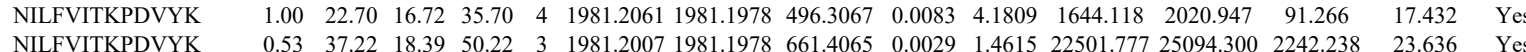

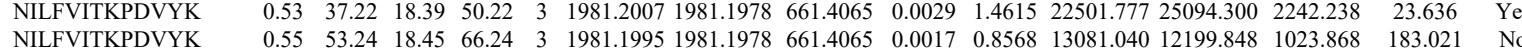

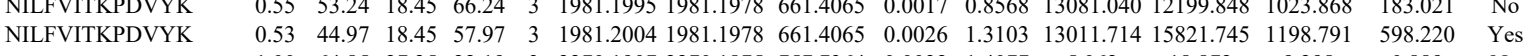

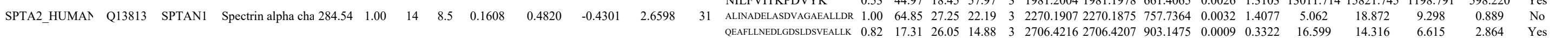




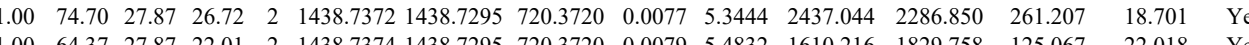
$\begin{array}{lllllllllllllll}1.00 & 64.37 & 27.87 & 22.01 & 2 & 1438.7374 & 1438.7295 & 720.3720 & 0.0079 & 5.4832 & 1610.216 & 1829.758 & 125.067 & 22.018 & \text { Yes } \\ 0.99 & 40.05 & 27.92 & 31.68 & 3 & 1438.7380 & 1438.7295 & 480.5838 & 0.0085 & 5.8956 & 7786.386 & 9512.995 & 4286356 & 1198.386 & \text { Yes }\end{array}$ $\begin{array}{llllllllllllllll}0.99 & 40.05 & 27.92 & 31.68 & 3 & 1438.7380 & 1438.7295 & 480.5838 & 0.0085 & 5.8956 & 7786.386 & 9512.995 & 4286.356 & 1198.386 & \text { Yes }\end{array}$

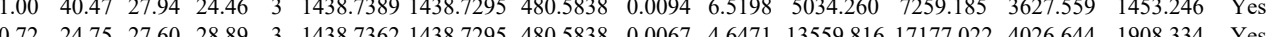

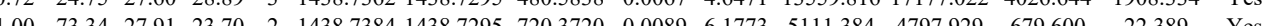

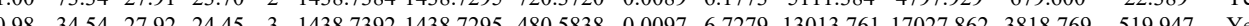

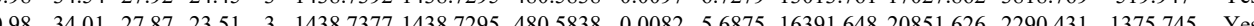
$\begin{array}{llllllllllllllll}0.86 & 26.06 & 27.94 & 22.99 & 3 & 14387389 & 1438 & 7295 & 480.5838 & 0.0094 & 65198 & 19124.783 & 23958.912 & 3467.176 & 813.176 & \text { Yes }\end{array}$ $\begin{array}{lllllllllllllllll}1.00 & 67.12 & 21.58 & 24.67 & 2 & 1424.8638 & 1424.8635 & 713.4390 & 0.0003 & 0.2102 & 16171.377 & 14992.363 & 1383.914 & 723.966 & \text { Yes }\end{array}$ $\begin{array}{lllllllllllllllll}1.00 & 67.12 & 21.58 & 24.67 & 2 & 1424.8638 & 1424.8635 & 713.4390 & 0.0003 & 0.2102 & 16171.377 & 14992.363 & 1383.914 & 723.966 & \text { Yes } \\ 1.00 & 81.97 & 21.37 & 25.70 & 2 & 1424.8654 & 1424.8635 & 713.4390 & 0.0019 & 1.3316 & 4402.680 & 4434.079 & 450.678 & 260.789 & \text { Yes }\end{array}$ $\begin{array}{lllllllllllllll}1.00 & 30.23 & 1.104 & 23.51 & 3 & 1424.8660 & 1424.8635 & 475.9618 & 0.0025 & 1.7508 & 640.114 & 389.558 & 120.281 & 65.366 & \text { Yes }\end{array}$ $\begin{array}{lllllllllllllll}1.00 & 30.23 & 21.04 & 23.51 & 3 & 1424.8660 & 1424.8635 & 47.4318 & 0.0025 & 1.7568 & 640.114 & 389.558 & 120.281 & 65.366 & \text { Y S } \\ 1.00 & 71.09 & 21.37 & 24.66 & 2 & 1424.8648 & 1424.8635 & 713.4390 & 0.0013 & 0.9111 & 3687.419 & 3413.818 & 461.223 & 229.823 & \text { Yes }\end{array}$ $\begin{array}{lllllllllllllllll}1.00 & 65.64 & 1.37 & 22.79 & 2 & 1424.8650 & 1424.8635 & 713.4390 & 0.0015 & 1.0512 & 4521.296 & 4712.240 & 453.681 & 240.698 & \text { Yes }\end{array}$ $\begin{array}{ccccccccccccccc}0.77 & 11.84 & 21.04 & 20.92 & 3 & 1424.8663 & 1424.8635 & 475.9618 & 0.0028 & 1.9609 & 267.249 & 417.958 & 96.796 & 32.250 & \text { Yes } \\ 0.78 & 28.02 & 20.53 & 32.44 & 2 & 799.5472 & 799.5401 & 400.7773 & 0.0071 & 8.8577 & 15155.427 & 12270.733 & 528.720 & 160.846 & \text { Yes }\end{array}$

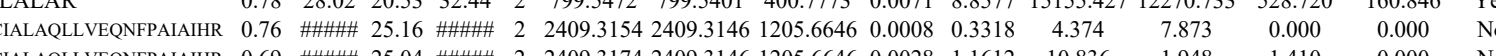

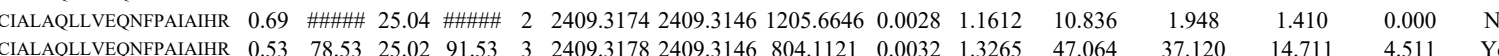

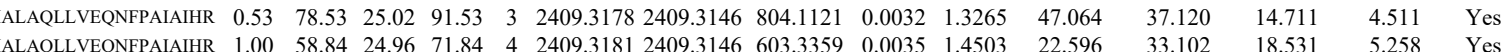
$\begin{array}{llllllllllllllll}\text { CIALALLLVENFPAAIAIHR } & 1.00 & 58.84 & 64.96 & 71.84 & 4 & 2409.3181 & 2409.3146 & 603.3359 & 0.0035 & 1.4503 & 22.596 & 33.102 & 18.531 & 5.258 & \text { Yes } \\ \text { CIAL.90 } & 78.40 & 4 & 2409.3197 & 2409.3146 & 603.3359 & 0.0051 & 2.1132 & 25.891 & 40.754 & 6.363 & 9.113 & \text { Yes }\end{array}$ $\begin{array}{lllllllllllllllll}\text { CIALAQLLVEQNFPAIAIHR } & 0.55 & 74.73 & 25.11 & 87.73 & 3 & 2409.3163 & 2409.3146 & 804.1121 & 0.0017 & 0.7047 & 39.299 & 39.776 & 12.348 & 3.738 & \text { Yes }\end{array}$ $\begin{array}{llllllllllllllll}\text { CIALAQLLVEQNFPAIAIHR } & 1.00 & 37.96 & 25.00 & 50.96 & 4 & 2409.3173 & 2409.3146 & 603.3359 & 0.0027 & 1.1188 & 30.951 & 23.809 & 11.020 & 8.364 & \text { Yes }\end{array}$

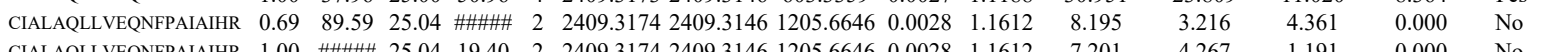

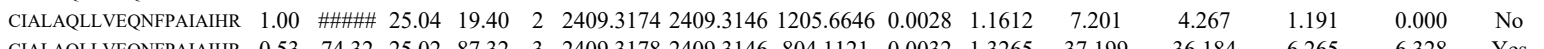

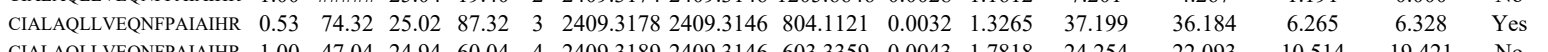

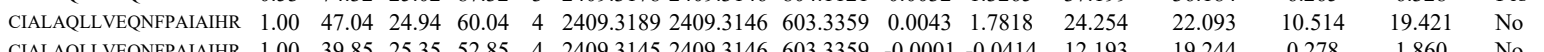

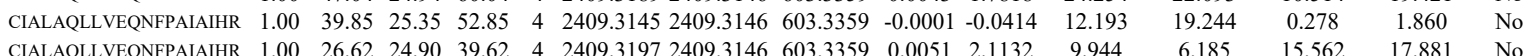

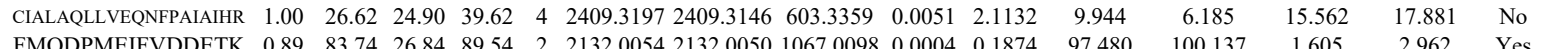

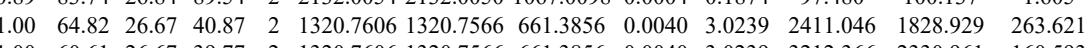
TLADIIMEK $\begin{array}{lllllllllllllll} & \text { LOPHPQLSPEIR } & 1.00 & 60.61 & 26.67 & 39.77 & 2 & 1320.7606 & 1320.7566 & 661.3856 & 0.0040 & 3.0239 & 3212.366 & 2330.961 & 160.593 \\ & 0.95 & 29.12 & 26.03 & 20.71 & 3 & 1557.8899 & 1557.8749 & 520.2989 & 0.0150 & 9.6098 & 563.668 & 772.113 & 618.873 & 37\end{array}$ $\begin{array}{llllllllllllll}\text { GILIPLCESGTCTLR } & 1.00 & 42.27 & 27.33 & 25.66 & 2 & 1810.8962 & 1810.8935 & 906.4540 & 0.0027 & 1.4893 & 115.973 & 61.741 & 113.157\end{array}$ 


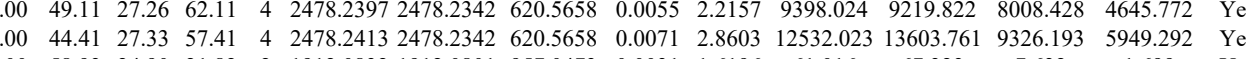
$\begin{array}{lllllllllllllllll} & \end{array}$ $\begin{array}{lllllllllllllllll} & 3245.432 & 3245.4516 & 1082.8245 & 0.0016 & 0.4925 & 320.121 & 322.035 & 957.163 & 177.028 & \mathrm{No}\end{array}$ $\begin{array}{llllllllllllllll} & \end{array}$ $\begin{array}{lllllllllllllllll} & 1.00 & 46.82 & 27.00 & 23.44 & 2 & 1244.6334 & 1244.6315 & 623.3230 & 0.0019 & 1.5241 & 1376.785 & 1468.261 & 3116.875 & 2704.363 & \text { Yes }\end{array}$

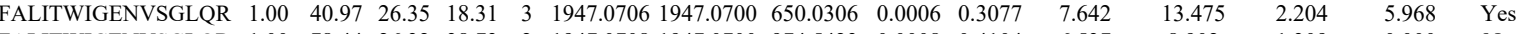

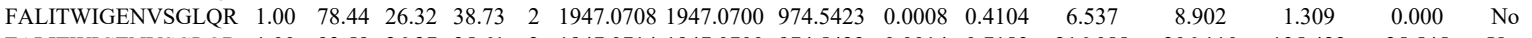

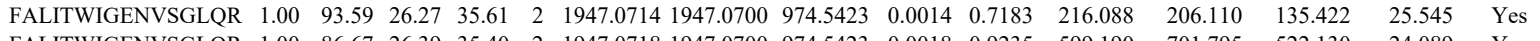
$\begin{array}{llllllllllllllll}\text { FALITWIGENVSGLQR } & 1.00 & 86.67 & 26.39 & 35.40 & 2 & 1947.0718 & 1947.0700 & 974.5423 & 0.0018 & 0.9235 & 599.190 & 701.795 & 522.130 & 24.089 & \text { Yes }\end{array}$ $\begin{array}{llllllllllllllll}\text { FALITWIGENVSGLQR } & 1.00 & 40.19 & 26.22 & 20.22 & 3 & 1947.0739 & 1947.0700 & 650.0306 & 0.0039 & 1.9999 & 50.139 & 31.190 & 12.679 & 10.243 & \text { Yes }\end{array}$

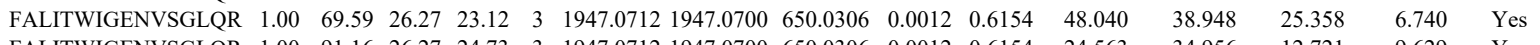

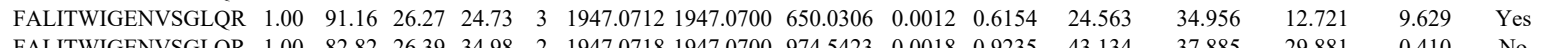

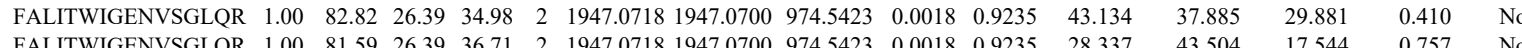

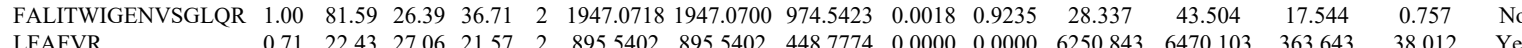

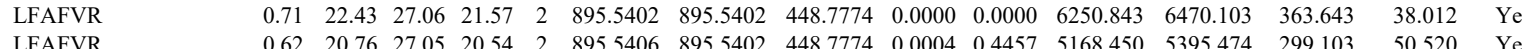

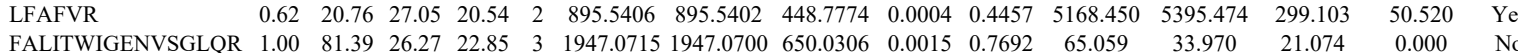

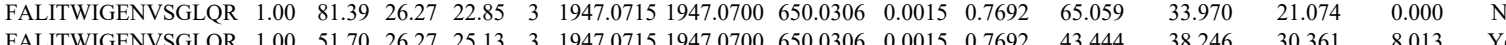

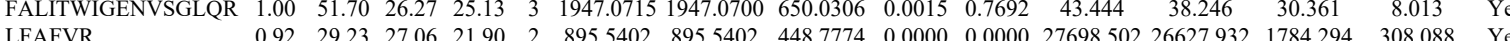

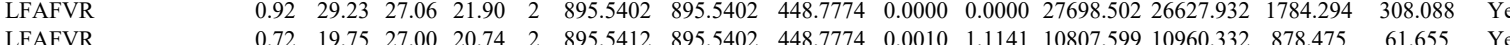

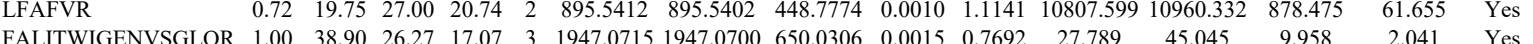

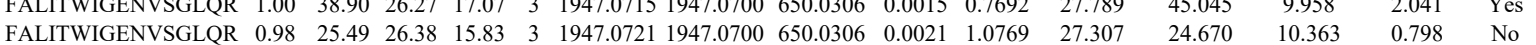

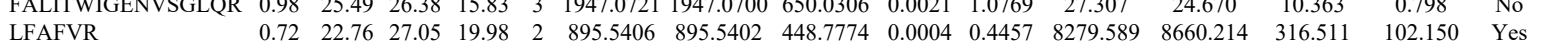

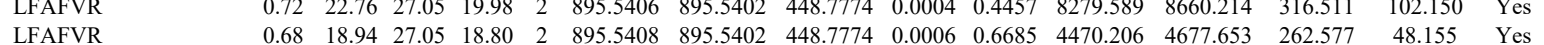
$\begin{array}{lllllllllllllll} & & & \end{array}$ $\begin{array}{lllllllllllllllll}\text { LFAFVR } & 0.84 & 22.75 & 27.00 & 19.75 & 2 & 895.5412 & 895.5402 & 448.7774 & 0.0010 & 1.1141 & 1310.703 & 1264.308 & 81.955 & 16.254 & \text { Yes }\end{array}$

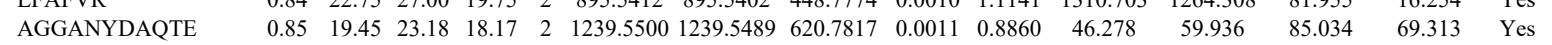

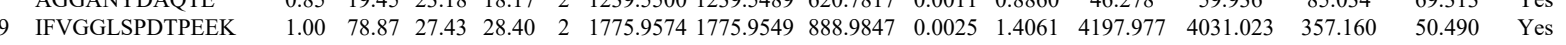
$\begin{array}{llllllllllllllllll}\text { IFVGGLSPDTPEEK } & 1.00 & 81.94 & 27.43 & 31.19 & 2 & 1775.9574 & 1775.9549 & 888.9847 & 0.0025 & 1.4061 & 1666.943 & 1363.650 & 155.574 & 49.427 & \text { Yes }\end{array}$ $\begin{array}{lllllllllllllllll}\text { IFVGGLSPDTPEEK } & 0.97 & 26.18 & 27.32 & 15.86 & 3 & 1775.9590 & 1775.9549 & 592.9922 & 0.0041 & 2.3047 & 226.488 & 236.726 & 222.022 & 121.293 & \text { Yes }\end{array}$ $\begin{array}{llllllllllllllll}\text { EYFGGFGEVESIELPMDNK } & 1.00 & 75.28 & 27.14 & 23.38 & 2 & 2448.1794 & 2448.1763 & 1225.0954 & 0.0031 & 1.2652 & 25.408 & 19.726 & 16.196 & 2.020 & \text { Yes }\end{array}$ $\begin{array}{llllllllllllllll}\text { EYFGGFGEVESIELPMDNK } & 1.00 & 51.15 & 27.14 & 20.75 & 3 & 2448.1795 & 2448.1763 & 817.0660 & 0.0032 & 1.3055 & 16.216 & 16.497 & 44.134 & 0.000 & \text { No }\end{array}$ $\begin{array}{llllllllllllllll}\text { EYFGGFGEVESIELPMDNK } & 1.00 & 57.10 & 27.19 & 21.71 & 3 & 2448.1801 & 2448.1763 & 817.0660 & 0.0038 & 1.5503 & 37.577 & 33.240 & 73.753 & 9.924 & \text { No }\end{array}$

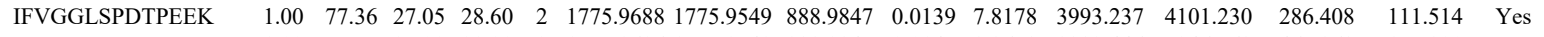
$\begin{array}{lllllllllllllll}\text { IFVGGLSPDTPEEK } & 1.00 & \text { \#\#\#\# } 27.00 & 29.90 & 2 & 1775.9696 & 1775.9549 & 888.9847 & 0.0147 & 8.2678 & 8382.446 & 7246.562 & 465.263 & 155.800 & \text { Yes }\end{array}$ $\begin{array}{lllllllllllllllll}\text { IFVGGLSPDTPEEK } & 0.68 & 23.63 & 26.97 & 14.50 & 3 & 1775.9722 & 1775.9549 & 592.9922 & 0.0173 & 9.7246 & 504.343 & 421.970 & 415.615 & 394.918 & \text { No }\end{array}$ $\begin{array}{llllllllllllllll}\text { EYFGGFGEVESIELPMDNK } & 1.00 & 58.62 & 27.11 & 22.07 & 3 & 2448.1792 & 2448.1763 & 817.0660 & 0.0029 & 1.1831 & 36.850 & 0.000 & 33.371 & 13.880 & \text { No }\end{array}$

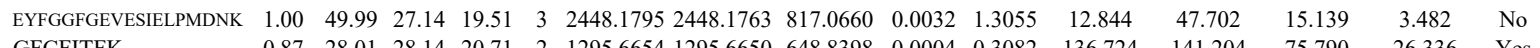

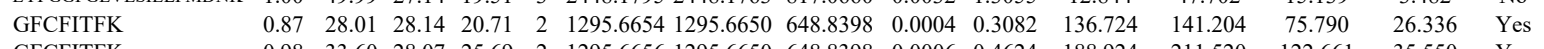

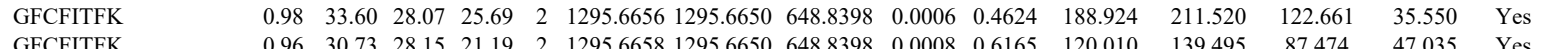

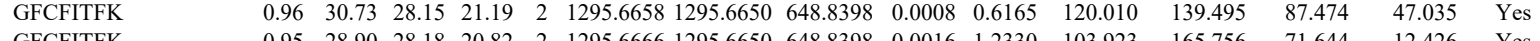

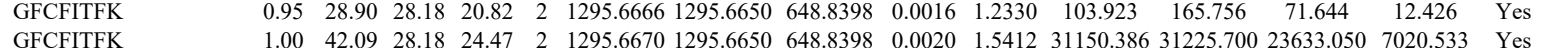
$\begin{array}{llllllllllllllll}1.00 & 42.09 & 28.18 & 24.47 & 2 & 1295.6670 & 1295.6650 & 648.8398 & 0.0020 & 1.5412 & 31150.386 & 31225.700 & 23633.050 & 7020.533 & \text { Yes }\end{array}$

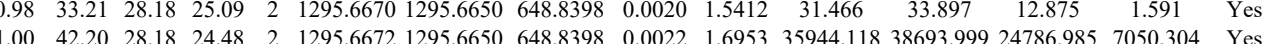
$\begin{array}{lllllllllllllll}1.00 & 42.20 & 28.18 & 24.48 & 2 & 1295.6672 & 1295.6650 & 648.8398 & 0.0022 & 1.6953 & 35944.118 & 38693.999 & 24786.985 & 7050.304 & \text { Yes } \\ 0.95 & 30.74 & 28.01 & 1.28 & 2 & 1295.6678 & 1295.6650 & 648.8398 & 0.0028 & 2.1577 & 148.769 & 179.988 & 116.816 & 25.836 & \text { Yes }\end{array}$ 
$\begin{array}{lllllllll} & 254.2234 & 2534.2200 & 1268.1173 & 0.0034 & 1.3406 & 13.157\end{array}$ $\begin{array}{lllllllllllll}0.58 & 17.03 & 24.05 & 25.54 & 2 & 1076.6948 & 1076.6950 & 539.3548 & -0.0002 & -0.1854 & 1907.577 & 1404.346 & 104.361\end{array}$ 8.952
2.311
18.960

LQEHEQIK

ILQEHEQIK

LEEIPLIK

QPALDVLYDVMK

QPALDVLYDVMK

QPALDVLYDVMK

QPALDVLYDVMK

LESLNIQR

LVQLDSAISMELWQEAFK

NICQQVNIK

VPPPALSR

VPPPALSR

$\begin{array}{lllllllllllllll}0.94 & 26.63 & 24.71 & 16.99 & 3 & 1424.8321 & 1424.8231 & 475.9483 & 0.0090 & 6.3032 & 43017.775 & 39265.584 & 3992.639 & 2163.044 & \text { Yes }\end{array}$

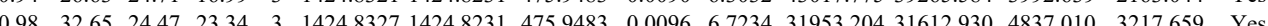
$\begin{array}{lllllllllllllll}1.00 & 51.61 & 22.20 & 34.83 & 2 & 1241.7872 & 1241.7838 & 621.8992 & 0.0034 & 2.7336 & 6617.660 & 5559.060 & 617.168 & 137.015 & \text { Yes }\end{array}$ $\begin{array}{lllllllllllllll}1.00 & 51.53 & 22.20 & 34.75 & 2 & 1241.7884 & 1241.7838 & 621.8992 & 0.0046 & 3.6983 & 6528.959 & 5543.639 & 605.135 & 173.167 & \text { Yes }\end{array}$ $\begin{array}{lllllllllllllll}1.00 & 38.50 & 26.89 & 16.40 & 2 & 1678.9232 & 1678.9208 & 840.4677 & 0.0024 & 1.4278 & 2446.889 & 2400.492 & 5475.048 & 5860.531 & \text { No }\end{array}$ $\begin{array}{llllllllllllllll}0.96 & 22.68 & 26.91 & 19.03 & 3 & 1678.9243 & 1678.9208 & 560.6475 & 0.0035 & 2.0809 & 63.485 & 57.104 & 65.519 & 72.740 & \mathrm{No}\end{array}$

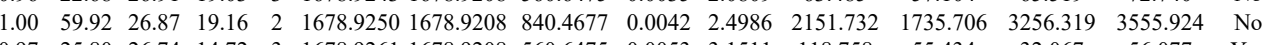
$\begin{array}{lllllllllllllll}0.97 & 25.80 & 26.74 & 14.72 & 3 & 1678.9261 & 1678.9208 & 560.6475 & 0.0053 & 3.1511 & 118.758 & 55.434 & 32.067 & 56.077 & \text { Yes }\end{array}$ $\begin{array}{llllllllllllllll}0.98 & 38.36 & 28.49 & 31.57 & 2 & 1115.6528 & 1115.6420 & 558.8283 & 0.0108 & 9.6630 & 16343.702 & 16711.157 & 1637.258 & 611.536 & \text { Yes }\end{array}$

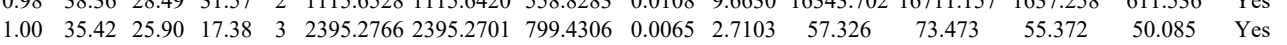
$\begin{array}{lllllllllllllll}1.00 & 53.63 & 27.87 & 28.91 & 2 & 1392.7594 & 1392.7461 & 697.3803 & 0.0133 & 9.5356 & 5499.786 & 5568.789 & 1464.565 & 939.397 & \text { Yes }\end{array}$ $\begin{array}{lllllllllllllllll}0.52 & 19.81 & 25.81 & 18.40 & 2 & 979.5974 & 979.5936 & 490.8041 & 0.0038 & 3.8712 & 3806.989 & 3682.195 & 3527.644 & 2627.336 & \text { Yes }\end{array}$ $\begin{array}{lllllllllllllllll}0.89 & 21.93 & 24.44 & 17.39 & 2 & 979.5954 & 979.5936 & 490.8041 & 0.0018 & 1.8337 & 2900.618 & 3254.620 & 3029.525 & 2506.793 & \text { Yes }\end{array}$ $\begin{array}{lllllllllllllllll} & 0.84 & 19.76 & 24.44 & 17.17 & 2 & 979.5954 & 979.5936 & 490.8041 & 0.0018 & 1.8337 & 3677.378 & 3263.384 & 3188.900 & 2148.851 & \text { Yes }\end{array}$ $\begin{array}{lllllllllllllll} & 28.36 & 2 & 1878.0388 & 1878.0373 & 940.0259 & 0.0015 & 0.7978 & 508.865 & 955.671 & 0.000 & 0.000 & \text { No }\end{array}$ $\begin{array}{lllllllllllllllll}\text { LTSLVPFVDAFQLER } & 0.53 & 49.49 & 26.53 & 62.49 & 3 & 1878.0406 & 1878.0373 & 627.0197 & 0.0033 & 1.7543 & 323.784 & 271.504 & 88.405 & 15.903 & \text { Yes } \\ \text { LTSLVPFVDAFQLER } & 0.53 & 35.54 & 26.53 & 48.54 & 3 & 1878.0406 & 1878.0373 & 627.0197 & 0.0033 & 1.7543 & 211.665 & 271.972 & 71.651 & 39.471 & \text { Yes }\end{array}$ $\begin{array}{llllllllllllllll}\text { LTSLVPFVDAFQLER } & 1.00 & 58.49 & 26.52 & 30.19 & 2 & 1878.0386 & 1878.0373 & 940.0259 & 0.0013 & 0.6915 & 144.197 & 138.961 & 0.000 & 16.496 & \text { No }\end{array}$ $\begin{array}{llllllllllllllll}\text { LTSLVPFVDAFQLER } & 1.00 & 62.54 & 26.61 & 28.55 & 2 & 1878.0388 & 1878.0373 & 940.0259 & 0.0015 & 0.7978 & 432.561 & 494.495 & 16.976 & 0.000 & \text { No }\end{array}$

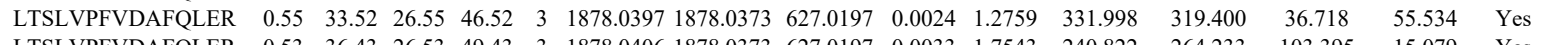

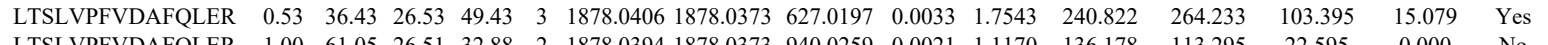

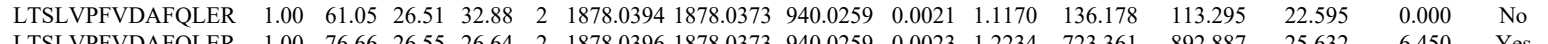

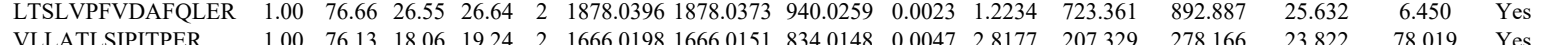

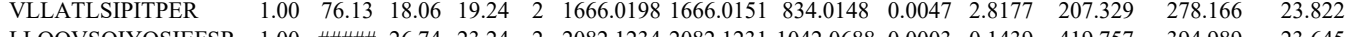

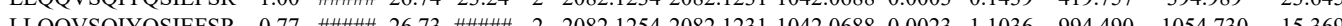

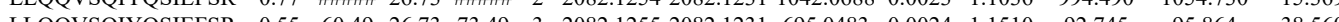

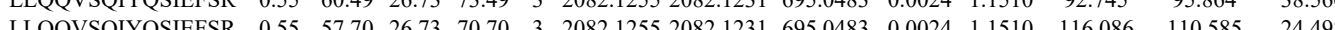

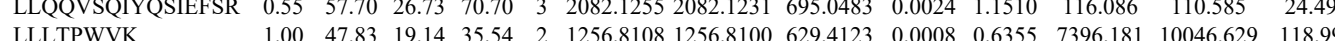
VLLATLSIPITP

VLLATLSIPITPER

$\begin{array}{lllllllllllll}1.00 & 47.83 & 19.14 & 35.54 & 2 & 1256.8108 & 1256.8100 & 629.4123 & 0.0008 & 0.6355 & 7396.181 & 10046.629 & 118.999 \\ 1.00 & 86.04 & 19.87 & 24.44 & 2 & 1666.0168 & 1666.0151 & 834.0148 & 0.0017 & 1.0192 & 149.759 & 109.933 & 16.459\end{array}$

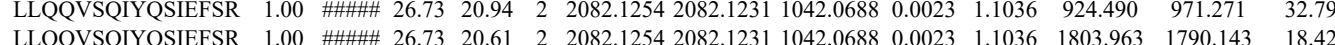
$\begin{array}{llllllllllll} & 26 & & \end{array}$

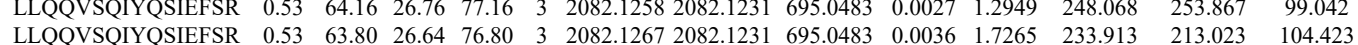
LLQQVSQIYQSIEFSR VLNWVR

VLNWVR

VLNWVR

VLNWVR

LATLLGLQAPPTR

LATLLGLQAPPTR

LATLLGLQAPPTR

LATLLGLQAPPTR

LATLLGLQAPPTR

LATLLGLQAPPTR

LATLLGLQAPPTR

LATLLGLQAPPTR

LATLLGLQAPPTR

LATLLGLQAPPTR

LATLLGLQAPPTR

LATLLGLQAPPTR

TKNETDEDGWTTVR

LATLLGLQAPPTR

$\begin{array}{lllllllllll}0.53 & 25.70 & 2 & 2082.1234 & 2082.1231 & 1042.0688 & 0.0003 & 0.1439 & 202.636 & 214.496 & 14.919\end{array}$

$\begin{array}{llllllllllllll}0.80 & 26.28 & 25.31 & 31.90 & 2 & 929.5656 & 929.5569 & 465.7857 & 0.0087 & 9.3390 & 12417.321 & 11736.826 & 495.520 & 1\end{array}$ $\begin{array}{llllllllllllll}0.79 & 25.96 & 25.31 & 28.83 & 2 & 929.5660 & 929.5569 & 465.7857 & 0.0091 & 9.7683 & 10717.085 & 10645.269 & 720.325\end{array}$ \begin{tabular}{llllllllllllll}
0.51 & 22.81 & 26.11 & 30.26 & 2 & 929.5636 & 929.5569 & 465.7857 & 0.0067 & 7.1921 & 1470.126 & 1575.643 & 267.786 \\
\hline
\end{tabular} $\begin{array}{llllllllllllll}0.62 & 24.41 & 25.35 & 33.03 & 2 & 929.5650 & 929.5569 & 465.7857 & 0.0081 & 8.6949 & 343.462 & 279.042 & 192.603 \\ 0.61 & 77.65 & 22.81 & 90.65 & 2 & 1493.9050 & 1493.9051 & 747.9598 & -0.0001 & -0.0668 & 1555.581 & 1298.718 & 75.239\end{array}$ $\begin{array}{lllllllllllll}0.61 & 77.65 & 22.81 & 90.65 & 2 & 1493.9050 & 1493.9051 & 747.9598 & -0.0001 & -0.0668 & 1555.581 & 1298.718 & 75.239 \\ 0.76 & 82.58 & 2.81 & 95.58 & 2 & 1493.9060 & 1493.9051 & 747.9598 & 0.0009 & 0.6016 & 3755.702 & 3015.577 & 258.105\end{array}$ $\begin{array}{lllllllllllll}0.76 & 82.58 & 22.81 & 95.58 & 2 & 1493.9060 & 1493.9051 & 747.9598 & 0.0009 & 0.6016 & 3755.702 & 3015.577 & 258.105 \\ 0.99 & 24.08 & 22.79 & 15.34 & 3 & 1493.9071 & 1493.9051 & 498.9756 & 0.0020 & 1.3361 & 47.913 & 59.107 & 23.465\end{array}$

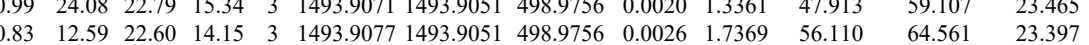
$\begin{array}{ccccccccccccc}0.76 & 71.99 & 22.81 & 84.99 & 2 & 1493.9077 & 1493.9051 & 498.9756 & 0.0026 & 1.7369 & 56.110 & 64.561 & 23.395 \\ 0.743 .9051 & 747.9598 & 0.0007 & 0.4679 & 2137.530 & 2155.697 & 127.340\end{array}$ $\begin{array}{llllllllllllll}0.76 & 75.08 & 22.70 & 88.08 & 2 & 1493.9062 & 1493.9051 & 747.9598 & 0.0011 & 0.7353 & 4851.820 & 4337.959 & 162.698\end{array}$ $\begin{array}{lllllllllllll}1.00 & 28.28 & 22.60 & 16.55 & 3 & 1493.9077 & 1493.9051 & 498.9756 & 0.0026 & 1.7369 & 35.196 & 73.436 & 120.445\end{array}$ $\begin{array}{lllllllllllll}0.76 & 71.51 & 22.81 & 84.51 & 2 & 1493.9058 & 1493.9051 & 747.9598 & 0.0007 & 0.4679 & 585.596 & 564.284 & 59.693 \\ 0.76 & 70.09 & 22.81 & 33.09 & 2 & 14939060 & 1499.9051 & 747.958 & 0.000 & 0.6016 & 84558 & 90.806 & 62.733\end{array}$ $\begin{array}{lllllllllllll}0.76 & 70.09 & 22.81 & 83.09 & 2 & 1493.9060 & 1493.9051 & 747.9598 & 0.0009 & 0.6016 & 846.558 & 904.806 & 62.733 \\ 1.00 & 28.49 & 22.60 & 14.90 & 3 & 1493.9074 & 1493.9051 & 498.9756 & 0.0023 & 1.5365 & 16.214 & 14.860 & 21.719\end{array}$ $\begin{array}{lllllllllllll}1.00 & 28.49 & 22.60 & 14.90 & 3 & 1493.9074 & 1493.9051 & 498.9756 & 0.0023 & 1.5365 & 16.214 & 14.860 & 21.719 \\ 0.55 & 13.44 & 22.60 & 26.44 & 3 & 1493.9077 & 1493.9051 & 498.9756 & 0.0026 & 1.7369 & 27.570 & 15.726 & 15.225\end{array}$ $\begin{array}{llllllllllll}0.55 & 13.44 & 22.60 & 26.44 & 3 & 1493.9077 & 1493.9051 & 498.9756 & 0.0026 & 1.7369 & 27.570 & 15.726\end{array}$ $\begin{array}{llllllllllll}0.99 & 25.12 & 22.79 & 15.77 & 3 & 1493.907 & 1493.9051 & 498.9756 & 0.0020 & 1.3361 & 25.144 & 27.026 \\ 0.55 & 31.43 & 22.60 & 44.43 & 3 & 1493.9074 & 1493.9051 & 498.9756 & 0.0023 & 1.5365 & 13.002 & 30.814\end{array}$ 
LATLLGLQAPPTR LATLLGLQAPPTR ILQEHEQIK
ILQEHEQIK

\section{ILQEHEQIK}

12 GNWEQPQNQNQTQHK NPSDSAVHSPFTK
NPSDSAVHSPFTK QRPQATAEQIR QRPQATAEQIR
QRPQATAEQIR

AINVLLEGNPDTHS

\section{IDLAVLLGK}

IDLAVLLGK

IFTASNVSSVPLPAENVTITAGOR

IFTASNVSSVPLPAENVTITAGQR

FPLDYYSIPFPTPTTPLTGR

$\begin{array}{llllllllllllllll} & 58.37 .01 & 18.73 & 2 & 2426.2654 & 2426.2644 & 1214.1395 & 0.0010 & 0.4118 & 36.240 & 35.072 & 43.193 & 2.133 & 14.671 \\ \end{array}$

$\begin{array}{lllllllllllllll}\text { FNQTYQLAHGTAEEK } & 1.00 & 54.80 & 28.36 & 22.19 & 3 & 2024.0293 & 2024.0207 & 675.6808 & 0.0086 & 4.2426 & 3062.991 & 2871.786 & 2650.832 & 2293.675\end{array}$ $\begin{array}{lllllllllllllllll}\text { FNQTYQLAHGTAEEK } & 1.00 & 55.33 & 28.36 & 19.92 & 3 & 2024.0320 & 2024.0207 & 675.6808 & 0.0113 & 5.5746 & 2158.681 & 2639.955 & 2169.373 & 2123.077 & \text { No }\end{array}$

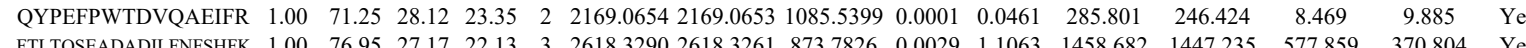
$\begin{array}{lllllllllllllllll}\text { FTLTQSEADADILFNFSHFK } & 1.00 & 76.95 & 27.17 & 22.13 & 3 & 2618.3290 & 2618.3261 & 873.7826 & 0.0029 & 1.1063 & 1458.682 & 1447.235 & 577.859 & 370.804 & \text { Yes } \\ \text { VYTDVQQVASSLTHPR } & 1.00 & 60.11 & 27.52 & 18.63 & 3 & 1944.0205 & 1944.0187 & 649.0135 & 0.0018 & 0.9245 & 3297.121 & 3710.308 & 503.206 & 544.858 & \text { Yes }\end{array}$ $\begin{array}{lllllllllllllllll}\text { TELPQFVSYFQQR } & 1.00 & 70.01 & 27.75 & 24.29 & 2 & 1785.9188 & 1785.9172 & 893.9659 & 0.0016 & 0.8949 & 2508.531 & 2343.960 & 176.122 & 129.350 & \text { Yes }\end{array}$

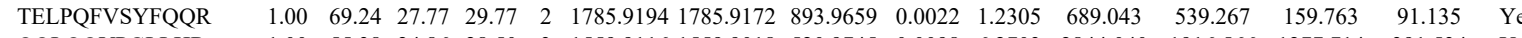
QQLQQVPGLLHR

QQLQQVPGLLHR

QQLQQVPGLLHR

KPITTGGVTYR

KPITTGGVTYR

KPITTGGVTYR

KPITTGGVTYR

KPITTGGVTYR

KATGOTR CAGCTNPISGLGGTK

$\begin{array}{llllllllllll}\text { DYHC1 HUMA } & \text { Q14204 } & \text { DYNC1H1 Cytoplasmic dyne } 532.41 & 1.00 & 43 & 12 & 0.1482 & 0.3677 & 0.1033 & 1.7770 & 122 & \text { VPQIEVETHK }\end{array}$ TPVSITEHPK

TPVSITEHPK

VMSQEIQEQLHK

LEGVEGVAHIIDPK

DFPLNDLLSATELDK

DFPLNDLLSATELDK

DFPLNDLLSATELDK

DFPLNDLLSATELDK

VQVALEELQDLK

VQVALEELQDLK

DFPLNDLLSATELDK

ILDDDTIITTLENLK

ILDDDTITTLENLK

ILDDDTIITTLENLK

GVWSELSK

LNTQEIFDDWAR

LNTQEIFDDWAR

ILDDDTIITTLENLK

ILDDDTIITTLENLK

ILDDDTIITTLENLK

ILDDDTIITTLENLK

GNEIVLSAGSTPR

GNEIVLSAGSTPR

LNTEIFDDWAR

LNREDDWR

ILDDDTIITTLENLK

GNEIVLSAGSTPR

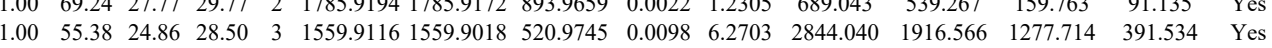
$\begin{array}{llllllllllllllll}1.00 & 54.56 & 25.17 & 29.87 & 3 & 1559.9125 & 1559.9018 & 520.9745 & 0.0107 & 6.8461 & 2723.355 & 2519.316 & 2037.971 & 706.647 & \text { Yes }\end{array}$ $\begin{array}{lllllllllllllll}0.97 & 33.60 & 25.04 & 27.60 & 3 & 1559.9104 & 1559.9018 & 520.9745 & 0.0086 & 5.5025 & 3271.661 & 3697.973 & 1403.875 & 793.694 & \text { Yes }\end{array}$ $\begin{array}{lllllllllllllll}0.99 & 38.24 & 24.79 & 24.26 & 2 & 1479.8696 & 1479.8653 & 740.9399 & 0.0043 & 2.9017 & 6161.340 & 5586.055 & 3586.239 & 2738.862 & \text { Yes }\end{array}$ $\begin{array}{lllllllllllllll}0.97 & 33.50 & 24.76 & 22.89 & 2 & 1479.8698 & 1479.8653 & 740.9399 & 0.0045 & 3.0367 & 3857.820 & 3519.250 & 2506.819 & 1799.556 & \text { Yes }\end{array}$ $\begin{array}{lllllllllllllll}0.98 & 33.48 & 25.66 & 20.31 & 2 & 1479.8680 & 4479.8653 & 740.9399 & 0.0027 & 1.8220 & 5590.443 & 5428.588 & 3115.557 & 2621.373 & \text { Yes }\end{array}$ $\begin{array}{lllllllllllllll}0.99 & 38.84 & 25.66 & 17.80 & 2 & 1479.8684 & 1479.8653 & 740.9399 & 0.0031 & 2.0919 & 8622.496 & 6984.012 & 3932.526 & 3403.046 & \text { Yes }\end{array}$ $\begin{array}{lllllllllllllll}1.00 & 41.43 & 25.04 & 18.29 & 3 & 1479.8689 & 1479.8653 & 494.2957 & 0.0036 & 2.4277 & 10730.035 & 10601.364 & 6768.479 & 5059.576 & \text { Yes }\end{array}$ $\begin{array}{lllllllllllllll}1.00 & 4.15 & 24.79 & 16.94 & 3 & 1479.8707 & 1479.8653 & 494.2957 & 0.0054 & 3.6415 & 2351.580 & 2102.030 & 1262.183 & 1259.246 & \text { Yes } \\ 1.00 & 9.41 & 25.51 & 2.31 & 2 & 1757.818 & 1757.8176 & 87.9961 & 0.001 & 0.6819 & 3964.934 & 3381.437 & 36.693 & 23.168 & \text { Yes }\end{array}$ \begin{tabular}{lllllllllllllll}
1.00 & 44.83 & 26.21 & 26.40 & 3 & 1466.8459 & 1466.8337 & 489.9518 & 0.0122 & 8.3001 & 3425.550 & 5445.607 & 4480.008 & 2908.884 & Yes \\
\hline
\end{tabular}

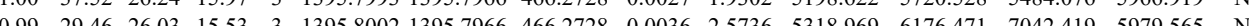
$\begin{array}{llllllllllllllll}0.99 & 37.04 & 27.32 & 17.07 & 3 & 17569537 & 1756.9385 & 586.6534 & 0.0152 & 8.6365 & 4123.565 & 4409.773 & 1960.960 & 2992.847 & \text { No }\end{array}$ $\begin{array}{lllllllllllllll}1.00 & 43.73 & 25.47 & 17.74 & 3 & 1764.0055 & 1764.0025 & 589.0081 & 0.0030 & 1.6978 & 2399.002 & 2726.346 & 687.391 & 245.188 & \text { Yes }\end{array}$ $\begin{array}{llllllllllllllll}0.92 & 20.52 & 25.37 & 16.28 & 3 & 1764.0073 & 1764.0025 & 589.0081 & 0.0048 & 2.7164 & 1100.574 & 1338.455 & 725.930 & 324.269 & \text { Yes }\end{array}$

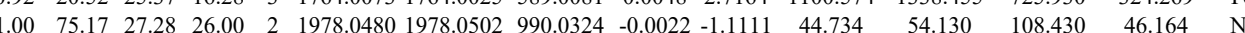
$\begin{array}{lllllllllllllll}1.00 & 58.98 & 27.49 & 18.31 & 3 & 1978.0513 & 1978.0502 & 660.3573 & 0.0011 & 0.5553 & 148.508 & 59.865 & 181.036 & 59.052 & \mathrm{No}\end{array}$

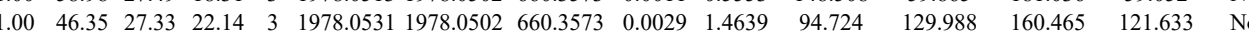
$\begin{array}{llllllllllllllll}0.93 & 18.53 & 24.94 & 19.68 & 3 & 1671.9670 & 1671.9651 & 558.3290 & 0.0019 & 1.1343 & 51.554 & 102.032 & 38.112 & 52.456 & \text { Yes }\end{array}$

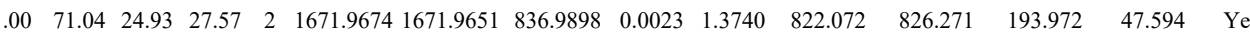

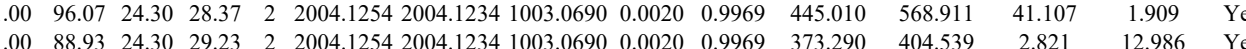

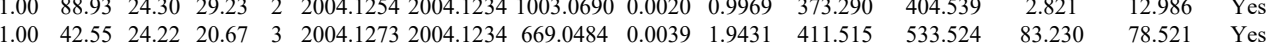

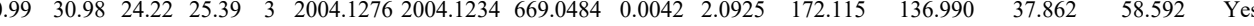
$\begin{array}{lllllllllllllll}0.97 & 36.83 & 27.56 & 25.23 & 2 & 1192.6804 & 1192.6696 & 597.3421 & 0.0108 & 9.0400 & 3809.335 & 4008.161 & 2626.019 & 1817.215 & \text { Yes }\end{array}$ $\begin{array}{llllllllllllllll}1.00 & 63.80 & 27.13 & 24.11 & 2 & 1650.8140 & 1650.8124 & 826.4135 & 0.0016 & 0.9680 & 1930.586 & 2346.883 & 407.031 & 848.445 & \text { Yes }\end{array}$

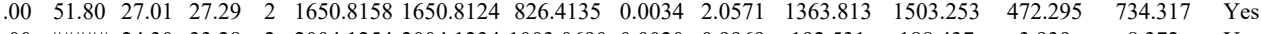

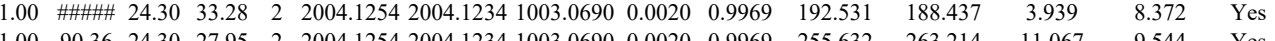

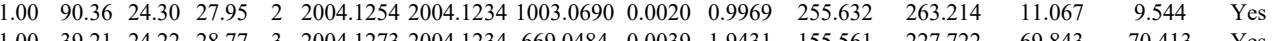

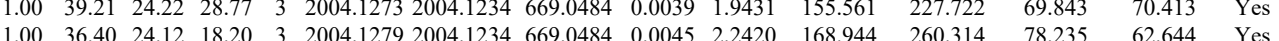
$\begin{array}{lllllllllllllll}1.00 & 36.40 & 24.12 & 18.20 & 3 & 2004.1279 & 2004.1234 & 669.0484 & 0.0045 & 2.2420 & 168.944 & 260.314 & 78.235 & 62.644 & \text { Yes } \\ 1.00 & 72.02 & 27.28 & 25.66 & 2 & 1443.7870 & 1443.7803 & 7228974 & 0.0067 & 4.6341 & 1185.479 & 1263.250 & 976.049 & 708.546 & \text { Yes }\end{array}$ \begin{tabular}{llllllllllllllll}
1.00 & 74.98 & 27.28 & 25.66 & 2 & 1443.7870 & 1443.7803 & 722.8974 & 0.0067 & 4.6341 & 1185.479 & 1263.250 & 97.04 .049 & 708.546 & Yes \\
\hline
\end{tabular}

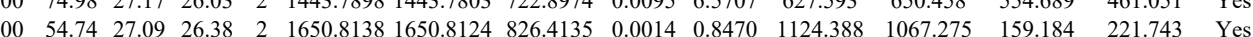

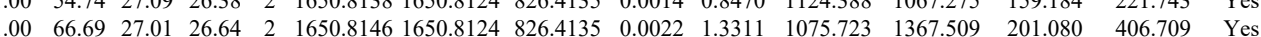

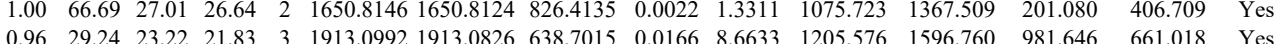

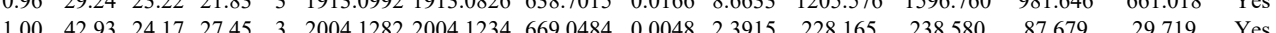

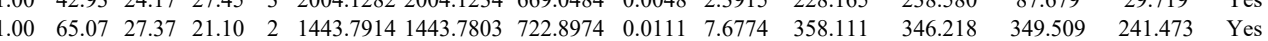


$\begin{array}{llllllllllll}\text { MDLEKPNYIVPDYMPVVYDK K } & 1.00 & 37.16 & 26.27 & 16.50 & 3 & 2860.4806 & 2860.4756 & 954.4991 & 0.0050 & 1.7461 & 220.970 \\ \text { SSLQSQCLNEVLK } & 1.00 & 53.53 & 28.93 & 26.39 & 2 & 1781.9320 & 1781.9259 & 891.9702 & 0.0061 & 3.4194 & 275.842 \\ \text { INEWLTLVEK } & 1.00 & 55.99 & 26.28 & 35.63 & 2 & 1531.8866 & 1531.8853 & 766.9499 & 0.0013 & 0.8475 & 533.850\end{array}$

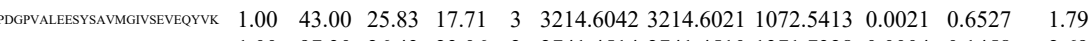

$\begin{array}{lllllllllllll}\text { GGNLLVQDVESYPVLNPVLNR } & 1.00 & 97.30 & 26.43 & 23.06 & 2 & 2741.4514 & 2741.4510 & 1371.7328 & 0.0004 & 0.1458 & 2.699\end{array}$

$\begin{array}{llllllll}26.43 & 23.06 & 2 & 2741.4514 & 2741.4510 & 1371.7328 & 0.0004 & 0.1458\end{array}$

3296.178

\section{VPLAIVNK}

VPLAIVNK

YATLATVSR

VPLAIVNK

VPLAIVNK

YATLATVSR

TFSSIPVSR

LLNTFLER

LLNTFLER

VNFLPEIITLSK

VNFLPEIITLSK

FQSISTEFLALMK

FQSISTEFLALMK

IPWSALK

TFSSIPVSR

(1)

$\begin{array}{lllll}1.00 & 82.31 & 27.57 & 28.23 \\ 1.00 & 69.88 & 27.52 & 25.27 & 2\end{array}$

$\begin{array}{lllllllllllll}0.98 & 32.45 & 18.98 & 24.33 & 2 & 1140.7558 & 1140.7474 & 571.3810 & 0.0084 & 7.3506 & 11963.144 & 10419.067\end{array}$

$\begin{array}{llllllllllllllll}1.00 & 47.89 & 18.39 & 25.31 & 2 & 1140.7578 & 1140.7474 & 571.3810 & 0.0104 & 9.1007 & 6144.559 & 5689.632 & 2036.782 & 1330.936 & \text { Yes } \\ 0.99 & 44.75 & 27.25 & 24.74 & 2 & 1124.6392 & 1124.6311 & 563.3228 & 0.0081 & 7.1894 & 766.829 & 837.553 & 214.664 & 110.338 & \text { Y }\end{array}$ $\begin{array}{llllllllllllllll}0.99 & 44.75 & 27.25 & 24.74 & 2 & 1124.6392 & 1124.6311 & 563.3228 & 0.0081 & 7.1894 & 766.829 & 837.553 & 214.664 & 110.338 & \text { Yes } \\ 0.93 & 35.32 & 28.45 & 23.82 & 2 & 1136.6390 & 1136.6312 & 569.3229 & 0.0078 & 6.8502 & 8427.251 & 8363.945 & 913.287 & 766.734 & \text { Yes }\end{array}$ $\begin{array}{lllllllllllllll}0.93 & 35.32 & 28.45 & 23.82 & 2 & 1136.6390 & 1136.6312 & 569.3229 & 0.0078 & 6.8502 & 8427.251 & 8363.945 & 913.287 & 766.734 & \text { Yes } \\ 0.97 & 34.78 & 27.94 & 29.41 & 2 & 1148.6680 & 1148.6675 & 575.3410 & 0.0005 & 0.4345 & 22201.662 & 26067.431 & 648.460 & 552.984 & \text { Yes }\end{array}$

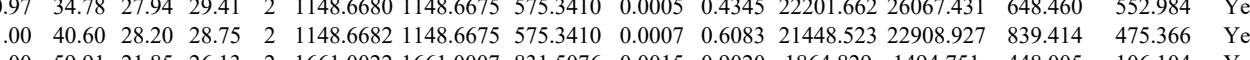
$\begin{array}{lllllllllllllll}1.00 & 59.91 & 21.85 & 26.13 & 2 & 1661.0022 & 1661.0007 & 831.5076 & 0.0015 & 0.9020 & 1864.829 & 1494.751 & 448.005 & 106.104 & \text { Yes }\end{array}$

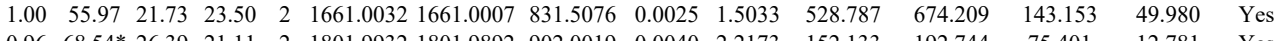

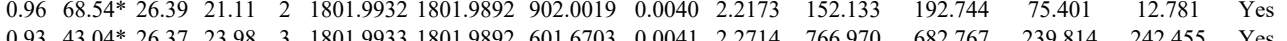

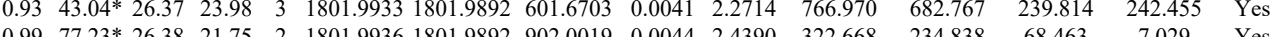

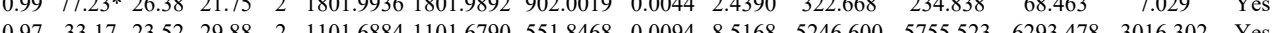

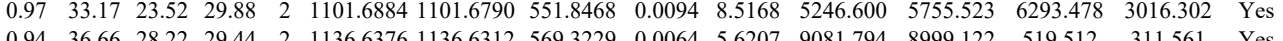

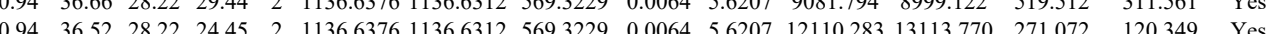
Q

$75.56 * 26.4021 .16 \quad 2$ $\begin{array}{llllllllll}0.96 .35 & 20.75 & 2 & 1801.9918 & 1801.9892 & 902.0019 & 0.0026 & 1.4412\end{array}$

$\begin{array}{lllllllllll} & \end{array}$

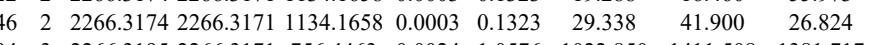

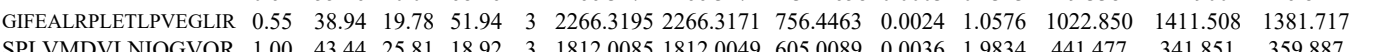
$\begin{array}{llllllllllllll} & \end{array}$

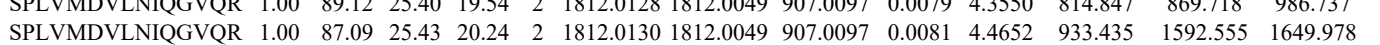
NTISLLVAGLK NTISLLVAGLK NTISLLVAGLK LSCLPAFK

LSCLPAFK

NTISLLVAGLK

LSCLPAFK

$\begin{array}{llllllllllllll}1.00 & 89.12 & 25.40 & 19.54 & 2 & 1812.0128 & 1812.004 & 907.0097 & 0.0079 & 4.3550 & 814.847 & 869 & & \\ 1.00 & 68.8 & 25.43 & 20.24 & 2 & 1812.0130 & 1812.0049 & 907.0097 & 0.0081 & 4.4652 & 933.435 & 1592 & & \end{array}$

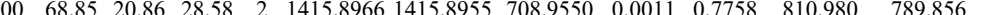
$\begin{array}{llllllllllllll}1.00 & 71.48 & 20.53 & 29.27 & 2 & 1415.8976 & 1415.8955 & 708.9550 & 0.0021 & 1.4811 & 409.492 & 162.261 & 265.758\end{array}$ $\begin{array}{llllllllllllll}0.99 & 26.21 & 20.53 & 23.72 & 3 & 1415.8981 & 1415.8955 & 472.9724 & 0.0026 & 1.8324 & 226.405 & 366.045 & 305.272\end{array}$ $\begin{array}{lllllllllllll}1.00 & 41.13 & 27.50 & 22.05 & 2 & 1211.6670 & 1211.6650 & 606.8398 & 0.0020 & 1.6479 & 14642.038 & 14632.744 & 713.870\end{array}$ $\begin{array}{llllllllllllll}0.99 & 36.48 & 27.41 & 22.02 & 2 & 1211.6672 & 1211.6650 & 606.8398 & 0.0022 & 1.8127 & 17262.713 & 18477.827 & 216.673\end{array}$

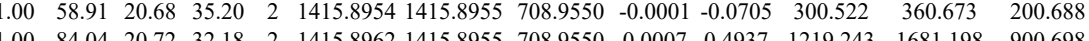
$\begin{array}{lllllllllllll}1.00 & 84.04 & 20.72 & 32.18 & 2 & 1415.8962 & 1415.8955 & 708.9550 & 0.0007 & 0.4937 & 1219.243 & 1681.198 & 900.698\end{array}$ $\begin{array}{lllllllllllll}0.99 & 37.05 & 27.47 & 19.81 & 2 & 1211.6664 & 1211.6650 & 606.8398 & 0.0014 & 1.1535 & 19875.782 & 23888.302 & 500.936\end{array}$

MLSAVSQQVQCIQEALR MLSAVSQQVQCIQEALR VPVNLLR

VPVNLLR

VPVNLLR VPVNLLR

WFTSQVIR

WFTSQIR

VTFVNFTVTR

VTFVNFTVTR $\begin{array}{llllllllllllll}1.00 & 40.72 & 27.52 & 22.47 & 2 & 1211.6666 & 1211.6650 & 606.8398 & 0.0016 & 1.3183 & 15548.400 & 15889.844 & 164.644 \\ 1.00 & \# \# \# \# 28.09 & 33.66 & 2 & 2093.0554 & 2093.0553 & 1047.5349 & 0.0001 & 0.0477 & 517.436 & 654.017 & 46.336\end{array}$ $\begin{array}{lllllllllllllll}1.00 & \text { 28.09 } & 32.71 & 2 & 2093.0554 & 2093.0553 & 1047.5349 & 0.0001 & 0.0477 & 521.521 & 627.548 & 57.938 & 21.839 & \text { Y }\end{array}$ $\begin{array}{llllllllllllllll}0.88 & 23.19 & 18.06 & 25.99 & 2 & 953.6232 & 953.6144 & 477.8145 & 0.0088 & 9.2085 & 11864.451 & 11964.547 & 14564.847 & 5283.018 & \text { Yes }\end{array}$ $\begin{array}{lllllllllllllllll}0.97 & 26.45 & 18.86 & 26.02 & 2 & 953.6228 & 953.6144 & 477.8145 & 0.0084 & 8.7899 & 7033.141 & 8755.420 & 9013.874 & 4905.203 & \text { Yes }\end{array}$

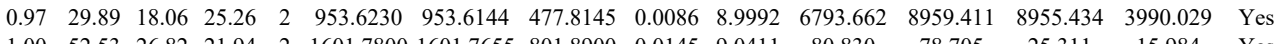
$\begin{array}{lllllllllllllll}1.00 & 52.53 & 26.82 & 21.94 & 2 & 1601.7800 & 1601.7655 & 801.8900 & 0.0145 & 9.0411 & 80.830 & 78.705 & 25.311 & 15.984 & \text { Yes } \\ 0.65 & 17.27 & 18.86 & 21.82 & 2 & 953.6224 & 953.6144 & 477.8145 & 0.0080 & 8.3714 & 690.979 & 876.378 & 429.844 & 305.698 & \text { Yes }\end{array}$ $\begin{array}{lllllllllllllll}0.65 & 17.27 & 18.86 & 21.82 & 2 & 953.6224 & 953.6144 & 477.8145 & 0.0080 & 8.3714 & 690.979 & 876.378 & 429.844 & 305.698 & \text { Yes } \\ 0.98 & 37.64 & 27.56 & 27.61 & 2 & 1179.6632 & 1179.6522 & 590.8334 & 0.0110 & 9.3088 & 10244.053 & 9419.790 & 268.821 & 132.060 & \text { Yes }\end{array}$ $\begin{array}{lllllllllllllll}0.98 & 37.64 & 27.56 & 27.61 & 2 & 1179.6632 & 1179.6522 & 590.8334 & 0.0110 & 9.3088 & 10244.053 & 9419.790 & 268.821 & 132.060 & \text { Yes } \\ 0.98 & 37.69 & 27.56 & 25.60 & 2 & 1179.6632 & 1179.6522 & 590.8334 & 0.0110 & 9.3088 & 9016.629 & 8645.844 & 215.583 & 70.327 & \text { Yes }\end{array}$

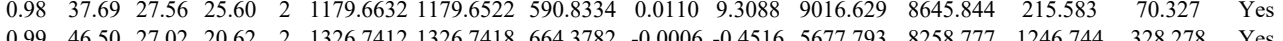

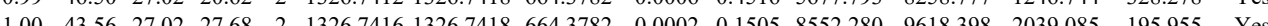

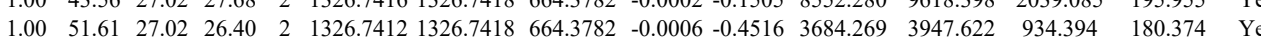

Table S-3 page 388 of 499 


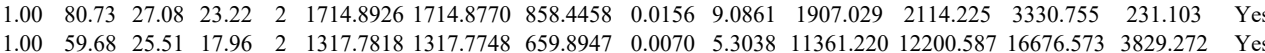
$\begin{array}{llllllllllllllll}1.00 & 62.93 & 25.39 & 17.59 & 2 & 1317.7828 & 1317.7748 & 659.8947 & 0.0080 & 6.0615 & 15227.067 & 18157.955 & 28035.696 & 5723.135 & \text { Yes }\end{array}$ $\begin{array}{lllllllllllllll}1.00 & 52.50 & 27.73 & 19.79 & 2 & 1358.7146 & 1358.7074 & 680.3610 & 0.0072 & 5.2913 & 3821.103 & 4922.999 & 7635.266 & 2279.516 & \text { Yes }\end{array}$ 

$\begin{array}{lllllllllllllllll}1.00 & 51.49 & 27.72 & 31.68 & 2 & 1193.6726 & 1193.6648 & 597.8397 & 0.0078 & 6.5234 & 5107.022 & 5803.913 & 8482.836 & 2903.230 & \text { Yes }\end{array}$ $\begin{array}{ccccccccccccccc}1.00 & 51.49 & 27.72 & 31.68 & 2 & 1193.6726 & 1193.6648 & 597.8397 & 0.0078 & 6.5234 & 5107.022 & 5803.913 & 8482.836 & 2903.230 & \text { Yes } \\ 0.98 & 34.03 & 27.36 & 15.84 & 2 & 1584.8430 & 1584.8422 & 793.4284 & 0.0008 & 0.5041 & 451.446 & 394.800 & 620.330 & 92.362 & \text { Yes } \\ \end{array}$ $\begin{array}{lllllllllllllll}0.98 & 35.22 & 27.39 & 15.63 & 2 & 1584.8448 & 1584.8422 & 793.4284 & 0.0026 & 1.6385 & 118.583 & 133.395 & 167.458 & 12.298 & \text { Yes } \\ 1.00 & 64.37 & 23.4 & 17.51 & 2 & 1584.8448 & 1584.8422 & 793.4284 & 0.0036 & 2.2686 & 328.866 & 61.748 & 957.491 & 59.042 & \text { Yes }\end{array}$ $\begin{array}{lllllllllllllll}1.00 & 50.37 & 27.44 & 17.51 & 2 & 1584.8458 & 1584.8422 & 793.4284 & 0.0036 & 2.2686 & 328.866 & 611.748 & 957.491 & 59.042 & \text { Yes } \\ 1.00 & 64.12 & 23.24 & 77.12 & 4 & 3619.6429 & 3619.6431 & 905.9181 & -0.0002 & -0.0552 & 15.483 & 26.508 & 14.642 & 24.083 & \end{array}$

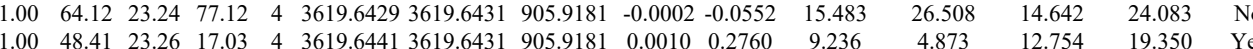

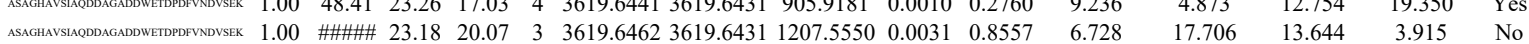

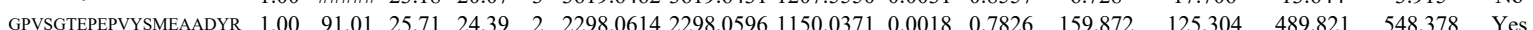

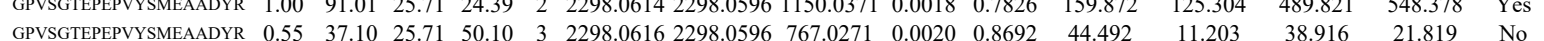

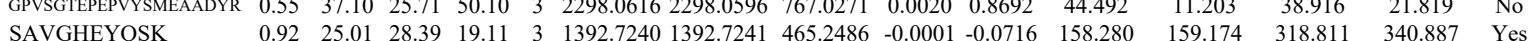

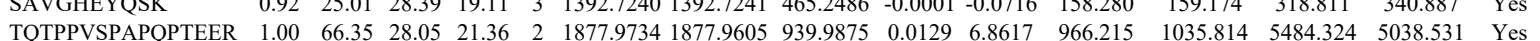
$\begin{array}{llllllllllllllll}\text { TQTPPVSPAPQPTEER } & 1.00 & 73.74 & 28.03 & 21.53 & 2 & 1877.9736 & 1877.9605 & 939.9875 & 0.0131 & 6.9681 & 1544.695 & 1802.047 & 9526.690 & 7480.466 & \text { Yes }\end{array}$

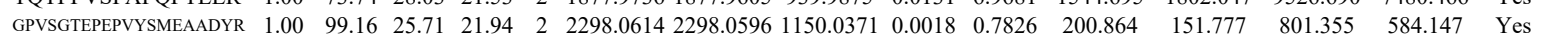

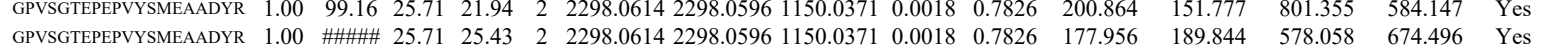

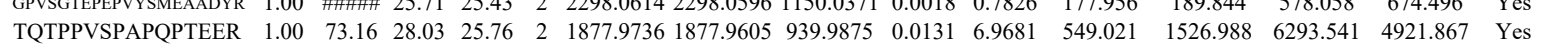
$\begin{array}{llllllllllllllll}\text { TQTPPSPAPQPEER } & 1.00 & 79.61 & 28.03 & 24.27 & 2 & 1877.9736 & 1877.9605 & 939.9875 & 0.0131 & 6.9681 & 599.454 & 1079.686 & 4768.307 & 3403.821 & \text { Yes }\end{array}$

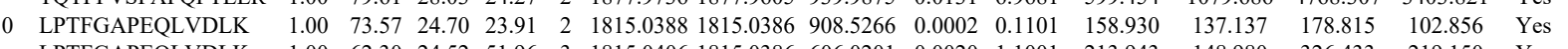
$\begin{array}{llllllllllllllll}\text { LPTFGAPEQLVDLK } & 1.00 & 62.30 & 24.52 & 51.96 & 3 & 1815.0406 & 1815.0386 & 606.0201 & 0.0020 & 1.1001 & 213.943 & 148.980 & 326.433 & 219.150 & \text { Yes }\end{array}$

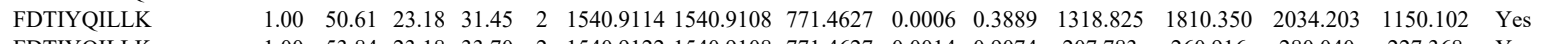
$\begin{array}{llllllllllllllll}\text { FDTIYQILLK } & 1.00 & 53.84 & 23.18 & 33.70 & 2 & 1540.9122 & 1540.9108 & 771.4627 & 0.0014 & 0.9074 & 207.783 & 260.916 & 280.040 & 227.368 & \text { Yes }\end{array}$

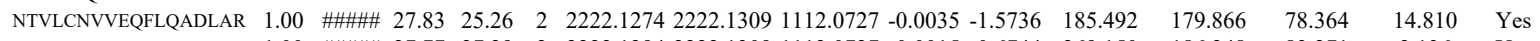

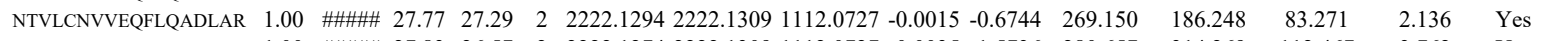

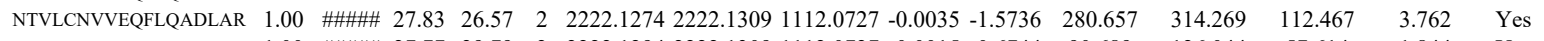
$\begin{array}{lllllllllllllll}\text { NTVLCNVVEQFLQADLAR } & 1.00 & \text { \#.77 } & 29.79 & 2 & 2222.1294 & 2222.1309 & 1112.0727 & -0.0015 & -0.6744 & 90.689 & 126.044 & 57.614 & 1.844 & \text { Yes }\end{array}$

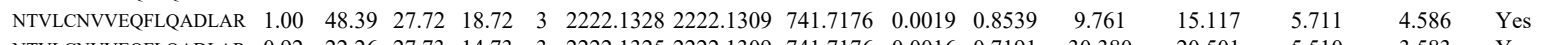

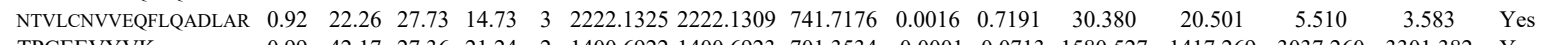
$\begin{array}{lllllllllllll}\text { FLNC_HUMAN } & \text { Q14315 } & \text { FLNC } & \text { Filamin-C } & 291.02 & 1.00 & 10 & 6.6 & -0.0408 & 0.5229 & 0.2046 & 1.0628 & 21\end{array}$ TPCEEVYYK TPCEEVYVK APSGNEEPCLLK APSGNEEPCLLK
TPCEEVYVK

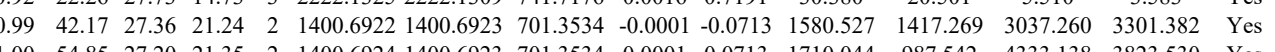
$\begin{array}{llllllllllllllll}1.00 & 54.85 & 27.20 & 21.35 & 2 & 1400.6924 & 1400.6923 & 701.3534 & 0.0001 & 0.0713 & 1710.044 & 987.542 & 4333.138 & 3823.530 & \text { Yes }\end{array}$ $\begin{array}{lllllllllllllll}1.00 & 58.42 & 27.55 & 24.87 & 2 & 1590.7982 & 1590.7989 & 796.4067 & -0.0007 & -0.4395 & 250.186 & 167.737 & 1107.853 & 1085.612 & \text { Yes }\end{array}$

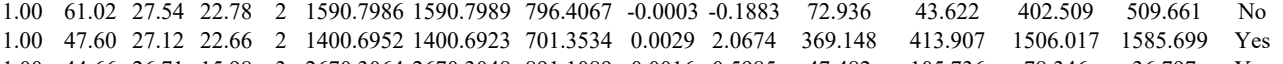

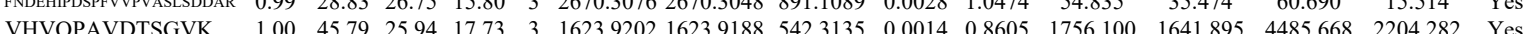

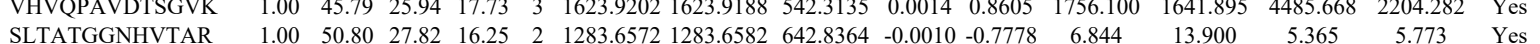

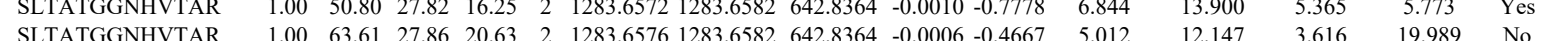

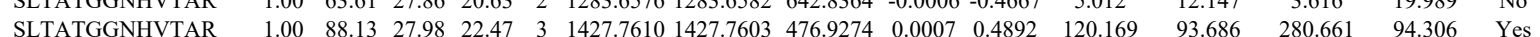

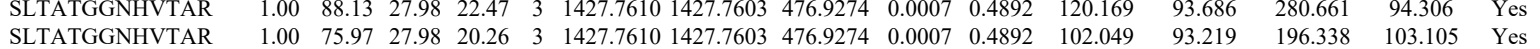

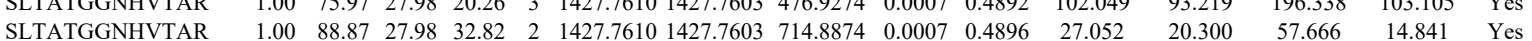

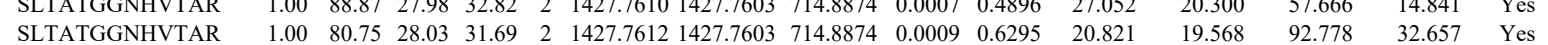
$\begin{array}{llllllllllllllll}\text { SLTATGGNHVTAR } & 1.00 & 75.85 & 28.09 & 17.81 & 3 & 1427.7601 & 1427.7603 & 476.9274 & -0.0002 & -0.1398 & 95.628 & 91.193 & 112.958 & 51.410 & \text { Yes }\end{array}$ $\begin{array}{llllllllllllllll}\text { GVAGVPAEFSIWTR } & 1.00 & 65.46 & 28.31 & 24.00 & 2 & 1632.8772 & 1632.8746 & 817.4446 & 0.0026 & 1.5903 & 421.285 & 321.799 & 1140.574 & 318.404 & \text { Yes }\end{array}$ $\begin{array}{llllllllllllllll}\text { GVAGVPAEFSIWTR } & 1.00 & 79.39 & 28.29 & 25.89 & 2 & 1632.8778 & 1632.8746 & 817.4446 & 0.0032 & 1.9573 & 225.337 & 200.321 & 889.258 & 253.520 & \text { Yes }\end{array}$

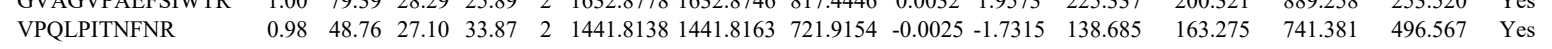
$\begin{array}{lllllllllllllllll}\text { VPQLPITNFNR } & 0.98 & 47.85 & 27.12 & 35.90 & 2 & 1441.8144 & 1441.8163 & 721.9154 & -0.0019 & -1.3159 & 122.017 & 237.242 & 448.897 & 411.633 & \text { Yes }\end{array}$ $\begin{array}{llllllllllllllll}\text { VPQLPITNFNR } & 0.96 & 41.83 & 27.12 & 33.71 & 2 & 1441.8142 & 1441.8163 & 721.9154 & -0.0021 & -1.4545 & 383.970 & 325.635 & 514.973 & 454.922 & \text { Yes }\end{array}$ $\begin{array}{llllllllllllllll}\text { VPQLPITNFNR } & 0.99 & 50.25 & 27.09 & 32.44 & 2 & 1441.8148 & 1441.8163 & 721.9154 & -0.0015 & -1.0389 & 699.204 & 717.948 & 801.613 & 713.627 & \text { Yes }\end{array}$

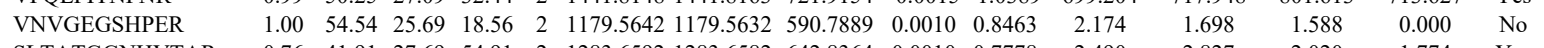

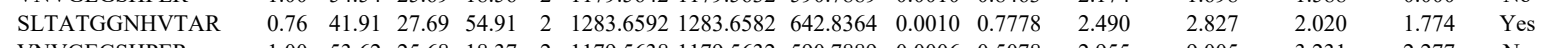

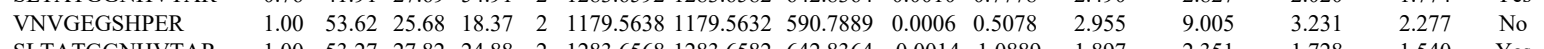

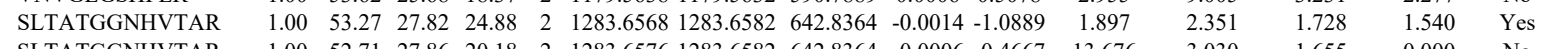

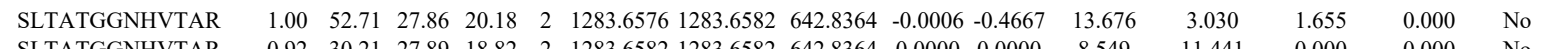

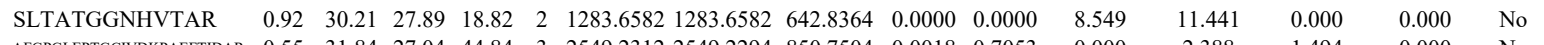

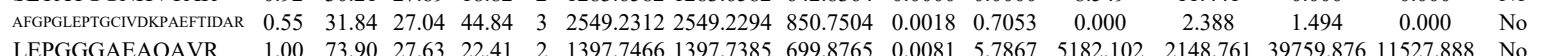

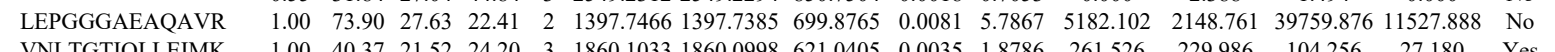

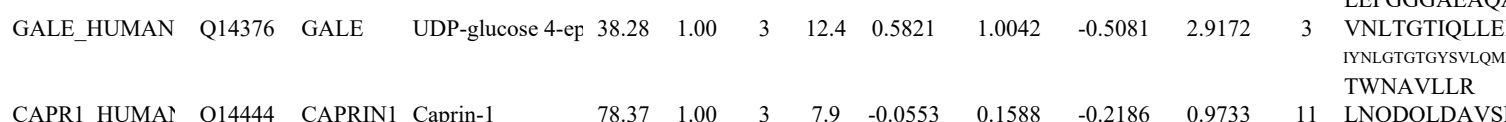
$\begin{array}{lllllllllllllllll}1.00 & 40.37 & 21.52 & 24.20 & 3 & 1860.1033 & 1860.0998 & 621.0405 & 0.0035 & 1.8786 & 261.526 & 229.986 & 104.256 & 27.180 & \text { Yes } \\ \end{array}$ $\begin{array}{llllllllllllllll}\text { LNQDQLDAVSK } & 1.00 & 56.49 & 27.57 & 25.26 & 2 & 1517.8422 & 1517.8293 & 759.9219 & 0.0129 & 8.4876 & 3557.254 & 3726.578 & 3158.249 & 642.736 & \text { Yes } \\ \text { LNQDQLDAVSK } & 1.00 & 70.24 & 27.65 & 26.97 & 2 & 1517.8434 & 1517.8293 & 759.9219 & 0.0141 & 9.2772 & 9713.727 & 8553.563 & 9782.081 & 1499.079 & \text { Yes } \\ \text { LNQDQLDAVSK } & 1.00 & 60.23 & 27.64 & 26.34 & 2 & 1517.8418 & 1517.8293 & 759.9219 & 0.0125 & 82245 & 8020.577 & 7519.582 & 6346.203 & 917.837 & \text { Yes }\end{array}$ $\begin{array}{ccccccccccccccc}1.00 & 39.86 & 27.36 & 28.13 & 2 & 1115.6596 & 1115.6573 & 558.8359 & 0.0023 & 2.0578 & 6596.134 & 8175.949 & 244.811 & 116.487 & \text { Yes }\end{array}$ LNQDQLDAVSK

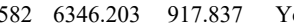
$\begin{array}{lllllllllllllll}1.00 & 60.40 & 27.57 & 26.32 & 2 & 1517.8420 & 1517.8293 & 759.9219 & 0.0127 & 8.3561 & 7364.473 & 5987.420 & 7443.993 & 613.199 & \text { Yes }\end{array}$

Table S-3 page 390 of 49 
LNQDQLDAVSK YQEVTNNLEFAK YQEVTNNLEFAK YQEVTNNLEFAK TVLELQYVLDK TVLELQYVLDK TVLELQYLDK TVFCMQLAAR CPSIAAAIAAVNALHGR CPSIAAAIAAVNALHGR CPSIAAAIAAVNALHG CPSIAAAIAAVNALHG CPSIAAAIAAVVNALHGR CPSIAAAIAAVNALHGR CPSIAAAIAAVNALHGR CPSIAAAIAAVNALHGR
CPSIAAAIAAVNALHGR CPSIAAAIAAVNALHGR

IQETQAELPR QQETQAELPR LFLDFLEEFQSSDGEIK YLQLAEELIRPER

\section{YLQLAEELIRPER}

YLQLAEELIRPER

YLQLAEELIRPER

ASSAAGLTAAVVR

ASSAAGLTAAVVR ASSAAGLTAAVVR QNINLSAPIMSR QNINLSAPIMSR QNINLSAPIMSR QNINLSAPIMSR

IGLLTR

EIESEIDSEEELINK

EIESEIDSEEELINK

IGLLTR

IGLLTR

YLLFAR

GVLLMLFGGVPK

GVLLMLFGGVPK

GVLLMLFGGVPK

YLLFAR

GVLLMLFGGVPK

GVLLMLFGGVPK

GVLLMLFGGVPK

GVLLMLFGGVPK

GVLLMLFGGVPK

GVLLMLFGGVPK

GVLLMLFGGVPK

GVLLMLFGGVPK

GVLLMLFGGVPK

GVLLMLFGGVPK

ISNLIVLHLR

ISNLIVLHLR

ISNLIVLHLR

ISNLIVLHLR

IGLLTR

LVFLACCVAPTNPR

LVFLACCVAPTNPR

LVFLACCVAPTNPR

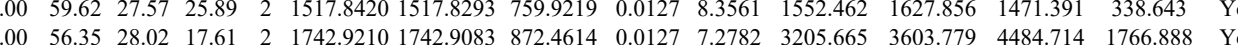

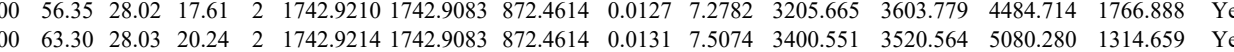
$\begin{array}{lllllllllllllllll}1.00 & 58.03 & 27.97 & 21.10 & 2 & 1742.9220 & 1742.9083 & 872.4614 & 0.0137 & 7.8513 & 1272.629 & 1111.957 & 1890.570 & 677.052 & \text { Yes }\end{array}$ $\begin{array}{llllllllllllll}1.00 & 58.61 & 23.56 & 21.76 & 2 & 1607.9416 & 1607.9378 & 804.9762 & 0.0038 & 2.3603 & 1491.642 & 1571.846 & 110.497 & 656.998\end{array}$ $\begin{array}{lllllllllllllll}1.00 & 73.43 & 23.26 & 22.76 & 2 & 1607.9430 & 1607.9378 & 804.9762 & 0.0052 & 3.2299 & 932.477 & 1061.860 & 126.571 & 421.930 & \text { Yce }\end{array}$

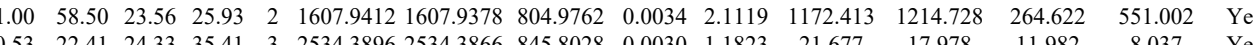
$\begin{array}{llllllllllllll}0.53 & 22.41 & 24.33 & 35.41 & 3 & 2534.3896 & 2534.3866 & 845.8028 & 0.0030 & 1.1823 & 21.677 & 17.978 & 11.982 & 8.037 \\ 0.99 & 37.34 & 26.64 & 26.53 & 2 & 1328.6532 & 1328.6525 & 665.3335 & 0.0007 & 0.5261 & 1020.869 & 1001.393 & 133.516 & 89.966\end{array}$ $\begin{array}{llllllllllllll}0.99 & 37.34 & 26.64 & 26.53 & 2 & 1328.6532 & 1328.6525 & 665.3335 & 0.0007 & 0.5261 & 1020.869 & 1001.393 & 133.516 & 89.966 \\ 1.00 & 87.61 & 27.88 & 19.39 & 3 & 1679.8609 & 1679.8599 & 560.9606 & 0.0010 & 0.5942 & 28.395 & 57.056 & 24.431 & 14.456\end{array}$

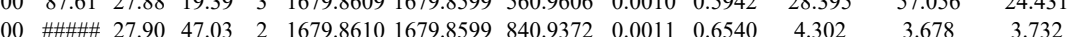
\begin{tabular}{lllllllllllll} 
& 88.35 & 27.76 & 21.61 & 3 & 1823.9632 & 1823.9620 & 608.9946 & 0.0012 & 0.6568 & 46.532 & 54.265 & 25.093 \\
\hline
\end{tabular} $\begin{array}{llllll} & \end{array}$ $\begin{array}{lllllllllllll}1.00 & \text { \#\#\# } 27.70 & 25.27 & 2 & 1823.9618 & 1823.9620 & 912.9883 & -0.0002 & -0.1095 & 9.405 & 12.379 & 17.303 & 6.752\end{array}$

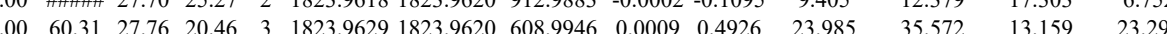
$\begin{array}{lllllllllllll}1.00 & \text { \#\#\# } 27.76 & 25.73 & 3 & 1823.9632 & 1823.9620 & 608.9946 & 0.0012 & 0.6568 & 22.086 & 36.300 & 16.173 & 16.067\end{array}$ $\begin{array}{llllllllllllll}.00 & 91.41 & 27.75 & 21.10 & 3 & 1823.9635 & 1823.9620 & 608.9946 & 0.0015 & 0.8210 & 34.155 & 30.084 & 18.494 & 4.827\end{array}$ $\begin{array}{lllllllllllllll}.00 & 94.80 & 27.75 & 25.87 & 3 & 1823.9638 & 1823.9620 & 608.9946 & 0.0018 & 0.9852 & 24.272 & 25.408 & 29.594 & 23.589 & \text { Yes }\end{array}$

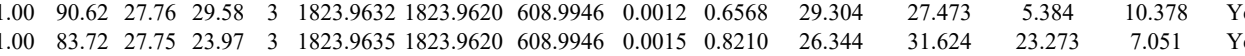
$\begin{array}{lllllllllllllll}1.00 & 50.86 & 27.51 & 32.40 & 2 & 1327.7300 & 1327.7217 & 664.8681 & 0.0083 & 6.2418 & 10071.938 & 10906.434 & 4744.776 & 1248.726 & \text { Yes }\end{array}$ $\begin{array}{llllllllllllllll}1.00 & 62.90 & 27.53 & 27.42 & 2 & 1327.7314 & 1327.7217 & 664.8681 & 0.0097 & 7.2946 & 14633.667 & 17064.566 & 7686.335 & 1542.522 & \text { Yes }\end{array}$ $\begin{array}{lllllllllllllll}1.00 & 74.56 & 27.38 & 23.14 & 2 & 2304.1814 & 2304.1769 & 1153.0957 & 0.0045 & 1.9513 & 27.380 & 11.721 & 6.491 & 1.760 & \text { No }\end{array}$

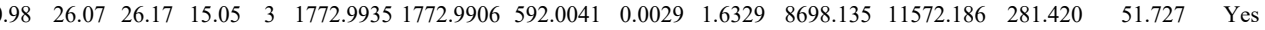

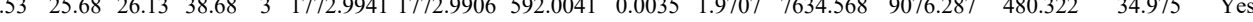
$\begin{array}{lllllllllllllll}.99 & 26.69 & 26.35 & 15.14 & 3 & 1772.9929 & 1772.9906 & 592.0041 & 0.0023 & 1.2950 & 4838.171 & 6068.984 & 352.798 & 36.077 & \text { Yes }\end{array}$ $\begin{array}{lllllllllllllll}.97 .19 & 26.01 & 14.99 & 3 & 1772.9947 & 1772.9906 & 592.0041 & 0.0041 & 2.3085 & 4486.257 & 5441.169 & 542.346 & 48.865 & \text { Yes }\end{array}$ $\begin{array}{lllllllllllllll}1.00 & 7.58 & 26.74 & 29.07 & 2 & 1316.7632 & 1316.7534 & 659.3840 & 0.0098 & 7.4311 & 7924.115 & 9068.316 & 2230.730 & 552.540 & \text { Yes }\end{array}$ $\begin{array}{lllllllllllllll}1.00 & 7.58 & 26.74 & 29.07 & 2 & 1316.7632 & 1316.7534 & 659.3840 & 0.0098 & 7.431 & 7924.115 & 9068.316 & 2230.730 & 552.540 & \text { Yes }\end{array}$ $\begin{array}{llllllllllllllll}1.00 & 76.52 & 26.95 & 25.77 & 2 & 1316.7620 & 1316.7534 & 659.3840 & 0.0086 & 6.5212 & 17420.790 & 19574.791 & 5241.526 & 726.865 & \text { Yes } \\ 1.00 & 76.41 & 27.27 & 29.45 & 2 & 1316.7602 & 1316.7534 & 659.3840 & 0.0068 & 5.1563 & 8014.481 & 9275.547 & 2105.963 & 912.193 & \text { Yes }\end{array}$ $\begin{array}{llllllllllllllll}1.00 & 61.69 & 27.27 & 24.37 & 2 & 1316.7604 & 1316.7534 & 659.3840 & 0.0070 & 5.3080 & 3410.066 & 3711.000 & 1126.980 & 1331.325 & \text { Yes }\end{array}$

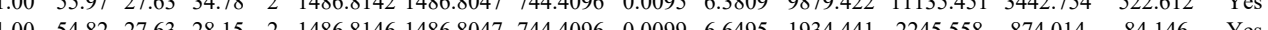

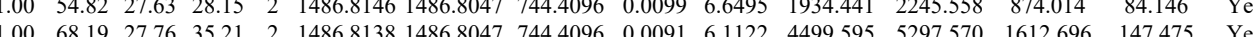

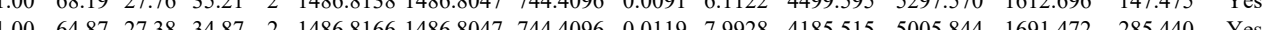

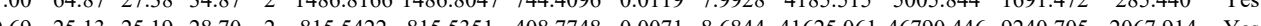

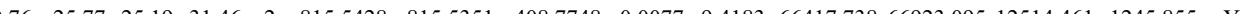
$\begin{array}{lllllllllll} & \end{array}$ $\begin{array}{llllllllllll} & \end{array}$ $\begin{array}{lllllllllllllll}0.70 & 25.29 & 25.19 & 29.97 & 2 & 815.5422 & 815.5351 & 408.7748 & 0.0071 & 8.6844 & 317728.844 & 33346.361 & 5132368 & 767.661 & \text { Y }\end{array}$ $\begin{array}{llllllllllllllll}0.51 & 21.11 & 25.19 & 29.57 & 2 & 815.5426 & 815.5351 & 408.7748 & 0.0075 & 9.1737 & 41570.511 & 44573.060 & 6666.999 & 203.461 & \text { Yes }\end{array}$ $\begin{array}{lllllllllllllll}1.00 & 66.38 & 21.64 & 26.80 & 2 & 1517.9260 & 1517.9247 & 759.9696 & 0.0013 & 0.8553 & 123.179 & 152.018 & 57.625 & 46.882 & \text { Yes }\end{array}$

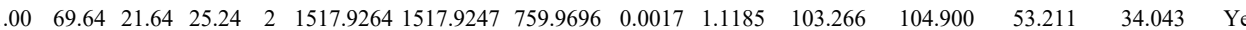

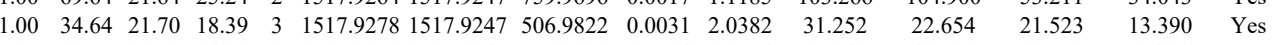
$\begin{array}{lllllllllllllllll}0.81 & 35.01 & 23.03 & 39.40 & 2 & 925.5590 & 925.5507 & 463.7826 & 0.0083 & 8.9481 & 13214.276 & 12688.941 & 366.606 & 77.916 & \text { Yes }\end{array}$

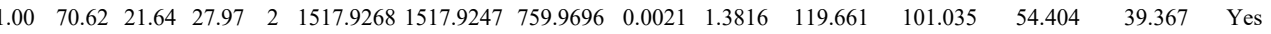
$\begin{array}{lllllllllllllll}1.00 & 28.51 & 21.64 & 17.41 & 3 & 1517.9272 & 1517.9247 & 506.9822 & 0.0025 & 1.6437 & 46.705 & 51.637 & 42.187 & 9.543 & \text { Yes }\end{array}$

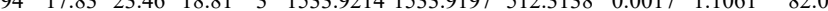

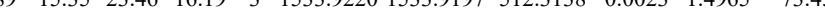
$\begin{array}{lllllllllllll}1.00 & 30.12 & 21.64 & 19.51 & 3 & 1517.9266 & 1517.9247 & 506.9822 & 0.0019 & 1.2492 & 39.600 & 26.493 & 13.646\end{array}$

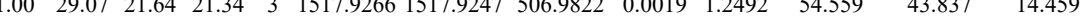
$\begin{array}{lllllllllllll}1.00 & 58.54 & 21.64 & 26.02 & 2 & 1517.9260 & 1517.9247 & 759.9696 & 0.0013 & 0.8553 & 86.508 & 65.749 & 31.911\end{array}$ $\begin{array}{lllllllllllll}1.06 & 57.74 & 21.64 & 30.14 & 2 & 1517.9266 & 1517.9247 & 759.9696 & 0.0019 & 1.2500 & 62.737 & 68.928 & 33.264 \\ 0.64 & 7.92 & 21.64 & 18.02 & 3 & 1517.9272 & 1517.9247 & 506.9822 & 0.0025 & 1.6437 & 67.032 & 55.727 & 13.703 \\ 1.06 & 56.08 & 19.19 & 22.30 & 3 & 1320.8380 & 1320.8363 & 441.280 & 0.0017 & 1.2841 & 240.014 & 30.526 & 360.36\end{array}$

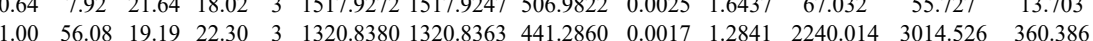
$\begin{array}{lllllllllllll}1.05 & 56.08 & 19.19 & 22.30 & 3 & 1320.8380 & 1320.8363 & 441.2860 & 0.0017 & 1.2841 & 2240.014 & 3014.526 & 360.386 \\ 0.55 & 38.65 & 19.19 & 51.65 & 3 & 1320.8383 & 1320.8363 & 441.2860 & 0.0020 & 1.5107 & 2575.400 & 3043.318 & 445.788\end{array}$

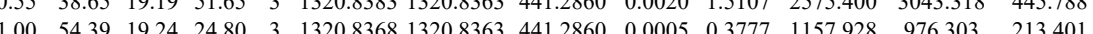
$\begin{array}{lllllllllllll}1.00 & 51.83 & 19.24 & 23.20 & 3 & 1320.8368 & 1320.8363 & 441.2860 & 0.0005 & 0.3777 & 947.569 & 977.640 & 192.163\end{array}$ $\begin{array}{lllllllllllllll}0.71 & 19.31 & 23.78 & 27.22 & 2 & 815.5346 & 815.5351 & 408.7748 & -0.0005 & -0.6116 & 762.221 & 916.114 & 169.229\end{array}$ $\begin{array}{llllllllllllllll}0.50 & 15.48 & 23.78 & 27.59 & 2 & 815.5350 & 815.5351 & 408.7748 & -0.0001 & -0.1223 & 952.639 & 912.435 & 192.184\end{array}$

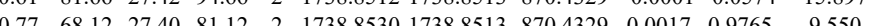
$\begin{array}{lllllllllllllll}0.58 & 12.63 & 27.39 & 13.88 & 3 & 1738.8535 & 1738.8513 & 580.6244 & 0.0022 & 1.2630 & 1.631 & 11.520 & 4.126\end{array}$ 

$\begin{array}{lllllllllllllllll}\text { ASPDQNASTHTPQSSVK } & 1.00 & 36.57 & 27.61 & 24.14 & 3 & 2042.0296 & 2042.0272 & 681.6830 & 0.0024 & 1.1736 & 573.710 & 566.371 & 352.989 & 223.942 & \text { Yes }\end{array}$ $\begin{array}{lllllllllllllllll}\text { GEFKDEEETVTTK } & 0.68 & 36.77 & 27.39 & 17.89 & 3 & 1944.0133 & 1944.0053 & 649.0090 & 0.0080 & 4.1088 & 7165.096 & 6436.069 & 5320.703 & 5366.548 & \text { Yes }\end{array}$

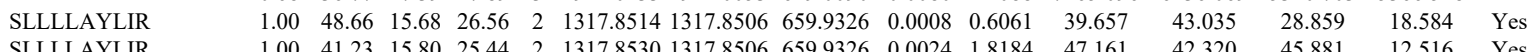

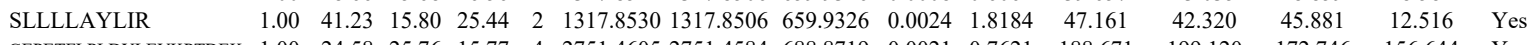

10 GEPETFLPLDYLEVKPTDEK $\begin{array}{llllllllllllllll}\text { SGVISGGASDLK } & 0.99 & 43.58 & 27.59 & 26.67 & 2 & 1377.7766 & 1377.7707 & 689.8926 & 0.0059 & 4.2760 & 5999.475 & 6228.844 & 3843.811 & 2222.486 & \text { Yes }\end{array}$ $\begin{array}{llllllllllllllllll}\text { SGVISGGASDLK } & 1.00 & 56.06 & 26.76 & 28.68 & 2 & 1377.7830 & 1377.7707 & 689.8926 & 0.0123 & 8.9144 & 4422.828 & 4938.785 & 3428.944 & 3667.275 & \text { Yes }\end{array}$ $\begin{array}{llllllllllllllll}\text { SNLMDAISFVLGEK } & 1.00 & 42.86 & 26.75 & 21.30 & 3 & 1810.9780 & 1810.9742 & 604.6653 & 0.0038 & 2.0948 & 142.408 & 137.635 & 97.196 & 37.173 & \text { Yes }\end{array}$ $\begin{array}{llllllllllllllll}\text { SNLMDAISFVLGEK } & 1.00 & 40.68 & 26.76 & 16.27 & 3 & 1810.9774 & 1810.9742 & 604.6653 & 0.0032 & 1.7641 & 113.642 & 117.507 & 90.962 & 47.693 & \text { Yes }\end{array}$

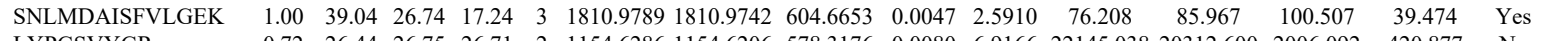

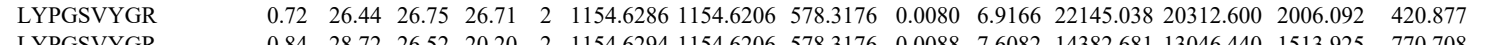
$\begin{array}{lllllllllllllll}\text { LYPGSVYGR } & 0.84 & 28.72 & 26.52 & 20.20 & 2 & 1154.6294 & 1154.6206 & 578.3176 & 0.0088 & 7.6082 & 14382.681 & 13046.440 & 1513.925 & 770.708\end{array}$ \begin{tabular}{llllllllllllllll} 
GEPETFLPLDYLEVKPTDEK & 0.53 & 38.13 & 25.73 & 51.13 & 3 & 2751.4615 & 2751.4584 & 918.1601 & 0.0031 & 1.1254 & 692.773 & 925.803 & 535.089 & 635.210 & Yes \\
\hline
\end{tabular}

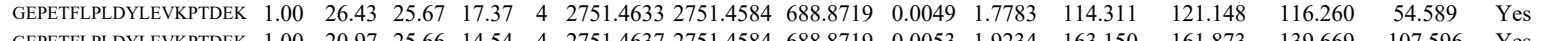

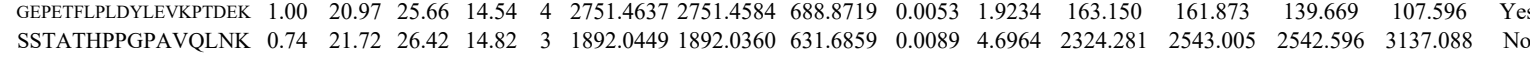

\section{SILVSPTGPSR}

(1) \begin{tabular}{llllllllllll}
0 & 12.24 & 20.21 & 3 & 1200.7420 & 1200.7434 & 401.2551 & -0.0014 & -1.1630 & 38.898 & 69.605 \\
\hline
\end{tabular} GFEAIVDQSP

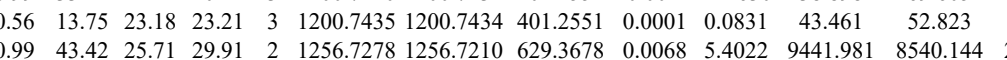
$\begin{array}{lllllllllll}0.56 & 13.75 & 23.18 & 23.21 & 3 & 100.7435 & 1200.7434 & 401.2551 & 0.0001 & 0.0831 & 43.461\end{array}$ 3 FQEAGELYNR $\begin{array}{lllllllllllll}0.93 & 22.06 & 27.42 & 18.51 & 3 & 2796.3808 & 27963772 & 933.1330 & 0.0036 & 1.2860 & 14.665 & 0.000\end{array}$$$
\text { TTEPGVTGLLLAVEGPAAK } 0.53
$$

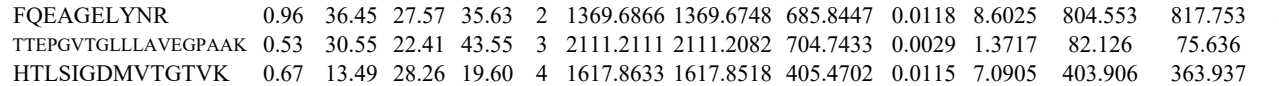
$\begin{array}{lllllllllllllll}\text { HTLSIGDMVTGTVK } & 0.67 & 13.49 & 28.26 & 19.60 & 4 & 1617.8633 & 1617.8518 & 405.4702 & 0.0115 & 7.0905 & 403.906 & 363.937 & 105 .\end{array}$ $\begin{array}{llllllllllllll} & \\ \text { GLVPPMHLADILMK } & 1.00 & 61.37 & 27.14 & 16.09 & 3 & 2483.2834 & 2483.2796 & 828.7671 & 0.0038 & 1.5284 & 17.106 & 17.971 & 26.0\end{array}$

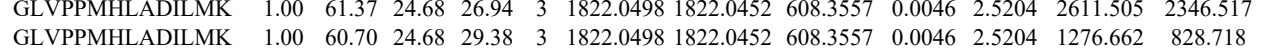
$\begin{array}{lllllllllllll}\text { NFSEIHPGMLLIGFVK } & 1.00 & 42.54 & 24.91 & 20.06 & 3 & 2089.1686 & 2089.1638 & 697.3952 & 0.0048 & 2.2942 & 2112.403 & 1654.794\end{array}$ IPLLLTSLSFK LGPSVVGLAR TLLCLSLTGPHK TLLCLSLTGPHK IPLLLTSLSFK IPLLLTSLSFK IPLLLTSLSFK IPLLLTSLSFK IPLLLTSLSFK IPLLLTSLSFK IPLLLTSLSFK IPLLLTSLSFK IPLLLTSLSFK IPLLLTSLSFK $\begin{array}{lllllllllllll}0.94 & 23.59 & 16.33 & 20.28 & 2 & 1518.9722 & 1518.9629 & 760.4887 & 0.0093 & 6.1145 & 13.956 & 64.228\end{array}$

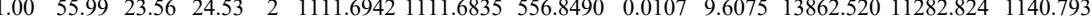
$\begin{array}{lllllllllllllll}1.00 & 70.47 & 26.31 & 21.92 & 3 & 1615.9069 & 1615.9033 & 539.6417 & 0.0036 & 2.2237 & 3074.313 & 2751.826 & 166.507\end{array}$ $\begin{array}{lllllllllllll}1.00 & 56.93 & 26.16 & 28.30 & 3 & 1615.9075 & 1615.9033 & 539.6417 & 0.0042 & 2.5943 & 1505.698 & 1311.438 \\ 0.69 & 76.24 & 15.05 & 89.24 & 2 & 1518.9656 & 1518.9629 & 760.4887 & 0.0027 & 1.7752 & 225.418 & 232.470 \\ 0.69 & 85.97 & 15.05 & 98.97 & 2 & 1518.9656 & 1518.9629 & 760.4887 & 0.0027 & 1.7752 & 29.513 & 272.748 & 12\end{array}$ $\begin{array}{llllllllllllll}0.69 & 76.24 & 15.05 & 89.24 & 2 & 1518.9656 & 1518.9629 & 760.4887 & 0.0027 & 1.7752 & 225.418 & 232.470 \\ 0.69 & 85.97 & 15.05 & 98.97 & 2 & 1518.9656 & 1518.9629 & 760.4887 & 0.0027 & 1.7752 & 291.513 & 272.748\end{array}$ $\begin{array}{llllllllllll}0.69 & 85.97 & 15.05 & 98.97 & 2 & 1518.9656 & 1518.9629 & 760.4887 & 0.0027 & 1.7752 & 291.513 & 272.748 \\ 0.53 & 6.78 & 14.77 & 19.78 & 3 & 1518.9661 & 1518.9629 & 507.3282 & 0.0032 & 2.1025 & 58.386 & 60.007\end{array}$ $\begin{array}{llllllllllll}1.00 & 40.32 & 14.77 & 17.86 & 3 & 1518.9661 & 1518.9629 & 507.3282 & 0.0032 & 2.1025 & 58.386 & 60.007 \\ 0.9664 & 1518.9629 & 507.3282 & 0.0035 & 2.2996 & 54.410 & 46.910\end{array}$ $\begin{array}{llllllllllll}0.77 & 66.27 & 15.80 & 79.27 & 2 & 1518.9646 & 1518.9629 & 760.4887 & 0.0017 & 1.1177 & 65.424 & 73.203 \\ 0\end{array}$ $\begin{array}{lllllllllllll}0.77 & 69.05 & 15.80 & 82.05 & 2 & 1518.9648 & 1518.9629 & 760.4887 & 0.0019 & 1.2492 & 176.086 & 138.054\end{array}$ $\begin{array}{lllllllllllll}0.53 & 24.93 & 15.05 & 37.93 & 3 & 1518.9658 & 1518.9629 & 507.3282 & 0.0029 & 1.9054 & 57.578 & 73.781\end{array}$

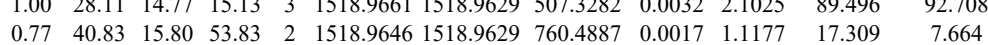
$\begin{array}{llllllllllll}0.77 & 40.83 & 15.80 & 53.83 & 2 & 1518.9646 & 1518.9629 & 760.4887 & 0.0017 & 1.1177 & 17.309 & 7.664 \\ 0.55 & 22.74 & 15.05 & 35.74 & 3 & 1518.9652 & 1518.9629 & 507.3282 & 0.0023 & 1.5112 & 90.833 & 82.113\end{array}$ $\begin{array}{llllllllllllll}0.77 & 55.25 & 15.05 & 68.25 & 2 & 1518.9652 & 1518.9629 & 760.4887 & 0.0023 & 1.5122 & 21.879 & 14.357\end{array}$ $\begin{array}{llllllllllllll}1.00 & 56.11 & 25.54 & 23.06 & 3 & 1246.5940 & 1246.5929 & 416.5382 & 0.0011 & 0.8803 & 4763.256 & 3711.660 \\ 1.00 & 62.13 & 25.53 & 22.76 & 3 & 1246.5946 & 1246.5929 & 416.5382 & 0.0017 & 1.3604 & 1197.090 & 990.128\end{array}$ 
$\begin{array}{llllllllllllll}1.00 & 44.53 & 26.59 & 30.39 & 2 & 1026.5374 & 1026.5369 & 514.2757 & 0.0005 & 0.4861 & 8463.016 & 9751.967 & 515.420 & 51\end{array}$

$\begin{array}{llllllllllllll}0.99 & 35.20 & 26.67 & 32.73 & 2 & 1026.5378 & 1026.5369 & 514.2757 & 0.0009 & 0.8750 & 8056.463 & 8422.088 & 390.526 & \\ 0.99 & 42.18 & 25.87 & 34.45 & 2 & 1115.6892 & 1115.6784 & 558.8465 & 0.0108 & 9.6627 & 15593.749 & 16926.297 & 957.805 & \\ 0\end{array}$ $\begin{array}{cccccccccccccccc} & 0.99 & 35.20 & 26.67 & 32.73 & 2 & 1026.5378 & 1026.5369 & 514.2757 & 0.0009 & 0.8750 & 8056.463 & 8422.088 & 390.526 & 351.093 & \text { Yes } \\ & 0.99 & 42.18 & 25.87 & 34.45 & 2 & 1115.6892 & 1115.6784 & 558.8465 & 0.0108 & 9.6627 & 15593.749 & 16926.297 & 957.805 & 653.630 & \text { Yes } \\ & 0.91 & 22.92 & 28.52 & 16.84 & 3 & 1634.8489 & 1634.8477 & 545.9565 & 0.0012 & 0.7327 & 553.238 & 491.533 & 1253.459 & 1151.284 & \text { No } \\ & 1.00 & 68.06 & 25.19 & 22.51 & 2 & 1711.7784 & 1711.7771 & 856.8958 & 0.0013 & 0.7586 & 1084.185 & 1014.068 & 729.359 & 731.300 & \text { Yes }\end{array}$ $\begin{array}{lllllllllllllll} & \end{array}$ $\begin{array}{llllllllllllll} & \end{array}$ $\begin{array}{lllllllllllllllll} & \text { SIRPGLSPYR } & 0.96 & 26.20 & 27.26 & 16.22 & 3 & 1288.7374 & 1288.7373 & 430.5864 & 0.0001 & 0.0774 & 1168.373 & 1796.172 & 182.485 & 34.612 & \text { Yes }\end{array}$ $\begin{array}{llllllllllllllll}\text { SIRPGLSPYR } & 0.66 & 21.92 & 27.42 & 20.29 & 2 & 1288.7376 & 1288.7373 & 645.3759 & 0.0003 & 0.2324 & 624.199 & 712.623 & 138.314 & 82.929 & \text { Ye }\end{array}$

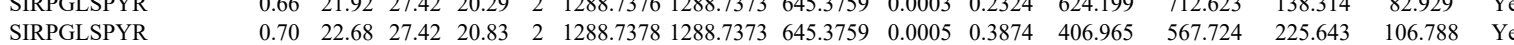
$\begin{array}{llllllllllllllll}\text { SIRPGLSPYR } & 0.96 & 25.47 & 27.47 & 21.87 & 3 & 1288.7386 & 1288.7373 & 430.5864 & 0.0013 & 1.0064 & 2984.301 & 4405.652 & 548.126 & 7.832 & \text { Yes }\end{array}$ $\begin{array}{llllllllllllllll}\text { SIRPGLSPYR } & 0.60 & 22.21 & 27.62 & 17.44 & 3 & 1288.7350 & 1288.7373 & 430.5864 & -0.0023 & -1.7805 & 299.624 & 386.741 & 56.672 & 5.892 & \text { Yes }\end{array}$

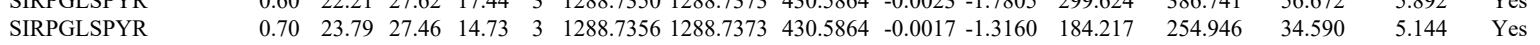
$\begin{array}{llllllllllllllllll}\text { APPPLPPYYSMETETPTAEDIQLKK } & 0.99 & 26.32 & 25.59 & 14.84 & 3 & 3024.5992 & 3024.5973 & 1009.2064 & 0.0019 & 0.6276 & 28.689 & 37.197 & 7.701 & 17.420 & \text { Yes }\end{array}$ $\begin{array}{lllllllllllllllll}\text { RPSNSTPPPTQLSK } & 0.97 & 29.60 & 26.22 & 14.97 & 3 & 1796.9980 & 1796.9988 & 600.0069 & -0.0008 & -0.4444 & 412.044 & 519.014 & 402.671 & 313.311 & \text { Yes }\end{array}$ $\begin{array}{llllllllllllllll}\text { RPSNSTPPPTQLSK } & 0.99 & 30.04 & 26.30 & 15.83 & 3 & 1797.0007 & 1796.9988 & 600.0069 & 0.0019 & 1.0555 & 862.136 & 882.772 & 721.542 & 593.356 & \text { Ye } \\ \text { RPSNSTPPTQLSK } & 1.00 & 35.52 & 26.22 & 15.40 & 3 & 1796.9986 & 1796.9988 & 600.0069 & -0.0002 & -0.1111 & 206.033 & 225.993 & 471.273 & 347.175 & \text { No }\end{array}$ RPSNSTPPPTQLSK TIHGLIYNALK

VLPIMFPALY

VLPIMFPALYR

VLPIMFPALYR

VLPIMFPALYR

VLPIMFPALYR

VLPIMFPALYR

VLPIMFPALYR

$\begin{array}{lllllllllllll}\text { CHD4_HUMAN } & \text { Q14839 } & \text { CHD4 } & \text { Chromodomain-hr } 217.99 & 1.00 & 10 & 7.2 & 0.0568 & 0.4271 & 0.2527 & 1.9331 & 17 & \begin{array}{l}\text { QLEELLSDMK } \\ \text { QLEELLSDMK }\end{array}\end{array}$ $\begin{array}{lllllllllllllll}0.95 & 27.12 & 23.32 & 18.48 & 3 & 1529.9278 & 1529.9173 & 510.9797 & 0.0105 & 6.8495 & 3913.462 & 4191.095 & 590.033\end{array}$ $\begin{array}{lllllllllllll}1.00 & 46.06 & 26.29 & 26.63 & 2 & 1462.8500 & 1462.8492 & 732.4319 & 0.0008 & 0.5461 & 225.913 & 247.438 & 0.000\end{array}$ $\begin{array}{llllllllllllll}1.00 & 42.75 & 25.94 & 26.17 & 2 & 1462.8506 & 1462.8492 & 732.4319 & 0.0014 & 0.9557 & 442.482 & 538.512 & 0.000\end{array}$ $\begin{array}{lllllllllllll}0.99 & 40.60 & 26.81 & 37.59 & 2 & 1478.8452 & 1478.8441 & 740.4293 & 0.0011 & 0.7428 & 274.062 & 342.342 & 13.868\end{array}$ $\begin{array}{llllllll}0.95 & 35.81 & 26.67 & 41.69 & 2 & 1478.8464 & 1478.84 & 0\end{array}$ $\begin{array}{lllllllllllll}1.00 & 43.03 & 26.27 & 35.29 & 2 & 1462.8502 & 1462.8492 & 732.4319 & 0.0010 & 0.6827 & 423.043 & 419.526\end{array}$ $\begin{array}{lllllllllllll}1.00 & 60.79 & 25.94 & 27.72 & 2 & 1462.8506 & 1462.8492 & 732.4319 & 0.0014 & 0.9557 & 264.103 & 213.293\end{array}$ $\begin{array}{llllllllllll}1.00 & 46.53 & 25.91 & 23.30 & 2 & 1462.8514 & 1462.8492 & 732.4319 & 0.0022 & 1.5018 & 41.838 & 56.396\end{array}$ $\begin{array}{llllllllllll}1.00 & 48.06 & 27.47 & 31.55 & 2 & 1492.8078 & 1492.8050 & 747.4098 & 0.0028 & 1.8731 & 822.901 & 611.383\end{array}$ \begin{tabular}{lllllllllllll}
1.00 & 48.06 & 27.47 & 31.55 & 2 & 1492.8078 & 1492.8050 & 747.4098 & 0.028 & 1.8731 & 822.901 & 611.383 \\
\hline
\end{tabular} $\begin{array}{llllllllllllll} & \text { QLE }\end{array}$

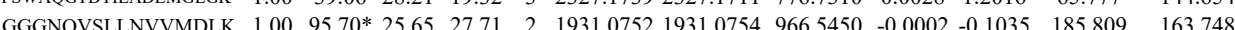
$\begin{array}{llllllllllll} & \end{array}$ $\begin{array}{llllllllllll} & 0.033 .229\end{array}$ $\begin{array}{llllllllllll} & \end{array}$ $\begin{array}{lllllllllll} & \end{array}$

LLLLQK

$\begin{array}{lllllllllllllll}0.91 & 21.38 & 14.77 & 21.87 & 2 & 1014.7120 & 1014.7045 & 508.3595 & 0.0075 & 7.3766 & 98395.802 & 80106.616 & 1741.731 & 1503.4 \\ 0.93 & 21.90 & 14.77 & 22.40 & 2 & 1014.7134 & 1014.7045 & 508.3595 & 0.0089 & 8.7536 & 96481.811 & 73492.345 & 736.454 & 74.2 \\ 1.00 & 37.24 & 22.41 & 17.39 & 4 & 3770.0105 & 3770.0046 & 943.5084 & 0.0059 & 1.5633 & 1.634 & 1.472 & 0.000 & 1.10\end{array}$

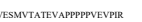

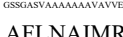

AFLNAIMR
AFLNAIMR

AFLNAIMR

IGVMSLIR

IGVMSLIR

IGVMSLIR

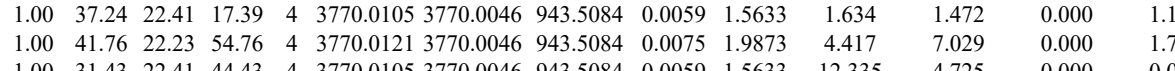

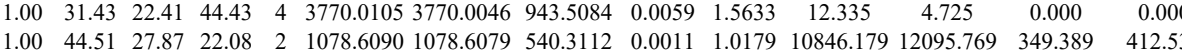
$\begin{array}{lllllllllllllll}0.99 & 39.10 & 27.92 & 21.77 & 2 & 1078.6096 & 1078.6079 & 540.3112 & 0.0017 & 1.5732 & 22970.082 & 23119.561 & 1434.248 & 999.261\end{array}$ $\begin{array}{llllllllllllllll}0.99 & 39.35 & 28.13 & 33.29 & 2 & 1031.6290 & 1031.6283 & 516.8214 & 0.0007 & 0.6772 & 2400.139 & 2555.452 & 473.080 & 149.301\end{array}$ $\begin{array}{llllllllllllllll}1.00 & 43.43 & 28.13 & 36.31 & 2 & 1031.6290 & 1031.6283 & 516.8214 & 0.0007 & 0.6772 & 3202.595 & 3392.765 & 446.527 & 135.382 & Y(5) & \end{array}$ $\begin{array}{lllllllllllllll}0.93 & 30.76 & 28.13 & 29.93 & 2 & 1031.6280 & 1031.6283 & 516.8214 & -0.0003 & -0.2902 & 1812.440 & 1964.019 & 256.040 & 66.987 & \text { Yes }\end{array}$

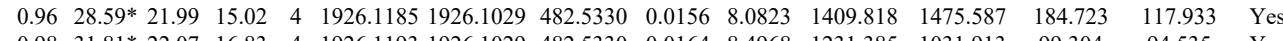
$\begin{array}{lllllllllllllll}\text { MMLTHLVVRPGLGSK } & 0.98 & 31.81 * 22.07 & 16.83 & 4 & 1926.1193 & 1926.1029 & 482.5330 & 0.0164 & 8.4968 & 1231.385 & 1031.913 & 99.304 & 94.535 & \text { Yes } \\ \text { MM } 23.80 & 23.38 & 4 & 1942.1101 & 1942.1100 & 486.5348 & 0.0001 & 0.0514 & 294.237 & 291.705 & 161.932 & 60.916 & \text { Yes }\end{array}$ $\begin{array}{llllllllllllllll}\text { SAIDLTPIVVEDKEEK } & 1.00 & 76.84 & 23.52 & 18.13 & 3 & 2217.2497 & 2217.2469 & 740.0896 & 0.0028 & 1.2611 & 778.926 & 860.378 & 590.383 & 437.827 & \text { Yes }\end{array}$

4 TQDQISNIK

TQDQISNIK

TQDQISNIK

TQDQISNIK

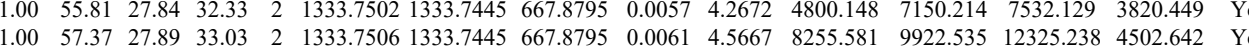
$\begin{array}{lllllllllllllllll}1.00 & 57.37 & 27.89 & 33.03 & 2 & 1333.7506 & 1333.7445 & 667.8795 & 0.0061 & 4.5667 & 8255.581 & 9922.535 & 12325.238 & 4502.642 & \text { Yes } \\ 1.00 & 61.76 & 28.01 & 28.72 & 2 & 1333.7470 & 1333.7445 & 667.8795 & 0.0025 & 1.8716 & 10661.207 & 14570.707 & 15269.711 & 5674.129 & \text { Yes }\end{array}$ $\begin{array}{llllllllllllllll}1.00 & 61.76 & 28.01 & 28.72 & 2 & 1333.7470 & 1333.7445 & 667.8795 & 0.0025 & 1.8716 & 10661.207 & 14570.707 & 15269.711 & 5674.129 & \text { Yes } \\ 1.00 & 63.98 & 27.99 & 31.56 & 2 & 13337478 & 1333.7445 & 667.8795 & 0.0033 & 2.4705 & 13530.225 & 18327.159 & 19919.767 & 6422.013 & \text { Yes } & \\ \end{array}$

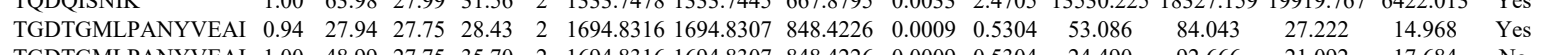

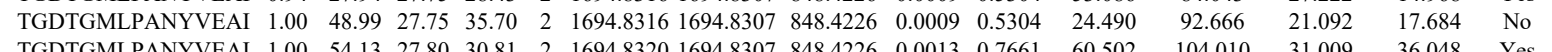

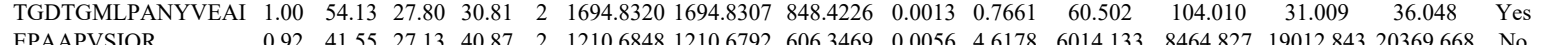

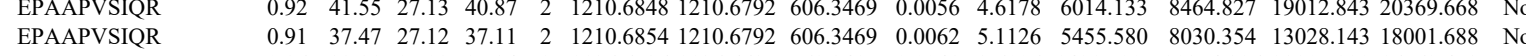
EPAAPVSIQR
IVYPTEK IVYPTEK

IVYPTEK

EPAAPVSIQR

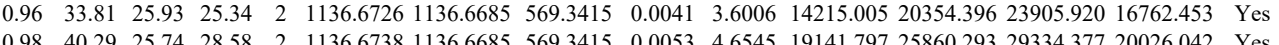

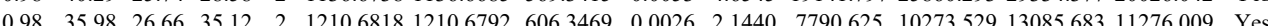

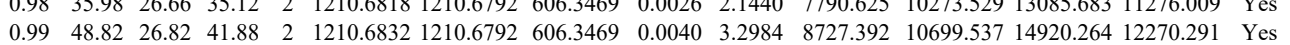


$\begin{array}{lllllllllllll}1.00 & 60.86 & 25.50 & 25.37 & 2 & 17775.8170 & 1775.8158 & 888.9152 & 0.0012 & 0.6750 & 922.867 & 837.357 & 158.542\end{array}$ (1) $\begin{array}{llllllllllll}1.00 & 68.68 & 25.54 & 31.60 & 2 & 1775.8172 & 1775.8158 & 888.9152 & 0.0014 & 0.7875 & 640.162\end{array}$ $\begin{array}{llll}1.00 & 70.45 & 26.28 \\ 1.00 & 70.89 & 26.32 & 22.2 \\ 1.00 & 40.89 & 26.36 & 22.2\end{array}$ $2841.36882841 .3656948 .1291 \quad 0.0032 \quad 1.125$ 8.302

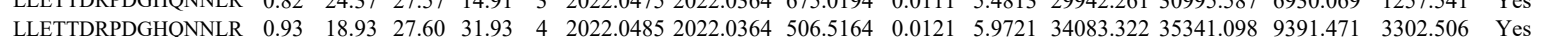
$\begin{array}{lllllllllllllllll}\text { LLETTDRPGHONNLR } & 0.96 & 21.02 & 27.66 & 20.32 & 4 & 2022.0493 & 2022.0364 & 506.5164 & 0.0129 & 6.3670 & 45652.150 & 42032.381 & 13364.701 & 3239.506 & \text { Yes }\end{array}$

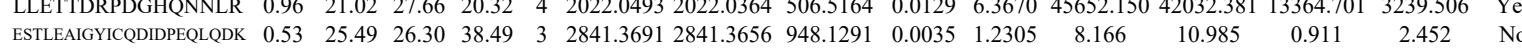

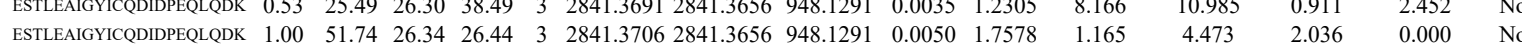
$\begin{array}{lllllllllllllllll}\text { LLETTDRPDGHQNNLR } & 0.98 & 26.18 & 27.39 & 15.81 & 3 & 2022.0385 & 2022.0364 & 675.0194 & 0.0021 & 1.0370 & 12966.206 & 12761.462 & 3089.698 & 836.380 & \text { Yes }\end{array}$ $\begin{array}{llllllllllllllll}\text { LLETTDRPDGHQNNLR } & 0.99 & 31.14 & 27.47 & 15.62 & 3 & 2022.0397 & 2022.0364 & 675.0194 & 0.0033 & 1.6296 & 3918.875 & 4119.446 & 1976.401 & 830.608 & \text { Yes }\end{array}$ $\begin{array}{llllllllllllllll}\text { LLETTDRPDGHQNNLR } & 0.97 & 14.47 & 27.47 & 17.29 & 4 & 2022.0397 & 2022.0364 & 506.5164 & 0.0033 & 1.6288 & 30692.935 & 32750.082 & 10152.297 & 2832.057 & \text { Yes }\end{array}$

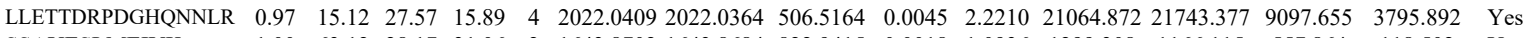
$\begin{array}{llllllllllllllll}\text { SSAYESLMEIVK } & 1.00 & 63.12 & 28.17 & 31.06 & 2 & 1643.8702 & 1643.8684 & 822.9415 & 0.0018 & 1.0936 & 1299.308 & 1166.115 & 557.864 & 118.502 & \text { Yes }\end{array}$ $\begin{array}{llllllllllllllll}1.00 & 74.73 & 28.17 & 31.98 & 2 & 1643.8708 & 1643.8684 & 822.9415 & 0.0024 & 1.4582 & 1639.668 & 1173.847 & 659.779 & 144.092 & \text { Yes }\end{array}$ SSAYESLMEIVK SSAYESLMEIVK SSAYESLMEIVK SSAYESLMEIVK SSAYESLMEIV VAAGLQIK VAAGLQIK TLATWATK VAAGLQIK

TLATWATK $\begin{array}{llllllllllllll}1.00 & 76.21 & 28.17 & 34.66 & 2 & 1643.8706 & 1643.8684 & 822.9415 & 0.0022 & 1.3367 & 2663.382 & 2769.461 & 1022.063\end{array}$ $\begin{array}{lllllllllllll}1.00 & 75.60 & 28.17 & 32.16 & 2 & 1643.8706 & 1643.8684 & 822.9415 & 0.0022 & 1.3367 & 2231.694 & 1846.841 & 685.001\end{array}$ $\begin{array}{lllllllllllll}0.99 & 31.38 & 28.15 & 27.11 & 3 & 1643.8711 & 1643.8684 & 548.9634 & 0.0027 & 1.6395 & 127.695 & 104.443 & 57.689\end{array}$ $\begin{array}{lllllllllllllll}0.99 & 31.49 & 27.98 & 26.31 & 3 & 1643.8726 & 1643.8684 & 548.9634 & 0.0042 & 2.5503 & 128.211 & 128.726 & 49.899 & 79 \\ 0.96 & 49.87 & 27.96 & 26.03 & 2 & 1643.8644 & 1643.8684 & 822.9415 & -0.0040 & -2.4303 & 602.144 & 434.893 & 434.498 & 241\end{array}$ $\begin{array}{lllllllllllll}0.96 & 49.87 & 27.96 & 26.03 & 2 & 1643.8644 & 1643.8684 & 822.9415 & -0.0040 & -2.4303 & 602.144 & 434.893 & 434.498\end{array}$ $\begin{array}{llllllllllllll}0.99 & 42.83 & 21.96 & 33.12 & 2 & 1086.7084 & 1086.7005 & 544.3575 & 0.0079 & 7.2562 & 44353.238 & 40834.226 & 3547.410\end{array}$

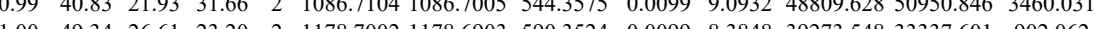
$\begin{array}{lllllllllllll}1.00 & 49.34 & 6.61 & 23.20 & 2 & 1178.7002 & 1178.6903 & 590.3524 & 0.0099 & 8.3848 & 39273.548 & 33337.601 & 902.062 \\ 0.99 & 39.67 & 21.96 & 30.11 & 2 & 1086.7098 & 1086.7005 & 544.3575 & 0.0093 & 8.5421 & 8330.492 & 6435.604 & 2545.227\end{array}$

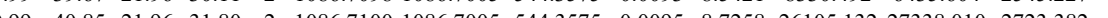
$\begin{array}{llllllllllllll}1.00 & 47.30 & 26.44 & 22.84 & 2 & 1178.7018 & 1178.6903 & 590.3524 & 0.0115 & 9.7398 & 4595.280 & 4250.084 & 196.117 & 40 \\ \end{array}$

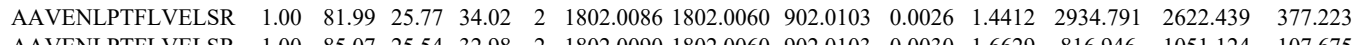
$\begin{array}{llllllllllllll}\text { VLANPGNSQVAR } & 1.00 & 66.34 & 27.41 & 32.58 & 2 & 1368.7600 & 1368.7595 & 685.3870 & 0.0005 & 0.3648 & 17257.141 & 15487.779 & 540.462 \\ \text { VLANPGNSOVAR } & 1.00 & 61.57 & 27.38 & 28.82 & 2 & 1368.7606 & 1368.7595 & 685.3870 & 0.0011 & 0.8025 & 51931.058 & 54264.822 & 3405.991\end{array}$ $\begin{array}{llllllllllllll}\text { AAVENLPTFLVELSR } & 1.00 & 88.96 & 25.74 & 31.34 & 2 & 1802.0074 & 1802.0060 & 902.0103 & 0.0014 & 0.7760 & 1443.506 & 1193.171 & 139.620\end{array}$

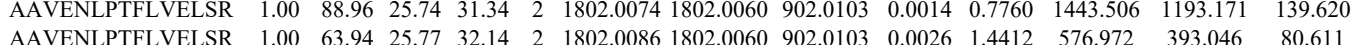
$\begin{array}{llllllllllllll}\text { LAATNALLNSLEFTK } & 1.00 & \text { \#\#\#\# } & 24.35 & 26.33 & 2 & 1893.0848 & 1893.0815 & 947.5480 & 0.0033 & 1.7413 & 569.170 & 289.361 & 88.234\end{array}$ $\begin{array}{lllllllllllllll}\text { LAATNALLNSLEFTK } & 1.00 & 86.81 & 24.33 & 19.25 & 2 & 1893.0862 & 1893.0815 & 947.5480 & 0.0047 & 2.4801 & 462.700 & 298.729 & 110.986\end{array}$ $\begin{array}{lllllllllllllll}\text { VLANPGNSQVAR } & 1.00 & 61.73 & 27.22 & 32.33 & 2 & 1368.7610 & 1368.7595 & 685.3870 & 0.0015 & 1.0943 & 43665.693 & 40275.346 & 2470.189\end{array}$ $\begin{array}{llllllllllllll}\text { VLANPGNSQVAR } & 1.00 & 57.92 & 26.78 & 29.40 & 2 & 1368.7620 & 1368.7595 & 685.3870 & 0.0025 & 1.8238 & 61736.921 & 58865.578 & 3509.577\end{array}$ $\begin{array}{llllllllllllll}\text { LAATNALLNSLEFTK } & 0.69 & 66.16 & 24.35 & 79.16 & 2 & 1893.0848 & 1893.0815 & 947.5480 & 0.0033 & 1.7413 & 1458.089 & 1199.147 & 446.573\end{array}$

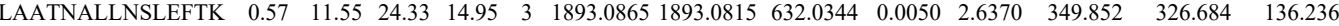

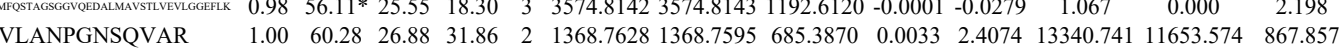
$\begin{array}{llllllllllllll} & \end{array}$ $\begin{array}{lllllllllllllll} & \end{array}$ $\begin{array}{llllllllllllll}\text { YLEVVLNTLQQASQAQVDK } & 1.00 & 97.49 & 25.08 & 31.03 & 2 & 2434.3294 & 2434.3311 & 1218.1728 & -0.0017 & -0.6978 & 14.627 & 39.288 & 13.170\end{array}$ $\begin{array}{llllllllllllll}\text { YLEVVLNTLQQASQAQVDK } & 1.00 & \text { \#\#\#\# } 24.83 & 27.95 & 2 & 2434.3334 & 2434.3311 & 1218.1728 & 0.0023 & 0.9440 & 29.317 & 23.461 & 17.703\end{array}$ $\begin{array}{lllllllllllllll}\text { YLEVVLNTLQQASQAQVDK } & 1.00 & 76.48 & 24.77 & 28.53 & 4 & 2434.3337 & 2434.3311 & 609.5901 & 0.0026 & 1.0663 & 143.688 & 96.592 & 60.320\end{array}$ $\begin{array}{llllllllllllll}\text { YLEVVLNTLQQASQAQVDK } & 1.00 & 70.36 & 24.73 & 27.06 & 3 & 2434.3348 & 2434.3311 & 812.4510 & 0.0037 & 1.5180 & 147.243 & 200.358 & 169.850\end{array}$ $\begin{array}{lllllllllllllll}\text { YLEVVLNTLQQASQAQVDK } & 1.00 & 47.22 & 24.73 & 20.71 & 3 & 2434.3360 & 2434.3311 & 812.4510 & 0.0049 & 2.0104 & 54.325 & 61.817 & 22.574\end{array}$

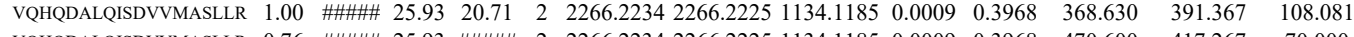

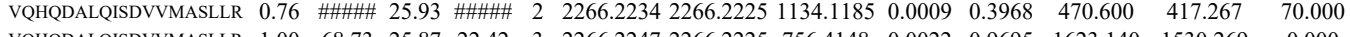

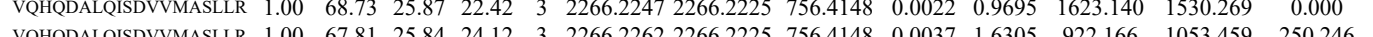

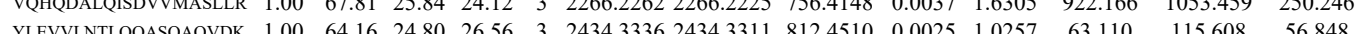

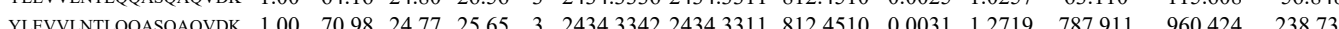
$\begin{array}{lllllllllllll}\text { HFIMQVVCEATOCPDTR } & 0.55 & 43.13 & 23.50 & 56.13 & 3 & 2212.9699 & 2212.9682 & 738.6633 & 0.0017 & 0.7672 & 115.955 & 134.592\end{array}$ 
$\begin{array}{llllllllllllllll}\text { VQHQDALQISDVVMASLLR } & 1.00 & 76.15 & 25.93 & 26.35 & 3 & 2266.2232 & 2266.2225 & 756.4148 & 0.0007 & 0.3085 & 710.599 & 1092.362 & 669.367 & 1278.921 & \text { No }\end{array}$

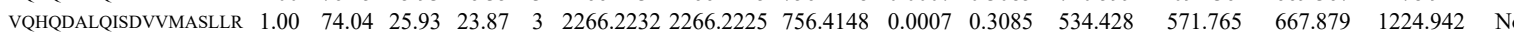
$\begin{array}{lllllllllllllllll}\text { YLEVVLNTLQQASQAQVDK } & 1.00 & 64.87 & 24.80 & 22.40 & 3 & 2434.3336 & 2434.3311 & 812.4510 & 0.0025 & 1.0257 & 112.327 & 136.915 & 45.739 & 29.186 & \text { Yes }\end{array}$

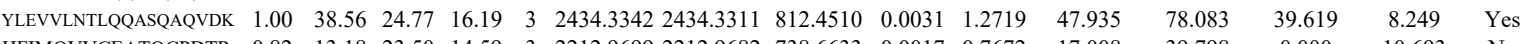

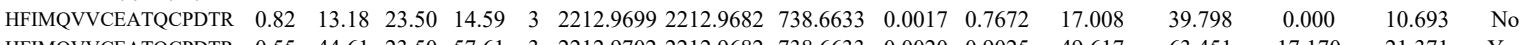

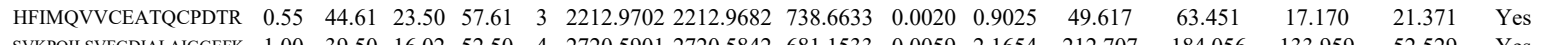

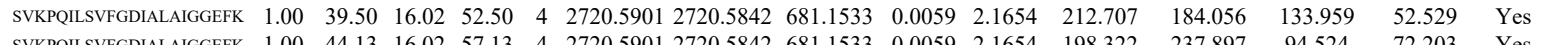

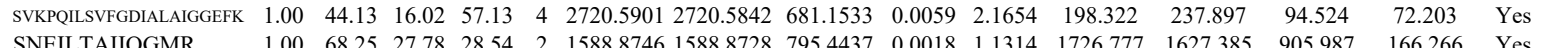

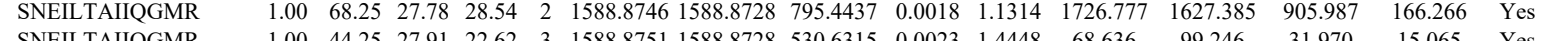

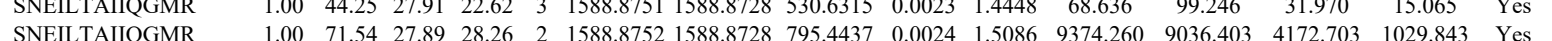

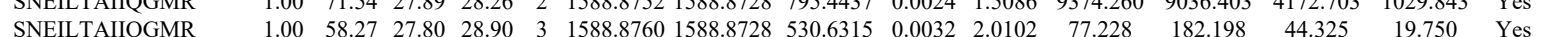

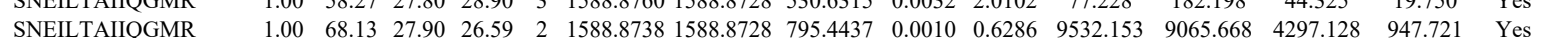

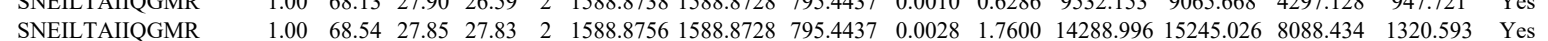
$\begin{array}{llllllllllllllll}\text { SNELTALGR } & 1.00 & 77.36 & 27.87 & 26.62 & 3 & 1588.8757 & 1588.8728 & 530.6315 & 0.029 & 1.8217 & 326.627 & 293.495 & 217.779 & 0.000 & \text { No }\end{array}$

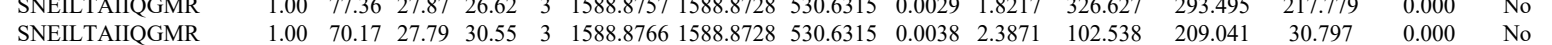

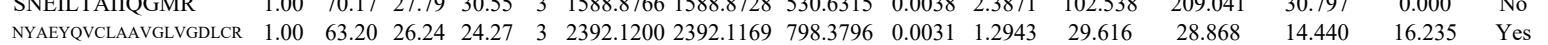

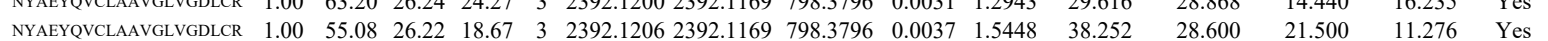
$\begin{array}{llllllllllllllll}\text { SNEILTAIIQGMR } & 1.00 & 76.31 & 27.83 & 28.75 & 2 & 1588.8762 & 1588.8728 & 795.4437 & 0.0034 & 2.1372 & 547.134 & 489.467 & 320.534 & 94.831 & \text { Yes }\end{array}$ $\begin{array}{llllllllllllllll}\text { SNEILTAIIQGMR } & 1.00 & 70.52 & 27.77 & 26.74 & 2 & 1588.8768 & 1588.8728 & 795.4437 & 0.0040 & 2.5143 & 371.762 & 192.205 & 123.871 & 39.100 & \text { Yes }\end{array}$

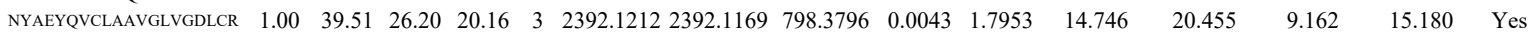

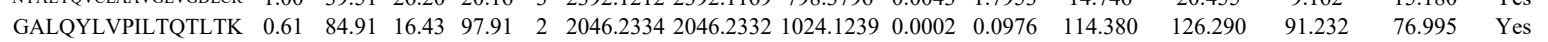
$\begin{array}{llllllllllllllll}\text { GALQYLVPILTQTLTK } & 0.77 & 79.33 & 15.44 & 92.33 & 2 & 2046.2354 & 2046.2332 & 1024.1239 & 0.0022 & 1.0741 & 226.327 & 169.602 & 214.654 & 91.106 & \text { Yes }\end{array}$

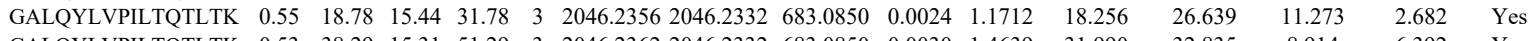
$\begin{array}{llllllllllllllll}\text { GALQYLVPILTQTLTK } & 0.53 & 38.29 & 15.31 & 51.29 & 3 & 2046.2362 & 2046.2332 & 683.0850 & 0.0030 & 1.4639 & 31.990 & 32.835 & 8.914 & 6.392 & \text { Yes }\end{array}$ $\begin{array}{llllllllllllllll}\text { GALQYLVPLTQTLTK } & 0.53 & 50.38 & 15.68 & 63.38 & 3 & 2046.2368 & 2046.2332 & 683.0850 & 0.0036 & 1.7567 & 51.178 & 30.872 & 8.972 & 9.868 & \text { Yes }\end{array}$

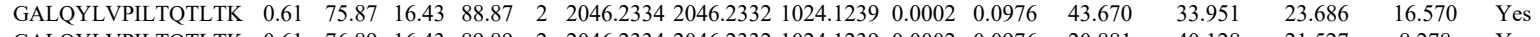

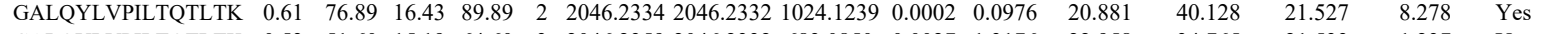

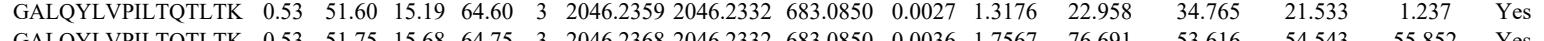
$\begin{array}{llllllllllllllll}\text { GALQYLVPLTQTLTK } & 0.53 & 51.75 & 15.68 & 64.75 & 3 & 2046.2368 & 2046.2332 & 683.0850 & 0.0036 & 1.7567 & 76.691 & 53.616 & 54.543 & 55.852 & \text { Yes }\end{array}$ \begin{tabular}{llllllllllllllll} 
GALQYLVALTQTLTK & 0.53 & 67.75 & 15.19 & 80.75 & 3 & 2046.2359 & 2046.2332 & 683.0850 & 0.0027 & 1.3176 & 26.886 & 9.313 & 12.721 & 11.649 & Yes \\
\hline
\end{tabular}

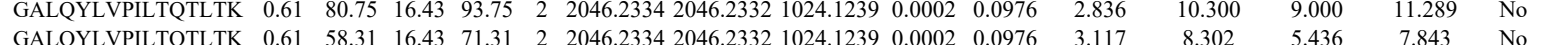

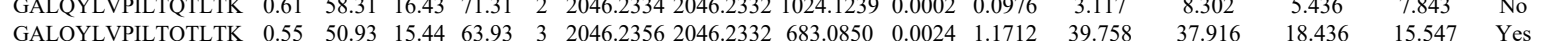

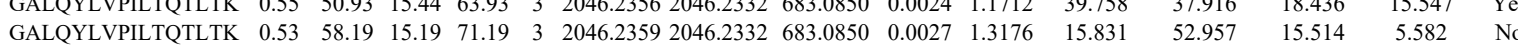

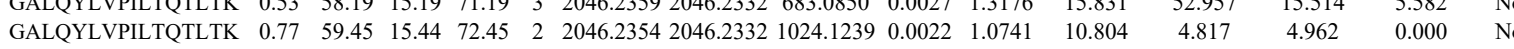

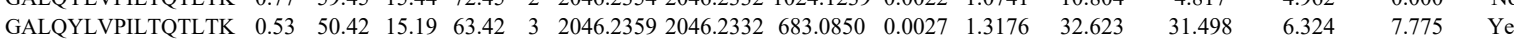

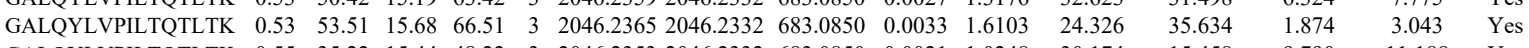
$\begin{array}{llllllllllll} & \end{array}$

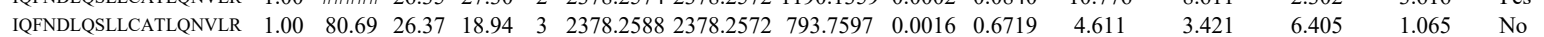

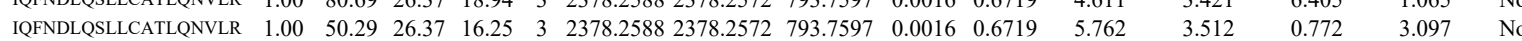

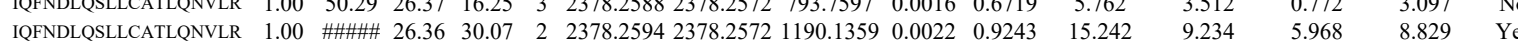

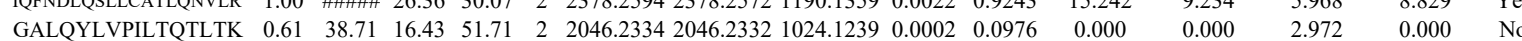

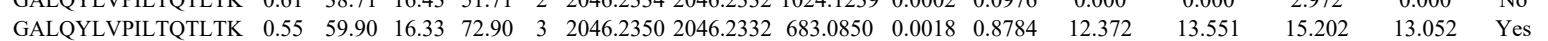

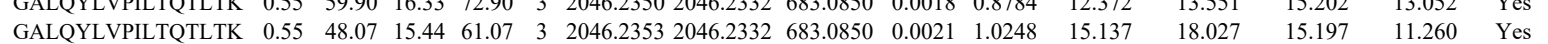
$\begin{array}{llllllllllllllll}\text { GALQYLVPILTQTLTK } & 0.77 & 37.92 & 15.44 & 50.92 & 2 & 2046.2354 & 2046.2332 & 1024.1239 & 0.0022 & 1.0741 & 0.947 & 2.804 & 0.000 & 2.390 & \text { No }\end{array}$ $\begin{array}{llllllllllllllll}\text { GQFNDLQSLLCATLQNVLR } & 1.00 & 54.21 & 26.37 & 19.77 & 3 & 2378.2588 & 2378.2572 & 793.7597 & 0.0016 & 0.6719 & 0.000 & 4.103 & 0.000 & 1.131 & \text { No }\end{array}$

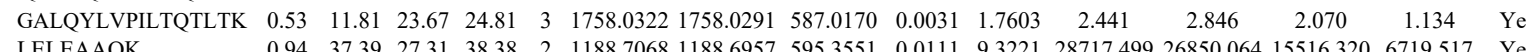

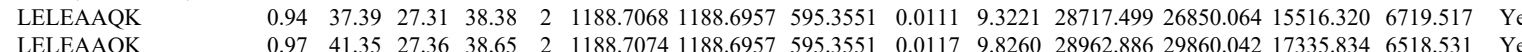

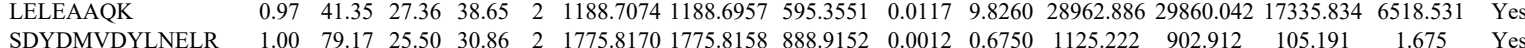
$\begin{array}{llllllllllllllll}\text { SDYDMVDYLNELR } & 1.00 & 79.17 & 25.50 & 30.86 & 2 & 1775.8170 & 1775.8158 & 888.9152 & 0.0012 & 0.6750 & 1125.222 & 902.912 & 105.191 & 1.675 & \text { Yes } \\ \text { SDYDMVDYLNELR } & 1.00 & 77.41 & 25.53 & 32.39 & 2 & 1775.8176 & 1775.8158 & 888.9152 & 0.0018 & 1.0125 & 1407.661 & 1393.651 & 236.113 & 31.706 & \text { Yes }\end{array}$ QPVGGGQK

NSSNKPAVTTK ATTKPPPAK ATTKPPPAK NSSNKPAVTTK NSSNKPAVTTK NSSNKPAVTTK
SPAVKPAAAPK SPAVKPAAAPK SPAVKPAAAPK SPAVKPAAAPK $\begin{array}{lllllllllllllll}0.88 & 23.28 & 26.55 & 23.06 & 2 & 1057.6148 & 1057.6124 & 529.8135 & 0.0024 & 2.2649 & 130.078 & 81.625\end{array}$ $\begin{array}{llllllllllll}0.82 & 16.08 & 25.30 & 15.07 & 3 & 1577.9140 & 1577.9102 & 526.9773 & 0.0038 & 2.4036 & 187.593 & 11\end{array}$ $\begin{array}{lllllllllllll}0.55 & 12.14 & 20.49 & 25.14 & 3 & 1341.8368 & 1341.8345 & 448.2854 & 0.0023 & 1.7102 & 398.881\end{array}$ $\begin{array}{llllllllllll}0.55 & 12.14 & 20.49 & 25.14 & 3 & 1341.8368 & 1341.8345 & 48.2854 & 0.0023 & 1.7102 & 398.881 & 263.719\end{array}$ $\begin{array}{llllllllllllll}0.92 & 1.57 & 25.30 & 22.32 & 3 & 1577.9143 & 1577.9102 & 526.9773 & 0.0041 & 2.5934 & 622.242 & 509.812 & 2.0068\end{array}$ $\begin{array}{lllllllllllll}0.52 & 15.58 & 24.84 & 18.63 & 3 & 1577.9170 & 1577.9102 & 526.9773 & 0.0068 & 4.3012 & 481.370 & 350.564 \\ 0.84 & 21.62 & 24.84 & 16.60 & 3 & 157.9170 & 1577.9102 & 56.9773 & 0.0068 & 4.3012 & 178.365 & 104.185\end{array}$ $\begin{array}{lllllllllllll}0.84 & 21.62 & 24.84 & 16.60 & 3 & 1577.9170 & 1577.9102 & 526.9773 & 0.0068 & 4.3012 & 178.365 & 104.185 & 56 \\ 1.00 & 27.24 & 18.39 & 15.27 & 3 & 1467.9169 & 1467.9138 & 490.3119 & 0.0031 & 2.1075 & 2487.778 & 172.833 & 115\end{array}$ SPATPAAATK

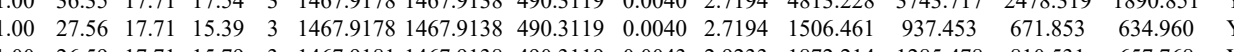
$\begin{array}{llllllllllllllllll} & \end{array}$ $\begin{array}{llllllllllllllll}\text { VAGGAAPSKPASAK } & 1.00 & 72.43 & 22.74 & 19.44 & 2 & 1642.9784 & 1642.9732 & 822.4939 & 0.0052 & 3.1611 & 280.581 & 178.194 & 50.736 & 8.745 & \text { Y }\end{array}$

Table S-3 page 395 of 499 


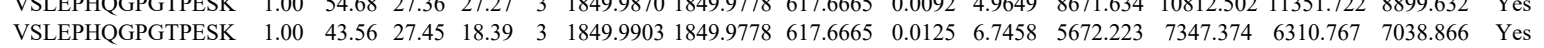

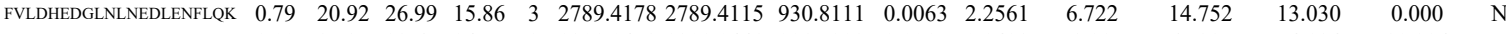
$\begin{array}{llllllllllllllll}\text { GEVLGDVLQLETLK } & 1.00 & 87.35 & 23.67 & 24.75 & 2 & 1801.0458 & 1801.0441 & 901.5293 & 0.0017 & 0.9428 & 58.225 & 67.297 & 74.184 & 80.224 & \text { Yes }\end{array}$

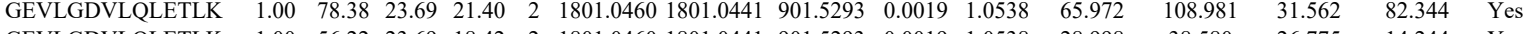

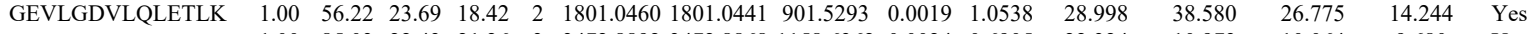
$\begin{array}{llllllllllllllll}\text { GTAQVALISELTLLATILQQDEELALIK } & 1.00 & 85.03 & 22.43 & 21.26 & 3 & 3472.8892 & 3472.8868 & 1158.6362 & 0.0024 & 0.6905 & 22.324 & 10.973 & 10.064 & 9.680 & \text { Yes }\end{array}$ $\begin{array}{llllllllllllllll} & \end{array}$

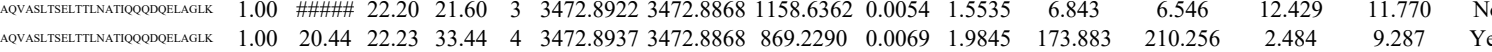

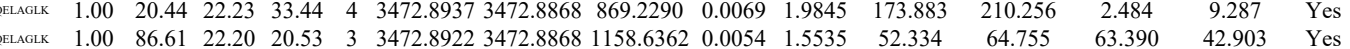

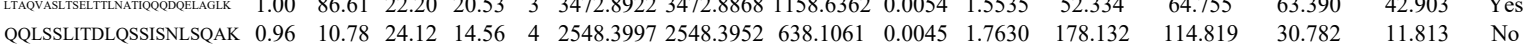

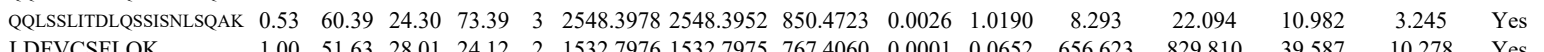
$\begin{array}{llllllllllllllll} & \\ \text { LDFVCSFLQK } & 1.00 & 51.63 & 28.01 & 24.12 & 2 & 1532.7976 & 1532.7975 & 767.4060 & 0.0001 & 0.0652 & 656.623 & 829.810 & 39.587 & 10.278 & \text { Yes } \\ \text { LDFVCSFLOK } & 1.00 & 54.78 & 27.92 & 24.88 & 2 & 1532.7988 & 1532.7975 & 767.4060 & 0.0013 & 0.8470 & 1086.923 & 1356.886 & 48.085 & 37.305 & \text { Yes }\end{array}$ $\begin{array}{lllllllllllllll} & \text { LDFVCSFLQK } & 1.00 & 54.78 & 27.92 & 24.88 & 2 & 1532.7988 & 1532.7975 & 767.4060 & 0.0013 & 0.8470 & 1086.923 & 1356.886 & 48.085\end{array}$ $\begin{array}{llllllllllll} & \end{array}$

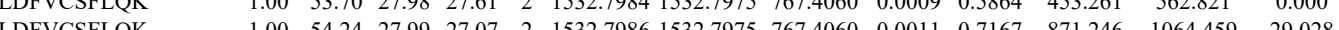
$\begin{array}{lllllllllllll} & 1.00\end{array}$

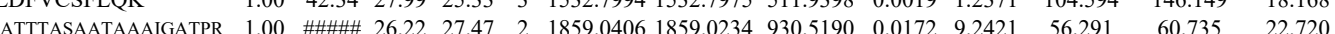
$\begin{array}{lllllllllllll}\text { IATTTASAATAAAIGATPR } & 1.00 & \text { \#\#\#\# } 26.22 & 24.35 & 2 & 1859.0414 & 1859.0234 & 930.5190 & 0.0180 & 9.6719 & 6.601 & 10.545 & 8.249\end{array}$ $\begin{array}{llllllllllllllll}\text { MTMLLLYHSTMSSK } & 1.00 & 46.79 & 27.69 & 19.00 & 3 & 1929.9991 & 1929.9970 & 644.3396 & 0.0021 & 1.0864 & 1127.543 & 1159.490 & 1009.498 & 537\end{array}$ $\begin{array}{llllllllllllllll}\text { MTMLLLYHSTMSSK } & 1.00 & 42.66 & 27.62 & 18.60 & 3 & 1930.0000 & 1929.9970 & 644.3396 & 0.0030 & 1.5520 & 622.171 & 704.034 & 426.451 & 3379.3\end{array}$ $\begin{array}{lllllllllllllll}\text { IATTTASAATAAAIGATPR } & 1.00 & 56.71 & 27.11 & 17.81 & 3 & 1859.0242 & 1859.0234 & 620.6817 & 0.0008 & 0.4296 & 45.893 & 47.632 & 31.087 & 11.019\end{array}$ $\begin{array}{llllllllllllllll}\text { IATTTASAATAAAIGATPR } & 1.00 & 56.71 & 27.11 & 17.81 & 3 & 1859.0242 & 1859.0234 & 620.6817 & 0.0008 & 0.4296 & 45.893 & 47.632 & 31.087 & 11.01 \\ \text { IATTASAATAAAIGATPR } & 0.55 & 39.42 & 27.07 & 52.42 & 3 & 1859.0254 & 1859.0234 & 620.6817 & 0.0020 & 1.0741 & 29.999 & 15.799 & 23.553 & 9.814\end{array}$ $\begin{array}{lllllllllllllll}\text { IATTTASAATAAAIGATPR } & 1.00 & 36.51 & 27.08 & 17.36 & 3 & 1859.0245 & 1859.0234 & 620.6817 & 0.0011 & 0.5907 & 26.442 & 45.616 & 26.924 & 14.0\end{array}$ $\begin{array}{lllllllllllllll}\text { IATTTASAATAAAIGATPR } & 1.00 & 47.50 & 27.11 & 20.02 & 3 & 1859.0242 & 1859.0234 & 620.6817 & 0.0008 & 0.4296 & 24.221 & 33.748 & 5.850 & \\ \end{array}$

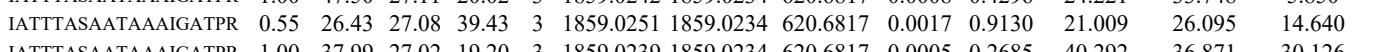
$\begin{array}{lllllllllllllll}\text { IATTTASAATAAAIGATPR } & 1.00 & 37.99 & 27.02 & 19.20 & 3 & 1859.0239 & 1859.0234 & 620.6817 & 0.0005 & 0.2685 & 40.292 & 36.871 & 30.126\end{array}$ $\begin{array}{llllllllllllll}\text { IATTTASAATAAAIGATPR } & 0.55 & 43.25 & 27.08 & 56.25 & 3 & 1859.0251 & 1859.0234 & 620.6817 & 0.0017 & 0.9130 & 27.602 & 33.851 & 21.000\end{array}$ $\begin{array}{llllllllllllll}\text { IATTTASAATAAAIGATPR } & 0.95 & 25.14 & 27.02 & 18.69 & 3 & 1859.0236 & 1859.0234 & 620.6817 & 0.0002 & 0.1074 & 37.153 & 59.099 & 21.713\end{array}$

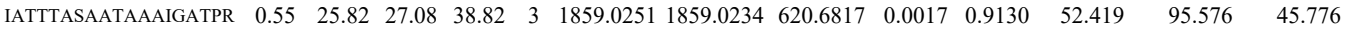

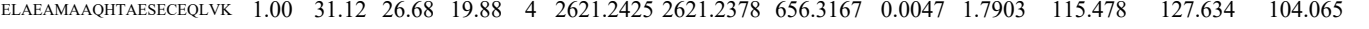

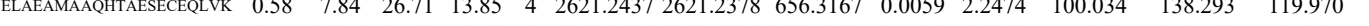
$\begin{array}{llllllllllllllll}\text { DPTGMDPDDIWQLSSSLK } & 1.00 & 86.53 & 27.22 & 79.02 & 2 & 2292.1214 & 2292.1188 & 1147.0667 & 0.0026 & 1.1333 & 75.249 & 101.598 & 67.387 & 147 .\end{array}$ $\begin{array}{lllllllllllllll}\text { SGGSGGCSGAGGASNGGTGSGR } & 1.00 & \ldots \text { mIII } & 12.04 & 29.22 & 2 & 1978.7494 & 1978.7472 & 990.3809 & 0.0022 & 1.1107 & 164.780 & 193.097 & 152.541 & 65.076\end{array}$ $\begin{array}{lllllllllllllll}0.52 & 23.65 & 27.62 & 28.26 & 2 & 936.5592 & 936.5515 & 469.2830 & 0.0077 & 8.2039 & 26786.847 & 25533.754 & 1075.071 & 780.8 & \end{array}$ VNEIVETNRPDSK
VNEIVETNRPDSK $\begin{array}{lllllllllllllllll}\text { VNEIVETNRPDSK } & 0.96 & 30.16 & 27.41 & 24.23 & 3 & 1787.9704 & 1787.9621 & 596.9946 & 0.0083 & 4.6343 & 9676.333 & 10099.417 & 9339.125 & 6194.533 & \text { Yes } \\ \text { NWQYQETIK } & 0.97 & 36.15 & 27.92 & 23.83 & 2 & 1496.7978 & 1496.7867 & 749.4006 & 0.0111 & 7.4059 & 1480.366 & 1868.999 & 531.501 & 114.229 & \text { Yes } \\ \text { NWQYQETIK } & 0.95 & 33.99 & 27.92 & 22.83 & 2 & 14967980 & 149.7867 & 749.4006 & 0.0113 & 7.5393 & 561.489 & 617.306 & 398.985 & 55.457 & \text { Yes }\end{array}$ $\begin{array}{lllllllllllllllll}0.81 & 28.57 & 27.47 & 29.46 & 2 & 936.5606 & 936.5515 & 469.2830 & 0.0091 & 9.6955 & 24203.943 & 21111.667 & 934.410 & 593.352 & \text { Yes }\end{array}$ $\begin{array}{llllllllllllllll}0.95 & 1.42 & 27.43 & 22.82 & 3 & 1787.9728 & 1787.9621 & 596.9946 & 0.0107 & 5.9743 & 30039.748 & 34678.324 & 29975.097 & 18503.097 & \text { Yes } & \\ 0.96 & 27.44 & 26.14 & 3 & 1787.9734 & 1787.9621 & 596.9946 & 0.0113 & 6.3093 & 25009.235 & 30005.759 & 21492.321 & 14859.055 & \text { Yes }\end{array}$

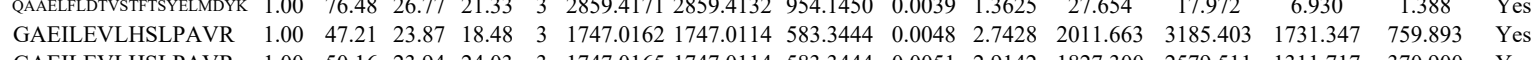
$\begin{array}{llllllllllllllll}\text { GAELEVLHSLPAVR } & 1.00 & 50.16 & 23.94 & 24.03 & 3 & 1747.0165 & 1747.0114 & 583.3444 & 0.0051 & 2.9142 & 1827.300 & 2579.511 & 1311.717 & 370.900 & \text { Yes } \\ \text { GAEILEVLHSLPAVR } & 1.00 & 58.66 & 24.05 & 23.36 & 3 & 1747.0150 & 1747.0114 & 583.3444 & 0.0036 & 2.0571 & 757.508 & 975.081 & 740.628 & 277.560 & \text { Yes }\end{array}$ 
$\begin{array}{lllllllllllllll}\text { TODLHYENFR } & 1.00 & 51.46 & 26.21 & 64.46 & 4 & 3005.4529 & 3005.4497 & 752.3697 & 0.0032 & 1.0633 & 328.270 & 629.401 & 0.000\end{array}$

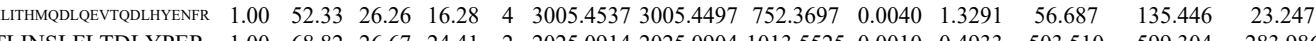

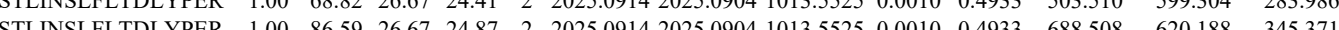

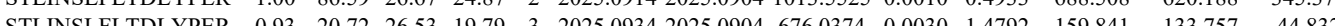

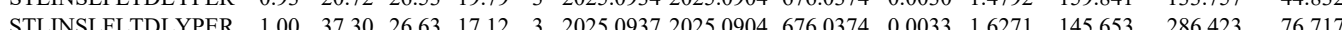
$\begin{array}{lllllllllllllll}\text { STLINSLFLTDLYPER } & 1.00 & 73.75 & 26.67 & 22.14 & 2 & 2025.0914 & 2025.0904 & 1013.5525 & 0.0010 & 0.4933 & 135.834 & 182.265 & 97.495\end{array}$

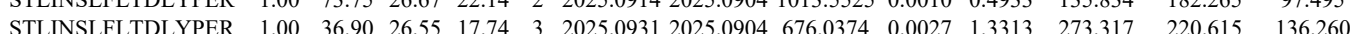
$\begin{array}{llllllllllllll}\text { STLINSLFLTDLYPER } & 1.00 & 50.27 & 26.63 & 24.24 & 3 & 2025.0937 & 2025.0904 & 676.0374 & 0.0033 & 1.6271 & 258.502 & 253.171 & 145.511\end{array}$

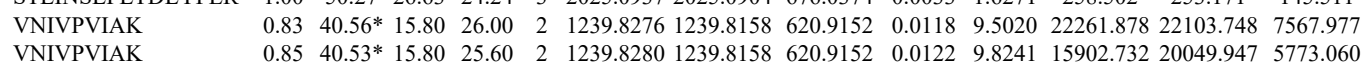
VNIVPVIAK VNIVPVIAK ILDEIEEHNIK ILDEIEEHNIK $\begin{array}{lllllllllllll}0.85 & 40.53 * & 15.80 & 25.60 & 2 & 1239.8280 & 1239.8158 & 620.9152 & 0.0122 & 9.8241 & 15902.732 & 20049.947 & 5773.060\end{array}$ $\begin{array}{llllllllllllll}0.83 & 42.60 * 15.05 & 25.14 & 2 & 1239.8234 & 1239.8158 & 620.9152 & 0.0076 & 6.1200 & 8261.982 & 9930.264 & 2621.738\end{array}$ $\begin{array}{lllllllllllll}0.64 & 51.96 * & 15.05 & 34.25 & 2 & 1239.8240 & 1239.8158 & 620.9152 & 0.0082 & 6.6031 & 7927.576 & 9526.397 & 1773.803\end{array}$ $\begin{array}{lllllllllllll}1.00 & 46.41 & 27.29 & 24.17 & 3 & 1639.9048 & 1639.9024 & 547.6414 & 0.0024 & 1.4608 & 4405.166 & 4939.797 & 185.641\end{array}$

GQVSEMAVLLIIPEPRIAALAK

$\begin{array}{lllllllllllll}.00 & 42.52 & 27.29 & 20.66 & 3 & 1639.9048 & 1639.9024 & 547.6414 & 0.0024 & 1.4608 & 3687.003 & 4676.478\end{array}$

GNAIYNLLPDIISR

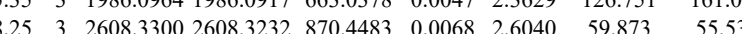

GNAIYNLLPDIISR $\begin{array}{lllllllllllll}1.00 & 71.96 & 26.58 & 22.76 & 2 & 1701.9536 & 1701.9535 & 851.9840 & 0.0001 & 0.0587 & 244.925 & 208.273\end{array}$

GNAIYNLLPDIISR

$\begin{array}{lllllllllllll}1.00 & 62.24 & 26.52 & 25.63 & 2 & 1701.9540 & 1701.9535 & 851.9840 & 0.0005 & 0.2934 & 41.264 & 55.465\end{array}$

GNAIYNLLPDIISR

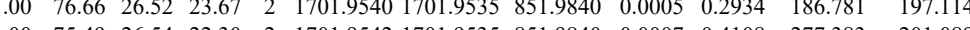

\section{ThM}

$\begin{array}{lllllllllllll}\text { AAAR } & 1.00 & 76.91 & 26.43 & 19.68 & 3 & 2714.4229 & 2714.4217 & 905.8145 & 0.0012 & 0.4416 & 3.877 \\ \end{array}$

$\begin{array}{llllllllllll} & & \end{array}$ $\begin{array}{llllllllllllll}0.99 & 24.27 & 17.24 & 18.89 & 3 & 1601.0185 & 1601.0160 & 534.6793 & 0.0025 & 1.5586 & 57.268 & 91.950\end{array}$

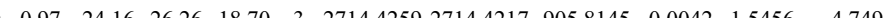

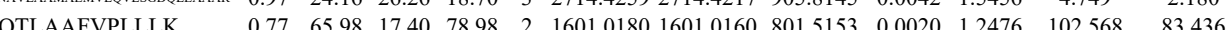
QTLAAFVPLLLK

QTLAAFVPLLLK $\begin{array}{llllllllllll}5.98 & 17.40 & 78.98 & 2 & 1601.0180 & 1601.0160 & 801.5153 & 0.0020 & 1.2476 & 102.568 & 83.436\end{array}$

QTLAAFVPLLLK $\begin{array}{lllllllllllll}0.77 & 68.50 & 17.24 & 81.50 & 2 & 1601.0182 & 1601.0160 & 801.5153 & 0.0022 & 1.3724 & 39.968 & 76.284\end{array}$

VLQLFTR

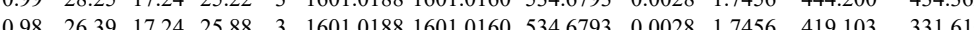

VLQLFTR

LLNILGLIFK

LLNILGLIFK

LLNILGLIFK

LLNILGLIFK

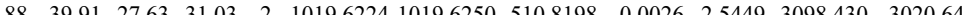
$\begin{array}{llllllllllllll}0.88 & 40.09 & 27.63 & 26.40 & 2 & 1019.6224 & 1019.6250 & 510.8198 & -0.0026 & 2.5449 & 2793.749 & 2751.978\end{array}$ $\begin{array}{lllllllllllll}1.00 & 53.16 & 12.04 & 35.44 & 2 & 1430.9476 & 1430.9468 & 7164807 & 0.0008 & 0.5583 & 105.595 & 11.539\end{array}$ $\begin{array}{llllllllllll}1.00 & 52.09 & 11.14 & 29.51 & 2 & 1430.9502 & 1430.9468 & 716.4807 & 0.0034 & 2.3727 & 167.766 & 11.54 .266\end{array}$ $\begin{array}{lllllllllllll}1.00 & 57.41 & 12.04 & 33.59 & 2 & 1430.9470 & 1430.9468 & 716.4807 & 0.0002 & 0.1396 & 29.651 & 28.255 \\ 1.00 & 54.30 & 11.14 & 31.92 & 2 & 1430.9508 & 1430.9468 & 716.4807 & 0.0040 & 2.7914 & 26.385 & 40.844\end{array}$

NLSETILELLLIVG

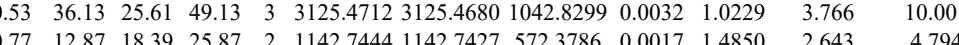

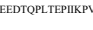
$\begin{array}{llllllllllll}1.00 & 30.45 & 22.67 & 20.21 & 4 & 4336.2629 & 4336.2619 & 1085.0728 & 0.0010 & 0.2304 & 11.436 & 11.841 \\ 1.00 & 74.89 & 26.36 & 20.23 & 3 & 3044.5642 & 3044.5586 & 1015.8601 & 0.0056 & 1.8375 & 31.515 & 33.694\end{array}$ $\begin{array}{llllllllllllll}\text { SIWAFGPATGPNIVDDTLPEEVDK } & 1.00 & 56.28 & 26.34 & 21.42 & 3 & 3044.5672 & 3044.5586 & 1015.8601 & 0.0086 & 2.8219 & 31.681 & 30.789\end{array}$

STPVTVVLPDTK

FFDDPMLLELAK

$\begin{array}{llllllllllll}0 & 69.21 & 23.87 & 22.13 & 2 & 1543.9216 & 1543.9065 & 772.9605 & 0.0151 & 9.7675 & 1401.242 & 1110.836\end{array}$

$\begin{array}{llllllllllllll}1.00 & 60.64 & 27.10 & 21.27 & 2 & 1725.9272 & 1725.9255 & 863.9700 & 0.0017 & 0.9838 & 2929.722 & 2704.237\end{array}$

YDWDLLAAR

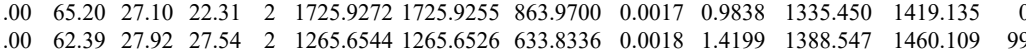

$\begin{array}{llllllllllllll} & \end{array}$

$\begin{array}{lllllllllllll}\text { ISDGVVLFIDAAEGVMLNTER } & 1.00 & \text { \#\#\#\# } 27.01 & 26.21 & 2 & 2392.2454 & 2392.2430 & 1197.1288 & 0.0024 & 1.0024 & 3.316 & 11.534 & 0.000\end{array}$

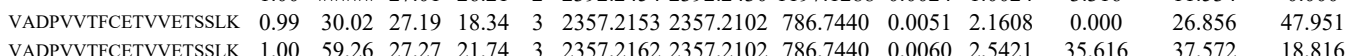

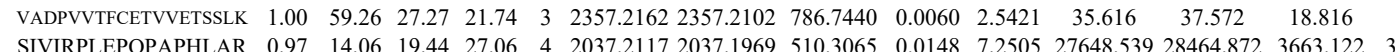

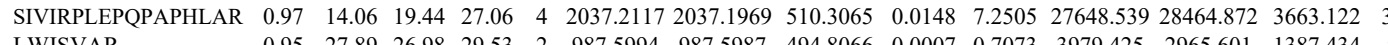
LWISVAR

LWISVAR

LWISVAR

GLSEDVSISK $\begin{array}{llllllllllllllll}0.95 & 27.89 & 26.98 & 29.53 & 2 & 987.5994 & 987.5987 & 494.8066 & 0.0007 & 0.7073 & 3979.425 & 2965.601 & 1387.434 & 99 \\ 0.94 & 27.03 & 26.70 & 27.32 & 2 & 987.6010 & 987.5987 & 494.8066 & 0.0023 & 2.3241 & 1697.642 & 1494.037 & 540.593 & 27 & \\ 0.96 & 30.08 & 26.91 & 34.05 & 2 & 987.5998 & 987.5987 & 494.8066 & 0.001 & 1.115 & 2825.218 & 1899.198 & 464.560 & 25 & \end{array}$

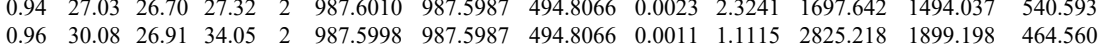
$\begin{array}{lllllllllllll} & \end{array}$ 
PTEEER

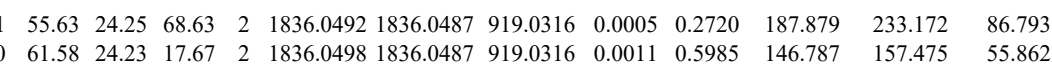

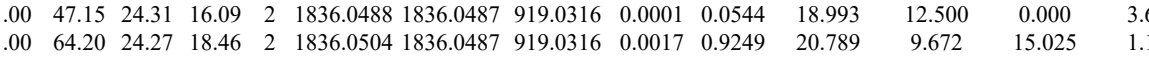
$\begin{array}{lllllllllllllll}1.00 & 63.56 & 26.42 & 21.61 & 2 & 1441.8214 & 1441.8133 & 721.9139 & 0.0081 & 5.6101 & 1847.788 & 1767.643 & 3219.675 & 2648.716 & \text { Yes }\end{array}$ $\begin{array}{ccccccccccccccc}1.00 & 63.66 & 26.47 & 23.78 & 2 & 1441.8216 & 1441.8133 & 721.9139 & 0.0083 & 5.7486 & 710.717 & 669.994 & 1009.392 & 907.769 & \text { Yes } \\ 1.00 & 69.16 & 26.53 & 23.72 & 2 & 1441.8198 & 1441.8133 & 721.9139 & 0.0065 & 4.5019 & 2505.691 & 2268.673 & 3487.262 & 3018.315 & \text { Yes }\end{array}$

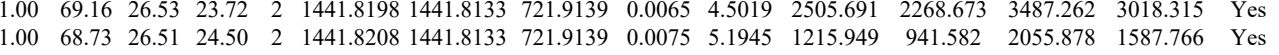
$\begin{array}{lllllllllllllll}1.00 & 68.73 & 26.51 & 24.50 & 2 & 1441.8208 & 1441.8133 & 721.9139 & 0.0075 & 5.1945 & 1215.949 & 941.582 & 2055.878 & 1587.766 & \text { Yes } \\ 1.00 & 50.24 & 27.54 & 24.80 & 2 & 1322.7262 & 1322.7182 & 662.3664 & 0.0080 & 6.0389 & 17114.708 & 19205.001 & 15.065 & 112.169 & \text { Yes }\end{array}$ $\begin{array}{lllllllllllllllll}1.00 & 40.88 & 25.90 & 26.27 & 3 & 1597.9165 & 1597.9144 & 533.6454 & 0.0021 & 1.3117 & 5230.351 & 5335.877 & 2301.948 & 1437.560 & \text { Yes }\end{array}$ \begin{tabular}{llllllllllllllll}
0.55 & 45.88 & 25.90 & 58.88 & 3 & 1597.9165 & 1597.9144 & 533.6454 & 0.0021 & 1.3117 & 7961.865 & 7958.300 & 3154.888 & 1132.359 & Yes \\
\hline
\end{tabular} $\begin{array}{llllllllllllllll}0.72 & 20.22 & 25.90 & 22.20 & 3 & 1211.7223 & 1211.7230 & 404.9149 & -0.0007 & -0.5763 & 1550.643 & 1587.581 & 412.191 & 128.406 & \text { Yes } \\ 1.00 & 44.52 & 26.47 & 25.83 & 3 & 1850.0230 & 1850.0182 & 617.6800 & 0.0048 & 2.5903 & 558.564 & 486.855 & 108.814 & 6.197 & \text { Yes }\end{array}$

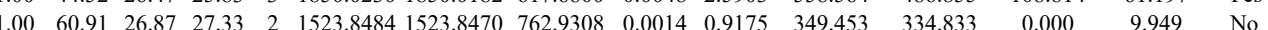
$\begin{array}{lllllllllllllll}1.00 & 57.33 & 26.65 & 27.84 & 2 & 1523.8492 & 1523.8470 & 7629308 & 0.0022 & 1.4418 & 692.172 & 569.488 & 0.000 & 11.284 & \text { No }\end{array}$

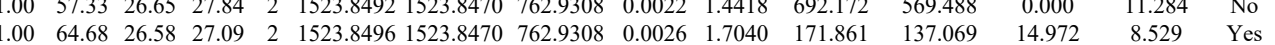
$\begin{array}{lllllllllllllll}1.00 & 66.20 & 26.51 & 28.47 & 2 & 1523.8500 & 1523.8470 & 762.9308 & 0.0030 & 1.9661 & 487.040 & 398.130 & 11.159 & 0.000 & \text { No }\end{array}$ $\begin{array}{llllllllllllllll}0.96 & 34.12 & 26.23 & 29.45 & 2 & 1082.6282 & 1082.6246 & 542.3196 & 0.0036 & 3.3191 & 11225.287 & 9895.720 & 120.520 & 65.234 & \text { Yes }\end{array}$ $\begin{array}{lllllllllllllll}0.93 & 31.45 & 26.35 & 27.00 & 2 & 1082.6284 & 1082.6246 & 542.3196 & 0.0038 & 3.5035 & 19242.786 & 15487.854 & 0.000 & 16.937 & \text { No }\end{array}$

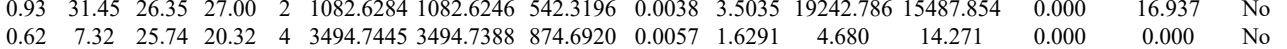
$\begin{array}{lllllllllllllll}1.00 & 36.04 & 28.16 & 20.43 & 3 & 1646.8558 & 1646.8507 & 549.9575 & 0.0051 & 3.0911 & 3242.542 & 3087.718 & 2709.014 & 1614.652 & \text { Yes }\end{array}$ $\begin{array}{lllllllllllllll}1.00 & 63.23 & 27.68 & 22.73 & 2 & 1721.8608 & 1721.8594 & 861.9370 & 0.0014 & 0.8121 & 704.435 & 703.036 & 450.490 & 658.007 & \text { Yes }\end{array}$ $\begin{array}{lllllllllllllll}1.00 & 55.93 & 28.16 & 30.86 & 2 & 1391.7596 & 1391.7574 & 696.8860 & 0.0022 & 1.5784 & 14157.172 & 13061.472 & 2244.715 & 1089.947 & \text { Yes }\end{array}$ $\begin{array}{lllllllllllllll}1.00 & 55.85 & 28.16 & 28.39 & 2 & 1391.7600 & 1391.7574 & 696.8860 & 0.0026 & 1.8654 & 11061.945 & 11039.646 & 2097.875 & 552.463 & \text { Yes }\end{array}$

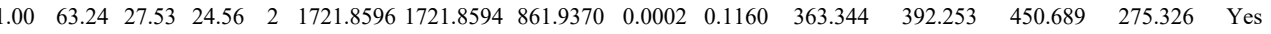

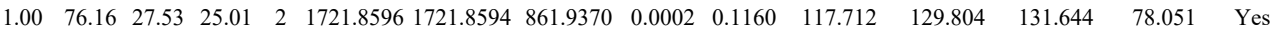
$\begin{array}{lllllllllllllll}0.84 & 22.15 & 23.40 & 22.03 & 2 & 969.4458 & 969.4460 & 485.7303 & -0.0002 & -0.2059 & 17.339 & 20.421 & 20.619 & 7.257 & \text { Yes }\end{array}$ $\begin{array}{lllllllllllllllll}0.56 & 16.31 & 23.73 & 19.44 & 2 & 969.4464 & 969.4460 & 485.7303 & 0.0004 & 0.4118 & 24.886 & 40.850 & 19.762 & 10.314 & \text { Yes }\end{array}$ $\begin{array}{llllllllllllllll}0.84 & 22.09 & 26.16 & 24.49 & 2 & 945.4836 & 945.4824 & 473.7485 & 0.0012 & 1.2665 & 57.559 & 81.872 & 29.831 & 13.434 & \text { Yes }\end{array}$ $\begin{array}{lllllllllllllll}0.84 & 24.46 & 25.84 & 24.48 & 2 & 945.4822 & 945.4824 & 473.7485 & -0.0002 & -0.2111 & 87.515 & 83.864 & 21.627 & 7.152 & \text { Yes }\end{array}$ $\begin{array}{llllllllllllllll}0.83 & 21.50 & 26.12 & 22.42 & 2 & 945.4832 & 945.4824 & 473.7485 & 0.0008 & 0.8443 & 98.122 & 67.473 & 21.313 & 9.497 & \text { Yes }\end{array}$ $\begin{array}{lllllllllllllll}0.95 & 29.37 & 23.65 & 34.18 & 2 & 1032.4856 & 1032.4845 & 517.2495 & 0.0011 & 1.0633 & 311.371 & 335.957 & 338.527 & 283.428 & \text { Yes }\end{array}$ $\begin{array}{lllllllllllllll}0.95 & 26.99 & 23.65 & 32.12 & 2 & 1032.4858 & 1032.4845 & 517.2495 & 0.0013 & 1.2566 & 177.949 & 199.689 & 204.265 & 218.552 & \text { Yes }\end{array}$

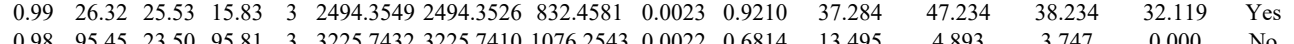

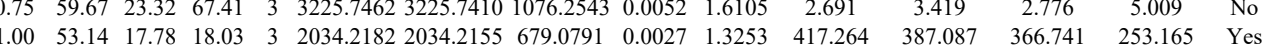

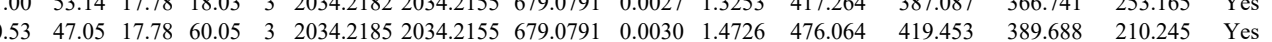

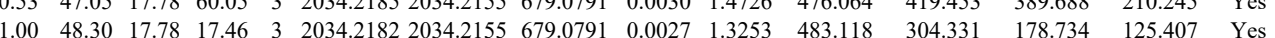
$\begin{array}{llllllllllllllll}1.00 & 53.58 & 17.56 & 16.68 & 3 & 2034.2191 & 2034.2155 & 679.0791 & 0.0036 & 1.7671 & 482.403 & 464.194 & 237.015 & 159.093 & \text { Yes }\end{array}$ $\begin{array}{lllllllllllllll}1.00 & 54.85 & 17.78 & 18.47 & 3 & 2034.2182 & 2034.2155 & 679.0791 & 0.0027 & 1.3253 & 405.306 & 411.921 & 261.222 & 119.757 & \text { Yes } \\ 0.53 & 46.28 & 17.56 & 59.28 & 3 & 2034.2188 & 2034.2155 & 6790791 & 0.0033 & 1.6198 & 453762 & 347.285 & 222.986 & 163.914 & \text { Yes }\end{array}$ $\begin{array}{lllllllllllllll}0.98 & 31.21 & 25.44 & 23.40 & 2 & 1170.7008 & 1170.6995 & 586.3570 & 0.0013 & 1.1085 & 4870.685 & 43.25 .960 & 89.884 & 86.747 & \text { Yes }\end{array}$

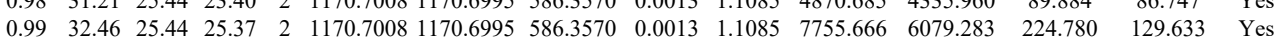
$\begin{array}{lllllllllllllll}1.00 & 44.58 & 25.75 & 24.77 & 2 & 1170.6998 & 1170.6995 & 586.3570 & 0.0003 & 0.2558 & 5412.155 & 4381.989 & 237.534 & 89.005 & \text { Yes }\end{array}$ $\begin{array}{lllllllllllllll}1.00 & 46.18 & 25.44 & 26.17 & 2 & 1170.7008 & 1170.6995 & 586.3570 & 0.0013 & 1.1085 & 6261.499 & 5310.094 & 142.274 & 51.423 & \text { Yes }\end{array}$ $\begin{array}{lllllllllllllll}1.00 & 43.02 & 25.38 & 25.30 & 2 & 1170.7002 & 1170.6995 & 586.3570 & 0.0007 & 0.5969 & 2749.328 & 2317.856 & 120.348 & 59.904 & \text { Yes }\end{array}$ $\begin{array}{lllllllllllllll}1.00 & 35.75 & 26.24 & 17.50 & 3 & 1899.0439 & 1899.0427 & 634.0215 & 0.0012 & 0.6309 & 7596.092 & 6797.978 & 10418.554 & 7676.007 & \text { No }\end{array}$ $\begin{array}{lllllllllllllll}0.85 & 16.68 & 26.20 & 16.66 & 3 & 1899.0445 & 1899.0427 & 634.0215 & 0.0018 & 0.9463 & 5538.182 & 5581.504 & 5177.635 & 4159.692 & \text { Yes }\end{array}$

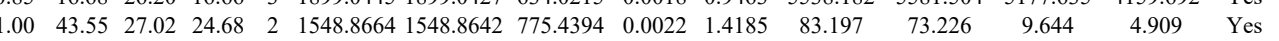
\begin{tabular}{llllllllllllllll}
1.00 & 42.70 & 27.02 & 27.88 & 2 & 1548.8666 & 1548.8642 & 775.4394 & 0.0024 & 1.5475 & 74.706 & 63.028 & 4.430 & 3.035 & Yes \\
\hline
\end{tabular} \begin{tabular}{lllllllllllllll}
1.00 & 48.72 & 26.97 & 26.23 & 2 & 1548.8660 & 1548.8642 & 775.4394 & 0.0018 & 1.1606 & 254.280 & 198.199 & 7.964 & 6.855 & Yes \\
\hline
\end{tabular}

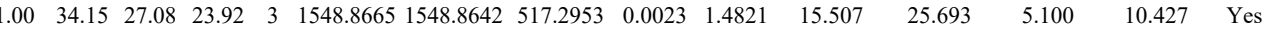

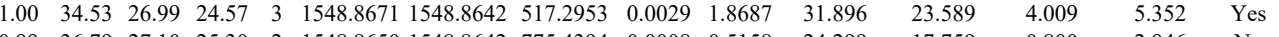

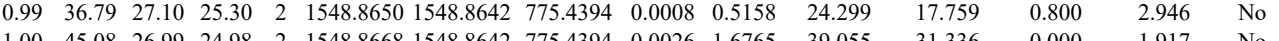

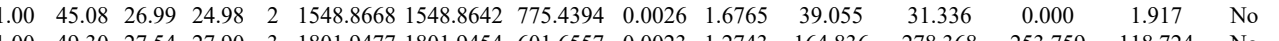

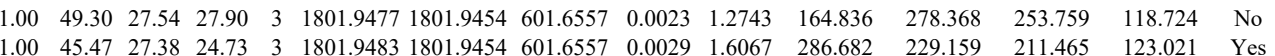

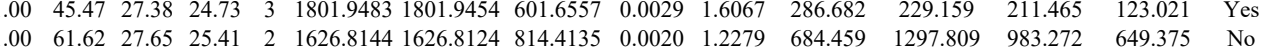

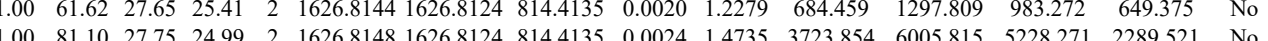

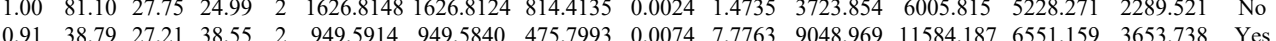
$\begin{array}{llllllllllllllll}0.91 & 38.79 & 27.21 & 38.55 & 2 & 949.5914 & 949.5840 & 475.7993 & 0.0074 & 7.7763 & 9048.969 & 11584.187 & 6551.159 & 3653.738 & \text { Yes } \\ 0.87 & 31.22 & 27.09 & 29.45 & 2 & 949.5922 & 949.5840 & 475.7993 & 0.0082 & 8.6170 & 14920.136 & 17572.033 & 11296.455 & 5401.991 & \text { Yes }\end{array}$ $\begin{array}{llllllllllllllll}0.878 & 1.22 & 27.09 & 29.45 & 2 & 949.5922 & 949.5840 & 475.7993 & 0.0082 & 8.6170 & 14920.136 & 17572.033 & 11296.455 & 5401.991 & \text { Yes }\end{array}$

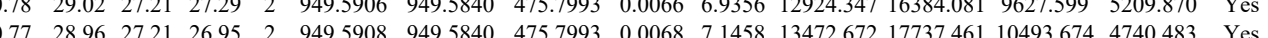

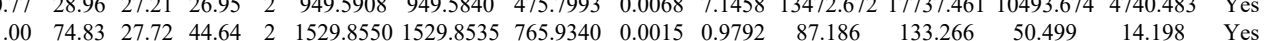
$\begin{array}{lllllllllllllll}1.00 & 85.81 & 27.72 & 31.16 & 2 & 1529.8552 & 1529.8535 & 765.9340 & 0.0017 & 1.1098 & 139.797 & 257.912 & 65.802 & 0.000 & \text { No }\end{array}$

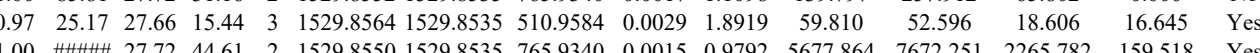


TGEAIVDAALSALR TGEAIVDAALSALR TGEAIVDAALSALR TGEAIVDAALSALR TGEAIVDAALSALR TGEAIVDAALSALR TGEAIVDAALSALR TGEAIVDAALSALR LAAVDATVNQVLASR LAAVDATVNQVLASR

LAAVDATVNQVLA

LAAVDATVNQVLAS

LAAVDATVNQVLAS

LAAVDATVNQVLAS

LAAVDATVNQVLASR
LAAVDATVNQVLASR

KDVIELTDDSFDK

KDVIELTDDSFDK

KDVIELTDDSFDK

KDVIELTDD
SGGYSSGK

SGGYSSGK

NLEPEWAAASEVK

NLEPEWAAAASEVK

NLEPEWAAAASEVK

RPDLLTMVVDY

ISEEDELDTK

QPSEEEIIK

QPSEEEIIK

LTVEEAVR

LVASMEEAR

VQMEELSK

VVIVDPETGK

VVIVDPETGK

AGLVGPEFHEK

AGLVGPEFHEK

AGLVGPEFHEK

LEQLFQDEVAK

LEQLFQDEVAK

TQLASWSDPTEETGPVAGLLDTETL

TQLASWSDPTEETG

LTVEEAVR

VVIVDPETGK

AQVEQELTTL

AQVEQELTTLR

AGLVGPEFHE

AGLVGPEFHE

LEQLFQDEVAK

LEQLFQDEVAK

DDGTGQLLLPLSDAR

DDGTGQLLLPLSDAR

AALAHSEEVTASQVAATK

AALAHSEEVTASQVAATK 1.00

$\begin{array}{ll}\text { AALAHSEEVTASQVAATK } & 1,00 \\ \text { EQELQQTLQQEQSVLDQLR } & 1,00 \\ \text { EQELQQTLQQESSVLDQR } & 1.00\end{array}$

EQELQQTLQQEQSVLDQLR
EQELQQTLQQEQSVLDQLR

EQELQQTLQQEQSVLDQLR

LAAEQELIR

LAAEQELIR

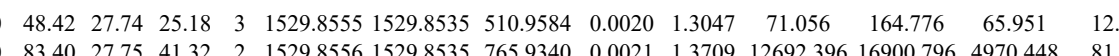

$\begin{array}{llllllllllllll}83.40 & 27.75 & 41.32 & 2 & 1529.8556 & 1529.8535 & 765.9340 & 0.0021 & 1.3709 & 12692.396 & 16900.796 & 4970.448 & 81.667 & \text { Yes }\end{array}$

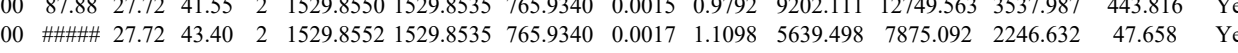

\begin{tabular}{lllllllllllllll}
1.00 & 57.03 & 27.75 & 27.93 & 3 & 1529.8558 & 1529.8535 & 510.9584 & 0.0023 & 1.5004 & 118.060 & 121.174 & 56.600 & 9.257 & Yes \\
\hline
\end{tabular}

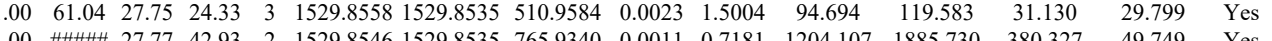
$\begin{array}{lllllllllllllll}1.00 & 27.77 & 42.93 & 2 & 1529.8546 & 1529.8535 & 765.9340 & 0.0011 & 0.7181 & 1204.107 & 1885.730 & 380.327 & 49.749 & \text { Yes } \\ 1.00 & 96.44 & 27.66 & 43.76 & 2 & 1529.8564 & 1529.8535 & 765.9340 & 0.0029 & 1.8931 & 783.022 & 1063.638 & 309.695 & 17.252 & \text { Yes }\end{array}$ \begin{tabular}{llllllllllllll}
10.44 & 27.66 & 43.16 & 2 & 1529.8564 & 1529.8535 & 765.9340 & 0.0029 & 1.8931 & 783.022 & 1063.638 & 309.695 & 17 \\
\hline
\end{tabular} $\begin{array}{lllllllllllll}.00 & 92.35 & 26.36 & 30.16 & 2 & 1670.9470 & 1670.9437 & 836.4791 & 0.0033 & 1.9725 & 796.294 & 9547.778 & 258.627\end{array}$

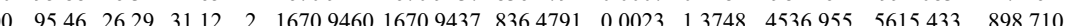
$\begin{array}{llllllllllll}42.34 & 26.29 & 19.16 & 3 & 1670.9461 & 1670.9437 & 557.9885 & 0.0024 & 1.4337 & 181.217 & 173.323 & 73.614\end{array}$ $\begin{array}{llllllllllllll}1.00 & 97.14 & 26.37 & 23.26 & 2 & 1670.9438 & 1670.9437 & 836.4791 & 0.0001 & 0.0598 & 4473.408 & 5081.278 & 752.755\end{array}$ $\begin{array}{lllllllllllll}0.03 & 1670.9442 & 1670.9437 & 836.4791 & 0.0005 & 0.2989 & 2204.305 & 3005.051 & 362.257\end{array}$ $\begin{array}{lllllllllllll} & 167.9458 & 1670.9437 & 836.4791 & 0.0021 & 1.2553 & 2001.732 & 2251.631 & 293.648\end{array}$ $\begin{array}{llllllllllllll} & 12956.0424 & 1956.0417 & 653.0212 & 0.0007 & 0.3573 & 1247.400 & 1321.737 & 590.083 & 2\end{array}$ $\begin{array}{llllllllllll}64.15 & 26.79 & 22.71 & 3 & 1956.0424 & 1956.0417 & 653.0212 & 0.0007 & 0.3573 & 1707.515 & 2227.645 & 1068.850\end{array}$ \begin{tabular}{lllllllllllllll} 
& \\
1 & 0.51 & 26.69 & 22.59 & 3 & 1956.0427 & 1956.0417 & 653.0212 & 0.0010 & 0.5104 & 2379.409 & 2173.142 & 1349.508 \\
\hline
\end{tabular} $\begin{array}{lllllllllllll}0.91 & 28.10 & 26.46 & 23.97 & 2 & 1029.5332 & 1029.5335 & 515.7740 & -0.0003 & -0.2908 & 105.625 & 115.834 & 97.833\end{array}$ $\begin{array}{llllllllllllll}.00 & 92.76 & 27.58 & 25.56 & 2 & 1801.9464 & 1801.9454 & 901.9800 & 0.0010 & 0.5543 & 4987.289 & 7734.421 & 1609.930 & \\ 1.00 & 77.56 & 27.57 & 23.24 & 2 & 1801.9470 & 1801.9454 & 901.9800 & 0.0016 & 0.8869 & 2145.258 & 2099.433 & 816.784 & \\ \end{array}$ $\begin{array}{lllllllllllll}77.56 & 27.57 & 23.24 & 2 & 1801.9470 & 1801.9454 & 901.9800 & 0.0016 & 0.8869 & 2145.258 & 2099.433 & 816.784 \\ 0\end{array}$

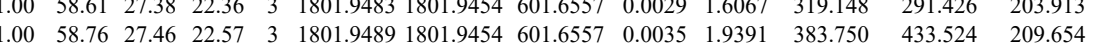
$\begin{array}{lllllllllllllll}1.00 & 44.26 & 27.98 & 18.62 & 3 & 1620.8827 & 1620.8779 & 541.2999 & 0.0048 & 2.9558 & 1163.796 & 877.006 & 387.364 & 178.43\end{array}$

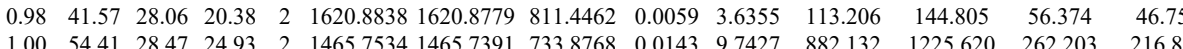

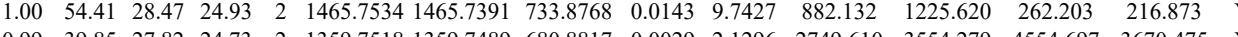

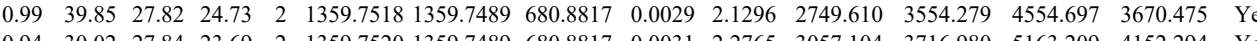
$\begin{array}{lllllllllllllll}0.94 & 30.02 & 27.84 & 23.69 & 2 & 1359.7520 & 1359.7489 & 680.8817 & 0.0031 & 2.2765 & 3057.104 & 3716.980 & 5163.209 & 4152.294 & \text { Yes } \\ 0.92 & 15.89 & 13.62 & 18.01 & 2 & 909.5756 & 909.5760 & 455.7953 & 0.0004 & -0.3388 & 7.465 & 9.416 & 6.277 & 7.891 & \text { Yes }\end{array}$

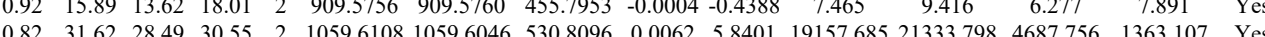
$\begin{array}{lllllllllllllllll}0.82 & 31.62 & 28.49 & 30.55 & 2 & 1059.6108 & 1059.6046 & 530.8096 & 0.0062 & 5.8401 & 715157.685 & 21333.798 & 4687.756 & 1363.107 & \text { Yes } \\ 0.99 & 47.64 & 27.75 & 29.00 & 2 & 1148.6040 & 1148.5981 & 575.3063 & 0.0059 & 5.1277 & 8046.096 & 8986.964 & 1663.390 & 1252.183 & \text { Yes }\end{array}$ $\begin{array}{llllllllllllllll}0.99 & 47.64 & 27.75 & 29.00 & 2 & 148.6040 & 148.5981 & 575.3063 & 0.0059 & 5.1277 & 8046.096 & 8986.964 & 1663.390 & 1252.183 & \text { Yes } \\ 0.95 & 38.06 & 28.36 & 28.45 & 2 & 1250.6844 & 1250.6784 & 626.3465 & 0.0060 & 4.7897 & 27052.145 & 34428.260 & 4152298 & 1994.168 & \text { Yes }\end{array}$ $\begin{array}{llllllllllllllll}1.00 & 53.78 & 28.39 & 30.01 & 2 & 1250.6856 & 1250.6784 & 6263465 & 0.0072 & 5.7476 & 21531.341 & 28800.450 & 2744.449 & 982.817 & \text { Yes }\end{array}$

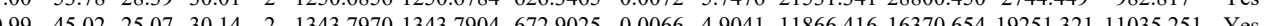

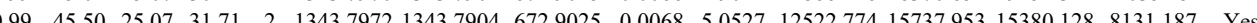

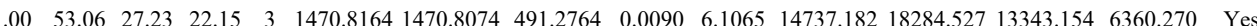
$\begin{array}{llllllllllllllll}1.00 & 45.25 & 27.18 & 20.68 & 3 & 1470.8185 & 1470.8074 & 491.2764 & 0.0111 & 7.5313 & 18822.103 & 23118.382 & 15870.614 & 7054.682 & \text { Yes }\end{array}$ $\begin{array}{llllllllllllllll}1.00 & 55.83 & 27.74 & 2.995 & 2 & 1606.8812 & 16068810 & 804.4478 & 0.0002 & 0.1243 & 3903.698 & 5470.565 & 905.671 & 225.463 & \text { Yes }\end{array}$ $\begin{array}{lllllllllllllll}1.00 & 69.46 & 27.59 & 24.67 & 2 & 1606.8824 & 16068810 & 804.4478 & 0.014 & 0.8702 & 12650.000 & 17725.167 & 2587.403 & 146.295 & \text { Yes }\end{array}$ $\begin{array}{lllllllllllllll}0.61 & 13.70 & 27.72 & 13.95 & 3 & 1606.8844 & 1606.8810 & 536.6343 & 0.0034 & 2.1119 & 56.118 & 95.128 & 31.812 & 52.054 & \text { Yes }\end{array}$

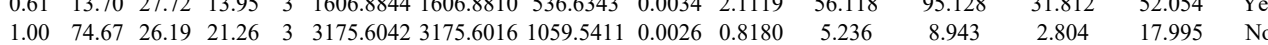

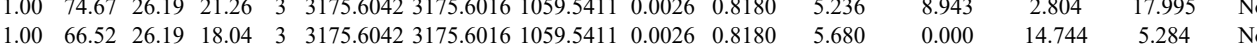
$\begin{array}{lllllllllllllllll}0.60 & 25.31 & 28.62 & 32.13 & 2 & 1059.6132 & 1059.6046 & 530.8096 & 0.0086 & 8.1008 & 13993.347 & 14364.868 & 4077.996 & 1747.596 & \text { Yes }\end{array}$ $\begin{array}{llllllllllllllll}1.00 & 57.57 & 25.07 & 31.14 & 2 & 1343.7970 & 1343.7904 & 672.9025 & 0.0066 & 4.9041 & 3848.430 & 4626.146 & 4109.722 & 2387.014 & \text { Yes }\end{array}$ $\begin{array}{lllllllllllllll}1.00 & 63.61 & 27.65 & 26.72 & 2 & 1430.7928 & 1430.7851 & 716.3998 & 0.0077 & 5.3741 & 1118.482 & 1675.093 & 1129.436 & 488.820 & \text { Yes }\end{array}$ $\begin{array}{llllllllllllllll}1.00 & 57.22 & 27.72 & 24.33 & 2 & 1430.7960 & 1430.7851 & 716.3998 & 0.0109 & 7.6074 & 2801.517 & 3091.516 & 3059.028 & 629.966 & \text { Yes }\end{array}$ $\begin{array}{lllllllllllllll}1.00 & 47.43 & 27.22 & 21.62 & 3 & 1470.8173 & 1470.8074 & 491.2764 & 0.0099 & 6.7172 & 18880.462 & 24895.609 & 17881.631 & 8468.264 & \text { Yes }\end{array}$

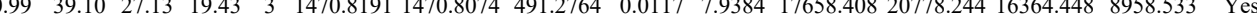
$\begin{array}{lllllllllllllllll}1.00 & 56.33 & 27.59 & 22.94 & 2 & 1606.8824 & 1606.8810 & 804.4478 & 0.0014 & 0.8702 & 3422.044 & 4520.767 & 686.280 & 69.693 & \text { Yes }\end{array}$ $\begin{array}{lllllllllllllll}1.04 & 57.50 & 27.72 & 22.17 & 2 & 1606.8826 & 1606.8810 & 804.4478 & 0.0016 & 0.9945 & 2134.369 & 2545.944 & 358.467 & 32.875 & \text { Yes }\end{array}$

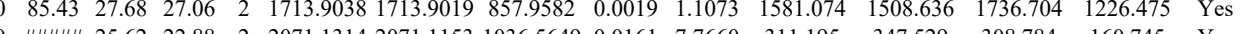
$\begin{array}{llllllllllllll}53.50 & 25.68 & 23.22 & 3 & 2071.1329 & 2071.1153 & 691.3790 & 0.0176 & 8.4854 & 2474.946 & 2173.955 & 765.302 & 659.683 & \text { Yes }\end{array}$

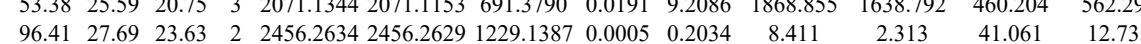

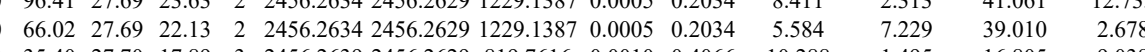
$\begin{array}{lllllllllll} & \end{array}$

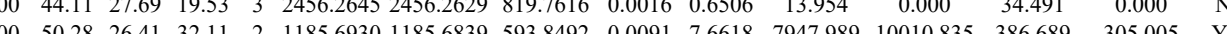




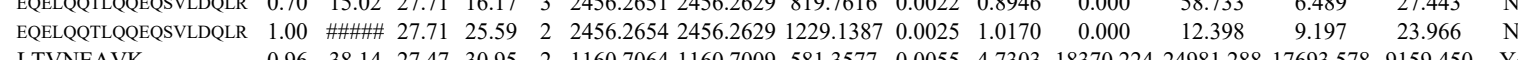

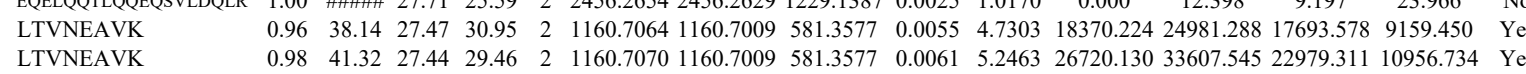
TAEDLFEAR $\begin{array}{lllllllllllllll}1.00 & 51.07 & 26.62 & 25.58 & 2 & 1183.6786 & 1183.6683 & 592.8414 & 0.0103 & 8.6869 & 2921.267 & 3652.625 & 3041.852 & 2861.753 & \text { Yes }\end{array}$ $\begin{array}{llllllllllllllll}0.99 & 39.03 & 26.62 & 24.39 & 2 & 1183.6788 & 1183.6683 & 592.8414 & 0.0105 & 8.8556 & 2833.232 & 4652.823 & 5690.841 & 4339.586 & \text { Yes }\end{array}$ $\begin{array}{lllllllllllllll}1.00 & 45.46 & 28.68 & 24.63 & 2 & 1307.6872 & 1307.6843 & 654.8494 & 0.0029 & 2.2142 & 6619.150 & 7607.476 & 470.405 & 648.623 & \text { Yes }\end{array}$ $\begin{array}{lllllllllllllll}1.00 & 70.37 & 27.36 & 29.39 & 2 & 1377.7788 & 1377.7781 & 689.8963 & 0.0007 & 0.5073 & 2004.556 & 2792.151 & 2897.325 & 1774.197 & \text { Yes }\end{array}$ $\begin{array}{llllllllllllllll}1.00 & 73.04 & 26.98 & 25.68 & 2 & 1377.7806 & 1377.7781 & 689.8963 & 0.0025 & 1.8119 & 4861.525 & 5976.578 & 4384.545 & 2041.012 & \text { Yes }\end{array}$ $\begin{array}{lllllllllllllll}1.00 & 61.06 & 24.96 & 18.95 & 2 & 1397.8182 & 1397.8122 & 699.9134 & 0.0060 & 4.2862 & 15046.286 & 22579.080 & 15406.035 & 9590.756 & \text { Yes }\end{array}$ $\begin{array}{lllllllllllllllll}0.72 & 17.48 & 24.96 & 18.38 & 3 & 1397.8183 & 1397.8122 & 466.9447 & 0.0061 & 4.3545 & 1295.974 & 1326.322 & 2975.186 & 1256.094 & \text { No }\end{array}$ $\begin{array}{lllllllllllllll}1.00 & 65.82 & 24.94 & 20.43 & 2 & 1397.8200 & 1397.8122 & 699.9134 & 0.0078 & 5.5721 & 11630.269 & 16810.222 & 13585.280 & 7869.164 & \text { Yes }\end{array}$ $\begin{array}{lllllllllllllll}1.00 & 65.71 & 26.00 & 35.25 & 2 & 1514.8750 & 1514.8660 & 758.4403 & 0.0090 & 5.9332 & 6050.209 & 8005.026 & 2181.668 & 0.000 & \text { No }\end{array}$ $\begin{array}{lllllllllllllll}1.00 & 81.60 & 27.23 & 33.49 & 2 & 1553.8360 & 1553.8284 & 777.9215 & 0.0076 & 4.8848 & 4964.325 & 6798.566 & 1953.141 & 460.256 & \text { Yes }\end{array}$ $\begin{array}{lllllllllllllll}1.00 & 81.74 & 27.24 & 25.73 & 2 & 1553.8362 & 1553.8284 & 777.9215 & 0.0078 & 5.0133 & 7273.598 & 8395.828 & 2265.562 & 314.654 & \text { Yes } \\ 1.00 & 56.93 & 27.24 & 21.46 & 3 & 1553.8366 & 1553.8284 & 518.9501 & 0.082 & 5.2670 & 8407.887 & 10583.950 & 4157.292 & 291.364 & \text { Y }\end{array}$ $\begin{array}{lllllllllllllllll}1.00 & 56.93 & 27.24 & 21.46 & 3 & 1553.8366 & 1553.8284 & 518.9501 & 0.0082 & 5.2670 & 8407.887 & 10583.950 & 4157.292 & 2901.364 & \text { Yes } & \\ 1.00 & 49.38 & 27.13 & 20.07 & 3 & 15538369 & 15538284 & 518.9501 & 0.085 & 5.4507 & 10705.267 & 14303.758 & 4113.252 & 2612.494 & \text { Yes }\end{array}$ $\begin{array}{lllllllllllllll}1.00 & 49.38 & 27.13 & 2.07 & 3 & 1553.8369 & 1553.8284 & 518.9501 & 0.0085 & 5.4597 & 10705.267 & 14503.758 & 4113.252 & 2612.494 & \text { Yes }\end{array}$ $\begin{array}{lllllllllllllllll}1.00 & 41.97 & 27.20 & 18.74 & 3 & 1622.8993 & 1622.8862 & 541.9693 & 0.0131 & 8.0570 & 6228.246 & 8269.576 & 3834.936 & 1467.662 & \text { Yes } \\ 1.00 & 40.73 & 27.17 & 17.58 & 3 & 1637.9131 & 1637.9021 & 54.9746 & 0.011 & 6.7035 & 4838.909 & 5932.402 & 4125.720 & 2678.564 & \text { Yes }\end{array}$ $\begin{array}{llllllllllllllllll}1.00 & 50.42 & 27.18 & 24.87 & 3 & 1637.9140 & 1637.9021 & 546.9746 & 0.0119 & 7.2520 & 5880061 & 6983.677 & 4289.545 & 3205.817 & \text { Yes }\end{array}$

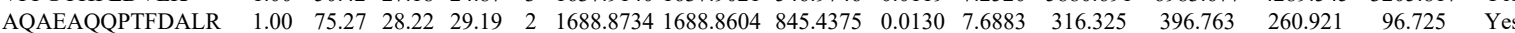

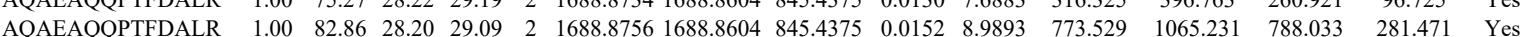

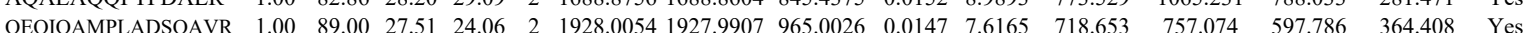

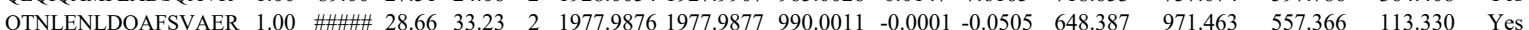
$\begin{array}{llllllllllll} & \end{array}$ $\begin{array}{llllllllllllllll}\text { QTNLELDQANSVAER } & 1.00 & \text { \#\#\#\# } & 28.60 & 37.00 & 2 & 1977.9896 & 197.9877 & 990.001 & 0.0019 & 0.9596 & 807.241 & 934.918 & 517.946 & 29.648 & \text { Yes } \\ \text { AGVVGPELHEOLSAEK } & 1.00 & 83.79 & 23.96 & 23.61 & 3 & 2064.1645 & 2064.1459 & 689.0559 & 0.0186 & 8.9977 & 4029.037 & 6359.670 & 4447.160 & 4276.757 & \text { Yes }\end{array}$ $\begin{array}{llllllllllllllll}\text { SEEMOTVOQELLLETOALOSFLLSKK } & 1.00 & 64.34 & 26.20 & 19.50 & 4 & 3467.7361 & 3467.7333 & 867.9406 & 0.0028 & 0.8065 & 25.156 & 31.718 & 17.336 & 25.275 & \text { Yes }\end{array}$

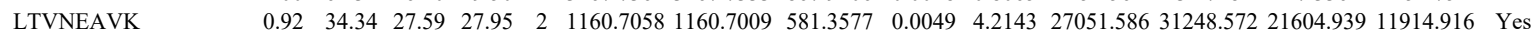

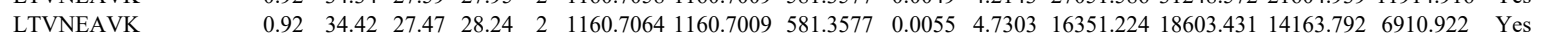
VPLDEALQR VPLDEALQR QLQLAQEAAQK QLQLAQEAAQK

LAQGHTTVDELAR

SLQEEHVAVAQLR

SLQEEHVAVAQLR

LKAEAELLQQQK

LKAEAELLQQQK

AGVVGPELHEQLLSAEK

CVEDPETGLCLLPLTDK

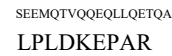

\section{LPLDKEPAR}

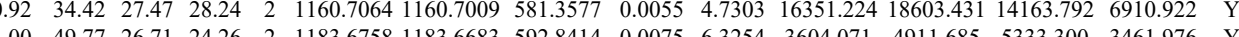

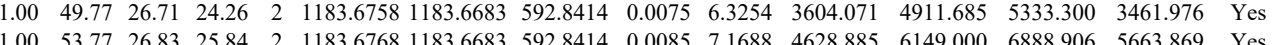
$\begin{array}{lllllllllllllll}1.00 & 53.77 & 26.83 & 25.84 & 2 & 1183.6768 & 1183.6683 & 592.8414 & 0.0085 & 7.1688 & 4628.885 & 6149.000 & 6888.906 & 5663.869 & \text { Yes } \\ 1.00 & 70.12 & 25.89 & 39.46 & 2 & 1514.8746 & 1514.8660 & 758.4403 & 0.0086 & 5.6695 & 3604.174 & 4786.496 & 1987.787 & 550.019 & \text { Yes }\end{array}$ $\begin{array}{lllllllllllllll}1.00 & 70.16 & 25.99 & 37.11 & 2 & 1514.8756 & 1514.8660 & 758.4403 & 0.0096 & 6.3287 & 4153.726 & 4263.409 & 1870.661 & 499.320 & \text { Yes }\end{array}$

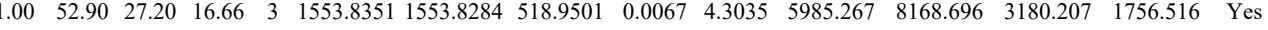
$\begin{array}{lllllllllllllll}1.00 & 43.72 & 27.42 & 19.73 & 3 & 1622.8975 & 1622.8862 & 541.9693 & 0.0113 & 6.9499 & 3559.388 & 4997.884 & 1972.909 & 1052.590 & \text { Yes }\end{array}$ $\begin{array}{llllllllllllllll}1.00 & 53.03 & 27.20 & 20.52 & 3 & 1622.8993 & 1622.8862 & 541.9693 & 0.0131 & 8.0570 & 3825.836 & 4626.966 & 2219.931 & 987.313 & \text { Yes }\end{array}$ $\begin{array}{lllllllllllllll}0.86 & 42.09 & 19.54 & 26.17 & 3 & 1830.1069 & 1830.0940 & 61.0386 & 0.0129 & 7.0371 & 4967.364 & 4609.222 & 3171.126 & 1524.168 & \text { Yes }\end{array}$ $\begin{array}{llllllllllllllll}0.96 & 44.38 & 19.44 & 21.58 & 3 & 1830.1081 & 1830.0940 & 611.0386 & 0.0141 & 7.6918 & 3569.196 & 3538.153 & 2339.999 & 1349.854 & \text { Yes }\end{array}$

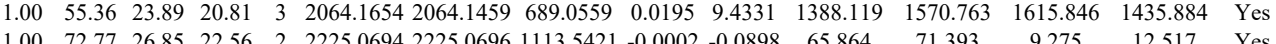

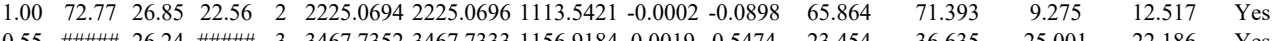

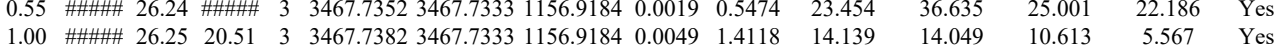

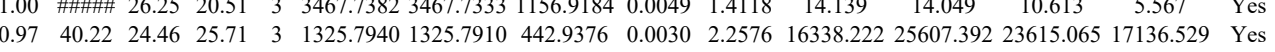
$\begin{array}{llllllllllllllll}0.92 & 38.08 & 24.46 & 27.56 & 3 & 1325.7943 & 1325.7910 & 442.9376 & 0.0033 & 2.4834 & 19360.123 & 30344.007 & 25015.680 & 19404.169 & \text { Yes }\end{array}$ $\begin{array}{llllllllllllllll}1.00 & 83.34 & 27.92 & 25.89 & 2 & 1604.8328 & 1604.8314 & 803.4230 & 0.0014 & 0.8713 & 6303.479 & 6329.493 & 3192.688 & 423.015 & \text { Yes } \\ 1.00 & 80.89 & 28.07 & 26.89 & 2 & 164.8332 & 164.8314 & 803.4230 & 0.018 & 1.1602 & 3545.033 & 4912.411 & 2531.971 & 659.649 & \text { Yes }\end{array}$ $\begin{array}{lllllllllllllll}1.00 & 80.89 & 28.07 & 26.89 & 2 & 1604.8332 & 1604.8314 & 803.4230 & 0.0018 & 1.1202 & 3545.083 & 4912.441 & 2531.971 & 659.649 & \text { Yes } \\ 1.00 & 49.57 & 26.96 & 24.06 & 2 & 1251.6182 & 1251.6073 & 626.8109 & 0.0109 & 86947 & 3627.202 & 4604.178 & 435.758 & 350.955 & \text { Yes }\end{array}$

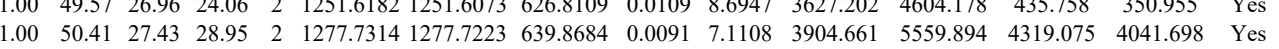
$\begin{array}{lllllllllllllll}1.00 & 54.94 & 27.82 & 36.00 & 2 & 1277.7340 & 1277.7223 & 639.8684 & 0.0117 & 9.1424 & 6910.851 & 7938.578 & 5946.864 & 5342.554 & \text { Yes }\end{array}$ 
$\begin{array}{llllllllllllllllll}\text { ATVSAPFGK } & 1.00 & 48.44 & 26.41 & 28.45 & 2 & 1164.6848 & 1164.6747 & 583.3446 & 0.0101 & 8.6569 & 16994.188 & 19842.972 & 16977.027 & 11575.736 & \text { Yes }\end{array}$

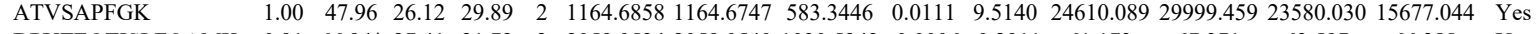
$\begin{array}{lllllllllllllll}\text { DPYTEQTISLFQAMK } & 0.91 & 66.94 * 27.41 & 21.72 & 2 & 2059.0534 & 2059.0540 & 1030.5343 & -0.0006 & -0.2911 & 61.173 & 67.371 & 63.597 & 66.388 & \text { Yes }\end{array}$ $\begin{array}{lllllllllllllll}\text { DPYTEQTISLFQAMK } & 0.85 & 42.11 * 27.26 & 20.83 & 3 & 2059.0543 & 2059.0540 & 687.3586 & 0.0003 & 0.1455 & 332.969 & 342.531 & 265.495 & 169.825 & \text { Yes }\end{array}$

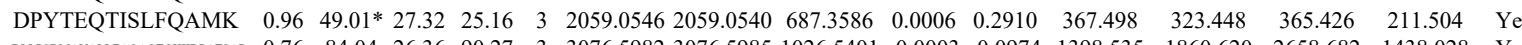
$\begin{array}{llllllllllllllll}\text { DLPSDMAVALLEAQGTCHIIPAATAR } & 0.76 & 84.04 & 26.36 & 90.27 & 3 & 3076.5982 & 3076.5985 & 1026.5401 & -0.0003 & -0.0974 & 1398.535 & 1860.620 & 2658.682 & 1438.028 & \text { Yes }\end{array}$

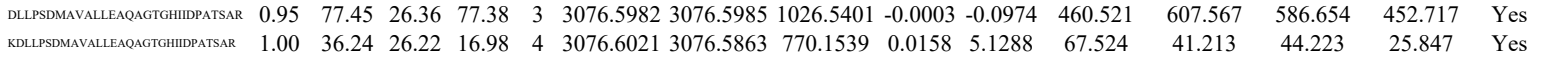
$\begin{array}{lllllllllllllll} & & & \end{array}$ $\begin{array}{llllllllllllllll}\text { ATVSAPFGK } & 1.00 & 46.51 & 26.47 & 30.01 & 2 & 1164.6850 & 1164.6747 & 583.3446 & 0.0103 & 8.8283 & 7093.003 & 9254.077 & 7362.345 & 4979.883 & \text { Yes } \\ \text { FLEVQYLTGGIEPDTPGR } & 0.55 & 37.55 & 27.12 & 50.55 & 3 & 2248.1878 & 2248.1861 & 750.4026 & 0.0017 & 0.7551 & 78.245 & 67.396 & 54.762 & 29.960 & \text { Yes }\end{array}$

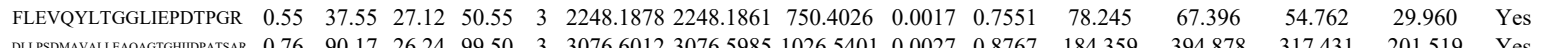

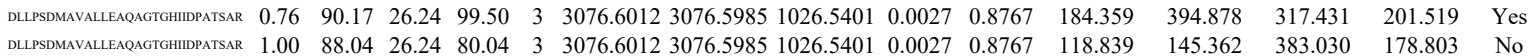
$\begin{array}{llllllllllllllllll} & \text { LLLEAQATGFLLDPVK } & 1.00 & 43.39 & 19.14 & 17.02 & 3 & 2086 & 2349 & 2086.2281 & 696.4166 & 0.0068 & 3.2547 & 163.691 & 232.688 & 120.410 & 38.048 & \text { YeS }\end{array}$

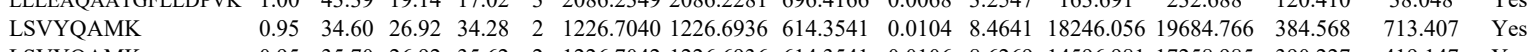

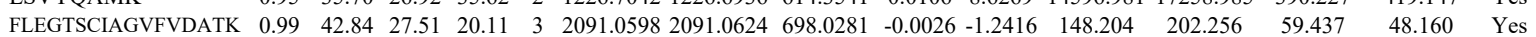
$\begin{array}{llllllllllllllll}\text { FLEGTSCIAGVFVDATK } & 0.99 & 42.84 & 27.51 & 20.11 & 3 & 2091.0598 & 2091.0624 & 698.0281 & -0.0026 & -1.2416 & 148.204 & 202.256 & 59.437 & 48.160 & \text { Yes } \\ \text { FLEGTSCIAGVFVDATK } & 0.57 & 23.85 & 27.51 & 20.32 & 3 & 2091.0598 & 2091.0624 & 698.0281 & -0.0026 & -1.2416 & 50.808 & 47.187 & 11.221 & 6.285 & \text { Yes }\end{array}$

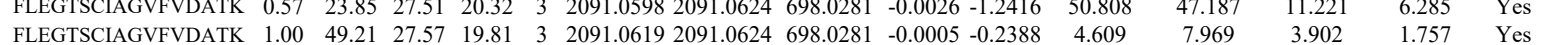

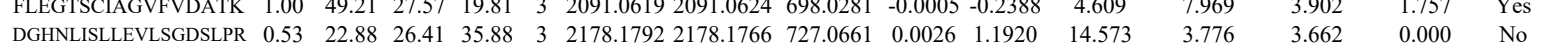

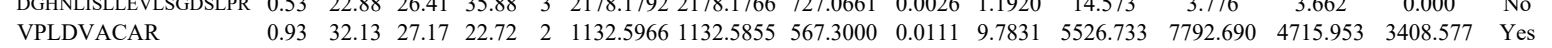

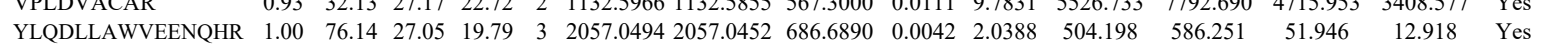
$\begin{array}{llllllllllllllll}\text { FLEGTSCIAGVFVDATK } & 0.99 & 38.23 & 27.51 & 20.47 & 3 & 2091.0613 & 2091.0624 & 698.0281 & -0.0011 & -0.5253 & 32.871 & 45.229 & 16.299 & 3.566 & \text { Yes }\end{array}$

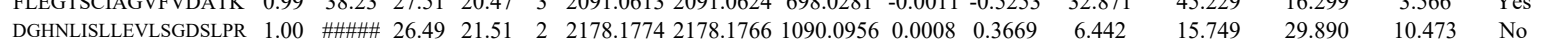
$\begin{array}{llllllllllllllll}\text { DGHNLISLLEVLSGDSLPR } & 0.55 & 21.48 & 26.47 & 34.48 & 3 & 2178.1783 & 2178.1766 & 727.0661 & 0.0017 & 0.7794 & 0.000 & 15.473 & 28.489 & 0.000 & \text { No }\end{array}$ $\begin{array}{lllllllllllllllll}\text { DGHNLISLLEVLSGDSLPR } & 0.53 & 34.57 & 26.41 & 47.57 & 3 & 2178.1792 & 2178.1766 & 727.0661 & 0.0026 & 1.1920 & 26.298 & 30.674 & 40.846 & 24.295 & \text { Yes }\end{array}$ $\begin{array}{lllllllllllllll}\text { DGHNLISLLEVLSGDSLPR } & 1.00 & \text { \#\#\#\# } 26.41 & 20.95 & 2 & 2178.1794 & 2178.1766 & 1090.0956 & 0.0028 & 1.2843 & 29.725 & 42.945 & 79.270 & 52.179 & \text { Yes }\end{array}$

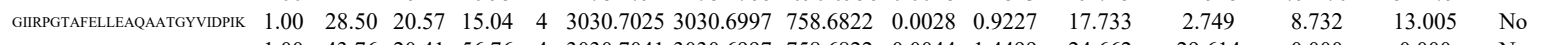
$\begin{array}{llllllllllllllll}\text { GIIRPGTAFELLEAQAATGYVIDPIK } & 1.00 & 43.76 & 20.41 & 56.76 & 4 & 3030.7041 & 3030.6997 & 758.6822 & 0.0044 & 1.4499 & 24.662 & 29.614 & 0.000 & 0.000 & \text { No }\end{array}$

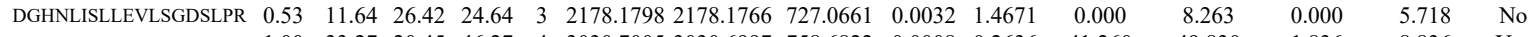

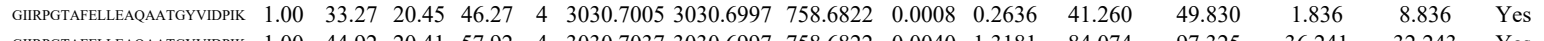

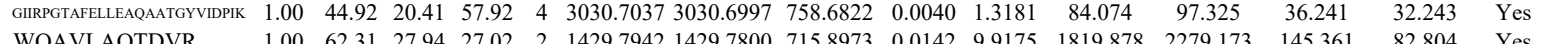
$\begin{array}{llllllllllllllll}\text { WQAVLAQTDVR } & 1.00 & 62.31 & 27.94 & 27.02 & 2 & 1429.7942 & 1429.7800 & 715.8973 & 0.0142 & 9.9175 & 1819.878 & 2279.173 & 145.361 & 82.804 & \text { Yes }\end{array}$ $\begin{array}{llllllllllllllll}\text { VLALPEPSPAAPTLR } & 0.99 & 41.88 & 22.12 & 35.51 & 2 & 1674.9940 & 1674.9790 & 838.4968 & 0.0150 & 8.9445 & 1874.627 & 2089.084 & 457.529 & 80.153 & \text { Yes }\end{array}$

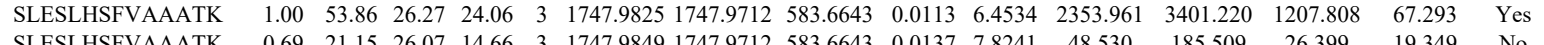
\begin{tabular}{llllllllllllllll} 
SLESLHSFVAAATK & 0.69 & 21.15 & 26.07 & 14.66 & 3 & 174.9849 & 1747.9712 & 583.6643 & 0.0137 & 7.8241 & 48.530 & 185.509 & 26.399 & 19.349 & No \\
\hline SLESLHSFVAAATK & 1.00 & 95.05 & 26.28 & 28.79 & 2 & 1747.9874 & 1747.9712 & 874.9929 & 0.0162 & 9.2571 & 11.062 & 1679.388 & 620.708 & 75.243 & Yos
\end{tabular}

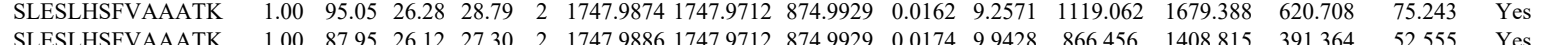
$\begin{array}{llllllllllllllll}\text { SLESLHSFVAAATK } & 1.00 & 87.95 & 26.12 & 27.30 & 2 & 1747.9886 & 1747.9712 & 874.9929 & 0.0174 & 9.9428 & 866.456 & 1408.815 & 391.364 & 52.555 & \text { Yes } \\ \text { LSIYNALK } & 1.00 & 47.05 & 24.67 & 26.77 & 2 & 1208.7462 & 1208.7372 & 605.3759 & 0.0090 & 7.4333 & 31100.668 & 43383.946 & 1134.447 & 1311.017 & \text { Yes }\end{array}$ $\begin{array}{lllllllllllllllll}\text { APVPASELLASGVLSR } & 0.77 & \text { \#\#\#\# } 24.83 & \text { \#\#\#\# } & 2 & 1709.9822 & 1709.9798 & 855.9972 & 0.0024 & 1.4019 & 2360.988 & 2881.594 & 2962.304 & 2552.050 & \text { Yes }\end{array}$

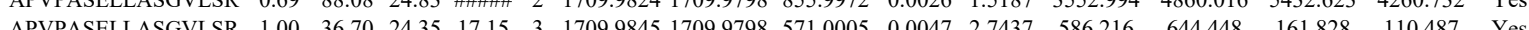




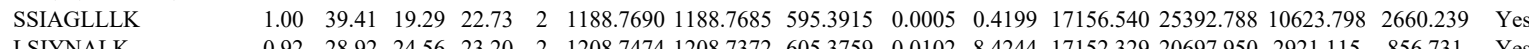
$\begin{array}{llllllllllllllll} & \\ \text { LSIYNALK } & 0.92 & 28.92 & 24.56 & 23.20 & 2 & 1208.7474 & 1208.7372 & 605.3759 & 0.0102 & 8.4244 & 17152.329 & 20697.950 & 2921.115 & 856.731 & \text { Yes } \\ \text { LSIYNALK } & 0.99 & 37.88 & 24.35 & 25.19 & 2 & 1208.7488 & 1208.7372 & 605.3759 & 0.0116 & 9.5807 & 12830.215 & 16886.563 & 1195.839 & 793.509 & \text { Yes }\end{array}$ $\begin{array}{llllllllllllll} & & 0.958 & \end{array}$

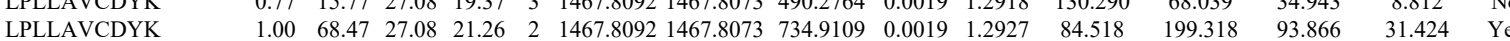

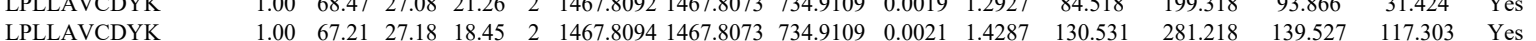

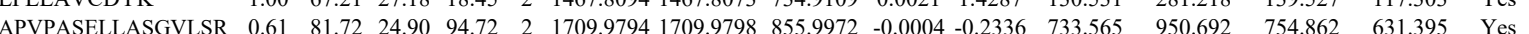

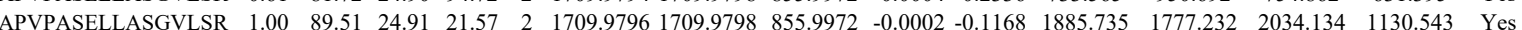
$\begin{array}{llllllllllllllll}\text { APVPASELLASGVLSR } & 1.00 & 31.29 & 24.80 & 18.73 & 3 & 1709.9821 & 1709.9798 & 571.0005 & 0.0023 & 1.3427 & 428.477 & 334.363 & 90.887 & 72.773 & \text { Yes }\end{array}$

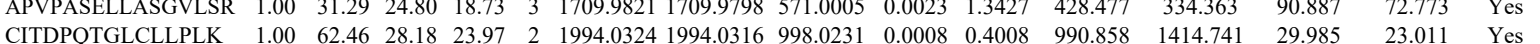

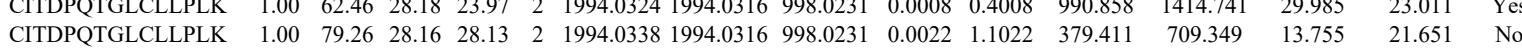
$\begin{array}{llllllllllllllll}\text { CITDPQTGLCLLPLK } & 0.80 & 18.70 & 28.12 & 27.08 & 3 & 1994.0344 & 1994.0316 & 665.6845 & 0.0028 & 1.4021 & 386.880 & 388.146 & 273.862 & 66.241 & \text { Yes }\end{array}$

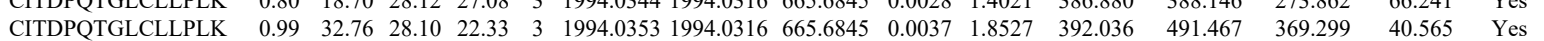
$\begin{array}{llllllllllllllll}\text { CRPDQLTGLSLLPLSEK } & 1.00 & 45.25 & 26.45 & 30.88 & 3 & 2203.2001 & 2203.1948 & 735.4055 & 0.0053 & 2.4023 & 1854.844 & 3118.650 & 2081.433 & 1684.314 & \text { Yes }\end{array}$ $\begin{array}{llllllllllllllll}\text { CRPDQLTGLSLLPLSEK } & 1.00 & 41.94 & 26.45 & 29.30 & 3 & 2203.2001 & 2203.1948 & 735.4055 & 0.0053 & 2.4023 & 1794.346 & 1488.498 & 1035.902 & 828.037 & \text { Yes }\end{array}$ $\begin{array}{llllllllllllllll} & 27.31 & 23.12 & 2 & 2258.1134 & 2258.1123 & 1130.0634 & 0.0011 & 0.4867 & 627.477 & 534.179 & 260.988 & 27.575 & \text { Yes }\end{array}$

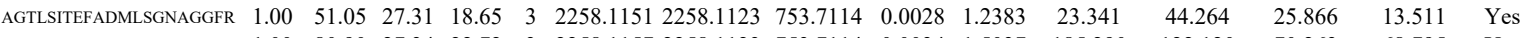

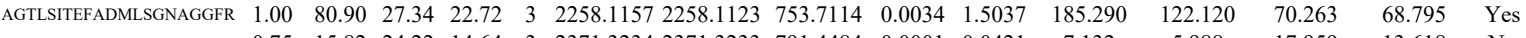

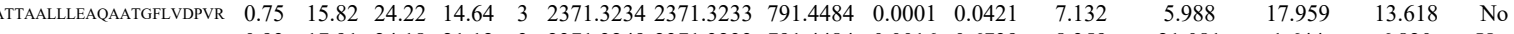

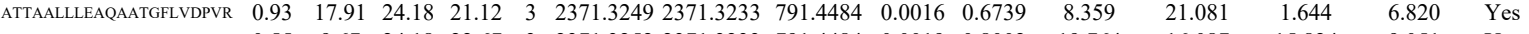
$\begin{array}{lllllllllllllll} & \end{array}$

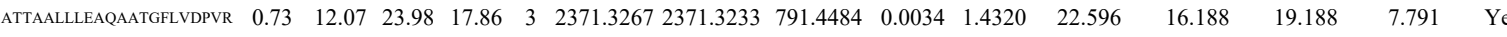

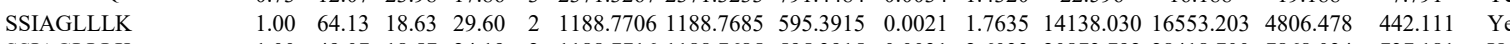

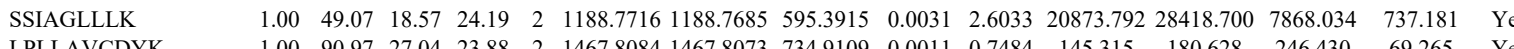

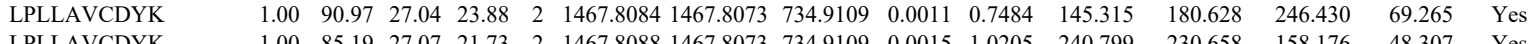

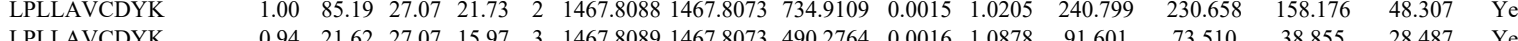

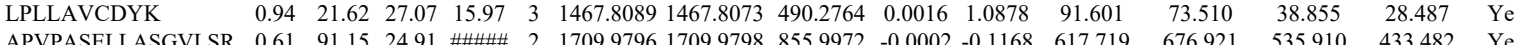

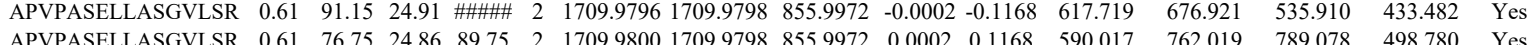

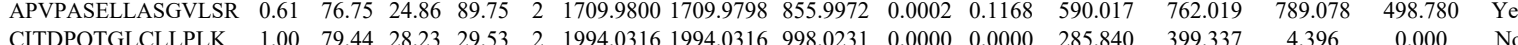
$\begin{array}{lllllllllllllll} & \end{array}$ $\begin{array}{lllllllllllllll} & \text { CRPDQLTGLSLPLSE } \\ 1.00 & 44.29 & 26.18 & 18.25 & 3 & 2203.1965 & 2203.1948 & 735.4055 & 0.0017 & 0.7705 & 1140.795 & 1754.008 & 1137.021 & 836.452 & \text { Yes }\end{array}$

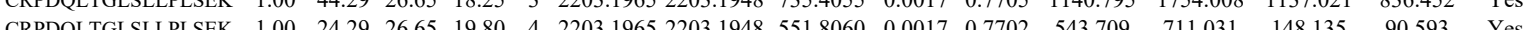

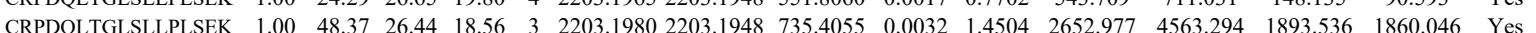
$\begin{array}{lllllllllllllllll}\text { CRPDQLTGLSLLPSSEK } & 1.00 & 25.07 & 26.44 & 17.28 & 4 & 2203.1981 & 2203.1948 & 551.8060 & 0.0033 & 1.4951 & 583.159 & 439.226 & 123.573 & 56.323 & \text { Yes }\end{array}$

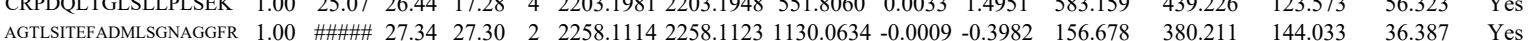

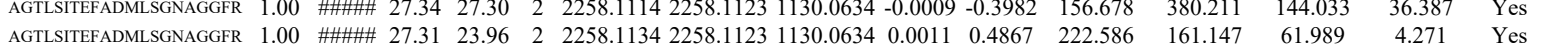

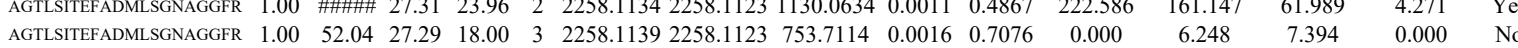

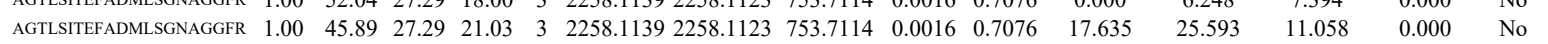
\begin{tabular}{llllllllllllllll} 
ATTAALLLEAQAATGFLVDPVR & 1.00 & 86.06 & 24.17 & 19.50 & 3 & 2371.3243 & 2371.3233 & 791.4484 & 0.0010 & 0.4212 & 36.394 & 20.291 & 13.002 & 16.970 & Yes \\
\hline
\end{tabular} $\begin{array}{lllllllllllllllll}\text { CRPDQLTGLSLLPLSEK } & 1.00 & 33.70 & 26.54 & 19.49 & 3 & 2203.1974 & 2203.1948 & 735.4055 & 0.0026 & 1.1785 & 7312.850 & 5851.298 & 1430.212 & 945.591 & \text { Yes }\end{array}$ $\begin{array}{llllllllllllllll}\text { AGTLSTEFADMLSGNAGGFR } & 1.00 & 73.75 & 27.32 & 26.51 & 3 & 2258.1133 & 2258.1123 & 753.7114 & 0.0010 & 0.4423 & 4.534 & 3.768 & 14.029 & 6.519 & \text { No }\end{array}$

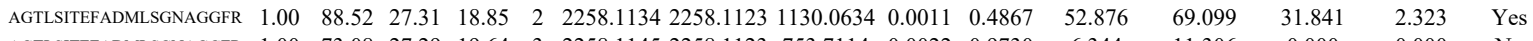

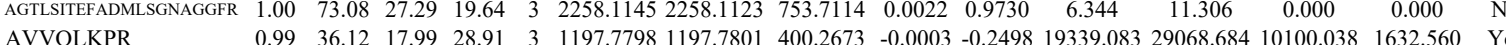

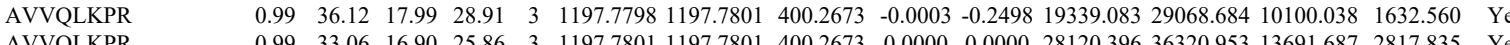

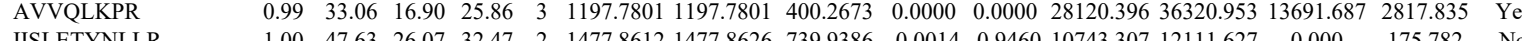
IISLETYNLLR IISLETYNLLR AVVQLKPR AVVQLKPR $\begin{array}{llllllllllllllll}\text { LQNVQIALDYLR } & 1.00 & 58.67 & 26.53 & 21.78 & 2 & 1588.9056 & 1588.9059 & 795.4602 & -0.0003 & -0.1886 & 5226.093 & 7614.154 & 402.628 & 0.000 & \text { No } \\ \text { LQNVQIALDYLR } & 1.00 & 67.57 & 26.27 & 18.98 & 2 & 1588.9072 & 1588.9059 & 795.4602 & 0.0013 & 0.8171 & 8496.789 & 11371.634 & 96.252 & 139.238 & \text { Yes }\end{array}$ $\begin{array}{lllllllllllllll}1.00 & 47.63 & 26.07 & 32.47 & 2 & 1477.8612 & 1477.8626 & 739.9386 & -0.0014 & -0.9460 & 10743.307 & 12111.627 & 0.000 & 175.782 & \text { No }\end{array}$ $\begin{array}{lllllllllllllll}1.00 & 43.18 & 25.82 & 31.03 & 2 & 1477.8624 & 1477.8626 & 739.9386 & -0.0002 & -0.1351 & 12449.427 & 14612.599 & 176.225 & 175.423 & \text { Yes } \\ 1.00 & 59.24 & 26.28 & 21.70 & 2 & 1588.9066 & 1588.9059 & 795.4602 & 0.0007 & 0.4400 & 4379.459 & 6017.518 & 142.806 & 32.489 & \text { Yes }\end{array}$

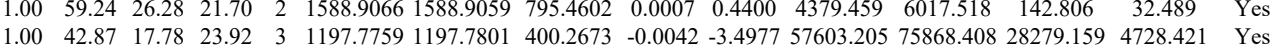
$\begin{array}{lllllllllllllll}1.00 & 42.87 & 17.78 & 23.92 & 3 & 1197.7759 & 1197.7801 & 400.2673 & -0.0042 & -3.4977 & 57603.205 & 75868.408 & 28279.159 & 4728.421 & \text { Yes } \\ 0.99 & 38.38 & 17.99 & 26.16 & 3 & 1197.7795 & 1197.7801 & 4002673 & -0.0006 & -0.4997 & 48234.283 & 65307.657 & 22339.161 & 3354.159 & \text { Yes }\end{array}$ $\begin{array}{llllllllllllllll}0.99 & 38.48 & 17.99 & 30.52 & 2 & 1197.7798 & 1197.7801 & 599.8973 & -0.0003 & -0.2500 & 741.930 & 899.670 & 216.839 & 66.060 & \text { Yes }\end{array}$

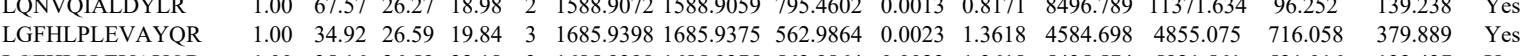
$\begin{array}{lllllllllllllllll}\text { LGFHLPLEVAYQR } & 1.00 & 35.16 & 26.59 & 22.18 & 3 & 1685.9398 & 1685.9375 & 562.9864 & 0.0023 & 1.3618 & 5435.574 & 5921.561 & 521.016 & 132.437 & \text { Yes }\end{array}$

Table S-3 page 402 of 499 
TISLVIR

TISLVIR

LSYTQLLR

LSYTQLLR
AVVQLKPR

$\begin{array}{llllllllllllll}0.55 & 63.83 & 23.78 & 76.83 & 3 & 2138.1946 & 2138.1930 & 713.7383 & 0.0016 & 0.7472 & 368.609 & 301.219 & 184.883\end{array}$

$\begin{array}{lllllllllllll}0.055 & 32.09 & 23.86 & 25.48 & 2 & 944.6226 & 944.6140 & 473.3143 & 0.0086 & 9.0848 & 14173.966 & 18690.772 & 3191.876\end{array}$

$\begin{array}{lllllllllllllll}0.96 & 31.82 & 22.81 & 25.56 & 2 & 944.6234 & 944.6140 & 473.3143 & 0.0094 & 9.9299 & 14493.763 & 17722.740 & 3494.301 & 101\end{array}$

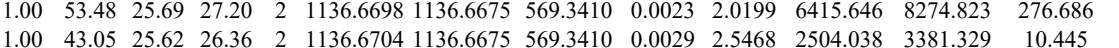

PST

$\begin{array}{llllllllllllllll}0.83 & 32.31 & 17.78 & 29.45 & 3 & 1197.7774 & 1197.7801 & 400.2673 & -0.0027 & -2.2485 & 3073.953 & 33846.857 & 1327.516\end{array}$

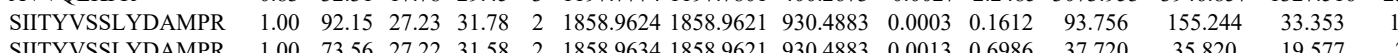

SIITYVSSLYDAMPR

AGVAAPATQVAQVTLQSVQR

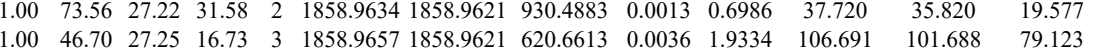

$\begin{array}{lllllllllllllll} & \end{array}$

$\begin{array}{lllllllllllllll}\text { AGVAAPATQVAQVTLQSVQR } & 0.53 & 59.42 & 23.77 & 72.42 & 3 & 2138.1964 & 2138.1930 & 713.7383 & 0.0034 & 1.5879 & 437.792 & 200.770 & 207.868\end{array}$

SWSLATFR

SWSLATFR

LSYTQLLR

LISLFQAMK

LISLFQAMK

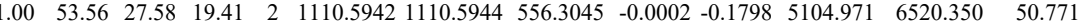

$\begin{array}{lllllllllllll}1.00 & 53.22 & 27.54 & 22.23 & 2 & 1110.5968 & 1110.5944 & 556.3045 & 0.0024 & 2.1571 & 7447.128 & 9693.815 & 84.991\end{array}$

$\begin{array}{lllllllllllll}1.00 & 43.03 & 25.16 & 22.75 & 2 & 1136.6680 & 1136.6675 & 569.3410 & 0.0005 & 0.4391 & 11767.063 & 14195.698 & 1185.492 \\ 1.00 & 40.90 & 26.05 & 24.11 & 2 & 1136.6692 & 1136.6675 & 56.3410 & 0.0017 & 1.4930 & 7077.790 & 8743.168 & 972.120\end{array}$

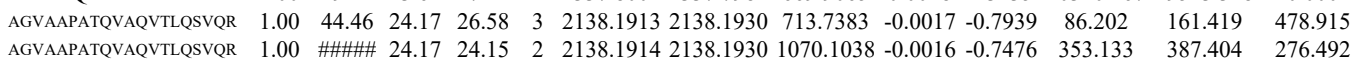

$\begin{array}{ccccccccccccc}1.00 & 40.90 & 26.05 & 24.11 & 2 & 1136.6692 & 1136.6675 & 569.3410 & 0.0017 & 1.4930 & 7077.790 & 8743.168 & 972.120 \\ 1.00 & 44.06 & 23.50 & 26.02 & 2 & 1337.7996 & 13377984 & 669.9065 & 0.0012 & 0.8956 & 32213.946 & 51620.861 & 0.000\end{array}$

$\begin{array}{lllllllllllll}1.00 & 44.06 & 23.50 & 26.02 & 2 & 1337.7996 & 1337.7984 & 669.9065 & 0.0012 & 0.8956 & 32213.946 & 51620.861 & 0.000 \\ 1.00 & 49.24 & 23.62 & 27.41 & 2 & 1337.8002 & 1337.7984 & 669.9065 & 0.0018 & 1.3435 & 20310.167 & 29523.318 & 0.000\end{array}$

$\begin{array}{lllllllllllllll}\text { AGVAAPATQVAQVTLQSVQR } & 1.00 & \# \# \# \# 23.82 & 29.16 & 2 & 2138.1954 & 2138.1930 & 1070.1038 & 0.0024 & 1.1214 & 186.678 & 199.161 & 230.086\end{array}$

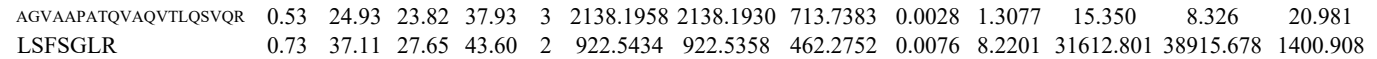

LSFSGLR

LSFSGLR

SWSLATFR

SWSLATFR

$\begin{array}{lllllllllllllll}0.73 & 37.11 & 27.65 & 43.60 & 2 & 922.5434 & 922.5358 & 462.2752 & 0.0076 & 8.2201 & 31612.801 & 38915.678 & 1400.908 & 5 \\ 0.87 & 37.09 & 27.65 & 39.61 & 2 & 922.5440 & 922.5358 & 462.2752 & 0.0082 & 8.8691 & 39663.643 & 52054.324 & 1884.906 & & \\ 1.0 & 50.76 & 27.5 & 9.91 & & & & \end{array}$

$\begin{array}{llllllllllllll}1.00 & 50.76 & 27.51 & 19.91 & 2 & 1110.5956 & 1110.5944 & 556.3045 & 0.0012 & 1.0785 & 7886.326 & 11115.496 & 260.037\end{array}$

LSYTQLLR

$\begin{array}{llllllllllllll}1.00 & 50.75 & 27.64 & 23.65 & 2 & 1110.5962 & 1110.5944 & 556.3045 & 0.0018 & 1.6178 & 5991.280 & 8688.018 & 126.537\end{array}$

LSYTQLLR

LSVLFQAMK

LISLFQAMK

AGVAAPATQVAQVT

EQAELEAAR

SLAAEEEAAR

SLAAEEEAAR

QQEELLAEEN

SWSLATFR

AGAAPATQVAQV

LFNAIIHR

LFNAIIHR
SLLAWQSLR

ELVLLLLQWMR

ELVLLLLQWMR

LLLWSQR

LLLWSQR

LLLWSQR

ELVLLLLQWMR

ELVLLLLQWMR

ATTAALLLEAQAA
LLLWSQR

LLLWSQR
ELVLLLLQWMR

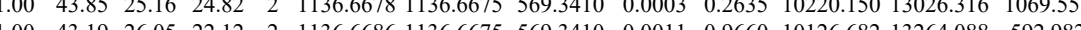

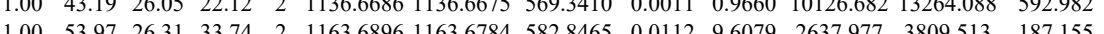

$\begin{array}{llllllllllllll}1.00 & 53.75 & 23.46 & 29.39 & 2 & 1337.8016 & 1337.7984 & 669.9065 & 0.0032 & 2.3884 & 15805.468 & 21458.874 & 0.000\end{array}$

$\begin{array}{llllllllllllllll}1.00 & 46.56 & 23.77 & 24.22 & 2 & 1337.8020 & 1337.7984 & 669.9065 & 0.0036 & 2.6869 & 11840.210 & 19134.601 & 0.000\end{array}$

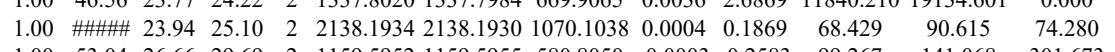

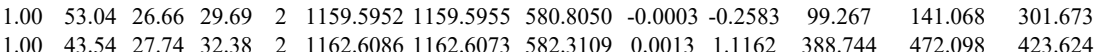

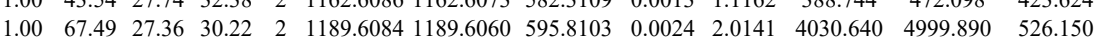

$\begin{array}{llllllllllllll}1.00 & 67.73 & 27.42 & 40.28 & 2 & 1189.6088 & 1189.6060 & 595.8103 & 0.0028 & 2.3497 & 4690.323 & 6612.265 & 374.485\end{array}$

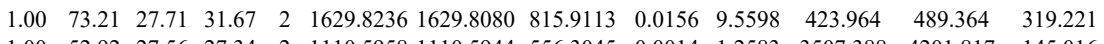
$\begin{array}{lllllllllllll}1.00 & 52.92 & 27.56 & 27.34 & 2 & 1110.5958 & 1110.5944 & 556.3045 & 0.0014 & 1.2583 & 3507.388 & 4201.817 & 145.016\end{array}$

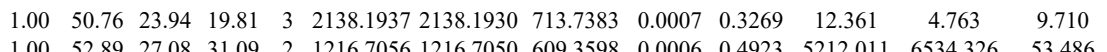
$\begin{array}{lllllllllllll}1.00 & 52.89 & 27.08 & 31.09 & 2 & 1216.7056 & 1216.7050 & 609.3598 & 0.0006 & 0.4923 & 5212.011 & 6534.326 & 53.486\end{array}$

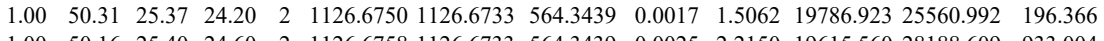
$\begin{array}{lllllllllllll}1.00 & 50.16 & 25.40 & 24.60 & 2 & 1126.6758 & 1126.6733 & 564.3439 & 0.0025 & 2.2150 & 19615.560 & 28188.609 & 933.004 \\ 0.99 & 36.88 & 27.10 & 36.34 & 2 & 12167074 & 1216.7050 & 609.3598 & 0.0024 & 1.9693 & 2006.602 & 2198.275 & 62.518\end{array}$

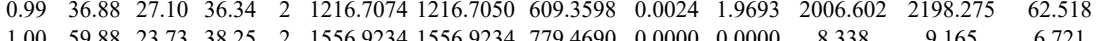

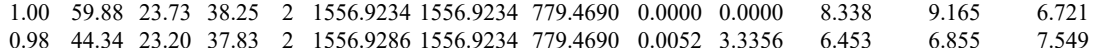

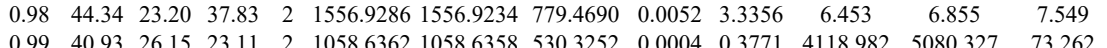
$\begin{array}{lllllllllllll}0.99 & 40.93 & 26.15 & 23.11 & 2 & 1058.6362 & 1058.6358 & 530.3252 & 0.0004 & 0.3771 & 4118.982 & 5080.327 & 73.262\end{array}$ $\begin{array}{llllllllllllll}1.00 & 38.88 & 26.06 & 29.82 & 2 & 1058.6370 & 1058.6358 & 530.3252 & 0.0012 & 1.1314 & 10734.828 & 12424.758 & 244.204\end{array}$ $\begin{array}{lllllllllllll}0.66 & 17.61 & 26.06 & 25.05 & 2 & 1058.6370 & 1058.6358 & 530.3252 & 0.0012 & 1.1314 & 47.915 & 61.481 & 8.606\end{array}$

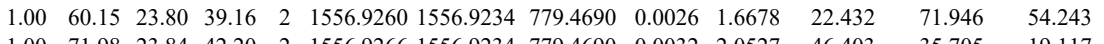

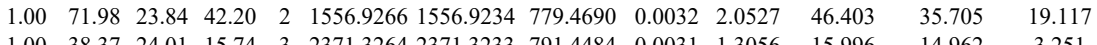
$\begin{array}{lllllllllllll}1.00 & 41.01 & 26.18 & 24.41 & 2 & 1058.6378 & 1058.6358 & 530.3252 & 0.0020 & 1.8856 & 7077.704 & 8035.079 & 176.602\end{array}$ 
$\begin{array}{llllllllllll} & 1058.6378 & 1058.6358 & 530.3252 & 0.0020 & 1.8856 & 6010.210 & 7225.990 & 19\end{array}$ $\begin{array}{lllllllllll}6.38 & 23.67 & 41.64 & 2 & 1556.9250 & 1556.9234 & 779.4690 & 0.0016 & 1.0263 & 71.620\end{array}$ $\begin{array}{llllllllllllll} & \end{array}$

QLAEEDLAQQR

QEQALLEEIER

REEAAVDAQQQK

LEDLLQDAQDEK

LEDLLQDAQDEK

LEDLLQDAQDEK

LLDPEDVDVPQPDEK

GLFDEEMNEILT
SWSLATFR

AGVAAPATQVAQVTLQSVQR

AQAQAAAEK

AQAQAAAEK

CVEDPETGLR
CVEDPETGLR

CVEDPETGLR
LQLEETDHQK

LQLEETDHQK
LQLEETDHQK

QEELQQLEQQR

GGAEGELQALR

GGAEGELQALR

AQAEVEGLGK

AQAEVALK

LQAEEVAQQK

LQEEVAQQK

AEAELLQQQK

AEAELLQQQK
QVEEEILALK

QVEEEILALK

QVEEEILALK

SQVEEELFSVR

RQELEAELAK

KQEELQQLEQQR

KQEELQQLEQQR

VPDVQDGVR

VPDVQDGVR

GGAEGELQALR

AQAEVEGLGK

AQAEVEGLGK

LAEVEAALEK

LAEVEAALEK

LAEVEAALEK

LAEVEAALEK

LQAEEVAQQK

LQAEEVAQQK

AEAELLQQQK

AEAELLQQQK

QVEEEILALK

QVEEEILALK

$\begin{array}{lllllllllll}1.00 & 52.01 & 25.17 & 23.93 & 3 & 2319.2704 & 2319.2683 & 774.0967 & 0.0021 & 0.9043 & 51.228 \\ 1.00 & 71.09 & 23.67 & 39.94 & 2 & 1556.9276 & 1556.9234 & 779.4690 & 0.0042 & 2.6941 & 8.223 \\ 0.92 & 35.02 & 27.99 & 23.60 & 2 & 1221.6180 & 1221.6111 & 611.8128 & 0.0069 & 5.6389 & 2708.066\end{array}$

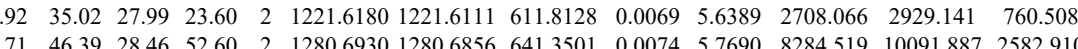

$\begin{array}{llllllllllllll}1.00 & 46.30 & 27.41 & 24.60 & 2 & 1443.7474 & 1443.7439 & 7228792 & 0.0035 & 2.4209 & 4635.228 & 5433.440 & 1659.666 & 203\end{array}$

$\begin{array}{llllllllllllllll}1.00 & 46.30 & 27.41 & 24.60 & 2 & 1443.7474 & 1443.7439 & 722.8792 & 0.0034 & 2.4209 & 4635.228 & 5433.440 & 1659.666 & 2030.574 & \text { Yes } \\ 1.00 & 58.58 & 27.41 & 27.77 & 2 & 1443.7482 & 1443.7439 & 72.8792 & 0.0043 & 2.9742 & 7910.024 & 10821.013 & 1631.241 & 2635.033 & \text { Yes }\end{array}$

$\begin{array}{lllllllllllllll}1.00 & 52.58 & 27.97 & 33.50 & 2 & 1500.7910 & 1500.7905 & 751.4025 & 0.0005 & 0.3327 & 1196.578 & 1606.184 & 280.840 & 2.242 & \text { Yes }\end{array}$

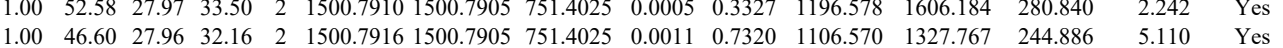

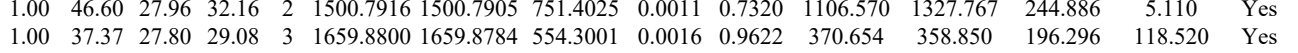

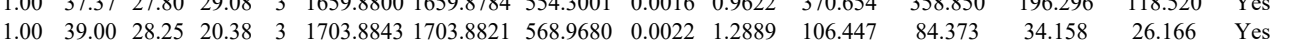

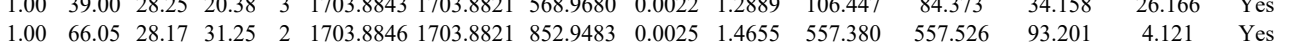

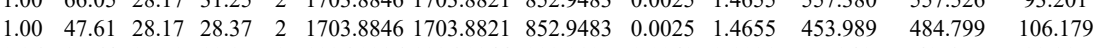

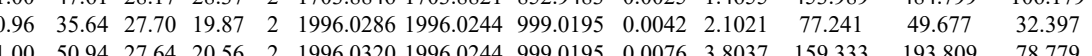

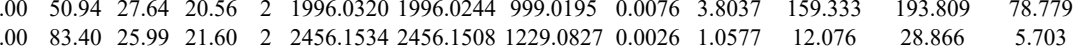
$\begin{array}{lllllllllllllll}0.99 & 37.62 & 27.56 & 19.45 & 2 & 1110.5958 & 1110.5944 & 556.3045 & 0.0014 & 1.2583 & 385.438 & 481.783 & 41.455\end{array}$ $\begin{array}{lllllllllllll}.00 & 5.58 & 23.87 & 17.11 & 3 & 2138.1940 & 2138.1930 & 713.7383 & 0.0010 & 0.4670 & 5.282 & 13.974 & 3.808\end{array}$ $\begin{array}{llllllllllllll}1.00 & 58.78 & 27.59 & 27.83 & 2 & 1174.6548 & 1174.6549 & 588.3347 & -0.0001 & -0.0850 & 301.789 & 366.077 & 336.190 & 22 \\ 0.99 & 39.40 & 27.62 & 22.78 & 2 & 1174.6554 & 1174.6549 & 588.3347 & 0.0005 & 0.4249 & 109.531 & 77.010 & 116.082 & 76\end{array}$

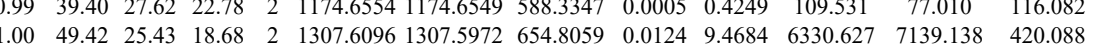
$\begin{array}{llllllllllllll}1.00 & 49.19 & 25.47 & 22.70 & 2 & 1307.6100 & 1307.5972 & 654.8059 & 0.0128 & 9.7738 & 3916.279 & 4862.636 & 867.759\end{array}$ $\begin{array}{llllllllllllll}1.00 & 41.84 & 27.48 & 28.14 & 3 & 1527.8194 & 1527.8136 & 510.2785 & 0.0058 & 3.7888 & 23241.914 & 29755.287 & 962.379 & 417 .\end{array}$

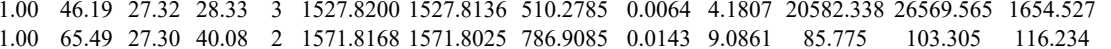

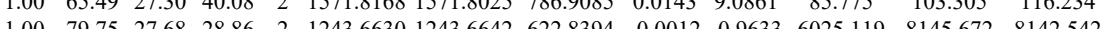
7.624 $\begin{array}{cc}42.919 & \text { Yes } \\ 1.177 & \text { Yes }\end{array}$ $\begin{array}{lllllllllllllllll}1.00 & 79.98 & 27.77 & 29.33 & 2 & 1243.6634 & 1243.6642 & 622.8394 & -0.0008 & -0.6422 & 7647.748 & 9950.362 & 9397.713 & 8563.213 & \text { Yes }\end{array}$ $\begin{array}{lllllllllllllll}1.00 & 52.64 & 27.45 & 26.11 & 2 & 1288.7324 & 1288.7230 & 645.3688 & 0.0094 & 7.2826 & 21738.949 & 2967.208 & 19160.595 & 8200.844 & \text { Yes }\end{array}$

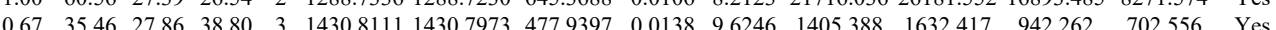

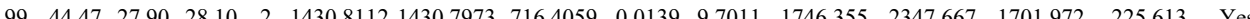
$\begin{array}{lllllllllllllll}100 & 67.03 & 26.80 & 35.10 & 2 & 1444.8246 & 1444.8129 & 723.4137 & 0.0117 & 8.0866 & 2630.221 & 2769.216 & 2480.843 & 2561.958 & \text { Yes }\end{array}$

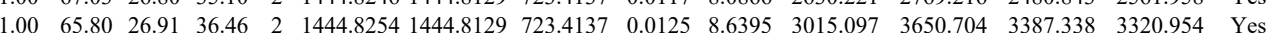
$\begin{array}{lllllllllllllll}1.00 & 69.62 & 2629 & 33.43 & 2 & 1458.8552 & 1458.8537 & 730.4341 & 0.0015 & 1.0268 & 5844.359 & 6198.940 & 1973.981 & 86.966 & \text { Yes }\end{array}$

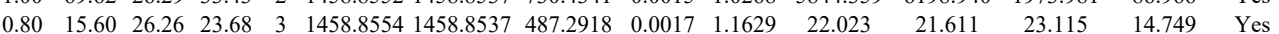
$\begin{array}{lllllllllllllll}1.00 & 69.62 & 26.26 & 27.82 & 2 & 1458.8556 & 1458.8537 & 730.4341 & 0.0019 & 1.3006 & 3365.122 & 4496.418 & 1140.856 & 83.188 & \text { Yes }\end{array}$

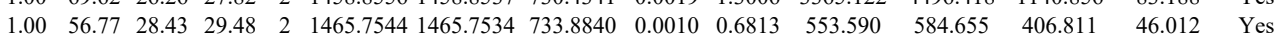
$\begin{array}{llllllllllllllll}0.97 & 32.49 & 26.21 & 26.09 & 3 & 1473.8491 & 1473.8394 & 492.2871 & 0.0097 & 6.5679 & 6293.420 & 9465.134 & 3023.916 & 523.258 & \text { Yes }\end{array}$ $\begin{array}{llllllllllllllll}0.99 & 39.96 & 26.14 & 27.68 & 3 & 1473.8494 & 1473.8394 & 492.2871 & 0.0100 & 6.7711 & 5537.890 & 7123.344 & 2384.065 & 586.871 & \text { Yes }\end{array}$ $\begin{array}{lllllllllllllll}1.00 & 68.49 & 26.67 & 32.51 & 3 & 1844.0161 & 1843.9995 & 615.6738 & 0.0166 & 8.9874 & 6924.881 & 10021.294 & 24322.905 & 16124.298 & \text { No }\end{array}$

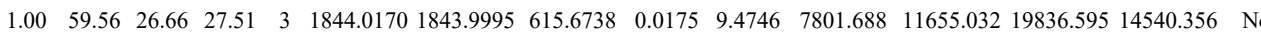

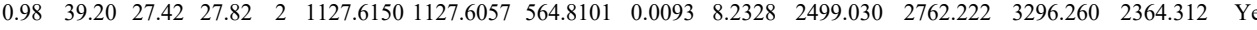

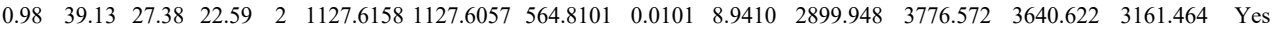
$\begin{array}{lllllllllllllll}1.00 & 60.85 & 28.58 & 35.24 & 2 & 1243.6758 & 1243.6642 & 622.8394 & 0.0116 & 9.3121 & 2411.781 & 2625.951 & 2291.715 & 1985.576 & \text { Yes }\end{array}$ $\begin{array}{lllllllllllllll}1.00 & 67.10 & 28.69 & 34.17 & 2 & 1243.6766 & 1243.6642 & 622.8394 & 0.0124 & 9.9543 & 3843.111 & 3794.375 & 3406.890 & 2944.477 & \text { Yes }\end{array}$

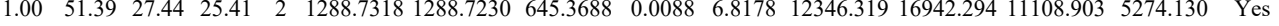

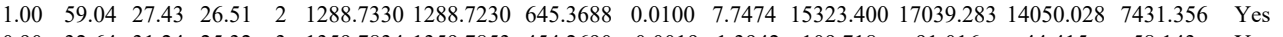

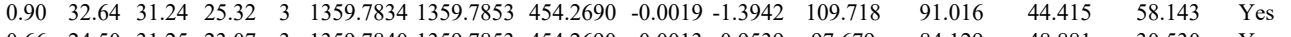

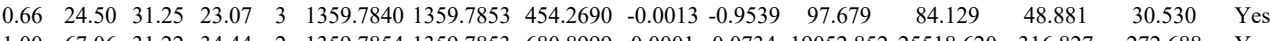

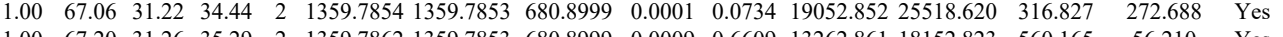
$\begin{array}{lllllllllllllll}1.00 & 67.20 & 31.26 & 35.29 & 2 & 1359.7862 & 1359.7853 & 680.8999 & 0.0009 & 0.6609 & 13262.861 & 18152.823 & 560.165 & 56.210 & \text { Yes } \\ 1.00 & 48.09 & 27.87 & 25.66 & 2 & 1430.8082 & 14307973 & 716.4059 & 0.0109 & 7.6074 & 13865.370 & 13791.273 & 6438.222 & 1347.121 & \text { Yes }\end{array}$ $\begin{array}{llllllllllllllll}1.00 & 48.09 & 27.87 & 25.66 & 2 & 1430.8082 & 1430.7973 & 716.4059 & 0.0109 & 7.6074 & 13865.370 & 13791.273 & 6438.222 & 1347.121 & \text { Yes } \\ 1.00 & 47.60 & 27.91 & 30.20 & 2 & 1430.8088 & 1430.7973 & 716.4059 & 0.0115 & 8.0261 & 7674.347 & 12160.983 & 4558.063 & 1249.102 & \text { Yes }\end{array}$ $\begin{array}{lllllllllllllllll}1.00 & 47.60 & 27.91 & 30.20 & 2 & 1430.8088 & 1430.7973 & 716.4059 & 0.0115 & 8.0261 & 7674.347 & 12160.983 & 4558.063 & 1249.102 & \text { Yes } \\ 1.00 & 56.22 & 26.80 & 32.63 & 2 & 1444.8246 & 1444.8129 & 723.4137 & 0.0117 & 8.0866 & 4823.380 & 5430.446 & 5753.526 & 5089.772 & \text { Yes }\end{array}$ $\begin{array}{lllllllllllllll}1.00 & 56.22 & 26.80 & 32.63 & 2 & 1444.8246 & 1444.8129 & 723.4137 & 0.0117 & 8.0866 & 4823.380 & 5430.446 & 5753.526 & 5089.772 & \text { Yes } \\ 1.00 & 56.74 & 27.03 & 37.00 & 2 & 1444.8258 & 1444.8129 & 723.4137 & 0.0129 & 8.9160 & 3374.667 & 4450.785 & 3671.378 & 3141.666 & \text { Yes }\end{array}$ $\begin{array}{lllllllllllllll}1.00 & 56.74 & 27.03 & 37.00 & 2 & 1444.8258 & 1444.8129 & 723.4137 & 0.0129 & 8.9160 & 3374.667 & 4450.785 & 3671.378 & 3141.666 & \text { Yes } \\ 1.00 & 65.87 & 26.58 & 31.84 & 2 & 1458.8542 & 1458.8537 & 730.4341 & 0.0005 & 0.3423 & 5280.133 & 6875.293 & 1581.632 & 371.109 & \text { Yes }\end{array}$ $\begin{array}{lllllllllllllll}1.00 & 65.64 & 26.29 & 28.81 & 2 & 1458.8552 & 1458.8537 & 730.4341 & 0.0015 & 1.0268 & 5173.078 & 6160.424 & 1526.221 & 254.929 & \text { Yes } \\ 0.72 & 13.98 & 26.26 & 21.75 & 3 & 1458.8554 & 1458.8537 & 487.2918 & 0.0017 & 1.1629 & 34.676 & 56.224 & 47.884 & 24.476 & \text { Yes }\end{array}$

Table S-3 page 404 of 499 


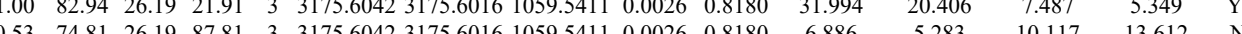

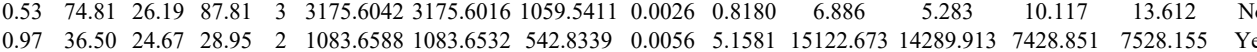

$\begin{array}{lllllllllllllll}0.98 & 36.50 & 24.67 & 28.95 & 2 & 1083.6588 & 1083.6532 & 542.8339 & 0.0056 & 5.1581 & 15122.673 & 14289.913 & 7428.851 & 7528.155 & \text { Yes } \\ 0.98 & 36.57 & 24.67 & 29.08 & 2 & 1083.6614 & 1083.6532 & 542.8339 & 0.0082 & 7.5529 & 17454.006 & 14930.668 & 11346.028 & 10287.356 & \text { Yes }\end{array}$ $\begin{array}{llllllllllllllll} & \end{array}$ $\begin{array}{llllllllllllll} & \end{array}$ $\begin{array}{llllllllllllllll}\text { VLGILAMIDEGETDWK } & 0.89 & 24.04 & 27.30 & 18.12 & 3 & 2077.1071 & 2077.1009 & 693.3742 & 0.0062 & 2.9806 & 263.013 & 297.331 & 70.789 & 59.644 & \text { Yes }\end{array}$ $\begin{array}{llllllllllllllllll}\text { GYIWNYGAIPQTWEDPGHNDK } & 1.00 & 46.67 & 26.60 & 16.01 & 3 & 2748.3214 & 2748.3176 & 917.1131 & 0.0038 & 1.3811 & 693.637 & 759.697 & 321.997 & 39.819 & \text { Yes }\end{array}$

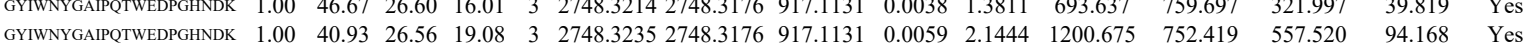

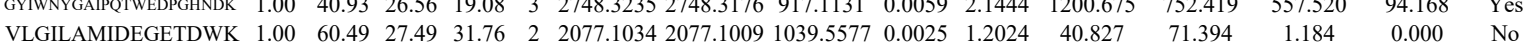

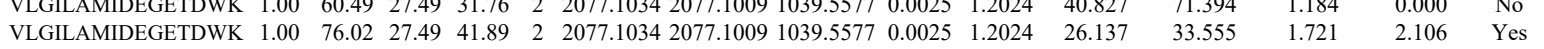
\begin{tabular}{llllllllllllllll} 
VLGILAMIDEGETDWK & 1.00 & 50.03 & 27.40 & 19.38 & 3 & 2077.1053 & 2077.1009 & 693.3742 & 0.0044 & 2.1153 & 237.443 & 240.851 & 120.181 & 29.526 & Yes \\
\hline
\end{tabular} $\begin{array}{llllllllllllllll}\text { GYIWNYGAIPQTWEDPGHNDK } & 1.00 & 44.28 & 26.57 & 15.84 & 3 & 2748.3199 & 2748.3176 & 917.1131 & 0.0023 & 0.8360 & 596.226 & 626.611 & 169.720 & 65.914 & \text { Yes }\end{array}$ $\begin{array}{llllllllllllllll}\text { GYIWNYGAIPQTWEDPGHNDK K } & 1.00 & 50.28 & 26.58 & 19.11 & 3 & 2748.3208 & 2748.3176 & 917.1131 & 0.0032 & 1.1631 & 755.934 & 975.055 & 384.348 & 84.883 & \text { Yes }\end{array}$ $\begin{array}{llllllllllllllll}\text { GQYISPFHDIPIYADK } & 1.00 & 40.99 & 27.38 & 22.14 & 3 & 2151.1279 & 2151.1244 & 718.0487 & 0.0035 & 1.6248 & 3907.838 & 3822.846 & 3651.315 & 2216.660 & \text { No }\end{array}$ $\begin{array}{lllllllllllllllll}\text { GQYISPFHDIPIYADK } & 1.00 & 33.64 & 27.39 & 16.67 & 3 & 2151.1282 & 2151.1244 & 718.0487 & 0.0038 & 1.7640 & 824.569 & 940.751 & 638.154 & 467.594 & \text { Yes }\end{array}$ $\begin{array}{llllllllllllllll}\text { GISCMNTTLSESPFK } & 1.00 & 79.31 & 26.53 & 24.89 & 2 & 1947.9354 & 1947.9348 & 974.9747 & 0.0006 & 0.3077 & 1029.011 & 947.143 & 278.455 & 95.536 & \text { Yes }\end{array}$ $\begin{array}{llllllllllllllll}\text { GISCMNTTLSESPFK } & 1.00 & 86.47 & 26.43 & 23.20 & 2 & 1947.9372 & 1947.9348 & 974.9747 & 0.0024 & 1.2308 & 839.033 & 842.297 & 248.501 & 23.952 & \text { Yes }\end{array}$ $\begin{array}{lllllllllllllllll}\text { LKPGYLEATVDWFR } & 0.69 & 58.41 & 26.17 & 71.41 & 2 & 1982.0900 & 1982.0869 & 992.0507 & 0.0031 & 1.5624 & 6476.624 & 7380.901 & 1403.549 & 50.268 & \text { Yes }\end{array}$ $\begin{array}{lllllllllllllllll}\text { LKPGYLEATVDWFR } & 1.00 & 64.17 & 25.87 & 18.94 & 3 & 1982.0938 & 1982.0869 & 661.7029 & 0.0069 & 3.4759 & 6577.274 & 6828.710 & 1460.327 & 54.543 & \text { Yes }\end{array}$ $\begin{array}{lllllllllllllllll}\text { LKPGYLEATVDWFR } & 0.53 & 65.76 & 26.14 & 78.76 & 3 & 1982.0902 & 1982.0869 & 661.7029 & 0.0033 & 1.6624 & 2646.019 & 2335.770 & 532.706 & 256.373 & \text { Yes }\end{array}$

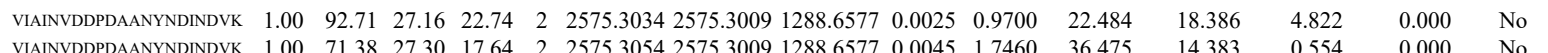

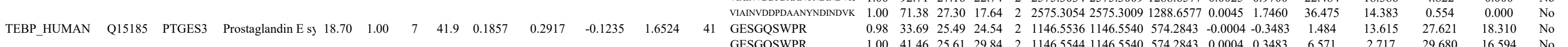

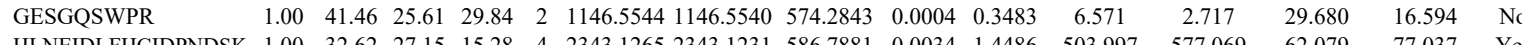

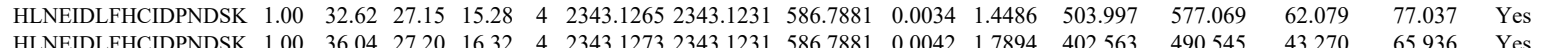
\begin{tabular}{llllllllllllllll} 
HLNEIDLFHCIDPNDSK & 1.00 & 36.04 & 27.20 & 16.32 & 4 & 2343.1273 & 2343.1231 & 586.7881 & 0.0042 & 1.7894 & 402.563 & 490.545 & 43.270 & 65.936 & Yes \\
\hline HLNEDLFHCIDPDSK & 1.00 & 27.25 & 27.20 & 40.25 & 4 & 2343.1273 & 2343.1231 & 586.7881 & 0.0042 & 1.7894 & 1667.236 & 2518.596 & 0.000 & 62.840 & No
\end{tabular}

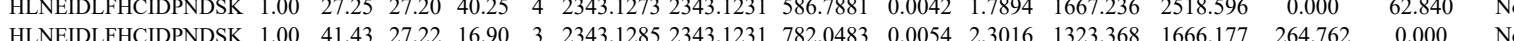
$\begin{array}{llllllllllllll} & \text { HLNEDFA }\end{array}$ $\begin{array}{llllllllllllllll}162.179 & \text { Yes }\end{array}$ $\begin{array}{llllllllllllll} & \end{array}$ $\begin{array}{llllllllllllllll}\text { KGESGQSWPR } & 0.99 & 31.65 & 28.16 & 17.14 & 3 & 1418.7511 & 1418.7510 & 473.9243 & 0.0001 & 0.0703 & 66.937 & 64.218 & 50.154 & 64.450 & \text { No }\end{array}$

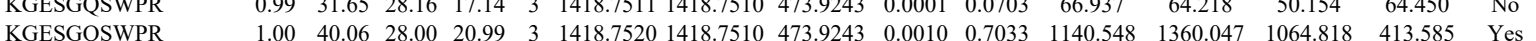
$\begin{array}{lllllllllllllllll} & \text { KGESGQSWR } & 1.00 & 40.06 & 28.00 & 20.99 & 3 & 1418.7520 & 1418.7510 & 473.9243 & 0.0010 & 0.7033 & 1140.548 & 1360.047 & 1064.818 & 413.585 & \text { Yes } \\ \text { KGESGQSWPR } & 1.00 & 50.09 & 28.00 & 21.07 & 3 & 1418.7520 & 1418.7510 & 473.9243 & 0.0010 & 0.7033 & 2169.530 & 2590.527 & 2001.526 & 638.995 & \text { Yes }\end{array}$ KGESGQSWPR KGESGQSWPR KGESGQSWPR LTFSCLGGSDNFK LTFSCLGGSDNFK LTFSCLGGSDNFK LTFSCLGGSDNFK

LTFSCLGGSDNFK

LNWLSVDFNNWK

LNWLSVDFNNWK

LNWLSVDFNNWK

LNWLSVDFNNWK

LNWLSVDFNNWK

LNWLSVDFNNWK

LNWLSVDFNNWK

LNWLSVDFNNWK

LNWLSVDFNNWK

SILCCLR

SILCCLR

SICCR

SILCCLR $\begin{array}{llllllllllllll}.00 & 50.09 & 28.00 & 21.07 & 3 & 1418.7520 & 1418.7510 & 473.9243 & 0.0010 & 0.7033 & 2169.530 & 2590.527 & 2001.526\end{array}$

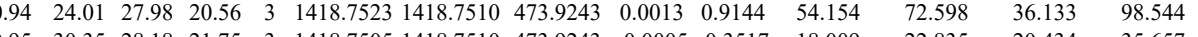

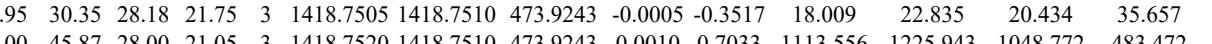

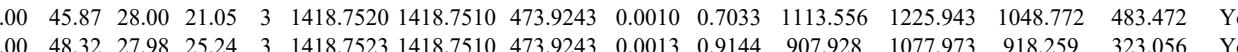
$\begin{array}{lllllllllllllll}1.00 & 4.32 & 27.98 & 25.24 & 3 & 1418.7523 & 1418.7510 & 473.9243 & 0.0013 & 0.9144 & 907.928 & 1077.973 & 918.259 & 323.056 & \text { Yes } \\ 0.76 & 67.36 & 6.93 & 80.36 & 2 & 1721.8370 & 1721.8361 & 861.9253 & 0.0009 & 0.5221 & 3028.952 & 3602.503 & 474.549 & 124.119 & \text { Yes }\end{array}$ $\begin{array}{lllllllllllllll}1.00 & 70.84 & 26.91 & 23.44 & 3 & 1721.8390 & 1721.8361 & 574.9526 & 0.0029 & 1.6813 & 489.342 & 558.635 & 94.319 & 90.344 & \text { Yes }\end{array}$ $\begin{array}{lllllllllllllll}1.00 & 47.19 & 26.99 & 16.22 & 3 & 1721.8399 & 1721.8361 & 574.9526 & 0.0038 & 2.2031 & 434.176 & 458.770 & 54.674 & 147.790 & \text { Yes }\end{array}$ $\begin{array}{lllllllllllllll}1.00 & 79.51 & 26.93 & 21.93 & 2 & 1721.8370 & 1721.8361 & 861.9253 & 0.0009 & 0.5221 & 921.356 & 737.071 & 110.713 & 25.517 & \text { Yes }\end{array}$

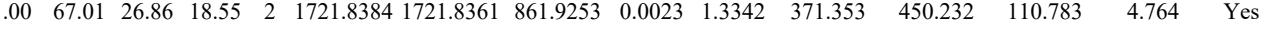
$\begin{array}{lllllllllllllll}1.00 & 47.43 & 28.06 & 19.69 & 2 & 1822.9640 & 1822.9610 & 912.4878 & 0.0030 & 1.6439 & 1343.668 & 1633.553 & 160.315 & 0.000 & \text { No }\end{array}$ $\begin{array}{lllllllllllllll}1.00 & 48.30 & 28.11 & 22.21 & 2 & 1822.9642 & 1822.9610 & 912.4878 & 0.0032 & 1.7534 & 405.567 & 335.236 & 17.406 & 0.000 & \text { No }\end{array}$ $\begin{array}{llllllllllllllll}1.00 & 35.46 & 28.01 & 25.01 & 3 & 1822.9663 & 1822.9610 & 608.6609 & 0.0053 & 2.9025 & 490.325 & 383.685 & 99.867 & 0.000 & \text { No }\end{array}$ $\begin{array}{lllllllllllllll}1.00 & 4.98 & 28.08 & 17.90 & 2 & 1822.9626 & 1822.9610 & 912.4878 & 0.0016 & 0.8767 & 1616.584 & 1569.150 & 38.168 & 0.000 & \text { No }\end{array}$ $\begin{array}{lllllllllllllll}1.00 & 45.34 & 28.06 & 16.46 & 2 & 1822.9640 & 1822.9610 & 912.4878 & 0.0030 & 1.6439 & 2425.593 & 1997.431 & 0.000 & 22.101 & \text { No }\end{array}$

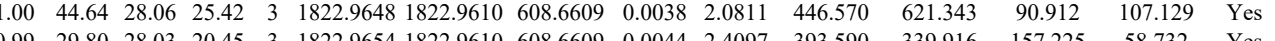
$\begin{array}{lllllllllllllll}1.00 & 41.20 & 28.03 & 20.45 & 3 & 1822.9654 & 1822.9610 & 608.6609 & 0.0044 & 2.4097 & 393.590 & 339.916 & 157.225 & 58.732 & \text { Yes }\end{array}$

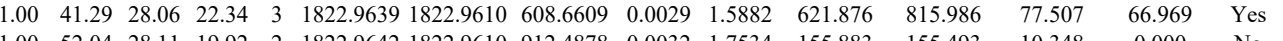

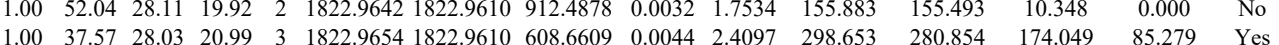

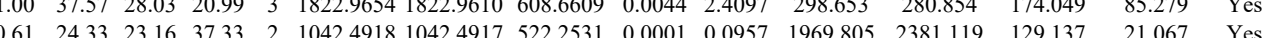
$\begin{array}{lllllllllllllll}0.61 & 24.33 & 23.16 & 37.33 & 2 & 1042.4918 & 1042.4917 & 522.2531 & 0.0001 & 0.0957 & 1969.805 & 2381.119 & 129.137 & 21.067 & \text { Yes } \\ 0.76 & 23.16 & 23.69 & 36.16 & 2 & 1042.4930 & 1042.4917 & 522.2531 & 0.0013 & 12446 & 22839.842 & 31221.460 & 1658.500 & 147.891 & \text { Yes }\end{array}$ $\begin{array}{llllllllllllllll}0.76 & 23.16 & 23.69 & 36.16 & 2 & 1042.4930 & 1042.4917 & 522.2531 & 0.0013 & 1.2446 & 22839.842 & 31221.460 & 1658.500 & 147.891 & \text { Yes } \\ 0.61 & 23.18 & 23.16 & 36.18 & 2 & 1042.4922 & 1042.4917 & 522.2531 & 0.0005 & 0.4787 & 5398.398 & 6290.295 & 433.153 & 46.014 & \text { Yes }\end{array}$

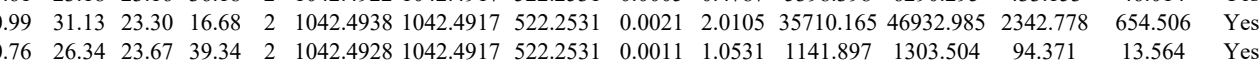

Table S-3 page 405 of 499 

$\begin{array}{llllllllllllllll}\text { MGQMAMGGAMGINNR } & 1.00 & 92.04 & 25.25 & 48.20 & 2 & 1681.7792 & 1681.7642 & 841.8894 & 0.0150 & 8.9085 & 4431.767 & 3513.725 & 501.580 & 2.809 & \text { Yes }\end{array}$ $\begin{array}{llllllllllllllll}\text { MGQMAMGGAMGINNR } & 1.00 & 94.80 & 25.05 & 41.26 & 2 & 1681.7772 & 1681.7642 & 841.8894 & 0.0130 & 7.7207 & 4584.207 & 4336.843 & 480.360 & 2.965 & \text { Yes }\end{array}$ $\begin{array}{lllllllllllllllll}\text { MGQMAMGGAMGINNR } & 1.00 & 89.95 & 25.07 & 41.33 & 2 & 1681.7774 & 1681.7642 & 841.8894 & 0.0132 & 7.8394 & 3849.721 & 3109.368 & 436.703 & 56.337 & \text { Yes }\end{array}$

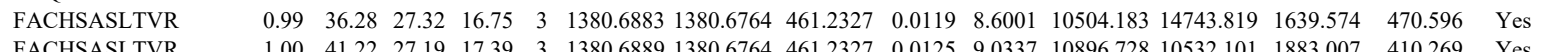

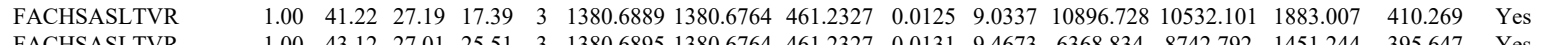
$\begin{array}{lllllllllllllllll}\text { FACHSASLTVR } & 1.00 & 43.12 & 27.01 & 25.51 & 3 & 1380.6895 & 1380.6764 & 461.2327 & 0.0131 & 9.4673 & 6368.834 & 8742.792 & 1451.244 & 395.647 & \text { Yes }\end{array}$ $\begin{array}{lllllllllllllllll}\text { MEELHNQEVQK } & 0.98 & 49.61 & 27.97 & 41.10 & 2 & 1671.8562 & 1671.8494 & 836.9320 & 0.0068 & 4.0624 & 3094.118 & 2417.399 & 1707.737 & 164.820 & \text { Yes }\end{array}$ $\begin{array}{llllllllllllllllll}\text { MEELHNQEVQK } & 0.98 & 48.24 & 27.97 & 40.04 & 2 & 1671.8564 & 1671.8494 & 836.9320 & 0.0070 & 4.1819 & 3817.279 & 2886.840 & 2007.546 & 215.765 & \text { Yes }\end{array}$ $\begin{array}{llllllllllllllll}\text { MEELHNQEVQK } & 0.92 & 27.87 & 28.06 & 19.41 & 3 & 1671.8572 & 1671.8494 & 558.2904 & 0.0078 & 4.6571 & 21930.020 & 20322.434 & 17919.035 & 1710.868 & \text { Yes }\end{array}$ MEELHNQEVQK 


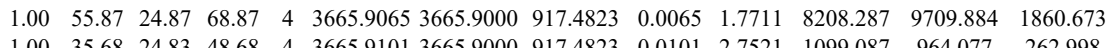

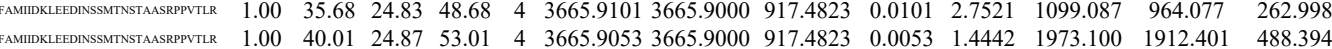

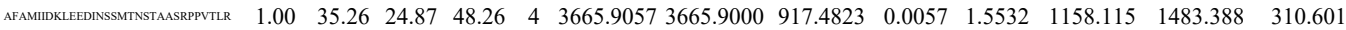
$\begin{array}{lllllllllllllll}\text { VMTPYQPMPASSPVICAGGQDR } & 1.00 & 61.76 & 26.46 & 18.75 & 2 & 2607.2454 & 2607.2439 & 1304.6292 & 0.0015 & 0.5749 & 179.342 & 268.038 & 19.313\end{array}$ $\begin{array}{lllllllllllllll}\text { VMTIPYQPMPASPPICAGGQDR } & 1.00 & 51.57 & 26.46 & 18.59 & 2 & 2607.2454 & 2607.2439 & 1304.6292 & 0.0015 & 0.5749 & 87.731 & 143.051 & 51.265\end{array}$ $\begin{array}{lllllllllllllll}\text { VMTIPYQPMPASSPVICAGGQDR } & 0.94 & 20.96 & 26.45 & 20.24 & 3 & 2607.2458 & 2607.2439 & 870.0886 & 0.0019 & 0.7279 & 17.671 & 39.860 & 40.356\end{array}$ $\begin{array}{lllllllllllllll}\text { VMTIPYQPMPASSPVICAGGQDR } & 0.53 & 31.81 & 26.49 & 44.81 & 3 & 2607.2467 & 2607.2439 & 870.0886 & 0.0028 & 1.0727 & 30.691 & 83.172 & 44.133\end{array}$ $\begin{array}{llllllllllllll}\text { IITLTGPTNAIFK } & 1.00 & 74.48 & 21.14 & 24.23 & 2 & 1676.0140 & 1676.0116 & 839.0131 & 0.0024 & 1.4302 & 9045.678 & 6895.538 & 165.217\end{array}$ IITLTGPTNAIFK

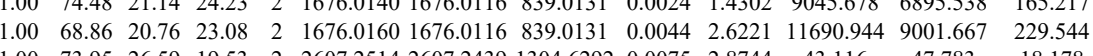
$\begin{array}{llllllllllllll}\text { VMTIPYQPMPASSPVICAGGQDR } & 1.00 & 73.95 & 26.59 & 19.53 & 2 & 2607.2514 & 2607.2439 & 1304.6292 & 0.0075 & 2.8744 & 43.116 & 47.783 & 18.178\end{array}$ $\begin{array}{llllllllllllll}\text { VMTIPYQPMPASSPVICAGGQDR } & 1.00 & 59.20 & 26.66 & 18.48 & 2 & 2607.2534 & 2607.2439 & 1304.6292 & 0.0095 & 3.6409 & 49.434 & 75.606 & 0.166 \\ \text { IITLTGPTNAIFK } & 1.00 & 76.40 & 20.86 & 24.98 & 2 & 1676.0150 & 1676.0116 & 839.0131 & 0.0034 & 2.0262 & 3640.774 & 2903.331 & 0.000\end{array}$

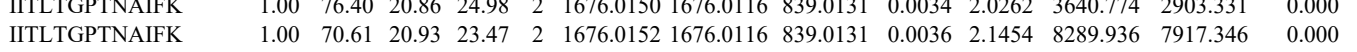

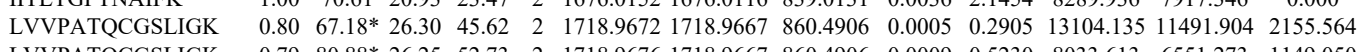
$\begin{array}{llllllllllllll}\text { LVVPATQCGSLIGK } & 0.79 & 80.88 * & 26.25 & 52.73 & 2 & 1718.9676 & 1718.9667 & 860.4906 & 0.0009 & 0.5230 & 8033.613 & 6551.273 & 1149.050 \\ \text { ITLTGPTNAIFK } & 1.00 & 73.36 & 21.61 & 2.87 & 2 & 1676.0118 & 1676.0116 & 839.0131 & 0.0002 & 0.1192 & 6695.390 & 7038561 & 192.571\end{array}$

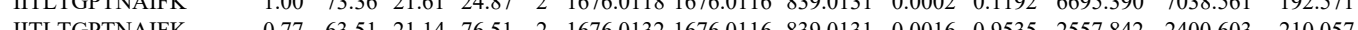
$\begin{array}{lllllllllllllll}\text { IITLTGPTNAIFK } & 0.55 & 8.74 & 21.21 & 21.74 & 3 & 1676.0137 & 1676.0116 & 559.6778 & 0.0021 & 1.2507 & 19040.255 & 18352.884 & 476.402\end{array}$ $\begin{array}{llllllllllllll}\text { IITLTGPTNAIFK } & 0.55 & 13.08 & 21.21 & 26.08 & 3 & 1676.0140 & 1676.0116 & 559.6778 & 0.0024 & 1.4294 & 10023.182 & 8255.024 & 229.258\end{array}$ $\begin{array}{llllllllllllll}\text { LVVPATQCGSLIGK } & 0.72 & 71.65 * & 26.25 & 49.74 & 2 & 1718.9680 & 1718.9667 & 860.4906 & 0.0013 & 0.7554 & 6649.822 & 7949.905 & 822.942\end{array}$

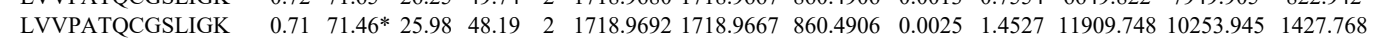
$\begin{array}{lllllllllllll}\text { LICLVMLETLSQSPQGR } & 1.00 & \text { \#\#\#\# } 27.87 & 20.71 & 2 & 2092.0614 & 2092.0601 & 1047.0373 & 0.0013 & 0.6208 & 520.327 & 541.694 & 62.562\end{array}$

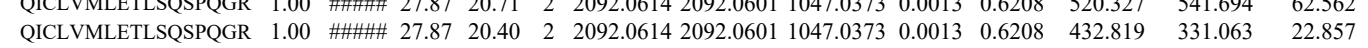

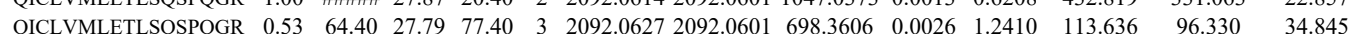

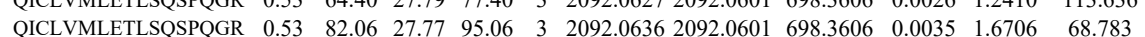
$\begin{array}{llllllllllllll}\text { QICLVMLETLSQSPQGR } & 0.53 & 86.24 & 27.77 & 99.24 & 3 & 2092.0636 & 2092.0601 & 698.3606 & 0.0035 & 1.6706 & 37.936\end{array}$ $\begin{array}{llllllllllllll}\text { QVTITGSAASISLAOYLINAR } & 0.53 & 32.12 & 25.53 & 45.12 & 3 & 2176.1881 & 2176.1851 & 726.4023 & 0.0030 & 1.3766 & 2.426\end{array}$ $\begin{array}{lllllllllllll}\text { QVTITGSAASISLAQYLINAR } & 1.00 & 50.35 & 23.96 & 17.61 & 3 & 2320.2889 & 2320.2872 & 774.4363 & 0.0017 & 0.7317 & 0.000\end{array}$ $\begin{array}{llllllllllll}\text { QVTITGSAASISLAQYLINAR } & 0.55 & 49.23 & 23.73 & 62.23 & 3 & 2320.2895 & 2320.2872 & 774.4363 & 0.0023 & 0.9900 & 5.399\end{array}$ $\begin{array}{lllllllllll}\text { QICLVMLETLSQSPQGR } & 1.00 & \text { \#\#\# } 27.87 & 22.01 & 2 & 2092.0614 & 2092.0601 & 1047.0373 & 0.0013 & 0.6208 & 126.196\end{array}$ $\begin{array}{llllllllllll}\text { QICLVMLETLSQSPQGR } & 0.53 & 65.54 & 27.72 & 78.54 & 3 & 2092.0633 & 2092.0601 & 698.3606 & 0.0032 & 1.5274 & 27.193\end{array}$ $\begin{array}{lllllllllllll}\text { QICLVMLETLSQSPQGR } & 1.00 & 51.12 & 27.73 & 17.07 & 3 & 2092.0639 & 2092.0601 & 698.3606 & 0.0038 & 1.8138 & 22.606\end{array}$

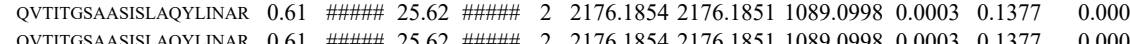
$\begin{array}{lllllllllll}\text { QVTITGSAASISLAQYLINAR } & 0.61 & \text { \#\#\#\# } 25.62 & \text { \#\#\#\# } & 2 & 2176.1854 & 2176.1851 & 1089.0998 & 0.0003 & 0.1377 & 0.000 \\ \text { QVTITGAASA }\end{array}$ $\begin{array}{llllllllllll}\text { QVTITGSAASISLAQYLINAR } & 0.55 & 12.56 & 25.48 & 25.56 & 3 & 2176.1872 & 2176.1851 & 726.4023 & 0.0021 & 0.9637 & 25.854 \\ \text { QVTIGGSASISLAQYLNAR } & 0.98 & 24.70 & 25.53 & 16.29 & 3 & 2176.1878 & 2176.1851 & 726.4023 & 0.0027 & 1.2390 & 43.381\end{array}$ $\begin{array}{llllllllllll}\text { QVTITGSAASISLAQYLINAR } & 0.98 & 24.70 & 25.53 & 16.29 & 3 & 2176.1878 & 2176.1851 & 726.4023 & 0.0027 & 1.2390 & 43.381 \\ \text { QICLVMLETLSQSPQGR } & 1.00 & 72.14 & 27.88 & 19.70 & 3 & 2092.0612 & 2092.0601 & 698.3606 & 0.0011 & 0.5250 & 26.532\end{array}$ $\begin{array}{lllllllllllll}\text { QICLVMLETLSQSPQGR } & 1.00 & 72.14 & 27.88 & 19.70 & 3 & 2092.0612 & 2092.0601 & 698.3606 & 0.0011 & 0.5250 & 26.532 \\ \text { QICLVMLETLSQSPQGR } & 1.00 & 72.68 & 27.87 & 20.57 & 3 & 2092.0615 & 2092.0601 & 698.3606 & 0.0014 & 0.6682 & 21.939\end{array}$ $\begin{array}{llllllllllll}\text { QICLVMLETLSQSPQGR } & 1.00 & 72.68 & 27.87 & 20.57 & 3 & 2092.0615 & 2092.0601 & 698.3606 & 0.0014 & 0.6682 & 21.939 \\ \text { QVTITGSAASISLAQYLINAR } & 0.61 & \# \# \# \# & 25.62 & \# \# \# \# & 2 & 2176.1854 & 2176.1851 & 1089.0998 & 0.0003 & 0.1377 & 0.000\end{array}$

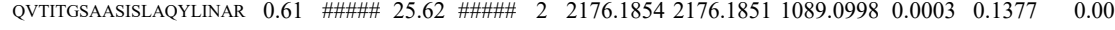

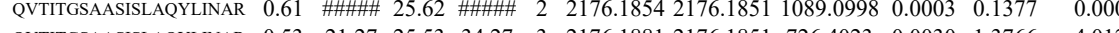
$\begin{array}{llllllllllll}\text { QVIITGSAASISLAQYLINAR } & 0.53 & 21.27 & 25.53 & 34.27 & 3 & 2176.1881 & 2176.1851 & 726.4023 & 0.0030 & 1.3766 & 4.012\end{array}$

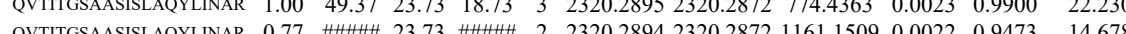

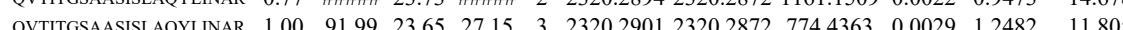

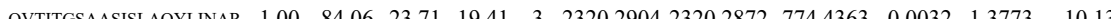

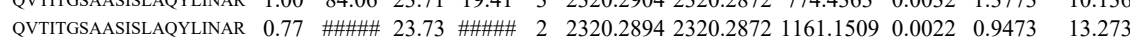


$\begin{array}{llllllllllllll}1.00 & 55.01 & 27.56 & 20.57 & 2 & 1301.6782 & 1301.6697 & 651.8421 & 0.0085 & 6.5199 & 53390.426 & 49017.383 & 20083.537\end{array}$

$\begin{array}{llllllllllll} & \end{array}$

AITIAGIPQSIIECVK $\begin{array}{llllllllllllll} & \end{array}$ AITIAGIPQSIIECVK
AITIAGIPQSIIECVK $\begin{array}{lllllllllllll}00 & 49.00 & 25.12 & 62.00 & 4 & 3638.8973 & 3638.8891 & 910.7296 & 0.0082 & 2.2509 & 2382.233 & 2036.302 & 436.065 \\ 1.04\end{array}$ $\begin{array}{llllllllllllll}1.00 & 69.16 & 24.13 & 31.50 & 2 & 1989.1268 & 1989.1246 & 995.5696 & 0.0022 & 1.1049 & 1120.495 & 1545.386 & 290.924\end{array}$ $\begin{array}{lllllllllllll}1.00 & 81.25 & 24.13 & 38.05 & 2 & 1989.1268 & 1989.1246 & 995.5696 & 0.0022 & 1.1049 & 527.678 & 494.782 & 94.728\end{array}$ $\begin{array}{llllllllllllll}1.00 & 64.07 & 24.22 & 31.32 & 3 & 1989.1279 & 1989.1246 & 6640488 & 0.0033 & 1.6565 & 2374.327 & 2280.899 & 661.454\end{array}$ $\begin{array}{lllllllllllll}1.00 & 81.32 & 24.13 & 33.02 & 2 & 19899.1268 & 1989.1246 & 995.5696 & 0.0022 & 1.1049 & 1843.505 & 2477.321 & 449.987\end{array}$ $\begin{array}{lllllllllllll}00 & 90.86 & 24.13 & 44.23 & 2 & 1989.1268 & 1989.1246 & 995.5696 & 0.0022 & 1.1049 & 826.964 & 959.302\end{array}$ AITIAGIPOSIIECVK $\begin{array}{lllllllllllll}1.00 & 59.93 & 24.22 & 25.06 & 3 & 1989.1279 & 1989.1246 & 664.0488 & 0.0033 & 1.6565 & 1892.883 & 1689.031 & 735.108\end{array}$ SIIECVK $\begin{array}{lllllllllllll}1.00 & 60.66 & 24.17 & 23.35 & 3 & 1989.1288 & 1989.1246 & 664.0488 & 0.0042 & 2.1083 & 7066.058 & 8354.207 & 1564.040\end{array}$ $\begin{array}{llllllllllllll}1.00 & 88.39 & 24.10 & 42.20 & 2 & 1989.1262 & 1989.1246 & 995.5696 & 0.0016 & 0.8036 & 386.123 & 426.386 & 85.526\end{array}$ AGIPQSIIECVK

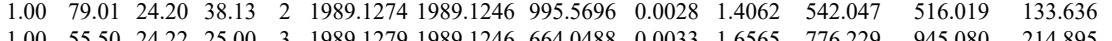
ATIAGIPQSIIECVK $\begin{array}{lllllllllllll}1.00 & 55.50 & 24.22 & 25.00 & 3 & 1989.1279 & 1989.1246 & 664.0488 & 0.0033 & 1.6565 & 776.229 & 945.080 & 214.895 \\ 1.00 & 48.01 & 24.22 & 21.24 & 3 & 1989.1279 & 1989.1246 & 66.0488 & 0.033 & 1.6565 & 2308.012 & 2437.423 & 654.855\end{array}$ ATHAGIPQSIIECVK AITIAGIPQSIIECVK $\begin{array}{lllllllllllll}1.00 & 48.01 & 24.22 & 21.24 & 3 & 1989.1279 & 1989.1246 & 664.0488 & 0.0033 & 1.6565 & 2308.012 & 2437.423 & 654.855 \\ 1.00 & 50.03 & 27.63 & 19.04 & 3 & 106.1162 & 2106.1131 & 703.0450 & 0.0031 & 1.4698 & 277.456 & 373.476 & 118.069\end{array}$ AITIAGIPQSIIECVK AITIAGIPQSIIECVK QICVVMLETLSQSPPK QICVVMLETLSQS IITLAGPTNAIFK

$\begin{array}{lllllllllllll}1.00 & 50.03 & 27.63 & 19.04 & 3 & 2106.1162 & 2106.1131 & 703.0450 & 0.0031 & 1.4698 & 277.456 & 373.476 & 118.069 \\ 1.00 & 66.86 & 24.20 & 28.89 & 3 & 1989.1252 & 1989.1246 & 664.0488 & 0.0006 & 0.3012 & 315.605 & 450.532 & 76.069\end{array}$

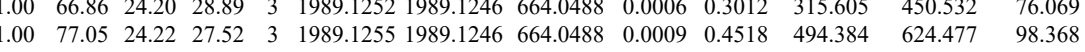
$\begin{array}{lllllllllllll}1.00 & 70.33 & 24.20 & 35.76 & 2 & 1989.1276 & 1989.1246 & 995.5696 & 0.0030 & 1.5067 & 43.745 & 51.167 & 27.461\end{array}$ IITLAGPTNAIFK $\begin{array}{llllllllllll}1.00 & 59.87 & 24.63 & 18.37 & 3 & 2106.1156 & 2106.1131 & 703.0450 & 0.0025 & 1.1853 & 298.743 & 254.278\end{array}$

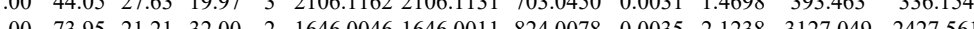
$\begin{array}{lllllllllllll}1.00 & 73.95 & 21.21 & 32.00 & 2 & 1646.0046 & 1646.0011 & 824.0078 & 0.0035 & 2.1238 & 3127.049 & 2427.561 & 73.592 \\ 1.00 & 73.37 & 21.27 & 31.19 & 2 & 1646.0050 & 1646.0011 & 824.0078 & 0.0039 & 2.3665 & 2035.300 & 1558.049 & 91.947\end{array}$

LVVPASQCGSLIGK

LVVPASQCGSLIGK

LVVPASQGSLIGK

ITT AGPTNAIFK

IILAGPTNAIFK

LVVPASQCGSLIGK

LVVPASQCGSLIGK

LVVPASOCGSLIGK LVVPASQCGSLIGK IITLAGPTNAIFK ITLAGPTNAIFK IITLAGPTNAIFK

IITLAGPTNAIFK

LVVPASQCGSLIGK

LVVPASQCGSLIGK LVVPASQCGSLIGK

ITLAGPTNAIFK

$\begin{array}{llllllllllllll}7.32 & 26.42 & 35.54 & 2 & 1704.9528 & 1704.9510 & 853.4828 & 0.0018 & 1.0545 & 13187.428 & 14694.714 & 1600.849\end{array}$ $\begin{array}{lllllllllllll}1.00 & 74.11 & 26.38 & 29.01 & 2 & 1704.9536 & 1704.9510 & 853.4828 & 0.0026 & 1.5232 & 6357.108 & 8140.850 & 827.776\end{array}$

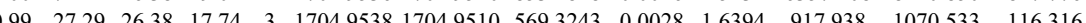
$\begin{array}{lllllllllllllll}1 & 104.93892 & 8737.786 & 0.000\end{array}$ $\begin{array}{lllllllllllllll}1.00 & 63.75 & 21.52 & 31.24 & 2 & 1646.0042 & 1646.0011 & 824.0078 & 0.0031 & 1.8810 & 6355.401 & 7072.974 & 0.000\end{array}$ $\begin{array}{lllllllllllll}100 & 70.67 & 26.55 & 33.22 & 2 & 1704.9514 & 1704.9510 & 853.4828 & 0.0004 & 0.2343 & 5495.658 & 5899.802 & 628.808\end{array}$ $\begin{array}{lllllllllllllll}1.00 & 75.15 & 26.55 & 28.40 & 2 & 1704.9514 & 1704.9510 & 853.4828 & 0.0004 & 0.2343 & 10809.495 & 9287.872 & 1063.021\end{array}$ $\begin{array}{lllllllllllllll}1.00 & 46.31 & 26.42 & 21.46 & 3 & 1704.9526 & 1704.9510 & 569.3243 & 0.0016 & 0.9368 & 581.646 & 752.197 & 77.820\end{array}$ $\begin{array}{lllllllllll} & \end{array}$ $\begin{array}{lllllllllllll}100 & 71.94 & 21.85 & 31.17 & 2 & 1646.0012 & 1646.0011 & 824.0078 & 0.0001 & 0.0607 & 5584.130 & 6061.625\end{array}$ $\begin{array}{lllllllllllll}100 & 71.72 & 21.85 & 32.23 & 2 & 16460020 & 1646.0011 & 824.0078 & 0.0009 & 0.5461 & 9280.424 & 7997.440 & 28\end{array}$ $\begin{array}{lllllllll} & \end{array}$ $\begin{array}{llllllllllllll}0.53 & 33.83 & 21.52 & 46.83 & 3 & 1646.0038 & 1646.0011 & 549.6743 & 0.0027 & 1.6373 & 5540.894 & 6006.261 & 126.025\end{array}$ $\begin{array}{llllllllllllll}1.00 & 68.24 & 26.50 & 34.74 & 2 & 1704.9504 & 1704.9510 & 853.4828 & -0.0006 & -0.3515 & 6350.053 & 4784.876 & 962.050\end{array}$ $\begin{array}{llllllllllllll}1.00 & 83.87 & 26.71 & 37.43 & 2 & 1704.9524 & 1704.9510 & 853.4828 & 0.0014 & 0.8202 & 6819.697 & 6359.584 & 762.015\end{array}$ $\begin{array}{llllllllllllll}1.00 & 83.87 & 26.71 & 37.43 & 2 & 1704.9524 & 1704.9510 & 853.4828 & 0.0014 & 0.8202 & 6819.697 & 359.584\end{array}$

IITLAGPTNAIFK $\begin{array}{lllllllllllllll}0.55 & 26.50 & 21.49 & 39.50 & 3 & 1646.0032 & 1646.0011 & 549.6743 & 0.0021 & 1.2735 & 625.857 & 635.909 & 55.873\end{array}$ $\begin{array}{llllllllllllll}0.53 & 25.25 & 21.55 & 38.25 & 3 & 1646.0044 & 1646.0011 & 549.6743 & 0.0033 & 2.0012 & 346.339 & 288.232\end{array}$

LVPASQCGSLIGK $\begin{array}{llllllllllll}0.62 & 13.43 & 26.40 & 16.07 & 3 & 1704.9547 & 1704.9510 & 569.3243 & 0.0037 & 2.1663 & 210.009 & 185.520\end{array}$ $\begin{array}{llllllllllllll}\text { QVTITGSAASISLAQYLINVR } & 0.53 & 32.86 & 24.31 & 45.86 & 3 & 2348.3218 & 2348.3185 & 783.7801 & 0.0033 & 1.4035 & 11.019 & 8.467 \\ \text { QVTITGSAASISLAQYLINVR } & 0.55 & 30.37 & 24.27 & 43.37 & 3 & 2348.3209 & 2348.3185 & 783.7801 & 0.0024 & 1.0207 & 2.243 & 0.000\end{array}$ QQTNTLLNLVWR 

$\begin{array}{llllllllllllllll}1.00 & 39.78 & 27.35 & 21.17 & 2 & 1096.5660 & 1096.5643 & 549.2894 & 0.0017 & 1.5475 & 10260.410 & 10461.814 & 248.387 & & & \\ \end{array}$ $\begin{array}{lllllllllllll}0.99 & 34.70 & 25.13 & 20.63 & 2 & 1033.6416 & 1033.6406 & 517.8276 & 0.0010 & 0.9656 & 6136.892 & 6375.449 & 193.678\end{array}$ $\begin{array}{lllllllllllll}0.99 & 36.31 & 25.11 & 21.87 & 2 & 1033.6422 & 1033.6406 & 517.8276 & 0.0016 & 1.5449 & 4355.885 & 4704.862 & 263.247\end{array}$ $\begin{array}{llllllllllllllll} & & 60.83 & 27.55 & 27.09 & 2 & 1441.7882 & 1441.7873 & 721.9009 & 0.0009 & 0.6234 & 3528.399 & 3621.032 & 46.202 \\ \text { GHR } & 0.93 & 13.48 & 27.50 & 20.05 & 4 & 1822.9933 & 1822.9924 & 456.7554 & 0.0009 & 0.4926 & 641.561 & 609.394 & 224.780\end{array}$

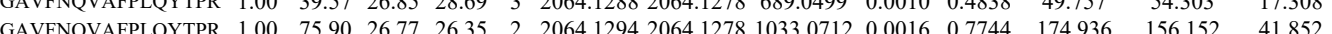
$\begin{array}{llllllllllllll}\text { LGAVFNQVAFPLOYTPR } & 1.00 & 84.95 & 26.77 & 29.41 & 2 & 2064.1294 & 2064.1278 & 1033.0712 & 0.0016 & 0.7744 & 338.629 & 276.122 & 27.656\end{array}$ $\begin{array}{lllllllllllllll}\text { LGAVFNQVAFPLQYTPR } & 0.99 & 29.32 & 26.77 & 19.95 & 3 & 2064.1300 & 2064.1278 & 689.0499 & 0.0022 & 1.0643 & 56.047 & 64.530 & 34.140\end{array}$

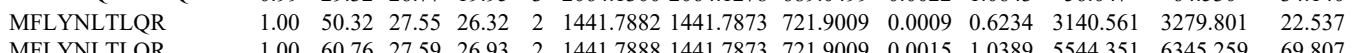
$\begin{array}{lllllllllllll}1.00 & 60.76 & 27.59 & 26.93 & 2 & 1441.7888 & 1441.7873 & 721.9009 & 0.0015 & 1.0389 & 5544.351 & 6345.259 & 69.807\end{array}$ $\begin{array}{llllllllllllll}\text { LGAVFNQVAFPLQYTPR } & 1.00 & 84.62 & 26.79 & 33.46 & 2 & 2064.1274 & 2064.1278 & 1033.0712 & -0.0004 & -0.1936 & 641.981 & 698.653 & 44.583\end{array}$ $\begin{array}{llllllllllllll}\text { LGAVFNQVAFPLQYTPR } & 1.00 & 86.83 & 26.77 & 27.12 & 2 & 2064.1294 & 2064.1278 & 1033.0712 & 0.0016 & 0.7744 & 531.110 & 369.011 & 37.827 \\ \end{array}$ $\begin{array}{llllllllllllllll}\text { LGAVFNQVAFPLQYTPR } & 1.00 & 34.46 & 26.76 & 19.40 & 3 & 2064.1297 & 2064.1278 & 689.0499 & 0.0019 & 0.9191 & 86.120 & & 1.901 & 21.278 \\ \text { LGAVFNOVAFPLOYTPR } & 0.92 & 20.00 & 26.59 & 16.63 & 3 & 2064.1306 & 2064.1278 & 689.0499 & 0.0028 & 1.3545 & 88.920 & 115.133 & 30.841\end{array}$ $\begin{array}{lllllllllllllll}\text { MFLYNLTLQR } & 1.00 & 60.36 & 27.44 & 26.46 & 2 & 1441.7874 & 1441.7873 & 721.9009 & 0.0001 & 0.0693 & 625.078 & 642.338 & 28.636 \\ \text { MFLYNLTLQR } & 1.00 & 62.52 & 27.53 & 26.94 & 2 & 1441.7788 & 1441.7873 & 721.9009 & 0.0005 & 0.3463 & 667.253 & 684.213 & 12.480\end{array}$ $\begin{array}{lllllllllllllll}\text { MFLYNLTLQR } & 1.00 & 62.52 & 27.53 & 26.94 & 2 & 1441.7878 & 1441.7873 & 721.9009 & 0.0005 & 0.3463 & 667.253 & 684.213 & 12.480 \\ \text { LANFNQVAFPLYTRR } & 1.00 & 86.83 & 2.79 & 29.33 & 2 & 206.1274 & 20641278 & 1033.0712 & 0.0004 & -0.1936 & 153.253 & 154.555 & 16.657\end{array}$ \begin{tabular}{llllllllllllll} 
LGAVFNQVAFPLQYTPR & 1.00 & 86.83 & 26.79 & 29.33 & 2 & 2064.1274 & 2064.1278 & 1033.0712 & -0.0004 & -0.1936 & 153.253 & 154.555 & 16.657 \\
\hline
\end{tabular} \begin{tabular}{llllllllllllllll} 
LGAVFNQVAFPLQYTPR & 1.00 & 91.74 & 26.77 & 27.64 & 2 & 2064.1294 & 2064.1278 & 1033.0712 & 0.0016 & 0.7744 & 93.469 & 116.067 & 8.002 \\
\hline LAVFNQVAFPLYTPR & 0.87 & 19.56 & 26.59 & 26.51 & 3 & 2064.1303 & 2064.1278 & 689.0499 & 0.0025 & 1.2094 & 98.501 & 170.618 & 10.322
\end{tabular} $\begin{array}{lllllllllllllll}\text { LGAVFNQVAFPLQYTPR } & 0.87 & 19.56 & 26.59 & 26.51 & 3 & 2064.1303 & 2064.1278 & 689.0499 & 0.0025 & 1.2094 & 98.501 & 170.618 & 10.322 \\ \text { LGAVFNQVAFPLQYTPR } & 1.00 & 31.94 & 26.59 & 25.91 & 3 & 2064.1303 & 2064.1278 & 689.0499 & 0.0025 & 1.2094 & 58.753 & 85.000 & 5.344\end{array}$

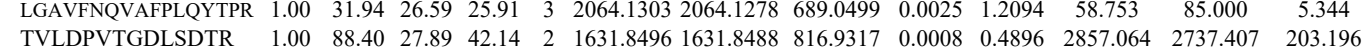
$\begin{array}{llllllllllllll}\text { TVLDPVTGDLSDTR } & 1.00 & 88.40 & 27.89 & 42.14 & 2 & 1631.8496 & 1631.8488 & 816.9317 & 0.0008 & 0.4896 & 2857.064 & 2737.407 & 203.196 \\ \text { TVLDPVTGDLSDTR } & 1.00 & 94.54 & 27.85 & 38.80 & 2 & 1631.8510 & 1631.8488 & 816.9317 & 0.0022 & 1.3465 & 2662.539 & 2965.871 & 143.683\end{array}$ $\begin{array}{llllllllllllll}\text { TVLDPVTGLSDTR } & 1.00 & 94.54 & 27.85 & 38.80 & 2 & 1631.8510 & 1631.8488 & 816.9317 & 0.0022 & 1.3465 & 2662.539 & 2965.871 & 143.683\end{array}$ $\begin{array}{lllllllllllllll}\text { TVLDPVTGDLSDTR } & 1.00 & 62.84 & 27.84 & 30.07 & 2 & 1631.8490 & 1631.8488 & 816.9317 & 0.0002 & 0.1224 & 857.316 & 575.624 & 90.838\end{array}$

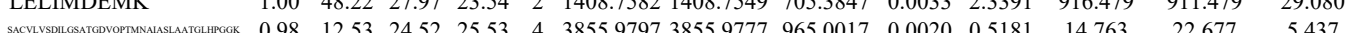

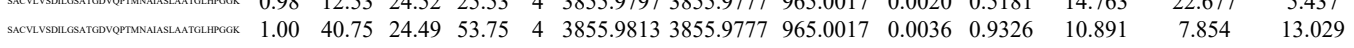

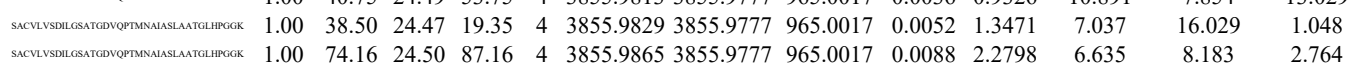

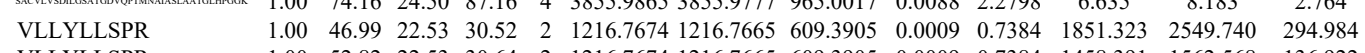
$\begin{array}{llllllllllllll}\text { VLLYLLSPR } & 1.00 & 52.82 & 22.53 & 30.64 & 2 & 1216.7674 & 1216.7665 & 609.3905 & 0.0009 & 0.7384 & 1458.391 & 1562.568 & 136.922\end{array}$ $\begin{array}{llllllllllllll}\text { VLLYLLSPR } & 1.00 & 47.93 & 22.50 & 32.51 & 2 & 1216.7670 & 1216.7665 & 69.5905 & 0.0005 & 0.4102 & 1176.847 & 1418.023 & 52.653\end{array}$ $\begin{array}{llllllllllllll}\text { QAFEELRDDLVELSK } & 0.73 & 32.58 & 27.25 & 19.05 & 3 & 2079.1147 & 2079.1091 & 694.0436 & 0.0056 & 2.6895 & 4235.462 & 3200.389 & 258.286\end{array}$

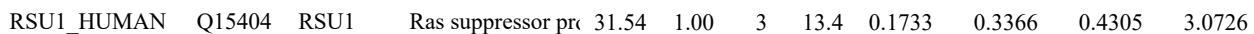

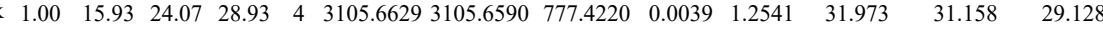

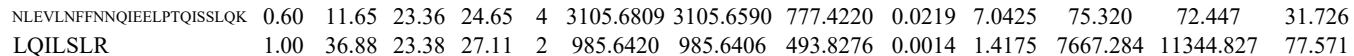
LQILSLR LQILSLR KPLAAK

10 GASQAGMLAPGTR GASQAGMLAPGTR GASQAGMLAPGTR $\begin{array}{lllllllllllll}67.69 & 27.92 & 29.15 & 2 & 1359.7048 & 1359.7051 & 680.8598 & -0.0003 & -0.2203 & 2420.423 & 2565.627 & 2565.389 & 21\end{array}$

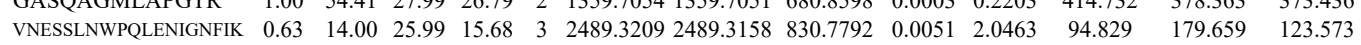
$\begin{array}{lllllllllllllll}\text { VNESSLNWPQLENIGNFIK } & 1.00 & 68.41 & 25.95 & 20.87 & 2 & 2489.3214 & 2489.3158 & 1245.6652 & 0.0056 & 2.2478 & 17.013 & 20.611 & 10.124\end{array}$ GMSVYGLGR GMSVYGLGR GMSVYGLGR FDFDACNEVPPAPK ILDILGETCK ILDILGETCK ILDILGETCK ILDILGETCK NFWVSGLSSTTR NFWVSGLSSTTR $\begin{array}{lllllllllllll}1.00 & 34.86 & 23.34 & 27.03 & 2 & 985.6428 & 9856406 & 493.8276 & 0.002 & 2.2275 & 7418.954 & 10576.267 & 142.492\end{array}$ $\begin{array}{lllllllllllllll}0.89 & 23.99 & 23.20 & 28.75 & 2 & 985.6408 & 985.6406 & 493.8276 & 0.0002 & 0.2025 & 2302.651 & 3240.168 & 214.782\end{array}$ $\begin{array}{lllllllllllllll}0.61 & 5.72 & 11.76 & 18.72 & 2 & 1058.7174 & 1058.7177 & 530.3661 & -0.0003 & -0.2828 & 203.566 & 181.984 & 346.785\end{array}$ $\begin{array}{lllllllllllll}1.00 & 72.50 & 27.92 & 33.33 & 2 & 1359.7068 & 1359.7051 & 680.8598 & 0.0017 & 1.2484 & 2486.906 & 2342.744 & 3109.198\end{array}$ $\begin{array}{lllllllllllll}1.00 & 54.45 & 27.73 & 27.92 & 2 & 1359.7080 & 1359.7051 & 680.8598 & 0.0029 & 2.1297 & 778.873 & 753.250 & 605.419\end{array}$

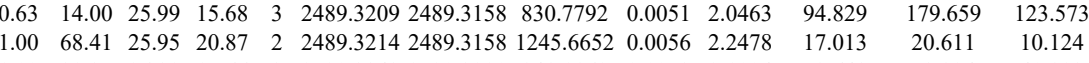

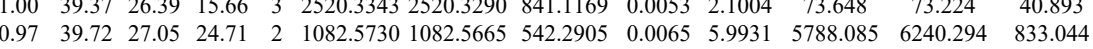
$\begin{array}{lllllllllllll}0.91 & 33.86 & 27.09 & 20.76 & 2 & 1082.5726 & 1082.5665 & 542.2905 & 0.0061 & 5.6243 & 1771.587 & 1534.040 & 406.398\end{array}$ $\begin{array}{llllllllllllll}0.94 & 35.92 & 27.05 & 23.98 & 2 & 1082.5732 & 1082.5665 & 542.2905 & 0.0067 & 6.1775 & 8438.765 & 9336.143 & 777.705\end{array}$ $\begin{array}{lllllllllllll}0.99 & 30.72 & 26.66 & 19.12 & 3 & 1882.8850 & 1882.8837 & 628.6352 & 0.0013 & 0.6893 & 43.836 & 61.762 & 40.686\end{array}$ $\begin{array}{lllllllllllll}0.97 & 50.80 & 27.36 & 47.59 & 2 & 1437.7856 & 1437.7815 & 719.8980 & 0.0041 & 2.8476 & 589.185 & 544.184 & 20.259\end{array}$ $\begin{array}{lllllllllllll}0.99 & 58.46 & 27.48 & 46.78 & 2 & 1437.7864 & 1437.7815 & 719.8980 & 0.0049 & 3.4032 & 794.688 & 837.607 & 31.803\end{array}$

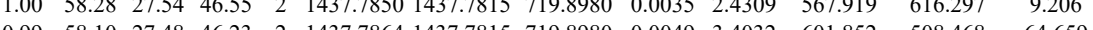

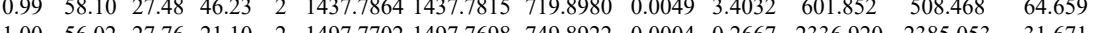

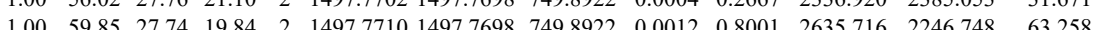

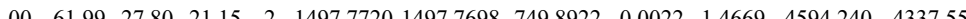


$\begin{array}{lllllllllll}0.93 & 17.29 & 23.34 & 20.53 & 3 & 200.2421 & 200.2387 & 734.4202 & 0.0034 & 1.5432 & 14.208\end{array}$

$\begin{array}{lllllllllll}.00 & 54.43 & 28.67 & 19.31 & 2 & 1447.7654 & 1447.7654 & 724.8900 & 0.0000 & 0.0000 & 26.46\end{array}$

AQEPSAAIPK

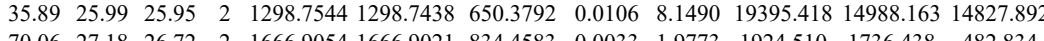

$\begin{array}{llllllllllllllll}1.00 & 70.06 & 27.18 & 26.72 & 2 & 1666.9054 & 1666.9021 & 834.4583 & 0.0033 & 1.9773 & 1924.510 & 1736.438 & 482.834 & 65.5701\end{array}$ $\begin{array}{llllllllllllllll}0.99 & 41.64 & 25.83 & 31.50 & 2 & 1298.7526 & 1298.7438 & 650.3792 & 0.0088 & 6.7652 & 11581.856 & 11999.077 & 7108.076 & 5393.518 & Y & \end{array}$

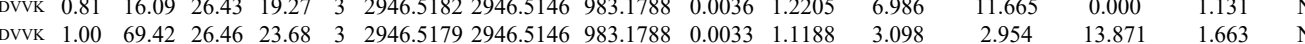
$\begin{array}{llllllllllllllll}\text { EPPPEFEFIADPPSISAFDLDVVK } & 1.00 & 32.97 & 26.43 & 16.20 & 3 & 2946.5182 & 2946.5146 & 983.1788 & 0.0036 & 1.2205 & 13.367 & 3.545 & 3.597 & 1.565 & \text { Yes }\end{array}$

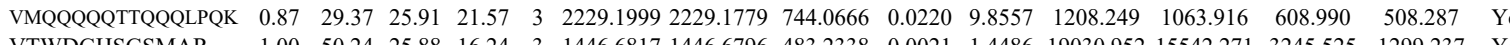
$\begin{array}{lllllllllllllllll}\text { VTWDGHSGSMAR } & 1.00 & 50.24 & 25.88 & 16.24 & 3 & 1446.6817 & 1446.6796 & 483.2338 & 0.0021 & 1.4486 & 19030.952 & 15542.271 & 3245.525 & 1299.237 & \text { Yes }\end{array}$ $\begin{array}{llllllllllllllll}\text { VTWDGHSGSMAR } & 0.95 & 20.73 & 25.83 & 17.42 & 3 & 1446.6826 & 1446.6796 & 483.2338 & 0.0030 & 2.0694 & 471.623 & 454.226 & 338.995 & 127.564 & \text { Yes }\end{array}$

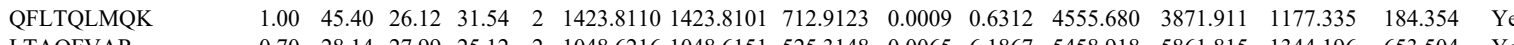

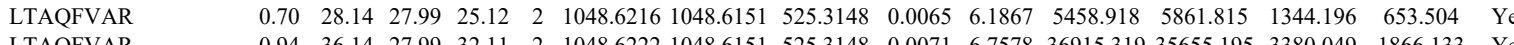

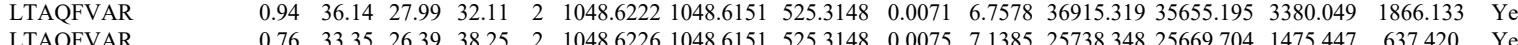

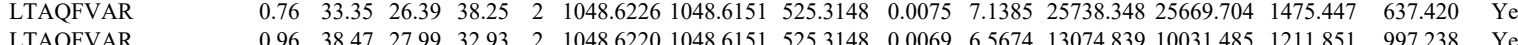

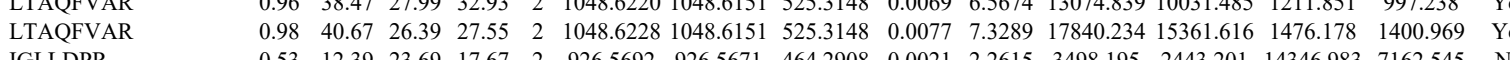

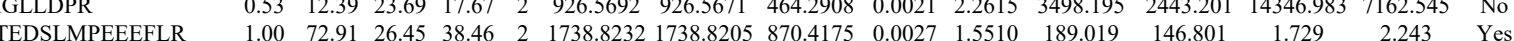

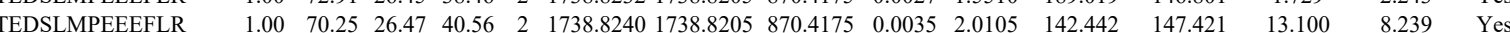
$\begin{array}{lllllllllllllllll}\text { IGEEEIQKPEEK } & 0.65 & 22.19 & 25.93 & 25.72 & 3 & 1860.0310 & 1860.0205 & 621.0141 & 0.0105 & 5.6359 & 19824.086 & 19625.988 & 11913.349 & 9361.605 & \text { Yes }\end{array}$

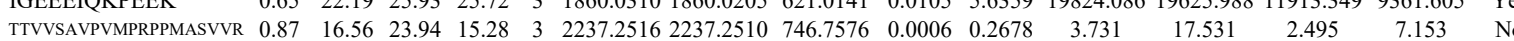

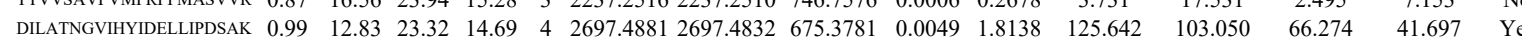

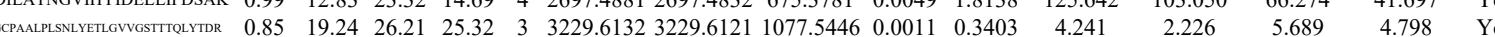

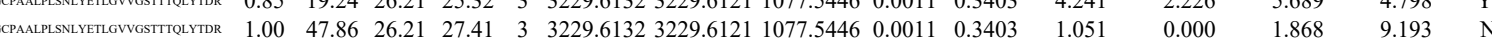

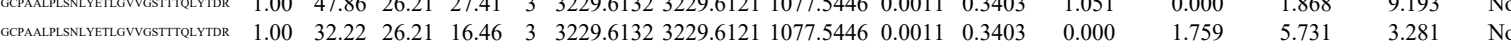

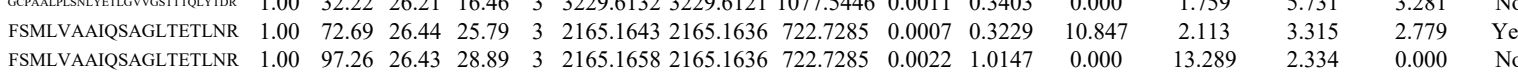

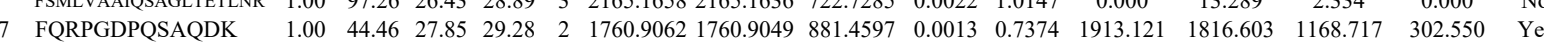
$\begin{array}{lllllllllllllllll}\text { FQRPGDPQSAQDK } & 1.00 & 53.75 & 27.85 & 25.48 & 2 & 1760.9064 & 1760.9049 & 881.4597 & 0.0015 & 0.8509 & 835.183 & 748.647 & 361.697 & 213.565 & \text { Yes }\end{array}$

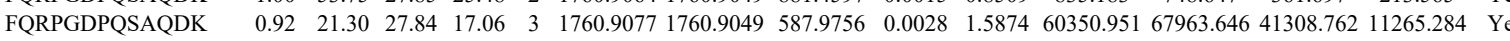
$\begin{array}{llllllllllllllll}\text { FQRPGDPQSAQDK } & 1.00 & 33.86 & 27.84 & 24.14 & 3 & 1760.9077 & 1760.9049 & 587.9756 & 0.0028 & 1.5874 & 18746.001 & 19768.269 & 11156.566 & 4258.528 & \text { Yes }\end{array}$

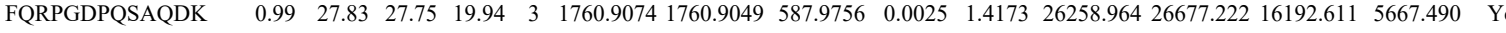

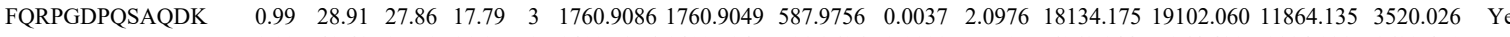
66.607 $5264.430-2884.038 \quad 1632.470 \quad \mathrm{No}$

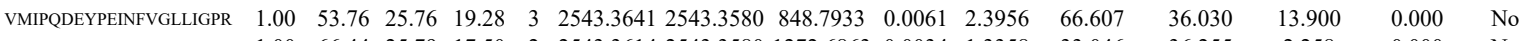

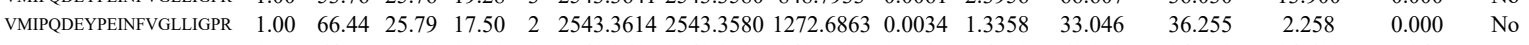

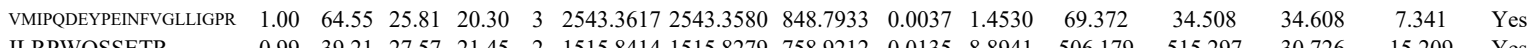

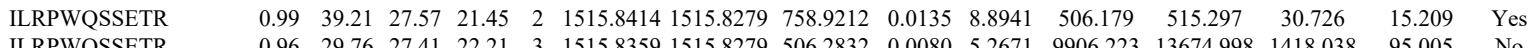
$\begin{array}{llllllllllllllll}\text { ILRPWQSSETR } & 0.96 & 29.76 & 27.41 & 22.21 & 3 & 1515.8359 & 1515.8279 & 506.2832 & 0.0080 & 5.2671 & 9906.223 & 13674.998 & 1418.038 & 95.005 & \text { No } \\ \text { ILRPWQSSETR } & 0.71 & 21.33 & 27.35 & 20.73 & 3 & 1515.8365 & 1515.8279 & 5062832 & 0.0086 & 5.6621 & 1889.725 & 1981.165 & 418.169 & 143013 & \text { Yes }\end{array}$ $\begin{array}{lccccccccccccccc}\text { ILRPWQSSETR } & 0.71 & 21.33 & 27.35 & 20.73 & 3 & 1515.8365 & 1515.8279 & 506.2832 & 0.0086 & 5.6621 & 1889.725 & 1981.165 & 418.169 & 143.013 & \text { Yes } \\ \text { TVIPGMPTVIPPGLTR } & 1.00 & 69.94 & 23.28 & 26.70 & 2 & 1792.0414 & 1792.0403 & 897.0274 & 0.0011 & 0.6131 & 162.892 & 195.867 & 121.273 & 12719 & \text { Yes }\end{array}$

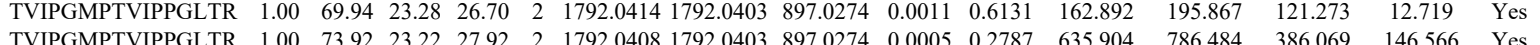
$\begin{array}{lllllllllllllll} & \end{array}$ $\begin{array}{llllllllllllllll}\text { TVIPGMPTVIPPGLTR } & 1.00 & 64.04 & 23.28 & 31.62 & 2 & 1792.0414 & 1792.0403 & 897.0274 & 0.0011 & 0.6131 & 236.580 & 275.462 & 201.619 & 37.465 & \text { Yes } \\ \text { TVIPGMPTVIPPGLTR } & 1.00 & 65.02 & 23.24 & 29.01 & 2 & 1792.0400 & 1792.0403 & 897.0274 & -0.0003 & -0.1672 & 730.969 & 557.004 & 514.961 & 95.034 & \text { Yes }\end{array}$ $\begin{array}{llllllllllllllll}\text { TVIPGMPTVIPPGLTR } & 1.00 & 78.35 & 23.22 & 33.65 & 2 & 1792.0406 & 1792.0403 & 897.0274 & 0.0003 & 0.1672 & 307.302 & 357.561 & 268.666 & 44.166 & \text { Yes }\end{array}$

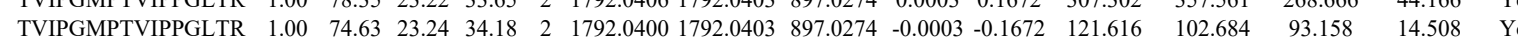




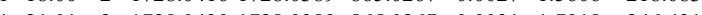

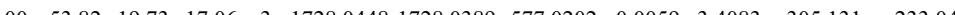

$\begin{array}{llllllllll} & \end{array}$

LSLLLNDISR

CQIIYPR

255.140

CQIIYPR

$\begin{array}{lllllllllllll}53.97 & 24.64 & 34.33 & 2 & 1286.7726 & 1286 & 04680 & 644.3913 & 0.0046 & 3.5692 & 455.034 & 579.038 & 24.069\end{array}$

$\begin{array}{lllllllllllll}0.98 & 39.03 & 27.38 & 18.68 & 2 & 1081.5630 & 1081.5534 & 541.7840 & 0.0096 & 8.8595 & 14759.738 & 16473.728 & 2491.853\end{array}$

$\begin{array}{llllllllllllllll}0.98 & 37.66 & 27.06 & 23.05 & 2 & 1081.5638 & 1081.5534 & 541.7840 & 0.0104 & 9.5978 & 11093.760 & 12706.766 & 589.741\end{array}$

\begin{tabular}{lllllllllllllll}
\hline GTPGPPAHGAALOPHPR & 1.00 & 92.58 & 27.51 & 25.62 & 2 & 1901.0144 & 1901.0142 & 951.5144 & 0.0002 & 0.1051 & 123.724 & 60.164 & 56.564 & 37.953
\end{tabular} $\begin{array}{llllllllllllllll}\text { GTPGPPPAHGAALQPHPR } & 1.00 & 79.61 & 27.57 & 92.61 & 4 & 1901.0165 & 1901.0142 & 476.2608 & 0.0023 & 1.2073 & 3212.399 & 2824.158 & 1290.346 & 1176.554 & \text { Y }\end{array}$ $\begin{array}{llllllllllllllllll}\text { GTPGPPAHGAALQPHPR } & 1.00 & 73.11 & 27.39 & 86.11 & 4 & 1901.0205 & 1901.0142 & 476.2608 & 0.0063 & 3.3070 & 6883.401 & 7173.538 & 3841.781 & 3062.847 & \text { Yes }\end{array}$ $\begin{array}{llllllllllllllll}\text { GTPGPPPAHGAALOPHPR } & 1.00 & 60.32 & 27.54 & 19.12 & 4 & 1901.0153 & 1901.0142 & 476.2608 & 0.0011 & 0.5774 & 6252.761 & 6488.326 & 3323.242 & 2059.856 & \text { Yes }\end{array}$ $\begin{array}{lllllllllllllllll}\text { GTPGPPPAHGAALQPHPR } & 1.00 & 69.17 & 27.53 & 21.36 & 4 & 1901.0157 & 1901.0142 & 476.2608 & 0.0015 & 0.7874 & 2509.065 & 2096.180 & 1703.245 & 1133.391 & \text { Yes }\end{array}$ $\begin{array}{llllllllllllllllll}\text { GTPGPPAHGAALQPHPR } & 1.00 & 68.97 & 27.53 & 81.97 & 4 & 1901.0157 & 1901.0142 & 476.2608 & 0.0015 & 0.7874 & 1943.839 & 2314.766 & 1228.157 & 832.392 & \text { Yes }\end{array}$ $\begin{array}{llllllllllllllllll}\text { GTPGPPAHGAALQPHPR } & 1.00 & 48.51 & 27.57 & 18.03 & 4 & 1901.0161 & 1901.0142 & 476.2608 & 0.0019 & 0.9974 & 2959.027 & 2385.637 & 1054.183 & 783.366 & \text { Yes }\end{array}$ $\begin{array}{lllllllllllllllll}\text { GTPGPPPAHGAALQPHPR } & 1.00 & 70.66 & 27.44 & 83.66 & 4 & 1901.0169 & 1901.0142 & 476.2608 & 0.0027 & 1.4173 & 1240.734 & 1213.348 & 834.692 & 646.961 & \text { Yes }\end{array}$ $\begin{array}{llllllllllllllll}\text { GASQASGPLPGPHFPLPGR } & 1.00 & 70.01 & 27.08 & 23.42 & 3 & 1986.0634 & 1986.0557 & 663.0258 & 0.0077 & 3.8711 & 2295.338 & 3068.535 & 1392.613 & 972.539 & \text { Yes }\end{array}$ $\begin{array}{lllllllllllllllll}\text { NPGVNGDDEAAELMQQVNVLK } & 1.00 & 49.01 & 27.02 & 20.73 & 3 & 2585.2990 & 2585.2999 & 862.7739 & -0.0009 & -0.3477 & 11.820 & 26.542 & 24.033 & 8.055 & \text { Yes }\end{array}$ $\begin{array}{llllllllllllllll}\text { KNPGVGNGDEAAELMQQVNVLK } & 1.00 & 46.13 & 25.69 & 59.13 & 4 & 2857.5021 & 2857.4969 & 715.3815 & 0.0052 & 1.8172 & 24.399 & 41.065 & 15.315 & 53.145 & \text { No } \\ \text { AGPGVVR } & 0.61 & 17.03 & 21.93 & 30.03 & 2 & 798.4832 & 798.4834 & 000.940 & 0.0002 & 0.2498 & 132399 & 96.627 & 50.942 & 23.282 & \text { Yes }\end{array}$

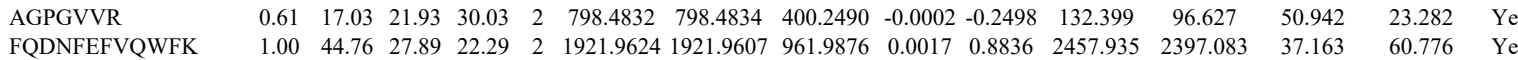
$\begin{array}{llllllllllllllll}\text { FQDNFEFVQWFK } & 1.00 & 44.76 & 27.89 & 22.29 & 2 & 1921.9624 & 1921.9607 & 961.9876 & 0.0017 & 0.8836 & 2457.935 & 2397.083 & 37.163 & 60.776 & \text { Yes } \\ \text { FQDNFEFVQWFK } & 1.00 & 57.77 & 27.90 & 20.00 & 2 & 1921.9636 & 1921.9607 & 961.9876 & 0.0029 & 1.5073 & 1835.470 & 1850.637 & 67.759 & 65.401 & \text { Yes }\end{array}$ ILQAGFK ILQAGFK

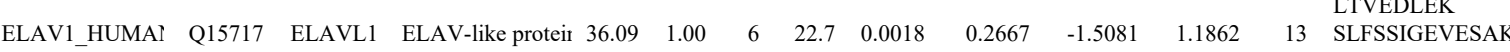
SLFSSIGEVESAK FAANPNQNK

VLVDQTTGLSR $\begin{array}{llllllllllllllll}0.91 & 41.01 & 24.28 & 41.66 & 2 & 1063.6718 & 1063.6633 & 532.8389 & 0.0085 & 7.9761 & 18834.976 & 16321.599 & 861.313 & 740.046 & \text { Yes } & \\ \end{array}$ $\begin{array}{lllllllllllllll}0.69 & 30.51 & 24.23 & 38.58 & 2 & 1063.6726 & 1063.6633 & 532.8389 & 0.0093 & 8.7268 & 27595.298 & 27588.570 & 1638.359 & 906.909 & \text { Yes }\end{array}$

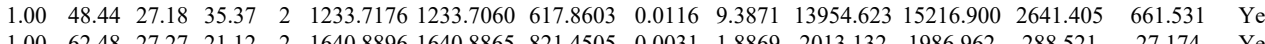

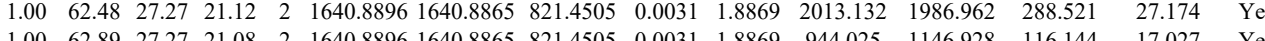
$\begin{array}{lllllllllllllll}1.00 & 62.89 & 27.27 & 21.08 & 2 & 1640.8896 & 1640.8865 & 821.4505 & 0.0031 & 1.8869 & 944.025 & 1146.928 & 116.144 & 17.027 & Y e s\end{array}$ $\begin{array}{llllllllllllllll}\text { TNLIVNYLPQNMTODELR } & 1.00 & 70.45 & 27.40 & 23.80 & 2 & 2305.1934 & 2305.1858 & 1153.6002 & 0.0076 & 3.2940 & 117.475 & 89.382 & 51.848 & 5.300 & \text { Yes }\end{array}$

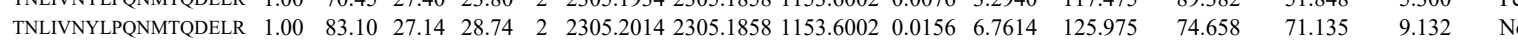
AINTLNGLR AINTLNGLR AINTLNGLR AINTLNGLR NVALLSQLYHSPAR NVALLSQLYHSPAR NVALLSQLYHSPAR

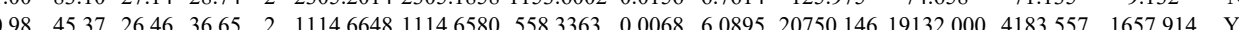
$\begin{array}{llllllllllllllll}0.98 & 43.11 & 26.46 & 36.31 & 2 & 1114.6650 & 1114.6580 & 558.3363 & 0.0070 & 6.2686 & 18277.444 & 15850.507 & 5018.980 & 1628.154 & \mathrm{Y} s \mathrm{~s}\end{array}$ $\begin{array}{lllllllllllllllll}0.99 & 45.39 & 26.42 & 33.19 & 2 & 114.6654 & 114.6580 & 558.3363 & 0.0074 & 6.6268 & 20995281 & 17549.279 & 6075.427 & 1156.904 & \text { Yes }\end{array}$ $\begin{array}{llllllllllllllllll}0.91 & 38.71 & 26.42 & 38.40 & 2 & 1114.6654 & 1114.6580 & 558.3363 & 0.0074 & 6.62268 & 26461.758 & 27635.728 & 6422.474 & 2180.971 & \text { Yes }\end{array}$

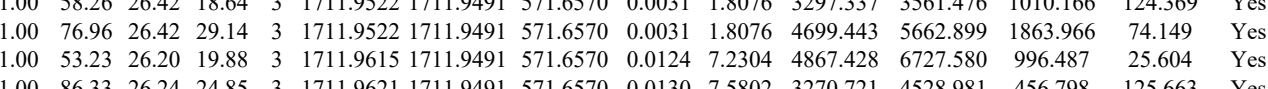
$\begin{array}{llllllllllllllll} & 1.00 \\ 1.06 .33 & 26.24 & 24.85 & 3 & 171.9621 & 171.19491 & 571.6570 & 0.0130 & 7.5802 & 3270.721 & 4528.981 & 456.798 & 125.663 & \text { Yes } & \\ & 1.00 & 60.36 & 23.14 & 17.89 & 2 & 2445.3634 & 2445.3610 & 1223.6878 & 0.0024 & 0.9806 & 13.391 & 15.833 & 21.749 & 31.164 & \text { Yes }\end{array}$

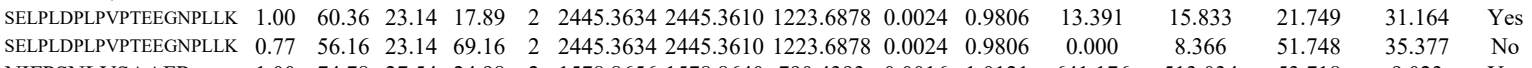
$\begin{array}{llllllllllllllll}1.00 & 74.78 & 27.54 & 24.98 & 2 & 1578.8656 & 1578.8640 & 790.4393 & 0.0016 & 1.0121 & 641.176 & 513.034 & 53.718 & 9.023 & \text { Yes }\end{array}$ $\begin{array}{lllllllllllllllll}\text { NIFPSNLVSAAFR } & 1.00 & 67.17 & 27.54 & 24.04 & 2 & 1578.8658 & 1578.8640 & 790.4393 & 0.0018 & 1.1386 & 476.357 & 409.602 & 44.683 & 4.599 & \text { Yes }\end{array}$

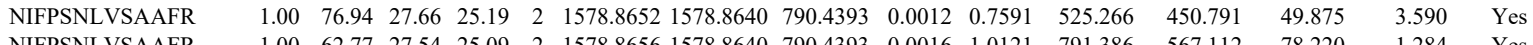

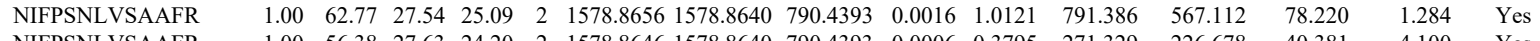

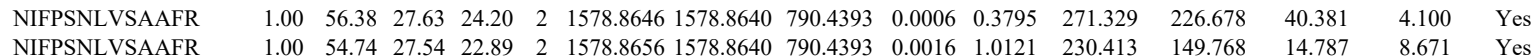
$\begin{array}{lllllllllllllllll} & \text { NIFSNLVAAFR } & 1.00 & 54.74 & 27.54 & 22.89 & 2 & 1578.8656 & 1578.8640 & 790.4393 & 0.0016 & 1.0121 & 230.413 & 149.768 & 14.787 & 8.671 & \text { Yes }\end{array}$

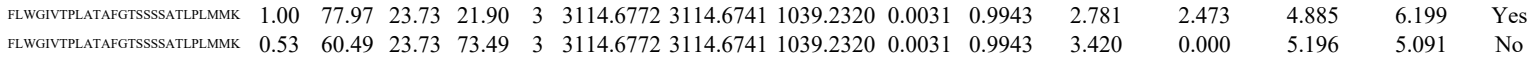

SSFADISNLLQIEPR LPSIPLVPVSAQK LPSIPLVPVSAQK LPSIPLVPVSAQK LPSIPLVPVSAQK

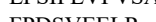
FPDSVEELR $\begin{array}{llllllllllllll}1.00 & \# \# \# \# 27.66 & 32.12 & 2 & 1832.9770 & 1832.9754 & 917.4950 & 0.0016 & 0.8719 & 1158.890 & 1055.387 & 383.250 & 36.824 & \text { Y }\end{array}$

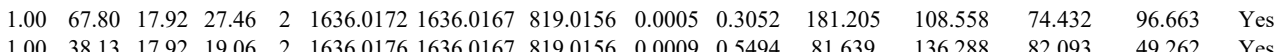
$\begin{array}{lllllllllllllll}1.00 & 38.13 & 17.92 & 19.06 & 2 & 1636.0176 & 1636.0167 & 819.0156 & 0.0009 & 0.5494 & 81.639 & 136.288 & 82.093 & 49.262 & \text { Yes } \\ 1.00 & 58.82 & 17.92 & 21.63 & 2 & 1636.0182 & 1636.0167 & 819.0156 & 0.0015 & 0.9157 & 422.951 & 281.005 & 292.439 & 214.126 & \text { Yes }\end{array}$

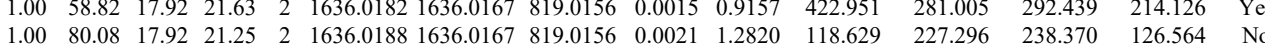
$\begin{array}{lllllllllllllll}1.00 & 80.08 & 17.92 & 21.25 & 2 & 1636.0188 & 1636.0167 & 819.0156 & 0.0021 & 1.2820 & 118.629 & 227.296 & 238.370 & 126.564 & \mathrm{No} \\ 1.00 & 47.09 & 17.92 & 20.46 & 2 & 1636.0178 & 1636.0167 & 819.0156 & 0.0011 & 0.6715 & 28.644 & 94.119 & 38.601 & 19.866 & \mathrm{No}\end{array}$

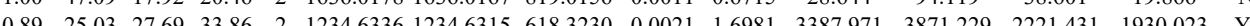

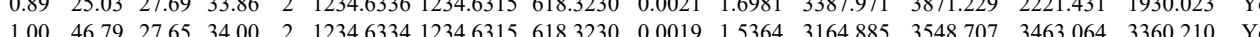




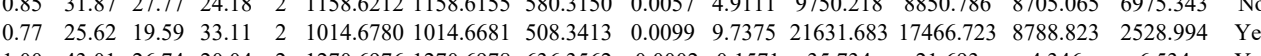

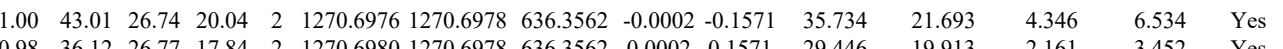

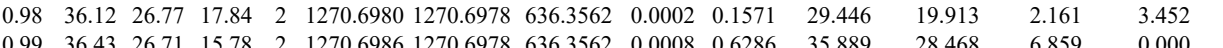

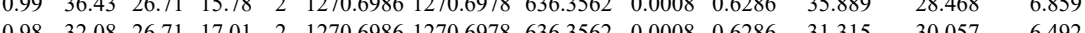

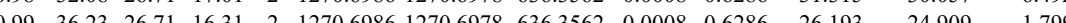

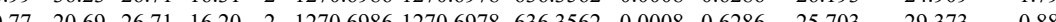
$\begin{array}{lllllllllllll}1.00 & 39.03 & 27.03 & 27.95 & 2 & 1270.6988 & 1270.6978 & 636.352 & 0.0010 & 0.7857 & 37.173 & 31.294 & 0.080\end{array}$

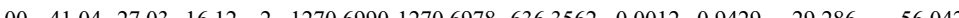
$\begin{array}{llllllllllllll}0.76 & 22.54 & 27.00 & 35.54 & 2 & 1270.6992 & 1270.6978 & 6363562 & 0.0014 & 1.1000 & 35.687 & 29.981\end{array}$ $\begin{array}{lllllllllllll}0.97 & 29.92 & 27.28 & 15.31 & 2 & 1270.6998 & 1270.6978 & 6363562 & 0.0020 & 1.5714 & 29.242 & 15.553\end{array}$

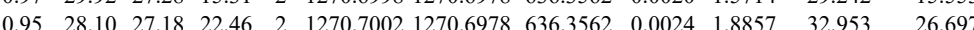
$\begin{array}{lllllllllllll}0.95 & 30.52 & 27.39 & 15.80 & 2 & 1270.7006 & 1270.6978 & 6363562 & 0.0028 & 2.2000 & 34.821 & 17.882\end{array}$ $\begin{array}{lllllllllllll}0.91 & 27.09 & 27.08 & 15.79 & 2 & 1270.7010 & 1270.6978 & 636.3562 & 0.0032 & 2.5143 & 31.981 & 17.804\end{array}$ $\begin{array}{lllllllllllll}1.00 & 43.48 & 27.10 & 19.20 & 2 & 1270.7012 & 1270.6978 & 6363562 & 0.0034 & 2.6715 & 30.172 & 36.101\end{array}$ $\begin{array}{lllllllllllll}0.83 & 27.74 & 27.11 & 17.32 & 2 & 1270.7016 & 1270.6978 & 6363562 & 0.0038 & 2.9857 & 23.345 & 36.101\end{array}$ $\begin{array}{lllllllllllll}0.93 & 31.49 & 26.93 & 23.61 & 2 & 1270.7018 & 1270.6978 & 636.3562 & 0.0040 & 3.1429 & 41.652 & 27.462\end{array}$ $\begin{array}{llllllllllllll}0.98 & 38.44 & 27.01 & 16.31 & 2 & 1270.7020 & 1270.6978 & 636.3562 & 0.0042 & 3.3000 & 44.884 & 28.012\end{array}$ $\begin{array}{lllllllllllll}0.98 & 32.30 & 27.00 & 20.71 & 2 & 1270.6994 & 1270.6978 & 636.3562 & 0.0016 & 1.2572 & 148.824 & 119.114\end{array}$ $\begin{array}{lllllllllllll}0.99 & 36.60 & 26.97 & 17.45 & 2 & 1270.6996 & 1270.6978 & 636.3562 & 0.0018 & 1.4143 & 140.790 & 99.02\end{array}$ $\begin{array}{lllllllllllllll}0.99 & 34.13 & 27.28 & 17.63 & 2 & 1270.6998 & 1270.6978 & 636.3562 & 0.0020 & 1.5714 & 120.858 & 87.574\end{array}$ $\begin{array}{lllllllllllll}1.00 & 47.88 & 27.18 & 18.81 & 2 & 1270.7002 & 1270.6978 & 636.3562 & 0.0024 & 1.8857 & 102.519 & 105.325\end{array}$ $\begin{array}{llllllllllll}1.00 & 43.61 & 27.18 & 19.61 & 2 & 1270.7002 & 1270.6978 & 636.3562 & 0.0024 & 1.8857 & 96.361 & 75.580\end{array}$ $\begin{array}{llllllllllllll}0.97 & 32.14 & 27.08 & 16.85 & 2 & 1270.7008 & 1270.6978 & 636.3562 & 0.0030 & 2.3572 & 161.539 & 117.629\end{array}$ $\begin{array}{lllllllllllll}1.00 & 43.56 & 27.08 & 19.77 & 2 & 1270.7010 & 1270.6978 & 636.3562 & 0.0032 & 2.5143 & 89.198 & 68.917\end{array}$ $\begin{array}{llllllllllllll}0.98 & 33.93 & 27.10 & 17.14 & 2 & 1270.7012 & 1270.6978 & 636.3562 & 0.0034 & 2.6715 & 99.038 & 81.696\end{array}$

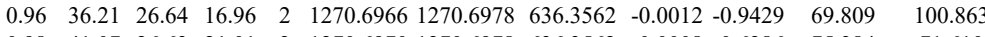
$\begin{array}{lllllllllllll}0.98 & 41.07 & 26.63 & 21.01 & 2 & 1270.6970 & 1270.6978 & 636.3562 & -0.0008 & -0.6286 & 75.384 & 71.610\end{array}$ $\begin{array}{lllllllllllll}1.00 & 45.06 & 26.71 & 18.99 & 2 & 1270.6986 & 1270.6978 & 636.3562 & 0.0008 & 0.6286 & 44.852 & 42.122 & 8.10 \\ 1.00 & 47.77 & 27.00 & 17.94 & 2 & 1270.6992 & 1270.6978 & 6363562 & 0.0014 & 1.1000 & 10846.824 & 9028.216 & 381.724\end{array}$

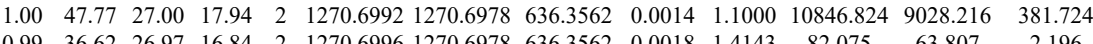

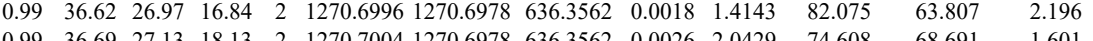
$\begin{array}{lllllllllllll}0.99 & 36.69 & 27.13 & 18.13 & 2 & 1270.7004 & 1270.6978 & 636.3562 & 0.0026 & 2.0429 & 74.608 & 68.691 & 1.601 \\ 0.99 & 35.52 & 27.08 & 20.17 & 2 & 1270.7008 & 1270.6978 & 636.3562 & 0.0030 & 2.3572 & 82.508 & 64.702 & 4.693\end{array}$

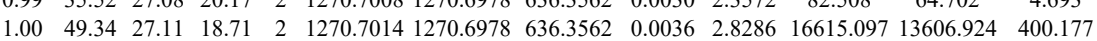
$\begin{array}{lllllllllllll}0.99 & 45.22 & 26.95 & 20.97 & 2 & 1270.7024 & 1270.6978 & 636.3562 & 0.0046 & 3.6143 & 79.007 & 67.075 & 7.160\end{array}$ $\begin{array}{lllllllllllll}0.92 & 34.10 & 27.07 & 17.00 & 2 & 1270.7036 & 1270.6978 & 636.3562 & 0.0058 & 4.5572 & 64.634 & 67.252 & 15.434\end{array}$ $\begin{array}{lllllllllllll}1.00 & 48.40 & 27.36 & 18.22 & 2 & 1286.6916 & 1286.6927 & 644.3536 & 0.0011 & -0.8536 & 6446.018 & 5349.704 & 17333.484\end{array}$ $\begin{array}{lllllllllllllll}1.00 & 46.47 & 27.78 & 22.34 & 2 & 1286.6940 & 1286.6927 & 644.3536 & 0.0013 & 1.0088 & 3878.179 & 3310.894 & 501.901 & 30 & \end{array}$ $\begin{array}{lllllllllllll}1.00 & 50.58 & 26.74 & 19.12 & 2 & 1270.6976 & 1270.6978 & 636.3562 & -0.0002 & -0.1571 & 3389.412 & 2878.402 & 67.635\end{array}$ $\begin{array}{llllllllllllll}1.00 & 49.31 & 27.00 & 24.38 & 2 & 1270.6992 & 1270.6978 & 636.3562 & 0.0014 & 1.1000 & 2477.833 & 2061.987 & 72.609\end{array}$ $\begin{array}{llllllllllllll}1.00 & 46.12 & 27.39 & 20.34 & 2 & 1286.6932 & 1286.6927 & 644.3536 & 0.0005 & 0.3880 & 1244.643 & 1222.684 & 119.241\end{array}$ $\begin{array}{llllllllllllll}1.00 & 42.47 & 27.78 & 23.40 & 2 & 1286.6938 & 1286.6927 & 644.3536 & 0.0011 & 0.8536 & 898.992 & 852.444 & 247.905\end{array}$ $\begin{array}{lllllllllllll}1.00 & 56.00 & 27.71 & 27.19 & 2 & 1474.8150 & 1474.8122 & 738.4134 & 0.0028 & 1.8960 & 1888.682 & 1953.605 & 3.354\end{array}$

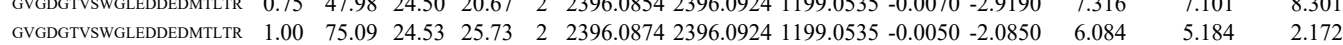
$\begin{array}{lllllllllllllll}\text { GVGDGTVSWGLEDDEDMTLTR } & 0.53 & 22.03 & 24.86 & 35.03 & 3 & 2396.0953 & 2396.0924 & 799.7047 & 0.0029 & 1.2088 & 17.406 & 19.682 & 11.919\end{array}$ $\begin{array}{lllllllllllll}\text { GVGDGTVSWGLEDDEDMTLTR } & 0.69 & 52.25 & 24.84 & 65.25 & 2 & 2396.0954 & 2396.0924 & 1199.0535 & 0.0030 & 1.2510 & 7.064\end{array}$ $\begin{array}{llllllllllll}\text { GVGDGISSWGEDDEDMILTR } & 1.00 & 60.30 & 24.84 & 19.60 & 2 & 2396.0954 & 2396.0924 & 1199.0535 & 0.0030 & 1.2510 & 5.449\end{array}$

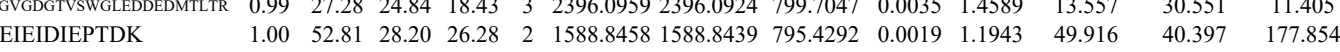
EIEIDIEPTDK $\begin{array}{lllllllllllllll} & \end{array}$ $\begin{array}{lllllllllllll}\text { ILGGSVLHLVLALR } & 1.00 & 54.92 & 15.31 & 18.80 & 2 & 1604.0254 & 1604.0259 & 803.0202 & -0.0005 & -0.3113 & 16.545 & 21.037\end{array}$

NEDD8_HUMA Q15843 NEDD8 NEDD8 $\begin{array}{lllllllll}9.07 & 1.00 & 2 & 30.9 & 0.1608 & 0.4518 & 0.3443 & 0.5559 & 3\end{array}$ ZYX_HUMAN Q15942 ZYX Zyxi $\begin{array}{llllllll}61.28 & 1.00 & 7 & 21 & 0.2342 & 0.5184 & 0.0498 & 0.9477\end{array}$

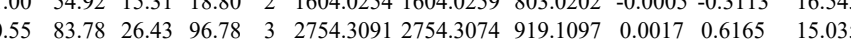

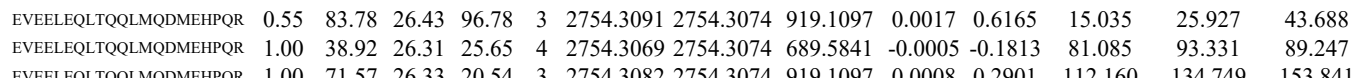
$\begin{array}{llllllllllllll}\text { EVEELELTQQLMQDMEHPQR } & 1.00 & 71.57 & 26.33 & 20.54 & 3 & 2754.3082 & 2754.3074 & 919.1097 & 0.0008 & 0.2901 & 112.160 & 134.749 & 153.841\end{array}$

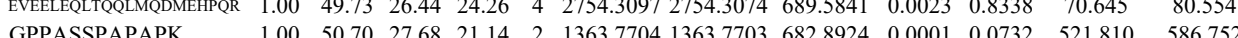
GPPASSPAPAPK GPPASSPAPAPK

$\begin{array}{llllllllllllll}1.00 & 50.70 & 27.68 & 21.14 & 2 & 1363.7704 & 1363.7703 & 682.8924 & 0.0001 & 0.0732 & 521.810 & 586.752 & 544.181 & 36 \\ \end{array}$

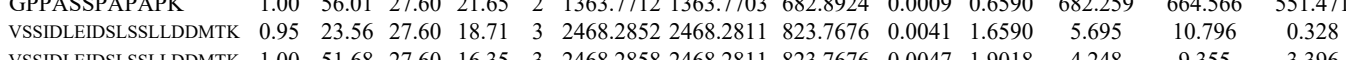

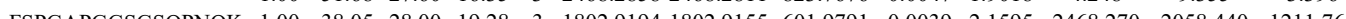
$\begin{array}{lllllllllllllll}\text { FSPGAPGGSGSQPNQK } & 1.00 & 51.31 & 27.96 & 18.39 & 3 & 1802.9206 & 1802.9155 & 601.9791 & 0.0051 & 2.8240 & 1644.046 & 2140.413 & 978.615\end{array}$ 
$\begin{array}{llllllllllll} & \end{array}$ $\begin{array}{llllllllllll}\text { QHPVPPPAQNQNQVR } & 1.00 & 47.93 & 27.61 & 27.14 & 3 & 1852.9795 & 1852.9778 & 618.6665 & 0.0017 & 0.9159 & 30.325\end{array}$ $\begin{array}{lllllllllllll}\text { QHPVPPPAQNQNQVR } & 1.00 & 39.39 & 27.60 & 25.85 & 3 & 1852.9783 & 1852.9778 & 618.6665 & 0.0005 & 0.2694 & 47.704 \\ \text { QHPVPPPAQNQNQVR } & 1.00 & 38.39 & 27.65 & 23.75 & 3 & 1852.9786 & 1852.9778 & 618.6665 & 0.0008 & 0.4310 & 12.159\end{array}$ $\begin{array}{llllllllllll}\text { QHPVPPPAQNQNQVR } & 1.00 & 38.39 & 27.65 & 23.75 & 3 & 1852.9786 & 1852.9778 & 618.6665 & 0.0008 & 0.4310 & 12.159\end{array}$ SPGAPGPLTLK

$\begin{array}{lllllllllll}1.00 & 46.66 & 23.52 & 26.98 & 2 & 1324.8078 & 1324.7958 & 663.4052 & 0.0120 & 9.0442 & 1908.796 \\ 1.00 & 73.33 & 27.25 & 23.44 & 3 & 2740.3960 & 2740.3691 & 914.4636 & 0.0269 & 9.8053 & 148.161\end{array}$

\section{AVLLLAGGQGTR}

$\begin{array}{lllllllllll}25.42 & 2 & 809.5274 & 809.5245 & 405.7695 & 0.0029 & 3.5734 & 3904.530 & 4225.84\end{array}$

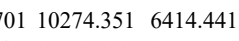

$\begin{array}{lllllllllllllllll}\text { VAVLLLAGGQGTR } & 1.00 & 74.24 & 23.16 & 24.91 & 2 & 1397.8466 & 1397.8476 & 699.9311 & -0.0010 & -0.7144 & 869.351 & 1217.584 & 233.770 & 66.967 & \text { Yes }\end{array}$

$\begin{array}{llllllllllllllllll}\text { VAVLLLAGGQGTR } & 1.00 & 82.46 & 23.38 & 26.00 & 2 & 1397.8478 & 1397.8476 & 699.9311 & 0.0002 & 0.1429 & 978.550 & 1438.832 & 246.970 & 107.238 & Y & \text { Y }\end{array}$

$\begin{array}{lllllllllllllllll}\text { CIIPWYIMTSGR } & 0.99 & 34.79 & 27.00 & 16.73 & 2 & 1628.8010 & 1628.7999 & 815.4072 & 0.0011 & 0.6745 & 63.114 & 59.347 & 2.146 & 6.526 & \text { Yes }\end{array}$

$\begin{array}{llllllllllllllllll}\text { ALAAQNIVEDMEQR } & 0.77 & 73.66 & 27.34 & 86.66 & 2 & 1730.8762 & 1730.8743 & 866.4444 & 0.0019 & 1.0964 & 166.167 & 204.188 & 51.420 & 37.951 & \text { Yes }\end{array}$

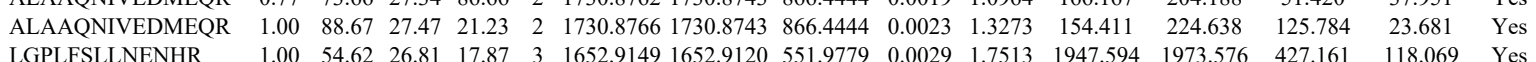

$\begin{array}{llllllllllllll}\text { PSMD5_HUMA] } & \text { Q16401 } & \text { PSMD5 } & \text { 26S proteasome n } & 56.20 & 1.00 & 2 & 4.4 & -0.1455 & 0.1993 & 0.2046 & 0.6291 & 3 & \text { LGPLFSLLNENHR } \\ \text { LGPLFSLLNENHR }\end{array}$ ILTLSQIGR $\begin{array}{lllllllllllllllll}1.00 & 65.33 & 26.89 & 18.65 & 3 & 1652.9155 & 1652.9120 & 551.9779 & 0.0035 & 2.1136 & 1730.121 & 1376.597 & 126.667 & 106.119 & \text { Yes }\end{array}$ $\begin{array}{lllllllllllllll}1.00 & 48.71 & 22.88 & 35.35 & 2 & 1143.7206 & 1143.7097 & 572.8621 & 0.0109 & 9.5135 & 11886.791 & 11982.646 & 388.558 & 340.624 & \text { Yes }\end{array}$ $\begin{array}{llllllllllllllll}\text { TEPATGFDGLIESFLDISRPK } & 1.00 & 97.47 & 25.60 & 34.03 & 3 & 2808.4819 & 2808.4789 & 937.1669 & 0.0030 & 1.0670 & 284.284 & 165.639 & 164.222 & 26.178 & \text { Yes }\end{array}$

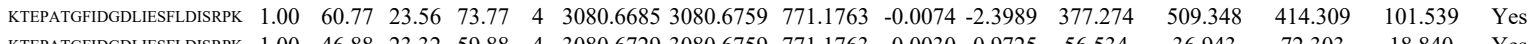
$\begin{array}{lllllllllllllllll}\text { KTEPATGFIDGDLIESFLDISRPK } & 1.00 & 46.88 & 23.32 & 59.88 & 4 & 3080.6729 & 3080.6759 & 771.1763 & -0.0030 & -0.9725 & 56.534 & 36.943 & 72.303 & 18.840 & \text { Yes }\end{array}$ $\begin{array}{llllllllllllllll}\text { KTEPATGFDGDLIESFLDISRPK } & 1.00 & 46.77 & 23.18 & 59.77 & 4 & 3080.6773 & 3080.6759 & 771.1763 & 0.0014 & 0.4539 & 235.928 & 346.512 & 186.410 & 104.506 & \text { No }\end{array}$ $\begin{array}{lrlllllllllllllll}\text { GDFILVGDLMR } & 1.00 & 44.52 & 28.16 & 30.04 & 2 & 1378.7406 & 1378.7401 & 690.3773 & 0.0005 & 0.3621 & 869.308 & 739.859 & 241.791 & 116.175 & \text { Yes } \\ \text { GDFILVGDLMR } & 0.99 & 39.33 & 28.22 & 34.98 & 2 & 1378.7408 & 1378.7401 & 690.3773 & 0.0007 & 0.5070 & 811.799 & 787.852 & 279.737 & 102.165 & \text { Yes }\end{array}$

LFMLLLEK

LVFSNVNLK LVFSNVNLK VTLGTQPTVLR VTLGTQPTVLR VTLGTQPTVLR VTLGTQPTVLR VTLGTQPTVLR $\begin{array}{llllllllllllllll}1.00 & 44.32 & 22.53 & 25.43 & 2 & 1293.7992 & 1293.7974 & 647.9060 & 0.0018 & 1.3891 & 8606.509 & 9199.675 & 0.000 & 50.634 & & N o\end{array}$ $\begin{array}{lllllllllllllll}1.00 & 58.80 & 22.55 & 27.62 & 2 & 1293.8002 & 1293.7974 & 647.9060 & 0.0028 & 2.1608 & 8754.951 & 9128.226 & 0.000 & 59.054 & \text { No }\end{array}$ $\begin{array}{lllllllllllllll}1.00 & 45.60 & 22.97 & 29.72 & 2 & 1320.8126 & 1320.8009 & 661.4077 & 0.0117 & 8.8447 & 20120.156 & 20177.548 & 1242.446 & 282.170 & \text { Yes }\end{array}$ $\begin{array}{lllllllllllllll}1.00 & 56.82 & 22.67 & 34.74 & 2 & 1320.8138 & 1320.8009 & 661.4077 & 0.0129 & 9.7518 & 22319.186 & 20929.548 & 1198.948 & 409.824 & \text { Yes }\end{array}$

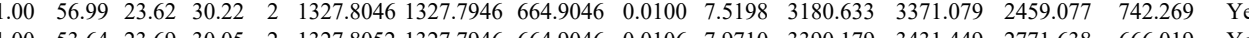

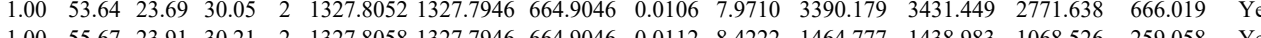
$\begin{array}{lllllllllllllll}1.00 & 55.67 & 23.91 & 30.21 & 2 & 1327.8058 & 1327.7946 & 664.9046 & 0.0112 & 8.4222 & 1464.777 & 1438.983 & 1068.526 & 259.058 & \text { Yes } \\ 1.00 & 57.87 & 23.67 & 30.01 & 2 & 1327.8030 & 1327.7946 & 664.9046 & 0.084 & 63167 & 1802.673 & 1759.538 & 1264.786 & 330.886 & \text { Yes }\end{array}$

$\begin{array}{llllllllllllllll}1.00 & 54.55 & 23.58 & 29.66 & 2 & 1327.8036 & 1327.7946 & 664.9046 & 0.0090 & 6.7678 & 2780.624 & 2752.130 & 1920.013 & 493.113\end{array}$ $\begin{array}{lllllllllllllll}0.99 & 44.19 & 25.98 & 36.64 & 2 & 1216.7378 & 1216.7261 & 609.3703 & 0.0117 & 9.6000 & 1093.893 & 996.355 & 132.473 & 59.276\end{array}$ $\begin{array}{llllllllll} & 0\end{array}$ $\begin{array}{lllllllllllllll}\text { LGPGGLDPVEVYESLPEELOK } & 0.99 & 28.76 & 25.83 & 18.85 & 3 & 2556.3610 & 2556.3567 & 853.1262 & 0.0043 & 1.6801 & 0.000 & 1.675 & 0.0\end{array}$

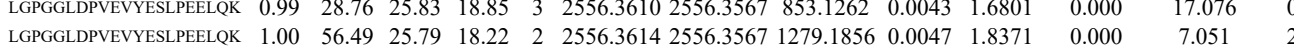
$\begin{array}{llllllllllllll}\text { LGPGGLDPVEVYESLPEELOK } & 1.00 & 41.84 & 25.71 & 17.48 & 3 & 2556.3622 & 2556.3567 & 853.1262 & 0.0055 & 2.1490 & 18.897 & 12.437 & 2.483 \\ 0.01\end{array}$

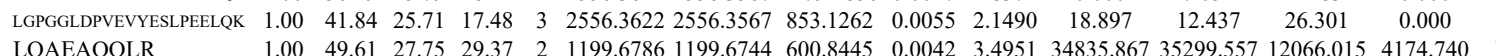

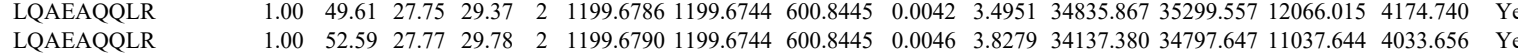

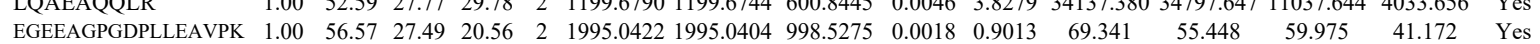

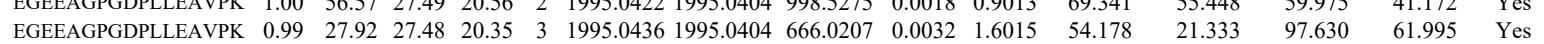
$\begin{array}{llllllllllllllll}\text { EGEEAGPGDPLLEAVPK } & 0.97 & 36.20 & 27.51 & 17.12 & 2 & 1995.0442 & 1995.0404 & 998.5275 & 0.0038 & 1.9028 & 14.237 & 32.213 & 9.547 & 26.566 & \text { Yes }\end{array}$ $\begin{array}{lllllllllllllllll}\text { EGEEAGPGDPLLEAVPK } & 0.98 & 27.91 & 27.61 & 17.82 & 3 & 1995.0448 & 1995.0404 & 666.0207 & 0.0044 & 2.2021 & 33.142 & 29.820 & 98.001 & 64.634 & \text { Yes }\end{array}$ $\begin{array}{llllllllllllllll}\text { QYMEGFNDELEAFK } & 1.00 & 84.49 & 26.33 & 26.35 & 2 & 2007.9514 & 2007.9491 & 1004.9818 & 0.0023 & 1.1443 & 519.423 & 587.157 & 14.816 & 35.887 & \text { Yes }\end{array}$ $\begin{array}{lllllllllllllllll}\text { QYMEGFNDELEAFK } & 1.00 & 97.18 & 26.33 & 24.92 & 2 & 2007.9514 & 2007.9491 & 1004.9818 & 0.0023 & 1.1443 & 438.381 & 353.324 & 0.000 & 29.074 & \text { No }\end{array}$

$\begin{array}{llllllllllllllll}\text { HPAKPDPSGECNPDLR } & 0.85 & 17.30 & 27.63 & 16.53 & 4 & 2066.0061 & 2065.9917 & 517.5052 & 0.0144 & 6.9564 & 2559.684 & 3368.005 & 2505.495 & 2595.404 & \text { Yes }\end{array}$ $\begin{array}{lllllllllllllllll}\text { HPAKPDPSGECNPDLR } & 0.53 & 20.19 & 27.67 & 21.81 & 3 & 2066.0068 & 2065.9917 & 689.6712 & 0.0151 & 7.2981 & 10207.645 & 8999.070 & 9134.226 & 7250.921 & \text { Yes }\end{array}$ $\begin{array}{lllllllllllllllll}\text { HPAKPDPSGECNPDLR } & 0.99 & 38.05 & 27.65 & 18.93 & 3 & 2066.0071 & 2065.9917 & 689.6712 & 0.0154 & 7.4431 & 4844.381 & 5326.173 & 5217.685 & 3771.109 & \text { Yes }\end{array}$ $\begin{array}{lllllllllllllllll}\text { HPAKPDPSGECNPDLR } & 0.85 & 26.28 & 27.66 & 17.03 & 3 & 2066.0062 & 2065.9917 & 689.6712 & 0.0145 & 7.0081 & 4188.478 & 5943.276 & 3992.622 & 4224.681 & \text { Yes }\end{array}$ $\begin{array}{llllllllllllllll}\text { HPAKPDPSGECNPDLR } & 0.80 & 24.95 & 27.67 & 19.42 & 3 & 2066.0068 & 2065.9917 & 689.6712 & 0.0151 & 7.2981 & 4929.297 & 4554.020 & 3618.568 & 4004.773 & \text { Yes }\end{array}$ $\begin{array}{lllllllllllllllll}\text { HPAKPDPSGECNPDLR } & 0.66 & 14.12 & 27.66 & 16.31 & 4 & 2066.0077 & 2065.9917 & 517.5052 & 0.0160 & 7.7293 & 2349.644 & 3153.177 & 2803.220 & 2167.863 & \text { Yes }\end{array}$ $\begin{array}{llllllllllllllll}\text { HPAKPDPSGECNPDLR } & 0.93 & 18.46 & 27.64 & 16.50 & 4 & 2066.0081 & 2065.9917 & 517.5052 & 0.0164 & 7.9226 & 2089.795 & 1835.868 & 2274.182 & 2132.256 & \text { Yes }\end{array}$ $\begin{array}{llllllllllllllll}\text { HPAKPDPSGECNPDLR } & 0.96 & 20.24 & 27.53 & 20.46 & 4 & 2066.0041 & 2065.9917 & 517.5052 & 0.0124 & 5.9902 & 4015.337 & 4031.877 & 3330.057 & 3954.350 & \text { Yes }\end{array}$

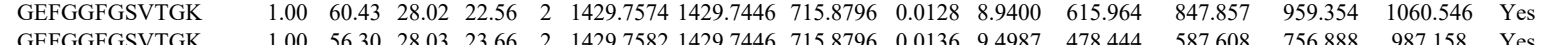

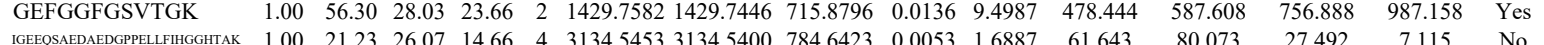

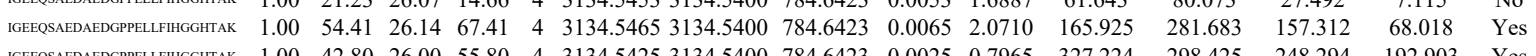

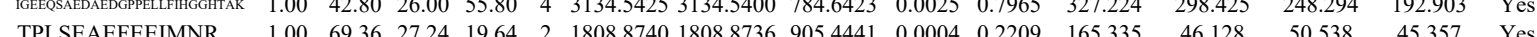
$\begin{array}{llllllllllllllll}\text { VLISSLQDCLHGIESK } & 1.00 & 61.74 & 28.05 & 23.47 & 3 & 2075.1064 & 2075.0999 & 692.7072 & 0.0065 & 3.1278 & 9842.569 & 9136.706 & 29.010 & 44.493 & \text { Yes }\end{array}$ 
$\begin{array}{llllllllllll}1.00 & 76.24 & 27.44 & 19.01 & 2 & 1808.8750 & 1808.8736 & 905.4441 & 0.0014 & 0.7731 & 785.157 & 8\end{array}$ $\begin{array}{lllllllllllll}\text { NGQLAASVETAGDSELFLMK } & 1.00 & 40.40 & 27.33 & 16.63 & 3 & 2368.2238 & 2368.2188 & 790.4135 & 0.0050 & 2.1086 & 10.127\end{array}$ $\begin{array}{lllllllllllll}\text { NGQLAASVETAGDSELFLMK } & 0.85 & 19.47 & 27.40 & 23.07 & 3 & 2368.2202 & 2368.2188 & 790.4135 & 0.0014 & 0.5904 & 10.194\end{array}$

$\begin{array}{lllllllllll}1.00 & 41.41 & 27.30 & 24.10 & 3 & 1361.7877 & 1361.7870 & 454.9363 & 0.0007 & 0.5129 & 655.691\end{array}$ KVTGTLDANR

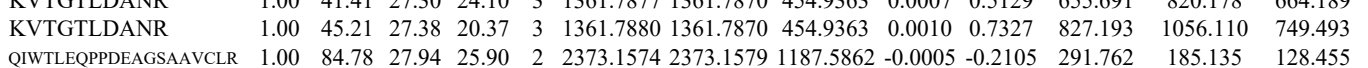

$\begin{array}{ll}352.975 & 225.08 \\ 365.665 & 296.56\end{array}$

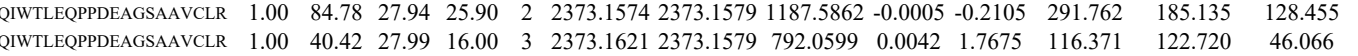

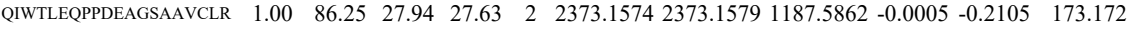
$\begin{array}{llllllllllll}\text { QWILEPPEAGSAVCLR } & 1.00 & 72.73 & 27.94 & 28.55 & 2 & 2373.1574 & 2373.1579 & 1187.5862 & -0.0005 & -0.2105 & 258.377\end{array}$

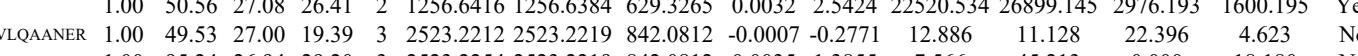
$\begin{array}{lllllllllllllll} & \end{array}$ 18.180

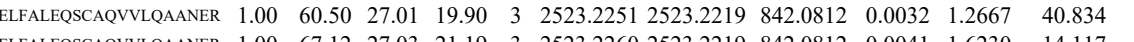
$40.374 \quad 25.140$

$\begin{array}{lllllllllllllll}\text { YLAPSGPSGTLK } & 1.00 & 67.12 & 27.03 & 21.19 & 3 & 2523.2250 & 2523.2219 & 842.0812 & 0.0041 & 1.6230 & 14.117 & 0.000 & 20.921\end{array}$

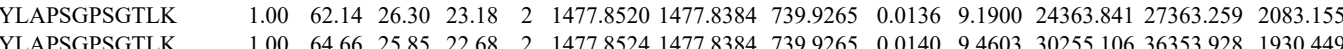
$\begin{array}{lllllllllllll}1.00 & 64.66 & 25.85 & 22.68 & 2 & 1477.8524 & 1477.8384 & 739.9265 & 0.0140 & 9.4603 & 30255.106 & 36353.928 & 1930.449\end{array}$ $\begin{array}{lllllllllllll}\text { GGKDELALEQSCAQVVLQAANER } & 1.00 & \text { \#\#\#\# } 26.61 & 45.35 & 3 & 2951.5147 & 2951.5088 & 984.8435 & 0.0059 & 1.9969 & 162.535 & 541 . \\ \end{array}$ $\begin{array}{llllllllllll}\text { VGKDELFALEOSCAQVVLQAANER } & 1.00 & 96.38 & 26.61 & 37.20 & 3 & 2951.5147 & 2951.5088 & 984.8435 & 0.0059 & 1.9969 & 34.954 \\ \text { VGKDELFALESCAQVVLAANER } & 1.00 & 81.77 & 26.61 & 33.75 & 4 & 2951.5149 & 2951.5088 & 738.8845 & 0.0061 & 2.0639 & 20.880\end{array}$

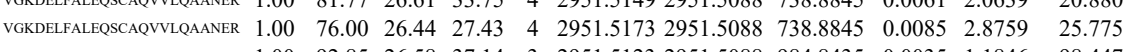
$\begin{array}{llllllllllll}\text { VGKDELFALESCAQVVLQAANER } & 1.00 & 92.85 & 26.58 & 37.14 & 3 & 2951.5123 & 2951.5088 & 984.8435 & 0.0035 & 1.1846 & 98.447\end{array}$ $\begin{array}{llllllllllll}\text { VGKDELFALESCAQVVLQAANER } & 1.00 & 52.85 & 26.60 & 22.20 & 4 & 2951.5141 & 2951.5088 & 738.8845 & 0.0053 & 1.7932 & 0.000\end{array}$ $\begin{array}{lllllllllllll}\text { VGKDELFALESCAQVVLLAANER } & 1.00 & 45.70 & 26.61 & 23.18 & 4 & 2951.5149 & 2951.5088 & 738.8845 & 0.0061 & 2.0639 & 0.000\end{array}$ $\begin{array}{llllllllllll}\text { DVPWGVDSLITLAFQDQR } & 1.00 & 69.59 & 27.63 & 23.36 & 3 & 2203.1416 & 2203.1395 & 735.3871 & 0.0021 & 0.9519 & 104.693\end{array}$

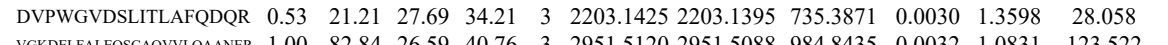

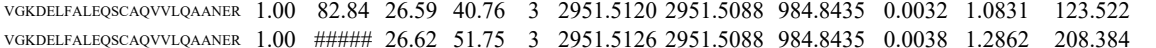
$\begin{array}{llllllllllll}\text { VGKDELFALESCAQVVLQAANER } & 1.00 & \text { \#\#\#\# } 26.62 & 51.75 & 3 & 2951.5126 & 2951.5088 & 984.8435 & 0.0038 & 1.2862 & 208.384 \\ \text { VI. }\end{array}$

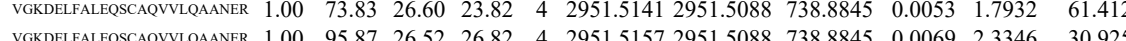

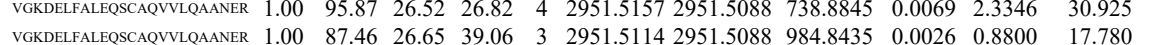

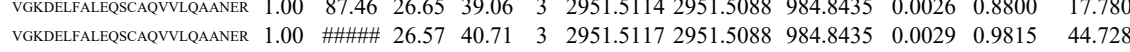
$\begin{array}{lllllllllllll}\text { VGKDELFALESCAQVVLQAANER } & 1.00 & 76.61 & 26.62 & 28.54 & 4 & 2951.5133 & 2951.5088 & 738.8845 & 0.0045 & 1.5226 & 5.468\end{array}$ $\begin{array}{llllllllllll}\text { VGKDELFALESCAQVVLLAANER } & 1.00 & 36.96 & 26.62 & 29.07 & 4 & 2951.5133 & 2951.5088 & 738.8845 & 0.0045 & 1.5226 & 21.809\end{array}$ $\begin{array}{lllllllllllll}\text { LVARPEPATGYTLEFR } & 1.00 & 48.08 & 25.76 & 18.77 & 3 & 1963.0843 & 1963.0649 & 655.3622 & 0.0194 & 9.8672 & 11727.838 \\ \text { YWTLTATGGVQSTASSK } & 0.75 & 15.60 & 27.45 & 14.72 & 3 & 2045.0695 & 2045.0673 & 682.6964 & 0.0022 & 1.0742 & 72.872\end{array}$ $\begin{array}{llllllllllll}\text { YWTLTATGGVQSTASSK } & 0.75 & 15.60 & 27.45 & 14.72 & 3 & 2045.0695 & 2045.0673 & 682.6964 & 0.0022 & 1.0742 & 72.872 \\ \text { YWTLTATGGVQSTASSK } & 0.93 & 21.19 & 27.47 & 15.15 & 3 & 2045.0704 & 2045.0673 & 682.6964 & 0.0031 & 1.5136 & 44.088\end{array}$ $\begin{array}{llllllllllll}\text { YWTLTATGGVQSTASSK } & 0.93 & 21.19 & 27.47 & 15.15 & 3 & 2045.0704 & 2045.0673 & 682.6964 & 0.0031 & 1.5136 & 44.088 \\ \text { YWTLTATGGVQSTASSK } & 0.69 & 15.63 & 27.44 & 14.59 & 3 & 2045.07162045 .0673 & 682.6964 & 0.0043 & 2.0995 & 58.960\end{array}$ $\begin{array}{llllllllllll}\text { YWTLTATGOVQSTASS } & 0.69 & 15.63 & 27.44 & 14.59 & 3 & 2045.0716 & 2045.0673 & 682.6964 & 0.0043 & 2.0995 & 58.960\end{array}$ $\left.\begin{array}{lllllllllllll}0.68 & 17.63 & 27.37 & 24.18 & 3 & 1219.6066 & 1219.6067 & 407.5428 & -0.0001 & -0.0818 & 18.200\end{array}\right]$

$\begin{array}{llllllllllll} & 0.66 & 13.93 & 20.76 & 15.02 & 3 & 1239.7810 & 1239.7815 & 414.2678 & -0.0005 & -0.4023 & 93.073\end{array}$ 
$\begin{array}{lllllllllll}0.99 & 30.96 & 20.86 & 21.80 & 2 & 1239.7826 & 1239.7815 & 620.8980 & 0.0011 & 0.8858 & 125.846\end{array}$ $\begin{array}{lllllllllll}1.00 & 32.14 & 20.17 & 18.08 & 3 & 1239.7873 & 1239.7815 & 414.2678 & 0.0058 & 4.6668 & 251.502\end{array}$ $\begin{array}{lllllllllllllll}\text { VTIAQGGVLPNIQAVLLPK } & 0.55 & 6.67 & 13.01 & 19.67 & 3 & 2218.3681 & 2218.3657 & 740.4625 & 0.0024 & 1.0804 & 44.012\end{array}$ $\begin{array}{lllllllllllll}\text { VTIAQGGVLPNIQAVLLPK } & 0.55 & 37.83 & 13.01 & 50.83 & 3 & 2218.3681 & 2218.3657 & 740.4625 & 0.0024 & 1.0804 & 26.535\end{array}$ $\begin{array}{llllllllllll} & \end{array}$ $\begin{array}{lllllllllllll}\text { VIAQGGVLPNQAVLLFK } & 0.53 & 4.31 & 13.01 & 17.31 & 3 & 2218.3690 & 2218.3657 & 740.4625 & 0.0033 & 1.4856 & 56.418\end{array}$

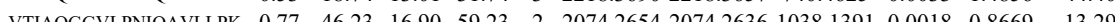

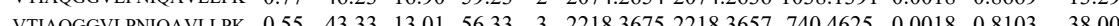

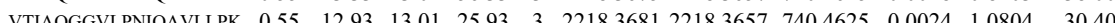
$\begin{array}{llllllllllllll}\text { VTILQGGVLPNIQAVLIPK } & 0.55 & 12.20 & 13.01 & 25.20 & 3 & 2218.3681 & 22183657 & 740.4625 & 0.0024 & 1.0804 & 40.3747\end{array}$ $\begin{array}{llllllllllll}\text { VTIAQGGVIPNIQAVLLPK } & 0.53 & 9.14 & 13.01 & 22.14 & 3 & 22183684 & 22183657 & 740.4625 & 0.0027 & 1.2155 & 18.513\end{array}$ VTIAQGGVLPNIQAVLIPK $\begin{array}{llllllllllllll}0.53 & 29.09 & 13.01 & 42.09 & 3 & 22183684 & 22183657 & 740.4625 & 0.0027 & 1.2155 & 34.719\end{array}$ $\begin{array}{lllllllllllll}\text { VTIAQGGVLPNIPAVLLPK } & 0.53 & 23.43 & 13.01 & 36.43 & 3 & 2218.3690 & 2218.3657 & 740.4625 & 0.0033 & 1.4856 & 43.650\end{array}$ $\begin{array}{llllllllllll}\text { VTIAQGGVLPNIPAVLLPK } & 0.53 & 30.34 & 13.01 & 43.34 & 3 & 2218.3690 & 2218.3657 & 740.4625 & 0.0033 & 1.4856 & 33.597\end{array}$ $\begin{array}{lllllllllllllll}\text { VTIAQGGVLPNIQAVLLPK } & 0.53 & 31.18 & 13.01 & 44.18 & 3 & 2218.3690 & 2218.3657 & 740.4625 & 0.0033 & 1.4856 & 0.000\end{array}$ $\begin{array}{lllllllllllllll}\text { VTIAQGGVLPNIQAVLLPK } & 0.61 & 77.41 & 13.22 & 90.41 & 2 & 2218.3654 & 2218.3657 & 1110.1901 & -0.0003 & -0.1351 & 7.407\end{array}$ $\begin{array}{lllllllllllll}\text { VTIAQGGVLPNIQAVLLPK } & 1.00 & 6.69 & 13.22 & 19.69 & 4 & 2218.3665 & 2218.3657 & 555.5987 & 0.0008 & 0.3600 & 76.445\end{array}$ $\begin{array}{lllllllllllll}\text { VTIAQGGVLPNIQAVLLPK } & 0.77 & 76.23 & 13.22 & 89.23 & 2 & 2218.3674 & 2218.3657 & 1110.1901 & 0.0017 & 0.7656 & 3448.876\end{array}$ $\begin{array}{llllllllllll}\text { VTIAQGGVLPNIQAVLLPK } & 0.77 & 72.51 & 13.22 & 85.51 & 2 & 2218.3674 & 2218.3657 & 1110.1901 & 0.0017 & 0.7656 & 3030.039\end{array}$

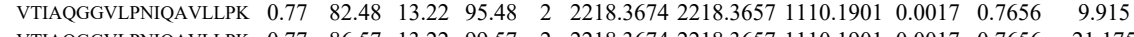
$\begin{array}{llllllllllllll}\text { VTIAQGGVLPNIQAVLLPK } & 0.77 & 86.57 & 13.22 & 99.57 & 2 & 2218.3674 & 2218.3657 & 1110.1901 & 0.0017 & 0.7656 & 21.175\end{array}$ $\begin{array}{llllllllllllll}\text { VTIAQGGVLPNIQAVLLPK } & 0.55 & 11.30 & 13.01 & 24.30 & 3 & 2218.3675 & 2218.3657 & 740.4625 & 0.0018 & 0.8103 & 22.724\end{array}$ $\begin{array}{lllllllllllll}\text { VTIAQGGVLPNIQAVLLPK } & 0.55 & 8.77 & 13.01 & 21.77 & 3 & 2218.3678 & 2218.3657 & 740.4625 & 0.0021 & 0.9454 & 32.863\end{array}$ $\begin{array}{lllllllllllll}\text { VTIAQGGVLPNIQAVLLPK } & 0.55 & 44.66 & 13.01 & 57.66 & 3 & 2218.3681 & 2218.3657 & 740.4625 & 0.0024 & 1.0804 & 31.673 \\ \text { VTIAQGGVLPNIQAVLLPK } & 0.55 & 29.76 & 13.01 & 4.76 & 3 & 22183681 & 22183657 & 740.4625 & 0.0024 & 1.0804 & 67.420\end{array}$ $\begin{array}{lllllllllllll}\text { VTIAQGGVLPNIQAVLLPK } & 0.55 & 29.76 & 13.01 & 42.76 & 3 & 2218.3681 & 2218.3657 & 740.4625 & 0.0024 & 1.0804 & 67.420 \\ \text { VTIAQGGVLPNIQAVLLPK } & 0.55 & 45.71 & 13.01 & 58.71 & 3 & 2218.3681 & 2218.3657 & 740.4625 & 0.0024 & 1.0804 & 46.573\end{array}$ $\begin{array}{lllllllllllll}\text { VTIAQGGVLPNIQAVLLPK } & 0.55 & 45.71 & 13.01 & 58.71 & 3 & 2218.3681 & 2218.3657 & 740.4625 & 0.0024 & 1.0804 & 46.573 \\ \text { VTIAQGGVLPNIQAVLLPK } & 0.55 & 7.05 & 13.01 & 20.05 & 3 & 2218.3681 & 2218.3657 & 740.4625 & 0.0024 & 1.0804 & 72.668\end{array}$ $\begin{array}{lllllllllllll}\text { VTIAQGGVLPNIQAVLLPK } & 0.55 & 7.05 & 13.01 & 20.05 & 3 & 2218.3681 & 2218.3657 & 740.4625 & 0.0024 & 1.0804 & 72.668 \\ \text { VTIAQGGVLPNIQAVLLPK } & 0.55 & 15.41 & 13.01 & 28.41 & 3 & 2218.3681 & 2218.3657 & 740.4625 & 0.0024 & 1.0804 & 48.794\end{array}$ $\begin{array}{lllllllllllll}\text { VTIAQGGVLPNIQAVLLPK } & 0.55 & 15.41 & 13.01 & 28.41 & 3 & 2218.3681 & 2218.3657 & 740.4625 & 0.0024 & 1.0804 & 48.794 \\ \text { VTIAQGGVLPNIQAVLLPK } & 0.53 & 39.42 & 13.01 & 52.42 & 3 & 2218.3684 & 2218.3657 & 740.4625 & 0.0027 & 1.2155 & 65.894\end{array}$

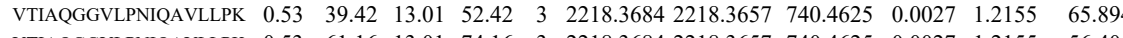
$\begin{array}{llllllllllll}\text { VTIAQGGVLPNIQAVLLPK } & 0.53 & 61.16 & 13.01 & 74.16 & 3 & 2218.3684 & 2218.3657 & 740.4625 & 0.0027 & 1.2155 & 56.406\end{array}$ $\begin{array}{lllllllllllll}\text { VIIAQGGVLPNIQAVLLPK } & 1.00 & 7.57 & 13.01 & 20.57 & 4 & 2218.3685 & 2218.3657 & 555.5987 & 0.0028 & 1.2599 & 71.100\end{array}$ $\begin{array}{llllllllllll}\text { VIIAQGGVLPNIQAVLLPK } & 1.00 & 4.77 & 13.01 & 17.77 & 4 & 2218.3685 & 2218.3657 & 555.5987 & 0.0028 & 1.2599 & 61.512\end{array}$ $\begin{array}{lllllllllllll}\text { VIIAQGGULNDANLLRK } & 1.00 & 32.34 & 13.01 & 45.34 & 4 & 2218.3685 & 2218.3657 & 555.5987 & 0.0028 & 1.2599 & 63.678\end{array}$ $\begin{array}{llllllllllll}\text { VTIAQGGVLPNIQAVLLPK } & 1.00 & 50.51 & 13.01 & 63.51 & 4 & 2218.3689 & 2218.3657 & 555.5987 & 0.0032 & 1.4399 & 158.313\end{array}$ $\begin{array}{llllllllllll}\text { VTIAQGGVLPNIQAVLLPK } & 0.53 & 35.86 & 13.01 & 48.86 & 3 & 2218.3690 & 2218.3657 & 740.4625 & 0.0033 & 1.4856 & 41.036\end{array}$ 


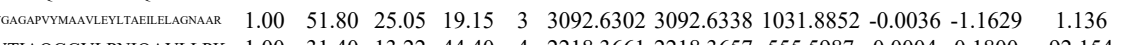

$\begin{array}{lllllllllllll}\text { VTIAQGGVLPNIQAVLLPK } & 1.00 & 31.40 & 13.22 & 44.40 & 4 & 2218.3661 & 2218.3657 & 555.5987 & 0.0004 & 0.1800 & 92.154 \\ \text { VTIAQGGVLPNIQAVLLPK } & 0.77 & 78.75 & 13.22 & 91.75 & 2 & 2218.3674 & 2218.3657 & 1110.1901 & 0.0017 & 0.7656 & 567.809\end{array}$ 2.172 $\begin{array}{lllllllllllll}\text { VTIAQGGVLPNIQAVLLPK } & 0.77 & 86.45 & 13.22 & 99.45 & 2 & 2218.3674 & 2218.3657 & 1110.1901 & 0.0017 & 0.7656 & 881.911\end{array}$ 683.509 $\begin{array}{llllllllllllllll}\text { VTIAQGGVLPNIQAVLLPK } & 0.77 & 88.83 & 13.22 & \text { \#\#\# } & 2 & 2218.3674 & 2218.3657 & 1110.1901 & 0.0017 & 0.7656 & 6.784\end{array}$ $\begin{array}{llllllllllll}\text { VTIAQGGVLPNIQAVLLPK } & 1.00 & 17.31 & 13.01 & 30.31 & 4 & 2218.3697 & 2218.3657 & 555.5987 & 0.0040 & 1.7999 & 191.187\end{array}$ $\begin{array}{lllllllllllll}\text { VIIAQGGVLPNIQAVLLPK } & 1.00 & 21.77 & 12.79 & 34.77 & 4 & 2218.3709 & 2218.3657 & 555.5987 & 0.0052 & 2.3398 & 111.775\end{array}$ $\begin{array}{llllllllllllll}\text { VTIAQGGVLPNIQAVLLPK } & 1.00 & 81.31 & 12.30 & 26.64 & 3 & 2218.3798 & 2218.3657 & 740.4625 & 0.0141 & 6.3473 & 2448.607\end{array}$ $\begin{array}{llllllllllllll}\text { VIIAQGGVLPNIQAVLLPK } & 0.77 & 83.47 & 13.22 & 96.47 & 2 & 2218.3674 & 2218.3657 & 1110.1901 & 0.0017 & 0.7656 & 669.482\end{array}$ $\begin{array}{llllllllllllll}\text { VTIAQGGVLPNIQAVLLPK } & 0.77 & 76.79 & 13.22 & 89.79 & 2 & 2218.3674 & 2218.3657 & 1110.1901 & 0.0017 & 0.7656 & 1164.761 & 145\end{array}$ $\begin{array}{llllllllllll}\text { VTIAQGGVLPNIQAVLLPK } & 1.00 & 39.40 & 13.01 & 52.40 & 4 & 2218.3685 & 2218.3657 & 555.5987 & 0.0028 & 1.2599 & 227.535 \\ \text { VIIST }\end{array}$

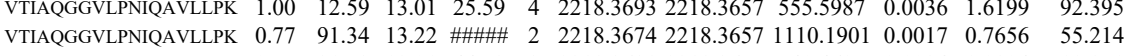
$\begin{array}{llllllllllllll}\text { VTIAQGGVLPNIQAVLLPK } & 0.55 & 31.53 & 13.01 & 44.53 & 3 & 2218.3681 & 2218.3657 & 740.4625 & 0.0024 & 1.0804 & 19.85\end{array}$ $\begin{array}{llllllllllllll}\text { VTIAQGGVLPNIQAVLLPK } & 1.00 & 20.01 & 13.01 & 33.01 & 4 & 2218.3689 & 2218.3657 & 555.5987 & 0.0032 & 1.4399 & 132.786\end{array}$ $\begin{array}{llllllllllll}\text { VTIAQGGVLPNIQAVLLPK } & 1.00 & 14.07 & 13.01 & 27.07 & 4 & 2218.3697 & 2218.3657 & 555.5987 & 0.0040 & 1.7999 & 101.170\end{array}$ $\begin{array}{lllllllllllll}\text { VTIAQGGVLPNIQAVLLPK } & 0.76 & 77.52 & 19.68 & 90.52 & 2 & 1930.1622 & 1930.1615 & 966.0880 & 0.0007 & 0.3623 & 2.904\end{array}$

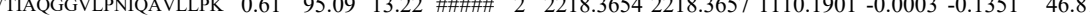
$\begin{array}{lllllllllllll}\text { VTIAQGGVLPNIQAVLLPK } & 0.77 & 98.54 & 13.22 & \text { \#\#\#\# } & 2 & 2218.3674 & 2218.3657 & 1110.1901 & 0.0017 & 0.7656 & 19.479\end{array}$ $\begin{array}{lllllllllllll}\text { VTIAQGGVLPNIQAVLLPK } & 0.55 & 69.26 & 13.01 & 82.26 & 3 & 2218.3681 & 2218.3657 & 740.4625 & 0.0024 & 1.0804 & 16.40\end{array}$

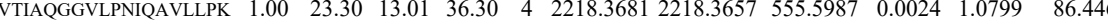

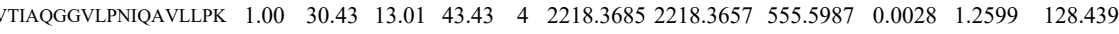
$\begin{array}{llllllllllllll} & \text { VTIAQGGVLPNIQAVLLPK } & 0.53 & 55.97 & 13.01 & 68.97 & 3 & 2218.3687 & 2218.3657 & 740.4625 & 0.0030 & 1.3505 & 15.601\end{array}$ $\begin{array}{lllllllllllllll}\text { VTIAQGGVLPNIQAVLLPK } & 0.61 & 78.51 & 19.68 & 91.51 & 2 & 1930.1616 & 1930.1615 & 966.0880 & 0.0001 & 0.0518 & 0.000\end{array}$

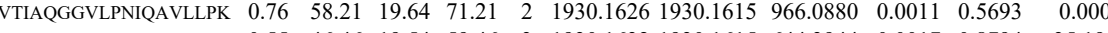
$\begin{array}{llllllllllll}\text { VTIAQGGVLPNIQAVLLPK } & 0.55 & 46.46 & 19.54 & 59.46 & 3 & 1930.1632 & 1930.1615 & 644.3944 & 0.0017 & 0.8794 & 35.196\end{array}$ $\begin{array}{lllllllllllll}\text { VTIAQGGVLPNIQAVLLPK } & 0.53 & 88.62 & 13.01 & \text { \#\#\#\#\# } & 3 & 2218.3687 & 2218.3657 & 740.4625 & 0.0030 & 1.3505 & 19.249\end{array}$ $\begin{array}{llllllllllll}\text { VIIAQGGVLPNIQAVLLK } & 0.53 & 74.41 & 13.01 & 87.41 & 3 & 2218.3690 & 2218.3657 & 740.4625 & 0.0033 & 1.4856 & 31.496\end{array}$

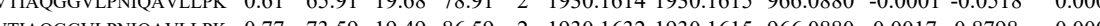

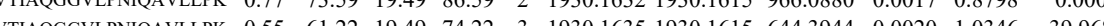
$\begin{array}{llllllllllll} & \end{array}$

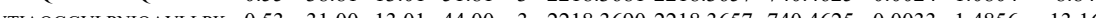

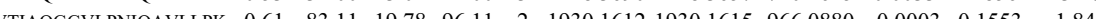

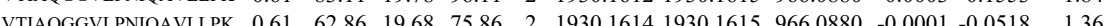

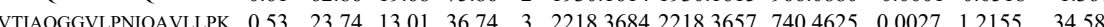

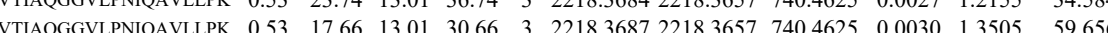
$\begin{array}{lllllllllllll}\text { VTIAQGGVIPNDANVLLP } & 0.55 & 4.638 & 13.01 & 17.38 & 3 & 2218.3675 & 2218.3657 & 740.4625 & 0.0018 & 0.8103 & 29.722\end{array}$ $\begin{array}{lllllllllllll}\text { VTIAQGGVLPNIAAVLLPK } & 0.55 & 5.38 & 13.01 & 18.38 & 3 & 2218.3681 & 22183657 & 740.4625 & 0.0024 & 1.0804 & 24.913\end{array}$ $\begin{array}{llllllllllllll}\text { VTIAOGGVLPNIQAVLLPK } & 0.61 & 41.62 & 19.68 & 54.62 & 2 & 19301616 & 19301615 & 966.0880 & 0.0001 & 0.0518 & 5.932\end{array}$ $\begin{array}{lllllllllllll}\text { VTIAQGGVLPNIQAVLLPK } & 0.55 & 58.40 & 13.01 & 71.40 & 3 & 2218.3678 & 2218.3657 & 740.4625 & 0.0021 & 0.9454 & 24.871\end{array}$ $\begin{array}{llllllllllllll}\text { VTIAOGGVLPNIQAVLLPK } & 0.53 & 74.13 & 13.01 & 87.13 & 3 & 2218.3687 & 22183657 & 740.4625 & 0.0030 & 1.3505 & 17.886\end{array}$ $\begin{array}{llllllllllllllll}\text { VTIAOGGVLPNIOAVLLPK } & 0.77 & 87.13 & 13.22 & \text { \#\#\# } & 2 & 2218.3674 & 2218.3657 & 1110.1901 & 0.0017 & 0.7656 & 6.300\end{array}$

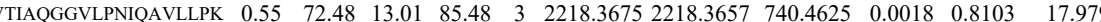

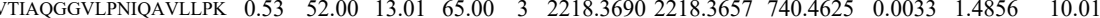
$\begin{array}{lllllllllllll}\text { VTIAQGGVLPNIQAVLLPK } & 0.61 & 77.90 & 19.68 & 90.90 & 2 & 1930.1620 & 1930.1615 & 966.0880 & 0.0005 & 0.2588 & 0.000\end{array}$ $\begin{array}{llllllllllllll}\text { VTIAQGGVLPNIQAVLLPK } & 0.95 & 0.44 & 13.22 & 13.44 & 4 & 2218.3669 & 2218.3657 & 555.5987 & 0.0012 & 0.5400 & 10.232\end{array}$ $\begin{array}{lllllllllllll}\text { VTIAQGGVLPNIQAVLLPK } & 0.77 & 82.83 & 13.22 & 95.83 & 2 & 2218.3674 & 2218.3657 & 1110.1901 & 0.0017 & 0.7656 & 7.568\end{array}$ $\begin{array}{lllllllllllll}\text { VTIAQGGVLPNIQAVLLPK } & 0.53 & 76.62 & 13.01 & 89.62 & 3 & 2218.3687 & 2218.3657 & 740.4625 & 0.0030 & 1.3505 & 20.029\end{array}$ $\begin{array}{llllllllllllll}\text { VTIAQGGVLPNIQAVLLPK } & 1.00 & 31.44 & 13.01 & 44.44 & 4 & 2218.3689 & 2218.3657 & 555.5987 & 0.0032 & 1.4399 & 17.193\end{array}$ $\begin{array}{llllllllllllll}\text { VTIAQGGVLPNIQAVLLPK } & 0.61 & 51.21 & 19.68 & 64.21 & 2 & 1930.1616 & 1930.1615 & 966.0880 & 0.0001 & 0.0518 & 0.000\end{array}$ $\begin{array}{lllllllllllll}\text { VTIAQGGVLPNIQAVLLPK } & 0.61 & 64.47 & 19.68 & 77.47 & 2 & 1930.1618 & 1930.1615 & 966.0880 & 0.0003 & 0.1553 & 0.000\end{array}$ $\begin{array}{lllllllllllll}\text { VTIAQGGVLPNIQAVLLPK } & 0.53 & 7.16 & 19.59 & 20.16 & 3 & 1930.1644 & 1930.1615 & 644.3944 & 0.0029 & 1.5001 & 1.907\end{array}$ $\begin{array}{lllllllllllll}\text { VTIAQGGVLPNIQAVLLPK } & 0.53 & 17.32 & 19.59 & 30.32 & 3 & 1930.1650 & 1930.1615 & 644.3944 & 0.0035 & 1.8105 & 1.610\end{array}$

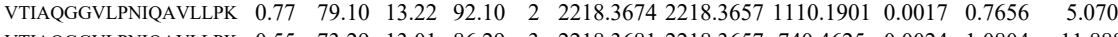
$\begin{array}{llllllllllll}\text { VITAQGGVLNQAVLLK } & 0.55 & 73.29 & 13.01 & 86.29 & 3 & 2218.3681 & 2218.3657 & 740.4625 & 0.0024 & 1.0804 & 11.888\end{array}$

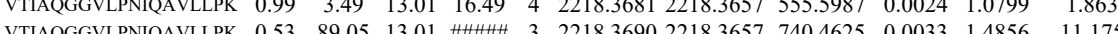
$\begin{array}{llllllllllll} & 11.175\end{array}$

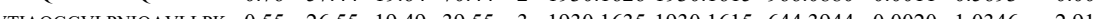
$\begin{array}{lllllllllllll} & \text { VTILQGGVLPNIQAVLLPK } & 0.55 & 76.53 & 13.01 & 89.53 & 3 & 2218.3678 & 22183657 & 740.4625 & 0.0021 & 0.9454 & 9.379\end{array}$ 


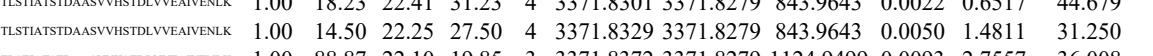

$\begin{array}{llllllllllllll} & & & \end{array}$

$\begin{array}{llllllllllll} & \end{array}$

$\begin{array}{llllllllllllll} & & \end{array}$

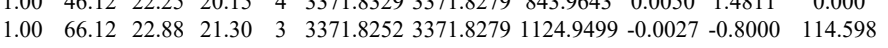

$\begin{array}{lllllllllllll}\text { LGAGYPMGPFELDYVGLDTTK } & 1.00 & 34.24 & 26.59 & 23.42 & 3 & 2644.3756 & 2644.3702 & 882.4640 & 0.0054 & 2.0397 & 28.205 & 45.569 \\ \text { IDDILQTLLDATYK } & 1.00 & 33.24 & 25.91 & 16.95 & 3 & 1909.0687 & 1909.0652 & 637.3623 & 0.0035 & 1.8305 & 134.676 & 224.503\end{array}$

$\begin{array}{lllllllllllllll} & \end{array}$ $\begin{array}{lllllllllllll}\text { MLLLLOAGGSVLGAMEK } & 1.00 & 60.47 & 22.46 & 16.87 & 3 & 23163169 & 2316.3153 & 773.1124 & 0.0016 & 0.6899 & 39.385 & 27.836\end{array}$

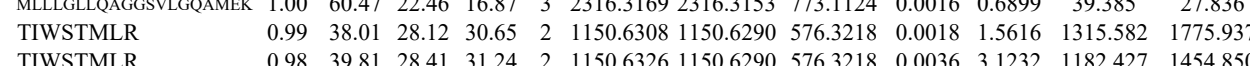

TIWSTMLR

$\begin{array}{llllllllllllll} & \text { NENTFLDLTVQQIEHLNK } & 1.00 & 52.85 & 26.45 & 19.22 & 3 & 2443.3003 & 2443.2951 & 815.4390 & 0.0052 & 2.1256 & 95.588 & 224.2\end{array}$

$\begin{array}{llllllllllllll}\text { NENTFLDLTVQQIEHLNK } & 0.53 & 48.77 & 26.41 & 61.77 & 3 & 2443.2979 & 2443.2951 & 815.4390 & 0.0028 & 1.1446 & 250.822 & 285.7 \\ \text { GLPDNISSVLNK } & 1.00 & 64.31 & 26.13 & 23.29 & 2 & 1543.8962 & 1543.8813 & 772.9479 & 0.0149 & 9.6383 & 2357.779 & 2813 .\end{array}$

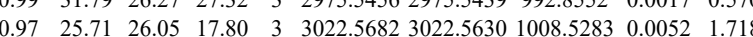

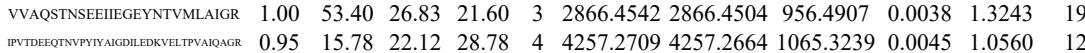

$\begin{array}{lllllllllllll}\text { VELTPVAIQAGR } & 1.00 & 55.06 & 24.61 & 26.71 & 2 & 1396.8298 & 1396.8160 & 699.4153 & 0.0138 & 9.8653 & 7896.407 & 3518\end{array}$

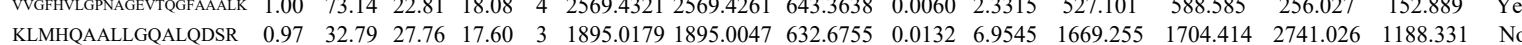

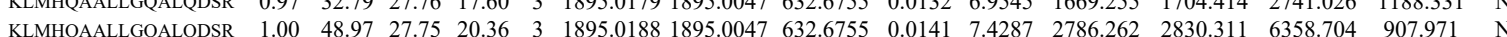
$\begin{array}{llllllllllllll} & \text { LMHQAALLGQALQDSR } \\ 0.070 & 17.18 & 27.75 & 27.82 & 3 & 1895.0188 & 1895.0169 & 632.6796 & 0.0019 & 1.0010 & 3883289 & 4286.752 & 3868.306 & 584.881\end{array}$ $\begin{array}{lllllllllllllll} & \end{array}$

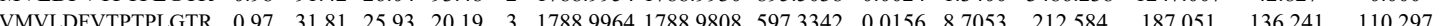
$\begin{array}{llllllllllllllllll} & \end{array}$

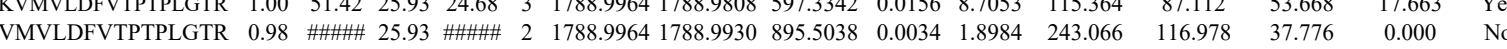

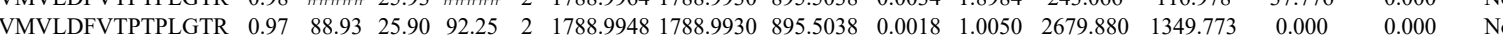

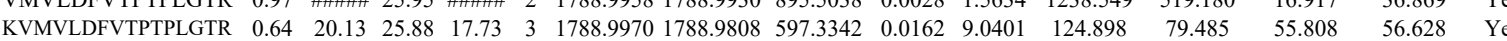
$\begin{array}{llllllllllllllll}\text { WGLGGTCVNVGCIPK } & 1.00 & 82.85 & 27.03 & 27.13 & 2 & 1882.9192 & 1882.9170 & 942.4658 & 0.0022 & 1.1671 & 2207.091 & 1009.008 & 94.465 & 75.662 & \text { Yes }\end{array}$

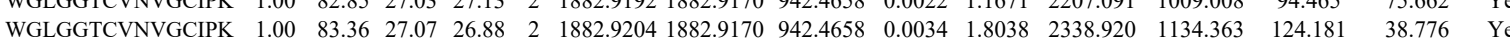

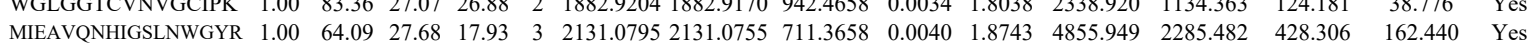

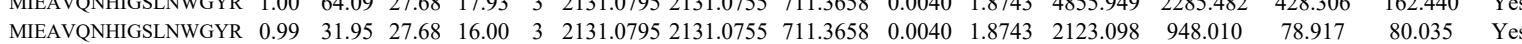
$\begin{array}{lllllllllllllllll}\text { FLIATGERPR } & 0.96 & 31.08 & 27.32 & 22.71 & 3 & 1302.7624 & 1302.7530 & 435.2583 & 0.0094 & 7.1987 & 83210.581 & 49916.395 & 2179.322 & 695.416 & \text { Yes }\end{array}$

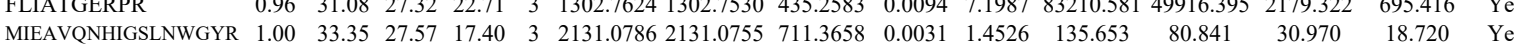
$\begin{array}{lllllllllllllllll}\text { FLIATGERPR } & 0.98 & 40.26 & 26.53 & 20.11 & 2 & 1302.7600 & 1302.7530 & 652.3838 & 0.0070 & 5.3649 & 7704.043 & 3976.088 & 211.730 & 119.005 & \text { Yes }\end{array}$ $\begin{array}{llllllllllllllllll}\text { FLIATGERPR } & 0.97 & 33.06 & 26.48 & 27.83 & 3 & 1302.7615 & 1302.7530 & 435.2583 & 0.0085 & 6.5095 & 53007.248 & 30302.938 & 1634.485 & 266.620 & \text { Yes }\end{array}$ $\begin{array}{llllllllllllllllll}\text { FLIATGERPR } & 0.96 & 29.98 & 26.48 & 22.64 & 3 & 1302.7618 & 1302.7530 & 435.2583 & 0.0088 & 6.7392 & 62201.919 & 31910.705 & 1620.357 & 305.224 & \text { Yes }\end{array}$ $\begin{array}{llllllllllllllll}\text { VMVLDFVTPTPLGTR } & 1.00 & 43.09 & 26.70 & 24.35 & 2 & 1804.9896 & 1804.9879 & 903.5012 & 0.0017 & 0.9408 & 23.698 & 10.426 & 4.997 & 0.000 & \text { No }\end{array}$ $\begin{array}{lllllllllllllllll}\text { FLIATGERPR } & 1.00 & 33.29 & 26.90 & 22.74 & 3 & 1302.7561 & 1302.7530 & 435.2583 & 0.0031 & 2.3741 & 850.608 & 519.827 & 102.360 & 42.507 & \text { Yes }\end{array}$

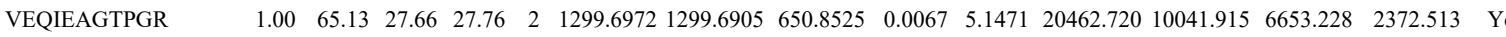
$\begin{array}{lllllllllllllllll}\text { VEQIEAGTPGR } & 1.00 & 62.87 & 27.47 & 21.09 & 2 & 1299.7014 & 1299.6905 & 650.8525 & 0.0109 & 8.3736 & 22566.904 & 10899.553 & 6906.278 & 3003.520 & \text { Yes }\end{array}$ $\begin{array}{llllllllllllllll}\text { VEQIEAGTPGR } & 1.00 & 64.22 & 27.52 & 22.09 & 2 & 1299.6992 & 1299.6905 & 650.8525 & 0.0087 & 6.6835 & 19850.800 & 9514.874 & 8552.193 & 1598.622 & \text { Yes }\end{array}$ $\begin{array}{lllllllllllllllll}1.00 & 60.91 & 27.52 & 23.17 & 2 & 1299.7002 & 1299.6905 & 650.8525 & 0.0097 & 7.4517 & 31781.241 & 13600.549 & 11340.847 & 1369.146 & \text { Yes }\end{array}$

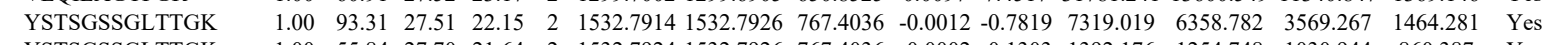

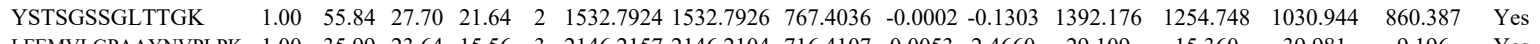

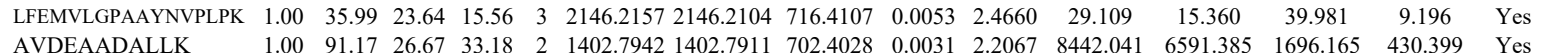
$\begin{array}{llllllllllllllll}\text { AVDEAADALLK } & 1.00 & 91.17 & 26.67 & 33.18 & 2 & 1402.7942 & 1402.7911 & 702.4028 & 0.0031 & 2.2067 & 8442.041 & 6591.385 & 1696.165 & 430.399 & \text { Yes } \\ \text { AVDEAADALLK } & 1.00 & 71.07 & 26.46 & 28.98 & 2 & 1402.7946 & 1402.7911 & 702.4028 & 0.0035 & 2.4914 & 8970.622 & 6613.430 & 1394.571 & 474.055 & \text { Yes }\end{array}$

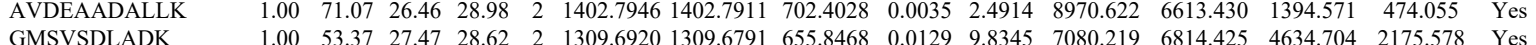
$\begin{array}{lllllllllllllllll}\text { VTQNLPMK } & 0.99 & 41.74 & 26.94 & 31.14 & 2 & 1217.7146 & 1217.7046 & 609.8596 & 0.0100 & 8.1985 & 14072.660 & 15820.370 & 9293.529 & 4299.321 & \text { Yes }\end{array}$ $\begin{array}{lllllllllllll} & \text { Y }\end{array}$ 
YNVLGAETVLNQMR AAEEQGDDQDSEK

AAEEQGDDQDSEK

YNVLGAETVLNQMR LVQIASR

LVQIASR

FPTLWSGAR

FPTLWSGAR
FPTLWSGAR

FPTLWSGAR

FPTLWSGAR

FPTLWSGAR

FPTLWSGAR

EVEGDDVPESIMLEMK

EVEGDDVPESIMLEMK

EVEGDDVPESIMLEM

21 ALDELFEAIEQK

ALDELFEAIEQK

ALDELFEAIEQK
ALDELFEAIEQK

DPTSLLGVLQAEADSTSEGLEDAVH

DPTSLLGVLQAEADSTSEGLEDAVHSR DPTSLLGVLLAEADSTSEGLLDAVHSR

DPTS GLAAEADSTSEGLEDAVHSR

DPTSLLGVLQAEADSTSEGLED,

FSSNQPPAAGSSR

FSSNQPPAAGSSR

FSSNQPPAAGSSR

NEFIGLQLLDVLAR

NEFIGLQLLDVLAR

SSQLLWEALESLVNR AEDEEELLR

AEDEEELLR AQLVLAACESLLTSR

LLQMPSVVNYSGLR

LLQMPSVVNYSGLR

AQLVLAACESLLTS

AQLVLAACESLLTS

AQLVLAACESLLTSR

AQLVLAACESLLTSR AQLVLAACESLLTSR

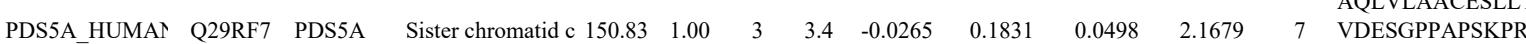
VDESGPPAPSKP STLIPILHQK STLIPILHQK

STLIPILHQK

NDDLNKPINK

NDDLNKPINK

ISLPEAMQLLQDR

ISLPEAMQLLQDR

VVLSGHPFK

VVLSGHPFK

MSVLNMVVR

MSVLNMVVR

MSVLNMVVR

MSVLNMVVR

IFQFQNFTNTR

IFQFQNFTNTR

IFQPNFTR

LEEMFPDEVDTPR

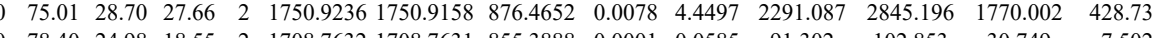
\begin{tabular}{lllllllllllll}
78.40 & 24.98 & 18.55 & 2 & 1708.7632 & 1708.7631 & 855.3888 & 0.0001 & 0.0585 & 91.302 & 102.853 & 30.749 & 7.502 \\
\hline 42.97 & 25.07 & 17.59 & 3 & 1708.7656 & 1708.7631 & 570.5950 & 0.0025 & 1.4605 & 49.110 & 54.225 & 53.955 & 4.29
\end{tabular} $\begin{array}{lllllllllllll} & \end{array}$

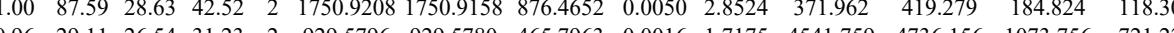

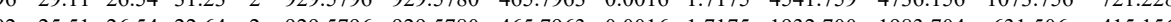

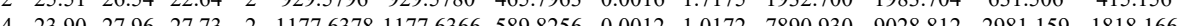

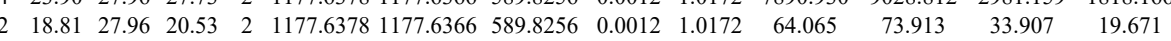

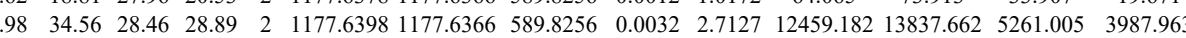
$\begin{array}{lllllllllllllll}0.82 & 23.36 & 28.52 & 32.23 & 2 & 1177.6388 & 1177.6366 & 589.8256 & 0.0022 & 1.8650 & 5063.088 & 5823.079 & 1278.194 & 808.749\end{array}$ $\begin{array}{llllllllllllllll} & \end{array}$ $\begin{array}{lllllllllllll}23.19 & 28.52 & 30.42 & 2 & 1177.6390 & 1177.6366 & 589.8256 & 0.0024 & 2.0345 & 2408.697 & 2445.268 & 368.240 & 236.228\end{array}$

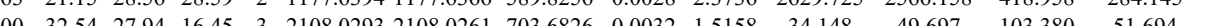
$\begin{array}{llllllllllllll} & \end{array}$

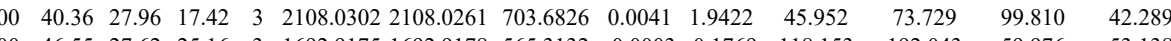
$\begin{array}{llllllllllllll}.00 & 46.55 & 27.62 & 25.16 & 3 & 1692.9175 & 1692.9178 & 565.3132 & -0.0003 & -0.1769 & 118.153 & 192.043 & 59.976 & 53.138\end{array}$ $\begin{array}{llllllllllllll}1.00 & 45.13 & 27.69 & 25.69 & 3 & 1692.9178 & 1692.9178 & 565.3132 & 0.0000 & 0.0000 & 98.315 & 182.279 & 66.783\end{array}$ $\begin{array}{lllllllllllll}1.00 & 50.94 & 27.59 & 28.21 & 3 & 1692.9169 & 1692.9178 & 565.3132 & -0.0009 & -0.5307 & 79.322 & 95.483 & 50.715\end{array}$ $\begin{array}{llllllllllllll}1.00 & 38.27 & 27.86 & 21.94 & 3 & 1692.9187 & 1692.9178 & 565.3132 & 0.0009 & 0.5307 & 91.046 & 98.915 & 92.739\end{array}$ $\begin{array}{lllllllll}0.55 & \text { \#\#\#\# } 27.29 \quad \text { \#\#\#\# } 32940.4453 & 2940.4434 & 981.1551 & 0.0019 & 0.6455 & 68.636\end{array}$ $\begin{array}{llllllllll} & 27.29 & 26.64 & 3 & 2940.4453 & 2940.4434 & 981.1551 & 0.0019 & 0.6455 & 14.520\end{array}$ $\begin{array}{lllllllll}27.32 & 22.76 & 3 & 2940.4459 & 2940.4434 & 981.1551 & 0.0025 & 0.8493 & 7.916\end{array}$ $\begin{array}{lllllllllll}1.00 & 26.94 & 28.41 & 2 & 1448.7130 & 1448.7130 & 725.3638 & 0.0000 & 0.0000 & 29.472 \\ 1.00 & 87.09 & 26.95 & 26.17 & 2 & 1448.7132 & 1448.7130 & 725.3638 & 0.0002 & 0.1379 & 55.770\end{array}$ $\begin{array}{llllllllll}1.00 & \# \# \# \text { 26.97 } 26.17 & 2 & 1488.7132 & 1448.7130 & 725.3638 & 0.0002 & 0.1379 & 55.770\end{array}$ $\begin{array}{llllllllllll} & 26.97 & 23.71 & 2 & 1484.7136 & 1448.7130 & 725.3638 & 0.0006 & 0.4136 & 36.851 \\ 1.45 & 27.03 & 31.14 & 2 & 1448.7142 & 1448.7130 & 725.3638 & 0.0012 & 0.8272 & 46.865\end{array}$ $\begin{array}{llllllllllll}1.00 & 91.45 & 27.03 & 31.14 & 2 & 1448.7142 & 1448.7130 & 725.3638 & 0.0012 & 0.8272 & 46.865 \\ 1.00 & 95.74 & 25.29 & 20.36 & 2 & 1744.0010 & 1744.0005 & 873.0075 & 0.0005 & 0.2864 & 296.501\end{array}$ $\begin{array}{lllllllllll}1.00 & 95.74 & 25.29 & 20.36 & 2 & 1744.0010 & 1744.0005 & 873.0075 & 0.0005 & 0.2864 & 296.501 \\ 1.00 & 97.48 & 25.20 & 24.72 & 2 & 1744.0018 & 1744.0005 & 873.0075 & 0.0013 & 0.7446 & 141.140\end{array}$ $\begin{array}{lllllllllll}1.00 & 46.87 & 26.82 & 27.89 & 3 & 1888.0207 & 1888.0176 & 630.3465 & 0.0031 & 1.6393 & 61.262\end{array}$ $\begin{array}{lllllllllll}0.78 & 33.86 & 26.96 & 28.71 & 3 & 1888.0213 & 1888.0176 & 630.3465 & 0.0037 & 1.9566 & 61.076\end{array}$ $\begin{array}{llllllllllll}1.00 & 51.46 & 27.82 & 17.49 & 3 & 1763.9410 & 1763.9395 & 588.9871 & 0.0015 & 0.8489 & 104.147\end{array}$ $\begin{array}{llllllllllll}1.00 & 49.73 & 27.82 & 18.74 & 3 & 1763.9413 & 1763.9395 & 588.9871 & 0.0018 & 1.0187 & 95.471 & \\ 1.00 & 76.75 & 27.50 & 29.07 & 2 & 1719.9462 & 1719.9463 & 860.9804 & -0.0001 & -0.0581 & 374.388\end{array}$ $\begin{array}{lllllllllllll}1.00 & 80.41 & 27.64 & 28.74 & 2 & 1719.9472 & 1719.9463 & 860.9804 & 0.0009 & 0.5227 & 366.575 & 6 & \\ 1.00 & 9.93 & 27.94 & 2.4 & 2 & 176.930 & & \end{array}$ $\begin{array}{lllllllllll}.00 & 90.93 & 27.94 & 26.43 & 2 & 1763.9390 & 1763.9395 & 882.9770 & -0.0005 & -0.2831 & 35.43\end{array}$ $\begin{array}{lllllllllll}1.00 & 86.07 & 27.88 & 23.13 & 2 & 1763.9392 & 1763.9395 & 882.9770 & -0.0003 & -0.1699 & 41.698\end{array}$ $\begin{array}{lllllllllll}1.05 & 50.65 & 27.87 & 17.13 & 3 & 1763.9407 & 1763.9395 & 588.9871 & 0.0012 & 0.6791 & 69.700\end{array}$ $\begin{array}{lllllllllll}0.55 & 59.06 & 27.82 & 72.06 & 3 & 1763.9413 & 1763.9395 & 588.9871 & 0.0018 & 1.0187 & 76.530 \\ 0.94 & 24.03 & 27.87 & 22.33 & 3 & 1763.9407 & 1763.9395 & 588.9871 & 0.0012 & 0.6791 & 4.836\end{array}$ $\begin{array}{llllllllllll}1.00 & 40.03 & 27.75 & 19.64 & 3 & 1763.9401 & 1763.9395 & 588.9871 & 0.0006 & 0.3396 & 12.877\end{array}$ $\begin{array}{llllllllllllllll}61.75 & 27.74 & 19.41 & 3 & 1623.8848 & 1623.8824 & 542.3014 & 0.0024 & 1.4752 & 8663.903 & 8664.603 & 13950.581 & 8403.028 & \text { Yes }\end{array}$ $\begin{array}{lllllllllllllllll}1.82 & 27.76 & 23.83 & 3 & 1623.8851 & 1623.8824 & 542.3014 & 0.0027 & 1.6596 & 12038.716 & 141.738 & 17110.656 & 9259.887 & \text { Yes } \\ 0.61 & 22.09 & 17.78 & 27.16 & 3 & 1436.9047 & 1436.8959 & 479.9726 & 0.0088 & 6.1114 & 13219.002 & 12640.081 & 1892.493 & 889.320 & \text { Y s }\end{array}$ $\begin{array}{lllllllllllllll}0.97 & 22.15 & 17.78 & 15.47 & 3 & 1436.9044 & 1436.8959 & 479.9726 & 0.0085 & 5.9031 & 18376.087 & 16598.537 & 1985.600 & 497.445 & \text { Yes }\end{array}$ $\begin{array}{llllllllllllllll}0.84 & 16.60 & 18.06 & 14.83 & 3 & 1436.9062 & 1436.8959 & 479.9726 & 0.0103 & 7.1531 & 18820.957 & 17259.096 & 4175.204 & 2145.179 & \text { Yes }\end{array}$ $\begin{array}{llllllllllllllll}0.98 & 25.28 & 26.32 & 20.80 & 3 & 1601.9131 & 1601.9102 & 534.9773 & 0.0029 & 1.8069 & 23170.868 & 29579.036 & 28601.699 & 21935.501 & \text { Yes }\end{array}$ $\begin{array}{lllllllllllllll}0.99 & 30.22 & 26.21 & 19.28 & 3 & 1601.9143 & 1601.9102 & 534.9773 & 0.0041 & 2.5546 & 24735.697 & 27518.174 & 27648.109 & 20723.483 & \text { Yes }\end{array}$ $\begin{array}{lllllllllllllll}1.00 & 70.68 & 27.35 & 28.77 & 2 & 1656.9010 & 1656.8990 & 829.4568 & 0.0020 & 1.2056 & 643.065 & 447.624 & 67.918 & 76.766 & \text { Yes }\end{array}$

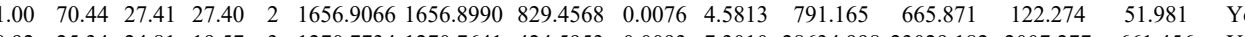
$\begin{array}{lllllllllllllll}0.92 & 25.34 & 24.81 & 19.57 & 3 & 1270.7734 & 1270.7641 & 424.5953 & 0.0093 & 7.3010 & 28634.998 & 23029.182 & 2007.277 & 661.456 & \text { Yes }\end{array}$ $\begin{array}{lllllllllllllll}0.95 & 27.47 & 24.81 & 19.45 & 3 & 1270.7734 & 1270.7641 & 424.5953 & 0.0093 & 7.3010 & 38241.148 & 29187.220 & 2126.451 & 701.490 & \text { Yes }\end{array}$

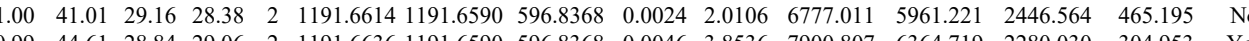
$\begin{array}{lllllllllllllll}0.99 & 44.61 & 28.84 & 29.06 & 2 & 1191.66361191 .6590 & 596.8368 & 0.0046 & 3.8536 & 7900.807 & 6364.719 & 2280.030 & 304.953 & \text { Yes } \\ 1.09 & 42.73 & 28.71 & 37.55 & 2 & 1191.6061191 .690 & 56.8368 & 0.006 & 1.3404 & 5950.679 & 4651.879 & 969.824 & 300.593 & \text { Yes }\end{array}$ $\begin{array}{llllllllllllllll}1.00 & 42.73 & 28.71 & 37.55 & 2 & 1191.6606 & 1191.6590 & 596.8368 & 0.0016 & 1.3404 & 5950.679 & 4651.879 & 969.824 & 300.593 & \text { Yes } \\ 0.98 & 38.01 & 28.71 & 39.31 & 2 & 1191.6610 & 1191.6590 & 596.8368 & 0.0020 & 1.6755 & 9458.771 & 6948.553 & 999.309 & 280.656 & \text { Yes }\end{array}$

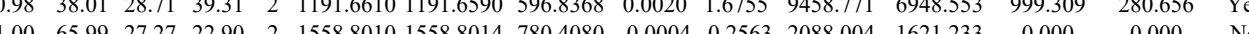

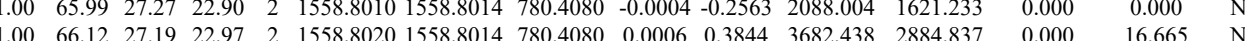
$\begin{array}{lllllllllllllll}1.00 & 66.12 & 27.19 & 22.97 & 2 & 1558.8020 & 1558.8014 & 780.4080 & 0.0006 & 0.3844 & 3682.438 & 2884.837 & 0.000 & 16.665 & \text { No }\end{array}$ \begin{tabular}{llllllllllllll}
1.00 & 66.17 & 27.30 & 23.08 & 2 & 1588.8016 & 1558.804 & 78.408 & 0.006 & 0.3844 & 3682.438 & 2884.837 & 0.000 & 16.665 \\
\hline
\end{tabular} $\begin{array}{llllllllllllll}1.00 & 69.34 & 26.60 & 24.96 & 2 & 1720.8116 & 1720.8100 & 861.4123 & 0.0016 & 0.9287 & 304.220 & 298.416 & 41.795 & 64.515\end{array}$ 
$\begin{array}{llllllllllllll}0.85 & 19.60 & 27.83 & 21.25 & 3 & 1802.9293 & 1802.9254 & 601.9824 & 0.0039 & 2.1595 & 1400.674 & 1304.580 & 1010.426\end{array}$

$\begin{array}{llllllllllll}\text { CE022 HUMAN Q49AR2 } & \text { C5orf22 } & \text { UPF0489 protein } 149.97 & 1.00 & 2 & 6.8 & 0.0702 & 0.8248 & -1.3561 & 0.9165 & 4 & \text { NLPNPTLVTIAR }\end{array}$

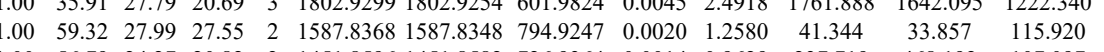
NLPNPTLVTIAR

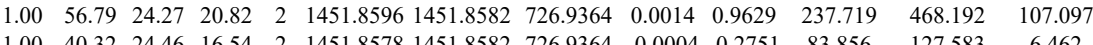
NLPNPTLVTIAR $\begin{array}{lllllllllll}1.00 & 40.32 & 24.46 & 16.54 & 2 & 1451.8578 & 1451.8582 & 726.9364 & -0.0004 & -0.2751 & 83.856\end{array}$ KPGTNLTEEDLVDIVD

$\begin{array}{llllllllll}\text { DHB12_HUMAI Q53GQ0 } & \text { HSD17B12Estradiol 17-beta-1 } & 34.32 & 1.00 & 4 & 17 & 0.2578 & 0.2753 & -1.2858 & 0.9918\end{array}$ VVLISR

VVLISR $\begin{array}{llllllllllllll}0.97 & 27.41 & 24.27 & 14.87 & 2 & 1451.8596 & 1451.8582 & 726.9364 & 0.0014 & 0.9629 & 86.865 & 49.250 & 12.514\end{array}$

$\begin{array}{lllllllllllllll}0.91 & 25.14 & 22.76 & 31.47 & 2 & 829.5534 & 829.5507 & 415.7826 & 0.0027 & 3.2469 & 46439.532 & 55837.156 & 5680.251 & 2001 .\end{array}$ $\begin{array}{lllllllllllllll}0.94 & 24.65 & 22.76 & 29.26 & 2 & 829.5538 & 829.5507 & 415.7826 & 0.0031 & 3.7279 & 30571.187 & 33540.034 & 5624.383 & 2901.066 & \text { Y }\end{array}$ GALNISSGSGMLPVPL

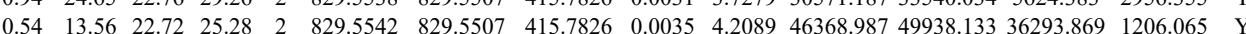
$\begin{array}{lllllllllllllllll}0.97 & 31.26 & 27.92 & 30.97 & 2 & 905.5218 & 905.5205 & 453.7675 & 0.0013 & 1.4324 & 4855.885 & 4845.512 & 1023.782 & 256.033 & \text { Yes }\end{array}$ $\begin{array}{llllllllllllllll}1.00 & 44.64 & 26.97 & 20.42 & 3 & 2098.1254 & 2098.1223 & 700.3814 & 0.0031 & 1.4754 & 245.447 & 290.884 & 46.014 & 40.185 & \text { No }\end{array}$ $\begin{array}{lllllllllllllll}1.00 & 54.55 & 26.80 & 32.36 & 2 & 1243.7200 & 1243.7192 & 622.8669 & 0.0008 & 0.6422 & 4244.902 & 3367.303 & 25.320 & 20.884 & \text { Yes }\end{array}$

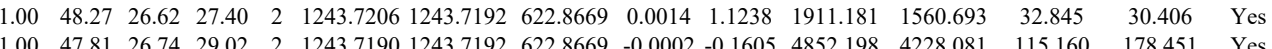

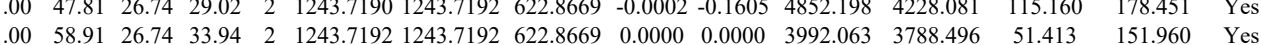

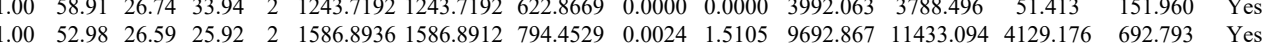
$\begin{array}{lllllllllllllll}1.00 & 60.15 & 26.62 & 23.99 & 2 & 1586.8960 & 1586.8912 & 794.4529 & 0.0048 & 3.0209 & 15743.765 & 15423.286 & 5570.053 & 1135.682 & \text { Yes }\end{array}$ $\begin{array}{lllllllllllllllll}1.00 & 63.17 & 26.61 & 27.05 & 2 & 1586.8940 & 1586.8912 & 794.4529 & 0.0028 & 1.7622 & 12235.739 & 9684.032 & 4893.060 & 989.946 & \text { Yes }\end{array}$

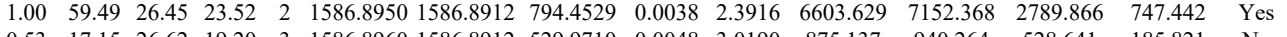
$\begin{array}{lllllllllllllllll}0.53 & 17.15 & 26.62 & 19.20 & 3 & 1586.8960 & 1586.8912 & 529.9710 & 0.0048 & 3.0190 & 875.137 & 940.264 & 528.641 & 185.821 & \text { No }\end{array}$ $\begin{array}{lllllllllllllll}0.71 & 19.93 & 26.59 & 21.96 & 3 & 1586.8963 & 1586.8912 & 529.9710 & 0.0051 & 3.2077 & 961.462 & 982.963 & 323.052 & 85.028 & \text { Yes } \\ 1.00 & 59.01 & 26.72 & 28.03 & 2 & 15868918 & 1586812 & 794.4529 & 0.006 & 0.3776 & 64.499 & 86.511 & 18.172 & 8.094 & \text { Yes }\end{array}$ $\begin{array}{lllllllllllllll}1.00 & 59.01 & 26.72 & 28.03 & 2 & 1586.8918 & 1586.8912 & 794.4529 & 0.0006 & 0.3776 & 64.499 & 86.511 & 18.172 & 8.094 & \text { Yes } \\ 1.00 & 57.89 & 26.67 & 26.99 & 2 & 15868926 & 15868912 & 794.4529 & 0.0014 & 0.8811 & 360.515 & 417.722 & 92529 & 16528 & \text { Yes }\end{array}$

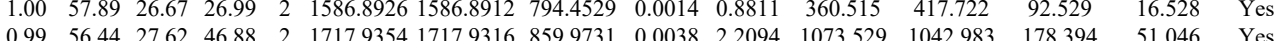
$\begin{array}{llllllllllllllll} & \end{array}$ $\begin{array}{llllllllllllll}\text { EPYMDEIFHLPQAQR } & 1.00 & 45.49 & 27.19 & 20.21 & 3 & 2016.9874 & 2016.9849 & 673.3356 & 0.0025 & 1.2376 & 1122.262 & 1993.554 & 328.400\end{array}$ LNIPLPPTSR

CAPPRPPSSPEQR

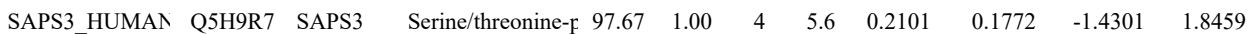
CAAPRPPSSSPEQR CAAPRPPSSSPEQR QEIIEQLLSNIFHK QEIIEQLLSNIFHK QEIIEQLLSNIFHK QEIIEQLLSNIFHK QEIIEQLLSNIFHK

VLSILISR

VLSILISR

VLSILISR

VLSILISR

VLSILISR

VLSILISR ELMDEEDVLQECK

$\begin{array}{llllllllllll}\text { RRP12_HUMAN Q5JTH9 } & \text { RRP12 } & \text { RRP12-like protei } 143.70 & 1.00 & 7 & 6.2 & -0.1769 & 0.4690 & 0.0498 & 2.9968 & 12 & \text { LLPEEYHR }\end{array}$

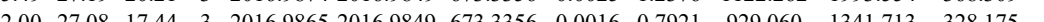
$\begin{array}{llllllllllllllll}1.00 & 42.68 & 25.29 & 21.77 & 2 & 1250.7474 & 1250.7468 & 6263807 & 0.0006 & 0.4789 & 6044.750 & 7710.574 & 685.590 & 590.017 & \text { Yes }\end{array}$

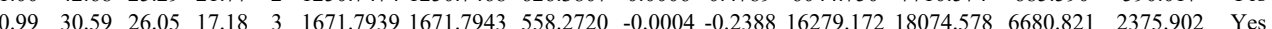
$\begin{array}{llllllllllllllll}0.86 & 18.53 & 26.05 & 17.78 & 3 & 1671.7954 & 1671.7943 & 558.2720 & 0.0011 & 0.6568 & 17789.173 & 17039.808 & 9040.822 & 5731.366 & \text { Yes }\end{array}$ $\begin{array}{lllllllllllllll}1.00 & 63.70 & 24.13 & 24.09 & 3 & 1999.1380 & 1999.1346 & 667.3855 & 0.0034 & 1.6982 & 1406.845 & 1629.391 & 368.799 & 0.000 & \text { No }\end{array}$ $\begin{array}{llllllllllllllll}1.00 & 63.73 & 24.13 & 23.61 & 3 & 1999.1383 & 1999.1346 & 667.3855 & 0.0037 & 1.8480 & 2094.426 & 2360.355 & 693.581 & 44.934 & \text { Yes }\end{array}$ $\begin{array}{lllllllllllllllll}1.00 & 82.86 & 24.12 & 23.43 & 3 & 1999.1377 & 1999.1346 & 667.3855 & 0.0031 & 1.5483 & 1762.974 & 1809.622 & 443.442 & 84.011 & \text { Yes } \\ 1.00 & 61.32 & 23.9 & 20.51 & 3 & 1999.1386 & 199.1346 & 667.385 & 0.000 & 1.9978 & 3120.931 & 3508.766 & 1035.891 & 119.261 & \text { Yes }\end{array}$ $\begin{array}{lllllllllllllll}1.00 & 79.53 & 24.15 & 22.31 & 3 & 1999.1371 & 1999.1346 & 667.3855 & 0.0025 & 1.2487 & 729.608 & 951.841 & 293.219 & 40.955 & \text { Yes }\end{array}$ $\begin{array}{lllllllllllllll}1.00 & 75.54 & 24.12 & 29.89 & 3 & 1999.1377 & 1999.1346 & 667.3855 & 0.0031 & 1.5483 & 1517.700 & 1582.616 & 412.937 & 42.428 & \text { Yes }\end{array}$ $\begin{array}{llllllllllllllll}1.00 & 44.34 & 20.17 & 19.95 & 2 & 1043.6832 & 1043.6824 & 522.8485 & 0.0008 & 0.7650 & 11048.218 & 14539.786 & 1128.664 & 34.961 & \text { Yes }\end{array}$ $\begin{array}{llllllllllllllll}1.00 & 44.57 & 20.17 & 19.54 & 2 & 1043.6836 & 1043.6824 & 522.8485 & 0.0012 & 1.1476 & 7474.204 & 9787.807 & 472.285 & 161.872 & \text { Yes }\end{array}$ $\begin{array}{llllllllllllllll}1.00 & 45.19 & 20.25 & 19.10 & 2 & 1043.6820 & 1043.6824 & 522.8485 & -0.0004 & -0.3825 & 3901.534 & 4842.925 & 193.882 & 50.874 & \text { Yes }\end{array}$ $\begin{array}{lllllllllllllll}1.00 & 45.95 & 20.25 & 19.54 & 2 & 1043.6828 & 1043.6824 & 522.8485 & 0.0004 & 0.3825 & 4533.762 & 6264.874 & 212.838 & 37.988 & \text { Yes }\end{array}$ $\begin{array}{llllllllllllllll}0.99 & 39.52 & 20.57 & 18.94 & 2 & 1043.6814 & 1043.6824 & 522.8485 & -0.0010 & -0.9563 & 720.399 & 956.971 & 146.261 & 50.429 & \text { Yes }\end{array}$ $\begin{array}{lllllllllllllll}1.00 & 37.32 & 20.25 & 16.76 & 2 & 1043.6826 & 1043.6824 & 522.8485 & 0.0002 & 0.1913 & 576.618 & 790.396 & 168.909 & 101.410 & \text { Yes }\end{array}$ $\begin{array}{lllllllllllllll} & & & \end{array}$ \begin{tabular}{llllllllllllllll} 
& \\
EFITALIPEVILCTK & 0.53 & 32.33 & 24.90 & 45.33 & 3 & 2431.3351 & 2431.3310 & 811.4509 & 0.0041 & 1.6842 & 12.777 & 31.328 & 23.269 & 16.254 & Yes \\
\hline
\end{tabular} \begin{tabular}{llllllllllllllll} 
LSVLDLVWEVICTK & 0.53 & 32.33 & 24.90 & 45.33 & 3 & 2023.1374 & 2023.1341 & 675.3853 & 0.0033 & 1.6287 & 156.658 & 120.548 & 83.901 & 42.718 & Yes \\
\hline
\end{tabular} $\begin{array}{llllllllllllllll} & \\ \text { LSVDDLVALAPCADEAAISK } & 1.00 & 33.21 & 24.53 & 16.66 & 3 & 2431.3345 & 2431.3310 & 811.4509 & 0.0035 & 1.4378 & 22.895 & 0.000 & 0.000 & 10.826 & \text { No }\end{array}$

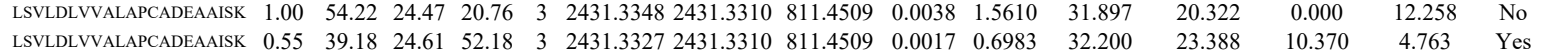

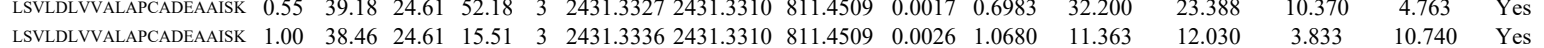

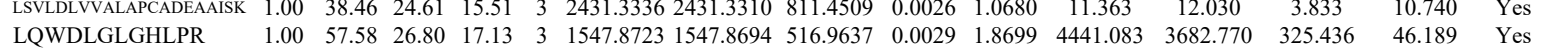
\begin{tabular}{llllllllllllllll} 
& \\
LQWDLGLGHLPR & 1.00 & 60.46 & 26.78 & 21.96 & 3 & 1547.8729 & 1547.8694 & 516.9637 & 0.0035 & 2.2568 & 5025.571 & 4070.140 & 116.717 & 95.098 & Yes \\
\hline
\end{tabular}

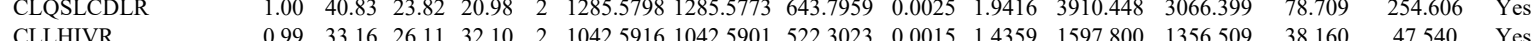


$\begin{array}{llllllllll} & \end{array}$

$\begin{array}{llllllllllll}0.61 & 59.89 & 25.81 & 72.89 & 2 & 1512.7108 & 1512.7113 & 757.3629 & -0.0005 & -0.3301 & 985.625\end{array}$

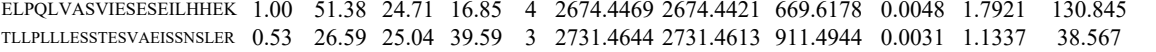
$\begin{array}{llllllllllllll} & \end{array}$ $\begin{array}{lllllllllllll}\text { TTLEVLQLFPINIK } & 1.00 & 41.41 & 18.33 & 20.27 & 3 & 1916.1616 & 1916.1590 & 639.7269 & 0.0026 & 1.3547 & 160.866 & 21 .\end{array}$

$\begin{array}{lllllllllll}33.27 & 18.33 & 21.46 & 3 & 1916.1625 & 1916.1590 & 639.7269 & 0.0035 & 1.8237 & 117.5\end{array}$ $\begin{array}{llllllllllll} & 16.86 \\ 1.00 & 29.70 & 25.87 & 16.86 & 3 & 2497.3186 & 2497.3186 & 833.4468 & 0.0000 & 0.0000 & 6.642\end{array}$

\section{TEALSVIELLLK} $\begin{array}{lllllllllll} & \\ 1.00 & 54.49 & 24.82 & 19.38 & 3 & 2152.1392 & 2152.1337 & 718.3852 & 0.0055 & 2.5520 & 1928.460\end{array}$ 

$\begin{array}{lllllllllll}1.00 & 54.17 & 27.54 & 19.14 & 3 & 2482.2706 & 2482.2681 & 828.4300 & 0.0025 & 1.0059 & 3.232\end{array}$

$\begin{array}{lllllllllllll} & \text { GAALGN }\end{array}$ $\begin{array}{lllllllllll} & \end{array}$

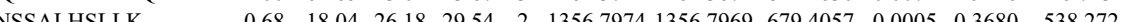

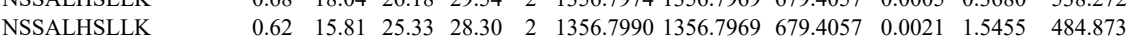
99.474

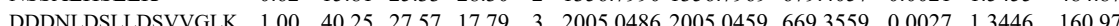
$\begin{array}{lllllllllll} & \end{array}$

$\begin{array}{lllllllllll}1.00 & 19.38 & 26.79 & 14.37 & 4 & 2334.2401 & 2334.2360 & 584.5663 & 0.0041 & 1.7492 & 8307.1634 \\ 99.526\end{array}$ IFSGVFVK $\begin{array}{lllllllllll} & \end{array}$

$\begin{array}{llllllllllll} & 1183.7228 & 1183.7209 & 592.8677 & 0.0019 & 1.6024 & 1707.178 & 2051.448 & 14\end{array}$

SSPSVKPAVDPAA ILRPGGCLFLK ILRPGGCLFLK $\begin{array}{lllllllllll}1.00 & 44.35 & 22.79 & 16.98 & 3 & 1856.0803 & 1856.0733 & 619.6984 & 0.0070 & 3.7653 & 30875.383\end{array}$ EPLTPEEVQSVR $\begin{array}{llllllllllll}0.81 & 20.86 & 28.06 & 24.55 & 3 & 1261.7044 & 1261.7039 & 421.5752 & 0.0005 & 0.3953 & 9.28\end{array}$ 25436.153 PLTPEEVQSVR $\begin{array}{llllllllllll}0.96 & 27.18 & 28.06 & 25.59 & 3 & 1261.7044 & 1261.7039 & 421.5752 & 0.0005 & 0.3953 & 3.255 \\ 1.06 & 51.33 & 28.02 & 259 & 3 & 1261.7044 & 1261.7039 & 421.5752 & 0.0005 & 0.3953 & 11.732\end{array}$ $\begin{array}{llllllllllllllll}\text { AHATTSNTVSK } & 0.99 & 35.51 & 28.25 & 21.53 & 3 & 1403.7613 & 1403.7612 & 468.9277 & 0.0001 & 0.0711 & 97.267 & 121.215 & 105.722 & 25.621 & \text { Yes }\end{array}$ $\begin{array}{llllllllllllllll}\text { QAEMEGAVQSIQGELSK } & 0.89 & 19.72 & 27.81 & 15.83 & 3 & 2092.0738 & 2092.0714 & 698.3644 & 0.0024 & 1.1455 & 306.981 & 272.382 & 293.071 & 186.731 & \text { Yes }\end{array}$ $\begin{array}{llllllllllllllll}\text { QAEMEGAVQSIQGELSK } & 0.79 & 18.90 & 27.80 & 16.80 & 3 & 2092.0765 & 2092.0714 & 698.3644 & 0.0051 & 2.4343 & 235.677 & 286.354 & 341.065 & 229.789 & \text { Yes }\end{array}$ $\begin{array}{lllllllllllllll}\text { IIGAVDQIQLTQAQLEER } & 0.76 & \# \# \# \# \text { 25.48 } & \text { \#\#\#\# } & 2 & 2168.1934 & 2168.1923 & 1085.1034 & 0.0011 & 0.5069 & 425.878 & 647.780 & 265.573 & 7.765 & \text { No }\end{array}$

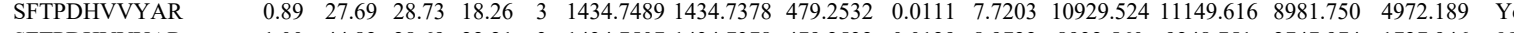
$\begin{array}{llllllllllllllll}\text { SFPPDHVVYAR } & 1.00 & 44.82 & 28.69 & 22.21 & 3 & 1434.7507 & 1434.7378 & 479.2532 & 0.0129 & 8.9722 & 8932.560 & 9248.751 & 2747.974 & 1727.946 & \text { No }\end{array}$

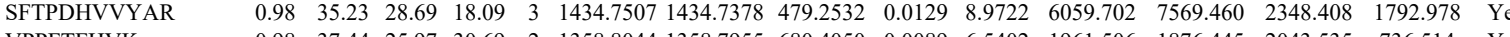

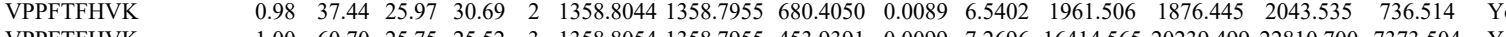

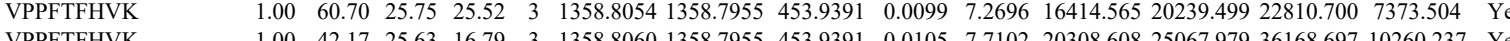

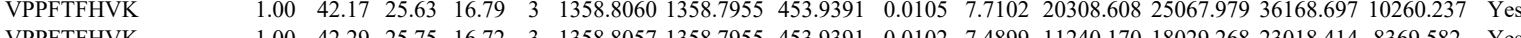
$\begin{array}{llllllllllllllll} & 1.00 & 42.29 & 25.75 & 16.72 & 3 & 1358.8057 & 1358.7955 & 453.9391 & 0.0102 & 7.4899 & 11240.170 & 18029.268 & 23018.414 & 8369.582 & \text { Yes }\end{array}$ $\begin{array}{lllllllllllllllll}\text { VPPTFHVK } & 1.00 & 54.84 & 25.63 & 22.84 & 3 & 1358.8060 & 1358.7955 & 453.9391 & 0.0105 & 7.7102 & 7158.914 & 11200.349 & 14610.081 & 4064.111 & \text { Yes }\end{array}$

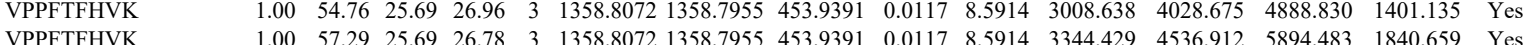
$\begin{array}{lllllllllllllll}1.00 & 57.29 & 25.69 & 26.78 & 3 & 1358.8072 & 1358.7955 & 453.9391 & 0.0117 & 8.5914 & 3344.429 & 4536.912 & 5894.483 & 1840.659 & \text { Yes }\end{array}$

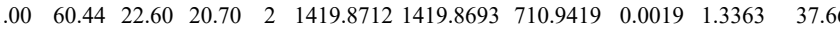
NIFAILQSVK $\begin{array}{llllllllllllll}1.00 & 73.50 & 21.67 & 22.21 & 2 & 1419.8750 & 1419.8693 & 710.9419 & 0.0057 & 4.0088 & 36.940 & 33.867 & 11.268\end{array}$ NIFAILQSVK

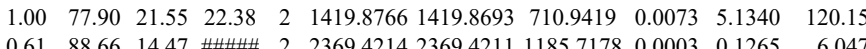

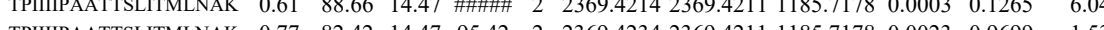
$\begin{array}{lllllllllllll}\text { TPIIIPAATTSLITMLNAK } & 1.00 & 51.80 & 16.63 & 20.83 & 3 & 2385.4189 & 2385.4160 & 796.1459 & 0.0029 & 1.2142 & 7.740\end{array}$ 

$\begin{array}{llllllllllll}\text { DEDPLELANTLYNNTIK } & 1.00 & 50.52 & 27.48 & 18.96 & 3 & 2250.1669 & 2250.1623 & 751.0614 & 0.0046 & 2.0416 & 32.397\end{array}$ $\begin{array}{lllllllllllll}\text { NEPCHIIQILEIMSAVR } & 1.00 & 68.96 & 27.78 & 30.81 & 3 & 2155.1110 & 2155.1073 & 719.3764 & 0.0037 & 1.7144 & 4.122\end{array}$ LPMFLHCR

$\begin{array}{lllllllllll}1.00 & 52.14 & 26.89 & 19.78 & 3 & 1205.5975 & 1205.5993 & 402.8737 & -0.0018 & -1.4893 & 292.13 \\ 1.00 & 43.56 & 26.90 & 23.66 & 3 & 1205.5987 & 1205.5993 & 402.8737 & -0.0006 & -0.4964 & 343.476\end{array}$

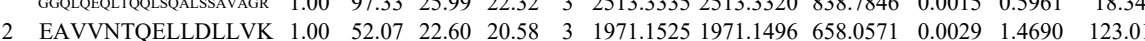
$\begin{array}{llllllllllll}\text { EAVVNTQELLDLLVK } & 1.00 & 53.20 & 22.53 & 20.48 & 3 & 1971.1531 & 1971.1496 & 658.0571 & 0.0035 & 1.7729 & 135.542\end{array}$ \begin{tabular}{lllllllllllll} 
TDMIQALGGVEGLLEHTLFK & 1.00 & 98.36 & 24.98 & 24.61 & 3 & 2459.3389 & 2459.3338 & 820.7852 & 0.0051 & 2.0712 & 216.302 \\
\hline
\end{tabular} $\begin{array}{lllllllllllllll} & & & \end{array}$ $\begin{array}{llllllllllllll}\text { TDMIQALGGVEGILEHTLFK } & 1.00 & 89.72 & 25.01 & 19.57 & 3 & 2459.3392 & 2459.3338 & 820.7852 & 0.0054 & 2.1930 & 2073.932 & 1705.500 & 87.866 \\ \text { TDMIQALGGVEGLEHTLFK } & 1.00 & 79.30 & 25.01 & 22.86 & 3 & 2459.3392 & 2459.3338 & 820.7852 & 0.0054 & 2.1930 & 9996.085 & 9517.559 & 744.773\end{array}$

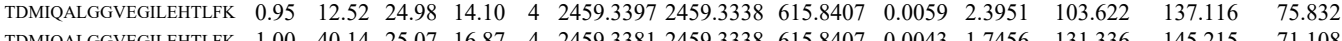
$\begin{array}{llllllllllllll}\text { TDMIQALGGVEGILEHTLFK } & 1.00 & 40.14 & 25.07 & 16.87 & 4 & 2459.3381 & 2459.3338 & 615.8407 & 0.0043 & 1.7456 & 131.336 & 145.215 & 71.108\end{array}$ $\begin{array}{llllllllllllll}\text { TDMIQALGGVEGILEHTLFK } & 1.00 & 85.66 & 25.01 & 20.14 & 3 & 2459.3392 & 2459.3338 & 820.7852 & 0.0054 & 2.1930 & 1870.439 & 2020.304 & 144.710 \\ \end{array}$

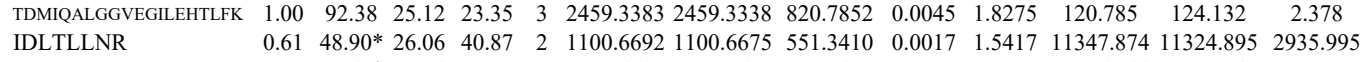
IDLTLLNR LDWVEVGLQVCR FICISDLR LLILALER AISAANLHLR AISAANLHL LLILALER

LPPVVFYTPK

FPPVVFYTPK

TILQHLSEAWR

TILOHLSEAWR

VPGLPTPIENMILR

VPGLPTPIENMILR

VPGLPTPIENMILR

VPGLPTPIENMILR

QGYNMLNLLIHR QGYNMLNLLIHR IHIFFR

WLGNLLAR

IHIFFR
IHIFFR

ISLIQIFR

ISLIQIFR

ISLIQIFR

ISLIQIFR

ISLIQIFR

ISLIQIFR

ISLIQIFR

ISLIQIFR

LTLEDLEDSWDR $\begin{array}{llllllllllllll}0.88 & 52.61 * 25.94 & 35.86 & 2 & 1100.6698 & 1100.6675 & 551.3410 & 0.0023 & 2.0858 & 20156.544 & 21070.143 & 5808.125 & 630.483\end{array}$

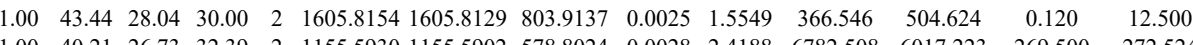
$\begin{array}{rrrrrrrrrrrrrr}1.00 & 40.21 & 26.73 & 32.39 & 2 & 1155.5930 & 1155.5902 & 578.8024 & 0.0028 & 2.4188 & 6782.508 & 6017.223 & 269.500 & 272.524 \\ 0.99 & 36.54 & 17.24 & 34.30 & 2 & 1083.7158 & 1083.7137 & 542.8641 & 0.0021 & 1.9342 & 7497.156 & 7434.433 & 425.420 & 0.000\end{array}$ $\begin{array}{llllllllllllll}1.00 & 40.21 & 26.73 & 32.39 & 2 & 1155.5930 & 1155.5902 & 578.8024 & 0.0028 & 2.4188 & 6782.508 & 6017.223 & 269.500\end{array}$

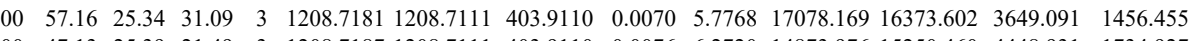

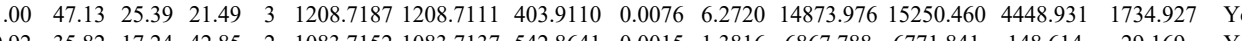

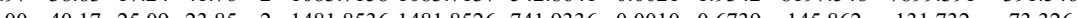
$\begin{array}{lllllllllllll}1.00 & 50.69 & 25.42 & 25.45 & 2 & 1481.85401481 .8526 & 741.9336 & 0.0014 & 0.9435 & 25.786 & 237.406 & 230.574\end{array}$

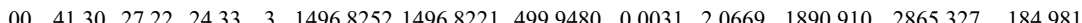

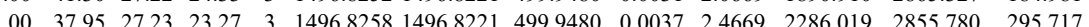
$\begin{array}{lllllllllllllll}0.76 & 43.20 & 24.65 & 56.20 & 2 & 1692.9728 & 1692.9718 & 847.4932 & 0.0010 & 0.5900 & 358.606 & 519.150 & 212.022 & 416\end{array}$ $\begin{array}{lllllllllllllll}1.00 & 54.96 & 24.65 & 17.65 & 2 & 1692.9730 & 1692.9718 & 847.4932 & 0.0012 & 0.7080 & 1062.878 & 837.477 & 574.181 & 771\end{array}$ $\begin{array}{llllllllllllll}0.76 & 46.74 & 24.53 & 59.74 & 2 & 1692.9724 & 1692.9718 & 847.4932 & 0.0006 & 0.3540 & 253.861 & 196.337 & 273.138\end{array}$ $\begin{array}{lllllllllllllll}0.76 & 46.85 & 24.53 & 59.85 & 2 & 1692.9724 & 1692.9718 & 847.4932 & 0.0006 & 0.3540 & 163.676 & 319.742 & 103.586\end{array}$ $\begin{array}{llllllllllllll}1.00 & 50.20 & 27.36 & 30.52 & 3 & 1614.8812 & 1614.8786 & 539.3001 & 0.0026 & 1.6070 & 181.840 & 217.737 & 44.764\end{array}$ $\begin{array}{llllllllllllll}1.00 & 52.82 & 27.36 & 27.15 & 3 & 1614.8812 & 1614.8786 & 539.3001 & 0.0026 & 1.6070 & 171.520 & 211.848 & 42.279\end{array}$ $\begin{array}{lllllllllllll}0.93 & 28.83 & 28.76 & 31.49 & 2 & 975.5790 & 975.5776 & 488.7961 & 0.0014 & 1.4321 & 2747.415 & 2169.454 & 274.350\end{array}$ $\begin{array}{llllllllllllll}0.78 & 23.87 & 26.09 & 36.58 & 2 & 1085.6486 & 1085.6467 & 543.8306 & 0.0019 & 1.7469 & 7797.258 & 7580.271 & 198.699 & 17.4\end{array}$ $\begin{array}{lllllllllllllll}0.91 & 26.77 & 28.76 & 28.81 & 2 & 975.5792 & 975.5776 & 488.7961 & 0.0016 & 1.6367 & 3520.725 & 2922.130 & 344.736 & 24\end{array}$ $\begin{array}{llllllllllllllll}0.80 & 22.96 & 28.77 & 26.44 & 2 & 975.5796 & 975.5776 & 488.7961 & 0.0020 & 2.0458 & 4119.418 & 2987.803 & 432.830 & 24 & \\ 1.00 & 50.49 & 25.67 & 25.61 & 2 & 1132.7104 & 11327090 & 567.3618 & 0.0014 & 1.2338 & 2528.169 & 2686.515 & 360.118 & 47\end{array}$ $\begin{array}{llllllllllllll}1.00 & 50.49 & 25.67 & 25.61 & 2 & 1132.7104 & 1132.7090 & 567.3618 & 0.0014 & 1.2338 & 2528.169 & 2686.515 & 360.118 \\ 0.99 & 35.54 & 25.67 & 28.86 & 2 & 1132.7106 & 1132.7090 & 567.3618 & 0.0016 & 1.4100 & 2172.804 & 2501.461 & 499.672 & 41\end{array}$ $\begin{array}{lllllllllllll}0.99 & 35.54 & 25.67 & 28.86 & 2 & 1132.7106 & 1132.7090 & 567.3618 & 0.0016 & 1.4100 & 2172.804 & 2501.461 & 499.672 \\ 1100 & 42.75 & 25.67 & 26.43 & 2 & 11327106 & 1132.7090 & 567.3618 & 0.0016 & 1.4100 & 1232.403 & 1217.376 & 63.597\end{array}$ $\begin{array}{lllllllllllll}1.00 & 42.75 & 25.67 & 26.43 & 2 & 1132.7106 & 1132.7090 & 567.3618 & 0.0016 & 1.4100 & 1232.403 & 1217.376 & 63.597 \\ 1.00 & 45.00 & 25.67 & 27.95 & 2 & 1132.7106 & 1132.7090 & 567.3618 & 0.0016 & 1.4100 & 1975.246 & 2024.846 & 188.470\end{array}$

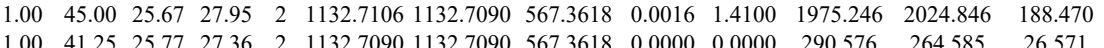
$\begin{array}{lllllllllllll}1.00 & 41.25 & 25.77 & 27.36 & 2 & 1132.7090 & 1132.7090 & 567.3618 & 0.0000 & 0.0000 & 290.576 & 264.585 & 26.571 \\ 0.99 & 39.64 & 25.49 & 38.83 & 2 & 1132.7096 & 1132.7090 & 567.3618 & 0.0006 & 0.5288 & 447.097 & 551.134 & 64.393\end{array}$ $\begin{array}{llllllllllllll}0.99 & 39.64 & 25.49 & 38.83 & 2 & 1132.7096 & 1132.7090 & 567.3618 & 0.0006 & 0.5288 & 447.097 & 551.134 & 64.393 \\ 0.70 & 24.29 & 25.77 & 35.56 & 2 & 1132.7090 & 1132.7090 & 567.3618 & 0.0000 & 0.0000 & 97.081 & 168.823 & 37.848\end{array}$ $\begin{array}{lllllllllllll}0.70 & 24.29 & 25.77 & 35.56 & 2 & 1132.7090 & 1132.7090 & 567.3618 & 0.0000 & 0.0000 & 97.081 & 168.823 & 37.848 \\ 0.59 & 15.68 & 25.49 & 26.02 & 2 & 1132.7096 & 1132.7090 & 567.3618 & 0.0006 & 0.5288 & 117.527 & 141.593 & 25.846 \\ 1.00 & 55.67 & 26.54 & 23.86 & 2 & 1634.7926 & 1634.790 & 818.4028 & 0.006 & 0.9775 & 171.780 & 339.439 & 0.351\end{array}$ $\begin{array}{llllllllllllll}0.59 & 15.68 & 25.49 & 26.02 & 2 & 1132.7096 & 1132.7090 & 567.3618 & 0.0006 & 0.5288 & 117.527 & 141.593 & 25.846\end{array}$ LTLEDLEDSWDR

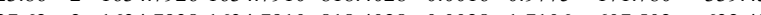

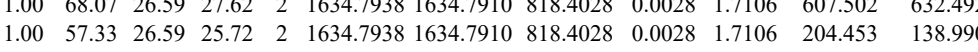
LTLEDLEDSWDR $\begin{array}{llllllllllllll} & 18.12 & 4 & 1938.0469 & 1938.0445 & 485.5184 & 0.0024 & 1.2358 & 461.595 & 561.132 & 1087.378\end{array}$ $\begin{array}{lllllllllllllll}\text { FTEDLVGSVVHVLSHR } & 1.00 & 45.40 & 26.98 & 17.45 & 4 & 1938.0473 & 1938.0445 & 485.5184 & 0.0028 & 1.4418 & 444.808 & 667.357 & 1159.468\end{array}$ 


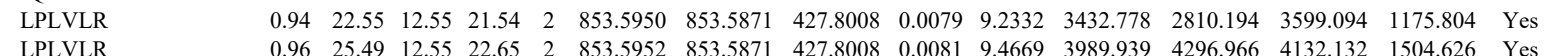
LPLVLR LPLVLR $\begin{array}{lllllllllllllllll}0.96 & 25.49 & 12.55 & 22.65 & 2 & 853.5952 & 853.5871 & 427.8008 & 0.0081 & 9.4669 & 3989.939 & 4296.966 & 4132.132 & 1504.626 & \text { Yes } \\ 0.87 & 18.69 & 13.62 & 23.41 & 2 & 853.5908 & 853.5871 & 427.8008 & 0.0037 & 4.3244 & 2668.927 & 3747.211 & 8296.421 & 3474.741 & \text { Yes }\end{array}$

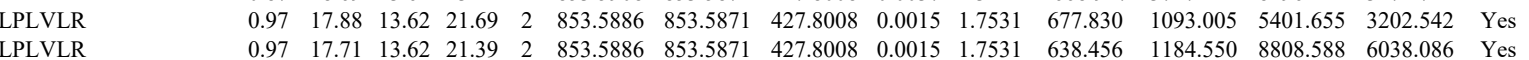

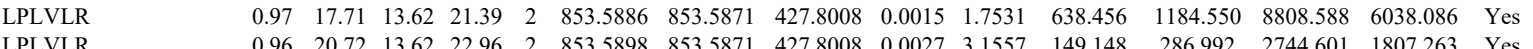
\begin{tabular}{llllllllllllllll} 
& 0.96 \\
LPLVLR & 0.96 & 20.72 & 13.62 & 22.96 & 2 & 853.5898 & 853.5871 & 427.8008 & 0.0027 & 3.1557 & 149.148 & 286.992 & 2744.601 & 1807.263 & Yes \\
\hline
\end{tabular}

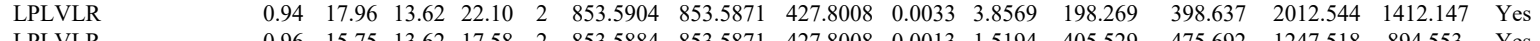
$\begin{array}{llllllllllllllll} & 0.96 & 15.82 & 13.62 & 17.62 & 2 & 853.5890 & 853.5871 & 427.8008 & 0.0019 & 2.2207 & 245.430 & 556.103 & 1385.632 & 976.082 & \text { Yes }\end{array}$

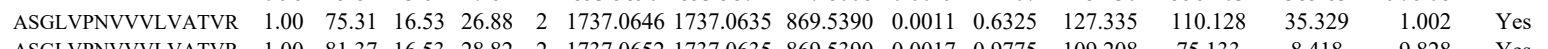

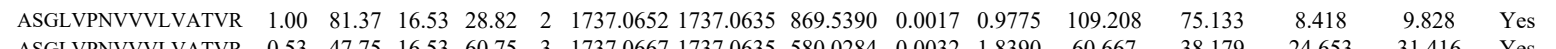

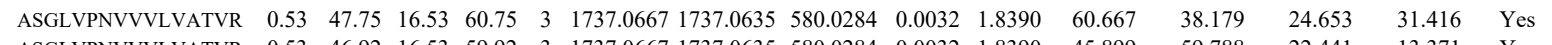

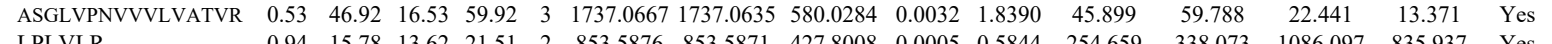

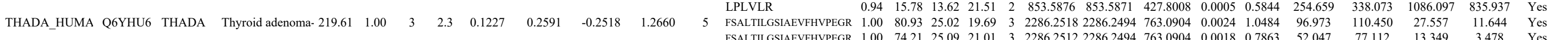

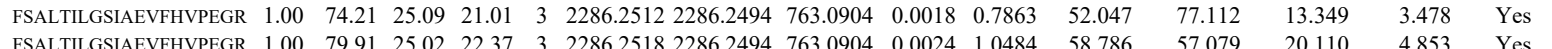

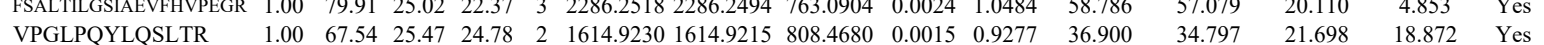

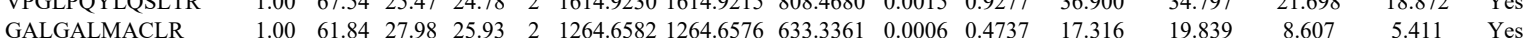

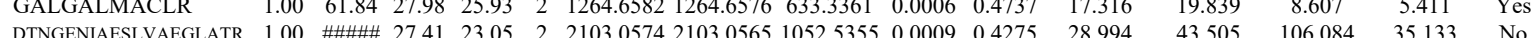

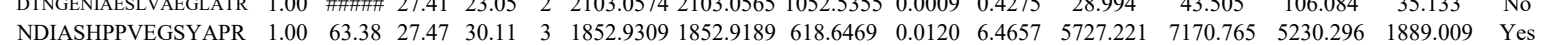
$\begin{array}{llllllllllllllll}\text { NLPGLVQEGEPFSEEATLFTK } & 1.00 & 76.14 & 26.77 & 25.39 & 3 & 2593.3531 & 2593.3519 & 865.4579 & 0.0012 & 0.4622 & 56.676 & 61.557 & 23.090 & 36.666 & \text { Yes }\end{array}$

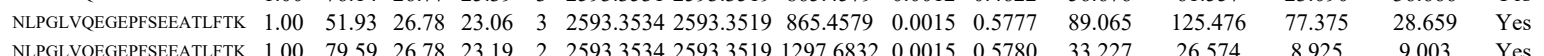

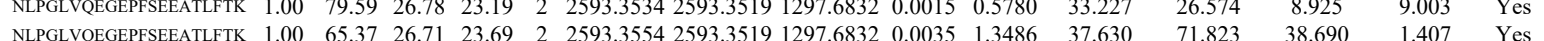

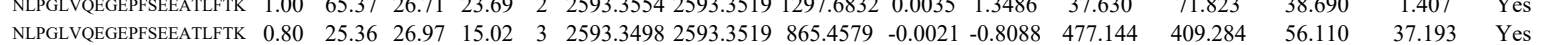

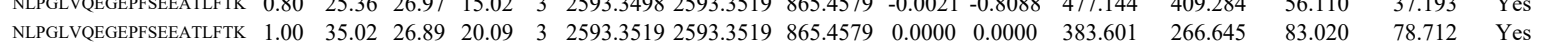

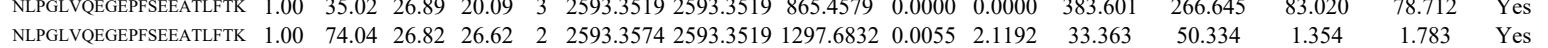

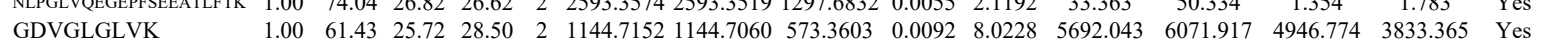

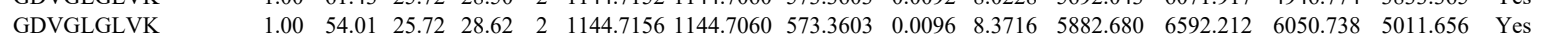
$\begin{array}{lllllllllllllllll}\text { GDVGLGLVK } & 1.00 & 56.40 & 25.72 & 26.51 & 2 & 1144.7158 & 1144.7060 & 573.3603 & 0.0098 & 8.5460 & 3557.478 & 3206.147 & 1980.599 & 1654.491 & \text { Yes }\end{array}$

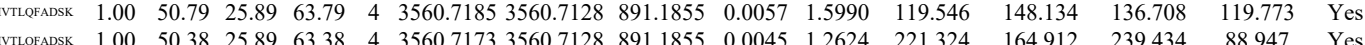

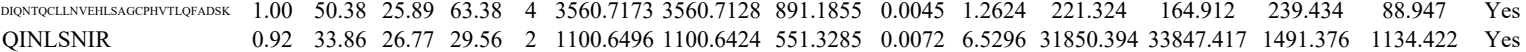
$\begin{array}{llllllllllllllll}\text { QINLSNIR } & 0.95 & 35.48 & 26.80 & 29.83 & 2 & 1100.6506 & 1100.6424 & 551.3285 & 0.0072 & 6.5296 & 31850.394 & 33847.417 & 1491.376 & 1134.422 & \text { Yes } \\ \text { QINTIR } & 0.4365 & 21301.833 & 24225.628 & 1596.512 & 937.249 & \text { Yes }\end{array}$ $\begin{array}{llllllllllllllll}\text { TCATVTIGGINIAEALVSK } & 1.00 & 52.42 & 25.99 & 24.67 & 3 & 2194.1965 & 2194.1945 & 732.4054 & 0.0020 & 0.9102 & 75.782 & 89.746 & 76.777 & 46.112 & \text { Yes }\end{array}$ $\begin{array}{lllllllllllllllll}\text { (1.00 } & 39.32 & 22.15 & 17.16 & 4 & 3786.0453 & 3786.0415 & 947.5177 & 0.0038 & 1.0026 & 24.197 & 88.912 & 24.939 & 50.703 & \text { Yes }\end{array}$

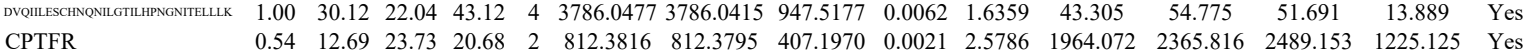

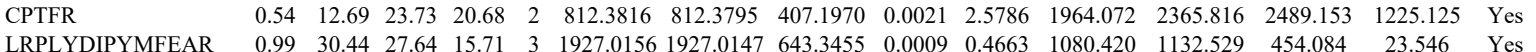
\begin{tabular}{llllllllllllllll} 
& \\
LRPLYDIPYMFEAR & 0.99 & 30.44 & 27.64 & 15.71 & 3 & 1927.0156 & 1927.0147 & 643.3455 & 0.0009 & 0.4663 & 1080.420 & 1132.529 & 454.084 & 23.546 & Yes \\
\hline
\end{tabular}

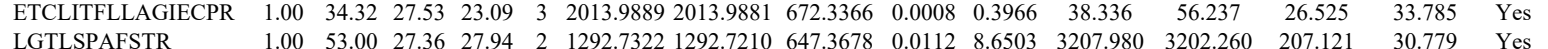

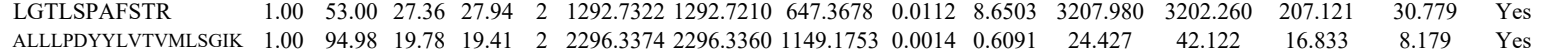

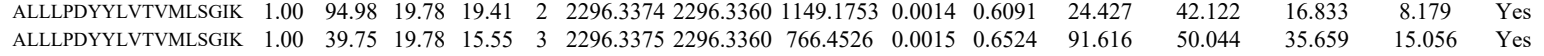

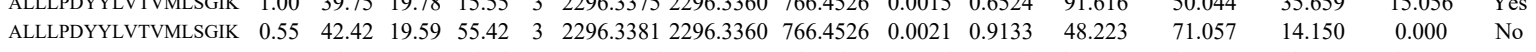
$\begin{array}{llllllllllllllll}\text { LGTLSPAFSTR } & 1.00 & 54.92 & 27.76 & 26.74 & 2 & 1292.7336 & 1292.7210 & 647.3678 & 0.0126 & 9.7316 & 14802.297 & 16767.825 & 642.119 & 65.338 & \text { Yes }\end{array}$

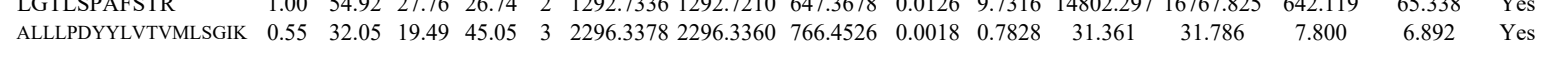



$\begin{array}{lllllllllll}1.00 & 39.41 & 27.12 & 26.78 & 2 & 1030.5654 & 1030.5641 & 516.2893 & 0.0013 & 1.2590 & 49.848 \\ 0.55 & 92.74 & 26.43 & \# \# \# & 3 & 3173.5522 & 3173.5505 & 1058.8574 & 0.0017 & 0.5352 & 18.205\end{array}$

FDPTOFEDCIIQGLLETGTDEAVA

FDPTOFEDCIIQLLETEGTLLEAVA

FDPTTFEDCIRGLLETGTLEAVA

FDPTTFPDCLIQGLLETGTLLEAVA

FDPTOFEDCILGLLETGTDLAVAA

QQRPTLSGQR

DINAVAASLR

DINAVAASLR

QQKPTLSGQR

QQKPTLSGQR

QQKPTLSGQR

QQKPTLSGQR

QQRPTLSQR

ALVLSEEPLK

AEVLSEEPILK

AEVLSEEPILK

KEELVAEQAIK

26 ALTQFPLPK

ALTQFPLPK

ALTQFPLPK

ALTQFPLPK

ALTQFPLPK

ALTQFPLPK

ALTQFPLPK

ALTQFPLPK

ALTQFPLPK

ALTQFPLPK

ALTQFPLPK

$\begin{array}{lllllllllll}1.00 & 68.05 & 26.51 & 81.05 & 4 & 3173.5565 & 3173.5505 & 794.3949 & 0.0060 & 1.8882 & 21.170 \\ 1.00 & 48.36 & 26.36 & 61.36 & 4 & 3173.5589 & 3173.5505 & 7943949 & 0.0084 & 2.6435 & 4.935\end{array}$

$\begin{array}{lllllllllllll}1.00 & 53.52 & 26.39 & 66.52 & 4 & 3173.5601 & 3173.5505 & 794.3949 & 0.0096 & 3.0212 & 10.336 & 22.553 \\ 1.00 & 90.98 & 26.43 & 18.70 & 3 & 3173.5522 & 31735505 & 1058.5574 & 0.0017 & 0.5352 & 6.548 & 0.000\end{array}$

$\begin{array}{llllllllllll}1.00 & 90.98 & 26.43 & 18.70 & 3 & 3173.5522 & 3173.5505 & 1058.8574 & 0.0017 & 0.5352 & 6.548 & 0.000 \\ 1.00 & 57.81 & 26.39 & 18.42 & 4 & 3173.5577 & 3173.5505 & 794.3949 & 0.0072 & 2.2659 & 2.914 & 9.826 \\ 0.91 & 25.82 & 26.38 & 16.78 & 3 & 3173.5582 & 3173.5505 & 1058.8574 & 0.077 & 2.424 & 18.137 & 0.000\end{array}$

$\begin{array}{llllllllllll}1.97 .81 & 26.39 & 18.42 & 4 & 3173.5577 & 3173.5505 & 794.3949 & 0.0072 & 2.2659 & 2.914 & 0.826 \\ 0.91 & 25.82 & 26.38 & 16.78 & 3 & 3173.5582 & 3173.5505 & 1058.8574 & 0.0077 & 2.4240 & 18.137 & 0.000\end{array}$

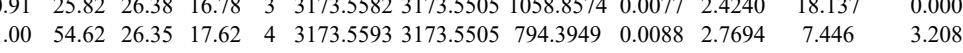

$\begin{array}{lllllllllllll}1.00 & 27.57 & 26.45 & 15.50 & 4 & 3173.5557 & 3173.5505 & 794.3949 & 0.0052 & 1.6365 & 65.566 & 98.796\end{array}$

$\begin{array}{llllllll} & \end{array}$ $\begin{array}{llllll}0.0109 & 9.2791 & 2538.164 & 2724.156 & 7245.409 & 5107.283\end{array}$

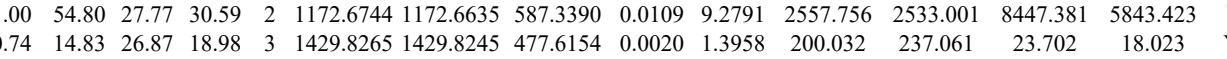

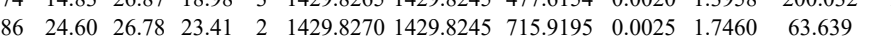
$\begin{array}{llllllllllll}0.94 & 29.01 & 26.86 & 25.72 & 2 & 1429.8278 & 1429.8245 & 715.9195 & 0.0033 & 2.3047 & 80.625\end{array}$

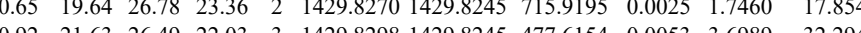

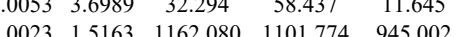

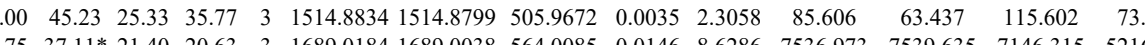
$\begin{array}{llllllllllllllll}0.94 & 50.11 * 21.40 & 21.10 & 3 & 1689.0184 & 1689.0038 & 54.0085 & 0.0146 & 8.6286 & 8319.283 & 7424.617 & 6618.006 & 4168.750 & \text { Yes }\end{array}$ $\begin{array}{lllllllllllllll}0.84 & 25.10 & 26.42 & 21.39 & 2 & 1157.6930 & 1157.6930 & 579.8538 & 0.0000 & 0.0000 & 274.930 & 329.191 & 125.871 & 87.064 & \text { Yes }\end{array}$ $\begin{array}{llllllllllllllll}0.80 & 25.84 & 26.31 & 24.95 & 2 & 1157.6972 & 1157.6930 & 579.8538 & 0.0042 & 3.6216 & 11227.831 & 15906.209 & 1235.727 & 272.022 & \text { Y }\end{array}$

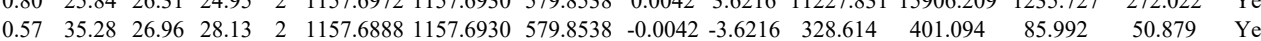
$\begin{array}{llllllllllllllll}0.71 & 26.17 & 26.32 & 22.43 & 2 & 1157.6918 & 1157.6930 & 579.8538 & -0.0012 & -1.0347 & 333.005 & 389.985 & 137.007 & 84.751 & \text { Yes }\end{array}$ $\begin{array}{lllllllllllllll}0.77 & 23.14 & 26.42 & 22.01 & 2 & 1157.6932 & 1157.6930 & 579.8538 & 0.0002 & 0.1725 & 239.868 & 390.842 & 111.613 & 54.942 & \text { Yes }\end{array}$ $\begin{array}{llllllllllllllll}0.93 & 26.19 & 26.42 & 23.21 & 2 & 1157.6942 & 1157.6930 & 579.8538 & 0.0012 & 1.0347 & 369.878 & 459.934 & 117.461 & 63.170 & \text { Yes }\end{array}$ $\begin{array}{lllllllllllllll}0.67 & 25.84 & 26.24 & 25.15 & 2 & 1157.6996 & 1157.6930 & 579.8538 & 0.0066 & 5.6911 & 67241.043 & 87714.651 & 7918.660 & 820.268 & \text { Yes }\end{array}$ $\begin{array}{llllllllllllllll}0.61 & 24.58 & 26.19 & 24.95 & 2 & 1157.7004 & 1157.6930 & 579.8538 & 0.0074 & 6.3809 & 41668.021 & 48052.030 & 3946.104 & 840.192 & \text { Yes }\end{array}$ $\begin{array}{llllllllllllllll}0.59 & 24.14 & 26.19 & 24.96 & 2 & 1157.7004 & 1157.6930 & 579.8538 & 0.0074 & 6.3809 & 29709.602 & 37691.085 & 4341.007 & 727.660 & \text { Yes }\end{array}$

ALTQFPLPK

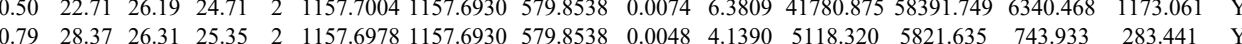

WLATNAETSTINDIVHVVDSGLH

SELALLPSVVEEHGQLLALLAF

AIFQQPPVGVR

LSQSLLELWR

LSQSLLELWR

NLLNSVIGR

NLLNSVIGR

RPCTIQVPEPILR

RPCTIQVPEPILR

RPCTQVEPLR $\begin{array}{lllllll} & \end{array}$ $\begin{array}{lllllllllllll}1.00 & 47.26 & 18.81 & 60.26 & 4 & 3159.7837 & 3159.7747 & 790.9510 & 0.0090 & 2.8447 & 70.961 & 49.797 & 38.564\end{array}$

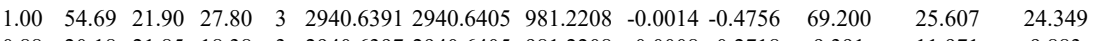
$\begin{array}{lllllllllllll}0.88 & 20.18 & 21.85 & 18.38 & 3 & 2940.6397 & 2940.6405 & 981.2208 & -0.0008 & -0.2718 & 9.391 & 11.971 & 9.883\end{array}$ $\begin{array}{lllllllllllll}1.00 & 50.85 & 25.60 & 19.68 & 2 & 1354.7964 & 1354.7843 & 678.3994 & 0.0121 & 8.9180 & 7964.561 & 5646.575 & 430.084\end{array}$ $\begin{array}{lllllllllllll}1.00 & 65.08 & 26.66 & 28.52 & 2 & 1387.7966 & 1387.7945 & 694.9045 & 0.0021 & 1.5110 & 5781.002 & 4876.595 & 145.025 \\ 1.00 & 55.34 & 26.41 & 27.67 & 2 & 1387.7972 & 1387.7945 & 694.9045 & 0.0027 & 1.9427 & 2951.201 & 2258.944 & 274.307 \\ 1.00 & 52.72 & 26.32 & 29.21 & 2 & 1 & 1\end{array}$

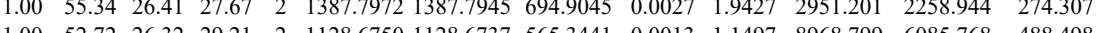

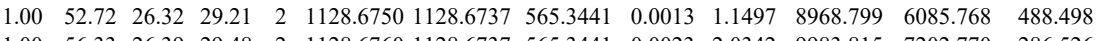

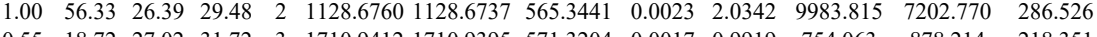
$\begin{array}{lllllllllllll}0.55 & 18.72 & 27.02 & 31.72 & 3 & 1710.9412 & 1710.9395 & 571.3204 & 0.0017 & 0.9919 & 754.063 & 878.214 & 218.351 \\ 0.96 & 22.49 & 26.83 & 15.53 & 3 & 1710.9424 & 1710.9395 & 571.3204 & 0.0029 & 1.6920 & 752.947 & 1023.723 & 384754\end{array}$

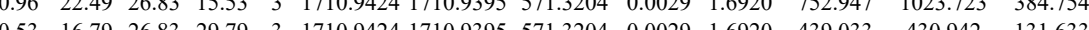
$\begin{array}{lllllllllllll}0.53 & 15.05 & 26.81 & 28.05 & 3 & 1710.9427 & 1710.9395 & 57.3204 & 0.0032 & 1.8670 & 146.735 & 60.764 & 37.462\end{array}$ 

$\begin{array}{llllllllllllll}\text { FLEGELIHDLLTIFVSAK } & 1.00 & 47.41 & 21.30 & 17.88 & 3 & 2332.3342 & 2332.3286 & 778.4501 & 0.0056 & 2.3979 & 107.333 & 82.539 & 11.657\end{array}$ $\begin{array}{llllllllllllll}\text { FLEGELIHDLLTIFVSAK } & 1.00 & 34.30 & 21.24 & 18.94 & 3 & 2332.3402 & 2332.3286 & 778.4501 & 0.0116 & 4.9671 & 54.203 & 33.631 & 18.202\end{array}$

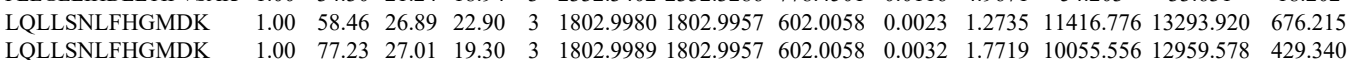
$\begin{array}{lllllllllllll}1.00 & 62.71 & 26.90 & 22.45 & 2 & 1802.9974 & 1802.9957 & 902.5051 & 0.0017 & 0.9418 & 266.842 & 272.248 & 45.818\end{array}$

$\begin{array}{llllllllllll}\text { CYFP1_HUMAI Q7L576 } & \text { CYFIP1 } & \text { Cytoplasmic FMR } 145.18 & 1.00 & 4 & 3.5 & 0.1355 & 0.1123 & -2.3561 & 1.6822 & 8 & \text { FQILNDEIITILDK }\end{array}$

LGTPQQIAIAR

GLQVLMGR

GLQVLMGR

NVIQSVLQAIR

NVIQSVLQAIR

NVIQSVLQAIR

NVIQSVLQAIR

NVIQSVQAIR

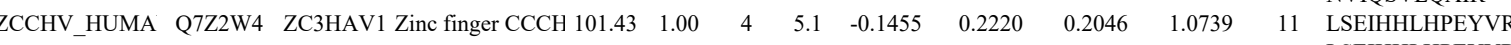

LSEIHHLHPEYVR

SEIHHLHPEYVR

LHICDHFTR

LHICDHFTR

NVVMFVAQVLVGK

NVVMFVAQVLVGK

NVVMFVAQVLVGK

NVVMFVAQVLVGK

NVVMFVAQVLVGK

NVVMFVAQVLVGK

NVVMFVAQVLVGK

VPLEELCLHIMK

ILQIITELIK

LQIITELIK

ILQIITELIK

LQIITELIK

ILQIITELIK

IPIPLMDYILNVMK

IPIPLMDYILNVMK

IPIPLMDYILNVMK

IPIPLMDYILNVMK

IPIPLMDYILNVMK

IPIPLMDYILNVMK

LPGGGVQNFPQFSALR

LPGGVQNFPQ

RPVMLTLLR

$\begin{array}{llllllllllllll}1.00 & 57.82 & 26.86 & 17.35 & 3 & 1802.9983 & 1802.9957 & 602.0058 & 0.0026 & 1.4396 & 7734.659 & 8695.464 & 968.423\end{array}$

$\begin{array}{llllllllllllll}1.00 & 61.08 & 26.86 & 20.28 & 3 & 1802.9983 & 1802.9957 & 602.0058 & 0.0026 & 1.4396 & 6367.180 & 7072.125 & 528.922 & 1\end{array}$

\begin{tabular}{lllllllllllll} 
& 12.02 & 22.28 & 13.82 & 3 & 1962.1312 & 1962.1281 & 655.0500 & 0.0031 & 1.5775 & 41.275 & 47.795 & 35.407 \\
\hline
\end{tabular}

$\begin{array}{llllllllllllll}1.00 & 56.94 & 24.13 & 26.68 & 2 & 1310.7878 & 1310.7792 & 656.3969 & 0.0086 & 6.5509 & 17099.363 & 16873.995 & 2719.120 & 3.9 \\ 0.76 & 23.88 & 28.06 & 35.25 & 2 & 1016.5954 & 1016.5923 & 509.3034 & 0.0031 & 3.0434 & 651.396 & 785.612 & 3397.156 & \end{array}$

$\begin{array}{lllllllllllll}0.60 & 25.71 & 27.55 & 33.69 & 2 & 1016.5970 & 1016.5923 & 509.3034 & 0.0047 & 4.6141 & 775.552 & 1081.484 & 6237.904\end{array}$

$\begin{array}{llllllllllllll}1.00 & 62.35 & 22.99 & 26.74 & 2 & 1383.8340 & 1383.8320 & 692.9233 & 0.0020 & 1.4432 & 507.591 & 596.972 & 341.574 & 47.005 \\ \end{array}$

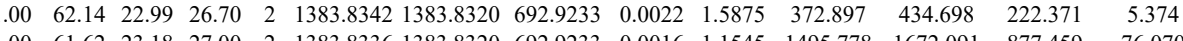

$\begin{array}{lllllllllllllll}1.00 & 61.62 & 23.18 & 27.00 & 2 & 1383.8336 & 1383.8320 & 62.9233 & 0.0016 & 1.1545 & 1495.778 & 1672.091 & 87.459 & 76.070 & Y_{\mathrm{C}}\end{array}$

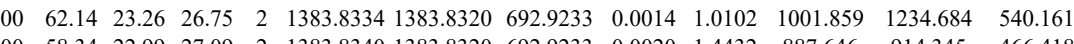

$\begin{array}{lllllllllllll}1 & \end{array}$

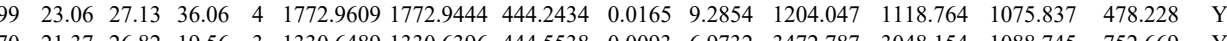

$\begin{array}{lllllllllllllll}0.98 & 34.14 & 26.76 & 20.93 & 3 & 1330.6492 & 1330.6396 & 444.5538 & 0.0096 & 7.1982 & 3448.033 & 3644.775 & 611.220 & 260.250 & \text { Yes }\end{array}$

$\begin{array}{lllllllllllllll}100 & 44.40 & 22.62 & 30.45 & 3 & 1691.0077 & 16910048 & 564.6755 & 0.0029 & 1.7119 & 57.814 & 52.976 & 17.218\end{array}$

$\begin{array}{lllllllllllll}1.00 & 38.38 & 22.76 & 29.89 & 3 & 1691.0062 & 1691.0048 & 564.6755 & 0.0014 & 0.8264 & 40.221 & 37.216 & 4.105\end{array}$

$\begin{array}{llllllllllll}100 & 83.05 & 22.76 & 25.49 & 2 & 1691.0062 & 1691.0048 & 846.5097 & 0.0014 & 0.8269 & 37.728\end{array}$

$\begin{array}{lllllllllllll}1.00 & 49.83 & 22.62 & 25.49 & 3 & 1691.0074 & 1691.0048 & 564.6755 & 0.0026 & 1.5348 & 24.719\end{array}$

$\begin{array}{lllllllllll}1.00 & 77.31 & 22.62 & 21.21 & 2 & 1691.0082 & 1691.0048 & 846.5097 & 0.0034 & 2.0082 & 20.142 \\ 1.00 & 4320 & 22.60 & 30.09 & 3 & 1691.0053 & 1691.0048 & 564.6755 & 0.0005 & 0.2952 & 10.706\end{array}$ $\begin{array}{lllllllllll}1.00 & 55.88 & 22.62 & 25.87 & 3 & 1691.0083 & 1691.0048 & 564.6755 & 0.0035 & 2.0661 & 12.297\end{array}$ $\begin{array}{llllllllllll}1.00 & 44.81 & 27.15 & 16.23 & 3 & 1757.9512 & 1757.9485 & 586.9901 & 0.0027 & 1.5332 & 628.896\end{array}$ $\begin{array}{lllllllllll}1.00 & 64.49 & 13.22 & 43.72 & 2 & 1470.9648 & 1470.9629 & 736.4887 & 0.0019 & 1.2899 & 561.777\end{array}$ $\begin{array}{llllllllllll}1.99 & 21.71 & 13.22 & 18.91 & 3 & 1470.9655 & 1470.9629 & 491.3282 & 0.0026 & 1.7639 & 157.174\end{array}$ $\begin{array}{llllllllllll}1.00 & 65.71 & 13.22 & 44.68 & 2 & 1470.9646 & 1470.9629 & 736.4887 & 0.0017 & 1.1541 & 318.359\end{array}$ $\begin{array}{llllllllllll}1.00 & 69.84 & 13.22 & 47.05 & 2 & 1470.9658 & 1470.9629 & 736.4887 & 0.0029 & 1.9688 & 371.547\end{array}$ $\begin{array}{llllllllllll}1.00 & 39.45 & 23.18 & 24.09 & 3 & 1947.1204 & 1947.1181 & 650.0466 & 0.0023 & 1.1794 & 99.825\end{array}$ $\begin{array}{llllllllllll}1.00 & 32.08 & 23.07 & 22.60 & 3 & 1947.1207 & 1947.1181 & 650.0466 & 0.0026 & 1.3332 & 165.178 \\ 1.00 & 32.38 & 23.18 & 22.01 & 3 & 1947.1204 & 1947.1181 & 650.0466 & 0.0023 & 1.1794 & 87.423\end{array}$ $\begin{array}{llllllllllll}1.00 & 32.38 & 23.18 & 22.01 & 3 & 1947.1204 & 1947.1181 & 650.0466 & 0.0023 & 1.1794 & 87.423 \\ 1.00 & 36.69 & 23.07 & 27.28 & 3 & 1947.1213 & 1947.1181 & 650.0466 & 0.0032 & 1.6409 & 106.964 \\ 1.00 & 33.58 & 22.88 & 24.01 & 3 & 1947.1201 & 1947.1181 & 650.0466 & 0.020 & 1.0256 & 56.472\end{array}$ $\begin{array}{lllllllllll}1.00 & 36.69 & 23.07 & 27.28 & 3 & 1947.1213 & 1947.1181 & 650.0466 & 0.0032 & 1.6409 & 106.964 \\ 1.00 & 33.58 & 22.88 & 24.01 & 3 & 1947.1201 & 1947.1181 & 650.0466 & 0.0020 & 1.0256 & 56.472\end{array}$ $\begin{array}{lllllllllll}1.00 & 45.90 & 23.07 & 26.25 & 3 & 1947.1207 & 1947.1181 & 650.0466 & 0.0026 & 1.3332 & 57.398\end{array}$

$\begin{array}{llllllllllll}1.00 & 85.88 & 27.29 & 26.87 & 2 & 1773.9648 & 1773.9648 & 887.9897 & 0.0000 & 0.0000 & 93.129\end{array}$ $\begin{array}{lllllllllll}1.00 & 79.87 & 27.36 & 24.40 & 2 & 1773.9656 & 1773.9648 & 887.9897 & 0.0008 & 0.4505 & 111.688 \\ 0.83 & 26.63 & 25.98 & 17.54 & 2 & 1267.7302 & 1267.7258 & 634.8702 & 0.0044 & 3.4653 & 32.409\end{array}$

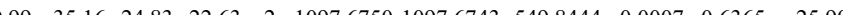

$\begin{array}{llllllllllll}1.00 & 44.17 & 24.83 & 20.78 & 2 & 1097.6750 & 1097.6743 & 549.8444 & 0.0007 & 0.6365 & 41.835\end{array}$ 

$\begin{array}{lllllllllllllllll} & 1.00 & 49.83 & 26.55 & 33.03 & 2 & 1217.7318 & 1217.7223 & 609.8684 & 0.0095 & 7.7885 & 3553.570 & 2633.173 & 2908.470 & 2032\end{array}$ $\begin{array}{lllllllllllllllll} & \\ \end{array}$ $\begin{array}{llllllllllllllllll}\text { GELTTLIHQLOEK } & 0.53 & 31.44 & 24.71 & 44.44 & 3 & 1797.0274 & 1797.0240 & 600.0153 & 0.0034 & 1.8888 & 2049.893 & 1422.376 & 1670.254 & 1853.400 & \text { Yes }\end{array}$ $\begin{array}{lllllllllllllllll}\text { GELTTLIHQLOEK } & 1.00 & 45.47 & 24.65 & 20.88 & 3 & 1797.0286 & 1797.0240 & 600.0153 & 0.0046 & 2.5555 & 1775.582 & 1532.408 & 1356.195 & 1720.392 & \text { Yes }\end{array}$ $\begin{array}{lllllllllllllllll}\text { TVEELLETGLIQVATK } & 0.99 & 26.34 & 22.65 & 14.81 & 3 & 2031.1738 & 2031.1707 & 678.0642 & 0.0031 & 1.5239 & 169.658 & 114.596 & 308.333 & 126.759 & \text { Yes }\end{array}$ $\begin{array}{llllllllllllllllll}\text { TVEELLETGLIQVATK } & 0.99 & 23.99 & 22.86 & 18.34 & 3 & 2031.1747 & 2031.1707 & 678.0642 & 0.0040 & 1.9664 & 131.692 & 100.316 & 298.455 & 131.169 & \text { Yes }\end{array}$ $\begin{array}{lllllllllllllllll}\text { WLQDLQEENESLK } & 1.00 & 58.66 & 28.16 & 24.12 & 2 & 1918.9926 & 1918.9880 & 960.5013 & 0.0046 & 2.3946 & 885.690 & 631.729 & 140.001 & 90.939 & \text { No }\end{array}$ $\begin{array}{lllllllllllllllll}\text { QPTPPSEAAASK } & 1.00 & 64.33 & 27.56 & 22.50 & 2 & 1470.7936 & 1470.7922 & 736.4034 & 0.0014 & 0.9506 & 4725.865 & 4269.544 & 5609.017 & 4821.815 & \text { Yes }\end{array}$ $\begin{array}{lllllllllllllllll}\text { QPTPPSEAAASK } & 0.99 & 34.77 & 27.48 & 18.25 & 2 & 1470.7946 & 1470.7922 & 736.4034 & 0.0024 & 1.6295 & 176.218 & 198.247 & 92.902 & 131.257 & \text { Yes }\end{array}$ $\begin{array}{lllllllllllllll}1.00 & 66.45 & 27.80 & 25.31 & 2 & 1467.7594 & 1467.7557 & 734.8851 & 0.0037 & 2.5174 & 3171.533 & 2680.774 & 40.423 & 58.706 & Y\end{array}$ MDMSLDDIIK SLGTADVHFER SLGTADVHFER

SLGTADVHFER

SLGTADVHFER

MDMSLDDIIK

MDMSLDDIIK

SLGTADVHFER

SLGTADVHFER

MDMSLDDIIK

MDMSLDDIIK

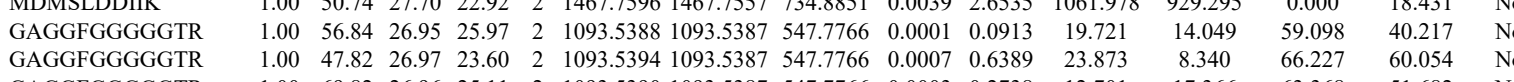

$\begin{array}{lllllllllllll}1.00 & 64.05 & 27.73 & 23.74 & 2 & 1467.7598 & 1467.7557 & 734.8851 & 0.0041 & 2.7895 & 3840.740 & 3395.346\end{array}$

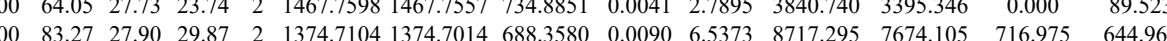

$\begin{array}{llllllllllllllll}1.00 & 83.05 & 27.88 & 32.83 & 2 & 1374.7112 & 1374.7014 & 688.3580 & 0.0098 & 7.1183 & 10056.743 & 10252.143 & 634.077 & 644.965 & \text { Yes } & \\ \end{array}$

$\begin{array}{lllllllllllllll}1.00 & 48.89 & 27.80 & 34.22 & 3 & 1374.7117 & 1374.7014 & 459.2411 & 0.0103 & 7.4760 & 13044.088 & 15726.946 & 1268.983 & 432.144 & \text { Yes }\end{array}$

$\begin{array}{llllllllllllllll}1.00 & 51.43 & 27.70 & 21.11 & 2 & 1467.7596 & 1467.7557 & 734.8851 & 0.0039 & 2.6535 & 1974.965 & 1614.136 & 0.000 & 92.242 & \text { No } & \\ 1.00 & 51.6 & 27.73 & 23.69 & 2 & 1467.7600 & 1467.7557 & 734.8851 & 0.0043 & 2.9256 & 5799.678 & 5829.737 & 23.814 & 0.02 & \text { No }\end{array}$

$\begin{array}{lllllllllllllll}1.00 & 51.66 & 27.73 & 23.69 & 2 & 1467.7600 & 1467.7557 & 734.8851 & 0.0043 & 2.9256 & 5799.678 & 5829.737 & 23.814 & 0.000 & \text { No }\end{array}$

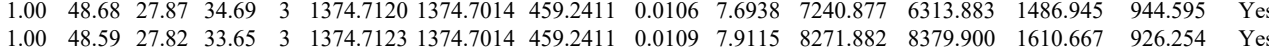

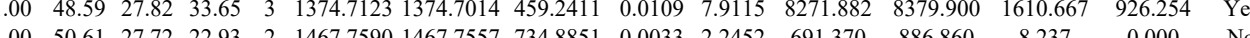
$\begin{array}{lllllllllllllll}1.00 & 50.61 & 27.72 & 22.93 & 2 & 1467.7590 & 1467.7557 & 734.8851 & 0.0033 & 2.2452 & 691.370 & 886.860 & 8.237 & 0.000 & \text { No } \\ 1.00 & 50.74 & 27.70 & 22.92 & 2 & 1467.7596 & 1467.7557 & 734.8851 & 0.0039 & 2.6535 & 1061.978 & 929.295 & 0.000 & 18.431 & \text { No }\end{array}$

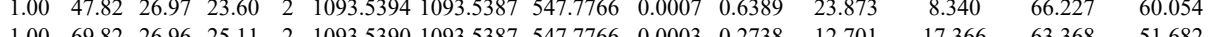
$\begin{array}{llllllllllll} & 14.682 & \text { Yes }\end{array}$ $\begin{array}{lllllllllllllllll}\text { QQLSAEELDAOLDAYNAR } & 1.00 & 61.18 & 27.66 & 22.79 & 3 & 2178.0703 & 2178.0674 & 727.0297 & 0.0029 & 1.3296 & 184.455 & 236.466 & 203.314 & 166.230 & \text { Yes }\end{array}$

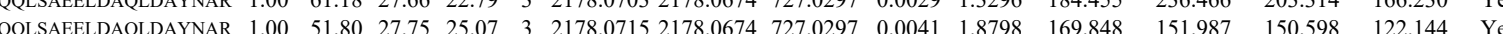

YLEK

SVILEAFSSPSEEVK

AVAALLTIPEAEK

AVAALLTIPEAEK

AVAALLTIPEAEK

FMATNDLMTELQK

FMATNDLMTELQK

LDIFEFLNHVEDGLK

LDIFEFLNHVEDGLK

EYQVETIVDTLCTNMLSDK

LDIFEFLNHVEDGLK

VYPSSLSK

VYPSSLSK

CLDAVVSTR

CLDAVVSTR

ITSEALLVTQQLVK

ITSEALLVTQQLVK

ITSEALLVTQQLVK

$\begin{array}{llllllllllllllll}0.53 & 25.47 & 26.20 & 36.55 & 2 & 1138.6570 & 1138.6477 & 570.3311 & 0.0093 & 8.1531 & 5922.792 & 6698.506 & 5865.378 & 7017.455 & \text { No }\end{array}$

$\begin{array}{lllllllllllllll}1.00 & 52.52 & 26.57 & 22.67 & 2 & 1358.7820 & 1358.7761 & 680.3953 & 0.0059 & 4.3357 & 4379.586 & 5079.579 & 2535.525 & 1990.072 & \text { Yes }\end{array}$

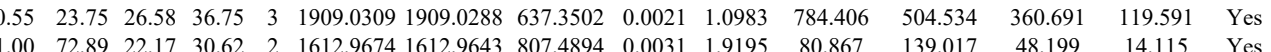

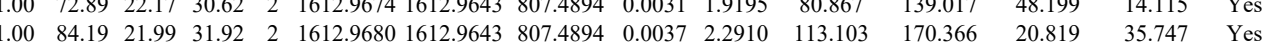

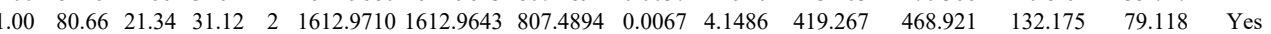

$\begin{array}{lllllllllllllll}1.00 & 76.14 & 27.38 & 21.95 & 2 & 1828.9342 & 1828.9307 & 915.4726 & 0.0035 & 1.9116 & 369.724 & 519.755 & 37.047 & 46.021 & \text { Yes }\end{array}$

$\begin{array}{lllllllllllllllll}1.00 & 46.87 & 27.06 & 21.57 & 3 & 2076.1150 & 2076.1135 & 693.0451 & 0.0015 & 0.7215 & 1249.645 & 1315.173 & 174.888 & 67.592 & \text { Yes }\end{array}$

$\begin{array}{cccccccccccccc}1.00 & 52.35 & 26.94 & 19.82 & 3 & 2076.1165 & 2076.1135 & 693.0451 & 0.0030 & 1.4429 & 1907.838 & 1553.516 & 211.193 & 90.168 \\ 1.00 & 58.33 & 26.66 & 18.25 & 3 & 2535.2179 & 25352150 & 846.0789 & 0.0029 & 1.1425 & 50.539 & 34.871 & 13.739 & 17.592\end{array}$

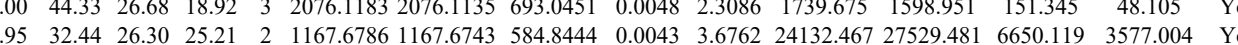
$\begin{array}{llllllllllllllll}0.96 & 39.25 & 26.26 & 34.54 & 2 & 1167.6794 & 1167.6743 & 584.8444 & 0.0051 & 4.3601 & 45312.010 & 52730.779 & 5572.217 & 2137.794 & \text { Yes }\end{array}$

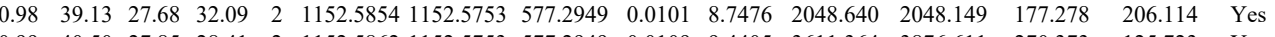
$\begin{array}{lllllllllllllll}0.99 & 40.50 & 27.85 & 28.41 & 2 & 1152.5862 & 1152.5753 & 577.2949 & 0.0109 & 9.4405 & 3611.364 & 3876.611 & 270.373 & 125.723 & \text { Yes }\end{array}$ TSEALLVTQQLVK $\begin{array}{llllllllllll} & \end{array}$ $\begin{array}{lllllllllllll}1.00 & 35.33 & 19.54 & 17.04 & 3 & 1830.1120 & 1830.1070 & 611.0429 & 0.0050 & 2.7276 & 272.384 & 272.899 & 153.711\end{array}$ $\begin{array}{lllllllllllll}1.00 & 44.91 & 19.54 & 19.37 & 3 & 1830.1120 & 1830.1070 & 611.0429 & 0.0050 & 2.7276 & 315.696 & 274.205 & 187.829\end{array}$

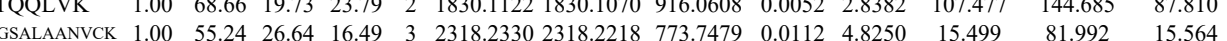

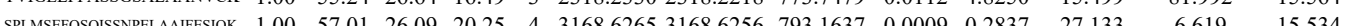
$\begin{array}{llllllllllllllll}\text { SPLMSEFSSEISSNPELAAIFESIOK } & 1.00 & 63.70 & 26.05 & 20.06 & 3 & 3168.6292 & 3168.6256 & 1057.2158 & 0.0036 & 1.1351 & 11.623 & 8.497 & 8.932\end{array}$ 43168.63213168 .6256 


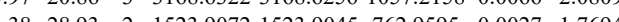

LTLIDPETLLPR

1.00

$\begin{array}{rlr}21.72 & 26.04 & 23.66 \\ 217.35\end{array}$

LTLIDPETLLPR

LGTLSALDILIK

LGTLSALDILIK

MLTGPVYSQSTALT

GYLISGSSYAR

GYLISGSSYAR

LGTLSALDILIK

LGTLSALDILIK

CLGPLVSK

CLGPLVSK

ALTLIAGSPLK

ALTLIAGSPLK

ALTLIAGSPLK

ALTLIAGSPLK

IIPLVVK

IIPLVVK

CLGPLVSK

CLGPLVSK

ALTLIAGSPLK

ALTLIAGSPLK

ALTLIAGSLK

ALTLIAGSPLK

ADVFHAYLSLLK

IIPLVVK

ADVFHAYLSLLK

ADVFHAYLSLLK

IIPLVVK

CVAALTR

CVAALTR

ISGSILNELIGLVR

ISGSILNELIGLVR

ISGSILNELIGLVR

ISGSILNELIGLVR

ISGSILNELIGLVR

ISGSILNELIGLVR

ISGSILNELIGLVR

TYIQCIAAISR

TYIQCIAAISR

TYIQCIAAISR

LSTLCPSAVLQR

LSTLCPSAVLQR

LSTLCPSAVLQR

LSTLCPSAVLQR
LSTLCPSAVLQR

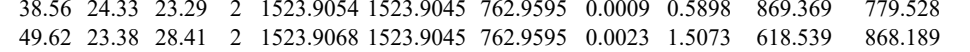

$\begin{array}{lllllllllllll}1.00 & 79.28 & 17.92 & 32.64 & 2 & 1543.9798 & 1543.9792 & 772.9969 & 0.0006 & 0.3881 & 1822.122 & 2329.256 & 746.45 \\ 1.00 & 76.00 & 17.92 & 33.67 & 2 & 1543.9804 & 1543.9792 & 772.9969 & 0.0012 & 0.7762 & 2268.679 & 2581.247 & 66.56\end{array}$

$\begin{array}{lllllllllllllll}0.93 & 10.63 & 16.72 & 15.09 & 3 & 1543.9822 & 1543.9792 & 515.6670 & 0.0030 & 1.9392 & 114.734 & 92.374 & 46.625\end{array}$

$\begin{array}{llllllllllllll}0.84 & 7.26 & 16.72 & 14.38 & 3 & 1543.9822 & 1543.9792 & 515.6670 & 0.0030 & 1.9392 & 145.054 & 116.503 & 48.544\end{array}$

$\begin{array}{lllllllllllll}1.00 & 79.95 & 26.59 & 22.48 & 3 & 2021.1016 & 2021.0859 & 674.7026 & 0.0157 & 7.7564 & 4524.683 & 6228.264 & 688.570\end{array}$ $\begin{array}{llllllllllllll}0.99 & 46.01 & 28.62 & 19.50 & 2 & 1316.6926 & 1316.6846 & 659.3496 & 0.0080 & 6.0665 & 6875.348 & 7173.429 & 2988.461\end{array}$ $\begin{array}{lllllllllllllll}0.99 & 43.34 & 28.36 & 18.43 & 2 & 1316.6940 & 1316.6846 & 659.3496 & 0.0094 & 7.1282 & 8570.591 & 9501.534 & 3481.090 \\ 1.00 & 82.74 & 17.92 & 34.31 & 2 & 1543.9800 & 1543.9792 & 772.9969 & 0.0008 & 0.5175 & 4935.023 & 5276.136 & 708.733\end{array}$ $\begin{array}{lllllllllllllll}0.99 & 25.61 & 17.71 & 23.94 & 3 & 1543.9816 & 1543.9792 & 515.6670 & 0.0024 & 1.5514 & 492.525 & 557.199 & 157.293\end{array}$ $\begin{array}{lllllllllllll}1.00 & 73.54 & 16.72 & 23.81 & 2 & 1543.9826 & 1543.9792 & 772.9969 & 0.0034 & 2.1992 & 7718.395 & 9533.913 & 1189.070\end{array}$ $\begin{array}{llllllllllllll}0.99 & 44.20 & 28.51 & 23.35 & 2 & 1149.6578 & 1149.6494 & 575.8320 & 0.0084 & 7.2937 & 70918.680 & 66674.735 & 477.904\end{array}$ $\begin{array}{llllllllllllll}0.95 & 36.06 & 28.50 & 27.99 & 2 & 1149.6582 & 1149.6494 & 575.8320 & 0.0088 & 7.6411 & 68958.862 & 63814.354 & 836.595\end{array}$ $\begin{array}{lllllllllllllll}.00 & 75.15 & 19.08 & 23.56 & 2 & 1370.8766 & 1370.8741 & 686.4443 & 0.0025 & 1.8210 & 8815.584 & 11193.535 & 514.842\end{array}$ $\begin{array}{llllllllllllll}1.00 & 28.35 & 19.08 & 17.05 & 3 & 1370.8768 & 1370.8741 & 457.9653 & 0.0027 & 1.9652 & 693.147 & 772.703 & 143.557 & 45 \\ 1.00 & 75.05 & 19.08 & 23.54 & 2 & 1370.8768 & 13708741 & 686.4443 & 0.0027 & 1.9667 & 10749.331 & 12835.066 & 320.733 & 470\end{array}$ $\begin{array}{llllllllllllll}1.00 & 75.05 & 19.08 & 23.54 & 2 & 1370.8768 & 1370.8741 & 686.4443 & 0.0027 & 1.9667 & 10749.331 & 12835.066 & 320.733 \\ 1.00 & 30.27 & 19.08 & 17.13 & 3 & 1370.8774 & 1370.8741 & 457.9653 & 0.0033 & 2.4019 & 948.626 & 1191.636 & 242.677\end{array}$ $\begin{array}{lllllllllllllll}1.00 & 30.27 & 19.08 & 17.13 & 3 & 1370.8774 & 1370.8741 & 457.9653 & 0.0033 & 2.4019 & 948.626 & 1191.636 & 242.677 & \\ 1.00 & 50.24 & 6.99 & 27.77 & 2 & 1068.7590 & 1068.7514 & 535.3830 & 0.0076 & 7.0977 & 30794.450 & 39585.648 & 1420.601 & 191 \\ 1.00 & 50.25 & 6.9 & 27.86 & 2 & & & \end{array}$ $\begin{array}{lllllllllllll}1.00 & 50.24 & 6.99 & 27.77 & 2 & 1068.7590 & 1068.7514 & 535.3830 & 0.0076 & 7.0977 & 30794.450 & 39585.648 & 1420.601 \\ 1.00 & 50.25 & 6.99 & 27.86 & 2 & 1068.7600 & 1068.7514 & 535.3830 & 0.0086 & 8.0316 & 37036.823 & 44193.122 & 1624.309\end{array}$ $\begin{array}{llllllllllllll}1.00 & 50.25 & 6.99 & 27.86 & 2 & 1068.7600 & 1068.7514 & 535.3830 & 0.0086 & 8.0316 & 37036.823 & 44193.122 & 1624.309 \\ 1.00 & 46.68 & 28.51 & 23.59 & 2 & 1149.6590 & 1149.6494 & 575.8320 & 0.0096 & 8.3357 & 17625.177 & 18261.595 & 0.000\end{array}$ $\begin{array}{llllllllllllll}1.00 & 46.68 & 28.51 & 23.59 & 2 & 1149.6590 & 1149.6494 & 575.8320 & 0.0096 & 8.3357 & 17625.177 & 18261.595 & 0.000\end{array}$ $\begin{array}{llllllllllllll}0.97 & 36.84 & 28.50 & 28.44 & 2 & 1149.6592 & 1149.6494 & 575.8320 & 0.0098 & 8.53094 & 18207.145 & 19268.850 & 0.000\end{array}$

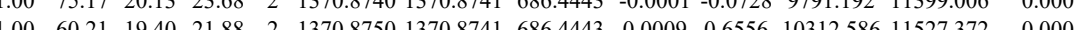
$\begin{array}{llllllllllllll}1.00 & 60.21 & 19.40 & 21.88 & 2 & 1370.8750 & 1370.8741 & 686.4443 & 0.0009 & 0.6556 & 10312.586 & 11527.372 & 0.000 \\ 1.00 & 52.39 & 19.08 & 16.41 & 3 & 1370.8765 & 1370.8741 & 457.9653 & 0.0024 & 1.7469 & 773.401 & 776.621 & 136.274 \\ 0 & & & \end{array}$ $\begin{array}{lllllllllllll}0.53 & 38.36 & 19.08 & 51.36 & 3 & 1370.8768 & 1370.8741 & 457.9653 & 0.0027 & 1.9652 & 560.111 & 601.346 & 148.055\end{array}$ $\begin{array}{llllllllllllll}1.00 & 48.05 & 24.84 & 19.65 & 3 & 1663.9570 & 1663.9541 & 555.6586 & 0.0029 & 1.7397 & 7938.993 & 8466.513 & 0.000\end{array}$ $\begin{array}{lllllllllllllll}1.00 & 53.10 & 24.97 & 23.36 & 3 & 1663.9579 & 1663.9541 & 555.6586 & 0.0038 & 2.2796 & 8535.420 & 10545.780 & 74.898\end{array}$ $\begin{array}{lllllllllllll}1.00 & 50.16 & 4.77 & 27.81 & 2 & 1068.7614 & 1068.7514 & 535.3830 & 0.0100 & 9.3390 & 42480.069 & 48813.573 & 568.874\end{array}$ $\begin{array}{lllllllllllll}1.00 & 41.04 & 24.97 & 18.66 & 3 & 1663.9582 & 1663.9541 & 555.6586 & 0.0041 & 2.4595 & 2095.063 & 2381.446 & 83.398 \\ 1.00 & 34.00 & 24.97 & 17.91 & 3 & 1663.9582 & 1663.954 & 55.5586 & 0.0041 & 2.4595 & 2770.978 & 3019.484 & 183.772\end{array}$ $\begin{array}{lllllllllllll}1.00 & 34.008 & 24.97 & 17.91 & 3 & 1663.9582 & 1663.9541 & 555.6386 & 0.0041 & 2.4595 & 277.978 & 301.484 & 183.772 \\ 1.00 & 46.88 & 6.99 & 26.51 & 2 & 1068.7608 & 1068.7514 & 535.3830 & 0.0094 & 8.7787 & 12745.013 & 14955.396 & 631.000\end{array}$ $\begin{array}{llllllllllllll}1.00 & 50.04 & 4.77 & 27.70 & 2 & 1068.7616 & 1068.7514 & 535.3830 & 0.0102 & 9.5258 & 21379.028 & 23753.044 & 914.622 & 62\end{array}$ $\begin{array}{lllllllllllllll}0.69 & 25.17 & 27.97 & 26.98 & 2 & 922.4892 & 922.4850 & 462.2498 & 0.0042 & 4.5430 & 15905.871 & 15661.011 & 2084.840 & 1269\end{array}$ $\begin{array}{lllllllllllllll}0.64 & 24.12 & 27.97 & 31.89 & 2 & 922.4892 & 922.4850 & 462.2498 & 0.0042 & 4.5430 & 17790.562 & 18479.916 & 1782.230\end{array}$ $\begin{array}{llllllllllllll}1.00 & 81.79 & 22.36 & 31.02 & 2 & 1626.9806 & 1626.9790 & 814.4968 & 0.0016 & 0.9822 & 856.498 & 1345.434 & 21.582 \\ 1.00 & 91.87 & 22.36 & 3.29 & 2 & 162.988 & 1626.970 & 84.498 & 0.018 & 1.1050 & 3461.15 & 4521.047 & 25.047\end{array}$ $\begin{array}{llllllllllllll}1.00 & 91.87 & 22.36 & 32.29 & 2 & 1626.9808 & 1626.9790 & 814.4968 & 0.0018 & 1.1050 & 3461.115 & 4521.047 & 25.047 \\ 1.00 & 53.80 & 22.38 & 26.67 & 3 & 1626.9817 & 1626.9790 & 543.3336 & 0.0027 & 1.6564 & 47.857 & 42.525 & 20.999\end{array}$ $\begin{array}{llllllllllllll}1.00 & 53.63 & 22.38 & 25.75 & 3 & 1626.98171626 .9790 & 543.3336 & 0.0027 & 1.6564 & 25.212 & 31.398 & 4.807\end{array}$ $\begin{array}{lllllllllllll}1.00 & 82.93 & 22.38 & 34.48 & 2 & 1626.9804 & 1626.9790 & 814.4968 & 0.0014 & 0.8594 & 1104.096 & 1520.870 & 11.931 \\ 1.00 & 90.55 & 22.36 & 31.38 & 2 & 1626.980 & 126970 & 814.968 & 0.0016 & 0.9822 & 2633.618 & 2920.235 & 25.167\end{array}$ $\begin{array}{lllllllllllll}1.00 & 90.55 & 22.36 & 31.38 & 2 & 1626.9806 & 1626.9790 & 814.4968 & 0.0016 & 0.9822 & 2633.618 & 2920.235 & 25.167\end{array}$ $\begin{array}{lllllllllllll}1.00 & 47.76 & 22.36 & 27.10 & 3 & 1626.9808 & 1626.9790 & 543.3336 & 0.0018 & 1.1043 & 33.009 & 26.436 & 5.968\end{array}$ $\begin{array}{lllllllllllll}1.00 & 35.58 & 22.38 & 27.64 & 3 & 1626.9823 & 1626.9790 & 543.3336 & 0.0033 & 2.0245 & 24.017 & 35.063 & 20.619\end{array}$ $\begin{array}{lllllllllllll}1.00 & 59.38 & 27.78 & 22.20 & 2 & 1427.7396 & 1427.7386 & 714.8766 & 0.0010 & 0.6994 & 732.975 & 784.720 & 127.528\end{array}$ $\begin{array}{lllllllllllll}1.00 & 65.28 & 27.82 & 30.24 & 2 & 1427.7398 & 1427.7386 & 714.8766 & 0.0012 & 0.8393 & 943.532 & 1058.274 & 137.585\end{array}$ $\begin{array}{lllllllllllll}0.99 & 39.47 & 27.77 & 21.38 & 2 & 1427.7412 & 1427.7386 & 714.8766 & 0.0026 & 1.8185 & 159.087 & 257.213 & 5.352\end{array}$ $\begin{array}{llllllllllllll}1.00 & 58.41 & 28.41 & 27.76 & 2 & 1476.7922 & 1476.7914 & 739.4030 & 0.0008 & 0.5410 & 2565.249 & 2755.463 & 159.808\end{array}$ $\begin{array}{lllllllllllll}0.90 & 22.29 & 28.31 & 17.68 & 3 & 1476.7927 & 1476.7914 & 493.2711 & 0.0013 & 0.8785 & 87.775 & 100.653 & 0.000\end{array}$ $\begin{array}{lllllllllllll}1.00 & 58.12 & 28.22 & 32.22 & 2 & 1476.7934 & 1476.7914 & 739.4030 & 0.0020 & 1.3524 & 4925.623 & 6479.221 & 123.022\end{array}$

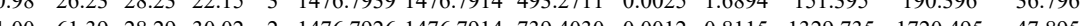
$\begin{array}{lllllllllllllll}\text { LSTLCPSAVLQR } & 1.00 & 60.34 & 28.31 & 26.37 & 2 & 1476.7928 & 1476.7914 & 739.4030 & 0.0014 & 0.9467 & 2350.658 & 2746.081 & 101.491\end{array}$ $12.094 \quad 2.184$ 

$\begin{array}{llllllllllll}0.99 & 36.38 & 27.75 & 18.28 & 2 & 1427.7400 & 1427.7386 & 714.8766 & 0.0014 & 0.9792 & 23.870\end{array}$ $\begin{array}{lllllllllll}1.00 & 49.34 & 27.82 & 28.20 & 2 & 1427.7406 & 1427.7386 & 714.8766 & 0.0020 & 1.3988 & 44.439\end{array}$ $\begin{array}{llllllllllll}0.65 & 17.38 & 26.11 & 18.14 & 2 & 1266.7328 & 1266.7314 & 634.3730 & 0.0014 & 1.1035 & 11.465\end{array}$ TYIQCIAAISR TYIQCIAAISR $\begin{array}{lllllllllll}0.93 & 34.76 & 27.55 & 23.61 & 2 & 1427.7376 & 1427.7386 & 714.8766 & -0.0010 & -0.6994 & 19.158\end{array}$ $\begin{array}{lllllllllll}0.99 & 38.90 & 27.73 & 20.98 & 2 & 1427.7390 & 1427.7386 & 714.8766 & 0.0004 & 0.2798 & 65.659\end{array}$

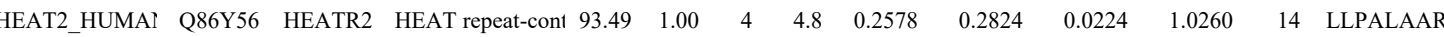
$\begin{array}{lllllllllllll}.00 & 55.53 & 20.79 & 22.03 & 2 & 1414.5992 & 1414.5979 & 708.3062 & 0.0013 & 0.9177 & 6000.722 & 8045.614 & 122.716 \\ 1.00 & 51.76 & 20.79 & 22.80 & 2 & 14145996 & 14145979 & 708.3062 & 0.0017 & 1.2000 & 7981.687 & 10850.609 & 21.500\end{array}$

LLPALAAR

RPVLGCR $\begin{array}{lllllllllllll}0.65 & 28.00 & 17.71 & 31.93 & 2 & 967.6390 & 967.6300 & 484.8223 & 0.0090 & 9.2817 & 7328.599 & 5659.302 & 162.359\end{array}$ $\begin{array}{lllllllllllll}0.65 & 32.00 & 17.71 & 40.85 & 2 & 967.6390 & 967.6300 & 484.8223 & 0.0090 & 9.2817 & 4218.966 & 4239.016 & 182.680\end{array}$

RPVLGCR

RPVLGCR

$\begin{array}{lllllllllll}0.94 & 28.39 & 25.28 & 16.57 & 2 & 845.4362 & 845.4364 & 423.7255 & -0.0002 & -0.2360 & 484.979\end{array}$ $\begin{array}{lllllllllllll}0.98 & 33.04 & 25.28 & 18.20 & 2 & 845.4366 & 845.4364 & 423.7255 & 0.0002 & 0.2360 & 415.642 & 54\end{array}$ $\begin{array}{lllllllllllll}0.93 & 28.26 & 25.28 & 20.16 & 2 & 845.4366 & 845.4364 & 423.7255 & 0.0002 & 0.2360 & 233.810 \\ 0.92 & 27.21 & 25.20 & 16.85 & 2 & 845.4368 & 845.4364 & 423.7255 & 0.0004 & 0.4720 & 303.827\end{array}$ $\begin{array}{llllllllllll} & 0.92 & 27.21 & 25.20 & 16.85 & 2 & 845.4368 & 845.4364 & 423.7255 & 0.0004 & 0.4720 & 303.827 \\ \text { TPSASGLLVLASAMR } & 1.00 & 86.85 & 26.89 & 27.38 & 2 & 1616.9028 & 1616.9041 & 809.4593 & -0.0013 & -0.8030 & 85.205\end{array}$ $\begin{array}{llllllllllll} & & & \end{array}$ $\begin{array}{llllllllllll}\text { TPSASGLLVLASAMR } & 1.00 & 85.40 & 27.01 & 23.08 & 2 & 1616.9032 & 1616.9041 & 809.4593 & -0.0009 & -0.5559 & 35.583 \\ \text { TPSASGLLVLASAMR } & 1.00 & 35.48 & 26.78 & 24.97 & 3 & 1616.9050 & 1616.9041 & 539.9753 & 0.0009 & 0.5556 & 47.242\end{array}$ $\begin{array}{lllllllllllll}\text { TPSASGLLVLASAMR } & 0.95 & 23.44 & 26.78 & 18.30 & 3 & 1616.9053 & 1616.9041 & 539.9753 & 0.0012 & 0.7408 & 20.894\end{array}$ RPVLGCR $\begin{array}{llllllllllll}0.95 & 23.44 & 26.78 & 18.30 & 3 & 1616.9053 & 1616.9041 & 539.9753 & 0.0012 & 0.7408 & 2.8 .894 \\ 0.62 & 18.98 & 25.20 & 16.54 & 2 & 845.4368 & 845.4364 & 423.7255 & 0.0004 & 0.4720 & 160.660\end{array}$ $\begin{array}{lllllllllllll}\text { TPSASGLLVLASAMR } & 1.00 & 93.64 & 27.12 & 25.30 & 2 & 1616.9000 & 1616.9041 & 809.4593 & -0.0041 & -2.5326 & 107.828\end{array}$ $\begin{array}{lllllllllllll}\text { TPSASGLLVLASAMR } & 1.00 & \# \# \# \# \frac{27.01}{27.76} & 2 & 1616.9032 & 1616.9041 & 809.4593 & -0.0009 & -0.5559 & 142.058\end{array}$ $\begin{array}{lllllllllllll}\text { TPSASGLLVLASAMR } & 0.98 & 27.83 & 26.78 & 19.76 & 3 & 1616.9056 & 1616.9041 & 539.9753 & 0.0015 & 0.9260 & 26.900\end{array}$

LLPALAAR

LFSILSTVLLR

IVSQPQPAR

LLPTPTVK

LLLPTPTVK

AGLLQPPVR

AGLLQPPVR

LLLPTPTVK

LLLPTPTVK

$\begin{array}{llllllllllll}0.80 & 14.95 & 17.32 & 23.47 & 2 & 823.5278 & 823.5279 & 412.7712 & -0.0001 & -0.1211 & 3.915\end{array}$

$\begin{array}{llllllllllll}1.00 & 66.17 & 18.69 & 26.52 & 2 & 1404.8850 & 14048826 & 703.4486 & 0.0024 & 1.7059 & 55.598\end{array}$

$\begin{array}{lllllllllll}1.00 & 38.28 & 26.24 & 20.58 & 2 & 1138.6596 & 1138.6580 & 570.3363 & 0.0016 & 1.4027 & 250.587\end{array}$

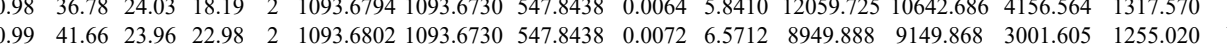

LLLPTPTVK

$\begin{array}{lllllllllllll}0.00 & 37.17 & 15.68 & 27.20 & 2 & 1268.8332 & 12688.831 & 635.4228 & 0.0021 & 1.6524 & 25315.699 & 23034.5305 & 0.000\end{array}$

$\begin{array}{lllllllllllllll}0.98 & 24.41 & 15.68 & 24.77 & 2 & 1268.8320 & 1268.8311 & 635.4228 & 0.0009 & 0.7082 & 14300.554 & 14127.640 & 32.607\end{array}$

$\begin{array}{llllllllllllll} & \end{array}$

$\begin{array}{llllllllllllll}\text { APEEELPPLDPEEIR } & 1.00 & 59.17 & 27.93 & 28.32 & 2 & 1876.9612 & 1876.9540 & 939.4843 & 0.0072 & 3.8319 & 31.566 & 1.9 . \\ \text { APEEEPPLDPEEIR } & 0.99 & 44.69 & 27.93 & 16.67 & 2 & 1876.9612 & 1876.9540 & 939.4843 & 0.0072 & 3.8319 & 20.544 & \end{array}$

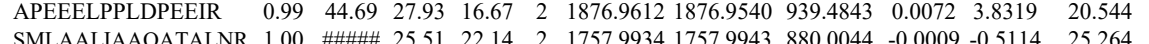
\begin{tabular}{llllllllllll} 
SMLAALIAAQATALNR & 1.00 & \#\#\#\# & 25.51 & 22.14 & 2 & 1757.9934 & 1757.9943 & 880.0044 & -0.0009 & -0.5114 & 25.264 \\
\hline SMLAALIAQATALNR & 1.00 & $\# \# \# \# \frac{25.42}{24.50}$ & 2 & 1757.9944 & 1757.9943 & 880.0044 & 0.0001 & 0.0568 & 4.040
\end{tabular} \begin{tabular}{llllllllllll} 
SMLAALIAAQATALNR & 1.00 & \#\#\#\# & 25.42 & 24.50 & 2 & 1757.9944 & 1757.9943 & 880.0044 & 0.0001 & 0.0568 & 4.040 \\
\hline SMLAALIAAQATALR & 1.00 & 56.46 & 25.44 & 18.93 & 3 & 1757.9953 & 1757.9943 & 587.0054 & 0.0010 & 0.5679 & 7.448
\end{tabular} $\begin{array}{llllllllllll}\text { SMLAALIAAQATALNR } & 1.00 & 56.46 & 25.44 & 18.93 & 3 & 1757.9953 & 1757.9943 & 587.0054 & 0.0010 & 0.5679 & 7.448 \\ \text { SMLAALIAAQATALNR } & 0.55 & 57.60 & 25.63 & 70.60 & 3 & 1757.9962 & 1757.9943 & 587.0054 & 0.0019 & 1.0789 & 7.975\end{array}$ $\begin{array}{lllllllllllll}\text { SMLAALIAAQATALNR } & 0.55 & 57.60 & 25.63 & 70.60 & 3 & 1757.9962 & 1757.9943 & 587.0054 & 0.0019 & 1.0789 & 7.975 \\ \text { SMLAALIAAQATALNR } & 1.00 & 40.77 & 26.58 & 20.96 & 3 & 1773.9904 & 1773.9892 & 592.3370 & 0.0012 & 0.6753 & 52.691\end{array}$ $\begin{array}{llllllllllll}\text { SMLAALIAAQATALNR } & 1.00 & 40.77 & 26.58 & 20.96 & 3 & 1773.9904 & 1773.9892 & 592.3370 & 0.0012 & 0.6753 & 52.691\end{array}$ $\begin{array}{lllllllllllll}\text { SMLAALIAAQATALNR } & 1.00 & 50.36 & 26.60 & 17.86 & 3 & 1773.9907 & 1773.9892 & 592.3370 & 0.0015 & 0.8441 & 34.683\end{array}$ $\begin{array}{lllllllllllllllll}\text { SMLAALIAAQATALNR } & 1.00 & 50.36 & 26.60 & 17.86 & 3 & 1773.9907 & 27.50 & 2 & 1757.9950 & 1757.9943 & 880.0044 & 0.0007 & 0.3977 & 31.254\end{array}$

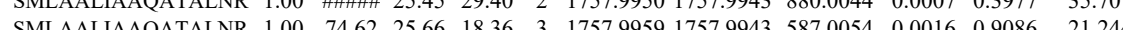

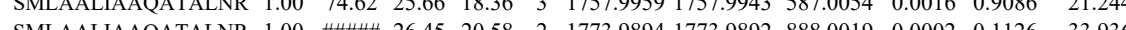

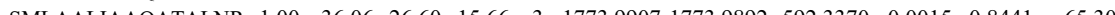

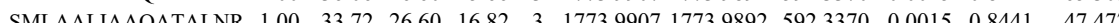




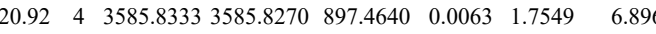

ACMTYFPR

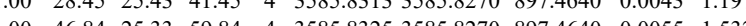

LLLESVSGLLQPR $\begin{array}{lllllllllllll}0.99 & 31.26 & 22.01 & 17.85 & 2 & 1177.5218 & 1177.5204 & 589.7675 & 0.0014 & 1.1869 & 8838.463 & 10\end{array}$

$\begin{array}{llllllllll}\text { K1967_HUMAN Q8N163 } & \text { KIAA1967 Protein KIAA196 } & 102.90 & 1.00 & 9 & 11.9 & -0.0553 & 0.2657 & 0.1799 & 2.6730\end{array}$

STKPGAAPTEHK

$\begin{array}{lllllllllll}\text { STAG2_HUMAI } & \text { Q8N3U4 } & \text { STAG2 } & \text { Cohesin subunit S } 141.33 & 1.00 & 2 & 3.3 & 0.3597 & 0.5849 & 0.2992 & 1.2060\end{array}$

$\begin{array}{lllllllllll}\text { CPSF7 HUMAN } & \text { Q8N684 } & \text { CPSF7 } & \text { Cleavage and poly } 52.05 & 1.00 & 4 & 13.2 & -0.1769 & 0.5725 & -0.5488 & 1.7505\end{array}$
LLLLEVSGLLQR

LLLLESVSGLLQPR

LLLESTSLQR

LLLLESVSGLLPR

LLLLESVSGLLQPR

LASFFLSR

LASFFLSR

LASFFLSR

LASFFLSR

LLPQVLNSWSIGR

LLPQVLNSWSIGR

LLPQVLNSWSIGR

STATEVTNK

FSATEVTNK

QEGLDGGLPEEVLFGNLDLLPPP

VLLLSSPGLEELYR

SPAPPLLHVAALGQK

SPAPPLLHVAALGQK
INPLPGGR

SPAPPLLHVAALGQK DDGEEEFAGAK

DGEEEFAGAK

ILLTLGIR

MLISLPEK

MLLSLPEK
MLLSLPEK

ILLTLGIR

ILLTLGIR

ILLTLGIR

ILLTLGIR

ILLTLGIR

ILLTLGIR

QMTDVLLTP

QMTDVLLTPATDALK

LTLSQFQK

CGDLLAASQVVNR

CGDLLAASQVVNR

LLSPVVPQISAPQSN

TLITFAGMIPYR

TLITFAGMIPYR

TLITFAGMIPYR

TLITFAGMIPYR

NLQEIQQAGER

$\begin{array}{llllllllllll}85.01 & 18.98 & 98.01 & 2 & 1681.0272 & 1681.0260 & 841.5203 & 0.0012 & 0.7130 & 169.190 & 179.462\end{array}$

$\begin{array}{llllllllllll} & \end{array}$

$\begin{array}{llllllllllll}33.64 & 18.86 & 15.39 & 3 & 1681.0294 & 1681.0260 & 561.3493 & 0.0034 & 2.0189 & 55.152 & 93.578\end{array}$

$\begin{array}{llllllllllll}0.76 & 84.58 & 18.98 & 97.58 & 2 & 1681.0266 & 1681.0260 & 841.5203 & 0.0006 & 0.3565 & 212.846 & 145.872\end{array}$ $\begin{array}{lllllllllllll}0.54 .84 & 18.98 & 57.84 & 3 & 1681.0282 & 1681.0260 & 561.3493 & 0.0022 & 1.3064 & 57.471 & 85.546 \\ 0.55 & 54.32 & 18.98 & 67.32 & 3 & 1681.0282 & 1681.0260 & 561.3493 & 0.0022 & 1.3064 & 37.756 & 46.497\end{array}$ $\begin{array}{lllllllllllll}0.97 & 32.24 & 26.44 & 34.37 & 2 & 1083.6212 & 1083.6199 & 542.8172 & 0.0013 & 1.1975 & 4338.018 & 4067.728\end{array}$ $\begin{array}{llllllllllll}1.00 & 44.63 & 26.44 & 25.96 & 2 & 1083.6212 & 1083.6199 & 542.8172 & 0.0013 & 1.1975 & 3820.528 & 3760.920\end{array}$ $\begin{array}{lllllllllllll}100 & 42.91 & 26.44 & 24.66 & 2 & 1083.6212 & 1083.6199 & 542.8172 & 0.0013 & 1.1975 & 3835.046 & 3588.127\end{array}$ $\begin{array}{lllllllllllll}100 & 48.95 & 26.44 & 25.36 & 2 & 1083.6212 & 1083.6199 & 542.8172 & 0.0013 & 1.1975 & 4404.840 & 4106.980\end{array}$ $\begin{array}{lllllllllllll}0.87 & 23.12 & 26.44 & 22.53 & 2 & 1083.6214 & 1083.6199 & 542.8172 & 0.0015 & 1.3817 & 601.762 & 565.797\end{array}$ $\begin{array}{lllllllllllll}1.00 & 69.82 & 25.20 & 21.18 & 2 & 1625.9382 & 1625.9375 & 813.9760 & 0.0007 & 0.4300 & 774.780 & 8511.560\end{array}$ $\begin{array}{lllllllllllllll}1.00 & 70.78 & 25.02 & 21.31 & 2 & 1625.9386 & 1625.9375 & 813.9760 & 0.0011 & 0.6757 & 878.401 & 871.630\end{array}$ $\begin{array}{lllllllllllll}1.00 & 51.17 & 25.20 & 26.53 & 2 & 1625.9380 & 1625.9375 & 813.9760 & 0.0005 & 0.3071 & 80.680 & 90.682\end{array}$ $\begin{array}{lllllllllllll}1.00 & 23.56 & 26.57 & 17.54 & 4 & 1654.9373 & 1654.9368 & 414.7415 & 0.0005 & 0.3014 & 234.030 & 265.179 & 328.222\end{array}$

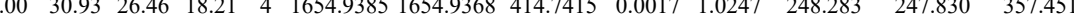
$\begin{array}{llllllllllllll}0.99 & 43.48 & 27.74 & 30.40 & 2 & 1283.7002 & 1283.6965 & 642.8555 & 0.0037 & 2.8778 & 19162.274 & 24236.346 & 14371.741 & 84\end{array}$

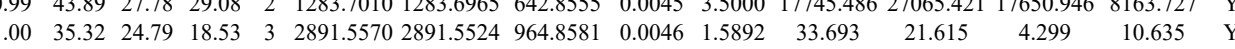
$\begin{array}{rllllllllllllll}1.00 & 56.66 & 25.51 & 24.42 & 2 & 1731.9906 & 1731.9892 & 867.0019 & 0.0014 & 0.8074 & 820.606 & 804.969 & 52.261 & 29.482 & \text { Yes }\end{array}$

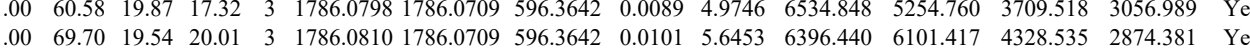
$\begin{array}{llllllllllllllll}.00 & 69.70 & 19.54 & 20.01 & 3 & 1786.0810 & 1786.0709 & 596.3642 & 0.0101 & 5.6453 & 6396.440 & 6101.417 & 4328.535 & 2874.381 & \text { Yes } \\ 0.83 & 23.23 & 26.27 & 23.90 & 2 & 966.5766 & 966.5732 & 484.2939 & 0.0034 & 3.5103 & 25238.791 & 18937.241 & 4484.080 & 954.167 & \text { Yes }\end{array}$ $\begin{array}{llllllllllllllll}1.00 & 59.65 & 19.54 & 17.30 & 3 & 1786.0810 & 1786.5732 & 484.2939 & 0.0034 & 3.5103 & 25238.791 & 18937.241 & 4484.080 & 954.167 & \text { Yes } \\ 1964.3642 & 0.0101 & 5.6453 & 4021.349 & 3803.643 & 2645.994 & 1549.772 & \text { Yes }\end{array}$ $\begin{array}{lllllllllllllll}1.00 & 64.40 & 19.54 & 21.25 & 3 & 1786.0810 & 1786.0709 & 596.3642 & 0.0101 & 5.6453 & 5698.920 & 5755.535 & 5060.387 & 2693.791 & \text { Yes } \\ 1.00 & 44.16 & 25.87 & 24.93 & 2 & 1454.6806 & 1454.6769 & 728.3457 & 0.0037 & 2.5400 & 747.672 & 601.742 & 896.456 & 570.926 & \text { Y }\end{array}$ $\begin{array}{lllllllllllllll}1.00 & 44.16 & 25.87 & 24.93 & 2 & 1454.6806 & 1454.6769 & 728.3457 & 0.0037 & 2.5400 & 747.672 & 601.742 & 896.456 & 570.926 & \text { Yes } \\ 1.00 & 51.76 & 26.15 & 25.50 & 2 & 1454.6844 & 1454.6769 & 728.3457 & 0.0075 & 5.1486 & 721.042 & 685.691 & 747.243 & 595.834 & \text { Yes }\end{array}$

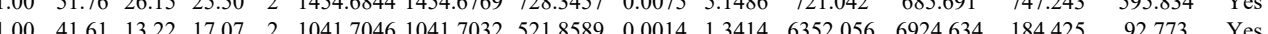

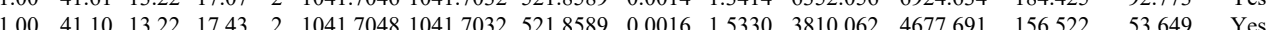

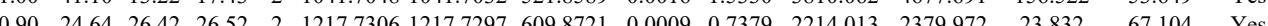

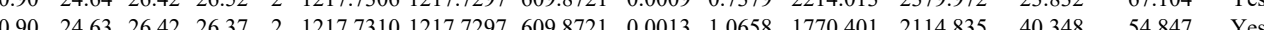
$\begin{array}{lllllllllllllll}100 & 40.46 & 13.22 & 16.64 & 2 & 1041.7042 & 1041.7032 & 521.8589 & 0.0010 & 0.9581 & 2085.381 & 2086.671 & 111.291 & 4.148 & \text { Yes }\end{array}$ $\begin{array}{lllllllllllllll}1.00 & 41.59 & 13.22 & 16.98 & 2 & 1041.7046 & 1041.7032 & 521.8589 & 0.0014 & 1.3414 & 3049.086 & 3025.712 & 150.560 & 11.849 & \text { Yes }\end{array}$

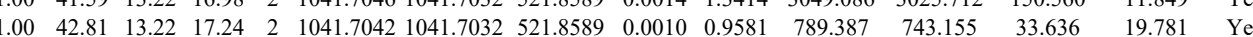
$\begin{array}{lllllllllllllll}1.00 & 41.01 & 13.22 & 17.24 & 2 & 1041.7046 & 1041.7032 & 521.8589 & 0.0014 & 1.3414 & 671.610 & 629.411 & 28.485 & 21.333 & \text { Yes }\end{array}$ $\begin{array}{lllllllllllllll}1.00 & 35.31 & 13.22 & 15.57 & 2 & 1041.7046 & 1041.7032 & 521.8589 & 0.0014 & 1.3414 & 243.572 & 263.124 & 26.983 & 24.444 & \text { Yes }\end{array}$ $\begin{array}{llllllllllllllll}0.77 & 30.47 & 16.43 & 43.47 & 2 & 1041.7054 & 1041.7032 & 521.8589 & 0.0022 & 2.1078 & 236.298 & 208.357 & 23.402 & 35.769 & \text { Yes }\end{array}$

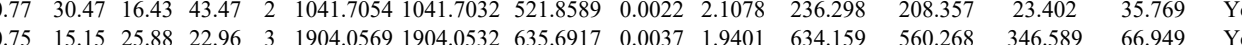

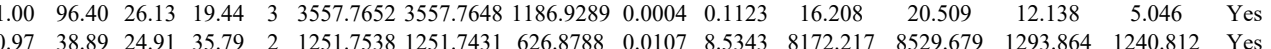
$\begin{array}{llllllllllll} & \end{array}$

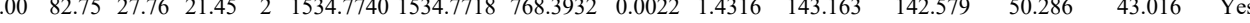

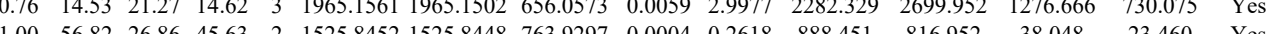
$\begin{array}{lllllllllllllll}1.00 & 56.82 & 26.86 & 45.63 & 2 & 1525.8452 & 1525.8448 & 763.9297 & 0.0004 & 0.2618 & 888.451 & 816.952 & 38.048 & 23.460 & \text { Yes } \\ \end{array}$

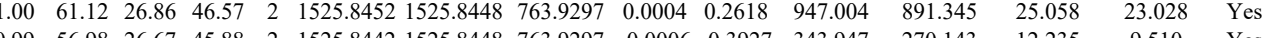

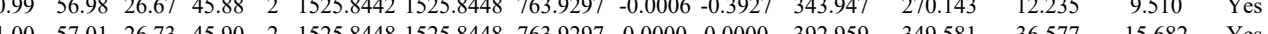

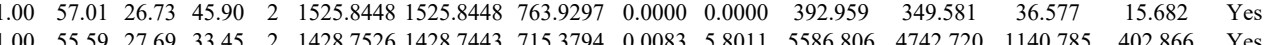
$\begin{array}{llllllllllllllll} & \end{array}$ $\begin{array}{lllllllllllllll} & \end{array}$

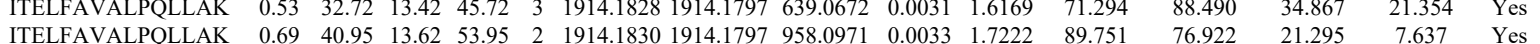
SYSVGASGSSSR

SYSVGASGSSSR

$\begin{array}{llllllllllll}1.00 & 62.15 & 25.61 & 21.02 & 2 & 1287.6190 & 1287.6177 & 64.8161 & 0.0013 & 1.0080 & 151.498\end{array}$

ATPSENLVPSSAR

$\begin{array}{lllllllllllll}25.60 & 21.04 & 2 & 1287.6194 & 1287.6177 & 644.8161 & 0.0017 & 13182 & 175.638 & 175.834 & 63.584 & 9.595 & \text { Yes }\end{array}$ 

$\begin{array}{lllllllllllll}1.00 & 27.65 & 28.16 & 40.65 & 4 & 1738.8793 & 1738.8774 & 435.7266 & 0.0019 & 1.0901 & 574.451 & 500.260 & 256.215 \\ 0.55 & 54.56 & 25.02 & 6.56 & 3 & 24803539 & 2480.3518 & 827.7912 & 0.021 & 0.845 & 491.386 & 829.945 & 98.360\end{array}$

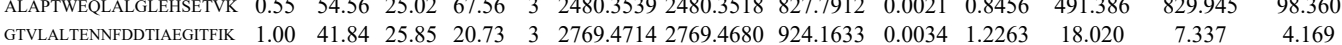
$\begin{array}{llllllllllllll}\text { GTVLALTENNFDDTIAEGITFIK } & 1.00 & 48.44 & 25.79 & 22.71 & 3 & 2769.4723 & 2769.4680 & 924.1633 & 0.0043 & 1.5510 & 8.777 & 5.367\end{array}$

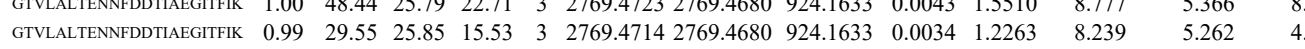
$\begin{array}{lllllllllllllll}\text { GTVLALTENNFDDTIAEGITFIK } & 1.00 & 21.50 & 25.80 & 16.59 & 4 & 2769.4717 & 2769.4680 & 693.3743 & 0.0037 & 1.3341 & 121.057 & 139.160 & 62.389\end{array}$ $\begin{array}{llllllllllllll}\text { GTVLALTENNFDDTIAEGITFIK } & 0.98 & 26.05 & 25.79 & 19.42 & 3 & 2769.4723 & 2769.4680 & 924.1633 & 0.0043 & 1.5510 & 0.000 & 19.075 & 13.964\end{array}$

FVLSQAK

FVLSQAK

FVLSQAK

GYPTLLLFR

GYPTLLLFR

GYPTLLLFR

GYPTLLLFR

GYPTLLWFR

GYPTLLWFR

GYPTLLWFR

GYPTLLWFR

GYPTLLWFR

GYPTLLWFR

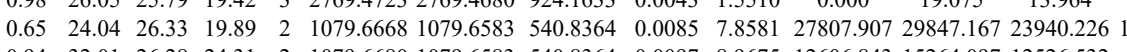

$\begin{array}{lllllllllllllllll}0.94 & 32.01 & 26.28 & 24.31 & 2 & 1079.6680 & 1079.6583 & 540.8364 & 0.0097 & 8.9675 & 12606.843 & 15264.097 & 12526.532 & 4850.06\end{array}$

$\begin{array}{llllllllllllll}0.92 & 31.77 & 26.28 & 24.01 & 2 & 1079.6672 & 1079.6583 & 540.8364 & 0.0089 & 8.2279 & 18410.182 & 20198.258 & 21157.046 & 8739.595\end{array}$ $\begin{array}{llllllllllllll}1.00 & 37.80 & 26.29 & 25.63 & 2 & 1222.7218 & 1222.7196 & 612.3671 & 0.0022 & 1.7963 & 1652.436 & 1860.417 & 968.969 & 83.209\end{array}$

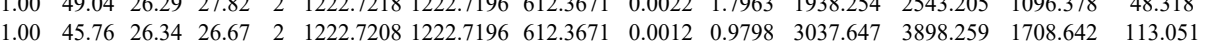
$\begin{array}{lllllllllllllll}1.00 & 45.76 & 26.34 & 26.67 & 2 & 1222.7208 & 1222.7196 & 612.3671 & 0.0012 & 0.9798 & 3037.647 & 3898.259 & 1708.642 & 113.051 \\ 0.99 & 37.06 & 26.31 & 26.04 & 2 & 1222.7220 & 1222.7196 & 6123671 & 0.0024 & 1.9596 & 4110.521 & 5303.186 & 2818.495 & 107.778\end{array}$ $\begin{array}{llllllllllllll}0.99 & 37.06 & 26.31 & 26.04 & 2 & 1222.7220 & 1222.7196 & 612.3671 & 0.0024 & 1.9596 & 4110.521 & 5303.186 & 2818.495 & 107.778 \\ 1.00 & 46.72 & 27.33 & 17.45 & 2 & 1295.7156 & 1295.7148 & 648.8647 & 0.0008 & 0.6165 & 461.501 & 602.801 & 155.363 & 12.365\end{array}$ $\begin{array}{lllllllllllll}1.00 & 46.72 & 27.33 & 17.45 & 2 & 1295.7156 & 1295.7148 & 648.8647 & 0.0008 & 0.6165 & 461.501 & 602.801 & 155.363 \\ 0.77 & 45.35 & 26.79 & 58.35 & 2 & 1295.7166 & 1295.7148 & 648.8647 & 0.0018 & 1.3870 & 403.348 & 548404 & 172.925\end{array}$

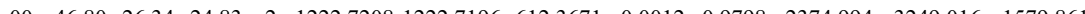

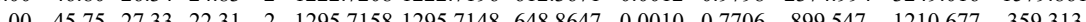
$\begin{array}{llllllllllllll}1.00 & 46.04 & 27.33 & 22.43 & 2 & 1295.7158 & 1295.7148 & 648.8647 & 0.0010 & 0.7706 & 1540.589 & 1968.889 & 428.462\end{array}$ $\begin{array}{lllllllllllll}1.00 & 44.15 & 27.34 & 19.77 & 2 & 1295.7152 & 1295.7148 & 648.8647 & 0.0004 & 0.3082 & 753.913 & 896.934 & 253.007\end{array}$

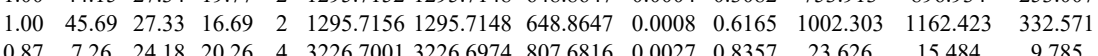

\section{GPEAGYATPAMVQAAMTLLDASHLPK}

\section{GPEAGYATPAMNVAAMTLLDASSHLP}

GEAGYATPRAMVAAMTLLDASHLPK

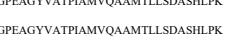

QATVVLNCVGPYR

RFEKPLEEK

RFEKPLEEK

KPNEGADGQWK

$\begin{array}{llllllllllll}0.87 & 7.26 & 24.18 & 20.26 & 4 & 3226.7001 & 3226.6974 & 807.6816 & 0.0027 & 0.8357 & 23.626 & 15.484 \\ 0.53 & 92.51 & 24.18 & & & \end{array}$

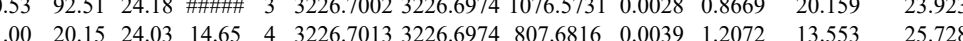

$\begin{array}{lllllllllll}0.53 & 99.07 & 24.18 & \# \# \# \# \quad 3 & 3226.7002 & 3226.6974 & 1076.5731 & 0.0028 & 0.8669 & 23.883\end{array}$

$\begin{array}{lllllllllll}0.98 & 11.87 & 24.10 & 15.16 & 4 & 3226.7005 & 3226.6974 & 807.6816 & 0.0031 & 0.9595 & 11.109\end{array}$

$\begin{array}{lllllllllllll} & & \end{array}$

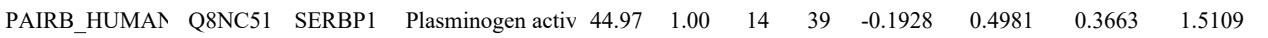

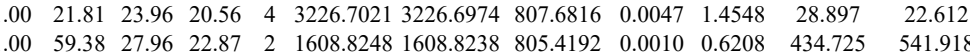

$\begin{array}{lllllllllllllll}0.99 & 13.48 & 23.60 & 20.31 & 4 & 1606.9457 & 1606.9408 & 402.7425 & 0.0049 & 3.0416 & 71951.944 & 69114.550 & 15168.714 & 681.715\end{array}$

$\begin{array}{lllllllllllllll} & 26.87 & 20.52 & 2 & 2231.0894 & 2231.0878 & 1116.5512 & 0.0016 & 0.7165 & 91.054 & 104.129 & 26.782 & 11.264 & \text { Yes }\end{array}$

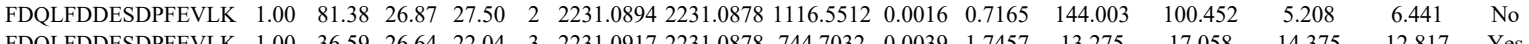

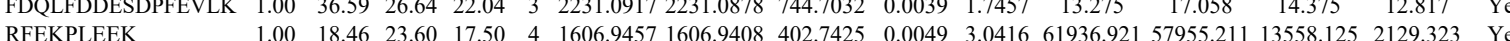

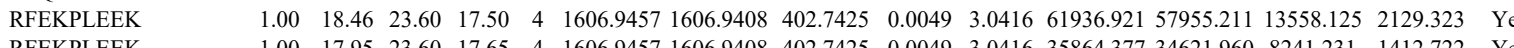
$\begin{array}{llllllllllllllll}\text { RFEKPLEEK } & 1.00 & 17.95 & 23.60 & 17.65 & 4 & 1606.9457 & 1606.9408 & 402.7425 & 0.0049 & 3.0416 & 35864.377 & 34621.960 & 8241.231 & 1412.722 & \text { Yes }\end{array}$

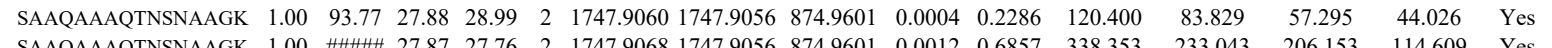

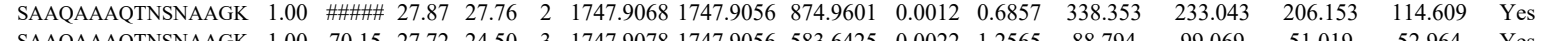

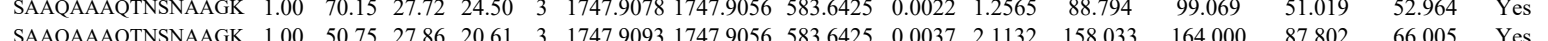

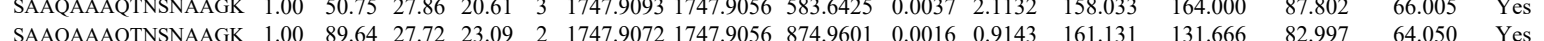
$\begin{array}{lllllllllllllllll}\text { SAAQAAAQTNSNAAGK } & 1.00 & 89.64 & 27.72 & 23.09 & 2 & 1747.9072 & 1747.9056 & 874.9601 & 0.0016 & 0.9143 & 161.131 & 131.666 & 82.997 & 64.050 & \text { Yes } \\ \text { SAAQAAAQTNSNAAGK } & 1.00 & 64.25 & 27.74 & 27.85 & 3 & 1747.9075 & 1747.9056 & 583.6425 & 0.0019 & 1.0851 & 89.102 & 88.053 & 41.768 & 49.098 & \text { Yes }\end{array}$

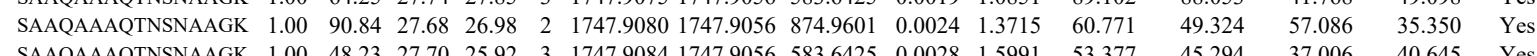
$\begin{array}{llllllllllllllll}\text { SAAQAAAQTNSNAAGK } & 1.00 & 48.23 & 27.70 & 25.92 & 3 & 1747.9084 & 1747.9056 & 583.6425 & 0.0028 & 1.5991 & 53.377 & 45.294 & 37.006 & 40.645 & \text { Yes }\end{array}$ 


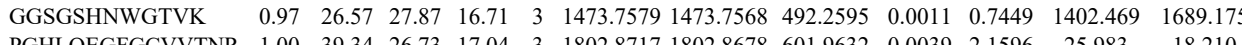

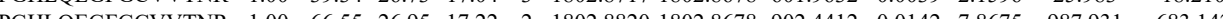

$\begin{array}{lllllllllllllll}\text { PGHLQEGFGCVVTNR } & 1.00 & 67.88 & 27.03 & 18.14 & 2 & 1802.8824 & 1802.8678 & 902.4412 & 0.0146 & 8.0891 & 1455.194 & 1288.001\end{array}$

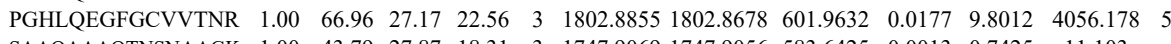

5413.183

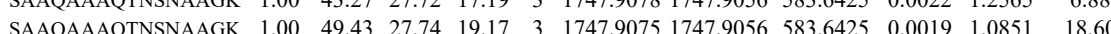

$\begin{array}{lllllllllllllll}\text { SAAQAAAAATNSNAAGK } & 0.55 & 42.22 & 27.68 & 55.22 & 3 & 1747.9081 & 1747.9056 & 583.6425 & 0.0025 & 1.4278 & 11.912\end{array}$

$\begin{array}{llllllllllll}\text { RADQALLQGEGK } & 0.61 & 20.90 & 27.34 & 19.22 & 2 & 1542.8354 & 1542.8358 & 772.4252 & -0.0004 & -0.2589 & 7.956\end{array}$

$\begin{array}{llllllllllll}\text { RPDQQLQGEGK } & 0.99 & 30.84 & 27.29 & 18.06 & 3 & 1542.8368 & 1542.8358 & 515.2859 & 0.0010 & 0.6469 & 57.419\end{array}$

$\begin{array}{lllllllllllll}\text { RPDQQLQGEGK } & 0.88 & 20.34 & 27.28 & 18.97 & 3 & 1542.8371 & 1542.8358 & 515.2859 & 0.0013 & 0.8410 & 29.039\end{array}$

$\begin{array}{llllllllllll}\text { KPNEGADGQWK } & 0.98 & 29.91 & 27.62 & 19.28 & 3 & 1660.8898 & 1660.8898 & 554.6372 & 0.0000 & 0.0000 & 380.868\end{array}$ $\begin{array}{lllllllllllll}\text { SAAQAAAQTNSNAAGK } & 1.00 & 36.97 & 27.87 & 18.22 & 3 & 1747.9069 & 1747.9056 & 583.6425 & 0.0013 & 0.7425 & 9.607 \\ \text { SAAQAAAQTNSNAAGK } & 0.55 & 39.05 & 27.74 & 52.05 & 3 & 1747.9075 & 1747.9056 & 583.6425 & 0.0019 & 1.0851 & 9.585\end{array}$

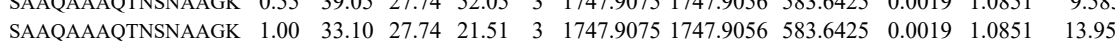
$\begin{array}{lllllllllllll}\text { SAAQAAAQTNSNAAGK } & 1.00 & 44.73 & 27.84 & 18.14 & 3 & 1747.9087 & 1747.9056 & 583.6425 & 0.0031 & 1.7705 & 3.162\end{array}$ \begin{tabular}{llllllllllll} 
SAAQAAAQTNSNAAGK & 0.96 & 23.83 & 27.70 & 17.02 & 3 & 1747.9084 & 1747.9056 & 583.6425 & 0.0028 & 1.5991 & 6.593 \\
\hline
\end{tabular} $\begin{array}{llllllllllll}\text { ENEVEEVK } & 0.99 & 43.03 & 28.36 & 38.40 & 2 & 1262.6598 & 1262.6598 & 632.3372 & 0.0000 & 0.0000 & 984.692\end{array}$ $\begin{array}{lllllllllllll}\text { ENEVEEVK } & 0.97 & 36.96 & 28.26 & 39.33 & 2 & 1262.6610 & 1262.6598 & 632.3372 & 0.0012 & 0.9489 & 769.282 \\ \text { ENEVEEVKEEGPK } & 0.90 & 25.83 & 27.44 & 20.84 & 4 & 1947.0337 & 1947.0162 & 487.7613 & 0.0175 & 8.9695 & 150.404\end{array}$ $\begin{array}{llllllllllll}\text { ENEVEEVKEEGPK } & 0.90 & 25.83 & 27.44 & 20.84 & 4 & 1947.0337 & 1947.0162 & 487.7613 & 0.0175 & 8.9695 & 150.404\end{array}$ $\begin{array}{lllllllllllll}\text { SAAQAAAQTNSNAAGK } & 0.79 & 16.73 & 27.72 & 24.00 & 3 & 1747.9078 & 1747.9056 & 583.6425 & 0.0022 & 1.2565 & 7.216\end{array}$ $\begin{array}{llllllllllll}\text { SEEAHAEDSVMDHHFR } & 1.00 & 59.22 & 23.60 & 24.19 & 4 & 2039.8917 & 2039.8877 & 510.9792 & 0.0040 & 1.9570 & 5258.529 \\ \text { SAAQAAAQTNSNAAGK } & 0.99 & 29.48 & 27.74 & 16.94 & 3 & 1747.9075 & 1747.9056 & 583.6425 & 0.0019 & 1.0851 & 6.498\end{array}$ \begin{tabular}{lllllllllllll} 
SAAQAAAQTNSNAAGK & 0.99 & 29.48 & 27.74 & 16.94 & 3 & 1747.9075 & 1747.9056 & 583.6425 & 0.0019 & 1.0851 & 6.498 \\
\hline SAAQAAAQTNSNAAGK & 0.61 & 17.06 & 27.82 & 20.02 & 3 & 1747.9060 & 1747.9056 & 583.6425 & 0.0004 & 0.2285 & 8.389
\end{tabular} $\begin{array}{llllllllllll}\text { SAAQAAAQTNSNAAGK } & 0.61 & 17.06 & 27.82 & 20.02 & 3 & 1747.9060 & 1747.9056 & 583.6425 & 0.0004 & 0.2285 & 8.389 \\ \text { SAAQAAAQTNSNAAGK } & 0.81 & 18.91 & 27.87 & 20.24 & 3 & 1747.9069 & 1747.9056 & 583.6425 & 0.0013 & 0.7425 & 12.059\end{array}$ $\begin{array}{lllllllllllll}\text { SAAQAAAQTNSNAAGK } & 0.81 & 18.91 & 27.87 & 20.24 & 3 & 1747.9069 & 1747.9056 & 583.6425 & 0.0013 & 0.7425 & 12.059\end{array}$ $\begin{array}{llllllllllll}\text { SAAQAAAQTNSNAAGK } & 0.53 & 13.95 & 27.87 & 20.30 & 3 & 1747.9069 & 1747.9056 & 583.6425 & 0.0013 & 0.7425 & 5.908 \\ \text { SSASAPDVDDPEAFPALA } & 0.92 & 25.36 & 26.33 & 15.83 & 2 & 1902.8990 & 1902.8969 & 952.4557 & 0.0021 & 1.1024 & 0.000\end{array}$

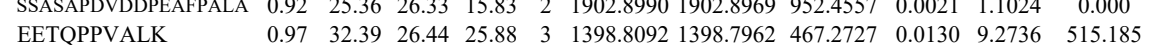

4.617
4.161

RPDQQLQGEGK

RPDQQLQGEGK

RPDQQLQGEGK

RPDQQLQGEGK

EETOPPVALK

FEKPLEEK

FEKPLEEK

\section{RPDQQLQGEGK}

RPDQQLQGEGK

RPDQQLQGEGK

RPDQQLQGEGK

KPNEGADGQWK

KPNEGADGQWK

RPDQQLQGEGK

KPNEGADGQWK

KPNEGADGQWK

KPNEGADGQWK

KPNEGADGQWK

FDQLFDDESDPF

LCAWLVSELR

TCISWAHLLR

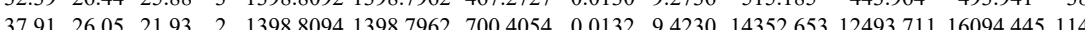

$\begin{array}{llllllllllll} & \end{array}$

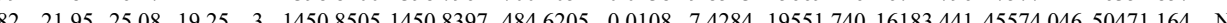
$\begin{array}{lllllllllllllll}0.51 & 16.30 & 25.08 & 16.93 & 3 & 1450.8508 & 1450.8397 & 484.6205 & 0.0111 & 7.6348 & 25361.779 & 22394.781 & 59700.259 & 67530.343 & \mathrm{No}\end{array}$

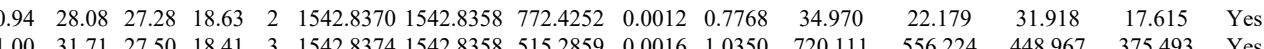

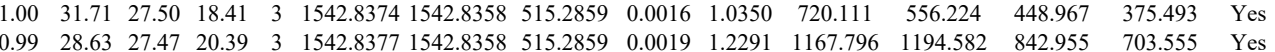

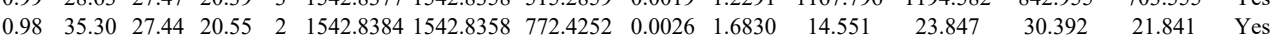
$\begin{array}{llllllllllllllll}0.99 & 42.63 & 26.41 & 27.40 & 2 & 1398.8082 & 1398.7962 & 700.4054 & 0.0120 & 8.5664 & 18634.490 & 17799.534 & 10734.816 & 8827.447 & \text { Yes }\end{array}$

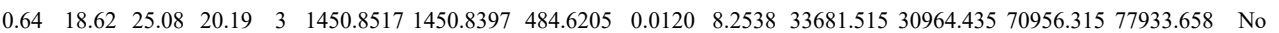
$\begin{array}{lllllllllllllll}0.55 & 17.35 & 25.05 & 17.47 & 3 & 1450.8523 & 1450.8397 & 484.6205 & 0.0126 & 8.6665 & 28325.001 & 21829.726 & 67536.644 & 68585.482 & \text { No }\end{array}$ $\begin{array}{lllllllllllllll}0.97 & 30.71 & 27.29 & 26.02 & 2 & 1542.8372 & 1542.8358 & 772.4252 & 0.0014 & 0.9062 & 200.426 & 159.669 & 123.212 & 150.096 & \text { Yes }\end{array}$ $\begin{array}{lllllllllllllll}0.98 & 32.23 & 27.50 & 15.66 & 2 & 1542.8374 & 1542.8358 & 772.4252 & 0.0016 & 1.0357 & 174.466 & 111.727 & 124.033 & 122.883 & \text { Yes }\end{array}$ $\begin{array}{lllllllllllllll}1.00 & 36.98 & 27.44 & 20.89 & 3 & 1542.8380 & 1542.8358 & 515.2859 & 0.0022 & 1.4232 & 2370.018 & 2536.511 & 1828.564 & 1534.217 & \text { Yes }\end{array}$

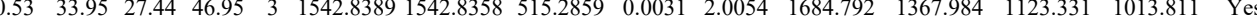

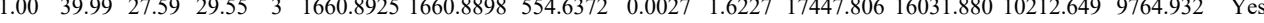
$\begin{array}{llllllllllllllll}0.99 & 31.99 & 27.54 & 26.42 & 3 & 1660.8934 & 1660.8898 & 554.6372 & 0.0036 & 2.1636 & 29479.043 & 25370.282 & 21855.596 & 17615.425 & \text { Yes }\end{array}$

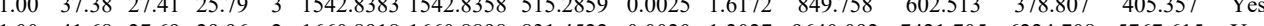
$\begin{array}{lllllllllllllll}1.00 & 41.68 & 27.69 & 29.96 & 2 & 1660.8918 & 1660.8898 & 831.4522 & 0.0020 & 1.2027 & 9640.092 & 7421.705 & 6224.708 & 5767.615 & \text { Yes }\end{array}$

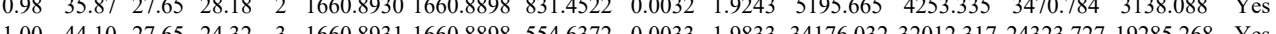
$\begin{array}{lllllllllllllll}1.00 & 44.10 & 27.65 & 24.32 & 3 & 1660.8931 & 1660.8898 & 554.6372 & 0.0033 & 1.9833 & 34176.032 & 32012.317 & 24323.727 & 19285.268 & \text { Yes }\end{array}$

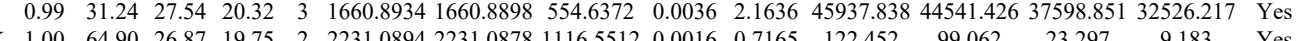

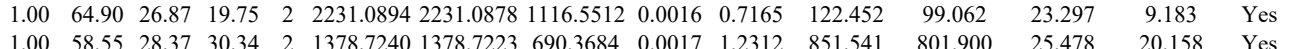

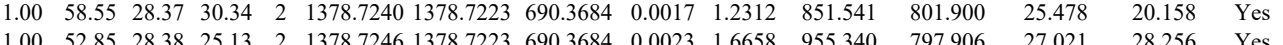




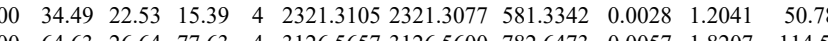

LPADTCLLEFAR

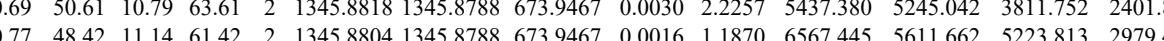

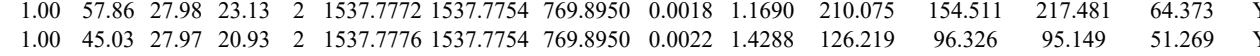
$\begin{array}{lccccccccccccccc} & 1.00 & 52.22 & 28.90 & 20.25 & 2 & 1247.6766 & 1247.6744 & 624.8445 & 0.0022 & 1.7604 & 4731.048 & 4598.759 & 4354.720 & 4704.650 & \text { No }\end{array}$ TALGVAELTVTDLFR LLAPPGR

$\begin{array}{lllllllllll}\text { WDR36_HUMA } & \text { Q8NI36 } & \text { WDR36 } & \text { WD repeat-contaii 105.32 } & 1.00 & 2 & 3 & -0.0848 & 0.4629 & -0.0634 & 2.6868\end{array}$

SAPFFIPTIPGLVPR

SAPFFIPTIPGLVPR

SAPFFIPTIPGLVPR

SAPFFIPTIPGLVPR

SAPFFIPTIPGLVPR

SAPFFIPTIPGLVPR

SAPFFIPTIPGLVPR

SAPFFIPTIPGLVPR

YAAPEQNNDPQQSK

$\begin{array}{llllllllllll}1.00 & 64.54 & 26.47 & 24.58 & 3 & 1748.9821 & 1748.9794 & 584.0004 & 0.0027 & 1.5411 & 89.090 & 113.9\end{array}$

$3.957 \quad 37.108$

$\begin{array}{lllllllllllllll}0.76 & 50.76 & 23.18 & 63.76 & 2 & 1755.0220 & 1755.0205 & 878.5175 & 0.0015 & 0.8537 & 322.911 & 274.817 & 5.241 & 2.860 & \text { Yes }\end{array}$

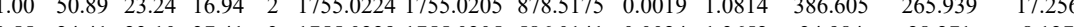

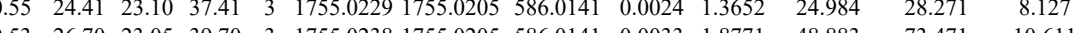

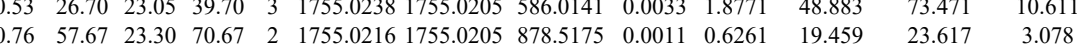

$\begin{array}{lllllllllllll}0.77 & 33.30 & 23.34 & 70.67 & 2 & 1755.0216 & 1755.0205 & 878.5175 & 0.0011 & 0.6261 & 19.459 & 23.617 & 3.078 \\ 0.56 & 2 & 1755.0224 & 1755.0205 & 878.5175 & 0.0019 & 1.0814 & 20.927 & 5.252 & 1.666\end{array}$ $\begin{array}{llllllllllll}0.77 & 33.30 & 23.24 & 46.30 & 2 & 1755.0224 & 1755.0205 & 878.5175 & 0.0019 & 1.0814 & 20.927 & \\ 0.55 & 16.68 & 23.24 & 2.68 & 3 & 1755.0226 & 1755.025 & 586.0141 & 0.0021 & 1.1945 & 1.220\end{array}$ $\begin{array}{lllllllllll}0.57 & 16.68 & 23.24 & 29.68 & 3 & 1755.0226 & 1755.0205 & 586.0141 & 0.0021 & 1.1945 & 11.220\end{array}$

$\begin{array}{llllllllllll} & \text { YAAPEQNAPEQN }\end{array}$ $\begin{array}{llllllllll} & 0.42 .2067\end{array}$ $\begin{array}{lllllllll} & \end{array}$

$\begin{array}{llllllllllllll}0.96 & 31.92 & 22.58 & 29.01 & 2 & 1071.6654 & 1071.6562 & 536.8354 & 0.0092 & 8.5687 & 16177.866 & 13648.400 & 899.178\end{array}$

$\begin{array}{lllllllllllllll}1.13 & 27.89 & 16.33 & 3 & 1272.7102 & 1272.7061 & 425.2426 & 0.0041 & 3.2138 & 6459.421 & 5678.048 & 1753.719\end{array}$

ALYPVIPR

$\begin{array}{lllllllllllllll}0.90 & 18.97 & 21.40 & 19.84 & 3 & 1947.1462 & 1947.1397 & 650.0538 & 0.0065 & 3.3330 & 1373.657 & 1242.160 & 168.353\end{array}$ YTQQIIQGIQQLVK

$\begin{array}{lllllllllllllll}0.98 & 34.41 & 23.62 & 24.73 & 2 & 1071.6664 & 1071.6562 & 536.8354 & 0.0102 & 9.5000 & 6107.128 & 5607.430 & 307.094 & 1\end{array}$ $\begin{array}{llllllllllll}1.00 & 36.76 & 21.30 & 21.52 & 3 & 1947.1435 & 1947.1397 & 650.0538 & 0.0038 & 1.9486 & 548.619 & 533.050\end{array}$

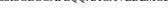

$\begin{array}{llllllllllll}1.00 & 48.16 & 21.37 & 23.32 & 3 & 1947.1438 & 1947.1397 & 650.0538 & 0.0041 & 2.1024 & 647.558 & 443.334\end{array}$

TACFLLPMFER

$\begin{array}{llllllllllll}1.00 & 63.46 & 25.77 & 21.61 & 3 & 3348.6412 & 3348.6378 & 1117.2199 & 0.0034 & 1.0144 & 2.834 & 3.674\end{array}$

TACFLLPMFER

$\begin{array}{llllllllllll}1.00 & 52.98 & 26.44 & 20.87 & 2 & 1516.7372 & 1516.7362 & 759.3754 & 0.0010 & 0.6584 & 521.195 & 562.874\end{array}$

$\begin{array}{llllllllllll}1.00 & 55.97 & 26.44 & 21.35 & 2 & 1516.7374 & 1516.7362 & 759.3754 & 0.0012 & 0.7901 & 719.127 & 751.644\end{array}$

TACFLLPMFER

$\begin{array}{lllllllllllll}1.00 & 56.19 & 26.44 & 21.52 & 2 & 1516.7374 & 1516.7362 & 759.3754 & 0.0012 & 0.7901 & 446.048 & 551.733\end{array}$ $\begin{array}{lllllllllllllll}\text { GQGASRPHAPGTPAGR } & 0.73 & 10.32 & 27.86 & 15.49 & 4 & 1659.8681 & 1659.8675 & 415.9742 & 0.0006 & 0.3606 & 62.199 & 79.476\end{array}$ $\begin{array}{llllllllllll}\text { GQGASRPHAPGTPAGR } & 0.95 & 29.41 & 27.89 & 16.48 & 2 & 1659.8686 & 1659.8675 & 830.9410 & 0.0011 & 0.6619 & 0.000\end{array}$ $\begin{array}{llllllllllll}\text { GQGASRPHAPGTPAGR } & 1.00 & 20.46 & 27.88 & 14.32 & 4 & 1659.8693 & 1659.8675 & 415.9742 & 0.0018 & 1.0818 & 24.096\end{array}$

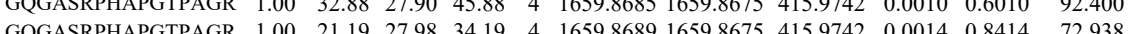

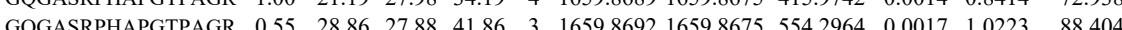
$\begin{array}{llllllllllllll}\text { GQGASRPHAPGTPAGR } & 0.55 & 34.48 & 27.88 & 47.48 & 3 & 1659.8695 & 1659.8675 & 554.2964 & 0.0020 & 1.2027 & 69.317\end{array}$ $\begin{array}{llllllllllllll}\text { GQGASRPHAPGTPAGR } & 0.99 & 21.51 & 27.81 & 34.51 & 4 & 1659.8673 & 1659.8675 & 415.9742 & -0.0002 & -0.1202 & 105.162\end{array}$ 

$\begin{array}{llllllllll} & \end{array}$

ILIFSSR

$\begin{array}{lllllllllllllll}0.93 & 34.77 & 25.81 & 23.77 & 2 & 978.5978 & 978.5984 & 490.3065 & -0.0006 & -0.6119 & 6299.174 & 7678.047 & 0.000\end{array}$

$\begin{array}{lllllllllllllll}\text { LLECPHLNVR } & 1.00 & 69.78 & 27.60 & 31.43 & 3 & 1382.7322 & 1382.7284 & 461.9167 & 0.0038 & 2.7422 & 10690.077 & 10311.906 & 644.150\end{array}$ $\begin{array}{llllllllllllllll} & & \end{array}$ $\begin{array}{lllllllllllllll} & 1832.9156 & 1832.9142 & 917.4644 & 0.0014 & 0.7630 & 435.679 & 468.496 & 0\end{array}$ $\begin{array}{llllllllllllll}\text { VVPSYMQAVNR } & 1.00 & 51.98 & 28.22 & 29.06 & 2 & 1406.7566 & 1406.7462 & 704.3804 & 0.0104 & 7.3823 & 2619.550 & 1881.318\end{array}$ VVPSYMQAVNR

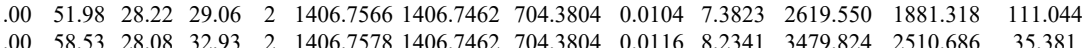
$\begin{array}{llllllllllllll} & \end{array}$

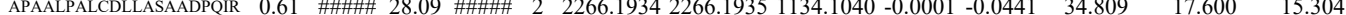

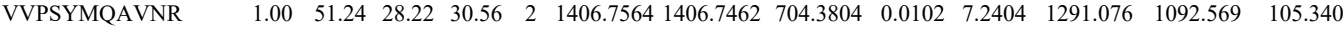
$\begin{array}{lllllllllllllll}\text { VVPSYMQAVNR } & 1.00 & 44.61 & 28.13 & 29.75 & 2 & 1406.7596 & 1406.7462 & 704.3804 & 0.0134 & 9.5118 & 944.915 & 886.154 & 40.793\end{array}$ $10.982 \quad 9.389$ $\begin{array}{llllllllllllll}\text { APAALPALCDLLASAADPQIR } & 1.00 & 45.18 & 28.03 & 16.70 & 3 & 2266.1965 & 2266.1935 & 756.4051 & 0.0030 & 1.3220 & 10.857 & 12.083 & 2.945\end{array}$ \begin{tabular}{llllllllllllll} 
APAALPALCDLLASAADPQIR & 1.00 & 57.14 & 27.99 & 16.69 & 3 & 2266.1980 & 2266.1935 & 756.4051 & 0.0045 & 1.9831 & 28.860 & 0.000 & 0.000 \\
\hline
\end{tabular} $\begin{array}{llllllllllllll}\text { APAALPALCDLLASAADPQIR } & 1.00 & 63.84 & 27.99 & 19.89 & 3 & 2266.1983 & 2266.1935 & 756.4051 & 0.0048 & 2.1153 & 8.247 & 18.578 & 9.615 \\ \text { APALPACDLSAAPOR } & 1.00 & 51.70 & 28.00 & 21.21 & 3 & 2266.2004 & 2266.1935 & 756.4051 & 0.0069 & 3.0407 & 2.678 & 3.711 & 2347\end{array}$

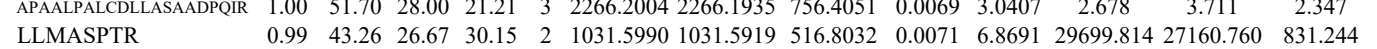

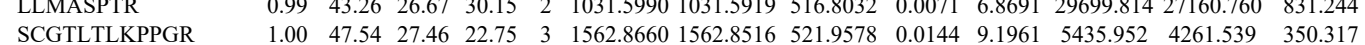
$\begin{array}{lllllllllllllll}\text { SCGTLLLRPGR } & 1.00 & 47.54 & 27.46 & 22.75 & 3 & 1562.8660 & 1562.8516 & 521.9578 & 0.0144 & 9.1961 & 5435.952 & 426.539 & 350.317 \\ \text { SCGTLTLKPPGR } & 1.00 & 52.26 & 27.35 & 20.07 & 3 & 1562.8666 & 1562.8516 & 521.9578 & 0.0150 & 9.5792 & 5008.445 & 4586.577 & 372.966\end{array}$ $\begin{array}{llllllllllllll}\text { SCGTLTLKPGR } & 1.00 & 52.26 & 27.35 & 2.07 & 3 & 1562.8666 & 1562.8516 & 521.9578 & 0.0150 & 9.5792 & 5008.445 & 4586.577 & 372.966\end{array}$

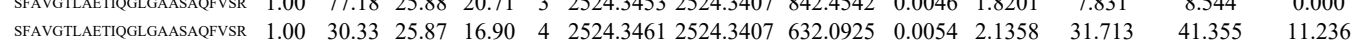
$\begin{array}{lllllllllllllll} & \text { SAAVGTLAETIQGLGAASAQFVSR } & 1.00 & 57.00 & 25.87 & 70.00 & 4 & 2524.3461 & 2524.3407 & 632.0925 & 0.0054 & 2.1358 & 43.784 & 36.506 & 30.468\end{array}$ $\begin{array}{llllllllllllll}\text { SLILTALQR } & 1.00 & 52.23 & 22.90 & 35.84 & 2 & 1157.7256 & 1157.7254 & 579.8700 & 0.0002 & 0.1725 & 16423.478 & 13880.830 & 890.968\end{array}$ SLILTALQR

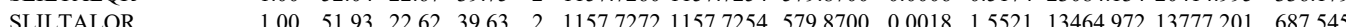
$\begin{array}{lllllllllllllll}\text { LLPPLQIVCK } & 0.55 & 12.14 & 20.72 & 25.14 & 3 & 1569.9619 & 1569.9594 & 524.3271 & 0.0025 & 1.5893 & 169.059 & 161.528 & 34.672\end{array}$

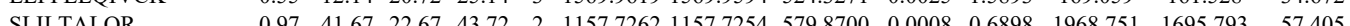

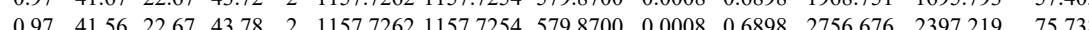

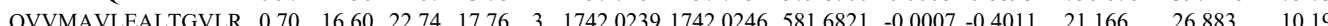

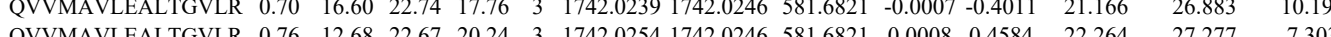

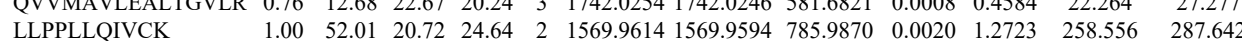
$\begin{array}{llllllllllllll}\text { LLPPLLQIVCK } & 1.00 & 53.72 & 20.49 & 24.32 & 2 & 1569.9624 & 1569.9594 & 785.9870 & 0.0030 & 1.9084 & 328.448 & 339.635\end{array}$ $\begin{array}{llllllllllllll}\text { LLPPLLQIVCK } & 0.53 & 19.76 & 20.49 & 32.76 & 3 & 1569.9628 & 1569.9594 & 524.3271 & 0.0034 & 2.1615 & 102.186 & 73.549\end{array}$ $\begin{array}{lllllllllllll}\text { QVVMAVLEALTGVLR } & 0.97 & 19.47 & 22.55 & 17.84 & 3 & 1742.0263 & 1742.0246 & 581.6821 & 0.0017 & 0.9742 & 32.726 & 38.241\end{array}$ $\begin{array}{llllllllllllll}\text { QVVMAVLEALTGVLR } & 1.00 & 77.96 & 22.60 & 31.72 & 2 & 1742.0264 & 1742.0246 & 872.0196 & 0.0018 & 1.0321 & 17.715 & 19.721\end{array}$ $\begin{array}{llllllllllllll}\text { QVVMAVLEALTGVLR } & 1.00 & 59.89 & 22.53 & 38.02 & 2 & 1742.0272 & 1742.0246 & 872.0196 & 0.0026 & 1.4908 & 8.812 & 24.256\end{array}$ $\begin{array}{lllllllllllll}\text { QVVMAVLEALTGVLR } & 0.87 & 17.35 & 24.46 & 14.37 & 3 & 1758.0202 & 1758.0195 & 587.0138 & 0.0007 & 0.3975 & 27.223 & 23.985\end{array}$ $\begin{array}{lllllllllllll}\text { QVVMAVLEALTGVLR } & 0.99 & 28.03 & 24.39 & 17.47 & 3 & 1758.0220 & 1758.0195 & 587.0138 & 0.0025 & 1.4196 & 26.915 & 16.560\end{array}$ $\begin{array}{llllllllllllll}\text { LLPPLLQIVCK } & 1.00 & 48.37 & 20.49 & 23.31 & 2 & 1569.9624 & 1569.9594 & 785.9870 & 0.0030 & 1.9084 & 108.799 & 105.698\end{array}$ $\begin{array}{lllllllllllllll}\text { LLPPLLQIVCK } & 0.53 & 13.97 & 20.49 & 26.97 & 3 & 1569.9628 & 1569.9594 & 524.3271 & 0.0034 & 2.1615 & 99.877 & 97.796\end{array}$

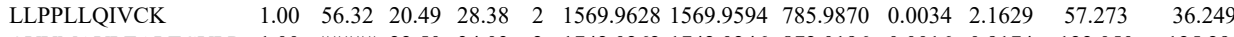
$\begin{array}{lllllllllllll}\text { QVVMAVLEALTGVLR } & 1.00 & \text { mmm } & 22.50 & 34.03 & 2 & 1742.0262 & 1742.0246 & 872.0196 & 0.0016 & 0.9174 & 122.050 & 125.290\end{array}$ $\begin{array}{llllllllllll}\text { QVVMAVLEALTGVLR } & 1.00 & \text { \#\#\#\# } 22.50 & 40.26 & 2 & 1742.0262 & 1742.0246 & 872.0196 & 0.0016 & 0.9174 & 86.014 & 112.754\end{array}$

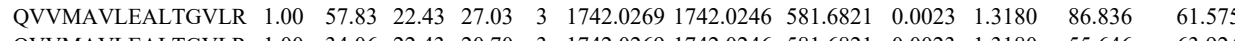
$\begin{array}{lllllllllllll}\text { QVVMAVLEALTGVLR } & 1.00 & 34.06 & 22.43 & 20.70 & 3 & 1742.0269 & 1742.0246 & 581.6821 & 0.0023 & 1.3180 & 55.646 & 63.924\end{array}$

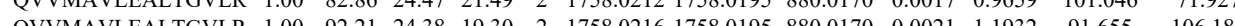

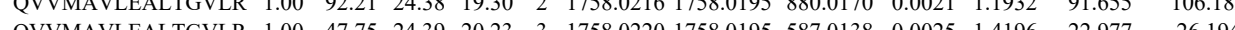

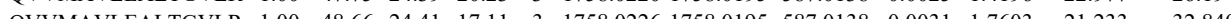

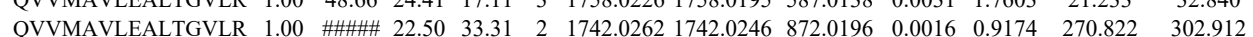



$\begin{array}{lllllllllllll}\text { QVVMAVLEALTGVLR } & 1.00 & 73.73 & 22.67 & 39.95 & 2 & 1742.0256 & 1742.0246 & 872.0196 & 0.0010 & 0.5734 & 18.736 \\ \text { QVVMAVLEALTGVLR } & 1.00 & 34.26 & 22.55 & 26.99 & 3 & 1742.0263 & 1742.0246 & 581.6821 & 0.0017 & 0.9742 & 13.894\end{array}$

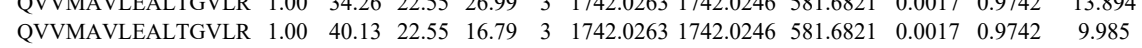
$\begin{array}{llllllllllll}\text { QVVMAVLEALTGVLR } & 1.00 & 40.13 & 22.55 & 16.79 & 3 & 1742.0263 & 1742.0246 & 581.6821 & 0.0017 & 0.9742 & 9.985 \\ \text { QVVMAVLEALTGVLR } & 0.98 & 20.41 & 22.43 & 16.45 & 3 & 1742.0269 & 1742.0246 & 581.6821 & 0.0023 & 1.3180 & 13.327\end{array}$

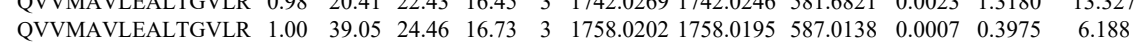
$\begin{array}{lllllllllllll}\text { QVVMAVLEALTGVLR } & 0.77 & 69.84 & 24.38 & 82.84 & 2 & 1758.0216 & 1758.0195 & 880.0170 & 0.0021 & 1.1932 & 6.426\end{array}$ $\begin{array}{llllllllllll}\text { QVVMAVLEALTGVLR } & 1.00 & 33.57 & 24.50 & 20.85 & 3 & 1758.0232 & 1758.0195 & 587.0138 & 0.0037 & 2.1010 & 7.290\end{array}$ $\begin{array}{llllllllllll}\text { LLGLLFPLLAR } & 1.00 & 54.03 & 14.15 & 23.99 & 2 & 1368.8982 & 1368.8979 & 685.4562 & 0.0003 & 0.2188 & 492.155\end{array}$

LLGLLFPLLAR

LLGLLFFPLLAR

LLGLLFPLLAR

LLGLLFPLLAR

LSALFINLISDPSR

FLLPIVVR

ELEEMIENLEP

FLLPIVVR

FLLPIVVR

FLLPIVVR

FLLPIVVR

FLLPIVVR

FLLPIVVR

KPIPLENPK

SPLLPAVLEGLAK

LVIVSLMELFK

LVIVSLMELFK
LVIVSLMELFK

$\begin{array}{lllllllllll}\text { COG1_HUMAN Q8WTW3 COG1 } & \text { Conserved oligom } 108.98 & 1.00 & 2 & 2.7 & 0.0967 & 0.3169 & 0.7482 & 0.7245 & 7 & \text { AQICSLVELLATTLK }\end{array}$

$\begin{array}{llllllllllll}1.00 & 51.27 & 14.15 & 23.58 & 2 & 1368.8990 & 1368.8979 & 685.4562 & 0.0011 & 0.8024 & 831.864\end{array}$

$\begin{array}{lllllllllll}0.61 & 47.54 & 16.13 & 60.54 & 2 & 1224.7960 & 1224.7958 & 613.4052 & 0.0002 & 0.1630 & 14.028\end{array}$

$\begin{array}{lllllllllll}1.00 & 50.46 & 14.15 & 23.60 & 2 & 1368.8978 & 1368.8979 & 685.4562 & -0.0001 & -0.0729 & 262.424\end{array}$ $\begin{array}{llllllllllll}1.00 & 73.29 & 25.42 & 25.72 & 2 & 1688.9600 & 1688.9583 & 845.4864 & 0.0017 & 1.0053 & 95.814\end{array}$ $\begin{array}{llllllllllll}0.58 & 12.46 & 19.49 & 20.60 & 2 & 1099.7242 & 1099.7239 & 550.8692 & 0.0003 & 0.2723 & 94.539\end{array}$ $\begin{array}{llllllllllll}0.82 & 54.14 & 26.95 & 55.97 & 3 & 2552.2639 & 2552.2559 & 851.7592 & 0.0080 & 3.1308 & 32.492\end{array}$ $\begin{array}{lllllllllll}0.99 & 30.66 & 19.49 & 20.30 & 2 & 1099.7246 & 1099.7239 & 550.8692 & 0.0007 & 0.6354 & 719.668\end{array}$ $\begin{array}{lllllllllll}0.99 & 28.41 & 19.49 & 18.14 & 2 & 1099.7252 & 1099.7239 & 550.8692 & 0.0013 & 1.1800 & 1067.833\end{array}$ $\begin{array}{llllllllllll}0.98 & 24.98 & 19.49 & 14.91 & 2 & 1099.7252 & 1099.7239 & 550.8692 & 0.0013 & 1.1800 & 368.426\end{array}$ $\begin{array}{llllllllllll}0.98 & 24.03 & 19.49 & 17.52 & 2 & 1099.7252 & 1099.7239 & 550.8692 & 0.0013 & 1.1800 & 338.502\end{array}$ $\begin{array}{llllllllllll}0.76 & 26.08 & 19.49 & 39.08 & 2 & 1099.7246 & 1099.7239 & 550.8692 & 0.0007 & 0.6354 & 284.653\end{array}$ $\begin{array}{llllllllllll}0.98 & 24.76 & 19.49 & 16.29 & 2 & 1099.7246 & 1099.7239 & 550.8692 & 0.0007 & 0.6354 & 260.677 \\ 0.97 & 25.91 & 19.49 & 18.97 & 2 & 1099.7244 & 1099.7239 & 550.8692 & 0.0005 & 0.4538 & 115.275\end{array}$ $\begin{array}{llllllllllll}0.97 & 25.91 & 19.49 & 18.97 & 2 & 1099.7244 & 1099.7239 & 550.8692 & 0.0005 & 0.4538 & 115.275\end{array}$ $\begin{array}{lllllllllllll}1.00 & 31.94 & 17.16 & 24.83 & 3 & 1466.9209 & 1466.9186 & 489.9801 & 0.0023 & 1.5647 & 2602.103 & 2298 \\ 1.00 & 28.84 & 18.26 & 16.31 & 3 & 1594.9924 & 1594.9901 & 532.6706 & 0.0023 & 1.4393 & 488.621 & \\ 0.85 & 10.52 & 18.81 & 14.47 & 3 & 1578.9700 & 1578.9662 & 527.3293 & 0.003 & 2.402 & 102.873 & 132\end{array}$ $\begin{array}{llllllllllll}1.00 & 28.84 & 18.26 & 16.31 & 3 & 1594.9924 & 1594.9901 & 532.6706 & 0.0023 & 1.4393 & 488.621 \\ 0.85 & 10.52 & 18.81 & 14.47 & 3 & 1578.9700 & 1578.9662 & 527.3293 & 0.0038 & 2.4020 & 102.873\end{array}$ $\begin{array}{llllllllllll}0.85 & 10.52 & 18.81 & 14.47 & 3 & 1578.9700 & 1578.9662 & 527.3293 & 0.0038 & 2.4020 & 102.873 \\ 1.00 & 62.18 & 18.81 & 18.14 & 2 & 1578.9702 & 1578.9662 & 790.4904 & 0.0040 & 2.5301 & 129.818\end{array}$ $\begin{array}{lllllllllll}1.00 & 62.18 & 18.81 & 18.14 & 2 & 1578.9702 & 1578.9662 & 790.4904 & 0.0040 & 2.5301 & 129.818 \\ 1.00 & 62.76 & 18.92 & 22.93 & 2 & 1578.9706 & 1578.9662 & 790.4904 & 0.0044 & 2.7831 & 189.699\end{array}$ AQICSLVELLATTLK AQICSLVELLATTLK $\begin{array}{llllllllllll}1.00 & 45.25 & 23.87 & 24.99 & 3 & 1936.1011 & 1936.0981 & 646.3733 & 0.0030 & 1.5471 & 79.082\end{array}$ $\begin{array}{lllllllllll}1.00 & 45.25 & 23.87 & 24.99 & 3 & 1936.1011 & 1936.0981 & 646.3733 & 0.0030 & 1.5471 & 79.082 \\ 0.97 & 20.65 & 23.89 & 16.04 & 3 & 1936.1005 & 1936.0981 & 646.3733 & 0.0024 & 1.2377 & 86.110\end{array}$ QAGSAAPRPPR $\begin{array}{llllllllllll}1.00 & 41.26 & 23.75 & 20.60 & 3 & 1936.1014 & 1936.0981 & 646.3733 & 0.0033 & 1.7018 & 93.420\end{array}$ $\begin{array}{lllllllllll}1.00 & 41.26 & 23.75 & 20.60 & 3 & 1936.1014 & 1936.0981 & 646.3733 & 0.0033 & 1.7018 & 93.420 \\ 0.93 & 24.86 & 27.66 & 18.90 & 3 & 1250.6971 & 1250.6965 & 417.9061 & 0.0006 & 0.4786 & 80.688\end{array}$ $\begin{array}{llllllllllll}0.99 & 35.09 & 27.66 & 18.35 & 3 & 1250.6971 & 1250.6965 & 417.9061 & 0.0006 & 0.4786 & 63.557\end{array}$

QAGSAARPR

QAGSAAPRPPR

QAGSAAPRPPR

QAGSAAPRPPR

QAGSAAPRPPR

QAGSAAPRPPR

QAGSAAPRPPR

QAGSAAPRPPR

QAGSAAPRPPR

QAGSAAPRPPR

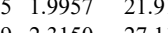
$\begin{array}{llllllllllll}0.99 & 35.10 & 27.66 & 21.29 & 3 & 1250.6971 & 1250.6965 & 417.9061 & 0.0006 & 0.4786 & 213.316\end{array}$ $\begin{array}{lllllllllllll}1.00 & 41.23 & 27.43 & 18.71 & 3 & 1250.6974 & 1250.6965 & 417.9061 & 0.0009 & 0.7179 & 112.492\end{array}$ $\begin{array}{lllllllllllll}0.97 & 30.73 & 27.43 & 15.20 & 2 & 1250.6974 & 1250.6965 & 626.3555 & 0.0009 & 0.7184 & 78.461\end{array}$ $\begin{array}{lllllllllllll}1.00 & 39.01 & 27.66 & 18.57 & 3 & 1250.6971 & 1250.6965 & 417.9061 & 0.0006 & 0.4786 & 71.748\end{array}$ $\begin{array}{lllllllllllll}0.95 & 25.83 & 27.66 & 16.16 & 3 & 1250.6971 & 1250.6965 & 417.9061 & 0.0006 & 0.4786 & 40.988\end{array}$ $\begin{array}{lllllllllllll}0.87 & 24.20 & 27.43 & 14.75 & 2 & 1250.6976 & 1250.6965 & 626.3555 & 0.0011 & 0.8781 & 28.701\end{array}$ $\begin{array}{llllllllllll}0.94 & 27.71 & 27.72 & 16.91 & 2 & 1250.6986 & 1250.6965 & 626.3555 & 0.0021 & 1.6764 & 53.502\end{array}$ $\begin{array}{lllllllllllll}0.56 & 20.33 & 27.66 & 17.65 & 2 & 1250.6970 & 1250.6965 & 626.3555 & 0.0005 & 0.3991 & 47.735\end{array}$ $\begin{array}{lllllllllllll}0.99 & 33.17 & 27.66 & 18.66 & 3 & 1250.6971 & 1250.6965 & 417.9061 & 0.0006 & 0.4786 & 79.893\end{array}$ QAGSAAPRPPR

$\begin{array}{lllllllllllll}\text { LAALASDFSEDMLQEK } & 0.64 & 13.94 & 27.42 & 14.60 & 3 & 2055.0472 & 2055.0438 & 686.0219 & 0.0034 & 1.6520 & 61.346\end{array}$ $\begin{array}{llllllllllllll}\text { LAALASDFSEDMLQEK } & 1.00 & 36.95 & 27.41 & 18.93 & 3 & 2055.0481 & 2055.0438 & 686.0219 & 0.0043 & 2.0893 & 66.899\end{array}$ $\begin{array}{llllllllllll}\text { LSDLVNTAILIALNK } & 0.53 & 36.70 & 15.56 & 49.70 & 3 & 1885.1527 & 1885.1492 & 629.3903 & 0.0035 & 1.8536 & 498.486\end{array}$ $\begin{array}{llllllllllll}\text { LSDLVNTAILIALNK } & 0.53 & 32.65 & 15.56 & 45.65 & 3 & 1885.1518 & 1885.1492 & 629.3903 & 0.0026 & 1.3770 & 72.147\end{array}$ $\begin{array}{llllllllllll}\text { LSDLVNTAILIALNK } & 1.00 & 53.70 & 15.56 & 20.12 & 3 & 1885.1518 & 1885.1492 & 629.3903 & 0.0026 & 1.3770 & 164.672 \\ \text { GLPLGAVSPVLSPVGR } & 0.53 & 54.24 & 23.67 & 67.24 & 3 & 1983.1306 & 1983.1275 & 662.0498 & 0.0031 & 1.5608 & 110.319\end{array}$ $\begin{array}{llllllllllll}\text { GLPLGSAVSSPVLFSPVGR } & 0.53 & 54.24 & 23.67 & 67.24 & 3 & 1983.1306 & 1983.1275 & 662.0498 & 0.0031 & 1.5608 & 110.319 \\ \text { GLPLGSAVSSPVIFPVGR } & 0.53 & 55.04 & 23.67 & 68.04 & 3 & 1983.1306 & 1983.1275 & 662.0498 & 0.0031 & 1.5608 & 73.233\end{array}$

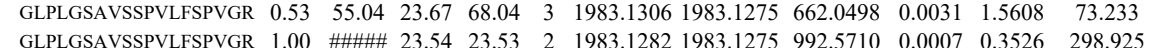

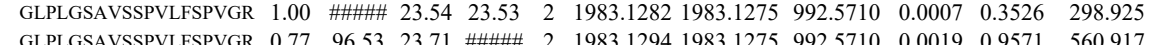
$\begin{array}{llllllllllll}\text { GLPLGSAVSSPVLFSPVGR } & 0.77 & 96.53 & 23.71 & \text { \#\#\#\# } & 2 & 1983.1294 & 1983.1275 & 992.5710 & 0.0019 & 0.9571 & 560.917 \\ \text { GLPLGSAVSSPVLFSPVGR } & 0.55 & 33.84 & 23.65 & 46.84 & 3 & 1983.1300 & 1983.1275 & 662.0498 & 0.0025 & 1.2587 & 307.322\end{array}$ $\begin{array}{llllllllllll}\text { GLPLGSAVSSPVLFSPVGR } & 0.55 & 33.84 & 23.65 & 46.84 & 3 & 1983.1300 & 1983.1275 & 662.0498 & 0.0025 & 1.2587 & 307.322 \\ \text { GLPLGSAVSPVIFSPVGR } & 0.76 & \# \# \# \# & 23.73 & \text { m\#\#\# } & 2 & 1983.1290 & 1983.1275 & 992.5710 & 0.0015 & 0.7556 & 305.144\end{array}$

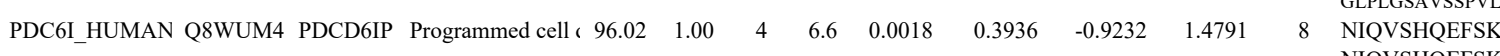

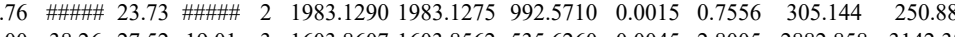
NIQVSHQEFSK

$\begin{array}{llllllllllllll}.00 & 38.26 & 27.52 & 19.01 & 3 & 1603.8607 & 1603.8562 & 535.6260 & 0.0045 & 2.8005 & 2882.858 & 3142.388 & 1774.602\end{array}$ $\begin{array}{llllllllllllll} & \end{array}$

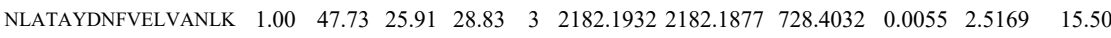

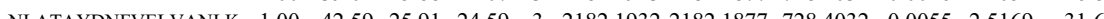

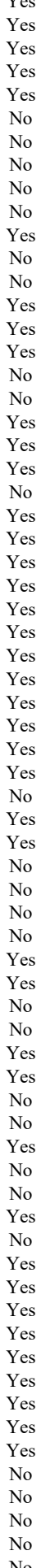



$\begin{array}{lllllllllllllll} & \end{array}$ $\begin{array}{llllllllllllllllll} & \end{array}$

$\begin{array}{lllllllllll} & \end{array}$

FNEENYGVK $\begin{array}{llllllllllll}1.00 & 85.08 & 23.16 & 98.08 & 4 & 4156.1469 & 4156.1432 & 1040.0431 & 0.0037 & 0.8894 & 0.00 & \\ 1.00 & 48.09 & 23.18 & 61.09 & 4 & 4156.1509 & 4156.1432 & 1040.0431 & 0.0077 & 1.8509 & 0.00\end{array}$

$\begin{array}{lllllllllllll}\text { NLSPVVSNELLEQAFSOFGPVEK } & 0.75 & 13.48 & 25.08 & 14.55 & 3 & 2819.4982 & 2819.4949 & 940.8389 & 0.0033 & 1.1692 & 66.241\end{array}$

$\begin{array}{llllllllll} & \end{array}$

FATHGAALTVK

$\begin{array}{llllllllllllll}34.01 & 25.34 & 20.83 & 3 & 1402.8235 & 1402.8176 & 468.6131 & 0.0059 & 4.1968 & 9045.921 & 7940.907 & 3391.014\end{array}$

$\begin{array}{lllllllllllllll}1.00 & 35.20 & 25.67 & 23.77 & 3 & 1402.8226 & 1402.8176 & 468.6131 & 0.0050 & 3.5566 & 15653.783 & 14674.209 & 2900.331\end{array}$

$\begin{array}{lllllllllllllll} & \end{array}$

$\begin{array}{llllllllllllll} & \end{array}$

$\begin{array}{lllllllllllllll}\text { FPQGPPSQMGSPMGSR } & 1.00 & 84.05 & 26.49 & 22.77 & 2 & 1803.8680 & 1803.8518 & 902.9332 & 0.0162 & 8.9707 & 784.583 & 872.926 & 309.9\end{array}$

$\begin{array}{lllllllllllllll}\text { FPQGPPSQMGSPMGSR } & 1.00 & 76.25 & 26.16 & 19.89 & 2 & 1803.8644 & 1803.8518 & 902.9332 & 0.0126 & 6.9772 & 249.997 & 294.797 & 130 .\end{array}$

FPQGPPSQMGSPMGSR

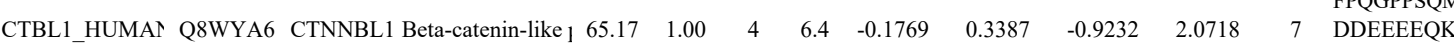
$\begin{array}{llllllllllllll}0.97 & 38.84 & 26.78 & 25.43 & 2 & 1075.6570 & 1075.6512 & 538.8329 & 0.0058 & 5.3820 & 13917.365 & 13065.501 & 461.560 \\ 1.00 & 41.09 & 26.84 & 24.98 & 2 & 1075.6526 & 1075.6512 & 538.8329 & 0.0014 & 1.2991 & 1615.305 & 1435.886 & 58.282\end{array}$ $\begin{array}{lllllllllllll}1.00 & 41.09 & 26.84 & 24.98 & 2 & 1075.6526 & 1075.6512 & 538.8329 & 0.0014 & 1.2991 & 1615.305 & 1435.886 & 58.282 \\ 0.99 & 43.93 & 27.01 & 24.12 & 2 & 1153.6554 & 1153.6512 & 577.8329 & 0.0042 & 3.6343 & 2200.986 & 1385.075 & 513.821\end{array}$ $\begin{array}{llllllllllllll}1.00 & 41.09 & 26.84 & 24.98 & 2 & 1075.6526 & 1075.6512 & 538.8329 & 0.0044 & 1.2991 & 1615.305 & 1435.886 & 58.282 & 39.276\end{array}$ 


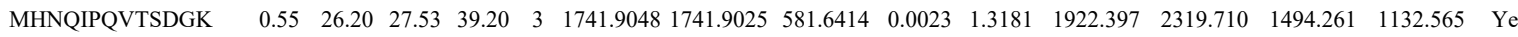
$\begin{array}{llllllllllllllll}\text { GHVDILAPTVQELAALEK } & 1.00 & 30.71 & 22.67 & 19.70 & 3 & 2191.2484 & 2191.2456 & 731.4225 & 0.0028 & 1.2761 & 41.638 & 89.371 & 154.813 & 171.588 & \text { No }\end{array}$

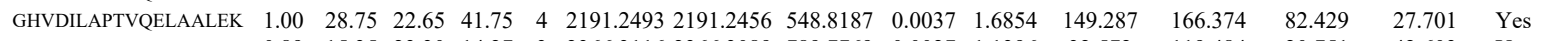
$\begin{array}{lllllllllllllllll}\text { GIDIHGVPYVINVTLPDEK } & 0.89 & 15.35 & 23.30 & 14.27 & 3 & 2366.3116 & 2366.3089 & 789.7769 & 0.0027 & 1.1396 & 32.572 & 119.484 & 20.751 & 42.603 & \text { Yes }\end{array}$ $\begin{array}{llllllllllllllll}\text { GIDIHGVPYVINVTLPDEK } & 1.00 & 36.44 & 23.34 & 17.51 & 3 & 2366.3128 & 2366.3089 & 789.7769 & 0.0039 & 1.6460 & 25.600 & 25.897 & 33.282 & 22.742 & \text { Yes } \\ \text { FLVLDEGLGSEINR } & 1.00 & \# \# \# 27.29 & 21.51 & 2 & 2515.2734 & 2515.2717 & 1258.6431 & 0.0017 & 0.6753 & 24.060 & 16.031 & 3.438 & 0.000 & \text { No }\end{array}$

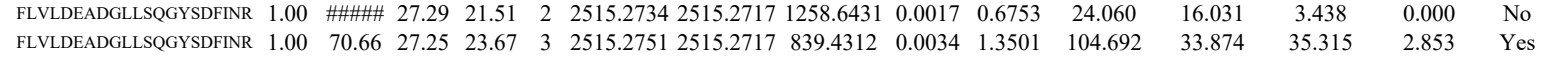

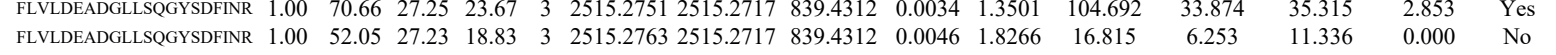

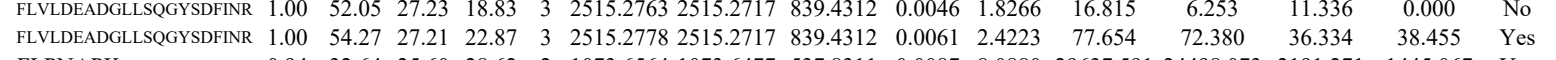

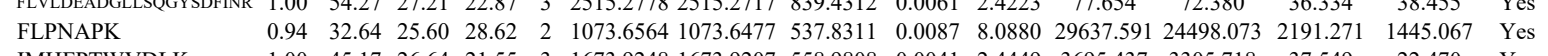
$\begin{array}{llllllllllllllll}\text { FLPNAPK } & 0.94 & 32.64 & 25.60 & 28.62 & 2 & 1073.6564 & 1073.6477 & 537.8311 & 0.0087 & 8.0880 & 29637.591 & 24498.073 & 2191.271 & 1445.067 & \text { Yes } \\ \text { IMHFPTWVDLK } & 1.00 & 45.17 & 26.64 & 21.55 & 3 & 1673.9248 & 1673.9207 & 558.9808 & 0.0041 & 2.4449 & 3695.437 & 3305.718 & 37.549 & 22.470 & \text { Yes }\end{array}$ \begin{tabular}{llllllllllllllll} 
& \\
IMHFPTWVDLK & 1.00 & 55.05 & 26.51 & 20.34 & 3 & 1673.9263 & 1673.9207 & 558.9800 & 0.0056 & 3.3394 & 3843.519 & 3717.067 & 1.179 & 44.559 & Yes \\
\hline
\end{tabular}

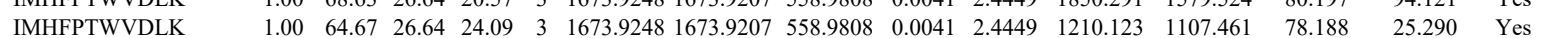

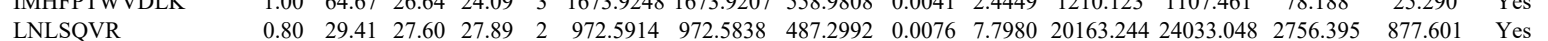
LNLSQVR

FLICTDVAAR

FLICTDVAAR

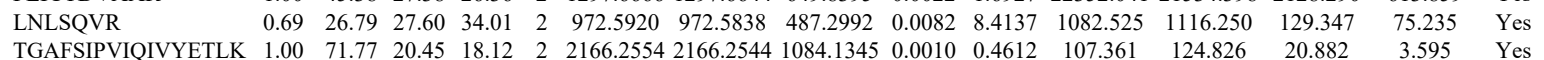

$\begin{array}{llllllllllllllll}0.80 & 29.41 & 27.60 & 27.89 & 2 & 972.5914 & 972.5838 & 487.2992 & 0.0076 & 7.7980 & 20163.244 & 24033.048 & 2756.395 & 877.601 & \text { Yes } \\ 0.90 & 32.96 & 27.60 & 31.51 & 2 & 972.5920 & 972.5838 & 487.2992 & 0.0082 & 8.4137 & 7585.878 & 8011.773 & 1146.403 & 312.823 & \text { Yes }\end{array}$

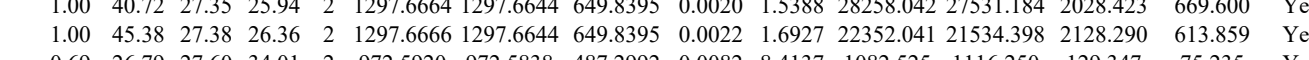
$\begin{array}{llllllllllllllll} & & \end{array}$ $\begin{array}{llllllllllllllll}\text { TGAFSIPVIQIVYETLK } & 0.53 & 7.72 & 20.49 & 20.72 & 3 & 2166.2575 & 2166.2544 & 723.0921 & 0.0031 & 1.4290 & 12.920 & 5.431 & 9.022 & 4.442 & \text { Yes }\end{array}$

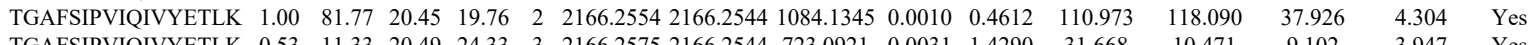
$\begin{array}{lllllllllllllllll}\text { TGAFSIPVIQIVYETLK } & 0.53 & 11.33 & 20.49 & 24.33 & 3 & 2166.2575 & 2166.2544 & 723.0921 & 0.0031 & 1.4290 & 31.668 & 10.471 & 9.102 & 3.947 & \text { Yes }\end{array}$ $\begin{array}{llllllllllllllll}\text { FLICTDVAAR } & 1.00 & 72.65 & 27.18 & 24.33 & 2 & 1297.6654 & 1297.6644 & 649.8395 & 0.0010 & 0.7694 & 124.830 & 150.352 & 22.694 & 20.767 & \text { Yes }\end{array}$

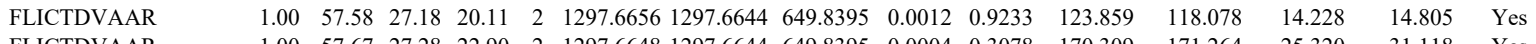

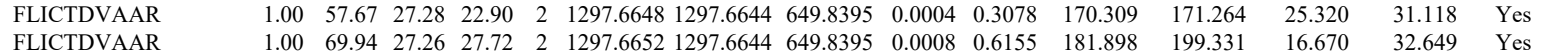
FNFGEEEFK

FNFGEEEFK

FNFGEEEFK

FNFGEEEFK

$\begin{array}{llllllllllll}\text { HS105_HUMAN Q92598 } & \text { HSPH1 } & \text { Heat shock proteir } 96.86 & 1.00 & 20 & 34.7 & -0.0408 & 0.3030 & -0.5906 & 2.0279 & 79 & \text { TPNGPNIDK }\end{array}$ TPNGPNIDK QDLPSLDEKPR QDLPSLDEKPR QDLPSLDEKPR QDLPSLDEKPR

QDLPSLDEKPR

AGGIETIANEFSDR

AGGIETIANEFSDR

AGGIETIANEFSR

AGGIETIANEFSDR

AGGIETIANEFSDR

AGGIETIANEFSDR

VEDVSAVEIVGGATR

VEDVSAVEIVGGATR

$\begin{array}{llllllllllllllll}1.00 & 69.94 & 27.26 & 27.72 & 2 & 1297.6652 & 1297.6644 & 649.8395 & 0.0008 & 0.6155 & 181.898 & 199.331 & 16.670 & 32.649 & \text { Yes } \\ \end{array}$ $\begin{array}{lllllllllllllll}0.99 & 38.07 & 27.53 & 20.74 & 2 & 1433.7080 & 1433.7071 & 717.8608 & 0.0009 & 0.6269 & 2579.462 & 2307.572 & 1958.671 & 982.171 & \text { Yes } \\ 0.99 & 35.94 & 27.47 & 19.67 & 2 & 1433.7088 & 1433.7071 & 717.8608 & 0.0017 & 1.1841 & 1368.416 & 1280.702 & 1080.556 & 563.181 & \text { Yes } \\ 0.99 & 38.20 & 27.54 & 20.56 & 2 & 1433.7084 & 1433.7071 & 717.868 & 0.0013 & 0.955 & 571.738 & 529.411 & 396.403 & 205.177 & Y\end{array}$ $\begin{array}{llllllllllllllll}0.99 & 38.20 & 27.54 & 20.56 & 2 & 1433.7084 & 1433.7071 & 717.8608 & 0.0013 & 0.9055 & 571.738 & 529.411 & 396.403 & 205.177 & \text { Yes }\end{array}$ $\begin{array}{llllllllllllllll}0.99 & 37.49 & 27.60 & 23.40 & 2 & 1433.7090 & 1433.7071 & 717.8608 & 0.0019 & 1.3234 & 2245.854 & 2483.666 & 1700.352 & 1188.778 & \text { Yes }\end{array}$ $\begin{array}{lllllllllllllll}0.88 & 29.76 & 27.53 & 20.48 & 2 & 1242.6848 & 1242.6812 & 622.3479 & 0.0036 & 2.8923 & 6427.845 & 5877.296 & 6010.854 & 4883.043 & \text { Yes }\end{array}$ $\begin{array}{llllllllllllllll}0.80 & 27.16 & 27.53 & 27.38 & 2 & 1242.6852 & 1242.6812 & 622.3479 & 0.0040 & 3.2136 & 5547.112 & 4754.893 & 6223.049 & 5387.329 & \text { Yes }\end{array}$ $\begin{array}{lllllllllllllll}1.00 & 62.10 & 27.03 & 23.72 & 2 & 1584.8802 & 1584.8715 & 793.4430 & 0.0087 & 5.4824 & 6764.277 & 7584.212 & 3790.943 & 1757.076 & \text { Yes }\end{array}$

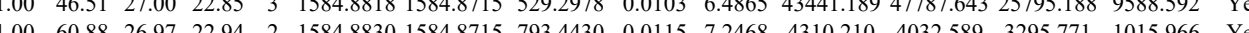

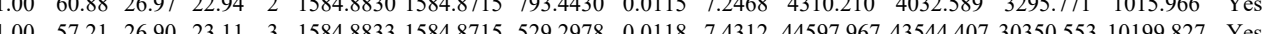

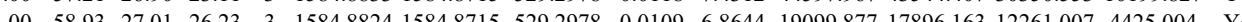
$\begin{array}{lllllllllllllll}1.00 & 50.20 & 26.89 & 22.80 & 3 & 1584.8836 & 1584.8715 & 529.2978 & 0.0121 & 7.8644 & 6611.631 & 6048.543 & 5003.681 & 2639.778 & \text { Yes }\end{array}$ $\begin{array}{lllllllllllllll}1.00 & 32.36 & 27.73 & 20.91 & 3 & 1622.8039 & 1622.8022 & 541.9413 & 0.0017 & 1.0456 & 59.542 & 45.273 & 72.468 & 15.350 & \text { No }\end{array}$

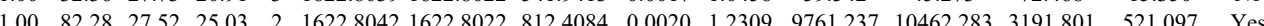

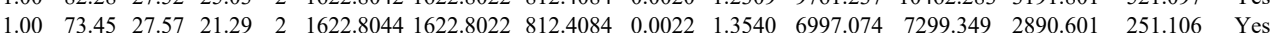

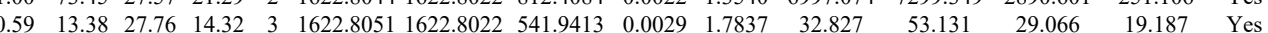

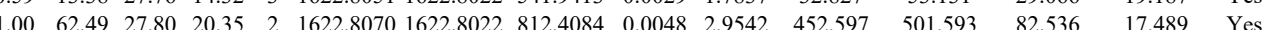
$\begin{array}{lllllllllllllll}1.00 & 62.16 & 27.66 & 29.96 & 2 & 1622.8074 & 1622.8022 & 812.4084 & 0.0052 & 3.9004 & 2226.164 & 1927.500 & 648.053 & 147.885 & \text { Yes } \\ 1.45\end{array}$

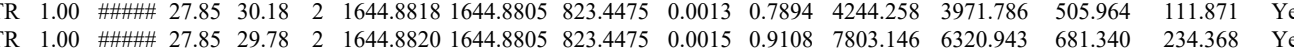
$\begin{array}{llllllllllllllllll} & \text { MFEELGQR } & 0.73 & 25.44 & 27.62 & 30.34 & 2 & 1152.5834 & 1152.5719 & 577.2932 & 0.0115 & 9.9602 & 859.266 & 664.877 & 84.097 & 205.383 & \text { Yes }\end{array}$ $\begin{array}{llllllllllllllllll}\text { GPFELEAFYSDPQGVPYPEAK } & 0.57 & 12.34 & 27.02 & 23.54 & 3 & 2628.3025 & 2628.2991 & 877.1070 & 0.0034 & 1.2921 & 271.364 & 269.740 & 189.959 & 23.602 & \text { Yes }\end{array}$ $\begin{array}{lllllllllllllllll}\text { GPFELEAFYSDPQGVPYPEAK } & 1.00 & 48.96 & 27.03 & 20.21 & 3 & 2628.3007 & 2628.2991 & 877.1070 & 0.0016 & 0.6081 & 51.165 & 10.659 & 52.975 & 15.075 & \text { No }\end{array}$

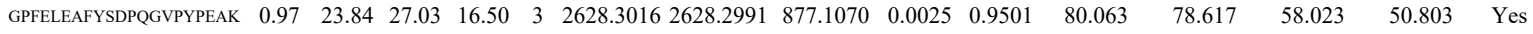
$\begin{array}{llllllllllllllll}\text { GPFELEAFYSDPQGVYYPEAK } & 0.99 & 28.13 & 27.03 & 15.39 & 3 & 2628.3022 & 2628.2991 & 877.1070 & 0.0031 & 1.1781 & 89.699 & 112.001 & 46.003 & 12.581 & \text { Yes }\end{array}$ $\begin{array}{lllllllllllllllll}\text { RGPELEAYYSDPQGVYPYEAK } & 1.00 & 46.43 & 26.66 & 16.66 & 3 & 2784.4024 & 2784.4003 & 929.1407 & 0.0021 & 0.7534 & 134.475 & 179.650 & 134.997 & 60.013 & \text { Yes }\end{array}$

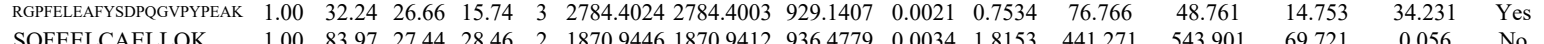

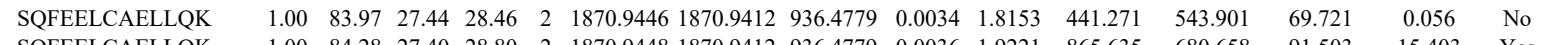

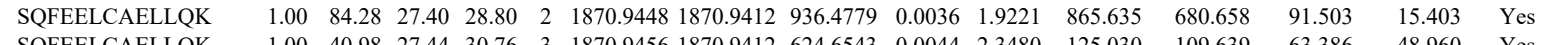

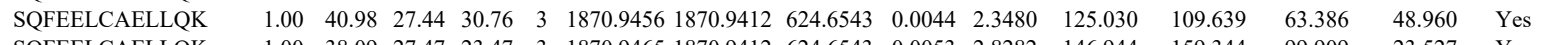

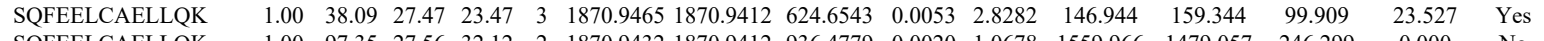

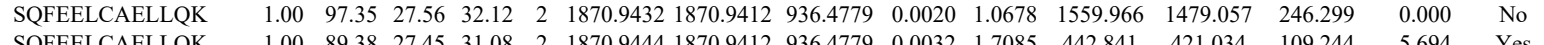

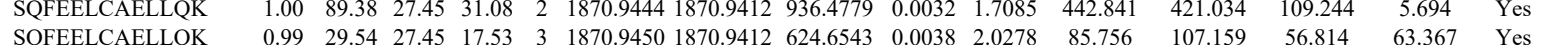

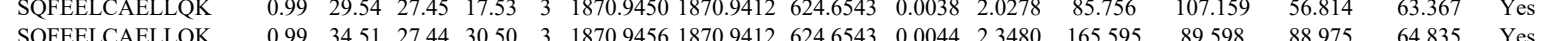

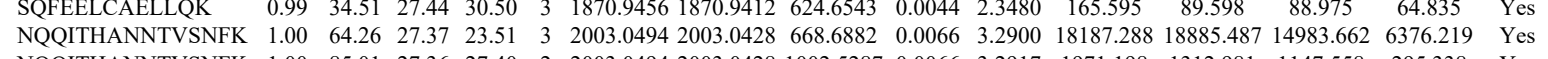
$\begin{array}{lllllllllllllll}\mathrm{N} Q Q & & \end{array}$

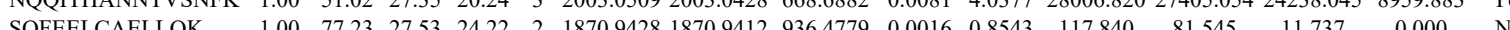

Table S-3 page 436 of 499 
$\begin{array}{lllllllllllllll}1.00 & 56.28 & 25.60 & 21.31 & 2 & 1406.8220 & 1406.8125 & 704.4135 & 0.0095 & 6.7432 & 8762.025 & 8417.736 & 8707.673 & 4357.970 & \text { Yes } \\ 1.00 & 55.62 & 25.82 & 20.63 & 2 & 1406.8232 & 1406.8125 & 704.4135 & 0.0107 & 7.5949 & 19657.275 & 20145.726 & 14877254 & 8415.920 & \text { Y }\end{array}$ $\begin{array}{llllllllllllll} & \end{array}$ KPVTDCVISYPSFFTDAER $\begin{array}{llllllllllllllll}0.89 & 19.38 & 27.32 & 14.79 & 3 & 2444.2345 & 2444.2324 & 815.7514 & 0.0021 & 0.8581 & 185.236 & 210.466 & 212.295 & 205.230 & \text { Yes }\end{array}$ $\begin{array}{llllllllllllll} & \end{array}$ KPVTDCVISVPSFFTDAER $\begin{array}{lllllllllllllllll}0.99 & 32.07 & 27.21 & 15.24 & 3 & 2444.2366 & 2444.2324 & 815.7514 & 0.0042 & 1.7162 & 540.409 & 336.877 & 382.779 & 457.922 & \text { No }\end{array}$ $\begin{array}{llllllllllllllll}\text { FVVQNVSAQK } & 1.00 & 57.88 & 25.94 & 22.24 & 2 & 1406.8242 & 1406.8125 & 704.4135 & 0.0117 & 83047 & 11903.967 & 12632.669 & 11158238 & 6408515 & \text { Yes }\end{array}$ $\begin{array}{lllllllllllllllll} & \text { FVVONVSAQK } & 1.00 & 59.94 & 25.83 & 21.20 & 2 & 1406.8252 & 1406.8125 & 704.4135 & 0.0127 & 9.0145 & 15790.535 & 16223.523 & 13645.241 & 6770.417 & \text { Yes }\end{array}$

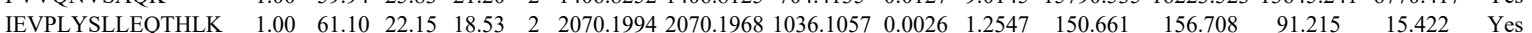
$\begin{array}{llllllllllllllll}\text { IEVPLYSLLEQTHLK } & 1.00 & 62.14 & 22.12 & 19.44 & 3 & 2070.2008 & 2070.1968 & 691.0729 & 0.0040 & 1.9294 & 4068.018 & 3943.123 & 2129.393 & 220.003 & \text { Yes }\end{array}$ $\begin{array}{llllllllllllllll}\text { IEVPLYSLLEQTHLK } & 1.00 & 69.21 & 21.70 & 19.57 & 3 & 2070.2026 & 2070.1968 & 691.0729 & 0.0058 & 2.7976 & 2113.091 & 1995.210 & 1005.602 & 69.859 & \text { Yes }\end{array}$ $\begin{array}{llllllllllllllll}\text { KPVTDCVISVPSFFTDAER } & 1.00 & 44.19 & 27.33 & 19.63 & 2 & 2444.2334 & 2444.2324 & 1223.1235 & 0.0010 & 0.4088 & 140.893 & 133.465 & 121.915 & 73.002 & \text { Yes }\end{array}$ $\begin{array}{llllllllllllllll}\text { KPVTDCVISVPSFFTDAER } & 0.76 & 42.31 & 27.33 & 55.31 & 2 & 2444.2334 & 2444.2324 & 1223.1235 & 0.0010 & 0.4088 & 59.400 & 78.326 & 111.554 & 43.997 & \text { No }\end{array}$ $\begin{array}{llllllllllllllll}\text { KPVTDCVISVPSFFTDAER } & 1.00 & 46.17 & 27.25 & 19.27 & 3 & 2444.2372 & 2444.2324 & 815.7514 & 0.0048 & 1.9614 & 434.760 & 611.396 & 1752.084 & 451.521 & \text { No }\end{array}$ $\begin{array}{lllllllllllllllll}\text { KPVTDCVISVPSFFTDAER } & 1.00 & 39.62 & 27.21 & 15.85 & 3 & 2444.2381 & 2444.2324 & 815.7514 & 0.0057 & 2.3291 & 315.721 & 565.322 & 620.670 & 202.418 & \text { Yes }\end{array}$ $\begin{array}{llllllllllllllll}\text { VLGTAFDPFLGGK } & 1.00 & 42.31 & 25.79 & 26.65 & 3 & 1608.9142 & 1608.9119 & 537.3112 & 0.0023 & 1.4269 & 64.246 & 85.938 & 34.145 & 12.806 & \text { Yes }\end{array}$ $\begin{array}{lllllllllllllllll}\text { VLGTAFDPFLGGK } & 1.00 & 79.52 & 25.80 & 27.68 & 2 & 1608.9142 & 1608.9119 & 805.4632 & 0.0023 & 1.4277 & 8556.696 & 7167.965 & 0.000 & 99.353 & \text { No }\end{array}$ $\begin{array}{lllllllllllllllll}\text { VLGTAFDPFLGGK } & 1.00 & 81.49 & 25.80 & 23.18 & 2 & 1608.9144 & 1608.9119 & 805.4632 & 0.0025 & 1.5519 & 5905.006 & 5661.587 & 115.701 & 101.432 & \text { Yes }\end{array}$

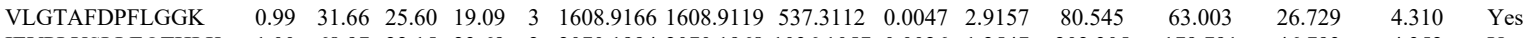

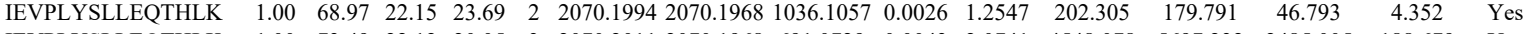

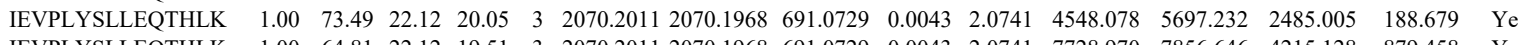

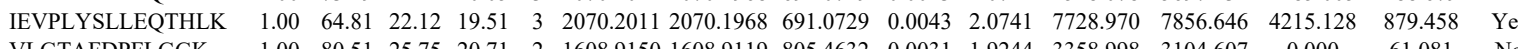
$\begin{array}{llllllllllllllll}\text { VLGTAFDPFLGGK } & 1.00 & 80.51 & 25.75 & 20.71 & 2 & 1608.9150 & 1608.9119 & 805.4632 & 0.0031 & 1.9244 & 3358.998 & 3104.607 & 0.000 & 61.081 & \text { No }\end{array}$ $\begin{array}{llllllllllllllll}\text { VLGTAFDPFLGGK } & 1.00 & 71.59 & 25.80 & 26.22 & 2 & 1608.9174 & 1608.9119 & 805.4632 & 0.0055 & 3.4142 & 3571.189 & 3498.432 & 0.000 & 72.105 & \text { No }\end{array}$

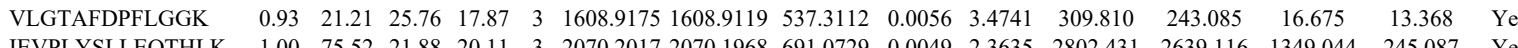

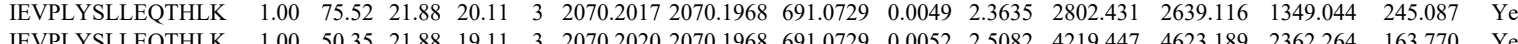

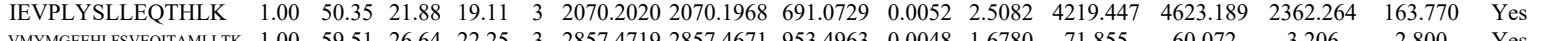

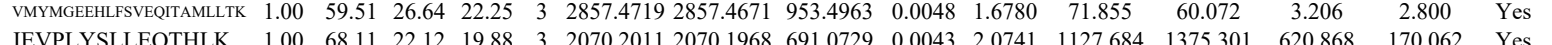

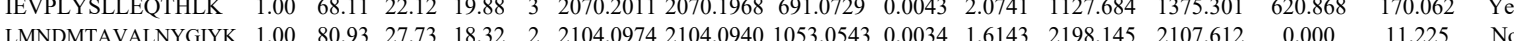
$\begin{array}{lllllllllllllllll} & \end{array}$

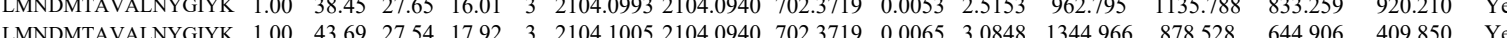
$\begin{array}{llllllllllllll} & \end{array}$

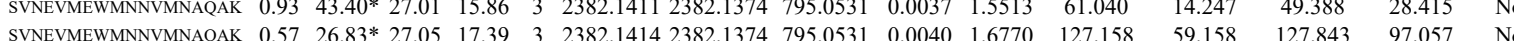
$\begin{array}{llllllllllllllll}\text { CTPSVISFGSK } & 1.00 & 59.84 & 28.15 & 19.04 & 2 & 1458.7596 & 1458.7455 & 730.3800 & 0.0141 & 9.6524 & 3923.017 & 3106.844 & 139.996 & 202.037 & \text { Y }\end{array}$ $\begin{array}{llllllllllllll}\text { SVNEVMEWMNNVMNAQAK } & 0.97 & 48.80 * 27.02 & 20.37 & 3 & 2382.1405 & 2382.1374 & 795.0531 & 0.0031 & 1.2997 & 42.388 & 55.239 & 77.254 & 50.393\end{array}$

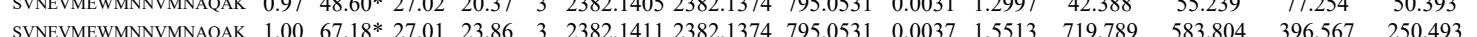

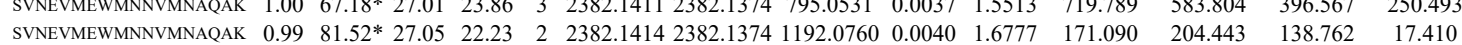
$\begin{array}{llllllllllllll}\text { CTPSVISFGSK } & 1.00 & 63.43 & 28.18 & 21.96 & 2 & 1458.7578 & 1458.7455 & 730.3800 & 0.0123 & 8.4202 & 33668.693 & 28745.735 & 155.844\end{array}$

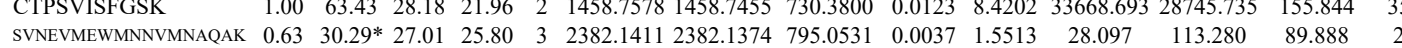

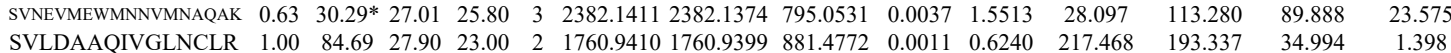
$\begin{array}{lllllllllllllll}\text { SVLDAAQIVGLNCLR } & 1.00 & 83.44 & 27.88 & 23.79 & 2 & 1760.9412 & 1760.9399 & 881.4772 & 0.0013 & 0.7374 & 108.186 & 131.988 & 19.093 & 3.550\end{array}$ $\begin{array}{llllllllllllll}\text { SVLDAAQIVGLNCLR } & 0.99 & 28.63 & 27.89 & 18.49 & 3 & 1760.9419 & 1760.9399 & 587.9872 & 0.0020 & 1.1338 & 108.511 & 136.151 & 72.622\end{array}$ $\begin{array}{llllllllllllll}\text { SVLDAAQIVGLNCLR } & 1.00 & 55.73 & 27.75 & 19.57 & 3 & 1760.9434 & 1760.9399 & 587.9872 & 0.0035 & 1.9842 & 92.455 & 133.182 & 68.652\end{array}$ $\begin{array}{llllllllllllll}\text { SVLDAAQIVGLNCLR } & 1.00 & 87.19 & 27.90 & 22.88 & 2 & 1760.9414 & 1760.9399 & 881.4772 & 0.0015 & 0.8508 & 1658.373 & 1736.939 & 312.843\end{array}$ $\begin{array}{lllllllllllll}\text { SVLDAAQIVGLNCLR } & 1.00 & \text { \#\#\#\# } 27.90 & 26.54 & 2 & 1760.9416 & 1760.9399 & 881.4772 & 0.0017 & 0.9643 & 3389.176 & 3198.006 & 485.565\end{array}$

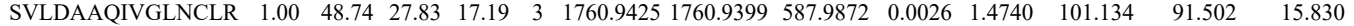
$\begin{array}{llllllllllllll}\text { SVLDAAQIVGLNCLR } & 1.00 & 57.18 & 27.71 & 22.35 & 3 & 1760.9431 & 1760.9399 & 587.9872 & 0.0032 & 1.8141 & 111.534 & 87.355 & 4.19 \\ \text { SVLDAAQIVGLNCLR } & 1.00 & \# \# \# ~ & 27.82 & 25.10 & 2 & 1760.9396 & 1760.9399 & 881.4772 & -0.0003 & -0.1702 & 503.733 & 557.050 & 87.18\end{array}$

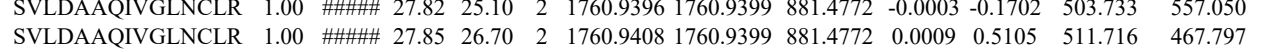
$\begin{array}{llllllllllllll}\text { SVLDAAQIVGLNCLR } & 0.99 & 31.21 & 27.90 & 23.56 & 3 & 1760.9416 & 1760.9399 & 587.9872 & 0.0017 & 0.9637 & 86.855 & 1 .\end{array}$ $\begin{array}{lllllllllllll}\text { SVLDAAQIVGLNCLR } & 0.92 & 20.88 & 27.81 & 15.96 & 3 & 1760.9422 & 1760.9399 & 587.9872 & 0.0023 & 1.3039 & 36.048 & 41\end{array}$

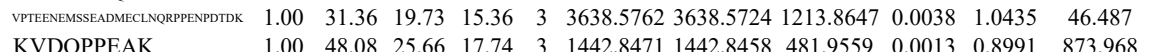
$\begin{array}{llllllllllllll}1.00 & 48.08 & 25.66 & 17.74 & 3 & 1442.8471 & 1442.8458 & 481.9559 & 0.0013 & 0.8991 & 873.968 & 940.278\end{array}$ TPNGPNIDK

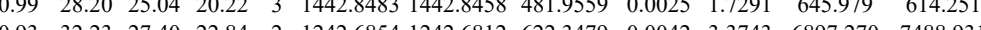

$87.187 \quad 20.546$

\begin{tabular}{rrr}
14.006 & 2.320 \\
\hline & 8.963
\end{tabular} $\begin{array}{lllllllllllllll} & 24.63\end{array}$

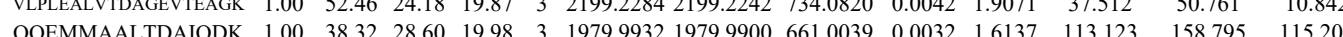




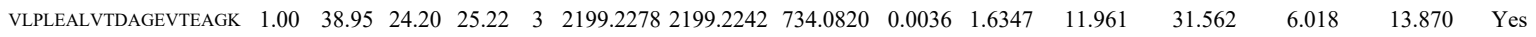

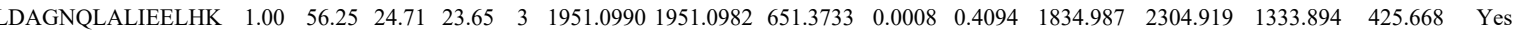
$\begin{array}{llllllllllllllll}\text { LDAGNQLALIEELHK } & 1.00 & 64.56 & 24.25 & 26.17 & 3 & 1951.1011 & 1951.0982 & 651.3733 & 0.0029 & 1.4840 & 1897.640 & 2415.272 & 1395.387 & 496.901 & \text { Yes }\end{array}$

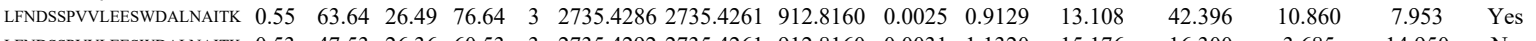

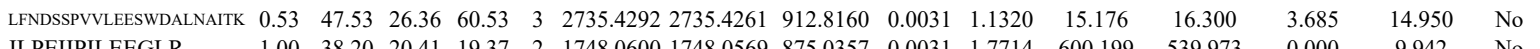

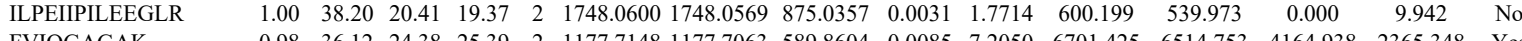
$\begin{array}{llllllllllllllll}\text { FVIQGAGAK } & 0.98 & 36.12 & 24.38 & 25.39 & 2 & 1177.7148 & 1177.7063 & 589.8604 & 0.0085 & 7.2050 & 6701.425 & 6514.753 & 4164.938 & 2365.348 & \text { Yes }\end{array}$

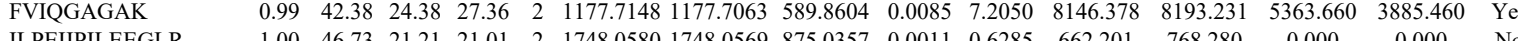

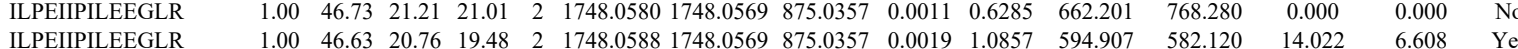

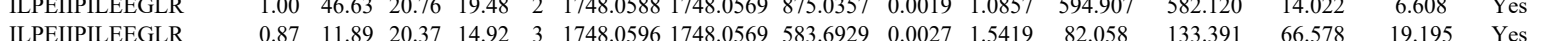

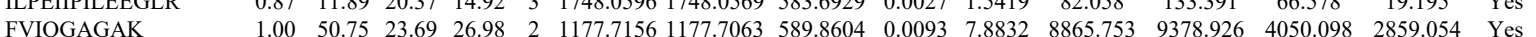

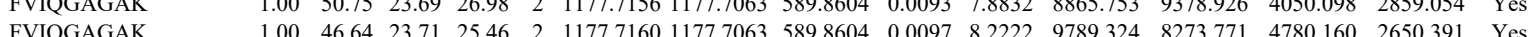

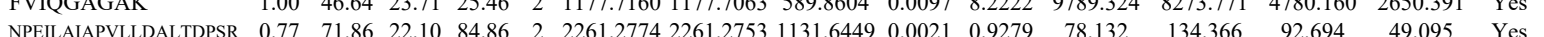

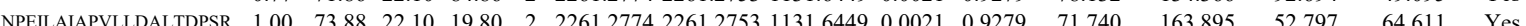

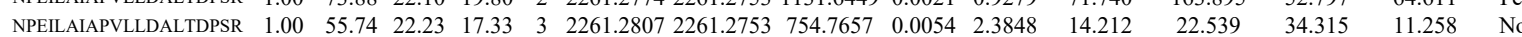

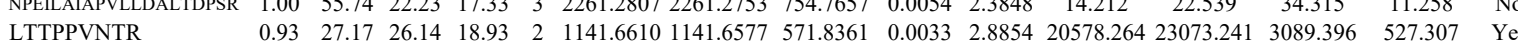

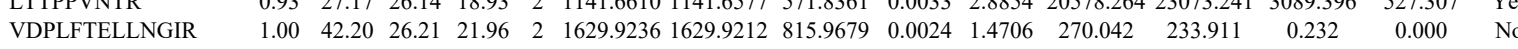

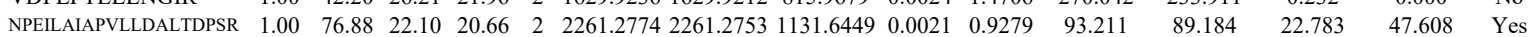
$\begin{array}{lllllllllllllllll}\text { NPEILAIAPVLLDALTDPSR } & 1.00 & 60.07 & 22.15 & 21.00 & 3 & 2261.2798 & 2261.2753 & 754.7657 & 0.0045 & 1.9874 & 4.522 & 11.313 & 18.341 & 9.380 & \text { No }\end{array}$ $\begin{array}{lllllllllllllllll}\text { NPEILAIAPVLLDALTDPSR } & 1.00 & 49.79 & 22.23 & 16.56 & 3 & 2261.2807 & 2261.2753 & 754.7657 & 0.0054 & 2.3848 & 15.545 & 26.171 & 25.427 & 28.502 & \text { No }\end{array}$ $\begin{array}{llllllllllllllll}\text { LTTPPVNTR } & 0.64 & 22.39 & 26.16 & 26.13 & 2 & 1141.6622 & 1141.6577 & 571.8361 & 0.0045 & 3.9347 & 9422.103 & 9068.938 & 1754.120 & 416.384 & \text { Yes }\end{array}$ $\begin{array}{llllllllllllllll}\text { CMLDAALATLNTHGK } & 1.00 & 56.85 & 27.97 & 16.58 & 3 & 1891.9582 & 1891.9562 & 631.6593 & 0.0020 & 1.0554 & 6221.761 & 6479.078 & 290.772 & 942.073 & \text { Yes }\end{array}$ $\begin{array}{lllllllllllllllll}\text { CMLDAALATLNTHGK } & 1.00 & 66.97 & 27.97 & 22.04 & 3 & 1891.9582 & 1891.9562 & 631.6593 & 0.0020 & 1.0554 & 5669.927 & 6106.649 & 808.191 & 764.782 & \text { Yes }\end{array}$ $\begin{array}{llllllllllllllll}\text { GDTLLQALDLLPLLIQTVEK } & 0.55 & 36.03 & 16.23 & 49.03 & 3 & 2480.4727 & 2480.4709 & 827.8309 & 0.0018 & 0.7248 & 3.970 & 9.310 & 4.079 & 2.994 & \text { Yes }\end{array}$

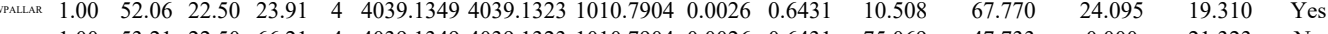

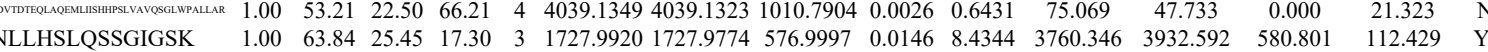
$\begin{array}{lllllllllllllll} & \end{array}$ LLSSLGGFK $\begin{array}{lllllllllllll}1.00 & 55.25 & 24.97 & 31.69 & 2 & 1208.7372 & 1208.7372 & 605.3759 & 0.0000 & 0.0000 & 34089.009 & 31466.914 & 385.467\end{array}$ LLSSLGGFK $\begin{array}{lllllllllllll}1.00 & 55.63 & 25.09 & 31.78 & 2 & 1208.7384 & 1208.7372 & 605.3759 & 0.0012 & 0.0911 & 40081.909 & 37357.369 & 238.467 \\ 23.002\end{array}$ $\begin{array}{lllllllllllllll}\text { VLQEALCVISGVPGLK } & 0.96 & 21.73 & 23.91 & 14.40 & 3 & 1959.1156 & 1959.1141 & 654.0453 & 0.0015 & 0.7645 & 58.979 & 58.644 & 41.892 & 33.132\end{array}$ $\begin{array}{lllllllllllllll}\text { VLQEALCVISGVPGLK } & 0.53 & 33.07 & 23.94 & 46.07 & 3 & 1959.1168 & 1959.1141 & 654.0453 & 0.0027 & 1.3760 & 85.452 & 47.054 & 73.813 & 48.970\end{array}$

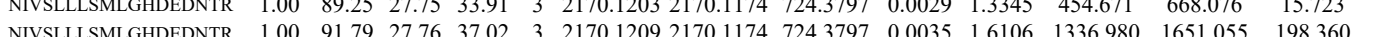

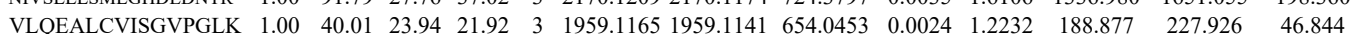
$\begin{array}{llllllllllllll}\text { VLQEALCVISGVPGLK } & 1.00 & 40.01 & 23.94 & 21.92 & 3 & 1959.1165 & 1959.1141 & 654.0453 & 0.0024 & 1.2232 & 188.877 & 227.926 & 46.844 \\ \text { VLQEALCVISGVPGLK } & 1.00 & 56.76 & 24.01 & 16.65 & 3 & 1959.1174 & 1959.1141 & 654.0453 & 0.0033 & 1.6818 & 189.428 & 209.586 & 73.915\end{array}$ $\begin{array}{lllllllllllllll}\text { NIVSLLLSMLGHDEDNTR } & 1.00 & 87.36 & 27.75 & 34.84 & 3 & 2170.1203 & 2170.1174 & 724.3797 & 0.0029 & 1.3345 & 502.940 & 810.948 & 30.722\end{array}$ $\begin{array}{llllllllllllll}\text { NIVSLLLSMLGHDEDNTR } & 1.00 & 94.92 & 27.79 & 38.16 & 3 & 2170.1212 & 2170.1174 & 724.3797 & 0.0038 & 1.7486 & 1238.298 & 1679.214 & 7.945\end{array}$ $\begin{array}{llllllllllllll}\text { IVSLLLSMLGHDEDNTR } & 1.00 & 85.00 & 27.79 & 37.77 & 3 & 2170.1212 & 2170.1174 & 724.3797 & 0.0038 & 1.7486 & 106.253 & 89.086 & 13.253\end{array}$ AALLETLSLLLAK SLVSGLIR SLVSGLIR AALLETLSLLLAK AALLETLSLLLAK AALLETLSLLLAK $\begin{array}{llllllllllllll}1.00 & 60.87 & 27.64 & 36.42 & 3 & 2170.1227 & 2170.1174 & 724.3797 & 0.0053 & 2.4389 & 139.088 & 149.968\end{array}$ $\begin{array}{llllllllllll}0.53 & 24.84 & 15.80 & 37.84 & 3 & 1643.0509 & 1643.0476 & 548.6898 & 0.0033 & 2.0048 & 29.453 & 42.589\end{array}$ $\begin{array}{llllllllllllll}0.97 & 41.09 & 25.30 & 43.60 & 2 & 987.6218 & 987.6199 & 494.8172 & 0.0019 & 1.9199 & 17271.343 & 18033.913 & 695.385\end{array}$ $\begin{array}{lllllllllllllll}0.76 & 82.29 & 16.13 & 95.29 & 2 & 1643.0488 & 1643.0476 & 822.5311 & 0.0012 & 0.7295 & 1130.959 & 1909.024 & 217.989\end{array}$ $\begin{array}{llllllllllllll}1.00 & 87.06 & 16.02 & 23.30 & 2 & 1643.0496 & 1643.0476 & 822.5311 & 0.0020 & 1.2158 & 1060.599 & 1562.422 & 139.903\end{array}$ $\begin{array}{lllllllllllllll}0.55 & 31.11 & 16.02 & 44.11 & 3 & 1643.0500 & 1643.0476 & 548.6898 & 0.0024 & 1.4580 & 47.824 & 41.265 & 17.978\end{array}$ $\begin{array}{llllllllllllll}1.00 & 26.19 & 15.80 & 15.42 & 3 & 1643.0503 & 1643.0476 & 548.6898 & 0.0027 & 1.6403 & 51.882 & 177.215 & 55.492\end{array}$ AALLE $\begin{array}{lllllllllllll}1.00 & 32.59 & 15.80 & 15.42 & 3 & 1643.0503 & 1643.0476 & 548.6898 & 0.0027 & 1.6403 & 51.882 \\ & 15.88 & 3 & 2601.5047 & 2601.5025 & 868.1748 & 0.0022 & 0.8447 & 59.966\end{array}$

NPSGLTQYIPVLVDSFLPLIK $\begin{array}{lllllllllllll}0.55 & 70.28 & 21.82 & 83.28 & 3 & 3193.7722 & 3193.7698 & 065.5972 & 0.0024 & 0.7508 & 6.776\end{array}$ $\begin{array}{llllllllllll}\text { LUALSTPSOQVOESVASCLPPLVPAIK } & 0.55 & 77.33 & 21.82 & 90.33 & 3 & 3193.7722 & 3193.7698 & 0655.5972 & 0.0024 & 0.7508 & 5.900\end{array}$

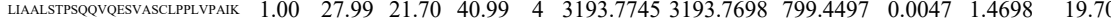
AALLETLSLLLAK AALLETLSLLLAK AALLETLSLLLAK $\begin{array}{llllllllllllll}0.93 & 27.22 & 21.17 & 8.28 & 2 & 1054.6714 & 1054.6621 & 528.3383 & 0.0093 & 8.8011 & 11587.167 & 12228.785 & 1531.182\end{array}$ $\begin{array}{llllllllllllll}0.61 & 79.38 & 16.13 & 92.38 & 2 & 1643.0480 & 1643.0476 & 822.5311 & 0.0004 & 0.2432 & 304.420 & 384.303 & 46.812 \\ 0.76 & 80.91 & 16.13 & 93.91 & 2 & 1643.0486 & 1643.0476 & 822.5311 & 0.0010 & 0.6079 & 148.803 & 194.100 & 25.730 & 1 \\ 1.00 & 37.18 & 16.13 & 16.78 & & 1643.0494 & 1643.0476 & 548.688 & 0.018 & 1.0935 & 40.856 & 40.93 & 22.537 & 1\end{array}$ $\begin{array}{llllllllllllll}0.76 & 80.91 & 16.13 & 93.91 & 2 & 1643.0486 & 1643.0476 & 822.5311 & 0.0010 & 0.6079 & 148.803 & 194.100 & 25.730 \\ 1.00 & 37.18 & 16.13 & 16.78 & 3 & 1643.0494 & 1643.0476 & 548.6898 & 0.0018 & 1.0935 & 40.856 & 40.939 & 22.537\end{array}$ $\begin{array}{lllllllllllll}1.00 & 37.18 & 16.13 & 16.78 & 3 & 1643.0494 & 1643.0476 & 548.6898 & 0.0018 & 1.0935 & 40.856\end{array}$ $\begin{array}{lllllllllllll}0.53 & 26.75 & 15.80 & 39.75 & 3 & 1643.0503 & 1643.0476 & 548.6898 & 0.0027 & 1.6403 & 39.346\end{array}$

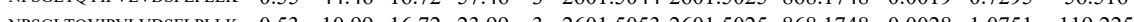
$\begin{array}{llllllllllllll}\text { LIAALSTPSQQVEESVASCLPPLVPAIK } & 1.00 & 17.40 & 21.55 & 16.36 & 4 & 3193.7773 & 3193.7698 & 799.4497 & 0.0075 & 2.3454 & 3.554\end{array}$

Table S-3 page 438 of 499 
$\begin{array}{llllllllllll}.00 & 95.78 & 25.83 & 30.69 & 2 & 1662.9458 & 1662.9427 & 832.4786 & 0.0031 & 1.8619 & 234.054 \\ 1.00 & 41.71 & 23.67 & 22.20 & 3 & 1409.8486 & 1409.8476 & 470.9565 & 0.0010 & 0.7078 & 19.806\end{array}$

VLAGLYMGR

$\begin{array}{llllllllllllll}0.98 & 38.30 & 27.23 & 24.23 & 2 & 1122.6428 & 1122.6341 & 562.3243 & 0.0087 & 7.7357 & 8222.859 & 7936.296\end{array}$

GVTSILPVLR

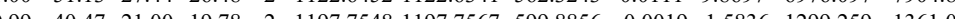

GVTSILPVLR

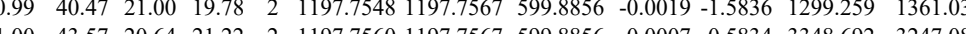

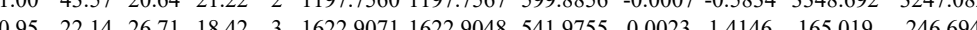

AVMLLHTHTITSR

$\begin{array}{llllllllllllll}0.99 & 28.39 & 26.94 & 17.61 & 3 & 1622.9074 & 1622.9048 & 541.9755 & 0.0026 & 1.5991 & 186.685 & 172.749\end{array}$

LTSADALRPSVV

$\begin{array}{lllllllllllll}1.00 & 5.44 & 18.81 & 49.44 & 3 & 2209.2943 & 2209.2916 & 737.4378 & 0.0027 & 1.204 & 1278.195 & 2000.294 & 801.855\end{array}$

$\begin{array}{lllllllllllllll} & \end{array}$

ALVAVLLSR

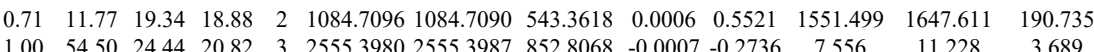

$\begin{array}{lllllllllllll}1.00 & 58.07 & 20.49 & 30.33 & 2 & 1084.7108 & 1084.7090 & 543.3618 & 0.0018 & 1.6564 & 4337.852 & 4932.126 & 298.814\end{array}$

$\begin{array}{ccccccccccccc}1.00 & 43.78 & 20.49 & 29.30 & 2 & 1084.7108 & 1084.7090 & 543.3618 & 0.0018 & 1.6564 & 5483.895 & 6194.514 & 279.669 \\ 1.00 & 76.94 & 24.01 & 21.36 & 3 & 2555.4067 & 2555.3987 & 852.8068 & 0.0080 & 3.1269 & 6.742 & 14.124 & 5394\end{array}$

ALVAVLLSR

$\begin{array}{llllllllllll}1.00 & 53.07 & 19.34 & 29.64 & 2 & 1084.7098 & 1084.7090 & 543.3618 & 0.0008 & 0.7362 & 1104.675 & 1198.784\end{array}$

ALVAVLLSR

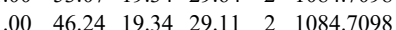

ALVAVLLSR

LLTWVIGTGSPR

$\begin{array}{lllllllllllll}1.00 & 39.74 & 19.34 & 21.34 & 2 & 1084.7098 & 1084.7090 & 543.3618 & 0.0008 & 0.7362 & 305.768 & \\ 1.00 & 79.95 & 25.63 & 28.13 & 2 & 1442.8374 & 1442.8367 & 722.4256 & 0.0007 & 0.4845 & 203.986 & \end{array}$

LFCLTLHR

LFCLTLHR

LLTWVIGTGSPR

$\begin{array}{lllllllllllll}7.95 & 25.63 & 28.13 & 2 & 1442.8374 & 1442.8367 & 722.4256 & 0.0007 & 0.4845 & 203.986 & 256.111\end{array}$

$\begin{array}{llllllllllll}.00 & 71.95 & 25.60 & 21.52 & 2 & 1442.8384 & 1442.8367 & 722.4256 & 0.0017 & 1.1766 & 320.420 & 373.300\end{array}$

$\begin{array}{llllllllllll}0.92 & 27.43 & 28.48 & 22.50 & 2 & 1191.6384 & 1191.6378 & 596.8262 & 0.0006 & 0.5027 & 121.285 & \end{array}$

$\begin{array}{llllllllllll}0.88 & 25.36 & 28.63 & 24.85 & 2 & 1191.6400 & 1191.6378 & 596.8262 & 0.0022 & 1.8431 & 173.317\end{array}$

LLTWVIGTGSPR

LFCLTLHR

LFCLTLHR

LLTWVIGTGSPR

LFCLTLHR

LFCLTLHR

$\begin{array}{lllllllllll}1.00 & 75.99 & 25.63 & 28.33 & 2 & 1442.8374 & 1442.8367 & 722.4256 & 0.0007 & 0.4845 & 381.723 \\ 1.00 & 77.49 & 25.56 & 21.24 & 2 & 1442.8390 & 1442.8367 & 722.4256 & 0.0023 & 1.5919 & 250.470\end{array}$

$\begin{array}{lllllllllll}1.00 & 41.10 & 28.48 & 22.58 & 2 & 1191.6386 & 1191.6378 & 596.8262 & 0.0008 & 0.6702 & 450.480\end{array}$

$\begin{array}{lllllllllll}0.98 & 34.74 & 28.44 & 21.96 & 2 & 1191.6390 & 1191.6378 & 596.8262 & 0.0012 & 1.0053 & 354.782\end{array}$

$\begin{array}{lllllllllll}1.00 & 72.25 & 25.61 & 19.34 & 2 & 1442.8386 & 1442.8367 & 722.4256 & 0.0019 & 1.3150 & 274.392 \\ 0.98 & 33.42 & 28.48 & 25.61 & 2 & 1191.6388 & 1191.6378 & 596.8262 & 0.0010 & 0.8378 & 279.189\end{array}$

$\begin{array}{lllllllllll}0.98 & 33.42 & 28.48 & 25.61 & 2 & 1191.6388 & 1191.6378 & 596.8262 & 0.0010 & 0.8378 & 279.189 \\ 0.95 & 30.17 & 28.48 & 21.46 & 2 & 1191.6388 & 1191.6378 & 596.8262 & 0.0010 & 0.8378 & 237.900\end{array}$

LLTWVIGTGSPR

$\begin{array}{lllllllllll}0.95 & 30.17 & 28.48 & 21.46 & 2 & 1191.6388 & 1191.6378 & 596.8262 & 0.0010 & 0.8378 & 237.900\end{array}$

LLTWVIGTGSP

$\begin{array}{lllllllllll}1.00 & 66.93 & 25.54 & 23.76 & 2 & 1442.8392 & 1442.8367 & 722.4256 & 0.0025 & 1.7303 & 167.218\end{array}$

LLTWVIGTGSPR

$\begin{array}{llllllllll}55.30 & 25.75 & 19.98 & 2 & 1442.8364 & 1442.8367 & 722.4256 & -0.0003 & -0.2076 & 89.835\end{array}$

NPFLSLAACVMPSR

NPFLSLAACVMPSR

NPFLSLAACVMPSR

LLTWVIGTGSPR

LLTWVIGTGSPR

$\begin{array}{llllllllllll}1.00 & 67.74 & 25.75 & 27.24 & 2 & 1442.8370 & 1442.8367 & 722.4256 & 0.0003 & 0.2076 & 96.743\end{array}$

$\begin{array}{lllllllllllll}0.99 & 28.46 & 28.14 & 15.65 & 3 & 1694844 & 1694.8428 & 565.9549 & 0.0016 & 0.9424 & 3.149\end{array}$

$\begin{array}{lllllllllllll}1.00 & 48.62 & 28.09 & 18.76 & 3 & 16948450 & 1694.8428 & 565.9549 & 0.0022 & 12957 & 0.000\end{array}$

$\begin{array}{llllllllllll}1.00 & 53.39 & 28.06 & 18.25 & 2 & 1694.8452 & 1694.8428 & 848.4287 & 0.0024 & 1.4144 & 7.358\end{array}$

LLTWVIGTGSPR

$\begin{array}{llllllllllll}1.00 & 69.04 & 25.73 & 27.39 & 2 & 1442.8368 & 1442.8367 & 722.4256 & 0.0001 & 0.0692 & 123.572\end{array}$

$\begin{array}{llllllllllll}1.00 & 69.98 & 25.68 & 24.38 & 2 & 1442.8380 & 1442.8367 & 722.4256 & 0.0013 & 0.8997 & 127.427\end{array}$

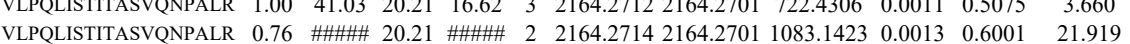

$\begin{array}{lllllllllll} & 75.80 & 25.56 & 20.87 & 2 & 1442.8390 & 1442.8367 & 722.4256 & 0.0023 & 1.5919 & 48.899\end{array}$

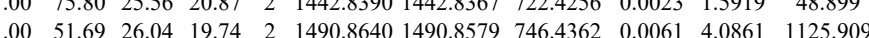

SLNTDVLFGLLR

$\begin{array}{llllllllllll}1.00 & 52.65 & 25.80 & 22.02 & 2 & 1490.8658 & 1490.8579 & 746.4362 & 0.0079 & 52918 & 1555.427 & 1244.893\end{array}$ $\begin{array}{lllllllllllll}\text { VHLMVHNLVPPFLDGR } & 0.96 & 12.41 & 25.87 & 18.51 & 4 & 1987.0993 & 1987.0948 & 497.7810 & 0.0045 & 2.2600 & 244.714 \\ \text { QYLPFI }\end{array}$ $\begin{array}{llllllllllll}\text { QYLPIFAVQQELLTIIR } & 1.00 & 85.13 & 19.49 & 25.72 & 2 & 2188.2754 & 2188.2741 & 1095.1443 & 0.0013 & 0.5935 & 28.959\end{array}$ $\begin{array}{llllllllllll}\text { QYLPIFAVQQELLTIIR } & 1.00 & 63.64 & 19.49 & 17.06 & 2 & 2188.2754 & 2188.2741 & 1095.1443 & 0.0013 & 0.5935 & 11.520 \\ \text { QYLPFAVQQELLTIR } & 1.00 & 50.42 & 19.49 & 20.83 & 3 & 21882766 & 2188.2741 & 730.4320 & 0.0025 & 1.1409 & 10.758\end{array}$ $\begin{array}{lllllllllllll}\text { QYLPIFAVQQELLTIIR } & 1.00 & 50.42 & 19.49 & 20.83 & 3 & 2188.2766 & 2188.2741 & 730.4320 & 0.0025 & 1.1409 & 10.758 \\ \text { QYLPIFAVQQELLTIIR } & 0.55 & 42.42 & 19.49 & 55.42 & 3 & 2188.2766 & 2188.2741 & 730.4320 & 0.0025 & 1.1409 & 15.693\end{array}$

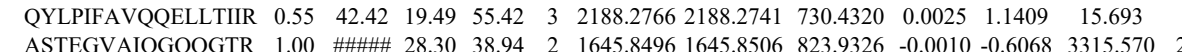

\begin{tabular}{lllllllllllll}
\hline ASTEGVAIQGQQGTR & 1.00 & \#\#\#\# & 28.30 & 38.94 & 2 & 1645.8496 & 1645.8506 & 823.9326 & -0.0010 & -0.6068 & 3315.570 & 2979 \\
CQDVSAGSLQELALLTGISK & 1.00 & 41.94 & 25.88 & 19.68 & 3 & 2479.3309 & 2479.3270 & 827.4496 & 0.0039 & 1.5711 & 21.091
\end{tabular} $\begin{array}{llllllllllll}\text { CQDVSAGSLQELALLTGIISK } & 1.00 & 41.94 & 25.88 & 19.68 & 3 & 2479.3309 & 2479.3270 & 827.4496 & 0.0039 & 1.5711 & 21.091 \\ \text { CQDVSAGSLQELALLTGIISK } & 1.00 & 45.61 & 25.98 & 20.49 & 3 & 2479.3327 & 2479.3270 & 827.4496 & 0.0057 & 2.2962 & 30.934\end{array}$

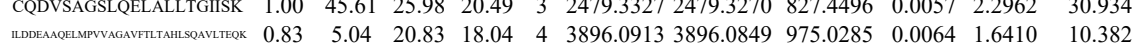

LLQCLHAK

$\begin{array}{ccccccccccc}0.83 & 5.04 & 20.83 & 18.04 & 4 & 3896.0913 & 3896.0849 & 975.0285 & 0.0064 & 1.6410 & 10.382 \\ 0.54 & 19.75 & 26.77 & 24.97 & 3 & 1258.7230 & 1258.7133 & 420.5784 & 0.0097 & 7.6878 & 9289.187\end{array}$ $\begin{array}{llllllllllll}\text { SPEIAASLWQSLEYTQILQTVR } & 0.53 & 39.01 & 25.13 & 52.01 & 3 & 2676.4276 & 2676.4244 & 893.1487 & 0.0032 & 1.1943 & 7.58\end{array}$ $\begin{array}{llllllllllll}\text { SPEIAASLWQSLEYTQILQTVR } & 1.00 & 42.39 & 25.07 & 19.85 & 3 & 2676.4291 & 2676.4244 & 893.1487 & 0.0047 & 1.7541 & 13.563 \\ \text { ESOLALIVCPLEQLLQGINPR } & 0.58 & 10.43 & 24.94 & 16.61 & 3 & 2523.3703 & 2523.3674 & 842.1297 & 0.0029 & 1.1479 & 56.648\end{array}$ $\begin{array}{llllllllllll}\text { LPGLQATVR } & 0.89 & 41.47 & 24.83 & 43.07 & 2 & 1097.6754 & 1097.6679 & 549.8412 & 0.0075 & 6.8201 & 704.191\end{array}$ 


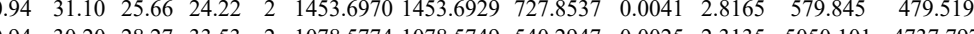
$\begin{array}{lllllllllllll}0.94 & 30.20 & 28.27 & 33.53 & 2 & 1078.5774 & 1078.5749 & 540.2947 & 0.0025 & 2.3135 & 5050.101 & 4737.797 & \end{array}$ $\begin{array}{llllllllll} & & \end{array}$

LPGLGIIIYLLK $\begin{array}{lllllllllllll}1.00 & 42.60 & 27.07 & 26.88 & 2 & 1239.7108 & 1239.7097 & 620.8621 & 0.0011 & 0.8859 & 1587.606 & 1760.631 & 152.339\end{array}$

GLGIIIYLLK

AVQHCLALLNLTLQ $\begin{array}{llllllllllll} & \end{array}$

VLVDSLVEDDR

DISTLEPLK

DISTLEPLKK

DISTLEPLKK

IFGGLDMLAEK

IFGGLDMLAEK

IFGGLDMLAEK

IFGGLDMLAEK

IFGGLDMLAEK

IFGGLDMLAEK

LPNLTHLNLSGNK

LPNLTHLNLSGNK

LPNLTHLNLSGNK

LPNLTHLNLSGNK

LPNLTHLNLSGNK

LPNLTHLNLSGNK

LPNLTHLNLSGNK

LPNLTHLNLSGNK

LPNLTHLNLSGNK

LPNLTHLNLSG

$\begin{array}{llllllllll}\text { PGTA_HUMAN Q92696 } & \text { RABGGTAGeranylgeranyl trı } 65.07 & 1.00 & 2 & 8.5 & 0.0018 & 0.2523 & -0.2186 & 1.6709\end{array}$

TLPPALAALR

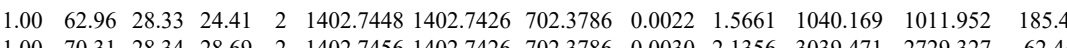

$\begin{array}{llllllllllllll}0.71 & 38.20 * 26.63 & 33.21 & 2 & 1302.7646 & 1302.7638 & 652.3892 & 0.0008 & 0.6131 & 2697.353 & 2319.667 & 6724.423 & 5380.154\end{array}$

$\begin{array}{lllllllllllllll}0.80 & 35.49 * & 20.21 & 19.60 & 3 & 1574.9719 & 1574.9609 & 525.9942 & 0.0110 & 6.9709 & 13766.348 & 10522.929 & 19927.777 & 13975.096 & \text { Yes }\end{array}$ $\begin{array}{ccccccccccccccc}0.94 & 46.91 * & 20.21 & 19.77 & 3 & 1574.9737 & 1574.9609 & 525.9942 & 0.0128 & 8.1116 & 12338.653 & 9833.952 & 22058.322 & 12519.435 & \text { Yes } \\ \end{array}$ $\begin{array}{llllllllllllll}0.94 & 21.97 & 27.48 & 21.13 & 3 & 1480.8235 & 1480.8203 & 494.6140 & 0.0032 & 2.1566 & 218.315 & 142.221 & 80.722 & 20.870\end{array}$ $\begin{array}{llllllllllllll}1.00 & 75.67 & 27.50 & 40.88 & 2 & 1480.8240 & 1480.8203 & 741.4174 & 0.0037 & 2.4952 & 24585.981 & 21302.639 & 0.000 & 119.412\end{array}$ $\begin{array}{lllllllllllllllll}0.80 & 18.00 & 27.50 & 24.38 & 3 & 1480.8241 & 1480.8203 & 494.6140 & 0.0038 & 2.5609 & 155.229 & 241.759 & 82.135 & 30.138 & \text { Yes }\end{array}$ $\begin{array}{lllllllllllllll}1.00 & 79.67 & 27.48 & 42.89 & 2 & 1480.8234 & 1480.8203 & 741.4174 & 0.0031 & 2.0906 & 3802.597 & 2777.126 & 17.281 & 57.514 & \text { Yes }\end{array}$ $\begin{array}{llllllllllllll}1.00 & 84.40 & 27.50 & 42.30 & 2 & 1480.8236 & 1480.8203 & 741.4174 & 0.0033 & 2.2255 & 4247.315 & 3387.670 & 20.970 & 39.041\end{array}$ $\begin{array}{lllllllllllllll}0.99 & 26.24 & 24.59 & 20.99 & 3 & 1707.9907 & 1707.9875 & 570.3364 & 0.0032 & 1.8702 & 23.788 & 15.254 & 9.933 & 0.000 & \text { No }\end{array}$ $\begin{array}{lllllllllllllll}1.00 & 53.60 & 23.71 & 18.61 & 3 & 1707.9997 & 1707.9875 & 570.3364 & 0.0122 & 7.1302 & 29169.763 & 33912.692 & 12637.066 & 9960.038 & \text { Yes }\end{array}$ $\begin{array}{lllllllllllllll}1.00 & 78.06 & 23.46 & 19.60 & 2 & 1708.0012 & 1707.9875 & 855.0010 & 0.0137 & 8.0116 & 2491.470 & 2275.118 & 2014.657 & 1673.185 & \text { Yes }\end{array}$ \begin{tabular}{lllllllllllllll}
1.00 & 79.16 & 23.46 & 19.76 & 2 & 1708.0012 & 1707.9875 & 855.0010 & 0.0137 & 8.0116 & 3197.619 & 2727.706 & 3475.483 & 2399.774 & Yes \\
\hline
\end{tabular}

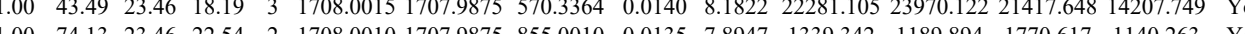
$\begin{array}{lllllllllllllll}1.00 & 74.13 & 23.46 & 22.54 & 2 & 1708.0010 & 1707.9875 & 855.0010 & 0.0135 & 7.8947 & 1339.342 & 1189.894 & 1770.617 & 1140.263 & \text { Yes } \\ 1.00 & 38.42 & 23.46 & 16.11 & 3 & 1708.0015 & 1707.9875 & 570.3364 & 0.0140 & 8.1822 & 2992.750 & 3904.227 & 14693.587 & 898.27 & \text { Yes }\end{array}$ $\begin{array}{llllllllllllllll}1.00 & 38.42 & 23.46 & 16.11 & 3 & 1708.0015 & 1707.9875 & 570.3364 & 0.0140 & 8.1822 & 29922.750 & 39094.227 & 14693.587 & 8988.271 & \text { Yes }\end{array}$

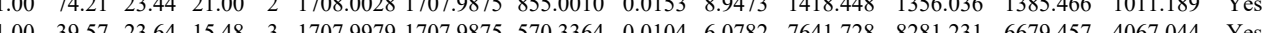
$\begin{array}{lllllllllllllll}1.00 & 74.21 & 23.44 & 21.00 & 2 & 1708.0028 & 1707.9875 & 855.0010 & 0.0153 & 8.9473 & 1418.448 & 1356.036 & 1385.466 & 1011.189 & \text { Yes } \\ 1.00 & 47.11 & 23.64 & 15.48 & 3 & 170.999 & 1707.985 & 57.3364 & 0.0104 & 6.0782 & 7641.728 & 8281.231 & 6679.457 & 406.044 & \text { Yes }\end{array}$

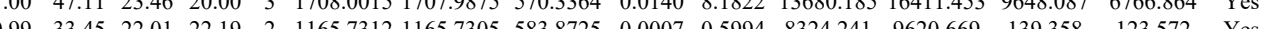
$\begin{array}{llllllllllllllll} & \end{array}$ $\begin{array}{llllllllllllll} & \end{array}$ $\begin{array}{lllllllllllll} & \end{array}$

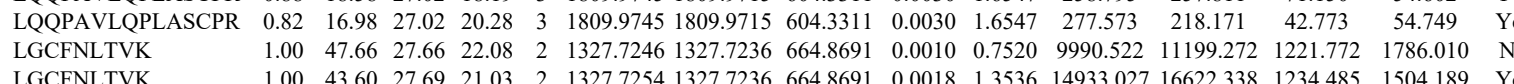

LGCFNLTVK

YYAVNFPMR
YYAVNFPMR

YYAVNFPMR
LGCFNLTVK

LGCFNLTVK

YYAVNFPMR

YYAVNFPMR

YYAVNFPMR

CTYLVLDEADR

CTYLVLDEADR

NFYVEHPEVAR

NFYVEHPEVAR

LIQLMEEIMAEK

LIQLMEEIMAEK

LIQLMEEIMAEK

LIQLMEEIMAEK

LIQLMEEIMAEK

LIQLMEEIMAEK

LIQLMEEIMAEK

LIQLMEEIMAEK

$\begin{array}{lllllllllllllll}1.00 & 47.66 & 27.66 & 22.08 & 2 & 1327.7246 & 1327.7236 & 664.8691 & 0.0010 & 0.7520 & 9990.522 & 11199.272 & 1221.772 & 1786.010 & \text { No } \\ 1.00 & 43.60 & 27.69 & 21.03 & 2 & 1327.7254 & 1327.7236 & 664.8691 & 0.0018 & 1.3536 & 14933.027 & 16622.338 & 1234.485 & 1504.189 & \text { Yes }\end{array}$ $\begin{array}{lllllllllllllll}1.00 & 47.01 & 27.47 & 22.32 & 2 & 1303.6520 & 1303.6505 & 652.8325 & 0.0015 & 1.1488 & 11814.369 & 13423.565 & 84.463 & 99.879 & \mathrm{Yes}\end{array}$ $\begin{array}{llllllllllllllll}1.00 & 44.85 & 27.49 & 24.77 & 2 & 1303.6522 & 1303.6505 & 652.8325 & 0.0017 & 1.3020 & 9618.602 & 9798.266 & 0.000 & 105.797 & \text { No }\end{array}$ $\begin{array}{lllllllllllllll}1.00 & 44.54 & 27.72 & 22.11 & 2 & 1327.7250 & 1327.7236 & 664.8691 & 0.0014 & 1.0528 & 12628.963 & 13958.256 & 477.940 & 449.498 & \text { Yes }\end{array}$ $\begin{array}{lllllllllllllll}1.00 & 42.24 & 27.66 & 20.74 & 2 & 1327.7252 & 1327.7236 & 664.8691 & 0.0016 & 1.2032 & 9619.138 & 9854.401 & 377.875 & 1027.882 & \text { Yes }\end{array}$ $\begin{array}{lllllllllllllll}1.00 & 46.89 & 27.58 & 19.17 & 2 & 1303.6536 & 1303.6505 & 652.8325 & 0.0031 & 2.3743 & 17388.561 & 18899.034 & 22.893 & 29.904 & \text { Yes }\end{array}$ $\begin{array}{lllllllllllllllll}0.99 & 47.06 & 27.68 & 17.38 & 2 & 1303.6552 & 1303.6505 & 652.8325 & 0.0047 & 3.5997 & 4118.417 & 3749.946 & 0.000 & 24.777 & \text { No }\end{array}$ $\begin{array}{lllllllllllllll}1.00 & 47.03 & 27.38 & 19.61 & 2 & 1303.6508 & 1303.6505 & 652.8325 & 0.0003 & 0.2298 & 4618.214 & 5302.752 & 169.603 & 100.403 & \text { Yes }\end{array}$ $\begin{array}{lllllllllllllll}1.00 & 42.87 & 27.47 & 25.15 & 2 & 1303.6530 & 1303.6505 & 652.8325 & 0.0025 & 1.9147 & 5516.148 & 4996.925 & 291.906 & 138.810 & \text { Yes }\end{array}$ $\begin{array}{lllllllllllllll}1.00 & 70.49 & 25.35 & 23.78 & 2 & 1486.6946 & 1486.6918 & 744.3532 & 0.0028 & 1.8808 & 551.640 & 503.069 & 22.002 & 0.000 & \text { No }\end{array}$ $\begin{array}{llllllllllllllll}1.00 & 50.76 & 25.43 & 17.03 & 2 & 1486.6948 & 1486.6918 & 744.3532 & 0.0030 & 2.0152 & 202.802 & 271.703 & 22.390 & 0.000 & \text { No }\end{array}$

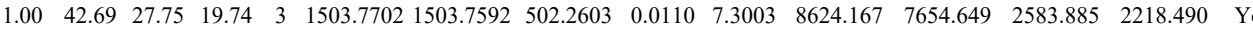
$\begin{array}{lllllllllllllll}0.99 & 36.98 & 27.74 & 22.05 & 3 & 1503.7720 & 1503.7592 & 502.2603 & 0.0128 & 8.4949 & 3955.543 & 4511.651 & 2576.652 & 2616.032 & \text { No }\end{array}$ $\begin{array}{lllllllllllllll}1.00 & 79.77 & 27.33 & 25.57 & 2 & 1734.9528 & 1734.9503 & 868.4824 & 0.0025 & 1.4393 & 1072.964 & 1144.777 & 0.918 & 4.756 & \text { No }\end{array}$ $\begin{array}{lllllllllllllll}1.00 & 75.24 & 27.33 & 24.14 & 2 & 1734.9528 & 1734.9503 & 868.4824 & 0.0025 & 1.4393 & 705.634 & 723.417 & 0.000 & 13.183 & \text { No }\end{array}$ $\begin{array}{llllllllllllllll}0.97 & 25.61 & 27.20 & 19.06 & 3 & 1734.9541 & 1734.9503 & 579.3240 & 0.0038 & 2.1865 & 46.983 & 47.825 & 30.519 & 10.159 & \text { Yes }\end{array}$ $\begin{array}{lllllllllllllll}0.73 & 16.15 & 27.19 & 17.36 & 3 & 1734.9544 & 1734.9503 & 579.3240 & 0.0041 & 2.3591 & 76.601 & 52.590 & 25.932 & 28.187 & \text { Yes }\end{array}$

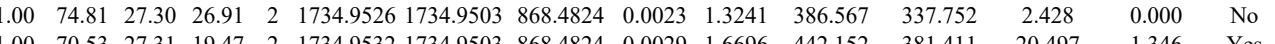
$\begin{array}{llllllllllllllll}1.00 & 70.53 & 27.31 & 19.47 & 2 & 1734.9532 & 1734.9503 & 868.4824 & 0.0029 & 1.6696 & 442.152 & 381.411 & 20.497 & 1.346 & \text { Yes } \\ \end{array}$ $\begin{array}{llllllllllllllll}0.93 & 22.32 & 27.20 & 22.15 & 3 & 1734.9541 & 1734.9503 & 579.3240 & 0.0038 & 2.1865 & 47.951 & 40.276 & 15.635 & 10.820 & \text { Yes } \\ & & \\ 0.93 & 24.19 & 27.21 & 26.56 & 3 & 173.9550 & 1734.9503 & 579.3240 & 0.0047 & 2.7043 & 66.875 & 40.638 & 13.594 & 15.632 & \text { Yes }\end{array}$ $\begin{array}{llllllllllllllll}\text { TLAYLLPAIVHINHQPYLER } & 1.00 & 22.23 & 22.38 & 35.23 & 4 & 2504.4081 & 2504.4025 & 627.1079 & 0.0056 & 2.2325 & 1376.697 & 1636.050 & 159.146 & 68.871 & \text { Yes } \\ \text { VFOTEAELOEVISDLQSK } & 1.00 & 46.06 & 26.84 & 28.05 & 3 & 2351.2477 & 2351.2464 & 784.7561 & 0.0013 & 0.5522 & 16.209 & 4.733 & 7.950 & 9.493 & \text { Yes }\end{array}$ $\begin{array}{llllllllllllllll}\text { VFQTEAELQEVISDLQSK } & 1.00 & 50.17 & 26.65 & 27.97 & 3 & 2351.2489 & 2351.2464 & 784.7561 & 0.0025 & 1.0619 & 23.562 & 15.696 & 4.141 & 4.022 & \text { Yes }\end{array}$

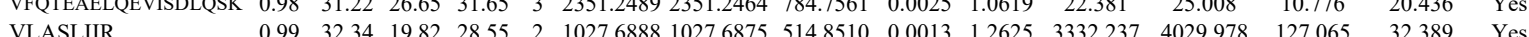



$\begin{array}{llllllllllllllll}\text { GNSGSHVNHLVR } & 1.00 & 58.93 & 27.90 & 19.31 & 3 & 1633.8772 & 1633.8770 & 545.6329 & 0.0002 & 0.1222 & 815.094 & 1053.587 & 1277.880 & 568.863 & \text { Yes }\end{array}$ $\begin{array}{llllllllllllllll}\text { GNTSGSHIVNHLVR } & 1.00 & 57.96 & 27.79 & 19.04 & 3 & 1633.8784 & 1633.8770 & 545.6329 & 0.0014 & 0.8553 & 1196.413 & 2334.676 & 1704.606 & 717.725 & \text { Yes }\end{array}$ $\begin{array}{llllllllllllllll}\text { GNTSGSHIVNHLVR } & 1.00 & 38.93 & 27.92 & 15.47 & 4 & 1633.8773 & 1633.8770 & 409.4765 & 0.0003 & 0.1832 & 7199.754 & 9255.470 & 4850.549 & 2415.098 & \text { Yes } \\ \text { GNTSG } & 1.00 & 60.36 & 27.82 & 22.23 & 3 & 1633.8775 & 1633.8770 & 545.6329 & 0.0005 & 0.3055 & 653.238 & 992.924 & 880.835 & 496.528 & \text { Yes }\end{array}$

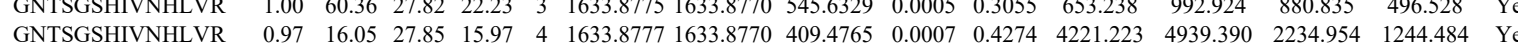
LVNTINPGAR

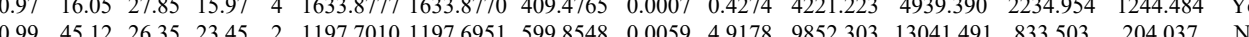
QPLWNHLLNYYK

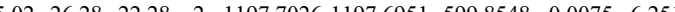

TTIEAHOLLEPQHVI

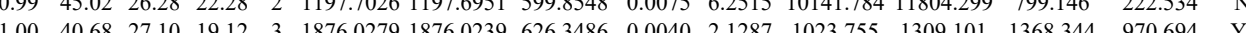

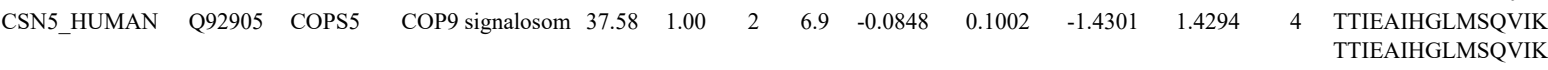

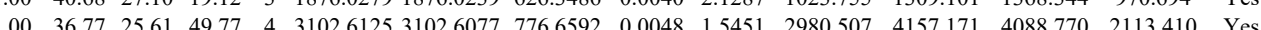

$\begin{array}{llllllllllllllll}1.00 & 41.16 & 23.84 & 20.71 & 3 & 1928.1052 & 1928.1008 & 643.7075 & 0.0044 & 2.2785 & 2463.698 & 2297.340 & 1265.413 & 278.561 & \text { Yes } \\ 1.00 & 53.86 & 24.08 & 20.76 & 3 & 1928.1031 & 1928.1008 & 643.7075 & 0.0023 & 1.1910 & 5010.623 & 4559.927 & 5673.036 & 897.047 & \text { Yes }\end{array}$ ISALALLK

3 VQISPDSGGLPER SVSLTGAPESVQK SVSLTGAPESVQK VQISPDSGGLPER SVSLTGAPESVQK SVSLTGAPESVQK IGGGIDVPVPR IGGGIDVPVPR IAHIMGPPDR IAHIMGPPDR

VPDGMVGLIIGR

VPDGMVGLIIGR

VQQACEMVMDILR VQQACEMVMDILR QQACEMVMDIL VPDGMVGLIIGR VPDGMVGLIIGR VQQACEMVMDILR VQQACEMVMDILR VQQACEMVMDILR VQQACEMVMDILR VQQACEMVMDILR IINDLLQSLR
IINDLLQSLR IINDLLQSLR IINDLLQSLR
IINDLLQSLR IINDLLQSLR
IINDLLQSLR IINDLLQSLR GSPQQIDHAK QLEDGDQPESK

CGLVIGR
CGLVIGR

GSPQQIDHAK

GSPQQIDHAK

GSPQQIDHAK

GSPQQIDHAK

GSPQQIDHAK

$\begin{array}{lllllllllllll}\text { TNPO1_HUMAI Q92973 } & \text { TNPO1 } & \text { Transportin-1 } & 102.36 & 1.00 & 9 & 15.3 & -0.1301 & 0.3174 & 0.0768 & 1.2164 & 12 & \text { YSDIDIILLK }\end{array}$ $\begin{array}{llllllllllllllllll}1.00 & 52.31 & 23.82 & 17.08 & 3 & 1928.1049 & 1928.1008 & 643.7075 & 0.0041 & 2.1231 & 5030.750 & 4852.067 & 4430.094 & 639.315 & \text { Yes }\end{array}$ $\begin{array}{lllllllllllllllll}1.00 & 51.65 & 18.51 & 42.51 & 2 & 1115.7530 & 1115.7521 & 558.8833 & 0.0009 & 0.8052 & 4200.891 & 4477.480 & 316.960 & 82.483 & \text { Yes } & \\ 1.00 & 55.18 & 27.92 & 31.23 & 2 & 1497.8022 & 1497.7909 & 749.9027 & 0.0113 & 7.5343 & 5275.973 & 4247.155 & 985.111 & 83.954 & \text { Yes }\end{array}$ $\begin{array}{lllllllllllllllll}1.00 & 72.88 & 26.81 & 27.65 & 2 & 1589.8984 & 1589.8868 & 795.9507 & 0.0116 & 7.2868 & 2707.547 & 2006.349 & 1041.246 & 652.175 & \text { Yes }\end{array}$ $\begin{array}{lllllllllllllll}1.00 & 74.55 & 26.79 & 28.71 & 2 & 1589.8988 & 1589.8868 & 795.9507 & 0.0120 & 7.5381 & 2338.817 & 2286.855 & 1605.459 & 689.741 & \text { Yes }\end{array}$ $\begin{array}{lllllllllllllll}1.00 & 52.29 & 28.03 & 25.50 & 2 & 1497.8036 & 1497.7909 & 749.9027 & 0.0127 & 8.4677 & 380.284 & 337.350 & 71.320 & 13.457 & \text { Yes }\end{array}$ $\begin{array}{lllllllllllllll}1.00 & 68.91 & 26.87 & 27.14 & 2 & 1589.9004 & 1589.8868 & 795.9507 & 0.0136 & 8.5432 & 1588.389 & 1166.611 & 677.124 & 401.464 & \text { Yes }\end{array}$ $\begin{array}{lllllllllllllll}1.00 & 71.62 & 26.95 & 25.72 & 2 & 1589.9006 & 1589.8868 & 795.9507 & 0.0138 & 8.6688 & 1130.973 & 1275.927 & 707.661 & 386.343 & \text { Yes }\end{array}$ $\begin{array}{llllllllllllllll}1.00 & 56.80 & 26.11 & 21.54 & 2 & 1222.7270 & 1222.7156 & 652.3651 & 0.0114 & 9.3081 & 12871.418 & 11995.119 & 4394.415 & 622.647 & \text { Yes }\end{array}$ $\begin{array}{lllllllllllllll}.00 & 64.65 & 26.11 & 18.36 & 2 & 1222.7274 & 1222.7156 & 612.3651 & 0.0118 & 9.6347 & 15733.935 & 15050.311 & 5958.156 & 1189.516 & \text { Yes }\end{array}$ $\begin{array}{lllllllllllllllll}0.98 & 28.15 & 28.43 & 20.07 & 3 & 1249.6768 & 1249.6723 & 417.5647 & 0.0045 & 3.5922 & 12177.961 & 14342.188 & 2169.354 & 2098.650 & \text { Yes }\end{array}$ $\begin{array}{lllllllllllllllll}.98 & 29.95 & 28.38 & 19.38 & 3 & 1249.6771 & 1249.6723 & 417.5647 & 0.0048 & 3.8317 & 8916.979 & 9223.570 & 1971.452 & 1108.978 & \text { Yes }\end{array}$

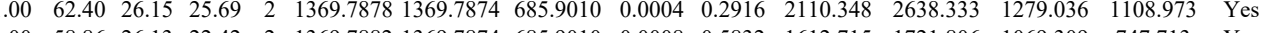
$\begin{array}{llllllllllllllll}1.00 & 58.86 & 26.13 & 22.42 & 2 & 1369.7882 & 1369.7874 & 685.9010 & 0.0008 & 0.5832 & 1612.715 & 1721.806 & 1069.309 & 747.713 & \text { Yes }\end{array}$

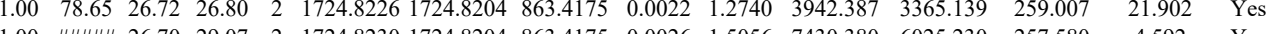

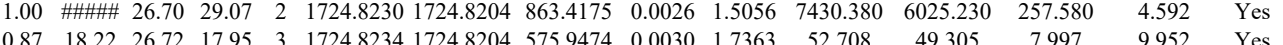
$\begin{array}{lllllllllllllll}1.87 & 18.22 & 26.72 & 17.95 & 3 & 1724.8234 & 1724.8204 & 575.9474 & 0.0030 & 1.7363 & 52.708 & 49.305 & 7.997 & 9.952 & \text { Yes } \\ 1.00 & 63.76 & 26.15 & 21.46 & 2 & 1369.7878 & 1369.7874 & 685.9010 & 0.004 & 0.2916 & 3491.983 & 3169.904 & 2119.364 & 1558.699 & \text { Yes }\end{array}$

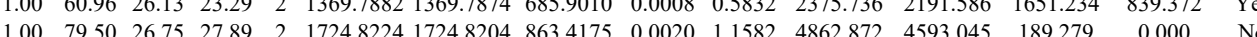

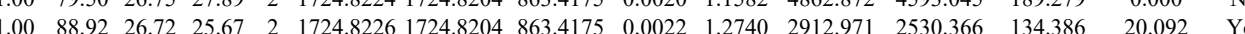

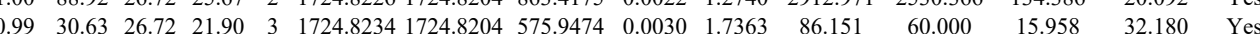

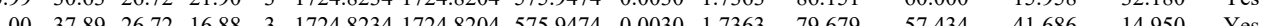

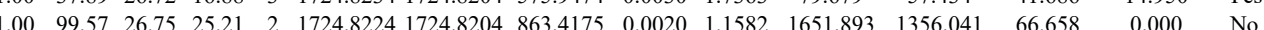
$\begin{array}{lllllllllllllll}1.00 & 31.63 & 2670 & 16.64 & 3 & 1724.8237 & 1724.8204 & 575.9474 & 0.0033 & 1.9099 & 144.692 & 117.348 & 27.026 & 24.560 & \text { Yes }\end{array}$ $\begin{array}{llllllllllllllll}1.00 & 62.92 & 24.62 & 37.04 & 2 & 1327.7972 & 1327.7945 & 664.9045 & 0.0027 & 2.0304 & 10386.410 & 7393.828 & 357.197 & 5.799 & \text { Yes }\end{array}$ $\begin{array}{lllllllllllllll}1.00 & 57.93 & 24.62 & 42.01 & 2 & 1327.7976 & 1327.7945 & 664.9045 & 0.0031 & 2.3312 & 8222.130 & 5731.665 & 0.000 & 33.481 & \text { No }\end{array}$ $\begin{array}{llllllllllllllll}1.00 & 59.69 & 24.62 & 36.01 & 2 & 1327.7970 & 1327.7945 & 664.9045 & 0.0025 & 1.8800 & 3274.402 & 2471.180 & 71.974 & 45.388 & \text { Y }\end{array}$ $\begin{array}{llllllllllllllll}1.00 & 63.04 & 24.62 & 36.29 & 2 & 1327.7974 & 1327.7945 & 664.9045 & 0.0029 & 2.1808 & 5915.594 & 4083.651 & 0.000 & 38.680 & \text { No }\end{array}$ $\begin{array}{lllllllllllllll}1.00 & 61.51 & 24.64 & 32.24 & 2 & 1327.7966 & 1327.7945 & 664.9045 & 0.0021 & 1.5792 & 6444.444 & 4085.298 & 105.740 & 26.001 & \text { Yes }\end{array}$ $\begin{array}{lllllllllllllll}1.00 & 61.54 & 24.62 & 42.51 & 2 & 1327.7974 & 1327.7945 & 664.9045 & 0.0029 & 2.1808 & 7101.660 & 4595.859 & 11.380 & 45.434 & \text { Yes }\end{array}$ $\begin{array}{llllllllllllllll}0.55 & 19.00 & 27.52 & 32.00 & 3 & 1367.7421 & 1367.7401 & 456.9206 & 0.0020 & 1.4590 & 82.909 & 80.141 & 77.328 & 39.982 & \text { No }\end{array}$ $\begin{array}{lllllllllllllllll}1.00 & 59.23 & 27.23 & 25.70 & 2 & 1532.7578 & 1532.7562 & 767.3854 & 0.0016 & 1.0425 & 426.860 & 338.099 & 24.441 & 20.370 & \text { Yes }\end{array}$ $\begin{array}{lllllllllllllllll}1.00 & 52.59 & 27.50 & 27.69 & 2 & 1532.7586 & 1532.7562 & 767.3854 & 0.0024 & 1.5637 & 437.406 & 450.245 & 76.745 & 57.961 & \text { Yes }\end{array}$ $\begin{array}{lllllllllllllllll}0.72 & 22.80 & 28.54 & 20.59 & 2 & 906.4932 & 906.4901 & 454.2523 & 0.0031 & 3.4122 & 10143.540 & 7677.455 & 1443.188 & 808.816 & \text { Yes }\end{array}$ $\begin{array}{llllllllllllllll}0.74 & 26.53 & 28.45 & 22.76 & 2 & 906.4940 & 906.4901 & 454.2523 & 0.0039 & 4.2927 & 12297.201 & 10616.636 & 1325.478 & 784.720 & \text { Yes }\end{array}$

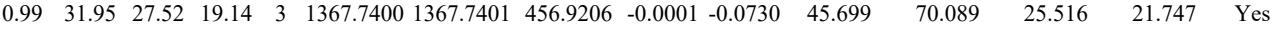

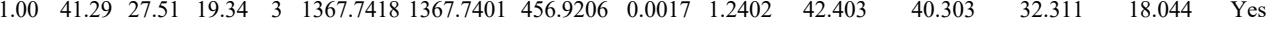

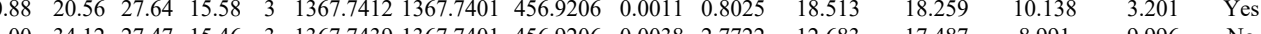

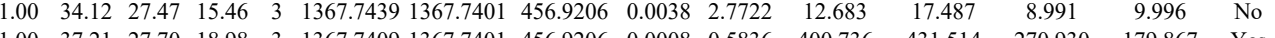
$\begin{array}{lllllllllllllll}1.00 & 37.21 & 27.70 & 18.98 & 3 & 1367.7409 & 1367.7401 & 456.9206 & 0.0008 & 0.5836 & 400.736 & 431.514 & 270.930 & 179.867 & \text { Yes }\end{array}$ $\begin{array}{lllllllllllllll}1.00 & 44.78 & 22.79 & 28.46 & 2 & 1479.8842 & 1479.8792 & 740.9469 & 0.0050 & 3.3740 & 417.447 & 534.607 & 96.908 & 22.372 & \text { Yes } \\ \end{array}$ $\begin{array}{lllllllllllllll}1.00 & 47.90 & 26.21 & 23.95 & 2 & 1696.9414 & 1696.9392 & 849.4769 & 0.0022 & 1.2949 & 103.937 & 126.184 & 24.738 & 47.833 & \text { Yes } \\ 0.98 & 32.51 & 2.32 & 22.20 & 2 & 166.9426 & 16969392 & 849.4769 & 0.0034 & 2.012 & 108.838 & 127.968 & 70.56 & 25.986 & \text { Yes }\end{array}$

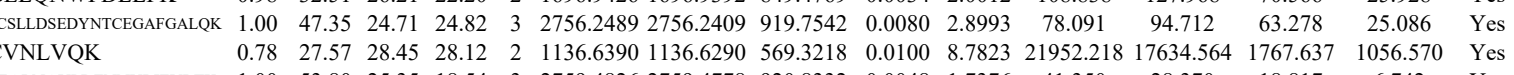

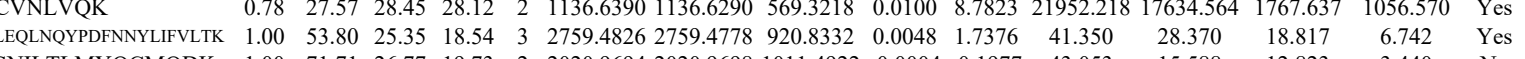

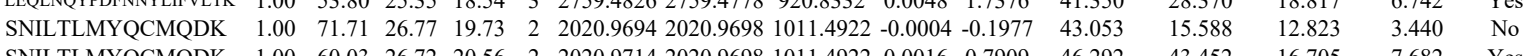
$\begin{array}{llllllllllllll} & \end{array}$

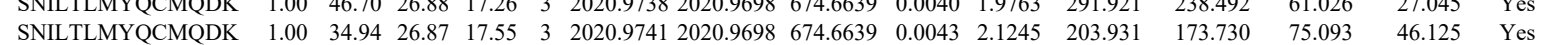




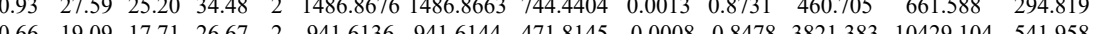
$\begin{array}{lllllllllllll}0.66 & 19.09 & 17.71 & 26.67 & 2 & 941.6136 & 941.6144 & 471.8145 & -0.0008 & -0.8478 & 3821.383 & 10429.104 & 541.958\end{array}$ $\begin{array}{lllllllllllll}1.00 & 59.85 & 24.96 & 28.04 & 2 & 1320.7894 & 1320.7887 & 661.4016 & 0.0007 & 0.5292 & 1451.031 & 1853.789 & 24.846 \\ 1.00 & 63.24 & 24.96 & 2.29 & 2 & 1320.7890 & 1320.7887 & 661.4016 & 0.0003 & 0.2268 & 1034.273 & 1178.281 & 18.851\end{array}$

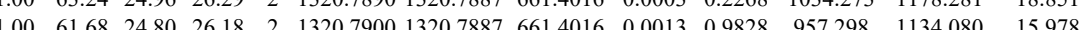
$\begin{array}{llllllllllllll}1.00 & 61.68 & 24.80 & 26.18 & 2 & 1320.7900 & 1320.7887 & 661.4016 & 0.0013 & 0.9828 & 957.298 & 1134.080 & 15.978\end{array}$

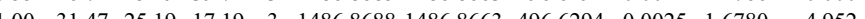
$\begin{array}{llllllllllllll} & \end{array}$

SGGLPLVLSMLTR

SGGLPLVLSMLTR

SGGLPLVLSMLTR

$\begin{array}{llllllllllllll}\text { TBRG4_HUMAI } & \text { Q969Z0 } & \text { TBRG4 } & \text { Protein TBRG4 } & 70.74 & 1.00 & 2 & 5.4 & -0.0553 & 0.0795 & -0.2186 & 0.9069 & 4 & \text { VLVMLAAQSR }\end{array}$

VLVMLAAQSR

VLVMLAAQSR

VLVMLAAQSR

VLVMLAAQSR

AQDITLPHLC
ILIWSGR

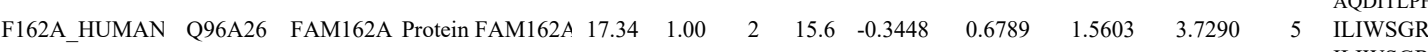

ILIWSGR
ILIWSGR

$\begin{array}{lllllllllllll}1.00 & 64.64 & 25.20 & 26.74 & 2 & 1486.8678 & 1486.8663 & 744.4404 & 0.0015 & 1.0075 & 149.588 & 186.190 & 31.793\end{array}$

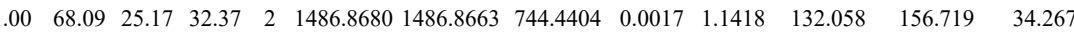

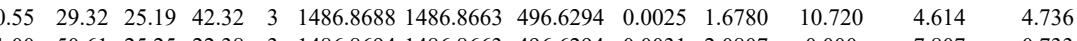

$\begin{array}{llllllllllllll}1.00 & 50.61 & 25.25 & 22.38 & 3 & 1486.8694 & 1486.8663 & 496.6294 & 0.0031 & 2.0807 & 0.000 & 4.614 & 4.736 \\ 0.55 & 16.4 & 25.19 & 2.49 & 3 & 1868688 & 1868663 & 496.624 & 0.002 & 1.6780 & 4.618 & 5.816 & 1.250\end{array}$

$\begin{array}{lllllllllllll}0.55 & 16.49 & 25.19 & 29.49 & 3 & 1486.8688 & 1486.8663 & 496.6294 & 0.0025 & 1.6780 & 4 & 0 \\ 0\end{array}$

$\begin{array}{llllllllllllllll}1.00 & 56.15 & 21.88 & 21.86 & 3 & 1668.9973 & 1668.9919 & 557.3379 & 0.0054 & 3.2296 & 1119.730 & 1973.586 & 2954.274 & 5419.388 & \mathrm{No}\end{array}$

$\begin{array}{llllllllllllllll}1.00 & 51.26 & 21.64 & 20.37 & 3 & 1668.9985 & 1668.9919 & 557.3379 & 0.0066 & 3.9473 & 949.142 & 1231.981 & 1239.375 & 1588.536 & \text { Yes }\end{array}$ $\begin{array}{llllllllllllllll}1.00 & 32.97 & 16.90 & 45.97 & 4 & 1941.1889 & 1941.1889 & 486.3045 & 0.0000 & 0.0000 & 524.402 & 1199.084 & 2089.690 & 451.214 & \text { Yes } \\ 1.00 & 32.09 & 16.9 & 56.0 & 4 & 1941.1905 & 454.1989 & 483045 & 0.0016 & 0.8225 & 593.38 & 1199.955 & 181.615 & 357.793 & \text { Yes }\end{array}$ $\begin{array}{lllllllllllllll}1.00 & 43.20 & 16.81 & 56.20 & 4 & 1941.1905 & 1941.1889 & 486.3045 & 0.0016 & 0.8225 & 593.386 & 1199.955 & 1861.615 & 357.793 & \text { Yes } \\ 1.00 & 32.09 & 16.90 & 45.09 & 4 & 1941.1889 & 1941.1889 & 486.3045 & 0.0000 & 0.0000 & 1127.453 & 2571.756 & 4186.856 & 1038.704 & \text { Yes }\end{array}$ $\begin{array}{llllllllllllllll}1.00 & 30.23 & 16.81 & 43.23 & 4 & 1941.1897 & 1941.1889 & 486.3045 & 0.0008 & 0.4113 & 1020.772 & 2201.638 & 4054.470 & 888.017 & \text { Yes } \\ 1.00 & 31.03 & 16.99 & 44.03 & 4 & 1941.1877 & 1941.1889 & 486.3045 & -0.0012 & -0.6169 & 616.289 & 803.941 & 893.889 & 318.050 & \text { Yes }\end{array}$ $\begin{array}{lllllllllllllll}1.00 & 58.31 & 26.35 & 33.72 & 2 & 1230.7236 & 1230.7240 & 616.3693 & -0.0004 & -0.3245 & 2446.293 & 2601.946 & 62.033 & 61.703 & \text { Yes }\end{array}$ $\begin{array}{lllllllllllllll}1.00 & 62.03 & 26.35 & 24.09 & 2 & 1230.7244 & 1230.7240 & 616.3693 & 0.0004 & 0.3245 & 2534.068 & 2558.075 & 76.185 & 54.625 & \text { Yes }\end{array}$ $\begin{array}{lllllllllllllll}1.00 & 47.36 & 27.47 & 24.73 & 2 & 1246.7196 & 1246.7189 & 624.3667 & 0.0007 & 0.5606 & 198.965 & 277.783 & 59.896 & 39.249 & \text { No } \\ 1.00 & 53.20 & 6.4 & 30.6 & 2 & 1230.724 & 130.724 & 6 & \end{array}$

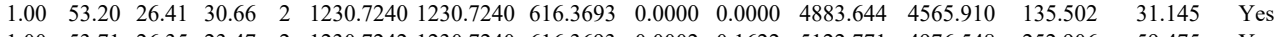
ILIWSGR

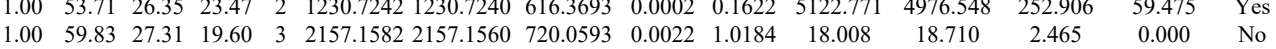
$\begin{array}{llllllllllllllll}0.94 & 29.00 & 25.87 & 27.13 & 2 & 987.5984 & 987.5987 & 494.8066 & -0.0003 & -0.3031 & 2821.164 & 2335.767 & 0.000 & 59.387 & \text { No } \\ 0.92 & 28.92 & 26.98 & 31.78 & 2 & 987.5990 & 987.5987 & 494.8066 & 0.0003 & 0.3031 & 3978.826 & 3815.022 & 47.664 & 72.111 & \text { Yes } \\ 0.88 & 28.6 & 26.98 & 38.00 & 2 & 987.5994 & 987.5987 & 49.806 & 0.0007 & 0.7073 & 7597.683 & 7220.301 & 415.629 & 382.734 & \text { Yes }\end{array}$ \begin{tabular}{lllllllllllllllll} 
& \\
LIWSR & 0.95 & 28.60 & 26.98 & 38.00 & 2 & 987.5994 & 987.5987 & 494.8066 & 0.0007 & 0.7073 & 7597.683 & 7220.301 & 415.629 & 382.734 & Yes \\
\hline
\end{tabular} \begin{tabular}{llllllllllllllll} 
& \\
EDEFETVLEMLDAAK & 1.00 & 95.76 & 28.06 & 30.59 & 2 & 2177.1034 & 2177.1017 & 1089.5581 & 0.0017 & 0.7801 & 51.941 & 42.527 & 111.138 & 75.446 & Yes \\
\hline
\end{tabular} $\begin{array}{lllllllllllllllll} & & \end{array}$ $\begin{array}{llllllllllll} & \end{array}$

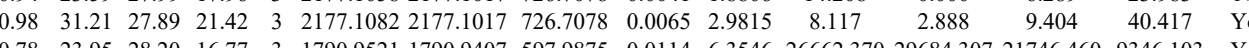

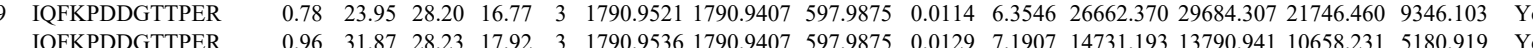
$\begin{array}{llllllllllllllll}\text { IQFKPDDGTTPER } & 0.96 & 31.87 & 28.23 & 17.92 & 3 & 1790.9536 & 1790.9407 & 597.9875 & 0.0129 & 7.1907 & 14731.193 & 13790.941 & 10658.231 & 5180.919 & \text { Yes } \\ \text { IQFKPDDGTTPER } & 0.90 & 28.00 & 28.49 & 21.93 & 3 & 1790.9494 & 1790.9407 & 597.9875 & 0.0087 & 4.8496 & 22961.671 & 24865895 & 18590.706 & 7901.330 & \text { Yes }\end{array}$

IQFKPDDGTTPER

LLDQIVEK

GTPQQIDYAR

IQIAPDSGGLPER

IQIAPDSGGLPER

IQIAPDSGGLPER

IAQITGPPDR

IAQITGPPDR

IAQITGPPDR

CQHAAEIITDLLR

CQHAAEIITDLLR

CQHAAEIITDLL

CQHAAEITTDLLR

CQHAAEIITDLLR

CQHAAEITTDLLR

VPDGMVGFIIGR

VPDGMVGFIIGR

VPDGMVGFIIGR

$\begin{array}{lllllllllllll}\text { LRC59_HUMAI } & \text { Q96AG4 } & \text { LRRC59 } & \text { Leucine-rich repe: } 34.93 & 1.00 & 9 & 34.2 & -0.0408 & 0.1769 & 0.0224 & 2.7536 & 18 & \text { NPNPNADPVNAMK } \\ \text { DNPLDLAK }\end{array}$

DNPLDPVLAK

DNPLDPVLAK

LDGNELDLSLSDL

LQQLPADFGR

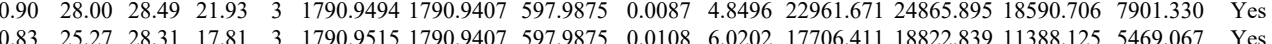

$\begin{array}{llllllllllllllll}0.83 & 48.34 & 24.31 & 41.29 & 2 & 1244.7612 & 1244.7584 & 623.3865 & 0.0028 & 22458 & 9538.366 & 9548.917 & 408.128 & 278.821 & \text { Yes }\end{array}$

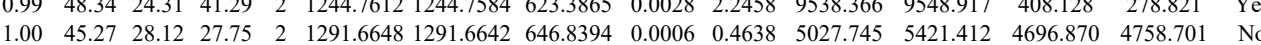
$\begin{array}{lllllllllllllll}1.00 & 64.10 & 27.51 & 38.04 & 2 & 1495.8238 & 1495.8116 & 748.9131 & 0.0122 & 8.1451 & 1347.957 & 1306.002 & 589.089 & 13.785 & \text { Yes }\end{array}$ $\begin{array}{lllllllllllllll}1.00 & 64.04 & 27.53 & 37.99 & 2 & 1495.8232 & 1495.8116 & 748.9131 & 0.0116 & 7.7445 & 5133.379 & 4483.557 & 1168.906 & 405.723 & \text { Yes }\end{array}$ $\begin{array}{llllllllllllllll}1.00 & 61.75 & 27.54 & 44.28 & 2 & 1495.8234 & 1495.8116 & 748.9131 & 0.0118 & 7.8780 & 3974.421 & 4835.060 & 1016.891 & 49.123 & \text { Yes }\end{array}$ $\begin{array}{lllllllllllllll}0.99 & 41.24 & 27.13 & 27.23 & 2 & 1210.6898 & 1210.6792 & 606.3469 & 0.0106 & 8.7408 & 10413.398 & 10084.087 & 2100.015 & 690.217 & \text { Yes }\end{array}$

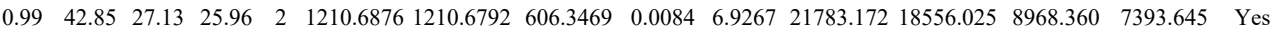
$\begin{array}{llllllllllllllll}0.99 & 44.91 & 27.12 & 26.08 & 2 & 1210.6878 & 1210.6792 & 606.3469 & 0.0086 & 7.0916 & 25510.917 & 23198.563 & 6656.972 & 5264.547 & \text { Yes }\end{array}$ $\begin{array}{lllllllllllllll}1.00 & 81.35 & 28.01 & 32.93 & 3 & 1671.8590 & 1671.8558 & 558.2925 & 0.0032 & 1.9106 & 1462.851 & 1461.541 & 415.421 & 22.712 & \text { Yes }\end{array}$ $\begin{array}{lllllllllllllll}1.00 & 73.07 & 28.01 & 25.18 & 2 & 1671.8588 & 1671.8558 & 836.9352 & 0.0030 & 1.7923 & 440.967 & 271.144 & 36.407 & 44.362 & \text { No }\end{array}$ $\begin{array}{lllllllllllllll}1.00 & 71.77 & 28.01 & 23.25 & 2 & 1671.8590 & 1671.8558 & 836.9352 & 0.0032 & 1.9117 & 413.359 & 465.056 & 54.622 & 64.024 & \text { Yes }\end{array}$ $\begin{array}{lllllllllllllll}1.00 & 78.82 & 27.89 & 29.47 & 3 & 1671.8599 & 1671.8558 & 558.2925 & 0.0041 & 2.4479 & 791.576 & 973.329 & 249.915 & 55.033 & \text { Yes }\end{array}$

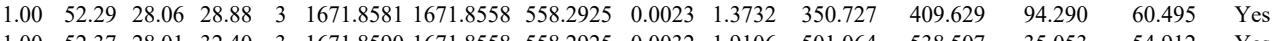
$\begin{array}{lllllllllllllll}1.00 & 52.37 & 28.01 & 32.40 & 3 & 1671.8590 & 1671.8558 & 558.2925 & 0.0032 & 1.9106 & 501.064 & 538.507 & 35.053 & 54.912 & \text { Yes } \\ 1.00 & 56.24 & 28.29 & 26.60 & 2 & 1403.7750 & 1403.7717 & 702.893 & 0.003 & 2.3474 & 2020.341 & 19.721 & 784.019 & 647.098 & \text { Yes }\end{array}$ $\begin{array}{lllllllllllllll}1.00 & 56.24 & 28.29 & 26.60 & 2 & 1403.7750 & 1403.7717 & 702.8931 & 0.0033 & 2.3474 & 2020.341 & 1915.721 & 784.019 & 647.098 & \text { Yes } \\ 1.00 & 54.24 & 27.68 & 26.06 & 2 & 1403.7720 & 1403.7717 & 702.8931 & 0.0003 & 0.2134 & 4431.680 & 4760.572 & 1526.793 & 11.432 & \text { Yes }\end{array}$ $\begin{array}{lllllllllllllll}1.00 & 54.24 & 27.68 & 26.06 & 2 & 1403.7720 & 1403.7717 & 702.8931 & 0.0003 & 0.2134 & 4431.680 & 4760.572 & 1526.793 & 1172.432 & \text { Yes } \\ 1.00 & 54.84 & 28.27 & 29.06 & 2 & 1403.7732 & 1403.7717 & 702.8931 & 0.0015 & 1.0670 & 1971.908 & 2396354 & 1101.233 & 734.341 & \text { Yes }\end{array}$

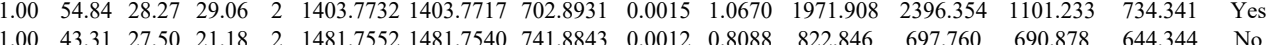

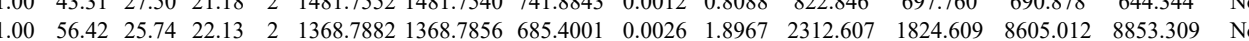

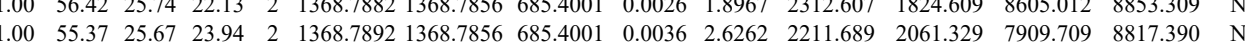
$\begin{array}{lllllllllllllll}1.00 & 59.05 & 25.47 & 25.40 & 2 & 1368.7902 & 1368.7856 & 685.4001 & 0.0046 & 3.3557 & 3693.481 & 3367.637 & 11213.545 & 8443.303 & \text { Y }\end{array}$

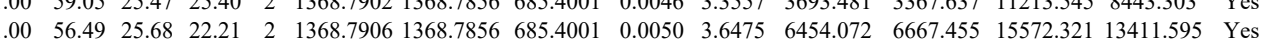

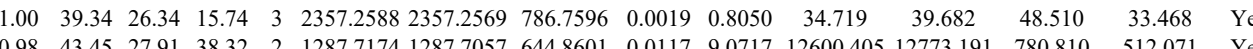


$\begin{array}{llllllllllllllll}\text { KPPPPSAPVIK } & 1.00 & 41.51 & 14.15 & 19.30 & 3 & 1561.9936 & 1561.9921 & 521.6713 & 0.0015 & 0.9585 & 2960.374 & 6714.470 & 13055.437 & 8715.672 & \text { Yes }\end{array}$ $\begin{array}{lllllllllllllllll}\text { KPPPPSAPVIK } & 1.00 & 46.80 & 14.15 & 20.83 & 3 & 1561.9936 & 1561.9921 & 521.6713 & 0.0015 & 0.9585 & 3382.240 & 7730.425 & 13940.707 & 13975.105 & \text { Yes }\end{array}$ KPPPPSAPVIK KPPPPSAPVIK $\begin{array}{llllllllllllllllll}.00 & 46.63 & 14.15 & 23.99 & 3 & 1561.9930 & 1561.9921 & 521.6713 & 0.0009 & 0.5751 & 2257.661 & 6527.026 & 8760.942 & 8113.297 & \text { Yes }\end{array}$

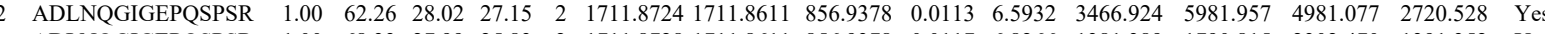

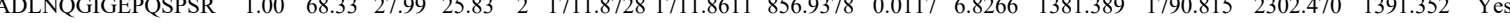
$\begin{array}{lllllllllllllllll}\text { ADLNQGIGEPQSPSR } & 1.00 & 62.28 & 28.08 & 25.25 & 2 & 1711.8716 & 1711.8611 & 856.9378 & 0.0105 & 6.1264 & 3530.296 & 6588.221 & 5764.915 & 3226.384 & \text { Yes }\end{array}$ $\begin{array}{llllllllllllllll}\text { ADLNQGIGEPQSPSR } & 1.00 & 67.33 & 28.08 & 24.91 & 2 & 1711.8716 & 1711.8611 & 856.9378 & 0.0105 & 6.1264 & 3944.355 & 7202.384 & 5769.816 & 4680.141 & \text { Yes }\end{array}$ $\begin{array}{llllllllllllllll}\text { LGAPQTHLGLK } & 0.99 & 33.81 & 21.99 & 16.45 & 3 & 1421.8723 & 1421.8598 & 474.9605 & 0.0125 & 8.7726 & 22071.183 & 40971.611 & 6832.203 & 647.715 & \text { Yes }\end{array}$ $\begin{array}{llllllllllllllll}\text { LGAPQTHLGLK } & 1.00 & 36.80 & 21.37 & 20.60 & 3 & 1421.8705 & 1421.8598 & 474.9605 & 0.0107 & 7.5093 & 18633.842 & 31318.616 & 4512.797 & 875.995 & \text { Yes }\end{array}$

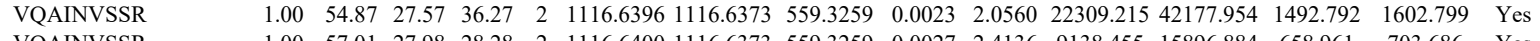

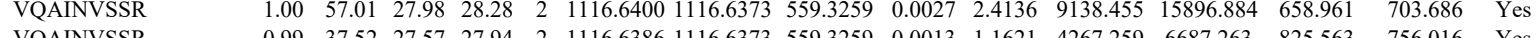

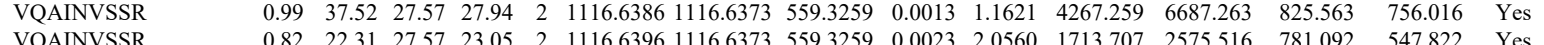

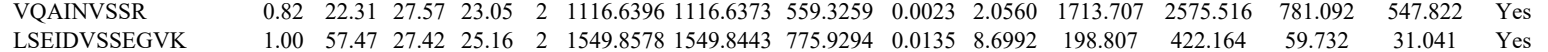

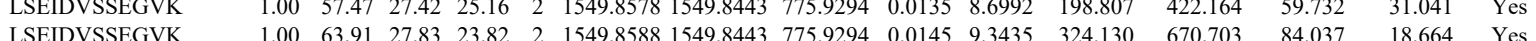
$\begin{array}{llllllllllllllll} & & \end{array}$

$\begin{array}{lllllllllllll}\text { P5CR2 HUMAI Q96C36 } & \text { PYCR2 } & \text { Pyrroline-5-carbor } 33.64 & 1.00 & 5 & 19.1 & -0.2089 & 0.3105 & -0.7239 & 20057 & 8 & \text { LME }\end{array}$

MGVNLTR

$\begin{array}{lllllllllllllll}0.87 & 29.57 & 27.51 & 22.65 & 2 & 1289.7532 & 1289.7409 & 645.8777 & 0.0123 & 9.5218 & 7358.031 & 6058.537 & 2151.909 & 2256.204 & \text { Yes } \\ 0.77 & 24.07 & 28.76 & 33.25 & 2 & 933.5214 & 933.5188 & 467.7667 & 0.0026 & 2.7792 & 20432.298 & 19676.037 & 5715.499 & 3400.188 & \end{array}$ $\begin{array}{llllllllllllllll}0.91 & 28.93 & 28.83 & 34.12 & 2 & 933.5218 & 933.5188 & 467.7667 & 0.0030 & 32067 & 26682.553 & 25734.912 & 6411.439 & 2752.182 & \text { Yes }\end{array}$

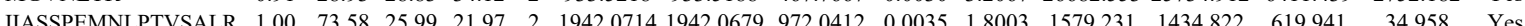
$\begin{array}{llllllllllllllllll}\text { IIASSPEMNLPTVSALR } & 1.00 & 92.56 & 26.18 & 29.40 & 2 & 1942.0698 & 1942.0679 & 972.0412 & 0.0019 & 0.9773 & 875.994 & 943.938 & 268.981 & 4.781 & \text { Yes }\end{array}$

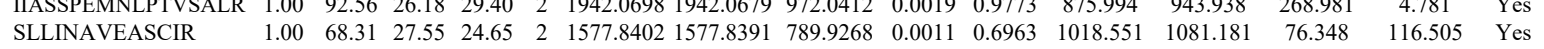

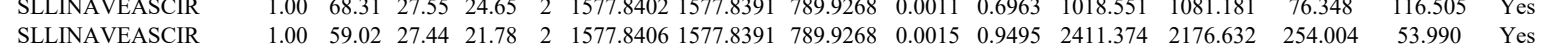

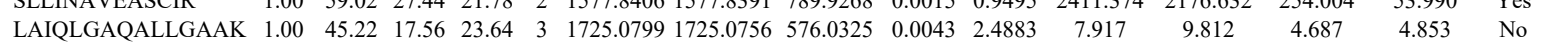

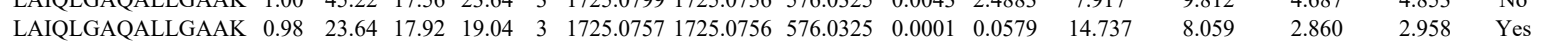
$\begin{array}{llllllllllllllll}\text { LAIQLGAQALLGAAK } & 1.00 & 42.47 & 17.71 & 18.36 & 3 & 1725.0763 & 1725.0756 & 576.0325 & 0.0007 & 0.4051 & 7.063 & 19.522 & 4.900 & 1.494 & \text { No }\end{array}$ $\begin{array}{llllllllllllllllll}3 & \text { LGALLDSFITISEAAK } & 1.00 & 36.14 & 22.67 & 28.42 & 3 & 1936.1164 & 1936.1124 & 646.3781 & 0.0040 & 2.0628 & 45.015 & 35.198 & 14.254 & 11.406 & \text { Yes }\end{array}$ $\begin{array}{llllllllllllllll}\text { LFFTSVPGGR } & 1.00 & 39.60 & 27.33 & 19.99 & 2 & 1223.6796 & 1223.6785 & 612.8465 & 0.0011 & 0.8975 & 3150.910 & 1971.099 & 127.137 & 228.946 & \text { Yes }\end{array}$ $\begin{array}{lllllllllllllllll}\text { LFFTSVPGGR } & 1.00 & 46.56 & 27.14 & 20.55 & 2 & 1223.6806 & 1223.6785 & 612.8465 & 0.0021 & 1.7133 & 4477.871 & 2770.495 & 88.165 & 160.158 & \text { Yes }\end{array}$ $\begin{array}{llllllllllllllll}\text { IPTPLNTSGVQVICMK } & 1.00 & 45.03 & 27.28 & 19.95 & 3 & 2034.0952 & 2034.0919 & 679.0379 & 0.0033 & 1.6199 & 578.537 & 763.242 & 859.235 & 439.994 & \text { Yes }\end{array}$ $\begin{array}{llllllllllllllll}\text { WARPPISMNFEVPFAPSGLK } & 0.94 & 40.16 & 25.50 & 40.52 & 3 & 2531.3599 & 2531.3602 & 844.7940 & -0.0003 & -0.1184 & 497.120 & 458.290 & 332.342 & 76.339 & \text { Yes }\end{array}$ $\begin{array}{llllllllllllllll}\text { WARPPSMNFEVPFAPSGLK } & 0.99 & 39.45 & 25.38 & 36.52 & 3 & 2531.3620 & 2531.3602 & 844.7940 & 0.0018 & 0.7102 & 1015.530 & 998.394 & 899.425 & 259.263 & \text { Yes }\end{array}$ $\begin{array}{llllllllllllllll}\text { GGPTVDPEELFR } & 1.00 & 50.83 & 27.57 & 17.24 & 2 & 1459.7452 & 1459.7429 & 730.8787 & 0.0023 & 1.5734 & 545.714 & 784.458 & 251.498 & 209.673 & \text { Yes }\end{array}$ $\begin{array}{llllllllllllllll}\text { GGPTVDPEELFR } & 1.00 & 47.89 & 27.51 & 17.39 & 2 & 1459.7458 & 1459.7429 & 730.8787 & 0.0029 & 1.9839 & 754.082 & 745.862 & 250.890 & 314.535 & \text { Yes }\end{array}$

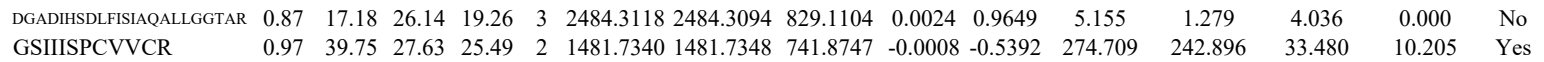

SSFIIYDIMNELMGK SPALQVLR VAVLQALASTVNR VAVLQALASTVNR VAVLQALASTVNR VAVLQALASTVNR VATLALASTRR LAVLANATMR $\begin{array}{llllllllllll}0.97 & 31.09 & 27.68 & 24.13 & 2 & 1481.7356 & 1481.7348 & 741.8747 & 0.0008 & 0.5392 & 254.557 & 235.450\end{array}$ $\begin{array}{llllllllllll}1.00 & 34.73 & 27.81 & 19.02 & 3 & 2048.0620 & 2048.0566 & 683.6928 & 0.0054 & 2.6328 & 113.054 & 116.580\end{array}$ $\begin{array}{llllllllllll}0.76 & 25.66 & 24.12 & 20.44 & 2 & 1026.6364 & 1026.6308 & 514.3227 & 0.0056 & 5.4440 & 605.137 & 545.514 \\ 1.00 & 80.87 & 25.11 & 35.28 & 2 & 1484.8810 & 1484.8797 & 743.4471 & 0.0013 & 0.8743 & 480.427 & 467.463\end{array}$ $\begin{array}{lllllllllllll}1.00 & 80.87 & 25.11 & 35.28 & 2 & 1484.8810 & 1484.8797 & 743.4471 & 0.0013 & 0.8743 & 480.427 & 467.463 \\ 1.00 & 77.65 & 25.11 & 35.69 & 2 & 1484.8812 & 1484.8797 & 743.4471 & 0.0015 & 1.0088 & 372.705 & 271.862\end{array}$

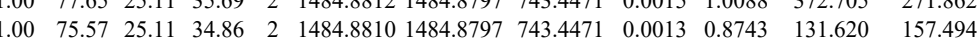
$\begin{array}{lllllllllllll}1.00 & 78.97 & 25.11 & 39.53 & 2 & 1484.8810 & 1484.8797 & 743.4471 & 0.0013 & 0.8743 & 108.059 & 92.909\end{array}$

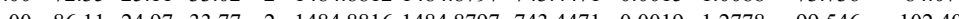

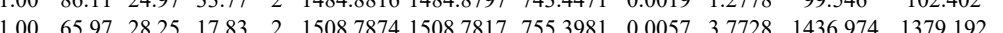


LIQNLDANHDGR LIQNLDANHDGR AVIVLVENFYK AVIVLVENFYK AVIVLVENFYK AVIVLVENFYK $\begin{array}{llllllllllll}\text { AVIVLVENFYK } & 1.00 & 58.31 & 22.53 & 30.91 & 3 & 1581.9403 & 1581.9374 & 528.3197 & 0.0029 & 1.8297 & 191.351 \\ \text { ISFDEYWTLIGGITGPIAK } & 1.00 & 85.22 & 25.55 & 19.03 & 2 & 2368.2934 & 2368.2922 & 1185.1534 & 0.0012 & 0.5063 & 31.556\end{array}$ $\begin{array}{lllllllllllll} & \end{array}$ $\begin{array}{lllllllllll} & \end{array}$ $\begin{array}{lllllllll} & 0\end{array}$ $\begin{array}{llllllllll} & 0\end{array}$ $\begin{array}{lllllllllllllll}1.00 & 60.56 & 28.36 & 21.51 & 3 & 1508.7889 & 1508.7817 & 503.9345 & 0.0072 & 4.7625 & 6969.537 & 9415.424 & 1108.552 & 1100.290 & \text { Yes }\end{array}$ $\begin{array}{ccccccccccccccc}1.00 & 52.04 & 28.31 & 18.98 & 3 & 1508.7892 & 1508.7817 & 503.9345 & 0.0075 & 4.9609 & 10119.673 & 11341.839 & 1237.257 & 1621.011 & \text { Yes } \\ 1.00 & 57.46 & 22.76 & 21.84 & 2 & 1581.9392 & 1581.9374 & 791.9760 & 0.0018 & 1.1364 & 564.456 & 599.743 & 71.791 & 96.922 & \text { Yes }\end{array}$

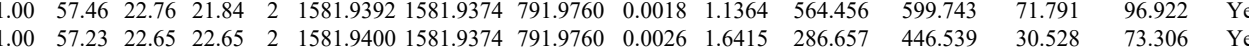
$\begin{array}{lllllllllllllll}1.00 & 57.23 & 22.65 & 22.65 & 2 & 1581.9400 & 1581.9374 & 791.9760 & 0.0026 & 1.6415 & 286.657 & 446.539 & 30.528 & 73.306 & \text { Yes } \\ 1.00 & 55.57 & 22.53 & 19.11 & 3 & 1581.9403 & 1581.9374 & 528.3197 & 0.0029 & 1.8297 & 222.756 & 316.544 & 25.436 & 34.116 & \text { Yes }\end{array}$

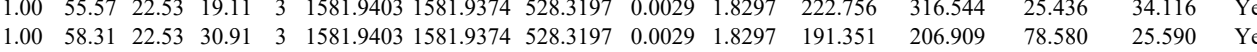
$39.266 \quad 2.600$ $0.000 \quad 17.814$ $77.625 \quad 43.391$ $\begin{array}{llllllllllllllll}\text { AFGFSHLEALLDDSK } & 1.00 & 52.95 & 28.13 & 32.01 & 3 & 1937.0164 & 1937.0138 & 646.6785 & 0.0026 & 1.3402 & 3231.377 & 3892.320 & 23.829\end{array}$ $\begin{array}{lllllllllllllll} & 132.829\end{array}$ $\begin{array}{llllllllllllll}\text { AFGFSHLEALLDDSK } & 1.00 & 45.75 & 27.74 & 23.49 & 3 & 1937.0185 & 1937.0138 & 646.6785 & 0.0047 & 2.4226 & 180.664 & 193.475 & 23.458\end{array}$ $\begin{array}{llllllllllllll}\text { LLTSGYLQR } & 0.86 & 34.44 & 26.18 & 39.50 & 2 & 1193.7004 & 1193.6890 & 597.8518 & 0.0114 & 9.5340 & 24662.309 & 27684.791 & 1093.442\end{array}$ $\begin{array}{llllllllllllll} & \\ \text { LLTSGYLQR } & 1.00 & 45.21 & 26.44 & 32.02 & 2 & 1193.7006 & 1193.6890 & 597.8518 & 0.0116 & 9.7013 & 15293.995 & 16960.179 & 983.917 \\ & 1.00 & 43.74 & 26.21 & 31.17 & 2 & 1193.6988 & 1193.6890 & 597.8518 & 0.0098 & 8.1959 & 14673317 & 16246.610 & 370277\end{array}$ LLTSGYLQR

$\begin{array}{llllllllllllll}1.00 & 43.74 & 26.21 & 31.17 & 2 & 1193.6988 & 1193.6890 & 597.8518 & 0.0098 & 8.1959 & 14673.317 & 16246.610 & 370.277 \\ 1.00 & 43.95 & 6.37 & 29.78 & 2 & 1193.696 & 1193.6890 & 597.8518 & 0.0106 & 8.8650 & 16162.653 & 18071.131 & 300.244\end{array}$

$\begin{array}{llllllllllllll}\text { ELNELVSAIEEHFFQPQK } & 1.00 & 23.94 & 26.79 & 15.62 & 4 & 2445.2829 & 2445.2783 & 612.3269 & 0.0046 & 1.8781 & 104.548 & 115.258 & 97.985\end{array}$ $\begin{array}{lllllllllllllll}\text { ELNELVSAIEEHFFQPQK } & 0.91 & 11.87 & 26.73 & 16.26 & 4 & 2445.2837 & 2445.2783 & 612.3269 & 0.0054 & 2.2047 & 112.055 & 129.755 & 95.018\end{array}$ $\begin{array}{llllllllllllll}\text { ELNELVSAIEEHFFQPQK } & 1.00 & 49.21 & 26.70 & 18.06 & 3 & 2445.2842 & 2445.2783 & 816.1000 & 0.0059 & 2.4098 & 13.210 & 37.532 & 52.631\end{array}$

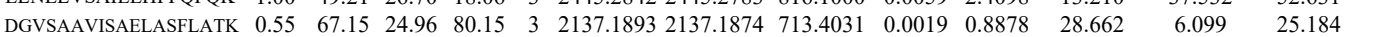

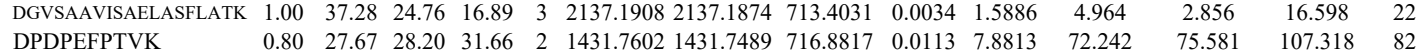

GPFLVALGK

GPFLVALGK

GPFLVALGK $\begin{array}{lllllllllllllll}\text { GPFLVALGK } & 1.00 & 36.71 & 20.41 & 18.64 & 2 & 1188.7480 & 1188.7474 & 595.3810 & 0.0006 & 0.5039 & 4264.677 & 5352.241 & 5047.2 \\ \text { SPSWQRPNQGVPSTGR } & 0.97 & 28.28 & 27.98 & 25.03 & 3 & 1896.9673 & 1896.9677 & 633.3298 & -0.0004 & -0.2105 & 241.406 & 461.573 & 34688\end{array}$ $107.318 \quad 82.762$

$\begin{array}{lllllllllllllll} & 1.00 & 35.39 & 20.41 & 19.16 & 2 & 1188.7478 & 1188.7474 & 595.3810 & 0.0004 & 0.3359 & 4312.107 & 6117.934 & 6383.020 & 6757.159\end{array}$ $\begin{array}{lllllllllllllll} & \end{array}$ $\begin{array}{llllllllllll}\text { SPSWQRPNQGVPSTGR } & 0.97 & 34.12 & 27.94 & 29.23 & 2 & 1896.9680 & 1896.9677 & 949.4911 & 0.0003 & 0.1580 & 10.848\end{array}$

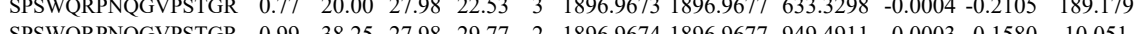
$\begin{array}{lllllllllllll}\text { SPSWQRPNQGVPSTGR } & 0.99 & 38.25 & 27.98 & 29.77 & 2 & 1896.9674 & 1896.9677 & 949.4911 & -0.0003 & -0.1580 & 10.051\end{array}$

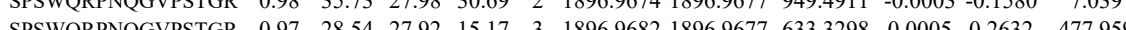

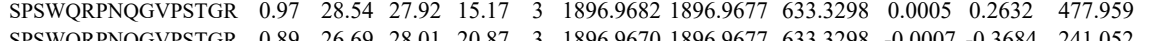
$\begin{array}{lllllllllll} & \text { SPSWRPVG }\end{array}$

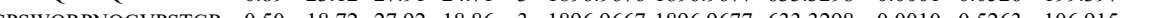

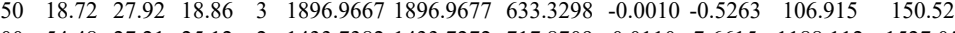
$\begin{array}{lllllllllllll}1.00 & 45.20 & 1.19 & 18.97 & 3 & 1638.9997 & 1638.9986 & 547.3401 & 0.0011 & 0.6699 & 3306.555 & 5161.058 & 0\end{array}$ MLLLEILHEIK MLLLEILHEIK

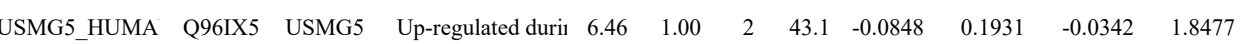

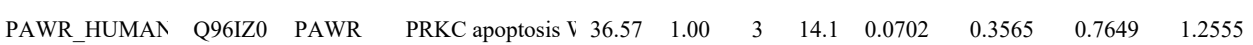

$\begin{array}{lllllllllll}\text { THOC3 HUMAl } & \text { Q96J01 } & \text { THOC3 } & \text { THO complex sub } 38.77 & 1.00 & 2 & 5.7 & -0.0553 & 0.1964 & -0.4301 & 2.5922\end{array}$ MLLLEILHEIK MLLLEILHEIK MLLLEILHEIK MLLLEILHEIK VLPFFERPDFQLFTG QEIVSLFNAFGR YSEEANNLIEECEQA

LLPAITILGCR

LLPAITILGCR

LLPAITILGCR

LLPAITILGCR

LLPAITILGCR

LLPAITILGCR

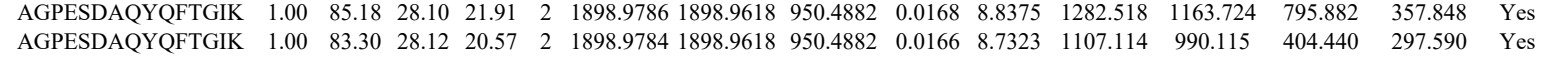
AGPESDAQYQFTGK
YFNSYTLTGR $\begin{array}{lllllllllllllll}1.00 & 54.16 & 19.19 & 20.06 & 3 & 1639.0000 & 1638.9986 & 547.3401 & 0.0014 & 0.8526 & 3275.171 & 5422.279 & 131.510 & 56.177 & \text { Yes }\end{array}$ $\begin{array}{llllllllllllllll}1.00 & 48.50 & 19.19 & 19.14 & 3 & 1639.0006 & 1638.9986 & 547.3401 & 0.0020 & 1.2180 & 2984.038 & 5113.151 & 0.000 & 44.345 & \text { No }\end{array}$ $\begin{array}{lllllllllllllll}1.00 & 44.16 & 19.73 & 19.55 & 3 & 1638.9967 & 1638.9986 & 547.3401 & -0.0019 & -1.1571 & 744.737 & 1160.802 & 33.866 & 23.980 & \text { Yes }\end{array}$ $\begin{array}{lllllllllllllllll}1.00 & 50.42 & 19.44 & 19.16 & 3 & 1638.9982 & 1638.9986 & 547.3401 & -0.0004 & -0.2436 & 663.049 & 899.518 & 23.890 & 30.572 & \text { Yes }\end{array}$

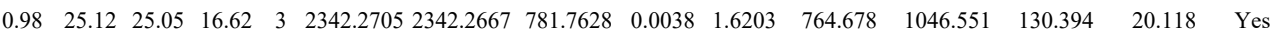

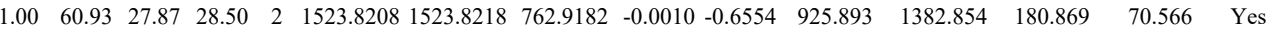

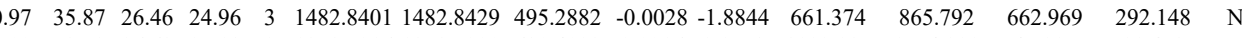
$\begin{array}{lllllllllllllll}1.00 & 53.72 & 26.62 & 25.18 & 2 & 1358.7916 & 1358.7900 & 680.4023 & 0.0016 & 1.1758 & 1192.235 & 1574.229 & 45.297 & 11.452 & \text { Yes }\end{array}$ $\begin{array}{lllllllllllllll}1.00 & 50.27 & 26.62 & 27.01 & 2 & 1358.7916 & 1358.7900 & 680.4023 & 0.0016 & 1.1758 & 707.004 & 889.453 & 12.466 & 8.086 & \text { Yes }\end{array}$

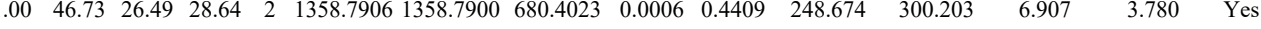
$\begin{array}{lllllllllllllll}1.00 & 63.78 & 26.79 & 28.05 & 2 & 1358.7912 & 1358.7900 & 680.4023 & 0.0012 & 0.8818 & 408.742 & 518.747 & 0.919 & 4.097 & \text { No }\end{array}$ $\begin{array}{llllllllllllllll}0.99 & 37.31 & 26.72 & 27.07 & 2 & 1358.7914 & 1358.7900 & 680.4023 & 0.0014 & 1.0288 & 190.461 & 216.613 & 1.793 & 9.664 & \text { Yes }\end{array}$

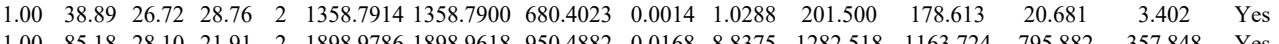
DEEEPDGVPEK DLDDIEDENEQLK DLDDEDENEQLK DLDDIEDENEQLK

YVLGMQELFR YVLGMQELFR

$\begin{array}{llllllllllll}1.00 & 83.30 & 28.12 & 20.57 & 2 & 1898.9784 & 1898.9618 & 950.4882 & 0.0166 & 8.7323 & 1107.114 & 960.115\end{array}$ $\begin{array}{lllllllllll} & \end{array}$

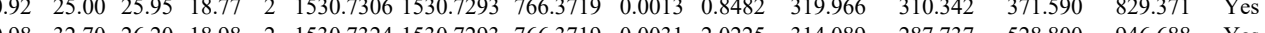

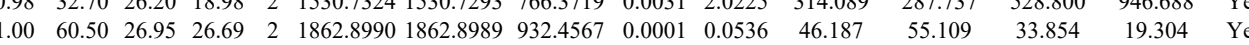

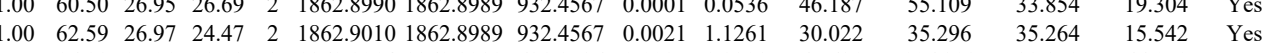

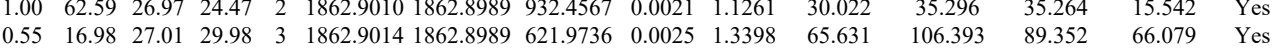

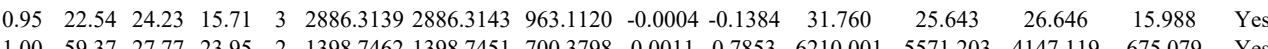
$\begin{array}{llllllllllllllll}1.00 & 61.62 & 27.92 & 24.07 & 2 & 1388.7474 & 1398.7451 & 700.3798 & 0.0023 & 1.6420 & 6809.637 & 6945.067 & 4957.631 & 683.748 & Y & \end{array}$

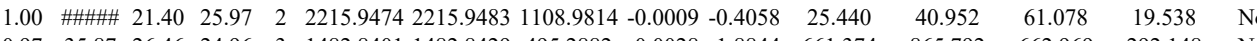
DEEEPDGVPEK 


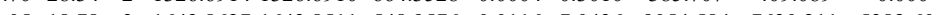
$\begin{array}{lllllllllllllllll}\text { DDGTVIHFNNPK } & 0.98 & 33.92 & 28.05 & 18.78 & 3 & 1643.8627 & 1643.8511 & 548.9576 & 0.0116 & 7.0436 & 9054.584 & 7630.211 & 5382.609 & 2552.296 & \text { Yes } \\ \text { DDGTVIHFNNPK } & 0.92 & 28.92 & 27.96 & 22.40 & 3 & 1643.8645 & 1643.8511 & 548.9576 & 0.0134 & 8.1366 & 9118.528 & 11041.900 & 6298.665 & 1931.284 & \text { Yes } \\ \text { NRPEDDEEDDVPDLVENFDEASK } & 0.65 & 7.58 & 25.69 & 15.42 & 4 & 3362.5953 & 3362.5891 & 841.6546 & 0.0062 & 1.8416 & 7.187 & 14.756 & 6.043 & 3.637 & \text { Yes } \\ \end{array}$ 436 No $\begin{array}{lllllllllllllllll} & 25.69 & 1.42 & 4 & 362.5953 & 3362.5891 & 841.6546 & 0.0062 & 1.8416 & 7.187 & 14.756 & 6.043 & 3.637 & \text { Yes } \\ \end{array}$ $\begin{array}{lllllllllllllllll} & \text { GNIPINANDESK } & 1.00 & 31.64 & 25.73 & 19.45 & 4 & 3362.5965 & 3362.5891 & 841.6546 & 0.0074 & 2.1980 & 8.241 & 10.077 & 3.874 & 8.082 & \text { Yes }\end{array}$ $\begin{array}{llllllllllllllll} & \\ \text { GNIPNEAVAAVIEEEHK } & 1.00 & 73.38 & 24.98 & 17.62 & 3 & 2491.3549 & 2491.3526 & 831.4581 & 0.0023 & 0.9221 & 95.772 & 64.080 & 61.144 & 56.675 & \text { Yes }\end{array}$

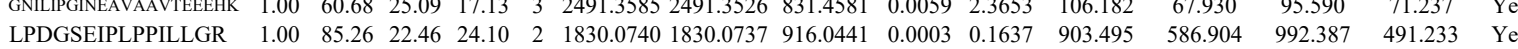
$\begin{array}{llllllllllllllll}\text { LPDGSEIPLPPILLGR } & 1.00 & 92.82 & 22.28 & 25.49 & 2 & 1830.0748 & 1830.0737 & 916.0441 & 0.0011 & 0.6004 & 792.896 & 802.492 & 586.337 & 509.079 & \text { Yes }\end{array}$

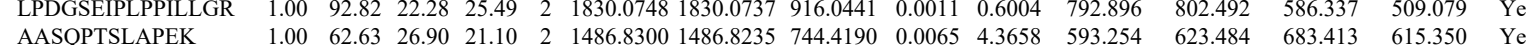
$\begin{array}{lllllllllllllllll}\text { MSPEEWTYLVVLLISIPGFLFK } & 1.00 & 15.22 & 20.68 & 16.46 & 4 & 2982.6805 & 2982.6788 & 746.6770 & 0.0017 & 0.5692 & 4.208 & 4.591 & 4.012 & 9.787 & \text { Yes }\end{array}$

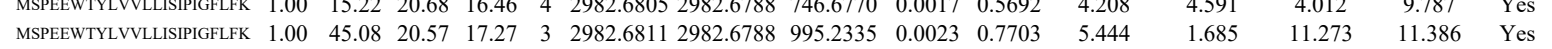

SAVRPASLNLNR SAVRPASLNLNR SAVRPASLNLNR

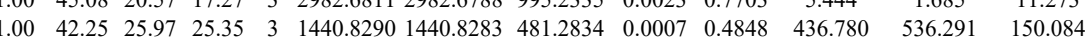
$\begin{array}{lllllllllllllll}0.98 & 38.96 & 25.92 & 36.84 & 2 & 1440.8282 & 1440.8283 & 721.4214 & -0.0001 & -0.0693 & 106.760 & 183.851 & 16.869\end{array}$ $\begin{array}{lllllllllllllll} & \text { SAVRPASLNLNR } & 1.00 & 39.56 & 25.97 & 24.92 & 3 & 1440.8290 & 1440.8283 & 481.2834 & 0.0007 & 0.4848 & 1176.326 & 1747.477 & 342.488\end{array}$

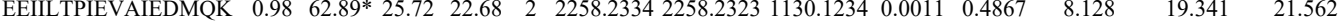

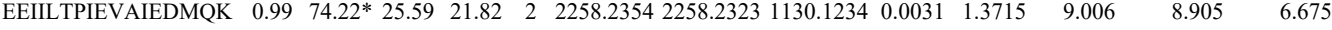

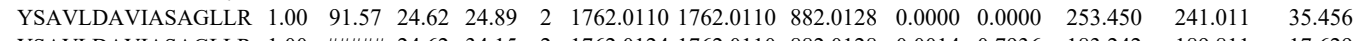

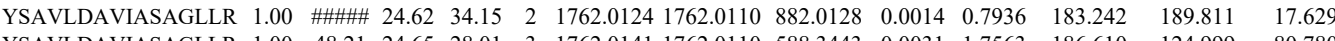
$\begin{array}{llllllllllllll}\text { YSAVLDAVIASAGLLR } & 1.00 & 48.21 & 24.65 & 28.01 & 3 & 1762.0141 & 1762.0110 & 588.3443 & 0.0031 & 1.7563 & 186.610 & 124.999 & 80.780\end{array}$

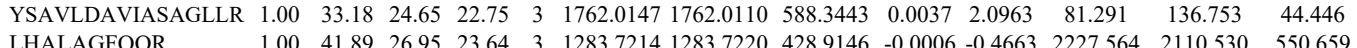
$\begin{array}{llllllllllllll}\text { LHALAGFQQR } & 1.00 & 41.89 & 26.95 & 23.64 & 3 & 1283.7214 & 1283.7220 & 428.9146 & -0.0006 & -0.4663 & 2227.564 & 2110.530 & 550.659\end{array}$ $\begin{array}{llllllllllllll}\text { YSAVLDAVIASAGLLR } & 0.99 & 26.06 & 24.62 & 21.13 & 3 & 1762.0123 & 1762.0110 & 588.3443 & 0.0013 & 0.7365 & 80.459 & 95.468 & 13.926\end{array}$

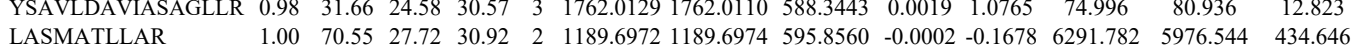

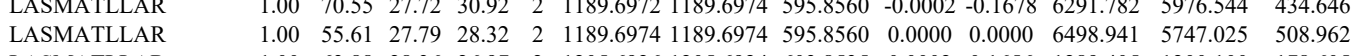
$\begin{array}{llllllllllllllll} & 1.00 & 63.88 & 28.36 & 26.97 & 2 & 1205.6926 & 1205.6924 & 603.8535 & 0.0002 & 0.1656 & 1289.405 & 1200.100 & 178.605\end{array}$

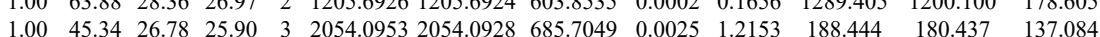

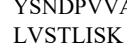
$\begin{array}{lllllllllllll}1.00 & 60.10 & 16.13 & 25.31 & 2 & 1147.7520 & 1147.7420 & 574.8783 & 0.0100 & 8.6974 & 9411.394 & 12877.785 & 246.351\end{array}$ $\begin{array}{lllll}0.7502 & 0.000\end{array}$

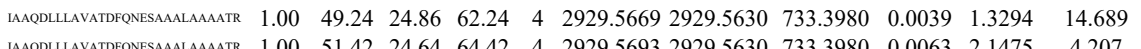

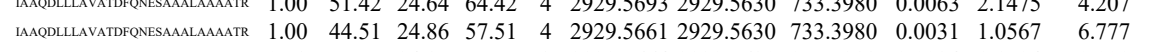

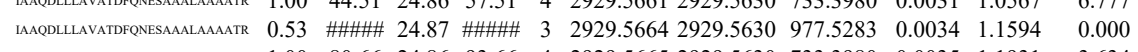

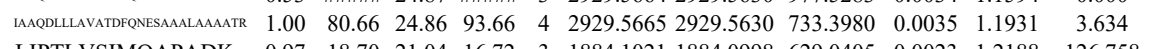
$\begin{array}{llllllllllllll}\text { LIPTLVSIMQAPADK } & 0.97 & 18.70 & 21.04 & 16.72 & 3 & 1884.1021 & 1884.0998 & 629.0405 & 0.0023 & 1.2188 & 126.758 & 1.9\end{array}$ $\begin{array}{lllllllllllll}\text { LIPTLVSIMQAPADK } & 0.91 & 13.80 & 21.04 & 18.12 & 3 & 1884.1021 & 1884.0998 & 629.0405 & 0.0023 & 1.2188 & 84.710\end{array}$ $\begin{array}{lllllllllll}\text { IAAQDLLLVATDFNESAAALAAATR } & 1.00 & \text { \#\#\#\# } 24.93 & 22.75 & 3 & 2929.5649 & 2929.5630 & 977.5283 & 0.0019 & 0.6479 & 0.000 \\ \text { IAAQDLLAVATDFNESAALAAAAT } & 1.00 & \text { \#\#\#\# } 24.84 & 22.78 & 3 & 2929.5658 & 2929.5630 & 977.5283 & 0.0028 & 0.9548 & 1.720\end{array}$ $\begin{array}{lllllllllllll}\text { LIPTLVSIMQAPADK } & 0.55 & 21.27 & 21.04 & 34.27 & 3 & 1884.1021 & 1884.0998 & 629.0405 & 0.0023 & 1.2188 & 123.204 & 14\end{array}$ $\begin{array}{llllllllllll} & \end{array}$

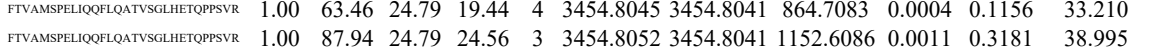

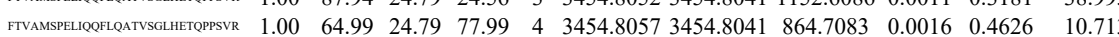

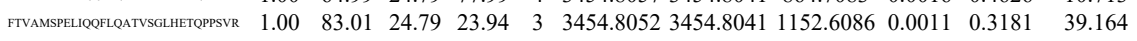
$\begin{array}{llllllllllllll}\text { FTVAMSPELLQOFLLATVSGLHETPPPSVR } & 1.00 & 80.16 & 24.79 & 19.04 & 3 & 3454.8052 & 3454.8041 & 1152.6086 & 0.0011 & 0.3181 & 20.700\end{array}$

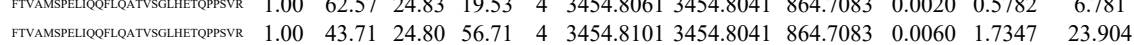

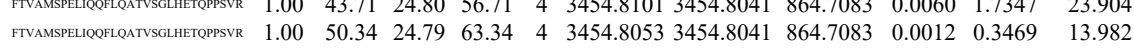
$\begin{array}{llllllllllllll}\text { FTVAMSPELLOFLLATVSGLHETPPBSVR } & 1.00 & 56.95 & 24.83 & 20.60 & 4 & 3454.8061 & 3454.8041 & 864.7083 & 0.0020 & 0.5782 & 21.408\end{array}$ $\begin{array}{llllllllllll}\text { FIVAMSPELLOFHLATVGLLHETPPSVR } & 1.00 & 59.30 & 24.86 & 18.76 & 3 & 3454.8082 & 3454.8041 & 152.6086 & 0.0041 & 1.1857 & 7.807 \\ \text { IPAGLCATAIDILTTVVR } & 1.00 & \text { \#\#\#\# } 26.63 & 30.13 & 2 & 1872.0220 & 1872.0213 & 937.0179 & 0.0007 & 0.3735 & 1.378\end{array}$

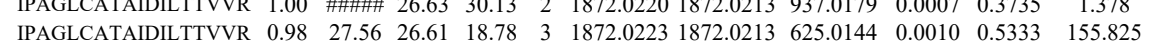

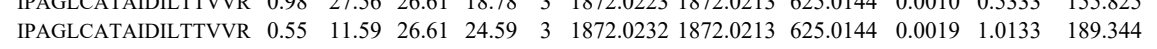
$\begin{array}{lllllllllll}\text { IPAGLCATADLITVVR } & 1.00 & \text { \#\#\#\# } 26.61 & 28.59 & 2 & 1872.0232 & 1872.0213 & 937.0179 & 0.0019 & 1.0139 & 1.374\end{array}$ 

$\begin{array}{lllllllllll} & \end{array}$ $\begin{array}{lllllllllllll} & \text { IPALCATAIDILTVVR } & 1.00 & 88.01 & 25.20 & 25.72 & 2 & 2016.1234 & 2016.1233 & 1009.0689 & 0.0001 & 0.0496 & 4.473\end{array}$

$\begin{array}{llllllllllllll} & 25.15 & 21.50 & 3 & 2016.1240 & 2016.1233 & 673.0484 & 0.0007 & 0.3467 & 6.275\end{array}$

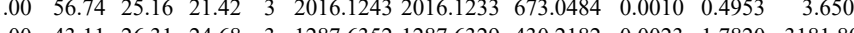

$\begin{array}{lllllllllllll}1.00 & 67.40 & 27.86 & 25.68 & 2 & 1539.8276 & 1539.8168 & 770.9157 & 0.0108 & 7.0046 & 1005.311 & 888.027 & 275.270\end{array}$ NIVSAFGIIPR

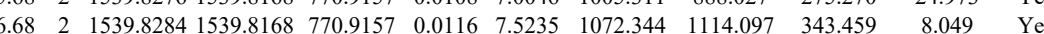

LASVLVSDWMAVIR

$\begin{array}{lllllllllllll}1.00 & 69.57 & 24.76 & 28.17 & 2 & 1329.7900 & 1329.7890 & 665.9018 & 0.0010 & 0.7509 & 1238.489 & 1295.878 & 117.693\end{array}$ $\begin{array}{llllllllllllllll} & \end{array}$ $\begin{array}{lllllllllllllll}\text { LPPVLANLMGSMGAGK } & 0.93 & 19.39 & 25.49 & 17.14 & 3 & 1843.0336 & 1843.0303 & 615.3507 & 0.0033 & 1.7876 & 57.696 & 63.125 & 19.103\end{array}$

$\begin{array}{lllllllllllll}\text { YELPLVIQALTNIEDK } & 1.00 & 23.60 & 37.61 & 2 & 2146.2154 & 2146.2129 & 1074.1137 & 0.0025 & 1.1637 & 116.826 & 139.516 & 32.917\end{array}$ $\begin{array}{llllllllllllll}\text { YELPLVIQALTNIEDK } & 1.00 & 71.74 & 23.60 & 41.25 & 2 & 2146.2154 & 2146.2129 & 1074.1137 & 0.0025 & 1.1637 & 264.826 & 324.003 & 147.619\end{array}$

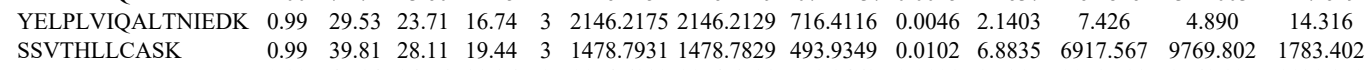

40 AELAELPLR LLDEAIQAVK LLDEAIQAVK IPVDTYNNILTVLK IPVDTYNNILTVLK IPVDTYNNILTVLK NIIALIDR HIALIDR

IPVDTYNNILTVLK

IPVDTYNNILTVLK

NIIIALIDR

NIIIALIDR

NIIIALIDR $\begin{array}{llllllllllllll}0.99 & 39.81 & 28.11 & 19.44 & 3 & 1478.7931 & 1478.7829 & 493.9349 & 0.0102 & 6.8835 & 6917.567 & 9769.802 & 1783.402 & 0\end{array}$ $\begin{array}{lllllllllllllll}0.99 & 45.14 & 24.76 & 38.36 & 2 & 1154.6882 & 1154.6781 & 578.3463 & 0.0101 & 8.7317 & 2978.523 & 3761.197 & 1131.879\end{array}$ $\begin{array}{llllllllllllllll}1.00 & 56.07 & 24.10 & 36.64 & 2 & 1386.8328 & 1386.8326 & 694.4236 & 0.0002 & 0.1440 & 7308.009 & 8774.251 & 122.311 & 300.796\end{array}$ $\begin{array}{lllllllllllllll}1.00 & 58.16 & 24.07 & 32.43 & 2 & 1386.8338 & 1386.8326 & 644.4236 & 0.0012 & 0.8640 & 7803.488 & 8553.722 & 176.905 & 354.656 & Y c s\end{array}$ $\begin{array}{lllllllllllllll}1.00 & 67.50 & 20.97 & 21.95 & 2 & 1890.1072 & 1890.1070 & 946.0608 & 0.0002 & 0.1057 & 2460.974 & 2597.875 & 1896.521 & 1112.576 & \text { Yes }\end{array}$

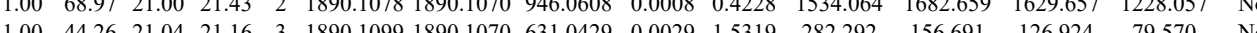

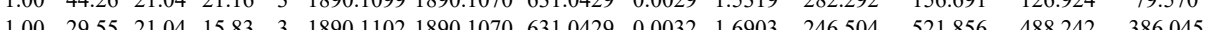
$\begin{array}{llllllllllllll}1.00 & 40.50 & 20.79 & 20.49 & 2 & 1183.742 & 1183.7410 & 592.8778 & 0.0032 & 2.6987 & 3769.699 & 5074.821 & 430.606 & 88.266\end{array}$ $\begin{array}{llllllllll}1.00 & 0\end{array}$

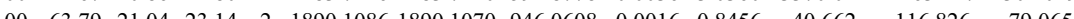
$\begin{array}{lllllllllllllll}1.00 & 41.28 & 21.04 & 21.31 & 3 & 1890.1087 & 1890.1070 & 631.0429 & 0.0017 & 0.8980 & 514.332 & 586084 & 404273 & 300.855 & \text { Y }\end{array}$ $\begin{array}{lllllllllllllll}1.00 & 35.57 & 21.04 & 21.31 & 3 & 1890.1105 & 1890.1070 & 631.0429 & 0.0035 & 1.8488 & 435.452 & 322.650 & 314.765 & 232.889 & \mathrm{~N}\end{array}$

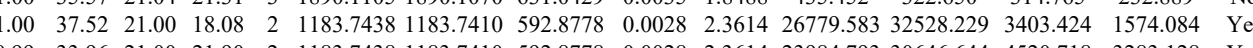
$\begin{array}{llllllllllllllll}0.99 & 33.96 & 21.00 & 21.90 & 2 & 1183.7438 & 1183.7410 & 592.8778 & 0.0028 & 2.3614 & 23984.793 & 30646.644 & 4520.718 & 3283.128 & \text { Yes }\end{array}$

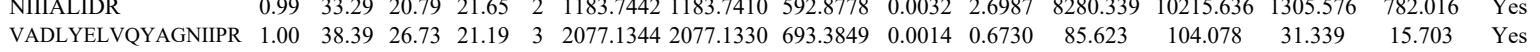
$\begin{array}{llllllllllllllll}\text { VADLYELVQYAGNIIPR } & 1.00 & 39.49 & 26.79 & 16.37 & 3 & 2077.1353 & 2077.1330 & 693.3849 & 0.0023 & 1.1057 & 108.183 & 168.556 & 35.238 & 10.500 & \text { Yes }\end{array}$ $\begin{array}{llllllllllllllll}\text { VADLYELVQYAGNIIPR } & 1.00 & 47.33 & 26.51 & 19.43 & 2 & 2077.1374 & 2077.1330 & 1039.5738 & 0.0044 & 2.1162 & 10.800 & 8.683 & 5.758 & 2.394 & \text { Yes }\end{array}$

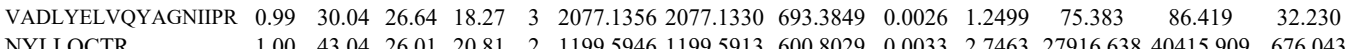
NYLLQCTR $\begin{array}{llllllllllllll}1.00 & 43.04 & 26.01 & 20.81 & 2 & 1199.5946 & 1199.5913 & 600.8029 & 0.0033 & 2.7463 & 27916.638 & 40415.909 & 676.043\end{array}$ $\begin{array}{lllllllllllll}1.00 & 47.17 & 25.87 & 21.56 & 2 & 1199.5964 & 1199.5913 & 600.8029 & 0.0051 & 4.2443 & 29586.215 & 39824.699 & 0.000\end{array}$

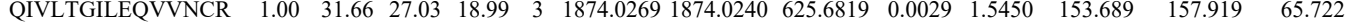
$\begin{array}{llllllllllllll}\text { QIVLTGILEQVVNCR } & 1.00 & 54.69 & 27.07 & 20.56 & 3 & 1874.0275 & 1874.0240 & 625.6819 & 0.0035 & 1.8646 & 189.942 & 206.038 & 36.221\end{array}$ $\begin{array}{llllllllllllll}\text { AQLAAITLIIGTFER } & 0.61 & 85.81 & 22.43 & 98.81 & 2 & 1760.0316 & 1760.0318 & 881.0232 & -0.0002 & -0.1135 & 52.705 & 55.070 & 35.447\end{array}$ $\begin{array}{lllllllllllllllll}\text { AQLAAITLIIGTFER } & 0.77 & 84.21 & 22.28 & 97.21 & 2 & 1760.0334 & 1760.0318 & 881.0232 & 0.0016 & 0.9080 & 46.240 & 68.822 & 20.254\end{array}$ $\begin{array}{llllllllllllll}\text { AQLAAITLIIGTFER } & 0.55 & 17.21 & 22.28 & 30.21 & 3 & 1760.0335 & 1760.0318 & 587.6845 & 0.0017 & 0.9642 & 43.039 & 55.512 & 13.839\end{array}$ $\begin{array}{llllllllllllll}\text { QIVLTGILEQVVNCR } & 0.79 & 16.06 & 27.01 & 14.22 & 3 & 1874.0260 & 1874.0240 & 625.6819 & 0.0020 & 1.0655 & 29.804 & 38.457 & 10.438\end{array}$ $\begin{array}{lllllllllllllll}\text { QIVLTGLEQVVNCR } & 1.00 & 54.73 & 27.07 & 18.75 & 3 & 1874.0272 & 1874.0240 & 625.6819 & 0.0032 & 1.7048 & 136.891 & 115.642 & 37.172\end{array}$ $\begin{array}{llllllllllllll}\text { QIVLTGILEQVVNCR } & 1.00 & 47.98 & 27.12 & 19.93 & 3 & 1874.0278 & 1874.0240 & 625.6819 & 0.0038 & 2.0245 & 96.507 & 148.716 & 40.599\end{array}$

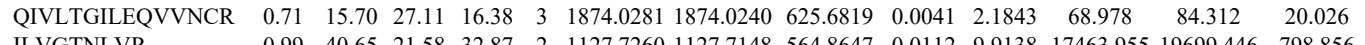
$\begin{array}{llllllllllllll}\text { ILVGTNLVR } & 0.99 & 40.65 & 21.58 & 32.87 & 2 & 1127.7260 & 1127.7148 & 564.8647 & 0.0112 & 9.9138 & 17463.955 & 19699.446 & 798.856 \\ \text { AQLAAITLIIGTFER } & 0.76 & \text { \#\#\#\# } 22.43 & \text { \#\#\#\# } & 2 & 1760.0330 & 1760.0318 & 881.0232 & 0.0012 & 0.6810 & 54.949 & 58.982 & 55.575\end{array}$

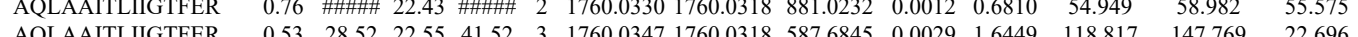

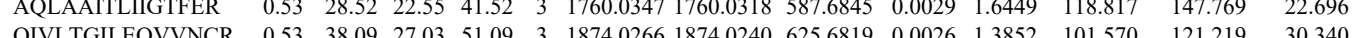

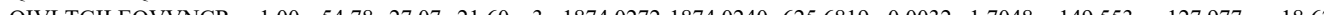
$\begin{array}{llllllllllllll}\text { QIVLTGLEQTILSR } & 1.00 & 54.78 & 27.07 & 21.60 & 3 & 1844.0272 & 1874.0240 & 625.6819 & 0.0032 & 1.7048 & 149.553 & 127.977 & 18.620\end{array}$ 
$\begin{array}{llllllllll}\text { EFGM HUMAN Q96RP9 } & \text { GFM1 Elongation factor } 183.47 & 1.00 & 2 & 4.7 & -0.0997 & 0.4004 & -0.2186 & 1.6122\end{array}$

$\begin{array}{llllllllllll}\text { WRIP1_HUMAI } & \text { Q96S55 } & \text { WRNIP1 } & \text { ATPase WRNIP1 } & 72.13 & 1.00 & 2 & 3.9 & 1.3868 & 1.0372 & 0.2761 & 1.0778\end{array}$

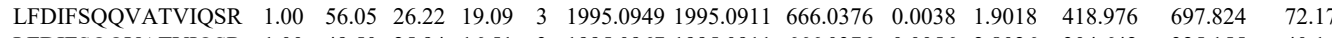
$\begin{array}{llllllllllllll} & \end{array}$ $\begin{array}{llllllllllllll}\text { ILVGTNLVR } & 0.79 & 23.28 & 22.15 & 29.02 & 2 & 1127.7242 & 1127.7148 & 564.8647 & 0.0094 & 8.3205 & 12919.031 & 14443.508 & 445.089\end{array}$ $\begin{array}{lllllllllllllll}0.7 & 23.28 & 22.15 & 29.02 & 2 & 1127.7242 & 1127.7148 & 564.8647 & 0.004 & 8.3205 & 12919.031 & 14413.508 & 445.089\end{array}$ $\begin{array}{llllllllllllll}\text { LFDIFSQQVATVIQSR } & 0.82 & 17.47 & 26.18 & 16.51 & 3 & 1995.0922 & 1995.0911 & 666.0376 & 0.0011 & 0.5505 & 161.105 & 176.590 & 34.170\end{array}$

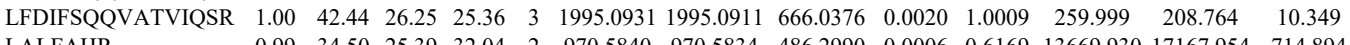
LALFAHR

LALFAHR

LALFAHR

LALFAHR $\begin{array}{llllllllllllll}0.99 & 34.50 & 25.39 & 32.04 & 2 & 970.5840 & 970.5834 & 486.2990 & 0.0006 & 0.6169 & 13669.930 & 17167.954 & 714.894\end{array}$ $\begin{array}{llllllllllllll}0.99 & 34.23 & 25.34 & 29.70 & 2 & 970.5850 & 970.5834 & 486.2990 & 0.0016 & 1.6451 & 15351.701 & 17049.427 & 311.646 \\ 0.99 & 34.68 & 25.33 & 32.15 & 2 & 970.5844 & 970.5834 & 486.2990 & 0.0010 & 1.0282 & 3121.416 & 3900.421 & 138.767\end{array}$

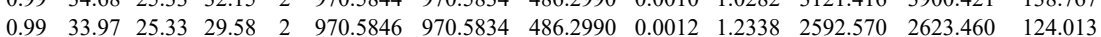
$\begin{array}{llllllllllllll}0.98 & 30.58 & 25.39 & 25.13 & 2 & 970.5840 & 970.5834 & 486.2990 & 0.0006 & 0.6169 & 646.566 & 779.880 & 149.675 & 1\end{array}$ $\begin{array}{lllllllllllllll} & 58.67 & 25.16 & 17.12 & 3 & 2531.2969 & 2531.2958 & 844.7725 & 0.0011 & 0.4340 & 153.918 & 151.692 & 110.515\end{array}$ $\begin{array}{lllllllllllllll}\text { SEDPDQQYLILNTAR } & 1.00 & 77.22 & 27.51 & 26.01 & 2 & 1905.9562 & 1905.9554 & 953.9850 & 0.0008 & 0.4193 & 278.039 & 329.204 & 157.906\end{array}$

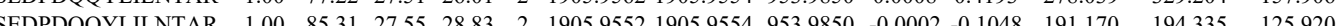
$\begin{array}{lllllllllllll} & \text { Gep }\end{array}$

GVPPLDAVLEYLPNBEVQNYALN GVQPLLDAVLEYLT

LPVEAMVTILMR LPVEAMVTILMR RPAAAAAAGSASPR RPAAAAAAGSASPR RPAAAAAAGSASPR RPAAAAAAGSASPR

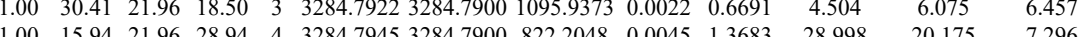

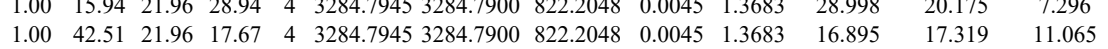
$\begin{array}{lllllllllllll}1.62 & 42.51 & 21.96 & 17.67 & 4 & 3284.7945 & 3284.7900 & 822.2048 & 0.0045 & 1.3683 & 16.898 & 17.319 & 11.065 \\ 1.00 & 23.94 & 26.04 & 24.40 & 2 & 1126.6338 & 1126.6257 & 564.3201 & 0.0081 & 7.1767 & 3960.206 & 3508.519 & 361.073\end{array}$

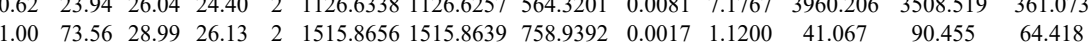

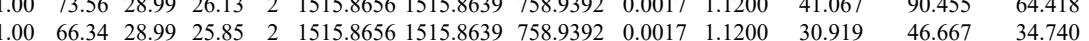

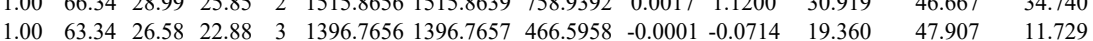

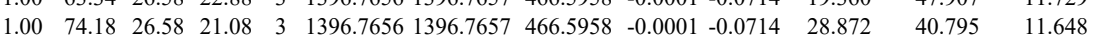
$\begin{array}{lllllllllllll}1.00 & 67.04 & 26.82 & 19.70 & 3 & 1396.7644 & 1396.7657 & 466.5958 & -0.0013 & -0.9287 & 18.782 & 60.266 & 31.757 \\ 1.00 & 4.4 .4 & 26.63 & 22.67 & 2 & 1396.650 & 1396.7657 & 699.3901 & -0.0007 & -0.504 & 2.508 & 20.937 & 7.055\end{array}$ $\begin{array}{lllllllllllll}0.99 & 44.99 & 26.63 & 22.67 & 2 & 1396.7650 & 1396.7657 & 699.3901 & -0.0007 & -0.5004 & 2.508 & 20.937 & 7.055\end{array}$

$\begin{array}{ccccccccccccc}1.00 & 34.45 & 23.87 & 18.85 & 3 & 1866.0730 & 1866.0706 & 623.0308 & 0.0024 & 1.2840 & 115.953 & 133.773 & 91.856 \\ 1.00 & 46.73 & 17.08 & 16.56 & 3 & 1989.2053 & 1989.2028 & 664.0749 & 0.0025 & 1.2549 & 1853.652 & 1735.380 & 626.503\end{array}$ DEDHIALIELLGK

$\begin{array}{lllllllllllll}1.00 & 40.91 & 16.90 & 17.32 & 3 & 1989.2062 & 1989.2028 & 664.0749 & 0.0034 & 1.7066 & 1702.146 & 1768.649 & 423.104 \\ 2\end{array}$

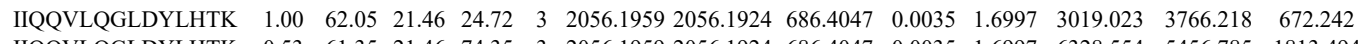
$\begin{array}{llllllllllllll}\text { IIQQVLQGLDYLHTK } & 0.53 & 61.35 & 21.46 & 74.35 & 3 & 2056.1959 & 2056.1924 & 686.4047 & 0.0035 & 1.6997 & 6328.554 & 5456.785 & 1813.494 \\ \text { IIQQVLQGLDYLHTK } & 0.53 & 62.02 & 21.46 & 75.02 & 3 & 2056.1959 & 2056.1924 & 686.4047 & 0.0035 & 1.6997 & 2277.161 & 2389.752 & 520.655\end{array}$ IIQQVLQGLDYLHTK $\begin{array}{llllllllllllll}0.53 & 62.02 & 21.46 & 75.02 & 3 & 2056.1959 & 2056.1924 & 686.4047 & 0.0035 & 1.6997 & 2277.161 & 2389.752 & 520.655 \\ 0.81 & 26.22 & 23.54 & 29.51 & 2 & 913.5898 & 913.5831 & 457.7988 & 0.0067 & 7.3176 & 40460.842 & 35256.321 & 8095.869\end{array}$ VLALQAR SGNYTVLQVVEALGSSLENPERR SGNYTVLQVVEALGSSLENPEPR
FAEFLLPLLIEK FAEFLLPLLIEK FAEFLLPLLIEK FAEFLLPLLIEK FAEFLLPLLIEK $\begin{array}{llllllllllllll}.00 & 34.86 & 19.82 & 24.08 & 3 & 1720.0444 & 1720.0418 & 574.3545 & 0.0026 & 1.5089 & 209.975 & 246.879 & 44.311\end{array}$ $\begin{array}{lllllllllllll}1.00 & 34.92 & 19.78 & 24.83 & 3 & 1720.0453 & 1720.0418 & 574.3545 & 0.0035 & 2.0313 & 113.929 & 149.452 & 9.171\end{array}$ $\begin{array}{lllllllllllll}1.00 & 34.92 & 19.78 & 24.83 & 3 & 1720.0453 & 1720.0418 & 574.3545 & 0.0035 & 2.0313 & 113.929 & 149.452 & 9.171\end{array}$ $\begin{array}{llllllllllllllll} & \end{array}$ $\begin{array}{lllllllllllllll}\text { VEARAALALACLSR } & 1.00 & 88.46 & 27.34 & 23.04 & 3 & 2030.0437 & 2030.0410 & 677.6876 & 0.0027 & 1.3280 & 1149.385 & 1244.543 & 108.638\end{array}$ $\begin{array}{lllllllllllllll}\text { VEAEGLAALHSLTACLSR } & 1.00 & 79.58 & 27.36 & 23.01 & 3 & 2030.0431 & 2030.0410 & 677.6876 & 0.0021 & 1.0329 & 519.061 & 628.072 & 131.473\end{array}$ $\begin{array}{lllllllllllllll}\text { VEAEGLAALHSLTACLSR } & 1.00 & 62.74 & 27.41 & 21.21 & 3 & 2030.0434 & 2030.0410 & 677.6876 & 0.0024 & 1.1805 & 581.798 & 789.514 & 83.578\end{array}$ $\begin{array}{llllllllllllll}\text { LLQAAAGASAR } & 1.00 & 58.36 & 26.61 & 31.27 & 2 & 1171.6858 & 1171.6795 & 586.8470 & 0.0063 & 5.3676 & 15213.942 & 15070.704 & 484.408\end{array}$ $\begin{array}{llllllllllllll}\text { LLQAAAGASAR } & 1.00 & 68.71 & 26.33 & 29.99 & 2 & 1171.6878 & 1171.6795 & 586.8470 & 0.0083 & 7.0716 & 23948.703 & 24539.093 & 563.630\end{array}$ $\begin{array}{llllllllllllll}\text { LLQAAAGASAR } & 1.00 & 67.47 & 26.40 & 29.80 & 2 & 1171.6882 & 1171.6795 & 586.8470 & 0.0087 & 7.4124 & 27904.380 & 28237.643 & 786.349\end{array}$

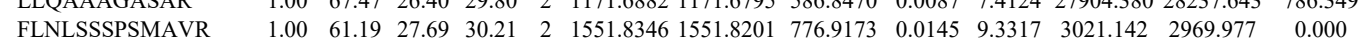
LGLTMQYPEGYLEALAN LNDTIQLLVR $\begin{array}{llllllllllll}1.00 & 61.19 & 27.69 & 30.21 & 2 & 1551.8346 & 1551.8201 & 776.9173 & 0.0145 & 9.3317 & 3021.142 & 2969.977\end{array}$ $\begin{array}{lllllllllllllll}\text { EQMDNAVYTFETLLHOELGK } & 1.00 & 71.40 & 27.28 & 22.60 & 3 & 2653.3318 & 2653.3301 & 885.4506 & 0.0017 & 0.6400 & 34.095 & 53.072 & 301.453\end{array}$ $\begin{array}{lllllllllllllll}\text { EQMDNAVYTFETLLHQELGK } & 1.00 & 78.36 & 27.22 & 27.45 & 3 & 2653.3309 & 2653.3301 & 885.4506 & 0.0008 & 0.3012 & 37.229 & 68.207 & 175.717\end{array}$ $\begin{array}{llllllllllllll}\text { FQELIFEDFAR } & 1.00 & 76.31 & 27.75 & 26.98 & 2 & 1557.7978 & 1557.7949 & 779.9047 & 0.0029 & 1.8592 & 936.215 & 1079.248 & 97.256 \\ \text { FQELIFEDFAR } & 1.00 & 76.33 & 27.76 & 27.08 & 2 & 1557.7980 & 1557.7949 & 779.9047 & 0.0031 & 1.9874 & 800.251 & 1211.253 & 114.419\end{array}$ $\begin{array}{lllllllllllllll} & \end{array}$

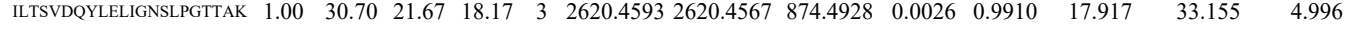

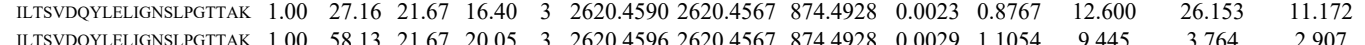
$\begin{array}{lllllllllllllll}\text { ILTSVDQYLELIGNSLPGTTAK } & 1.00 & 58.13 & 21.67 & 20.05 & 3 & 2620.4596 & 2620.4567 & 874.4928 & 0.0029 & 1.1054 & 9.445 & 3.764 & 2.907\end{array}$ VQQVQPAMQAVIR VQQVQPAMQAY WQAVLQDCIR VQQVQPAMQA WQAVLQDCIR

$\begin{array}{llllllllllllll}1.00 & 61.72 & 25.99 & 28.73 & 2 & 1610.9134 & 1610.9048 & 806.4597 & 0.0086 & 5.3319 & 5497.418 & 6380.760 & 4544.492 & 53 \\ 0.99 & 38.94 & 25.99 & 27.99 & 2 & 1610.9144 & 1610.9048 & 806.4597 & 0.0096 & 5.9519 & 2487.486 & 2614.768 & 1489.050 & 31\end{array}$

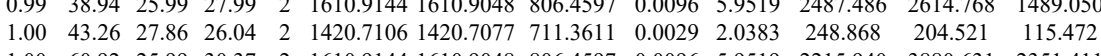

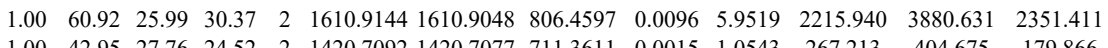

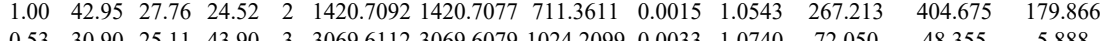
$\begin{array}{lllllllllll} & \end{array}$ $\begin{array}{llllllllllllll}\text { NHVQPYIPSLEALMVPTSQGFTEVR } & 0.53 & 28.98 & 25.11 & 41.98 & 3 & 3069.6112 & 3069.6079 & 1024.2099 & 0.0033 & 1.0740 & 54.078 & 42.636 & 2.938\end{array}$

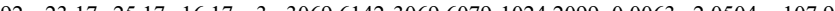

GTTAVLTEK $\begin{array}{lllllllllllll}0.99 & 43.39 & 26.69 & 28.72 & 2 & 1206.7120 & 1206.7063 & 604.3604 & 0.0057 & 4.7157 & 2111.880 & 2415.540 & 2627.406\end{array}$ 
FRPDMEEEEAK FRPDMEEEEAK

FRPDMEEEEAK

FRPDMEEEEAK

ATEGMVVADK

ATEGMVVADK

GLQSGVDIGVK

GLQSGVDIGVK

TWIEGLTGLSIGPDFQK

CASQVGMTAPGTR

CASQVGMTAPGTR

LVLPAPQISDAELQEVYK

ILQEAQNLMALTNVDTPLK

EIDDTYIEDAADVDAR

21 EPEPNFOLLDNP

QDVYDLLK

ITSAAGIISLLDEDEPQLK ITSAAGIISLLDEDEPQLK MEEADALIESLCR

LNAVVNDFWAEISESVDK MITSAAGIISLLDEDEPQL

VMPAQLK

QFAALVASK

QFAALVASK

TPEQCPSVVSLLSESYNPHVR

TPEQCPSVVSLLSESYNPHVR
NNNTDLMILK

AAVESLGFILFR DTSEDIEELVEPVAAHGPK $\begin{array}{ll}\text { FTATASLGVIHK } & \\ \text { NAQAIEDMVGYAQETQHEK } & 1.00 \\ \text { NAQAIEDMVGYAQETQHEK } & 1.00\end{array}$ NAQAIEDMVGYAQETQHEK

NQLDQEVEFLSTSIAQLK 1.00

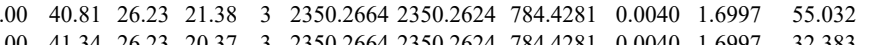
$\begin{array}{llllllllllllll} & \end{array}$ $\begin{array}{lllllllllllll}\text { NQLDQEVEFLSTSIAQLK } & 1.00 & 42.81 & 26.20 & 23.36 & 3 & 2350.2667 & 2350.2624 & 784.4281 & 0.0043 & 1.8272 & 51.488 \\ \text { NQLDQEVEFLSTSIAQLK } & 1.00 & 54.34 & 26.27 & 22.80 & 3 & 2350.2655 & 2350.2624 & 784.4281 & 0.0031 & 1.3173 & 34.617 & \end{array}$

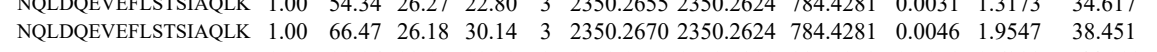
$\begin{array}{lllllllllllll}\text { IQQLTALGAAQATAK } & 1.00 & 89.16 & 22.17 & 23.22 & 2 & 1772.0570 & 1772.0399 & 887.0272 & 0.0171 & 9.6388 & 744.093 & 77\end{array}$ $\begin{array}{llllllllllllll}\text { GAEEMETVIPVDVMR } & 1.00 & 86.52 & 27.18 & 24.62 & 2 & 1818.8976 & 1818.8978 & 910.4562 & -0.0002 & -0.1098 & 348.121 & 520\end{array}$ $\begin{array}{lllllllllllll}\text { GAEEMETVIPVDVMR } & 1.00 & 91.62 & 27.24 & 25.54 & 2 & 1818.8990 & 1818.8978 & 910.4562 & 0.0012 & 0.6590 & 945.646 & \end{array}$

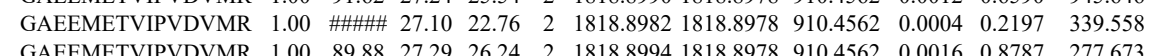
$\begin{array}{llllllllllll}\text { GAEEMETVIPVDVMR } & 1.00 & 89.88 & 27.29 & 26.24 & 2 & 1818.8994 & 1818.8978 & 910.4562 & 0.0016 & 0.8787 & 277.673\end{array}$ $\begin{array}{lllllllllllll}\text { EGPYDVVLLFGGLGGANNLESAAVK } & 1.00 & 85.71 & 26.00 & 23.37 & 2 & 2871.5194 & 2871.5222 & 1436.7684 & -0.0028 & -0.9744 & 2.157\end{array}$

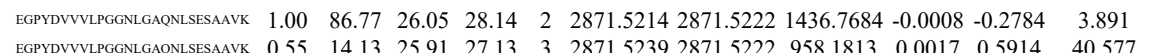

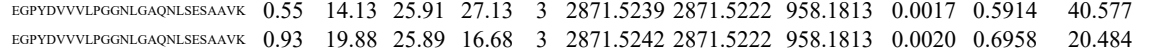

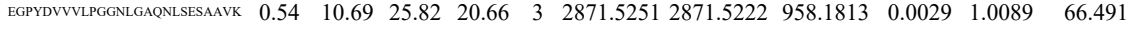

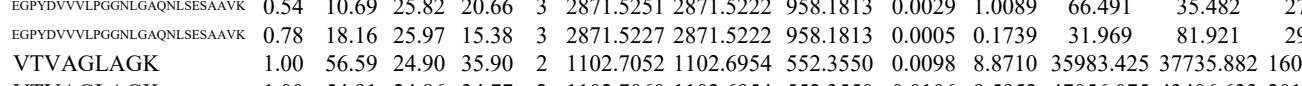
VTVAGLAGK VTVAGLAGK VTVAGLAGK ALVILAK ALVILAK GPGTSFEFALAIVEALNGK GPGTSFEFALAIVEALNGK GPGTSFEFALAIVEALNGK GPGTSFEFALAIVEALNGK

\footnotetext{
Yes
}

Table S-3 page 448 of 499 
$\begin{array}{llllllllllll}1.00 & 69.08 & 25.39 & 23.22 & 2 & 1470.6914 & 1470.6903 & 736.3524 & 0.0011 & 0.7469 & 561.730 \\ 1.00 & 71.33 & 25.68 & 23.71 & 2 & 1470.640 & 1470.6903 & 7363524 & 0.0037 & 2.5124 & 509.493\end{array}$ $\begin{array}{lllllllllllll}.00 & 71.33 & 25.68 & 23.71 & 2 & 1470.6940 & 1470.6903 & 736.3524 & 0.0037 & 2.5124 & 509.493 & 8\end{array}$

$\begin{array}{llllllllllll}\text { EIF3C HUMAN Q99613 } & \text { EIF3C } & \text { Eukaryotic transla 105.34 } & 1.00 & 9 & 10.1 & -0.0997 & 0.1932 & -0.6781 & 2.3674 & 22 & \text { LGSLVENNER }\end{array}$

LGSLVENNER

VWDLFPEADK

VWDLFPEADK

VWDLFPEADK

CLEEFELLGK

CLEEFELLGK

CLEEFELLGK

CLEEFELLGK

GTEITHAVVIK

GTEITHAVVIK

GTEITHAVVIK

GTEITHAVVIK

MIINEELMASLDQPT

LNEILQAR

LNEILQAR

GCILTLVER

GCILTLVER

GCILTLVER

TMVQLGICAFR

TMVQLGICAFR

TMVQLGICAFR

KLNEILQAR

CLEEFELLGK

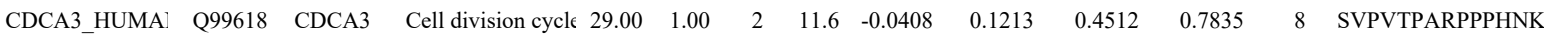

\section{SVPVTPARPPPHNK}

SVPVTPARPPPHNK

SVPVTPARPPPHNK

SVPVTPARPPPHNK

QPTETPVASQSSDKPS QPTETPVASQSSDKPSR

27 VLPSIVNEVLK

VLPSIVNEVLK

VLPSIVNEVLK

VLPSIVNEVLK

VLPSIVNEVLK

$\begin{array}{llllllllllll}1.00 & 71.33 & 25.68 & 33.71 & 2 & 1470.640 & 1470.693 & 736.3524 & 0.0037 & 2.5124 & 509.493 & 889.840\end{array}$

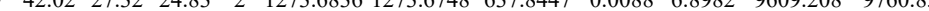

$\begin{array}{lllllllllllll}.0 & & \end{array}$

$\begin{array}{lllllllllllll}0.99 & 40.27 & 28.30 & 27.08 & 2 & 1506.7992 & 1506.7962 & 754.4054 & 0.0030 & 1.9883 & 556.474 & 483.383 & \\ \end{array}$

$\begin{array}{llllllllllll}1.00 & 61.34 & 28.23 & 24.60 & 2 & 1506.7998 & 1506.7962 & 754.4054 & 0.0036 & 2.3860 & 541.810 & 398.867 \\ 0.97 & 36.91 & 28.23 & 27.19 & 2 & 1506.8000 & 1506.7962 & 754.4054 & 0.0038 & 2.5185 & 375.640 & 443.593\end{array}$

$\begin{array}{llllllllllll}1.00 & 45.06 & 27.61 & 21.36 & 2 & 1513.7796 & 1513.7764 & 757.8955 & 0.0032 & 2.1111 & 2059.241 & 1723.002\end{array}$

$\begin{array}{lllllllllllll}1.00 & 53.08 & 27.46 & 24.79 & 2 & 1513.7800 & 1513.7764 & 757.8955 & 0.0036 & 2.3750 & 2109.946 & 2064.930 \\ 1.00 & 52.80 & 27.61 & 26.96 & 2 & 1513.7788 & 1513.7764 & 757.8955 & 0.0024 & 1.5833 & 1493.365 & 1403.677\end{array}$

$\begin{array}{lllllllllllll}1.00 & 52.80 & 27.61 & 26.96 & 2 & 1513.7788 & 1513.7764 & 757.8955 & 0.0024 & 1.5833 & 1493.365 & 1403.677 \\ 1.00 & 51.53 & 27.61 & 26.08 & 2 & 1513.7788 & 151377764 & 757.8955 & 0.0024 & 1.5833 & 1489.710 & 1591.627\end{array}$

$\begin{array}{lllllllllllll} & \end{array}$

$\begin{array}{llllllllllllll} & \end{array}$

$\begin{array}{lllllllllllllllll}1.00 & 41.54 & 22.23 & 25.07 & 3 & 1454.8759 & 1454.8701 & 485.9640 & 0.0058 & 3.9783 & 13573.753 & 13066.748 & 10368.378 & 7212.717 & \text { Yes }\end{array}$

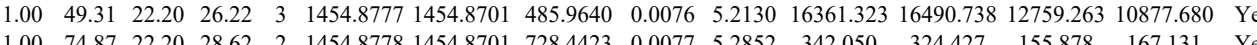

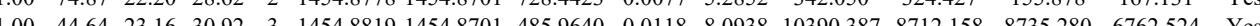
$\begin{array}{llllllllllllllll}0.55 & 81.36 & 27.16 & 94.36 & 3 & 2699.3590 & 2699.3566 & 900.7928 & 0.0024 & 0.8881 & 460.966 & 491.595 & 229.178 & 91.376 & \text { Yes }\end{array}$ $\begin{array}{llllllllllllllll}0.98 & 39.56 & 26.48 & 28.60 & 2 & 1099.6562 & 1099.6471 & 550.8308 & 0.0091 & 8.8602 & 11254106 & 9757.149 & 2093.417 & 465.208 & \text { Yes }\end{array}$ $\begin{array}{llllllllllllllll}0.98 & 39.66 & 26.48 & 30.94 & 2 & 1099.6564 & 1099.6471 & 550.8308 & 0.0093 & 8.4417 & 9501.277 & 8741.594 & 1598.104 & 258.147 & \text { Yes }\end{array}$ $\begin{array}{lllllllllllllll}0.97 & 40.25 & 27.99 & 25.05 & 2 & 1192.6478 & 1192.6430 & 597.3288 & 0.0048 & 4.0179 & 12084.465 & 13736.470 & 2839.648 & 47.391 & \text { Yes }\end{array}$ $\begin{array}{lllllllllllllll}0.98 & 41.56 & 27.88 & 24.99 & 2 & 11926482 & 1122.6430 & 597.3288 & 0.0052 & 43527 & 13886.689 & 12716.443 & 3438.991 & 258.818 & \text { Yes }\end{array}$ $\begin{array}{llllllllllllllll}0.99 & 41.36 & 28.35 & 24.00 & 2 & 1192.6456 & 1192.6430 & 597.3288 & 0.0026 & 2.1764 & 8849.870 & 9778.325 & 1780.590 & 166.848 & \text { Yes }\end{array}$ $\begin{array}{lllllllllllllll}0.99 & 41.19 & 28.29 & 23.51 & 2 & 1192.6462 & 1192.6430 & 597.3288 & 0.0032 & 2.6786 & 9214.236 & 8896.361 & 1399.412 & 257.217 & \text { Yes }\end{array}$ $\begin{array}{lllllllllllllll}100 & 56.88 & 27.23 & 26.39 & 2 & 1427.7226 & 1427.7209 & 714.8677 & 0.0017 & 1.1890 & 287.751 & 313.430 & 19.464 & 4.388 & \text { Yes }\end{array}$

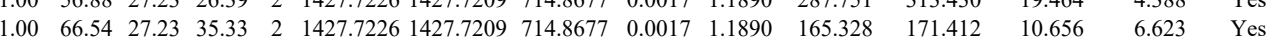
$\begin{array}{lllllllllllllll}1.00 & 56.25 & 27.23 & 23.98 & 2 & 1427.7228 & 1427.7209 & 714.8677 & 0.0019 & 1.3289 & 75.114 & 80.807 & 11.813 & 3.709 & \text { Yes }\end{array}$ $\begin{array}{llllllllllllll}0.57 & 27.80 * 23.98 & 28.41 & 2 & 127.7432 & 1227.7421 & 614.8783 & 0.0011 & 0.8945 & 295.685 & 282.458 & 115.133 & 33.035 & \text { Yes }\end{array}$ $\begin{array}{lllllllllllllll}0.55 & 12.55 & 27.61 & 17.37 & 3 & 1513.7791 & 1513.7764 & 505.5994 & 0.0027 & 1.7801 & 87.542 & 63.752 & 183.788 & 93.732 & \text { No }\end{array}$ $\begin{array}{lllllllllllllll}1.00 & 27.23 & 23.38 & 40.23 & 4 & 1784.0297 & 1784.0301 & 447.0148 & -0.0004 & -0.2237 & 4069.071 & 3608.111 & 2666.462 & 1685.769 & \text { Yes }\end{array}$ $\begin{array}{lllllllllllllll}1.00 & 43.87 & 23.44 & 17.43 & 3 & 1784.0305 & 1784.0301 & 595.6840 & 0.0004 & 0.2238 & 477.896 & 508.627 & 478.126 & 295.776 & \text { Yes } \\ 1.00 & 22.37 & 23.44 & 35.37 & 4 & 1784.0309 & 1784.0301 & 447.0148 & 0.0008 & 0.4474 & 3388.322 & 3750.333 & 3223.709 & 1831.434 & \text { Yes } \\ 1.00 & 23.05 & 23.44 & 36.05 & 4 & 1784.0309 & 1784.0301 & 447.048 & 0.000 & 0.4474 & 270.509 & 2592.400 & 2245.765 & 1132.163 & \text { Yes }\end{array}$ $\begin{array}{llllllllllllllll}1.00 & 23.05 & 23.44 & 36.05 & 4 & 1784.0309 & 1784.0301 & 447.0148 & 0.0008 & 0.4474 & 2710.509 & 2592.400 & 2245.765 & 1132.163 & \text { Yes }\end{array}$ $\begin{array}{lllllllllllllll}1.00 & 37.87 & 23.28 & 16.98 & 3 & 1784.0320 & 1784.0301 & 595.6840 & 0.0019 & 1.0632 & 502.227 & 465.277 & 617.760 & 293.164 & \text { Yes }\end{array}$

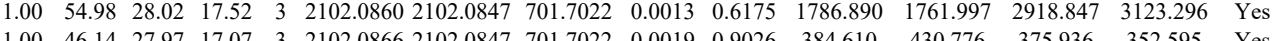
$\begin{array}{lllllllllllllll}1.00 & 46.14 & 27.97 & 17.07 & 3 & 2102.0866 & 2102.0847 & 701.7022 & 0.0019 & 0.9026 & 384.610 & 430.776 & 375.936 & 352.595 & \text { Yes } \\ 1.00 & 56.79 & 27.97 & 16.79 & 3 & 2102.0866 & 2102.0847 & 701.722 & 0.003 & 0.026 & 1620.063 & 1633.083 & 2023.953 & 23.568 & \text { Yes }\end{array}$

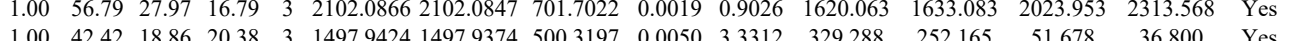
$\begin{array}{llllllllllllll} & & \end{array}$ $\begin{array}{lllllllllllllll}1.00 & 58.50 & 18.26 & 22.17 & 2 & 1497.9436 & 1497.9374 & 749.9760 & 0.0062 & 4.1334 & 2822.308 & 2274.561 & 353.366 & 34.028 & \text { Yes }\end{array}$ $\begin{array}{llllllllllllllll}1.00 & 56.91 & 18.26 & 19.90 & 2 & 1497.9438 & 1497.9374 & 749.9760 & 0.0064 & 4.2668 & 1785.554 & 1391.468 & 301.347 & 14.982 & \text { Yes } \\ 1.00 & 35.53 & 18.45 & 16.41 & 3 & 1497.9451 & 1497.9374 & 500.3197 & 0.0077 & 5.1300 & 259.494 & 205.533 & 45.337 & 8.308 & \text { Yes }\end{array}$

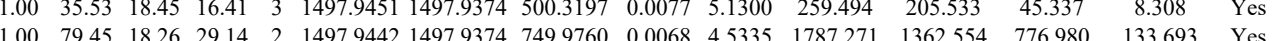

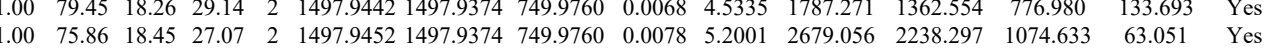
$\begin{array}{lllllllllllllllll} & \text { VLSRPNAQELPSMYQR } & 1.00 & 43.52 & 27.09 & 20.29 & 3 & 2032.0822 & 2032.0645 & 678.3621 & 0.0177 & 8.6973 & 11645.084 & 10182.673 & 3157.504 & 240.224 & \text { Yes }\end{array}$ $\begin{array}{lllllllllllllll} & \end{array}$ 


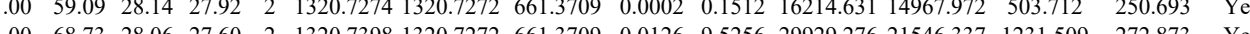
$\begin{array}{llllllllllllllll}1.00 & 68.73 & 28.06 & 27.60 & 2 & 1320.7398 & 1320.7272 & 661.3709 & 0.0126 & 9.5256 & 29929.276 & 21546.337 & 1231.509 & 272.873 & \text { Yes } \\ 0.95 & 33.99 & 27.28 & 16.53 & 2 & 1367.0190 & 1867.0154 & 934.5150 & 0.026 & 1.926 & 49.132 & 15.660 & 51.735 & 5.401 & \end{array}$ $\begin{array}{llllllllllllll}0.95 & 33.99 & 27.28 & 16.53 & 2 & 1867.0190 & 1867.0154 & 934.5150 & 0.0036 & 1.9261 & 49.132 & 15.660 & 51.735 & 5.401 \\ 1 & & \end{array}$

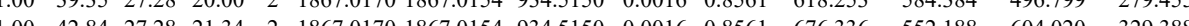

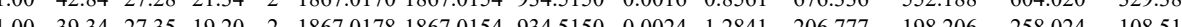

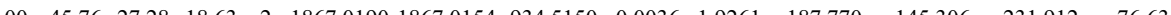

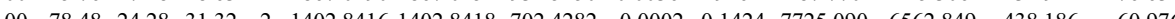

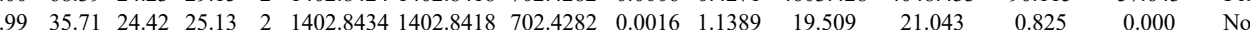

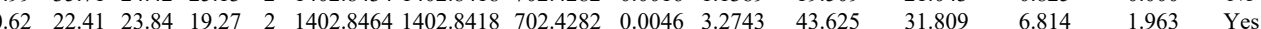
$\begin{array}{lllllllllllllll}1.00 & 80.98 & 24.80 & 31.12 & 2 & 1402.8414 & 1402.8418 & 702.4282 & -0.0004 & -0.2847 & 4048.638 & 3308.451 & 185.550 & 59.386 & \text { Yes }\end{array}$ $\begin{array}{lllllllllllllll}1.00 & 73.95 & 24.23 & 29.14 & 2 & 1402.8426 & 1402.8418 & 702.4282 & 0.0008 & 0.5695 & 3463.974 & 2998.292 & 198.241 & 25.093 & \text { Yes }\end{array}$ $\begin{array}{lllllllllllllll}1.00 & 68.94 & 24.98 & 29.98 & 2 & 1402.8404 & 1402.8418 & 702.4282 & -0.0014 & -0.9965 & 1874.677 & 1522.000 & 125.698 & 58.190 & \text { Yes }\end{array}$

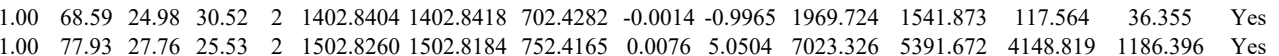

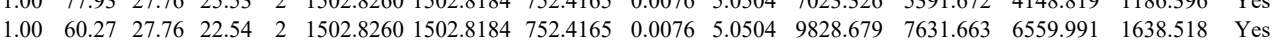
$\begin{array}{lllllllllllllllll}0.77 & 20.72 & 26.78 & 31.03 & 2 & 910.5158 & 910.5147 & 456.2646 & 0.0011 & 1.2054 & 1562.085 & 1282.213 & 62.465 & 62.188 & \text { Yes }\end{array}$ $\begin{array}{llllllllllllllll}0.75 & 19.47 & 26.15 & 23.86 & 2 & 910.5160 & 910.5147 & 456.2646 & 0.0013 & 1.4246 & 1418.441 & 1122.771 & 105.206 & 45.788 & \text { Yes }\end{array}$ $\begin{array}{lllllllllllllll}1.00 & 41.57 & 28.26 & 23.78 & 2 & 1320.7288 & 1320.7272 & 661.3709 & 0.0016 & 1.2096 & 433.422 & 410.948 & 87.039 & 29.257 & \text { Yes }\end{array}$

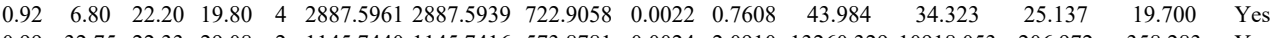
$\begin{array}{lllllllllllllll}0.99 & 32.75 & 22.33 & 29.08 & 2 & 1145.7440 & 1145.7416 & 573.8781 & 0.0024 & 2.0910 & 13260.329 & 10918.053 & 206.972 & 358.283 & \text { Yes }\end{array}$

GLVAVITGGasglglataer GLVAVITGGASGLGLATA GGIVGMTLPIAR GGIVGMTLPIAR VCNFLASQVPFPSR VCNFLASQVPFPSR VCNFLASQVPFPSR VCNFLASQVPFPSR GLVAVITGGASGLGLATAER GLVAVITGGASGLGLATAER

6 GFVFITFK GFVFITFK GFVFITFK
GFVFITFK GFVFITFK GFVFITFK GFVFITFK GFGFILFK GFGFILFK GFGFILFK GFVFITFK GFVFITFK GFGFILFK GFGFILFK GFGFILFK NEEDAGK MDPNTGR LTDQVMQNPR
LTDQVMQNPR QVPNESFFNFFNPLK QVPNESFFNFFNPLK QVPNESFFNFFN

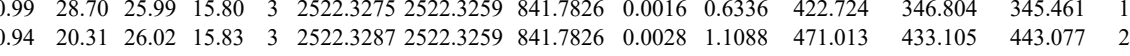

$\begin{array}{lllllllllllllll}0.94 & 20.31 & 26.02 & 15.83 & 3 & 2522.3287 & 2522.3259 & 841.7826 & 0.0028 & 1.1088 & 471.013 & 433.105 & 443.077 & 222.419 & \text { Yes } \\ 0.76 & 22.70 & 22.62 & 35.70 & 2 & 927.4292 & 927.4284 & 464.7215 & 0.0008 & 0.8607 & 4143.256 & 4970.105 & 273.771 & 78.559 & \text { Yes }\end{array}$ $\begin{array}{llllllllllllllll}0.76 & 22.70 & 22.62 & 35.70 & 2 & 927.4292 & 927.4284 & 464.7215 & 0.0008 & 0.8607 & 4143.256 & 43.10 .105 & 273.771 & 78.559 & \text { Yes } \\ 0.97 & 26.82 & 22.60 & 18.96 & 2 & 927.4294 & 927.4284 & 464.7215 & 0.0010 & 1.0759 & 4419.537 & 4567.379 & 316.781 & 6.521 & \text { Yes }\end{array}$ $\begin{array}{lllllllllllllll}00 & 58.46 & 23.73 & 19.25 & 3 & 1956.1168 & 1956.1126 & 653.0448 & 0.0042 & 2.1438 & 177.882 & 165.841 & 85.813 & 62.574 & \text { Yes }\end{array}$

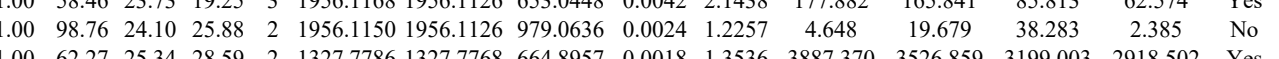
$\begin{array}{lllllllllllllll}1.00 & 62.27 & 25.34 & 28.59 & 2 & 1327.7786 & 1327.7768 & 664.8957 & 0.0018 & 1.3536 & 3887.370 & 3526.859 & 3199.003 & 2918.502 & \text { Yes }\end{array}$ $\begin{array}{llllllllllllllll}1.00 & 60.76 & 25.17 & 27.20 & 2 & 1327.7794 & 1327.7768 & 664.8957 & 0.0026 & 1.9552 & 4485.012 & 3820.997 & 2916.563 & 3749.869 & \text { Yes }\end{array}$

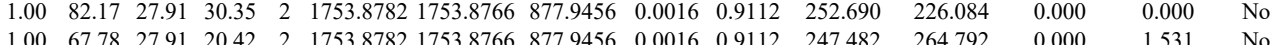

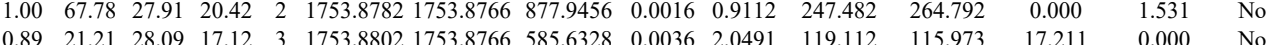

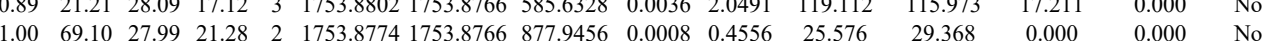

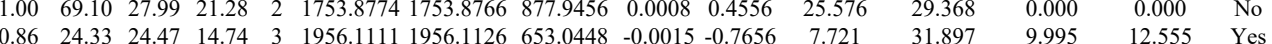

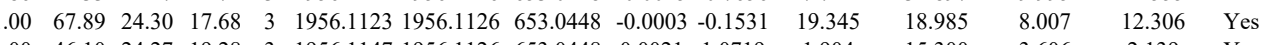

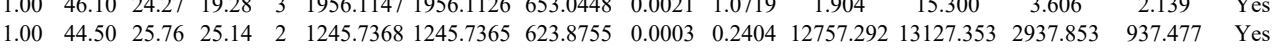

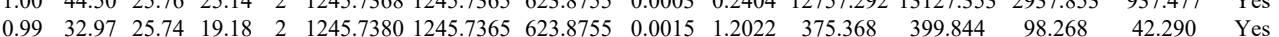

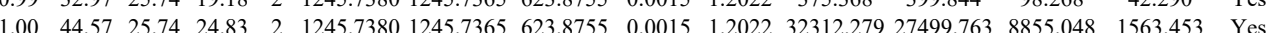

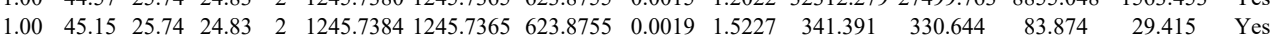

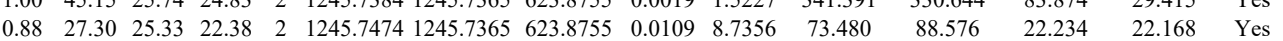

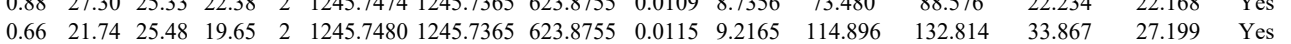
$\begin{array}{lllllllllllllll}1.00 & 46.98 & 25.26 & 24.84 & 2 & 1215.7292 & 1215.7260 & 608.8703 & 0.0032 & 2.6278 & 35734.495 & 27786.345 & 1788.298 & 1028.011 & \text { Yes }\end{array}$ $\begin{array}{llllllllllllllll}1.00 & 49.61 & 25.12 & 30.81 & 2 & 1215.7302 & 1215.7260 & 608.8703 & 0.0042 & 3.4490 & 68990.338 & 59343.258 & 2615.462 & 1412.298 & \text { Yes }\end{array}$ $\begin{array}{llllllllllllllll}0.99 & 41.33 & 25.74 & 27.34 & 2 & 1215.7324 & 1215.7260 & 608.8703 & 0.0064 & 5.2556 & 545.938 & 409.656 & 59.680 & 10.462 & \text { Yes }\end{array}$

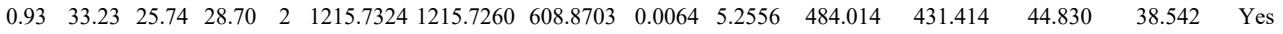
$\begin{array}{lllllllllllllll}1.00 & 44.38 & 25.74 & 24.72 & 2 & 1245.7378 & 1245.7365 & 623.8755 & 0.0013 & 1.0419 & 19370.931 & 15129.108 & 4624.747 & 1196.133 & \text { Yes }\end{array}$ $\begin{array}{llllllllllllllll}1.00 & 44.49 & 25.74 & 25.30 & 2 & 1245.7386 & 1245.7365 & 623.8755 & 0.0021 & 1.6830 & 29163.337 & 26049.560 & 8334.908 & 2982.625 & \text { Yes }\end{array}$ $\begin{array}{lllllllllllllll}1.00 & 47.79 & 25.34 & 26.47 & 2 & 1215.7278 & 1215.7260 & 608.8703 & 0.0018 & 1.4781 & 60130.860 & 50991.921 & 1473.561 & 1249.228 & \text { Yes }\end{array}$

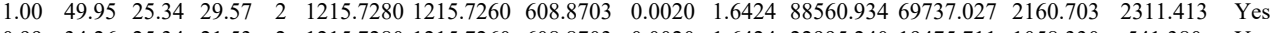

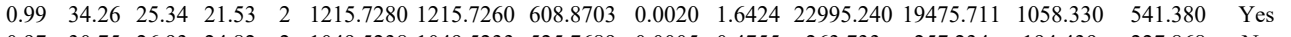
$\begin{array}{lllllllllllllll}0.97 & 30.75 & 26.93 & 24.82 & 2 & 1049.5238 & 1049.5233 & 525.7689 & 0.0005 & 0.4755 & 263.733 & 257.234 & 194.439 & 227.868 & \text { No }\end{array}$

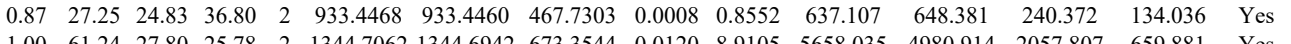

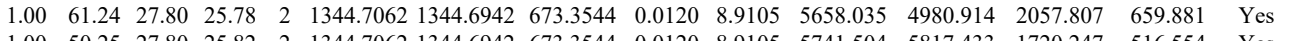

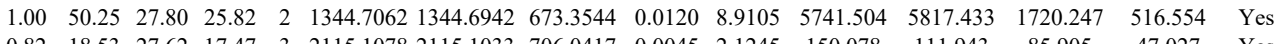

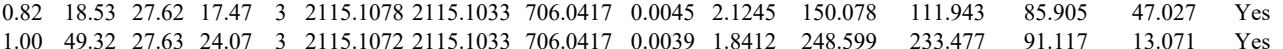

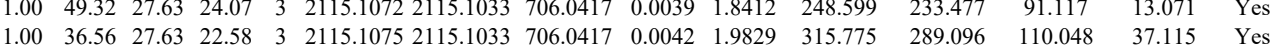

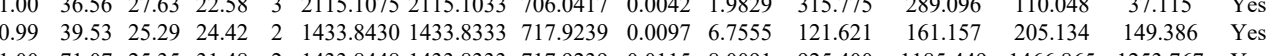

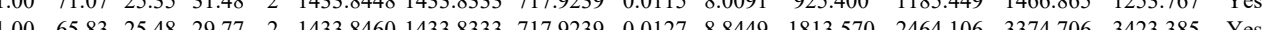

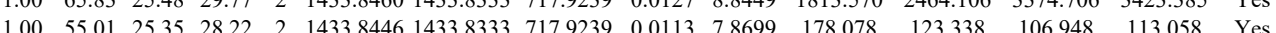



$\begin{array}{llllllllllll}\text { SDPLCVLLQDVGGGSWAELGR } & 1.00 & 97.09 & 27.82 & 22.93 & 3 & 2361.1627 & 2361.1579 & 788.0599 & 0.0048 & 2.0303 & 8.648 \\ \text { SDPLCVLLQDVGGGSWAELGR } & 1.00 & 89.22 & 27.87 & 23.18 & 2 & 2361.1594 & 2361.1579 & 1181.5862 & 0.0015 & 0.6347 & 79.825\end{array}$ $\begin{array}{lllllllllllll}\text { SDPLCVLLQDVGGGSWAELGR } & 1.00 & 89.22 & 27.87 & 23.18 & 2 & 2361.1594 & 2361.1579 & 1181.5862 & 0.0015 & 0.6347 & 79.825\end{array}$

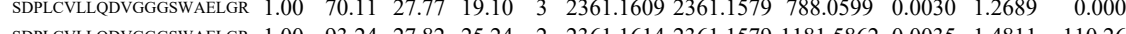
$\begin{array}{llllllllllllll}3 & \end{array}$

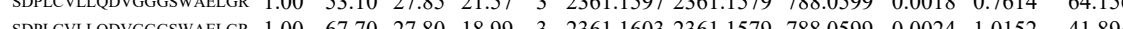

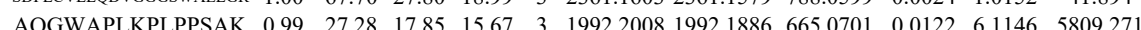

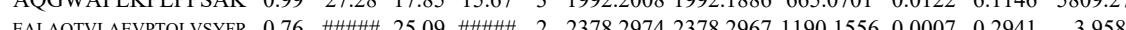
\begin{tabular}{lllllllllllll}
\hline EALAOTVLAEVPTOLVSYFR & 0.53 & 52.33 & 25.01 & 65.33 & 3 & 2378.2999 & 2378 & 2967 & 793.7728 & 0.0032 & 1.3438 & 20.054
\end{tabular} $\begin{array}{llllllllllllll}\text { EALAOTVLAEVPTOLVSYFR } & 1.00 & 40.89 & 25.01 & 20.53 & 3 & 2378.2999 & 2378.2967 & 793.7728 & 0.0032 & 1.3438 & 5.653\end{array}$ $\begin{array}{llllllllllll}\text { LYGPTNFAPIINHVAR } & 1.00 & 51.90 & 26.62 & 18.40 & 3 & 1926.0622 & 1926.0597 & 643.0272 & 0.0025 & 1.2960 & 1322.823\end{array}$ $\begin{array}{lllllllllllll}\text { LYGPTNFAPIINHVAR } & 1.00 & 45.76 & 26.61 & 17.46 & 3 & 1926.0631 & 1926.0597 & 643.0272 & 0.0034 & 1.7625 & 1522.609 & 2390\end{array}$

$\begin{array}{lllllllllllll}\text { INALTAASEAACLIVSVDETIK } & 1.00 & 48.86 & 25.97 & 24.74 & 3 & 2565.3676 & 2565.3637 & 856.1285 & 0.0039 & 1.5185 & 4.765\end{array}$

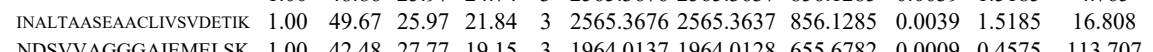
$\begin{array}{lllllllllllll}\text { NDSVVAGGGAIEMELSK } & 1.00 & 42.48 & 27.77 & 19.15 & 3 & 1964.0137 & 1964.0128 & 655.6782 & 0.0009 & 0.4575 & 113.707 \\ \text { NDSVVAGG }\end{array}$ $\begin{array}{llllllllllll}\text { NDSVVAGGGAIEMELSK } & 0.55 & 12.72 & 27.76 & 25.72 & 3 & 1964.0152 & 1964.0128 & 655.6782 & 0.0024 & 1.2201 & 98.486\end{array}$ $\begin{array}{llllllllllll}\text { NDSVVAGGGAIEMELSK } & 0.54 & 12.41 & 27.76 & 14.28 & 3 & 1964.0152 & 1964.0128 & 655.6782 & 0.0024 & 1.2201 & 72.488 \\ \text { NDSVVAGGGE }\end{array}$ $\begin{array}{lllllllllllll}\text { NDSVVAGGGAIEMELSK } & 0.92 & 21.21 & 27.77 & 18.49 & 3 & 1964.0155 & 1964.0128 & 655.6782 & 0.0027 & 1.3726 & 40.071\end{array}$ $\begin{array}{llllllllllll}\text { NDSVVAGGGAIEMELSK } & 1.00 & 37.10 & 27.75 & 16.27 & 3 & 1964.0158 & 1964.0128 & 655.6782 & 0.0030 & 1.5251 & 120.899\end{array}$ $\begin{array}{lllllllllllll}\text { NDSVVAGGGAIEMELSK } & 0.76 & 17.26 & 27.64 & 17.35 & 3 & 1964.0170 & 1964.0128 & 655.6782 & 0.0042 & 2.1352 & 127.408\end{array}$ $\begin{array}{lllllllllllll}\text { NDSVVAGGGAIEMELSK } & 0.89 & 20.86 & 27.66 & 16.57 & 3 & 1964.0173 & 1964.0128 & 655.6782 & 0.0045 & 2.2877 & 106.341\end{array}$ $\begin{array}{llllllllllllll}\text { NDSVVAGGGAIEMELSK } & 1.00 & 34.23 & 27.66 & 16.32 & 3 & 1964.0179 & 1964.0128 & 655.6782 & 0.0051 & 2.5927 & 74.482 & & \\ \text { NDSVVAGGGAIEMELSK } & 0.92 & 25.92 & 27.69 & 15.59 & 3 & 1964.0188 & 1964.0128 & 655.6782 & 0.0060 & 3.0503 & 121.227 & 13\end{array}$

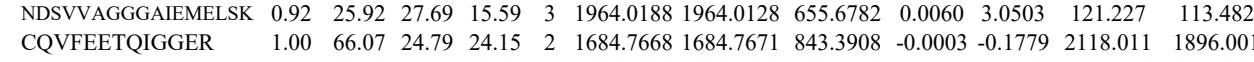
$\begin{array}{lllllllllllll}\text { CQVFEETQIGGER } & 1.00 & 62.94 & 25.07 & 22.67 & 2 & 1684.7688 & 1684.7671 & 843.3908 & 0.0017 & 1.0078 & 2117.916 & 209 \\ \text { SQDAEVGDGTTVTLLAAEFLK } & 0.53 & 26.24 & 26.61 & 39.24 & 3 & 2539.3291 & 2539.3261 & 847.4493 & 0.0030 & 1.1800 & 38.502\end{array}$ $\begin{array}{lllllllllllll}\text { SQDAEVGDGTTSVTLLAAEFLK } & 0.53 & 26.24 & 26.61 & 39.24 & 3 & 2539.3291 & 2539.3261 & 847.4493 & 0.0030 & 1.1800 & 38.502 & \\ \text { SODAEVGDGTTSVTLLAAFLLK } & 1.00 & \# \# \# \# \quad 26.61 & 29.43 & 2 & 2539.3294 & 2539.3261 & 1270.6703 & 0.0033 & 1.2985 & 34.322 & \end{array}$

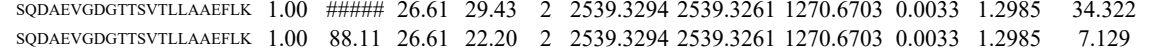
$\begin{array}{llllllllllll}\text { SQDAEVGDGTTSVTLLAAEFLK } & 1.00 & 88.11 & 26.61 & 22.20 & 2 & 2539.3294 & 2539.3261 & 1270.6703 & 0.0033 & 1.2985 & 7.129 \\ \text { SQDAEVGDGTSVTLLAAFLLK } & 1.00 & 86.08 & 26.64 & 20.33 & 3 & 2539.3327 & 2539.3261 & 847.4493 & 0.0066 & 2.5960 & 202.744\end{array}$ $\begin{array}{llllllllllll}\text { SQDAEVGDGTTSVTLLAAEFLK } & 1.00 & 86.08 & 26.64 & 20.33 & 3 & 2539.3327 & 2539.3261 & 847.4493 & 0.0066 & 2.5960 & 202.744 \\ \text { SQDAEVGDGTSVTLLAAFLLK } & 1.00 & 65.79 & 26.51 & 20.43 & 3 & 2539.3336 & 2539.3261 & 847.4493 & 0.0075 & 2.9500 & 43.895\end{array}$ $\begin{array}{llllllllllllll}\text { SQDAEVGDGGTSVILLAAEFLK } & 1.00 & 65.79 & 6.51 & 20.43 & 3 & 2539.3336 & 2539.3261 & 847.4493 & 0.0075 & 2.9500 & 43.895 \\ \text { SQDAEVGDGTSVILLAAEFLK } & 1.00 & 59.55 & 26.51 & 19.64 & 3 & 2539.3336 & 2539.3261 & 847.4493 & 0.0075 & 2.9500 & 21.967\end{array}$

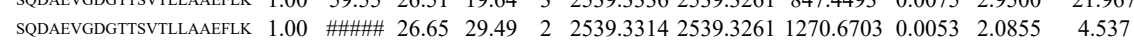
$\begin{array}{llllllllllll}\text { SQDAEVGDGTTSVTLLAAEFLK } & 1.00 & 49.18 & 26.54 & 18.48 & 3 & 2539.3345 & 2539.3261 & 847.4493 & 0.0084 & 3.3040 & 30.032\end{array}$ $\begin{array}{lllllllllllll}\text { SQDAEVGDGTSVILLAEELK K } & 1.00 & 49.18 & 26.54 & 18.48 & 3 & 2539.3345 & 2539.3261 & 847.4493 & 0.0084 & 3.3040 & 30.032 & 19 \\ \text { ATISNDGATILK } & 1.00 & 67.81 & 25.92 & 42.46 & 2 & 1490.8666 & 1490.8548 & 746.4347 & 0.0118 & 7.9042 & 951.161\end{array}$ $\begin{array}{llllllllllllll}\text { ATISNDGATILK } & 1.00 & 62.73 & 25.91 & 36.78 & 2 & 1490.8672 & 1490.8548 & 746.4347 & 0.0124 & 8.3061 & 2580.188 & 2300.647 & 1260.48\end{array}$ $\begin{array}{lllllllllllllll}\text { ATISNDGATILK } & 1.00 & 67.11 & 25.82 & 36.87 & 2 & 1490.8656 & 1490.8548 & 746.4347 & 0.0108 & 7.2343 & 1767.929 & 1802.432 & 994.140\end{array}$ $\begin{array}{llllllllllllllll}\text { ATISNDGATILK } & 1.00 & 71.96 & 25.81 & 42.85 & 2 & 1490.8660 & 1490.8548 & 746.4347 & 0.0112 & 7.5023 & 2117.473 & 1349.427 & 1051.460\end{array}$ $\begin{array}{llllllllllllllll}\text { VQGGALEDSQLVAGVAFK } & 1.00 & 48.34 & 25.67 & 16.23 & 3 & 2076.1495 & 2076.1459 & 693.0559 & 0.0036 & 1.7315 & 126.862 & 159.851 & 138.228\end{array}$ $\begin{array}{lllllllllllllll}\text { VQGGALEDSQLVAGVAFK } & 1.00 & 44.22 & 25.53 & 17.05 & 3 & 2076.1501 & 2076.1459 & 693.0559 & 0.0042 & 2.0200 & 100.418 & 101.034 & 111.035\end{array}$ $\begin{array}{lllllllllllllll}\text { VQGGALEDSQLVAGVAFK } & 1.00 & 41.45 & 25.50 & 19.80 & 3 & 2076.1510 & 2076.1459 & 693.0559 & 0.0051 & 2.4529 & 106.077 & 138.852 & 129.343\end{array}$ $\begin{array}{llllllllllllll}\text { VQGGALEDSQLVAGVAFK } & 1.00 & 41.50 & 25.50 & 20.25 & 3 & 2076.1510 & 2076.1459 & 693.0559 & 0.0051 & 2.4529 & 129.817 & 115.051 & 136.675\end{array}$ $\begin{array}{llllllllllllll}\text { VQGGALEDSQLVAGVAFK } & 1.00 & 49.98 & 25.49 & 17.66 & 3 & 2076.1513 & 2076.1459 & 693.0559 & 0.0054 & 2.5972 & 146.686 & 148.084 & 114.232\end{array}$ $\begin{array}{llllllllllllll}\text { VQGGALEDSQLVAGVAFK } & 1.00 & 33.70 & 25.49 & 19.93 & 3 & 2076.1513 & 2076.1459 & 693.0559 & 0.0054 & 2.5972 & 91.908 & 106.982 & 97.231\end{array}$ $\begin{array}{llllllllllllll}\text { VQGGALEDSQLVAGVAFK } & 1.00 & 39.32 & 25.58 & 25.00 & 3 & 2076.1489 & 2076.1459 & 693.0559 & 0.0030 & 1.4429 & 30.726 & 33.599 & 39.311\end{array}$

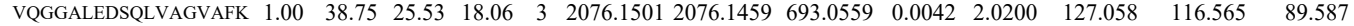
$\begin{array}{llllllllllllll}\text { VQGGALEDSQLVAGVAFK } & 1.00 & 39.52 & 25.50 & 16.38 & 3 & 2076.1510 & 2076.1459 & 693.0559 & 0.0051 & 2.4529 & 45.782 & 34.434 & 29.176\end{array}$ $\begin{array}{llllllllllllll}\text { VQGGALEDSQLVAGVAFK } & 0.91 & 23.19 & 25.43 & 16.76 & 3 & 2076.1516 & 2076.1459 & 693.0559 & 0.0057 & 2.7415 & 135.261 & 133.690 & 104.904\end{array}$

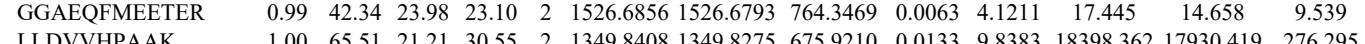
$\begin{array}{llllllllllllll}\text { LLDVVHPAAK } & 1.00 & 65.51 & 21.21 & 30.55 & 2 & 1349.8408 & 1349.8275 & 675.9210 & 0.0133 & 9.8383 & 18398.362 & 17930.419 & 276.295 \\ \text { QLCDNAGFDATNINK } & 1.00 & \# \# \# \# & 27.62 & 21.53 & 2 & 2070.0134 & 2070.0118 & 1036.0132 & 0.0016 & 0.7722 & 3296.942 & 2988.228 & 93.249\end{array}$ $\begin{array}{llllllllllllll}\text { QLCDNAGFDATNILNK } & 1.00 & \text { \#\#\#\# } & 27.62 & 21.53 & 2 & 2070.0134 & 2070.0118 & 1036.0132 & 0.0016 & 0.7722 & 3296.942 & 2988.228 & 93.249 \\ \text { QLCDNAGFDATNILNK } & 1.00 & 9629 & 27.58 & 21.97 & 2 & 2070.0154 & 2070.0118 & 1036.0132 & 0.0036 & 1.7374 & 3226.583 & 2852.629 & 154.752\end{array}$

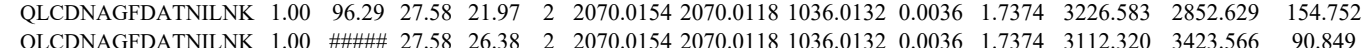
$\begin{array}{lllllllllllll}\text { QLCDNAGFDATNILNK } & 1.00 & \text { 27.58 } & 26.38 & 2 & 2070.0154 & 2070.0118 & 1036.0132 & 0.0036 & 1.7374 & 3112.320 & 3423.566 & 90.849\end{array}$ QLCDNAGFDATNILNK $1.00 \quad$ \#\#\#\# $27.57 \quad 26.47 \quad 2 \quad 2070.01742070 .01181036 .0132 \quad 0.0056 \quad 2.7027 \quad 3209.978 \quad 3481.022$ $\begin{array}{lllllllllllll}\text { INALTAASEAACLIVSVDETIK } & 0.95 & 20.96 & 26.02 & 15.38 & 3 & 2565.3661 & 2565.3637 & 856.1285 & 0.0024 & 0.9344 & 26.293 & 13.619\end{array}$

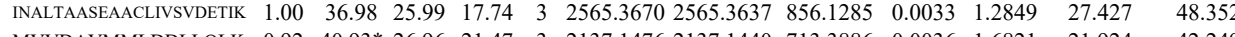
$\begin{array}{lllllllllllll}\text { MVIDAVMMLDDLQLK } & 0.92 & 40.93 & 26.96 & 21.47 & 3 & 2137.1476 & 2137.1440 & 713.3886 & 0.0036 & 1.6821 & 21.924 & 42.249\end{array}$

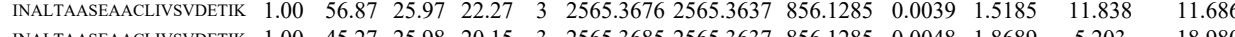
$\begin{array}{lllllllllllll}\text { INALTAASEAACLIVSVDETIK } & 0.98 & 26.96 & 25.98 & 14.92 & 3 & 2565.3685 & 2565.3637 & 856.1285 & 0.0048 & 1.8689 & 13.656 & 13.772\end{array}$ $\begin{array}{llllllllllllll}\text { INALTAASEAACLIVSVDETIK } & 1.00 & 54.66 & 26.00 & 19.28 & 3 & 2565.3688 & 2565.3637 & 856.1285 & 0.0051 & 1.9857 & 19.790 & 48.536\end{array}$ $\begin{array}{lllllllllllll}\text { INALTAASEAACLIVSVDETIK } & 1.00 & 68.22 & 26.02 & 23.45 & 3 & 25653691 & 25653637 & 856.1285 & 0.0054 & 2.1025 & 28.345 & 18.895\end{array}$ 

$\begin{array}{lllllllllllll} & \text { MVVDAVMMLDDLLQLK } & 1.00 & 80.71 & 26.84 & 26.94 & 2 & 2121.1514 & 2121.1491 & 1061.5818 & 0.0023 & 1.0833 & 93.146\end{array}$

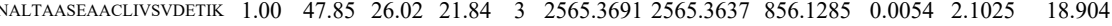
\begin{tabular}{lllllllllllll} 
& 255.39 & 2565.367 & 85.1285 & 0.0054 & 2.025 & 18.94 \\
\hline
\end{tabular}

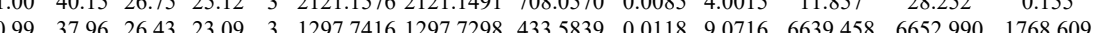

\section{TCTFILR}

\section{TMMACGGSIQTSVNALSADVLGR}

LLDVVHPAAK

LLDVVHPAAK

LLDVVHPAAK

$\begin{array}{llllllllllll}26.55 & 26.07 & 2 & 1042.5442 & 1042.5425 & 522.2785 & 0.0017 & 1.6275 & 53591.471 & 60274.289 & 1272.8\end{array}$ $\begin{array}{lllllllllllll} & 0.53 & 36.60 & 26.39 & 49.60 & 3 & 2471.1796 & 2471.1763 & 824.7327 & 0.0033 & 1.3338 & 6.86\end{array}$ $\begin{array}{lllllllllllll} & & & \end{array}$ $\begin{array}{lllllllllllllll} & \end{array}$ $\begin{array}{llllllllllllll}\text { NDSVVAGGGAIEMELSK } & 1.00 & 43.01 & 27.76 & 17.43 & 3 & 1964.0143 & 1964.0128 & 655.6782 & 0.0015 & 0.7626 & 16.006\end{array}$ $\begin{array}{llllllllllll}\text { NDSVVAGGGAIEMELSK } & 1.00 & 61.66 & 27.77 & 18.52 & 2 & 1964.0150 & 1964.0128 & 983.0137 & 0.0022 & 1.1190 & 28.947\end{array}$

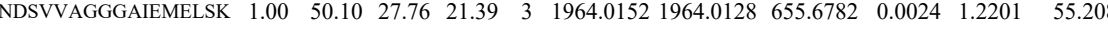
$\begin{array}{lllllllllllll}\text { NDSVVAGGGAIEMELSK } & 0.61 & 13.72 & 27.77 & 16.07 & 3 & 1964.0155 & 1964.0128 & 655.6782 & 0.0027 & 1.3726 & 72.306\end{array}$ $\begin{array}{llllllllllll}\text { NDSVVAGGGAIEMELSK } & 1.00 & 70.80 & 27.77 & 23.16 & 3 & 1964.0155 & 1964.0128 & 655.6782 & 0.0027 & 1.3726 & 19.231\end{array}$ $\begin{array}{llllllllllllll}\text { NDSVVAGGGAIEMELSK } & 1.00 & 50.18 & 27.68 & 24.34 & 3 & 1964.0161 & 1964.0128 & 655.6782 & 0.0033 & 1.6776 & 82.376\end{array}$ $\begin{array}{llllllllllll}\text { NDSVVAGGGAIEMELSK } & 1.00 & 50.08 & 27.71 & 19.47 & 2 & 1964.0168 & 1964.0128 & 983.0137 & 0.0040 & 2.0346 & 19.065\end{array}$ $\begin{array}{llllllllllll}\text { NDSVVAGGGAIEMELSK } & 1.00 & 81.04 & 27.64 & 24.48 & 3 & 1964.0170 & 1964.0128 & 655.6782 & 0.0042 & 2.1352 & 12.715\end{array}$

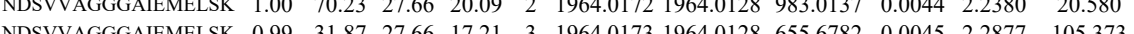

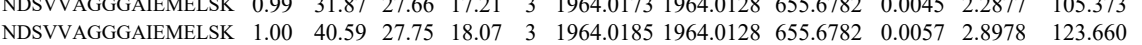
$\begin{array}{lllllllllllll}\text { NDSVVAGGGAIEMELSK } & 1.00 & 68.68 & 27.75 & 21.36 & 2 & 1964.0200 & 1964.0128 & 983.0137 & 0.0072 & 3.6622 & 6.934\end{array}$

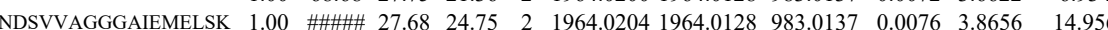
$\begin{array}{lllllllllllll}\text { NDSVVAGGGAIFMELSK } & 1.00 & 78.87 & 27.72 & 24.17 & 2 & 1964.0206 & 1964.0128 & 983.0137 & 0.0078 & 3.9674 & 10.731\end{array}$ 


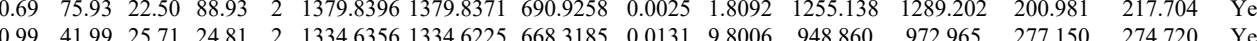

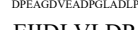

EIIDLVLDR 
$\begin{array}{llllllllllllll}\text { TIQFVDWCPTGFK } & 1.00 & 69.47 & 27.30 & 20.40 & 2 & 1874.9316 & 1874.9303 & 938.4724 & 0.0013 & 0.6926 & 2227.279 & 2309.176\end{array}$ $\begin{array}{llllllllllllllll} & 27.29 & 14.88 & 3 & 1874.9323 & 1874.9303 & 625.9840 & 0.0020 & 1.0650 & 132.195 & 227.411 & 28.020\end{array}$ $\begin{array}{lllllllllllllll}\text { TIQFVDWCPTGFK } & 1.00 & 66.37 & 27.31 & 17.70 & 2 & 1874.9336 & 1874.9303 & 938.4724 & 0.0033 & 1.7582 & 12683.628 & 13514.722 & 0.000\end{array}$ $\begin{array}{llllllllllllll} & 1.00 & 36.42 & 27.21 & 16.42 & 3 & 1874.9347 & 1874.9303 & 625.9840 & 0.0044 & 2.3430 & 582.823 & 738.740 & 87.319\end{array}$ $\begin{array}{lllllllllllllllll}\text { IIQFVDWCPTGFK } & 1.00 & 65.61 & 27.32 & 20.21 & 2 & 1874.9314 & 1874.9303 & 938.4724 & 0.0011 & 0.5861 & 7550.866 & 8242.586 & 0.000\end{array}$ $\begin{array}{llllllllllllll}\text { TIQFVDWCPTGFK } & 1.00 & 78.38 & 27.30 & 22.21 & 2 & 1874.9316 & 1874.9303 & 938.4724 & 0.0013 & 0.6926 & 10707.222 & 12738.694 & 0.000\end{array}$

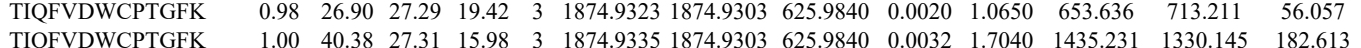
$\begin{array}{llllllllllllll}\text { TIQFVDWCPTGFK } & 1.00 & 40.38 & 27.31 & 15.98 & 3 & 1874.9335 & 1874.9303 & 625.9840 & 0.0032 & 1.7040 & 1435.231 & 1330.145 & 182.613 \\ \text { TIQFVDWCPTGFK } & 1.00 & 68.04 & 27.32 & 19.74 & 2 & 1874.9314 & 1874.9303 & 938.4724 & 0.0011 & 0.5861 & 2360.864 & 2805.943 & 0.000\end{array}$ $\begin{array}{lllllllllllllll}\text { TIQFVDWCPTGFK } & 1.00 & 68.04 & 27.32 & 19.74 & 2 & 1874.9314 & 1874.9303 & 938.4724 & 0.0011 & 0.5861 & 2360.864 & 2805.943 & 0.000\end{array}$ $\begin{array}{lllllllllllllll}\text { TIQFVDWCPTGFK } & 1.00 & 76.07 & 27.27 & 20.58 & 2 & 1874.9330 & 1874.9303 & 938.4724 & 0.0027 & 1.4385 & 2909.621 & 2670.893\end{array}$ $\begin{array}{lllllllllllll}\text { AVCMLSNTTAVAEAWAR } & 1.00 & \text { \#\#\#\# } 27.36 & 22.65 & 2 & 1982.9502 & 1982.9498 & 992.4822 & 0.0004 & 0.2015 & 29.191 & 32.709\end{array}$ $\begin{array}{llllllllllll}\text { AVCMLSNTTAVAEAWAR } & 1.00 & \text { \#\#\# } 27.38 & 23.19 & 2 & 1982.9508 & 1982.9498 & 992.4822 & 0.0010 & 0.5038 & 30.161 & 35.726\end{array}$ $\begin{array}{lllllllllllll}\text { AVCMLSNTTAVAEAWAR } & 1.00 & 39.55 & 27.38 & 15.91 & 3 & 1982.9509 & 1982.9498 & 661.9905 & 0.0011 & 0.5539 & 103.752 & 110.018\end{array}$

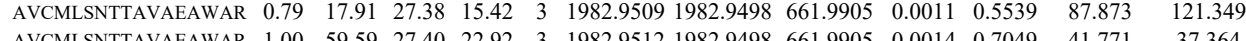

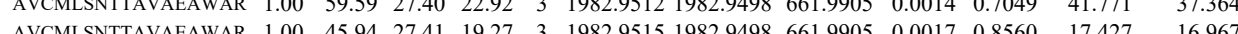
$\begin{array}{llllllllllll} & \end{array}$ $\begin{array}{llllllllllll} & \end{array}$ $\begin{array}{lllllllllll} & \end{array}$

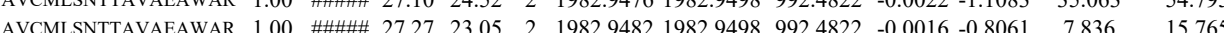

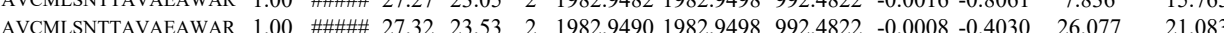
$\begin{array}{lllllllllllll}\text { AVCMLSNTTAVAEAWAR } & 0.55 & 18.40 & 27.41 & 31.40 & 3 & 1982.9518 & 1982.9498 & 661.9905 & 0.0020 & 1.0071 & 116.198 & 133.126\end{array}$ $\begin{array}{lllllllllllll}\text { AVCMLSNTTAVAEAWAR } & 0.55 & 29.57 & 27.32 & 42.57 & 3 & 1982.9521 & 1982.9498 & 661.9905 & 0.0023 & 1.1581 & 102.113 & 107.716\end{array}$ $\begin{array}{lllllllllllll}\text { AVCMLSNTTAVAEAWAR } & 1.00 & 56.88 & 27.32 & 19.47 & 3 & 1982.9521 & 1982.9498 & 661.9905 & 0.0023 & 1.1581 & 6.516 & 10.444\end{array}$ $\begin{array}{lllllllllllll}\text { AVCMLSNTTAVAEAWAR } & 1.00 & 49.48 & 27.34 & 18.57 & 3 & 1982.9548 & 1982.9498 & 661.9905 & 0.0050 & 2.5177 & 230.033 & 288.723\end{array}$ $\begin{array}{lllllllllllll}\text { AVCMLSNTTAVAEAWAR } & 1.00 & \text { \#\#\#\# } 27.32 & 30.20 & 2 & 1982.9486 & 1982.9498 & 992.4822 & -0.0012 & -0.6045 & 3.097 & 12.688\end{array}$

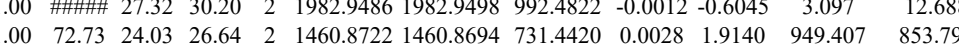
$\begin{array}{lllllllllllll}\text { ALVDILSEVSK } & 1.00 & 77.19 & 23.98 & 25.12 & 2 & 1460.8728 & 1460.8694 & 731.4420 & 0.0034 & 2.3242 & 1235.450 & 809.738\end{array}$ ATLQEILPEVLK $\begin{array}{lllllllllllll}1.00 & 49.56 & 20.76 & 16.12 & 2 & 1460.8728 & 1460.8694 & 71.4420 & 0.0034 & 2.3242 & 1235.450 & 809.73\end{array}$ ATLQEILPEVLK

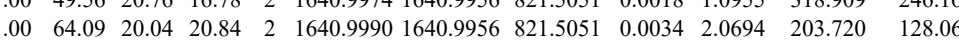

ATLQEILPEVLK

TLQEILPEVLK

ATLQEILPEVLK $\begin{array}{llllllllllll}0.60 & 12.52 & 19.96 & 23.59 & 3 & 1640.9998 & 1640.9956 & 548.0058 & 0.0042 & 2.5547 & 89.378 & 79.043\end{array}$

ATLQEILPEVLK

$\begin{array}{lllllllllllll}0.60 & 12.52 & 19.96 & 23.59 & 3 & 1640.998 & 1640.9956 & 548.058 & 0.0042 & 2.5547 & 89.378 & 19.043 \\ 0.79 & 13.54 & 20.04 & 22.25 & 3 & 1640.9983 & 1640.9956 & 548.0058 & 0.0027 & 1.6423 & 67.754 & 81.043\end{array}$

ATLQEILPEVLK

$\begin{array}{llllllllllll}0.79 & 13.54 & 0.04 & 22.25 & 3 & 164.9983 & 1640.9956 & 548.058 & 0.002 & 1.6423 & 67.754\end{array}$ $\begin{array}{llllllllllllllll} & \end{array}$ $\begin{array}{llllllllllllll} & \end{array}$

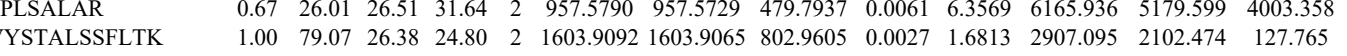
$\begin{array}{llllllllllllll}\text { QPENALVLELLEPLLSIIR } & 0.53 & 11.40 & 18.06 & 24.40 & 3 & 2303.3614 & 2303.3586 & 768.7935 & 0.0028 & 1.2140 & 19.928 & 20.096 & 3.261\end{array}$ $\begin{array}{llllllllllllll}\text { QPENALVLELLEPLLSIIR } & 1.00 & 81.51 & 17.92 & 26.34 & 2 & 2303.3614 & 2303.3586 & 1152.6866 & 0.0028 & 1.2146 & 15.325 & 17.250 & 9.171\end{array}$ Q $\begin{array}{lllllllllllllll} & \text { LLQALAQYQNHLQEQPR } & 1.00 & 89.46 & 26.62 & 23.40 & 3 & 2193.1795 & 2193.1776 & 732.0665 & 0.0019 & 0.8651 & 9504.138 & 10454.681 & 1219.286\end{array}$ 

$\begin{array}{lllllllllllll}1.00 & 61.83 & 14.31 & 18.60 & 2 & 1396.9278 & 1396.9261 & 699.4703 & 0.0017 & 1.2152 & 20291.234 & 16796.192 & 250.499\end{array}$

$\begin{array}{llllllllllllll}1.00 & 55.89 & 28.14 & 30.08 & 2 & 1289.6780 & 1289.6771 & 645.8458 & 0.0009 & 0.6968 & 8064.752 & 13329.051 & 648.702\end{array}$ $\begin{array}{lllllllllllll}1.00 & 56.06 & 28.15 & 29.98 & 2 & 1289.6790 & 1289.6771 & 645.8458 & 0.0019 & 1.4709 & 6646.374 & 12026.540 & 929.298\end{array}$ $\begin{array}{lllllllllllll}1.00 & 46.11 & 26.44 & 20.44 & 3 & 1363.7881 & 1363.7846 & 455.6021 & 0.0035 & 2.5607 & 16583.374 & 25924.390 & 2635.120\end{array}$ $\begin{array}{llllllllllllll}1.00 & 35.89 & 26.51 & 20.99 & 3 & 1363.7884 & 1363.7846 & 455.6021 & 0.0038 & 2.7802 & 9888.449 & 16320.339 & 1523.954\end{array}$

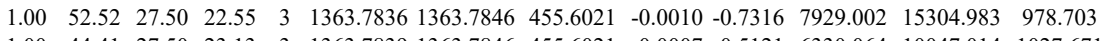
$\begin{array}{llllllllllllllll}1.00 & 44.41 & 27.50 & 23.13 & 3 & 1363.7839 & 1363.7846 & 455.6021 & -0.0007 & -0.5121 & 6330.064 & 10047.014 & 1027.671 & 33 . & & \\ 0.97 & 24.82 & 27.19 & 17.97 & 3 & 1363.7863 & 1363.7846 & 455.6021 & 0.0017 & 1.2438 & 1046.335 & 1412.423 & 396.132 & 23\end{array}$ $\begin{array}{lllllllllllllll}0.97 & 24.82 & 27.19 & 17.97 & 3 & 1363.7863 & 1363.7846 & 455.6021 & 0.0017 & 1.2438 & 1046.335 & 1412.423 & 396.132 & 23 & \\ 0.98 & 25.38 & 27.18 & 19.78 & 3 & 1363.7866 & 1363.7846 & 455.6021 & 0.0020 & 1.4633 & 1063.275 & 1490.403 & 597.749 & 268 & \\ 1.00 & 43.11 & 17.71 & 27.48 & 2 & 1228.8116 & 1228.799 & 615.4072 & 0.017 & 9.5058 & 13917.392 & 1493.759 & 695.323 & 589\end{array}$ $\begin{array}{llllllllllllll}0.98 & 25.38 & 27.18 & 19.78 & 3 & 1363.7866 & 1363.7846 & 455.6021 & 0.0020 & 1.4633 & 1063.275 & 1490.403 & 597.749 & 268 \\ 1.00 & 43.11 & 17.71 & 27.48 & 2 & 1228.8116 & 1228.7999 & 615.4072 & 0.0117 & 9.5058 & 13917.392 & 14937.759 & 6959.323 & 589 \\ 0.99 & 37.32 & 17.85 & 29.70 & 2 & 1228.8110 & & \end{array}$

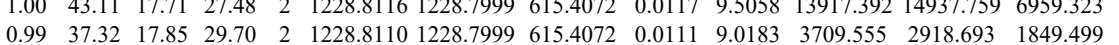
TIFAYFTGSK

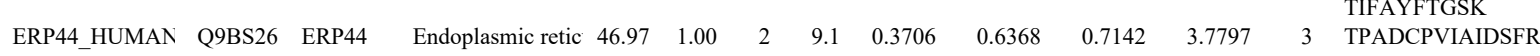

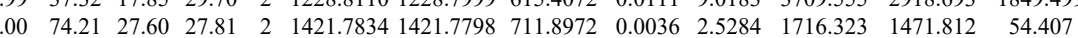
$\begin{array}{lllllllllllll}1.00 & 74.21 & 27.60 & 27.81 & 2 & 1421.7834 & 1421.7798 & 71.8972 & 0.0036 & 2.5284 & 1716.323 & 1471.812 & 54.407\end{array}$ $\begin{array}{llllllllllllll}1.00 & 72.41 & 17.99 & 23.54 & 2 & 1452.9168 & 1452.9150 & 727.4648 & 0.0018 & 1.2372 & 268.546 & 259.190 \\ 1.00 & 33.64 & 17.99 & 18.56 & 3 & 1452.9166 & 1452.9150 & 485.3123 & 0.0016 & 1.0989 & 24.760 & 43.225\end{array}$ $\begin{array}{lllllllllllll}1.00 & 33.64 & 17.99 & 18.56 & 3 & 1452.9166 & 1452.9150 & 485.3123 & 0.0016 & 1.0989 & 24.760 & 43.225 & 16.500 \\ 1.00 & 70.58 & 17.99 & 22.48 & 2 & 1452.9166 & 1452.9150 & 727.4648 & 0.0016 & 1.0997 & 47.693 & 83.271 & 0.000 \\ 0.55 & 31.01 & 17.99 & 44.01 & 3 & 1452.9169 & 1452.9150 & 4853123 & 0.0019 & 1.3050 & 27.065 & 33.501 & 14.553\end{array}$ $\begin{array}{lllllllllllll}0.55 & 31.01 & 17.99 & 44.01 & 3 & 1452.9169 & 1452.9150 & 485.3123 & 0.0019 & 1.3050 & 27.065 & 33.501 & 14.553 \\ 1.00 & 79.92 & 17.99 & 21.67 & 2 & 1452.9170 & 1452.9150 & 727.4648 & 0.0020 & 1.3746 & 154.627 & 134.716 & 3.334\end{array}$ $\begin{array}{lllllllllllll}1.00 & 75.20 & 19.14 & 24.34 & 2 & 1452.9158 & 1452.9150 & 727.4648 & 0.0008 & 0.5499 & 126.628 & 160.447 & 3.915\end{array}$ $\begin{array}{llllllllllllll}1.00 & 87.93 & 17.99 & 25.70 & 2 & 1452.9166 & 1452.9150 & 727.4648 & 0.0016 & 1.0997 & 22.528 & 30.102 & 0.000\end{array}$

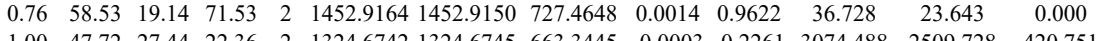

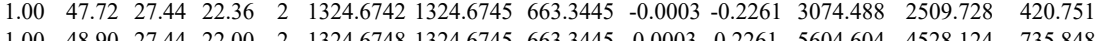
$\begin{array}{lllllllllllll}1.00 & 48.90 & 27.44 & 22.00 & 2 & 1324.6748 & 1324.6745 & 663.3445 & 0.0003 & 0.2261 & 5604.604 & 4528.124 & 735.848\end{array}$ $\begin{array}{llllllllllllll}1.00 & 59.47 & 27.47 & 21.31 & 2 & 1324.6758 & 1324.6745 & 663.3445 & 0.0013 & 0.9799 & 9742.957 & 7790.589 & 1131.049 & 1\end{array}$ $\begin{array}{llllllllllllll}1.00 & 55.85 & 27.47 & 17.95 & 2 & 1324.6760 & 1324.6745 & 663.3445 & 0.0015 & 1.1306 & 7528.444 & 6123.825 & 1008.131 \\ 1.00 & 57.55 & 27.46 & 23.94 & 2 & 1324.6746 & 1324.6745 & 663.3445 & 0.0001 & 0.0754 & 3702361 & 3110.015 & 421.396\end{array}$ $\begin{array}{rrrrlllllllllll}1.00 & 57.55 & 27.46 & 23.94 & 2 & 1324.6746 & 1324.6745 & 663.3445 & 0.0001 & 0.0754 & 3702.361 & 3110.015 & 421.396 & 78.241\end{array}$ $\begin{array}{lllllllllllllllll}0.85 & 22.26 & 16.63 & 23.45 & 3 & 1208.7931 & 1208.7849 & 403.9356 & 0.0082 & 6.7667 & 15411.415 & 10736.960 & 2239.762 & 1518.456 & \text { Yes }\end{array}$ $\begin{array}{llllllllllllllll}0.83 & 23.66 & 16.63 & 25.32 & 3 & 1208.7931 & 1208.7849 & 403.9356 & 0.0082 & 6.7667 & 15066.723 & 12527.777 & 1707.176 & 1656.892 & \text { Yes }\end{array}$ $\begin{array}{lllllllllllllll}1.00 & 44.92 & 16.63 & 19.51 & 2 & 1208.7932 & 1208.7849 & 605.3997 & 0.0083 & 6.8549 & 8564.236 & 5315.624 & 1123.451 & 896.279 & \text { Yes } \\ 0.90 & 17.19 & 16.63 & 15.87 & 3 & 120.8943 & 128.7849 & 403.935 & 0.0094 & 7.7570 & 1483.65 & 10373.87 & 268.431 & 1489.986 & \text { Yes }\end{array}$ $\begin{array}{llllllllllllllll}0.90 & 17.1 & 16.63 & 15.87 & 3 & 1208.7943 & 1208.7849 & 403.9356 & 0.0094 & 7.7570 & 11483.654 & 10373.871 & 2698.431 & 1481.886 & \text { Yes } \\ 1.00 & 4.64 & 27.32 & 18.74 & 3 & 1302.7624 & 1302.7530 & 435.2583 & 0.0094 & 7.1987 & 29223.917 & 27073.858 & 9371.781 & 4895.987 & \text { Yes }\end{array}$ $\begin{array}{lllllllllllllllll}1.00 & 44.64 & 27.32 & 18.74 & 3 & 1302.7624 & 1302.7530 & 435.2583 & 0.0094 & 7.1987 & 29223.917 & 27073.858 & 9371.781 & 4895.987 & \text { Yes } \\ 0.94 & 19.73 & 25.33 & 20.58 & 3 & 1907.0761 & 1907.0728 & 636.6982 & 0.0033 & 1.7277 & 12826580 & 14205.214 & 1774.914 & 214.121 & \text { Yes }\end{array}$ $\begin{array}{llllllllllllllll}0.53 & 10.75 & 25.30 & 23.75 & 3 & 1907.0758 & 1907.0728 & 636.6982 & 0.0030 & 1.5706 & 5437.793 & 5652.090 & 966.448 & 599.550 & \text { Yes }\end{array}$ $\begin{array}{lllllllllllllll}0.99 & 28.83 & 25.42 & 19.83 & 3 & 1907.0782 & 1907.0728 & 636.6982 & 0.0054 & 2.8271 & 8070.909 & 9117.872 & 1507.052 & 293.676 & \text { Yes } \\ 0.89 & 17.07 & 25.17 & 17.38 & 3 & 1007.0749 & 1907.0728 & 636.6982 & 0.0021 & 1.094 & 1507.111 & 1463.360 & 380.347 & 109.404 & \text { Yes }\end{array}$ $\begin{array}{lllllllllllllll}0.55 & 29.42 & 24.33 & 42.42 & 3 & 1423.8439 & 1423.8421 & 475.6213 & 0.0018 & 1.2615 & 1669.687 & 2338.948 & 1542.169 & 945.858 & \text { No }\end{array}$ 
$\begin{array}{llllllllllllll}\text { CPNLTYLNLSGNK } & 1.00 & 86.67 & 28.25 & 24.70 & 2 & 1769.9070 & 1769.9048 & 885.9597 & 0.0022 & 1.2416 & 4715.091 & 5568.089 & 3\end{array}$

$\begin{array}{llllllllllllll}\text { CPNLTYLNLSGNK } & 1.00 & 83.08 & 28.21 & 24.83 & 2 & 1769.9074 & 1769.9048 & 885.9597 & 0.0026 & 1.4673 & 2762.088 & 3017.542\end{array}$ $\begin{array}{llllllllllllll}\text { CPNLTYLNLSGNK } & 1.00 & 68.34 & 28.22 & 22.04 & 2 & 1769.9044 & 1769.9048 & 885.9597 & -0.0004 & -0.2257 & 1081.155 & 1353.932\end{array}$ $\begin{array}{llllllllllll}\text { GHYTEGAELVDAVLDVVR } & 1.00 & 53.36 & 27.68 & 24.97 & 3 & 2086.0840 & 2086.0817 & 696.3678 & 0.0023 & 1.1009 & 86.241\end{array}$ $\begin{array}{lllllllllllll}\text { GHYTEGAELVDAVLDVVR } & 1.00 & 75.43 & 27.60 & 23.19 & 3 & 2086.0852 & 2086.0817 & 696.3678 & 0.0035 & 1.6754 & 232.690 \\ \text { ALTVPELTQQMFEDAR } & 1.00 & 68.63 & 27.71 & 22.12 & 2 & 1862.9688 & 1862.9682 & 932.4914 & 0.0006 & 0.3217 & 411.978\end{array}$

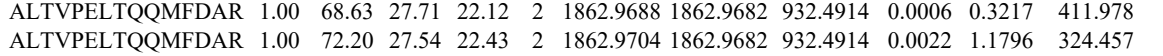
$\begin{array}{lllllllllllllll} & \end{array}$ $\begin{array}{lllllllllll} & \end{array}$ $\begin{array}{lllllllll} & 09.004\end{array}$

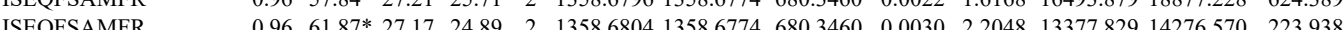
$\begin{array}{llllllllllllll} & 0\end{array}$

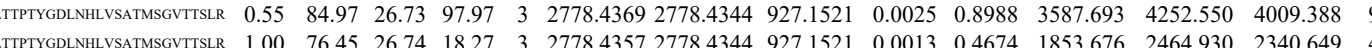
$\begin{array}{llllllllllllllll}\text { SGPFGQLRPDNFFFGTGGGANWAK } & 1.00 & 75.85 & 26.71 & 25.31 & 3 & 3113.5732 & 3113.5715 & 1038.8644 & 0.0017 & 0.5455 & 80.971 & 159.643 & 126.589 & 79.20\end{array}$

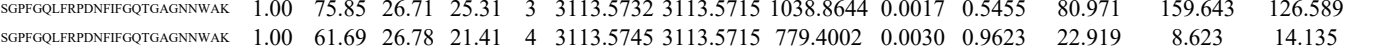
$\begin{array}{lllllllllllllllll}\text { SGPGGLLRPDNFFGQTGAGNNWAK } & 1.00 & 56.03 & 26.74 & 16.79 & 4 & 3113.5765 & 3113.5715 & 779.4002 & 0.0050 & 1.6038 & 22.799 & 25.392 & 5.972 & 0.000\end{array}$ $\begin{array}{lllllllllllllll}\text { LTTPYGDLNHLVATMSGVTTSLR } & 0.55 & 64.76 & 26.75 & 77.76 & 3 & 2778.4360 & 2778.4344 & 927.1521 & 0.0016 & 0.5752 & 22.885 & 39.354 & 40.563 & 19.22\end{array}$

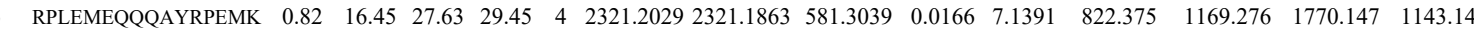
$\begin{array}{llllllllllllll}\text { WDVLIQQATQCLNR } & 1.00 & 81.28 & 27.57 & 27.31 & 2 & 1876.9412 & 1876.9409 & 939.4777 & 0.0003 & 0.1597 & 209.091 & 248.776 & 35.448\end{array}$

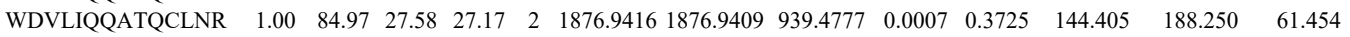
$\begin{array}{llllllllllllll}\text { WDVLIQQATQCLNR } & 0.53 & 48.16 & 27.75 & 61.16 & 3 & 1876.9441 & 1876.9409 & 626.6542 & 0.0032 & 1.7022 & 66.899 & 55 .\end{array}$ $\begin{array}{lllllllllllll}\text { WDVLIQQATQCLNR } & 1.00 & 61.64 & 27.75 & 25.12 & 3 & 1876.9441 & 1876.9409 & 626.6542 & 0.0032 & 1.7022 & 66.923 & \end{array}$ $\begin{array}{lllllllllllllll}\text { WDVLIQQATQCLNR } & 1.00 & 45.21 & 27.59 & 16.10 & 3 & 1876.9417 & 1876.9409 & 626.6542 & 0.0008 & 0.4255 & 36.540 & 33.003 & 14.062\end{array}$

SIPAITR

SIPAITR

SIPAITR

NFLSTPQFLYR

NFLSTPQFLYR NFLSTPQFLYR

$\begin{array}{llllllllllllll}0.97 & 31.57 & 26.38 & 34.24 & 2 & 900.5538 & 900.5514 & 451.2830 & 0.0024 & 2.6591 & 18809.448 & 17091.760 & 5032.936\end{array}$ $\begin{array}{lllllllllllllll}0.93 & 27.85 & 26.31 & 32.34 & 2 & 900.5540 & 900.5514 & 451.2830 & 0.0026 & 2.8807 & 23868.524 & 25509.046 & 5686.146\end{array}$ $\begin{array}{llllllllllllllll}0.97 & 31.64 & 24.01 & 34.11 & 2 & 900.5532 & 900.5514 & 451.2830 & 0.0018 & 1.9943 & 24167.168 & 23853.932 & 6826.327 & 2277.250 & \text { Ys } & \end{array}$ FLSTPQFLYR

$\begin{array}{llllllllllllll}1.00 & 31.57 & 24.01 & 34.03 & 2 & 900.5534 & 900.5514 & 451.2830 & 0.0020 & 2.2159 & 28978.272 & 29492.407 & 8642.384 & 2.3\end{array}$ $\begin{array}{lllllllllllll}1.00 & 43.43 & 27.48 & 22.15 & 2 & 1528.8170 & 1528.8160 & 765.4153 & 0.0010 & 0.6532 & 2169.916 & 1991.569 & 39.695\end{array}$ $\begin{array}{llllllllllllll}\text { YR } & 1.00 & 49.56 & 27.46 & 24.36 & 2 & 1528.8164 & 1528.8160 & 765.4153 & 0.0004 & 0.2613 & 1307.153 & 1115.097 & 0.000 \\ \text { YR } & 1.00 & 48.87 & 27.51 & 20.09 & 2 & 1528.8166 & 1528.8160 & 765.4153 & 0.0006 & 0.3919 & 1771.807 & 1834.834 & 0.000 \\ \end{array}$

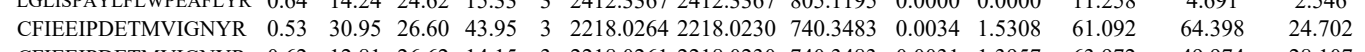

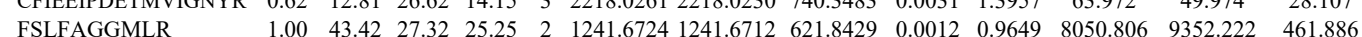
$\begin{array}{llllllllllllll}\text { FSLFAGGMLR } & 1.00 & 43.42 & 27.32 & 25.25 & 2 & 1241.6724 & 1241.6712 & 621.8429 & 0.0012 & 0.9649 & 8050.806 & 9352.222 & 461.886 \\ \text { FSLFAGGMLR } & 1.00 & 39.68 & 27.59 & 25.62 & 2 & 1241.6726 & 1241.6712 & 621.8429 & 0.0014 & 1.1257 & 4762890 & 5350.332 & 182.865\end{array}$ 
FSLFAGGMLR FSLFAGGMLR FSLFAGGMLR FSLFAGGMLR

GGIPNVEGAAK GGIPNVEGAAK GGIPNVEGAAK VIEASDVVLEVLDAR VIEASDVVLEVLDAR VIEASDVVLEVLDAR VIEASDVVLEVLDAR KDPGVPNSAPFK KDPGVPNSAPFK VGVIGFPNVGK VGVIGFPNVGK

LVLILNK QITIIDSPSFIVSPLNSSSALALR QITIIDSPSFIVSPLNSSSALALR SGFNLEELEK

ASTPAILFLDEIDSILGAR ASTPAILFLDEIDSILGAR LLLVPCPPLR

LLLVPCPPLR

LLLVPCPPLR
LLLVPCPPLR

LLLVPCPPLR
LLLVPCPPLR

CDPVDYSNSPEALR CDPVDYSNSPEALR ALQQNGAPGIAK KPFQLR

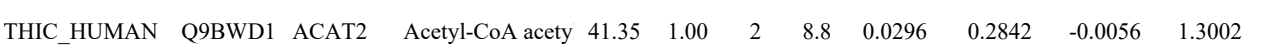
$\begin{array}{llllllllll}\text { NAA15 HUMAI Q9BXJ9 } & \text { NAA15 } & \text { N-alpha-acetyltrar 101.27 } & 1.00 & 5 & 5.9 & -0.0700 & 0.1289 & -0.6337 & 0.7821\end{array}$ VAVLSQNR VAVLSQNR

1 GELLLQLCR GELLLQLCR GELLLQLCR TLMLSYK GCPPVNTLR GCPPVFNTLR GCPPVFNTLR FLLMLQSVK GLPPVYNTLR GCPPVFNTLR WMDEAQALDTADR VETPLEEAIK

VETPLEEAIK

FVTSNTQELGK FVTSNTQELGK WLCPLSGK CGIIHVR

LTPLLSVR

LTPLLSVR

LTPLLSVR

LLLYLR

LLLYLR

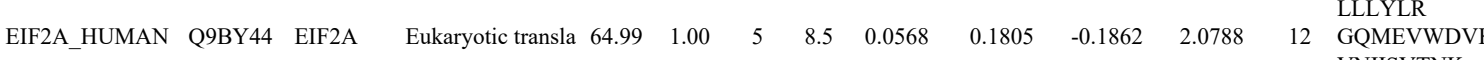
VNIISVTNK VNIISVTNK APSTPLLTVR APSTPLLTVR APSTLLTVR

IWHYTGSILHK

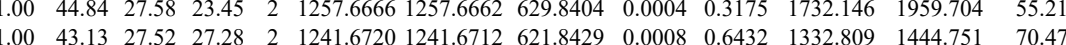
$\begin{array}{lllllllllllll} & \end{array}$

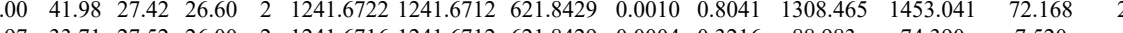

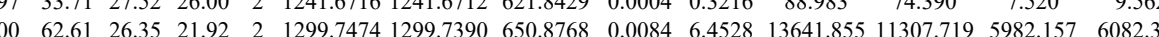
$\begin{array}{llllllllllllllll}1.00 & 62.61 & 26.35 & 21.92 & 2 & 1299.7474 & 1299.7390 & 650.8768 & 0.0084 & 6.4528 & 13641.855 & 11307.719 & 5982.157 & 6082.378 & \text { Yes }\end{array}$

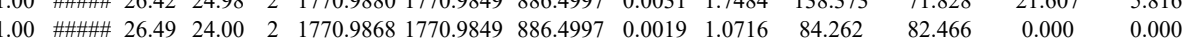

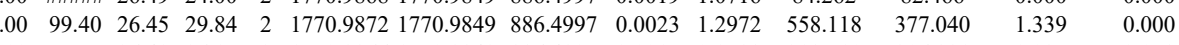
$\begin{array}{llllllllllll} & \end{array}$

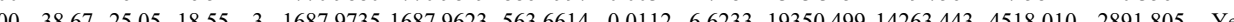
$\begin{array}{llllllllllllllll}0.94 & 26.90 & 24.86 & 18.57 & 3 & 1687.9756 & 1867.9623 & 563.6614 & 0.0133 & 7.62652 & 13291.640 & 10681.911 & 3780.913 & 305.903 & \text { Yes }\end{array}$ $\begin{array}{lllllllllllllll}1.00 & 59.31 & 24.35 & 19.84 & 3 & 2728.4725 & 2728.4673 & 910.4964 & 0.0052 & 1.9037 & 843.991 & 691.489 & 473.242 & 147.867 & \text { Yes }\end{array}$

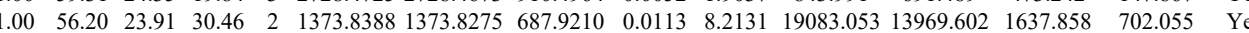
$\begin{array}{llllllllllllllll}1.00 & 56.74 & 23.58 & 29.00 & 2 & 1373.8404 & 1373.8275 & 687.9210 & 0.0129 & 9.3760 & 15457.464 & 12786.499 & 2434.345 & 857.938 & \text { Yes }\end{array}$ $\begin{array}{llllllllllllll}1.00 & 45.87 & 12.55 & 34.70 & 2 & 1099.7680 & 1099.7572 & 550.8859 & 0.0108 & 9.8023 & 42336.949 & 41538.988 & 0.000 & 382.781\end{array}$

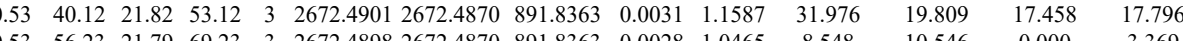
$\begin{array}{rlllllllllllll}0.53 & 56.23 & 21.79 & 69.23 & 3 & 2672.4898 & 2672.4870 & 891.8363 & 0.0028 & 1.0465 & 8.548 & 10.546 & 0.000 & 3.369\end{array}$ $\begin{array}{llllllllllllll}1.00 & 52.74 & 28.06 & 30.28 & 2 & 1452.7730 & 1452.7704 & 727.3925 & 0.0026 & 1.7872 & 909.920 & 728.878 & 297.782 & 289.721\end{array}$ $\begin{array}{lllllllllllll}1.00 & 55.90 & 25.43 & 16.63 & 3 & 2145.1834 & 2145.1803 & 716.0674 & 0.0031 & 1.4431 & 7.081 & 9.532 & 5.462\end{array}$ $\begin{array}{llllllllllll} & \end{array}$ $\begin{array}{lllllllllllll}0.99 & 31.57 & 24.42 & 26.12 & 2 & 1309.7746 & 1309.7736 & 655.8941 & 0.0010 & 0.7623 & 156.575 & 150.706 & 8.523\end{array}$ $\begin{array}{llllllllllll}0.99 & 31.57 & 24.42 & 26.12 & 2 & 1309.7746 & 309.7736 & 655.8941 & 0.010 & 0.7623 & 156.575 & 150.706\end{array}$ $\begin{array}{lllllllllllll}0.98 & 33.37 & 24.38 & 27.16 & 2 & 1309.7740 & 1309.7736 & 655.8941 & 0.0004 & 0.3049 & 198.878 & 214.593 & 21.402\end{array}$ $\begin{array}{llllllllllllll}0.97 & 29.82 & 24.42 & 32.01 & 2 & 1309.7442 & 1309.7736 & 655.8941 & 0.0006 & 0.4574 & 328.481 & 344.560 & 0.000\end{array}$ $\begin{array}{llllllllllllll}0.99 & 33.03 & 24.42 & 26.80 & 2 & 1309.7744 & 1309.7736 & 655.8941 & 0.0008 & 0.6099 & 19.401 & 249.968 & 6.397\end{array}$ $\begin{array}{lllllllllllll}1.00 & 76.78 & 23.80 & 17.82 & 2 & 1754.7788 & 1754.7725 & 878.3935 & 0.0063 & 3.5861 & 1072.299 & 910.696 & 64.163\end{array}$ $\begin{array}{lllllllllllll}1.00 & 65.73 & 23.91 & 17.52 & 2 & 1754.7796 & 1754.7725 & 878.3935 & 0.0071 & 4.0415 & 294.496 & 263.591 & 28.055\end{array}$ $\begin{array}{lllllllllllllll}1.00 & 45.95 & 25.25 & 22.73 & 2 & 1454.8502 & 1454.8449 & 728.4297 & 0.0053 & 3.6379 & 521.339 & 493.766 & 303.306 & 29.1 . \\ 0.69 & 15.70 & 23.94 & 18.01 & 2 & 1075.6764 & 1075.6746 & 538.8446 & 0.0018 & 1.6702 & 10784.069 & 12397.869 & 10591.713 & 7677\end{array}$ $\begin{array}{lllllllllllllll}0.69 & 15.70 & 23.94 & 18.01 & 2 & 1075.6764 & 1075.6746 & 538.8446 & 0.0018 & 1.6702 & 10784.069 & 12397.869 & 10591.713 & 7677\end{array}$ $\begin{array}{llllllllllllll}1.00 & 66.71 & 26.74 & 17.47 & 3 & 2925.4600 & 2925.4599 & 976.1606 & 0.0001 & 0.0341 & 48.126 & 40.237 & 58.396 \\ 1.00 & 45.75 & 27.05 & 35.38 & 2 & 1029.6078 & 1029.6053 & 515.8099 & 0.0025 & 2.4234 & 3095.496 & 3564.465 & 775.332\end{array}$ $\begin{array}{lllllllllllll}1.00 & 45.75 & 27.05 & 35.38 & 2 & 1029.6078 & 1029.6053 & 515.8099 & 0.0025 & 2.4234 & 3095.496 & 3564.465 & 775.332 \\ 1.00 & 43.86 & 27.05 & 35.33 & 2 & 1029.6078 & 1029.6053 & 515.8099 & 0.0025 & 2.4234 & 4304.882 & 5153.404 & 731.230\end{array}$ $\begin{array}{llllllllllllll}1.00 & 43.86 & 27.05 & 35.33 & 2 & 1029.6078 & 1029.6053 & 515.8099 & 0.0025 & 2.4234 & 4304.882 & 5153.404 & 731.230 & 468 . \\ 1.00 & 50.99 & 28.56 & 29.13 & 2 & 1233.6704 & 1233.6695 & 617.8420 & 0.0009 & 0.7283 & 16417.751 & 14340.626 & 6270.022 & 1\end{array}$

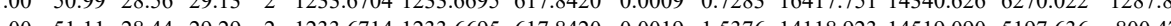

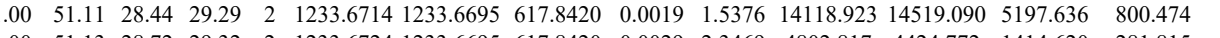

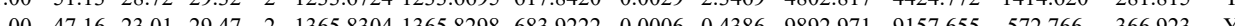
$\begin{array}{llllllllllllllll}1.00 & 48.76 & 22.94 & 34.58 & 2 & 1365.8308 & 1365.8298 & 683.9222 & 0.0010 & 0.7311 & 10488.644 & 9720.551 & 573.239 & 352.177 & \text { Yes }\end{array}$ $\begin{array}{lllllllllllllll}1.00 & 46.81 & 27.47 & 21.23 & 2 & 1292.6494 & 1292.6491 & 647.3318 & 0.0003 & 02317 & 3675.197 & 3561.782 & 254.821 & 75.714 & \text { Yes }\end{array}$

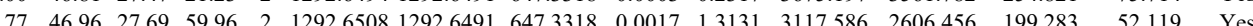
$\begin{array}{lllllllllllllll}100 & 49.07 & 22.94 & 33.68 & 2 & 1365.8306 & 1365.8298 & 683.9222 & 0.0008 & 0.5849 & 3894.596 & 3896.207 & 177.497 & 94.225 & \text { Yes }\end{array}$ $\begin{array}{lllllllllllllll}1.00 & 47.24 & 22.94 & 29.56 & 2 & 1365.8308 & 1365.8298 & 683.9222 & 0.0010 & 0.7311 & 4346.379 & 4387.460 & 165.170 & 102.300 & \text { Yes }\end{array}$ $\begin{array}{lllllllllllllll}1.00 & 45.17 & 27.78 & 17.73 & 2 & 1292.6510 & 1292.6491 & 647.3318 & 0.0019 & 1.4676 & 5172.382 & 5045.258 & 0.000 & 83.415 & \text { No }\end{array}$ $\begin{array}{llllllllllllllll}1.00 & 43.64 & 27.78 & 18.11 & 2 & 1292.6512 & 1292.6491 & 647.3318 & 0.0021 & 1.6220 & 13679.281 & 12857.820 & 772.628 & 182.586 & \text { Yes }\end{array}$ $\begin{array}{llllllllllllllll}1.00 & 45.99 & 24.55 & 18.95 & 2 & 1664.7610 & 1664.7586 & 833.3866 & 0.0024 & 1.4399 & 468.601 & 495.449 & 87.335 & 28.357 & \text { Yes }\end{array}$ $\begin{array}{lllllllllllllll}1.00 & 55.34 & 26.64 & 30.35 & 2 & 1415.8144 & 1415.8115 & 708.9130 & 0.0029 & 2.0454 & 587.723 & 691.040 & 131.996 & 31.346 & \text { Yes }\end{array}$ $\begin{array}{lllllllllllllll}1.00 & 55.90 & 26.43 & 31.55 & 2 & 1415.8160 & 1415.8115 & 708.9130 & 0.0045 & 3.1739 & 1423.660 & 1003.780 & 328.241 & 113.266 & \text { No }\end{array}$ $\begin{array}{lllllllllllllllll}1.00 & 54.55 & 28.08 & 27.86 & 2 & 1510.8362 & 1510.8235 & 756.4190 & 0.0127 & 8.3947 & 1049.604 & 785.262 & 916.581 & 540.951 & \mathrm{~N} 0\end{array}$ $\begin{array}{lllllllllllllll}1.00 & 64.23 & 28.12 & 36.58 & 2 & 1510.8366 & 1510.8235 & 756.4190 & 0.0131 & 8.6591 & 3470.340 & 3124.486 & 2603.678 & 1559.695 & \text { Y }\end{array}$ $\begin{array}{lllllllllllllll}0.99 & 42.83 & 28.16 & 18.08 & 2 & 1510.8338 & 1510.8235 & 756.4190 & 0.0103 & 6.8083 & 1923.524 & 1367.194 & 2153.868 & 611.553 & \end{array}$ $\begin{array}{llllllllllllllll}0.80 & 22.78 & 28.01 & 19.10 & 2 & 1236.6610 & 236.6602 & 619.3374 & 0.0008 & 0.6459 & 11841.601 & 9671.289 & 1435.041 & 398.796 & \text { Yes }\end{array}$ $\begin{array}{lllllllllllllll}0.79 & 29.23 & 27.08 & 20.43 & 2 & 986.5328 & 986.5276 & 494.2711 & 0.0052 & 5.2602 & 11191.658 & 10284.393 & 1802.977 & 1678.299 & \text { Yes }\end{array}$ $\begin{array}{lllllllllllllllll}0.92 & 27.08 & 21.43 & 23.92 & 2 & 1041.6754 & 1041.6668 & 521.8407 & 0.0086 & 8.2400 & 19525.234 & 16374.391 & 1977.185 & 330.881 & \text { Yes }\end{array}$ $\begin{array}{llllllllllllllll}0.88 & 24.70 & 21.30 & 23.56 & 2 & 1041.6758 & 1041.6668 & 521.8407 & 0.0090 & 8.6232 & 24855.201 & 22711.076 & 1893.813 & 799.984 & \text { Yes }\end{array}$ $\begin{array}{lllllllllllllll}0.95 & 27.26 & 21.14 & 24.38 & 2 & 1041.6766 & 1041.6668 & 521.8407 & 0.0098 & 9.3898 & 5286.962 & 4946.265 & 283.276 & 90.324 & \text { Yes }\end{array}$ $\begin{array}{llllllllllllllll}0.68 & 27.49 & 16.23 & 39.19 & 2 & 933.6136 & 933.6133 & 467.8139 & 0.0003 & 0.3206 & 15217.343 & 15471.538 & 1367.591 & 94.834 & \text { Yes }\end{array}$ $\begin{array}{llllllllllllllll}0.68 & 27.54 & 16.23 & 39.23 & 2 & 933.6132 & 933.6133 & 467.8139 & -0.0001 & -0.1069 & 4549.932 & 4876.243 & 272.120 & 70.638 & \text { Yes }\end{array}$ $\begin{array}{lllllllllllllllll}0.84 & 28.79 & 16.23 & 39.66 & 2 & 933.6140 & 933.6133 & 467.8139 & 0.0007 & 0.7482 & 6865.430 & 6809.068 & 459.599 & 53.377 & \text { Yes }\end{array}$ $\begin{array}{lllllllllllllll}0.94 & 47.35 & 27.94 & 45.87 & 2 & 1378.7148 & 1378.7159 & 690.3652 & -0.0011 & -0.7967 & 3954.562 & 3867.153 & 1853.493 & 1347.512 & \text { Yes } \\ 1.00 & 49.73 & 23.96 & 22.39 & 2 & 127.7918 & 1274.7802 & 638.3974 & 0.016 & 9.0852 & 4910.553 & 4043.943 & 849.080 & 464.693 & \text { Yes }\end{array}$ \begin{tabular}{lllllllllllllll}
1.00 & 49.73 & 23.96 & 22.39 & 2 & 1274.7918 & 1274.7802 & 638.3974 & 0.0116 & 9.0852 & 4910.553 & 4043.943 & 849.080 & 464.693 & Yes \\
\hline
\end{tabular} $\begin{array}{lllllllllllllll}1.00 & 47.80 & 23.52 & 21.97 & 2 & 1274.7904 & 1274.7802 & 638.3974 & 0.0102 & 7.9887 & 9533.467 & 9187.555 & 1828.669 & 475.732 & \text { Yes }\end{array}$ $\begin{array}{lllllllllllllll}0.99 & 40.91 & 22.67 & 16.23 & 2 & 1197.7280 & 1197.7203 & 599.8674 & 0.0077 & 6.4180 & 6894.408 & 7048.119 & 4912.319 & 1944.278 & \text { Yes } \\ 0.99 & 41.19 & 22.15 & 16.55 & 2 & 1197.7316 & 1197.7203 & 599.8674 & 0.0113 & 9.4187 & 8007.849 & 9666305 & 5618.091 & 2884210 & \text { Yes }\end{array}$ \begin{tabular}{lllllllllllllll}
0.99 & 41.24 & 22.67 & 16.51 & 2 & 1197.7184 & 1197.7203 & 599.8674 & 0.0113 & 9.487 & 8007.849 & 966.303 & 5618.091 & 2884.210 & Yes \\
\hline
\end{tabular}

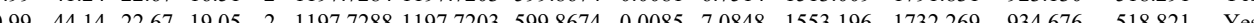

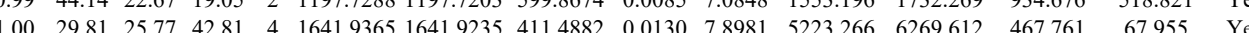


$\begin{array}{llllllllll} & \end{array}$ $\begin{array}{lllllllllllll}\text { GTLGGLFSQILQGEDIVR } & 1.00 & 42.97 & 25.75 & 25.13 & 3 & 2046.1255 & 2046.1232 & 683.0483 & 0.0023 & 1.1224 & 127.836 & 13\end{array}$ $\begin{array}{llllllllllllll} & \\ \text { A } & 0.53 & 50.11 & 12.04 & 63.11 & 3 & 2412.4630 & 2412.4599 & 805.1606 & 0.0031 & 1.2834 & 89.177 & 116.672 & 73.581 \\ \end{array}$

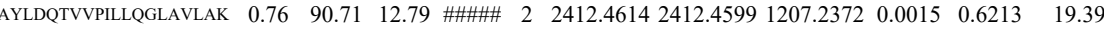
$\begin{array}{lllllllllllll}\text { AYLDQTVVPILLQGLAVLAK } & 0.76 & 84.41 & 12.79 & 97.41 & 2 & 2412.4614 & 2412.4599 & 1207.2372 & 0.0015 & 0.6213 & 10.175\end{array}$ $\begin{array}{llllllllllllll}\text { AYLDQTVVPILLQGLAVLAK } & 0.55 & 45.85 & 12.04 & 58.85 & 3 & 2412.462 & 2412.4599 & 805.1606 & 0.0022 & 0.9108 & 6.093\end{array}$

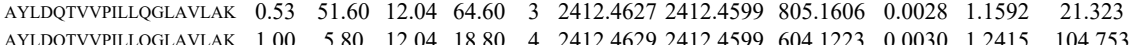
$\begin{array}{lllllllllllll}\text { AYLDQTVVPILLGLAVLAK } & 1.00 & 5.80 & 12.04 & 18.80 & 4 & 2412.4629 & 2412.4599 & 604.1223 & 0.0030 & 1.2415 & 104.753 \\ \text { AYLDOTVVPILLGLAVLAK } & 0.99 & 3.29 & 12.30 & 16.29 & 4 & 2412.4637 & 2412.4599 & 604.1223 & 0.0038 & 1.5725 & 108.020 & 13\end{array}$ $\begin{array}{lllllllllllll}\text { AYLDQTVVPILLQGLAVLAK } & 0.99 & 3.29 & 12.30 & 16.29 & 4 & 2412.4637 & 2412.4599 & 604.1223 & 0.0038 & 1.5725 & 108.020 & \\ \text { AYLDQTVYPILQGLAVLAK } & 0.55 & 67.17 & 12.04 & 80.17 & 3 & 2412.4621 & 2412.4599 & 805.1606 & 0.0022 & 0.9108 & 21.396\end{array}$ $\begin{array}{llllllllllllll}\text { AYLDQTVVPILLQGLAVLAK } & 0.55 & 67.17 & 12.04 & 80.17 & 3 & 2412.4621 & 2412.4599 & 805.1606 & 0.0022 & 0.9108 & 21.396 \\ \text { AYLDQTVYPILQGLAVLAK } & 0.55 & 58.45 & 12.04 & 71.45 & 3 & 2412.4621 & 2412.4599 & 805.1606 & 0.0022 & 0.9108 & 23.547\end{array}$ $\begin{array}{llllllllllll}\text { AYLDQTVVPILLGLAVLAK } & 0.55 & 58.45 & 12.04 & 71.45 & 3 & 2412.4621 & 2412.4599 & 805.1606 & 0.0022 & 0.9108 & 23.547 \\ \text { AYLDQTVVPILLGLAVLAK } & 0.69 & 83.59 & 12.30 & 96.59 & 2 & 2412.4634 & 2412.4599 & 1207.2372 & 0.0035 & 1.4496 & 4.983\end{array}$ $\begin{array}{llllllllllllll}\text { AYLDQTVVPLLQGLAVLAK } & 0.69 & 83.59 & 12.30 & 96.59 & 2 & 2412.4634 & 2412.4599 & 1207.2372 & 0.0035 & 1.4496 & 4.983\end{array}$ $\begin{array}{lllllllllllll} & \end{array}$ DDASMPLPFDLTDIVSELR NEILTAILASLTAR 促TALASLTar IEILTAILASLTAR NEILTAILASLTAR NEILTAILASLTAR NEILTAILASLTAR NEILTAILASLTAR NEILTAILASLTAR NEILTAILASLTAR NEILTAILASLTAR NEILTAILASLTAR

$\begin{array}{lllllllllll}1.00 & 15.98 & 12.30 & 28.98 & 4 & 2412.4645 & 2412.459 & 604.1223 & 0.0046 & 1.9036 & 67.176 \\ 0.73 & 18.85 & 27.51 & 37.11 & 2 & 2277.1334 & 2277.1321 & 1159.5733 & 0.0013 & 0.5704 & 42.775\end{array}$

$\begin{array}{llllllllll}1.00 & \text { \#\#\#\# 23.82 } & 33.37 & 2 & 1628.9586 & 1628.9583 & 815.4864 & 0.0003 & 0.1839 & 143.377\end{array}$

$\begin{array}{llllllll}1.00 & \end{array}$ $\begin{array}{llllllllllll}00 & 38.61 & 23.77 & 25.28 & 3 & 1628.9596 & 1628.9583 & 543.9934 & 0.0013 & 0.7966 & 87.691\end{array}$ $\begin{array}{lllllllllllll}1.00 & 33.78 & 23.80 & 26.13 & 3 & 1628.9599 & 1628.9583 & 543.9934 & 0.0016 & 0.9804 & 72.491\end{array}$ $\begin{array}{lllllllllllll}15.45 & 23.73 & 21.02 & 3 & 1628.9593 & 1628.9583 & 543.9934 & 0.0010 & 0.6128 & 28.336\end{array}$ $\begin{array}{lllllllllll}1.00 & 75.84 & 23.78 & 28.96 & 2 & 1628.9608 & 1628.9583 & 815.4864 & 0.0025 & 1.5328 & 30.543\end{array}$ $\begin{array}{lllllllllllll}1.00 & 86.44 & 23.82 & 29.14 & 2 & 1628.9586 & 1628.9583 & 815.4864 & 0.0003 & 0.1839 & 82.218\end{array}$ $\begin{array}{llllllllll}.00 & \text { \#\#\#\# } 23.78 & 28.96 & 2 & 1628.9590 & 1628.9583 & 815.4864 & 0.0007 & 0.4292 & 70.871\end{array}$ $\begin{array}{lllllllllll}1.00 & 37.74 & 23.77 & 27.59 & 3 & 1628.9596 & 1628.9583 & 543.9934 & 0.0013 & 0.7966 & 51.583\end{array}$ $\begin{array}{llllllllllll}0.61 & 10.41 & 23.48 & 18.80 & 3 & 1628.9602 & 1628.9583 & 543.9934 & 0.0019 & 1.1642 & 26.899 \\ 1.00 & 54.47 & 3.75 & 23.42 & 2 & 1628.958 & 1628.9583 & 543.9934 & 0.0043 & 2.6348 & 25.986\end{array}$ $\begin{array}{lllllllllll}1.00 & 54.47 & 23.75 & 23.42 & 2 & 1628.9580 & 1628.9583 & 815.4864 & -0.0003 & -0.1839 & 16.955\end{array}$

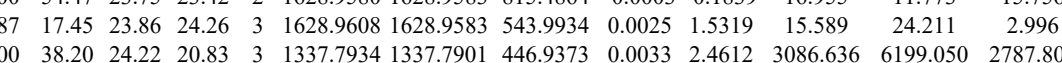
$\begin{array}{lllllllllll} & \end{array}$

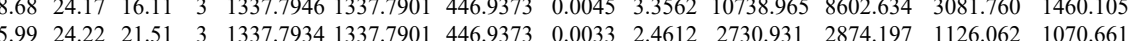
$\begin{array}{lllllllllllllll}0.92 & 17.77 & 20.53 & 19.60 & 3 & 1334.8402 & 3334.8398 & 445.9539 & 0.0004 & 0.2990 & 54.144 & 49.661 & 5.685 & 7.568 & \text { Yes } \\ \end{array}$

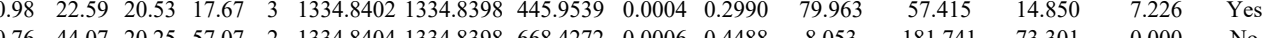
$\begin{array}{lllllllllllllll}0.76 & 44.07 & 20.25 & 57.07 & 2 & 1334.8404 & 1334.8398 & 668.4272 & 0.0006 & 0.4488 & 8.053 & 181.741 & 73.301 & 0.000 & \text { No }\end{array}$

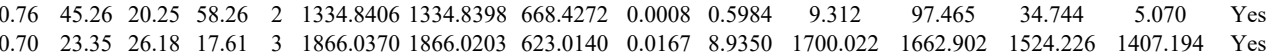
$\begin{array}{lllllllllllllll}0.70 & 23.35 & 26.18 & 17.61 & 3 & 1866.0370 & 1866.0203 & 623.0140 & 0.0167 & 8.9350 & 1700.022 & 1662.902 & 1524.226 & 1407.194 & \text { Yes } \\ 1.00 & 4.13 & 26.28 & 17.19 & 3 & 166379 & 1866.023 & 623.0140 & 0.0176 & 9.4165 & 8732.591 & 7537.158 & 4359.318 & 2949.693 & \text { Yes }\end{array}$ $\begin{array}{llllllllllllllllll}1.0 & 41.13 & 26.28 & 17.19 & 3 & 1866.0379 & 1866.0203 & 623.0140 & 0.0176 & 9.4165 & 8732.591 & 7537.158 & 4359.318 & 2949.693 & \text { Yes }\end{array}$

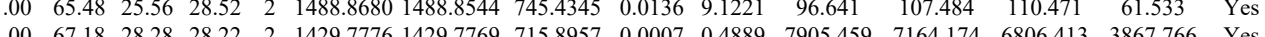

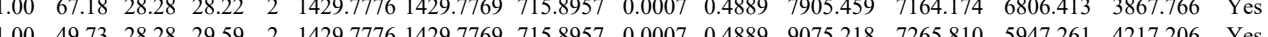
$\begin{array}{lllllllllllllll}1.00 & 44.55 & 28.26 & 25.44 & 2 & 1429.7782 & 1429.7769 & 7158957 & 0.0013 & 0.9080 & 692.394 & 880.960 & 870.082 & 421.206 & \text { Yes }\end{array}$ $\begin{array}{lllllllllllllll}0.98 & 31.53 & 25.42 & 16.93 & 3 & 1507.8718 & 1507.8602 & 503.6273 & 0.0116 & 7.6776 & 4052.598 & 2788.260 & 1782.081 & 1031.364 & \text { Yes }\end{array}$ $\begin{array}{llllllllllllll}.00 & 47.16 & 25.44 & 17.43 & 3 & 1507.8736 & 1507.8602 & 503.6273 & 0.0134 & 8.8689 & 11585.657 & 10624.044 & 5544.080 & 1935.802\end{array}$ $\begin{array}{llllllllllllllll}0.54 & 18.24 & 25.51 & 14.45 & 3 & 1507.8742 & 1507.8602 & 503.6273 & 0.0140 & 9.2660 & 1022.491 & 987.075 & 582.126 & 571.893 & \text { Yes }\end{array}$

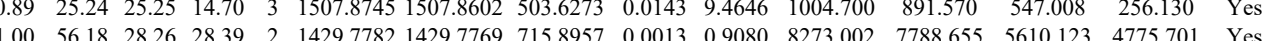




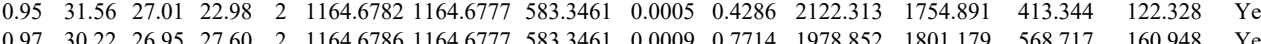
$\begin{array}{llllllllllllllll}\text { VQMIMLAVGEVEDSIFK } & 1.00 & 45.29 & 26.42 & 21.83 & 3 & 2196.1831 & 2196.1778 & 733.0665 & 0.0053 & 2.4100 & 30.963 & 26.611 & 11.750 & 9.948 & \text { Yes }\end{array}$

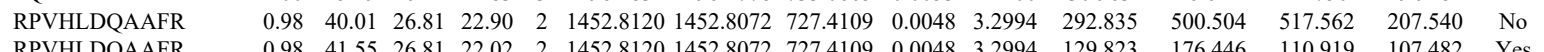

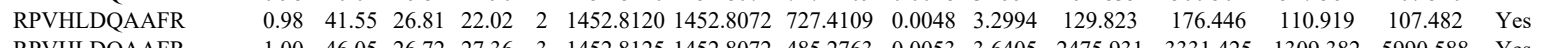
$\begin{array}{llllllllllllllll}\text { RPVHLDQAAFR } & 1.00 & 46.05 & 26.72 & 27.36 & 3 & 1452.8125 & 1452.8072 & 485.2763 & 0.0053 & 3.6405 & 2475.931 & 3331.425 & 1309.382 & 5990.588 & \text { Yes }\end{array}$

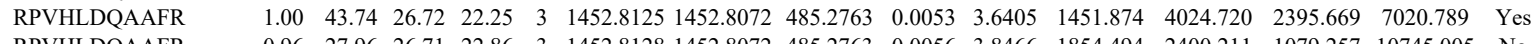
$\begin{array}{lllllllllllllllll}\text { RPVHLDQAAFR } & 0.96 & 27.96 & 26.71 & 22.86 & 3 & 1452.8128 & 1452.8072 & 485.2763 & 0.0056 & 3.8466 & 1854.494 & 2400.211 & 1079.257 & 10745.005 & \text { No }\end{array}$ KYPLPPPSGR

KYPLPPPSGR

AVMLPGAR

AVMLPGAR

LFSIVRPR

LFSIVRPR

DPQFAEDYIFK DPQFAEDYIFK $\begin{array}{llllllllllllllll}0.86 & 16.47 & 24.59 & 18.36 & 3 & 1398.8263 & 1398.8227 & 467.2815 & 0.0036 & 2.5680 & 5781.245 & 5255.361 & 727.073 & 409.950 & \text { Yes }\end{array}$ $\begin{array}{llllllllllllllll}0.90 & 17.83 & 24.58 & 16.77 & 3 & 1398.8269 & 1398.8227 & 467.2815 & 0.0042 & 2.9960 & 4871.780 & 4899.954 & 532.049 & 455.999 & \text { Yes }\end{array}$ $\begin{array}{llllllllllllllll}0.88 & 30.53 & 25.50 & 25.55 & 2 & 957.5598 & 957.5551 & 479.7848 & 0.0047 & 4.8980 & 22690.557 & 22545.351 & 3434.556 & 1590.220 & \text { Yes }\end{array}$ $\begin{array}{lllllllllllllllll}0.89 & 30.67 & 25.34 & 25.87 & 2 & 957.5606 & 957.5551 & 479.7848 & 0.0055 & 5.7317 & 24907.018 & 24975.944 & 3823.362 & 1661.477 & \text { Yes }\end{array}$

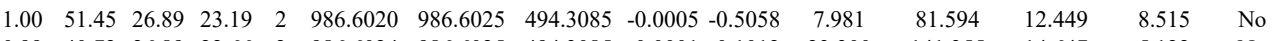
$\begin{array}{ccccccccccccccc}0.99 & 40.72 & 26.89 & 22.66 & 2 & 986.6024 & 986.6025 & 494.3085 & -0.0001 & -0.1012 & 23.300 & 141.355 & 14.647 & 5.122 & \text { No } \\ 0.76 & 40.92 & 27.60 & 53.92 & 2 & 1659.8398 & 1659.8388 & 830.9267 & 0.0010 & 0.6017 & 235.167 & 267.643 & 473.000 & 238.673 & \text { No }\end{array}$

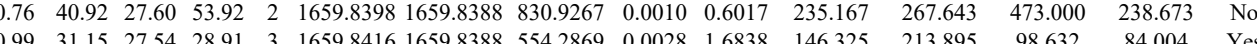

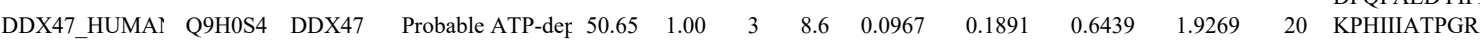
KPHIIIATPGR

KPHIIATPGR $\begin{array}{lllllllllllllllll} & \text { KPHIIATPGR } & 1.00 & 38.75 & 16.63 & 1.34 & 3 & 1489.9381 & 1489.9336 & 497.6518 & 0.0045 & 3.0141 & 4684.100 & 4954.912 & 2720.421 & 1813.100 & \text { Yes } \\ \text { KPHIIIATPGR } & 1.00 & 39.41 & 18.33 & 16.21 & 3 & 1489.9348 & 1489.9336 & 497.6518 & 0.0012 & 0.8038 & 2849.774 & 2909.747 & 1339.015 & 753.514 & \text { Yes } \\ \text { KPHHIATPGR } & 0.82 & 822 & 1833 & 13.75 & 3 & 1489.9363 & 1489.9336 & 497.6518 & 0.0027 & 1.8085 & 1560.549 & 1610.856 & 1299.072 & 382.945 & \text { Yes }\end{array}$ $\begin{array}{llllllllllllll} & \end{array}$ $\begin{array}{lllllllllllllll}1.00 & 46.37 & 18.33 & 21.43 & 2 & 1489.9360 & 1489.9336 & 745.9741 & 0.0024 & 1.6086 & 1844.855 & 2405.795 & 1696.294 & 1363.952 & \text { No } \\ & & \\ 1.00 & 45.48 & 18.26 & 22.28 & 3 & 1489.9366 & 1489.9336 & 497.6518 & 0.0030 & 2.0094 & 2971.307 & 3621.818 & 2276.764 & 1314.619 & \text { Yes }\end{array}$ $\begin{array}{lllllllllllllll}1.00 & 45.88 & 18.26 & 22.83 & 2 & 1498.9368 & 1489.9336 & 745.9741 & 0.0032 & 2.1448 & 1573.669 & 2269.809 & 1745.631 & 1134.245 & \text { No }\end{array}$ $\begin{array}{lllllllllllllll}1.00 & 38.75 & 16.63 & 19.34 & 3 & 148.9381 & 1489.9336 & 497.6518 & 0.0045 & 3.0141 & 4684.600 & 4954.912 & 2720.421 & 1813.100 & \text { Yes }\end{array}$ $\begin{array}{llllllllllllllll}0.82 & 8.22 & 18.33 & 13.75 & 3 & 1489.9363 & 1489.9336 & 497.6518 & 0.0027 & 1.8085 & 1560.549 & 1610.856 & 1299.072 & 382.945 & \text { Yes }\end{array}$ $\begin{array}{llllllllllllll} & & & \end{array}$ $\begin{array}{llllllllllllllll} & 23.67 & 24.12 & 2 & 2068.1814 & 2068.1802 & 1035.0974 & 0.0012 & 0.5797 & 90.084 & 104.289 & 20.303 & 1.472 & \text { Yes }\end{array}$

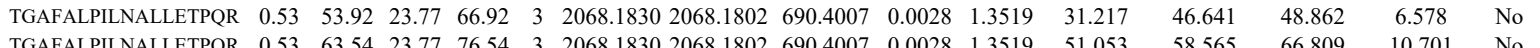

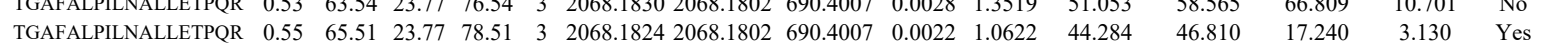

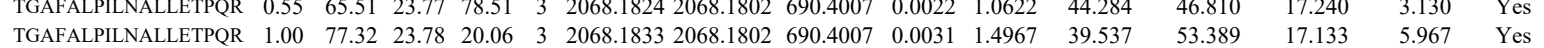

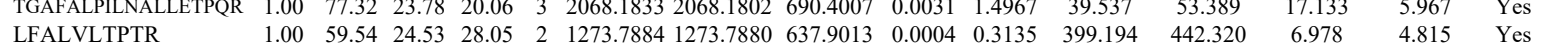

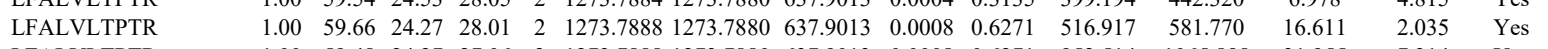

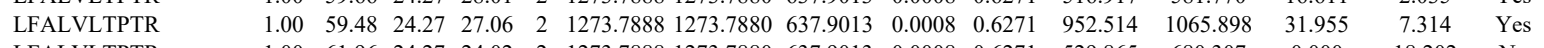
$\begin{array}{llllllllllllllll}\text { LFALVLTPTR } & 1.00 & 61.96 & 24.27 & 24.02 & 2 & 1273.7888 & 1273.7880 & 637.9013 & 0.0008 & 0.6271 & 529.865 & 680.307 & 0.000 & 18.202 & \text { No }\end{array}$ $\begin{array}{llllllllllllllll}\text { LFALVLTPTR } & 1.00 & 59.50 & 24.42 & 26.79 & 2 & 1273.7886 & 1273.7880 & 637.9013 & 0.0006 & 0.4703 & 470.896 & 505.004 & 2.359 & 16.529 & \text { Yes }\end{array}$ $\begin{array}{llllllllllllllll}\text { LFALVLTPTR } & 1.00 & 59.56 & 24.27 & 27.79 & 2 & 1273.7888 & 1273.7880 & 637.9013 & 0.0008 & 0.6271 & 953.465 & 1031.538 & 3.780 & 7.604 & \text { Yes }\end{array}$

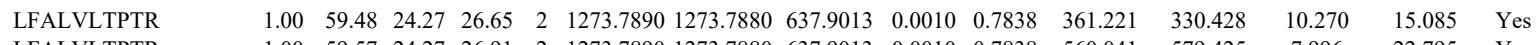
$\begin{array}{lllllllllllllllll}\text { LFALVLTPTR } & 1.00 & 59.57 & 24.27 & 26.91 & 2 & 1273.7890 & 1273.7880 & 637.9013 & 0.0010 & 0.7838 & 560.041 & 579.425 & 7.996 & 22.795 & \text { Yes }\end{array}$ $\begin{array}{lllllllllllllllll}\text { LFALVLTPTR } & 1.00 & 58.48 & 24.42 & 22.85 & 2 & 1273.7886 & 1273.7880 & 637.9013 & 0.0006 & 0.4703 & 298.589 & 342.803 & 9.276 & 20.071 & \text { Yes }\end{array}$ $\begin{array}{llllllllllllllll}\text { LFALVLTPTR } & 1.00 & 59.20 & 24.27 & 27.60 & 2 & 1273.7888 & 1273.7880 & 637.9013 & 0.0008 & 0.6271 & 381.274 & 397.875 & 16.345 & 26.172 & \text { Yes }\end{array}$ $\begin{array}{llllllllllllllll}\text { LFALVLTPTR } & 1.00 & 61.42 & 24.42 & 27.34 & 2 & 1273.7886 & 1273.7880 & 637.9013 & 0.0006 & 0.4703 & 359.947 & 331.345 & 14.176 & 35.861 & \text { Yes }\end{array}$ \begin{tabular}{llllllllllllllll} 
LFALVLTPTR & 1.00 & 61.60 & 24.27 & 24.97 & 2 & 1273.7888 & 1273.7880 & 637.9013 & 0.0008 & 0.6271 & 512.716 & 470.847 & 31.793 & 28.976 & Yes \\
\hline LFALVLPTR & 1.00 & 57.96 & 24.27 & 2.18 & 2 & 1273.788 & 1273.780 & 637.9013 & 0.008 & 0.6271 & 101.624 & 160.467 & 2.807 & 10.63 & Yes
\end{tabular}

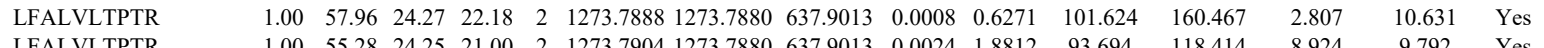
LFALVLTPTR $\begin{array}{llllllllllll}\text { RAB1B_HUMAl Q9H0U4 } & \text { RAB1B } & \text { Ras-related protei } 22.17 & 1.00 & 4 & 23.9 & 0.1980 & 0.1060 & -1.2186 & 1.1183 & 7 & \text { QWLQEIDR } \\ & & & & & & & & & & \end{array}$

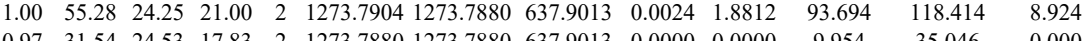

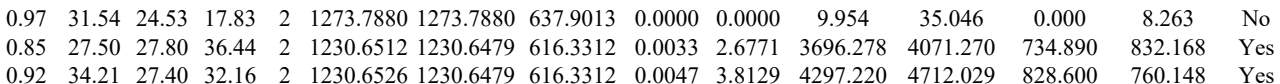

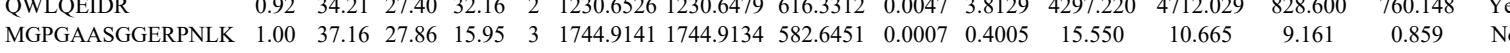
$\begin{array}{llllllllllllllllll} & \end{array}$

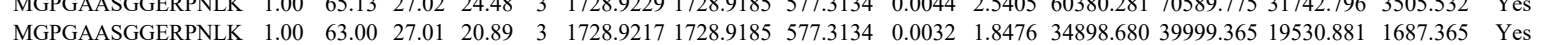




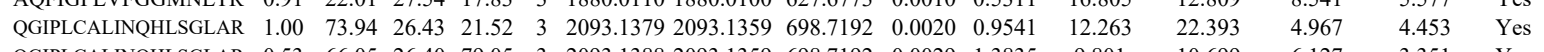

PININ HUMAN Q9H307 PNN Pinin

$\begin{array}{llllllll}81.61 & 1.00 & 4 & 8.9 & 0.0835 & 0.8134 & 0.3219 & 2.3849\end{array}$

3.351 Yes

$\begin{array}{llllllllllllllll}\text { GFSDSGGGPPAK } & 1.00 & 85.15 & 27.92 & 21.27 & 2 & 1363.6992 & 1363.6976 & 682.8561 & 0.0016 & 1.1715 & 16420.767 & 12860.884 & 11869.591 & 8523.913 & \text { Yes }\end{array}$

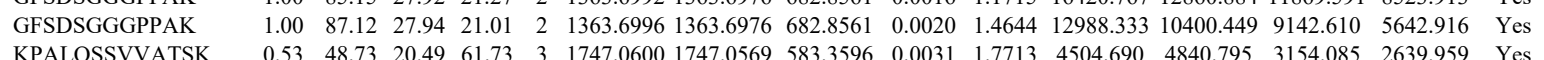

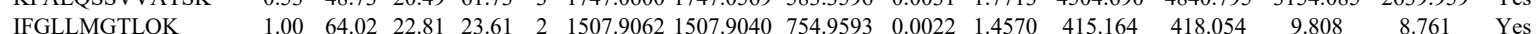
$\begin{array}{llllllllllllllll}\text { IFGLLMGTLQK } & 1.00 & 64.02 & 22.81 & 23.61 & 2 & 1507.9062 & 1507.9040 & 754.9593 & 0.0022 & 1.4570 & 415.164 & 418.054 & 9.808 & 8.761 & \text { Yes } \\ \text { IFGLLMGTLQK } & 1.00 & 64.60 & 22.97 & 28.06 & 2 & 1507.9066 & 1507.9040 & 754.9593 & 0.0026 & 1.7219 & 440.510 & 366.852 & 36.992 & 5.032 & \text { Yes }\end{array}$

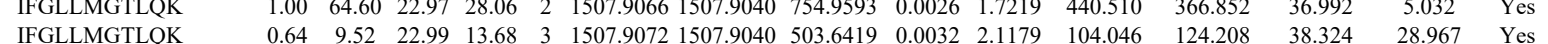

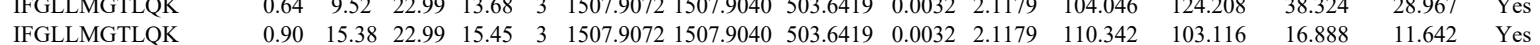
$\begin{array}{llllllllllllllll}\text { IFGLLMGTLQK } & 0.85 & 14.58 & 22.94 & 15.01 & 3 & 1507.9084 & 1507.9040 & 503.6419 & 0.0044 & 2.9121 & 107.811 & 82.367 & 15.342 & 8.212 & \text { Yes }\end{array}$

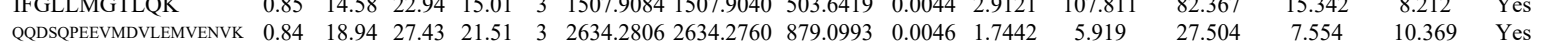

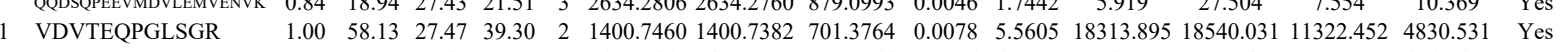

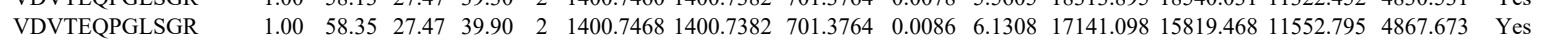
$\begin{array}{lllllllllllllllll}\text { VDVTEQPGLSGR } & 0.99 & 47.12 & 27.41 & 37.98 & 2 & 1400.7480 & 1400.7382 & 701.3764 & 0.0098 & 6.9862 & 4978.210 & 4930.964 & 2527.030 & 1564.621 & \text { Yes }\end{array}$ $\begin{array}{lllllllllllllllll}\text { VDVTEQPGLSGR } & 1.00 & 52.35 & 27.86 & 37.62 & 2 & 1400.7506 & 1400.7382 & 701.3764 & 0.0124 & 8.8397 & 5019.630 & 5131.019 & 2983.657 & 1530.742 & \text { Yes }\end{array}$

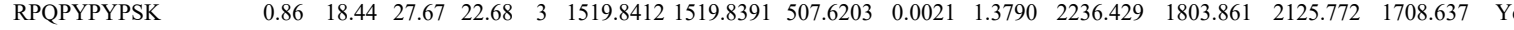
$\begin{array}{llllllllllllllll}\text { RPQPYPYPSK } & 0.74 & 15.75 & 27.60 & 23.14 & 3 & 1519.8418 & 1519.8391 & 507.6203 & 0.0027 & 1.7730 & 4404.949 & 4665.824 & 3943.021 & 1670.680 & \text { Yes }\end{array}$

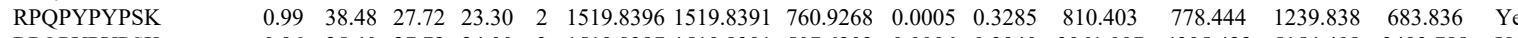
$\begin{array}{llllllllllllllll}\text { RPQPYPYPSK } & 0.96 & 25.40 & 27.72 & 24.00 & 3 & 1519.8397 & 1519.8391 & 507.6203 & 0.0006 & 0.3940 & 3961.007 & 4395.422 & 5154.408 & 3493.788 & \text { Yes }\end{array}$ $\begin{array}{llllllllllllllllll}\text { RPQPYPYPSK } & 0.95 & 24.29 & 27.72 & 18.69 & 3 & 1519.8406 & 1519.8391 & 507.6203 & 0.0015 & 0.9850 & 6088.371 & 5841.378 & 9391.877 & 6254.677 & \text { Yes }\end{array}$ $\begin{array}{llllllllllllllll}\text { RPQPYPYPSK } & 0.97 & 43.91 & 28.11 & 26.77 & 2 & 1519.8374 & 1519.8391 & 760.9268 & -0.0017 & -1.1171 & 245.796 & 327.331 & 417.306 & 265.501 & \text { Yes }\end{array}$

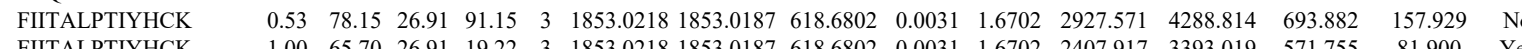
$\begin{array}{llllllllllllllll}\text { FIITALPTIYHCK } & 1.00 & 65.70 & 26.91 & 19.22 & 3 & 1853.0218 & 1853.0187 & 618.6802 & 0.0031 & 1.6702 & 2407.917 & 3393.019 & 571.755 & 81.900 & \text { Yes }\end{array}$

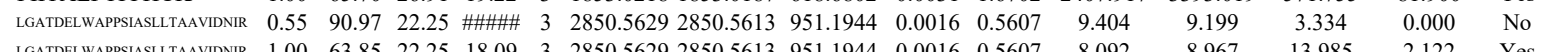

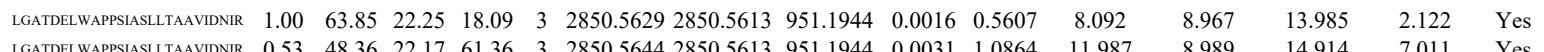

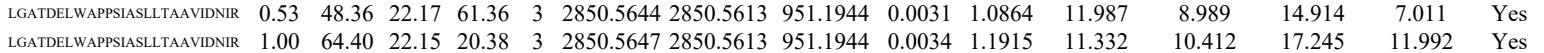

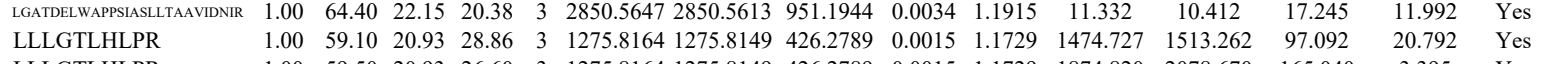

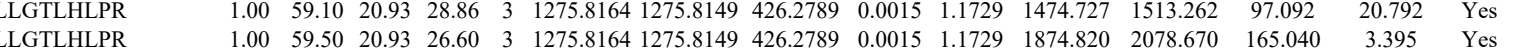

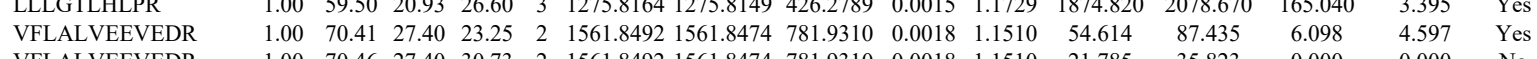
$\begin{array}{lllllllllllllllll} & \text { VFLALVEEVEDR } & 1.00 & 70.46 & 27.40 & 30.73 & 2 & 1561.8492 & 1561.8474 & 781.9310 & 0.0018 & 1.1510 & 21.785 & 35.823 & 0.000 & 0.000 & \mathrm{No}\end{array}$

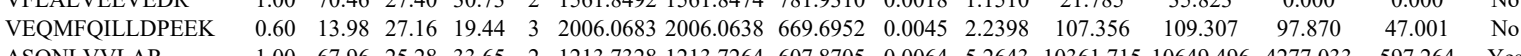
\begin{tabular}{llllllllllllllll} 
ASQNLVVLAR & 1.00 & 67.96 & 25.28 & 33.65 & 2 & 1213.7328 & 1213.7264 & 607.8705 & 0.0064 & 5.2643 & 10361.715 & 10649.496 & 4277.033 & 597.264 & Yes \\
\hline ASQNLVVLAR & 1.07 & 68.07 & 25.09 & 33.96 & 2 & 123.7330 & &
\end{tabular}

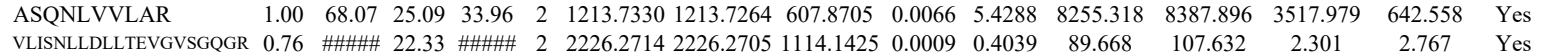

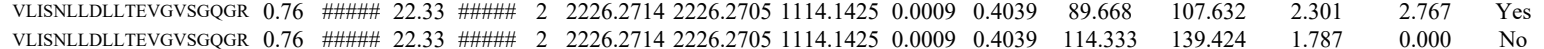

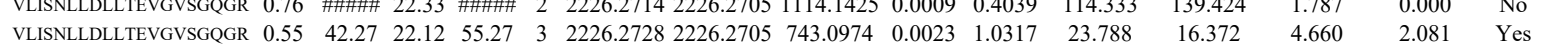

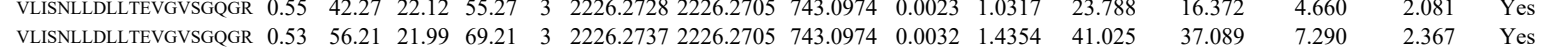

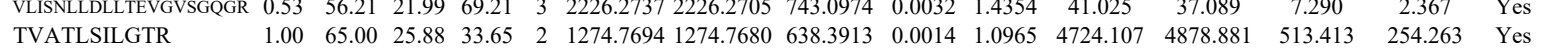

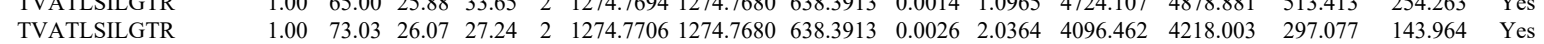
12 AEFGPPGGAGSR $\quad \begin{array}{lllllllllllllllll}0.99 & 42.98 & 27.47 & 17.46 & 2 & 1342.6738 & 1342.6752 & 672.3449 & -0.0014 & -1.0411 & 4516.110 & 6511.679 & 5402.523 & 3243.059 & \text { Yes }\end{array}$ $\begin{array}{llllllllllllllll}\text { VDIIPGFEFDR } & 1.00 & 57.46 & 28.04 & 25.54 & 2 & 1450.7588 & 1450.7578 & 726.3862 & 0.0010 & 0.6883 & 437.916 & 826.046 & 127.607 & 172.519 & \text { Yes }\end{array}$ $\begin{array}{lllllllllllllllll}\text { RPLHSAQAVDVASASNFR } & 1.00 & 56.24 & 26.67 & 29.74 & 4 & 2069.1009 & 2069.0888 & 518.2795 & 0.0121 & 5.8366 & 1440.619 & 1121.748 & 1336.095 & 732.881 & \text { Yes }\end{array}$ $\begin{array}{lllllllllllllllll}\text { RPLHSAQAVDVASASNFR } & 1.00 & 51.78 & 26.58 & 25.65 & 4 & 2069.1017 & 2069.0888 & 518.2795 & 0.0129 & 6.2225 & 1491.198 & 1594.009 & 1145.975 & 682.662 & \text { Yes }\end{array}$

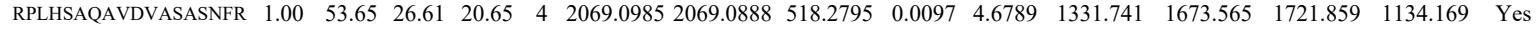
$\begin{array}{llllllllllllllll}\text { RPLHSAQAVDVASASNFR } & 1.00 & 50.67 & 26.62 & 18.69 & 4 & 2069.0989 & 2069.0888 & 518.2795 & 0.0101 & 4.8719 & 1042.470 & 1755.231 & 1643.933 & 923.263 & \text { Yes }\end{array}$ $\begin{array}{llllllllllllllll}\text { ETFASTASQLHSNVVNYVQQIVAPK } & 0.78 & 6.44 & 24.79 & 15.15 & 4 & 3018.6041 & 3018.6018 & 755.6577 & 0.0023 & 0.7609 & 17.009 & 19.390 & 10.841 & 0.000 & \text { No }\end{array}$ $\begin{array}{llllllllllllllll}\text { ETFASTASQLHSNVNYVQQIVAPK } & 0.96 & 11.03 & 24.65 & 15.16 & 4 & 3018.6057 & 3018.6018 & 755.6577 & 0.0039 & 1.2903 & 24.660 & 7.050 & 12.355 & 17.237 & \text { No }\end{array}$

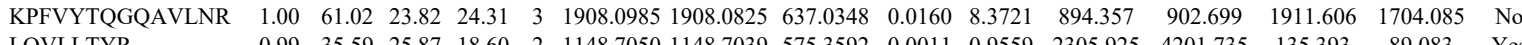

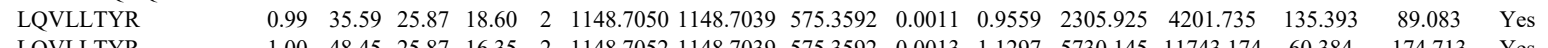

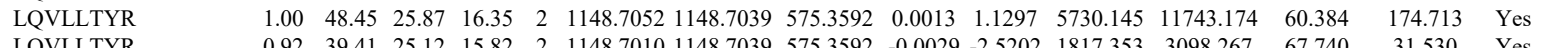

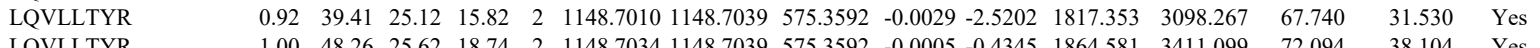

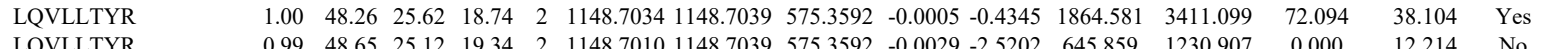

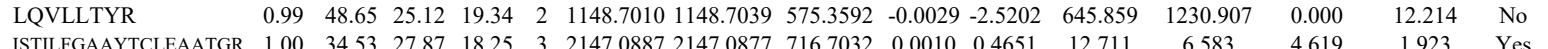

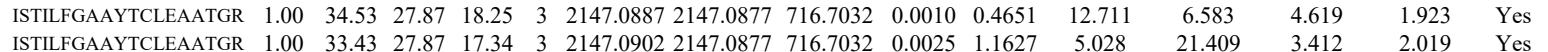

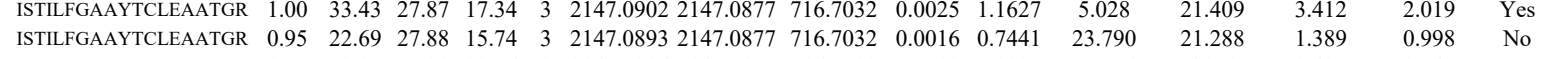

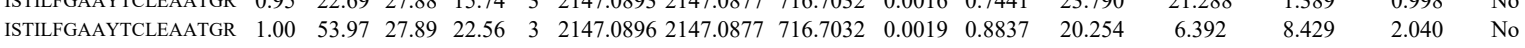

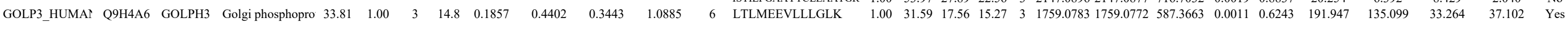


$\begin{array}{llllllllllllllll}1.00 & 43.22 & 28.18 & 22.98 & 2 & 1379.7438 & 1379.7431 & 690.8788 & 0.0007 & 0.5066 & 7291.614 & 7821.605 & 0.000\end{array}$

$\begin{array}{lllllllllllll}\text { LNAFGNAFLNR } & 1.00 & 44.97 & 28.23 & 23.81 & 2 & 1379.7440 & 1379.7431 & 690.8788 & 0.0009 & 0.6513 & 7044.108 & 7180.557 \\ \text { LNAFGNAFLNR } & 0.95 & 44.77 & 28.20 & 23.52 & 2 & 1379.7400 & 1379.7431 & 690.8788 & -0.0031 & -2.2435 & 7019.448 & 7812.190\end{array}$

GNAFLNR

LDISDEFSEVIK

LDISDEFSEVIK

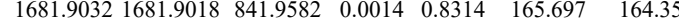

\begin{tabular}{llllllllllll}
1.00 & 59.26 & 27.20 & 23.03 & 2 & 1681.9046 & 1681.9018 & 841.9582 & 0.0028 & 1.6628 & 285.295 & 310.093 \\
\hline
\end{tabular}

$\begin{array}{llllllllllllll} & \end{array}$

$\begin{array}{llllllllll}\text { HEAT1_HUMAI Q9H583 } & \text { HEATR1 } & \text { HEAT repeat-cont } 242.37 & 1.00 & 13 & 9.2 & 0.0296 & 0.3291 & -0.0931 & 1.7695\end{array}$

GWEEALENVIK

GWEEALENVIK

GWEEALENVIK

$\begin{array}{llllllllllll}.00 & 58.00 & 27.85 & 27.94 & 2 & 1574.8580 & 1574.8548 & 788.4347 & 0.0032 & 2.0293 & 690.014 & 7\end{array}$

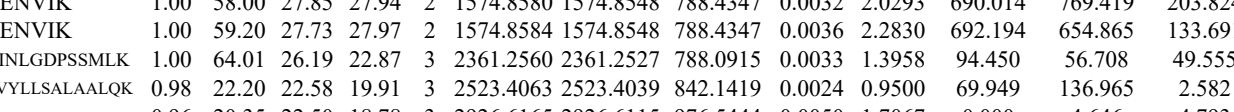

\section{GLVGNPLPSVR}

GLVGNPLPSV

FAALITVLALAEK

FAALITVLALAEK

LVPDLLAIVQR

LVPDLLAIVQR

FAALITVLALAEK

FAALITVLALAEK

VSLLNEQFLPLIR

VSLLNEQFLPLIR

VSLLNEQFLPLIR

VSLLNEQFLPLIR

SGICSLHPLLR

SGICSLHPLLR

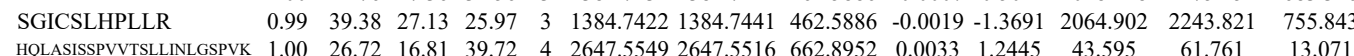

$\begin{array}{ccccccccccccc}0.96 & 20.35 & 22.50 & 18.78 & 3 & 2926.6165 & 2926.6115 & 976.5444 & 0.0050 & 1.7067 & 0.000 & 4.646 \\ 1.00 & 43.87 & 25.12 & 18.50 & 2 & 1251.7518 & 1251.7421 & 626.8783 & 0.0097 & 7.7367 & 3788.963 & 3715.261\end{array}$

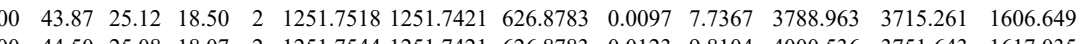
$\begin{array}{llllllllllllll}0.53 & 40.04 & 16.23 & 53.04 & 3 & 1594.0090 & 1594.0061 & 532.3426 & 0.0029 & 1.8159 & 1013.320 & 1019.388 & 201.851\end{array}$ $\begin{array}{lllllllllllll}00 & 45.29 & 18.06 & 16.03 & 3 & 1647.0247 & 1647.0214 & 550.0144 & 0.0033 & 1.9999 & 94.178 & 83.751 & 12.041\end{array}$

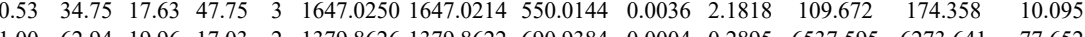

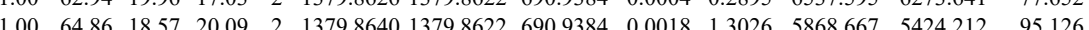
$\begin{array}{llllllllllllll}1.00 & 25.80 & 18.06 & 15.64 & 3 & 1647.0244 & 1647.0214 & 550.0144 & 0.0030 & 1.8181 & 43.642 & 71.346 & 4.110\end{array}$ $\begin{array}{lllllllllllll}0.53 & 34.30 & 18.06 & 47.30 & 3 & 1647.0244 & 1647.0214 & 550.0144 & 0.0030 & 1.8181 & 60.636 & 61.231 & 12.929\end{array}$ $\begin{array}{lllllllllllll}1.00 & 78.25 & 22.20 & 26.09 & 2 & 1685.0008 & 1684.9998 & 843.5072 & 0.0010 & 0.5928 & 989.898 & 944.349 & 39.217\end{array}$ $\begin{array}{llllllllllllll}1.00 & 71.10 & 22.20 & 25.86 & 2 & 1685.0008 & 1684.9998 & 843.5072 & 0.0010 & 0.5928 & 202.079 & 177.494 & 0.000\end{array}$ $\begin{array}{rrrrrrrrrrrrr}1.00 & 56.48 & 21.67 & 23.21 & 2 & 1826.0802 & 1826.0788 & 914.0467 & 0.0014 & 0.7658 & 1000.165 & 937.240 & 164.988\end{array}$ $\begin{array}{lllllllllllll}1.00 & 73.18 & 22.20 & 26.69 & 2 & 1685.0010 & 1684.9998 & 843.5072 & 0.0012 & 0.7113 & 1421.125 & 1197.388 & 0.000\end{array}$ $\begin{array}{lllllllllllll}1.00 & 54.59 & 22.79 & 24.96 & 2 & 1684.9988 & 1684.9998 & 843.5072 & -0.0010 & -0.5928 & 222.586 & 238.373 & 73.711\end{array}$

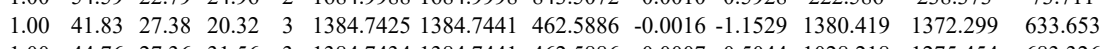

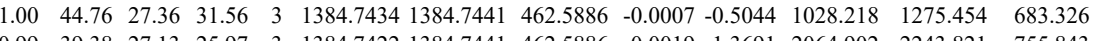
$\begin{array}{llllllllllllll} & \end{array}$ $\begin{array}{lllllllllllll}\text { SPQILVPTLFNLLSR } & 0.99 & 29.42 & 22.01 & 20.89 & 2 & 1841.0908 & 1841.0896 & 921.5521 & 0.0012 & 0.6511 & 10.304 & 9.635\end{array}$ $\begin{array}{lllllllllllll}\text { SPQILVPTLFNLLSR } & 0.55 & 28.04 & 21.79 & 41.04 & 3 & 1841.0917 & 1841.0896 & 614.7038 & 0.0021 & 1.1388 & 5.378 & 3.100\end{array}$

LAELLTQQHGLQCR QLPLLTSALHGLQQQHPAFSGVAR QLPLLTSALHGLQQQHPAFSGVA

NISHDTFGTTYGR KPYGVLYK SLLIDFFR SLLIDFFR SLLIDFFR

QAITQVVVSR

QAITQVVVSR 

$\begin{array}{lllllllllllll}26.85 & 19.14 & 17.92 & 3 & 2451.4225 & 2451.4182 & 818.1467 & 0.0043 & 1.7519 & 9.644 & 19.070 & 2.594\end{array}$

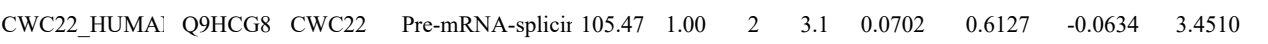
S10AE HUMAN Q Q SFWELIGEAAK SFWELIGEAAK SFWELIGEAAK $\begin{array}{llllllllllllll}1.00 & 46.74 & 26.00 & 25.35 & 2 & 1023.6004 & 1023.5987 & 512.8066 & 0.0017 & 1.6575 & 1464.110 & 1302.670 & 13.5\end{array}$ $\begin{array}{llllllllllllll}1.00 & 46.71 & 26.00 & 25.48 & 2 & 1023.6006 & 1023.5987 & 512.8066 & 0.0019 & 1.8525 & 1649.241 & 1276.519 & 75.084\end{array}$ $\begin{array}{llllllllllllllll}0.99 & 36.52 & 26.04 & 20.14 & 2 & 1023.6008 & 1023.5987 & 512.8066 & 0.0021 & 2.0476 & 240.106 & 237.367 & 17.246\end{array}$ $\begin{array}{lllllllllllll}1.00 & 67.27 & 27.53 & 24.65 & 2 & 1537.8400 & 1537.8384 & 769.9265 & 0.0016 & 1.0391 & 194.395 & 193.934 & 16.587\end{array}$ SFWELIGEAAK $\begin{array}{llllllllllll}1.00 & 67.27 & 27.53 & 24.65 & 2 & 1537.8400 & 1537.8384 & 769.9265 & 0.0016 & 1.0391 & 194.395 & 193.934\end{array}$ $\begin{array}{llllllllllllll}\text { SANAEDAQEFSDVER } & 1.00 & 96.78 & 24.84 & 26.95 & 2 & 1810.8268 & 1810.8091 & 906.4118 & 0.0177 & 9.7637 & 131.459 & 146.719 & 9.858 \\ \text { FPNGVQLSPAEDFLVAETTMAR } & 1.00 & 70.39 & 26.65 & 24.25 & 3 & 2635.3462 & 2635.3438 & 879.4552 & 0.0024 & 0.9097 & 49.959 & 64.515 & 20.98\end{array}$

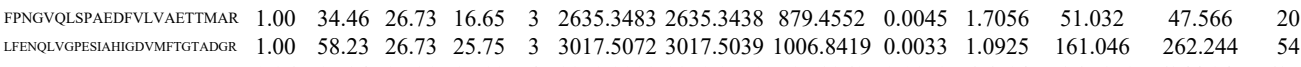
$\begin{array}{lllllllllllll} & \end{array}$

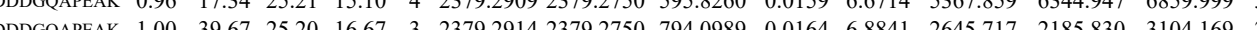

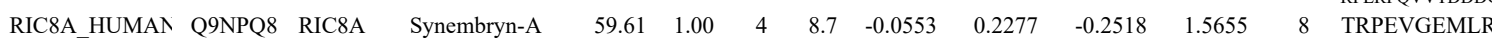
$\begin{array}{llllllllllllll}0.91 & 20.15 & 27.51 & 18.55 & 3 & 1330.7173 & 1330.7149 & 444.5789 & 0.0024 & 1.7995 & 2308.421 & 2410.887 & 2294.203 & 11\end{array}$

1551.810 Yes 


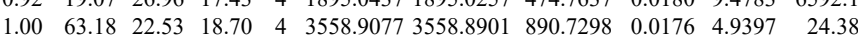
$\begin{array}{lllllllllllll} & \end{array}$ $\begin{array}{llllllllllll}0.98 & 17.36 & 22.55 & 30.36 & 4 & 3558.9029 & 3558.8901 & 890.7298 & 0.0128 & 3.5925 & 20.268\end{array}$ $\begin{array}{llllllllllll}1.00 & 41.52 & 22.65 & 54.52 & 4 & 3558.9037 & 3558.8901 & 890.7298 & 0.0136 & 3.8171 & 47.910\end{array}$ $\begin{array}{llllllllll} & \end{array}$ $\begin{array}{lllllllllllll}\text { AYLESEVAISEELVQK } & 1.00 & 37.53 & 27.07 & 20.50 & 3 & 2095.1344 & 2095.1292 & 699.3837 & 0.0052 & 2.4784 & 48.014\end{array}$ $\begin{array}{lllllllllllll}\text { AYLESEVAISEELVQK } & 0.98 & 35.31 & 26.89 & 18.53 & 3 & 2095.1392 & 2095.1292 & 699.3837 & 0.0100 & 4.7661 & 82.815\end{array}$ $\begin{array}{llllllllllll}\text { AYLESEVAISEELVQK } & 0.55 & 29.58 & 27.14 & 42.58 & 3 & 2095.1311 & 2095.1292 & 699.3837 & 0.0019 & 0.9056 & 15.007\end{array}$ $\begin{array}{lllllllllllll}\text { AYLESEVAISEELVQK } & 0.99 & 28.86 & 27.00 & 15.39 & 3 & 2095.1329 & 2095.1292 & 699.3837 & 0.0037 & 1.7635 & 30.762\end{array}$ $\begin{array}{lllllllllll}1.00 & 24.95 & 18.92 & 19.02 & 3 & 1679.0242 & 1679.0216 & 560.6811 & 0.0026 & 1.5457 & 27.371 \\ 0.98 & 37.48 & 27.75 & 19.41 & 2 & 1378.7798 & 1378.7803 & 690.3974 & -0.0005 & 0.3621 & 1.309\end{array}$ $\begin{array}{lllllllllll}0.98 & 37.48 & 27.75 & 19.41 & 2 & 1378.7798 & 1378.7803 & 690.3974 & -0.0005 & -0.3621 & 198.309\end{array}$ $\begin{array}{llllllllllllll} & 1.08\end{array}$

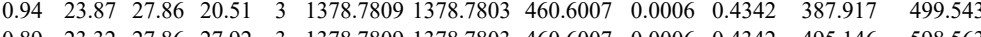

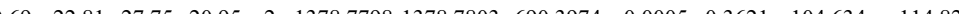
$\begin{array}{llllllllllll}0.87 & 22.81 & 27.75 & 20.95 & 2 & 1378.7798 & 1378.7803 & 690.3974 & -0.0005 & -0.3621 & 104.634 & 14.822\end{array}$

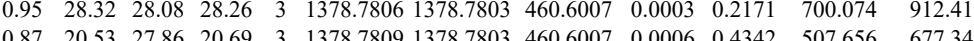
$\begin{array}{llllllllllll}0.99 & 38.47 & 27.17 & 20.01 & 2 & 1455.7520 & 1455.7522 & 728.8834 & -0.0002 & -0.1372 & 29.171 & 21.394\end{array}$ $\begin{array}{llllllllllll}0 & 00 & 51.99 & 27.62 & 18.98 & 2 & 1455.7538 & 1455.7522 & 728.8834 & 0.0016 & 1.0976 & 20.859\end{array}$ $\begin{array}{llllllllllll}0.83 & 30.13 & 27.29 & 15.82 & 2 & 1455.7512 & 1455.7522 & 728.8834 & 0.0010 & -0.6860 & 22.866\end{array}$ $\begin{array}{llllllllllll}0.99 & 37.89 & 27.65 & 20.04 & 2 & 1455.7552 & 1455.7522 & 728.8834 & 0.0030 & 2.0579 & 15.718\end{array}$

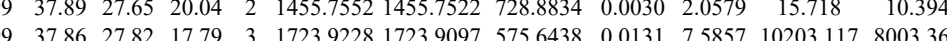
$\begin{array}{lllllllllllllll}1.00 & 62.42 & 24.59 & 25.58 & 3 & 1877.0701 & 1877.0583 & 626.6934 & 0.0118 & 6.2763 & 4208.562 & 3382.080 & 2078\end{array}$

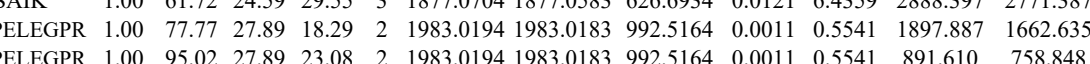
$\begin{array}{lllllllllllllll} & \text { WQLE }\end{array}$ $\begin{array}{llllllllllllll}\text { GLDIPEVDLVIQSSPPK } & 0.55 & 30.01 & 23.80 & 43.01 & 3 & 2094.1837 & 2094.1816 & 699.0678 & 0.0021 & 1.0013 & 446.510 & 61\end{array}$ $\begin{array}{lllllllllllll}\text { GLDIPEVDLVIQSSPPK } & 0.53 & 22.35 & 23.48 & 35.35 & 3 & 2094.1849 & 2094.1816 & 699.0678 & 0.0033 & 1.5735 & 475.383 & 542.672\end{array}$ $\begin{array}{llllllllllllll}\text { GLDIPEVDLVIQSSPPK } & 1.00 & 66.83 & 23.82 & 18.65 & 2 & 2094.1834 & 2094.1816 & 1048.0981 & 0.0018 & 0.8587 & 339.038 & 353.287\end{array}$ $\begin{array}{lllllllllllll}\text { GLDIPEVDLVIQSSPPK } & 1.00 & 33.77 & 23.80 & 15.66 & 3 & 2094.1837 & 2094.1816 & 699.0678 & 0.0021 & 1.0013 & 441.030\end{array}$ $\begin{array}{llllllllllll}\text { GLDIPEVDLVIQSSPPK } & 0.98 & 22.83 & 23.48 & 19.46 & 3 & 2094.1852 & 2094.1816 & 699.0678 & 0.0036 & 1.7166 & 286.065\end{array}$ $\begin{array}{llllllllllll}\text { GLDIPEVDLVIQSSPPK } & 1.00 & 69.18 & 23.46 & 21.46 & 2 & 2094.1854 & 2094.1816 & 1048.0981 & 0.0038 & 1.8128 & 513.302 \\ \text { LGVCFDVPTASVTEIQEK } & 1.00 & 68.18 & 27.30 & 21.22 & 2 & 2269.1614 & 2269.1578 & 1135.5862 & 0.0036 & 1.5851 & 267.245\end{array}$ $\begin{array}{lllllllllllll}\text { LGVCFDVPTASVTEIQEK } & 1.00 & 79.04 & 27.30 & 18.30 & 2 & 2269.1614 & 2269.1578 & 1135.5862 & 0.0036 & 1.5851 & 291.404\end{array}$ $\begin{array}{llllllllllll}\text { LGVCFDVPTASVTEIQEK } & 1.00 & 73.68 & 27.30 & 22.54 & 3 & 2269.1620 & 2269.1578 & 757.3932 & 0.0042 & 1.8484 & 114.651 \\ \text { LGVCFDVPTASVTEIOEK } & 1.00 & 79.46 & 27.13 & 27.08 & 3 & 2269.1632 & 2269.1578 & 757.3932 & 0.0054 & 2.3766 & 168.983\end{array}$ $\begin{array}{llllllllllll}\text { LGVCFDVPAASTEC } & 1.00 & 79.46 & 27.13 & 27.08 & 3 & 2269.1632 & 2269.1578 & 557.3932 & 0.0054 & 2.3766 & 168.983\end{array}$ TFHHVYSGK 
LISLPLSR

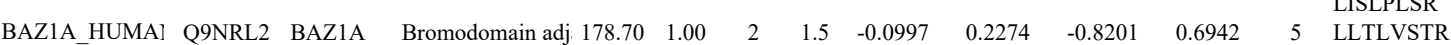

LLTLVSTR

IQSAIACTNIFPLGR

IQSAIACTNIFPLGR

$\begin{array}{lllllllllllllll}1.00 & 47.78 & 21.49 & 25.88 & 2 & 1307.8170 & 1307.8047 & 540.6377 & 0.0030 & 1.8497 & 29.417 & 22.280 & 8.181 & 4.112 & \text { Yes } \\ 1.00 & 42.46 & 1.49 & 22.90 & 2 & 1307.8176 & 1307.8047 & 654.906 & 0.0123 & 9.3905 & 1648.091 & 1740.856 & 720.282 & 429.124 & \text { Yes }\end{array}$

$\begin{array}{llllllllllllllll}1.00 & 42.46 & 21.49 & 22.90 & 2 & 1307.8176 & 1307.8047 & 654.9096 & 0.0129 & 9.8486 & 5812.031 & 5525.911 & 2736.568 & 1814.492 & \text { Yes }\end{array}$ $\begin{array}{lllllllllllllll}1.00 & 65.49 & 27.51 & 22.10 & 2 & 1511.7454 & 1511.7381 & 756.8763 & 0.0073 & 4.8224 & 583.653 & 476.195 & 262.878 & 98.779 & \text { Yes } \\ 1.00 & 3.55 & 27.51 & 21.19 & 2 & 151.756 & 151.781 & 756.8763 & 0.075 & 4.9545 & 602.079 & 398.74 & 292.517 & 129.177 & \text { Yes }\end{array}$ $\begin{array}{lllllllllllllll}1.00 & 63.55 & 27.51 & 21.19 & 2 & 1511.7456 & 1511.7381 & 756.8763 & 0.0075 & 4.9545 & 602.079 & 398.745 & 292.517 & 129.177 & \text { Yes } \\ 1.00 & 40.38 & 27.59 & 25.38 & 3 & 2143.1044 & 2143.1010 & 715.3743 & 0.0034 & 1.5842 & 1955.940 & 1750.476 & 1010.140 & 1083.521 & \text { Yes }\end{array}$ $\begin{array}{lllllllllllllll}0.81 & 10.07 & 27.56 & 18.71 & 4 & 2143.1053 & 2143.1010 & 536.7825 & 0.0043 & 2.0027 & 862.413 & 1041.606 & 894.876 & 669.070 & \text { Yes }\end{array}$ $\begin{array}{lllllllllllllll}1.00 & 45.60 & 27.63 & 17.94 & 3 & 2143.1056 & 2143.1010 & 715.3743 & 0.0046 & 2.1434 & 4875.593 & 4433.137 & 4501.155 & 2291.839 & \text { No }\end{array}$ $\begin{array}{lllllllllllllll}0.74 & 9.67 & 27.66 & 20.02 & 4 & 2143.1065 & 2143.1010 & 536.7825 & 0.0055 & 2.5616 & 1722.190 & 2048.495 & 1190.632 & 695.934 & \text { Yes }\end{array}$ $\begin{array}{lllllllllllllll}0.76 & 47.52 & 21.14 & 60.52 & 2 & 1307.8058 & 1307.8047 & 654.9096 & 0.0011 & 0.8398 & 243.883 & 238.242 & 138.555 & 65.890 & \text { Yes }\end{array}$ $\begin{array}{lllllllllllllll}0.76 & 47.79 & 21.14 & 60.79 & 2 & 1307.8062 & 1307.8047 & 654.9096 & 0.0015 & 1.1452 & 214.329 & 217.151 & 125.696 & 79.476 & \text { Yes } \\ 1.00 & 72.90 & 27.31 & 30.19 & 2 & 1590.7830 & 1590.7803 & 796.3974 & 0.0027 & 1.6951 & 9717.009 & 8726.351 & 8607.248 & 7929.715 & \mathrm{~N} o\end{array}$ $\begin{array}{llllllllllllllll}1.00 & 76.43 & 27.21 & 29.01 & 2 & 1590.7834 & 1590.7803 & 796.3974 & 0.0031 & 1.9463 & 9990.854 & 7224.633 & 6880.321 & 6664.473 & \text { No }\end{array}$ $\begin{array}{lllllllllllllll}1.00 & 46.42 & 27.62 & 29.99 & 3 & 1862.9821 & 1862.9773 & 621.9997 & 0.0048 & 2.5723 & 13283.173 & 10429.025 & 5286.170 & 2038.664 & \text { Yes }\end{array}$ $\begin{array}{lllllllllllllll}1.00 & 55.91 & 27.63 & 30.35 & 3 & 1862.9827 & 1862.9773 & 621.9997 & 0.0054 & 2.8939 & 11320.110 & 8563.158 & 3762.669 & 3367.401 & \text { Yes }\end{array}$

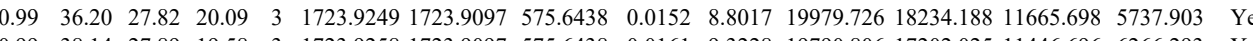
$\begin{array}{lllllllllllllll}0.99 & 38.14 & 27.89 & 19.58 & 3 & 1723.9258 & 1723.9097 & 575.6438 & 0.0161 & 9.3228 & 19790.806 & 17202.025 & 11446.696 & 6266.293 & \text { Yes }\end{array}$ $\begin{array}{llllllllllllllll}1.00 & 41.92 & 27.60 & 26.97 & 3 & 1862.9842 & 1862.9773 & 621.9997 & 0.0069 & 3.6977 & 889.722 & 757.098 & 392.715 & 253.141 & \text { Yes }\end{array}$ $\begin{array}{lllllllllllllll}0.97 & 32.31 & 27.90 & 15.54 & 3 & 1723.9219 & 1723.9097 & 575.6438 & 0.0122 & 7.0645 & 24316.985 & 23435.516 & 14460.234 & 7068.742 & \text { Yes }\end{array}$ $\begin{array}{lllllllllllllll}1.00 & 42.10 & 27.81 & 16.90 & 3 & 1723.9222 & 1723.9097 & 575.6438 & 0.0125 & 7.2382 & 17458.380 & 17769.612 & 10003.985 & 5617.364 & \text { Yes }\end{array}$ $\begin{array}{lllllllllllllll}0.96 & 19.99 & 22.10 & 19.68 & 3 & 1575.6808 & 1575.6757 & 526.2325 & 0.0051 & 3.2305 & 10165.594 & 12206.674 & 11032.572 & 10458.132 & \text { Yes } \\ 0.53 & 1.05 & 17.24 & 31.05 & 3 & 2555.5062 & 25955032 & 854.1750 & 0.003 & 1.1707 & 36.882 & 16.843 & 68.038 & 6.939 & \text { Yes }\end{array}$

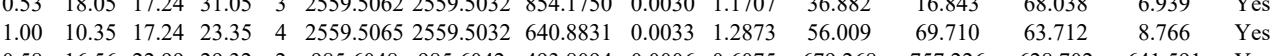
$\begin{array}{ccccccccccccccc}0.58 & 16.56 & 22.99 & 29.32 & 2 & 985.6048 & 985.6042 & 493.8094 & 0.0006 & 0.6075 & 679.268 & 757.226 & 628.702 & 641.591 & \text { Yes } \\ 1.00 & 49.58 & 25.04 & 21.14 & 3 & 3200.6902 & 3200.6849 & 1067.9022 & 0.0053 & 1.6543 & 9.079 & 22.385 & 12.132 & 7.415 & Y\end{array}$

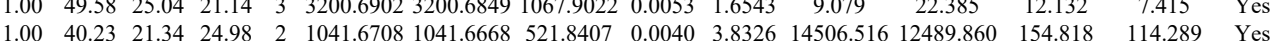

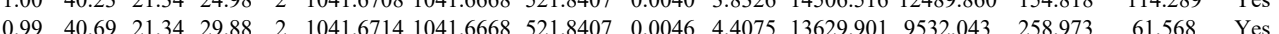

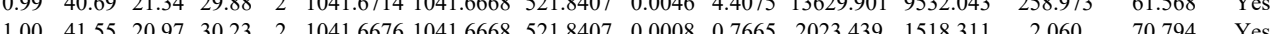
$\begin{array}{lllllllllllllll}1.00 & 38.44 & 21.37 & 30.83 & 2 & 1041.6688 & 1041.6668 & 521.8407 & 0.0020 & 1.9163 & 1788.896 & 1380.370 & 16.487 & 22.922 & \text { Yes }\end{array}$

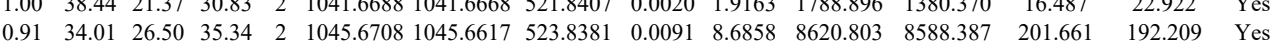
$\begin{array}{lllllllllllllll}0.79 & 37.38 & 22.72 & 49.49 & 2 & 1045.6624 & 1045.6617 & 523.8381 & 0.0007 & 0.68681 & 3362.857 & 3176.062 & 186.325 & 26.790 & \text { Yes }\end{array}$ $\begin{array}{lllllllllllllll}0.89 & 41.08 & 22.72 & 50.05 & 2 & 1045.6626 & 1045.6617 & 523.8381 & 0.0009 & 0.8590 & 3798.891 & 3947.732 & 127.514 & 28.049 & \text { Yes }\end{array}$

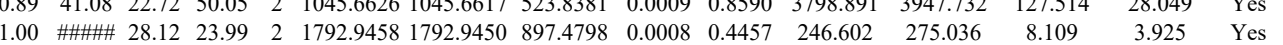
$\begin{array}{lllllllllllllll}1.00 & 97.95 & 28.08 & 23.54 & 2 & 1792.9468 & 1792.9450 & 897.4798 & 0.0018 & 1.0028 & 304.016 & 224.421 & 31.466 & 4.801 & \text { Yes }\end{array}$ $\begin{array}{llllllllllllll}0.98 & 28.53 & 27.99 & 28.56 & 3 & 1792.9477 & 1792.9450 & 598.6556 & 0.0027 & 1.5034 & 49.621 & 43.768 & 24.598 & 6.505 \\ 1.00 & 5.41 & 28.07 & 29.91 & 3 & 1792.9492 & 1792.9450 & 598.655 & 0.0042 & 2.3386 & 43.867 & 53.215 & 6.131 & 13.595\end{array}$

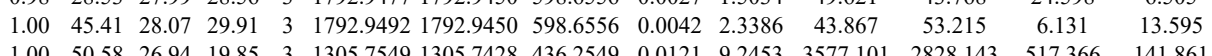
$\begin{array}{lllllllllllllllll}\text { HQDVPSQDDSKPTQR } & 0.00 & 50.58 & 26.94 & 19.85 & 3 & 1305.7549 & 1305.7428 & 436.2549 & 0.0121 & 9.2453 & 3577.101 & 2828.143 & 517.366 & 141.861 & \text { Y } \\ \text { Hes. } & 27.60 & 36.98 & 3 & 2025.0148 & 2025.0119 & 676.0112 & 0.0029 & 1.4300 & 175.738 & 148.180 & 92.658 & 89.901 & \text { Yes }\end{array}$ $\begin{array}{llllllllllllllllll}\text { HQDVPSQDDSKPTQR } & 1.00 & 29.78 & 27.59 & 22.36 & 4 & 2025.0153 & 2025.0119 & 507.2603 & 0.0034 & 1.6757 & 182.620 & 185.582 & 188.752 & 169.344 & \text { Yes }\end{array}$ $\begin{array}{llllllllllllllll}\text { HQDVPSQDDSKPTQR } & 1.00 & 29.54 & 27.60 & 21.28 & 4 & 2025.0157 & 2025.0119 & 507.2603 & 0.0038 & 1.8728 & 235.324 & 235.938 & 229.230 & 284.313 & \text { Yes }\end{array}$

9 KIPVPANR $\begin{array}{lllllllllllllll}0.84 & 17.77 & 22.30 & 19.60 & 2 & 1181.7506 & 1181.7488 & 591.8817 & 0.0018 & 1.5206 & 5132.850 & 3920.802 & 1102.183 & 234.622 & \text { Yes }\end{array}$ $\begin{array}{llllllllllllllll} & 0.94 & 22.37 & 22.38 & 15.25 & 2 & 1181.7512 & 1181.7488 & 591.8817 & 0.0024 & 2.0274 & 4638.118 & 3746.824 & 1093.989 & 175.448 & \text { Yes }\end{array}$ $\begin{array}{lllllllllllllllll}\text { RPVFPPLCGDGLLSGK } & 1.00 & 61.20 & 26.88 & 24.85 & 3 & 1989.0817 & 1989.0784 & 664.0334 & 0.0033 & 1.6565 & 1644.968 & 1289.355 & 1049.550 & 469.038 & \text { Yes }\end{array}$ $\begin{array}{llllllllllllllll}\text { RPVFPPLCGDGLLSGK } & 1.00 & 55.63 & 26.86 & 21.50 & 3 & 1989.0829 & 1989.0784 & 664.0334 & 0.0045 & 2.2589 & 2605.332 & 1916.357 & 986.209 & 498.469 & \text { Yes }\end{array}$ $\begin{array}{llllllllllllllllll}\text { RPVFPPLCGDGLLSGK } & 1.00 & 55.97 & 26.88 & 26.39 & 3 & 1989.0781 & 1989.0784 & 664.0334 & -0.0003 & -0.1506 & 1003.231 & 917.234 & 436.793 & 224.528 & \text { Yes }\end{array}$ $\begin{array}{llllllllllllllll}\text { RPVFPPLCGDGLLSGK } & 1.00 & 55.30 & 26.88 & 29.22 & 3 & 1989.0784 & 1989.0784 & 664.0334 & 0.0000 & 0.0000 & 1205.809 & 1058.153 & 525.280 & 157.235 & \text { Yes }\end{array}$

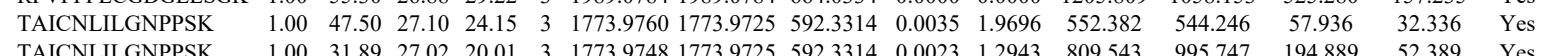

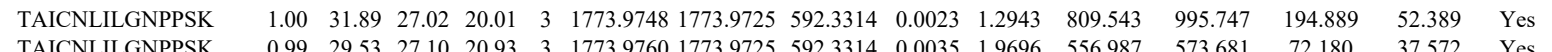
TAICNLILGNPPS

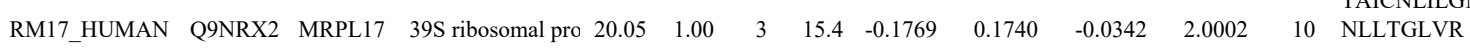
$\begin{array}{llllllllllllllll}0.99 & 29.53 & 27.10 & 20.93 & 3 & 1773.9760 & 1773.9725 & 592.3314 & 0.0035 & 1.9696 & 556.987 & 573.681 & 72.180 & 37.572 & \text { Yes } \\ 0.88 & 32.26 & 24.42 & 42.04 & 2 & 10286482 & 1028.9464 & 5153305 & 0.0018 & 1.7464 & 6364581 & 5279.673 & 9.2513 & 109.257 & \text { Yes }\end{array}$ $\begin{array}{llllllllllll}0.88 & 32.26 & 24.42 & 42.04 & 2 & 1028.6482 & 1028.6464 & 515.3305 & 0.0018 & 1.7464 & 6364.581 & 5279.673\end{array}$ $\begin{array}{lllllllllllll}0.99 & 32.37 & 25.11 & 30.20 & 2 & 1028.6486 & 1028.6464 & 515.3305 & 0.0022 & 2.1345 & 7058.529 & 6008.263 & 86.609\end{array}$ 

$\begin{array}{llllllllllllllllll} & \end{array}$

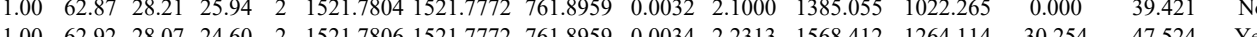

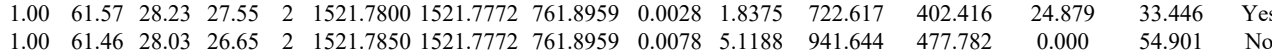

$\begin{array}{llllllllllllllll}\text { LWLLPNTGLSGGMPGALPLLPG } & 1.00 & 46.84 & 21.46 & 16.86 & 3 & 2562.4483 & 2562.4447 & 855.1555 & 0.0036 & 1.4033 & 147.999 & 164.004 & 90.719 & 91.982 & \text { Yes } \\ \text { OHLGNTGLGGMPGAPSLGG } & 1.00 & 43.65 & 21.46 & 19.91 & 3 & 2562.4489 & 2562.4447 & 855.1555 & 0.0042 & 1.6371 & 58.406 & 95.460 & 18.569 & 42.790 & \text { Yes }\end{array}$ OILLGPNTGLSGGMPGALPSLPGK

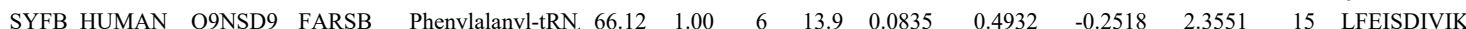
LFEISDIVIK

\section{ADIHACDIVEDAIAYGYNNION} YDLLCLEGLVR YDLLCLEGLVR NPGFEIIHGLLDR NPGFEIIHGLLDR YDLLCLEGLVR YDLLCLEGLVR NPGFEIIHGLLDR NPGFEIIHGLLDR TTLLPGLLK TTLLPGLLK TTLLPGLLK TTLLPGLLK IRPFAVAAVLR $\begin{array}{llllllllllll}1.00 & 63.31 & 21.46 & 24.69 & 3 & 2562.4501 & 2562.4447 & 855.1555 & 0.0054 & 2.1049 & 124.611 & 130.608\end{array}$ $\begin{array}{lllllllllllll}1.00 & 52.64 & 21.21 & 19.72 & 2 & 1463.8874 & 1463.8843 & 732.9494 & 0.0031 & 2.1147 & 728.693 & 806.477\end{array}$ $\begin{array}{llllllllllll}1.00 & 50.57 & 21.14 & 29.12 & 2 & 1463.8876 & 1463.8843 & 732.9494 & 0.0033 & 2.2512 & 772.453 & 825.992\end{array}$ $\begin{array}{llllllllllll}1.00 & 66.55 & 21.21 & 26.17 & 2 & 1463.8872 & 1463.8843 & 732.9494 & 0.0029 & 1.9783 & 1273.979 & 994.337\end{array}$ $\begin{array}{llllllllllll}0.95 & 16.23 & 26.63 & 29.23 & 4 & 3395.6889 & 3395.6807 & 849.9275 & 0.0082 & 2.4120 & 82.272 & 56.325\end{array}$ $\begin{array}{llllllllllll}1.00 & 70.34 & 27.30 & 18.47 & 3 & 1623.8896 & 1623.8855 & 542.3024 & 0.0041 & 2.5201 & 625.148 & 740.503\end{array}$ $\begin{array}{lllllllllllll}1.00 & 52.63 & 28.08 & 34.50 & 2 & 1482.7720 & 1482.7696 & 742.3921 & 0.0024 & 1.6164 & 847.074 & 959.959\end{array}$ $\begin{array}{llllllllllllll}1.00 & 61.45 & 28.14 & 35.02 & 2 & 1482.7730 & 1482.7696 & 742.3921 & 0.0034 & 2.2899 & 853.244 & 925.182 & 6\end{array}$ $\begin{array}{lllllllllllllll} & \end{array}$ $\begin{array}{llllllllllllll} & \end{array}$

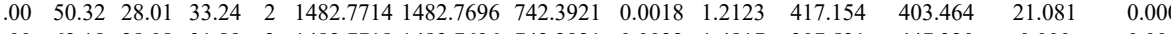
$\begin{array}{lllllllllllllll} & \end{array}$ $\begin{array}{lllllllllllllll}1.00 & 77.36 & 27.35 & 21.47 & 3 & 1623.8947 & 1623.8855 & 542.3024 & 0.0092 & 5.6549 & 641.950 & 1033.113 & 614.158 & 414.833 & \text { Yes } \\ 1.00 & 89.14 & 27.29 & 21.56 & 3 & 1623.8953 & 1623.8855 & 542.3024 & 0.0098 & 6.0237 & 644.476 & 802.615 & 534.584 & 455.236 & \text { Yes }\end{array}$

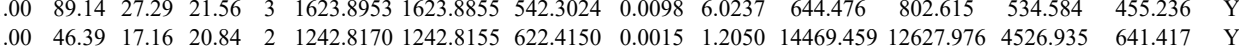
$\begin{array}{llllllllllllllll}1.00 & 49.83 & 17.16 & 20.60 & 2 & 1242.8172 & 1242.8155 & 622.4150 & 0.0017 & 1.3656 & 6805.000 & 6295.003 & 2267.109 & 370.200 & \text { Yes }\end{array}$ $\begin{array}{lllllllllllllll}1.00 & 48.82 & 17.16 & 18.89 & 2 & 1242.8172 & 1242.8155 & 622.4150 & 0.0017 & 1.3656 & 6740.001 & 6899.280 & 2209.495 & 421.364 & \text { Yes }\end{array}$ $\begin{array}{lllllllllllllll}1.00 & 49.80 & 16.99 & 19.82 & 2 & 1242.8182 & 1242.8155 & 622.4150 & 0.0027 & 2.1690 & 14859.365 & 12571.304 & 3963.100 & 499.775 & \text { Yes }\end{array}$ $\begin{array}{lllllllllllllll}1.00 & 68.33 & 22.50 & 43.37 & 2 & 1211.7506 & 1211.7502 & 606.8824 & 0.0004 & 0.3296 & 30.333 & 117.156 & 12.982 & 10.438 & \text { No } \\ 1.00 & 56.60 & 2.43 & 32.36 & 2 & 121.7512 & 1211.7502 & 606.8824 & 0.0010 & 0.8239 & 22.097 & 64.897 & 19.642 & 4.297 & \text { Yes }\end{array}$

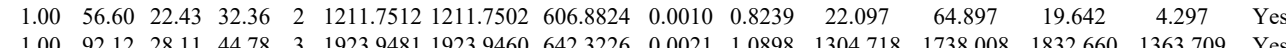
$\begin{array}{lllllllllll}1.00 & 35.44 & 24.42 & 16.68 & 4 & 4066.0389 & 4066.0370 & 1017.5165 & 0.0019 & 0.4668 & 2.665\end{array}$

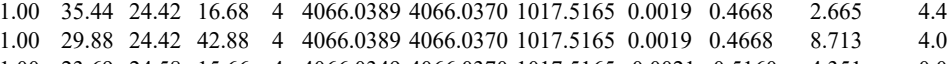

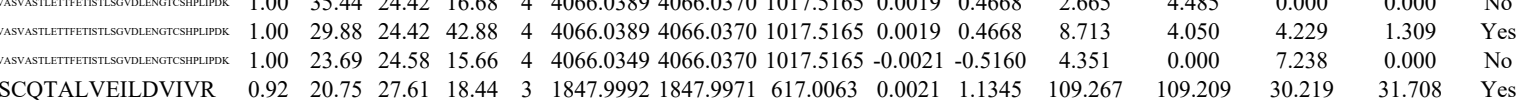

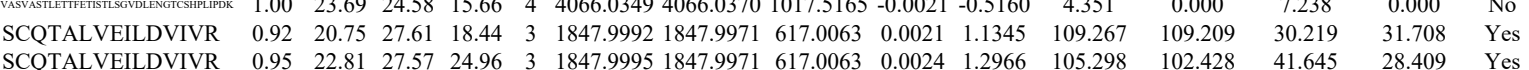
$\begin{array}{lllllllllllll} & \end{array}$

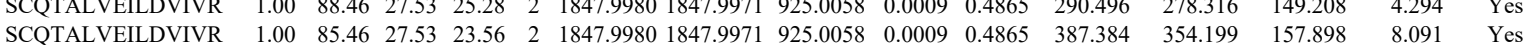
$\begin{array}{llllllllllllllll}\text { SCQTALVEILDVIVR } & 0.99 & 42.93 & 27.57 & 38.37 & 3 & 1847.9995 & 1847.9971 & 617.0063 & 0.0024 & 1.2966 & 75.090 & 90.346 & 38.511 & 22.769 & \text { Yes }\end{array}$ $\begin{array}{lllllllllllllllll}\text { SCQTALVEILDVIVR } & 0.99 & 34.85 & 27.54 & 29.25 & 3 & 1848.0001 & 1847.9971 & 617.0063 & 0.0030 & 1.6207 & 61.542 & 70.063 & 21.976 & 20.522 & \text { Yes }\end{array}$

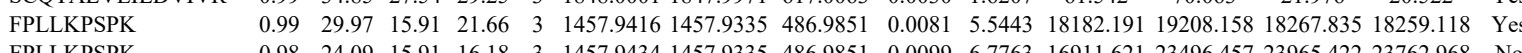
$\begin{array}{llllllllllllllll} & 0.98 & 24.09 & 15.91 & 16.18 & 3 & 1457.9434 & 1457.9335 & 486.9851 & 0.0099 & 6.7763 & 16911.621 & 23496.457 & 23965.422 & 23762.968 & \text { No }\end{array}$

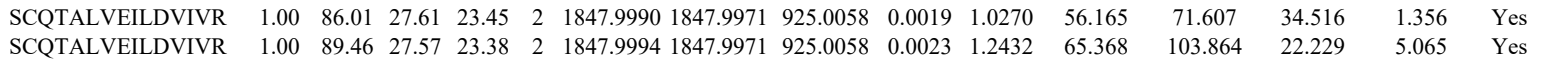

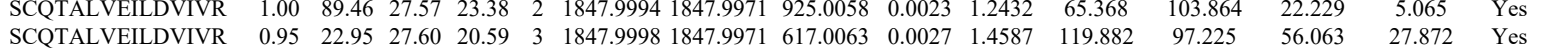

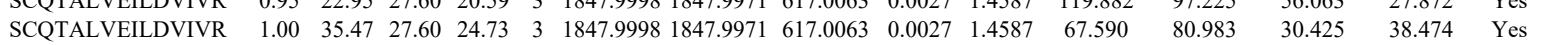
$\begin{array}{lllllllllllllll} & & & \end{array}$

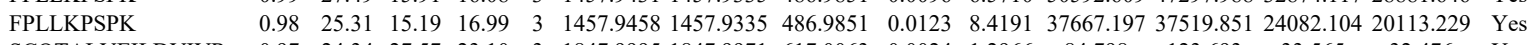
$\begin{array}{llllllllllllllll}\text { SCQTALVEILDVIVR } & 0.97 & 24.34 & 27.57 & 23.10 & 3 & 1847.9995 & 1847.9971 & 617.0063 & 0.0024 & 1.2966 & 84.798 & 123.693 & 33.565 & 32.476 & \text { Yes }\end{array}$

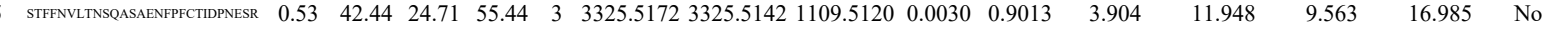
$\begin{array}{llllllllllllllll}\text { STFFNLITNSASAANFPCTIDNNESR } & 1.00 & 52.11 & 24.70 & 19.58 & 3 & 3325.5202 & 3325.5142 & 1109.5120 & 0.0060 & 1.8026 & 15.428 & 14.846 & 18.811 & 20.471 & \text { Yes }\end{array}$ $\begin{array}{llllllllllllllll}\text { IGIVGLPNVGK } & 0.61 & 43.66 & 18.20 & 56.66 & 2 & 1353.8590 & 1353.8588 & 677.9367 & 0.0002 & 0.1475 & 12001.532 & 15996.244 & 8787.433 & 2908.709 & \text { Yes }\end{array}$ $\begin{array}{lllllllllllllllll}\text { IGIVGLPNVGK } & 1.00 & 36.23 & 18.06 & 17.87 & 2 & 1353.8598 & 1353.8588 & 677.9367 & 0.0010 & 0.7375 & 7088.085 & 9195.714 & 6482.974 & 2195.630 & \text { Yes }\end{array}$ $\begin{array}{llllllllllllllll}\text { IPAFLNVVDIAGLVK } & 0.77 & 82.54 & 17.63 & 95.54 & 2 & 1856.1394 & 1856.1379 & 929.0762 & 0.0015 & 0.8073 & 178.530 & 471.380 & 262.255 & 149.045 & \text { Yes }\end{array}$ $\begin{array}{llllllllllllllll}\text { IPAFLNVVDIAGLVK } & 0.77 & 71.75 & 17.63 & 84.75 & 2 & 1856.1396 & 1856.1379 & 929.0762 & 0.0017 & 0.9149 & 1091.009 & 1153.297 & 1102.047 & 544.560 & \text { Yes }\end{array}$ $\begin{array}{llllllllllllllll}\text { IPAFLNVVDIAGLVK } & 1.00 & 54.01 & 17.63 & 23.91 & 3 & 1856.1406 & 1856.1379 & 619.7199 & 0.0027 & 1.4523 & 187.918 & 187.800 & 134.397 & 9.323 & \text { Yes }\end{array}$

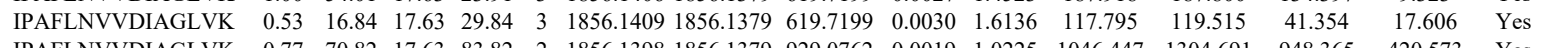
$\begin{array}{llllllllllllllll}\text { IPAFLNVVDIAGLVK } & 0.77 & 70.82 & 17.63 & 83.82 & 2 & 1856.1398 & 1856.1379 & 929.0762 & 0.0019 & 1.0225 & 1046.447 & 1304.691 & 948.365 & 420.573 & \text { Yes }\end{array}$ $\begin{array}{lllllllllllllllll}\text { IPAFLNVVDIAGLVK } & 0.77 & 70.12 & 17.63 & 83.12 & 2 & 1856.1400 & 1856.1379 & 929.0762 & 0.0021 & 1.1302 & 560.743 & 614.974 & 595.319 & 312.090 & \text { Yes }\end{array}$

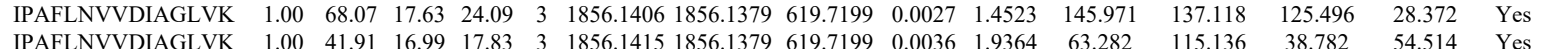
$\begin{array}{llllllllllllllll}\text { IPAFLNVVDIAGLVK } & 1.00 & 41.91 & 16.99 & 17.83 & 3 & 1856.1415 & 1856.1379 & 619.7199 & 0.0036 & 1.9364 & 63.282 & 115.136 & 38.782 & 54.514 & \text { Yes } \\ \text { IPAFLNVVDIAGLVK } & 0.77 & 95.30 & 17.63 & \# \# \# \# & 2 & 1856.1396 & 1856.1379 & 929.0762 & 0.0017 & 0.9149 & 346.008 & 383.218 & 194.497 & 151.873 & \text { Yes }\end{array}$ $\begin{array}{llllllllllllllll}\text { IPAFLNVVDIAGLVK } & 0.77 & 70.98 & 17.63 & 83.98 & 2 & 1856.1400 & 1856.1379 & 929.0762 & 0.0021 & 1.1302 & 537.214 & 542.234 & 435.616 & 160.285 & \text { Yes }\end{array}$ $\begin{array}{lllllllllllllllll}\text { IPAFLNVVDIAGLVK } & 0.71 & 6.91 & 17.63 & 17.12 & 3 & 1856.1409 & 1856.1379 & 619.7199 & 0.0030 & 1.6136 & 305.915 & 319.224 & 88.693 & 99.462 & \text { Y }\end{array}$ 
$\begin{array}{lllllllllllll}\text { LFNLVHOAYEVLSDPOTR } & 1.00 & 39.38 & 27.04 & 18.72 & 3 & 2273.1955 & 2273.1926 & 758.7381 & 0.0029 & 1.2740 & 140.366\end{array}$ $\begin{array}{lllllllllllllll} & 227.1838 & 227.1926 & 758.7381 & -0.0088 & -3.8661 & 138.592 & 156.061\end{array}$

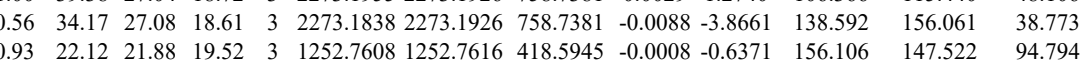
$\begin{array}{lllllllllllll}1.00 & 52.24 & 22.04 & 17.02 & 2 & 1252.7614 & 1252.7616 & 627.3881 & -0.0002 & -0.1594 & 37.450 & 113.581 & 29.767 \\ 1.00 & 40.42 & 21.99 & 19.87 & 2 & 1252.7616 & 1252.7616 & 627.3881 & 0.0000 & 0.0000 & 58.223 & 103.039 & 1.824\end{array}$

GIRPGLTTVLAR

GIRPGLTTVLAR

GIRPGLTTVLAR

GIRPGLTTVLAR

GIRPGLTTVLAR

$\begin{array}{lllllllllll}\text { FANCI_HUMAI } & \text { QNNVI1 } & \text { FANCI } & \text { Fanconi anemia g1 149.32 } & 1.00 & 4 & 4.9 & -0.0123 & 0.1921 & -0.5488 & 1.4499\end{array}$

EALLLVTVLTSLSK

EALLLVTVLTSLSK

SLELLPIILTALATK

SLELPIIILTALATK

SLELLPIILTALATATK

MNLQEIPPLVYQLLVLSS

$\begin{array}{llllllllllllll}0.97 & 28.97 & 21.99 & 17.77 & 2 & 1252.7618 & 1252.7616 & 627.3881 & 0.0002 & 0.1594 & 24.286 & 65.893\end{array}$

$\begin{array}{llllllllllll}44.67 & 22.23 & 19.03 & 2 & 1252.7622 & 1252.7616 & 627.3881 & 0.0006 & 0.4782 & 31.976 & 65.578 & 24.256\end{array}$

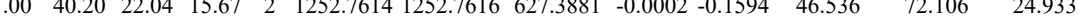

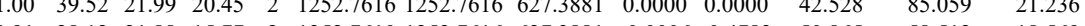

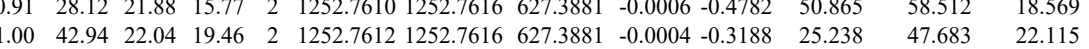

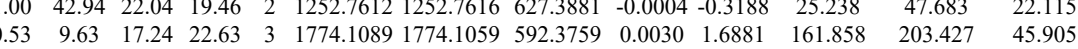

$\begin{array}{lllllllllllll}0.87 & 11.49 & 17.24 & 18.10 & 3 & 1774.1092 & 1774.1059 & 592.3759 & 0.0033 & 1.8569 & 166.212 & 147.982 & 61.824\end{array}$

$\begin{array}{lllllllllllll}0.76 & 80.59 & 12.79 & 93.59 & 2 & 1883.1962 & 1883.1950 & 942.6048 & 0.0012 & 0.6365 & 153.616 & 154.703 & 16.786\end{array}$

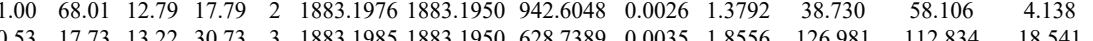
$\begin{array}{lllllllllllll}0.53 & 17.73 & 13.22 & 30.73 & 3 & 1883.1985 & 1883.1950 & 628.7389 & 0.0035 & 1.8556 & 126.981 & 112.834 & 18.541 \\ 0.69 & 83.59 & 12.79 & 96.59 & 2 & 1883.1978 & 1883.1950 & 942.6048 & 0.0028 & 1.4852 & 113.418 & 117.414 & 20.958 \\ 1.00 & 76.57 & 13.2 & 17.91 & 2 & 1883.1982 & 1883.1950 & 942.648 & 0.032 & 1.6974 & 6.833 & 31.668 & 7.639\end{array}$

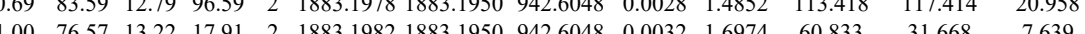

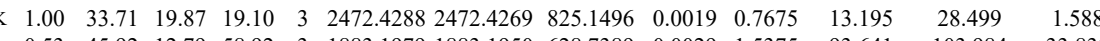
$\begin{array}{lllllllllllllll} & & & \end{array}$

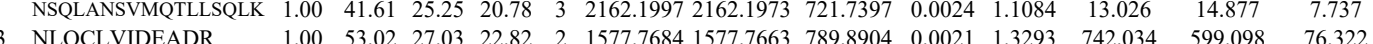
NLQCLVIDEADR NLQCLVIDEADR VPLSEFDFSWSK

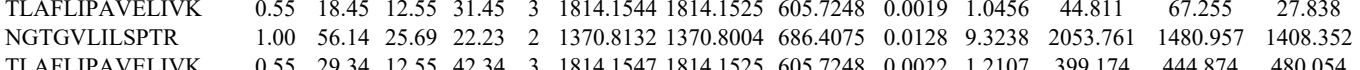

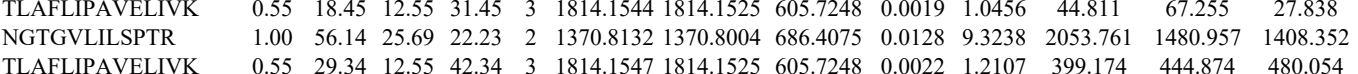
$\begin{array}{lllllllllllll}1.00 & 53.02 & 27.03 & 22.82 & 2 & 1577.7684 & 1577.7663 & 789.8904 & 0.0021 & 1.3293 & 742.034 & 599.098 & 76.322 \\ 1.00 & 72.96 & 27.08 & 24.15 & 2 & 1577.7690 & 1577.7663 & 789.8904 & 0.0027 & 1.7091 & 779.384 & 619.849 & 44.135\end{array}$

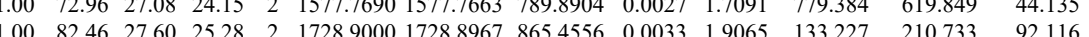
$\begin{array}{lllllllllllllll} & & & \end{array}$ $\begin{array}{llllllllllllll}\text { GHALLILRPEELGFLR } & 0.55 & 37.69 & 19.73 & 50.69 & 3 & 1977.1663 & 1977.1645 & 660.0621 & 0.0018 & 0.9090 & 3062.324 & 2899.758 & 973.926\end{array}$ $\begin{array}{lllllllllllllll} & \text { GHALLILRPELGFLR } & 0.55 & 34.04 & 19.87 & 47.04 & 3 & 1977.1669 & 1977.1645 & 660.0621 & 0.0024 & 1.2120 & 3978.672 & 3546.562 & 1339.100\end{array}$ $\begin{array}{llllllllllllll}\text { GHALLILRPEELGFLR } & 1.00 & 36.65 & 19.87 & 49.65 & 4 & 1977.1669 & 1977.1645 & 495.2984 & 0.0024 & 1.2114 & 858.296 & 1547.621 & 592.538\end{array}$ $\begin{array}{llllllllllllll}\text { GHALLILRPEELGFLR } & 1.00 & 27.58 & 19.73 & 40.58 & 4 & 1977.1681 & 1977.1645 & 495.2984 & 0.0036 & 1.8171 & 1404.881 & 2143.222 & 1546.578\end{array}$ $\begin{array}{lllllllllllllll}\text { LGNGINIIVATPGR } & 1.00 & 91.42 & 23.22 & 23.02 & 2 & 1537.9070 & 1537.9062 & 769.9604 & 0.0008 & 0.5195 & 2730.205 & 2208.920 & 1126.204\end{array}$

$\begin{array}{llllllllllllll}\text { LGNGINIIVATPGR } & 1.00 & 90.57 & 23.22 & 25.00 & 2 & 1537.9070 & 1537.9062 & 769.9604 & 0.0008 & 0.5195 & 3937.299 & 3243.771 & 1445.341 \\ \text { GKPTEASIEAR } & 0.95 & 26.24 & 27.98 & 21.48 & 3 & 1445.8078 & 1445.8082 & 482.9433 & -0.0004 & -0.2761 & 12689.696 & 8316.769 & 10938.949\end{array}$

GKPTEASIEAR

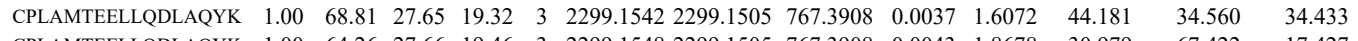
$\begin{array}{llllllllllllll}\text { CPLAMTEELLQDLAQYK } & 1.00 & 64.26 & 27.66 & 19.46 & 3 & 2299.1548 & 2299.1505 & 767.3908 & 0.0043 & 1.8678 & 30.979 & 67.422 & 17.427\end{array}$ $\begin{array}{llllllllllllll}\text { CPLAMTLELLQDLAQYK } & 1.00 & 54.44 & 27.67 & 16.81 & 3 & 2299.1551 & 2299.1505 & 767.3908 & 0.0046 & 1.9981 & 58.486\end{array}$ $\begin{array}{lllllllllllll}\text { CPLAMTEELLQDLAQYK } & 1.00 & 57.97 & 27.75 & 21.07 & 3 & 2299.1569 & 2299.1505 & 767.3908 & 0.0064 & 2.7800 & 19.890\end{array}$ LPSNLPQLQNLIK LPSNLPQLQNL

$\begin{array}{llllllllllll}1.00 & 67.07 & 19.03 & 17.72 & 3 & 1765.0741 & 1765.0705 & 589.3641 & 0.0036 & 2.0361 & 607.231 \\ 1.00 & 42.99 & 18.98 & 21.90 & 3 & 1765.0747 & 1765.0705 & 589.3641 & 0.0042 & 2.3754 & 293.428\end{array}$ 

LGPCSFAELVFR KPVPVLLGSLLNR KPVPVLLGSLLNR KPVPVLLGSLLNR KPVPVLLGSLLNR KPVPVLLGSLLNR

NPELSTQLIDIIHTAAAR LAAVQLLQFLAPK

LAAVQLLQFLAPK

LAAVQLLQARK

GGIGALGGGLCR

GGIGAGLGGGLCR

LNVGGTYFLTTR

FPEDGPELEELLTQLAT

FPEDGPELEEILTQLATADAR FPEDGPELEEILTQLATADAR FPEDGPELEELLTQLATADAR FPEDGPELEELLTLLATADAR
LEGSDVQLLEYEASAAGLIR FVPNLPK

FVPNLPK DLPK $\begin{array}{llllllllllll}0.98 & 34.11 & 22.52 & 23.33 & 2 & 1101.6862 & 1101.6790 & 551.8468 & 0.0072 & 6.5235 & 21561.535 & 20392 \\ 0.9801 .6790 & 551.8468 & 0.0096 & 8.6980 & 8236.043 & 8549.6\end{array}$ $\begin{array}{rrrrrrrrrrrr} & \end{array}$ $\begin{array}{llllllllllllll}\text { NVSLGNVLAVAYATQR } & 1.00 & 43.80 & 26.41 & 20.33 & 3 & 1819.0090 & 1819.0074 & 607.3431 & 0.0016 & 0.8781 & 96.746 & 129.638\end{array}$ $\begin{array}{llllllllllll}\text { NVSLGNVLAVAYATQR } & 0.77 & \text { \#\#\#\# } 26.41 & \text { \#\#\# } & 2 & 1819.0094 & 1819.0074 & 910.5110 & 0.0020 & 1.0983 & 166.686 & 206.966\end{array}$ $\begin{array}{llllllllllllll}\text { NVSLGNVLAVAYATQR } & 1.00 & 44.90 & 26.32 & 22.32 & 3 & 1819.0099 & 1819.0074 & 607.3431 & 0.0025 & 1.3721 & 135.073 & 174.029\end{array}$ $\begin{array}{llllllllllllll}\text { NVSLGNVLAVAYATQR } & 0.54 & 14.73 & 26.64 & 15.42 & 3 & 1819.0075 & 1819.0074 & 607.3431 & 0.0001 & 0.0549 & 42.563 & 46.093 \\ \text { GPILLPYQFR } & 1.00 & 51.07 & 25.65 & 22.11 & 2 & 1346.7848 & 1346.7832 & 674.3989 & 0.0016 & 1.1862 & 1594545 & 1468.786\end{array}$

GPILLPYQFR GPILLPYQFR GPILLPYQFR $\begin{array}{llllllllllllll}1.00 & 51.07 & 25.65 & 22.11 & 2 & 1346.7848 & 1346.7832 & 674.3989 & 0.0016 & 1.1862 & 1594.545 & 1468.786 & 618.806\end{array}$ $\begin{array}{lllllllllllllll}1.00 & 40.19 & 25.66 & 21.44 & 2 & 1346.7856 & 1346.7832 & 674.3989 & 0.0024 & 1.7794 & 1778.533 & 1542.592 & 603.892\end{array}$

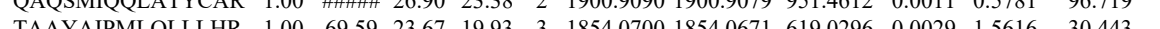

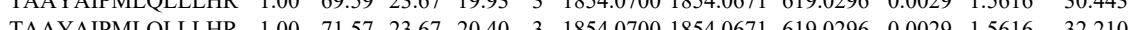
SNDPVATAFAEMLK FGYQFTQQGP FGYQFTQQGPR

FGYQFTQQGPR

FGYQFTQQGPR

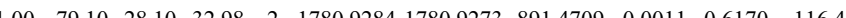

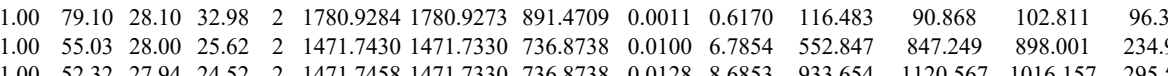
23.140 23.140

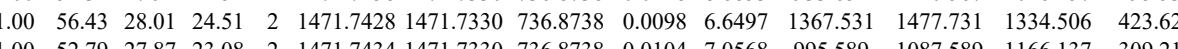
$\begin{array}{lllllllllllllll}1.00 & 47.57 & 27.92 & 26.31 & 2 & 1471.7450 & 1471.7330 & 736.8738 & 0.0120 & 8.1424 & 354.673 & 479.624 & 293.500 & 102.767 & \text { Y }\end{array}$

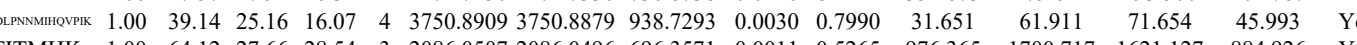
$\begin{array}{llllllllllllllll}\text { EQLDPDELETITMHK } & 1.00 & 64.12 & 27.66 & 28.54 & 3 & 2086.0507 & 2086.0496 & 696.3571 & 0.0011 & 0.5265 & 976.365 & 1700.717 & 1621.127 & 884.926 & \text { Yes }\end{array}$

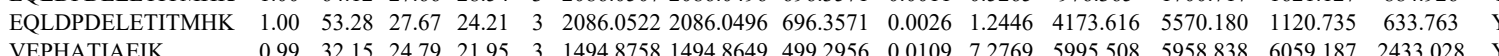
VEPHATIAEIK VEPHATIAEIK LPVGTTATLYFR $\begin{array}{llllllllllllll}0.99 & 32.15 & 24.79 & 21.95 & 3 & 1494.8758 & 1494.8649 & 499.2956 & 0.0109 & 7.2769 & 5995.508 & 5958.838 & 6059.187 & 2433.028 \\ 0.91 & 24.81 & 24.10 & 17.68 & 3 & 1494.8791 & 1494.8649 & 499.2956 & 0.0142 & 9.4799 & 720.663 & 710.195 & 418.667 & 315.911\end{array}$ $\begin{array}{ccccccccccccccc}0.91 & 24.81 & 24.10 & 17.68 & 3 & 1494.8791 & 1494.8649 & 499.2956 & 0.0142 & 9.4799 & 720.663 & 710.195 & 418.667 & 315.911 & Y \\ 1.00 & 41.30 & 25.55 & 23.14 & 3 & 1270.7524 & 1270.7519 & 424.5912 & 0.0005 & 0.3925 & 1098.434 & 1612.748 & 103.181 & 17.880 & Y\end{array}$

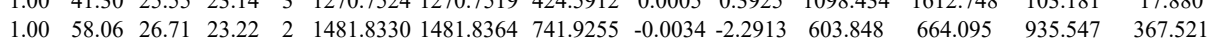
$\begin{array}{llllllllllllll}\text { TPLIDLCDGQADQAAK } & 1.00 & 57.54 & 28.22 & 24.65 & 3 & 1991.9929 & 1991.9900 & 665.0039 & 0.0029 & 1.4536 & 91.591 & 172.694 & 97.362\end{array}$ TPLIDLCDGQADQAAK GVISTPVIR GVISTPVIR GVISTPVIR

GVISTPVIR

QRPPQTPLR QRPPQTPLR AEGSSTASSGSQLAEGK QRPPQTPLR LMSNALSTVTR LMSNALSTVTR MLAHPLHVISMR MLAHPLHVISMR $\begin{array}{lllllllllllllll}0.98 & 37.58 & 22.99 & 28.42 & 2 & 1084.6786 & 1084.6726 & 543.3436 & 0.0060 & 5.5213 & 8673.659 & 8752.086 & 13835.544 & 8176.157 & \text { Yes }\end{array}$

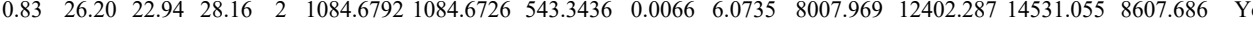
$\begin{array}{llllllllllllllll}0.98 & 37.93 & 22.99 & 28.63 & 2 & 1084.6782 & 1084.6726 & 543.3436 & 0.0056 & 5.1533 & 8173.860 & 9799.065 & 11890.915 & 8435.553 & \text { Yes }\end{array}$ $\begin{array}{lllllllllllllll}0.94 & 31.88 & 22.99 & 28.52 & 2 & 1084.6782 & 1084.6726 & 543.3436 & 0.0056 & 5.1533 & 8051.055 & 11325.053 & 13855.331 & 10201.841 & \text { Yes }\end{array}$ $\begin{array}{lllllllllllllll}0.76 & 21.53 & 26.53 & 16.00 & 3 & 1235.7214 & 1235.7220 & 412.9146 & -0.0006 & -0.4844 & 271.551 & 373.350 & 117.381 & 31.903 & \text { Yes }\end{array}$

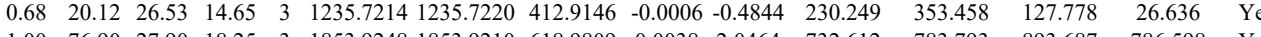
$\begin{array}{llllllllllllllll}1.00 & 76.90 & 27.90 & 18.25 & 3 & 1853.9248 & 1853.9210 & 618.9809 & 0.0038 & 2.0464 & 732.612 & 783.793 & 893.687 & 786.598 & \text { Yes } \\ 0.89 & 21.83 & 26.46 & 18.89 & 3 & 135.722 & 1235.722 & 412.946 & 0.0006 & 0.4844 & 188.743 & 295.782 & 632.85 & 13.684 & \text { Yes }\end{array}$ $\begin{array}{lllllllllllllll}0.89 & 21.83 & 26.46 & 18.89 & 3 & 1235.7226 & 1235.7220 & 412.9146 & 0.0006 & 0.4844 & 188.743 & 295.782 & 63.211 & 13.608 & \text { Yes }\end{array}$

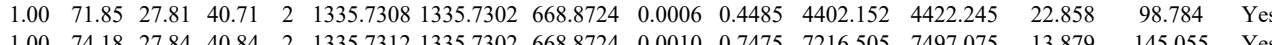
$\begin{array}{rllllllllllllll}1.00 & 74.18 & 27.84 & 40.84 & 2 & 1335.7312 & 1335.7302 & 668.8724 & 0.0010 & 0.7475 & 7216.505 & 7497.075 & 13.879 & 145.055 & \text { Yes } \\ 1.00 & 39.99 & 27.47 & 16.70 & 3 & 1547.8561 & 1547.8550 & 516.9589 & 0.0011 & 0.7093 & 721.689 & 714.754 & 200.222 & 133.339 & \text { Yes } \\ 1.00 & 45.35 & 27.45 & 18.65 & 3 & 1547.8570 & 1547.8550 & 516.9589 & 0.0020 & 1.2896 & 651360 & 697.504 & 290.134 & 157.801 & \text { Yes }\end{array}$

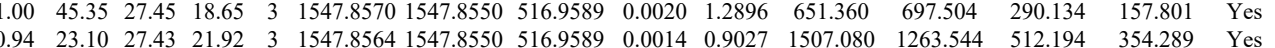

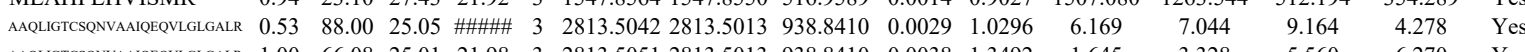

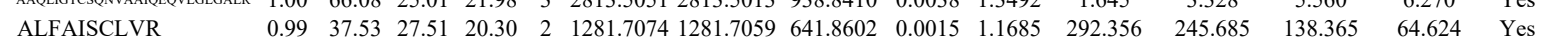




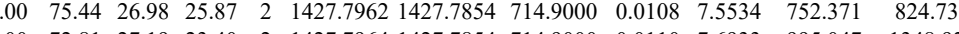

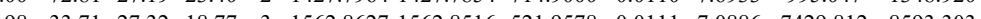

PTFLEK

853.303

ILVELATFEK

ILVELATLEK

LDAVNTLLAMAER

LDAVNTLLAMAER

$\begin{array}{llllllllllll}0.55 & 28.43 & 20.25 & 41.43 & 3 & 1562.9545 & 1562.9527 & 521.9915 & 0.0018 & 1.1494 & 89.314 & 148 .\end{array}$

$\begin{array}{lllllllllllll}0.55 & 28.43 & 2.25 & 41.43 & 3 & 1562.9545 & 1562.9527 & 521.9915 & 0.0018 & 1.1464 & 89.314 & 148.471 & 23\end{array}$

$\begin{array}{llllllllllllll}1.00 & 54.44 & 20.13 & 21.31 & 2 & 1562.9556 & 1562.9527 & 782.4836 & 0.0029 & 1.8531 & 140.597 & 224.718 & 0.91\end{array}$

LDAVNTLLAMAER

LDAVNTLLAMAER

FVFPFDYLPAEQLCIVAK LDLPNRPETSFLW
WGTSGLVGR

$\begin{array}{llllllllllllll}1.00 & 86.98 & 27.77 & 41.85 & 2 & 1559.8472 & 1559.8463 & 780.9304 & 0.0009 & 0.5762 & 1477.061 & 2414.730 & 44.78 \\ 1.00 & 72.26 & 27.58 & 24.79 & 2 & 1559.8480 & 1559.8463 & 780.9304 & 0.0017 & 1.0884 & 1110.966 & 1677.710 & 167.58\end{array}$

$\begin{array}{lllllllllllll}1.00 & 73.25 & 27.69 & 30.90 & 2 & 1559.8464 & 1559.8463 & 780.9304 & 0.0001 & 0.0640 & 4707.398 & 6641.820 & 170.389\end{array}$

$\begin{array}{lllllllllllll}1.00 & 73.59 & 27.76 & 30.87 & 2 & 1559.8468 & 1559.8463 & 780.9304 & 0.0005 & 0.3201 & 2904.122 & 4074.803 & 12.049\end{array}$

$\begin{array}{llllllllllllll} & \\ \text { PFDYLPAEQLCIVAK } & 0.88 & 18.34 & 26.63 & 17.12 & 3 & 2433.2749 & 2433.2720 & 812.0979 & 0.0029 & 1.1903 & 17.928 & 13.776 & 13.194 \\ \text { NRPETSFLWFTNPCK } & 0.99 & 31.46 & 27.19 & 17.90 & 3 & 2611.3186 & 2611.3171 & 871.4463 & 0.0015 & 0.5738 & 123.066 & 195.657 & 12.343 \\ \text { NSGLVGR } & 0.99 & 49.48 & 28.11 & 35.48 & 2 & 1075.5958 & 1075.5896 & 538.8021 & 0.0062 & 5.7535 & 16941.140 & 25965.561 & 1548.381\end{array}$

DQLRPTQLLQNVAR

DQLRPTQLLQNVAR
VIVESASNIPK

DQLRPTQLLQNVAR

DQLRPTQLLQNVAR

ASLLSAPPCR

ASLLSAPPCR
SLGPPGPPFNITPR

SLGPPGPPFNITPR

SLGPPGPPFNITPR

SLGPPGPPFNITPR
ASLLSAPPCR

ASLLSAPPCR

ASLLSAPPCR

LALHILR

LIDEVIEDTR

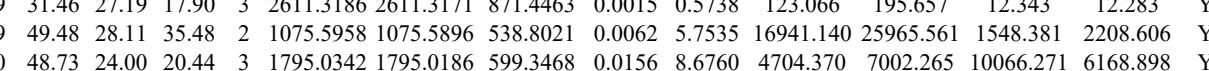

VHVCGQTHR

STLAEIEDWLDK

$\begin{array}{llllllllllllll}0 & \end{array}$

$\begin{array}{llll}301 & 5685.547 & \text { Yes } & 0 \\ 0 & 0\end{array}$ $\begin{array}{llllllllllllllll}0.83 & 29.48 & 26.19 & 26.77 & 2 & 1299.7582 & 1299.7520 & 650.8833 & 0.0062 & 4.7627 & 2631.487 & 2865.723 & 2360.972 & 842.668 & \text { Yes } \\ 100 & 43.87 & 25.17 & 21.89 & 3 & 1795.0183 & 1795.0186 & 599.3468 & 0.0003 & 0.1668 & 2377.759 & 2575.375 & 2991.906 & 2748.061 & \text { No }\end{array}$ $\begin{array}{lllllllllllllll}1.00 & 50.40 & 25.13 & 22.78 & 3 & 1795.0201 & 1795.0186 & 599.3468 & 0.0015 & 0.8342 & 1555.204 & 1902.546 & 2349.600 & 1621.544 & \text { Yes }\end{array}$ $\begin{array}{lllllllllllllll}1.00 & 48.15 & 28.06 & 22.37 & 2 & 1203.6240 & 1203.6226 & 602.8186 & 0.0014 & 1.1612 & 5774.549 & 7242.489 & 359.228 & 182.781 & \text { Yes }\end{array}$ $\begin{array}{lllllllllllllll}0.99 & 43.18 & 29.17 & 25.68 & 2 & 1203.6262 & 1203.6226 & 602.8186 & 0.0036 & 2.9860 & 4041.191 & 4514.085 & 419.389 & 369.890 & \text { Yes }\end{array}$

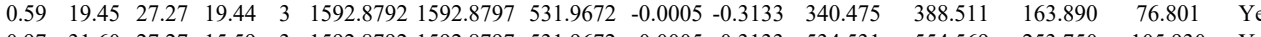

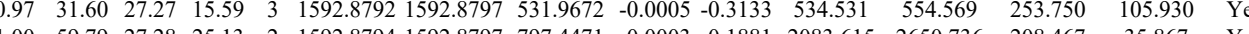

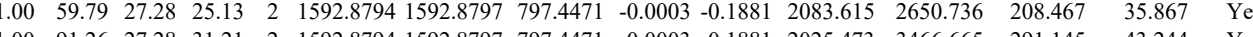

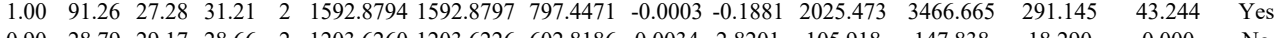

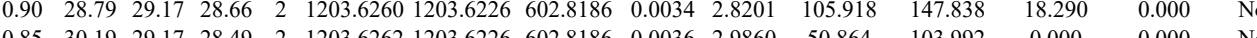

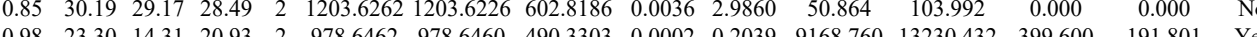
$\begin{array}{llllllllllllll}1.98 & 23.30 & 14.31 & 20.93 & 2 & 978.6462 & 978.6460 & 490.3303 & 0.0002 & 0.2039 & 9168.760 & 13230.432 & 399.600 & 1\end{array}$

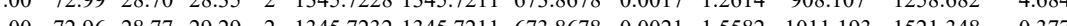

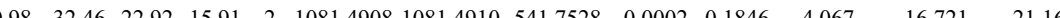

STLAEIEDWLDK

$\begin{array}{lllllllllllll} & \text { DILAE }\end{array}$

$\begin{array}{lllllllllllllll}\text { LLEALDEMLTHDIAK } & 1.00 & 47.23 & 25.90 & 18.37 & 3 & 1999.0936 & 1999.0903 & 667.3707 & 0.0033 & 1.6483 & 488.262 & 555.304 & 34.453\end{array}$ $\begin{array}{lllllllllllllll} & \text { LLEALDEMLTHDIAK } & 1.00 & 58.54 & 25.87 & 19.86 & 3 & 1999.0942 & 1999.0903 & 667.3707 & 0.0039 & 1.9479 & 1885.643 & 1922.270\end{array}$ $\begin{array}{lllllllllllllll}\text { LLEALDEMLTHDIAK } & 1.00 & 57.84 & 25.89 & 17.66 & 3 & 1999.0945 & 1999.0903 & 667.3707 & 0.0042 & 2.0978 & 1400.011 & 1506.619 & 7\end{array}$ $\begin{array}{llllllllllllllll}\text { LLEALDEMLTHDIAK } & 1.00 & 48.05 & 25.90 & 17.28 & 3 & 1999.0909 & 1999.0903 & 667.3707 & 0.0006 & 0.2997 & 567.550 & 614.774\end{array}$ $\begin{array}{lllllllllllllll} & \text { LLEALDEMLTHDIAK } & 1.00 & 50.54 & 25.87 & 19.54 & 3 & 1999.0921 & 1999.0903 & 667.3707 & 0.0018 & 0.8990 & 506.984 & 539.856\end{array}$ LPNSVLGR $\begin{array}{llllllllllllll} & \\ 0.88 & 31.26 & 26.21 & 27.85 & 2 & 998.6042 & 998.5995 & 500.3070 & 0.0018 & 0.8990 & 506.984 & 539.856 & 58.610 \\ 0\end{array}$

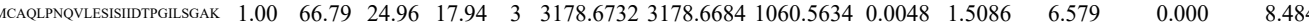

LNPFGNTFLNR

LNPFGNTFLNR

LNPFGNTFLNR

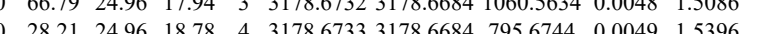

DGMLDDEEFALASH $\begin{array}{lllllllllllll}1.00 & 79.76 & 28.03 & 26.62 & 2 & 1435.7696 & 1435.7694 & 718.8920 & 0.0002 & 0.1391 & 1893.137 & 1700.783 & 201.782\end{array}$

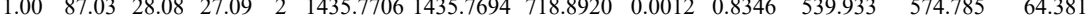

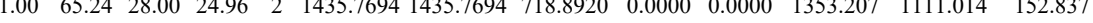
ALLPILQWHK

LLGLLMPFR LLGLLMPFR LLGLLMPFR $\begin{array}{lllllllllllll}1.00 & 49.97 & 27.07 & 18.00 & 3 & 2391.1903 & 2391.1871 & 798.0696 & 0.0032 & 1.3366 & 112.562 & 97.649\end{array}$ $\begin{array}{llllllllllllll}1.00 & 49.04 & 19.34 & 24.25 & 3 & 1505.9338 & 1505.9326 & 502.9848 & 0.0012 & 0.7953 & 1203.316 & 2084.862\end{array}$ $\begin{array}{llllllllllllll}0.97 & 36.08 & 25.44 & 19.61 & 2 & 1202.7326 & 1202.7331 & 602.3738 & -0.0005 & -0.4150 & 274.989 & 486.033\end{array}$ $\begin{array}{lllllllllllll}0.99 & 35.61 & 25.44 & 18.75 & 2 & 1202.7328 & 1202.7331 & 602.3738 & -0.0003 & -0.2490 & 324.340 & 684.516\end{array}$ $\begin{array}{lllllllllllllll}0.99 & 42.54 & 25.44 & 23.89 & 2 & 1202.7324 & 1202.7331 & 62.37378 & -0.0007 & -0.5810 & 57.201 & 71.928\end{array}$ $\begin{array}{lllllllllllll}0.97 & 31.88 & 25.47 & 25.12 & 2 & 1202.7336 & 1202.7331 & 602.3738 & 0.0005 & 0.4150 & 41.506 & 57.596\end{array}$ $\begin{array}{llllllllllll}1.00 & 34.25 & 26.99 & 15.86 & 3 & 1711.9270 & 1711.9245 & 571.6488 & 0.0025 & 1.4578 & 86.904 & 121.353 \\ 0.99 & 30.08 & 26.95 & 25.02 & 3 & 1711.9276 & 1711.9245 & 571.6488 & 0.0031 & 1.8076 & 34.782 & 73.460\end{array}$ CANLFEALVGTLK CANLFEALVGTLK CANLFEALVGTLK CANLFEALVGTLK $\begin{array}{llllllllllll}1.00 & 96.52 & 27.31 & 27.02 & 2 & 1711.9254 & 1711.9245 & 856.9695 & 0.0009 & 0.5251 & 2862.010 & 3623.308\end{array}$

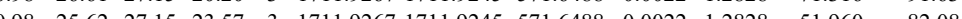


$\begin{array}{llllllllllll}\text { RCC2 HUMAN } & \text { Q9P258 } & \text { RCC2 } & \text { Protein RCC2 } & 56.08 & 1.00 & 3 & 8 & -0.0123 & 0.2204 & 0.0224 & 1.3502\end{array}$

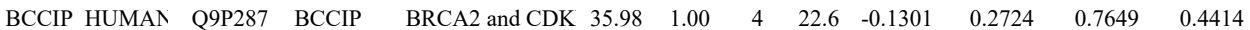

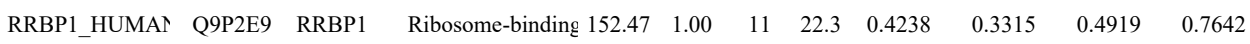

SYLC_HUMAN Q9P2J5 LAR

Leucyl-tRNA synt $134.47 \quad 1.00$
$8.7-0.1301$
0.6439

1.2414 AGGAAVVITEPE GQLUIFGATNWDLIGR

AGGAAVVITEPEHTK

AGGAAVVITEPEHTK

AGGAAVVITEPEHTK

GTQCVEQIQELVLR
GTQCVEQIQELVLR GTQCVEQIQELVLR APVNTAELTDLLIQQNHIGSVIK
APVNTAELTDLLLQQNHIGSVIK GTQCVEQIQELVLR GTQCVEQIQELVLR GTQCVEQIQELVLR FLNDTTKPVGLLLSER
FINVPPQIALPMYQQLQK GNTPATGTTQG GDPVAILK
GDPVAILK

(1.0
APANAVAPTVQPPPIVAPVATVPAMPEEK VEPAVSSVVNSIQVL
VGAAEEELQK
VGAAEEELQK VGAAEEELQK AEGAQNQGK KAEGAQNQGK

HPPAPAEPSSDLASK AQEQQQQMAELHSK HPPAPAEPSSDLASK

QEFEFWYPVDLR QEFEFWYPVDLR
VDIGDTIIYLVH
VDIGDTIIYLVH

NFEATLGWLQEHACSR NYPPWQHTTLSVLR VIYVLPMLTIK VIYVLPMLTIK VIYVLPMLTIK WQFLTLR WQFLTLR WQFLTLR WQFLTLR
CANLFEALVGTLK CANLFEALVGTLK FGVLFR FGVLFR FGVLFR FGVLFR GVLFR CANLFEALVGTLK

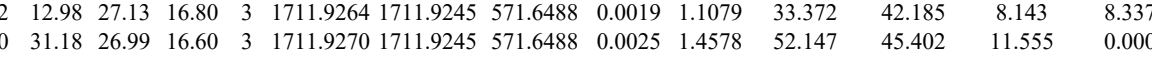

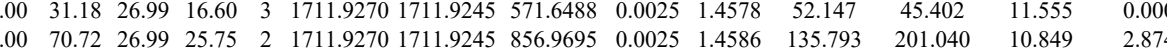
$\begin{array}{lllllllllllllll}0.87 & 23.36 & 26.70 & 23.47 & 2 & 881.5266 & 881.5245 & 441.7695 & 0.0021 & 2.3768 & 13391.903 & 18492.860 & 844.557 & 442.803\end{array}$ $\begin{array}{lllllllllllllll}0.87 & 23.36 & 26.70 & 23.47 & 2 & 881.5266 & 881.524 & 441.765 & 0.0021 & 2.3788 & 13391.903 & 18492.860 & 844.557 & 42.803 \\ 0.58 & 18.44 & 26.86 & 24.73 & 2 & 881.5274 & 881.5245 & 441.7695 & 0.0029 & 3.2822 & 7763.059 & 10726.904 & 688.403 & 554.885 & \end{array}$

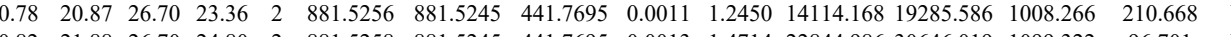
$\begin{array}{lllllllllllllllll}0.82 & 21.88 & 26.70 & 24.80 & 2 & 881.5258 & 881.5245 & 441.7695 & 0.0013 & 1.4714 & 22844.986 & 30646.019 & 1099.322 & 96.701 & \text { Yes }\end{array}$ $\begin{array}{llllllllllllllll}0.54 & 10.69 & 26.70 & 24.33 & 2 & 881.5260 & 881.5245 & 441.7695 & 0.0015 & 1.6977 & 10192.596 & 13857.701 & 920.761 & 246.487 & \text { Yes }\end{array}$ $\begin{array}{llllllllllllllll}1.00 & 53.83 & 26.78 & 23.62 & 3 & 881.5244 & 881.5245 & 441.7695 & -0.0001 & -0.1132 & 117.210 & 1681.758 & 79.677 & 150.476 & \text { Yes }\end{array}$ $\begin{array}{lllllllllllllllllll}0.81 & 24.79 & 28.33 & 21.51 & 3 & 1434.7708 & 1434.7602 & 479.2607 & 0.0106 & 7.3724 & 20753.255 & 23428.275 & 9365.389 & 3098.066 & \text { Yes }\end{array}$ $\begin{array}{llllllllllllllll}0.93 & 19.07 & 28.38 & 25.28 & 3 & 1434.7711 & 1434.7602 & 479.2607 & 0.0109 & 7.5811 & 15774.273 & 17447.126 & 7779.811 & 1504.449 & \text { Yes }\end{array}$

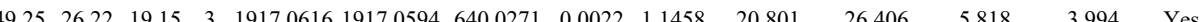
$\begin{array}{lllllllllllllll} & 17.06\end{array}$ $\begin{array}{llllllllllllllll}1.00 & 63.26 & 25.95 & 22.68 & 3 & 1766.9935 & 1766.9770 & 589.9996 & 0.0165 & 9.3220 & 4965.860 & 5287.269 & 5168.432 & 2716.501 & \text { Yes }\end{array}$ $\begin{array}{lllllllllllllll}1.00 & 64.71 & 26.45 & 21.93 & 3 & 1766.9881 & 1766.9770 & 589.9996 & 0.0111 & 6.2712 & 5362.127 & 5414.970 & 4646.141 & 3871.656 & \text { Yes }\end{array}$ $\begin{array}{lllllllllllllll}.00 & 58.33 & 26.28 & 21.81 & 3 & 1766.9896 & 1766.9770 & 589.9996 & 0.0126 & 7.1186 & 5838.603 & 5763.275 & 5826.172 & 3795.010 & \text { Yes } \\ 1.00 & 78.56 & 28.31 & 23.36 & 2 & 1804.9320 & 1804.9297 & 903.4721 & 0.002 & 1.2729 & 1607.846 & 1697.768 & 1669.761 & 1506.507 & \text { Yes }\end{array}$ $\begin{array}{lllllllllllllll}1.00 & 76.87 & 28.31 & 25.40 & 2 & 1804.9318 & 1804.9297 & 903.4721 & 0.0021 & 1.1622 & 1056.731 & 1077.441 & 1280.124 & 1020.744 & \text { Yes } \\ 1.00 & 78.56 & 28.31 & 23.36 & 2 & 1804.9320 & 1804.9297 & 903.4721 & 0.0023 & 1.2729 & 1607.846 & 1697.768 & 1669.761 & 1506.507 & \text { Yes }\end{array}$

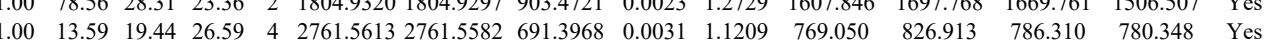

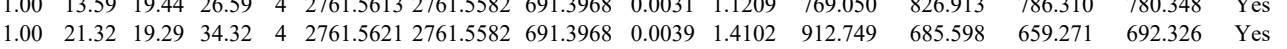

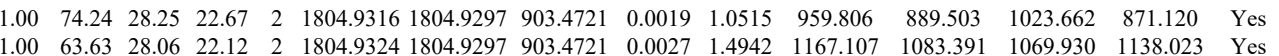
$\begin{array}{lllllllllllllll}0.55 & 59.05 & 19.68 & 72.05 & 3 & 2761.5601 & 2761.5582 & 921.5267 & 0.0019 & 0.6873 & 370.677 & 263.652 & 212.360 & 340.862 & \text { Yes }\end{array}$ $\begin{array}{lllllllllllllll}1.00 & 91.86 & 28.27 & 25.04 & 2 & 1804.9314 & 1804.9297 & 903.4721 & 0.0017 & 0.9408 & 268.952 & 201.931 & 262.600 & 144.207 & \text { Yes }\end{array}$

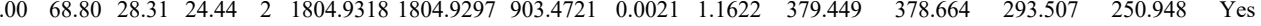

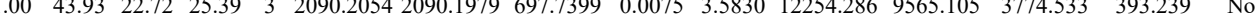

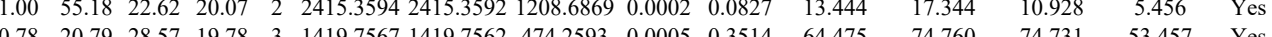
$\begin{array}{lllllllllllllll}0.78 & 20.79 & 28.57 & 19.78 & 3 & 1419.7567 & 1419.7562 & 474.2593 & 0.0005 & 0.3514 & 64.475 & 74.760 & 74.731 & 53.457 & \text { Yes } \\ 1.00 & 44.34 & 24.35 & 27.84 & 2 & 109.6926 & 109.6845 & 550.8495 & 0.008 & 7.3522 & 35.363 & 3953.928 & 3684.180 & 343.97 & \text { Yes }\end{array}$ $\begin{array}{lllllllllllllll}0.00 & 44.34 & 24.35 & 27.84 & 2 & 1099.6926 & 099.6845 & 550.8495 & 0.0081 & 7.3522 & 3513.863 & 3953.928 & 3684.180 & 3443.197 & \text { Yes }\end{array}$ $\begin{array}{lllllllllllllll}.57 & 21.29 & 24.35 & 23.93 & 2 & 1099.6926 & 1099.6845 & 550.8495 & 0.0081 & 7.3522 & 2031.522 & 2220.733 & 1566.041 & 1340.845 & \text { Yes }\end{array}$

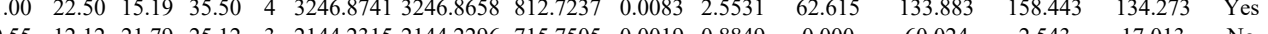
$\begin{array}{lllllllllllllll}0.55 & 33.10 & 21.79 & 46.10 & 3 & 2144.2321 & 2144.2296 & 715.7505 & 0.0025 & 1.1643 & 36.558 & 51.405 & 21.333 & 22.159 & \text { Yes }\end{array}$

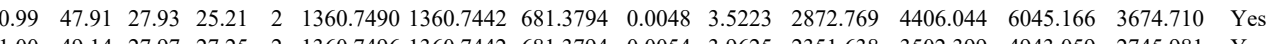

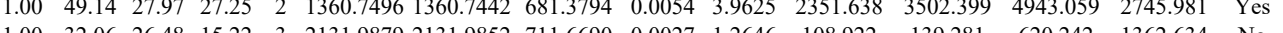

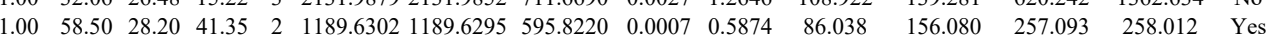

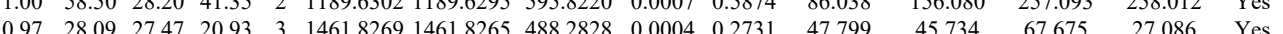

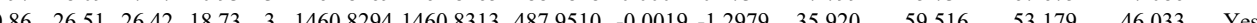
$\begin{array}{llllllllllllllll}1.00 & 47.83 & 28 & 20 & 16.03 & 3 & 1790.9521 & 1790.9406 & 597.9875 & 0.0115 & 6.4103 & 5074.305 & 6260.905 & 26503.259 & 8122.755 & \text { No }\end{array}$ $\begin{array}{llllllllllllllll}1.00 & 58.91 & 27.69 & 22.41 & 3 & 1942.9798 & 1942.9774 & 648.6664 & 0.0024 & 1.2333 & 2496.087 & 3297.914 & 6500.978 & 5421.580 & \text { Yes }\end{array}$ $\begin{array}{lllllllllllllll}1.00 & 59.18 & 28.31 & 21.17 & 3 & 1790.9515 & 1790.9406 & 597.9875 & 0.0109 & 6.0759 & 3650.623 & 4855.187 & 10547.367 & 4319.276 & \text { Yes }\end{array}$

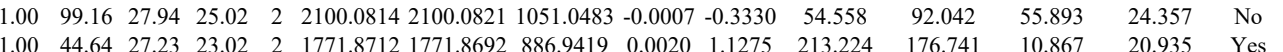
$\begin{array}{ccccccccccccccc}1.00 & 44.64 & 27.23 & 23.02 & 2 & 1771.8712 & 1771.8692 & 886.9419 & 0.0020 & 1.1275 & 213.224 & 176.741 & 10.867 & 20.935 & \text { Yes } \\ 1.00 & 53.32 & 27.04 & 19.62 & 2 & 1500.8324 & 1500.8310 & 751.4228 & 0.0014 & 0.9316 & 120.456 & 155.898 & 8.437 & 0.000 & \text { No }\end{array}$

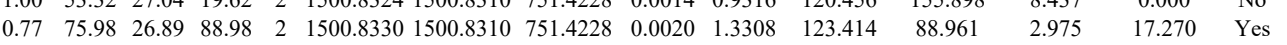
$\begin{array}{lllllllllllllllll}1.00 & 61.75 & 27.00 & 20.51 & 3 & 1854.9874 & 1854.9863 & 619.3360 & 0.0011 & 0.5920 & 941.351 & 1334.238 & 304.198 & 97.126 & \text { Yes }\end{array}$ $\begin{array}{lllllllllllllll}1.00 & 62.22 & 26.93 & 17.91 & 3 & 1854.9892 & 1854.9863 & 619.3360 & 0.0029 & 1.5608 & 657.644 & 536.934 & 286.430 & 91.818 & \text { Yes }\end{array}$ $\begin{array}{llllllllllllllll}1.00 & 70.59 & 17.40 & 26.03 & 2 & 1576.9878 & 1576.9870 & 789.5008 & 0.0008 & 0.5066 & 22.203 & 16.599 & 4.994 & 0.000 & \text { No }\end{array}$ $\begin{array}{lllllllllllllll}0.53 & 24.00 & 17.16 & 37.00 & 3 & 1576.9897 & 1576.9870 & 526.6696 & 0.0027 & 1.7088 & 61.796 & 101.866 & 3.395 & 17.821 & \text { No }\end{array}$

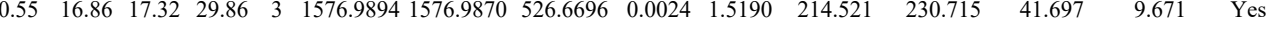
$\begin{array}{lllllllllllllll}0.96 & 29.50 & 27.21 & 28.72 & 2 & 1106.6366 & 1106.6358 & 554.3252 & 0.0008 & 0.7216 & 2565.964 & 2594.745 & 64.604 & 42.506 & \text { Yes } \\ \end{array}$ $\begin{array}{lllllllllllllllll}0.98 & 33.41 & 27.21 & 29.13 & 2 & 1106.6366 & 1106.6358 & 554.3252 & 0.0008 & 0.7216 & 2777.489 & 2680.038 & 81.241 & 36.592 & \text { Yes }\end{array}$ $\begin{array}{llllllllllllllll}0.96 & 29.28 & 27.21 & 30.17 & 2 & 1106.6368 & 1106.6358 & 554.3252 & 0.0010 & 0.9020 & 9859.147 & 9169.086 & 400.633 & 322.671 & \text { Yes }\end{array}$ $\begin{array}{lllllllllllllll}0.95 & 28.19 & 27.23 & 30.38 & 2 & 1106.6378 & 1106.6358 & 554.3252 & 0.0020 & 1.8040 & 9597.337 & 9408.466 & 110.812 & 337.788 & \text { Yes } \\ 0.76 & 50.62 & 23.32 & 63.62 & 2 & 1430.6304 & 1430.6292 & 7163219 & 0.001 & 0.8376 & 554.094 & 768.751 & 0.000 & 0.006 & \end{array}$ $\begin{array}{llllllllllllllll}0.76 & 50.62 & 23.32 & 63.62 & 2 & 1430.6304 & 1430.6292 & 716.3219 & 0.0012 & 0.8376 & 554.094 & 768.751 & 0.000 & 0.000 & \text { No }\end{array}$ $\begin{array}{llllllllllllllll} & \\ \text { LPESEWPPQDLEALR } & 1.00 & 36.64 & 25.16 & 19.49 & 2 & 1952.0908 & 1952.0887 & 977.0516 & 0.0021 & 1.0747 & 78.570 & 75.765 & 13.504 & 7.006 & \text { Yes }\end{array}$

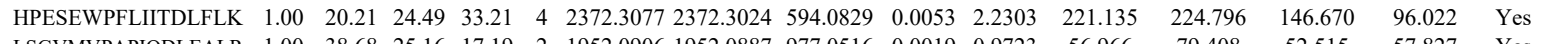

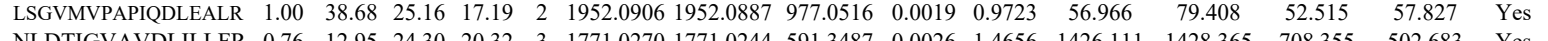
$\begin{array}{llllllllllllllll}\text { NLDTIGVAVDLILLFR } & 0.76 & 12.95 & 24.30 & 20.32 & 3 & 1771.0270 & 1771.0244 & 591.3487 & 0.0026 & 1.4656 & 1426.111 & 1428.365 & 708.355 & 502.683 & \text { Yes }\end{array}$

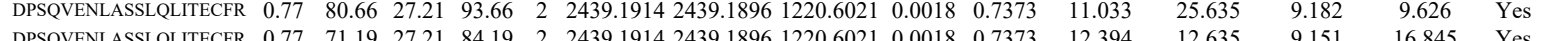

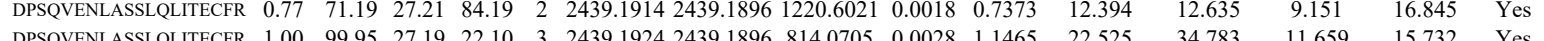

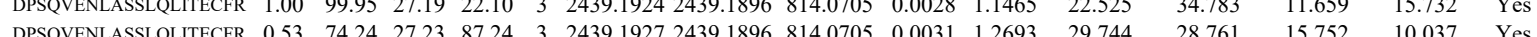

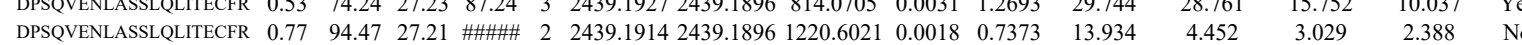




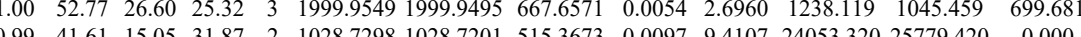
$\begin{array}{ccccccccccccc}0.99 & 39.20 & 15.05 & 28.88 & 2 & 1028.7300 & 1028.7201 & 515.3673 & 0.0099 & 9.6047 & 6191.551 & 5549.225 & 326.204 \\ 0.93 & 31.48 & 26.46 & 22.31 & 2 & 1124.6430 & 1124.6330 & 563.3238 & 0.0100 & 8.8758 & 18651.000 & 17304.716 & 865.969 \\ 1.00 & 60.73 & 27.01 & 20.50 & 3 & 2806.3849 & 28063844 & 936.4687 & 0.0005 & 0.1780 & 4.785 & 8.586 & 5.766\end{array}$ $\begin{array}{lllllllllll}.00 & 60.73 & 27.01 & 20.50 & 3 & 2806.3849 & 2806.3844 & 936.4687 & 0.0005 & 0.1780 & 4.78\end{array}$

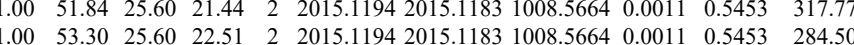
$\begin{array}{lllllllllll}1.00 & 68.90 & 28.25 & 29.86 & 2 & 1289.6816 & 1289.6809 & 645.8477 & 0.0007 & 0.5419 & 8.448\end{array}$ $\begin{array}{lllllllllll}1.00 & 54.17 & 28.47 & 24.01 & 2 & 1289.6820 & 1289.6809 & 645.8477 & 0.0011 & 0.8516 & 15.476\end{array}$ TASTNNIAQAR TASTNNIAQAR TASTNNIAQAR $\begin{array}{lllllllllll}1 & 0.00 \\ 1.00 & 46.24 & 28.45 & 24.93 & 2 & 1289.6818 & 1289.6809 & 645.8477 & 0.0009 & 0.6968 & 18.161\end{array}$ $\begin{array}{lllllllllll}.00 & 50.08 & 28.25 & 20.81 & 2 & 1289.6816 & 12896809 & 645.8477 & 0.0007 & 0.5419 & 10.228\end{array}$

\section{YTAAVPYR} $\begin{array}{lllllllllll}1.00 & 46.08 & 28.23 & 26.04 & 2 & 1289.6818 & 1289.6809 & 645.8477 & 0.0009 & 0.6968 & 6.624\end{array}$

YTAAVPYR

YTAAVPYR

YTAAVPYR

GYFFPTSAR

GYFFPTSAR

LLVSGFWGVAR

LLVSGFWGVAR

LLVSGFWGVAR

LLVSGFWGVAR

LLVSGFWGVR

LLVSGFWGVAR

$\begin{array}{lllllllllllllll}0.99 & 36.13 & 27.06 & 21.39 & 2 & 1083.5868 & 11083.5835 & 542.793 & 0.0033 & 3.0398 & 15269.733 & 19508.002 & 3377.671\end{array}$

$\begin{array}{lllllllllllll}0.97 & 36.21 & 27.06 & 22.38 & 2 & 1083.5870 & 1083.5835 & 542.7990 & 0.0035 & 3.2240 & 11171.868 & 16223.661 & 2154.514\end{array}$

$\begin{array}{lllllllllllll}0.99 & 36.27 & 27.47 & 23.06 & 2 & 1083.5858 & 1083.5835 & 542.7990 & 0.0023 & 2.1186 & 14561.440 & 20159.483 & 3233.356\end{array}$

$\begin{array}{llllllllllllll}0.99 & 36.39 & 27.27 & 23.01 & 2 & 1083.5864 & 1083.5835 & 542.7990 & 0.0029 & 2.6713 & 13160.398 & 17233.510 & 2761.408 & 883 .\end{array}$ $\begin{array}{llllllllllllll}0.98 & 38.72 & 27.40 & 25.12 & 2 & 1188.6146 & 1188.6049 & 595.3097 & 0.0097 & 8.1470 & 12904.072 & 16056.055 & 2716.638 \\ 0.99 & 44.29 & 27.40 & 27.27 & 2 & 1188.6148 & 1188.6049 & 595.3097 & 0.0099 & 8.3149 & 15683.730 & 18849.495 & 3019.092\end{array}$

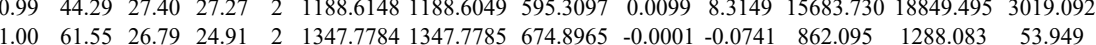

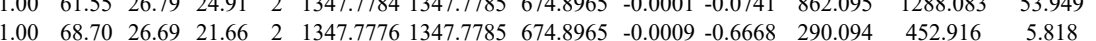

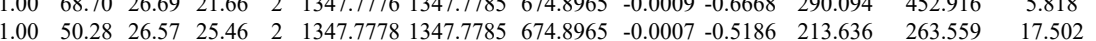

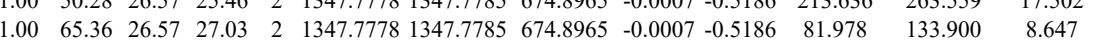

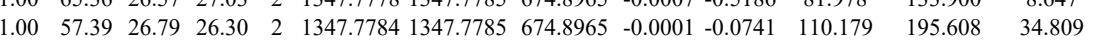

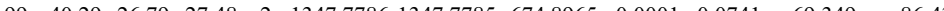

LLVSGT

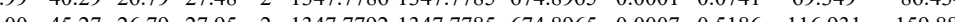

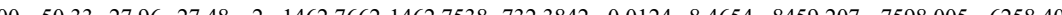

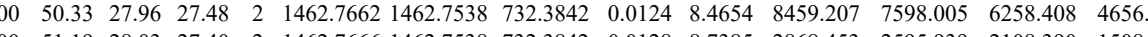

YNPENLATLE

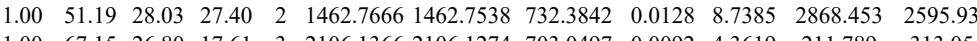

WLLAEML $\begin{array}{llllllllllllll}\text { WLLAEMLGDLSDSQLK } & 1.00 & 53.26 & 26.80 & 16.94 & 3 & 2106.1366 & 2106.1274 & 703.0497 & 0.0092 & 4.3619 & 277.232\end{array}$

$\begin{array}{llllllllllll}1.00 & 53.26 & 26.80 & 16.94 & 3 & 2106.1366 & 2106.1274 & 703.0497 & 0.0092 & 4.3619 & 277.232 & 199.246 \\ 1.00 & 53.26 & 26.66 & 18.12 & 3 & 2106.1384 & 2106.1274 & 703.0497 & 0.0110 & 5.2153 & 187.459 & 146.587\end{array}$

LKPFGVQR

$\begin{array}{llllllllllllll}\text { NTMSLLAANNLLAGLR } & 1.00 & \text { \#\#.22 } & 23.36 & 2 & 1815.0172 & 1815.0158 & 908.5152 & 0.0014 & 0.7705 & 193.409 & 230.153 & 68.245\end{array}$

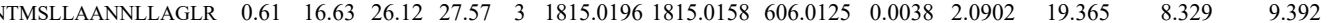
$\begin{array}{llllllllllllll}\text { NTMSLLAANNLLAGLR } & 1.00 & 97.58 & 26.28 & 24.96 & 2 & 1815.0166 & 1815.0158 & 908.5152 & 0.0008 & 0.4403 & 529.633 & 512.95\end{array}$ $\begin{array}{lllllllllllll}\text { NTMSLLAANNLLAGLR } & 1.00 & \text { \#\#\#\# } 26.28 & 29.21 & 2 & 1815.0166 & 1815.0158 & 908.5152 & 0.0008 & 0.4403 & 270.257 & 303\end{array}$ $\begin{array}{lllllllllllll}\text { NTMSLLAANNLLAGLR } & 1.00 & 68.82 & 26.11 & 17.61 & 3 & 1815.0199 & 1815.0158 & 606.0125 & 0.0041 & 2.2552 & 10.303\end{array}$ $\begin{array}{lllllllllllll}\text { NTMSLLAANNLLAGLR } & 1.00 & 38.61 & 26.11 & 18.56 & 3 & 1815.0202 & 1815.0158 & 606.0125 & 0.0044 & 2.4202 & 23.224 & 2\end{array}$ $\begin{array}{llllllllllllll}\text { NTMSLLAANNLLAGLR } & 1.00 & 47.72 & 26.18 & 22.28 & 3 & 1815.0187 & 1815.0158 & 606.0125 & 0.0029 & 1.5951 & 53.282 & 8\end{array}$ NTMSLLAANNLLAGL

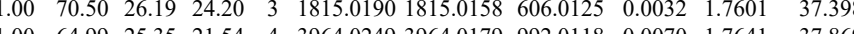
$\begin{array}{llllllllllll}1.00 & 64.99 & 25.35 & 21.54 & 4 & 3964.0249 & 3964.0179 & 992.0118 & 0.0070 & 1.7641 & 37.869\end{array}$

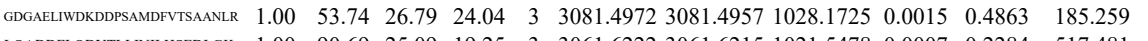
$\begin{array}{lllllllllll}1.00 & 86.91 & 25.01 & 21.63 & 3 & 3061.6222 & 3061.6215 & 3021.5478 & 0.0007 & 0.2284 & 517.481 \\ 0.6252 & 3061.6215 & 1021.5478 & 0.0037 & 1.2073 & 516.565 & 50\end{array}$ TFPGCTIR $\begin{array}{lllllllllll}0.86 & 18.52 & 26.51 & 15.44 & 3 & 2884.5034 & 2884.4992 & 962.5070 & 0.0042 & 1.4545 & 34.405 \\ 0.91 & 24.84 & 26.46 & 31.81 & 2 & 1083.5338 & 1083.5327 & 542.7736 & 0.0011 & 1.0133 & 1308.640\end{array}$ $\begin{array}{llllllllllll} & & & & \end{array}$

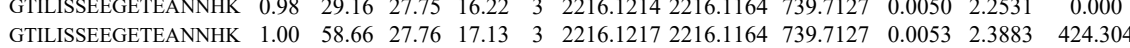

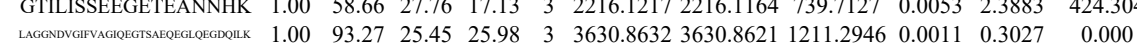
$\begin{array}{llllllllllll}1.00 & 93.27 & 25.45 & 25.98 & 3 & 3630.8632 & 3630.8621 & 1211.2946 & 0.0011 & 0.3027 & 0.000 \\ 1.00 & 27.88 & 25.12 & 15.07 & 4 & 3630.8693 & 3630.8621 & 908.7228 & 0.0072 & 1.9808 & 0.000\end{array}$ 
EDAVLYLLEIPK GEMVTILAQSR GFGIAVSGGR GFGIAVSGGR GFGIAVSGGR LQLVVLR LQLVVLR LQLVVLR LGNWLAVR

\section{GRPGPIGVLLMK}

GRPGPIGVLLMK

GRPGPIGVLLMK

GRPGPIGVLLMK

GRPGPIGVLLMK

GRPGPIGVLLMK

GRPGPIGVLLMK

GRPGPIGVLLMK

GRPGPIGVLLMK GRPGPIGVLLMK AFEVMDEFDGR YQEEPPAPQPK

YQEEPPAPQPK SNPSAVAGNETPGAS

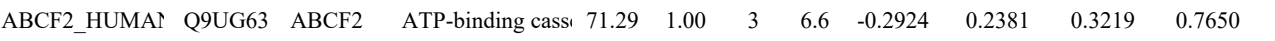

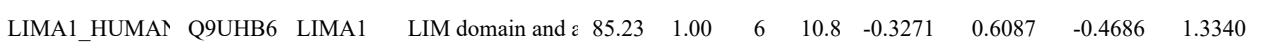

$\begin{array}{lllllllll}\text { CHRD1_HUMA: Q9UHD1 CHORDC1 Cysteine and histi } 37.49 & 1.00 & 3 & 16.3 & -0.0997 & 0.3129 & -0.8201 & 1.3656\end{array}$ ILHGLGFTPAMQR ILHGLGFTPAMQR

IAw ISANENSLAVR SANENSLAVR YNVPLNR

LSLGTYASLHGR TEVTIYPQESAHR $\begin{array}{lllllllllll}0.94 & 23.49 & 24.22 & 27.53 & 3 & 1689.9814 & 1689.9796 & 564.3338 & 0.0018 & 1.0632 & 57.131\end{array}$ $\begin{array}{lllllllllllll} & \end{array}$ $\begin{array}{lllllllllllllll}0.99 & 45.60 & 28.57 & 29.71 & 2 & 1063.5968 & 1063.5896 & 532.8021 & 0.0072 & 6.7567 & 8726.694 & 10816.527 & 3656.679 & 518.507 & \text { Yes }\end{array}$ $\begin{array}{lllllllllllllllll}0.99 & 43.55 & 28.12 & 25.41 & 2 & 1063.5940 & 1063.5896 & 532.8021 & 0.0044 & 4.1291 & 3992.309 & 5464.957 & 3118.463 & 979.626 & \text { Yes }\end{array}$ $\begin{array}{llllllllllllllll}0.99 & 46.84 & 28.64 & 29.05 & 2 & 1063.5946 & 1063.5896 & 532.8021 & 0.0050 & 4.6922 & 4839.886 & 5900.640 & 3242.851 & 890.828 & \text { Yes } \\ 1.09 & 47.06 & 18.45 & 33.39 & 2 & 983.6702 & 933.6613 & 42.8379 & 0.058 & 9.0293 & 9281.260 & 1132.002 & 190.977 & 515.93 & \text { Yes }\end{array}$ $\begin{array}{lllllllllllllll}1.00 & 47.06 & 18.45 & 33.39 & 2 & 983.6702 & 983.6613 & 492.8379 & 0.0089 & 9.0293 & 9281.260 & 11342.002 & 1190.977 & 515.931 & \text { Yes } \\ 0.97 & 42.15 & 18.45 & 37.23 & 2 & 983.660 & 983.6613 & 492.8379 & 0.0077 & 7.8118 & 4917.891 & 5488.773 & 1790.435 & 1417.420 & \text { Yes }\end{array}$ $\begin{array}{lllllllllllllll}0.97 & 42.15 & 18.45 & 37.23 & 2 & 983.669 & 983.6613 & 492.8379 & 0.0077 & 7.8118 & 4917.891 & 5488.773 & 1790.435 & 1417.420 & \text { Yes } \\ 0.97 & 42.38 & 18.45 & 37.58 & 2 & 983.6692 & 983.6613 & 4928379 & 0.0079 & 8.0147 & 4742.50 & 5549.482 & 1422.142 & 1089.621 & \text { Yes }\end{array}$

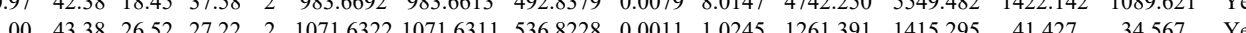

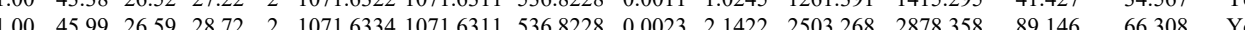
$\begin{array}{lllllllllllllll}1.00 & 24.78 & 18.26 & 15.09 & 3 & 1524.9442 & 1524.9418 & 509.3212 & 0.0024 & 1.5707 & 2989.727 & 3381.990 & 357.391 & 48.272 & \text { Yes }\end{array}$ $\begin{array}{lllllllllllllll}0.62 & 28.66 & 22.67 & 25.04 & 3 & 154.9318 & 1540.9367 & 514.6528 & 0.0049 & -3.1737 & 553.128 & 617.569 & 102.940 & 51.085 & \text { Yes }\end{array}$

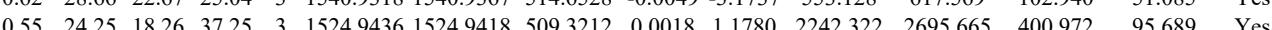

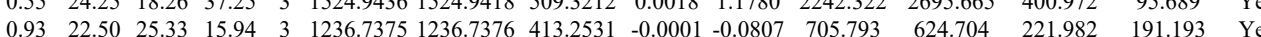

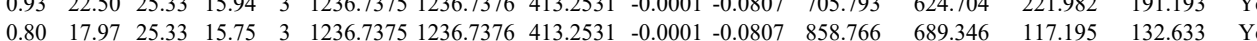
$\begin{array}{lllllllllllllll}0.72 & 24.34 & 25.48 & 18.42 & 3 & 1236.7351 & 1236.7376 & 4132531 & -0.0025 & -2.0165 & 87.388 & 100.021 & 66.343 & 57.869 & \text { Yes }\end{array}$ $\begin{array}{lllllllllllllll}0.86 & 25.29 & 25.48 & 14.80 & 3 & 1236.7354 & 1236.7376 & 413.2531 & -0.0022 & -1.7745 & 86.694 & 82.448 & 25.734 & 24.551 & \text { Yes }\end{array}$ $\begin{array}{lllllllllllllll}0.96 & 30.49 & 25.33 & 15.50 & 2 & 1236.7376 & 1236.7376 & 6193761 & 0.0000 & 0.0000 & 25.264 & 31.862 & 19.376 & 10.328 & \text { Yes }\end{array}$ $\begin{array}{llllllllllllllll}1.00 & 54.98 & 25.26 & 21.25 & 2 & 12367380 & 12367376 & 619.3761 & 0.0004 & 0.3229 & 28.383 & 32.678 & 7.883 & 8.119 & \text { Yes }\end{array}$ $\begin{array}{llllllllllllllll}1.00 & 39.26 & 25.38 & 21.99 & 2 & 1236.7386 & 1236.7376 & 619.3761 & 0.0010 & 0.8073 & 39.996 & 30.393 & 18.886 & 12.583 & \text { Yes }\end{array}$ $\begin{array}{lllllllllllllll}1.00 & 55.43 & 24.03 & 18.92 & 2 & 1458.6594 & 1458.6571 & 730.3358 & 0.0023 & 1.5746 & 225.084 & 265.658 & 37.191 & 19.221 & \text { Yes }\end{array}$ $\begin{array}{lllllllllllllll}0.97 & 32.40 & 27.80 & 16.66 & 2 & 1570.8260 & 1570.8235 & 786.4190 & 0.0025 & 1.5895 & 4763.776 & 4681.654 & 4999.746 & 3522.087 & \text { Yes }\end{array}$

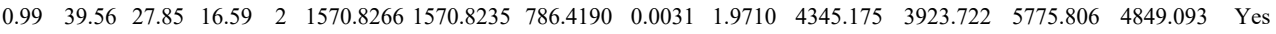
$\begin{array}{lllllllllllllll}1.00 & 82.75 & 27.36 & 19.64 & 3 & 1874.9602 & 1874.9577 & 625.9932 & 0.0025 & 1.3312 & 652.519 & 722.770 & 1104.421 & 683.378 & \text { Yes }\end{array}$ $\begin{array}{llllllllllllllll}1.00 & 65.83 & 26.16 & 22.59 & 2 & 1671.9352 & 1671.9351 & 836.9748 & 0.0001 & 0.0597 & 915.256 & 553.488 & 35.917 & 36.888 & \text { Yes }\end{array}$ $\begin{array}{llllllllllllllll}1.00 & 66.20 & 26.21 & 23.29 & 2 & 1671.9354 & 1671.9351 & 836.9748 & 0.0003 & 0.1792 & 1292.343 & 936.068 & 27.994 & 86.397 & \text { Yes }\end{array}$

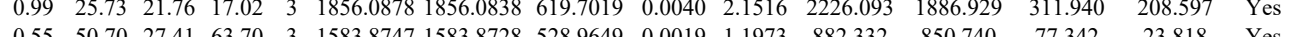
$\begin{array}{llllllllllllllll}0.55 & 5.70 & 27.41 & 63.70 & 3 & 1583.8747 & 1583.8728 & 528.9649 & 0.0019 & 1.1973 & 882.332 & 850.740 & 77.342 & 23.818 & \text { Yes }\end{array}$ $\begin{array}{lllllllllllllll}1.00 & 43.32 & 27.60 & 16.41 & 3 & 1583.8735 & 1583.8728 & 528.9649 & 0.0007 & 0.4411 & 1621.426 & 1374.685 & 178.625 & 74.247 & \text { Yes } \\ 1.00 & 59.08 & 27.62 & 21.23 & 3 & 1583.8738 & 1583.8728 & 528.949 & 0.0010 & 0.6302 & 102.670 & 1094.639 & 72.022 & 3.98 & \text { Yes }\end{array}$ $\begin{array}{lllllllllllllll}1.00 & 59.08 & 27.62 & 21.23 & 3 & 1583.8738 & 1583.8728 & 528.9649 & 0.0010 & 0.6302 & 1192.670 & 1094.639 & 72.022 & 33.980 & \text { Yes } \\ 1.00 & 40.52 & 27.60 & 15.64 & 3 & 1583.8741 & 1583.8728 & 528.9649 & 0.0013 & 0.8192 & 1085.179 & 1094.505 & 240.260 & 113.934 & \text { Yes }\end{array}$

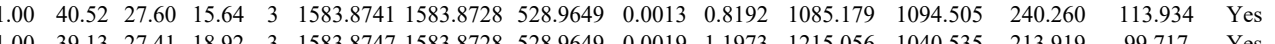

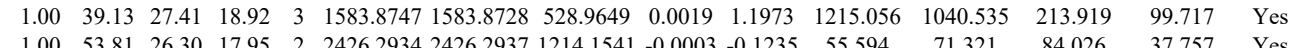

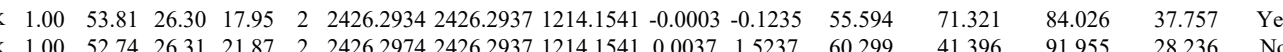
AWPPPTELGSSGSALEEGIK $\begin{array}{llllllllllllll}0.95 & 23.69 & 26.30 & 18.29 & 3 & 2426.2984 & 2426.2937 & 809.7718 & 0.0047 & 1.9347 & 71.802 & 23.968 & 30.386\end{array}$ $\begin{array}{lllllllllll} & \end{array}$ $\begin{array}{llllllllllllll} & \end{array}$ $\begin{array}{llllllllllllllllll} & 1.00 & 61.99 & 27.62 & 36.64 & 3 & 1417.7941 & 1417.7799 & 473.6006 & 0.0142 & 9.9943 & 3336.795 & 3571.409 & 1549.743 & 1233.880 & \text { Yes }\end{array}$

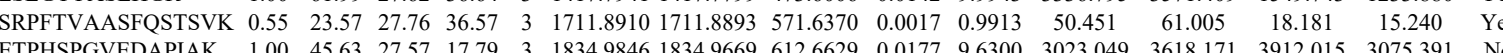
$\begin{array}{lllllllllllllllll}\text { RPSPDEPMTNLELK } & 1.00 & 45.86 & 27.39 & 20.73 & 3 & 1914.0286 & 1914.0124 & 639.0114 & 0.0162 & 8.4505 & 2106.172 & 1826.608 & 1171.396 & 1043.921 & N o\end{array}$ $\begin{array}{llllllllllllllll}\text { RPSPDEPMTNLELK } & 1.00 & 52.54 & 27.39 & 18.68 & 3 & 1914.0286 & 1914.0124 & 639.0114 & 0.0162 & 8.4505 & 1971.396 & 2151.214 & 1183.582 & 808.238 & \text { No. }\end{array}$ $\begin{array}{lllllllllllllllll}\text { FDPETNSDDACTYHPGYPYFHDALK } & 1.00 & 39.90 & 24.58 & 52.90 & 4 & 3108.4245 & 3108.4201 & 778.1123 & 0.0044 & 1.4137 & 6292.159 & 7175.443 & 1909.947 & 606.329 & \text { Y }\end{array}$

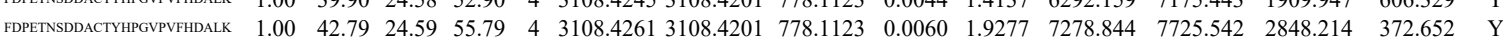

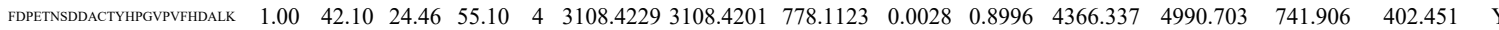

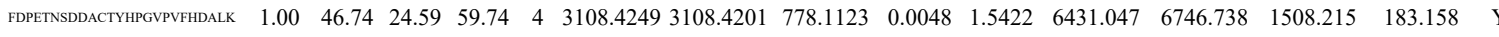

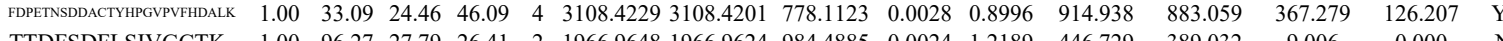
$\begin{array}{lllllllllllllllll}\text { TTDFSDFLSIVGCTK } & 1.00 & 96.27 & 27.79 & 26.41 & 2 & 1966.9648 & 1966.9624 & 984.4885 & 0.0024 & 1.2189 & 446.729 & 389.032 & 9.006 & 0.000 & \text { No }\end{array}$ $\begin{array}{llllllllllllllll}\text { TTDFSDFLSIVGCTK } & 1.00 & 59.37 & 27.77 & 18.68 & 3 & 1966.9651 & 1966.9624 & 656.6614 & 0.0027 & 1.3706 & 390.840 & 272.826 & 26.688 & 11.622 & \text { Yes }\end{array}$ $\begin{array}{llllllllllllllll}\text { TTDFSDFLSIVGCTK } & 1.00 & 94.27 & 27.94 & 22.19 & 2 & 1966.9658 & 1966.9624 & 984.4885 & 0.0034 & 1.7268 & 976.471 & 906.003 & 0.000 & 4.665 & \text { No }\end{array}$ $\begin{array}{llllllllllllllll}\text { TTDFSDFLSIVGCTK } & 1.00 & 42.86 & 27.95 & 15.88 & 3 & 1966.9672 & 1966.9624 & 656.6614 & 0.0048 & 2.4366 & 294.829 & 219.181 & 64.758 & 37.646 & \text { Yes }\end{array}$

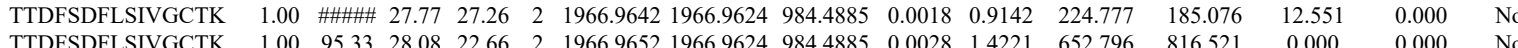

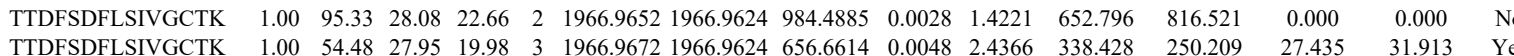
$\begin{array}{lllllllllllllll} & \end{array}$ VPEVPTAPATGCTK TEITIVKPQESAHR $\begin{array}{llllllllllllllll}1.00 & 51.60 & 27.98 & 21.63 & 3 & 1966.9675 & 1966.9624 & 656.6614 & 0.0051 & 2.5888 & 407.362 & 502.977 & 64.748 & 3.086\end{array}$

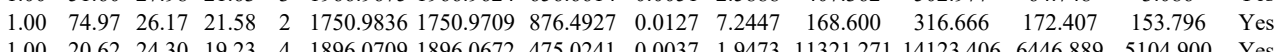
$\begin{array}{llllllllllllllllll}1.00 & 20.62 & 24.30 & 19.23 & 4 & 1896.0709 & 1896.0672 & 475.0241 & 0.0037 & 1.9473 & 11321.271 & 14123.406 & 6446.889 & 5104.900 & \text { Yes }\end{array}$ $\begin{array}{lllllllllllllllll}1.00 & 20.21 & 24.30 & 14.82 & 4 & 1896.0709 & 1896.0672 & 475.0241 & 0.0037 & 1.9473 & 11020.034 & 10801.570 & 8224.025 & 5443.429 & \text { Yes } \\ 1.00 & 6.65 & 23.73 & 39.65 & 4 & 2052.1681 & 2052.1683 & 51.0494 & 0.0002 & -0.0973 & 7677.907 & 13529.756 & 4873.220 & 2093.333 & \text { Yes }\end{array}$

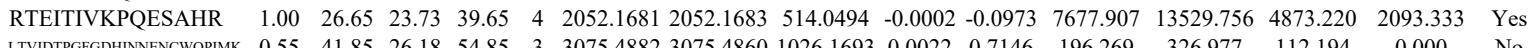

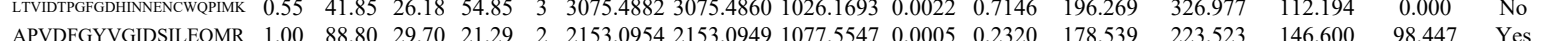

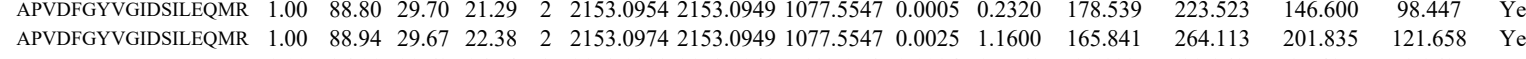

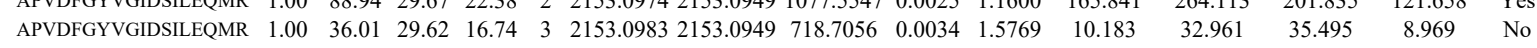

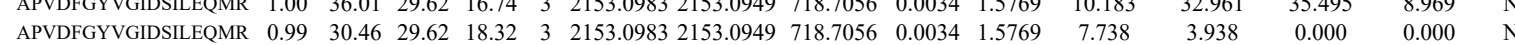

Table S-3 page 471 of 499 


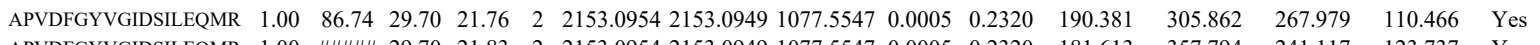

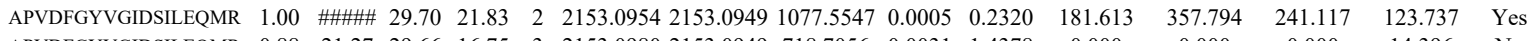

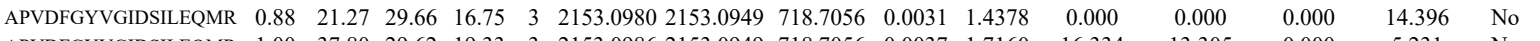

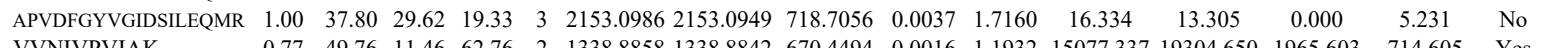

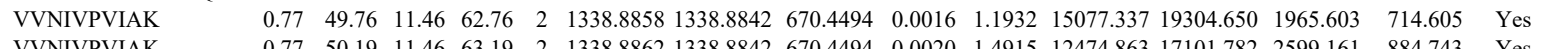

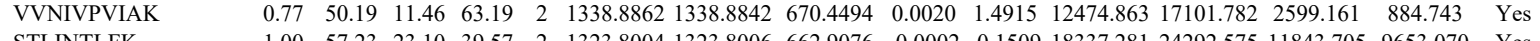

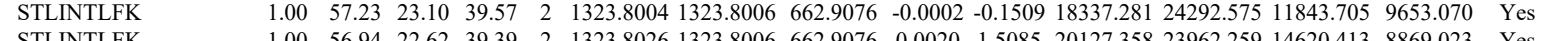

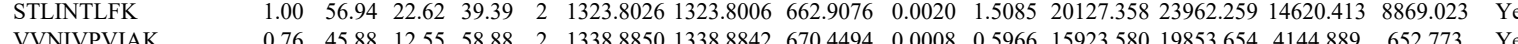
$\begin{array}{llllllllllllllll}\text { VVNIVPVIAK } & 0.76 & 45.88 & 12.55 & 58.88 & 2 & 1338.8850 & 1338.8842 & 670.4494 & 0.0008 & 0.5966 & 15923.580 & 19853.654 & 4144.889 & 652.773 & \text { Yes } \\ \text { VVNIVPVIAK } & 0.76 & 46.00 & 12.55 & 59.00 & 2 & 1338.8852 & 1338.8842 & 670.4494 & 0.0010 & 0.7458 & 20592.840 & 25601.009 & 5338.805 & 1301.329 & \text { Yes } \\ \text { STLNTLE } & 1.00 & 50.72 & 22.65 & 39.09 & 2 & 1323.8012 & 1323.8006 & 662.907 & 0.000 & 0.4526 & 9774.974 & 12203.504 & 7077.455 & 4680.334 & \text { Yes }\end{array}$ STLINTLFK STLINTLFK KQESTVMVLR $\begin{array}{lllllllllllllllll}1.00 & 48.88 & 22.55 & 39.09 & 2 & 1323.8022 & 1323.8006 & 662.9076 & 0.0016 & 12068 & 7569.633 & 8950.475 & 4398.428 & 3432.430 & \text { Yes }\end{array}$ $\begin{array}{llllllllllllllll}0.77 & 28.33 & 22.07 & 33.10 & 2 & 969.6168 & 969.6093 & 485.8119 & 0.0075 & 7.7190 & 1440.426 & 1569.856 & 205.084 & 134.874 & \text { Yes } \\ 1.00 & 37.65 & 25.49 & 26.11 & 3 & 1477.8586 & 1477.530 & 493.6249 & 0.0056 & 3.7815 & 24004.417 & 19962.467 & 7840.892 & 3081.559 & \text { Yes }\end{array}$ $\begin{array}{llllllllllllllll}1.00 & 12.25 & 19.03 & 25.25 & 4 & 3081.7521 & 3081.7504 & 771.4449 & 0.0017 & 0.5509 & 80.600 & 85.519 & 59.254 & 8.214 & \text { Yes }\end{array}$ $\begin{array}{llllllllllllllll} & \end{array}$ $\begin{array}{llllllllllllllll}\text { DIDDDLEGEVTEECGK } & 0.54 & 11.68 & 23.60 & 15.40 & 3 & 2099.9122 & 2099.9119 & 700.9779 & 0.0003 & 0.1427 & 32.115 & 16.734 & 29.791 & 24.010 & \text { Yes }\end{array}$

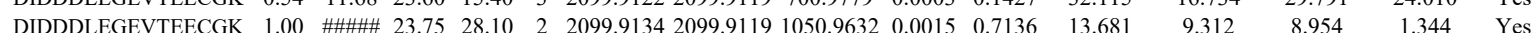

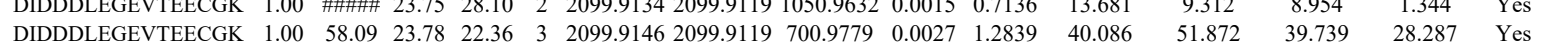

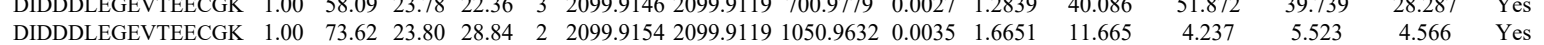
$\begin{array}{llllllllllllllll}\text { DIDDDLEGEVTEECGK } & 1.00 & 51.93 & 23.80 & 19.75 & 3 & 2099.9161 & 2099.9119 & 700.9779 & 0.0042 & 1.9972 & 27.518 & 61.158 & 33.202 & 36.363 & \text { Yes }\end{array}$ $\begin{array}{lllllllllllllllll}\text { AUTPPMLLIPA APGGLPPAAVAAAATAK } & 0.55 & 52.52 & 19.03 & 65.52 & 3 & 3081.7522 & 3081.7504 & 1028.2574 & 0.0018 & 0.5835 & 4.125 & 5.916 & 1.875 & 2.401 & \text { Yes }\end{array}$

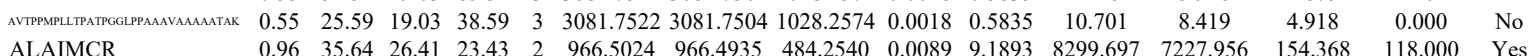

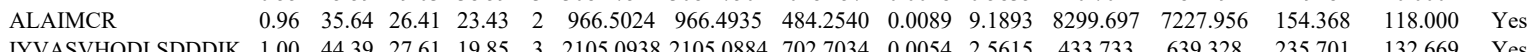
$\begin{array}{lrllllllllllllll}\text { IYVASVHQDLSDDDIK } & 1.00 & 44.39 & 27.61 & 19.85 & 3 & 2105.0938 & 2105.0884 & 702.7034 & 0.0054 & 2.5615 & 433.733 & 639.328 & 235.701 & 132.669 & \text { Yes } \\ \text { LPEYPQVDDLLLR } & 1.00 & 40.00 & 26.96 & 30.71 & 2 & 1713.9446 & 1713.9423 & 857.9784 & 0.0023 & 1.3404 & 180.646 & 147.818 & 83.781 & 85.62 & Y \text { Yes }\end{array}$ $\begin{array}{llllllllll} & \\ \text { VGTAQLALVAR } & 1.00 & 40.00 & 26.96 & 30.71 & 2 & 1713.9446 & 1713.9423 & 857.9784 & 0.0023\end{array}$ $\begin{array}{llllllllllllll}\text { IVLAAQAISR } & 1.00 & 59.89 & 23.16 & 34.92 & 2 & 1241.7682 & 1241.7578 & 621.8862 & 0.0104 & 8.3616 & 3408\end{array}$ IVLAAQAISR $\begin{array}{lllllllllllllllll}1.00 & 48.19 & 23.20 & 30.12 & 2 & 1184.7434 & 1184.7363 & 593.3754 & 0.0071 & 5.9827 & 16036.119 & 15206.368 & 1725.048 & 231.708 & \text { Yes }\end{array}$ $\begin{array}{lllllllllllllll}.00 & 52.55 & 22.62 & 32.42 & 2 & 1184.7446 & 1184.7363 & 593.3754 & 0.0083 & 6.9938 & 13886.367 & 13265.824 & 985.615 & 1\end{array}$ $\begin{array}{lllllllllllllllll}\text { YNIPVISDDLQENAQR } & 1.00 & 87.74 & 26.80 & 22.47 & 3 & 2734.3219 & 2734.3176 & 912.4465 & 0.0043 & 1.5709 & 41.365 & 50.683 & 67.544 & 316\end{array}$ $\begin{array}{llllllllllllll}\text { YNIIPVLSDILQESVK } & 0.96 & 19.38 & 22.50 & 19.41 & 3 & 2118.2218 & 2118.2180 & 707.0799 & 0.0038 & 1.7914 & 15.442 & 13.668 & 21.798\end{array}$ $\begin{array}{lllllllllllllll}\text { YNIIPVLSDILQESVK } & 1.00 & 36.32 & 22.55 & 16.65 & 3 & 2118.2227 & 2118.2180 & 707.0799 & 0.0047 & 2.2157 & 14.595 & 29.027 & 0.000\end{array}$ $\begin{array}{llllllllllllll}\text { YNIIPVLSDILQESVK } & 0.99 & 24.18 & 22.70 & 15.95 & 3 & 2118.2212 & 2118.2180 & 707.0799 & 0.0032 & 1.5085 & 28.647 & 37.863 & 16.158 \\ \text { IILAAFR } & 0.96 & 34.93 & 25.29 & 24.49 & 2 & 946.6076 & 946.6086 & 474.3116 & -0.0010 & -1.0542 & 1004.264 & 960.545 & 35.680\end{array}$ IILAAFR IILAAFR IILAAFR $\begin{array}{llllllllllllll}0.99 & 43.35 & 25.29 & 24.77 & 2 & 946.6078 & 946.6086 & 474.3116 & -0.0008 & -0.8433 & 864.888 & 836.551 & 30.175\end{array}$ $\begin{array}{lllllllllllll}1.00 & 44.34 & 25.08 & 24.93 & 2 & 946.6088 & 946.6086 & 474.3116 & 0.0002 & 0.2108 & 3388.225 & 3995.047 & 78.980\end{array}$

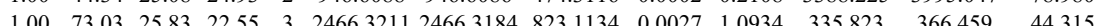

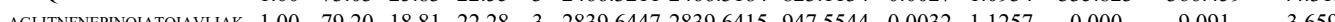

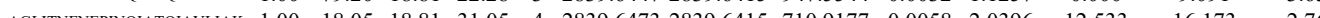

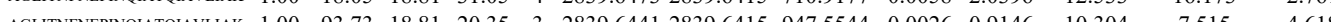

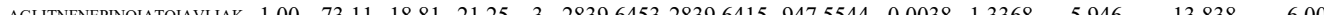

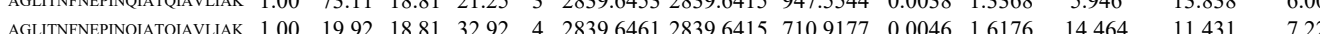
$\begin{array}{llllllllllllll} & 0.98\end{array}$

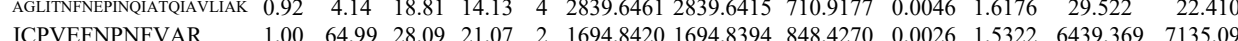
ICPVEFNPNFVAR LLTHNLLSSHVR LLTHNLLSSHVR LLTHNLLSSHVR

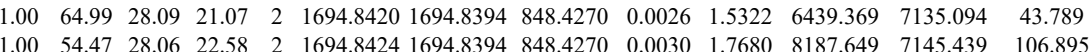
$\begin{array}{lllllllllllll}0.99 & 26.71 & 25.72 & 21.93 & 3 & 1532.8936 & 1532.8909 & 511.9709 & 0.0027 & 1.7579 & 1414.397 & 1256.308 & 526.868\end{array}$ $\begin{array}{llllllllllllll}1.50 & 25.68 & 17.24 & 3 & 1532.8921 & 1532.8909 & 511.9709 & 0.0012 & 0.7813 & 2793.975 & 2966.768 & 887.791\end{array}$ $\begin{array}{lllllllllllll}1.00 & 60.12 & 25.67 & 23.38 & 3 & 1532.8924 & 1532.8909 & 511.9709 & 0.0015 & 0.9766 & 3584.190 & 3912.539 & 1050.687\end{array}$ ENEEFLR $\begin{array}{llllllllllll}.65 & 28.79 & 26.22 & 16.72 & 2 & 1810.8480 & 1810.8495 & 906.4320 & -0.0015 & -0.8274 & 13.458 & 13.239\end{array}$ TTFYTALGR

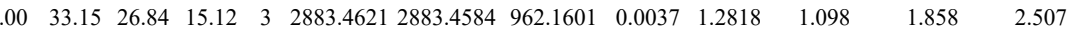

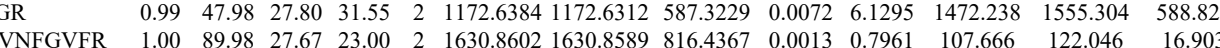

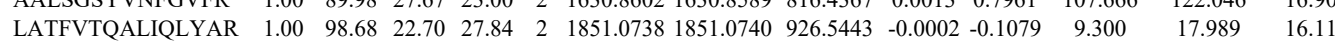
LATFVTQALIQLYAR

4 GILNGQK GILNGQK GILNGQK GILNGQK FSWPFR LQILTALCHR LQILTALCHR LQILTALCHR LQILTALCHR LQILTALCHR $\begin{array}{llllllllllllll}0.91 & 23.47 & 25.11 & 26.36 & 2 & 1016.6240 & 1016.6222 & 509.3184 & 0.0018 & 1.7671 & 1297.930 & 989.651 & 825.742\end{array}$ $\begin{array}{lllllllllllll}0.91 & 23.31 & 25.11 & 26.79 & 2 & 1016.6240 & 1016.6222 & 509.3184 & 0.0018 & 1.7671 & 1408.078 & 1105.702 & 935.161\end{array}$ $\begin{array}{lllllllllllll}0.79 & 21.95 & 24.56 & 25.25 & 2 & 1016.6226 & 1016.6222 & 509.3184 & 0.0004 & 0.3927 & 535.802 & 531.607 & 330.640\end{array}$ $\begin{array}{lllllllllllllll}0.91 & 23.04 & 24.49 & 25.38 & 2 & 1016.6232 & 1016.6222 & 509.3184 & 0.0010 & 0.9817 & 707.118 & 644.811 & 488.665\end{array}$ $\begin{array}{lllllllllllllll}0.60 & 18.57 & 26.67 & 27.15 & 2 & 982.5176 & 982.5147 & 492.2646 & 0.0029 & 2.9456 & 2455.402 & 1892.849 & 48.360\end{array}$ $\begin{array}{llllllllllllll}1.00 & 60.44 & 27.53 & 23.36 & 2 & 1356.7498 & 1356.7492 & 679.3819 & 0.0006 & 0.4416 & 243.352 & 229.678 & 14.668\end{array}$ $\begin{array}{lllllllllllll}0.99 & 33.01 & 27.90 & 25.83 & 3 & 1356.7504 & 1356.7492 & 453.2570 & 0.0012 & 0.8825 & 268.037 & 263.441 & 15.482\end{array}$

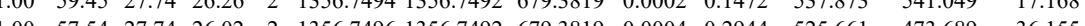

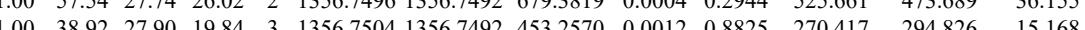

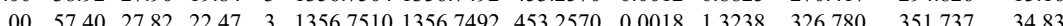

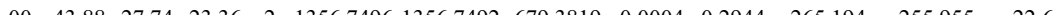
$\begin{array}{llllllllllll}1.00 & 43.88 & 27.74 & 23.36 & 2 & 1356.7406 & 1356.7492 & 679.3819 & 0.0004 & 0.2544 & 265.194 & 255.955\end{array}$ 

$\begin{array}{llllllllllllllll}0.67 & 27.99 & 26.29 & 34.97 & 2 & 973.6114 & 973.6042 & 487.8094 & 0.0072 & 7.3799 & 4610.219 & 4506.323 & 847.625 & 770.709 & \text { Yes }\end{array}$

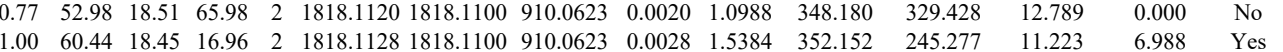
$\begin{array}{lllllllllllllll}0.77 & 64.71 & 18.45 & 77.71 & 2 & 1818.1122 & 1818.1100 & 910.0623 & 0.0022 & 1.2087 & 1675.861 & 1357.493 & 53.396 & 19.361 & \text { Yes }\end{array}$

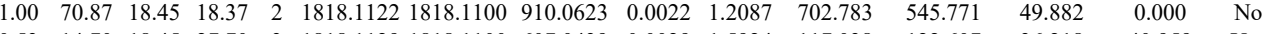

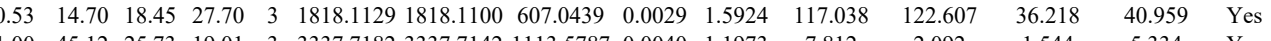

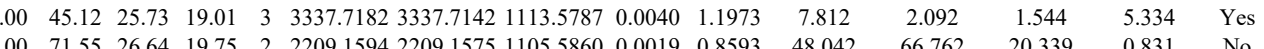

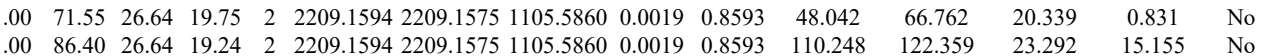

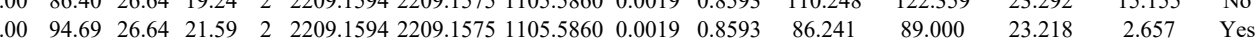
$\begin{array}{lllllllllllllll}0.99 & 36.86 & 28.76 & 24.95 & 2 & 1076.5962 & 1076.5956 & 539.3051 & 0.0006 & 0.5563 & 6059.494 & 6073.829 & 265.255 & 130.855 & \text { Yes }\end{array}$ $\begin{array}{llllllllllllllll}0.99 & 38.68 & 28.58 & 24.96 & 2 & 1076.5980 & 1076.5956 & 539.3051 & 0.0024 & 2.2251 & 7697.540 & 7339.645 & 307.441 & 126.275 & \text { Yes } \\ 1.00 & 42.92 & 28.58 & 25.54 & 2 & 10765978 & 10765956 & 539.3051 & 0.0022 & 2.0397 & 10670.305 & 10464.974 & 202.463 & 184.557 & \text { Yes }\end{array}$

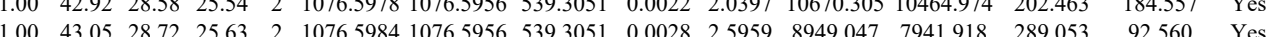

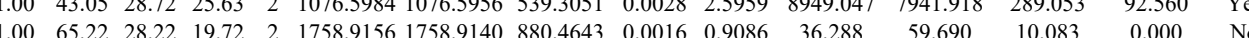

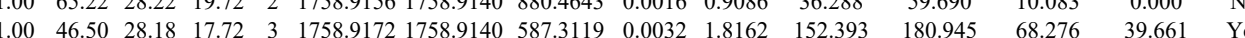

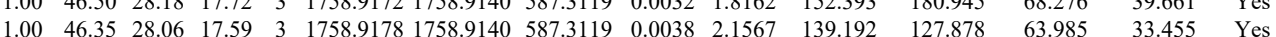
$\begin{array}{llllllllllllllll}0.97 & 39.01 & 28.09 & 17.70 & 2 & 1503.8018 & 1503.8030 & 752.9088 & -0.0012 & -0.7969 & 394.676 & 301.720 & 285.483 & 162.997 & \text { Yes } & \end{array}$ $\begin{array}{lllllllllllllll}1.00 & 49.25 & 28.09 & 20.29 & 2 & 1503.8022 & 1503.8030 & 752.9088 & -0.0008 & -0.5313 & 268.621 & 140.921 & 102.367 & 82.595 & \text { Yes }\end{array}$ $\begin{array}{llllllllllllllll}0.83 & 38.65 & 28.03 & 16.71 & 2 & 1503.8004 & 1503.8030 & 752.9088 & -0.0026 & -1.7266 & 106.712 & 86.202 & 68.875 & 51.166 & \text { Yes } \\ 1.00 & 55.70 & 27.19 & 26.49 & 2 & 1312.7180 & 1312.7118 & 657.3632 & 0.0062 & 4.7158 & 902.236 & 880.843 & 1122.529 & 943.723 & \text { No }\end{array}$

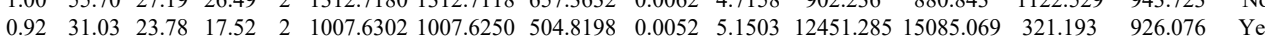
$\begin{array}{lllllllllllllll}0.92 & 30.94 & 23.78 & 17.42 & 2 & 1007.6308 & 1007.6250 & 504.8198 & 0.0058 & 5.7446 & 24755.267 & 29073.120 & 690.040 & 1588.174 & \text { Yes }\end{array}$ $\begin{array}{llllllllllllllll}0.95 & 33.37 & 23.78 & 21.21 & 2 & 1007.6306 & 1007.6250 & 504.8198 & 0.0056 & 5.5465 & 20614.424 & 23968.671 & 126.834 & 686.427 & \text { Yes }\end{array}$ $\begin{array}{lllllllllllllll}0.96 & 33.95 & 23.78 & 16.51 & 2 & 1007.6318 & 1007.6250 & 504.8198 & 0.0068 & 6.7350 & 14077.498 & 16003.254 & 273.574 & 395.993 & \text { Yes }\end{array}$ $\begin{array}{lllllllllllllllll}0.93 & 30.53 & 17.92 & 29.16 & 2 & 926.6090 & 926.6035 & 464.3090 & 0.0055 & 5.9227 & 33866.511 & 38782.018 & 15285.632 & 1678.148 & \text { Yes }\end{array}$ $\begin{array}{llllllllllllllllll}0.93 & 30.45 & 17.92 & 28.93 & 2 & 926.6094 & 926.6035 & 464.3090 & 0.0059 & 6.3535 & 42100.456 & 50231.277 & 21076.873 & 2730.367 & \text { Yes }\end{array}$ $\begin{array}{lllllllllllllllll}1.00 & 59.84 & 27.12 & 36.81 & 2 & 1316.7662 & 1316.7543 & 659.3844 & 0.0119 & 9.0235 & 26515.325 & 26970.168 & 12580.774 & 2529.450 & \text { Yes }\end{array}$ $\begin{array}{lllllllllllllllll}1.00 & 52.11 & 26.87 & 38.03 & 2 & 1316.7670 & 1316.7543 & 659.3844 & 0.0127 & 9.6301 & 25628.234 & 28454.789 & 11856.442 & 2424.722 & \text { Yes }\end{array}$ $\begin{array}{llllllllllllllll}1.00 & 45.25 & 26.74 & 32.77 & 2 & 1316.7650 & 1316.7543 & 659.3844 & 0.0107 & 8.1136 & 9970.393 & 10939.936 & 4746.549 & 1200.016 & \text { Yes } & \\ \end{array}$ $\begin{array}{lllllllllllllll}0.99 & 33.13 & 24.73 & 17.67 & 3 & 1501.8790 & 1501.8708 & 501.6309 & 0.0082 & 5.4489 & 23951.815 & 25733.441 & 15974.244 & 10433.119 & \text { Yes }\end{array}$ $\begin{array}{llllllllllllllll}0.99 & 31.65 & 24.73 & 17.57 & 3 & 1501.8790 & 1501.8708 & 501.6309 & 0.0082 & 5.4489 & 25792.794 & 29201.419 & 20517.323 & 12657.429 & \text { Yes }\end{array}$ $\begin{array}{lllllllllllllllll}0.91 & 25.85 & 27.57 & 29.49 & 2 & 1143.6304 & 1143.6280 & 572.8213 & 0.0024 & 2.0949 & 3502.289 & 3615.406 & 2955.501 & 2626.257 & \text { Yes }\end{array}$

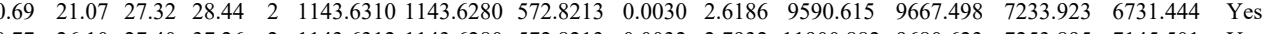

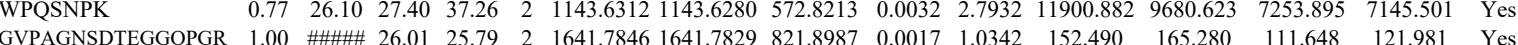

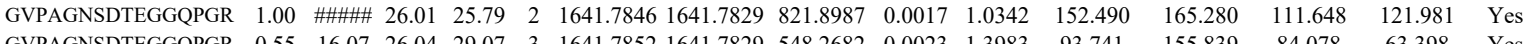

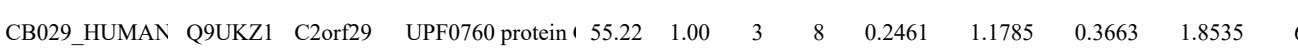

$\begin{array}{lllllllllllllllll} & \end{array}$ $\begin{array}{lllllllllllllll} & \end{array}$

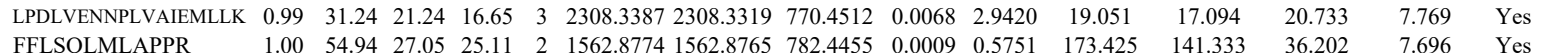

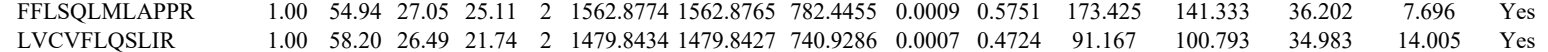

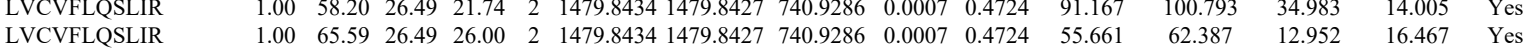

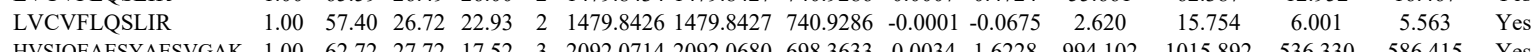

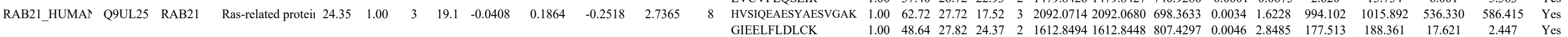




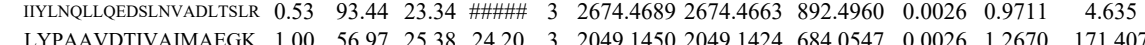
$\begin{array}{llllllllllll}\text { LYPAAVDTIVAIMAEGK } & 1.00 & 57.21 & 25.31 & 23.12 & 3 & 2049.1462 & 2049.1424 & 684.0547 & 0.0038 & 1.8517 & 191.469\end{array}$ $\begin{array}{llllllllllll}\text { LYPAAVDTIVAIMAEGK } & 0.53 & 11.49 & 25.38 & 24.49 & 3 & 2049.1450 & 2049.1424 & 684.0547 & 0.0026 & 1.2670 & 136.854\end{array}$ $\begin{array}{llllllllllll}\text { LYPAAVDTIVAIMAEGK } & 1.00 & 50.30 & 25.38 & 21.09 & 3 & 2049.1453 & 2049.1424 & 684.0547 & 0.0029 & 1.4131 & 314.803\end{array}$ $\begin{array}{llllllllllll}\text { LYPAAVDTIVAIMAEGK } & 1.00 & \# \# \# \# \text { 25.42 } & 29.90 & 2 & 2049.1454 & 2049.1424 & 1025.5785 & 0.0030 & 1.4626 & 220.303\end{array}$ $\begin{array}{lllllllllllll}\text { LYPAAVDTIVAIMAEGK } & 0.53 & 56.44 & 25.38 & 69.44 & 3 & 2049.1450 & 2049.1424 & 684.0547 & 0.0026 & 1.2670 & 192.061\end{array}$ $\begin{array}{llllllllllll}\text { LYPAAVDTIVAIMAEGK } & 1.00 & 54.26 & 25.40 & 20.97 & 3 & 2049.1456 & 2049.1424 & 684.0547 & 0.0032 & 1.5593 & 181.156\end{array}$

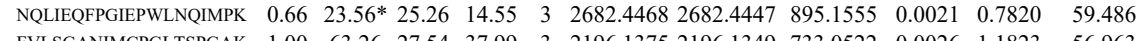
$\begin{array}{llllllllllll}\text { FVLSGANIMCPGLTSPGAK } & 1.00 & 63.26 & 27.54 & 37.99 & 3 & 2196.1375 & 2196.1349 & 733.0522 & 0.0026 & 1.1823 & 56.963 \\ \text { FVLSGNMCG }\end{array}$

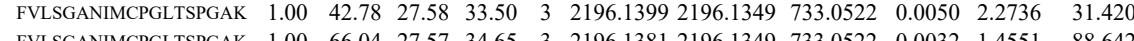
\begin{tabular}{lllllllllllll} 
FVLSGANIMCPGLTSPGAK & 1.00 & 66.04 & 27.57 & 34.65 & 3 & 2196.1381 & 2196.1349 & 733.0522 & 0.0032 & 1.4551 & 88.642 \\
\hline FVLSGNIMPGLTPGAK & 0.98 & 27.40 & 27.57 & 22.47 & 3 & 2196.1381 & 2196.1349 & 733.0522 & 0.0032 & 1.4551 & 60.057
\end{tabular} $\begin{array}{llllllllllll}\text { FVLSGANIMCPGLTSPGAK } & 0.98 & 27.40 & 27.57 & 22.47 & 3 & 2196.1381 & 2196.1349 & 733.0522 & 0.0032 & 1.4551 & 60.057 \\ \text { MEPLATVESLEQYLLK } & 0.96 & 22.97 & 25.75 & 19.34 & 3 & 2151.1780 & 2151.1740 & 718.0653 & 0.0040 & 1.8568 & 5.515\end{array}$ $\begin{array}{llllllllllll}\text { MEPLATVESLEQYLLK } & 0.96 & 22.97 & 25.75 & 19.34 & 3 & 2151.1780 & 2151.1740 & 718.0653 & 0.0040 & 1.8568 & 5.515 \\ \text { MEPLATVESLOYLLK } & 1.00 & 44.19 & 25.67 & 19.77 & 3 & 2151.1792 & 2151.1740 & 718.0653 & 0.0052 & 2.4139 & 9.943\end{array}$

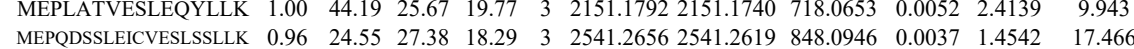
$\begin{array}{lllllllllllll}\text { MEPQDSSLEICVESLSSLLK } & 0.96 & 24.55 & 27.38 & 18.29 & 3 & 2541.2656 & 2541.2619 & 848.0946 & 0.0037 & 1.4542 & 17.466 \\ \text { LSYSSLAAGAPMSSSASYPNLSSR } & 1.00 & 61.36 & 25.98 & 17.46 & 3 & 2532.3355 & 2532.3339 & 845.1186 & 0.0016 & 0.6311 & 18.601\end{array}$ $\begin{array}{llllllllllll}\text { LSVSSLLAGAPMSSASAPNLSSR } & 1.00 & 61.36 & 25.98 & 17.46 & 3 & 2532.3355 & 2532.3339 & 845.1186 & 0.0016 & 0.6311 & 18.601 \\ \text { ISYSSLAAGAPMSSASVPNISSR } & 1.00 & 43.80 & 25.91 & 16.46 & 3 & 2532.3370 & 2532.3339 & 845.1186 & 0.0031 & 1.2227 & 65.513\end{array}$ $\begin{array}{lllllllllllll}\text { LSVSSLLAAGAPMSSSASVPNLSSR } & 1.00 & 43.80 & 25.91 & 16.46 & 3 & 2532.3370 & 2532.3339 & 845.1186 & 0.0031 & 1.2227 & 65.513 \\ \text { LLPVFAQTFQQTMLPSIR } & 1.00 & 50.57 & 25.19 & 18.96 & 3 & 2249.2384 & 2249.2364 & 750.7527 & 0.0020 & 0.8880 & 8.702\end{array}$ $\begin{array}{llllllllllll}\text { LLPVAQTFQQTMLPSTR } & 1.00 & 50.57 & 25.19 & 18.96 & 3 & 2249.2384 & 2249.2364 & 750.7527 & 0.0020 & 0.8880 & 8.702 \\ \text { LSNQVSTIVSLLSTLCR } & 0.69 & 69.76 & 26.58 & 82.76 & 2 & 2023.0954 & 2023.0928 & 1012.5537 & 0.0026 & 1.2839 & 3.791\end{array}$

LSNQVSTIVSLLST

NILDSKPTANK NILDSKPTANK QLALWNPK QLALWNPK

QLALWNPK

QLALIIMTVPR

CEPIIMTVPR

VTWDSSFCAVNPR

VTWDSSFCAVNPR

VTWDSSFCAVNPR

VTWDSSFCAVNPR AIFLADGNVFTTGFSR AIFLADGNVFTTGFS VGIVAWHPTAR

VGIVAWHPTAR

VGIVAWHPTAR

VGIVAWHPTAR

VGIVAWHPTAR

VGIVAWHPTAR

VGIVAWHPTAR

VGIVAWHPTAR

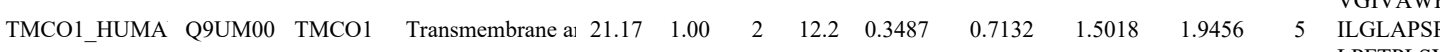

\section{LPFTPLSYIQGLSHR}

LPFTPLSYIQGLSHR

LPFTPLSYIQGLSHR

LPFTPLSYIQGLSHR

IWSVPNASCVQVVR

IWSVPNASCVQVVR

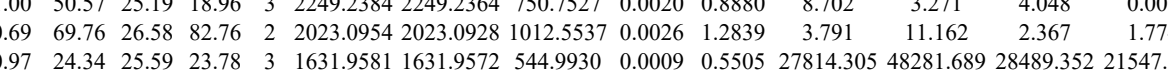
$\begin{array}{lllllllllllllll}26.92 & 25.59 & 30.39 & 3 & 1631.9581 & 1631.9572 & 544.9930 & 0.0009 & 0.5505 & 29959.724 & 44331.860 & 28762.985 & 20843.371 & Y c s\end{array}$

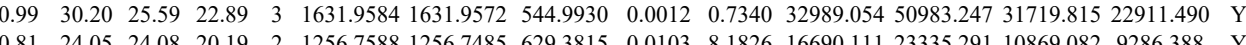

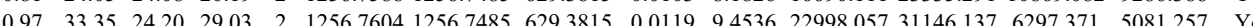
$\begin{array}{lllllllllllllllll}0.66 & 20.60 & 24.08 & 18.04 & 2 & 1256.7588 & 1256.7485 & 629.3815 & 0.0103 & 8.1826 & 11527.051 & 17228849 & 10939.082 & 9475.430 & \text { No }\end{array}$ $\begin{array}{lllllllllllllllll}0.99 & 43.18 & 27.84 & 18.55 & 2 & 1347.6824 & 1347.6835 & 674.8490 & -0.0011 & -0.8150 & 10349.786 & 16520.62 & 366.939 & 542.820 & \text { Y }\end{array}$ $\begin{array}{llllllllllllllll}1.00 & 43.17 & 27.64 & 24.45 & 2 & 1374.6842 & 1374.6835 & 674.840 & 0.0007 & 0.5186 & 14347.884 & 20562.975 & 777.419 & 502.609 & \text { Yes }\end{array}$ $\begin{array}{lllllllllllllll}0.61 & 69.46 & 25.05 & 82.46 & 2 & 1670.7668 & 1670.7667 & 8363906 & 0.0001 & 0.0598 & 2084.956 & 4243.754 & 187.846 & 113.183 & \text { Yes }\end{array}$ $\begin{array}{llllllllllllllll}0.76 & 70.60 & 24.97 & 83.60 & 2 & 1670.7676 & 1670.7667 & 8363906 & 0.0009 & 0.5380 & 2949.413 & 4977.834 & 177.026 & 127.560 & \text { Yes }\end{array}$ $\begin{array}{lllllllllllllll}0.77 & 69.92 & 25.01 & 82.92 & 2 & 1670.7682 & 1670.7667 & 836.3906 & 0.0015 & 0.8967 & 4186.510 & 6043.184 & 287.101 & 121.535 & \text { Yes }\end{array}$ $\begin{array}{lllllllllllllll}0.69 & 71.79 & 25.07 & 84.79 & 2 & 1670.7698 & 1670.7667 & 836.3906 & 0.0031 & 1.8532 & 4226.942 & 6250.603 & 446.702 & 365.565 & \text { Yes }\end{array}$ $\begin{array}{llllllllllllll}1.00 & \# \# \# 27.47 & 21.89 & 2 & 1858.9690 & 1858.9700 & 930.4923 & -0.0010 & -0.5374 & 1992.120 & 3108.226 & 164.908 & 31.475 & \text { Yes }\end{array}$

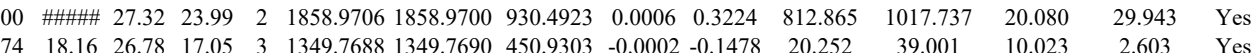

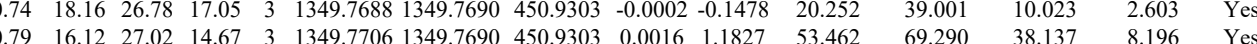
$\begin{array}{lllllllllllllll}1.00 & 40.71 & 26.67 & 18.68 & 3 & 1349.7799 & 1349.7690 & 450.9303 & 0.0109 & 8.0574 & 13600.364 & 19812.968 & 2293.103 & 365.561 & \text { Yes }\end{array}$ $\begin{array}{lllllllllllllll}1.00 & 46.71 & 26.67 & 16.51 & 3 & 1349.7799 & 1349.7690 & 450.9303 & 0.0109 & 8.0574 & 19982.210 & 33564.782 & 3264.592 & 305.951 & \text { Yes }\end{array}$ $\begin{array}{llllllllllllllll}1.00 & 53.60 & 26.67 & 16.82 & 2 & 1349.7800 & 1349.7690 & 675.8918 & 0.0110 & 8.1373 & 4441.757 & 7426.758 & 395.267 & 78.757 & \text { Yes }\end{array}$ $\begin{array}{llllllllllllllll}1.00 & 41.57 & 27.01 & 16.33 & 3 & 1349.7709 & 1349.7690 & 450.9303 & 0.0019 & 1.4045 & 7870.513 & 11201.708 & 1297.246 & 234.940 & \text { Yes }\end{array}$ $\begin{array}{llllllllllllllll}1.00 & 41.72 & 27.02 & 17.19 & 3 & 1349.7712 & 1349.7690 & 450.9303 & 0.0022 & 1.6263 & 12033.424 & 18369.025 & 1301.440 & 168.331 & \text { Yes }\end{array}$ \begin{tabular}{lllllllllllllll}
1.00 & 38.72 & 26.71 & 15.77 & 3 & 1349.7694 & 1349.7690 & 450.9303 & 0.0004 & 0.2957 & 2463.897 & 3314.880 & 305.711 & 165.331 & Yes \\
\hline
\end{tabular} $\begin{array}{lllllllllllllll}0.99 & 40.52 & 21.93 & 23.31 & 2 & 969.6182 & 969.6093 & 485.8119 & 0.0089 & 9.1598 & 42663.753 & 40221.646 & 1750.259 & 4031.283 & \text { Yes }\end{array}$

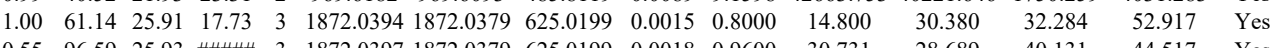

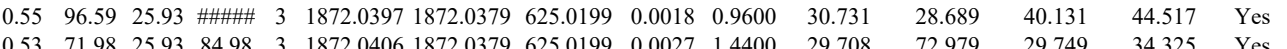

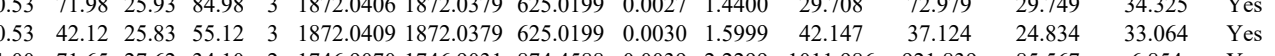
$\begin{array}{lllllllllllllll}1.00 & 71.65 & 27.62 & 34.10 & 2 & 1746.9070 & 1746.9031 & 874.4588 & 0.0039 & 2.2299 & 1011.986 & 921.839 & 85.567 & 6.854 & \text { Yes } \\ 1.00 & 69.23 & 27.65 & 34.65 & 2 & 1746.9072 & 1746.9031 & 874.458 & 0.0041 & 23443 & 1810.342 & 1946.736 & 114.841 & 42.852 & \text { Yes }\end{array}$

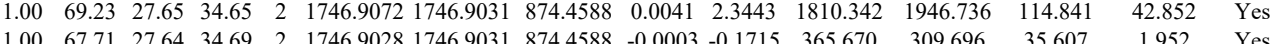
$\begin{array}{lllllllllllllll}1.00 & 80.63 & 27.70 & 41.21 & 2 & 1746.9048 & 1746.9031 & 874.4588 & 0.0017 & 0.9720 & 261.393 & 209.031 & 12.959 & 10.603 & \text { Yes }\end{array}$ 

$\begin{array}{llllllllllllllll}\text { LPNFGFVVFDDSEPVQR } & 0.94 & 22.41 & 28.01 & 16.00 & 3 & 2109.0670 & 2109.0653 & 704.0290 & 0.0017 & 0.8049 & 43.891 & 87.970 & 82.653 & 13.944 & \text { Yes }\end{array}$ $\begin{array}{lllllllllllllllll}\text { LPNFGFVVFDDSEPVQR } & 1.00 & 69.04 & 27.94 & 22.95 & 2 & 2109.0674 & 2109.0653 & 1055.5399 & 0.0021 & 0.9948 & 148.985 & 120.579 & 142.303 & 42.965 & \text { Yes }\end{array}$ $\begin{array}{lllllllllllllllll}\text { LPNFGFVVFDDSEPVQR } & 1.00 & 77.88 & 28.01 & 21.96 & 2 & 2109.0614 & 2109.0653 & 1055.5399 & -0.0039 & -1.8474 & 172.210 & 125.071 & 248.309 & 79.839 & \text { Yes }\end{array}$ \begin{tabular}{llllllllllllllll} 
LPNFGFVVFDDSEPVQR & 1.00 & 80.84 & 27.97 & 19.06 & 2 & 2109.0634 & 2109.0653 & 1055.5399 & -0.0019 & -0.9000 & 199.348 & 243.517 & 272.915 & 74.710 & Yes \\
\hline
\end{tabular} $\begin{array}{llllllllllllllll}\text { LPNFGFVVFDDSEPVQR } & 0.93 & 23.34 & 27.98 & 14.70 & 3 & 2109.0667 & 2109.0653 & 704.0290 & 0.0014 & 0.6629 & 61.697 & 90.585 & 38.589 & 31.752 & \text { Yes }\end{array}$ $\begin{array}{lllllllllllllllll}\text { LPNFGFVVFDDSEPVQR } & 1.00 & 49.18 & 27.94 & 22.89 & 3 & 2109.0673 & 2109.0653 & 704.0290 & 0.0020 & 0.9469 & 58.673 & 60.512 & 66.064 & 18.132 & \text { Yes }\end{array}$

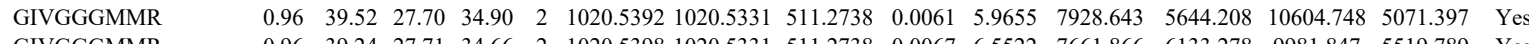
$\begin{array}{llllllllllllllll}\text { GIVGGGMMR } & 0.96 & 39.24 & 27.71 & 34.66 & 2 & 1020.5398 & 1020.5331 & 511.2738 & 0.0067 & 6.5522 & 7661.866 & 6133.278 & 9981.847 & 5519.789 & \text { Yes }\end{array}$ \begin{tabular}{llllllllllllllll} 
TEELKPQVEEK & 0.95 & 22.75 & 26.04 & 18.62 & 3 & 1760.9893 & 1760.9885 & 588.0034 & 0.0008 & 0.4535 & 5554.669 & 4381.202 & 11924.976 & 5565.461 & Yes \\
\hline
\end{tabular} $\begin{array}{llllllllllllllll}\text { TEELKPQVEEK } & 0.96 & 22.03 & 25.98 & 18.48 & 3 & 1760.9908 & 1760.9885 & 588.0034 & 0.0023 & 1.3038 & 10109.068 & 5354.368 & 19762.072 & 8408.238 & \text { Yes }\end{array}$ \begin{tabular}{lllllllllllllllll} 
SSDEAVILCK & 1.00 & 70.76 & 27.92 & 24.48 & 2 & 1397.7150 & 1397.7138 & 699.8642 & 0.0012 & 0.8573 & 3029.471 & 3643.227 & 2245.812 & 1057.720 & Yes \\
\hline SSDEAVILCK & 1.00 & 53.00 & 27.88 & 2.33 & & 1397.758 & 1397.7138 & 699.8642 & 0.020 & 1.428 & 310.447 & 2210.623 & 185.05 & 715.025 & Yes
\end{tabular} $\begin{array}{llllllllllllllll}\text { SSDEAVILCK } & 1.00 & 53.00 & 27.88 & 25.33 & 2 & 1397.7158 & 1397.7138 & 699.8642 & 0.0020 & 1.4288 & 3109.447 & 2210.623 & 1805.405 & 715.025 & \text { Yes }\end{array}$

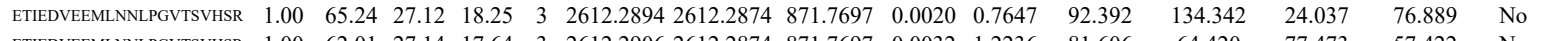
$\begin{array}{llllllllllllllll}\text { ETIEDVEEMLNNLPGVTSVHSR } & 1.00 & 62.01 & 27.14 & 17.64 & 3 & 2612.2906 & 2612.2874 & 871.7697 & 0.0032 & 1.2236 & 81.606 & 64.420 & 77.473 & 57.422 & \text { No }\end{array}$

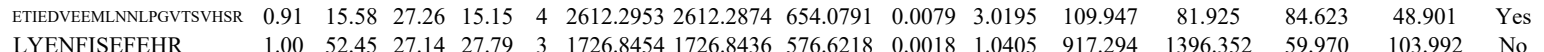

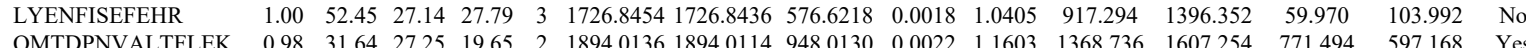

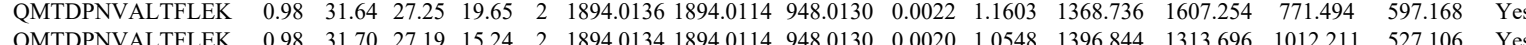

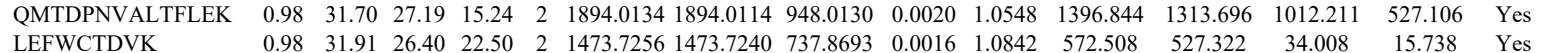

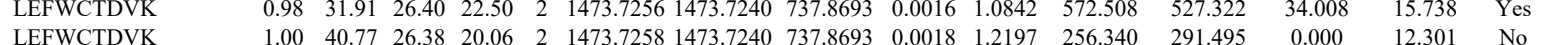

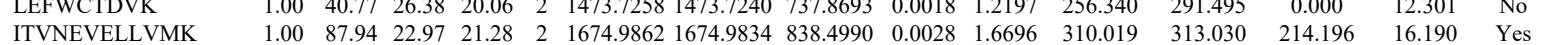
$\begin{array}{lllllllllllll} & \end{array}$

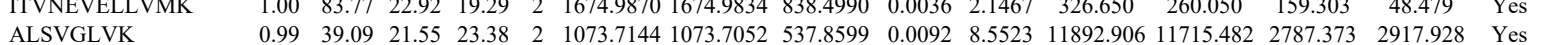

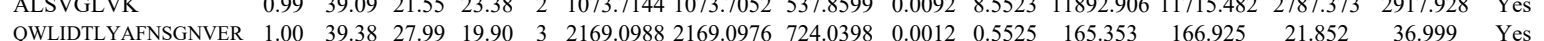

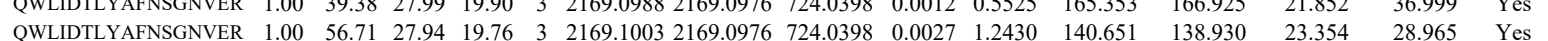

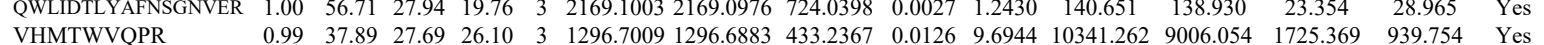

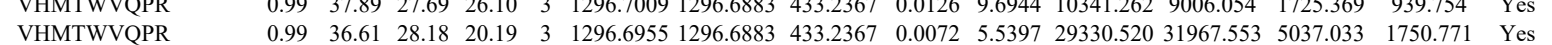
$\begin{array}{llllllllllllllll}\text { VHMTWVPR } & 0.85 & 25.20 & 28.06 & 17.48 & 3 & 1296.6961 & 1296.6883 & 433.2367 & 0.0078 & 6.0013 & 25398.942 & 24508.631 & 4301.671 & 2072.794 & \text { Yes }\end{array}$

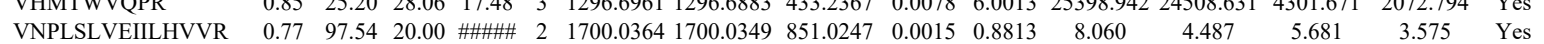

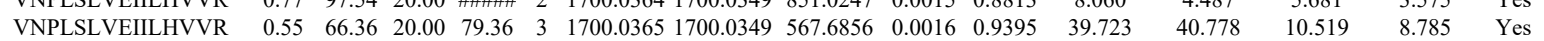
$\begin{array}{llllllllllllllll}\text { VNPLSLVEIILHVVR } & 0.55 & 71.83 & 17.32 & 84.83 & 3 & 1844.1388 & 1844.1369 & 615.7196 & 0.0019 & 1.0286 & 24.760 & 19.667 & 13.636 & 5.774 & \text { Yes }\end{array}$

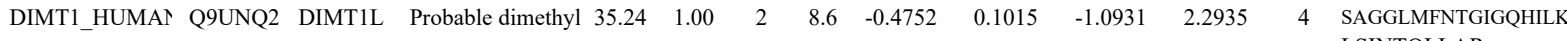
LSINTQLLAR LSINTQLLAR TFLTLSLQDMASR

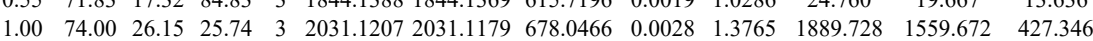
$\begin{array}{llllllllllllll}1.00 & 56.79 & 24.23 & 29.74 & 2 & 1271.7706 & 1271.7683 & 636.8914 & 0.0023 & 1.8056 & 9569.325 & 6771.625 & 245.667\end{array}$ $\begin{array}{llllllllllllll}1.00 & 44.85 & 24.31 & 29.87 & 2 & 1271.7716 & 1271.7683 & 636.8914 & 0.0033 & 2.5907 & 1249.506 & 915.601 & 169.373\end{array}$

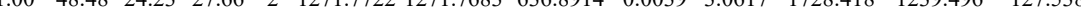
$\begin{array}{lllllllllllll}1.00 & 79.77 & 27.53 & 22.24 & 2 & 1625.8600 & 1625.8569 & 813.9357 & 0.0031 & 1.9043 & 1375.710 & 1189.136 & 38.337\end{array}$ $\begin{array}{llllllllllllll}\text { YATDTFAGLCHQLTNALVER } & 1.00 & 48.93 & 27.65 & 20.54 & 3 & 2412.1699 & 2412.1688 & 805.0635 & 0.0011 & 0.4555 & 404.564 & 505.737 & 350.144\end{array}$ $\begin{array}{llllllllllllll}\text { YATDTFAGLCHQLTNALVER } & 1.00 & 76.64 & 27.68 & 20.20 & 3 & 2412.1705 & 2412.1688 & 805.0635 & 0.0017 & 0.7039 & 696.794 & 631.809 & 315.741\end{array}$

$\begin{array}{lllllllllllllll}\text { VQLSGPQEAEK } & 1.00 & 51.75 & 27.46 & 35.88 & 2 & 1472.8190 & 1472.8078 & 737.4112 & 0.0112 & 7.5941 & 5252.295 & 5030.084 & 4507.564 & 1095.115 \\ \text { VQLSGPQEAEK } & 1.00 & 50.45 & 27.44 & 28.31 & 2 & 1472.8200 & 1472.8078 & 737.4112 & 0.0122 & 8.2721 & 3932.632 & 4090.114 & 2943.936 & 807.178\end{array}$

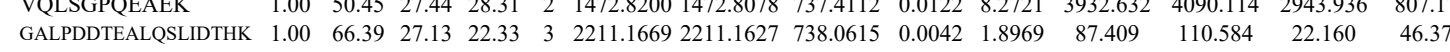
$\begin{array}{llllllllllllllll}\text { GTSLENLIMEITAPDSQGK } & 0.99 & 29.33 & 27.13 & 19.19 & 3 & 2291.1949 & 2291.1922 & 764.7380 & 0.0027 & 1.1769 & 20.196 & 20.284 & 24.017 & 18.152 & \text { Noses }\end{array}$ $\begin{array}{lllllllllllllllll}\text { GTSLENLIMEITAPDSQGK } & 1.00 & 38.07 & 27.15 & 20.50 & 3 & 2291.1958 & 2291.1922 & 764.7380 & 0.0036 & 1.5692 & 11.905 & 24.358 & 8.955 & 15.017 & \text { Yes }\end{array}$

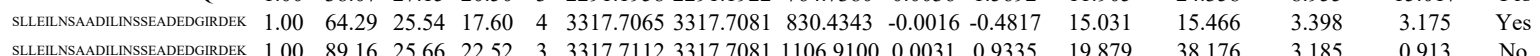

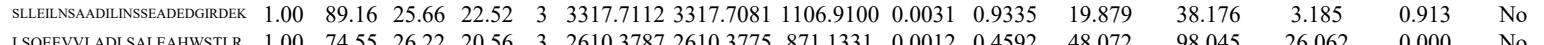

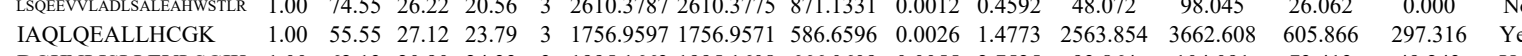
$\begin{array}{lllllllllllll}\text { DGHNLISLLEVLSGIK } & 1.00 & 62.13 & 20.90 & 24.33 & 3 & 1995.1663 & 1995.1608 & 666.0609 & 0.0055 & 27525\end{array}$

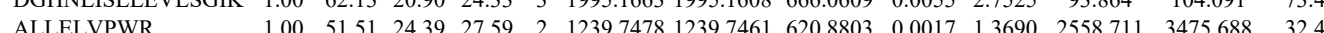




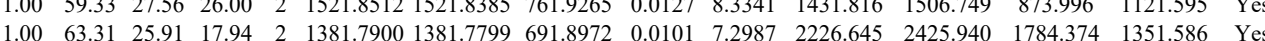

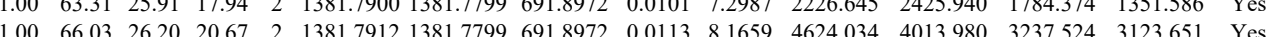

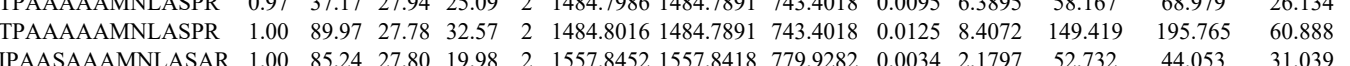

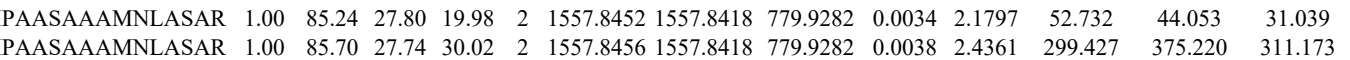

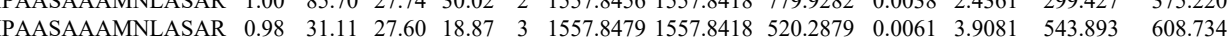
$\begin{array}{lllllllllllllll} & 1\end{array}$ $\begin{array}{lllllllllllll}\text { IPAASAAAMNLASAR } & 1.00 & 81.79 & 27.75 & 21.28 & 2 & 1557.8444 & 1557.8418 & 779.9282 & 0.0026 & 1.6668 & 243.808 & 378 .\end{array}$ $\begin{array}{llllllllllllll} & \end{array}$

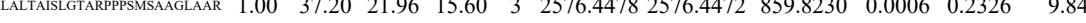
$\begin{array}{llllllllllll} & \end{array}$

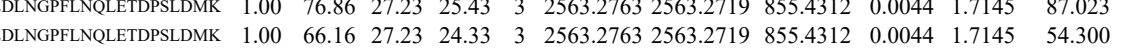
$\begin{array}{lllllllllllll}\text { AEFEVHEVYAVDVLVSSGEGK } & 0.95 & 27.57 & 26.80 & 17.90 & 4 & 2551.2953 & 2551.3050 & 638.8335 & -0.0097 & -3.7960 & 19.318\end{array}$

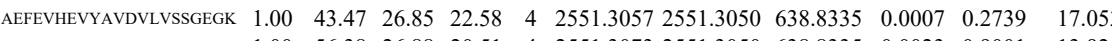
$\begin{array}{lllllllllllll}\text { AEFEVHEVYAVDVLVSSGEGK } & 1.00 & 56.38 & 26.88 & 20.51 & 4 & 2551.3073 & 2551.3050 & 638.8335 & 0.0023 & 0.9001 & 13.926\end{array}$ $\begin{array}{llllllllllll}\text { AEFEVHEVYAVDVLVSSGEGK } & 1.00 & 31.37 & 26.75 & 15.82 & 4 & 2551.3077 & 2551.3050 & 638.8335 & 0.0027 & 1.0566 & 25.815 \\ \text { AEFEVHEVYAVDVLVSSGEGK } & 1.00 & 30.83 & 26.67 & 16.79 & 4 & 2551.3117 & 2551.3050 & 638.8335 & 0.0067 & 2.6220 & 7.660\end{array}$ $\begin{array}{llllllllllll}\text { AEFEVHEVYAVDVLVSSGEGK } & 1.00 & 30.83 & 26.67 & 16.79 & 4 & 2551.3117 & 2551.3050 & 638.8335 & 0.0067 & 2.6220 & 7.660 \\ \text { AEFEVHEVYAVDVLVSSGEGK } & 1.00 & 38.71 & 26.65 & 16.25 & 4 & 2551.3177 & 2551.3050 & 6388335 & 0.0127 & 4.9700 & 12.476\end{array}$

TIIQNPTDQQK

TIIQNPTDQQK

TILNPTDQQK

TIQNPTDQQK

TILNPTDQQK

TIIQNPTDQQK

ITSGPFEPDLYK
ITSGPFEPDLYK

ITSGPFEPDLYK

ITSGPFEPDLYK

MGVVECAK

MGVVECAK

\begin{tabular}{lllll}
.00 & 38.71 & 26.65 & 16.25 & 4 \\
\hline
\end{tabular}

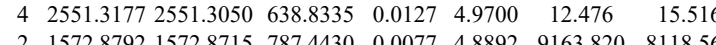

$\begin{array}{llllllll}6.565 & \end{array}$

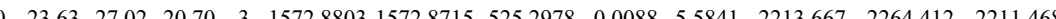

$\begin{array}{llllllllllllll}.00 & 71.81 & 27.11 & 33.72 & 2 & 1572.8778 & 1572.8715 & 787.4430 & 0.0063 & 4.0003 & 10727.364 & 10002.638 & 4777.787\end{array}$

$\begin{array}{lllllllllllll}17.73 & 26.90 & 18.47 & 3 & 1572.8791 & 1572.8715 & 525.2978 & 0.0076 & 4.8226 & 2501.683 & 2072.463 & 1961.830\end{array}$

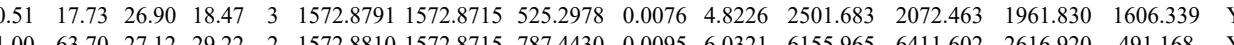

$\begin{array}{llllllllllllllll}1.00 & 79.60 & 27.85 & 34.84 & 2 & 1653.8904 & 1653.8858 & 827.9502 & 0.0046 & 2.7779 & 8718.307 & 8932.090 & 1577.540 & 385.282 & \text { Yes }\end{array}$

$\begin{array}{llllllllllllllll}1.00 & 79.23 & 27.74 & 25.65 & 2 & 1653.8928 & 1653.8858 & 827.9502 & 0.0070 & 4.72273 & 5829.655 & 5308.816 & 1136.148 & 167.514 & \text { Yes }\end{array}$

$\begin{array}{lllllllllllllllll}1.00 & 79.60 & 27.61 & 22.13 & 2 & 1653.8998 & 1653.8858 & 827.9502 & 0.0140 & 8.4545 & 10205.386 & 9007.350 & 1861.368 & 250.071 & \text { Yes }\end{array}$

$\begin{array}{lllllllllllllll}1.00 & 66.76 & 27.69 & 26.38 & 2 & 1653.9010 & 1653.8858 & 827.9502 & 0.0152 & 9.1792 & 6798.188 & 5412.336 & 1508.899 & 523.931 & \text { Yes }\end{array}$ $\begin{array}{lllllllllllllll}1.00 & 48.34 & 26.88 & 25.10 & 2 & 1169.5946 & 1169.5850 & 585.7998 & 0.0096 & 8.1939 & 26096.573 & 22915.164 & 3288.213 & 1143.426 & \text { Yes } \\ 0.98 & 38.17 & 26.67 & 25.10 & 2 & 1169.562 & 1169.580 & 55.7998 & 0.012 & 9.5595 & 24403.810 & 2293.805 & 389.651 & 1389.427 & \text { Yes }\end{array}$

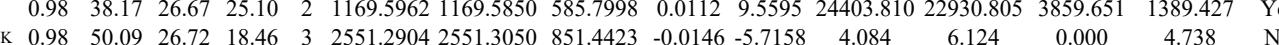

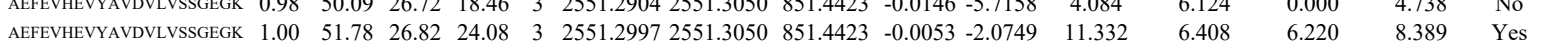

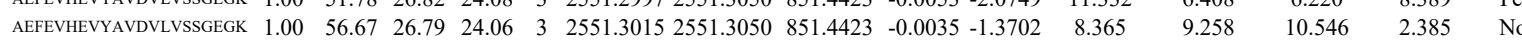
$\begin{array}{lllllllllllllllll}\text { AEFEVHEVYAVDVLVSSGEGK } & 0.85 & 29.85 & 26.79 & 18.08 & 3 & 2551.3015 & 2551.3050 & 851.4423 & -0.0035 & -1.3702 & 6.275 & 2.392 & 5.058 & 4.234 & \text { No }\end{array}$ $\begin{array}{llllllllllllllll}\text { AEFEVHEVYAVDVLVSSGEGK } & 1.00 & 51.88 & 26.78 & 28.58 & 3 & 2551.3027 & 2551.3050 & 851.4423 & -0.0023 & -0.9004 & 4.812 & 9.264 & 8.437 & 2.628 & \text { No }\end{array}$ $\begin{array}{lllllllllllllllll}\text { AEFEVHEVYAVDVLVSSGEGK } & 1.00 & 39.75 & 26.88 & 17.47 & 4 & 2551.3073 & 2551.3050 & 638.8335 & 0.0023 & 0.9001 & 31.340 & 20.466 & 18.881 & 15.320 & \text { Yes }\end{array}$ $\begin{array}{llllllllllllllll}\text { AEFEVHEVYAVDVLVSSGEGK } & 1.00 & 27.96 & 26.75 & 16.00 & 4 & 2551.3077 & 2551.3050 & 638.8335 & 0.0027 & 1.0566 & 31.092 & 22.779 & 9.590 & 16.865 & \text { Yes }\end{array}$

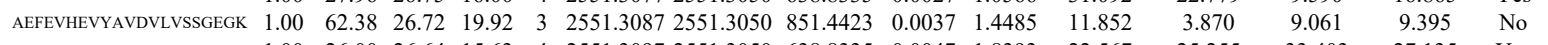

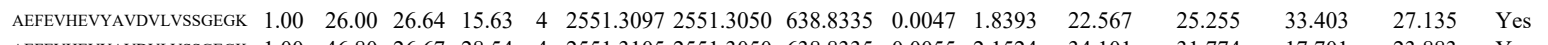
$\begin{array}{llllllllllllllll}\text { AEFEVHEVYAVDVLVSSGEGK } & 1.00 & 46.80 & 26.67 & 28.54 & 4 & 2551.3105 & 2551.3050 & 638.8335 & 0.0055 & 2.1524 & 34.101 & 31.774 & 17.701 & 23.883 & \text { Yes }\end{array}$ $\begin{array}{llllllllllllllll}\text { AEFEVHEVYAVDVLVSSGEGK } & 1.00 & 49.61 & 26.67 & 17.34 & 4 & 2551.3105 & 2551.3050 & 638.8335 & 0.0055 & 2.1524 & 31.924 & 31.714 & 14.617 & 12.076 & \text { Yes }\end{array}$

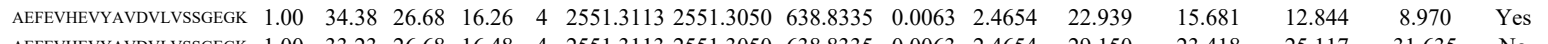

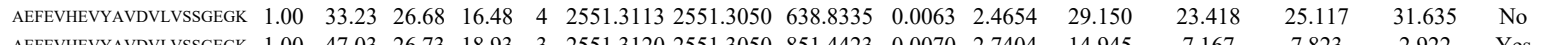

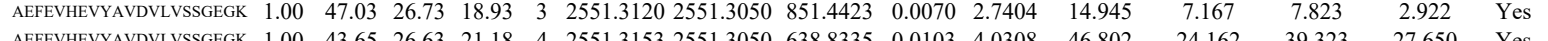

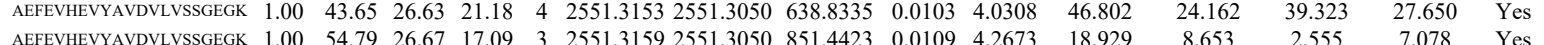

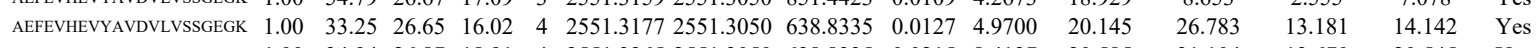

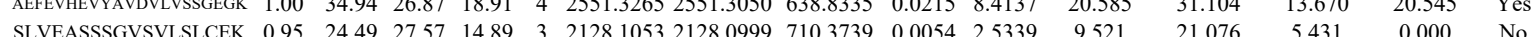

Table S-3 page 476 of 499 

$\begin{array}{lllllllllll}0.87 & 38.61 * 28.19 & 21.65 & 3 & 1534.8139 & 1534.8122 & 512.6113 & 0.0017 & 1.1054 & 5.402\end{array}$ $\begin{array}{llllllllllll}0.97 & 25.03 & 28.14 & 15.60 & 3 & 1534.8148 & 1534.8122 & 512.6113 & 0.0026 & 1.6907 & 13.803\end{array}$ $\begin{array}{lllllllllll}1.00 & 60.75 & 27.99 & 26.42 & 2 & 1518.8186 & 1518.8173 & 760.4159 & 0.0013 & 0.8548 & 92.978\end{array}$ LDQVEQELNELR

ETEGGTVLTATTSE
SLPSASTSK

SLPSASTSK

SLPSASTSK

SLPSASTSK

TLQTMQNFQK

TLQTMQNFQ
QLELEIK

QLELEIK

$\begin{array}{lllllllllllllll}43.47 & 27.97 & 42.16 & 2 & 1268.6974 & 1268.6856 & 635.3501 & 0.0118 & 9.2861 & 13343.388 & 12940.230 & 117\end{array}$

$\begin{array}{lllllllllllll}1.00 & 61.58 & 27.00 & 20.32 & 2 & 1474.7312 & 4474.7320 & 738.3733 & -0.0008 & -0.5417 & 1919.333 & 1460.324 & 844.968\end{array}$

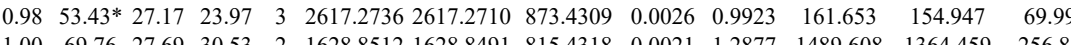

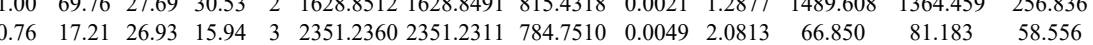
$\begin{array}{lllllllllllll}0.99 & 48.98 & 27.78 & 24.42 & 2 & 1164.6572 & 1164.6594 & 583.3370 & -0.0022 & -1.8857 & 2424.835 & 3788.625 & 172.099\end{array}$ $\begin{array}{lllllllllllll}1.00 & 60.54 & 27.92 & 31.44 & 2 & 1164.6586 & 1164.6594 & 583.3370 & -0.0008 & -0.6857 & 2836.568 & 5162.378 & 312.181\end{array}$ $\begin{array}{lllllllllllll}1.00 & 53.79 & 27.92 & 26.28 & 2 & 1164.6586 & 1164.6594 & 583.3370 & -0.0008 & -0.6857 & 1615.816 & 2512.197 & 126.760\end{array}$ $\begin{array}{lllllllllllll}1.00 & 47.10 & 27.82 & 23.03 & 2 & 1164.6598 & 1164.6594 & 583.3370 & 0.0004 & 0.3429 & 2286.006 & 3709.802 & 328.885\end{array}$ $\begin{array}{lllllllllllll}1.00 & 53.00 & 27.62 & 24.80 & 2 & 1525.8274 & 1525.8166 & 763.9156 & 0.0108 & 7.0688 & 8186.926 & 11978.179 & 0.000\end{array}$

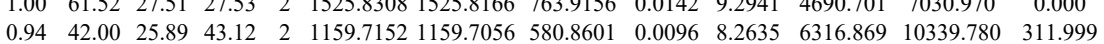
$\begin{array}{llllllllllllll}0.94 & 42.00 & 25.89 & 43.12 & 2 & 159.7152 & 1159.7056 & 580.8601 & 0.0096 & 8.2635 & 6316.869 & 10339.780 & 311.999\end{array}$

VWIKPGAEQSFLY

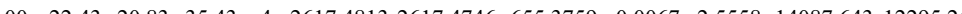

\section{LVSLGTCFGK}

$\begin{array}{llllllllllllll}1.00 & 59.44 & 27.50 & 23.43 & 2 & 1357.7364 & 1357.7342 & 679.8744 & 0.0022 & 1.6179 & 12552.287 & 10053.204 & 53.245\end{array}$

$\begin{array}{llllllllllllll}1.00 & 57.66 & 27.60 & 24.88 & 2 & 1357.7374 & 1357.7342 & 679.8744 & 0.0032 & 2.3534 & 4416.905 & 3574.002 & 30.33 \\ 0.55 & 16.53 & 26.86 & 2.53 & 3 & 2100.1120 & 2100.1095 & 701.0438 & 0.0025 & 1.1887 & 326.172 & 256.791 & 110.2\end{array}$

$\begin{array}{llllllllll}\text { CN166 HUMAN Q9Y224 } & \text { C14orf166 UPF0568 protein } 128.07 & 1.00 & 5 & 28.3 & 0.0432 & 0.4617 & -0.3927 & 1.2687\end{array}$

NAEPLINLDVNN

$\begin{array}{llllllllllll}0.55 & 16.53 & 26.86 & 29.53 & 3 & 2100.1120 & 2100.1095 & 701.0438 & 0.0025 & 1.1887 & 326.172 & 256.791 \\ 0.99 & 36.01 & 27.48 & 18.72 & 2 & 1578.8666 & 1578.8650 & 790.4398 & 0.0016 & 1.0121 & 509.662 & 320.520 \\ 0.53 & 21.78 & 19.82 & 34.78 & 3 & 1952.1580 & 1952.1550 & 651.7256 & 0.0030 & 1.5344 & 84.682 & 88.485\end{array}$

$\begin{array}{llllllllllllll}\text { INEAIVAVQAIIADPK } & 0.53 & 21.78 & 19.82 & 34.78 & 3 & 1952.1580 & 1952.1550 & 651.7256 & 0.0030 & 1.5344 & 84.682 & 88.485 & 65.017\end{array}$

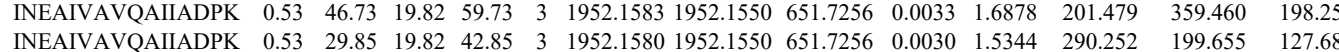

$\begin{array}{lllllllllllllll}\text { INEAIVAVQAIIADPK } & 0.55 & 18.11 & 20.00 & 31.11 & 3 & 1952.1574 & 1952.1550 & 651.7256 & 0.0024 & 1.2275 & 193.513 & 218.777 & 127.669\end{array}$

QEAIDWLLGLAVR

QEAIDWLLGLAVR

$\begin{array}{llllllllllll}0.55 & 18.11 & 20.00 & 31.11 & 3 & 1952.1574 & 1952.1550 & 651.7256 & 0.0024 & 1.2275 & 193.513 & 218.777 \\ 1.00 & 87.14 & 63.39 & 27.96 & 2 & 1626.9220 & 1626.9215 & 8144680 & 0.0005 & 0.3069 & 5097.504 & 4339.179\end{array}$

AGVMALANLLQIQR

$\begin{array}{llllllllllll}1.00 & 79.34 & 26.09 & 23.43 & 2 & 1626.9232 & 1626.9215 & 814.4680 & 0.0017 & 1.0436 & 3110.734 & 2688.397\end{array}$

$\begin{array}{llllllllllll}1.00 & 46.42 & 25.85 & 33.65 & 3 & 1626.9244 & 1626.9215 & 543.3144 & 0.0029 & 1.7792 & 54.906 & 129.649\end{array}$ $\begin{array}{lllllllllllll} & & 1640.9524 & 1640.9518 & 821.4832 & 0.0006 & 0.3652 & 110.912 & 93.823\end{array}$ $\begin{array}{llllllllllllll}\text { AGVMALANLLQIQR } & 1.00 & 91.20 & 24.15 & 24.60 & 2 & 1640.9526 & 1640.9518 & 821.4832 & 0.0008 & 0.4869 & 44.038 & 58.870\end{array}$

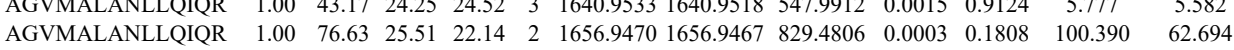
AGVMALANLLQIQR $\begin{array}{lllllllllllll}1.00 & 82.71 & 25.51 & 25.43 & 2 & 1656.9474 & 1656.9467 & 829.4806 & 0.0007 & 0.4220 & 80.213 & 69.275\end{array}$ AGVMALANLLQIQR AGVMALANLLQIQR AGVMALANLLQIQR AGVMALANLLQIQ AGVMALANLLQIQR AGVMALANLLQIQR

$\begin{array}{llllllllllll}1.00 & 38.93 & 25.49 & 16.44 & 3 & 1656.9478 & 1656.9467 & 553.3228 & 0.0011 & 0.6627 & 83.875 & 93.617\end{array}$

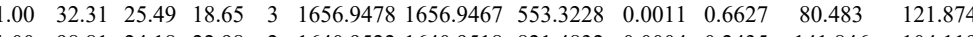

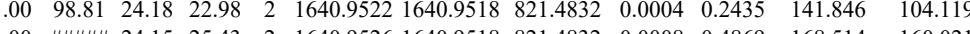
$\begin{array}{llllllllllll}1.00 & 4.14 \mathrm{~m} & 24.15 & 25.43 & 2 & 1640.9526 & 1640.9518 & 821.4832 & 0.0008 & 0.4869 & 168.514\end{array}$ $\begin{array}{llllllllllll}1.00 & 45.57 & 24.22 & 30.63 & 3 & 1640.9536 & 1640.9518 & 547.9912 & 0.0018 & 1.0949 & 57.338\end{array}$ $\begin{array}{llllllllllll}1.00 & 54.93 & 24.22 & 31.61 & 3 & 1640.9548 & 1640.9518 & 547.9912 & 0.0030 & 1.8248 & 52.860\end{array}$ AGVMALANLLQIQR AGVMALANLLQIQR

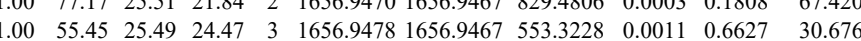
$\begin{array}{lllllllllll}1.00 & 55.45 & 25.49 & 24.47 & 3 & 1656.9478 & 1656.9467 & 553.3228 & 0.0011 & 0.6627 & 30.676 \\ 1.00 & 89.97 & 25.59 & 23.00 & 2 & 1656.9482 & 1656.9467 & 829.4806 & 0.0015 & 0.9042 & 86.309\end{array}$ AGVMALANLLQIQR 
$\begin{array}{lllllllllllll} & \end{array}$ $\begin{array}{lllllllllll} & \end{array}$ AVLIAGQPGTGK

$\begin{array}{lllllllllllll} & 0\end{array}$ $\begin{array}{lllllllllllllll}1.00 & 73.77 & 27.22 & 31.04 & 2 & 1298.6980 & 1298.6952 & 650.3549 & 0.0028 & 2.1527 & 6459.625 & 7550.096 & 1167.891 & 555.396 & \text { Yes }\end{array}$ $\begin{array}{llllllllllllllll}0.99 & 40.30 & 27.58 & 31.17 & 2 & 1305.7490 & 1305.7384 & 653.8765 & 0.0106 & 8.1054 & 7746.200 & 6908.182 & 2455.538 & 2024.451 & \text { Yes }\end{array}$

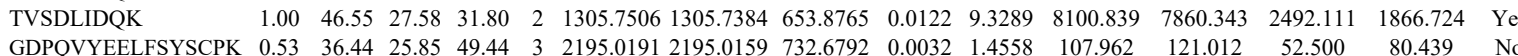
\begin{tabular}{llllllllllllllll} 
LAGFLDLTEQEFR & 0.53 & 36.44 & 25.85 & 49.44 & 3 & 2195.0191 & 2195.0159 & 732.6792 & 0.0032 & 1.4558 & 107.962 & 121.012 & 52.500 & 80.439 & No \\
\hline
\end{tabular} LAGFLDLTEQEFR LYTTMPVAK

LYTTMPVAK

IQLLVFK

IQLLVFK

IQLLVFK

IQLLVFK

MLGYFSLVGLLR MLGYFSLVGL
VSSDVIDQK $\begin{array}{llllllllllllll}2.78 .20 & 3 & 2092.0942 & 2092.0922 & 698.3713 & 0.0020 & 0.9546 & 1287.866 & 1470.746 & 1320.531 & 79.895 & \text { Yes } & \\ \end{array}$

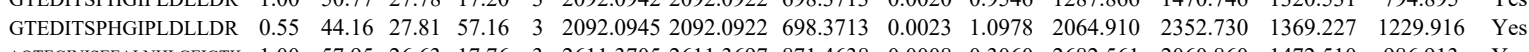
$\begin{array}{lllllllllllllll} & \end{array}$ $\begin{array}{llllllllllllll} & \end{array}$ $\begin{array}{lllllllllllllllll}\text { GTEDITSPHGIPLDLLDR } & 1.00 & 52.50 & 27.82 & 17.14 & 3 & 2092.0948 & 2092.0922 & 698.3713 & 0.0026 & 1.2410 & 563.704 & 870.246 & 546.511 & 470.944 & \text { No }\end{array}$ $\begin{array}{llllllllllllllll}\text { AQTEGINISEALNHLGEIGTKK } & 1.00 & 80.69 & 26.62 & 20.09 & 3 & 2611.3711 & 2611.3697 & 871.4638 & 0.0014 & 0.5355 & 2480.862 & 2889.116 & 1200.647 & 1026.284 & \text { Yes }\end{array}$ $\begin{array}{llllllllllllllll}\text { AQTEGINISEALNHLGEIGTK } & 0.53 & 62.28 & 26.55 & 75.28 & 3 & 2611.3726 & 2611.3697 & 871.4638 & 0.0029 & 1.1092 & 1435.647 & 1247.947 & 889.439 & 411.017 & \text { Yes }\end{array}$ $\begin{array}{llllllllllllllll}\text { AQTEGINISEALNHLGEIGTK } & 1.00 & 66.91 & 26.60 & 22.64 & 3 & 2611.3714 & 2611.3697 & 871.4638 & 0.0017 & 0.6502 & 503.073 & 548.287 & 250.949 & 165.124 & \text { Yes }\end{array}$ $\begin{array}{llllllllllllllll}\text { AQTEGINISEEALNHLGEIGTK } & 0.53 & 63.61 & 26.58 & 76.61 & 3 & 2611.3723 & 2611.3697 & 871.4638 & 0.0026 & 0.9945 & 859.260 & 792.466 & 525.739 & 299.424 & \text { Yes }\end{array}$

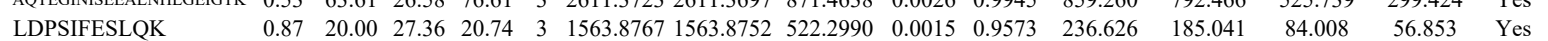

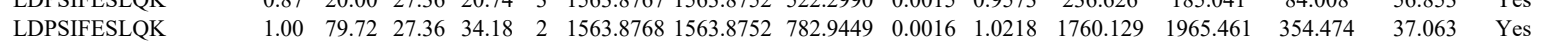

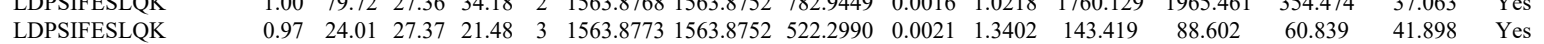

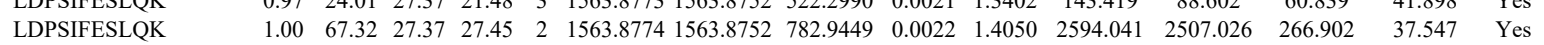
$\begin{array}{llllllllllllllll}\text { VPFCPMVGSEVYSTEIK } & 1.00 & 43.91 & 28.06 & 19.40 & 3 & 2219.0953 & 2219.0920 & 740.7046 & 0.0033 & 1.4851 & 84.133 & 117.693 & 89.289 & 82.334 & \text { No }\end{array}$ $\begin{array}{llllllllllllllll}\text { AVLLAGPPGTGK } & 1.00 & 73.80 & 21.49 & 24.15 & 2 & 1367.8486 & 1367.8380 & 684.9263 & 0.0106 & 7.7380 & 4644.559 & 4373.752 & 1590.760 & 672.398 & \text { Yes }\end{array}$ GTGK AVLLAGPPGTGK AVLLAGPPGTGK TALALAIAQELGSK TALALAIAQELGSK TALALAIAQELGSK TALALAIAQELGSK TISHVIIGLK TISHVIIGLK TISHVIIGLK $\begin{array}{lllllllllllllll}0.51 .1 & 7.43 & 84.19 & 2 & 1367.8852 & 1367.8744 & 684.9445 & 0.0108 & 7.8838 & 4839.810 & 4743.826 & 423.607 & 230.617 & \text { Yes } \\ 1.00 & 55.48 & 15.80 & 24.27 & 3 & 1367.8849 & 1367.8744 & 456.9654 & 0.0105 & 7.6592 & 14662032 & 13412.081 & 545.931 & 464.493 & \text { Yes }\end{array}$ \begin{tabular}{lllllllllllllll}
1.0 & 5.48 & 15.80 & 24.27 & 3 & 1367.8849 & 1367.8744 & 456.9654 & 0.0105 & 7.6592 & 14662.032 & 13412.081 & 545.931 & 464.493 & Yes \\
\hline
\end{tabular} $\begin{array}{lllllllllllllllll} & 1.06 & 68.03 & 24.71 & 21.54 & 2 & 1831.0448 & 1831.0325 & 916.5235 & 0.0123 & 6.7101 & 805.781 & 1003.842 & 68.760 & 11.008 & \text { No } \\ & 1.00 & 77.41 & 21.04 & 25.54 & 2 & 1818.0860 & 1818.0858 & 910.0502 & 0.0002 & 0.1099 & 653.288 & 783.114 & 278.474 & 89.522 & \text { Yes } \\ & 0.99 & 23.98 & 20.61 & 14.95 & 3 & 1818.0883 & 1818.0858 & 607.0359 & 0.0025 & 1.3728 & 849.026 & 1093.984 & 634.103 & 48.836 & \text { Yes }\end{array}$

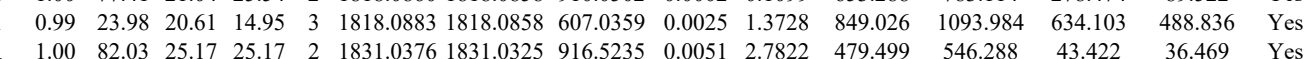




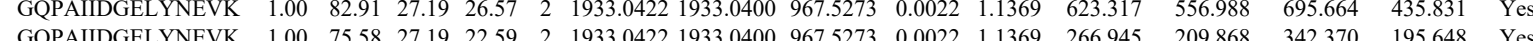

$\begin{array}{lllllllllllll}\text { VDAC3 HUMA Q9Y277 } & \text { VDAC3 } & \text { Voltage-dependen } 30.66 & 1.00 & 2 & 10.6 & -0.2252 & 0.1416 & -1.5081 & 0.7624 & 10 & \text { LTLSALIDGK }\end{array}$

\section{LTLSALIGK}

LTLSALIDGK

LTLSALIDGK

LTLSALIDGK

LTLSALIDGK

LTLSALIDGK

LTLSALIDGK

LTLSALIDGK

LTLSALIDGK

$\begin{array}{llllllllllllllll}0.60 & 14.62 & 27.02 & 23.31 & 3 & 1933.0447 & 1933.0400 & 645.3539 & 0.0047 & 2.4276 & 1791.829 & 2811.017 & 1207.488 & 677.307 & \text { Yes } & \\ 0.82 & 28.51 * & 22.86 & 17.78 & 3 & 1317.8122 & 1317.811 & 44.2776 & 0.0011 & 0.8328 & 45632 & 431.583 & 51.25 & 23.843 & \text { Yes }\end{array}$

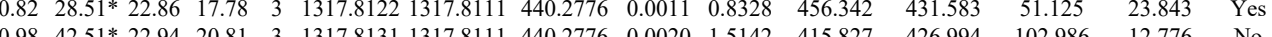

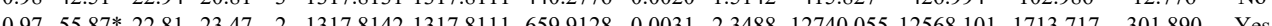
$\begin{array}{llllllllllllll}0.93 & 54.09 * 22.3 & 28.42 & 2 & 1317.8154 & 1317.8111 & 659.9128 & 0.0043 & 3.32580 & 22274.062 & 21375.263 & 3097.060 & 407.544 & \text { Yes }\end{array}$ $\begin{array}{lllllllllllllll}0.94 & 35.50 * 2.94 & 21.41 & 3 & 1317.8131 & 1317.8111 & 440.2776 & 0.0020 & 1.5142 & 774.657 & 552.159 & 82.199 & 26.809 & \text { Yes }\end{array}$ $\begin{array}{llllllllllllll}0.93 & 35.06 * 23.03 & 21.75 & 3 & 1317.8134 & 1317.8111 & 440.2776 & 0.0023 & 1.7413 & 828.079 & 679.611 & 139.667 & 39.514 & \text { Yes }\end{array}$ $\begin{array}{llllllllllllll}0.99 & 63.67 * 22.81 & 29.40 & 2 & 1317.8142 & 1317.8111 & 659.9128 & 0.0031 & 23488 & 12020.421 & 10635.510 & 1531.086 & 335.470 & \text { Yes }\end{array}$ $\begin{array}{llllllllllllllll}0.98 & 57.83 * 22.28 & 23.81 & 2 & 1317.8146 & 1317.811 & 6599.9128 & 0.0035 & 2.6519 & 313280078 & 26469.083 & 3127.953 & 362.409 & \text { Yes }\end{array}$ $\begin{array}{llllllllllllllllll}0.89 & 50.59 * 22 & 38.51 & 2 & 1317.8148 & 1317.8111 & 659.9128 & 0.0037 & 2.8034 & 15265.091 & 14359.276 & 2472.023 & 274.727 & \text { Yes }\end{array}$ $\begin{array}{llllllllllllllll}0.90 & 51.37 * 22.30 & 21.36 & 2 & 1317.8152 & 1317.8111 & 659.9128 & 0.0041 & 3.1065 & 17266.129 & 16172.177 & 2026.883 & 194.807 & \text { Yes }\end{array}$ $\begin{array}{lllllllllllllll}0.61 & 41.15 * & 22.23 & 20.57 & 2 & 1317.8160 & 1317.8111 & 659.9128 & 0.0049 & 3.7126 & 4498.670 & 3795.062 & 568.984 & 91.757 & \text { Yes }\end{array}$

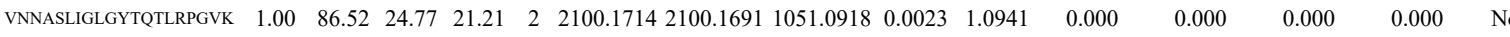
$\begin{array}{llllllllllllllll}\text { QETELSPEMISSGSWR } & 1.00 & 71.19 & 26.88 & 23.84 & 2 & 1979.9404 & 1979.9380 & 990.9763 & 0.0024 & 1.2109 & 408.501 & 333.393 & 106.306 & 39.360 & \text { Yes }\end{array}$ $\begin{array}{llllllllllllllll}\text { DPAEALQLPMDYVQR } & 1.00 & 88.11 & 27.79 & 22.08 & 2 & 1888.9498 & 1888.9475 & 945.4810 & 0.0023 & 1.2163 & 417.300 & 352.220 & 331.375 & 392.400 & \text { No }\end{array}$

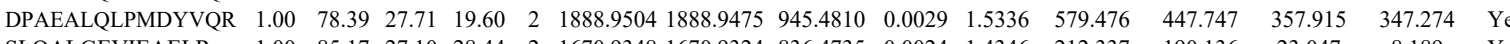

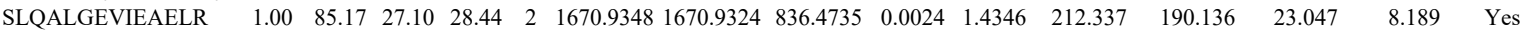

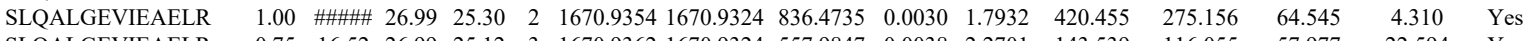

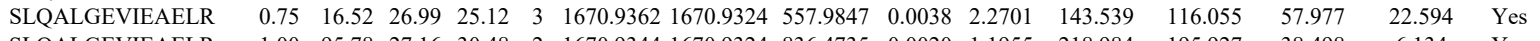
$\begin{array}{llllllllllllllll} & 1670.9344 & 1670.9324 & 836.4735 & 0.0020 & 1.1955 & 218.984 & 195.927 & 38.498 & 6.134 & \text { Yes } \\ \text { SLQALGEVIEAELR } & 1.00 & 95.78 & 27.16 & 30.48 & 2 & 167 & \end{array}$

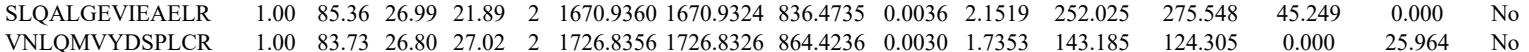

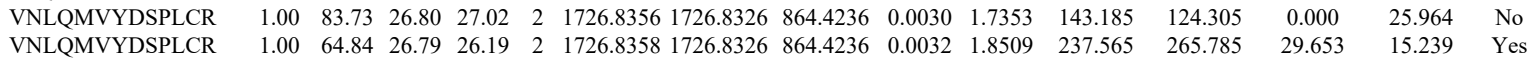
LGITQLR $\begin{array}{lllllllllllllllll}0.68 & 25.37 & 25.74 & 28.56 & 2 & 943.6004 & 943.5936 & 472.8041 & 0.0068 & 7.1911 & 41343.724 & 35036.690 & 5362.821 & 2558.679 & \text { Yes } & \end{array}$ $\begin{array}{lllllllllllllllll}0.82 & 28.67 & 25.74 & 28.05 & 2 & 943.6006 & 943.5936 & 472.8041 & 0.0070 & 7.4026 & 33984.163 & 30797.968 & 5228.166 & 2330.508 & \text { Yes }\end{array}$

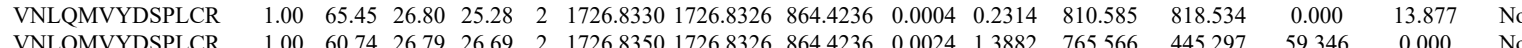
LGITQLR LGITQLR

LDAEPRPPPTQEAA

$\begin{array}{lllllllllllllll}1.00 & 65.45 & 26.80 & 25.28 & 2 & 1726.8330 & 1726.8326 & 864.4236 & 0.004 & 0.2314 & 810.585 & 818.534 & 0.000 & 13.877 & N \\ \end{array}$ $\begin{array}{llllllllllllllll}0.81 & 28.46 & 25.74 & 31.90 & 2 & 943.6004 & 943.5936 & 472.8041 & 0.0068 & 7.1911 & 36353.262 & 35657.186 & 2794.891 & 1646.502 & \text { Yes }\end{array}$ WNFDDLLEK IENELELK IIENELEGFGIR IQLLDLPGIIEGAK IQLLDLPGIIEGAK IQLLDLPGIIEGAK SDATADDLIDVVEGNR GGGGGGPGEGFDVAK

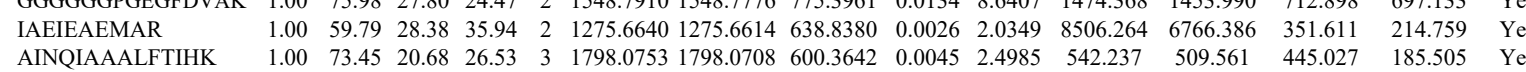
$\begin{array}{llllllllllllllll}0.81 & 31.24 & 28.41 & 17.32 & 2 & 16348454 & 1634.8386 & 818.4266 & 0.0068 & 4.1543 & 102.364 & 121.215 & 72.940 & 80.051 & \text { No }\end{array}$ $\begin{array}{lllllllllllllllll}1.00 & 52.51 & 28.07 & 26.14 & 2 & 1466.7688 & 1466.7649 & 734.389 & 0.0039 & 2.6553 & 1059.737 & 911.170 & 103.940 & 3.089 & \text { Yes }\end{array}$

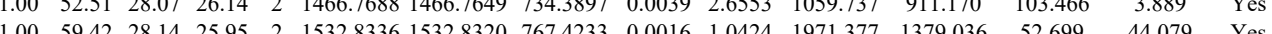
$\begin{array}{lllllllllllllllll}1.00 & 61.08 & 28.12 & 29.94 & 2 & 1532.8340 & 1532.8320 & 767.423 & 0.0020 & 1.3031 & 1464.955 & 1135.494 & 26.896 & 28.883 & \text { Yes }\end{array}$ $\begin{array}{lllllllllllllll}1.00 & 80.91 & 18.45 & 37.98 & 2 & 1767.0772 & 1767.0749 & 884.5447 & 0.0023 & 13001 & 833.064 & 718.324 & 70.772 & 76.333 & \text { Yes }\end{array}$ $\begin{array}{lllllllllllllll}0.53 & 22.36 & 18.33 & 35.36 & 3 & 1767.0784 & 1767.0749 & 590.0322 & 0.0035 & 1.9773 & 255.317 & 146.853 & 177.159 & 348.329 & \text { No }\end{array}$ $\begin{array}{lllllllllllllllll}0.98 & 18.83 & 17.99 & 16.74 & 3 & 1767.0799 & 1767.0749 & 590.0322 & 0.0050 & 2.8247 & 120.925 & 139.731 & 89.829 & 165.042 & \text { Yes }\end{array}$ \begin{tabular}{|cccccccccccccccc} 
& 27.25 & 27.87 & 2 & 1832.8886 & 1832.8874 & 917.4510 & 0.0012 & 0.6540 & 176.056 & 179.052 & 155.304 & 25.771 & No & \\
DVAK & 1.00 & 75.98 & 27.80 & 24.47 & 2 & 1548.7910 & 1548.7776 & 775.3961 & 0.0134 & 8.6407 & 1474.368 & 1453.990 & 712.898 & 697.133 & Yes
\end{tabular} \begin{tabular}{lllllllllllllllll} 
AINQIAAALFTIHK & 1.00 & 73.45 & 20.68 & 26.53 & 3 & 1798.0753 & 1798.0708 & 600.3642 & 0.0045 & 2.4985 & 542.237 & 509.561 & 445.027 & 185.505 & Yes \\
\hline
\end{tabular} $\begin{array}{cccccccccccccccc}\text { AINQIAAALFTIHK } & 1.00 & 42.41 & 20.37 & 16.28 & 3 & 1798.0762 & 1798.0708 & 600.3642 & 0.0054 & 2.9982 & 24.038 & 47.462 & 7.674 & 4.459 & \text { Yes } \\ \text { AINQIAAALFTIHK } & 1.00 & 73.60 & 20.86 & 28.56 & 3 & 1798.0729 & 1798.0708 & 600.3642 & 0.0021 & 1.1660 & 1364.636 & 2773.030 & 1700.508 & 734.892 & \text { Yes } \\ \text { AINQIAAALFTIHK } & 1.00 & 58.97 & 20.76 & 25.12 & 3 & 1798.0744 & 1798.0708 & 600.3642 & 0.0036 & 1.9988 & 1724.393 & 2222.118 & 1729.776 & 645.234 & \text { Yes }\end{array}$ $\begin{array}{lllllllllllllllll}\text { LALQSSSCLSLFR } & 1.00 & 75.67 & 28.15 & 32.07 & 2 & 1613.8402 & 1613.8391 & 807.9268 & 0.0011 & 0.6808 & 494.582 & 624.843 & 42.198 & 30.344 & \text { Yes }\end{array}$ $\begin{array}{llllllllllllllllll}\text { LALQSSSCLSLFR } & 1.00 & 62.91 & 28.15 & 32.02 & 2 & 1613.8402 & 1613.8391 & 807.9268 & 0.0011 & 0.6808 & 397.128 & 472.526 & 25.895 & 18.478 & \text { Yes }\end{array}$ $\begin{array}{llllllllllllllllll}\text { LALQSSSCLSLFR } & 1.00 & 59.28 & 28.08 & 33.34 & 2 & 1613.8384 & 1613.8391 & 807.9268 & -0.0007 & -0.4332 & 242.243 & 276.282 & 20.764 & 32.411 & \text { Yes }\end{array}$

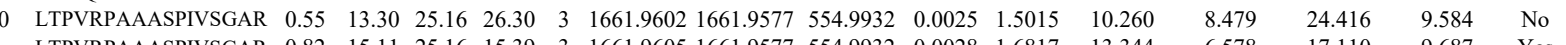
$\begin{array}{lllllllllllllllll}\text { LTPVRPAAASPIVSGAR } & 0.82 & 15.11 & 25.16 & 15.39 & 3 & 1661.9605 & 1661.9577 & 554.9932 & 0.0028 & 1.6817 & 13.344 & 6.578 & 17.110 & 9.687 & \text { Yes }\end{array}$

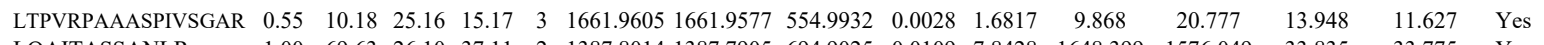
$\begin{array}{llllllllllllllll}\text { LQAITASSANLR } & 1.00 & 69.63 & 26.10 & 37.11 & 2 & 1387.8014 & 1387.7905 & 694.9025 & 0.0109 & 7.8428 & 1648.399 & 1576.049 & 33.835 & 33.775 & \text { Yes }\end{array}$

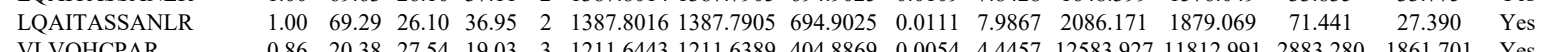

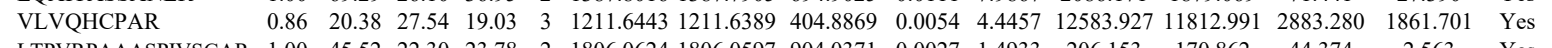

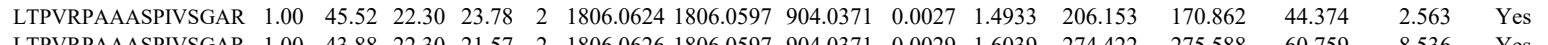

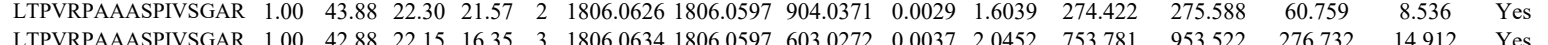
\begin{tabular}{llllllllllllllll} 
LTPVRPAAASPIVSGAR & 1.00 & 42.88 & 22.15 & 16.35 & 3 & 1806.0634 & 1806.0597 & 603.0272 & 0.0037 & 2.0452 & 753.781 & 953.522 & 276.732 & 14.912 & Yes \\
\hline LTPVRPAASPIVSGAR & 1.00 & 41.13 & 22.65 & 24.36 & 3 & 1806.0589 & 1806.0597 & 603.0272 & -0.0008 & -0.4422 & 144.578 & 150.383 & 53.092 & 6.657 & Yes
\end{tabular} $\begin{array}{llllllllllllllll}\text { LTPVRPAAASPIVSGAR } & 1.00 & 4.13 & 22.65 & 24.36 & 3 & 1806.0589 & 1806.0597 & 603.0272 & -0.0008 & -0.4422 & 144.578 & 150.383 & 53.092 & 6.657 & \text { Yes } \\ \text { LTPVRPAAASPIVSGAR } & 1.00 & 36.43 & 22.55 & 19.22 & 3 & 1806.0598 & 1806.0597 & 603.0272 & 0.0001 & 0.0553 & 136.551 & 186.467 & 71.817 & 14.998 & \text { Yes }\end{array}$ $\begin{array}{lllllllllllllllll}\text { SPPSTGSTYGSSQK } & 0.96 & 25.68 & 27.78 & 14.80 & 3 & 1670.8366 & 1670.8355 & 557.9524 & 0.0011 & 0.6572 & 91.985 & 97.123 & 116.753 & 182.544 & \text { No }\end{array}$ $\begin{array}{lllllllllllllllll}\text { SPPSTGSTYGSSQK } & 0.78 & 16.70 & 27.82 & 15.51 & 3 & 1670.8372 & 1670.8355 & 557.9524 & 0.0017 & 1.0156 & 87.962 & 86.646 & 51.235 & 88.699 & \text { Y }\end{array}$ 


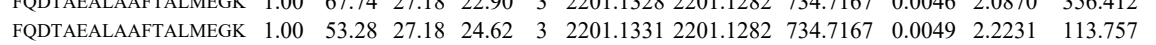
$\begin{array}{llllllllllllll}\text { FQDTAEALAAFTALMEGK } & 1.00 & 67.74 & 27.18 & 22.90 & 3 & 2201.1328 & 2201.1282 & 734.7167 & 0.0046 & 2.0870 & 356.412 & 228.778 & 419.102 \\ \text { FQDTAEALAAFTALMEGK } & 1.00 & 53.28 & 27.18 & 24.62 & 3 & 2201.1331 & 2201.1282 & 734.7167 & 0.0049 & 2.2231 & 113.757 & 57.316 & 126.157 \\ \text { FQDTAEALAAFTALMEGK } & 1.00 & 64.41 & 27.15 & 25.23 & 3 & 2201.1325 & 2201.1282 & 734.7167 & 0.0043 & 1.9509 & 590.189 & 741.787 & 385.319\end{array}$

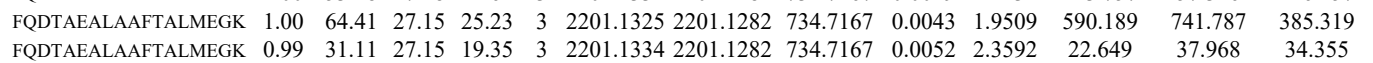
$\begin{array}{llllllllllllll} & \end{array}$ $\begin{array}{llllllllllllllll}\text { LIAHAGSLLNLAK } & 0.53 & 51.31 & 15.56 & 64.31 & 3 & 1608.0001 & 1607.9966 & 537.0061 & 0.0035 & 2.1725 & 8420.565 & 8016.030 & 676.583\end{array}$

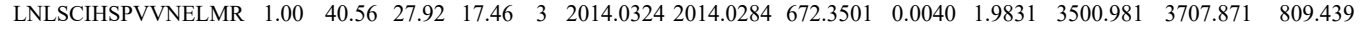
$\begin{array}{lllllllllllllll}\text { LNLSCIHSPVVNELMR } & 1.00 & 54.99 & 27.97 & 16.94 & 3 & 2014.0330 & 2014.0284 & 672.3501 & 0.0046 & 2.2806 & 2260.332 & 2534.986 & 716.575 & 4\end{array}$ $\begin{array}{llllllllllllllll}\text { LIAHAGSLLNLAK } & 0.55 & 46.88 & 15.31 & 59.88 & 3 & 1607.9986 & 1607.9966 & 537.0061 & 0.0020 & 1.2414 & 11040.643 & 12247.478 & 467.850 & 476 \\ \text { LIAHAGSLLNLAK } & 0.53 & 41.11 & 15.56 & 54.11 & 3 & 1608.0001 & 1607.9966 & 537.0061 & 0.0035 & 2.1725 & 11884.188 & 12769284 & 770.691\end{array}$

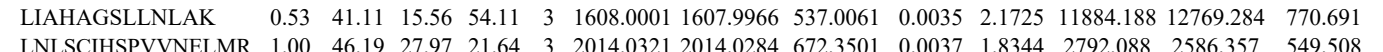
$\begin{array}{llllllllllllllll}\text { LNLSCIHSPVVNELMR } & 1.00 & 46.19 & 27.97 & 21.64 & 3 & 2014.0321 & 2014.0284 & 672.3501 & 0.0037 & 1.8344 & 2792.088 & 2586.357 & 549.508 \\ \text { LNLSCIHSPVVNELMR } & 1.00 & 47.68 & 27.97 & 21.05 & 3 & 2014.0321 & 2014.0284 & 672.3501 & 0.0037 & 1.8344 & 2693.549 & 2962.113 & 734.727\end{array}$ $\begin{array}{llllllllllllllll}\text { LNLSCIHSPVVNELMR } & 1.00 & 47.68 & 27.97 & 21.05 & 3 & 2014.0321 & 2014.0284 & 672.3501 & 0.0037 & 1.8344 & 2693.549 & 2962.113 & 734.727\end{array}$ $\begin{array}{lllllllllllllll}\text { MMAIAPNVTVMVGELVGAR } & 1.00 & 94.49 & 27.13 & 20.67 & 2 & 2102.1194 & 2102.1172 & 1052.0659 & 0.0022 & 1.0456 & 1046.513 & 911.782 & 62.334\end{array}$ $\begin{array}{llllllllllllll}\text { MMAIAPNVTVMVGELVGAR } & 1.00 & 51.57 & 26.95 & 23.40 & 3 & 2102.1208 & 2102.1172 & 701.7130 & 0.0036 & 1.7101 & 70.490 & 174.238 & 86.727\end{array}$

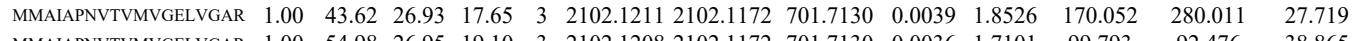

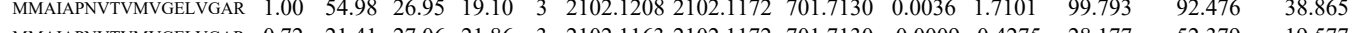
\begin{tabular}{llllllllllllll} 
MMAIANTMMGELVAR & 0.72 & 21.41 & 27.06 & 21.86 & 3 & 2102.1163 & 2102.1172 & 701.7130 & -0.0009 & -0.4275 & 28.177 & 52.379 & 19.577 \\
\hline
\end{tabular}

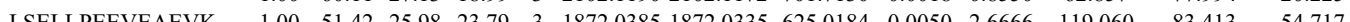

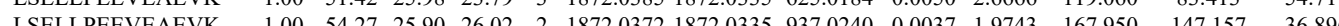
$\begin{array}{llllllllllllll}\text { LSELLPEEVEAEVK } & 1.00 & 59.76 & 25.97 & 24.90 & 2 & 1872.0378 & 1872.0335 & 937.0240 & 0.0043 & 2.2945 & 144.859 & 128.100 & 24.682\end{array}$ $\begin{array}{lllllllllllll}1.00 & 40.08 & 24.62 & 17.66 & 4 & 1715.9933 & 1715.9957 & 430.0062 & -0.0024 & -1.3953 & 1649.127 & 1980.047 & 321.961\end{array}$ $\begin{array}{lllllllllllll}1.00 & 52.65 & 24.59 & 26.91 & 3 & 1715.9929 & 1715.9957 & 573.0058 & -0.0028 & -1.6288 & 1216.412 & 1297.426 & 180.048 \\ 1.00 & 5939 & 24.62 & 31.19 & 3 & 1715.9932 & 1715.9957 & 573.0058 & -0.0025 & -1.4543 & 674.549 & 810.150 & 132.078\end{array}$ $\begin{array}{lllllllllllll}1.00 & 35.39 & 24.58 & 16.08 & 4 & 1715.9945 & 1715.9957 & 430.0062 & -0.0012 & -0.6977 & 985.876 & 1117.155 & 120.991\end{array}$ $\begin{array}{llllllllllllll}1.00 & 44.31 & 24.31 & 18.69 & 4 & 1715.9957 & 1715.9957 & 430.0062 & 0.0000 & 0.0000 & 950.473 & 1232.981 & 220.553\end{array}$ $\begin{array}{lllllllllllll}0.99 & 47.30 & 27.77 & 35.48 & 3 & 1520.8054 & 1520.8078 & 507.9432 & -0.0024 & -1.5750 & 624.329 & 549.227 & 170.419\end{array}$ $\begin{array}{lllllllllllll}1.00 & 31.08 & 25.85 & 44.08 & 4 & 1793.0057 & 1793.0048 & 449.2585 & 0.0009 & 0.5008 & 2363.812 & 2456.883 & 352.532 \\ 1.00 & 81.47 & 18.45 & 21.49 & 2 & 1725.0696 & 1725.0674 & 863.5410 & 0.0022 & 1.2738 & 26.502 & 18.332 & 20.090\end{array}$ $\begin{array}{ccccccccccccc}1.00 & 81.47 & 18.45 & 21.49 & 2 & 1725.0696 & 1725.0674 & 863.5410 & 0.0022 & 1.2738 & 26.502 & 18.332 & 20.090 \\ 1.00 & 53.45 & 18.45 & 28.74 & 2 & 1725.0696 & 1725.0674 & 863.5410 & 0.0022 & 1.2738 & 25.924 & 5.526 & 10.315\end{array}$

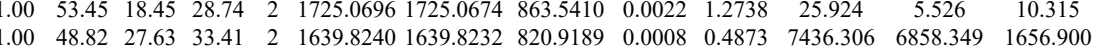

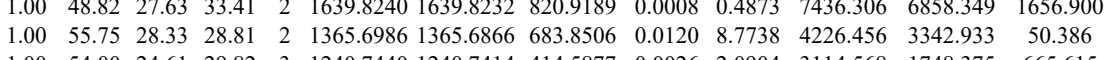

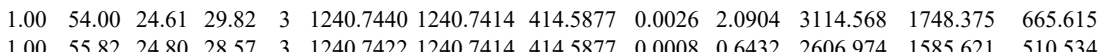
$\begin{array}{llllllllllllll}1.00 & 55.82 & 24.80 & 28.57 & 3 & 1240.7422 & 1240.7414 & 414.5877 & 0.0008 & 0.6432 & 2606.974 & 1585.621 & 510.534 \\ 1.00 & 54.14 & 24.65 & 30.42 & 3 & 1240.7434 & 1240.7414 & 414.5877 & 0.0020 & 1.6080 & 1198.610 & 939.160 & 280.567\end{array}$ 
$\begin{array}{lllllllllllll}1.00 & 49.74 & 27.97 & 21.63 & 3 & 1877.9686 & 1877.9655 & 626.9958 & 0.0031 & 1.6481 & 248.786 & 272.527 & 103.924\end{array}$ ITAEEMYDIFGK

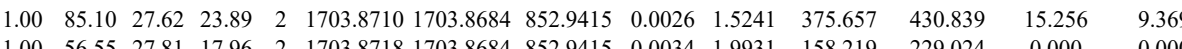

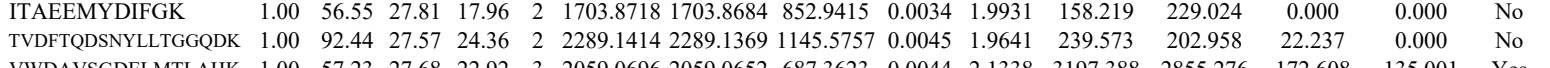
$\begin{array}{lllllllllllll} & \end{array}$ $\begin{array}{llllllllllllllll}\text { VWDAVSGDELMTLAHK } & 1.00 & 62.31 & 27.71 & 23.28 & 3 & 205.0693 & 2059.0652 & 687.3623 & 0.0041 & 1.9883 & 6398.862 & 4806.375 & 312.712 & 315.802 & \text { Yes }\end{array}$ $\begin{array}{lllllllllllllllll}\text { QGDTGDWIGTFLGHK } & 1.00 & 77.62 & 28.12 & 23.62 & 3 & 1918.9813 & 1918.9781 & 640.6666 & 0.0032 & 1.6649 & 17800706 & 1799.321 & 616.148 & 138.008 & \text { Yes }\end{array}$ $\begin{array}{lllllllllllllllll}\text { GAVWGATLNK } & 1.00 & 59.43 & 27.26 & 24.35 & 2 & 1303.7592 & 1303.7492 & 652.8819 & 0.0100 & 7.6583 & 7302.078 & 6600.834 & 8054.386 & 6352.776 & \text { Yes }\end{array}$ $\begin{array}{llllllllllllllll}\text { GAVWGATLNK } & 1.00 & 59.43 & 27.26 & 24.35 & 2 & 1303.7592 & 1303.7492 & 652.8819 & 0.030 & 7.6583 & 7302.078 & 6600.834 & 8054.386 & 6352.776 & \text { Yes } \\ \text { GAVWGATLNK } & 1.00 & 50.29 & 27.39 & 25.01 & 2 & 1303.7604 & 1303.7492 & 652.8819 & 0.0112 & 85773 & 5386.154 & 5202.993 & 5339.363 & 3605.461 & \text { Yes }\end{array}$ $\begin{array}{llllllllllllllll}\text { GAVWGATL } & 1.00 & 50.29 & 27.39 & 25.01 & 2 & 1303.7604 & 1303.7492 & 62.8819 & 0.012 & 8.573 & 5386.154 & 5202.993 & 535.363 & 3605.461 & \text { Yes } \\ \text { GAVWGATLNK } & 1.00 & 49.61 & 27.27 & 26.47 & 2 & 1303.7594 & 1303.7492 & 652.8819 & 0.0102 & 7.8115 & 7928.485 & 7247.899 & 5951.731 & 4216757 & \text { Yes }\end{array}$

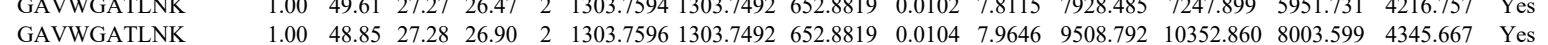
$\begin{array}{lllllllllllllllllll}\text { GAVWGATLNK } & 1.00 & 59.29 & 27.39 & 27.09 & 2 & 1303.7604 & 1303.7492 & 652.8819 & 0.0112 & 85773 & 2648.923 & 3164.095 & 1681.566 & 1214211 & \text { Yes }\end{array}$

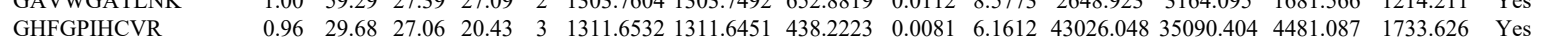
GHFGPIHCVR

$\begin{array}{lllllllllllll}\text { CV028_HUMAN } & \text { Q9Y3I0 } & \text { C22orf28 } & \text { UPF0027 protein } 55.21 & 1.00 & 5 & 11.3 & -0.1455 & 0.2283 & 0.6439 & 1.6645 & 11 & \text { LRPIAVIK }\end{array}$ LRPIAVIK NLDFQDVLDK NLDFQDVLDK LRPIAVIK
LRPIAVIK $\begin{array}{lllllllllllllll}0.96 & 29.68 & 27.06 & 20.43 & 3 & 1311.6532 & 1311.6451 & 438.2223 & 0.0081 & 6.1612 & 43026.048 & 35090.404 & 4481.087 & 1733.626 & \text { Yes } \\ 1.00 & 39.23 & 27.00 & 9.19 & 3 & 131.6535 & 131.6451 & 382223 & 0.0084 & 6.3894 & 29391.474 & 27815.781 & 3913.580 & 722.677 & \text { Yes }\end{array}$

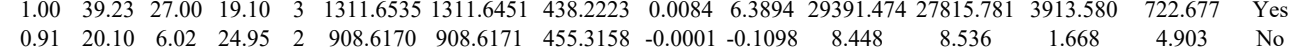

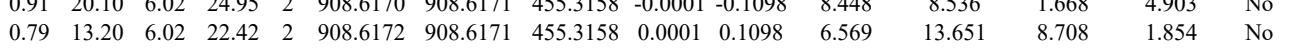

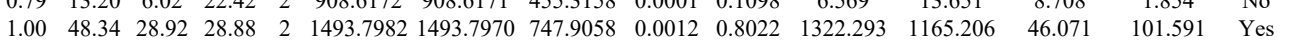
$\begin{array}{lllllllllllllll}1.00 & 52.52 & 28.79 & 28.17 & 2 & 1493.7998 & 1493.7970 & 747.9058 & 0.0028 & 1.8719 & 1415.837 & 1373.069 & 28.035 & 56.990 & \text { Y s } \\ 0.87 & 13.21 & 6.02 & 22.77 & 2 & 908.6178 & 908.6171 & 455.3158 & 0.0007 & 0.7687 & 14.145 & 19.332 & 6.119 & 11.703 & \text { No }\end{array}$ $\begin{array}{lllllllllllllllll} & 0.99 & 22.56 & 6.02 & 22.29 & 2 & 908.6186 & 908.6171 & 455.3158 & 0.0015 & 1.6472 & 19.641 & 17.578 & 4.867 & 10.401 & \text { Yes }\end{array}$ $\begin{array}{llllllllllllllll}\text { GMAAAGNYAWVNR } & 1.00 & 93.27 & 27.55 & 25.90 & 2 & 1523.7512 & 1523.7425 & 762.8785 & 0.0087 & 5.7021 & 4746.464 & 4798.350 & 703.689 & 242.746 & \text { Yes }\end{array}$

$\begin{array}{llllllllllllllll}\text { GMAAAGNYAWVNR } & 1.00 & 93.84 & 27.44 & 38.38 & 2 & 1523.7534 & 1523.7425 & 762.8785 & 0.0109 & 7.1439 & 1384.394 & 1160.491 & 423.052 & 109.571 & \text { Yes } \\ \text { QIGNVAALPGIVHR } & 1.00 & 59.02 & 24.00 & 19.88 & 3 & 1587.9349 & 1587.9331 & 530.3183 & 0.0018 & 1.1314 & 2483.911 & 3393.106 & 1648.335 & 763.797 & \text { Yes }\end{array}$ QIGNVAALPGIVHR LRPIAVIK TNLDESDVQPVK TNLDESDVQPVK NLDFQDVLDK

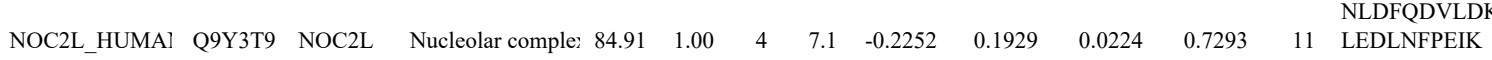
LEDLNFPEIK

LFHEVVQAFR

LFHEVVQAFR

LFHEVVQAFR
LFHEVVQAFR

AYLGSAIQLVSCLSETT

VLAFLVLSR

VLAFLVLSR

VLAFLVLSR

VLAFLVLSR

VLAFLVLSR

EELSNVLAAMR

YPMAVGLNK

YPMAVGLNK $\begin{array}{lllllllllllllll}0.55 & 14.79 & 23.48 & 15.63 & 3 & 1587.9403 & 1587.9331 & 530.3183 & 0.0072 & 4.5256 & 887.969 & 641.095 & 140.110 & 123.250 & \text { Yes } \\ 0.95 & 16.71 & 7.78 & 18.23 & 2 & 196.8328 & 196.8212 & 599.479 & 0.016 & 9.6760 & 9076.360 & 832.642 & 54.26 & 191.297 & \text { Yes }\end{array}$ $\begin{array}{lllllllllllllll}0.95 & 18.71 & 7.78 & 18.23 & 2 & 1196.8328 & 1196.8212 & 599.4179 & 0.0116 & 9.6760 & 9076.360 & 8352.642 & 54.262 & 191.297 & \text { Yes }\end{array}$ $\begin{array}{lllllllllllllll}1.00 & 63.21 & 27.80 & 29.50 & 2 & 1631.8640 & 1631.8610 & 816.9378 & 0.0030 & 1.8361 & 1502.986 & 1242.407 & 728.182 & 213.899 & \text { Yes } \\ 1.00 & 59.05 & 27.79 & 31.09 & 2 & 131.8642 & 1531.8610 & 816.978 & 0.0032 & 1.9585 & 6055.473 & 562.424 & 2151.278 & 895.234 & \text { Ye }\end{array}$

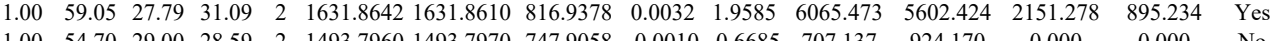

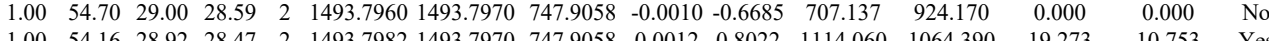
$\begin{array}{lllllllllllllll}1.00 & 54.16 & 28.92 & 28.47 & 2 & 1493.7982 & 1493.7970 & 747.9058 & 0.0012 & 0.8022 & 1114.060 & 1064.390 & 19.273 & 10.753 & \text { Yes } \\ 1.00 & 50.47 & 27.10 & 36.89 & 2 & 1504.8420 & 1504.8381 & 753.4263 & 0.0039 & 25882 & 335.986 & 280.912 & 64.371 & 0.000 & \text { No }\end{array}$

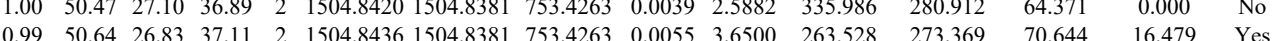

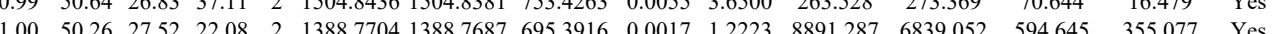
$\begin{array}{lllllllllllllll}1.00 & 63.24 & 27.52 & 18.32 & 2 & 1388.7704 & 1388.7687 & 695.3916 & 0.0017 & 1.2223 & 10340.288 & 7758.933 & 896.640 & 45.07 & \text { Yes }\end{array}$ $\begin{array}{lllllllllllllll}1.00 & 42.99 & 27.52 & 21.49 & 3 & 1388.7706 & 1388.7687 & 463.9302 & 0.0019 & 1.3651 & 4250.431 & 3784.695 & 751.790 & 422.774 & \text { Yes }\end{array}$ $\begin{array}{llllllllllllllll}1.00 & 51.80 & 27.26 & 21.87 & 3 & 1388.7712 & 1388.7687 & 463.9302 & 0.0025 & 1.7962 & 5171.886 & 5800.093 & 721.179 & 384.228 & \text { Yes } \\ \end{array}$

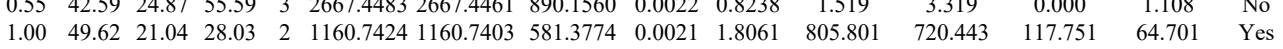
$\begin{array}{lllllllllllllll}1.00 & 48.71 & 20.97 & 26.86 & 2 & 1160.7434 & 1160.7403 & 581.3774 & 0.0031 & 2.6661 & 278.897 & 277.953 & 54.205 & 65.778 & \text { Yes }\end{array}$

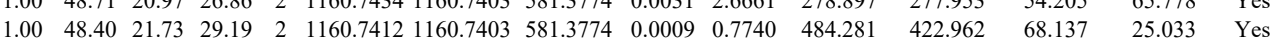
$\begin{array}{lllllllllllllll}1.00 & 50.92 & 21.73 & 34.81 & 2 & 1160.7416 & 1160.7403 & 581.3774 & 0.0013 & 1.1180 & 1118.901 & 919.611 & 164.669 & 62.062 & \text { Yes }\end{array}$ $\begin{array}{lllllllllllllll}1.00 & 48.04 & 21.73 & 27.76 & 2 & 1160.7412 & 1160.7403 & 581.3774 & 0.0009 & 0.7740 & 494.387 & 388.469 & 122.852 & 43.149 & \text { Yes }\end{array}$ $\begin{array}{lllllllllllllllll}1.00 & 47.62 & 21.73 & 27.07 & 2 & 1160.7412 & 1160.7403 & 581.3774 & 0.0009 & 0.7740 & 380.199 & 294.506 & 36.422 & 38.460 & \text { Yes }\end{array}$ $\begin{array}{llllllllllllllll}1.00 & 70.01 & 28.36 & 36.59 & 2 & 1375.7296 & 1375.7251 & 688.8698 & 0.0045 & 3.2662 & 2880.722 & 2733.183 & 9025.065 & 4480.249 & \text { Yes }\end{array}$ $\begin{array}{llllllllllllllllll}1.00 & 54.43 & 28.49 & 34.61 & 2 & 1375.7300 & 1375.7251 & 688.8698 & 0.0049 & 3.5565 & 2663.025 & 2064.341 & 5827.976 & 3259.588 & \text { Yes }\end{array}$ $\begin{array}{llllllllllllllll}1.00 & 49.55 & 27.73 & 26.94 & 2 & 1279.7316 & 1279.7202 & 640.8674 & 0.0114 & 8.8941 & 9544.288 & 10552.753 & 8733.220 & 5471.373 & \text { Yes }\end{array}$ $\begin{array}{lllllllllllllllll}1.00 & 46.48 & 27.66 & 23.32 & 2 & 1279.7314 & 1279.7202 & 640.8674 & 0.0112 & 8.7381 & 19037.790 & 21223.040 & 16502.835 & 12080.074 & \text { Yes }\end{array}$

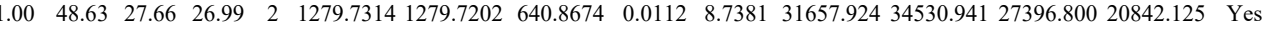
$\begin{array}{lllllllllllllll}1.00 & 21.70 & 26.28 & 34.70 & 4 & 3338.7157 & 3338.7125 & 835.6854 & 0.0032 & 0.9573 & 12.817 & 11.333 & 16.310 & 2.723 & \text { Yes }\end{array}$ $\begin{array}{llllllllllllllll}\text { GTEWDPRDAMAENELGAAAAEAAK } & 1.00 & 49.64 & 26.31 & 62.64 & 4 & 3338.7169 & 3338.7125 & 835.6854 & 0.0044 & 1.3163 & 15.469 & 7.998 & 14.042 & 10.423 & \text { Yes }\end{array}$

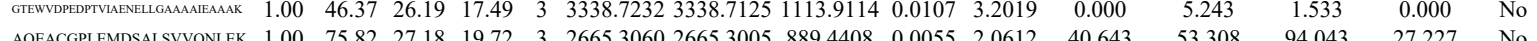

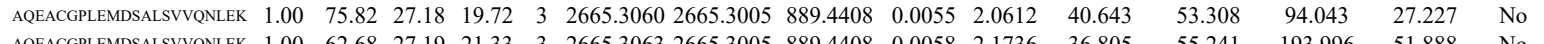
$\begin{array}{llllllllllllllll}\text { AQEACGPLEMDSALSVVQNLEK } & 1.00 & 62.68 & 27.19 & 21.33 & 3 & 2665.3063 & 2665.3005 & 889.4408 & 0.0058 & 2.1736 & 36.805 & 55.241 & 193.996 & 51.888 & \text { No }\end{array}$

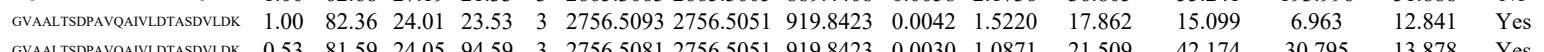

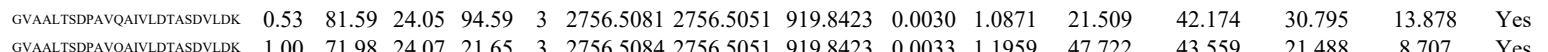

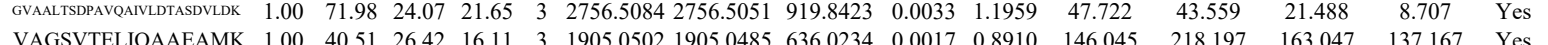
$\begin{array}{llllllllllllllll}\text { VAGSVTELIQAAEAMK } & 1.00 & 40.51 & 26.42 & 16.11 & 3 & 1905.0502 & 1905.0485 & 636.0234 & 0.0017 & 0.8910 & 146.045 & 218.197 & 163.047 & 137.167 & \text { Yes } \\ \text { VAGSVTELIQAAEAMK } & 0.53 & 25.64 & 26.42 & 38.64 & 3 & 1905.0514 & 1905.0485 & 636.0234 & 0.0029 & 1.5199 & 208.613 & 207.378 & 178.599 & 179.757 & \text { Yes }\end{array}$

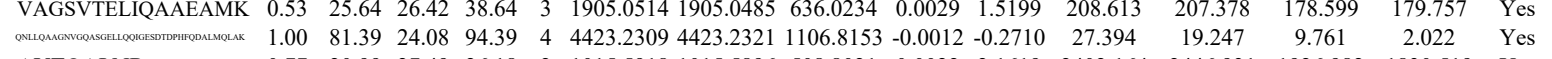

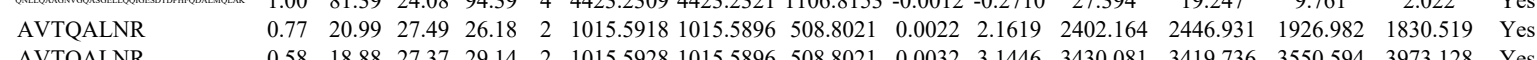




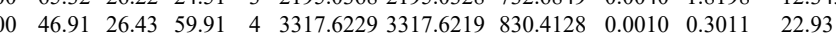

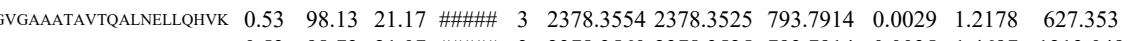


$\begin{array}{llllllllllll}0.53 & 29.82 & 25.72 & 42.82 & 3 & 2238.2164 & 2238.2130 & 747.0783 & 0.0034 & 1.5170 & 45.274 & 123.899 \\ 0.77 & 16.74 & 20.41 & 29.74 & 2 & 1131.7396 & 1131.7372 & 566.8759 & 0.0024 & 2.1169 & 6003.257 & 6950.123\end{array}$

$\begin{array}{llllllllllll}17.01 & 20.41 & 30.01 & 2 & 1131.7400 & 1131.7372 & 566.8759 & 0.0028 & 2.4697 & 4605.842 & 5484.921\end{array}$

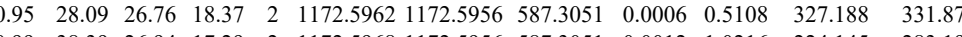

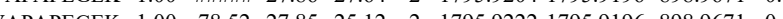

648.195

$\begin{array}{llllllllllll}\text { AEAGPEGVAPAPEGEK } & 1.00 & 78.52 & 27.85 & 25.12 & 2 & 1795.9222 & 1795.9196 & 898.9671 & 0.0026 & 1.4461 & 653.422\end{array}$

648.243

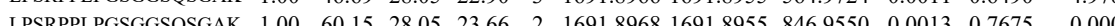
$\begin{array}{llllllllllllll}\text { LPSRPPLPGSGGSQSGAK } & 1.00 & 35.11 & 28.05 & 22.45 & 3 & 1691.8969 & 1691.8955 & 564.9724 & 0.0014 & 0.8260 & 6.599\end{array}$ $\begin{array}{llllllllllll}\text { LPSRPPLPGSGGSQSGAK } & 1.00 & 69.61 & 28.05 & 25.60 & 2 & 1691.8970 & 1691.8955 & 846.9550 & 0.0015 & 0.8855 & 4.078\end{array}$ $\begin{array}{lllllllllllll}\text { LPSRPPLPGSGGSQSGAK } & 1.00 & 47.90 & 28.20 & 24.14 & 2 & 1691.8952 & 1691.8955 & 846.9550 & -0.0003 & -0.1771 & 2.174\end{array}$ $\begin{array}{lllllllllllll}\text { LPSRPPLPGSGGSQSGAK } & 0.73 & 19.33 & 28.09 & 17.31 & 3 & 1691.8960 & 1691.8955 & 564.9724 & 0.0005 & 0.2950 & 8.222\end{array}$ $\begin{array}{llllllllllllll}\text { LPSRPPLPGSGGSQSGAK } & 1.00 & 37.24 & 28.05 & 19.49 & 3 & 1691.8966 & 1691.8955 & 564.9724 & 0.0011 & 0.6490 & 12.296\end{array}$ $\begin{array}{lllllllllllll}\text { LPSRPPLPGSGGSQSGAK } & 0.98 & 33.45 & 28.06 & 20.93 & 2 & 1691.8972 & 1691.8955 & 846.9550 & 0.0017 & 1.0036 & 0.000\end{array}$ $\begin{array}{llllllllllll}\text { LPSRPPLPGSGGSOSGAK } & 0.60 & 15.17 & 28.05 & 17.82 & 3 & 1691.8966 & 1691.8955 & 564.9724 & 0.0011 & 0.6490\end{array}$ LLLLAGVDR LLLLAGVDR LLLLAGVDR

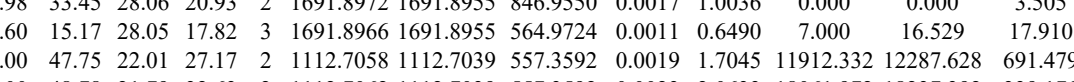
LLLLAGVDR

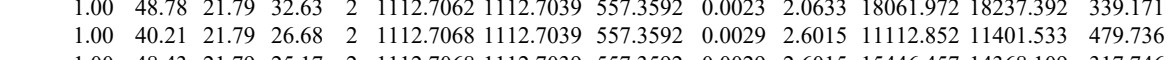

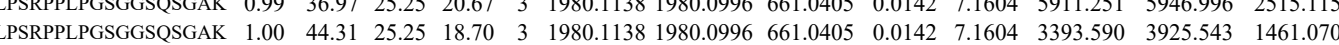
$\begin{array}{llllllllllllll}\text { LPSRPPLPGSGGSQSGAK } & 0.96 & 28.72 & 25.50 & 19.62 & 3 & 1980.1108 & 1980.0996 & 661.0405 & 0.0112 & 5.6476 & 5200.053 & 5446.754 & 1835.645\end{array}$

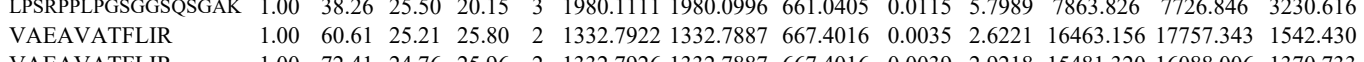
VAEAVATFLIR VAEAVATFLIR GLSNLFLSCPIPK NPEDLSAETMAK
NPEDLSAETMAK

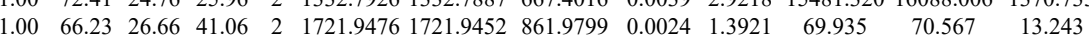
$\begin{array}{llllllllllllll}1.00 & 63.00 & 27.85 & 22.12 & 2 & 1592.8110 & 1592.7959 & 797.4052 & 0.0151 & 9.4681 & 303.785 & 301.080 & 132.519\end{array}$ $\begin{array}{lllllllllllll}.00 & 50.16 & 27.82 & 20.69 & 2 & 1592.8116 & 1592.7959 & 797.4052 & 0.0157 & 9.8443 & 233.788 & 205.825\end{array}$

NEGNIFPNPEATFVK

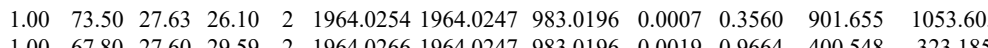
$\begin{array}{lllllllllllll} & \end{array}$

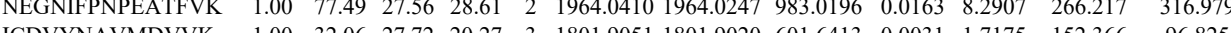

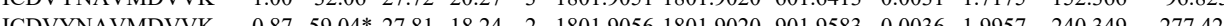
$\begin{array}{lllllllllllll}\text { CDVYNAVMVYK } & 0.87 & 52.04 & 27.81 & 18.24 & 2 & 1801.9056 & 1801.9020 & 901.9583 & 0.0036 & 1.9957 & 240.349 & 277.426\end{array}$

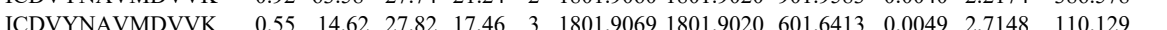
$\begin{array}{lllllllllllll}\text { ICDVYNAVMDVVK } & 0.97 & 64.72 * & 27.72 & 17.06 & 2 & 1801.9050 & 1801.9020 & 901.9583 & 0.0030 & 1.6630 & 299.067 & 213.2\end{array}$

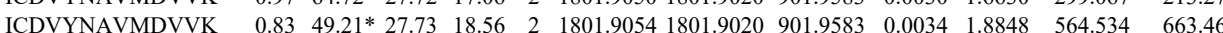
$\begin{array}{llllllllllllll}\text { ICDVYNAVMDVVK } & 0.95 & 23.66 & 27.74 & 16.98 & 3 & 1801.9063 & 1801.9020 & 601.6413 & 0.0043 & 2.3824 & 70.494 & 68.223\end{array}$ $\begin{array}{lllllllllllll}\text { APGEOTVPALNLNAFR } & 0.77 & 91.49 & 27.40 & \text { \#\#\# } & 2 & 1969.0518 & 1969.0503 & 985.5324 & 0.0015 & 0.7610 & 748.351 & 733.026\end{array}$

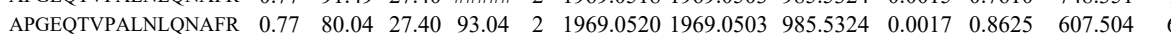
$\begin{array}{llllllllllll}\text { VTMINAPVASLPIIKEWLNSCDIK } & 0.97 & 38.44 & 23.86 & 17.83 & 3 & 3247.7392 & 3247.7384 & 1083.5867 & 0.0008 & 0.2461 & 252.740\end{array}$

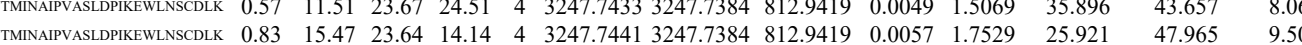
IIFMASK

SYCSNLVR

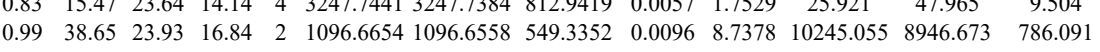
YCSNLVR $\begin{array}{lllllllllllllll}0.69 & 24.41 & 25.34 & 26.04 & 2 & 1130.5412 & 1130.5334 & 566.2740 & 0.0078 & 6.8871 & 18314.447 & 20047.951 & 2103.744\end{array}$

SYCSNLVR

SYCSNLVR

INFYCPGSALGR

INFYCPGSALGR

INFYCPGSALGR

INFYCPGSALGR

INFYCPGSALGR $\begin{array}{lllll} & 0\end{array}$ $\begin{array}{lllllllllllll}0.92 & 17.54 & 23.60 & 15.86 & 4 & 3247.7449 & 3247.7384 & 812.9419 & 0.0065 & 1.9989 & 24.785 & 30.136 & 9.646 \\ 0.6 & 24.38 & 2.528 & 25.57 & 2 & 130.5418 & 130.5334 & 5662740 & 0.008 & 7.4168 & 9834.066 & 9668.303 & 1118.797\end{array}$ $\begin{array}{llllllllllllll}0.69 & 24.38 & 25.28 & 25.57 & 2 & 1130.5418 & 1130.5334 & 566.2740 & 0.0084 & 7.4168 & 9834.066 & 9668.303 & 1118.797 & 2\end{array}$ $\begin{array}{llllllllllllll}0.98 & 36.63 & 25.08 & 29.45 & 2 & 1130.5436 & 1130.5334 & 566.2740 & 0.0102 & 9.0062 & 9064.300 & 9525.238 & 960.072 \\ 1.00 & 51.84 & 25.89 & 20.22 & 2 & 1486.7188 & 1486.7183 & 7443664 & 0.0005 & 0.3359 & 4785.812 & 5276590 & 34.744\end{array}$ $\begin{array}{llllllllllllll}1.00 & 51.84 & 25.89 & 20.22 & 2 & 1486.7188 & 1486.7183 & 744.3664 & 0.0005 & 0.3359 & 4785.812 & 5276.590 & 34.744 \\ 1.00 & 51.29 & 25.91 & 18.56 & 2 & 1486.7198 & 1486.7183 & 744.3644 & 0.0015 & 1.0076 & 3068.993 & 3201.830 & 10.096\end{array}$ $\begin{array}{lllllllllllll}1.00 & 51.29 & 25.91 & 18.56 & 2 & 1486.7198 & 1486.7183 & 744.3664 & 0.0015 & 1.0076 & 3068.993 & 3201.830 & 10.096\end{array}$ $\begin{array}{lllllllllllll}0.76 & 47.15 & 25.89 & 60.15 & 2 & 1486.7188 & 1486.7183 & 744.3664 & 0.0005 & 0.3359 & 671.849 & 688.800 & 0.000 \\ 1.00 & 53.57 & 25.90 & 16.89 & 2 & 14867196 & 14867183 & 744.3664 & 0.0013 & 0.8732 & 2210.093 & 2230.301 & 88.978\end{array}$ $\begin{array}{lllllllllllll}1.00 & 53.57 & 25.90 & 16.89 & 2 & 1486.7196 & 1486.7183 & 744.3664 & 0.0013 & 0.8732 & 2210.093 & 2230.301 & 88.978 \\ 1.00 & 40.52 & 25.94 & 16.96 & 2 & 1486.7192 & 1486.7183 & 744.3664 & 0.0009 & 0.6045 & 143.272 & 176.211 & 5.174\end{array}$ $\begin{array}{llllllllllll}1.00 & 40.52 & 25.94 & 16.96 & 2 & 1486.7192 & 4866.7183 & 744.3664 & 0.0009 & 0.6045 & 143.272 & 176.211 \\ 0.76 & 33.70 & 25.94 & 46.70 & 2 & 1486.7192 & 1486.7183 & 744.3664 & 0.0009 & 0.6045 & 136.500 & 112.253\end{array}$ $\begin{array}{lllllllllllllll}\text { AGAGPGGPPQKPAPSSQR } & 1.00 & 53.79 & 26.76 & 19.81 & 3 & 1947.0547 & 1947.0530 & 650.0249 & 0.0017 & 0.8718 & 77.381 & 64.120\end{array}$ $\begin{array}{llllllllllllll}\text { AGAGPGGPPQKPAPSSQR } & 1.00 & 32.91 & 26.75 & 45.91 & 4 & 1947.0561 & 1947.0530 & 487.7705 & 0.0031 & 1.5889 & 116.202 & 95.965\end{array}$

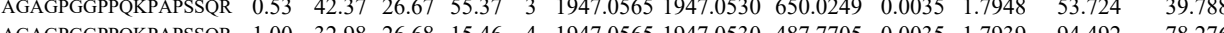

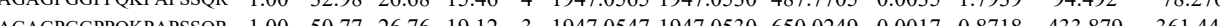
$\begin{array}{llllllllll} & \end{array}$ $\begin{array}{lllllllllllllll}\text { AGAGPGGPPQKPAPSSQR } & 1.00 & 34.83 & 26.75 & 20.45 & 4 & 1947.0561 & 1947.0530 & 487.7705 & 0.0231 & 1.5889 & 103.691 & 92.948\end{array}$ 
$\begin{array}{lllllllllllll}0.88 & 39.06 & 25.60 & 40.49 & 2 & 943.5988 & 943.5936 & 472.8041 & 0.0052 & 5.4991 & 780.006\end{array}$

$\begin{array}{lllllllllllll}\text { LLALLFEVLQQDK } & 0.55 & 17.36 & 18.86 & 30.36 & 3 & 1817.0923 & 1817.0906 & 606.7041 & 0.0017 & 0.9340 & 160.113\end{array}$ $\begin{array}{llllllllllll}\text { LLALLFEVLQQDK } & 0.55 & 34.23 & 18.86 & 47.23 & 3 & 1817.0923 & 1817.0906 & 606.7041 & 0.0017 & 0.9340 & 121.360 \\ & 0.53 & 15.95 & 18.63 & 28.95 & 3 & 1817.0932 & 1817.0906 & 606.7041 & 0.0026 & 1.4285 & 136.674\end{array}$ $\begin{array}{lllllllllllll}\text { SQVVIPILQWAIASTTLDHR } & 0.55 & 71.72 & 22.58 & 84.72 & 3 & 2391.3418 & 2391.3396 & 798.1205 & 0.0022 & 0.9188 & 28.519\end{array}$

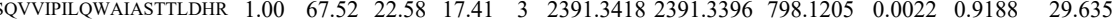

$\begin{array}{lllllllllllll} & \end{array}$ $\begin{array}{lllllllllllll}\text { SRPGTASSSGGSIAR } & 1.00 & 42.03 & 28.14 & 17.64 & 3 & 1533.7987 & 1533.7981 & 512.2733 & 0.0006 & 0.3904 & 8.799\end{array}$ SRPGTASSSGGSIAR SRPGTASSSGGSIAR SRPGTASSSGGSIAR SRPGTASSSGGSIAR SRPGTASSSGGSIAR

$\begin{array}{llllllllllll}1.00 & 38.35 & 28.16 & 16.85 & 3 & 1533.7993 & 1533.7981 & 512.2733 & 0.0012 & 0.7808 & 22.188\end{array}$ $\begin{array}{llllllllllll}0.90 & 29.17 & 28.29 & 28.14 & 2 & 1533.7982 & 1533.7981 & 767.9063 & 0.0001 & 0.0651 & 2.340\end{array}$ $\begin{array}{lllllllllll}0.99 & 38.76 & 28.12 & 22.57 & 2 & 1533.7984 & 1533.7981 & 767.9063 & 0.0003 & 0.1953 & 15.609 \\ 1.00 & 61.18 & 28.16 & 23.17 & 3 & 1533.7993 & 1533.7981 & 512.2733 & 0.0012 & 0.7808 & 33.187\end{array}$ $\begin{array}{lllllllllllll}1.00 & 61.18 & 28.16 & 23.17 & 3 & 1533.7993 & 1533.7981 & 512.2733 & 0.0012 & 0.7808 & 33.187 \\ 1.00 & 58.24 & 28.13 & 24.21 & 3 & 1533.7999 & 1533.7981 & 512.2733 & 0.0018 & 1.1712 & 20.706\end{array}$ TESTPITAVK

$\begin{array}{lllllllllll}1.00 & 45.55 & 28.16 & 24.34 & 3 & 1533.7993 & 1533.7981 & 512.2733 & 0.0012 & 0.7808 & 6.849\end{array}$ ILYLNeGEHLGTTEATEAFAM $\begin{array}{llllllllllllll}1.00 & 62.25 & 27.05 & 36.33 & 2 & 1333.7760 & 1333.7697 & 667.8921 & 0.0063 & 4.7163 & 5146.733 & 62 & \\ \end{array}$

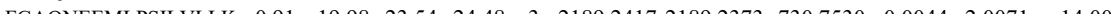

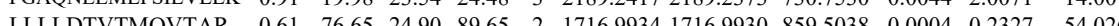

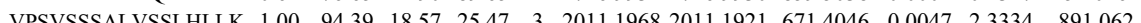
$\begin{array}{llllllllllll}\text { VPSVSSSALVSSLHLLK } & 1.00 & 82.37 & 18.51 & 21.43 & 3 & 2011.1986 & 2011.1921 & 671.4046 & 0.00065 & 3.2271 & 1682.956\end{array}$ $\begin{array}{lllllllllllll}\text { LLLLDTVTMQVTAR } & 1.00 & 80.25 & 24.94 & 18.49 & 2 & 1716.9936 & 1716.9930 & 859.5038 & 0.0006 & 0.3490 & 32.567\end{array}$ $\begin{array}{llllllllllll}\text { LLLLDTVTMQVTAR } & 1.00 & 82.30 & 24.73 & 24.36 & 2 & 1716.9938 & 1716.9930 & 859.5038 & 0.0008 & 0.4654 & 39.843\end{array}$ $\begin{array}{llllllllllll}\text { SIATLAITTLLK } & 1.00 & 83.25 & 16.81 & 35.72 & 2 & 1531.9778 & 1531.9792 & 766.9969 & -0.0014 & -0.9127 & 228.980\end{array}$ SIATLAITTLLK SIATLAITTLLK SIATLAITTLLK SIATLAITTLLK VVVVQAISALCQK VVVVQAISALCQK VVVVQAISALCQK VVVVQAISALCQK VVVVQAISALCQK VVVVQAISALCQK

VVVVQAISALCQK

VVVVQAISALCQK

VVVVQAISALCQK

VVVVQAISALCQK

VVVVQAISALCQK VVVVQAISALCQK VVVQAISALCQK VVVQAISALCQK VVVVAISALCQK VVVVQAISALCQK VVVVASALCQK SIATLAITTLLK $\begin{array}{llllllllllll}1.00 & 83.25 & 16.81 & 35.72 & 2 & 1531.9778 & 1531.9792 & 766.9969 & -0.0014 & -0.9127 & 228.980 \\ 1.00 & 30.03 & 16.90 & 17.37 & 3 & 1531.9801 & 1531.9792 & 511.6670 & 0.0009 & 0.5863 & 33.694\end{array}$ $\begin{array}{lllllllllllll}1.00 & 45.76 & 16.90 & 23.65 & 3 & 1531.9807 & 1531.9792 & 511.6670 & 0.0015 & 0.9772 & 67.441\end{array}$ $\begin{array}{lllllllllll}1.00 & 24.98 & 16.90 & 17.94 & 3 & 1531.9816 & 1531.9792 & 511.6670 & 0.0024 & 1.5635 & 53.487\end{array}$ $\begin{array}{lllllllllllll}0.53 & 24.87 & 14.62 & 37.87 & 3 & 1531.9819 & 1531.9792 & 511.6670 & 0.0027 & 1.7590 & 69.692\end{array}$ $\begin{array}{lllllllllllll}1.00 & 35.35 & 24.55 & 20.54 & 3 & 1690.9741 & 1690.9718 & 564.6645 & 0.0023 & 1.3577 & 19.510\end{array}$ $\begin{array}{llllllllllll}1.00 & 32.80 & 24.52 & 17.46 & 3 & 1690.9747 & 1690.9718 & 564.6645 & 0.0029 & 1.7119 & 33.027\end{array}$ $\begin{array}{llllllllllll}1.00 & 77.21 & 24.56 & 21.56 & 2 & 1690.9734 & 1690.9718 & 846.4932 & 0.0016 & 0.9451 & 277.160\end{array}$ $\begin{array}{lllllllllll}1.00 & 68.82 & 24.58 & 21.58 & 2 & 1690.9736 & 1690.9718 & 846.4932 & 0.0018 & 1.0632 & 231.758\end{array}$ $\begin{array}{lllllllllllll}0.53 & 36.31 & 24.41 & 49.31 & 3 & 1690.9750 & 1690.9718 & 564.6645 & 0.0032 & 1.8890 & 84.669\end{array}$ $\begin{array}{llllllllllll}1.00 & 37.04 & 24.41 & 17.07 & 3 & 1690.9753 & 1690.9718 & 564.6645 & 0.0035 & 2.0661 & 111.616\end{array}$ $\begin{array}{lllllllllll}1.00 & 42.34 & 24.71 & 18.30 & 3 & 1690.9729 & 1690.9718 & 564.6645 & 0.0011 & 0.6494 & 172.772\end{array}$ $\begin{array}{llllllllllll}1.00 & 71.64 & 24.71 & 21.14 & 2 & 1690.9730 & 1690.9718 & 846.4932 & 0.0012 & 0.7088 & 242.331\end{array}$ $\begin{array}{llllllllllll}1.00 & 83.64 & 24.56 & 24.64 & 2 & 1690.9732 & 1690.9718 & 846.4932 & 0.0014 & 0.8269 & 509.849\end{array}$ $\begin{array}{llllllllllll}0.55 & 37.76 & 24.55 & 50.76 & 3 & 1690.9741 & 1690.9718 & 564.6645 & 0.0023 & 1.3577 & 136.867\end{array}$

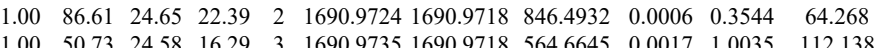
$\begin{array}{llllllllllll}1.00 & 50.73 & 24.58 & 16.29 & 3 & 1690.9735 & 1690.9718 & 564.6645 & 0.0017 & 1.0035 & 112.138 \\ 1.00 & 72.14 & 24.58 & 20.90 & 2 & 1690.9736 & 1690.9718 & 846.4932 & 0.0018 & 1.0632 & 46.927\end{array}$ $\begin{array}{lllllllllll}1.00 & 72.14 & 24.58 & 20.90 & 2 & 1690.9736 & 1690.9718 & 846.4932 & 0.0018 & 1.0632 & 46.927 \\ 1.00 & 31.33 & 24.55 & 15.49 & 3 & 1690.9741 & 1690.9718 & 564.6645 & 0.0023 & 1.3577 & 95.275\end{array}$ $\begin{array}{llllllllllll}1.00 & 31.33 & 24.55 & 15.49 & 3 & 1690.9741 & 1690.9718 & 564.6645 & 0.0023 & 1.3577 & 95.275 \\ 0.61 & 65.47 & 24.70 & 78.47 & 2 & 1690.9716 & 1690.9718 & 846.4932 & -0.0002 & -0.1181 & 61.186\end{array}$ $\begin{array}{llllllllllll}0.61 & 65.47 & 24.70 & 78.47 & 2 & 1690.9716 & 1690.9718 & 846.4932 & -0.0002 & -0.1181 & 61.186 \\ 1.00 & 70.15 & 24.56 & 20.29 & 2 & 1690.9734 & 1690.9718 & 846.4932 & 0.0016 & 0.9451 & 52.180\end{array}$ $\begin{array}{lllllllllll}1.00 & 70.15 & 24.56 & 20.29 & 2 & 1690.9734 & 1690.9718 & 846.4932 & 0.0016 & 0.9451 & 5.180 \\ 0.55 & 18.12 & 24.58 & 31.12 & 3 & 1690.9738 & 1690.9718 & 564.6645 & 0.0020 & 1.1806 & 147.073\end{array}$ $\begin{array}{lllllllllllll}0.53 & 13.17 & 4.52 & 26.17 & 3 & 1690.9747 & 1690.9718 & 564.6645 & 0.0029 & 1.7119 & 193.783\end{array}$ $\begin{array}{llllllllllll}0.99 & 32.77 & 22.90 & 16.29 & 2 & 1243.7760 & 1243.7751 & 622.8948 & 0.0009 & 0.7224 & 28.535\end{array}$ 


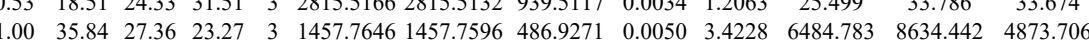

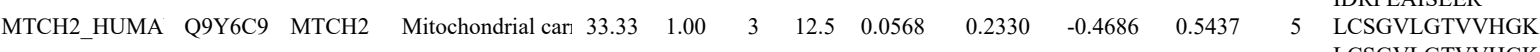
LCSGVLGTVVHG

$\begin{array}{llllllllllllll}1.00 & 62.45 & 27.87 & 19.43 & 3 & 1602.8863 & 1602.8830 & 535.3016 & 0.0033 & 2.0549 & 10981.592 & 10519.508 & 296.730\end{array}$ $\begin{array}{lllllllllllll}1.00 & 57.32 & 27.81 & 19.68 & 3 & 1602.8872 & 1602.8830 & 535.3016 & 0.0042 & 2.6153 & 10562.256 & 9252.565 & 735.936 \\ 0.94 & 35.59 & 27.49 & 27.59 & 2 & 1104.6406 & 1104.6413 & 553.3279 & -0.0007 & -0.6325 & 12611.668 & 14341.785 & 3552.641\end{array}$ $\begin{array}{lllllllllllll}1.00 & 52.23 & 22.86 & 65.23 & 4 & 1920.1061 & 1920.1067 & 481.0340 & -0.0006 & -0.3118 & 944.090 & 1253.400 & 219.735\end{array}$

VLFLIPK

VLFLIPK

$\begin{array}{lllllllllllll}0.78 & 16.16 & 20.45 & 23.48 & 2 & 1116.7542 & 1116.7514 & 559.3830 & 0.0028 & 2.5028 & 50404.808 & 53864.484 & 0\end{array}$ $\begin{array}{lllllllllllll}0.85 & 22.17 & 20.45 & 30.91 & 2 & 1116.7540 & 1116.7514 & 559.3830 & 0.0026 & 2.3240 & 47308.720 & 52607.312 & 0.000\end{array}$

VLFLIPK

VLFLIPK

VLFLIPK

VLFLIPK

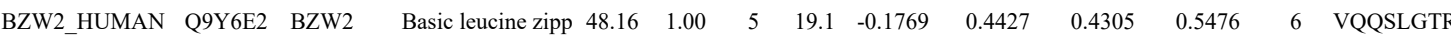

LLELFPVNR

LLELFPVNR

YADTLFDILVAGSMLAPGGTR YADTLFDILVAGSML
HQKPVLTGQR

HQKPVLTGQR
HQKPVLTGQR

HQKPVLTGQR

HQKPVLTGQR
HQKPVLTGQR

HQKPVLTGQR

HQKPVLTGQR
HQKPVLTGQR

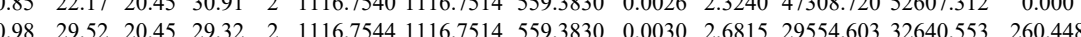

$\begin{array}{lllllllllllll}0.89 & 18.19 & 20.45 & 23.77 & 2 & 1116.7522 & 1116.7514 & 559.3830 & 0.0008 & 0.7151 & 13491.391 & 13278.778 & 350.087\end{array}$ $\begin{array}{llllllllllllll}0.84 & 15.86 & 20.45 & 20.24 & 2 & 1116.7534 & 1116.7514 & 559.3830 & 0.0020 & 1.7877 & 10470.865 & 12122.462 & 431.483\end{array}$ $\begin{array}{llllllllllllll}0.86 & 18.86 & 22.67 & 28.39 & 2 & 972.6510 & 972.6494 & 487.3320 & 0.0016 & 1.6416 & 1235.931 & 1330.622 & 163.294\end{array}$ $\begin{array}{lllllllllllll}1.00 & 34.77 & 22.67 & 29.17 & 2 & 972.6516 & 972.6494 & 487.3320 & 0.0022 & 2.2572 & 1311.452 & 1705.677 & 93.724 \\ 1.98 & 33.36 & 27.66 & 3.69 & 2 & 1031.5858 & 1031.5845 & 516.7995 & 0.0013 & 1.2577 & 91.546 & 103.160 & 24.962\end{array}$ $\begin{array}{lllllllllllll}0.98 & 33.36 & 27.66 & 34.69 & 2 & 1031.5858 & 1031.5845 & 516.7995 & 0.0013 & 1.2577 & 91.546 & 103.160 & 24.962 \\ 1.00 & 43.74 & 25.85 & 3.93 & 2 & 1243.744 & 1243.740 & 62.8778 & 0.004 & 0.321 & 11.52 .149 & 10292.182 & 0.000\end{array}$ $\begin{array}{lllllllllllll}1.00 & 43.74 & 25.85 & 32.93 & 2 & 1243.7414 & 1243.7410 & 622.8778 & 0.0004 & 0.3211 & 11462.149 & 10292.182 & 0.000\end{array}$ $\begin{array}{lllllllllllll}1.00 & 48.57 & 25.71 & 31.20 & 2 & 1243.7424 & 1243.7410 & 622.8778 & 0.0014 & 1.1238 & 9641.616 & 9477.913 & 0.000\end{array}$

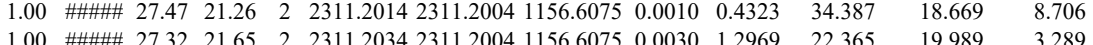

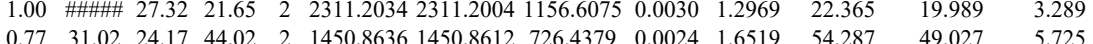
$\begin{array}{ccccccccccccc}0.77 & 31.02 & 24.17 & 44.02 & 2 & 1450.8636 & 1450.8612 & 726.4379 & 0.0024 & 1.6519 & 54.287 & 49.027 & 5.725 \\ 0.53 & 24.64 & 24.23 & 37.64 & 3 & 1450.8640 & 1450.8612 & 484.6277 & 0.0028 & 1.9259 & 127.816 & 143.917 & 10.584 \\ 0.82 & 13.98 & 23.93 & 16.92 & 3 & 1450.8646 & 1450.8612 & 484.6277 & 0.0034 & 2.3386 & 128.531 & 156.458 & 31.589\end{array}$ $\begin{array}{lllllllllllll}0.53 & 24.64 & 24.23 & 37.64 & 3 & 1450.8640 & 1450.8612 & 484.6277 & 0.0028 & 1.9259 & 127.816 & 143.917 & 10.584 \\ 0.82 & 13.98 & 23.93 & 16.92 & 3 & 1450.8646 & 1450.8612 & 484.6277 & 0.0034 & 23386 & 128.531 & 156.458 & 31.589 \\ 0.56 & 17.10 & 24.38 & 30.10 & 2 & 1450.8616 & 1450.8612 & 726.437 & 0.0004 & 0.2753 & 27.884 & 14.689 & 0.00\end{array}$ $\begin{array}{lllllllllllll}0.82 & 13.98 & 23.93 & 16.92 & 3 & 1450.8646 & 1450.8612 & 484.6277 & 0.0034 & 2.3386 & 128.531 & 156.458 & 31.589\end{array}$

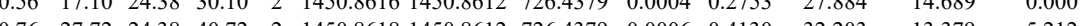

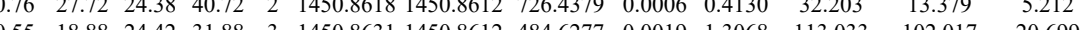
QKPVLTGQR

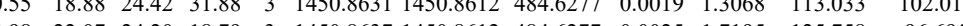

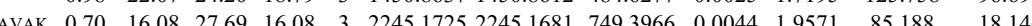

$\begin{array}{lllllllllllllllll}0.72 & 17.08 & 27.92 & 17.60 & 3 & 1662.8935 & 1662.8923 & 555.3047 & 0.0012 & 0.7203 & 316.016 & 363.525 & 200.086\end{array}$ $\begin{array}{lllllllllllllll} & \end{array}$ $\begin{array}{llllllllllllll} & \end{array}$

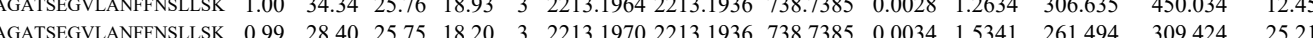

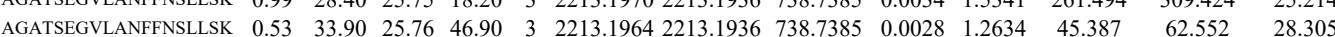

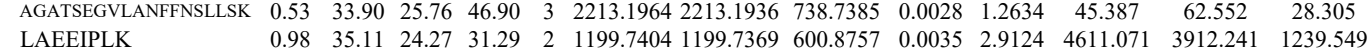
ILVPTQFVGAIIGK ILVPTQFVGAIIGK ILVPTQFVGAIIGK ILVPTQFVGAIIGK IIGHFFASQTAQR IIGHFFASQTAQR IIGHFFASQTAQR IIGHFFASQTAQR IIGHFFASQTAQR IAPAEGPDVSER IAPAEGPDVSER SGYQALPWVR SGYQALPWVR IEHFMPLLVQR IEHFMPLLVQR IEHFMPLLVQR

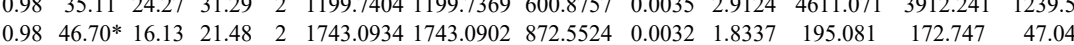

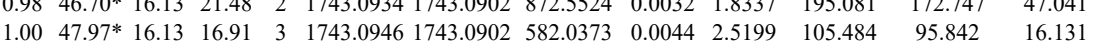
$\begin{array}{lllllllllllll}0.98 & 36.17 * & 16.13 & 16.33 & 3 & 1743.0946 & 1743.0902 & 582.0373 & 0.0044 & 2.5199 & 145.957 & 111.971 & 20.539\end{array}$ $\begin{array}{lllllllllllll}0.96 & 25.38 * 16.13 & 14.99 & 3 & 1743.0931 & 1743.0902 & 582.0373 & 0.0029 & 1.6608 & 106.950 & 114.322 & 24.090\end{array}$ $\begin{array}{llllllllllllll}0.55 & 27.24 & 28.26 & 40.24 & 3 & 1618.8721 & 1618.8702 & 540.6307 & 0.0019 & 1.1715 & 262.492 & 361.776 & 50.228 \\ 1 & 1.00 & 47.61 & 28.29 & 19.19 & 3 & 1618.827 & 1618.8702 & 540.6307 & 0.0025 & 1.5414 & 629.84 & 918397 & 98.109\end{array}$

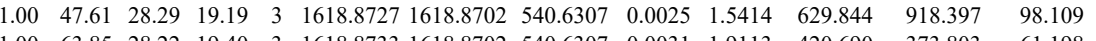
$\begin{array}{lllllllllllll}1.00 & 63.85 & 28.22 & 19.40 & 3 & 1618.8733 & 1618.8702 & 540.6307 & 0.0031 & 1.9113 & 420.690 & 373.803 & 61.198\end{array}$ $\begin{array}{llllllllllllll}1.00 & 60.12 & 28.27 & 20.46 & 3 & 1618.8724 & 1618.8702 & 540.6307 & 0.0022 & 1.3564 & 947.179 & 1108.005 & 175.408 \\ 100 & 39.96 & 28.29 & 16.89 & 3 & 1618.8727 & 1618.8702 & 540.6307 & 0.0025 & 1.5414 & 569.864 & 620.857 & 177.844\end{array}$ $\begin{array}{llllllllllllll}1.00 & 48.21 & 27.42 & 22.28 & 2 & 1383.7172 & 1383.7116 & 692.8631 & 0.0056 & 4.0412 & 16857.408 & 16193.583 & 1794.750\end{array}$ $\begin{array}{llllllllllllll}1.00 & 53.99 & 27.47 & 22.22 & 2 & 1383.7176 & 1383.7116 & 692.8631 & 0.0060 & 4.3298 & 9104.090 & 8758.672 & 799.293 & 103\end{array}$

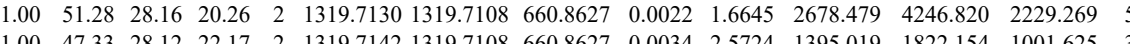
$\begin{array}{llllllllllllll}1.00 & 47.33 & 28.12 & 22.17 & 2 & 1319.7142 & 1319.7108 & 660.8627 & 0.0034 & 2.5724 & 1395.019 & 1822.154 & 1001.625 \\ 1.00 & 59.91 & 26.13 & 22.22 & 3 & 1525.8571 & 1525.8561 & 509.6260 & 0.0010 & 0.6541 & 1126.819 & 1886.318 & 216.123\end{array}$ $\begin{array}{llllllllllllll}1.00 & 59.91 & 26.13 & 22.22 & 3 & 1525.8571 & 1525.8561 & 509.6260 & 0.0010 & 0.6541 & 1126.819 & 1886.318 & 216.123 \\ 0.94 & 22.01 & 26.12 & 22.08 & 3 & 1525.8574 & 1525.8561 & 509.6260 & 0.0013 & 0.8503 & 1466.458 & 1601.690 & 186.128\end{array}$ $\begin{array}{lllllllllllll}0.94 & 22.01 & 26.12 & 22.08 & 3 & 1525.8574 & 1525.8561 & 509.6260 & 0.0013 & 0.8503 & 1466.458 & 1601.690 & 186.128 \\ 1.00 & 49.29 & 26.18 & 21.14 & 3 & 1525.8577 & 1525.8561 & 509.6260 & 0.0016 & 1.0465 & 898.956 & 1138.127 & 300.063\end{array}$ $\begin{array}{lllllllllllll}1.00 & 49.29 & 26.18 & 21.14 & 3 & 1525.8577 & 1525.8561 & 509.6260 & 0.0016 & 1.0465 & 898.956 & 138.67 .670 & 30.063 \\ 0.89 & 18.17 & 26.16 & 17.78 & 3 & 1525.8583 & 1525.8561 & 509.6260 & 0.0022 & 1.4390 & 919.670 & 1044.667 & 241.108\end{array}$ VAAEALNDGELQK

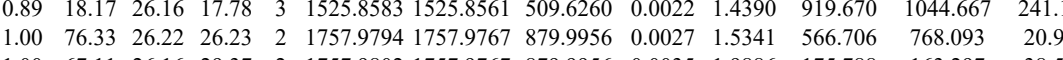
VAATEALNDGEQR VAAIEALNDGELQK AAIEALNDGELQK $\begin{array}{lllllllllllll}1.00 & 58.72 & 26.12 & 25.13 & 3 & 1757.9806 & 1757.9767 & 586.9995 & 0.0039 & 2.2146 & 420.765 & 351.090 & 146.661\end{array}$

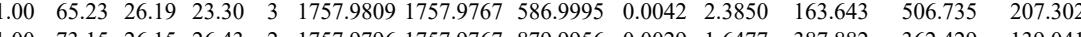
AIEINPDSAQPYK 
YTSSK

YTSSK

EIQTAVR

EIQTAVR
EIQTAVR

QVHPDTGISSK

QVHPDTGISSK

QVHPDTGISSK

QVHPDTGISSK

QVHPDTGISSK

QVHPDTGISSK

SAPAPK

SAPAPK

YTSSK

YTSSK

QVHPDTGISSK

QVHPDTGISSK

QVHPDTGISSK

QVHPDTGISSK

QVHPDTGISSK

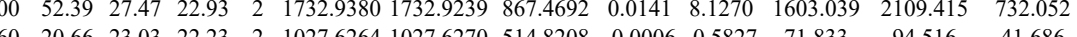
$\begin{array}{llllllllllll}0.61 .627 .6264 & 1027.6270 & 514.8208 & -0.0006 & -0.5827 & 71.833 & 94.516 & 41.686\end{array}$ $\begin{array}{llllllllllllll}1.00 & 68.81 & 25.45 & 32.63 & 2 & 1393.8086 & 1393.8060 & 697.9103 & 0.0026 & 1.8627 & 5584.215 & 6412.805 & 174.930 & 30.89\end{array}$ $\begin{array}{llllllllllllll}1.00 & 68.53 & 25.30 & 32.34 & 2 & 1393.8096 & 1393.8060 & 697.9103 & 0.0036 & 2.5791 & 6043.342 & 6634.657 & 247.480\end{array}$ $\begin{array}{llllllllllllll}1.00 & 7.43 & 25.60 & 33.98 & 2 & 1393.8072 & 1393.8060 & 697.9103 & 0.0012 & 0.8597 & 13489.098 & 13983.050 & 73.277\end{array}$ $\begin{array}{lllllllllllll}1.00 & 68.44 & 25.43 & 32.58 & 2 & 1393.8080 & 1393.8060 & 697.9103 & 0.0020 & 1.4328 & 12412.504 & 13499.145 & 72.321\end{array}$ $\begin{array}{lllllllllllll}1.00 & 42.22 & 27.47 & 55.22 & 4 & 2210.1265 & 2210.1220 & 553.5378 & 0.0045 & 2.0324 & 847.483 & 935.934 & 22.846\end{array}$ $\begin{array}{lllllllllllllll}0.91 & 37.72 & 24.55 & 39.24 & 2 & 1091.6704 & 1091.6616 & 546.8381 & 0.0088 & 8.0462 & 32769.569 & 36708.547 & 579.958\end{array}$

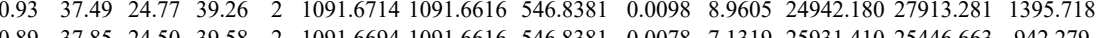

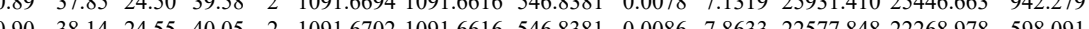

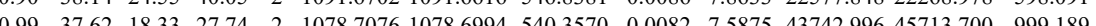
$\begin{array}{lllllllllllll}0.99 & 40.33 & 18.33 & 28.87 & 2 & 1078.7084 & 1078.6994 & 540.03570 & 0.0090 & 8.3278 & 33680.036 & 33181.853 & 849.159\end{array}$ $\begin{array}{lllllllllllllll}0.80 & 10.87 & 21.61 & 18.31 & 3 & 1297.8094 & 1297.8074 & 433.6097 & 0.0020 & 1.5375 & 12517.949 & 16156.255 & 1552.641\end{array}$ $\begin{array}{llllllllllllll}0.91 & 14.25 & 21.40 & 17.99 & 3 & 1297.8100 & 1297.8074 & 433.6097 & 0.0026 & 1.9987 & 9966.725 & 12475.984 & 1750.829\end{array}$

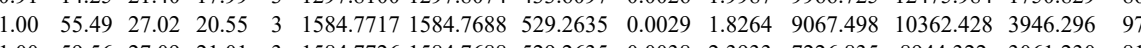

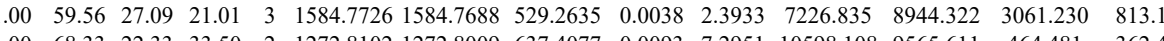
$\begin{array}{lllllllllllllll}1.00 & 68.33 & 22.33 & 33.50 & 2 & 1272.8102 & 1272.8009 & 637.4077 & 0.0093 & 7.2951 & 10598.108 & 9565.611 & 464.481\end{array}$ $\begin{array}{llllllllllllll}1.00 & 76.15 & 22.50 & 37.82 & 2 & 1272.8116 & 1272.8009 & 637.4077 & 0.0107 & 8.3933 & 7027.490 & 7228.568 & 728.166 & 36\end{array}$

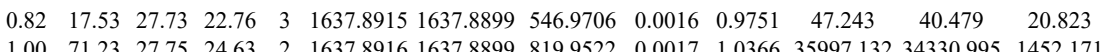
$\begin{array}{llllllllllllll}1.00 & 71.23 & 27.75 & 24.63 & 2 & 1637.8916 & 1637.8899 & 819.9522 & 0.0017 & 1.0366 & 35997.132 & 34330.995 & 1452.171 \\ 00 & 83.81 & 27.80 & 30.66 & 2 & 1637.8922 & 1637.8899 & 819.9522 & 0.0023 & 1.4025 & 24793.325 & 22973.316 & 650.618\end{array}$ $\begin{array}{llllllllllllll}0.55 & 35.18 & 23.52 & 48.18 & 3 & 1953.1204 & 1953.1179 & 652.0466 & 0.0025 & 1.2780 & 78.802 & 65.082 & 46.775 & 25.802\end{array}$

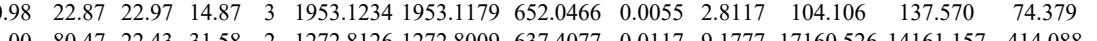

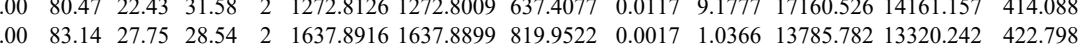
$\begin{array}{llllllllllllll}1.00 & 83.47 & 27.88 & 29.08 & 2 & 1637.8930 & 1637.8899 & 819.9522 & 0.0031 & 1.8904 & 31213.240 & 30960.971 & 1409.869 & 21.4\end{array}$ $\begin{array}{lllllllllllllll}1.00 & 83.14 & 27.80 & 28.79 & 2 & 1637.8922 & 1637.8899 & 819.9522 & 0.0023 & 1.4025 & 3086.256 & 2725.310 & 81.418 \\ 1.00 & 85.33 & 27.84 & 25.22 & 2 & 1637.8926 & 1637.8899 & 819.9522 & 0.0027 & 1.6464 & 3532.319 & 3813.251 & 206.226 & 0.0 \\ 0.94 & 19.26 & 23.44 & 16.31 & & 1953.18 & 1953.1179 & 652.0466 & 0.0270 & 0.512 & 8.381 & 5.459 & 3.536 & 3.7\end{array}$ $\begin{array}{llllllllllllll}1.00 & 85.33 & 27.84 & 25.22 & 2 & 1637.8926 & 1637.8899 & 819.9522 & 0.0027 & 1.6464 & 3532.319 & 3813.251 & 206.226 & 0.0 \\ 0.94 & 19.26 & 23.44 & 16.31 & 3 & 1953.1189 & 1953.1179 & 6520466 & 0.0010 & 0.5112 & 8.381 & 5.459 & 3.536 & 3.7\end{array}$ $\begin{array}{llllllllllllll}0.94 & 19.26 & 23.44 & 16.31 & 3 & 1953.1189 & 1953.1179 & 652.0466 & 0.0010 & 0.5112 & 8.381 & 5.459 & 3.536 & 3.725\end{array}$ $\begin{array}{lllllllllllllll}1.00 & 49.13 & 25.22 & 20.93 & 2 & 1401.6532 & 1401.6534 & 701.8340 & -0.0002 & -0.1425 & 5662.052 & 6296.177 & 4986.013 & 4599.931 & \text { No } \\ 1.00 & 6239 & 25.20 & 19.12 & 2 & 1401.6534 & 1401.6534 & 701.8340 & 0.0000 & 0.0000 & 5856.474 & 5964.136 & 4554.763 & 4082.898 & \text { No }\end{array}$ $\begin{array}{lllllllllllllll}1.00 & 62.39 & 25.20 & 19.12 & 2 & 1401.6534 & 1401.6534 & 701.8340 & 0.0000 & 0.0000 & 5856.474 & 5964.136 & 4554.763 & 4082.898 & \text { No } \\ 1.00 & 46.20 & 28.06 & 23.53 & 2 & 1703.9040 & 1703.9008 & 852.9577 & 0.0032 & 1.8758 & 164.327 & 132.751 & 95.540 & 47.344 & \text { Yes } \\ 0.99 & 28.95 & 25.17 & 22.44 & 2 & 57.5224 & 57.52 & 29.7680 & 0.000 & 1.163 & 2120.88 & 1949.166 & 15.952 & 53.348 & \text { Yes }\end{array}$

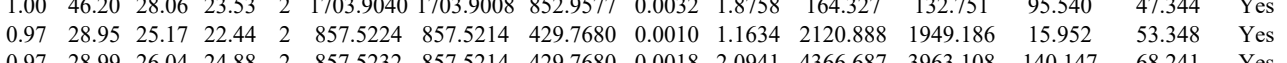
$\begin{array}{lllllllllllllllll}0.97 & 28.95 & 25.17 & 22.44 & 2 & 857.5224 & 857.5214 & 42.7578 & 0.0032 & 1.8758 & 164.327 & 132.751 & 95.540 & 47.344 & \text { Yes } \\ 0.97 & 28.99 & 26.04 & 24.88 & 2 & 857.5232 & 857.5214 & 429.7680 & 0.0018 & 2.0941 & 4366.687 & 3963.108 & 140.147 & 68.241 & \text { Yes }\end{array}$ $\begin{array}{llllllllllllllll}0.94 & 41.55 & 27.67 & 44.72 & 2 & 959.5518 & 959.5522 & 480.7834 & -0.0004 & -0.4160 & 3708.770 & 4206.275 & 6717.186 & 4156.094 & \text { Yes } \\ 0.95 & 39.97 & 27.52 & 42.43 & 2 & 959.5522 & 959.5522 & 480.7834 & 0.0000 & 0.0000 & 22.158 & 251.545 & 470.261 & 284.916 & \end{array}$

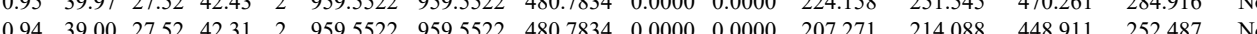
$\begin{array}{llllllllllllllll}1.00 & 55.26 & 28.21 & 39.59 & 2 & 1455.7926 & 1455.7925 & 728.9035 & 0.0001 & 0.0686 & 13036.303 & 13609.079 & 8422.371 & 1320.379 & \text { Yes }\end{array}$

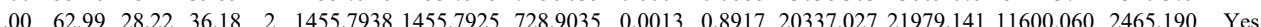
$\begin{array}{lllllllllllll}1.00 & 43.31 & 27.73 & 22.29 & 3 & 1455.7960 & 1455.7925 & 4862714 & 0.0035 & 2.3992 & \text { \#\#\#\#\#\# \#\#\#\#\# } 66684.994 & 18211.095 & \text { Yes }\end{array}$

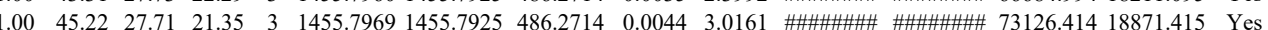
$\begin{array}{lllllllllllllll}0.97 & 2.04 & 26.04 & 23.85 & 2 & 857.5232 & 857.5214 & 429.7680 & 0.0018 & 2.0941 & 7206.081 & 6903203 & 112.176 & 17.992 & \text { Yes }\end{array}$

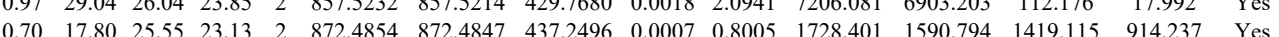
$\begin{array}{lllllllllllllllll}0.76 & 19.08 & 25.55 & 24.11 & 2 & 872.4858 & 872.4847 & 437.2496 & 0.0011 & 1.2579 & 2260.058 & 2213.417 & 1996.251 & 1220.250 & \text { Yes }\end{array}$ $\begin{array}{llllllllllllllll}0.84 & 42.03 & 27.67 & 45.19 & 2 & 959.5516 & 959.5522 & 480.7834 & -0.0006 & -0.6240 & 4293.670 & 4041.030 & 8190.780 & 5358.704 & \text { No }\end{array}$ $\begin{array}{llllllllllllllll}0.94 & 41.54 & 27.52 & 44.67 & 2 & 959.5526 & 959.5522 & 480.7834 & 0.0004 & 0.4160 & 398.833 & 379.049 & 859.896 & 583.272 & \text { No }\end{array}$ $\begin{array}{lllllllllllllll}0.93 & 38.46 & 27.52 & 42.19 & 2 & 959.5526 & 959.5522 & 480.7834 & 0.0004 & 0.4160 & 334.638 & 346.761 & 804.720 & 490.386 & \text { No }\end{array}$ $\begin{array}{ccccccccccccccc}0.93 & 38.46 & 2.52 & 42.19 & 2 & 959.5526 & 559.5522 & 480.7834 & 0.0004 & 0.4160 & 334.638 & 346.761 & 804.720 & 490.386 & \text { No } \\ 1.00 & 51.11 & 28.23 & 23.41 & 3 & 1455.7930 & 1455.7925 & 486.2714 & 0.0005 & 0.3427 & 79.223 & 82.206 & 40.593 & 12.923 & \text { Yes }\end{array}$ $\begin{array}{llllllllllllllll}1.00 & 39.57 & 28.31 & 15.74 & 3 & 1455.7933 & 1455.7925 & 486.2714 & 0.0008 & 0.5484 & 59.269 & 87.919 & 28.362 & 17.037 & \text { Yes }\end{array}$ $\begin{array}{lllllllllllllll}1.00 & 63.54 & 28.25 & 46.29 & 2 & 1455.7934 & 1455.7925 & 728.9035 & 0.0009 & 0.6174 & 10019.232 & 8532.306 & 5209.058 & 1400.409 & \text { Yes }\end{array}$ $\begin{array}{llllllllllllllll}1.00 & 61.61 & 28.22 & 36.41 & 2 & 1455.7938 & 1455.7925 & 728.9035 & 0.0013 & 0.8917 & 2646.172 & 2207.170 & 1898.657 & 278.635 & \text { Yes }\end{array}$ $\begin{array}{llllllllllllllll}1.00 & 52.03 & 27.83 & 23.98 & 3 & 1455.7954 & 1455.7925 & 486.2714 & 0.0029 & 1.9879 & 14642.091 & 15282.088 & 9970.785 & 2712.118 & \text { Yes }\end{array}$ $\begin{array}{llllllllllllllll}1.00 & 44.46 & 27.71 & 23.26 & 3 & 1455.7969 & 1455.7925 & 486.2714 & 0.0044 & 3.0161 & 78500.652 & 75901.038 & 49855.007 & 10952.471 & \text { Yes }\end{array}$ $\begin{array}{lllllllllllllllll}0.65 & 16.45 & 25.17 & 23.26 & 2 & 857.5224 & 857.5214 & 429.7680 & 0.0010 & 1.1634 & 1100.700 & 917.444 & 14.966 & 17.273 & \text { Yes }\end{array}$ $\begin{array}{rrlllllllllllll}0.69 & 17.30 & 25.17 & 29.45 & 2 & 857.5226 & 857.5214 & 429.7680 & 0.0012 & 1.3961 & 1409.038 & 1250.854 & 0.000 & 20.900 & \text { No }\end{array}$ $\begin{array}{lllllllllllllll}0.93 & 28.36 & 25.55 & 30.06 & 2 & 872.4850 & 872.4847 & 437.2496 & 0.0003 & 0.3431 & 1652.405 & 1624.943 & 1375.616 & 950.117 & \text { Yes }\end{array}$ $\begin{array}{lllllllllllllllll}0.76 & 18.95 & 25.31 & 23.96 & 2 & 872.4860 & 872.4847 & 437.2496 & 0.0013 & 1.4866 & 2778.759 & 2618.809 & 2262.344 & 1445.224 & \text { Yes } \\ 1.00 & 42.50 & 28.19 & 21.45 & 3 & 1455.7942 & 1455.7925 & 46.2714 & 0.017 & 1.1653 & 1882.616 & 1569.007 & 1009.99 & 193.354 & \text { Yes }\end{array}$ $\begin{array}{llllllllllllllll}1.00 & 42.50 & 28.19 & 21.45 & 3 & 1455.7942 & 1455.7925 & 486.2714 & 0.0017 & 1.1653 & 18802.616 & 15696.007 & 10099.919 & 1903.354 & \text { Yes }\end{array}$ $\begin{array}{lllllllllllllll}1.00 & 48.16 & 27.83 & 21.03 & 3 & 1455.7951 & 1455.7925 & 486.2714 & 0.0026 & 1.7823 & 15407.354 & 15488.612 & 11015.632 & 2187.964 & \text { Yes }\end{array}$ $\begin{array}{llllllllllllllll}1.00 & 40.46 & 28.22 & 21.05 & 3 & 1455.7939 & 1455.7925 & 486.2714 & 0.0014 & 0.9597 & 3449.719 & 3534.240 & 1998.181 & 1649.086 & \text { Yes } \\ 1.00 & 48.04 & 28.19 & 23.23 & 3 & 1455.7942 & 1455.7925 & 4862714 & 0.0017 & 1.1653 & 3257.737 & 2817.470 & 1832.288 & 1153.630 & \text { Yes }\end{array}$ $\begin{array}{lllllllllllllll}1.00 & 48.04 & 28.19 & 23.23 & 3 & 1455.7942 & 1455.7925 & 486.2714 & 0.0017 & 1.1653 & 3257.737 & 2817.470 & 1832.288 & 1153.630 & \text { Yes } \\ 1.00 & 43.77 & 27.83 & 21.78 & 3 & 1455.7951 & 1455.7925 & 486.2714 & 0.0026 & 1.7823 & 974.672 & 978.348 & 726.102 & 1108.108 & \text { No }\end{array}$ $\begin{array}{llllllllllllllll}1.00 & 43.77 & 27.83 & 21.78 & 3 & 1455.7951 & 1455.7925 & 486.2714 & 0.0026 & 1.7823 & 974.672 & 978.348 & 726.102 & 1108.108 & \text { No } \\ 0.99 & 29.98 & 27.73 & 16.86 & 3 & 1455.7960 & 1455.7925 & 4862714 & 0.0035 & 23992 & 624.638 & 665.210 & 506.765 & 1175.094 & \text { No }\end{array}$

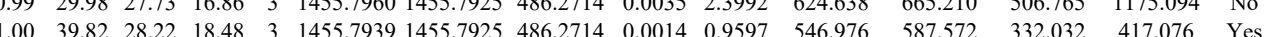

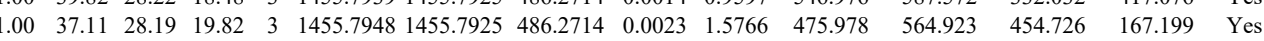
$\begin{array}{lllllllllllllll}1.00 & 40.60 & 28.29 & 28.54 & 2 & 1032.5980 & 1032.5960 & 517.3053 & 0.0020 & 1.9331 & 1848.496 & 1747.454 & 37.468 & 79.408 & \text { Yes }\end{array}$ 
LLLPGELAK

LLLPGELAK
LLLPGELAK $\begin{array}{lllllllllllllll}1.00 & 4.07 & 25.71 & 19.62 & 2 & 169.9542 & 1696.9401 & 849.4773 & 0.044 & 8.2992 & 28047.687 & 26436.194 & 8545.587 & 172.905\end{array}$

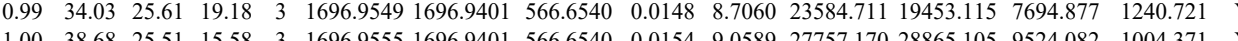

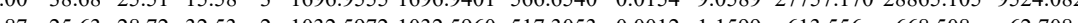

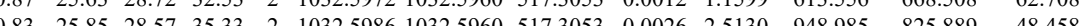
$\begin{array}{llllllllllllll}1.00 & 38.28 & 28.22 & 21.78 & 3 & 1455.7939 & 1455.7925 & 486.2714 & 0.0014 & 0.9597 & 482.480 & 438.850 & 297.998\end{array}$ $\begin{array}{llllllllllllll}1.00 & 41.60 & 28.20 & 21.78 & 3 & 1455.7945 & 1455.7925 & 486.2714 & 0.0020 & 1.3710 & 443.024 & 483.145 & 316.144\end{array}$ $\begin{array}{lllllllllllll}0.98 & 36.40 & 25.61 & 18.50 & 2 & 1696.9548 & 1696.9401 & 849.4773 & 0.0147 & 8.6523 & 17171.818 & 14505.700 & 3253.299\end{array}$ $\begin{array}{lllllllllllll}0.99 & 3.18 & 25.51 & 18.37 & 2 & 1696.9554 & 1696.9401 & 849.4773 & 0.0153 & 9.0055 & 11794.473 & 10374.988 & 3583.173\end{array}$ $\begin{array}{llllllllllllll}0.98 & 32.18 & 25.60 & 16.34 & 3 & 1696.9564 & 1696.9401 & 566.6540 & 0.0163 & 9.5884 & 18249.256 & 15256.180 & 6317.791\end{array}$ $\begin{array}{llllllllllllllll}0.99 & 43.46 & 19.59 & 41.48 & 2 & 1240.8014 & 1240.7998 & 621.4072 & 0.0016 & 1.2874 & 150.753 & 174.452 & 2.798\end{array}$ $\begin{array}{lllllllllllll}0.98 & 41.77 & 19.59 & 41.72 & 2 & 1240.8018 & 1240.7998 & 621.4072 & 0.0020 & 1.6092 & 294.204 & 257.431 & 6.257\end{array}$ $\begin{array}{lllllllllllll}1.00 & 40.07 & 28.29 & 21.66 & 3 & 1455.7924 & 1455.7925 & 486.2714 & -0.0001 & -0.0685 & 490.636 & 577.773 & 382.619\end{array}$ $\begin{array}{lllllllllllll}1.00 & 42.64 & 25.51 & 20.08 & 3 & 1696.9555 & 1696.9401 & 566.6540 & 0.0154 & 9.0589 & 11756.637 & 10798.342 & 3593.068\end{array}$

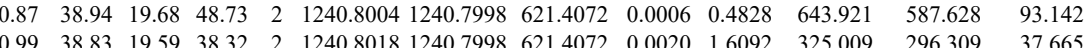
$\begin{array}{llllllllllllll}0.99 & 38.83 & 19.59 & 38.32 & 2 & 1240.8018 & 1240.7998 & 621.4072 & 0.0020 & 1.6092 & 325.009 & 296.309 & 37.665 \\ 0.72 & 36.28 & 19.59 & 48.57 & 2 & 1240.8032 & 1240.7998 & 621.4072 & 0.0034 & 2.7357 & 641.253 & 556.866 & 93.977\end{array}$ $\begin{array}{llllllllllllll}0.99 & 53.61 & 19.59 & 48.88 & 2 & 1240.8032 & 1240.7998 & 621.4072 & 0.0034 & 2.7357 & 297.016 & 308.982 & 38.817\end{array}$ $\begin{array}{llllllllllllll}0.97 & 41.77 & 19.59 & 39.61 & 2 & 1240.8036 & 1240.7998 & 621.4072 & 0.0038 & 3.0576 & 558.773 & 616.706 & 81.538\end{array}$ $\begin{array}{llllllllllllll}0.97 & 42.03 & 19.59 & 39.83 & 2 & 1240.8036 & 1240.7998 & 621.4072 & 0.0038 & 3.0576 & 832.442 & 747.810 & 96.637\end{array}$ $\begin{array}{lllllllllllll}0.97 & 46.02 & 19.59 & 39.96 & 2 & 1240.8046 & 1240.7998 & 621.4072 & 0.0048 & 3.8622 & 769.442 & 777.085 & 71.556 \\ 1.00 & 39.31 & 28.19 & 21.87 & 3 & 1455.7942 & 1455.7925 & 4862714 & 0.0017 & 1.1653 & 301.648 & 396.238 & 318.901\end{array}$ $\begin{array}{llllllllllllll}1.00 & 39.31 & 28.19 & 21.87 & 3 & 1455.7942 & 1455.7925 & 486.2714 & 0.0017 & 1.1653 & 301.648 & 396.238 & 318.901 \\ 1.00 & 44.46 & 28.20 & 21.78 & 3 & 1455.7945 & 1455.7925 & 486.2714 & 0.0020 & 1.3710 & 353.847 & 532.459 & 366.222\end{array}$ $\begin{array}{llllllllllllll}1.00 & 44.46 & 28.20 & 21.78 & 3 & 1455.7945 & 1455.7925 & 486.2714 & 0.0020 & 1.3710 & 353.847 & 532.459 & 366.222 \\ 0.99 & 41.85 & 19.68 & 39.66 & 2 & 1240.8010 & 1240.7998 & 621.4072 & 0.0012 & 0.9655 & 538.391 & 488.163 & 31.313 \\ 0.91 & 1.25 & 19.59 & 9.53 & 2 & 1240.8014 & 1240.7998 & 621.402 & 0.006 & 1.2874 & 0.672 & 98.248 & 26.034\end{array}$ $\begin{array}{llllllllllllll}0.99 & 41.85 & 19.68 & 39.66 & 2 & 1240.8010 & 1240.7998 & 621.4072 & 0.0012 & 0.9655 & 538.391 & 488.163 & 31.313 \\ 0.91 & 31.25 & 19.59 & 39.53 & 2 & 1240.8014 & 1240.7998 & 621.4072 & 0.0016 & 1.2874 & 1016.172 & 982.248 & 26.034 \\ 0.98 & 4.62 & 19.59 & 1.64 & 2 & 240.8018 & 1240.7998 & 621.4072 & 0.020 & 1.6092 & 363.953 & 341.62 & 31.698\end{array}$ $\begin{array}{lllllllllllll}0.91 & 31.25 & 19.59 & 39.53 & 2 & 1240.8014 & 1240.7998 & 621.4072 & 0.0016 & 1.2874 & 1016.172 & 982.248 & 26.034 \\ 0.98 & 41.62 & 19.59 & 41.64 & 2 & 1240.8018 & 1240.7998 & 621.4072 & 0.0020 & 1.6092 & 363.953 & 341.162 & 31.698\end{array}$ $\begin{array}{llllllllllll}0.98 & 41.62 & 19.59 & 41.64 & 2 & 1240.8018 & 1240.7998 & 621.4072 & 0.0020 & 1.6092 & 363.953 & 341.162 \\ 0.91 & 45.04 & 19.59 & 53.07 & 2 & 1240.8022 & 1240.7998 & 621.4072 & 0.0024 & 1.9311 & 1224.161 & 1227.174\end{array}$ $\begin{array}{llllllllllll}0.91 & 45.04 & 19.59 & 53.07 & 2 & 1240.8022 & 1240.7998 & 621.4072 & 0.0024 & 1.9311 & 1224.161 & 1227.174 \\ 0.98 & 42.52 & 19.59 & 42.55 & 2 & 1240.8026 & 1240.7998 & 621.4072 & 0.028 & 2.2529 & 1051.149 & 936.565\end{array}$ $\begin{array}{llllllllllll}0.98 & 42.52 & 19.59 & 42.55 & 2 & 1240.8026 & 1240.7998 & 621.4072 & 0.0028 & 2.2529 & 1051.149 & 936.565 \\ 0.99 & 55.12 & 19.59 & 50.23 & 2 & 1240.8032 & 1240.7998 & 621.4072 & 0.0034 & 2.7357 & 935.648 & 876.958\end{array}$ $\begin{array}{llllllllllll}0.96 & 41.55 & 19.59 & 40.24 & 2 & 1240.8036 & 1240.7998 & 621.4072 & 0.0038 & 3.0576 & 1360.189 & 1275.016\end{array}$ $\begin{array}{llllllllllllll}0.99 & 46.46 & 19.59 & 40.42 & 2 & 1240.8038 & 1240.7998 & 621.4072 & 0.0040 & 3.2185 & 963.309 & 885.960 \\ 0.96 & 57.44 & 19.59 & 56.75 & 2 & 1240.8042 & 1240.7998 & 621.4072 & 0.0044 & 3.5403 & 1019.763 & 901.085\end{array}$ $\begin{array}{llllllllllll}0.92 & 38.55 & 20.213 & 38.13 & 2 & 1240.7992 & 1240.7998 & 621.4072 & 0.0006 & 0.4828 & 241.092 & 267.118\end{array}$

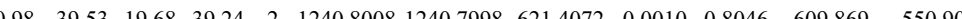
$\begin{array}{llllllllllll}0.99 & 38.10 & 19.59 & 37.56 & 2 & 1240.8016 & 1240.7998 & 621.4072 & 0.0018 & 1.4483 & 262.903 & 22.257\end{array}$

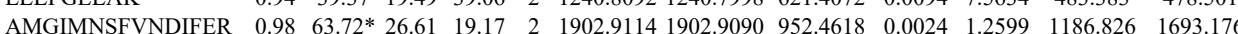
$\begin{array}{lllllllllllllll}\text { AMGIMNSFVNDIFER } & 0.98 & 67.80 * 26.67 & 22.28 & 2 & 1902.9116 & 1902.9090 & 952.4618 & 0.0026 & 1.3649 & 524.806 & 725.944\end{array}$ $\begin{array}{lllllllllllll}\text { AMGIMNSFVNDIFER } & 0.96 & 63.29 * & 26.40 & 17.30 & 2 & 1902.9088 & 1902.9090 & 952.4618 & -0.0002 & -0.1050 & 930.110 & 1037.606\end{array}$ $\begin{array}{llllllllllll}\text { AMGIMNSFVNDIFER } & 1.00 & 85.31 * 26.41 & 18.58 & 2 & 1902.9100 & 1902.9090 & 952.4618 & 0.0010 & 0.5250 & 198.199 & 281.925\end{array}$ $\begin{array}{lllllllllllll}\text { AMGIMNSFVNDIFER } & 0.99 & 67.62 * 26.49 & 17.50 & 2 & 1902.9102 & 1902.9090 & 952.4618 & 0.0012 & 0.6299 & 1952.322 & 2552.306\end{array}$ $\begin{array}{lllllllllllllll}\text { AMGIMNSFVNDIFER } & 0.99 & 69.98 * 26.49 & 22.24 & 2 & 1902.9102 & 1902.9090 & 952.4618 & 0.0012 & 0.6299 & 528.182 & 861.278 & 1\end{array}$

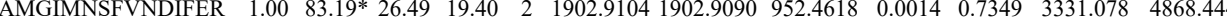
$\begin{array}{llllllllllllll} & \text { AMGIMNSFVNDIFER } & 1.00 & 87.97 * 26.52 & 19.36 & 2 & 1902.9110 & 1902.9090 & 952.4618 & 0.0020 & 1.0499 & 3669.627 & 6436.086 & 423.957\end{array}$ $\begin{array}{llllllllllllll}\text { AMGIMNSFVNDIFER } & 0.81 & 32.91 * & 26.66 & 16.66 & 3 & 1902.9118 & 1902.9090 & 635.3103 & 0.0028 & 1.4691 & 127.726 & 200.221 & 119.841\end{array}$ $\begin{array}{lllllllllllllll}\text { AMGIMNSFVNDIFER } & 1.00 & 81.48 & 26.00 & 21.05 & 2 & 1742.8130 & 1742.8120 & 872.4133 & 0.0010 & 0.5731 & 51.170 & 48.240 & 28.364\end{array}$ $\begin{array}{llllllllllllll}\text { AMGIMNSFVNDIFER } & 0.99 & 73.53 * & 26.39 & 18.19 & 2 & 1902.9094 & 1902.9090 & 952.4618 & 0.0004 & 0.2100 & 1391.704 & 1904.368 & 64.807\end{array}$

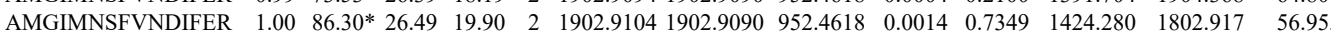
$\begin{array}{lllllllllllllll}\text { AMGIMNSFVNDIFER } & 1.00 & \text { \#\#\#\# } 27.36 & 22.64 & 2 & 1886.9168 & 1886.9141 & 944.4643 & 0.0027 & 1.4294 & 60.376 & 44.240 & 1.478\end{array}$ $\begin{array}{lllllllllllllll}\text { AMGIMNSFVNDIFER } & 1.00 & 82.09 & 27.36 & 25.13 & 2 & 1886.9174 & 1886.9141 & 944.4643 & 0.0033 & 1.7470 & 84.793 & 57.855 & 9.353\end{array}$

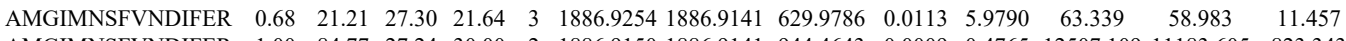
$\begin{array}{llllllllllllll}\text { AMGIMNSFVNDIFER } & 1.00 & 84.77 & 27.24 & 30.00 & 2 & 1886.9150 & 1886.9141 & 944.4643 & 0.0009 & 0.4765 & 12507.109 & 11183.605 & 823.343\end{array}$ $\begin{array}{lllllllllllllll}\text { AMGIMNSFVNDIFER } & 1.00 & 52.29 & 27.40 & 23.89 & 3 & 1886.9173 & 1886.9141 & 629.9786 & 0.0032 & 1.6932 & 573.548 & 1007.377 & 11.732 \\ \text { AMGIMNSFVNDIFER } & 0.99 & 30.82 & 27.30 & 17.25 & 3 & 1886.9179 & 1886.9141 & 629.9786 & 0.0038 & 2.0106 & 167.945 & 202.176 & 82.984\end{array}$

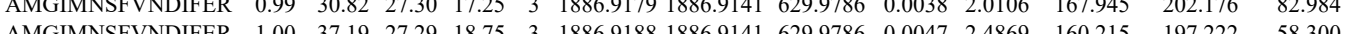

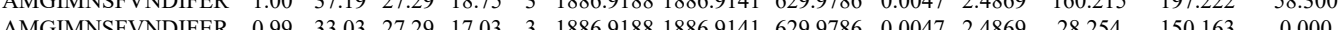
$\begin{array}{lllllllllllllll} & \text { AMGIMNSFVNDFER } & 0.9 & 33.03 & 27.29 & 17.03 & 3 & 1886.9188 & 1886.9141 & 629.9786 & 0.0047 & 2.4869 & 28.254 & 150.163 & 0.000\end{array}$ $\begin{array}{llllllllllllll}\text { AMGIMNSFVNDIFER } & 1.00 & 76.98 & 27.29 & 26.25 & 2 & 18866.9188 & 1886.9141 & 944.4643 & 0.0047 & 2.4882 & 15513.917 & 12484.841 & 373.202\end{array}$ $\begin{array}{lllllllllllllll}\text { AMGIMNSFVNDIFER } & 1.00 & 89.74 & 27.29 & 30.02 & 2 & 1886.9188 & 1886.9141 & 944.4643 & 0.0047 & 2.4882 & 10615.435 & 9570.665\end{array}$ 

$\begin{array}{lllllllllllll} & \text { AMG }\end{array}$

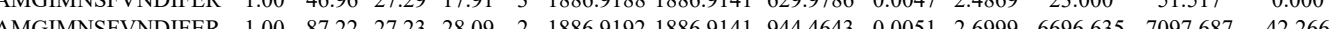
$\begin{array}{lllllllllllllll}\text { AMGIMNSFVNDIFER } & 1.00 & 72.91 & 27.23 & 24.25 & 2 & 1886.9192 & 1886.9141 & 944.4643 & 0.0051 & 2.6999 & 4797.722 & 3062.466 & 41.927\end{array}$

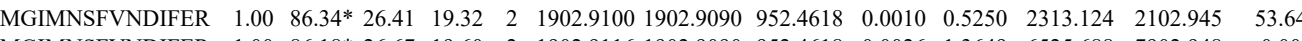

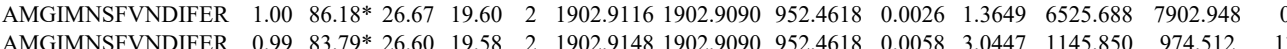
$\begin{array}{lllllllllllllll}\text { LLLPGELAK } & 0.99 & 40.81 & 19.59 & 38.34 & 2 & 1240.8014 & 1240.7998 & 621.4072 & 0.0016 & 1.2874 & 107.848 & 128.827 & 27.5\end{array}$ LLLPGELAK $\begin{array}{lllllllllllll}0.99 & 40.81 & 19.59 & 38.34 & 2 & 1240.8014 & 1240.7998 & 621.4072 & 0.0016 & 1.2874 & 107.848 & 128.827 \\ 0.98 & 41.43 & 19.59 & 41.51 & 2 & 1240.8028 & 1240.7998 & 621.4072 & 0.0030 & 2.4139 & 228.970 & 229.719\end{array}$ $\begin{array}{lllllllllllll}\text { AMGIMNSFVNDIFER } & 1.00 & 46.90 & 27.28 & 20.49 & 3 & 18866.9185 & 1886.9141 & 629.9786 & 0.0044 & 2.3281 & 165.570 & 95.339\end{array}$ $\begin{array}{llllllllllll}\text { AMGIMNSFVNDIFER } & 1.00 & 88.91 * 26.45 & 19.79 & 2 & 1902.9092 & 1902.9090 & 952.4618 & 0.0002 & 0.1050 & 695.122 & 714.343\end{array}$ $\begin{array}{llllllllllllll}\text { AMGIMNSFVNDIFER } & 1.00 & 84.83 * & 26.47 & 19.18 & 2 & 1902.9106 & 1902.9090 & 952.4618 & 0.0016 & 0.8399 & 514.654 & 455.378\end{array}$ $\begin{array}{llllllllllllll}\text { AMGIMNSFVNDIFER } & 1.00 & \text { \# } 27.38 & 28.05 & 2 & 1886.9170 & 1886.9141 & 944.4643 & 0.0029 & 1.5353 & 10187.629 & 7300.360\end{array}$

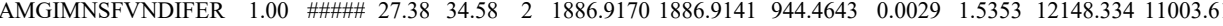
$\begin{array}{lllllllllllllll} & \text { AMGIMNSFVNDIFER } & 1.00 & 53.92 & 27.30 & 28.05 & 3 & 1886.9182 & 1886.9141 & 629.9786 & 0.0041 & 2.1694 & 197.574 & 191.628\end{array}$ AMGIMNSFVNDIFER

$\begin{array}{llllllllllll}1.00 & 62.56 & 27.28 & 29.86 & 3 & 1886.9185 & 1886.9141 & 629.9786 & 0.0044 & 2.3281 & 139.132 & 155.072\end{array}$ AMGIMNSFVNDIFE $\begin{array}{lllllllllllll}1.00 & 89.96 & 27.40 & 34.32 & 2 & 1886.9166 & 1886.9141 & 944.4643 & 0.0025 & 1.3235 & 3100.832 & 3442.501 & 85.1 \\ 1.00 & 82.29 & 27.36 & 27.80 & 2 & 1886.9168 & 1886.9141 & 944.4643 & 0.0027 & 1.4294 & 8083.458 & 5952.909 & 366.5\end{array}$

$\begin{array}{cccccccccccc}1.00 & 82.29 & 27.36 & 27.80 & 2 & 1886.9168 & 1886.9141 & 944.4643 & 0.0027 & 1.4294 & 8083.458 & 5952.909 \\ 1.00 & 51.75 & 27.28 & 26.93 & 3 & 1886.9185 & 1886.9141 & 629.9786 & 0.0044 & 2.3281 & 92.510 & 109.809\end{array}$

LLLPGELAK

$\begin{array}{ccccccccccccc}1.00 & 46.67 & 27.28 & 22.88 & 3 & 1886.9185 & 1886.9141 & 629.9786 & 0.0044 & 2.3281 & 76.503 & 86.302 & 47.182 \\ 0.94 & 42.12 & 19.49 & 39.94 & 2 & 1240.8058 & 1240.7998 & 621.4072 & 0.0060 & 4.8277 & 21749.294 & 16313.205 & 1145.031 \\ 0.57 & 42.06 & 19.49 & 52.41 & 2 & 1240.8092 & 1240.7998 & 621.4072 & 0.0094 & 7.5634 & 17048.967 & 1695.670 & 388.187\end{array}$ LLLPGELAK $\begin{array}{lllllllllllllll} & 0.048\end{array}$ AMGIMNSFVNDIFER QVHPDTGISSK

QVHPDTGISSK $\begin{array}{llllllllllll}1.57 & 42.06 & 19.4 & 52.41 & 2 & 1240.8092 & 1240.7998 & 621.472 & 0.004 & 7.5634 & 17048.967 & 1654.670\end{array}$

QVHPDTGISSK

QVHPDTGISSK

QVHPDTGISSK

QVHPDTGISSK

QVHPDTGISSK

QVHPDTGISSK

QVHPDTGISSK

QVHPDTGISSK

QVHPDTGISSK

QVHPDTGISSK

QVHPDTGISSK

QVHPDTGISSK

QVHPDTGISSK

QVHPDTGISS

QVHPDTGISSK

QVHPDTGISSK

QVHPDTGISSK

EIQTAVR

EIQTAVR

QVHPDTGISSK

QVHPDTGISSK

EIQTAVR

EIQTAVR

QVHPDTGISSK

QVHPDTGISSK

QVIDPTGISSK

QVHPT $\begin{array}{llllllllllllll}1.00 & 39.95 & 28.22 & 21.75 & 3 & 1455.7939 & 1455.7925 & 486.2714 & 0.0014 & 0.9597 & 313.331 & 307.223\end{array}$ $\begin{array}{lllllllllllll}.00 & 46.34 & 28.22 & 24.30 & 3 & 1455.7939 & 1455.7925 & 486.2714 & 0.0014 & 0.9597 & 179.924 & 182.38\end{array}$

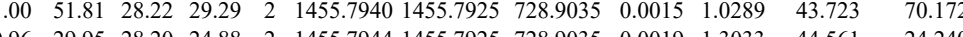

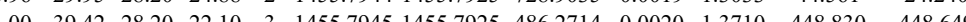
$\begin{array}{llllllllllll}1.00 & 32.78 & 28.20 & 19.87 & 3 & 1455.7945 & 1455.7925 & 486.2714 & 0.0020 & 1.3710 & 263.166 & 201.551\end{array}$ $\begin{array}{llllllllllllll}1.00 & 62.55 & 28.19 & 35.58 & 2 & 1455.7946 & 1455.7925 & 728.9035 & 0.0021 & 1.4405 & 128.746 & 94.779\end{array}$ $\begin{array}{lllllllllllll}1.00 & 53.10 & 28.22 & 36.54 & 2 & 1455.7936 & 1455.7925 & 728.9035 & 0.0011 & 0.7546 & 52.199 & 66.772\end{array}$ $\begin{array}{llllllllllllll}1.00 & 63.96 & 28.22 & 29.06 & 2 & 1455.7938 & 1455.7925 & 728.9035 & 0.0013 & 0.8917 & 102.050 & 88.208\end{array}$ $\begin{array}{lllllllllllllll}100 & 39.32 & 28.22 & 23.16 & 3 & 1455.7939 & 1455.7925 & 486.2714 & 0.0014 & 0.9597 & 531.110 & 419.067\end{array}$ $\begin{array}{lllllllllllll}1.00 & 49.92 & 28.19 & 23.26 & 3 & 1455.7942 & 1455.7925 & 486.2714 & 0.0017 & 1.1653 & 366.987 & 370.839\end{array}$ $\begin{array}{llllllllllll}1.00 & 41.80 & 28.22 & 23.50 & 3 & 1455.7939 & 1455.7925 & 486.2714 & 0.0014 & 0.9597 & 464.656 & 365.267\end{array}$ $\begin{array}{llllllllllllll}1.00 & 56.46 & 28.22 & 32.52 & 2 & 1455.7940 & 1455.7925 & 728.9035 & 0.0015 & 1.0289 & 140.112 & 124.168\end{array}$ $\begin{array}{lllllllllllll}1.00 & 37.78 & 28.19 & 20.01 & 3 & 1455.7942 & 1455.7925 & 486.2714 & 0.0017 & 1.1653 & 643.860 & 636.504\end{array}$ $\begin{array}{lllllllllllll}1.00 & 59.18 & 27.83 & 31.90 & 2 & 1455.7950 & 1455.7925 & 728.9035 & 0.0025 & 1.7149 & 114.404 & 133.922\end{array}$ $\begin{array}{llllllllllll}.00 & 49.92 & 28.31 & 32.85 & 2 & 1455.7932 & 1455.7925 & 728.9035 & 0.0007 & 0.4802 & 121.789 & 15 \\ \end{array}$ $\begin{array}{llllllllllllll}1.00 & 56.13 & 28.22 & 31.79 & 2 & 1455.7938 & 1455.7925 & 728.9035 & 0.0013 & 0.8917 & 187.435 & 148.465\end{array}$ $\begin{array}{llllllllllllll}0.99 & 31.43 & 28.22 & 17.75 & 3 & 1455.7939 & 1455.7925 & 486.2714 & 0.0014 & 0.9597 & 371.746 & 362.458\end{array}$ $\begin{array}{llllllllllllll}1.00 & 44.45 & 28.20 & 18.98 & 3 & 1455.7945 & 1455.7925 & 486.2714 & 0.0020 & 1.3710 & 544.681 & 572.459\end{array}$ $\begin{array}{llllllllllllll}0.85 & 24.37 & 27.45 & 34.70 & 2 & 959.5528 & 959.5522 & 480.7834 & 0.0006 & 0.6240 & 139.015 & 156.111\end{array}$ $\begin{array}{lllllllllllll}0.97 & 35.99 & 27.45 & 39.09 & 2 & 959.5534 & 959.5522 & 480.7834 & 0.0012 & 1.2480 & 195.649 & 168.451\end{array}$ $\begin{array}{llllllllllllll}1.00 & 45.04 & 28.22 & 20.34 & 3 & 1455.7939 & 1455.7925 & 486.2714 & 0.0014 & 0.9597 & 606.082 & 571.731 \\ 1.00 & 52.69 & 28.20 & 33.47 & 2 & 1455.7944 & 1455.7925 & 728.9035 & 0.0019 & 1.3033 & 175.183 & 175.699 & 13\end{array}$ $\begin{array}{lllllllllllll}1.00 & 52.69 & 28.20 & 33.47 & 2 & 1455.7944 & 1455.7925 & 728.9035 & 0.0019 & 1.3033 & 175.183 & 175.699 \\ 1.00 & 34.69 & 28.19 & 18.16 & 3 & 1455.7948 & 1455.7925 & 486.2714 & 0.0023 & 1.5766 & 299.481 & 362.770\end{array}$ $\begin{array}{lllllllllllll}1.00 & 34.69 & 28.19 & 18.16 & 3 & 1455.7948 & 1455.7925 & 486.2714 & 0.0023 & 1.5766 & 299.481 & 362.770 \\ 0.96 & 33.42 & 27.52 & 35.00 & 2 & 959.5524 & 959.5522 & 480.7834 & 0.0002 & 0.2080 & 192.697 & 172.610\end{array}$ $\begin{array}{lllllllllllll}0.96 & 33.42 & 27.52 & 35.00 & 2 & 959.5524 & 959.5522 & 480.7834 & 0.0002 & 0.2080 & 192.697 & 172.610 \\ 0.89 & 28.06 & 27.52 & 31.31 & 2 & 959.5526 & 959.5522 & 480.7834 & 0.0004 & 0.4160 & 205.821 & 205.285\end{array}$ $\begin{array}{lllllllllllll}0.89 & 28.06 & 27.52 & 31.31 & 2 & 959.5526 & 959.5522 & 480.7834 & 0.0004 & 0.4160 & 205.821 & 205.285 \\ 1.00 & 36.04 & 28.19 & 20.62 & 3 & 1455.7942 & 1455.7925 & 486.2714 & 0.0017 & 1.1653 & 357.626 & 385.198\end{array}$ $\begin{array}{llllllllllllll}1.00 & 36.04 & 28.19 & 20.62 & 3 & 1455.7942 & 1455.7925 & 486.2714 & 0.0017 & 1.1653 & 357.626 & 385.198\end{array}$ $\begin{array}{lllllllllllll}1.00 & 53.05 & 28.20 & 34.71 & 2 & 1455.7942 & 1455.7925 & 728.9035 & 0.0017 & 1.1661 & 109.211 & 124.013\end{array}$

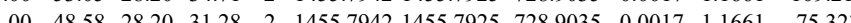


EIQTAVR

LLLPGELAK

QVHPDTGISSK
QVHPDTGISSK

QVHPDTGISSK
QVHPDTGISSK

EIQTAVR
EIQTAVR

LLLPGELAK

LLLPGELAK

LLLPGELAK

QVHPDTGISSK

QVHPDTGISSK

EIQTAVR

EIQTAVR

LLLPGELAK

LLLPGELAK

QVHPDTGISSK

EIQTAVR

EIQTAVR

LLLPGELAK

LLLPGELAK
QVHPDTGISSK

QVHPDTGISSK

QVHPDTGIST

LLLPGELAK

LLLPGELAK $\begin{array}{llllllllllll}0.81 & 24.69 & 27.45 & 36.23 & 2 & 959.5528 & 959.5522 & 480.7834 & 0.0006 & 0.6240 & 150.258 & 197.9\end{array}$ $\begin{array}{lllllllllllll}0.81 & 24.69 & 27.45 & 36.23 & 2 & 95.5528 & 959.5522 & 480.7834 & 0.0006 & 0.6240 & 150.258\end{array}$ $\begin{array}{llllllllllll}0.90 & 43.91 & 27.83 & 32.12 & 2 & 1455.7950 & 1455.7925 & 728.9035 & 0.0025 & 1.7149 & 90.339 \\ 1.96 & 30.23 & 27.73 & 17.56 & 3 & 1455.7958 & 1455.7925 & 728.9035 & 0.0033 & 2.2637 & 77.783\end{array}$ $\begin{array}{lllllllllll}0.99 & 30.23 & 27.73 & 17.56 & 3 & 145.7956 & 145.7925 & 728.9035 & 0.0033 & 2.2637 & 77.783 \\ 0.90 & 37.83 & 27.52 & 43.38 & 2 & 959.5522 & 959.5522 & 486.2714 & 0.0041 & 2.8105 & 229.799\end{array}$ $\begin{array}{lllllllllllll}0.90 & 37.83 & 27.52 & 43.38 & 2 & 959.5522 & 959.5522 & 480.7834 & 0.0000 & 0.0000 & 109.298\end{array}$ $\begin{array}{lllllllllllll}0.77 & 28.38 & 27.52 & 38.04 & 2 & 959.5526 & 959.5522 & 480.7834 & 0.0004 & 0.4160 & 111.890\end{array}$ $\begin{array}{lllllllllllll}0.55 & 26.96 & 28.19 & 39.96 & 3 & 1455.7948 & 1455.7925 & 486.2714 & 0.0023 & 1.5766 & 312.898 \\ 0.99 & 29.30 & 28.19 & 18.05 & 3 & 1455.7948 & 1455.7925 & 486.2714 & 0.0023 & 1.5766 & 250.814\end{array}$ $\begin{array}{lllllllllll}0.99 & 29.30 & 28.19 & 18.05 & 3 & 1455.7948 & 455.7925 & 486.2714 & 0.0023 & 1.5766 & 250.814 \\ 0.66 & 20.92 & 27.83 & 25.13 & 2 & 1455.7954 & 1455.7925 & 728.9035 & 0.0029 & 1.9893 & 45.626\end{array}$ $\begin{array}{llllllllllll}0.82 & 28.01 & 27.69 & 24.35 & 2 & 1455.7964 & 1455.7925 & 728.9035 & 0.0039 & 2.6752 & 76.164\end{array}$

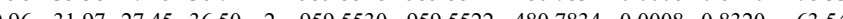
$\begin{array}{lllllllllllll}0.78 & 24.49 & 27.52 & 31.00 & 2 & 959.5524 & 959.5522 & 480.7834 & 0.0002 & 0.2080 & 168.336\end{array}$ $\begin{array}{lllllllllllll}0.785 & 32.411 & 27.45 & 37.34 & 2 & 959.5528 & 959.5522 & 480.7834 & 0.0006 & 0.6240 & 154.353\end{array}$ $\begin{array}{llllllllllll}0.95 & 30.14 & 28.22 & 18.46 & 3 & 1455.7918 & 1455.7925 & 4862714 & 0.0007 & 0.4798 & 609.094\end{array}$ $\begin{array}{llllllllllll}0.95 & 29.02 & 28.18 & 22.73 & 2 & 1455.7948 & 1455.7925 & 728.9035 & 0.0023 & 1.5777 & 159.625\end{array}$ $\begin{array}{llllllllllll}0.79 & 27.14 & 27.76 & 23.15 & 2 & 1455.7966 & 1455.7925 & 728.9035 & 0.0041 & 2.8124 & 131.500\end{array}$ $\begin{array}{lllllllllllll}0.78 & 24.55 & 27.52 & 29.65 & 2 & 959.5522 & 959.5522 & 480.7834 & 0.0000 & 0.0000 & 121.165\end{array}$ $\begin{array}{lllllllllllll}0.55 & 20.09 & 27.52 & 26.11 & 2 & 959.5526 & 959.5522 & 480.7834 & 0.0004 & 0.4160 & 161.290\end{array}$ $\begin{array}{llllllllllll}0.98 & 31.37 & 28.21 & 20.95 & 3 & 1455.7927 & 1455.7925 & 486.2714 & 0.0002 & 0.1371 & 811.317 \\ 0.98 & 29.86 & 28.21 & 20.57 & 3 & 1455.7927 & 1455.7925 & 4862714 & 0.0002 & 0.1371 & 528.286\end{array}$ $\begin{array}{lllllllllllll}0.98 & 29.86 & 28.21 & 20.57 & 3 & 1455.7927 & 1455.7925 & 486.2714 & 0.0002 & 0.1371 & 528.286 \\ 0.94 & 30.12 & 27.83 & 29.35 & 2 & 1455.7952 & 1455.7925 & 728.9035 & 0.0027 & 1.8521 & 229.059 \\ 0.92 & 32.06 & 27.6 & 25.63 & 2 & 1455.7964 & 1455.7925 & 728.9035 & 0.003 & 2.6752 & 173.820\end{array}$ $\begin{array}{lllllllllllll}0.92 & 32.06 & 27.69 & 25.63 & 2 & 1455.7964 & 1455.7925 & 728.9035 & 0.0039 & 2.6752 & 173.820\end{array}$ $\begin{array}{llllllllllll}1.00 & 72.62 & 27.30 & 20.37 & 2 & 1886.9182 & 1886.9141 & 944.4643 & 0.0041 & 2.1705 & 31.525\end{array}$ $\begin{array}{lllllllllllll}0.71 & 19.94 & 27.45 & 27.09 & 2 & 959.5528 & 959.5522 & 480.7834 & 0.0006 & 0.6240 & 44.615\end{array}$ $\begin{array}{llllllllllllll}0.96 & 30.24 & 27.45 & 31.93 & 2 & 959.5532 & 959.5522 & 480.7834 & 0.0010 & 1.0400 & 63.013 \\ 1.00 & 48.72 & 28.31 & 16.78 & 3 & 1455.7933 & 1455.7925 & 4862714 & 0.0008 & 0.5484 & 145.376\end{array}$ $\begin{array}{llllllllllll}1.00 & 61.95 & 28.22 & 38.99 & 2 & 1455.7936 & 1455.7925 & 728.9035 & 0.0011 & 0.7546 & 17.368\end{array}$ $\begin{array}{llllllllllll}0.99 & 30.68 & 28.19 & 19.60 & 3 & 1455.7942 & 1455.7925 & 486.2714 & 0.0017 & 1.1653 & 89.812\end{array}$ $\begin{array}{lllllllllllll}0.95 & 29.49 & 28.19 & 28.21 & 2 & 1455.7946 & 1455.7925 & 728.9035 & 0.0021 & 1.4405 & 18.732\end{array}$ $\begin{array}{llllllllllllll}0.81 & 29.46 & 27.52 & 38.00 & 2 & 959.5524 & 959.5522 & 480.7834 & 0.0002 & 0.2080 & 53.944\end{array}$ $\begin{array}{lllllllllllll}0.80 & 27.14 & 27.52 & 36.22 & 2 & 959.5526 & 959.5522 & 480.7834 & 0.0004 & 0.4160 & 57.264\end{array}$ $\begin{array}{llllllllllll}1.00 & 44.86 & 1.68 & 39.09 & 2 & 1240.8004 & 1240.7998 & 621.4072 & 0.0006 & 0.4828 & 299.180\end{array}$ $\begin{array}{lllllllllllll}0.99 & 43.87 & 19.68 & 43.06 & 2 & 1240.8010 & 1240.7998 & 621.4072 & 0.0012 & 0.9655 & 307.630\end{array}$ $\begin{array}{llllllllllll}0.77 & 23.47 & 28.27 & 15.80 & 3 & 1455.7921 & 1455.7925 & 486.274 & -0.0004 & -0.2742 & 41.454\end{array}$ $\begin{array}{lllllllllll}1.00 & 44.31 & 28.31 & 19.87 & 3 & 1455.7933 & 455.7925 & 486.2714 & 0.0008 & 0.5484 & 47.853 \\ 0.66 & 23.94 & 27.52 & 36.13 & 2 & 959.5526 & 959.5522 & 480.7834 & 0.0004 & 0.4160 & 63.989\end{array}$ $\begin{array}{llllllllllll}0.95 & 35.67 & 27.52 & 37.48 & 2 & 959.5526 & 959.5522 & 480.7834 & 0.0004 & 0.4160 & 73.631\end{array}$ $\begin{array}{lllllllllllll}0.99 & 42.73 & 19.68 & 40.82 & 2 & 1240.8008 & 1240.7998 & 621.4072 & 0.0010 & 0.8046 & 388.385\end{array}$ $\begin{array}{lllllllllllll}0.99 & 43.82 & 19.59 & 41.53 & 2 & 1240.8016 & 1240.7998 & 621.4072 & 0.0018 & 1.4483 & 601.15\end{array}$ $\begin{array}{lllllllllllll}0.98 & 27.22 & 28.19 & 15.90 & 3 & 1455.7942 & 1455.7925 & 486.2714 & 0.0017 & 1.1653 & 75.061 \\ 1.00 & 45.78 & 27.83 & 29.48 & 2 & 1455.7952 & 1455.7925 & 728.9035 & 0.0027 & 1.8521 & 17.700\end{array}$ $\begin{array}{llllllllllll}0.97 & 39.52 & 27.71 & 37.08 & 2 & 1455.7962 & 1455.7925 & 728.9035 & 0.0037 & 2.5381 & 24.856\end{array}$ $\begin{array}{lllllllllllll}0.93 & 31.18 & 27.52 & 34.60 & 2 & 959.5524 & 959.5522 & 480.7834 & 0.0002 & 0.2080 & 46.840\end{array}$ $\begin{array}{lllllllllllll}0.89 & 30.81 & 27.45 & 39.61 & 2 & 959.5528 & 959.5522 & 480.7834 & 0.0006 & 0.6240 & 55.855\end{array}$ $\begin{array}{llllllllllll}0.99 & 52.10 & 23.12 & 49.11 & 2 & 1096.6984 & 1096.6978 & 549.3562 & 0.0006 & 0.5461 & 53.604\end{array}$ $\begin{array}{llllllllllll}0.91 & 37.86 & 23.12 & 45.63 & 2 & 1096.6984 & 1096.6978 & 549.3562 & 0.0006 & 0.5461 & 21.814\end{array}$ $\begin{array}{llllllllllll}0.99 & 44.97 & 19.68 & 38.76 & 2 & 1240.8002 & 1240.7998 & 621.4072 & 0.0004 & 0.3219 & 434.392\end{array}$ $\begin{array}{llllllllllll}0.98 & 41.51 & 19.59 & 41.48 & 2 & 1240.8016 & 1240.7998 & 621.4072 & 0.0018 & 1.4483 & 515.462\end{array}$ $\begin{array}{llllllllllll}0.58 & 20.15 & 28.20 & 19.30 & 3 & 1455.7912 & 1455.7925 & 486.2714 & -0.0013 & -0.8911 & 63.904\end{array}$ $\begin{array}{lllllllllll}1.00 & 34.51 & 28.31 & 18.79 & 3 & 1455.7933 & 1455.7925 & 486.2714 & 0.0008 & 0.5484 & 79.856\end{array}$ $\begin{array}{lllllllllllll}0.86 & 28.47 & 27.52 & 35.50 & 2 & 959.5524 & 959.5522 & 480.7834 & 0.0002 & 0.2080 & 64.725\end{array}$ $\begin{array}{llllllllllll}0.94 & 31.24 & 27.52 & 34.28 & 2 & 959.5526 & 959.5522 & 480.7834 & 0.0004 & 0.4160 & 75.892\end{array}$ $\begin{array}{llllllllllll}0.98 & 42.00 & 19.59 & 41.96 & 2 & 1240.8018 & 1240.7998 & 621.4072 & 0.0020 & 1.6092 & 662.174 \\ 0.99 & 44.05 & 19.59 & 41.82 & 2 & 1240.8020 & 1240.7998 & 621.4072 & 0.0022 & 1.7702 & 629.580 & 5\end{array}$ $\begin{array}{llllllllllll}0.99 & 44.05 & 19.59 & 41.82 & 2 & 1240.8020 & 1240.7998 & 621.4072 & 0.0022 & 1.7702 & 629.580 \\ 0.99 & 33.94 & 28.29 & 18.35 & 3 & 1455.7924 & 1455.7925 & 486.2714 & -0.0001 & -0.0685 & 80.300\end{array}$ $\begin{array}{lllllllllll}0.99 & 33.94 & 28.29 & 18.35 & 3 & 1455.7924 & 1455.7925 & 486.2714 & -0.0001 & -0.0685 & 80.300\end{array}$ $\begin{array}{llllllllllll}0.98 & 30.24 & 28.21 & 17.38 & 3 & 1455.7927 & 1455.7925 & 486.2714 & 0.0002 & 0.1371 & 125.703\end{array}$ $\begin{array}{lllllllllllll}0.71 & 27.44 & 27.52 & 38.54 & 2 & 959.5524 & 959.5522 & 480.7834 & 0.0002 & 0.2080 & 38.979\end{array}$ $\begin{array}{lllllllllllll}0.84 & 34.67 & 27.52 & 42.41 & 2 & 959.5526 & 959.5522 & 480.7834 & 0.0004 & 0.4160 & 70.523\end{array}$ $\begin{array}{llllllllllll}0.99 & 41.87 & 19.59 & 39.63 & 2 & 1240.8020 & 1240.7998 & 621.4072 & 0.0022 & 1.7702 & 515.940\end{array}$

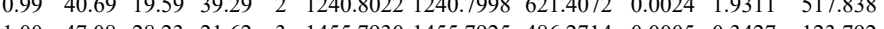
$\begin{array}{llllllllllll}1.00 & 47.08 & 28.23 & 21.62 & 3 & 1455.7930 & 1455.7925 & 486.2714 & 0.0005 & 0.3427 & 123.792\end{array}$ $\begin{array}{llllllllllll}0.99 & 33.29 & 28.22 & 15.93 & 3 & 1455.7939 & 1455.7925 & 486.274 & 0.0014 & 0.9597 & 87.403\end{array}$ $\begin{array}{llllllllllll}0.94 & 32.67 & 27.45 & 38.50 & 2 & 959.5530 & 959.5522 & 480.7834 & 0.0008 & 0.8320 & 134.277\end{array}$ $\begin{array}{lllllllllll}0.99 & 42.85 & 19.59 & 39.91 & 2 & 1240.8014 & 1240.7998 & 621.4072 & 0.0016 & 1.2874 & 953.418\end{array}$ $\begin{array}{llllllllllll}0.99 & 45.88 & 19.59 & 42.20 & 2 & 1240.8016 & 1240.7998 & 621.4072 & 0.0018 & 1.4483 & 872.477\end{array}$ 

$\begin{array}{lllllllllllll}0.99 & 36.08 & 23.48 & 32.17 & 2 & 952.5960 & 952.5957 & 477.3051 & 0.0003 & 0.3143 & 53.002\end{array}$ $\begin{array}{lllllllllllll}0.70 & 28.60 & 27.52 & 39.83 & 2 & 959.5524 & 959.5522 & 480.7834 & 0.0002 & 0.2080 & 64.715\end{array}$ $\begin{array}{llllllllllll}0.99 & 41.68 & 19.59 & 39.40 & 2 & 1240.8014 & 1240.7998 & 621.4072 & 0.0016 & 1.2874 & 502.165\end{array}$ $\begin{array}{llllllllllllll}0.99 & 42.88 & 19.59 & 42.18 & 2 & 1240.8016 & 1240.7998 & 621.4072 & 0.0018 & 1.4483 & 692.743\end{array}$ $\begin{array}{lllllllllllll}0.96 & 25.93 & 28.31 & 18.79 & 3 & 1455.7933 & 1455.7925 & 486.2714 & 0.0008 & 0.5484 & 119.500\end{array}$ $\begin{array}{llllllllllll}0.95 & 25.15 & 27.73 & 20.15 & 3 & 1455.7981 & 1455.7925 & 486.2714 & 0.0056 & 3.8387 & 79.583\end{array}$

LLLPGELAK

LLLPGELAK

LLLPGGLLAK

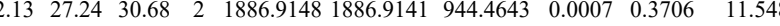
$\begin{array}{lllllllllll}1.00 & 27.30 & 24.88 & 2 & 1886.9178 & 1886.9141 & 944.4643 & 0.0037 & 1.9588 & 18.087\end{array}$

LLLPGELAK $\begin{array}{lllllllllll}1 & 1.82 .82 & 23.48 & 37.26 & 2 & 952.5958 & 952.5957 & 477.3051 & 0.0001 & 0.1048 & 48.322 \\ 0.96 & 36.98 & 23.48 & 37.94 & 2 & 9525958 & 952.5957 & 477.3051 & 0.0001 & 0.1048 & 43.449\end{array}$

AMGIMNSFVNDIFE

AMGIMNSFVNDIFE

LLLPGELAK

EIQTAVR

EIQTAVR

LLLPGELAK

HAVSEGTK

IASEASR

$\begin{array}{lllllllllll}\text { DD19A HUMAI Q9NUU7 DDX19A ATP-dependent R } 53.98 & 1.00 & 3 & 7.5 & -0.3628 & 0.1930 & -0.1235 & 0.5121 & 12 & \text { DPNSPLYSVK }\end{array}$

DPNSPLYSVK

TAAFVLAMLSR

TAAFVLAMLSR

TAAFVLAMLSR

TAAFVLAMLSR

TAAFVLAMLSR

TAAFVLAMLSR

TAAFVLAMLSR

TAAFVLAMLSR

TAAFVLAMLSR

TAAFVLAMLSR

TAAFVLAMLSR

$\begin{array}{lllllllllllll}0.98 & 37.56 & 23.12 & 34.52 & 2 & 1096.6982 & 1096.6978 & 549.3562 & 0.0004 & 0.3641 & 22.811\end{array}$

$\begin{array}{lllllllllll}0.94 & 28.72 & 23.12 & 34.87 & 2 & 1096.6986 & 1096.6978 & 549.3562 & 0.0008 & 0.7281 & 22.874\end{array}$

$\begin{array}{lllllllllllll}0.97 & 35.47 & 19.59 & 35.91 & 2 & 1240.8028 & 1240.7998 & 621.4072 & 0.0030 & 2.4139 & 660.964\end{array}$

$\begin{array}{llllllllllll}1.00 & 61.66 & 27.19 & 24.53 & 2 & 1886.9162 & 1886.9141 & 944.4643 & 0.0021 & 1.1117 & 11.975 \\ 1.00 & 91.11 & 27.30 & 24.35 & 2 & 1886.9182 & 1886.9141 & 944.4643 & 0.0041 & 2.1705 & 11.740\end{array}$ $\begin{array}{llllllllllll}0.83 & 18.84 & 23.44 & 29.33 & 2 & 952.5964 & 952.5957 & 477.3051 & 0.0007 & 0.7333 & 7.535\end{array}$ $\begin{array}{llllllllllll}0.85 & 29.09 & 27.52 & 36.61 & 2 & 959.5520 & 959.5522 & 480.7834 & -0.0002 & -0.2080 & 29.289\end{array}$ $\begin{array}{rrrrrrrrrrrrr}0.78 & 26.37 & 27.52 & 35.95 & 2 & 959.5522 & 959.5522 & 480.7834 & 0.0000 & 0.0000 & 9.681 \\ 0.98 & 40.07 & 19.68 & 39.83 & 2 & 1240.8010 & 1240.7998 & 621.4072 & 0.0012 & 0.9655 & 138.467 \\ 0.77 & 40.67 & 27.07 & 53.67 & 2 & 115.6194 & 115.6179 & 558.8162 & 0.0015 & 1.3421 & 200.640\end{array}$ $\begin{array}{lllllllllll}0.98 & 40.07 & 19.68 & 39.83 & 2 & 1240.8010 & 1240.7998 & 621.4072 & 0.0012 & 0.9655 & 138.467 \\ 0.77 & 40.67 & 27.07 & 53.67 & 2 & 1115.6194 & 1115.6179 & 558.8162 & 0.0015 & 1.3421 & 200.640\end{array}$ $\begin{array}{llllllllllll}0.83 & 24.12 & 28.49 & 27.72 & 2 & 876.4794 & 876.4787 & 439.2466 & 0.0007 & 0.7968 & 475.880\end{array}$ $\begin{array}{llllllllllll}0.62 & 19.30 & 28.49 & 18.77 & 2 & 876.4798 & 876.4787 & 439.2466 & 0.0011 & 1.2521 & 287.441\end{array}$ $\begin{array}{llllllllllll}0.92 & 34.76 & 28.28 & 22.58 & 2 & 1406.7734 & 1406.7649 & 704.3897 & 0.0085 & 6.0336 & 347.192\end{array}$ $\begin{array}{llllllllllll}0.93 & 35.20 & 28.28 & 22.61 & 2 & 1406.7734 & 1406.7649 & 704.3897 & 0.0085 & 6.0336 & 313.860\end{array}$ $\begin{array}{llllllllllll}1.00 & 60.69 & 26.98 & 22.81 & 2 & 1322.7512 & 1322.7502 & 662.3824 & 0.0010 & 0.7549 & 544.949\end{array}$ $\begin{array}{llllllllllll}1.00 & 61.01 & 26.95 & 21.58 & 2 & 1322.7514 & 1322.7502 & 662.3824 & 0.0012 & 0.9058 & 332.607\end{array}$ $\begin{array}{lllllllllllll}0.61 & 62.86 & 27.46 & 75.86 & 2 & 1338.7456 & 1338.7451 & 670.3798 & 0.0005 & 0.3729 & 236.601\end{array}$ $\begin{array}{llllllllllllll}1.00 & 61.92 & 26.98 & 20.83 & 2 & 1322.7512 & 1322.7502 & 662.3824 & 0.0010 & 0.7549 & 465.956\end{array}$ $\begin{array}{llllllllllll}1.00 & 57.22 & 26.98 & 21.36 & 2 & 1322.7512 & 1322.7502 & 662.3824 & 0.0010 & 0.7549 & 294.691\end{array}$ $\begin{array}{lllllllllllll}0.76 & 51.78 & 27.46 & 64.78 & 2 & 1338.7458 & 1338.7451 & 670.3798 & 0.0007 & 0.5221 & 116.617\end{array}$ $\begin{array}{llllllllllll}0.76 & 54.16 & 27.47 & 67.16 & 2 & 1338.7460 & 1338.7451 & 670.3798 & 0.0009 & 0.6713 & 168.729 \\ 1.06 & 73.20 & 26.95 & 21.97 & 2 & 13227514 & 13227502 & 662.3824 & 0.0012 & 0.9058 & 192.438\end{array}$ $\begin{array}{lllllllllllll}0.00 & 73.20 & 26.95 & 21.97 & 2 & 1322.7514 & 1322.7502 & 662.3824 & 0.0012 & 0.9058 & 192.438 & 136.860\end{array}$ $\begin{array}{llllllllllll}1.00 & 52.06 & 26.95 & 20.31 & 2 & 1322.7516 & 1322.7502 & 662.3824 & 0.0014 & 1.0568 & 251.180 & 18\end{array}$ $\begin{array}{llllllllllll}1 & & 57.53 & 26.95 & 21.18 & 2 & 1322.7516 & 1322.7502 & 662.3824 & 0.0014 & 1.0568 & 163.740\end{array}$ $\begin{array}{llllllllllll}1.00 & 56.11 & 26.95 & 22.60 & 2 & 1322.7516 & 1322.7502 & 662.3824 & 0.0014 & 1.0568 & 122.675 \\ 0.99 & 33.90 & 26.95 & 23.12 & 2 & 1322.7524 & 1322.7502 & 6623824 & 0.0022 & 1.6607 & 61.024\end{array}$

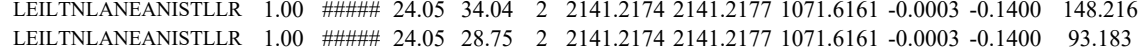
$\begin{array}{llllllllllll} & \end{array}$ VPIIVPIMMLAIK VPIIVPIMMLAIK VPIIVPIMMLAIK VPIVPIMMLAIK VPIIVPIMMLAIK VPIIVPIMMLAIK VPIIVPIMMLAIK VPIIVPIMMLAIK $\begin{array}{lllllllllllll}0.77 & 62.54 & 16.13 & 75.54 & 2 & 1725.0926 & 1725.0904 & 863.5525 & 0.0022 & 1.2738 & 35.048\end{array}$ $\begin{array}{llllllllllll}0.53 & 24.55 & 15.19 & 37.55 & 3 & 1725.0931 & 1725.0904 & 576.0374 & 0.0027 & 1.5624 & 39.100\end{array}$ $\begin{array}{lllllllllllll}0.53 & 17.30 & 15.19 & 30.30 & 3 & 1725.0934 & 1725.0904 & 576.0374 & 0.0030 & 1.7360 & 38.362\end{array}$ $\begin{array}{lllllllllllll}0.76 & 53.83 & 16.23 & 66.83 & 2 & 1725.0914 & 1725.0904 & 863.5525 & 0.0010 & 0.5790 & 24.879\end{array}$ $\begin{array}{llllllllllll}0.76 & 49.02 & 16.23 & 62.02 & 2 & 1725.0918 & 1725.0904 & 863.5525 & 0.0014 & 0.8106 & 16.575\end{array}$

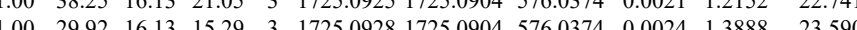
$\begin{array}{lllllllllll}1.00 & 29.92 & 16.13 & 15.29 & 3 & 1725.0928 & 1725.094 & 57.0374 & 0.024 & 1.2152 & 22.741\end{array}$ $\begin{array}{lllllllllllll}1.00 & 50.95 & 15.19 & 18.92 & 3 & 1725.0931 & 1725.0904 & 576.0374 & 0.0027 & 1.5624 & 2.673\end{array}$ $\begin{array}{lllllllllllll}0.53 & 34.08 & 15.19 & 47.08 & 3 & 1725.0937 & 1725.0904 & 576.0374 & 0.0033 & 1.9096 & 14.864\end{array}$

\section{$40.999-95.957$}


$\begin{array}{llllllllllll}1.00 & 88.13 & 26.95 & 28.61 & 2 & 1650.8032 & 1650.8013 & 826.4079 & 0.0019 & 1.1496 & 581.992 \\ 0.97 & 23.23 & 24.28 & 14.57 & 3 & 2072.1658 & 2072.1609 & 691.7276 & 0.0049 & 2.3612 & 101.475\end{array}$ $\begin{array}{llllllllllll}\text { MVLVDLPGVINTVTSGMAPDTK } & 0.55 & 77.89 & 25.35 & 90.89 & 3 & 2545.3759 & 2545.3739 & 849.4652 & 0.0020 & 0.7848 & 132.984\end{array}$

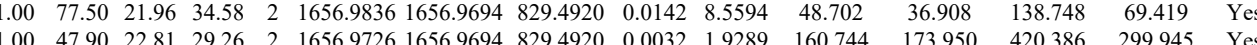
$\begin{array}{lllllllllllllll}1.00 & 47.90 & 22.81 & 29.26 & 2 & 1656.9726 & 1656.9694 & 829.4920 & 0.0032 & 1.9289 & 160.744 & 173.950 & 420.386 & 299.945 & \text { Yes } \\ 1.00 & 64.27 & 26.48 & 22.14 & 2 & 1502.8628 & 1502.8612 & 752.4379 & 0.0016 & 1.0632 & 243.872 & 313.435 & 12.852 & 4.098 & \text { Yes }\end{array}$

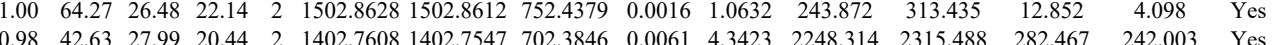

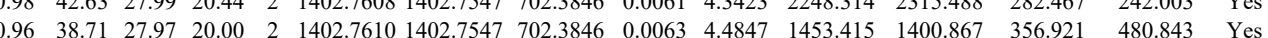
DALR

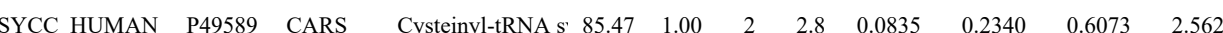
LAFLMHSWK $\begin{array}{lllllllllllllll} & \end{array}$ $\begin{array}{llllllllllllllll}0.96 & 25.25 & 27.62 & 16.74 & 3 & 1419.7951 & 1419.7940 & 474.2719 & 0.0011 & 0.7731 & 2643.222 & 2669.470 & 92.814 & 90.821 & \text { Yes } \\ 0.98 & 25.47 & 27.33 & 23.12 & 3 & 1419.7969 & 1419.7944 & 4742719 & 0.0029 & 2.0382 & 2350.771 & 286.056 & 125.726 & 93.148 & \text { Yes }\end{array}$

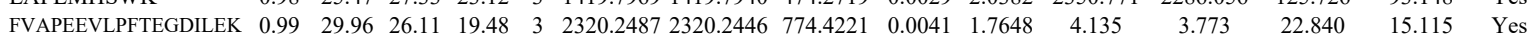

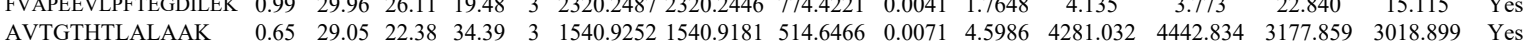

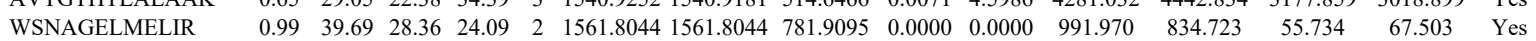

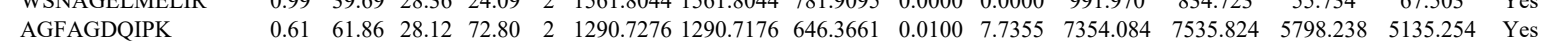
$\begin{array}{lllllllllllllllllll}\text { AGFAGDQIPK } & 0.71 & 50.23 & 28.20 & 59.15 & 2 & 1290.7280 & 1290.7176 & 646.3661 & 0.0104 & 8.0449 & 8722.340 & 9206.077 & 8727.625 & 5104.531 & \text { Yes }\end{array}$ $\begin{array}{lllllllllllllllll}\text { AGFAGDQIPK } & 0.91 & 33.01 & 28.13 & 32.58 & 2 & 1290.7266 & 1290.7176 & 646.3661 & 0.0090 & 6.9620 & 1336.244 & 1300.251 & 1255.904 & 901.433 & \text { Yes }\end{array}$ $\begin{array}{lllllllllllllllll}\text { AGFAGDQIPK } & 0.70 & 50.17 & 28.12 & 59.27 & 2 & 1290.7278 & 1290.7176 & 646.3661 & 0.0102 & 7.8902 & 3123.323 & 2959.694 & 2725.791 & 1732.500 & \text { Yes }\end{array}$

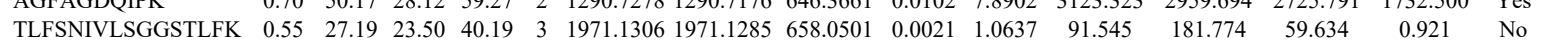
$\begin{array}{llllllllllllllll}\text { TLFSNIVLSGGSTLFK } & 1.00 & 47.13 & 23.50 & 23.11 & 3 & 1971.1315 & 1971.1285 & 658.0501 & 0.0030 & 1.5196 & 179.248 & 174.747 & 39.819 & 55.201 & \text { Yes }\end{array}$

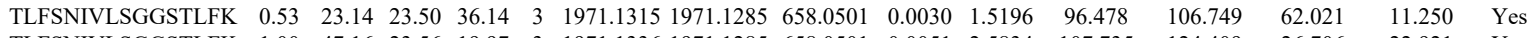

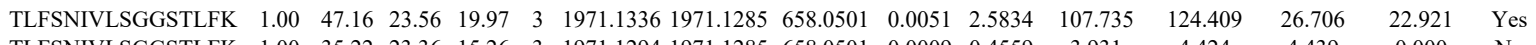

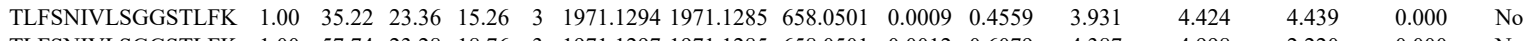
$\begin{array}{llllllllllllllll}\text { TLFSNIVLSGGSTLFK } & 1.00 & 57.74 & 23.28 & 18.76 & 3 & 1971.1297 & 1971.1285 & 658.0501 & 0.0012 & 0.6079 & 4.387 & 4.998 & 2.220 & 0.000 & \text { No }\end{array}$

2 NGELENIKPK NGELENIKPK IIVLGLLPR IIVLGLLPR IIVLGLLPR IIVLGLLPR IIVLGLLPR IIVLGLLPR IIVLGLLPR IIVLGLLPR $\begin{array}{llllllllllllllll}0.99 & 31.24 & 22.86 & 18.70 & 3 & 1572.9313 & 1572.9200 & 525.3139 & 0.0113 & 7.1703 & 19675.723 & 20314.424 & 20639.992 & 17595.866 & \text { No } & \\ 0.85 & 21.21 & 23.14 & 1635 & 3 & 1572.9328 & 1572.920 & 525.3139 & 0.0128 & 8.1221 & 17671.825 & 18137.521 & 21916.029 & 14998.480 & \text { No }\end{array}$ $\begin{array}{lllllllllllllll}0.85 & 21.21 & 23.14 & 16.35 & 3 & 1572.9328 & 1572.9200 & 525.3139 & 0.0128 & 8.1221 & 17671.825 & 18137.521 & 21916.029 & 14998.480 & \text { No } \\ 0.76 & 40.34 & 9.03 & 53.34 & 2 & 1136.7776 & 1136.7767 & 569.3956 & 0.0009 & 0.7903 & 2240.869 & 2842.724 & 118.727 & 26.262 & \text { Yes }\end{array}$ $\begin{array}{lllllllllllllll}0.76 & 40.34 & 9.03 & 53.34 & 2 & 1136.7776 & 1136.7767 & 569.3956 & 0.0009 & 0.7903 & 2240.869 & 2842.724 & 118.727 & 26.262 & \text { Yes } \\ 0.76 & 43.84 & 9.03 & 56.84 & 2 & 1136.7778 & 1136.7767 & 569.3956 & 0.0011 & 0.9659 & 1503.187 & 1934.287 & 21.560 & 28.924 & \text { Yes }\end{array}$ $\begin{array}{lllllllllllllll}0.76 & 43.84 & 9.03 & 56.84 & 2 & 1136.7778 & 1136.7767 & 569.3956 & 0.0011 & 0.9659 & 1503.187 & 1934.287 & 21.560 & 28.924 & \text { Yes } \\ 0.76 & 38.61 & 9.03 & 51.61 & 2 & 1136.7778 & 1136.7767 & 569.3956 & 0.0011 & 0.9659 & 1000.812 & 1260.071 & 26.560 & 20.113 & \text { Yes }\end{array}$ $\begin{array}{lllllllllllllll}0.76 & 38.61 & 9.03 & 51.61 & 2 & 1136.7778 & 1136.7767 & 569.3956 & 0.0011 & 0.9659 & 1000.812 & 1260.071 & 26.560 & 20.113 & \text { Yes } \\ 0.76 & 40.42 & 9.03 & 53.42 & 2 & 1136.7778 & 1136.7767 & 569.3956 & 0.0011 & 0.9659 & 1817.730 & 2417.457 & 73.069 & 30.179 & \text { Yes } \\ 0.69 & 40.79 & 9.54 & 53.79 & 2 & 1136.780 & 1136.767 & 56.3956 & 0.003 & 2.8978 & 1966.904 & 263.903 & 101.373 & 18.080 & \text { Yes }\end{array}$

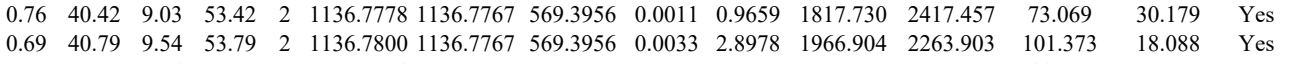
$\begin{array}{ccccccccccccccc}0.69 & 40.79 & 9.54 & 53.79 & 2 & 1136.7800 & 1136.7767 & 569.3956 & 0.0033 & 2.8978 & 1966.904 & 2263.903 & 101.373 & 18.088 & \text { Yes } \\ 1.00 & 36.32 & 9.54 & 15.28 & 2 & 1136.7794 & 1136.7767 & 569.3956 & 0.0027 & 2.3709 & 616.112 & 731.535 & 44.037 & 2.960 & \text { Yes }\end{array}$ $\begin{array}{lllllllllllllll}0.69 & 40.86 & 9.54 & 53.86 & 2 & 1136.7800 & 1136.7767 & 569.3956 & 0.0033 & 2.8978 & 610.030 & 710.654 & 41.184 & 12.782 & \text { Yes } \\ 0.76 & 34.42 & 9.03 & 47.42 & 2 & 1136.7780 & 11367767 & 569.3956 & 0.0013 & 1.1416 & 648.704 & 775.345 & 25.619 & 13.681 & \text { Yes }\end{array}$ $\begin{array}{lllllllllllllll}0.76 & 34.42 & 9.03 & 47.42 & 2 & 1136.7780 & 1136.7767 & 569.3956 & 0.0013 & 1.1416 & 648.704 & 775.345 & 25.619 & 13.681 & \text { Yes } \\ 0.77 & 40.68 & 9.54 & 53.68 & 2 & 1136.7784 & 1136.7767 & 569.3956 & 0.0017 & 1.4928 & 654.366 & 780.102 & 34.075 & 15.318 & \text { Yes }\end{array}$

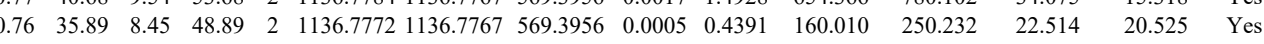
$\begin{array}{lllllllllllllll}0.76 & 33.60 & 9.03 & 46.60 & 2 & 1136.7776 & 1136.7767 & 569.3956 & 0.0009 & 0.7903 & 182.070 & 258.100 & 12.301 & 14.451 & \text { Yes }\end{array}$ 

ALQLLDEVLHTMPIAD FCLGQLSNVHR FCLGQLSNVH ASVTIQAR ASVTIQAR ASVTIQAR SGGIVISPFR SGGIVISPFR VTAFPATR
VTAFPATR TFIGIFLIDGVTGR

LVFPQDLLEK

LVFPQDLLEK

FFPASFPNR

FFPASFPNR
FFPASFPNR

YPSATNNTPAK

YPSATNNTPAK DGIVVIIDISK VTALCWHPTK VTALCWHPTK

ITRPGNTDDPSGGN

ITRPGNTDDPSGGNK ITRPGNTDDPSGGNK VSVSPVVHHVR

YITASTFAQAR
IPILLIQQPGK GLVLLRPPASLQYR GLVLLRPPASLQYR QQTTVPQKPR KQQTTVPQKPR KQQTTVPQKPR KQQTTVPQKPR KQQTTVPQKPR KQQTTVPQRR KQQTTVPKPR KQQTTVPKP

QNMGPSGQTHPPPQTL QNMGPSGQTHPPPQTLPR
FIQVHPITK FIQVHPITK FIQVHPITK
FIQVHPITK

ILVKPDR

AGLAMPGPPLGPVLGQR AGLAMPGPPLGPVLGQR WVGILEGLQSILHK WVGILEGLQSILHK IVILLCGR IVILLCGR
IVILLCGR

KGTDDSMTLQSQK KGTDDSMTLQSQK TCPLLLR TCPLLLR TCPLLLR TCPLLLR KGTDDSMTLQSQK KGTDDSMTLQSQK NSVCIIPLR

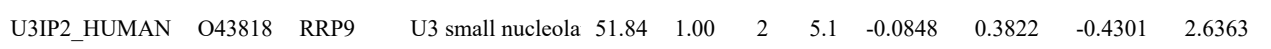

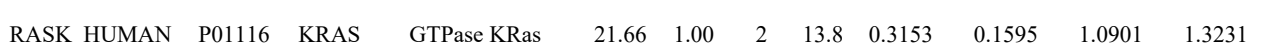

$\begin{array}{lllllllllll}0.76 & 22.09 & 9.03 & 35.09 & 2 & 1136.7778 & 1136.7767 & 569.3956 & 0.0011 & 0.9659 & 34.226\end{array}$

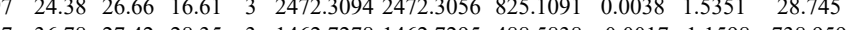
$\begin{array}{lllllllllllll}0.97 & 36.78 & 27.42 & 28.35 & 3 & 1462.7278 & 1462.7295 & 488.5838 & -0.0017 & -1.1598 & 738.959 & 77 & \\ 1.00 & 42.86 & 27.67 & 18.28 & 3 & 1462.7326 & 1462.7295 & 488.5838 & 0.0031 & 2.1150 & 19693 & 23 & \end{array}$ $\begin{array}{lllllllllllll}1.97 & 36.78 & 27.42 & 28.35 & 3 & 1462.7278 & 1462.7295 & 488.5838 & -0.0017 & -1.1598 & 738.959 & 35.48 \\ 1.00 & 52.86 & 27.67 & 18.28 & 3 & 1462.7326 & 1462.7295 & 488.5838 & 0.0031 & 2.1150 & 196.573 & 232.766\end{array}$

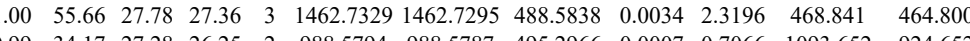
$\begin{array}{lllllllllllll}1.99 & 34.17 & 27.28 & 26.25 & 2 & 988.5794 & 988.5787 & 495.2966 & 0.0007 & 0.7066 & 1093.652 & 924.652\end{array}$ $\begin{array}{llllllllllllll}1.00 & 40.48 & 27.34 & 32.36 & 2 & 988.5804 & 988.5787 & 495.2966 & 0.0017 & 1.7161 & 1301.648 & 1356.037 & \\ 0 & 31.56 & 27.27 & 23.62 & 2 & 988.5792 & 988.5787 & 495.2966 & 0.0005 & 0.5047 & 917.830 & 888.750 & \end{array}$ \begin{tabular}{llllllllllll} 
& 0.05 \\
\hline
\end{tabular} $\begin{array}{lllllllllllll} & \end{array}$

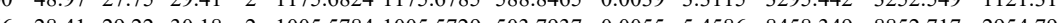

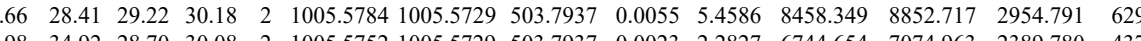

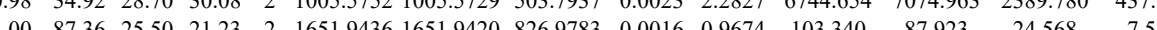
$\begin{array}{lllllllllllll}0.99 & 35.26 & 24.39 & 19.22 & 2 & 1488.8806 & 1488.8795 & 745.4470 & 0.0011 & 0.7378 & 761.189 & 999.986 & 202.556\end{array}$ $\begin{array}{llllllllllllll}1.00 & 36.99 & 24.23 & 15.68 & 2 & 1488.8818 & 1488.8795 & 745.4470 & 0.0023 & 1.5427 & 1111.598 & 923.033 & 226.625\end{array}$ $\begin{array}{lllllllllllll}1.00 & 48.00 & 27.41 & 30.11 & 2 & 1225.6470 & 1225.6366 & 613.8256 & 0.0104 & 8.4714 & 2528.245 & 2395.024 & 306.201\end{array}$ $\begin{array}{lllllllllllllll}0.95 & 33.81 & 27.40 & 24.06 & 2 & 12256476 & 12256366 & 613.8256 & 0.0110 & 8.9601 & 365.118 & 395.898 & 74.377 & 217.818\end{array}$ $\begin{array}{llllllllllllll}100 & 47.93 & 27.08 & 30.09 & 2 & 1225.6486 & 1225.6366 & 6138256 & 0.0120 & 9.7747 & 6200.212 & 6286.428 & 923.320 & 461.476\end{array}$ $\begin{array}{llllllllllllll}1.00 & 50.69 & 27.47 & 16.75 & 2 & 1450.7696 & 1450.7660 & 726.3903 & 0.0036 & 2.4780 & 2277.313 & 1641.986 & 954.801 & 808.287\end{array}$ $\begin{array}{lllllllllllllll}0.93 & 23.15 & 23.03 & 30.07 & 2 & 1458.8912 & 1458.8901 & 730.4523 & 0.0011 & 0.7530 & 117.950 & 76.013 & 352.193 & 1335.629 & \text { Yse }\end{array}$ $\begin{array}{llllllllllllllll}0.81 & 17.95 & 23.03 & 24.43 & 2 & 1458.8916 & 1458.8901 & 730.4523 & 0.0015 & 1.0268 & 60.631 & 67.491 & 415.869 & 1383.759 & \text { Yes }\end{array}$ $\begin{array}{lllllllllllllll}0.59 & 20.85 & 27.94 & 19.34 & 3 & 1488.7957 & 1488.7825 & 497.2681 & 0.0132 & 8.8483 & 4838.551 & 3698.938 & 413.716 & 280.226 & \text { Yes }\end{array}$ $\begin{array}{lllllllllllllll}0.81 & 24.87 & 27.94 & 21.24 & 3 & 1488.7957 & 1488.7825 & 497.2681 & 0.0132 & 8.8483 & 14978.477 & 11913.874 & 775.629 & 183.333 & \text { Yes }\end{array}$

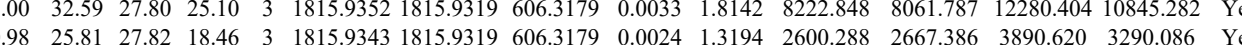
$\begin{array}{lllllllllllllll}0.99 & 32.00 & 27.80 & 18.03 & 3 & 1815.9352 & 1815.9319 & 606.3179 & 0.0033 & 1.8142 & 3009.503 & 2832.521 & 4182.956 & 3674.727 & \text { Yes }\end{array}$ $\begin{array}{llllllllllllllll}0.99 & 33.35 & 25.25 & 17.01 & 3 & 1221.7399 & 1221.7316 & 408.2511 & 0.0083 & 6.7768 & 5836.944 & 7010.310 & 3817.580 & 2417.582 & \text { Yes }\end{array}$ $\begin{array}{llllllllllllllll}1.00 & 74.38 & 28.40 & 28.62 & 2 & 1371.7356 & 1371.7268 & 686.8707 & 0.0088 & 6.4058 & 4051.442 & 1927.724 & 934.468 & 151.971 & \text { Yes } \\ 0.73 & 5.24 & 12.04 & 13.49 & 3 & 1506.9793 & 1506.9741 & 503.332 & 0.052 & 3.4437 & 551.307 & 784.948 & 187.778 & 4.775 & \text { Yes } \\ 0.77 & 13.37 & 23.14 & 17.70 & 3 & 1581.9370 & 1581.9355 & 528.3191 & 0.0015 & 0.9464 & 60.676 & 34.726 & 30.477 & 10.201 & \end{array}$ $\begin{array}{lllllllllllllll}0.73 & 5.24 & 12.04 & 13.49 & 3 & 1506.9793 & 1506.9741 & 503.3320 & 0.0052 & 3.4437 & 551.307 & 784.948 & 187.778 & 40.775 & \text { Yes }\end{array}$ \begin{tabular}{lllllllllllllll}
0.73 & 5.24 & 12.04 & 13.49 & 3 & 150.9793 & 1506.974 & 503.3320 & 0.0052 & 3.4437 & 551.307 & 784.948 & 187.778 & 40.775 & Yes \\
\hline
\end{tabular} \begin{tabular}{lllllllllllllll}
0.82 & 14.57 & 23.14 & 15.17 & 3 & 1581.9370 & 1581.9355 & 528.3191 & 0.0015 & 0.9464 & 23.105 & 58.233 & 14.929 & 10.730 & Yes \\
\hline
\end{tabular} $\begin{array}{lllllllllllllll}1.00 & 18.63 & 20.68 & 31.63 & 4 & 1742.0541 & 1742.0528 & 436.5205 & 0.0013 & 0.7445 & 88.798 & 95.455 & 6.822 & 4.596 & \text { Yes } \\ 0.55 & 18.51 & 20.72 & 1.51 & 3 & 1742.0551 & 1742.0528 & 581.6915 & 0.0023 & 1.3180 & 56.249 & 51.104 & 2.610 & 1.476 & \text { Yes }\end{array}$ \begin{tabular}{lllllllllllllll}
0.55 & 18.51 & 20.72 & 31.51 & 3 & 1742.0551 & 1742.0528 & 581.6915 & 0.0023 & 1.3180 & 56.249 & 51.104 & 2.610 & 1.476 & Yes \\
\hline
\end{tabular}

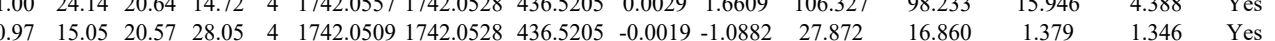

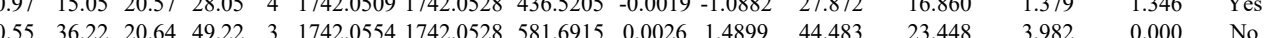

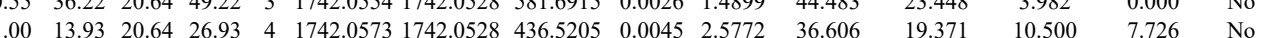

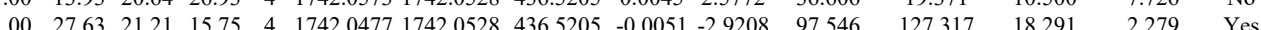

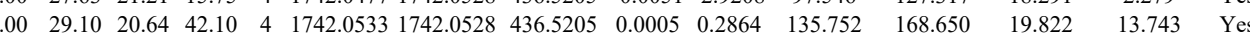

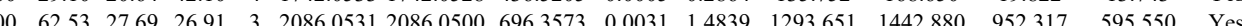
$\begin{array}{lllllllllllllll}100 & 52.15 & 27.76 & 20.30 & 3 & 2086.0543 & 2086.0500 & 696.3573 & 0.0043 & 2.0583 & 2756.626 & 2899.360 & 1660.087 & 1392.875 & \text { Yes }\end{array}$ $\begin{array}{llllllllllllllll}0.97 & 27.48 & 22.41 & 21.22 & 3 & 1369.8433 & 1369.8326 & 457.6181 & 0.0107 & 7.7939 & 12690.748 & 11391.208 & 2359.471 & 497.593 & \text { Yes }\end{array}$ $\begin{array}{lllllllllllllll}0.98 & 30.18 & 22.43 & 15.43 & 3 & 1369.8427 & 1369.8326 & 457.6181 & 0.0101 & 7.3569 & 4382.994 & 3997.321 & 795.024 & 454.267 & \text { Yes }\end{array}$ $\begin{array}{llllllllllllllll}0.91 & 22.31 & 22.41 & 17.66 & 3 & 1369.8436 & 1369.8326 & 457.6181 & 0.0110 & 8.0124 & 8248.275 & 7347.262 & 1417.729 & 593.275 & \text { Yes }\end{array}$ $\begin{array}{lllllllllllllll}0.96 & 24.84 & 17.92 & 25.80 & 2 & 1127.7274 & 1127.7270 & 564.8708 & 0.0004 & 0.3541 & 9303.565 & 10024.283 & 407.525 & 109.615 & \text { Yes }\end{array}$

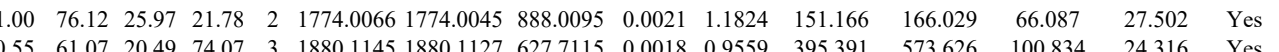
$\begin{array}{lllllllllllllll}0.55 & 61.07 & 20.49 & 74.07 & 3 & 1880.1145 & 1880.1127 & 627.7115 & 0.0018 & 0.9559 & 395.391 & 573.626 & 100.834 & 24.316 & \text { Yes } \\ 1.00 & 67.18 & 20.41 & 21.39 & 3 & 1880.1166 & 1880.1127 & 627.7115 & 0.0039 & 2.0710 & 278.161 & 400.942 & 45.139 & 40.245 & \text { Yes }\end{array}$ $\begin{array}{llllllllllllllll}0.97 & 30.16 & 27.23 & 25.50 & 2 & 1075.6384 & 1075.6368 & 538.8257 & 0.0016 & 1.4847 & 358.855 & 487.782 & 128.487 & 41.734 & \text { Yes }\end{array}$ $\begin{array}{lllllllllllllll}0.90 & 25.74 & 27.44 & 22.20 & 2 & 1075.6374 & 1075.6368 & 538.8257 & 0.0006 & 0.5568 & 126.054 & 138.480 & 37.219 & 11.505 & \text { Yes }\end{array}$

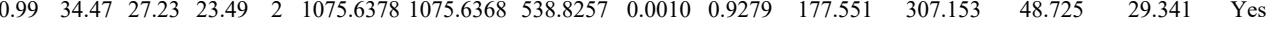
$\begin{array}{lllllllllllllll}1.00 & 53.98 & 27.19 & 26.42 & 3 & 1869.9862 & 1869.9832 & 624.3350 & 0.0030 & 1.6017 & 9528.713 & 9159.195 & 6458.670 & 4864.827 & \text { Yes }\end{array}$ $\begin{array}{llllllllllllllll}1.00 & 48.80 & 27.19 & 24.54 & 3 & 1869.9862 & 1869.9832 & 624.3350 & 0.0030 & 1.6017 & 6146.064 & 6191.597 & 4415.168 & 4021.356 & \text { Yes }\end{array}$ $\begin{array}{llllllllllllllll}0.68 & 21.00 & 29.03 & 32.73 & 2 & 1004.5646 & 1004.5633 & 503.2889 & 0.0013 & 1.2915 & 9137.029 & 9841.981 & 283.677 & 105.269 & \text { Yes }\end{array}$ $\begin{array}{llllllllllllllll}0.93 & 28.60 & 29.03 & 31.17 & 2 & 1004.5648 & 1004.5633 & 503.2889 & 0.0015 & 1.4902 & 8508.769 & 6551.146 & 147.213 & 96.449 & \text { Yes }\end{array}$ $\begin{array}{lllllllllllllll}0.87 & 25.16 & 28.41 & 31.32 & 2 & 1004.5638 & 1004.5633 & 503.2889 & 0.0005 & 0.4967 & 2244.459 & 1984.544 & 2.568 & 39.630 & \text { Yes } \\ 0.93 & 28.10 & 28.41 & 33.62 & 2 & 1004.5642 & 1004.563 & 503.2889 & 0.0009 & 0.8941 & 757.187 & 720.797 & 33.522 & 1.673 & \text { Yes }\end{array}$ $\begin{array}{lllllllllllllll}0.93 & 28.10 & 28.41 & 33.62 & 2 & 1004.5642 & 1004.5633 & 503.2889 & 0.0009 & 0.8941 & 757.187 & 720.797 & 33.522 & 14.673 & \text { Yes } \\ 1\end{array}$ $\begin{array}{lllllllllllllll}1.00 & 47.49 & 27.19 & 26.85 & 3 & 1869.9862 & 1869.9832 & 624.3350 & 0.0030 & 1.6017 & 10931.388 & 10051.497 & 6857.560 & 6053.539 & \text { Yes }\end{array}$

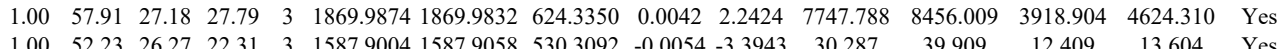

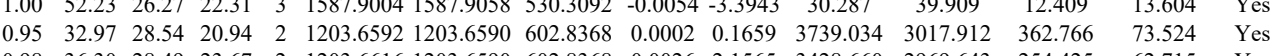
$\begin{array}{ccccccccccccccc}0.98 & 36.30 & 28.49 & 23.67 & 2 & 1203.6616 & 1203.6590 & 602.8368 & 0.0026 & 2.1565 & 3428.660 & 2969.643 & 254.425 & 62.715 & \text { Yes } \\ 0.98 & 2.89 & 24.83 & 20.23 & 3 & 2061.1561 & 2061.1506 & 688.0575 & 0.0055 & 2.6645 & 2073.008 & 3093.306 & 1744.883 & 1152.011 & \text { Yes }\end{array}$

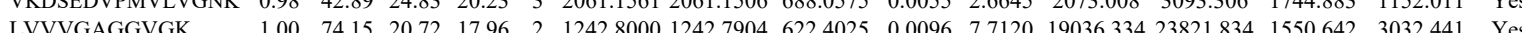

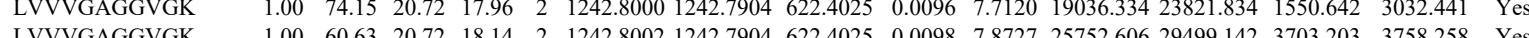


$\begin{array}{lllllllllll}\text { TXTP_HUMAN } & \text { P53007 } & \text { SLC25A1 } & \text { Tricarboxylate tral } 34.01 & 1.00 & 2 & 13.8 & -0.3096 & 1.1373 & 0.4919 & 2.2894\end{array}$ $\begin{array}{lllllllllllllll}0.51 & 16.78 & 26.39 & 23.41 & 2 & 829.5300 & 829.5273 & 415.7709 & 0.0027 & 3.2470 & 235.971 & 222.916 & 61.060 & 17.883 & \text { Yes }\end{array}$

$\begin{array}{lllllllllllll}\text { AFAD_HUMAN } & \text { P55196 } & \text { MLLT4 } & \text { Afadin } & 206.80 & 1.00 & 2 & 2.2 & 0.2222 & 0.3203 & -0.4301 & 0.7436\end{array}$

$\begin{array}{lllllllllll}\text { RL19 HUMAN } & \text { P84098 } & \text { RPL19 } & \text { 60S ribosomal pro } 23.47 & 1.00 & 2 & 12.8 & -0.1301 & 0.1704 & 0.2761 & 1.1538\end{array}$

$\begin{array}{llllllllllll}\text { REEP5_HUMAR } & \text { Q00765 } & \text { REEP5 } & \text { Receptor expressi } 21.49 & 1.00 & 3 & 10.1 & 0.8072 & 0.5906 & 1.4615 & 0.5143\end{array}$

UBP4_HUMAN Q13107 USP4

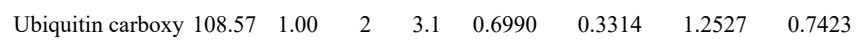

$\begin{array}{llllllllll}\text { ROA0_HUMAN } & \text { Q13151 HNRNPA0Heterogeneous nu } & 30.84 & 1.00 & 2 & 11.8 & -0.0265 & 0.4114 & -0.4301 & 2.2630\end{array}$

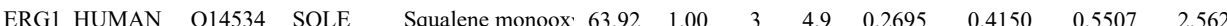

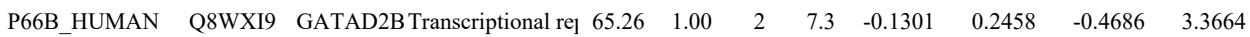

FAF2_HUMAN Q96CS3 FAF2

FUBP3_HUMAP Q96124 FUBP3

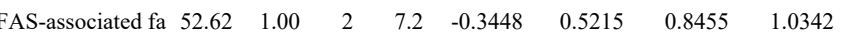

$\begin{array}{lllllllllll} & & & & & & & & & & \\ \text { TMCO7_HUMA } & \text { Q9C0B7 } & \text { TMCO7 } & \text { Transmembrane al } 120.75 & 1.00 & 2 & 3.1 & 0.6282 & 0.7525 & 0.8765 & 1.3282\end{array}$

SEP11_HUMAN Q9NVA2 SEPT11 Septin-11

$\begin{array}{llllllll}49.40 & 1.00 & 2 & 5.4 & 0.2811 & 0.2407 & 0.1799 & 2.2574\end{array}$

VPS29 HUMAN Q9UBQ0 VPS

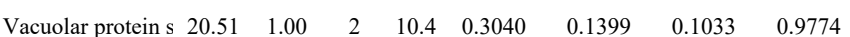

FFVMTSLR

FFVMTSLR

IDDVLHTLTGAMSLLR

IDDVLHTLT $\begin{array}{ccccccccccccc}0.51 & 16.78 & 26.39 & 23.41 & 2 & 829.5300 & 829.5273 & 415.7709 & 0.0027 & 3.2470 & 235.971 & 222.916 & 61.060 \\ 1.00 & 48.37 & 20.13 & 61.37 & 4 & 3927.1333 & 3927.1294 & 982.7896 & 0.0039 & 0.9921 & 11.684 & 2.990 & 3.585 \\ 0.87 & 26.76 & 27.17 & 30.18 & 2 & 1143.6234 & 1143.6232 & 572.8189 & 0.0002 & 0.1746 & 4355.364 & 4908.895 & 116.106\end{array}$

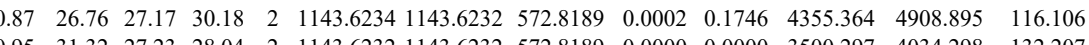
$\begin{array}{lllllllllllll}0.95 & 31.37 & 27.17 & 28.17 & 2 & 1143.623 & 1433.6232 & 5728189 & 0.0002 & 0.1746 & 3581.467 & 5042.389 & 22.207\end{array}$ $\begin{array}{llllllllllllll} & 42.81 & 26.45 & 18.63 & 3 & 1898.0437 & 1898.0417 & 633.6878 & 0.0020 & 1.0520 & 433.567 & 599.325 & 51.821 \\ & 1.00 & 57.10 & 26.40 & 20.18 & 3 & 1898.0440 & 18980417 & 633.6878 & 0.0023 & 1.2098 & 357.561 & 482817 & 54.470\end{array}$ $\begin{array}{llllllllllllll}\text { MLSSPK } & 0.84 & 22.52 & 27.12 & 26.86 & 2 & 821.4462 & 821.4439 & 411.7292 & 0.0023 & 2.7931 & 10307.669 & 9592.251 & 1142.503\end{array}$ $\begin{array}{llllllllllllll}\text { VWLDPNETNEIANANSR } & 1.00 & 88.92 & 27.55 & 25.40 & 2 & 2086.0214 & 2086.0201 & 1044.0173 & 0.0013 & 0.6226 & 5885.263 & 5861.708 & 593.127\end{array}$ $\begin{array}{lllllllllllllllll}\text { VWLDPNETNEIANANSR } & 1.00 & 84.46 & 27.52 & 21.91 & 2 & 2086.0234 & 2086.0201 & 1044.0173 & 0.0033 & 1.5804 & 7349.048 & 8133.637 & 328.313 & 605.489\end{array}$ $\begin{array}{llllllllllllllll}\text { VWLDPNETNEIANANSR } & 1.00 & 85.58 & 27.52 & 25.73 & 2 & 2086.0234 & 2086.0201 & 1044.0173 & 0.0033 & 1.5804 & 2206.035 & 2246.597 & 381.854 & 175 .\end{array}$ $\begin{array}{llllllllllllll}\text { VWLDPNETNEIANANSR } & 1.00 & 83.67 & 27.52 & 26.22 & 2 & 2086.0234 & 2086.0201 & 1044.0173 & 0.0033 & 1.5804 & 1562.377 & 1247.908 & 225.492\end{array}$ ILMEHIHK ILMEHIHK ATVNLLGEEK ATVNLLGEE $\begin{array}{lllllllllllll}0.93 & 26.12 & 25.05 & 17.22 & 3 & 1307.7745 & 1307.7627 & 436.9282 & 0.0118 & 9.0022 & 61468.131 & 54970.692 & 1363.490\end{array}$ $\begin{array}{llllllllllllll}0.93 & 26.73 & 25.21 & 20.31 & 3 & 1307.7751 & 1307.7627 & 436.9282 & 0.0124 & 9.4599 & 59622.701 & 52451.750 & 2388.648\end{array}$ $\begin{array}{llllllllllllll}1.00 & 65.02 & 27.13 & 23.87 & 2 & 1360.7918 & 1360.7805 & 681.3975 & 0.0113 & 8.2917 & 2249.955 & 2811.390 & 1511.512 & 17\end{array}$

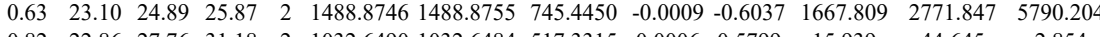

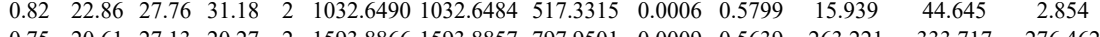
$\begin{array}{lllllllllllll}0.75 & 20.61 & 27.13 & 20.27 & 2 & 1593.8866 & 1593.8857 & 797.9501 & 0.0009 & 0.5639 & 263.221 & 333.717 & 276.462 \\ 1\end{array}$

GEIAEAYAELIK $\begin{array}{lllllllllllll}1.00 & 74.29 & 27.86 & 19.49 & 2 & 2050.0434 & 2050.0383 & 1026.0264 & 0.0051 & 2.4853 & 94.736 & 127.222 & 37.227\end{array}$ VTVPLMAVSDLCEASR 1.0 $\begin{array}{lllllllllllllll}\text { VTVPLMGAVSDLCEALSR } & 1.00 & 74.12 & 27.86 & 19.34 & 2 & 2050.0434 & 2050.0383 & 1026.0264 & 0.0051 & 2.4853 & 90.154 & 158.548 & 20.466\end{array}$ $\begin{array}{llllllllllllll}\text { VTVPLMGAVSDLCEALSR } & 1.00 & 86.05 & 27.90 & 18.85 & 2 & 2050.0414 & 2050.0383 & 1026.0264 & 0.0031 & 1.5107 & 106.669 & 172.150 & 4.161 \\ \text { VTVPLMGAVSDLCEALSR } & 0.60 & 15.44 & 27.87 & 19.36 & 3 & 2050.0432 & 2050.0383 & 684.3534 & 0.0049 & 2.3867 & 42.293 & 100.394 & 31.604\end{array}$ $\begin{array}{llllllllllllll}\text { VTVPLMGAVSDLCEALSR } & 0.60 & 15.44 & 27.87 & 19.36 & 3 & 2050.0432 & 2050.0383 & 684.3534 & 0.0049 & 2.3867 & 42.293 & 100.394 & 31.604 \\ \text { VTVPLMGAVSDLCEALSR } & 1.00 & 62.74 & 27.86 & 17.28 & 2 & 2050.0434 & 2050.0383 & 1026.0264 & 0.0051 & 2.4853 & 54.733 & 102.413 & 8.640\end{array}$

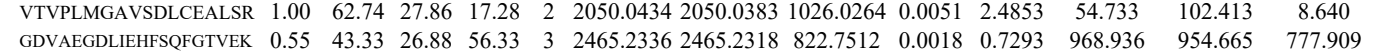
$\begin{array}{lllllllllllllll}\text { GDVAEGDLIEHFSQFGTVEK } & 0.55 & 43.33 & 26.88 & 56.33 & 3 & 2465.2336 & 2465.2318 & 822.7512 & 0.0018 & 0.7293 & 968.936 & 954.665 & 777.909 & 343.71 \\ \text { GDVAFGDLIFHFSOFGTVEK } & 0.53 & 16.33 & 26.88 & 29.33 & 3 & 2465.2345 & 2465.2318 & 822.7512 & 0.0027 & 1.0939 & 37.588 & 53.185 & 41.353 & 19.77\end{array}$ $\begin{array}{lllllllllllllll}\text { GDVAEGDLIEHFSQFGTVEK } & 0.53 & 16.33 & 26.88 & 29.33 & 3 & 2465.2345 & 2465.2318 & 822.7512 & 0.0027 & 1.0939 & 37.588 & 53.185 & 41.353 & 19.777 \\ \text { GDVAEGDLIEHFSOFGTVEK } & 0.53 & 43.21 & 26.88 & 56.21 & 3 & 2465.2345 & 2465.2318 & 822.7512 & 0.0027 & 1.0939 & 858.055 & 945.409 & 651.205 & 370.638\end{array}$ $\begin{array}{lllllllllllllll}\text { GDVAEGDLIEHFSQFGTVEK } & 0.53 & 43.21 & 26.88 & 56.21 & 3 & 2465.2345 & 2465.2318 & 822.7512 & 0.0027 & 1.0939 & 858.055 & 945.409 & 651.205 & 370.638 \\ \text { GDVAEGDLIEHFSOFGTVEK } & 0.53 & 22.20 & 26.95 & 35.20 & 3 & 2465.2354 & 2465.2318 & 822.7512 & 0.0036 & 1.4585 & 53.384 & 38.707 & 37.617 & 7.723\end{array}$

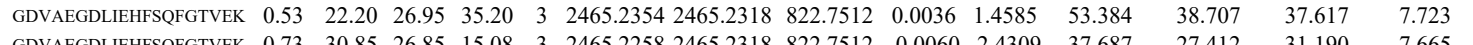

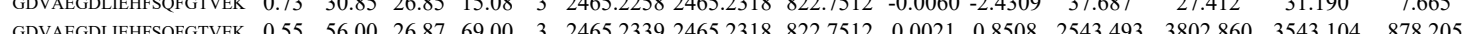

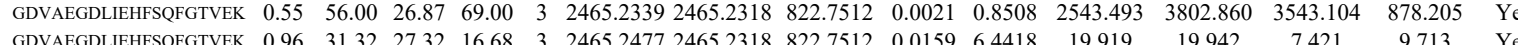

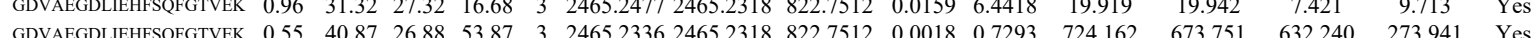

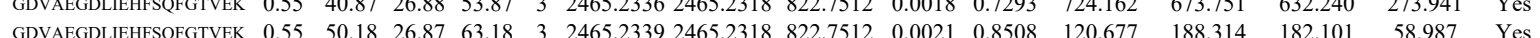

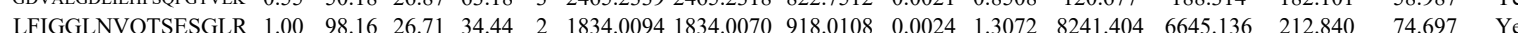

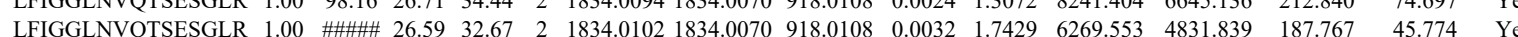

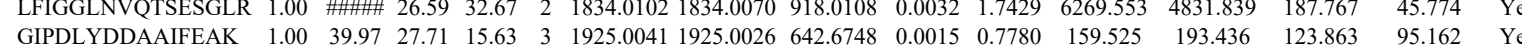
$\begin{array}{lllllllllllllllll}\text { NGGLLGR } & 0.67 & 21.46 & 25.39 & 33.45 & 2 & 829.4892 & 829.4892 & 415.7519 & 0.0000 & 0.0000 & 61.477 & 58.068 & 72.160 & 31.332 & \text { Yes }\end{array}$

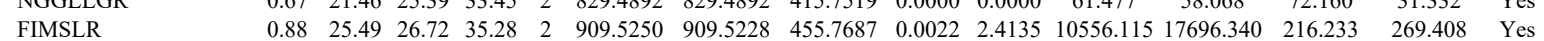
$\begin{array}{lllllllllllllllll}\text { GPPKPGLVR } & 0.55 & 8.46 & 22.10 & 14.14 & 3 & 1207.7653 & 1207.7645 & 403.5954 & 0.0008 & 0.6607 & 10703.159 & 11051.568 & 8706.173 & 6305.935 & \text { Yes }\end{array}$ $\begin{array}{lllllllllllllllll}\text { GPPKPGLVR } & 0.81 & 13.16 & 22.10 & 19.09 & 3 & 1207.7653 & 1207.7645 & 403.5954 & 0.0008 & 0.6607 & 9533.614 & 9994.100 & 7795.311 & 5879.515 & \text { Yes }\end{array}$ $\begin{array}{llllllllllllllll}\text { VIAPNPAQLQGQR } & 1.00 & 78.52 & 26.34 & 22.47 & 2 & 1534.8778 & 1534.8701 & 768.4423 & 0.0077 & 5.0101 & 3767.878 & 2919.183 & 448.367 & 39.911 & \text { Yes }\end{array}$ $\begin{array}{lllllllllllllllll}\text { LLQFQDLTGIESMDQCR } & 1.00 & 96.85 & 26.79 & 34.78 & 2 & 2186.0274 & 2186.0292 & 1094.0219 & -0.0018 & -0.8227 & 435.110 & 497.209 & 45.320 & 46.876 & \text { Yes }\end{array}$ $\begin{array}{llllllllllllllll}\text { NTLCAPEVISLINTR } & 0.72 & 15.84 & 28.18 & 17.22 & 3 & 1832.9632 & 1832.9610 & 611.9943 & 0.0022 & 1.1983 & 49.596 & 27.546 & 6.267 & 20.116 & \text { Yes }\end{array}$ $\begin{array}{lllllllllllllllll}\text { NTLCAPEVISLINTR } & 0.77 & 70.92 & 28.18 & 83.92 & 2 & 1832.9630 & 1832.9610 & 917.4878 & 0.0020 & 1.0899 & 209.252 & 173.823 & 114.848 & 27.272 & \text { Yes }\end{array}$ GVPQQIEVAR GVPQQIEVAR MVMIQDGPLPTGADKPL VGLVIGR VGLVIGR $\begin{array}{llllllllllllllll}0.81 & 29.66 & 26.94 & 26.33 & 2 & 1239.7124 & 1239.7057 & 620.8601 & 0.0067 & 5.3957 & 3730.767 & 4424.091 & 8455.592 & 5787.054 & \text { Yes } & \end{array}$ $\begin{array}{lllllllllllllllll}0.99 & 45.52 & 26.88 & 28.55 & 2 & 1239.7118 & 1239.7057 & 620.8601 & 0.0061 & 4.9125 & 7611.177 & 8598.896 & 10483.871 & 9539.344 & \text { Yes }\end{array}$ $\begin{array}{llllllllllllllll}0.92 & 22.79 & 26.46 & 24.64 & 3 & 2258.2006 & 2258.2007 & 753.7408 & -0.0001 & -0.0442 & 3114.363 & 3478.803 & 1523.401 & 205.915 & \text { Yes }\end{array}$ $\begin{array}{lllllllllllllll}0.59 & 26.39 & 22.83 & 34.79 & 2 & 856.5688 & 856.5616 & 429.2881 & 0.0072 & 8.3859 & 5736.226 & 6231.464 & 2153.458 & 454.841 & \text { Yes }\end{array}$ $\begin{array}{llllllllllllllll} & \end{array}$ $\begin{array}{llllllllllllll} & \end{array}$

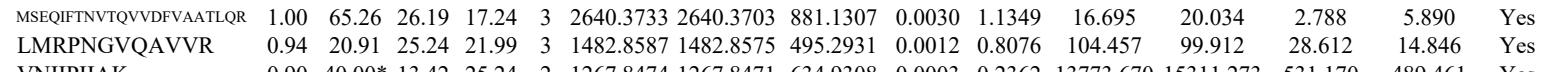
VNIIPIIAK VNIIPIIAK FESDPATHNEPGVR $\begin{array}{lllllllllllll}0.90 & 40.00 * 13.42 & 25.24 & 2 & 1267.8474 & 1267.8471 & 634.9308 & 0.0003 & 0.2362 & 13773.670 & 15311.273 & 531.170\end{array}$

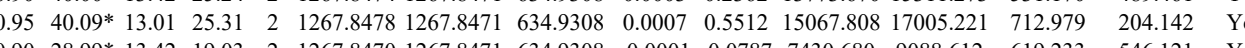
$\begin{array}{lllllllllllllll}0.90 & 28.99 * & 13.42 & 19.03 & 2 & 1267.8470 & 1267.8471 & 634.9308 & -0.0001 & -0.0787 & 7430.680 & 9088.612 & 619.233 & 546.121 & \text { Yes } \\ 1.00 & 75.35 & 2.43 & 21.49 & 3 & 1698.8128 & 1698.8084 & 567.2767 & 0.0044 & 2.5854 & 5042.478 & 8033.090 & 5711.504 & 2739.034 & \text { Yes }\end{array}$

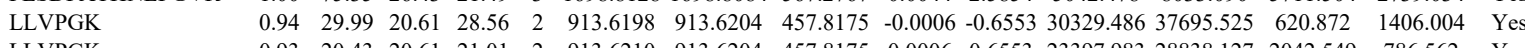
$\begin{array}{llllllllllllllll}\text { LLNILCTGNLCTK } & 1.00 & 47.75 & 27.81 & 21.06 & 2 & 913.6210 & 913.6204 & 457.8175 & 0.0006 & 0.6553 & 23397.983 & 28838.127 & 2042.549 & 786.562 & \text { Yes }\end{array}$ 
IQHILCTGNLCTK IQHILCTGNLCTK IQHILCTGNLCTK

FTRPEHLGSSAK

LPIVACFHLK

LPIVACFHLK

LIEDFLAR

MSSELFTLTYG

IDAVNAETIR

SPAIAAVGPIK

SPAIAAVGHK

EDPNLVPSISNK

EDPNLVPSISNK

LVPQQLAH

LVPQQLAH

IDPLAPLDK

IDPLAPLDK

AGDTVIPLYIPQCGECK

FCLNPK

FLTYFPGR

TLMIQLLR

TLMIQLLR

TLMIQLLR
TLMIQLLR

ETPFLSNPGTNLVFEDEITALPPEVDK

TPFLSPGTINLVFEDEITALPPEVI

LAPAQYIR

LAPAQYIR

EGPVQFEEDPFGLDK

EGPVQFEEDPFGLD

KELDILLQEK

KELDILLQEK

IVCTQPR

IVCTQPR

IVCTQPR

IVQPSRPVK

SLLIGVFK

FVFLLCTR

FVFLLCTR

FVFLLCTR

TPHQKPTEQPQQAK LTYLVNLLTR

LTYLVNLLTR

DACFTLLMNTLMTSLP

IPILSTFLTAR

IPILSTFLTAR

IPILSTFLTAR

IPILSTFLTAR

IPILSTFLTAR

LLLAANVATLGLLM
YTTLIAK

STPAAVGAMEDK

STPAAVGAMEDK

GLVVPSGGGR

GLVVPSGGGR

NATMPVTMLIR

LLFQNLWKPR

LLFQNLWK

TPNQNQTR

FPNQNQTR

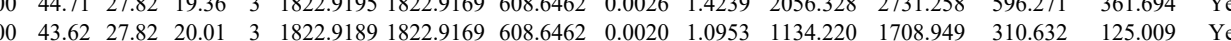
$\begin{array}{lllllllllllll} & \end{array}$ \begin{tabular}{llllllllllllllll}
0.94 & 20.20 & 27.55 & 17.75 & 4 & 1616.8857 & 1616.8878 & 405.2292 & -0.0021 & -1.2956 & 2288.525 & 2205.155 & 1991.794 & 940.205 & Yes \\
\hline
\end{tabular}

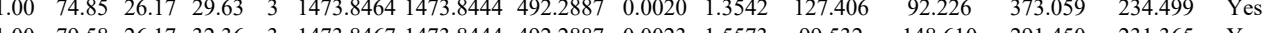

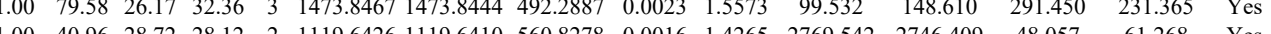
$\begin{array}{lllllllllllllll}1.00 & 40.96 & 28.72 & 28.12 & 2 & 1119.6426 & 1119.6410 & 560.8278 & 0.0016 & 1.4265 & 2769.542 & 2746.409 & 48.057 & 61.268 & \text { Yes } \\ 0.99 & 36.63 & 28.76 & 28.03 & 2 & 1119.6428 & 1119.6410 & 560.8278 & 0.0018 & 1.6048 & 5065.582 & 4389.340 & 139.735 & 35.564 & \text { Yes }\end{array}$ $\begin{array}{lllllllllllllll}0.99 & 36.63 & 28.76 & 28.03 & 2 & 1119.6428 & 1119.6410 & 560.8278 & 0.0018 & 1.6048 & 5065.582 & 4389.340 & 139.735 & 35.564 & \text { Yes } \\ 0.99 & 36.89 & 27.34 & 1.16 & 3 & 2438.2564 & 2438.2381 & 813.7533 & 0.0183 & 7.4961 & 11.101 & 12.395 & 7.318 & 5.098 & \text { Yes }\end{array}$

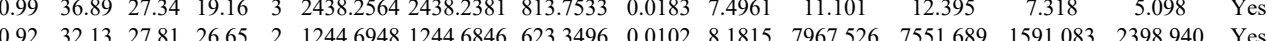
$\begin{array}{lllllllllllllll}0.92 & 32.13 & 27.81 & 26.65 & 2 & 1244.6948 & 1244.6846 & 623.3496 & 0.0102 & 8.1815 & 7967.526 & 7551.689 & 1591.083 & 2398.940 & \text { Yes } \\ 1.00 & 55.19 & 19.68 & 21.36 & 2 & 1310.8274 & 1310.8165 & 656.4155 & 0.0109 & 8.3026 & 1717.228 & 2064.236 & 1169.363 & 927.365 & \text { Yes }\end{array}$ $\begin{array}{llllllllllllllll}0.98 & 3.38 & 19.49 & 1.83 & 2 & 1310.8268 & 1310.8165 & 6564155 & 0.0103 & 7.8456 & 1300.371 & 1968.786 & 462.554 & 310.175 & \text { Yes }\end{array}$ $\begin{array}{lllllllllllllllll}1.00 & 42.75 & 20.00 & 19.08 & 2 & 1310.8276 & 1310.8165 & 6564155 & 0.0111 & 8.4549 & 2838.537 & 4138.250 & 962.064 & 768.255 & \text { Yes }\end{array}$

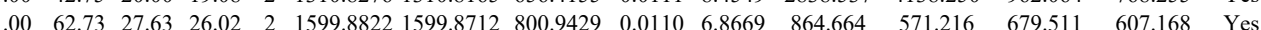

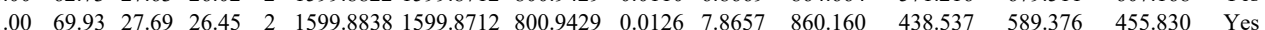
$\begin{array}{lllllllllllllll}0.93 & 27.53 & 27.94 & 16.93 & 2 & 1048.6162 & 1048.6151 & 525.3148 & 0.0011 & 1.0470 & 326.986 & 246.634 & 63.886 & 13.804 & \text { Yes }\end{array}$ $\begin{array}{lllllllllllllll}0.89 & 25.50 & 28.08 & 19.09 & 2 & 1048.6168 & 1048.6151 & 525.3148 & 0.0017 & 1.6181 & 301.627 & 237.356 & 69.337 & 20.604 & \text { Yes }\end{array}$ $\begin{array}{llllllllllllllll}1.00 & 43.62 & 22.65 & 16.56 & 2 & 1268.7596 & 1268.7584 & 635.3865 & 0.0012 & 0.9443 & 2073.098 & 2416.754 & 1953.071 & 1272.613 & \text { Yes }\end{array}$ $\begin{array}{lllllllllllllllll}1.00 & 45.33 & 22.83 & 16.85 & 2 & 1268.7600 & 1268.7584 & 635.3865 & 0.0016 & 1.2591 & 1560.091 & 1962.904 & 1864.158 & 958.780 & \text { Yes }\end{array}$

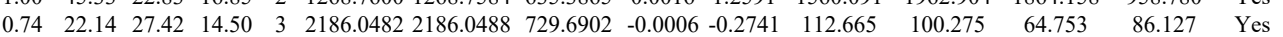
$\begin{array}{lllllllllllllll}0.68 & 26.92 & 27.13 & 28.12 & 2 & 1054.5608 & 1054.5547 & 528.2846 & 0.0061 & 5.7734 & 24593.742 & 25539.847 & 3032.801 & 965.345 & \text { Yes }\end{array}$ $\begin{array}{llllllllllllllll}0.97 & 31.43 & 27.70 & 23.92 & 2 & 1143.6210 & 1143.6199 & 572.8172 & 0.0011 & 0.9602 & 1079.949 & 750.417 & 104.627 & 46.591 & \text { Yes }\end{array}$ $\begin{array}{llllllllllllllll}0.99 & 36.07 & 25.47 & 26.10 & 2 & 1130.6982 & 1130.6967 & 566.3556 & 0.0015 & 1.3243 & 2727.085 & 2495.615 & 102.141 & 54.160 & \text { Yes }\end{array}$ $\begin{array}{lllllllllllllll}1.00 & 42.54 & 25.48 & 29.52 & 2 & 1130.6986 & 1130.6967 & 566.3556 & 0.0019 & 1.6774 & 2019.186 & 1840.886 & 21.703 & 43.591 & \text { Yes }\end{array}$

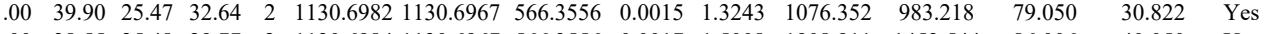

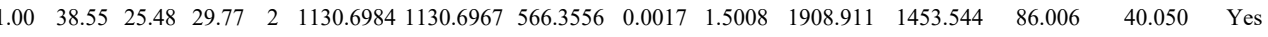

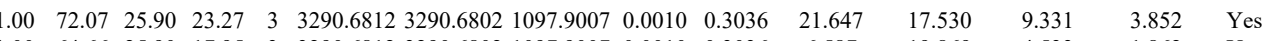

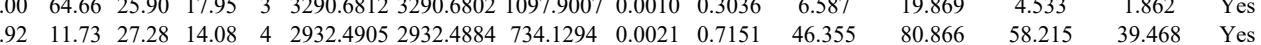

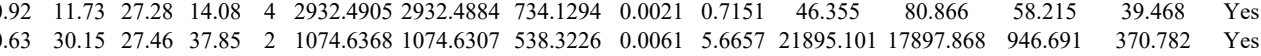
\begin{tabular}{lllllllllllllllll}
0.91 & 34.01 & 27.46 & 33.01 & 2 & 1074.6374 & 1074.6307 & 538.3226 & 0.0067 & 6.2230 & 19360.530 & 14778.445 & 629.526 & 392.135 & Yes \\
\hline
\end{tabular}

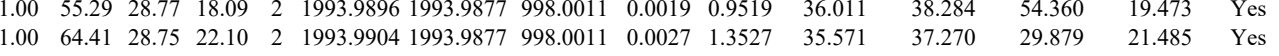
$\begin{array}{lllllllllllllll}0.79 & 20.74 & 24.87 & 27.91 & 2 & 1371.8122 & 1371.8095 & 686.9120 & 0.0027 & 1.9653 & 12073.256 & 16907.405 & 183.487 & 111.876 & \text { Yes }\end{array}$ $\begin{array}{llllllllllllllll}0.86 & 28.51 & 24.22 & 29.73 & 2 & 1371.8148 & 1371.8095 & 686.9120 & 0.0053 & 3.8578 & 16280.426 & 23151.757 & 0.000 & 245.776 & \text { No } \\ 0.99 & 34.58 & 27.56 & 31.20 & 3 & 1619894 & 1619.880 & 549.9696 & 0.0024 & 1.4788 & 113.064 & 106.933 & 75.100 & 43.753 & \text { No }\end{array}$

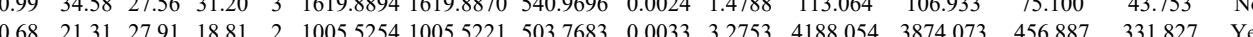
$\begin{array}{lllllllllllllll}0.68 & 21.31 & 27.91 & 18.81 & 2 & 1005.5254 & 1005.5221 & 503.7683 & 0.0033 & 3.2753 & 4188.054 & 3874.073 & 456.887 & 331.827 & \text { Yes } \\ 0.91 & 28.19 & 27.91 & 23.42 & 2 & 1005.5254 & 1005.5221 & 503.7683 & 0.0033 & 3.2753 & 5479.001 & 5234.690 & 585.481 & 158.684 & \text { Yes }\end{array}$ $\begin{array}{lllllllllllllll}0.71 & 22.05 & 27.91 & 18.12 & 2 & 1005.5254 & 1005.5221 & 503.7683 & 0.0033 & 3.2753 & 1268.647 & 1427.312 & 433.076 & 178.287 & \text { Yes }\end{array}$ $\begin{array}{lllllllllllllll}0.96 & 21.20 & 20.00 & 19.96 & 3 & 1310.8282 & 1310.8278 & 437.9499 & 0.0004 & 0.3044 & 8548.167 & 9002877 & 2094.577 & 1369.829 & \text { Yes }\end{array}$

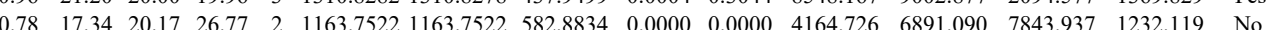

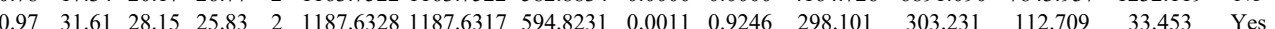
$\begin{array}{lllllllllllllll}0.97 & 32.27 & 28.08 & 25.49 & 2 & 1187.6332 & 1187.6317 & 594.8231 & 0.0015 & 1.2609 & 281.073 & 262.211 & 121.363 & 57.065 & \text { Yes }\end{array}$

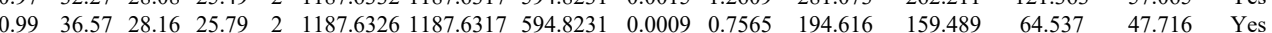
$\begin{array}{lllllllllllllll}0.98 & 33.32 & 28.15 & 23.08 & 2 & 1187.6328 & 1187.6317 & 594.8231 & 0.0011 & 0.9246 & 125.803 & 96.882 & 37.011 & 23.871 & \text { Yes }\end{array}$ $\begin{array}{lllllllllllllll}0.92 & 10.84 & 25.98 & 17.87 & 4 & 2049.1373 & 2049.1333 & 513.2906 & 0.0040 & 1.9482 & 53.796 & 63.982 & 65.952 & 36.169 & \text { Yes }\end{array}$ $\begin{array}{llllllllllllllll}1.00 & 49.62 & 23.36 & 25.08 & 2 & 1348.8208 & 1348.8200 & 675.4173 & 0.0008 & 0.5922 & 169.452 & 246.972 & 41.752 & 22.843 & \text { Yes }\end{array}$

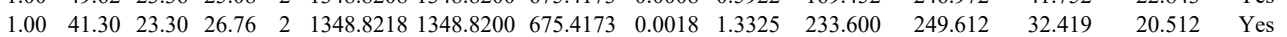
$\begin{array}{lllllllllllllll}0.66 & 18.19 & 26.62 & 15.93 & 3 & 2814.3724 & 2814.3658 & 939.1292 & 0.0066 & 2.3426 & 4.412 & 5.594 & 3.789 & 0.000 & \text { No }\end{array}$ \begin{tabular}{llllllllllllllll}
1.00 & 53.89 & 23.77 & 23.90 & 2 & 1374.8368 & 1374.8357 & 688.4251 & 0.0011 & 0.7989 & 125.506 & 161.679 & 61.241 & 39.701 & Yes \\
\hline
\end{tabular}

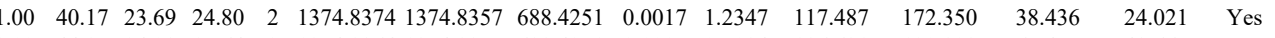

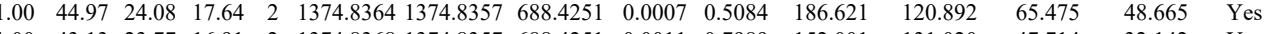
$\begin{array}{lllllllllllllll}1.00 & 43.13 & 23.77 & 16.91 & 2 & 1374.8368 & 1374.8357 & 688.4251 & 0.0011 & 0.7989 & 152.001 & 131.020 & 47.714 & 32.142 & \text { Yes }\end{array}$

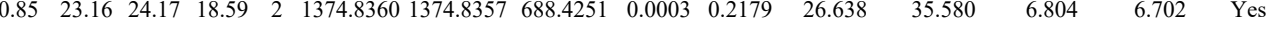

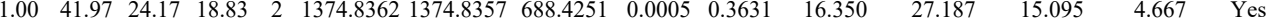
$\begin{array}{lllllllllllllll}0.69 & 78.66 & 18.26 & 91.66 & 2 & 1783.0902 & 1783.0875 & 892.5510 & 0.0027 & 1.5125 & 14.445 & 19.907 & 4.291 & 1.633 & \text { Yes }\end{array}$ $\begin{array}{lllllllllllllll}0.92 & 28.02 & 21.90 & 20.98 & 2 & 1096.6818 & 1096.6736 & 549.3441 & 0.0082 & 7.4634 & 7273.811 & 7932.476 & 12325.802 & 9896.821 & \text { Yes }\end{array}$

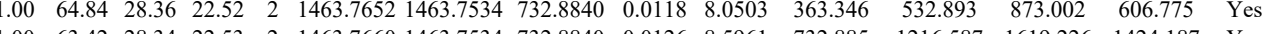
$\begin{array}{llllllllllllllll}1.00 & 63.42 & 28.34 & 22.53 & 2 & 1463.7660 & 1463.7534 & 732.8840 & 0.0126 & 8.5961 & 732.885 & 1216.587 & 1619.226 & 1424.187 & \text { Yes } \\ 0.99 & 36.30 & 26.33 & 31.6 & 2 & 1041.6086 & 1041.6053 & 521.8099 & 0.0233 & 3.1621 & 3351.670 & 3255.356 & 1179.712 & 362.895 & \text { Yes }\end{array}$ $\begin{array}{llllllllllllllll}0.99 & 36.30 & 26.33 & 31.69 & 2 & 1041.6086 & 1041.6053 & 521.8099 & 0.0033 & 3.1621 & 3351.670 & 3255.356 & 1179.712 & 362.895 & \text { Yes } \\ 0.74 & 24.63 & 6.56 & 24.01 & 2 & 1041.6090 & 1041.6053 & 521.809 & 0.0037 & 3.5453 & 1223.498 & 185.979 & 221.705 & 177.396 & \text { Yes }\end{array}$ $\begin{array}{llllllllllllllll}0.74 & 24.63 & 26.56 & 24.01 & 2 & 1041.6090 & 1041.6053 & 521.8099 & 0.0037 & 3.5453 & 1223.498 & 1185.979 & 221.705 & 177.396 & \text { Yes } \\ 0.99 & 39.22 & 2.3 & 23.45 & 2 & 1389.7610 & 1389.7594 & 695.8870 & 0.0016 & 1.1496 & 6816.758 & 7650.693 & 527.238 & 1.720 & \text { Yes }\end{array}$ \begin{tabular}{lllllllllllllll}
0.99 & 39.22 & 28.23 & 23.45 & 2 & 1389.7610 & 1389.7594 & 69.8870 & 0.0016 & 1.1496 & 6816.758 & 7650.693 & 527.238 & 16.720 & Yes \\
\hline
\end{tabular} $\begin{array}{lllllllllllllll}0.90 & 4.08 & 27.68 & 21.47 & 3 & 2080.0819 & 2080.0793 & 694.3670 & 0.0026 & 1.2481 & 10001.290 & 9001.869 & 8490.665 & 8946.732 & \text { Yes } \\ 1.00 & 45.66 & 25.97 & 23.84 & 3 & 1313.7613 & 1313.7608 & 438.9275 & 0.0005 & 0.3797 & 40.173 & 21.278 & 8.613 & 7.042 & \text { Yes }\end{array}$

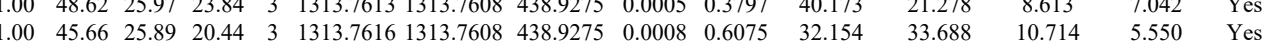
\begin{tabular}{lllllllllllllll}
0.86 & 23.93 & 27.32 & 26.04 & 2 & 1147.5862 & 1147.5856 & 574.8001 & 0.0006 & 0.5219 & 31.036 & 41.401 & 29.864 & 7.882 & Yes \\
\hline
\end{tabular}

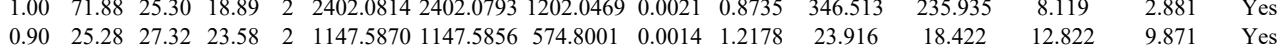

Table S-3 page 494 of 499 
$\begin{array}{lllllllllllll}\text { NU153_HUMAI } & \text { P49790 } & \text { NUP153 } & \text { Nuclear pore com] } 153.94 & 1.00 & 2 & 1.5 & 0.0432 & 0.4839 & 0.7142 & 0.7219 & 4 & \begin{array}{l}\text { CHQGPIKPYQQGR } \\ \text { CHOGPIKPYQQGR }\end{array}\end{array}$ CHQGPIKPYQQGR
NIVPGWLQR NIVPGWLQR GNDTFVTLDEILR GNDTFVTLDEILR IPLHTVR

GPPPSWGR GPPPSWGR AFGYYGPLR VALVLLR

VALVLLR VALVLLR

ILLWDTR

ILLWDTR

VWDLAQQVVLSSYR

VWDLAQQVVLSSYR

VWDLAQQVVLSSYR

4 LGLIPIHADPR

LGLIPIHADPR FSPVATASYR

SGMVQTEAQYR

NPMVETLGTVLQLK NPMVETLGTVLQLK NPMVETLGTVLQLK NPMVETLGTVLQLK VDPALFPPVPLFTAVPSR
VDPALFPPVPLFTAVPSR VDPALFPPVPLFTAVPSR CWVALGAR CWVALGAR

CWVALGAR
CWVALGAR VAEAIIDAIEDFVQK VAEAIIDAIEDFVQK VAEAIIDAIEDFVQK SIAIPAISSGVFGFPLGR

IPLNNGAGCR

IPLNNGAGCR

IIPAIWFR

IIPAIWFR
IIPAIWFR

IIPAIWFR

VGQTAFDVADEDIL LAYVAPTIPR
LAYVAPTIPR

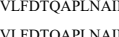
LPTVPMLGLTQR

ASGQAFELILSPR ASGQAFELILSPR ASGQAFELILSP AIEENNNFSK AIEENNNFSK GSDVIIMLVG

SLIPSYIR
SLIPSYIR

QITDNIFLTTAEVIAQQVSDK QITDNIFLTTAEVIAQQVSDK
QITDNFLTTAEVIAQQVSDK QITDNIFLTTAEVIAQQVSDK
QITDNIFLTTAEVIAQQVSDK IWLVDSK

IWLVDSK

FPNFTNQLLR

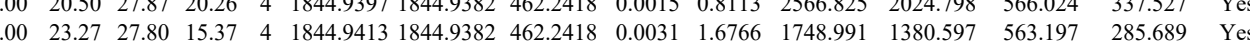
$\begin{array}{llllllllllllllllll}0.91 & 27.53 & 25.91 & 22.49 & 2 & 1225.7058 & 1225.7053 & 613.8599 & 0.0005 & 0.4073 & 1717.053 & 2433.118 & 72.479 & 167.382 & \text { Yes }\end{array}$ $\begin{array}{lllllllllllllllll}0.93 & 24.71 & 25.01 & 21.41 & 2 & 1225.7074 & 1225.7053 & 613.8599 & 0.0021 & 1.7105 & 2726.086 & 3828.491 & 200.374 & 140.834 & \text { Yes }\end{array}$ $\begin{array}{lllllllllllllll}1.00 & 79.39 & 28.23 & 29.51 & 2 & 1635.8610 & 1635.8590 & 818.9368 & 0.0020 & 1.2211 & 309.424 & 316.004 & 190.074 & 155.318 & \text { Yes } \\ 1.00 & 69.69 & 28.33 & 21.46 & 2 & 1635.8606 & 1635.8590 & 818.9368 & 0.0016 & 0.9769 & 125.764 & 179.329 & 194.128 & 139.474 & \text { Yes } \\ 0.88 & 20.02 & 23.16 & 20.50 & 2 & 98.6112 & 978.6096 & 49.3121 & 0.006 & 1.6316 & 5883.070 & 328.804 & 2526.542 & 200.445 & \text { Yes }\end{array}$ $\begin{array}{llllllllllllllll}0.88 & 20.02 & 23.16 & 20.50 & 2 & 978.6112 & 978.6096 & 490.3121 & 0.0016 & 1.6316 & 2583.070 & 3428.804 & 2526.542 & 2090.445 & \text { Yes }\end{array}$ $\begin{array}{llllllllllllllll}0.97 & 33.43 & 26.67 & 29.37 & 2 & 996.5268 & 996.5263 & 499.2704 & 0.0005 & 0.5007 & 2949.951 & 2622.917 & 2172.078 & 1294.026 & \text { Yes }\end{array}$ $\begin{array}{lllllllllllllllll}0.99 & 37.63 & 26.67 & 26.25 & 2 & 996.5268 & 996.5263 & 499.2704 & 0.0005 & 0.5007 & 4068.059 & 3868.670 & 3227.878 & 1955.025 & \text { Yes } \\ 0\end{array}$ $\begin{array}{llllllllllllllll}0.94 & 35.46 & 27.30 & 16.68 & 2 & 1186.6244 & 1186.6257 & 594.3201 & 0.0013 & -1.0937 & 24000.730 & 18724.170 & 317.712 & 313.469 & \text { Yes }\end{array}$ $\begin{array}{llllllllllllllllll}0.89 & 18.63 & 7.78 & 24.64 & 2 & 926.6396 & 926.6399 & 464.3272 & 0.0003 & 0.3230 & 2098.117 & 6080.398 & 2438.732 & 842.342 & \text { Yes }\end{array}$ $\begin{array}{llllllllllllllll}0.91 & 17.46 & 7.78 & 22.61 & 2 & 926.6396 & 926.6399 & 464.3272 & 0.0003 & 0.3230 & 2327.251 & 6061.324 & 2542.101 & 6647.758 & \text { Y }\end{array}$ $\begin{array}{lllllllllllllll}1.00 & 28.06 & 26.12 & 14.91 & 4 & 2001.9385 & 2001.9375 & 501.4917 & 0.0010 & 0.4985 & 145.129 & 179.168 & 165.076 & 138.324 & \text { Yes }\end{array}$ $\begin{array}{llllllllllllllll}0.81 & 27.29 & 27.50 & 21.87 & 2 & 1059.6234 & 1059.6199 & 530.8172 & 0.0035 & 3.2968 & 8616.611 & 6062.936 & 1075.940 & 79.090 & \text { Yes }\end{array}$ $\begin{array}{lllllllllllllllll}0.90 & 30.79 & 27.78 & 26.91 & 2 & 1059.6240 & 1059.6199 & 530.8172 & 0.0041 & 3.8620 & 9970.965 & 6998.669 & 626.817 & 146.379 & \text { Yes }\end{array}$ \begin{tabular}{llllllllllllll}
1.00 & $\# \# \# \# 26.98$ & 27.76 & 2 & 1806.9768 & 180699750 & 904.4948 & 0.0018 & 0.9950 & 1359.842 & 1213.179 & 17.141 & 6.062 & Yes \\
\hline
\end{tabular}

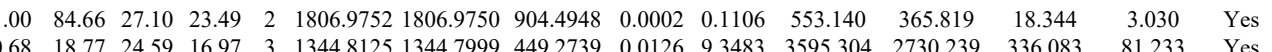
$\begin{array}{llllllllllllllll}0.68 & 18.77 & 24.59 & 16.97 & 3 & 1344.8125 & 1344.7999 & 449.2739 & 0.0126 & 9.3483 & 3595.304 & 2730.239 & 336.083 & 81.233 & \text { Yes } \\ 0.71 & 19.53 & 24.61 & 14.31 & 3 & 134.8134 & 1344.7999 & 449.2739 & 0.0135 & & 443 & 4260.169 & 3596.993 & 166.864 & 108.614 & \text { Yes }\end{array}$ $\begin{array}{llllllllllllllll}1.00 & 54.74 & 27.43 & 29.01 & 2 & 1244.6604 & 1241.6526 & 621.8336 & 0.0078 & 6.2717 & 5851.648 & 4273.685 & 64.375 & 165.355 & \text { Yes }\end{array}$ $\begin{array}{lllllllllllllll}0.89 & 54.08 & 24.42 & 60.20 & 3 & 1830.0547 & 1830.0528 & 611.0249 & 0.0019 & 1.0365 & 300.884 & 505.237 & 193.755 & 131.305 & \text { Yes } \\ 0.87 & 53.12 & 4.38 & 59.95 & 3 & 180.0550 & 1830528 & 61.024 & 0.022 & 1.200 & 35.606 & 41.16 & 264.26 & 188.008 & \text { Yes }\end{array}$

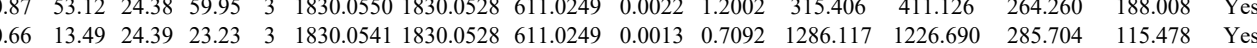
$\begin{array}{lllllllllllllll}0.88 & 23.41 & 24.38 & 29.94 & 3 & 1830.0550 & 1830.0528 & 611.0249 & 0.0022 & 1.2002 & 821.308 & 1004.098 & 265.357 & 87.303 & \text { Yes }\end{array}$ $\begin{array}{lllllllllllllll}0.76 & 73.59 & 23.77 & 86.59 & 2 & 2066.1694 & 2066.1687 & 1034.0916 & 0.0007 & 0.3385 & 486.465 & 442.284 & 247.304 & 50.336 & \text { Yes }\end{array}$ $\begin{array}{llllllllllllllll}.53 & 13.60 & 23.60 & 26.60 & 3 & 2066.1715 & 2066.1687 & 689.7302 & 0.0028 & 1.3532 & 164.638 & 179.104 & 96.934 & 71.049 & \text { No }\end{array}$ $\begin{array}{llllllllllllllll}0.99 & 34.72 & 27.49 & 25.87 & 2 & 1064.5394 & 1064.5381 & 533.2763 & 0.0013 & 1.2189 & 3619.370 & 3123.156 & 87.507 & 81.937 & \text { Yes }\end{array}$ $\begin{array}{lllllllllllllll}0.99 & 35.08 & 27.49 & 25.66 & 2 & 1064.5394 & 1064.5381 & 533.2763 & 0.0013 & 1.2189 & 4483.893 & 3398.000 & 130.509 & 122.054 & \text { Yes } \\ 0.99 & 1.04 & 27.51 & 26.35 & 2 & 1064.5382 & 1064.5381 & 53.2763 & 0.001 & 0.0938 & 135.593 & 1071.54 & 13.055 & 58.14 & \text { Yes }\end{array}$ $\begin{array}{lllllllllllllll}0.99 & 41.04 & 27.51 & 25.35 & 2 & 1064.5382 & 1064.5381 & 533.2763 & 0.0001 & 0.0938 & 1355.953 & 1071.544 & 13.065 & 58.164 & \text { Yes } \\ 0.98 & 33.63 & 27.33 & 26.28 & 2 & 1064.5416 & 1064.5381 & 533.2763 & 0.0035 & 3.2816 & 2238.461 & 1734.052 & 96.952 & 85.868 & \text { Yes }\end{array}$ $\begin{array}{llllllllllllllll}0.98 & 33.63 & 27.33 & 26.28 & 2 & 1064.5416 & 064.5381 & 533.2763 & 0.0035 & 3.2816 & 2238.461 & 1734.052 & 96.952 & 85.868 & \text { Yes } \\ 0.98 & 36.43 & 26.07 & 21.82 & 3 & 1948.0735 & 1948.0761 & 650.3660 & 0.0026 & -13326 & 144.458 & 171.610 & 73.879 & 53.337 & \text { Yes } \\ 1.00 & 39.38 & 25.76 & 21.63 & 3 & 1948.0762 & 1948.0761 & 650.3660 & 0.0001 & 0.051 & 158.417 & 167.216 & 70.156 & 51.266 & Y \text { Yes }\end{array}$

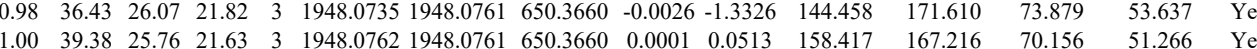
$\begin{array}{llllllllllllllll}1.00 & 44.39 & 25.55 & 1.86 & 3 & 1948.0777 & 1948.0761 & 650.3660 & 0.0016 & 0.0201 & 121.222 & 148.353 & 80.586 & 60.978 & \text { Yes }\end{array}$

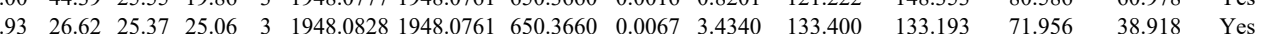
$\begin{array}{lllllllllllllll}0.96 & 22.49 & 25.45 & 19.60 & 3 & 1948.0804 & 1948.0761 & 650.3660 & 0.0043 & 2.2039 & 125.344 & 161.769 & 63.928 & 50.511 & \text { Yes }\end{array}$

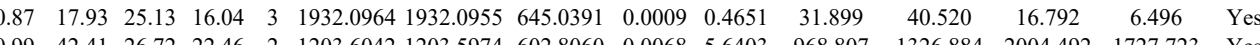
$\begin{array}{llllllllllllllll}0.98 & 40.08 & 27.01 & 19.46 & 2 & 1203.6052 & 1203.5974 & 602.8060 & 0.0078 & 6.64697 & 1206.733 & 1186.857 & 1862.332 & 1473.658 & \text { Yes }\end{array}$

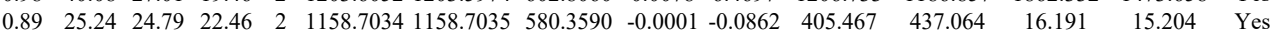
$\begin{array}{lllllllllllllll}0.99 & 37.14 & 24.87 & 29.15 & 2 & 1158.7040 & 1158.7035 & 580.3590 & 0.0005 & 0.4308 & 424.313 & 484.768 & 22.812 & 12.155 & \text { Yes } \\ 0.97 & 29.23 & 24.89 & 30.35 & 2 & 158.7046 & 158.7035 & 580.350 & 0.001 & 0.9477 & 522.17 & 690.677 & 32.62 & 17.646 & \text { Yes }\end{array}$ $\begin{array}{lllllllllllllll}0.97 & 29.23 & 24.89 & 30.35 & 2 & 1158.7046 & 1158.7035 & 580.3590 & 0.0011 & 0.9477 & 522.171 & 690.677 & 32.642 & 17.646 & \text { Yes }\end{array}$ $\begin{array}{lllllllllllllll}0.95 & 26.42 & 24.89 & 21.98 & 2 & 1158.7046 & 1158.7035 & 580.3590 & 0.0011 & 0.9477 & 494.948 & 560.644 & 0.000 & 6.706 & \text { No }\end{array}$

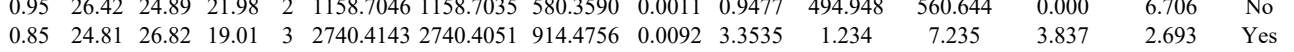
$\begin{array}{llllllllllllllll}1.00 & 56.90 & 25.93 & 27.03 & 2 & 1243.7408 & 1243.7410 & 622.8778 & -0.0002 & -0.1605 & 4863.166 & 6786.994 & 333.142 & 303.632 & \text { Yes }\end{array}$ $\begin{array}{llllllllllllllll}1.00 & 46.19 & 25.79 & 30.11 & 2 & 1243.7416 & 1243.7410 & 622.8778 & 0.0006 & 0.4816 & 8279.755 & 12839.137 & 427.838 & 315.453 & \text { Yes }\end{array}$

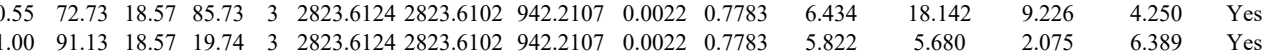

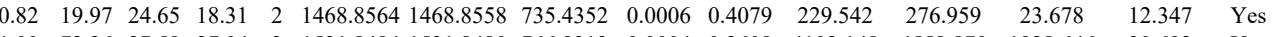
$\begin{array}{lllllllllllllll}1.00 & 72.26 & 27.58 & 27.04 & 2 & 1531.8484 & 1531.8480 & 766.9313 & 0.0004 & 0.2608 & 4102.148 & 4558.870 & 1928.646 & 30.692 & \text { Yes }\end{array}$ $\begin{array}{lllllllllllllll}1.00 & 72.70 & 27.60 & 26.72 & 2 & 1531.8478 & 1531.8480 & 766.9313 & -0.0002 & -0.1304 & 6215.577 & 9894.399 & 3718.570 & 48.855 & \text { Yes }\end{array}$ $\begin{array}{lllllllllllllll}1.00 & 72.15 & 27.47 & 22.73 & 2 & 1531.8492 & 1531.8480 & 766.9313 & 0.0012 & 0.7823 & 1568.434 & 2713.803 & 831.357 & 0.000 & \text { No }\end{array}$

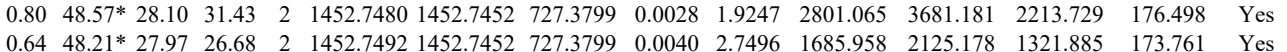

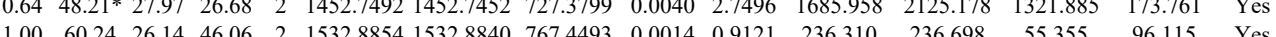

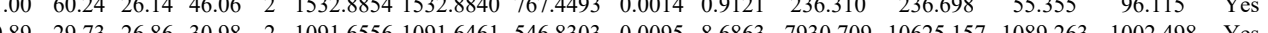
$\begin{array}{lllllllllllllll}0.87 & & \end{array}$

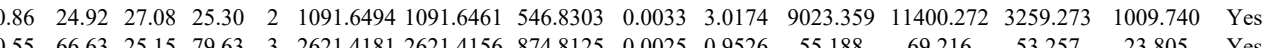

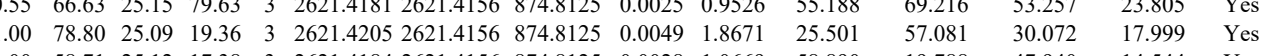

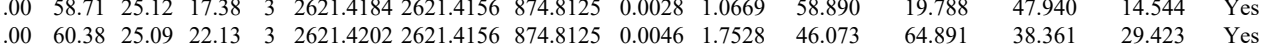

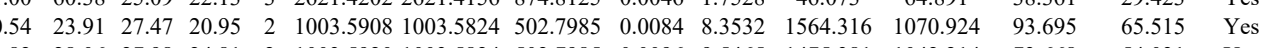
$\begin{array}{llllllllllllllll}0.85 & 28.55 & 27.01 & 24.90 & 2 & 1003.5927 & 1303.5824 & 502.7985 & 0.0096 & 9.5465 & 1475.381 & 042.214 & 73.668 & 54.031 & \text { Yes }\end{array}$ 
FPNFTNQLLR PPTSIFVKPQGR

VPKPEPIPEPK

VPKPEPIPEPK

VPKPEPIPEPK

VPKPEPIPEPK

VNLEVIKPWIT

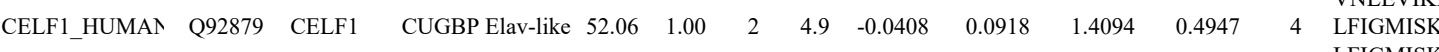

LFIGMISK

MFVGQVPR

FQLQLLR

LFCLETFLSDLIAHQ

LILVQVIPVVAR

LILVQVIPVVAR

LILVQVIPVVAR

LILVQVIPVVAR

LILVQVIPVVAR

LILVQVIPVVAR

LILVQVIPVVAR

LILVQVIPVVAR

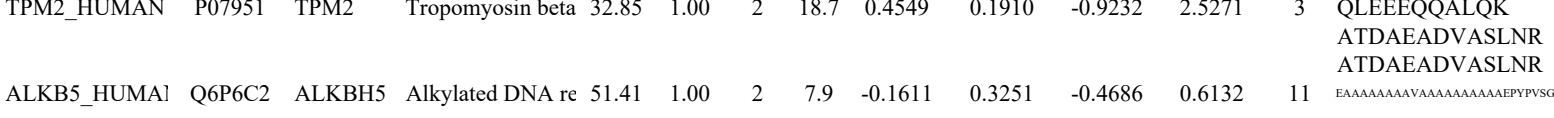

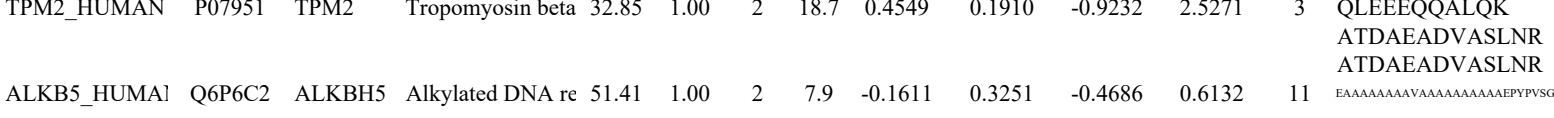

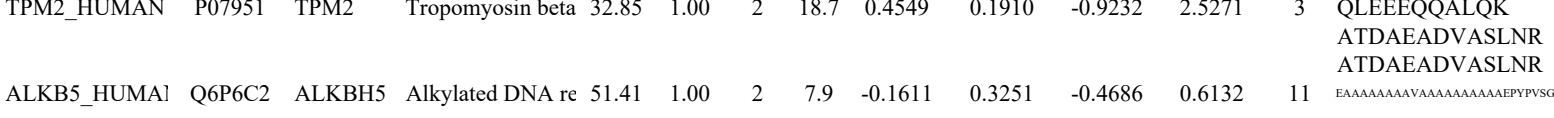

EAAAAAAAANAAAAAAAAAAEAPYPYSS

EAAAAAAAVAAAAAAAAAEPYPSGGKK

EAAIILRK

AVIILRK

AVIILRK

AVIILRK

AVILRK

AVIILRK

AVILRK

LVHIIGALR

LVHIIGALR

LVHIIGALR

LEDPHVDIIR

EGPGLAELLANVASSILSHIK EGPGLAELLANVASSILSH

LFQTAITR

LLFGPTVR

LLFGPTVR

MVLVNAVYFK

ITNCILFFGR

ITNCILFFGR

ITNCILFFGR

ITNCILFFGR

IGTVMTFL

CAAAASILGKPADR

DOPD_HUMAN P30046 DDT

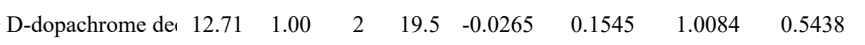

$\begin{array}{llllllllll}\text { NELFD_HUMA] Q8IXH7 } & \text { TH1L } & \text { Negative elongatic } 66.25 & 1.00 & 2 & 4.6 & -0.0123 & 0.3532 & 0.1033 & 0.8473\end{array}$

$\begin{array}{llllllllll}\text { PDIP2_HUMAN Q9Y2S7 POLDIP2 Polymerase delta- } 42.03 & 1.00 & 2 & 4.6 & -0.1148 & 0.1886 & -0.4301 & 1.9161\end{array}$ FPVVAMGVLK

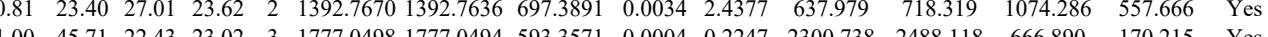
$\begin{array}{lllllllllllllll} & \end{array}$ $\begin{array}{lllllllllllllllll}0.70 & 23.55 & 20.04 & 26.25 & 3 & 1662.0184 & 1662.0081 & 555.0100 & 0.0103 & 6.1860 & 4263.432 & 5803.867 & 4077.141 & 3929.527 & \text { Yes }\end{array}$

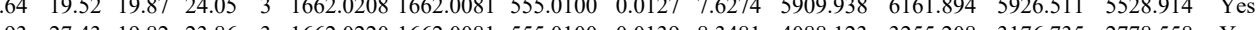
$\begin{array}{llllllllllllllll}0.64 & 1.52 & 19.87 & 24.05 & 3 & 1662.0208 & 1662.0881 & 555.0100 & 0.0127 & 7.6274 & 590.938 & 6161.894 & 5926.511 & 5528.914 & \text { Yes } \\ 0.60 & 2 . .9 & 1.82 & 23.86 & 3 & 1662.0220 & 1662.0081 & 555.0100 & 0.0139 & 8.3481 & 4088.123 & 3255.208 & 3176.735 & 2778.558 & \text { Yes }\end{array}$ \begin{tabular}{llllllllllllllll}
0.93 & 27.43 & 19.82 & 23.86 & 3 & 1662.0220 & 1662.0881 & 555.0100 & 0.0139 & 8.3481 & 4088.123 & 3255.208 & 3176.735 & 2778.558 & Yes \\
\hline
\end{tabular}

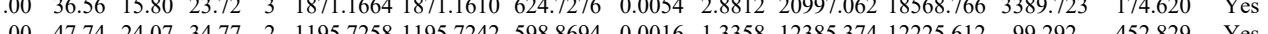

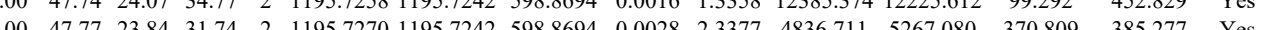
$\begin{array}{llllllllllllllll}0.63 & 27.04 & 28.38 & 18.59 & 2 & 107.5990 & 1076.5923 & 539.3034 & 0.0067 & 6.3117 & 30860.785 & 28866250 & 2190.195 & 1342.038 & \text { Yes }\end{array}$

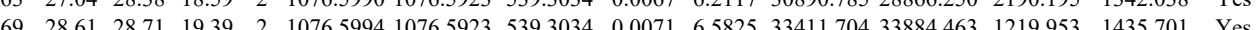
$\begin{array}{lllllllllllllllll} & \end{array}$

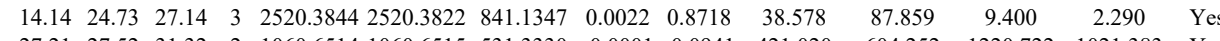

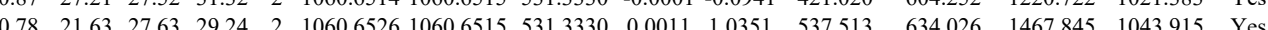

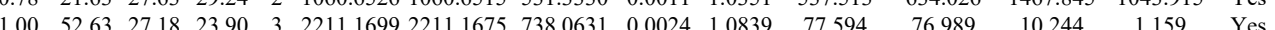
$\begin{array}{llllllllllllllll}0.61 & 53.42 & 6.99 & 66.42 & 2 & 1462.9722 & 1462.9721 & 732.4933 & 0.0001 & 0.0683 & 64.362 & 82.087 & 11.409 & 6.787 & \text { Yes }\end{array}$ $\begin{array}{llllllllllllllll}0.76 & 57.95 & 6.99 & 70.95 & 2 & 1462.9728 & 1462972 & 732.493 & 0.0007 & 0.4778 & 155.463 & 219.469 & 5.143 & 7.511 & \text { Yes } \\ 0\end{array}$ $\begin{array}{lllllllllllllll}0.61 & 64.16 & 6.99 & 77.16 & 2 & 1462.9724 & 1462.9721 & 732.4933 & 0.0003 & 0.2048 & 177.746 & 257.330 & 30.816 & 12.274 & \text { Yes }\end{array}$

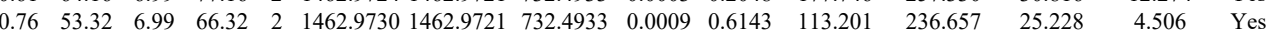
$\begin{array}{llllllllllllllll}0.61 & 56.52 & 6.99 & 69.52 & 2 & 1462.9724 & 1462.9721 & 732.4933 & 0.0003 & 0.2048 & 170.970 & 277.759 & 30.447 & 9.924 & \text { Yes } \\ 0.76 & 53.48 & 6.99 & 66.48 & 2 & 462.9728 & 146.921 & 732.93 & 0.37 & 0.478 & 12.978 & 21.35 & 30.62 & 8.748 & \text { Yes }\end{array}$ $\begin{array}{lllllllllllllll}0.76 & 53.48 & 6.99 & 66.48 & 2 & 1462.9728 & 1462.9721 & 732.4933 & 0.0007 & 0.4778 & 122.978 & 216.357 & 30.362 & 8.748 & \text { Yes }\end{array}$ $\begin{array}{llllllllllllllll}0.61 & 54.31 & 6.99 & 67.31 & 2 & 1462.9726 & 1462.9721 & 732.4933 & 0.0005 & 0.3413 & 82.325 & 120.586 & 20.472 & 2.656 & \text { Yes }\end{array}$

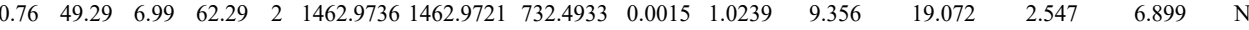

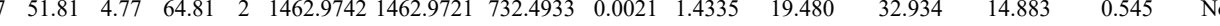

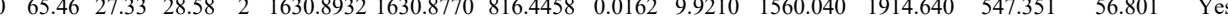
$\begin{array}{llllllllllllll} & 147.7478 & 1475.7338 & 738.8742 & 0.0140 & 9.4738 & 2736.981 & 3896.909 & 4295.735 & 1659.206 & \text { Yes }\end{array}$

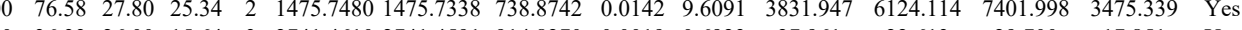

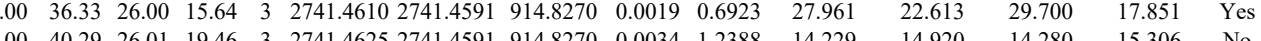
$\begin{array}{lllllllllllll}10 & 27.4625 & 2741.4591 & 914.8270 & 0.0034 & 1.2388 & 14.229 & 14.920 & 14.280 & 15.306 & \text { No }\end{array}$

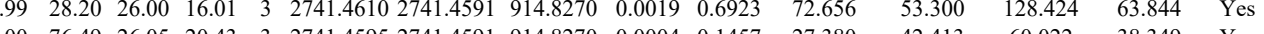

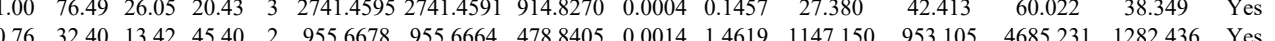

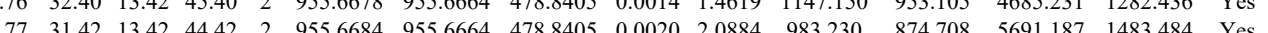
$\begin{array}{lllllllllllllllll}0.76 & 24.52 & 13.42 & 37.52 & 2 & 955.6678 & 955.6664 & 478.8405 & 0.0014 & 1.4619 & 479.512 & 47.08 & 5691.187 & 1483.484 & \text { Yes }\end{array}$ $\begin{array}{llllllllllllllll}0.77 & 32.35 & 13.42 & 45.35 & 2 & 955.6680 & 955.6664 & 478.8405 & 0.0016 & 1.6707 & 445.487 & 349.268 & 2034.528 & 535.626 & \text { Yes }\end{array}$ $\begin{array}{llllllllllllllll}0.76 & 18.00 & 13.42 & 31.00 & 2 & 955.6674 & 955.6664 & 478.8405 & 0.0010 & 1.0442 & 120.719 & 135.935 & 397.400 & 128.219 & \text { Yes }\end{array}$ $\begin{array}{lllllllllllllllll}0.76 & 21.69 & 13.42 & 34.69 & 2 & 955.6674 & 955.6664 & 478.8405 & 0.0010 & 1.0442 & 119.441 & 135.792 & 636.154 & 254.181 & \text { Yes }\end{array}$ $\begin{array}{lllllllllllllll}0.76 & 17.31 & 13.42 & 30.31 & 2 & 955.6672 & 955.6664 & 478.8405 & 0.0008 & 0.8354 & 142.390 & 107.206 & 323.925 & 93.189 & \text { Yes }\end{array}$ $\begin{array}{lllllllllllllll}1.00 & 43.47 & 21.37 & 21.89 & 2 & 1134.7356 & 1134.7359 & 568.3752 & 0.0003 & 0.2639 & 6072.936 & 7727.296 & 253.521 & 62.251 & \text { Yes }\end{array}$ $\begin{array}{llllllllllllllll}1.00 & 51.98 & 21.17 & 24.30 & 2 & 1134.7368 & 1134.7359 & 568.3752 & 0.0009 & 0.7917 & 3004.527 & 3609.023 & 154.340 & 86.002 & \text { Yes }\end{array}$ $\begin{array}{lllllllllllllll}1.00 & 52.09 & 21.17 & 24.33 & 2 & 1134.7362 & 1134.7359 & 568.3752 & 0.0003 & 0.2639 & 3307.332 & 3545.704 & 50.921 & 62.157 & \text { Yes }\end{array}$ $\begin{array}{lllllllllllllllll}1.00 & 52.05 & 21.17 & 24.27 & 2 & 1134.7364 & 1134.7359 & 568.3752 & 0.0005 & 0.4399 & 4120.239 & 5179.063 & 86.232 & 57.767 & \text { Yes }\end{array}$ $\begin{array}{lllllllllllllllll}0.81 & 27.38 & 28.31 & 28.75 & 3 & 1349.7559 & 1349.7425 & 450.9214 & 0.0134 & 9.9055 & 1977.438 & 1925.151 & 213.081 & 162.934 & \text { Yes }\end{array}$

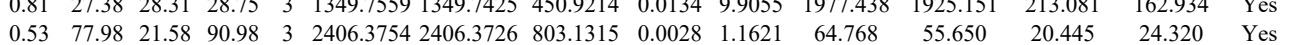

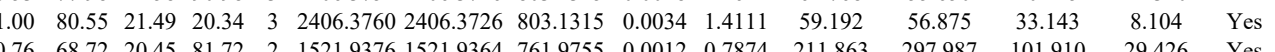
$\begin{array}{ccccccccccccccc}0.76 & 68.72 & 20.45 & 81.72 & 2 & 1521.9376 & 1521.9364 & 761.9755 & 0.0012 & 0.7874 & 211.863 & 297.987 & 101.910 & 29.426 & \text { Yes } \\ 0.95 & 41.41 & 25 & 30.58 & 2 & 1092.6516 & 092.643 & 57.3279 & 0.0103 & 9.4093 & 1047.418 & 8064.377 & 176.254 & 163.153 & \text { Yes }\end{array}$ $\begin{array}{llllllllllllllll}0.99 & 41.41 & 27.03 & 30.58 & 2 & 1092.6516 & 1092.6413 & 547.3279 & 0.0103 & 9.4093 & 10474.418 & 8064.377 & 176.254 & 163.153 & \text { Yes } \\ 0.95 & 32.88 & 25.19 & 30.59 & 2 & 1045.6498 & 1045.6406 & 523.8276 & 0.0092 & 8.7814 & 12038.979 & 10332.658 & 59.026 & 410.430 & \text { Yes }\end{array}$ $\begin{array}{lllllllllllllll}0.98 & 33.19 & 27.52 & 30.01 & 2 & 1045.6426 & 1045.6406 & 523.8276 & 0.0020 & 1.9090 & 34335.985 & 25663.227 & 576.749 & 216.542 & \text { Yes }\end{array}$ $\begin{array}{lllllllllllllll}0.96 & 41.18 & 27.55 & 29.77 & 2 & 1045.6386 & 1045.6406 & 523.8276 & -0.0020 & -1.9090 & 4375.561 & 3612.362 & 279.151 & 108.070 & \text { Yes }\end{array}$

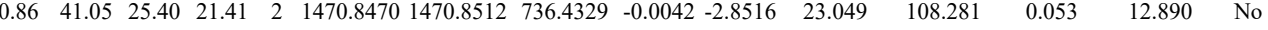

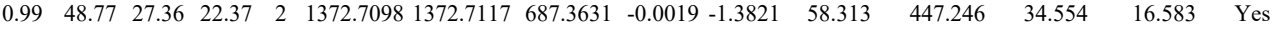
\begin{tabular}{lllllllllllllll}
0.99 & 43.47 & 27.31 & 19.94 & 2 & 1372.7106 & 1372.7117 & 687.3631 & -0.0011 & -0.8002 & 53.173 & 648.068 & 21.999 & 26.042 & Yes \\
\hline
\end{tabular}

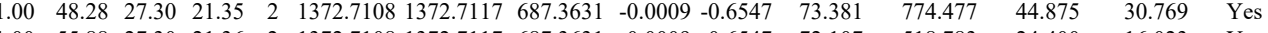

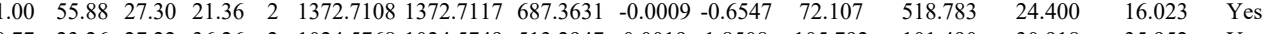

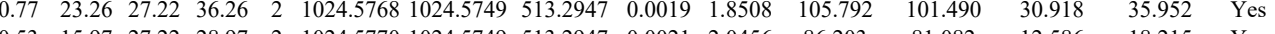

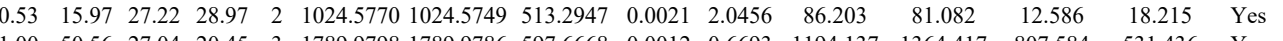
$\begin{array}{lllllllllllllll} & \end{array}$ $\begin{array}{llllllllllllllll}\text { GASELVAELSTLYQCIR } & 1.00 & 36.75 & 27.64 & 22.63 & 3 & 2042.0338 & 2042.0298 & 681.6839 & 0.0040 & 1.9559 & 63.423 & 87.519 & 51.238 & 34.195 & \text { Yes } \\ \text { GASELVAFLSTLYQCIR } & 1.00 & 47.33 & 27.64 & 16.19 & 3 & 2042.0338 & 2042.0298 & 681.6839 & 0.0040 & 1.9559 & 61.150 & 63.827 & 48.722 & 19.699 & \text { Yes }\end{array}$ $\begin{array}{llllllllllllllll} & \end{array}$

APPFVAR

APPFVAR

APPFVAR

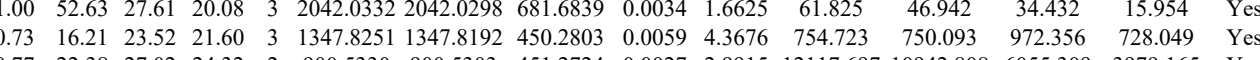

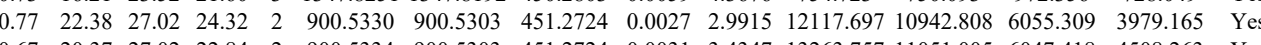
$\begin{array}{llllllllllllllll}0.77 & 20.53 & 27.02 & 28.14 & 2 & 000.5328 & 900.5303 & 451.2724 & 0.0025 & 2.7699 & 9076.935 & 7375.946 & 4762.675 & 2621.395 & \text { Yes }\end{array}$

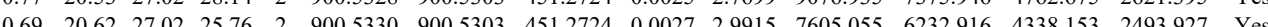




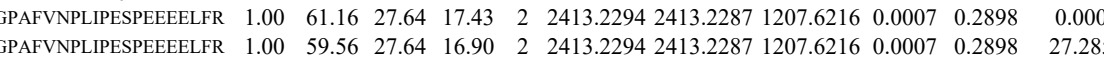

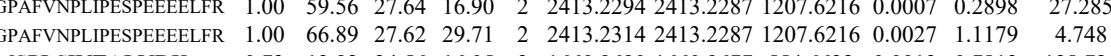
$\begin{array}{lllllllllllllll} & \end{array}$ $\begin{array}{llllllllllll}\text { WAASLENLLEDPEGVK } & 0.84 & 19.16 & 27.70 & 17.82 & 3 & 2058.0922 & 2058.0877 & 687.0365 & 0.0045 & 2.1833 & 96.664\end{array}$ $\begin{array}{lllllllll} & 0\end{array}$ QDQIFNLMK $\begin{array}{lllllllllllll}1.00 & 66.87 & 26.44 & 18.49 & 3 & 2867.4712 & 2867.4693 & 956.8304 & 0.0019 & 0.6619 & 3.431 & 1.158 & 3.280\end{array}$ \begin{tabular}{lllllllllllll}
\hline & EPWYDPNSPVLEDPVLCALAK & 0.99 & 28.15 & 26.47 & 19.87 & 3 & 2867.4703 & 2867.4693 & 956.8304 & 0.0010 & 0.3484 & 45.236
\end{tabular} TPALIALR

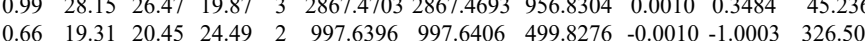
$\begin{array}{lllllllllllll} & 0.67 & 15.18 & 20.45 & 20.68 & 2 & 997.6408 & 997.6406 & 499.8276 & 0.0002 & 0.2001 & 276.069 & \end{array}$ $\begin{array}{lllllllllllll}\text { IGTTPDIILDDLLETDR } & 1.00 & \# \# \# \# 27.45 & 30.18 & 2 & 2043.0854 & 2043.0858 & 1022.5502 & -0.0004 & -0.1956 & 151.656 & 164\end{array}$

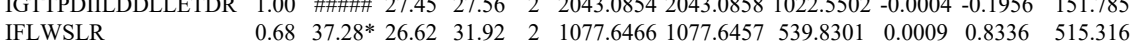
IFLWSLR $\begin{array}{lllllllllllllll} & \end{array}$ $\begin{array}{llllllllllllll} & \end{array}$

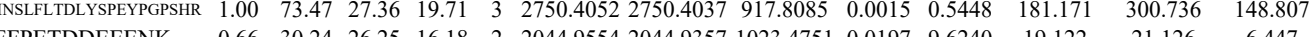
$\begin{array}{llllllll}50.68 & 1.00 & 2 & 8.5 & 0.6990 & 0.3873 & -0.9232 & 1.2768\end{array}$

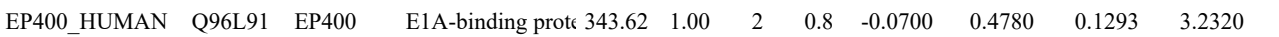

$\begin{array}{llllllllll}\text { MRRP3_HUMA } & \text { O15091 } & \text { KIAA0391 Mitochondrial ribr } 67.32 & 1.00 & 2 & 3.1 & 0.1227 & 0.0839 & 0.8297 & 1.4726\end{array}$ $\begin{array}{lllllllllll}\text { DHX57_HUMAl } & \text { Q6P158 } & \text { DHX57 } & \text { Putative ATP-dep 155.60 } & 1.00 & 2 & 1.3 & 0.0158 & 0.3172 & 0.2992 & 1.2822\end{array}$

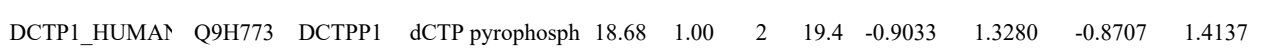

MDN1_HUMAN Q9NU22 MDN1_ Midasin

$\begin{array}{llllllll}632.82 & 1.00 & 2 & 0.4 & 0.1097 & 0.4526 & 1.0634 & 2.0171\end{array}$

RS27 HUMAN P42677 RPS27

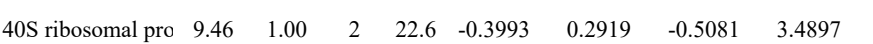

NHP2_HUMAN Q9NX24 NHP2

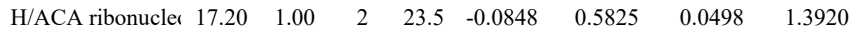

TELO2 HUMAT Q9Y4R8 TELO2

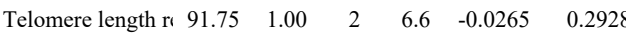

$1.1163 \quad 2.1720$

TPP2_HUMAN P29144 TPP2

Tripeptidyl-peptid $138.35 \quad 1.00 \quad 2 \quad 2.6 \quad 0.0835 \quad 0.1154 \quad 0.2046 \quad 1.5136$

$\begin{array}{lllllllllll}\text { CND2_HUMAN } & \text { Q15003 } & \text { NCAPH } & \text { Condensin comple } 82.56 & 1.00 & 2 & 2.8 & 0.1227 & 0.2889 & -0.2858 & 1.2262\end{array}$

SMC4_HUMAN Q9NTJ3 SMC4

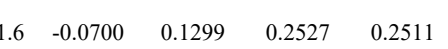

$\begin{array}{lllllllllll}\text { RBP2 HUMAN P49792 RANBP2 } & \text { E3 SUMO-protein } 358.20 & 1.00 & 2 & 1.1 & -0.1928 & 0.1103 & 1.1923 & 2.5692\end{array}$
LEALAILLQK

LEALAILLQK

SLLAWVAAK

LLDILSYLR

LLDILSYLR

VPLEQLCLR

LMLFGSIFR

LMLFGSIFR

LMLFGSIFR

LMLFGSIFR

FSFSPEPTLEDIR

ACVLLSTLAQLLLDK

LIWLPLR

LIWLPLR

LIWLPLR
LIWLPLR

LTEGCSFR

LTEGCSFR

DLLHPSPEEEK

$\begin{array}{llllllllll} & \\ 8.25 & 26.25 & 16.18 & 2 & 2044.9554 & 2044.9357 & 1023.4751 & 0.0197 & 9.6240 & 19.122\end{array}$

21.126

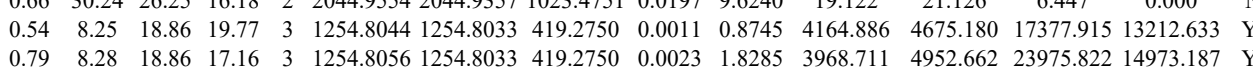

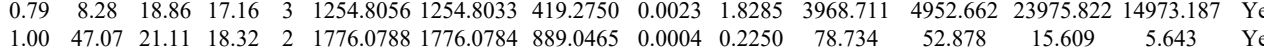
$\begin{array}{llllllllllllllll}0.68 & 16.77 & 21.85 & 27.46 & 2 & 1245.7692 & 1245.7689 & 623.8917 & 0.0003 & 0.2404 & 4616.993 & 5373.618 & 2263.873 & 686.862 & \text { Yes } \\ 1.00 & 52.79 & 24.00 & 31.50 & 2 & 1248.7582 & 1248.7563 & 625.385 & 0.001 & .519 & 1333.48 & 1525.943 & 14.269 & 3.768 & \text { Yes }\end{array}$ $\begin{array}{llllllllllllllll}1.00 & 52.79 & 24.00 & 31.50 & 2 & 1248.7582 & 1248.7563 & 625.3854 & 0.0019 & 1.5191 & 1333.480 & 1525.943 & 14.209 & 30.768 & \text { Yes }\end{array}$

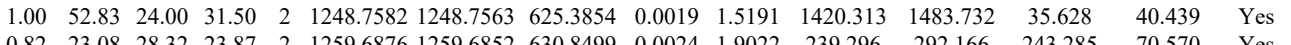
$\begin{array}{lllllllllllllll}0.82 & 23.08 & 28.32 & 23.87 & 2 & 1259.6876 & 1259.6852 & 630.8499 & 0.0024 & 1.9022 & 239.296 & 292.166 & 243.285 & 70.570 & \text { Yes }\end{array}$ $\begin{array}{lllllllllllllll}1.00 & 46.63 & 26.85 & 26.94 & 2 & 1226.6978 & 1226.6967 & 614.3556 & 0.0011 & 0.8952 & 623.200 & 493.956 & 24.212 & 29.033 & \text { Yes } \\ 1.00 & 39.68 & 26.85 & 27.91 & 2 & 1226.6980 & 1226.6967 & 614356 & 0.0013 & 1.0580 & 664.248 & 624.066 & 38.042 & 20.475 & \text { Yes }\end{array}$ $\begin{array}{lllllllllllllll}1.00 & 39.68 & 26.85 & 27.91 & 2 & 1226.6980 & 1226.6967 & 614.3556 & 0.0013 & 1.0580 & 664.248 & 624.066 & 38.042 & 20.475 & \text { Yes } \\ 0.93 & 26.73 & 26.85 & 2.16 & 2 & 1226.6980 & 12266967 & 614356 & 0.0013 & 1.0580 & 249.22 & 246731 & 1.7217 & 15.46 & \text { Yes }\end{array}$ $\begin{array}{lllllllllllllll}0.93 & 26.73 & 26.85 & 22.16 & 2 & 1226.6980 & 1226.6967 & 614.3556 & 0.0013 & 1.0580 & 249.226 & 246.731 & 17.217 & 15.466 & \text { Yes } \\ 0.55 & 16.05 & 26.96 & 25.60 & 2 & 1226.6986 & 1266967 & 614.3556 & 0.0019 & 1.5463 & 159.707 & 220.863 & 32.936 & 1.787 & \text { Yes }\end{array}$

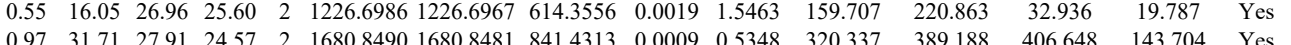

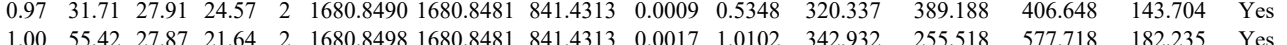

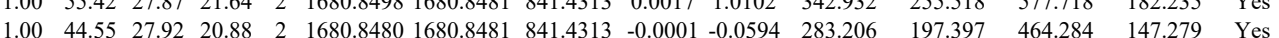

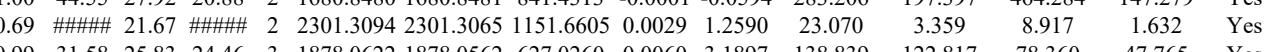

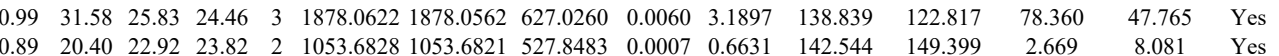

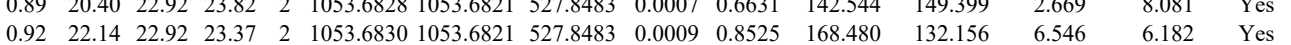
$\begin{array}{lllllllllllllll}0.91 & 21.32 & 22.92 & 24.95 & 2 & 1053.6832 & 1053.6821 & 527.8483 & 0.0011 & 1.0420 & 284.155 & 402.599 & 2.060 & 2.050 & \text { Yes }\end{array}$ $\begin{array}{lllllllllllllll}0.98 & 27.46 & 22.92 & 24.74 & 2 & 1053.6832 & 1053.6821 & 527.8483 & 0.0011 & 1.0420 & 232.924 & 385.152 & 7.769 & 6.361 & \text { Yes }\end{array}$

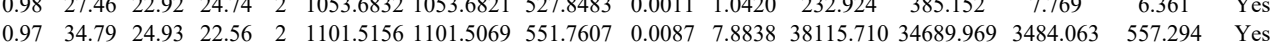
$\begin{array}{llllllllllllllll}0.98 & 35.02 & 24.61 & 20.56 & 2 & 1101.5172 & 1101.5069 & 551.7607 & 0.0103 & 9.3337 & 38694.560 & 33309.980 & 1356.244 & 781.465 & \text { Yes }\end{array}$ $\begin{array}{lllllllllllllllll}0.98 & 28.18 & 27.81 & 18.90 & 3 & 1580.8342 & 1580.8289 & 527.9502 & 0.0053 & 3.3463 & 2592.696 & 1506.079 & 7405.876 & 2976.655 & \text { Yes }\end{array}$ $\begin{array}{llllllllllllllll}0.98 & 29.45 & 27.84 & 15.15 & 3 & 1580.8345 & 1580.8289 & 527.9502 & 0.0056 & 3.5357 & 4650.152 & 3810.784 & 11178.604 & 5144.151 & \text { Yes }\end{array}$

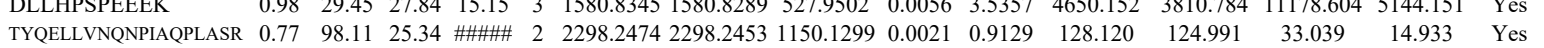
$\begin{array}{lllllllllllllllll}\text { ADPDGPEAQAEACSGER } & 0.91 & 25.57 & 20.33 & 15.91 & 2 & 1891.7966 & 1891.7798 & 946.8972 & 0.0168 & 8.8710 & 46.541 & 30.157 & 14.316 & 5.561 & \text { Yes }\end{array}$ $\begin{array}{lllllllllllllllll}\text { ADPDGPEAQAEACSGER } & 1.00 & 51.33 & 20.41 & 16.34 & 2 & 1891.7978 & 1891.7798 & 946.8972 & 0.0180 & 9.5046 & 31.034 & 45.093 & 23.062 & 19.474 & \text { Yes }\end{array}$

LLFLQSR LLFLQSR

RPLLLQVLK

RPLLLQVLK

RPLLLQVLK

RPLLLQVLK

TDPRPDAATIK

TDPRPDAATIK

NWVQTLRPVSAK

QSMWSLLTALSGK

VFPMPLPR

FTASIQR

SNVIDSML

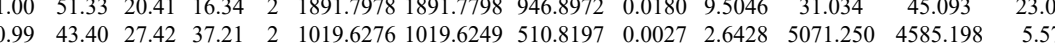
$\begin{array}{lllllllllllllll}0.99 & 43.72 & 27.44 & 30.73 & 2 & 1019.6286 & 1019.6249 & 510.8197 & 0.0037 & 3.6216 & 4468.875 & 3626.651 & 75.594 & 48.773 & \text { Yes }\end{array}$ $\begin{array}{lllllllllllllll}0.61 & 22.40 & 12.55 & 35.40 & 2 & 1078.7226 & 1078.7226 & 540.3686 & 0.0000 & 0.0000 & 518.608 & 464.752 & 125.515 & 70.260 & \text { Yes }\end{array}$ $\begin{array}{lllllllllllllll}0.61 & 17.41 & 12.55 & 30.41 & 2 & 1078.7228 & 1078.7226 & 540.3686 & 0.0002 & 0.1851 & 427.979 & 458.046 & 171.195 & 95.430 & \text { Yes }\end{array}$

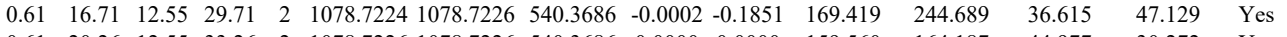
$\begin{array}{lllllllllllllll}0.61 & 20.26 & 12.55 & 33.26 & 2 & 1078.7226 & 1078.7226 & 540.3686 & 0.0000 & 0.0000 & 159.560 & 164.187 & 44.977 & 30.272 & \text { Yes }\end{array}$

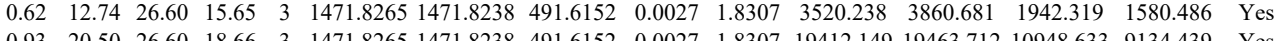

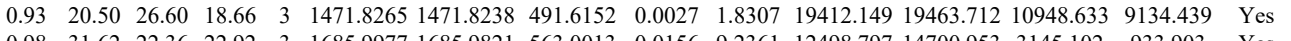

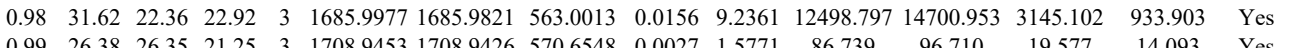
$\begin{array}{lllllllllllllll}0.99 & 26.38 & 26.35 & 21.25 & 3 & 1708.9453 & 1708.9426 & 570.6548 & 0.0027 & 1.5771 & 86.739 & 96.710 & 19.577 & 14.093 & \text { Yes } \\ 0.71 & 14.03 & 63.33 & 19.44 & 3 & 1708.9459 & 1708.9426 & 570.658 & 0.0033 & 1.9276 & 55.135 & 76.016 & 13.84 & 4.061 & \text { Yes }\end{array}$

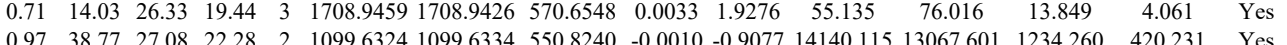
$\begin{array}{lllllllllllllll}0.97 & 38.77 & 27.08 & 22.28 & 2 & 1099.6324 & 1099.6334 & 550.8240 & -0.0010 & -0.9077 & 14140.115 & 13067.601 & 1234.260 & 420.231 & \text { Yes } \\ 0.83 & 22 & 26.99 & 23.32 & 2 & 965.5440 & 965.5416 & 483.7781 & 0.0024 & 2.4805 & 13532.064 & 14207.617 & 12282.866 & 6884.780 & \text { Yes }\end{array}$ $\begin{array}{llllllllllllllll}0.83 & 22.20 & 26.99 & 23.32 & 2 & 965.5440 & 965.5416 & 483.7781 & 0.0024 & 2.4805 & 13532.064 & 14207.617 & 12282.866 & 6884.780 & \text { Yes } \\ 0.85 & 24.60 & 27.08 & 26.17 & 2 & 965.5446 & 965.5416 & 483.7781 & 0.0030 & 3.1006 & 7960.730 & 8097.604 & 6281.096 & 4078.117 & \text { Yes }\end{array}$

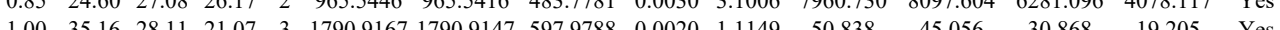
$\begin{array}{llllllllllllllll}0.76 & 33.48 & 17.24 & 46.48 & 2 & 1097.4374 & 1097.4360 & 549.7253 & 0.0014 & 1.2734 & 6955.097 & 6253.162 & 85.934 & 192.069 & \text { Yes }\end{array}$ 


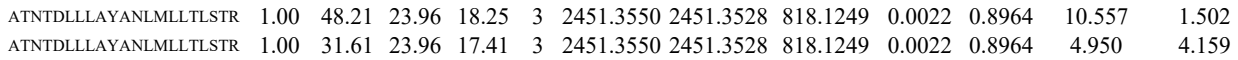

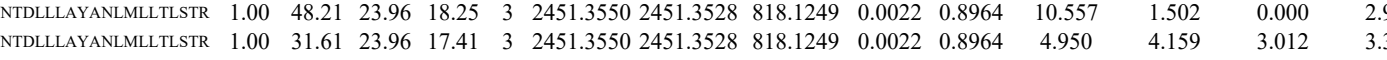

$\begin{array}{lllllllllllll} & \end{array}$

$\begin{array}{lllllllllllllll}\text { VLGVNVMLR } & 1.00 & 53.49 & 25.48 & 38.06 & 2 & 1143.7030 & 1143.6920 & 572.8533 & 0.0110 & 9.6010 & 9618.546 & 23278.924 & 703.851 & 325.591 \\ \text { VLGVNVMLR } & 0.99 & 40.00 & 26.07 & 29.10 & 2 & 1143.6924 & 1143.6920 & 572.8533 & 0.0004 & 0.3491 & 1808.971 & 4255.160 & 198.407 & 319.043\end{array}$ $\begin{array}{lllllllllllllll}0.70 & 38.72 & 27.77 & 33.41 & 2 & 1395.7452 & 1395.7489 & 98.8533 & 0.004 & 0.3491 & 1808.971 & 4255.160 & 198.407 & 319.043 & \text { Yes }\end{array}$

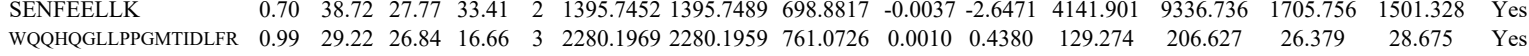

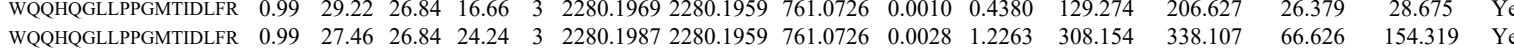
$\begin{array}{lllllllllllllllll}\text { WQQHQGLLPPGMTIDLFR } & 0.99 & 27.46 & 26.84 & 24.24 & 3 & 2280.1987 & 2280.1959 & 761.0726 & 0.0028 & 1.2263 & 308.154 & 338.107 & 66.626 & 154.319 & \text { Yes } \\ \text { LMALLGQALK } & 0.93 & 23.19 & 21.27 & 26.30 & 3 & 1344.8449 & 1344.8406 & 449.2875 & 0.0043 & 3.1902 & 346.061 & 316.624 & 61.852 & 16.694 & \text { Yes } \\ \text { L } & 0.98 & 33.71 & 17.63 & 35.03 & 2 & 955.6312 & 955.6300 & 478.8223 & 0.0012 & 1.2531 & 5193.321 & 4353.143 & 279.774 & 13.206 & \text { Yes }\end{array}$

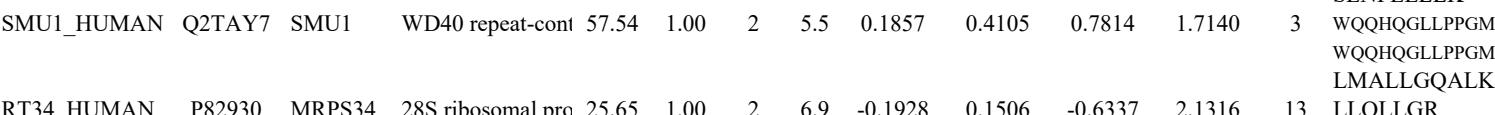
LLQLLGR LLQLLGR LLQLLGR LLQLLGR
LPLFGLGR LPLFGLGR LPLFGLGR LPLFGLGR LPLFGLGR
LPLFGLGR LPLFGLGR LPLFGLGR LPLFGLGR LPLFGLGR EPMNPIK EPMNPIK YVANIFPYK

YVANIFPYK

YVANIFPYK

YVANIFPYK

YVANIFPYK

HILANFK

HILANFK

LEEQRPER

ALHSLLLR

VVVLGLLPR

VVVLGLLPR

VVVLGLLPR

VVVGLLPR

VYCENQPMLPIGL

RPANQFVPR $\begin{array}{llllllllllllll}0.98 & 33.71 & 17.63 & 35.03 & 2 & 955.6312 & 955.6300 & 478.8223 & 0.0012 & 1.2531 & 5193.321 & 4353.143 & 279.774 & 1 \\ 0.98 & 40.30 & 18.45 & 42.37 & 2 & 955.6318 & 955.6300 & 478.8223 & 0.0018 & 1.8796 & 6374.848 & 5027.827 & 100.907\end{array}$

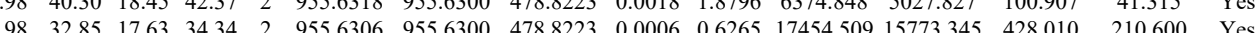
$\begin{array}{llllllllllllllll}0.98 & 35.19 & 17.63 & 36.49 & 2 & 955.6308 & 955.6300 & 478.8223 & 0.0008 & 0.8354 & 9143.343 & 8109.826 & 343.606 & 122.663 & \text { Yes }\end{array}$ $\begin{array}{lllllllllllllllll}0.98 & 33.26 & 17.63 & 34.91 & 2 & 955.6308 & 955.6300 & 478.8223 & 0.0008 & 0.8354 & 5693.908 & 5027.038 & 151.218 & 111.773 & \text { Yes }\end{array}$ $\begin{array}{lllllllllllllll}0.90 & 24.11 & 26.27 & 22.64 & 2 & 1015.6316 & 1015.6300 & 508.8223 & 0.0016 & 1.5723 & 2770.576 & 2604.579 & 1050.773 & 256.117 & \text { Yes }\end{array}$

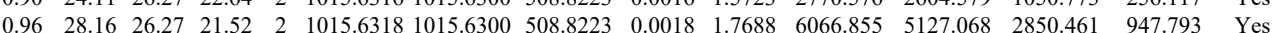
$\begin{array}{lllllllllllllll}0.88 & 23.14 & 26.27 & 20.12 & 2 & 1015.6316 & 1015.6300 & 5088223 & 0.0016 & 1.5723 & 2263294 & 2158.676 & 898.479 & 291.522 & \text { Yes }\end{array}$

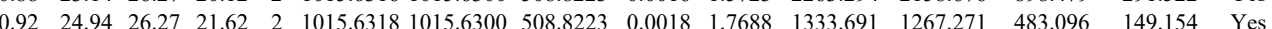
$\begin{array}{lllllllllllllll}0.82 & 21.49 & 26.27 & 24.94 & 2 & 1015.6314 & 1015.6300 & 508.8223 & 0.0014 & 1.3757 & 371.981 & 291.551 & 154.349 & 39.590 & \text { Yes }\end{array}$

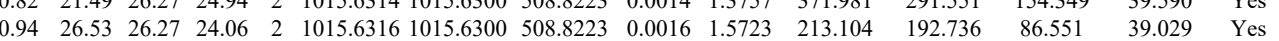
$\begin{array}{lllllllllllllll}0.93 & 25.87 & 26.27 & 22.05 & 2 & 1015.6314 & 1015.6300 & 508.8223 & 0.0014 & 1.3757 & 237.430 & 229.398 & 74.200 & 31.746 & \text { Yes }\end{array}$

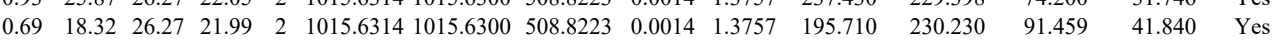

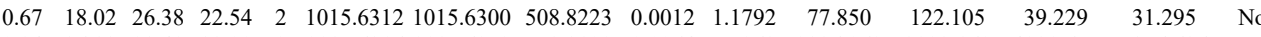

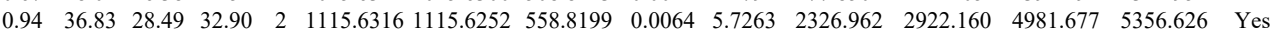
$\begin{array}{lllllllllllllll}0.91 & 35.04 & 28.43 & 31.82 & 2 & 1115.6324 & 1115.6252 & 558.8199 & 0.0072 & 6.4421 & 2529.087 & 2406.782 & 4669.873 & 5059.488 & \text { Yes }\end{array}$ $\begin{array}{llllllllllllll}0.70 & 54.28 * 27.20 & 23.50 & 2 & 1401.7948 & 1401.7900 & 701.9023 & 0.0048 & 3.4193 & 26324.370 & 22495.463 & 2245.254 & 577.492 & \text { Yes }\end{array}$ $\begin{array}{lllllllllllllll}0.76 & 40.78 * 26.67 & 23.61 & 2 & 1401.7914 & 1401.7900 & 701.9023 & 0.0014 & 0.9973 & 23759.195 & 23766.526 & 1801.706 & 422.270 & \text { Yes }\end{array}$ $\begin{array}{lllllllllllllll}0.90 & 53.21 * 26.88 & 23.47 & 2 & 1401.7926 & 1401.7900 & 701.9023 & 0.0026 & 1.8521 & 29909.739 & 26692.849 & 2930.392 & 270.147 & \text { Yes }\end{array}$ $\begin{array}{llllllllllllll}0.91 & 50.60^{*} 26.88 & 24.44 & 2 & 1401.7910 & 1401.7900 & 701.9023 & 0.0010 & 0.7123 & 7211.690 & 6145.136 & 1618.770 & 395.631 & \text { Yes }\end{array}$ $\begin{array}{llllllllllllll}0.94 & 54.66 * 26.67 & 26.45 & 2 & 1401.7914 & 1401.7900 & 701.9023 & 0.0014 & 0.9973 & 5593.266 & 4581.418 & 819.468 & 125.346 & \text { Yes }\end{array}$ $\begin{array}{lllllllllllllll}0.99 & 44.43 & 26.00 & 24.12 & 2 & 1129.6934 & 1129.6851 & 565.8498 & 0.0083 & 7.3340 & 22614.623 & 20380.318 & 1764.389 & 970.374 & \text { Yes }\end{array}$ $\begin{array}{llllllllllllllll}0.97 & 36.38 & 26.00 & 25.30 & 2 & 1129.6938 & 1129.6851 & 565.8498 & 0.0087 & 7.6875 & 19503.468 & 16220.406 & 953.805 & 922.574 & \text { Yes }\end{array}$

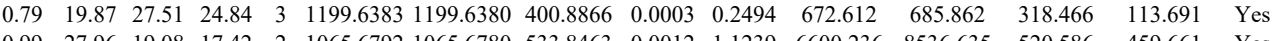
$\begin{array}{llllllllllllllll}0.99 & 27.96 & 19.08 & 17.42 & 2 & 1065.6792 & 1065.6780 & 533.8463 & 0.0012 & 1.1239 & 6600.236 & 8536.635 & 520.586 & 459.661 & \text { Yes }\end{array}$ $\begin{array}{lllllllllllllllll}0.99 & 27.27 & 19.34 & 23.39 & 2 & 1065.6796 & 1065.6780 & 533.8463 & 0.0016 & 1.4986 & 6956.199 & 8505.922 & 430.613 & 257.614 & \text { Yes } \\ 0.77 & 32.93 & 7.78 & 45.93 & 2 & 1108.7472 & 1108.7454 & 555.3800 & 0.0018 & 1.6205 & 3809.981 & 4213.303 & 160.257 & 160.285 & \text { Yes }\end{array}$

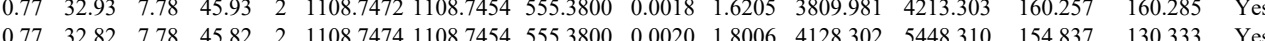

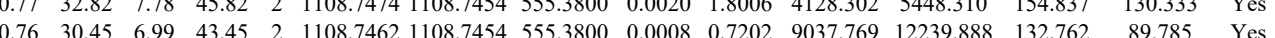

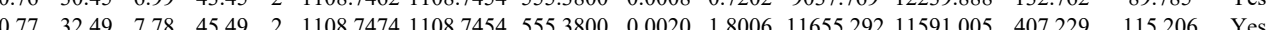

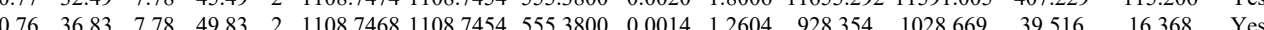
$\begin{array}{lllllllllllllll}0.76 & 36.83 & 7.78 & 49.83 & 2 & 1108.7468 & 1108.7454 & 555.3800 & 0.0014 & 1.2604 & 928.354 & 1028.669 & 39.516 & 16.368 & \text { Yes } \\ 0.99 & 31.32 & 27.02 & 19.05 & 3 & 2837.4127 & 2837.4079 & 946.8099 & 0.0048 & 1.6899 & 118.609 & 150.908 & 87.264 & 42.544 & \text { Yes }\end{array}$ $\begin{array}{lllllllllllllll}0.57 & 19.30 & 26.54 & 22.22 & 2 & 1083.5934 & 1083.5938 & 542.8042 & -0.0004 & -0.3685 & 56.809 & 101.643 & 27.438 & 20.766 & \text { Yes } \\ 0.70 & 21.88 & 26.54 & 18.47 & 2 & 1083.5934 & 1083.5938 & 542.8042 & -0.0004 & -0.3685 & 84.075 & 85.114 & 27.682 & 23.657 & \text { Yes }\end{array}$ $\begin{array}{lllllllllllllllll} & & & \end{array}$

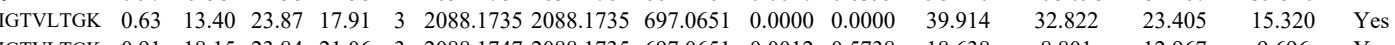

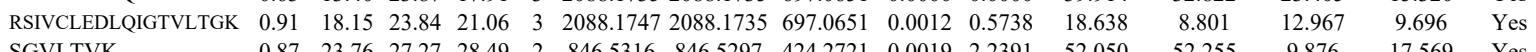
SGVLTVK
SGVLTVK RSISLAQMFVIK

$\begin{array}{llllllllllllll}\text { NUDT4_HUMA: } & \text { Q9NZJ9 } & \text { NUDT4 } & \text { Diphosphoinositol } 20.31 & 0.99 & 2 & 9.4 & -0.0265 & 0.4788 & 0.4717 & 1.6785 & 3 & \begin{array}{l}\text { AACLCFR } \\ \text { AACLCFR }\end{array} \\ & & & & & & & & & & & & & \text { LLGIFENQD }\end{array}$

$\begin{array}{llllllllllllll}\text { NUDT4_HUMA: } & \text { Q9NZJ9 } & \text { NUDT4 } & \text { Diphosphoinositol } 20.31 & 0.99 & 2 & 9.4 & -0.0265 & 0.4788 & 0.4717 & 1.6785 & 3 & \begin{array}{l}\text { AACLCFR } \\ \text { AACLCFR }\end{array} \\ & & & & & & & & & & & & & \text { LLGIFENQD }\end{array}$

$\begin{array}{llllllllllllll}\text { NUDT4_HUMA: } & \text { Q9NZJ9 } & \text { NUDT4 } & \text { Diphosphoinositol } 20.31 & 0.99 & 2 & 9.4 & -0.0265 & 0.4788 & 0.4717 & 1.6785 & 3 & \begin{array}{l}\text { AACLCFR } \\ \text { AACLCFR }\end{array} \\ & & & & & & & & & & & & \\ \text { LLGIFENQDR }\end{array}$

ITDILR

ITDILR

ITDILR

ITDILR

RMETTTTALK

SYNE2_HUMAI Q8WXH0 SYNE2 Nesprin-2

$\begin{array}{llllllll}796.44 & 0.98 & 4 & 0.5 & 0.1980 & 0.8356 & -0.4301 & 0.7806\end{array}$

INNILEKK

KNLEDGINNLK

KNLEDGINNLK

NICAMSMER

ILLMGLR

ILLMGLR

ILLMGLR $\begin{array}{llllllllllllll}0.87 & 23.76 & 27.27 & 28.49 & 2 & 846.5316 & 846.5297 & 424.2721 & 0.0019 & 2.2391 & 52.050 & 52.255 & 9.876 \\ 0.89 & 27.51 & 28.15 & 29.05 & 2 & 846.5324 & 846.5297 & 424.2721 & 0.0027 & 3.1819 & 53.869 & 36.854 & 17.118\end{array}$ $\begin{array}{llllllllllllll}0.59 & 15.03 & 24.74 & 27.21 & 2 & 1535.8986 & 1535.8979 & 768.9562 & 0.0007 & 0.4552 & 1910.799 & 1792.264 & 186.121\end{array}$ $\begin{array}{lllllllllllll}0.90 & 22.19 & 24.42 & 26.35 & 2 & 1535.8996 & 1535.8979 & 768.9562 & 0.0017 & 1.1054 & 829.178 & 921.477 & 141.121\end{array}$ $\begin{array}{lllllllllllll}0.77 & 18.54 & 19.19 & 31.54 & 2 & 1018.4362 & 1018.4342 & 510.2244 & 0.0020 & 1.9599 & 1962.940 & 1690.198 & 117.659 \\ 0.98 & 24.71 & 19.44 & 14.82 & 2 & 1018.4366 & 1018.4342 & 5102244 & 0.0024 & 2.3519 & 1882279 & 1513.167 & 50.763\end{array}$ $\begin{array}{lllllllllllllll}0.98 & 24.71 & 19.44 & 14.82 & 2 & 1018.4366 & 1018.4342 & 510.2244 & 0.0024 & 2.3519 & 1882.279 & 1513.167 & 50.763 \\ 0.85 & 24.62 & 29.11 & 22.37 & 3 & 1203.6307 & 1203.6248 & 402.2155 & 0.0059 & 4.8896 & 121.896 & 179.648 & 81.051\end{array}$ $\begin{array}{llllllllllllll}0.85 & 24.62 & 29.11 & 22.37 & 3 & 1203.6307 & 1203.6248 & 402.2155 & 0.0059 & 4.8896 & 121.896 & 179.648 & 81.051 \\ 0.65 & 17.35 & 26.09 & 22.13 & 2 & 873.5416 & 873.5405 & 4377775 & 0.0011 & 1.2563 & 142.906 & 127.125 & 31.460\end{array}$ $\begin{array}{lllllllllllll}0.65 & 17.08 & 26.09 & 22.38 & 2 & 873.5424 & 873.5405 & 437.7775 & 0.0019 & 2.1700 & 123.774 & 118.836 & 34.062\end{array}$ $\begin{array}{lllllllllllll}0.67 & 17.72 & 26.09 & 23.30 & 2 & 873.5420 & 873.5405 & 437.7775 & 0.0015 & 1.7132 & 303.209 & 304.721 & 84.761\end{array}$ \begin{tabular}{lllllllllllllll}
0.75 & 19.41 & 26.09 & 32.09 & 2 & 873.5420 & 873.5405 & 437.7775 & 0.0015 & 1.7132 & 240.975 & 217.889 & 47.940 \\
\hline
\end{tabular} $\begin{array}{llllllllllllll}0.69 & 17.83 & 26.09 & 27.95 & 2 & 873.5424 & 873.5405 & 437.7775 & 0.0019 & 2.1700 & 308.247 & 275.735 & 100.675\end{array}$ $\begin{array}{lllllllllllll}0.98 & 26.72 & 28.31 & 20.88 & 3 & 1294.7065 & 1294.7037 & 432.5752 & 0.0028 & 2.1576 & 13298.189 & 13606.602 & 529.262\end{array}$ $\begin{array}{lllllllllllll}0.65 & 21.60 & 23.93 & 29.45 & 2 & 970.5904 & 970.5811 & 486.2978 & 0.0093 & 9.5620 & 262.157 & 259.077 & 193.080\end{array}$ $\begin{array}{lllllllllllll}0.87 & 26.74 & 23.93 & 31.21 & 2 & 970.5906 & 970.5811 & 486.2978 & 0.0095 & 9.7676 & 425.092 & 173.138 & 257.779\end{array}$ $\begin{array}{lllllllllllll}0.51 & 14.55 & 24.22 & 26.81 & 2 & 1688.9812 & 1688.9786 & 845.4966 & 0.0026 & 1.5376 & 34.841 & 61.869 & 505.885 \\ 0.58 & 15.85 & 24.20 & 25.58 & 2 & 1688.9820 & 1688.9786 & 845.4966 & 0.0034 & 2.0106 & 31.970 & 50.757 & 599.088\end{array}$

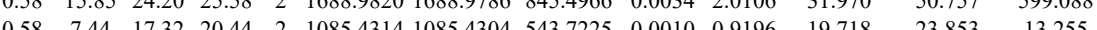
$\begin{array}{llllllllllllll}0.58 & 7.44 & 17.32 & 20.44 & 2 & 1085.4314 & 1085.4304 & 543.7225 & 0.0010 & 0.9196 & 19.718 & 23.853 & 13.255 \\ 0.62 & 21.09 & 25.31 & 30.79 & 2 & 1088.6784 & 1088.6685 & 545.3415 & 0.0099 & 9.0768 & 392.074 & 769.442 & 1868.420 & 4\end{array}$ $\begin{array}{llllllllllllll}0.62 & 21.09 & 25.31 & 30.79 & 2 & 1088.6784 & 1088.6685 & 545.3415 & 0.0099 & 9.0768 & 392.074 & 769.442 & 1868.420 \\ 0.95 & 31.37 & 25.50 & 33.24 & 2 & 958.6116 & 958.6119 & 480.3132 & -0.0003 & -0.3123 & 4543.462 & 5086.679 & 130.027 \\ 0.92 & 0.78 & 25.50 & 35.25 & 2 & 958.618 & 958.619 & 480.3132 & -0.0001 & -0.141 & 577.128 & 664.352 & 294.46\end{array}$ $\begin{array}{llllllllllllll}0.92 & 30.78 & 25.50 & 35.25 & 2 & 958.6118 & 958.6119 & 480.3132 & -0.0001 & -0.1041 & 5377.128 & 6764.352 & 294.496\end{array}$ $\begin{array}{lllllllllllll}0.91 & 30.08 & 25.50 & 34.81 & 2 & 958.6116 & 958.6119 & 480.3132 & -0.0003 & -0.3123 & 954.981 & 997.201 & 68.290\end{array}$

Yes

Table S-3 page 498 of 499 

$\begin{array}{lllllllllllllll}0.70 & 11.79 & 16.99 & 20.88 & 3 & 1607.9866 & 1607.9854 & 537.0024 & 0.0012 & 0.7449 & 90.702 & 81.675 & 184.820 & 85.482 & \text { No } \\ 0.77 & 11.56 & 16.90 & 20.76 & 3 & 1607.9878 & 1607.9854 & 537.0024 & 0.0024 & 1.4897 & 132.311 & 88.784 & 203.613 & 30.584 & \text { Y }\end{array}$

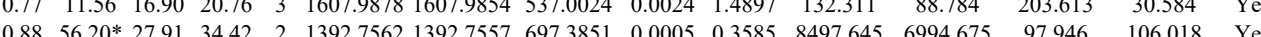

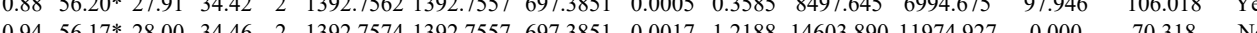

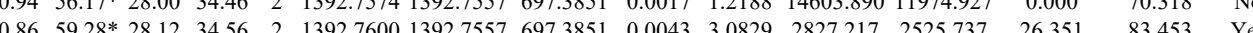
$\begin{array}{lllllllllllllll}0.76 & 59.23 * 28.14 & 28.37 & 2 & 1392.7610 & 1392.7557 & 697.3851 & 0.0053 & 3.08999 & 2052.984 & 1865.722 & 44.036 & 103.891 & \text { Yes }\end{array}$ $\begin{array}{lllllllllllllllll}0.87 & 38.36 & 25.75 & 40.76 & 2 & 957.6176 & 957.6093 & 479.8119 & 0.003 & 8.6491 & 27865.743 & 33874.402 & 2269.574 & 284.367 & \text { Yes }\end{array}$ $\begin{array}{llllllllllllllll}0.87 & 38.36 & 25.75 & 40.76 & 2 & 957.6176 & 957.603 & 47.8119 & 0.008 & 8.6491 & 2785.743 & 33657.402 & 2269.574 & 284.367 & \text { Yes } \\ 0.84 & 33.71 & 25.75 & 37.36 & 2 & 957.6176 & 957.6093 & 479.8119 & 0.0083 & 8.6491 & 33901.397 & 42375.556 & 2288.721 & 675.059 & \text { Yes }\end{array}$ $\begin{array}{llllllllllllllll}0.92 & 32.10 & 27.65 & 28.68 & 2 & 1429.8138 & 1429.8020 & 715.9083 & 0.0118 & 8.2412 & 177.064 & 170.651 & 191.727 & 0.000 & \text { No }\end{array}$ $\begin{array}{lllllllllllllll}0.93 & 32.36 & 27.65 & 22.60 & 2 & 1429.8138 & 1429.8020 & 715.9083 & 0.0118 & 8.2412 & 103.241 & 99.028 & 31.496 & 57.153 & \text { Yes }\end{array}$ $\begin{array}{lllllllllllllll}0.95 & 29.24 & 14.91 & 28.16 & 2 & 10687238 & 1068.7150 & 535.3648 & 0.0088 & 8.2186 & 2177.101 & 3122.572 & 3543.496 & 2820.828 & \text { Yes }\end{array}$ $\begin{array}{lllllllllllllll}0.94 & 27.32 & 14.31 & 27.67 & 2 & 1068.7246 & 1068.7150 & 535.3648 & 0.0096 & 8.9658 & 1565.121 & 2280.865 & 2410.696 & 2032.256 & \text { Yes }\end{array}$ $\begin{array}{lllllllllllllll}0.52 & 17.02 & 21.40 & 29.40 & 2 & 12267840 & 1226.7720 & 6143933 & 0.0120 & 9.7656 & 225.622 & 523.926 & 2560.772 & 1154.655 & \text { Yes }\end{array}$ $\begin{array}{lllllllllllllll}0.52 & 15.60 & 21.40 & 17.26 & 2 & 1226.7842 & 1226.7720 & 614.3933 & 0.0122 & 9.9284 & 285.011 & 365.202 & 2533.327 & 1065.698 & \text { Yes }\end{array}$ \begin{tabular}{llllllllllllllll}
0.58 & 19.69 & 21.40 & 31.10 & 2 & 1226.7838 & 1226.7720 & 614.3933 & 0.0118 & 9.6029 & 48.796 & 70.219 & 761.701 & 392.413 & Yes \\
\hline
\end{tabular} $\begin{array}{lllllllllllllll}0.52 & 17.16 & 21.40 & 29.66 & 2 & 1226.7842 & 1226.7720 & 614.3933 & 0.0122 & 9.9284 & 52.457 & 114.598 & 671.782 & 340.668 & \text { Yes }\end{array}$

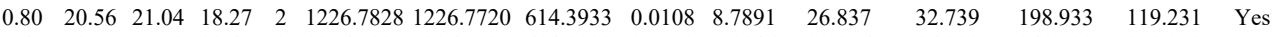

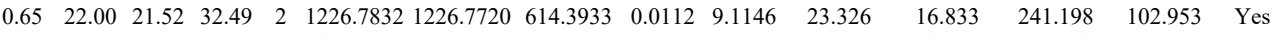

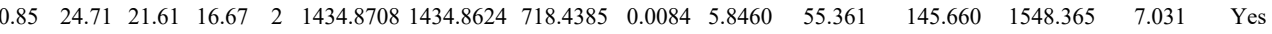
$\begin{array}{lllllllllllllll}0.92 & 25.25 & 21.24 & 20.64 & 2 & 1434.8728 & 1434.8624 & 718.4385 & 0.0104 & 7.2379 & 62.738 & 70.648 & 968.181 & 40.900 & \text { Yes }\end{array}$

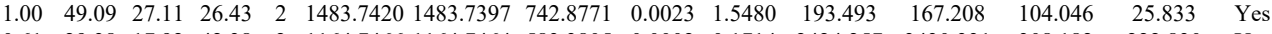

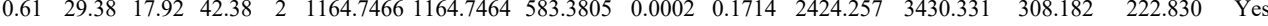
$\begin{array}{llllllllllllllll}0.76 & 32.82 & 17.32 & 45.82 & 2 & 1164.7470 & 1164.7464 & 583.3805 & 0.0006 & 0.5142 & 3439.134 & 3671.909 & 191.713 & 134.251 & \text { Yes }\end{array}$

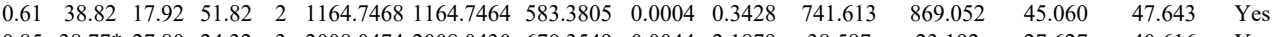
ARPTLWAAALTLLVLL

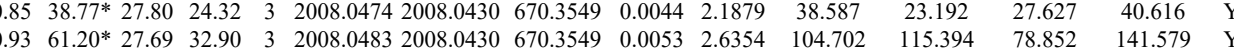
IIIIK

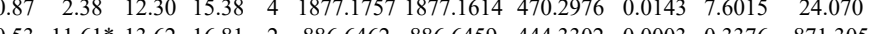
$\begin{array}{lllllllllllllllll}0.53 & 11.61 & 13.62 & 16.81 & 2 & 886.6462 & 886.6459 & 444.3302 & 0.0003 & 0.3376 & 871.305 & 1031.939 & 448.446 & 192.206 & \text { Yes }\end{array}$ $\begin{array}{lllllllllllllllll}0.85 & 19.41 * & 13.62 & 20.63 & 2 & 886.6474 & 886.6459 & 444.3302 & 0.0015 & 1.6879 & 917.214 & 1061.559 & 453.115 & 197.542 & \text { Yes } \\ 0\end{array}$ $\begin{array}{llllllllllllllll}0.56 & 22.42 & 25.04 & 26.73 & 2 & 959.6310 & 959.6259 & 480.8202 & 0.0051 & 5.3034 & 57.872 & 50.662 & 52.316 & 3.667 & \text { Yes }\end{array}$

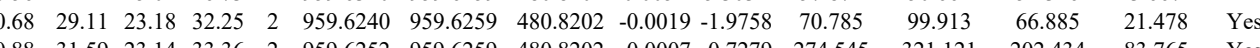

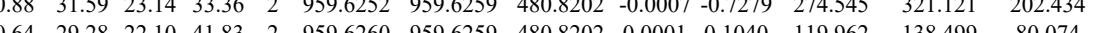

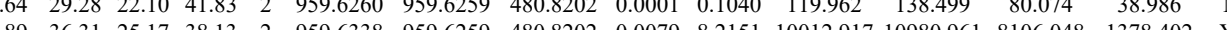


Table S-4. Information of peptides identified in areca nut extract (ANE)-trained cell lines (set 2)

\begin{tabular}{|c|c|c|c|c|c|c|c|c|c|c|c|c|c|c|c|c|c|c|c|c|c|c|c|c|c|c|c|c|}
\hline \multirow[b]{2}{*}{$\begin{array}{l}\text { Unique and } \\
\text { stable accession } \\
\text { no. of a } \\
\text { UniProtKB } \\
\text { entry }\end{array}$} & \multirow[b]{2}{*}{$\begin{array}{c}\text { Mnemonic } \\
\text { accession } \\
\text { no. of a } \\
\text { UniProtKB } \\
\text { entry }\end{array}$} & \multirow[b]{2}{*}{$\begin{array}{l}\text { Gene } \\
\text { names }\end{array}$} & \multirow[b]{2}{*}{ Protein names } & & & & $\Xi_{\infty}$ & Log2 ratio & $\mathrm{O}$ of ANE- & trained/pare & ntal cells & & & & & ascot sec & & & & $\approx$ & & & & & iTRAQ repor & rter intensity & & \\
\hline & & & & $\begin{array}{c}\mathrm{MW} \\
(\mathrm{kDa})\end{array}$ & 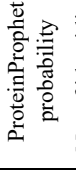 & 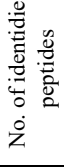 & 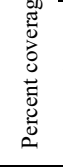 & $\begin{array}{l}\text { CGHNK2 } \\
(115 / 114)\end{array}$ & $\begin{array}{l}\text { SD of } \\
\text { peptide } \\
\text { ratios } \\
\text { from the } \\
\text { protein }\end{array}$ & $\begin{array}{l}\text { CGHNC9 } \\
(117 / 116)\end{array}$ & $\begin{array}{l}\text { SD of } \\
\text { peptide } \\
\text { ratios } \\
\text { from the } \\
\text { protein }\end{array}$ & 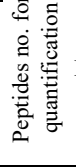 & Peptide sequence & 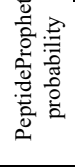 & $\begin{array}{l}\text { o. } \\
0 \\
.0 \\
.0 \\
.0\end{array}$ & 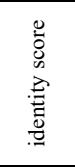 & 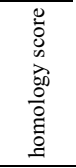 & $\begin{array}{l}\text { 总 } \\
\text { 豝 }\end{array}$ & 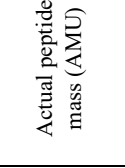 & 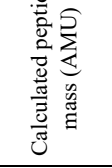 & 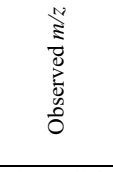 & $\begin{array}{l}\text { Error } \\
\text { (AMU) }\end{array}$ & $\begin{array}{l}\text { Error } \\
(\mathrm{ppm})\end{array}$ & 114 & 115 & 116 & 117 & 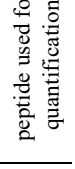 \\
\hline UBA6_HUMAN & A0AVT1 & UBA6 & Ubiquitin-like mo & 117.97 & 1.00 & 9 & 12.9 & 0.0373 & 0.5194 & 0.5197 & 0.5313 & 18 & QDVIITALDNVEAR & 1.00 & 77.21 & 27.57 & 30.53 & 2 & 1699.92401 & 1699.9226 & 850.9686 & 0.0014 & 0.8226 & 243.722 & 168.927 & 28.868 & 194.387 & No \\
\hline & & & & & & & & & & & & & QDVIITALDNVEAR & 1.00 & 65.40 & 27.63 & 31.11 & 2 & 1699.92461 & 1699.9226 & 850.9686 & 0.0020 & 1.1751 & 200.032 & 194.419 & 69.759 & 236.600 & Yes \\
\hline & & & & & & & & & & & & & YVLGDTAMQK & 0.90 & 30.03 & 27.02 & 21.19 & 2 & 1412.7712 & 1412.7577 & 707.3861 & 0.0135 & 9.5421 & 601.553 & 517.192 & 168.054 & 766.483 & Yes \\
\hline & & & & & & & & & & & & & YVLGDTAMQK & 0.87 & 29.00 & 27.02 & 20.28 & 2 & 1412.77141 & 1412.7577 & 707.3861 & 0.0137 & 9.6834 & 424.331 & 446.445 & 157.153 & 612.951 & Yes \\
\hline & & & & & & & & & & & & & FDLNEPLHLSFLQNAAK & 0.55 & 54.29 & 26.11 & 67.29 & 3 & 2244.21612 & 2244.2146 & 749.0788 & 0.0015 & 0.6675 & 261.801 & 143.289 & 92.347 & 456.893 & Yes \\
\hline & & & & & & & & & & & & & SFPAAIEHTIQWAR & 0.60 & 60.60 & 27.86 & 73.60 & 3 & 1769.9374 & 1769.9335 & 590.9851 & 0.0039 & 2.1997 & 3507.936 & 2911.601 & 155.120 & 3403.353 & Yes \\
\hline & & & & & & & & & & & & & NCFLNLAIPIVVFTETTEVR & 0.99 & 27.75 & 27.41 & 16.70 & 3 & 2468.29512 & 2468.2929 & 823.7716 & 0.0022 & 0.8902 & 22.450 & 9.334 & 8.120 & 14.006 & No \\
\hline & & & & & & & & & & & & & NCFLNLAIPIVVFTETTEVR & 0.60 & 22.93 & 27.30 & 35.93 & 3 & 2468.29692 & 2468.2929 & 823.7716 & 0.0040 & 1.6186 & 4.828 & 5.738 & 9.239 & 21.985 & Yes \\
\hline & & & & & & & & & & & & & NCFLNLAIPIVVFTETTEVR & 0.92 & 19.35 & 27.42 & 15.16 & 3 & 2468.29602 & 2468.2929 & 823.7716 & 0.0031 & 1.2544 & 6.465 & 8.247 & 6.412 & 14.833 & Yes \\
\hline & & & & & & & & & & & & & NCFLNLAIPIVVFTETTEVR & 0.69 & 14.26 & 27.31 & 14.31 & 3 & 2468.2972 & 2468.2929 & 823.7716 & 0.0043 & 1.7400 & 7.160 & 6.637 & 4.801 & 10.936 & Yes \\
\hline & & & & & & & & & & & & & IIPAIATTTATVSGLVALEMIK & 0.55 & 15.32 & 17.40 & 28.32 & 3 & 2500.48092 & 2500.4794 & 834.5004 & 0.0015 & 0.5992 & 7.808 & 12.173 & 0.920 & 8.361 & No \\
\hline & & & & & & & & & & & & & IIPAIATTTATVSGLVALEMIK & 1.00 & 47.38 & 17.40 & 16.79 & 3 & 2500.4818 & 2500.4794 & 834.5004 & 0.0024 & 0.9587 & 6.356 & 7.685 & 10.186 & 14.770 & Yes \\
\hline & & & & & & & & & & & & & IIPAIATTTATVSGLVALEMIK & 1.00 & 46.94 & 17.40 & 19.43 & 3 & 2500.4818 & 2500.4794 & 834.5004 & 0.0024 & 0.9587 & 4.094 & 5.058 & 1.341 & 12.907 & No \\
\hline & & & & & & & & & & & & & IIPAIATTTATVSGLVALEMIK & 1.00 & 70.46 & 17.63 & 23.66 & 3 & 2500.4788 & 2500.4794 & 834.5004 & $-0.0006-$ & -0.2397 & 4.626 & 7.907 & 17.313 & 16.869 & No \\
\hline & & & & & & & & & & & & & IIPAIATTTATVSGLVALEMIK & 1.00 & 57.35 & 17.40 & 18.84 & 3 & 2500.4803 & 2500.4794 & 834.5004 & 0.0009 & 0.3595 & 10.818 & 15.545 & 9.999 & 17.833 & Yes \\
\hline & & & & & & & & & & & & & ALQLLHCFPLDIR & 1.00 & 38.08 & 27.34 & 17.60 & 3 & 1727.9359 & 1727.9337 & 576.9852 & 0.0022 & 1.2710 & 153.653 & 210.128 & 71.125 & 275.049 & Yes \\
\hline & & & & & & & & & & & & & IIPAIATTTATVSGLVALEMIK & 1.00 & 56.13 & 17.40 & 24.07 & 3 & 2500.47942 & 2500.4794 & 834.5004 & 0.0000 & 0.0000 & 6.458 & 19.457 & 2.188 & 11.278 & No \\
\hline & & & & & & & & & & & & & IIPAIATTTATVSGLVALEMIK & 1.00 & 57.08 & 17.40 & 21.30 & 3 & 2500.4803 & 2500.4794 & 834.5004 & 0.0009 & 0.3595 & 6.686 & 13.110 & 3.562 & 27.136 & No \\
\hline & & & & & & & & & & & & & ALQLLHCFPLDIR & 1.00 & 45.81 & 27.28 & 18.20 & 3 & 1727.9368 & 1727.9337 & 576.9852 & 0.0031 & 1.7909 & 74.100 & 64.666 & 24.895 & 122.726 & Yes \\
\hline & & & & & & & & & & & & & ALQLLHCFPLDIR & 1.00 & 36.02 & 27.27 & 15.55 & 3 & 1727.93711 & 1727.9337 & 576.9852 & 0.0034 & 1.9642 & 58.236 & 60.871 & 18.484 & 90.872 & Yes \\
\hline & & & & & & & & & & & & & IIPAIATTTATVSGLVALEMIK & 0.66 & 41.31 & 17.40 & 54.31 & 3 & 2500.4818 & 2500.4794 & 834.5004 & 0.0024 & 0.9587 & 5.891 & 4.253 & 16.485 & 9.852 & No \\
\hline & & & & & & & & & & & & & KPDHVPISSEDER & 1.00 & 38.23 & 27.62 & 17.97 & 4 & 1795.93291 & 1795.9308 & 449.9900 & 0.0021 & 1.1667 & 750.093 & 452.858 & 498.482 & 599.491 & Yes \\
\hline & & & & & & & & & & & & & KPDHVPISSEDER & 1.00 & 19.25 & 27.62 & 23.58 & 4 & 1795.93291 & 1795.9308 & 449.9900 & 0.0021 & 1.1667 & 4912.238 & 2617.818 & 3191.783 & 7672.890 & Yes \\
\hline & & & & & & & & & & & & & IIPAIATTTATVSGLVALEMIK & 0.66 & 36.32 & 17.40 & 49.32 & 3 & 2500.4815 & 2500.4794 & 834.5004 & 0.0021 & 0.8388 & 4.938 & 10.388 & 5.480 & 6.798 & Yes \\
\hline & & & & & & & & & & & & & DPPEEEIPFCTLK & 0.98 & 36.61 & 27.02 & 17.57 & 2 & 1850.9034 & 1850.9038 & 926.4592 & $-0.0004-$ & -0.2159 & 203.212 & 235.792 & 118.713 & 345.696 & Yes \\
\hline & & & & & & & & & & & & & DPPEEEIPFCTLK & 1.00 & 41.18 & 27.05 & 22.92 & 2 & 1850.9050 & 1850.9038 & 926.4592 & 0.0012 & 0.6476 & 156.748 & 239.738 & 124.673 & 231.732 & Yes \\
\hline CNOT1_HUMAl & A5YKK6 & CNOT1 & CCR4-NOT transc & ، 266.94 & 1.00 & 3 & 1.8 & 0.0927 & 0.2658 & 2.7441 & 0.2631 & 6 & AQAEQQHNPAANPTMIR & 1.00 & 55.20 & 27.85 & 20.77 & 3 & 2020.0048 & 2020.0030 & 674.3416 & 0.0018 & 0.8898 & 1487.091 & 1757.473 & 1879.659 & 3323.884 & No \\
\hline & & & & & & & & & & & & & VLGIVVGVLLQDHDVR & 0.66 & 73.50 & 21.30 & 86.50 & 3 & 1875.10811 & 1875.1064 & 626.0427 & 0.0017 & 0.9052 & 159.575 & 125.235 & 48.163 & 189.026 & Yes \\
\hline & & & & & & & & & & & & & VLGIVVGVLLQDHDVR & 1.00 & 68.14 & 21.14 & 17.92 & 3 & 1875.10901 & 1875.1064 & 626.0427 & 0.0026 & 1.3844 & 138.700 & 188.253 & 62.340 & 275.109 & Yes \\
\hline & & & & & & & & & & & & & NLILSAFPR & 1.00 & 49.50 & 26.82 & 33.83 & 2 & 1173.70041 & 1173.6992 & 587.8569 & 0.0012 & 1.0207 & 1865.341 & 1804.101 & 108.028 & 2579.459 & Yes \\
\hline & & & & & & & & & & & & & NLILSAFPR & 1.00 & 52.09 & 26.79 & 35.55 & 2 & 1173.7014 & 1173.6992 & 587.8569 & 0.0022 & 1.8712 & 1819.802 & 2127.435 & 42.951 & 3061.499 & Yes \\
\hline & & & & & & & & & & & & & NLILSAFPR & 1.00 & 45.84 & 26.82 & 32.82 & 2 & 1173.7008 & 1173.6992 & 587.8569 & 0.0016 & 1.3609 & 2143.598 & 2322.966 & 203.367 & 2868.290 & Yes \\
\hline & & & & & & & & & & & & & NLILSAFPR & 1.00 & 55.34 & 26.82 & 31.30 & 2 & 1173.70101 & 1173.6992 & 587.8569 & 0.0018 & 1.5310 & 2651.908 & 2809.577 & 217.360 & 3962.794 & Yes \\
\hline TPM3L_HUMAI & A6NL28 & - & Putative tropomyo & 26.269 & 1.00 & 2 & 13 & -0.1594 & 0.3844 & 0.2275 & 0.1545 & 4 & LMDQNLK & 0.87 & 30.73 & 28.33 & 30.24 & 2 & 1148.65701 & 1148.6467 & 575.3306 & 0.0103 & 8.9513 & 26121.675 & 20789.196 & 7394.802 & 34768.667 & Yes \\
\hline & & & & & & & & & & & & & LMDQNLK & 0.76 & 27.01 & 28.03 & 30.16 & 2 & 1148.6572 & 1148.6467 & 575.3306 & 0.0105 & 9.1251 & 29205.814 & +26105.631 & 8316.578 & 39393.562 & Yes \\
\hline & & & & & & & & & & & & & IQVLQQQADDAEER & 1.00 & 78.04 & 27.68 & 29.21 & 2 & 1785.9124 & 1785.8979 & 893.9562 & 0.0145 & 8.1100 & 4698.791 & 3239.594 & 1900.570 & 6173.794 & Yes \\
\hline & & & & & & & & & & & & & IQVLQQQADDAEER & 1.00 & 48.61 & 27.73 & 22.21 & 3 & 1785.91301 & 1785.8979 & 596.3066 & 0.0151 & 8.4408 & 417.951 & 537.321 & 901.165 & 449.557 & Yes \\
\hline DDX39_HUMAI & 000148 & DDX39 & ATP-dependent $R$ & 49.13 & 1.00 & 5 & 28.3 & 0.2228 & 0.2678 & 0.5946 & 0.3378 & 15 & NCPHVVVGTPGR & 1.00 & 90.64 & 27.69 & 21.63 & 2 & 1424.7264 & 1424.7139 & 713.3642 & 0.0125 & 8.7612 & 2000.128 & 1969.762 & 89.426 & 1639.702 & Yes \\
\hline & & & & & & & & & & & & & NCPHVVVGTPGR & 0.99 & 36.58 & 27.54 & 22.09 & 3 & 1424.7268 & 1424.7139 & 475.9119 & 0.0129 & 9.0352 & 17812.021 & 21218.085 & 6434.878 & 25828.246 & Yes \\
\hline & & & & & & & & & & & & & NCPHVVVGTPGR & 1.00 & 41.75 & 27.54 & 17.15 & 3 & 1424.72681 & 1424.7139 & 475.9119 & 0.0129 & 9.0352 & 18838.057 & 19184.571 & 9140.278 & 23362.704 & Yes \\
\hline & & & & & & & & & & & & & NCPHVVVGTPGR & 1.00 & 48.08 & 27.68 & 18.14 & 3 & 1424.72711 & 1424.7139 & 475.9119 & 0.0132 & 9.2453 & 9348.852 & 12732.480 & 4093.208 & 11595.690 & Yes \\
\hline & & & & & & & & & & & & & NCPHVVVGTPGR & 0.94 & 30.22 & 27.70 & 19.73 & 3 & 1424.72621 & 1424.7139 & 475.9119 & 0.0123 & 8.6150 & 7254.276 & 7170.292 & 2699.505 & 8877.848 & Yes \\
\hline & & & & & & & & & & & & & NCPHVVVGTPGR & 1.00 & 41.58 & 27.64 & 21.31 & 3 & 1424.7274 & 1424.7139 & 475.9119 & 0.0135 & 9.4554 & 7177.390 & 7171.828 & 2755.157 & 9868.851 & Yes \\
\hline & & & & & & & & & & & & & VSVFFGGLSIK & 1.00 & 54.44 & 23.73 & 23.29 & 2 & 1440.85961 & 1440.8584 & 721.4365 & 0.0012 & 0.8317 & 1263.244 & 1337.248 & 458.012 & 940.091 & Yes \\
\hline & & & & & & & & & & & & & VSVFFGGLSIK & 1.00 & 50.31 & 23.52 & 24.85 & 2 & 1440.86001 & 1440.8584 & 721.4365 & 0.0016 & 1.1089 & 1271.763 & 1356.728 & 324.601 & 1168.845 & Yes \\
\hline & & & & & & & & & & & & & VSVFFGGLSIK & 1.00 & 55.66 & 23.40 & 23.16 & 3 & 1440.8608 & 1440.8584 & 481.2934 & 0.0024 & 1.6622 & 137.755 & 206.007 & 147.079 & 176.597 & Yes \\
\hline & & & & & & & & & & & & & VSVFFGGLSIK & 1.00 & 44.82 & 23.62 & 20.99 & 2 & 1440.8594 & 1440.8584 & 721.4365 & 0.0010 & 0.6931 & 366.268 & 347.684 & 129.459 & 278.904 & Yes \\
\hline & & & & & & & & & & & & & VSVFFGGLSIK & 1.00 & 53.59 & 23.52 & 22.58 & 2 & 1440.86021 & 1440.8584 & 721.4365 & 0.0018 & 1.2475 & 631.892 & 678.009 & 203.988 & 525.965 & Yes \\
\hline & & & & & & & & & & & & & CMALAQLLVEQNFPAIAIHR & 0.67 & 69.75 & 26.65 & 82.75 & 3 & 2427.27372 & 2427.2710 & 810.0976 & 0.0027 & 1.1110 & 11.401 & 19.401 & 12.701 & 14.563 & Yes \\
\hline & & & & & & & & & & & & & CMALAQLLVEQNFPAIAIHR & 0.67 & 89.26 & 26.60 & \#\#\#\# & 3 & 2427.27462 & 2427.2710 & 810.0976 & 0.0036 & 1.4813 & 3.198 & 11.836 & 6.168 & 7.837 & No \\
\hline & & & & & & & & & & & & & CMALAQLLVEQNFPAIAIHR & 1.00 & 61.66 & 26.65 & 20.96 & 3 & 2427.27312 & 2427.2710 & 810.0976 & 0.0021 & 0.8641 & 8.327 & 13.026 & 6.292 & 6.773 & Yes \\
\hline & & & & & & & & & & & & & FMQDPMEVFVDDETK & 0.84 & 79.79 & 26.63 & 85.39 & 2 & 2117.9934 & 2117.9893 & 1060.0019 & 0.0041 & 1.9340 & 213.213 & 251.205 & 44.130 & 247.944 & Yes \\
\hline & & & & & & & & & & & & & FMQDPMEVFVDDETK & 0.51 & 52.73 & 26.63 & 65.55 & 2 & 2117.99342 & 2117.9893 & 1060.0019 & 0.0041 & 1.9340 & 39.916 & 22.162 & 0.651 & 35.774 & No \\
\hline & & & & & & & & & & & & & FMQDPMEVFVDDETK & 0.94 & 26.38 & 26.68 & 20.23 & 3 & 2117.99562 & 2117.9893 & 707.0037 & 0.0063 & 2.9703 & 20.689 & 20.516 & 31.254 & 26.239 & No \\
\hline & & & & & & & & & & & & & HFVLDECDK & 1.00 & 31.53 & 26.61 & 23.21 & 3 & 1438.6864 & 1438.6828 & 480.5682 & 0.00362 & 2.4970 & 610.358 & 677.879 & 46.188 & 678.473 & Yes \\
\hline PDLII_HUMAN & O00151 & PDLIM1 & PDZ and LIM don & 36.072 & 1.00 & 8 & 34.3 & -0.1922 & 0.3106 & 0.0390 & 0.4514 & 28 & QSTSFLVLQEILESEEK & 1.00 & 46.46 & 26.75 & 25.27 & 3 & 2267.21772 & 2267.2140 & 756.7453 & 0.0037 & 1.6298 & 36.087 & 25.682 & 62.033 & 19.989 & No \\
\hline & & & & & & & & & & & & & QSTSFLVLQEILESEEK & 1.00 & 76.26 & 26.77 & 27.87 & 3 & 2267.21892 & 2267.2140 & 756.7453 & 0.00492 & 2.1584 & 32.346 & 57.126 & 23.616 & 30.095 & No \\
\hline & & & & & & & & & & & & & VWSPLVTEEGK & 0.63 & 16.37 & 27.34 & 21.84 & 2 & 1531.8506 & 1531.8490 & 766.9318 & 0.0016 & 1.0431 & 803.038 & 605.093 & 465.033 & 851.203 & Yes \\
\hline & & & & & & & & & & & & & VWSPLVTEEGK & 1.00 & 72.89 & 27.26 & 29.98 & 2 & 1531.8512 & 1531.8490 & 766.9318 & 0.0022 & 1.4343 & 4631.296 & 3930.267 & 1439.735 & 6069.402 & Yes \\
\hline & & & & & & & & & & & & & QSTSFLVLQEILESEEK & 0.99 & 36.61 & 26.67 & 23.51 & 3 & 2267.2198 & 2267.2140 & 756.7453 & 0.00582 & 2.5548 & 27.449 & 40.016 & 33.566 & 37.481 & Yes \\
\hline
\end{tabular}



$\begin{array}{llllllllllllllll}\text { TNIVTASVDAINFHDK } & 1.00 & 88.83 & 27.02 & 24.14 & 3 & 2032.0876 & 2032.0833 & 678.3684 & 0.0043 & 2.1129 & 2830.456 & 2465.128 & 1034.572 & 4181.085 & \text { Yes } \\ \text { TNIVTASVDAINFHDK } & 1.00 & \text { \#\#\# } 27.02 & 25.60 & 3 & 2032.0876 & 2032.2833 & 678.3684 & 0.0043 & 2.1129 & 4612.321 & 4277.280 & 1437.114 & 7279.647 & \text { Yes }\end{array}$ $\begin{array}{lllllllllllllllll}\text { TNIVTASVDAINFHDK } & 1.00 & & 27.02 & 25.60 & 3 & 2032.0876 & 2032.0833 & 678.3684 & 0.0043 & 2.1129 & 4612.321 & 4277.280 & 1437.114 & 7279.647 & \text { Yes } \\ \text { TNIVASVDAINFHDK } & 1.00 & 86.77 & 26.94 & 25.34 & 3 & 2032.0852 & 2032.0833 & 678.3684 & 0.0019 & 0.9336 & 4289.655 & 2917.354 & 1902.758 & 5024.545 & \text { Yes }\end{array}$

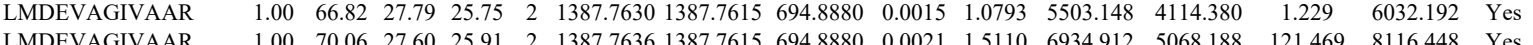
\begin{tabular}{llllllllllllllll} 
& 1.00 & 70.06 & 27.60 & 25.91 & 2 & 1387.7636 & 387.7615 & 94.8880 & 0.0021 & 1.5110 & 6934.912 & 5068.188 & 121.469 & 8116.448 & Yes \\
\hline
\end{tabular}

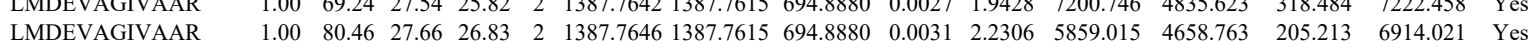

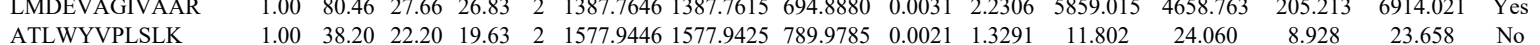

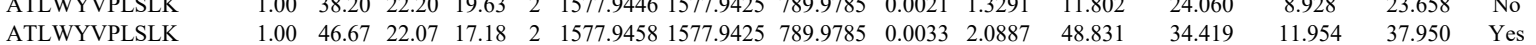

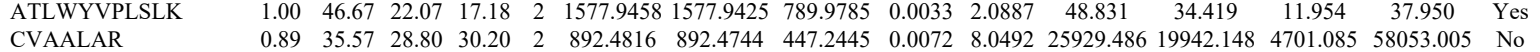

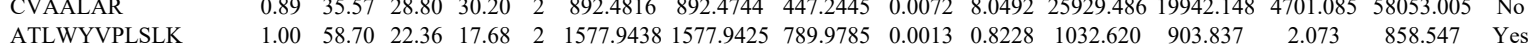

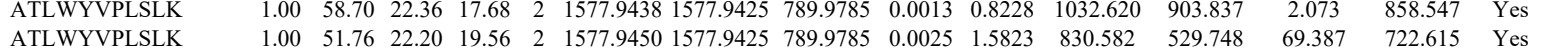

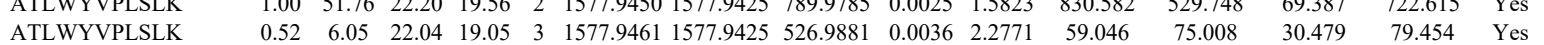

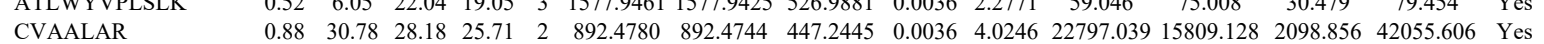
$\begin{array}{lllllllllllllllllll}\text { CVAALAR } & 0.70 & 25.89 & 28.18 & 29.40 & 2 & 892.4780 & 892.4744 & 447.2445 & 0.0036 & 4.0246 & 19601.994 & 14944.796 & 2963.277 & 38885.130 & \text { Yes }\end{array}$

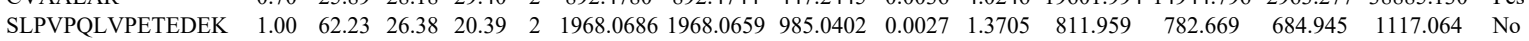
$\begin{array}{lllllllllllllllll}\text { SLPVPQLVPETEDEK } & 0.98 & 23.36 & 26.38 & 16.58 & 3 & 1968.0688 & 1968.0659 & 657.0292 & 0.0029 & 1.4713 & 166.183 & 119.678 & 58.963 & 120.387 & \text { Yes }\end{array}$ $\begin{array}{lllllllllllllll}1.00 & 58.25 & 27.80 & 27.15 & 2 & 1394.7408 & 1394.7393 & 698.3769 & 0.0015 & 1.0739 & 2713.630 & 2220.854 & 44.544 & 6896.741 & \text { Yes }\end{array}$ $\begin{array}{llllllllllllllll}1.00 & 58.34 & 27.84 & 26.73 & 2 & 1394.7414 & 1394.7393 & 698.3769 & 0.0021 & 1.5035 & 2441.866 & 1966.411 & 117.851 & 5736.885 & \text { Yes }\end{array}$ $\begin{array}{llllllllllllllll}\text { GDVVLQSDHVIETLTK } & 0.66 & 47.59 & 25.48 & 60.59 & 3 & 2041.1317 & 2041.1299 & 681.3839 & 0.0018 & 0.8806 & 630.320 & 692.593 & 994.618 & 1181.617 & \text { Yes }\end{array}$ $\begin{array}{llllllllllllllll}\text { GISILDEELLRPEATDLTFLEK } & 0.95 & 26.26 & 25.84 & 16.68 & 3 & 2995.5550 & 2995.5489 & 999.5236 & 0.0061 & 2.0343 & 86.335 & 65.944 & 267.744 & 291.538 & \text { No }\end{array}$ $\begin{array}{lllllllllllllllll} & \text { GISLDEECLRPGEATDLTFLEK } & 0.98 & 18.48 & 25.83 & 31.48 & 4 & 2995.5581 & 2995.5489 & 749.8945 & 0.0092 & 3.0671 & 9.464 & 20.610 & 13.362 & 0.000 & \text { No }\end{array}$

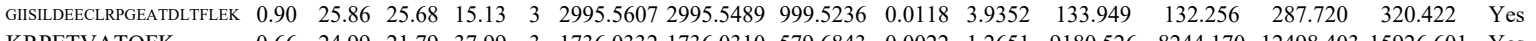
$\begin{array}{llllllllllllllll}\text { KRPETVATQFK } & 0.66 & 24.99 & 21.79 & 37.99 & 3 & 1736.0332 & 1736.0310 & 579.6843 & 0.0022 & 1.2651 & 9180.526 & 8244.170 & 12498.403 & 15926.601 & \text { Yes }\end{array}$ $\begin{array}{lllllllllllllllll}\text { KRPETVATQFK } & 1.00 & 14.43 & 21.79 & 27.43 & 4 & 1736.0333 & 1736.0310 & 435.0150 & 0.0023 & 1.3218 & 5772.581 & 5100.169 & 3952.704 & 6841.696 & \text { Yes }\end{array}$ TFTWLVGK TFTWLVGK MSLLQLVEILQSK MSLLQLVEILQSK

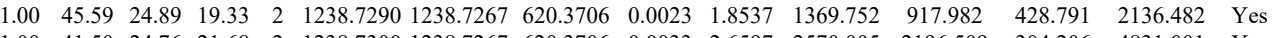

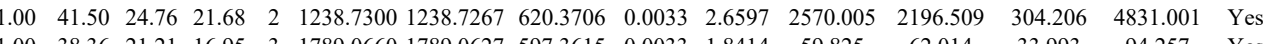

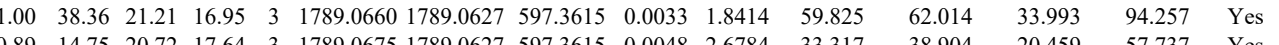

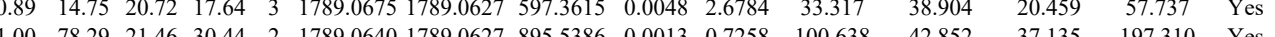
$\begin{array}{lllllllllllllllll} & \end{array}$

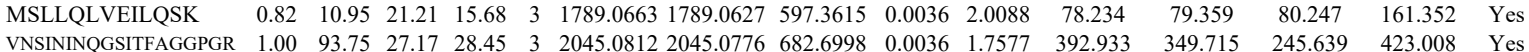


TSFLLNLR

\section{TSFLLNLR}

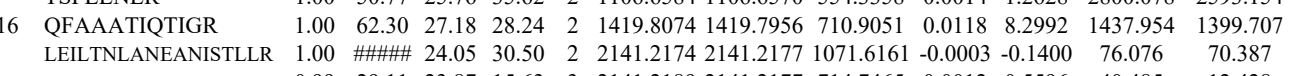

$\begin{array}{lllllllllllll}\text { QFAAATIQTIGR } & 1.00 & 62.30 & 27.18 & 28.24 & 2 & 1419.8074 & 1419.7956 & 710.9051 & 0.0118 & 8.2992 & 1437.954 & 1399.707 \\ \text { LEILTNLANEANISTLLR } & 1.00 & \# \# \# \frac{24.05}{30.50} & 2 & 2141.2174 & 2141.2177 & 1071.6161 & -0.0003 & -0.1400 & 76.076 & 70.387\end{array}$

$\begin{array}{lllllllllllll} & \end{array}$

$\begin{array}{llllllllllll}\text { LELINLANEANSTLLR } & 1.00 & 29.33 & 23.78 & 14.99 & 3 & 2141.2195 & 2141.2177 & 714.7465 & 0.0018 & 0.8395 & 37.93\end{array}$

$\begin{array}{llllllllllll}\text { LELINLANEANISTLLR } & 1.00 & 60.26 & 23.73 & 20.62 & 3 & 2141.2207 & 2141.2177 & 714.7465 & 0.0030 & 1.3991 & 22.380 \\ \text { LEILANEANISTLR } & 1.00 & 28.44 & 23.64 & 17.51 & 3 & 2141.2213 & 2141.2177 & 714.7465 & 0.0036 & 1.6789 & 7.553\end{array}$

TVIGSVLLR

TVIGSVLLR

TIGSVLR

VPIIVPIMMLAIK

VPIVPIMMLAIK

VPIIVPIMMLAIK

VPIVPIMMLAIK

LEILTNLANEANISTL

VPIIVPIMMLAIK

VPIIVPIMMLAIK

VPIIVPIMMLAIK

12 LQATLDMOSGIHAAAER

FHGILDQGEGVLIIFDEPPVDK

FHGILDQGEGVLIIFDEP

TYEAALETIQNMSK

LYDNLLEQNLIR

LYDNLLEQNLIR

IMLNTPEDVQALVSGK

IMLNTPEDVQALVSGK
LYDNLLEQNLIR
YQEALHLGSQLLR

YQEALHLGSQLLR
YQEALHLGSLLLR

YQEALHLGSQLLR
YQEALHLGSQLLR YQEALHLGSQLLR

$\begin{array}{lllllllllll}\text { PSD12_HUMAN } & \text { O00232 } & \text { PSMD12 } & \text { 26S proteasome ni 52.904 } & 1.00 & 10 & 28.1 & 0.0513 & 0.5444 & 1.7686 & 0.6204\end{array}$ $\begin{array}{lllllllllllllll}1.00 & 39.67 & 22.53 & 33.56 & 2 & 1100.7052 & 1100.7039 & 551.3592 & 0.0013 & 1.1789 & 1826.934 & 1863.470 & 343.903 & 4749.239 & \mathrm{No} \\ 1.00 & 43.12 & 22.53 & 36.35 & 2 & 1100.7054 & 1100.7039 & 551.3592 & 0.0015 & 1.3603 & 2023.369 & 1777.654 & 632.609 & 4856.970 & \mathrm{Y}\end{array}$ $\begin{array}{lllllllllllllll}1.00 & 43.11 & 2.582 & 21.99 & 3 & 1321.7155 & 1321.7053 & 441.5757 & 0.0102 & 7.6996 & 2511.689 & 3213.448 & 4414.558 & 5776.322 & \text { Yes }\end{array}$

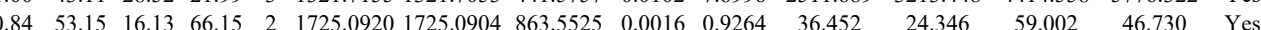

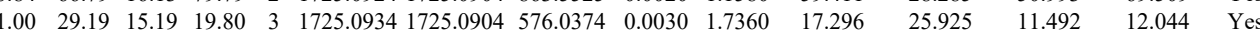

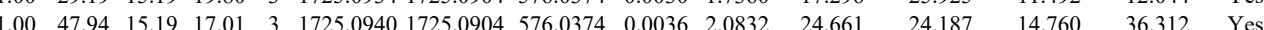

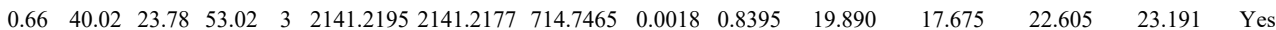
$\begin{array}{lllllllllllllll}0.64 & 54.97 & 16.63 & 67.97 & 2 & 1725.0902 & 1725.0904 & 863.5525 & -0.0002 & -0.1158 & 13.685 & 10.580 & 25.289 & 28.799 & \text { Yes }\end{array}$ $\begin{array}{llllllllllllllll}0.67 & 38.74 & 15.19 & 51.74 & 3 & 1725.0931 & 1725.0904 & 576.0374 & 0.0027 & 1.5624 & 25.477 & 24.738 & 26.135 & 30.051 & \text { Yes }\end{array}$ $\begin{array}{lllllllllllllll}0.67 & 42.34 & 15.19 & 55.34 & 3 & 1725.0931 & 1725.0904 & 576.0374 & 0.0027 & 1.5624 & 29.064 & 12.422 & 22.150 & 28.903 & \text { Yes }\end{array}$ $\begin{array}{lllllllllllllll}0.60 & 59.45 & 26.85 & 72.45 & 3 & 2242.1908 & 2242.1871 & 748.4030 & 0.0037 & 1.6480 & 1284.030 & 1599.884 & 2065.694 & 2947.737 & \text { No }\end{array}$

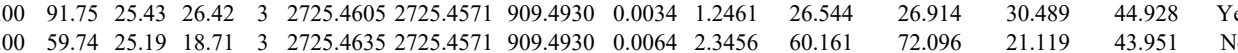

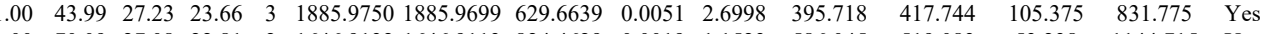
$\begin{array}{lllllllllllllll}1.00 & 70.09 & 27.08 & 22.81 & 2 & 1646.9132 & 1646.9113 & 824.4629 & 0.0019 & 1.1523 & 586.045 & 519.083 & 53.238 & 1144.715 & \text { Yes }\end{array}$ $\begin{array}{lllllllllllllll}1.00 & 62.29 & 26.90 & 19.29 & 2 & 1646.9154 & 1646.9113 & 824.4629 & 0.0041 & 2.4865 & 1074.365 & 1003.763 & 198.995 & 1757.763 & \text { Yes }\end{array}$ $\begin{array}{lllllllllllllll}1.00 & 62.25 & 26.00 & 18.06 & 3 & 2002.1044 & 2002.1012 & 668.3743 & 0.0032 & 1.5959 & 650.459 & 452.208 & 184.853 & 427.805 & \text { Yes }\end{array}$

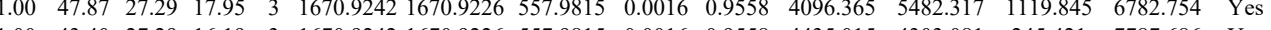
$\begin{array}{llllllllllllllll}1.00 & 43.40 & 27.29 & 16.19 & 3 & 1670.9242 & 1670.9226 & 557.9815 & 0.0016 & 0.9558 & 4435.015 & 4303.081 & 245.421 & 7787.686 & \text { Yes }\end{array}$ $\begin{array}{lllllllllllllll}1.00 & 51.11 & 27.12 & 19.36 & 3 & 167.9257 & 1670.9226 & 557.9815 & 0.0031 & 1.8519 & 3654.669 & 3498.930 & 886.410 & 6778.467 & \text { Yes }\end{array}$

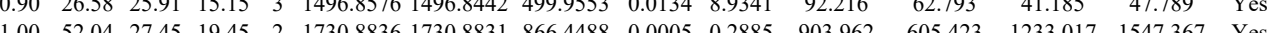
$\begin{array}{llllllllllll}1.00 & 52.04 & 27.45 & 19.45 & 2 & 1730.8836 & 1730.8831 & 866.4488 & 0.0005 & 0.2885 & 903.962 & 605.423\end{array}$

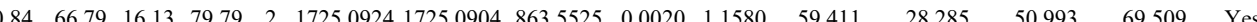
$\begin{array}{lllllllllllllll}0.98 & 31.51 & 27.08 & 27.28 & 2 & 1646.9132 & 1646.9113 & 824.4629 & 0.0019 & 1.1523 & 653.483 & 794.627 & 116.941 & 998.101 & \text { Yes }\end{array}$

WSTLVEDYGMELR $\begin{array}{llllllllllll}5 & 57.04 & 27.45 & 19.45 & 2 & 1730.8836 & 1730.8831 & 866.4488 & 0.005 & 0.2885 & 903.962 & 605.423\end{array}$ $\begin{array}{lllllllllll}1.00 & 57.71 & 27.08 & 23.67 & 2 & 1741.8476 & 1741.8467 & 871.9306 & 0.0009 & 0.5161 & 485.150\end{array}$

463.092

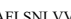
$\begin{array}{lllllllllll}1.00 & 55.12 & 25.12 & 18.04 & 3 & 2822.5009 & 2822.4979 & 941.8399 & 0.0030 & 1.0618 & 1.811 \\ 1.00 & 67.80 & 25.07 & 25.05 & 3 & 2822.5030 & 2822.4979 & 941.8399 & 0.0051 & 1.805 & 17.546\end{array}$

LQEVIETLLSLEK

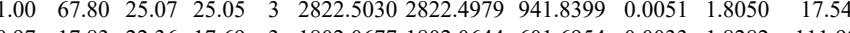

\section{LQEVIETLLSLEK}

MAQLLDL

MAQLLDLSVDESEAFLSNLVYK
LQEVIETLLSLEK

LQEVIETLLSLEK

LQEVIETLLSLEK

LQEVIETLLSLEK

LQEVIETLLSLEK

LQEVIETLLSLEK

LQEVIETLLSLEK

LQEVIETLLSLEK

LQEVIETLLSLEK

LQEVIETLLSLEK

SVVLYVILAPFDNEQSDLVHK

LCLAVK

LCLAVK

LFTTMELMR

LFTTMELMR

LFTTMELMR

LNSLMSLVNK

LNSLMSLVNK

LNSLMSLVNK

LNSLMSLVNK

AIYDTPCIQAESEK \begin{tabular}{llllllllllll}
0.67 & 17.83 & 22.36 & 17.69 & 3 & 182.0677 & 182.0644 & 601.6954 & 0.003 & 1.8282 & 11.996 & 78.69 \\
\hline
\end{tabular} $\begin{array}{lllllllllllll}1.00 & 86.72 & 25.04 & 21.61 & 3 & 28225024 & 2822.4979 & 941.8399 & 0.045 & 1.5926 & 0.000 & 25.446\end{array}$ $\begin{array}{llllllllllll}1.00 & 83.15 & 22.46 & 23.45 & 2 & 1802.0660 & 1802.0644 & 902.0395 & 0.0016 & 0.8869 & 720.271 & 520.725\end{array}$ $\left.\begin{array}{llllllllllll}1.00 & 83.61 & 22.46 & 30.31 & 2 & 18202.0664 & 1802.0644 & 902.0395 & 0.0020 & 1.1086 & 355.060\end{array}\right)$ $\begin{array}{lllllllllll}1.00 & 54.26 & 22.36 & 21.48 & 3 & 1802.0674 & 1802.0644 & 601.6954 & 0.0030 & 1.6620 & 149.548\end{array}$ $\begin{array}{lllllllllll}1.00 & 31.00 & 22.36 & 19.67 & 3 & 1802.0677 & 1802.0644 & 601.6954 & 0.0033 & 1.8282 & 86.332\end{array}$ $\begin{array}{llllllllllll}1.00 & 1.99 & 22.46 & 22.68 & 2 & 1802.0654 & 1802.0644 & 902.0395 & 0.0010 & 0.5543 & 37.358\end{array}$ $\begin{array}{lllllllllll}1.00 & 33.89 & 22.43 & 24.91 & 3 & 1802.0668 & 1802.0644 & 601.6954 & 0.0024 & 1.3296 & 68.454\end{array}$ $\begin{array}{lllllllllll}1.00 & 43.63 & 22.36 & 24.66 & 3 & 1802.0674 & 1802.0644 & 601.6954 & 0.0030 & 1.6620 & 63.763\end{array}$ $\begin{array}{lllllllllllll}1.00 & 30.90 & 22.43 & 21.69 & 3 & 1802.0668 & 1802.0644 & 601.6954 & 0.0024 & 1.3296 & 116.606 & 125.613\end{array}$ $\begin{array}{lllllllllllll}1.00 & 36.93 & 22.36 & 21.51 & 3 & 1802.0674 & 1802.0644 & 601.6954 & 0.0030 & 1.6620 & 101.290 & 116.837\end{array}$ $\begin{array}{llllllllllll}1.00 & 59.14 & 25.35 & 21.17 & 3 & 2557.3684 & 2557.3662 & 853.4627 & 0.0022 & 0.8592 & 18.104 & 27.029\end{array}$ $\begin{array}{llllllllllllll}0.89 & 31.33 & 25.25 & 32.26 & 2 & 979.5884 & 979.5802 & 490.7974 & 0.0082 & 8.3537 & 7192.714 & 5956.912\end{array}$ $\begin{array}{lllllllllllll}0.70 & 23.95 & 25.24 & 29.32 & 2 & 979.5892 & 979.5802 & 490.7974 & 0.0090 & 9.1687 & 6649.787 & 6445.912\end{array}$ $\begin{array}{lllllllllllll}0.99 & 41.63 & 27.99 & 18.08 & 2 & 1284.6718 & 1284.6692 & 643.3419 & 0.0026 & 2.0207 & 365.428 & 363.369 \\ 1.00 & 61.37 & 28.04 & 25.02 & 2 & 1284.6724 & 1284.6692 & 643.3419 & 0.0032 & 2.4870 & 646.479 & 731.572 & 4 \\ 1.00 & 44.01 & 28.15 & 23.37 & 2 & 1284.6710 & 1284.6692 & 643.3419 & 0.0018 & 1.3989 & 5575.093 & 596.294 & 14\end{array}$ $\begin{array}{lllllllllllll}1.00 & 61.37 & 28.04 & 25.02 & 2 & 1284.6724 & 1284.6692 & 643.3419 & 0.0032 & 2.4870 & 646.479 & 731.572 \\ 1.00 & 44.01 & 28.15 & 23.37 & 2 & 1284.6710 & 1284.6692 & 6433419 & 0.0018 & 1.3989 & 5575.093 & 5996294\end{array}$

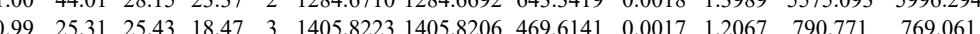
$\begin{array}{llllllllllll}0.99 & 25.31 & 25.43 & 18.47 & 3 & 1405.8223 & 1405.8206 & 469.6141 & 0.0017 & 1.2067 & 790.771 & 769.061 \\ 1.00 & 51.31 & 25.21 & 25.76 & 2 & 1405.8226 & 1405.8206 & 703.9176 & 0.0020 & 1.4206 & 8032.116 & 7820.062\end{array}$

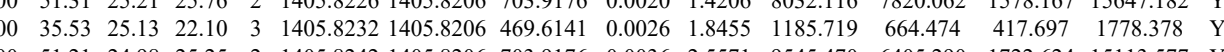

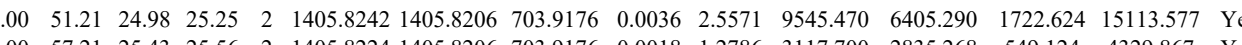

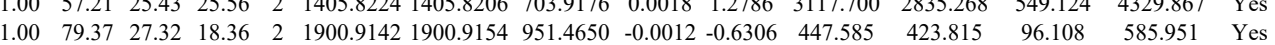




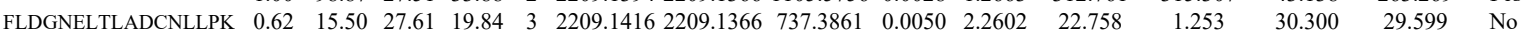
$\begin{array}{lllllllllllllllll}\text { LAALNPESNTAGLDIFAK } & 1.00 & 91.90 & 25.53 & 19.00 & 2 & 2132.1734 & 2132.1721 & 1067.0933 & 0.0013 & 0.6091 & 2269.407 & 2349.628 & 617.591 & 1745.652 & \text { Yes }\end{array}$

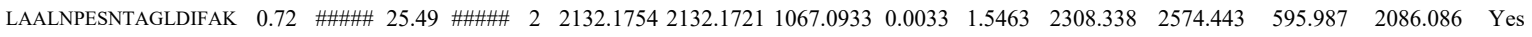
$\begin{array}{llllllllllllllll}\text { LAALNPESNTAGLDIFAK } & 0.60 & 52.85 & 25.53 & 65.85 & 3 & 2132.1766 & 2132.1721 & 711.7313 & 0.0045 & 2.1075 & 1164.422 & 904.387 & 2029.172 & 2285.620 & \text { No }\end{array}$ $\begin{array}{lllllllllllllllll}\text { LAALNPESNTAGLDIFAK } & 0.60 & 35.56 & 25.53 & 48.56 & 3 & 2132.1766 & 2132.1721 & 711.7313 & 0.0045 & 2.1075 & 826.237 & 333.277 & 717.124 & 1685.600 & \text { Yes }\end{array}$ $\begin{array}{llllllllllllllll}\text { FLDGNELTLADCNLLPK } & 1.00 & 93.70 & 27.51 & 25.27 & 2 & 2209.1394 & 2209.1366 & 1105.5756 & 0.0028 & 1.2663 & 453.527 & 567.593 & 13.230 & 464.252 & \text { Yes }\end{array}$ $\begin{array}{lllllllllllllllll}\text { FLDGNELTLADCNLLPK } & 1.00 & 98.74 & 27.51 & 36.12 & 2 & 2209.1394 & 2209.1366 & 1105.5756 & 0.0028 & 1.2663 & 432.678 & 646.674 & 119.347 & 370.305 & \text { Yes }\end{array}$ $\begin{array}{llllllllllllllll} & \end{array}$ \begin{tabular}{lllllllllllllll} 
LAALNPESNTAGLDIFAK & 1.00 & \#\# 25.53 & 21.88 & 2 & 2132.1734 & 2132.1721 & 1067.0933 & 0.0013 & 0.6091 & 392.784 & 277.913 & 80.285 & 186.726 & Yes \\
\hline
\end{tabular}

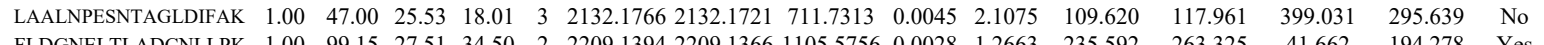
$\begin{array}{llllllllllllllll}\text { FLDGNELTLADCNLLPK } & 1.00 & 99.15 & 27.51 & 34.50 & 2 & 2209.1394 & 2209.1366 & 1105.5756 & 0.0028 & 1.2663 & 235.592 & 263.325 & 41.662 & 194.278 & \text { Yes }\end{array}$

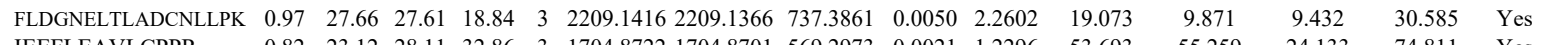

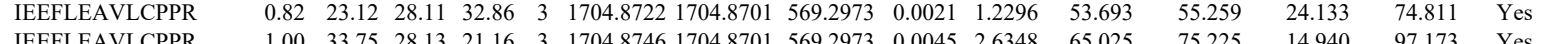

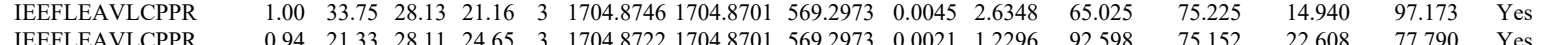

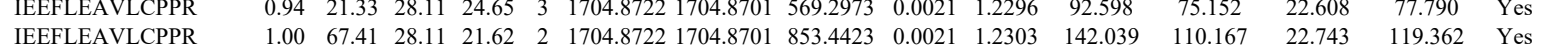

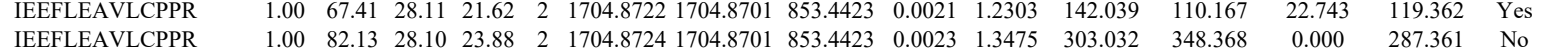

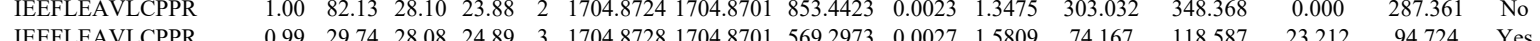

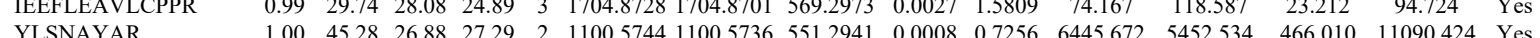

YLSNAYAR

IESFLEAVLCPPR

IEEFLEAVLCPPR

IEEFLEAVLCPPR

IEEFLEAVLCPPR

YLSNAYAR

YLSNAYAR
GFTIPEAFR

GFTIPEAFR
GFTIPEAFR

IEEFLEAVLCPPR

IEEFLEAVLCPPR

IEEFLEAVLCPPR

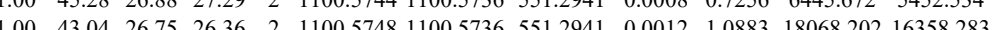

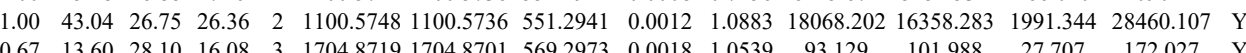

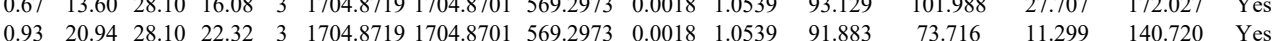

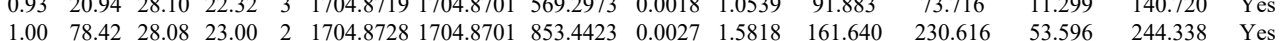
$\begin{array}{llllllllllllllll}1.00 & 72.92 & 28.13 & 24.24 & 2 & 1704.8734 & 1704.8701 & 853.4423 & 0.0033 & 1.9333 & 140.069 & 129.020 & 21.770 & 141.161 & \text { Yes }\end{array}$ $\begin{array}{llllllllllllllll}0.99 & 40.00 & 26.64 & 30.21 & 2 & 1100.5770 & 1100.5736 & 551.2941 & 0.0034 & 3.0836 & 5540.757 & 4876.990 & 308.976 & 8889.883 & \text { Yes }\end{array}$ $\begin{array}{lllllllllllllllll}0.98 & 31.23 & 28.00 & 23.03 & 2 & 1180.6378 & 1180.6362 & 591.3254 & 0.0016 & 1.3529 & 13290.053 & 16947.526 & 994.711 & 11704.227 & \text { Yes }\end{array}$ $\begin{array}{lllllllllllllllll}0.98 & 31.80 & 27.99 & 25.78 & 2 & 1180.6386 & 1180.6362 & 591.3254 & 0.0024 & 2.0293 & 29841.271 & 34547.424 & 508.132 & 25075.676 & \text { Yes }\end{array}$ $\begin{array}{lllllllllllllll}1.00 & 82.13 & 28.08 & 30.12 & 2 & 1704.8720 & 1704.8701 & 853.4423 & 0.0019 & 1.1131 & 83.253 & 118.422 & 2.023 & 151.149 & \text { Yes }\end{array}$ $\begin{array}{llllllllllllllll}0.81 & 16.46 & 28.11 & 21.07 & 3 & 1704.8722 & 1704.8701 & 569.2973 & 0.0021 & 1.2296 & 83.072 & 117.230 & 32.996 & 204.070 & \text { Yes }\end{array}$ $\begin{array}{lllllllllllllllll}1.00 & 69.72 & 28.18 & 21.74 & 2 & 1704.8738 & 1704.8701 & 853.4423 & 0.0037 & 2.1677 & 199.890 & 205.040 & 29.329 & 198.824 & \text { Yes }\end{array}$

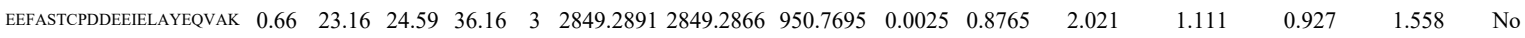

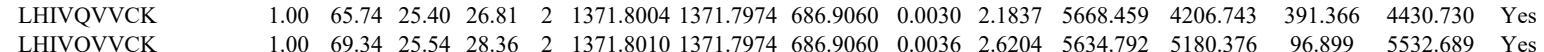

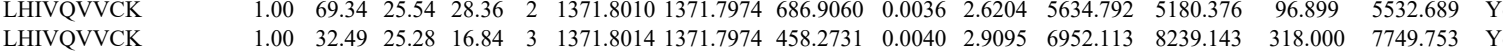
$\begin{array}{lllllllllllllllll}\text { LHIVQVVCK } & 1.00 & 37.09 & 25.28 & 18.05 & 3 & 1371.8014 & 1371.7974 & 458.2731 & 0.0040 & 2.9095 & 9650.758 & 8846.841 & 388.456 & 8383.029 & \text { Yes }\end{array}$

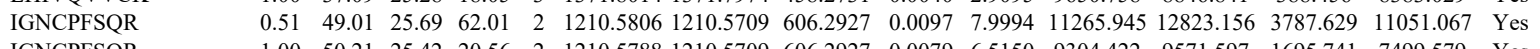
IGNCPFSQR $\begin{array}{lllllllllllllllll}1.00 & 50.21 & 25.42 & 20.56 & 2 & 1210.5788 & 1210.5709 & 606.2927 & 0.0079 & 6.5150 & 9304.422 & 9571.597 & 1695.741 & 7499.579 & \text { Yes } & \end{array}$

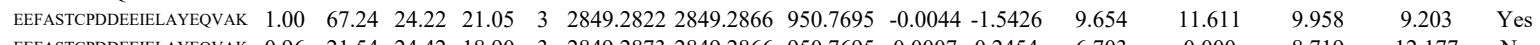

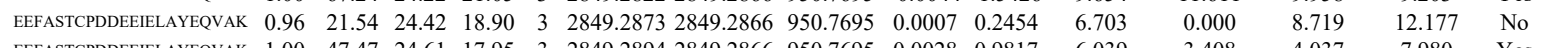

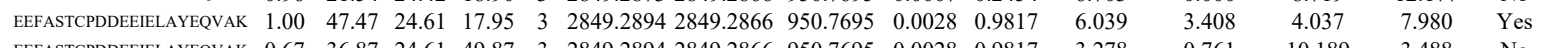

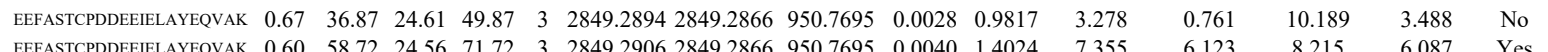

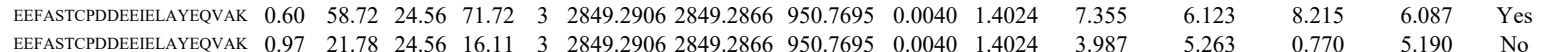

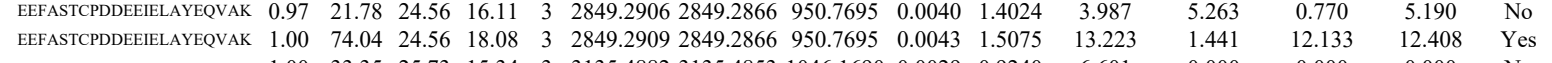

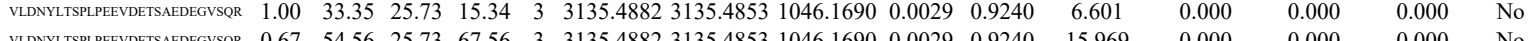

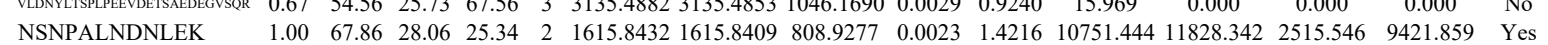


NSNPALNDNLEK NSNPALNDNLEK NSNPALNDNLEK

33. VIGTLLGTVDK VIGLSSDLQQVGGASAR VIGLSSDLQQVGGASAR
LHPVILASIVDSYER LHPVILASIVDSYER

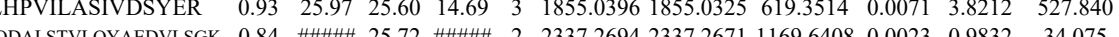

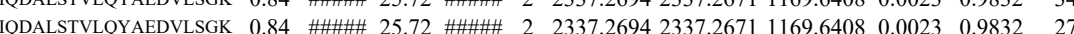
$\begin{array}{llllllllllllll}\text { QDALSTVLQYAEDVLSGK } & 0.84 & 8.25 & 25.56 & 17.60 & 4 & 2337.2701 & 2337.2671 & 585.3241 & 0.0030 & 1.2813 & 125.922\end{array}$ $\begin{array}{lllllllllllll} & \text { Q }\end{array}$

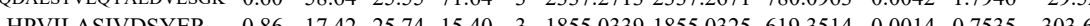
$\begin{array}{llllllllllll}\text { LHPVILASIVDSYER } & 0.99 & 25.50 & 25.66 & 21.23 & 3 & 1855.0351 & 1855.0325 & 619.3514 & 0.0026 & 1.3993 & 427.141\end{array}$ $\begin{array}{lllllllllllll}\text { IODALSTVLOYAEDVLSGK } & 1.00 & 96.58 & 25.72 & 21.07 & 2 & 233.72694 & 233772671 & 11696408 & 0.0023 & 0.9832 & 27.347\end{array}$ $\begin{array}{lllllllllllll}\text { IQDALSTVLQYAEDVLSGK } & 1.00 & 85.72 & 25.72 & 20.82 & 2 & 2337.2694 & 2337.2671 & 1169.6408 & 0.0023 & 0.9832 & 27.339\end{array}$ $\begin{array}{llllllllllllll}\text { IODALSTVLOYAEDVLSGK } & 0.99 & 15.95 & 25.56 & 18.55 & 4 & 2337.2701 & 2337.2671 & 585.3241 & 0.0030 & 1.2813 & 123.335\end{array}$ $\begin{array}{lllllllllllllll}\text { IQDALSTVLOYAEDVLSGK } & 1.00 & 54.00 & 25.56 & 17.19 & 3 & 2337.2710 & 2337.2671 & 780.0963 & 0.0039 & 1.6665 & 30.304\end{array}$ $\begin{array}{llllllllllll}\text { IQDALSTVLOYAEDVLSGK } & 0.60 & 59.25 & 25.55 & 72.25 & 3 & 2337.2716 & 2337.2671 & 780.0963 & 0.0045 & 1.9228 & 8.298\end{array}$ $\begin{array}{llllllllllll}\text { IQDALSTVLQYAEDVLSGK } & 1.00 & \text { \#\#\#\#\# } & 25.71 & 22.13 & 2 & 2337.2674 & 2337.2671 & 1169.6408 & 0.0003 & 0.1282 & 13.448\end{array}$ $\begin{array}{llllllllllll}\text { IQDALSTVLQYAEDVLSGK } & 1.00 & 57.83 & 25.51 & 20.48 & 3 & 2337.2725 & 2337.2671 & 780.0963 & 0.0054 & 2.3074 & 9.866\end{array}$ $\begin{array}{llllllllllll}\text { IQDALSTVLQYAEDVLSGK } & 0.55 & 22.02 & 25.74 & 35.02 & 3 & 2337.2683 & 2337.2671 & 780.0963 & 0.0012 & 0.5128 & 9.424 \\ \text { IQDASTVQYAEDVST } & 0.66 & 49.96 & 25.69 & 2.96 & 3 & 2337.269 & 2337.261 & 700.0963 & 0.018 & 0.7691 & 17.887\end{array}$ $\begin{array}{llllllllllll}\text { IQDALSTVLQYAEDVLSGK } & 0.66 & 49.96 & 25.69 & 62.96 & 3 & 2337.2689 & 2337.2671 & 780.0963 & 0.0018 & 0.7691 & 17.887\end{array}$ TCFSPNR

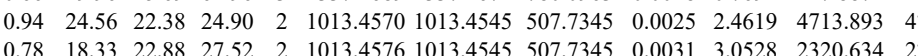
$\begin{array}{lllllllllllll}0.78 & 18.33 & 22.88 & 27.52 & 2 & 1013.4576 & 1013.4545 & 507.7345 & 0.0031 & 3.0528 & 2320.634 & 2204 \\ 0.55 & 34.46 & 25.72 & 47.46 & 3 & 2337.2677 & 2337.2671 & 780.0963 & 0.0006 & 0.2564 & 15.635 & 7.8\end{array}$ $\begin{array}{lllllllllllll}\text { IQDALSTVLQYAEDVLSGK } & 0.55 & 32.54 & 25.72 & 45.54 & 3 & 2337.2680 & 2337.2671 & 780.0963 & 0.0009 & 0.3846 & 30.800\end{array}$ $\begin{array}{llllllllllll}\text { IQDALSTVLQYAEDVLSGK } & 0.66 & 15.63 & 25.72 & 28.63 & 3 & 2337.2695 & 2337.2671 & 780.0963 & 0.0024 & 1.0255 & 18.517 \\ \text { FLMSLVNQVPK } & 1.00 & 57.11 & 24.93 & 24.92 & 2 & 1562.9086 & 1562.9098 & 782.4622 & -0.0012 & -0.7668 & 266.458\end{array}$

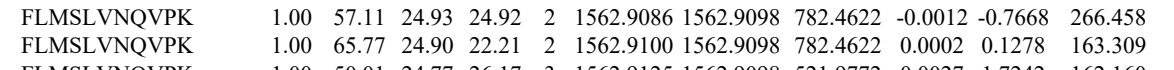
$\begin{array}{llllllllllll}\text { FLMSLVNQVPK } & 1.00 & 50.01 & 24.77 & 26.17 & 3 & 1562.9125 & 1562.9098 & 521.9772 & 0.0027 & 1.7242 & 162.160\end{array}$

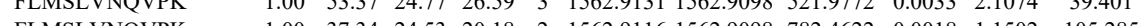

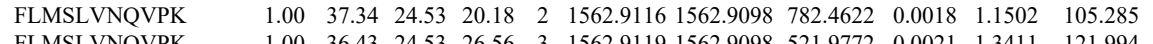
$\begin{array}{llllllllllll}\text { FLMSLVNQVPK } & 1.00 & 36.43 & 24.53 & 26.56 & 3 & 1562.9119 & 1562.9098 & 521.9772 & 0.0021 & 1.3411 & 121.994 \\ \text { FLMSLVNQVPK } & 1.00 & 54.66 & 24.79 & 24.83 & 2 & 1562.9120 & 1562.9098 & 782.4622 & 0.0022 & 1.4058 & 81.213\end{array}$ FLMSLNQVPK

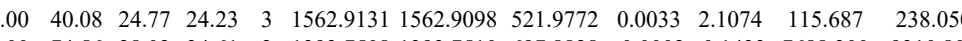

AYVSTLMGVPGR

AYSTLMTGR

FLMSLVNQVPK

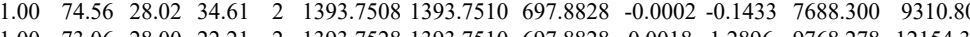

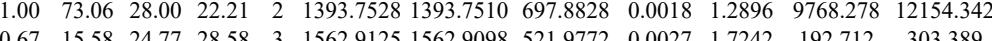
$\begin{array}{llllllllllll}0.96 & 20.10 & 24.77 & 22.21 & 3 & 1562.9125 & 1562.9098 & 521.9772 & 0.0027 & 1.7242 & 172.432\end{array}$ 112.843

\section{AYVSTLMGVPGR}

$\begin{array}{llllllllllllll}1.00 & 76.55 & 27.98 & 27.10 & 2 & 1393.7514 & 1393.7510 & 697.8828 & 0.0004 & 0.2866 & 5090.408 & 5\end{array}$

$\begin{array}{llllllllllll}1.00 & 76.55 & 27.98 & 27.10 & 2 & 1393.7514 & 1393.7510 & 697.8828 & 0.0004 & 0.2866 & 5090.408 & 5664.254 \\ 1.00 & 70.10 & 28.06 & 24.10 & 2 & 1393.7518 & 1393.7510 & 697.8828 & 0.0008 & 0.5732 & 3602.423 & 3258.857\end{array}$ 6258.857 250.254. \begin{tabular}{lllllllllllll} 
LVLEQVVTSIASVADTAEEK & 1.00 & 68.36 & 24.01 & 17.34 & 3 & 2389.3228 & 2389.3196 & 797.4471 & 0.0032 & 1.3376 & 21.924 \\
\hline
\end{tabular} $\begin{array}{lllllllllllll}\text { AIGTEPDSDVLSEIMHSFAK } & 0.55 & 70.19 & 27.47 & 83.19 & 3 & 2434.2304 & 2434.2294 & 812.4171 & 0.0010 & 0.4103 & 352.240 & 413 .\end{array}$ $\begin{array}{llllllllllllllll} & \end{array}$

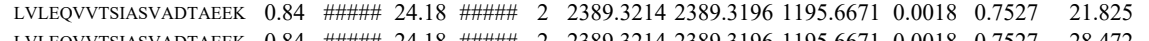
$\begin{array}{lllllllllll}\text { LVLEQVVTSIASVADTAEEK K } & 0.84 & \text { \#\#\#\# } 24.18 \text { \#\#\#\# } 2 & 2389.3214 & 2389.3196 & 1195.6671 & 0.0018 & 0.7527 & 28.472 \\ \end{array}$ $\begin{array}{lllllllllllll}\text { LVLEQVVTSIASVADTAEEK } & 0.67 & 75.15 & 24.01 & 88.15 & 3 & 2389.3228 & 2389.3196 & 797.4471 & 0.0032 & 1.3376 & 15.465 \\ \text { LVLEQVVTSISSVADTAEK } & 1.00 & 56.19 & 23.98 & 21.84 & 3 & 2389.3234 & 2389.3196 & 797.4471 & 0.0038 & 1.5884 & 22.444\end{array}$

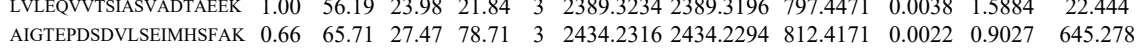
$\begin{array}{lllllllllllll}\text { LVLEQVVTSIASVADTAEEK } & 1.00 & \text { \#\#\# } 24.18 & 20.41 & 2 & 2389.3214 & 2389.3196 & 1195.6671 & 0.0018 & 0.7527 & 2.398\end{array}$ $\begin{array}{llllllllllllll}\text { LVLEQVVTSIASVADTAEEK } & 1.00 & 71.43 & 24.01 & 18.21 & 3 & 2389.3228 & 2389.3196 & 797.4471 & 0.0032 & 1.3376 & 4.320\end{array}$ $\begin{array}{lllllllllllll}\text { LVLEQVVTSIASVADTAEEK } & 1.00 & 81.56 & 23.98 & 20.04 & 3 & 2389.3234 & 2389.3196 & 797.4471 & 0.0038 & 1.5884 & 26.055\end{array}$ $\begin{array}{llllllllllll}\text { AIGTEPDSDVLSEIMHSFAK } & 0.66 & 61.15 & 27.44 & 74.15 & 3 & 2434.2313 & 2434.2294 & 812.4171 & 0.0019 & 0.7796 & 200.317\end{array}$ $\begin{array}{llllllllllllll} & \text { LVLEQVVISIASVADTAEEK } & 1.00 & 75.45 & 24.17 & 22.96 & 3 & 2389.3219 & 2389.3196 & 797.4471 & 0.0023 & 0.9614 & 6.90\end{array}$ $\begin{array}{llllllllllllll} & \text { LULEQVVTSIASVADTAEEK } & 1.00 & 41.28 & 24.01 & 20.11 & 3 & 2389.3228 & 2389.3196 & 797.4471 & 0.0032 & 1.3376 & 12.392\end{array}$ $\begin{array}{llllllllllllll}\text { LLSAFDEVYPALPSDVQTAIK } & 0.66 & 18.24 & 25.09 & 31.24 & 3 & 2651.4325 & 2651.4302 & 884.8173 & 0.0023 & 0.8665 & 15.162\end{array}$ $\begin{array}{lllllllllllll}\text { LLSSAFDEVYPALPSDVQTAIK } & 0.66 & 18.24 & 25.09 & 31.24 & 3 & 2651.4325 & 2651.4302 & 884.8173 & 0.0023 & 0.8665 & 15.162 & 4.371 \\ \text { LLSSAFDEVYPALPSDVQTAIK } & 0.63 & 9.68 & 25.08 & 16.85 & 3 & 2651.4334 & 2651.4302 & 884.8173 & 0.0032 & 1.2055 & 17.817 & 25.924 \\ \text { VCDIAAELAR } & 1.00 & 58.76 & 28.11 & 32.07 & 2 & 1249.6286 & 1249.6280 & 625.8213 & 0.0006 & 0.4794 & 3298.066 & 2982.466\end{array}$ $\begin{array}{lllllllllllll}\text { VCDIAAELAR } & 1.00 & 50.81 & 28.10 & 31.42 & 2 & 1249.6296 & 1249.6280 & 625.8213 & 0.0016 & 1.2783 & 3866.062 & 3715.500\end{array}$

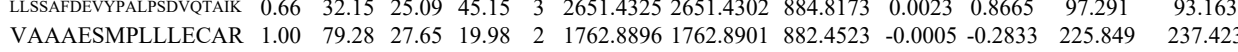
$\begin{array}{lllllllllllll}\text { VAAAESMPLLLECAR } & 1.00 & 78.54 & 27.75 & 22.78 & 2 & 1762.8918 & 1762.8901 & 882.4523 & 0.0017 & 0.9632 & 196.883 & 185.55\end{array}$

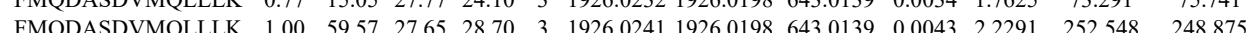

Yes 

$\begin{array}{llllllllllll} & 0.66 & 55.27 & 25.30 & 68.27 & 3 & 2674.2313 & 2674.2294 & 892.4171 & 0.0017 & 0.6350 & 138.559\end{array}$ \begin{tabular}{lllllllllllll}
\hline & 0.0017
\end{tabular} $\begin{array}{lllllllllllll} & \end{array}$ $\begin{array}{llllllllllllllll} & \end{array}$ $\begin{array}{lllllllllllllll}\text { SLLIPYLDNLVK } & 1.00 & 63.05 & 18.63 & 18.24 & 3 & 1675.0195 & 1675.0164 & 559.3461 & 0.0031 & 1.6474 & 91.479\end{array}$ $\begin{array}{lllllllllllll}\text { SLLIPYLDNLVK } & 1.00 & 53.61 & 18.63 & 16.63 & 3 & 1675.0195 & 1675.0164 & 559.3461 & 0.0031 & 1.8474 & 85.542\end{array}$ $\begin{array}{llllllllllll}\text { FLFDSVSSQNVGLR } & 1.00 & 74.18 & 27.47 & 24.58 & 2 & 1711.9016 & 1711.9015 & 856.9580 & 0.0001 & 0.0583 & 1086.258\end{array}$ TIECISLIGLAVGK LMVPLLK TIECISLIGLAVGK $\begin{array}{lllllllllll}1.00 & 47.14 & 27.37 & 23.02 & 2 & 1711.9048 & 1711.9015 & 856.9580 & 0.0033 & 1.9254 & 752.662 \\ 0 & 46.92 & 3 & 1750.0015 & 1749.9976 & 584.3398 & 0.0039 & 22247 & 82.848\end{array}$ $\begin{array}{llllllllllll}0.99 & 33.04 & 21.27 & 26.40 & 2 & 1750.0015 & 1749.9976 & 584.3398 & 0.0039 & 2.2247 & 82.848 & 85.790 \\ \end{array}$ VSDILHSIFSSYK $\begin{array}{lllllllllll}0.78 & 17.04 & 25.37 & 17.96 & 3 & 1749.9973 & 1749.9976 & 584.3398 & -0.0003 & -0.1711 & 50.753\end{array}$ VSDILHSIFSSYK VSDILHSIFSSYK QMAAVLLR
QMAAVLLR

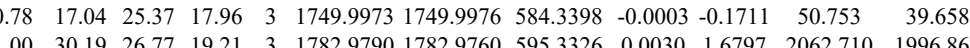
$\begin{array}{llllllllllll}0.67 & 36.12 & 26.77 & 49.12 & 3 & 1782.9790 & 1782.9760 & 595.3326 & 0.0030 & 1.6797 & 1761.360 & 2134.78\end{array}$ $\begin{array}{llllllllllll}0.67 & 34.11 & 26.77 & 47.11 & 3 & 1782.9790 & 1782.9760 & 595.3326 & 0.0030 & 1.6797 & 699.443\end{array}$ $\begin{array}{llllllllllll}0.89 & 30.08 & 25.84 & 28.97 & 2 & 1044.6324 & 1044.6236 & 523.3191 & 0.0088 & 8.4078 & 234.429 & \end{array}$

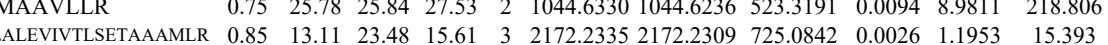
$\begin{array}{llllllllllllll}\text { QLALEVVILSETAAAMLR } & 0.66 & 20.99 & 23.48 & 33.99 & 3 & 2172.2335 & 2172.2309 & 725.0842 & 0.0026 & 1.1953 & 21.164 & 1 & \\ \end{array}$ $\begin{array}{lllllllllll}\text { QLALEVIVTLSETAAAMLR } & 1.00 & \text { \#\#\#\# } 23.54 & 29.29 & 2 & 2172.2314 & 2172.2309 & 1087.1227 & 0.0005 & 0.2300 & 16.603 \\ \text { QLALEVIVTLSETAAAMLR } & 1.00 & \text { \#\#\#\# } 23.54 & 31.02 & 2 & 2172.2314 & 2172.2309 & 1087.1227 & 0.0005 & 0.2300 & 1.687\end{array}$ $\begin{array}{llllllllllll}\text { QLALEVIVTLSETAAAMLR } & 1.00 & 68.71 & 23.54 & 21.14 & 3 & 2172.2332 & 2172.2309 & 725.0842 & 0.0023 & 1.0573 & 9.136\end{array}$ $\begin{array}{llllllllllll}\text { QLALEVIVTLSETAAAMLR } & 1.00 & 64.13 & 23.48 & 20.08 & 3 & 2172.2335 & 2172.2309 & 725.0842 & 0.0026 & 1.1953 & 14.108\end{array}$ $\begin{array}{lllllllllll}\text { QLALEVIVTLSETAAAMLR } & 1.00 & \text { \#\#\#\# } 23.54 & 29.48 & 2 & 2172.2314 & 2172.2309 & 1087.1227 & 0.0005 & 0.2300 & 3.207\end{array}$ $\begin{array}{llllllllllll}\text { QLALEVIVTLSETAAAMLR } & 1.00 & 33.30 & 23.50 & 15.72 & 3 & 2172.2326 & 2172.2309 & 725.0842 & 0.0017 & 0.7815 & 19.210 \\ \text { QLALEVIVTLSETAAAMLR } & 1.00 & 61.65 & 23.48 & 19.76 & 3 & 2172.2335 & 2172.2309 & 725.0842 & 0.0026 & 1.1953 & 21.062\end{array}$ $\begin{array}{llllllllllll}\text { QLALEVIVTLSETAAAMLR } & 1.00 & 61.65 & 23.48 & 19.76 & 3 & 2172.2335 & 2172.2309 & 725.0842 & 0.0026 & 1.1953 & 21.062 \\ \text { QLALEVIVTLSETAAAMLR } & 0.66 & 62.59 & 23.54 & 75.59 & 3 & 2172.2329 & 2172.2309 & 725.0842 & 0.0020 & 0.9194 & 15.404\end{array}$

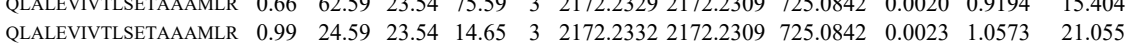
$\begin{array}{llllllllllll}\text { ITFLLQAIR } & 1.00 & 55.80 & 23.86 & 31.78 & 2 & 1217.7626 & 1217.7618 & 609.8882 & 0.0008 & 0.6559 & 231.979\end{array}$ ITFLLAIR

ITFLLQAR

ITFLPAIR

ITFLLQAIR $\begin{array}{lllllllllllll}\text { DNM1L_HUMA } & \text { O00429 } & \text { DNM1L } & \text { Dynamin-1-like p1 } 81.877 & 1.00 & 13 & 27.9 & 0.0230 & 0.3885 & 0.6832 & 0.4477 & 42 & \text { AEELLAEEK }\end{array}$ $\begin{array}{lllllllllll}1.00 & 55.80 & 23.86 & 31.78 & 2 & 1217.7626 & 1217.7618 & 609.8882 & 0.0008 & 0.6559 & 231.919 \\ 1.00 & 51.69 & 23.56 & 31.73 & 2 & 1217.7630 & 1217.7618 & 609.8882 & 0.0012 & 0.9838 & 512.459\end{array}$

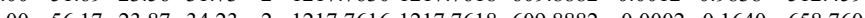
AEELLAEEK $\begin{array}{llllllllllll}1.00 & 58.63 & 23.87 & 35.97 & 2 & 1217.7618 & 1217.7618 & 609.8882 & 0.0000 & 0.0000 & 2135.508\end{array}$

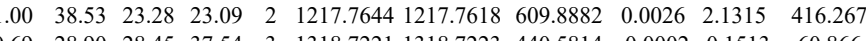

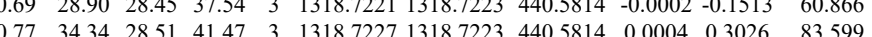
$\begin{array}{lllllllllllll}1.00 & 58.63 & 28.65 & 35.37 & 2 & 1318.7246 & 1318.7223 & 660.3684 & 0.0023 & 1.7414 & 445.253 & \end{array}$ \begin{tabular}{llllllllllllll} 
& 1.00 & 58.63 & 28.65 & 35.37 & 2 & 1318.7246 & 138.7223 & 60.3684 & 0.0023 & 1.7414 & 445.253 \\
\hline
\end{tabular} $\begin{array}{llllllllllllll}\text { LDLMDAGTDAMDVLMGR } & 0.55 & 12.17 & 26.95 & 17.73 & 3 & 1966.9291 & 1966.9284 & 656.6501 & 0.0007 & 0.3553 & 76.851\end{array}$ $\begin{array}{llllllllllllll}\text { LDLMDAGTDAMDVLMGR } & 1.00 & \# \# \# \# \frac{26.90}{23.89} & 2 & 1966.9294 & 1966.9284 & 984.4715 & 0.0010 & 0.5079 & 309.152\end{array}$ $\begin{array}{llllllllllllll}\text { LDLMDAGTDAMDVLMGR } & 1.00 & 97.19 & 26.87 & 24.41 & 2 & 1966.9304 & 1966.9284 & 984.4715 & 0.0020 & 1.0158 & 211.690\end{array}$ $\begin{array}{lllllllllllll}\text { LDLMDAGTDAMDVLMGR } & 1.00 & 98.57 & 26.91 & 25.73 & 2 & 1966.9298 & 1966.9284 & 984.4715 & 0.0014 & 0.7110 & 484.004\end{array}$ $\begin{array}{llllllllllllll}\text { LDLMDAGTDAMDVLMGR } & 1.00 & 96.34 & 26.92 & 21.39 & 2 & 1966.9310 & 1966.9284 & 984.4715 & 0.0026 & 1.3205 & 21.897\end{array}$ $\begin{array}{lllllllllllll}\text { INVLAAOYQSLLNSYGEPVDDK } & 0.60 & 65.33 & 26.28 & 78.33 & 3 & 2724.4252 & 2724.4214 & 909.1477 & 0.0038 & 1.3932 & 35.784\end{array}$

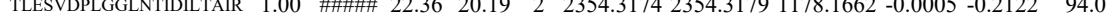
$\begin{array}{llllllllllll}\text { TLESVDPLGGLNTIDILTAIR } & 0.55 & 22.59 & 22.38 & 35.59 & 3 & 2354.3194 & 2354.3179 & 785.7799 & 0.0015 & 0.6363 & 23.651\end{array}$ $\begin{array}{lllllllllllll}\text { TLESVDPLGGLNTIDILTAIR } & 0.60 & 41.61 & 22.17 & 54.61 & 3 & 2354.3215 & 2354.3179 & 785.7799 & 0.0036 & 1.5271 & 22.021\end{array}$ TLESVDPLGGLNTIDILTAIR 0.84 \#\#\#\# 22.33 \#\#\#\# 2 2 $2354.31942354 .31791178 .16620 .0015 \quad 0.6366 \quad 83.446$ $\begin{array}{llllllllllll}\text { TLESVDPLGGLNTIDILTAIR } & 0.84 & 94.43 & 22.33 & \text { \#\#\#\# } & 2 & 2354.3194 & 2354.3179 & 1178.1662 & 0.0015 & 0.6366 & 80.182\end{array}$ $\begin{array}{llllllllllll}\text { TLESVDPLGGLNTIDILTAIR } & 0.99 & 25.30 & 22.38 & 18.47 & 3 & 2354.3203 & 2354.3179 & 785.7799 & 0.0024 & 1.0181 & 11.060\end{array}$ $\begin{array}{llllllllllll}\text { TLESVDPLGGLNTIDILTAIR } & 0.67 & 31.26 & 22.30 & 44.26 & 3 & 2354.3209 & 2354.3179 & 785.7799 & 0.0030 & 1.2726 & 0.000\end{array}$ SSVLESLVGR $\begin{array}{lllllllllll}1.00 & 52.39 & 28.18 & 24.86 & 2 & 1189.6898 & 1189.6788 & 595.8467 & 0.0110 & 9.2305 & 2612.509 \\ 1.00 & 85.66 & 22.23 & 20.78 & 3 & 2354.32123543179 & 785.7799 & 0.0042 & 1.7817 & 25.660\end{array}$ $\begin{array}{lllllllllllll}\text { TLESVDPLGGLNTIDILTAIR } & 1.00 & 85.66 & 22.23 & 20.78 & 3 & 2354.3221 & 2354.3179 & 785.7799 & 0.0042 & 1.7817 & 25.660 \\ \text { LPVTNEMVHNLVAIELAYINTK } & 1.00 & 21.55 & 22.79 & 15.58 & 4 & 2769.5333 & 2769.5342 & 693.3908 & -0.0009 & -0.3245 & 84.587\end{array}$ $\begin{array}{llllllllllll}\text { LPVTNEMVHNLVAIELAYINTK } & 1.00 & 21.55 & 22.79 & 15.58 & 4 & 2769.5333 & 2769.5342 & 693.3908 & -0.0009 & -0.3245 & 84.587 \\ \text { LPVTNEMVHNLVAIELAYINTK } & 1.00 & 47.90 & 22.53 & 22.91 & 3 & 2769.5368 & 2769.5342 & 924.1853 & 0.0026 & 0.9378 & 24.668\end{array}$ $\begin{array}{llllllllllll}\text { LPVTNEMVHNLVAIELAYINTK } & 1.00 & 43.50 & 22.43 & 20.38 & 3 & 2769.5383 & 2769.5342 & 924.1853 & 0.0041 & 1.4788 & 7.134\end{array}$ $\begin{array}{llllllllllllll}\text { LPVTNEMVHNLVAIELAYINTK } & 1.00 & 22.03 & 22.15 & 16.15 & 4 & 2769.5413 & 2769.5342 & 693.3908 & 0.0071 & 2.5599 & 55.625\end{array}$ $\begin{array}{lllllllllllll}\text { LPVTNEMVHNLVAIELAYINTK } & 1.00 & 21.10 & 22.33 & 16.87 & 4 & 2769.5393 & 2769.5342 & 693.3908 & 0.0051 & 1.8388 & 79.394\end{array}$ $\begin{array}{lllllllllllll}\text { LPVTNEMVHNLVAIELAYINTK } & 1.00 & 25.46 & 22.33 & 15.66 & 4 & 2769.5393 & 2769.5342 & 693.3908 & 0.0051 & 1.8388 & 77.213\end{array}$ 
$\begin{array}{llllllllllll}\text { NVPOEESLEDSDVDADFK } & 0.66 & 12.68 & 25.87 & 25.68 & 3 & 2324.0923 & 2324.0900 & 775.7039 & 0.0023 & 0.9883 & 14.189\end{array}$ $\begin{array}{lllllllllllll}\text { NVPOEESLEDSDVDADFK } & 0.67 & 11.37 & 26.02 & 24.37 & 3 & 2324.0932 & 2324.0900 & 775.7039 & 0.0032 & 1.3751 & 15.462\end{array}$

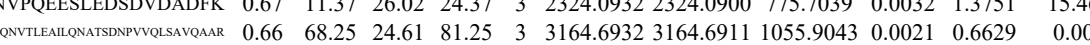

VTWVIVNLCR

VTWVIVNLCR

NVTWVINLCR

NLSSTTDDEAPR

GPWALEEESLVGR

GLPCTELFVAPVGVASK 1.00

GLPCTELFVAPVGVASK
TLEDEEEQER

TLEDEEEQER

TQESGDQDPQEAQK

SLAPGMALGSGR

SLAPGMALGSGR

LNLWISR

LNLWTR $\begin{array}{llllllllll} & 4.61 .25 & 3 & 3164.6932 & 3164.6911 & 1055.9043 & 0.032 & 0.6729 & 15.462 & 23.948\end{array}$ $\begin{array}{llllllllllllll}1.00 & 51.84 & 28.33 & 30.65 & 2 & 1259.6902 & 1259.6778 & 630.8462 & 0.0124 & 9.8280 & 1856.706 & 1529.987\end{array}$ 


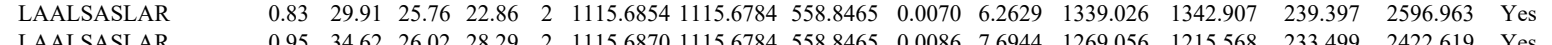

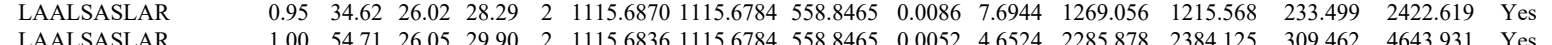

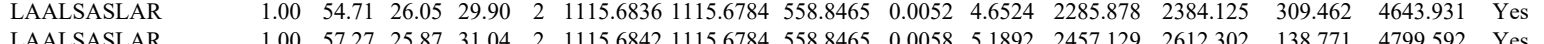
$\begin{array}{llllllllllllllll}\text { LAALSASLAR } & 1.00 & 57.27 & 25.87 & 31.04 & 2 & 1115.6842 & 1115.6784 & 558.8465 & 0.0058 & 5.1892 & 2457.129 & 2612.302 & 138.771 & 4799.592 & \text { Yes }\end{array}$ \begin{tabular}{llllllllllllllll} 
MSQVAPSLSALIGEAVGAR & 1.00 & 36.69 & 26.82 & 15.91 & 3 & 2000.0878 & 2000.0846 & 667.7021 & 0.0032 & 1.5975 & 96.798 & 77.128 & 81.504 & 111.596 & Yes \\
\hline
\end{tabular}

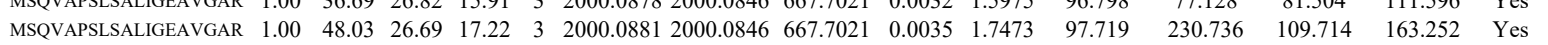
$\begin{array}{llllllllllllllll}\text { MSQVAPSLSALIGEAVGAR } & 1.00 & 61.48 & 26.79 & 24.74 & 3 & 2000.0875 & 2000.0846 & 667.7021 & 0.0029 & 1.4477 & 73.767 & 127.412 & 85.626 & 134.244 & \text { Yes }\end{array}$

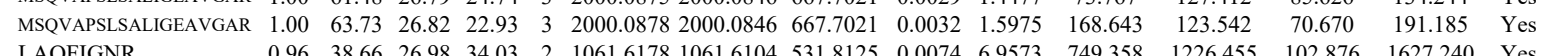

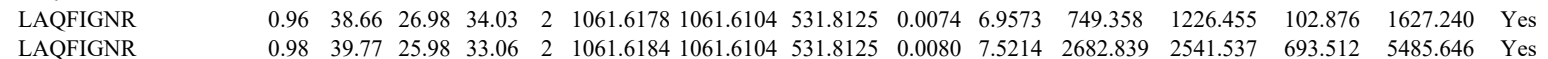
$\begin{array}{llllllllllllllll}\text { EVEEISLLPQVEESVLNLGK } & 1.00 & 59.62 & 23.65 & 19.46 & 3 & 2640.4489 & 2640.4465 & 881.1561 & 0.0024 & 0.9079 & 0.000 & 7.588 & 5.041 & 8.692 & \text { No }\end{array}$

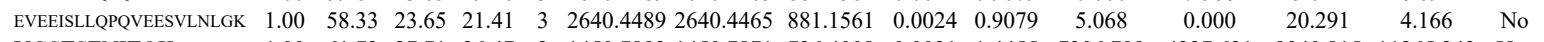

$\begin{array}{lllllllllllll}\text { DDX3X_HUMA } & \text { O00571 } & \text { DDX3X } & \text { ATP-dependent R } 73.243 & 1.00 & 10 & 21 & -0.3132 & 0.5651 & 0.7421 & 0.3823 & 49 & \text { VGSTSENITQK }\end{array}$ VGSTSENITQK VGSTSENITQK YTRPTPVQK YTRPTPVQK YTRPTPVQK YTRPTPVQK SFLLDLLNATGK SFLLDLLNATGK SFLDLNAT SFLLDLLNATGK

SFLDNAT

SFLLDLLNATGK

VGNLGLATSFFNER

\section{FSGGFGAR}

SFLLDLLNATGK

VFLLDLLNATGK

VGNLGLATSFFNER VGNLGLATSFFNER VGNLGLATSFFNER FSGGFGAR

VGNLGLATSFFNER TAAFLLPLLSOIYSDGPGEALR AAFLLPILSOIYSDGPGEAL

TAAFLLPLSOYYSDGGGE

TAAFLLPLSSIYYSDGPGEALR

TAAFLLPLSOIYSDGPGEALR VRPCVVYGGADIGQQIR VRPCVVYGGADIGQQIR VRPCVVYGGADIGQ
SPILVATAVAAR SPILVATAVAAR SPILVATAVAAR GCHLLVATPGR SPILVATAVAAR GCULATAAR

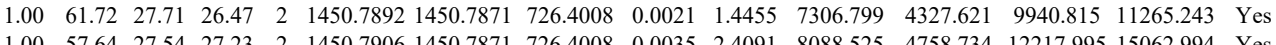

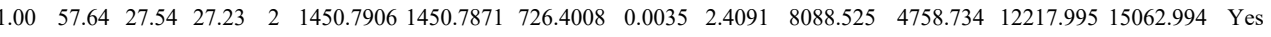
$\begin{array}{llllllllllllllll}0.60 & 14.57 & 27.48 & 27.57 & 3 & 1450.7908 & 1450.7871 & 484.6030 & 0.0037 & 2.5450 & 2358.658 & 1962.553 & 1444.980 & 2371.937 & \text { Yes }\end{array}$ $\begin{array}{lllllllllllllll}0.64 & 13.46 & 26.66 & 23.33 & 3 & 1376.8030 & 1376.8020 & 459.9413 & 0.0010 & 0.7247 & 915.376 & 746.391 & 1766.535 & 1634.407 & \text { Yes }\end{array}$ $\begin{array}{llllllllllllllll}0.58 & 12.38 & 26.64 & 16.83 & 3 & 1376.8033 & 1376.8020 & 459.9413 & 0.0013 & 0.9421 & 1033.473 & 975.217 & 1917.237 & 1761.600 & \text { Yes }\end{array}$

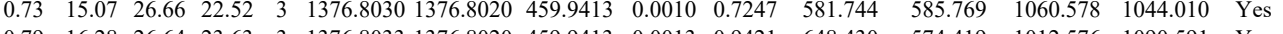
$\begin{array}{lllllllllllllll}0.79 & 16.28 & 26.64 & 23.63 & 3 & 1376.8033 & 1376.8020 & 459.9413 & 0.0013 & 0.9421 & 648.430 & 574.419 & 1012.576 & 1090.591 & \text { Yes } \\ 1.00 & 87.29 & 24.94 & 29.35 & 2 & 1578.9248 & 1578.9225 & 79.4685 & 0.0023 & 1.4548 & 170.432 & 159.988 & 6.600 & 308.743 & \text { Yes }\end{array}$ $\begin{array}{lllllllllllllll}1.00 & 87.29 & 24.94 & 29.35 & 2 & 1578.9248 & 1578.9225 & 790.4685 & 0.0023 & 1.4548 & 170.432 & 159.988 & 6.600 & 308.743 & \text { Yes } \\ 1.00 & 42.72 & 24.80 & 20.16 & 3 & 1578.9253 & 1578.9225 & 527.3148 & 0.0028 & 1.7700 & 125.895 & 78.550 & 70.853 & 179.892 & \text { Yes }\end{array}$ $\begin{array}{llllllllllllllll}1.00 & 42.72 & 24.80 & 20.16 & 3 & 1578.9253 & 1578.9225 & 527.3148 & 0.0028 & 1.7700 & 125.895 & 78.550 & 70.853 & 179.892 & \text { Yes } \\ 1.00 & 77.49 & 24.86 & 32.74 & 2 & 1578.9258 & 1578.9225 & 790.4685 & 0.0033 & 2.0874 & 223.866 & 136.991 & 45.744 & 508.023 & Y 5\end{array}$

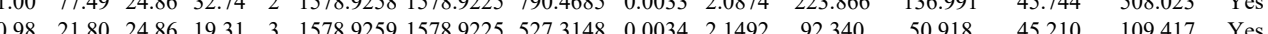

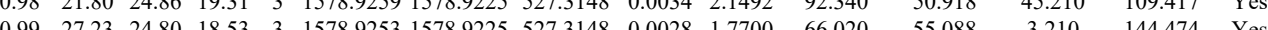

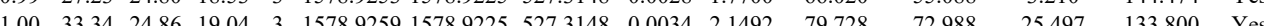

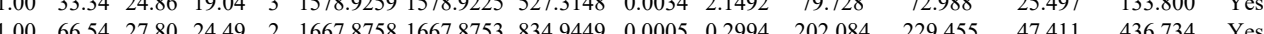
$\begin{array}{lllllllllllllll}1.00 & 74.82 & 27.83 & 24.37 & 2 & 1667.8770 & 1667.8753 & 834.9449 & 0.0017 & 1.0180 & 139.474 & 156.096 & 51.089 & 385.330 & \text { Yes }\end{array}$ $\begin{array}{lllllllllllllll}0.97 & 31.19 & 25.83 & 30.53 & 2 & 941.4876 & 941.4841 & 471.7493 & 0.0035 & 3.7096 & 6982.102 & 4636778 & 1548.013 & 16188.854 & \text { Yes }\end{array}$ $\begin{array}{llllllllllllllll}0.90 & 29.30 & 25.83 & 27.29 & 2 & 941.4878 & 941.4841 & 471.7493 & 0.0037 & 3.9216 & 4745.588 & 4011.243 & 997.737 & 10511.886 & \text { Yes }\end{array}$ $\begin{array}{lllllllllllllll}1.00 & 36.27 & 24.71 & 23.39 & 3 & 1578.9262 & 1578.9225 & 527.3148 & 0.0037 & 2.3389 & 114.721 & 106.279 & 32.644 & 248.329 & \text { Yes }\end{array}$ $\begin{array}{llllllllllllllll}1.00 & 68.43 & 27.92 & 23.61 & 2 & 1667.8766 & 1667.8753 & 834.9449 & 0.0013 & 0.7785 & 1258.154 & 1082.421 & 422.093 & 3105.924 & \text { Yes }\end{array}$ $\begin{array}{lllllllllllllll}1.00 & 77.92 & 27.88 & 25.44 & 2 & 1667.8774 & 1667.8753 & 834.9449 & 0.0021 & 1.2576 & 2872.430 & 1992.419 & 671.309 & 6401.528 & \text { Yes }\end{array}$ $\begin{array}{llllllllllllllll}1.00 & 36.96 & 27.82 & 17.96 & 3 & 1667.8792 & 1667.8753 & 556.9657 & 0.0039 & 2.3341 & 602.816 & 430.465 & 167.056 & 618.352 & \text { Yes }\end{array}$ $\begin{array}{llllllllllllllll}0.60 & 24.91 & 27.78 & 37.91 & 3 & 1667.8795 & 1667.8753 & 556.9657 & 0.0042 & 2.5136 & 648.762 & 583.802 & 119.497 & 1013.257 & \text { Yes }\end{array}$ $\begin{array}{llllllllllllllll}1.00 & 38.96 & 25.47 & 27.09 & 2 & 941.4866 & 941.4841 & 471.7493 & 0.0025 & 2.6497 & 4315.699 & 3639.076 & 1076.471 & 10637.683 & \text { Yes }\end{array}$

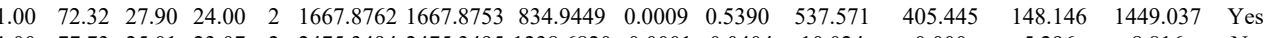

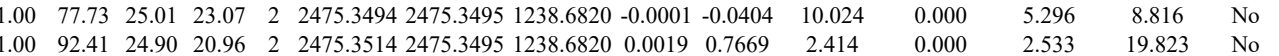
$\begin{array}{lllllllllllllll}0.97 & 20.56 & 24.89 & 14.97 & 3 & 2475.3529 & 2475.3495 & 826.1238 & 0.0034 & 1.3719 & 0.000 & 3.006 & 0.000 & 3.512 & \text { No }\end{array}$ $\begin{array}{lllllllllllllll} & 245.3514 & 2475.3495 & 826.1238 & 0.0019 & 0.7666 & 0.000 & 8.828 & 13.618 & 10.694 & \text { No } \\ 1.00 & 63.68 & 24.79 & 20.36 & 3 & 2475.3535 & 2475.3495 & 826.1238 & 0.0040 & 1.6140 & 11.112 & 25.920 & 11.404 & 2.831 & \text { No }\end{array}$

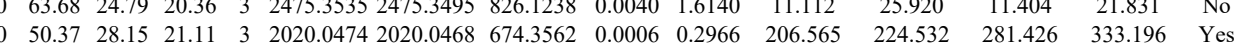
$\begin{array}{lllllllllllllll}1.00 & 79.93 & 27.58 & 24.68 & 3 & 2020.0636 & 2020.0468 & 674.3562 & 0.0168 & 8.3041 & 332.489 & 365.454 & 318.274 & 536.164 & \text { Yes } \\ 1.00 & 59.58 & 28.17 & 21.21 & 3 & 2020.0468 & 2020.0468 & 674.3562 & 0.0000 & 0.0000 & 441.419 & 263.055 & 208.360 & 357.444 & \text { No }\end{array}$ $\begin{array}{lllllllllllllll}19.00 & 28.17 & 21.21 & 3 & 2020.0468 & 2020.0468 & 674.3562 & 0.0000 & 0.0000 & 441.419 & 263.055 & 208.360 & 357.444 & \text { No } \\ 1.00 & 6.59 & 28.14 & 21.87 & 3 & 2020.0471 & 2020.0468 & 674.3562 & 0.0003 & 0.1483 & 391.835 & 666.125 & 518.866 & 619.044 & \text { Yes }\end{array}$

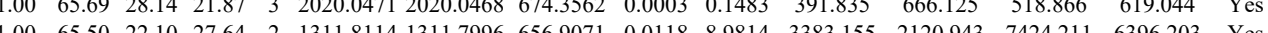
$\begin{array}{lllllllllllllll}1.00 & 61.00 & 22.28 & 27.64 & 2 & 1311.814 & 1311.790 & 656.9011 & 0.018 & 8.9814 & 3383.155 & 2120.943 & 7424.211 & 6396.203 & \text { Yes }\end{array}$

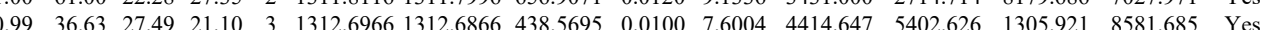

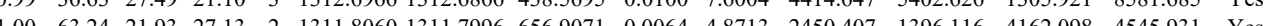
$\begin{array}{llllllllllllllllll}1.00 & 65.93 & 21.90 & 27.90 & 2 & 1311.8074 & 1311.7996 & 656.9071 & 0.0078 & 5.9369 & 4198.355 & 236.551 & 7347.522 & 5580.267 & \text { Yes }\end{array}$ $\begin{array}{lllllllllllllll}0.93 & 31.99 & 27.48 & 28.91 & 3 & 1312.6945 & 1312.6866 & 438.5695 & 0.0079 & 6.0043 & 5952.963 & 9273.557 & 1699.444 & 12923.139 & \text { Yes }\end{array}$ 
GCHLLVATPGR QYPISLVLAPTR QYPISLVLAPTR SPILVATAVAAR SPILVATAVAAR GCHLLVATPGR GCHLLVATPGR QYPISLVLAPTR QYPISLVLAPTR

QYMSLVLAPTR

TAAFLLPILSQIYSDGPGEALR

TAAFLLPLSOIYSDGPC

SPILVATAVAAR

SPILVATAVAAR

SPILVATANAVAAR

DAQVVQVVLDGLSNILK \begin{tabular}{lllllllllll} 
& \\
\hline
\end{tabular} $\begin{array}{llllllllllll}\text { DAQVVQVVLDGLSNILK } & 1.00 & 74.96 & 20.68 & 20.28 & 3 & 2098.2286 & 2098.2242 & 700.4153 & 0.0044 & 2.0940 & 93.468\end{array}$ $\begin{array}{llllllllllll}\text { DAQVVQVVLDGLSNILK } & 1.00 & 61.90 & 20.97 & 26.73 & 3 & 2098.2268 & 2098.2242 & 700.4153 & 0.0026 & 1.2374 & 59.010\end{array}$ $\begin{array}{llllllllllll}\text { DAQVVQVVLDGLSNILK } & 1.00 & 94.83 & 20.72 & 29.10 & 3 & 2098.2280 & 2098.2242 & 700.4153 & 0.0038 & 1.8084 & 63.170\end{array}$ $\begin{array}{llllllllllll}\text { DAQVVQVVLDGLSNILK } & 0.99 & 23.34 & 21.11 & 19.68 & 3 & 2098.2256 & 2098.2242 & 700.4153 & 0.0014 & 0.6663 & 115.795\end{array}$ NVTWVMVNLCR NVTWVMVNLCR NVTWVMVNLCR NVTWVMVNLCR

$\begin{array}{lllllllllll}0.82 & 56.60 & 27.41 & 69.60 & 2 & 1523.7544 & 1523.7533 & 762.8839 & 0.0011 & 0.7209 & 104.972\end{array}$ $\begin{array}{lllllllllll}1.00 & 60.60 & 27.42 & 18.68 & 2 & 1523.7546 & 1523.7533 & 762.8839 & 0.0013 & 0.8520 & 122.875\end{array}$ $\begin{array}{llllllllllll}0.82 & 43.29 & 27.44 & 56.29 & 2 & 1523.7538 & 1523.7533 & 762.8839 & 0.0005 & 0.3277 & 4.635 \\ 0.84 & 37.91 & 27.56 & 50.91 & 2 & 1532.7550 & 1532.7533 & 762.8839 & 0.0017 & 1.142 & 18.773\end{array}$

$\begin{array}{lllllllllll}1.00 & 32.90 & 27.79 & 24.14 & 3 & 2060.0461 & 2060.0418 & 687.6879 & 0.0043 & 2.0843 & 1339.395\end{array}$

$\begin{array}{lllllllllllll} & \text { GQVLNSDELQELYEGLR } & 1.00 & 85.63 & 27.72 & 23.96 & 2 & 2106.0734 & 2106.0715 & 1054.0430 & 0.0019 & 0.9013 & 611.644\end{array}$ $\begin{array}{lllllllllllll}\text { GQVLNSDELQELYEGLR } & 1.00 & 83.50 & 27.72 & 23.00 & 2 & 2106.0734 & 2106.0715 & 1054.0430 & 0.0019 & 0.9013 & 706.533\end{array}$ $\begin{array}{lllllllllllll}\text { GQVLNSDELQELYEGLR } & 0.98 & 25.09 & 27.80 & 25.90 & 3 & 2106.0748 & 2106.0715 & 703.0311 & 0.0033 & 1.5647 & 186.024 & 160 \\ \text { VVPLADITPNOFEAELSGR } & 1.00 & 52.71 & 24.12 & 19.71 & 2 & 2425.3334 & 2425.3338 & 1213.6742 & -0.0004 & -0.1648 & 70.052 & \end{array}$ $\begin{array}{lllllllllllll}\text { VVPLADIITPNOFEAELLSGR } & 1.00 & 52.71 & 24.12 & 19.71 & 2 & 2425.3334 & 2425.3338 & 1213.6742 & -0.0004 & -0.1648 & 70.052 \\ \text { VVPLADITPNOFEAELLSGR } & 1.00 & 61.52 & 24.05 & 18.10 & 2 & 2425.3354 & 2425.3338 & 1213.6742 & 0.0016 & 0.6592 & 109.975\end{array}$ $\begin{array}{llllllllllllll}\text { VVPLADIITPNOFEAELLSGR } & 1.00 & 61.52 & 24.05 & 18.10 & 2 & 2425.3354 & 2425.3338 & 1213.6742 & 0.0016 & 0.6592 & 109.975 & 57 . \\ \text { VVPLADITPNOFEAELLSGR } & 0.67 & 24.37 & 24.07 & 37.37 & 3 & 2425.3369 & 2425.3338 & 809.4519 & 0.0031 & 1.2766 & 14.726\end{array}$ $\begin{array}{lllllllllllll}\text { VVPLADIITPNQFEAELLSGR } & 0.67 & 24.37 & 24.07 & 37.37 & 3 & 2425.3369 & 2425.3338 & 809.4519 & 0.0031 & 1.2766 & 14.726 \\ \text { VVPLDUTNOFEAELSGR } & 0.60 & 16.55 & 24.05 & 29.55 & 3 & 2425.3384 & 2425.3338 & 809.4519 & 0.0046 & 1.8943 & 0.000\end{array}$ $\begin{array}{llllllllllll}\text { VVPLADITPNQFEAELLSGR } & 0.60 & 16.55 & 24.05 & 29.55 & 3 & 2425.3384 & 2425.3338 & 809.4519 & 0.0046 & 1.8943 & 0.000 \\ \text { VVPLADITPNOFEAELLSGR } & 1.00 & 65.27 & 24.05 & 19.72 & 2 & 2425.3354 & 2425.3338 & 1213.6742 & 0.0016 & 0.6592 & 26.117\end{array}$ $\begin{array}{llllllllllll}\text { VVPLADIITPNOFEAELLSGR } & 1.00 & 63.45 & 24.05 & 18.93 & 2 & 2425.3354 & 2425.3338 & 1213.6742 & 0.0016 & 0.6592 & 50.881\end{array}$ $\begin{array}{llllllllllll}\text { VVPLADIITPNOFEAELLGGR } & 1.00 & 63.45 & 24.05 & 18.93 & 2 & 2425.3354 & 2425.3338 & 123.6742 & 0.0016 & 0.6592 & 50.881 \\ \text { VVPLADITPNOFEAELLGGR } & 0.60 & 54.38 & 24.03 & 67.38 & 3 & 2425.3378 & 2425.3338 & 809.4519 & 0.0040 & 1.6472 & 81.803\end{array}$

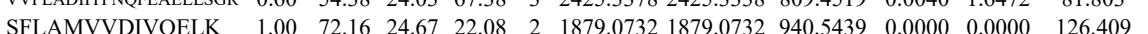
$\begin{array}{lllllllllllll}\text { SFLAMVVDIVQELK } & 1.00 & 72.16 & 24.67 & 22.08 & 2 & 1879.0732 & 1879.0732 & 940.5439 & 0.0000 & 0.0000 & 126.409 & 15\end{array}$ $\begin{array}{lllllllllllll}\text { SFLAMVDDVELK } & 1.00 & 73.60 & 24.56 & 22.05 & 2 & 1879.0734 & 1879.0732 & 940.5439 & 0.0002 & 0.1063 & 127.119 & 146.8 \\ \text { SFLAMVVDIVQELK } & 0.60 & 9.74 & 24.50 & 17.28 & 3 & 1879.0771 & 1879.0732 & 627.3650 & 0.0039 & 2.0722 & 479.132 & 512.4\end{array}$ $\begin{array}{lllllllllllll}\text { SFLAMVVDVELK } & 0.60 & 9.74 & 24.50 & 17.28 & 3 & 1879.0771 & 1879.0732 & 627.3650 & 0.0039 & 2.0722 & 479.132 \\ \text { SFLAMVVDIVQELK } & 1.00 & 88.36 & 24.58 & 24.26 & 2 & 1879.0742 & 1879.0732 & 940.5439 & 0.0010 & 0.5316 & 97.988 \\ \text { SFLAMVVDIVELK } & 1.00 & 90.22 & 24.62 & 22.58 & 2 & 1879.0748 & 1879.0732 & 940.5439 & 0.0016 & 0.8506 & 127.795\end{array}$

SFLAMVVDIVQELK

SFLAMVVDIVQELK

SFLAMVVDIVQELK

SFLAMVVDIVQELK

SFLAMVVDIVQELK SFLAMVVDIVQELK SFLAMVVDIVQELK SFLAMVVDIVQELK TVSTLHHVLQR

TVSTLHHVLQR

TVSTLHHVLQR

TVSTLHHVLQR

TVSTLHHVLQ

TVSTLHHVLQR

$\begin{array}{llllllllllll}1.00 & 78.99 & 24.67 & 19.00 & 2 & 1879.0746 & 1879.0732 & 940.5439 & 0.0014 & 0.7442 & 28.768 \\ 1.00 & 32.31 & 24.58 & 17.35 & 3 & 1879.0756 & 1879.0732 & 627.3650 & 0.0024 & 1.2752 & 180.332\end{array}$

$\begin{array}{llllllllllll}1.00 & 35.39 & 24.58 & 22.28 & 3 & 1879.0756 & 1879.0732 & 627.3650 & 0.0024 & 1.2752 & 223.860\end{array}$
LVMFQR

LVMFQR WHINFTTFFIDCMAALGLAYDR GSTLDLSDLEAEK GSTLDSDLEAEK

GSTLDLSDLEAEK

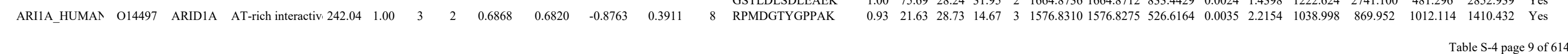

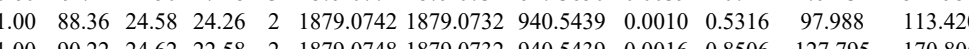

$\begin{array}{llllllllllll}0.92 & 17.76 & 24.50 & 15.24 & 3 & 1879.0771 & 1879.0732 & 627.3650 & 0.0039 & 2.0722 & 250.321 & 288.910\end{array}$

$\begin{array}{lllllllllll}1.00 & 75.66 & 24.67 & 21.41 & 2 & 1879.0726 & 1879.0732 & 940.5439 & -0.0006 & -0.3190 & 90.814\end{array}$

$\begin{array}{llllllllllll}1.00 & 85.19 & 24.58 & 23.70 & 2 & 1879.0740 & 1879.0732 & 940.5439 & 0.0008 & 0.4253 & 80.461\end{array}$

$\begin{array}{llllllllllll}1.00 & 36.43 & 24.62 & 20.37 & 3 & 1879.0753 & 1879.0732 & 627.3650 & 0.0021 & 1.1158 & 180.767\end{array}$

$\begin{array}{lllllllllllll}0.55 & 35.10 & 24.61 & 48.10 & 3 & 1879.0744 & 1879.0732 & 627.3650 & 0.0012 & 0.6376 & 146.202\end{array}$

$\begin{array}{llllllllllll}1.00 & 74.09 & 26.79 & 21.48 & 3 & 1433.8249 & 1433.8225 & 478.9481 & 0.0024 & 1.6703 & 6507.879 & 7105.589\end{array}$

$\begin{array}{llllllllllllll}1.00 & 80.45 & 26.20 & 28.42 & 2 & 1433.8256 & 1433.8225 & 717.9185 & 0.0031 & 2.1590 & 1799.997 & 2304.038\end{array}$

$\begin{array}{lllllllllllllll}1.00 & 61.38 & 26.20 & 18.47 & 3 & 1433.8258 & 1433.8225 & 478.9481 & 0.0033 & 2.2967 & 8798.207 & 11003.860 & 2310.393 & 7644.847 & \text { Yes } \\ 1.00 & 82.25 & 26.26 & 29.55 & 2 & 1433.8262 & 1433.8225 & 717.9185 & 0.0037 & 2.5769 & 1944.422 & 2595.732 & 0.000 & 1780.123 & \text { No }\end{array}$

$\begin{array}{lllllllllllllll}1.00 & 42.93 & 26.26 & 55.93 & 3 & 1433.8261 & 1433.8225 & 478.9481 & 0.0036 & 2.5055 & 6696.124 & 8320.508 & 1519.149 & 10243.968 & \text { Y }\end{array}$

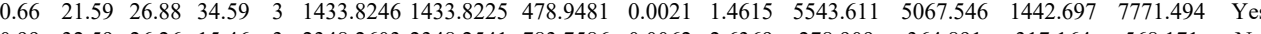

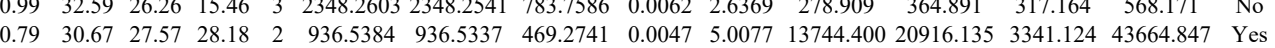

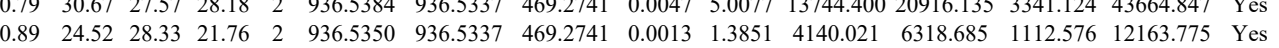

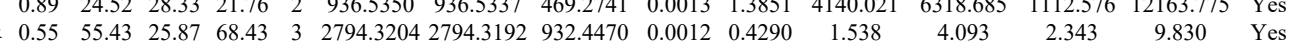

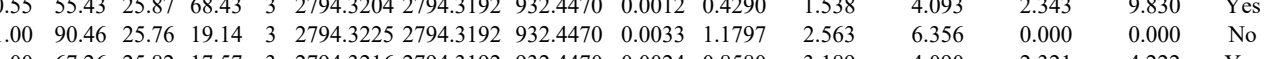

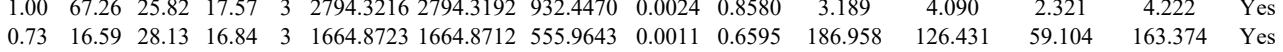

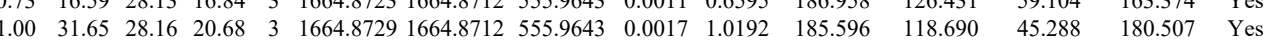

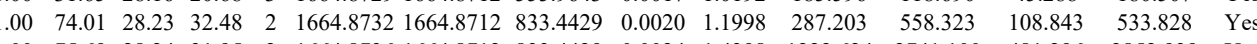

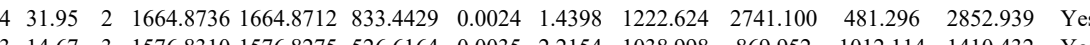




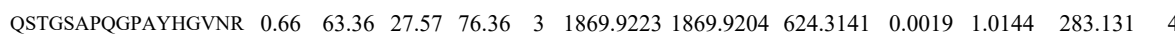
$\begin{array}{lllllllllllll}\text { QSTGSAPQGPAYHGVNR } & 0.95 & 22.92 & 27.45 & 17.29 & 3 & 1869.9244 & 1869.9204 & 624.3141 & 0.0040 & 2.1357 & 282.078\end{array}$ $\begin{array}{llllllllllll}\text { RPAGGPQNQFPFQFGR } & 1.00 & 35.46 & 27.91 & 19.94 & 3 & 1947.0001 & 1946.9986 & 650.0068 & 0.0015 & 0.7692 & 12.548 \\ \text { RPAGGPQNQFPFFGR } & 1.00 & 36.68 & 27.91 & 29.82 & 3 & 1947.0001 & 1946.9986 & 6500068 & 0.0015 & 0.7692 & 18.868\end{array}$ $\begin{array}{llllllllllll}\text { RPAGGPQNQFPFQFGR } & 1.00 & 36.68 & 27.91 & 29.82 & 3 & 1947.0001 & 1946.9986 & 650.0068 & 0.0015 & 0.7692 & 18.868 \\ \text { RPAGGPQNOFPFOFGR } & 1.00 & 40.22 & 27.92 & 20.79 & 3 & 1947.0007 & 1946.9986 & 650.0068 & 0.0021 & 1.0769 & 35.479\end{array}$ $\begin{array}{llllllllllll}\text { RPAGGPQNQFPFQFGR } & 1.00 & 40.22 & 27.92 & 20.79 & 3 & 1947.0007 & 1946.9986 & 650.0068 & 0.0021 & 1.0769 & 35.479 \\ \text { RPAGGPNQFPQFGR } & 1.00 & 44.44 & 27.96 & 19.55 & 3 & 1947.0010 & 1946.9986 & 650.0068 & 0.0024 & 1.2308 & 37.122\end{array}$

$\begin{array}{lllllllllllll}\text { RPAGGPQNQFPFQFGR } & 1.00 & 44.44 & 27.96 & 19.55 & 3 & 1947.0010 & 1946.9986 & 650.0068 & 0.0024 & 1.2308 & 37.122 & 52.370 \\ \text { RPAGGPQNQFPFQFGR } & 1.00 & 40.77 & 27.96 & 20.86 & 3 & 1947.0010 & 1946.9986 & 650.0068 & 0.0024 & 1.2308 & 46.078 & 77.402\end{array}$

$\begin{array}{lllllllllll}77.93 & 29.07 & 27.70 & 2 & 1970.9778 & 1970.9759 & 986.4952 & 0.0019 & 0.9630 & 1754.390 & 1888.020\end{array}$

$\begin{array}{lllllllllllll}\text { LMCPOEIVDYIADK } & 1.00 & 64.70 & 28.09 & 27.88 & 2 & 1970.9784 & 1970.9759 & 986.4952 & 0.0025 & 1.2671 & 1348.418 & 1082.320\end{array}$

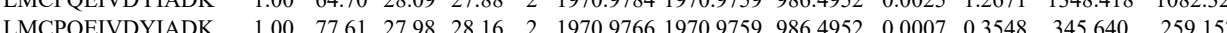
$\begin{array}{llllllllllllll}\text { LMCPQEIVDYIADK } & 1.00 & 74.27 & 28.07 & 29.30 & 2 & 1970.9778 & 1970.9759 & 986.4952 & 0.0019 & 0.9630 & 452.827 & 491.879\end{array}$ $\begin{array}{lllllll}1.00 & 74.27 & 28.07 & 29.30 & 2 & 1970.9778\end{array}$

$\begin{array}{llllllllllll}1.00 & 41.52 & 28.34 & 20.09 & 3 & 1349.7466 & 1349.7369 & 450.9196 & 0.0097 & 7.1705 & 15510.222 & 16491.704\end{array}$

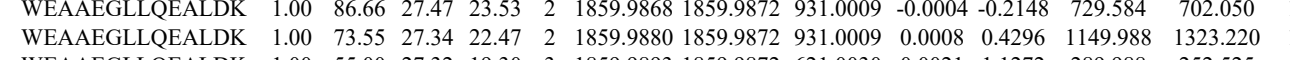
$\begin{array}{llllllllllllll}\text { WEAAEGLLQEALDK } & 1.00 & 55.00 & 27.32 & 19.30 & 3 & 1859.9893 & 1859.9872 & 621.0030 & 0.0021 & 1.1272 & 289.988 & 252.525\end{array}$

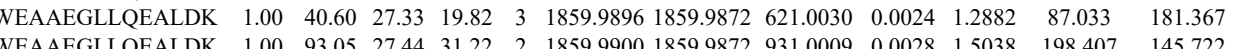
$\begin{array}{llllllllllll}\text { WEAAEGLLQEALDK } & 1.00 & \text { \#\#\#\# } 27.44 & 29.98 & 2 & 1859.9900 & 1859.9872 & 931.0009 & 0.0028 & 1.5038 & 198.407 & 145.722\end{array}$

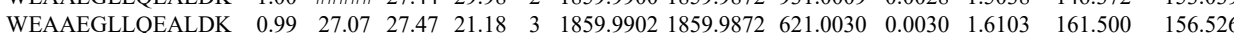
$\begin{array}{llllllllllllll}\text { WEAAEGLLOEALDK } & 1.00 & 56.14 & 27.48 & 22.09 & 3 & 1859.9905 & 1859.9872 & 621.0030 & 0.0033 & 1.7713 & 296.400 & 253.579\end{array}$ $\begin{array}{lllllllllllll}\text { LQDAYYIFQEMADK } & 0.99 & 31.47 & 27.63 & 21.90 & 3 & 2022.0061 & 2022.0012 & 675.0077 & 0.0049 & 2.4197 & 222.697 & 140.109\end{array}$ $\begin{array}{llllllllllllll}\text { LQDAYYIFQEMADK } & 0.89 & 18.30 & 27.65 & 17.05 & 3 & 2022.0043 & 2022.0012 & 675.0077 & 0.0031 & 1.5308 & 125.205 & 132.337\end{array}$ $\begin{array}{lllllllllllllll}\text { LQDAYYIFQEMADK } & 1.00 & 32.77 & 27.69 & 23.94 & 3 & 2022.0049 & 2022.0012 & 675.0077 & 0.0037 & 1.8271 & 127.170 & 131.284\end{array}$ $\begin{array}{llllllllllll}\text { MQDLDEATLITLLATAWVLLATGGEK } & 1.00 & 61.25 & 26.59 & 19.69 & 4 & 3051.5357 & 3051.5314 & 763.8901 & 0.0043 & 1.4073 & 14.128 \\ \text { MODLDEALITOLATAWVSLATGGEK } & 1.00 & 84.40 & 26.58 & 20.67 & 3 & 3051.5362 & 3051.5314 & 1018.1844 & 0.0048 & 1.5714 & 22.303\end{array}$ $\begin{array}{llllllllllllll}\text { FGVVLDEIKPSSAPELQAVR } & 0.67 & 46.64 & 22.38 & 59.64 & 3 & 2442.3757 & 2442.3726 & 815.1315 & 0.0031 & 1.2677 & 3468.368 & 4087.597\end{array}$ $\begin{array}{lllllllllllll}\text { FGVVLDEIKPSSAPELQAVR } & 0.67 & 28.74 & 22.38 & 41.74 & 3 & 2442.3760 & 2442.3726 & 815.1315 & 0.0034 & 1.3904 & 1909.507 & 1907.825\end{array}$

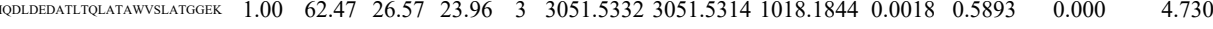
$\begin{array}{lllllllllllll}\text { MQDLDEDALLQLATAWVLLATGEKK } & 1.00 & 38.46 & 26.58 & 18.37 & 4 & 3051.5353 & 3051.5314 & 763.8901 & 0.0039 & 1.2764 & 12.381 & 13.209 \\ \end{array}$ $\begin{array}{lllllllllllllll} & & & \end{array}$ $\begin{array}{llllllllllll} & \end{array}$ $\begin{array}{lllllllllllll} & \end{array}$

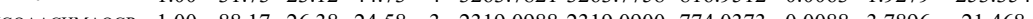

VWINTSDILVGLR VWINTSDIILVGLR EDGQEYAQVIK AYGELPEHAK

DYPYAEFYSAFAG

YPESLRPAFPR

NYLSLAPLFFK

SLIIDEGEDDLGR

MGSGQLLNLGAAVALGGGGGTVG

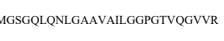

AVALGGGGTVQGVVR

(a)

AFANPEDALR

AFANPEDALR

STTYTLAQLPCASMALQLLWEAAR

SVTYTLAQLPCASMALQLW

VSEQGLIEILK
VSEQGLIEILK

VSEQGLIEILK

VSEQGLIEILK

VSEQGLIEILK

LSNLALVKPEK

AVENYLIQMAR

STLAVIDQSAR

NSILAVLDQSAR

SILAQVLDQSA

$\begin{array}{llllllllllll}1.7 .17 & 26.38 & 24.58 & 3 & 2319.0988 & 2319.0900 & 774.0373 & 0.0088 & 3.7896 & 21.468\end{array}$

$\begin{array}{llllllllllll}1.00 & 81.60 & 23.38 & 24.39 & 2 & 1742.0222 & 1742.0212 & 872.0179 & 0.0010 & 0.5734 & 782.186 & 996.776\end{array}$

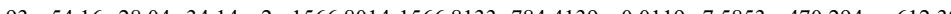

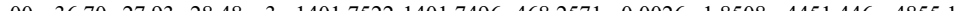

$\begin{array}{lllllllllllll}1.00 & 39.05 & 27.84 & 25.29 & 3 & 1401.7528 & 1401.7496 & 468.2571 & 0.0032 & 2.2779 & 6893.893 & 7679.149\end{array}$ $\begin{array}{lllllllllllll}1.00 & 41.12 & 24.33 & 16.91 & 3 & 2539.3828 & 2539.3777 & 847.4665 & 0.0051 & 2.0060 & 6.642\end{array}$

$\begin{array}{llllllllllll}0.69 & 22.80 & 27.72 & 19.78 & 3 & 1475.8141 & 1475.8007 & 492.9408 & 0.0134 & 9.0612 & 1620.609 & 2990.097\end{array}$ $\begin{array}{llllllllllllll}1.00 & 28.74 & 24.77 & 18.34 & 3 & 1599.9298 & 1599.9268 & 534.3162 & 0.0030 & 1.8715 & 51.830 & 61.065\end{array}$

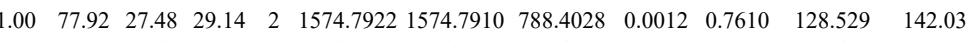
$\begin{array}{lllllllllll}1.00 & 78.20 & 27.43 & 30.30 & 2 & 1574.7932 & 1574.7910 & 788.4028 & 0.0022 & 1.3952 & 195.455\end{array}$ $\begin{array}{lllllllllll}1.00 & 74.89 & 24.22 & 21.73 & 3 & 2750.5000 & 2750.4984 & 917.8401 & 0.0016 & 0.5811 & 6.455\end{array}$ $\begin{array}{llllllllllll} & \end{array}$ $\begin{array}{llllllllll} & \end{array}$ $\begin{array}{lllllllllll}1.07 & 69.73 & 24.17 & 24.60 & 3 & 2750.5006 & 2750.4984 & 917.8401 & 0.0022 & 0.7990 \\ 0.55 & 76.31 & 24.30 & 89.31 & 3 & 2750.4991 & 2750.4984 & 917.8401 & 0.0007 & 0.2542\end{array}$ $\begin{array}{lllllllllll}1.00 & 70.41 & 24.22 & 22.68 & 3 & 2750.4997 & 2750.4984 & 917.8401 & 0.0013 & 0.472\end{array}$ $\begin{array}{llllllllllll}46.15 & 27.95 & 30.49 & 2 & 1246.6548 & 1246.6428 & 624.3287 & 0.0120 & 9.6102 & 1330.690 & 1745.447\end{array}$ $\begin{array}{lllllllllllll}1.00 & 59.63 & 26.72 & 17.13 & 3 & 2825.4424 & 2825.4400 & 942.8206 & 0.0024 & 0.8485 & 3.817 & 6.066\end{array}$ $\begin{array}{llllllllllll}0.60 & 43.27 & 26.82 & 56.27 & 3 & 2825.4442 & 2825.4400 & 942.8206 & 0.0042 & 1.4849 & 3.519\end{array}$

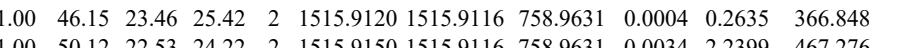
$\begin{array}{lllllllllllll}1.00 & 50.12 & 22.53 & 24.22 & 2 & 1515.9150 & 1515.9116 & 758.9631 & 0.0034 & 2.2399 & 467.276 & 624.859\end{array}$ $\begin{array}{lllllllllllll}1.00 & 51.26 & 22.53 & 27.62 & 2 & 1515.9148 & 1515.9116 & 758.9631 & 0.0032 & 2.1081 & 362.987 & 416.610\end{array}$ $\begin{array}{llllllllllll}1.00 & 66.09 & 22.53 & 27.83 & 2 & 1515.9152 & 1515.9116 & 758.9631 & 0.0036 & 2.3717 & 321.115 & 682.554\end{array}$ $\begin{array}{lllllllllll} & \end{array}$

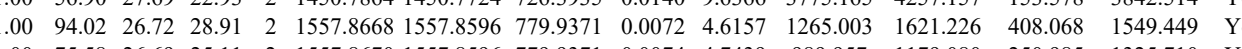

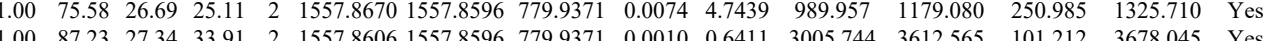
$\begin{array}{lllllllllllllll}1.00 & 87.23 & 27.34 & 33.91 & 2 & 1557.8606 & 1557.8596 & 77.937 & 0.0010 & 0.6411 & 305.744 & 3612.565 & 01.212 & 367.045 & \text { Yes }\end{array}$

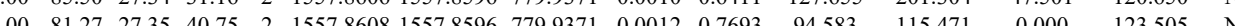

$\begin{array}{llllllllllllllll}1.00 & 81.27 & 27.35 & 40.75 & 2 & 1557.860 & 1557.8596 & 79.9371 & 0.0012 & 0.7693 & 94.583 & 115.471 & 0.000 & \text { No }\end{array}$ 


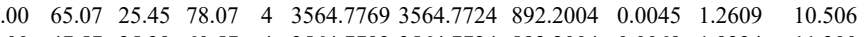

AILPTSIFLTNK

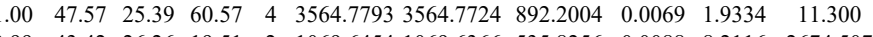
$\begin{array}{llllllllllll}0.99 & 43.42 & 26.26 & 19.51 & 2 & 1069.6454 & 1069.6366 & 535.8256 & 0.0088 & 8.2116 & 2674.507 & 23\end{array}$ 10.205

$\begin{array}{llllllllllllll} & \end{array}$

AAILPTSIFLTNK $\begin{array}{llllllllllll}0.66 & 19.19 & 21.14 & 32.19 & 3 & 1676.0134 & 1676.0116 & 559.6778 & 0.0018 & 1.0720 & 269.243\end{array}$

$\begin{array}{lllllllllll}0.66 & 29.67 & 21.21 & 42.67 & 3 & 1676.0140 & 1676.0116 & 559.6778 & 0.0024 & 1.4294 & 361.326\end{array}$

WWYEWAVTAPVCSAHNPT $\begin{array}{llllllllllll}100 & 44.09 & 26.49 & 17.13 & 3 & 1882.8829 & 1882.8803 & 628.6340 & 0.0026 & 1.3786 & 266.953\end{array}$ $\begin{array}{llllllllllll}1.00 & 36.28 & 26.46 & 18.12 & 3 & 1882.8832 & 1882.8803 & 628.6340 & 0.0029 & 1.5377 & 286.040\end{array}$ $\begin{array}{llllllllllll}0.55 & 73.91 & 27.39 & 86.91 & 3 & 2546.2330 & 2546.2321 & 849.7513 & 0.0009 & 0.3530 & 14.032\end{array}$

GPPPPPTASEPTR GPPPPTASEPTR RGPPPPPTASEPTR
RGPPPPTASEPTR EEEMTEEEK

EEEMTEEEK

VFFYNPTTR

GPPPPPTASEPTR

$\begin{array}{llllllllllll}1.00 & 59.95 & 28.40 & 24.83 & 2 & 1446.7606 & 14467589 & 7243867 & 0.0017 & 1.1734 & 6356.456\end{array}$

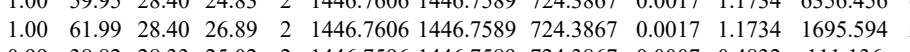
$\begin{array}{lllllllllll}0.99 & 38.82 & 28.33 & 25.02 & 2 & 1446.7596 & 1446.7589 & 724.3867 & 0.0007 & 0.4832 & 111.136\end{array}$ $\begin{array}{lllllllllllll}1.00 & 46.04 & 28.12 & 19.90 & 3 & 1602.8611 & 1602.8600 & 535.2939 & 0.0011 & 0.6850 & 94.698\end{array}$ $\begin{array}{llllllllllll}0.66 & 42.96 & 28.15 & 55.96 & 3 & 1602.8620 & 1602.8600 & 535.2939 & 0.0020 & 1.2454 & 108.919\end{array}$ $\begin{array}{lllllllllll}1.00 & 42.80 & 24.52 & 27.27 & 2 & 1440.6534 & 1440.6533 & 721.3339 & 0.0001 & 0.0693 & 52.268\end{array}$ $\begin{array}{llllllllllll}100 & 37.56 & 24.53 & 23.99 & 2 & 1440.6542 & 1440.6533 & 721.3339 & 0.0009 & 0.6238 & 44.672\end{array}$ $\begin{array}{lllllllllllll}1.00 & 50.95 & 28.20 & 22.22 & 2 & 1287.6826 & 14287.6734 & 644.4840 & 0.0092 & 7.6238 & 44.672 & 4060.757 & 46.776\end{array}$

GPPPPPTASEPTR

$\begin{array}{lllllllllll} & \end{array}$ $\begin{array}{lllllllllll}1.00 & 54.62 & 28.39 & 26.16 & 2 & 1446.7604 & 1446.7589 & 724.3867 & 0.0015 & 1.0354 & 6938.933 \\ 1.00 & 55.16 & 23.22 & 19.48 & 4 & 3422.8493 & 3422.8441 & 856.7183 & 0.0052 & 1.5174 & 51.711\end{array}$

NLLLYYDAGTLADSVGHHLNOPEY

$\begin{array}{llllllllllll}\text { NLLLYDAIGTLADVVGHHLNOPEYIQK } & 1.00 & 51.09 & 23.22 & 21.23 & 4 & 3422.8497 & 3422.8441 & 856.7183 & 0.0056 & 1.6341 & 43.458 \\ \text { GDVEDDEAVPDSEQDIKPR } & 1.00 & 35.24 & 27.13 & 15.40 & 3 & 2415.1642 & 2415.1645 & 806.0621 & -0.0003 & -0.1241 & 37.215\end{array}$

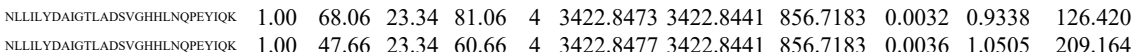

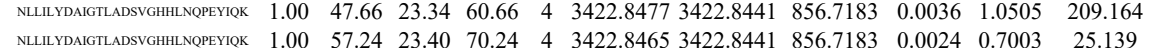
$\begin{array}{llllllllllll}\text { NLLLIYDAGGLADSVGHHNNPPYYIKK } & 1.00 & 57.24 & 23.40 & 70.24 & 4 & 3422.8465 & 3422.8441 & 856.7183 & 0.0024 & 0.7003 & 25.139 \\ \text { EVLASHLVQLIPILVNGMK } & 1.00 & 19.60 & 16.90 & 32.60 & 4 & 2361.4093 & 2361.4061 & 591.3588 & 0.0032 & 1.3528 & 109.988\end{array}$ $\begin{array}{llllllllllll}\text { EVLASHLVQLIPILVNGMK } & 1.00 & 19.60 & 16.90 & 32.60 & 4 & 2361.4093 & 2361.406 & 59.3588 & 0.0032 & 1.3528 & 109.988\end{array}$ $\begin{array}{llllllllllll}\text { EVLASHLVQLIPILVNGMK } & 1.00 & 31.79 & 16.23 & 17.52 & 4 & 2361.4105 & 2361.4061 & 591.3588 & 0.0044 & 1.8601 & 49.168\end{array}$ $\begin{array}{llllllllllll}\text { EVLASHLVQLPILVNGMK } & 1.00 & 36.75 & 16.13 & 19.94 & 4 & 2361.4117 & 2361.4061 & 591.3588 & 0.0056 & 2.3674 & 34.188\end{array}$

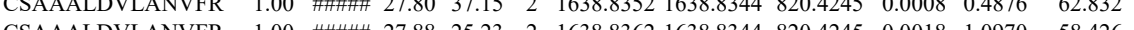
$\begin{array}{lllllllllllll} & \text { CSAAALDVLANVFR } & 0.60 & 12.11 & 27.84 & 18.69 & 3 & 1688.8368 & 16388344 & 547.2854 & 0.0024 & 1.4618 & 79.260\end{array}$

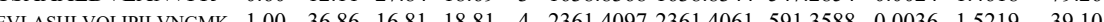

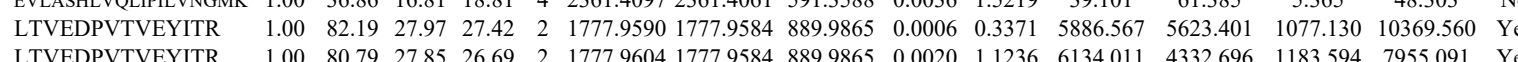

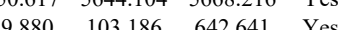
$\begin{array}{llll}3 & \\ 657.095 & 60.346 & 1009.363 & \text { Yes }\end{array}$ $\begin{array}{llll}36.430 & 239.556 & 598.859 & \text { Yes }\end{array}$ $\begin{array}{lllll}3 & 5.552 & 7.287 & 324.447 & \text { Yes }\end{array}$ $\begin{array}{llll}0.569 & 63.989 & 377.584 & \text { Yes }\end{array}$ $\begin{array}{llll}16.092 & 5.925 & 4.380 & \text { No }\end{array}$ $\begin{array}{lllll}6 & 18.906 & 8384.427 & 7886.863 & \text { Yes }\end{array}$ $\begin{array}{lllll}2328.584 & 3738.139 & 2956.160 & \text { Yes }\end{array}$ $\begin{array}{lllll}123.811 & 120.118 & 148.879 & \text { Yes }\end{array}$ $\begin{array}{llll}9.437 & 114.597 & 147.210 & \text { Yes }\end{array}$ $\begin{array}{lllll}34.192 & 78.398 & 163.139 & \text { Yes }\end{array}$ $\begin{array}{llll}153.643 & 78.255 & \text { Yes } \\ 66.776 & 142.557 & 75.909 & \text { Yes }\end{array}$ \begin{tabular}{rrrr}
0.000 & $8674.976 \quad$ No \\
\hline 395 & 7455.930 & 7622.612 & Yos
\end{tabular} $\begin{array}{llllllllllllllll}\text { LTVEDPVTVEYITR } & 1.00 & 69.02 & 27.90 & 30.09 & 2 & 1777.9598 & 1777.9584 & 889.9865 & 0.0014 & 0.7865 & 411.281 & 253.653 & 29.014 & 788.740 & \text { Yes }\end{array}$ $\begin{array}{lllllllllllllllll}\text { LTVEDPVTVEYITR } & 1.00 & 59.30 & 27.87 & 25.49 & 2 & 1777.9610 & 1777.9584 & 889.9865 & 0.0026 & 1.4607 & 332.320 & 276.085 & 36.460 & 283.931 & \text { Yes }\end{array}$

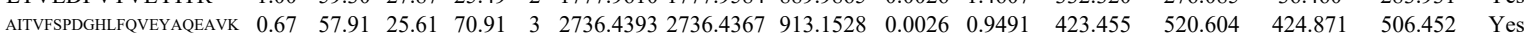
$\begin{array}{llllllllllllllllll}\text { AITVFSPDGHLFQVEYAQEAVK } & 1.00 & 56.26 & 25.62 & 16.64 & 3 & 2736.4399 & 2736.4367 & 913.1528 & 0.0032 & 1.1681 & 423.241 & 571.490 & 773.814 & 582.313 & \text { Yes }\end{array}$

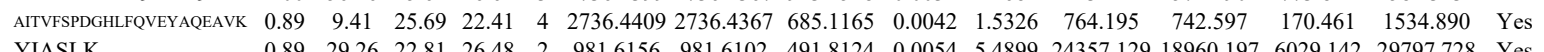

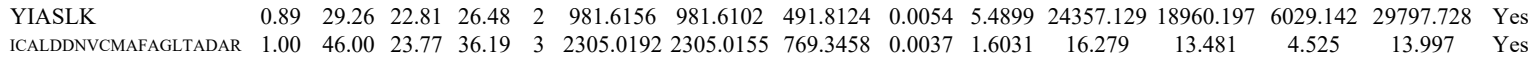

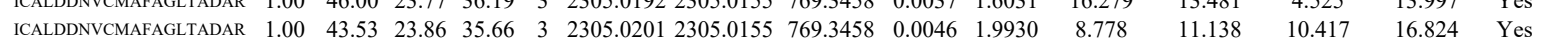
$\begin{array}{lllllllllllllllll}\text { RPFGISALIVGFDFDGTPR } & 0.67 & 14.77 & 26.55 & 27.77 & 3 & 2208.1846 & 2208.1814 & 737.0677 & 0.0032 & 1.4472 & 81.871 & 71.248 & 103.565 & 152.091 & \text { Yes }\end{array}$ $\begin{array}{llllllllllllllll}\text { RPFGISALIVGFDFDGTPR } & 0.60 & 24.27 & 26.55 & 37.27 & 3 & 2208.1852 & 2208.1814 & 737.0677 & 0.0038 & 1.7185 & 47.628 & 115.457 & 123.044 & 146.479 & \text { Yes }\end{array}$ $\begin{array}{llllllllllllllll}\text { RPFGISALIVGFDFDGTPR } & 0.67 & 18.17 & 26.55 & 31.17 & 3 & 2208.1843 & 2208.1814 & 737.0677 & 0.0029 & 1.3115 & 4.730 & 0.000 & 29.706 & 22.489 & \text { No }\end{array}$

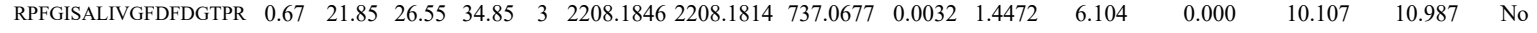

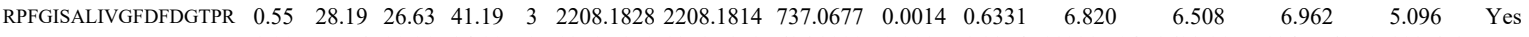
$\begin{array}{llllllllllllllll}\text { ILNPEEIEK } & 1.00 & 57.56 & 29.21 & 34.99 & 2 & 1371.7870 & 1371.7853 & 686.8999 & 0.0017 & 1.2374 & 11238.704 & 8623.917 & 1347.561 & 17823.658 & \text { Yes }\end{array}$ $\begin{array}{llllllllllllll}\text { ILNPEEIEK } & 1.00 & 55.59 & 29.20 & 36.40 & 2 & 1371.7876 & 1371.7853 & 686.8999 & 0.0023 & 1.6742 & 10927.093 & 10383.359\end{array}$

$\begin{array}{llllllllllllll}\text { LFCLETFLSDLIAHQK } & 1.00 & 45.65 & 27.20 & 20.45 & 3 & 2211.1705 & 2211.1675 & 738.0631 & 0.0030 & 1.3549 & 328.873\end{array}$ $\begin{array}{llllllllllllll}\text { LFCLETFLSDLIAHQK } & 1.00 & 49.96 & 27.16 & 21.70 & 3 & 2211.1720 & 2211.1675 & 738.0631 & 0.0045 & 2.0323 & 365.302 & 29\end{array}$ $\begin{array}{llllllllllll}\text { LFCLETFLSDLIAHQK } & 1.00 & 45.84 & 27.18 & 25.09 & 3 & 2211.1699 & 2211.1675 & 738.0631 & 0.0024 & 1.0839 & 99.530 \\ \text { LILVQVIPVVAR } & 0.82 & 52.02 & 6.99 & 65.02 & 2 & 1462.9728 & 1462.9721 & 732.4933 & 0.0007 & 0.4778 & 75.433\end{array}$ $\begin{array}{llllllllllll}\text { LILVQVIPVVAR } & 0.82 & 52.02 & 6.99 & 65.02 & 2 & 1462.9728 & 1462.9721 & 732.4933 & 0.0007 & 0.4778 & 75.433 \\ \text { LILVQVIPVVAR } & 0.55 & 29.85 & 6.99 & 42.85 & 3 & 1462.9732 & 1462.9721 & 488.6646 & 0.0011 & 0.7503 & 15.730\end{array}$ LILVQVIPVVARTVR LILVQVIPVVAR LILVQVIPVVAR LILVQVIPVVAR LILVWTPVAR

LILVWIPVAR $\begin{array}{lllllllllll}0.66 & 34.66 & 4.77 & 47.66 & 3 & 1462.9738 & 1462.9721 & 488.6646 & 0.0017 & 1.1596 & 3.444\end{array}$ $\begin{array}{lllllllllll}0.66 & 34.66 & 4.77 & 47.66 & 3 & 1462.9738 & 1462.9721 & 488.6646 & 0.0017 & 1.1596 & 3.444 \\ 0.84 & 56.41 & 4.77 & 69.41 & 2 & 1462.9740 & 1462.9721 & 732.4933 & 0.0019 & 1.2969 & 284.628\end{array}$ $\begin{array}{llllllllllll}0.84 & 56.41 & 4.77 & 69.41 & 2 & 1462.9740 & 1462.9721 & 732.4933 & 0.0019 & 1.2969 & 284.628 \\ 0.82 & 52.81 & 6.99 & 65.81 & 2 & 1462.9734 & 1462.9721 & 732.4933 & 0.0013 & 0.8874 & 50.201\end{array}$ $\begin{array}{lllllllllllll}0.82 & 63.90 & 6.99 & 76.90 & 2 & 1462.9736 & 14629721 & 732.4933 & 0.0015 & 1.0239 & 144.632\end{array}$

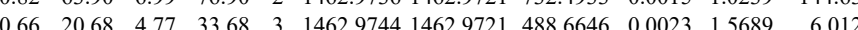

$\begin{array}{llll} & \\ & \end{array}$

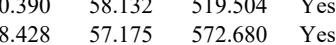

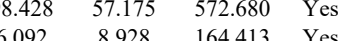

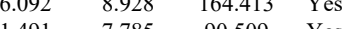

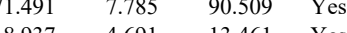
$\begin{array}{llll}81.370-61.941-183.715 & \text { Yes }\end{array}$ $\begin{array}{llll}18.696-8.277 & 183.715 & \text { Yes } & \\ 11.314 & \mathrm{No}\end{array}$

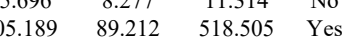
$\begin{array}{llll}76.731-35.528 & 2.812 & -1771 & \text { Yes }\end{array}$

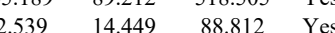


$\begin{array}{llllllllllll}1.00 & 45.87 & 24.53 & 16.06 & 4 & 3129.6661 & 3129.6628 & 783.4230 & 0.0033 & 1.0531 & 45.024 & 51.013\end{array}$

$\begin{array}{llllllllllllll}\text { VFHTQLAHGSPTGR } & 1.00 & 65.07 & 27.56 & 21.23 & 3 & 1763.9590 & 1763.9553 & 588.9924 & 0.0037 & 2.0940 & 1995.545 & 1997.029\end{array}$

$\begin{array}{llllllllllllll} & \text { LVFHTQLAHGSPTGR } & 1.00 & 59.30 & 27.62 & 19.69 & 4 & 1763.9601 & 1763.9553 & 441.9961 & 0.0048 & 2.7149 & 4459.804 & 5394.287\end{array}$

LVFHTQLAHGSPTGR

\section{NPDELAEALDER}

$\begin{array}{llllllllllll}1.00 & 48.04 & 27.63 & 19.85 & 4 & 1763.9613 & 1763.9553 & 441.9961 & 0.0060 & 3.3937 & 6044.196 & 6569 .\end{array}$

NPDELAEALDER

$\begin{array}{llllllllll}1.00 & 39.56 & 24.67 & 17.76 & 4 & 3129.6629 & 3129.6628 & 783.4230 & 0.0001 & 0.0319\end{array}$

46.738

APPLVENEEAEPGR

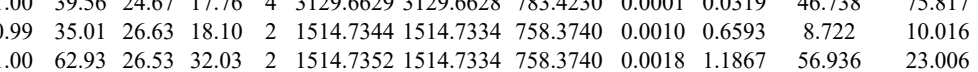

APPLVENEEAEPGR

\begin{tabular}{lllllllllllll}
1.00 & 90.28 & 28.36 & 26.37 & 2 & 1650.8444 & 1650.8335 & 826.4240 & 0.0109 & 6.5946 & 151.608 & 153.982 \\
\hline
\end{tabular}

$\begin{array}{lllllllllllllll} & \end{array}$ $\begin{array}{llllllllllllll} & \text { LVFTE }\end{array}$

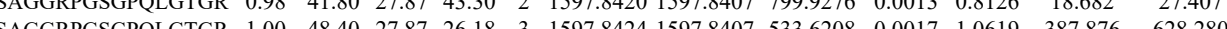
$\begin{array}{lllllllllllll} & \text { SAGG }\end{array}$ $\begin{array}{llllllllllll} & \text { SAG }\end{array}$

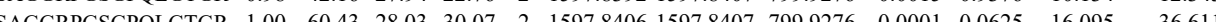

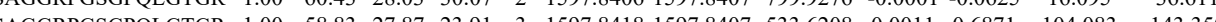
$\begin{array}{lllllllllllll} & \text { SAG }\end{array}$ $\begin{array}{lllllllllllllll} & \end{array}$

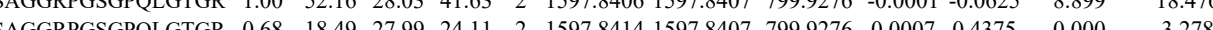
$\begin{array}{llllllllllllll} & \text { SAGGRPGSPQLGTGR } & 0.97 & 26.01 & 27.87 & 23.33 & 3 & 1597.8418 & 1597.8407 & 533.6208 & 0.0011 & 0.6871 & 30.214 & 38.520\end{array}$ $\begin{array}{llllllllllllll} & \text { SAGGRPGSGPLGTGR } & 1.00 & 46.43 & 27.87 & 26.45 & 3 & 1597.8421 & 1597.8407 & 533.6208 & 0.0014 & 0.8745 & 60.783 & 97.024\end{array}$ $\begin{array}{llllllllllllll} & \text { SAGGRPGSGPLGTGR } & 1.00 & 42.04 & 28.01 & 25.08 & 2 & 1597.8412 & 1597.8407 & 799.9276 & 0.0005 & 0.3125 & 7.728 & 12.858\end{array}$ $\begin{array}{lllllllllllllll}\text { SAGGRPGSGPQLGTGR } & 0.86 & 27.50 & 28.03 & 16.62 & 2 & 1597.8406 & 1597.8407 & 799.9276 & -0.0001 & -0.0625 & 2.084 & 4.002\end{array}$

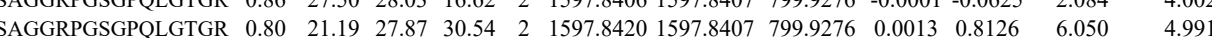
$\begin{array}{lllllllllllllll}\text { SAGGRPGSGPQLGTGR } & 0.56 & 15.82 & 28.04 & 17.39 & 3 & 1597.8412 & 1597.8407 & 533.6208 & 0.0005 & 0.3123 & 14.326 & 26.829\end{array}$

$\begin{array}{llllllllllll} & \end{array}$ $\begin{array}{lllllllllllll}\text { DGFIDKEDLHDMLASLGK } & 0.99 & 25.24 & 26.32 & 38.24 & 4 & 2435.2785 & 2435.2732 & 609.8256 & 0.0053 & 2.1727 & 854.495 & 461.140\end{array}$ $\begin{array}{lllllllllllll}\text { DGFIDKEDLHDMLASLGK } & 0.99 & 53.13 & 26.36 & 17.71 & 3 & 2435.2801 & 2435.2732 & 812.7650 & 0.0069 & 2.8298 & 2715.457 & 1624.836\end{array}$ $\begin{array}{llllllllllllllllll}\text { DGFIDKEDLHDMLASLGK } & 0.73 & 21.45 & 26.24 & 34.45 & 4 & 2435.2829 & 2435.2732 & 609.8256 & 0.0097 & 3.9765 & 9237.563 & 5157.323 & 9264.441 & 9899.133 & \text { Yes }\end{array}$ $\begin{array}{lllllllllllllllll} & 245.2792 & 2435.2732 & 812.7650 & 0.0060 & 2.4607 & 206.491 & 201.128 & 226.614 & 268.265 & \text { Yes }\end{array}$ $\begin{array}{lllllllllllllllll}\text { ATSNVFAMFDQSQIQEFK } & 1.00 & 33.79 & 27.23 & 22.79 & 3 & 2378.1847 & 2378.1820 & 793.7346 & 0.0027 & 1.1339 & 248.117 & 200.495 & 88.018 & 259.383 & \text { Yes }\end{array}$

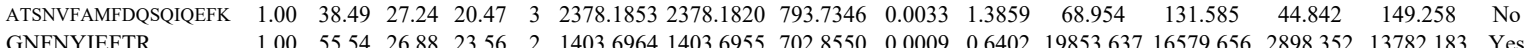
GNFNYIEFTR GNAYIETR GNFNYIEFTR FTDEEVDELYR FTDEEVDELYR FTDEEVDELYR LNGTDPEDVIR

$\begin{array}{llllllllllllllll}1.00 & 55.54 & 26.88 & 23.56 & 2 & 1403.6964 & 1403.6955 & 702.8550 & 0.0009 & 0.6402 & 19853.637 & 16579.656 & 2898.352 & 13782.183 & \text { Yes }\end{array}$ $\begin{array}{llllllllllllllllll}1.00 & 55.81 & 26.59 & 28.79 & 2 & 1403.6978 & 1403.6955 & 702.8550 & 0.0023 & 1.6362 & 6953.735 & 4567.143 & 1036.198 & 5650.654 & \text { Yes }\end{array}$ $\begin{array}{llllllllllllllll}1.00 & 49.53 & 27.59 & 19.51 & 2 & 1403.7086 & 1403.6955 & 702.8550 & 0.0131 & 9.3190 & 16827.057 & 10409.394 & 2862.205 & 10509.949 & \text { Yes }\end{array}$ $\begin{array}{lllllllllllllll}1.00 & 58.42 & 25.42 & 24.18 & 2 & 1558.7286 & 1558.7273 & 780.3709 & 0.0013 & 0.8329 & 2553.972 & 1902.180 & 184.319 & 2235.494 & \text { Yes } \\ 1.00 & 6.68 & 25.42 & 24.12 & 2 & 1558.7888 & 1558.7273 & 780.3709 & 0.0015 & 0.9611 & 1255.160 & 806539 & 74.522 & 966.831 & \end{array}$ $\begin{array}{lllllllllllllll}1.00 & 66.68 & 25.42 & 24.12 & 2 & 1558.7288 & 1558.7273 & 780.3709 & 0.0015 & 0.9611 & 1255.160 & 806.539 & 74.522 & 966.831 & \text { Yes } \\ \end{array}$ $\begin{array}{llllllllllllllll}1.00 & 66.62 & 25.62 & 30.29 & 2 & 1558.7274 & 1558.7273 & 780.3709 & 0.0001 & 0.0641 & 1975.141 & 1732.806 & 0.000 & 1833.733 & \text { No } & \\ 1.00 & 66.25 & 25.48 & 24.01 & 2 & 1558.7278 & 1558.7273 & 780.3709 & 0.0005 & 0.3204 & 3953.473 & 3875.032 & 319.373 & 4184.107 & \text { Yes }\end{array}$ $\begin{array}{lllllllllllllll}1.00 & 66.25 & 25.48 & 24.01 & 2 & 1558.7278 & 1558.7273 & 780.3709 & 0.0005 & 0.3204 & 3953.473 & 3875.032 & 319.373 & 4184.107 & \text { Yes } \\ 1.00 & 65.63 & 27.82 & 35.14 & 2 & 1371.7140 & 1371.7116 & 686.8631 & 0.0024 & 1.7471 & 9591.299 & 6771.129 & 384.462 & 5088.458 & \text { Yes }\end{array}$ $\begin{array}{lllllllllllllll}1.00 & 65.63 & 27.82 & 35.14 & 2 & 1371.7140 & 1371.7116 & 686.8631 & 0.0024 & 1.7471 & 9591.299 & 6771.129 & 384.462 & 5088.458 & \text { Yes } \\ 1.00 & 61.58 & 27.82 & 37.83 & 2 & 1371.7140 & 1371.7116 & 686.8631 & 0.0024 & 1.7471 & 13362.865 & 9025.597 & 393.158 & 7368.605 & \text { Yes }\end{array}$

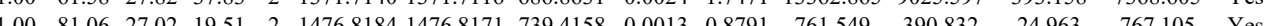
$\begin{array}{lllllllllllllll}1.00 & 77.25 & 27.13 & 20.55 & 2 & 1476.8194 & 1476.8171 & 739.4158 & 0.0023 & 1.5553 & 1729.690 & 1075.269 & 119.143 & 1987.470 & \text { Yes }\end{array}$ 
$\begin{array}{lllllllllll} & \end{array}$ $\begin{array}{llllllllllll} & \end{array}$ $\begin{array}{llllllllll} & \end{array}$ $\begin{array}{llllllllllll}\text { EPEVLSTMAIIVNK } & 1.00 & 33.07 & 24.90 & 15.70 & 3 & 1831.0405 & 1831.0368 & 611.3529 & 0.0037 & 2.0174 & 151.741\end{array}$ $\begin{array}{llllllllllll}0.60 & 79.24 & 27.02 & 92.24 & 3 & 2673.3169 & 2673.3125 & 892.1114 & 0.0044 & 1.6440 & 1965.937 & 2341.726 \\ 1.00 & 43.74 & 18.26 & 26.18 & 2 & 1191.7848 & 1191.7835 & 596.8990 & 0.0013 & 1.0890 & 1873.480 & 1602.988\end{array}$

$\begin{array}{lllllllll} & 0\end{array}$

LVLDSIIWAFK

LVLDSIIWAFK

LVLDSIIWAFK

LVLDSIIWAFK

LVLDSIIWAFK

YMLLPNQVWDSHQQAT

LVLDSIIWAFK
LVLDSIIWAFK

$\begin{array}{llllllllllll}0.93 & 41.71 & 20.37 & 41.08 & 2 & 1106.7386 & 1106.7307 & 554.3726 & 0.0079 & 7.1251 & 9192.118 & 9 \\ 1 & 1106.7410 & 1106.7307 & 554.3726 & 0.0103 & 9.2897 & 11197.667 & 1029 .\end{array}$ $\begin{array}{lllllllllllll}1.00 & 37.78 & 21.88 & 29.07 & 3 & 1591.9615 & 1591.9581 & 531.6600 & 0.0034 & 2.1317 & 67.778\end{array}$ $\begin{array}{lllllllllllll}0.99 & 28.26 & 21.99 & 24.54 & 3 & 1591.9618 & 1591.9581 & 531.6600 & 0.0037 & 2.3198 & 49.490 & 4 & \\ 1.00 & 64.35 & 22.01 & 27.76 & 2 & 1591.9592 & 1591.9581 & 796.9863 & 0.0011 & 0.6901 & 165.139 & 27\end{array}$ $\begin{array}{lllllllllllll}1.00 & 88.80 & 21.99 & 29.44 & 2 & 1591.9602 & 1591.9581 & 796.9863 & 0.0021 & 1.3175 & 401.527 & 31 & \end{array}$ $\begin{array}{lllllllllll}0.99 & 24.85 & 21.90 & 2.24 & 3 & 1591.9606 & 1591.9581 & 531.6600 & 0.0025 & 1.5674 & 98.603\end{array}$ $\begin{array}{llllllllllll}1.00 & 27.57 & 21.93 & 21.15 & 3 & 1591.9609 & 1591.9581 & 531.6600 & 0.0028 & 1.7555 & 50.454 \\ 0.55 & 8.82 & 25.60 & 21.82 & 3 & 2435.3152 & 2435.3126 & 812.7781 & 0.0026 & 1.063 & 23.997\end{array}$ $\begin{array}{lllllllllllll} & 1.00 & 33.29 & 23.28 & 20.88 & 3 & 2197.2406 & 2197.2391 & 733.4203 & 0.0015 & 0.6817 & 29.470\end{array}$ $\begin{array}{lllllllllllll}\text { LFVTGLFSLNQDIPAFK } & 1.00 & 32.24 & 23.03 & 15.58 & 3 & 2197.2421 & 2197.2391 & 733.4203 & 0.0030 & 1.3635 & 49.447\end{array}$ $\begin{array}{lllllllllllll}\text { YMLLPNQVWDSIIQQATK } & 1.00 & 55.55 & 25.56 & 17.69 & 2 & 2435.3154 & 2435.3126 & 1218.6636 & 0.0028 & 1.1488 & 7.446\end{array}$ $\begin{array}{lllllllllll} & \end{array}$ $\begin{array}{llllllllllllll} & \end{array}$ $\begin{array}{lllllllllllll}\text { QLYLPMLFK } & 1.00 & 46.44 & 24.35 & 18.70 & 2 & 1439.8484 & 1439.8454 & 720.9300 & 0.0030 & 2.0806 & 920.673\end{array}$ $\begin{array}{llllllllllllll}\text { HWPTFISDIVGASR } & 1.00 & 52.18 & 27.52 & 25.63 & 3 & 1728.9097 & 1728.9070 & 577.3096 & 0.0027 & 1.5590 & 206.811 & 359.3\end{array}$ $\begin{array}{llllllllllll}\text { HWPTFISDIVGASR } & 1.00 & 57.43 & 27.52 & 28.48 & 3 & 1728.9097 & 1728.9070 & 577.3096 & 0.0027 & 1.5590 & 144.879\end{array}$ $\begin{array}{lllllllllllll}\text { LFVTGLFSLNQDIPAFK } & 0.81 & 12.43 & 23.10 & 15.41 & 3 & 2197.2430 & 2197.2391 & 733.4203 & 0.0039 & 1.7725 & 8.237\end{array}$ $\begin{array}{lllllllllllll}\text { LFVTGLFSLNQDIPAFK } & 0.60 & 14.86 & 23.10 & 27.86 & 3 & 2197.2430 & 2197.2391 & 733.4203 & 0.0039 & 1.7725 & 17.402 & 9.38 \\ \text { QLYLPMLFK } & 1.00 & 46.64 & 25.05 & 36.42 & 2 & 1439.8462 & 1439.8454 & 720.9300 & 0.0008 & 0.5548 & 774.393 & 948.8\end{array}$ QLYLPMLFK QLYLPMLFK LNMILVQILK LNMILVQILK LNMILVQILK LNMILVQILK LNMILVQILK

LNMLVILK

LISGWVSR $\begin{array}{lllllllllllll}1.00 & 46.64 & 25.05 & 36.42 & 2 & 1439.8462 & 1439.8454 & 720.9300 & 0.0008 & 0.5548 & 774.393 \\ 1.00 & 40.47 & 25.08 & 35.11 & 2 & 1439.8470 & 1439.8454 & 720.9300 & 0.0016 & 1.1097 & 926.005 & \end{array}$ $\begin{array}{llllllllllll}1.00 & 40.47 & 25.08 & 35.11 & 2 & 1439.8470 & 1439.8454 & 720.9300 & 0.0016 & 1.1097 & 926.005\end{array}$ $\begin{array}{lllllllllll}1.00 & 69.54 & 18.13 & 26.83 & 2 & 1471.9416 & 1471.9404 & 736.9775 & 0.0012 & 0.8141 & 109.883\end{array}$ $\begin{array}{lllllllllll}1.00 & 69.98 & 18.13 & 26.88 & 2 & 1471.9416 & 1471.9404 & 736.9775 & 0.0012 & 0.8141 & 97.349 \\ 0.96 & 17.22 & 18.39 & 19.36 & 3 & 1471.9417 & 1471.9404 & 491.6541 & 0.0013 & 0.8814 & 43.481\end{array}$ $\begin{array}{lllllllllllll}0.96 & 17.22 & 18.39 & 19.36 & 3 & 1471.9417 & 1471.9404 & 491.6541 & 0.0013 & 0.8814 & 43.481 & \\ 1.00 & 68.18 & 18.39 & 23.39 & 2 & 1471.9418 & 1471.9404 & 736.9775 & 0.0014 & 0.9498 & 790.961 & 6\end{array}$ $\begin{array}{lllllllllllll}1.00 & 68.18 & 18.39 & 23.39 & 2 & 1471.9418 & 1471.9404 & 736.9775 & 0.0014 & 0.9498 & 790.961 & 6 \\ 1.00 & 70.21 & 18.39 & 24.88 & 2 & 1471.9424 & 1471.9404 & 736.9775 & 0.0020 & 1.3569 & 690.133\end{array}$ $\begin{array}{llllllllllll}1.00 & 70.21 & 18.39 & 24.88 & 2 & 1471.9424 & 1471.9404 & 736.9775 & 0.0020 & 1.3569 & 690.133 & \\ 1.00 & 28.08 & 18.39 & 20.63 & 3 & 1471.9429 & 1471.9404 & 491.6541 & 0.0025 & 1.6950 & 32.256\end{array}$

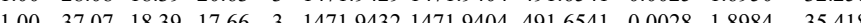
$\begin{array}{lllllllllllll}0.94 & 42.39 & 27.64 & 41.73 & 2 & 1060.6238 & 1060.6151 & 531.3148 & 0.0087 & 8.1872 & 2988.848 & 3171.466\end{array}$ (18725.178 Yes $\begin{array}{llll}.015 & 15.161 & 88.119 & \text { Yes }\end{array}$ 277.993 


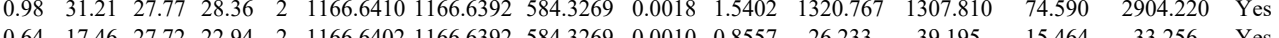

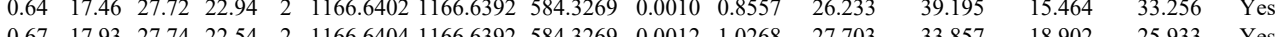

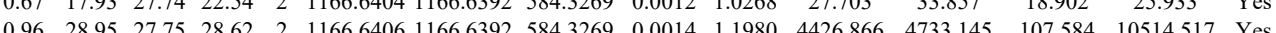

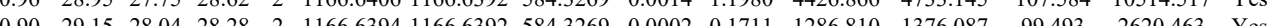

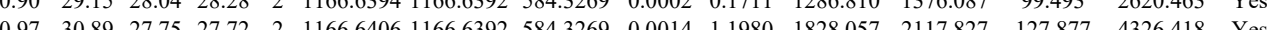
$\begin{array}{lllllllllllllll} & 9\end{array}$

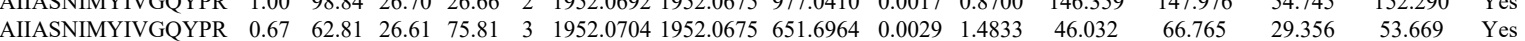
$\begin{array}{llllllllllllllll}\text { AIIASNIMYIVGQYPR } & 0.67 & 61.08 & 26.61 & 74.08 & 3 & 1952.0704 & 1952.0675 & 651.6964 & 0.0029 & 1.4833 & 55.211 & 94.794 & 17.399 & 74.378 & \text { Yes }\end{array}$

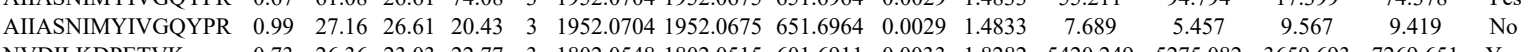

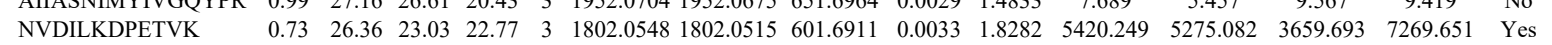

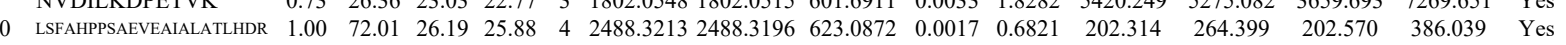
$\begin{array}{llllllllllllllll}\text { LSFAHPPSAEVEAIALATLHDR } & 1.00 & 57.62 & 26.22 & 26.54 & 4 & 2488.3265 & 2488.3196 & 623.0872 & 0.0069 & 2.7685 & 247.151 & 320.435 & 221.850 & 360.837 & \text { Yes }\end{array}$ $\begin{array}{llllllllllllllll}\text { GWAAAVTFHPR } & 0.98 & 33.80 & 27.03 & 21.42 & 3 & 1355.7322 & 1355.7220 & 452.9146 & 0.0102 & 7.5069 & 3354.737 & 4211.673 & 1335.971 & 5257.816 & \text { Yes }\end{array}$ $\begin{array}{llllllllllllllll}\text { LNFSTPTSTNIVSVCR } & 1.00 & 84.96 & 27.58 & 26.94 & 2 & 1927.9618 & 1927.9618 & 964.9882 & 0.0000 & 0.0000 & 119.357 & 159.784 & 15.704 & 149.087 & \text { Yes }\end{array}$ $\begin{array}{lllllllllllllllll}\text { LNFSTPTSTNIVSVCR } & 1.00 & 78.82 & 27.54 & 26.25 & 2 & 1927.9622 & 1927.9618 & 964.9882 & 0.0004 & 0.2073 & 143.651 & 324.366 & 40.910 & 261.696 & \text { No }\end{array}$ $\begin{array}{llllllllllllllll}\text { LNFSTPTSTNIVSVCR } & 1.00 & 74.47 & 27.58 & 23.09 & 2 & 1927.9614 & 1927.9618 & 964.9882 & -0.0004 & -0.2073 & 328.659 & 443.453 & 117.743 & 401.298 & \text { Yes }\end{array}$ $\begin{array}{lllllllllllllllll}\text { LNFSTPTSTNIVSVCR } & 1.00 & 84.86 & 27.54 & 28.01 & 2 & 1927.9622 & 1927.9618 & 964.9882 & 0.0004 & 0.2073 & 212.709 & 295.725 & 67.514 & 316.625 & \text { Yes }\end{array}$ $\begin{array}{llllllllllllllll}\text { GHLLYVALSPGQHR } & 1.00 & 28.13 & 26.93 & 41.13 & 4 & 1690.9385 & 1690.9389 & 423.7420 & -0.0004 & -0.2360 & 2344.285 & 2285.724 & 798.927 & 3060.063 & \text { Yes }\end{array}$ $\begin{array}{llllllllllllllll}\text { GHLLYVALSPGQHR } & 1.00 & 29.74 & 26.96 & 42.74 & 4 & 1690.9393 & 1690.9389 & 423.7420 & 0.0004 & 0.2360 & 2251.384 & 2034.097 & 991.680 & 3455.492 & \text { Yes }\end{array}$

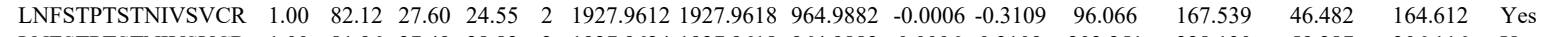
$\begin{array}{llllllllllllllll}\text { LNFSTPTSTNIVSVCR } & 1.00 & 81.96 & 27.49 & 28.82 & 2 & 1927.9624 & 1927.9618 & 964.9882 & 0.0006 & 0.3109 & 202.251 & 228.130 & 59.287 & 306.116 & \text { Yes }\end{array}$

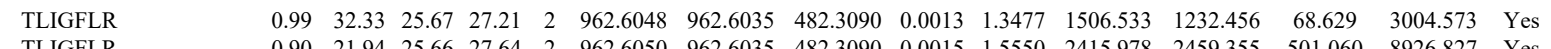
$\begin{array}{llllllllllllllll}\text { TLIGFLR } & 0.90 & 21.94 & 25.66 & 27.64 & 2 & 962.6050 & 962.6035 & 482.3090 & 0.0015 & 1.5550 & 2415.978 & 2459.355 & 501.060 & 8926.827 & \text { Yes }\end{array}$ $\begin{array}{llllllllllllllll}\text { TLIGFLR } & 0.86 & 20.81 & 25.73 & 33.04 & 2 & 962.6058 & 962.6035 & 482.3090 & 0.0023 & 2.3844 & 42.115 & 26.698 & 7.466 & 118.623 & \text { Yes }\end{array}$

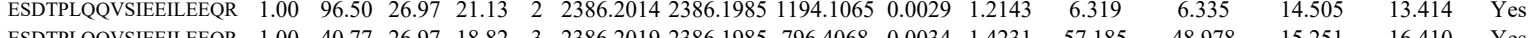

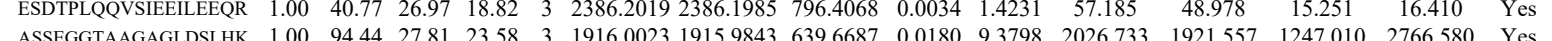

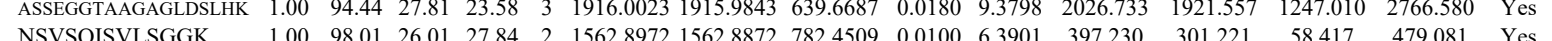

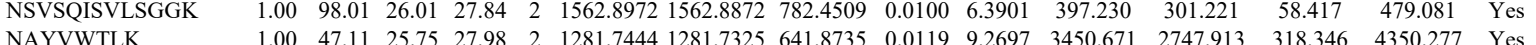

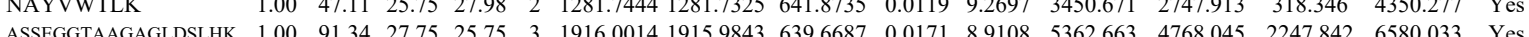

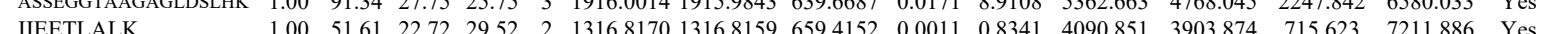
IIEETLALK $\begin{array}{lllllllllllllll}1.00 & 51.61 & 22.72 & 29.52 & 2 & 1316.8170 & 1316.8159 & 659.4152 & 0.0011 & 0.8341 & 4090.851 & 3903.874 & 715.623 & 7211.886 & \text { Yes } \\ 1.00 & 55.23 & 2.60 & 29.84 & 2 & 1316.8176 & 1316.8159 & 659.4152 & 0.0017 & 1.2890 & 6101.711 & 6366350 & 1001.432 & 12070.255 & \text { Yes }\end{array}$ MLLEVNN ASHTAPQVLFSHR ASHTAPQVL EPPLELK

10 DTDIVDEAIYYFK DTDIVDEAIYYFK VFDPQNDKPSK VFDPQNDKPSK AYLQQLR AYLQQLR AYLQQLR AYLQQLR WWTCFVK LIGNMALLPIR VFDPQNDKPSK VFDPQNDKPSK

ILQAVQAADAAGQAL
GLLLFTAR

LGLVWAALQGAR

LGLVWAALQGAR LGLVWAALQGAR

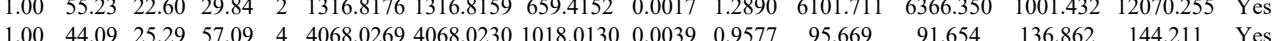
$\begin{array}{lllllllllllllll}1.00 & 47.84 & 26.87 & 32.81 & 2 & 1244.7148 & 1244.7032 & 623.3589 & 0.0116 & 9.3043 & 4671.152 & 4574.186 & 384.937 & 8057.519 & \text { Yes }\end{array}$ $\begin{array}{lllllllllllllll}0.67 & 47.83 & 28.32 & 60.83 & 3 & 1593.8533 & 1593.8498 & 532.2905 & 0.0035 & 21918 & 1460.536 & 2260.756 & 613.642 & 1727.482 & \text { No }\end{array}$ \begin{tabular}{lllllllllllllll}
0.97 & 25.89 & 23.86 & 27.76 & 2 & 1112.6704 & 1112.6685 & 557.3415 & 0.0019 & 1.7045 & 1612.175 & 1598.296 & 2455.642 & 2489.113 & Yes \\
\hline
\end{tabular} $\begin{array}{llllllllllllllll}0.95 & 27.11 & 23.94 & 30.25 & 2 & 1112.6718 & 1112.6685 & 557.3415 & 0.0033 & 2.9605 & 1535.029 & 1552.564 & 2212.762 & 2445.673 & \text { Yes } \\ 0\end{array}$

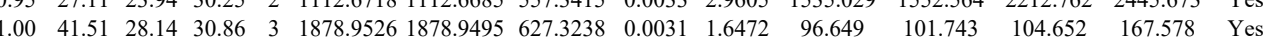

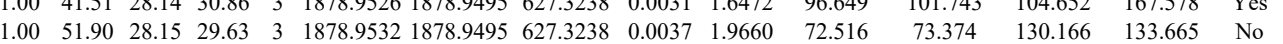

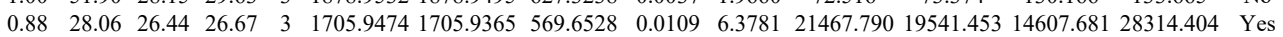

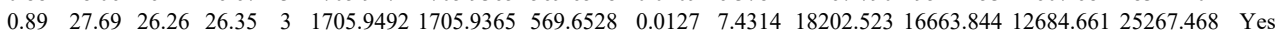
$\begin{array}{llllllllllllllll}0.97 & 38.34 & 26.99 & 31.71 & 2 & 1034.6080 & 1034.5994 & 518.3070 & 0.0086 & 8.2962 & 10790.205 & 9496.452 & 1856.811 & 16628.652 & \text { Yes }\end{array}$

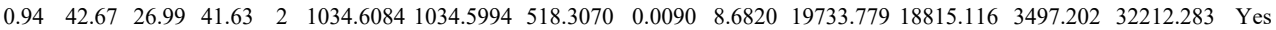
$\begin{array}{lllllllllllllll}0.98 & 40.50 & 26.99 & 28.38 & 2 & 1034.6080 & 1034.5994 & 518.3070 & 0.0086 & 8.2962 & 6987.876 & 6674.428 & 906.247 & 10041.690 & \text { Yes }\end{array}$ $\begin{array}{llllllllllllllll}0.97 & 37.56 & 26.99 & 33.11 & 2 & 1034.6082 & 1034.5994 & 518.3070 & 0.0088 & 8.4891 & 3550.389 & 3391.611 & 705.790 & 5107.208 & \text { Yes }\end{array}$

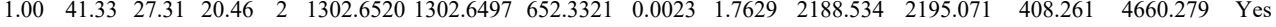
$\begin{array}{lllllllllllllll}1.00 & 64.07 & 22.04 & 22.57 & 2 & 1353.8282 & 1353.8288 & 677.9217 & -0.0006 & -0.4425 & 328.325 & 314.839 & 111.119 & 1030.762 & \text { No }\end{array}$ $\begin{array}{lllllllllllllllll}0.93 & 29.08 & 26.44 & 23.78 & 3 & 1705.9471 & 1705.9365 & 569.6528 & 0.0106 & 6.2026 & 12871.814 & 13608.948 & 8694.160 & 21184.087 & \text { Yes }\end{array}$ $\begin{array}{lllllllllllllll}0.79 & 27.42 & 26.41 & 29.31 & 3 & 1705.9483 & 1705.9365 & 569.6528 & 0.0118 & 6.9047 & 19244.705 & 18838.083 & 13315.711 & 28215.527 & \text { Yes }\end{array}$

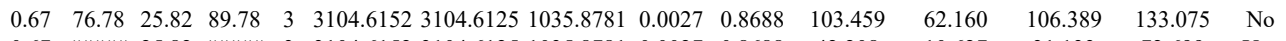
$\begin{array}{lllllllllll}0.67 & \text { \#\#\# 25.82 \#\#\#\# } 33104.6152 & 3104.6125 & 1035.8781 & 0.0027 & 0.8688 & 42.208 & 10.627 & 31.133 & 72.699 & \text { Yes }\end{array}$ $\begin{array}{lllllllllllllll}0.96 & 27.09 & 25.67 & 25.31 & 2 & 1033.6412 & 1033.6406 & 517.8276 & 0.0006 & 0.5793 & 785.709 & 567.771 & 64.692 & 803.780 & \text { Yes }\end{array}$

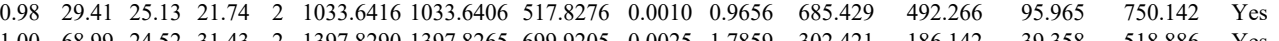

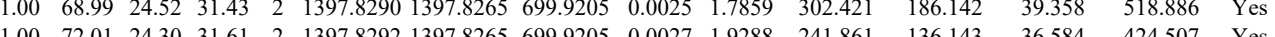
$\begin{array}{lllllllllllllll}1.00 & 72.01 & 24.30 & 31.61 & 2 & 1397.8292 & 1397.8265 & 699.9205 & 0.0027 & 1.9288 & 241.861 & 136.143 & 36.584 & 424.507 & \text { Yes } \\ 1.00 & 67.88 & 24.31 & 25.66 & 2 & 1397.8274 & 1397.8265 & 699.9205 & 0.0009 & 0.6429 & 179.361 & 104.495 & 36.146 & 275.864 & \text { Yes }\end{array}$

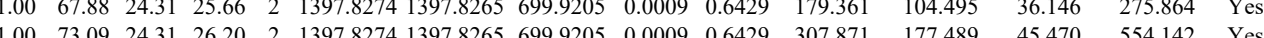
$\begin{array}{lllllllllllllll} & 3.04 .16 & 26.02 & 21.55 & 3 & 2171.0104 & 2171.0075 & 724.6764 & 0.0029 & 1.3339 & 9.105 & 0.000 & 8.123 & 0.000 & \text { No }\end{array}$

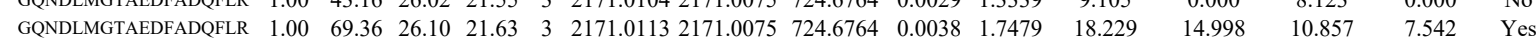




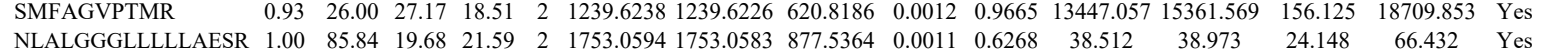

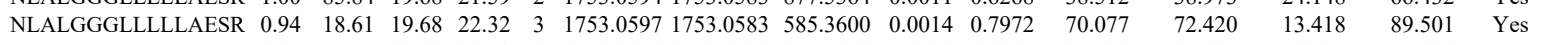

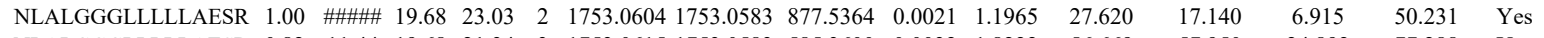
$\begin{array}{lllllllllllllllll}\text { NLALGGGLLLLLAESR } & 0.82 & 11.44 & 19.68 & 21.34 & 3 & 1753.0615 & 1753.0583 & 585.3600 & 0.0032 & 1.8222 & 56.669 & 57.950 & 24.892 & 77.288 & \text { Yes }\end{array}$ $\begin{array}{lllllllllllllllll}\text { SMFAGVPTMR } & 0.95 & 34.87 & 27.75 & 23.85 & 2 & 1239.6322 & 1239.6226 & 620.8186 & 0.0096 & 7.7317 & 3374.308 & 3192.794 & 850.188 & 4776.506 & \text { Yes }\end{array}$ $\begin{array}{lllllllllllllll}\text { NLALGGGLLLLAESR } & 1.00 & \text { \#\#\# } 19.68 & 25.18 & 2 & 1753.0600 & 1753.0583 & 877.5364 & 0.0017 & 0.9686 & 496.594 & 527.652 & 258.315 & 769.221 & \text { Yes }\end{array}$

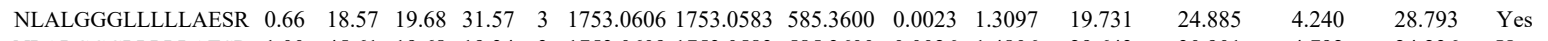
$\begin{array}{llllllllllllllll}\text { NLALGGGLLLLLAESR } & 1.00 & 45.61 & 19.68 & 19.34 & 3 & 1753.0609 & 1753.0583 & 585.3600 & 0.0026 & 1.4806 & 29.643 & 30.901 & 4.792 & 24.236 & \text { Yes }\end{array}$ $\begin{array}{llllllllllllllll}\text { NLALGGGLLLLLAESR } & 1.00 & 96.00 & 19.68 & 21.36 & 2 & 1753.0618 & 1753.0583 & 877.5364 & 0.0035 & 1.9942 & 384.467 & 477.912 & 224.606 & 667.079 & \text { Yes }\end{array}$ $\begin{array}{llllllllllllllll}\text { NLALGGGLLLLLAESR } & 1.00 & 58.99 & 19.64 & 23.22 & 3 & 1753.0621 & 1753.0583 & 585.3600 & 0.0038 & 2.1639 & 42.720 & 39.795 & 31.485 & 54.264 & \text { Yes }\end{array}$

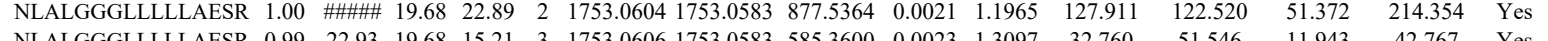
$\begin{array}{llllllllllllllll}\text { NLALGGGLLLLLAESR } & 0.99 & 22.93 & 19.68 & 15.21 & 3 & 1753.0606 & 1753.0583 & 585.3600 & 0.0023 & 1.3097 & 32.760 & 51.546 & 11.943 & 42.767 & \text { Yes }\end{array}$ $\begin{array}{lllllllllllllllll}\text { NLALGGGLLLLLAESR } & 1.00 & 29.11 & 19.68 & 23.11 & 3 & 1753.0609 & 1753.0583 & 585.3600 & 0.0026 & 1.4806 & 50.246 & 27.603 & 15.199 & 55.641 & \text { Yes } \\ \text { ALEDAFLAIDAK } & 0.98 & 24.49 & 27.24 & 20.74 & 3 & 1563.8782 & 1563.8752 & 522.2990 & 0.0030 & 1.9146 & 42.529 & 67.496 & 31.076 & 94.074 & \text { Yes }\end{array}$

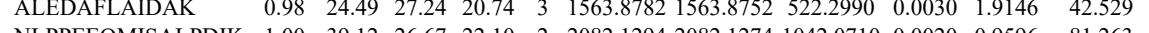

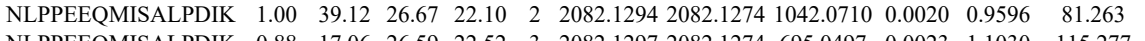
$\begin{array}{llllllllllllllll}\text { NLPPEQQMISALPDIK } & 0.88 & 17.06 & 26.59 & 22.52 & 3 & 2082.1297 & 2082.1274 & 695.0497 & 0.0023 & 1.1030 & 115.277 & 118.438 & 90.973 & 161.754 & \text { Yes } \\ \text { NLPPEEQMISALPDIK } & 0.78 & 14.28 & 26.63 & 22.98 & 3 & 2082.1303 & 2082.1274 & 695.0497 & 0.0029 & 1.3908 & 165.748 & 165.778 & 146.020 & 198.332 & \text { Yes } \\ \text { NLPPEEQMISALPDIK } & 1.00 & 72.11 & 26.52 & 24.86 & 2 & 2082.1314 & 2082.1274 & 1042.0710 & 0.0040 & 1.9193 & 235.806 & 217.691 & 235.437 & 304.514 & \text { Yes }\end{array}$ 67.496 31.076 $\begin{array}{llllllllllllll} & & & \end{array}$

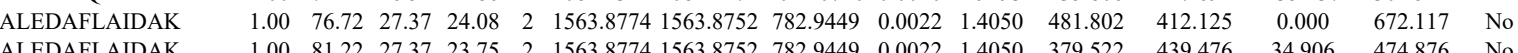
$\begin{array}{llllllllllll} & \end{array}$

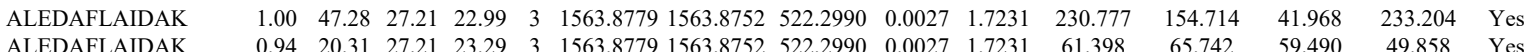

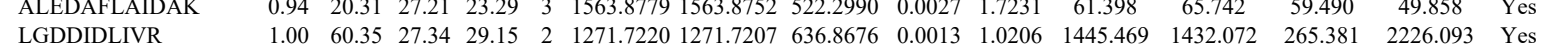

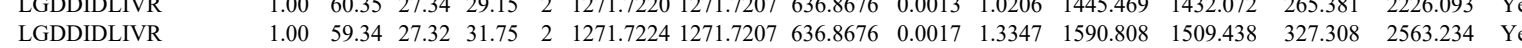
$\begin{array}{llllllllllllllll}\text { YNFPNNPFYEDDMDKNEASYAYYR } & 1.00 & 52.86 & 25.83 & 16.64 & 3 & 3232.5382 & 3232.5379 & 1078.5199 & 0.0003 & 0.0927 & 377.638 & 411.139 & 875.725 & 689.993 & \text { No }\end{array}$ $\begin{array}{lllllllllllllllll}\text { NLAMEATYINHNFSQQCLR } & 1.00 & 50.24 & 26.32 & 16.86 & 3 & 2442.1435 & 2442.1364 & 815.0527 & 0.0071 & 2.9037 & 584.402 & 525.988 & 99.360 & 947.811 & \text { Yes }\end{array}$ $\begin{array}{lllllllllllllllll}\text { NLAMEATYINHNFSQQCLR } & 0.67 & 53.28 & 26.34 & 66.28 & 3 & 2442.1390 & 2442.1364 & 815.0527 & 0.0026 & 1.0633 & 321.949 & 247.390 & 61.923 & 398.538 & \text { Yes }\end{array}$ $\begin{array}{llllllllllllllll}\text { TQGNVFATDALLATLMSCTR } & 1.00 & 95.35 & 27.49 & 22.14 & 2 & 2302.1254 & 2302.1241 & 1152.0693 & 0.0013 & 0.5642 & 11.767 & 13.674 & 10.196 & 23.437 & \text { Yes }\end{array}$ $\begin{array}{lllllllllllllllll}\text { TQGNVFATDAILATLMSCTR } & 1.00 & 48.81 & 27.56 & 21.56 & 3 & 2302.1266 & 2302.1241 & 768.3820 & 0.0025 & 1.0845 & 10.061 & 8.894 & 0.255 & 10.524 & \text { No }\end{array}$ $\begin{array}{lllllllllllllll}\text { TQGNVFATDAILATLMSCTR } & 1.00 & \text { \#\#\#\# } 27.52 & 22.75 & 2 & 2302.1234 & 2302.1241 & 1152.0693 & -0.0007 & -0.3038 & 28.894 & 30.918 & 18.649 & 41.311 & \text { Yes }\end{array}$

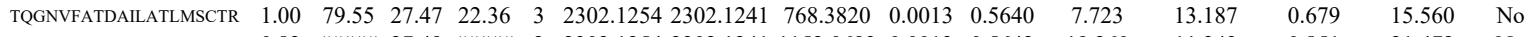
$\begin{array}{lllllllllllll}\text { TQGNVFATDAILATLMSCTR } & 0.82 & \text { \#\#\#\# } 27.49 & \text { \#\#\#\# } 2 \text { 2 } 2302.12542302 .1241 & 1152.0693 & 0.0013 & 0.5642 & 19.260 & 11.243 & 0.851 & 21.472 & \text { No }\end{array}$

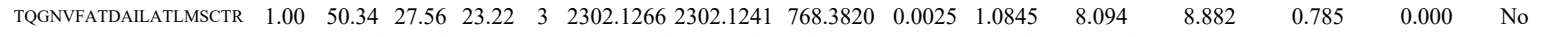

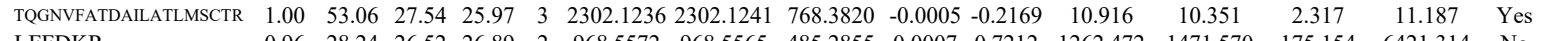

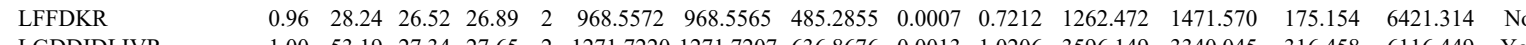

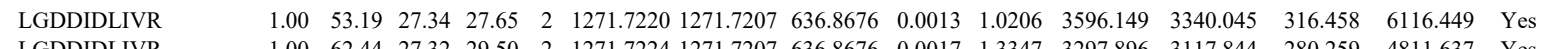

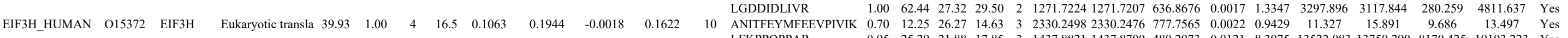
$\begin{array}{llllllllllllllll}\text { LFKPPQPPAR } & 0.95 & 25.29 & 21.88 & 17.85 & 3 & 1437.8821 & 1437.8700 & 480.2973 & 0.0121 & 8.3975 & 13522.083 & 13750.290 & 8170.425 & 19193.223 & \text { Yes } \\ \text { LFPPQPPAR } & 0.67 & 1209 & 21.24 & 1.89 & 3 & 1437.870 & 1437.8700 & 470.2973 & 0.040 & 2.776 & 1692.406 & 18239.727 & 1479.194 & 3259.700 & \text { Yes }\end{array}$

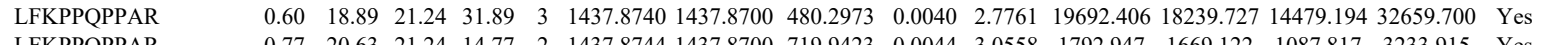
$\begin{array}{llllllllllllllll}\text { LFKPPQPPAR } & 0.77 & 20.63 & 21.24 & 14.77 & 2 & 1437.8744 & 1437.8700 & 719.9423 & 0.0044 & 3.0558 & 1792.947 & 1669.122 & 1087.817 & 3233.915 & \text { Yes } \\ \text { LFKPPQPPAR } & 0.99 & 28.02 & 21.24 & 16.87 & 3 & 1437.8752 & 1437.8700 & 480.2973 & 0.0052 & 3.6089 & 18494304 & 18068395 & 10818.665 & 29840.842 & \text { Yes }\end{array}$ $\begin{array}{llllllllllllllllll}\text { LFKPPQPPAR } & 0.99 & 28.02 & 21.24 & 16.87 & 3 & 1437.8752 & 1437.8700 & 480.2973 & 0.0052 & 3.6089 & 18494.304 & 18068.395 & 10818.665 & 29840.842 & \text { Yes } \\ \text { LFKPPQPPAR } & 0.55 & 21.14 & 22.15 & 34.14 & 3 & 1437.8713 & 1437.8700 & 480.2973 & 0.0013 & 0.9022 & 11359.190 & 11844.549 & 7985.065 & 18581630 & \text { Yes }\end{array}$ $\begin{array}{llllllllllllllllllll}\text { LFKPPQPPAR } & 0.55 & 21.14 & 22.15 & 34.14 & 3 & 1437.8713 & 1437.8700 & 480.2973 & 0.0013 & 0.9022 & 11359.190 & 11844.549 & 7985.065 & 18581.630 & \text { Yes } \\ \text { LFKPPQPPAR } & 1.00 & 28.87 & 22.10 & 17.87 & 3 & 1437.8725 & 1437.8700 & 480.2973 & 0.0025 & 1.7350 & 9118.617 & 9942.058 & 6978.507 & 13315.264 & \text { Yes }\end{array}$

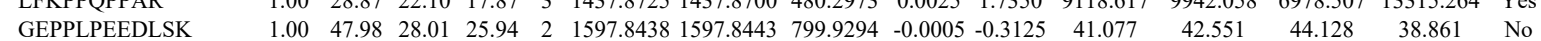
$\begin{array}{llllllllllllllll}\text { GEPPLPEEDLSK } & 0.99 & 36.33 & 27.94 & 17.88 & 2 & 1597.8464 & 1597.8443 & 799.9294 & 0.0021 & 1.3126 & 47.815 & 61.987 & 43.332 & 74.106 & \text { Yes }\end{array}$ 
$\begin{array}{llllllllllllllll}1.00 & 49.23 & 25.42 & 18.79 & 3 & 1691.9593 & 1691.9562 & 564.9927 & 0.0031 & 1.8289 & 15555.006 & 11542.815 & 9203.514 & 13825.576 & \text { Yes }\end{array}$ $\begin{array}{lllllllllllllllll}1.00 & 4.23 & 25.42 & 18.79 & 3 & 1691.9593 & 1691.9562 & 564.9927 & 0.0031 & 1.8289 & 15555.006 & 1542.815 & 9203.514 & 13825.4576 & \text { Yes } \\ 1.00 & 25.11 & 17.88 & 4 & 1691.9621 & 1691.9562 & 423.9963 & 0.0059 & 3.4788 & 9137.666 & 6725.940 & 4953.851 & 8805.870 & \text { Yes }\end{array}$ $\begin{array}{lllllllllllllllll}1.00 & 28.95 & 25.11 & 21.86 & 4 & 1691.9621 & 1691.9562 & 423.9963 & 0.0059 & 3.4788 & 9780.729 & 7171.672 & 5964.607 & 12302.616 & \text { Yes }\end{array}$ LHKPPADSGVDLR LHKPPADSGVDLR LHKPPADSGVDLR LHKPADSGVDLR EPQPEVAAAEEEK

EPQPEVAAAEEEK

LLDLSVFR

GGAVVDEGPTGVK $\begin{array}{lllllllllll} & \end{array}$ $\begin{array}{lllllllllllllll}1.00 & 30.89 & 25.11 & 17.69 & 4 & 1691.9621 & 1691.9562 & 423.9963 & 0.0059 & 3.4788 & 4944.415 & 3765.556 & 2439.932 & 5751.747 & \text { Yes }\end{array}$

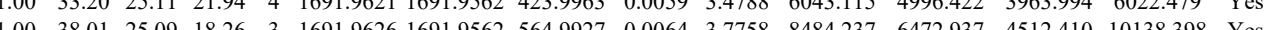

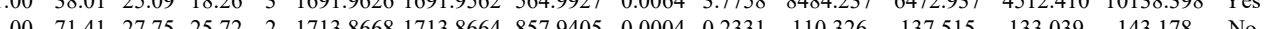

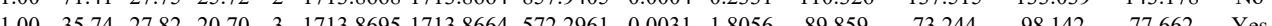

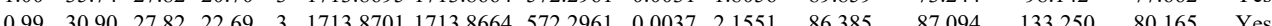
$\begin{array}{lllllllllllllll}1.00 & 44.95 & 26.87 & 27.00 & 2 & 1105.6628 & 1105.6617 & 553.8381 & 0.0011 & 0.9931 & 9785.909 & 9870.921 & 254.013 & 22357.177 & \text { No }\end{array}$ $\begin{array}{llllllllllllllll}1.00 & 53.32 & 26.59 & 33.98 & 2 & 1105.6642 & 1105.6617 & 553.8381 & 0.0025 & 2.2570 & 9485.798 & 7858.845 & 846.093 & 16648.678 & \text { Yes }\end{array}$ $\begin{array}{llllllllllllllll}1.00 & 75.53 & 27.40 & 21.83 & 2 & 1472.8104 & 1472.8079 & 737.4112 & 0.0025 & 1.6951 & 1569.531 & 1471.059 & 1905.298 & 1563.022 & \text { Yes }\end{array}$ $\begin{array}{lllllllllllllllll} & 2024.620 & 1870.190 & \text { No }\end{array}$

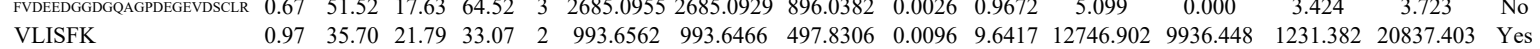

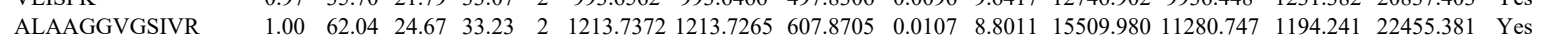
$\begin{array}{llllllllllllllll}\text { ALAAGGVGSIVR } & 1.00 & 58.22 & 24.67 & 31.22 & 2 & 1213.7372 & 1213.7265 & 607.8705 & 0.0107 & 8.8011 & 11744.157 & 10813.944 & 244.595 & 19645.605 & \text { Yes }\end{array}$ $\begin{array}{llllllllllllllll}\text { ALAAGGVGSIVR } & 1.00 & 70.40 & 24.67 & 32.26 & 2 & 1213.7376 & 1213.7265 & 607.8705 & 0.0111 & 9.1302 & 16491.929 & 14677.213 & 703.662 & 27703.574 & \text { Yes }\end{array}$ $\begin{array}{lllllllllllllllll}\text { ALAAGGVGSIVR } & 1.00 & 67.09 & 24.73 & 32.01 & 2 & 1213.7378 & 1213.7265 & 607.8705 & 0.0113 & 9.2947 & 15983.246 & 11824.393 & 910.334 & 26141.310 & \text { Yes }\end{array}$ $\begin{array}{lllllllllllllllll}\text { ALAAGGVGSIVR } & 1.00 & 73.71 & 24.67 & 32.65 & 2 & 1213.7372 & 1213.7265 & 607.8705 & 0.0107 & 8.8011 & 4654.248 & 3599.584 & 547.203 & 7020.285 & \text { Yes }\end{array}$

FVPLPASAK FVPLPASAK IHHPSLPASGR IHHPSLPASGR IHHPSLPASGR IHHPSLPASGR IHHPSLPASGR IHHPSLPASGR IHHPSLPASGR IHHPSLPASGR IHHPSLPASGR

$\begin{array}{lllllllllllllll}1.00 & 45.13 & 23.56 & 23.01 & 2 & 1216.7526 & 1216.7423 & 609.3784 & 0.0103 & 8.4512 & 15275.471 & 13956.498 & 1968.130 & 10161.387 & \text { Yes }\end{array}$

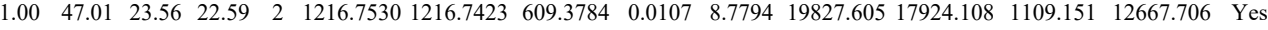
$\begin{array}{llllllllllllllll}0.99 & 38.42 & 27.42 & 25.92 & 2 & 1314.7278 & 1314.7278 & 658.3712 & 0.0000 & 0.0000 & 1796.995 & 1421.705 & 475.358 & 966.538 & \text { Yes }\end{array}$ $\begin{array}{llllllllllllllll}0.95 & 25.35 & 27.42 & 24.14 & 3 & 1314.7282 & 1314.7278 & 439.2499 & 0.0004 & 0.3035 & 1038.305 & 1204.770 & 523.086 & 1033.536 & \text { Yes }\end{array}$ $\begin{array}{lllllllllllllll}0.99 & 36.79 & 27.28 & 21.75 & 2 & 1314.7284 & 1314.7278 & 658.3712 & 0.0006 & 0.4557 & 965.155 & 921.486 & 321.142 & 677.882 & \text { Yes }\end{array}$ $\begin{array}{lllllllllllllll}0.98 & 26.60 & 27.28 & 25.26 & 3 & 1314.7285 & 1314.7278 & 439.2499 & 0.0007 & 0.5312 & 1536.239 & 1612.736 & 643.037 & 986.571 & \text { Yes }\end{array}$ $\begin{array}{lllllllllllllll}0.98 & 36.39 & 27.42 & 18.96 & 2 & 1314.7278 & 1314.7278 & 658.3712 & 0.0000 & 0.0000 & 977.399 & 975.502 & 381.095 & 890.537 & \text { Yes }\end{array}$ $\begin{array}{lllllllllllllll}0.98 & 37.40 & 27.42 & 25.08 & 2 & 1314.7278 & 3314.7278 & 658.3712 & 0.0000 & 0.0000 & 945.159 & 997.993 & 362.402 & 686.947 & \text { Yes }\end{array}$ $\begin{array}{lllllllllllllll}0.99 & 34.17 & 27.42 & 22.08 & 3 & 1314.7282 & 1314.7278 & 439.2499 & 0.0004 & 0.3035 & 517.305 & 640.650 & 647.385 & 538.479 & \text { No } \\ 0.98 & 26.34 & 27.28 & 24.88 & 3 & 1314.7285 & 1314.7278 & 439.249 & 0.0007 & 0.5312 & 779.634 & 1104.682 & 906.262 & 832.140 & \text { Yo }\end{array}$

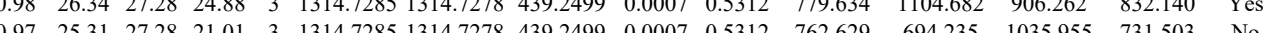

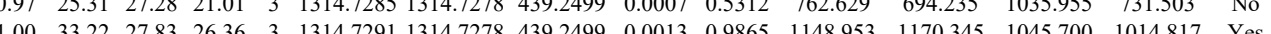

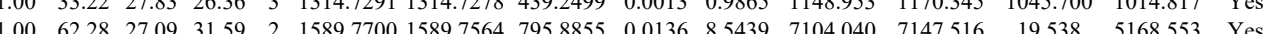
$\begin{array}{llllllllllllllll}1.00 & 61.14 & 26.94 & 32.37 & 2 & 1589.7704 & 1589.7564 & 795.8555 & 0.0140 & 8.7952 & 11517.463 & 9319.894 & 0.864 & 6158.491 & & \end{array}$ $\begin{array}{llllllllllllllll}1.00 & 64.15 & 26.87 & 32.87 & 2 & 1589.7678 & 1589.7564 & 795.8855 & 0.0114 & 7.71618 & 2191.503 & 1992591 & 0.000 & 1395.720 & \text { No }\end{array}$ $\begin{array}{lllllllllllllll}1.00 & 61.92 & 27.08 & 31.73 & 2 & 1589.7684 & 1589.7564 & 795.8855 & 0.0120 & 7.5387 & 1573.643 & 1638.478 & 25.565 & 1144.644 & Y 05\end{array}$ $\begin{array}{lllllllllllllll}0.83 & 27.00 & 26.55 & 23.51 & 2 & 1201.7090 & 1201.6974 & 601.8560 & 0.0116 & 9.6368 & 37.571 & 143.020 & 7.257 & 142.703 & \text { No }\end{array}$ $\begin{array}{lllllllllllllll}.83 & 27.00 & 26.55 & 23.51 & 2 & 1201.7090 & 1201.6974 & 601.8560 & 0.0116 & 9.6368 & 37.571 & 143.020 & 7.257 & 142.703 & \text { No } \\ 1.00 & 57.86 & 26.65 & 24.25 & 2 & 1589.7656 & 1589.7564 & 795.8855 & 0.0092 & 5.7797 & 419.987 & 370.003 & 3.604 & 210.527 & \text { Yes }\end{array}$ $\begin{array}{llllllllllllllll}0.94 & 33.14 & 26.74 & 28.74 & 2 & 1589.7660 & 1589.7564 & 795.8855 & 0.0096 & 6.0310 & 128.050 & 90.692 & 22.070 & 123.896 & \text { Yes }\end{array}$ $\begin{array}{lllllllllllllllll}0.89 & 32.06 & 26.55 & 36.28 & 2 & 1201.7090 & 1201.6974 & 601.8560 & 0.0116 & 9.6368 & 20986.798 & 18953.671 & 293.411 & 19694.778 & \text { Yes }\end{array}$ $\begin{array}{lllllllllllllll}0.98 & 36.41 & 26.54 & 29.03 & 2 & 1201.7092 & 1201.6974 & 601.8560 & 0.0118 & 9.8029 & 14664.526 & 13465.188 & 677.010 & 11963.683 & \text { Yes }\end{array}$

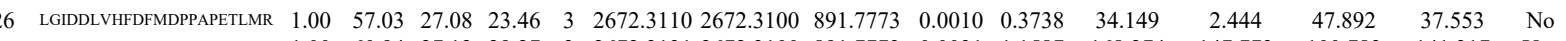

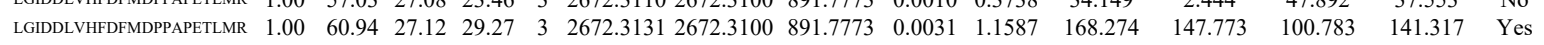
$\begin{array}{lllllllllllllllll}\text { IAPQYYDMSNFPQCEAK } & 1.00 & 40.76 & 25.04 & 20.81 & 3 & 2338.0705 & 2338.0676 & 780.3631 & 0.0029 & 1.2387 & 73.068 & 77.205 & 77.663 & 163.170 & \text { Yes }\end{array}$ $\begin{array}{llllllllllllllll}\text { LGIDDLVHFDFMDPPAPETLMR } & 1.00 & 47.01 & 27.09 & 21.85 & 3 & 2672.3125 & 2672.3100 & 891.7773 & 0.0025 & 0.9345 & 130.821 & 109.353 & 103.379 & 172.444 & \text { Yes }\end{array}$ $\begin{array}{llllllllllllllll}\text { LGIDDLVHFDFMDPPAPETLMR } & 1.00 & 63.68 & 27.13 & 25.03 & 3 & 2672.3128 & 2672.3100 & 891.7773 & 0.0028 & 1.0466 & 68.162 & 64.999 & 50.061 & 89.258 & \text { Yes }\end{array}$

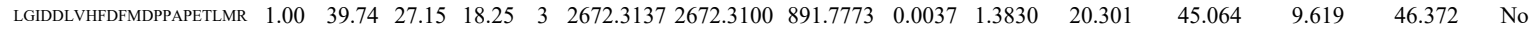
$\begin{array}{lllllllllllllllll}\text { LGIDDLVHFDFMDPPAPETLMR } & 1.00 & 57.55 & 27.15 & 26.50 & 3 & 2672.3140 & 2672.3100 & 891.7773 & 0.0040 & 1.4951 & 42.142 & 50.089 & 74.423 & 92.979 & \text { No }\end{array}$ $\begin{array}{llllllllllllllll}\text { VESLLVTAISK } & 1.00 & 55.20 & 21.00 & 17.97 & 2 & 1446.8922 & 1446.8901 & 724.4523 & 0.0021 & 1.4494 & 206.407 & 266.916 & 37.746 & 352.227 & \text { Yes }\end{array}$ $\begin{array}{lccccccccccccccc}\text { VESLLVTAISK } & 0.72 & 65.84 & 20.97 & 78.84 & 2 & 1446.8934 & 1446.8901 & 724.4523 & 0.0033 & 2.2776 & 267.052 & 171.986 & 71.611 & 230.025 & \text { Yes } \\ \text { GVACTQPR } & 0.93 & 23.71 & 25.87 & 14.89 & 2 & 1020.4982 & 1020.4967 & 511.2556 & 0.0015 & 1.4670 & 34.116 & 39.703 & 33.208 & 51.591 & \text { Yes }\end{array}$ LQLPVWEYK LQLPVWEYK TLATDILMGVLK TLATDILMGVLK TLATDILMGVLK TLATDILMGVLK VAAMSVAQR SNLGSVVLLLK SNIGSVVLQLK $\begin{array}{lllllllllllllllll}0.81 & 22.24 & 26.09 & 23.83 & 2 & 1462.8456 & 1462.8428 & 732.4287 & 0.0028 & 1.9114 & 582.331 & 373.867 & 203.281 & 917.470 & \text { Yes }\end{array}$ $\begin{array}{lllllllllllllll}1.00 & 64.60 & 22.04 & 29.19 & 2 & 1561.9376 & 1561.9357 & 781.9751 & 0.0019 & 1.2149 & 4840.505 & 4479.476 & 226.019 & 6995.684 & \text { Yes }\end{array}$

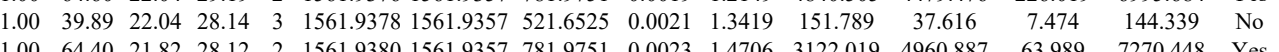

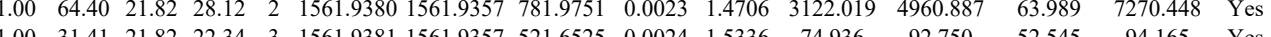
$\begin{array}{lllllllllllllll}1.00 & 31.41 & 21.82 & 22.34 & 3 & 1561.9381 & 1561.9357 & 521.6525 & 0.024 & 1.5336 & 74.936 & 92.750 & 52.545 & 94.165 & \text { Yes } \\ 1.00 & 44.19 & 27.90 & 29.06 & 2 & 1075.5932 & 1075.5930 & 538.8038 & 0.0002 & 0.1856 & 8041.955 & 7970.967 & 2233.516 & 14319.779 & \text { Yes }\end{array}$ $\begin{array}{lllllllllllllll}1.00 & 44.19 & 27.90 & 29.06 & 2 & 107.5932 & 1075.5930 & 538.8038 & 0.0002 & 0.1856 & 8041.955 & 7970.967 & 2233.516 & 14319.779 & \text { Yes } \\ 1.00 & 68.85 & 2238 & 22.16 & 2 & 144.8876 & 144.8857 & 723.4501 & 0.0019 & 1.3132 & 5883.521 & 4918.454 & 4030.603 & 7742.197 & \text { Yes }\end{array}$

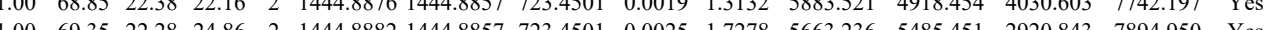

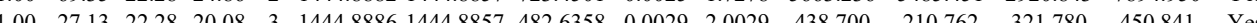
$\begin{array}{lllllllllllllll}0.60 & 18.84 & 21.96 & 31.84 & 3 & 1444.8895 & 1444.8857 & 482.6358 & 0.0038 & 2.6245 & 507.552 & 403.970 & 294.115 & 566.423 & \text { Yes }\end{array}$ 
TLATDILMGVLK

TLATDILMGVLK

TLATDILMGVLK

TLATDILMGVLK

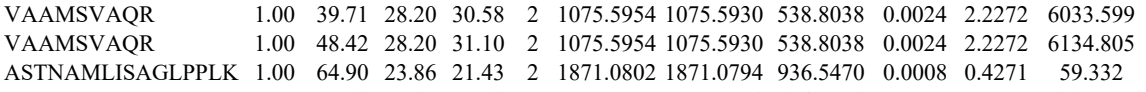

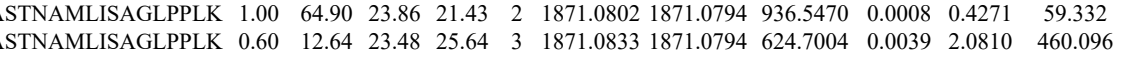
EVDDLGPEVGDIK FQIYFDNCPLLTIPGR

$\begin{array}{llllllllll}\text { K0406_HUMAN } & \text { O43156 } & \text { KIAA0406 Uncharacterized p } 122.07 & 1.00 & 6 & 8.8 & 0.4201 & 0.4118 & 0.2566 & 0.3272\end{array}$

LELVELVDLLLK

LELVELVEDLLLK

LELVELVEDLLLK

LELVELVEDLLLK

LELVELVEDLLLK

LELVELVEDLLLK

LELVLDECVVVLOS

$\begin{array}{llllllllllllll} & & 18313.1080 & 1813.1056 & 605.3758 & 0.0024 & 1.3215 & 90.272 \\ \end{array}$ $\begin{array}{lllllllllllll} & 213.1920 & 2113.1883 & 705.4034 & 0.0037 & 1.7484 & 77.686\end{array}$ $\begin{array}{lllllllllllll}\text { LLDVLDLCVVVLQSHK } & 1.00 & 59.77 & 24.84 & 18.63 & 3 & 2113.1908 & 2113.1883 & 705.4034 & 0.0025 & 1.1814 & 4.087 \\ \text { ALADILSESLHSLATSLPR } & 0.55 & 82.97 & 25.02 & 95.97 & 3 & 2137.1875 & 2137.1864 & 713.4027 & 0.0011 & 0.5140 & 34.171\end{array}$ $\begin{array}{lllllllllllll}\text { ALADILSESLHSLATSLPR } & 0.55 & 63.63 & 25.02 & 76.63 & 3 & 2137.1875 & 2137.1864 & 713.4027 & 0.0011 & 0.5140 & 221.063\end{array}$ $\begin{array}{llllllllllll}\text { ALADILSESLHSLATSLPR } & 0.66 & 83.47 & 24.91 & 96.47 & 3 & 2137.1884 & 2137.1864 & 713.4027 & 0.0020 & 0.9345 & 277.537\end{array}$ $\begin{array}{llllllllllll}\text { LQAVSDSALQELQQYILFPLR } & 0.73 & 10.72 & 24.20 & 22.46 & 3 & 2575.4149 & 2575.4131 & 859.4783 & 0.0018 & 0.6981 & 6.942\end{array}$ $\begin{array}{llllllllllll}\text { LAGSLVTQAPISAR } & 1.00 & 84.05 & 24.28 & 27.65 & 2 & 1526.9022 & 1526.8902 & 764.4524 & 0.0120 & 7.8487 & 113.347\end{array}$ $\begin{array}{llllllllllll}\text { LAGSLVTQAPISAR } & 1.00 & 81.13 & 24.22 & 25.96 & 2 & 1526.9032 & 1526.8902 & 764.4524 & 0.0130 & 8.5027 & 400.047\end{array}$ $\begin{array}{lllllllllllll}\text { INFVLNSVAHLQR } & 0.66 & 62.32 & 25.24 & 75.32 & 3 & 1653.9454 & 1653.9436 & 552.3218 & 0.0018 & 1.0863 & 704.976\end{array}$ INFVLNSVAHLQR $\begin{array}{llllllllllll}1.00 & 63.21 & 24.25 & 76.21 & 4 & 3770.7453 & 3770.7418 & 943.6927 & 0.0035 & 0.9272 & 40.206 \\ 1.00 & 58.94 & 24.27 & 17.33 & 4 & 3770.7461 & 3770.7418 & 943.6927 & 0.0043 & 1.1391 & 83.522\end{array}$ $\begin{array}{llllllllllll} & \end{array}$ $\begin{array}{lllllllllllll}\text { GQEVETSVTYYR } & 1.00 & 62.42 & 27.08 & 25.92 & 2 & 1574.7704 & 1574.7698 & 788.3922 & 0.0006 & 0.3805 & 1254.794\end{array}$ $\begin{array}{llllllllllll}\text { GQEVETSVTYYR } & 1.00 & 61.00 & 26.96 & 24.54 & 2 & 1574.7714 & 1574.7698 & 788.3922 & 0.0016 & 1.0147 & 859.424\end{array}$

$\begin{array}{lllllllllllll}\text { EELIAELQDCEGLIVR } & 0.97 & 23.19 & 27.52 & 20.94 & 3 & 2019.0163 & 2019.0138 & 674.0119 & 0.0025 & 1.2364 & 117.446 & 105 \\ \text { EELIAELQDCEGLIVR } & 1.00 & 32.52 & 27.52 & 21.87 & 3 & 2019.0166 & 2019.0138 & 674.0119 & 0.0028 & 1.3847 & 110.542 & 12\end{array}$ $\begin{array}{llllllllllll}\text { EELAAELQDCEGLIVR } & 1.00 & 32.52 & 27.52 & 21.87 & 3 & 2019.0166 & 2019.0138 & 674.0119 & 0.0028 & 1.3847 & 11.0 .542 \\ \text { EELIAELQDCEGLIVR } & 1.00 & 65.44 & 27.48 & 25.57 & 3 & 2019.0157 & 2019.0138 & 674.0119 & 0.0019 & 0.9396 & 162.319\end{array}$

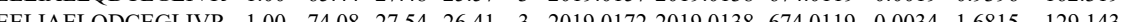
$\begin{array}{lllllllllllll} & \text { LQDGGLQVVEK } & 1.00 & 58.77 & 24.93 & 20.49 & 2 & 1585.9302 & 1585.9283 & 793.9714 & 0.0019 & 1.1965 & 150.299\end{array}$ (2) $\begin{array}{lllllllllllll}\text { CGEEALPFVMVK } & 1.00 & 74.55 & 27.22 & 34.80 & 2 & 1950.9350 & 1900.9341 & 951.4743 & 0.0009 & 0.4730 & 148.950\end{array}$ $\begin{array}{llllllllllllll}\text { CGEEIAVQFVDMVK } & 1.00 & 33.86 & 27.38 & 23.89 & 3 & 1900.9375 & 1900.9341 & 634.6520 & 0.0034 & 1.7858 & 162139\end{array}$ $\begin{array}{lllllllllllll}\text { CGEEIAVQFVDMVK } & 1.00 & 41.05 & 27.42 & 23.46 & 3 & 1900.9381 & 1900.9341 & 634.6520 & 0.0040 & 2.1009 & 267.235\end{array}$ $\begin{array}{llllllllllll}\text { CGEEIAVQFVDMVK } & 1.00 & 37.81 & 27.47 & 25.52 & 3 & 1900.9390 & 1900.9341 & 634.6520 & 0.0049 & 2.5736 & 123.968\end{array}$ CGEEIAVQFVDMVK QIPQATASMK QIPQATASMK QIPQATASMK GTIQVITQGTSLK GTIQVITQGTSLK GTIQVITQGTSLK QTSDPAMLPTMIGLLAEAGVR 1.00 TQTSDAMLTH

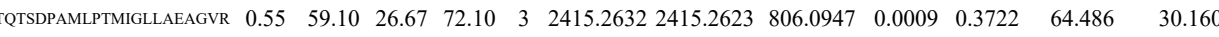

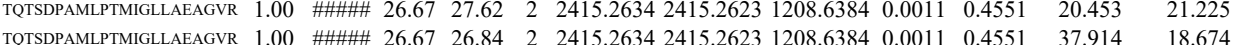

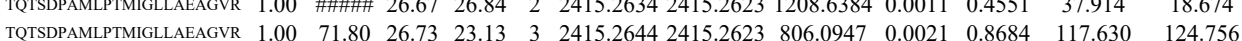
$\begin{array}{lllllllllllll}\text { TQTSDPAMLPTMIGLLAEAGVR } & 1.00 & 71.80 & 26.73 & 23.13 & 3 & 2415.2644 & 2415.2623 & 806.0947 & 0.0021 & 0.8684 & 117.630 & 124.756 \\ \text { TQTSDPAMLPTMGGLAEAGVR } & 0.66 & 59.04 & 26.74 & 72.04 & 3 & 2415.2641 & 2415.2623 & 806.0947 & 0.0018 & 0.7443 & 51.586 & 90.261\end{array}$ $\begin{array}{llllllllllllll} & \text { NASDAGM }\end{array}$ $\begin{array}{lllllllllllll}\text { NAGNCLSPAVIVGLLK } & 1.00 & 48.64 & 25.00 & 26.21 & 3 & 1902.0712 & 1902.0674 & 635.0297 & 0.0038 & 1.9947 & 167.228 & 181.767\end{array}$ $\begin{array}{llllllllllllll}\text { NAGNCLSPAVIVGLLK } & 1.00 & 92.96 & 24.97 & 28.90 & 2 & 1902.0684 & 1902.0674 & 952.0410 & 0.0010 & 0.5252 & 682.196 & 624.889\end{array}$ $\begin{array}{lllllllllllll}\text { NAGNCLSPAVIVGLLK } & 0.55 & 15.82 & 24.98 & 28.82 & 3 & 1902.0685 & 1902.0674 & 635.0297 & 0.0011 & 0.5774 & 141.584 & 137.629\end{array}$

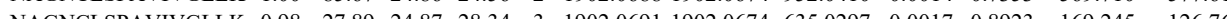
$\begin{array}{lllllllllllll}\text { NAGNCLSPAVIVGLLK } & 1.00 & 52.00 & 25.00 & 28.39 & 3 & 1902.0712 & 1902.0674 & 635.0297 & 0.0038 & 1.9947 & 124.492 & 118.829\end{array}$ $\begin{array}{llllllllllll}0.67 & 50.95 & 24.98 & 63.95 & 3 & 1653.9463 & 1653.9436 & 552.3218 & 0.0027 & 1.6295 & 821.308\end{array}$ $\begin{array}{llllllllllll}1.00 & 58.77 & 24.93 & 20.49 & 2 & 1585.9302 & 1585.9283 & 793.9714 & 0.0019 & 1.1965 & 150.299\end{array}$

$50.238 \quad 1199.174 \quad$ Yes \begin{tabular}{lll}
111.275 & Yes \\
7.255 & 1355.020 & Yes \\
\hline & 75.593 & No
\end{tabular} $0.000 \quad 75.593 \quad$ No $837.328 \quad 10013.546$ Yes 1064.43611457 .861 Yes $\begin{array}{llll}28.610 & 74.113 & \text { Yes }\end{array}$ $\begin{array}{lll}147.924 & 554.172 & \text { Yes }\end{array}$ $\begin{array}{lll}2.814 & 21.004 & \text { Yes }\end{array}$

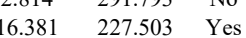
$\begin{array}{lll}13.845 & 42.507 & \text { Yes }\end{array}$ $\begin{array}{llll}71.432 & 154.655 & Y e\end{array}$ $\begin{array}{lll}92.859 & 152.359 & \text { Y }\end{array}$ $\begin{array}{llll}45.976 & 171.355 & \text { Yes }\end{array}$ $\begin{array}{lll}6.819 & 11.523 & \text { Yes }\end{array}$ $\begin{array}{llll}22.768 & 38.178 & \text { No }\end{array}$ $\begin{array}{lll}161.060 & 328.057 & \text { Yes }\end{array}$ $\begin{array}{llll}118.525 & 475.204 & \text { Yes }\end{array}$ $\begin{array}{lll}0.891 & 2.276 & \text { No }\end{array}$ $\begin{array}{lll}0.6 .629 & 212.103 & \text { Yes }\end{array}$ $\begin{array}{lll}146.038 & 664.021 & \text { Yes }\end{array}$ $\begin{array}{lll}544.964 & 1050.626 & \text { Yes }\end{array}$ $\begin{array}{lll}97.520 & 83.369 & \text { Yes }\end{array}$ $\begin{array}{lll}87.274 & 109.877 & \text { Yes } \\ 17.977 & 7.301 & \text { Yes }\end{array}$ $\begin{array}{llll}577.851 & 1864.774 & \text { Yes }\end{array}$ $\begin{array}{lll}308.398 & 1158.869 & \text { Yes }\end{array}$ $\begin{array}{lll}84.778 & 120.420 & \text { Yes } \\ 79.552 & 116.704 & \text { Yes }\end{array}$ $\begin{array}{lll}79.552 & 116.704 & \text { Yes } \\ 74.909 & 126.441 & \text { Yes }\end{array}$ $63.295 \quad 89.621$ Yes $\begin{array}{lll}0.000 & 89.137 & \mathrm{No} \\ 9.248 & 96.569 & \mathrm{No}\end{array}$ $\begin{array}{lll}11.501 & 34.676 \quad \mathrm{~N}\end{array}$ $58.072 \quad 106.925 \quad \mathrm{Y}$ $22.223 \quad 132.932 \quad \mathrm{~N}$ $\begin{array}{lll}43.901 & 74.630 & \mathrm{Y}\end{array}$ $\begin{array}{llll}39.461 & 109.447 & \text { Yes }\end{array}$ $1944.329 \quad 16914.470$ Yes $\begin{array}{lllllllllllllll}1.00 & 46.86 & 28.21 & 24.77 & 2 & 1361.7618 & 1361.7580 & 681.8863 & 0.0038 & 2.7864 & 24108.606 & 22856.412 & 739.593 & 16652.135 & \text { Yes } \\ 1.00 & 45.38 & 28.80 & 28.00 & 2 & 1361.7588 & 1361.7580 & 681.8863 & 0.0008 & 0.5866 & 7060.573 & 7219.309 & 661.945 & 5088.636 & \text { Yes } \\ 1.00 & 67.81 & 22.25 & 37.56 & 2 & 1632.9740 & 1632.9654 & 817.4900 & 0.0086 & 5.2600 & 1041.125 & 989.789 & 536.816 & 661.851 & \text { Yes }\end{array}$ $\begin{array}{lllllllllllllll}1.00 & 46.86 & 28.21 & 24.77 & 2 & 1361.7618 & 1361.7580 & 681.8863 & 0.0038 & 2.7864 & 24108.606 & 22856.412 & 739.593 & 16652.135 & \text { Yes } \\ 1.00 & 45.38 & 28.80 & 28.00 & 2 & 1361.7588 & 1361.7580 & 681.8863 & 0.0008 & 0.5866 & 7060.573 & 7219.309 & 661.945 & 5088.636 & \text { Yes } \\ 1.00 & 67.81 & 22.25 & 37.56 & 2 & 1632.9740 & 1632.9654 & 817.4900 & 0.0086 & 5.2600 & 1041.125 & 989.789 & 536.816 & 661.851 & \text { Yes }\end{array}$

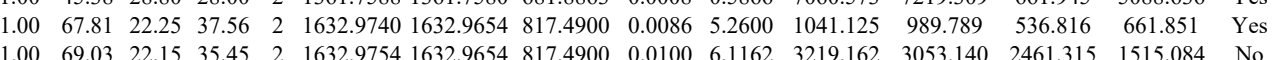

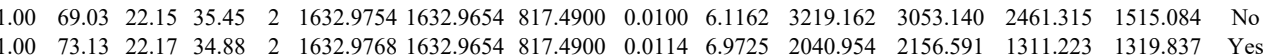
$\begin{array}{lll}9.153 & 20.052 & \text { No }\end{array}$ $19.564 \quad 33.546$ No $\begin{array}{lll}0.000 & 21.220 \quad \text { No }\end{array}$ $\begin{array}{lll}0.000 & 21.560 \quad \text { No } \\ 19.016 & 42.073 & \end{array}$ $\begin{array}{lll}19.016 & 42.073 & \text { No } \\ 11.288 & 13.154 & \text { Y }\end{array}$ $1.288 \quad 10.061$ Yes $\begin{array}{lll}11.288 & 10.061 & \text { Y } \\ 5.063 & 13.104 & \text { No }\end{array}$ $0.000-67.814-\mathrm{No}$ $55.611 \quad 389.690 \quad \mathrm{No}$ $\begin{array}{lll}38.221 & 193.348 & \text { Yes } \\ 234.165 & 369.684 & \text { Y }\end{array}$ $28.874 \quad 21634$ Yes $\begin{array}{llll}177.412 & 342.648 & \text { Yes }\end{array}$

$\begin{array}{lll}16.879 & 115.046 & \text { Yes }\end{array}$ 


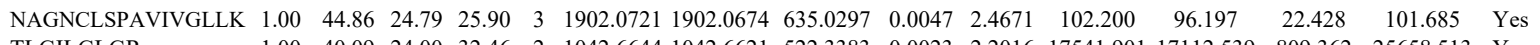
$\begin{array}{llllllllllllll} & \end{array}$ $\begin{array}{llllllllllllll} & \end{array}$

$\begin{array}{llllllllll}\text { DC1L2_HUMAN O43237 DYNC1LI2Cytoplasmic dyne } 54.099 & 1.00 & 3 & 14.4 & -0.5266 & 0.4936 & -0.3254 & 0.6255\end{array}$

$\begin{array}{lllllllllll}\text { PSMD3_HUMAl } & \text { O43242 } & \text { PSMD3 } & \text { 26S proteasome nı } 60.978 & 1.00 & 5 & 16.5 & 0.1850 & 0.3403 & -0.2093 & 0.8581\end{array}$

$\begin{array}{llllllllllll}\text { PAPS1_HUMAN } & \text { O43252 } & \text { PAPSS1 } & \text { Bifunctional 3'-ph } 70.833 & 1.00 & 3 & 8.7 & -0.1274 & 0.5982 & 0.2681 & 0.7096\end{array}$

$\begin{array}{lllllllllll}\text { SNUT1_HUMAR O43290 } & \text { SART1 U4/U6.U5 tri-snR } & 90.255 & 1.00 & 2 & 4 & -0.1922 & 0.4826 & -0.7434 & 0.6843\end{array}$

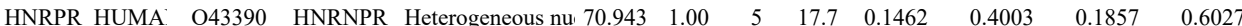

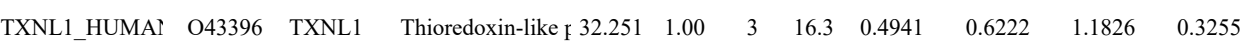

11 TGSPG

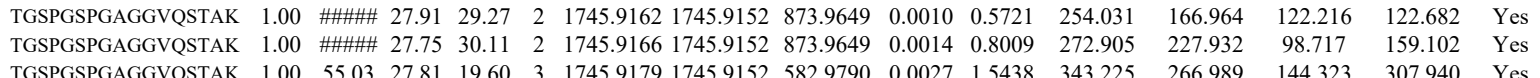

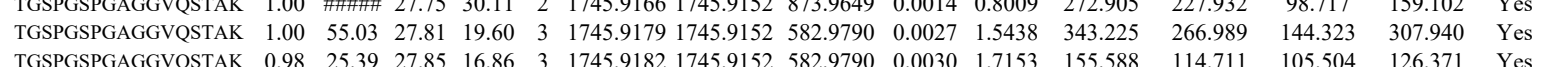
$\begin{array}{lllllllllllllllll} & \end{array}$

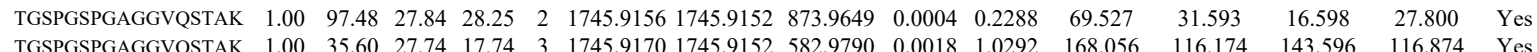

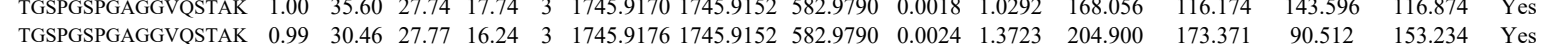

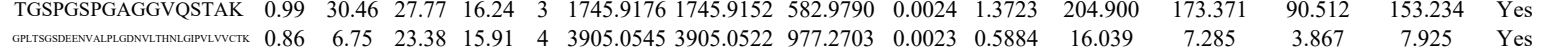

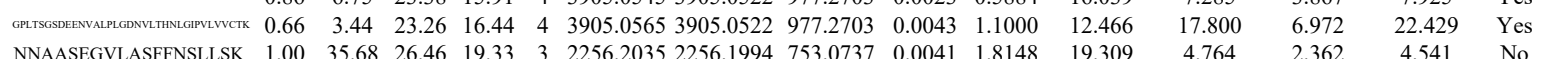

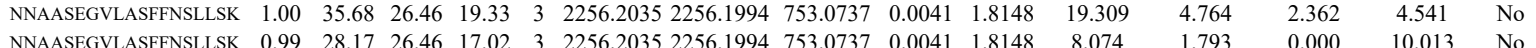

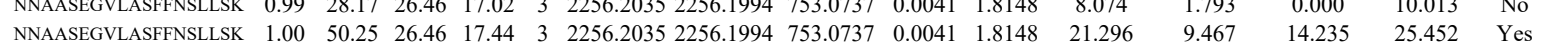
$\begin{array}{llllllllllllllll}\text { NNAASEGVLASFFNSLLSK } & 1.00 & 46.69 & 26.46 & 17.62 & 3 & 2256.2035 & 2256.1994 & 753.0737 & 0.0041 & 1.8148 & 14.320 & 14.206 & 19.829 & 4.935 & \text { No }\end{array}$

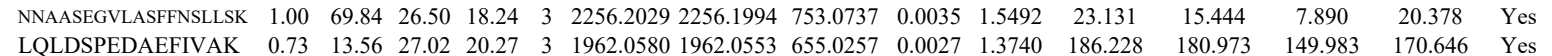
$\begin{array}{llllllllllllllll}\text { LQLDSPEDAEFIVAK } & 0.73 & 13.56 & 27.02 & 20.27 & 3 & 1962.0580 & 1962.0553 & 655.0257 & 0.0027 & 1.3740 & 186.228 & 180.973 & 149.983 & 170.646 & \text { Yes } \\ \text { DFLLPLEEPMDTEADLOFRPR } & 1.00 & 47.51 & 26.86 & 16.56 & 3 & 2822.4088 & 2822.4071 & 941.8096 & 0.0017 & 0.6017 & 137.008 & 233.018 & 615.542 & 890.078 & \text { Yes }\end{array}$ $\begin{array}{lllllllllllllllllll}\text { DFLLPFLEPMDTEADLQFRPR } & 1.00 & 32.15 & 26.86 & 16.37 & 3 & 2822.4088 & 2822.4071 & 941.8096 & 0.0017 & 0.6017 & 303.701 & 400.122 & 789.240 & 875.317 & \text { Yes }\end{array}$ $\begin{array}{llllllllllllllll}\text { FNQVLDQFGEK } & 1.00 & 59.76 & 27.80 & 30.19 & 2 & 1611.8498 & 1611.8501 & 806.9323 & -0.0003 & -0.1859 & 817.044 & 1045.435 & 282.044 & 1896.553 & \text { Yes }\end{array}$

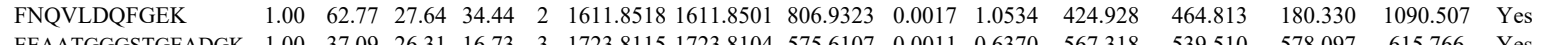

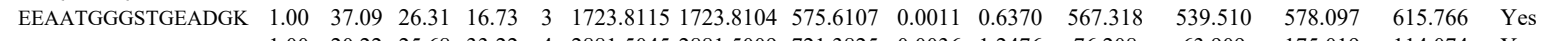
\begin{tabular}{lllllllllllllllll} 
AKPPGGGEQEPPPPAPQDVEMK & 1.00 & 20.22 & 25.68 & 33.22 & 4 & 2881.5045 & 2881.5009 & 721.3825 & 0.0036 & 1.2476 & 76.208 & 63.909 & 175.019 & 114.074 & Yes \\
\hline LPLDSPPPAFIVAK & 1.00 & 77.06 & 26.88 & 22.41 & 2 & 1962.0564 & 1962.0553 & 982.034 & 0.0011 & 0.560 & 1182.370 & 1753.598 & 958.936 & 35787 & Yes
\end{tabular} $\begin{array}{llllllllllllllll}\text { LQLDSPEDAEFIVAK } & 1.00 & 77.06 & 26.88 & 22.41 & 2 & 1962.0564 & 1962.0553 & 982.0349 & 0.0011 & 0.5601 & 1182.370 & 1753.598 & 958.936 & 3578.417 & \text { Yes }\end{array}$ $\begin{array}{llllllllllllllll}\text { LQLDSPEDAEFIVAK } & 0.82 & 80.43 & 26.88 & 93.43 & 2 & 1962.0566 & 1962.0553 & 982.0349 & 0.0013 & 0.6619 & 665.013 & 858.226 & 358.903 & 1727.588 & \text { Yes }\end{array}$ $\begin{array}{llllllllllllllll}\text { LQLDSPEDAEFIVAK } & 1.00 & 39.74 & 27.06 & 19.80 & 3 & 1962.0583 & 1962.0553 & 655.0257 & 0.0030 & 1.5267 & 148.165 & 132.563 & 224.081 & 160.796 & \text { Yes } \\ \text { LQLDSPEDAEFIVAK } & 1.00 & 3.7 & 26.99 & 24.79 & 3 & 1962.0589 & 1962.0553 & 55.0257 & 0.0036 & 1.8320 & 135.885 & 119.770 & 163.137 & 164.106 & \text { Yes }\end{array}$ $\begin{array}{lllllllllllllllll}\text { LQLDSPEDAEFIVAK } & 1.00 & 39.78 & 26.99 & 24.79 & 3 & 1962.0589 & 1962.0553 & 655.0257 & 0.0036 & 1.8320 & 135.885 & 119.770 & 163.137 & 164.106 & \text { Yes }\end{array}$ \begin{tabular}{llllllllllllllll} 
QIHEGASLPFEVYVDAPLHVCER & 1.00 & 60.81 & 26.68 & 20.52 & 4 & 3057.5033 & 3057.4963 & 765.3814 & 0.0070 & 2.2864 & 31.922 & 12.870 & 13.565 & 21.643 & Yes \\
\hline
\end{tabular} $\begin{array}{llllllllllllllll}\text { QIHEGASLPFEVVFDAPLHVCEQR } & 1.00 & 64.33 & 26.53 & 19.67 & 4 & 3057.5013 & 3057.4963 & 765.3814 & 0.0050 & 1.6332 & 41.623 & 46.544 & 18.513 & 15.773 & \text { Yes } \\ \text { LSNNAQNWGMQR } & 1.00 & 80.58 & 27.59 & 32.61 & 2 & 1561.7672 & 1561.7541 & 781.8843 & 0.0131 & 83771 & 302.368 & 258.583 & 20.293 & 238.626 & \text { Yes }\end{array}$

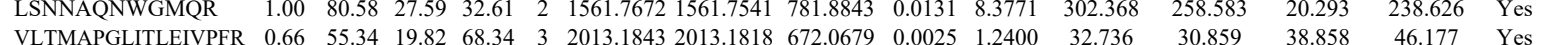
$\begin{array}{llllllllllllllll}\text { VLTMAPGLTLEVPFR } & 0.66 & 55.34 & 19.82 & 68.34 & 3 & 2613.1843 & 2013.1818 & 672.0679 & 0.0025 & 1.2400 & 32.736 & 30.859 & 38.858 & 46.177 & \text { Yes } \\ \text { VLTMAPGLITLEIVPFR } & 1.00 & 99.16 & 20.53 & 25.82 & 2 & 2013.1814 & 2013.1818 & 1007.5982 & 0.0004 & -0.1985 & 87.800 & 101.231 & 21.533 & 131.261 & \text { Yes }\end{array}$

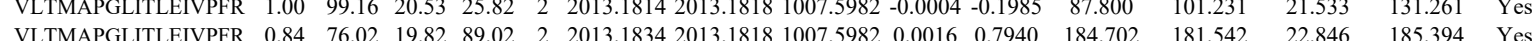

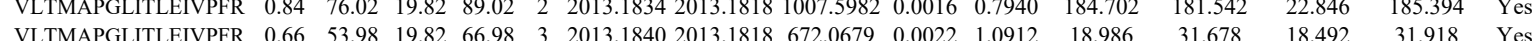
$\begin{array}{lllllllllllllllll}\text { VLTMAPGLILEIVPFR } & 1.00 & 48.69 & 19.82 & 18.57 & 3 & 2013.1849 & 2013.1818 & 672.0679 & 0.0231 & 1.5375 & 24.743 & 17.473 & 21.199 & 21.207 & \text { Yes }\end{array}$

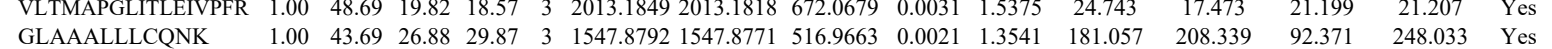

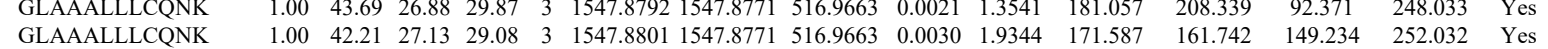
$\begin{array}{lllllllllllllllll}\text { EAAGTTAAAGTGGATEQPPR } & 1.00 & 58.63 & 27.60 & 22.61 & 3 & 1956.9619 & 1956.9623 & 653.3280 & -0.0004 & -0.2041 & 180.027 & 107.841 & 259.766 & 112.547 & \text { Yes }\end{array}$ $\begin{array}{lllllllllllllllll}10 & \text { VWGNVVTVEWADPVEEPDPEMAK } & 1.00 & 74.50 & 27.10 & 18.36 & 3 & 2983.4905 & 2983.4881 & 995.5033 & 0.0024 & 0.8036 & 0.000 & 5.723 & 4.194 & 8.196 & \text { No }\end{array}$ $\begin{array}{llllllllllllllll}\text { VTEGLVDVILYHQPDDK } & 1.00 & 49.16 & 26.41 & 18.24 & 3 & 2228.1958 & 2228.1933 & 743.7384 & 0.0025 & 1.1205 & 1207.066 & 1526.788 & 1844.396 & 2328.988 & \text { Yes }\end{array}$ $\begin{array}{llllllllllllllll}\text { VTEGLVDVILYHQPDDK } & 0.66 & 35.33 & 26.41 & 48.33 & 3 & 2228.1958 & 2228.1933 & 743.7384 & 0.0025 & 1.1205 & 244.101 & 383.548 & 615.061 & 911.903 & \text { Yes }\end{array}$ $\begin{array}{lllllllllllllllll}\text { YGGPPDSVYSGVPPGIGTEVFVGK } & 1.00 & 47.23 & 26.10 & 29.03 & 3 & 2794.4455 & 2794.4422 & 932.4880 & 0.0033 & 1.1796 & 35.837 & 57.615 & 24.809 & 76.988 & \text { Yes }\end{array}$ $\begin{array}{lllllllllllllllll}\text { DLYEDELVPLFEK } & 1.00 & 72.63 & 27.29 & 24.96 & 2 & 1896.9972 & 1896.9964 & 949.5055 & 0.0008 & 0.4213 & 78.065 & 88.097 & 67.904 & 282.318 & \text { Yes }\end{array}$ $\begin{array}{llllllllllllllll}\text { DLYEDELVPLFEK } & 1.00 & 55.59 & 27.16 & 19.38 & 2 & 1896.9986 & 1896.9964 & 949.5055 & 0.0022 & 1.1585 & 56.809 & 49.860 & 63.139 & 185.710 & \text { Yes }\end{array}$ $\begin{array}{llllllllllllllllll}\text { NLATTVTEEILEK } & 1.00 & 88.70 & 26.24 & 27.74 & 2 & 1747.9830 & 1747.9811 & 874.9978 & 0.0019 & 1.0857 & 2193.685 & 1854.297 & 1048.851 & 4252.700 & \text { Yes }\end{array}$ $\begin{array}{llllllllllllllllll}\text { NLATTVTEEILEK } & 1.00 & 75.85 & 26.24 & 22.72 & 2 & 1747.9830 & 1747.9811 & 874.9978 & 0.0019 & 1.0857 & 628.406 & 933.797 & 402.711 & 1939.240 & \text { Yes }\end{array}$ $\begin{array}{lllllllllllllllll}\text { NLATTVTEEILEK } & 1.00 & 45.94 & 26.23 & 25.31 & 3 & 1747.9834 & 1747.9811 & 583.6676 & 0.0023 & 1.3135 & 54.981 & 53.269 & 65.368 & 156.716 & \text { Yes }\end{array}$ $\begin{array}{llllllllllllllll}\text { NLATTVTEEILEK } & 1.00 & 41.60 & 26.17 & 21.61 & 3 & 1747.9840 & 1747.9811 & 583.6676 & 0.0029 & 1.6562 & 207.855 & 81.626 & 65.809 & 166.832 & \text { No }\end{array}$ $\begin{array}{lllllllllllllllll}\text { NLATTVTEEILEK } & 1.00 & 51.23 & 26.24 & 22.72 & 3 & 1747.9837 & 1747.9811 & 583.6676 & 0.0026 & 1.4849 & 78.470 & 71.152 & 92.051 & 106.052 & \text { Yes }\end{array}$ $\begin{array}{lllllllllllllllll}\text { NLATTVTEEILEK } & 1.00 & 36.75 & 26.17 & 16.16 & 3 & 1747.9843 & 1747.9811 & 583.6676 & 0.0032 & 1.8275 & 93.530 & 71.015 & 66.900 & 103.967 & \text { Yes }\end{array}$

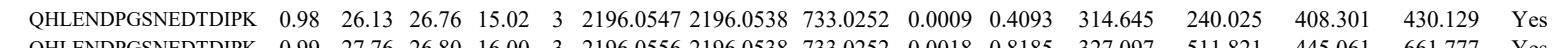
$\begin{array}{llllllllllllllll}\text { QHLENDPGSNEDTDIPK } & 0.99 & 27.76 & 26.80 & 16.00 & 3 & 2196.0556 & 2196.0538 & 733.0252 & 0.0018 & 0.8185 & 327.097 & 511.821 & 445.061 & 661.777 & \text { Yes }\end{array}$

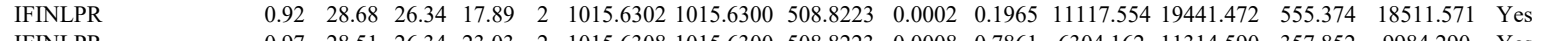

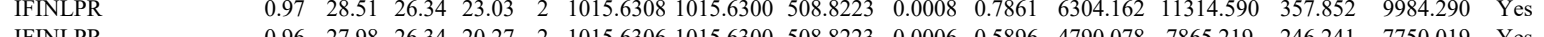
$\begin{array}{llllllllllllllll}\text { IFINLPR } & 0.96 & 27.98 & 26.34 & 20.27 & 2 & 1015.6306 & 1015.6300 & 508.8223 & 0.0006 & 0.5896 & 4790.078 & 7865.219 & 246.241 & 7750.019 & \text { Yes } \\ \text { IFINLPR } & 0.97 & 27.98 & 26.41 & 20.98 & 2 & 1015.6322 & 1015.6300 & 508.8223 & 0.0022 & 2.1619 & 3275.068 & 5185.649 & 151.885 & 5363.480 & \text { Yes }\end{array}$ $\begin{array}{lllllllllllllllll}\text { IFINLPR } & 0.97 & 27.98 & 26.41 & 20.98 & 2 & 1015.6322 & 1015.6300 & 508.8223 & 0.0022 & 2.1619 & 3275.068 & 5185.649 & 151.885 & 5363.480 & \text { Yes } \\ \text { SEPTQALELTEDDIKEDGIVPLR } & 1.00 & 56.78 & 25.05 & 16.70 & 3 & 2855.5030 & 2855.5007 & 952.8408 & 0.0023 & 0.8046 & 680.729 & 1584.821 & 1325.003 & 1305.267 & \text { Yes }\end{array}$

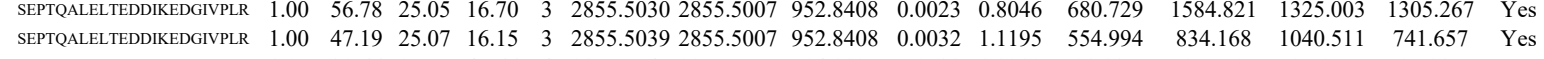
$\begin{array}{llllllllllll} & \text { STE }\end{array}$ 
$\begin{array}{lllllllllllllll}\text { TPAVEGLTEAEEEELR } & 1.00 & \text { \#\#\#\# } 20.01 & 2 & 1915.9510 & 1915.9496 & 958.9821 & 0.0014 & 0.7299 & 31.524 & 35.012 & 165.108 & 107.121 & \text { Yes }\end{array}$ $\begin{array}{llllllllllllllll}\text { TPAVEGLTEAEEEELR } & 0.67 & 65.16 & 27.11 & 78.16 & 3 & 1915.9522 & 1915.9496 & 639.6571 & 0.0026 & 1.3549 & 52.448 & 52.824 & 107.871 & 50.221 & \text { No }\end{array}$

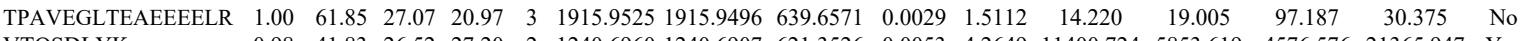

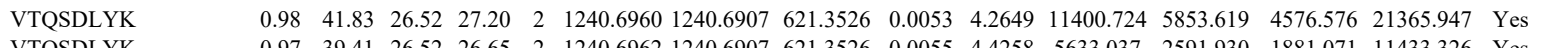
$\begin{array}{llllllllllllllll}\text { VTQSDLYK } & 0.97 & 39.41 & 26.52 & 26.65 & 2 & 1240.6962 & 1240.6907 & 621.3526 & 0.0055 & 4.4258 & 5633.037 & 2591.930 & 1881.071 & 11433.326 & \text { Yes }\end{array}$

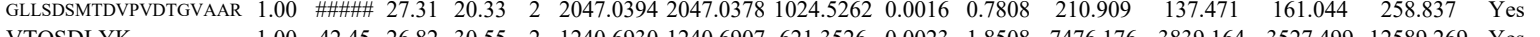

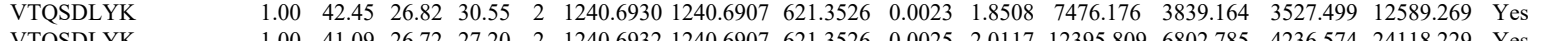

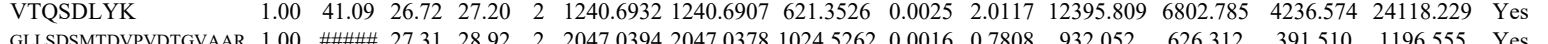

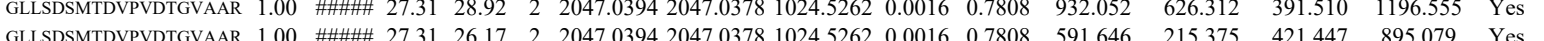
$\begin{array}{lllllllllllll} & \end{array}$

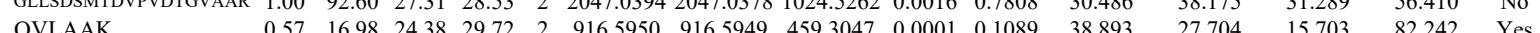

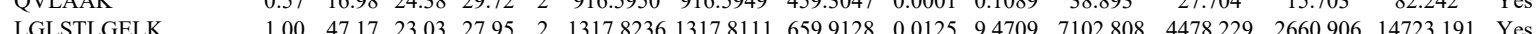

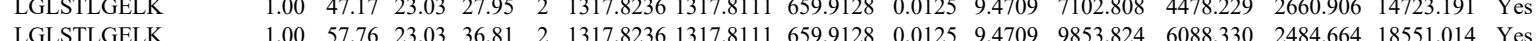

LGLSTLGELK

TSAALSTVGSAISR

TSAALSTVGSAISR

TSAALSTVGSAISR

TPAVEGLTEAEEEE

TPAVEGLTEAEEEELR VEEEIVTLR VEEEIVTLR

LAQVSPELLLASVR

LAQVSPELLLASVR

LAQVSPELLLASVR

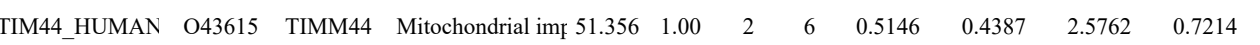
$\begin{array}{llllllllllll}\text { ASNA_HUMAN } & \text { O43681 } & \text { ASNA1 } & \text { ATPase ASNA1 } & 38.793 & 1.00 & 4 & 18.7 & 0.0087 & 0.0900 & 4.0632 & 0.2396\end{array}$ TEMSEVLTEILR TEMSEVLTEILR

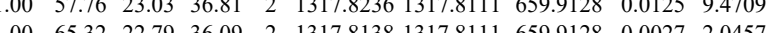

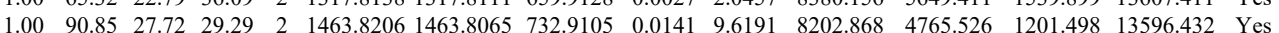
$\begin{array}{lllllllllllllll}1.00 & 8630 & 27.72 & 27.85 & 2 & 1463.8204 & 1463.8065 & 732.9105 & 0.0139 & 9.4827 & 8636.830 & 4111.280 & 1923.472 & 12791.815 & \text { Yes }\end{array}$

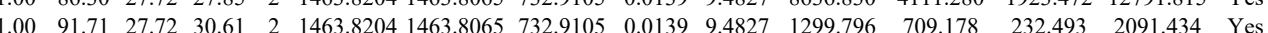

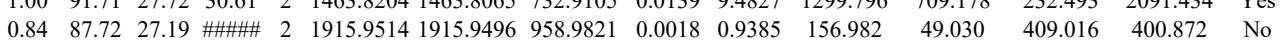
$\begin{array}{lllllllllllllll}0.73 & 13.74 & 27.17 & 14.83 & 3 & 1915.9519 & 1915.9496 & 639.6571 & 0.0023 & 1.1986 & 165.023 & 147.381 & 195.340 & 212.634 & \text { Yes }\end{array}$

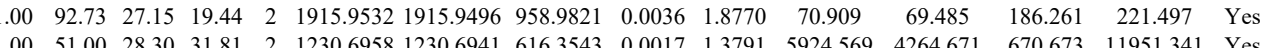
$\begin{array}{llllllllllllllll}1.00 & 51.00 & 28.30 & 31.81 & 2 & 1230.6958 & 1230.6941 & 616.3543 & 0.0017 & 1.3791 & 5924.569 & 4264.671 & 670.673 & 11951.341 & \text { Yes } \\ 1.00 & 51.61 & 28.30 & 36.80 & 2 & 1230.6960 & 1230.6941 & 616.3543 & 0.0019 & 1.5413 & 5294.155 & 4154.620 & 672.810 & 9757.567 & \text { Yes }\end{array}$ $\begin{array}{lllllllllllllllll}0.67 & 33.49 & 27.92 & 46.49 & 3 & 1857.9547 & 1857.9514 & 620.3244 & 0.0033 & 1.7733 & 1359.806 & 1844.163 & 40.155 & 1773.526 & \text { Yes }\end{array}$ $\begin{array}{lllllllllllllll}1.00 & 43.87 & 27.92 & 21.72 & 3 & 1857.9556 & 1857.9514 & 620.3244 & 0.0042 & 2.2569 & 964.573 & 1138.828 & 66.671 & 1322.790 & \text { Yes }\end{array}$ $\begin{array}{lllllllllllllll}1.00 & 86.76 & 22.15 & 21.88 & 2 & 1638.9782 & 1638.9790 & 820.4968 & -0.0008 & -0.4875 & 566.952 & 687.102 & 187.077 & 639.174 & \text { Yes }\end{array}$ $\begin{array}{lllllllllllllll}1.00 & 72.45 & 22.17 & 19.34 & 2 & 1638.9790 & 1638.9790 & 820.4968 & 0.0000 & 0.0000 & 284.374 & 301.417 & 35.268 & 294.316 & \text { Yes }\end{array}$

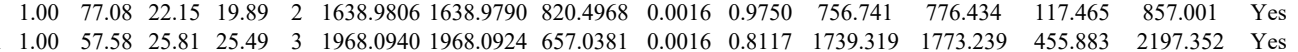
$\begin{array}{lllllllllllllll}1.00 & 57.58 & 25.81 & 25.49 & 3 & 1968.0940 & 1968.0924 & 657.0381 & 0.0016 & 0.8117 & 1739.319 & 1773.239 & 455.883 & 2197.352 & \text { Yes } \\ 1.00 & 88.14 & 28.09 & 32.53 & 2 & 1563.8330 & 1563.8300 & 782.9223 & 0.0030 & 1.9159 & 303.166 & 560.613 & 55.375 & 1041.013 & \text { Yes }\end{array}$

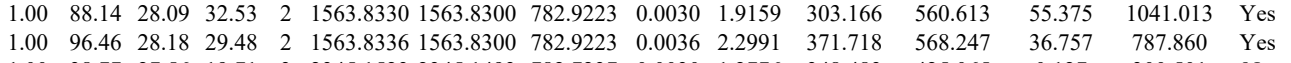
$\begin{array}{llllllllllllllll} & \\ \text { YLDQMDLPEHIVK } & 1.00 & 38.77 & 27.56 & 19.71 & 3 & 2345.1523 & 2345.1493 & 782.7237 & 0.0030 & 1.2776 & 348.483 & 425.065 & 0.127 & 300.501 & \text { No }\end{array}$

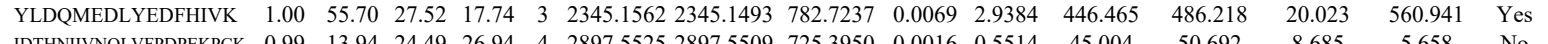

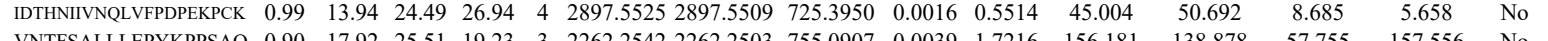
$\begin{array}{llllllllllllll} & \end{array}$ LLNFPTIVER LLNFPTVR LLNFPTIVER

LLNFPTIVER

LLNTPTVER

LNQPPEDGISSVK

LNQPPEDGISSVK

VLVWDLR

VLVWDLR

LIVGTAGR

LIVGTAGR

LIVGTAGR

LNQPPEDGISSVK

$\begin{array}{llllllllllllllll}1.00 & 48.38 & 25.37 & 32.51 & 2 & 1344.7938 & 1344.7887 & 673.4016 & 0.0051 & 3.7867 & 8045.372 & 7683.154 & 112.374 & 7147.582 & \text { Yes }\end{array}$ $\begin{array}{rrrrrrrrrrrrrrr}1.00 & 48.31 & 25.37 & 32.33 & 2 & 1344.7938 & 1344.7887 & 673.4016 & 0.0051 & 3.7867 & 15440.978 & 13812.200 & 0.000 & 12030.399 & \text { No } \\ 1.00 & 48.14 & 26.19 & 27.32 & 2 & 1344.7886 & 1344.7887 & 673.4016 & 0.0001 & 0.0742 & 14970.865 & 15078.876 & 150.762 & 11976.547 & \text { Yes }\end{array}$

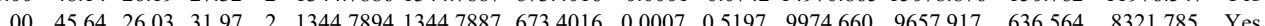

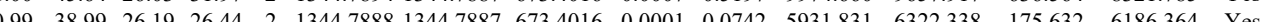

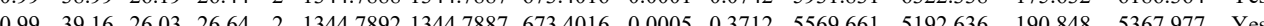

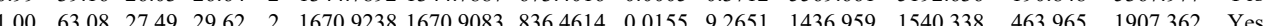
$\begin{array}{llllllllllllllll}1.00 & 54.69 & 27.34 & 26.13 & 2 & 1670.9240 & 1670.9083 & 836.4614 & 0.0157 & 9.3847 & 1403.257 & 1432.089 & 417.491 & 1577.433 & \text { Yes }\end{array}$ $\begin{array}{lllllllllllllll}0.98 & 31.91 & 27.11 & 34.58 & 2 & 1043.6262 & 1043.6250 & 522.8198 & 0.0012 & 1.1476 & 2523.878 & 2791.229 & 87.298 & 8722.023 & \text { No }\end{array}$ $\begin{array}{lllllllllllllll}0.95 & 26.65 & 27.00 & 25.71 & 2 & 1043.6266 & 1043.6250 & 522.8198 & 0.0016 & 1.5302 & 842.669 & 776.483 & 161.427 & 1356.421 & \text { Yes }\end{array}$ $\begin{array}{llllllllllllllll}0.52 & 17.12 & 27.00 & 26.52 & 2 & 929.5806 & 929.5780 & 465.7963 & 0.0026 & 2.7909 & 1527.143 & 1902.057 & 2191.635 & 3061.233 & \text { No }\end{array}$ $\begin{array}{lllllllllllllllll}0.99 & 36.29 & 27.00 & 33.78 & 2 & 929.5802 & 929.5780 & 465.7963 & 0.0022 & 2.3615 & 12560.320 & 14488 & 192 & 969.906 & 25828.087 & \text { Yes }\end{array}$ $\begin{array}{lllllllllllllll}0.98 & 31.88 & 27.00 & 33.24 & 2 & 929.5804 & 929.5780 & 465.7963 & 0.0024 & 2.5762 & 11283.240 & 12931.757 & 2916.513 & 23823.388 & \text { Yes }\end{array}$ $\begin{array}{lllllllllllllll}1.00 & 60.63 & 27.26 & 34.41 & 2 & 1670.9242 & 1670.9083 & 836.4614 & 0.0159 & 9.5042 & 218.737 & 181.506 & 89.235 & 311.036 & \text { Yes }\end{array}$ $\begin{array}{lllllllllllllllll} & \text { LVSIGAEEIVDGNAK } & 1.00 & 57.93 & 25.91 & 19.13 & 2 & 1802.0048 & 1802.0029 & 902.0087 & 0.0019 & 1.0532 & 889.733 & 873.119 & 663.694 & 1243.405 & \text { Yes }\end{array}$ $\begin{array}{llllllllllllllll}\text { LVSIGAEEIVDGNAK } & 1.00 & 31.14 & 25.91 & 21.56 & 3 & 1802.0050 & 1802.0029 & 601.6749 & 0.0021 & 1.1634 & 308.886 & 356.152 & 276.554 & 420.857 & \text { Yes }\end{array}$

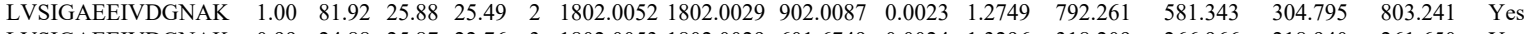
$\begin{array}{lllllllllllllllll}\text { LVIGAEEIVDGNAK } & 0.99 & 24.88 & 25.87 & 22.76 & 3 & 1802.0053 & 1802.0029 & 601.6749 & 0.0024 & 1.3296 & 318.209 & 266.966 & 218.940 & 261.650 & \text { Yes }\end{array}$

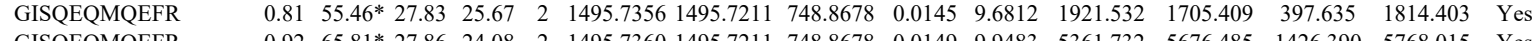
$\begin{array}{lllllllllllllll}\text { GISQEQMQEFR } & 0.92 & 65.81 * 27.86 & 24.08 & 2 & 1495.7360 & 1495.7211 & 748.8678 & 0.0149 & 9.9483 & 5361.732 & 5676.485 & 1426.390 & 5768.015 & \text { Yes }\end{array}$ $\begin{array}{llllllllllllllll}\text { QLEAIDQLHLEYAK } & 0.66 & 42.56 & 26.57 & 55.56 & 3 & 1958.0737 & 1958.0716 & 653.6978 & 0.0021 & 1.0708 & 3342.199 & 2248.279 & 413.628 & 3540.604 & \text { Yes }\end{array}$ $\begin{array}{llllllllllllllllll}\text { QLEAIDQLHLEYAK } & 0.67 & 52.72 & 26.64 & 65.72 & 3 & 1958.0749 & 1958.0716 & 653.6978 & 0.0033 & 1.6827 & 3647.067 & 2562.717 & 435.240 & 3420.197 & \text { Yes }\end{array}$ $\begin{array}{lllllllllllllllll}\text { QLEAIDQLHLEYAK } & 0.67 & 45.56 & 26.58 & 58.56 & 3 & 1958.0752 & 1958.0716 & 653.6978 & 0.0036 & 1.8357 & 2276.876 & 2112.559 & 465.619 & 2462.786 & \text { Yes }\end{array}$ $\begin{array}{llllllllllllllllll}\text { MAPYQGPDAVPGALDYK } & 1.00 & 82.05 & 27.75 & 28.09 & 2 & 2080.0594 & 2080.0543 & 1041.0344 & 0.0051 & 2.4495 & 2697.418 & 2203.837 & 155.852 & 2783.456 & \text { Yes }\end{array}$

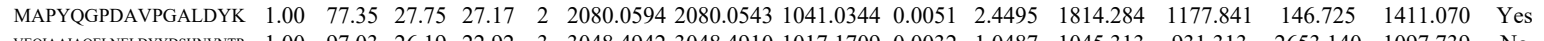

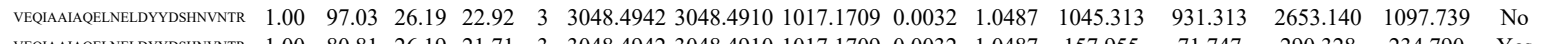

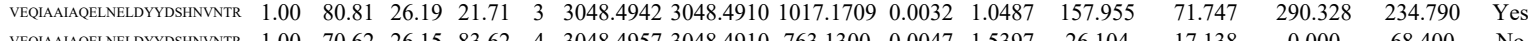

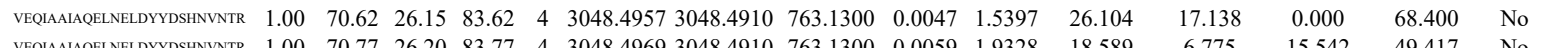

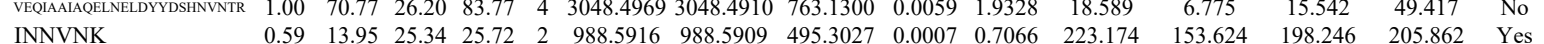

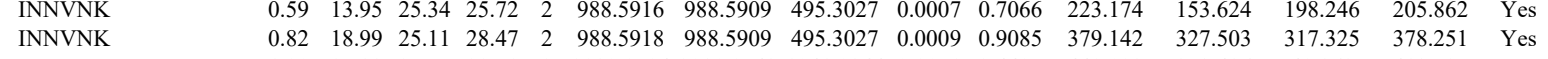

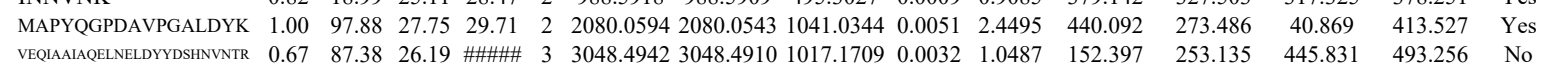


$\begin{array}{lllllllllll}1.00 & 58.64 & 26.15 & 71.64 & 4 & 3048.4957 & 3048.4910 & 763.1300 & 0.0047 & 1.5397 & 31.127\end{array}$

$\begin{array}{lllllllllllll}0.99 & 34.48 & 27.66 & 33.78 & 2 & 1172.6320 & 1172.6311 & 587.3228 & 0.0009 & 0.7662 & 9221.586 & 6859.348\end{array}$ $\begin{array}{llllllllllllllllll}\text { QFASQANVVGPWIQTK } & 0.86 & 16.98 & 26.32 & 16.85 & 3 & 2061.1294 & 2061.1251 & 688.0490 & 0.0043 & 2.0832 & 1349.991 & 1119.120 & 283.384 & 2417.557 & \text { Yes }\end{array}$

$\begin{array}{llllllllllll}0.67 & 18.02 & 26.31 & 4.87 & 3 & 2061.1312 & 2061.1251 & 688.0490 & 0.0061 & 2.9552 & 1018.205 & 607.398\end{array}$

275.547

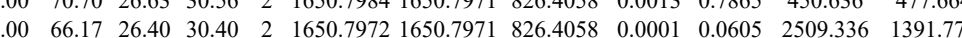

$\begin{array}{llllllllllllllll}\text { AGTQIENIDEDFR } & 1.00 & 66.17 & 26.40 & 30.40 & 2 & 1650.7972 & 1650.7971 & 826.4058 & 0.0001 & 0.0605 & 2509.336 & 1391.777 & 522.482 & 2156.851 & \text { Yes } \\ \text { AGTQIENIDEDFR } & 1.00 & 70.74 & 26.56 & 30.53 & 2 & 1650.7982 & 1650.7971 & 826.4058 & 0.0011 & 0.6655 & 2547.269 & 2210.361 & 830.662 & 2822.876 & \text { Yes } \\ \text { DYETATLSIK } & 1.00 & 60.09 & 27.90 & 29.75 & 2 & 1542.8036 & 1542.8021 & 772.4083 & 0.0015 & 0.9710 & 197.642 & 57.767 & 353.606 & 247.896 & \text { No }\end{array}$

$\begin{array}{lcccccccccccccccc} & \\ \text { GTQIENIDEDFR } & 1.00 & 66.17 & 26.40 & 30.40 & 2 & 1650.7972 & 1650.7971 & 826.4058 & 0.0001 & 0.0605 & 2509.336 & 1391.777 & 522.482 & 2156.851 & \text { Yes } \\ \text { GTQIENIDEDFR } & 1.00 & 70.74 & 26.56 & 30.53 & 2 & 1650.7982 & 1650.7971 & 826.4058 & 0.0011 & 0.6655 & 2547.269 & 2210.361 & 830.662 & 2822.876 & \text { Yes } \\ \text { DYETATLSDIK } & 1.00 & 60.09 & 27.90 & 29.75 & 2 & 1542.8036 & 1542.8021 & 772.4083 & 0.0015 & 0.9710 & 197.642 & 57.767 & 353.606 & 247.896 & \text { No }\end{array}$

$\begin{array}{lllllllllllllll}1.00 & 60.09 & 27.90 & 29.75 & 2 & 1542.8036 & 1542.8021 & 772.4083 & 0.0015 & 0.9710 & 197.642 & 57.767 & 353.606 & 247.896 & \text { No }\end{array}$

$\begin{array}{lllllllllllllll} & & & \end{array}$

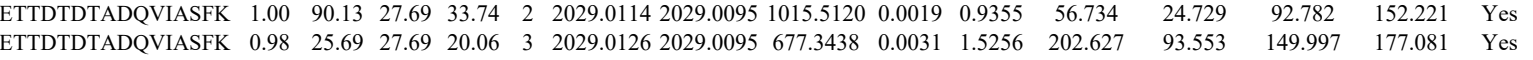

\begin{tabular}{llllllllllllllll} 
& \\
ETTDTDTADQVIASFK & 1.00 & 49.82 & 27.68 & 20.06 & 3 & 2029.0126 & 2029.0095 & 677.3438 & 0.0031 & 1.5256 & 202.627 & 93.553 & 149.997 & 177.081 & Yes \\
\hline
\end{tabular}

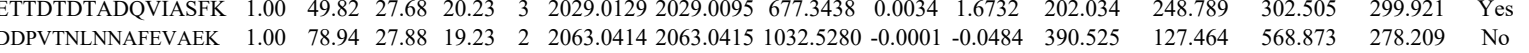

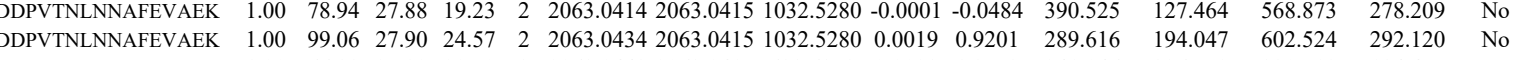

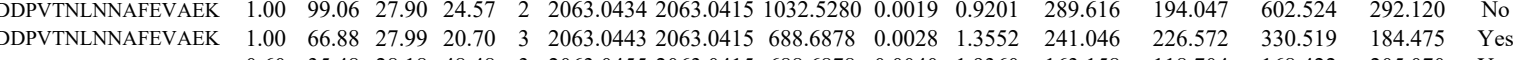
\begin{tabular}{llllllllllllllll} 
DDPVINLNNAFEVAEK & 0.60 & 35.48 & 28.18 & 48.48 & 3 & 2063.0453 & 2063.0415 & 688.6878 & 0.0028 & 1.3552 & 241.046 & 226.572 & 330.519 & 184.475 & Yes \\
\hline
\end{tabular} $\begin{array}{llllllllllllllll} & \end{array}$ $\begin{array}{lllllllllllllllll} & \end{array}$ $\begin{array}{lllllllllllllll} & \end{array}$ $\begin{array}{lllllllllllllllll}0.85 & 25.81 & 27.34 & 20.33 & 3 & 1586.8765 & 1586.8660 & 529.9626 & 0.0105 & 6.6042 & 8576.529 & 6764.534 & 2202369 & 9468.421 & Y & Y\end{array}$ $\begin{array}{llllllllllllllllll}\text { MLDAEDIVNTARPDEK } & 1.00 & 48.26 & 28.10 & 25.84 & 3 & 2104.0753 & 2104.0714 & 702.3644 & 0.0039 & 1.8509 & 12208.250 & 9733.122 & 3821171 & 14285.052 & \text { Yes }\end{array}$ $\begin{array}{lllllllllllllllll}\text { SFSTALYGESDL } & 0.64 & 14.67 & 25.54 & 14.90 & 2 & 1432.6866 & 1432.6844 & 717.3495 & 0.0022 & 1.5334 & 119.582 & 117.005 & 106.114 & 126.391 & \text { Yes }\end{array}$ $\begin{array}{llllllllllllllll}\text { HRPELIEYDK } & 0.52 & 19.42 & 27.40 & 14.46 & 3 & 1586.8756 & 1586.8660 & 529.9626 & 0.0096 & 6.0381 & 21158.736 & 17627.652 & 3508.515 & 21425.028 & \text { Yes }\end{array}$ $\begin{array}{llllllllllllllllll}\text { HRPELIEYDK } & 0.71 & 22.57 & 27.40 & 18.86 & 3 & 1586.8759 & 15868660 & 529.9626 & 0.0099 & 6.2268 & 21965.022 & 19368.649 & 1950.785 & 27033.715 & \text { Yes }\end{array}$ $\begin{array}{lllllllllllllll}\text { GISQEQMQEFR } & 0.93 & 66.51 * 27.81 & 25.03 & 2 & 1495.7352 & 1495.7211 & 748.8678 & 0.0141 & 9.4141 & 8978.528 & 7538.980 & 1329.950 & 9442.090 & \text { Yes }\end{array}$

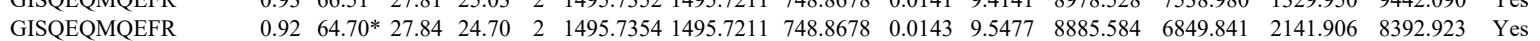

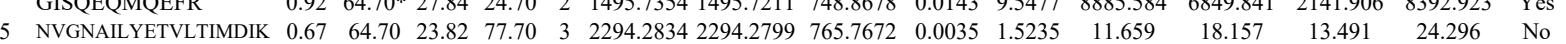
$\begin{array}{llllllllllllllll}\text { NVGNAILYETVLTIMDIK } & 0.67 & 15.17 & 23.82 & 28.17 & 3 & 2294.2834 & 2294.2799 & 765.7672 & 0.0035 & 1.5235 & 11.631 & 6.753 & 5.479 & 31.139 & \text { Yes }\end{array}$ $\begin{array}{llllllllllllllll}\text { NVGNAILYETVLTIMDIK } & 1.00 & 76.42 & 23.94 & 18.16 & 3 & 2294.2807 & 2294.2799 & 765.7672 & 0.0008 & 0.3482 & 54.321 & 45.355 & 60.982 & 75.084 & \text { No }\end{array}$

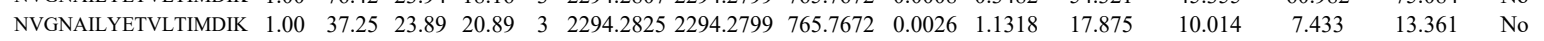
$\begin{array}{llllllllllllllll}\text { VLTTAGSYVR } & 1.00 & 50.24 & 26.71 & 29.77 & 2 & 1209.6940 & 1209.6839 & 655.8492 & 0.0101 & 8.3353 & 11942.716 & 9877.284 & 1236.030 & 20703.380 & \text { Yes }\end{array}$ $\begin{array}{lllllllllllllllll} & \text { VLTTAGSYVR } & 1.00 & 52.24 & 26.71 & 31.27 & 2 & 1209.6942 & 1209.6839 & 605.8492 & 0.0103 & 8.5004 & 8651.399 & 8409.345 & 548.018 & 13830.144 & \text { Yes }\end{array}$ $\begin{array}{lllllllllllllllll}\text { VLTTAGSYVR } & 1.00 & 57.09 & 26.88 & 34.46 & 2 & 1209.6944 & 1209.6839 & 605.8492 & 0.0105 & 8.6654 & 8771.060 & 7109.945 & 1233.455 & 13370.185 & \text { Yes }\end{array}$ $\begin{array}{lllllllllllllllll}\text { VLTTAGSYVR } & 1.00 & 50.09 & 26.88 & 26.46 & 2 & 1209.6946 & 1209.6839 & 605.8492 & 0.0107 & 8.8305 & 2816.870 & 2737.968 & 620.009 & 4674.131 & \text { Yes }\end{array}$ LVPQLVR LVPQLVR

AALCAVHVIR AALCAVHVIR AALCAVHVIR AALCAVHVIR VLAINILGR $\begin{array}{lllllllllllllllll}0.71 & 22.85 & 18.26 & 28.53 & 2 & 967.6374 & 967.6300 & 484.8223 & 0.0074 & 7.6316 & 625.942 & 452.272 & 167.659 & 1056.471 & \text { Yes }\end{array}$ $\begin{array}{llllllllllllllll}0.66 & 21.17 & 18.26 & 28.51 & 2 & 967.6380 & 967.6300 & 484.8223 & 0.0080 & 8.2504 & 459.134 & 454.697 & 160.153 & 962.284 & \text { Yes }\end{array}$ $\begin{array}{lllllllllllllll}0.99 & 39.76 & 26.21 & 19.46 & 3 & 1241.6947 & 1241.6858 & 414.9025 & 0.0089 & 7.1502 & 7836.935 & 8029.899 & 2176.271 & 13409.923 & \text { Yes }\end{array}$ $\begin{array}{lllllllllllllll}1.00 & 43.69 & 26.20 & 24.08 & 3 & 1241.6950 & 1241.6858 & 414.9025 & 0.0092 & 7.3912 & 8239.236 & 10027.373 & 2274.300 & 16770.010 & \text { Yes }\end{array}$ $\begin{array}{lllllllllllllll}1.00 & 38.98 & 26.41 & 17.32 & 3 & 1241.6881 & 1241.6858 & 414.9025 & 0.0023 & 1.8478 & 3784.295 & 4568.445 & 1475.615 & 7532.574 & \text { Yes }\end{array}$ $\begin{array}{lllllllllllllll}0.98 & 23.77 & 26.37 & 20.45 & 3 & 1241.6893 & 1241.6858 & 414.9025 & 0.0035 & 2.8119 & 5745.066 & 5708.933 & 1461.076 & 11945.696 & \text { Yes }\end{array}$ $\begin{array}{lllllllllllllll}1.00 & 46.72 & 18.51 & 29.61 & 2 & 1111.7214 & 1111.7199 & 556.8672 & 0.0015 & 1.3468 & 1024.618 & 956.643 & 92.293 & 2212.245 & \text { Yes }\end{array}$ $\begin{array}{lllllllllllllll}1.00 & 45.03 & 18.81 & 29.63 & 2 & 1111.7218 & 1111.7199 & 556.8672 & 0.0019 & 1.7060 & 1035.602 & 941.441 & 15.352 & 2174.684 & \text { Yes } \\ 1.00 & 46.55 & 16.99 & 30.59 & 2 & 1111.7206 & 1111.7199 & 5568672 & 0.0007 & 0.6285 & 438.858 & 399.926 & 48.832 & 882.087 & \text { Yes }\end{array}$ 
QEEENPAEETGEEK QEEENPAEETGEEK QEEENPAEETGEEK QEEENPAEETGEEK QEEENPAEETG
QLPSAGPDK

$\begin{array}{lllllllllll}\text { SYNC_HUMAN } & \text { O43776 } & \text { NARS } & \text { Asparaginyl-tRN } 6 \text { 62.943 } & 1.00 & 8 & 17.3 & 0.2352 & 0.1420 & 2.6094 & 0.2929\end{array}$ 19 LEDAGCDVY

LEDLVCDVVDR EPFPTIYVDSQK FDSEEILAGYK LTESVDVLMPNVGEIVGGSM LMTDTINEPILLCR

LMTDTINEPILLCR

LMTDTINEPILLCR

LMTDTINEPILLCR

NLMFLVLR

NLMFLVLR

NLMFLVLR

NLMFLVLR

NLMFLVLR

NLMFLVLR

NLMFLVLR

NDPSLPEPK

NDPSLPEPK

FLTWILNR

FLTWILNR

FLTWILNR

FLTWILNR

FLTWILNR

FLTWILNR

LEDLVCDVVDR

LEDLVCDVVDR

$\begin{array}{llllllllll}131.99 & 1.00 & 13 & 17.9 & -0.0806 & 0.3883 & 0.2450 & 0.5026 & 52 & \text { VLYQVEGFVDK }\end{array}$

GVEVLFNELEIPVEEYSFG GVEVLFNELEPVVEYYSFGR

GDFLFSSDHLIEMATK

LEDLATLIQK

LEDLATLIQK

LEDLATLIQK

LEDLATLIQK

GDPLGGVISNYLLEK

$\begin{array}{llllllllllll}1 & \end{array}$

$\begin{array}{llllllllllllll}\text { GDPLGGVISNYLLEK } & 1.00 & 40.44 & 25.84 & 24.36 & 3 & 1862.0434 & 1862.0393 & 621.6870 & 0.0041 & 2.1983 & 458.614 & 544.219\end{array}$

$\begin{array}{llllllllllllll}\text { GDPLGGVISNYLLEK } & 1.00 & 49.83 & 25.84 & 21.16 & 3 & 1862.0434 & 1862.0393 & 621.6870 & 0.0041 & 2.1983 & 244.065 & 137.267\end{array}$ LEDLATLIQK

LEDLATLIQK $\begin{array}{lllllllllll}00 & 58.04 & 24.12 & 27.46 & 2 & 1430.8606 & 1430.8588 & 716.4367 & 0.0018 & 1.2562 & 265.625\end{array}$

$\begin{array}{lllllllllllll} & \end{array}$ $\begin{array}{lllllllllllll}\text { GDPLGGVISNYLLEK } & 1.00 & 39.79 & 25.97 & 23.24 & 3 & 1862.0422 & 1862.0393 & 621.6870 & 0.0029 & 1.5549 & 529.422 & 48\end{array}$ GDPLGGVISNYLLEK

GDPLGGVISNYLLEK

TSLLDMGGGDMVLLFLNETTHNLK

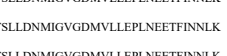

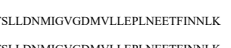

RPPTAGSQFK

RPPACSQK

BPPTAGSQFK

RPPTAGSQFK $\begin{array}{lllllllllll}100 & 58.99 & 24.12 & 27.55 & 2 & 1430.8602 & 1430.8588 & 716.4367 & 0.0014 & 0.9771 & 390.860\end{array}$

$\begin{array}{lllllllllll}77.19 & 24.89 & 28.34 & 2 & 1905.8684 & 1905.8683 & 953.9414 & 0.0001 & 0.0524 & 73.185 & 76.400\end{array}$ $\begin{array}{llllllllllll}.00 & 76.87 & 24.83 & 27.86 & 2 & 1905.8666 & 1905.8683 & 953.9414 & -0.0017 & -0.8910 & 38.763\end{array}$

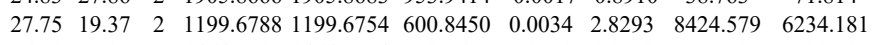

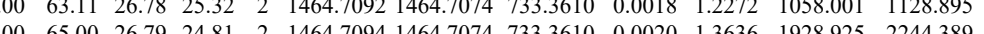
$\begin{array}{lllllllllllll}1.00 & 70.20 & 27.51 & 37.02 & 2 & 1710.9084 & 1710.9072 & 856.4609 & 0.0012 & 0.7006 & 281.933 & 279.098\end{array}$

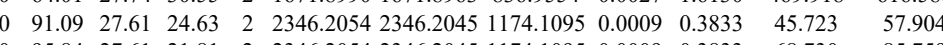
$\begin{array}{lllllllllllll}1.00 & 75.92 & 28.22 & 19.31 & 2 & 1820.9320 & 1820.9320 & 911.4733 & 0.0000 & 0.0000 & 274.180 & 578.227\end{array}$

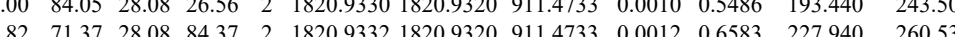
$\begin{array}{lllllllllllll}0.84 & 73.33 & 28.04 & 86.33 & 2 & 1820.9338 & 1820.9320 & 911.4733 & 0.0018 & 0.9874 & 172.811 & 251.908\end{array}$ $\begin{array}{lllllllllllll}1.00 & 39.39 & 25.90 & 19.36 & 2 & 1148.6872 & 1148.6862 & 575.3504 & 0.0010 & 0.8690 & 1363.926 & 1537.829\end{array}$ $\begin{array}{llllllllllll}1.00 & 40.85 & 25.76 & 19.65 & 2 & 1148.6882 & 1148.6862 & 575.3504 & 0.0020 & 1.7381 & 1362.025 & 1587\end{array}$ $\begin{array}{llllllllllll}1.00 & 39.37 & 25.91 & 19.35 & 2 & 1148.6880 & 1148.6862 & 575.3504 & 0.0018 & 1.5643 & 851.803 \\ 1.00 & 39.30 & 25.91 & 19.39 & 2 & 1148.68801148 .6862 & 575.3504 & 0.0018 & 1.5643 & 809.422\end{array}$ $\begin{array}{llllllllllll}0.83 & 29.61 & 26.85 & 15.07 & 2 & 1164.6804 & 1164.6811 & 583.3478 & -0.0007 & -0.6000 & 233.917\end{array}$ $\begin{array}{lllllllllll}0.96 .74 & 25.90 & 17.79 & 2 & 1148.6872 & 1148.6862 & 575.3504 & 0.0010 & 0.8690 & 85.709\end{array}$ $\begin{array}{lllllllllll}1.00 & 38.47 & 25.90 & 20.14 & 2 & 1148.6874 & 1148.6862 & 575.3504 & 0.0012 & 1.0428 & 71.895 \\ 0.86 & 20.52 & 25.76 & 17.64 & 2 & 1148.6882 & 1148.6862 & 575.3504 & 0.0020 & 1.7381 & 23.137\end{array}$ $\begin{array}{llllllllllll}32.71 & 27.63 & 24.56 & 2 & 1283.6954 & 1283.6965 & 642.8555 & -0.0011 & -0.8556 & 5341.333 & 5401.932 & 16 \\ & 42.02 & 26.64 & 25.61 & 2 & 1205.7058 & 1205.7043 & 603.8594 & 0.0015 & 1.2420 & 3074.127 & 3879.775\end{array}$ $\begin{array}{llllllllllllll}1.00 & 48.41 & 26.60 & 27.01 & 2 & 1205.7068 & 1205.7043 & 603.8594 & 0.0025 & 2.0700 & 4277.610 & 6124.915 \\ 1.00 & 45.49 & 26.65 & 25.87 & 2 & 1205.7050 & 1205.7043 & 603.8594 & 0.0007 & 0.5796 & 577.460 & 600.787\end{array}$ $\begin{array}{llllllllllll}.00 & 4.11 & 26.57 & 25.75 & 2 & 1205.7054 & 1205.7043 & 603.8594 & 0.0011 & 0.9108 & 487.441 & 594.940\end{array}$ $\begin{array}{llllllllllll}1.00 & 43.87 & 26.65 & 23.26 & 2 & 1205.7050 & 1205.7043 & 603.8594 & 0.0007 & 0.5796 & 91.850 & 119.995 \\ 1.00 & 39.65 & 26.66 & 22.62 & 2 & 1205.7052 & 1205.7043 & 603.8594 & 0.0009 & 0.7452 & 70.381 & 115.292\end{array}$ $\begin{array}{llllllllllll}1.00 & 39.65 & 26.66 & 22.62 & 2 & 1205.7052 & 1255.1043 & 603.8594 & 0.0009 & 0.7452 & 70.381 & 115.292 \\ 1.00 & 67.32 & 26.78 & 23.48 & 2 & 1464.7092 & 1464.7074 & 733.3610 & 0.0018 & 1.2272 & 1001.164 & 1314.78\end{array}$ $\begin{array}{llllllllllll}1.00 & 71.61 & 26.83 & 28.51 & 2 & 1464.7096 & 1464.7074 & 733.3610 & 0.0022 & 1.4999 & 2314.659 & 2388.396\end{array}$ $\begin{array}{llllllllllll}1.00 & 71.61 & 26.83 & 28.51 & 2 & 1464.7096 & 1464.7074 & 733.3610 & 0.0022 & 1.499 & 2314.659 & 2388.396 \\ 1.00 & 7.15 & 26.83 & 28.47 & 2 & 1464.0096 & 464.7074 & 733.3610 & 0.0022 & 1.4999 & 42.189 & 528.317\end{array}$ $\begin{array}{llllllllll}34.41 & 27.32 & 17.75 & 3 & 2556.2905 & 2556.2870 & 853.1029 & 0.0035 & 1.3676 & 18.667\end{array}$ 17.024 $\begin{array}{llllllllll}27.29 & 23.88 & 3 & 2556.2896 & 2556.2870 & 853.1029 & 0.0026 & 1.0159 & 4.639 & 5.733\end{array}$ \begin{tabular}{lllllllll} 
& 2.69 .573 & 5.733 \\
\hline
\end{tabular} $\begin{array}{lllllllllllll}17.11 & 24.12 & 19.27 & 3 & 1430.8606 & 1430.8588 & 477.9602 & 0.0018 & 1.2553 & 162.738 & 102.704 & 8\end{array}$ $\begin{array}{llllllllllll}17.11 & 24.12 & 19.27 & 3 & 140.8606 & 140.8588 & 477.962 & 0.0018 & 1.253 & 162.738 & 102.704\end{array}$ $\begin{array}{lllllllllll}1.00 & 87.08 & 25.98 & 23.11 & 2 & 1862.0426 & 1862.0393 & 932.0269 & 0.0033 & 1.7703 & 201.685 \\ 15.89 & 25.84 & 15.69 & 3 & 1862.0452 & 1862.0393 & 621.6870 & 0.0059 & 3.1634 & 320.880\end{array}$ $\begin{array}{lllllllllllll}1.00 & 48.77 & 23.89 & 19.14 & 3 & 3519.8482 & 3519.8448 & 1174.2889 & 0.0034 & 0.9651 & 1.836\end{array}$ $\begin{array}{lllllllllll}1.00 & 68.15^{*} & 23.86 & 81.15 & 4 & 3519.8485 & 3519.8448 & 880.9685 & 0.0037 & 1.0500 & 4.360 \\ 1.00 & 37.21 * 23.82 & 50.21 & 4 & 3519.8501 & 3519.8448 & 880.9685 & 0.0053 & 1.5040 & 10.784\end{array}$ $\begin{array}{llllllllllll}1.00 & 37.21 * & 23.82 & 50.21 & 4 & 3519.8501 & 3519.8448 & 880.9685 & 0.0053 & 1.5040 & 10.784 \\ 1.00 & 52.13 & 23.98 & 65.13 & 4 & 3519.8473 & 3519.8448 & 880.9685 & 0.0025 & 0.7094 & 22.752\end{array}$

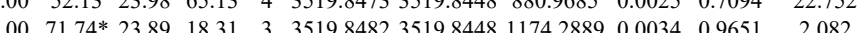

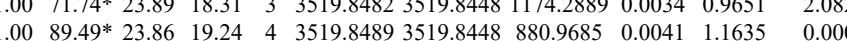

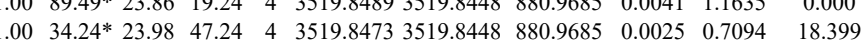
$\begin{array}{llllllllll}1.00 & 72.09 * 23.94 & 22.28 & 4 & 3519.8477 & 3519.8448 & 880.9685 & 0.0029 & 0.8230 & 29.455\end{array}$ $\begin{array}{lllllllllllll}0.57 & 20.66 & 28.08 & 25.20 & 2 & 1375.7814 & 1375.7816 & 688.8981 & -0.0002 & -0.1452 & 100.477\end{array}$ $\begin{array}{llllllllllllll}1.00 & 41.34 & 28.08 & 19.44 & 3 & 1375.7815 & 1375.7816 & 459.6011 & -0.0001 & -0.0725 & 331.322\end{array}$

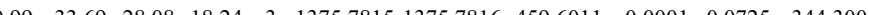
$\begin{array}{lllllllllllll}0.55 & 38.06 & 27.84 & 51.06 & 3 & 1375.7824 & 1375.7816 & 459.6011 & 0.0008 & 0.5802 & 445.025\end{array}$ $\begin{array}{lllllllllll}0.723 & 23.26 & 2 & 1283.6948 & 1283.6965 & 642.8555 & -0.0017 & -1.3222 & 4385.689 & 4473.498\end{array}$ $\begin{array}{lll}160.651 & 208.597 & \text { Yes }\end{array}$ $70.751 \quad 46.871 \quad$ Yes 96.130 Y 1191.986 Yes 2424.188 Yes 272.434 No $30.161-61.724$ Yes $0.000-281.511 \quad \mathrm{No}$ $12.280 \quad 172.473$ No $55.023 \quad 1930.092$ Yes $112.551 \quad 1725.018$ Yes $84.708 \quad 1167.077 \quad$ Yes $\begin{array}{lll}17.837 & 110.355 & \text { Yes }\end{array}$ $\begin{array}{lll}2.734 & 109.400 & \text { Yes }\end{array}$ $\begin{array}{lll}7.486 & 36.652 & \text { Yes }\end{array}$ $\begin{array}{lll}1480.336 & 3006.100 & \text { Yes } \\ 661.518 & 4721.840 & \text { Yes }\end{array}$ $9.628 \quad 633.980$ Yes $\begin{array}{lll}7.254 & 122.181 & \mathrm{No} \\ 69.176 & 1187.099 & \mathrm{Yes}\end{array}$ $\begin{array}{lll}6.176 & 1187.099 & \text { Yes }\end{array}$ $\begin{array}{lll}0.000 & 2712.044 & \text { Yes }\end{array}$

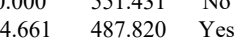
$\begin{array}{lll}1.172 & 5.367 & \text { Yes }\end{array}$ $\begin{array}{lll}9.1732 & 5.767 & \text { Yes } \\ 3 & 7.91094 & \text { Yes }\end{array}$ $\begin{array}{lll}32.954 & 2681.794 & \text { Yes }\end{array}$ $\begin{array}{lll}732.954 & 2681.794 & \text { Yes } \\ 89.525 & 233.439 & \text { Yes }\end{array}$ $80.276 \quad 112.170$ Yes $\begin{array}{llll}106.376 \quad 4536.524 & \text { Yes }\end{array}$ $329.778 \quad 519.011 \quad$ Yes $\begin{array}{lll}728.668 & \text { Yes }\end{array}$ $\begin{array}{lll}38.823 & 239.684 & \text { Yes }\end{array}$

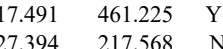
$\begin{array}{lll}69.480 & 17.568 & \text { No }\end{array}$ $\begin{array}{lll}221.584 & 829.534 & \text { Yes }\end{array}$ $\begin{array}{lll}34.612 & 649.427 & \text { Yes }\end{array}$ $\begin{array}{lll}2.392 & 2.880 & \text { Yes } \\ 13.307 & 0.000 & \mathrm{No}\end{array}$ $\begin{array}{lll}13.307 & 0.000 & \text { No } \\ 6.145 & 5.213 & \\ 12.568 & 16.708 & \text { Yes }\end{array}$ $\begin{array}{lll}13.145 & 5.213 & \mathrm{No} \\ 12.568 & 16.708 & \mathrm{Yas}\end{array}$ $\begin{array}{lll}2.568 & 16.708 & \text { Yes } \\ 2.504 & 2.316 & \text { Yes }\end{array}$ $\begin{array}{lll}2.504 & 2.316 & \text { Yes } \\ 5.695 & 8.999 & \end{array}$ $6.837-3.990$ No $\begin{array}{lll}61.937 & 30.869 & \text { Yes }\end{array}$ $132.337 \quad 105.995 \quad$ Yes $\begin{array}{llll}472.847-444.903 & \text { Yes }\end{array}$ $\begin{array}{lll}55.297-70.018 & \text { Yes }\end{array}$ 


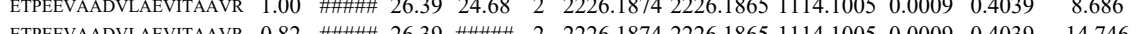
(15) $\begin{array}{llllllllllll} & \text { ETPEEVADAEVAAVR } \\ 0.67 & 15.23 & 26.42 & 28.23 & 3 & 2226.1897 & 2226.1865 & 743.0694 & 0.0032 & 1.4355 & 29.932\end{array}$ $\begin{array}{llllllllll} & 0\end{array}$

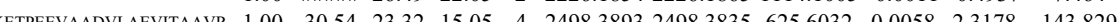

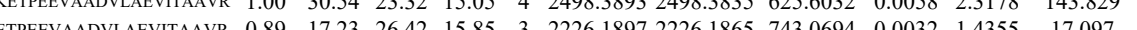


$\begin{array}{lllllllllllll}\text { YMNGGPVVAMVWEGLNVVK } & 1.00 & 87.98 & 26.85 & 22.04 & 2 & 2380.2534 & 2380.2527 & 1191.1336 & 0.0007 & 0.2938 & 258.711\end{array}$ $\begin{array}{llllllllllll}\text { YMNSGPVVAMVWEGLNVVK } & 1.00 & 80.86 & 26.85 & 19.94 & 2 & 2380.2554 & 2380.2527 & 1191.1336 & 0.0027 & 1.1334 & 495.890 \\ \text { YMNSGPVYMYVWEGNVYK } & 0.53 & 13.23 & 26.79 & 13.84 & 3 & 2380.2574 & 2380.2527 & 794.4248 & 0.0047 & 1.9721 & 91.405\end{array}$ \begin{tabular}{lllllllllllll} 
YMNSGPVAMVWEGLNVWK & 0.53 & 13.23 & 26.79 & 13.84 & 3 & 2380.2574 & 2380.2527 & 794.4248 & 0.0047 & 1.9721 & 91.405 \\
\hline
\end{tabular} $\begin{array}{lllllllllllll}\text { YMNSGPVVAMVWEGLNVVK } & 0.54 & 9.84 & 26.84 & 22.84 & 3 & 2380.2562 & 2380.2527 & 794.4248 & 0.0035 & 1.4686 & 11.259\end{array}$

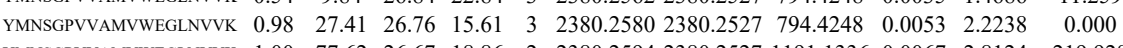
$\begin{array}{llllllllllll}\text { YMNSGPVVAMVWEGLNVVK } & 1.00 & 77.62 & 26.67 & 18.86 & 2 & 2380.2594 & 2380.2527 & 1191.1336 & 0.0067 & 2.8124 & 219.928\end{array}$

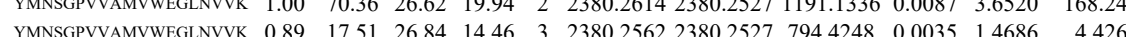
$\begin{array}{lllllllllllll}\text { YMNNSGPVVAMVWEGLNVVK } & 0.94 & 20.97 & 26.81 & 16.06 & 3 & 2380.2571 & 2380.2527 & 794.4248 & 0.0044 & 1.8462 & 0.426\end{array}$ $\begin{array}{llllllllllll}\text { YMNSGPVVAMVWEGLNVVK } & 0.98 & 24.03 & 26.84 & 16.43 & 3 & 2380.2562 & 2380.2527 & 794.4248 & 0.0035 & 1.4686 & 17.013\end{array}$ $\begin{array}{lllllllllllll}\text { SCAHDWVYE } & 100 & 35.14 & 18.86 & 23.33 & 2 & 1298.5214 & 1298.5182 & 650.2664 & 0.0032 & 2.4605 & 790.605\end{array}$ SCAHDWYYE FKPEELVDYK FKPEELVDYK FKPEELVDYK $\begin{array}{llllllllllll}0.64 & 14.81 & 18.98 & 17.38 & 2 & 1298.5308 & 1298.5182 & 650.2664 & 0.0126 & 9.6882 & 741.458\end{array}$ FKPEELVYK $\begin{array}{lllllllllllll}0.64 & 1.97 & 25.53 & 16.91 & 3 & 1698.9619 & 1698.9558 & 567.3259 & 0.0061 & 3.5841 & 153.056\end{array}$

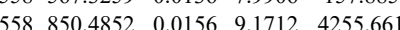
TAEDYSVDENGQR AKPTSDKPGSPYR $\begin{array}{lllllllllllll}0.91 & 29.96 & 24.87 & 16.54 & 2 & 1698.9722 & 1698.9558 & 850.4852 & 0.0164 & 9.6415 & 3542.228 & 25\end{array}$ AKPTSDKPGSPYR AKPTSDKPGSPYR 


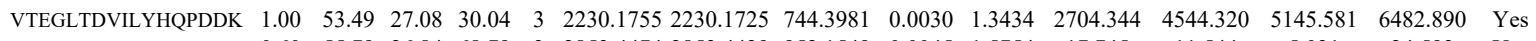

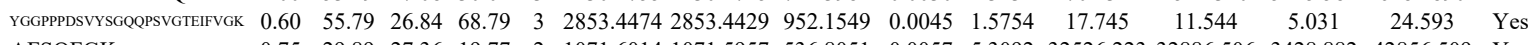

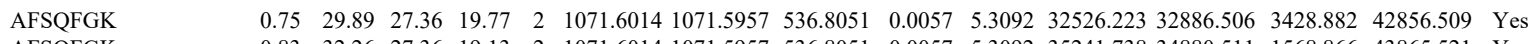
$\begin{array}{llllllllllllllll}\text { AFSQFGK } & 0.83 & 32.26 & 27.36 & 19.13 & 2 & 1071.6014 & 1071.5957 & 536.8051 & 0.0057 & 5.3092 & 35241.738 & 34880.511 & 1568.866 & 43865.521 & \text { Yes }\end{array}$ $\begin{array}{llllllllllllllll}\text { LMMDPLTGLNR } & 1.00 & 50.88 & 28.12 & 28.50 & 2 & 1403.7412 & 1403.7387 & 702.8766 & 0.0025 & 1.7784 & 9060.009 & 9167.275 & 0.000 & 13246.579 & \text { No }\end{array}$ $\begin{array}{lllllllllllllllll}\text { LMMDPLTGLNR } & 1.00 & 48.09 & 28.48 & 24.01 & 2 & 1403.7424 & 1403.7387 & 702.8766 & 0.0037 & 2.6320 & 10176.626 & 14621.746 & 0.000 & 17359.273 & \text { No }\end{array}$ $\begin{array}{llllllllllllllll}\text { LMMDPLTGLNR } & 1.00 & 51.28 & 28.29 & 29.35 & 2 & 1403.7396 & 1403.7387 & 702.8766 & 0.0009 & 0.6402 & 6797.994 & 9248.488 & 107.750 & 10723.322 & \text { Yes }\end{array}$ GYAFVTFCTK GYGVISVANNR HIGVCISVANR AMEEMNGK

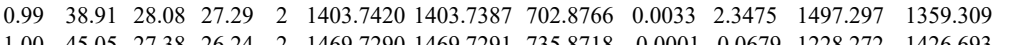
$\begin{array}{lllllllllllllll}1.00 & 45.05 & 27.38 & 26.24 & 2 & 1469.7290 & 1469.7291 & 735.8718 & -0.0001 & -0.0679 & 1228.272 & 1426.693 & 587.604 & 1226.756 & \text { Yes } \\ 0.56 & 22.7 \% & 2.79 & 16.57 & 3 & 1471.7527 & & \end{array}$

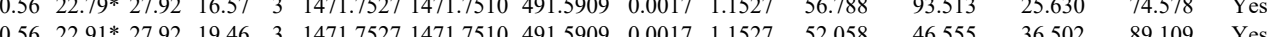
$\begin{array}{lllllllllllllll}0.81 & 30.67 & 26.55 & 21.13 & 2 & 11965832 & 1196.5773 & 599.2959 & 0.0059 & 4.9224 & 22.0017 & 28.484 & 6.497 & 13.520 & \text { Yes }\end{array}$ $\begin{array}{lllllllllllllll} & & \end{array}$

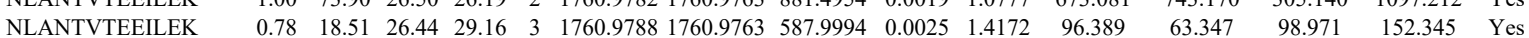

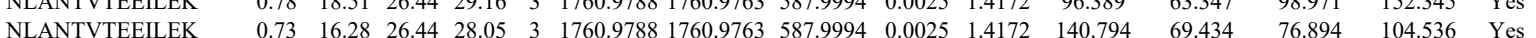

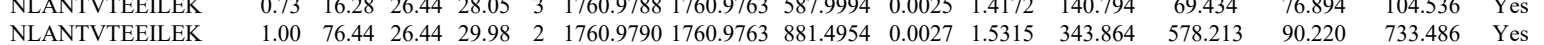

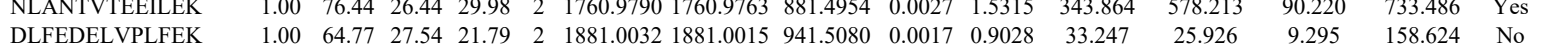

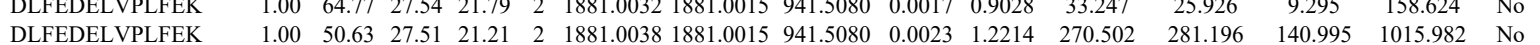

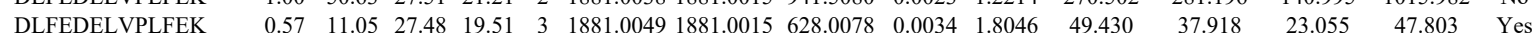
\begin{tabular}{llllllllllllllll} 
NLANTVTEEILEK & 1.00 & 75.17 & 26.38 & 31.38 & 2 & 1760.9770 & 1760.9763 & 881.4954 & 0.0007 & 0.3971 & 959.097 & 1126.528 & 380.115 & 1483.774 & Yes \\
\hline
\end{tabular} $\begin{array}{llllllllllllllllll}\text { NLANTVTEEILEK } & 1.00 & 75.13 & 26.51 & 26.26 & 2 & 1760.9778 & 1760.9763 & 881.4954 & 0.0015 & 0.8508 & 2553.299 & 2599.837 & 1076.687 & 3948.379 & \text { Yes }\end{array}$ $\begin{array}{llllllllllllllll}\text { NLANTVTEEILEK } & 1.00 & 35.51 & 26.44 & 29.80 & 3 & 1760.9788 & 1760.9763 & 587.9994 & 0.0025 & 1.4172 & 84.623 & 103.157 & 96.691 & 84.484 & \text { Yes }\end{array}$ $\begin{array}{lllllllllllllllll}\text { NLANTVTEEILEK } & 1.00 & 61.09 & 26.46 & 27.70 & 3 & 1760.9797 & 1760.9763 & 587.9994 & 0.0034 & 1.9274 & 336.600 & 270.798 & 313.526 & 515.876 & \text { Yes }\end{array}$ $\begin{array}{llllllllllllllll}\text { DLFEDELVPLFEK } & 1.00 & 71.07 & 27.63 & 26.93 & 2 & 1881.0022 & 1881.0015 & 941.5080 & 0.0007 & 0.3717 & 64.185 & 47.994 & 21.925 & 151.578 & \text { Yes }\end{array}$ $\begin{array}{llllllllllllllll}\text { DLEGENIEIVFAKPPDQK } & 0.55 & 61.53 & 24.96 & 74.53 & 3 & 2473.3441 & 2473.3430 & 825.4549 & 0.0011 & 0.4442 & 437.984 & 484.278 & 690.484 & 693.605 & \text { Yes }\end{array}$ $\begin{array}{lllllllllllllllll}\text { NLANTVTDEDIDEKAK } & 0.60 & 40.87 & 26.60 & 53.87 & 3 & 2941.4449 & 2941.4412 & 981.4877 & 0.0037 & 1.2566 & 9.081 & 21.509 & 66.576 & 18.846 & \text { No }\end{array}$ $\begin{array}{lllllllllllllllll}\text { NLANTVTEEILEK } & 1.00 & 76.48 & 26.51 & 31.32 & 2 & 1760.9778 & 1760.9763 & 881.4954 & 0.0015 & 0.8508 & 262.671 & 333.332 & 87.568 & 584.529 & \text { Yes }\end{array}$ \begin{tabular}{llllllllllllllll} 
NLANTVTEEILEK & 1.00 & 84.68 & 26.46 & 26.78 & 2 & 1760.9784 & 1760.9763 & 881.4954 & 0.0021 & 1.1912 & 153.447 & 167.033 & 90.179 & 177.275 & Yes \\
\hline
\end{tabular} $\begin{array}{llllllllllllllll}\text { NLANTVTEEILEK } & 1.00 & 63.71 & 26.44 & 30.51 & 3 & 1760.9788 & 1760.9763 & 587.9994 & 0.0025 & 1.4172 & 121.120 & 105.916 & 49.821 & 103.324 & \text { Yes } \\ \text { NLANTVTEEILEK } & 1.00 & 37.10 & 26.37 & 32.14 & 3 & 176.9794 & 176.9763 & 587.9994 & 0.0031 & 1.7574 & 70.22 & 66.81 & 5.72 & 84.58 & \text { Yes }\end{array}$ $\begin{array}{llllllllllllllll}\text { VWANGVIEEILEK } & 1.00 & 37.10 & 26.37 & 32.14 & 3 & 1760.9794 & 1760.9763 & 587.9994 & 0.0031 & 1.7574 & 70.229 & 66.871 & 51.726 & 84.585 & \text { Yes } \\ \text { VWGCTEWAPIEPDPEVMAK } & 1.00 & 82.59 & 26.66 & 27.73 & 3 & 2941.4452 & 2941.4412 & 981.4877 & 0.0040 & 1.3585 & 37.995 & 23.610 & 0.000 & 16.696 & \text { No }\end{array}$

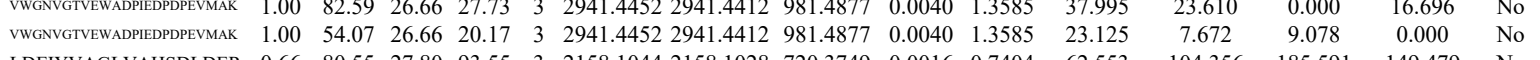

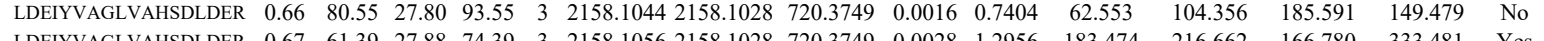

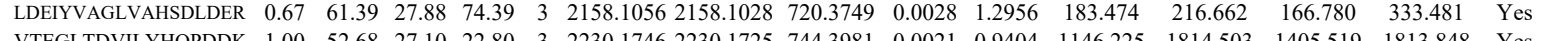

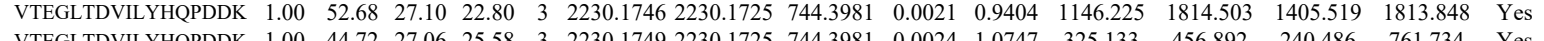
\begin{tabular}{lllllllllllllllll}
\hline &
\end{tabular}

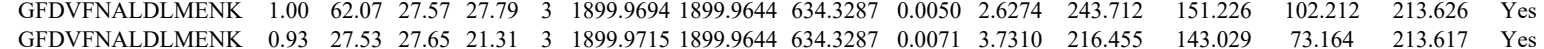

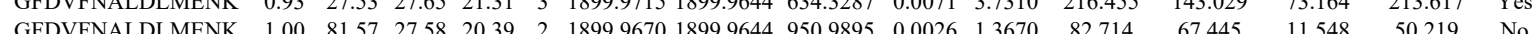

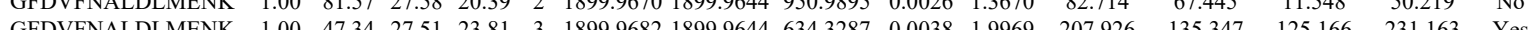

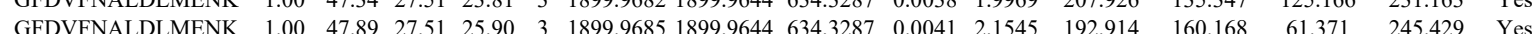

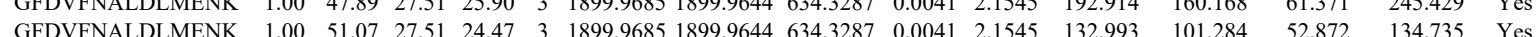

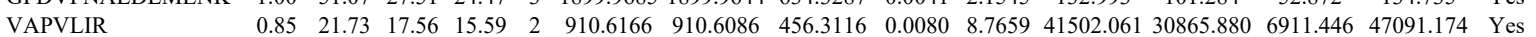
$\begin{array}{lllllllllllllllll}\text { VAPVLIR } & 0.85 & 21.73 & 17.56 & 15.59 & 2 & 910.6166 & 910.6086 & 456.3116 & 0.0080 & 8.7659 & 41502.061 & 30865.880 & 6911.446 & 47091.174 & \text { Yes } \\ \text { VAPVLIR } & 0.91 & 22.11 & 16.99 & 19.02 & 2 & 910.6172 & 910.6086 & 456.3116 & 0.0086 & 9.4233 & 35397.470 & 29688.022 & 5348.800 & 37391.491 & \text { Yes }\end{array}$

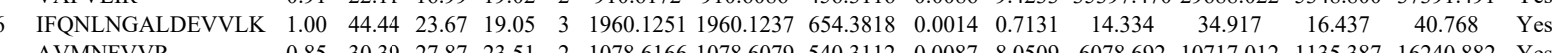

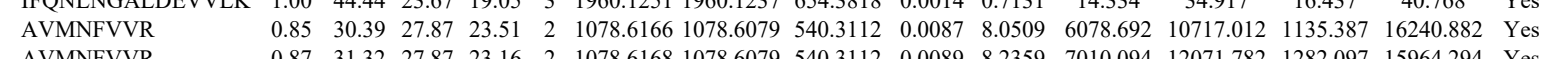

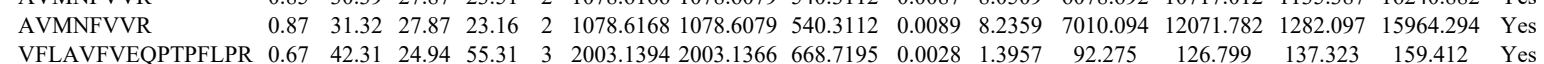

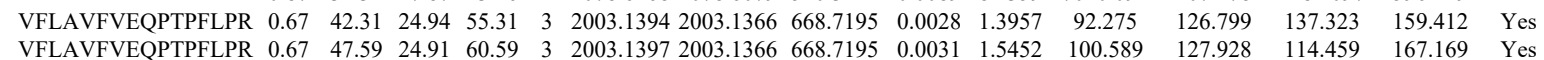

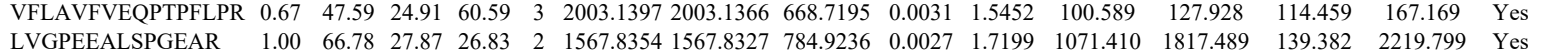
$\begin{array}{lllllllllllllllll}42 & \text { MPYQEIK } & 0.82 & 27.38 & 26.74 & 25.34 & 2 & 1195.6628 & 1195.6514 & 598.8330 & 0.0114 & 9.5184 & 1170.170 & 1827.949 & 1849.956 & 1982.317 & \text { Yes }\end{array}$ $\begin{array}{llllllllllllllll} & 33.85\end{array}$ $\begin{array}{llllllllllllllll}\text { AMDPAVPNMMIDAAK } & 1.00 & 68.40 & 27.55 & 19.44 & 2 & 1861.9368 & 1861.9344 & 931.9745 & 0.0024 & 1.2876 & 176.711 & 99.317 & 111.990 & 198.586 & \text { Yes }\end{array}$ $\begin{array}{llllllllllllllll}\text { HLQIEIEGLIDQMIDK } & 0.59 & 10.80 & 25.75 & 18.60 & 3 & 2182.1950 & 2182.1911 & 728.4043 & 0.0039 & 1.7847 & 38.293 & 35.014 & 25.735 & 27.410 & \text { Yes }\end{array}$ $\begin{array}{llllllllllllllllll}\text { LQFSEVINREIVVTAACEELR } & 1.00 & 64.49 & 26.05 & 19.77 & 3 & 3165.6322 & 3165.6293 & 1056.2170 & 0.0029 & 0.9152 & 426.548 & 332.891 & 673.848 & 839.210 & \text { Yes }\end{array}$ $\begin{array}{llllllllllllllll} & \end{array}$ $\begin{array}{llllllllllllllll}\text { LQFEEQVENIKPEIVSVTAACEELR } & 1.00 & 43.75 & 26.06 & 56.75 & 4 & 3165.6349 & 3165.6293 & 792.4146 & 0.0056 & 1.7667 & 15.883 & 15.029 & 9.373 & 18.712 & \text { Yes }\end{array}$

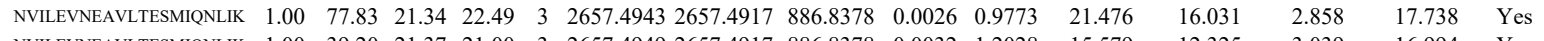

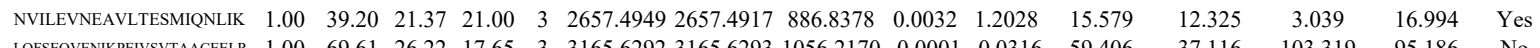
$\begin{array}{llllllllllllllll}\text { LQFEEQVENIRPEIVSVAAACEELR } & 1.00 & 69.61 & 26.22 & 17.65 & 3 & 3165.6292 & 3165.6293 & 1056.2170 & -0.0001 & -0.0316 & 59.406 & 37.116 & 103.319 & 95.186 & \text { No }\end{array}$

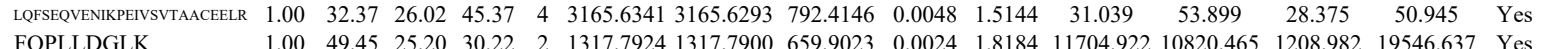
$\begin{array}{llllllllllllllll}\text { FQPLLDGLK } & 1.00 & 49.45 & 25.20 & 30.22 & 2 & 1317.7924 & 1317.7900 & 659.9023 & 0.0024 & 1.8184 & 11704.922 & 10820.465 & 1208.982 & 19546.637 & \text { Yes }\end{array}$ \begin{tabular}{llllllllllllllll} 
FQPLLDGLK & 1.00 & 50.51 & 25.02 & 31.15 & 2 & 1317.7934 & 1317.7900 & 659.9023 & 0.0034 & 2.5761 & 12304.232 & 8131.439 & 1188.393 & 17726.969 & Yes \\
\hline
\end{tabular}

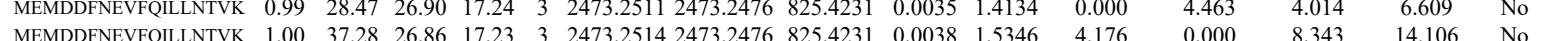

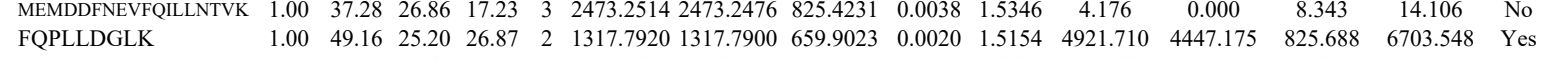

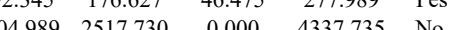


$\begin{array}{llllllllllll}\text { VGCLQLINALITPAEELDFR } & 1.00 & \text { \#\#\# } 26.75 & 26.56 & 2 & 2404.2634 & 2404.2616 & 1203.1381 & 0.0018 & 0.7480 & 8.723\end{array}$ $\begin{array}{llllllllllllll} & \end{array}$ TAQNLSIFLGSF $\begin{array}{llllllllllll}\text { TAQNLSIFLGSFR } & 1.00 & 76.11 & 27.49 & 23.66 & 2 & 1596.8752 & 1596.8746 & 799.4446 & 0.0006 & 0.3753 & 382.414\end{array}$ $\begin{array}{llllllllllll}\text { TAQNLSIFLGSFR } & 1.00 & 70.28 & 27.57 & 23.74 & 2 & 1596.8742 & 1596.8746 & 799.4446 & -0.0004 & -0.2502 & 324.522\end{array}$ $\begin{array}{lllllllllllll}\text { TAQNLSIFLGSFR } & 0.98 & 29.80 & 27.48 & 19.34 & 3 & 1596.8749 & 1596.8746 & 533.2988 & 0.0003 & 0.1875 & 20.027\end{array}$

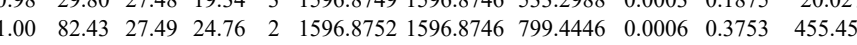
$\begin{array}{lllllllllllll}0.69 & 12.88 & 27.11 & 17.57 & 3 & 1596.8770 & 1596.8746 & 533.2988 & 0.0024 & 1.5001 & 15.395\end{array}$

$\begin{array}{llllllllllll}1.00 & 49.12 & 27.50 & 25.00 & 2 & 1596.8750 & 1596.8746 & 799.4446 & 0.0004 & 0.2502 & 570.338\end{array}$

$\begin{array}{lllllllllllll}\text { DVQNFPAATDEKDK } & 1.00 & 49.37 & 27.76 & 19.66 & 3 & 2009.0449 & 2009.0431 & 670.6883 & 0.0018 & 0.8946 & 8970.351 \\ \text { QDLEAEVSOLTGEVAK } & 1.00 & 82.11 & 27.60 & 22.66 & 2 & 2004.0634 & 2004.0619 & 1003.0382 & 0.0015 & 0.7477 & 372.800\end{array}$ $\begin{array}{lllllllllllll} & \text { QDLAEVSQLTGEVAK } & 1.00 & 82.11 & 27.60 & 22.66 & 2 & 2004.0634 & 2004.0619 & 1003.0382 & 0.0015 & 0.7477 & 372.800\end{array}$

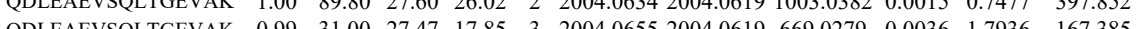
QDLEAEVSQLTGEVAK FPDELAHVEK

$\begin{array}{lllllllllll}0.60 & 20.82 & 27.47 & 33.82 & 3 & 2004.0655 & 2004.0619 & 669.0279 & 0.0036 & 1.7936\end{array}$ 148.896 VSGAQEMVSSAK

$\begin{array}{llllllllllll}41.01 & 27.44 & 21.44 & 3 & 1471.7965 & 1471.7915 & 491.6044 & 0.0050 & 3.3902 & 4257.484\end{array}$

20.584

\section{VSGAQEMVSSAK}

$\begin{array}{llllllllllll}.00 & 95.88 & 27.77 & 29.36 & 2 & 1480.7944 & 1480.7799 & 741.3972 & 0.0145 & 9.7787 & 862.682 & 8\end{array}$ $\begin{array}{lllllllllllll}\text { LGQMVLSGVDTVLGK } & 1.00 & 62.58 & 23.94 & 22.62 & 2 & 1804.0394 & 1804.0372 & 903.0259 & 0.0022 & 1.2181 & 596.284\end{array}$ $\begin{array}{llllllllllllll}\text { LGQMVLSGVDTVLGK } & 1.00 & 39.14 & 23.71 & 16.48 & 2 & 1804.0404 & 1804.0372 & 903.0259 & 0.0032 & 1.7718 & 228.369 & 1\end{array}$ $\begin{array}{lllllllllllll}\text { AQEALLQLSQALSLMETVK } & 1.00 & 30.27 & 23.20 & 15.84 & 3 & 2360.3266 & 2360.3228 & 787.7815 & 0.0038 & 1.6079 & 40.571 & \\ \end{array}$ $\begin{array}{llllllllllllll} & \end{array}$ $\begin{array}{lllllllllll} & \end{array}$ LGQMVLSGVDTVLGK $\begin{array}{llllllllllll}0.00 & 46.87 & 23.60 & 18.89 & 3 & 1804.0399 & 1804.0372 & 602.3530 & 0.0027 & 1.4941 & 85.838\end{array}$ $\begin{array}{llllllllllllll}\text { LGQMVLSGVDTVLGK } & 0.60 & 60.62 & 23.65 & 73.62 & 3 & 1804.0408 & 1804.0372 & 602.3530 & 0.0036 & 1.9922 & 87.644 & 14\end{array}$

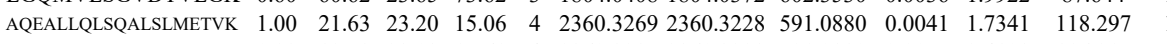
$\begin{array}{llllllllllllll}\text { AQEALLQLSQALSLMETVK } & 0.99 & 12.78 & 23.03 & 17.61 & 4 & 2360.3285 & 2360.3228 & 591.0880 & 0.0057 & 2.4108 & 116.215 & 78 . & \\ \text { AQEALLLSQALSLMETVK } & 0.77 & 11.71 & 23.20 & 15.45 & 3 & 2360.3266 & 2360.3228 & 787.7815 & 0.0038 & 1.6079 & 19.992\end{array}$ $\begin{array}{llllllllllllll}\text { AQEALLQLSQALSLMETVK } & 0.77 & 11.71 & 23.20 & 15.45 & 3 & 2360.3266 & 2360.3228 & 787.7815 & 0.0038 & 1.6079 & 19.992\end{array}$ $\begin{array}{lllllllllllllll}\text { SVVTGGVQSVMGSR } & 1.00 & 96.86 & 28.33 & 22.35 & 2 & 1506.8080 & 1506.7946 & 754.4046 & 0.0134 & 8.8811 & 14825.165 & 8591.165 & 320\end{array}$ $\begin{array}{lllllllllllllllllll} & \end{array}$ $\begin{array}{llllllllllllllll} & \end{array}$ $\begin{array}{lllllllllllllllll} & \end{array}$ $\begin{array}{llllllllllllll} & \end{array}$

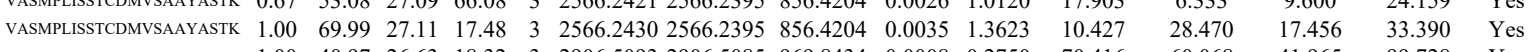

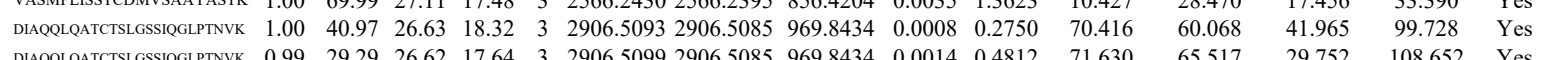

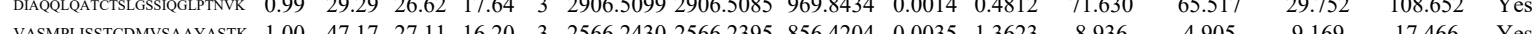

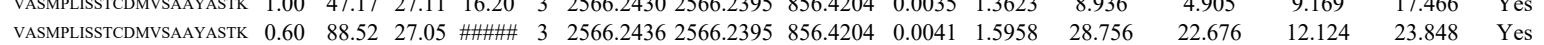


VSPCLPVLSR

VSPCLPVLSR

VSPCLPVLSR

VSPCLPVLSR

VSPCLPVLSR
VSPCLPVLSR

VSPCLPVLSR
VSPCLPVLSR

VSPCLPVLSR

EPSPPIDEVINTPR

IIDSLFNTVTDK
IIDSLFNTVTDK $\begin{array}{lllllllllll} & & & & & & & & & & \\ \text { LEENLPILQQPTEK }\end{array}$ $\begin{array}{lllllllllll}0.55 & 64.29 & 26.63 & 77.29 & 3 & 2906.5093 & 2906.5085 & 969.8434 & 0.0008 & 0.2750 & 41.746\end{array}$ $\begin{array}{llllllllllll}1.00 & 88.88 & 26.63 & 26.47 & 3 & 2906.5105 & 2906.5085 & 969.8434 & 0.0020 & 0.6874 & 47.227\end{array}$ $\begin{array}{lllllllllllll}1.00 & 34.80 & 27.81 & 20.88 & 3 & 1757.9311 & 1757.9279 & 586.9832 & 0.0032 & 1.8172 & 963.178\end{array}$ $\begin{array}{llllllllllll}0.60 & 28.88 & 27.72 & 41.88 & 3 & 1757.9323 & 1757.9279 & 586.9832 & 0.0044 & 2.4986 & 715.994\end{array}$

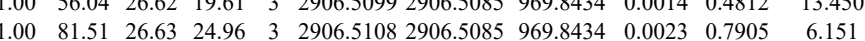
$\begin{array}{lllllllllll}0.96 & 27.52 & 27.68 & 24.96 & 3 & 2906.5108 & 2906.5085 & 969.8434 & 0.0023 & 0.7905 & 6.151 \\ 0 & 27.65 & 3 & 1582.8589 & 1582.8558 & 528.6259 & 0.0031 & 1.9547 & 5531.424 & 5\end{array}$ $\begin{array}{llllllllllll}0.97 & 27.70 & 27.11 & 28.82 & 3 & 1582.8595 & 1582.8558 & 528.6259 & 0.0037 & 2.3331 & 7739.597\end{array}$ $\begin{array}{llllllllllll}1.00 & 70.15 & 25.09 & 37.32 & 2 & 1939.0866 & 1939.0869 & 970.5507 & -0.0003 & -0.1546 & 142.719\end{array}$

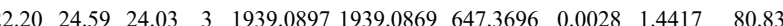
$\begin{array}{lllllllllllll}1.00 & 40.86 & 24.59 & 22.15 & 3 & 1939.0900 & 1939.0869 & 647.3696 & 0.0031 & 1.5962 & 209.497 & 187.45\end{array}$ $\begin{array}{llllllllllll}0.94 & 27.34 & 28.32 & 23.24 & 2 & 1259.6876 & 1259.6852 & 630.8499 & 0.0024 & 1.9022 & 1226.506 & 1095.677\end{array}$ $\begin{array}{llllllllllllll}0.94 & 29.99 & 28.32 & 26.32 & 2 & 1259.6878 & 1259.6852 & 630.8499 & 0.0026 & 2.0607 & 1407.899 & 1075.285\end{array}$ $\begin{array}{llllllllllll} & & \end{array}$ $\begin{array}{lllllllllllll}1.99 & 34.73 & 28.41 & 21.60 & 2 & 1259.6866 & 1259.6852 & 630.8499 & 0.0014 & 1.1096 & 2716.175 & 2653.646\end{array}$ $\begin{array}{llllllllllllll}100 & 46.14 & 28.37 & 22.69 & 2 & 1259.6858 & 12596852 & 630.8499 & 0.0006 & 0.4755 & 2209.651 & 1720.863\end{array}$ $\begin{array}{lllllllllllll}1.00 & 41.69 & 28.45 & 21.57 & 2 & 1259.6860 & 1259.6852 & 630.8499 & 0.0008 & 0.6341 & 2157.727 & 2168302\end{array}$ $\begin{array}{llllllllllll}0.98 & 38.47 & 28.56 & 23.30 & 2 & 1259.6852 & 1259.6852 & 630.8499 & 0.0000 & 0.0000 & 698.360 & 679.175\end{array}$ $\begin{array}{llllllllllll}1.99 & 38.11 & 28.37 & 30.70 & 2 & 1259.6858 & 1259.6852 & 630.8499 & 0.0006 & 0.4755 & 827.299 & 7\end{array}$ $\begin{array}{llllllllllll}1.00 & 69.79 & 28.34 & 24.27 & 2 & 1706.8950 & 1706.8961 & 854.4553 & -0.0011 & -0.6437 & 156.025\end{array}$ $\begin{array}{llllllllllll}1.00 & 78.28 & 26.73 & 25.56 & 2 & 1652.9236 & 1652.9229 & 827.4687 & 0.0007 & 0.4230 & 544.138\end{array}$ $\begin{array}{llllllllllllll}1.00 & 64.63 & 26.69 & 25.00 & 2 & 1652.9248 & 1652.9229 & 827.4687 & 0.0019 & 1.1481 & 614.632\end{array}$ $\begin{array}{llllllllll}0.66 & \# \# \# \text { 25.88 \#\#\#\# } 3 \quad 3240.54523240 .5434 & 1081.1884 & 0.0018 & 0.5549 & 1.024\end{array}$ $\begin{array}{lllllllllll}0.66 & 75.87 & 25.88 & 88.87 & 3 & 3240.5452 & 3240.5434 & 1081.1884 & 0.0018 & 0.5549 & 8.115\end{array}$ $\begin{array}{lllllllllll}.00 & 23.41 & 25.98 & 36.41 & 4 & 3240.5477 & 3240.5434 & 811.1431 & 0.0043 & 1.3253 & 3.310\end{array}$ $\begin{array}{lllllllllll}1.00 & 38.38 & 26.01 & 17.62 & 4 & 3240.5481 & 3240.5434 & 811.1431 & 0.0047 & 1.4486 & 7.823\end{array}$

$\begin{array}{llllllllllllll}\text { VLDGLHNELQTIGFIETIGK } & 1.00 & 43.31 & 22.92 & 56.31 & 4 & 2612.4481 & 2612.4417 & 654.1177 & 0.0064 & 2.4460 & 94.544\end{array}$ $\begin{array}{llllllllllll}\text { CTND1_HUMAl } & \text { O60716 } & \text { CTNND1 } & \text { Catenin delta-1 } & 108.17 & 1.00 & 17 & 24 & 0.0373 & 0.4656 & 0.6789 & 0.4572\end{array}$

QDVYGPQPQVR $\begin{array}{llllllllllll}1.00 & 88.22 & 27.39 & 24.29 & 3 & 1930.9705 & 1930.9668 & 644.6629 & 0.0037 & 1.9131 & 152.762\end{array}$ VQALCAVYEHWVPR

QDVYGPQPQVR

GYELLFQPEVVR

ALSAIADLLTNEHER GSLASLDSLRK DMDLTEVITGTLWNLSSHDSIK YRPSMEGYR

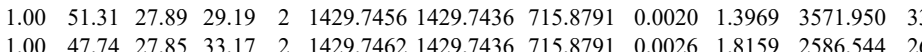
$\begin{array}{llllllllll} & \end{array}$ $\begin{array}{llllllllllll}1.00 & 73.03 & 27.82 & 32.20 & 3 & 1795.9579 & 1795.9550 & 599.6589 & 0.0029 & 1.6120 & 211.579 & 46\end{array}$ $\begin{array}{lllllllllllll}1.00 & 96.56 & 27.66 & 24.22 & 3 & 1795.9594 & 1795.9550 & 599.6589 & 0.0044 & 2.4458 & 353.346 & 301 .\end{array}$ $\begin{array}{llllllllllll}0.54 & 18.92 & 28.59 & 27.41 & 2 & 1145.6436 & 1145.6404 & 573.8275 & 0.0032 & 2.7883 & 4090.007 \\ 0.60 & 81.01 & 27.47 & 94.01 & 3 & 2762.4082 & 2762.4040 & 921.8086 & 0.0042 & 1.5188 & 89.047\end{array}$

$469.027 \quad 131.4$
469.027
301.048

50.831 19.577 $\begin{array}{lllllllllll}0.83 & 20.00 & 27.08 & 16.19 & 3 & 1301.6305 & 1301.6308 & 434.8842 & -0.0003 & -0.2299 & 21656.724\end{array}$

LVLINK

GIPVLVGLLDHPK

KGGPPPPNWR

KGGPPPPNWR

GIPVLVGLLDHPK

GIPVLVGLLDHPK

KGGPPPPNWR

QPELPEVIAMLGFR

QPELPEVIAMLGFR

QPELPEVIAMLGF

LVENCVCLLR

LVENCVCLLR

LVENCVCLLR

LVENCVCLLR

$\begin{array}{llllllllll}0.83 & 80.78 & 26.70 & 24.81 & 3 & 3129.5902 & 3129.5887 & 1044.2035 & 0.0015 & 0.4788\end{array}$

19.416

9.146

1.881 $\begin{array}{llllllllllllllll}1.00 & 71.84 & 18.69 & 22.07 & 3 & 1645.0207 & 1645.0171 & 549.3463 & 0.0036 & 2.1844 & 1900.342 & 2003.065 & 1007.137 & 3433.697 & \text { Yes }\end{array}$ $\begin{array}{llllllllllllllll}0.99 & 30.59 & 27.16 & 17.09 & 3 & 1392.7885 & 1392.7870 & 465.2696 & 0.0015 & 1.0746 & 1105.519 & 1058.311 & 701.651 & 2535.926 & \text { Yes } & \\ \end{array}$ $\begin{array}{lllllllllllllll}1.00 & 78.55 & 18.86 & 24.73 & 3 & 13945.0204 & 1645.0171 & 549.3463 & 0.0033 & 2.0746 & 879.738 & 895.959 & 533.848 & 2112.681 & \text { Yes } \\ 0\end{array}$ $\begin{array}{llllllllllllllll}0.60 & 65.37 & 18.45 & 78.37 & 3 & 1645.0216 & 1645.0171 & 549.3463 & 0.0045 & 2.7305 & 3265.836 & 2518.297 & 1685.056 & 4216.104 & \text { Yes }\end{array}$ $\begin{array}{llllllllllllllll}0.98 & 27.42 & 27.18 & 14.96 & 3 & 1392.7879 & 1392.7870 & 465.2696 & 0.0009 & 0.6448 & 709.215 & 673.269 & 425.643 & 1028.355 & \text { Yes }\end{array}$ $\begin{array}{lllllllllllllll}0.99 & 30.61 & 27.05 & 26.54 & 3 & 1742.9536 & 1742.9511 & 581.9910 & 0.0025 & 1.4319 & 62.973 & 54.883 & 21.574 & 77.005 & \text { Yes }\end{array}$ $\begin{array}{lllllllllllllll}1.00 & 34.92 & 27.08 & 23.88 & 3 & 1742.9539 & 1742.9511 & 581.9910 & 0.0028 & 1.6037 & 55.825 & 79.160 & 21.560 & 62.300 & \text { Yes }\end{array}$ $\begin{array}{lllllllllllllll}0.98 & 34.31 & 27.07 & 24.09 & 2 & 1742.9544 & 1742.9511 & 872.4828 & 0.0033 & 1.8912 & 46.944 & 25.261 & 51.033 & 85.575 & \text { Yes }\end{array}$ $\begin{array}{llllllllllllllll}1.00 & 50.56 & 27.03 & 22.08 & 2 & 1396.6858 & 1396.6821 & 699.3483 & 0.0037 & 2.6453 & 7652.501 & 7207.846 & 425.971 & 16534.182 & \text { Yes }\end{array}$ $\begin{array}{llllllllllllllll}0.99 & 49.11 & 27.16 & 21.68 & 2 & 1396.6866 & 1396.6821 & 699.3483 & 0.0045 & 3.2173 & 5645.409 & 6834.256 & 495.486 & 12791.630 & \text { Yes }\end{array}$ $\begin{array}{llllllllllllllll}1.00 & 63.25 & 26.81 & 26.36 & 2 & 1396.6844 & 1396.6821 & 699.3483 & 0.0023 & 1.6444 & 1366.715 & 1337.547 & 135.426 & 2819.501 & \text { Yes }\end{array}$

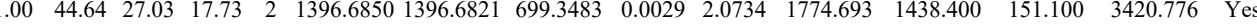
$\begin{array}{lllllllllllllllll}\text { TPAILEASAGAIQNLCAGR } & 1.00 & 60.21 & 27.55 & 23.55 & 3 & 2045.0536 & 2045.0519 & 682.6912 & 0.0017 & 0.8300 & 60.571 & 23.874 & 21.027 & 38.671 & \text { No }\end{array}$

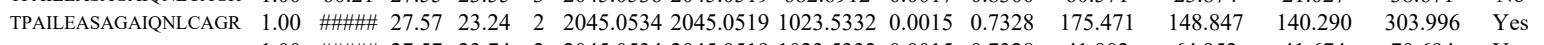
$\begin{array}{lllllllllllllll}\text { TPAILEASAGAIQNLCAGR } & 1.00 & \text { \#\#\#\# } 27.57 & 23.74 & 2 & 2045.0534 & 2045.0519 & 1023.5332 & 0.0015 & 0.7328 & 41.902 & 64.952 & 41.674 & 70.694 & \text { Yes }\end{array}$

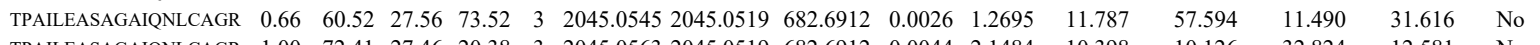
$\begin{array}{llllllllllllllll}\text { TPAILEASAGAIQNLCAGR } & 1.00 & 72.41 & 27.46 & 20.38 & 3 & 2045.0563 & 2045.0519 & 682.6912 & 0.0044 & 2.1484 & 10.398 & 10.126 & 32.824 & 12.581 & \text { No }\end{array}$

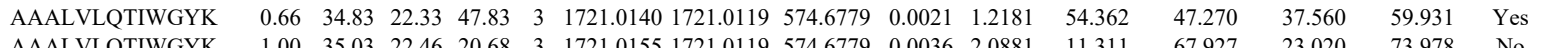

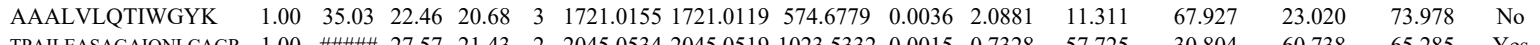

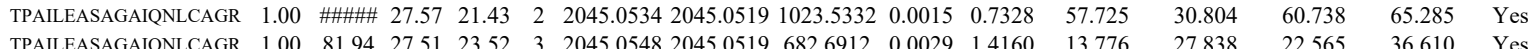

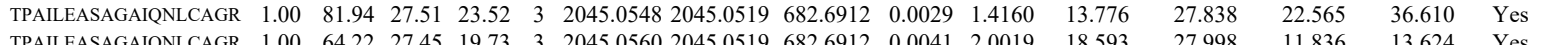

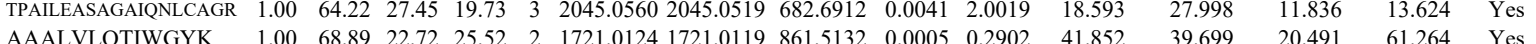

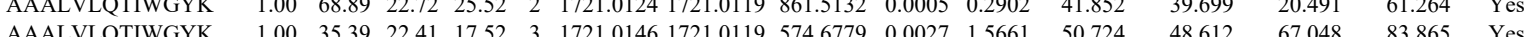
$\begin{array}{lllllllllllll} & \text { AAALVLQTIWGYK } & 1.00 & 40.32 & 22.53 & 20.76 & 3 & 1721.0152 & 1721.0119 & 574.6779 & 0.0033 & 1.9141 & 44.504\end{array}$ 
$\begin{array}{llllllllllll} & 235.2685 & 2345.2647 & 587.3235 & 0.0042 & 1.7878 & 897.676\end{array}$

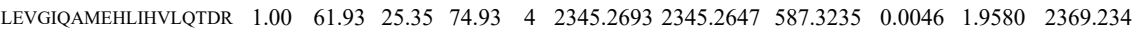
$\begin{array}{lllllllllllll}\text { LEVGILAMEHLIHVLQTDR } & 1.00 & 49.81 & 25.45 & 20.71 & 4 & 2345.2685 & 2345.2647 & 587.3235 & 0.0038 & 1.6175 & 608.750 & 772.838 \\ \text { LEVGIQAMEHLIHLLOTDR } & 1.00 & 57.00 & 25.42 & 19.54 & 4 & 2345.2689 & 2345.2647 & 587.3235 & 0.0042 & 1.7878 & 775.787 & 1009.590\end{array}$ $\begin{array}{lllllllllllll}\text { NDGVLLLQALTR } & 1.00 & 61.26 & 25.29 & 25.22 & 2 & 1455.8538 & 1455.8531 & 728.9338 & 0.0007 & 0.4802 & 434.416 & 383.552\end{array}$ $\begin{array}{llllllllllllllll} & \text { QLGPQVQQIILVSPMGVSR } & 0.82 & 95.36 & 23.38 & \# \# \# \text { } & 2 & 2193.2434 & 2193.2426 & 1097.6286 & 0.0008 & 0.3644 & 146.931 & 144.790\end{array}$ $\begin{array}{lllllllllllll}\text { QLGPQVQQIILVSPMGVSR } & 0.66 & 23.13 & 23.40 & 36.13 & 3 & 2193.2443 & 2193.2426 & 732.0881 & 0.0017 & 0.7740 & 40.110\end{array}$ $\begin{array}{llllllllllll} & \end{array}$ $\begin{array}{llllllllllllll} & 2 & 2193.2434 & 2193.2426 & 1097.6286 & 0.0008 & 0.3644 & 174.598\end{array}$ $\begin{array}{lllllllllllll} & \end{array}$

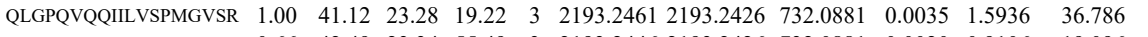
$\begin{array}{lllllllllllll}\text { QLGPQVQQIILVSPMGVSR } & 0.66 & 42.49 & 23.34 & 55.49 & 3 & 2193.2446 & 2193.2426 & 732.0881 & 0.0020 & 0.9106 & 19.096\end{array}$ $\begin{array}{llllllllllll}\text { VTNLHLMLQLVR } & 1.00 & 38.95 & 22.60 & 16.95 & 3 & 1579.9366 & 1579.9354 & 527.6524 & 0.0012 & 0.7581 & 89.141\end{array}$ $\begin{array}{lllllllllllll}\text { VTNLHLMLQLVR } & 1.00 & 51.96 & 22.60 & 18.52 & 3 & 1579.9366 & 1579.9354 & 527.6524 & 0.0012 & 0.7581 & 67.275 \\ \text { EQDDLLVLLADQDQK } & 1.00 & 78.08 & 27.08 & 22.48 & 2 & 2030.0794 & 2030.0775 & 1016.0460 & 0.0019 & 0.9350 & 31.216\end{array}$ $\begin{array}{llllllllllll}\text { EQDDLLVLLADQDQK } & 1.00 & 78.08 & 27.08 & 22.48 & 2 & 2030.0794 & 2030.0775 & 1016.0460 & 0.0019 & 0.9350 & 31.216 \\ \text { EQDDLIVLLADQDQK } & 0.93 & 19.58 & 26.99 & 16.98 & 3 & 2030.0803 & 2030.0775 & 677.6998 & 0.0028 & 1.3772 & 105.627\end{array}$ $\begin{array}{llllllllllll}\text { EQDDLLVLLADQDQK } & 0.93 & 19.58 & 26.99 & 16.98 & 3 & 2030.0803 & 2030.0775 & 677.6998 & 0.0028 & 1.3772 & 105.627\end{array}$

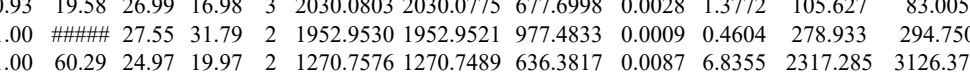

LDTSOWPLLLK

$\begin{array}{lllllllllllll}1.00 & 65.81 & 24.05 & 38.17 & 2 & 1600.9436 & 1600.9432 & 801.4789 & 0.0004 & 0.2495 & 247.933 & 448.202\end{array}$

$\begin{array}{lllllllllllllll} & \end{array}$ $\begin{array}{lllllll} & \end{array}$

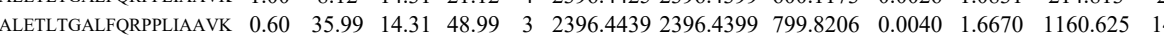
$\begin{array}{lllllllllllllll}\text { ALETLTGALFRRPLIAAVK } & 0.55 & 25.93 & 14.91 & 38.93 & 3 & 2396.4412 & 2396.4399 & 799.8206 & 0.0013 & 0.5418 & 914.038 & 963.5\end{array}$ $\begin{array}{llllllllllllll}\text { ALETLTGALFQRPPLIAAVK } & 1.00 & 26.85 & 14.91 & 39.85 & 4 & 2396.4413 & 2396.4399 & 600.1173 & 0.0014 & 0.5832 & 134.558\end{array}$ $\begin{array}{lllllllllllll}\text { ALETLIGALFORPPLIAAVK } & 1.00 & 17.00 & 14.31 & 30.00 & 4 & 2396.4421 & 2396.4399 & 600.1173 & 0.0022 & 0.9165 & 135.898 & 178 . \\ \text { ALETLTGALFQRPPIAAVK } & 0.66 & 42.51 & 14.31 & 55.51 & 3 & 2396.4424 & 2396.4399 & 799.8206 & 0.0025 & 1.0419 & 1485.666 & 1882 .\end{array}$

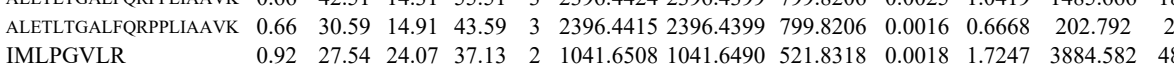

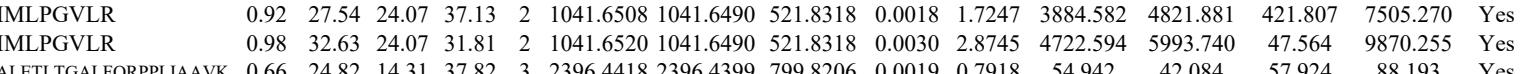

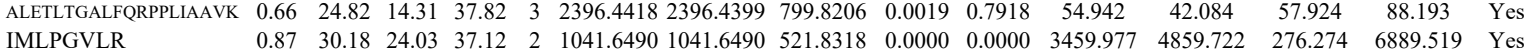
$\begin{array}{llllllllllllllll}\text { IMLPGVLR } & 0.97 & 32.59 & 24.03 & 31.73 & 2 & 1041.6490 & 1041.6490 & 521.8318 & 0.0000 & 0.0000 & 3569.163 & 4597.154 & 412.891 & 6911.642 & \text { Yes }\end{array}$ $\begin{array}{llllllllllllllll}\text { IMLPGVLR } & 0.99 & 37.22 & 24.03 & 32.81 & 2 & 1041.6492 & 1041.6490 & 521.8318 & 0.0002 & 0.1916 & 1012.279 & 997.606 & 46.376 & 1728.250 & \text { Yes }\end{array}$

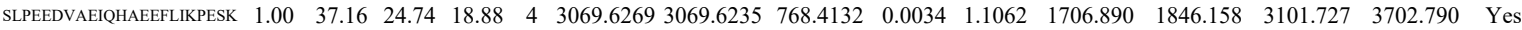
$\begin{array}{llllllllllllllllll} & \text { SLEEDVAELQHAEFFLIKESKK } & 1.00 & 29.82 & 24.74 & 17.64 & 4 & 3069.6293 & 3069.6235 & 768.4132 & 0.0058 & 1.8870 & 662.180 & 712.918 & 1572.574 & 1915.528 & \text { Yes }\end{array}$ $\begin{array}{llllllllllllllll}\text { SLPEEDVAEIOHAEEFLLKPESK } & 1.00 & 28.73 & 24.74 & 41.73 & 4 & 3069.6293 & 3069.6235 & 768.4132 & 0.0058 & 1.8870 & 114.600 & 146.786 & 215.884 & 211.936 & \text { Yes }\end{array}$ $\begin{array}{llllllllllllllll}\text { APQVVAEAAK } & 1.00 & 63.31 & 24.97 & 20.19 & 2 & 1270.7568 & 1270.7489 & 636.3817 & 0.0079 & 6.2069 & 2121.301 & 2312.355 & 5546.853 & 4973.868 & \text { Yes }\end{array}$ $\begin{array}{llllllllllllllll}\text { APQVVAEAAK } & 1.00 & 60.94 & 24.97 & 23.04 & 2 & 1270.7570 & 1270.7489 & 636.3817 & 0.0081 & 6.3641 & 2527.484 & 2832.991 & 6017.117 & 5571.713 & \text { Yes }\end{array}$ \begin{tabular}{llllllllllllllll} 
IPGMLIIDTPGHESFSNLR & 1.00 & 49.58 & 27.02 & 21.85 & 3 & 2240.1832 & 2240.1745 & 747.7321 & 0.0087 & 3.8784 & 714.053 & 1076.248 & 1056.521 & 918.763 & Yes \\
\hline
\end{tabular} $\begin{array}{lllllllllllllllll}\text { IPGMLIIDTPGHESFSNLR } & 1.00 & 56.68 & 26.96 & 24.77 & 3 & 2240.1844 & 2240.1745 & 747.7321 & 0.0099 & 4.4133 & 732.119 & 576.029 & 687.434 & 791.008 & \text { Yes } \\ \text { APIICVLGHVDTGK } & 1.00 & 6.44 & 26.76 & 18.14 & 3 & 1755.9643 & 1755.9619 & 586.3279 & 0.0024 & 1.364 & 2384.548 & 21.1552 & 1840.402 & 2427.989 & \text { Yes }\end{array}$ $\begin{array}{llllllllllllllll}\text { APIICVLGHVDTGK } & 1.00 & 60.44 & 26.76 & 18.14 & 3 & 1755.9643 & 1755.9619 & 586.3279 & 0.0024 & 1.3644 & 2384.548 & 2141.552 & 1840.402 & 2427.989 & \text { Yes } \\ \text { APIICVLGHVDTGK } & 0.67 & 55.27 & 26.67 & 68.27 & 3 & 1755.9649 & 1755.9619 & 5863279 & 0.0030 & 1.7055 & 1813.584 & 1813.190 & 1093.772 & 2192.469 & \text { Yes }\end{array}$

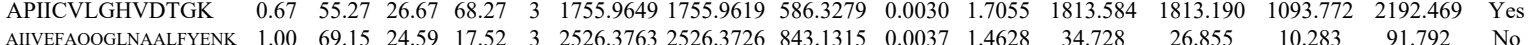
$\begin{array}{lllllllllllllll} & \end{array}$ $\begin{array}{llllllllllllll} & \end{array}$ 


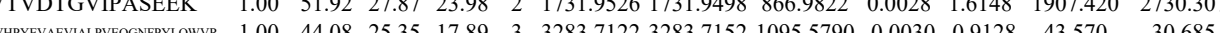

$\begin{array}{llllllllllll} & \end{array}$

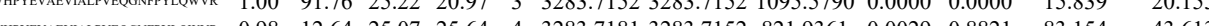

$\begin{array}{llllllllllllll}\text { SUHPYEAEVALLPVEGGNPPLLWVR } & 1.00 & 22.11 & 25.00 & 14.77 & 4 & 3283.7189 & 3283.7152 & 821.9361 & 0.0037 & 1.1254 & 52.341 & 72.629\end{array}$

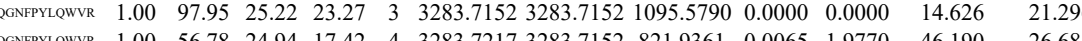

$\begin{array}{lllllllllllll}\text { TOSSLVPALTDFVR } & 1.00 & 72.23 & 27.59 & 31.30 & 2 & 1676.9224 & 1676.921 & 83994682 & 0.0005 & 0.9978 & 2517.415 & 1725233\end{array}$

$\begin{array}{llllllllllllll}\text { TQSSLVPALTDFVR } & 1.00 & 77.01 & 27.58 & 31.56 & 2 & 1676.9230 & 1676.9219 & 839.4682 & 0.0011 & 0.6552 & 1872.950 & 1643.337\end{array}$

$\begin{array}{lllllllllllllll}\text { TQSSLVPALTDFVR } & 1.00 & 61.46 & 27.51 & 28.44 & 2 & 1676.9234 & 1676.9219 & 839.4682 & 0.0015 & 0.8934 & 153.776 & 268.356\end{array}$

$\begin{array}{lllllllllllll}\text { LATGSDDNCAAFFEGPPFK } & 1.00 & 39.83 & 25.84 & 28.47 & 3 & 2320.0777 & 2320.0748 & 774.3655 & 0.0029 & 1.2483 & 4.815 & 5.720\end{array}$ $\begin{array}{lllllllllllll}\text { LATGSDDNCAAFFEGPPFK } & 0.97 & 23.71 & 25.84 & 17.99 & 3 & 2320.0786 & 2320.0748 & 774.3655 & 0.0038 & 1.6357 & 8.154\end{array}$

$\begin{array}{llllllllllll}0.99 & 8.23 & 19.40 & 21.23 & 4 & 1678.0285 & 1678.0255 & 420.5137 & 0.0030 & 1.7835 & 12055.046 & 12695.171\end{array}$

VFASLPQVER

VFASLPQVER

SIQCLTVHK

SIQCLTVHK

LYSILGTTLK

LYSILGTTLK

LYSILGTTLK

LYSILGTTLK

LYSILGTTLK

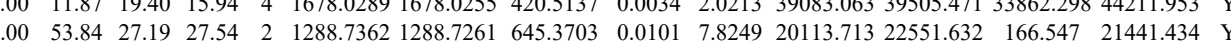
$\begin{array}{lllllllllllllllll}1.00 & 53.80 & 27.28 & 30.62 & 2 & 1288.7368 & 1288.7261 & 645.3703 & 0.0107 & 8.2897 & 14626.438 & 12194.144 & 513.635 & 14428.749 & \text { Yes }\end{array}$

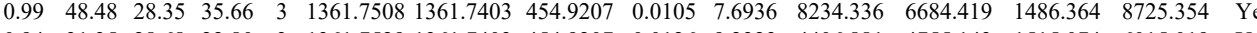
$\begin{array}{lllllllllllllll}0.94 & 31.35 & 28.68 & 22.80 & 3 & 1361.7529 & 1361.7403 & 454.9207 & 0.0126 & 9.2323 & 4406.881 & 4755.143 & 1515.074 & 6015.019 & \text { Yes }\end{array}$ $\begin{array}{llllllllllllllllll}1.00 & 48.01 & 21.34 & 18.20 & 2 & 1395.8584 & 1395.8581 & 698.9363 & 0.0003 & 0.2146 & 11619.890 & 12338.141 & 234.147 & 11803.572 & \text { Yes }\end{array}$ $\begin{array}{llllllllllllllll}1.00 & 56.25 & 21.34 & 18.08 & 2 & 1395.8586 & 1395.8581 & 698.9363 & 0.0005 & 0.3577 & 16976.055 & 17592.249 & 0.000 & 17487.767 & \text { No }\end{array}$ $\begin{array}{llllllllllllllll}0.50 & 2.85 & 2.37 & 15.85 & 3 & 1395.8605 & 1395.8581 & 466.2933 & 0.0024 & 1.7157 & 122.728 & 59.869 & 33.523 & 126.456 & \text { Yes }\end{array}$ $\begin{array}{llllllllllllllllll} & .50 & 48.08 & 20.37 & 16.62 & 2 & 1395.8602 & 1395.8581 & 698.9363 & 0.0021 & 1.5023 & 11507.364 & 10179.565 & 422.379 & 11661.287 & \text { Yes } & \\ \end{array}$ $\begin{array}{llllllllllllllll}1.00 & 50.68 & 19.91 & 17.31 & 2 & 1395.8614 & 1395.8581 & 698.9363 & 0.0033 & 2.3607 & 17195.860 & 13832.876 & 558.370 & 16390.996 & \text { Yes } & \\ \end{array}$

TIELSDDDFLGEC $\begin{array}{lllllllllllllll}0.96 & 34.95 & 26.19 & 26.75 & 2 & 1026.5748 & 1026.5654 & 514.2900 & 0.0094 & 9.1387 & 7292.819 & 6738.601 & 1310.513 & 6555.533 & \text { Yes }\end{array}$ LTRPLVMK $\begin{array}{llllllllllllllll}0.66 & 13.05 & 20.64 & 25.08 & 3 & 1244.7928 & 1244.7882 & 415.9367 & 0.0046 & 3.6864 & 18821.654 & 13446.763 & 11446.724 & 23348.402 & \text { Yes }\end{array}$ $\begin{array}{lllllllllllllllll} & 0.88 & 10.99 & 20.64 & 15.67 & 3 & 1244.7910 & 1244.7882 & 415.9367 & 0.0028 & 2.2439 & 7062.433 & 5671.595 & 3242.098 & 8214.485 & \text { Yes }\end{array}$ $\begin{array}{lllllllllllllll} & \end{array}$ $\begin{array}{llllllllllllllll}196.477 & 703.504 & \text { Yes } \\ \text { LYGPTNFSPINHVAR } & 1.00 & 78.73 & 26.45 & 18.08 & 3 & 1942.0588 & 1942.0547 & 6483588 & 0.0041 & 2.1079 & 402883 & 328.300 & 124.038 & 684.703 & \text { Yes }\end{array}$

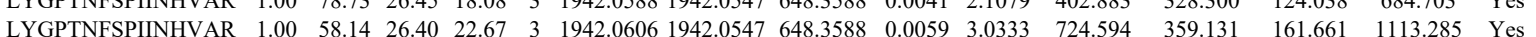

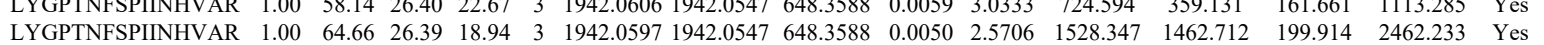
$\begin{array}{lllllllllllllllll}\text { SSPVEFECINEK } & 1.00 & 47.56 & 26.80 & 23.95 & 2 & 1714.8170 & 1714.8150 & 858.4148 & 0.0020 & 1.1649 & 625.290 & 453.642 & 968.343 & 1349.302 & \text { No }\end{array}$ SSPVEFECINEK
IGIGELITR

VALSHHLVAR CLTQQAVALQR VALSHHLVAR VALSHHLVAR CLTQQAVALQR CLTQQAVALQR $\begin{array}{llllllllllll}\text { DJC13 HUMAN O75165 } & \text { DNAJC13 DnaJ homolog sut 254.43 } & 1.00 & 2 & 1.3 & -0.0806 & 0.7660 & -0.3782 & 0.9162 & 3 & \text { IFIAQPAWVL }\end{array}$ $\begin{array}{ccccccccccccccc}1.00 & 47.56 & 26.80 & 23.95 & 2 & 1714.8170 & 1714.8150 & 858.4148 & 0.0020 & 1.1649 & 625.290 & 453.642 & 968.343 & 1349.302 & \text { No } \\ 0.99 & 34.19 & 25.07 & 25.09 & 2 & 1114.6866 & 1114.6832 & 558.3489 & 0.0034 & 3.0447 & 235.015 & 263.679 & 0.000 & 268.998 & \text { No }\end{array}$ $\begin{array}{lllllllllllllllll}0.98 & 27.78 & 25.79 & 18.20 & 3 & 1245.7429 & 1245.7428 & 416.2549 & 0.0001 & 0.0801 & 5216.326 & 5114.676 & 2240.220 & 6298.617 & \text { Yes }\end{array}$ $\begin{array}{lllllllllllllllll}1.00 & 74.24 & 28.69 & 33.47 & 2 & 1419.7588 & 1419.7448 & 710.8797 & 0.0140 & 9.8469 & 1049.967 & 1358.718 & 37.204 & 1920.126 & \text { Yes }\end{array}$ $\begin{array}{lllllllllllllllll}1.00 & 36.90 & 25.92 & 15.65 & 3 & 1245.7426 & 1245.7428 & 416.2549 & -0.0002 & -0.1602 & 2946.011 & 2896.617 & 3580.220 & 3438.941 & \text { Yes }\end{array}$ $\begin{array}{lllllllllllllllll}1.00 & 40.85 & 25.82 & 20.25 & 3 & 1245.7438 & 1245.7428 & 416.2549 & 0.0010 & 0.8008 & 2972.770 & 3166.377 & 3893.649 & 3675.578 & \text { Yes }\end{array}$ $\begin{array}{llllllllllllllll}1.00 & 66.01 & 28.57 & 33.06 & 2 & 1419.7568 & 1419.7448 & 710.8797 & 0.0120 & 8.4402 & 832.885 & 1389.984 & 90.251 & 1897.574 & \text { Yes }\end{array}$ $\begin{array}{lllllllllllllll}1.00 & 74.16 & 28.62 & 34.76 & 2 & 1419.7574 & 1419.7448 & 710.8797 & 0.0126 & 8.8622 & 1558.863 & 1834.678 & 73.000 & 2455.058 & \text { Yes }\end{array}$ $\begin{array}{lrllllllllllllll} & 1.00 & 46.11 & 22.86 & 16.24 & 2 & 1456.8696 & 1456.8676 & 729.4411 & 0.0020 & 1.3709 & 39.632 & 35.182 & 21.783 & 85.549 & \text { Yes } \\ \end{array}$ $\begin{array}{llllllllllllllll}\text { GALIYLLDMFCNSTHPQVR } & 1.00 & 65.86 & 27.97 & 18.48 & 3 & 2367.1684 & 2367.1659 & 790.0626 & 0.0025 & 1.0548 & 18.582 & 10.526 & 16.538 & 11.798 & \text { Yes }\end{array}$ $\begin{array}{llllllllllllllll} & & \end{array}$ \begin{tabular}{|llllllllllllllll} 
NPVTYR & 1.00 & 44.07 & 27.43 & 30.18 & 2 & 1728.9100 & 1728.9079 & 865.4612 & 0.0021 & 1.2132 & 507.384 & 291.169 & 108.328 & 674.803 & Yes \\
\end{tabular} $\begin{array}{llllllllllllll} & & & \end{array}$

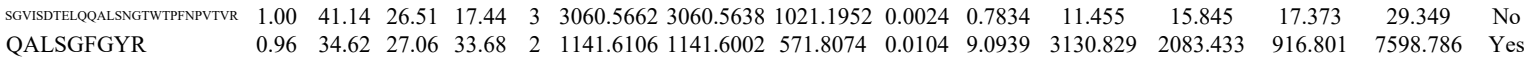

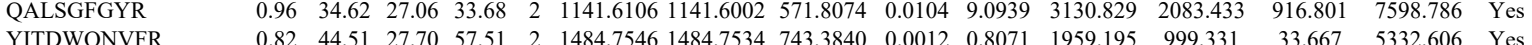
YITDWQNVFR $\begin{array}{lllllllllllllll}0.82 & 44.51 & 27.70 & 57.51 & 2 & 1484.7546 & 1484.7534 & 743.3840 & 0.0012 & 0.8071 & 1959.195 & 999.331 & 33.667 & 5332.606 & \text { Yes } \\ 1.00 & 57.03 & 27.70 & 17.78 & 2 & 1484.7546 & 184.7534 & 743.380 & 0.0012 & 0.8071 & 2954.334 & 1376.402 & 65.99 & 629.225 & \end{array}$ $\begin{array}{llllllllllllllll}1.00 & 57.03 & 27.70 & 17.78 & 2 & 1484.7546 & 1484.7534 & 743.3840 & 0.0012 & 0.8071 & 2954.334 & 1376.402 & 65.990 & 6294.225 & \text { Yes } \\ 1.00 & 49.64 & 27.70 & 18.67 & 2 & 1484.7546 & 1484.7534 & 743.3840 & 0.0012 & 0.8071 & 2322.267 & 1114.795 & 48.515 & 4913.965 & \text { Yes }\end{array}$

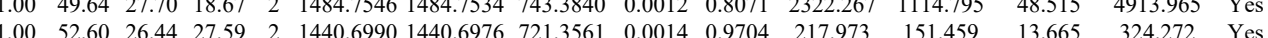

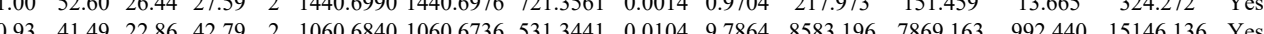
LVLDSVK $\begin{array}{lllllllllllllll}1.93 & 41.49 & 22.86 & 42.79 & 2 & 1060.6840 & 1060.6736 & 531.3441 & 0.0104 & 9.7864 & 8583.196 & 7869.163 & 992.440 & 15146.136 & \text { Yes } \\ 1.00 & 57.30 & 28.11 & 25.52 & 2 & 1334.7356 & 1334.7316 & 668.3731 & 0.0040 & 2.9923 & 12503.408 & 12440.514 & 608.827 & 17645.916 & \text { Yes }\end{array}$ 


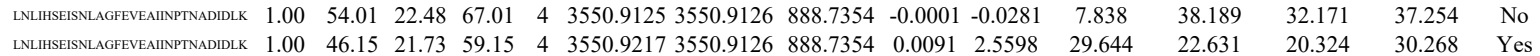

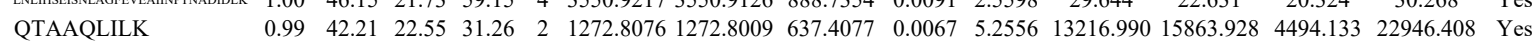
$\begin{array}{llllllllllllllll}\text { QTAAQLILK } & 0.99 & 52.06 & 22.58 & 41.25 & 2 & 1272.8082 & 1272.8009 & 637.4077 & 0.0073 & 5.7263 & 16828.859 & 18687.169 & 3910.761 & 32965.879 & \text { Yes }\end{array}$ $\begin{array}{llllllllllllllll}\text { NGPLEVAGAAVSAGHGLPAK } & 1.00 & 87.41 & 24.27 & 18.55 & 3 & 2103.1858 & 2103.1680 & 702.0633 & 0.0178 & 8.4512 & 2782.461 & 3293.887 & 2683.189 & 4836.050 & \text { Yes }\end{array}$ $\begin{array}{llllllllllllllll}\text { QTAAQLILK } & 0.99 & 46.52 & 22.33 & 34.38 & 2 & 1272.8090 & 1272.8009 & 637.4077 & 0.0081 & 6.3538 & 2153.511 & 2000.866 & 518.717 & 2729.175 & \text { Yes }\end{array}$ $\begin{array}{llllllllllllllll}\text { NGPLEVAGAAVSAGHGLPAK } & 1.00 & 74.46 & 25.02 & 18.50 & 3 & 2103.1687 & 2103.1680 & 702.0633 & 0.0007 & 0.3324 & 4834.216 & 4854.928 & 4023.143 & 6769.473 & \text { Yes }\end{array}$ $\begin{array}{llllllllllllllll}\text { NGPLEVAGAAVSAGHGLPAK } & 1.00 & 86.35 & 24.77 & 22.45 & 3 & 2103.1702 & 2103.1680 & 702.0633 & 0.0022 & 1.0445 & 2909.938 & 3008.989 & 2714.296 & 3898.834 & \text { Yes }\end{array}$ $\begin{array}{llllllllllllllll}\text { FVIHCNSPVWGADK } & 1.00 & 34.93 & 27.67 & 21.49 & 3 & 1905.9496 & 1905.9473 & 636.3230 & 0.0023 & 1.2048 & 5284.472 & 4950.153 & 602.650 & 10612.529 & \text { Yes }\end{array}$

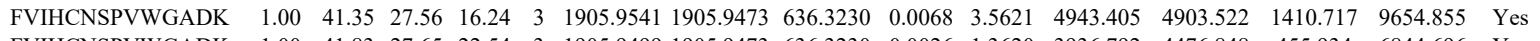
$\begin{array}{llllllllllllllll}\text { FVIHCNSPVWGADK } & 1.00 & 41.83 & 27.65 & 22.54 & 3 & 1905.9499 & 1905.9473 & 636.3230 & 0.0026 & 1.3620 & 3936.792 & 4476.848 & 455.934 & 6844.696 & \text { Yes }\end{array}$ $\begin{array}{llllllllllllllll}\text { FVIHCNSPVWGADK } & 1.00 & 39.94 & 27.63 & 27.53 & 3 & 1905.9511 & 1905.9473 & 636.3230 & 0.0038 & 1.9906 & 3966.707 & 4424.596 & 502.973 & 5765.944 & \text { Yes }\end{array}$ $\begin{array}{llllllllllllllll}\text { SIAFPSIGSGR } & 1.00 & 57.71 & 28.18 & 32.55 & 2 & 1234.6902 & 1234.6792 & 618.3469 & 0.0110 & 8.8946 & 13391.851 & 15254.419 & 471.829 & 23938.795 & \text { Yes }\end{array}$

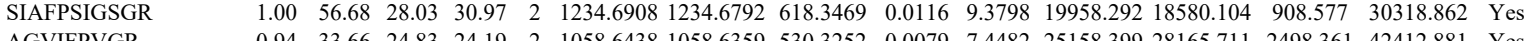

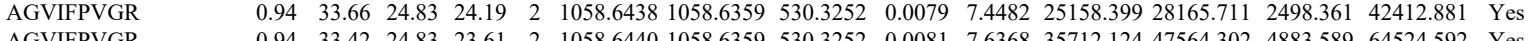
$\begin{array}{lllllllllllllllllll}\text { AGVIFPVGR } & 0.94 & 33.42 & 24.83 & 23.61 & 2 & 1058.6440 & 1058.6359 & 530.3252 & 0.0081 & 7.6368 & 35712.124 & 47564.302 & 4883.589 & 64524.592 & \text { Yes } \\ \text { SIAPSIGSGR } & 1.00 & 52.35 & 27.83 & 30.61 & 2 & 1234.684 & 1234.6792 & 6183469 & 0.0092 & 7.4391 & 1712.369 & 1758.581 & 261.664 & 2678.707 & \text { Yes }\end{array}$

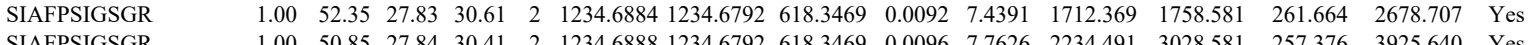
$\begin{array}{llllllllllllllll} & \\ \text { AGPSBGSGR } & 1.00 & 50.85 & 27.84 & 30.41 & 2 & 1234.6888 & 1234.6792 & 618.3469 & 0.0096 & 7.7626 & 2234.491 & 3028.581 & 257.376 & 3925.640 & \text { Yes }\end{array}$

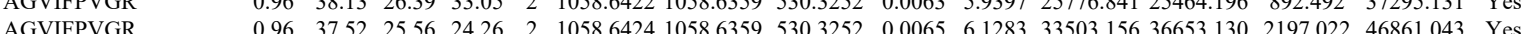

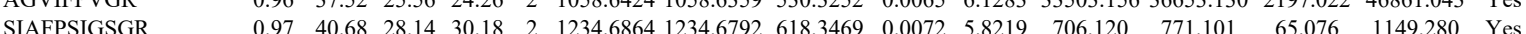

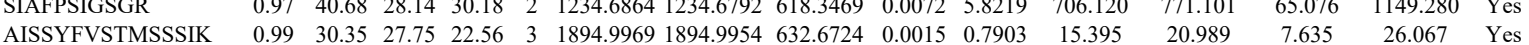

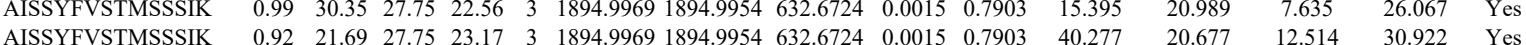

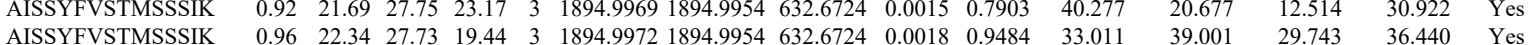

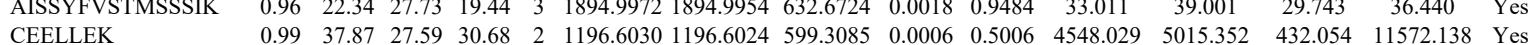

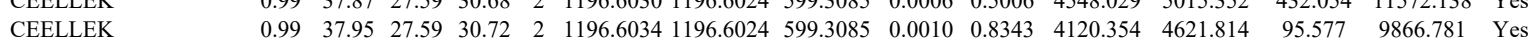

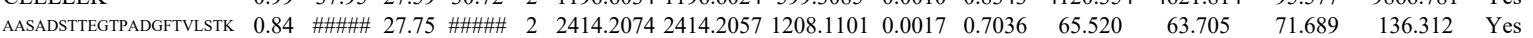

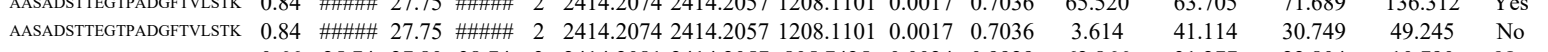

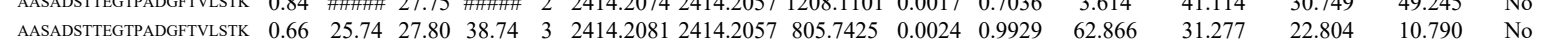

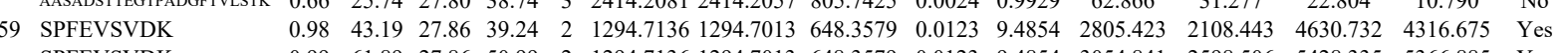
$\begin{array}{llllllllllllllll}\text { SPFEVSVDK } & 0.99 & 61.89 & 27.86 & 50.99 & 2 & 1294.7136 & 1294.7013 & 648.3579 & 0.0123 & 9.4854 & 3054.841 & 2598.506 & 5428.335 & 5366.885 & \text { Yes }\end{array}$

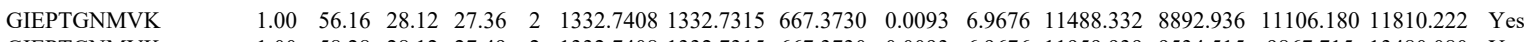
GIEPTGNMVK $\begin{array}{lllllllllllllllll}1.00 & 58.28 & 28.12 & 27.49 & 2 & 1332.7408 & 1332.7315 & 667.3730 & 0.0093 & 6.9676 & 11959.939 & 9534.515 & 9867.715 & 13480.080 & \text { Yes }\end{array}$ $\begin{array}{lllllllllllllllll}\text { FNDEHIPESPYLVPVIAPSDDAR } & 1.00 & 48.11 & 27.32 & 18.86 & 3 & 2724.3541 & 2724.3517 & 909.1245 & 0.0024 & 0.8800 & 237.098 & 314.734 & 525.758 & 425.884 & \text { No }\end{array}$ $\begin{array}{llllllllllllllll}\text { SPFEVQVGPEAGMQK } & 1.00 & 73.02 & 27.63 & 22.73 & 2 & 1890.9770 & 1890.9753 & 946.4949 & 0.0017 & 0.8980 & 52.079 & 26.357 & 82.014 & 56.178 & \text { No }\end{array}$ $\begin{array}{llllllllllllllll}\text { SPFEVQVGPEAGMQK } & 1.00 & 61.30 & 27.74 & 19.83 & 2 & 1890.9778 & 1890.9753 & 946.4949 & 0.0025 & 1.3207 & 64.656 & 111.759 & 145.368 & 140.406 & \text { Yes }\end{array}$ \begin{tabular}{lllllllllllllllll} 
FNDEHIPESPYLVYVIAPSDDAR & 1.00 & 36.47 & 27.41 & 17.31 & 3 & 2724.3553 & 2724.3517 & 909.1245 & 0.0036 & 1.3199 & 93.162 & 61.347 & 55.037 & 91.545 & Yes \\
\hline
\end{tabular} $\begin{array}{llllllllllllllll}\text { FNDEHIPESPYLVPVIAPSDDAR } & 0.93 & 21.31 & 27.47 & 16.45 & 3 & 2724.3562 & 2724.3517 & 909.1245 & 0.0045 & 1.6499 & 36.963 & 42.063 & 49.369 & 48.390 & \text { Yes }\end{array}$

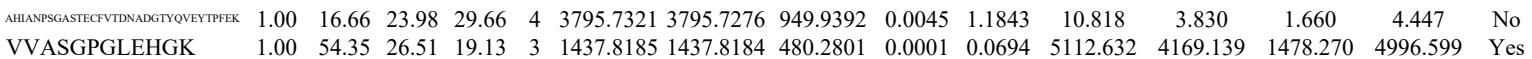

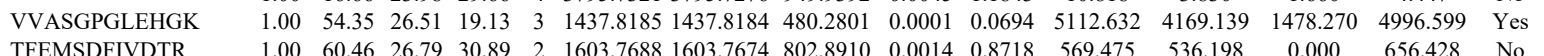

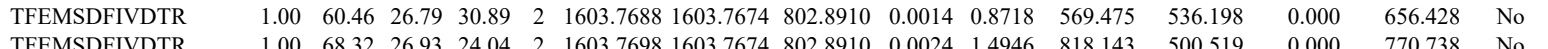
$\begin{array}{llllllllllllllll}\text { TFEMSDFIVDTR } & 1.00 & 68.32 & 26.93 & 24.04 & 2 & 1603.7698 & 1603.7674 & 802.8910 & 0.0024 & 1.4946 & 818.143 & 500.519 & 0.000 & 770.738 & \text { No } \\ \text { SPFEVQVGPEAGMQK } & 1.00 & 70.53 & 27.63 & 22.96 & 2 & 1890.9762 & 1890.9753 & 946.4949 & 0.0009 & 0.4754 & 289.178 & 303.091 & 308.733 & 376.434 & \text { Yes }\end{array}$

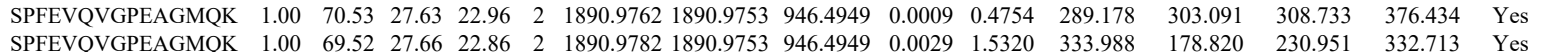
$\begin{array}{llllllllllllllll}\text { SPFEVQVGPEAGMQK } & 1.00 & 69.52 & 27.66 & 22.86 & 2 & 1890.9782 & 1890.9753 & 946.4949 & 0.0029 & 1.5320 & 333.988 & 178.820 & 230.951 & 332.713 & \text { Yes } \\ \text { KGEITGEVHMPSGK } & 1.00 & 39.44 & 26.45 & 52.44 & 4 & 1901.0569 & 1901.0406 & 476.2674 & 0.0163 & 8.5560 & 5916.436 & 6021.012 & 2482.601 & 8163598 & \text { Yes }\end{array}$

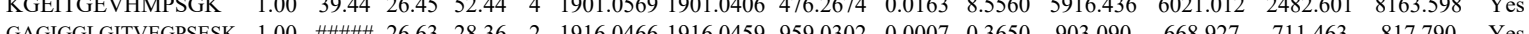
$\begin{array}{llllllllllllllll}\text { GAGIGGLGITVEGPSESK } & 1.00 & \# \# \# \# \text { 26.63 } & 26.99 & 2 & 1916.0466 & 1916.0459 & 959.0302 & 0.0007 & 0.3650 & 511.581 & 252.372 & 539.753 & 555.012 & \text { Yes }\end{array}$ 


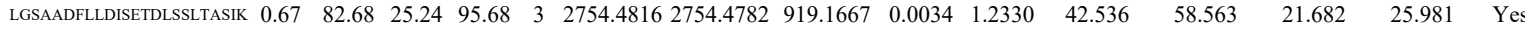

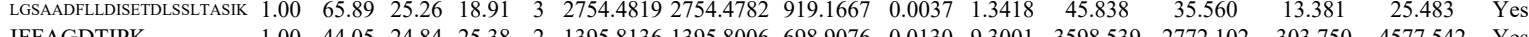
$\begin{array}{llllllllllllllll}\text { IFFAGDTIPK } & 1.00 & 44.05 & 24.84 & 25.38 & 2 & 1395.8136 & 1395.8006 & 698.9076 & 0.0130 & 9.3001 & 3598.539 & 2772.102 & 303.750 & 4577.542 & \text { Yes }\end{array}$

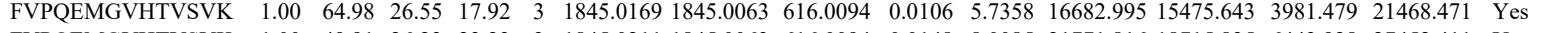

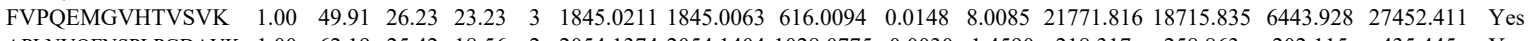

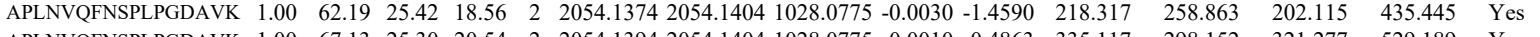
$\begin{array}{llllllllllllllll}\text { APLNVQFNSPLPGDAVK } & 1.00 & 67.13 & 25.30 & 20.54 & 2 & 2054.1394 & 2054.1404 & 1028.0775 & -0.0010 & -0.4863 & 335.117 & 298.152 & 321.277 & 529.189 & \text { Yes }\end{array}$ $\begin{array}{llllllllllllllll}\text { APLNVQFNSPLPGDAVK } & 0.96 & 22.23 & 25.17 & 18.87 & 3 & 2054.1415 & 2054.1404 & 685.7207 & 0.0011 & 0.5347 & 1657.492 & 1244.401 & 480.095 & 1759.303 & \text { Yes }\end{array}$

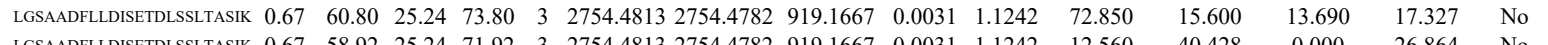

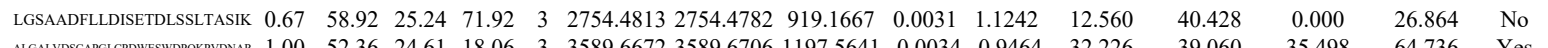

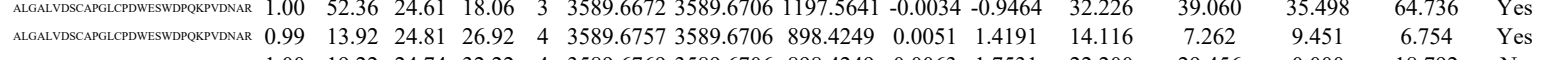

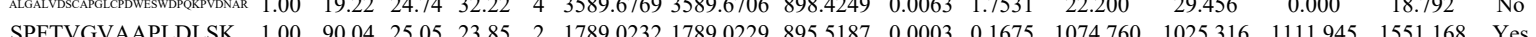

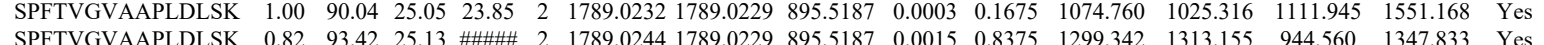
\begin{tabular}{lllllllllllllll}
\hline & SPFTVGVAAPDDLSK \\
\hline
\end{tabular}

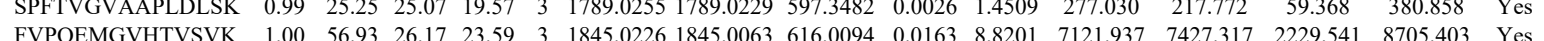
$\begin{array}{llllllllllllllllll}\text { GOHUTGSPFOFTVGPGGEGGAHK } & 1.00 & 56.60 & 26.64 & 23.12 & 4 & 2595.3485 & 2595.3438 & 649.8432 & 0.0047 & 1.8081 & 1418.487 & 1819.457 & 1366.287 & 1662.977 & \text { Yes }\end{array}$

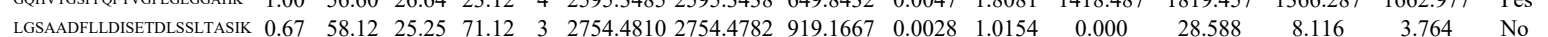

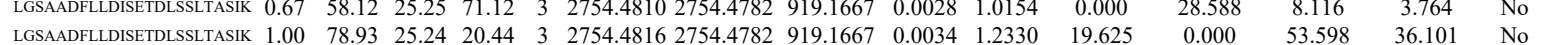

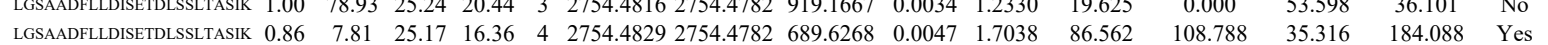
\begin{tabular}{lllllllllllllllll} 
YGGELVPHFPAR & 1.00 & 58.24 & 27.70 & 17.46 & 3 & 1485.7966 & 1485.7850 & 496.2689 & 0.0116 & 7.7914 & 6165.951 & 6476.044 & 2106.908 & 6966.218 & Yes \\
\hline
\end{tabular} \begin{tabular}{llllllllllllllll} 
APSVATVGSICDLNLK & 1.00 & 86.26 & 27.31 & 21.19 & 2 & 1921.0262 & 1921.0256 & 961.5201 & 0.0006 & 0.3120 & 73.837 & 47.477 & 41.767 & 54.607 & Yes \\
\hline
\end{tabular}

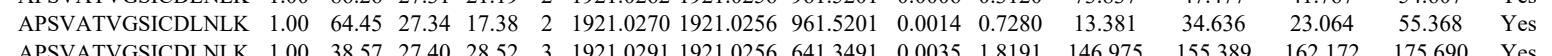

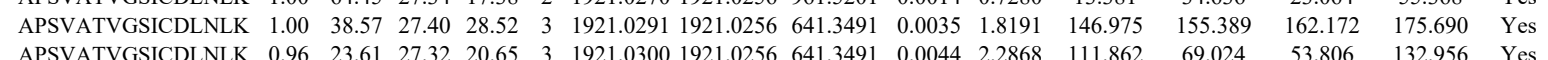

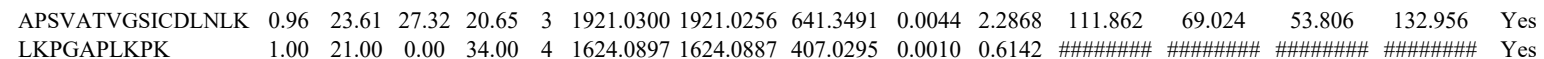

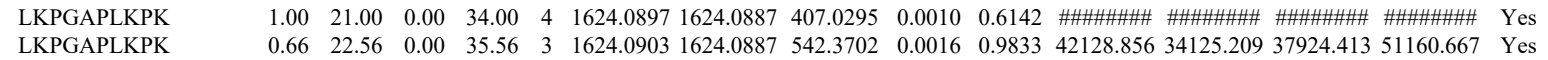
$\begin{array}{lllllllllllllll} & & & \end{array}$

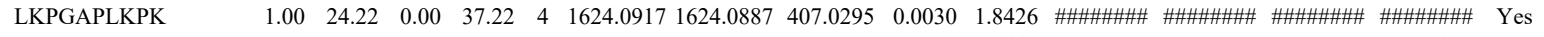

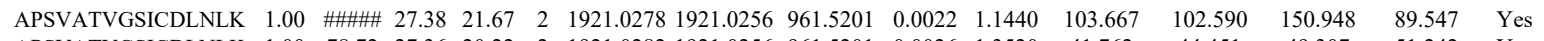

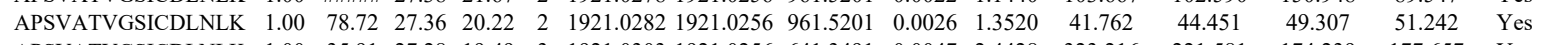
$\begin{array}{llllllllllllllll}\text { APSVATVGSICDLNLK } & 1.00 & 35.91 & 27.28 & 19.49 & 3 & 1921.0303 & 1921.0256 & 641.3491 & 0.0047 & 2.4428 & 323.216 & 221.581 & 174.239 & 177.657 & \text { Yes }\end{array}$ $\begin{array}{llllllllllllllll}\text { APSVATVGSICDLNLK } & 1.00 & 63.97 & 27.28 & 30.90 & 3 & 1921.0303 & 1921.0256 & 641.3491 & 0.0047 & 2.4428 & 280.340 & 297.136 & 217.278 & 123.762 & \text { Yes }\end{array}$

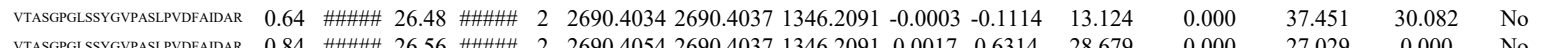

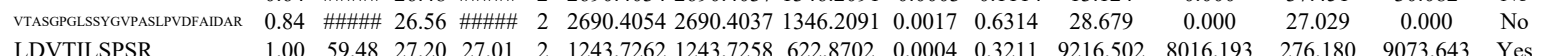

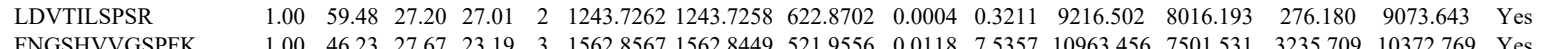

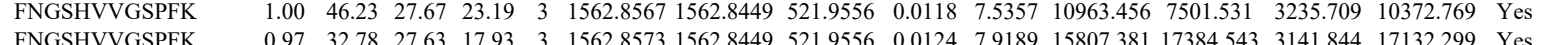
$\begin{array}{llllllllllllllllll}\text { FNGSHVVGSPFK } & 0.97 & 32.78 & 27.63 & 17.93 & 3 & 1562.8573 & 1562.8449 & 521.9556 & 0.0124 & 7.9189 & 15807.381 & 17384.543 & 3141.844 & 17132.299 & \text { Yes } \\ \text { LKPGGPLKPK } & 0.66 & 17.04 & 0.00 & 30.04 & 3 & 1624.0906 & 16240887 & 542.3702 & 0.0019 & 1.1677 & 21286.118 & 14190.140 & 18935.241 & 21028535 & \text { Yes }\end{array}$

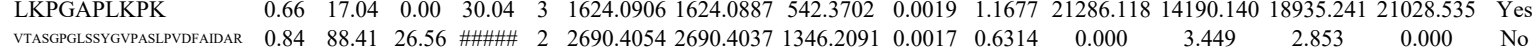

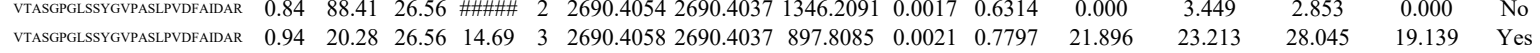

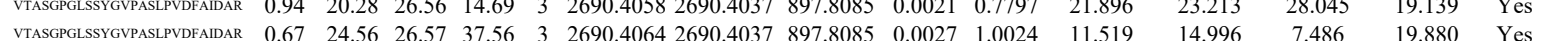




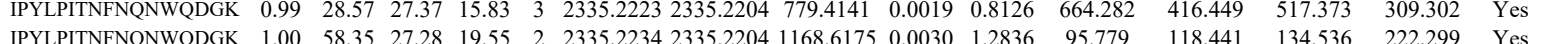
\begin{tabular}{llllllllllllllll} 
CVYKPMQPGPHVVK & 0.91 & 18.36 & 26.02 & 31.36 & 4 & 2335.2234 & 2335.2204 & 1168.6175 & 0.0030 & 1.2836 & 95.779 & 118.441 & 134.536 & 222.299 & Yes \\
\hline
\end{tabular}

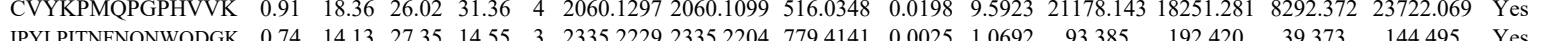

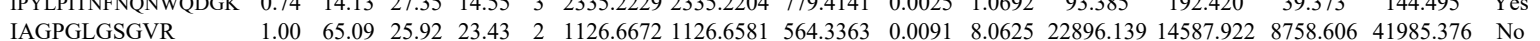

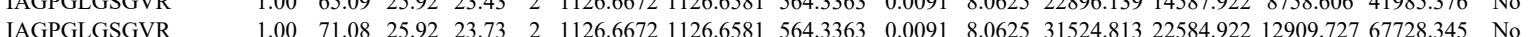

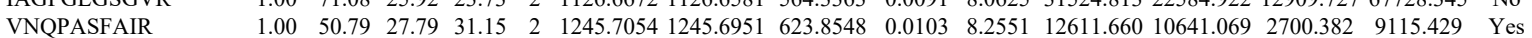

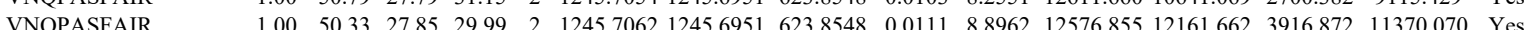
$\begin{array}{llllllllllllllll}\text { CVYKPMQPGPHVVK } & 0.85 & 15.99 & 26.05 & 28.99 & 4 & 20601273 & 20601099 & 516.0348 & 0.0174 & 8.4296 & 16149246 & 14856649 & 5181828 & 16515211 & \text { Yes }\end{array}$ IAGPGLGSGVR VAGPGLGSGVR VTVLFAGQHISK VTVLFAGQHISK VLFASQEIPASPFR VLFASQEIPASPFR VLFASQEIPASPFR IAGPGLGSGVR VTVLFAGQHISK

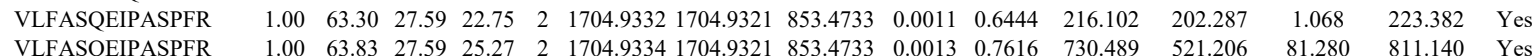
$\begin{array}{llllllllllllllllll}1.00 & 64.72 & 25.92 & 27.15 & 2 & 1126.6672 & 1126.6581 & 564.3363 & 0.0091 & 8.0625 & 22374.011 & 16965.460 & 8525.497 & 42118.567 & \text { No } \\ 1.00 & 62.84 & 25.92 & 23.03 & 2 & 1126.6674 & 1126.6581 & 564.3363 & 0.0093 & 8.2397 & 23985.541 & 19530.899 & 9839.204 & 46858.904 & \text { No }\end{array}$ $\begin{array}{lllllllllllllll}1.00 & 62.84 & 25.92 & 23.03 & 2 & 1126.6674 & 1126.6581 & 564.3363 & 0.0093 & 8.2597 & 23985.541 & 19530.899 & 9859.204 & 4858.904 & \text { No } \\ 0.99 & 43.43 & 27.80 & 30.75 & 2 & 1245.7058 & 1245.6951 & 623.8548 & 0.0107 & 8.5756 & 9149.929 & 7841.281 & 2164.313 & 7396.937 & \text { Yes }\end{array}$ $\begin{array}{lllllllllllllll}1.00 & 56.90 & 22.76 & 30.09 & 2 & 1586.9514 & 1586.9388 & 794.4767 & 0.0126 & 7.9297 & 1955.616 & 1281.438 & 274.206 & 2043.591 & \text { Yes }\end{array}$ $\begin{array}{lllllllllllllll}1.00 & 53.15 & 22.41 & 21.88 & 3 & 1586.9545 & 1586.9388 & 529.9869 & 0.0157 & 9.8744 & 21391.264 & 18034.001 & 3996.915 & 29449.128 & \text { Yes }\end{array}$ $\begin{array}{lllllllllllllllll}1.00 & 66.87 & 27.56 & 25.30 & 2 & 1704.9320 & 1704.9321 & 853.4733 & -0.0001 & -0.0586 & 2830.592 & 2892.503 & 0.000 & 4445.602 & \text { No }\end{array}$ $\begin{array}{llllllllllllllll}1.00 & 64.57 & 27.59 & 25.12 & 2 & 1704.9332 & 1704.9321 & 853.4733 & 0.0011 & 0.6444 & 4594.574 & 4201.455 & 0.000 & 5407.030 & \text { No }\end{array}$ $\begin{array}{lllllllllllllllll}0.95 & 26.24 & 27.53 & 29.46 & 3 & 1704.9358 & 1704.9321 & 569.3180 & 0.0037 & 2.1663 & 292.246 & 376.464 & 175.192 & 349.314 & \text { Yes }\end{array}$ $\begin{array}{lllllllllllllllll}1.00 & 59.80 & 25.92 & 21.03 & 2 & 1126.6676 & 1126.6581 & 564.3363 & 0.0095 & 8.4169 & 6142.716 & 4909.337 & 2487.081 & 11002.743 & \text { Yes }\end{array}$ $\begin{array}{llllllllllllllllll}1.00 & 52.16 & 22.41 & 26.25 & 3 & 1586.9545 & 1586.9388 & 529.9869 & 0.0157 & 9.8744 & 12589.527 & 11377.137 & 3678.778 & 15800.954 & \text { Yes }\end{array}$ $\begin{array}{llllllllllllllll}\text { VMYTPMAPGNYLISVK } & 1.00 & 63.83 & 27.59 & 25.27 & 2 & 1704.9334 & 1704.9321 & 853.4733 & 0.0013 & 0.7616 & 730.489 & 521.206 & 81.280 & 811.140 & \text { Yes } \\ \text { VMY } & 27.00 & 63.64 & 2 & 2071.1094 & 2071.1090 & 1036.5618 & 0.0004 & 0.1929 & 846.411 & 668.388 & 92.481 & 1086.092 & \text { Yes }\end{array}$ $\begin{array}{lllllllllllllllll}\text { VMYTPMAPGNYLISVK } & 1.00 & 61.97 & 26.78 & 23.33 & 3 & 2071.1161 & 2071.1090 & 691.3769 & 0.0071 & 3.4231 & 944.773 & 930.946 & 724.823 & 1236.849 & \text { Yes }\end{array}$ $\begin{array}{llllllllllllllll}\text { VMYTPMAPGNYLISVK } & 0.96 & 31.00 & 26.80 & 19.68 & 3 & 2071.1167 & 2071.1090 & 691.3769 & 0.0077 & 3.7124 & 881.590 & 1079.322 & 327.308 & 832.815 & \text { Yes }\end{array}$

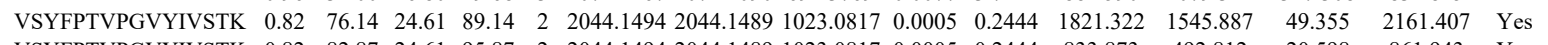

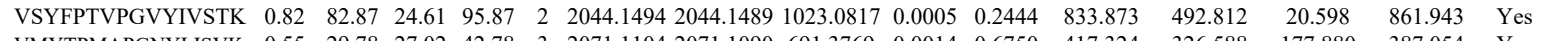
$\begin{array}{llllllllllllllll}\text { VMYTPMAPGNYLISVK } & 0.55 & 29.78 & 27.02 & 42.78 & 3 & 2071.1104 & 2071.1090 & 691.3769 & 0.0014 & 0.6750 & 417.324 & 326.588 & 177.880 & 387.054 & \text { Yes }\end{array}$ $\begin{array}{llllllllllllllll}\text { AWGPGLHGGIVGR } & 1.00 & 72.32 & 27.62 & 19.32 & 3 & 1419.7951 & 1419.7857 & 474.2692 & 0.0094 & 6.6066 & 12580.336 & 12349.909 & 6308.326 & 13521.492 & \text { Yes }\end{array}$

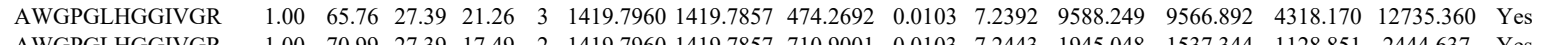
AWGPGLHGGIVGR AWGPGLHGGIVGR AWGPGLHGGIVGR AWGPGLHGGIVGR AWGPGLHGGIVGR AWGPGLHGGIVGR

AWGPGLHGGIVG
YADEEIPR

YADEEIPR

LPNNHIGISFIPR

LPNNHIGISFIPR

LPNNHIGISFIPR

LPNNHIGISFIPR

LPNNHIGISFIPR

LPNNHIGISFIPR

LPNNHIGISFIPR

LPNNHIGISFIPR

LPNNHIGISFIPR

LPNNHIGISFIPR

LPNNHIGISFIPR

LPNNHIGISFIPR

VVPCLVTPVTGR

VVPCLVTPVTGR

VVPCLVTPVTGR

VVPCLVTPVTGR

VVPCLVTPVTGR

VVPCLVTPVTGR

VVPCLVTPVTGR

VVPCLVTPVTGR

VNIGQGSHPQ $\begin{array}{lllllllllllllll}1.00 & 70.99 & 27.39 & 17.49 & 2 & 1419.7960 & 1419.7857 & 710.9001 & 0.0103 & 7.2443 & 1945.048 & 1537.344 & 1128.851 & 2444.637 & \text { Yes }\end{array}$

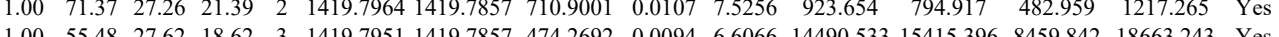
$\begin{array}{lllllllllllllll}1.00 & 55.48 & 27.62 & 18.62 & 3 & 1419.7951 & 1419.7857 & 474.2692 & 0.0094 & 6.6066 & 14490.533 & 15415.396 & 8459.842 & 18663.243 & \text { Yes } \\ 1.00 & 65.51 & 27.26 & 22.74 & 3 & 1419.7966 & 1419.7857 & 474.2692 & 0.0109 & 7.6609 & 9294.260 & 8841.710 & 5296397 & 10568.050 & \text { Yes }\end{array}$

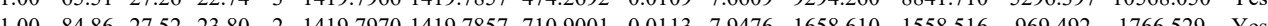

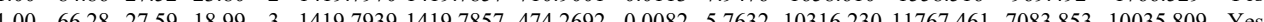

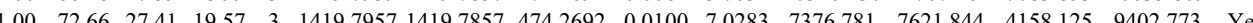

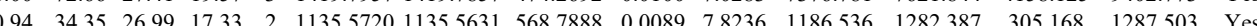

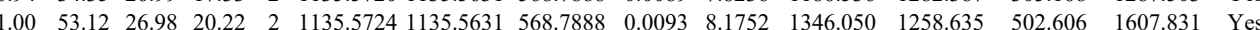
$\begin{array}{lllllllllllllll}0.99 & 29.91 & 25.40 & 16.38 & 3 & 1620.9229 & 1620.9222 & 541.3147 & 0.0007 & 0.4310 & 51.243 & 57.185 & 22.018 & 58.690 & \text { Yes }\end{array}$

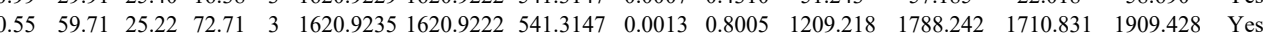

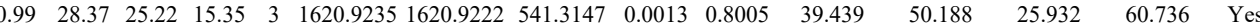
$\begin{array}{lllllllllllllll}0.66 & 26.06 & 25.22 & 39.06 & 3 & 1620.9238 & 1620.9222 & 541.3147 & 0.0016 & 0.9853 & 37.164 & 49.373 & 42.520 & 59.301 & \text { Yes }\end{array}$ $\begin{array}{llllllllllllllll}0.66 & 34.93 & 25.15 & 47.93 & 3 & 1620.9241 & 1620.9222 & 541.3147 & 0.0019 & 1.1700 & 60.551 & 57.190 & 39.888 & 90.705 & \text { Yes }\end{array}$

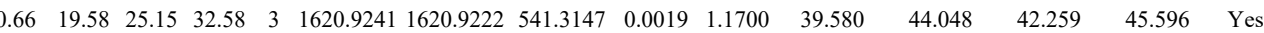

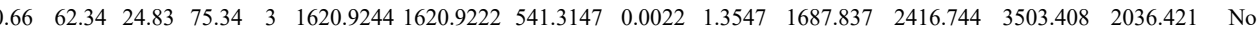

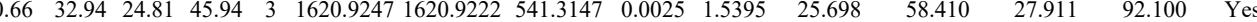

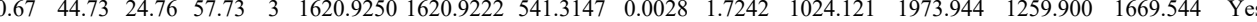

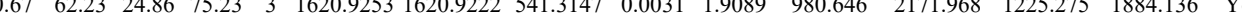
\begin{tabular}{lllllllllllllll}
0.67 & 62.23 & 24.86 & 75.23 & 3 & 162.9253 & 1620.9222 & 51.3147 & 0.031 & 1.908 & 98.646 & 2171.968 & 1225.275 & 184.136 & Yes \\
\hline .74 & 16.30 & 25.43 & 19.47 & 3 & 1620.9226 & 1620.9222 & 541.3147 & 0.0004 & 0.2463 & 118.514 & 248.031 & 182.884 & 264.364 & Yes
\end{tabular} $\begin{array}{llllllllllllllll}0.55 & 10.69 & 25.40 & 16.10 & 3 & 1620.9229 & 1620.9222 & 541.3147 & 0.0007 & 0.4310 & 263.634 & 230.230 & 296.538 & 473.184 & \text { Yes }\end{array}$ $\begin{array}{lllllllllllllll}1.00 & 58.68 & 28.29 & 23.35 & 2 & 1429.7910 & 1429.7907 & 715.9026 & 0.0003 & 0.2095 & 5188.796 & 3820.697 & 0.000 & 5839.482 & \text { No }\end{array}$ $\begin{array}{lllllllllllllllll}1.00 & 57.86 & 28.12 & 21.64 & 2 & 1429.7914 & 1429.7907 & 715.9026 & 0.0007 & 0.4889 & 2808.638 & 2010.989 & 0.000 & 2928.824 & N o\end{array}$ $\begin{array}{lllllllllllllll}1.00 & 58.30 & 28.29 & 21.91 & 2 & 1429.7910 & 1429.7907 & 715.9026 & 0.0003 & 0.2095 & 1522.005 & 1344.189 & 77.716 & 1603.798 & \text { Yes }\end{array}$ $\begin{array}{lllllllllllllll}1.00 & 61.76 & 28.10 & 24.37 & 2 & 1429.7924 & 1429.7907 & 715.9026 & 0.0017 & 1.1873 & 3048.246 & 2371.281 & 0.000 & 2950.104 & \text { No } \\ 0.99 & 49.91 & 2.21 & 22.05 & 2 & 1429.7892 & 1429.7907 & 715.9026 & -0.015 & 1.0476 & 260.029 & 216328 & 17.278 & 265.178 & \text { Ye }\end{array}$

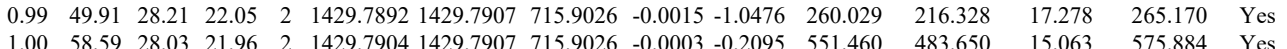

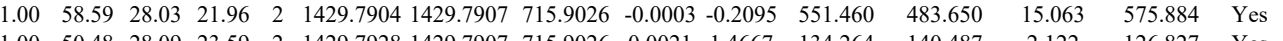
$\begin{array}{lllllllllllllll}1.00 & 5.48 & 28.09 & 23.59 & 2 & 1429.7928 & 1429.7907 & 715.9026 & 0.0021 & 1.4667 & 134.264 & 140.487 & 2.122 & 126.827 & \text { Yes } \\ 1.00 & 43.12 & 27.94 & 22.88 & 2 & 1429.7938 & 1429.7007 & 715.9026 & 0.0031 & 2.1651 & 16.983 & 130272 & 5.426 & 160.379 & \text { Yes }\end{array}$ $\begin{array}{lllllllllllllll}1.00 & 43.12 & 27.94 & 22.88 & 2 & 1429.7938 & 1429.7907 & 715.9026 & 0.0031 & 2.1651 & 167.983 & 130.272 & 5.426 & 160.379 & \text { Yes }\end{array}$

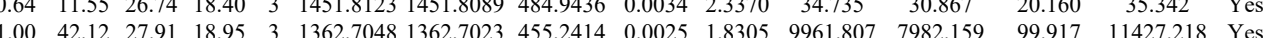

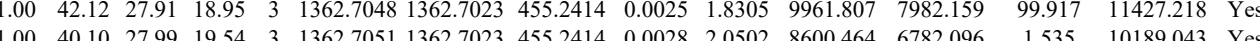
$\begin{array}{lllllllllllllll}1.00 & 55.65 & 27.40 & 29.59 & 2 & 1446.8204 & 14468173 & 724.4159 & 0.0031 & 2.1397 & 141.639 & 100.539 & 0.000 & 242.376 & \end{array}$ NTVELLVEDK 
$\begin{array}{lllllllllllll}\text { GDVSVGIK } & 1.00 & 23.70 & 26.22 & 14.69 & 4 & 2809.3209 & 2809.3143 & 703.3359 & 0.0066 & 2.3460 & 47.838 & 46.188\end{array}$

$\begin{array}{lllllllllllll}\text { AYGPGLEK } & 0.99 & 46.75 & 27.72 & 32.96 & 2 & 1121.6390 & 1121.6324 & 561.8235 & 0.0066 & 5.8737 & 8347.756 & 5730.242\end{array}$

AYGPGLEK

SLPNDPMFK

HLPNDPMFK

YWELIYEDSMDLIAK HLPNDPMFK

HLPNDPMFK

HLPNDPMFK

GFSIPECQK

GFSIPECQK

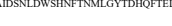
$\begin{array}{lllllllllllllll}0.97 & 35.79 & 27.13 & 23.24 & 2 & 1270.6630 & 1270.6505 & 636.3325 & 0.0125 & 9.8218 & 21779.439 & 20858187 & 2354.155 & 21613.939 & \text { Yes }\end{array}$ $\begin{array}{lllllllllllllll}0.98 & 35.85 & 27.43 & 18.27 & 3 & 1385.7496 & 1385.7369 & 462.9196 & 0.0127 & 9.1448 & 4720.484 & 4858.596 & 2838.055 & 5591.923 & \text { Yes }\end{array}$

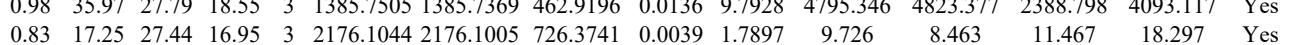
$\begin{array}{lllllllllllllll}0.54 & 20.38 & 27.38 & 19.10 & 3 & 1385.7484 & 1385.7369 & 462.9196 & 0.0115 & 8.2807 & 10953.696 & 8715.601 & 2729.392 & 12070.362 & \text { Yes } \\ \end{array}$ $\begin{array}{lllllllllllllll}0.88 & 27.05 & 27.32 & 17.46 & 3 & 1385.7487 & 1385.7369 & 462.9196 & 0.0118 & 8.4967 & 12443.637 & 10952.133 & 3158.123 & 11682.182 & \text { Yes } \\ \end{array}$ $\begin{array}{llllllllllllllll}0.92 & 28.53 & 27.40 & 17.49 & 3 & 1385.7469 & 1385.7369 & 462.9196 & 0.0100 & 7.2006 & 5752.317 & 5728.887 & 2895.761 & 5782.142 & \text { Yes } \\ 0.95 & 30.52 & 27.46 & 19.63 & 3 & 1385.7475 & 1385.7369 & 462.9196 & 0.0106 & 7.6327 & 6505.428 & 5966.483 & 2367.966 & 5985.680 & \text { Yes }\end{array}$ $\begin{array}{llllllllllllllll}0.95 & 30.52 & 27.46 & 19.63 & 3 & 1385.7475 & 385.7369 & 462.9196 & 0.0106 & 7.6327 & 6505.428 & 5966.483 & 2367.966 & 5985.680 & \text { Yes } \\ 0.9 & 42.41 & 27.38 & 26.11 & 2 & 1341.6776 & 1341.6665 & 671.8405 & 0.0111 & 8.2608 & 3299.274 & 3301.293 & 320.425 & 3630.270 & \text { Yes }\end{array}$ $\begin{array}{llllllllllllllll}0.98 & 37.89 & 27.23 & 26.61 & 2 & 1341.6784 & 1341.6665 & 671.8405 & 0.0119 & 8.8562 & 3362.977 & 3624.762 & 514.154 & 3486.229 & \text { Yes }\end{array}$

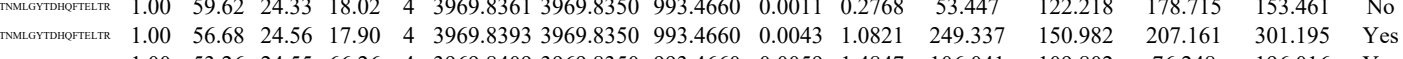
$\begin{array}{llllllllllllllll} & 1.00 & 53.26 & 24.55 & 66.26 & 4 & 3969.8409 & 3969.8350 & 993.4660 & 0.0059 & 1.4847 & 106.041 & 109.802 & 76.248 & 196.016 & \text { Yes }\end{array}$

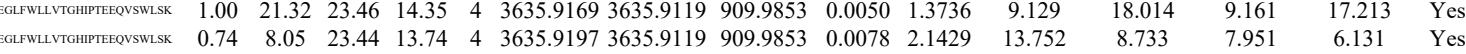
LVAQLYK

LVAQLYK

VVPGYGHAVLR VVPGYGHAVLR VVPGYGHAVLR
VVPGYGHAVLR $\begin{array}{lllllllllllllll}0.97 & 36.84 & 23.07 & 23.63 & 2 & 1121.7112 & 1121.7052 & 561.8599 & 0.0060 & 5.3394 & 9984.316 & 9946.123 & 910.550 & 14102.167 & \text { Yes }\end{array}$

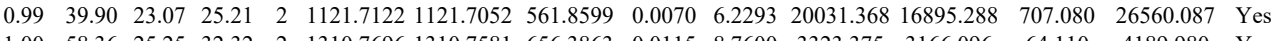

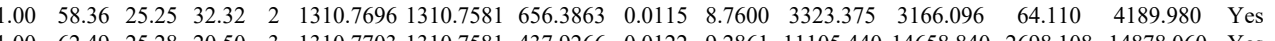
$\begin{array}{lllllllllllllll}1.00 & 62.49 & 25.28 & 20.50 & 3 & 1310.7703 & 1310.7581 & 437.9266 & 0.0122 & 9.2861 & 11105.440 & 14658.840 & 2698.108 & 14878.060 & \text { Yes } \\ 1100 & 54.87 & 25.28 & 32.65 & 2 & 130.7704 & 1310.7581 & 656363 & 0.0123 & 9.3694 & 2655.472 & 2696.106 & 0.000 & 3537776 & \text { No }\end{array}$

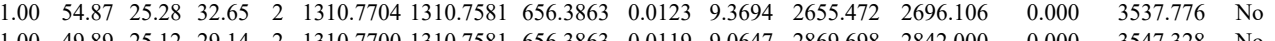
$\begin{array}{lllllllllllllll}1.00 & 4.89 & 25.12 & 29.14 & 2 & 1310.7700 & 1310.7581 & 656.3863 & 0.0119 & 9.0647 & 2869.698 & 2842.000 & 0.000 & 3547.328 & \text { No }\end{array}$ $\begin{array}{lllllllllllllll}1.00 & 60.28 & 25.25 & 20.10 & 3 & 1310.7709 & 1310.7581 & 437.9266 & 0.0128 & 9.7428 & 17409.426 & 18048.654 & 3203.963 & 20317.822 & \text { Yes } \\ 1.00 & 54.11 & 25.01 & 18.44 & 3 & 1310.7712 & 1310.7581 & 437.9266 & 0.0131 & 9.9711 & 13615.012 & 14370.423 & 3603.197 & 16503.745 & \text { Yes }\end{array}$

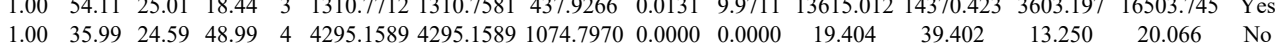

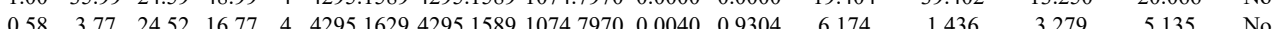

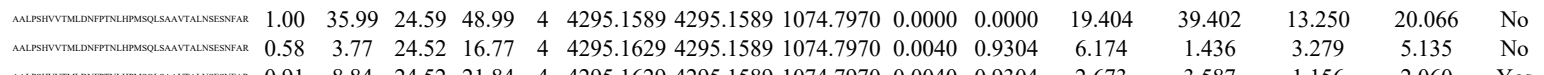




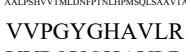
VVPGYGHAVLR VVPGYGHAVLR ALGVLAQLIWSR ALGVLAQLIWSR
ALGVLAQLIWSR ALGVLAQLIWSR ALGVLAQLIWSR ALGVLAQLIWSR ALGLAQLIWSR ALGVLAQUIWSR ALGVLAQUIWSR ALGLAQLIWSR ALGVLAQLIWSR ALGVLAQLIWSR ALGVLAQLIWSR ALGVLAQLIWSR ALGVLAQLIWSR ALGVLAQLIWSR ALGVLAQLIWSR ALGVLAQLIWSR ALGVLAQLIWSR ALGVLAQLIWSR ALGVLAQLIWSR ALGVLAQLIWS ALGVLAQLIWS ALGVLAQLIWS ALGVLAQLIWSR ALGVLAQLIWSR ALGVLAQLIWSR ALGVLAQLIWSR ALGVLAQLIWSR ALGVLAQLIWSR VYETSVLDPDE GLVYETSVLDPDEGIR 1.00 GLVYETSVLDPDEGIR GLVYETSVLDPDEG DLQQYQSQAK
DLQQYQSQAK IMVANIEEVLQR IMVANIEEVLQR

VLLTMIAR VLLTMIAR VLLTMIAR
VLLTMIAR

AVDITTPK

FSSQQAATK LPIFFFGTHETAFLGPK VDEVPDGAVKPPTNK

VVAEPVELAQEFR

VVAEPVELAQEFR

FEIVYNLLSLR

FEIVYNLLSLR

FEIVYNLLSLR

FQTMSDQIIGR

QTMSDQIIGR

VQDLTSVVQTLLQQMQD

TVQDLTSVVQTLLQQMQD

TVQDLTSVVQTLLQQMQD

VQDLTSYVOTLLQQMQDK

NIADLMTQAGVEELESENK

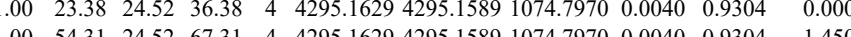
$\begin{array}{llllllllllll} & \end{array}$ $\begin{array}{lllllllllllll}1.00 & 38.37 & 26.05 & 19.96 & 3 & 1310.7583 & 1310.7581 & 437.9266 & 0.0002 & 0.1522 & 1.081 .609\end{array}$ $\begin{array}{lllllllllll}1.08 & 27.33 & 26.13 & 17.78 & 3 & 1310.7577 & 1310.7581 & 437.9266 & -0.0004 & -0.3045 & 490.321\end{array}$ $\begin{array}{llllllllllll}1.00 & 46.62 & 26.06 & 17.12 & 3 & 1310.7580 & 1310.7581 & 437.9266 & -0.0001 & -0.0761 & 551.043 \\ 1.00 & 74.73 & 23.34 & 26.83 & 2 & 1469.8850 & 1469.8840 & 735.9493 & 0.0010 & 0.6794 & 51.731\end{array}$ $\begin{array}{lllllllllll}1.00 & 35.48 & 23.30 & 18.93 & 3 & 1469.8855 & 1469.8840 & 490.9686 & 0.0015 & 1.0184 & 7.657\end{array}$ $\begin{array}{llllllllllll}1.00 & 72.52 & 23.32 & 24.89 & 2 & 146.8856 & 1469.8840 & 735.9493 & 0.0016 & 1.0870 & 152.955\end{array}$ $\begin{array}{lllllllllll}98 & 21.38 & 23.26 & 18.20 & 3 & 1469.8858 & 1469.8840 & 490.9686 & 0.0018 & 1.2221 & 3.771\end{array}$ $\begin{array}{lllllllllllll}1.00 & 73.20 & 23.32 & 25.06 & 2 & 1469.8852 & 1469.8840 & 735.9493 & 0.0012 & 0.8153 & 124.970\end{array}$

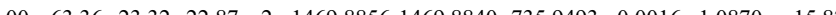

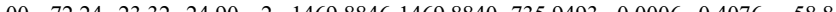
$\begin{array}{lllllllllll}1.00 & 73.30 & 23.32 & 24.52 & 2 & 1469.88461469 .8840 & 735.9493 & 0.0006 & 0.4076 & 43.580\end{array}$ $\begin{array}{llllllllllll}0.98 & 23.55 & 23.34 & 17.10 & 3 & 1469.8849 & 1469.8840 & 490.9686 & 0.0009 & 0.6110 & 6.976\end{array}$ $\begin{array}{llllllllllll}0.87 & 15.27 & 23.30 & 13.97 & 3 & 1469.8855 & 1469.8840 & 490.9686 & 0.0015 & 1.0184 & 13.506\end{array}$ $\begin{array}{lllllllllllll}1.00 & 75.13 & 23.32 & 26.17 & 2 & 1469.8844 & 1469.8840 & 735.9493 & 0.0004 & 0.2718 & 110.677\end{array}$ $\begin{array}{lllllllllllll}1.00 & 79.26 & 23.30 & 20.09 & 2 & 1469.8854 & 1469.8840 & 735.9493 & 0.0014 & 0.9512 & 64.799\end{array}$ $\begin{array}{llllllllllll}1.00 & 32.61 & 23.26 & 15.47 & 3 & 1469.8858 & 1469.8840 & 490.9686 & 0.0018 & 1.2221 & 25.535\end{array}$ $\begin{array}{lllllllllllll}0.99 & 23.53 & 23.26 & 20.26 & 3 & 1469.8858 & 1469.8840 & 490.9686 & 0.0018 & 1.2221 & 22.051\end{array}$ $\begin{array}{llllllllllll}1.00 & 78.61 & 23.32 & 25.91 & 2 & 1469.8846 & 1469.8840 & 735.9493 & 0.0006 & 0.4076 & 86.260\end{array}$ $\begin{array}{llllllllllll}1.00 & 61.10 & 23.34 & 23.85 & 2 & 1469.8850 & 1469.8840 & 735.9493 & 0.0010 & 0.6794 & 102.404\end{array}$ $\begin{array}{lllllllllll}1.00 & 38.07 & 23.30 & 19.68 & 3 & 1469.8855 & 1469.8840 & 490.9686 & 0.0015 & 1.0184 & 12.231\end{array}$ $\begin{array}{llllllllllll}0.55 & 37.54 & 23.30 & 50.54 & 3 & 1469.8855 & 1469.8840 & 490.9686 & 0.0015 & 1.0184 & 24.450\end{array}$ $\begin{array}{llllllllllll}1.00 & 61.84 & 24.33 & 23.80 & 2 & 1469.8828 & 1469.8840 & 735.9493 & -0.0012 & -0.8153 & 9.732 \\ 1.00 & 63.31 & 23.30 & 24.18 & 2 & 1469854 & 1469.8840 & 735.943 & 0.0014 & 0.9512 & 39.977\end{array}$ $\begin{array}{lllllllllll}1.00 & 63.31 & 23.30 & 24.18 & 2 & 1469.8854 & 1469.8840 & 735.9493 & 0.0014 & 0.9512 & 39.977\end{array}$ $\begin{array}{llllllllllll}0.85 & 14.42 & 23.30 & 15.04 & 3 & 1469.8855 & 1469.8840 & 490.9686 & 0.0015 & 1.0184 & 15.207\end{array}$ $\begin{array}{llllllllllll}0.93 & 20.33 & 23.62 & 15.49 & 3 & 1469.8843 & 1469.8840 & 490.9686 & 0.0003 & 0.2037 & 15.329\end{array}$ $\begin{array}{llllllllllll}1.00 & 74.88 & 23.34 & 25.55 & 2 & 1469.8850 & 1469.8840 & 735.9493 & 0.0010 & 0.6794 & 86.217 \\ 0.55 & 21.23 & 23.30 & 34.23 & 3 & 1469.8855 & 1469.8840 & 490.9686 & 0.0015 & 1.0184 & 18.965\end{array}$ $\begin{array}{llllllllllll}0.55 & 21.23 & 23.30 & 34.23 & 3 & 1469.8855 & 1469.8840 & 490.9686 & 0.0015 & 1.0184 & 18.965 \\ 1.00 & 65.41 & 23.34 & 24.21 & 2 & 1469.8858 & 1469.8840 & 735.9493 & 0.0018 & 1.2229 & 93.034 \\ 1.00 & 73.98 & 3.34 & 18.92 & 2 & 469.8850 & 146.840 & 735.943 & 0.061 & 0.6794 & 78.528\end{array}$ $\begin{array}{llllllllllll}1.00 & 65.41 & 23.34 & 24.21 & 2 & 1469.8858 & 1469.8840 & 735.9493 & 0.0018 & 1.2229 & 93.034 \\ 1.00 & 73.98 & 23.34 & 18.92 & 2 & 1469.8850 & 1469.8840 & 735.9493 & 0.0010 & 0.6794 & 78.528\end{array}$ $\begin{array}{llllllllllll}1.00 & 73.98 & 23.34 & 18.92 & 2 & 1469.8850 & 1469.8840 & 735.9493 & 0.0010 & 0.6794 & 78.528 \\ 0.63 & 10.03 & 23.34 & 15.05 & 3 & 1469.8852 & 1469.8840 & 490.9686 & 0.0012 & 0.8147 & 20.388\end{array}$ $\begin{array}{llllllllllll}0.63 & 10.03 & 23.34 & 15.05 & 3 & 1469.8852 & 1469.8840 & 490.9686 & 0.0012 & 0.8147 & 20.388 \\ 1.00 & 84.04 & 23.32 & 25.45 & 2 & 1469.8852 & 1469.8840 & 735.9493 & 0.0012 & 0.8153 & 56.548\end{array}$ $\begin{array}{lllllllllll}1.00 & 84.04 & 23.32 & 25.45 & 2 & 1469.8852 & 1469.8840 & 735.9493 & 0.0012 & 0.8153 & 56.548 \\ 0.61 & 7.57 & 23.26 & 18.63 & 3 & 1469.8858 & 1469.8840 & 490.9686 & 0.0018 & 1.2221 & 10.305\end{array}$ $\begin{array}{lllllllllll}0.61 & 7.57 & 23.26 & 18.63 & 3 & 1469.8858 & 1469.8840 & 490.9686 & 0.0018 & 1.2221 & 10.305 \\ 1.00 & 83.71 & 27.98 & 27.80 & 2 & 1905.9814 & 1905.9806 & 953.9976 & 0.0008 & 0.4193 & 351.109\end{array}$

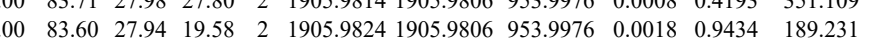
$\begin{array}{llllllllllll}1.00 & 79.65 & 27.96 & 19.24 & 2 & 1905.9818 & 1905.9806 & 953.9976 & 0.0012 & 0.6289 & 224.710\end{array}$ $\begin{array}{lllllllllllll}0.99 & 37.68 & 28.06 & 20.50 & 2 & 1495.7908 & 1495.7874 & 748.9010 & 0.0034 & 2.3620 & 219.830 & 14\end{array}$ $\begin{array}{lllllllllllll}1.00 & 66.49 & 26.49 & 19.09 & 2 & 1557.8688 & 1557.8670 & 779.9408 & 0.0018 & 1.1539 & 2064.936 & 1431.315\end{array}$ $\begin{array}{llllllllllll}1.00 & 71.28 & 26.85 & 28.16 & 2 & 1557.8694 & 1557.8670 & 779.9408 & 0.0024 & 1.5386 & 1102.226 & 766.603\end{array}$

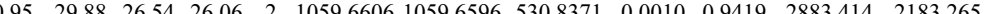
$\begin{array}{lllllllllllll}0.98 & 34.04 & 26.54 & 26.46 & 2 & 1059.6608 & 1059.6596 & 530.8371 & 0.0012 & 1.1303 & 1913.930 & 1540.276 & 2660\end{array}$

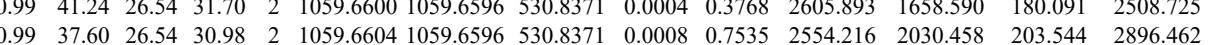
$\begin{array}{lllllllllllllll}1.00 & 51.44 & 26.70 & 27.64 & 2 & 1131.6804 & 1131.6743 & 566.8444 & 0.0061 & 5.3806 & 4054.055 & 5021.063 & 1870.335 & 4841.220 & \text { Yes }\end{array}$ $\begin{array}{lllllllllllllll}0.98 & 35.49 & 27.65 & 21.83 & 2 & 1254.6808 & 1254.6812 & 628.3479 & -0.0004 & -0.3183 & 118.242 & 159.401 & 69.780 & 183.294 & \text { Yes } \\ 1.00 & 42.32 & 25.04 & 16.08 & 3 & 2209.2166 & 2209.2180 & 737.4133 & -0.0014 & -0.6328 & 75.779 & 116.602 & 126.947 & 101.559 & \text { Yes }\end{array}$ $\begin{array}{llllllllll} & \end{array}$ $\begin{array}{lllllllllll}1.00 & 61.18 & 27.23 & 21.88 & 2 & 1629.8868 & 1629.8848 & 815.9497 & 0.0020 & 1.2256 & 336.032\end{array}$ $\begin{array}{llllllllllll}1.00 & 66.25 & 27.23 & 22.40 & 2 & 1629.8870 & 1629.8848 & 815.9497 & 0.0022 & 1.3481 & 97.517\end{array}$

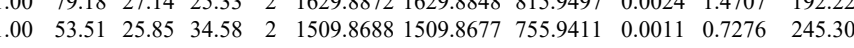
$\begin{array}{llllllllllll}1.00 & 54.09 & 25.60 & 36.97 & 2 & 1509.8692 & 1509.8677 & 755.9411 & 0.0015 & 0.9921 & 249.539\end{array}$

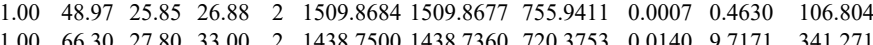
$\begin{array}{llllllllllll}1.00 & 66.30 & 27.80 & 33.00 & 2 & 1438.7500 & 1438.7360 & 720.3753 & 0.0140 & 9.7171 & 341.271 \\ 1.00 & 53.69 & 27.80 & 26.73 & 2 & 1438.7500 & 1438.7360 & 720.3753 & 0.0140 & 9.7171 & 360.307\end{array}$ $\begin{array}{ccccccccccc}1.00 & 53.69 & 27.80 & 26.73 & 2 & 1438.7500 & 1438.7360 & 720.3753 & 0.0140 & 9.7171 & 360.307 \\ 0.55 & 55.47 & 25.15 & 68.47 & 3 & 2462.3305 & 2462.3294 & 821.7837 & 0.0011 & 0.4462 & 41.588\end{array}$ $\begin{array}{llllllllllll}0.55 & 69.44 & 25.13 & 82.44 & 3 & 2462.3308 & 2462.3294 & 821.7837 & 0.0014 & 0.5679 & 49.560\end{array}$ $\begin{array}{lllllllllll}0.60 & 45.31 & 25.15 & 58.31 & 3 & 2462.3332 & 2462.3294 & 821.7837 & 0.0038 & 1.5414 & 215.55 \\ 1.06 & 67.57 & 25.12 & 80.57 & 4 & 24623333 & 2462.3294 & 61.5896 & 0.039 & 1.5813 & 42.722\end{array}$

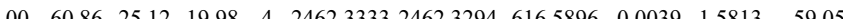
31.018

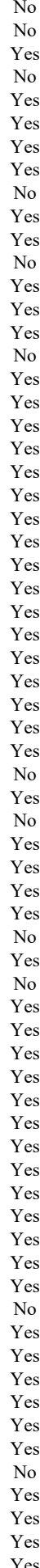



$\begin{array}{lllllllllll}.00 & 65.67 & 16.99 & 25.43 & 2 & 1637.0176 & 1637.0160 & 819.5153 & 0.0016 & 0.9762 & 198.272\end{array}$

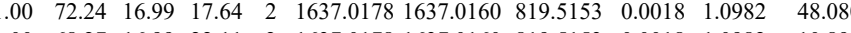

AYVVLGQFLVLK $\begin{array}{lllllllllll}1.00 & 68.27 & 16.99 & 22.11 & 2 & 1637.0178 & 1637.0160 & 819.5153 & 0.0018 & 1.0982 & 10.895\end{array}$ $\begin{array}{lllllllllll}1.00 & 66.89 & 17.32 & 20.53 & 2 & 1637.0162 & 1637.0160 & 819.5153 & 0.0182 & 0.1220 & 19.221\end{array}$ $\begin{array}{lllllllllll}1.00 & 72.78 & 17.32 & 20.53 & 2 & 1637.0162 & 1637.0160 & 819.5153 & 0.0702 & 0.1220 & 19.221\end{array}$ $\begin{array}{lllll}-1 & 0\end{array}$

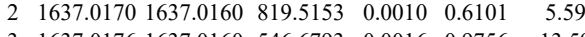
$\begin{array}{lllllllllll}1.00 & 54.70 & 17.32 & 19.72 & 2 & 1637.0170 & 1637.0160 & 819.5153 & 0.0010 & 0.6101 & 5.595 \\ 0.66 & 12.35 & 16.99 & 25.35 & 3 & 1637.0176 & 1637.0160 & 546.6793 & 0.0016 & 0.9756 & 13.597\end{array}$

AYVVLGQFLVLK $\begin{array}{llllllllllll}0.66 & 12.35 & 16.99 & 25.35 & 3 & 1637.0176 & 1637.0160 & 546.6793 & 0.0016 & 0.9756 & 15.164\end{array}$

AYVVLGQFLVLK

AYVVLGQFLVLK

AYVVLGQFLVLK $\begin{array}{llllllllllll}0.99 & 20.67 & 17.16 & 14.38 & 3 & 1637.0173 & 1637.0160 & 546.6793 & 0.0013 & 0.7927 & 4.582\end{array}$ $\begin{array}{llllllllllll}0.64 & 67.35 & 17.32 & 80.35 & 2 & 1637.0162 & 1637.0160 & 819.5153 & 0.0002 & 0.1220 & 6.705\end{array}$ $\begin{array}{llllllllllll}1.00 & 64.96 & 17.32 & 17.41 & 2 & 1637.0170 & 1637.0160 & 819.5153 & 0.0010 & 0.6101 & 12.275\end{array}$ $\begin{array}{lllllllllllll}1.00 & 34.86 & 17.16 & 17.21 & 3 & 1637.0173 & 1637.0160 & 546.6793 & 0.0013 & 0.7927 & 6.298\end{array}$ $\begin{array}{lllllllllll}0.99 & 16.11 & 16.99 & 14.91 & 3 & 1637.0182 & 1637.0160 & 546.6793 & 0.0022 & 1.3414 & 16.415\end{array}$ $\begin{array}{lllllllllll}0.84 & 64.65 & 16.72 & 77.65 & 2 & 1637.0184 & 1637.0160 & 819.5153 & 0.0024 & 1.4643 & 8.601\end{array}$ $\begin{array}{lllllllllll}1.00 & 23.04 & 16.72 & 15.73 & 3 & 1637.0188 & 1637.0160 & 546.6793 & 0.0028 & 1.7073 & 18.662\end{array}$ $\begin{array}{lllllllllll}0.82 & 66.99 & 17.32 & 79.99 & 2 & 1637.0166 & 1637.0160 & 819.5153 & 0.0006 & 0.3661 & 14.782\end{array}$ $\begin{array}{llllllllllll}1.00 & 26.35 & 17.16 & 18.39 & 3 & 1637.0173 & 1637.0160 & 546.6793 & 0.0013 & 0.7927 & 18.526\end{array}$

$\begin{array}{lllllllllll}1.00 & 22.93 & 16.99 & 15.83 & 3 & 1637.0179 & 1637.0160 & 546.6793 & 0.0019 & 1.1585 & 26.152\end{array}$

YYVVLGQFLVLK

$\begin{array}{lllllllllll}1.00 & 67.02 & 16.72 & 23.78 & 2 & 1637.0184 & 1637.0160 & 819.5153 & 0.0024 & 1.4643 & 22.528\end{array}$

AYVVLGQFLVLK

$\begin{array}{llllllllllll}0.56 & 17.16 & 22.25 & 3 & 1637.0173 & 1637.0160 & 546.6793 & 0.0013 & 0.7927 & 22.029 \\ 0.66 & 9.84 & 16.99 & 22.84 & 3 & 1637.0179 & 1637.0160 & 546.6793 & 0.0019 & 1.1585 & 16.946\end{array}$

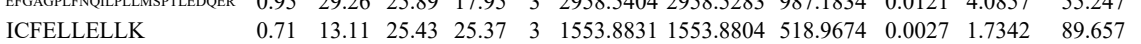
$\begin{array}{lllllllllllll}\text { IGPHDVLATLLNNLK } & 1.00 & 29.73 & 20.00 & 17.17 & 4 & 1976.1697 & 1976.1662 & 495.0488 & 0.0035 & 1.7675 & 156.438\end{array}$ $\begin{array}{lllllllllllll}\text { AIGPHDVLATLLNNLK } & 1.00 & 45.78 & 20.00 & 16.63 & 4 & 1976.1701 & 1976.1662 & 495.0488 & 0.0039 & 1.9695 & 665.565\end{array}$

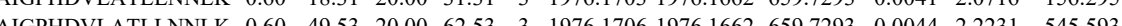

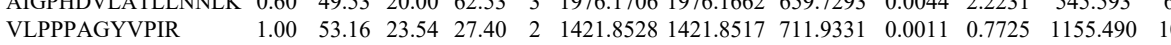
$\begin{array}{lllllllllllll}\text { VLPPPAGYVPIR } & 1.00 & 55.28 & 23.30 & 20.56 & 2 & 1421.8540 & 1421.8517 & 711.9331 & 0.0023 & 1.6153 & 3215.552 & 3471.2\end{array}$ $\begin{array}{llllllllllllll}\text { AIGPHDVLATLLNNLK } & 1.00 & 46.36 & 19.96 & 18.21 & 3 & 1976.1688 & 1976.1662 & 659.7293 & 0.0026 & 1.3137 & 180.978 & 178\end{array}$ $\begin{array}{llllllllllll}\text { AIGPHDVLATLLNNLK } & 1.00 & 41.16 & 19.96 & 15.63 & 4 & 1976.1689 & 1976.1662 & 495.0488 & 0.0027 & 1.3635 & 239.862\end{array}$ $\begin{array}{llllllllllll}\text { AIGPHDVLATLLNNLK } & 1.00 & 43.99 & 20.00 & 56.99 & 4 & 1976.1697 & 1976.1662 & 495.0488 & 0.0035 & 1.7675 & 97.736\end{array}$ $\begin{array}{llllllllllll}\text { VLPPPAGYVPIR } & 1.00 & 41.05 & 23.34 & 21.80 & 2 & 1421.8534 & 1421.8517 & 711.9331 & 0.0017 & 1.1939 & 196.086\end{array}$ $\begin{array}{lllllllllllll}\text { VLPPPAGYVPIR } & 0.98 & 28.09 & 23.34 & 22.86 & 2 & 1421.8534 & 1421.8517 & 711.9331 & 0.0017 & 1.1939 & 87.912\end{array}$ $\begin{array}{lllllllllllll}\text { AIGPHDVLATLLNNLK } & 0.67 & 59.18 & 19.91 & 72.18 & 3 & 1976.1694 & 1976.1662 & 659.7293 & 0.0032 & 1.6168 & 206.699\end{array}$ $\begin{array}{llllllllllll}\text { AFAVVASALGIPSLLPFLK } & 0.60 & 10.67 & 12.79 & 23.67 & 3 & 2201.3473 & 2201.3431 & 734.7883 & 0.0042 & 1.9053 & 5.504\end{array}$ $\begin{array}{lllllllllllll}\text { AFAVVASALGIPSLLPFLK } & 1.00 & 46.90 & 13.42 & 18.41 & 3 & 2201.3464 & 2201.3431 & 734.7883 & 0.0033 & 1.4970 & 3.140\end{array}$ $\begin{array}{llllllllllll}\text { LLVDVDESTLSPEEQK } & 0.50 & 14.29 & 27.50 & 15.88 & 3 & 2089.1035 & 2089.1034 & 697.3751 & 0.0001 & 0.0478 & 1694.838\end{array}$ $\begin{array}{llllllllllll}\text { VKPYLPQICGTVLWR } & 0.67 & 52.10 & 25.35 & 65.10 & 3 & 2106.1759 & 2106.1726 & 703.0648 & 0.0033 & 1.5646 & 116.848\end{array}$ $\begin{array}{llllllllllll}\text { VKPYLPQICGTVLWR } & 0.67 & 36.93 & 25.35 & 49.93 & 3 & 2106.1759 & 2106.1726 & 703.0648 & 0.0033 & 1.5646 & 115.020 \\ \text { GGDSIGETPTPGASK } & 1.00 & 89.12 & 27.87 & 23.13 & 2 & 1660.8520 & 1660.8512 & 831.4329 & 0.0008 & 0.4811 & 1062.443\end{array}$ $\begin{array}{lllllllllllll}\text { NRPLSDEELDAMFPEGYK } & 1.00 & 37.81 & 27.19 & 24.78 & 3 & 2398.1740 & 2398.1718 & 800.3979 & 0.0022 & 0.9162 & 61.599\end{array}$

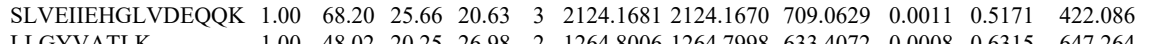

9 LLGYVATLK

VIRPLR

QRPGQQVATCVR

QRPGQQVATCVR

QRPGQQVATCVR

QRPGQQVATCVR

QRPGQQVATCVR

QRPGQQVATCVR

QRPGQVATCVR

QRPGQQVATCVR

QRPGQQVATCVR $\begin{array}{lllllllllllll}1.00 & 48.02 & 20.25 & 26.98 & 2 & 1264.8006 & 1264.7998 & 633.4072 & 0.0008 & 0.6315 & 647.264 & 749.257\end{array}$

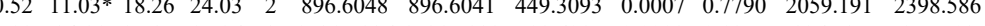
$\begin{array}{lllllllllllll}0.99 & 34.81 & 27.87 & 17.96 & 3 & 1531.7836 & 1531.7833 & 511.6017 & 0.0003 & 0.1955 & 126.535 & 157.5 \\ 1.00 & 43.40 & 28.03 & 16.68 & 3 & 1531.7851 & 1531.783 & 511.6017 & 0.0018 & 1.1728 & 176.840 & 179.4\end{array}$ $\begin{array}{lllllllllllll}1.00 & 43.40 & 28.03 & 16.68 & 3 & 1531.7851 & 1531.7833 & 511.6017 & 0.0018 & 1.1728 & 176.840 & 179.4 \\ 0.98 & 33.66 & 27.99 & 22.43 & 2 & 1531.7842 & 1531.7833 & 766.8989 & 0.0009 & 0.5868 & 278.656 & 368.6 \\ 1.00 & 47.54 & 27.99 & 17.25 & 3 & 1531.785 & 1531.783 & 51.6017 & 0.002 & 0.789 & 89.430 & \end{array}$ $\begin{array}{lllllllllllll}1.00 & 47.54 & 27.99 & 22.43 & 2 & 1531.7842 & 1531.7833 & 766.8989 & 0.0009 & 0.5868 & 278.656 & 368 .\end{array}$ $\begin{array}{llllllllllllll}.00 & 53.52 & 27.99 & 17.73 & 3 & 1531.7848 & 1531.7833 & 511.6017 & 0.0015 & 0.9773 & 2587.903 & 2881\end{array}$ $\begin{array}{lllllllllllll}0.99 & 34.42 & 27.99 & 20.99 & 2 & 1531.7848 & 1531.7833 & 766.8989 & 0.0015 & 0.9780 & 106.831 & 147.58 \\ 0.97 & 35.08 & 27.87 & 20.58 & 2 & 1531.7834 & 1531.7833 & 766.8989 & 0.0001 & 0.0652 & 143.000 & 206.73\end{array}$ $\begin{array}{lllllllllllll}0.99 & 42.89 & 27.90 & 25.41 & 2 & 1531.7838 & 1531.7833 & 766.8989 & 0.0005 & 0.3260 & 282.561 & 353.112\end{array}$

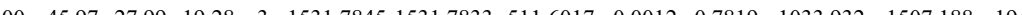
$\begin{array}{lllllllllllll}1.00 & 45.97 & 27.99 & 19.28 & 3 & 1531.7845 & 1531.7833 & 511.6017 & 0.0012 & 0.7819 & 1033.932 & 1507.188 & 1947.774 \\ 1.00 & 5258 & 27.99 & 23.68 & 3 & 1531.7845 & 1531.7833 & 511.6017 & 0.0012 & 0.7819 & 1478.204 & 1889.782 & 1973.384\end{array}$ 
QRPGQQVATCVR QRPGQQVATCVR QRPGQQVATCVR QRPGQQVATCVR QRPGQQVATCVR QRPGQQVATCVR QRPGQQVATCVR QRPGQQVATCVR

$\begin{array}{llllllllllll} & & & \end{array}$ ASFPQGPIGGANR SFPQGPIGGANR ASPQGPIGGANR ASFPQGPIGGANR ASFPOGPIGGANR LAGVTALSCWLPLR LAGVTALSCWLPLR LAGVTALSCWLPLR LAGVTALSCWLPLR LAGVTALSCWLPLR LAGVTALSCWLPLR LAGVTALSCWLPLR

$\begin{array}{llllllllllll}\text { U520_HUMAN } & \text { O75643 } & \text { SNRNP20C U5 small nuclear I } 244.51 & 1.00 & 22 & 14.7 & -0.2089 & 0.4865 & 0.8870 & 0.4954 & 41 & \text { KLPEEVVK }\end{array}$ RQLCLLGQNAQTMAYNITP ASFPOGPIGGANR $\begin{array}{llllllllllll}0.98 & 35.6 & 27.90 & 24.47 & 2 & 1531.7830 & 1531.783 & 766.898 & 0.0003 & 0.1956 & 17.912\end{array}$ $\begin{array}{lllllllllll}1.00 & 53.01 & 27.90 & 22.09 & 3 & 1531.7839 & 1531.7833 & 511.6017 & 0.0006 & 0.3909 & 755.754\end{array}$ $\begin{array}{lllllllllll}1.03 & 30.70 & 27.91 & 22.44 & 2 & 1531.7828 & 1531.7833 & 766.8989 & -0.0005 & -0.3260 & 48.205\end{array}$

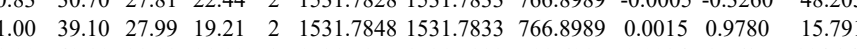
$\begin{array}{lllllllllll}1.00 & 42.11 & 28.08 & 21.99 & 3 & 1531.7857 & 1531.7833 & 511.6017 & 0.0024 & 1.5637 & 114.342\end{array}$

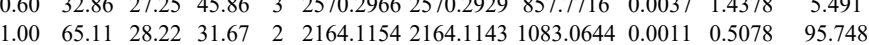
$\begin{array}{lllllllllll}0.66 & 30.21 & 28.06 & 43.21 & 3 & 1531.7854 & 1531.7833 & 511.6017 & 0.0021 & 1.3683 & 17.467\end{array}$

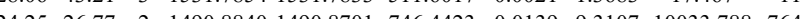
$\begin{array}{lllllllllllllll} & \end{array}$ $\begin{array}{llllllllllllllll}1.00 & 75.14 & 27.41 & 28.13 & 2 & 1414.7534 & 1414.7439 & 708.3792 & 0.0095 & 6.7054 & 2012.524 & 1608.196 & 833.524 & 3699.531 & \text { Yes } & \\ 1.00 & 73.72 & 27.37 & 29.29 & 2 & 144.7560 & 1414.73 & 768.3792 & 0.011 & 8.58 & 1328.772 & 585.322 & 289.095 & 1146.178 & \text { Yes }\end{array}$

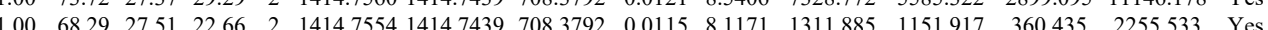

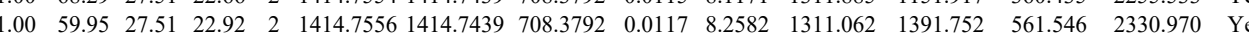

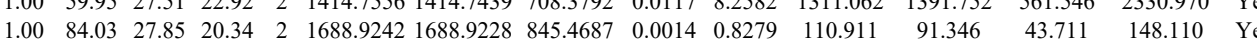
$\begin{array}{lllllllllllllll}1.00 & 81.49 & 27.69 & 20.44 & 2 & 1688.9258 & 1688.9228 & 845.4687 & 0.0030 & 1.7742 & 122.758 & 85.188 & 45.706 & 181.267 & \text { Yes }\end{array}$ $\begin{array}{lllllllllllllll}1.00 & 83.10 & 27.86 & 24.94 & 2 & 1688.9240 & 1688.9228 & 845.4687 & 0.0012 & 0.7097 & 89.055 & 46.490 & 38.460 & 103.150 & \text { Yes }\end{array}$

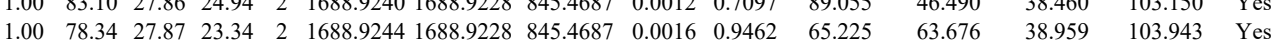
$\begin{array}{llllllllllllllll}0.86 & 17.78 & 27.89 & 18.20 & 3 & 1688.9248 & 1688.9228 & 563.9815 & 0.0020 & 1.1821 & 15.007 & 18.757 & 0.000 & 21.423 & \text { No }\end{array}$

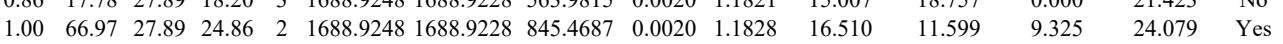
$\begin{array}{llllllllllll}1.00 & 59.17 & 27.75 & 29.11 & 2 & 1688.9250 & 1688.9228 & 845.4687 & 0.0022 & 1.3011 & 10.890 & 2.369\end{array}$ $\begin{array}{lllllllllllll}\text { KLPECWAK } & 1.00 & 49.24 & 19.59 & 24.53 & 3 & 1372.8754 & 1372.8655 & 458.6291 & 0.0099 & 7.1953 & 19446.480 & 18836.785 \\ \text { DILCGAADEVLAVLK } & 0.55 & 10.53 & 27.32 & 16.76 & 3 & 1863.0124 & 1863.0089 & 622.0102 & 0.0035 & 1.8756 & 241.235 & 271.783\end{array}$ $\begin{array}{llllllllllllll}\text { NALLQLTDSQIADVAR } & 1.00 & 89.76 & 26.44 & 25.02 & 2 & 1871.0260 & 1871.0234 & 936.5190 & 0.0026 & 1.3881 & 122.811 & 54.073\end{array}$ QVLDLEDLVFTQGSHFMA $\begin{array}{lllllllllllll} & 0.66 & 42.71 & 26.97 & 55.71 & 3 & 2579.3320 & 2579.3298 & 860.7839 & 0.0022 & 0.8519 & 129.312 & 100.268\end{array}$ $\begin{array}{lllllllllllllll}\text { OVLDISNAAEYENIFIR } & 0.60 & 47.62 & 25.50 & 60.62 & 3 & 2158.1800 & 2158.1755 & 720.3991 & 0.0045 & 2.0822 & 41.675 & 29.316\end{array}$ $\begin{array}{lllllllllllll}\text { GLLEDLFRGSHFMANK } & 0.55 & 49.01 & 26.95 & 62.01 & 3 & 2579.3311 & 2579.3298 & 860.7839 & 0.0013 & 0.5034 & 102.460 & 46.309 \\ \text { GLIEIISNAAEYENIPIR } & 1.00 & 61.06 & 25.44 & 20.25 & 3 & 2158.1791 & 2158.1755 & 720.3991 & 0.0036 & 1.6657 & 19.299 & 8.744\end{array}$

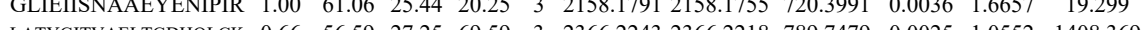

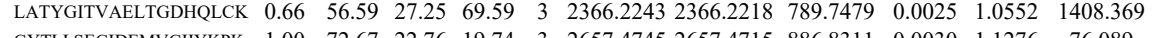
$\begin{array}{lllllllllllllll} & \text { GATLSEMVGIYKPK } & 1.00 & 72.67 & 22.76 & 19.74 & 3 & 2657.4745 & 2657.4715 & 886.8311 & 0.0030 & 1.1276 & 76.089 & 77.018\end{array}$ $\begin{array}{lllllllllllll}\text { GYTLLSEGIDEMVGIIYKPK } & 1.00 & 41.47 & 22.58 & 54.47 & 4 & 2657.4789 & 2657.4715 & 665.3752 & 0.0074 & 2.7804 & 114.564 & 9\end{array}$ $\begin{array}{llllllllllllll}\text { LDLVHAALMLDK } & 1.00 & 41.80 & 24.80 & 17.51 & 3 & 1726.9924 & 1726.9895 & 57.6704 & 0.0029 & 1.6763 & 237.663 & 190\end{array}$ $\begin{array}{llllllllllllll}\text { LDLVHTAALMLDK } & 1.00 & 41.62 & 24.80 & 22.14 & 3 & 1726.9927 & 1726.9895 & 576.6704 & 0.0032 & 1.8497 & 481.765 & 41\end{array}$

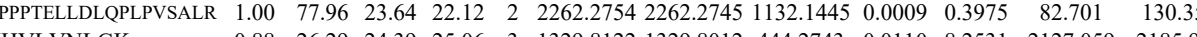

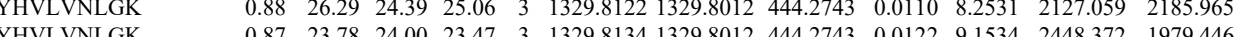

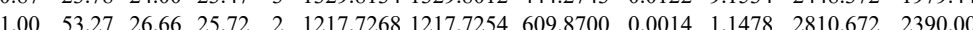

$\begin{array}{llllllllllll}1.00 & 53.27 & 26.66 & 25.72 & 2 & 1217.7268 & 1217.7254 & 609.8700 & 0.0014 & 1.1478 & 2810.672 & 2390.001 \\ 1.00 & 61.56 & 26.66 & 26.23 & 2 & 1217.7268 & 1217.7254 & 609.8700 & 0.0014 & 1.1478 & 3479.340 & 3248.184\end{array}$

AFEIVLNR

MTQNPNYYNLQGISH $\begin{array}{lllllllllllll}.00 & 59.00 & 27.54 & 21.07 & 3 & 2079.0244 & 2079.0078 & 694.0099 & 0.0166 & 7.9729 & 1064.442 & 909.052\end{array}$

$\begin{array}{llllllllllllll}\text { LTAIDILTTCAADIQR } & 1.00 & 88.38 & 27.68 & 30.39 & 2 & 1906.9988 & 1906.9978 & 954.5062 & 0.0010 & 0.5238 & 23.965 & 7.804 \\ \end{array}$

$\begin{array}{lllllllllllll}\text { LTAIDILTTCAADIQR } & 1.00 & 84.72 & 27.66 & 27.08 & 2 & 1906.9990 & 1906.9978 & 954.5062 & 0.0012 & 0.6286 & 26.015 & 14.659 \\ \text { LTAITI } & 24 & 1907.0011 & 1906.9978 & 636.6732 & 0.0033 & 1.7277 & 61.535 & 51.407\end{array}$

$\begin{array}{lllllllllllllll} & \text { LTAIDITTCAADIQR } & 1.00 & 5978 & 27.57 & 25.55 & 3 & 1907.0014 & 1906.9978 & 636.6732 & 0.0036 & 1.8848 & 31.120 & 58.566\end{array}$ $\begin{array}{llllllllllllll}\text { TICAEFAILR } & 1.00 & 69.75 & 27.58 & 38.31 & 2 & 1325.6970 & 1325.6957 & 663.8551 & 0.0013 & 0.9791 & 1842.658 & 2082.010 & 1\end{array}$ $\begin{array}{llllllllllllll}\text { LTAIDILTTCAADIQR } & 1.00 & 67.05 & 27.63 & 27.50 & 2 & 1906.9996 & 1906.9978 & 954.5062 & 0.0018 & 0.9429 & 6.937 & 1.078\end{array}$ $\begin{array}{lllllllllllll}\text { LTAIDILTTCAADIQR } & 1.00 & 45.62 & 27.59 & 18.67 & 3 & 1907.0008 & 1906.9978 & 636.6732 & 0.0030 & 1.5707 & 234.636 & 213.507\end{array}$ $\begin{array}{llllllllllllll}\text { LTAIDILTTCAADIQR } & 1.00 & 44.89 & 27.61 & 18.87 & 3 & 1907.0011 & 1906.9978 & 636.6732 & 0.0033 & 1.7277 & 123.713 & 101.71\end{array}$ $\begin{array}{lllllllllllll}\text { LIGLSATLPNYEDVATFLR } & 1.00 & \text { 25.16 } & 23.83 & 2 & 2236.2234 & 2236.2225 & 1119.1185 & 0.0009 & 0.4021 & 73.607 & 62.640\end{array}$

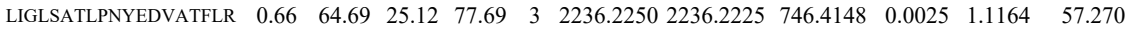
$\begin{array}{lllllllllllll}\text { LIGLSATLPNYEDVATFLR } & 0.60 & 71.91 & 25.08 & 84.91 & 3 & 2236.2265 & 2236.2225 & 746.4148 & 0.0040 & 1.7863 & 28.369 & 46.84\end{array}$ $\begin{array}{llllllllllll}\text { WTELGALDILQMLGR } & 1.00 & \text { \#冊冊 } 26.69 & 26.29 & 2 & 1859.0106 & 1859.0097 & 930.5121 & 0.0009 & 0.4836 & 200.505 & 188.718\end{array}$ $\begin{array}{lllllllllllll}\text { WTELGALDILQMLGR } & 1.00 & 96.09 & 26.69 & 23.34 & 2 & 1859.0106 & 1859.0097 & 930.5121 & 0.0009 & 0.4836 & 175.178 & 188.416\end{array}$ $\begin{array}{lllllllllllll}\text { WTELGALDILQMLGR } & 0.97 & 23.12 & 26.82 & 24.72 & 3 & 1859.0122 & 1859.0097 & 620.6772 & 0.0025 & 1.3426 & 43.225 & 18.592\end{array}$

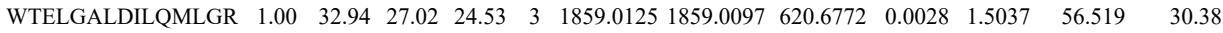
$\begin{array}{lllllllllllll}\text { WTELGALDILQMLGR } & 1.00 & 88.71 & 26.77 & 20.39 & 2 & 1859.0088 & 1859.0097 & 930.5121 & -0.0009 & -0.4836 & 296.379 & 265.330\end{array}$

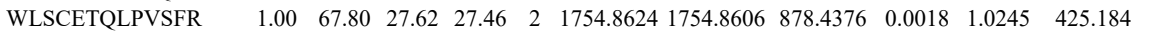
$\begin{array}{lllllllllllll}\text { GVESVFDIMEMEDEER } & 1.00 & 87.82 & 24.50 & 20.48 & 2 & 2057.9054 & 2057.9043 & 1029.9594 & 0.0011 & 0.5340 & 4.642\end{array}$

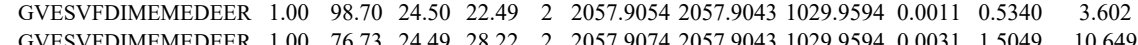
KPVIVFVPSR KPVIVFVPSR $\begin{array}{lllllllllllllllll}\text { KPVIVFVPSR } & 0.66 & 45.31 & 17.08 & 58.31 & 3 & 1428.9082 & 1428.9061 & 477.3093 & 0.0021 & 1.4666 & 2224.389 & 3090.959 & 2197.901 & 3222.125 & \text { Yes } \\ \text { KPVIVFVPSR } & 0.67 & 45.75 & 17.08 & 58.75 & 3 & 1428.9088 & 1428.9061 & 477.3093 & 0.0027 & 1.8856 & 2626.574 & 3541.849 & 4016.147 & 4579.470 & \text { Yes } \\ \text { KPVIFVPSR } & 0.55 & 31.17 & 17.78 & 44.17 & 3 & 1428.9076 & 1428.906 & 477.3093 & 0.0015 & 1.0475 & 341.546 & 349.027 & 242.132 & 548.560 & \text { Yes }\end{array}$ $\begin{array}{lllllllllllllllll}\text { KPVIVFVPSR } & 0.66 & 45.31 & 17.08 & 58.31 & 3 & 1428.9082 & 1428.9061 & 477.3093 & 0.0021 & 1.4666 & 2224.389 & 3090.959 & 2197.901 & 3222.125 & \text { Yes } \\ \text { KPVIVFVPSR } & 0.67 & 45.75 & 17.08 & 58.75 & 3 & 1428.9088 & 1428.9061 & 477.3093 & 0.0027 & 1.8856 & 2626.574 & 3541.849 & 4016.147 & 4579.470 & \text { Yes } \\ \text { KPVIFVPSR } & 0.55 & 31.17 & 17.78 & 44.17 & 3 & 1428.9076 & 1428.906 & 477.3093 & 0.0015 & 1.0475 & 341.546 & 349.027 & 242.132 & 548.560 & \text { Yes }\end{array}$

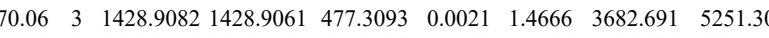
$\begin{array}{lll}160.672 & 31198.890 & \text { Yes }\end{array}$ $82.308 \quad 460.747 \quad$ Yes $97.620 \quad 195.279 \quad$ Yes $30.051 \quad 48.901 \quad$ Yes $\begin{array}{llll}19.680 & 2174.317 & \text { Yes }\end{array}$ $\begin{array}{lll}65.790 & 113.643 & \text { Yes } \\ 37.883 & 167.109 & \text { Yes }\end{array}$ $65.514 \quad 585.647$ Yes (19.075 Yes .2213093 .312 Yes $\begin{array}{lll}1.886 & 291.726 & \text { Yes }\end{array}$ $\begin{array}{lll}25.076 & 4038.439 & \text { Yes } \\ 03.584 & 5221.125 & \text { Yes }\end{array}$ $309.162 \quad 1076.421$ Yes $0.000 \quad 24.599 \quad \mathrm{~N}$ $\begin{array}{lll}55.402 & \text { Yes } \\ & 117.644 & \text { Yes }\end{array}$ $\begin{array}{llll}16.924 & 3028.737 & \text { Yes }\end{array}$ $\begin{array}{lll}0.000 & 5.055 & \text { No }\end{array}$ $\begin{array}{lll}69.887 & 279.843 & \text { Yes }\end{array}$ $\begin{array}{lll}16.620 & 107.989 & \text { Yes }\end{array}$ $\begin{array}{lll}27.831 & 141.779 & \text { Yes } \\ 35.222 & 50.072 & \text { Yes }\end{array}$ $\begin{array}{lll}28.504 & 16.641 & \text { No }\end{array}$ $30.592 \quad 261.271$ Yes $0.000 \quad 245.826 \quad$ No $\begin{array}{lll}0.000 & 245.826 & \text { Yos }\end{array}$ $\begin{array}{lll}18.240 & 39.542 & \text { Yes } \\ 20.275 & 452.244 & \text { Yes }\end{array}$ $\begin{array}{lll}18.275 & 452.244 & \text { Yes } \\ 0.000 & 860.364 & \end{array}$ $\begin{array}{ccc}0.000 & 860.364 & \text { No } \\ 15.057 & 15.807 & \end{array}$ $11.489-4.946 \quad \mathrm{~N}$ $\begin{array}{ll}15.057 & 15.807 \\ 8.667 & 9.946 \\ 57787\end{array}$ $\begin{array}{llllllllllllllll}0.55 & 31.17 & 17.78 & 44.17 & 3 & 1428.9076 & 1428.9061 & 477.3093 & 0.0015 & 1.0475 & 341.546 & 349.027 & 242.132 & 548.560 & \text { Yes }\end{array}$ 
$\begin{array}{lllllllllllll}\text { EDLNCQEEEDPMNK } & 0.60 & 20.16 & 20.57 & 33.16 & 3 & 2026.8562 & 2026.8525 & 676.6248 & 0.0037 & 1.8228 & 115.130\end{array}$

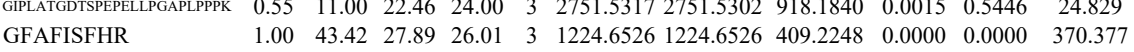

GFAFISFHR

GFAFISFHR

GFAFISFHR

LPGELEPVQATQNK

EIF3J_HUMAN O75822 EIF3J

Eukaryotic transla $29.062 \quad 1.00 \quad 3 \quad 11.6 \quad 0.1722 \quad 0.2798 \quad 1.7462 \quad 0.2602$

LEEPE

VLTPEEQLADK

VLTPEEQLADK

$\begin{array}{lllllllllllll}\text { AP1G2_HUMA } & 075843 & \text { AP1G2 } & \text { AP-1 complex sut } 87.117 & 1.00 & 3 & 4.8 & -0.4854 & 0.1858 & 0.1674 & 0.2553 & 6 & \begin{array}{l}\text { VPELSSFFLPPAC } \\ \text { YVALTSLLR }\end{array}\end{array}$ QEESDLELAK YVALTSLLR YVALISLLK

GGLPTQLR

GGLPITQLFR

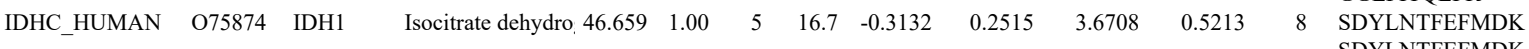

SDYLNTFEFMDK

LIDDMVAQAMK

LIDDMVAQAMK

IIWELIK

IIWELIK

IIWELIK

IIWELIK

GQETSTNPIASIFAWTR

LVSGWVKPIIIGR

LVSGWVKPIIIGR

\section{AWDDFFPSDR} \begin{tabular}{llllllllllllll} 
& \\
\hline
\end{tabular} $\begin{array}{lllllllllllll} & \text { AW } & 59.34 & 27.43 & 72.34 & 2 & 2256.1574 & 2256.1542 & 1129.0844 & 0.0032 & 1.4171 & 6.917 & 37.087\end{array}$ $\begin{array}{lllllllllllll} & 25.125 & 25.1579 & 2256.1542 & 753.0587 & 0.0037 & 1.6378 & 11.142 & 23.686\end{array}$ $\begin{array}{llllllllllllll} & 19.04 .069\end{array}$ $\begin{array}{llllllllllllll}\text { TPMGIVLDALEQQEEGINR } & 0.66 & 62.92 & 27.47 & 75.92 & 3 & 2256.1564 & 2256.1542 & 753.0587 & 0.0022 & 0.9738 & 11.939 & 12.314 \\ \text { TPMGIVLDALEQQEEGINR } & 1.00 & 34.18 & 27.44 & 21.16 & 3 & 2256.1576 & 2256.1542 & 753.0587 & 0.0034 & 1.5050 & 4.716 & 23.219\end{array}$ GELVGGLDIVK

YEISSVPTFLFFK

YEISSVPTFLFFK

YEISSVPTFLFFK

YEISSVPTFLFFK

LEALGVPEVEK

ELEASEELDTICPK

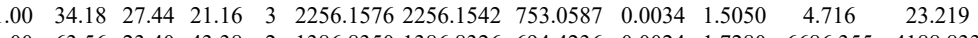
$\begin{array}{lllllllllllll} & 22.46 & 28.44 & 3 & 2751.5329 & 2751.5302 & 918.1840 & 0.0027 & 0.9802 & 58.447\end{array}$ $\begin{array}{llllllllllll} & 22.46 & 39.30 & 3 & 2751.5317 & 2751.5302 & 918.1840 & 0.0015 & 0.5446 & 40.202\end{array}$

\begin{tabular}{lll}
0.2248 & $-0.0006-0.4887 \quad 678.4$ \\
\hline
\end{tabular} $\begin{array}{llllllllllll}1.00 & 36.88 & 27.89 & 21.38 & 3 & 1224.6526 & 1224.6526 & 409.2248 & 0.0000 & 0.0000 & 487.132 & \\ 0.99 & 36.80 & 27.92 & 22.17 & 3 & 1224.6520 & 1224.6526 & 409.2248 & -0.0006 & -0.4887 & 620.279 & 5\end{array}$ $\begin{array}{lllllllllll}0.99 & 36.80 & 27.92 & 22.17 & 3 & 1224.6520 & 1224.6526 & 409.2248 & -0.0006 & -0.4887 & 620.279\end{array}$ $\begin{array}{llllllllllll}1.00 & 45.67 & 25.13 & 22.81 & 2 & 1811.0204 & 1811.0032 & 906.5089 & 0.0172 & 9.4869 & 1159.025 & 101 \\ 0.94 & 31.49 & 27.73 & 23.86 & 2 & 1257.6696 & 1257.6696 & 629.8421 & 0.0000 & 0.0000 & 142.643 & 17\end{array}$ $\begin{array}{llllllllllll}0.94 & 31.49 & 27.73 & 23.86 & 2 & 1257.6696 & 1257.6696 & 629.8421 & 0.0000 & 0.0000 & 142.643 \\ 0.98 & 31.62 & 27.81 & 25.35 & 2 & 1257.6704 & 1257.6696 & 629.8421 & 0.0008 & 0.6351 & 190.194\end{array}$ $\begin{array}{lllllllllll}0.98 & 31.62 & 27.81 & 25.35 & 2 & 1257.6704 & 1257.6696 & 629.8421 & 0.0008 & 0.6351 & 190.194 \\ 1.00 & 49.43 & 27.66 & 27.69 & 2 & 1529.8564 & 1529.8544 & 765.9345 & 0.0020 & 1.3056 & 384.207\end{array}$

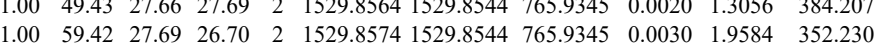

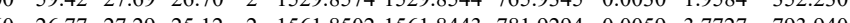
$\begin{array}{lllllllllll}0.60 & 26.77 & 27.29 & 25.12 & 2 & 1561.8502 & 1561.8443 & 781.9294 & 0.0059 & 3.7727 & 793.940\end{array}$ $\begin{array}{lllllllllll}0.60 & 38.01 & 27.44 & 19.91 & 3 & 2324.2156 & 2324.2143 & 775.7454 & 0.0013 & 0.5586 & 39.270\end{array}$ $\begin{array}{llllllllllll}1.00 & 53.03 & 25.65 & 28.55 & 2 & 1244.7368 & 1244.7363 & 623.3754 & 0.0005 & 0.4010 & 861.620\end{array}$

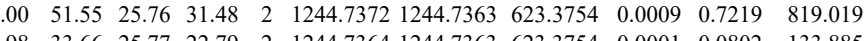
$\begin{array}{llllllllllll}1.00 & 45.67 & 25.65 & 26.10 & 2 & 12447 & 12468 & 1244.7363 & 623.3754 & 0.0005 & 0.4010 & 179.624\end{array}$ $\begin{array}{llllllllllll}100 & 66.43 & 26.30 & 21.33 & 2 & 1796.8550 & 1796.8535 & 899.4340 & 0.0015 & 0.8339 & 322 & 200\end{array}$ $\begin{array}{llllllllllll}1.00 & 65.02 & 26.30 & 23.60 & 2 & 1796.8550 & 1796.8535 & 899.4340 & 0.0015 & 0.8339 & 338.936\end{array}$ $\begin{array}{llllllllllll} & 17.038 & 251.027\end{array}$ $\begin{array}{lllllllllllll}1.00 & 7.82 & 26.30 & 23.29 & 2 & 176.8550 & 176.8535 & 89.4340 & 0.0015 & 0.8339 & 330.821 & 449.796 \\ 1.00 & 71.27 & 28.25 & 43.85 & 2 & 1521.8166 & 1521.8138 & 761.9142 & 0.0028 & 1.8375 & 334.152 & 274.281\end{array}$ $\begin{array}{lllllllllllll}1.00 & 62.26 & 28.12 & 39.92 & 2 & 1521.8174 & 1521.8138 & 761.9142 & 0.0036 & 2.3625 & 451.637 & 258.595\end{array}$ $\begin{array}{lllllllllllll}1.00 & 49.21 & 23.46 & 35.99 & 2 & 1201.7688 & 1201.7678 & 601.8912 & 0.0010 & 0.8307 & 2229.939 & 1676.573\end{array}$ $\begin{array}{llllllllllll}1.00 & 49.13 & 23.46 & 35.91 & 2 & 1201.7692 & 1201.7678 & 601.8912 & 0.0014 & 1.1630 & 2778.687 & 2326.895\end{array}$ $\begin{array}{llllllllllllll}100 & 48.90 & 23.40 & 35.64 & 2 & 1201.7704 & 1201.7678 & 601.8912 & 0.0026 & 2.1599 & 5505.587 & 3944.593\end{array}$ $\begin{array}{lllllllllllll}100 & 48.97 & 23.36 & 35.72 & 2 & 1201.7720 & 1201.7678 & 601.8912 & 0.0042 & 3.4890 & 5421.621 & 4089.757\end{array}$

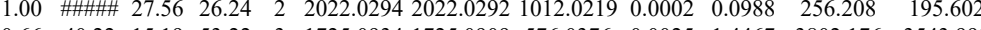
$\begin{array}{llllllllllll}0.66 & 40.22 & 15.19 & 53.22 & 3 & 1725.0934 & 1725.0909 & 576.0376 & 0.0025 & 1.4467 & 3802.176 & 3543.999 \\ 0.67 & 4.23 & 15.19 & 59.23 & 3 & 1725.0940 & 1725.099 & 5760376 & 0.031 & 1.7939 & 4150.295 & 4183.672\end{array}$

19

191.407 $\begin{array}{lllllllllllll}1.00 & 63.56 & 23.40 & 43.38 & 2 & 1386.8350 & 1386.8326 & 694.4236 & 0.0024 & 1.7280 & 6686.355 & 4188.833\end{array}$ $\begin{array}{llllllllllll}0.84 & 54.78 & 26.78 & 67.78 & 2 & 1865.0240 & 1865.0219 & 933.5182 & 0.0021 & 1.1248 & 1239.738 & 815.553 \\ 1.00 & 52.54 & 26.76 & 19.72 & 2 & 1865.0248 & 1865.0219 & 933.5182 & 0.0029 & 1.5533 & 1051.633 & 705.643\end{array}$ $\begin{array}{llllllllllll}1.00 & 52.54 & 26.76 & 19.72 & 2 & 1865.0248 & 1865.0219 & 933.5182 & 0.0029 & 1.5533 & 1051.633 & 705.643 \\ 0.96 & 25.25 & 26.81 & 14.68 & 3 & 1865.0269 & 1865.0219 & 622.6812 & 0.0050 & 2.6766 & 753.603 & 576.638\end{array}$ $\begin{array}{lllllllllllll}0.96 & 25.25 & 26.81 & 14.68 & 3 & 1865.0269 & 1865.0219 & 622.6812 & 0.0050 & 2.6766 & 753.603 & 576.638 \\ 0.99 & 36.74 & 26.67 & 18.05 & 3 & 1865.0278 & 1865.0219 & 622.6812 & 0.0059 & 3.1584 & 358.456 & 364.211\end{array}$

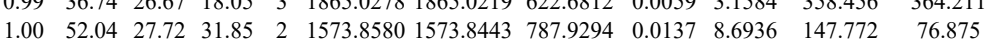
$\begin{array}{llllllllllll}1.00 & 59.50 & 27.69 & 31.92 & 2 & 1573.85961573 .8443 & 787.9294 & 0.0153 & 9.7089 & 196.184 & 110.237\end{array}$ $\begin{array}{lllllllllll}1.00 & 94.05 & 26.77 & 27.94 & 2 & 1909.9270 & 1909.9256 & 955.9701 & 0.0014 & 0.7322 & 109.645\end{array}$ 
ELEASEELDTICPK ELEASEELDTICPK ELEASEELDTICPK LDGAHAPELTK

DLPASETPK

ALPASETPK

ALPASETPK

AVDALLTHCK

AVDALLTHCK

LLSSFDFFLTDAR

LLSSFDFFLTDAR

(IG

IGHVGMQIEHIENIVAVTK

IGHVGMQIEHIENIVAVTK

TVSQIISLQTLK

$\begin{array}{llllllllllll}0.67 & 25.90 & 18.26 & 38.90 & 3 & 1617.9943 & 1617.9909 & 540.3376 & 0.0034 & 2.4074 & 660.719 & 218.849\end{array}$

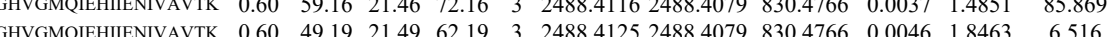
$\begin{array}{lllllllllllll}\text { IGHVGMIEHIENIVAVTK } & 0.67 & 50.40 & 21.43 & 63.40 & 3 & 2488.4113 & 2488.4079 & 830.4766 & 0.0034 & 1.3647 & 4.754 & 0.54\end{array}$ LLPSLIGR

LLPSLIGR

LLPSLIGR

LLPSLIGR

LLPSLIGR

LLPSLIGR

ALPASETPK

ALPASETPK

$\begin{array}{lllllllllll}\text { SRP72_HUMAN } & 076094 & \text { SRP72 } & \text { Signal recognition } 74.606 & 1.00 & 5 & 17.4 & 0.0791 & 0.4932 & -0.7903 & 0.4262\end{array}$$$
1.00
$$

$\begin{array}{llllllllllll} & \end{array}$

$\begin{array}{lllllllllllll}1.00 & 40.29 & 17.92 & 34.40 & 2 & 1011.6574 & 1011.6562 & 506.8354 & 0.0012 & 1.1838 & 6425.672 & 7050.027 & 2\end{array}$

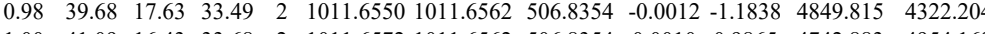
$\begin{array}{lllllllllllllll}1.00 & 41.09 & 16.43 & 33.68 & 2 & 1011.6572 & 1011.6562 & 506.8354 & 0.0010 & 0.9865 & 4742.883 & 4954.163 & 160.657 & 10758.971 & \text { Yes } \\ 0.74 & 28.25 & 21.07 & 31.08 & 2 & 1011.6538 & 1011.6562 & 506.8354 & -0.0024 & -23676 & 3504.041 & 3198.092 & 462.122 & 7118.381 & \text { Yes } \\ 0.97 & 40.86 & 17.63 & 32.09 & 2 & 01.6544 & 101.6562 & 506.8354 & -0.0018 & -1.7757 & 2615.430 & 2599.056 & 60.017 & 5549.083 & \end{array}$ $\begin{array}{lllllllllllllll}0.97 & 40.86 & 17.63 & 32.09 & 2 & 1011.6544 & 1011.6562 & 506.8354 & -0.0018 & -1.7757 & 2615.430 & 2599.056 & 60.017 & 5549.083 & \text { Yes }\end{array}$ $\begin{array}{lllllllllllllll}0.99 & 45.18 & 27.06 & 30.99 & 2 & 1200.6994 & 1200.6958 & 601.3552 & 0.0036 & 2.9932 & 5586.712 & 5378.161 & 842.540 & 9951.964 & \text { Yes }\end{array}$

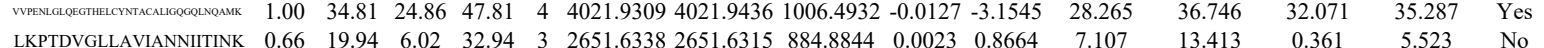
$\begin{array}{llllllllllllllll} & \\ \text { LKPTDVGLAVANNIITTNK } & 0.66 & 19.94 & 6.02 & 32.94 & 3 & 2651.6338 & 2651.6315 & 884.8844 & 0.0023 & 0.8664 & 7.107 & 13.413 & 0.361 & 5.523 & \text { No }\end{array}$ $\begin{array}{llllllllllllllll} & \end{array}$

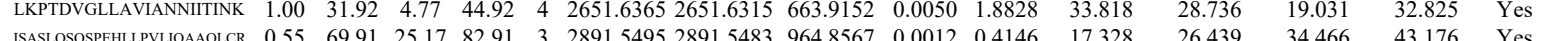
$\begin{array}{lllllllllllllll} & \end{array}$

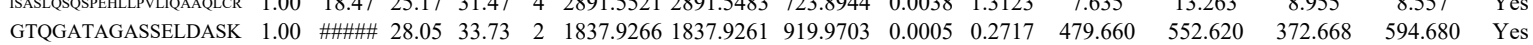

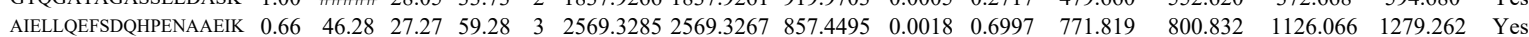
$\begin{array}{llllllllllllllll}\text { AIELLOEFSDPHPENAAEIK } & 1.00 & 41.71 & 27.10 & 15.99 & 3 & 2569.3300 & 2569.3267 & 857.4495 & 0.0033 & 1.2829 & 740.520 & 468.893 & 1419.817 & 1419.180 & \text { Yes }\end{array}$

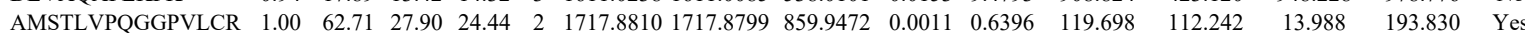
$\begin{array}{llllllllllllllll}\text { AMSTLVPOGGPVLCR } & 1.00 & 69.37 & 27.93 & 27.96 & 2 & 1717.8812 & 1717.8799 & 859.9472 & 0.0013 & 0.7559 & 383.395 & 405.835 & 105.373 & 503.102 & \text { Yes }\end{array}$ $\begin{array}{llllllllllllllll}\text { AMSTLVPOGGPVLCR } & 1.00 & 76.08 & 27.93 & 26.80 & 2 & 1717.8812 & 1717.8799 & 859.9472 & 0.0013 & 0.7559 & 117.774 & 251.505 & 7.154 & 260.581 & \text { Yes }\end{array}$ $\begin{array}{lllllllllllllllll}\text { VVCLFR } & 0.63 & 23.94 & 25.81 & 21.14 & 2 & 925.4994 & 925.5000 & 463.7573 & -0.0006 & -0.6469 & 419.422 & 501.818 & 93.709 & 1069.094 & \text { Yes }\end{array}$ $\begin{array}{llllllllllllllll}\text { VVCLFR } & 0.93 & 25.30 & 26.47 & 20.57 & 2 & 925.5010 & 925.5000 & 463.7573 & 0.0010 & 1.0781 & 2693.945 & 3922.340 & 290.132 & 8397.025 & \text { Yes }\end{array}$ VVCLFR DLVAQAPLKPK DLVAQAPLKPK DLVAQAPLKPK DLVAQAPLKPK DLVAQAPLKPK DLVAQAPLKPK

DLVAQAPLKPK

DLVAQAPLKPK

DLVAQAPLKPK

DLVAQAPLKPK

ILLDQVEAVADFDECIR

LRPESALAQAQK

LRPESALAQAQK

YRESALAQAQK GLLQLQWK GLLQLQWK $\begin{array}{llllllllllllll}0.79 & 19.54 & 26.6 & 18.29 & 2 & 925.5012 & 925.5000 & 463.7573 & 0.0012 & 1.2938 & 2713.745 & 3942.308 & 4\end{array}$ $\begin{array}{llllllllllllllll}0.95 & 25.62 & 25.87 & 20.54 & 2 & 925.5006 & 925.5000 & 463.7573 & 0.0006 & 0.6469 & 782.062 & 1186.552\end{array}$ $\begin{array}{lllllllllllllll}0.52 & 1.80 * & 18.20 & 14.80 & 3 & 1466.9095 & 1466.9064 & 489.9761 & 0.0031 & 2.1089 & 37.263 & 107.046\end{array}$ $\begin{array}{llllllllllllll}0.53 & 1.94 * 18.20 & 14.94 & 3 & 1466.9095 & 1466.9064 & 489.9761 & 0.0031 & 2.1089 & 21.125 & 102.973\end{array}$ $\begin{array}{lllllllllllllll}0.52 & 1.79 * & 18.20 & 14.79 & 3 & 1466.9095 & 1466.9064 & 489.9761 & 0.0031 & 2.1089 & 32.769 & 56.268\end{array}$ $\begin{array}{lllllllllllll}0.51 & 1.53 * & 18.20 & 14.53 & 3 & 1466.9098 & 1466.9064 & 489.9761 & 0.0034 & 2.3130 & 22.446 & 88.451\end{array}$ $\begin{array}{lllllllllllll}0.51 & 1.53 * 18.20 & 14.53 & 3 & 1466.9098 & 1466.9064 & 489.9761 & 0.0034 & 2.3130 & 22.446 & 88.451\end{array}$ $\begin{array}{llllllllllllll}0.52 & 1.65 * & 18.20 & 14.65 & 3 & 1466.9095 & 1466.9064 & 489.9761 & 0.0031 & 2.1089 & 25.954 & 71.790\end{array}$ $\begin{array}{lllllllllllll}0.52 & 1.88 * & 18.20 & 14.88 & 3 & 1466.9095 & 1466.9064 & 489.9761 & 0.0031 & 2.1089 & 17.673 & 86.482\end{array}$ $\begin{array}{llllllllllll}0.52 & 1.90 * & 18.20 & 14.90 & 3 & 1466.9092 & 1466.9064 & 489.9761 & 0.0028 & 1.9049 & 18.482 & 90.345\end{array}$ $\begin{array}{llllllllllllll}0.53 & 1.96 * & 18.20 & 14.96 & 3 & 1466.9095 & 1466.9064 & 489.9761 & 0.0031 & 2.1089 & 25.769 & 52.227\end{array}$ $\begin{array}{llllllllllllll}0.51 & 1.42 * & 18.20 & 14.42 & 3 & 1466.9095 & 1466.9064 & 489.9761 & 0.0031 & 2.1089 & 48.605 & 65.902\end{array}$ $\begin{array}{llllllllllll}1.00 & 91.53 & 26.87 & 21.07 & 2 & 2267.0934 & 2267.035 & 1134.5540 & -0.0001 & -0.0441 & 2.387\end{array}$

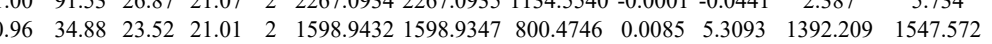

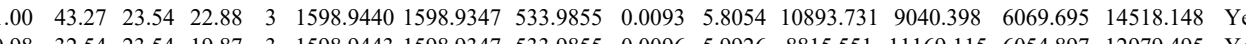
$\begin{array}{lllllllllllllll}0.66 & 39.67 & 25.39 & 52.67 & 3 & 2569.1833 & 2569.1816 & 857.4011 & 0.0017 & 0.6609 & 157.468 & 275.333 & 47.876 & 222.329 & \text { No }\end{array}$ $\begin{array}{lllllllllllllll}1.00 & 43.03 & 23.65 & 26.64 & 2 & 1272.7816 & 1272.7798 & 637.3972 & 0.0018 & 1.4120 & 5953.393 & 5117.797 & 878.693 & 8002.053 & \text { Yes } \\ \end{array}$ $\begin{array}{llllllllllllllll}1.96 & 33.26 & 23.40 & 27.29 & 2 & 1272.7832 & 1272.7798 & 637.3972 & 0.0034 & 2.6671 & 2401.948 & 2278.964 & 1238.637 & 3560.837 & \text { Yes } & \\ 0.99 & 2 & 1272.7812 & 1272.7798 & 637.3972 & 0.0014 & 1.0982 & 1519.985 & 1504.414 & 392.671 & 2499.233 & \text { Yes }\end{array}$ $\begin{array}{lllllllllllllll} & \text { GLLQLWK }\end{array}$ $\begin{array}{lllllllllllllll} & \end{array}$ 
$\begin{array}{lllllllllllll}\text { GRPGPVAGHHQMPR } & 0.97 & 15.35 & 28.22 & 28.35 & 4 & 1639.8625 & 1639.8600 & 410.9723 & 0.0025 & 1.5208 & 40.81\end{array}$ $\begin{array}{llllllllllll}\text { GRPGPVAGHHQMPR } & 0.67 & 19.68 & 28.24 & 32.68 & 3 & 1639.8628 & 1639.8600 & 547.6273 & 0.0028 & 1.7043 & 8.741\end{array}$ $\begin{array}{llllllllllll}\text { MADAIILAIAGGQELLAR } & 1.00 & \text { \#\#\#\# } 24.20 & 29.45 & 2 & 1969.1166 & 1969.1152 & 985.5649 & 0.0014 & 0.7103 & 94.517 \\ \end{array}$ $\begin{array}{lllllllllllll}\text { MADAILAIAGGQELLAR } & 1.00 & 97.09 & 24.05 & 22.52 & 2 & 1969.1174 & 1969.1152 & 985.5649 & 0.0022 & 1.1161 & 38.339 & 3 \\ \end{array}$ $\begin{array}{llllllllllllll} & \text { MADAILAIAGGQELLAR } & 1.00 & 66.17 & 23.93 & 18.05 & 3 & 1969.1188 & 1969.1152 & 657.3790 & 0.0036 & 1.8254 & 46.952 & 3\end{array}$ $\begin{array}{llllllllllll}\text { MADAIILAIAGGQELLAR } & 1.00 & 31.17 & 24.01 & 20.18 & 3 & 1969.1191 & 1969.1152 & 657.3790 & 0.0039 & 1.9775 & 52.955\end{array}$ $\begin{array}{llllllllllllllll} & \text { GLAIAWSMADPELLLSCGK } & 0.93 & 19.47 & 26.85 & 15.89 & 3 & 2421.2740 & 2421.2713 & 808.0977 & 0.0027 & 1.1137 & 3.244 & 10.864\end{array}$ $\begin{array}{lllllllllllllll}\text { QVQHILASASPSGR } & 1.00 & 67.39 & 26.88 & 17.65 & 3 & 1593.8842 & 1593.8709 & 532.2976 & 0.0133 & 8.3286 & 1381.761 & 2207.990\end{array}$ $\begin{array}{lllllllllllll}\text { QVQHILASASPSGR } & 1.00 & 56.14 & 26.95 & 17.80 & 3 & 1593.8848 & 1593.8709 & 532.2976 & 0.0139 & 8.7043 & 1543.221 & 2096.458 \\ \text { MADAIILAIAGGOELLAR } & 1.00 & \# \# \# \# \text { 24.36 } & 31.21 & 2 & 1969.1162 & 1969.1152 & 985.5649 & 0.0010 & 0.5073 & 15.450 & 8.277\end{array}$

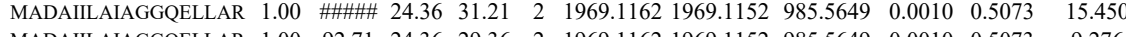
$\begin{array}{llllllllllllll}\text { MADAIILAIAGGQELLAR } & 1.00 & 92.71 & 24.36 & 29.36 & 2 & 1969.1162 & 1969.1152 & 985.5649 & 0.0010 & 0.5073 & 9.276 \\ \text { MADAILAIAGGQELLAR } & 1.00 & 46.83 & 24.05 & 21.66 & 3 & 1969.1176 & 1969.1152 & 657.3790 & 0.0024 & 1.2170 & 10.422\end{array}$ $\begin{array}{lllllllllllll}\text { MADAIILAIAGGQELLAR } & 1.00 & 46.83 & 24.05 & 21.66 & 3 & 1969.1176 & 1969.1152 & 657.3790 & 0.0024 & 1.2170 & 10.422 \\ \text { MADAIILAIAGGQELLAR } & 1.00 & 62.64 & 24.00 & 18.48 & 3 & 1969.1185 & 1969.1152 & 657.3790 & 0.0033 & 1.6733 & 16.327\end{array}$ $\begin{array}{llllllllllll}\text { MADAIILAIAGGQELLAR } & 1.00 & 62.64 & 24.00 & 18.48 & 3 & 1969.1185 & 1969.1152 & 657.3790 & 0.0033 & 1.6733 & 16.327 \\ \text { GRPGPVAGHHQMPR } & 0.97 & 17.73 & 28.08 & 16.31 & 4 & 1639.8601 & 1639.8600 & 410.9723 & 0.0001 & 0.0608 & 133.057\end{array}$ $\begin{array}{lllllllllllll}\text { GRPGPVAGHHQMPR } & 0.97 & 17.73 & 28.08 & 16.31 & 4 & 1639.8601 & 1639.8600 & 410.9723 & 0.0001 & 0.0608 & 133.057 & 15 \\ \text { GRPGPVAGHHQMPR } & 0.99 & 20.06 & 28.13 & 33.06 & 4 & 1639.8609 & 1639.8600 & 410.9723 & 0.0009 & 0.5475 & 48.138 & \end{array}$

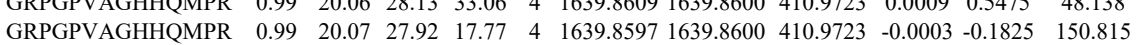
$\begin{array}{lllllllllllll}\text { GRPGPVAGHHOMPR } & 0.80 & 12.65 & 27.92 & 15.57 & 4 & 1639.8597 & 1639.8600 & 410.9723 & -0.0003 & -0.1825 & 85.420\end{array}$ $\begin{array}{lllllllllllll}\text { GRPGPVAGHHOMPR } & 1.00 & 37.87 & 28.22 & 19.30 & 3 & 1639.8610 & 1639.8600 & 547.6273 & 0.0010 & 0.6087 & 47.255\end{array}$

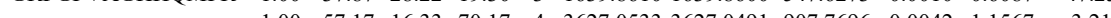

GscL $\begin{array}{lllllllllll}1.00 & 57.17 & 16.33 & 70.17 & 4 & 3627.0533 & 3627.0491 & 907.7696 & 0.0042 & 1.1567 & 3.219 \\ 1.00 & 47.02 & 16.33 & 60.02 & 4 & 3627.0533 & 3627.0491 & 907.7696 & 0.0042 & 1.1567 & 3.896\end{array}$ $\begin{array}{lllllllllllll}\text { LSAVEAIANAISVVSSNGPGNR } & 1.00 & 77.19 & 26.21 & 27.31 & 3 & 2269.2169 & 2269.2148 & 757.4122 & 0.0021 & 0.9242 & 19.232 & 14.748\end{array}$ $\begin{array}{llllllllllllllll}\text { LSAVEAIANAISYVSSNGPGNR } & 0.66 & 63.57 & 26.21 & 76.57 & 3 & 2269.2172 & 2269.2148 & 757.4122 & 0.0024 & 1.0562 & 18.550 & 1.1269\end{array}$ $\begin{array}{lllllllllllllll}\text { LSAVEAINASYYSSNGPGNR } & 1.00 & 71.28 & 26.22 & 21.45 & 3 & 2269.2166 & 2269.2148 & 757.4122 & 0.0018 & 0.7922 & 12.942 & 25.366\end{array}$ $\begin{array}{llllllllllll}\text { LSAVEAIANAISVUSSNGPGNR } & 0.67 & 62.70 & 26.11 & 75.70 & 3 & 2269.2181 & 2269.2148 & 757.4122 & 0.0033 & 1.4523 & 20.624\end{array}$ $\begin{array}{lllllllllllll} & \text { EDVODYSEDLOEIK } & 1.00 & 63.72 & 27.49 & 28.25 & 3 & 1997.9698 & 1997.9673 & 666.9964 & 0.0025 & 1.2494 & 41.342\end{array}$ $\begin{array}{lllllllllllll}\text { AMYLPDTLSPADQLK } & 0.95 & 37.46 & 27.23 & 23.68 & 2 & 1950.0424 & 1950.0376 & 976.0261 & 0.0048 & 2.4589 & 429.914\end{array}$ $\begin{array}{lllllllllllll}\text { VQQMIGQIDGLISOLEMDQQAGK } & 0.67 & 46.28 & 26.05 & 59.28 & 3 & 2817.4642 & 2817.4608 & 940.1609 & 0.0034 & 1.2055 & 5.227\end{array}$

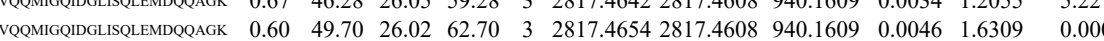
$\begin{array}{llllllllllll}\text { VQQMIGQIDGLISQLEMDQQAGK } & 1.00 & 66.96 & 26.03 & 19.66 & 3 & 2817.4636 & 2817.4608 & 940.1609 & 0.0028 & 0.9927 & 3.196 \\ \text { VQQMIGQIDGLLQLEMDQQAGK } & 0.67 & 57.83 & 26.03 & 70.83 & 3 & 2817.4639 & 2817.4608 & 940.1609 & 0.0031 & 1.0991 & 1.863\end{array}$

5 TETPIVSK

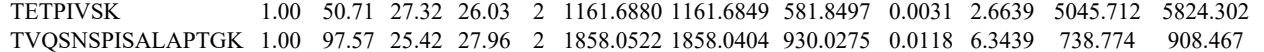
TVQSNSPISALAPTGK $1.00 \quad 25.327 .27 .26 \quad 2 \quad 1858.0538$

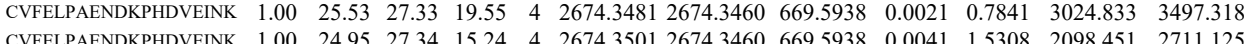
$\begin{array}{lllllllllllll}\text { LPPPSQVVITINPLLPVEAAEDYAK } & 1.00 & 40.02 & 24.05 & 53.02 & 4 & 3152.6785 & 3152.6736 & 789.1757 & 0.0049 & 1.5523 & 8.449 & 16.800\end{array}$ $\begin{array}{lllllllllllll}\text { LPPIESQVITINPELPVEAAEDYAK } & 1.00 & 40.05 & 24.07 & 18.48 & 4 & 3152.6797 & 3152.6736 & 789.1757 & 0.0061 & 1.9324 & 22.592 & 11.012\end{array}$ $\begin{array}{lllllllllllll}\text { LPIPSSQVITINPELPVEEAAEDYAK } & 0.66 & 29.97 & 24.27 & 42.97 & 3 & 3152.6752 & 3152.6736 & 1051.8985 & 0.0016 & 0.5070 & 7.287 & 2.261\end{array}$ $\begin{array}{lllllllllllll}\text { IVAPISDSPKPPPR } & 1.00 & 47.37 & 21.67 & 16.34 & 3 & 1889.1073 & 1889.0978 & 630.7065 & 0.0095 & 5.0208 & 15244.568 & 15383.605 \\ \text { IVAPISDSPKPPPQR } & 0.98 & 30.18 & 21.52 & 15.44 & 3 & 1889.1106 & 1889.0978 & 630.7065 & 0.0128 & 6.7649 & 7542.180 & 8074.744\end{array}$ $\begin{array}{llllllllllllll}0.98 & 30.18 & 21.52 & 15.44 & 3 & 1889.1106 & 1889.0978 & 630.7065 & 0.0128 & 6.7649 & 7542.180 & 8074.744 \\ 1.00 & 62.48 & 26.00 & 20.02 & 2 & 1483.7092 & 1483.7074 & 742.8610 & 0.0018 & 1.2115 & 4192.545 & 4555.793\end{array}$ LCWFLDAAAR $\begin{array}{llllllllllll}1.00 & 59.82 & 26.16 & 16.85 & 2 & 1483.7096 & 1483.7074 & 742.8610 & 0.0022 & 1.4808 & 2818.481 & 2721.912\end{array}$

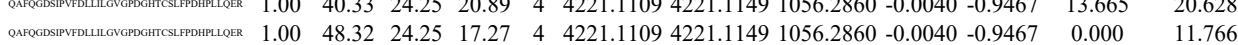




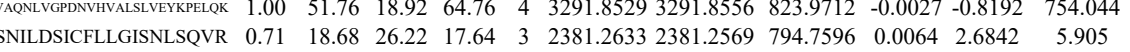

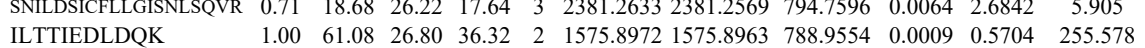
$\begin{array}{lllllllllllll}\text { TILEEEITPTIQK } & 1.00 & 48.29 & 24.15 & 20.67 & 2 & 1802.0300 & 1802.0280 & 902.0213 & 0.0020 & 1.1086 & 121.940\end{array}$ TIIQK

$\begin{array}{llllllllllll}1.00 & 48.29 & 24.15 & 20.67 & 2 & 1802.0300 & 1802.0280 & 902.0213 & 0.0020 & 1.1086 & 121.940 \\ 1.00 & 33.20 & 24.05 & 16.64 & 3 & 1802.0311 & 1802.0280 & 601.6833 & 0.0031 & 1.7174 & 251.187\end{array}$ $\begin{array}{llllllllllll}\text { MVMPSWFDLMGLSPDAPEDEAGIK } & 1.00 & 49.42 & 26.78 & 21.43 & 3 & 2923.4062 & 2923.4050 & 975.4756 & 0.0012 & 0.4101 & 15.498\end{array}$

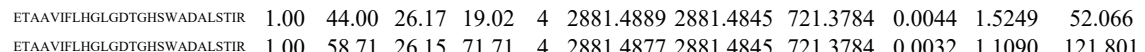

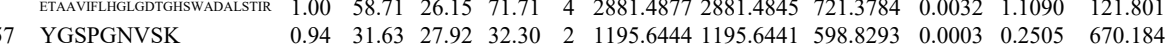
$\begin{array}{llllllllllll}\text { YGSPGNVS } & 0.94 & 31.63 & 27.92 & 32.30 & 2 & 1195.6444 & 1195.6441 & 598.8293 & 0.0003 & 0.2505 & 670.184 \\ \text { SDQNLQTALELTR } & 1.00 & 86.18 & 27.64 & 34.07 & 2 & 1631.8598 & 1631.8600 & 816.9373 & -0.0002 & -0.1224 & 801.976\end{array}$ $\begin{array}{llllllllllll}\text { QLQDIATLADQR } & 1.00 & 70.33 & 28.01 & 28.99 & 2 & 1514.8186 & 1514.8174 & 758.4160 & 0.0012 & 0.7911 & 357.832\end{array}$ $\begin{array}{llllllllllll}\text { QLQDIATLADQR } & 1.00 & 71.79 & 27.99 & 28.06 & 2 & 1514.8188 & 1514.8174 & 758.4160 & 0.0014 & 0.9230 & 1561.995\end{array}$ $\begin{array}{llllllllllll}\text { GNDQCIPLFVEAAR } & 1.00 & 54.95 & 26.53 & 21.63 & 3 & 1876.0555 & 1876.0540 & 626.3586 & 0.0015 & 0.7983 & 216.036 \\ \text { GIDER } & 1.00 & 58.02 & 28.18 & 28.69 & 2 & 1963.0048 & 1963.0029 & 9825087 & 0.0019 & 0.9669 & 43.539\end{array}$ $\begin{array}{lllllllllllll}\text { GIDQCIPLFVEAALER } & 1.00 & 58.12 & 28.18 & 29.76 & 2 & 1963.0048 & 1963.0029 & 982.5087 & 0.0019 & 0.9669 & 115.603\end{array}$ $\begin{array}{lllllllllllll}\text { GIDQCIPLFVEAALER } & 1.00 & 40.21 & 28.20 & 17.95 & 2 & 1963.0046 & 1963.0029 & 982.5087 & 0.0017 & 0.8651 & 0.000\end{array}$ $\begin{array}{llllllllllllll}\text { GIDQCIPLFVEAALER } & 1.00 & 56.55 & 28.22 & 28.94 & 2 & 1963.0050 & 1963.0029 & 982.5087 & 0.0021 & 1.0687 & 15.051\end{array}$ $\begin{array}{llllllllllll}\text { GIDQCIPLFVEAALER } & 1.00 & 45.87 & 28.26 & 23.21 & 3 & 1963.0060 & 1963.0029 & 655.3416 & 0.0031 & 1.5768 & 75.955\end{array}$ $\begin{array}{lllllllllllll}\text { GIDQCIPLFVEAALER } & 1.00 & 38.31 & 28.23 & 28.33 & 3 & 1963.0063 & 1963.0029 & 655.3416 & 0.0034 & 1.7294 & 107.640\end{array}$ $\begin{array}{lllllllllllll}\text { GIDQCIPLFVEAALER } & 1.00 & 44.35 & 28.20 & 25.32 & 2 & 1963.0052 & 1963.0029 & 982.5087 & 0.0023 & 1.1705 & 2.984\end{array}$ $\begin{array}{lllllllllllll}\text { AVTAMGILNTIDTLLSVVEDHK } & 1.00 & 95.03 & 23.67 & 21.17 & 3 & 2627.4454 & 2627.4448 & 876.8222 & 0.0006 & 0.2281 & 11.225\end{array}$ $\begin{array}{lllllllllllll}\text { AVTAMGILNTIDTLSVVEDHK } & 1.00 & 50.27 & 23.84 & 16.28 & 4 & 2627.4461 & 2627.4448 & 657.8685 & 0.0013 & 0.4940 & 122.914\end{array}$ $\begin{array}{llllllllllll}\text { AVTAMGILNTIDTLLSVVEDHK } & 1.00 & 88.47 & 23.64 & 28.22 & 3 & 2627.4484 & 2627.4448 & 876.8222 & 0.0036 & 1.3686 & 57.140\end{array}$ $\begin{array}{llllllllllll}\text { AVTAMGILNTIDTLLSVVEDHK } & 1.00 & 36.97 & 23.30 & 15.77 & 4 & 2627.4505 & 2627.4448 & 657.8685 & 0.0057 & 2.1661 & 104.657\end{array}$ $\begin{array}{llllllllllll}\text { AVTAMGILNTIDTLLSVVEDHK } & 1.00 & 88.46 & 23.89 & 22.90 & 3 & 2643.4414 & 2643.4397 & 882.1538 & 0.0017 & 0.6424 & 20.985 \\ \text { AVTAMGIINTIDTLSVVEDHK } & 0.54 & 3.16 & 23.87 & 15.42 & 4 & 2643.4417 & 2643.4397 & 661.8672 & 0.0020 & 0.7554 & 282544\end{array}$ $\begin{array}{lllllllllllll}\text { AVTAMGILNTIDTLLVVEDHK } & 0.54 & 3.16 & 23.87 & 15.42 & 4 & 2643.4417 & 2643.4397 & 661.8672 & 0.0020 & 0.7554 & 282.544 \\ \text { AVTAMGILNTIDTLSVVEDHK } & 0.98 & 12.40 & 23.58 & 14.99 & 4 & 2643.4453 & 2643.4397 & 661.8672 & 0.0056 & 2.1152 & 226.453\end{array}$ $\begin{array}{llllllllllll}\text { AVTAMGILNTIDTLLSVVEDHK } & 0.98 & 12.40 & 23.58 & 14.99 & 4 & 2643.4453 & 2643.4397 & 661.8672 & 0.0056 & 2.1152 & 226.453 \\ \text { AVTAMGILNTIDTLLSVVEDHK } & 0.55 & 91.71 & 23.84 & \# \# \# \# & 3 & 2627.4463 & 2627.4448 & 876.8222 & 0.0015 & 0.5702 & 100.647\end{array}$ $\begin{array}{lllllllllllll}\text { AVTAMGILNTIDTLLSVVEDHK } & 0.55 & 91.71 & 23.84 & \text { \#\#\#\#\# } & 2627.4463 & 2627.4448 & 876.8222 & 0.0015 & 0.5702 & 100.647 \\ \text { AVTAMGILNTIDTLLSVVEDHK } & 0.55 & 94.37 & 23.84 & \text { \#\#\#\# } & 3 & 2627.4463 & 2627.4448 & 876.8222 & 0.0015 & 0.5702 & 99.405\end{array}$

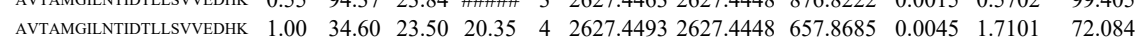
$\begin{array}{lllllllllllll}\text { AVTAMGILNTIDTLLSVVEDHK } & 1.00 & 49.88 & 23.46 & 18.56 & 4 & 2627.4497 & 2627.4448 & 657.8685 & 0.0049 & 1.8621 & 116.73\end{array}$ $\begin{array}{llllllllllll}\text { DGALHMIGSLAEILLK } & 0.97 & 60.15 & 22.90 & 62.41 & 3 & 1968.1348 & 1968.1321 & 657.0513 & 0.0027 & 1.3698 & 121.705\end{array}$

51.820

29.951

25.546

39.176

6.431

54.968

.

85.067

31.252

0.000 
$\begin{array}{llllllllllll}0.99 & 41.80 & 26.85 & 28.77 & 2 & 1233.7048 & 1233.6951 & 617.8548 & 0.0097 & 7.8497 & 1479.659 & 19\end{array}$ $\begin{array}{lllllllllllll}\text { SPLVAAMQHFLPVLK } & 0.66 & 39.65 & 20.90 & 52.65 & 3 & 1938.1393 & 1938.1368 & 647.0529 & 0.0025 & 1.2879 & 113.626\end{array}$ $\begin{array}{lllllllllllll}\text { SPLVAAMQHFLPVLK } & 0.55 & 38.85 & 20.97 & 51.85 & 3 & 1938.1381 & 1938.1368 & 647.0529 & 0.0013 & 0.6697 & 108.947\end{array}$ $\begin{array}{llllllllllll}\text { SPLVAAMQHFLPVLK } & 0.66 & 39.93 & 20.97 & 52.93 & 3 & 1938.1387 & 1938.1368 & 647.0529 & 0.0019 & 0.9788 & 32.796\end{array}$ $\begin{array}{llllllllllll}\text { EYITPFIRPVMQALLHIIR } & 1.00 & 23.57 & 19.49 & 36.57 & 4 & 2453.4121 & 2453.4102 & 614.3598 & 0.0019 & 0.7732 & 13.831 \\ \text { EYITPFIRPVMQALLHIIR } & 0.60 & 28.02 & 19.44 & 41.02 & 3 & 2453.4142 & 2453.4102 & 818.8107 & 0.0040 & 1.6284 & 16.018\end{array}$ $\begin{array}{lllllllllllll}\text { SPLVAMMQHFLPVLK } & 1.00 & 36.67 & 21.24 & 15.69 & 3 & 1938.1363 & 1938.1368 & 647.0529 & -0.0005 & -0.2576 & 17.923\end{array}$ $\begin{array}{llllllllllll}\text { SPLVAAMQHFLPVLK } & 0.94 & 25.11 & 21.27 & 15.07 & 3 & 1938.1345 & 1938.1368 & 647.0529 & -0.0023 & -1.1849 & 32.237\end{array}$

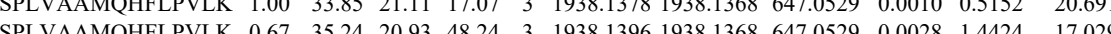

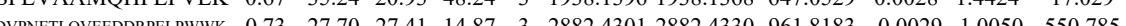
\begin{tabular}{lllllllllll}
\hline & DELVAAMQ
\end{tabular} $\begin{array}{llllllllllll}\text { VLTGVAGEDAECHAAK } & 1.00 & 76.45 & 27.56 & 20.01 & 3 & 1903.9405 & 1903.9375 & 635.6531 & 0.0030 & 1.5732 & 2683.635\end{array}$ $\begin{array}{lllllllllll}1.00 & 28.12 & 10.79 & 21.02 & 3 & 1577.0230 & 1577.0200 & 526.6806 & 0.0030 & 1.8987 & 28.857\end{array}$ $\begin{array}{llllllllllll}0.66 & 7.44 & 11.14 & 20.44 & 3 & 1577.0221 & 1577.0200 & 526.6806 & 0.0021 & 1.3291 & 8.036\end{array}$ $\begin{array}{llllllllllll}0.64 & 50.77 & 20.04 & 63.77 & 2 & 1418.8888 & 1418.8884 & 710.4515 & 0.0004 & 0.2815 & 16.327\end{array}$ $\begin{array}{llllllllllll}1.00 & 53.77 & 20.04 & 17.03 & 2 & 1418.8890 & 1418.8884 & 710.4515 & 0.0006 & 0.4223 & 32.370\end{array}$ $\begin{array}{llllllllllll}1.00 & 50.48 & 20.04 & 21.70 & 2 & 1418.8888 & 1418.8884 & 710.4515 & 0.0004 & 0.2815 & 33.656 \\ 1.00 & 66.81 & 20.04 & 18.20 & 2 & 1418.8890 & 14188884 & 710.4515 & 0.0006 & 0.4223 & 13292\end{array}$ 
LPLGLLLHPFR

WLCTGDIGEFEPDGC

AKPVNSKPDSAYR

AKPVNSKPDSAYR

AKPVNSKPDSAYR

AKPVNSKPDSAYR

AKPVNSKPDSAYR

AKPVNSKPDSAYR

AKPVNSKPDSAYR

$\begin{array}{llllllllllll}\text { AKPVNSKPDSAYR } & 0.99 & 17.08 & 25.50 & 16.92 & 4 & 1864.0533 & 1864.0532 & 467.0206 & 0.0001 & 0.0535 & 216.748 \\ \text { SVNSLDGLASVLYPGCDTLDK } & 0.67 & 19.06 & 27.64 & 32.06 & 3 & 2500.2466 & 2500.2433 & 834.4217 & 0.0033 & 1.3183 & 53.098 \\ \end{array}$ $\begin{array}{llllllllllllll} & \end{array}$ $\begin{array}{lllllllllllll} & 24.2728 & 2463.2779 & 822.0999 & 0.0009 & 0.3649 & 74.2\end{array}$ $\begin{array}{lllllllllllll}\text { NTPLCDSFVFR } & 1.00 & 51.45 & 24.96 & 26.55 & 2 & 1487.7036 & 1487.7023 & 744.8584 & 0.0013 & 0.8726 & 455.604 & 4 \\ \text { NTPLCDSFVFR } & 1.00 & 40.16 & 25.11 & 21.77 & 2 & 1487.7042 & 1487.7023 & 744.8584 & 0.0019 & 1.2754 & 55.158 & 5\end{array}$ \begin{tabular}{lllllllllllll} 
& \\
LLLCGGAPLSATTQR & 1.00 & 40.30 & 27.78 & 21.77 & 2 & 1487.7042 & 1487.7023 & 744.8584 & 0.0019 & 1.2754 & 550.158 \\
\hline
\end{tabular}

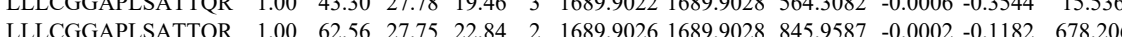
$\begin{array}{llllllllllll}\text { LLLCGGAPLSATTQR } & 1.00 & 61.76 & 27.77 & 26.94 & 2 & 1689.9034 & 1689.9028 & 845.9587 & 0.0006 & 0.3546 & 822.291\end{array}$ $\begin{array}{lllllllllllll}\text { LLLCGGAPLSATTQR } & 0.74 & 16.68 & 27.98 & 15.32 & 3 & 1689.9040 & 1689.9028 & 564.3082 & 0.0012 & 0.7088 & 68.865\end{array}$ $\begin{array}{llllllllllllll}\text { LLLGGAPLSATTOR } & 1.00 & 62.36 & 27.77 & 30.33 & 2 & 1689.9034 & 1689.9028 & 845.9587 & 0.0006 & 0.3546 & 222.727\end{array}$ $\begin{array}{lllllllllllll}\text { LLLCGGAPLSATTQR } & 1.00 & 45.97 & 27.97 & 18.71 & 3 & 1689.9037 & 1689.9028 & 564.3082 & 0.0009 & 0.5316 & 70.963\end{array}$ $\begin{array}{lllllllllllll}\text { LLLCGGAPLSATTQR } & 1.00 & 47.78 & 27.97 & 21.85 & 3 & 1689.9046 & 1689.9028 & 564.3082 & 0.0018 & 1.0632 & 55.585\end{array}$ $\begin{array}{lllllllllllll}\text { LLLCGGAPLSATTQR } & 1.00 & 39.64 & 27.77 & 19.59 & 3 & 1689.9034 & 1689.9028 & 564.3082 & 0.0006 & 0.3544 & 34.199\end{array}$

$\begin{array}{lllllllllll}\text { HS74L_HUMAN } & \text { O95757 } & \text { HSPA4L } & \text { Heat shock } 70 \text { kDi } 94.486 & 1.00 & 4 & 10.3 & 0.1063 & 0.1886 & 0.5482 & 0.1910\end{array}$

$\begin{array}{lllllllllll}\text { ROD1_HUMAN } & \text { O95758 } & \text { ROD1 } & \text { Regulator of diffel } 59.69 & 1.00 & 2 & 12.5 & -0.5691 & 0.4373 & 0.5245 & 0.7726\end{array}$ $\begin{array}{lllllllllll}\text { AP2A1_HUMAr } & \text { O95782 } & \text { AP2A1 } & \text { AP-2 complex sut } 107.55 & 1.00 & 5 & 9.8 & -0.4854 & 0.3640 & 1.9703 & 0.2784\end{array}$ .2784

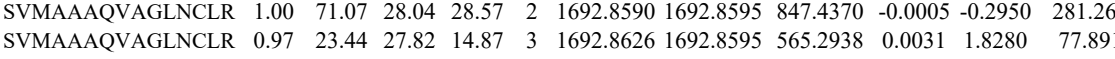

Probable ATP-der $106.6 \quad 1.00 \quad 2 \quad 2.8 \quad-0.2258 \quad 0.1068$ $\begin{array}{lllllllllllll}\text { LLLCGGAPLSATTQR } & 0.99 & 28.16 & 27.97 & 14.92 & 3 & 1689.9046 & 1689.9028 & 564.3082 & 0.0018 & 1.0632 & 29.963\end{array}$

0.99 $\begin{array}{llllllllllll}1.00 & 75.29 & 27.83 & 27.84 & 2 & 1638.8354 & 1638.8343 & 820.4244 & 0.0011 & 0.6704 & 865.681\end{array}$ $\begin{array}{llllllllllllll}\text { AQFEQLCASLLAR } & 1.00 & 75.29 & 27.83 & 27.84 & 2 & 1638.8354 & 1638.8343 & 820.4244 & 0.0011 & 0.6704 & 865.681 \\ \text { SVMAAAQVAGLNCLR } & 1.00 & 71.07 & 28.04 & 28.57 & 2 & 1692.8590 & 1692.8595 & 847.4370 & -0.0005 & -0.2950 & 281.267\end{array}$ $\begin{array}{lllllllllllll}\text { IPCDVTEAEIISLGLPFGK } & 1.00 & 44.02 & 26.64 & 15.81 & 3 & 2335.2421 & 2335.2411 & 779.4210 & 0.0010 & 0.4277 & 51.544 \\ \text { IPCDVTEAEISLGLPFGK } & 0.55 & 46.18 & 26.64 & 59.18 & 3 & 2335.2421 & 2335.2411 & 779.4210 & 0.0010 & 0.4277 & 60.257\end{array}$ $\begin{array}{llllllllllllll}\text { PCDVIEALISLGLPFGK } & 0.55 & 46.18 & 26.64 & 59.18 & 3 & 2335.2421 & 2335.2411 & 779.4210 & 0.0010 & 0.4277 & 60.257\end{array}$

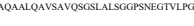

LVECLETVLNK LVECLETVLNK $\begin{array}{lllllllllllll}0.99 & 28.89 & 27.61 & 21.95 & 3 & 1593.8740 & 1593.8714 & 532.2977 & 0.0026 & 1.6282 & 91.880 \\ 1.00 & 35.36 & 27.63 & 22.96 & 3 & 1593.8746 & 1593.8714 & 532.2977 & 0.0032 & 2.0039 & 95.595\end{array}$

VLQIVTNR VLQIVTNR ALQVGCLLR ALQVGCLLR ALQVGCLLR FHLCSVATR FHLCSVATR

FHLCSVATR LSFLKPGILTGR LSFLKPGILTGR LSFLKPGILTGR AAGFDEIEQDLTQR

3 LEVNGR

NAAENMLEILGFK NAAENMLEILGFK NAAENMLEILGFK NAAENMLEILGFK VPQAQPTKPALK VPQAQPTKPALK VPQAQPTKPALK VPQAQPTKPALK NEFVSLINCSSQPPLISHGIGK NEFVSLINCSSQPPLISHGIGK NEFVSLINCSSQPPLISHGIGK VGNHTAEGTGTNK AAPNPAK

VQGLEQAVDNFEGK $\begin{array}{lllllllllll}1.00 & 35.36 & 27.63 & 22.96 & 3 & 1593.8746 & 1593.8714 & 532.2977 & 0.0032 & 2.0039 & 95.595 \\ 1.00 & 5.74 & 23.87 & 67.74 & 4 & 3186722131867169 & 797.6865 & 0.0052 & 1.6297 & 18.849\end{array}$

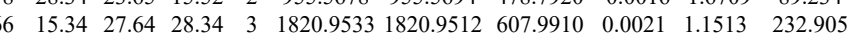
$\begin{array}{llllllllllll}0.58 & 11.29 & 27.63 & 13.90 & 3 & 1820.9539 & 1820.9512 & 607.9910 & 0.0027 & 1.4803 & 204.894\end{array}$ $\begin{array}{lllllllllllll}0.93 & 42.09 & 24.68 & 42.13 & 2 & 10856764 & 10856679 & 543.8412 & 0.0085 & 78147 & 6742.818 & 3887.492\end{array}$ $\begin{array}{lllllllllllll}1.00 & 44.70 & 28.60 & 27.02 & 2 & 1161.6510 & 1161.6484 & 581.8315 & 0.0026 & 2.2343 & 3244.370 & 1988.322\end{array}$ $\begin{array}{llllllllllll}0.99 & 41.72 & 28.67 & 26.68 & 2 & 1161.6526 & 1161.6484 & 581.8315 & 0.0042 & 3.6093 & 2405.708 & 1724.372\end{array}$ $\begin{array}{llllllllllll}0.99 & 37.50 & 28.78 & 19.52 & 2 & 1161.6500 & 1161.6484 & 581.8315 & 0.0016 & 1.3750 & 265.205 & 167.526\end{array}$ $\begin{array}{llllllllllll}0.97 & 26.05 & 27.47 & 16.03 & 3 & 1222.6081 & 1222.6073 & 408.5430 & 0.0008 & 0.6527 & 1508.744 & 981.335\end{array}$ $\begin{array}{llllllllllllll}0.97 & 25.24 & 27.42 & 16.05 & 3 & 1222.6084 & 1222.6073 & 408.5430 & 0.0011 & 0.8975 & 1423.451 & 1209.583\end{array}$ $\begin{array}{llllllllllllll}0.98 & 28.01 & 27.47 & 19.10 & 3 & 1222.6081 & 1222.6073 & 408.5430 & 0.0008 & 0.6527 & 408.582 & 229.248\end{array}$ $\begin{array}{lllllllllllll}1.00 & 38.72 & 18.45 & 17.26 & 3 & 1588.9891 & 1588.9908 & 530.6709 & -0.0017 & -1.0678 & 3744.101 & 3239.557\end{array}$ $\begin{array}{lllllllllllll}1.00 & 55.47 & 18.26 & 17.35 & 3 & 1588.9915 & 1588.9908 & 530.6709 & 0.0007 & 0.4397 & 2716.741 & 2191.702 & 2\end{array}$ $\begin{array}{lllllllllllll}0.66 & 44.68 & 18.06 & 57.68 & 3 & 1588.9933 & 1588.9908 & 530.6709 & 0.0025 & 1.5703 & 1346.401 & 1251.357\end{array}$ $\begin{array}{lllllllllllll}0.67 & 43.40 & 17.99 & 56.40 & 3 & 1588.9936 & 1588.9908 & 530.6709 & 0.0028 & 1.7588 & 1257.118 & 1129.689\end{array}$ $\begin{array}{lllllllllllll}1.00 & 79.31 & 27.36 & 25.13 & 2 & 1735.8520 & 1735.8499 & 868.9322 & 0.0021 & 1.2084 & 130.720 & 101.664\end{array}$ $\begin{array}{lllllllllllll}0.81 & 27.86 & 27.13 & 36.90 & 2 & 830.4734 & 830.4732 & 416.2439 & 0.0002 & 0.2402 & 79.764 & 91.030 \\ 1.00 & 70.87 & 27.40 & 24.52 & 2 & 1736.9370 & 1736.9374 & 869.4760 & -0.0004 & -0.2300 & 308.441 & 470.993\end{array}$ $\begin{array}{llllllllllll}00 & 70.87 & 27.40 & 24.52 & 2 & 1736.9370 & 1736.9374 & 869.4760 & -0.0004 & -0.2300 & 308.441 & 470.993\end{array}$ $\begin{array}{lllllllllllll}.00 & 78.86 & 27.49 & 21.66 & 2 & 1736.9388 & 1736.9374 & 869.4760 & 0.0014 & 0.8051 & 275.063 & 427.377\end{array}$ $\begin{array}{llllllllllllll}0.76 & 14.81 & 27.50 & 14.52 & 3 & 1736.9389 & 1736.9374 & 579.9864 & 0.0015 & 0.8621 & 107.295 & 116.422 & 24.165 & 224.59 \\ 1.00 & 2.63 & 16.81 & 4.63 & 3 & 1709.059 & 17369 & 579.9864 & 0.0018 & 1.0345 & 157.591 & 151.512 & 23.397 & 245.03\end{array}$ $\begin{array}{llllllllllllllll}1.00 & 20.63 & 16.81 & 14.60 & 3 & 1709.0599 & 1709.0565 & 570.6928 & 0.0034 & 1.9859 & 9064.771 & 14947.630 & 22249.286 & 24473.374 & \text { Yes }\end{array}$

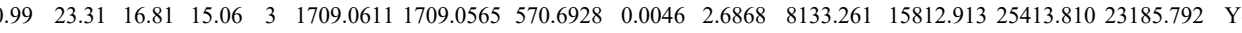
$\begin{array}{lllllllllllllll}1.00 & 37.01 & 16.72 & 16.79 & 3 & 1709.0566 & 1709.0565 & 570.6928 & 0.0001 & 0.0584 & 5736.719 & 11894.100 & 16459.671 & 17468.936 & \text { Yes }\end{array}$ \begin{tabular}{llllllllllllllll}
0.99 & 18.08 & 16.72 & 14.83 & 3 & 1709.0581 & 1709.0565 & 570.6928 & 0.0016 & 0.9345 & 7245.514 & 13327.759 & 19545.081 & 19769.181 & Yes \\
\hline
\end{tabular} $\begin{array}{llllllllllllllll}0.55 & 66.42 & 26.94 & 79.42 & 3 & 2673.3874 & 2673.3862 & 892.1360 & 0.0012 & 0.4484 & 164.758 & 149.915 & 186.177 & 197.722 & \text { Yes } \\ 1.00 & 51.11 & 26.94 & 16.47 & 4 & 2673.3893 & 2673.3862 & 669.3538 & 0.0031 & 1.1578 & 22.619 & 171.992 & 98.926 & 280.721 & \text { Yes }\end{array}$ $\begin{array}{lllllllllllllll}1.14 & 26.94 & 16.47 & 4 & 2673.3893 & 2673.3862 & 669.3538 & 0.0031 & 1.1578 & 222.619 & 171.992 & 98.926 & 280.721 & \text { Yes } \\ 1.00 & 57.48 & 2.95 & 16.67 & 3 & 2673.3895 & 26733862 & 892.1360 & 0.0033 & 1.2330 & 145.873 & 210.450 & 18.826 & 136.635 & \text { No }\end{array}$

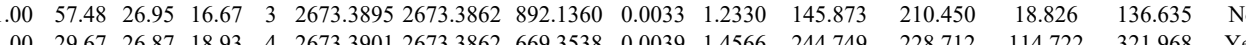

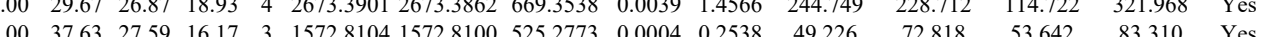
$\begin{array}{lllllllllllllll}0.78 & 28.34 & 23.65 & 15.52 & 2 & 955.5678 & 955.5694 & 478.7920 & -0.0016 & -1.6709 & 89.234 & 54.828 & 102.447 & 77.183 & \text { Yes }\end{array}$ $\begin{array}{lllllllllll}1.00 & 27.35 & 24.15 & 15.39 & 4 & 4226.1549 & 4226.1483 & 1057.5444 & 0.0066 & 1.5602 & 0.000\end{array}$ 

$\begin{array}{lllllllllllll} & \end{array}$

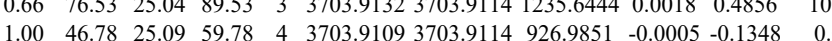

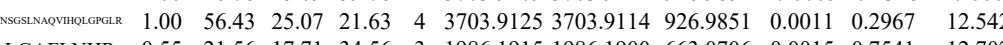
$\begin{array}{llllllllllllll}\text { PPLPLTLALGAFLNHR } & 0.55 & 21.56 & 17.71 & 34.56 & 3 & 1986.1915 & 1986.1900 & 663.0706 & 0.0015 & 0.7541 & 12.702\end{array}$

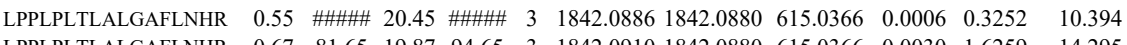
$\begin{array}{lllllllllllll}\text { LPPLPLTLALGAFLNHR } & 0.67 & 81.65 & 19.87 & 94.65 & 3 & 1842.0910 & 1842.0880 & 615.0366 & 0.0030 & 1.6259 & 14.295\end{array}$ $\begin{array}{llllllllllll}\text { LPPLPLTLALGAFLNHR } & 1.00 & 58.67 & 17.48 & 21.94 & 3 & 1986.1918 & 1986.1900 & 663.0706 & 0.0018 & 0.9049 & 5.918\end{array}$ $\begin{array}{lllllllllllll}\text { LPPLPLILALGAFLNHR } & 1.00 & 68.52 & 17.48 & 20.91 & 3 & 1986.1918 & 1986.1900 & 663.0706 & 0.0018 & 0.9049 & 25.129 \\ \text { LPPLPLTLALGAFLNHR } & 1.00 & 60.97 & 17.48 & 21.07 & 3 & 1986.1921 & 1986.1900 & 663.0706 & 0.0021 & 1.0557 & 8.733\end{array}$ $\begin{array}{lllllllllllll}\text { LPPLPLTLALGAFLNHR } & 1.00 & 47.69 & 17.16 & 24.91 & 3 & 1986.1927 & 1986.1900 & 663.0706 & 0.0027 & 1.3573 & 16.369\end{array}$ $\begin{array}{lllllllllllll}\text { LPPLPLTLALGAFLNHR } & 0.55 & 93.33 & 19.91 & \text { \#\#\#\# } & 1842.0892 & 1842.0880 & 615.0366 & 0.0012 & 0.6504 & 8.503\end{array}$ $\begin{array}{lllllllllllll} & \end{array}$ $\begin{array}{llllllllllllll}\text { LPPLPLTLALGAFLNHR } & 1.00 & 77.69 & 17.71 & 17.89 & 2 & 1986.1914 & 1986.1900 & 994.1023 & 0.0014 & 0.7042 & 5.219\end{array}$ $\begin{array}{llllllllllllll}\text { LPPLPLTLALGAFLNHR } & 1.00 & 71.49 & 17.71 & 22.40 & 3 & 1986.1915 & 1986.1900 & 663.0706 & 0.0015 & 0.7541 & 30.825\end{array}$ $\begin{array}{lllllllllllll}\text { LPPLPLTLALGAFLNHR } & 1.00 & 71.33 & 17.48 & 22.71 & 3 & 1986.1918 & 1986.1900 & 663.0706 & 0.0018 & 0.9049 & 26.343\end{array}$ $\begin{array}{lllllllllllll}\text { LPPLPLTLALGAFLNHR } & 0.97 & 21.01 & 16.99 & 21.93 & 3 & 1986.1942 & 1986.1900 & 663.0706 & 0.0042 & 2.1114 & 14.580\end{array}$ $\begin{array}{llllllllllll}\text { LPPLPLTLALGAFLNHR } & 1.00 & 74.25 & 16.99 & 20.17 & 2 & 1986.1942 & 1986.1900 & 994.1023 & 0.0042 & 2.1125 & 3.317\end{array}$ $\begin{array}{lllllllllllll}\text { KLPPLPLTLALGAFLNHR } & 1.00 & 56.76 & 11.76 & 69.76 & 4 & 2258.3893 & 2258.3870 & 565.6040 & 0.0023 & 1.0166 & 21.236 \\ \text { LPPLPLTLALGAFLNHR } & 1.00 & 64.27 & 17.63 & 27.31 & 3 & 1986.1903 & 1986.1900 & 663.0706 & 0.0003 & 0.1508 & 18.715\end{array}$ $\begin{array}{llllllllllll}\text { LPPLPLTLALGAFLNHR } & 1.00 & 64.27 & 17.63 & 27.31 & 3 & 1986.1903 & 1986.1900 & 663.0706 & 0.0003 & 0.1508 & 18.715\end{array}$ $\begin{array}{llllllllllll}\text { LPPLPLTLALGAFLNHR } & 1.00 & 65.36 & 17.63 & 22.92 & 3 & 1986.1909 & 1986.1900 & 663.0706 & 0.0009 & 0.4524 & 26.787\end{array}$ $\begin{array}{llllllllllll}\text { LPPLPLTLALGAFLNHR } & 1.00 & 44.27 & 17.16 & 29.35 & 3 & 1986.1927 & 1986.1900 & 663.0706 & 0.0027 & 1.3573 & 14.829 \\ \text { KLPPLPLTLALGAFLNHR } & 0.66 & 56.00 & 11.76 & 69.00 & 3 & 2258.3896 & 2258.3870 & 753.8029 & 0.0026 & 1.1497 & 9.801\end{array}$ $\begin{array}{llllllllllll}\text { KLPPLPLTLALGAFLNHR } & 0.66 & 56.00 & 11.76 & 69.00 & 3 & 2258.3896 & 2258.3877 & 753.8029 & 0.0026 & 1.1497 & 9.801 \\ \text { KLPPLPLTLALGAFLNHR } & 1.00 & 65.73 & 11.76 & 78.73 & 4 & 2258.3905 & 2258.3870 & 565.6040 & 0.0035 & 1.5470 & 35.549\end{array}$ $\begin{array}{lllllllllllll}\text { KLPPLPLTLALGAFLNHR } & 1.00 & 65.73 & 11.76 & 78.73 & 4 & 2258.3905 & 2258.3870 & 565.6040 & 0.0035 & 1.5470 & 35.549 \\ \text { LPPLPLTLALGAFLNHR } & 1.00 & 48.24 & 17.56 & 23.90 & 3 & 1986.1885 & 1986.1900 & 663.0706 & -0.0015 & -0.7541 & 12.724\end{array}$

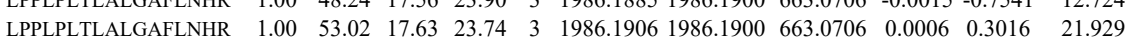
$\begin{array}{llllllllllllll}\text { LPPLPLTLALGAFLNHR } & 1.00 & 47.71 & 17.56 & 21.92 & 3 & 1986.1885 & 1986.1900 & 663.0706 & -0.0015 & -0.7541 & 18.652\end{array}$ $\begin{array}{lllllllllllll}\text { LPPLPLTLALGAFLNHR } & 1.00 & 55.17 & 17.48 & 35.74 & 3 & 1986.1918 & 1986.1900 & 663.0706 & 0.0018 & 0.9049 & 20.085\end{array}$ 
$\begin{array}{lllllllllll}1.00 & 4.36 & 26.96 & 19.68 & 3 & 1945.0516 & 1945.0499 & 649.3572 & 0.0017 & 0.8727 & 24.485\end{array}$ $\begin{array}{llllllllllll} & \end{array}$

$\begin{array}{llllllllllll}1 & 1551.8794 & 1551.8752 & 518.2990 & 0.0042 & 2.7011 & 680.607 & 401.14\end{array}$

701.562 $\begin{array}{ll}1.00 & 59.03 \\ 0.99 & 24.71 \\ 0.62 & 33.85 \\ 1.00 & 71.97 \\ 0.97 & 30.51\end{array}$ 1.00 1.00
0.97
0.98 $\begin{array}{lllllllllllll}1.00 & 42.97 & 25.93 & 26.83 & 3 & 1551.8803 & 1551.8752 & 518.2990 & 0.0051 & 3.2799 & 584.796 & 72.7 \\ 1.00 & 68.43 & 25.59 & 25.45 & 2 & 1551.8906 & 1551.8752 & 776.9449 & 0.0154 & 9.9105 & 3550.701 & 3606 .\end{array}$ $\begin{array}{lllllllllllllll}1.00 & 68.43 & 25.59 & 25.45 & 2 & 1551.8906 & 1551.8752 & 776.9449 & 0.0154 & 9.9105 & 3550.701 & 3606.398\end{array}$ SADTLWGQK SADTLWGIQK SADTLWGIQK SADTLWGIQK

\section{SADTLWGIQK}

DLADELALVDVIEDK $\begin{array}{llllllllllll} & \end{array}$ $\begin{array}{lllllllllllll} & \\ \text { GEMMDLQHGSLFLR } & 0.66 & 16.08 & 27.59 & 19.80 & 3 & 1947.0525 & 1945.0499 & 649.3572 & 0.0026 & 1.3347 & 28.298 & 1756.8773 \\ 593.2997 & 0.0051 & 2.8653 & 250.734 & 275\end{array}$ $\begin{array}{llllllllllllll}\text { GEMMDLQHGSLFLR } & 1.00 & 31.70 & 27.41 & 18.50 & 3 & 1776.8797 & 1776.8773 & 593.2997 & 0.0024 & 1.3484 & 212.129 & 178\end{array}$ $\begin{array}{lllllllllllll}\text { GEMMDLQHGSLFLR } & 0.97 & 22.96 & 27.35 & 19.97 & 3 & 1776.8800 & 1776.8773 & 593.2997 & 0.0027 & 1.5169 & 202.833 \\ \text { GEMMDLQHGSLFLR } & 1.00 & 35.36 & 27.35 & 22.39 & 3 & 1776.8800 & 1776.8773 & 593.2997 & 0.0027 & 1.5169 & 189.936\end{array}$ $\begin{array}{llllllllllllll}\text { GEMMDLQHGSLFLR } & 1.00 & 35.36 & 27.35 & 22.39 & 3 & 1776.8800 & 1776.8773 & 593.2997 & 0.0027 & 1.5169 & 189.936 & 183 \\ \text { GEMMDLQHGSLFLR } & 1.00 & 31.01 & 27.35 & 18.24 & 3 & 1776.8803 & 1776.8773 & 593.2997 & 0.0030 & 1.6855 & 237.686 & 186\end{array}$ $\begin{array}{llllllllllllll}\text { GEMMDLQHGSLFLR } & 1.00 & 39.83 & 27.47 & 21.29 & 3 & 1776.8809 & 1776.8773 & 593.2997 & 0.0036 & 2.0226 & 221.575\end{array}$ $\begin{array}{lllllllllllllll}\text { GEMMDLQHGSLFLR } & 1.00 & 33.48 & 27.56 & 22.45 & 3 & 1776.8818 & 1776.8773 & 593.2997 & 0.0045 & 2.5282 & 227.531 & 2.17 .3 \\ \text { GEMMDLQHGSLFL } & 0.97 & 26.61 & 27.62 & 19.37 & 3 & 1776.8827 & 1776.8773 & 593.2997 & 0.0054 & 3.0339 & 176.615 & 195.6\end{array}$ $\begin{array}{lllllllllllllll}\text { GEMMDLQHGSLFLR } & 0.97 & 26.61 & 27.62 & 19.37 & 3 & 1776.8827 & 1776.8773 & 593.2997 & 0.0054 & 3.0339 & 176.615 & 195.652\end{array}$ $\begin{array}{lllllllllllll}\text { GEMMDLQHGSLFLR } & 0.97 & 26.96 & 27.62 & 16.15 & 3 & 1776.8827 & 1776.8773 & 593.2997 & 0.0054 & 3.0339 & 170.254 & 210.290\end{array}$ $\begin{array}{lllllllllllll}\text { GEMMDLQHGSLFLR } & 1.00 & 93.86 & 27.75 & 25.13 & 2 & 1776.8924 & 1776.8773 & 889.4459 & 0.0151 & 8.4884 & 1965.346 & 2710.961\end{array}$ $\begin{array}{llllllllllllll}\text { GEMMDLQHGSLFLR } & 1.00 & 78.23 & 27.78 & 20.87 & 2 & 1776.8930 & 1776.8773 & 889.4459 & 0.0157 & 8.8256 & 3332.697 & 3295.531\end{array}$

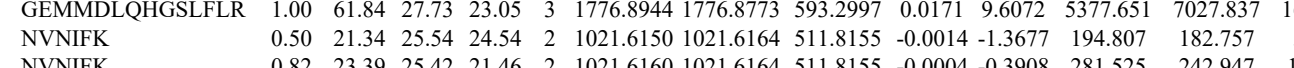

NVNIFK

NVNIFK

NVNIFK

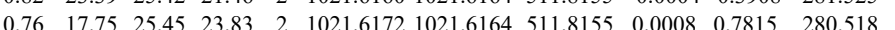
$\begin{array}{llllllllllll}0.92 & 23.29 & 25.61 & 28.29 & 2 & 1021.6180 & 1021.6164 & 511.8155 & 0.0016 & 1.5631 & 170.170 & 196.5\end{array}$

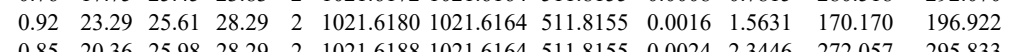
$\begin{array}{llllllllllll}0.85 & 20.36 & 25.98 & 28.29 & 2 & 1021.6188 & 1021.6164 & 511.8155 & 0.0024 & 2.3446 & 272.057 & 295.833 \\ 0.78 & 29.73 & 26.50 & 32.12 & 2 & 1021.6224 & 1021.6164 & 511.8155 & 0.0060 & 5.8615 & 39227.646 & 31822.048\end{array}$

NVNIFK $\begin{array}{lllllllllllll}\text { GEMMDLQHGSLFLR } & 0.52 & 72.72 & 27.83 & 85.72 & 2 & 1776.8908 & 1776.8773 & 889.4459 & 0.0135 & 7.5889 & 787.335 & 757 . \\ \text { GEMMDLQHGSLFLR } & 1.00 & 78.92 & 27.70 & 23.45 & 2 & 1776.8918 & 1776.8773 & 889.4459 & 0.0145 & 8.1511 & 324.246 & 45.8\end{array}$ $\begin{array}{lllllllllllll}\text { GEMMDLQGSLFLR } & 1.00 & 78.92 & 27.70 & 23.45 & 2 & 1776.8918 & 1776.8773 & 889.4459 & 0.0145 & 8.1511 & 324.246 & 451.085 \\ \text { GEMMDLQHGSLFLR } & 1.00 & 47.66 & 27.74 & 20.11 & 3 & 1776.8923 & 1776.8773 & 593.2997 & 0.0150 & 8.4274 & 5761.507 & 5738.822\end{array}$ $\begin{array}{lllllllllllll}\text { GEMMDQHSLFR } & 1.00 & 47.66 & 27.74 & 20.11 & 3 & 1776.8923 & 1776.8773 & 593.2997 & 0.0150 & 8.4274 & 5761.507 & 5738.822 \\ \text { GEMMDLHGSLFLR } & 1.00 & 53.31 & 27.71 & 20.96 & 3 & 1776.8935 & 1776.8773 & 593.2997 & 0.0162 & 9.1016 & 2873.445 & 3711.612\end{array}$ $\begin{array}{lllllllllllll}\text { GEMMDLQRHGSLFLR } & 1.00 & 53.31 & 27.71 & 20.96 & 3 & 1776.8935 & 1776.8773 & 593.2997 & 0.0162 & 9.1016 & 2873.445 & 3711.612 \\ \text { DDVFLVPCILGQNGISDLVK } & 1.00 & 67.54 & 26.66 & 17.98 & 2 & 2565.3434 & 2565.3426 & 1283.6786 & 0.0008 & 0.3116 & 17.741 & 0.000\end{array}$

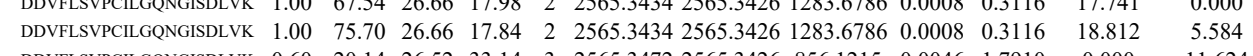
$\begin{array}{llllllllllllll}\text { DDVFLSVPCILGQNGISDLVK } & 0.60 & 20.14 & 26.52 & 33.14 & 3 & 2565.3472 & 2565.3426 & 856.1215 & 0.0046 & 1.7910 & 0.000 & 11.624\end{array}$ $\begin{array}{llllllllllllll}\text { DDVFLSVPCILGQNGISDLVK } & 0.99 & 30.17 & 26.41 & 16.28 & 3 & 2565.3478 & 2565.3426 & 856.1215 & 0.0052 & 2.0246 & 59.112 & 12.257 & 0.0\end{array}$ $\begin{array}{lllllllllllllllll}\text { GEMMDLQHGSLFLR } & 1.00 & 54.84 & 27.63 & 21.74 & 3 & 1776.8833 & 1776.8773 & 593.2997 & 0.0060 & 3.3710 & 3753.007 & 3323.657 & 548.611 & 6999.623 & \text { Yes } \\ \text { GEMMDLQHGSLFLR } & 1.00 & 58.23 & 27.66 & 20.85 & 3 & 1776.8839 & 1776.8773 & 593.2997 & 0.0066 & 3.7081 & 3900.498 & 5080.474 & 1516.041 & 8265.578 & \text { Yes }\end{array}$ $\begin{array}{llllllllllllllll}\text { DDVFLSVPCLGQNGISDLVK } & 1.00 & 65.75 & 26.51 & 17.24 & 2 & 2565.3454 & 2565.3426 & 1283.6786 & 0.0028 & 1.0906 & 0.000 & 7.795 & 5.178 & 24.088 & \text { No }\end{array}$ $\begin{array}{llllllllllllllll}\text { DDVFLSVPCLGGQNGISDLVK } & 1.00 & 79.10 & 26.51 & 18.88 & 2 & 2565.3454 & 2565.3426 & 1283.6786 & 0.0028 & 1.0906 & 13.489 & 18.110 & 0.000 & 15.967 & \text { No }\end{array}$

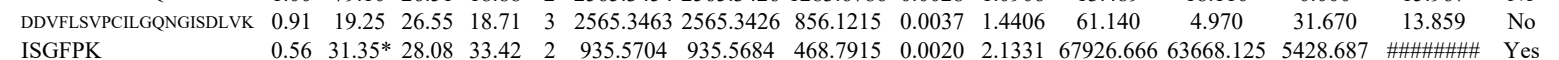

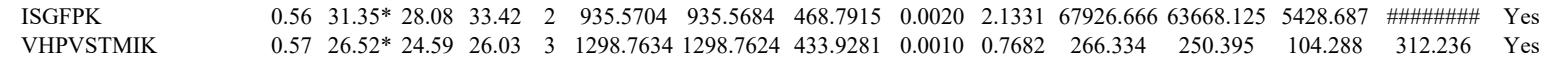
$\begin{array}{llllllllllllllll} & \\ \text { VHPVSTMIK } & 0.57 & 26.52 * 24.59 & 26.03 & 3 & 1298.7634 & 1298.7624 & 433.9281 & 0.0010 & 0.7682 & 266.334 & 250.395 & 104.288 & 312.236 & \text { Yes } \\ & 0.76 & 27.37 * 24.59 & 20.37 & 3 & 1298.7634 & 1298.7624 & 433.9281 & 0.0010 & 0.7682 & 9613.010 & 9567.263 & 1424.017 & 16297.703 & \text { Yes }\end{array}$ $\begin{array}{lllllllllllllllll}\text { GEMMDLQHGSLFLR } & 0.73 & 21.59 & 27.66 & 18.22 & 3 & 1776.8845 & 1776.8773 & 593.2997 & 0.0072 & 4.0452 & 3006.359 & 3092.487 & 1673.270 & 5732.165 & \text { Yes }\end{array}$

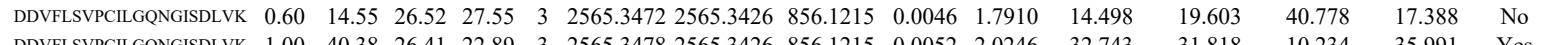

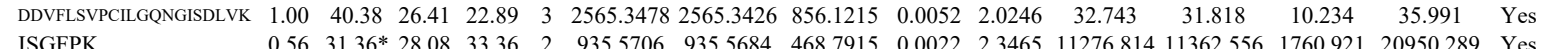

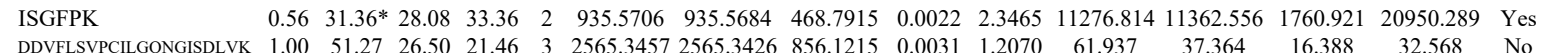
$\begin{array}{lllllllllllllllll}\text { DDVFLSVPCILGQNGISDLVK } & 1.00 & 51.27 & 26.50 & 21.46 & 3 & 2565.3457 & 2565.3426 & 856.1215 & 0.0031 & 1.2070 & 61.937 & 37.364 & 16.388 & 32.568 & \text { No } \\ \text { VHPVSTMIK } & 0.52 & 29.32 * & 24.59 & 34.52 & 2 & 1298.7634 & 1298.7624 & 650.3885 & 0.0010 & 0.7688 & 26736224 & 29427.404 & 3401.637 & 42695261 & \text { Yes }\end{array}$ $\begin{array}{lllllllllllllllllll}\text { VHPVSTMIK } & 0.52 & 29.32 * & 24.59 & 34.52 & 2 & 1298.7634 & 1298.7624 & 550.3885 & 0.0010 & 0.7688 & 26736.224 & 29427.404 & 3401.637 & 42695.261 & \text { Yes }\end{array}$ $\begin{array}{lllllllllllllll}\text { VHPVSTMIK } & 0.76 & 23.03 * 24.36 & 21.05 & 3 & 1298.7655 & 1298.7624 & 433.9281 & 0.0031 & 2.3813 & 26623.271 & 33597.094 & 6555.705 & 50539.271 & \text { Yes } \\ \text { VHPVSTMIK } & 0.68 & 23.81 * 25.16 & 20.38 & 3 & 1298.7664 & 1298.7624 & 433.9281 & 0.0040 & 3.0727 & 12201.104 & 11809.814 & 1731.800 & 19542.470 & \text { Yes }\end{array}$ 
$\begin{array}{lllllllllllll}\text { DLADELALVDVIEDK } & 0.97 & 26.13 & 26.97 & 27.50 & 3 & 1945.0537 & 1945.0499 & 649.3572 & 0.0038 & 1.9506 & 39.599\end{array}$

$\begin{array}{lllllllllllll}\text { DLADELALVDVIEDK } & 0.70 & 16.51 & 27.00 & 27.81 & 3 & 1945.0540 & 1945.0499 & 649.3572 & 0.0041 & 2.1046 & 40.579\end{array}$ FIIPNVVK $\begin{array}{llllllllllll}1.00 & 38.44 & 20.72 & 26.26 & 2 & 1216.7792 & 1216.7787 & 609.3966 & 0.0005 & 0.4102 & 22857.187 & 25731.717\end{array}$ $\begin{array}{lllllllllllllll}1.00 & 37.41 & 20.72 & 27.13 & 2 & 1216.7800 & 1216.7787 & 609.3966 & 0.0013 & 1.0666 & 14279.549 & 14253.504 & 2493.670 & 21975.742 & \text { Yes }\end{array}$

RVHPVSTMIK $\begin{array}{lllllllllllll}1.00 & 35.49 & 20.72 & 27.13 & 2 & 1216.7810 & 1216.7787 & 609.3966 & 0.0023 & 1.8871 & 7211.413 & 646 .\end{array}$

LVIITAGAR $\begin{array}{llllllllllll}1.00 & 32.63 & 23.30 & 17.15 & 3 & 1454.8642 & 1454.8635 & 485.9618 & 0.0007 & 0.4801 & 615.176 & 9\end{array}$ $\begin{array}{lllllllllllll}0.99 & 36.55 & 21.73 & 24.83 & 2 & 1056.6778 & 1056.6777 & 529.3461 & 0.0001 & 0.0945 & 54.398\end{array}$

LVITAGAR $\begin{array}{llllllllllll}0.87 & 20.91 & 21.70 & 32.42 & 2 & 1056.6788 & 1056.6777 & 529.3461 & 0.0011 & 1.0390 & 155.437\end{array}$

LVITTAGAR $\begin{array}{lllllllllll}0.95 & 21.72 & 21.70 & 24.50 & 2 & 1056.6788 & 1056.6777 & 529.3461 & 0.0011 & 1.0390 & 89.379 \\ 0.84 & 21.64 & 22.65 & 34.37 & 2 & 1056.6798 & 1056.6777 & 529.3461 & 0.0021 & 1.9836 & 79.652 \\ 0.88 & 21.92 & 22.65 & 33.10 & 2 & 1556.6800 & 1056.6777 & 529.346 & 0.023 & 2.1725 & 156.748\end{array}$

LVITTAGR $\begin{array}{llllllllllll}0.88 & 21.92 & 22.65 & 33.10 & 2 & 1056.6800 & 1056.6777 & 529.3461 & 0.0023 & 2.1725 & 156.748 \\ 0.97 & 37.84 & 21.70 & 41.53 & 2 & 1056.6786 & 1056.6777 & 529.3461 & 0.0009 & 0.8501 & 132.598\end{array}$ $\begin{array}{lllllllllll}0.97 & 37.84 & 21.70 & 41.53 & 2 & 1056.6786 & 1056.6777 & 529.3461 & 0.0009 & 0.8501 & 132.598 \\ 0.97 & 35.77 & 21.70 & 39.69 & 2 & 1056.6786 & 1056.6777 & 529.3461 & 0.0009 & 0.8501 & 185.310\end{array}$ $\begin{array}{lllllllllllll}0.95 & 34.64 & 21.70 & 41.30 & 2 & 1056.6786 & 1056.6777 & 529.3461 & 0.0009 & 0.8501 & 181.540 \\ 0.98 & 37.58 & 21.70 & 39.85 & 2 & 1056.6786 & 1056.6777 & 529.3461 & 0.0009 & 0.8501 & 166.274\end{array}$ $\begin{array}{llllllllllll}0.99 & 42.62 & 21.70 & 40.10 & 2 & 1056.6786 & 1056.6777 & 529.3461 & 0.0009 & 0.8501 & 151.818\end{array}$ $\begin{array}{lllllllllll}0.99 & 42.62 & 21.70 & 40.10 & 2 & 056.6786 & 1056.6777 & 529.3461 & 0.0009 & 0.8501 & 151.818 \\ 0.97 & 35.75 & 21.70 & 39.66 & 2 & 1056.6788 & 1056.6777 & 529.3461 & 0.0011 & 1.0390 & 189.390\end{array}$ $\begin{array}{llllllllllll}0.97 & 36.09 & 21.70 & 40.06 & 2 & 1056.6788 & 1056.6777 & 529.3461 & 0.0011 & 1.0390 & 201.524\end{array}$

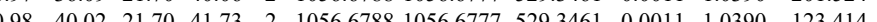

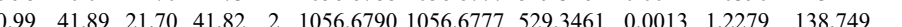
$\begin{array}{llllllllllll}0.98 & 36.82 & 21.65 & 39.55 & 2 & 1056.6796 & 1056.6777 & 529.3461 & 0.0019 & 1.7947 & 192.357 & 188 .\end{array}$ $\begin{array}{llllllllllllllll}0.87 & 32.40 & 22.65 & 41.05 & 2 & 1056.6808 & 1056.6777 & 529.3461 & 0.0031 & 2.9281 & 18.364 & 34.594\end{array}$

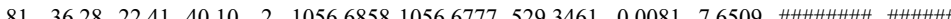

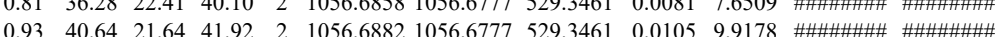

LVITAGAR

LVIITAGAR

LVIITAGAR

LVIITAGAR

LVITTAGAR

LVIITAGAR

LVIITAGAR

EEQTPQNK

VTLTSEEEAR

VTLTSEEEAR

VTLTSEEEAR

VTLTSEEEAR

VTLTSEEEAR

VTLTSEEEAR

VTLTSEEEAR

VTLTSEEEAR

VTLTSEEEAR

VTLTSEEEAR

VTLTSEEEAR

VTLTSEEEAR

$\begin{array}{lllllllllll}0.93 & 40.64 & 21.64 & 41.92 & 2 & 1056.6882 & 1056.6777 & 529.3461 & 0.0105 & 9.9178 & \text { \#\#冊册 } \\ 0.98 & 33.22 & 27.71 & 30.00 & 2 & 1260.6566 & 1260.6554 & 631.3350 & 0.0012 & 0.9504 & 177.583\end{array}$ $\begin{array}{llllllllllll}0.98 & 33.22 & 27.71 & 30.00 & 2 & 1260.6566 & 1260.6554 & 631.3350 & 0.0012 & 0.9504 & 177.583 \\ 0.97 & 34.79 & 28.50 & 21.93 & 2 & 1277.6584 & 1277.6585 & 639.8365 & -0.0001 & -0.0781 & 34.570\end{array}$

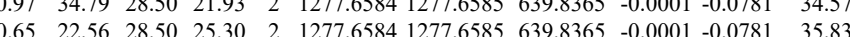
$\begin{array}{llllllllllll}1.00 & 43.73 & 28.52 & 23.80 & 2 & 1277.6590 & 1277.6585 & 639.8365 & 0.0005 & 0.3907 & 136.385\end{array}$ $\begin{array}{lllllllllllll}1.00 & 43.76 & 28.43 & 28.16 & 2 & 1277.6592 & 1277.6585 & 639.8365 & 0.0007 & 0.5470 & 83.032\end{array}$ $\begin{array}{llllllllllll}28.48 & 31.93 & 2 & 1277.6596 & 1277.6585 & 639.8365 & 0.0011 & 0.8596 & 18436.792 & 16485.753 & 25\end{array}$ $\begin{array}{llllllllllll}1.00 & 52.46 & 28.54 & 33.72 & 2 & 1277.6600 & 1277.6585 & 639.8365 & 0.0015 & 1.1722 & 9337.008\end{array}$ 

$\begin{array}{llllllllllllll}\text { DLADELALVDVIEDK } & 1.00 & 92.07 & 26.90 & 28.46 & 2 & 1945.0520 & 1945.0499 & 973.5322 & 0.0021 & 1.0785 & 14.867\end{array}$ $\begin{array}{llllllllllll}\text { DLADELALVDVIEDK } & 0.67 & 12.32 & 26.92 & 17.02 & 3 & 1945.0522 & 1945.0499 & 649.3572 & 0.0023 & 1.1807 & 93.276 \\ \text { DLADELALVDVIEDK } & 0.56 & 10.46 & 26.92 & 22.30 & 3 & 1945.0522 & 1945.0499 & 649.3572 & 0.0023 & 1.1807 & 93.016\end{array}$ $\begin{array}{llllllllllll}\text { DLADELALVDVIEDK } & 0.98 & 25.31 & 26.92 & 24.30 & 3 & 1945.0522 & 1945.0499 & 649.3572 & 0.0023 & 1.1807 & 114.918\end{array}$ $\begin{array}{llllllllllll}\text { DLADELALVDVIEDK } & 0.99 & 34.12 & 26.92 & 30.01 & 3 & 1945.0522 & 1945.0499 & 649.3572 & 0.0023 & 1.1807 & 97.582\end{array}$ $\begin{array}{lllllllllllll}\text { DLADELALVDVIEDK } & 1.00 & 85.33 & 26.93 & 22.22 & 2 & 1945.0522 & 1945.0499 & 973.5322 & 0.0023 & 1.1813 & 32.952\end{array}$ $\begin{array}{llllllllllll} & 85.33 & 6.93 & 22.22 & 2 & 1945.0522 & 1945.0499 & 973.5322 & 0.0023 & 1.1813 & 32.952\end{array}$

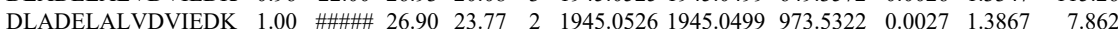

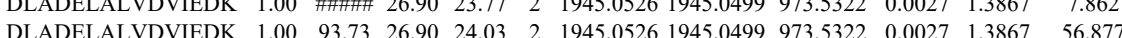
$\begin{array}{llllllllllll}\text { DLADELALVDVIEDK } & 1.00 & \text { \#\#\#\# } 26.90 & 27.44 & 2 & 1945.0526 & 1945.0499 & 973.5322 & 0.0027 & 1.3867 & 25.569\end{array}$ $\begin{array}{lllllllllllll}\text { DLADELALVDVIEDK } & 0.61 & 11.08 & 26.90 & 21.36 & 3 & 1945.0528 & 1945.0499 & 649.3572 & 0.0029 & 1.4886 & 100.698\end{array}$ $\begin{array}{lllllllllllll}\text { DLADELALVDVIEDK } & 0.99 & 27.11 & 26.90 & 25.49 & 3 & 1945.0528 & 1945.0499 & 649.3572 & 0.0029 & 1.4886 & 145.874\end{array}$ $\begin{array}{lllllllllllll}\text { DLADELALVDVIEDK } & 0.95 & 21.14 & 26.90 & 23.50 & 3 & 1945.0528 & 1945.0499 & 649.3572 & 0.0029 & 1.4886 & 80.303\end{array}$ $\begin{array}{llllllllllllll}\text { DLADELALVDVIEDK } & 0.71 & 13.12 & 26.94 & 19.53 & 3 & 1945.0531 & 1945.0499 & 649.3572 & 0.0032 & 1.6426 & 98.273\end{array}$ $\begin{array}{lllllllllllll}\text { DLADELALVDVIEDK } & 0.98 & 23.87 & 26.94 & 19.99 & 3 & 1945.0531 & 1945.0499 & 649.3572 & 0.0032 & 1.6426 & 76.242\end{array}$ $\begin{array}{lllllllllllll}\text { DLADELALVDVIEDK } & 0.96 & 22.27 & 26.94 & 24.36 & 3 & 1945.0531 & 1945.0499 & 649.3572 & 0.0032 & 1.6426 & 146.287\end{array}$

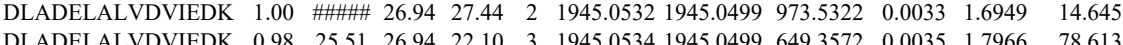
$\begin{array}{llllllllllll}\text { DLADELALVDVIEDK } & 0.98 & 25.51 & 26.94 & 22.10 & 3 & 1945.0534 & 1945.0499 & 649.3572 & 0.0035 & 1.7966 & 78.613\end{array}$ $\begin{array}{llllllllllll}\text { DLADELALVDVIEDK } & 1.00 & 38.74 & 26.94 & 22.72 & 3 & 1945.0534 & 1945.0499 & 649.3572 & 0.0035 & 1.7966 & 258.401\end{array}$ $\begin{array}{lllllllllllll}\text { DLADELALVDVIEDK } & 1.00 & \text { \#\#\# } & 26.94 & 26.94 & 2 & 1945.0534 & 1945.0499 & 973.5322 & 0.0035 & 1.7976 & 71.119 \\ \text { DLADELALVDVIEDK } & 0.89 & 25.76 & 26.97 & 32.31 & 3 & 1945.0537 & 1945.0499 & 649.3572 & 0.0038 & 1.9506 & 111.474\end{array}$ $\begin{array}{lllllllllllll}\text { DLADELALVDVIEDK } & 0.89 & 25.76 & 26.97 & 32.31 & 3 & 1945.0537 & 1945.0499 & 649.3572 & 0.0038 & 1.9506 & 111.474 \\ \text { DLADELALVDVIEDK } & 0.83 & 16.98 & 26.97 & 21.00 & 3 & 1945.0537 & 1945.0499 & 649.3572 & 0.0038 & 1.9506 & 81.637\end{array}$ $\begin{array}{llllllllllll}\text { DLADELALVDVIEDK } & 0.83 & 16.98 & 26.97 & 21.00 & 3 & 1945.0537 & 1945.0499 & 649.3572 & 0.0038 & 1.9506 & 81.637 \\ \text { DLADELALVDVIEDK } & 1.00 & 76.41 & 27.01 & 26.09 & 2 & 1945.0538 & 1945.0499 & 973.5322 & 0.0039 & 2.0030 & 19.554\end{array}$ $\begin{array}{llllllllllll}\text { DLADELALVDVIEDK } & 1.00 & \text { \#\#\# } 26.95 & 26.17 & 2 & 1945.0548 & 1945.0499 & 973.5322 & 0.0049 & 2.5166 & 11.763\end{array}$ $\begin{array}{lllllllllllll}\text { DLADELALVDVIEDK } & 1.00 & 95.81 & 26.95 & 24.23 & 2 & 1945.0548 & 1945.0499 & 973.5322 & 0.0049 & 2.5166 & 11.628 \\ \text { DLADELALVDVIEDK } & 1.00 & 36.00 & 26.95 & 28.12 & 3 & 1945.0549 & 1945.0499 & 649.3572 & 0.0050 & 2.5666 & 268.990\end{array}$

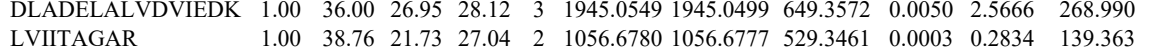
LVIITAGAR LVIITAGAR LVIITAGAR LVIITAGAR LVITTAGAR LVITTAGAR LVIITAGAR LVIITAGAR LVIITAGAR LVIITAGAR LVIITAGAR LVIITAGAR LVIITAGAR LVIITAGAR LVIITAGAR LVIITAGAR LVIITAGAR LVIITAGAR

LVIITAGAR

LVIITAGAR

LVIITAGAR

LVIITAGAR

LVIITAGAR

LVIITAGAR

LVIITAGAR

LVIITAGAR

LVIITAGAR

LVIITAGAR $\begin{array}{lllllllllllll}1.00 & 38.76 & 21.73 & 27.04 & 2 & 1056.6780 & 1056.6777 & 529.3461 & 0.0003 & 0.2834 & 139.363 \\ 1.00 & 40.10 & 21.73 & 27.74 & 2 & 1056.6780 & 1056.6777 & 529.3461 & 0.0003 & 0.2834 & 154.075\end{array}$ $\begin{array}{llllllllllll}0.99 & 42.99 & 21.70 & 40.57 & 2 & 1056.6786 & 1056.6777 & 529.3461 & 0.0009 & 0.8501 & 212.803\end{array}$ $\begin{array}{lllllllllll}0.99 & 42.99 & 21.70 & 40.57 & 2 & 1056.6786 & 1056.6777 & 529.3461 & 0.0009 & 0.8501 & 212.803 \\ 0.97 & 36.10 & 21.70 & 40.04 & 2 & 1056.6786 & 1056.6777 & 529.3461 & 0.0009 & 0.8501 & 150.146\end{array}$

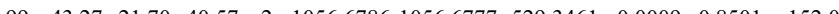
$\begin{array}{llllllllllll}0.98 & 38.98 & 21.70 & 40.30 & 2 & 1056.6786 & 1056.6777 & 529.3461 & 0.0009 & 0.8501 & 152.878\end{array}$ $\begin{array}{lllllllllllll}0.98 & 36.74 & 21.70 & 39.55 & 2 & 1056.6788 & 1056.6777 & 529.3461 & 0.0011 & 1.0390 & 23.434\end{array}$ $\begin{array}{lllllllllllll}1.00 & 48.12 & 21.70 & 40.76 & 2 & 1056.6788 & 1056.6777 & 529.3461 & 0.0011 & 1.0390 & 240.866\end{array}$ $\begin{array}{lllllllllll}0.97 & 36.03 & 21.70 & 39.97 & 2 & 1056.6788 & 1056.6777 & 529.3461 & 0.0011 & 1.0390 & 179.965\end{array}$ $\begin{array}{llllllllllll}0.97 & 38.16 & 21.70 & 41.80 & 2 & 1056.6788 & 1056.6777 & 529.3461 & 0.001 & 1.0390 & 170.191 \\ 0.95 & 32.89 & 21.70 & 39.58 & 2 & 1056.6788 & 1056.6777 & 529.3461 & 0.0011 & 1.0390 & 163.868 & \\ \end{array}$ $\begin{array}{lllllllllllll}0.99 & 44.64 & 21.70 & 42.18 & 2 & 1056.6788 & 1056.6777 & 529.3461 & 0.0011 & 1.0390 & 126.150\end{array}$ $\begin{array}{lllllllllllll}0.99 & 44.77 & 21.70 & 40.64 & 2 & 1056.6792 & 1056.6777 & 529.3461 & 0.0015 & 1.4168 & 186.275\end{array}$

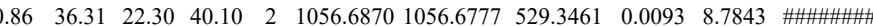

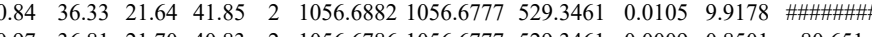
$\begin{array}{llllllllllll}0.97 & 36.81 & 21.70 & 40.83 & 2 & 1056.6786 & 1056.6777 & 529.3461 & 0.0009 & 0.8501 & 80.651\end{array}$ $\begin{array}{lllllllllll}0.99 & 40.02 & 21.70 & 39.08 & 2 & 1056.6786 & 1056.6777 & 529.3461 & 0.0009 & 0.8501 & 91.199\end{array}$ $\begin{array}{llllllllllll}0.95 & 28.55 & 21.70 & 34.75 & 2 & 1056.6786 & 1056.6777 & 529.3461 & 0.0009 & 0.8501 & 50.305\end{array}$ $\begin{array}{lllllllllllll}0.99 & 38.42 & 21.70 & 39.25 & 2 & 1056.6788 & 1056.6777 & 529.3461 & 0.0011 & 1.0390 & 105.465 \\ 0.97 & 36.86 & 21.70 & 40.49 & 2 & 1056.6788 & 1056.6777 & 529.3461 & 0.0011 & 1.0390 & 38.806 & 64\end{array}$ $\begin{array}{lllllllllllll}0.96 & 34.68 & 21.70 & 40.49 & 2 & 1056.6788 & 1056.6777 & 529.3461 & 0.0011 & 1.0390 & 38.806 & 84.0 \\ 0.94 & 2 & 1056.6790 & 1056.6777 & 529.3461 & 0.0013 & 1.2279 & 85.021 & 73.5\end{array}$ $\begin{array}{lllllllllll}0.94 & 32.93 & 22.65 & 40.66 & 2 & 1056.6794 & 1056.6777 & 529.3461 & 0.0017 & 1.6058 & 108.662 \\ 0.95 & 67.4 & \end{array}$ $\begin{array}{llllllllllll}0.95 & 38.55 & 22.65 & 45.23 & 2 & 1056.6796 & 1056.6777 & 529.3461 & 0.0019 & 1.7947 & 75828.848 & 87126.731\end{array}$

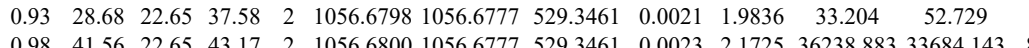
$\begin{array}{llllllllllll}0.98 & 41.56 & 22.65 & 43.17 & 2 & 1056.6800 & 1056.6777 & 529.3461 & 0.0023 & 2.1725 & 36238.883 & 33684.143\end{array}$ $\begin{array}{llllllllllll}0.87 & 21.38 & 21.73 & 24.54 & 2 & 1056.6774 & 1056.6777 & 529.3461 & -0.0003 & -0.2834 & 48.958\end{array}$ $\begin{array}{llllllllllll}0.85 & 23.51 & 21.70 & 35.41 & 2 & 1056.6790 & 1056.6777 & 529.3461 & 0.0013 & 1.2279 & 34.261\end{array}$ $\begin{array}{lllllllllll}0.99 & 44.84 & 21.70 & 45.21 & 2 & 1056.6792 & 1056.6777 & 529.3461 & 0.0015 & 1.4168 & 17842.113 \\ 0.86 & 20.75 & 21.70 & 32.54 & 2 & 1056.6792 & 1056.6777 & 529.3461 & 0.0015 & 1.4168 & 63.095\end{array}$ 31.962 $\begin{array}{llllllllllll}0.86 & 20.75 & 21.70 & 32.54 & 2 & 1056.6792 & 1056.6777 & 529.3461 & 0.0015 & 1.4168 & 63.095 \\ 0.84 & 16.15 & 21.70 & 28.62 & 2 & 1056.6792 & 1056.6777 & 529.3461 & 0.0015 & 1.4168 & 47.586\end{array}$ $\begin{array}{llllllllllllll}0.08 & 41.57 & 2.65 & 21.19 & 2 & 1056.6796 & 1056.6777 & 529.3461 & 0.0019 & 1.7947 & 36844.675 & 37891.57\end{array}$ $\begin{array}{llllllllllllll}0.98 & 41.77 & 21.70 & 43.06 & 2 & 1056.6784 & 1056.6777 & 529.34661 & 0.0007 & 0.6612 & 11551.230 & 10027.214 & 914.94\end{array}$ 

$\begin{array}{llllllllllllllll}0.99 & 40.07 & 21.70 & 38.50 & 2 & 1056.6784 & 1056.6777 & 529.3461 & 0.0007 & 0.6612 & 301.328 & 291.639 & 89.738 & 517.537 & \text { Yes }\end{array}$ $\begin{array}{lllllllllllllll}1.00 & 39.97 & 21.73 & 26.62 & 2 & 1056.6780 & 1056.6777 & 529.5461 & 0.0003 & 0.2834 & 11.525 & 98.424 & 7.349 & 231.764 & \text { Yes }\end{array}$ $\begin{array}{lllllllllllll}0.99 & 41.89 & 21.70 & 40.88 & 2 & 1056.6786 & 1056.6777 & 529.3461 & 0.0009 & 0.8501 & 371.357 & 339.147 & 3.07\end{array}$

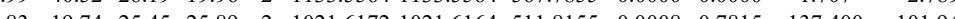

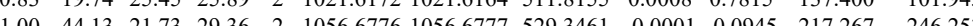
$\begin{array}{lllllllllllll}1.0 .83 & 19.74 & 25.45 & 25.89 & 2 & 1021.6172 & 1021.6164 & 511.8155 & 0.0008 & 0.7815 & 137.400 & 101.945\end{array}$ $\begin{array}{llllllllllllllllllll}0.52 & 22.04 & 25.98 & 23.14 & 2 & 1133.5558 & 1133.5564 & 567.7855 & -0.0006 & -0.5284 & 7.408 & 10.008\end{array}$

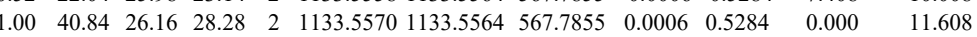

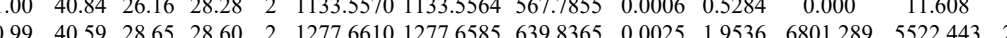

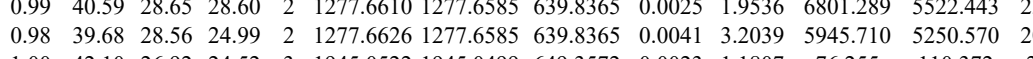
$\begin{array}{lllllllllllll}\text { DLADELALVDVIEDK } & 1.00 & 42.10 & 26.92 & 24.52 & 3 & 1945.0522 & 1945.0499 & 649.3572 & 0.0023 & 1.1807 & 76.255 & 110.372 \\ \text { D. } & 95.93 & 26.93 & 2 & 1945.0522 & 1945.0499 & 973.5322 & 0.0023 & 1.1813 & 187.399 & 265.333\end{array}$ $\begin{array}{lllllllllllll}\text { DLADELALVDVIEDK } & 1.00 & 97.98 & 26.93 & 26.07 & 2 & 1945.0524 & 1945.0499 & 973.5322 & 0.0025 & 1.2840 & 781.424 & 496.633\end{array}$ $\begin{array}{llllllllllll}\text { DLADELALVDVIEDK } & 1.00 & 32.93 & 26.90 & 22.34 & 3 & 1945.0528 & 1945.0499 & 649.3572 & 0.0029 & 1.4886 & 161.847\end{array}$ $\begin{array}{llllllllllllll}\text { DLADELALVDVIEDK } & 1.00 & 52.18 & 26.95 & 25.01 & 3 & 1945.0549 & 1945.0499 & 649.3572 & 0.0050 & 2.5666 & 526.433\end{array}$ $\begin{array}{lllllllllllllll} & \text { DLADELALVDVIEDK } & 0.94 & 23.77 & 26.95 & 24.26 & 3 & 1945.0552 & 1945.0499 & 649.3572 & 0.0053 & 2.7206 & 88.417 & 102.457\end{array}$ DLADELALV NVNIFK

VTILTSEEEAR

VTLTSEEEAR

LVIITAGAR

LVIITAGAR

VTLTSEEEAR

LVIITAGAR

LVIITAGAR

VTLTSEEEAR

LVIITAGAR

LVIITAGAR

LVIITAGAR

LVIITAGAR

LVIITAGAR

LVITAGAR

LVIITAGAR

LVIITAGAR

LVIITAGAR

LVIITAGAR

LVIITAGAR

GYTSWAIGLSVADLAES

TLHPDLGTDKDK

LVIITAGAR

LVIITAGAR

TLHPDLGTDK

LHPDLGTDK

TLHPDLGTDK

TLHPDLGTDKDK

TLHPDLGTDKDK

TLHPDLGTDKDK

TLHPDLGTDKDK

TLHPDLGTDK

TLHPDLGTDK

TLHPDLGTDK

TLHPDLGTDK

TLHPDLGTDKDK

$\begin{array}{lllllllllllll}\text { DHE3_HUMAN } & \text { P00367 } & \text { GLUD1 } & \text { Glutamate dehydr } 61.398 & 1.00 & 9 & 26.5 & 0.3190 & 0.2595 & 0.8065 & 0.3211 & 27 & \text { CIAVGESDGSIWNPDC } \\ & & & & & & & & & \end{array}$ $\begin{array}{lllllllllll}30.78 & 26.95 & 27.71 & 3 & 1945.0552 & 945.0499 & 649.3572 & 0.0053 & 2.7206 & 92.745 & 65.263\end{array}$ $\begin{array}{llllllllllll}0.71 & 20.67 & 25.42 & 18.47 & 2 & 1021.6168 & 1021.6164 & 511.8155 & 0.0004 & 0.3908 & 156.179 & 176.192\end{array}$ $\begin{array}{lllllllllllll}0.99 & 48.82 & 22.86 & 36.02 & 2 & 1056.6768 & 1056.6777 & 529.3461 & -0.0009 & -0.8501 & 765.676\end{array}$ $\begin{array}{llllllllllll}1.00 & 41.70 & 26.19 & 26.05 & 2 & 1133.5564 & 1133.5564 & 567.7855 & 0.0000 & 0.0000 & 28.337\end{array}$ $\begin{array}{llllllllllllll}0.99 & 41.38 & 26.19 & 20.70 & 2 & 1133.5564 & 1133.5564 & 567.7855 & 0.0000 & 0.0000 & 21.239\end{array}$ $\begin{array}{llllllllllll}0.99 & 47.18 & 23.01 & 31.15 & 2 & 1056.6758 & 1056.6777 & 529.3461 & -0.0019 & -1.7947 & 629.778\end{array}$ $\begin{array}{llllllllllll}0.96 & 41.52 & 23.01 & 33.64 & 2 & 1056.6760 & 1056.6777 & 529.3461 & -0.0017 & -1.6058 & 865.593 & \end{array}$ $\begin{array}{llllllllllll}1.00 & 38.96 & 26.16 & 17.57 & 2 & 1133.5570 & 1133.5564 & 567.7855 & 0.0006 & 0.5284 & 14.870 & \\ 0.99 & 45.49 & 22.86 & 34.96 & 2 & 1056.6766 & 10566777 & 529.3461 & -0.0011 & -1.0390 & 616.145 & 53\end{array}$ $\begin{array}{llllllllllll}1.99 & 45.49 & 22.86 & 34.96 & 2 & 1056.6766 & 1056.6777 & 529.3461 & -0.0011 & -1.0390 & 616.145\end{array}$ $\begin{array}{lllllllllllll}0.98 & 42.18 & 22.86 & 34.38 & 2 & 1056.6766 & 1056.6777 & 529.3461 & -0.0011 & -1.0390 & 518.896 & 5\end{array}$ $\begin{array}{lllllllllllll}0.76 & 22.67 & 26.16 & 21.04 & 2 & 1133.5566 & 1133.5564 & 567.7855 & 0.0002 & 0.1761 & 18.648 & \\ 0 & 0.98 & 4.19 & 21.73 & 34.70 & 2 & 1056.6772 & 1056.6777 & 529.3461 & -0.0005 & -0.4723 & 514.081 & 5\end{array}$ $\begin{array}{lllllllllll}0.98 & 42.19 & 21.73 & 34.70 & 2 & 1056.6772 & 1056.6777 & 529.3461 & -0.0005 & -0.4723 & 514.081 \\ 0.99 & 47.21 & 21.73 & 35.90 & 2 & 1056.6772 & 1056.6777 & 529.3461 & -0.0005 & -0.4723 & 512.997\end{array}$ $\begin{array}{llllllllllll}0.99 & 4.21 & 21.73 & 35.90 & 2 & 1056.672 & 1056.6777 & 529.3461 & 0.0005 & 0.4723 & 512.997 & 6\end{array}$

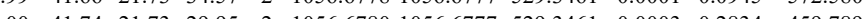
$\begin{array}{lllllllllll}1.00 & 43.23 & 21.73 & 31.52 & 2 & 1056.6780 & 1056.6777 & 529.3461 & 0.0003 & 0.2834 & 476.155\end{array}$ $\begin{array}{llllllllllll}1.00 & 43.22 & 21.73 & 28.27 & 2 & 1056.6782 & 1056.6777 & 529.3461 & 0.0005 & 0.4723 & 398.843 & 35\end{array}$

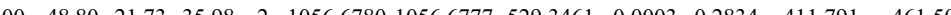
$\begin{array}{llllllllllllll}1.00 & 43.39 & 21.73 & 31.58 & 2 & 1056.6782 & 1056.6777 & 529.3461 & 0.0005 & 0.4723 & 358.865 & 397.002\end{array}$ $\begin{array}{llllllllllllll}1.00 & 42.91 & 21.73 & 33.23 & 2 & 1056.6780 & 1056.6777 & 529.3461 & 0.0003 & 0.2834 & 397.930 & 378.908\end{array}$ $\begin{array}{lllllllllllll}0.99 & 43.25 & 21.70 & 41.09 & 2 & 1056.6786 & 1056.6777 & 529.3461 & 0.0009 & 0.8501 & 466.137 & 545.175\end{array}$ $\begin{array}{lllllllllllll}1.00 & 45.86 & 21.73 & 31.03 & 2 & 1056.6778 & 1056.6777 & 529.3461 & 0.0001 & 0.0945 & 276.010 & 280.924\end{array}$

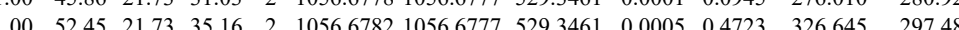
$\begin{array}{lllllllll}15.34 & 3 & 2399.2660 & 2399.2650 & 800.7623 & 0.0010 & 0.4163 & 9.579\end{array}$ $\begin{array}{llllllllllllll}0 & 170.9865 & 170.984 & 443.753 & 0.0024 & 1.3521 & 11113.845 & 10525.534 & 1480.770 & 23270.068 & \text { Yes }\end{array}$

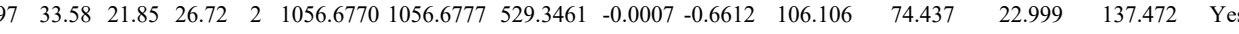
$\begin{array}{ccccccccccccccc}0.94 & 30.06 & 21.73 & 27.26 & 2 & 1056.6772 & 1056.6777 & 529.3461 & -0.0005 & -0.4723 & 71.703 & 83.472 & 2.205 & 189.552 & \text { Yes } \\ \end{array}$ $\begin{array}{lllllllllllllllll}0.99 & 45.51 & 26.95 & 24.33 & 2 & 1383.7678 & 1383.7602 & 692.8874 & 0.0076 & 5.4843 & 14860.777 & 14649.435 & 1969.977 & 25530.592 & \text { Yes }\end{array}$ $\begin{array}{lllllllllllllll}0.94 & 29.41 & 27.01 & 18.98 & 3 & 1383.7681 & 1383.7602 & 462.2607 & 0.0079 & 5.6966 & 20132.787 & 20746.914 & 1364.256 & 36672.854 & \text { Yes }\end{array}$ $\begin{array}{llllllllllllllll}0.91 & 54.50 & 26.49 & 21.22 & 2 & 1770.9868 & 1770.9841 & 886.4993 & 0.0027 & 1.5228 & 740.801 & 869.888 & 74.858 & 1537.679 & \text { Yes }\end{array}$ $\begin{array}{lllllllllllllll}0.75 & 48.25 & 26.49 & 25.37 & 2 & 1770.9868 & 1770.9841 & 886.4993 & 0.0027 & 1.5228 & 1025.216 & 1124.999 & 62.308 & 2245.380 & \text { Yes }\end{array}$ $\begin{array}{lllllllllllllll}0.92 & 18.73 & 26.40 & 17.71 & 4 & 1770.9889 & 1770.9841 & 443.7533 & 0.0048 & 2.7042 & 35057.483 & 33536.286 & 7002.235 & 73656.238 & \text { Yes }\end{array}$

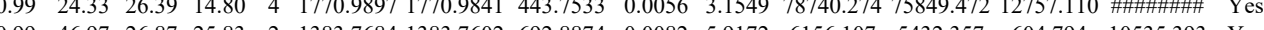

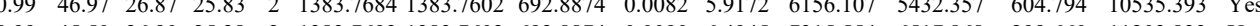
$\begin{array}{llllllllllllllll}0.99 & 45.50 & 26.90 & 25.28 & 2 & 1383.7692 & 1383.7602 & 692.8874 & 0.0090 & 6.4945 & 7315.554 & 6517.868 & 299.660 & 11203.833 & \text { Yes }\end{array}$ $\begin{array}{lllllllllllllllll}0.94 & 29.1 & 27.01 & 20.75 & 3 & 1383.7702 & 1383.7602 & 462.2607 & 0.0100 & 7.2109 & 23185.158 & 19717.333 & 2320.651 & 33640.764 & \text { Yes }\end{array}$ $\begin{array}{llllllllllllllllll}0.95 & 1 . .37 & 27.32 & 22.34 & 3 & 1383.7711 & 1383.7602 & 462.2607 & 0.0109 & 7.8599 & 21474.567 & 22715.560 & 2042.022 & 38858.354 & \text { Yes }\end{array}$ \begin{tabular}{llllllllllllllll}
1.00 & 47.43 & 25.28 & 25.01 & 4 & 1770.9925 & 1770.9841 & 443.7533 & 0.0084 & 4.7323 & 13157.917 & 13136.017 & 1925.521 & 26233.848 & Yes \\
\hline
\end{tabular}

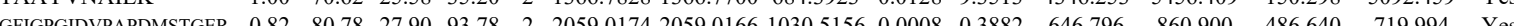
$\begin{array}{lllllllllllllllll}\text { GFIGPGIDVPAPDMSTGER } & 0.82 & 75.39 & 27.90 & 88.39 & 2 & 2059.0174 & 2059.0166 & 1030.5156 & 0.0008 & 0.3882 & 669.454 & 607.144 & 475.521 & 643.691 & \text { No }\end{array}$ 


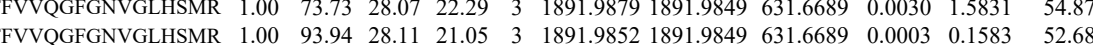

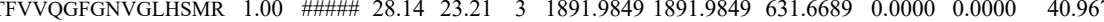
IIAEGANGPTTPEADK $\quad \begin{array}{lllllllllllll}1.00 & 86.81 & 27.67 & 30.43 & 2 & 1870.9894 & 1870.9880 & 936.5013 & 0.0014 & 0.7475 & 219.951\end{array}$ $\begin{array}{llllllllllllll} & \text { SVGMIAGGTGITPMLQVIR } & 0.67 & 30.27 & 25.24 & 43.27 & 3 & 2044.1329 & 2044.1295 & 682.3838 & 0.0034 & 1.6608 & 57.669\end{array}$ $\begin{array}{lllllllllll}\text { SVGMIAGGTGITPMLQVIR } & 1.00 & \# \# \# \text { 25.55 } & 27.95 & 2 & 2044.1294 & 2044.1295 & 1023.0720 & -0.0001 & -0.0489 & 57.770\end{array}$ $\begin{array}{llllllllllll}\text { SVGMIAGGTGITPMLQVIR } & 1.00 & 80.68 & 25.31 & 24.98 & 3 & 2044.1320 & 2044.1295 & 682.3838 & 0.0025 & 1.2212 & 25.389 \\ \text { SVGMIAGGTGTPMLQIR } & 1.00 & 61.31 & 25.30 & 2.62 & 3 & 04.1326 & 2044.1295 & 682.3838 & 0.0031 & 1.5143 & 16552\end{array}$ $\begin{array}{llllllllllllll} & \end{array}$

LDYNNITVVFSHPPIGTVGLLT

ALLTPVAIAAGR ALLTPVAIAAGR

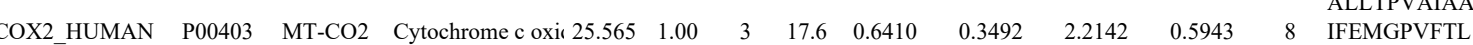

VVLPIEAPIR

VVLPIEAPIR

VVLPIEAPIR

$\begin{array}{llllllllllll}.00 & 44.46 & 23.78 & 57.46 & 4 & 3463.8285 & 3463.8231 & 866.9631 & 0.0054 & 1.5572 & 269.305 & 104.999\end{array}$ $\begin{array}{lllllllllllll}1.00 & 54.48 & 22.50 & 29.63 & 2 & 1295.8058 & 1295.8047 & 648.9096 & 0.0011 & 0.8476 & 5671.325 & 4565.892\end{array}$ $\begin{array}{llllllllllll}1.00 & 52.50 & 22.04 & 17.49 & 2 & 1295.8064 & 1295.8047 & 648.9096 & 0.0017 & 1.3099 & 3498.319 & 2648.80\end{array}$ $\begin{array}{llllllllllll}1.00 & 47.74 & 22.04 & 19.06 & 2 & 1295.8164 & 1295.8047 & 648.9096 & 0.0117 & 9.0150 & 4049.494 & 2972.984 \\ 1.00 & 40.13 & 27.98 & 19.54 & 2 & 1296.6928 & 1296.6910 & 649.3528 & 0.0018 & 1.3860 & 81.056 & 92.282\end{array}$

$\begin{array}{lllllllllllll}00 & 48.54 & 20.90 & 24.97 & 2 & 1249.7890 & 1249.7880 & 625.9013 & 0.0010 & 0.7988 & 5299.664 & 7892.200 & 88\end{array}$ $\begin{array}{llllllllllllll}1.00 & 48.54 & 20.68 & 24.46 & 2 & 1249.7892 & 1249.7880 & 625.9013 & 0.0012 & 0.9586 & 6684.010 & 9122.736\end{array}$

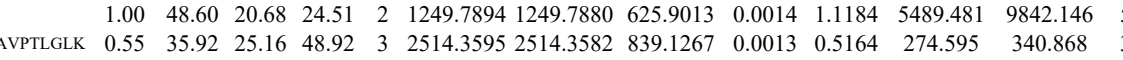
$\begin{array}{lllllllllllll} & \end{array}$ $\begin{array}{llllllllllllllll} & \end{array}$

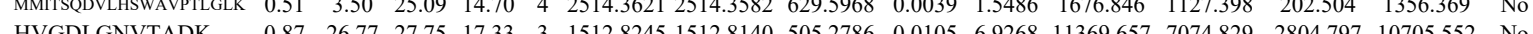
$\begin{array}{llllllllllllllll}\text { GDGPVOGINFEQK } & 1.00 & 79.29 & 27.29 & 20.06 & 2 & 1788.9626 & 1788.9614 & 895.4880 & 0.0012 & 0.6700 & 1334.522 & 1799.174 & 1817.763 & 2526.484 & \text { Yes }\end{array}$ 


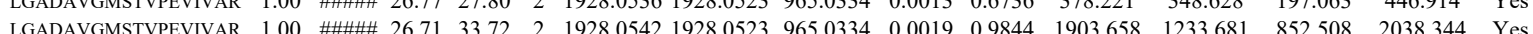

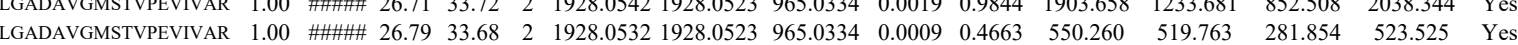

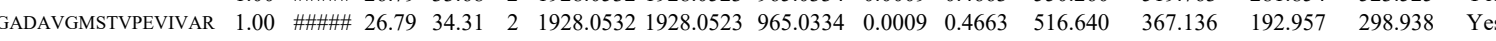

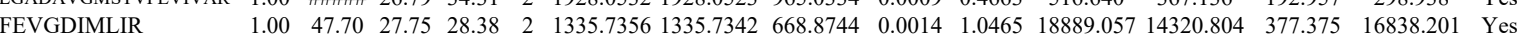

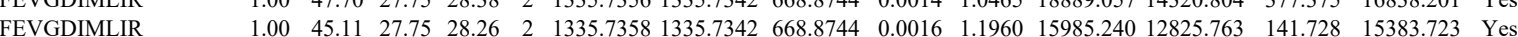

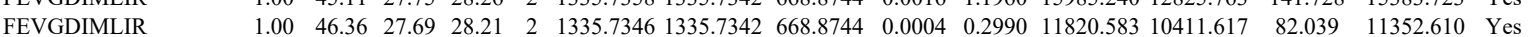
$\begin{array}{llllllllllllllll} & \\ \text { FEVGDIMLIR } & 1.00 & 41.90 & 27.72 & 27.95 & 2 & 1335.7352 & 1335.7342 & 668.8744 & 0.0010 & 0.7475 & 13031.863 & 10111.653 & 301.803 & 12126.128 & \text { Yes }\end{array}$

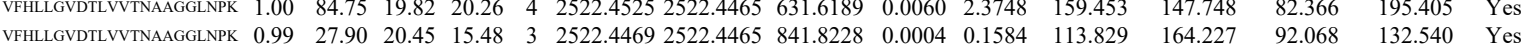

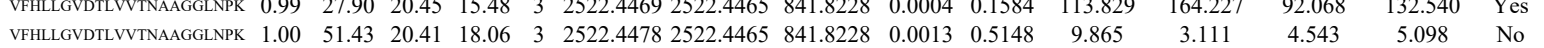

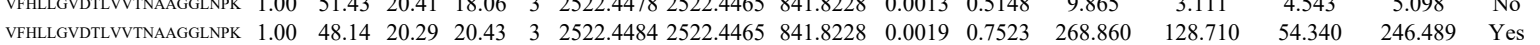

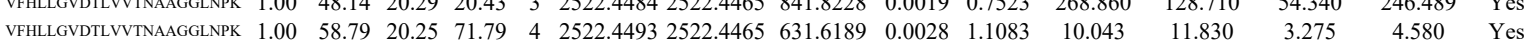
$\begin{array}{lllllllllllllllll}\text { VFHLLVDTLVVTNAAGGLNPK } & 1.00 & 76.51 & 20.17 & 89.51 & 4 & 2522.4505 & 2522.4465 & 631.6189 & 0.0040 & 1.5832 & 395.437 & 273.641 & 241.753 & 612.367 & \text { Yes }\end{array}$

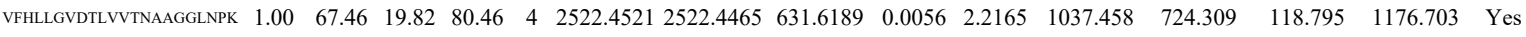

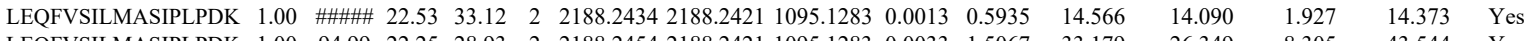

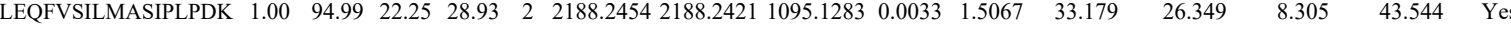
$\begin{array}{lllllllllllllll} & & & \end{array}$ $\begin{array}{lllllllllllllllll} & & \end{array}$ $\begin{array}{llllllllllllllll}\text { VFHLLGVTLVVTNAAGGLNPK } & 1.00 & 31.60 & 20.29 & 44.60 & 4 & 2522.4485 & 2522.4465 & 631.6189 & 0.0020 & 0.7916 & 176.877 & 98.678 & 128.526 & 259.048 & \text { Yes }\end{array}$

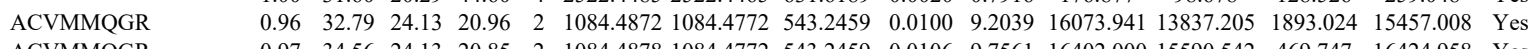

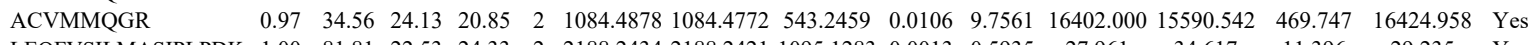

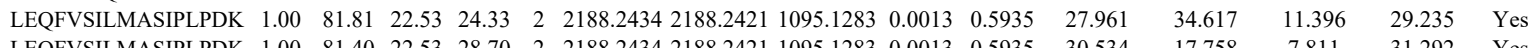

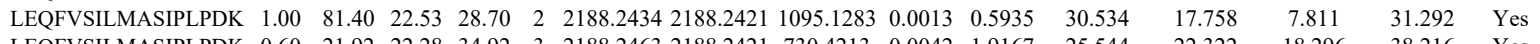

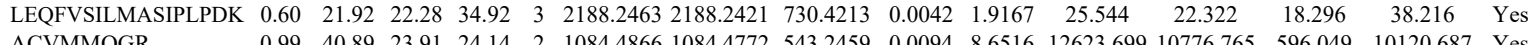

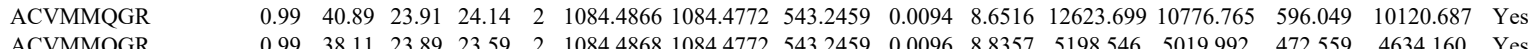

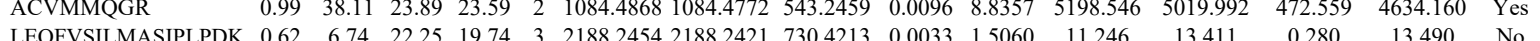

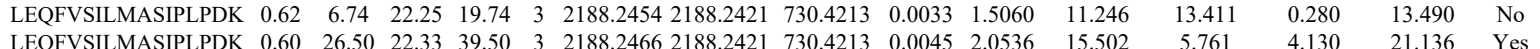

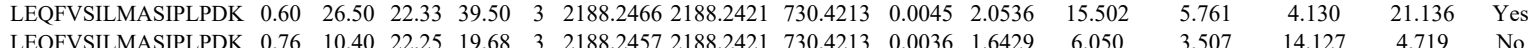

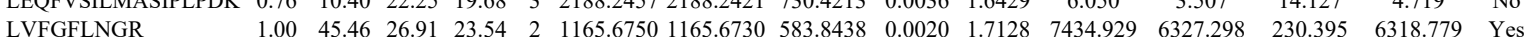
$\begin{array}{lrllllllllllllll}\text { LVFGFLNGR } & 1.00 & 45.46 & 26.91 & 23.54 & 2 & 1165.6750 & 1165.6730 & 583.8438 & 0.0020 & 1.7128 & 7434.929 & 6327.298 & 230.395 & 6318.779 & \text { Yes } \\ \text { LVFGFLNGR } & 1.00 & 45.27 & 26.92 & 23.40 & 2 & 1165.6742 & 1165.6730 & 583.8438 & 0.0012 & 1.0277 & 2542.806 & 2090.852 & 24.787 & 2152.843 & \text { Yes }\end{array}$ 

$\begin{array}{lllllllllllll}1.00 & 60.92 & 24.41 & 17.03 & 3 & 1715.9947 & 1715.9913 & 573.0044 & 0.0034 & 1.9779 & 129.915 & 74.693 \\ 1.00 & 36.97 & 2.4 & 19.51 & 3 & 1715.9950 & 1715.9913 & 573.0044 & 0.0037 & 2.1524 & 101.501 & 61.492\end{array}$ $\begin{array}{llllllllllll}1.00 & 36.97 & 24.42 & 19.51 & 3 & 1715.9950 & 1715.9913 & 573.0044 & 0.0037 & 2.1524 & 101.501 & 61.492 \\ 0.99 & 28.32 & 24.42 & 19.15 & 3 & 1715.9953 & 1715.9913 & 573.0044 & 0.0040 & 2.3269 & 57.355 & 76.966\end{array}$

FFADLLDYIK

FFADLLDYIK

FFADLLDYIK

FFADLLDYIK

VASLLVK

SIPMTVDFIR

TMQTLLSLVR

TMQTLLSLVR
TMQTLLSLVR

TMQTLLSLVR

TMQTLLSLVR

TMQTLLSLVR

TMQTLLSLVR

NVLIVEDIIDTGK

NVLIVEDIIDTGK

3 KAEAQIAAK

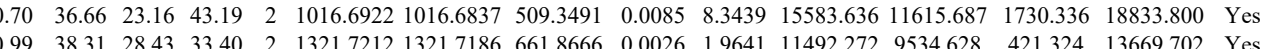
$\begin{array}{llllllllllllllll}0.90 & 31.88 & 28.37 & 26.97 & 2 & 1321.7230 & 1321.7186 & 661.8666 & 0.0044 & 3.3239 & 13078.517 & 10911.231 & 1832.328 & 13895.578 & \text { Yes }\end{array}$ $\begin{array}{llllllllllllllll}1.00 & 64.64 & 26.80 & 23.25 & 2 & 1304.7624 & 1304.7608 & 653.3877 & 0.0016 & 1.2244 & 3548.301 & 2825.341 & 127.456 & 4789.187 & \text { Yes }\end{array}$ $\begin{array}{lllllllllllllll}1.00 & 65.46 & 26.80 & 21.96 & 2 & 1304.7624 & 1304.7608 & 653.3877 & 0.0016 & 1.2244 & 1846.166 & 1932.329 & 141.166 & 2833.289 & \text { Yes }\end{array}$ $\begin{array}{llllllllllllllll}1.00 & 66.82 & 26.90 & 26.21 & 2 & 1304.7610 & 1304.7608 & 653.3877 & 0.0002 & 0.1530 & 963.996 & 881.770 & 26.600 & 1395.105 & \text { Yes }\end{array}$ $\begin{array}{llllllllllllllll}1.00 & 64.63 & 26.90 & 24.03 & 2 & 1304.7612 & 1304.7608 & 653.3877 & 0.0004 & 0.3061 & 1244.786 & 1125.829 & 7.899 & 1823.748 & \text { Yes }\end{array}$ $\begin{array}{llllllllllllllll}1.00 & 62.99 & 26.83 & 22.83 & 2 & 1304.7618 & 1304.7608 & 653.3877 & 0.0010 & 0.7652 & 1515.667 & 1231.785 & 30.878 & 1893.298 & \text { Yes }\end{array}$

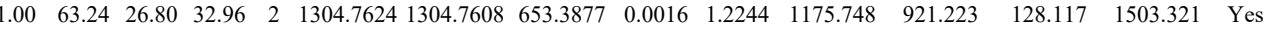
$\begin{array}{lllllllllllllll}1.00 & 73.53 & 24.62 & 25.08 & 2 & 1715.9942 & 1715.9913 & 859.0029 & 0.0029 & 1.6880 & 179.601 & 84.141 & 25.217 & 186.090 & \text { Yes }\end{array}$ $\begin{array}{lllllllllllllll}1.00 & 52.40 & 24.62 & 21.98 & 3 & 1715.9944 & 1715.9913 & 573.0044 & 0.0031 & 1.8034 & 88.278 & 88.261 & 73.054 & 107.479 & \text { Yes }\end{array}$ \begin{tabular}{llllllllllllllll}
0.60 & 63.40 & 24.42 & 76.40 & 3 & 1715.9950 & 1715.9913 & 573.0044 & 0.0037 & 2.1524 & 105.220 & 75.414 & 64.526 & 179.972 & Yes \\
\hline
\end{tabular} $\begin{array}{lllllllllllllll}1.00 & 34.22 & 22.48 & 21.57 & 3 & 1360.8406 & 1360.8403 & 454.6207 & 0.0003 & 0.2200 & 903.045 & 834.103 & 248.401 & 1272.706 & \text { Yes }\end{array}$ $\begin{array}{lllllllllllllll}0.67 & 18.91 & 26.79 & 31.91 & 3 & 1922.9029 & 1922.8998 & 641.9739 & 0.0031 & 1.6096 & 396.602 & 294.934 & 291.283 & 654.464 & \text { Yes }\end{array}$

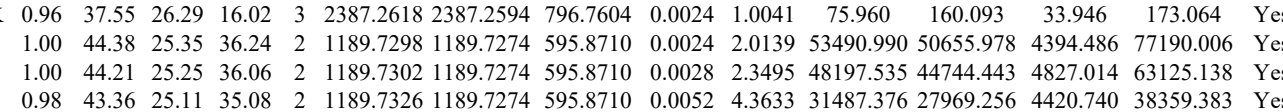

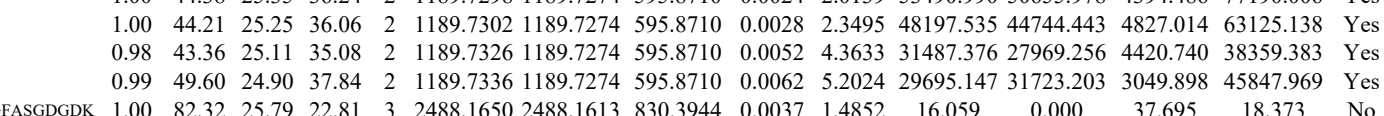

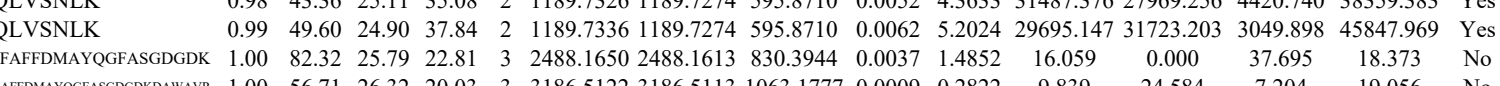
$\begin{array}{lllllllllllllll} & \end{array}$ $\begin{array}{lllllllllll} & & & \end{array}$ $\begin{array}{lllllllllllllll}1 & \end{array}$ $\begin{array}{llllllllllllllll}\text { NDPRPEQWK } & 1.00 & 41.73 & 25.01 & 18.38 & 4 & 3368.7433 & 3368.7365 & 843.1914 & 0.0068 & 2.0161 & 263.700 & 238.858 & 477.778 & 371.991 & \text { No } \\ \mathrm{DLR} & 1.00 & 60.18 & 24.65 & 36.62 & 2 & 1410.8304 & 1410.8316 & 706.4231 & -0.0012 & -0.8494 & 2591.479 & 2202.982 & 410.356 & 3366.064 & \text { Yes }\end{array}$

IAAAILNTPDLR IAAAILNTPDLR

IAAAILNTPDLR

IAAAAILNTPDLR

IAAAILNTPDLR IAAAILNTPDLR MNLGVGAYR MNLGVGAYR

VGAFTMVCK

MNLGVGAYR

MNLGVGAYR

VGAFTMVCK

VGAFTMVCK

MNLGVGAYR

MNLGVGAYR

IGASFLQR

IGASFLQR

IGASFLQR

FVTVQTISGTGALR

FVTVQTISGTGALR

IGASFLQR

FVTVQTISGTGALR $\begin{array}{lllllllllllllll}1.00 & 60.18 & 24.65 & 36.62 & 2 & 1410.8304 & 1410.8316 & 706.4231 & -0.0012 & -0.8494 & 2591.479 & 2202.982 & 410.356 & 3366.064 & \text { Yes } \\ 1.00 & 62.10 & 24.90 & 34.83 & 2 & 1410.8318 & 1410.8316 & 706.4231 & 0.0002 & 0.1416 & 3681.068 & 3469.112 & 648.392 & 5853.372 & \text { Yes } \\ 1.00 & 25.28 & 25.26 & 6.7 & 4 & 368.740 & 3368.7365 & 843.1914 & 0.0036 & 1.0674 & 377.82 & 329.032 & 535.818 & 373.195 & \text { No }\end{array}$ $\begin{array}{lllllllllllllll}1.00 & 25.28 & 25.26 & 16.70 & 4 & 3368.7401 & 3368.7365 & 843.1914 & 0.0036 & 1.0674 & 377.821 & 329.032 & 535.818 & 373.195 & \text { No }\end{array}$ $\begin{array}{llllllllllllllll}1.00 & 57.44 & 24.90 & 32.25 & 2 & 1410.8322 & 1410.8316 & 706.4231 & 0.0006 & 0.4247 & 1642.484 & 1629.145 & 476.399 & 2803.348 & \text { Yes }\end{array}$ $\begin{array}{llllllllllllllll}1.00 & 66.16 & 24.87 & 31.07 & 2 & 1410.8324 & 1410.8316 & 706.4231 & 0.0008 & 0.5662 & 4929.747 & 2989.527 & 624.564 & 7544.607 & \text { Yes }\end{array}$ \begin{tabular}{llllllllllllllll}
1.00 & 66.59 & 24.68 & 24.47 & 2 & 1410.8330 & 1410.8316 & 706.4231 & 0.0014 & 0.9909 & 808.515 & 695.699 & 71.412 & 1084.032 & Yes \\
\hline
\end{tabular} $\begin{array}{llllllllllllllll}1.00 & 55.29 & 24.47 & 25.97 & 2 & 1410.8336 & 1410.8316 & 706.4231 & 0.0020 & 1.4156 & 2567.209 & 2373.938 & 230.472 & 4206.868 & \text { Yes }\end{array}$ $\begin{array}{lllllllllllllll}0.95 & 36.36 & 28.24 & 23.02 & 2 & 1123.6022 & 1123.5930 & 562.8038 & 0.0092 & 8.1733 & 17310.819 & 20225.123 & 892.582 & 25642.126 & \text { Yes }\end{array}$ $\begin{array}{lllllllllllllll}0.98 & 38.88 & 28.33 & 23.60 & 2 & 1123.6028 & 1123.5930 & 562.8038 & 0.0098 & 8.7063 & 23147.378 & 22186.737 & 1505.333 & 30231.942 & \text { Yes }\end{array}$ $\begin{array}{llllllllllllllll}1.00 & 43.69 & 27.94 & 29.66 & 2 & 1288.6606 & 1288.6586 & 645.3366 & 0.0020 & 1.5496 & 11254.751 & 11607.705 & 1078.865 & 16022.538 & \text { Yes }\end{array}$ $\begin{array}{lllllllllllllll}0.99 & 46.05 & 28.24 & 25.50 & 2 & 1123.6024 & 1123.5930 & 562.8038 & 0.0094 & 8.3510 & 22441.865 & 22833.641 & 1531.726 & 32712.231 & \text { Yes }\end{array}$ $\begin{array}{lllllllllllllll}0.90 & 31.81 & 28.33 & 24.57 & 2 & 1123.6028 & 1123.5930 & 562.8038 & 0.0098 & 8.7063 & 11708.660 & 12301.391 & 1753.416 & 18051.219 & \text { Yes }\end{array}$ $\begin{array}{lllllllllllllll}1.00 & 51.49 & 27.90 & 25.86 & 2 & 1288.6592 & 1288.6586 & 645.3366 & 0.0006 & 0.4649 & 17798.739 & 18074.520 & 1349.725 & 21711.817 & \text { Yes }\end{array}$ $\begin{array}{llllllllllllllll}1.00 & 44.42 & 27.86 & 31.56 & 2 & 1288.6604 & 1288.6586 & 645.3366 & 0.0018 & 1.3946 & 17864.536 & 14505.964 & 783.400 & 19450.520 & \text { Yes }\end{array}$

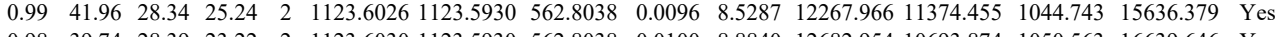
$\begin{array}{lllllllllllllll}0.98 & 39.74 & 28.39 & 23.22 & 2 & 1123.6030 & 1123.5930 & 562.8038 & 0.0100 & 8.8840 & 12682.954 & 10693.874 & 1050.563 & 16639.646 & \text { Yes }\end{array}$

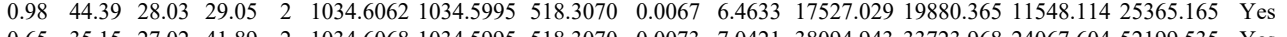

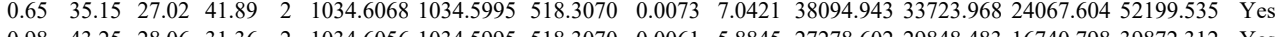

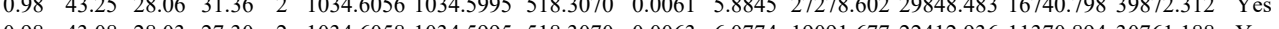
$\begin{array}{llllllllllllllllll}0.98 & 43.08 & 28.03 & 27.30 & 2 & 1034.6058 & 1034.5995 & 518.3070 & 0.0063 & 6.0774 & 19091.677 & 22412.936 & 11370.894 & 30761.188 & \text { Yes }\end{array}$ $\begin{array}{lllllllllllllll}1.00 & 86.95 & 26.94 & 24.98 & 2 & 1592.9038 & 1592.9008 & 797.4577 & 0.0030 & 1.8810 & 5378.750 & 4938.272 & 1470.936 & 7265.072 & \text { Yes } \\ 1.00 & 77.59 & 26.92 & 24.69 & 2 & 1592.9040 & 1592.9008 & 797.4577 & 0.0032 & 2.0064 & 6547.556 & 4962.433 & 1668.027 & 8169.239 & \text { Yes }\end{array}$

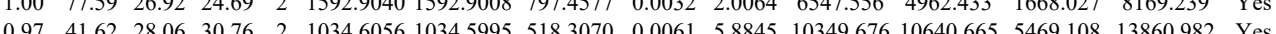

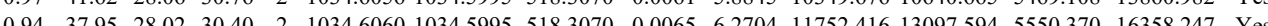
$\begin{array}{lllllllllllllllllll}1.00 & 81.46 & 26.35 & 22.65 & 2 & 1592.9150 & 1592.9008 & 797.4577 & 0.0142 & 8.9032 & 12390.163 & 11425.424 & 2252.196 & 16168.160 & \text { Yes }\end{array}$ 
GDSFTHTPPLDPQELDILK

\section{IPVAIK} \begin{tabular}{lllllllllllll} 
& 65.17 & 27.08 & 22.53 & 2 & 1592.9006 & 1592.9008 & 797.4577 & -0.0002 & -0.1254 & 92.763 \\
\hline$K$ & 1.00 & 37.83 & 27.36 & 21.65 & 3 & 24102667 & 2410.2624 & 804.4281 & 0.0043 & 1.7818 & 16.597 & 39
\end{tabular}

IPLENLQIIR

IPLENLQIIR

IPLENLQIIR

IPLENLQIIR

WMALESILHR

WMALESILHR

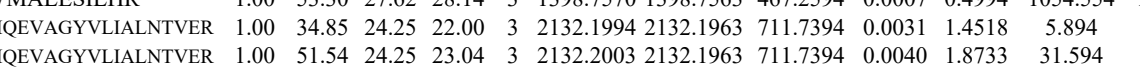
$\begin{array}{lllllllllllll}\text { TIQEVAGYVLIALNTVER } & 1.00 & 47.57 & 24.18 & 16.31 & 3 & 2132.1973 & 2132.1963 & 711.7394 & 0.0010 & 0.4683 & 14.903\end{array}$ $\begin{array}{llllllllllll} & 1.00 & 47.57 & 24.18 & 16.31 & 3 & 2132.1973 & 2132.1963 & 711.7394 & 0.0010 & 0.4683 & 14.903\end{array}$ $\begin{array}{lllllllllllll} & 11\end{array}$

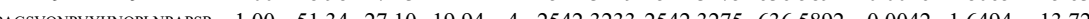
$\begin{array}{lllllllllllllll}\text { RPAGSVONPVYHNOPLNPAPSR } & 1.00 & 37.47 & 26.76 & 50.47 & 4 & 2542.3317 & 2542.3275 & 6365892 & 0.0042 & 1.6494 & 103.757 & 10\end{array}$ $\begin{array}{lllllllllllll}\text { RPAGSYONPYYHNOPIPAPSR } & 1.00 & 41.48 & 26.95 & 54.48 & 4 & 2542.3289 & 2542.3275 & 636.5892 & 0.0014 & 0.5498 & 22.781\end{array}$ $\begin{array}{lllllllllllllll}\text { GDSFTHTPPLDPQELDILK } & 1.00 & 41.62 & 27.34 & 15.77 & 3 & 2410.2661 & 2410.2624 & 804.4281 & 0.0037 & 1.5332 & 45.231\end{array}$

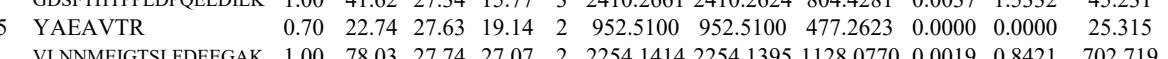

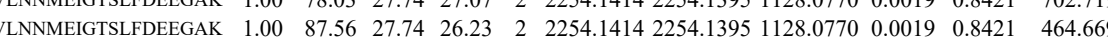
$\begin{array}{lllllllllllll}\text { VLNNMEIGTSLFDEEGAK } & 1.00 & 41.42 & 27.66 & 18.01 & 3 & 2254.1431 & 2254.1395 & 752.3871 & 0.0036 & 1.5949 & 40.846\end{array}$ $\begin{array}{llllllllllll}\text { VLNNMEIGTSLFDEEGAK } & 1.00 & 36.09 & 27.60 & 19.73 & 3 & 2254.1434 & 2254.1395 & 752.3871 & 0.0039 & 1.7278 & 33.206\end{array}$ NNQITNNQR NNQITNNQR $\begin{array}{llllllllllll}1.00 & 51.60 & 27.13 & 29.23 & 2 & 1244.6350 & 1244.6343 & 623.3244 & 0.0007 & 0.5615 & 79.892\end{array}$

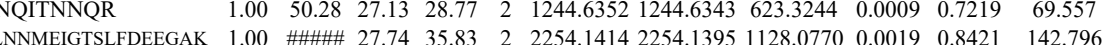
$\begin{array}{llllllllllllll}\text { VLNNMEIGTSLFDEEGAK } & 1.00 & 64.27 & 27.66 & 25.47 & 3 & 2254.1431 & 2254.1395 & 752.3871 & 0.0036 & 1.5949 & 66.723\end{array}$ $\begin{array}{lllllllllllll}\text { VLNNMEIGTSLFDEEGAK } & 1.00 & 49.32 & 27.60 & 23.04 & 3 & 2254.1434 & 2254.1395 & 752.3871 & 0.0039 & 1.7278 & 18.293\end{array}$ NNQITNNQR

NNQITNNQR

YSLEPVAVELK

YSLEPVAVELK

YSLEPVAVELK

YSLEPVAVELK YSLEPVAVELK YSLEPVAVELK YSLEPVAVELK YSLEPVAVELK $\begin{array}{llllllllllllll}1.00 & 54.11 & 27.13 & 29.45 & 2 & 1244.6350 & 1244.6343 & 623.3244 & 0.0007 & 0.5615 & 91.759 & 130.981\end{array}$ $\begin{array}{lllllllllllll}0.99 & 35.74 & 27.13 & 25.54 & 2 & 1244.6354 & 1244.6343 & 623.3244 & 0.0011 & 0.8824 & 23.699 & 33.563\end{array}$ $\begin{array}{lllllllllllll}1.00 & 53.12 & 26.33 & 34.07 & 2 & 1534.8850 & 1534.8850 & 768.4498 & 0.0000 & 0.0000 & 1632.538 & 2051.936\end{array}$ $\begin{array}{lllllllllllll}1.00 & 53.12 & 26.33 & 34.07 & 2 & 1534.8850 & 1534.8850 & 768.4498 & 0.000 & 0.000 & 1632.538 & 2051.936\end{array}$ $\begin{array}{llllllllllll}0.98 & 28.16 & 25.61 & 28.30 & 3 & 1534.8883 & 1534.8850 & 512.6356 & 0.0033 & 2.1458 & 131.543 & 94.965 \\ 1.00 & 34.16 & 25.80 & 25.08 & 3 & 1534.8874 & 1534.8850 & 512.6356 & 0.0024 & 1.5606 & 81.649 & 82.795\end{array}$ $\begin{array}{llllllllllll}1.00 & 34.16 & 25.80 & 25.08 & 3 & 1534.8874 & 1534.8850 & 512.6356 & 0.0024 & 1.5606 & 81.649 & 82.795 \\ 0.99 & 25.79 & 25.80 & 23.61 & 3 & 1534.8874 & 1534.8850 & 512.6356 & 0.0024 & 1.5606 & 91.348 & 43.304\end{array}$ $\begin{array}{llllllllllll}0.99 & 25.79 & 25.80 & 23.61 & 3 & 1534.8874 & 1534.8850 & 512.6356 & 0.0024 & 1.5606 & 91.348 & 43.304 \\ 1.00 & 60.31 & 25.79 & 33.28 & 2 & 1534.8874 & 1534.8850 & 768.4498 & 0.0024 & 1.5616 & 9538.568 & 11277.568\end{array}$ $\begin{array}{lllllllllllll}1.00 & 60.31 & 25.79 & 33.28 & 2 & 1534.8874 & 1534.8850 & 768.4498 & 0.024 & 1.5616 & 9538.568 & 11277.568\end{array}$

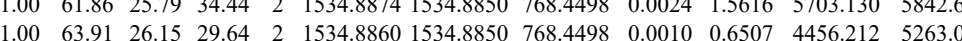
ITLPVDFVTADKFDENAK $\begin{array}{lllllllllllll}1.00 & 53.96 & 25.83 & 25.82 & 2 & 1534.8868 & 1534.8850 & 768.4498 & 0.0018 & 1.1712 & 890.420 & 1271.865\end{array}$

$\begin{array}{llll}1468.338 & 9973.557 & \text { Yes } \\ 1495.401 & 10674.555 & \text { Yes } & 0 \\ 0 & 0\end{array}$

$\begin{array}{llllllllllll}1.00 & 46.86 & 25.02 & 16.37 & 3 & 2454.3391 & 2454.3372 & 819.1197 & 0.0019 & 0.7732 & 18880.635 & 24652.734\end{array}$

$\begin{array}{lllllllllllllll}1.00 & 48.98 & 25.02 & 21.26 & 3 & 2454.3391 & 2454.3372 & 819.1197 & 0.0019 & 0.7732 & 20168.743 & 20652.285 & 9991.938 & 17989.013 & \text { Ycc }\end{array}$ $\begin{array}{llllllllllllllll}\text { ITLPVDFVTADKFDENAK } & 0.66 & 13.15 & 24.73 & 14.59 & 4 & 2454.3417 & 2454.3372 & 614.5916 & 0.0045 & 1.8305 & 339.879 & 424.568 & 137.453 & 228.740 & \text { Yes }\end{array}$ 


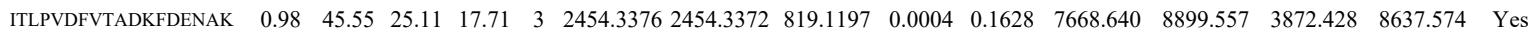

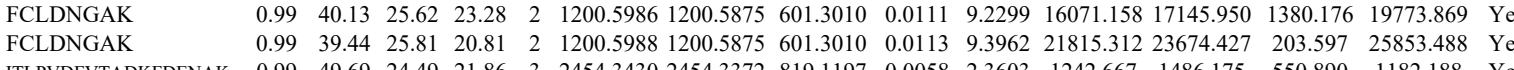

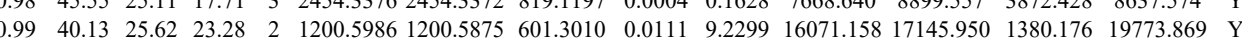

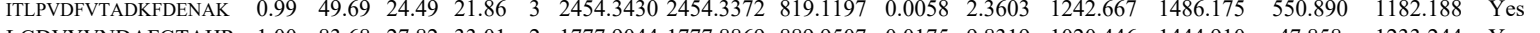
\begin{tabular}{llllllllllllllll} 
LGDVYVNDAFGTAHR & 1.00 & 83.68 & 27.82 & 33.01 & 2 & 1777.9044 & 1777.8869 & 889.9507 & 0.0175 & 9.8319 & 1020.446 & 1444.910 & 47.858 & 1233.244 & Yes \\
\hline
\end{tabular} AAVPSIK

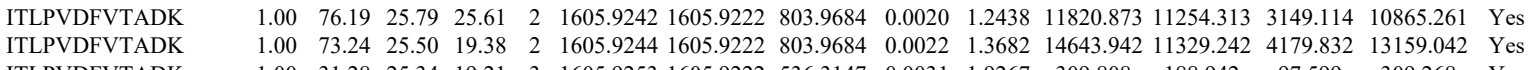
$\begin{array}{lllllllllllllllll}1.00 & 39.15 & 22.94 & 31.98 & 2 & 972.6222 & 972.6211 & 487.3178 & 0.0011 & 1.1286 & 12057.233 & 12625.660 & 1598.224 & 11897.919 & \text { Yes }\end{array}$ ITLPVDFVTADK ITLPVDFVTADK
VDFNVPMK $\begin{array}{llllllllllllllll}1.00 & 73.24 & 25.50 & 19.38 & 2 & 1605.9244 & 1605.9222 & 803.9684 & 0.0022 & 1.3682 & 14643.942 & 11329.242 & 4179.832 & 13159.042 & \text { Yes }\end{array}$

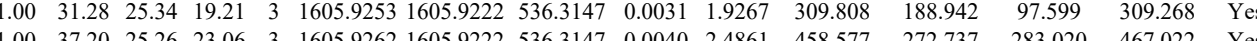
$\begin{array}{lllllllllllllllllll}1.00 & 37.20 & 25.26 & 23.06 & 3 & 1605.9262 & 1605.9222 & 536.3147 & 0.004 & 2.4861 & 458.57 & 27.737 & 283.020 & 467.022 & \text { Yes }\end{array}$ $\begin{array}{lllllllllllllll}1.00 & 51.52 & 28.07 & 26.80 & 2 & 1236.6830 & 1236.6780 & 619.3463 & 0.0050 & 4.0365 & 22027.632 & 22470.855 & 2051.193 & 24193.487 & \text { Yes } \\ 1.00 & 58.44 & 25.53 & 25.03 & 2 & 1240.7162 & 1240.7149 & 621.3647 & 0.0013 & 1.0461 & 413.896 & 448.125 & 81.533 & 873.682 & \text { No }\end{array}$ VLPGVDALSNI $\begin{array}{lllllllllllllll}1.00 & 58.44 & 25.53 & 25.03 & 2 & 1240.7162 & 1240.7149 & 621.3647 & 0.0013 & 1.0461 & 413.896 & 448.125 & 81.533 & 873.682 & \text { No }\end{array}$

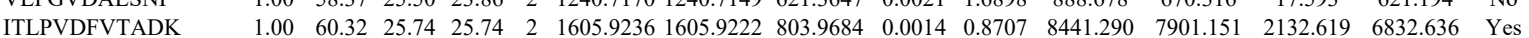
$\begin{array}{llllllllllllllll}\text { ITLPVDFVTADK } & 0.84 & 14.91 & 25.83 & 19.08 & 3 & 1605.9238 & 1605.9222 & 5363147 & 0.0016 & 0.9944 & 80.365 & 36.875 & 55.637 & 160.962 & \text { No }\end{array}$

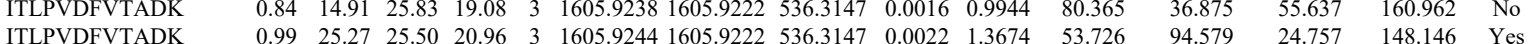
ITLPVDFVTADK
ITLPVDFVTADK

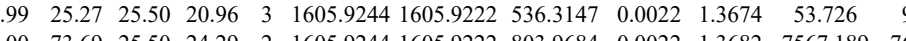
GQATVASGIPAGWMGLDGGPESS

VLPGVDALSNI ITLPVDFVTADK

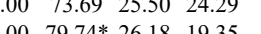

ITLPVDFVTADK

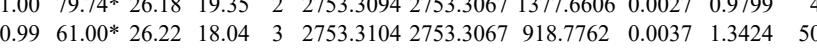
TGQATVASGPAGWMGLDCGPES $\begin{array}{llllllllllll}1.00 & 54.34 & 25.44 & 24.46 & 2 & 1240.7168 & 1240.7149 & 621.3647 & 0.0019 & 1.5289 & 373.302\end{array}$

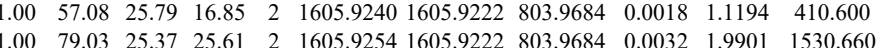
$\begin{array}{llllllllll}1.00 & 113.01 * 26.18 & 24.43 & 2 & 2753.3094 & 2753.3067 & 1377.6606 & 0.0027 & 0.9799 & 6.405\end{array}$ $2.780 \quad 1376.798$ $\begin{array}{lllll}2322.2440 & 2322.2432 & 775.0883 & 0.0106 & 6.3935 \\ 4 & 0.0008 & 0.3440 \\ 4 & 2322.24542322 .232 & 152.128 & 0.002 & 0.465\end{array}$ \begin{tabular}{lllllll}
4396.660 & 5014.934 & 2210.046 & 4923.689 & Ye \\
\hline
\end{tabular}

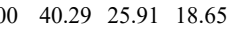
2322.24612322 .24

\section{HSSMVGVNLPQK}

SVVLMSHLGRPDGVPMPI

IQLINNMLDK

IQLINNMLDK $\begin{array}{lllllll} & \end{array}$ $\begin{array}{llllllllllllllll}67.19 & 27.19 & 26.30 & 2 & 1654.9150 & 1654.9068 & 828.4607 & 0.0082 & 4.9489 & 1443.134 & 2132.284 & 710.221 & 1810.455 & \text { Yes }\end{array}$ $\begin{array}{llllllllllllllllll}0.91 & 29.27 & 27.23 & 18.31 & 3 & 1654.9156 & 1654.9068 & 552.642 & 0.0088 & 53078 & 12242.070 & 11856.266 & 12991.509 & 9508.749 & \text { Ne }\end{array}$

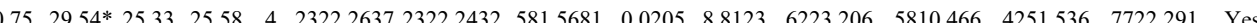
$\begin{array}{lllllllllllllllll}1.00 & 42.61 & 25.69 & 27.89 & 2 & 1488.8594 & 1488.8577 & 745.4361 & 0.0017 & 1.1403 & 10241.014 & 9296.349 & 1375.379 & 13424.731 & \text { Yes }\end{array}$ $\begin{array}{llllllllllllllll} & 0.95 & 20.05 & 25.99 & 17.81 & 3 & 1488.8611 & 1488.8577 & 497.2932 & 0.0034 & 2.2790 & 273.439 & 232.963 & 67.151 & 458.671 & \text { Yes }\end{array}$ $\begin{array}{lllllllllllllll} & \end{array}$

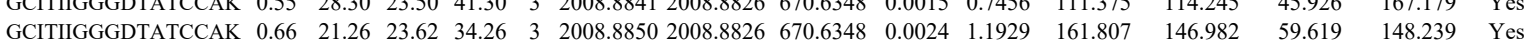
$\begin{array}{llllllllllllllll}\text { GCITIIGGGDTATCCAK } & 0.67 & 15.12 & 23.67 & 28.12 & 3 & 2008.8859 & 2008.8826 & 670.6348 & 0.0033 & 1.6402 & 172.356 & 152.991 & 49.491 & 163.830 & \text { Yes }\end{array}$

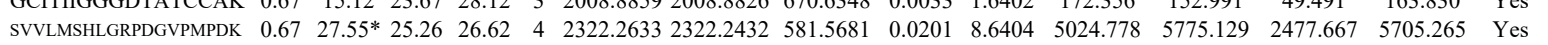

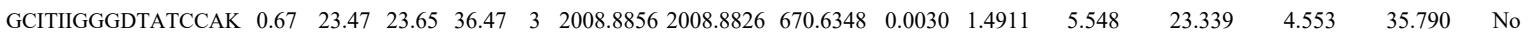
$\begin{array}{llllllllllllllll}\text { GCITIIGGGDTATCCAK } & 0.60 & 18.44 & 23.82 & 31.44 & 3 & 2008.8868 & 2008.8826 & 670.6348 & 0.0042 & 2.0876 & 168.304 & 147.747 & 60.606 & 234.332 & \text { Yes }\end{array}$ $\begin{array}{lllllllllllllllll}\text { ALESPERPFLAILGGAK } & 1.00 & 59.18 & 21.58 & 17.97 & 2 & 2056.1934 & 2056.1924 & 1029.1035 & 0.0010 & 0.4859 & 1429.652 & 1160.042 & 473.971 & 1402.888 & \text { Yes }\end{array}$

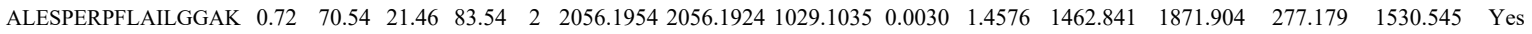

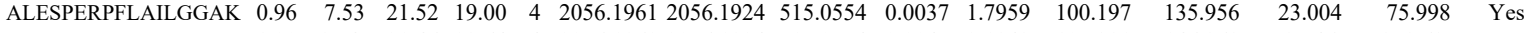

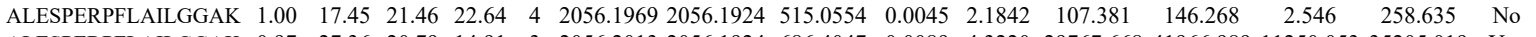

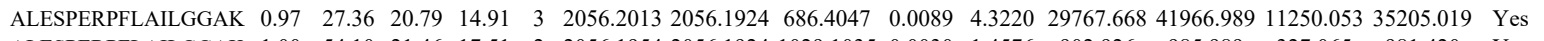
$\begin{array}{llllllllllllllll}\text { ALESPERPFLAILGGAK } & 1.00 & 54.10 & 21.46 & 17.51 & 2 & 2056.1954 & 2056.1924 & 1029.1035 & 0.0030 & 1.4576 & 902.926 & 985.989 & 327.065 & 981.420 & \text { Yes }\end{array}$ $\begin{array}{llllllllllllllll}\text { ALESPERPFLAILGGAK } & 1.00 & 66.41 & 21.46 & 18.52 & 2 & 2056.1954 & 2056.1924 & 1029.1035 & 0.0030 & 1.4576 & 945.713 & 1223.318 & 257.937 & 870.966 & \text { Yes }\end{array}$

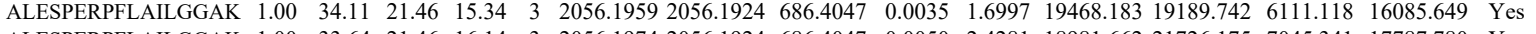

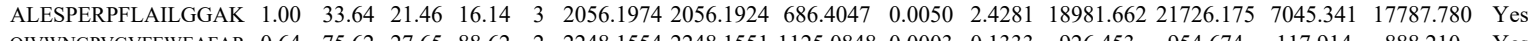
\begin{tabular}{llllllllllllllll} 
QIVWNGPVGVFEWEAFAR & 0.64 & 75.62 & 27.65 & 88.62 & 2 & 2248.1554 & 2248.1551 & 1125.0848 & 0.0003 & 0.1333 & 926.453 & 954.674 & 117.914 & 888.210 & Yes \\
\hline
\end{tabular}

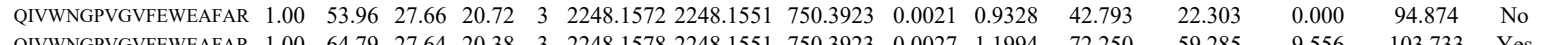
$\begin{array}{lllllllllllllll} & \end{array}$

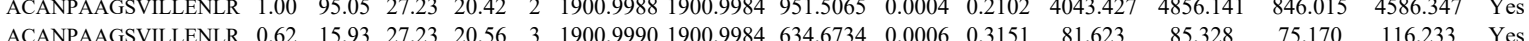
$\begin{array}{llllllllllllll} & \end{array}$ $\begin{array}{lllllllllllllllll}\text { ACANPAAGSVILLENLR } & 1.00 & 81.06 & 27.12 & 21.22 & 2 & 1901.0002 & 1900.9984 & 951.5065 & 0.0018 & 0.9459 & 292.514 & 218.960 & 133.764 & 276.841 & \text { Yes }\end{array}$ 

$\begin{array}{llllllllllllllll}\text { GQLVPETLDMLR } & 1.00 & 62.49 & 25.07 & 19.38 & 2 & 1726.9794 & 1726.9773 & 864.4959 & 0.0021 & 1.2146 & 462.291 & 524.977 & 28.936 & 810.861 & \text { Yes } \\ \text { GQLVPLETVLDMLR } & 1.00 & 65.21 & 25.07 & 22.24 & 3 & 1726.9798 & 1726.9773 & 576.6664 & 0.0025 & 1.4451 & 93.725 & 75.078 & 34.913 & 105.906 & \text { Yes }\end{array}$

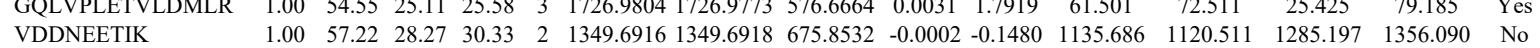

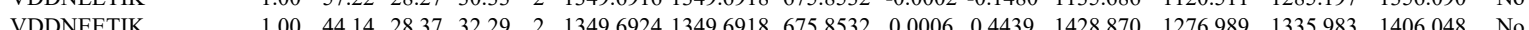

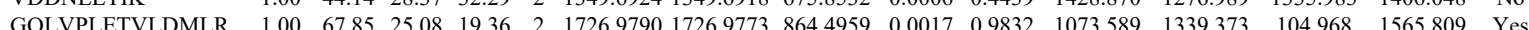
$\begin{array}{lllllllllllllllllll}\text { GQLVPLETVLDMLR } & 1.00 & 96.62 & 25.07 & 21.76 & 2 & 1726.9792 & 1726.9773 & 864.4959 & 0.0019 & 1.0989 & 1692.297 & 1344.044 & 428.046 & 2128.108 & \text { Yes }\end{array}$

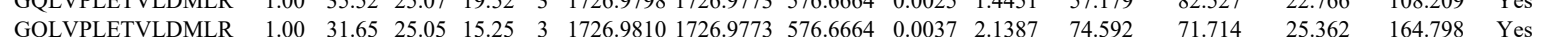
$\begin{array}{llllllllllllllll}\text { GQLVPLETVLDMLR } & 1.00 & 31.65 & 25.05 & 15.25 & 3 & 1726.9810 & 1726.9773 & 576.6664 & 0.0037 & 2.1387 & 74.592 & 71.714 & 25.362 & 164.798 & \text { Yes } \\ \text { GQLVPLETVLDMLR } & 1.00 & 75.66 & 25.31 & 20.47 & 2 & 1726.9780 & 1726.9773 & 864.4959 & 0.0007 & 0.4049 & 1356.547 & 990.650 & 154.759 & 1757.789 & \text { Yes }\end{array}$

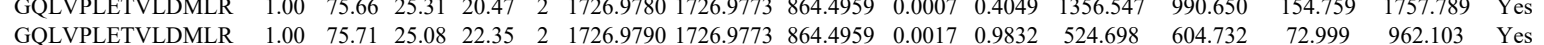

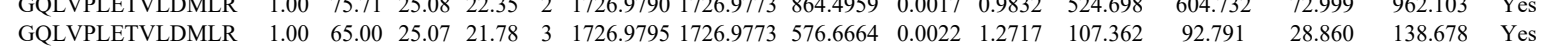

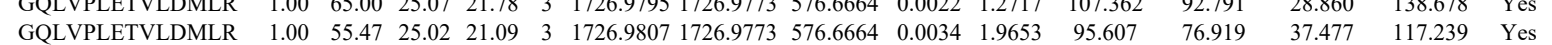

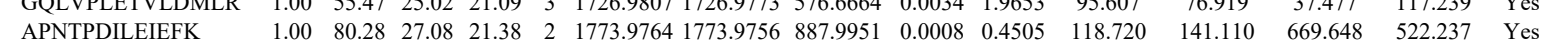
$\begin{array}{llllllllllllllll}\text { APNTPDILEIEFK } & 1.00 & 82.00 & 27.13 & 21.54 & 2 & 1773.9768 & 1773.9756 & 887.9951 & 0.0012 & 0.6757 & 67.967 & 174.278 & 471.937 & 577.689 & \text { Yes }\end{array}$ $\begin{array}{llllllllllllllll}\text { NQAPPGLYTK } & 1.00 & 49.43 & 28.18 & 20.10 & 2 & 1375.7732 & 1375.7703 & 688.8924 & 0.0029 & 2.1048 & 2067.258 & 4327.046 & 845.586 & 13195.376 & \text { Yes }\end{array}$ NQAPPGLYTK

FIEDYLLPDTCFR $\begin{array}{llllllllllllllll}1.00 & 49.64 & 28.07 & 22.33 & 2 & 1375.7734 & 1375.7703 & 688.8924 & 0.0031 & 2.2500 & 2025.769 & 4388.796 & 2816.356 & 11598.848 & \text { Yes }\end{array}$ FIEDYLLPDTCFR $\begin{array}{llllllllllllll} & \end{array}$ $\begin{array}{lllllllllllll}\text { SDADLVVFLSPLTTFQDQLNR } & 1.00 & 50.62 & 26.42 & 16.18 & 3 & 2522.3176 & 2522.3139 & 841.7786 & 0.0037 & 1.4651 & 18.309\end{array}$ LIEECTDLQK $\begin{array}{lllllllllll}1.00 & 43.91 & 28.26 & 24.95 & 2 & 1380.7218 & 1380.7203 & 691.3674 & 0.0015 & 1.0848 & 599.809\end{array}$ QFTSSSSMK

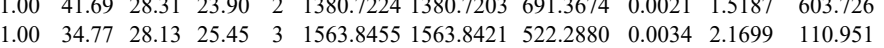

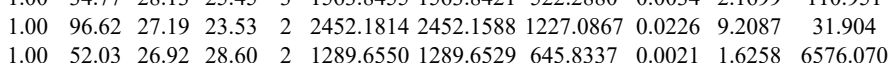
$\begin{array}{lllllllllll}1.00 & 52.03 & 26.92 & 28.60 & 2 & 1289.6550 & 1289.6529 & 645.8337 & 0.0021 & 1.6258 & 6576.070\end{array}$

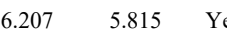




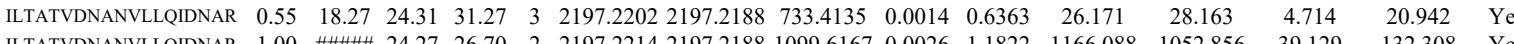

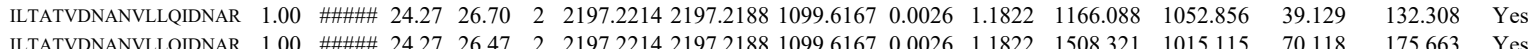

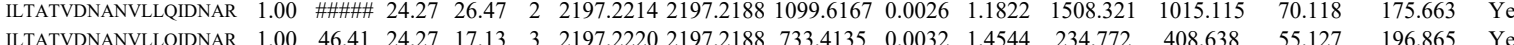
$\begin{array}{lllllllllllllll} & \end{array}$

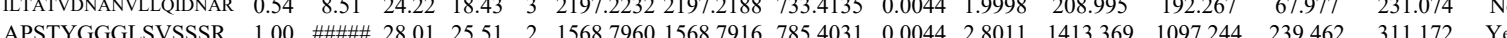

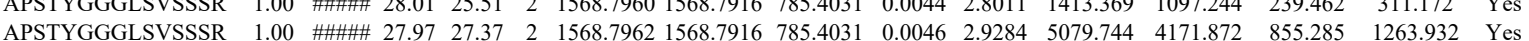
$\begin{array}{llllllllllll} & \end{array}$ $\begin{array}{lllllllllll} & \end{array}$ $\begin{array}{llllllllllllll} & 24.25 & 33.03 & 2 & 2197.2234 & 2197.2188 & 1099.6167 & 0.0046 & 2.0916 & 599.358 & 401.191 & 8.930 & 95.999 & \text { Yes } \\ \end{array}$

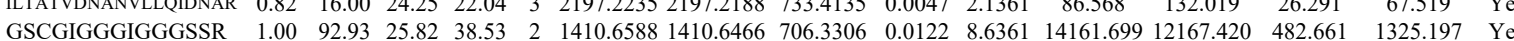
$\begin{array}{llllllllllllllll}\text { GSCGIGGGIGGGSSR } & 1.00 & 96.32 & 25.68 & 31.20 & 2 & 1410.6604 & 1410.6466 & 706.3306 & 0.0138 & 9.7687 & 15259.597 & 12688.325 & 514.368 & 1927.401 & \text { Yes }\end{array}$ $\begin{array}{llllllllllllllll}\text { GSCGIGGGIGGGSSR } & 1.00 & 87.44 & 27.63 & 30.74 & 2 & 1364.6720 & 1364.6589 & 683.3367 & 0.0131 & 9.5852 & 4186.302 & 3855.309 & 381.815 & 529.549 & \text { Yes }\end{array}$ $\begin{array}{llllllllllllllll}\text { GSCGIGGGIGGGSSR } & 1.00 & 55.73 & 24.90 & 19.57 & 2 & 1410.6476 & 1410.6466 & 706.3306 & 0.0010 & 0.7079 & 41.457 & 25.334 & 13.334 & 26.543 & \text { Yes }\end{array}$

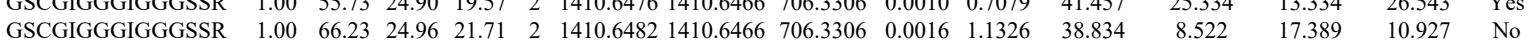

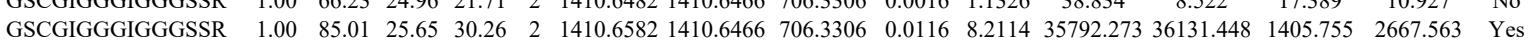

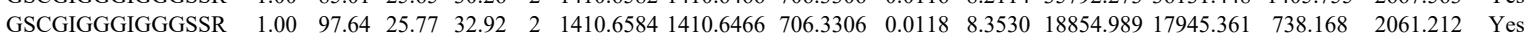
VVSTHEQVLR $\begin{array}{lllllllllllllllll}1.00 & 39.46 & 27.02 & 17.98 & 3 & 1310.7451 & 1310.7428 & 437.9215 & 0.0023 & 1.7507 & 2083.524 & 2499.603 & 975.735 & 1769.456 & \text { Yes } & \\ 1\end{array}$

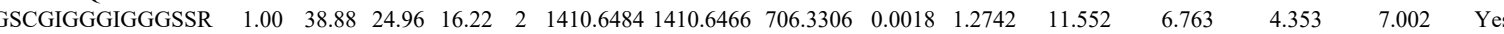

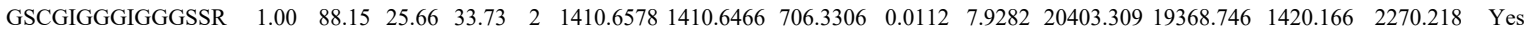

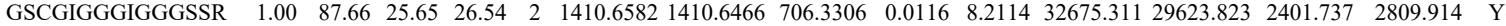
$\begin{array}{lllllllllllllllll}\text { GSCGIGGGIGGGSSR } & 0.97 & 30.91 & 25.69 & 22.99 & 3 & 1410.6598 & 1410.6466 & 471.2228 & 0.0132 & 9.3373 & 679.538 & 1213.261 & 442.072 & 824.946 & \text { No }\end{array}$ $\begin{array}{llllllllllllllll}\text { GSCGIGGGIGGGSSR } & 1.00 & 99.09 & 25.83 & 35.94 & 2 & 1410.6586 & 1410.6466 & 706.3306 & 0.0120 & 8.4945 & 13724.339 & 11711.173 & 850.482 & 1733.204 & \text { Yes }\end{array}$ GSCGIGGGIGGGSS GSCGIGGGIGGGSSR GSCGIGGGIGGGSSR GSCGIGGGIGGGSSR GSCGIGGGIGGGSSR
ISSVLAGGSCR $\begin{array}{lllllllllllll}1.00 & 83.37 & 25.82 & 31.30 & 2 & 1410.6588 & 1410.6466 & 706.3306 & 0.0122 & 8.6361 & 6226.124 & 5930.717 & 164.023 \\ 1.00 & 89.03 & 25.63 & 31.06 & 2 & 1410.6592 & 1410.6466 & 706.3306 & 0.0126 & 8.9193 & 7813.841 & 6479.398 & 162.033 \\ 1.00 & 93.04 & 25.75 & 26.19 & 2 & 140.6598 & 110.646 & 7063306 & 0.0132 & 9.3440 & 2084.513 & 1845253 & 120.617\end{array}$ $\begin{array}{lllllllllllll}1.00 & 93.04 & 25.75 & 26.19 & 2 & 1410.6598 & 1410.6466 & 706.3306 & 0.0132 & 9.3440 & 2084.513 & 1845.253 & 120.617\end{array}$

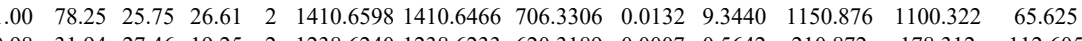
$\begin{array}{lllllllllllll}1.08 & 31.94 & 27.46 & 19.25 & 2 & 1238.6240 & 1238.6233 & 620.3189 & 0.0007 & 0.5642 & 210.872 & 178.312\end{array}$

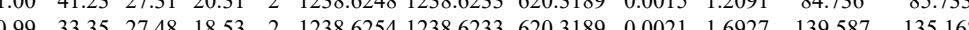
$\begin{array}{llllllllllll}1.90 & 33.35 & 27.48 & 18.53 & 2 & 1238.6254 & 1238.6233 & 620.3189 & 0.0021 & 1.6927 & 139.587 & 155.168\end{array}$

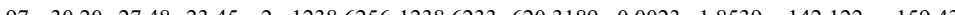



$\begin{array}{lllllllllllllllll}1.00 & 5.87 & 27.75 & 19.97 & 2 & 1238.6328 & 1238.6233 & 620.3189 & 0.0095 & 7.6573 & 46628.930 & 42380.387 & 3937.010 & 6620.129 & \text { Yes }\end{array}$

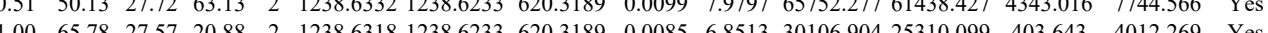

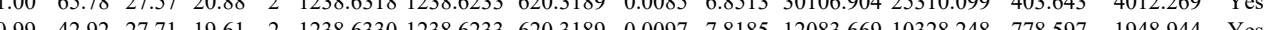

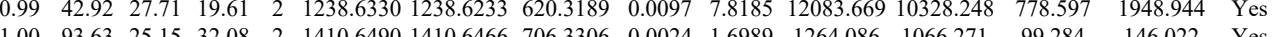

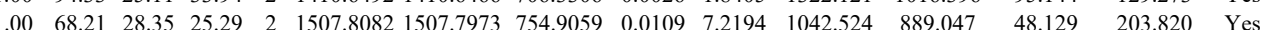
$\begin{array}{lllllllllllllll}100 & 67.92 & 28.36 & 25.01 & 2 & 1507.8098 & 1507.7973 & 754.9059 & 0.0125 & 8.2791 & 679.838 & 734.180 & 56.375 & 204.794 & \text { Yes }\end{array}$ $\begin{array}{lllllllllllllll}1.00 & 52.48 & 27.56 & 21.37 & 2 & 1238.6310 & 1238.6233 & 620.3189 & 0.0077 & 62064 & 13106.859 & 13229.875 & 344.184 & 1935.387 & \text { Yes }\end{array}$ $\begin{array}{lllllllllllllll}1.00 & 56.08 & 27.56 & 19.67 & 2 & 1238.6310 & 1238.6233 & 620.3189 & 0.0077 & 6.2064 & 18168.560 & 18212.992 & 0.000 & 2549.725 & \text { No }\end{array}$ $\begin{array}{lllllllllllllll}1.00 & 87.89 & 24.52 & 30.55 & 2 & 1410.6462 & 1410.6466 & 706.3306 & -0.0004 & -0.2832 & 905.975 & 792.469 & 63.079 & 129.384 & \text { Yes }\end{array}$ $\begin{array}{lllllllllllllll}1.00 & 87.64 & 24.90 & 27.47 & 2 & 1410.6476 & 1410.6466 & 706.3306 & 0.0010 & 0.7079 & 936.698 & 834.943 & 56.426 & 119.088 & \text { Yes }\end{array}$ $\begin{array}{llllllllllllll}24.39 & 31.05 & 2 & 1410.6452 & 1410.6466 & 706.3306 & -0.0014 & -0.9910 & 1340.752 & 1020.590 & 528.371 & 269.388 & \text { Yes }\end{array}$

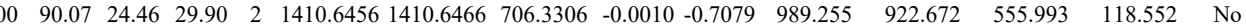
$\begin{array}{llllllllllllllll}1 & 05 & 65.79 & 27.52 & 23.30 & 2 & 1238.6262 & 1238.6233 & 620.3189 & 0.0029 & 2.3375 & 6129.821 & 6044.627 & 370.635 & 1034.570 & \text { Yes }\end{array}$ $\begin{array}{lllllllllllllll}1.00 & 52.92 & 27.51 & 22.53 & 2 & 1238.6266 & 1238.6233 & 620.3189 & 0.0033 & 2.6599 & 5839.744 & 4781.211 & 509.665 & 998.396 & \text { Yes }\end{array}$

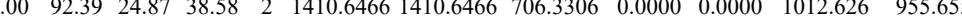
$\begin{array}{llllllllllllll} & \end{array}$ $\begin{array}{llllllllllllll}54.69 & 27.28 & 22.76 & 2 & 1238.6250 & 1238.6233 & 620.3189 & 0.0017 & 1.3703 & 3141.634 & 3237.873 & 265.813\end{array}$

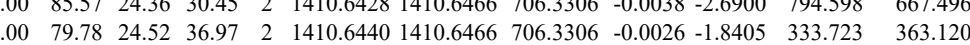
$\begin{array}{lllllllllllll}1.00 & 48.27 & 28.05 & 25.78 & 2 & 1233.6266 & 1233.6257 & 617.8201 & 0.0009 & 0.7284 & 213.320 & 226.186\end{array}$ $\begin{array}{lllllllllllll}1.00 & 60.18 & 27.46 & 23.12 & 2 & 1238.6240 & 1238.6233 & 620.3189 & 0.0007 & 0.5642 & 1114.786 & 1092.368 \\ 1.00 & 57.10 & 27.24 & 24.26 & 2 & 1238.6246 & 1238.6233 & 620.3189 & 0.0013 & 1.0478 & 1262.942 & 1051.240 & 1\end{array}$

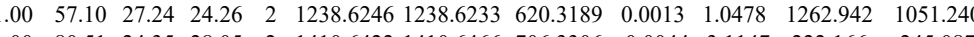

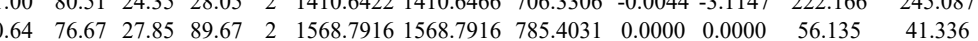

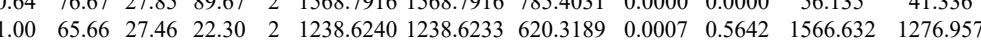

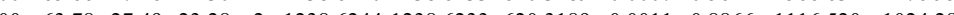

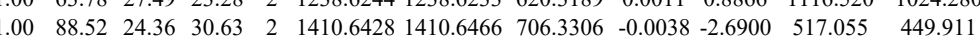
$\begin{array}{llllllllll}1 & \end{array}$ $\begin{array}{lllllllllllll}.00 & 56.13 & 27.46 & 21.82 & 2 & 1238.6240 & 1238.6233 & 620.3189 & 0.0007 & 0.5642 & 1764.272 & 1426.773\end{array}$ $\begin{array}{llllllllllll}1.00 & 95.78 & 24.31 & 30.73 & 2 & 1410.6426 & 1410.6466 & 706.3306 & -0.0040 & -2.8315 & 825.576 & 727.841\end{array}$ $\begin{array}{lllllllllllll}1.00 & 85.48 & 24.39 & 26.61 & 2 & 1410.6432 & 1410.6466 & 706.3306 & 0.0034 & -2.4068 & 640.966 & 601.539\end{array}$ $\begin{array}{llllllllllll}100 & 71.67 & 27.89 & 22.97 & 2 & 1568.7936 & 1568.7916 & 785.4031 & 0.0020 & 1.2732 & 68.673 & 49.858\end{array}$ $\begin{array}{llllllllllll}1.00 & 64.97 & 27.28 & 23.39 & 2 & 1238.6250 & 1238.6233 & 620.3189 & 0.0017 & 1.3703 & 387.819 & 351.865\end{array}$ $\begin{array}{llllllllllllll}1.00 & 53.95 & 27.28 & 23.46 & 2 & 1238.6250 & 1238.6233 & 620.3189 & 0.0017 & 1.3703 & 406.627 & 366.577\end{array}$ $\begin{array}{llllllllllll}1.00 & 95.96 & 24.31 & 36.72 & 2 & 1410.6414 & 1410.6466 & 706.3306 & -0.0052 & -3.6810 & 300.762 & 305.310 \\ 1.00 & 74.66 & 27.69 & 18.21 & 2 & 1468.796 & 1410.6466 & 706.3306 & -0.0040 & -2.8315 & 499.838 & 462.219\end{array}$ $\begin{array}{lllllllllllll}1.00 & 74.66 & 27.69 & 18.21 & 2 & 1568.7910 & 1568.7916 & 785.4031 & -0.0006 & -0.3820 & 74.082\end{array}$ $\begin{array}{llllllllllll}1.00 & 74.66 & 27.69 & 18.21 & 2 & 1568.7910 & 1568.7916 & 785.401 & 0.006 & 0.3820 & 74.082\end{array}$ \begin{tabular}{lllllllllllll}
\hline .67 & 22.31 & 27.83 & 21.55 & 2 & 1233.6260 & 1233.6257 & 617.8201 & 0.0003 & 0.2428 & 51.733 & 47.768
\end{tabular} $\begin{array}{llllllllllll}1.00 & 51.54 & 27.44 & 19.43 & 2 & 1238.6258 & 1238.6233 & 620.3189 & 0.0025 & 2.0151 & 312.236 & 346.300\end{array}$ $\begin{array}{llllllllllll}1.00 & 86.29 & 24.44 & 24.67 & 2 & 1410.6438 & 1410.6466 & 706.3306 & -0.0028 & -1.9821 & 143.316 & 153.178\end{array}$ $\begin{array}{llllllllllll}1.00 & 62.02 & 27.89 & 17.00 & 2 & 1568.7912 & 1568.7916 & 785.4031 & -0.0004 & -0.2546 & 34.996 & 24.955\end{array}$ $\begin{array}{lllllllllllll}1.00 & 42.60 & 28.05 & 22.34 & 2 & 1233.6266 & 1233.6257 & 617.8201 & 0.0009 & 0.7284 & 101.538 & 127.129\end{array}$ $\begin{array}{llllllllllllll}1.00 & 5.13 & 27.40 & 19.58 & 2 & 1238.6242 & 1238.6233 & 620.3189 & 0.0009 & 0.7254 & 355.908 & 282.925\end{array}$ $\begin{array}{llllllllllll}1.00 & 45.03 & 27.53 & 21.79 & 2 & 1238.6264 & 1238.6233 & 620.3189 & 0.0031 & 2.4987 & 293.025 & 259.336\end{array}$ $\begin{array}{llllllllll}1.00 & \text { \#冊 24.35 } 30.11 & 2 & 1410.6422 & 1410.6466 & 706.3306 & -0.0044 & -3.1147 & 567.222 & 480.202\end{array}$

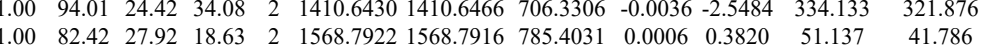
$\begin{array}{lllllllllll}1.00 & 72.42 & 27.92 & 18.63 & 2 & 1568.7922 & 1568.7916 & 785.4031 & 0.0006 & 0.3820 & 51.137 \\ 1.74 & 2 & 1507.7906 & 1507.7973 & 754.9059 & -0.0067 & -4.4377 & 10897.109 & 9044.318\end{array}$ $\begin{array}{llllllllllllll}.00 & 88.40 & 28.02 & 26.83 & 2 & 1507.7910 & 1507.7973 & 754.9059 & -0.0063 & -4.1727 & 22782.365 & 20147.400\end{array}$ $\begin{array}{llllllllllllll}0.82 & 32.56 & 27.94 & 24.03 & 3 & 1507.7923 & 1507.7973 & 503.6064 & -0.0050 & -3.3095 & 378.956 & 289.467\end{array}$ $\begin{array}{llllllllllll}1.95 & 37.21 & 28.01 & 22.60 & 3 & 1507.7929 & 1507.7973 & 503.6064 & -0.0044 & -2.9123 & 250.610 & 279.548\end{array}$ $\begin{array}{llllllllllll}1.00 & 94.28 & 25.42 & 26.20 & 2 & 1410.6540 & 1410.6466 & 706.3306 & 0.0074 & 5.2383 & 292.125 & 191.160 \\ 1.00 & 42.68 & 27.87 & 28.62 & 2 & 1233.6268 & 1233.6257 & 617.8201 & 0.0011 & 0.8902 & 250.859 & 210.87\end{array}$ $\begin{array}{lllllllllllll}1.00 & 65.23 & 27.28 & 21.84 & 2 & 1238.6250 & 1238.6233 & 620.3189 & 0.0017 & 1.3703 & 589.309 & 459.821\end{array}$ 


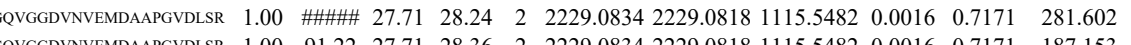

$\begin{array}{lllllllllllll}\text { GQVGGDVNVEMDAAPGVDLSR } & 1.00 & 91.22 & 27.71 & 28.36 & 2 & 2229.0834 & 2229.0818 & 1115.5482 & 0.0016 & 0.7171 & 187.153\end{array}$ $\begin{array}{lllllllllllll}\text { GQVGGDVNVEMDAAPGVDLSR } & 1.00 & 94.69 & 27.71 & 25.14 & 2 & 2229.0834 & 2229.0818 & 1115.5482 & 0.0016 & 0.7171 & 138.308\end{array}$

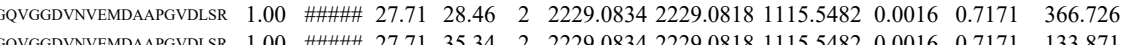

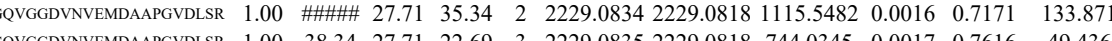

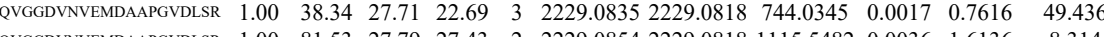

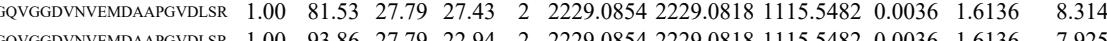
$\begin{array}{lllllllllll} & \end{array}$ $\begin{array}{llllllllllllllll}\text { GQVGGDVNVEMDAAPGVDLSR } & 1.00 & 82.36 & 27.79 & 24.10 & 2 & 2229.0854 & 2229.0818 & 1115.5482 & 0.0036 & 1.6136 & 4.246 & \end{array}$ $\begin{array}{llllllllllll}\text { ADLEMQIESLK } & 0.81 & 48.51 * 28.19 & 26.51 & 2 & 1563.8452 & 1563.8421 & 782.9283 & 0.0031 & 1.9797 & 2899.621 & 2491.8\end{array}$ $\begin{array}{lllllllllllllll}\text { ADLEMQIESLK } & 0.98 & 69.61 * & 28.13 & 32.09 & 2 & 1563.8454 & 1563.8421 & 782.9283 & 0.0033 & 2.1075 & 918.048 & 658.981\end{array}$ $\begin{array}{llllllllllllll} & \end{array}$ $\begin{array}{lllllllllllllll}\text { GQVGGDVNVEMDAAPGVDLSR } & 1.00 & 39.73 & 27.70 & 20.58 & 3 & 2229.0826 & 2229.0818 & 744.0345 & 0.0008 & 0.3584 & 8.809 & 3.952 & 13.274\end{array}$ $\begin{array}{lllllllllllllll}\text { GQVGGDVNVEMDAAPGVDLSR } & 1.00 & 97.22 & 27.71 & 25.93 & 2 & 2229.0834 & 2229.0818 & 1115.5482 & 0.0016 & 0.7171 & 211.773 & 254.614 & 25.222\end{array}$

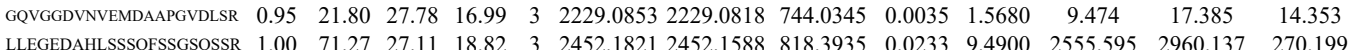
YEELQVTAGR $\begin{array}{llllllllllll}1.00 & 71.27 & 27.11 & 18.82 & 3 & 2452.1821 & 2452.1588 & 818.3935 & 0.0233 & 9.4900 & 2555.595 & 2960.137\end{array}$

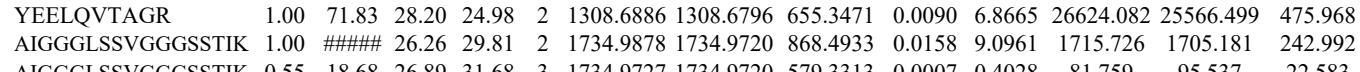
$\begin{array}{lllllllllllllll}.00 & 58.54 & 28.09 & 24.34 & 2 & 1308.6882 & 1308.6796 & 655.3471 & 0.0086 & 6.5614 & 26227.735 & 26121.104 & 0.000 & 73\end{array}$ $\begin{array}{llllllllllllllll}\text { AIGGGLSSVGGGSSTK } & 0.55 & 18.68 & 26.89 & 31.68 & 3 & 1734.9727 & 1734.9720 & 579.3313 & 0.0007 & 0.4028 & 81.759 & 95.537 & 22.583\end{array}$ $\begin{array}{lllllllllllllll}\text { AIGGGLSSVGGGSSTIK } & 1.00 & \text { MIm\# } & 26.41 & 32.12 & 2 & 1734.9822 & 1734.9720 & 868.4933 & 0.0102 & 5.8722 & 16223.447 & 15233.042 & 933.886 \\ \text { AIGGGLSSVGGGSSTIK } & 1.00 & 43.11 & 26.50 & 17.18 & 3 & 1734.9829 & 1734.9720 & 579.3313 & 0.0109 & 6.2716 & 2326.982 & 2054.185 & 596.945\end{array}$ 


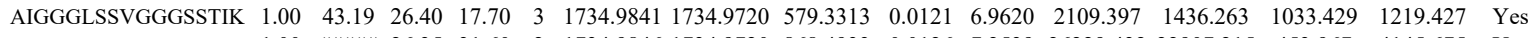

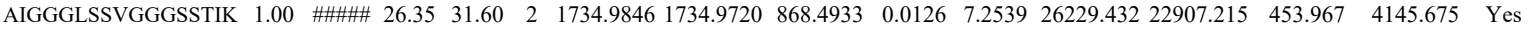
$\begin{array}{lllllllllllllll}\text { AlGGGLSSVGGGSSTKK } & 1.00 & \text { \#冊冊 } 26.41 & 32.48 & 2 & 1734.9822 & 1734.9720 & 868.4933 & 0.0102 & 5.8722 & 11127.974 & 8712.196 & 426.115 & 1771.297 & \text { Yes }\end{array}$

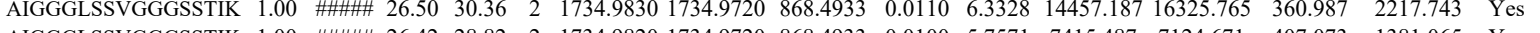

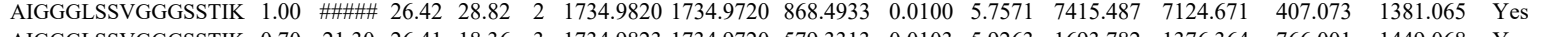
$\begin{array}{llllllllllllllll}\text { AIGGGLSSVGGGSSTIK } & 0.70 & 21.30 & 26.41 & 18.36 & 3 & 1734.9823 & 1734.9720 & 579.3313 & 0.0103 & 5.9263 & 1693.782 & 1376.364 & 766.001 & 1449.068 & \text { Yes }\end{array}$ \begin{tabular}{lllllllllllllll} 
AIGGGLSSVGGGSSTIK & 1.00 & \#\#\# 26.46 & 36.14 & 2 & 1734.9834 & 1734.9720 & 868.4933 & 0.0114 & 6.5630 & 8097.993 & 7038.561 & 166.307 & 1029.694 & Yes \\
\hline
\end{tabular}

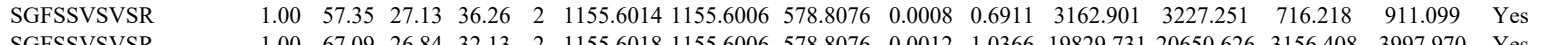
$\begin{array}{llllllllllllllll}\text { SGFSVSVSR } & 1.00 & 67.09 & 26.84 & 32.13 & 2 & 1155.6018 & 1155.6006 & 578.8076 & 0.0012 & 1.0366 & 19829.731 & 20650.626 & 3156.408 & 3997.970 & \text { Yes } \\ \text { SGFSVSVSR } & 1.00 & 66.91 & 26.97 & 31.87 & 2 & 1155.6020 & 1155.6006 & 578.8076 & 0.0014 & 1.2094 & 22304.498 & 20841.032 & 4184.375 & 4621.557 & \text { Yes }\end{array}$

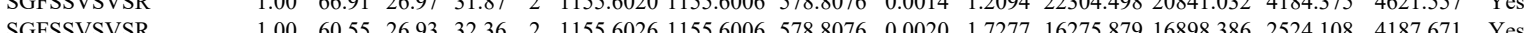

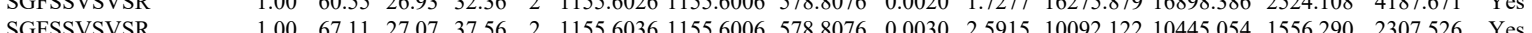
SGFSSVSVSR

SGFSSVSVR

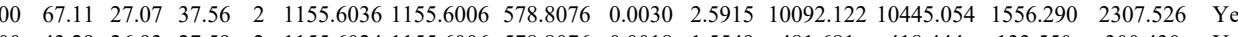
GFSSVSV $\begin{array}{lllllllllllllll}1.00 & 43.29 & 26.93 & 27.59 & 2 & 1155.6024 & 1155.6006 & 578.8076 & 0.0018 & 1.5549 & 481.681 & 418.444 & 133.550 & 300.430 & \text { Yes } \\ 1.00 & 52.08 & 26.93 & 3.78 & 2 & 1155.6026 & 1155.6006 & 578.8076 & 0.002 & 1.7277 & 551.021 & 598.773 & 166.715 & 282.325 & \text { Yes }\end{array}$ SGFSSVSVRR

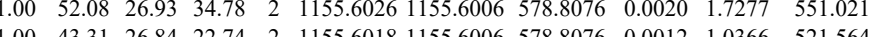

443.588

$\begin{array}{llllllllllll}1.00 & 49.08 & 26.97 & 32.39 & 2 & 1155.6020 & 1155.6006 & 578.8076 & 0.0014 & 1.2094 & 536.890 & 602.850\end{array}$

$\begin{array}{llll}0 & 0\end{array}$ $\begin{array}{lllllllllllll}\text { IIGGGLSSVGGGSSTIK } & 1.00 & 94.86 & 26.94 & 24.05 & 2 & 1734.9730 & 1734.9720 & 868.4933 & 0.0010 & 0.5757 & 77.928\end{array}$ $\begin{array}{llllllllllll}\text { AIGGGLSSVGGGSSTIK } & 1.00 & 50.59 & 26.96 & 19.37 & 3 & 1734.9736 & 1734.9720 & 579.3313 & 0.0016 & 0.9206 & 114.879\end{array}$ $\begin{array}{llllllllllllll}\text { AIGGGLSSVGGGSSTIK } & 0.87 & 17.35 & 27.06 & 16.22 & 3 & 1734.9742 & 1734.9720 & 579.3313 & 0.0022 & 1.2658 & 127.230\end{array}$ 
DLEALLNSK

LADALQELR

LADALQELR

SGAQASSTPLSPTR

SGAQASSTPLSPTR

SGAQASSTPLSPTR
SGAQASSTPLSPTR

SGAQASSTPLSPTR

TVLCGTCGQPADK

LAVYIDR

SGAQASSTPLSPTR

TVLCGTCGQPADK

LKDLEALLNSK

LSPSPTSQR

LSPSTTSQR

LSPSPTSQR

LSPSPTSQR

IDSLSAQLSQLQK

IDSLSAQLSQLQK

LSPSPTSQR

LSPSPTSQR

IDSLSAQLSQLQK

IDSLSAQLSQLQK

IDSLSAQLSQLQK

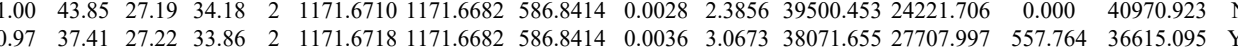

$\begin{array}{llllllllllllllll}1.00 & 47.65 & 27.69 & 21.72 & 2 & 1502.7824 & 1502.7811 & 752.3978 & 0.0013 & 0.8639 & 10.349 & 14.244 & 4.253 & 0.000 & \text { No }\end{array}$

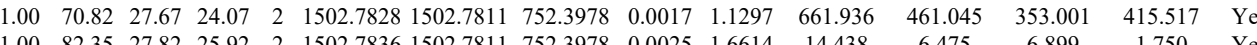
$\begin{array}{llllllllllllllll}1.00 & 82.35 & 27.82 & 25.92 & 2 & 1502.7836 & 1502.7811 & 752.3978 & 0.0025 & 1.6614 & 14.438 & 6.475 & 6.899 & 1.750 & \text { Yes } \\ 1.00 & 55.23 & 25.92 & 20.76 & 2 & 167.7858 & 1671.7696 & 386.8921 & 0.0162 & 9.6786 & 84.509 & 385.804 & 109.717 & 440.888 & \text { Yes }\end{array}$ $\begin{array}{lllllllllllllll}1.00 & 55.23 & 25.97 & 20.76 & 2 & 1671.7858 & 1671.7696 & 836.8921 & 0.0162 & 9.6786 & 849.509 & 385.804 & 109.717 & 440.888 & \text { Yes } \\ 1.00 & 50.30 & 25.99 & 16.90 & 2 & 1671.7860 & 1671.7696 & 836.8921 & 0.0164 & 9.7981 & 1071.292 & 489.634 & 0.000 & 550.908 & \mathrm{~N}\end{array}$ $\begin{array}{llllllllllllllll}1.00 & 50.30 & 25.99 & 16.90 & 2 & 1671.7860 & 1671.7696 & 836.8921 & 0.0164 & 9.7981 & 1071.292 & 489.634 & 0.000 & 550.908 & \text { No }\end{array}$ $\begin{array}{lllllllllllllll}1.00 & 52.83 & 27.66 & 27.06 & 2 & 99.5870 & 992.5777 & 497.2961 & 0.0093 & 9.3505 & 5073.222 & 3386.885 & 1131.039 & 6716.531 & \text { Yes }\end{array}$

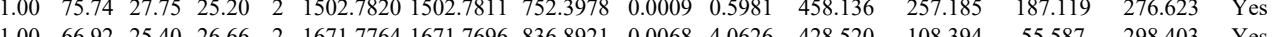
$\begin{array}{lllllllllllllll}1.00 & 66.92 & 25.40 & 26.66 & 2 & 1671.7764 & 1671.7696 & 836.8921 & 0.0068 & 4.0626 & 428.520 & 108.394 & 55.587 & 298.403 & \text { Yes } \\ 1.00 & 46.65 & 18.39 & 21.38 & 3 & 1675.0282 & 1675.0245 & 559.3488 & 0.0037 & 22049 & 2485.781 & 1767.143 & 670.913 & 3873.351 & \text { Yes }\end{array}$ $\begin{array}{lllllllllllllll}1.00 & 46.65 & 8.39 & 21.38 & 3 & 1675.0282 & 1675.02457 & 559.3488 & 0.0037 & 2.2049 & 2485.181 & 1767.143 & 610.913 & 387.551 & \text { Yes }\end{array}$

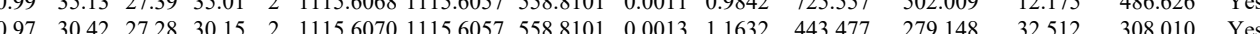

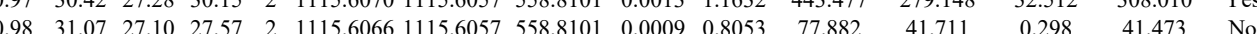

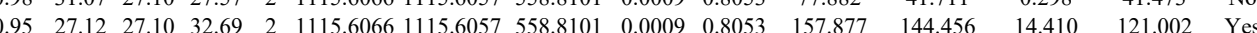

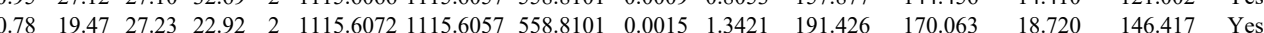

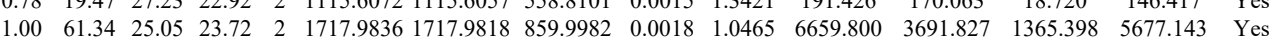
$\begin{array}{llllllllllllllll}0.90 & 23.27 & 24.96 & 29.48 & 3 & 1717.9858 & 1717.9818 & 573.6679 & 0.0040 & 2.3242 & 4523.875 & 3356.264 & 264.046 & 13502.307 & \text { No }\end{array}$

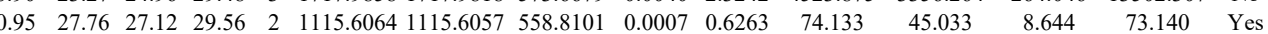
$\begin{array}{llllllllllllllll}0.99 & 35.74 & 27.12 & 30.22 & 2 & 1115.6064 & 1115.6057 & 558.8101 & 0.0007 & 0.6263 & 69.288 & 54.298 & 8.948 & 51.879 & \text { Yes }\end{array}$

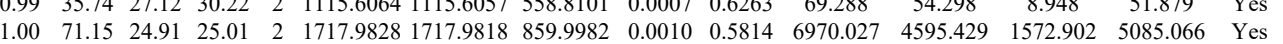
$\begin{array}{lllllllllllllllll}1.00 & 64.94 & 25.05 & 24.32 & 2 & 1717.9836 & 1717.9818 & 859.9982 & 0.0018 & 1.0465 & 11180.733 & 6107.812 & 1618.157 & 6853.955 & \text { Yes }\end{array}$ $\begin{array}{lllllllllllllll}1.00 & 35.64 & 25.04 & 20.39 & 3 & 1717.9849 & 1717.9818 & 573.6679 & 0.0031 & 1.8013 & 1370.274 & 1271.026 & 234.170 & 1968.037 & \text { Yes }\end{array}$ $\begin{array}{llllllllllllllll}\text { IDSLSAQLSQLQK } & 1.00 & 56.51 & 24.94 & 28.36 & 3 & 1717.9855 & 1717.9818 & 573.6679 & 0.0037 & 2.1499 & 1906.786 & 1479.331 & 420.012 & 3534.017 & \text { No }\end{array}$ $\begin{array}{llllllllllllllll}\text { AGQVVTIWAAGAGATHSPTDLVWK } & 1.00 & 44.74 & 23.80 & 16.29 & 4 & 2820.5225 & 2820.5167 & 706.1365 & 0.0058 & 2.0534 & 223.427 & 162.428 & 114.275 & 443.925 & \text { No }\end{array}$ $\begin{array}{llllllllllllllllll} & \end{array}$ $\begin{array}{lllllllllllllllll}\text { AGQVUTWAAGAGATHSPPDLVWWK } & 0.67 & 80.01 & 24.17 & 93.01 & 3 & 2820.5197 & 2820.5167 & 941.1795 & 0.0030 & 1.0625 & 1853.029 & 1444.790 & 1265.175 & 2002.319 & \text { Yes }\end{array}$ $\begin{array}{lllllllllllllllll} & \end{array}$ $\begin{array}{llllllllllllllll}\text { AGGVVTIWAAGAGATHSPPDLVWKK } & 0.60 & 66.74 & 23.89 & 79.74 & 3 & 2820.5212 & 2820.5167 & 941.1795 & 0.0045 & 1.5937 & 2458.056 & 1022.795 & 1755.131 & 2245.774 & \text { Yes } \\ \text { AGQVVTIWAGAGATHSPPDLVWK } & 1.00 & 17.89 & 23.77 & 14.38 & 4 & 2820.5229 & 2820.5167 & 706.1365 & 0.0062 & 2.1950 & 85.113 & 108.057 & 70.868 & 140.187 & \text { Yes }\end{array}$ GGQVTIIAAGAGATHSPTDLVW

EDLQELNDR

EDLQELNDR $\begin{array}{llllllllllllllll}\text { VAVEEVDEEGK } & 1.00 & 69.69 & 28.31 & 22.24 & 2 & 1490.7732 & 1490.7708 & 746.3927 & 0.0024 & 1.6077 & 9162.908 & 6542.526 & 1286.586 & 9445.264 & \text { Yes } \\ \text { VAVEEVDEEGK } & 1.00 & 64.66 & 28.40 & 23.01 & 2 & 1490.7738 & 1490.7708 & 746.3927 & 0.0030 & 2.0097 & 16062.849 & 10802.959 & 1916.399 & 13156.698 & \text { Yes }\end{array}$

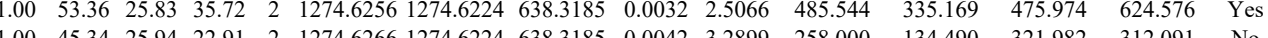
GQVUTIWAGGAGATSPPDDLVIK ITESEEVVSR $\begin{array}{lllllllllllllll}1.00 & 64.66 & 28.40 & 23.01 & 2 & 1490.7738 & 1490.7708 & 746.3927 & 0.0030 & 2.0097 & 16062.849 & 10802.959 & 1916.399 & 13156.698 & \text { Yes } \\ 0.55 & 50.88 & 44.30 & 63.88 & 3 & 2820.5179 & 2820.5167 & 941.1795 & 0.0012 & 0.4250 & 590.366 & 284.972 & 504.931 & 527.639 & \text { Yes }\end{array}$ TESEEVVSR

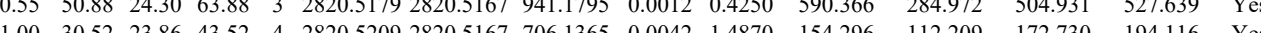

$\begin{array}{lllllllllllllllll}1.00 & 66.85 & 28.34 & 27.70 & 2 & 1291.6786 & 1291.6741 & 646.8443 & 0.0045 & 3.4784 & 5581.372 & 4046.537 & 4877.072 & 5204.543 & \text { Yes } \\ 1.00 & 67.01 & 28.34 & 29.94 & 2 & 1291.6786 & 1291.6741 & 646.8443 & 0.0045 & 3.4784 & 11288.059 & 8642.185 & 9459.125 & 12331.939 & \text { Yes }\end{array}$ 
VAVEEVDEEGK VAVEEVDEEGK AQHEDQVEQYK AQHEDQVEQYK SGAQASSTPLSPTR SGAQASSTPLSPTR SGAQASSTPLSP ITESEEVVSR

TTESEEVVSR

AAYEAELGDAR

AAYEAELGDAR

AQHEDQVEQYK

SGAQASSTPLSPTR

SGAQASSTPLSPTR

SGAQASSTPLSPTR

SGAQASSTPLSPTR

SGAQASSTPLSPTR

SGAQASSTPLSPTR

SGAQASSTPLSPTR

SGAQASSTPLSPTR

AGeVVTIWAAGAGATHSPPTDLVW

GVVTIWAAGAGATHSPPTDLVW

TLEGELHDLR

TLEGELHDLR

TLEGELHDLR

TLEGELHDLR

LVEIDNGK

LEAALGEAK

QNGDDPLLTYR

QNGDDPLLTYR

KEGDLIAAQAR

MQQQLDEYQELLDIK

MQQQLDEYQELLDIK

MQQQLDEYQ

QYNVGPSVSK

QYNVGPSVSK

QYNVGPSVSK

SSPVVIDASTAID

LGVRPSQGGEAPR

EAPR

VTIMWTPPESAVTGYR

VPGTSTSATLTGLTR

VPGTSTSATLTGLTR

VPGTSTSATLTGLTR

LTVGLTR

NSITLTNLTP

ISCTIANR

ISCTIANR
WLPSSSPVTGYR

VTWAPPPSIDLTNFLVR

VTWAPPPSIDLTNFLVR
VTWAPPPSIDLTNFLVR
VTWAPPPSIDLTNFLVR

VTWAPPPSIDLTNF

WLPSSSPVTGYR

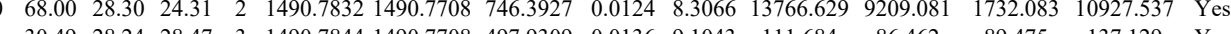

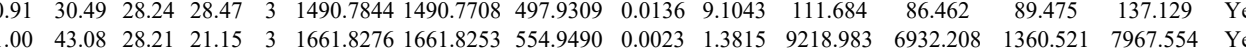

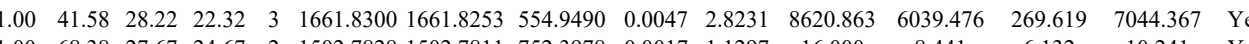

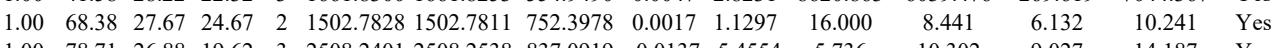

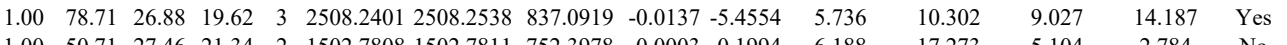

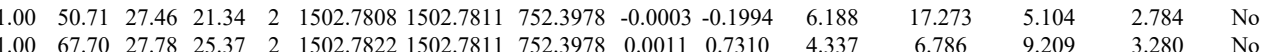

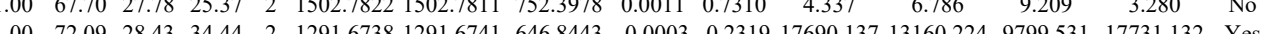

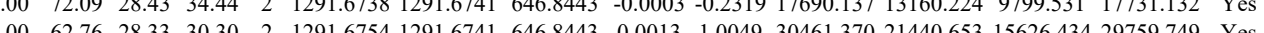

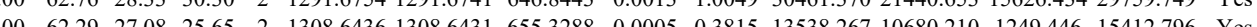

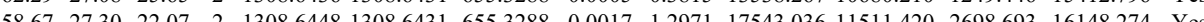
$\begin{array}{llllllllllll} & 0\end{array}$ $\begin{array}{llllllllllllll} & \end{array}$

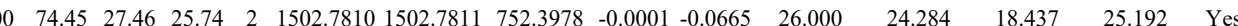

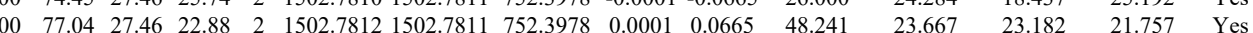

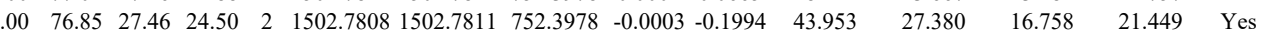

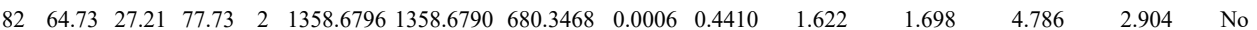
$\begin{array}{lllllllllllllll}0.84 & 45.49 & 27.26 & 58.49 & 2 & 1358.6810 & 1358.6790 & 680.3468 & 0.0020 & 1.4698 & 12.643 & 6.608 & 1.073 & 1.559 & \text { No }\end{array}$

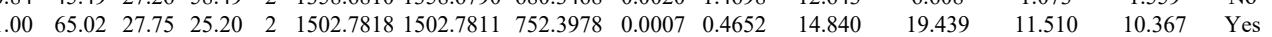

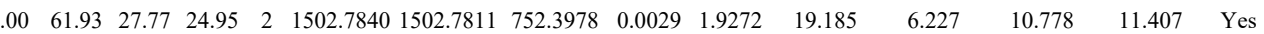

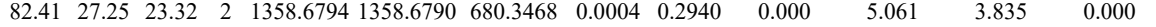
$\begin{array}{lllllllllllll}69.82 & 27.25 & 25.44 & 2 & 1358.6794 & 1358.6790 & 680.3468 & 0.0004 & 0.2940 & 3.850 & 3.834 & 0.000 & 2.738\end{array}$ $\begin{array}{lllllllllllll} & \end{array}$

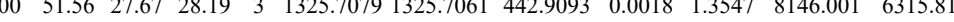
$\begin{array}{lllllllllllllll} & \end{array}$ $\begin{array}{llllllllllllllll}1.00 & 49.28 & 27.63 & 26.59 & 2 & 1325.7084 & 1325.7061 & 663.8603 & 0.0023 & 1.7323 & 5109.465 & 3303.112 & 567.263 & 4772.741 & \text { Yes }\end{array}$

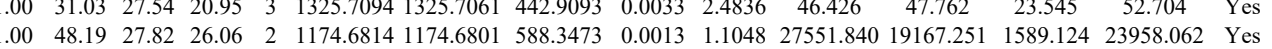
$\begin{array}{lllllllllllllll}1.00 & 48.19 & 27.82 & 26.06 & 2 & 1174.6814 & 1174.6801 & 588.3473 & 0.0013 & 1.1048 & 27551.840 & 19167.251 & 1589.124 & 23958.062 & \text { Yes } \\ 1.00 & 58.70 & 27.72 & 35.98 & 2 & 1188.7062 & 1188.6957 & 595.3551 & 0.0105 & 8.8182 & 21313.014 & 14521.107 & 2540.560 & 17742.466 & \text { Yes }\end{array}$ $\begin{array}{llllllllllllll}.08 & & \end{array}$ $\begin{array}{llllllllllllllll}0.93 & 26.15 & 27.68 & 21.04 & 2 & 1434.7242 & 1434.7225 & 718.3685 & 0.0017 & 1.1832 & 9125.822 & 5313.861 & 215.732 & 8912.710 & \text { Yes }\end{array}$ $\begin{array}{llllllllllllllll}1.00 & 41.15 & 26.30 & 20.08 & 3 & 1458.8464 & 1458.8398 & 487.2872 & 0.0066 & 4.5148 & 16638.501 & 10995.783 & 1863.358 & 8622.547 & \text { Yes }\end{array}$ $\begin{array}{lllllllllllllll}1.00 & 44.42 & 26.30 & 22.21 & 3 & 1458.8464 & 1458.8398 & 487.2872 & 0.0066 & 4.5148 & 20336.350 & 14188.205 & 3406.374 & 9338.051 & \text { Yes }\end{array}$

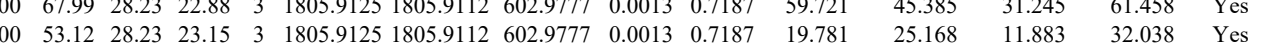

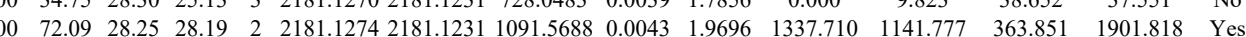

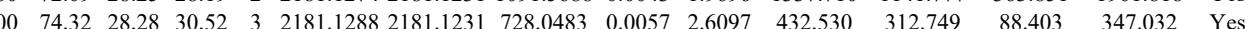
$\begin{array}{lllllllllllllll}1.00 & 41.12 & 27.39 & 26.52 & 2 & 1253.6396 & 1253.6374 & 627.8260 & 0.0022 & 1.7521 & 10777.613 & 34137.024 & 1946.040 & 5851.491 & \text { Yes }\end{array}$ $\begin{array}{lllllllllllllll}1.00 & 49.53 & 27.99 & 21.86 & 2 & 1365.7488 & 1365.7496 & 683.8821 & -0.0008 & -0.5849 & 4917.410 & 15725.578 & 0.000 & 748.712 & \mathrm{No}\end{array}$ $\begin{array}{llllllllllllllll}1.00 & 53.18 & 28.06 & 17.43 & 2 & 1365.7496 & 1365.7496 & 683.8821 & 0.0000 & 0.0000 & 9986.190 & 45763.012 & 0.000 & 1956.534 & \mathrm{No}\end{array}$

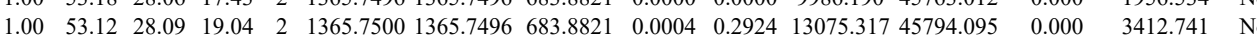

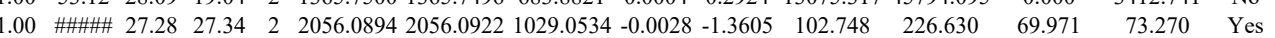
$\begin{array}{llllllllllllllll}0.63 & 27.11 & 27.52 & 24.78 & 2 & 1294.6512 & 1294.6462 & 648.3304 & 0.0050 & 3.8560 & 1402.848 & 3514.118 & 377.042 & 1763.748 & \text { Yes }\end{array}$ $\begin{array}{lllllllllllllll}1.00 & 36.52 & 27.16 & 22.44 & 3 & 1466.8075 & 1466.8076 & 489.9431 & -0.0001 & -0.0680 & 659.407 & 2104.031 & 326.238 & 323.600 & \text { Yes }\end{array}$ $\begin{array}{lllllllllllll} & & \end{array}$ $\begin{array}{lllllllllllllll}8.98 & 28.32 & 72.38 & 2 & 1951.0000 & 1950.9995 & 976.5070 & 0.0005 & 0.2560 & 488.458 & 2076.076 & 0.000 & 59.945 & \text { Yes } \\ & 27.06 & 21.27 & 2 & 1604.8976 & 1604.8856 & 803.4501 & 0.0120 & 7.4677 & 2291.179 & 6209.505 & 2025.964 & 541.071 & \text { Yes }\end{array}$ $\begin{array}{llllllll} & \end{array}$

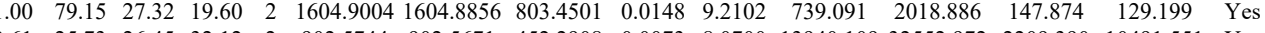
$\begin{array}{lllllllllllllllll}0.61 & 25.73 & 26.45 & 32.12 & 2 & 902.5744 & 902.5671 & 452.2908 & 0.0073 & 8.0700 & 13940.109 & 32552.972 & 2209.390 & 10491.551 & \text { Yes }\end{array}$

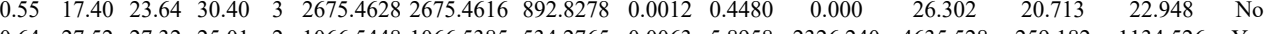
$\begin{array}{lllllllllllllll}0.64 & 27.52 & 27.32 & 25.01 & 2 & 1066.5448 & 1066.5385 & 534.2765 & 0.0063 & 5.8958 & 2326.240 & 4635.528 & 259.182 & 1134.526 & \text { Yes }\end{array}$ $\begin{array}{llllllllllllllll}0.87 & 33.51 & 27.32 & 29.79 & 2 & 1066.5448 & 0666.5385 & 534.2765 & 0.0063 & 5.8958 & 2691.071 & 5726.732 & 117.260 & 1314.818 & \text { Yes }\end{array}$

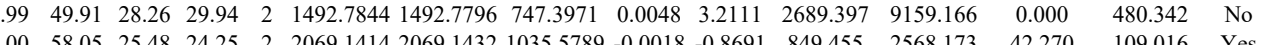

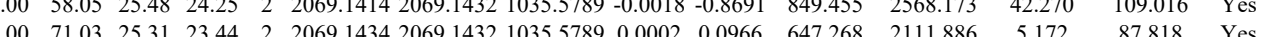

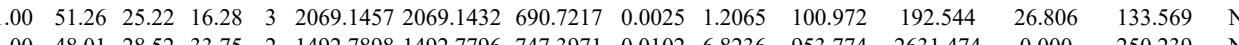

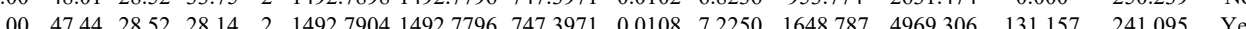


$0.1261 \quad 687.433$

$\begin{array}{llllllllllll}1.00 & 70.69 & 27.18 & 30.06 & 2 & 1666.8948 & 1666.9022 & 834.4584 & -0.0074 & -4.4340 & 670.974\end{array}$

EEPGEDFPAAR $\begin{array}{llllllllllll}1.00 & 56.32 & 25.22 & 29.20 & 2 & 1360.6384 & 1360.6381 & 681.3263 & 0.0003 & 0.2202 & 95.992\end{array}$

\section{LAVDEEENADNNTK} $\begin{array}{llllllllllll}\text { LAVDEEENADNNTK } & 0.96 & 24.08 & 27.68 & 23.51 & 3 & 1848.8953 & 1848.8945 & 617.3054 & 0.0008 & 0.4320 & 85.496\end{array}$ 
$\begin{array}{llllllllllll}\text { FSHEEIAMATVTALR } & 1.00 & 39.09 & 27.82 & 16.02 & 3 & 1818.9436 & 1818.9420 & 607.3213 & 0.0016 & 0.8782 & 76.801\end{array}$ 

$\begin{array}{llllllllllllllll}\text { CPLLKPWALTFSYGR } & 1.00 & 42.42 & 26.92 & 22.11 & 3 & 2085.1165 & 2085.1147 & 696.0455 & 0.0018 & 0.8620 & 102.008 & 63.379 & 81.542 & 114.772 & \text { Yes } \\ \text { CPLIKPWALTFSYGR } & 1.00 & 30.60 & 26.98 & 20.62 & 3 & 2085.1171 & 2085.1147 & 696.0455 & 0.0024 & 1.1493 & 100.530 & 77.034 & 78.005 & 96.841 & \text { Yes }\end{array}$ \begin{tabular}{llllllllllllllll} 
CPLLKPWALTFSYGR & 0.97 & 24.02 & 26.84 & 22.75 & 3 & 2085.1186 & 2085.1147 & 696.045 & 0.0024 & 1.1493 & 100.530 & 77.034 & 78.005 & 96.841 & Yes \\
\hline
\end{tabular}

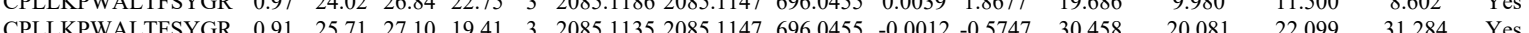
$\begin{array}{lllllllllllll} & \text { CPLLKPWALL }\end{array}$

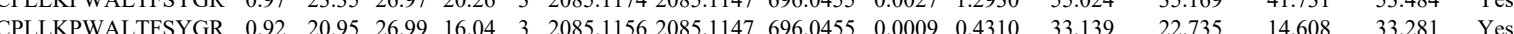

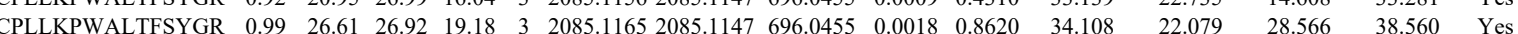

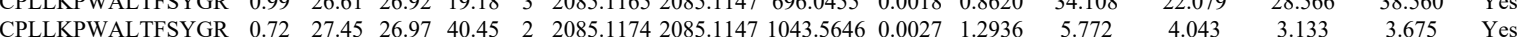
\begin{tabular}{llllllllllllll} 
& CPLLKPALATFGR \\
\hline
\end{tabular} $\begin{array}{llllllllllllllll}\text { CPLLKPWALTFSYGR } & 0.91 & 25.50 & 26.58 & 15.70 & 3 & 2085.1219 & 2085.1147 & 696.0455 & 0.0072 & 3.4480 & 53.898 & 9.540 & 24.499 & 26.332 & \text { No }\end{array}$ $\begin{array}{lllllllllllllllll}\text { CPLLKPWALTFSYGR } & 1.00 & 37.90 & 26.97 & 21.96 & 3 & 2085.1174 & 2085.1147 & 696.0455 & 0.0027 & 1.2930 & 43.953 & 18.108 & 22.838 & 24.170 & \text { Yes }\end{array}$ $\begin{array}{llllllllllllllll}\text { CPLLKPWALTFSYGR } & 0.89 & 24.79 & 26.56 & 23.49 & 3 & 2085.1213 & 2085.1147 & 696.0455 & 0.0066 & 3.1607 & 53.482 & 44.858 & 53.004 & 46.239 & \text { Yes }\end{array}$ $\begin{array}{llllllllllllllll}\text { CPLLKPWALTFSYGR } & 1.00 & 33.67 & 26.95 & 19.13 & 3 & 2085.1180 & 2085.1147 & 696.0455 & 0.0033 & 1.5804 & 35.864 & 41.552 & 37.296 & 36.136 & \text { Yes }\end{array}$ \begin{tabular}{lllllllllllllllll} 
CPLLKPWALTFSYGR & 0.95 & 23.74 & 26.72 & 15.67 & 3 & 2085.1195 & 2085.1147 & 696.0455 & 0.0048 & 2.2987 & 40.167 & 18.358 & 27.266 & 27.129 & Yes \\
\hline
\end{tabular} $\begin{array}{llllllllllllllll}\text { CPLLKPWALTFSYGR } & 1.00 & 43.93 & 26.98 & 23.23 & 3 & 2085.1171 & 2085.1147 & 696.0455 & 0.0024 & 1.1493 & 299.296 & 159.183 & 228.666 & 248.995 & \text { Yes }\end{array}$

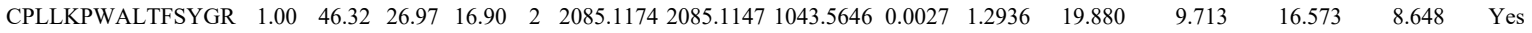

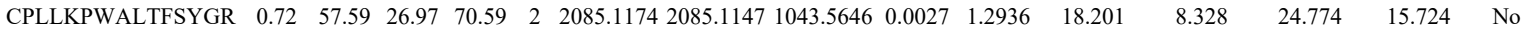
$\begin{array}{llllllllllllllll}\text { CPLLKPWALTFSYGR } & 1.00 & 42.14 & 26.95 & 21.57 & 3 & 2085.1180 & 2085.1147 & 696.0455 & 0.0033 & 1.5804 & 228.939 & 125.486 & 153.260 & 148.366 & \text { Yes }\end{array}$ $\begin{array}{lllllllllllllllll}\text { RLQSIGTENTEENR } & 1.00 & 65.76 & 28.23 & 18.74 & 3 & 1789.9057 & 1789.9040 & 597.6419 & 0.0017 & 0.9482 & 778.439 & 1127.324 & 925.863 & 1337.828 & \text { Yes }\end{array}$ $\begin{array}{lllllllllllllllll}\text { LQSIGTENTEENRR } & 1.00 & 64.20 & 28.20 & 24.05 & 2 & 1789.9066 & 1789.9040 & 895.9593 & 0.0026 & 1.4510 & 3688.995 & 2684.889 & 852.038 & 3650.751 & \text { Yes }\end{array}$ $\begin{array}{llllllllllllllll}\text { LQSIGTENTEENRR } & 0.99 & 34.54 & 28.16 & 17.39 & 3 & 1789.9093 & 1789.9040 & 597.6419 & 0.0053 & 2.9561 & 27439.677 & 24584.610 & 4319.923 & 44887.847 & \text { Yes }\end{array}$ $\begin{array}{llllllllllllllll}\text { LQSIGTENTEENRR } & 1.00 & 42.03 & 28.23 & 21.61 & 3 & 1789.9111 & 1789.9040 & 597.6419 & 0.0071 & 3.9600 & 40063.857 & 32019.125 & 5505.915 & 60163.855 & \text { Yes }\end{array}$ $\begin{array}{llllllllllllllll}\text { GILAADESTGSIAK } & 1.00 & 92.59 & 26.78 & 45.56 & 2 & 1619.9134 & 1619.8974 & 810.9560 & 0.0160 & 9.8648 & 9174.698 & 9743.204 & 3824.258 & 11933.911 & \text { Yes }\end{array}$

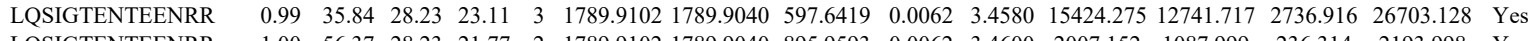

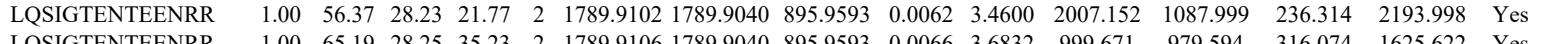

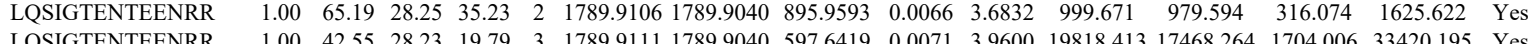
\begin{tabular}{llllllllllllllllll} 
LQSIGTENTEENRR & 1.00 & 42.55 & 28.23 & 19.79 & 3 & 1789.9111 & 1789.9040 & 597.6419 & 0.0071 & 3.9600 & 19818.413 & 17468.264 & 1704.006 & 33420.195 & Yes \\
\hline
\end{tabular}

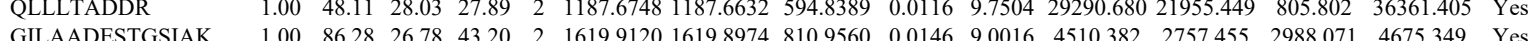

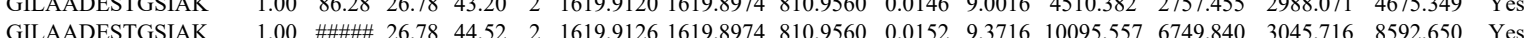

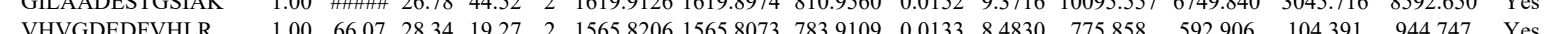

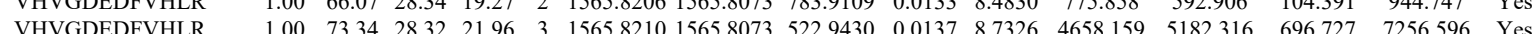

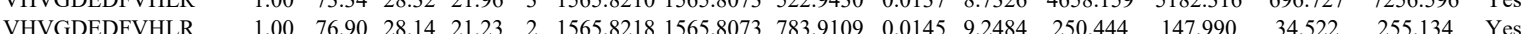

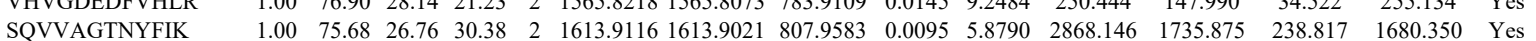
$\begin{array}{llllllllllllllll}\text { SQVVAGTNYFIK } & 1.00 & 79.00 & 26.79 & 25.96 & 2 & 1613.9120 & 1613.9021 & 807.9583 & 0.0099 & 6.1265 & 11544.965 & 11176.783 & 271.589 & 9975.489 & \text { Yes }\end{array}$ $\begin{array}{llllllllllllllll}\text { SQVVAGTNYFIK } & 1.00 & 76.58 & 26.65 & 30.43 & 2 & 1613.9132 & 1613.9021 & 807.9583 & 0.0111 & 6.8691 & 4202.766 & 3693.070 & 260.631 & 4494.117 & \text { Yes }\end{array}$

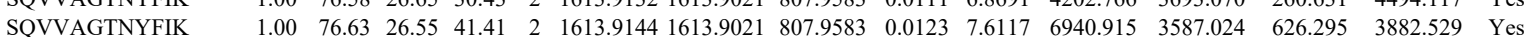

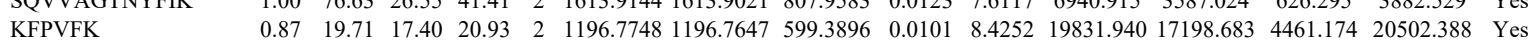

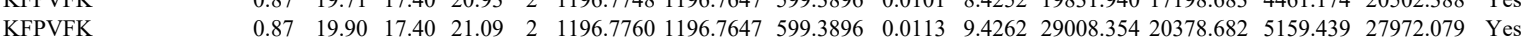
$\begin{array}{llllllllllllllll}0.83 & 25.79 & 23.82 & 17.25 & 2 & 924.5764 & 924.5677 & 463.2911 & 0.0087 & 9.3893 & 10116.832 & 8556.328 & 25765.548 & 9609.272 & \text { No }\end{array}$ KFPVFK $\begin{array}{llllllllllllllll}0.83 & 25.79 & 23.82 & 17.25 & 2 & 924.5764 & 924.5677 & 463.2911 & 0.0087 & 9.3893 & 10116.832 & 8556.328 & 25765.548 & 9609.272 & \text { No } \\ 0.98 & 28.44 & 17.40 & 21.57 & 2 & 1196.7754 & 1196.7647 & 599.3896 & 0.0107 & 8.9257 & 26820.798 & 20143.991 & 2100.911 & 24223.663 & \text { Yes }\end{array}$

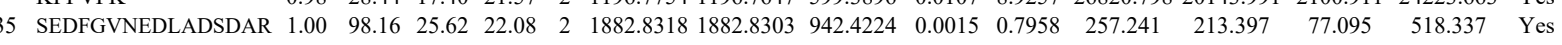

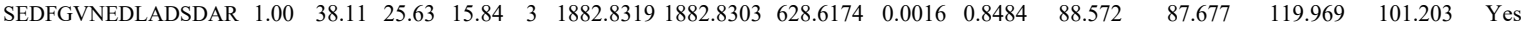

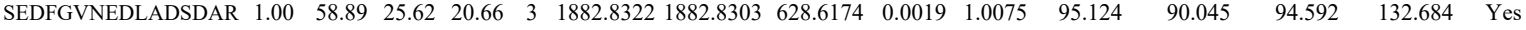

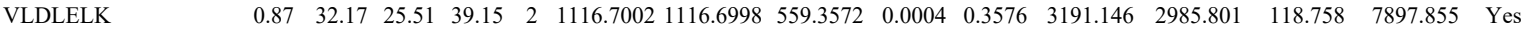

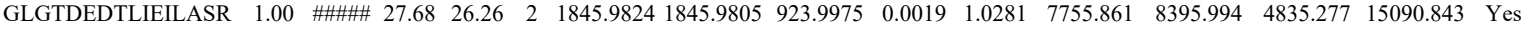

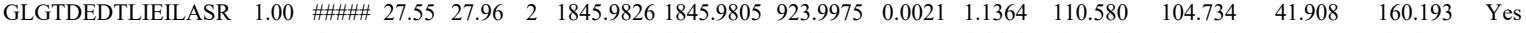
$\begin{array}{llllllllllllllll}\text { GLGTDEDTLIEILASR } & 0.52 & 10.45 & 27.72 & 17.45 & 3 & 1845.9832 & 1845.9805 & 616.3341 & 0.0027 & 1.4602 & 17.084 & 17.949 & 11.759 & 19.307 & \text { Yes }\end{array}$ $\begin{array}{llllllllllllllll}\text { GLGTDEDTLIEILASR } & 1.00 & 54.60 & 27.72 & 30.00 & 3 & 1845.9832 & 1845.9805 & 616.3341 & 0.0027 & 1.4602 & 71.738 & 67.935 & 17.238 & 139.661 & \text { Yes }\end{array}$

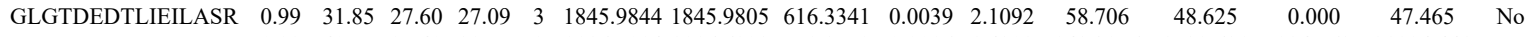
$\begin{array}{llllllllllllllll}0.99 & 40.55 & 25.40 & 39.55 & 2 & 1116.7014 & 1116.6998 & 559.3572 & 0.0016 & 1.4302 & 9436.256 & 8532.631 & 224.763 & 21924.441 & \text { Yes }\end{array}$

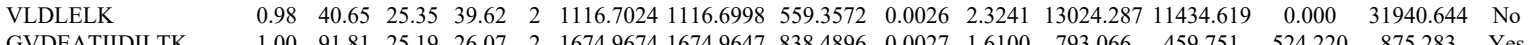

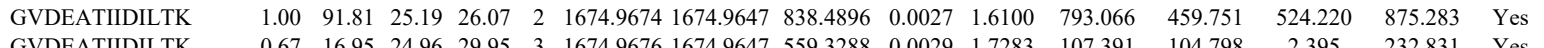

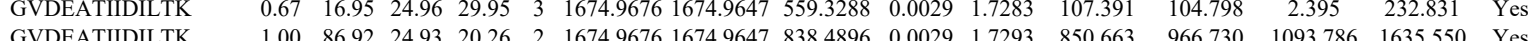
$\begin{array}{llllllllllllllll}\text { GVDEATIDILTK } & 1.00 & 86.92 & 24.93 & 20.26 & 2 & 1674.9676 & 1674.9647 & 838.4896 & 0.0029 & 1.7293 & 850.663 & 966.730 & 1093.786 & 1635.550 & \text { Yes }\end{array}$

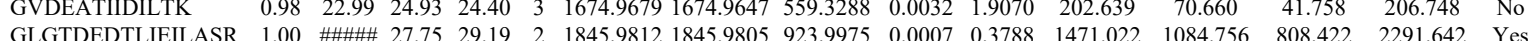
$\begin{array}{llllllllllllll} & \end{array}$

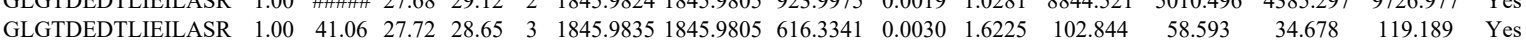
$\begin{array}{llllllllllllllll}\text { GLGTDEDTLIEILASR } & 1.00 & 42.78 & 27.66 & 31.86 & 3 & 1845.9838 & 1845.9805 & 616.3341 & 0.0033 & 1.7847 & 83.985 & 83.641 & 83.656 & 82.277 & \text { Yes }\end{array}$ 
VLDLELK

\section{VLDLELK}

GVDEATIIDILTK

GVDEATIIDILTK

GVDEATIIDILTK

GVEATIDILTK

GLGTDEDTLIELLASR

GLGTDEDTLIEILASR

GVDEATIIDILTK

GVDEATIDILTK

GVEATIDILTK

GVDEATIDILTK

GLGTDEDTLIEILAS

GVDEATIIDILTK

GVDEATIIDILTK

GVDEATIIDILTK

GVDEATIIDILTK

GVDEATIIDILTK

GVDEATIIDILTK

GVDEATIIDILTK

GVDEATIIDILTK

GLGTDEDTLIEILAS

LHQAMK

LHQAMK
TPAQFDADELR

SEDFGVNEDLADSD

LHQAMK

GGPGSAVSPYPTFNPSSDVAALHK

GPGSAVSPYPTFNPSSDVAALHK

SYPQLR

GGPGSAVSPYPTFNPSSDVAAL

GGPGSAVSPYPTFNPSDDVAAI

GGSAVSPYPTFNPSSDVAALHK

$\begin{array}{llll}1.00 & 82.63 & 26.87 & 22.09 \\ 1.00 & 74.42 & 26.96 & 24.37\end{array}$

MYGISLCQAILDETK

MYGISLCQAILDETK

NALLSLAK

NALLSLAK

MYGISLCQAILDETK

MYGISLCQAILDETK

MYGISLCQAILD

NALLSLAK
NALLSLAK

ALTGHLEEVVLALLK

ALTGHLEEVVLALLK

ALTGHLEEVV

ALTGHLEEVVLALLK

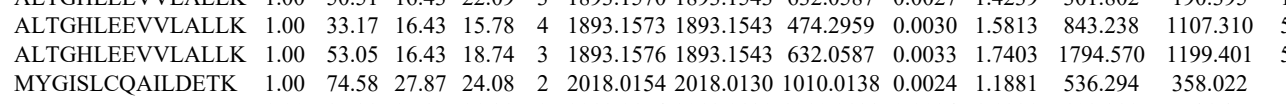

$\begin{array}{llllllllllllll}\text { MYGISLCQAILDETK } & 1.00 & 74.58 & 27.87 & 24.08 & 2 & 2018.0154 & 2018.0130 & 1010.0138 & 0.0024 & 1.1881 & 536.294 & 358.022 & 54.5 \\ \text { MYGISLCQAILDETK } & 1.00 & 87.38 & 27.87 & 21.38 & 2 & 2018.0154 & 2018.0130 & 1010.0138 & 0.0024 & 1.1881 & 103.389 & 76.367 & 26.2\end{array}$

$\begin{array}{llllllllllllll}\text { MYGISLCQAILDETK } & 1.00 & 87.38 & 27.87 & 21.38 & 2 & 2018.0154 & 2018.0130 & 1010.0138 & 0.0024 & 1.1881 & 103.389 & 76.367 & 26.2 \\ \text { MYGISLCQAILDETK } & 0.99 & 28.07 & 27.87 & 19.05 & 3 & 2018.0164 & 2018.0130 & 673.6783 & 0.0034 & 1.6823 & 116.725 & 105.701 & 68.6 \\ \text { MYGISLCQAILDETK } & 1.00 & 40.65 & 27.87 & 21.32 & 3 & 2018.0173 & 2018.0130 & 673.6783 & 0.0043 & 2.1276 & 46.348 & 19.689 & 85.5 \\ \text { ALTGHLEEVVLALLK } & 1.00 & 97.66 & 16.33 & 24.32 & 2 & 1893.1558 & 1893.1543 & 947.5844 & 0.0015 & 0.7915 & 1293.561 & 1116.598 & 6\end{array}$

$\begin{array}{llllllllllllll}\text { ALTGHLEEVVLALLK } & 1.00 & 94.99 & 16.43 & 24.15 & 2 & 1893.1562 & 1893.1543 & 947.5844 & 0.0019 & 1.0025 & 1334.205 & 1135.745 & 62.5 \\ \text { ALTGHLEVVVLALK } & 1.00 & 28.12 & 16.43 & 41.12 & 4 & 1893.1569 & 1893.1543 & 474.2959 & 0.0026 & 1.3705 & 100.53 & 58.174 & 29.86\end{array}$

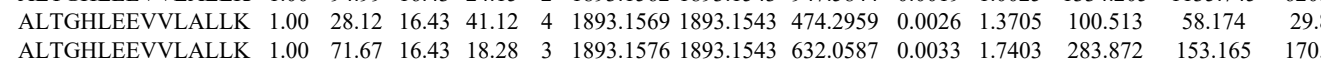
$\begin{array}{llllllllllllll}\text { ALTGHLEEVVLALLK } & 1.00 & 71.67 & 16.43 & 18.28 & 3 & 1893.1576 & 1893.1543 & 632.0587 & 0.0033 & 1.7403 & 283.872 & 153.165 & 170.781 \\ \text { ALTGHLEEVVLALLK } & 0.60 & 52.37 & 16.43 & 65.37 & 3 & 1893.1579 & 1893.1543 & 632.0587 & 0.0036 & 1.8986 & 2600.301 & 2704.655 & 1323.660\end{array}$

$\begin{array}{lllllllllllllll}\text { ALTGHLEEVVLALLK } & 0.60 & 52.37 & 16.43 & 65.37 & 3 & 1893.1579 & 1893.1543 & 632.0587 & 0.0036 & 1.8986 & 2600.301 & 2704.655 & 1323.468 \\ \text { ALTGHLEEVVLALLK } & 1.00 & 43.45 & 16.02 & 56.45 & 4 & 1893.1585 & 1893.1543 & 474.2959 & 0.0042 & 2.2138 & 41.336 & 115.068 & 47.600\end{array}$ 


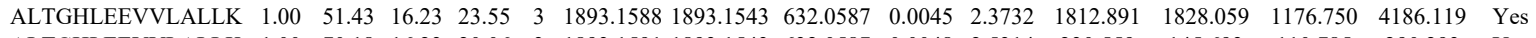
$\begin{array}{lllllllllllllllll}\text { ALTGHLEEVVLALLK } & 1.00 & 70.18 & 16.23 & 20.06 & 3 & 1893.1591 & 1893.1543 & 632.0587 & 0.0048 & 2.5314 & 230.559 & 145.693 & 110.785 & 290.293 & \text { Yes }\end{array}$ $\begin{array}{llllllllllllllll}\text { MYGISLCQAILDETK } & 0.98 & 26.80 & 27.85 & 15.89 & 3 & 2018.0170 & 2018.0130 & 673.6783 & 0.0040 & 1.9792 & 98.926 & 99.238 & 67.010 & 90.065 & \text { Yes }\end{array}$

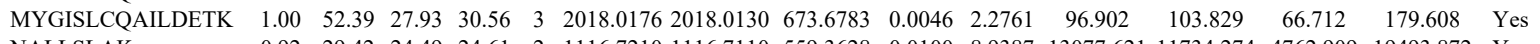

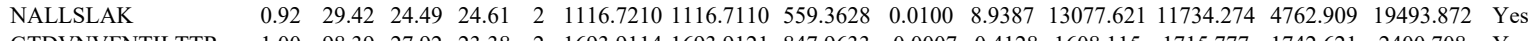

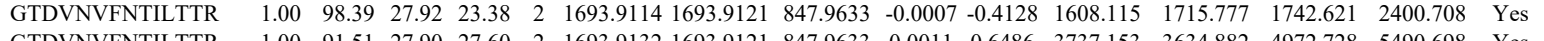

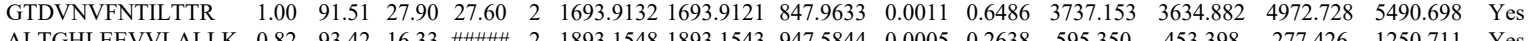

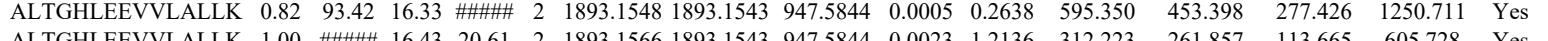

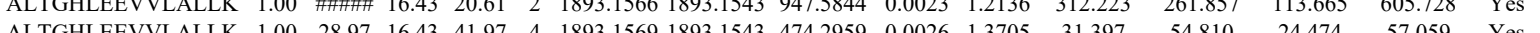
$\begin{array}{lllllllllllllll} & \end{array}$ $\begin{array}{lllllllllllll} & \end{array}$ $\begin{array}{lllllllllllllll} & \end{array}$

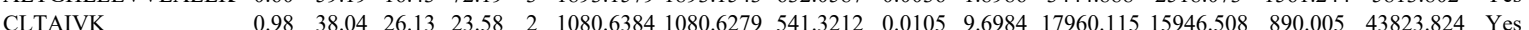
$\begin{array}{lllllllllllllllll}\text { GTDVNVFNTILTTR } & 1.00 & 73.33 & 27.97 & 19.22 & 2 & 1693.9120 & 1693.9121 & 847.9633 & 0.0001 & 0.0590 & 12218.832 & 11325.205 & 15746.794 & 15729.282 & \text { Yes }\end{array}$ $\begin{array}{llllllllllllllllll}\text { GTDVNVFNTIITTR } & 1.00 & 91.74 & 27.87 & 24.22 & 2 & 1693.9124 & 1693.9121 & 847.9633 & 0.0003 & 0.1769 & 4183.951 & 4328.839 & 6079.949 & 5193.071 & \text { Yes }\end{array}$

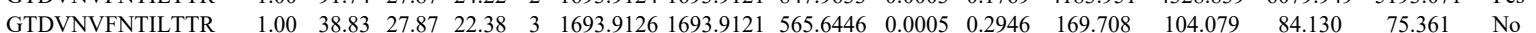

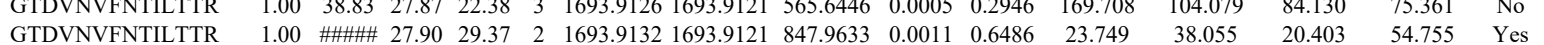

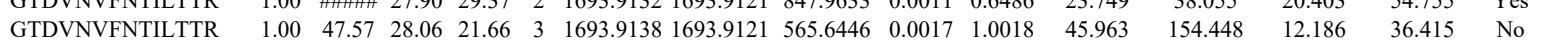
$\begin{array}{lllllllllllllllll}\text { ALTGHLEEVVLALLK } & 1.00 & 49.35 & 16.43 & 18.13 & 3 & 1893.1573 & 1893.1543 & 632.0587 & 0.0030 & 1.5821 & 210.879 & 223.333 & 109.420 & 627.233 & \text { Yes }\end{array}$ $\begin{array}{llllllllllllllll}\text { ALTGHLEEVVLALLK } & 1.00 & 21.89 & 16.43 & 34.89 & 4 & 1893.1577 & 1893.1543 & 474.2959 & 0.0034 & 1.7921 & 49.396 & 41.742 & 13.265 & 36.239 & \text { Yes }\end{array}$ \begin{tabular}{llllllllllllllll} 
ALTGHLEEVVLALLK & 0.60 & 56.33 & 16.02 & 69.33 & 3 & 1893.1582 & 1893.1543 & 632.0587 & 0.0039 & 2.0568 & 1250.482 & 1278.189 & 599.062 & 3077.815 & Yes \\
\hline
\end{tabular}

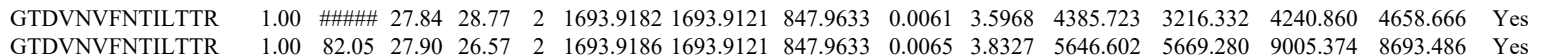
$\begin{array}{lllllllllllllllll}\text { GTDVNVFNTILTTR } & 1.00 & 82.05 & 27.90 & 26.57 & 2 & 1693.9186 & 1693.9121 & 847.9633 & 0.0065 & 3.8327 & 5646.602 & 5669.280 & 9005.374 & 8693.486 & \text { Yes } \\ \text { GTDVNVFNTILTTR } & 0.98 & 33.07 & 27.77 & 13.68 & 3 & 163.920 & \text { Yes }\end{array}$ $\begin{array}{llllllllllllllll}\text { GTDVNVFNTILTTR } & 0.98 & 33.07 & 27.77 & 18.68 & 3 & 1693.9195 & 1693.9121 & 565.6446 & 0.0074 & 4.3608 & 119.595 & 88.137 & 57.525 & 106.683 & \text { Yes } \\ \text { GTDVNVNTILTTR } & 0.98 & 35.87 & 27.72 & 23.96 & 3 & 1693.9201 & 1693.9121 & 565.6446 & 0.0080 & 47144 & 156.870 & 84.466 & 43.878 & 146.058 & \text { Yes }\end{array}$ $\begin{array}{lllllllllllllllll}\text { GTDVNVFNTILTTR } & 0.98 & 35.87 & 27.72 & 23.96 & 3 & 1693.9201 & 1693.9121 & 565.6446 & 0.0080 & 4.7144 & 156.870 & 84.466 & 43.878 & 146.058 & \text { Yes } \\ \text { ALTG } & 1.00 & 57.22 & 16.43 & 18.97 & 3 & 1893.1570 & 1893.1543 & 632.0587 & 0.0027 & 1.4239 & 281.835 & 159.219 & 67.347 & 356.397 & \text { Yes }\end{array}$ $\begin{array}{llllllllllllllll}\text { ALTGHLEEVVLALLK } & 1.00 & 57.22 & 16.43 & 18.97 & 3 & 1893.1570 & 1893.1543 & 632.0587 & 0.0027 & 1.4239 & 281.835 & 159.219 & 67.347 & 36.058 & \text { Yes } \\ \text { ALTGHLEVVLALLK } & 1.00 & 65.48 & 16.43 & 17.38 & 3 & 1893.1579 & 1893.1543 & 632.0587 & 0.0036 & 1.8986 & 247.840 & 199.865 & 131.986 & 267.192 & \text { Yes }\end{array}$ $\begin{array}{lllllllllllllllll} & \\ \text { KGTDVNVFNTILTTR } & 0.60 & 53.99 & 24.53 & 66.99 & 3 & 1966.1137 & 1966.1091 & 656.3770 & 0.0046 & 2.3361 & 1291.369 & 989.388 & 1024.533 & 2063.990 & \text { Yes }\end{array}$ $\begin{array}{llllllllllllllll}\text { GTDVNVFNTILTTR } & 1.00 & 99.65 & 28.05 & 23.88 & 2 & 1693.9140 & 1693.9121 & 847.9633 & 0.0019 & 1.1203 & 4150.662 & 3192.266 & 4389.759 & 4255.317 & \text { Yes }\end{array}$ $\begin{array}{lllllllllllllllll}\text { GTDVNVFNTILTTR } & 1.00 & 95.65 & 28.05 & 28.51 & 2 & 1693.9150 & 1693.9121 & 847.9633 & 0.0029 & 1.7100 & 5187.492 & 3999.974 & 5775.716 & 6062.471 & \text { Yes }\end{array}$ $\begin{array}{lllllllllllllllll}\text { KGTDVNVFNTILTTR } & 1.00 & 94.48 & 24.50 & 24.17 & 3 & 1966.1101 & 1966.1091 & 656.3770 & 0.0010 & 0.5078 & 1354.395 & 1311.176 & 1097.773 & 4859.893 & \text { Yes }\end{array}$ \begin{tabular}{lllllllllllllllll} 
KGTDVNVFNTILTTR & 1.00 & 82.57 & 24.52 & 27.02 & 3 & 1966.1104 & 1966.1091 & 656.3770 & 0.0013 & 0.6602 & 1113.784 & 1591.133 & 1332.061 & 3285.907 & Yes \\
\hline
\end{tabular}

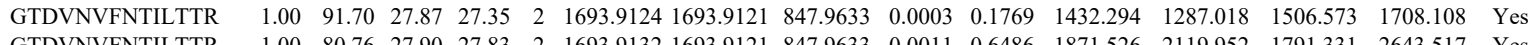
\begin{tabular}{lllllllllllllllll} 
& \\
GTDVNVFNILTR & 1.00 & 80.76 & 27.90 & 27.83 & 2 & 1693.9132 & 1693.9121 & 847.9633 & 0.0011 & 0.6486 & 1871.526 & 2119.952 & 1791.331 & 2643.517 & Yes \\
\hline
\end{tabular} ILVALCGGN

ILVALCGGN

ILVALCGGN $\begin{array}{lllllllllllll}.00 & 62.44 & 28.34 & 23.33 & 2 & 1048.5548 & 1048.5531 & 525.2838 & 0.0017 & 1.6182 & 56.867 & 78.42\end{array}$ $\begin{array}{llllllllllll}1.00 & 68.62 & 28.34 & 19.26 & 2 & 1048.5550 & 1048.5531 & 525.2838 & 0.0019 & 1.8085 & 1041.887 & 596.209\end{array}$

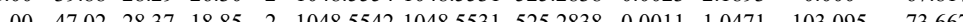

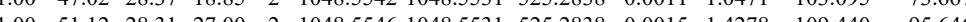
$\begin{array}{llllllllllll}0.97 & 30.40 & 28.39 & 17.73 & 2 & 1048.5544 & 1048.5531 & 525.2838 & 0.0013 & 1.42374 & 90.680 & 61.1\end{array}$

(1) $\begin{array}{llllllllllll}17.97 & 30.40 & 28.39 & 17.73 & 2 & 1048.5544 & 1048.5531 & 525.2838 & 0.0013 & 1.2374 & 90.680\end{array}$

ILVALCGGN

ILVALCGGN $\begin{array}{lllllllllll}1.00 & 44.96 & 28.34 & 18.92 & 2 & 1048.5548 & 1048.5531 & 525.2838 & 0.0017 & 1.6182 & 71.571 \\ 1.00 & 39.54 & 28.34 & 18.96 & 2 & 1048.5548 & 1048.5531 & 525.2838 & 0.0017 & 1.6182 & 73.25\end{array}$ $\begin{array}{llllllllllll}1.00 & 3.54 & 28.34 & 18.96 & 2 & 1048.5548 & 1048.5531 & 525.2838 & 0.0017 & 1.6182 & 73.295 \\ 1.00 & 84.01 & 27.87 & 23.73 & 2 & 1693.9126 & 1693.9121 & 847.9633 & 0.005 & 0.2948 & 337.595\end{array}$

VFNTILTTR ILVALCGGN GTDVNVFNTILTTR SEIDMNDIK
SEIDMNDIK TPAQFDADELR $\begin{array}{lllllllllllll}1.00 & 96.47 & 27.87 & 27.50 & 2 & 1693.9128 & 1693.9121 & 847.9633 & 0.0007 & 0.4128 & 489.144 & 4\end{array}$ $\begin{array}{lllllllllllll}100 & 39.22 & 28.31 & 19.01 & 2 & 1048.5546 & 1048.5531 & 525.2838 & 0.0015 & 1.4278 & 32.166\end{array}$ $\begin{array}{lllllllllllll}1.00 & 87.56 & 27.87 & 25.19 & 2 & 1693.9126 & 1693.9121 & 847.9633 & 0.0005 & 0.2948 & 165.871\end{array}$ 
$\begin{array}{llllllllllllll} & \end{array}$

$\begin{array}{llllllllllllll} & \text { QAVI. }\end{array}$ $\begin{array}{llllllllllllll} & \end{array}$

$\begin{array}{lllllllllllll} & 34.91 & 23.36 & 21.95 & 3 & 2240.1292 & 2240.1245 & 747.7154 & 0.0047 & 2.0953 & 64.934 & 4\end{array}$

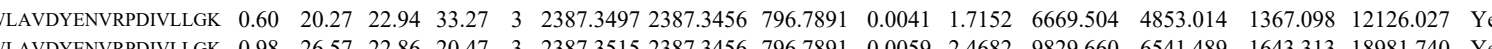

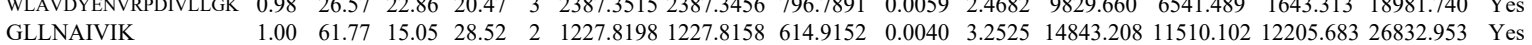

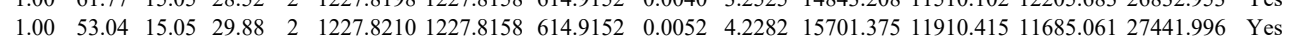

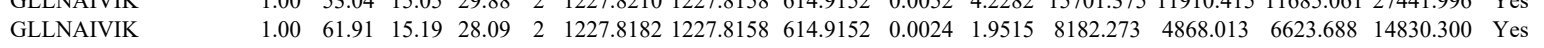

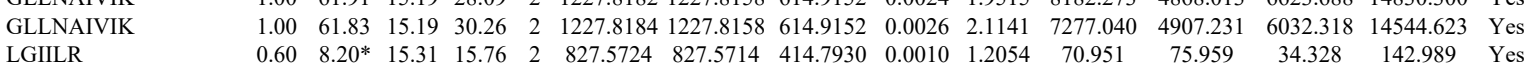

LGIILR

$\begin{array}{llllllllllllllll}0.66 & 22.95 * & 15.31 & 28.82 & 2 & 827.5738 & 827.5714 & 414.7930 & 0.0024 & 2.8930 & 21875.511 & 21002.616 & 2613.845 & 46412.038 & \text { Yes }\end{array}$ $\begin{array}{lllllllllllllllll}\text { IVFAAGNFWGR } & 1.00 & 47.16 & 27.94 & 23.14 & 2 & 1380.7432 & 1380.7424 & 691.3785 & 0.0008 & 0.5786 & 1772.956 & 1455.600 & 285.269 & 4684.416 & \text { Yes }\end{array}$ $\begin{array}{llllllllllllllll}\text { IVFAAGNFWGR } & 1.00 & 47.85 & 27.92 & 20.73 & 2 & 1380.7434 & 1380.7424 & 691.3785 & 0.0010 & 0.7232 & 2076.419 & 1357.245 & 168.489 & 5045.682 & \text { Yes }\end{array}$ $\begin{array}{lllllllllllllllll}\text { IVFAAGNFWGR } & 1.00 & 51.97 & 27.95 & 25.80 & 2 & 1380.7438 & 1380.7424 & 691.3785 & 0.0014 & 1.0125 & 1220.670 & 1028.913 & 124.604 & 3446.656 & \text { Yes }\end{array}$ $\begin{array}{llllllllllllllll}\text { IVFAAGNFWGR } & 1.00 & 49.20 & 27.94 & 22.11 & 2 & 1380.7440 & 1380.7424 & 691.3785 & 0.0016 & 1.1571 & 1173.775 & 973.021 & 123.048 & 3004.836 & \text { Yes }\end{array}$

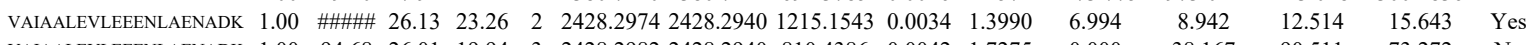
$\begin{array}{llllllllllllllll}\text { VAIAALEVLEEENLAENADK } & 1.00 & 94.68 & 26.01 & 19.94 & 3 & 2428.2982 & 2428.2940 & 810.4386 & 0.0042 & 1.7275 & 0.000 & 38.167 & 90.511 & 73.272 & \text { No }\end{array}$

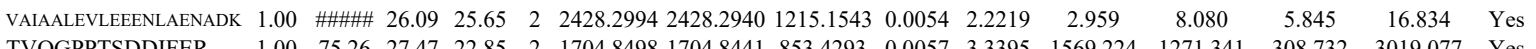

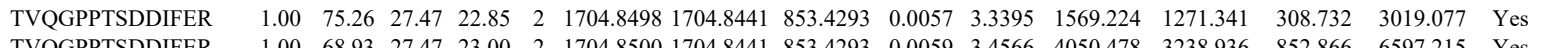
$\begin{array}{llllllllllllllll}\text { TVQGPPTSDDIFER } & 1.00 & 68.93 & 27.47 & 23.00 & 2 & 1704.8500 & 1704.8441 & 853.4293 & 0.0059 & 3.4566 & 4050.478 & 3238.936 & 852.866 & 6597.215 & \text { Yes } \\ \text { TVQGPPTSDDFER } & 1.00 & 63.22 & 28.01 & 18.25 & 2 & 1704.8602 & 1704.8441 & 853.4293 & 0.0161 & 9.4324 & 1310.789 & 1163.957 & 370.415 & 1962.063 & \text { Yes }\end{array}$ \begin{tabular}{lllllllllllllllll} 
TVQGPPTSDDIFER & 1.00 & 63.22 & 28.01 & 18.25 & 2 & 1704.8602 & 1704.8441 & 853.4293 & 0.0161 & 9.4324 & 1310.789 & 1163.957 & 370.415 & 1962.063 & Yes \\
\hline KPFG
\end{tabular} $\begin{array}{llllllllllllllll}\text { KPFGAILNLVPLAESVVK } & 1.00 & 48.57 & 11.14 & 61.57 & 4 & 2326.4393 & 2326.4353 & 582.6161 & 0.0040 & 1.7164 & 121.688 & 107.096 & 92.213 & 119.307 & \text { Yes } \\ \text { LFAPQQILQCSPAN } & 0.52 & 14.48 & 27.68 & 27.48 & 2 & 1718.8622 & 1718.8606 & 860.4376 & 0.0016 & 0.9298 & 13.164 & 9.198 & 6.154 & 16595 & \text { Yes }\end{array}$

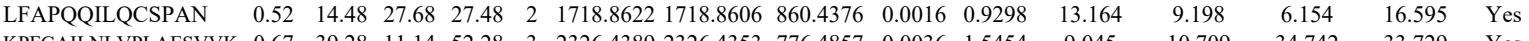

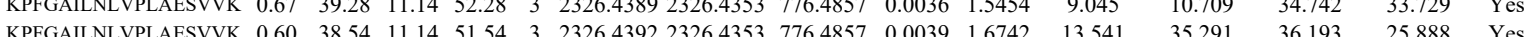

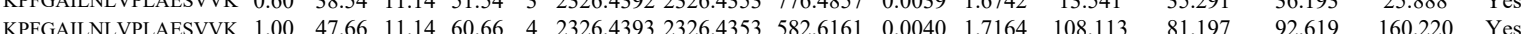
$\begin{array}{llllllllllllll} & \end{array}$

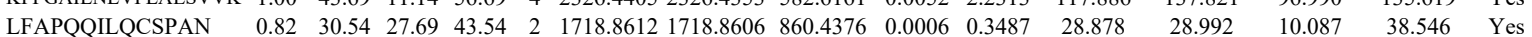

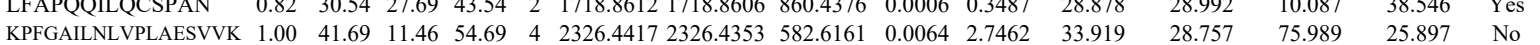

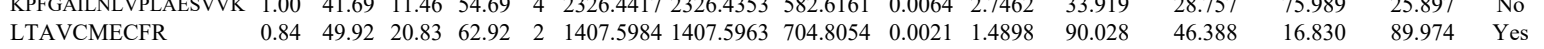

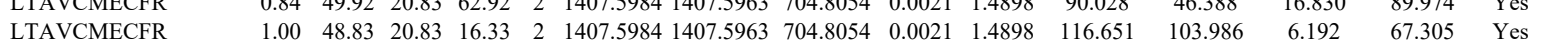

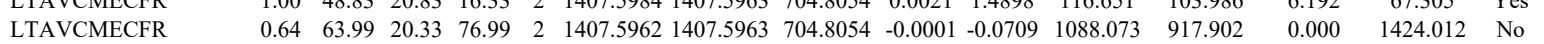
$\begin{array}{lllllllllllllll}\text { ATGGGLSSVGGGSSTIK } & 1.00 & \text { \#\#\#\# } 27.31 & 27.20 & 2 & 1722.9424 & 1722.9356 & 862.4751 & 0.0068 & 3.9421 & 11825.121 & 7987.805 & 1205.490 & 1870.875 & \text { Yes }\end{array}$

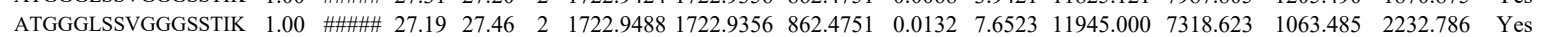
$\begin{array}{lllllllllllllll}\text { ATGGGLSSVGGGSSTIK } & 1.00 & \text { 27.23 } & 26.23 & 2 & 1722.9476 & 1722.9356 & 862.4751 & 0.0120 & 6.9567 & 8821.431 & 5243.597 & 950.746 & 1205.406 & \text { Yes }\end{array}$ $\begin{array}{llllllllllllllll}\text { ATGGGLSSVGGGSSTIK } & 0.99 & 37.66 & 27.20 & 22.94 & 3 & 1722.9481 & 1722.9356 & 575.3191 & 0.0125 & 7.2423 & 2788.616 & 2715.613 & 1165.097 & 4789.926 & \text { No }\end{array}$

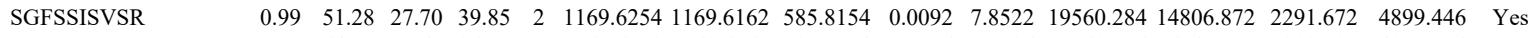
$\begin{array}{llllllllllllllll}\text { SGFSSISVSR } & 1.00 & 64.51 & 27.60 & 36.17 & 2 & 1169.6258 & 1169.6162 & 585.8154 & 0.0096 & 8.1936 & 21063.216 & 16047.118 & 2388.731 & 4917.054 & \text { Yes }\end{array}$

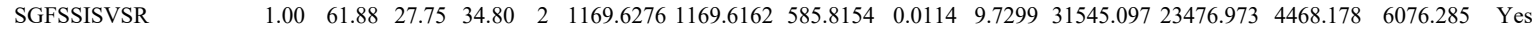

YDNSLK

YDNSLK

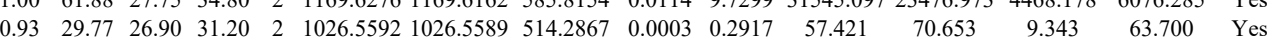
YDNSLK

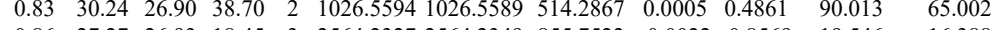
$\begin{array}{lllllllllllll} & \end{array}$

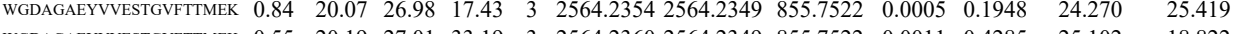

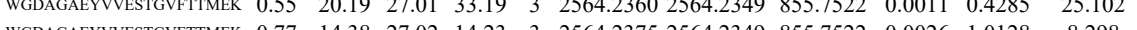
$\begin{array}{llllllllllll}\text { WGDAGAEYVVESTGVFTTMEK } & 0.77 & 14.38 & 27.02 & 14.23 & 3 & 2564.2375 & 2564.2349 & 855.7522 & 0.0026 & 1.0128 & 8.298\end{array}$ $\begin{array}{lllllllllllll}\text { WGDAGAEYVVESTGVFTTMEK } & 1.00 & 56.99 & 27.08 & 17.16 & 3 & 2564.2384 & 2564.2349 & 855.7522 & 0.0035 & 1.3633 & 7.966\end{array}$

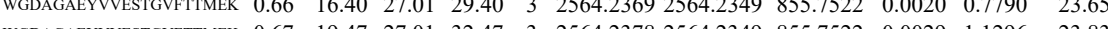

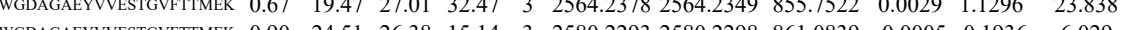
$\begin{array}{llllllllll} & 0\end{array}$

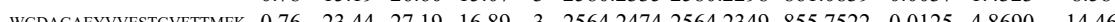
$\begin{array}{llllllllllll}\text { TVDGPSGK } & 0.99 & 34.28 & 28.01 & 29.04 & 2 & 1047.5818 & 1047.5804 & 524.7975 & 0.0014 & 1.3338 & 64.942\end{array}$ 


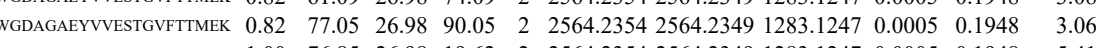

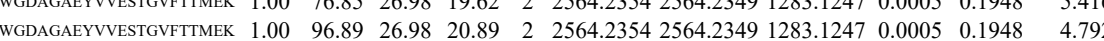

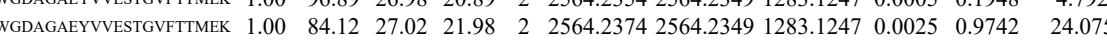
$\begin{array}{llllllllll} & 0.0756\end{array}$ $\begin{array}{lllllllllll} & \text { W }\end{array}$ $\begin{array}{lllllllllllll}\text { WGDAGAEYVVESTGVFTTMEK } & 0.72 & 80.84 & 27.02 & 93.84 & 2 & 2564.2374 & 2564.2349 & 1283.1247 & 0.0025 & 0.9742 & 34.105\end{array}$

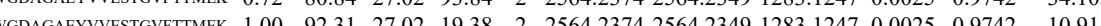

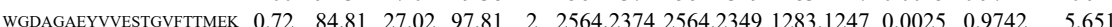
WGDAGAEYVVESTGVFTTMEK $\begin{array}{lllllllllllll}0.72 & 94.97 & 27.02 & \text { \#\#\#\# } 2 & 2 & 2564.2374 & 2564.2349 & 1283.1247 & 0.0025 & 0.9742 & 11.507\end{array}$

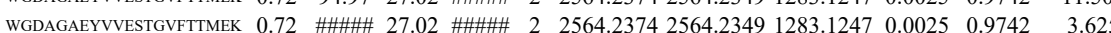
$\begin{array}{lllllllllllll}\text { WGDAGAEYVVESTGVFTTMEK } & 1.00 & 99.40 & 27.02 & 22.17 & 2 & 2564.2374 & 2564.2349 & 1283.1247 & 0.0025 & 0.9742 & 9.207\end{array}$ $\begin{array}{llllllllllll}\text { WGDAGAEYVVESTGVFTTMEK } & 0.72 & 84.26 & 27.02 & 97.26 & 2 & 2564.2374 & 2564.2349 & 1283.1247 & 0.0025 & 0.9742 & 18.010 \\ \text { WGDAGAEYVVESTGVFTMMEK } & 1.00 & 94.49 & 27.02 & 18.97 & 2 & 2564.2374 & 2564.2349 & 1283.1247 & 0.0025 & 0.9742 & 5.575\end{array}$ $\begin{array}{lllllllllllll}\text { WGDAGAEYVVESTGVFTTMEK } & 1.00 & 79.60 & 27.02 & 18.04 & 2 & 2564.2374 & 2564.2349 & 1283.1247 & 0.0025 & 0.9742 & 13.573\end{array}$ $\begin{array}{llllllllllll}\text { WGDAGAEYVVESTGVFTTMEK } & 1.00 & 62.04 & 27.02 & 19.25 & 2 & 2564.2374 & 2564.2349 & 1283.1247 & 0.0025 & 0.9742 & 5.647\end{array}$

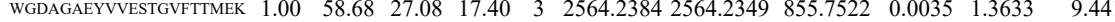
$\begin{array}{llllllllllll}\text { WGDAGAEYVVESTGVFTTMEK } & 1.00 & 65.40 & 27.04 & 19.50 & 3 & 2564.2387 & 2564.2349 & 855.7522 & 0.0038 & 1.4802 & 22.584\end{array}$

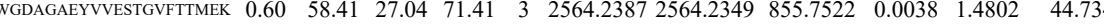

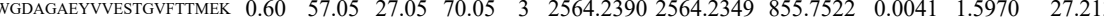

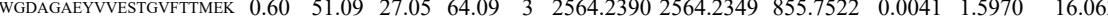

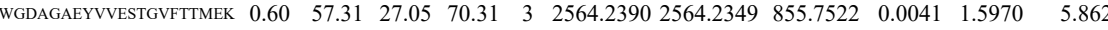
$\begin{array}{llllllllllll}\text { WGDAGAEYVVESTGVFTTMEK } & 0.60 & 62.95 & 27.05 & 75.95 & 3 & 2564.2390 & 2564.2349 & 855.7522 & 0.0041 & 1.5970 & 12.08\end{array}$ $\begin{array}{llllllllllll}\text { WGDAGAEYVVESTGVFTTMEK } & 1.00 & 98.29 & 27.08 & 19.31 & 2 & 2564.2394 & 2564.2349 & 1283.1247 & 0.0045 & 1.7535 & 7.215\end{array}$ $\begin{array}{llllllllllll}\text { WGDAGAEYVVESTGVFTTMEK } & 1.00 & 70.87 & 27.08 & 17.67 & 2 & 2564.2394 & 2564.2349 & 1283.1247 & 0.0045 & 1.7535 & 11.734 \\ \text { WGDAGAEYVVESTGVFTTMEK } & 1.00 & 62.09 & 27.02 & 20.57 & 3 & 2564.2396 & 2564.2349 & 855.7522 & 0.0047 & 1.8307 & 21.737\end{array}$

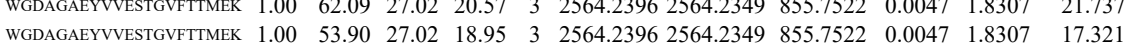
$\begin{array}{lllllllllllll}\text { WGDAGAEYVVESTGVFTTMEK } & 1.00 & 26.60 & 27.05 & 14.69 & 4 & 2564.2401 & 2564.2349 & 642.0660 & 0.0052 & 2.0247 & 17.236\end{array}$ $\begin{array}{llllllllllllll}\text { WGDAGAEYVUESTGVFTMEK K } & 1.00 & 59.18 & 27.06 & 18.51 & 3 & 2564.2402 & 2564.2349 & 855.7522 & 0.0053 & 2.0645 & 19.397\end{array}$ $\begin{array}{lllllllll} & 0.0645 & 58.838\end{array}$

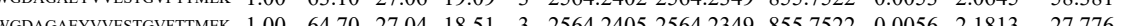

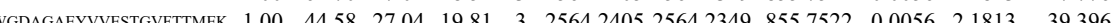
$\begin{array}{lllllllll} & \text { WGDAG }\end{array}$

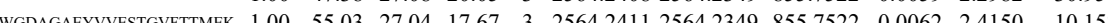
WGDAGAEYYVESTGYFTTMEK $1 \begin{array}{lllllllllllll}1.00 & 37.41 & 27.04 & 16.50 & 3 & 2564.2411 & 2564.2349 & 855.7522 & 0.0062 & 2.4150 & 56.902\end{array}$

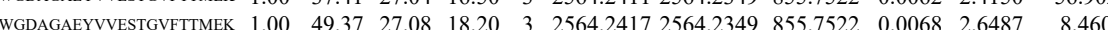

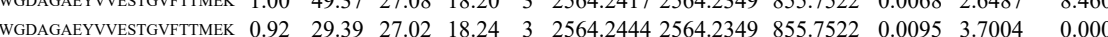
WGDAGAEYVVESTGVFTTMFK $\begin{array}{llllllllllllll}0.91 & 21.95 & 26.46 & 16.10 & 3 & 2580.2299 & 2580.2298 & 8610839 & 0.0001 & 0.0387 & 0.000\end{array}$ AAFNSGK AAFNSGK AAFNSGK LEKPAK LEKPAK AGAHLQGGAK

AGAHLQGGAK $\begin{array}{lllllllllllll}1.00 & 41.01 & 25.90 & 21.58 & 2 & 981.5494 & 981.5487 & 491.7816 & 0.0007 & 0.7117 & 989.582\end{array}$ $\begin{array}{llllllllllll}1.00 & 37.92 & 26.09 & 25.32 & 2 & 981.5496 & 981.5487 & 491.7816 & 0.0009 & 0.9150 & 1002.174\end{array}$ $\begin{array}{llllllllllllllll}1.00 & 37.40 & 26.10 & 21.10 & 2 & 981.5500 & 981.5487 & 491.7816 & 0.0013 & 1.3217 & 975.435 & 741.3919\end{array}$

$\begin{array}{llllllllllllll}1.00 & 40.00 & 26.05 & 21.60 & 2 & 981.5506 & 981.5487 & 491.7816 & 0.0019 & 1.9317 & 1454.360 & 1050.09\end{array}$ AGAHLQGAK $\begin{array}{llllllllllll}1.00 & 40.00 & 26.05 & 21.60 & 2 & 981.5506 & 981.5487 & 491.7816 & 0.0019 & 1.9317 & 1454.361050 .091 & \end{array}$ $\begin{array}{llllllllllll}0.88 & 31.13 & 26.31 & 21.75 & 2 & 1196.6864 & 1196.6869 & 599.3507 & -0.0005 & -0.4171 & 27.311 & 45.620 \\ 1.00 & 45.61 & 26.32 & 20.41 & 2 & 1196.6882 & 1196.6869 & 599.3507 & 0.0013 & 1.0845 & 77.712 & 63.326\end{array}$ $\begin{array}{rllllllllllll}1.00 & 43.65 & 26.88 & 16.75 & 2 & 1196.6900 & 1196.6869 & 599.3507 & 0.0031 & 2.5861 & 49.869\end{array}$ $\begin{array}{llllllllllll} & \end{array}$ $\begin{array}{llllllllllllll}\text { WGDAGAEYVVESTGVFTTMEK } & 0.82 & 85.35 & 26.98 & 98.35 & 2 & 2564.2354 & 2564.2349 & 1283.1247 & 0.0005 & 0.1948 & 2.296\end{array}$ $\begin{array}{lllllllllllll}\text { WGDAGAEYVVESTGVFTTMEK } & 0.66 & 74.45 & 27.01 & 87.45 & 3 & 2564.2372 & 2564.2349 & 855.7522 & 0.0023 & 0.8959 & 167.413\end{array}$

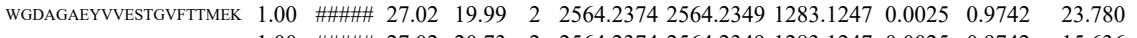

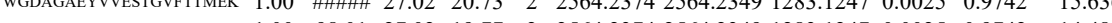

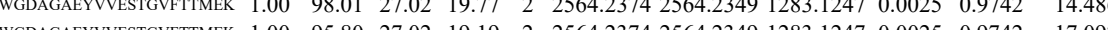
$\begin{array}{lllllllllll} & 0\end{array}$

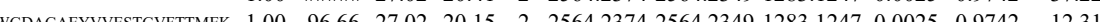

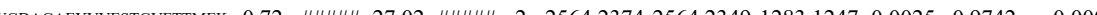

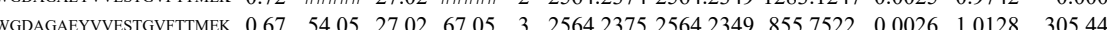

3

18.




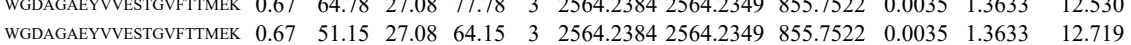
$\begin{array}{llllllllllll}\text { VGDAGAEYVVESTGVFTTMEK } & 0.67 & 23.20 & 27.08 & 36.20 & 3 & 2564.2384 & 2564.2349 & 855.7522 & 0.0035 & 1.3633 & 27.500\end{array}$ $\begin{array}{lllllllllllll} & \text { WDAGAEYVESTGVFTTMEK } & 0.60 & 52.98 & 27.04 & 65.98 & 3 & 2564.2387 & 2564.2349 & 855.7522 & 0.0038 & 1.4802 & 20.26\end{array}$ $\begin{array}{llllllllll} & 1.4802 & 18.095\end{array}$

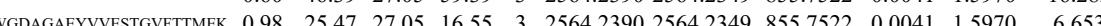
$\begin{array}{lllllllllll} & \text { WGDAG }\end{array}$

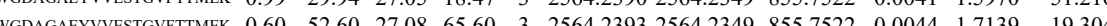

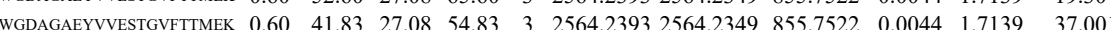

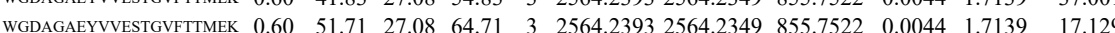

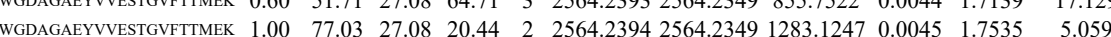

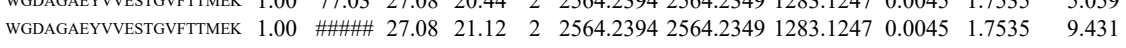
$\begin{array}{llllllllllllll}\text { WGDAGAEYVVESTGVFTTMEK } & 0.98 & 28.22 & 27.02 & 18.39 & 3 & 2564.2396 & 2564.2349 & 855.7522 & 0.0047 & 1.8307 & 7.952\end{array}$ $\begin{array}{lllllllllllll}\text { WGDAGAEYVVESTGVFTTMEK } & 0.96 & 12.99 & 27.05 & 14.30 & 4 & 2564.2401 & 2564.2349 & 642.0660 & 0.0052 & 2.0247 & 16.684\end{array}$ $\begin{array}{llllllllllll}\text { WGDAGAEYVVESTGVFTTMEK } & 1.00 & 56.08 & 27.06 & 20.04 & 3 & 2564.2402 & 2564.2349 & 855.7522 & 0.0053 & 2.0645 & 6.399\end{array}$ $\begin{array}{llllllllllllll}\text { WDDAGAEYUVSTGVFTTMEK } & 0.81 & 21.61 & 27.04 & 18.24 & 3 & 2564.2405 & 2564.2349 & 855.7522 & 0.0056 & 2.1813 & 0.000\end{array}$ $\begin{array}{lllllllllllll} & \text { GDAGAEYVVESTGVFTTMEK } & 1.00 & 95.88 & 27.11 & 19.42 & 2 & 2564.2434 & 2564.2349 & 1283.1247 & 0.0085 & 3.3122 & 13.573\end{array}$

$\begin{array}{lrlllllllll} & & & \end{array}$ $\begin{array}{lllllllllllll}0.99 & 33.95 & 26.05 & 24.17 & 2 & 981.5504 & 981.5487 & 491.7816 & 0.0017 & 1.7284 & 1398.696\end{array}$

LEKPAK

VIPELNGK

VIPELNGK

VIPELNGK

VIPELNGK

VIPELNGK

VIPELNGK

VIPELNGK

VIPELNGK

VIPELNGK

VIPELNGK

$\begin{array}{lllllllllll}0.60 & 25.37 & 24.49 & 24.27 & 2 & 1116.7214 & 1116.7232 & 559.3689 & -0.0018 & -1.6090 & 1197.641 \\ 0.96 & 29.13 & 23.98 & 19.29 & 2 & 1156.7062 & 1156.7059 & 579.3602 & 0.0003 & 0.2589 & 315.238\end{array}$

$\begin{array}{llllllllllll}0.96 & 29.13 & 23.98 & 19.29 & 2 & 1156.7062 & 1156.7059 & 579.3602 & 0.0003 & 0.2589 & 315.238 \\ 0.98 & 32.49 & 24.25 & 2.00 & 2 & 1156.7064 & 1156.7059 & 579.3602 & 0.0005 & 0.4315 & 303.440 & 23\end{array}$

$\begin{array}{llllllllllll}0.98 & 32.49 & 24.25 & 20.00 & 2 & 1156.7064 & 1156.7059 & 579.3602 & 0.0005 & 0.4315 & 303.440 & 23 \\ 0.98 & 28.80 & 24.33 & 22.62 & 2 & 1156.7070 & 1156.7059 & 579.3602 & 0.0011 & 0.9493 & 321.990 & 25\end{array}$

$\begin{array}{llllllllllll}0.98 & 28.80 & 24.33 & 22.62 & 2 & 1156.7070 & 1156.7059 & 579.3602 & 0.0011 & 0.9493 & 321.990 & \\ 0.97 & 27.15 & 24.36 & 20.84 & 2 & 1156.7076 & 1156.7059 & 579.3602 & 0.0017 & 1.4671 & 127.449 & \\ 0.92 & 21.75 & 17.36 & 17.13 & 2 & 156.7078 & 156.7059 & 579.362 & 0.019 & \end{array}$ $\begin{array}{llllllllllll}0.97 & 27.15 & 24.36 & 20.84 & 2 & 1156.7076 & 1156.7059 & 579.3602 & 0.0017 & 1.4671 & 127.449 \\ 0.92 & 21.75 & 24.36 & 17.13 & 2 & 1156.7078 & 1156.7059 & 579.3602 & 0.0019 & 1.6397 & 171.981 & \end{array}$ $\begin{array}{lllllllllll}0.92 & 21.75 & 24.36 & 17.13 & 2 & 1156.7078 & 1156.7059 & 579.3602 & 0.0019 & 1.6397 & 171.981 \\ 0.99 & 30.80 & 24.36 & 20.25 & 2 & 1156.7082 & 1156.7059 & 579.3602 & 0.0023 & 1.9849 & 351.060\end{array}$ $\begin{array}{lllllllllll}0.99 & 30.43 & 24.25 & 21.61 & 2 & 1156.7084 & 1156.7059 & 579.3602 & 0.0025 & 2.1575 & 285.337\end{array}$ $\begin{array}{lllllllllll}0.99 & 30.43 & 24.25 & 21.61 & 2 & 1156.7084 & 1156.7059 & 579.3602 & 0.0025 & 2.1575 & 285.337 \\ 0.96 & 27.89 & 24.44 & 19.14 & 2 & 1156.7092 & 1156.7059 & 579.3602 & 0.0033 & 2.8480 & 335.182\end{array}$ $\begin{array}{lllllllllll}0.98 & 36.16 & 24.36 & 22.70 & 2 & 1156.7096 & 1156.7059 & 579.3602 & 0.0037 & 3.1932 & 288.929\end{array}$

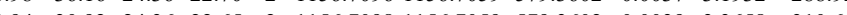

AGAHLQGGAK

$\begin{array}{llllllllllll}0.94 & 34.10 & 24.05 & 20.75 & 2 & 1156.7126 & 1156.7059 & 579.3602 & 0.0067 & 5.7822 & 393.577\end{array}$

$\begin{array}{llllllllllll}0.00 & 46.51 & 26.32 & 19.36 & 2 & 1196.6880 & 1196.6869 & 599.3507 & 0.0011 & 0.9177 & 44.594\end{array}$

$\begin{array}{lllllllllllll}\text { WGDAGAEYVVESTGVFTTMEK } & 0.87 & 21.23 & 27.01 & 15.42 & 3 & 2564.2351 & 2564.2349 & 855.7522 & 0.0002 & 0.0779 & 22.104\end{array}$ WGAGAEYVVESTGVFTTMEK 0.82 \#\#\#\#\# 26.98 \#\#\#\# 2 2 $2564.23542564 .2349 \begin{array}{llllllll}1283.1247 & 0.0005 & 0.1948 & 7.457\end{array}$

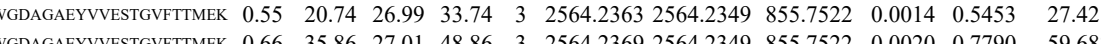

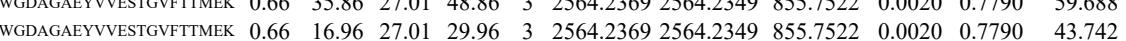

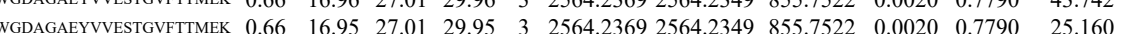
$\begin{array}{lllllllllllll}\text { WGDAGAEYVVESTGVFTTMEK } & 0.66 & 21.15 & 27.01 & 34.15 & 3 & 2564.2372 & 2564.2349 & 855.7522 & 0.0023 & 0.8959 & 36.913\end{array}$ $\begin{array}{lllllllllllllll}\text { WGDAGAEYVVESTGVFTTMEK } & 0.72 & \text { \#\#\#\# } & 27.02 & \text { \#\#\#\# } & 2 & 2564.2374 & 2564.2349 & 1283.1247 & 0.0025 & 0.9742 & 13.902\end{array}$

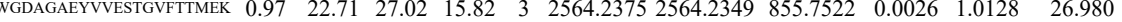

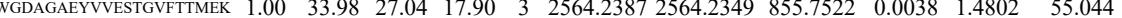
$\begin{array}{llllllllllll}\text { WGDAGAEYVVESTGVFTMMEK } & 0.60 & 43.12 & 27.04 & 56.12 & 3 & 2564.2387 & 2564.2349 & 855.7522 & 0.0038 & 1.4802 & 20.798\end{array}$ $\begin{array}{llllllllllll}\text { WGDAGAEYVVESTGVFTTMEK } & 0.60 & 25.19 & 27.04 & 38.19 & 3 & 2564.2387 & 2564.2349 & 855.7522 & 0.0038 & 1.4802 & 10.900\end{array}$

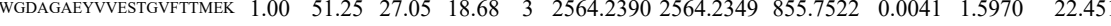
$\begin{array}{lllllllllllll}1.00 & 51.25 & 27.05 & 18.68 & 3 & 2564.2390 & 2564.2349 & 855.7522 & 0.0041 & 1.5970 & 22.451\end{array}$

VIPELNGK VIPELNGK VIPELNGK VIPELNGK VIPELNGK VIPELNGK VIPELNGK

VIPELNGK $\begin{array}{lllllllllll}1.00 & 49.22 & 24.55 & 20.57 & 4 & 4324.0909 & 4324.0917 & 1082.0302 & -0.0008 & -0.1848 & 7.469 \\ 1.00 & 39.65 & 24.94 & 18.06 & 4 & 4324.189 & 4324.0917 & 1082.0302 & 0.0272 & 6.2844 & 6.943\end{array}$ $\begin{array}{llllllllllll}1.00 & 39.65 & 24.94 & 18.06 & 4 & 4324.1189 & 4324.0917 & 1082.0302 & 0.0272 & 6.2844 & 6.943 \\ 0.97 & 30.41 & 23.98 & 23.72 & 2 & 1156.7060 & 11567059 & 579.3602 & 0.0001 & 0.0863 & 153.297\end{array}$ $\begin{array}{llllllllllll}0.97 & 30.41 & 23.98 & 23.72 & 2 & 1156.7060 & 1156.7059 & 579.3602 & 0.0001 & 0.0863 & 153.297 \\ 0.98 & 28.75 & 24.33 & 25.71 & 2 & 1156.7068 & 1156.7059 & 579.3602 & 0.0009 & 0.7767 & 387.470 \\ 1.00 & 37.74 & 24.33 & 25.29 & 2 & 156.7068 & 156.7059 & 579.3602 & 0.000 & 0.7767 & 395.755\end{array}$ $\begin{array}{llllllllllll}0.98 & 28.75 & 24.33 & 25.71 & 2 & 1156.7068 & 1156.7059 & 579.3602 & 0.0009 & 0.7767 & 387.470 & 38.3\end{array}$ $\begin{array}{lllllllllll}1.00 & 37.74 & 4.33 & 25.29 & 2 & 1156.7068 & 156.7059 & 579.3602 & 0.0009 & 0.7767 & 395.755 \\ 1.00 & 35.98 & 24.33 & 21.63 & 2 & 1156.7068 & 1156.7059 & 579.3602 & 0.0009 & 0.7767 & 323.921\end{array}$ $\begin{array}{lllllllllll}1.08 & 28.65 & 24.33 & 22.01 & 2 & 1156.7070 & 1156.7059 & 579.3602 & 0.0011 & 0.9493 & 392.788\end{array}$ $\begin{array}{lllllllllll}0.98 & 28.22 & 24.36 & 24.08 & 2 & 1156.7080 & 1156.7059 & 579.3602 & 0.0021 & 1.8123 & 502.142\end{array}$ $\begin{array}{llllllllllll}0.99 & 34.09 & 4.44 & 23.59 & 2 & 1156.7088 & 1156.7059 & 579.3602 & 0.0029 & 2.5028 & 187.614\end{array}$ $\begin{array}{lllllllllll}0.99 & 39.14 & 24.30 & 25.91 & 2 & 1156.7100 & 1156.7059 & 579.3602 & 0.0041 & 3.5384 & 312.464\end{array}$ $\begin{array}{lllllllllllll}0.89 & 30.93 & 24.22 & 20.78 & 2 & 1156.7114 & 1156.7059 & 579.3602 & 0.0055 & 4.7466 & 442.715 & 371.480\end{array}$ 


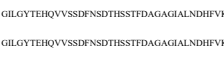
$\begin{array}{lllllllllll}1.00 & 48.17 & 24.52 & 19.97 & 4 & 4324.0949 & 4324.0917 & 1082.0302 & 0.0032 & 0.7394 & 16.151\end{array}$ $\begin{array}{lllllllllll}10 & 57.28 & 24.52 & 70.28 & 4 & 4324.0949 & 4324.0917 & 1082.0302 & 0.0032 & 0.7394 & 4.836\end{array}$

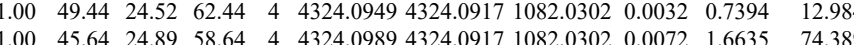
$\begin{array}{lllllllllll}1.00 & 45.64 & 24.89 & 58.64 & 4 & 4324.0989 & 4324.0917 & 1082.0302 & 0.0072 & 1.6635 & 74.389 \\ 1.00 & 54.60 & 24.89 & 67.60 & 4 & 4324.0989 & 4324.0917 & 1082.0302 & 0.0072 & 1.6635 & 2271\end{array}$

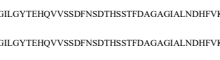
$\begin{array}{lllllllllll}1.00 & 54.60 & 24.89 & 67.60 & 4 & 4324.0989 & 4324.0917 & 1082.0302 & 0.0072 & 1.6635 & 2.271 \\ 1.00 & 62.02 & 24.93 & 75.02 & 4 & 4324.1109 & 4324.0917 & 10820302 & 0.0192 & 4.4361 & 13.509\end{array}$ $\begin{array}{llllllllllll}0.85 & 29.19 & 25.76 & 23.16 & 2 & 981.5482 & 981.5487 & 491.7816 & -0.0005 & -0.5084 & 86.897\end{array}$

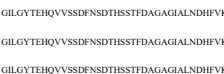
$\begin{array}{lllllllllllll}1.00 & 59.85 & 24.55 & 17.13 & 4 & 4324.0909 & 4324.0917 & 10820302 & -0.0008 & -0.1848 & 35.837\end{array}$

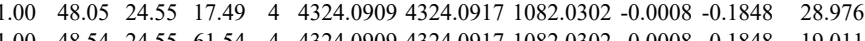
$\begin{array}{llllllllllll}1.00 & 48.54 & 24.55 & 61.54 & 4 & 4324.0909 & 4324.0917 & 1082.0302 & -0.0008 & -0.1848 & 19.011 \\ 1.00 & 57.10 & 24.52 & 70.10 & 4 & 4324.0949 & 4324.0917 & 1082.0302 & 0.0032 & 0.7394 & 49.773\end{array}$ $\begin{array}{lllllllllllll}1.00 & 53.34 & 24.52 & 66.34 & 4 & 4324.0949 & 4324.0917 & 1082.0302 & 0.0032 & 0.7394 & 60.388\end{array}$ $\begin{array}{llllllllllll}1.00 & 50.01 & 24.52 & 19.36 & 4 & 4324.0949 & 4324.0917 & 1082.0302 & 0.0032 & 0.7394 & 96.443\end{array}$ $\begin{array}{llllllllllll}1.00 & 51.41 & 24.52 & 16.23 & 4 & 4324.0949 & 4324.0917 & 1082.0302 & 0.0032 & 0.7394 & 35.592 \\ 1.00 & 38.11 & 24.52 & 16.25 & 4 & 4324.0949 & 4324.0917 & 1082.0302 & 0.0032 & 0.7394 & 150.706\end{array}$ $\begin{array}{lllllllllll}1.00 & 38.11 & 24.52 & 16.25 & 4 & 4324.0949 & 4324.0917 & 1082.0302 & 0.0032 & 0.7394 & 150.706\end{array}$ $\begin{array}{llllllllllll}1.00 & 48.52 & 24.52 & 61.52 & 4 & 4324.0949 & 4324.0917 & 1082.0302 & 0.0032 & 0.7394 & 25.455\end{array}$ $\begin{array}{lllllllllll}1.00 & 47.64 & 24.52 & 20.78 & 4 & 4324.0949 & 4324.0917 & 1082.0302 & 0.0032 & 0.7394 & 28.392 \\ 1.00 & 44.91 & 24.52 & 57.91 & 4 & 4324.0949 & 4324.0917 & 1082.0302 & 0.0032 & 0.7394 & 18.76\end{array}$ $\begin{array}{llllllllllll}1.00 & 50.71 & 24.52 & 63.71 & 4 & 4324.0949 & 4324.0917 & 1082.0302 & 0.0032 & 0.7394 & 18.79\end{array}$ $\begin{array}{lllllllllll}1.00 & 72.87 & 24.52 & 85.87 & 4 & 4324.0949 & 4324.0917 & 1082.0302 & 0.0032 & 0.7394 & 9.268\end{array}$

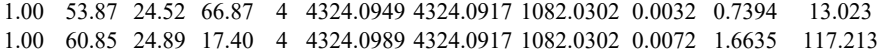
$\begin{array}{lllllllllll}1.00 & 58.20 & 24.89 & 71.20 & 4 & 4324.0989 & 4324.0917 & 1082.0302 & 0.0072 & 1.6635 & 78.173\end{array}$ $\begin{array}{lllllllllll}1.00 & 41.03 & 24.87 & 17.39 & 4 & 4324.1029 & 4324.0917 & 1082.0302 & 0.0112 & 2.5877 & 30.065\end{array}$ $\begin{array}{llllllllllll}1.00 & 52.49 & 24.87 & 18.74 & 4 & 4324.1029 & 4324.0917 & 1082.0302 & 0.0112 & 2.5877 & 29.886 \\ 1.00 & 38.17 & 24.91 & 19.09 & 4 & 4324.1069 & 4324.0917 & 1082.0302 & 0.0152 & 3.5119 & 57.783\end{array}$ $\begin{array}{lllllllllll}1.00 & 52.42 & 24.50 & 16.29 & 4 & 4324.0869 & 4324.0917 & 1082.0302 & -0.0048 & -1.1090 & 12.702\end{array}$

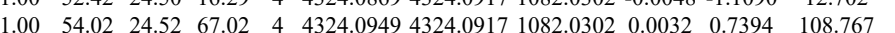
$\begin{array}{llllllllllll}1.00 & 52.54 & 24.52 & 65.54 & 4 & 4324.0949 & 4324.0917 & 1082.0302 & 0.0032 & 0.7394 & 34.130\end{array}$

FHGTVK $\begin{array}{lllllllllllll}0.64 & 18.25 & 28.55 & 22.78 & 2 & 975.5760 & 975.5746 & 488.7946 & 0.0014 & 1.4321 & 449.943 & 2\end{array}$ $\begin{array}{llllllllllll}\text { VIISAPSADAPMFVMGVNHEK } & 0.67 & 57.68 & 26.69 & 0.68 & 3 & 250.3093 & 2500.3062 & 834.4427 & 0.0031 & 1.2383 & 44.263 \\ \text { VIISAPSADAPMFVMGVNHEK } & 1.00 & 69.09 & 26.60 & 20.05 & 3 & 2500.3129 & 2500.3062 & 834.4427 & 0.0067 & 2.6764 & 34.260\end{array}$ $\begin{array}{lllllllllllll}\text { VIISAPSADAPMFVMGVNHEK } & 0.98 & 55.48 * & 27.16 & 21.58 & 3 & 2516.3026 & 2516.3011 & 839.7743 & 0.0015 & 0.5954 & 1293.433\end{array}$

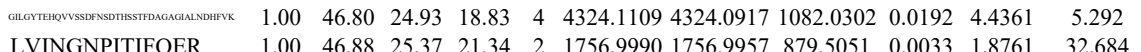

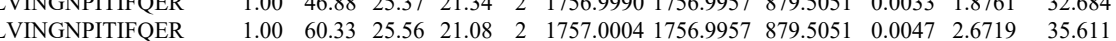
$\begin{array}{lllllllllllll}\text { WGDAGAEYVVESTGVFTTMEK } & 0.75 & 17.98 & 26.95 & 20.02 & 3 & 2564.2345 & 2564.2349 & 855.7522 & -0.0004 & -0.1558 & 10.048\end{array}$

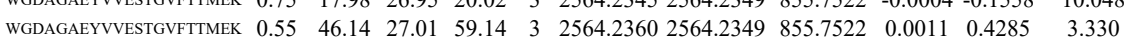
$\begin{array}{llllllllllll}\text { LISWYDNEFGYSNR } & 0.98 & 58.33 & 25.44 & 17.34 & 2 & 1906.8856 & 1906.8971 & 954.4558 & -0.0115 & -6.0244 & 21.833\end{array}$

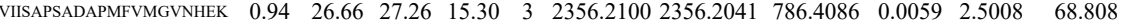

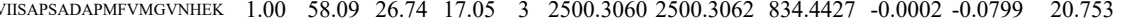

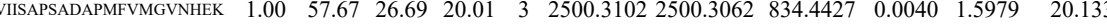

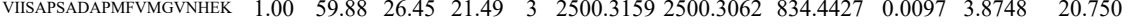
$\begin{array}{lllllllllllll}\text { VIISAPSADAPMFVMGVNHEK } & 0.96 & 43.57 * & 27.13 & 16.65 & 3 & 2516.3038 & 2516.3011 & 839.7743 & 0.0027 & 1.0717 & 1546.708 & 97 .\end{array}$ $\begin{array}{lllllllllllll}\text { LISWYDNEFGYSNR } & 0.64 & 64.07 & 26.16 & 77.07 & 2 & 1906.8968 & 1906.8971 & 954.4558 & -0.0003 & -0.1572 & 39.732 \\ \text { LISWYDNEFGYSNR } & 0.99 & 40.93 & 26.19 & 18.35 & 2 & 1906.8970 & 1906.8971 & 954.4558 & -0.0001 & -0.0524 & 11.057\end{array}$ $\begin{array}{lllllllllllll}\text { LISWYDNEFGYSNR } & 0.99 & 40.93 & 26.19 & 18.35 & 2 & 1906.8970 & 1906.8971 & 954.4558 & -0.0001 & -0.0524 & 11.057 & 6.688 \\ \text { LSWYDNEFGYSNR } & 0.82 & 74.48 & 26.27 & 87.78 & 2 & 19068986 & 19068971 & 954.4558 & 0.0015 & 0.7858 & 621.791 & 5157.577\end{array}$

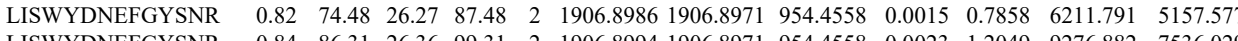
LISWYDNEFGYSNR $\begin{array}{lllllllllllllll}0.84 & 86.31 & 26.36 & 99.31 & 2 & 1906.8994 & 1906.8971 & 954.4558 & 0.0023 & 1.2049 & 9276.882 & 7536.029\end{array}$ $\begin{array}{llllllllllll}0.61 & 14.14 & 26.44 & 14.80 & 3 & 1906.9024 & 1906.8971 & 636.6396 & 0.0053 & 2.7750 & 128.002 \\ 1.00 & 41.79 & 26.44 & 18.90 & 3 & 1906.9024 & 1906.8771 & 636.6396 & 0.0053 & 2.7750 & 305.023\end{array}$ $\begin{array}{llllllllllllll}\text { VIISAPSADAPMFVMGVNHEK } & 1.00 & 81.41 & 26.77 & 18.92 & 2 & 2500.3074 & 2500.3062 & 1251.1604 & 0.0012 & 0.4796 & 289.033\end{array}$ $\begin{array}{llllllllllllll}\text { VISAPADAPMFVMGVNHEK } & 0.82 & 68.30 & 26.77 & 81.30 & 2 & 2500.3074 & 2500.3062 & 1251.1604 & 0.0012 & 0.4796 & 425.605\end{array}$ 
$\begin{array}{llllllllllllll}\text { MISAPSADAPMFVMGVNHEK } & 0.84 & 57.50 * & 26.53 & 24.77 & 3 & 2516.3248 & 2516.3011 & 839.7743 & 0.0237 & 9.4072 & 979.846 \\ \text { VIISAPSADAPMFVMGVNHEK } & 0.80 & 57.25 * & 26.53 & 26.38 & 3 & 2516.3248 & 2516.3011 & 839.7743 & 0.0237 & 9.4072 & 675.613\end{array}$

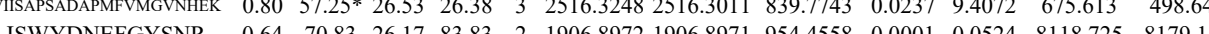

$\begin{array}{llllllllllll} & 0.00724 & 675.613 & 498.649\end{array}$

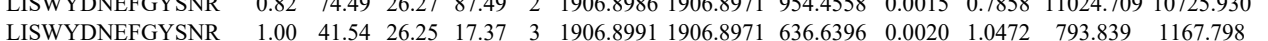

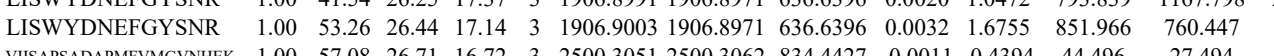

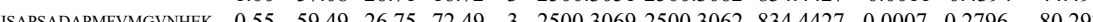

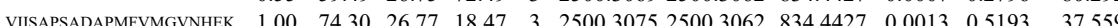

$\begin{array}{lllllllllllllll}\text { VIISAPSADAPMFVMGVNHEK } & 0.66 & 69.55 & 26.75 & 82.55 & 3 & 2500.3081 & 2500.3062 & 834.4427 & 0.0019 & 0.7590 & 36.200 & 3\end{array}$

$\begin{array}{llllllllllll}\text { VIISAPSADAPMFYMGVNHEK } & 0.72 & 65.21 & 26.69 & 78.21 & 2 & 2500.3094 & 2500.3062 & 1251.1604 & 0.0032 & 1.2788 & 292.715\end{array}$

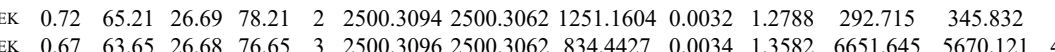

$\begin{array}{llllllllllllll} & \end{array}$

$\begin{array}{llllllllllll} & \end{array}$

$\begin{array}{llllllllllllll}\text { VIISAPSADAPMFVMGVNHEK } & 1.00 & 70.95 & 26.69 & 21.50 & 3 & 2500.3102 & 2500.3062 & 834.4427 & 0.0040 & 1.5979 & 55.376 & 56.707 & \end{array}$

$\begin{array}{lllllllllllllll} & 26.14 & 3 & 2500.3102 & 2500.3062 & 834.4427 & 0.0040 & 1.5979 & 42.450 & 26.780\end{array}$

$\begin{array}{lllllllllllll}\text { VISAPSADAPMFVMGVNHEK } & 1.00 & 71.43 & 26.65 & 20.38 & 3 & 2500.3108 & 2500.3062 & 834.4427 & 0.0046 & 1.8376 & 56.681 & 40.106 \\ \text { VISAPSADAPMFVMGVNHEK } & 1.00 & 36.48 & 26.60 & 17.06 & 4 & 2500.3133 & 25003062 & 626.0838 & 0.0071 & 2.8351 & 211.276 & 409.024\end{array}$

$\begin{array}{llllllllllllll} & \end{array}$

$\begin{array}{lllllllllllllll} & \text { VISAPSADAPMFVMGVNHEK } & 0.96 & 68.32 * & 26.54 & 20.72 & 3 & 2516.3218 & 2516.3011 & 839.7743 & 0.0207 & 8.2164 & 982.058 & 671.469\end{array}$

$\begin{array}{lllllllllllll}\text { VIIIAPSADAPMFVMGVNHEK } & 1.00 & 54.31 & 27.28 & 19.10 & 3 & 2532.2908 & 2532.2960 & 845.1059 & -0.0052 & -2.0510 & 202.274 & 111.602 \\ \text { LISWYYDNEFGYSNR } & 0.64 & 74.31 & 26.16 & 87.31 & 2 & 1906.8968 & 1906.8971 & 954.4558 & -0.0003 & -0.1572 & 8628.905 & 9480.013\end{array}$

$\begin{array}{lllllllllllllll}\text { LISWYDNEFGYSNR } & 0.64 & 79.38 & 26.15 & 92.38 & 2 & 1906.8976 & 1906.8971 & 954.4558 & 0.0005 & 0.2619 & 3667.288 & 2641.259\end{array}$

$\begin{array}{lllllllllllllll}\text { VIISAPSADAPMFVMGVNHEK } & 0.82 & 70.84 & 26.77 & 83.84 & 2 & 2500.3074 & 2500.3062 & 1251.1604 & 0.0012 & 0.4796 & 241.167 & 256.117\end{array}$

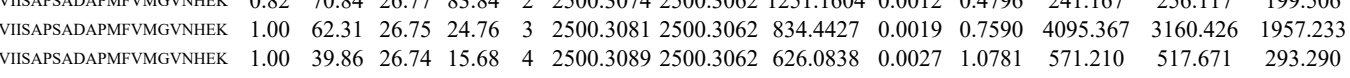

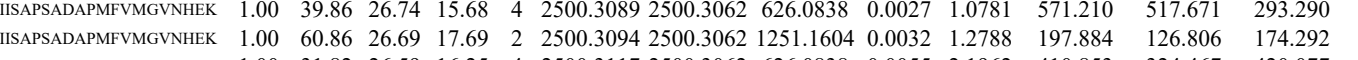

$\begin{array}{llllllllllllll} & \end{array}$

VVDLMAHMASK

$\begin{array}{llllllllllll}1.00 & 56.24 & 27.94 & 26.50 & 3 & 1488.8143 & 1488.8036 & 497.2751 & 0.0107 & 7.1724 & 8637.983 & 6282.810\end{array}$

.077

$\begin{array}{lllllllllllll}\text { LISWYDNEFGYSNR } & 0.64 & 61.81 & 26.16 & 74.81 & 2 & 1906.8968 & 1906.8971 & 954.4558 & -0.0003 & -0.1572 & 3276.895 & 3166.725\end{array}$

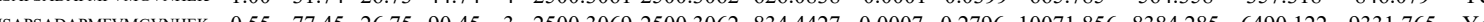

$\begin{array}{llllllllllllllll}\text { VIISAPSADAPMFYMGVNHEK } & 1.00 & 86.11 & 26.77 & 20.09 & 2 & 2500.3074 & 2500.3062 & 1251.1604 & 0.0012 & 0.4796 & 167.071 & 86.174 & 62.653 & 82.776 & \text { YeS }\end{array}$

$\begin{array}{lllllllllllllllll}\text { VIISAPSADAPMFVMGVNHEK } & 1.00 & 73.88 & 26.75 & 18.39 & 3 & 2500.3081 & 2500.3062 & 834.4427 & 0.0019 & 0.7590 & 2933.079 & 3372.868 & 2842.424 & 4099.470 & \text { Yes }\end{array}$

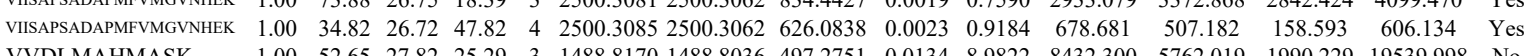

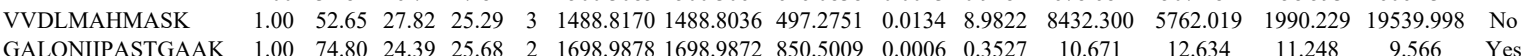

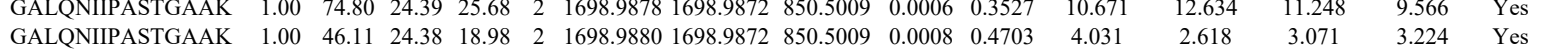

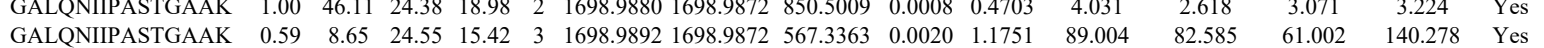
$\begin{array}{llllllllllllllll}\text { GALQNIIPASTGAAK } & 1.00 & 85.00 & 23.65 & 21.18 & 2 & 1699.0024 & 1698.9872 & 850.5009 & 0.0152 & 8.9358 & 9560.480 & 6817.793 & 5407.264 & 7711.716 & \text { Yes }\end{array}$ $\begin{array}{llllllllllllllll}\text { GALQNIIPASTGAAK } & 1.00 & 58.73 & 23.50 & 18.60 & 2 & 1699.0038 & 1698.9872 & 850.5009 & 0.0166 & 9.7589 & 35043.696 & 28535.672 & 22744.890 & 34142.167 & \text { Yes }\end{array}$

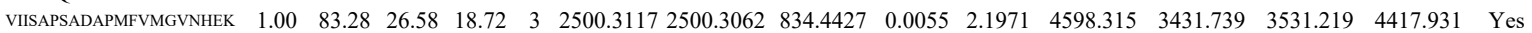

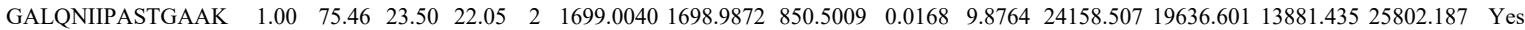

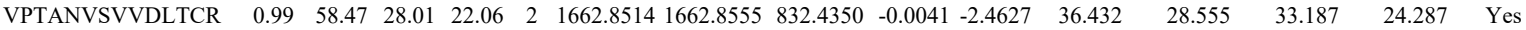
$\begin{array}{llllllllllllllll}\text { VPTANVSVVDLTCR } & 1.00 & 49.71 & 27.99 & 25.27 & 3 & 1662.8578 & 1662.8555 & 555.2924 & 0.0023 & 1.3807 & 95.708 & 125.902 & 63.540 & 108.237 & \text { Yes }\end{array}$

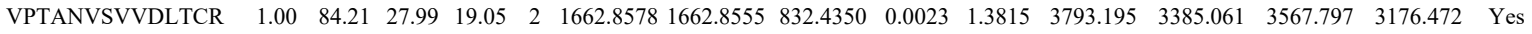
$\begin{array}{lllllllllllllllll}\text { VPTANVSVVDLTCR } & 1.00 & 58.48 & 28.06 & 17.72 & 2 & 1662.8580 & 1662.8555 & 832.4350 & 0.0025 & 1.5016 & 3296.444 & 3289.765 & 2889.174 & 4859.520 & \text { Yes }\end{array}$ $\begin{array}{llllllllllllllll}\text { VPTANVSVVDLTCR } & 1.00 & 59.29 & 28.04 & 24.15 & 2 & 1662.8582 & 1662.8555 & 832.4350 & 0.0027 & 1.6217 & 159.727 & 97.849 & 39.660 & 149.098 & \text { Yes }\end{array}$ $\begin{array}{llllllllllllllll}\text { VPTANVSVVDLTCR } & 0.99 & 27.51 & 27.94 & 19.80 & 3 & 1662.8587 & 1662.8555 & 555.2924 & 0.0032 & 1.9209 & 166.480 & 161.664 & 62.169 & 147.797 & \text { Yes }\end{array}$ $\begin{array}{llllllllllllllll}\text { VPTANVSVVDLTCR } & 1.00 & 70.67 & 27.87 & 24.59 & 2 & 1662.8588 & 1662.8555 & 832.4350 & 0.0033 & 1.9821 & 130.757 & 162.282 & 193.010 & 149.743 & \text { No }\end{array}$

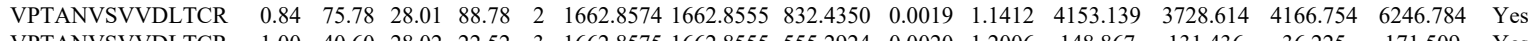

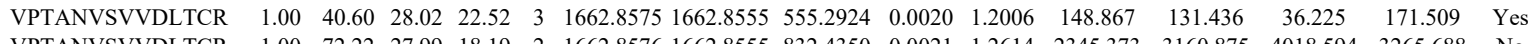

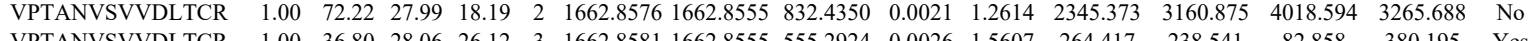
$\begin{array}{lllllllllllllllll}\text { VPTANVSVVDLTCR } & 1.00 & 36.80 & 28.06 & 26.12 & 3 & 1662.8581 & 1662.8555 & 555.2924 & 0.0026 & 1.5607 & 264.417 & 238.541 & 82.858 & 380.195 & \text { Yes } \\ \text { VPTANVSVVDLTCR } & 1.0 & 85.48 & 27.58 & 23.59 & 2 & 16628638 & 16628555 & 832.435 & 0.0083 & 4.9853 & 1519.526 & 1345.02 & 130.430 & 1409243 & \text { Yes }\end{array}$

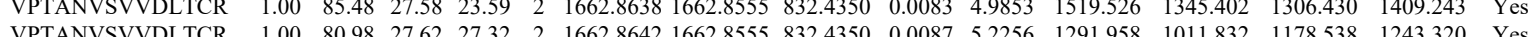

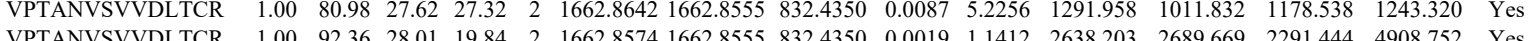

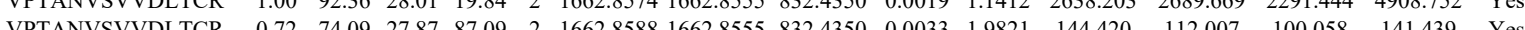

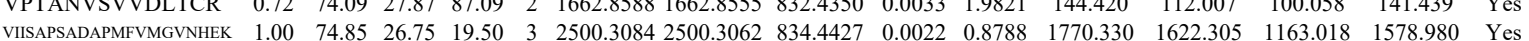




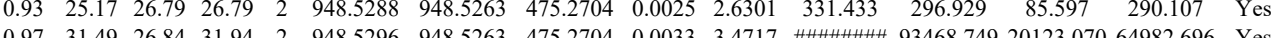

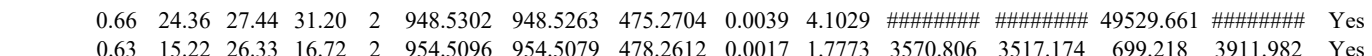

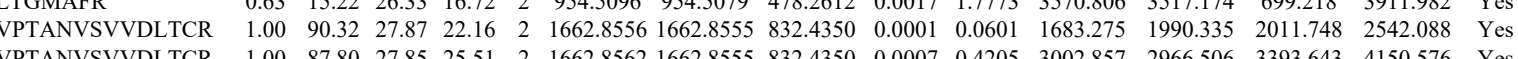

$\begin{array}{lllllllllllllllll}\text { VPTANVSVVDLTCR } & 1.00 & 87.80 & 27.85 & 25.51 & 2 & 1662.8562 & 1662.8555 & 832.4350 & 0.0007 & 0.4205 & 3002.857 & 2966.506 & 3393.643 & 4150.576 & \text { Yes } \\ \text { VGVNGFGR } & 0.61 & 25.21 & 27.54 & 19.66 & 2 & 948.5256 & 948.5263 & 475.2704 & -0.0007 & -0.7364 & 75.441 & 73.551 & 24.185 & 68.639 & \text { Yes } \\ \text { VGVGE }\end{array}$

VGVNGFGR

VGVNGFGR

VGVNGFGR

VGVNGFGR

VPTANVSVVDLTCR

LVINGNPITIFQER VGVNGFGR

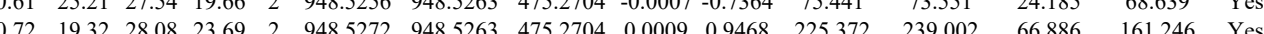
$\begin{array}{llllllllllllllll}0.90 & 23.23 & 26.81 & 23.61 & 2 & 948.5280 & 948.5263 & 475.2704 & 0.0017 & 1.7885 & 110.769 & 100.288 & 22.192 & 95.502 & \text { Yes }\end{array}$ $\begin{array}{lllllllllllllll}0.99 & 36.53 & 26.84 & 30.41 & 2 & 948.5292 & 948.5263 & 475.2704 & 0.0029 & 3.0509 & 34653.323 & 30045297 & 7100.869 & 21007.740 & \text { Yes }\end{array}$ $\begin{array}{lllllllllllllll}0.94 & 29.17 & 26.84 & 29.52 & 2 & 948.5292 & 948.5263 & 475.2704 & 0.0029 & 3.0509 & 84438.336 & 78486.041 & 17526.293 & 50206.444 & \text { Yes }\end{array}$

$\begin{array}{lllllllllllllll}1.00 & 85.75 & 27.98 & 19.07 & 2 & 16628566 & 16628555 & 832.4350 & 0.0011 & 0.6607 & 323.582 & 178.576 & 294.541 & 321.575 & \text { Yes }\end{array}$

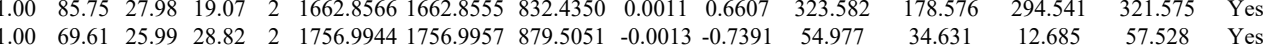

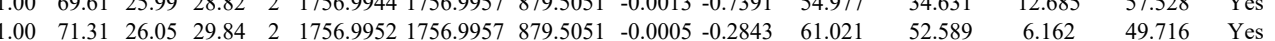
$\begin{array}{llllllllllllllll}0.99 & 35.14 & 26.81 & 30.23 & 2 & 948.5280 & 948.5263 & 475.2704 & 0.0017 & 1.7885 & 53237.649 & 50288.029 & 9574.863 & 29936.978 & \text { Yes }\end{array}$ $\begin{array}{llllllllllllllllll} & 0.97 & 28.86 & 26.83 & 29.35 & 2 & 948.5282 & 948.5263 & 475.2704 & 0.0019 & 1.9989 & 29467.293 & 25204.829 & 6222.756 & 19103.996 & \text { Yes } \\ \text { LVINGNPITIFQER } & 1.00 & 45.21 & 25.90 & 28.31 & 2 & 1756.9966 & 1756.9957 & 879.5051 & 0.0009 & 0.5117 & 1527.074 & 1086.579 & 94.778 & 2569.954 & \text { Ys }\end{array}$ $\begin{array}{lllllllllllll} & & 1.00 & 45.21 & 25.90 & 28.31 & 2 & 1756.9966 & 1756.9957 & 879.5051 & 0.0009 & 0.5157 & 15\end{array}$ VINGNPITIFQE

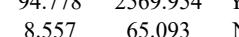

LVINGNPITIFQE $\begin{array}{lllllllllllllll}1.00 & 68.08 & 25.88 & 29.52 & 2 & 1756.9972 & 1756.9957 & 879.5051 & 0.0015 & 0.8528 & 75.313 & 51.217 & 0.000 & 76.457 & \text { No }\end{array}$

LVINGNPITIFQER

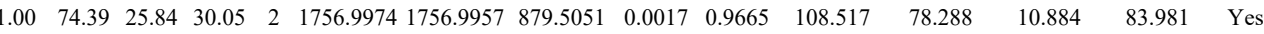
LVINGNPITIFQER

VIHDNFGIVEGLMTTVHATATQ $\begin{array}{lllllllllllll}1.00 & 74.04 & 25.58 & 30.02 & 2 & 1756.9980 & 1756.9957 & 879.5051 & 0.0023 & 1.3076 & 70.786 & 55.187\end{array}$ $\begin{array}{llllllllllllll}0.91 & 17.20 & 25.40 & 15.79 & 3 & 1756.9990 & 1756.9957 & 586.6725 & 0.0033 & 1.8750 & 272.685 & 174.523\end{array}$

VGVNGFGR

VGVNGFGR

LVINGNPITIFQER

LVINGNPITIFQER

LVINGNPITFQER

UVINGNTER

LVINGPITIFQER

DVINGPITIFQER

VINGNPITIFQER

VINGNPITIFQER

LVINGNPITIFQER

LVINGNPITIFOER

LVINGNPITIFOER

LVINGNPITIFQER

LVINGNPITIFQER

LVINGNPITIFQER

LVINGNPITIFQER

LVINGNPITIFQER

LVINGNPITIFQER

DVINGNPITFQER

LVINGNPITIFQER

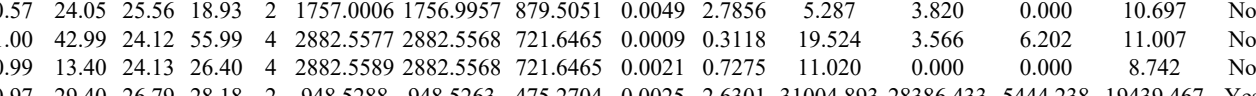

3.820

$\begin{array}{lll}0.574 & 54.768 & \text { No }\end{array}$ $\begin{array}{llllllllllllllll}0.97 & 29.40 & 26.79 & 28.18 & 2 & 948.5288 & 948.5263 & 475.2704 & 0.0025 & 2.6301 & 31004.893 & 28386.433 & 5444.238 & 19439.467 & \text { Yo }\end{array}$ $\begin{array}{lllllllllllllllll} & \end{array}$

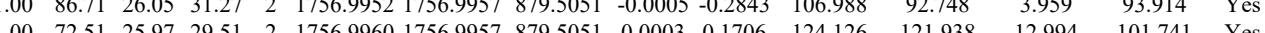

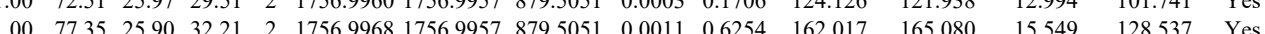
$\begin{array}{llllllllllllll}1.00 & \end{array}$ $\begin{array}{lllllllllllllll}1.00 & 78.24 & 25.90 & 32.39 & 2 & 17569968 & 1756.9957 & 879.5051 & 0.0011 & 0.6254 & 151.334 & 113.672 & 16.613 & 82.617 & \text { Yes }\end{array}$

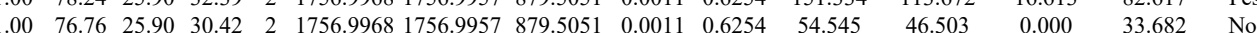

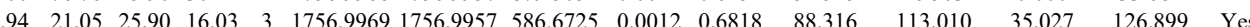
$\begin{array}{lllllllllllllllll}0.72 & 14.11 & 25.90 & 17.61 & 3 & 1756.9969 & 17569957 & 586.6725 & 0.0012 & 0.6818 & 56.739 & 67.090 & 28.136 & 97.914 & \text { Yes }\end{array}$ $\begin{array}{lllllllllllllll}1.00 & 46.03 & 25.90 & 30.01 & 2 & 1756.9970 & 1756.9957 & 879.5051 & 0.0013 & 0.7391 & 5780.109 & 2983.781 & 368.865 & 8707.161 & \text { Yes }\end{array}$

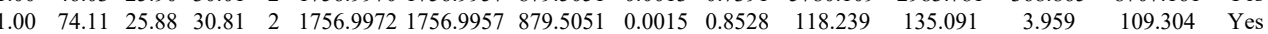
$\begin{array}{lllllllllllllll}1.00 & 60.40 & 25.88 & 28.78 & 2 & 1756.9972 & 1756.9957 & 879.5051 & 0.0015 & 0.8528 & 2461.052 & 1778.449 & 84.729 & 2509.725 & \text { Yes }\end{array}$ $\begin{array}{llllllllllllllll}1.00 & 86.61 & 25.84 & 31.81 & 2 & 1756.9974 & 1756.9957 & 879.5051 & 0.0017 & 0.9665 & 137.104 & 88.767 & 12.281 & 94.665 & \text { Yes }\end{array}$

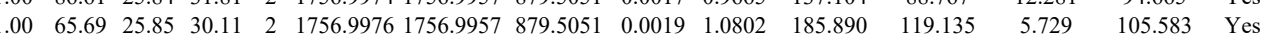

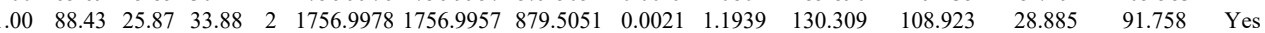

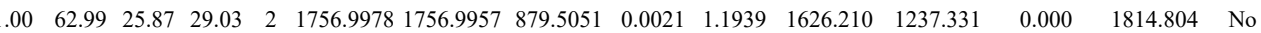
$\begin{array}{lllllllllllllll}1.00 & 86.48 & 25.58 & 31.70 & 2 & 1756.9980 & 1756.9957 & 879.5051 & 0.0023 & 1.3076 & 158.855 & 98.819 & 12.864 & 124.102 & \text { Yes }\end{array}$

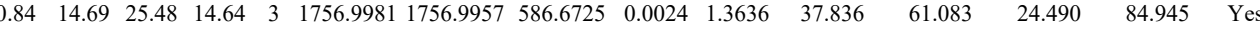

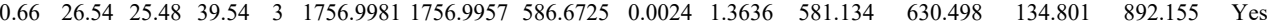
$\begin{array}{lllllllllllllll}1.00 & 53.55 & 25.37 & 29.92 & 2 & 1756.9984 & 1756.9957 & 879.5051 & 0.0027 & 1.5350 & 9494.061 & 6525.846 & 0.000 & 15451.062 & \text { No }\end{array}$

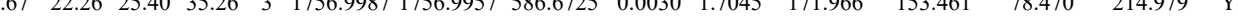

LVINGNPITIFQER

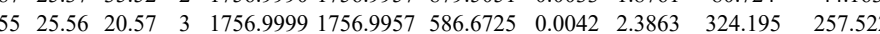
No

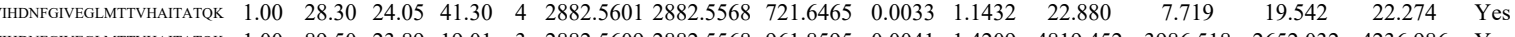
$\begin{array}{llllllllllllllllll} & & \end{array}$ $\begin{array}{llllllllllllllll}\text { VIHDNFGIVEGLMTTVHAITATQK } & 1.00 & 15.84 & 23.84 & 28.84 & 4 & 2882.5613 & 2882.5568 & 721.6465 & 0.0045 & 1.5589 & 10.879 & 26.443 & 12.743 & 62.222 & \text { No }\end{array}$

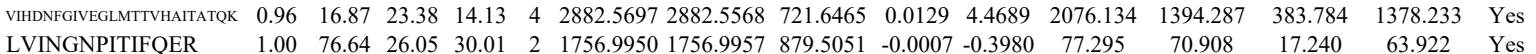
LVINGNPITIFQER

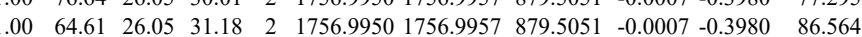
$\begin{array}{lllllllllll}.00 & 92.50 & 25.90 & 31.24 & 2 & 1756.9968 & 1756.9957 & 879.5051 & 0.0011 & 0.6254 & 59.722\end{array}$ $\begin{array}{lllllllllllll}1.00 & 7.54 & 25.88 & 29.91 & 2 & 1756.9972 & 1756.9957 & 879.5051 & 0.0015 & 0.8528 & 77.732\end{array}$ $\begin{array}{llllllllllll}1.00 & 36.40 & 25.84 & 24.95 & 2 & 1756.9974 & 1756.9957 & 879.5051 & 0.0017 & 0.9665 & 679.923 & 310.620\end{array}$ 

\begin{tabular}{lllllllllllllllll} 
VHDNFGIVEGLMTTVHAITATOK & 1.00 & 36.19 & 23.50 & 18.44 & 4 & 2882.5661 & 2882.5568 & 721.646 & 0.006 & 2.1132 & 18.737 & 9.189 & 14.040 & 18.780 & Yes \\
\hline
\end{tabular} $\begin{array}{lllllllllllllllll} & \end{array}$

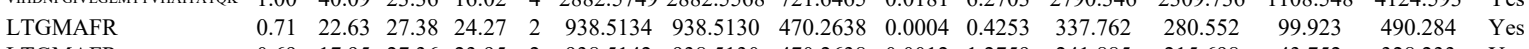
$\begin{array}{lllllllllllllll}0.69 & 17.95 & 27.36 & 23.95 & 2 & 938.5142 & 938.5130 & 470.2638 & 0.0012 & 1.42759 & 271.885 & 215.598 & 43.752 & 328.233 & \text { Yes }\end{array}$

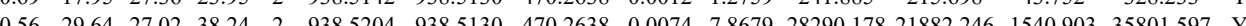

VKVGVNGFGR

VVINGNPITIFQER

LVINGNPITIFQER

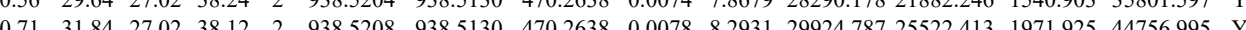

LVINGNPITIFQER

$\begin{array}{lllllllllllllll}0.72 & 32.81 & 23.86 & 19.70 & 3 & 1319.7976 & 1319.7918 & 440.9379 & 0.0058 & 4.3846 & 13292.487 & 12531.839 & 4803.303 & 10895.376 & \text { Yes }\end{array}$ $\begin{array}{llllllllllllllll}0.99 & 41.18 & 26.06 & 15.99 & 3 & 1756.9924 & 1756.9957 & 586.6725 & -0.0033 & -1.8750 & 1699.041 & 1815.652 & 562.972 & 1668.532 & \text { Yes }\end{array}$ $\begin{array}{lllllllllllllll}1.00 & 82.05 & 25.97 & 33.04 & 2 & 1756.9930 & 1756.9957 & 879.5051 & -0.0027 & -1.5350 & 14918.621 & 12437.432 & 751.996 & 10479.282 & \text { Yes }\end{array}$

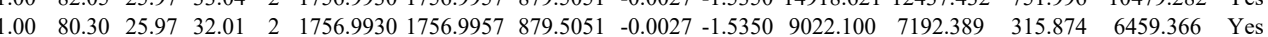
$\begin{array}{llllllllllllllllll} & & 1756.869 & 814.402 & \text { Yes }\end{array}$ $\begin{array}{llllllllllllllll}\text { VIHDNFGIVEGLMTTVHAITATOK } & 0.66 & 93.65 & 24.13 & \text { \#\#\#\# } 3 & 2882.5591 & 2882.5568 & 961.8595 & 0.0023 & 0.7971 & 2607.133 & 2174.123 & 1253.435 & 2621.290 & \text { Yes }\end{array}$ $\begin{array}{lllllllllllllllll}\text { LTGMAFR } & 0.97 & 30.24 & 27.46 & 27.75 & 2 & 938.5136 & 938.5130 & 470.2638 & 0.0006 & 0.6379 & 488.650 & 399.241 & 42.230 & 776.292 & \text { Yes }\end{array}$ $\begin{array}{llllllllllllllll}\text { LTGMAFR } & 0.96 & 28.25 & 27.49 & 29.05 & 2 & 938.5138 & 938.5130 & 470.2638 & 0.0008 & 0.8506 & 472.935 & 447.718 & 43.943 & 646.969 & \text { Yes }\end{array}$ $\begin{array}{lllllllllllllllll}\text { LTGMAFR } & 0.98 & 31.74 & 27.39 & 28.71 & 2 & 938.5140 & 938.5130 & 470.2638 & 0.0010 & 1.0632 & 448.626 & 397.700 & 49.084 & 665.546 & \text { Yes }\end{array}$

LTGMAFR

LTGMAFR

LTGMAFR

LTGMAFR

LTGMAFR

LTGMAFR

LTGMAFR

LTGMAFR

LTGMAR

LTGMAFR

LTGMAFR

LTGMAFR

LTGMAFR

LTGMAFR

LVINGNPITIFQER

LVINGNPITIFQER $\begin{array}{lllllllllllllllll}0.96 & 28.25 & 27.39 & 30.80 & 2 & 938.5140 & 938.5130 & 470.2638 & 0.0010 & 1.0632 & 449.708 & 459.229 & 53.993 & 653.541 & \text { Yes }\end{array}$

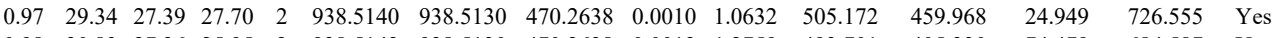
$\begin{array}{lllllllllllllll}0.98 & 30.83 & 27.36 & 25.95 & 2 & 938.5142 & 938.5130 & 470.2638 & 0.0012 & 1.2759 & 493.701 & 405.330 & 74.479 & 684.587 & \text { Yes }\end{array}$ $\begin{array}{lllllllllllllll}0.98 & 32.80 & 27.36 & 26.12 & 2 & 938.5142 & 938.5130 & 470.2638 & 0.0012 & 1.2759 & 578.353 & 442.154 & 47.620 & 819.018 & \text { Yes }\end{array}$ $\begin{array}{llllllllllllllll}0.96 & 29.15 & 27.36 & 24.64 & 2 & 938.5142 & 938.5130 & 470.2638 & 0.0012 & 1.2759 & 478.650 & 478.022 & 44.283 & 757.119 & \text { Yes }\end{array}$ $\begin{array}{lllllllllllllll}0.97 & 29.21 & 27.36 & 31.06 & 2 & 938.5142 & 938.5130 & 470.2638 & 0.0012 & 1.2759 & 468.746 & 382.490 & 52.483 & 744.551 & \text { Yes } \\ 0.95 & 2.25 & 27.36 & 42.28 & 2 & 98.5142 & 98.5130 & 40.263 & 0.0012 & 1.275 & 51262 & 39.80 & 57.189 & 716.428 & \text { Yes }\end{array}$ $\begin{array}{llllllllllllllll}0.95 & 27.25 & 27.36 & 24.28 & 2 & 938.5142 & 938.5130 & 470.2638 & 0.0012 & 1.2759 & 512.612 & 391.890 & 57.189 & 716.428 & \text { Yes }\end{array}$ $\begin{array}{ccccccccccccccc}0.97 & 29.21 & 27.36 & 25.76 & 2 & 938.5142 & 938.5130 & 470.2638 & 0.0012 & 1.2759 & 466.241 & 439.817 & 64.138 & 649.888 & \text { Yes } \\ 0.87 & 2.21 & 27.10 & 25.21 & 2 & 938.5146 & 9385130 & 4702638 & 0.0016 & 1.7012 & 106.667 & 94.210 & 5.819 & 187.029 & \text { Yes }\end{array}$

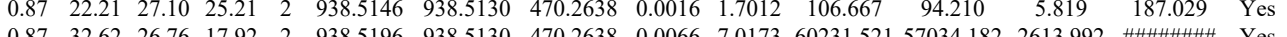

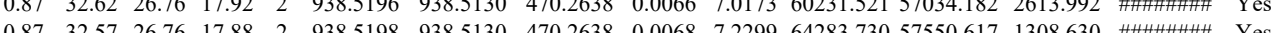

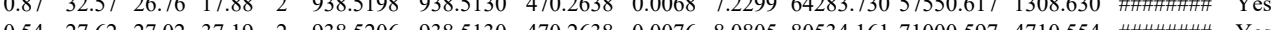

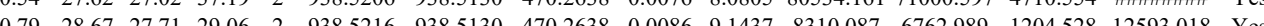

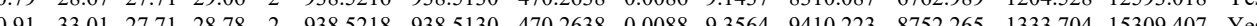

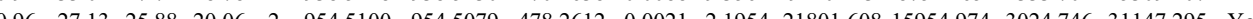

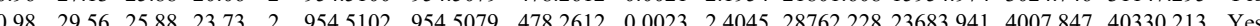
$\begin{array}{llllllllllllllll}1.00 & 70.71 & 25.97 & 28.97 & 2 & 1756.9962 & 1756.9957 & 879.5051 & 0.0005 & 0.2843 & 9948.675 & 9181.836 & 314.814 & 8404.215 & \text { Yes }\end{array}$ $\begin{array}{llllllllllllllll}1.00 & 67.73 & 25.97 & 28.33 & 2 & 1756.9962 & 1756.9957 & 879.5051 & 0.0005 & 0.2843 & 10913.242 & 8948.691 & 635.087 & 8253.752 & \text { Yes }\end{array}$ $\begin{array}{llllllllllllllll}1.00 & 33.34 & 25.89 & 16.78 & 3 & 1756.9972 & 1756.9957 & 586.6725 & 0.0015 & 0.8523 & 1067.573 & 973.913 & 244.123 & 1609.198 & \text { Yes }\end{array}$ $\begin{array}{lllllllllllllll}0.98 & 22.49 & 25.48 & 15.84 & 3 & 1756.9981 & 1756.9957 & 586.6725 & 0.0024 & 1.3636 & 441.629 & 577.375 & 117.192 & 903.018 & \text { Yes }\end{array}$ LVINGNPITIFQE $\begin{array}{llllllllllllll}0.98 & 22.49 & 25.48 & 15.84 & 3 & 1756.9981 & 1756.9957 & 586.6725 & 0.0024 & 1.3636 & 441.629 & 5 & \\ 0.66 & 84.07 & 24.13 & 97.07 & 3 & 2882.5588 & 28825568 & 961.8595 & 0.020 & 0.6931 & 709.966 & 53 & \end{array}$ IVEGLMTTVHAITA VIHDNFGIVEGLMTTVHAITATOK LTGMAFR

LTGMAFR

LTGMAFR

LTGMAFR

LTGMAFR

LTGMAFR

LTGMAFR

LTGMAFR

LTGMAFR

LTGMAFR

LTGMAFR

LTGMAFR

LTGMAFR

LTGMAFR

LTGMAFR $\begin{array}{llll}36.17 & 23.84 & 15.60 \\ 1.00 & 36.49 & 23.86 & 49.49\end{array}$ $\begin{array}{llllllllllll}0.91 & 24.59 & 27.46 & 30.98 & 2 & 938.5136 & 938.5130 & 470.2638 & 0.0006 & 0.6379 & 309.108\end{array}$ $\begin{array}{lllllllllllll}0.95 & 27.39 & 27.39 & 27.60 & 2 & 938.5140 & 938.5130 & 470.2638 & 0.0010 & 1.0632 & 296.990\end{array}$

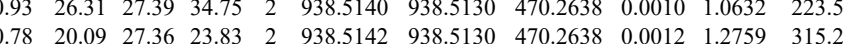
$\begin{array}{lllllllllllll}0.77 & 19.95 & 27.36 & 26.86 & 2 & 938.5142 & 938.5130 & 470.2638 & 0.0012 & 1.2759 & 260.940\end{array}$ $\begin{array}{llllllllllllllll}0.83 & 21.44 & 27.36 & 31.44 & 2 & 938.5144 & 938.5130 & 470.2638 & 0.0014 & 1.4885 & 265.731 & 235.96 .1\end{array}$ $\begin{array}{llllllllllllllll}0.92 & 25.47 & 27.36 & 27.88 & 2 & 938.5144 & 938.5130 & 470.2638 & 0.0014 & 1.4885 & 294.534 & 259.115\end{array}$ $\begin{array}{lllllllllllllll}0.94 & 25.71 & 27.10 & 22.11 & 2 & 938.5146 & 938.5130 & 470.2638 & 0.0016 & 1.7012 & 297.009 & 258.523\end{array}$ $\begin{array}{lllllllllllll}0.82 & 20.64 & 27.26 & 26.55 & 2 & 938.5148 & 938.5130 & 470.2638 & 0.0018 & 1.9138 & 259.749 & 243.439\end{array}$ $\begin{array}{llllllllllllll}0.91 & 24.15 & 27.26 & 28.69 & 2 & 938.5148 & 938.5130 & 470.2638 & 0.0018 & 1.9138 & 244.146 & 241.940\end{array}$ $\begin{array}{lllllllllllll}0.71 & 17.53 & 26.99 & 18.94 & 2 & 938.5150 & 938.5130 & 470.2638 & 0.0020 & 2.1265 & 93.234 & 93.929 \\ 0.81 & 20.07 & 26.99 & 27.00 & 2 & 938.5150 & 938.5130 & 470.2638 & 0.0020 & 2.1265 & 55.512 & 52.472\end{array}$

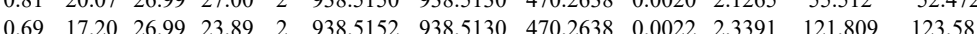
$\begin{array}{llllllllllllll} & \end{array}$ $\begin{array}{lllllllllllllllll}0.80 & 19.68 & 26.49 & 20.89 & 2 & 954.5092 & 954.5079 & 478.2612 & 0.0013 & 1.3591 & 14959.393 & 11930.805 & 2937.535 & 21694.232 & \text { Yes }\end{array}$ $\begin{array}{llllllllllllllllll}0.91 & 23.63 & 26.47 & 21.19 & 2 & 954.5094 & 954.5079 & 478.2612 & 0.0015 & 1.5682 & 21539.263 & 16387.534 & 3198.461 & 28113.520 & \text { Yes }\end{array}$ 
$\begin{array}{llllllllllllllll}\text { LVINGNPITIFOER } & 1.00 & 89.23 & 26.76 & 16.54 & 2 & 938.5198 & 938.5130 & 47.2638 & 0.0068 & 7.2299 & 25253.685 & 22494.971 & 2300.425 & 35631.974 & \text { Yes }\end{array}$ \begin{tabular}{llllllllllllllll} 
LVINGNPITIFOER & 1.00 & 65.42 & 25.90 & 33.02 & 2 & 1756.9962 & 1756.9957 & 879.5051 & 0.0001 & 0.2843 & 10011.888 & 7420.591 & 626.638 & 6752.754 & Yes \\
\hline
\end{tabular} \begin{tabular}{llllllllllllllll} 
& LVINGNPITIFQER \\
\hline
\end{tabular}

LTGMAFR

LVINGNPITIFQER

LVINGNPITIFQER
LVINGNPITIFQER

LVINGNPITIFQER

LVINGNPITIFQER

VIISAPSADAPMFVMGV VIISAPSADAPMFVMGVNHEK

LTGMAFR
LTGMAFR

LVINGNPITIFQER

LVINGNPITIFQER

LVINGNPITIFQER

LVINGNPITIFQER

LTGMAFR
LTGMAFR

VPTANVSVVDLTCR

VPTANVSVVDLTCR
VPTANVSVVDLTCR

VPTANVSVVDLTC

LVINGNPITIFQER

LVINGNPITIFQER
LVINGNPITIFQER

LVINGNPITIFQER
LVINGNPITIFQER

LVINGNPITIE

LTGMAFR
LTGMAFR

LTGMAFR
VPTANVSVVDLTCR

LVINGNPITIFQER

LVINGNPITIFQER

LVINGNPITIFQER

LVINGNPITIFQER

LTGMAFR

LTGMAFR

LTGMAFR
LTGMAFR

LTGMAFR

YDNSLK

LTGMAFR
LTGMAFR

LVINGNPITIFQER

\begin{tabular}{lllllllllllllll}
1.00 & 65.42 & 25.9 & 27.78 & 2 & 1756.9968 & 1756.9957 & 879.5051 & 0.0011 & 0.6254 & 356.187 & 2683.570 & 175.509 & 2728.232 & Yes \\
\hline
\end{tabular}

$\begin{array}{lllllllllllllllll}0.94 & 28.62 & 26.92 & 23.09 & 2 & 938.5162 & 938.5130 & 470.2638 & 0.0032 & 3.4023 & 22924.588 & 19257.530 & 1150.892 & 33748.476 & \text { Yes } \\ 0.93 & 32.16 & 27.00 & 23.29 & 2 & 938.5166 & 938.5130 & 470.2638 & 0.0036 & 3.8276 & 33768.656 & 27602794 & 779.097 & 49527.170 & \text { Yes }\end{array}$

$\begin{array}{lllllllllllllll}0.93 & 32.16 & 27.00 & 23.29 & 2 & 938.5166 & 938.5130 & 470.2638 & 0.0036 & 3.8276 & 33768.656 & 27602.794 & 719.097 & 49527.170 & \text { Yes } \\ 1.00 & 79.40 & 25.90 & 31.12 & 2 & 1756.9966 & 1756.9957 & 879.5051 & 0.0009 & 0.5117 & 820.218 & 630.998 & 12.861 & 728.719 & \text { Yes }\end{array}$

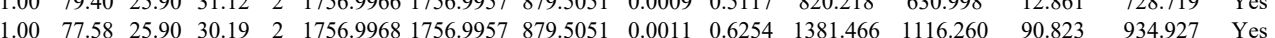

$\begin{array}{lllllllllllllll}0.66 & 18.27 & 25.48 & 31.27 & 3 & 1756.9981 & 1756.9957 & 586.6725 & 0.0024 & 1.3636 & 187.209 & 185.004 & 53.701 & 207.545 & \text { Yes }\end{array}$

$\begin{array}{lllllllllllllll}1.00 & 35.19 & 25.37 & 24.43 & 3 & 1756.9984 & 1756.9957 & 586.6725 & 0.0027 & 1.5341 & 278.237 & 158.363 & 67.983 & 245.759 & \text { Yes }\end{array}$

$\begin{array}{lllllllllllllll}1.00 & 75.59 & 25.65 & 20.01 & 3 & 2500.3108 & 2500.3062 & 834.4427 & 0.0046 & 1.8376 & 39.929 & 30.962 & 24.452 & 45.907 & \text { Yes }\end{array}$

$\begin{array}{lllllllllllllll}1.00 & 65.29 & 26.59 & 18.63 & 3 & 2500.3126 & 2500.3062 & 834.4427 & 0.0064 & 2.5566 & 10.982 & 26.529 & 14.554 & 23.683 & \text { Yes }\end{array}$

$\begin{array}{llllllllllllllll}0.93 & 28.32 & 26.99 & 23.15 & 2 & 938.5156 & 938.5130 & 470.2638 & 0.0026 & 2.7644 & 25295.278 & 21349.141 & 1346.509 & 38515.378 & \text { Yes } \\ 0.97 & 32.16 & 2.92 & 23.32 & 2 & & & \end{array}$ $\begin{array}{ccccccccccccccc}0.97 & 32.16 & 26.92 & 23.32 & 2 & 938.5160 & 938.5130 & 470.2638 & 0.0030 & 3.1897 & 21320.877 & 17875.778 & 2052.223 & 31208.331 & \text { Yes } \\ 1.00 & 78.58 & 5.97 & 30.88 & 2 & 175.962 & 77.9957 & 879.5051 & 0.0005 & 0.2843 & 214.391 & 799.258 & 92.827 & 733.448 & \text { Yes }\end{array}$

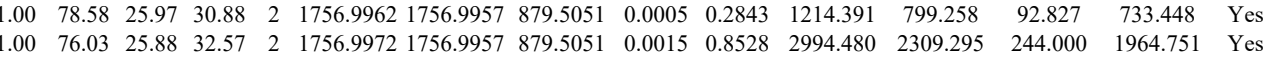
$\begin{array}{lllllllllllllll}1.00 & 31.03 & 25.87 & 17.20 & 3 & 1756.9978 & 1756.9957 & 586.6725 & 0.0021 & 1.1932 & 120.286 & 69.584 & 48.777 & 81.886 & \text { Yes }\end{array}$ $\begin{array}{lllllllllllllll}0.66 & 25.32 & 25.48 & 38.32 & 3 & 1756.9981 & 1756.9957 & 586.6725 & 0.0024 & 1.3636 & 68.127 & 71.858 & 41.052 & 98.018 & \text { Yes }\end{array}$ $\begin{array}{lllllllllllllll}0.92 & 34.07 & 27.13 & 23.54 & 2 & 938.5116 & 938.5130 & 470.2638 & -0.0014 & -1.4885 & 9884.578 & 7884.461 & 660.867 & 15270.721 & \text { Yes }\end{array}$ $\begin{array}{llllllllllllllll}0.85 & 30.84 & 27.44 & 23.35 & 2 & 938.5120 & 938.5130 & 470.2638 & -0.0010 & -1.0632 & 10002.436 & 7964.723 & 1064.420 & 14062.681 & \text { Yes }\end{array}$ $\begin{array}{lllllllllllllll}1.00 & 97.73 & 27.87 & 21.49 & 2 & 1662.8556 & 1662.8555 & 832.4350 & 0.0001 & 0.0601 & 322.742 & 213.688 & 196.868 & 356.511 & \text { Yes }\end{array}$ $\begin{array}{lllllllllllllll}1.00 & 75.00 & 27.87 & 24.59 & 2 & 1662.8556 & 1662.8555 & 832.4350 & 0.0001 & 0.0601 & 131.722 & 111.319 & 94.967 & 137.721 & \text { Yes } \\ 1.00 & 86.93 & 27.98 & 19.24 & 2 & 16628568 & 1662.8555 & 832.4350 & 0.0013 & 0.7808 & 367.235 & 262.997 & 279.067 & 377.726 & Y s\end{array}$

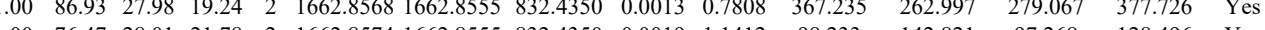
$\begin{array}{llllllllllllllll}1.00 & 76.47 & 28.01 & 21.78 & 2 & 1662.8574 & 1662.8555 & 832.4350 & 0.0019 & 1.1412 & 98.233 & 142.821 & 97.268 & 128.496 & \text { Yes } \\ 1.00 & 77.77 & 25.88 & 31.15 & 2 & 1756.9972 & 1756.9957 & 87.5051 & 0.0015 & 0.8528 & 1875.506 & 929.904 & 58.08 & 874.492 & Y \text { Ses }\end{array}$ $\begin{array}{llllllllllllllll}1.00 & 76.47 & 28.01 & 11.78 & 2 & 1662.8574 & 1662.85 & 832.4350 & 0.00 & 1.1412 & 98.233 & 142.821 & 97.268 & 128.496 & \text { Yes }\end{array}$

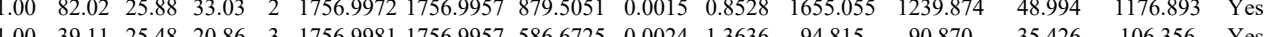

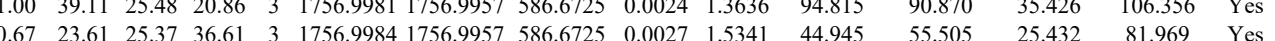

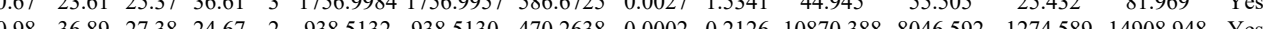
\begin{tabular}{llllllllllllllll}
0 & 0.67 \\
0.98 & 35.22 & 27.38 & 24.74 & 2 & 938.5132 & 938.5130 & 470.2638 & 0.002 & 0.2126 & 10870.388 & 8046.592 & 1274.589 & 14908.948 & Yes \\
\hline
\end{tabular} $\begin{array}{llllllllllllll}1.00 & 67.75 & 25.90 & 29.06 & 2 & 17569968 & 17569957 & 879.5051 & 0.0011 & 0.6254 & 792.654 & 657.101\end{array}$ $\begin{array}{lllllllllllll}100 & 76.50 & 25.85 & 31.10 & 2 & 17569976 & 17569957 & 879.5051 & 0.0019 & 1.0802 & 801.240 & 8570.005\end{array}$ $\begin{array}{llllllllllll}66 & 33.99 & 25.48 & 46.99 & 3 & 1756.9981 & 1756.9957 & 586.6725 & 0.0024 & 1.3636 & 43.520 & 48.207\end{array}$ $\begin{array}{lllllllllllll}0.67 & 29.78 & 27.48 & 42.01 & 3 & 1756.9990 & 1756.9957 & 586.6725 & 0.0033 & 1.8750 & 35.444 & 46.322\end{array}$ $\begin{array}{llllllllllllll}0.91 & 28.81 & 27.28 & 23.29 & 2 & 938.5130 & 938.5130 & 470.2638 & 0.0000 & 0.0000 & 5460.472 & 5059.957\end{array}$ $\begin{array}{lllllllllllll}0.92 & 29.61 & 27.38 & 23.14 & 2 & 938.5132 & 938.5130 & 470.2638 & 0.0002 & 0.2126 & 1273.107 & 1129.071\end{array}$ $\begin{array}{llllllllllllll}0.92 & 29.61 & 27.38 & 23.14 & 2 & 938.5132 & 938.5130 & 470.2638 & 0.0002 & 0.2126 & 1273.107 & 1129.071\end{array}$ $\begin{array}{lllllllllllll}0.51 & 18.47 & 26.90 & 26.48 & 2 & 1026.5590 & 10265589 & 514.2867 & 0.0001 & 0.0972 & 102.553 & 76.929\end{array}$ $\begin{array}{lllllllllllll}0.97 & 29.62 & 27.46 & 23.11 & 2 & 938.5136 & 938.5130 & 470.2638 & 0.0006 & 0.6379 & 1547.072 & 1489.504\end{array}$ $\begin{array}{llllllllllllll}0.97 & 29.68 & 27.49 & 23.28 & 2 & 938.5138 & 938.5130 & 470.2638 & 0.0008 & 0.8506 & 1842.107 & 1680.956\end{array}$ $\begin{array}{lllllllllllll}1.00 & 66.63 & 25.84 & 28.92 & 2 & 1756.9974 & 1756.9957 & 879.5051 & 0.0017 & 0.9665 & 1111.365 & 984.578\end{array}$ LVINGNPITIFQER

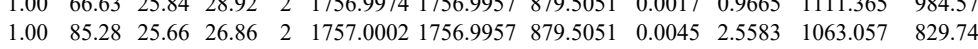

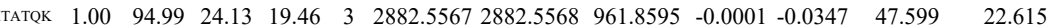

NAFGIVEGLMTTVHAITATKK

LTGMAFR

LTGMAFR

LVINGNPITIFQER
LVINGNPITIFQER

VIDDNGGIVEGLMTTVHAITAT

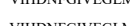

LTGMAFR

LVINGNPITIFQER

LVINGNPITIFQ

LTGMAFR

LVINGNPITIFQER

\subsection{96
1.00 \begin{tabular}{ll} 
& 1.00 \\
& 1.00 \\
$\mathrm{QK}$ & 1.00 \\
$\mathrm{QK}$ & 0.94 \\
\hline $\mathrm{K}$ & 1.00
\end{tabular} 1.00
0.9
1.00
0.94
1.00}


$\begin{array}{llllllllllll}0.64 & 64.73 & 24.58 & 77.73 & 2 & 1698.9870 & 1698.9872 & 850.5009 & -0.0002 & -0.1176 & 34.244 \\ 1.00 & 76.21 & 25.90 & 29.95 & 2 & 1756.9970 & 1756.9957 & 879.5051 & 0.0013 & 0.7391 & 212.668\end{array}$

LVINGNPITIFQE

$\begin{array}{lllllllllll}1.00 & 73.88 & 25.88 & 29.81 & 2 & 1756.9972 & 1756.9957 & 879.5051 & 0.0015 & 0.8528 & 163.163\end{array}$

VIISAPSADAPMFVMGVNHE

$\begin{array}{lllllllllll}1.00 & 78.38 & 26.73 & 20.93 & 3 & 2500.3087 & 2500.3062 & 834.4427 & 0.0025 & 0.9987\end{array}$

$\begin{array}{llllllllllllll}\text { WGDAGAETUESTGVFTTMEK } & 0.99 & 38.72 & 27.14 & 15.68 & 3 & 2564.2438 & 2564.2349 & 855.7522 & 0.0089 & 3.4667 & 5.488\end{array}$

LTGMAFR

$\begin{array}{lllllllllllll}0.96 & 29.17 & 27.49 & 23.68 & 2 & 938.5138 & 938.5130 & 470.2638 & 0.0008 & 0.8506 & 646.551 \\ 0.96 & 28.08 & 27.39 & 21.37 & 2 & 938.5140 & 938.5130 & 470.2638 & 0.0010 & 1.0632 & 551.589\end{array}$

AGAHLQGGAK

VPTANVSVVDLTCR

$\begin{array}{cccccccccccc}0.99 & 36.13 & 26.32 & 20.74 & 2 & 1196.6880 & 1196.6869 & 599.3507 & 0.0011 & 0.9177 & 8.942 \\ 1.00 & 78.89 & 27.85 & 23.34 & 2 & 16628562 & 16628555 & 832.4350 & 0.0007 & 0.4205 & 37.213\end{array}$

$\begin{array}{llllllllllll}\text { VPTANVSVVDLTCR } & 1.00 & 78.89 & 27.85 & 23.34 & 2 & 1662.8562 & 1662.8555 & 832.4350 & 0.0007 & 0.4205 & 37.213 \\ \text { VPTA } & 27.94 & 24.25 & 2 & 1662.8564 & 1662.8555 & 832.4350 & 0.0009 & 0.5406 & 37.788\end{array}$

$\begin{array}{llllllllllll}\text { GALQNIIPASTGAAK } & 1.00 & 70.20 & 24.39 & 22.36 & 2 & 1698.9886 & 1698.9872 & 850.5009 & 0.0014 & 0.8230 & 31.973 \\ \text { LVINGNPITIFOER } & 1.00 & 68.79 & 25.97 & 30.48 & 2 & 1756.9958 & 1756.9957 & 879.5051 & 0.0001 & 0.0569 & 100.753\end{array}$

LVINGNPITIFQER

$\begin{array}{lllllllllll}1.00 & 68.79 & 25.97 & 30.48 & 2 & 1756.9958 & 1756.9957 & 879.5051 & 0.0001 & 0.0569 & 100.753 \\ 1.00 & 70.77 & 25.37 & 28.98 & 2 & 1756.9984 & 1756.9957 & 879.5051 & 0.0027 & 1.5350 & 95.856\end{array}$ $\begin{array}{lllllllllllll}\text { LVINGNPITIFQER } & 1.00 & 70.77 & 25.37 & 28.98 & 2 & 1756.9984 & 1756.9957 & 879.5051 & 0.0027 & 1.5350 & 95.856 \\ \text { VIISAPSADAPMFVMGVNHEK } & 0.66 & 70.60 & 26.75 & 83.60 & 3 & 2500.3078 & 2500.3062 & 834.4427 & 0.0016 & 0.6391 & 14.999\end{array}$

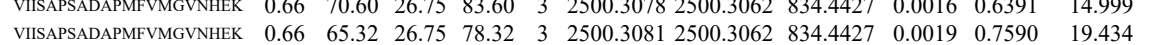

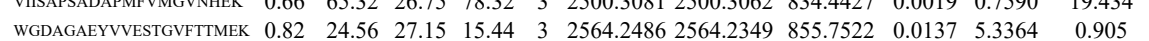

LTGMAFR

$\begin{array}{llllllllllll}0.91 & 28.82 & 27.38 & 25.37 & 2 & 938.5132 & 938.5130 & 470.2638 & 0.0002 & 0.2126 & 458.236 & 43\end{array}$

$\begin{array}{lllllllllllll} & 0.93 & 30.08 & 27.38 & 23.56 & 2 & 938.5132 & 938.5130 & 470.2638 & 0.0002 & 0.2126 & 588.842\end{array}$

$\begin{array}{llllllllllll}\text { VPTANVSVVDLTCR } & 1.00 & 76.34 & 27.85 & 26.51 & 2 & 1662.8560 & 1662.8555 & 832.4350 & 0.0005 & 0.3003 & 41.302\end{array}$

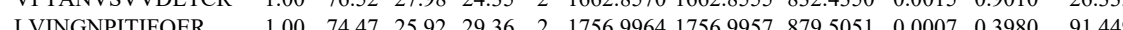

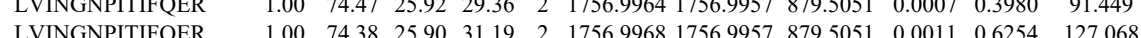

$\begin{array}{lllllllllllll}\text { LVISAPSAPMFYGVNAEK } & 0.66 & 69.03 & 26.75 & 82.03 & 3 & 2500.3078 & 2500.3062 & 834.4427 & 0.0016 & 0.6391 & 28.558\end{array}$

$\begin{array}{llllllllllll}\text { WGDAGAEYVVESTGVFTTMEK } & 1.00 & 40.33 & 27.14 & 17.73 & 3 & 2564.2426 & 2564.2349 & 855.7522 & 0.0077 & 2.9993 & 7.962\end{array}$

$\begin{array}{llllllllllll}\text { LTGMAFR } & 0.93 & 29.95 & 27.38 & 22.54 & 2 & 938.5134 & 938.5130 & 470.2638 & 0.0004 & 0.4253 & 511.533 \\ \text { LTGMAFR } & 0.5 & 27.94 & 27.46 & 24.26 & 2 & 938.5136 & 938.513 & 470.2635 & 0.006 & 0.0379 & 573.795\end{array}$

$\begin{array}{lllllllllllll}\text { LTGMAFR } & 0.95 & 27.94 & 27.46 & 24.26 & 2 & 938.5136 & 938.5130 & 470.2638 & 0.0006 & 0.6379 & 573.795 \\ \text { VPTANVSVVDLTCR } & 1.00 & 65.40 & 27.92 & 19.26 & 2 & 1662.8546 & 1662.8555 & 832.4350 & -0.0009 & -0.5406 & 20.112\end{array}$

$\begin{array}{llllllllllll}\text { VPTANVSVVDLTCR } & 1.00 & 74.99 & 27.85 & 21.10 & 2 & 1662.8562 & 1662.8555 & 832.4350 & 0.0007 & 0.4205 & 46.095\end{array}$

\begin{tabular}{lllllllllllll} 
LVINGNPITIFQER & 1.00 & 70.53 & 25.90 & 29.81 & 2 & 1756.9966 & 1756.9957 & 879.5051 & 0.0009 & 0.5117 & 88.726 \\
\hline
\end{tabular} $\begin{array}{llllllllllll}\text { VIISAPSADAPMFVMGVNHEK } & 1.00 & 85.29 & 26.65 & 18.47 & 3 & 2500.3108 & 2500.3062 & 834.4427 & 0.0046 & 1.8376 & 58.392\end{array}$ $\begin{array}{lllllllllllll}\text { WGDAGAEYVVESTGVFTTMEK } & 0.99 & 35.71 & 27.05 & 22.19 & 3 & 2564.2453 & 2564.2349 & 855.7522 & 0.0104 & 4.0510 & 9.356\end{array}$

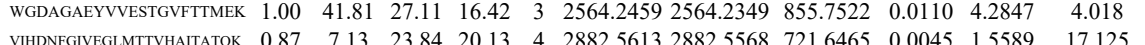
$\begin{array}{llllllllllll}\text { VIHDNFGIVEGLMTTVHATATQK } & 0.87 & 7.13 & 23.84 & 20.13 & 4 & 2882.5613 & 2882.5568 & 721.6465 & 0.0045 & 1.5589 & 17.125 \\ \text { LTGMAFR } & 0.91 & 25.12 & 27.46 & 23.16 & 2 & 938.5136 & 938.5130 & 470.2638 & 0.0006 & 0.6379 & 548.628\end{array}$

LTGMAFR $\begin{array}{lllllllllll}0.91 & 25.12 & 27.46 & 23.16 & 2 & 938.5136 & 938.5130 & 470.2638 & 0.0006 & .6389 & 548.628 \\ 0.95 & 27.96 & 27.46 & 23.31 & 2 & 938.5136 & 9385130 & 470.2638 & 0.0006 & 0.6379 & 452.119\end{array}$

VPTANVSVVDLTCR

LVINGNPITIFQER

LVINGNPITIFQER
LVINGNPITIFOER

LVINGNPITIFQER
LVINGNPITIFQER

$\begin{array}{lllllllllll}1.00 & 75.24 & 27.94 & 21.10 & 2 & 1662.8564 & 1662.8555 & 832.4350 & 0.0009 & 0.5406 & 31.774 \\ 0.98 & 28.71 & 25.97 & 16.47 & 3 & 1756.9960 & 1756.9957 & 586.6725 & 0.0003 & 0.1705 & 22.332\end{array}$

$\begin{array}{llllllllllll}1.00 & 73.72 & 25.97 & 31.72 & 2 & 1756.9960 & 1756.9957 & 586.6725 & 0.0003 & 0.1705 & 22.332 \\ 1756.9957 & 879.5051 & 0.0005 & 0.2843 & 128.867\end{array}$ $\begin{array}{llllllllllll}1.00 & 63.34 & 25.84 & 28.84 & 2 & 1756.9974 & 1756.9957 & 879.5051 & 0.0017 & 0.9665 & 107.353 \\ 1.00 & 29.02 & 25.48 & 18.88 & 3 & 1756.9981 & 1756.9957 & 586.6725 & 0.0024 & 1.3636 & 13.948\end{array}$

$\begin{array}{llllllllllll}\text { LISAPADAPMFVMGVNHEK K } & 1.00 & 59.58 & 26.75 & 17.11 & 3 & 2500.3084 & 2500.3062 & 834.4427 & 0.0022 & 0.8788 & 12.010 \\ \text { LTGMAFR } & 0.95 & 27.61 & 27.36 & 25.22 & 2 & 938.5142 & 938.5130 & 470.2638 & 0.0012 & 1.2759 & 463.045\end{array}$

$\begin{array}{llllllllllll}\text { LTGMAFR } & 0.88 & 23.46 & 27.36 & 22.80 & 2 & 938.5144 & 938.5130 & 470.2638 & 0.0014 & 1.4885 & 474.096\end{array}$

$\begin{array}{llllllllllll}\text { VPTANVSVDLTCR } & 1.00 & 69.01 & 27.98 & 24.34 & 2 & 1662.8568 & 1662.8555 & 832.4350 & 0.0013 & 0.7808 & 34.790\end{array}$

\begin{tabular}{lllllllllllll} 
LVINGNPITIFQER & 1.00 & 68.30 & 27.97 & 21.78 & 2 & 1662.8572 & 1662.8555 & 832.4350 & 0.0017 & 1.0211 & 19.943 \\
\hline
\end{tabular} 

$\begin{array}{llllllllllll}\text { GGVISAISEAAAQYNPEPPPR } & 0.67 & 83.39 & 25.37 & 96.39 & 3 & 2590.3909 & 2590.3877 & 864.4698 & 0.0032 & 1.2339 & 21.512\end{array}$ $\begin{array}{lllllllllllllll} & \text { LGGVISAISEAAAQYNPEPPPR } & 1.00 & 21.22 & 25.20 & 34.22 & 4 & 2590.3921 & 2590.3877 & 648.6042 & 0.0044 & 1.6959 & 42.720\end{array}$ \begin{tabular}{llllllllllllll}
\hline GGVVISAISEAAAQYNPEPPPPR & 0.93 & 10.15 & 25.20 & 14.12 & 4 & 2590.3921 & 2590.3877 & 648.6042 & 0.0044 & 1.6959 & 62.136
\end{tabular}

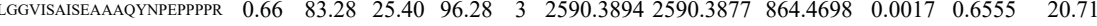

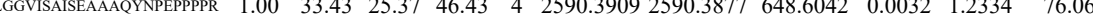
$\begin{array}{lllllllllllll}\text { LGGVISAISEAAAQYNPEPPPR } & 1.00 & 53.02 & 25.20 & 17.73 & 4 & 2590.3921 & 2590.3877 & 648.6042 & 0.0044 & 1.6959 & 46.942\end{array}$ $\begin{array}{llllllllllll}\text { ILGGVISAISEAAAQYNPEPPPPR } & 0.66 & 80.68 & 25.37 & 93.68 & 3 & 2590.3900 & 2590.3877 & 864.4698 & 0.0023 & 0.8869 & 7.722\end{array}$

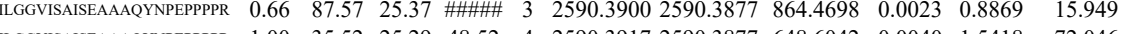

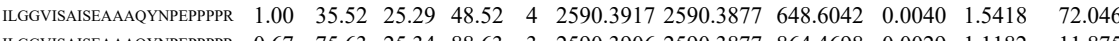

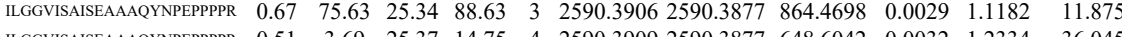
$\begin{array}{llllllllllll}\text { LLGGVISAISEAAAQYNPEPPPR } & 0.51 & 3.69 & 25.37 & 14.75 & 4 & 2590.3909 & 2590.3877 & 648.6042 & 0.0032 & 1.2334 & 36.045\end{array}$

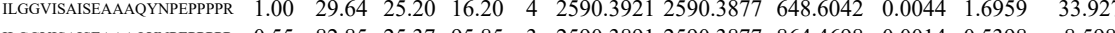

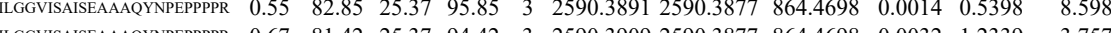
$\begin{array}{lllllllllll} & 10.5\end{array}$ $\begin{array}{llllllllllll}\text { IGGVISAISAAAAQYNPEPPPPR } & 0.95 & 10.80 & 25.30 & 13.90 & 4 & 2590.3921 & 2590.03877 & 648.6042 & 0.0044 & 1.6959 & 28.305\end{array}$

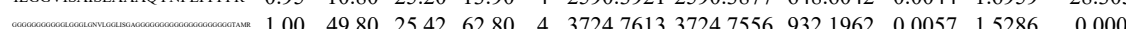




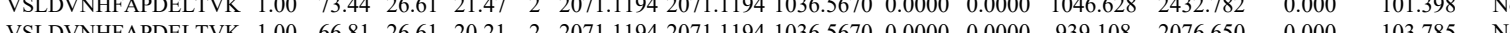

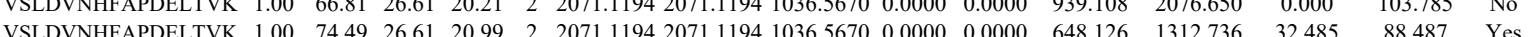

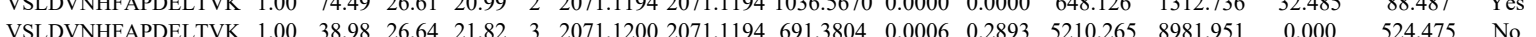

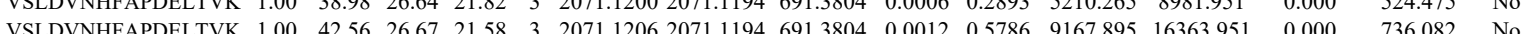
$\begin{array}{llllllllllllllll}\text { VSLDNNFAPELTVK } & 1.00 & 41.93 & 26.63 & 26.09 & 3 & 2071.1203 & 2071.1194 & 691.3804 & 0.0009 & 0.4339 & 2272.700 & 4216.953 & 65.617 & 564.212 & \text { Yes }\end{array}$

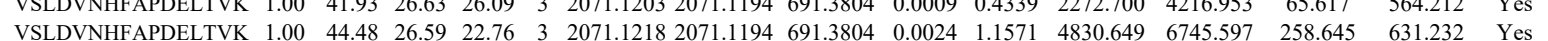

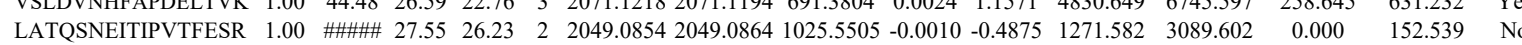

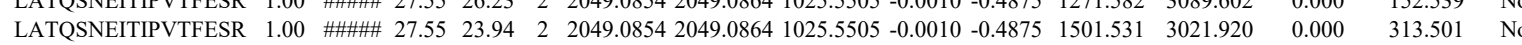

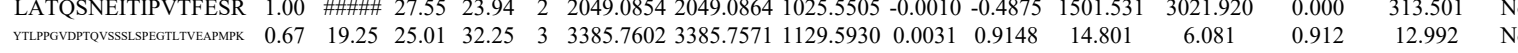
$\begin{array}{llllllllllllllll}\text { YTLPGVDPTVVSSLSPFGTLIVEAPMPK } & 0.67 & 39.82 & 25.01 & 52.82 & 3 & 3385.7602 & 3385.7571 & 1129.5930 & 0.0031 & 0.9148 & 0.000 & 9.770 & 0.000 & 0.000 & \text { No }\end{array}$

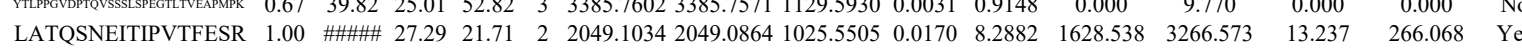

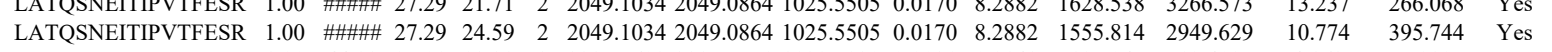

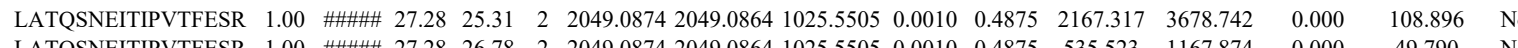

LFDQAFGLPR

LFDQAFGLPR

LFDQAFGLPR

LFDQAFGLPR

$\begin{array}{lllllllllllll}\text { RPN1_HUMAN } & \text { P04843 } & \text { RPN1 } & \text { Dolichyl-diphospt } 68.569 & 1.00 & 16 & 35.7 & 0.0927 & 0.3800 & 1.0357 & 0.4106 & 51 & \text { LFDQAFGLPR } \\ \text { SELLDGPFR }\end{array}$ SEDLLDYGPFR IDHILDAL IDHILDAL SEDLLDYGPFR SEDLLDYGPF IDHILDAL

(DHIDAL

DOHLDAL

FVDHVFDEQVIDSLTVK

IILPEGAK

TVDESSHLAK

TVDLSSHLAK

TVDLSSHLAK

ATSFLLALEPELEAR ATSFLLALEPELEAR ATSFLLALEPELEAR TVDLSSHLAK TVDLSSHLAK

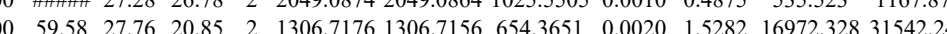

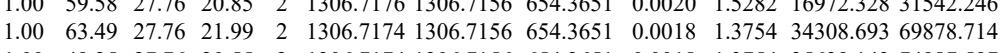
$\begin{array}{llllllllllll}1.00 & 49.25 & 27.76 & 20.55 & 2 & 1306.7174 & 1306.7156 & 654.3651 & 0.0018 & 1.3754 & 35639.143 & 74987.597 \\ 1.00 & 48.08 & 27.94 & 21.85 & 2 & 1306.7154 & 1306.7156 & 654.3651 & -0.0002 & -0.1528 & 687.944 & 1288.795\end{array}$ $\begin{array}{lllllllllllll}1.00 & 48.13 & 27.95 & 19.58 & 2 & 1306.7156 & 1306.7156 & 654.3651 & 0.0000 & 0.0000 & 958.826 & 1878.205\end{array}$ $\begin{array}{llllllllllll}1.00 & 52.99 & 26.95 & 20.82 & 2 & 1454.7162 & 1454.7163 & 728.3654 & -0.0001 & -0.0686 & 430.870 & 445.174\end{array}$ $\begin{array}{lllllllllllll}1.00 & 52.84 & 27.33 & 19.89 & 2 & 1454.7174 & 1454.7163 & 728.3654 & 0.0011 & 0.7551 & 184.149 & 211.312 \\ 1.00 & 44.10 & 27.54 & 26.70 & 2 & 1052.6000 & 1052.5988 & 527.3067 & 0.0012 & 1.1379 & 558.130 & 561.948\end{array}$ $\begin{array}{llllllllllll}1.00 & 44.10 & 27.54 & 26.70 & 2 & 1052.6000 & 1052.5988 & 527.3067 & 0.0012 & 1.1379 & 558.130 & 561.948\end{array}$

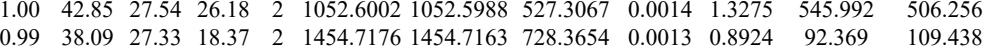
$\begin{array}{llllllllllll}0.99 & 38.09 & 27.33 & 18.37 & 2 & 1454.7176 & 1454.7163 & 728.3654 & 0.0013 & 0.8924 & 92.369 & 109.438 \\ 1.00 & 47.30 & 27.31 & 18.06 & 2 & 1454.7182 & 1454.7163 & 728.3654 & 0.0019 & 1.3043 & 57.933 & 39.936\end{array}$

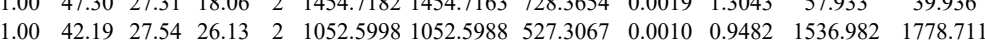

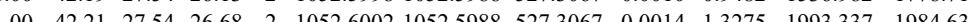
$\begin{array}{lllllllllllllll}1.03 & 0.3793 & 557.336 & 509.839\end{array}$ $\begin{array}{lllllllllllll}1.00 & 42.04 & 27.54 & 26.81 & 2 & 1052.6000 & 1052.5988 & 527.3067 & 0.0012 & 1.1379 & 680.556 & 868.682\end{array}$

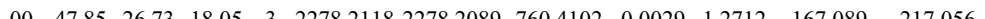
$\begin{array}{llllllllllll}0.99 & 47.39 & 21.58 & 40.82 & 2 & 1127.7258 & 1127.7158 & 564.8652 & 0.0100 & 8.8516 & 8889.735 & 9716.201\end{array}$ $\begin{array}{llllllllllllll}0.99 & 4.39 & 21.58 & 40.82 & 2 & 1127.7258 & 1127.7158 & 564.8652 & 0.0100 & 8.8516 & 8889.735 & 9716.201 & 11.87 .4 \\ 0.98 & 34.40 & 26.73 & 20.45 & 3 & 1357.7923 & 1357.7809 & 453.6009 & 0.0114 & 8.3773 & 17949.616 & 16923.986 & 1248 .\end{array}$ $0.000 \quad 4583.308$ No

$0.000-5740.289$ No

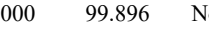
$1.844 \quad 518.576 \quad$ Yes

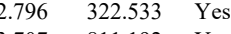
$153 \quad 804.406 \quad$ Yes

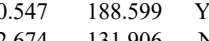

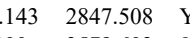
$\begin{array}{lll}0.000 & 3579.603 & \text { No } \\ 72.017 & 844.242 & \text { Yes }\end{array}$ \begin{tabular}{rrr}
9.273 & 918.457 & Yes \\
\hline & 531.777 &
\end{tabular}

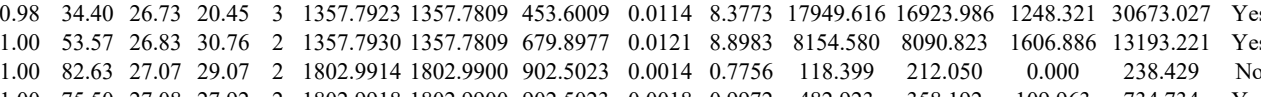

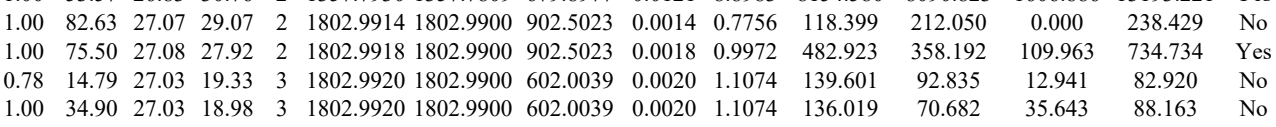
$\begin{array}{llllllllllllllll} & & & \end{array}$

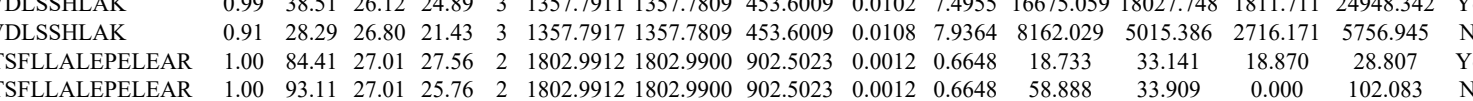

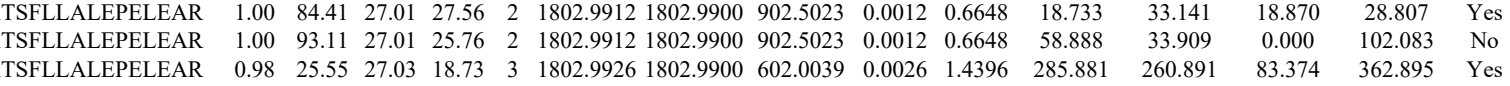
$\begin{array}{lllllllllllllllll} & \end{array}$ \begin{tabular}{llllllllllllllll} 
ATSFLLALEPELEAR & 1.00 & 91.52 & 27.13 & 28.06 & 2 & 1802.9908 & 1802.9900 & 902.5023 & 0.0008 & 0.4432 & 88.733 & 94.361 & 30.404 & 119.713 & Yes \\
\hline
\end{tabular}

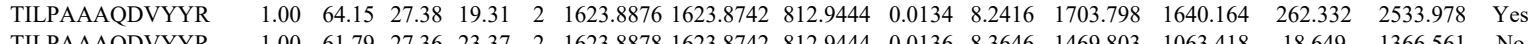
$\begin{array}{lllllllllllllllll}\text { TILPAAAQDVYYR } & 1.00 & 61.79 & 27.36 & 23.37 & 2 & 1623.8878 & 1623.8742 & 812.9444 & 0.0136 & 8.3646 & 1469.803 & 1063.418 & 18.649 & 1366.561 & \text { No }\end{array}$ $\begin{array}{llllllllllllllll}\text { ALTSEIALLQSR } & 1.00 & 66.43 & 26.39 & 25.27 & 2 & 1444.8396 & 1444.8371 & 723.4258 & 0.0025 & 1.7279 & 1342.235 & 1622.225 & 38.777 & 2133.857 & \text { Yes }\end{array}$ $\begin{array}{llllllllllllllll}\text { NLVEQHIQDIVVHYTFNK } & 1.00 & 53.13 & 25.71 & 66.13 & 4 & 2484.3385 & 2484.3369 & 622.0915 & 0.0016 & 0.6430 & 2232.592 & 2564.604 & 1571.748 & 4309.878 & \text { Yes }\end{array}$

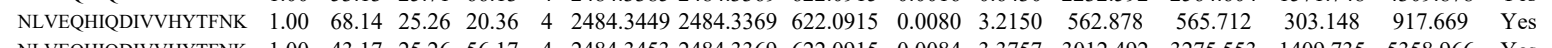

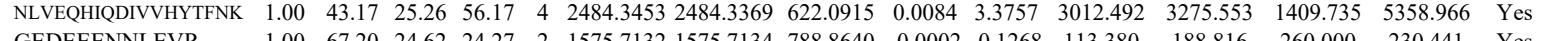

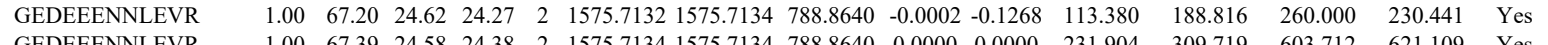

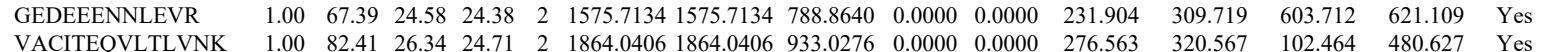
$\begin{array}{lllllllllllllllll}\text { VACITEVLTLVNK } & 1.00 & 82.41 & 26.34 & 24.71 & 2 & 1864.0406 & 1864.0406 & 933.0276 & 0.0000 & 0.0000 & 276.563 & 320.567 & 102.464 & 480.627 & \text { Yes } \\ \text { VACITEQVLTLVNK } & 1.00 & 79.20 & 26.06 & 25.27 & 2 & 1864.0416 & 1864.0406 & 933.0276 & 0.0010 & 0.5359 & 187.882 & 167.622 & 39.653 & 357.182 & \text { Yes }\end{array}$

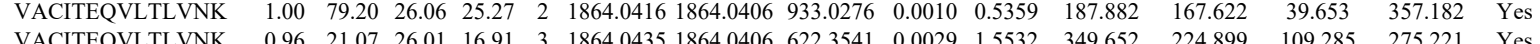
$\begin{array}{llllllllllllllll}\text { VACITEQVLTLVNK } & 1.00 & 39.95 & 26.01 & 22.04 & 3 & 1864.0435 & 1864.0406 & 622.3541 & 0.0029 & 1.5532 & 644.678 & 798.472 & 132.324 & 1032.625 & \text { Yes }\end{array}$ 


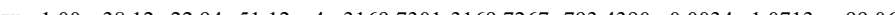

$\begin{array}{lllllllllllllll} & \end{array}$

\begin{tabular}{lllllllllllll}
\hline & VACTICVLILVNK & 1.00 & 78.13 & 26.44 & 25.16 & 2 & 1864.0404 & 1864.0406 & 933.0276 & 0.002 & 0.1072 & 274.389
\end{tabular}

20.909

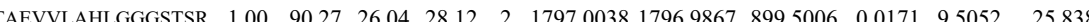

142.194

VTAEVVLAHLGGGSTSR 
$\begin{array}{llllllll} & 0.135\end{array}$

$\begin{array}{lllllllllllll}1.00 & 71.52 & 27.93 & 41.33 & 2 & 1515.8280 & 1515.8266 & 758.9206 & 0.0014 & 0.9224 & 719.878 & 63\end{array}$ $\begin{array}{lllllllllll} & \end{array}$ $\begin{array}{llllllllllllll} & & 220.13 & 2201.0799 & 734.7006 & 0.0031 & 1.4065 & 123.547 & 96.384\end{array}$ $\begin{array}{lllllllllllll}\text { QAADMILDDNFASIVTGVEEGR } & 0.60 & 62.05 & 27.51 & 75.05 & 3 & 2607.3013 & 2607.2972 & 870.1063 & 0.0041 & 1.5707 & 18.245 & 18.377\end{array}$

ACVVHGSDLK

$\begin{array}{llll}1.00 & 47.55 & 24.36 & 21.24 \\ 0.93 & 26.05 & 24.41 & 14.72\end{array}$

$\begin{array}{lllllllllllllllll}1.00 & 46.28 & 26.12 & 29.31 & 2 & 1548.9898 & 1548.8755 & 775.4450 & 0.0143 & 9.4929 & 15436.363 & 15502.653 & 5737.583 & 19522.587 & \text { Yes } \\ & 870.513 & 821.161 & 550.343 & 1343.220 & \text { Yes }\end{array}$

$\begin{array}{llllllllllllllll}\text { AVFQANQENLPILK } & 1.00 & 86.53 & 24.55 & 27.88 & 2 & 1872.0740 & 1872.0712 & 937.0429 & 0.0028 & 1.4941 & 180.088 & 275.846 & 68.081 & 373.246 & \text { Yes } \\ \text { AVFQANQENLPILK } & 1.00 & 87.09 & 23.64 & 33.71 & 2 & 1872.0870 & 1872.0712 & 937.0429 & 0.0158 & 8.4307 & 130.666 & 115.736 & 42.561 & 231.157 & \text { Yes }\end{array}$ LIIVEGCQR

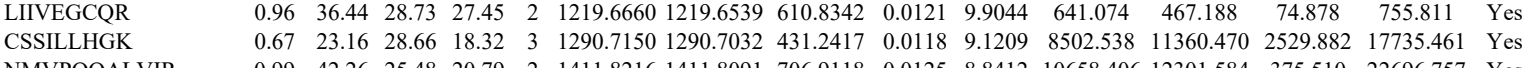
$\begin{array}{llllllllllllllll}1.00 & 87.09 & 23.64 & 33.71 & 2 & 1872.0870 & 1872.0712 & 937.0429 & 0.0158 & 8.4307 & 130.666 & 115.736 & 42.561 & 231.157 & \text { Yes } \\ 0.94 & 34.42 & 28.65 & 25.86 & 2 & 1219.6656 & 1219.6539 & 610.8342 & 0.0117 & 9.5770 & 479.427 & 648.219 & 133.146 & 653.283 & \text { Yes } \\ 0.67 & 23.44 & 28.66 & 27.45 & 2 & 1219.6660 & 1219.6539 & 610.8342 & 0.0121 & 9.9044 & 641.074 & 467.188 & 74.878 & 755.811 & \text { Yes }\end{array}$ $\begin{array}{llllllllllllllll} & & \end{array}$

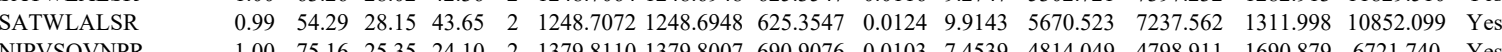
LNIPVSQVNPR $\begin{array}{llllllllllllllll} & \\ \text { LNIPVSQVNPR } & 1.00 & 67.40 & 25.39 & 25.40 & 2 & 1379.8112 & 1379.8007 & 690.9076 & 0.0105 & 7.5986 & 4798.225 & 5263.691 & 1653.251 & 7672.315 & \text { Yes }\end{array}$ $\begin{array}{lllllllllllllllll} & \text { VDNSSLTGESEPOTR } & 1.00 & 89.43 & 27.13 & 27.28 & 2 & 1762.8460 & 1762.8455 & 882.4300 & 0.0005 & 0.2833 & 1213.975 & 1511.377 & 499.945 & 2480.528 & \text { Yes }\end{array}$ $\begin{array}{llllllllllllllll}\text { VDNSSLTGESEPOTR } & 1.00 & 91.12 & 27.03 & 29.69 & 2 & 1762.8464 & 1762.8455 & 882.4300 & 0.0009 & 0.5100 & 679.442 & 975.742 & 288.239 & 1680.254 & \text { Yes }\end{array}$ $\begin{array}{lllllllllllllll}\text { GVGIISEGNETVEDIAAR } & 1.00 & \text { \#\#\#\# } 27.45 & 30.09 & 2 & 1973.0194 & 1973.0187 & 987.5166 & 0.0007 & 0.3544 & 407.135 & 378.501 & 472.611 & 464.367 & \text { Yes }\end{array}$

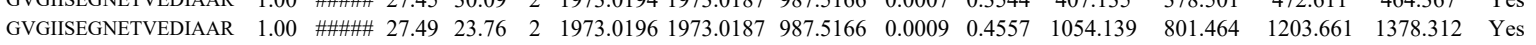
$\begin{array}{llllllllllllllll}\text { AVAGDASESALLK } & 1.00 & 99.71 & 26.23 & 28.45 & 2 & 1518.8612 & 1518.8497 & 760.4321 & 0.0115 & 7.5614 & 1800.266 & 2358.321 & 300.077 & 3299.220 & \text { Yes }\end{array}$ $\begin{array}{lllllllllllllll}\text { AVAGDASESALLK } & 1.00 & \text { \#\#.18 } & 31.30 & 2 & 1518.8614 & 1518.8497 & 760.4321 & 0.0117 & 7.6929 & 752.121 & 1086.762 & 196.629 & 1864.100 & \text { Yes }\end{array}$ $\begin{array}{llllllllllllllll}\text { SPDFTNENPLETR } & 1.00 & 66.40 & 26.71 & 24.59 & 2 & 1662.8014 & 1662.7971 & 832.4058 & 0.0043 & 2.5829 & 568.908 & 436.516 & 635.101 & 853.701 & \text { Yes }\end{array}$ \begin{tabular}{llllllllllllllll} 
SPDFTNENPLETR & 0.99 & 47.54 & 26.86 & 19.81 & 2 & 1662.8020 & 1662.7971 & 832.4058 & 0.0049 & 2.9433 & 94.052 & 105.062 & 157.433 & 328.708 & Yes \\
\hline
\end{tabular}

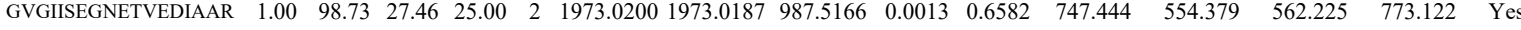
$\begin{array}{llllllllllllllll}\text { GVGIISEGNETVEDIAAR } & 1.00 & 99.74 & 27.46 & 27.03 & 2 & 1973.0200 & 1973.0187 & 987.5166 & 0.0013 & 0.6582 & 225.600 & 317.399 & 209.546 & 379.351 & \text { Yes }\end{array}$ $\begin{array}{llllllllllllllll}\text { AAVPDAVGK } & 0.99 & 46.76 & 26.88 & 21.75 & 2 & 1114.6642 & 1114.6590 & 558.3368 & 0.0052 & 4.6567 & 11939.741 & 15236.563 & 2191.549 & 22080.005 & \text { Yes } \\ \text { AAVPDAVGK } & 0.99 & 44.71 & 26.60 & 21.06 & 2 & 1114.6672 & 1114.6590 & 5583368 & 0.0082 & 7.3432 & 15750.250 & 18073212 & 2421.121 & 26441297 & \text { Yes }\end{array}$ $\begin{array}{llllllllllllllll} & 0.99 & 44.71 & 26.60 & 21.06 & 2 & 1114.6672 & 1144.6590 & 558.3368 & 0.0082 & 7.3432 & 15750.250 & 18073.212 & 2421.121 & 26441.297 & \text { Yes } \\ \text { MSINAEEVVVGDLVEVK } & 1.00 & 32.67 & 27.37 & 20.75 & 3 & 2118.1510 & 2118.1486 & 707.0568 & 0.0024 & 1.1314 & 23.579 & 8.722 & 1.127 & 17.700 & \text { No }\end{array}$

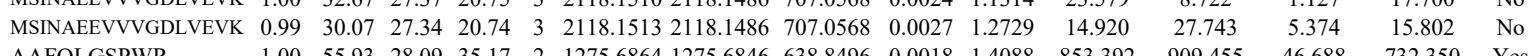
$\begin{array}{lllllllllllll}\text { ALDH2_HUMA] } & \text { P05091 } & \text { ALDH2 } & \text { Aldehyde dehydro 56.381 } & 1.00 & 2 & 7 & 0.5146 & 0.4357 & 0.1917 & 0.6835 & 6 & \text { AAFQLGSPWR }\end{array}$ AAFQLGSPWR AAFQLGSPWR AAFQLGSPWR

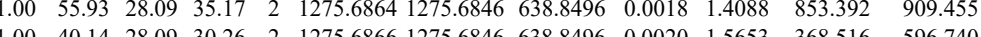
$\begin{array}{llllllllllll}1.00 & 40.14 & 28.09 & 30.26 & 2 & 1275.6866 & 1275.6846 & 638.8496 & 0.0020 & 1.5653 & 368.516 & 596.740\end{array}$ $\begin{array}{llllllllllll}0.99 & 33.79 & 28.14 & 28.05 & 2 & 1275.6862 & 1275.6846 & 638.8496 & 0.0016 & 1.2522 & 78.509 & 150.332\end{array}$ VICQVAEGDKEDVD $\begin{array}{lllllllllll}0.98 & 35.50 & 27.93 & 30.99 & 2 & 1275.6872 & 1275.6846 & 638.8496 & 0.0026 & 2.0349 & 147.949\end{array}$ $\begin{array}{llllllllllll}0.72 & 15.53 & 26.59 & 16.05 & 4 & 3255.6033 & 3255.6005 & 814.9074 & 0.0028 & 0.8590 & 26.505\end{array}$

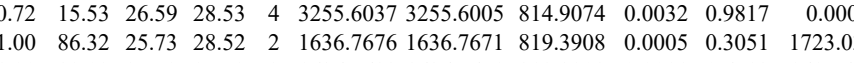

TESPASDEAGEK 


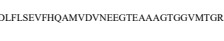

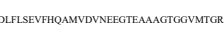

LNIGYIEDLK

LNIGYIEDLK

LNIGYIEDLK

LNIGYIEDLK

LNGLYPFR

LNGLYPFR

LECAEEAR

YYSSEPQAVDFLECAEEAR

GSYPDAILQAQAADK

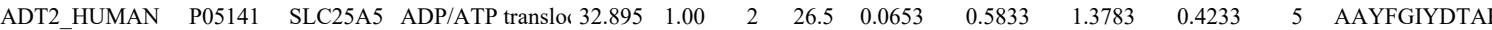

\section{AAYFGIYDTAK}

AAYFGIYDTAK

GTDIMYTGTLDCWR

GTDIMYTGTL
CDEPLSILVR

CDEPLSILVR

CDEPLSILVR

CDEPLSILVR

LAVHPSGVALQDR

LAVHPSGVALQDR

LAVHPSGVALQD
LTQTVAHLK

LTQTVAHLK

LAVHPSGVALQDR

LAVHPSGVALQDR

LAYHFPGVALQDR

LAVHPSGVALQDR

LTQTVAHLK

LTQTVAHLK
LTQTVAHLK

LTQTVAHLK

LTQTVAHLK

VPLASQGLGPGSTVLLVVDK

VPLASQGLGPGSTVLLVVDK
VPLASQGGGPGSVLLVVVIVK
VPLASGTVLLVDK

IGVHAFQQR

IGVHAFQQR

IGVHAFQQR

IGVHAFQQR

IGVHAFQQR

IGVHAFQQR

IGVHAFQQR

IGVHAFQQR

IGVHAFQQR

IGVHAFQQR

IGVHAFQQR

IGVHAFQQR

IGVHAFQQR

IGVHAFQQR

IGVHAFQQR $\begin{array}{llllllllllll} & \end{array}$ $\begin{array}{lllllllllll}1.00 & 53.55 & 25.01 & 16.51 & 4 & 3695.7357 & 3695.7318 & 924.9402 & 0.0039 & 1.0541 & 5.487\end{array}$ $\begin{array}{lllllllllll}1.00 & 30.67 & 24.98 & 15.23 & 4 & 3695.7361 & 3695.7318 & 924.9402 & 0.0043 & 1.1622 & 4.257\end{array}$ $\begin{array}{lllllllllll}1.00 & 56.16 & 26.29 & 42.17 & 2 & 1464.8426 & 1464.8431 & 733.4288 & -0.0005 & -0.3409 & 286.207\end{array}$ $\begin{array}{lllllllllll}100 & 59.69 & 26.29 & 41.90 & 2 & 1464.8426 & 1464.8431 & 733.4288 & -0.0005 & -0.3409 & 242.760\end{array}$ $\begin{array}{llllllllllllll}23.37 & 22.46 & 36.37 & 3 & 2396.0455 & 2396.0422 & 799.6880 & 0.0033 & 1.3755 & 44.436 & 24.088 & 28.526 & 30.832 & \text { Yes } \\ 97.53 & 27.90 & 66.61 & 2 & 1834.9828 & 1834.9668 & 918.497 & 0.0160 & 8.7099 & 130.785 & 207.770 & 751.374 & 234.252 & \text { Yes }\end{array}$ $\begin{array}{llllllllllllll} & & & \end{array}$ $\begin{array}{lllllllllllllll} & 1377.312 & \text { Yes }\end{array}$ $\begin{array}{llllllllllllll}5.96 & 28.00 & 26.18 & 2 & 1506.8112 & 1506.7962 & 754.4054 & 0.0150 & 9.9415 & 945.659 & 622.463 & 216.562 & 1283.446 & \text { Yes }\end{array}$ $\begin{array}{llllllllllllll}1.03 & 28.28 & 28.09 & 2 & 1506.8084 & 1506.7962 & 754.4054 & 0.0122 & 8.0858 & 64.759 & 112.179 & 64.048 & 177.577 & \text { Yes }\end{array}$

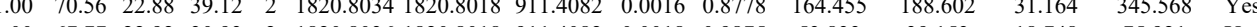
$\begin{array}{lllllllllllllll}1.00 & 67.77 & 22.92 & 30.93 & 2 & 1820.8036 & 1820.8018 & 911.4082 & 0.0018 & 0.9875 & 53.833 & 39.153 & 18.748 & 75.921 & \text { Yes }\end{array}$ $\begin{array}{lllllllllllllll}1.00 & 57.77 & 2.92 & 30.93 & 2 & 1820.8036 & 1820.8018 & 91.408 & 0.018 & 0.9875 & 53.83 & 39.15 & 18.748 & 75.921 & \text { Yes } \\ 1.00 & 50.2 & 27.67 & 38.26 & 2 & 1333.6892 & 1333.6856 & 667.8501 & 0.0036 & 2.6952 & 11946.660 & 3922.087 & 168.224 & 1396.409 & \text { Yes }\end{array}$

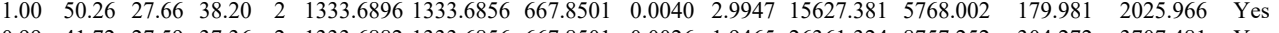
\begin{tabular}{llllllllllllllll}
0.99 & 41.72 & 27.59 & 37.36 & 2 & 1333.6882 & 1333.6856 & 667.8501 & 0.0026 & 1.9465 & 26361.324 & 8757.252 & 304.272 & 3707.481 & Yes \\
\hline
\end{tabular} $\begin{array}{llllllllllllllll}1.00 & 50.48 & 27.60 & 37.99 & 2 & 1333.6888 & 1333.6856 & 667.8501 & 0.0032 & 2.3957 & 18730.448 & 6278.481 & 577.764 & 2615.309 & \text { Yes } \\ 1.00 & 59.48 & 27.12 & 21.67 & 2 & 1505.8556 & 1505.8436 & 753.9291 & 0.0120 & 7.9582 & 4000.791 & 2088.536 & 146.147 & 431.801 & \text { Yes }\end{array}$ $\begin{array}{llllllllllllllll}1.00 & 59.48 & 27.12 & 21.67 & 2 & 1505.8556 & 1505.8436 & 753.9291 & 0.0120 & 7.9582 & 4000.791 & 2088.536 & 146.147 & 431.801 & \text { Yes } \\ 1.00 & 54.92 & 27.12 & 26.21 & 2 & 1505.5558 & 1505.8436 & 753.9291 & 0.0122 & 8.0909 & 11853.209 & 5928.777 & 399.772 & 1423.146 & \text { Yes }\end{array}$ $\begin{array}{lllllllllllllllll}1.00 & 54.92 & 27.12 & 26.21 & 2 & 1505.8558 & 1505.8436 & 753.9291 & 0.0122 & 8.0909 & 11853.209 & 5928.777 & 399.772 & 1423.146 & \text { Yes }\end{array}$

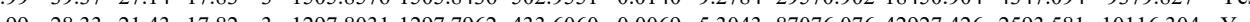
$\begin{array}{lllllllllllllll}0.99 & 28.33 & 21.43 & 17.82 & 3 & 1297.8031 & 1297.7962 & 433.6060 & 0.0069 & 5.3043 & 87076.076 & 42927.426 & 2593.581 & 10116.304 & \text { Yes }\end{array}$

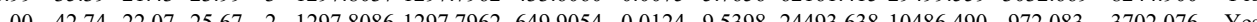
$\begin{array}{llllllllllllllll}1.00 & 51.01 & 22.88 & 26.64 & 2 & 1505.8530 & 1505.8436 & 753.9291 & 0.0094 & 632340 & 8790.555 & 4363.640 & 2058.336 & 1590.297 & \text { Yes }\end{array}$ $\begin{array}{lllllllllllllllll}1.00 & 56.45 & 26.86 & 25.44 & 2 & 1505.8534 & 1505.8436 & 753.9291 & 0.0098 & 6.4992 & 8318.602 & 4697.955 & 2431.432 & 1957.095 & \text { Yes }\end{array}$ $\begin{array}{llllllllllllllll}0.97 & 32.80 & 27.17 & 17.23 & 3 & 1505.8543 & 1505.8436 & 502.9551 & 0.0107 & 7.0914 & 30228.836 & 16761.100 & 6416.964 & 11568.493 & \text { Yes }\end{array}$ $\begin{array}{llllllllllllllll}0.97 & 32.82 & 27.12 & 15.29 & 3 & 1505.8558 & 1505.8436 & 502.9551 & 0.0122 & 8.0855 & 28425.575 & 19784.121 & 8859.421 & 19216.604 & \text { No }\end{array}$ $\begin{array}{lllllllllllllll}1.00 & 28.22 & 21.24 & 16.33 & 3 & 1297.8016 & 1297.7962 & 433.6060 & 0.0054 & 4.1512 & 59177.743 & 31496.109 & 2448.295 & 8398.553 & \text { Yes }\end{array}$ $\begin{array}{lllllllllllllllll}1.00 & 44.84 & 21.24 & 24.59 & 2 & 1297.8016 & 1297.7962 & 649.9054 & 0.0054 & 4.1544 & 1482.494 & 6986.199 & 3327.748 & 3258.881 & \text { Yes }\end{array}$ $\begin{array}{lllllllllllllll}100 & 48.23 & 21.17 & 25.98 & 2 & 1297.8022 & 1297.7962 & 649.9054 & 0.0060 & 4.6160 & 34393.748 & 18024.273 & 1820.074 & 6235.451 & \text { Yes }\end{array}$ $\begin{array}{llllllllllllllll}1.00 & 37.16 & 21.24 & 19.17 & 3 & 1297.8019 & 1297.7962 & 433.6060 & 0.0057 & 4.3818 & 28845.596 & 15282.827 & 745.041 & 3580.445 & \text { Yes }\end{array}$ $\begin{array}{llllllllllllll} & 20.99 & 20.95 & 2 & 2237.3374 & 2237.3239 & 1119.6692 & 0.0135 & 6.0285 & 3651.126 & 1928.394 & 116.199 & 195.821 & \text { Yes }\end{array}$

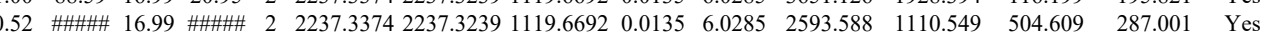
$\begin{array}{ccccccccccccccc}0.62 & 2.22 & 17.78 & 15.22 & 3 & 2237.3272 & 2237.3239 & 746.7819 & 0.0033 & 1.4730 & 35.724 & 61.931 & 133.907 & 36.776 & \text { No } \\ 0.60 & 55.62 & 17.85 & 68.62 & 3 & 2237.3281 & 2237.3239 & 746.7819 & 0.0042 & 1.8747 & 835.776 & 443.759 & 168.907 & 455.720 & \text { No }\end{array}$ $\begin{array}{lllllllllllllll}0.70 & 14.81 & 27.85 & 21.37 & 3 & 1198.6729 & 1198.6693 & 400.5637 & 0.0036 & 2.9958 & 7715.310 & 6926.864 & 2887.816 & 3607.795 & \text { Yes }\end{array}$

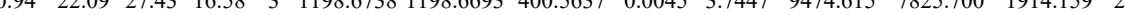
$\begin{array}{lllllllllllllll}1.00 & 43.73 & 27.85 & 25.82 & 3 & 1198.6714 & 1198.6693 & 400.5637 & 0.0021 & 1.7475 & 10897.356 & 6659.302 & 1251.989 & 1843.592 & \text { Yes }\end{array}$ $\begin{array}{llllllllllllllll}1.00 & 36.06 & 27.85 & 24.69 & 3 & 1198.6726 & 1198.6693 & 400.5637 & 0.0033 & 2.7461 & 17492.508 & 11642.928 & 1987.983 & 2440.591 & \text { Yes }\end{array}$

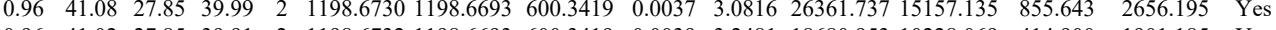
$\begin{array}{llllllllllllllll}0.96 & 41.02 & 27.85 & 39.91 & 2 & 1198.6732 & 1198.6693 & 600.3419 & 0.0039 & 3.2481 & 18680.953 & 10228.069 & 414.900 & 1901.185 & \text { Yes }\end{array}$ $\begin{array}{lllllllllllllll}1.00 & 35.77 & 27.85 & 22.28 & 3 & 1198.6726 & 1198.6693 & 400.5637 & 0.0033 & 2.7461 & 6106.788 & 3485.844 & 1431.804 & 1603.299 & \text { Yes }\end{array}$ \begin{tabular}{llllllllllllllll}
1.00 & 41.03 & 27.85 & 27.32 & 3 & 1198.6732 & 1198.6693 & 400.5637 & 0.0039 & 3.2454 & 16193.598 & 10232.012 & 2144.691 & 2416.099 & Yes \\
\hline
\end{tabular} $\begin{array}{lllllllllllllllll}0.97 & 41.00 & 27.44 & 22.06 & 2 & 1198.6738 & 1198.6693 & 600.3419 & 0.0045 & 3.7479 & 10601.678 & 5550.668 & 545.435 & 1450.783 & \text { Yes }\end{array}$ $\begin{array}{lllllllllllllllll}0.98 & 42.27 & 27.44 & 21.76 & 2 & 1198.6738 & 1198.6693 & 600.3419 & 0.0045 & 3.7479 & 15820.137 & 8059.125 & 480.098 & 2302.450 & \text { Yes } \\ \end{array}$ $\begin{array}{lllllllllllllll}1.00 & 39.44 & 27.87 & 23.24 & 3 & 1198.6717 & 1198.6693 & 400.5637 & 0.0024 & 1.9972 & 7568.956 & 5723.294 & 1905.229 & 1658.569 & \text { Yes }\end{array}$ $\begin{array}{lllllllllllllll}1.00 & 40.43 & 27.86 & 27.05 & 3 & 1198.6723 & 1198.6693 & 400.5637 & 0.0030 & 2.4965 & 10875.332 & 6007.872 & 1996.036 & 2565.898 & \text { Yes }\end{array}$ $\begin{array}{llllllllllllll}.89 & 36.07 & 27.85 & 39.52 & 2 & 1988.6730 & 198.6693 & 600.3419 & 0.0037 & 3.0816 & 5405.629 & 3198.092 & 241.441 & 1338.919\end{array}$ $\begin{array}{llllllllllllll} & \end{array}$

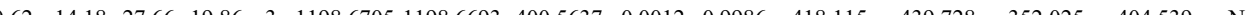




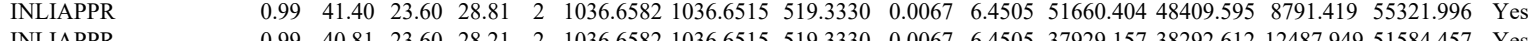

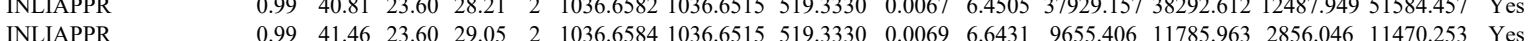

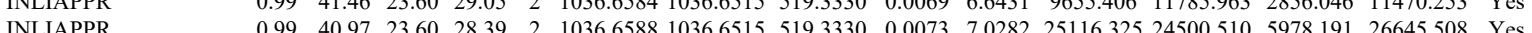

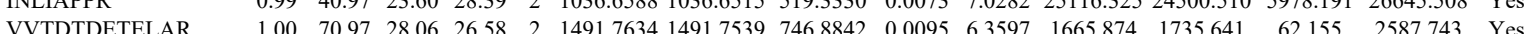

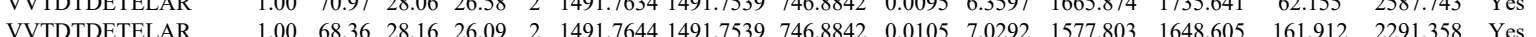

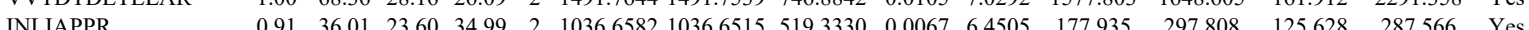

VVTDTDETELAR

HAVSDPSILDSLDLNEDER HAVSDPSIDSLDLNEDER DEQLESLFQR DEQLESLFQR $\begin{array}{llllllllllll}0.66 & 16.07 & 26.73 & 16.23 & 3 & 2149.0312 & 2149.0315 & 717.3511 & -0.0003 & -0.1394 & 23.302 \\ 0.52 & 20.71 & 21.14 & 26.97 & 2 & 958.642 & 958.6419 & 480.3282 & -0.0017 & -1.7696 & 179.887\end{array}$ $\begin{array}{lllllllllllll}0.82 & 14.94 & 21.00 & 22.06 & 2 & 958.6428 & 958.6419 & 480.3282 & 0.0009 & 0.9369 & 432.677\end{array}$ $\begin{array}{llllllllllll}0.83 & 15.94 & 22.17 & 26.49 & 2 & 958.6442 & 958.6419 & 480.3282 & 0.0023 & 2.3942 & 332.333 & 338.8\end{array}$ $\begin{array}{llllllllllllllll}0.78 & 31.43 & 22.12 & 35.93 & 2 & 958.6498 & 958.6419 & 480.3282 & 0.0079 & 8.2235 & 28198.500 & 30308.480 & 12036.247 & 45529.486 & \text { Yes }\end{array}$ $\begin{array}{lllllllllll}1.00 & 40.09 & 24.49 & 53.09 & 4 & 4085.0949 & 4085.0917 & 1022.2802 & 0.0032 & 0.7826 & 3.118\end{array}$ $\begin{array}{lllllllllll}0.60 & 7.30 & 24.36 & 87.30 & 3 & 4085.0962 & 085.0917 & 1362.7045 & 0.0045 & 1.1008 & 0.000\end{array}$ $\begin{array}{lllllllllll}1.00 & 36.05 & 24.49 & 16.95 & 4 & 4085.0949 & 4085.0917 & 1022.2802 & 0.0032 & 0.7826 & 5.089\end{array}$

$\begin{array}{lllllllllll} & \end{array}$ $\begin{array}{lllllllllllll}\text { AAGVNVEPFWPGLFAK } & 1.00 & 44.77 & 26.61 & 19.13 & 3 & 1990.0912 & 1990.0920 & 664.3713 & -0.0008 & -0.4014 & 113.492 & 101.949 \\ \text { AAGVNVEPFWPGLFAK } & 0.58 & 12.05 & 26.31 & 17.04 & 3 & 1990.0927 & 1990.0920 & 664.3713 & 0.0007 & 0.3512 & 124.333 & 89.583\end{array}$ $\begin{array}{lllllllllllll}\text { AAGVNVEPFWPGLFAK } & 1.00 & 77.47 & 26.25 & 21.83 & 2 & 1990.0944 & 1990.0920 & 996.0533 & 0.0024 & 1.2048 & 2407.389 & 2314.630\end{array}$

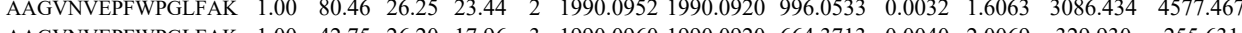

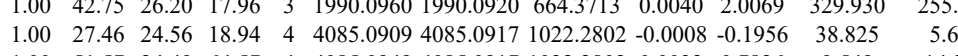

$0.000 \quad 0.000 \quad 0.000 \quad$ No $\begin{array}{llll}0.000 & 0.000 & 0.000 & \text { No }\end{array}$ $\begin{array}{llll}0.000 & 0.000 & 0.000 & \text { No }\end{array}$

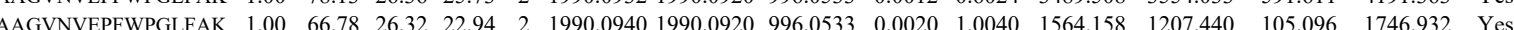
$\begin{array}{lllllllllllllllll} & \text { AAGVNVEPFWPGLFAK } & 0.60 & 31.24 & 26.20 & 44.24 & 3 & 1990.0960 & 1990.0920 & 664.3713 & 0.0040 & 20069 & 444.181 & 283.389 & 192.290 & 471.708 & \text { Yes }\end{array}$ $\begin{array}{lllllllllllllllll}\text { AAGVNVEPFWPGLFAK } & 1.00 & 69.23 & 26.31 & 23.28 & 2 & 1990.0928 & 1990.0920 & 996.0533 & 0.0008 & 0.4016 & 1008.318 & 880.763 & 0.000 & 1834.264 & \text { No }\end{array}$

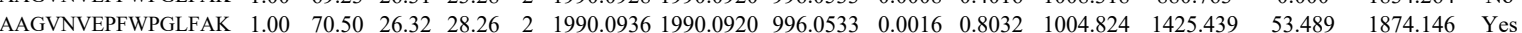
$\begin{array}{llllllllllllllll}\text { AAGVNVEPFWPGLFAK } & 1.00 & 57.92 & 26.27 & 17.90 & 3 & 1990.0951 & 1990.0920 & 664.3713 & 0.0031 & 1.5554 & 228.764 & 329.572 & 63.940 & 323.284 & \text { Yes }\end{array}$ $\begin{array}{llllllllllllllll}\text { AAGVNVEPFWPGLFAK } & 0.67 & 44.16 & 26.27 & 57.16 & 3 & 1990.0951 & 1990.0920 & 664.3713 & 0.0031 & 1.5554 & 231.921 & 304.952 & 77.080 & 331.537 & \text { Yes }\end{array}$

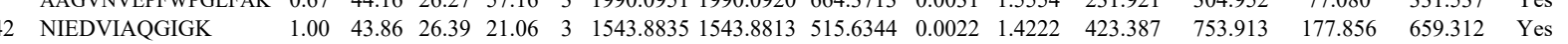
$\begin{array}{llllllllllllllllll}\text { NIEDVIAQGIGK } & 1.00 & 50.13 & 26.43 & 21.49 & 3 & 1543.8841 & 1543.8813 & 515.6344 & 0.0028 & 1.8101 & 786.112 & 582.945 & 116.261 & 920.092 & \text { Yes }\end{array}$ $\begin{array}{llllllllllllllll}\text { NIEDVIAQGIGK } & 1.00 & 82.44 & 26.30 & 30.58 & 2 & 1543.8846 & 1543.8813 & 772.9479 & 0.0033 & 2.1347 & 10955.725 & 11082.862 & 1678.447 & 18140.899 & \text { Yes }\end{array}$ $\begin{array}{llllllllllllllll}\text { NIEDVIAQGIGK } & 1.00 & 65.61 & 26.29 & 24.99 & 2 & 1543.8850 & 1543.8813 & 772.9479 & 0.0037 & 2.3934 & 11352.872 & 11280.270 & 2433.246 & 19818.698 & \text { Yes }\end{array}$ $\begin{array}{llllllllllllllll} & 24.91 & 22.97 & 2 & 3061.6294 & 3061.6287 & 1531.8216 & 0.0007 & 0.2285 & 0.000 & 0.000 & 0.000 & 0.000 & \text { No }\end{array}$

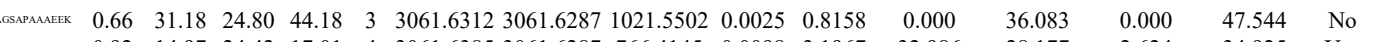

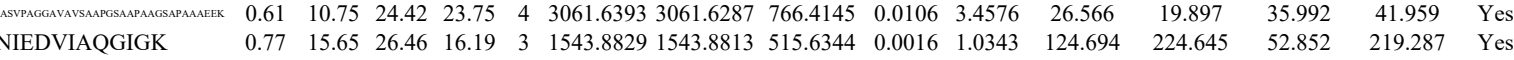
$\begin{array}{llllllllllllllll}1.00 & 47.38 & 26.38 & 16.77 & 3 & 1543.8832 & 1543.8813 & 515.6344 & 0.0019 & 1.2283 & 235.268 & 590.432 & 48.005 & 191.070 & \mathrm{~N} 0\end{array}$ $\begin{array}{lllllllllllllllll}1.00 & 63.38 & 26.43 & 24.67 & 2 & 1543.8840 & 1543.8813 & 772.9479 & 0.0027 & 1.7466 & 28355.840 & 26015.793 & 5214.399 & 59221.711 & \text { Yes }\end{array}$ $\begin{array}{lllllllllllllll}1.00 & 84.59 & 26.45 & 27.52 & 2 & 1543.8842 & 1543.8813 & 772.9479 & 0.0029 & 1.8759 & 15217.423 & 15657.808 & 2554.010 & 23079.658 & \text { Yes }\end{array}$

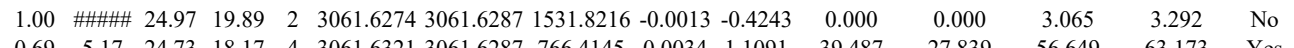
NIEDVIAQGIGK NIEDVIAQGIGK NIEDVIAQGIGK NIEDVIAQGIGK

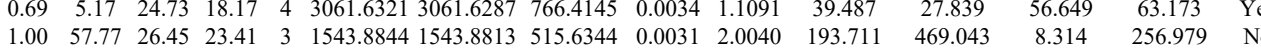

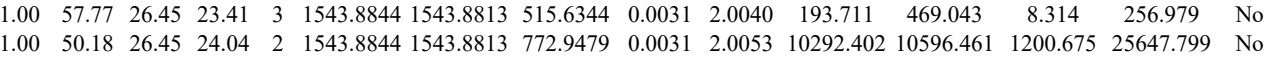
$\begin{array}{llllllllllllllllll}1.00 & 50.18 & 26.45 & 24.04 & 2 & 1543.8844 & 1543.8813 & 772.9479 & 0.0031 & 2.0053 & 10292.402 & 10596.461 & 1200.675 & 25647.799 & \text { No } \\ 1.00 & 61.24 & 26.30 & 24.63 & 2 & 1543.8846 & 1543.8813 & 772.9479 & 0.0033 & 2.1347 & 14814.518 & 16237.211 & 1691.563 & 30824.474 & \text { Yes }\end{array}$ $\begin{array}{lllllllllllllll}1.00 & 1.24 & 26.30 & 24.63 & 2 & 1543.8846 & 1543.8813 & 772.9479 & 0.0033 & 2.1347 & 14814.518 & 16237.211 & 1691.563 & 30824.474 & \text { Yes } \\ 1.00 & 55.27 & 26.29 & 25.06 & 3 & 1543.8850 & 1543.8813 & 515.6344 & 0.0037 & 2.3919 & 379.649 & 614.317 & 99.816 & 544.779 & \text { Yes }\end{array}$ $\begin{array}{lllllllllllllll}1.00 & 55.27 & 26.29 & 25.06 & 3 & 1543.8850 & 1543.8813 & 515.6344 & 0.0037 & 2.3919 & 379.649 & 614.317 & 99.816 & 544.779 & \text { Yes } \\ 1.00 & 60.52 & 26.39 & 24.36 & 2 & 1543.8802 & 1543.8813 & 772.9479 & -0.0011 & -0.7116 & 2267.801 & 1826.149 & 692.910 & 4112.592 & \text { Yes }\end{array}$ $\begin{array}{llllllllllllllll}\text { NIEDVIAQGIGK } & 1.00 & 61.03 & 26.38 & 24.95 & 2 & 1543.8810 & 1543.8813 & 772.9479 & -0.0003 & -0.1941 & 1922.842 & 1955.367 & 448.851 & 3253.300 & \text { Yes } \\ \end{array}$ $\begin{array}{llllllllllllll} & \end{array}$ 


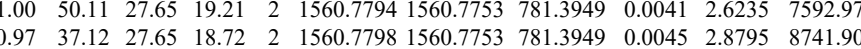

$\begin{array}{llllllllllll}\text { YVASYLLAALGGNSSPSAK } & 1.00 & \# \# \# \# \text { 25.84 } & 24.63 & 2 & 2156.1714 & 2156.1721 & 1079.0933 & -0.0007 & -0.3243 & 15.269\end{array}$

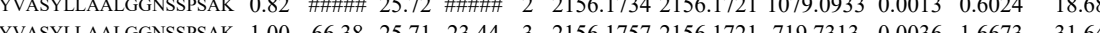

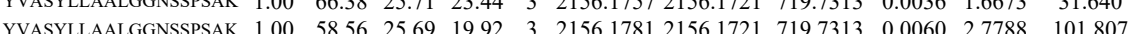

$\begin{array}{lllllllllllll}\text { YVASYLLAALGGNSSPSAK } & 1.00 & 41.09 & 25.71 & 16.77 & 3 & 2156.1763 & 2156.1721 & 719.7313 & 0.0042 & 1.9452 & 24.085\end{array}$

$\begin{array}{lllllllllllll}\text { YVASYLLAALGGNSSPSAK } & 1.00 & 56.80 & 25.67 & 17.44 & 3 & 2156.1775 & 2156.1721 & 719.7313 & 0.0054 & 2.5009 & 4.080\end{array}$

YVASYLLAALGGNSSPSAK $\begin{array}{lllllllllllll}0.60 & 52.16 & 5.671 & 65.16 & 3 & 2156.1757 & 2156.1721 & 719.7313 & 0.0036 & 1.6673 & 16.666\end{array}$

$\begin{array}{lllllllllllll}\text { YVASYLLAALGGNSSPSAK } & 0.60 & 28.09 & 25.63 & 41.09 & 3 & 2156.1760 & 2156.1721 & 719.7313 & 0.0039 & 1.8062 & 10.268\end{array}$

$\begin{array}{lllllllllllll}\text { ILDSVGIEADDDR } & 1.00 & 78.55 & 27.54 & 23.14 & 2 & 1560.7766 & 1560.7753 & 781.3949 & 0.0013 & 0.8318 & 5394.601\end{array}$ LDSVGIEADDD

$\begin{array}{llllllllllllll}1.00 & 75.10 & 27.40 & 23.64 & 2 & 1560.7772 & 1560.7753 & 781.3949 & 0.0019 & 1.2158 & 4643.022 & 5096.676\end{array}$

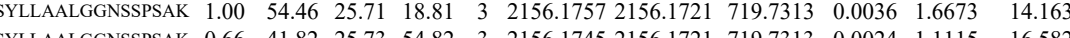
$\begin{array}{lllllllllllll}\text { YVASYLLAALGGNSSPSAK } & 0.66 & 41.82 & 25.73 & 54.82 & 3 & 2156.1745 & 2156.1721 & 719.7313 & 0.0024 & 1.1115 & 16.582\end{array}$ $\begin{array}{llllllllllll}\text { YVASYLLAALGGNSSPSAK } & 0.98 & 23.86 & 25.73 & 17.76 & 3 & 2156.1745 & 2156.1721 & 719.7313 & 0.0024 & 1.1115 & 14.294\end{array}$

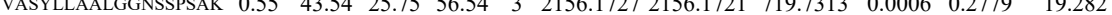
$\begin{array}{llllllllllllll}\text { YVASYLLAALGGNSSPSAK } & 1.00 & 36.36 & 25.73 & 16.08 & 3 & 2156.1736 & 2156.1721 & 719.7313 & 0.0015 & 0.6947 & 9.353\end{array}$ $\begin{array}{lllllllllllll} & \text { WASYLLALGGNSSPSAK } & 0.99 & 29.25 & 25.73 & 17.23 & 3 & 2156.1736 & 2156.1721 & 719.7313 & 0.0015 & 0.6947 & 10.760\end{array}$ $\begin{array}{llllllllllllll} & \text { WVASYLLAALGGNSPSAK } & 0.66 & 21.54 & 25.75 & 34.54 & 3 & 2156.1742 & 2156.1721 & 719.7313 & 0.0021 & 0.9726 & 27.545\end{array}$ $\begin{array}{llllllllllll}\text { YVASYLLAALGGNSSPSAK } & 0.55 & 21.03 & 25.67 & 34.03 & 3 & 2156.1730 & 2156.1721 & 719.7313 & 0.0009 & 0.4168 & 13.039 \\ \text { YVASYLLALGGSSPSAK } & 0.66 & 15.97 & 25.74 & 28.97 & 3 & 2156.1739 & 2156.1721 & 719.7313 & 0.0018 & 0.8336 & 11.609\end{array}$

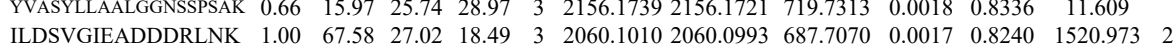
$\begin{array}{lllllllllll}1.00 & 44.92 & 25.72 & 25.26 & 2 & 1504.8750 & 1504.8745 & 753.4445 & 0.0005 & 0.3318 & 418.357 \\ 1.00 & 49.03 & 25.49 & 23.93 & 2 & 1504.8758 & 1504.8745 & 753.4445 & 0.0013 & 0.8627 & 462.228\end{array}$ $\begin{array}{llllllllllll}1.00 & 49.03 & 25.49 & 23.93 & 2 & 1504.8758 & 1504.8745 & 753.4445 & 0.0013 & 0.8627 & 462.228 \\ 0.62 & 14.31 & 22.67 & 17.23 & 3 & 1716.0268 & 1716.0277 & 573.0165 & -0.0009 & -0.5235 & 36.449\end{array}$ $\begin{array}{lllllllllll}0.62 & 14.31 & 22.67 & 17.23 & 3 & 1716.0268 & 1716.0277 & 573.0165 & -0.0009 & -0.5235 & 36.449 \\ 0.88 & 27.76 & 22.58 & 31.83 & 3 & 176.0280 & 1716.0277 & 573.0165 & 0.0003 & 0.1745 & 98.444\end{array}$ $\begin{array}{lllllllllllll}1.00 & 99.73 & 22.50 & 29.91 & 2 & 1716.0292 & 1716.0277 & 859.0211 & 0.0015 & 0.8731 & 86.123\end{array}$ $\begin{array}{llllllllllll}.00 & 5.9 & 2.38 & 24.21 & 3 & 1716.0307 & 1716.0277 & 573.0165 & 0.0030 & 1.7451 & 124.373 & 124.566\end{array}$ $\begin{array}{llllllllllll}1.00 & 67.61 & 27.73 & 24.07 & 2 & 1542.7932 & 1542.7778 & 772.3962 & 0.0154 & 9.9689 & 436.977 & 316.844 \\ 1.00 & 67.78 & 27.97 & 19.91 & 2 & 1542.7920 & 1542.7778 & 772.3962 & 0.0142 & 9.1921 & 6728.102 & 6188.244\end{array}$ $\begin{array}{llllllllllll}1.00 & 67.78 & 27.97 & 19.91 & 2 & 1542.7920 & 1542.7778 & 772.3962 & 0.0142 & 9.1921 & 6728.102 & 6188.244\end{array}$

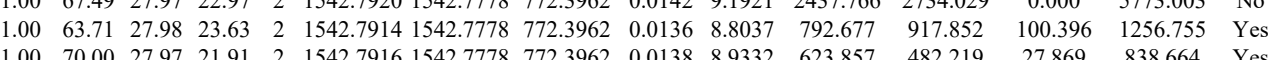
$\begin{array}{lllllllllllllllll}1.00 & 51.85 & 26.40 & 25.27 & 2 & 1255.7244 & 1255.7169 & 628.8657 & 0.0075 & 5.9631 & 14911.112 & 13698.979 & 9036.888 & 17943.385 & \text { Yes } \\ \end{array}$ $\begin{array}{llllllllllllll}2638 & 25.08 & 2 & 1255.7260 & 1255.7169 & 628.8657 & 0.0091 & 7.2352 & 24356.645 & 25768.317 & 17150.852 & 34167.693 & \text { Yes }\end{array}$

Table S-4 page 80 of 614 
AFLAD $\begin{array}{llllllllllll}0.60 & 27.07 & 22.33 & 40.07 & 3 & 3039.6682 & 3039.6637 & 1014.2285 & 0.0045 & 1.4790 & 20.781\end{array}$

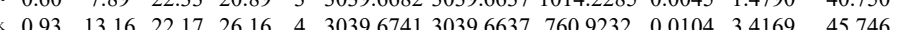

a

AFLADPSAFYAAPVAATTAAPAAN

TSFFQALGITTK TSFFQALGITTK TSFFQALGITTK TSFFQALGITTK TSFFQALGITTK TSFFQALGITTK TSFFQALGITTK TSFFQALGITTK TSFFQALGITTK TSFFQALGITTK TSFFQALGITTK LLPHIR

TSFFQALGITTK

TSFFQALGITTK

GTIEILSDVQLIK GTIEILSDVQLIK GHLENNPALEK GHLENNPALEK $\begin{array}{llllllllllllll}0.82 & 65.50 & 26.15 & 78.50 & 2 & 1600.9076 & 1600.9068 & 801.4607 & 0.0008 & 0.4991 & 4616.169 & 4685.755 & 245\end{array}$ $\begin{array}{llllllllllll}1.00 & 32.12 & 26.10 & 19.78 & 3 & 1600.9090 & 1600.9068 & 534.6429 & 0.0022 & 1.3716 & 258.649 & 334 .\end{array}$ $\begin{array}{llllllllllllll}0.96 & 20.95 & 26.12 & 21.71 & 3 & 1600.9093 & 1600.9068 & 534.6429 & 0.0025 & 1.5587 & 247.325 & 258.731 \\ 0 & 13.51 & 25.97 & 16.93 & 2 & 891.5796 & 891.5776 & 446.7961 & 0.0020 & 2.2382 & 7203.655 & 8780.623\end{array}$ $\begin{array}{lllllllllllll}1.00 & 55.71 & 26.11 & 20.81 & 2 & 1600.9080 & 1600.9068 & 801.4607 & 0.0012 & 0.7486 & 44.858 & 57.934\end{array}$ $\begin{array}{lllllllllllll}0.71 & 12.32 & 26.10 & 15.89 & 3 & 1600.9090 & 1600.9068 & 534.6429 & 0.0022 & 1.3716 & 166.261 & 159.233\end{array}$ $\begin{array}{llllllllllll}0.86 & 12.37 & 22.50 & 16.29 & 3 & 1716.0298 & 1716.0277 & 573.0165 & 0.0021 & 1.2216 & 13.422\end{array}$ $\begin{array}{lllllllllll}0.57 & 12.82 & 21.76 & 15.91 & 3 & 1716.0343 & 1716.0277 & 573.0165 & 0.0066 & 3.8393 & 9.061\end{array}$ $\begin{array}{llllllllllll}0.98 & 26.34 & 27.74 & 20.61 & 3 & 1508.8228 & 1508.8190 & 503.9469 & 0.0038 & 2.5135 & 3404.706 & 4208.074\end{array}$ $\begin{array}{lllllllllllllll}0.98 & 29.57 & 27.63 & 27.88 & 3 & 1508.8243 & 1508.8190 & 503.9469 & 0.0053 & 3.5056 & 2638.410 & 3602.680\end{array}$ $\begin{array}{llllllllllll}0.98 & 31.25 & 27.66 & 24.57 & 3 & 1508.8249 & 1508.8190 & 503.9469 & 0.0059 & 3.9025 & 4065.596 & 3795.250 \\ 1.00 & 49.46 & 26.02 & 27.26 & 2 & 1830.0224 & 1830.0205 & 916.0175 & 0.0019 & 1.0371 & 1171.720 & 919.779\end{array}$ $\begin{array}{llllllllllll}1.00 & 58.55 & 26.02 & 29.27 & 2 & 1830.0226 & 1830.0205 & 916.0175 & 0.0021 & 1.1463 & 800.613 & 1092.633\end{array}$ $\begin{array}{lllllllllll}1.00 & & \end{array}$

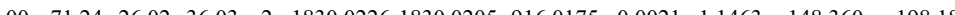

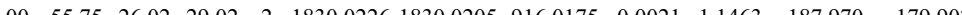

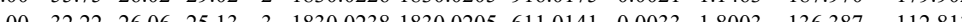

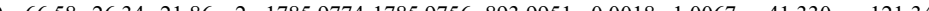
$\begin{array}{lllllllllllll}1.00 & \end{array}$ $\begin{array}{lllllllllllll}1.00 & 51.45 & 26.44 & 18.07 & 3 & 1785.9787 & 1785.9756 & 5963325 & 0.0031 & 1.7328 & 114.692 & 148.613\end{array}$ $\begin{array}{llllllllllllll}1.89 & 20.61 & 26.44 & 28.36 & 3 & 1785.9787 & 1785.9756 & 596.3325 & 0.0031 & 1.7328 & 148.945 & 138.6166\end{array}$ $\begin{array}{llllllllllllll}0.97 & 22.83 & 26.44 & 2.05 & 3 & 1785.9787 & 1785.9756 & 596.3325 & 0.0031 & 1.7328 & 202.002 & 138.163\end{array}$ $\begin{array}{llllllllllll}1.00 & 80.72 & 24.91 & 24.51 & 2 & 1837.0460 & 1837.0441 & 919.5293 & 0.0019 & 1.0331 & 247.752 & 181.451\end{array}$ $\begin{array}{llllllllllll}1.00 & 90.77 & 24.89 & 25.89 & 2 & 1837.0464 & 1837.0441 & 919.5293 & 0.0023 & 1.2506 & 225.774 & 224.73\end{array}$ $\begin{array}{lllllllllll}24.77 & 19.52 & 3 & 1837.0480 & 1837.0441 & 613.3553 & 0.0039 & 2.1195 & 439.704 & 240.261\end{array}$ $\begin{array}{lllllllllllll}19.00 & 3 & 1837.0480 & 1837.0441 & 613.3553 & 0.0039 & 2.1195 & 117.395 & 105.797\end{array}$

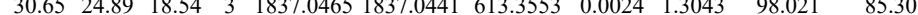

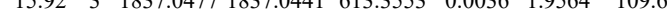
$\begin{array}{llllllllllll}1.00 & 37.60 & 27.08 & 23.77 & 2 & 1251.6278 & 1251.6260 & 626.8203 & 0.0018 & 1.4358 & 878.764 & 913.102\end{array}$ $\begin{array}{lllllllllllll}1.00 & 49.68 & 27.07 & 23.71 & 2 & 1251.6284 & 1251.6260 & 626.8203 & 0.0024 & 1.9144 & 1184.365 & 1306.788\end{array}$ $\begin{array}{llllllllllll}0.96 & 57.11 & 27.73 & 30.06 & 2 & 1693.8754 & 1693.8736 & 847.9441 & 0.0018 & 1.0614 & 39.447 & 47\end{array}$ $\begin{array}{llllllllllllllllll}0.90 & 30.72 & 25.25 & 32.55 & 2 & 979.5888 & 979.5802 & 490.7974 & 0.0086 & 8.7612 & 50635.301 & 46021.187 & 1775.004 & 52.614 & \text { No } & \end{array}$ $\begin{array}{lllllllllllllllll}1.00 & 49.50 & 27.69 & 26.33 & 2 & 1201.6818 & 1201.6723 & 601.8434 & 0.0095 & 7.8924 & 16380.623 & 17191.208 & 2076.880 & 17097.779 & \text { Yes }\end{array}$

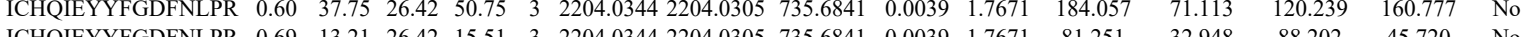
$\begin{array}{llllllllllllllll} & \end{array}$

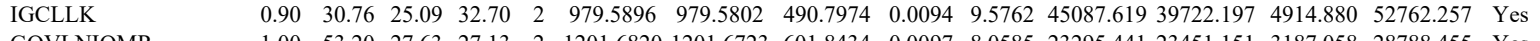
\begin{tabular}{llllllllllllllllll} 
GQVLNIQMR & 1.00 & 53.20 & 27.63 & 27.13 & 2 & 1201.6820 & 1201.6723 & 601.8434 & 0.0097 & 8.0585 & 23295.441 & 23451.151 & 3187.058 & 28788.455 & Yes \\
\hline GQVLNIQMR & 1.0 & 5.23 & 27.63 & 26.26 & 2 & 1201.6820 & 1201.6723 & 601.8434 & 0.0097 & 8.0585 & 25878.840 & 25688739 & 3799.076 & 29333.134 & Yes
\end{tabular} $\begin{array}{llllllllllllllll}\text { GQVLNIQMR } & 1.00 & 51.23 & 27.63 & 26.26 & 2 & 1201.6820 & 1201.6723 & 601.8434 & 0.0097 & 8.0585 & 25878.840 & 25688.739 & 3799.076 & 29333.134 & \text { Yes }\end{array}$

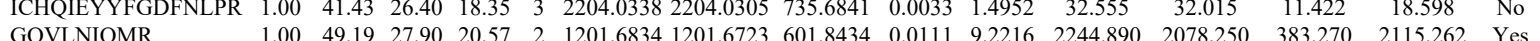
$\begin{array}{llllllllllllllll}\text { GQVLNIQMR } & 1.00 & 49.19 & 27.90 & 20.57 & 2 & 1201.6834 & 1201.6723 & 601.8434 & 0.0111 & 9.2216 & 2244.890 & 2078.250 & 383.270 & 2115.262 & \text { Yes } \\ \text { GQVLNIQMR } & 1.00 & 53.00 & 27.90 & 24.62 & 2 & 1201.6842 & 1201.6723 & 601.8434 & 0.0119 & 9.8862 & 1957.634 & 2014.947 & 325.459 & 1887.560 & \text { Yes }\end{array}$

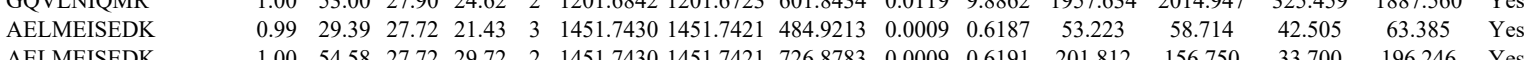

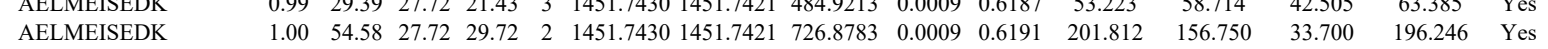



$\begin{array}{lllllllllllllllll}\text { LKPEDITQIQPQQLVLR } & 0.60 & 54.50 & 17.56 & 67.50 & 3 & 2306.3602 & 2306.3565 & 769.7928 & 0.0037 & 1.6022 & 2195.229 & 1452.825 & 683.063 & 1438.567 & \text { Yes }\end{array}$ $\begin{array}{lllllllllllllllll}\text { LKPEDITQIQPQQLVLR } & 0.60 & 36.74 & 17.56 & 49.74 & 3 & 2306.3602 & 2306.3565 & 769.7928 & 0.0037 & 1.6022 & 808.248 & 755.554 & 350.314 & 767.796 & \text { Yes }\end{array}$ CDDLEALK $\begin{array}{llllllllllllllll}1.00 & 46.48 & 27.29 & 19.59 & 2 & 1239.6106 & 1239.6083 & 620.8114 & 0.0023 & 1.8524 & 8179.630 & 5474.524 & 197.769 & 5703.887 & \text { Yes }\end{array}$ VIDDTNITR $\begin{array}{lllllllllllllll}1.00 & 46.46 & 27.19 & 18.82 & 2 & 1239.6108 & 1239.6083 & 620.8114 & 0.0025 & 2.0135 & 7548.473 & 5741.779 & 138.838 & 5402.350 & \text { Yes }\end{array}$

LLEDGEDFNLGDALDSSNSMQTí,

LQLETEIEALK

LQLETEIEALK

TVQSLEIDLDSMR

TVQSLEIDLDSMR

TVQSLEIDLDSMR

TVQSLEIDLDSMR

TVQSLEIDLDSMR

TVQSLEIDLDSMR

TVQSLEIDLDSMR

QAQEYEALLNK

QAQEYEALLNIK

QAQEYEALLNIK

TVQSLEIDLDSMR

TVQSLEIDLDSMR

QAQEYEALLNIK

QAQEYEALLNIK

QAQEYEALLNIK

QAQEYEALLNIK

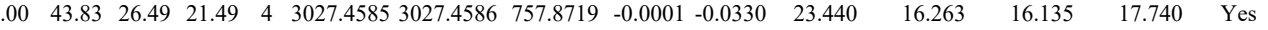

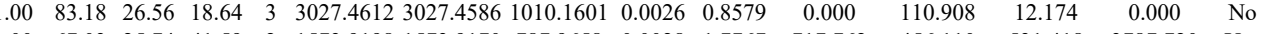

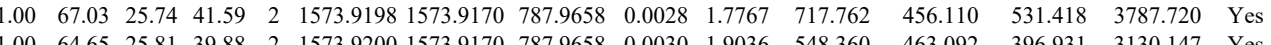
$\begin{array}{lllllllllllllll}1.00 & 64.65 & 25.81 & 39.88 & 2 & 1573.9200 & 1573.9170 & 787.9658 & 0.0030 & 1.9036 & 548.360 & 463.092 & 396.931 & 3130.147 & \text { Yes }\end{array}$ \begin{tabular}{lllllllllllllll}
1.00 & 72.42 & 28.09 & 29.30 & 2 & 1649.8430 & 1649.8416 & 825.9281 & 0.0014 & 0.8475 & 279.326 & 272.007 & 146.911 & 1279.912 & Yes \\
\hline
\end{tabular}

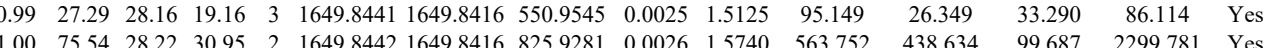

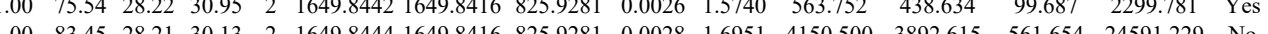

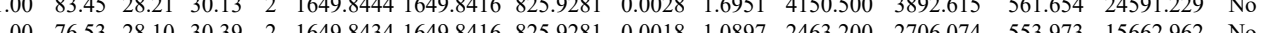

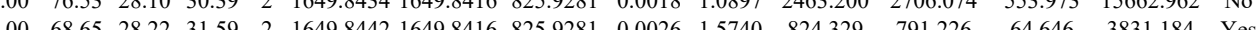

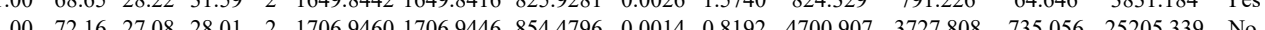

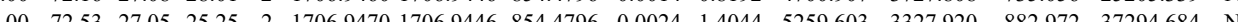
$\begin{array}{lllllllllllll} & \end{array}$ $\begin{array}{lllllllllllllll}0.99 & 36.80 & 27.00 & 31.16 & 3 & 1706.9494 & 17069446 & 569.9888 & 0.0048 & 2.8071 & 686.834 & 454.839 & 200.770 & 1722.504 & \text { Yes }\end{array}$ $\begin{array}{lllllllllllllll}100 & 74.58 & 28.21 & 26.45 & 2 & 1649.8446 & 1649.8416 & 825.9281 & 0.0030 & 18161 & 815.792 & 872598 & 268.018 & 3084.264 & \text { Yes }\end{array}$

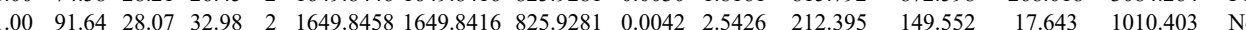
$\begin{array}{lllllllllllllll}1.00 & 71.90 & 27.08 & 25.21 & 2 & 1706.9460 & 1706.9446 & 854.4796 & 0.0014 & 0.8192 & 2244.409 & 1448.249 & 379.977 & 12405.476 & \text { No }\end{array}$ $\begin{array}{lllllllllllllll}1.00 & 39.23 & 27.03 & 26.87 & 3 & 1706.9473 & 1706.9446 & 569.9888 & 0.0027 & 1.5790 & 145.531 & 195.293 & 73.203 & 398.400 & \text { Yes }\end{array}$

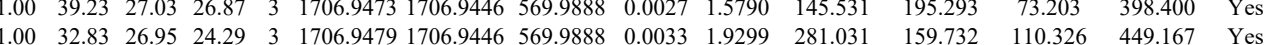

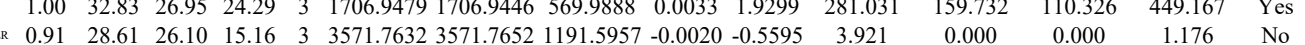
$\begin{array}{llllllllll} & \end{array}$

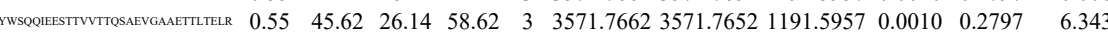

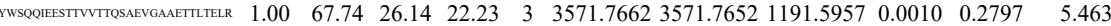
$\begin{array}{lllllllllllll} & 15.19 & 28.40 & 4 & 3571.7677 & 3571.7652 & 893.9486 & 0.0025 & 0.6991 & 15.313\end{array}$

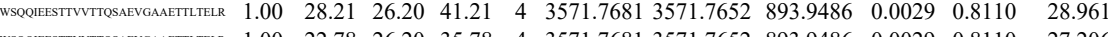

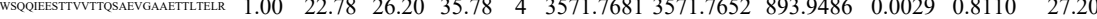
$\begin{array}{lllllllllllll}2 & \end{array}$ $\begin{array}{lllllllllllll} & \end{array}$ $\begin{array}{llllllllllll} & 0.60 & 82.27 & 26.20 & 95.27 & 3 & 3571.7692 & 3571.7652 & 1191.5957 & 0.0040 & 1.1189 & 1.481\end{array}$ $\begin{array}{llllllllllll}1.00 & 93.74 & 26.20 & 28.48 & 3 & 3571.7692 & 3571.7652 & 1191.5957 & 0.0040 & 1.1189 & 2.229\end{array}$ $\begin{array}{lllllllllll} & 1.00 & 44.78 & 26.20 & 28.57 & 3 & 3571.7692 & 3571.76521191 .5957 & 0.0040 & 1.1189 & 2.229 \\ 1.00 & 50.01 & 2.19 & 63.01 & 4 & 3571.7693 & 351.76521191 .5957 & 0.0040 & 1.1189 & 3.388\end{array}$ $\begin{array}{lrrrrrrrrrr} & \end{array}$ $\begin{array}{lccccccccccc} & \end{array}$ $\begin{array}{lllllllllll}1.00 & 29.43 & 26.21 & 15.18 & 4 & 3517.7729 & 351.7652 & 893.9486 & 0.0057 & 1.3940 & 6.16 \\ 1.00 & 70.54 & 26.25 & 20.19 & 3 & 3571.7722 & 3571.7652 & 1191.5957 & 0.0070 & 1.9582 & 3.386\end{array}$ $\begin{array}{llllllllllll} & & & 357.7725 & 3571.7652 & 893.9486 & 0.0073 & 2.0415 & 17.798\end{array}$ 


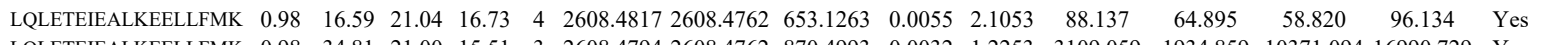

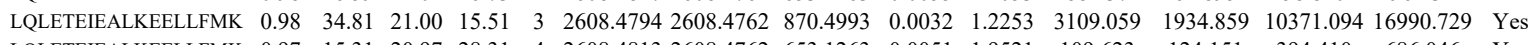
$\begin{array}{lllllllllllllllll}\text { LQLETEIEALKEELLFMK } & 0.97 & 15.31 & 20.97 & 28.31 & 4 & 2608.4813 & 2608.4762 & 653.1263 & 0.0051 & 1.9521 & 109.623 & 124.151 & 394.410 & 686.046 & \text { Yes }\end{array}$

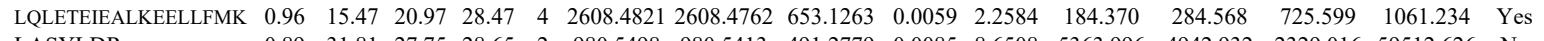
$\begin{array}{llllllllllllllll}\text { LASYLDR } & 0.89 & 31.81 & 27.75 & 28.65 & 2 & 980.5498 & 980.5413 & 491.2779 & 0.0085 & 8.6508 & 5363.996 & 4942.932 & 2329.016 & 59512.626 & \text { No }\end{array}$

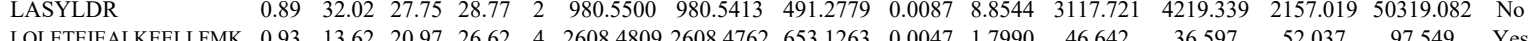

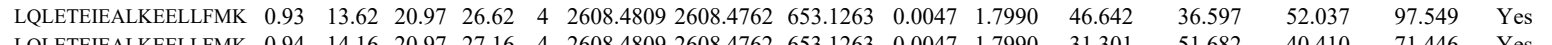

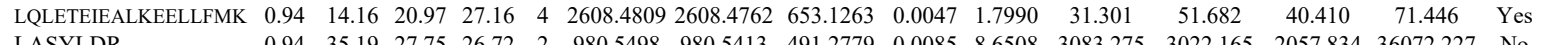

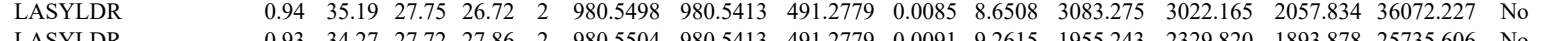

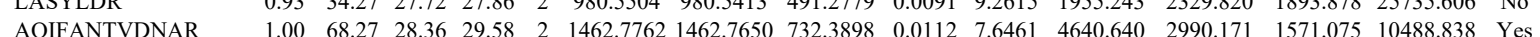

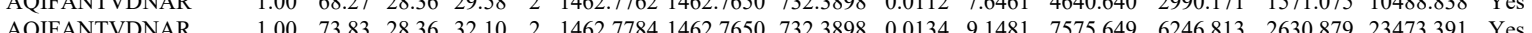

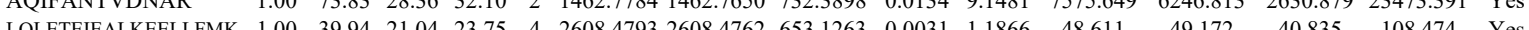

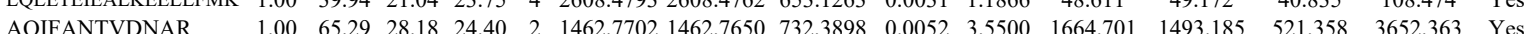
$\begin{array}{llllllllllllllll}\text { AQIFANTVDNAR } & 1.00 & 66.96 & 27.92 & 29.65 & 2 & 146.7718 & 1462.7650 & 732.3898 & 0.0068 & 4.6423 & 3290.134 & 3187.895 & 1260.003 & 11393.390 & \text { Yes }\end{array}$ $\begin{array}{lllllllllllllllll}1.00 & 66.96 & 27.92 & 29.65 & 2 & 1462.7718 & 1462.7650 & 732.3898 & 0.0068 & 4.6423 & 329.134 & 3187.895 & 121.358 & 3652.363 & \text { Yes }\end{array}$ $\begin{array}{llllllllllllllll} & \end{array}$

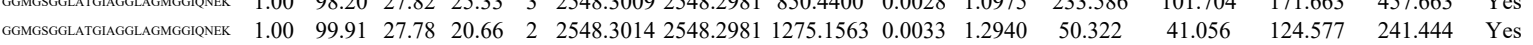

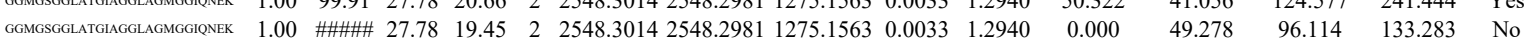

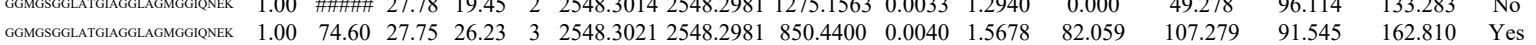
GGMGSGGLATGIAGLLAGMGGINNEK $\quad \begin{array}{lllllllllllll}1.00 & 69.74 & 27.72 & 19.37 & 3 & 2548.3033 & 2548.2981 & 850.4400 & 0.0052 & 2.0382 & 188.961 & 41\end{array}$

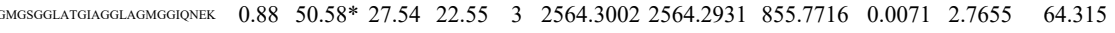

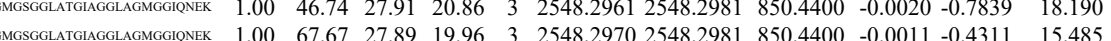
$\begin{array}{lllllllllllll} & \end{array}$ $\begin{array}{lllllllllll} & \\ \end{array}$ $\begin{array}{lllllllllllll} & \\ \end{array}$

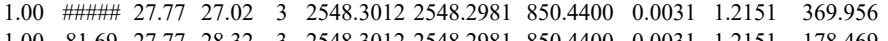

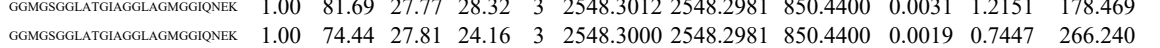
$\begin{array}{llllllllllll}\text { GGMGSGGLATGIAGGLAGMGGIQNEK } & 1.00 & 46.78 & 27.73 & 19.66 & 3 & 2548.3027 & 2548.2981 & 850.4400 & 0.0046 & 1.8030 & 64.183\end{array}$ $\begin{array}{llllllllllll}\text { YALQMEQLNGILLHLESELAQTR } & 0.55 & 77.94 & 25.54 & 90.94 & 3 & 2813.4874 & 2813.4867 & 938.8362 & 0.0007 & 0.2485 & 17.90\end{array}$ $\begin{array}{llllllllllll}\text { YALQMEQLNGILLHLESELAQTR } & 0.66 & 76.52 & 25.49 & 89.52 & 3 & 2813.4892 & 2813.4867 & 938.8362 & 0.0025 & 0.8876 & 11.169\end{array}$

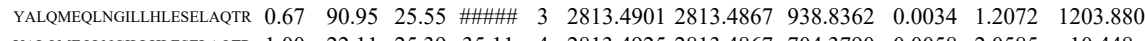

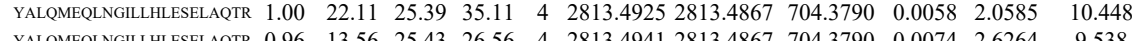
$\begin{array}{lllllllllllll}\text { YALQMEQLNGILHLESELAQTR } & 0.55 & 69.99 & 25.54 & 82.99 & 3 & 2813.4880 & 2813.4867 & 938.8362 & 0.0013 & 0.4616 & 286.531 & 3\end{array}$

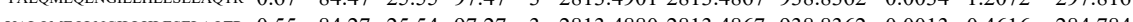

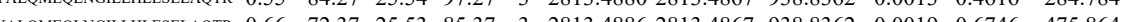
$\begin{array}{llllllllll} & \text { Y }\end{array}$ $\begin{array}{llllllllllll} & \text { y }\end{array}$

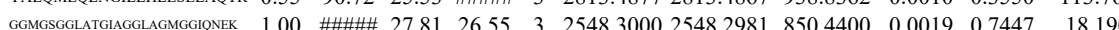

VVSETNDTK

VVSETNDTK

QSVENDIHGLR

VIDDTNITR

QSVENDIHGL

QSVENDIHGLR

QSVENDIHGLR

QSVENDIHGLR

KVIDDTNITR

KVIDDTNITR

QSVENDIHGLR

QSVENDIHGLR

QSVENDIHGLR

QSSENDIHGLR

QSVENDIHGLR

VIDDTNITR

QSVENDIHGLR

QSVENDIHGLR

QSVENDIHGLR

QSVENDIHGLR

QSVENDIHGLR

VIDDTNITR $\begin{array}{lllllllllll}1.00 & \text { mlm } & 27.81 & 26.55 & 3 & 2548.3000 & 2548.2981 & 850.4400 & 0.0019 & 0.7447 & 18.190 \\ 1.00 & 42.54 & 27.48 & 21.62 & 2 & 1279.6880 & 1279.6863 & 640.8504 & 0.0017 & 1.3264 & 244.514\end{array}$ $\begin{array}{lllllllllll}1.00 & 42.54 & 27.48 & 21.62 & 2 & 1279.6880 & 1279.6863 & 640.8504 & 0.0017 & 1.3264 & 244.514 \\ 1.00 & 50.69 & 27.51 & 24.73 & 2 & 1279.6888 & 1279.6863 & 640.8504 & 0.0025 & 1.9505 & 246.954\end{array}$ $\begin{array}{lllllllllll}0.97 & 28.25 & 27.51 & 20.25 & 3 & 1266.6313 & 1266.6317 & 423.2178 & -0.0004 & -0.3150 & 320.966\end{array}$ $\begin{array}{llllllllllll}0.92 & 28.45 & 26.21 & 22.86 & 2 & 1045.5400 & 1045.5404 & 523.7775 & -0.0004 & -0.3818 & 19.209\end{array}$ $\begin{array}{llllllllllll}1.00 & 71.00 & 27.51 & 32.42 & 2 & 1266.6312 & 1266.6317 & 634.3231 & -0.0005 & -0.3941 & 4.873\end{array}$ $\begin{array}{llllllllllll}1.00 & 38.21 & 27.47 & 24.32 & 3 & 1266.6316 & 1266.6317 & 423.2178 & -0.0001 & -0.0788 & 57.983\end{array}$ $\begin{array}{llllllllllll}1.00 & 72.26 & 27.47 & 26.97 & 2 & 1266.6316 & 1266.6317 & 634.3231 & -0.0001 & -0.0788 & 16.893\end{array}$ $\begin{array}{llllllllllll}1.00 & 36.25 & 27.43 & 19.68 & 3 & 1266.6319 & 1266.6317 & 423.2178 & 0.0002 & 0.1575 & 85.986\end{array}$ $\begin{array}{lllllllllll}0.78 & 41.47 * 28.99 & 23.50 & 3 & 1317.7372 & 1317.7374 & 440.2531 & -0.0002 & -0.1514 & 43.295\end{array}$ $\begin{array}{lllllllllll}0.94 & 63.84 * 28.54 & 25.70 & 2 & 1317.7376 & 1317.7374 & 659.8760 & 0.0002 & 0.1515 & 49.094\end{array}$ $\begin{array}{lllllllllll}1.00 & 55.26 & 27.50 & 24.14 & 2 & 1266.6314 & 1266.6317 & 634.3231 & -0.0003 & -0.2365 & 32.896\end{array}$ $\begin{array}{llllllllllll}0.99 & 31.70 & 27.47 & 16.51 & 3 & 1266.6322 & 1266.6317 & 423.2178 & 0.0005 & 0.3938 & 202.699\end{array}$ $\begin{array}{lllllllllllll}1.00 & 71.35 & 27.43 & 26.80 & 2 & 1266.6302 & 1266.6317 & 634.3231 & -0.0015 & -1.1824 & 23.610\end{array}$ $\begin{array}{lllllllllll}0.64 & 16.50 & 27.43 & 16.02 & 3 & 1266.6319 & 1266.6317 & 423.2178 & 0.0002 & 0.1575 & 179.118\end{array}$ $\begin{array}{llllllllllll}1.00 & 76.82 & 27.92 & 25.22 & 3 & 2548.2967 & 2548.2981 & 850.4400 & -0.0014 & -0.5487 & 20.563\end{array}$

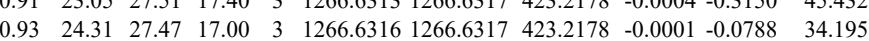
$\begin{array}{lllllllllll}0.98 & 34.69 & 26.20 & 27.54 & 2 & 1045.5406 & 1045.5404 & 523.7775 & 0.0002 & 0.1909 & 4.475\end{array}$ $\begin{array}{llllllllllll}1.00 & 62.18 & 27.51 & 25.43 & 2 & 1266.6312 & 1266.6317 & 634.3231 & -0.0005 & -0.3941 & 5.785\end{array}$ $\begin{array}{lllllllllll}1.00 & 40.71 & 27.51 & 18.96 & 3 & 1266.6313 & 1266.6317 & 423.2178 & -0.0004 & -0.3150 & 13.337 \\ 1.00 & 63.03 & 27.47 & 26.23 & 2 & 1266.6316 & 1266.6317 & 634.3231 & -0.0001 & -0.0788 & 0.000\end{array}$

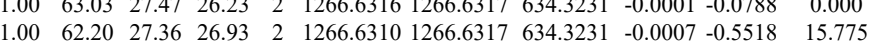
$\begin{array}{lllllllllll}0.95 & 26.09 & 27.51 & 15.46 & 3 & 1266.6313 & 1266.6317 & 423.2178 & -0.0004 & -0.3150 & 43.766\end{array}$ $\begin{array}{lllllllllllll}0.95 & 25.81 & 27.43 & 15.56 & 3 & 1266.6319 & 1266.6317 & 423.2178 & 0.0002 & 0.1575 & 49.684\end{array}$ $\begin{array}{llllllllllll}0.91 & 27.96 & 26.20 & 20.59 & 2 & 1045.5406 & 1045.5404 & 523.7775 & 0.0002 & 0.1909 & 48.452\end{array}$ 

$\begin{array}{lllllllllll}1.00 & \text { \#\#\#\# 27.89 } & 27.68 & 3 & 2548.2976 & 2548.2981 & 850.4400 & -0.0005 & -0.1960 & 6.703\end{array}$

GGMGSGGLATGIAGG $\begin{array}{llllllllll}0.99 & 76.35 * 27.52 & 35.51 & 3 & 2564.2939 & 2564.2931 & 855.7716 & 0.0008 & 0.3116 & 8.46\end{array}$ $\begin{array}{lllllllllllll}0.94 & 29.42 & 26.21 & 23.34 & 2 & 1045.5404 & 1045.5404 & 523.7775 & 0.0000 & 0.0000 & 41.664\end{array}$

QSVENDIHGLR

QSVENDIHGLR

QSVENDIHGL

KVIDDTNITR

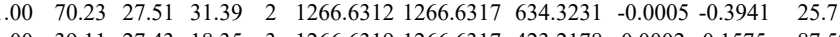

KVIDDTNITR
KVIDDTNITR $\begin{array}{llllllllllll}1.00 & 38.53 & 27.47 & 19.47 & 3 & 1266.6322 & 1266.6317 & 423.2178 & 0.0005 & 0.3938 & 88.279\end{array}$ $\begin{array}{lllllllllllll}0.59 & 33.51 * 28.55 & 19.56 & 3 & 1317.7378 & 1317.7374 & 440.2531 & 0.0004 & 0.3029 & 82.337\end{array}$ $\begin{array}{llllllllllll}0.97 & 65.51 * 28.53 & 30.16 & 2 & 1317.7378 & 1317.7374 & 659.8760 & 0.0004 & 0.3031 & 144.083 \\ 0.97 & 61.38 * 28.54 & 25.93 & 2 & 1317.7380 & 1317.7374 & 659.8760 & 0.0006 & 0.4546 & 107.319\end{array}$ $\begin{array}{lllllllllll}0.95 & 49.62 * & 28.54 & 24.36 & 3 & 1317.7381 & 1317.7374 & 440.2531 & 0.0007 & 0.5300 & 43.844\end{array}$

GGMSSGGLATGIAGGLLAGMGGiPNB

VIDDTNITR $\begin{array}{llllllllll}1.00 & \text { \#\#\# 27.76 } & 28.71 & 3 & 2548.2994 & 2548.2981 & 850.4400 & 0.0013 & 0.5095 & 8.802 \\ 1.00 & 27.42 & 27.31 & 3 & 2548.3003 & 25482981 & 850.4400 & 0.0022 & 0.8623 & 5.549\end{array}$

VIDDTNITR

QSVENDIHGLR

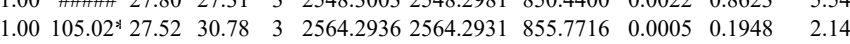

QSVENDIHGLR

QSVENDIHGLR

QSVENDIHGLR

KVIDDTNITR

KVIDDTNITR $\begin{array}{llllllllllll}0.93 & 28.83 & 27.20 & 21.25 & 2 & 1045.5406 & 1045.5404 & 523.7775 & 0.0002 & 0.1909 & 28.290\end{array}$ $\begin{array}{lllllllllllll}0.96 & 27.99 & 26.22 & 20.35 & 2 & 1045.5412 & 1045.5404 & 523.7775 & 0.0008 & 0.7637 & 28.453\end{array}$ $\begin{array}{lllllllllll}1.00 & 65.43 & 27.35 & 25.01 & 2 & 1266.6294 & 1266.6317 & 634.3231 & -0.0023 & -1.8130 & 18.448\end{array}$ $\begin{array}{lllllllllll}1.00 & 67.14 & 27.34 & 23.98 & 2 & 1266.6300 & 1266.6317 & 634.3231 & -0.0017 & -1.3400 & 25.917\end{array}$

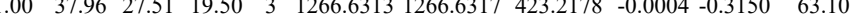
$\begin{array}{llllllllllll}0.99 & 34.51 & 27.47 & 18.80 & 3 & 1266.6316 & 1266.6317 & 423.2178 & -0.0001 & -0.0788 & 76.118\end{array}$ $\begin{array}{llllllllllll}0.88 & 57.69 * 28.54 & 26.21 & 2 & 1317.7376 & 1317.7374 & 659.8760 & 0.0002 & 0.1515 & 100.450\end{array}$ $\begin{array}{lllllllllll}0.88 & 57.53 * 28.53 & 30.19 & 2 & 1317.7378 & 1317.7374 & 659.8760 & 0.0004 & 0.3031 & 122.678\end{array}$ $\begin{array}{llllllllllll}0.99 & 59.64 * 28.54 & 25.83 & 3 & 1317.7381 & 1317.7374 & 440.2531 & 0.0007 & 0.5300 & 41.324\end{array}$

KVIDDTNITR
$\begin{array}{lllllllllll}1.00 & 27.86 & 30.20 & 3 & 2548.2985 & 2548.2981 & 850.4400 & 0.0004 & 0.1568 & 6.402\end{array}$

GGMGGGLATGIAGGLAGMGG

QSVENDIHGLR

QSVENDIHGLR $\begin{array}{llllllllllll}0.99 & 29.32 & 27.54 & 18.06 & 3 & 2564.2945 & 2564.2931 & 855.7716 & 0.0014 & 0.5453 & 11.43\end{array}$ $\begin{array}{lllllllllllll}1.00 & 57.71 & 27.51 & 22.19 & 2 & 1266.6312 & 1266.6317 & 634.3231 & -0.0005 & -0.3941 & 29.083 \\ 1.00 & 4.23 & 27.47 & 17.77 & 3 & 1266 & 0.6316 & 1266.6317 & 423.2178 & 0.0001 & -0.0788 & 66.336\end{array}$ $\begin{array}{lllllllllll}1.00 & 44.23 & 27.47 & 17.77 & 3 & 1266.6316 & 1266.6317 & 423.2178 & -0.0001 & -0.0788 & 66.336 \\ 1.00 & \# \# \# & 27.76 & 28.25 & 3 & 2548.2994 & 2548.2981 & 850.4400 & 0.0013 & 0.5095 & 6.556\end{array}$

IIAGLLAGMGGION

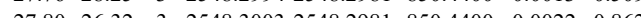

QSVENDIHGLR $\begin{array}{lllllllllllll}1.00 & 73.09 & 27.54 & 26.70 & 3 & 2564.2942 & 2564.2931 & 855.7716 & 0.0011 & 0.4285 & 7.099\end{array}$

AGMGGien
1.00

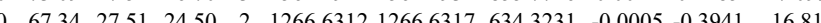

QSVENDIHGLR

QSVENDIHGLR $\begin{array}{lllllllllll}1.00 & 27.77 & 25.31 & 3 & 2548.2997 & 2548.2981 & 850.4400 & 0.0016 & 0.6271 & 4.463\end{array}$

QSVENDIHGLR $\begin{array}{llllllllllll}1.00 & 67.39 & 27.36 & 19.18 & 2 & 1266.6298 & 1266.6317 & 634.3231 & -0.0019 & -1.4977 & 8.717\end{array}$

GGMGSGGLATGIAGGLAGMGGIOOH $\begin{array}{llllllll}19.18 & 2 & 1266.6298 & 1266.6317 & 64.33231 & -0.0019 & -1.4977 & 8.717\end{array}$

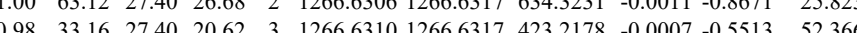

QSVENDIHGLR

QSVENDIHGLR
QSVENDIHGLR $\begin{array}{lllllllll}1.00 & \text { \#\#曲 27.76 } 25.82 & 3 & 2548.2994 & 25482981 & 850.4400 & 0.0013 & 0.5095 & 5.962\end{array}$

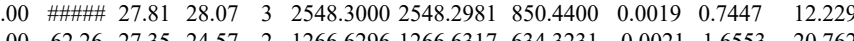
$\begin{array}{lllllllllll}1.00 & 62.26 & 27.35 & 24.57 & 2 & 1266.6296 & 1266.6317 & 634.3231 & -0.0021 & -1.6553 & 20.762\end{array}$ $\begin{array}{lllllllllll}38.17 & 27.47 & 18.62 & 3 & 1266.6307 & 1266.6317 & 423.2178 & -0.0010 & -0.7876 & 56.296 \\ 33.78 & 27.40 & 15.48 & 3 & 1266.6310 & 1266.6317 & 423.2178 & -0.0007 & -0.5513 & 59.206\end{array}$

QSVENDIHGLR

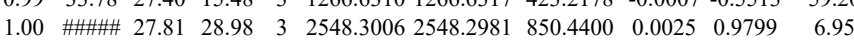

QSVENDIHGLR

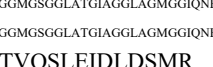

TVQSLEIDLDSM

QSVENDIHGLR

QSVENDIHGLR

LLEGEENALDALDSSN

QSVENDIHGLR

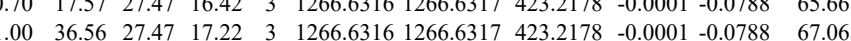
$\begin{array}{llllllllllll}1.00 & 96.62 & 27.84 & 25.53 & 3 & 2548.2979 & 2548.2981 & 850.4400 & -0.0002 & -0.0784 & 3.479\end{array}$

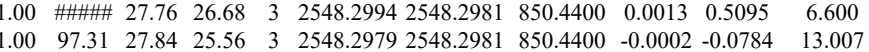
$\begin{array}{lllllllllll}1.00 & 56.19 & 28.01 & 20.75 & 2 & 1649.8426 & 1649.8416 & 825.9281 & 0.0010 & 0.6054 & 18.303\end{array}$ $\begin{array}{llllllllllll}1.00 & 56.17 & 27.85 & 25.75 & 2 & 1410.7430 & 1410.7337 & 706.3741 & 0.0093 & 6.5829 & 1212.330 & 91\end{array}$ $\begin{array}{lllllllllllll}1.00 & 52.46 & 27.71 & 22.97 & 3 & 1410.7441 & 1410.7337 & 471.2518 & 0.0104 & 7.3562 & 4150.280 \\ 0.92 & 32.26 & 27.72 & 25.47 & 2 & 1410.7444 & 1410.7337 & 706.3741 & 0.0107 & 7.5738 & 284.298\end{array}$ $\begin{array}{lllllllllllll}0.92 & 32.26 & 27.72 & 25.47 & 2 & 1410.7444 & 1410.7337 & 706.3741 & 0.0107 & 7.5738 & 284.298 \\ 1.00 & 85.55 & 26.55 & 32.79 & 3 & 3043.4512 & 3043.4536 & 1015.4918 & -0.0024 & -0.7878 & 21.719\end{array}$ $\begin{array}{rrrrrrrrrrrr}1.00 & 85.55 & 26.55 & 32.79 & 3 & 3043.4512 & 3043.4536 & 1015.4918 & -0.0024 & -0.7878 & 21.719 & 27.512 \\ 1.00 & 54.90 & 27.84 & 27.31 & 3 & 1410.7432 & 1410.7337 & 471.2518 & 0.0095 & 6.7196 & 3390.167 & 4355.408\end{array}$

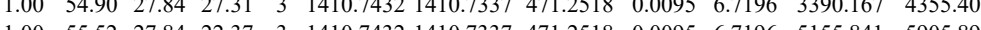

LLEDGEDFNLGDALDSSNSM 0.66

LQLETEIEALK

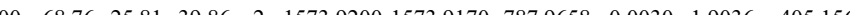

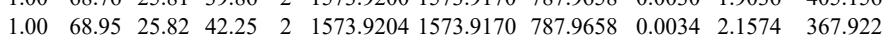
\begin{tabular}{cccc} 
& 64.658 & 69.483 & Yes \\
\hline .408 & 973.222 & 32.690 & Yes \\
\hline & 1550.172 & Yes
\end{tabular} $\begin{array}{lllll}5.898 & 1640.189 & 18805.297 & \text { Yes } \\ 0.240 & 5.933 & 10.126 & Y \text { Ses }\end{array}$ \begin{tabular}{cccc}
5.240 & 5.933 & 10.126 & Yes \\
\hline & 0.000 & 9.988 & No
\end{tabular} \begin{tabular}{llll}
9.988 & & \\
\hline
\end{tabular}

.

Table S-4 page 84 of 614 
LLEDGEDFNLGDALDSSNSMQT

GELAIK

GELAIK

AEAESMYQIK

LVSESSDVLPK
LVSESSDVLPK

LVSESSDVLPK

LQAEIEGLK
LQAEIEGLK

LVSESSDVLPK

SLDMDSIIAEVK

DSIIAEVK

SLDMDSIIAEVK
LQAEIEGLK

SLDMDSIIAEVK

SLDMDSIIAEVK

SLDMDSIIAEVK

SLDMDSIIAEVK

LEAELGNMQGLVEDFK

LEAELGNMQGLVEDFK

ELQSQISDTSVVL

SYTSGPGSR

SYTSGPGSR

LQAEIEGLK

SLDMDSIIAEVK

SLDMDSIIAEVK

SLDMDSIIAEVK

LEAELGNMQGLVEDHK

$\begin{array}{lccccccccccc}\text { LEAELGNMQGLVEDFK } & 1.00 & 88.61 & 27.77 & 22.33 & 2 & 2080.0754 & 2080.0754 & 1041.0450 & 0.0000 & 0.0000 & 160.315 \\ \text { LEAELGNMQGLVEDK } & 1.00 & 91.33 & 27.77 & 23.09 & 2 & 2080.0754 & 2080.0754 & 1041.0450 & 0.0000 & 0.0000 & 51.472 \\ \text { LEAELGNMQGLVEDFK } & 1.00 & 57.41 & 27.76 & 20.49 & 3 & 2080.0795 & 2080.0754 & 694.3657 & 0.0041 & 1.9682 & 316.372\end{array}$

$\begin{array}{lllllllllllll}\text { ELQSQISDTSVVLSMDNSR } & 1.00 & 95.70 & 27.74 & 26.78 & 2 & 2252.1074 & 2252.1076 & 1127.0611 & -0.0002 & -0.0887 & 105.356\end{array}$

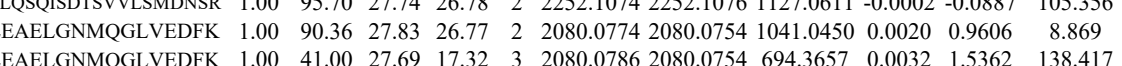

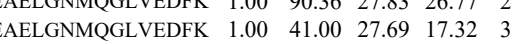

AVVVK

LSELEAALQR

$\begin{array}{lllllll}0.81 & 20.82 & 18.75 & 20.69 & 2\end{array}$

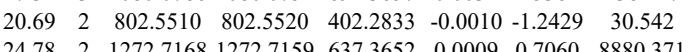

-1
0

LKLEAELGNMQGLVED

VSTSGPR
LSELAATR

LSELEAALQR

LSELEAALQR

LEGLTDEINFLR

LEGLTDEINFLR

LEGLTDEINFLR

LKLEAELGN

LSELEAALQR

LSELEAALQR

LEGLTDEINFLR

LEGLTDEINFLR

LSELEAALQR

LSELEAALQR

LEGLTDEINFLR

LEGLTDEINFLR

LQAEIEGLK

VGSSNFR
VGSSNFR

$\begin{array}{lllllllllll}1.00 & 49.38 & 23.71 & 62.38 & 4 & 2465.3609 & 2465.3565 & 617.3464 & 0.0044 & 1.7818 & 107.339\end{array}$

$\left.\begin{array}{lllllllllll}0.65 & 28.22 & 28.51 & 36.60 & 2 & 846.4676 & 846.4681 & 424.2413 & -0.0005 & -0.5893 \\ 1.00 & 53.18 & 28.01 & 31.53 & 2 & 1272.7166 & 1272.7159 & 637.3652 & 0.0007 & 0.5491\end{array}\right)$

715.292
77.647
83.833

$\begin{array}{llllll}1.00 & 58.45 & 27.80 & 26.99 & 2 & 12\end{array}$

$\begin{array}{lllllllllllll}1.00 & 58.45 & 27.80 & 26.99 & 2 & 1272.7176 & 1272.7159 & 637.3652 & 0.0017 & 1.3336 & 25873.180 & 24 \\ 1.00 & 76.34 & 28.20 & 27.03 & 2 & 1562.8426 & 1562.8426 & 782.4286 & 0.0000 & 0.0000 & 1286.641 & 10 .\end{array}$

$\begin{array}{lllllllllllll}1.00 & 78.53 & 28.13 & 28.03 & 2 & 1562.8436 & 1562.8426 & 782.4286 & 0.0010 & 0.6390 & 4305.299 & 3932 . \\ 1.00 & 49.05 & 8.06 & 23.49 & 3 & 1562.8441562 .8426 & 52.9548 & 0.015 & 0.9579 & 88.909 & 59.9\end{array}$

$\begin{array}{llllllllllll}1.00 & 49.05 & 28.06 & 23.49 & 3 & 1562.8441 & 1562.8426 & 521.9548 & 0.0015 & 0.9579 & 88.900 \\ 1.00 & 50.98 & 28.00 & 27.12 & 3 & 1562.8447 & 1562.8426 & 521.9548 & 0.0021 & 1.3411 & 92.106\end{array}$

$\begin{array}{cccccccccccc}1.00 & 49.27 & 23.71 & 62.27 & 4 & 2465.3609 & 2465.35655 & 617.3464 & 0.0044 & 1.7818 & 353.523 \\ 0.51 & 19.96 & 28.55 & 24.96 & 2 & 846.4678 & 846.4681 & 424.2413 & -0.0003 & -0.3536 & 47.190\end{array}$

$\begin{array}{llll}9.96 & 28.55 & 24.96\end{array}$

$\begin{array}{llllllllllll}32.40 & 2 & 1272.7164 & 1272.7159 & 637.3652 & 0.0005 & 0.3922 & 10518.725 & 12318.5\end{array}$

$\begin{array}{llllllllllll}1.00 & 62.09 & 28.12 & 34.49 & 2 & 1272.7164 & 1272.7159 & 637.3652 & 0.0005 & 0.3922 & 13909.004 & 15066.98 \\ 1.00 & 75.62 & 28.00 & 36.01 & 2 & 1562.8446 & 1562.8426 & 782.4286 & 0.0020 & 1.2781 & 5222.417 & 4534\end{array}$

$\begin{array}{llllllllllll}1.00 & 67.68 & 28.03 & 29.64 & 2 & 1562.8448 & 1562.8426 & 782.4286 & 0.0022 & 1.4059 & 2554.629\end{array}$

$\begin{array}{llllllllllll}1.00 & 61.76 & 27.70 & 29.16 & 2 & 1272.7174 & 1272.7159 & 637.3652 & 0.0015 & 1.1767 & 2774.993 & 288.1 \\ 1.00 & 54.15 & 27.70 & 26.62 & 2 & 17272.7174 & 1272.7159 & 637.3652 & 0.0015 & 1.1767 & 3658540 & 3758 .\end{array}$

$\begin{array}{lllllllllllll}1.00 & 54.15 & 27.70 & 26.62 & 2 & 1272.7174 & 1272.7159 & 637.3652 & 0.0015 & 1.1767 & 3658.540 & 3758.3668\end{array}$

$\begin{array}{llllllllllllll}1.00 & 81.86 & 28.13 & 32.55 & 2 & 1562.8436 & 1562.8426 & 782.4286 & 0.0010 & 0.6390 & 262.342 & 271.488\end{array}$

$\begin{array}{llllllllllll}1.00 & 65.63 & 28.06 & 26.19 & 2 & 1562.8442 & 1562.8426 & 782.4286 & 0.0016 & 1.0225 & 1151.628 & 1138.113\end{array}$

$\begin{array}{lllllllllll}0.82 & 37.02 & 26.13 & 25.80 & 2 & 1287.7616 & 1287.7642 & 644.8894 & -0.0026 & -2.0159 & 40.318 \\ 0.87 & 26.14 & 26.56 & 25.92 & 2 & 909.4792 & 909.4790 & 455.748 & 0.0002 & 0.2194 & 206783\end{array}$

$\begin{array}{llllllllllll}0.87 & 26.14 & 26.56 & 25.92 & 2 & 909.4792 & 909.4790 & 455.7468 & 0.0002 & 0.2194 & 206.783\end{array}$

$\begin{array}{lllllllllllll}0.94 & 29.76 & 26.56 & 23.58 & 2 & 909.4794 & 909.4790 & 455.7468 & 0.0004 & 0.4388 & 293.46\end{array}$

SNMDNMFESYINNL

SNMDNMFESYINNLR

VGSSNFR

VGSSNFR

$\begin{array}{lllllllll}1.00 & 86.24 & 24.42 & 20.62 & 2 & 1\end{array}$

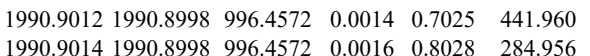
$\begin{array}{lllllllllllll}0.79 & 23.81 & 26.56 & 24.10 & 2 & 909.4790 & 909.4790 & 455.7468 & 0.0000 & 0.0000 & 307.690\end{array}$ $\begin{array}{llllllllllll}0.93 & 29.06 & 2.56 & 24.90 & 2 & 909.4790 & 90.4490 & 455.7468 & 0.0000 & 0.0000 & 179.858\end{array}$

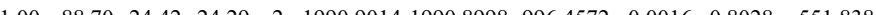

$\begin{array}{llllllllllllll}\text { SNMDNMFESYINNLR } & 1.00 & \# \# \# \text { 24.31 } & 25.33 & 2 & 1990.9020 & 1990.8998 & 996.4572 & 0.0022 & 1.1039 & 450.404\end{array}$

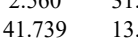

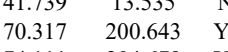

$74.111 \quad 204.679$ Yes

3.0952292 .672 Yes

$184.920 \quad 7295.532$ Yes 95.824 16186.830 Yes $2129.985 \quad 80044.697$ Yes $306.728-15583.860$ Yes $0.000 \quad 898.076$ No $\begin{array}{rrr}0.000 & 898.076 & \text { No } \\ 221.843 & 1863.264 & \text { Yes }\end{array}$ $\begin{array}{lll}106.387 & 59755.583 \text { Yes } \\ 0.000 & 13656.781 & \text { No }\end{array}$ $0.000 \quad 20646.994$ No $92.015 \quad 1203.244$ Yes $273.034 \quad 1822.285$ Yes $936.968 \quad 2064.633$ Yes $\begin{array}{lll}402.281 & 1253.108 \text { Yes }\end{array}$ $\begin{array}{lll}456.394 & 1265.642 & \text { Yes }\end{array}$ $\begin{array}{lll}748.638 & 1904.891 & \text { Yes }\end{array}$ $\begin{array}{lll}105.484 & 122.591 & \text { No }\end{array}$ $\begin{array}{lll}51.808 & 296.684 & \text { Yes }\end{array}$ $\begin{array}{lll}24.088 & 216.692 & \text { Yes } \\ 354.768 & 2683.480 & \text { Yes }\end{array}$ $\begin{array}{lll}354.768 & 26832.480 & \text { Yes } \\ 65.486 & 2158.467 & \text { Yes }\end{array}$ $210.773 \quad 7101.932$ Yes $\begin{array}{lll}36.375 & 597.588 & \text { Yes }\end{array}$ $\begin{array}{lll}47.257 & 154.307 & \text { Yes }\end{array}$ $\begin{array}{lll}253.300 & 774.303 & \text { Yes }\end{array}$ $\begin{array}{lll}140.368 & 379.620 & \text { Yes }\end{array}$ $275.097 \quad 1403.910 \quad$ Yes $\begin{array}{lll}293.978 & 437.410 & \text { Yes }\end{array}$ $\begin{array}{lll}22.367 & 77.777 & \text { Yes }\end{array}$ $\begin{array}{lll}135.701 & 178.183 & \text { Yes } \\ 28.226 & 178.457 & \text { Yes }\end{array}$ \begin{tabular}{llll} 
& 36.384 & 166.735 & Yes \\
\hline & 199.088 & Yes
\end{tabular} $\begin{array}{lll}65.384 & 199.088 & \text { Yes } \\ 45.798 & 151.545 & \text { Yes }\end{array}$

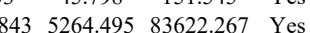
(14.947 5656.504 \#\#\#\#\#\# Yes $\begin{array}{lllll} & 428.272 & 7101.828 & \text { Yes }\end{array}$ $\begin{array}{llll} & \\ 9.938 & 1174.610 & 31023.016 & \text { Yes }\end{array}$ $\begin{array}{llll}9.995 & 57.736 & 120.950 & \text { Yes }\end{array}$ \begin{tabular}{llll}
\hline .836 & 49.935 & 146.716 & Yes
\end{tabular} $\begin{array}{lll}115.614 & 257.849 & \text { Yes }\end{array}$ $\begin{array}{lll}50.689 & 101.962 & \text { Yes }\end{array}$ 1619.89752350 .739 Yes $\begin{array}{lll}545.698 & 23326.070 & \text { Yes }\end{array}$ $\begin{array}{lll}70.965 & 1756.407 & \text { Yes }\end{array}$ $\begin{array}{lll}181.465 & 7178.596 & \text { Yes }\end{array}$ $\begin{array}{lll}31.847 & 147.253 & \text { Yes } \\ 327.067 & 5005 & \text { Yes }\end{array}$

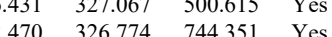
\begin{tabular}{lllll}
9.42 .47 & 327.067 & 500.615 & Yes \\
45.253 & 317.656 & 744.351 & Yes \\
\hline
\end{tabular} $\begin{array}{lllll}242.470 & 326.774 & 744.351 & \text { Yes }\end{array}$ $\begin{array}{llll}2.553 & 303.897 & 719.502 & Y \text { Y }\end{array}$ $\begin{array}{llll} & 37.933 & 714.026 & \text { Yes }\end{array}$ 17.225 429.560 Yes 

$\begin{array}{lllllllllllll}0.98 & 38.41 & 26.12 & 27.69 & 2 & 1317.7744 & 1317.7648 & 659.8897 & 0.0096 & 7.2739 & 12007.937 & 11323.154\end{array}$ $\begin{array}{lllllllllllll}0.99 & 40.54 & 26.17 & 27.39 & 2 & 1317.7764 & 1317.7648 & 659.8897 & 0.0116 & 8.7893 & 7968.193 & 8752.528 \\ 0.99 & 0.552 & 26.17 & 26.68 & 2 & 1317.7764 & 1317.7648 & 6598897 & 0.0116 & 8.7893 & 1359.392 & 14735.644\end{array}$ $\begin{array}{lllllllllllll}0.99 & 40.52 & 26.17 & 26.68 & 2 & 1317.7764 & 1317.7648 & 659.8897 & 0.0116 & 8.7893 & 13529.392 & 14735.644\end{array}$

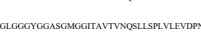
$\begin{array}{lllllllllll}1.00 & 52.34 & 21.37 & 65.34 & 4 & 4068.1469 & 4068.1436 & 1018.0432 & 0.0033 & 0.8104 & 4.040\end{array}$

$415-2112.526 \quad 1818.554 \quad \mathrm{No}$

SNMDNMFESYINNLR $\begin{array}{llllllllll} & \end{array}$

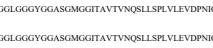

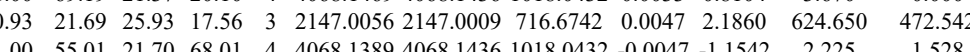

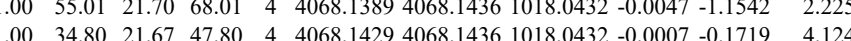

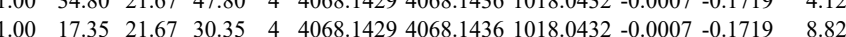
$\begin{array}{lllllllllll}1.00 & 58.45 & 21.37 & 71.45 & 4 & 4068.1469 & 4068.1436 & 1018.0432 & 0.0033 & 0.8104 & 9.823\end{array}$

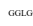
$\begin{array}{llllllllllll}1.00 & 64.09 & 21.37 & 21.48 & 4 & 4068.1469 & 4068.1436 & 1018.0432 & 0.0033 & 0.8104 & 0.000 \\ 1.00 & 61.44 & 27.91 & 21.21 & 2 & 1418.7406 & 1418.7405 & 710.3775 & 0.0001 & 0.0704 & 40.939\end{array}$ $\begin{array}{lllllllllllll}\text { SNMDNMFESYINNLRR } & 1.00 & 31.60 & 25.69 & 17.26 & 3 & 2147.0023 & 2147.0009 & 716.6742 & 0.0014 & 0.6512 & 23.719\end{array}$ $\begin{array}{llllllllllll}\text { SNMDNMFESYNNLRR } & 0.87 & 19.91 & 25.65 & 23.79 & 3 & 2147.0014 & 2147.0009 & 716.6742 & 0.0005 & 0.2326 & 14.784\end{array}$ $\begin{array}{llllllllllllll}\text { SNMDNMFESYINNLRR } & 0.93 & 20.11 & 25.69 & 19.97 & 3 & 2147.0017 & 2147.0009 & 716.6742 & 0.0008 & 0.3721 & 19.753 & 37.0\end{array}$ $\begin{array}{lllllllllllll}\text { SNMDNMFESYINNLRR } & 0.91 & 19.29 & 25.69 & 15.89 & 3 & 2147.0020 & 2147.0009 & 716.6742 & 0.0011 & 0.5116 & 39.467 & 45.485\end{array}$ $\begin{array}{llllllllllllll}\text { SNMDNMFESYINNLRR } & 0.95 & 21.92 & 25.69 & 14.65 & 3 & 2147.0017 & 2147.0009 & 716.6742 & 0.0008 & 0.3721 & 28.007 & 35.802\end{array}$ ASLEAAIADAEQR
ASLEAAIADAEQR ASLEAAIADAEQR
ASLEAAIADAEQR ASLEAAIADAEQR ASLEAAIADAEQR
ASLEAAIADAEQR ASLEAAIADAEQR
AQYEDIANR AQYEDIANR
AQYEDIANR AQYEDIANR
AEAESMYQIK AEAESMYQIK AEAESMYQIK AEAESMYQIK AEAESMYQIK AEAESMYQIK AEAESMYQIK

ASLEAAIADAEQR

ASLEAAIADAEQR

ASLEAAIADAEQR ASLEAAIADAEQ TEMENEFVLIK TEMENEFVLIK TEMENEFVLIK AQYEDIANR ASLEAAIADAEQR ASLEAAIADAEQR

TEMENEFVLIK
TEMENEFVLIK

GELAIK

LQAEIEGLK

LQAEIEGLK

LVSESSDVLPK

12 AQPVQVAEGSEP $\begin{array}{lllllllllllll}1.00 & 94.00 & 27.40 & 31.81 & 2 & 1487.7708 & 1487.7701 & 744.8923 & 0.0007 & 0.4699 & 2137.524 & 1892.926 & \\ 1.00 & 96.44 & 27.39 & 33.17 & 2 & 1487.7710 & 1487.7701 & 744.8923 & 0.0009 & 0.6041 & 2503.177 & 3193.753 & 35.1 .9\end{array}$ $\begin{array}{llllllllllll}1.00 & 66.30 & 27.30 & 27.03 & 3 & 1487.7718 & 1487.7701 & 496.9306 & 0.0017 & 1.1403 & 40.803 & 4.480 \\ 1.00 & 46.46 & 27.72 & 23.06 & 3 & 1487.7721 & 1487.7701 & 496.9306 & 0.0020 & 1.3416 & 0.000 & 57.448\end{array}$ $\begin{array}{cccccccccccc}1.00 & 46.46 & 27.29 & 23.06 & 3 & 1487.7721 & 1487.7701 & 496.9306 & 0.0020 & 1.3416 & 0.000 & 57.448 \\ 1.00 & 74.68 & 27.40 & 30.62 & 2 & 1487.7708 & 1487.7701 & 744.8923 & 0.0007 & 0.4699 & 18.989 & 25.166\end{array}$ $\begin{array}{lllllllllllll}1.00 & 74.68 & 27.40 & 30.62 & 2 & 1487.7708 & 1487.7701 & 744.8923 & 0.0007 & 0.4699 & 18.989 & 25.166 \\ 1.00 & 39.84 & 27.52 & 27.82 & 2 & 1222.6086 & 1222.6064 & 612.3105 & 0.0022 & 1.7965 & 7096.183 & 7410.116\end{array}$ $\begin{array}{llllllllllllll}1.00 & 39.84 & 27.52 & 27.82 & 2 & 1222.6086 & 1222.6064 & 612.3105 & 0.0022 & 1.7965 & 7096.183 & 7410.116 & 0.00 \\ 1.00 & 52.46 & 27.62 & 28.29 & 2 & 1222.6090 & 1222.6064 & 612.3105 & 0.0026 & 2.1231 & 10122.359 & 9280.045 & 10.6 \\ 0.73 & 19.13 & 27.57 & 20.75 & 2 & 1456.7486 & 1456.7475 & 729.3810 & 0.0011 & 0.7541 & 50.647 & 25.173 & 21.6\end{array}$ $\begin{array}{llllllllllll}0.73 & 19.13 & 27.57 & 20.75 & 2 & 1456.7486 & 1456.7475 & 729.3810 & 0.0011 & 0.7541 & 50.647 & 25.173 \\ 0.98 & 31.32 & 27.59 & 22.39 & 2 & 1456.7496 & 1456.7475 & 729.3810 & 0.0021 & 1.4396 & 32.791 & 53.366\end{array}$ $\begin{array}{llllllllllll}0.98 & 28.05 & 27.99 & 27.12 & 3 & 1456.7518 & 1456.7475 & 486.5898 & 0.0043 & 2.9457 & 331.563 & 299.648\end{array}$ $\begin{array}{llllllllllll}0.98 & 31.32 & 27.59 & 22.39 & 2 & 1456.7496 & 1456.7475 & 729.3810 & 0.0021 & 1.4396 & 32.791\end{array}$ $\begin{array}{lllllllllll}0.53 & 25.73 & 28.05 & 28.01 & 2 & 1456.7530 & 14567475 & 729.3810 & 0.0055 & 3.7703 & 51.526\end{array}$ $\begin{array}{llllllllllll}1.00 & 50.99 & 27.03 & 28.36 & 2 & 145.2746 & 14772.7424 & 737.3785 & 0.0022 & 1.4918 & 528.932 & 65\end{array}$ $\begin{array}{lllllllllllll}1.00 & 69.31 & 27.92 & 25.30 & 2 & 1639.8740 & 1639.8735 & 820.9440 & 0.0005 & 0.3045 & 496.781 & 860.667\end{array}$ $\begin{array}{llllllllllllll}1.00 & 71.04 & 27.86 & 25.41 & 2 & 1639.8748 & 1639.8735 & 820.9440 & 0.0013 & 0.7918 & 1405.452 & 1180.969\end{array}$ $\begin{array}{lllllllllllll}0.89 & 18.99 & 27.74 & 26.51 & 3 & 1639.8760 & 1639.8735 & 547.6318 & 0.0025 & 1.5217 & 46.106 & 59.985\end{array}$ $\begin{array}{llllllllllllll}0.63 & 12.34 & 27.80 & 18.01 & 3 & 1639.8766 & 1639.8735 & 547.6318 & 0.0031 & 1.8869 & 38.787 & 62.816\end{array}$ $\begin{array}{lllllllllllll}1.00 & 50.68 & 27.31 & 25.91 & 2 & 1222.6108 & 1222.6064 & 612.3105 & 0.0044 & 3.5929 & 3056.891 & 3395.203\end{array}$ $\begin{array}{llllllllllll}0.97 & 39.75 & 27.32 & 28.19 & 2 & 1222.6112 & 1222.6064 & 612.3105 & 0.0048 & 3.9196 & 5523.405 & 5694.130\end{array}$ $\begin{array}{llllllllllll}1.00 & 76.06 & 27.39 & 26.36 & 2 & 1487.7710 & 1487.7701 & 744.8923 & 0.0009 & 0.6041 & 135.825 & 281.292\end{array}$ $\begin{array}{llllllllllll}1.00 & 75.69 & 27.30 & 25.16 & 2 & 1487.7716 & 1487.7701 & 744.8923 & 0.0015 & 1.0069 & 222.060 & 237.384 \\ 1.00 & 71.08 & 27.82 & 26.26 & 2 & 1639.8738 & 1639.8735 & 820.940 & 0.0003 & 0.1827 & 325.968 & 265.950\end{array}$ $\begin{array}{lllllllllllll}1.00 & 71.08 & 27.82 & 26.26 & 2 & 1639.8738 & 1639.8735 & 820.9440 & 0.0003 & 0.1827 & 325.968 & 265.950 & 247.5 \\ 1.00 & 71.82 & 27.92 & 26.25 & 2 & 1639.8740 & 1639.8735 & 820.9440 & 0.0005 & 0.3045 & 228.408 & 174.331 & 98.6\end{array}$ $\begin{array}{lllllllllllll}1.00 & 71.82 & 27.92 & 26.25 & 2 & 1639.8740 & 1639.8735 & 820.9440 & 0.0005 & 0.3045 & 228.408 & 174.331 \\ 0.58 & 28.47^{*} 25.83 & 32.50 & 2 & 917.5804 & 917.5789 & 459.7967 & 0.0015 & 1.6312 & 336.318 & 283.958\end{array}$ $\begin{array}{ccccccccccccc}0.58 & 28.47 * & 25.83 & 32.50 & 2 & 917.5804 & 917.5789 & 459.7967 & 0.0015 & 1.6312 & 336.318 & 283.958 & 126.5 \\ 1.00 & 44.90 & 26.00 & 26.38 & 2 & 1287.7760 & 1287.7642 & 644.8894 & 0.0118 & 9.1488 & 5456.934 & 5819.746\end{array}$

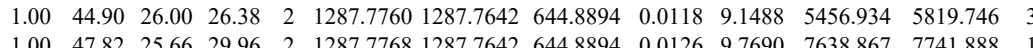
$\begin{array}{llllllllllll}1.00 & 47.82 & 25.66 & 29.96 & 2 & 1287.7768 & 1287.7642 & 644.8894 & 0.0126 & 9.7690 & 7638.867 & 7741.888\end{array}$ $\begin{array}{llllllllllll}1.00 & 51.69 & 27.07 & 35.13 & 2 & 1460.8458 & 1460.8330 & 731.4238 & 0.0128 & 8.7500 & 896.569 & 1134.868 \\ 1.00 & 56.86 & 26.86 & 33.90 & 2 & 1460.8472 & 1460.8330 & 731.4238 & 0.0142 & 9.7070 & 3633.417 & 3193.839\end{array}$ TASDFITK $\begin{array}{llllllllllllllll}0.60 & 22.51 & 27.54 & 35.51 & 3 & 2559.2893 & 2559.2849 & 854.1022 & 0.0044 & 1.7172 & 0.000 & 0.000 & 0.000 & 0.000 & \text { Yes }\end{array}$

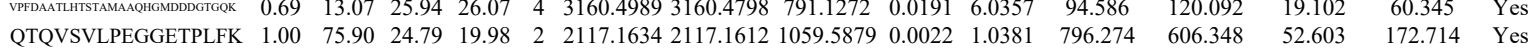
$\begin{array}{lllllllllllllllll}\text { QTQVSVLPEGGETPLFK } & 0.94 & 19.23 & 24.67 & 15.49 & 3 & 2117.1658 & 2117.1612 & 706.7277 & 0.0046 & 2.1696 & 91.848 & 40.367 & 10.200 & 89.652 & \text { Yes }\end{array}$ $\begin{array}{llllllllllllllll}\text { HVVNEVVQR } & 0.99 & 27.11 & 26.36 & 22.04 & 3 & 1418.8159 & 1418.8116 & 473.9445 & 0.0043 & 3.0243 & 5131.683 & 5146.829 & 4575.890 & 5231.741 & \text { Yes } \\ \text { HVVPNEVVVQR } & 0.96 & 22.91 & 26.36 & 20.28 & 3 & 1418.8159 & 1418.8116 & 473.9445 & 0.0043 & 3.0243 & 4140.932 & 4020.689 & 3416.442 & 5452.337 & \text { Yes }\end{array}$ 

$\begin{array}{lllllllllll}0.94 & 20.30 & 22.30 & 24.71 & 3 & 1724.7508 & 1724.7468 & 575.9229 & 0.0040 & 2.3151 & 85.581\end{array}$ $\begin{array}{lllllllllll}1.00 & 77.47 & 22.23 & 23.66 & 2 & 1724.7510 & 1724.7468 & 863.3807 & 0.0042 & 2.4323 & 17.070\end{array}$ 


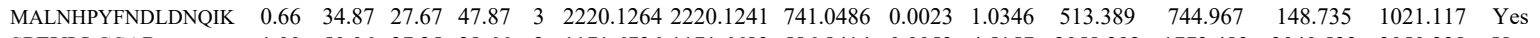
SPEVLLGSAR

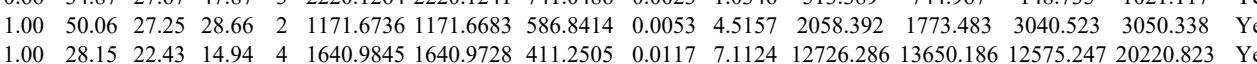
$\begin{array}{llllllllllllllll} & \end{array}$ $\begin{array}{llllllllllllllll}\text { WKPGSLASHVK } & 1.00 & 28.50 & 22.17 & 15.74 & 4 & 1640.9861 & 1640.9728 & 411.2505 & 0.0133 & 8.0850 & 7607.396 & 8337.225 & 7043.079 & 12506.377 & \text { Yes }\end{array}$

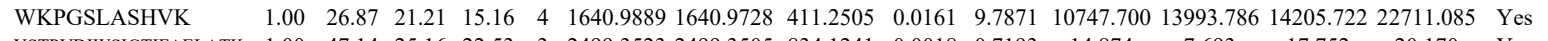

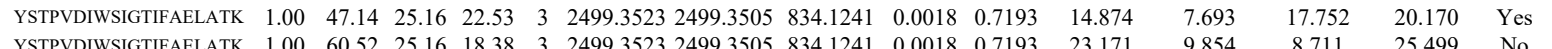

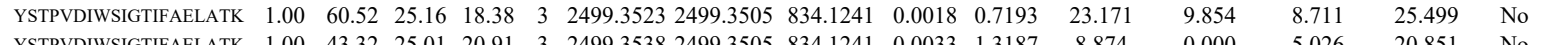

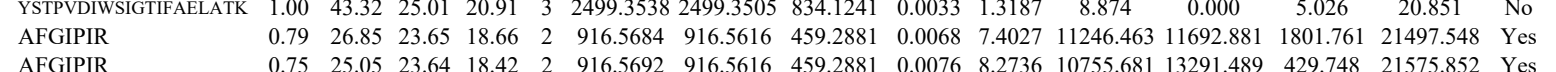
$\begin{array}{llllllllllllllll}\text { LESEEEGVPSTAIR } & 1.00 & 66.78 & 27.88 & 30.41 & 2 & 1659.8536 & 1659.8437 & 830.9291 & 0.0099 & 5.9572 & 82.035 & 120.930 & 113.141 & 226.786 & \text { Yes }\end{array}$

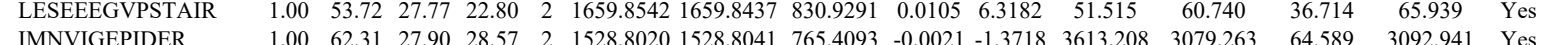

TIAMDGTEGLVR $\begin{array}{llllllllllllllll}1.00 & 62.31 & 27.90 & 28.57 & 2 & 1528.8020 & 1528.8041 & 765.4093 & -0.0021 & -1.3718 & 3613.208 & 3079.263 & 64.589 & 3092.941 & \text { Yes } \\ \end{array}$ $\begin{array}{lllllllllllllllll}\text { IMDPNIVGSEHYDVAR } & 1.00 & 78.29 & 27.40 & 27.38 & 3 & 1958.9689 & 1958.9642 & 653.9953 & 0.0047 & 2.3955 & 2963.769 & 1999.426 & 1814.017 & 2903.641 & \text { Yes }\end{array}$

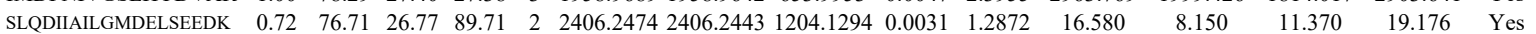
$\begin{array}{lllllllllllllllll}\text { IMDPNIVGSEHYDVAR } & 1.00 & 82.14 & 27.38 & 23.79 & 3 & 1958.9671 & 1958.9642 & 653.9953 & 0.0029 & 1.4781 & 2293.697 & 2368.917 & 247.729 & 2176.477 & \text { Yes }\end{array}$ $\begin{array}{llllllllllllllll}\text { SLQDIIAILGMDELSEEDK } & 1.00 & 81.12 & 26.77 & 19.58 & 2 & 2406.2474 & 2406.2443 & 1204.1294 & 0.0031 & 1.2872 & 0.000 & 8.566 & 5.013 & 8.395 & \text { No }\end{array}$ $\begin{array}{llllllllllllllll}\text { SLQDIIAILGMDELSEEDK } & 0.60 & 20.18 & 26.78 & 33.18 & 3 & 2406.2482 & 2406.2443 & 803.0887 & 0.0039 & 1.6187 & 8.108 & 20.138 & 3.120 & 15.432 & \text { Yes }\end{array}$ $\begin{array}{lllllllllllllll}\text { SLQDIIAILGMDELSEEDK } & 1.00 & \text { \#\#\#\# } 26.78 & 22.06 & 2 & 2406.2494 & 2406.2443 & 1204.1294 & 0.0051 & 2.1177 & 8.790 & 9.956 & 9.413 & 15.871 & \text { Yes }\end{array}$

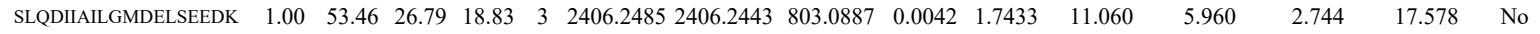
$\begin{array}{lllllllllllllllll}\text { ITTTK } & 0.77 & 16.89 & 24.33 & 17.31 & 2 & 850.5378 & 850.5368 & 426.2757 & 0.0010 & 1.1729 & 209.746 & 171.197 & 172.160 & 164.530 & \text { Yes }\end{array}$ $\begin{array}{lllllllllllllllll}\text { SLQDIIAILGMDELSEEDK } & 0.99 & 38.46 & 26.57 & 18.04 & 3 & 2406.2527 & 2406.2443 & 803.0887 & 0.0084 & 3.4865 & 10.407 & 8.562 & 4.921 & 16.047 & \text { Yes }\end{array}$

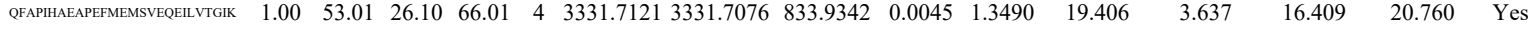

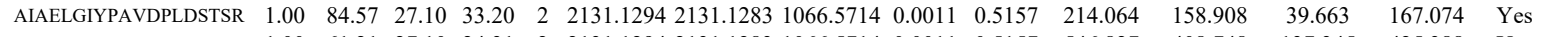
$\begin{array}{llllllllllllllll}\text { AIAELGIYPAVDPLDSTSR } & 1.00 & 61.21 & 27.10 & 24.31 & 2 & 2131.1294 & 2131.1283 & 1066.5714 & 0.0011 & 0.5157 & 546.827 & 408.748 & 137.345 & 425.388 & \text { Yes }\end{array}$ \begin{tabular}{llllllllllllllll} 
AIAELGIYPAVDPLDSTSR & 0.67 & 24.18 & 27.04 & 37.18 & 3 & 2131.1311 & 2131.1283 & 711.3834 & 0.0028 & 1.3120 & 181.719 & 124.398 & 134.887 & 114.939 & Yes \\
\hline
\end{tabular} $\begin{array}{llllllllllllllll}\text { DQEGQDVLLFIDNIFR } & 1.00 & 86.61 & 27.38 & 23.83 & 2 & 2065.0614 & 2065.0602 & 1033.5374 & 0.0012 & 0.5805 & 29.245 & 23.379 & 48.115 & 58.260 & \text { No }\end{array}$

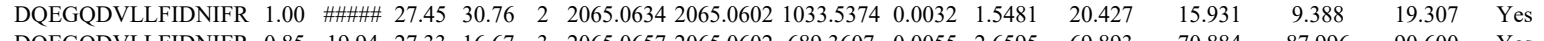

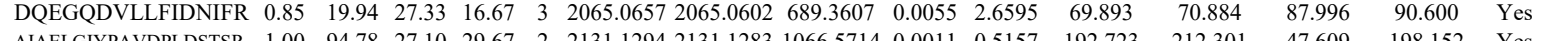

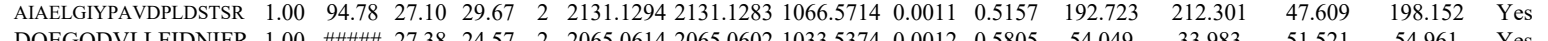

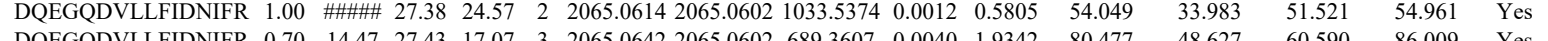
$\begin{array}{lllllllllllllll} & \end{array}$

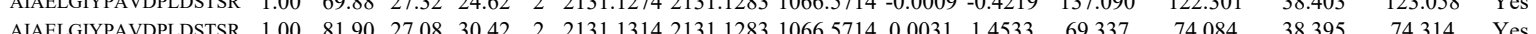

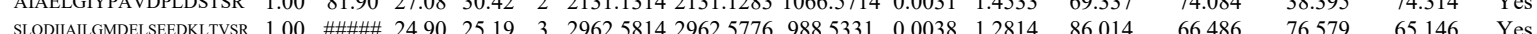

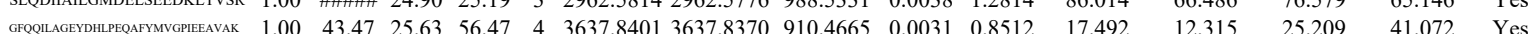

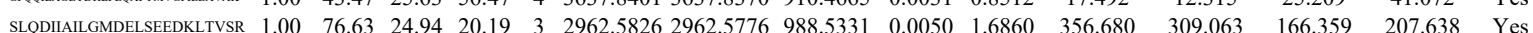

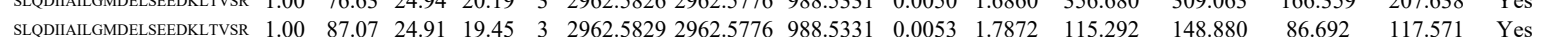

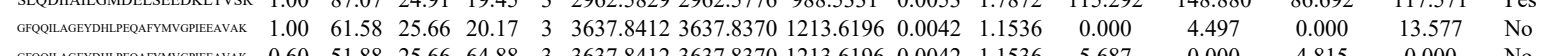

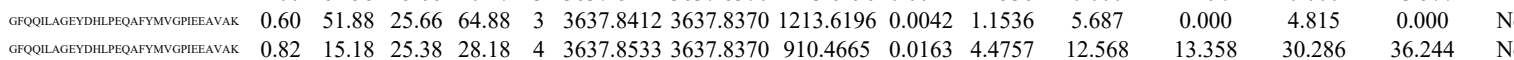

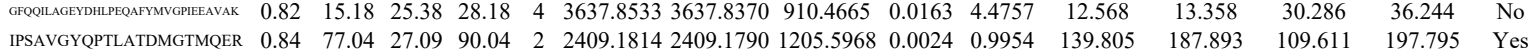

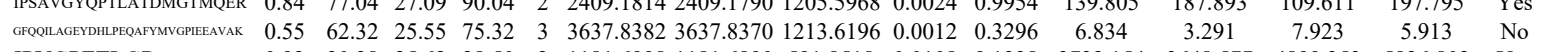

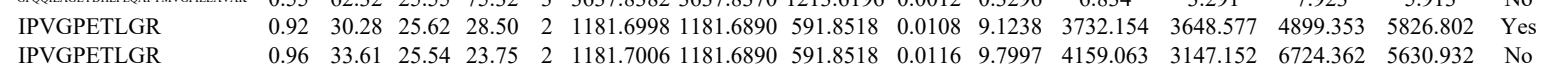
$\begin{array}{llllllllllllllll}\text { IPVGPETLGR } & 0.96 & 33.61 & 25.54 & 23.75 & 2 & 1181.7006 & 1181.6890 & 591.8518 & 0.0116 & 9.7997 & 4159.063 & 3147.152 & 6724.362 & 5630.932 & \text { No } \\ \end{array}$

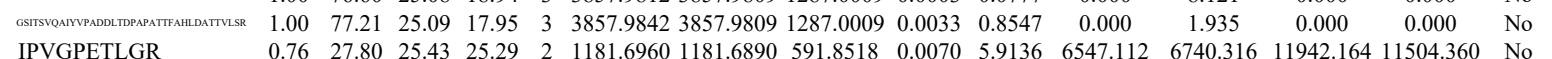

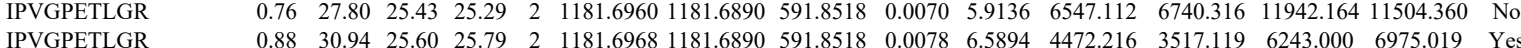
$\begin{array}{lllllllllllllllll}\text { VVDLLAPYAK } & 1.00 & 70.78 & 24.87 & 18.20 & 2 & 1375.8350 & 1375.8319 & 688.9232 & 0.0031 & 2.2499 & 7863.974 & 7596.575 & 532.883 & 7091.368 & \text { Yes }\end{array}$ $\begin{array}{lllllllllllllllll}\text { VVDLLAPYAK } & 1.00 & 70.71 & 24.68 & 17.97 & 2 & 1375.8352 & 1375.8319 & 688.9232 & 0.0033 & 2.3950 & 8463.547 & 8246.696 & 555.977 & 7658.227 & \text { Yes }\end{array}$ IPVGPETLGR VVIDLTAR $\begin{array}{lllllllllllllllll}0.97 & 37.38 & 25.60 & 26.15 & 2 & 1181.6972 & 1181.6890 & 591.8518 & 0.0082 & 6.9274 & 3195.250 & 1898.282 & 3296.065 & 3747.407 & \text { Yes }\end{array}$ $\begin{array}{llllllllllllllllll} & 1.00 & 70.93 & 24.71 & 18.02 & 2 & 1375.8358 & 1375.8319 & 688.9232 & 0.0039 & 2.8305 & 5194.919 & 5220.163 & 361.666 & 4633.551 & \text { Yes }\end{array}$ $\begin{array}{lllllllllllllllll}\text { LVLEVAQHLGESTVR } & 1.00 & 70.81 & 24.86 & 24.66 & 2 & 1794.0134 & 1794.0121 & 898.0133 & 0.0013 & 0.7238 & 1722.875 & 1759.392 & 315.425 & 1388.357 & \text { Yes }\end{array}$

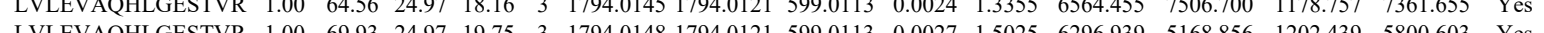

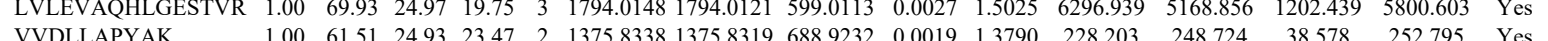
$\begin{array}{llllllllllllllll}\text { VVDLLAPYAK } & 1.00 & 61.51 & 24.93 & 23.47 & 2 & 1375.8338 & 1375.8319 & 688.9232 & 0.0019 & 1.3790 & 228.203 & 248.724 & 38.578 & 252.795 & \text { Yes } \\ \text { VALVYGQMNEPGAR } & 1.00 & 85.96 & 27.87 & 24.70 & 2 & 1744.9144 & 1744.9052 & 873.4599 & 0.0092 & 5.2664 & 623.032 & 544.431 & 69.952 & 487.078 & \text { Yes }\end{array}$

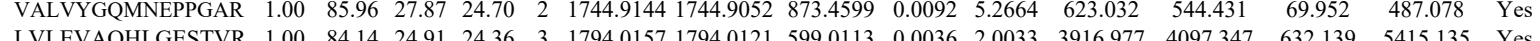

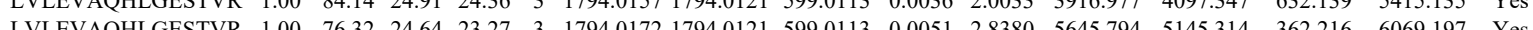
$\begin{array}{llllllllllllllll}\text { FTQAGSEVSALLGR } & 1.00 & 83.21 & 28.37 & 26.91 & 2 & 1578.8520 & 1578.8488 & 790.4317 & 0.0032 & 2.0242 & 6196.018 & 7063.180 & 501.521 & 5153.357 & \text { Yes }\end{array}$ 

$\begin{array}{lllllllllll}1.00 & 60.05 & 21.82 & 32.99 & 2 & 1745.0386 & 1745.0364 & 873.5255 & 0.0022 & 1.2593 & 107.059\end{array}$

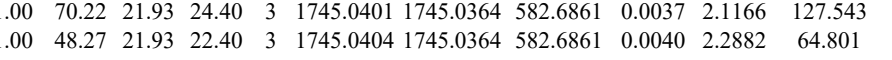

$\begin{array}{llllllllllllll}1.00 & 76.74 & 26.90 & 21.13 & 3 & 2310.2110 & 2310.2075 & 771.0764 & 0.0035 & 1.5130 & 5337.849 & 4631.992\end{array}$ $\begin{array}{llllllllllll}1.00 & 91.08 & 26.20 & 29.41 & 2 & 1582.8860 & 1582.8841 & 792.4493 & 0.0019 & 1.1988 & 1625.917 & 1394.246\end{array}$ $\begin{array}{llllllllllllll}1.00 & 42.58 & 26.21 & 17.22 & 3 & 1582.8862 & 1582.8841 & 528.6353 & 0.0021 & 1.3242 & 116.565 & 188.949\end{array}$ $\begin{array}{lllllllllllll}1.00 & 94.35 & 26.21 & 30.31 & 2 & 1582.8864 & 1582.8841 & 792.4493 & 0.0023 & 1.4512 & 2041.632 & 1875.384\end{array}$ $\begin{array}{llllllllllllll}0.99 & 27.07 & 26.26 & 19.97 & 3 & 1582.8871 & 1582.8841 & 528.6353 & 0.0030 & 1.8917 & 65.210 & 62.487\end{array}$ $\begin{array}{llllllllllll}.99 & 2.19 & 22.12 & 16.69 & 3 & 1745.0380 & 1745.0364 & 582.6861 & 0.0016 & 0.9153 & 119.659 & 68.162\end{array}$ $\begin{array}{llllllllllllll}1.00 & 64.34 & 21.82 & 24.96 & 3 & 1745.0386 & 1745.0364 & 582.6861 & 0.0022 & 1.2585 & 153.125 & 97.295 \\ 0.67 & 56.65 & 26.97 & 69.65 & 3 & 2310.2101 & 2310.075 & 771.0764 & 0.0026 & 1.1240 & 434.966 & 446.540\end{array}$ $\begin{array}{llllllllllllll}0.67 & 56.65 & 26.97 & 69.65 & 3 & 2310.2101 & 2310.2075 & 771.0764 & 0.0026 & 1.1240 & 434.966 & 446.540 & \\ 1.00 & 83.64 & 26.46 & 25.10 & 2 & 1582.8840 & 1582.8841 & 792.4493 & -0.0001 & -0.0631 & 1463.567 & 1619.396 & \\ 1.00 & 79.9 & 26.32 & 27.24 & 2 & 15828850 & 1582884 & 792.493 & 0.00 & 0.5679 & 3374.52 & 384.49 & 0.6\end{array}$ $\begin{array}{lllllllllllll}1.00 & 83.64 & 26.46 & 25.10 & 2 & 1582.8840 & 1582.8841 & 792.4493 & -0.0001 & -0.0631 & 1463.567 & 1619.396 \\ 1.00 & 79.91 & 26.32 & 27.24 & 2 & 1582.8850 & 1582.8841 & 792.4493 & 0.0009 & 0.5679 & 3374.528 & 3894.499\end{array}$ $\begin{array}{lllllllllllll}1.00 & 50.96 & 26.21 & 23.61 & 3 & 1582.8862 & 1582.8841 & 528.6353 & 0.0021 & 1.3242 & 51.938 & 119.120\end{array}$ $\begin{array}{llllllllllll}1.00 & 31.82 & 26.26 & 19.03 & 3 & 1582.8874 & 1582.8841 & 528.6353 & 0.0033 & 2.0808 & 67.932 & 115.543 \\ 1.00 & 84.87 & 26.40 & 27.85 & 2 & 1582.8836 & 1582.8841 & 792.4493 & -0.0005 & -0.3155 & 584.723 & 669.317\end{array}$

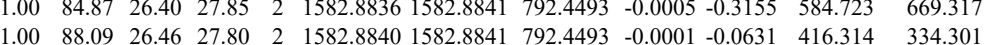
$\begin{array}{llllllllllllll}1.00 & 88.09 & 26.46 & 27.80 & 2 & 1582.8840 & 1582.8841 & 792.4493 & -0.0001 & -0.0631 & 416.314 & 334.301\end{array}$ $\begin{array}{llllllllllll}1.00 & 62.73 & 27.77 & 29.58 & 2 & 1528.8040 & 1528.8041 & 765.4093 & -0.0001 & -0.0653 & 4313.185 & 4412.377\end{array}$ $\begin{array}{llllllllllll}0.86 & 22.27 & 27.63 & 29.56 & 2 & 1058.5862 & 1058.5842 & 530.2994 & 0.0020 & 1.8857 & 129.503 & 67.036\end{array}$

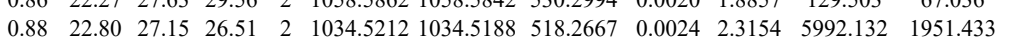
$\begin{array}{lllllllllllll}0.94 & 25.71 & 27.15 & 32.46 & 2 & 1034.5212 & 1034.5188 & 518.2667 & 0.0024 & 2.3154 & 20659.867 & 7021.399 & 184\end{array}$ $\begin{array}{lllllllllllll}0.59 & 22.41 & 26.88 & 26.50 & 2 & 1034.5226 & 1034.5188 & 518.2667 & 0.0038 & 3.6661 & 5806.752 & 2054.784\end{array}$ $\begin{array}{llllllllllll}0.75 & 25.61 & 26.93 & 27.59 & 2 & 1034.5230 & 1034.5188 & 518.2667 & 0.0042 & 4.0520 & 18280.196 & 6401.284\end{array}$ $\begin{array}{lllllllllllll}0.96 & 26.99 & 26.67 & 27.30 & 2 & 1050.5156 & 1050.5137 & 526.2641 & 0.0019 & 1.8052 & 848.958 & 255.998 \\ 0.92 & 27.22 & 26.56 & 27.80 & 2 & 1050.5168 & 1050.5137 & 526.2641 & 0.0031 & 2.9453 & 1437.884 & 419.408\end{array}$

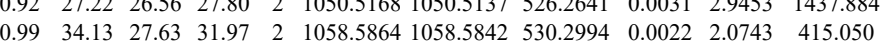
$\begin{array}{lllllllllll}0.98 & 34.23 & 27.74 & 28.97 & 2 & 1058.5874 & 1058.5842 & 530.2994 & 0.0032 & 3.0172 & 278.081\end{array}$ $\begin{array}{llllllllllll}0.99 & 38.80 & 24.12 & 16.48 & 3 & 21422011 & 2142.1937 & 715.0718 & 0.0032 & 3.0172 & 278.081 & 133.247 \\ 0.87 & 26.03 & 27.74 & 27.99 & 2 & 1058.5874 & 1058.5842 & 530.2994 & 0.0032 & 3.0172 & 13.267 & 10.877\end{array}$ $\begin{array}{lllllllllllll}0.87 & 26.03 & 27.74 & 27.99 & 2 & 1058.5874 & 1058.5842 & 530.2994 & 0.0032 & 3.0172 & 120.268 & 56.599\end{array}$ $\begin{array}{llllllllllll}0.96 & 28.90 & 27.75 & 28.33 & 2 & 1058.5866 & 1058.5842 & 530.2994 & 0.0024 & 2.2629 & 89.445 & 38.817\end{array}$ $\begin{array}{llllllllllllll}0.87 & 30.12 & 27.63 & 28.94 & 2 & 1058.5884 & 1058.5842 & 530.2994 & 0.0042 & 3.9600 & 142.865 & 40.841\end{array}$ $\begin{array}{lllllllllllll}0.87 & 30.12 & 27.63 & 28.94 & 2 & 1058.5884 & 1058.5842 & 530.2994 & 0.0042 & 3.9600 & 142.865 & 4.841 \\ 0.93 & 28.67 & 27.75 & 34.01 & 2 & 1058.5868 & 1058.5842 & 530.2994 & 0.0026 & 2.4514 & 262.840 & 104.951\end{array}$ $\begin{array}{llllllllllllll}0.86 & 25.32 & 27.71 & 26.89 & 2 & 1058.5876 & 1058.5842 & 530.2994 & 0.0034 & 3.2057 & 209.710 & 72.210\end{array}$ $\begin{array}{lllllllllllll}0.66 & 20.04 & 27.28 & 31.78 & 2 & 1034.5216 & 1034.5188 & 518.2667 & 0.0028 & 2.7013 & 6760.084 & 2379.615\end{array}$ $\begin{array}{llllllllllll}0.72 & 20.78 & 26.95 & 31.12 & 2 & 1034.5218 & 1034.5188 & 518.2667 & 0.0030 & 2.8943 & 7154.562 & 2015.528\end{array}$ $\begin{array}{llllllllllll}0.94 & 29.57 & 27.74 & 27.05 & 2 & 1058.5874 & 1058.5842 & 530.2994 & 0.0032 & 3.0172 & 648.063 & 323.961\end{array}$ $\begin{array}{lllllllllllll}0.88 & 26.21 & 27.74 & 27.57 & 2 & 1058.5874 & 1058.5842 & 530.2994 & 0.0032 & 3.0172 & 224.165 & 115.981\end{array}$ $\begin{array}{lllllllllllll}0.97 & 35.08 & 27.74 & 35.89 & 2 & 1058.5874 & 1058.5842 & 530.2994 & 0.0032 & 3.0172 & 25751.574 & 7205.309 \\ 0.93 & 28.74 & 27.71 & 29.95 & 2 & 1058.5876 & 1058.5842 & 530.2994 & 0.0034 & 3.2057 & 730.878 & 302.705\end{array}$ $\begin{array}{llllllllllll}0.93 & 28.74 & 27.71 & 29.95 & 2 & 1058.5876 & 1058.5842 & 530.2994 & 0.0034 & 3.2057 & 730.878 & 302.705\end{array}$ $\begin{array}{llllllllllll}0.89 & 26.78 & 27.71 & 27.63 & 2 & 1058.5876 & 1058.5842 & 530.2994 & 0.0034 & 3.2057 & 78.462 & 34.888\end{array}$ $\begin{array}{lllllllllllll}0.99 & 41.15 & 27.71 & 34.36 & 2 & 1058.5878 & 1058.5842 & 530.2994 & 0.0036 & 3.3943 & 12873.453 & 3984.943\end{array}$ $\begin{array}{lllllllllllll}0.79 & 27.50 & 27.71 & 27.11 & 2 & 1058.5878 & 1058.5842 & 530.2994 & 0.0036 & 3.3943 & 111.777 & 47.443\end{array}$ $\begin{array}{llllllllllllll}0.88 & 30.48 & 27.75 & 29.85 & 2 & 1058.5882 & 1058.5842 & 530.2994 & 0.0040 & 3.7714 & 702.355 & 285.002\end{array}$ $\begin{array}{lllllllllllll}0.92 & 32.45 & 27.75 & 28.13 & 2 & 1058.5882 & 1058.5842 & 530.2994 & 0.0040 & 3.7714 & 628.662 & 261.689 \\ 0.73 & 25.92 & 27.63 & 28.70 & 2 & 1058.5886 & 1058.5842 & 530.2994 & 0.0044 & 4.1486 & 170.516 & 74.755\end{array}$ $\begin{array}{lllllllllllll}0.60 & 26.99 & 28.02 & 24.94 & 2 & 1058.5890 & 1058.5842 & 530.2994 & 0.0048 & 4.5257 & 517.971 & 203.555\end{array}$ $\begin{array}{lllllllllllll}0.55 & 26.18 & 28.02 & 27.98 & 2 & 1058.5890 & 1058.5842 & 530.2994 & 0.0048 & 4.5257 & 205.554 & 120.295\end{array}$ 

$\begin{array}{llllllllllllllll}\text { YISPQLADLYK } & 0.95 & 24.33 & 27.36 & 28.85 & 3 & 1712.9257 & 1712.9229 & 571.9816 & 0.0028 & 1.6318 & 30.538 & 239.786 & 315.803 & 171.388 & \text { No } \\ \text { IGAEVYHNLK } & 0.57 & 15.61 & 27.72 & 2.78 & 3 & 143.829 & 1430.25 & 477.944 & 0.024 & 0.2790 & 114.882 & 86.874 & 51.978 & 156.428 & \text { Yes }\end{array}$ $\begin{array}{llllllllllllllll}\text { IGAEVYHNLK } & 0.57 & 15.61 & 27.72 & 20.78 & 3 & 1430.8129 & 1430.8125 & 477.9448 & 0.0004 & 0.2790 & 114.882 & 86.874 & 51.978 & 156.428 & \text { Yes } \\ \text { IGAEVYHNLK } & 0.65 & 14.71 & 27.69 & 15.20 & 3 & 1430.8132 & 1430.8125 & 477.9448 & 0.0007 & 0.4882 & 106.057 & 87.355 & 60.634 & 139.871 & \text { Yes }\end{array}$

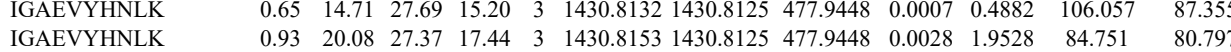
$\begin{array}{llllllllllllll}\text { YISPDQLADLYK } & 0.51 & 12.11 & 27.51 & 16.64 & 3 & 1712.9236 & 1712.9229 & 571.9816 & 0.0007 & 0.4079 & 146.897 & 106.247\end{array}$ $\begin{array}{lllllllllllllll}\text { YISPDQLADLYK } & 1.00 & 67.79 & 27.48 & 25.95 & 2 & 1712.9250 & 1712.9229 & 857.4687 & 0.0021 & 1.2245 & 8181.354 & 8265.004\end{array}$ $\begin{array}{llllllllllllll}\text { YISPDQLADLYK } & 1.00 & 74.87 & 27.48 & 24.56 & 2 & 1712.9250 & 1712.9229 & 857.4687 & 0.0021 & 1.2245 & 19557.579 & 16065.956 & 0.4\end{array}$ YISPDQLADLYK

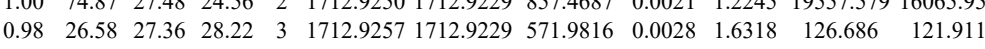

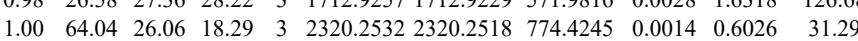

$\begin{array}{llllllllllllll}\text { FTASAGIQVVGDDLTVTNPK } & 1.00 & 96.79 & 26.06 & 22.02 & 2 & 2320.2534 & 2320.2518 & 1161.1332 & 0.0016 & 0.6890 & 84.777\end{array}$

$\begin{array}{lllllllllllllll}\text { FTASAGIQVVGDDLTVTNPK } & 0.66 & 36.49 & 26.06 & 49.49 & 3 & 2320.2535 & 2320.2518 & 774.4245 & 0.0017 & 0.7317 & 159.651 & 170.697\end{array}$ $\begin{array}{llllllllllllll}\text { FTASAGIQVVGDDLTVTNPK } & 0.66 & 34.89 & 26.05 & 47.89 & 3 & 2320.2544 & 2320.2518 & 774.4245 & 0.0026 & 1.1191 & 26.485 & 170.697\end{array}$ $\begin{array}{llllllllllllll}\text { FTASAGIQVVGDDLTVTNPK } & 0.98 & 24.60 & 26.05 & 15.02 & 3 & 2320.2544 & 2320.2518 & 774.4245 & 0.0026 & 1.1191 & 28.763\end{array}$

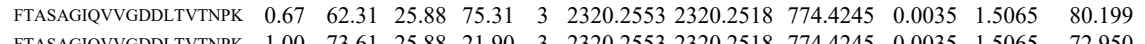

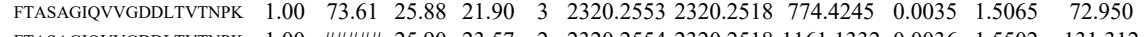
$\begin{array}{lllllllllllll} & \text { HASAGIQVUGDDLTVINPK } & 1.00 & 25.90 & 23.57 & 2 & 2320.2554 & 2320.2518 & 1161.1332 & 0.0036 & 1.5502 & 131.312 & 87.487\end{array}$

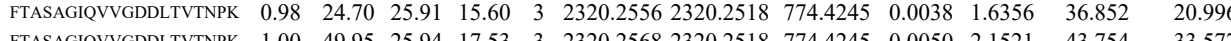
$\begin{array}{lllllllllll} & 0\end{array}$

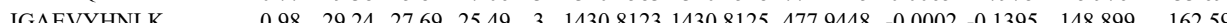
IGAEVYHNLK

IGAEVYHNLK

IGAEVYHNLK

IGAEVYHNLK

IGAEVYHNLK

IGAEVYHNLK

IGAEVYHNLK

IGAEEVYHNLK IGAEVYHNLK IGAEVYHNLK

YISPDQLADLYK

YISPDQLADLYK $\begin{array}{lllllllllllll}0.98 & 29.24 & 27.69 & 25.49 & 3 & 1430.8123 & 1430.8125 & 477.9448 & -0.0002 & 0.1395 & 148.899\end{array}$ $\begin{array}{lllllllllll}0.95 & 23.69 & 27.63 & 20.69 & 3 & 1430.8135 & 1430.8125 & 477.9448 & 0.0010 & 0.6974 & 134.130\end{array}$ $\begin{array}{lllllllllllll}0.99 & 28.56 & 27.54 & 18.94 & 3 & 1430.8141 & 1430.8125 & 477.9448 & 0.0016 & 11159 & 170.454 & 178.892\end{array}$

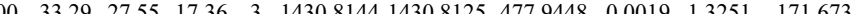
$\begin{array}{lllllllllllll}100 & 37.84 & 27.37 & 19.63 & 3 & 1430.8147 & 1430.8125 & 477.9448 & 0.0022 & 1.5343 & 218.135\end{array}$ $\begin{array}{llllllllllll}1.82 & 15.85 & 27.37 & 14.70 & 3 & 1430.8153 & 1430.8125 & 477.9448 & 0.0028 & 1.9528 & 106.606\end{array}$ $\begin{array}{lllllllllllll}0.79 & 20.82 & 26.80 & 16.13 & 3 & 1430.8189 & 1430.8125 & 477.9448 & 0.0064 & 4.4635 & 194.195\end{array}$ $\begin{array}{lllllllllll} & \end{array}$ $196.048 \quad 12634.569$

YISPDQLADLY

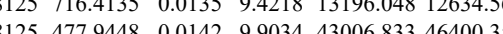
YISPDQLADLYK $\begin{array}{llllllllllll}1.00 & 71.40 & 27.47 & 23.53 & 2 & 1712.9246 & 1712.9229 & 857.4687 & 0.0017 & 0.9913 & 15223.744 & 15132.854\end{array}$ FTASAGIQVVGDDLTVTN $\begin{array}{lllllllllllll}1.00 & 69.48 & 27.37 & 24.61 & 2 & 1712.9254 & 1712.9229 & 857.4687 & 0.0025 & 1.4578 & 8596.259 & 6811.213\end{array}$ $\begin{array}{lllllllllllll}0.98 & 26.14 & 27.56 & 25.86 & 3 & 1712.9260 & 1712.9229 & 571.9816 & 0.0031 & 1.8066 & 193.591 & 143.931 \\ 0.98 & 25.34 & 27.45 & 24.73 & 3 & 1712.9263 & 1712.9229 & 571.9816 & 0.0034 & 1.9814 & 88.717 & 151.576\end{array}$

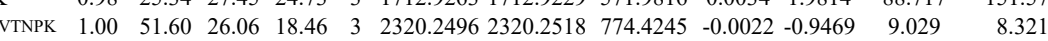
$\begin{array}{lllllllllllll} & 26.06 & 23.64 & 2 & 2320.2534 & 2320.2518 & 1161.1332 & 0.0016 & 0.6890 & 110.054 & 136.848\end{array}$ $\begin{array}{llllllllllllll}\text { FASAGQVEDDLININKK } & 1.00 & 83.35 & 26.06 & 21.77 & 3 & 2320.2535 & 2320.2518 & 774.4245 & 0.0017 & 0.7317 & 27.485 & 17.386\end{array}$ $\begin{array}{llllllllllllll} & 1.00 & 83.35 & 26.06 & 21.77 & 3 & 2320.2535 & 2320.2518 & 774.4245 & 0.0017 & 0.7317 & 27.485 & 17.386\end{array}$

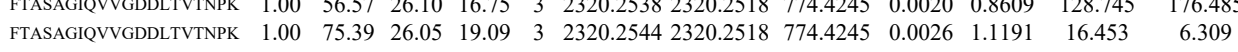

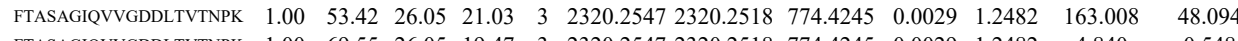
$\begin{array}{lllllllllllll}\text { FTASAGQVWGDDLIVTNK } & 1.00 & 69.55 & 26.05 & 19.47 & 3 & 2320.2547 & 2320.2518 & 774.4245 & 0.0029 & 1.2482 & 4.840 & 0.548\end{array}$ $\begin{array}{llllllllllllll}\text { FTASAGIQVVGDDLTVTNPK } & 0.67 & 42.85 & 25.89 & 55.85 & 3 & 2320.2550 & 2320.2518 & 774.4245 & 0.0032 & 1.3774 & 56.786 & 45.806 \\ \text { FTASAGIQVVGDDLTVTNPK } & 1.00 & 75.97 & 25.89 & 21.84 & 3 & 2320.2550 & 2320.2518 & 774.4245 & 0.0032 & 1.3774 & 7.878 & 3.174 \\ \text { FTASAGQVVGDDTVNRK } & 0.66 & 11.07 & 25.88 & 24.07 & 3 & 2320.2553 & 2320.518 & 774.4245 & 0.0035 & 1.5065 & 9.419 & 14.829\end{array}$

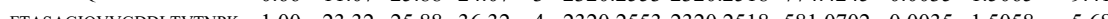

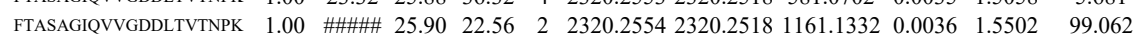


$\begin{array}{llllllllllll}1.00 & 57.72 & 25.73 & 19.42 & 3 & 2320.2613 & 2320.2518 & 774.4245 & 0.0095 & 4.0890 & 10.943 & 32.230 \\ 1.00 & 58.31 & 27.19 & 37.80 & 2 & 1430.8240 & 1430.8125 & 716.4135 & 0.0115 & 8.0260 & 10899.603 & 9508.650\end{array}$

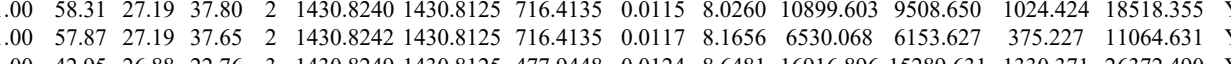

YISPDQLADLYK

YISPDQLADLYK

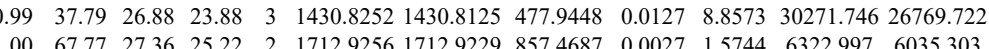

YISPDQLADLYK

$\begin{array}{lllll}1.00 & 57.12 & 27.45 & 25.00\end{array}$

$0.81 \quad 16.94 \quad 27.43 \quad 20.07$

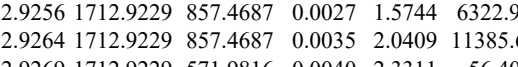

FTASAGIQVVGDDLTVTN
FTASAGIOVVGDDLTVTN

FTASAGIQVVGDDLTVTNPK

FTASAGIQVVGD

IGAEVYHNLK

IGAEVYHNLK

IGAEVYHNLK

IGAEVYHNLK

YISPDQLADLYK

TIAPALVSK

TIAPALVSK

IGAEVYHNLK

IGAEVYHNLK

IGAEVYHNLK

IGAEVYHNLK

TIAPALVSK

TIAPALVSK

TIAPALVSK

TIAPALVSK

YISPDQLADLYK

TIAPALVSK

TIAPALVSK

TIAPALVSK

VVIGMDVAASEFFR

VVIGMDVAASEFFR

VVIGMDVAASEFFR

VVIGMDVAASEFFR

TIAPALVSK

TIAPALVS

VVIGMDVAASEFFR 0.58

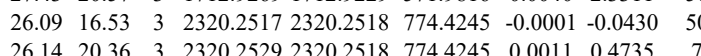

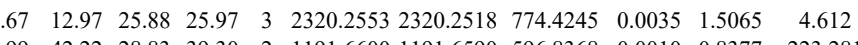
$\begin{array}{lllllllllllll}1.00 & 55.74 & 26.88 & 27.95 & 2 & 1430.8252 & 1430.8125 & 716.4135 & 0.0127 & 8.8635 & 18288.505 & 14465.704\end{array}$ $\begin{array}{lllllllllllllll} & 52.50 & 26.87 & 28.15 & 2 & 1430.8256 & 1430.8125 & 716.4135 & 0.0131 & 9.1427 & 15685.305 & 13408.586 & 456.315 & 21175.057 & \text { Yes }\end{array}$ $\begin{array}{llllllllllllllll}0.96 & 31.02 & 26.97 & 20.74 & 3 & 1430.8264 & 1430.8125 & 477.9448 & 0.0139 & 9.6942 & 47911.297 & 36465.714 & 1594.784 & 64185.097 & \text { Yes } \\ 0.93 & 28.98 & 26.97 & 21.66 & 3 & 1430.8264 & 1430.8125 & 477.9448 & 0.0139 & 9.6942 & 33947.498 & 32857.579 & 2380.750 & 46562.477 & \text { Yes }\end{array}$

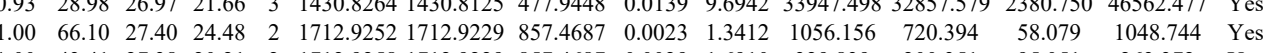
$\begin{array}{lllllllllllllll}1.00 & 43.41 & 27.38 & 20.21 & 2 & 1712.9258 & 1712.9229 & 857.4687 & 0.0029 & 1.6910 & 329.839 & 200.351 & 95.051 & 263.372 & \text { Yes }\end{array}$ $\begin{array}{lllllllllllllll}1.00 & 47.01 & 21.58 & 16.50 & 2 & 1186.7624 & 1186.7529 & 594.3837 & 0.0095 & 7.9914 & 35112.384 & 32991.917 & 0.000 & 49757.621 & \text { No }\end{array}$ $\begin{array}{llllllllllllllll}1.00 & 44.05 & 21.58 & 17.77 & 2 & 1186.7632 & 1186.7529 & 594.3837 & 0.0103 & 8.6644 & 24695.853 & 23667.653 & 664.420 & 33151.691 & \text { Yes }\end{array}$

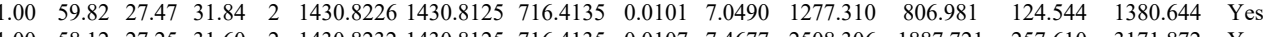
\begin{tabular}{llllllllllllllll}
1.00 & 58.12 & 27.25 & 31.60 & 2 & 1430.8232 & 1430.8125 & 716.4135 & 0.0107 & 7.4677 & 2508.306 & 1887.721 & 257.610 & 3171.872 & Yes \\
\hline
\end{tabular} $\begin{array}{lllllllllllllllll}0.99 & 38.20 & 27.19 & 26.44 & 3 & 1430.8243 & 1430.8125 & 477.9448 & 0.0118 & 8.2296 & 13527.687 & 11784.161 & 268.869 & 15398.969 & \text { Yes }\end{array}$ \begin{tabular}{llllllllllllllll}
0.99 & 37.59 & 27.19 & 25.53 & 3 & 1430.8243 & 1430.8125 & 477.9448 & 0.0118 & 8.2296 & 20486.440 & 15959.502 & 268.006 & 23367.662 & Yes \\
\hline
\end{tabular} $\begin{array}{llllllllllllllll}1.00 & 54.13 & 27.51 & 24.34 & 2 & 1732.2234 & 1712.9229 & 857.4687 & 0.0005 & 0.2916 & 1479.700 & 1187.717 & 156.171 & 171.629 & \text { Yes }\end{array}$

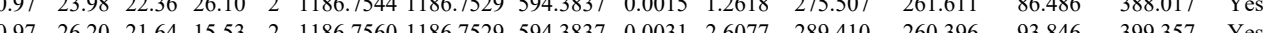

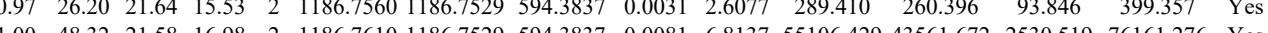

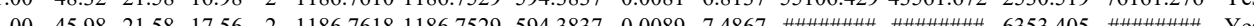

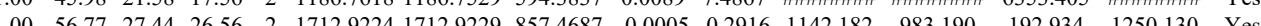

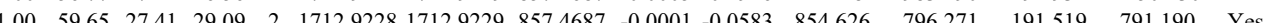

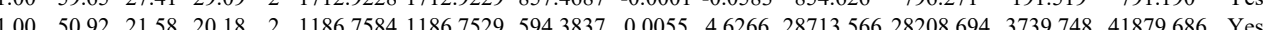

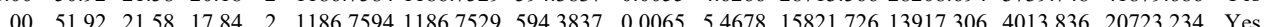
$\begin{array}{llllllllllllllll}100 & 44.81 & 21.64 & 16.32 & 2 & 11867596 & 11867529 & 594.3837 & 0.0067 & 5.6361 & 26152.670 & 23159.868 & 1938.463 & 36096.219 & \text { Yes }\end{array}$

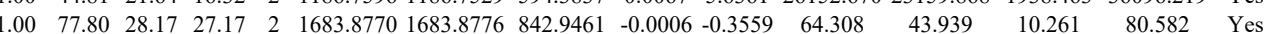
$\begin{array}{lllllllllllllll}1.00 & 53.82 & 28.18 & 19.37 & 2 & 1683.8810 & 1683.8776 & 842.9461 & 0.0034 & 2.0167 & 31.469 & 69.496 & 18.625 & 50.014 & \text { No }\end{array}$

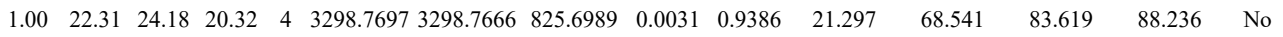

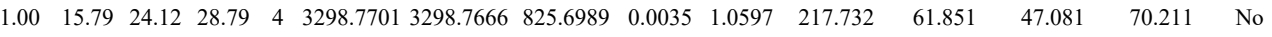
$\begin{array}{lllllllllllllllll} & 1.00 & 44.31 & 21.58 & 18.18 & 2 & 1186.7608 & 1186.7529 & 594.3837 & 0.0079 & 6.6455 & 10285.870 & 8826.553 & 827.386 & 13627.189 & \text { Yes } \\ \text { AASEFFR } & 1.00 & 98.01 & 28.15 & 27.61 & 2 & 1683.8774 & 1683.8776 & 842.9461 & -0.0002 & -0.1186 & 170.989 & 166.934 & 7.521 & 221388 & \text { Yes }\end{array}$ $\begin{array}{lllllllllllllllll} & & & \end{array}$

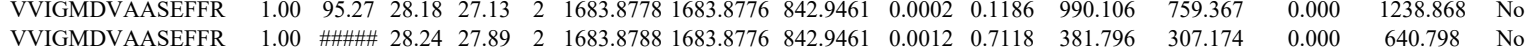

VVIGMDVAASEFFR

VVIGMDVAASEFFR

VVIGMDVAASEFFR

VVIGMDVAASEFFR

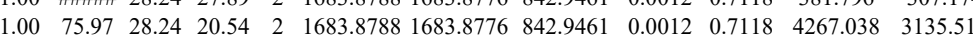

$\begin{array}{llllllllllll}1.00 & 96.21 & 28.24 & 28.96 & 2 & 1683.8788 & 1683.8776 & 842.9461 & 0.0012 & 0.7118 & 1176.735 & 843.421\end{array}$

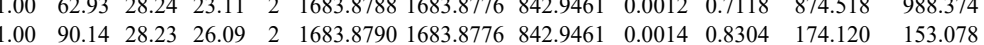
$\begin{array}{llllllllllll}1.00 & 79.47 & 28.23 & 25.09 & 2 & 1683.8790 & 1683.87776 & 842.946 & 0.0014 & 0.8304 & 174.120 & 153.078 \\ 16838776 & 842.9461 & 0.0014 & 0.8304 & 220.643 & 186.022\end{array}$

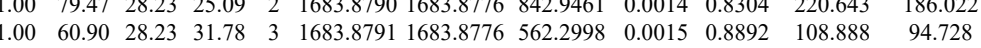
$\begin{array}{lllllllllllll}1.00 & 33.07 & 28.08 & 23.33 & 3 & 1683.8794 & 1683.8776 & 562.2998 & 0.0018 & 1.0670 & 92.459 & 75.527\end{array}$

VVIGMDVAASEFFR

$\begin{array}{ccccccccccccc}1.00 & 52.38 & 28.08 & 21.05 & 3 & 1683.8794 & 1683.8776 & 562.2998 & 0.0018 & 1.0670 & 57.840 & 69.323 \\ 1.00 & 83.41 & 28.09 & 24.04 & 2 & 1683.8794 & 1683.8776 & 842.9461 & 0.0018 & 1.0677 & 6810.407 & 5712.456\end{array}$

VVIGMDVAASEFFR

VVIGMDVAASEFFR

VVIGMDVAASEFFR

$\begin{array}{lllllllllllll}1.00 & 76.03 & 28.09 & 26.09 & 2 & 1683.8794 & 1683.8776 & 842.9461 & 0.0018 & 1.0677 & 167.421 & 118.589 \\ 1.00 & 81.30 & 28.0 & 26.00 & 2 & 1683.8794 & 1683.8776 & 842.9461 & 0.018 & 1.0677 & 184.098 & 114.236\end{array}$

$\begin{array}{llllllllllll}1.00 & 81.30 & 28.09 & 26.00 & 2 & 1683.8794 & 1683.8776 & 842.946 & 0.0018 & 1.0677 & 184.098 & 114.236 \\ 1.00 & 83.09 & 28.09 & 25.93 & 2 & 1683.8794 & 1683.8776 & 842.9461 & 0.0018 & 1.0677 & 294.155 & 260.086\end{array}$

$\begin{array}{llllllllllll}1.00 & 85.96 & 28.10 & 26.25 & 2 & 1683.8796 & 1683.8776 & 842.9461 & 0.0020 & 1.1863 & 154.710 & 148298\end{array}$

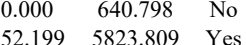

$0.000 \quad 1242.836$ No

$22.958 \quad 1600.366 \quad$ Yes

$\begin{array}{lll}9.031 & 233.513 & \text { Yes } \\ 0 & 0.000 & 0\end{array}$

$\begin{array}{llll}0.000 & 419.152 & \text { No }\end{array}$ $51.153-159.312$ Yes $51.153 \quad 95.855$ Yes $\begin{array}{lll}067.916 & 9663.026 & \text { Yes }\end{array}$ $\begin{array}{lll}0.000 & 269.951 & \text { No } \\ 0.000 & 209.652 & \text { No }\end{array}$ 446.048 Yes

No

Table S-4 page 91 of 614 
VVIGMDVAASEFFR

VVIGMDVAASEFFR $\begin{array}{lllllllllllll}0.68 & 13.65 & 28.10 & 15.58 & 3 & 1683.8803 & 1683.8776 & 562.2998 & 0.0027 & 1.6006 & 120.816 \\ 10.87 & 3 & 1683.8803 & 1683.8776 & 562.2998 & 0.0027 & 1.6006 & 63.391\end{array}$ $\begin{array}{lllllllllll}1.00 & 83.09 & 28.10 & 27.42 & 3 & 1683.8803 & 1683.8776 & 562.2998 & 0.0027 & 1.6006 & 91.924\end{array}$

$\begin{array}{llllllllll}8.09 & 16.88 & 3 & 1683.8809 & 1683.8776 & 562.2998 & 0.0033 & 1.9562 & 124.803\end{array}$

VVIGMDVAASEFFR $\begin{array}{llllllllllll}1.00 & 65.12 & 23.71 & 17.62 & 4 & 3298.7749 & 3298.7666 & 825.6989 & 0.0083 & 2.5130 & 172.051\end{array}$

VVIGMDVAASEFFR $\begin{array}{lllllllllll}1.00 & 53.98 & 28.18 & 16.98 & 2 & 1683.8778 & 1683.8776 & 842.9461 & 0.0002 & 0.1186 & 154.950\end{array}$ \begin{tabular}{lllllllllll}
1.00 & 53.98 & 28.18 & 21.93 & 2 & 1683.8784 & 1683.8776 & 842.9461 & 0.0008 & 0.4745 & 470.294 \\
\hline
\end{tabular} $\begin{array}{llllllllllll}1.00 & 92.14 & 28.23 & 25.86 & 2 & 1683.8790 & 1683.8776 & 842.9461 & 0.0014 & 0.8304 & 1784.119 & 1370.548\end{array}$ $\begin{array}{lllllllllllll}91.05 & 28.08 & 22.31 & 2 & 1683.8792 & 1683.8776 & 842.9461 & 0.0016 & 0.9491 & 91.662 \\ 0 & 7683.8776 & 842.9461 & 0.0016 & 0.9491 & 343.564 & 52\end{array}$ $\begin{array}{llllllllllll}1.00 & 82.23 & 28.09 & 26.42 & 2 & 1683.8794 & 1683.8776 & 842.9461 & 0.0018 & 1.0677 & 579.839\end{array}$ $\begin{array}{lllllllllllll}1.00 & 87.53 & 28.09 & 26.14 & 2 & 1683.8794 & 1683.8776 & 842.9461 & 0.0018 & 1.0677 & 126.101 \\ 1.00 & 75.93 & 28.09 & 24.51 & 2 & 16838794 & 1683.8776 & 8429461 & 0.0018 & 1.0677 & 165.186\end{array}$ $\begin{array}{lllllllllll}1.00 & 80.40 & 28.09 & 24.86 & 2 & 1683.8794 & 1683.8776 & 842.9461 & 0.0018 & 1.0677 & 1209.367\end{array}$ $\begin{array}{lllllllllll}1.00 & 92.18 & 28.10 & 26.75 & 2 & 1683.8796 & 1683.8776 & 842.9461 & 0.0020 & 1.1863 & 205.806\end{array}$ $\begin{array}{llllllllllll}1.00 & 68.30 & 28.16 & 27.52 & 3 & 1683.8800 & 1683.8776 & 562.2998 & 0.0024 & 1.4227 & 38.923 \\ 1.00 & 91.33 & 28.16 & 26.10 & 2 & 1683.8800 & 1683.8776 & 842.9461 & 0.0024 & 1.4236 & 610.748\end{array}$ $\begin{array}{lllllllllll}1.00 & 92.99 & 28.16 & 26.49 & 2 & 1683.8800 & 1683.8776 & 842.9461 & 0.0024 & 1.4236 & 104.559\end{array}$ $\begin{array}{lllllllllllll}1.00 & 76.65 & 28.16 & 24.49 & 2 & 1683.8800 & 1683.8776 & 842.9461 & 0.0024 & 1.4236 & 47.593 \\ 1.00 & 78.46 & 28.16 & 23.49 & 2 & 1683.8800 & 1683.8776 & 842.9461 & 0.0024 & 1.4236 & 828.630\end{array}$ $\begin{array}{lllllllllllll}1.00 & 71.02 & 28.10 & 24.13 & 2 & 1683.8800 & 1683.8802 & 1683.8776 & 842.9461 & 0.0024 & 1.4236 & 828.630 \\ 1.00 & 89.68 & 28.10 & 26.81 & 2 & 1683.8802 & 1683.8776 & 842.9461 & 0.0026 & 1.5422 & 544.851 \\ 1.00 & 94.80 & 28.12 & 22.02 & 2 & 1683.8804 & 1683.8776 & 842.9461 & 0.0026 & 1.5422 & 128.191\end{array}$ $\begin{array}{llllllllllll}1.00 & 89.68 & 28.10 & 26.81 & 2 & 1683.8802 & 1683.8776 & 842.9461 & 0.0026 & 1.5422 & 128.191\end{array}$ $\begin{array}{llllllllllll}1.00 & 37.61 & 28.08 & 19.70 & 3 & 1683.8806 & 1683.8776 & 562.2998 & 0.0030 & 1.7784 & 51.853\end{array}$ $\begin{array}{llllllllllll}1.00 & 56.07 & 28.08 & 27.32 & 3 & 1683.8806 & 1683.8776 & 562.2998 & 0.0030 & 1.7784 & 71.982 \\ 1.00 & 97.69 & 28.09 & 27.87 & 2 & 1683.8808 & 1683.8776 & 842.9461 & 0.0032 & 1.8981 & 28.235\end{array}$ $\begin{array}{lllllllllll}1.00 & 97.69 & 28.09 & 27.87 & 2 & 1683.8808 & 1683.8776 & 842.9461 & 0.0032 & 1.8981 & 28.235 \\ 1.00 & 75.82 & 28.18 & 30.18 & 2 & 1683.8812 & 1683.8776 & 842.9461 & 0.0036 & 2.1354 & 191.154\end{array}$ $\begin{array}{llllllllllll}0.60 & 13.74 & 28.18 & 26.74 & 3 & 1683.8815 & 1683.8776 & 562.2998 & 0.0039 & 2.3119 & 143.828\end{array}$ $\begin{array}{llllllllllll}0.83 & 17.97 & 28.18 & 16.22 & 3 & 1683.8815 & 1683.8776 & 562.2998 & 0.0039 & 2.3119 & 70.985\end{array}$ $\begin{array}{lllllllllllll}1.00 & 82.18 & 28.22 & 26.35 & 2 & 1683.8820 & 1683.8776 & 842.9461 & 0.0044 & 2.6099 & 89.300 \\ 1.00 & 73.31 & 23.69 & 19.62 & 3 & 3298.7752 & 3298.7666 & 1100.5961 & 0.0086 & 2.6046 & 115.581\end{array}$ $\begin{array}{lllllllllll}1.0 & 32.66 & 23.98 & 18.36 & 4 & 3298.7781 & 3298.7666 & 825.6989 & 0.0115 & 3.4819 & 26.304\end{array}$ 101.932 

$\begin{array}{lllllllllllll}0.53 & 15.72 & 28.27 & 21.82 & 2 & 949.5476 & 949.5467 & 475.7806 & 0.0009 & 0.9458 & 45.993\end{array}$ $\begin{array}{llllllll}0.53 & 15.72 & 28.27 & 21.82 & 2 \\ 0.55 & 25.42 & 28.01 & 25.28\end{array}$

$\left.\begin{array}{llllllll}949.5548 & 949.5467 & 475.7806 & 0.0081 & 8.5123 & 17692.155 & 17618.672 & 19.7\end{array}\right]$ $\begin{array}{llllll}25.31 & 2 & 1191.6622 & 1191.6590 & 596.8368\end{array}$

$$
\begin{aligned}
& 0.95 \\
& 0.90 \\
& 0.97
\end{aligned}
$$

VVIGMDVAASEFFR $\begin{array}{lll} & 1.00 \\ \text { ANFR } & 1.00\end{array}$

LAMQEF LAMQEFMILPVGAANFR $\begin{array}{llll}1.00 & 86.83 & 2 \\ 1.00 & 86.85 & 2\end{array}$

LAMQEFMILPVGAA

LAQANGWGVMVSHR

$\begin{array}{ll} & \\ \text { ANFR } & 0.99 \\ \text { SHR } & 0.99 \\ \text { SHR } & 0.98 \\ \text { SHR } & 1.00\end{array}$

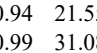

LAQANGWGVMVSHR

LAQANGWGVMVSHR

LAQANGWGVMVSHR

$\begin{array}{lllllllllllllll}\text { LAQANGWGVMVSHR } & 1.00 & 58.56 & 27.70 & 21.77 & 3 & 1668.8779 & 1668.8640 & 557.2953 & 0.0139 & 8.3139 & 8183.456 & 6350.573 & 1123 \\ \text { LAMQEFMILPVGAANFR } & 1.00 & 88.46 & 27.57 & 26.50 & 2 & 2051.0834 & 2051.0818 & 1026.5482 & 0.0016 & 0.7793 & 912.988 & 827.752\end{array}$

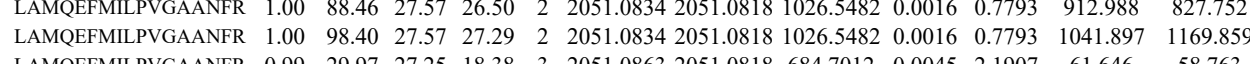
LAMQEFMILP

$\begin{array}{llll}0.99 & 29.97 & 27.25 & 18.38 \\ 0.98 & 30.23 & 26.10 & 23.44 \\ 0\end{array}$

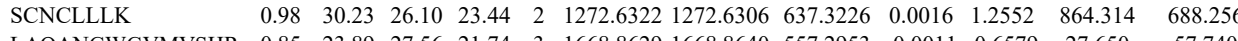

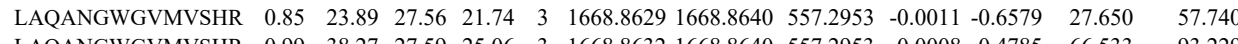
$\begin{array}{lllllllllllll}\text { LAQANGWGVMVSHR } & 0.99 & 38.27 & 27.59 & 25.06 & 3 & 1668.8632 & 1668.8640 & 557.2953 & -0.0008 & -0.4785 & 66.533 & 93.229\end{array}$

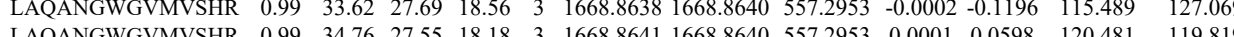

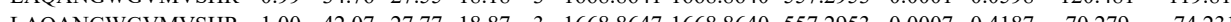

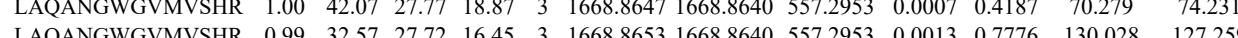

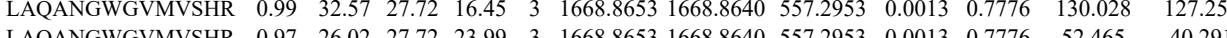
$\begin{array}{lllllllllllll}\text { LAQANGWGVMVSHR } & 0.97 & 26.02 & 27.72 & 23.99 & 3 & 1668.8653 & 1668.8640 & 557.2953 & 0.0013 & 0.7776 & 52.465 & 40.291\end{array}$ $\begin{array}{llllllllllllll}\text { LAQANGWGVMVSHR } & 1.00 & 42.62 & 27.70 & 17.80 & 3 & 1668.8656 & 1668.8640 & 557.253 & 0.0016 & 0.9570 & 80.878 & 77.123 \\ \text { LAQANGWGVMVSHR } & 1.00 & 33.76 & 27.70 & 17.86 & 3 & 1668.8656 & 1668.8640 & 557.2953 & 0.0016 & 0.9570 & 79.409 & 68.605\end{array}$ $\begin{array}{lllllllllllll}\text { LAQANGWGMVSHR } & 1.00 & 33.76 & 27.70 & 17.86 & 3 & 1668.8656 & 1668.8640 & 557.2953 & 0.0016 & 0.9570 & 79.409 & 68.605 \\ \text { LAQANGWGVMVSHR } & 1.00 & 42.66 & 27.68 & 20.67 & 3 & 1668.8671 & 1668.8640 & 557.2953 & 0.0031 & 1.8542 & 83.108 & 103.334\end{array}$ $\begin{array}{lllllllllllll}\text { LAQANGWGVMVSHR } & 1.00 & 42.66 & 27.68 & 20.67 & 3 & 1668.8671 & 1668.8640 & 557.295 & 0.0031 & 1.8542 & 83.108 & 103.334 \\ \text { LAQANGWGVMVSHR } & 1.00 & 94.05 & 27.57 & 27.24 & 2 & 1668.8738 & 1668.8640 & 835.4393 & 0.0098 & 5.8651 & 3747.880 & 3439.793\end{array}$ $\begin{array}{llllllllllllll}\text { LAQANGWGVMVSHR } & 1.00 & 94.05 & 27.57 & 27.24 & 2 & 1668.8738 & 1668.8640 & 835.4393 & 0.0098 & 5.8651 & 3747.880 & 3439.793 & \\ \text { LAQANGWGVMVSHR } & 1.00 & 54.12 & 27.63 & 23.94 & 3 & 1668.8746 & 1668.8640 & 557.2953 & 0.0106 & 6.3401 & 6633.655 & 6259.896 & 113 .\end{array}$ $\begin{array}{llllllllllllll}\text { LAQANGWGVMVSHR } & 1.00 & 63.63 & 27.63 & 26.07 & 3 & 1668.8746 & 1668.8640 & 557.2953 & 0.0106 & 6.3401 & 3743.751 & 3499.291 & 1322 \\ \text { LAQANGWGVMVSHR } & 1.00 & 98.45 & 27.75 & 26.02 & 2 & 1668.8752 & 1668.8640 & 835.4393 & 0.0112 & 6.7030 & 6963.473 & 6287.373\end{array}$ $\begin{array}{lllllllllllll}\text { LAQANGWIGMVAR } & 1.00 & 98.45 & 27.75 & 26.02 & 2 & 1668.8752 & 1668.8640 & 835.4393 & 0.0112 & 6.7030 & 6963.473 & 6287.373 \\ \text { LAMQEFMILPVGAANFR } & 1.00 & 87.12 & 27.47 & 26.32 & 2 & 2051.0814 & 2051.0818 & 1026.5482 & -0.0004 & -0.1948 & 170.479 & 209.160\end{array}$ $\begin{array}{lllllllllllll}\text { LAMQEFMILPVGAANFR } & 1.00 & 98.31 & 27.57 & 27.17 & 2 & 2051.0834 & 2051.0818 & 1026.5482 & 0.0016 & 0.7793 & 210.983 & 196.771\end{array}$ $\begin{array}{lllllllllllll}\text { LAMQEFMILPVGAANFR } & 1.00 & 47.54 & 27.34 & 18.85 & 3 & 2051.0851 & 2051.0818 & 684.7012 & 0.0033 & 1.6065 & 50.198 & 55.00\end{array}$ $\begin{array}{llllllllllllll}\text { LAMQEFMILPVGAANFR } & 0.95 & 22.40 & 27.32 & 15.48 & 3 & 2051.0857 & 2051.0818 & 684.7012 & 0.0039 & 1.8986 & 69.174 & 65.070\end{array}$ $\begin{array}{llllllllllllll}\text { LAQANGWGVMVSHR } & 0.98 & 33.00 & 27.59 & 19.09 & 3 & 1668.8632 & 1668.8640 & 557.2953 & -0.0008 & -0.4785 & 69.423 & 58.897\end{array}$

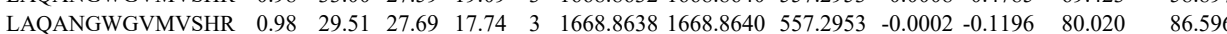
$\begin{array}{llllllllllllllll}\text { LAQANGWGVMVSHR } & 0.99 & 32.34 & 27.58 & 18.85 & 3 & 1668.8644 & 1668.8640 & 557.2953 & 0.0004 & 0.2393 & 79.871 & 69.258\end{array}$ $\begin{array}{llllllllllllll}\text { LAQANGWGVMVSHR } & 0.79 & 17.43 & 27.77 & 18.96 & 3 & 1668.8647 & 1668.8640 & 557.2953 & 0.0007 & 0.4187 & 32.275 & 40.447\end{array}$ $\begin{array}{lllllllllllll}\text { LAQANGWGVMVSHR } & 1.00 & 94.79 & 27.65 & 30.80 & 2 & 1668.8744 & 1668.8640 & 835.4393 & 0.0104 & 6.2242 & 1926.408 & 1603.950\end{array}$ $\begin{array}{lllllllllllllll}\text { LAQANGWGVMVSHR } & 1.00 & 97.54 & 27.63 & 27.42 & 2 & 1668.8746 & 16688.8640 & 835.4393 & 0.0106 & 6.3439 & 1713.041 & 1609.109 & 358.51 \\ \text { LAQANGWGVMVSHR } & 1.00 & 66.12 & 27.75 & 21.51 & 3 & 1668.8752 & 1668.8640 & 557.2953 & 0.0112 & 6.6990 & 4776.552 & 4639.806 & 981.30\end{array}$ $\begin{array}{llllllllllllllll}\text { LAQANGWGVMVSHR } & 1.00 & 66.12 & 27.75 & 21.51 & 3 & 1668.8752 & 1668.8640 & 557.2953 & 0.0112 & 6.6990 & 4776.552 & 4639.806 & 981.30 \\ \text { LAQANGWGVMVSHR } & 1.00 & 60.72 & 27.75 & 22.38 & 3 & 1668.8755 & 1668.8640 & 557.2953 & 0.0115 & 6.8784 & 3845.654 & 4799.177 & 1315.9\end{array}$ $\begin{array}{llllllllllllll}\text { LAQANGWGVMVSHR } & 1.00 & 60.72 & 27.75 & 22.38 & 3 & 1668.8755 & 1668.8640 & 557.2953 & 0.0115 & 6.8784 & 3845.654 & 4799.177 & 1315.9 \\ \text { LAQANGWGVMVSHR } & 1.00 & 37.47 & 27.97 & 18.57 & 3 & 1684.8643 & 1684.8589 & 562.6269 & 0.0054 & 3.1993 & 1133.967 & 883.269 & 450.57 \\ \text { LAQANGWGVMVSHR } & 1.00 & 50.96 & 27.92 & 20.46 & 3 & 1684.8649 & 1684.8589 & 562.6269 & 0.0060 & 3.5547 & 2281.033 & 1641.002 & 510.43\end{array}$ $\begin{array}{llllllllllllll}\text { LAQANGWGVMVSHR } & 1.00 & 50.96 & 27.92 & 20.46 & 3 & 1684.8649 & 1684.8589 & 562.6269 & 0.0060 & 3.5547 & 2281.033 & 1641.002\end{array}$ 
$\begin{array}{llllllllllll}\text { LAQANGWGVMVSHR } & 1.00 & 63.24 & 27.55 & 28.90 & 3 & 1668.8641 & 1668.8640 & 557.2953 & 0.0001 & 0.0598 & 270.426\end{array}$

$\begin{array}{llllllllllll}\text { LAQANGWGVMVSHR } & 1.00 & 61.40 & 27.72 & 28.66 & 3 & 1668.8653 & 1668.8640 & 557.2953 & 0.0013 & 0.7776 & 315.403 \\ \text { LAMQEFMILPVGAANFR } & 0.97 & 22.86 & 27.29 & 16.94 & 3 & 2051.0845 & 2051.0818 & 684.7012 & 0.0027 & 1.3144 & 27.486\end{array}$

$\begin{array}{llllllllllll}\text { LAMOEFMILPVGAANFR } & 0.99 & 27.23 & 27.34 & 16.95 & 3 & 2051.0851 & 2051.0818 & 684.7012 & 0.0033 & 1.6065 & 24.928\end{array}$

YNQLL

$\begin{array}{lllllllllll}0.57 & 20.71 & 28.17 & 22.02 & 2 & 949.5464 & 949.5467 & 475.7806 & -0.0003 & -0.3153 & 548.635\end{array}$ IGAEVYHNLK

$\begin{array}{lllllllllll}0.98 & 29.21 & 27.69 & 22.30 & 3 & 1430.8123 & 1430.8125 & 477.9448 & -0.0002 & -0.1395 & 702.609 \\ 0.99 & 29.89 & 27.54 & 20.86 & 3 & 1430.8141 & 1430.8125 & 477.9448 & 0.0016 & 1.1159 & 366.940\end{array}$ $\begin{array}{llllllllllll}\text { IGAEVYNGWGVMVSHR } & 1.00 & 68.30 & 27.69 & 29.07 & 3 & 1668.8638 & 1668.8640 & 557.2953 & -0.0002 & -0.1196 & 191.868\end{array}$ $\begin{array}{llllllllllll}\text { LAQANGWGVMVSHR } & 1.00 & 55.54 & 27.72 & 24.20 & 3 & 1668.8653 & 1668.8640 & 557.2953 & 0.0013 & 0.7776 & 245.939\end{array}$ $\begin{array}{lllllllllllll}\text { LAMQEFMILPVGAANFR } & 0.98 & 24.58 & 27.40 & 15.70 & 3 & 2051.0842 & 2051.0818 & 684.7012 & 0.0024 & 1.1684 & 8.562\end{array}$ $\begin{array}{lllllllllllll}\text { LAMQEFMILPVGAANFR } & 1.00 & 35.36 & 27.34 & 18.39 & 3 & 2051.0851 & 2051.0818 & 684.7012 & 0.0033 & 1.6065 & 15.825\end{array}$

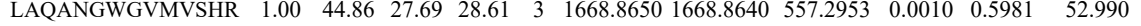
$\begin{array}{lllllllllllll}\text { LAQANGWGVMVSHR } & 0.66 & 44.57 & 27.62 & 57.57 & 3 & 1668.8662 & 1668.8640 & 557.2953 & 0.0022 & 1.3159 & 36.691\end{array}$ $\begin{array}{lllllllllllll}\text { LAQANGWGVMVSHR } & 1.00 & 48.33 & 27.58 & 26.95 & 3 & 1668.8665 & 1668.8640 & 557.2953 & 0.0025 & 1.4953 & 33.264\end{array}$ $\begin{array}{lllllllllllll}\text { LAQANGWGVMVSHR } & 1.00 & 54.93 & 27.66 & 29.28 & 3 & 1668.8680 & 1668.8640 & 557.2953 & 0.0040 & 2.3925 & 40.856\end{array}$ $\begin{array}{llllllllllll}\text { FTASAGIQVVGDDLTVTNPK } & 1.00 & 47.39 & 25.89 & 16.23 & 3 & 2320.2550 & 2320.2518 & 774.4245 & 0.0032 & 1.3774 & 10.517 \\ \text { TIAPALVSK } & 0.90 & 32.29 & 22.41 & 38.21 & 2 & 1186.7530 & 1186.7529 & 594.3837 & 0.0001 & 0.0841 & 157.217\end{array}$

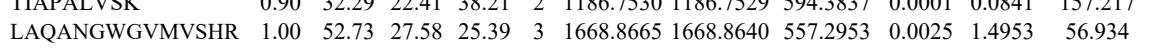
$\begin{array}{llllllllllll}\text { LAQANGWGVMVSHR } & 1.00 & 38.84 & 27.58 & 16.49 & 3 & 1668.8665 & 1668.8640 & 557.2953 & 0.0025 & 1.4953 & 37.044\end{array}$ IEEELGSK

IEEELGSK $\begin{array}{lllllllllll}0.89 & 36.43 & 28.64 & 38.10 & 2 & 1191.6576 & 1191.6590 & 596.8368 & -0.0014 & -1.1729 & 192.152 \\ 0.89 & 36.19 & 28.64 & 37.75 & 2 & 1191.6578 & 1191.6590 & 596.8368 & -0.0012 & -1.0053 & 173.526\end{array}$ $\begin{array}{lllllllllllll}0.89 & 36.19 & 28.64 & 37.75 & 2 & 1191.6578 & 1191.6590 & 596.8368 & -0.0012 & -1.0053 & 173.526 & & \\ 0.74 & 28.92 & 28.64 & 26.65 & 2 & 1191.6578 & 1191.6590 & 596.8368 & -0.0012 & 1.0053 & 175.138 & & \end{array}$ $\begin{array}{llllllllllll}0.74 & 28.92 & 28.64 & 26.65 & 2 & 1191.6578 & 1191.6590 & 596.8368 & -0.0012 & -1.0053 & 175.138 & 16 \\ 0.96 & 36.06 & 28.94 & 37.67 & 2 & 1191.6588 & 1191.6590 & 596.8368 & -0.0002 & -0.1676 & 181.782 & 18\end{array}$

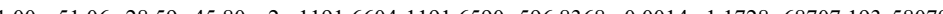

IEEELGSK

IEEELGSK

YNQLLR $\begin{array}{lllllllllllll}1.00 & 51.06 & 28.59 & 45.80 & 2 & 1191.6604 & 1191.6590 & 596.8368 & 0.0014 & 1.1728 & 68707.193 & 180 \\ 0.99 & 49.95 & 29.16 & 49.12 & 2 & 1191.6614 & 1191.6590 & 596.8368 & 0.0024 & 2.0106 & 48647.865 & & \end{array}$

YNQLLR $\begin{array}{lllllllllllll}0.99 & 49.95 & 29.16 & 49.12 & 2 & 1191.6614 & 1191.6590 & 596.8368 & 0.0024 & 2.0106 & 48647.865 & 42\end{array}$ $\begin{array}{llllllllllll}\text { TIAPALVSK } & 1.00 & 36.42 & 22.41 & 23.56 & 2 & 1186.7534 & 1186.7529 & 594.3837 & 0.0005 & 0.4206 & 270.084 \\ \text { TIAPALVSK } & 1.00 & 35.11 & 22.36 & 22.58 & 2 & 1186.7544 & 1186.7529 & 594.3837 & 0.0015 & 1.2618 & 275.873\end{array}$ $\begin{array}{llllllllllll}0.61 & 25.99 & 28.18 & 25.59 & 2 & 949.5460 & 949.5467 & 475.7806 & -0.0007 & -0.7356 & 550.88 \\ 0.81 & 25.94 & 28.06 & 21.22 & 2 & 949.5466 & 949.5467 & 475.7806 & -0.0001 & -0.1051 & 489.76\end{array}$ $\begin{array}{llllllllllll}\text { LAQANGWGVMVSHR } & 1.00 & 64.56 & 27.72 & 22.89 & 3 & 1668.8653 & 16688640 & 557.2953 & 0.0013 & 0.7776 & 106301\end{array}$ $\begin{array}{lllllllllllll}\text { LAQANGWGVMVSHR } & 1.00 & 60.36 & 27.62 & 26.65 & 3 & 1668.8662 & 1668.8640 & 557.2953 & 0.0022 & 1.3159 & 97.115\end{array}$ $\begin{array}{lllllllllllll}\text { FTASAGIQVVGDDLTVTNPK } & 1.00 & 66.23 & 26.14 & 20.06 & 3 & 2320.2529 & 2320.2518 & 774.4245 & 0.0011 & 0.4735 & 22.606\end{array}$

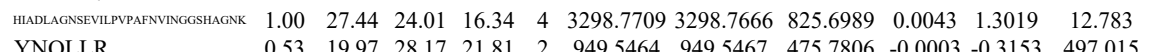
\begin{tabular}{llllllllllll} 
& 0.53 & 19.97 & 28.17 & 21.81 & 2 & 949.5464 & 949.5467 & 475.7806 & -0.0003 & -0.3153 & 497.015 \\
\hline LAQANGWGVMVSHR & 1.00 & 55.99 & 27.77 & 25.06 & 3 & 1668.8647 & 1668.8640 & 557.2953 & 0.0007 & 0.4187 & 78.419
\end{tabular} $\begin{array}{lllllllllllll}\text { LAQANGWGVMVSHR } & 1.00 & 54.79 & 27.70 & 26.55 & 3 & 1668.8656 & 1668.8640 & 557.2953 & 0.0016 & 0.9570 & 98.840\end{array}$ $\begin{array}{lllllllllllll}\text { FTASAGIQVVGDDLTVTNPK } & 0.55 & 58.58 & 26.06 & 71.58 & 3 & 2320.2532 & 2320.2518 & 774.4245 & 0.0014 & 0.6026 & 20.727\end{array}$ YNQLLR $\begin{array}{llllllllllll}0.52 & 19.77 & 28.17 & 24.09 & 2 & 949.5464 & 949.5467 & 475.7806 & -0.0003 & -0.3153 & 344.251\end{array}$ $\begin{array}{llllllllllll}\text { LAQANGWGVMVSHR } & 1.00 & 52.95 & 27.72 & 23.45 & 3 & 1668.8653 & 1668.8640 & 557.2953 & 0.0013 & 0.7776 & 65.166\end{array}$ $\begin{array}{llllllllllll}\text { LAQANGWGVMVSHR } & 1.00 & 62.84 & 27.58 & 23.12 & 3 & 1668.8665 & 1668.8640 & 557.2953 & 0.0025 & 1.4953 & 57.153\end{array}$ $\begin{array}{lllllllllllll}\text { FTASAGIQVVGDDLTVTNPK } & 1.00 & 72.41 & 26.10 & 18.81 & 3 & 2320.2538 & 2320.2518 & 774.4245 & 0.0020 & 0.8609 & 11.338\end{array}$ $\begin{array}{llllllllllll}\text { LAQANGWGVMVSHR } & 1.00 & 69.45 & 27.58 & 24.69 & 3 & 1668.8665 & 1668.8640 & 557.2953 & 0.0025 & 1.4953 & 51.992\end{array}$ $\begin{array}{llllllllllll}\text { LAQANGWGVMVSHR } & 1.00 & 52.03 & 27.55 & 23.10 & 3 & 1668.8668 & 1668.8640 & 557.2953 & 0.0028 & 1.6748 & 45.790\end{array}$ TIAPALVSK $\begin{array}{llllllllllll}0.97 & 25.52 & 22.41 & 25.34 & 2 & 1186.7538 & 1186.7529 & 594.3837 & 0.0009 & 0.7571 & 101.258 \\ 0.67 & 63.57 & 25.88 & 76.57 & 3 & 2320.2553 & 2320.2518 & 774.4245 & 0.0035 & 1.5065 & 8.315\end{array}$ $\begin{array}{lllllllllllll}\text { FTASAGIQVVGDDLTVTNPK } & 0.67 & 63.57 & 25.88 & 76.57 & 3 & 2320.2553 & 2320.2518 & 774.4245 & 0.0035 & 1.5065 & 8.315 \\ \text { IMDLGNSEVIPVPAFVIIGGSHAGKK } & 1.00 & 50.61 & 24.33 & 21.35 & 4 & 3298.7669 & 3298.7666 & 825.6989 & 0.0003 & 0.0908 & 6.251\end{array}$ $\begin{array}{llllllllllll}\text { FTASAGIQVVGDDLTVTNNKK } & 0.55 & 48.07 & 26.06 & 61.07 & 3 & 2320.2532 & 2320.2518 & 774.4245 & 0.00014 & 0.6026 & 12.196\end{array}$ $\begin{array}{llllllllllll}\text { HLDLAGNEVILPVAANVINGGSHAGNK K } & 1.00 & 36.16 & 24.31 & 16.96 & 4 & 3298.7657 & 3298.7666 & 825.6989 & -0.0009 & -0.2725 & 6.513\end{array}$ $\begin{array}{lllllllllllll}\text { FTASAGIQVVGDDLTVTNPK } & 0.66 & 69.96 & 26.10 & 82.96 & 3 & 2320.2538 & 2320.2518 & 774.4245 & 0.0020 & 0.8609 & 7.319\end{array}$

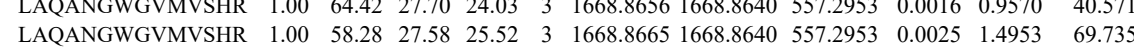
$\begin{array}{lllllllllllll}\text { FTASAGIOVVGDDLTVTNPK } & 0.66 & 43.57 & 26.05 & 56.57 & 3 & 232.02544 & 2320.2518 & 774.4245 & 0.0026 & 1.1191 & 10.716\end{array}$ 
LAQANGWGVMVSHR 1.00 AGAVEK

AGAVEK

AGYTDK

AGYTDK

LNVTEQEK

LMIEMDGTENK

LMIEMDGTENK

LMIEMDGTENK

LMEMTE

LMIEMDGTENK

LMIMDGTENK

LMIEMDGTENK

LMIEMDGTENK

LMIEMDGTENK

LMIEMDGTENK

LMIEMDGTENK

LMIEMDGTENK

LMIEMDGTENK

LMIEMDGTENK

LMIEMDGTENK

LMIEMDGTENK

LMIEMDGTENK

DATNVGDEGGFAPNILENK

FTASAGIQVVGDDLTVTNPK

KLNVTEQEK

LMIEMDGTENK

LMIEMDGTENK

LMIEMDGTENK

DVSIEDPFDQDDWGAWQK

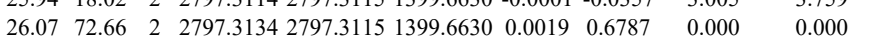

$\begin{array}{llllllllllll} & \end{array}$

$\begin{array}{llllllllllllll} & 0.93 & 19.71 & 26.20 & 16.34 & 3 & 2797.3153 & 2797.3115 & 933.4444 & 0.0038 & 1.3570 & 0.000 & 8.863\end{array}$

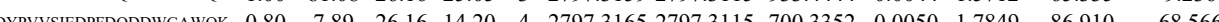
$\begin{array}{lllllllllllll} & 0.564\end{array}$ $\begin{array}{llllllllllll} & 0.054\end{array}$

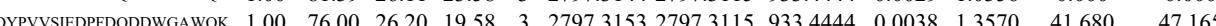

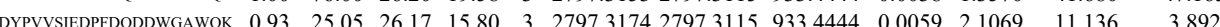

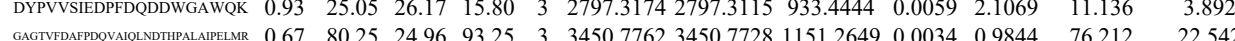

$\begin{array}{lllllllllllll}\text { WLLLCNPGLAELIAEK } & 1.00 & 43.53 & 25.35 & 22.62 & 3 & 2116.1716 & 2116.1668 & 706.3962 & 0.0048 & 2.2650 & 48.743 & 42.237\end{array}$ $\begin{array}{lllllllllllll}\text { INMAHLCIVGSHAVNGVAK } & 1.00 & 30.94 & 27.28 & 15.30 & 4 & 2267.1985 & 2267.1944 & 567.8059 & 0.0041 & 1.8052 & 885.400 & 680.101\end{array}$ $\begin{array}{lllllllllllll}\text { INMAHLCIVGSHAVNGVAK } & 1.00 & 29.86 & 27.29 & 19.58 & 4 & 2267.1993 & 2267.1944 & 567.8059 & 0.0049 & 2.1574 & 1113.234 & 746.104\end{array}$

80 SPEDLER

SPEDLE

SPEDLE

SPEDLER

SNTPILVDGK

SNTPILVDGK

SNTPILVDGK

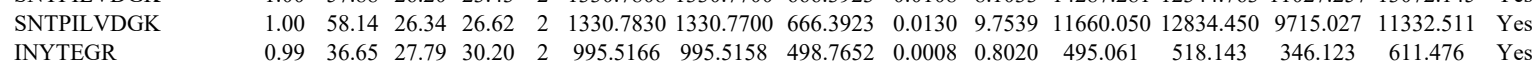

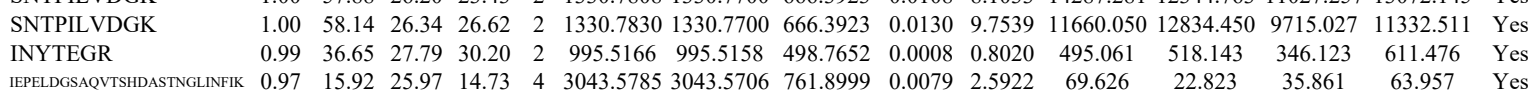
$\begin{array}{lllllllllllll}0.87 & 20.63 & 25.12 & 27.02 & 2 & 988.4956 & 988.4947 & 495.2546 & 0.0009 & 0.9086 & 140.030 & 148.85\end{array}$ $\begin{array}{lllllllllllll}0.96 & 26.91 & 25.12 & 30.81 & 2 & 988.4956 & 988.4947 & 495.2546 & 0.0009 & 0.9086 & 79.429 & 75.810\end{array}$ $\begin{array}{llllllllllllll}0.93 & 24.39 & 25.69 & 28.77 & 2 & 988.4962 & 988.4947 & 495.2546 & 0.0015 & 1.5144 & 98.065 & 126.418\end{array}$ $\begin{array}{lllllllllllll}0.97 & 28.86 & 25.69 & 27.54 & 2 & 988.4962 & 988.4947 & 495.2546 & 0.0015 & 1.5144 & 108.531 & 93.821\end{array}$ $\begin{array}{lllllllllllllll}1 & & \end{array}$

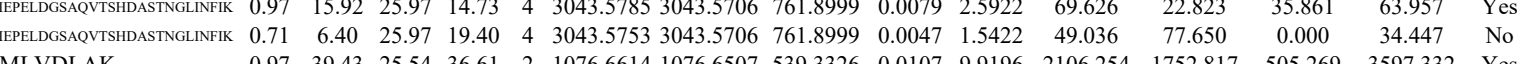
$\begin{array}{llllllllllllllll}\text { MLVDLAK } & 0.97 & 39.43 & 25.54 & 36.61 & 2 & 1076.6614 & 1076.6507 & 539.3326 & 0.0107 & 9.9196 & 2106.254 & 1752.817 & 505.269 & 3597.332 & \text { No }\end{array}$ $\begin{array}{lllllllllllllllllll} & \text { WWYVSNIDGTHIAK } & 1.00 & 63.09 & 26.75 & 20.23 & 2 & 1890.0404 & 1890.0243 & 946.0194 & 0.0161 & 8.5093 & 899.310 & 1007.123 & 952.125 & 1440.205 & \text { Yes }\end{array}$

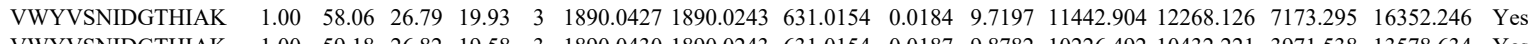
$\begin{array}{llllllllllllllll}\text { VWYVNIDGTHKK } & 1.00 & 59.18 & 26.82 & 19.58 & 3 & 1890.0430 & 1890.0243 & 631.0154 & 0.0187 & 9.8782 & 14226.492 & 10432.221 & 3971.538 & 13578.634 & \text { Yes }\end{array}$ \begin{tabular}{lllllllllllllllllll} 
HFVALSTNITK & 1.00 & 52.92 & 27.36 & 20.97 & 2 & 1505.8446 & 1505.8446 & 753.9296 & 0.0000 & 0.0000 & 8421.451 & 8150.219 & 706.130 & 10072.804 & Yes \\
\hline HFVALSTNTTK & & 0.55 & 25.93 & 27.37 & 38.93 & 3 & 1505.8459 & 1505.846 & 502.9555 & 0.0013 & 0.8616 & 4601.572 & 5820.616 & 7395.996 & 5803.312 & No
\end{tabular}

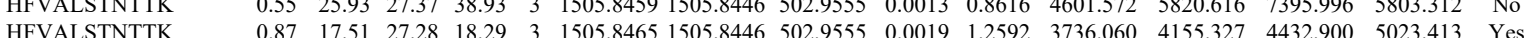
$\begin{array}{lllllllllllllllll}\text { TLAQLNPESSLFIIASK } & 0.84 & 83.07 & 21.88 & 96.07 & 2 & 2119.2154 & 2119.2132 & 1060.6139 & 0.0022 & 1.0371 & 1916.437 & 1748.283 & 639.369 & 2417.607 & \text { Yes }\end{array}$

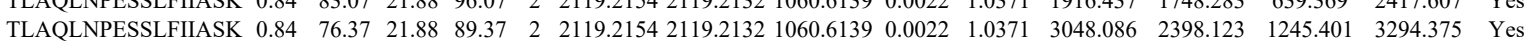

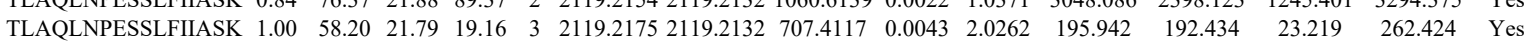

Table S-4 page 95 of 614 


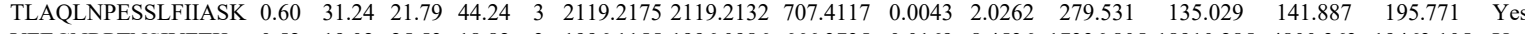
$\begin{array}{llllllllllllllll}\text { VFEGNRPTNSIVFTK } & 0.52 & 19.02 & 25.53 & 18.82 & 3 & 1996.1155 & 1996.0986 & 666.3735 & 0.0169 & 8.4536 & 17336.805 & 18910.285 & 4800.363 & 19463.105 & \text { Yes }\end{array}$ $\begin{array}{lllllllllllllllll}\text { VFEGNRPTNSIVFTK } & 1.00 & 49.56 & 25.61 & 21.03 & 2 & 1996.1166 & 1996.0986 & 999.0566 & 0.0180 & 9.0084 & 1718.868 & 1801.590 & 358.972 & 1866.155 & \text { Yes }\end{array}$ $\begin{array}{llllllllllllllll}\text { VFEGNRPTNSIVFTK } & 0.99 & 43.37 & 25.61 & 20.76 & 2 & 1996.1170 & 1996.0986 & 999.0566 & 0.0184 & 9.2086 & 857.850 & 789.503 & 263.603 & 927.307 & \text { Yes }\end{array}$ $\begin{array}{llllllllllllllll}\text { TLAQLNPESSLFIIASK } & 0.84 & 91.13 & 21.88 & \text { \#\#\#\# } & 2 & 2119.2154 & 2119.2132 & 1060.6139 & 0.0022 & 1.0371 & 1866.753 & 2287.751 & 521.822 & 3095.785 & \text { Yes }\end{array}$

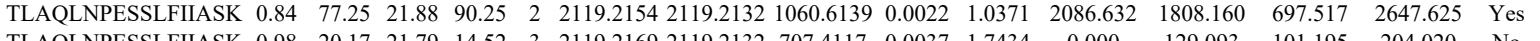

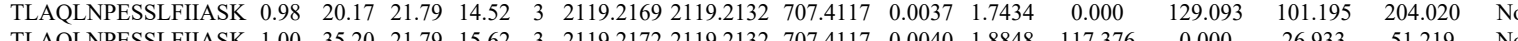

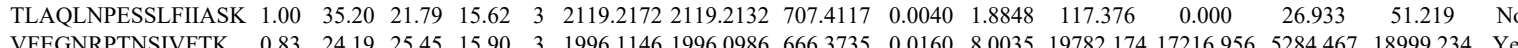

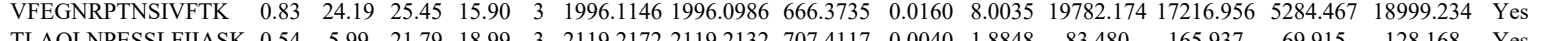
$\begin{array}{lllllllllllllll} & \end{array}$

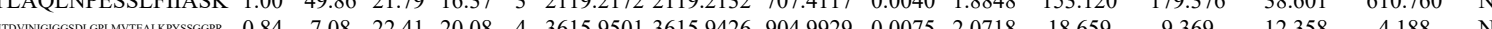

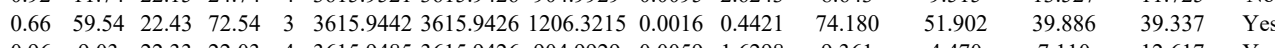
$\left.\begin{array}{lllllllllllll}\text { AVLHVALR } & 0.51 & 38.07 & 20.25 & 51.07 & 2 & 1021.6614 & 1021.6518 & 511.8332 & 0.0096 & 9.3780 & 19403.861 & 223\end{array}\right)$

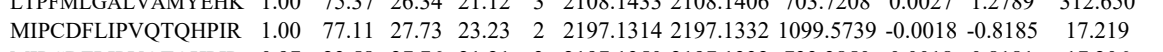
$\begin{array}{llllllllllllll}\text { MIPCDFLIPVQTQHPIR } & 0.97 & 23.58 & 27.76 & 21.21 & 3 & 2197.1350 & 2197.1332 & 733.3850 & 0.0018 & 0.8181 & 17.206 & 21.16\end{array}$

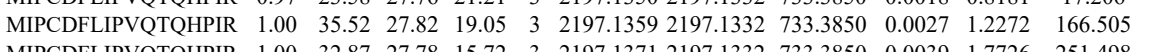
$\begin{array}{llllllllllll}\text { MIPCDFLIPVQTQHPIR } & 1.00 & 32.87 & 27.78 & 15.72 & 3 & 2197.1371 & 2197.1332 & 733.3850 & 0.0039 & 1.7726 & 251.498 \\ \text { MIPCDFLPVQTQHPIR } & 0.95 & 2.72 & 27.81 & 20.42 & 3 & 2197.1374 & 2197.1332 & 733.3850 & 0.0042 & 1.9090 & 25.052\end{array}$ $\begin{array}{llllllllllll}\text { MIPCDFLIPVQTOHPIR } & 0.99 & 29.21 & 27.81 & 16.21 & 3 & 2197.1374 & 2197.1332 & 733.3850 & 0.0042 & 1.9090 & 16.872\end{array}$

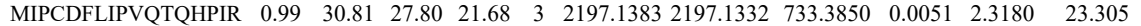

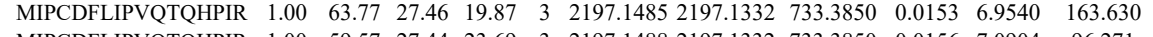
$\begin{array}{llllllllllll}\text { MIPCDFLIPVQTQHPIR } & 1.00 & 59.57 & 27.44 & 23.69 & 3 & 2197.1488 & 2197.1332 & 733.3850 & 0.0156 & 7.0904 & 96.27\end{array}$ $\begin{array}{llllllllllll}\text { MIPCDFLIPVQTQHPIR } & 0.99 & 34.94 & 27.75 & 19.64 & 3 & 2197.1323 & 2197.1332 & 733.3850 & -0.0009 & -0.4091 & 17.331\end{array}$ $\begin{array}{lllllllllllll}\text { MIPCDFLIPVQTQHPIR } & 0.96 & 30.11 & 27.75 & 15.06 & 3 & 2197.1323 & 2197.1332 & 733.3850 & -0.0009 & -0.4091 & 18.380\end{array}$

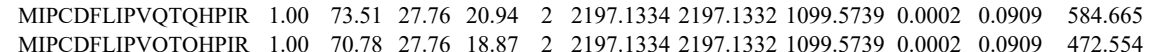
$\begin{array}{llllllllllll}\text { MIPCDFLIPVQTQHPIR } & 1.00 & 70.78 & 27.76 & 18.87 & 2 & 2197.1334 & 2197.1332 & 1099.5739 & 0.0002 & 0.0909 & 472.554 \\ \text { MIPCDFLIPVQTQHPIR } & 0.97 & 26.35 & 27.76 & 18.59 & 3 & 2197.1344 & 2197.1332 & 733.3850 & 0.0012 & 0.5454 & 14.959\end{array}$ $\begin{array}{lllllllllllll}\text { MIPCDFLIPVQTQHPIR } & 0.97 & 26.35 & 27.76 & 18.59 & 3 & 2197.1344 & 2197.1332 & 733.3850 & 0.0012 & 0.5454 & 14.959 \\ \text { MIPCDFLIPVQTOHPIR } & 1.00 & 32.80 & 27.79 & 21.54 & 4 & 2197.1361 & 2197.1332 & 550.2906 & 0.0029 & 1.3175 & 68.951\end{array}$ $\begin{array}{lllllllllllll}\text { MIPCDFLIPVQTQHPIR } & 1.00 & 32.80 & 27.79 & 21.54 & 4 & 2197.1361 & 2197.1332 & 550.2906 & 0.0029 & 1.3175 & 68.951 \\ \text { MIPCDFLIPVQTOHPIR } & 1.00 & 36.02 & 27.79 & 23.59 & 4 & 2197.1361 & 2197.1332 & 550.2906 & 0.0029 & 1.3175 & 48.906\end{array}$ $\begin{array}{llllllllllll}\text { MIPCDFLIPVQTQHPIR } & 1.00 & 36.02 & 27.79 & 23.59 & 4 & 2197.1361 & 2197.1332 & 550.2906 & 0.0029 & 1.3175 & 48.906 \\ \text { MIPCDFLIPVQTQHPIR } & 1.00 & 36.65 & 27.85 & 21.38 & 3 & 2197.1365 & 2197.1332 & 733.3850 & 0.0033 & 1.4999 & 26.181\end{array}$

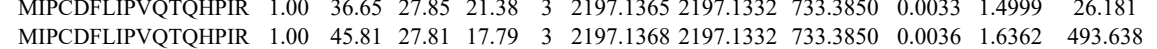
$\begin{array}{llllllllllll}\text { MIPCDFLIPVQTQHPIR } & 1.00 & 45.81 & 27.81 & 17.79 & 3 & 2197.1368 & 2197.1332 & 733.3850 & 0.0036 & 1.6362 & 493.638 \\ \text { MIPCDFLIPVQTQHPIR } & 1.00 & 36.05 & 27.81 & 17.27 & 3 & 2197.1386 & 2197.1332 & 733.3850 & 0.0054 & 2.4544 & 24.347\end{array}$ $\begin{array}{llllllllllll}\text { MIPCDFLIPVQTQHPIR } & 0.98 & 32.16 & 27.53 & 18.89 & 3 & 2197.1401 & 2197.1332 & 733.3850 & 0.0069 & 3.1361 & 27.809\end{array}$

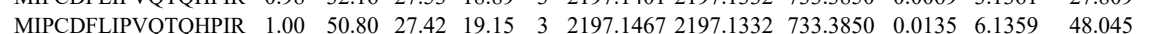
$\begin{array}{llllllllllll}\text { MIPCDFLIPVQTQHPIR } & 0.97 & 23.64 & 27.72 & 15.59 & 3 & 2213.1313 & 2213.1281 & 738.7166 & 0.0032 & 1.4439 & 138.413\end{array}$ $\begin{array}{llllllllllll}\text { MIPCDFLIPVQTQHPIR } & 1.00 & 73.17 & 27.78 & 22.88 & 2 & 2197.1354 & 2197.1332 & 1099.5739 & 0.0022 & 1.0004 & 220.632\end{array}$ $\begin{array}{lllllllllllll}\text { MIPCDFLIPVQTQHPIR } & 1.00 & 53.64 & 27.82 & 19.63 & 3 & 2197.1359 & 2197.1332 & 733.3850 & 0.0027 & 1.2272 & 453.310\end{array}$ $\begin{array}{llllllllllll}\text { ILLANFLAQTEALMR } & 1.00 & 89.20 & 24.98 & 18.88 & 2 & 1847.0472 & 1847.0460 & 924.5303 & 0.0012 & 0.6490 & 148.532\end{array}$

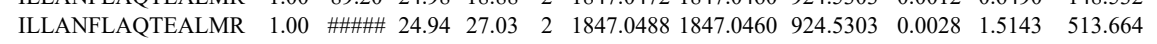
$\begin{array}{llllllllllll}\text { ILLANFLAQTEALMR } & 0.67 & 40.94 & 24.90 & 53.94 & 3 & 1847.0491 & 1847.0460 & 616.6893 & 0.0031 & 1.6756 & 49.323\end{array}$ $\begin{array}{lllllllllllll}\text { ILLANFLAQTEALMR } & 0.67 & 34.36 & 24.70 & 47.36 & 3 & 1847.0494 & 1847.0460 & 616.6893 & 0.0034 & 1.8378 & 29.173\end{array}$ $\begin{array}{lllllllllllll}\text { MIPCDFLIPVQTQHPIR } & 1.00 & 37.49 & 27.82 & 16.87 & 3 & 2197.1359 & 2197.1332 & 733.3850 & 0.0027 & 1.2272 & 267.906\end{array}$ $\begin{array}{llllllllllll}\text { MIPCDFLIPVQTQHPIR } & 1.00 & 33.43 & 27.85 & 15.58 & 3 & 2197.1365 & 2197.1332 & 733.3850 & 0.0033 & 1.4999 & 476.520\end{array}$ $\begin{array}{llllllllllll}\text { ILLANFLAQTEALMR } & 1.00 & \text { \#\#\#\# } 25.00 & 25.88 & 2 & 1847.0470 & 1847.0460 & 924.5303 & 0.0010 & 0.5408 & 230.075\end{array}$ $\begin{array}{lllllllllll}\text { ILLANFLAQTEALMR } & 1.00 & \text { 24.98 } & 25.37 & 2 & 1847.0472 & 1847.0460 & 924.5303 & 0.0012 & 0.6490 & 176.504\end{array}$ $\begin{array}{llllllllllll}\text { ILLANFLAQTEALMR } & 0.66 & 52.99 & 24.94 & 65.99 & 3 & 1847.0482 & 1847.0460 & 616.6893 & 0.0022 & 1.1891 & 41.444 \\ \text { ILLANFLATEALMR } & 0.67 & 56.22 & 24.94 & 6.92 & 3 & 1847.0488 & 1847.0460 & 616.6893 & 0.028 & 1.5135 & 33.594\end{array}$ $\begin{array}{llllllllllll}\text { ILLANFLAQTEALMR } & 0.67 & 56.22 & 24.94 & 69.22 & 3 & 1847.0488 & 1847.0460 & 616.6893 & 0.0028 & 1.5135 & 33.594\end{array}$ $\begin{array}{llllllllllllll}\text { MIPCDFLIPVQTQHPIR } & 1.00 & 48.78 & 27.76 & 19.62 & 3 & 2197.1344 & 2197.1332 & 733.3850 & 0.0012 & 0.5454 & 49.826\end{array}$

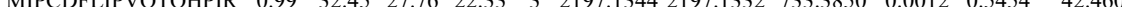
$\begin{array}{lllllllllllll}\text { ILLANFLAQTEALMR } & 1.00 & 86.63 & 25.02 & 21.25 & 2 & 1847.0460 & 1847.0460 & 924.5303 & 0.0000 & 0.0000 & 26.549\end{array}$ $\begin{array}{lllllllllllll}\text { ILLANFLAQTEALMR } & 1.00 & \text { \#\#\#\# } 25.05 & 26.80 & 2 & 1847.0462 & 1847.0460 & 924.5303 & 0.0002 & 0.1082 & 44.276\end{array}$ $\begin{array}{llllllllllll}\text { ILLANFLAQTEALMR } & 0.76 & 12.17 & 24.91 & 16.09 & 3 & 1847.0485 & 1847.0460 & 616.6893 & 0.0025 & 1.3513 & 14.734\end{array}$ $\begin{array}{llllllllllll}\text { ILLANFLAQTEALMR } & 0.67 & 65.25 & 24.94 & 78.25 & 3 & 1847.0488 & 1847.0460 & 616.6893 & 0.0028 & 1.5135 & 25.843\end{array}$ $\begin{array}{llllllllllll}\text { ILLANFLAQTEALMR } & 1.00 & 30.95 & 26.03 & 16.50 & 3 & 1863.0433 & 1863.0410 & 622.0209 & 0.0023 & 1.2325 & 19.537 \\ \text { MIPCDFLPVQTQHPIR } & 1.00 & 48.10 & 27.76 & 18.68 & 3 & 2197.1344 & 2197.1332 & 733.3850 & 0.0012 & 0.5454 & 29.905\end{array}$ $\begin{array}{lllllllllllll}\text { MIPCDFLIPVQTQHPIR } & 1.00 & 48.10 & 27.76 & 18.68 & 3 & 2197.1344 & 2197.1332 & 733.3850 & 0.0012 & 0.5454 & 29.905\end{array}$ $\begin{array}{llllllllllll}\text { MIPCDFLIPVQTQHPIR } & 1.00 & 48.24 & 27.75 & 20.10 & 3 & 2197.1353 & 2197.1332 & 733.3850 & 0.0021 & 0.9545 & 41.035\end{array}$

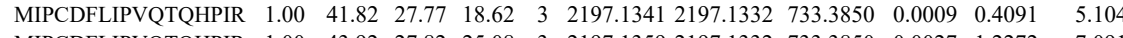

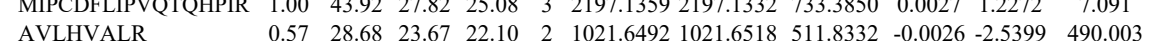
$\begin{array}{llllllllllll}\text { AVLHVALR } & 0.57 & 28.68 & 23.67 & 22.10 & 2 & 1021.6492 & 1021.6518 & 511.8332 & -0.0026 & -2.5399 & 490.003 \\ \text { MIPCDFLIPVQTOHPIR } & 1.00 & 52.80 & 27.75 & 20.01 & 3 & 2197.1353 & 2197.1332 & 733.3850 & 0.0021 & 0.9545 & 8.575\end{array}$

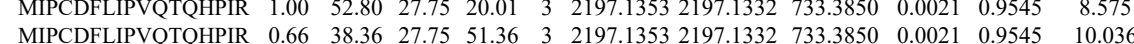

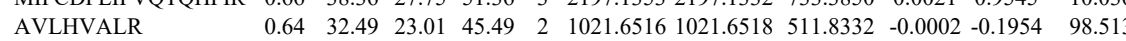

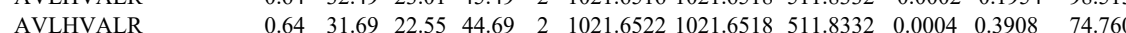
$\begin{array}{llllllllllll}\text { MIPCDFLIPVQTQHPIR } & 1.00 & 43.42 & 27.74 & 26.95 & 3 & 2197.1335 & 2197.1332 & 733.3850 & 0.0003 & 0.1364 & 31.614\end{array}$

379.019 2093.079 1.165 (1.836 8.705 0.609

434.759 518.498

2.230

50.937 51.702
28.331

408.51

16.863

265.305
323.905 
$\begin{array}{lllllllllllllll}\text { TFTTQETITNAETAK } & 1.00 & \text { 27.23 } & 21.49 & 2 & 1943.0270 & 1943.0091 & 972.5118 & 0.0179 & 9.2029 & 1133.073 & 885.463 & 306.096 & 1514.268 & \text { Yes }\end{array}$

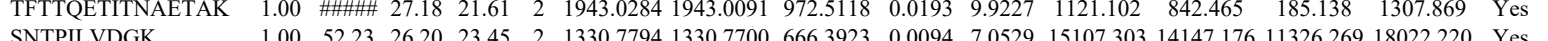

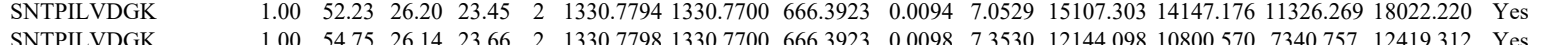
$\begin{array}{lllllllllllllll}1.00 & 54.75 & 26.14 & 23.66 & 2 & 1330.7798 & 1330.7700 & 666.3923 & 0.0098 & 7.3530 & 12144.098 & 10800.570 & 7340.757 & 12419.312 & \text { Yes }\end{array}$

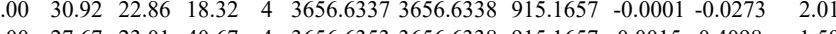

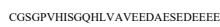

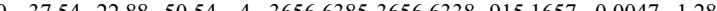

$\begin{array}{llll}2.870 & 8.006 & 8.397 & \mathrm{Y} \\ 0.000 & 0.000 & 1.749 & (2.00\end{array}$

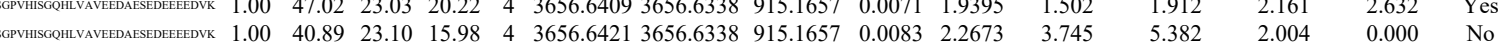

$\begin{array}{llllllllllllllll}\text { CGSGPVHSGOHLVAVEDAESBEEEEDVK } & 1.00 & 40.73 & 23.07 & 53.73 & 4 & 3656.6433 & 3656.6338 & 915.1657 & 0.0095 & 2.5952 & 0.000 & 3.166 & 2.530 & 4.474 & \text { No }\end{array}$

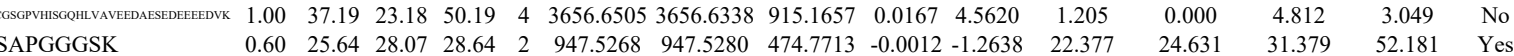

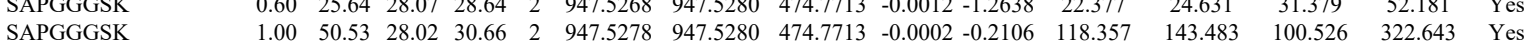
$\begin{array}{llllllllllllllll}\text { GGSLPK } & 0.72 & 21.63 & 26.18 & 29.95 & 2 & 845.5212 & 845.5214 & 423.7680 & -0.0002 & -0.2360 & 408.769 & 372.320 & 535.390 & 638.911 & \text { Yes }\end{array}$ $\begin{array}{lllllllllllllllll}\text { GGSLPK } & 0.74 & 23.37 & 26.18 & 34.18 & 2 & 845.5218 & 845.5214 & 423.7680 & 0.0004 & 0.4720 & 463.707 & 519.141 & 755.856 & 984.384 & \text { Yes }\end{array}$ $\begin{array}{lllllllllllllllll}\text { GGSLPK } & 0.94 & 25.29 & 26.18 & 29.89 & 2 & 845.5220 & 845.5214 & 423.7680 & 0.0006 & 0.7079 & 601.573 & 672.501 & 1317.294 & 1341.444 & \text { Yes }\end{array}$

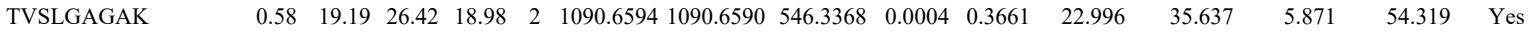

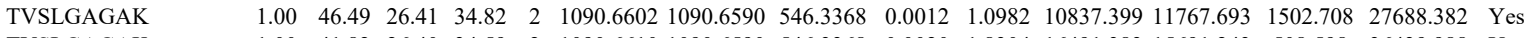
$\begin{array}{llllllllllllllll}\text { TVSLGAGAK } & 1.00 & 41.82 & 26.40 & 34.59 & 2 & 1090.6610 & 1090.6590 & 546.3368 & 0.0020 & 1.8304 & 16491.383 & 15691.243 & 508.598 & 36439.988 & \text { Yes }\end{array}$

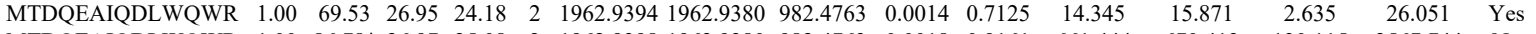
$\begin{array}{llllllllllllllll}\text { MTDQEAIQDLWQWR } & 1.00 & 86.78 * & 26.97 & 25.08 & 2 & 1962.9398 & 1962.9380 & 982.4763 & 0.0018 & 0.9161 & 661.444 & 670.413 & 130.115 & 2567.744 & \text { No }\end{array}$

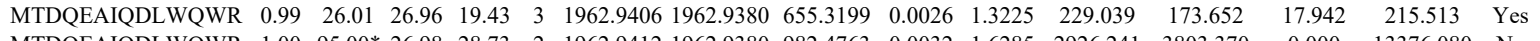
$\begin{array}{lllllllllllllll}\text { MTDQEAIQDLWQWR } & 1.00 & 95.00 * 26.98 & 28.73 & 2 & 1962.9412 & 1962.9380 & 982.4763 & 0.0032 & 1.6285 & 2926.241 & 3803.370 & 0.000 & 13376.080 & \text { No }\end{array}$

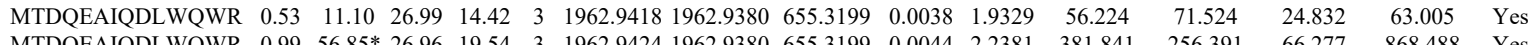

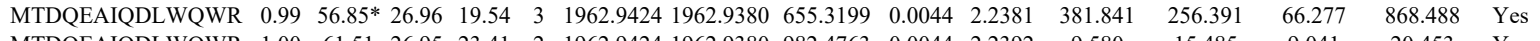

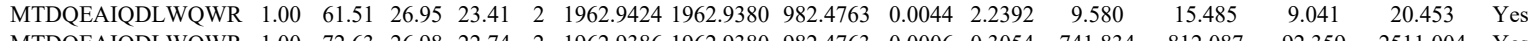

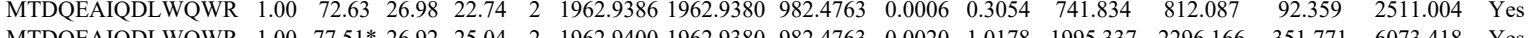

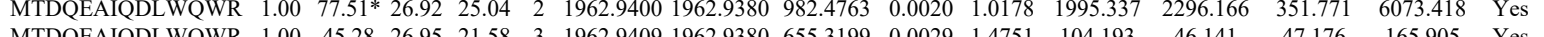

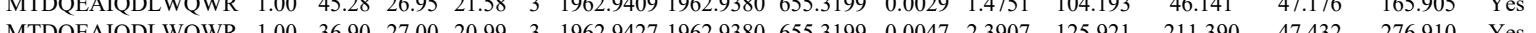

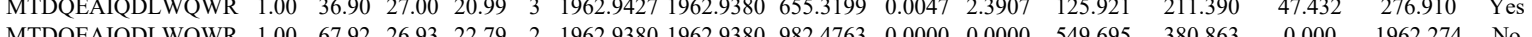
$\begin{array}{llllllllllllll} & \end{array}$

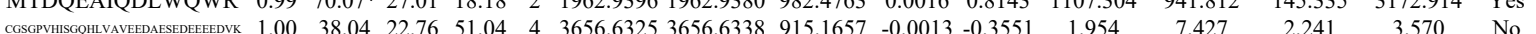

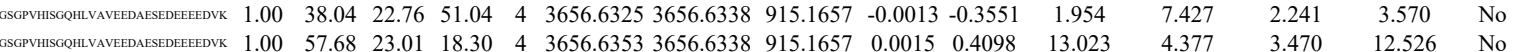

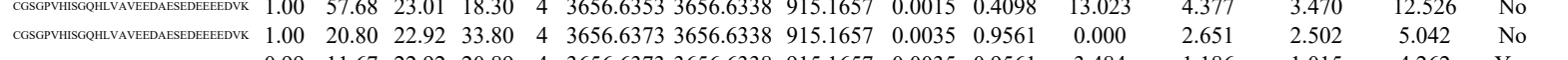

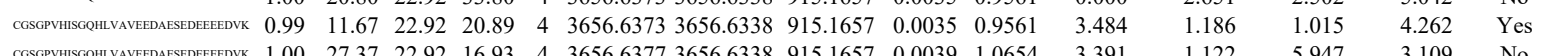

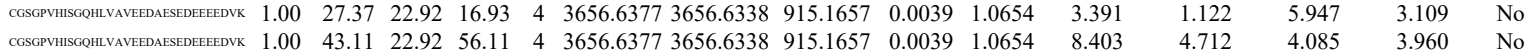

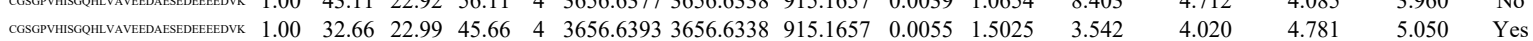

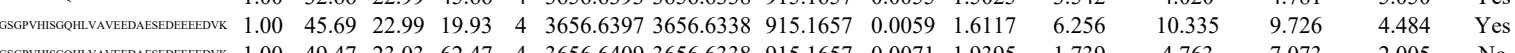

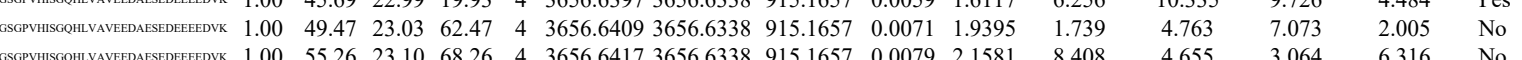

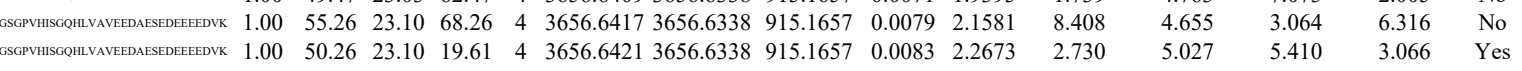

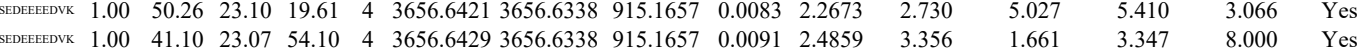

VTLATLK

VTLATLK

VTLATLK

VTLATLK

FINYVK

FINYVK

VTLATLK

VTLATLK

VTLATLK

FINYVK

VTLATLK

VTLATLK

FINYVK

VTLATLK

VTLATLK $\begin{array}{lllllllll} & \end{array}$

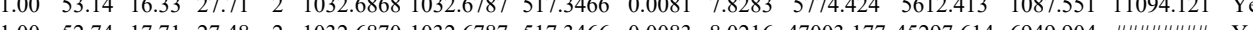

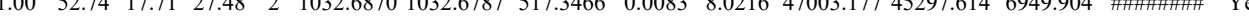
$\begin{array}{lllllllllllllll}1.00 & 52.76 & 17.71 & 27.37 & 2 & 1032.6888 & 1032.6787 & 517.3466 & 0.0101 & 9.7613 & 5703.179 & 5108.043 & 1189.478 & 10820.518 & \text { Yes }\end{array}$ $\begin{array}{llllllllllllllll}0.92 & 33.84 & 24.93 & 24.96 & 2 & 1070.6430 & 1070.6368 & 536.3257 & 0.0062 & 5.7800 & 17646.568 & 18705.063 & 2608.899 & 51884.359 & \text { Yes }\end{array}$ $\begin{array}{llllllllllllllll}0.92 & 33.87 & 24.93 & 25.02 & 2 & 1070.6432 & 1070.6368 & 536.3257 & 0.0064 & 5.9665 & 20417.156 & 22172.987 & 3115.894 & 63763.190 & \text { Yes }\end{array}$

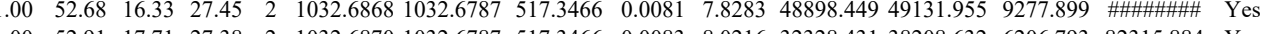
$\begin{array}{llllllllllllllll}1.00 & 52.91 & 17.71 & 27.38 & 2 & 1032.6870 & 1032.6787 & 517.3466 & 0.0083 & 8.0216 & 32328.431 & 38208.632 & 6206.793 & 82315.884 & \text { Yes }\end{array}$ $\begin{array}{lllllllllllllll}0.98 & 32.92 & 17.71 & 27.00 & 2 & 1032.6880 & 1032.6787 & 517.3466 & 0.0093 & 8.9881 & 4886.834 & 4671.219 & 1074.126 & 7288.675 & \text { Yes }\end{array}$ $\begin{array}{lllllllllllllll}0.94 & 34.05 & 24.33 & 25.32 & 2 & 1070.6438 & 1070.6368 & 536.3257 & 0.0070 & 6.5258 & 21407.645 & 19395.142 & 984.771 & 70814.712 & \text { No }\end{array}$

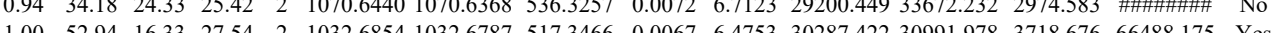
$\begin{array}{lllllllllllllll}1.00 & 52.94 & 16.33 & 27.54 & 2 & 1032.6854 & 1032.6787 & 517.3466 & 0.0067 & 6.4753 & 30287.422 & 30991.978 & 3718.676 & 66488.175 & \text { Yes } \\ 1.00 & 53.01 & 16.33 & 27.64 & 2 & 1032.6868 & 1032.6787 & 517.3466 & 0.0081 & 7.8283 & 21223.877 & 22427.726 & 3382.377 & 49026.928 & \text { Yes }\end{array}$ $\begin{array}{lllllllllllllll}1.00 & 53.01 & 16.33 & 27.64 & 2 & 1032.6868 & 1032.6787 & 517.3466 & 0.0081 & 7.8283 & 21223.877 & 22427.726 & 3382.377 & 49026.928 & \text { Yes } \\ 0.95 & 34.57 & 24.33 & 23.78 & 2 & 1070.6438 & 1070.6368 & 5363257 & 0.0070 & 65258 & 22864.196 & 21279.097 & 0.000 & 7549.088 & \text { No }\end{array}$

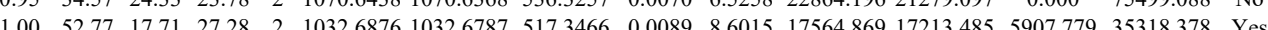

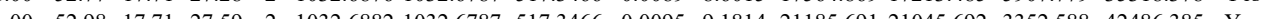
$\begin{array}{lllllllllllllllllllll}0.97 & 33.96 & 23.86 & 25.05 & 2 & 1070.6462 & 1070.6368 & 536.3257 & 0.0094 & 8.7633 & 11102.461 & 10239.263 & 1005.401 & 33625.092 & \text { Yes }\end{array}$ 
$\begin{array}{lllllllllllll} & \end{array}$

$\begin{array}{llllllllllll}\text { MSVQPTVSLGGFEITPPVVLR } & 0.55 & 11.64 & 25.00 & 24.64 & 3 & 2386.3066 & 2386.3052 & 796.4423 & 0.0014 & 0.5859 & 131.404\end{array}$

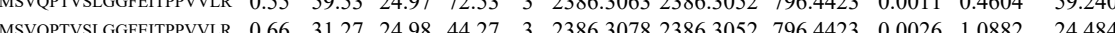

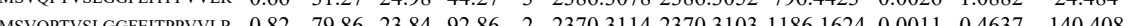
$\begin{array}{llllllllllllllll}\text { MSVQPTVSLGGFEITPPVVLR } & 0.82 & 88.08 & 23.84 & \# \# \# \# & 2 & 2370.3114 & 2370.3103 & 1186.1624 & 0.0011 & 0.4637 & 341.029\end{array}$

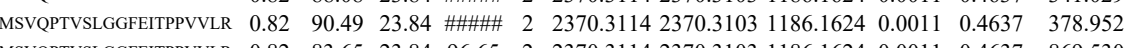

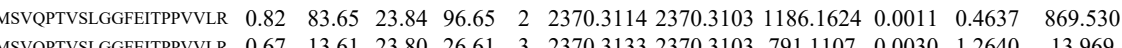
\begin{tabular}{llllllllllll} 
MSVQPTVSLGGFEITPPVVLR & 0.67 & 13.61 & 23.80 & 26.61 & 3 & 2370.3133 & 2370.3103 & 791.1107 & 0.0030 & 1.2640 & 13.969 \\
\hline
\end{tabular} $\begin{array}{llllllllllll}\text { MSVQPTVSLGGFEITPPVVLR } & 1.00 & 25.81 & 23.62 & 38.81 & 4 & 2370.3165 & 2370.3103 & 593.5849 & 0.0062 & 2.6112 & 79.102\end{array}$ $\begin{array}{llllllllllll}\text { MSVQPTVSLGGFEITPPVYLR } & 0.64 & 66.39 & 24.98 & 79.39 & 2 & 2386.3054 & 2386.3052 & 1194.1599 & 0.0002 & 0.0837 & 156.629\end{array}$ $\begin{array}{llllllllllll}\text { MSVQPTVSLGGFEITPPVVLR } & 0.99 & 30.78 & 23.98 & 20.77 & 3 & 2370.3097 & 2370.3103 & 791.1107 & -0.0006 & -0.2528 & 28.009\end{array}$ $\begin{array}{llllllllllll}\text { MSVQPTVSLGGFEITPPVVLR } & 0.80 & 13.86 & 23.91 & 15.22 & 3 & 2370.3112 & 2370.3103 & 791.1107 & 0.0009 & 0.3792 & 8.651\end{array}$ $\begin{array}{lllllllllllll}\text { MSVQPTVSLGGFEITPPVVLR } & 0.82 & 89.43 & 23.84 & \# \# \# \# 2 & 2370.3114 & 2370.3103 & 1186.1624 & 0.0011 & 0.4637 & 126.040\end{array}$ $\begin{array}{llllllllllllll}\text { MSVQPTVSLGGFEITPPVVLR } & 0.82 & 94.31 & 23.84 & \# \# \# \quad 2 & 2370.3114 & 2370.3103 & 1186.1624 & 0.0011 & 0.4637 & 384.450\end{array}$

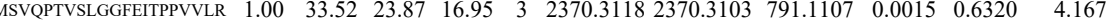
$\begin{array}{lllllllllllll}\text { MSVQPTVSLGGFETPPVVLR } & 0.82 & 96.62 & 23.84 & \text { \# } & 2 & 2370.3114 & 2370.3103 & 1186.1624 & 0.0011 & 0.4637 & 43.903\end{array}$ $\begin{array}{llllllllllll}\text { MSVQPTVSLGGFEITPPVVLR } & 0.82 & 79.53 & 23.84 & 92.53 & 2 & 2370.3114 & 2370.3103 & 1186.1624 & 0.0011 & 0.4637 & 61.979\end{array}$ $\begin{array}{lllllllllllll}\text { MSVQPTVSLGGFEITPPVVLR } & 1.00 & 53.42 & 23.84 & 19.06 & 3 & 2370.3115 & 2370.3103 & 791.1107 & 0.0012 & 0.5056 & 19.522\end{array}$

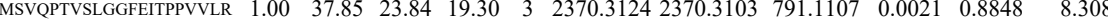

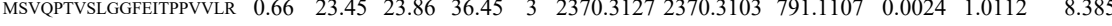
$\begin{array}{llllllllllll}\text { MSVQPTVSLGGFEITPPVVLR } & 0.67 & 21.36 & 23.80 & 34.36 & 3 & 2370.3133 & 2370.3103 & 791.1107 & 0.0030 & 1.2640 & 10.475\end{array}$ $\begin{array}{llllllllllll}\text { VDNDENEHQLSLR } & 0.99 & 33.94 & 26.70 & 16.92 & 3 & 1711.8247 & 1711.8247 & 571.6155 & 0.0000 & 0.0000 & 136.986\end{array}$ VDNDENEHQLSLR VDNDENEHQLSLR VDNDENEHQLSLR VDNDENEHQLSLR VDNDENEHQLSLR $\begin{array}{llllllllllll}0.55 & 17.75 & 26.73 & 30.75 & 3 & 1711.8259 & 1711.8247 & 571.6155 & 0.0000 & 0.0000 & 136.986\end{array}$ $\begin{array}{llllllllllll}1.00 & 26.13 & 26.81 & 27.58 & 2 & 1711.8264 & 1711.8247 & 856.9196 & 0.0017 & 0.9919 & 1336.856 \\ 0.96 & 22.27 & 26.80 & 15.42 & 3 & 1711.8265 & 1711.8247 & 571.6155 & 0.0018 & 1.0497 & 121.036\end{array}$ $\begin{array}{lllllllllllll}0.96 & 22.27 & 26.80 & 15.42 & 3 & 1711.8265 & 1711.8247 & 571.6155 & 0.0018 & 1.0497 & 121.036\end{array}$ $\begin{array}{lllllllllll}1.00 & 33.10 & 26.80 & 1 . .53 & 3 & 1711.8265 & 1711.8247 & 571.6155 & 0.0018 & 1.0497 & 121.036 \\ 0.6 & 22.09 & 2.8 & 35.09 & 3 & 171.8255 & 1711.8247 & 571.6155 & 0.0018 & 1.0497 & 93.001\end{array}$ VDNDENEHQLSLR $\begin{array}{llllllllllll}1.00 & 95.38 & 26.80 & 31.73 & 2 & 1711.8266 & 1711.8247 & 856.9196 & 0.0019 & 1.1086 & 1119.106\end{array}$ VDNDENHQLSLR $\begin{array}{lllllllllllll}1.00 & 53.41 & 26.84 & 16.36 & 3 & 1711.8271 & 1711.8247 & 571.6155 & 0.0024 & 1.3995 & 3357.892\end{array}$ DNDENEHQLSLR $\begin{array}{llllllllllll}0.99 & 26.02 & 26.84 & 19.02 & 3 & 1711.8271 & 1711.8247 & 571.6155 & 0.0024 & 1.3995 & 130.027\end{array}$ DDNDER $\begin{array}{lllllllllll}.00 & 32.78 & 26.88 & 19.14 & 3 & 1711.8280 & 1711.8247 & 51.6155 & 0.0033 & 1.9244 & 83.098\end{array}$

VDNDENEHQLSLR $\begin{array}{lllllllllll}61.08 & 26.82 & 74.08 & 3 & 1711.8283 & 1711.8247 & 571.6155 & 0.0036 & 2.0993 & 6383.501\end{array}$ VDNDENEHQLSLR $\begin{array}{lllllllllll}0.98 & 24.88 & 26.79 & 15.30 & 3 & 1711.8286 & 1711.8247 & 571.6155 & 0.0039 & 2.2743 & 151.983\end{array}$ $\begin{array}{llllllllllllll} & \text { VDNDE }\end{array}$ $\begin{array}{lllllllllllll} & \text { VDNDENG }\end{array}$

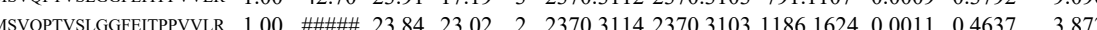
$\begin{array}{llllllllllllll}\text { MSVOPTVSLGGFEITPPVVLR } & 0.66 & 14.02 & 23.86 & 27.02 & 3 & 2370.3121 & 2370.3103 & 791.1107 & 0.0018 & 0.7584 & 9.386\end{array}$ $\begin{array}{lllllllllllll}\text { MSVOPTVSLGGFEITPPVVLR } & 1.00 & 42.82 & 23.84 & 19.98 & 3 & 2370.3124 & 2370.3103 & 791.1107 & 0.0021 & 0.8848 & 17.603\end{array}$ $\begin{array}{lllllllllllll}\text { MSVOPTVSLGGFEITPPVVLR } & 1.00 & 80.10 & 23.82 & 18.27 & 2 & 2370.3134 & 2370.3103 & 1186.1624 & 0.0031 & 1.3067 & 2.576\end{array}$ $\begin{array}{lllllllllllllll}\text { MSVQPTVSLGGFEITPPVVLR } & 0.82 & 95.48 & 23.84 & \text { \#\#\#\# } 2 & 2370.3114 & 2370.3103 & 1186.1624 & 0.0011 & 0.4637 & 30.659\end{array}$ MSVQPTVSLGGFEITPPVVLR $0.82 \quad 96.26 \quad 23.84 \quad \begin{array}{lllllllllllll}2 & 2 & 2370.3114 & 2370.3103 & 1186.1624 & 0.0011 & 0.4637 & 44.013\end{array}$

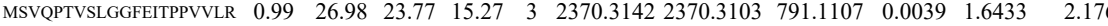
$\begin{array}{llllllllllll}\text { MSVQPTVSLGGFEITPVVLR } & 0.82 & 93.80 & 23.84 & \# \# \# \# \quad 2370.3114 & 2370.3103 & 1186.1624 & 0.0011 & 0.4637 & 31.967\end{array}$ $\begin{array}{llllllllllllll}\text { MSVQPTVSLGGFEITPPVVLR } & 0.82 & 77.60 & 23.84 & 90.60 & 2 & 2370.3114 & 2370.3103 & 1186.1624 & 0.0011 & 0.4637 & 53.442\end{array}$

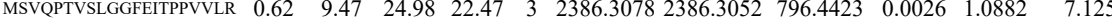
$\begin{array}{lllllllllllll} & \text { USVQPTVSLGGFEITPPVVLR } & 1.00 & 31.84 & 23.91 & 22.02 & 3 & 2370.3112 & 2370.3103 & 791.1107 & 0.0009 & 0.3792 & 12.060\end{array}$

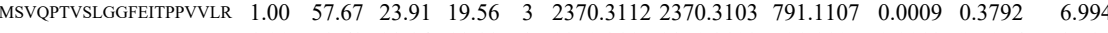
$\begin{array}{llllllllllll}\text { MSVQPTVSLGGFETPPVVLR } & 1.00 & 58.68 & 23.84 & 18.83 & 3 & 2370.3115 & 2370.3103 & 791.1107 & 0.0012 & 0.5056 & 3.797\end{array}$ VDNDENEHQLSLR VDNDENEHQLSLR $\begin{array}{llllllllllll}1.00 & 94.49 & 26.74 & 27.04 & 2 & 17118260 & 1711.8247 & 8569196 & 0.0013 & 0.7585 & 452.118 & \end{array}$ $\begin{array}{llllllllllll}1.00 & 61.36 & 26.74 & 18.72 & 3 & 1711.8262 & 1711.8247 & 571.6155 & 0.0015 & 0.8747 & 1690.474 \\ 0.66 & 13.89 & 26.80 & 26.89 & 3 & 1711.8265 & 1711.8247 & 571.6155 & 0.0018 & 1.0497 & 15.394\end{array}$ VDNDENEHQLSLR

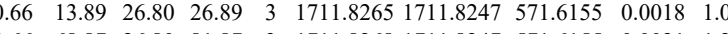
VDNDENEHQLSL $\begin{array}{lllllllllll} & & \end{array}$ $\begin{array}{llllllllllll}1.00 & 35.00 & 15.80 & 24.14 & 2 & 1032.6792 & 1032.6787 & 517.3466 & 0.0005 & 0.4832 & 333.203\end{array}$

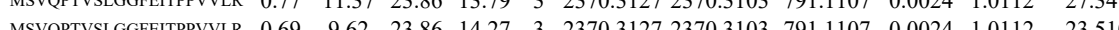



$\begin{array}{llllllllllll}\text { DELHIVEAEAMNYEGSPIK } & 1.00 & 61.02 & 27.23 & 18.54 & 4 & 2432.2169 & 2432.2137 & 609.0607 & 0.0032 & 1.3135 & 112.496 \\ \text { DELHIVEAEAMNYEGSPK } & 0.98 & 14.99 & 27.23 & 17.93 & 4 & 2432.2169 & 2432.137 & 609.0607 & 0.0032 & 1.3135 & 133.089\end{array}$ $\begin{array}{lllllllllllll}\text { DELHIVEAEAMNYEGSPIK } & 1.00 & 52.79 & 27.23 & 21.18 & 4 & 2432.2169 & 2432.2137 & 609.0607 & 0.0032 & 1.3135 & 66.978\end{array}$ $\begin{array}{lllllllllllll}\text { DELHIVEAEAMNYEGSPIK } & 1.00 & 68.78 & 27.25 & 23.29 & 3 & 2432.2171 & 2432.2137 & 811.7452 & 0.0034 & 1.3962 & 7.952\end{array}$

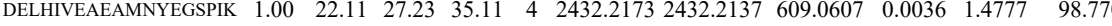
$\begin{array}{llllllllllll}\text { DELHIVEAEAMNYEGSPIK } & 0.98 & 15.86 & 27.23 & 17.31 & 4 & 2432.2173 & 2432.2137 & 609.0607 & 0.0036 & 1.4777 & 57.695\end{array}$

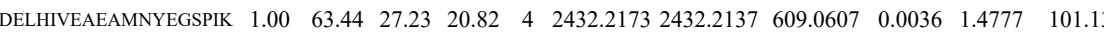

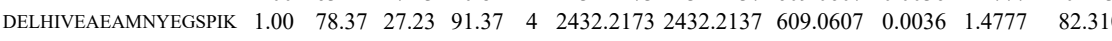

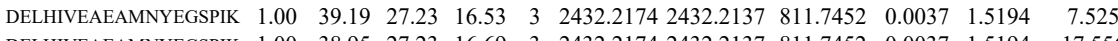
$\begin{array}{lllllllllllll}\text { DELHIVEAEAMNYEGSPIK } & 1.00 & 38.95 & 27.23 & 16.69 & 3 & 2432.2174 & 2432.2137 & 811.7452 & 0.0037 & 1.5194 & 17.556 \\ \text { DELHIVEAEAMNYEGSPIK } & 1.00 & 76.71 & 27.28 & 19.21 & 3 & 2432.2177 & 2432.2137 & 811.7452 & 0.0040 & 1.6425 & 27.633\end{array}$ $\begin{array}{llllllllllll}\text { DELHIVEAEAMNYEGSPIK } & 1.00 & 76.71 & 27.28 & 19.21 & 3 & 2432.2177 & 2432.2137 & 811.7452 & 0.0040 & 1.6425 & 27.633 \\ \text { DELHIVEAEAMNYEGSPIK } & 1.00 & 79.52 & 27.28 & 18.55 & 3 & 2432.2177 & 2432.2137 & 811.7452 & 0.0040 & 1.6425 & 20.225\end{array}$ $\begin{array}{llllllllllll}\text { DELHIVEAEAMNYEGSPIK } & 1.00 & 79.52 & 27.28 & 18.55 & 3 & 2432.2177 & 2432.2137 & 811.7452 & 0.0040 & 1.6425 & 20.225 \\ \text { DELHIVEAEAMNYEGSPIK } & 0.60 & 78.91 & 27.28 & 91.91 & 3 & 2432.2177 & 2432.2137 & 811.7452 & 0.0040 & 1.6425 & 6.962\end{array}$

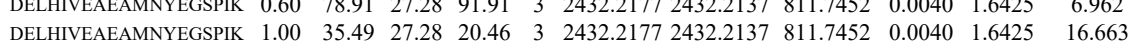

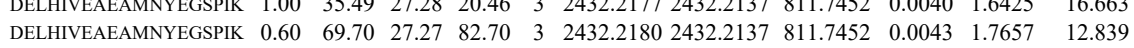

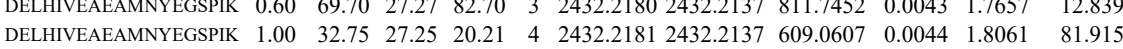
$\begin{array}{llllllllllll}\text { DELHIVEAEAMNYEGSPIK } & 1.00 & 91.71 & 27.28 & 21.92 & 3 & 2432.2183 & 2432.2137 & 811.7452 & 0.0046 & 1.8889 & 28.424\end{array}$ $\begin{array}{llllllllllll} & \text { DEDHE }\end{array}$ $\begin{array}{llllllllllll} & D E\end{array}$

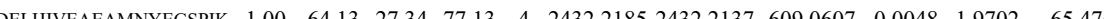
$\begin{array}{llllllllllll}\text { DELHVEAEMNYEGSPI } & 1.00 & 71.90 & 27.35 & 21.07 & 3 & 24322189 & 24322137 & 811.7452 & 0.0052 & 2.1353 & 31.868\end{array}$ $\begin{array}{llllllllllll}\text { DELHIVEAEAMNYEGSPIK } & 1.00 & 87.33 & 27.35 & 21.27 & 3 & 2432.2189 & 2432.2137 & 811.7452 & 0.0052 & 2.1353 & 19.732\end{array}$ $\begin{array}{lllllllllllll}\text { DELHIVEAEAMNYEGSPIK } & 1.00 & 69.77 & 27.36 & 18.84 & 4 & 2432.2193 & 2432.2137 & 609.0607 & 0.0056 & 2.2986 & 45.974\end{array}$ $\begin{array}{llllllllllll}\text { DELHIVEAEAMNYEGSPIK } & 1.00 & 48.57 & 27.36 & 61.57 & 4 & 2432.2201 & 2432.2137 & 609.0607 & 0.0064 & 2.6270 & 96.324\end{array}$ $\begin{array}{llllllllllll}\text { DELHIVEAEAMNYEGSPIK } & 1.00 & 49.92 & 27.36 & 29.08 & 4 & 2432.2201 & 2432.2137 & 609.0607 & 0.0064 & 2.6270 & 81.376\end{array}$ $\begin{array}{lllllllllllll}\text { DELHIVEAEAMNYEGSPIK } & 1.00 & 66.57 & 27.35 & 20.57 & 3 & 2432.2204 & 2432.2137 & 811.7452 & 0.0067 & 2.7513 & 23.770\end{array}$ $\begin{array}{lllllllllllll}\text { DELHIVEAEAMNYEGSPIK } & 0.66 & 44.02 & 27.66 & 57.02 & 3 & 2448.2110 & 2448.2086 & 817.0768 & 0.0024 & 0.9791 & 48.660\end{array}$ $\begin{array}{lllllllllllll}\text { VDNDENEHQLSLR } & 0.55 & 65.17 & 26.69 & 78.17 & 3 & 1711.8253 & 1711.8247 & 571.6155 & 0.0006 & 0.3499 & 23.045\end{array}$ $\begin{array}{llllllllllll}\text { VDNDENEHQLSLR } & 1.00 & 63.00 & 26.80 & 18.80 & 3 & 1711.8265 & 1711.8247 & 571.6155 & 0.0018 & 1.0497 & 23.509\end{array}$

$\begin{array}{lllllllllllllll}56.75 & 27.68 & 29.94 & 2 & 947.5284 & 947.5280 & 474.7713 & 0.0004 & 0.4213 & 427.199 & 380.584 & 297.961 & 958.342 & \text { Yes } \\ 49.37 & 28.54 & 28.41 & 2 & 1218.6792 & 1218.6700 & 610.3423 & 0.0092 & 7.5367 & 6512.548 & 5907.438 & 20246.786 & 22261.337 & \text { Yes }\end{array}$ $\begin{array}{lllllllllll}0.57 & 25.10 & 28.07 & 21.48 & 2 & 1463.7850 & 1463.7864 & 732.9005 & -0.0014 & -0.9551 & 41.361\end{array}$ 

$\begin{array}{lllllllllllllll}1.00 & 49.34 & 28.07 & 22.35 & 2 & 1463.7876 & 1463.7864 & 732.9005 & 0.0012 & 0.8187 & 1269.831 & 1611.956 & 251.750 & 1415.003 & \text { Yes }\end{array}$

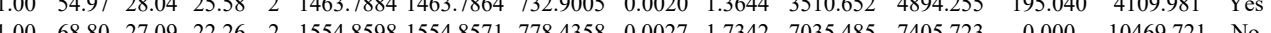
$\begin{array}{llllllllllllllll}1.00 & 68.80 & 27.04 & 22.26 & 2 & 1554.8598 & 1554.8571 & 778.4358 & 0.0027 & 1.7342 & 7035.485 & 7405.723 & 0.000 & 10469.721 & \text { No } & \\ \end{array}$

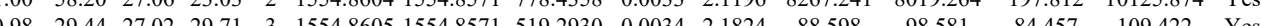
$\begin{array}{llllllllllllllll}\text { MVVESAYEVIK } & 0.99 & 32.18 & 27.09 & 27.86 & 3 & 1554.8608 & 1554.8571 & 519.2930 & 0.0037 & 2.3750 & 100.766 & 114.514 & 83.603 & 131.392 & \text { Yes } \\ \text { MVVESAYEVIK } & 1.00 & 52.38 & 26.99 & 24.46 & 2 & 1554.8570 & 1554.8571 & 778.4358 & -0.0001 & -0.0642 & 425.784 & 352.416 & 27.748 & 458.624 & \text { Yes }\end{array}$ $\begin{array}{lllllllllllllll}0.98 & 29.44 & 27.02 & 29.71 & 3 & 1554.8605 & 1554.8571 & 519.2930 & 0.0034 & 2.1824 & 88.598 & 98.581 & 84.457 & 109.422 & \text { Yes } \\ \end{array}$ $\begin{array}{lllllllllllll} & \end{array}$ $\begin{array}{lllllllllllllllll}\text { GEMMDLOHGSLFLOTPK } & 1.00 & 54.20 & 27.73 & 21.14 & 3 & 2219.1364 & 2219.1322 & 740.7180 & 0.0042 & 1.8901 & 3937.058 & 3856.826 & 2244.365 & 5447.620 & \text { Yes }\end{array}$

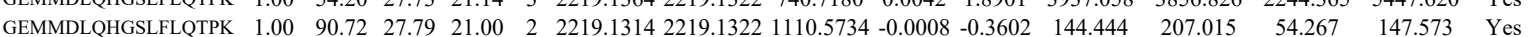
$\begin{array}{llllllllllllllll}\text { GEMMDLOHGSLFLOTPK } & 1.00 & 46.64 & 27.69 & 19.84 & 3 & 2219.1334 & 2219.1322 & 740.7180 & 0.0012 & 0.5400 & 227.149 & 228.686 & 90.393 & 39.020 & \text { No }\end{array}$ $\begin{array}{lllllllllllllll}\text { GEMMDLQHGSLFLQTPK } & 1.00 & \text { \#\#\#\# } 27.70 & 23.55 & 2 & 2219.1334 & 2219.1322 & 1110.5734 & 0.0012 & 0.5403 & 408.498 & 662.753 & 143.099 & 720.965 & \text { Yes }\end{array}$ $\begin{array}{llllllllllllllll}\text { GEMMDLQHGSLFLQTPK } & 1.00 & 50.80 & 27.73 & 22.66 & 3 & 2219.1364 & 2219.1322 & 740.7180 & 0.0042 & 1.8901 & 4473.673 & 6543.979 & 2162.175 & 7178.356 & \text { Yes }\end{array}$

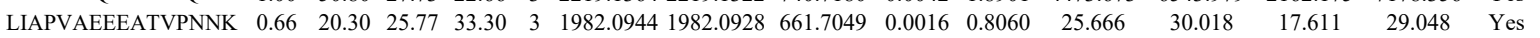
$\begin{array}{llllllllllllllll}\text { GEMMDLQHGSLFLQTPK } & 1.00 & 71.23 & 27.79 & 17.74 & 2 & 2219.1314 & 2219.1322 & 1110.5734 & -0.0008 & -0.3602 & 222.593 & 212.717 & 100.317 & 184.338 & \text { Yes }\end{array}$ $\begin{array}{llllllllllllllll}\text { GEMMDLQHGSLFLQTPK } & 1.00 & 52.14 & 27.76 & 17.00 & 3 & 2219.1343 & 2219.1322 & 740.7180 & 0.0021 & 0.9450 & 2094.860 & 1913.786 & 744.408 & 2098.845 & \text { Yes }\end{array}$

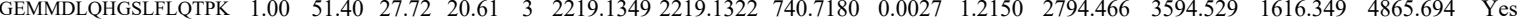

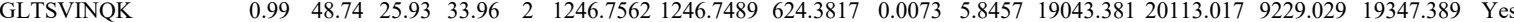

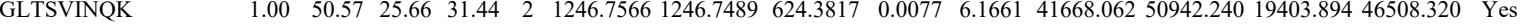

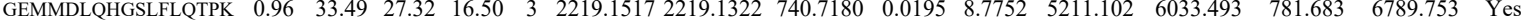

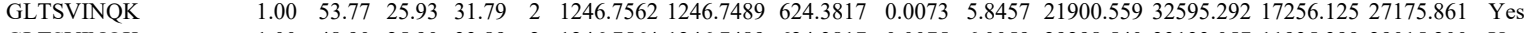

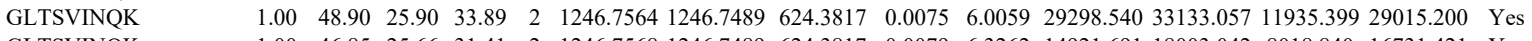
$\begin{array}{lllllllllllllllll}\text { GLTSVINQK } & 1.00 & 46.85 & 25.66 & 31.41 & 2 & 1246.7568 & 1246.7489 & 624.3817 & 0.0079 & 6.3262 & 14921.691 & 18003.042 & 8018.840 & 16731.421 & \text { Yes }\end{array}$ $\begin{array}{lllllllllllllllllll}\text { GLTSVINQK } & 1.00 & 53.49 & 25.66 & 31.38 & 2 & 1246.7570 & 1246.7489 & 624.3817 & 0.0081 & 6.4864 & 14994.361 & 20062.335 & 10868.823 & 17497.196 & \text { Yes }\end{array}$

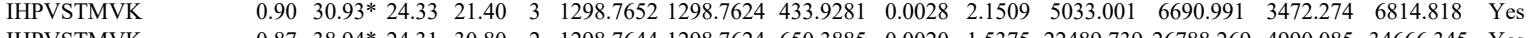
$\begin{array}{lllllllllllllll}\text { IHPVSTMVK } & 0.87 & 38.94 * 24.31 & 30.80 & 2 & 1298.7644 & 1298.7624 & 650.3885 & 0.0020 & 1.5375 & 22489.739 & 26788.269 & 4990.085 & 34666.345 & \text { Yes }\end{array}$

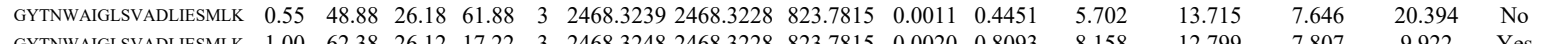

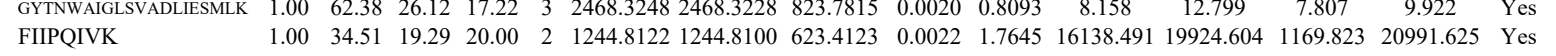

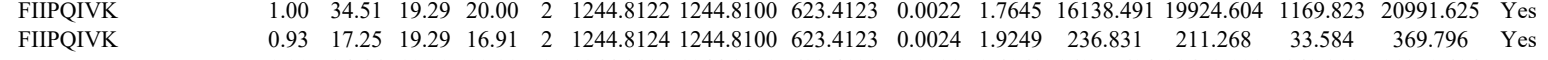
$\begin{array}{llllllllllllllll}\text { FIIPQIVK } & 1.00 & 34.46 & 19.29 & 19.98 & 2 & 1244.8130 & 1244.8100 & 623.4123 & 0.0030 & 2.4061 & 16075.694 & 20453.009 & 842.319 & 21350.494 & \text { Yes }\end{array}$

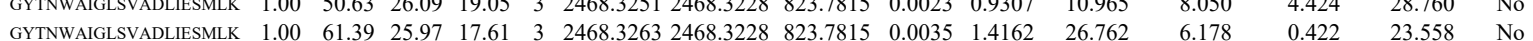

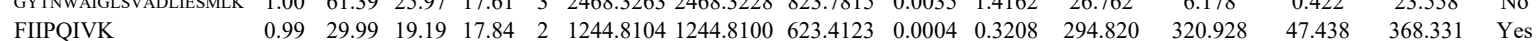

FIIPQIVK

FIIPQIVK

FIIPQIVK

FIIPQIVK

FIIPQIVK

FIIPQIVK

FIIPQIVK

FIIIPQIVK

FIIPQIVK

FIIPQIVK

FIIPQIVK

FIIPQIVK

FIIPQIVK

GYTNWAIGLSVADLIESM

IVVVTAGVR

FIIPQIVK

FIIPQIVK

FIIPQIVK

FIIPQIVK

FIIPQIVK

FIIPQIVK

IVVVTAGVR

IVVVTAGVR

IVVVAGGR

FIIPQIVK $\begin{array}{lllllllllllll}0.99 & 29.99 & 19.19 & 17.84 & 2 & 1244.8104 & 1244.8100 & 623.4123 & 0.0004 & 0.3208 & 294.820 & 320.928\end{array}$ $\begin{array}{lllllllllllllll}0.99 & 30.96 & 19.19 & 23.29 & 2 & 1244.8104 & 1244.8100 & 623.4123 & 0.0004 & 0.3208 & 83.759 & 77.975 & 23 \\ 0.98 & 29.09 & 19.19 & 16.67 & 2 & 1244.8104 & 1244.8100 & 623.4123 & 0.0004 & 0.3208 & 77.854 & 88.833\end{array}$ $\begin{array}{cccccccccccc}0.57 & 6.99 & 19.19 & 14.18 & 3 & 1244.8105 & 1244.8100 & 415.9439 & 0.0005 & 0.4007 & 68.061 & 69.113 \\ 0.96 & 25.00 & 19.19 & 26.64 & 3 & 1244.8108 & 1244.8100 & 415.9439 & 0.0008 & 0.6411 & 2392.092 & 2079.300\end{array}$ $\begin{array}{lllllllllllll}0.98 & 23.65 & 19.19 & 17.32 & 2 & 1244.8108 & 1244.8100 & 623.4123 & 0.0008 & 0.6416 & 317.289 & 333.862\end{array}$ $\begin{array}{lllllllllllll}0.98 & 23.65 & 1.19 & 17.32 & 2 & 1244.8108 & 1244.8100 & 623.4123 & 0.008 & 0.6416 & 317.289 & 333.862\end{array}$ $\begin{array}{lll}0.646 & 317.289 & 333.862 \\ 0.6416 & 213.717 & 217.609\end{array}$ $\begin{array}{llllllllllll}1.00 & 31.85 & 19.19 & 17.88 & 2 & 1244.8110 & 1244.8100 & 623.4123 & 0.0010 & 0.8020 & 217.593 & 216.247\end{array}$ $\begin{array}{llllllllllll}1.00 & 35.70 & 19.19 & 19.69 & 2 & 1244.8116 & 1244.8100 & 623.4123 & 0.0016 & 1.2833 & 50065.942 & 61169.470\end{array}$ $\begin{array}{llllllllllll}0.99 & 30.30 & 19.19 & 26.75 & 3 & 1244.8117 & 1244.8100 & 415.9439 & 0.0017 & 1.3624 & 1942.930 & 2910.950\end{array}$ $\begin{array}{lllllllllllll}0.85 & 15.84 & 19.19 & 24.86 & 3 & 1244.8120 & 1244.8100 & 415.9439 & 0.0020 & 1.6028 & 46.455 & 56.245 \\ 0.98 & 22.18 & 19.19 & 16.99 & 2 & 1244.8120 & 12448100 & 623.4123 & 0.0020 & 1.6041 & 222.125 & 204.968\end{array}$ $\begin{array}{lllllllllllll}0.98 & 22.18 & 19.19 & 16.99 & 2 & 1244.8120 & 1244.8100 & 623.4123 & 0.0020 & 1.6041 & 222.125 & 204.968 \\ 1.00 & 32.97 & 19.29 & 23.42 & 2 & 1244.8126 & 1244.8100 & 623.4123 & 0.0026 & 2.0853 & 93595.842 & \# \# \# \# \#\end{array}$ $\begin{array}{lllllllllllll}0.55 & 25.86 & 26.18 & 38.86 & 3 & 2468.3239 & 2468.3228 & 823.7815 & 0.0011 & 0.4451 & 21.671 & 11.725\end{array}$ $\begin{array}{lllllllllllllll}0.71 & 12.79 & 21.70 & 17.21 & 2 & 1056.6792 & 1056.6777 & 529.3461 & 0.0015 & 1.4168 & 25.379 & 43.704\end{array}$ $\begin{array}{llllllllllllll}0.99 & 29.95 & 19.49 & 21.62 & 2 & 1244.8102 & 1244.8100 & 623.4123 & 0.0002 & 0.1604 & 169.104 & 147.245\end{array}$ $\begin{array}{lllllllllllll}0.88 & 19.83 & 19.49 & 21.05 & 2 & 1244.8102 & 1244.8100 & 623.4123 & 0.0002 & 0.1604 & 132.864 & 144.955\end{array}$ $\begin{array}{lllllllllllll}0.96 & 20.06 & 19.19 & 21.39 & 2 & 1244.8108 & 1244.8100 & 623.4123 & 0.0008 & 0.6416 & 130.881 & 155.307\end{array}$ $\begin{array}{llllllllllll}0.99 & 28.32 & 19.19 & 16.82 & 2 & 1244.8114 & 1244.8100 & 623.4123 & 0.0014 & 1.1229 & 187.827 & 216.774\end{array}$ $\begin{array}{lllllllllllllllll}1.00 & 32.91 & 19.29 & 18.74 & 2 & 1244.8122 & 1244.8100 & 623.4123 & 0.0022 & 1.7645 & 38544.115 & 53004.938 & 535.087 & 54517.627 & \text { Yes } \\ 1.00 & 44.79 & 19.29 & 24.01 & 2 & 1244.8126 & 1244.8100 & 623.4123 & 0.0026 & 2.0853 & 21942.656 & 27168.145 & 832.847 & 27972.190 & \text { Yes }\end{array}$

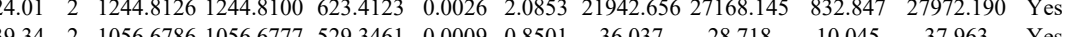
$\begin{array}{llllllllllll} & 1.70 \\ 27.34 & 2 & 10566788 & 1056.6777 & 529.3461 & 0.0011 & 1.0390 & 44.505 & 44.030 & 10.202 & 39.225 & \text { Yes }\end{array}$ $\begin{array}{llllllllll} & & \end{array}$ $\begin{array}{llllllllllllllll} & 22.30 & 26.22 & 2 & 1056.6866 & 1056.6777 & 529.3461 & 0.0089 & 8.4065 & 35289.830 & 40790.302 & 4892.821 & 45502.830 & \text { Yes }\end{array}$ $\begin{array}{lllllllllllllll}1.00 & 44.76 & 19.19 & 25.06 & 2 & 1244.8108 & 1244.8100 & 623.4123 & 0.0008 & 0.6416 & 31399.074 & 39466.284 & 374.529 & 38481.137 & \text { Yes }\end{array}$

Table S-4 page 100 of 614 


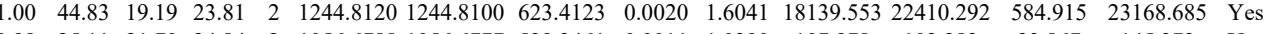
$\begin{array}{llllllllllllll}2.11 & 21.70 & 24.84 & 2 & 1056.6788 & 1056.6777 & 529.3461 & 0.0011 & 1.0390 & 107.978 & 102.283 & 33.867 & 145.373 & \text { Yes }\end{array}$

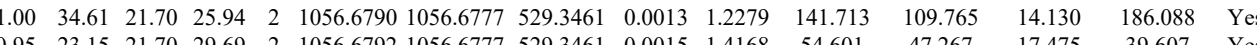

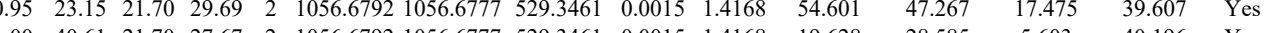
$\begin{array}{lllllllllllllll}1.00 & 40.61 & 21.70 & 27.67 & 2 & 1056.6792 & 1056.6777 & 529.3461 & 0.0015 & 1.4168 & 19.628 & 28.585 & 5.603 & 40.196 & \text { Yes }\end{array}$

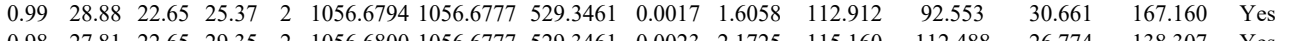
$\begin{array}{lllllllllllllll}0.98 & 27.81 & 22.65 & 29.35 & 2 & 1056.6800 & 1056.6777 & 529.3461 & 0.0023 & 2.1725 & 115.160 & 112.488 & 26.774 & 138.307 & \text { Yes } \\ 0.99 & 32.17 & 22.65 & 28.18 & 2 & 1056.680 & 1056.6777 & 529.3461 & 0.0023 & 2.1725 & 55.527 & 74.880 & 24.305 & 74.786 & \text { Yes }\end{array}$ $\begin{array}{llllllllllllllll}0.99 & 32.17 & 22.65 & 28.18 & 2 & 1056.6800 & 1056.6777 & 529.3461 & 0.0023 & 2.1725 & 55.527 & 74.880 & 24.305 & 74.786 & \text { Yes }\end{array}$

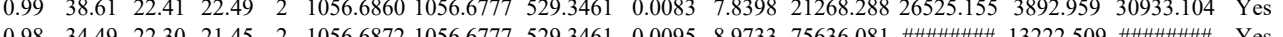

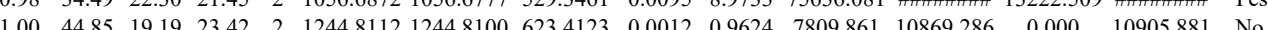

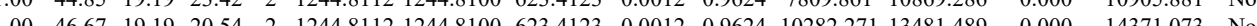

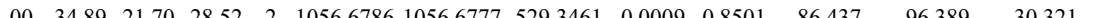

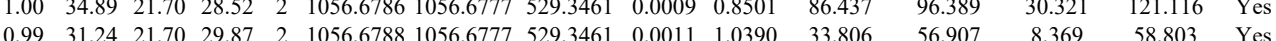

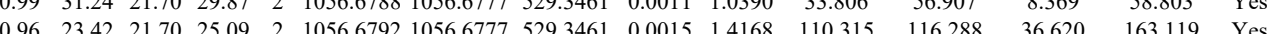

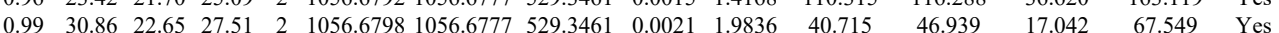
$\begin{array}{lllllllllllllll}0.96 & 27.12 & 22.65 & 27.14 & 2 & 1056.6804 & 1056.6777 & 529.346 & 0.0027 & 25503 & 136.658 & 141.821 & 25.026 & 185.014 & \text { Yes }\end{array}$ $\begin{array}{lllllllllllllll}0.97 & 36.33 & 22.41 & 30.27 & 2 & 10566852 & 1056.6777 & 529.3461 & 0.0075 & 7.0842 & 37065.627 & 48103.222 & 2587.907 & 53065.515 & \text { Yes }\end{array}$

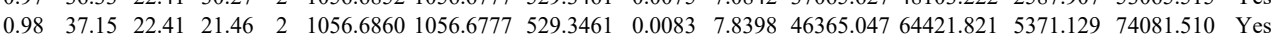
$\begin{array}{lllllllllllllll}1.00 & 35.74 & 19.19 & 19.81 & 2 & 1244.8104 & 1244.8100 & 623.4123 & 0.0004 & 0.3208 & 2384.986 & 2466.361 & 74.293 & 2342.035 & \text { Yes }\end{array}$ $\begin{array}{llllllllllllllll}1.00 & 44.89 & 19.19 & 20.68 & 2 & 1244.8108 & 1244.8100 & 623.4123 & 0.0008 & 0.6416 & 7087.011 & 8450.271 & 0.000 & 8745.292 & \text { No }\end{array}$ $\begin{array}{llllllllllllllllll}0.99 & 40.84 & 22.41 & 29.64 & 2 & 1056.6842 & 1056.6777 & 529.3461 & 0.0065 & 6.1396 & 26154.343 & 32391.334 & 1679.212 & 39951.111 & \text { Yes }\end{array}$ $\begin{array}{llllllllllllllll}0.99 & 41.60 & 22.41 & 30.89 & 2 & 1056.6848 & 1056.6777 & 529.3461 & 0.0071 & 6.7063 & 22139.243 & 28874.979 & 975.797 & 35567.484 & \text { Yes }\end{array}$ $\begin{array}{llllllllllllllll}1.00 & 46.73 & 19.19 & 24.07 & 2 & 1244.8110 & 1244.8100 & 623.4123 & 0.0010 & 0.8020 & 4951.991 & 6405.848 & 159.844 & 6603.595 & \text { Yes }\end{array}$ $\begin{array}{lllllllllllllll}1.00 & 34.53 & 19.19 & 20.00 & 2 & 1244.8116 & 1244.8100 & 623.4123 & 0.0016 & 1.2833 & 7417.106 & 9621.622 & 58.954 & 9654.029 & \text { Yes }\end{array}$ $\begin{array}{lllllllllllllllll}1.00 & 40.83 & 22.65 & 25.97 & 2 & 1056.6804 & 1056.6777 & 529.3461 & 0.0027 & 2.5503 & 5574.074 & 6003.681 & 743.422 & 7675.704 & \text { Yes }\end{array}$

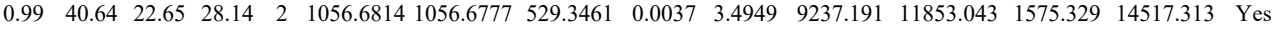
$\begin{array}{lllllllllllllll}1.00 & 34.43 & 19.19 & 19.92 & 2 & 1244.8108 & 1244.8100 & 623.4123 & 0.0008 & 0.6416 & 753.482 & 842.148 & 47.555 & 945.488 & \text { Yes }\end{array}$

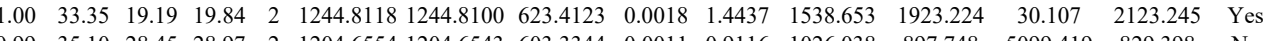
$\begin{array}{lllllllllllllll}0.99 & 35.10 & 28.45 & 28.97 & 2 & 1204.6554 & 1204.6543 & 603.3344 & 0.0011 & 0.9116 & 1026.038 & 897.748 & 5099.419 & 829.398 & \text { No }\end{array}$ $\begin{array}{lllllllllllllll}0.89 & 24.45 & 28.47 & 21.85 & 2 & 1204.6564 & 1204.6543 & 603.3344 & 0.0021 & 1.7403 & 382.583 & 385.924 & 1555.936 & 235.757 & \text { No }\end{array}$ $\begin{array}{lllllllllllllll}1.00 & 41.84 & 22.65 & 27.87 & 2 & 1056.6808 & 1056.6777 & 529.3461 & 0.0031 & 2.9281 & 5147.682 & 6641.859 & 700.427 & 8512.445 & \text { Yes }\end{array}$ $\begin{array}{lllllllllllllll}1.00 & 34.55 & 19.19 & 23.35 & 2 & 1244.8110 & 1244.8100 & 623.4123 & 0.0010 & 0.8020 & 2339.501 & 2723.145 & 37.729 & 2838.787 & \text { Yes } \\ 1.00 & 33.41 & 19.19 & 19.80 & 2 & 124.8114 & 124.8100 & 623.4123 & 0.014 & 1.1229 & 2679.309 & 3121.633 & 0.07 & 342.552 & \mathrm{No}\end{array}$ $\begin{array}{lllllllllllllll}1.00 & 33.41 & 19.19 & 19.80 & 2 & 1244.8114 & 1244.8100 & 623.4123 & 0.0014 & 1.1229 & 2679.309 & 3121.633 & 0.000 & 3452.552 & \text { No }\end{array}$

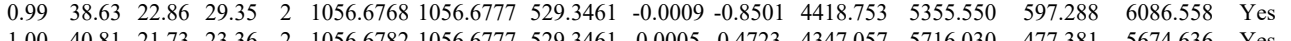

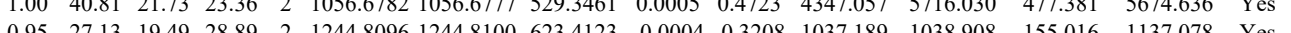

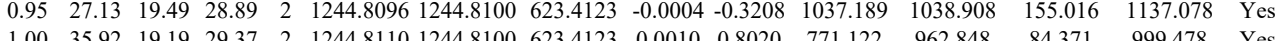

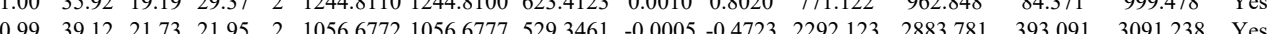

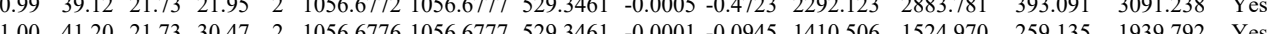

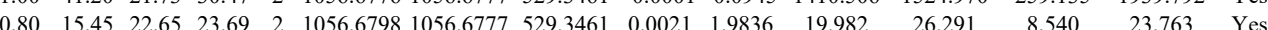

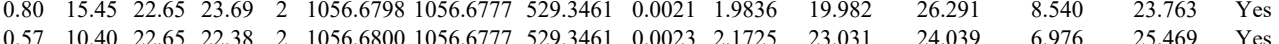

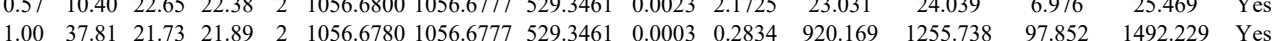
$\begin{array}{lllllllllllllll}1.00 & 37.81 & 21.73 & 1.89 & 2 & 1056.6780 & 1056.6777 & 529.3461 & 0.0003 & 0.2834 & 920.169 & 1255.738 & 97.852 & 1492.229 & \text { Yes } \\ 1.00 & 40.55 & 21.73 & 21.97 & 2 & 1056.6780 & 1056.6777 & 529.3461 & 0.0003 & 0.2834 & 1776.797 & 2121.754 & 45.627 & 2480.902 & \text { Yes }\end{array}$ $\begin{array}{llllllllllllllll}1.00 & 40.118 & 21.73 & 30.42 & 2 & 1056.6780 & 1056.6777 & 529.3461 & 0.0003 & 0.2834 & 1055.579 & 1167.922 & 161.490 & 1364.890 & \text { Yes }\end{array}$ $\begin{array}{llllllllllllllll}1.00 & 41.18 & 21.73 & 30.42 & 2 & 1056.670 & 056.677 & 52 . .3461 & 0.0003 & 0.2834 & 1055.579 & 1167.922 & 161.490 & 1364.890 & \text { Yes } \\ 1.00 & 39.11 & 21.73 & 21.81 & 2 & 1056.6780 & 1056.6777 & 529.3461 & 0.0003 & 0.2834 & 1907.061 & 2348.846 & 158.129 & 2733.726 & \text { Yes }\end{array}$ $\begin{array}{lllllllllllllll}1.00 & 41.41 & 21.73 & 28.20 & 2 & 1056.6782 & 1056.6777 & 529.3461 & 0.0005 & 0.4723 & 1250.686 & 1354.983 & 162.264 & 1668.685 & \text { Yes }\end{array}$ $\begin{array}{lllllllllllllll}0.99 & 36.35 & 21.73 & 28.08 & 2 & 1056.6782 & 1056.6777 & 529.3461 & 0.0005 & 0.4723 & 3523.025 & 3845.700 & 167.482 & 4513.902 & \text { Yes }\end{array}$

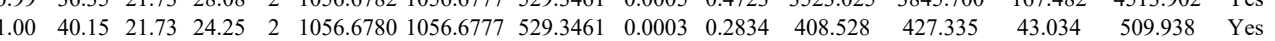
$\begin{array}{llllllllllllllll}1.00 & 40.47 & 21.73 & 22.01 & 2 & 1056.6782 & 1056.6777 & 529.3461 & 0.0005 & 0.4723 & 701.274 & 874.417 & 56.115 & 970.361 & \text { Yes }\end{array}$ $\begin{array}{lllllllllllllll}1.00 & 41.70 & 21.70 & 28.44 & 2 & 1056.6786 & 1056.6777 & 529.3461 & 0.0009 & 0.8501 & 345.019 & 459.734 & 34.693 & 489.187 & \text { Yes }\end{array}$

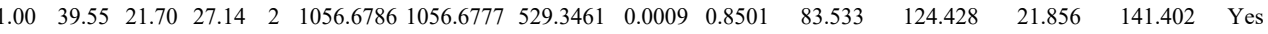
$\begin{array}{llllllllllllllll}0.99 & 37.20 & 21.73 & 30.15 & 2 & 1056.6780 & 1056.6777 & 529.3461 & 0.0003 & 0.2834 & 394.397 & 502.770 & 63.943 & 543.967 & \text { Yes }\end{array}$ $\begin{array}{lllllllllllllll}0.99 & 32.17 & 21.73 & 28.08 & 2 & 1056.6782 & 1056.6777 & 529.3461 & 0.0005 & 0.4723 & 273.040 & 304.888 & 65.639 & 326.071 & \text { Yes }\end{array}$

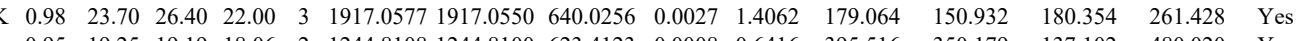
$\begin{array}{lllllllllllllll}0.95 & 19.25 & 19.19 & 18.06 & 2 & 1244.8108 & 1244.8100 & 623.4123 & 0.0008 & 0.6416 & 395.516 & 350.179 & 137.102 & 480.020 & \text { Yes }\end{array}$ $\begin{array}{lllllllllllllll}0.99 & 38.21 & 21.73 & 30.27 & 2 & 1056.6776 & 1056.6777 & 529.3461 & -0.0001 & -0.0945 & 803.717 & 931.228 & 43.936 & 888.785 & \text { Yes }\end{array}$ $\begin{array}{lllllllllllllll}1.00 & 40.48 & 21.73 & 28.36 & 2 & 1056.6780 & 1056.6777 & 529.3461 & 0.0003 & 0.2834 & 695.522 & 771.370 & 78.170 & 852.674 & \text { Yes }\end{array}$ $\begin{array}{llllllllllllllll}0.53 & 11.09 & 19.19 & 16.81 & 2 & 1244.8104 & 1244.8100 & 623.4123 & 0.0004 & 0.3208 & 148.789 & 209.510 & 68.749 & 302.959 & \text { Yes }\end{array}$

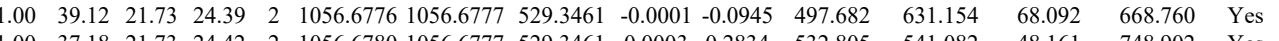
$\begin{array}{llllllllllllllll}1.00 & 37.18 & 21.73 & 24.42 & 2 & 1056.6780 & 1056.6777 & 529.3461 & 0.0003 & 0.2834 & 532.805 & 541.082 & 48.161 & 748.902 & \text { Yes } \\ 1.94 & 27.88 & 19.5 & 24.20 & 2 & 124.8094 & 124.8100 & 623.4123 & 0.0006 & 0.4812 & 103.455 & 105.116 & 23.911 & 9.916 & \text { Yes }\end{array}$

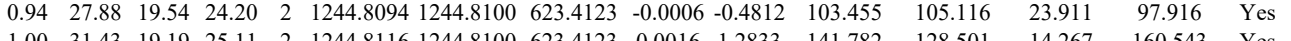
$\begin{array}{lllllllllllllll}1.00 & 31.43 & 19.19 & 25.11 & 2 & 1244.8116 & 1244.8100 & 623.4123 & 0.0016 & 1.2833 & 141.782 & 128.501 & 14.267 & 160.543 & \text { Yes } \\ 1.00 & 39.21 & 21.73 & 28.19 & 2 & 10566780 & 10566777 & 529.3461 & 0.0003 & 0.2834 & 490.891 & 616.832 & 29.146 & 671.818 & \text { Yes }\end{array}$

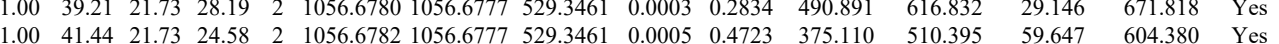

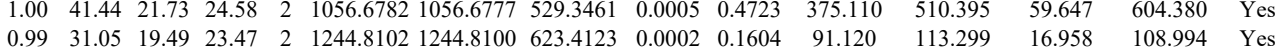

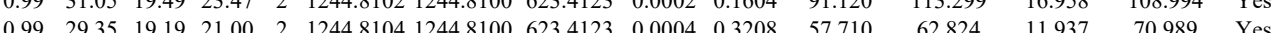

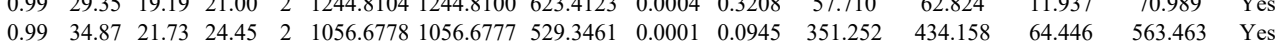

Table S-4 page 101 of 614 


\section{SLADELALVDVLEDK}

$\begin{array}{llllllllllll}0.89 .73 & 23.12 & 26.74 & 2 & 1589.9414 & 1589.9354 & 795.9750 & 0.0060 & 3.7689 & 11793.712 & 15 & \\ 0.91 & 28.73 & 26.63 & 17.85 & 3 & 1917.0529 & 1917.0550 & 640.0256 & -0.0021 & -1.0937 & 165.057 & 1\end{array}$

$\begin{array}{lllllllllllll}\text { SLADELALVDVLEDK } & 0.99 & 32.56 & 26.55 & 26.59 & 3 & 1917.0547 & 1917.0550 & 640.0256 & -0.0003 & -0.1562 & 101.479 & 13\end{array}$

$\begin{array}{llllllllllll}\text { SLADELALVDVLEDK } & 1.00 & 93.43 & 26.44 & 31.26 & 2 & 1917.0564 & 1917.0550 & 959.5348 & 0.0014 & 0.7295 & 26.999 \\ \text { SLADELALVDVLEDK } & 1.00 & \text { \#\#\#\#\# } & 26.43 & 31.05 & 2 & 1917.0566 & 1917.0550 & 959.5348 & 0.0016 & 0.8337 & 3333.259\end{array}$

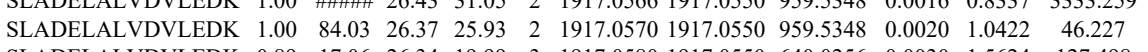
$\begin{array}{llllllllllll}\text { SLADELALVDVLEDK } & 0.89 & 17.06 & 26.34 & 19.99 & 3 & 1917.0580 & 1917.0550 & 640.0256 & 0.0030 & 1.5624 & 127.498\end{array}$ $\begin{array}{lllllllllllll}\text { SLADELALVDVLEDK } & 1.00 & 42.57 & 26.34 & 26.97 & 3 & 1917.0580 & 1917.0550 & 640.0256 & 0.0030 & 1.5624 & 110.478\end{array}$ $\begin{array}{llllllllllll}\text { SLADELALVDVLEDK } & 1.00 & 48.80 & 26.34 & 28.64 & 3 & 1917.0580 & 1917.0550 & 640.0256 & 0.0030 & 1.5624 & 125.447\end{array}$ $\begin{array}{lllllllllllll}\text { SLADELALVDVLEDK } & 0.79 & 14.27 & 26.39 & 18.14 & 3 & 1917.0583 & 1917.0550 & 640.0256 & 0.0033 & 1.7187 & 135.880\end{array}$ $\begin{array}{lllllllllllll}\text { SLADELALVDVLEDK } & 0.71 & 12.44 & 26.39 & 18.35 & 3 & 1917.0583 & 1917.0550 & 640.0256 & 0.0033 & 1.7187 & 99.658 & 11.28\end{array}$ $\begin{array}{lllll}1167.012 & 616789.524 & \text { Y } & 16 \\ \end{array}$ $\begin{array}{llllllllllll}\text { SLADELALVDVLEDK } & 1.00 & \text { \#\#\# } 26.42 & 31.88 & 2 & 1917.0586 & 1917.0550 & 959.5348 & 0.0036 & 1.8759 & 2001.730 & 3348\end{array}$ $\begin{array}{lllllllllllll}\text { SLADELALVDVLEDK } & 0.99 & 26.78 & 26.40 & 19.55 & 3 & 1917.0589 & 1917.0550 & 640.0256 & 0.0039 & 2.0312 & 151.766 & \\ \text { SLADELALVDVLEDK } & 0.81 & 18.07 & 26.40 & 20.52 & 3 & 1917.0601 & 1917.0550 & 640.0256 & 0.0051 & 2.6561 & 124.941 & 114 .\end{array}$ $\begin{array}{llllllllllllll}\text { SLADELALVDVLEDK } & 1.00 & 51.67 & 26.22 & 25.80 & 3 & 1917.0616 & 1917.0550 & 640.0256 & 0.0066 & 3.4374 & 201.867 & 133.7\end{array}$ $\begin{array}{lllllllllllll}\text { LIAPVAEEEATVPNNK } & 1.00 & 95.41 & 25.87 & 20.69 & 2 & 1982.0936 & 1982.0928 & 992.0537 & 0.0008 & 0.4032 & 796.602 & 852.76\end{array}$

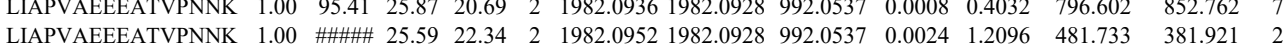

LKDDEVAQLK

LKDDEVAQL $\begin{array}{llllllllllllllll}0.95 & 57.50 & 23.87 & 29.48 & 2 & 1589.9352 & 1589.9354 & 795.9750 & -0.0002 & -0.1256 & 5205.911 & 6385.444 & 2365.734 & 6791.142 & \text { Yes } \\ 0.98 & 57.58 & 23.69 & 27.71 & 2 & 1589.9372 & 1589.9354 & 795.9750 & 0.0018 & 1.1307 & 9331.106 & 10577.017 & 4067.044 & 11992.644 & \text { Yes }\end{array}$

LKDDEVAQLK LKDDEVAQLK $\begin{array}{llllllllllllllllll}0.89 & 30.57 & 23.80 & 19.47 & 3 & 1589.9380 & 1589.9354 & 530.9857 & 0.0026 & 1.6322 & 14000.100 & 14327.668 & 6820.324 & 16854.875 & \text { Yes } & \end{array}$ $\begin{array}{llllllllllllllll} & 0.96 & 36.02 & 23.48 & 22.35 & 3 & 1589.9398 & 1589.9354 & 530.9857 & 0.0044 & 2.7622 & 23849.612 & 31655.190 & 11316.383 & 28169.194 & \text { Yes }\end{array}$ $\begin{array}{llllllllllllll} & \end{array}$

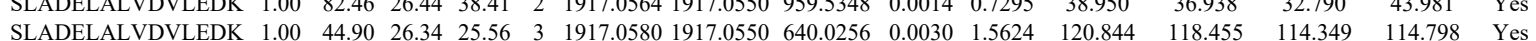
$\begin{array}{lllllllllllllll} & \end{array}$

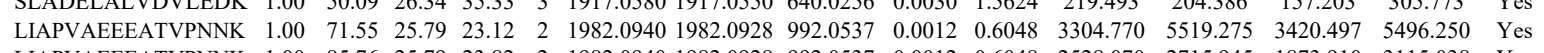
$\begin{array}{llllllllllllllll} & & & \end{array}$ $\begin{array}{llllllllllllllll}\text { LIAPVAEEEATV } & 1.00 & 47.77 & 25.76 & 23.09 & 3 & 1982.0965 & 1982.0928 & 661.7049 & 0.0037 & 1.8639 & 142.477 & 126.582 & 64.444 & 133.450 & \text { Yes } \\ \text { LKDDEVAQLK } & 0.94 & 57.49 & 22.79 & 27.42 & 2 & 1589.9498 & 1589.9354 & 795.9750 & 0.0144 & 9.0454 & 3335.000 & 4087.754 & 1636.963 & 4017.018 & \text { Yes }\end{array}$ $\begin{array}{llllllllllllllll}\text { LKDDEVAQLK } & 0.94 & 57.49 & 22.79 & 27.42 & 2 & 1589.9498 & 989.9354 & 795.9750 & 0.0144 & 9.0454 & 3335.000 & 4087.754 & 1636.963 & 4017.018 & \text { Yes } \\ \text { LKDDEVAQLK } & 0.95 & 59.30 & 22.67 & 28.73 & 2 & 1589.9508 & 1589.9354 & 795.9750 & 0.0154 & 9.6736 & 2263.668 & 2832.033 & 920.417 & 3086.847 & \text { Yes }\end{array}$

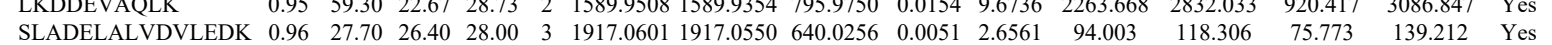
$\begin{array}{llllllllllllllll}\text { SLADELALVDVEDDK } & 0.80 & 22.73 & 25.87 & 23.17 & 3 & 1917.0691 & 1917.0550 & 440.0256 & 0.0141 & 7.3434 & 125.642 & 163.284 & 148.241 & 247.906 & \text { Yes }\end{array}$

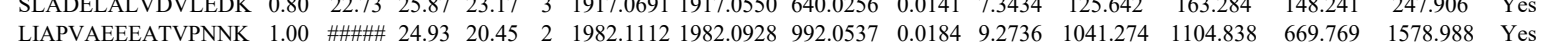

$\begin{array}{lllllllllllllllll}95 & \text { ALAPEYAK } & 1.00 & 53.01 & 27.77 & 22.54 & 2 & 1149.6694 & 1149.6637 & 575.8391 & 0.0057 & 4.9493 & 16616.578 & 10222.720 & 1136.016 & 9901.614 & \text { Yes }\end{array}$ $\begin{array}{lllllllllllllllll}\text { ALAPEYAK } & 0.95 & 38.97 & 27.75 & 21.60 & 2 & 1149.6698 & 1149.6637 & 575.8391 & 0.0061 & 5.2966 & 7978.198 & 4595.879 & 943.577 & 4243.943 & \text { Yes }\end{array}$ $\begin{array}{llllllllllllllll}\text { InSEVAVGFKK } & 1.00 & 98.23 & 25.19 & 19.45 & 3 & 3222.6952 & 3222.6904 & 1075.2374 & 0.0048 & 1.4880 & 0.000 & 8.193 & 0.000 & 4.745 & \text { No }\end{array}$

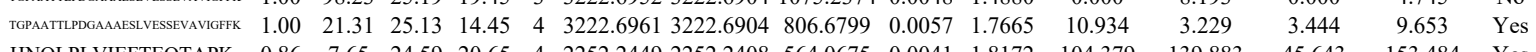
$\begin{array}{lllllllllllllllll}\text { HNQLPLVIEFTEQTAPK } & 0.86 & 7.65 & 24.59 & 20.65 & 4 & 2252.2449 & 2252.2408 & 564.0675 & 0.0041 & 1.8172 & 104.379 & 139.883 & 45.643 & 153.484 & \text { Yes } \\ \text { HNQLEV }\end{array}$ $\begin{array}{llllllllllllllll}\text { HNQLPLVIEFTEQTAPK } & 1.00 & 51.35 & 24.70 & 26.48 & 3 & 2252.2456 & 2252.2408 & 751.7542 & 0.0048 & 2.1284 & 141.509 & 115.900 & 65.440 & 189.672 & \text { Yes }\end{array}$ $\begin{array}{llllllllllllllll}\text { HNQLPLVIEFTEQTAPK } & 1.00 & 57.66 & 24.67 & 20.65 & 3 & 2252.2462 & 2252.2408 & 751.7542 & 0.0054 & 2.3944 & 146.932 & 60.721 & 115.245 & 211.436 & \text { Yes }\end{array}$ $\begin{array}{llllllllllllllll}\text { OFLQAAEADDIPFGITNSDVFSK } & 0.60 & 30.43 & 26.51 & 43.43 & 3 & 3000.5362 & 3000.5324 & 1001.1847 & 0.0038 & 1.2652 & 10.860 & 9.714 & 0.000 & 6.912 & \text { No }\end{array}$ $\begin{array}{llllllllllllllll}\text { ORLQAAEAIDDIFGIITSNSDVFSK } & 1.00 & 71.79 & 26.57 & 17.83 & 3 & 3000.5392 & 3000.5324 & 1001.1847 & 0.0068 & 2.2640 & 22.097 & 0.000 & 18.687 & 0.000 & \text { No }\end{array}$

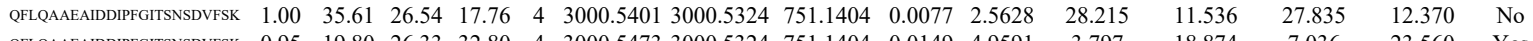
\begin{tabular}{lllllllllllllllll}
\hline & 26.33 & 32.80 & 4 & 3000.5473 & 3000.5324 & 751.1404 & 0.0149 & 4.9591 & 3.797 & 18.874 & 7.036 & 23.560 & Yes
\end{tabular}

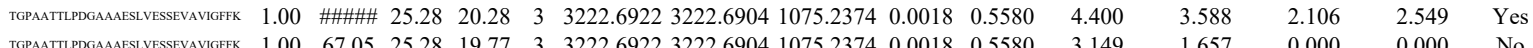
$\begin{array}{llllllllllllllll} & 1.00 & 67.05 & 25.28 & 19.77 & 3 & 3222.6922 & 3222.6904 & 1075.2374 & 0.0018 & 0.5580 & 3.149 & 1.657 & 0.000 & 0.000 & \text { No }\end{array}$ $\begin{array}{lllllllllllllll} & \end{array}$ $\begin{array}{lllllllllllllll} & \end{array}$

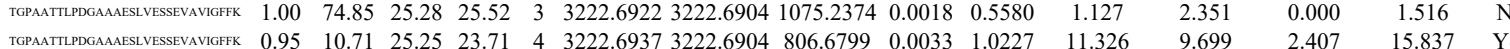

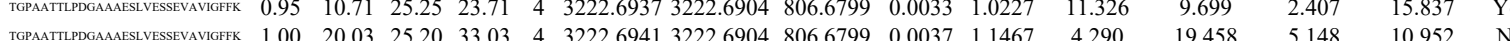

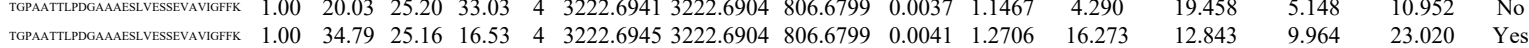

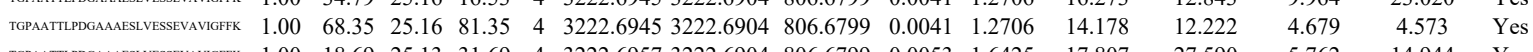

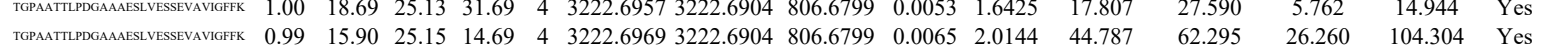




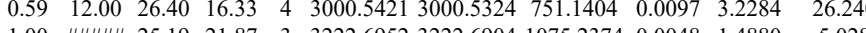
$\begin{array}{lllllllllll} & 0.0040\end{array}$

$\begin{array}{llllllllllll} & \end{array}$

FFPASADR

ILFIFIDSDHTDNQR

ILFIFIDSDHTDNQR $\begin{array}{llllll} & (14.582 & 67.194\end{array}$

$\begin{array}{lllllllllllllll}1.00 & 2.51 & 27.85 & 27.58 & 3 & 1977.0124 & 1977.0078 & 660.0099 & 0.0046 & 2.3232 & 8477.342 & 5710.010\end{array}$

$\begin{array}{lllllllllllll}0.80 & 30.73 & 26.82 & 26.65 & 2 & 1053.5426 & 1053.5365 & 527.7755 & 0.0061 & 5.7789 & 22520.183 & 16429.691 \\ 0.50 & 24.50 & 26.82 & 32.78 & 2 & 1053.5426 & 1053.5365 & 527.7755 & 0.0061 & 5.7789 & 30759.197 & 21185.315 \\ 1.00 & 7.86 & 27.90 & 34.21 & 2 & 197.62\end{array}$

$\begin{array}{llllllllllll}0.50 & 24.50 & 26.82 & 32.78 & 2 & 1053.5426 & 1053.5365 & 527.7755 & 0.0061 & 5.7789 & 30759.197 & 21185.315 \\ 1.00 & 78.86 & 27.90 & 34.21 & 2 & 1977.0122 & 1977.0078 & 989.5112 & 0.0044 & 2.2233 & 126.996 & 88.695\end{array}$

LFIFIDSDHTDNQR $\begin{array}{llllllllllll}1.00 & 85.96 & 27.92 & 23.23 & 3 & 1977.0145 & 1977.0078 & 660.0099 & 0.0067 & 3.3838 & 2639.365 & 1727.097\end{array}$ $\begin{array}{llllllllllll}1.00 & 73.03 & 27.92 & 22.25 & 3 & 1977.0145 & 1977.0078 & 660.0099 & 0.0067 & 3.3838 & 2751.175 & 1681.891\end{array}$

VHSTLK

VHSFTKK

VHSFPTLK

VHSFPTLK

VHSFPTLK

VHSFPTLK

THSFTK

ILEFFGLK

ILEFFGLK

ILEFFGLK

ILEFFGLK

ILEFFGLK

ILEFFGLK

ILEFFGLK

THILLFLPK

THILLFLPK

THILLFLPK

THILLFLPK

THILLFLPK

THILLFLPK

THILLFLPK

THILLFLPK

THILLFLPK

THILLFLPK

THILLFLPK

THILLFLPK

THILLFLPK

THILLFLPK

THILLFLPK $\begin{array}{lllllllllllllllll}0.95 & 20.31 & 25.35 & 21.37 & 3 & 1215.7264 & 1215.7219 & 406.2479 & 0.0045 & 3.6923 & 15065.277 & 8797.995 & 1230.714 & 8458.129 & \text { Y S S }\end{array}$ $\begin{array}{llllllllllllllll}1.00 & 51.88 & 25.35 & 23.31 & 2 & 1215.7266 & 1215.7219 & 608.8682 & 0.0047 & 3.8596 & 38603.229 & 20123.404 & 905.822 & 22855.384 & \text { Yes }\end{array}$ $\begin{array}{lllllllllllllll}0.86 & 18.24 & 25.35 & 2.42 & 3 & 1215.7267 & 1215.7219 & 406.2479 & 0.0048 & 3.9385 & 72291.499 & 47127.246 & 4383.622 & 42376.512 & \text { Yes }\end{array}$ $\begin{array}{lllllllllllllllll}1.00 & 51.82 & 25.35 & 23.31 & 2 & 1215.7268 & 1215.7219 & 608.8682 & 0.0049 & 4.0238 & 38582.143 & 17673.954 & 1630.627 & 21437.676 & \text { Yes } \\ 1.00 & 51.39 & 25.77 & 22.72 & 2 & 1215.7320 & 1215.7219 & 608.8682 & 0.0101 & 82940 & 21116550 & 11551.598 & 1398.512 & 10667.891 & \text { Yes }\end{array}$ $\begin{array}{llllllllllllllllll}0.63 & 19.56 & 25.77 & 19.18 & 3 & 1215.7321 & 1215.7219 & 4062479 & 0.0102 & 8.3692 & 16856.608 & 11186.080 & 1302.777 & 9831.361 & \text { Yes }\end{array}$

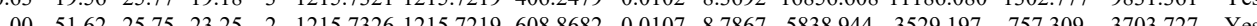
$\begin{array}{llllllllllllllll}1.00 & 51.18 & 23.724 & 36.67 & 2 & 1253.7656 & 1253.7627 & 627.8886 & 0.0029 & 23093 & 23080715 & 12351.654 & 0.000 & 18314553 & \text { No }\end{array}$ $\begin{array}{lllllllllllllll}100 & 5128 & 23.24 & 38.93 & 2 & 1253.76561253 .7627 & 627.8886 & 0.0029 & 2.3093 & 17824.644 & 10797.899 & 192254 & 15342.596 & \text { Yes }\end{array}$ $\begin{array}{lllllllllllllll}0.86 & 15.05 & 23.30 & 21.86 & 3 & 1253.7637 & 1253.7627 & 418.9282 & 0.0010 & 0.7957 & 584.091 & 204.276 & 44.542 & 549.050 & \text { Yes }\end{array}$

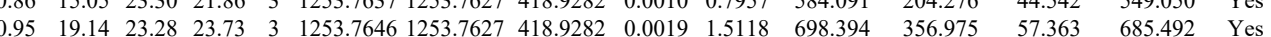
$\begin{array}{lllllllllllllll}1.00 & 51.24 & 23.14 & 38.83 & 2 & 1253.7660 & 1253.7627 & 627.8886 & 0.0033 & 2.6278 & 17788.571 & 10054.321 & 0.000 & 15580.416 & \text { No }\end{array}$ $\begin{array}{lllllllllllllll}1.00 & 51.37 & 23.14 & 39.26 & 2 & 1253.7660 & 1253.7627 & 627.8886 & 0.0033 & 2.6278 & 58403.727 & 32464.680 & 0.000 & 53360.586 & \text { No }\end{array}$ $\begin{array}{llllllllllllllll}1.00 & 51.11 & 23.14 & 38.92 & 2 & 1253.7660 & 1253.7627 & 627.8886 & 0.0033 & 2.6278 & 10865.528 & 5772.212 & 0.000 & 9671.964 & \text { No }\end{array}$ $\begin{array}{lllllllllllllllll}1.00 & 51.29 & 23.12 & 36.78 & 2 & 1253.7662 & 1253.7627 & 627.8886 & 0.0035 & 2.7871 & 20768.342 & 13119.477 & 0.000 & 18500.541 & \text { No }\end{array}$

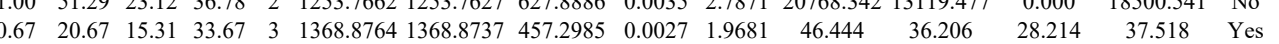
$\begin{array}{lllllllllllllll}0.67 & 13.65 & 15.31 & 26.65 & 3 & 1368.8770 & 1368.8737 & 457.2985 & 0.0033 & 2.4054 & 100.936 & 83.723 & 90.426 & 122.256 & \text { Yes }\end{array}$ $\begin{array}{llllllllllllllll}0.60 & 13.40 & 15.31 & 26.40 & 3 & 1368.8773 & 1368.8737 & 457.2985 & 0.0036 & 2.6241 & 48.856 & 34.681 & 48.043 & 28.906 & \text { No }\end{array}$ $\begin{array}{lllllllllllllll}0.60 & 3.80 & 15.31 & 16.80 & 3 & 1368.8779 & 1368.8737 & 457.2985 & 0.0042 & 3.0614 & 125.199 & 98.779 & 108.265 & 146.080 & \text { Yes }\end{array}$ $\begin{array}{llllllllllllllll}1.00 & 46.79 & 15.44 & 19.87 & 2 & 1368.8794 & 1368.8737 & 685.4441 & 0.0057 & 4.1579 & 13495.603 & 5311.561 & 1253.895 & 6940.312 & \text { Yes }\end{array}$

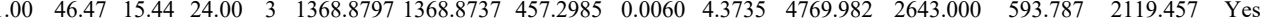
$\begin{array}{lllllllllllllll}1.00 & 50.53 & 15.44 & 20.77 & 2 & 1368.8800 & 1368.8737 & 685.4441 & 0.0063 & 4.5955 & 15554.515 & 6146.787 & 1361.600 & 7553.902 & \text { Yes }\end{array}$ $\begin{array}{lllllllllllllll}1.00 & 28.06 & 16.13 & 15.45 & 3 & 1368.8806 & 1368.8737 & 457.2985 & 0.0069 & 5.0295 & 33537.518 & 15964.238 & 2649.651 & 19554.870 & \text { Yes }\end{array}$ $\begin{array}{llllllllllllllll}0.66 & 20.59 & 15.56 & 33.59 & 3 & 1368.8761 & 1368.8737 & 457.2985 & 0.0024 & 1.7494 & 23.578 & 20.496 & 20.984 & 18.452 & \text { No }\end{array}$ $\begin{array}{llllllllllllllll}1.00 & 30.14 & 15.31 & 21.98 & 3 & 1368.8779 & 1368.8737 & 457.2985 & 0.0042 & 3.0614 & 5659.398 & 3921.778 & 56.645 & 3602.280 & \text { Yes }\end{array}$ $\begin{array}{lllllllllllllllll}1.00 & 52.36 & 15.31 & 20.95 & 2 & 1368.8788 & 1368.8737 & 685.4441 & 0.0051 & 3.7202 & 13041.855 & 4236.833 & 1973.331 & 6620.638 & \text { Yes }\end{array}$ $\begin{array}{lllllllllllllllll}1.00 & 52.46 & 16.13 & 26.45 & 2 & 1368.8802 & 1368.8737 & 685.4441 & 0.0065 & 4.7414 & 14039.062 & 4847.655 & 1332.188 & 7005.781 & \text { Yes }\end{array}$ $\begin{array}{lllllllllllllllll}1.00 & 28.71 & 16.13 & 15.96 & 3 & 1368.8806 & 1368.8737 & 457.2985 & 0.0069 & 5.0295 & 30641.987 & 17758.375 & 1315.169 & 17089.497 & \text { Yes }\end{array}$ $\begin{array}{llllllllllllllll}0.99 & 23.45 & 15.56 & 20.40 & 3 & 1368.8755 & 1368.8737 & 457.2985 & 0.0018 & 1.3121 & 4878.774 & 2605.805 & 667.501 & 3076.504 & \text { Yes }\end{array}$ $\begin{array}{llllllllllllllll}1.00 & 38.05 & 15.31 & 21.31 & 3 & 1368.8764 & 1368.8737 & 457.2885 & 0.0027 & 1.9681 & 14367.847 & 7984.647 & 742.476 & 9416.779 & \text { Yes }\end{array}$ $\begin{array}{lllllllllllllll}1.00 & 50.35 & 15.31 & 20.59 & 2 & 1368.8766 & 1368.8737 & 685.4441 & 0.0029 & 2.1154 & 5520.734 & 1945.494 & 684.535 & 2647.282 & \text { Yes } \\ 1.00 & 52.44 & 15.31 & 20.71 & 2 & 1368.8768 & 1368.8737 & 685.441 & 0.0031 & 2.2613 & 5889.487 & 2054.914 & 836.910 & 2783.638 & \text { Yes }\end{array}$

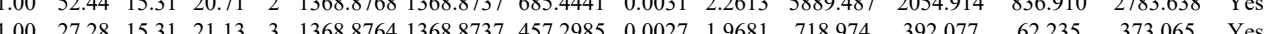

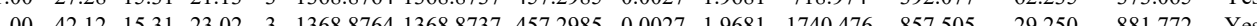

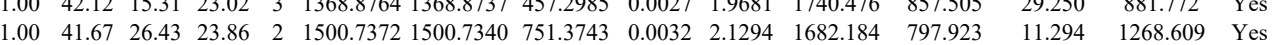

Table S- 4 page 103 of 614 

SNFAEALAAHK SNFAEALAAHK

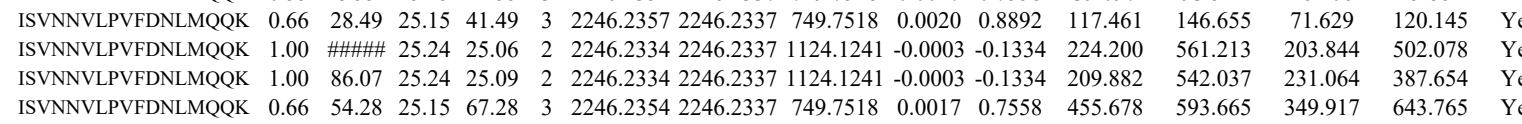


$\begin{array}{llllllllllll}0.99 & 43.87 & 28.23 & 20.03 & 2 & 1509.8060 & 1509.7918 & 755.9032 & 0.0142 & 9.3926 & 3387.285 & 1856.612\end{array}$

Table S-4 page 105 of 614 


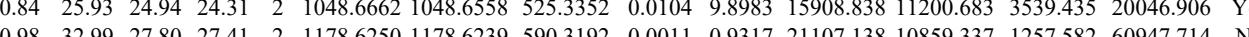

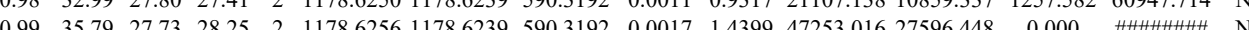

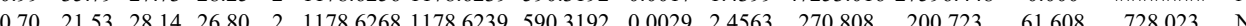
$\begin{array}{lllllllllllllll}0.99 & 43.63 & 19.73 & 33.23 & 2 & 1032.6698 & 1032.6609 & 517.3377 & 0.0089 & 8.6017 & 62808.035 & 36514.105 & 402.308 & 96136.913 & \text { Y }\end{array}$

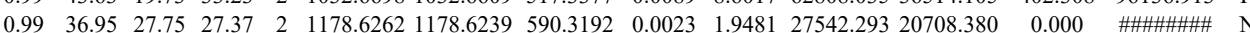
$\begin{array}{llllllllllllllllll}0.97 & 32.75 & 28.12 & 27.51 & 2 & 1178.6274 & 1178.6239 & 590.3192 & 0.0035 & 2.9645 & 18417.574 & 12252.190 & 0.000 & 55614.795 & \mathrm{No}\end{array}$ $\begin{array}{llllllllllllllll}0.69 & 26.40 & 28.17 & 35.76 & 2 & 1178.6282 & 1178.6239 & 590.3192 & 0.0043 & 3.6421 & 219.330 & 168.450 & 57.858 & 421.659 & \text { Y S }\end{array}$ $\begin{array}{lllllllllllllll}0.69 & 26.40 & 28.17 & 35.76 & 2 & 1778.6282 & 1778.6239 & 590.3192 & 0.0043 & 3.6421 & 219.330 & 168.450 & 57.858 & 421.659 & \text { Yes } \\ 0.99 & 40.73 & 19.73 & 31.39 & 2 & 1032.6696 & 1032.6609 & 517.3377 & 0.0087 & 8.4084 & 31112.493 & 19905.601 & 2461.021 & 42479.481 & \text { Yes }\end{array}$ $\begin{array}{llllllllllllllll}0.99 & 34.40 & 27.79 & 28.99 & 2 & 1178.6260 & 1178.6239 & 590.3192 & 0.0021 & 1.7084 & 1172.493 & 1854.157 & 10935.373 & 2462.309 & 50968.800 & \text { No }\end{array}$ $\begin{array}{lllllllllllllllll}0.99 & 37.44 & 27.77 & 27.67 & 2 & 1178.6266 & 1178.6239 & 590.3192 & 0.0027 & 2.2869 & 23125.462 & 13678.668 & 995.587 & 76549.684 & \text { No }\end{array}$ \begin{tabular}{|llllllllllllllll}
0.64 & 17.44 & 27.80 & 25.26 & 2 & 1178.6248 & 1178.6239 & 590.3192 & 0.0009 & 0.7623 & 354.058 & 403.241 & 446.090 & 901.044 & Yes
\end{tabular} $\begin{array}{llllllllllllllll}\text { SALSGHLETVILGLLK } & 0.66 & 37.96 & 15.05 & 50.96 & 3 & 1938.1774 & 1938.1757 & 647.0658 & 0.0017 & 0.8757 & 169.103 & 150.150 & 75.631 & 246.267 & \text { Yes }\end{array}$ $\begin{array}{lllllllllllllllll}\text { SALSGHLETVILGLLK } & 0.84 & 91.73 & 15.05 & \text { \#\#\#\# } & 2 & 1938.1776 & 1938.1757 & 970.0951 & 0.0019 & 0.9793 & 828.551 & 481.160 & 246.001 & 918.571 & \text { Yes }\end{array}$

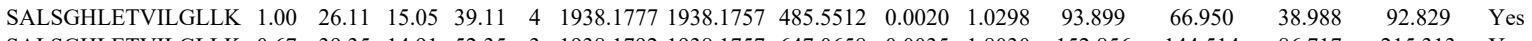
\begin{tabular}{llllllllllllllll} 
SALSGHLETVILGLLK & 0.67 & 39.35 & 14.91 & 52.35 & 3 & 1938.1792 & 1938.1757 & 647.0658 & 0.0035 & 1.8030 & 152.856 & 144.514 & 86.717 & 215.313 & Yes \\
\hline
\end{tabular}

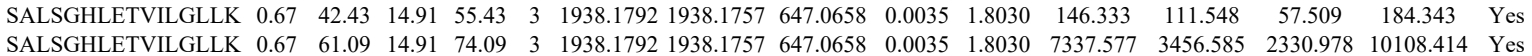

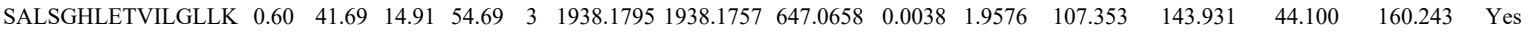
$\begin{array}{llllllllllllllll}\text { SALSGHLETVILGLLK } & 1.00 & 26.88 & 14.91 & 39.88 & 4 & 1938.1797 & 1938.1757 & 485.5512 & 0.0040 & 2.0595 & 132.467 & 114.054 & 92.935 & 67.886 & \text { Yes }\end{array}$ $\begin{array}{llllllllllllllll}\text { SALSGHLETVILGLLK } & 0.60 & 63.80 & 15.44 & 76.80 & 3 & 1938.1801 & 1938.1757 & 647.0658 & 0.0044 & 2.2666 & 535.065 & 338.534 & 135.272 & 645.013 & \text { Yes }\end{array}$ $\begin{array}{lllllllllllllllll}\text { SALSGHLETVILGLLK } & 1.00 & 24.47 & 15.44 & 16.71 & 4 & 1938.1801 & 1938.1757 & 485.5512 & 0.0044 & 2.2655 & 118.641 & 59.424 & 6.072 & 226.585 & \text { No }\end{array}$ $\begin{array}{llllllllllllllll}\text { SALSGHLETVILGLLK } & 1.00 & 37.00 & 15.44 & 19.34 & 4 & 1938.1817 & 1938.1757 & 485.5512 & 0.0060 & 3.0893 & 26.400 & 24.127 & 48.108 & 48.785 & \text { No }\end{array}$

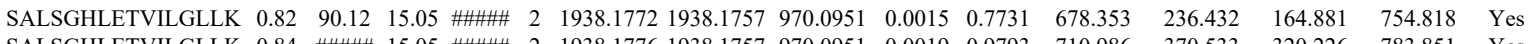

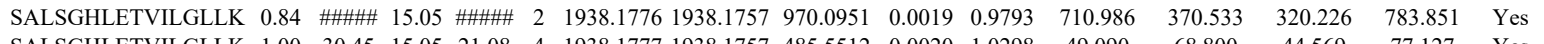
$\begin{array}{llllllllllllllll}\text { SALSGHLETVILGLLK } & 1.00 & 30.45 & 15.05 & 21.08 & 4 & 1938.1777 & 1938.1757 & 485.5512 & 0.0020 & 1.0298 & 49.090 & 68.800 & 44.569 & 77.127 & \text { Yes }\end{array}$

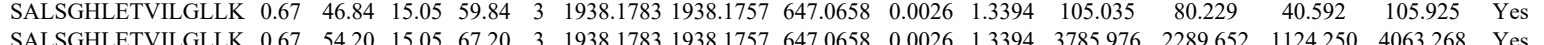

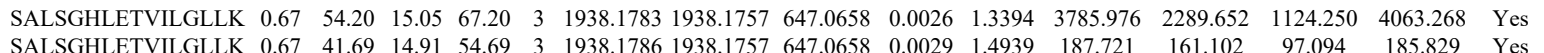

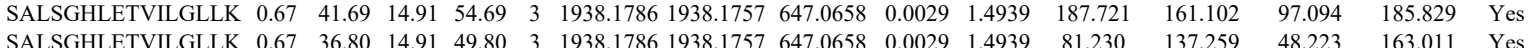
$\begin{array}{llllllllllllll} & \end{array}$

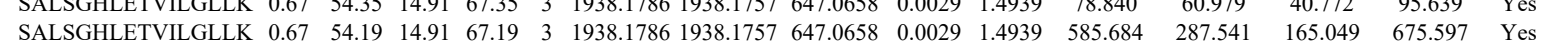

Table S-4 page 106 of 614 
\begin{tabular}{llllllllllll} 
SALSGHLETVILGLLK & 0.72 & 91.06 & 14.91 & \#\#\#\# & 2 & 1938.1786 & 1938.1757 & 970.0951 & 0.0029 & 1.4947 & 458.152 \\
\hline
\end{tabular}

$\begin{array}{llllllllllllll}\text { GDLENAFLNLVQCIONKPLYFADR } & 1.00 & \text { \#\#\#\# } 26.07 & 19.96 & 3 & 3114.5962 & 3114.5874 & 1039.2031 & 0.0088 & 2.8227 & 3832.687 & 22\end{array}$ $\begin{array}{llllllllllllll} & & & \end{array}$

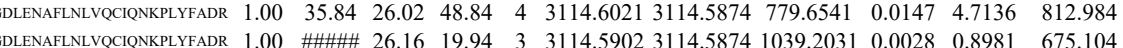

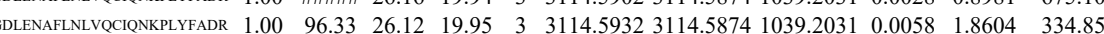

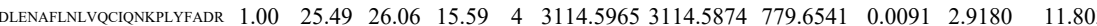
$\begin{array}{llllllll}17.41 & 4 & 3114.5965 & 3114.5874 & 779.6541 & 0.0091 & 2.9180 & 34.633\end{array}$ $\begin{array}{lllllllllllll}\text { TDLEK } & 0.68 & 18.32 & 27.85 & 26.87 & 2 & 892.5118 & 892.5109 & 447.2627 & 0.0009 & 1.0061 & 2027.990 \\ \text { TDLEK } & 0.64 & 17.56 & 27.85 & 26.03 & 2 & 892.5122 & 892.5109 & 447.2627 & 0.0013 & 1.4533 & 1778351\end{array}$ $\begin{array}{lllllllllllll}0.64 & 17.56 & 27.85 & 26.03 & 2 & 892.5122 & 892.5109 & 447.2627 & 0.0013 & 1.4533 & 1778.351\end{array}$ $\begin{array}{lllllllllllll}\text { AEDGSVIDYELIDQDAR } & 0.86 & 44.07 & 26.02 & 17.74 & 2 & 2051.9614 & 2051.9769 & 1026.9957 & -0.0155 & -7.5463 & 23.463\end{array}$ $\begin{array}{llllllllllll}\text { AEDGSVIDYELIDQDAR } & 1.00 & \text { \#\#\#\# } 26.83 & 28.84 & 2 & 2051.9794 & 2051.9769 & 1026.9957 & 0.0025 & 1.2171 & 11.689 \\ \text { AEDGSVIDYELDQDAR } & 1.00 & 93.80 & 26.83 & 30.10 & 2 & 2051.9794 & 2051.9769 & 1026.9957 & 0.0025 & 1.2171 & 19.192\end{array}$

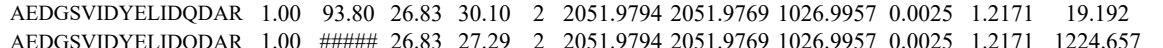
$\begin{array}{lllllllllll}\text { AEDGSVIDYELIDQDAR } & 1.00 & \text { \#\#\#\# } 26.83 & 27.29 & 2 & 2051.9794 & 2051.9769 & 1026.9957 & 0.0025 & 1.2171 & 1224.657 \\ \text { AEDGSVIDYELIDQDAR } & 1.00 & \text { \#\#\#\# } 26.83 & 27.17 & 2 & 2051.9794 & 2051.9769 & 1026.9957 & 0.0025 & 1.2171 & 23.502\end{array}$ $\begin{array}{llllllllllll}\text { AEDGSVIDYELIDQDAR } & 1.00 & \text { \#\#\#\# } & 26.83 & 27.17 & 2 & 2051.9794 & 2051.9769 & 1026.9957 & 0.0025 & 1.2171 & 23.502 \\ \text { AEDGSVIDYELIDQDAR } & 1.00 & 40.44 & 26.86 & 21.26 & 3 & 2051.9803 & 2051.9769 & 684.9996 & 0.0034 & 1.6545 & 254.112\end{array}$ $\begin{array}{lllllllllllll}\text { AEDGSVIDYELIDQDAR } & 1.00 & 40.44 & 26.86 & 21.26 & 3 & 2051.9803 & 2051.9769 & 684.9996 & 0.0034 & 1.6545 & 254.112 \\ \text { AEDGSVIDYELIDQDAR } & 1.00 & \# \# \# \# 27.01 & 30.10 & 2 & 2051.9814 & 2051.9769 & 1026.9957 & 0.0045 & 2.1909 & 457.889\end{array}$

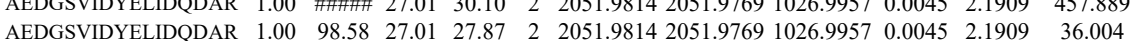

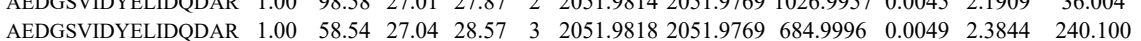

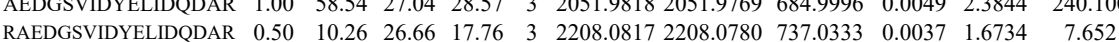
$\begin{array}{llllllllllllll}\text { SALSGHLETVILGLLK } & 0.67 & 40.25 & 14.91 & 53.25 & 3 & 1938.1789 & 1938.1757 & 647.0658 & 0.0032 & 1.6485 & 101.305\end{array}$ $\begin{array}{llllllllllll}\text { SALSGHLETVILGLLK } & 0.67 & 59.66 & 15.05 & 72.66 & 3 & 1938.1783 & 1938.1757 & 647.0658 & 0.0026 & 1.3394 & 18.643\end{array}$ $\begin{array}{llllllllllll}\text { SALSGHLETVILGLLK } & 0.60 & 76.00 & 14.91 & 89.00 & 3 & 1938.1795 & 1938.1757 & 647.0658 & 0.0038 & 1.9576 & 103.625\end{array}$ $\begin{array}{lllllllllllll}\text { SALSGHLETVILGLLK } & 0.60 & 72.36 & 15.44 & 85.36 & 3 & 1938.1798 & 1938.1757 & 647.0658 & 0.0041 & 2.1121 & 114.705\end{array}$ $\begin{array}{lllllllllllll}\text { SALSGHLETVILGLLK } & 0.66 & 60.00 & 15.05 & 73.00 & 3 & 1938.1774 & 1938.1757 & 647.0658 & 0.0017 & 0.8757 & 90.617\end{array}$ $\begin{array}{llllllllllll}\text { SALSGHLETVILGLLK } & 0.67 & 57.13 & 15.05 & 70.13 & 3 & 1938.1783 & 1938.1757 & 647.0658 & 0.0026 & 1.3394 & 107.447\end{array}$ $\begin{array}{llllllllllll}\text { SALSGHLETVILGLLK } & 0.67 & 52.16 & 15.05 & 65.16 & 3 & 1938.1783 & 1938.1757 & 647.0658 & 0.0026 & 1.3394 & 48.521\end{array}$ $\begin{array}{llllllllllllll}\text { SALSGHLETVILGLLK } & 0.67 & 70.38 & 15.05 & 83.38 & 3 & 1938.1783 & 1938.1757 & 647.0658 & 0.0026 & 1.3394 & 17.637\end{array}$

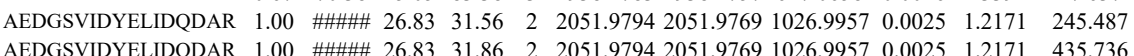

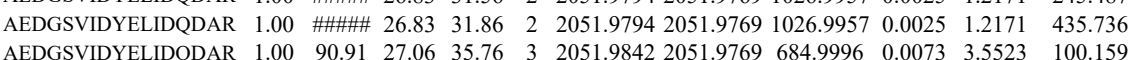
$\begin{array}{lllllllllllllll}\text { AEDGSVIDYELIDQDAR } & 1.00 & 90.91 & 27.06 & 35.76 & 3 & 2051.9842 & 2051.9769 & 684.9996 & 0.0073 & 3.5523 & 100.159\end{array}$ $\begin{array}{llllllllllllll}\text { AEDGSVIDYELIDQDAR } & 1.00 & 71.89 & 27.04 & 31.61 & 3 & 2051.9845 & 2051.9769 & 684.9996 & 0.0076 & 3.6983 & 29.393 \\ \end{array}$ $\begin{array}{lllllllllllll}\text { RAEDGSVIDYELIDQDAR } & 1.00 & 66.47 & 26.63 & 22.68 & 2 & 2208.0794 & 2208.0780 & 105.0463 & 0.0014 & 0.6335 & 24.327 \\ \end{array}$ $\begin{array}{llllllllllllll}\text { RAEDGSVIDYELIDQDAR } & 1.00 & 60.31 & 26.66 & 33.14 & 3 & 2208.0817 & 2208.0780 & 737.0333 & 0.0037 & 1.6734 & 177.833\end{array}$ $\begin{array}{llllllllllll}\text { SALSGHLETVILGLLK } & 0.60 & 40.08 & 14.91 & 53.08 & 3 & 1938.1795 & 1938.1757 & 647.0658 & 0.0038 & 1.9576 & 108.074\end{array}$ $\begin{array}{llllllllllll}\text { SALSGHLETVILGLLK } & 0.60 & 39.29 & 14.91 & 52.29 & 3 & 1938.1795 & 1938.1757 & 647.0658 & 0.0038 & 1.9576 & 85.491\end{array}$ $\begin{array}{lllllllllllll}\text { GVDEVTIVNILTNR } & 1.00 & 33.98 & 26.87 & 17.73 & 3 & 1685.9461 & 1685.9434 & 562.9884 & 0.0027 & 1.5986 & 21.401\end{array}$ $\begin{array}{lllllllllllll}\text { GVDEVTIVNILTNR } & 1.00 & 32.43 & 26.84 & 17.42 & 3 & 1685.9458 & 1685.9434 & 562.9884 & 0.0024 & 1.4210 & 25.116\end{array}$ $\begin{array}{llllllllllll}\text { SALSGHLETVILGLLK } & 1.00 & 36.66 & 14.91 & 49.66 & 4 & 1938.1785 & 1938.1757 & 485.5512 & 0.0028 & 1.4417 & 9.548\end{array}$

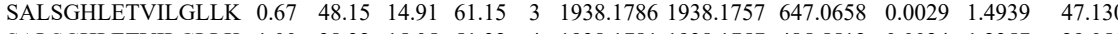
$\begin{array}{lllllllllllll}\text { SALSGHLETVILGLLK } & 1.00 & 38.32 & 15.05 & 51.32 & 4 & 1938.1781 & 1938.1757 & 485.5512 & 0.0024 & 1.2357 & 29.055\end{array}$

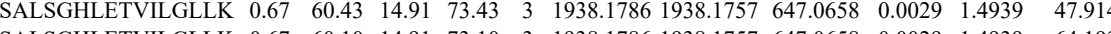

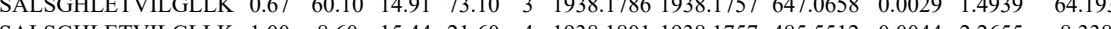
$\begin{array}{lllllllllllll}\text { SALSGHLETVILGLLK } & 1.00 & 8.60 & 15.44 & 21.60 & 4 & 1938.1801 & 1938.1757 & 485.5512 & 0.0044 & 2.2655 & 8.338\end{array}$ $\begin{array}{llllllllllllll} & \text { SALSGHLETVLGLK } & 1.00 & 45.75 & 15.05 & 58.75 & 4 & 1938.1781 & 1938.1757 & 485.5512 & 0.0024 & 1.2357 & 13.248\end{array}$

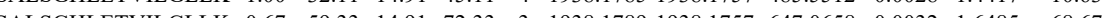
$\begin{array}{llllllllllll}\text { SALSGHLETVILGLLK } & 1.00 & 43.54 & 15.05 & 56.54 & 4 & 1938.1761 & 1938.1757 & 485.5512 & 0.0004 & 0.2060 & 27.156\end{array}$ 
$\begin{array}{llllllllllll}\text { SALSGHLETVILGLLK } & 0.67 & 52.27 & 14.91 & 65.27 & 3 & 1938.1786 & 1938.1757 & 647.0658 & 0.0029 & 1.4939 & 16.339\end{array}$ $2.8833 \quad 10.76$ $\begin{array}{llllllllllllll}\text { SALSGHLETVILGLLK } & 1.00 & 26.73 & 15.44 & 39.73 & 4 & 1938.1805 & 1938.1757 & 485.5512 & 0.0048 & 2.4714 & 14.617\end{array}$ $\begin{array}{lllllllllllll}\text { SALSGHLETVILGLLK } & 1.00 & 25.78 & 15.44 & 17.45 & 4 & 1938.1809 & 1938.1757 & 485.5512 & 0.0052 & 2.6774 & 23.246 \\ \text { SALSGHLETVILGLLK } & 0.67 & 53.85 & 14.91 & 66.85 & 3 & 1938.1786 & 1938.1757 & 647.0658 & 0.0029 & 1.4939 & 57.633\end{array}$ $\begin{array}{lllllllllllll}\text { SALSGHLETVILGLLK } & 0.67 & 53.85 & 14.91 & 66.85 & 3 & 1938.1786 & 1938.1757 & 647.0658 & 0.0029 & 1.4939 & 57.633 \\ \text { SALSGHLETVILGLLK } & 1.00 & 31.21 & 14.91 & 44.21 & 4 & 1938.1793 & 1938.1757 & 485.5512 & 0.0036 & 1.8536 & 20.244\end{array}$ $\begin{array}{llllllllllll}\text { SALSGHLETVILGLLK } & 1.00 & 31.21 & 14.91 & 44.21 & 4 & 1938.1793 & 1938.1757 & 485.5512 & 0.0036 & 1.8536 & 20.244 \\ \text { SALSGHLETVILGLLK } & 0.60 & 49.50 & 15.44 & 62.50 & 3 & 1938.1801 & 1938.1757 & 647.0658 & 0.0044 & 2.2666 & 41.729\end{array}$ $\begin{array}{llllllllllll}\text { SALSGHLETVILGLLK } & 0.60 & 49.50 & 15.44 & 62.50 & 3 & 1938.1801 & 1938.1757 & 647.0658 & 0.0044 & 2.2666 & 41.729 \\ \text { SALSGHLETVILGLLK } & 1.00 & 18.21 & 15.44 & 31.21 & 4 & 1938.1813 & 1938.1757 & 485.5512 & 0.0056 & 2.8833 & 9.127\end{array}$

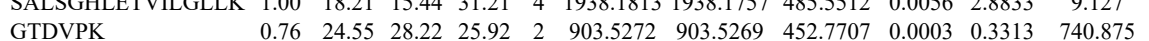
$\begin{array}{llllllllllll}0.76 & 24.55 & 28.22 & 25.92 & 2 & 903.5272 & 903.5269 & 452.7707 & 0.0003 & 0.3313 & 740.875 \\ 0.96 & 29.21 & 28.22 & 22.96 & 2 & 903.5276 & 903.5269 & 452.7707 & 0.0007 & 0.7730 & 391.574\end{array}$ AYTNFDAER $\begin{array}{lllllllllllll}0.96 & 29.21 & 28.22 & 22.96 & 2 & 903.5276 & 903.5269 & 452.7707 & 0.0007 & 0.7730 & 391.574\end{array}$ TNQELQEINR $\begin{array}{lllllllllllll}0.73 & 16.77 & 25.21 & 17.04 & 2 & 122.5838 & 1229.5798 & 615.7972 & 0.0010 & 0.8120 & 19.150\end{array}$

TNQELQEINR $\begin{array}{llllllllllll}0.99 & 37.68 & 28.08 & 25.22 & 2 & 1387.7182 & 1387.7177 & 64.8661 & 0.0005 & 0.3598 & 25.789\end{array}$

TNQELQEINR

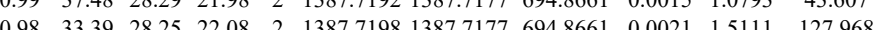

TNQELQEINR

TPAQYDASELK

TPAQYDASELK
TPAQYDASELK

AYTNFDAER

AYTNFDAER

TNQELQEINR

TPAQYDASELK

TPAQYDASELK

TPAQYDASELK

TPAQYDASELK

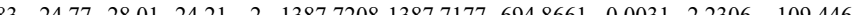
$\begin{array}{llllllllllllllll}0.88 & 26.79 & 28.02 & 28.66 & 3 & 1509.7981 & 1509.7918 & 504.2712 & 0.0063 & 4.1644 & 398.196 & 199.417 & 391.002 & 383.690 & \text { Yes }\end{array}$ $\begin{array}{lllllllllllllllll}0.99 & 54.13 & 25.55 & 41.96 & 2 & 1229.584 & 1229.5798 & 615.7972 & 0.0086 & 6.9828 & 11594.967 & 9103.080 & 917.609 & 17217.092 & \text { Yes }\end{array}$ $\begin{array}{lllllllllllllllllll}1.00 & 51.28 & 28.16 & 29.50 & 2 & 1387.7254 & 1387.7177 & 694.8661 & 0.0077 & 5.5406 & 9603.680 & 6301.431 & 1020.570 & 9133.605 & \text { Yes }\end{array}$ $\begin{array}{llllllllllllllll}1.00 & 63.57 & 28.23 & 25.63 & 2 & 1509.7932 & 1509.7918 & 755.9032 & 0.0014 & 0.9260 & 6724.241 & 4752.085 & 7901.166 & 8152.994 & \text { Yes }\end{array}$ $\begin{array}{llllllllllllllll}1.00 & 61.54 & 28.20 & 25.03 & 2 & 1509.7940 & 1509.7918 & 755.9032 & 0.0022 & 1.4552 & 8180.425 & 5643.144 & 11379.254 & 11988.184 & \text { Yes }\end{array}$ $\begin{array}{lllllllllllllllll}1.00 & 47.75 & 28.18 & 30.43 & 3 & 1509.7948 & 1509.7918 & 504.2712 & 0.0030 & 1.9831 & 702.446 & 537.348 & 440.491 & 425.492 & \text { Yes }\end{array}$ $\begin{array}{llllllllllllllll}.98 & 26.67 & 28.20 & 23.94 & 3 & 1509.7954 & 1509.7918 & 504.2712 & 0.0036 & 2.3797 & 460.908 & 370.032 & 421.737 & 286.135 & \text { Yes }\end{array}$ $\begin{array}{lllllllllllllllll} & \end{array}$ \begin{tabular}{lllllllllllllllll} 
& 27.17 \\
LLDTDLDGVVTFDFK & 1.00 & 38.15 & 27.17 & 19.56 & 3 & 2086.1110 & 2086.1078 & 696.3765 & 0.0032 & 1.5317 & 164.711 & 149.522 & 94.877 & 218.376 & Yes \\
\hline
\end{tabular} $\begin{array}{llllllllllllllll} & \end{array}$

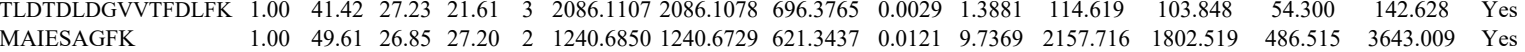
\begin{tabular}{llllllllllllllll} 
& \\
LEICNLTPDALK & 1.00 & 49.61 & 26.85 & 27.20 & 2 & 1240.6850 & 1240.6729 & 621.3437 & 0.0121 & 9.7369 & 2157.716 & 1802.519 & 486.515 & 3643.009 & Yes \\
\hline & 1.00 & 78.96 & 27.90 & 32.28 & 2 & 1662.8942 & 1662.8928 & 832.4537 & 0.0014 & 0.8409 & 6870.127 & 5435.539 & 349.060 & 10013.595 & $Y$
\end{tabular} \begin{tabular}{lllllllllllllllll} 
& LEICNLTPDALK & 1.00 & 78.96 & 27.90 & 32.28 & 2 & 1662.8942 & 1662.8928 & 832.4537 & 0.0014 & 0.8409 & 6870.127 & 5435.539 & 349.060 & 10013.595 & Yes \\
\hline
\end{tabular} \begin{tabular}{llllllllllllllll} 
& \\
LEICNLTPDALK & 1.00 & 63.70 & 27.99 & 30.41 & 2 & 1662.8946 & 1662.8928 & 832.4537 & 0.0018 & 1.0811 & 1103.836 & 909.574 & 224.683 & 1269.480 & Yes \\
\hline
\end{tabular} APSDYYILK APSDLYQIILK LEICNLTPDALK LEICNLTPDALK

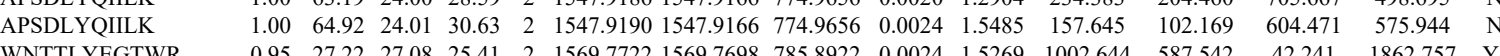

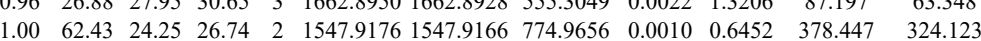

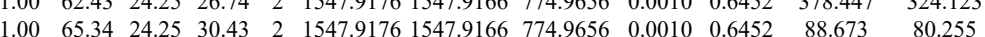
40.007

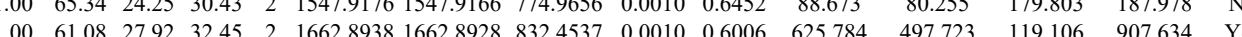

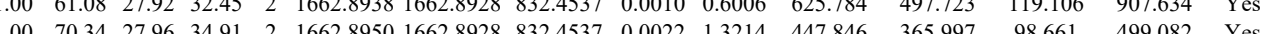

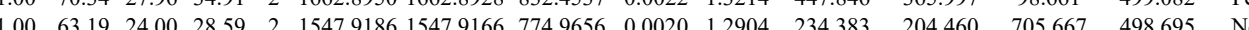

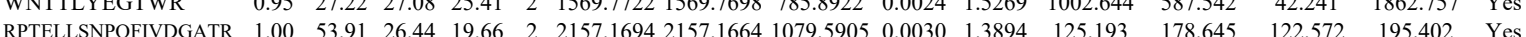
$\begin{array}{llllllllllllllll}\text { RPTELLSNPOFIVDGATR } & 1.00 & 46.65 & 26.30 & 16.19 & 3 & 2157.1717 & 2157.1664 & 720.0627 & 0.0053 & 2.4535 & 378.695 & 3432.077 & 540.438 & 675.068 & \text { No }\end{array}$ $\begin{array}{llllllllllllllllll}\text { RPTELLSNPQFIVDGATR } & 0.67 & 42.93 & 26.40 & 55.93 & 3 & 2157.1696 & 2157.1664 & 720.0627 & 0.0032 & 1.4814 & 225.082 & 1347.840 & 350.062 & 627.520 & \text { No }\end{array}$ $\begin{array}{llllllllllllllll}\text { RPTELLSNPOFIVDGATR } & 0.60 & 53.61 & 26.44 & 66.61 & 3 & 2157.1702 & 2157.1664 & 720.0627 & 0.0038 & 1.7591 & 485.425 & 1587.683 & 359.442 & 823.590 & \text { No }\end{array}$

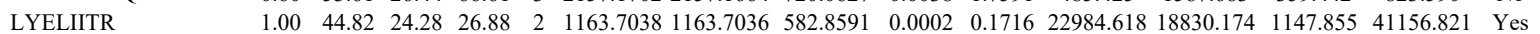
$\begin{array}{llllllllllllllll}\text { LYELIITR } & 1.00 & 46.82 & 24.79 & 29.23 & 2 & 1163.7048 & 1163.7036 & 582.8591 & 0.0012 & 1.0294 & 16951.416 & 13514.747 & 1545.305 & 33037.697 & \text { Yes }\end{array}$ $\begin{array}{lllllllllllllllll}\text { LDETDDPDDYGDR } & 0.84 & 62.34 & 20.64 & 75.34 & 2 & 1668.6892 & 1668.6873 & 835.3509 & 0.0019 & 1.1372 & 289.315 & 367.898 & 82.396 & 716.007 & \text { Yes }\end{array}$ LYELITR GQVVSLIR GQVVSLIR

NYPATFWVNPQFK NYPATFWVNPQFK GQVVSLIR

GQVVSLIR

NYPATFWVNPQFK

GQVVSLIR

GQVVSLIR

LGLVEFNILWNR

LGLVEFNILWNR

LGLVEFNILWNR

NYLSIFR

NYLLIFR

LGLVEFNILWNR
LGLVEFNILWNR
NYLSIFR

NYLSIFR

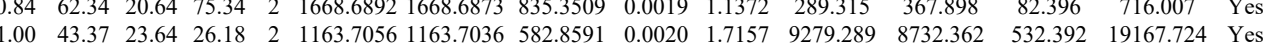
$\begin{array}{lllllllllllllll}0.98 & 40.26 & 26.19 & 24.88 & 2 & 1014.6384 & 1014.6308 & 508.3227 & 0.0076 & 7.4755 & 29560.664 & 29818.024 & 9999.762 & 52576.462 & \text { Yes }\end{array}$

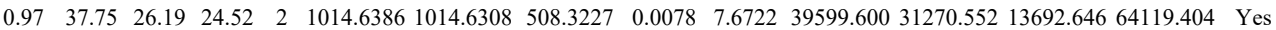

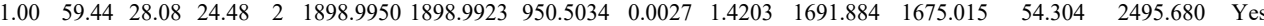
$\begin{array}{llllllllllllllll}1.00 & 5.44 & 28.28 & 28.08 & 27.50 & 2 & 1898.9950 & 1898.9923 & 950.5034 & 0.0027 & 1.4203 & 2581.739 & 2319.800 & 0.000 & 4006.763 & \text { No }\end{array}$ $\begin{array}{lllllllllllllll}1.00 & 62.28 & 28.08 & 27.50 & 2 & 1898.9950 & 1898.9923 & 950.503 & 0.0027 & 1.4203 & 2581.739 & 2319.800 & 0.000 & 406.763 & \\ 0.98 & 39.97 & 26.19 & 27.15 & 2 & 1014.6394 & 1014.6308 & 508.3227 & 0.0086 & 8.4591 & 10953.533 & 9485.354 & 2931.769 & 16062.565 & \text { Yes }\end{array}$ $\begin{array}{lllllllllllllll}0.86 & 29.17 & 26.19 & 26.74 & 2 & 1014.6398 & 1014.6308 & 508.3227 & 0.0090 & 8.8526 & 4136.251 & 3298.973 & 1257.230 & 5420.851 & \text { Yes }\end{array}$ $\begin{array}{llllllllllllllll}1.00 & 60.34 & 28.04 & 22.92 & 2 & 1898.9940 & 1898.9923 & 950.5034 & 0.0017 & 0.8943 & 199.111 & 160.268 & 11.033 & 231.825 & \text { Yes }\end{array}$ $\begin{array}{lllllllllllllll}0.52 & 21.44 & 26.19 & 26.32 & 2 & 1014.6400 & 1014.6308 & 508.3227 & 0.0092 & 9.0493 & 18118.854 & 15465.579 & 3360.184 & 24067.521 & \text { Yes }\end{array}$ $\begin{array}{lllllllllllllll}0.94 & 32.32 & 26.12 & 27.84 & 2 & 1014.6404 & 1014.6308 & 508.3227 & 0.0096 & 9.4427 & 12968.980 & 11438.560 & 3048.986 & 19265.920 & \text { Yes }\end{array}$ $\begin{array}{lllllllllllllll}1.00 & 67.25 & 26.30 & 25.09 & 2 & 1616.9172 & 1616.9160 & 809.4653 & 0.0012 & 0.7412 & 1634.165 & 1200.224 & 152.692 & 2652.685 & \text { Yes }\end{array}$

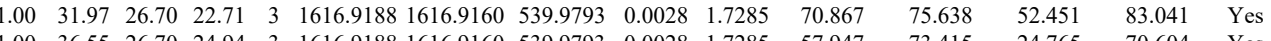
$\begin{array}{lllllllllllllll}1.00 & 36.55 & 26.70 & 24.94 & 3 & 1616.9188 & 1616.9160 & 539.9793 & 0.0028 & 1.7285 & 57.947 & 73.415 & 24.765 & 70.604 & \text { Yes }\end{array}$ $\begin{array}{llllllllllllllll}1.00 & 44.90 & 26.24 & 21.27 & 2 & 1055.5896 & 1055.5885 & 528.8015 & 0.0011 & 1.0401 & 3397.769 & 3238.510 & 423.661 & 6421.514 & \text { Yes }\end{array}$

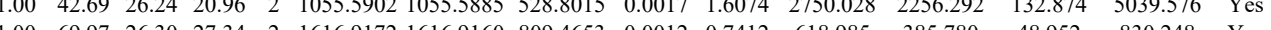

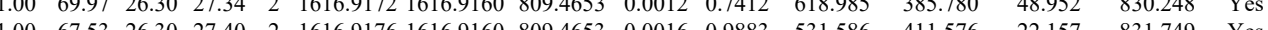

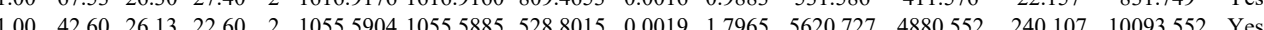
$\begin{array}{lllllllllllllll}1.00 & 42.39 & 26.25 & 20.54 & 2 & 1055.5904 & 1055.5885 & 528.8015 & 0.0016 & 0.9883 & 531.586 & 41.576 & 22.157 & 831.749 & \text { Yes }\end{array}$ $\begin{array}{llllllllllllllll}1.09 & 42.39 & 26.25 & 20.54 & 2 & 1055.5906 & 1055.5885 & 528.8015 & 0.0021 & 1.9856 & 10322.509 & 7306.904 & 209.012 & 17431.850 & \text { Yes } \\ 0.95 & 33.15 & 23.41 & 2 & 1213.6180 & 1213.6069 & 607.8107 & 0.0111 & 9.1310 & 1372.113 & 1088.480 & 245.660 & 2728.128 & \text { Yes }\end{array}$ 


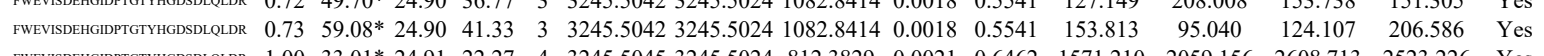

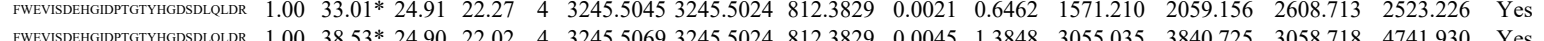

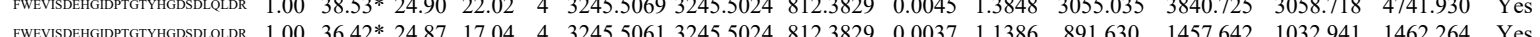

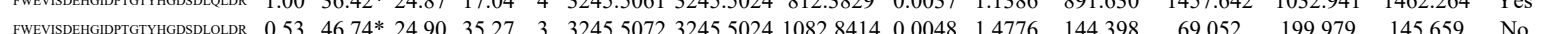

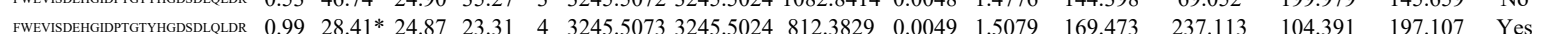

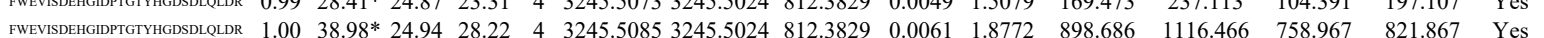
$\begin{array}{llllllllllllllll}\text { ISVYYNEATGGK } & 1.00 & 71.79 & 28.00 & 34.27 & 2 & 1588.8490 & 1588.8340 & 795.4243 & 0.0150 & 9.4288 & 2526.777 & 2600.302 & 0.000 & 3522.783 & \text { No }\end{array}$ $\begin{array}{llllllllllllllll} & \\ \text { ISVYYNEATGGK } & 1.00 & 75.35 & 28.06 & 31.77 & 2 & 1588.8496 & 1588.8340 & 795.4243 & 0.0156 & 9.8060 & 2831.311 & 3410.082 & 0.000 & 4469.041 & \text { No }\end{array}$ \begin{tabular}{llllllllllllllll} 
ISVYNEATGGK & 1.00 & 72.88 & 28.00 & 34.33 & 2 & 1588.8490 & 1588.8340 & 795.4243 & 0.0150 & 9.4288 & 1825.102 & 1726.277 & 88.769 & 1952.536 & Yes \\
\hline
\end{tabular}

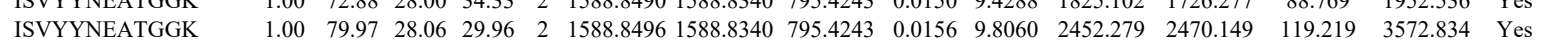

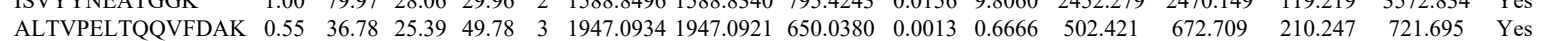
\begin{tabular}{lllllllllllllllll} 
ALTVPELTQQVFDAK & 0.58 & 9.27 & 25.43 & 17.52 & 3 & 1947.0940 & 1947.0921 & 650.0380 & 0.0019 & 0.9743 & 126.176 & 127.207 & 43.963 & 143.602 & Yes \\
\hline
\end{tabular} $\begin{array}{lllllllllllllllll}\text { ALTVPELTQQVFDAK } & 1.00 & 77.31 & 25.43 & 25.58 & 2 & 1947.0940 & 1947.0921 & 974.5533 & 0.0019 & 0.9748 & 503.541 & 366.772 & 112.503 & 559.668 & \text { Yes }\end{array}$ $\begin{array}{llllllllllllllll}\text { ALTVPELTQQVFDAK } & 1.00 & 73.94 & 25.43 & 25.85 & 2 & 1947.0940 & 1947.0921 & 974.5533 & 0.0019 & 0.9748 & 1062.232 & 989.384 & 47.670 & 1204.402 & \text { Yes }\end{array}$ $\begin{array}{lllllllllllllllll}\text { ALTVPELTQQVFDAK } & 1.00 & 59.50 & 25.49 & 17.47 & 3 & 1947.0949 & 1947.0921 & 650.0380 & 0.0028 & 1.4358 & 429.122 & 336.124 & 173.688 & 487.922 & \text { Yes }\end{array}$ $\begin{array}{lllllllllllllllll}\text { ALTVPELTQQVFDAK } & 1.00 & 31.79 & 25.49 & 18.32 & 3 & 1947.0958 & 1947.0921 & 650.0380 & 0.0037 & 1.8973 & 6191.771 & 8262.589 & 1440.073 & 7477.928 & \text { Yes }\end{array}$ $\begin{array}{lllllllllllllllll}\text { ALTVPELTQQVFDAK } & 1.00 & 62.99 & 25.30 & 22.62 & 2 & 1947.0966 & 1947.0921 & 974.5533 & 0.0045 & 2.3087 & 2120.603 & 1894.712 & 77.117 & 2349.448 & \text { Yes }\end{array}$ $\begin{array}{llllllllllllllll}\text { ALTVPELTQQVFDAK } & 1.00 & 56.03 & 24.46 & 18.67 & 2 & 1947.1036 & 1947.0921 & 974.5533 & 0.0115 & 5.9001 & 1236.869 & 1051.262 & 328.157 & 1676.553 & \text { Yes }\end{array}$

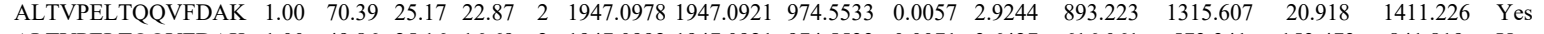
$\begin{array}{lllllllllllllllll}\text { ALTVPELTQQVFDAK } & 1.00 & 49.86 & 25.16 & 16.69 & 2 & 1947.0992 & 1947.0921 & 974.5533 & 0.0071 & 3.6427 & 616.061 & 573.341 & 153.473 & 841.819 & \text { Yes }\end{array}$ $\begin{array}{llllllllllllllll}\text { ALTVPELTQQVFDAK } & 1.00 & 58.42 & 25.51 & 22.36 & 2 & 1947.0958 & 1947.0921 & 974.5533 & 0.0037 & 1.8983 & 584.197 & 600.569 & 167.671 & 584.223 & \text { Yes }\end{array}$ $\begin{array}{llllllllllllllll}\text { ALTVPELTQQVFDAK } & 1.00 & 76.51 & 25.30 & 22.87 & 2 & 1947.0970 & 1947.0921 & 974.5533 & 0.0049 & 2.5140 & 330.853 & 339.687 & 43.810 & 343.527 & \text { Yes }\end{array}$ $\begin{array}{llllllllllllllll}\text { MAVTFIGNSTAIQELFK } & 0.99 & 40.23 & 26.28 & 20.47 & 3 & 2157.1729 & 2157.1747 & 720.0655 & -0.0018 & -0.8333 & 49.971 & 57.320 & 3.991 & 56.884 & \text { Yes }\end{array}$

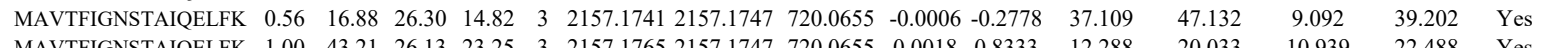

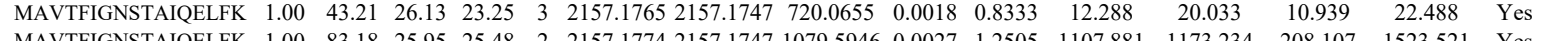

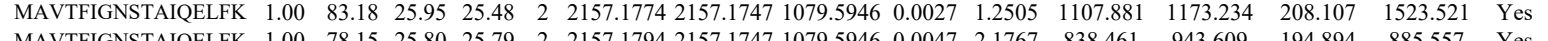
$\begin{array}{llllllllllllllll}\text { MAVTFIGNSTAIQELFK } & 1.00 & 78.15 & 25.80 & 25.79 & 2 & 2157.1794 & 2157.1747 & 1079.5946 & 0.0047 & 2.1767 & 838.461 & 943.609 & 194.894 & 885.557 & \text { Yes }\end{array}$

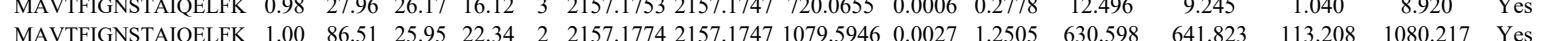

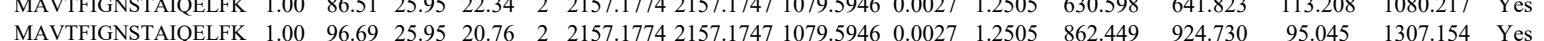

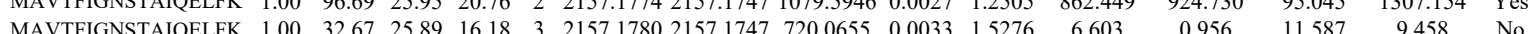

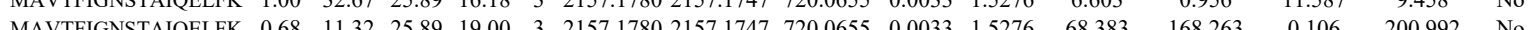

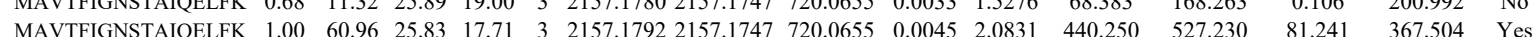

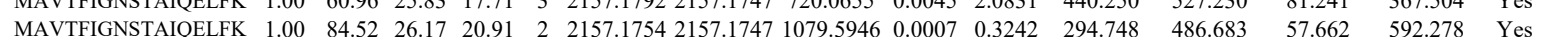

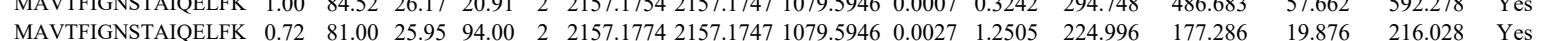

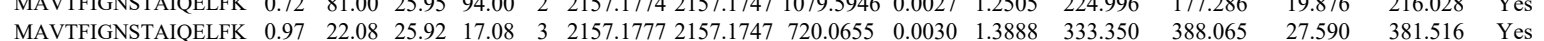

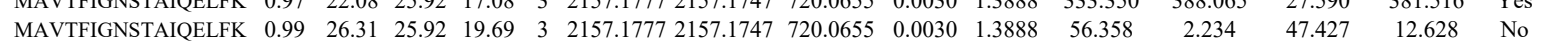

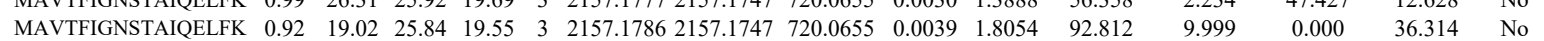

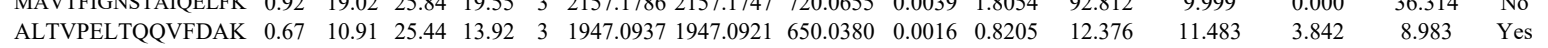
$\begin{array}{llllllllllllllll}\text { ALTVPELTQQVFDAK } & 0.99 & 27.88 & 25.44 & 16.06 & 3 & 1947.0937 & 1947.0921 & 650.0380 & 0.0016 & 0.8205 & 27.533 & 27.327 & 7.859 & 32.960 & \text { Yes }\end{array}$

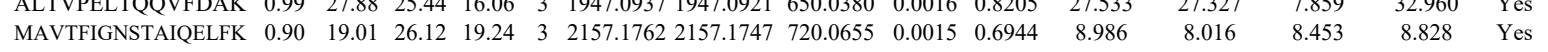
$\begin{array}{llllllllllllllll}\text { MAVTFIGNSTAIQELFK } & 0.96 & 21.50 & 25.94 & 15.66 & 3 & 2157.1768 & 2157.1747 & 720.0655 & 0.0021 & 0.9721 & 6.400 & 9.609 & 15.646 & 11.738 & \text { No }\end{array}$ $\begin{array}{llllllllllllllll}\text { MAVTFIGNSTAIQELFK } & 0.76 & 13.37 & 26.13 & 16.87 & 3 & 2157.1765 & 2157.1747 & 720.0655 & 0.0018 & 0.8333 & 7.114 & 10.247 & 5.388 & 12.847 & \text { Yes }\end{array}$ $\begin{array}{llllllllllllllll}\text { MAVTFIGNSTAIQELFK } & 1.00 & 42.69 & 25.92 & 19.74 & 3 & 2157.1777 & 2157.1747 & 720.0655 & 0.0030 & 1.3888 & 14.130 & 23.434 & 2.227 & 11.657 & \text { No }\end{array}$

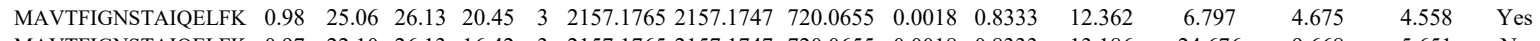

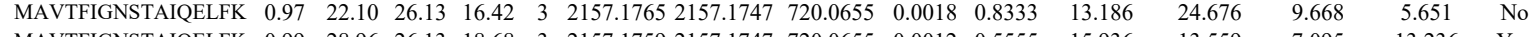

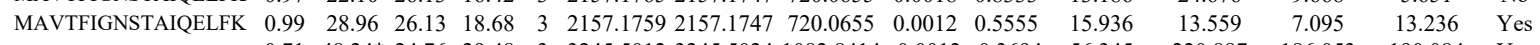
$\begin{array}{lllllllllllllll}\text { FWEVISDEHGIPTGTYHGDSDLLLDR } & 0.71 & 48.24 * 24.76 & 29.48 & 3 & 3245.5012 & 3245.5024 & 1082.8414 & -0.0012 & -0.3694 & 56.345 & 220.887 & 186.053 & 190.084 & \text { Yes }\end{array}$

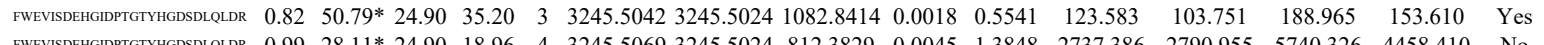
$\begin{array}{lllllllllllllll} & \end{array}$

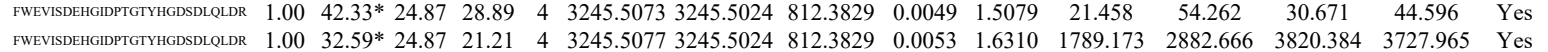

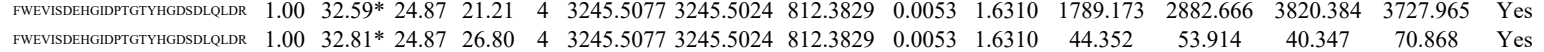

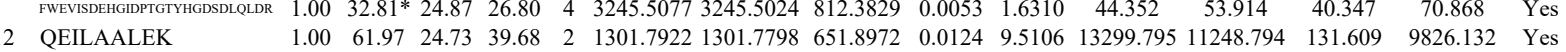

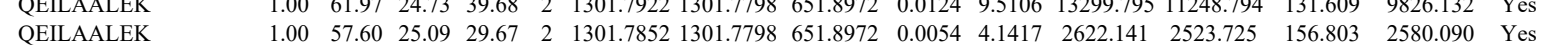

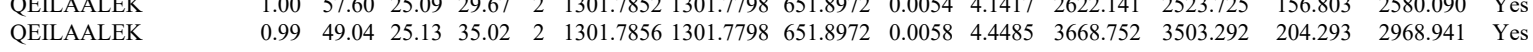
$\begin{array}{lllllllllllllllll}\text { QEILAALEK } & 0.99 & 35.27 & 26.21 & 26.69 & 2 & 1301.7806 & 1301.7798 & 651.8972 & 0.0008 & 0.6136 & 4003.012 & 2814.191 & 164.613 & 2238.829 & \text { No }\end{array}$

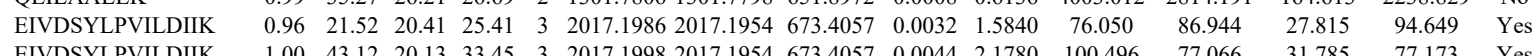

Table S-4 page 109 of 614

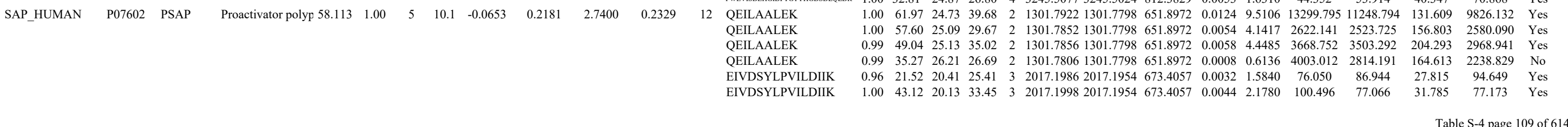




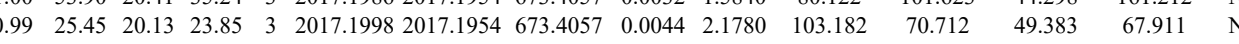

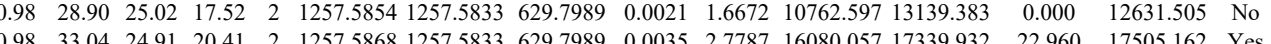
$\begin{array}{llllllllllllllll}1.00 & 59.75 & 26.86 & 24.86 & 2 & 1587.7698 & 1587.7669 & 7948907 & 0.0029 & 1.8241 & 568.964 & 468.183 & 84.257 & 548.080 & \text { Yes }\end{array}$ $\begin{array}{lllllllllllllll} & & & \end{array}$ $\begin{array}{lllllllllllllllll}\text { STGGAPTFNVTVTK } & 0.75 & 15.99 & 27.12 & 15.32 & 3 & 1666.9144 & 1666.9134 & 556.6451 & 0.0010 & 0.5988 & 21.616 & 12.843 & 9.313 & 30.129 & \text { Yes }\end{array}$

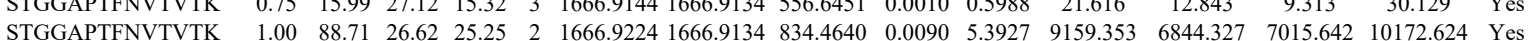
$\begin{array}{llllllllllllllll}\text { STGGAPTFNVTVTK } & 1.00 & 88.01 & 26.51 & 22.41 & 2 & 1666.9230 & 1666.9134 & 834.4640 & 0.0096 & 5.7522 & 17401.361 & 13353.980 & 11991.244 & 13343.805 & \text { Yes }\end{array}$ $\begin{array}{llllllllllllllll}\text { STGGAPTFNVTVTK } & 1.00 & 86.95 & 26.40 & 24.22 & 2 & 1666.9238 & 1666.9134 & 834.4640 & 0.0104 & 6.2315 & 5387.096 & 3912.801 & 3575.773 & 5124.353 & \text { Yes }\end{array}$ \begin{tabular}{llllllllllllllll} 
STGGAPTFNVTVTK & 1.00 & 87.05 & 26.29 & 23.41 & 2 & 1666.9254 & 1666.9134 & 834.4640 & 0.0120 & 7.1902 & 10659.542 & 8623.464 & 8567.713 & 9196.000 & Yes \\
\hline
\end{tabular} $\begin{array}{lllllllllllllllll}\text { STGGAPTFNVTVTK } & 0.78 & 23.23 & 26.36 & 15.75 & 3 & 1666.9264 & 1666.9134 & 556.6451 & 0.0130 & 7.7847 & 350.799 & 296.898 & 130.164 & 226.983 & \text { Yes }\end{array}$ $\begin{array}{lllllllllllllllll}\text { CYEMASHLR } & 0.81 & 13.27 & 23.20 & 19.30 & 3 & 1298.5699 & 1298.5691 & 433.8636 & 0.0008 & 0.6146 & 347.892 & 472.365 & 140.354 & 434.339 & \text { Yes }\end{array}$ $\begin{array}{lllllllllllllllll}\text { CYEMASHLR } & 0.99 & 44.54 & 23.50 & 22.07 & 2 & 1298.5760 & 1298.5691 & 650.2918 & 0.0069 & 5.3053 & 13008.485 & 8976.317 & 158.467 & 28868.664 & \text { No }\end{array}$ $\begin{array}{lllllllllllllllll}\text { CYEMASHLR } & 1.00 & 48.77 & 23.56 & 23.16 & 2 & 1298.5762 & 1298.5691 & 650.2918 & 0.0071 & 5.4591 & 9436.986 & 7020.440 & 810.581 & 20747.314 & \text { No }\end{array}$ $\begin{array}{llllllllllllllll}\text { CYEMASHLR } & 1.00 & 56.16 & 23.64 & 25.89 & 3 & 1298.5777 & 1298.5691 & 433.8636 & 0.0086 & 6.6073 & 6047.698 & 4477.624 & 1813.417 & 11230.314 & \text { Yes }\end{array}$ $\begin{array}{llllllllllllllllll}\text { STGGAPTFNVTVTK } & 1.00 & 87.26 & 26.40 & 25.09 & 2 & 1666.9236 & 1666.9134 & 834.4640 & 0.0102 & 6.1117 & 7198.924 & 6541.396 & 5235.699 & 6649.353 & \text { Yes }\end{array}$ $\begin{array}{llllllllllllllll}\text { STGGAPTFNVTVTK } & 1.00 & 84.79 & 26.40 & 22.66 & 2 & 1666.9236 & 1666.9134 & 834.4640 & 0.0102 & 6.1117 & 5948.023 & 3833.184 & 3405.558 & 4878.494 & \text { Yes }\end{array}$ $\begin{array}{llllllllllllllll}\text { CYEMASHLR } & 1.00 & 41.78 & 23.38 & 23.66 & 3 & 1298.5768 & 1298.5691 & 433.8636 & 0.0077 & 5.9158 & 8296.759 & 5248.841 & 1621.202 & 14089.645 & \text { Yes }\end{array}$ $\begin{array}{llllllllllllllll}\text { CYEMASHLR } & 0.99 & 39.36 & 23.42 & 26.04 & 3 & 1298.5771 & 1298.5691 & 433.8636 & 0.0080 & 6.1463 & 8690.994 & 6396.163 & 1753.575 & 15864.952 & \text { Yes }\end{array}$ $\begin{array}{lllllllllllllllll}\text { STGGAPTFNVTVTK } & 1.00 & 84.04 & 26.42 & 21.09 & 2 & 1666.9242 & 1666.9134 & 834.4640 & 0.0108 & 6.4712 & 561.130 & 437.913 & 418.147 & 598.522 & \text { Yes }\end{array}$

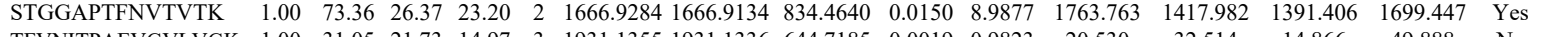
$\begin{array}{llllllllllllllll}\text { TFVNITPAEVGVLVGK } & 1.00 & 31.05 & 21.73 & 14.97 & 3 & 1931.1355 & 1931.1336 & 644.7185 & 0.0019 & 0.9823 & 20.530 & 32.514 & 14.866 & 49.888 & \text { No }\end{array}$

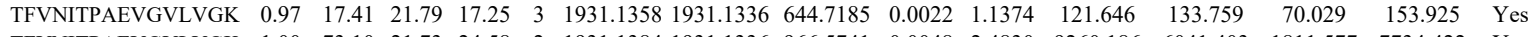
$\begin{array}{llllllllllllllll}\text { TFVNITPAEVGVLVGK } & 1.00 & 73.10 & 21.73 & 24.58 & 2 & 1931.1384 & 1931.1336 & 966.5741 & 0.0048 & 2.4830 & 9260.186 & 6041.403 & 1811.577 & 7734.422 & \text { Yes }\end{array}$ $\begin{array}{llllllllllllllll}\text { TFVNITPAEVGVLVGK } & 1.00 & 89.37 & 21.46 & 26.86 & 2 & 1931.1394 & 1931.1336 & 966.5741 & 0.0058 & 3.0003 & 6822.901 & 6270.827 & 1674.701 & 7074.226 & \text { Yes }\end{array}$

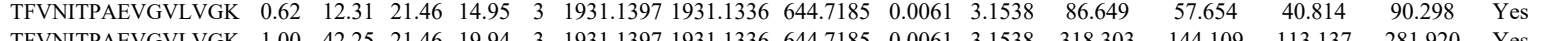

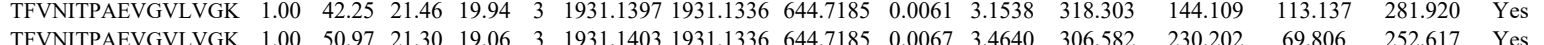
$\begin{array}{lllllllllllllll} & \end{array}$

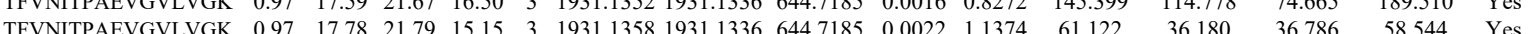
$\begin{array}{lllllllllllll} & \end{array}$ $\begin{array}{llllllllllllll} & \end{array}$ $\begin{array}{llllllllllllllll}\text { TFVNITPAEVGVLVGK } & 1.00 & 31.72 & 21.61 & 17.43 & 3 & 1931.1376 & 1931.1336 & 644.7185 & 0.0040 & 2.0681 & 77.578 & 134.436 & 70.577 & 114.058 & \text { Yes }\end{array}$

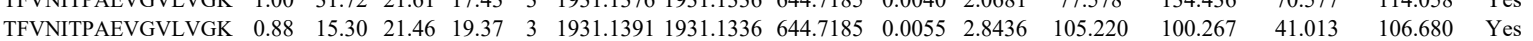
$\begin{array}{llllllllllllllll}\text { TFVNITPAEVGVLVGK } & 1.00 & 36.43 & 21.46 & 18.77 & 3 & 1931.1394 & 1931.1336 & 644.7185 & 0.0058 & 2.9987 & 79.939 & 64.986 & 35.084 & 65.291 & \text { Yes }\end{array}$

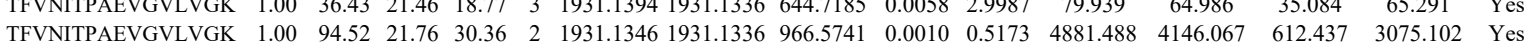
$\begin{array}{lllllllllllllllll}\text { TFVNITPAEVGVLVGK } & 1.00 & 63.64 & 21.73 & 21.27 & 3 & 1931.1355 & 1931.1336 & 644.7185 & 0.0019 & 0.9823 & 1128.691 & 1473.361 & 482.232 & 842.190 & \text { No }\end{array}$ $\begin{array}{llllllllllllllll}\text { TFVNITPAEVGVLVGK } & 1.00 & 89.91 & 21.73 & 25.96 & 2 & 1931.1356 & 1931.1336 & 966.5741 & 0.0020 & 1.0346 & 9305.033 & 6521.045 & 2328.598 & 9124.385 & \text { Yes }\end{array}$ $\begin{array}{llllllllllllllll}\text { TFVNITPAEVGVLVGK } & 1.00 & 55.93 & 21.73 & 21.75 & 3 & 1931.1367 & 1931.1336 & 644.7185 & 0.0031 & 1.6028 & 210.968 & 422.926 & 109.902 & 296.883 & \text { No }\end{array}$ \begin{tabular}{lllllllllllllllll} 
TFVNITPAEVGVLVGK & 1.00 & 84.44 & 21.40 & 24.69 & 2 & 1931.1398 & 1931.1336 & 966.5741 & 0.0062 & 3.2072 & 2297.380 & 1449.620 & 528.386 & 1930.372 & Yes \\
\hline
\end{tabular} $\begin{array}{llllllllllllllll}\text { TFVNITPAEVGVLVGK } & 1.00 & 88.94 & 21.30 & 28.12 & 2 & 1931.1400 & 1931.1336 & 966.5741 & 0.0064 & 3.3107 & 2613.342 & 1542.866 & 533.632 & 1915.565 & \text { Yes }\end{array}$ $\begin{array}{llllllllllllllll}\text { TFVNITPAEVGVLVGK } & 1.00 & 60.85 & 21.07 & 22.10 & 3 & 1931.1415 & 1931.1336 & 644.7185 & 0.0079 & 4.0845 & 472.082 & 619.513 & 302.951 & 513.321 & \text { Yes }\end{array}$ $\begin{array}{llllllllllllllll}\text { TFVNITPAEVGVLVGK } & 1.00 & 78.23 & 21.07 & 23.75 & 3 & 1931.1415 & 1931.1336 & 644.7185 & 0.0079 & 4.0845 & 321.652 & 292.329 & 99.361 & 229.099 & \text { Yes }\end{array}$ $\begin{array}{llllllllllllllll}\text { TFVNITPAEVGVLVGK } & 1.00 & 77.03 & 21.67 & 22.46 & 2 & 1931.1332 & 1931.1336 & 966.5741 & -0.0004 & -0.2069 & 1018.982 & 936.798 & 146.423 & 1072.443 & \text { Yes }\end{array}$

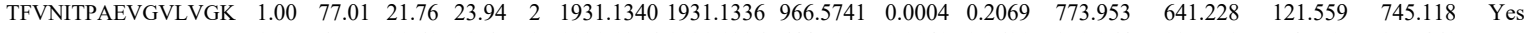
$\begin{array}{llllllllllllllll}\text { TFVNITPAEVGVLVGK } & 1.00 & 60.77 & 21.61 & 23.67 & 3 & 1931.1376 & 1931.1336 & 644.7185 & 0.0040 & 2.0681 & 370.264 & 337.953 & 74.752 & 275.461 & \text { Yes }\end{array}$ \begin{tabular}{llllllllllllllll} 
TFVNITPAEVGVLVGK & 1.00 & 53.04 & 21.61 & 17.37 & 3 & 1931.1376 & 1931.1336 & 644.7185 & 0.0040 & 2.0681 & 192.825 & 203.684 & 46.899 & 168.815 & Yes \\
\hline
\end{tabular}

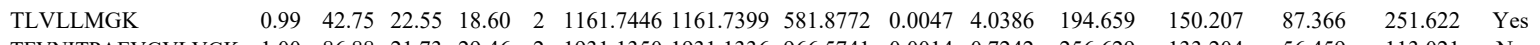
$\begin{array}{llllllllllllllll}\text { TFVNITPAEVGVLVGK } & 1.00 & 86.88 & 21.73 & 29.46 & 2 & 1931.1350 & 1931.1336 & 966.5741 & 0.0014 & 0.7242 & 256.629 & 133.204 & 56.459 & 113.021 & \text { No }\end{array}$

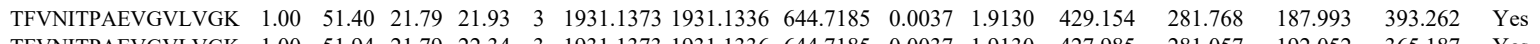

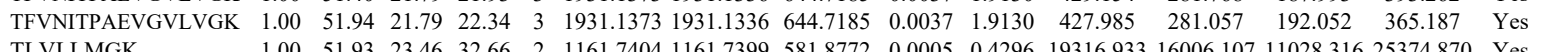

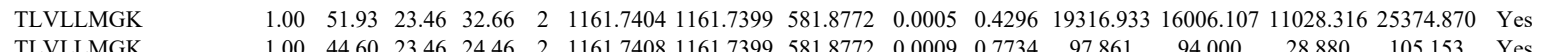

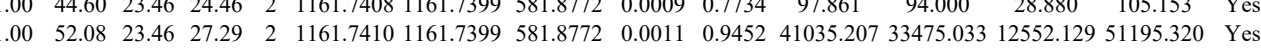

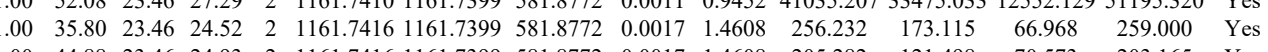



$\begin{array}{llll}0.65 & 12.25 & 27.08 & 15.22\end{array}$

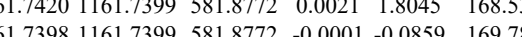

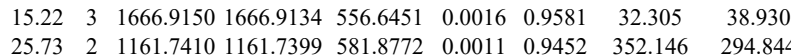
$\begin{array}{llllllllllll}1.00 & 51.63 & 23.46 & 31.27 & 2 & 1161.7416 & 1161.7399 & 581.8772 & 0.0017 & 1.4608 & 443.834 & 257.296\end{array}$

TFNITAE $\begin{array}{lllllllllll} & \end{array}$

$\begin{array}{llllllllllllll} & \end{array}$

$\begin{array}{lllllllllllll} & 1.00 & 52.15 & 23.46 & 27.26 & 2 & 1161.7408 & 1161.7399 & 581.8772 & 0.0009 & 0.7734 & 382.056 & 263.013\end{array}$

$\begin{array}{llllllllllllll}\text { TFNNPAEVGVLVGK } & 1.00 & 60.55 & 21.73 & 21.81 & 3 & 1931.1355 & 1931.1336 & 644.7185 & 0.0019 & 0.9823 & 27.480 & 42.006 \\ \text { TFVNITPAEVGVLVGK } & 1.00 & 51.39 & 21.76 & 20.82 & 3 & 1931.1379 & 1931.1336 & 644.7185 & 0.0043 & 2.2232 & 29.537 & 41.145\end{array}$

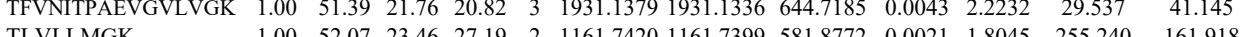

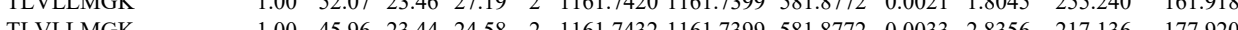

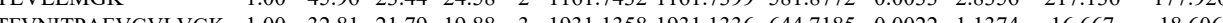

$\begin{array}{lllllllllllll} & \end{array}$ $\begin{array}{llllllllllll}1.00 & 61.71 & 21.73 & 19.36 & 3 & 1931.1367 & 1931.1336 & 644.7185 & 0.0031 & 1.6028 & 13.038 & 16.626 \\ 1.00 & 36.31 & 23.46 & 25.25 & 2 & 1161.7414 & 1161.7399 & 581.8772 & 0.0015 & 1.2889 & 255.527 & 186.190 \\ 1.00 & 47.51 & 21.76 & 25.02 & 3 & 1631.1340 & 1931.1336 & 647.185 & 0.004 & 0.2068 & 26.862 & 12813\end{array}$

$\begin{array}{lllllllllll} & \end{array}$

TLVLLMGK

TLVLLMGK

TLVLLMGK $\begin{array}{llllllllllll}1.00 & 41.07 & 23.46 & 25.81 & 2 & 1161.7422 & 1161.7399 & 581.8772 & 0.0023 & 1.9764 & 236.104\end{array}$

$\begin{array}{lllllllllll}1.00 & 39.23 & 23.76 & 25.35 & 2 & 1161.7416 & 1161.7399 & 581.8772 & 0.0017 & 1.4608 & 239.363\end{array}$

$\begin{array}{lllllllllllll} & & 1.00\end{array}$

$\begin{array}{lllllllllllll}\text { TFVNITPAEVGVLVGK } & 1.00 & 55.28 & 21.73 & 22.28 & 3 & 1931.1355 & 1931.1336 & 644.7185 & 0.0019 & 0.9823 & 37.764\end{array}$

TLVLLMGK

$\begin{array}{lllllllllll}1.00 & 55.28 & 21.73 & 22.28 & 3 & 1931.1355 & 1931.1336 & 644.7185 & 0.0019 & 0.9823 & 37.764 \\ 1.03 & 23.46 & 26.71 & 2 & 1161.7402 & 1161.7399 & 581.8772 & 0.0003 & 0.2578 & 202.656\end{array}$

\begin{tabular}{llllllllllll|} 
& 1.00 & 43.29 & 23.46 & 24.96 & 2 & 1161.7414 & 1161.7399 & 581.8772 & 0.0015 & 1.2889 & 195.993 \\
\hline
\end{tabular} $\begin{array}{llllllllllllll}\text { FFVNTPAEVGVLVGK } & 1.00 & 45.62 & 21.73 & 20.38 & 3 & 1931.1367 & 1931.1336 & 644.7185 & 0.0031 & 1.6028 & 23.044 \\ \text { TFVNITPAEVGVLVGK } & 1.00 & 49.33 & 21.79 & 16.67 & 3 & 1931.1373 & 1931.1336 & 644.7185 & 0.0037 & 1.9130 & 25.011\end{array}$ $\begin{array}{lllllllllllll}\text { TLVLLMGK } & 0.99 & 42.75 & 23.40 & 23.18 & 2 & 1161.7390 & 1161.7399 & 581.8772 & -0.0009 & -0.7734 & 28.550\end{array}$ TLVLLMGK $\begin{array}{llllllllllll}1.00 & 42.51 & 23.46 & 20.60 & 2 & 1161.7408 & 1161.7399 & 581.8772 & 0.0009 & 0.7734 & 50.158\end{array}$ $\begin{array}{llllllllllllll} & 0.66 & 45.35 & 21.79 & 58.35 & 3 & 1931.1358 & 1931.1336 & 644.7185 & 0.0022 & 1.1374 & 12.160\end{array}$ $\begin{array}{lllllllllllll}\text { DSLLQDGEFSMDLR } & 1.00 & 42.10 & 26.68 & 17.83 & 2 & 1768.8420 & 1768.8423 & 885.4284 & -0.0003 & -0.1694 & 4.095\end{array}$ $\begin{array}{lllllllllllll}\text { DSLLQDGEFSMDLR } & 1.00 & 34.36 & 26.79 & 21.42 & 3 & 1768.8436 & 1768.8423 & 590.6214 & 0.0013 & 0.7337 & 36.965\end{array}$ $\begin{array}{llllllllllllll}\text { DSLLQDGEFSMDLR } & 1.00 & 78.80 & 26.83 & 23.11 & 2 & 1768.8440 & 1768.8423 & 885.4284 & 0.0017 & 0.9600 & 287.159\end{array}$ $\begin{array}{lllllll} & \end{array}$ IDYIAGLDSR

$\begin{array}{lllllllllll}1.00 & 45.45 & 24.30 & 17.08 & 3 & 2307.276 & 2307.2673 & 770.0964 & 0.0043 & 1.8612 & 0.000\end{array}$

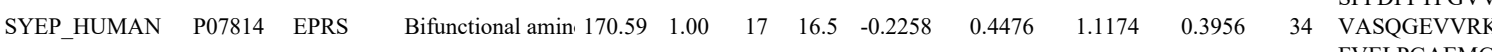
$\begin{array}{lllllllllllll}\text { FVELPGAEMGK } & 1.00 & 49.95 & 28.22 & 28.37 & 2 & 1464.7930 & 1464.7890 & 733.4018 & 0.0040 & 2.7270 & 606.123 & 573.756 \\ \text { TELAEPAIRPTSETVMYPAYAK } & 0.67 & 26.28 & 25.21 & 39.28 & 3 & 2838.5116 & 2838.5081 & 947.1766 & 0.0035 & 1.2317 & 820.725 & 648.900\end{array}$ $\begin{array}{llllllllllllll}1.00 & 44.45 & 27.66 & 18.18 & 2 & 1608.8430 & 1608.8423 & 805.4284 & 0.0007 & 0.4346 & 2447.782 & 2681.939 & 0 \\ 0.69 & 17.50 & 24.30 & 23.76 & 2 & 1359.8104 & 1359.8078 & 680.9112 & 0.0026 & 1.9092 & 2069.352 & 1795.492 & 511\end{array}$

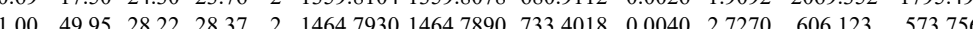
\begin{tabular}{lll}
42.666 & 225.926 & Yes \\
\hline & 2.969 & 0
\end{tabular} 


\section{CLELFTELAEDK}

CLELFTELAEDK

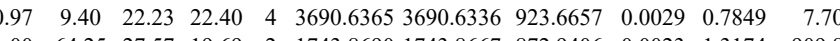

YYTSASGDMVSLK

CLELFTELAEDK

CLELFTELAEDK

CLELFTELAEDK

YYTSASGDEMVSLK CLELFTELAEDK

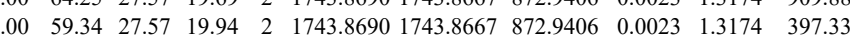

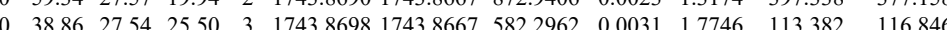
$\begin{array}{lllllllllllll}0.62 & 12.05 & 27.59 & 18.95 & 3 & 1837.9039 & 1837.9011 & 613.6410 & 0.0028 & 1.5210 & 15.512\end{array}$

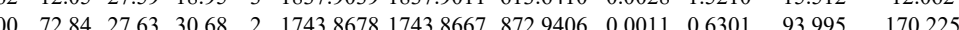
$\begin{array}{lllllllllllll}1.00 & 74.42 & 27.61 & 23.95 & 2 & 1743.8680 & 1743.8667 & 872.9406 & 0.0013 & 0.7446 & 189.540 & 194.030\end{array}$ $\begin{array}{llllllllllll}1.00 & 43.83 & 27.51 & 16.89 & 3 & 1743.8704 & 1743.8667 & 582.2962 & 0.0037 & 2.1180 & 74.399\end{array}$ $\begin{array}{lllllllllll}1.00 & 43.83 & 27.51 & 16.89 & 3 & 1743.8704 & 1743.8667 & 582.2962 & 0.0037 & 2.1180 & 74.399 \\ 1.00 & 76.11 & 27.71 & 19.23 & 2 & 1837.8988 & 1837.9011 & 919.9578 & -0.0023 & -1.2501 & 43.983\end{array}$

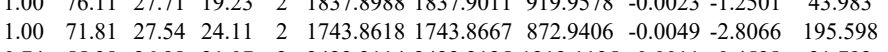
$\begin{array}{lllllllllllllll} & \end{array}$ $\begin{array}{llllllllllllll} & 2422.2172 & 222.2125 & 88.414 & 0.047 & 1.930 & 9682.74 & 8524.650\end{array}$ $\begin{array}{lllllllllllll}\text { CLELFTELAEDKENYK } & 1.00 & 27.06 & 26.96 & 16.03 & 4 & 2422.2189 & 2422.2125 & 606.5604 & 0.0064 & 2.6378 & 4093.848 & 4165.825\end{array}$ $\begin{array}{lllllllllllllll} & \text { CLELFTELAEDKENYK } & 1.00 & 32.75 & 26.96 & 17.13 & 4 & 2422.2181 & 2422.2125 & 606.5604 & 0.0056 & 2.3081 & 4013.833 & 3636.610 & 1\end{array}$ CLELFTELAEDK

HIYYITGETK

HLEINPDHSIIETLR $\begin{array}{lllllllllll}1.00 & 30.12 & 26.97 & 17.01 & 4 & 2422.2185 & 2422.2125 & 606.5604 & 0.0060 & 2.4730 & 3811.994 \\ 0.51 & 45.76 & 26.88 & 58.76 & 2 & 1511.8332 & 1511.8228 & 756.9187 & 0.0104 & 6.8699 & 1107.325\end{array}$ $\begin{array}{llllllllllll}0.51 & 45.76 & 26.88 & 58.76 & 2 & 1511.8332 & 1511.8228 & 756.9187 & 0.0104 & 6.8699 & 1107.325 \\ 0.87 & 18.69 & 26.82 & 15.69 & 4 & 1930.0349 & 1930.0394 & 483.5171 & 0.0045 & -2.3267 & 83.008\end{array}$ HLEINPDHSIIETLR HLEINPDHSIIETLR HLEINPDHSIIETLR HLEINPDHSIIETLR HLEINPDHSIIETLR HLEINPDHSTIETLR $\begin{array}{lllllllllllll}0.87 & 18.69 & 26.82 & 15.69 & 4 & 1930.0349 & 1930.0394 & 483.5171 & -0.0045 & -2.3267 & 83.008 & 105.145\end{array}$ $\begin{array}{llllllllllll}1.00 & 94.79 & 26.86 & 26.42 & 2 & 1930.0382 & 1930.0394 & 966.0270 & -0.0012 & -0.6211 & 1003.246 & 864.969\end{array}$ $\begin{array}{lllllllllllll}1.00 & 94.92 & 26.73 & 27.32 & 2 & 1930.0396 & 1930.0394 & 966.0270 & 0.0002 & 0.1035 & 991.358 & 918.71\end{array}$

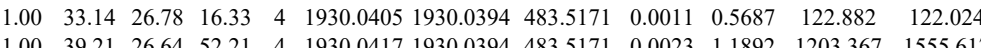
$\begin{array}{lllllllllllll}1.00 & 39.21 & 26.64 & 52.21 & 4 & 1930.0417 & 1930.0394 & 483.5171 & 0.0023 & 1.1892 & 1203.367 & 1555.617 & \\ 1.00 & 27.65 & 26.58 & 40.65 & 4 & 1930.0421 & 1930.0394 & 483.5171 & 0.0027 & 1.3960 & 109.256 & 124.798 & 8\end{array}$ $\begin{array}{llllllllllllll}1.00 & 27.65 & 26.58 & 40.65 & 4 & 1930.0421 & 1930.0394 & 483.5171 & 0.0027 & 1.3960 & 109.256 & 124.798\end{array}$ $\begin{array}{llllllllllll}1.00 & 54.90 & 26.66 & 67.90 & 4 & 1930.0425 & 1930.0394 & 483.5171 & 0.0031 & 1.6028 & 1322.769 & 1854.280\end{array}$

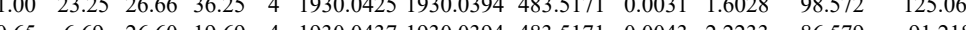

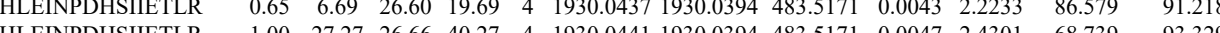
TLENTHET $\begin{array}{lllllllllll}1.00 & 27.27 & 26.66 & 40.27 & 4 & 1930.0441 & 1930.0394 & 483.5171 & 0.0047 & 2.4301 & 68.739\end{array}$

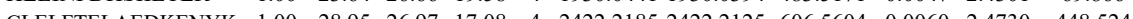
$\begin{array}{lllllllllll}C & \end{array}$
$17.964 \quad \mathrm{No}$

$\begin{array}{llll}16.557 & 153.815 & \text { Y }\end{array}$

$29.383 \quad 140.560$ Yes

$\begin{array}{llll}22.774 & 96.397 & \text { Yes }\end{array}$

$\begin{array}{lll}27.568 & 320.579 & \text { Y }\end{array}$

$\begin{array}{lll}72.954 & 346.654 & \text { Yes }\end{array}$

$\begin{array}{lll} & \\ 5.783 & 195.546 & \text { Yes }\end{array}$ $\begin{array}{lll}20.912 & 2830.488 & \text { Yes }\end{array}$ \begin{tabular}{lll}
1938.101 & Yes \\
\hline .272 & 666.789 & Yes
\end{tabular} $\begin{array}{lll} & \end{array}$ $\begin{array}{lll} & 4596.987 & \text { Yes }\end{array}$ $\begin{array}{lll}64.884 & 4722.262 \text { Yes }\end{array}$ $\begin{array}{llll}64.884 & 640.521 & \text { Yes } \\ 160.355 & 77.080 & & 0 \\ 73.202 & 787.791 & \text { Yes }\end{array}$ $\begin{array}{lll}160.355 & 77.080 \text { No } \\ 73.202 & 787.91 & \text { Yco }\end{array}$ $\begin{array}{lll}73.202 & 787.791 & \text { Yes }\end{array}$ $140.986 \quad 248.47$ Yes $\begin{array}{lll}95.357 & 165.262 & \text { Yes } \\ 11.068 & 9.456 & \text { Yes }\end{array}$ $\begin{array}{lll}5.878 \quad 1464.407 & \text { Yes }\end{array}$ $\begin{array}{llll}4.803 & 19.379 & \text { Yes }\end{array}$ $\begin{array}{llll}20.437 & 228.672 & \text { Yes }\end{array}$ $13.863 \quad 359.626$ Yes $88.541 \quad 153.514$ Yes $\begin{array}{llll}61.342 & 155.159 & \text { Yes }\end{array}$ $\begin{array}{lll}11.637 & 60.559 & \text { Yes }\end{array}$ $\begin{array}{lll}14.215 & 322.162 & \text { Yes }\end{array}$ $14.788 \quad 73.486$ Yes $\begin{array}{lll}1467.423 & 6353.653 & \text { Yes }\end{array}$ $\begin{array}{llll} & 1467.423 & 6353.653 & Y e s \\ 941.390 & 5239.731 & \text { Yes }\end{array}$ $\begin{array}{lll}28.922 & 1523.245 & \text { Yes }\end{array}$ $73.019 \quad 114.198$ Yes $\begin{array}{llll}93.927 & 1209.577 & \text { Yes } \\ 89.480 & 184.963 & \text { Yes }\end{array}$ $85.480 \quad 1484.963$ Yes $\begin{array}{lll}65.016 & 151.955 & \text { Yes } \\ 787.514 & 226.525 & \text { Yes }\end{array}$ $\begin{array}{lll}787.514 & 2246.625 & \text { Yes } \\ 82.217 & 117.86 & \text { Yes }\end{array}$ $\begin{array}{lll}82.217 & 117.863 & \text { Yes } \\ 651.797 & 1993.091 & \text { Yes }\end{array}$ $\begin{array}{llll}85.423 & 1173.091 & \text { Yes } \\ 77.683 & \text { Yes }\end{array}$ $\begin{array}{lll}77.707 & 148.494 & \text { Yes }\end{array}$ $52.574 \quad 123.974$ Yes $\begin{array}{lll}47.353 & 70.873 & \text { Yes }\end{array}$ 
HLEINPDHSIIETLR HLEINPDHSIIETLR HLEINPDHSIIETLR HLEINPDHSIIETLR HLEINPDHSIIETLR HLEINPDHSIIETL FYEQFSK

APFDLFENR APFDLFENR APFDLFENR APFDLFENR

APFDLFENR

APFDLFENR

HGLEVIY

APFDLFENR

HGLEVIYMIEPIDEYCVQQLK

ELHINLIPNK

ELHINLIPNK
ELHINLIPNK

HGLEVIYMIEPIDEYCVQQ RAPFDLFENR

RAPFDLFENR

VFIMDNCEELIPEYLNF

DLVILLYETALLSSGGSLEDPPTHA

DLVLLYYTALLLSSGFSLEDPTHAN

DLVILLYETALLSSGFLLEPPTHAN

DLVILYYTALLLSGGSLERPQTHAN

DLVILLYETALLLSGGFLLEPPTHA

DLVILLYETALLSSGFSLEPPTHA

DLVILYYETALSSGFSLEDPQTHA

DLVILYETALLLSGGFLLEDPPTH

DLVILLYETALLSSGFSLEDPQTH

HSQFIGYPITLFVEK

HSQFIGYPITLFVEK

HSQFIGYPITLFVEK

HSQFIGYPITLFVEK

DLVILLYETALLSSGFLLEPPTHAN

DLVLLLYETALSSGFSLEDPQTHA

DLVILLYETALLSSGFFLEDPPTHA

DLVILLYETALLSSGFSLEDPPTHA

HSQFIGYPITLFVEEK

HSQFIGYPITLFVEK

DVILLYETALLSSGFSLEPPTTHAN

HSQFIGYPITLFVEK

HSQFIGYPITLFVEK

HSQFIGYPITLFVEK

HSQFIGYPITLFVEK

HSQFIGYPITLFVEK

HSQFIGYPITLFVEK

LVTSPCCIVTSTYGWTANME

TDTGEPMGR

NPDDITNEEYGE

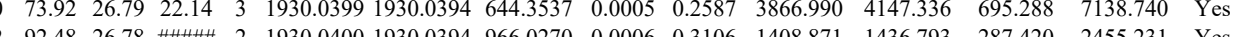

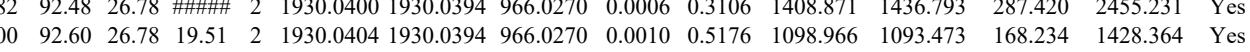

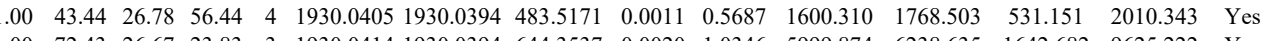

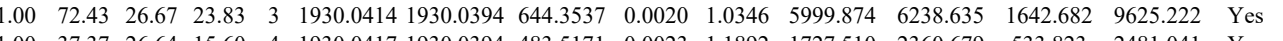
$\begin{array}{lllllllllllllll}1.00 & 37.37 & 26.64 & 15.60 & 4 & 1930.0417 & 1930.0394 & 483.5171 & 0.0023 & 1.1892 & 1727.510 & 2360.679 & 533.823 & 2481.041 & \text { Yes } \\ 0.92 & 32.29 & 28.33 & 30.68 & 2 & 1235.6546 & 1235.4430 & 618.8288 & 0.0116 & 9.3725 & 4632.250 & 3850.880 & 732.449 & 13565.750 & \text { No }\end{array}$ $\begin{array}{llllllllllllllll}0.92 & 32.29 & 28.33 & 30.68 & 2 & 1235.6546 & 1235.6430 & 618.8288 & 0.0116 & 9.3725 & 4632.250 & 3850.880 & 732.449 & 13565.750 & \text { No }\end{array}$ $\begin{array}{lllllllllllllll}0.73 & 30.82 & 27.23 & 22.18 & 2 & 1251.6346 & 1251.6370 & 626.8258 & -0.0024 & -1.9144 & 122.492 & 170.020 & 115.461 & 223.347 & \text { Yes } \\ 0.53 & 19.34 & 27.53 & 19.55 & 2 & 1251.6374 & 1251.6370 & 626.8258 & 0.0004 & 0.3191 & 169.346 & 177.172 & 135.320 & 189.846 & \text { Yes }\end{array}$

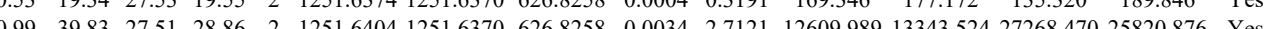

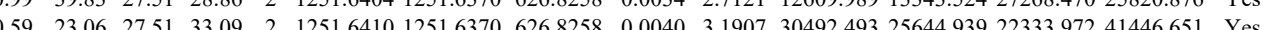

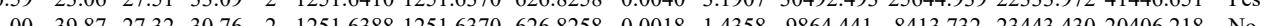

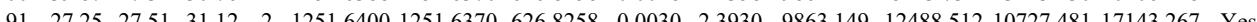

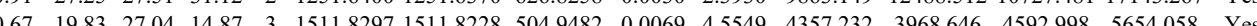

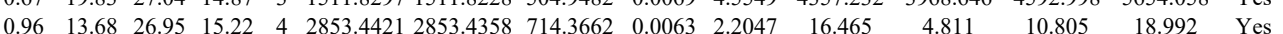

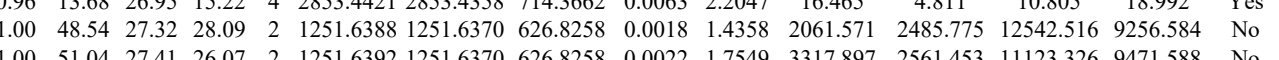
$\begin{array}{lllllllllllllll}1.00 & 51.04 & 27.41 & 26.07 & 2 & 1251.6392 & 1251.6370 & 626.8258 & 0.0022 & 1.7549 & 3317.897 & 2561.453 & 11123.326 & 9471.588 & \text { No }\end{array}$

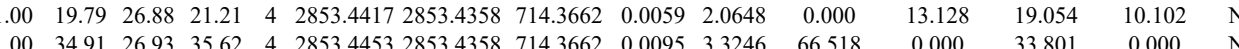

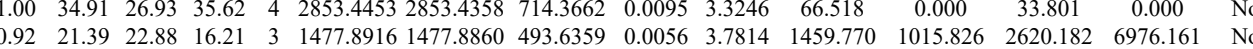
$\begin{array}{lllllllllllllll}1.00 & 47.10 & 22.65 & 21.87 & 2 & 1477.8928 & 1477.8860 & 739.9503 & 0.0068 & 4.5949 & 12.107 & 27.851 & 35.843 & 75.432 & \text { Yes }\end{array}$ $\begin{array}{lllllllllllllll}0.94 & 24.62 & 22.43 & 20.02 & 3 & 1477.8940 & 1477.8860 & 493.6359 & 0.0080 & 5.4021 & 2869.022 & 1639.768 & 3320.263 & 9224.886 & \text { Yes }\end{array}$ $\begin{array}{lllllllllllllll}0.95 & 12.15 & 26.95 & 17.70 & 4 & 2853.4413 & 2853.4358 & 714.3662 & 0.0055 & 1.9248 & 9.050 & 0.000 & 27.618 & 19.324 & \text { No }\end{array}$

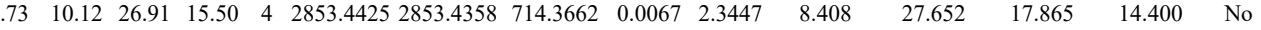

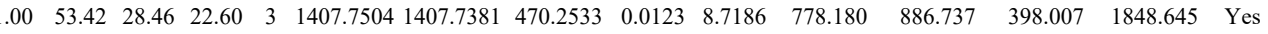

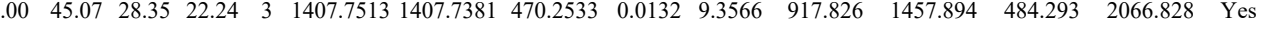

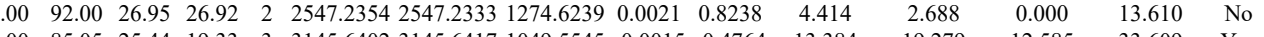

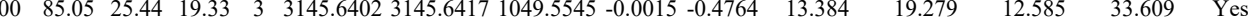

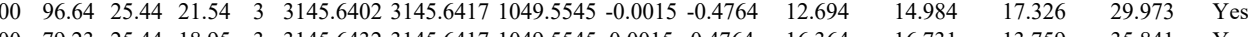

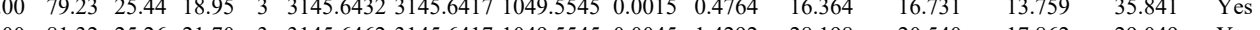

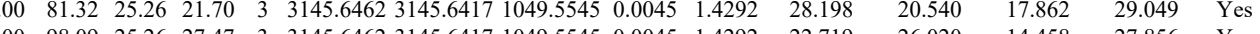

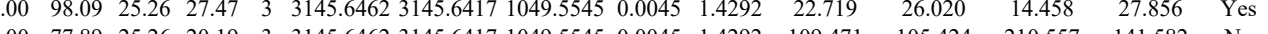
$\begin{array}{lllllllllllll} & \end{array}$

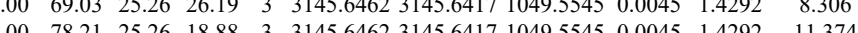
$\begin{array}{lllllllllll}1.00 & 53.98 & 25.24 & 17.32 & 4 & 3145.6465 & 3145.6417 & 787.4177 & 0.0048 & 1.5240 & 18.441\end{array}$ $\begin{array}{lllllllllll}0.99 & 14.32 & 25.20 & 17.88 & 4 & 3145.6477 & 3145.6417 & 787.4177 & 0.0060 & 1.9050 & 3.622\end{array}$

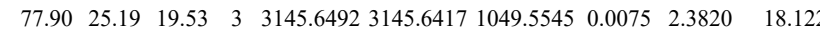

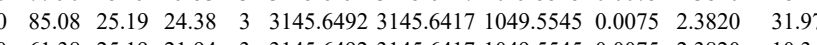
$\begin{array}{llllllllllll}0.82 & 73.77 & 25.51 & 86.77 & 2 & 2066.1454 & 2066.1444 & 1034.0795 & 0.0010 & 0.4835 & 303.378\end{array}$ $\begin{array}{llllllllllllll}0.72 & 60.83 & 25.33 & 73.83 & 2 & 2066.1474 & 2066.1444 & 1034.0795 & 0.0030 & 1.4506 & 243.238 & 3 & & \\ 1.00 & 34.20 & 2.98 & 6.04 & 3 & 2066.196 & 2066.144 & 68.7221 & 0.0052 & 2.531 & 723.717 & 10\end{array}$ $\begin{array}{lllllllllll}1.00 & 34.20 & 24.98 & 16.04 & 3 & 2066.1496 & 2066.1444 & 689.7221 & 0.0052 & 2.5131 & 723.717\end{array}$ $\begin{array}{llllllllllll}1.00 & 42.22 & 24.77 & 23.08 & 3 & 2066.1508 & 2066.1444 & 689.7221 & 0.0064 & 3.0930 & 1144.950 \\ 1.00 & 79.43 & 25.44 & 20.41 & 3 & 3145.6402 & 3145.6417 & 1049.5545 & -0.0015 & -0.4764 & 18.046\end{array}$ $\begin{array}{llllllllllll}1.00 & 71.03 & 25.44 & 21.16 & 3 & 3145.6432 & 3145.6417 & 1049.5545 & 0.0015 & 0.4764 & 49.314\end{array}$ $\begin{array}{llllllllllll}1.00 & 91.77 & 25.44 & 21.66 & 3 & 3145.6432 & 3145.6417 & 1049.5545 & 0.0015 & 0.4764 & 23.912\end{array}$ $\begin{array}{llllllllllll}1.00 & 78.31 & 25.26 & 19.10 & 3 & 3145.6462 & 3145.6417 & 1049.5545 & 0.0045 & 1.4292 & 144.619\end{array}$

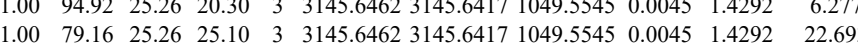
$\begin{array}{llllllllllll}0.99 & 35.85 & 24.80 & 20.60 & 3 & 2066.1526 & 2066.1444 & 689.7221 & 0.0082 & 3.9629 & 813.232\end{array}$ $\begin{array}{llllllllllll}1.00 & 47.36 & 24.73 & 23.83 & 3 & 2066.1538 & 2066.1444 & 689.7221 & 0.0094 & 4.5429 & 2570.698 & 153 \\ 1.00 & 83.46 & 25.44 & 2.83 & 3 & 31456432 & 31456417 & 1049.5545 & 0.0015 & 0.4764 & 53.892 & 33\end{array}$ $\begin{array}{lllllllllll}1.00 & 83.46 & 25.44 & 20.83 & 3 & 3145.6432 & 3145.6417 & 1049.5545 & 0.0015 & 0.4764 & 53.892 \\ 1.00 & 83.15 & 25.44 & 19.50 & 3 & 3145.6432 & 3145.6417 & 1049.5545 & 0.0015 & 0.4764 & 44.272\end{array}$ $\begin{array}{lllllllllllll}1.00 & 60.52 & 25.33 & 17.68 & 2 & 2066.1474 & 2066.1444 & 1034.0795 & 0.0030 & 1.4506 & 731.894 & 686.7 \\ 1.00 & 42.73 & 25.01 & 16.45 & 3 & 2066.1493 & 2066.1444 & 689.7221 & 0.0049 & 23681 & 907.319 & 962.1\end{array}$ $\begin{array}{lllllllllllllll}1.00 & 42.73 & 25.01 & 16.45 & 3 & 2066.1493 & 2066.1444 & 689.7221 & 0.0049 & 2.3681 & 907.319 & 962.1 \\ 0.99 & 25.42 & 25.31 & 17.52 & 3 & 2066.1478 & 2066.1444 & 689.7221 & 0.0034 & 1.6432 & 1088.614 & 1404 \\ 0.78 & 14.08 & 25.30 & 15.15 & 3 & 2066.1487 & 2066.144 & 689.722 & 0.004 & 2.0781 & 3627.228 & 3202\end{array}$ $\begin{array}{llllllllllllll}0.78 & 14.08 & 25.30 & 15.15 & 3 & 2066.1487 & 2066.1444 & 689.7221 & 0.0043 & 2.0781 & 3627.228 & 320 .\end{array}$ $\begin{array}{llllllllllll}0.60 & 15.70 & 25.33 & 28.70 & 3 & 2066.1484 & 2066.1444 & 689.7221 & 0.0040 & 1.9331 & 897.875 & 1160.96 \\ 1.00 & 36.85 & 25.51 & 18.19 & 3 & 2066.1457 & 2066.1444 & 689.7221 & 0.0013 & 0.6283 & 1631.482 & 1599.09\end{array}$ $\begin{array}{llllllllllll}1.00 & 38.01 & 25.35 & 19.18 & 3 & 2066.1460 & 2066.1444 & 689.7221 & 0.0016 & 0.7733 & 404.333 & 399.721\end{array}$ $\begin{array}{llllllllllll}0.66 & 25.09 & 24.12 & 38.09 & 3 & 2567.1496 & 2567.1473 & 856.7230 & 0.0023 & 0.8949 & 9.999\end{array}$ $\begin{array}{llllllllllll}0.97 & 26.28 & 24.71 & 22.58 & 2 & 1106.5170 & 1106.5148 & 554.2647 & 0.0022 & 1.9846 & 300.162\end{array}$

17.942



$\begin{array}{llllllllllllllll} & \end{array}$

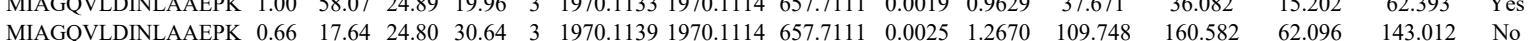

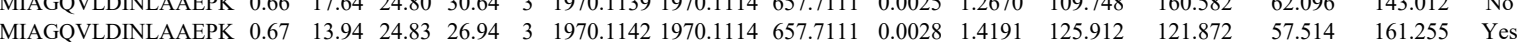
$\begin{array}{llllllllllll} & \end{array}$ $\begin{array}{lllllllllllllll} & \end{array}$ $\begin{array}{lllllllllllllll} & \end{array}$ $\begin{array}{llllllllllllllll}\text { MIAGQVDDNAAEPK } & 1.00 & 39.10 & 24.73 & 18.71 & 3 & 1970.1148 & 1970.1114 & 657.7111 & 0.0034 & 1.7231 & 60.883 & 44.808 & 29.013 & 59.149 & \text { Yes }\end{array}$

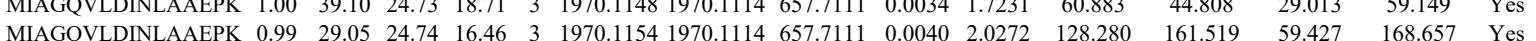

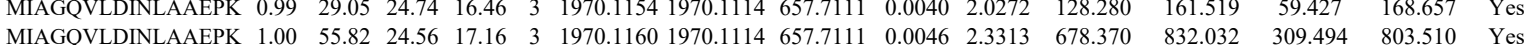

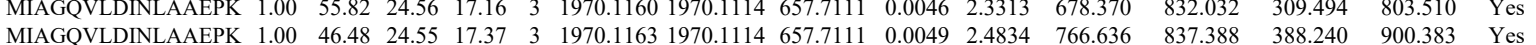

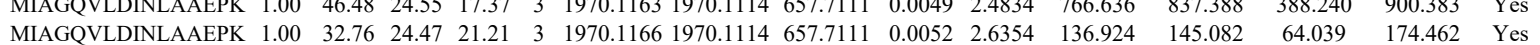
$\begin{array}{lllllllllllllllll}\text { MIAGQVLDINLAAEPK } & 0.78 & 15.44 & 24.47 & 22.60 & 3 & 1970.1169 & 1970.1114 & 657.7111 & 0.0055 & 2.7874 & 58.082 & 48.244 & 20.222 & 69.544 & \text { Yes }\end{array}$

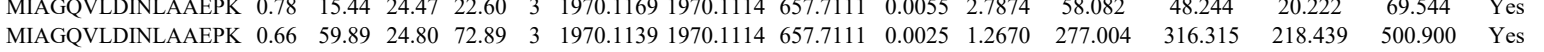

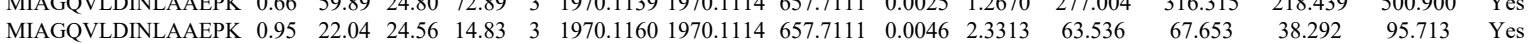

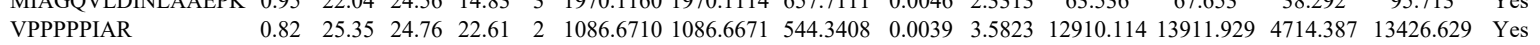
$\begin{array}{llllllllllllllll}\text { VPPPPPIAR } & 0.94 & 34.95 & 24.79 & 24.39 & 2 & 1086.6728 & 1086.6671 & 544.3408 & 0.0057 & 5.2357 & 10564.007 & 10874.135 & 4595.427 & 11894.957 & \text { Yes }\end{array}$ $\begin{array}{lllllllllllllllll}\text { VPPPPPIAR } & 0.91 & 27.61 & 22.58 & 30.06 & 2 & 1086.6768 & 1086.6671 & 544.3408 & 0.0097 & 8.9098 & 4042.638 & 5287.133 & 2187.496 & 4468.852 & \text { No }\end{array}$ $\begin{array}{lllllllllllllllll}\text { VPPPPPIAR } & 0.80 & 22.48 & 22.58 & 27.49 & 2 & 1086.6768 & 1086.6671 & 544.3408 & 0.0097 & 8.9098 & 5709.232 & 5355.654 & 2821.413 & 3901.645 & \text { No }\end{array}$ $\begin{array}{llllllllllllllll}\text { VPPPPPIAR } & 0.91 & 27.48 & 22.41 & 22.28 & 2 & 1086.6760 & 1086.6671 & 544.3408 & 0.0089 & 8.1750 & 916.569 & 750.845 & 502.241 & 1104.465 & \text { Yes }\end{array}$ $\begin{array}{llllllllllllllll}\text { VFIGNLNTLVVK } & 1.00 & 73.08 & 19.68 & 22.69 & 2 & 1603.9918 & 1603.9905 & 803.0025 & 0.0013 & 0.8095 & 9193.595 & 11214.591 & 2491.672 & 18409.631 & \text { Yes }\end{array}$ $\begin{array}{llllllllllllllll}\text { VFIGNLNTLVVK } & 1.00 & 70.67 & 18.92 & 27.24 & 2 & 1603.9986 & 1603.9905 & 803.0025 & 0.0081 & 5.0435 & 7817.158 & 5037.923 & 2780.995 & 12379.773 & \text { Yes }\end{array}$ $\begin{array}{llllllllllllllll}\text { VFIGNLNTLVVK } & 1.00 & 68.70 & 19.68 & 22.59 & 2 & 1603.9924 & 1603.9905 & 803.0025 & 0.0019 & 1.1831 & 9469.424 & 7583.843 & 2062.729 & 17719.779 & \text { Yes }\end{array}$ $\begin{array}{lllllllllllllllll}\text { VFIGNLNTLVVK } & 1.00 & 70.56 & 19.59 & 22.82 & 2 & 1603.9926 & 1603.9905 & 803.0025 & 0.0021 & 1.3076 & 12112.551 & 9410.671 & 1168.000 & 19251.000 & \text { Yes }\end{array}$ VDSLLENLEK VDSLLENLEK $\begin{array}{llllllllllllllllll}1.00 & 60.28 & 27.60 & 32.17 & 2 & 1282.7140 & 1282.7012 & 642.3579 & 0.0128 & 9.9632 & 6264.189 & 5985.999 & 1417.351 & 8611.796 & \text { Yes }\end{array}$

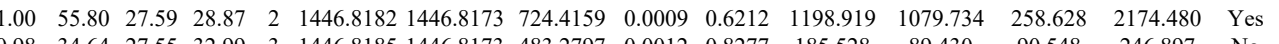

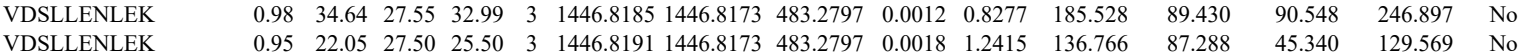

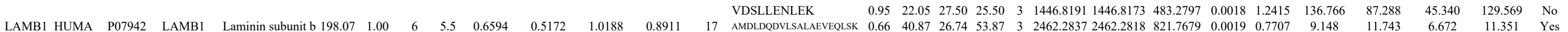

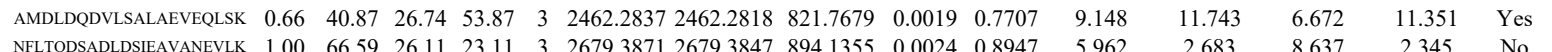

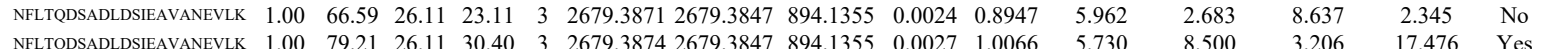

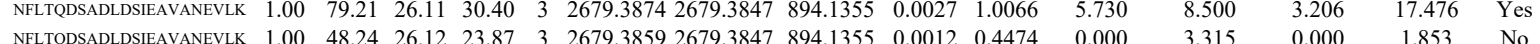
$\begin{array}{llllllllllllll} & \end{array}$

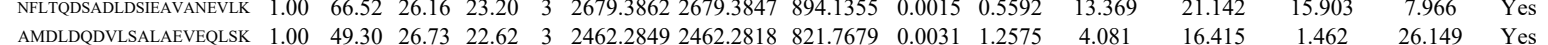

Table S-4 page 114 of 614 

$\begin{array}{lllllllllllll}\text { THTQDAVPLTLGeEFSGYVQQVK } & 1.00 & 44.99 & 26.59 & 18.76 & 3 & 2833.4860 & 2833.4854 & 945.5024 & 0.0006 & 0.2115 & 89.974 \\ \text { THTDDAVPLLGQEFSGYVQOVK } & 1.00 & 50.18 & 26.50 & 20.32 & 4 & 2833.4897 & 2833.4854 & 709.3786 & 0.0043 & 1.5154 & 75.612\end{array}$ $\begin{array}{llllllllllll}\text { THTODAVPLILGQEFGGYVQQVK } & 1.00 & 50.18 & 26.50 & 20.32 & 4 & 2833.4897 & 2833.4854 & 709.3786 & 0.0043 & 1.5154 & 75.612 \\ \text { IYELAAGGTAVGTGLNTR } & 1.00 & \text { \#\#\#\# } 26.59 & 29.07 & 2 & 1907.0424 & 1907.0234 & 954.5190 & 0.0190 & 9.9526 & 381.777\end{array}$

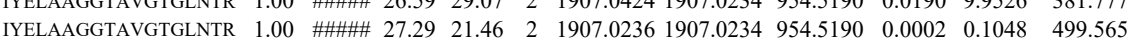
YELAAGGTAVGTGLNTR 1.00 \#\#\#\# $27.29 \begin{array}{llllllllll}25.94 & 2 & 1907.0240 & 1907.0234 & 954.5190 & 0.0006 & 0.3143 & 143.28\end{array}$ $\begin{array}{lllllllllll} & 0.3630 & 14.535\end{array}$ $\begin{array}{llllllllllllll} & \end{array}$

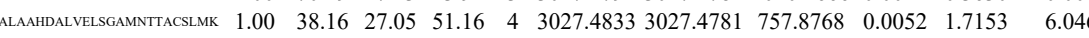

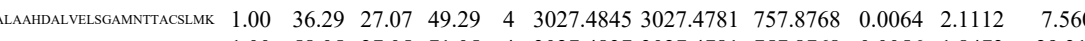
$\begin{array}{llllllllllll} & \end{array}$

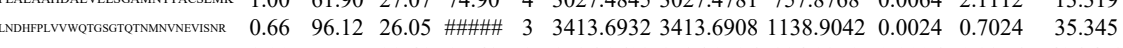

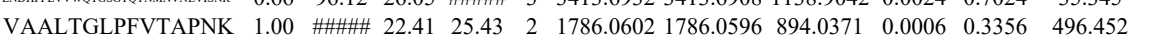
$\begin{array}{lllllllllllll}\text { AAAEVNQDYGLDPK } & 1.00 & 74.65 & 27.84 & 25.33 & 2 & 1777.9122 & 1777.9090 & 889.9618 & 0.0032 & 1.7978 & 81.367\end{array}$ \begin{tabular}{lllllllllllllllll} 
GGVNDNFQGVLQNVR & 1.00 & 92.33 & 28.12 & 30.84 & 2 & 1759.9092 & 1759.9088 & 880.9617 & 0.0004 & 0.2270 & 1072.313 & 1302.610 & 562.778 & 292.992 & Yes \\
\hline
\end{tabular} $\begin{array}{lllllllllllllll} & \end{array}$

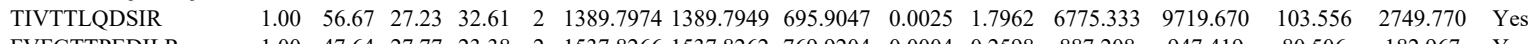

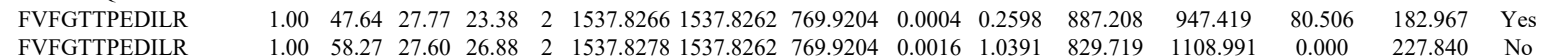

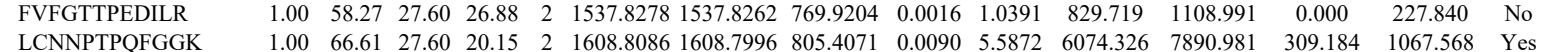




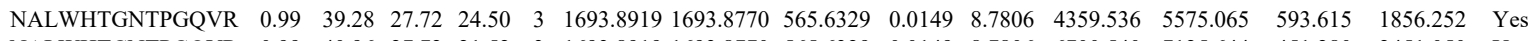
$\begin{array}{lllllllllllllllll}\text { NALWHTGNTPGQVR } & 0.99 & 40.96 & 27.72 & 21.52 & 3 & 1693.8919 & 1693.8770 & 565.6329 & 0.0149 & 8.7806 & 6700.540 & 7125.644 & 451.280 & 2451.050 & \text { Yes }\end{array}$ $\begin{array}{lllllllllllllllll}\text { NALWHTGNTPGQVR } & 0.97 & 33.93 & 27.89 & 15.26 & 3 & 1693.8853 & 1693.8770 & 565.6329 & 0.0083 & 4.8913 & 1409.881 & 1573.248 & 160.012 & 758.771 & \text { Yes }\end{array}$ $\begin{array}{llllllllllllllll}\text { GFLLLASLR } & 0.99 & 38.69 & 25.49 & 31.41 & 2 & 1132.7092 & 1132.7090 & 567.3618 & 0.0002 & 0.1763 & 590.477 & 631.790 & 87.903 & 274.490 & \text { Yes }\end{array}$ $\begin{array}{llllllllllllllll}\text { GFLLLASLR } & 0.96 & 27.82 & 25.49 & 33.37 & 2 & 1132.7096 & 1132.7090 & 567.3618 & 0.0006 & 0.5288 & 192.742 & 266.075 & 46.349 & 189.413 & \text { No }\end{array}$

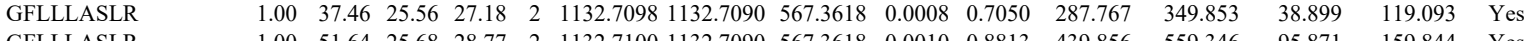
$\begin{array}{llllllllllllllll}\text { GFLLLASLR } & 1.00 & 51.64 & 25.68 & 28.77 & 2 & 1132.7100 & 1132.7090 & 567.3618 & 0.0010 & 0.8813 & 439.856 & 559.346 & 95.871 & 159.844 & \text { Yes }\end{array}$

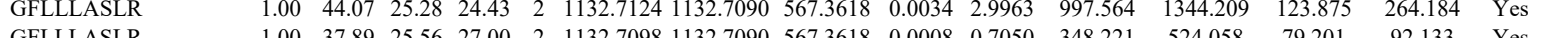

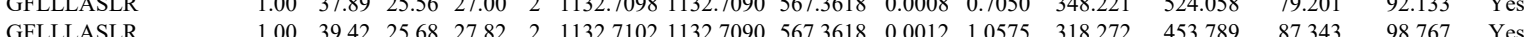

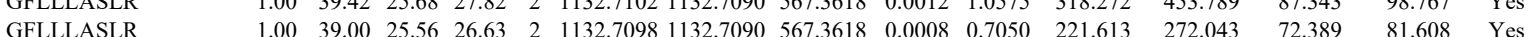

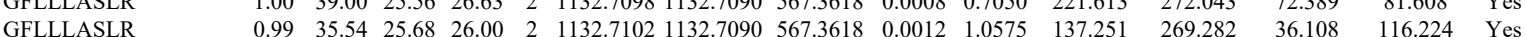

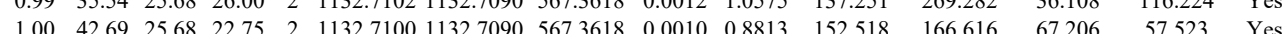

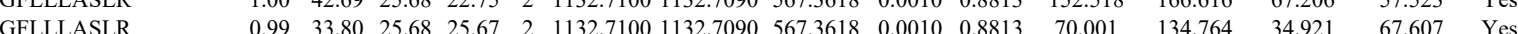

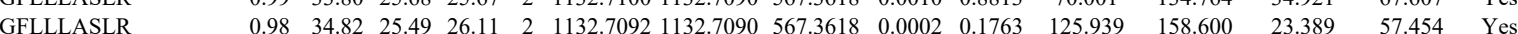
GFLLLASLR GFLLLASLR GFLLLASLR GFLLLASLR GFLLLASLR GFLLLASLR GFLLLASLR GFLLLASLR IEDANLIPPVPDDK $\begin{array}{llllllllllll}100 & 40.13 & 25.68 & 26.19 & 2 & 1132.7100 & 1132.7090 & 567.3618 & 0.0010 & 0.8813 & 74.966 & 145.536\end{array}$ $\begin{array}{lllllllllllllll}100 & 38.76 & 25.56 & 26.40 & 2 & 1132.7098 & 1132.7090 & 567.3618 & 0.0008 & 0.7050 & 99.533 & 115.924\end{array}$ $\begin{array}{lllllllllllll}0.95 & 25.55 & 25.68 & 25.05 & 2 & 1132.7102 & 1132.7090 & 567.3618 & 0.0012 & 1.0575 & 90.428 & 98.176\end{array}$ $\begin{array}{lllllllllllll}0.99 & 38.69 & 25.49 & 26.91 & 2 & 1132.7094 & 1132.7090 & 567.3618 & 0.0004 & 0.3525 & 115.679 & 134.89\end{array}$ $\begin{array}{lllllllllllll}0.99 & 32.76 & 25.49 & 21.44 & 2 & 1132.7096 & 1132.7090 & 567.3618 & 0.0006 & 0.5288 & 112.123 & 90.654\end{array}$

GGSGSGPTIEEVD

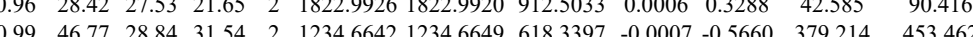
$\begin{array}{llllllllllll}1.00 & 49.95 & 28.98 & 32.21 & 2 & 1234.6648 & 1234.6649 & 618.3397 & -0.0001 & -0.0809 & 404.818 & 626.367\end{array}$ $\begin{array}{lllllllllllll}0.85 & 21.39 & 26.69 & 20.32 & 2 & 1347.6284 & 1347.6276 & 674.8211 & 0.0008 & 0.5927 & 203.587 & 184.007\end{array}$ $\begin{array}{llllllllllllll} & \end{array}$ $\begin{array}{lllllllllllllll}\text { CQEVISWLDANTLAEKDEFEHK } & 0.98 & 27.00 & 26.90 & 40.00 & 4 & 3082.5189 & 3082.5105 & 771.6349 & 0.0084 & 2.7215 & 80.564 & 100.625 \\ \text { CQEVISWLDANTLAFKDEFEHK } & 1.00 & 38.66 & 26.87 & 51.66 & 4 & 30825165 & 30825105 & 771.6349 & 0.0060 & 1.9439 & 612.910 & 900.579 & \end{array}$ $\begin{array}{lllllllllllll}\text { CQEVISWLDANTLAEKDEFEHK } & 1.00 & 38.66 & 26.87 & 51.66 & 4 & 3082.5165 & 3082.5105 & 711.6349 & 0.0060 & 1.9439 & 612.910 & 900.579\end{array}$ $\begin{array}{lllllllllllll}\text { CQEVISWLDANTLAEKDEFEHK } & 1.00 & 48.54 & 26.90 & 61.54 & 4 & 3082.5177 & 3082.5105 & 771.6349 & 0.0072 & 2.3327 & 1995.639 & 3255.26\end{array}$ $\begin{array}{lllllllllllllll}\text { CQEVISWLDANTLAEKDEFEHK } & 1.00 & 60.25 & 26.79 & 73.25 & 4 & 3082.5133 & 3082.5105 & 771.6349 & 0.0028 & 0.9072 & 1058.861 & 2013.550 & 17 \\ \text { CQEVISWLDANTLAEKDEFEHK } & 0.99 & 25.55 & 26.87 & 38.55 & 4 & 3082.5149 & 3082.5105 & 771.6349 & 0.0044 & 1.4255 & 42.150 & 22.729 & \end{array}$ COEVISWLDANTLAF LVNHFVEEFK LVNHFVEEFK

LVNHFVEFK

LVNHFVEEFK

LVNHFVEEFK

LVNHFVEEFK

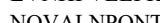
$\begin{array}{llllllllllll}0.99 & 25.55 & 26.87 & 38.55 & 4 & 3082.5149 & 3082.5105 & 771.6349 & 0.0044 & 1.4255 & 42.150 & 22.729 \\ 1.00 & 50.99 & 27.29 & 24.45 & 2 & 1548.8562 & 1548.8544 & 775.4345 & 0.0018 & 1.1606 & 3629.371 & 5652.782\end{array}$ $\begin{array}{llllllllllll}1.00 & 50.99 & 27.29 & 24.45 & 2 & 1548.8562 & 1548.8544 & 775.4345 & 0.0018 & 1.1606 & 3629.371 & 5652.782 \\ 0.67 & 42.63 & 27.14 & 55.63 & 3 & 1548.8572 & 1548.8544 & 517.2921 & 0.0028 & 1.8043 & 8060.796 & 11869.239\end{array}$ $\begin{array}{lllllllllllll}0.99 & 48.45 & 27.06 & 22.17 & 2 & 1548.8594 & 1548.8544 & 775.4345 & 0.0050 & 3.2240 & 3968.359 & 5119.325\end{array}$ $\begin{array}{lllllllllllll}1.00 & 40.21 & 27.06 & 16.86 & 3 & 1548.8596 & 1548.8544 & 517.2921 & 0.0052 & 3.3508 & 7203.426 & 11039.586\end{array}$ $\begin{array}{llllllllllllll}1.00 & 51.82 & 27.17 & 23.20 & 2 & 1548.8558 & 1548.8544 & 775.4345 & 0.0014 & 0.9027 & 6673.798 & 8890.353 & 0\end{array}$ $\begin{array}{lllllllllllllll}1.00 & 49.08 & 26.79 & 21.39 & 2 & 1548.8586 & 1548.8544 & 775.4345 & 0.0042 & 2.7082 & 5697.169 & 8956.623\end{array}$ $\begin{array}{llllllllllll}1.00 & 49.81 & 27.06 & 16.39 & 3 & 1548.8599 & 1548.8544 & 517.2921 & 0.0055 & 3.5441 & 7589.902 & 11771.575 \\ 1.00 & 7233 & 26.41 & 22.55 & 2 & 1946.0658 & 1946.0465 & 974.0305 & 0.0193 & 9.9072 & 809.968 & 1182.629\end{array}$ $\begin{array}{lllllllllllllll}\text { NQVALNPNTFAK } & 1.00 & 72.33 & 26.41 & 22.55 & 2 & 1946.0658 & 1946.0465 & 974.0305 & 0.0193 & 9.9072 & 809.968 & 1182.629 & 392.2 \\ \text { NQVALNPQNTVDAK } & 0.99 & 37.85 & 26.41 & 16.86 & 3 & 1946.0659 & 1946.0465 & 649.6894 & 0.0194 & 9.9534 & 1256.457 & 1284.307 & 755.5 \\ \text { LVNHFFVEFK } & 0.97 & 33.69 & 27.19 & 21.28 & 2 & 1548.8540 & 1548.8544 & 775.4345 & -0.0004 & -0.2579 & 336.385 & 459.755 & 84.4\end{array}$ LVNHFVEEFK $\begin{array}{lllllllllllll}\text { NQVALNPQNTVFDAK } & 1.00 & 87.12 & 26.41 & 24.29 & 2 & 1946.0656 & 1946.0465 & 974.0305 & 0.0191 & 9.8045 & 647.045 & 683.761\end{array}$ $\begin{array}{lllllllllllllll}\text { NQVALNPQNTVFDAK } & 1.00 & 95.44 & 26.41 & 23.27 & 2 & 1946.0658 & 1946.0465 & 974.0305 & 0.0193 & 9.9072 & 704.808 & 1147.358 & 515.24 \\ \text { IINEPTAAAIAYGLDR } & 1.00 & 88.40 & 26.76 & 27.76 & 2 & 1830.9972 & 1830.9961 & 916.5053 & 0.0011 & 0.6001 & 5525.192 & 9247.824 & 559.63\end{array}$

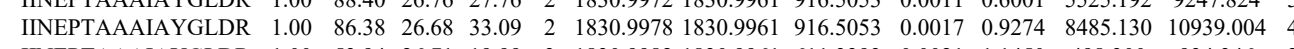
$\begin{array}{llllllllllllll}\text { IINEPTAAAIAYGLDR } & 1.00 & 53.94 & 26.71 & 19.99 & 3 & 1830.9982 & 1830.9961 & 611.3393 & 0.0021 & 1.1450 & 498.300 & 934.346\end{array}$ FEELCSDLFR $\begin{array}{lllllllllllll}1.00 & 56.36 & 24.42 & 28.97 & 2 & 1447.6612 & 1447.6597 & 724.8371 & 0.0015 & 1.0347 & 4662.439 & 7819.95\end{array}$ EELCSDLFR $\begin{array}{lllllllllllll}1.00 & 57.24 & 24.41 & 24.94 & 2 & 1447.6614 & 1447.6597 & 724.8371 & 0.0017 & 1.1727 & 330.276 & 621.652\end{array}$

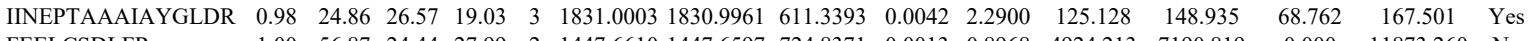
$\begin{array}{llllllllllllllll} & 1.00 & 56.87 & 24.44 & 27.99 & 2 & 1447.6610 & 1447.6597 & 724.8371 & 0.0013 & 0.8968 & 4924.213 & 7190.819 & 0.000 & 11873.260 & \text { No }\end{array}$

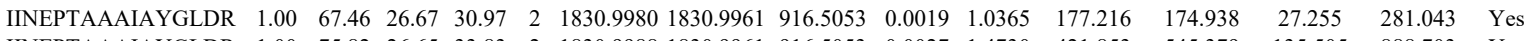

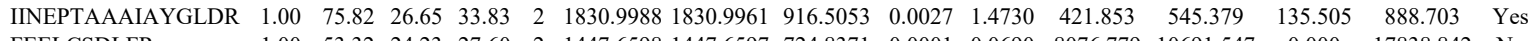

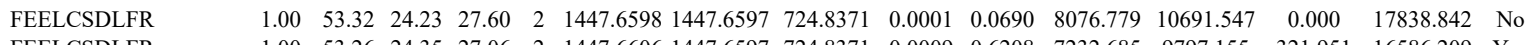
$\begin{array}{llllllllllllllll}\text { FEELCSDLFR } & 1.00 & 53.26 & 24.35 & 27.06 & 2 & 1447.6606 & 1447.6597 & 724.8371 & 0.0009 & 0.6208 & 7232.685 & 9797.155 & 321.951 & 16586.209 & \text { Yes }\end{array}$

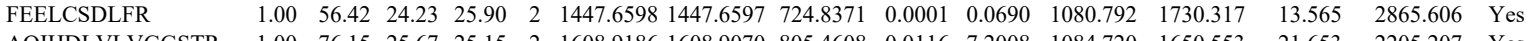

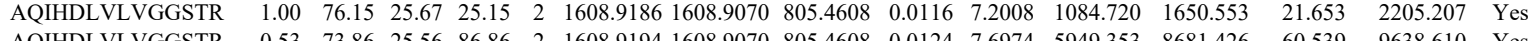

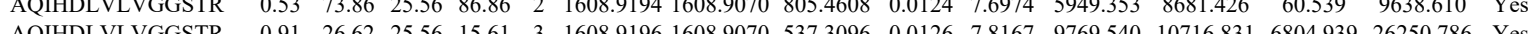
$\begin{array}{lllllllllllllllllll}\text { AQRHDLVLVGGSR } & 0.91 & 26.62 & 25.56 & 15.61 & 3 & 1608.9196 & 1608.9070 & 537.3096 & 0.0126 & 7.8167 & 9769.540 & 10716.831 & 6804.939 & 26250.786 & \text { Yes }\end{array}$ $\begin{array}{lllllllllllllllll}\text { AQIHDLVLVGGSTR } & 0.99 & 35.52 & 25.72 & 22.17 & 3 & 1608.9211 & 1608.9070 & 537.3096 & 0.0141 & 8.7472 & 10171.092 & 10071.373 & 6107.262 & 21971.401 & \text { Yes }\end{array}$

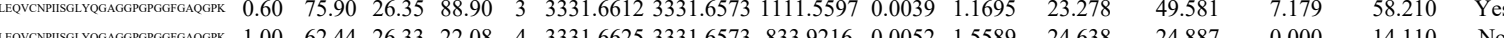

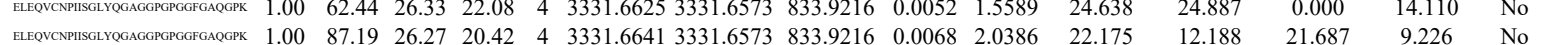

Table S-4 page 116 of 614 
$\begin{array}{llllllll} & \end{array}$

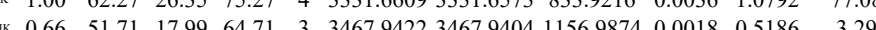

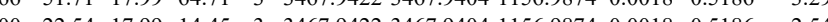

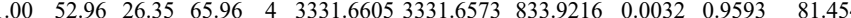

ENVQDLLLDVAPLLLLLETAGGYMTAL $\begin{array}{lllllllllll}1.00 & 25.41 & 26.31 & 38.41 & 4 & 3331.6617 & 3331.6573 & 833.9216 & 0.0044 & 1.3191 & 38.639\end{array}$

LLQDFFNGR $\begin{array}{llllllllll}0.66 & 63.00 & 17.99 & 76.00 & 3 & 3467.9422 & 3467.9404 & 1156.9874 & 0.0018 & 0.5186\end{array}$

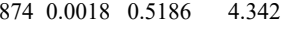
4.342

$\begin{array}{llllllllll} & \end{array}$

$\begin{array}{lllllllll} & \end{array}$

FGDPVVQSDMK

$\begin{array}{lllllllllll}27.40 & 30.05 & 2 & 1252.6708 & 1252.6686 & 627.3416 & 0.0022 & 1.7534 & 22488.153 & 33302.621\end{array}$

FGDPVVQSDMK

$\begin{array}{lllllllllllll}1.00 & 44.42 & 27.40 & 30.05 & 2 & 1252.6708 & 1252.6686 & 627.3416 & 0.0022 & 1.7534 & 22488.153 & 33302.621\end{array}$

GDPVVQSDMK

$\begin{array}{llllllllllll}1.00 & 66.44 & 28.10 & 23.77 & 2 & 1509.7888 & 1509.7741 & 755.8943 & 0.0147 & 9.7235 & 844.248 & 1046.575\end{array}$

$\begin{array}{llllllllllll}1.00 & 51.63 & 28.11 & 17.56 & 2 & 1509.7876 & 1509.7741 & 755.8943 & 0.0135 & 8.9297 & 993.017 & 1142.221 \\ 1.00 & 51.09 & 28.03 & 2.27 & 2 & 1509.7886 & 1509.7741 & 755.8943 & 0.0145 & 9.5912 & 1356.041 & 2242.864\end{array}$

GLGTDEDTHDIITH

GLGTDEDTIIDIITHR

GLGTDEDTIDITHR 0.6

ALIEILATR

ALIEILATR

ALIEILATR

CLIEILASR

CLIEILASR

ILISLATGHR

ILISLATGHR

ILISLATGHR

ILISLATGHR

ILISLATGHR
ILISLATGHR

ILISLATGHR

FMTILCTR

MLVVLLQGTR

MLVVLLQGTR

MLVVLLQGTR
MLVVLLQGTR

FMTILCTR

FMTILCTR

FMTILCTR

FMTILCTR

MLVVLLQGTR

MLVVLLQGTR

MLVVLLQGTR
FMTILCTR

FMTILCTR

FMTILCTR

MLVVLLQGTR

MLVVLLQGT

FMTILCTR

FMTILCTR

MLVVLLQGTR

$\begin{array}{lllllllllllll}1.00 & 51.09 & 28.03 & 20.27 & 2 & 1509.7886 & 1509.7741 & 755.8943 & 0.0145 & 9.5912 & 1356.041 & 2242.864 & 617.3 \\ 0.60 & 49.61 & 27.71 & 62.61 & 3 & 1912.0063 & 1912.0024 & 638.3414 & 0.0039 & 2.0365 & 697.594 & 828.304 & 176 .\end{array}$

$\begin{array}{lllllllllllll}0.60 & 49.61 & 27.71 & 62.61 & 3 & 19912.0063 & 1912.0024 & 638.3414 & 0.0039 & 2.0365 & 697.594 & 828.304 & 176.595\end{array}$

$\begin{array}{lllllllllllll}0.60 & 56.90 & 27.71 & 69.90 & 3 & 1912.0063 & 1912.0024 & 638.3414 & 0.0039 & 2.0365 & 1124.796 & 1362.332 & 65.171\end{array}$

$\begin{array}{lllllllllllll}0.97 & 22.35 & 26.19 & 15.88 & 3 & 2811.3439 & 2811.3418 & 938.1212 & 0.0021 & 0.7462 & 67.045 & 10.136 & 3.4\end{array}$

$\begin{array}{lllllllllllll}0.99 & 40.21 & 23.32 & 34.59 & 2 & 1142.7140 & 1142.7145 & 572.3645 & -0.0005 & -0.4368 & 11852.304 & 10690.257\end{array}$ $\begin{array}{llllllllllllll}1.00 & 41.97 & 24.07 & 34.90 & 2 & 1142.7164 & 1142.7145 & 572.3645 & 0.0019 & 1.6598 & 7617.980 & 8151.882\end{array}$ $\begin{array}{llllllllllll}.99 & 41.87 & 23.86 & 34.92 & 2 & 1142.7180 & 1142.7145 & 572.3645 & 0.0035 & 3.0575 & 8093.600 & 8257.009 \\ 1.00 & 49.66 & 28.38 & 23.47 & 2 & 1206.6588 & 1206.6586 & 604.3366 & 0.0002 & 0.1655 & 2966.528 & 2709.272\end{array}$

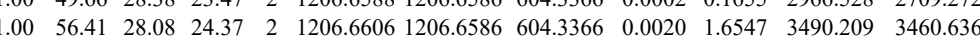

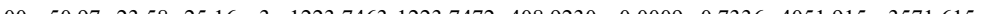

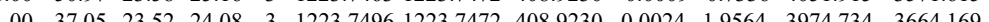
$\begin{array}{llllllllllllll}0.55 & 48.94 & 23.44 & 61.94 & 3 & 1223.7478 & 1223.7472 & 408.9230 & 0.0006 & 0.4891 & 1463.940 & 1270.039 & 39.3\end{array}$ $\begin{array}{lllllllllllll}0.55 & 44.24 & 23.82 & 57.24 & 3 & 1223.7487 & 1223.7472 & 408.9230 & 0.0015 & 1.2227 & 816.587 & 834.931\end{array}$ $\begin{array}{lllllllllllll}1.00 & 36.24 & 23.82 & 18.92 & 3 & 1223.7487 & 1223.7472 & 408.9230 & 0.0015 & 1.2227 & 2076.041 & 1571.434\end{array}$ $\begin{array}{lllllllllllll}1.00 & 46.96 & 23.54 & 26.13 & 3 & 1223.7493 & 1223.7472 & 408.9230 & 0.0021 & 1.7118 & 1771.823 & 1231.637 & 251.2\end{array}$ $\begin{array}{llllllllllllll}1.00 & 43.72 & 24.18 & 19.67 & 3 & 1223.7481 & 1223.7472 & 408.9230 & 0.0009 & 0.7336 & 443.496 & 374.730\end{array}$ $\begin{array}{llllllllllllll}0.98 & 30.81 & 26.72 & 19.60 & 2 & 1173.5852 & 1173.5830 & 587.7988 & 0.0022 & 1.8714 & 744.607 & 741.872 & 21.136\end{array}$ $\begin{array}{lllllllllllll}1.00 & 69.37 & 24.70 & 27.28 & 2 & 1272.7726 & 1272.7710 & 637.3928 & 0.0016 & 1.2551 & 2231.923 & 2008.325\end{array}$ $\begin{array}{lllllllllllll}1.00 & 47.28 & 26.67 & 18.96 & 2 & 1288.7674 & 1288.7659 & 645.3902 & 0.0015 & 1.1621 & 816.035 & 731.326\end{array}$ $\begin{array}{lllllllllllll}1.00 & 50.17 & 26.54 & 24.97 & 2 & 1288.7678 & 1288.7659 & 645.3902 & 0.0019 & 1.4720 & 835.470 & 751.576\end{array}$ $\begin{array}{lllllllllllll}1.00 & 40.99 & 26.63 & 21.75 & 2 & 1173.5840 & 1173.5830 & 587.7988 & 0.0010 & 0.8506 & 793.669 & 830.933\end{array}$ $\begin{array}{llllllllllll}1.00 & 41.59 & 26.63 & 20.80 & 2 & 1173.5842 & 1173.5830 & 587.7988 & 0.0012 & 1.0208 & 924.422 & 1018.962\end{array}$ $\begin{array}{llllllllllll}0.92 & 24.76 & 26.52 & 20.00 & 2 & 1189.5790 & 1189.5779 & 595.7962 & 0.0011 & 0.9231 & 193.413 & 180.457\end{array}$ $\begin{array}{lllllllllllll}0.97 & 28.39 & 26.65 & 18.73 & 2 & 1189.5802 & 1189.5779 & 595.7962 & 0.0023 & 1.9302 & 185.491 & 237.773\end{array}$ $\begin{array}{lllllllllllll}1.00 & 69.73 & 24.70 & 27.66 & 2 & 1272.7724 & 1272.7710 & 637.3928 & 0.0014 & 1.0982 & 981.249 & 832.739\end{array}$ $\begin{array}{lllllllllllll}1.00 & 60.14 & 24.70 & 27.61 & 2 & 1272.7726 & 1272.7710 & 637.3928 & 0.0016 & 1.255 & 490.424 & 511.962\end{array}$ $\begin{array}{llllllllllll}0.96 & 37.13 & 26.68 & 21.08 & 2 & 1288.7650 & 1288.7659 & 645.3902 & -0.0009 & -0.6973 & 183.015 & 188.367\end{array}$ $\begin{array}{llllllllllll}0.98 & 33.91 & 26.57 & 20.68 & 2 & 1288.7688 & 1288.7659 & 645.3902 & 0.0029 & 2.2467 & 108.446 & 98.687\end{array}$ $\begin{array}{llllllllllll}1.00 & 44.10 & 26.74 & 23.91 & 2 & 1173.5848 & 1173.5830 & 587.7988 & 0.0018 & 1.5311 & 757.334 & 715.873\end{array}$ $\begin{array}{llllllllllll}0.99 & 34.28 & 26.72 & 18.97 & 2 & 1173.5852 & 1173.5830 & 587.7988 & 0.0022 & 1.8714 & 552.157 & 527.915\end{array}$

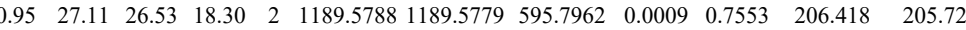
$\begin{array}{llllllllllll}0.99 & 54.29 & 25.00 & 21.65 & 2 & 1272.7678 & 1272.7710 & 637.3928 & -0.0032 & -2.5102 & 356.733 & 381.756\end{array}$

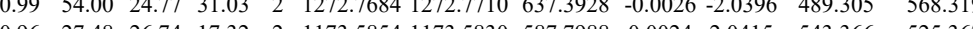

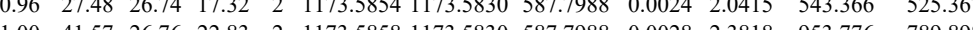
$\begin{array}{lllllllllllllll}1.00 & 41.57 & 26.76 & 22.83 & 2 & 1173.5858 & 1173.5830 & 587.7988 & 0.0028 & 2.3818 & 953.776 & 789.898\end{array}$

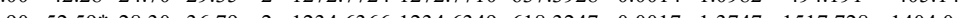

GLGTDEDTIDDITHR

GLGTDEDTIIDITHR $\quad 0.60$ 


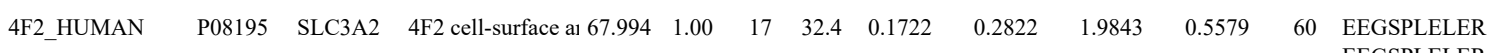
EEGSPLELER EVELNELEPEK EVELNELEPEK EVELNELEPEK DDVAQTDLLQIDPNFGS DDVAQTDLLQIDPNFGS GENSWFSTQVDTVATK LEPHEGLLLR

GQSEDPGSLLSLFR GQSEDPGSLLSLFR

LDYLSSLK LDYLSSLK ADLLLSTQPGR GQSEDPGSLLSLFR GQSEDPGSLLSLFR ADLLLSTQPGR ADLLLSTQPGR GQSEDPGSLLSLFR ADLLLSTQPGR IGDLQAFQGHGAGNLAA GLVLGPIHK

GLVLGPIHK

GLVLGPIHK

GLVLGPIHK

VILDLTPNYR

VILDLTPNYR

VAGSPGWVR

VAGSPGWVR

VAGSPGWVR

VAGSPGWVR

VAGSPGWVR

SLVTQYLNATGNR

VAEDEAEAAAAAK

VAEDEAEAAAAAK

VAEDEAEAAAAK

EVELNELEPEK

EVELNELEPEK

WCSWSLSQAR

WCSWSLSQAR

LLTSFLPAQLLR

LLTSFLPAQLLR

LLTSFLPAQLLR

VAEDEAEAAAAAK

LLTSFLPAQLLR

LLTSFLPAQLLR

LLTSFLPAQLLR

LLTSFLPAQLLR

LLTSFLPAQLLR

LLTSFLPAQLLR
LLTSFLPAOLLR

LLTSFLPAQLLR
LLTSFLPAQLLR

LLTSFLPAQLLR

LLTSFLPAQLLR

LLTSFLPAQLLR

LLTSFLPALLR

LLTSFLPAQLLR
LLTSFLPAQLLR

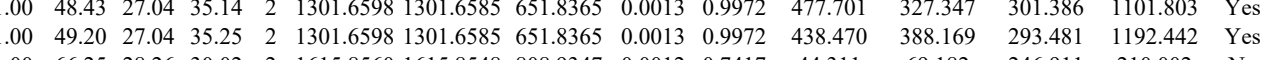
$\begin{array}{lllllllllllllll}1.00 & 66.25 & 28.26 & 30.02 & 2 & 1615.8560 & 1615.8548 & 808.9347 & 0.0012 & 0.7417 & 44.311 & 69.182 & 246.911 & 210.002 & \text { No }\end{array}$

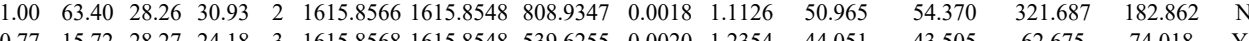
$\begin{array}{lllllllllllllll}0.77 & 15.72 & 28.27 & 24.18 & 3 & 1615.8568 & 1615.8548 & 539.6255 & 0.0020 & 1.2354 & 44.051 & 43.505 & 62.675 & 74.018 & \text { Yes } \\ 0.61 & 12.77 & 28.30 & 23.39 & 3 & 1615.8571 & 1615.8548 & 539.6255 & 0.0023 & 1.4207 & 50.093 & 38.847 & 72.675 & 35.337 & \end{array}$

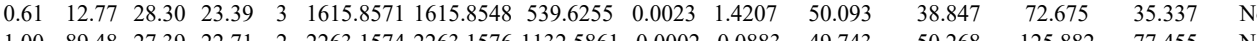

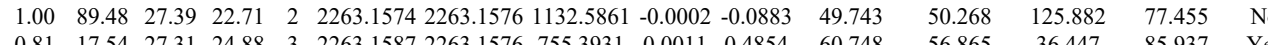

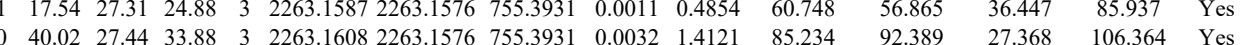

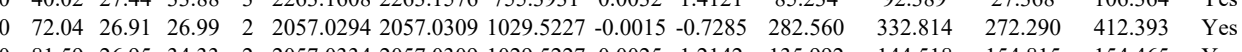
$\begin{array}{lllllllllll} & 2057.0334 & 2057.0309 & 1029.5227 & 0.0025 & 1.2142 & 155.932 & 14.548 & 154.815 & 154.465 & \text { Yes }\end{array}$

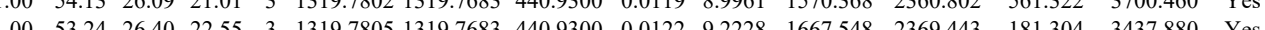

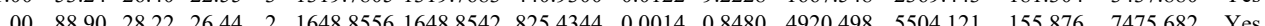
$\begin{array}{lllllllllllllll}100 & 9423 & 28.20 & 25.06 & 2 & 16488558 & 1648.8542 & 825.434 & 0.0016 & 0.9692 & 1715.893 & 1488.846 & 233.307 & 3128301 & \text { Yes }\end{array}$ $\begin{array}{lllllllllllllll}1.00 & 45.64 & 24.07 & 19.63 & 2 & 1225.7262 & 1225.7162 & 613.8654 & 0.0100 & 8.1450 & 14443.560 & 16142.337 & 240.888 & 22031.672 & \text { Yes }\end{array}$ $\begin{array}{llllllllllllllll}1.00 & 45.27 & 24.38 & 19.02 & 2 & 1225.7270 & 1225.7162 & 613.8654 & 0.0108 & 8.7966 & 21983.275 & 27376.778 & 0.000 & 29489.697 & \text { No }\end{array}$ $\begin{array}{lllllllllllllllll}1.00 & 58.80 & 26.25 & 26.43 & 2 & 1313.7518 & 1313.7425 & 657.8785 & 0.0093 & 7.0681 & 14375.976 & 18067.988 & 2626.472 & 24253.083 & \text { Yes }\end{array}$ $\begin{array}{llllllllllllllll}1.00 & 63.72 & 26.27 & 27.47 & 2 & 1313.7522 & 1313.7425 & 657.8785 & 0.0097 & 7.3721 & 15895.862 & 17587.034 & 1544.395 & 26901.048 & \text { Yes }\end{array}$

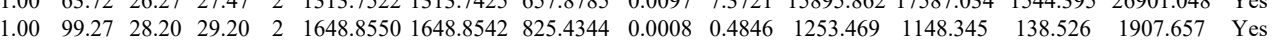
$\begin{array}{llllllllllllllll}1.00 & 88.55 & 28.20 & 26.02 & 2 & 1648.8558 & 1648.8542 & 825.4344 & 0.0016 & 0.9692 & 2324.216 & 2127.425 & 5.522 & 3611.689 & \text { Yes }\end{array}$ $\begin{array}{llllllllllllllll}1.00 & 70.31 & 26.22 & 27.03 & 2 & 1313.7516 & 1313.7425 & 657.8785 & 0.0091 & 6.9161 & 12548.059 & 12802.014 & 1946.508 & 18686.998 & \text { Yes }\end{array}$ $\begin{array}{llllllllllllllll}1.00 & 55.41 & 26.27 & 30.21 & 2 & 1313.7526 & 1313.7425 & 657.8785 & 0.0101 & 7.6761 & 12766.274 & 15418.583 & 2202.460 & 22504.326 & \text { Yes }\end{array}$ $\begin{array}{lllllllllllllll}1.00 & 83.14 & 28.13 & 24.79 & 2 & 1648.8574 & 1648.8542 & 825.4344 & 0.0032 & 1.9384 & 228.635 & 289.307 & 27.149 & 549.506 & \text { Yes }\end{array}$

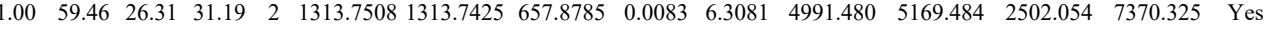

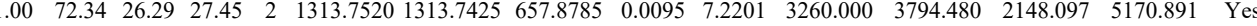

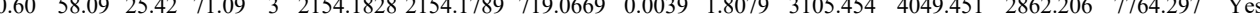
$\begin{array}{lllllllllllllll}0.00 & 44.07 & 18.33 & 16.25 & 3 & 1220.7934 & 1220.7849 & 407.9356 & 0.0085 & 6.9455 & 7347.358 & 7639.233 & 893.654 & 13336.380 & \text { Yes }\end{array}$ $\begin{array}{lllllllllllllll}1.00 & 43.60 & 18.33 & 20.33 & 3 & 1220.7937 & 1220.7849 & 407.9356 & 0.0088 & 7.1906 & 12023.573 & 16817.049 & 2178.287 & 23169.582 & \text { Yes }\end{array}$ $\begin{array}{lllllllllllllll}1.00 & 40.36 & 18.33 & 15.80 & 3 & 1220.7931 & 1220.7849 & 407.9356 & 0.0082 & 6.7004 & 13531.858 & 15565.330 & 2231.711 & 23242.828 & \text { Yes }\end{array}$ $\begin{array}{llllllllllllllll}1.00 & 43.47 & 18.33 & 25.03 & 3 & 1220.7934 & 1220.7849 & 407.9356 & 0.0085 & 6.9455 & 15939.865 & 19872.958 & 2526.833 & 27316.285 & \text { Yes }\end{array}$ $\begin{array}{llllllllllllllll}1.00 & 52.30 & 16.90 & 17.85 & 2 & 1220.7942 & 1220.7849 & 611.3997 & 0.0093 & 7.6054 & 1659.012 & 1972.973 & 704.606 & 2506.958 & \text { Yes }\end{array}$ $\begin{array}{llllllllllllllll}1.00 & 43.25 & 27.43 & 25.13 & 2 & 1346.7708 & 1346.7680 & 674.3913 & 0.0028 & 2.0759 & 2006.378 & 2752.730 & 369.572 & 3942.225 & \text { Yes }\end{array}$ $\begin{array}{llllllllllllllll}1.00 & 46.03 & 27.35 & 25.72 & 2 & 1346.7716 & 1346.7680 & 674.3913 & 0.0036 & 2.6691 & 2553.940 & 3164.096 & 394.160 & 4184.299 & \text { Yes }\end{array}$

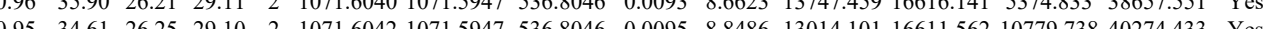

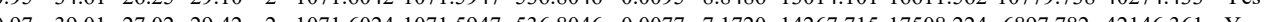
$\begin{array}{llllllllllllllll}0.97 & 39.01 & 27.02 & 29.42 & 2 & 1071.6024 & 1071.5947 & 536.8046 & 0.0077 & 7.1720 & 14267.715 & 17508.224 & 6897.782 & 42146.361 & \text { Yes }\end{array}$

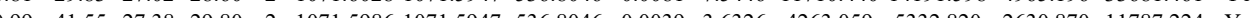

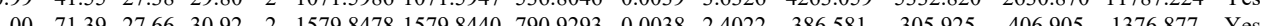

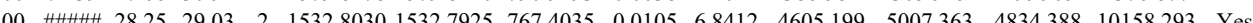
$\begin{array}{lllllllllllllll}1.00 & 99.33 & 28.25 & 28.46 & 2 & 15328030 & 1532.7925 & 767.4035 & 0.0105 & 6.8412 & 1702.696 & 2740.706 & 2338.220 & 4265.294 & \text { Yes }\end{array}$ $\begin{array}{lllllllllllllll}0.99 & 38.95 & 28.19 & 25.02 & 3 & 15328039 & 1532.7925 & 511.9381 & 0.0114 & 7.4227 & 68.411 & 106.357 & 105.236 & 141.588 & \text { Yes }\end{array}$ $\begin{array}{lllllllllllllll}1.00 & 46.17 & 28.08 & 20.52 & 3 & 1532.8045 & 1532.7925 & 511.9381 & 0.0120 & 7.8134 & 59.403 & 71.841 & 176.172 & 147.215 & \text { No }\end{array}$ $\begin{array}{llllllllllllllll}1.00 & 48.29 & 28.22 & 38.27 & 2 & 1615.8562 & 1615.8548 & 808.9347 & 0.0014 & 0.8653 & 123.734 & 126.550 & 212.015 & 156.031 & \text { Yes }\end{array}$ $\begin{array}{llllllllllllllll}1.00 & 46.65 & 28.27 & 36.75 & 2 & 1615.8568 & 1615.8548 & 808.9347 & 0.0020 & 1.2362 & 141.766 & 168.009 & 207.328 & 119.989 & \text { Yes }\end{array}$ $\begin{array}{llllllllllllllll}1.00 & 74.13 & 25.31 & 26.91 & 2 & 1412.6456 & 1412.6451 & 707.3298 & 0.0005 & 0.3534 & 1846.218 & 1919.952 & 82.610 & 7094.415 & \text { Yes }\end{array}$ $\begin{array}{llllllllllllllll}1.00 & 67.17 & 25.25 & 25.79 & 2 & 1412.6458 & 1412.6451 & 707.3298 & 0.0007 & 0.4948 & 2075.824 & 2001.121 & 0.000 & 7773.678 & \text { No }\end{array}$

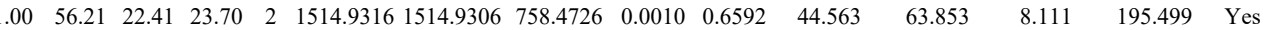

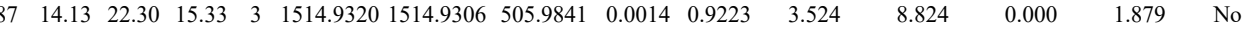

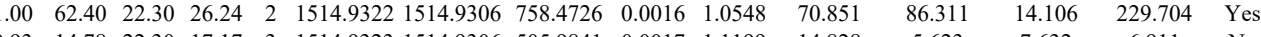
$\begin{array}{lllllllllllllll}0.93 & 14.78 & 22.30 & 17.17 & 3 & 1514.9323 & 1514.9306 & 505.9841 & 0.0017 & 1.1199 & 14.828 & 5.623 & 7.632 & 6.911 & \text { No }\end{array}$

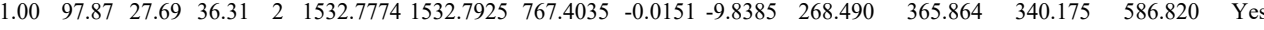

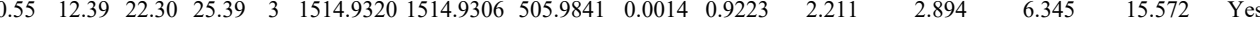

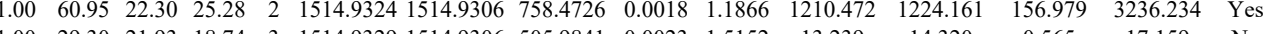
$\begin{array}{lllllllllllllll}1.00 & 29.30 & 21.93 & 18.74 & 3 & 1514.9329 & 1514.9306 & 505.9841 & 0.0023 & 1.5152 & 13.239 & 14.320 & 0.565 & 17.159 & \text { No }\end{array}$ $\begin{array}{lllllllllllllll}1.00 & 63.49 & 21.90 & 24.21 & 2 & 1514.9308 & 1514.9306 & 758.4726 & 0.0002 & 0.1318 & 155.496 & 215.971 & 16.576 & 517.745 & \text { Yes } \\ 1.00 & 56.14 & 22.43 & 22.48 & 2 & 151.9314 & 1514.9306 & 758.4726 & 0.008 & 0.5274 & 14.118 & 128.664 & 0.000 & 445.515 & \text { Nes }\end{array}$ \begin{tabular}{llllllllllllll} 
& 1.00 \\
\hline
\end{tabular}

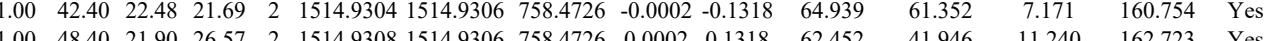

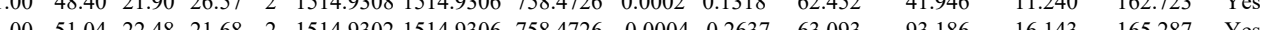

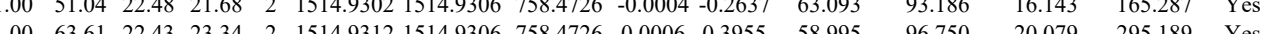
$\begin{array}{lllllllllllllll}1.00 & 57.43 & 22.36 & 23.98 & 2 & 1514.9318 & 1514.9306 & 758.4726 & 0.0012 & 0.7911 & 45.718 & 45.326 & 18.411 & 142.413 & \text { Y }\end{array}$ $\begin{array}{llllllllllllll}1 & \end{array}$ $\begin{array}{lllllllllllllll}52.72 & 22.43 & 22.43 & 2 & 1514.9310 & 1514.9306 & 758.4726 & 0.0004 & 0.2637 & 54.964 & 48.920 & 12.621 & 131.849 & \text { Yes }\end{array}$

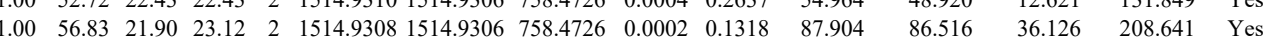

Table S-4 page 118 of 614 

$\begin{array}{lllllllllll}1.00 & 56.53 & 28.37 & 24.24 & 2 & 1707.8940 & 1707.8923 & 854.9534 & 0.0017 & 0.9942 & 261.334\end{array}$ $\begin{array}{lllllllllllllll} & \end{array}$

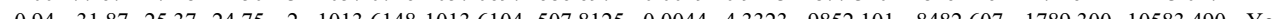

IQGNR

GIFTGAR

VGIFTGAR

VGIFTGAR

VGIFTGAR

LRPILK

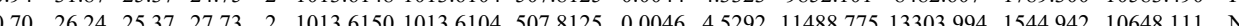
$\begin{array}{llllllllllllllll}0.81 & 30.65 & 27.79 & 24.39 & 2 & 963.5702 & 963.5624 & 482.7885 & 0.0078 & 8.0780 & 9262.298 & 9410302 & 1285.985 & 13582.876 & \text { Y }\end{array}$ $\begin{array}{llllllllllllllll}0.59 & 25.96 & 27.79 & 25.71 & 2 & 963.5704 & 963.5624 & 482.7885 & 0.0080 & 82851 & 6617.241 & 7242.185 & 919.183 & 11307.372 & \text { Yes }\end{array}$ $\begin{array}{llllllllllllllll}0.96 & 36.99 & 27.81 & 28.12 & 2 & 963.5662 & 963.5624 & 482.7885 & 0.0038 & 3.9355 & 8153.401 & 7478.989 & 708.700 & 11619.501 & \text { Yes }\end{array}$ $\begin{array}{llllllllllllllll}0.96 & 36.25 & 27.81 & 31.08 & 2 & 963.5666 & 963.5624 & 482.7885 & 0.0042 & 43497 & 6089.303 & 5598.005 & 543.235 & 8747.059 & \text { Yes }\end{array}$ $\begin{array}{lllllllllllllll}0.80 & 15.42 * & 14.47 & 20.53 & 2 & 1026.7172 & 1026.7157 & 514.3651 & 0.0015 & 1.4581 & 3025.401 & 3323.449 & 1828.109 & 3058.614 & \text { No }\end{array}$ $\begin{array}{lllllllllllllll}0.80 & 15.82 * & 14.47 & 22.00 & 2 & 1026.7178 & 1026.7157 & 514.3651 & 0.0021 & 2.0413 & 5036.255 & 5023.906 & 1998.484 & 5507.783 & \text { Yes }\end{array}$ CLELFSELAEDK CLELFSELAEDK CLELFSELAEDK CLELFSELAEDK

CLELFSELAEDK

CLELFSELAEDK

CLELFSELAEDK $\begin{array}{lllllllllllll}0.60 & 9.47 & 27.12 & 16.70 & 4 & 1926.0445 & 1926.0445 & 482.5184 & 0.0000 & 0.0000 & 64.003\end{array}$

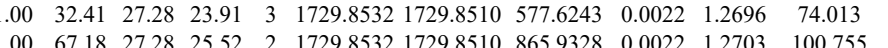
$\begin{array}{llllllllllll}1.00 & 67.18 & 27.28 & 25.52 & 2 & 1729.8532 & 1729.8510 & 865.9328 & 0.0022 & 1.2703 & 100.755 \\ 1.00 & 59.85 & 27.26 & 29.30 & 2 & 1729.8534 & 1729.8510 & 865.9328 & 0.0024 & 1.3858 & 519.833\end{array}$

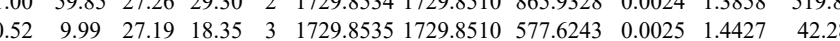
$\begin{array}{llllllllllll}1.00 & 31.13 & 27.19 & 25.25 & 3 & 1729.8535 & 1729.8510 & 577.6243 & 0.0025 & 1.4427 & 63.280 & 10\end{array}$ 74.231 184.385

\section{HLEINPDHPIVETLR}

$\begin{array}{llllllllllll}1.00 & 68.38 & 27.19 & 25.14 & 2 & 1729.8538 & 1729.8510 & 865.9328 & 0.0028 & 1.6168 & 150.366\end{array}$ $\begin{array}{lcccccccccccc}\text { HLEINPDHPIVETLR } & 0.69 & 8.64 & 27.11 & 17.23 & 4 & 1926.0453 & 1926.0445 & 482.5184 & 0.0008 & 0.4145 & 24.952 \\ \text { CLELFSELAEDKENYK } & 1.00 & 36.40 & 27.77 & 17.49 & 4 & 2408.2017 & 2408.1969 & 603.0565 & 0.0048 & 1.9899 & 383.548\end{array}$ $\begin{array}{llllllllllll}68.43 & 27.19 & 25.56 & 2 & 1729.8538 & 1729.8510 & 865.9328 & 0.0028 & 1.6168 & 132.538 \\ 11.72 & 27.12 & 15.00 & 4 & 1926.0449 & 1926.0445 & 482.5184 & 0.0004 & 0.2072 & 107.934\end{array}$ $\begin{array}{lllllllllllll} & \end{array}$ $\begin{array}{lllllllllllll}\text { CLELFSELAEDKENYK } & 0.97 & 26.44 & 27.76 & 18.69 & 4 & 2408.2053 & 2408.1969 & 603.0565 & 0.0084 & 3.4822 & 491.643\end{array}$ APFDLFENK APFDLFENK APFDLFENK

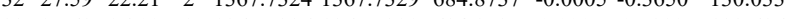

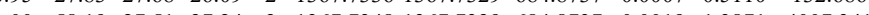

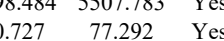
$\begin{array}{lllllllllllllllll} & \\ \text { C. } & 21.77 & 27.20 & 23.13 & 3 & 1729.8547 & 1729.8510 & 577.6243 & 0.0037 & 2.1352 & 87.081 & 86.682 & 64.242 & 77.961 & \text { Yes }\end{array}$

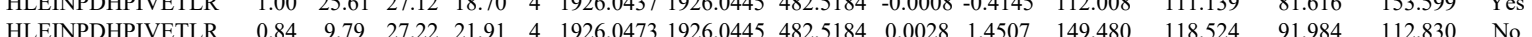

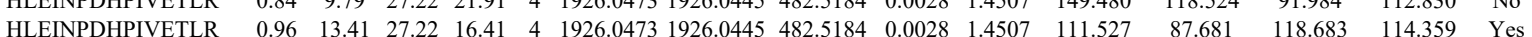

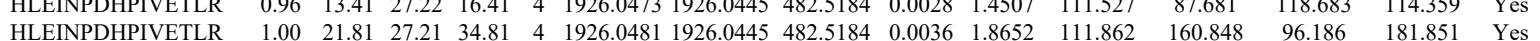
$\begin{array}{llllllllllllllllll}\text { HLEINPDHPIVETLR } & 0.78 & 9.02 & 26.97 & 16.84 & 4 & 1926.0501 & 1926.0445 & 482.5184 & 0.0056 & 2.9014 & 164.392 & 107.180 & 133.474 & 150.819 & \text { Yes }\end{array}$ $\begin{array}{llllllllllllllll}\text { CLELFSELAEDKENYK } & 0.50 & 33.50 & 27.68 & 15.30 & 3 & 2408.1955 & 2408.1969 & 803.7396 & -0.0014 & -0.5806 & 45.919 & 65.306 & 16.429 & 96.095 & \text { Yes }\end{array}$

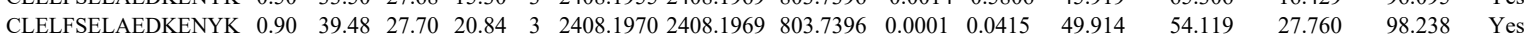

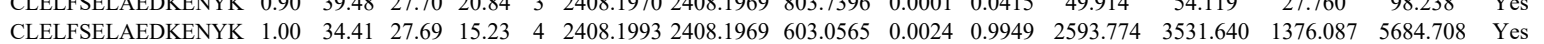

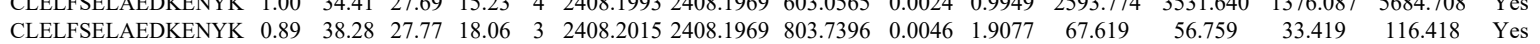
$\begin{array}{llllllllllllllll}\text { CLELFSELAEDKENYK } & 1.00 & 27.31 & 27.77 & 15.38 & 4 & 2408.2017 & 2408.1969 & 603.0565 & 0.0048 & 1.9899 & 3483.031 & 4619.928 & 1011.749 & 6614.142 & \text { Yes }\end{array}$ $\begin{array}{lllllllllllllllll}\text { CLELFSELAEDKENYK } & 0.99 & 48.97 & 27.75 & 16.88 & 3 & 2408.2024 & 2408.1969 & 803.7396 & 0.0055 & 2.2810 & 14317.495 & 18243.097 & 3774.658 & 33519.339 & \text { Yes }\end{array}$

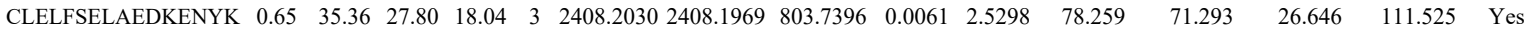

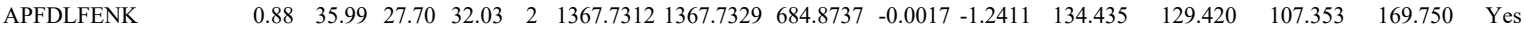

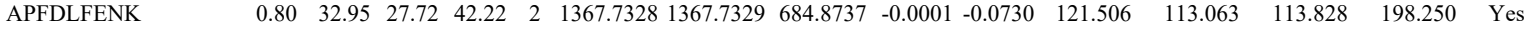

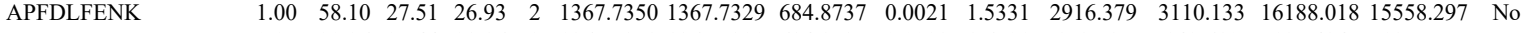
APFDLFENK APFDLFENK APFDLFENK

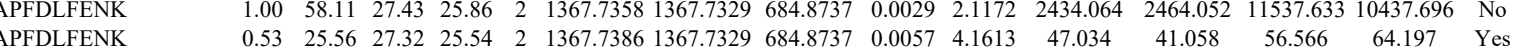

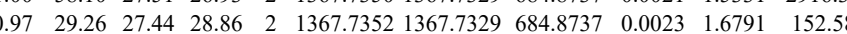
$\begin{array}{lllllllllllllllll}0.85 & 24.81 & 27.43 & 25.36 & 2 & 1367.7358 & 1367.7329 & 684.8737 & 0.0029 & 2.1172 & 104.780 & 130.252 & 95.916 & 193.096 & \text { Yes }\end{array}$ $\begin{array}{lrlllllllllllllll} & 1 & & & \end{array}$ $\begin{array}{lllllllllllllll} & \end{array}$ $\begin{array}{lllllllllllllll} & \end{array}$ $\begin{array}{llllllllllllllll}\text { HLEINPDHPIVETLR } & 1.00 & 30.45 & 27.13 & 15.51 & 4 & 1926.0457 & 1926.0445 & 482.5184 & 0.0012 & 0.6217 & 157.339 & 139.590 & 115.061 & 196.615 & \text { Yes }\end{array}$ $\begin{array}{llllllllllllllllll} & \end{array}$

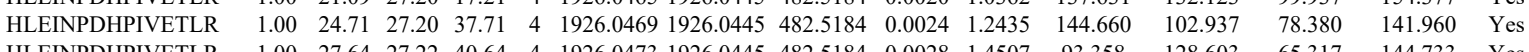

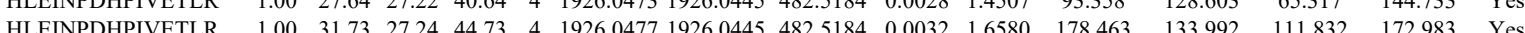

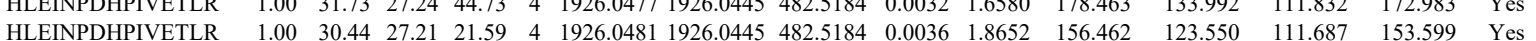




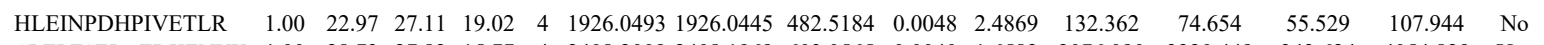
$\begin{array}{llllllllllllllll}\text { CLELFSELAEDKENYK } & 1.00 & 28.73 & 27.82 & 15.77 & 4 & 2408.2009 & 2408.1969 & 603.0565 & 0.0040 & 1.6582 & 2076.090 & 3320.449 & 343.624 & 4054.829 & \text { Yes }\end{array}$ $\begin{array}{llllllllllllllll}\text { CLELFSELAEDKENYK } & 0.82 & 18.11 & 27.80 & 31.11 & 4 & 2408.2013 & 2408.1969 & 603.0565 & 0.0044 & 1.8240 & 1483.372 & 1854.887 & 598.810 & 2887.497 & \text { Yes }\end{array}$

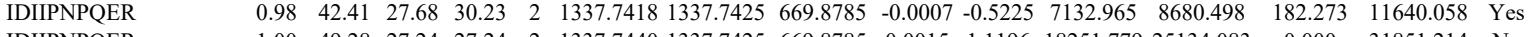

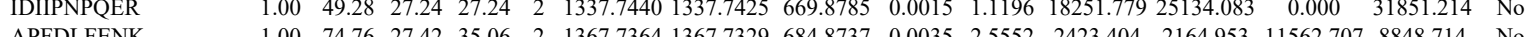

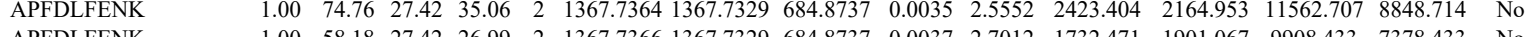
$\begin{array}{llllllllllllllll}\text { APFDLFENK } & 1.00 & 58.18 & 27.42 & 26.99 & 2 & 1367.7366 & 1367.7329 & 684.8737 & 0.0037 & 2.7012 & 1732.471 & 1901.067 & 9908.433 & 7378.433 & \text { No }\end{array}$

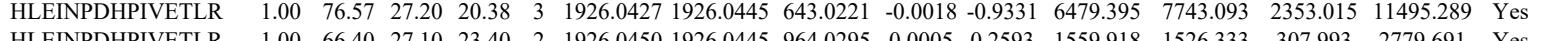
$\begin{array}{llllllllllllllll}\text { HLEINPDHPIVETLR } & 1.00 & 66.40 & 27.10 & 23.40 & 2 & 1926.0450 & 1926.0445 & 964.0295 & 0.0005 & 0.2593 & 1559.918 & 1526.333 & 307.993 & 2779.691 & \text { Yes }\end{array}$ $\begin{array}{lllllllllllllll} & \end{array}$ $\begin{array}{llllllllllllllll}262.150 & 179.265 & \text { Yes }\end{array}$ $\begin{array}{lllllllllllllll} & \end{array}$ $\begin{array}{lllllllllllllll} & \end{array}$ $\begin{array}{lllllllllllllllll}\text { CLELFSELAEDKENYK } & 0.95 & 21.38 & 27.80 & 18.12 & 4 & 2408.2013 & 2408.1969 & 603.0565 & 0.0044 & 1.8240 & 419.793 & 407.310 & 149.975 & 812.904 & \text { Yes }\end{array}$ $\begin{array}{llllllllllllllll}\text { CLELNPLER } & 0.99 & 44.84 & 27.40 & 26.58 & 2 & 1337.7540 & 1337.7425 & 669.8785 & 0.0115 & 8.5836 & 7109.721 & 788.296 & 450.315 & 11366.402 & \text { Yes }\end{array}$ $\begin{array}{lllllllllllllllll} & \text { IDIIPNPQER } & 0.99 & 44.22 & 27.56 & 31.63 & 2 & 1337.7556 & 1337.7425 & 669.8785 & 0.0131 & 97778 & 11339.803 & 14879.473 & 439.418 & 22402.003 & \text { Yes }\end{array}$ $\begin{array}{llllllllllllllll}\text { SIYYITGESK } & 1.00 & 52.77 & 28.03 & 24.37 & 2 & 1447.7926 & 1447.7802 & 724.8974 & 0.0124 & 8.5529 & 5052.751 & 6134.895 & 371.912 & 10438.956 & \text { Yes }\end{array}$ $\begin{array}{llllllllllllllll}\text { SIYYITGESK } & 1.00 & 54.52 & 27.79 & 27.32 & 2 & 1447.7938 & 1447.7802 & 724.8974 & 0.0136 & 9.3806 & 904.186 & 989.053 & 25.463 & 1703.035 & \text { Yes }\end{array}$ $\begin{array}{llllllllllllllll}\text { HLEINPDHPIVETLR } & 1.00 & 71.67 & 26.62 & 20.76 & 2 & 1926.0620 & 1926.0445 & 964.0295 & 0.0175 & 9.0764 & 500.781 & 754.496 & 295.567 & 960.693 & \text { Yes }\end{array}$ $\begin{array}{llllllllllllllll}\text { HLEINPDHPIVETLR } & 1.00 & 41.76 & 26.55 & 54.76 & 4 & 1926.0633 & 1926.0445 & 482.5184 & 0.0188 & 9.7405 & 1539.009 & 1833.869 & 734.085 & 2110.948 & \text { Yes }\end{array}$ $\begin{array}{lllllllllllllllll}\text { HLEINPDHPIVETLR } & 1.00 & 40.60 & 26.55 & 20.33 & 4 & 1926.0633 & 1926.0445 & 482.5184 & 0.0188 & 9.7405 & 2441.026 & 2374.851 & 1395.253 & 4059.424 & \text { Yes }\end{array}$

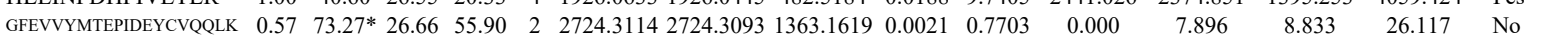
$\begin{array}{llllllllllllllll}\text { GFEVVYMTEPIDEYCVQQLK } & 0.88 & 20.11 * & 26.59 & 29.05 & 4 & 2724.3121 & 2724.3093 & 682.0846 & 0.0028 & 1.0263 & 92.250 & 94.689 & 68.470 & 95.404 & \text { Yes }\end{array}$ $\begin{array}{llllllllllllllll}\text { GFEVYYMTEPIDEYCVQQLK } & 0.65 & 12.48 * & 26.55 & 24.19 & 4 & 2724.3141 & 2724.3093 & 682.0846 & 0.0048 & 1.7593 & 100.938 & 97.702 & 70.159 & 121.818 & \text { Yes }\end{array}$ SIYYITGESK

SLVSVTK

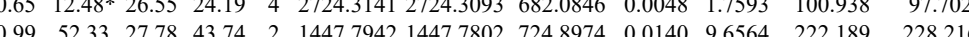

RAPFDLFENK

RAPFDLFENK

RAPFDLFENK

RAPFDLFENK
RAPFDLFENK

RAPFDLFENK

VVVITK

VVVITK

VVVITK

VTISNR

VTISNR

VTISNR

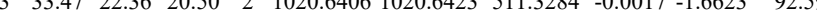
$\begin{array}{llllllllllll}0.84 & 31.78 & 27.21 & 25.43 & 2 & 1523.8408 & 1523.8340 & 762.9243 & 0.0068 & 4.4565 & 683.436 & 1008.190\end{array}$ $\begin{array}{lllllllllllll}0.97 & 39.81 & 27.21 & 29.69 & 2 & 1523.8410 & 1523.8340 & 762.9243 & 0.0070 & 4.5876 & 218.997 & 298.316\end{array}$ $\begin{array}{llllllllllll}0.97 & 32.07 & 27.08 & 25.04 & 3 & 1523.8417 & 1523.8340 & 508.9519 & 0.0077 & 5.0430 & 3149.844 & 3683.736\end{array}$ $\begin{array}{lllllllllllll}0.95 & 30.83 & 27.08 & 26.26 & 3 & 1523.8423 & 1523.8340 & 508.9519 & 0.0083 & 5.4360 & 3894.460 & 3418.444\end{array}$ $\begin{array}{lllllllllllll}0.99 & 39.84 & 26.87 & 26.26 & 3 & 1523.8489 & 1523.8340 & 508.9519 & 0.0149 & 9.7585 & 1004.408 & 1307.044\end{array}$ $\begin{array}{llllllllllllll}0.95 & 22.26 & 15.05 & 28.49 & 2 & 945.6476 & 945.6467 & 473.8306 & 0.0009 & 0.9497 & 26.322 & 21.973\end{array}$ $\begin{array}{lllllllllllll}0.98 & 26.21 & 15.05 & 28.53 & 2 & 945.6488 & 945.6467 & 473.8506 & 0.0021 & 2.2160 & 67.399 & 106.877\end{array}$

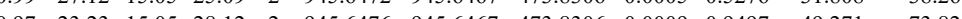

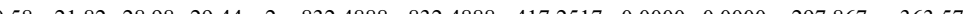

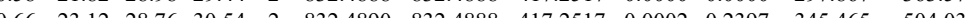
$\begin{array}{lllllllllllll}0.53 & 23.78 & 28.98 & 29.92 & 2 & 832.4886 & 832.488 & 417.2517 & 0.0002 & 0.2397 & 156.917 & 227.424\end{array}$ $\begin{array}{lllllllllllll}0.76 & 25.43 & 28.98 & 29.43 & 2 & 832.4888 & 832.4888 & 417.2517 & 0.0000 & 0.0000 & 194.174 & 252.293\end{array}$

HSQFIGYPITLYLEK $\begin{array}{lllllllllllll}0.76 & 25.43 & 28.98 & 29.43 & 2 & 832.4888 & 832.4888 & 417.2517 & 0.0000 & 0.0000 & 194.174 & 252.293 \\ 0.95 & 59.53 * & 25.71 & 19.35 & 2 & 2096.1554 & 2096.1550 & 1049.0848 & 0.0004 & 0.1906 & 922.442 & 1043.483 \\ 0.74 & 41.15 * & 25.05 & 21.04 & 3 & 206.1628 & 206.155 & 69.7256 & 0.007 & 3.7157 & & \end{array}$

HSQFIGYPITLYLEK

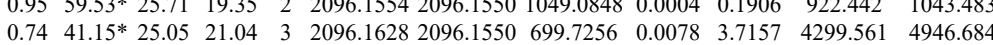

HSQFIGYPITLYLEK

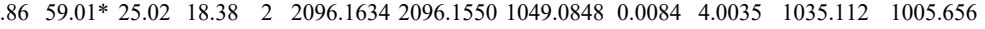

HSQFIGYPITLYLEK $\begin{array}{llllllllllll}1.00 & 77.40 & 24.94 & 23.82 & 3 & 2096.1640 & 2096.1550 & 699.7256 & 0.0090 & 4.2874 & 1879.241 & 2472\end{array}$

HSQFIGYPITLYLEK $\begin{array}{lllllllllll}1.00 & 89.18 & 25.75 & 22.41 & 3 & 3131.6332 & 3131.6261 & 1044.8826 & 0.0071 & 2.2650 & 13.25\end{array}$

$.68 * 25.71 \quad 18.49$

$\begin{array}{llll}2096.15532096 .1550 & 699.7256 & 0.0003 & 0.1429\end{array}$

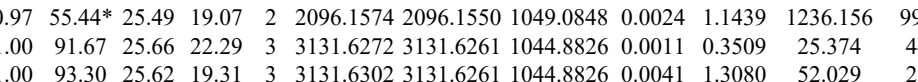
$\begin{array}{lllllllllll}0 & 83.11 & 25.66 & 21.57 & 3 & 3131.6272 & 3131.6261 & 1044.8826 & 0.0011 & 0.3509 & 12.527\end{array}$ $\begin{array}{lllllllll}25.66 & 21.70 & 3 & 3131.6272 & 3131.6261 & 1044.8826 & 0.0011 & 0.3509\end{array}$

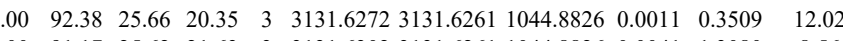

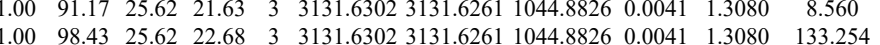
$\begin{array}{llllllllllll}\text { DLVVLLETALLSSGFLEDPTTHSNR } & 1.00 & 82.50 & 25.62 & 21.10 & 3 & 3131.6302 & 3131.6261 & 1044.8826 & 0.0041 & 1.3080 & 18.073\end{array}$ $\begin{array}{llllllllllll}\text { DLVVLLFETALSSGGSLEDPQTHSNR } & 1.00 & 17.88 & 25.65 & 14.16 & 4 & 3131.6309 & 3131.6261 & 783.9138 & 0.0048 & 1.5308 & 0.000\end{array}$

$\begin{array}{lllllllllll} & \end{array}$ $\begin{array}{lllllllllll}1.00 & 63.37 & 25.56 & 28.09 & 4 & 3131.6293 & 3131.6261 & 783.9138 & 0.0032 & 1.0205 & 0.000\end{array}$ 
ALLFIPR

ALLFIPR

ALLFIPR
ALLFIPR

ALLFIPR
ALLFIPR

ALLFIPR
ALLFIPR

ALLFIPR

ALLFIPR

ALLFIPR

ALLFIPR

ALLFIPR

ALLFIPR

ALLFIPR

ALLFIPR

ALLFIPR

ALLFIPR

ALLFIPR

ALLFIPR

ALLFIPR

ALLFIPR

ALLFIPR

ALLFIPR
ALLFIPR

ALLFIPR

ALLFIPR

ALLFIPR

ALLFIPR
ALLFIPR

ALLFIPR
ALLFIPR

ALLFIPR
ALLFIPR

ALLFIPR
ALLFIPR

ALLFIPR
ALLFIPR

ALLFIPR
ALLFIPR

ALLFIPR
ALLFIPR

ALLFIPR
ALLFIPR

ALLFIPR

ALLFIPR

ALLFIPR

ALLFIPR

ALLFIPR

ALLFIPR

ALLFIPR

ALLFIPR

ALLFIPR

ALLFIPR

ALLFIPR

ALLFIPR

ALLFIPR

ALLFIPR

ALLFIPR

ALLFIPR
ALLFIPR $\begin{array}{lllllllllll}0.99 & 22.28 & 26.10 & 35.28 & 4 & 3675.7489 & 3675.7397 & 919.9422 & 0.0092 & 2.5002 & 3.579 \\ 1.00 & 28.01 & 26.09 & 41.01 & 4 & 3675.7493 & 3675.7397 & 919.9422 & 0.0096 & 2.6089 & 1.697\end{array}$ $\begin{array}{lllllllllllll}0.77 & 20.30 & 23.52 & 28.34 & 2 & 972.6242 & 972.6242 & 487.3194 & 0.0000 & 0.0000 & 48.832\end{array}$ $\begin{array}{lllllllllll}0.86 & 19.05 & 23.71 & 26.52 & 2 & 972.6250 & 972.6242 & 487.3194 & 0.0008 & 0.8208 & 75.427\end{array}$ $\begin{array}{llllllllllllll}0.97 & 31.08 & 25.90 & 32.64 & 2 & 828.5254 & 828.5221 & 415.2683 & 0.0033 & 3.9733 & 177.093\end{array}$ $\begin{array}{lllllllllllll}0.59 & 16.50 & 23.52 & 25.73 & 2 & 972.6242 & 972.6242 & 487.3194 & 0.0000 & 0.0000 & 69.287\end{array}$ $\begin{array}{llllllllllll}0.88 & 23.98 & 23.71 & 28.35 & 2 & 972.6244 & 972.6242 & 487.3194 & 0.0002 & 0.2052 & 104.463\end{array}$ $\begin{array}{lllllllllllll}0.53 & 15.51 & 23.71 & 24.76 & 2 & 972.6244 & 972.6242 & 487.3194 & 0.0002 & 0.2052 & 110.346\end{array}$ $\begin{array}{lllllllllllll}0.72 & 19.20 & 23.71 & 24.64 & 2 & 972.6244 & 972.6242 & 487.3194 & 0.0002 & 0.2052 & 55.686\end{array}$ $\begin{array}{lllllllllllll}0.56 & 16.19 & 23.71 & 25.93 & 2 & 972.6244 & 972.6242 & 487.3194 & 0.0002 & 0.2052 & 66.373\end{array}$ $\begin{array}{lllllllllllll}0.58 & 16.51 & 23.71 & 26.26 & 2 & 972.6244 & 972.6242 & 487.3194 & 0.0002 & 0.2052 & 70.895 \\ 0.97 & 30.76 & 23.71 & 30.88 & 2 & 972.6246 & 972.6242 & 487.3194 & 0.0004 & 0.4104 & 36.840\end{array}$ $\begin{array}{lllllllllllll}0.97 & 30.76 & 23.71 & 30.88 & 2 & 972.6246 & 972.6242 & 487.3194 & 0.0004 & 0.4104 & 36.840\end{array}$ $\begin{array}{llllllllllllll}0.75 & 15.75 & 23.65 & 22.60 & 2 & 972.6252 & 972.6242 & 487.3194 & 0.0010 & 1.0260 & 40.253 \\ 0.76 & 15.97 & 23.65 & 25.33 & 2 & 972.6254 & 972.6242 & 487.3194 & 0.0012 & 1.2312 & 34.396\end{array}$ $\begin{array}{llllllllllll}0.76 & 15.97 & 23.65 & 25.33 & 2 & 972.6254 & 972.6242 & 487.3194 & 0.0012 & 1.2312 & 34.396 \\ 0.96 & 24.61 & 23.54 & 25.15 & 2 & 972.6264 & 972.6242 & 487.3194 & 0.0022 & 2.2572 & 30.326\end{array}$ $\begin{array}{lllllllllllll}0.96 & 24.61 & 23.54 & 25.15 & 2 & 972.6264 & 972.6242 & 487.3194 & 0.0022 & 2.2572 & 30.326 \\ 0.95 & 30.88 & 23.52 & 33.10 & 2 & 972.6240 & 972.6242 & 487.3194 & -0.0002 & -0.2052 & 46.774\end{array}$ $\begin{array}{lllllllllllll}0.95 & 30.88 & 23.52 & 33.10 & 2 & 972.6240 & 972.6242 & 487.3194 & -0.0002 & -0.2052 & 46.774 \\ 0.95 & 34.08 & 23.71 & 35.87 & 2 & 972.6244 & 972.6242 & 487.3194 & 0.0002 & 0.2052 & 68.200\end{array}$ $\begin{array}{lllllllllllll}0.95 & 34.08 & 23.71 & 35.87 & 2 & 972.6244 & 972.6242 & 487.3194 & 0.0002 & 0.2052 & 68.200 & 10 \\ 0.95 & 29.36 & 23.71 & 32.03 & 2 & 972.6244 & 972.6242 & 487.3194 & 0.0002 & 0.2052 & 97.570\end{array}$ $\begin{array}{lllllllllllll}0.95 & 29.36 & 23.71 & 32.03 & 2 & 972.6244 & 972.6242 & 487.3194 & 0.0002 & 0.2052 & 97.570 \\ 0.95 & 34.02 & 23.71 & 35.99 & 2 & 972.6244 & 972.6242 & 487.3194 & 0.0002 & 0.2052 & 92.049\end{array}$ $\begin{array}{llllllllllllll}0.95 & 34.02 & 23.71 & 35.99 & 2 & 972.6244 & 972.6242 & 487.3194 & 0.0002 & 0.2052 & 92.049 & 11 \\ 0.90 & 24.59 & 23.71 & 28.27 & 2 & 972.6244 & 972.6242 & 487.3194 & 0.0002 & 0.2052 & 118.277 & 11 \\ 0.95 & 33.00 & 23.71 & 35.06 & 2 & 972.6244 & 972.6242 & 487.3194 & 0.002 & 0.2052 & 101.903 & 7 .\end{array}$ $\begin{array}{llllllllllll}0.90 & 24.59 & 23.71 & 28.27 & 2 & 972.6244 & 972.6242 & 487.3194 & 0.0002 & 0.2052 & 118.277 \\ 0.95 & 33.00 & 23.71 & 35.06 & 2 & 972.6244 & 972.6242 & 487.3194 & 0.0002 & 0.2052 & 101.903\end{array}$ $\begin{array}{lllllllllll}0.95 & 33.51 & 23.71 & 35.82 & 2 & 972.6244 & 972.6242 & 487.3194 & 0.0002 & 0.2052 & 25.971\end{array}$ $\begin{array}{llllllllllll}0.97 & 33.78 & 23.71 & 34.16 & 2 & 972.6246 & 972.6242 & 487.3194 & 0.0004 & 0.4104 & 148.975\end{array}$ $\begin{array}{lllllllllllll}0.89 & 24.15 & 23.71 & 28.17 & 2 & 972.6246 & 972.6242 & 487.3194 & 0.0004 & 0.4104 & 93.556\end{array}$ $\begin{array}{lllllllllllll}0.95 & 31.59 & 23.71 & 33.88 & 2 & 972.6246 & 972.6242 & 487.3194 & 0.0004 & 0.4104 & 148.687\end{array}$ $\begin{array}{llllllllllllll}0.95 & 23.68 & 23.71 & 27.82 & 2 & 972.6248 & 972.6242 & 487.3194 & 0.0006 & 0.6156 & 74.539\end{array}$ $\begin{array}{lllllllllllll}0.98 & 32.46 & 23.71 & 34.65 & 2 & 972.6250 & 972.6242 & 487.3194 & 0.0008 & 0.8208 & 91.527\end{array}$ $\begin{array}{llllllllllll}0.98 & 32.46 & 23.71 & 34.65 & 2 & 972.6250 & 972.6242 & 487.3194 & 0.0008 & 0.8208 & 91.527 \\ 0.95 & 24.33 & 23.71 & 30.06 & 2 & 972.6250 & 972.6242 & 487.3194 & 0.0008 & 0.8208 & 91.59\end{array}$ $\begin{array}{lllllllllllllll}0.95 & 25.01 & 23.71 & 31.22 & 2 & 972.6250 & 972.6242 & 487.3194 & 0.0008 & 0.8208 & 56.890 & 84.44\end{array}$ $\begin{array}{llllllllllllll}0.97 & 27.91 & 23.71 & 32.57 & 2 & 972.6250 & 972.6242 & 487.3194 & 0.0008 & 0.8208 & 14805.157 & 22636.644\end{array}$ $\begin{array}{lllllllllllll}0.98 & 30.37 & 23.65 & 32.52 & 2 & 972.6252 & 972.6242 & 487.3194 & 0.0010 & 1.0260 & 113.159 & 157.165 \\ 0.97 & 25.53 & 23.65 & 27.56 & 2 & 972.6252 & 972.6242 & 487.3194 & 0.0010 & 1.0260 & 73.450 & 122.166\end{array}$ $\begin{array}{lllllllllllll}0.97 & 25.53 & 23.65 & 27.56 & 2 & 972.6252 & 972.6242 & 487.3194 & 0.0010 & 1.0260 & 73.450 & 122.166 \\ 0.98 & 31.92 & 23.65 & 33.95 & 2 & 972.6252 & 972.6242 & 487.3194 & 0.0010 & 1.0260 & 89.184 & 96.141\end{array}$ $\begin{array}{rrrrrrrrrrrrr}0.94 & 23.35 & 23.65 & 29.10 & 2 & 972.6252 & 972.6242 & 487.3194 & 0.0010 & 1.0260 & 78.416 & 96.474\end{array}$ $\begin{array}{llllllllllllll}0.97 & 27.73 & 23.65 & 32.35 & 2 & 972.6254 & 972.6242 & 487.3194 & 0.0012 & 1.2312 & 7526.842 & 8631.755\end{array}$ $\begin{array}{llllllllllllll}0.92 & 27.34 & 23.71 & 32.08 & 2 & 972.6244 & 972.6242 & 487.3194 & 0.0002 & 0.2052 & 265.414 & 399.982\end{array}$ $\begin{array}{llllllllllllll}0.96 & 35.77 & 23.71 & 36.80 & 2 & 972.6244 & 972.6242 & 487.3194 & 0.0002 & 0.2052 & 213.796 & 336.606 \\ 0.92 & 27.28 & 23.71 & 31.57 & 2 & 972.6244 & 972.6242 & 487.3194 & 0.0002 & 0.2052 & 248.559 & 330.026\end{array}$ $\begin{array}{lllllllllllll}0.92 & 27.28 & 23.71 & 31.57 & 2 & 972.6244 & 972.6242 & 487.3194 & 0.0002 & 0.2052 & 248.559 & 330.026\end{array}$ $\begin{array}{llllllllllllll}0.96 & 33.05 & 23.71 & 34.22 & 2 & 972.6244 & 972.6242 & 487.3194 & 0.0002 & 0.2052 & 169.113 & 236.428\end{array}$ $\begin{array}{llllllllllllll}0.94 & 28.60 & 23.71 & 32.11 & 2 & 972.6244 & 972.6242 & 487.3194 & 0.0002 & 0.2052 & 182.126 & 236.820\end{array}$ $\begin{array}{llllllllllllll}0.95 & 36.85 & 23.71 & 38.78 & 2 & 972.6244 & 972.6242 & 487.3194 & 0.0002 & 0.2052 & 150.903 & 264.812\end{array}$ $\begin{array}{lllllllllllll}0.96 & 33.29 & 23.71 & 34.38 & 2 & 972.6244 & 972.6242 & 487.3194 & 0.0002 & 0.2052 & 34615.099 & 48509.336\end{array}$ $\begin{array}{lllllllllllllll}0.95 & 34.23 & 23.71 & 36.48 & 2 & 972.6246 & 972.6242 & 487.3194 & 0.0004 & 0.4104 & 242.618 & 291.490\end{array}$ $\begin{array}{llllllllllllll}0.86 & 26.76 & 23.71 & 34.24 & 2 & 972.6246 & 972.6242 & 487.3194 & 0.0004 & 0.4104 & 225.090 & 297.628\end{array}$ $\begin{array}{lllllllllllll}0.95 & 35.07 & 23.71 & 37.08 & 2 & 972.6246 & 972.6242 & 487.3194 & 0.0004 & 0.4104 & 190.447 & 270.778\end{array}$ $\begin{array}{llllllllllllll}0.95 & 33.33 & 23.7 & 37.40 & 2 & 972.6246 & 972.6242 & 487.3194 & 0.0004 & 0.4104 & 160.330 & 218.342\end{array}$ $\begin{array}{llllllllllllll}0.96 & 33.10 & 23.71 & 34.20 & 2 & 972.6246 & 972.6242 & 487.3194 & 0.0004 & 0.4104 & 205.848 & 287.236\end{array}$ $\begin{array}{lllllllllllll}0.93 & 26.59 & 23.71 & 30.31 & 2 & 972.6246 & 972.6242 & 487.3194 & 0.0004 & 0.4104 & 159.725 & 236.989\end{array}$ $\begin{array}{lllllllllllll}0.96 & 31.60 & 23.71 & 33.04 & 2 & 972.6246 & 972.6242 & 487.3194 & 0.0004 & 0.4104 & 182.097 & 232.173\end{array}$ $\begin{array}{lllllllllllllll}0.95 & 33.69 & 23.71 & 35.85 & 2 & 972.6246 & 972.6242 & 487.3194 & 0.0004 & 0.4104 & 151.290 & 235.281\end{array}$ $\begin{array}{llllllllllllll}0.98 & 35.31 & 23.71 & 37.37 & 2 & 972.6248 & 972.6242 & 487.3194 & 0.0006 & 0.6156 & 174.984 & 200.368\end{array}$ 

$\begin{array}{lllllllllllll}0.97 & 28.54 & 23.71 & 31.96 & 2 & 972.6248 & 972.6242 & 487.3194 & 0.0006 & 0.6156 & 198.496\end{array}$ $\begin{array}{llllllllllll}0.98 & 33.16 & 23.71 & 34.36 & 2 & 972.6248 & 972.6242 & 487.3194 & 0.0006 & 0.6156 & 168.959\end{array}$ $\begin{array}{llllllllllllll}0.97 .11 & 23.71 & 35.93 & 2 & 972.6250 & 972.6242 & 487.3194 & 0.0008 & 0.8208 & 288.863 & 3\end{array}$ $\begin{array}{llllllllll} & \end{array}$

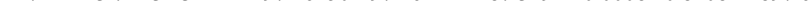
$\begin{array}{lllllllllllll}0.93 & 27.00 & 23.65 & 35.48 & 2 & 972.6252 & 972.6242 & 487.3194 & 0.0010 & 1.0260 & 21.67 .684\end{array}$ $\begin{array}{lllllllll} & \end{array}$

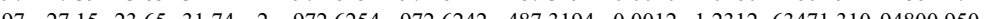
$\begin{array}{lllllllllllll}0.97 & 30.07 & 23.65 & 33.43 & 2 & 972.6256 & 972.6242 & 487.3194 & 0.0014 & 1.4364 & 249.659 & 424.089\end{array}$ $\begin{array}{lllllllllllll}0.98 & 30.46 & 23.65 & 33.41 & 2 & 972.6260 & 972.6242 & 487.3194 & 0.0018 & 1.8468 & 26.396 & 31.708\end{array}$

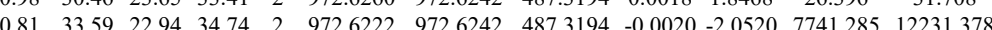
$\begin{array}{llllllllllll}0.81 & 33.59 & 22.94 & 34.74 & 2 & 97.6222 & 972.6242 & 487.3194 & 0.0020 & -2.0520 & 2741.285 & 12231.378\end{array}$ $\begin{array}{llllllllllll}0.87 & 30.53 & 23.52 & 37.63 & 2 & 972.6238 & 972.6242 & 487.3194 & 0.0004 & -0.4104 & 47.753\end{array}$ $\begin{array}{lllllllllll}0.87 & 27.44 & 23.52 & 34.49 & 2 & 972.6240 & 972.6242 & 487.3194 & -0.0002 & -0.2052 & 39.919\end{array}$ $\begin{array}{lllllllllllll}0.72 & 24.58 & 23.52 & 35.95 & 2 & 972.6242 & 972.6242 & 487.3194 & 0.0000 & 0.0000 & 29.975\end{array}$ $\begin{array}{lllllllllllllll}0.65 & 22.55 & 23.52 & 35.34 & 2 & 972.6242 & 972.6242 & 487.3194 & 0.0000 & 0.0000 & 26.999\end{array}$ $\begin{array}{lllllllllllll}0.77 & 26.86 & 23.52 & 37.09 & 2 & 972.6242 & 972.6242 & 487.3194 & 0.0000 & 0.0000 & 31.878\end{array}$ $\begin{array}{llllllllllllll}0.93 & 29.32 & 23.71 & 33.20 & 2 & 972.6244 & 972.6242 & 487.3194 & 0.0002 & 0.2052 & 50.635\end{array}$ $\begin{array}{lllllllllllll}0.91 & 27.11 & 23.71 & 32.21 & 2 & 972.6244 & 972.6242 & 487.3194 & 0.0002 & 0.2052 & 60.598\end{array}$ $\begin{array}{lllllllllllll}0.85 & 22.62 & 23.71 & 30.44 & 2 & 972.6244 & 972.6242 & 487.3194 & 0.0002 & 0.2052 & 50.708\end{array}$ $\begin{array}{lllllllllllll}0.72 & 19.26 & 23.71 & 30.43 & 2 & 972.6244 & 972.6242 & 487.3194 & 0.0002 & 0.2052 & 44.916\end{array}$ $\begin{array}{lllllllllllll}0.93 & 29.07 & 23.71 & 32.78 & 2 & 972.6244 & 972.6242 & 487.3194 & 0.0002 & 0.2052 & 48.772\end{array}$ $\begin{array}{lllllllllllll}0.93 & 28.16 & 23.71 & 32.33 & 2 & 972.6244 & 972.6242 & 487.3194 & 0.0002 & 0.2052 & 33.026\end{array}$ $\begin{array}{llllllllllllll}0.95 & 32.67 & 23.71 & 34.57 & 2 & 972.6244 & 972.6242 & 487.3194 & 0.0002 & 0.2052 & 59.826 & 5\end{array}$ $\begin{array}{lllllllllllllll}0.95 & 28.12 & 23.71 & 35.17 & 2 & 972.6248 & 972.6242 & 487.3194 & 0.0006 & 0.6156 & 42.849 & 71\end{array}$ $\begin{array}{lllllllllllll}0.86 & 22.11 & 23.71 & 33.76 & 2 & 972.6248 & 972.6242 & 487.3194 & 0.0006 & 0.6156 & 34.589\end{array}$ $\begin{array}{lllllllllllll}0.95 & 27.86 & 23.71 & 34.67 & 2 & 972.6250 & 972.6242 & 487.3194 & 0.0008 & 0.8208 & 40.216\end{array}$ $\begin{array}{lllllllllllll}0.93 & 22.00 & 23.65 & 30.52 & 2 & 972.6252 & 972.6242 & 487.3194 & 0.0010 & 1.0260 & 39.131 & 65.7 & \\ 0.72 & 29.10 & 22.94 & 32.55 & 2 & 972.622 & 972.622 & 487.3194 & 0.0020 & -2.0520 & 025.349 & 1598\end{array}$

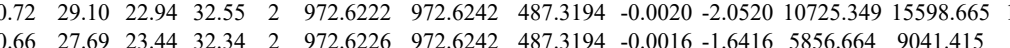

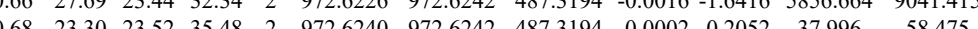

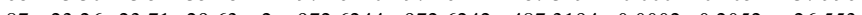
$\begin{array}{lllllllllllll}0.65 & 22.52 & 23.71 & 35.44 & 2 & 972.6244 & 972.6242 & 487.3194 & 0.0002 & 0.2052 & 24.638\end{array}$

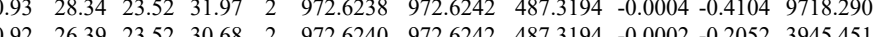
$\begin{array}{llllllllllll}0.93 & 27.15 & 23.71 & 30.88 & 2 & 972.6246 & 972.6242 & 487.3194 & 0.0004 & 0.4104 & 563.205 & \end{array}$

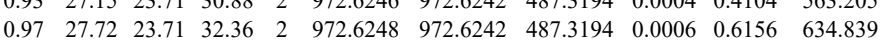
$\begin{array}{lllllllllllll}0.96 & 33.16 & 23.71 & 34.27 & 2 & 972.6244 & 972.6242 & 487.3194 & 0.0002 & 0.2052 & 317.655\end{array}$ $\begin{array}{llllllllllllll}0.98 & 33.47 & 23.71 & 34.63 & 2 & 972.6250 & 972.6242 & 487.3194 & 0.0008 & 0.8208 & 583.520 & 8\end{array}$ $\begin{array}{lllllllllllll} & 0.98 & 27.75 & 23.65 & 31.37 & 2 & 972.6260 & 972.6242 & 487.3194 & 0.0018 & 1.8468 & 180.520\end{array}$

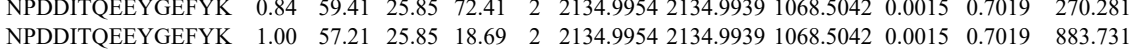
$\begin{array}{lllllllllllll}\text { NPDDITQEEYGEFYK } & 1.00 & 33.55 & 25.89 & 16.86 & 3 & 2134.9963 & 2134.9939 & 712.6719 & 0.0024 & 1.1225 & 48.009\end{array}$ ALLFIPR ALLFIPR ALLFIPR ALLFIPR ALLFIPR ALLFIPR ALLFIPR

ALLFIPR

ALLFIPR

ALLFIPR

ALLFIPR

ALLFIPR HSQFIGYPITLYLEK

ALLFIPR

ALLFIPR

ALLFIPR $\begin{array}{llllllllllllll}0.95 & 37.09 & 23.71 & 38.99 & 2 & 972.6244 & 972.6242 & 487.3194 & 0.0002 & 0.2052 & 516.306\end{array}$ $\begin{array}{lllllllllllll}0.96 & 24.94 & 23.71 & 28.85 & 2 & 972.6248 & 972.6242 & 487.3194 & 0.0006 & 0.6156 & 425.870\end{array}$ $\begin{array}{lllllllllllll}0.94 & 28.75 & 23.71 & 32.23 & 2 & 972.6246 & 972.6242 & 487.3194 & 0.0004 & 0.4104 & 419.691 \\ 0.98 & 32.95 & 23.71 & 34.03 & 2 & 972.6250 & 972.6242 & 487.3194 & 0.0008 & 0.8208 & 261.428\end{array}$ $\begin{array}{lllllllllllll}0.98 & 32.95 & 23.71 & 34.03 & 2 & 972.6250 & 972.6242 & 487.3194 & 0.0008 & 0.8208 & 261.428\end{array}$ $\begin{array}{llllllllllll}0.94 & 28.35 & 23.71 & 31.82 & 2 & 972.6244 & 972.6242 & 487.3194 & 0.0002 & 0.2052 & 173.375 \\ 0.98 & 35.13 & 23.71 & 37.23 & 2 & 972.6250 & 972.6242 & 4873194 & 0.0008 & 0.8208 & 298.029\end{array}$ $\begin{array}{lllllllllllll}0.98 & 35.13 & 23.71 & 37.23 & 2 & 972.6250 & 972.6242 & 487.3194 & 0.0008 & 0.8208 & 298.029 \\ 0.96 & 31.16 & 23.71 & 32.56 & 2 & 972.6246 & 972.6242 & 487.3194 & 0.0004 & 0.4104 & 159.118\end{array}$ $\begin{array}{lllllllllllll}0.96 & 31.16 & 23.71 & 32.56 & 2 & 972.6246 & 972.6242 & 487.3194 & 0.0004 & 0.4104 & 159.118 \\ 0.98 & 32.26 & 23.71 & 34.15 & 2 & 972.6250 & 972.6242 & 487.3194 & 0.0008 & 0.8208 & 282.331\end{array}$ $\begin{array}{llllllllllll}0.98 & 32.26 & 23.71 & 34.15 & 2 & 972.6250 & 972.6242 & 487.3194 & 0.0008 & 0.8208 & 282.331 \\ 0.98 & 31.96 & 23.71 & 34.52 & 2 & 972.6248 & 972.6242 & 487.3194 & 0.0006 & 0.6156 & 181.923\end{array}$ $\begin{array}{lllllllllllll}0.98 & 31.96 & 23.71 & 34.52 & 2 & 972.6248 & 972.6242 & 487.3194 & 0.0006 & 0.6156 & 181.923 \\ 0.97 & 27.35 & 23.65 & 31.09 & 2 & 972.6252 & 972.6242 & 487.3194 & 0.0010 & 1.0260 & 312.195\end{array}$ $\begin{array}{llllllllllllll}0.97 & 27.35 & 23.65 & 31.09 & 2 & 972.6252 & 972.6242 & 487.3194 & 0.0010 & 1.0260 & 312.195 \\ 0.97 & 28.29 & 23.71 & 31.88 & 2 & 972.6248 & 972.6242 & 487.3194 & 0.0006 & 0.6156 & 375.051\end{array}$ $\begin{array}{llllllllllllll}0.97 & 28.29 & 23.71 & 31.88 & 2 & 972.6248 & 972.6242 & 487.3194 & 0.0006 & 0.6156 & 375.051 \\ 0.98 & 34.20 & 23.71 & 35.71 & 2 & 972.6248 & 972.6242 & 487.3194 & 0.0006 & 0.6156 & 345.638\end{array}$ $\begin{array}{llllllllllllll}0.98 & 34.20 & 23.71 & 35.71 & 2 & 972.6248 & 972.6242 & 487.3194 & 0.0006 & 0.6156 & 345.638\end{array}$ $\begin{array}{llllllllllll}93.01 & 23.52 & 34.57 & 2 & 972.6242 & 972.6242 & 487.3194 & 0.0000 & 0.0000 & 210.734\end{array}$ $\begin{array}{llllllllllllll}0.93 & 28.10 & 23.71 & 31.73 & 2 & 972.6244 & 972.6242 & 487.3194 & 0.0002 & 0.2052 & 289.364\end{array}$ $\begin{array}{lllllllllllll}0.95 & 34.54 & 23.71 & 36.91 & 2 & 972.6244 & 972.6242 & 487.3194 & 0.0002 & 0.2052 & 274.988 \\ 0.95 & 32.27 & 23.71 & 34.18 & 2 & 972.6244 & 972.6242 & 487.3194 & 0.0002 & 0.2052 & 330.513\end{array}$ $\begin{array}{ccc}39.254 & 660.236 & \text { Yes } \\ 1.106 & 69.853 & \text { Yes }\end{array}$ $\begin{array}{llll}0.000 & 22856.714 & \text { No }\end{array}$ 

$\begin{array}{llllllllllll}0.66 & 23.82 & 26.40 & 36.82 & 3 & 2786.3182 & 2786.3166 & 929.7795 & 0.0016 & 0.5736 & 43.246 & 29.323\end{array}$ $\begin{array}{llllllllllll}0.99 & 33.27 & 24.98 & 19.52 & 2 & 1568.9068 & 1568.9057 & 785.4601 & 0.0011 & 0.7002 & 86.802 & 100.917 \\ 1.00 & 46.47 & 24.89 & 27.56 & 2 & 1568.9076 & 15689057 & 785.4601 & 0.0019 & 1.2095 & 74.227 & 165379\end{array}$

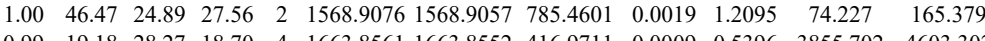
$\begin{array}{lllllllllllll}0.99 & 19.18 & 28.27 & 18.70 & 4 & 1663.8561 & 1663.8552 & 416.9711 & 0.0009 & 0.5396 & 3855.702 & 4603.302\end{array}$ $\begin{array}{llllllllllllll}1.00 & 20.95 & 28.18 & 16.37 & 4 & 1663.8565 & 1663.8552 & 416.9711 & 0.0013 & 0.7794 & 7043.888 & 7229.315 & 589 & \\ 0.72 & 20.20 & 24.77 & 33.20 & 2 & 1568.9084 & 1568.9057 & 785.4601 & 0.0027 & 1.7187 & 127.732 & 92.471 & 31\end{array}$ $\begin{array}{lllllllllllll}0.72 & 20.20 & 24.77 & 33.20 & 2 & 1568.9084 & 1568.9057 & 785.4601 & 0.0027 & 1.7187 & 127.732 & 92.471 \\ 0.93 & 26.28 & 24.87 & 15.31 & 2 & 1568.9092 & 1568.9057 & 785.4601 & 0.0035 & 2.2280 & 79.393 & 44.981\end{array}$

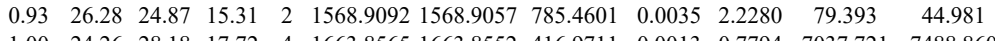
$\begin{array}{llllllllllllll}1.00 & 24.26 & 28.18 & 17.72 & 4 & 1663.8565 & 1663.8552 & 416.9711 & 0.0013 & 0.7794 & 7037.721 & 7488.860 & 63\end{array}$ $\begin{array}{lllllllllllll}0.97 & 25.00 & 28.08 & 16.03 & 3 & 1663.8571 & 1663.8552 & 555.6257 & 0.0019 & 1.1399 & 6956.393 & 8334.471 \\ 1.00 & 21.99 & 28.10 & 18.84 & 4 & 1663.8573 & 1663.8552 & 416.9711 & 0.0021 & 1.2591 & 5857.023 & 7149.530 & 687\end{array}$

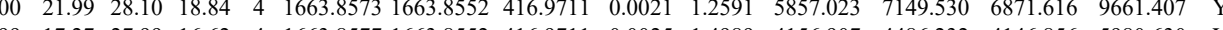
$\begin{array}{lllllllllllllll}0.99 & 17.27 & 27.99 & 16.62 & 4 & 1663.8577 & 1663.8552 & 46.9711 & 0.0025 & 1.4989 & 4156.907 & 4486.232 & 4146.856 & 5980.630 & \text { Yes } \\ 1.00 & 41.35 & 28.21 & 32.70 & 2 & 1390.7560 & 1390.7547 & 696.3846 & 0.0013 & 0.9334 & 8616.044 & 9408.238 & 4583.657 & 14432.989 & \text { Yes }\end{array}$ $\begin{array}{lllllllllllllll}1.00 & 43.52 & 28.16 & 29.76 & 2 & 1390.7568 & 1390.7547 & 696.3846 & 0.0021 & 1.5078 & 5870.008 & 6072.988 & 4045.130 & 9421.592 & \text { Yes }\end{array}$

$\begin{array}{llllllllllllllll} & 0.96 & 38.02 & 28.30 & 36.15 & 2 & 1189.6360 & 1189.6247 & 595.8196 & 0.0113 & 9.4826 & 22653.545 & 19732.684 & 1136.536 & 3464.581 & \text { Yes }\end{array}$ $\begin{array}{lllllllllllllllll} & & & \end{array}$

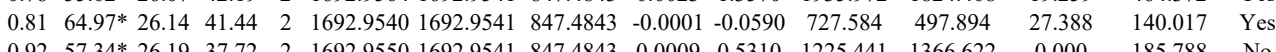
SVSSSSYR

SVSSSSYR

SYVTTSTR $\begin{array}{lllllllllllll}0.97 & 27.49 & 24.71 & 21.10 & 2 & 1015.5074 & 1015.5056 & 508.7601 & 0.0018 & 1.7690 & 160.357 & 105.465\end{array}$ $\begin{array}{llllllllllll}0.95 & 24.50 & 24.76 & 20.54 & 2 & 1015.5076 & 1015.5056 & 508.7601 & 0.0020 & 1.76956 & 126.568 & 81.094\end{array}$

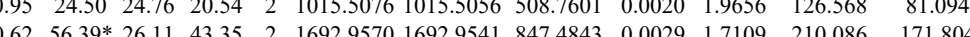
$\begin{array}{lllllllllllll}1.00 & 59.23 & 21.27 & 18.15 & 3 & 1965.1555 & 1965.1512 & 656.0577 & 0.0043 & 2.1848 & 4502.704 & 3127.831\end{array}$ $\begin{array}{llllllllllll}0.66 & 17.85 & 27.77 & 17.23 & 2 & 1057.5540 & 1057.5526 & 529.7836 & 0.0014 & 1.3213 & 178.073 & 115.738\end{array}$ $\begin{array}{llllllllllllll}\text { LLQDSVDFSLADAINTEFK } & 0.61 & 15.19 & 26.68 & 14.71 & 3 & 2413.2619 & 2413.2620 & 805.4279 & -0.0001 & -0.0414 & 37.954 & 33.416\end{array}$ $\begin{array}{llllllllllllll}\text { LLQDSVDFSLADAINTEFK } & 1.00 & 58.23 & 26.46 & 23.27 & 3 & 2413.2646 & 2413.2620 & 805.4279 & 0.0026 & 1.0760 & 24.048 & 41.276\end{array}$ $\begin{array}{lllllllllllll}\text { LLQDSVDFSLADAINTEFK } & 0.88 & 16.92 & 26.45 & 20.57 & 3 & 2413.2655 & 2413.2620 & 805.4279 & 0.0035 & 1.4485 & 29.443 & 14.234\end{array}$

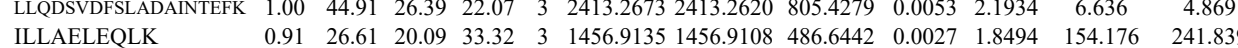
ILLAELEQLK

ILLAELEQLK

ILLAELEQLK

SSVPGVR

ILLAELEQLK

ILLAELEQLK ILLAELEQLK ILLAELEQLK ILLAELEQLK $\begin{array}{llllllllllll}1.00 & 60.30 & 20.09 & 27.40 & 2 & 1456.9138 & 1456.9108 & 729.4627 & 0.0030 & 2.0563 & 39254.274 & 29760.518\end{array}$ $\begin{array}{llllllllllll}1.00 & 68.78 & 20.25 & 28.27 & 2 & 1456.9142 & 1456.9108 & 729.4627 & 0.0034 & 2.3305 & 36960.708 & 30495.661\end{array}$ $\begin{array}{llllllllllll}1.00 & 34.07 & 20.25 & 28.33 & 3 & 1456.9144 & 1456.9108 & 486.6442 & 0.0036 & 2.4659 & 1652.927 & 1466.406\end{array}$ $\begin{array}{llllllllllllll}0.71 & 16.34 & 25.76 & 25.18 & 2 & 844.4906 & 844.4889 & 423.2517 & 0.0017 & 2.0083 & 211.488 & 174.964\end{array}$ $\begin{array}{lllllllllllll}0.99 & 33.23 & 20.49 & 29.86 & 3 & 1456.9132 & 1456.9108 & 486.6442 & 0.0024 & 1.6439 & 107.087 & 117.431 \\ 0.99 & 24.44 & 20.49 & 21.70 & 3 & 1456.9132 & 1456.9108 & 486.6442 & 0.0024 & 1.6439 & 167.265 & 117.129 \\ 1.0 & 30.62 & 20.0 & 36.2 & & \end{array}$ $\begin{array}{lllllllllllll}0.99 & 24.44 & 20.49 & 21.70 & 3 & 1456.9132 & 1456.9108 & 486.6442 & 0.0024 & 1.6439 & 167.265 & 117.129 \\ 1.00 & 70.62 & 20.09 & 26.12 & 2 & 1456.9134 & 1456.9108 & 729.4627 & 0.0026 & 1.7821 & 13520.904 & 11005.971\end{array}$ $\begin{array}{llllllllllll}1.00 & 70.62 & 20.09 & 26.12 & 2 & 1456.9134 & 1456.9108 & 729.4627 & 0.0026 & 1.7821 & 13520.904 & 11005.971 \\ 1.00 & 72.49 & 20.09 & 31.11 & 2 & 1456.9138 & 1456.9108 & 729.4627 & 0.0030 & 2.0563 & 17700.393 & 14210.403\end{array}$ LLAELEQLK

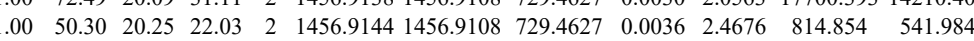
$\begin{array}{lllllllllllllll}1.00 & 51.53 & 20.17 & 23.47 & 2 & 1456.9148 & 1456.9108 & 729.4627 & 0.0040 & 2.7417 & 492.947 & 273.17\end{array}$ $\begin{array}{lllllllllllllll} & & \end{array}$ 


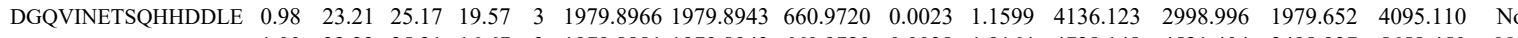
$\begin{array}{llllllllllllllllll}\text { DGQVINETSQHHDDLE } & 1.00 & 32.33 & 25.21 & 16.67 & 3 & 1979.8981 & 1979.8943 & 660.9720 & 0.0038 & 1.9164 & 4728.148 & 4521.404 & 2498.937 & 5658.450 & \text { No }\end{array}$ $\begin{array}{lllllllllllllllll}\text { ISLPLPNFSSLNLR } & 1.00 & 57.27 & 24.87 & 27.07 & 2 & 1713.9902 & 1713.9899 & 858.0022 & 0.0003 & 0.1748 & 5510.414 & 4286.723 & 71.277 & 419.807 & \text { Yes }\end{array}$ $\begin{array}{llllllllllllllll}\text { ISLPLPNFSSLNLR } & 0.99 & 24.67 & 23.80 & 15.12 & 3 & 1713.9931 & 1713.9899 & 572.3372 & 0.0032 & 1.8637 & 92.172 & 118.852 & 1.577 & 22.077 & \text { Yes }\end{array}$ $\begin{array}{llllllllllllllll}\text { ISLPLPNFSSLNR } & 0.99 & 26.32 & 23.64 & 19.89 & 3 & 1713.9946 & 1713.9899 & 572.3372 & 0.0047 & 2.7373 & 90.240 & 74.478 & 19.936 & 26.582 & \text { Yes }\end{array}$

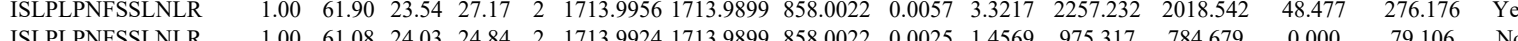

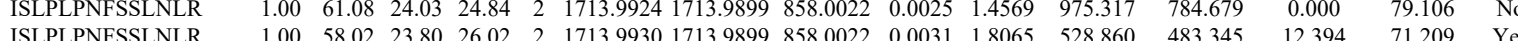

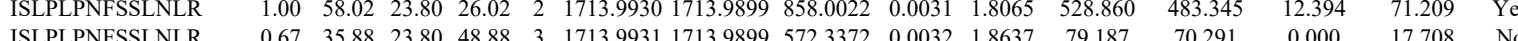

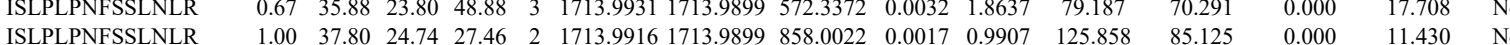

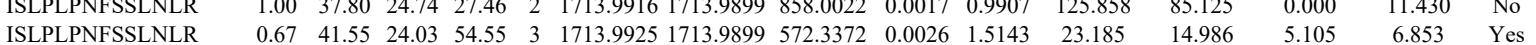
$\begin{array}{lllllllllllllll} & \end{array}$ $\begin{array}{lllllllllllll} & \end{array}$ QVDQTINK

LGDLYEEEMR

MFGGPGTASRPSSS

TYSLGSALRPSTSR

TYSLGSALRPSTSR

TYSLGSALRPSTSR

TYSLGSALRPSTSR

TYSLGSALRPSTSR

TYSLGSALRPSTSR

TYSLGSALRPSTSR

TYSLGSALRPSTSR

TYSLGSALRPSTSR

TYSLGSALRPSTSR

MFGGPGTASRPSSS

MFGGPGTASRPSSSR

MFGGPGTASRPSSS

TYSLGSALRPSTSR

TYSLGSALRPSTSR

TYSLGSALRPSTSR

MFGGPGTASRPSSS

$\begin{array}{llllllllllllll} & 33.026 & \text { Yes } \\ 0\end{array}$

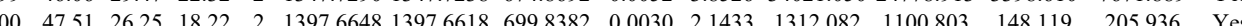

$\begin{array}{lllllllllllllll}0.58 & 20.18 & 27.40 & 18.07 & 2 & 1493.7042 & 1493.7045 & 747.8595 & -0.0003 & -0.2006 & 0.000 & 8.594 & 0.000 & 3.686 & \text { No }\end{array}$

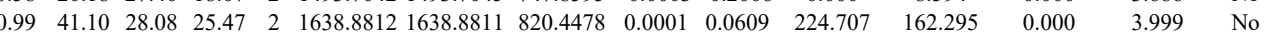
$\begin{array}{lllllllllllllll}0.98 & 38.00 & 28.01 & 22.78 & 2 & 1638.8816 & 1638.8811 & 820.4478 & 0.0005 & 0.3047 & 121.403 & 104.875 & 0.000 & 9.169 & \text { No }\end{array}$ $\begin{array}{llllllllllll} & \end{array}$ $\begin{array}{llllllllllll}25.19 & 2 & 1638.8816 & 1638.8811 & 820.4478 & 0.0005 & 0.3047 & 412.446 & 267.997 & 6.519 & 16.572 & \text { Yes }\end{array}$

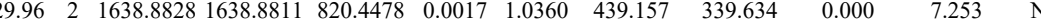
$\begin{array}{lllllllllllllll} & 1638.8836 & 1638.8811 & 547.3010 & 0.0025 & 1.5226 & 5130.813 & 4287.191 & 404.186 & 199.056 & \text { Yes }\end{array}$ $\begin{array}{lllllllllll}27.99 & 23.90 & 2 & 1638.8810 & 1638.8811 & 820.4478 & -0.0001 & -0.0609 & 229.417 & 154.289 & 19.938\end{array}$ $\begin{array}{lllllllllllll} & \end{array}$

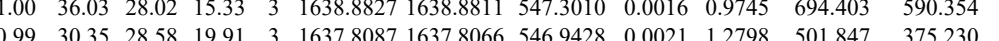
$\begin{array}{llllllllllll}0.99 & 30.35 & 28.58 & 19.91 & 3 & 1637.8087 & 1637.8066 & 546.9428 & 0.0021 & 1.2798 & 501.847 & 375.230 \\ 0.98 & 33.92 & 28.63 & 23.61 & 2 & 1637.8088 & 1637.8066 & 819.9106 & 0.0022 & 1.3416 & 52.687 & 23.515\end{array}$ $\begin{array}{llllllllllll}0.97 & 24.92 & 28.63 & 23.61 & 2 & 1637.8088 & 1637.8066 & 819.9106 & 0.0022 & 1.3416 & 52.687 & 23.515 \\ 1.97 & 4.74 & 17.78 & 3 & 1637.8099 & 1637.066 & 546.9428 & 0.0033 & 2.012 & 634.401 & 434.779\end{array}$ $\begin{array}{llllllllllll}0.97 & 24.41 & 28.74 & 17.78 & 3 & 1637.8099 & 1637.8066 & 546.9428 & 0.0033 & 2.0112 & 634.401 & 434.779 \\ 1.00 & 40.22 & 28.00 & 18.51 & 3 & 1638.8488 & 1638.8811 & 547.3010 & 0.0037 & 2.255 & 769.543 & 684.729\end{array}$ $\begin{array}{lllllllllllll}1.00 & 39.68 & 27.98 & 15.58 & 3 & 1638.8860 & 1638.8811 & 547.3010 & 0.0049 & 2.9843 & 721.930 & 663.99\end{array}$ $\begin{array}{lllllllllllll}0.97 & 41.64 & 27.57 & 26.12 & 2 & 1638.8872 & 1638.8811 & 820.4478 & 0.0061 & 3.7175 & 50.802 & 52.404\end{array}$ $\begin{array}{lllllllllllll}0.87 & 33.06 & 27.52 & 21.66 & 2 & 1638.8882 & 1638.8811 & 820.4478 & 0.0071 & 4.3269 & 62.428 & 58.539 \\ 0.97 & 26.66 & 28.55 & 17.61 & 3 & 1637.8075 & 1637.8066 & 546.9428 & 0.0009 & 0.5485 & 362.866 & 348.510\end{array}$ $\begin{array}{llllllllllll}0.96 & 25.92 & 28.55 & 17.19 & 3 & 1637.8078 & 1637.8066 & 546.9428 & 0.0012 & 0.7313 & 657.044 & 544.108\end{array}$ $\begin{array}{llllllllllllll} & \text { MFGGPGTASRPSSSR } & 0.68 & 18.56 & 28.63 & 1.19 & 2 & 1637.8082 & 1637.8066 & 819.9106 & 0.006 & 0.9757 & 23.794 & 25.878\end{array}$

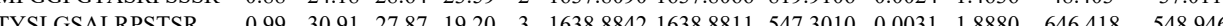

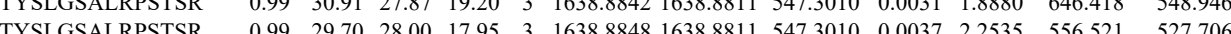

$\begin{array}{llllllllllllll}\text { TYSLGSALRPSTSR } & 0.93 & 37.14 & 27.98 & 21.95 & 2 & 1638.8860 & 1638.8811 & 820.4478 & 0.0049 & 2.9862 & 63.143 & 28.799\end{array}$

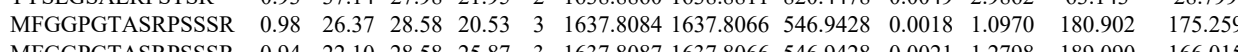
$\begin{array}{lllllllllllll}0.93 & 37.14 & 27.98 & 21.95 & 2 & 1638.8860 & 1638.8811 & 820.4478 & 0.0049 & 2.9862 & 63.143 & 28.799\end{array}$

MFGGPGTASRPSSSR

TYSLGSALRPSTSR

VELQELNDR

VELQELNDR

NLQEAEEWYK

LQEEMLQR

LQEEMLQR

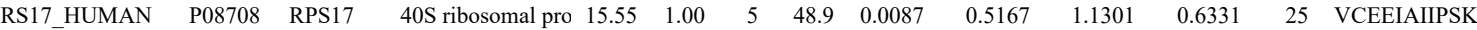

VCEEIAIIPSK

VCEEIAIIPSK

VCEEIAIIPSK

VCEEIAIIPSK

VCEEIAIIPSK

IAGYVTHLMK

IAGYVTHLMK

IAGYVTHLMK

IAGYVTHLMK

IAGYVTHLMK

IAGYVTHLMK

$\begin{array}{llllllllllllll}0.50 & 14.85 & 28.05 & 19.17 & 3 & 1638.8815 & 1638.8811 & 547.3010 & 0.0004 & 0.2436 & 256.302 & 250.064\end{array}$

$\begin{array}{lllllllllllll}1.00 & 33.35 & 27.99 & 17.53 & 3 & 1638.8830 & 1638.8811 & 547.3010 & 0.0019 & 1.1572 & 533.744 & 497.260\end{array}$

$\begin{array}{llllllllllll} & \end{array}$

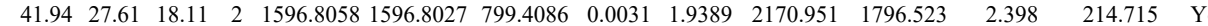
$\begin{array}{lllllllllllllll}0.98 & 40.78 & 28.25 & 36.07 & 2 & 1189.6344 & 1189.6247 & 595.8196 & 0.0097 & 8.1400 & 22673.277 & 18907.483 & 1404.136 & 3544.293 & \text { Yes } \\ 1.00 & 49.27 & 28.30 & 33.51 & 2 & 1189.6356 & 1189.6247 & 595.8196 & 0.0109 & 9.1470 & 24771.111 & 19876.547 & 1869.502 & 4252.965 & \text { Yes }\end{array}$ $\begin{array}{lllllllllllllllll}0.82 & 42.72 & 27.87 & 43.32 & 2 & 1534.8326 & 153.48342 & 768.4244 & -0.0016 & -1.0411 & 201.987 & 208.614 & 246.875 & 187.886 & \text { No } & \end{array}$

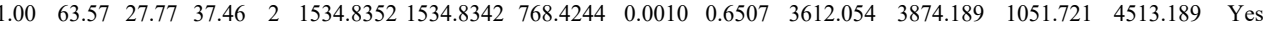
$\begin{array}{lllllllllllllll}1.00 & 62.66 & 27.77 & 35.59 & 2 & 1534.8354 & 1534.8342 & 768.4244 & 0.0012 & 0.7808 & 613.003 & 753.912 & 347.357 & 459.714 & \text { Yes }\end{array}$ $\begin{array}{llllllllllllllll}0.97 & 23.36 & 27.87 & 24.47 & 3 & 1534.8373 & 1534.8342 & 512.6187 & 0.0031 & 2.0158 & 18.843 & 35.891 & 0.000 & 30.007 & \text { No }\end{array}$

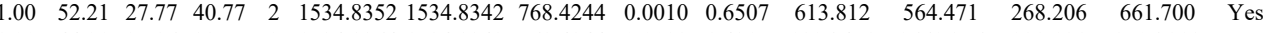
$\begin{array}{lllllllllllllll}1.00 & 44.21 & 27.86 & 32.55 & 2 & 1534.8364 & 1534.8342 & 768.4244 & 0.0022 & 1.4315 & 1826.451 & 1661.376 & 229.131 & 2706.918 & \text { Yes }\end{array}$

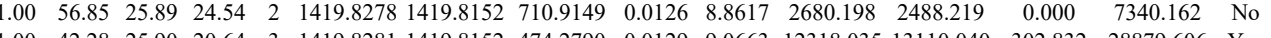
$\begin{array}{lllllllllllllll}1.00 & 42.28 & 25.90 & 20.64 & 3 & 1419.8281 & 1419.8152 & 474.2790 & 0.0129 & 9.0663 & 12318.035 & 13110.040 & 302.832 & 28879.606 & \text { Yes } \\ 1.00 & 53.26 & 26.05 & 26.28 & 2 & 14198290 & 1419.852 & 710.9149 & 0.0138 & 9.7057 & 148.216 & 1169.910 & 0.057 & 271.973 & \mathrm{No}\end{array}$

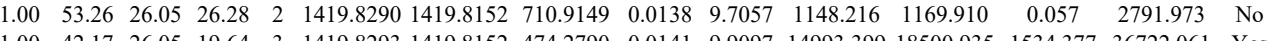
$\begin{array}{lllllllllllllll}1.00 & 42.17 & 26.05 & 19.64 & 3 & 1419.8293 & 1419.8152 & 474.2790 & 0.0141 & 9.9097 & 1499.399 & 1850.935 & 1534.377 & 36722.061 & \text { Yes }\end{array}$ $\begin{array}{lllllllllllllll}1.00 & 47.50 & 25.82 & 19.76 & 3 & 1419.8266 & 1419.8152 & 474.2790 & 0.014 & 8.0121 & 17545.704 & 18823.923 & 330.553 & 42311.942 & \text { Yes } \\ 1.00 & 50.57 & 25.89 & 19.10 & 3 & 1419.8275 & 1419.8152 & 4742790 & 0.0123 & 8.6446 & 14889.448 & 17123.876 & 1243.272 & 39083.077 & \text { Yes }\end{array}$ $\begin{array}{lllllllllllllll}1.00 & 46.51 & 25.89 & 19.103 & 3 & 1419.827 & 1419.8152 & 474.2790 & 0.0123 & 8.6446 & 14889.448 & 17123.876 & 1243.272 & 39083.077 & \text { Yes }\end{array}$

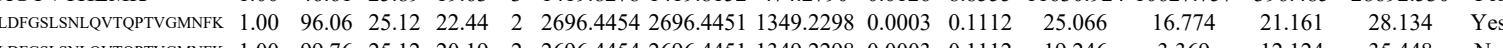
$\begin{array}{llllllllllll} & \text { L }\end{array}$

Table S-4 page 124 of 614 
$\begin{array}{lllllllllllll}\text { RDNYVPEVSALDQEIIEVDPDTK } & 1.00 & 53.54 & 27.26 & 17.39 & 3 & 2932.4935 & 2932.4909 & 978.5042 & 0.0026 & 0.8857 & 0.000\end{array}$ $\begin{array}{cccccccccccc}0.80 & 9.50 & 27.13 & 15.21 & 4 & 2932.4973 & 2932.4909 & 734.1300 & 0.0064 & 2.1794 & 48.442 \\ 0.93 & 23.88 & 26.00 & 21.97 & 2 & 841.4544 & 841.4528 & 421.7337 & 0.0016 & 1.8969 & 190.651\end{array}$ $\begin{array}{lllllllllllll}0.94 & 24.98 & 26.09 & 22.99 & 2 & 841.4548 & 841.4528 & 421.7337 & 0.0020 & 2.3712 & 408.823\end{array}$ $\begin{array}{llllllllllll}1.00 & 51.74 & 28.19 & 19.67 & 2 & 1563.8468 & 1563.8422 & 782.9284 & 0.0046 & 2.9377 & 829.540\end{array}$ $\begin{array}{lllllllllll}1.00 & 63.81 & 28.19 & 25.80 & 2 & 1563.8468 & 1563.8422 & 782.9284 & 0.0046 & 2.9377 & 1221.686\end{array}$

GVSVSSAR

GVSVSSAR

GVSVSSAR

GVSVSSAR

GVSVSSAR

GVSVSSAR

ILGATIENSR

$\begin{array}{llllllllllll}0.8 & 35.40 & 24.01 & 26.42 & 4 & 2554.4001 & 25354.3929 & 639.6055 & 0.0072 & 2.8142 & 303.682 \\ 1.00 & 40.18 & 28.11 & 24.23 & 2 & 905.5068 & 905.5052 & 453.7599 & 0.0016 & 1.7630 & 203.758\end{array}$

$\begin{array}{lllllllllllll}1.00 & 39.48 & 28.14 & 29.74 & 2 & 905.5074 & 905.5052 & 453.7599 & 0.0022 & 2.4242 & 150.105\end{array}$

$\begin{array}{llllllllllllll}0.99 & 34.99 & 28.14 & 27.72 & 2 & 905.5074 & 905.5052 & 453.7599 & 0.0022 & 2.4242 & 164.518\end{array}$

$\begin{array}{lllllllllllll}1.00 & 43.16 & 28.14 & 27.46 & 2 & 905.5076 & 905.5052 & 453.7599 & 0.0024 & 2.6446 & 199.88\end{array}$

$\begin{array}{lllllllllllll}0.66 & 21.72 & 28.97 & 22.57 & 2 & 905.5084 & 905.5052 & 453.7599 & 0.0032 & 3.5261 & 82.125 \\ 0.62 & 20.88 & 28.97 & 23.45 & 2 & 905.5084 & 905.5052 & 453.7599 & 0.0032 & 3.5261 & 81.979\end{array}$

GATIENSR

$\begin{array}{llllllllllll}58.51 & 27.66 & 28.65 & 2 & 1216.7002 & 1216.6897 & 609.3521 & 0.0105 & 8.6156 & 25123.196 & 4540.70\end{array}$

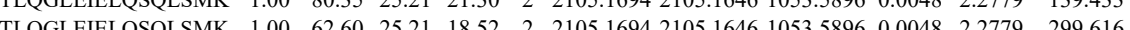

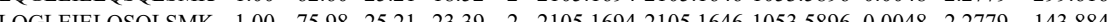
$\begin{array}{lllllllll} & 0\end{array}$ $\begin{array}{llllllllllll} & \end{array}$

$\begin{array}{lllllllllllll} & \end{array}$

$\begin{array}{lllllllllllll}\text { TLQGLEIELQSQLSMK } & 1.00 & 46.66 & 25.12 & 18.48 & 3 & 2105.1703 & 2105.1646 & 702.7288 & 0.0057 & 2.7037 & 281.811 & 127.419\end{array}$

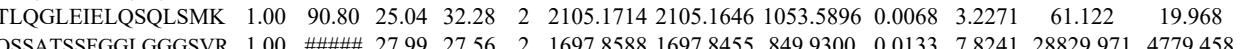

$\begin{array}{lllllllllllll}\text { QSSATSSFGGLGGGSVR } & 1.00 & \text { \#\#\#\# } 27.99 & 27.56 & 2 & 1697.8588 & 1697.8455 & 849.9300 & 0.0133 & 7.8241 & 28829.971\end{array}$

$\begin{array}{llllllllllll} & \end{array}$ $\begin{array}{llllllllllllll} & \text { QSSATSSFGGLGGGSVR } & 0.90 & 28.01 & 28.00 & 16.95 & 3 & 1697.8597 & 1697.8455 & 566.9558 & 0.0142 & 8.3486 & 2641.592 & 2239.261\end{array}$

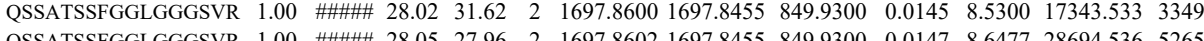
$\begin{array}{lllllllllllll} & \end{array}$ $\begin{array}{llllllllllll} & \end{array}$ $\begin{array}{lllllllllllll}\text { QSSATSSFGLGGGSVR } & 1.00 & \text { \#\#\#\#\# } 28.03 & 29.28 & 2 & 1697.8606 & 1697.8455 & 849.9300 & 0.0151 & 8.8830 & 5128.167 & 1120.501 & 12\end{array}$ $\begin{array}{llllllllllllll} & \end{array}$ $\begin{array}{lllllllllllll}\text { FGAQLAHIQALISGIEAQLGDVR } & 1.00 & 75.52 & 23.73 & 17.81 & 3 & 2550.4090 & 2550.4040 & 851.1419 & 0.0050 & 1.9581 & 106.879 & 0.474\end{array}$ \begin{tabular}{lllllllllllll} 
FGAQLAHIQALISGIEAQLGDVR & 1.00 & 77.41 & 23.60 & 21.30 & 4 & 2550.4117 & 2550.4040 & 638.6083 & 0.0077 & 3.0144 & 37.840 & 47.732 \\
FGPGVAFR & 0.95 & 30.81 & 27.81 & 25.94 & 2 & 993.5546 & 993.5518 & 497.7832 & 0.0028 & 2.8125 & 606.697 & 228.425 \\
\hline
\end{tabular} FGPGVAFR FGPGVAFR FGPGVAFR FGPGVAFR $\begin{array}{llllllllllllll}0.95 & 30.81 & 27.81 & 25.94 & 2 & 993.5546 & 993.5518 & 497.7832 & 0.0028 & 2.8125 & 606.697 & 228.425 \\ 0.89 & 26.83 & 27.81 & 25.82 & 2 & 993.5546 & 993.5518 & 497.7832 & 0.0028 & 2.8125 & 587.177 & 202.85\end{array}$ $\begin{array}{llllllllllll}0.89 & 26.83 & 27.81 & 25.82 & 2 & 993.5546 & 993.5518 & 497.7832 & 0.0028 & 2.8125 & 587.177 & 202.850 \\ 0.76 & 22.55 & 27.81 & 25.26 & 2 & 993.5546 & 993.5518 & 497.7832 & 0.0028 & 2.8125 & 344.910 & 107.370\end{array}$ $\begin{array}{llllllllllll}0.76 & 22.55 & 27.81 & 25.26 & 2 & 993.5546 & 993.5518 & 497.7832 & 0.0028 & 2.8125 & 344.910 & 107.370 \\ 0.71 & 21.44 & 27.83 & 25.26 & 2 & 993.5550 & 993.5518 & 497.7832 & 0.0032 & 3.2142 & 393.549 & 126.283\end{array}$ $\begin{array}{lllllllllllll}0.69 & 2.113 & 27.83 & 24.96 & 2 & 993.5550 & 993.5518 & 497.7832 & 0.0032 & 3.2142 & 379.245 & 125.960\end{array}$ $\begin{array}{lllllllllllll}0.70 & 21.27 & 27.83 & 25.08 & 2 & 993.5550 & 993.5518 & 497.7832 & 0.0032 & 3.2142 & 409.898 & 127.239\end{array}$ 


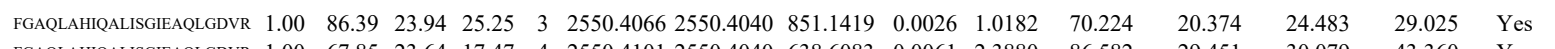
$\begin{array}{lllllllllllllllll}\text { FGAQLAHIQALISGIEAQLGDVR } & 1.00 & 67.85 & 23.64 & 17.47 & 4 & 2550.4101 & 2550.4040 & 638.6083 & 0.0061 & 2.3880 & 86.582 & 29.451 & 30.079 & 43.360 & \text { Yes }\end{array}$

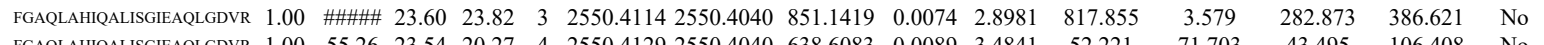

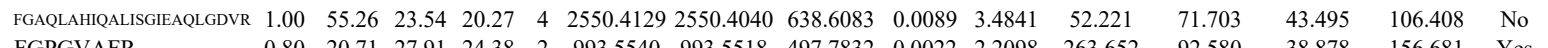

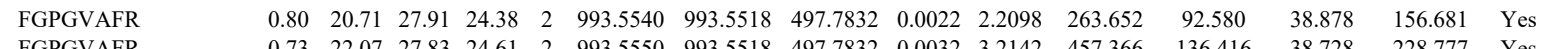

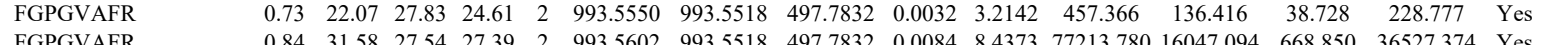

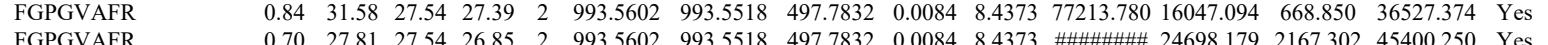

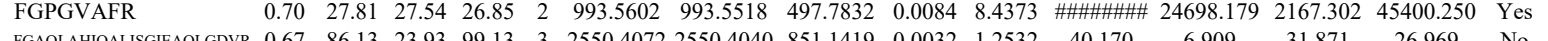

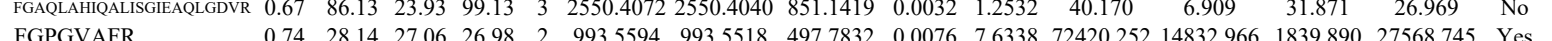
$\begin{array}{llllllllllllllll}\text { FGPGVAFR } & 0.74 & 28.14 & 27.06 & 26.98 & 2 & 993.5594 & 993.5518 & 497.7832 & 0.0076 & 7.6338 & 72420.252 & 64832.966 & 1839.890 & 27568.745 & \text { Yes } \\ \text { FGPGVAFR } & 0.84 & 31.58 & 27.54 & 27.50 & 2 & 993.5602 & 993.5518 & 497.7832 & 0.0084 & 8.4373 & 73276.618 & 13488.978 & 1102.585 & 27018.352 & \text { Yes }\end{array}$ $\begin{array}{llllllllllllllll} & 0.74 & 28.14 & 27.06 & 26.98 & 2 & 993.554 & 993.5518 & 497.7832 & 0.076 & 7.6338 & 72420.252 & 14832.966 & 1839.890 & 27568.745 & \text { Yes }\end{array}$

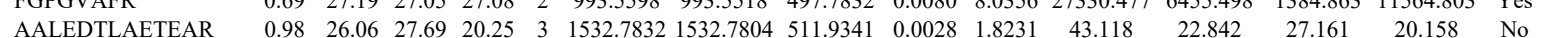

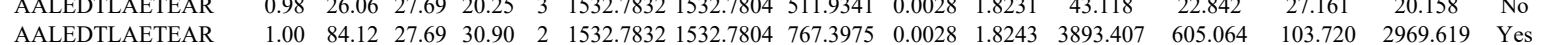

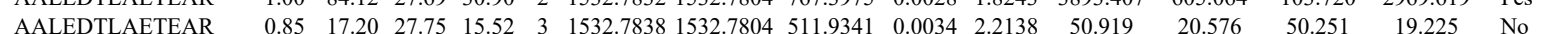

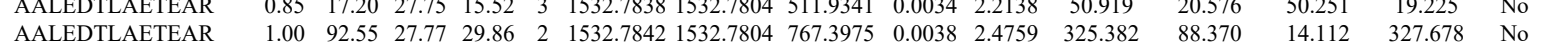
AALEDTLAETEAR
FGPGVAFR FGPGVAFR FGPGVAFR FGPGVAFR $\begin{array}{llllllllllllllll}\text { QSSATSSFGGLGGGSVR } & 1.00 & 87.55 & 27.41 & 26.90 & 2 & 1697.8484 & 1697.8455 & 849.9300 & 0.0029 & 1.7060 & 67.020 & 20.456 & 16.028 & 32.600 & \text { Yes } \\ \text { FGPGVAFR } & 0.77 & 20.16 & 28.09 & 25.41 & 2 & 993.5536 & 993.5518 & 497.7832 & 0.0018 & 1.8080 & 1091.753 & 400.879 & 220.347 & 563.573 & \text { Yes }\end{array}$

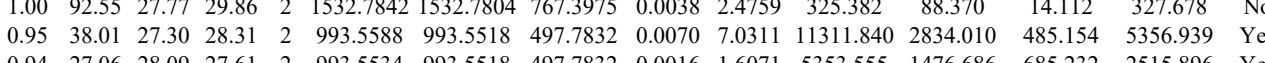
$\begin{array}{llllllllllllllllll}0.94 & 27.06 & 28.09 & 27.61 & 2 & 993.5534 & 993.5518 & 497.7832 & 0.0016 & 1.6071 & 5353.555 & 1476.686 & 685.232 & 2515.896 & \text { Yes } \\ \end{array}$ $\begin{array}{llllllllllllllll}0.98 & 32.60 & 27.91 & 28.08 & 2 & 993.5540 & 993.5518 & 497.7832 & 0.0022 & 2.2098 & 5630.598 & 1555.390 & 533.923 & 2347.839 & \text { Yes }\end{array}$ $\begin{array}{lllllllllllllllll}0.89 & 24.19 & 27.88 & 26.74 & 2 & 993.5532 & 993.5518 & 497.7832 & 0.0014 & 1.4062 & 3275.174 & 916.992 & 484.443 & 1696.776 & \text { Yes }\end{array}$

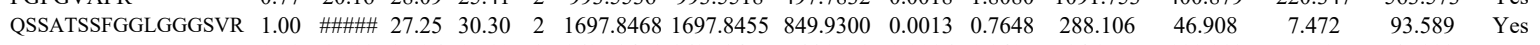
$\begin{array}{llllllllllllllll}\text { QSSATSSFGGLGGGSVR } & 0.79 & 15.08 & 27.26 & 17.10 & 3 & 1697.8471 & 1697.8455 & 566.9558 & 0.0016 & 0.9407 & 84.977 & 111.913 & 57.707 & 67.993 & \text { No }\end{array}$

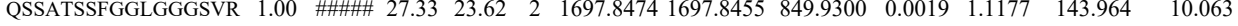
$\begin{array}{lllllllllllll}\text { PGPGVAFR } & 0.96 & 29.16 & 27.91 & 27.53 & 2 & 993.5542 & 993.5518 & 497.7832 & 0.0024 & 2.4107 & 1346.927 & 329.899\end{array}$ $\begin{array}{lllllllllllll}\text { QSSATSSFGGLGGGSVR } & 1.00 & \text { \#\#\#\# } 27.36 & 28.00 & 2 & 1697.8480 & 1697.8455 & 849.9300 & 0.0025 & 1.4707 & 155.581 & 26.367\end{array}$ $\begin{array}{llllllllllll}\text { QSSATSSFGGLGGGSVR } & 1.00 & \text { \#\#\# } 27.21 & 31.52 & 2 & 1697.8464 & 1697.8455 & 849.9300 & 0.0009 & 0.5295 & 139.744 & 30.123\end{array}$ $\begin{array}{lllllllllllll}\text { QSSATSSFGGLGGGSVR } & 1.00 & 96.54 & 27.37 & 21.32 & 2 & 1697.8472 & 1697.8455 & 849.9300 & 0.0017 & 1.0001 & 71.997 & 15.411\end{array}$ GQVGGQVSUEVSWTIDLAK FGPGVAFR AALEDTLAETEAR AALEDTLAETEAR APSIHGGSGGR $\begin{array}{rrrrrrrrrrrr}0.97 & 32.42 & 26.95 & 18.17 & 3 & 2301.2134 & 2301.2056 & 768.0758 & 0.0078 & 3.3851 & 15.578 & 3.818 \\ 0.60 & 19.51 & 27.91 & 24.92 & 2 & 993.5544 & 993.5518 & 497.7832 & 0.0026 & 2.6116 & 524.210 & 140.127\end{array}$ $\begin{array}{llllllllllll}0.73 & 21.92 & 27.83 & 24.92 & 2 & 993.5544 & 993.5518 & 497.7832 & 0.0026 & 2.6116 & 524.210 & 140.127 \\ 0.75 & 99348 & 993.5518 & 497.7832 & 0.0030 & 3.0134 & 471.653 & 135.263\end{array}$ APSIHGGSGGR $\begin{array}{lllllllllllll}1.00 & 71.32 & 27.80 & 27.23 & 2 & 1532.7844 & 1532.7804 & 767.3975 & 0.0040 & 2.6062 & 4544.621 & 651.742\end{array}$ $\begin{array}{llllllllllll}1.00 & 79.83 & 27.69 & 33.39 & 2 & 1532.7850 & 1532.7804 & 767.3975 & 0.0046 & 2.9971 & 13872.868 & 2575.870\end{array}$ $\begin{array}{llllllllllll}1.00 & 42.20 & 27.44 & 21.54 & 2 & 1138.5986 & 1138.5965 & 570.3055 & 0.0021 & 1.8411 & 38.922 & 13.068\end{array}$

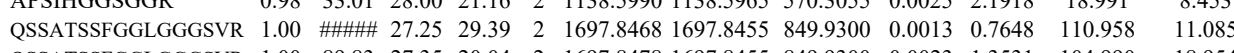

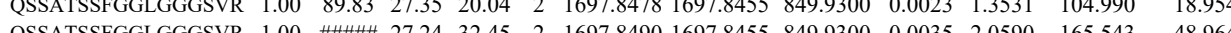

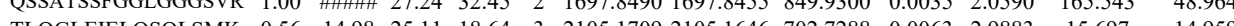

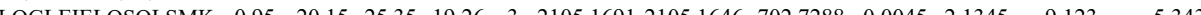

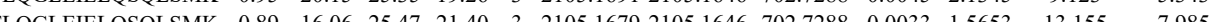

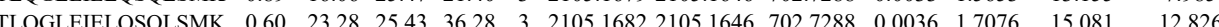
$\begin{array}{llllllllllll}\text { QSSATSSFGGLGGGSVR } & 100 & \text { \#\#\#\# } 27.54 & 29.29 & 2 & 1697.8512 & 1697.8455 & 849.9300 & 0.0057 & 3.3532 & 169.927 & 41.031\end{array}$ $\begin{array}{lllllllllllll}\text { TLOGLEIELOSQLSMK } & 0.67 & 26.22 & 25.47 & 39.22 & 3 & 2105.1679 & 2105.1646 & 702.7288 & 0.0033 & 1.5653 & 25.338 & 5.374\end{array}$

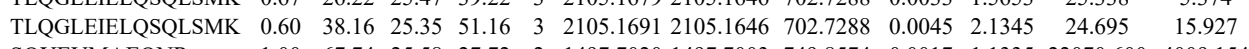
$\begin{array}{lllllllllllll}\text { SQYEVMAEQNR } & 1.00 & 67.74 & 25.58 & 27.72 & 2 & 1497.7020 & 1497.7003 & 749.8574 & 0.0017 & 1.1335 & 22070.600 & 4009.154 \\ \text { SQYEVMAEQNR } & 1.00 & 64.96 & 25.84 & 19.09 & 2 & 1497.7030 & 1497.7003 & 749.8574 & 0.0027 & 1.8003 & 37887.214 & 6766.014\end{array}$ SQYEVMAEQNR SQYEVMAEQNR ALEAANGELEVK ALEAANGELEVK SQYEVMAEQNR TDLEMQIEGLK TDLEMQIEGLK TDLEMQIEGLK QGPGPSR QGPGPSR

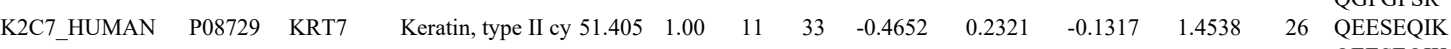
QEESEQIK LQAEIDNIK LQAEIDNIK SLDLDGIIAEVK SLDLDGIIAEVK SLDLDGIIAEVK SLDLDIIAEVK

SLDLDGIIAEVK $\begin{array}{llllllllllll}1.00 & 37.56 & 26.04 & 22.09 & 3 & 1497.7042 & 1497.7003 & 500.2407 & 0.0039 & 2.5987 & 364.808 & 359.155\end{array}$ $\begin{array}{llllllllllllll}1.00 & 43.81 & 26.03 & 28.96 & 3 & 1497.7048 & 1497.7003 & 500.2407 & 0.0045 & 2.9985 & 513.250 & 453.351\end{array}$ $\begin{array}{lllllllllllll}0.90 & 33.12 & 26.84 & 30.89 & 2 & 1530.8572 & 1530.8497 & 766.4321 & 0.0075 & 4.8928 & 66.961 & 64.674\end{array}$ $\begin{array}{llllllllllll}1.00 & 65.50 & 26.79 & 29.00 & 2 & 1530.8600 & 1530.8497 & 766.4321 & 0.0103 & 6.7194 & 6735.579 & 1755.308\end{array}$ $\begin{array}{lllllllllllll}1.00 & 68.35 & 26.65 & 24.13 & 2 & 1497.7114 & 1497.7003 & 749.8574 & 0.0111 & 7.4014 & 1985.863 & 393.524 \\ 1.00 & 59.78 & 27.99 & 25.68 & 2 & 1563.8470 & 1563.8422 & 782.9284 & 0.0048 & 3.0654 & 8882.723 & 2302.042 & 1046\end{array}$ $\begin{array}{llllllllllll}1.00 & 43.39 & 28.20 & 20.84 & 3 & 1563.8479 & 1563.8422 & 522.288 & 0.0048 & 3.0654 & 8882.723 & 2302.042 \\ 0 & 0.6378 & 186.935 & 102.811\end{array}$ $\begin{array}{lllllllllllll}0.99 & 35.97 & 28.20 & 22.74 & 3 & 1563.8479 & 1563.8422 & 522.2880 & 0.0057 & 3.6378 & 318.745 & 70.687\end{array}$ $\begin{array}{lllllllllllll}0.93 & 23.99 & 26.00 & 23.40 & 2 & 841.4544 & 841.4528 & 421.7337 & 0.0016 & 1.8969 & 277.967 & 37.948\end{array}$ $\begin{array}{llllllllllllll}0.99 & 34.92 & 26.00 & 26.79 & 2 & 841.4546 & 841.4528 & 421.7337 & 0.0018 & 2.1340 & 118.288 & 26.499\end{array}$ $\begin{array}{llllllllllll}0.90 & 28.27 & 28.80 & 31.16 & 2 & 1277.6732 & 1277.6707 & 639.8426 & 0.0025 & 1.9536 & 234.848 & 145.654 \\ 0.57 & 27.38 & 28.98 & 29.46 & 2 & 1277.6756 & 1277.6707 & 639.8426 & 0.0049 & 3.8291 & 128.217 & 110.980 \\ 0.99 & 50.3 & 26.70 & 39.31 & 2 & 1330.7822 & 1330.7700 & 6663923 & 0.0122 & 9.1537 & 2588.348 & 17914.523\end{array}$ $\begin{array}{llllllllllll}0.57 & 27.38 & 28.98 & 29.46 & 2 & 1277.6756 & 1277.6707 & 639.8426 & 0.0049 & 3.8291 & 128.217 & 110.980 \\ 0.99 & 50.33 & 26.70 & 39.31 & 2 & 1330.7822 & 1330.7700 & 666.3923 & 0.0122 & 9.1537 & 25584.348 & 17914.523\end{array}$ $\begin{array}{llllllllllll}0.99 & 50.33 & 26.70 & 39.31 & 2 & 1330.7822 & 1330.7700 & 666.3923 & 0.0122 & 9.1537 & 25584.348 & 17914.523 \\ 1.00 & 48.96 & 26.34 & 36.58 & 2 & 1330.7824 & 1330.7700 & 666.3923 & 0.0124 & 9.3037 & 23872.900 & 14687.165\end{array}$ $\begin{array}{llllllllllll}1.00 & 48.96 & 26.34 & 36.58 & 2 & 1330.7824 & 1330.7700 & 666.3923 & 0.0124 & 9.3037 & 23872.900 & 14687.165 \\ 1.00 & 68.61 & 25.40 & 32.57 & 2 & 1559.9052 & 1559.9014 & 780.9580 & 0.0038 & 2.4329 & 8810.402 & 5967.118\end{array}$ $\begin{array}{lllllllllllll}1.00 & 71.99 & 25.43 & 34.11 & 2 & 1559.9054 & 1559.9014 & 780.9580 & 0.0040 & 2.5610 & 13020.426 & 9028.103\end{array}$ $\begin{array}{lllllllllllll}1.00 & 3.75 & 25.43 & 33.12 & 3 & 1559.9056 & 1559.9014 & 520.974 & 0.0042 & 2.6873 & 2798.787 & 2416.677 & 22\end{array}$ $\begin{array}{lllllllllllll}1.00 & 35.16 & 25.43 & 28.17 & 3 & 15599056 & 15599014 & 520.9744 & 0.0042 & 2.6873 & 903.447 & 601.044\end{array}$ $\begin{array}{llllllllllll}0.92 & 18.71 & 25.39 & 21.78 & 3 & 1559.9059 & 1559.9014 & 520.9744 & 0.0045 & 2.8792 & 639.166 & 649.100\end{array}$ 
SLDLDGIIAEVK SLLDGIAEVK

VDALNDEINFLR

VDALNDEINFLR

FETLQAQAGK

VDALAQAGK

VDALNDEINFLR

VDALNDEINFLR

FETLQAQAGK

FTQAQAGK

VDALNDEINFLR

SAYGGPVGAGIR

SAYGGPVGAGIR

SAYGGPVGAGIR

SAYGGPVGAGIR

SAYGGPVGAGIR

LPDIFEAQIAGLR

LPDIFEAQIAGLR

LPDIFEAQIAGLR

LPDIFEAQIAGLR

LPDIFEAQIAGLR

LPDIFEAQIAGLR

LPDIFEAQIAGLR

LPDIFEAQIAGLR

LEAAIAEAEER

LEAAIAEAEER

QEELEAALQR

QEELEAALQR

SMQDVVEDFK

SMQDVVEDFK

AEAEAWYQTK

AEAEAWYQT

ANXA5_HUMA P08758 ANXA5 Annexin As

$\begin{array}{llllllll}35.937 & 1.00 & 15 & 61.6 & -0.0353 & 0.3537 & 1.3325 & 0.5332\end{array}$ GTVTDPF

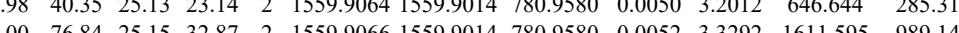

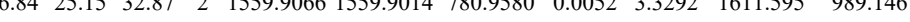

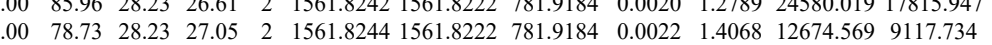
$\begin{array}{llllllllllllll}1.00 & 57.29 & 27.29 & 32.07 & 2 & 1379.7786 & 1379.7652 & 690.8899 & 0.0134 & 9.6975 & 70330.232 & 45210.354 & 231\end{array}$ $\begin{array}{llllllllllllll}1.00 & 53.65 & 27.35 & 39.18 & 2 & 1379.7788 & 1379.7652 & 690.8899 & 0.0136 & 9.8423 & 55255.684 & 42579.872 & 80\end{array}$ $\begin{array}{lllllllllllll}1.00 & 80.64 & 28.34 & 28.48 & 2 & 1561.8238 & 1561.8222 & 781.9184 & 0.0016 & 1.0231 & 2501.154 & 1997.281 & \\ 1.00 & 76.12 & 28.23 & 31.98 & 2 & 1561.8248 & 1561.8222 & 781.9184 & 0.0026 & 1.6626 & 9128.950 & 6611.011 & 2\end{array}$ $\begin{array}{lllllllllll} & \end{array}$

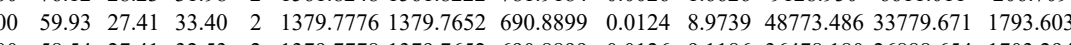

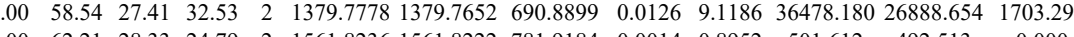

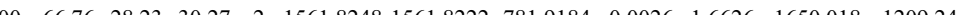

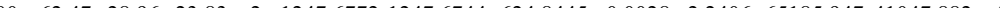

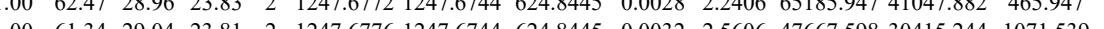
$\begin{array}{lllllllllllllll}1.00 & 61.18 & 28.79 & 21.88 & 2 & 1247.6758 & 1247.6744 & 624.8445 & 0.0014 & 1.1203 & 77385.294 & 47398.415 & 546.332 & 712\end{array}$ $\begin{array}{llllllllllllll}1.00 & 61.21 & 28.88 & 22.21 & 2 & 1247.6764 & 1247.6744 & 624.8445 & 0.0020 & 1.6004 & 80539.099 & 54831.227 & 699.286\end{array}$ $\begin{array}{llllllllllllll}1.00 & 55.82 & 28.79 & 21.69 & 2 & 1247.6758 & 1247.6744 & 624.8445 & 0.0014 & 1.1203 & 13374.161 & 8846.558 & 1501.301\end{array}$ $\begin{array}{llllllllllll}1.00 & 72.25 & 26.71 & 25.63 & 2 & 1585.8956 & 1585.8950 & 793.9548 & 0.0006 & 0.3779 & 2022.299 & 1099.010\end{array}$ $\begin{array}{llllllllllll}1.00 & 72.28 & 26.66 & 25.58 & 2 & 1585.8966 & 1585.8950 & 793.9548 & 0.0016 & 1.0076 & 2606.389 & 1467.075\end{array}$ $\begin{array}{lllllllllllll}1.00 & 71.74 & 26.71 & 24.83 & 2 & 1585.8960 & 1585.8950 & 793.9548 & 0.0010 & 0.6298 & 8078.463 & 4820.903\end{array}$ $\begin{array}{lllllllllllll}100 & 71.70 & 26.50 & 24.52 & 2 & 1585.8970 & 1585.8950 & 793.9548 & 0.0020 & 1.2595 & 5795.112 & 4158.047\end{array}$ $\begin{array}{lllllllllllll}1.00 & 48.56 & 26.46 & 20.72 & 3 & 1585.8976 & 1585.8950 & 529.6389 & 0.0026 & 1.6363 & 93.252 & 197.164\end{array}$ $\begin{array}{lllllllllllll}1.00 & 32.95 & 26.44 & 22.26 & 3 & 1585.8985 & 1585.8950 & 529.6389 & 0.0035 & 2.2028 & 69.366 & 101.113\end{array}$

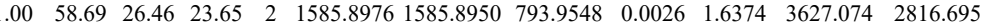
$\begin{array}{lllllllllllll}1.00 & 61.80 & 26.44 & 20.97 & 2 & 1585.8984 & 1585.8950 & 793.9548 & 0.0034 & 2.1412 & 1185.421 & 828.752\end{array}$ $\begin{array}{llllllllllll}1.00 & 72.64 & 27.50 & 34.81 & 2 & 1344.7026 & 1344.7006 & 673.3576 & 0.0020 & 1.4851 & 4558.586 & 3861.091\end{array}$ $\begin{array}{lllllllllllll}1.00 & 70.20 & 27.52 & 33.53 & 2 & 1344.7036 & 1344.7006 & 673.3576 & 0.0030 & 2.2276 & 3805.071 & 3227.194 & 1\end{array}$

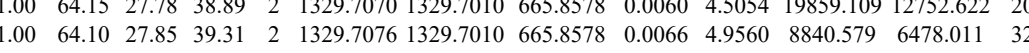
$\begin{array}{llllllllllll}0.91 & 54.89 * 27.50 & 30.26 & 2 & 1484.7458 & 1484.7425 & 743.3785 & 0.0033 & 2.2196 & 6727.142 & 3928.914\end{array}$ $\begin{array}{lrlllllllllll}0.78 & 53.82 * 27.48 & 30.59 & 2 & 1484.7460 & 1484.7425 & 743.3785 & 0.0035 & 2.3541 & 10466.172 & 7527.758\end{array}$ $\begin{array}{lllllllllllll}0.97 & 41.59 & 27.60 & 24.71 & 2 & 1483.7610 & 1483.7551 & 742.8848 & 0.0059 & 3.9710 & 801.037 & 773.441\end{array}$ $\begin{array}{lllllllllllll}0.93 & 35.75 & 27.65 & 22.73 & 2 & 1483.7628 & 1483.7551 & 742.8848 & 0.0077 & 5.1825 & 404.905 & 273.205\end{array}$ $\begin{array}{llllllllllllll}0.99 & 50.52 & 26.70 & 39.48 & 2 & 1330.7822 & 1330.7700 & 666.3923 & 0.0122 & 9.1537 & 12790.242 & 8858.777\end{array}$ $\begin{array}{llllllllllll}0.84 & 66.36 & 26.14 & 79.36 & 2 & 1250.6024 & 1250.6008 & 626.3077 & 0.0016 & 1.2773 & 47.561 & 97.775 \\ 1.00 & 44.98 & 26.10 & 18.92 & 2 & 1483.7104 & 1483.7065 & 742.8605 & 0.0039 & 2.6250 & 928.994 & 753.770\end{array}$ GTVTDFPGFDER QEISAAFK

YMTISGFOIEETIDR YETDLFNR

SEIDLFNIR

SEIDLFNIR

GLGTDEESILTLLTSR

GLGTDEESILTLLTSR

GLGTDEESILTLLTSR

GLGTDEESILTLLTSR GLGTDEESLILTLLTSR GLGTDEESILTLLTSR AVVK ETSGNLEQLLLAVVK

GLGTDEESILTLLTSR

GLGTDEESILTLLTS

ETSGNLEQLLLAVVK ETSGNLEQLLLAVYK NFATSLYSMIK NFATSLYSMIK NFATSLYSMIK NFATSLYSMIK NATSLYMIK NFATSLYSMIK $\begin{array}{llllll}0.0049 & 3.2981 & 1231.441 & 1443.471 & 487.702\end{array}$

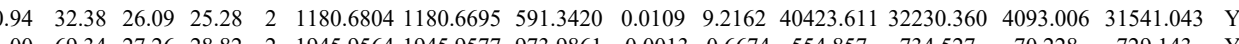
$\begin{array}{lllllllllllllll}1.00 & 54.74 & 28.56 & 34.89 & 2 & 1259.6798 & 1249.6788 & 625.8467 & 0.0010 & 0.7989 & 17207.056 & 15247.395 & 334.686 & 17663.178 & \text { Yes }\end{array}$ $\begin{array}{llllllllllllllll}1.00 & 54.96 & 28.56 & 33.85 & 2 & 1249.6798 & 1249.6788 & 625.8467 & 0.0010 & 0.7989 & 18348.280 & 19708.761 & 0.000 & 21248.688 & \text { No }\end{array}$ $\begin{array}{lllllllllllllll}1.00 & 49.48 & 28.56 & 32.09 & 2 & 1249.6816 & 1249.6788 & 625.8467 & 0.0028 & 2.2370 & 11158.147 & 13181.420 & 0.000 & 14035.590 & \text { No }\end{array}$

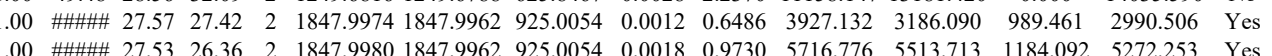

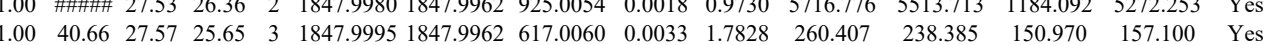
$\begin{array}{llllllllllllllll}1.00 & 31.64 & 27.57 & 23.53 & 3 & 1847.9995 & 1847.9962 & 617.0060 & 0.0033 & 1.7828 & 184.799 & 73.804 & 77.994 & 88.314 & \text { No }\end{array}$

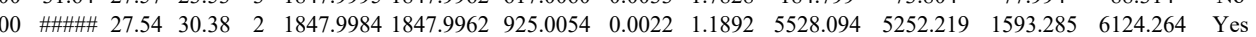
$\begin{array}{llllllllllllll} & 27.54 & 31.35 & 2 & 1847.9984 & 1847.9962 & 925.0054 & 0.0022 & 1.1892 & 8870.825 & 11830.144 & 3406.287 & 8758.296 & \text { Yes }\end{array}$ \begin{tabular}{lllllllllllllll}
0.59 & 12.66 & 27.54 & 20.16 & 3 & 1848.0001 & 1847.9962 & 617.0060 & 0.0039 & 2.1069 & 87.403 & 53.386 & 33.689 & 79.061 & Yes \\
\hline .96 & 23.80 & 27.54 & 21.10 & 3 & 1848.001 & 847.962 & 617.0060 & 0.009 & 2.1069 & 54.431 & 70.634 & 42.80 & 19.331 & Yes
\end{tabular}

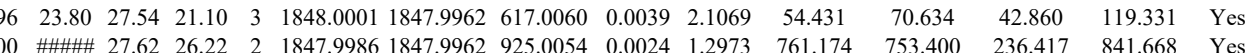
$\begin{array}{llllllllllllll} & \end{array}$

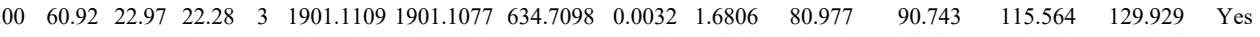

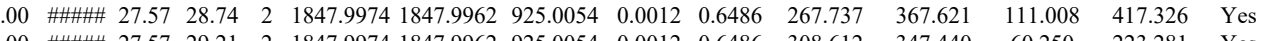

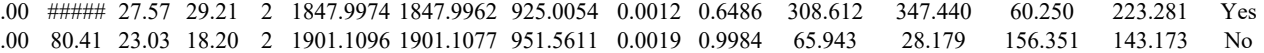

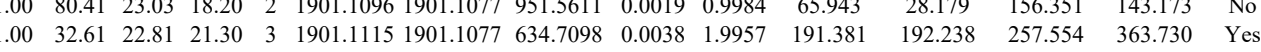

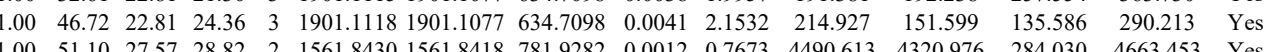

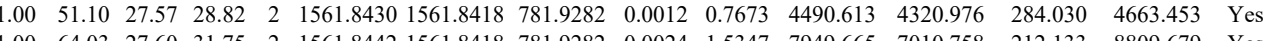

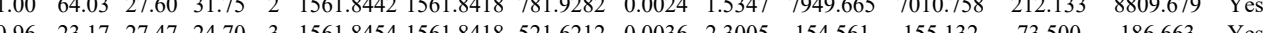

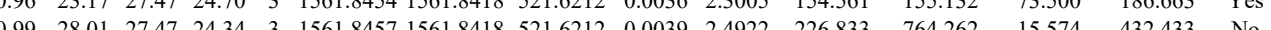

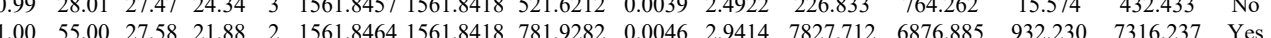
$\begin{array}{lllllllllllllll}1.00 & 55.00 & 27.58 & 21.88 & 2 & 1561.8464 & 1561.8418 & 781.9282 & 0.0046 & 2.9414 & 7827.712 & 6876.885 & 932.230 & 7316.237 & \text { Yes }\end{array}$

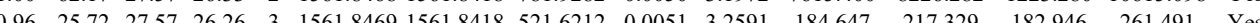
$\begin{array}{lllllllllllllll}0.96 & 25.72 & 27.57 & 26.26 & 3 & 1561.8469 & 1561.8418 & 521.6212 & 0.0051 & 3.2591 & 184.647 & 217.329 & 182.946 & 261.491 & \text { Yes } \\ 0.79 & 22.82 & 27.59 & 25.39 & 3 & 1561.8484 & 1561.8418 & 521.6212 & 0.0066 & 4.2176 & 185.937 & 277.712 & 144.145 & 402.337 & \text { Yes }\end{array}$

Table S-4 page 127 of 614 

$\begin{array}{lllllllllllll}\text { SIPAYLAETLYYAMK } & 1.00 & 35.13 & 27.21 & 26.34 & 3 & 2021.0836 & 2021.0787 & 674.7002 & 0.0049 & 2.4208 & 192.272 & 170.256\end{array}$ $\begin{array}{lllllllllllll}\text { SIPAYLAETLYYAMK } & 1.00 & 50.01 & 27.20 & 21.59 & 3 & 2021.0842 & 2021.0787 & 674.7002 & 0.0055 & 2.7172 & 143.993 & 204.384 \\ \text { SIPAYLAETLYYAMK } & 1.00 & 70.77 & 26.96 & 21.90 & 2 & 2021.0814 & 2021.0787 & 1011.5466 & 0.0027 & 1.3346 & 346.969 & 380.358\end{array}$ $\begin{array}{lllllllllllll}\text { SIPAYLAETLYYAMK } & 1.00 & 70.77 & 26.96 & 21.90 & 2 & 2021.0814 & 2021.0787 & 1011.5466 & 0.0027 & 1.3346 & 346.969 & 380.358 \\ \text { SIPAYLAETLYYAMK } & 1.00 & 42.92 & 26.98 & 24.59 & 3 & 2021.0830 & 2021.0787 & 674.7002 & 0.0043 & 2.1244 & 142.267 & 170.023\end{array}$

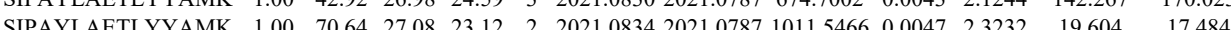
$\begin{array}{llllllllllll} & \end{array}$ $\begin{array}{llllllllll} & 0\end{array}$

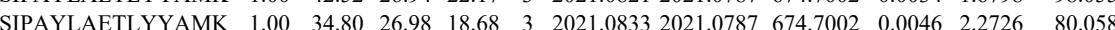

$\begin{array}{lll}67.153 & 0988780-6313.179\end{array}$

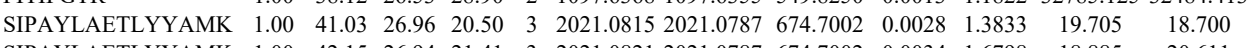

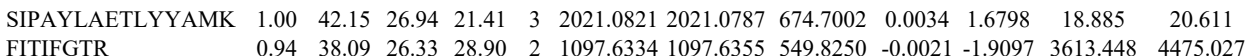
MLVVLLQANR MLVVLLQANR LIVALMKPSR
LIVALMKPSR $\begin{array}{llllllllllll}0.94 & 38.09 & 26.33 & 28.90 & 2 & 1097.6334 & 1097.6355 & 549.8250 & -0.0021 & -1.9097 & 3613.448 & 4475.027 \\ 1.00 & 65.06 & 2.58 & 37.97 & 2 & 1299.7826 & 1299.7818 & 650.8982 & 0.0008 & 0.6145 & 2359.775 & 2582.782\end{array}$ $\begin{array}{llllllllllll}1.00 & 65.14 & 24.53 & 38.06 & 2 & 1299.7832 & 1299.7818 & 650.8982 & 0.0014 & 1.0754 & 2915.430 & 2929.576\end{array}$ $\begin{array}{llllllllllll}1.00 & 54.07 & 19.34 & 29.15 & 2 & 1414.8936 & 1414.8937 & 708.4541 & -0.0001 & -0.0706 & 480.520 & 444.395\end{array}$ LIVALMKPSR $\begin{array}{lllllllllllll}1.00 & 40.46 & 19.34 & 22.12 & 3 & 1414.8943 & 1414.8937 & 472.6385 & 0.0006 & 0.4232 & 5295.760 & 6610.899\end{array}$ $\begin{array}{llllllllllll}1.00 & 40.68 & 19.34 & 19.97 & 3 & 1414.8946 & 1414.8937 & 472.6385 & 0.0009 & 0.6347 & 3817.090 & 4558.328\end{array}$ $\begin{array}{lllllllllllll}0.99 & 41.08 & 26.60 & 30.50 & 2 & 1097.6354 & 1097.6355 & 549.8250 & -0.0001 & -0.0909 & 4401.286 & 4362.562 \\ 1.00 & 38.14 & 26.47 & 28.97 & 2 & 1097.6362 & 1097.6355 & 549.8250 & 0.0007 & 0.6366 & 1484.765 & 1402.676\end{array}$ $\begin{array}{lllllllllllll}1.00 & 45.02 & 24.64 & 29.39 & 2 & 1299.7808 & 1299.7818 & 650.8982 & -0.0010 & -0.7682 & 47.098 & 22.248\end{array}$ $\begin{array}{llllllllllll}0.99 & 35.75 & 24.68 & 25.92 & 2 & 1299.7814 & 1299.7818 & 650.8982 & -0.0004 & -0.3073 & 16.361 & 16.973\end{array}$

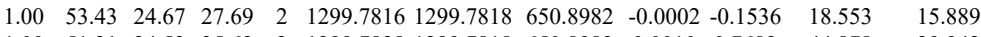
$\begin{array}{llllllllllll}1.00 & 51.21 & 24.53 & 35.62 & 2 & 1299.7828 & 1299.7818 & 650.8982 & 0.0010 & 0.7682 & 44.878 & 29.942\end{array}$ $\begin{array}{llllllllllll}1.00 & 67.01 & 24.53 & 40.56 & 2 & 1299.7832 & 1299.7818 & 650.8982 & 0.0014 & 1.0754 & 3937.968 & 4129.800\end{array}$ $\begin{array}{lllllllllllll}1.00 & 42.70 & 24.53 & 28.64 & 2 & 1299.7832 & 1299.7818 & 650.8982 & 0.0014 & 1.0754 & 37.066 & 19.757\end{array}$ $\begin{array}{lllllllllllll}0.74 & 32.33 & 24.53 & 42.11 & 3 & 1299.7834 & 1299.7818 & 434.2679 & 0.0016 & 1.2281 & 83.297 & 119.855\end{array}$ $\begin{array}{llllllllllll}0.85 & 43.04 & 24.53 & 50.25 & 3 & 1299.7834 & 1299.7818 & 434.2679 & 0.0016 & 1.2281 & 56.410 & 80.125\end{array}$ $\begin{array}{llllllllllllll}1.00 & 42.64 & 24.53 & 28.18 & 2 & 1299.7834 & 1299.7818 & 650.8982 & 0.0016 & 1.2291 & 31.248 & 30.062\end{array}$ $\begin{array}{llllllllllll}1.00 & 46.13 & 24.53 & 27.50 & 2 & 1299.7834 & 1299.7818 & 650.8982 & 0.001 & 1.2291 & 19.677 & 26.092\end{array}$ $\begin{array}{lllllllllllll}1.00 & 44.92 & 24.53 & 27.94 & 2 & 1299.7834 & 1299.7818 & 650.8982 & 0.0016 & 1.2291 & 11.662 & 12.368\end{array}$ $\begin{array}{llllllllllll}1.00 & 42.38 & 24.46 & 2.684 & 2 & 1299.7836 & 1299.7818 & 650.8982 & 0.018 & 1.3827 & 38.549 & 32.039\end{array}$ $\begin{array}{llllllllllll}1.00 & 42.38 & 24.46 & 26.84 & 2 & 1299.784 & 29.729 .7818 & 650.8982 & 0.016 & 1.381 & 38.549 & 32.039\end{array}$ $\begin{array}{llllllllllllll}1.00 & 42.10 & 24.46 & 26.90 & 2 & 1299.7840 & 1299.7818 & 650.8982 & 0.0022 & 1.6900 & 34.093 & 27.704\end{array}$ $\begin{array}{lllllllllllll}1.00 & 41.99 & 24.46 & 27.61 & 2 & 1299.7840 & 1299.7818 & 650.8982 & 0.0022 & 1.6900 & 23.997 & 29.511\end{array}$

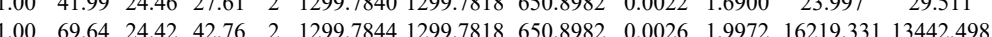
$\begin{array}{lllllllllllll}1.00 & 56.81 & 24.46 & 32.18 & 2 & 1299.7850 & 1299.7818 & 650.8982 & 0.0032 & 2.4581 & 24.640 & 23.965\end{array}$ $\begin{array}{llllllllllll}0.99 & 30.87 & 25.76 & 26.95 & 3 & 1315.7776 & 13157768 & 439.5995 & 0.0008 & 0.6066 & 81.229 & 65.629\end{array}$ $\begin{array}{lllllllllllll}1.00 & 57.45 & 25.72 & 36.05 & 2 & 1315.7778 & 1315.7768 & 658.8957 & 0.0010 & 0.7588 & 1308.530 & 1287.996\end{array}$ $\begin{array}{lllllllllllll}1.00 & 38.73 & 25.72 & 30.12 & 3 & 1315.7782 & 1315.7768 & 439.5995 & 0.0014 & 1.0616 & 56.260 & 42.018\end{array}$ $\begin{array}{lllllllllllllll}1.00 & 57.49 & 25.68 & 37.36 & 2 & 1315.7784 & 1315.7768 & 658.8957 & 0.0016 & 1.2142 & 747.601 & 615.228\end{array}$ $\begin{array}{llllllllllllll}1.00 & 37.41 & 19.34 & 20.74 & 3 & 1414.8952 & 1414.8937 & 472.6385 & 0.0015 & 1.0579 & 1593.815 & 1968.791 & 5\end{array}$ $\begin{array}{llllllllllllll}1.00 & 54.03 & 19.34 & 28.31 & 2 & 1414.8954 & 1414.8937 & 728.4541 & 0.0017 & 1.1998 & 362.590 & 403.626\end{array}$ $\begin{array}{lllllllllllll}1.00 & 39.01 & 19.34 & 15.70 & 3 & 1414.8955 & 1414.8937 & 472.6385 & 0.0018 & 1.2695 & 1115.248 & 1366.801 \\ 1.00 & 53.54 & 19.34 & 31.49 & 2 & 1414.8956 & 1414937 & 708.4541 & 0.0019 & 1.3409 & 298.435 & 316.183\end{array}$ $\begin{array}{lllllllllllll}1.00 & 53.54 & 19.34 & 31.49 & 2 & 1414.8956 & 1414.8937 & 708.4541 & 0.0019 & 1.3409 & 298.435 & 316.183\end{array}$

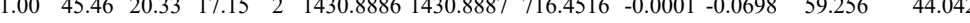
$\begin{array}{llllllllllllll}0.55 & 30.82 & 20.33 & 43.82 & 3 & 1430.8894 & 1430.8887 & 477.9702 & 0.0007 & 0.4882 & 478.550 & 491.993\end{array}$ $\begin{array}{llllllllllllll}0.97 & 28.56 & 26.47 & 27.70 & 2 & 1097.6362 & 1097.6355 & 549.8250 & 0.0007 & 0.6366 & 240.811 & 275.432\end{array}$ $\begin{array}{llllllllllll}1.00 & 41.15 & 26.47 & 30.53 & 2 & 1097.6366 & 1097.6355 & 549.8250 & 0.0011 & 1.0003 & 564.044 & 516.155\end{array}$ $\begin{array}{lllllllllllll}0.91 & 38.12 & 24.53 & 43.35 & 3 & 1299.7828 & 1299.7818 & 434.2679 & 0.0010 & 0.7676 & 11.392 & 19.878\end{array}$ $\begin{array}{lllllllllllll}0.91 & 38.17 & 24.53 & 43.39 & 3 & 1299.7834 & 1299.7818 & 434.2679 & 0.0016 & 1.2281 & 24.074 & 30.119 \\ 1.00 & 67.63 & 24.53 & 39.41 & 2 & 1299.7834 & 1299.7818 & 650.8982 & 0.0016 & 1.2291 & 496.443 & 527.754\end{array}$ $\begin{array}{cccccccccccc}1.00 & 67.63 & 24.53 & 39.41 & 2 & 1299.7834 & 1299.7818 & 650.8982 & 0.0016 & 1.2291 & 496.443 & 527.754 \\ 1.00 & 65.87 & 24.53 & 42.93 & 2 & 1299.7834 & 1299.7818 & 650.8982 & 0.0016 & 1.2291 & 1120.100 & 1165.600\end{array}$ $\begin{array}{lllllllllllll}1.00 & 65.87 & 24.53 & 42.93 & 2 & 1299.7834 & 1299.7818 & 650.8982 & 0.0016 & 1.2291 & 1120.100 & 1165.600 & 1\end{array}$ $\begin{array}{llllllllllll}1.00 & 58.08 & 25.68 & 35.63 & 2 & 1315.7784 & 1315.7768 & 658.8957 & 0.0016 & 1.2142 & 283.455 & 320.430\end{array}$ $\begin{array}{llllllllllll}1.00 & 50.03 & 25.39 & 35.14 & 2 & 1315.792 & 1315.7768 & 658.8957 & 0.0024 & 1.8212 & 227.074 & 184.762\end{array}$

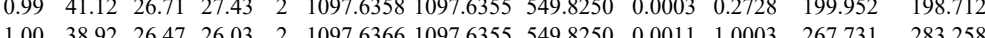
$\begin{array}{llllllllllll}1.072 & 12.75 & 24.53 & 19.91 & 3 & 1299.7828 & 1299.7818 & 434.2679 & 0.0010 & 0.7676 & 13.791 & 17.450\end{array}$ $\begin{array}{lllllllllllll}0.75 & 15.94 & 2.53 & 25.57 & 3 & 1299.7834 & 1299.7818 & 434.2679 & 0.0016 & 1.2281 & 21.924\end{array}$ 
$\begin{array}{lllllllll} & \end{array}$

$\begin{array}{llllllllllll}\text { DPDAGIDEAVEDAQALFAGGLKK } & 0.55 & 69.53 & 26.02 & 82.53 & 3 & 2945.4508 & 2945.4498 & 982.8239 & 0.0010 & 0.3392 & 5.745\end{array}$

$\begin{array}{lllllllllll}1.00 & \text { \#\#\#\# } 26.11 & 22.21 & 2 & 2945.4514 & 2945.4498 & 1473.7322 & 0.0016 & 0.5428\end{array}$

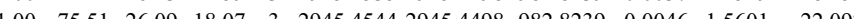
$\begin{array}{lllllllllll}1.00 & 43.26 & 26.12 & 56.26 & 4 & 2945.4561 & 2945.4498 & 737.3697 & 0.0063 & 2.1360 & 07.43\end{array}$

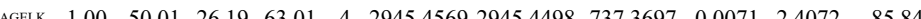

MLVVLLQANR

MLVVLLQANR

GTVTDFPGFDER

$\begin{array}{llllllllllll}1.00 & 45.57 & 24.58 & 30.70 & 2 & 1299.7820 & 1299.7818 & 650.8982 & 0.0002 & 0.1536 & 30.080\end{array}$

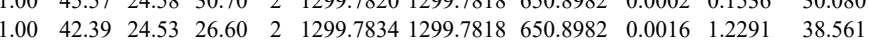
$\begin{array}{llllllllllll}0.82 & 50.25 & 25.98 & 63.25 & 2 & 1483.7074 & 1483.7065 & 7428605 & 0.0009 & 0.6058 & 1284.386 & 10.1\end{array}$

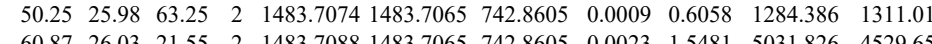

ALLLLCGEDD

ALLLLCGEDD

GTVTDFPGFDER

GTVTDFPGFDER

ALLLLCGEDD

ALLLLCGEDD

\section{EEDVLK}

DPEEIEKEEQAAAEK $\begin{array}{llllllllllll}\text { AIVAIENPADVSVISSR } & 1.00 & \# \# \# \# & 25.58 & 26.71 & 2 & 1884.0458 & 1884.0438 & 943.0292 & 0.0020 & 1.0604 & 131.716 \\ \text { SDGIYIINLK } & 1.00 & 65.32 & 24.61 & 34.85 & 2 & 1422.8346 & 1422.8326 & 712.4236 & 0.0020 & 1.4037 & 786.265\end{array}$ $\begin{array}{llllllllllll}\text { AIVAIENPADVSVISSR } & 1.00 & \text { \#\#\# } & 25.58 & 26.71 & 2 & 1884.0458 & 1884.0438 & 943.0292 & 0.0020 & 1.0604 & 131.716 \\ \text { SDGIYINLK } & 1.00 & 65.32 & 24.61 & 34.85 & 2 & 1422.8346 & 1422.8326 & 712.4236 & 0.0020 & 1.4037 & 786.265 \\ \text { SDGIYINLK } & 1.00 & 55.04 & 24.49 & 41.46 & 2 & 1422.8348 & 1422.8326 & 712.4236 & 0.0022 & 1.5440 & 881.486\end{array}$ $\begin{array}{llllllllllllll}1.00 & 90.93 & 26.02 & 19.08 & 3 & 2945.4508 & 2945.4498 & 982.8239 & 0.0010 & 0.3392 & 18.346 & 15.751\end{array}$ $\begin{array}{llllllllllll}0.96 & 27.79 & 26.14 & 18.04 & 2 & 1250.6020 & 1250.6008 & 626.3077 & 0.0012 & 0.9580 & 82.027 & 36.634\end{array}$ $\begin{array}{lllllllllllll}0.92 & 23.79 & 26.14 & 21.88 & 2 & 1250.6024 & 1250.6008 & 626.3077 & 0.0016 & 1.2773 & 59.459\end{array}$

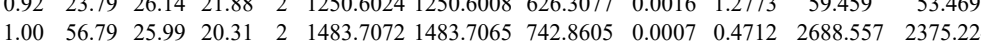
$\begin{array}{lllllllllllll}1.00 & 56.01 & 26.03 & 18.87 & 2 & 1483.7084 & 1483.7065 & 742.8605 & 0.0019 & 1.2788 & 7766.522 & 6791.910\end{array}$ $\begin{array}{llllllllllll}0.56 & 14.28 & 26.14 & 19.07 & 2 & 1250.6022 & 1250.6008 & 626.3077 & 0.0014 & 1.1177 & 45.256\end{array}$ $\begin{array}{lllllllllllll}1.00 & 48.33 & 26.14 & 16.49 & 2 & 1250.6024 & 1250.6008 & 626.3077 & 0.0016 & 1.2773 & 59.830\end{array}$ $\begin{array}{lllllllllllll}1.00 & 47.77 & 28.01 & 25.74 & 2 & 1301.7240 & 1301.7111 & 651.8628 & 0.0129 & 9.8946 & 9995.951 & 83 & \\ 0.96 & 29.31 & 27.75 & 31.29 & 2 & 1019.5748 & 1019.5742 & 51.07944 & 0.0006 & 0.5873 & 461.647 & 43 & \end{array}$ $\begin{array}{llllllllllll}0.96 & 29.31 & 27.75 & 31.29 & 2 & 1019.5748 & 1019.5742 & 510.7944 & 0.0006 & 0.5873 & 461.647 \\ 0.97 & 31.03 & 27.75 & 32.79 & 2 & 1019.5750 & 1019.5742 & 510.7944 & 0.0008 & 0.7831 & 497.396 & \\ 0.78 & 31.50 & 27.98 & 17.23 & 3 & 2147.0992 & 2147.0959 & 716.7059 & 0.0033 & 1.5348 & 522.422\end{array}$ $\begin{array}{llllllllllllll} & 1.00 & 55.04 & 24.49 & 41.46 & 2 & 1422.8348 & 1422.8326 & 712.4236 & 0.0022 & 1.5440 & 881.486\end{array}$ $\begin{array}{llllllllllll}\text { AIVAIENPADVSVISSR } & 1.00 & \text { 25 } & 25.55 & 23.38 & 2 & 1884.0470 & 1884.0438 & 943.0292 & 0.0032 & 1.6967 & 2222.689\end{array}$

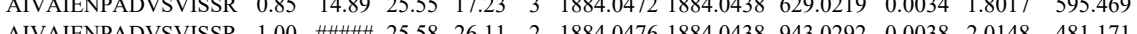
SDGIYIINLK

$\begin{array}{lllllllllll}1.00 & \# 25.58 & 25.58 & 26.11 & 2 & 1884.0476 & 1884.0438 & 943.0292 & 0.0038 & 2.0148 & 481.171 \\ 1.00 & 52.89 & 24.49 & 34.41 & 2 & 1422.8348 & 1422.8326 & 712.4236 & 0.0022 & 1.5440 & 252.821\end{array}$

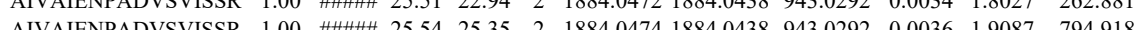

$\begin{array}{lllllllllllll}\text { YVDIAIPCNNK } & 1.00 & 58.75 & 27.87 & 30.70 & 2 & 1582.8232 & 1582.8091 & 792.4118 & 0.0141 & 8.8968 & 233.957\end{array}$ 


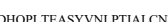
$\begin{array}{lllllllllll}0.98 .35 & 26.41 & 19.56 & 3 & 3128.5402 & 3128.5392 & 1043.8537 & 0.0010 & 0.3193 & 44.693\end{array}$

LPTIALCNTDSP 0.93

Table S-4 page 130 of 614 
$\begin{array}{llllllllllll}\text { AVQGGGATPVGAVGCPVPCMPPMTAAPR } & 0.60 & 23.48 & 25.79 & 36.48 & 3 & 2870.5057 & 2870.5017 & 957.8412 & 0.0040 & 1.3920 & 6.306 \\ \text { HDIAFVEFDNEVQAGAAR } & 1.00 & 53.61 & 26.93 & 16.91 & 3 & 2132.0425 & 2132.0409 & 711.6876 & 0.0016 & 0.7494 & 19.843\end{array}$ $\begin{array}{llllllllllll}\text { HDIAFVEFDNEVQAGAAR } & 1.00 & 53.61 & 26.93 & 16.91 & 3 & 2132.0425 & 2132.0409 & 711.6876 & 0.0016 & 0.7494 & 19.843 \\ \text { HDIAFVEFDNEVQAGAAR } & 0.66 & 29.64 & 26.95 & 42.64 & 3 & 2132.0428 & 2132.0409 & 711.6876 & 0.0019 & 0.8899 & 28.559\end{array}$ $\begin{array}{llllllllllll}\text { HDIAFVEFDNEVQAGAAR } & 0.66 & 29.64 & 26.95 & 42.64 & 3 & 2132.0428 & 2132.0409 & 711.6876 & 0.0019 & 0.8899 & 28.559 \\ \text { HDIAFVEFDNEVQAGAAR } & 0.67 & 16.17 & 26.91 & 29.17 & 3 & 2132.0443 & 2132.0409 & 711.6876 & 0.0034 & 1.5925 & 19.558\end{array}$

$\begin{array}{lllllllllll}\text { THIK HUMAN } & \text { P09110 ACAA1 } & \text { 3-ketoacyl-CoA tr 44.292 } & 1.00 & 3 & 12.5 & 0.6594 & 0.6843 & -0.3083 & 0.8186\end{array}$ $\begin{array}{lllllllllll}\text { GSTP1_HUMAR } & \text { P09211 } & \text { GSTP1 } & \text { Glutathione S-tran 23.356 } & 1.00 & 9 & 56.2 & -0.0653 & 0.6361 & 0.3623 & 0.7363\end{array}$

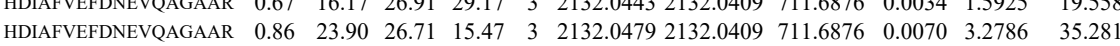

$\begin{array}{lllllllllllll}\text { DITPELLSAVMTAVLK } & 1.00 & 32.33 & 25.93 & 21.14 & 3 & 2091.1414 & 2091.1377 & 698.0532 & 0.0037 & 1.7668 & 72.309\end{array}$

\begin{tabular}{llllllllllll} 
QCSSGLQAVASIAGGIR & 0.86 & 192.63 & 25.67 & 20.08 & 3 & 2243.2309 & 2243.2283 & 748.7500 & 0.0026 & 1.1575 & 58.550 \\
\hline
\end{tabular}

7. MLLADQGQSWK

DQQEAALVD

$\begin{array}{llllllllllll}1.00 & 51.33 & 28.20 & 28.73 & 2 & 1563.8478 & 1563.8323 & 782.9234 & 0.0155 & 9.8987 & 8531.551 & \\ 0.94 & 27.20 & 27.05 & 17.85 & 3 & 2260.0753 & 2260.0763 & 754.3660 & 0.0010 & 0.4419 & 10.882\end{array}$

$\begin{array}{lllllllllllll}0.94 & 27.027 .05 & 17.85 & 3 & 2260.0753 & 2260.0763 & 754.3660 & -0.0010 & -0.4419 & 10.882 & 11.023\end{array}$

$\begin{array}{llllllllllll} & \end{array}$

$\begin{array}{llllllllllllll}\text { FQDGDLTLYQSNTILR } & 1.00 & 88.43 & 27.22 & 21.69 & 2 & 2027.0454 & 2027.0446 & 1014.5296 & 0.0008 & 0.3943 & 2167.526 & 1668.431\end{array}$

$\begin{array}{lllllllllllllll}\text { FQDGDLTLYQSNTILR } & 1.00 & 96.01 & 27.22 & 24.92 & 2 & 2027.0454 & 2027.0446 & 1014.5296 & 0.0008 & 0.3943 & 1828.935 & 1461.519\end{array}$ TLGLYGK
TLGLYGK

$\begin{array}{llllllllllllll}1.00 & 96.01 & 27.22 & 24.92 & 2 & 2027.0454 & 2027.0446 & 1014.5296 & 0.0008 & 0.3943 & 1828.935 & 1461.519\end{array}$

$\begin{array}{lllllllllllll} & 1.00 & 41.43 & 26.31 & 22.27 & 2 & 1038.6346 & 1038.6317 & 520.3231 & 0.0029 & 2.7867 & 60740.170 & 48482.895\end{array}$

MLLADQGQSWK

$\begin{array}{llllllllllllll}1.00 & 49.24 & 28.01 & 28.23 & 2 & 1563.8446 & 1563.8323 & 782.9234 & 0.0123 & 7.8551 & 4027.471 & 3527.253\end{array}$

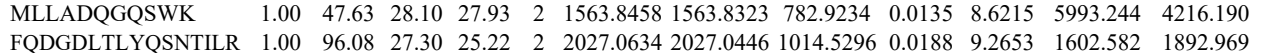

$\begin{array}{lllllllllllll}\text { FQDGDLTLYQSNTILR } & 1.00 & \text { \#\#\#\# } 27.30 & 25.47 & 2 & 2027.0634 & 2027.0446 & 1014.5296 & 0.0188 & 9.2653 & 949.288 & 988.258\end{array}$

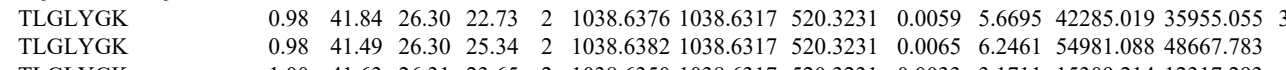

TLGLYGK

$\begin{array}{lllllllllllll} & 1.00 & 41.63 & 26.31 & 23.65 & 2 & 1038.6350 & 1038.6317 & 520.3231 & 0.0033 & 3.1711 & 15309.214 & 12317.293 \\ \text { AFLASPEYVNLPINGNGK } & 1.00 & 84.03 & 25.89 & 23.06 & 2 & 2191.1894 & 2191.1881 & 1096.6013 & 0.0013 & 0.5927 & 949.347 & 1392.364\end{array}$

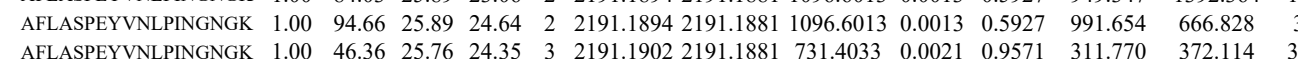

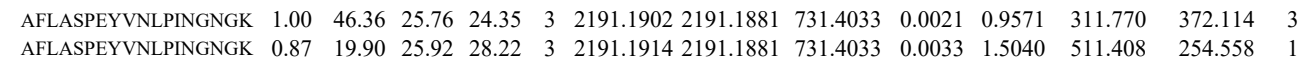

$\begin{array}{lllllllllllll}\text { AFLASPEYNLANGNGK } & 0.87 & 19.90 & 25.92 & 28.22 & 3 & 2191.1914 & 2191.1881 & 731.4033 & 0.0033 & 1.5040 & 511.408 & 2\end{array}$

$\begin{array}{llllllllllll}\text { AFLASPEYVNLPINGNGK } & 0.60 & 12.57 & 25.80 & 25.57 & 3 & 2191.1926 & 2191.1881 & 731.4033 & 0.0045 & 2.0508 & 79.425\end{array}$

$\begin{array}{lllllllllllllll}\text { AFLASPEYVNLPINGNGK } & 1.00 & 75.17 & 25.77 & 24.89 & 2 & 2191.1934 & 2191.1881 & 1096.6013 & 0.0053 & 2.4166 & 78.041 & 95.672 & 12.5\end{array}$

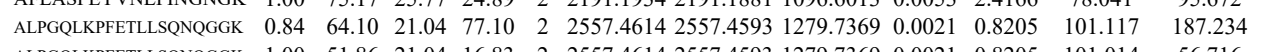

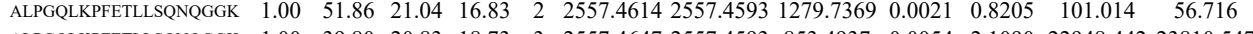
$\begin{array}{lllllllllllllllllll}\text { ALPGQLKPFETLLSQNQGGK } & 1.00 & 17.67 & 20.53 & 14.69 & 4 & 2557.4669 & 2557.4593 & 640.3721 & 0.074 & 2.967 & 9843.837 & 12202.679 & 9177.081 & 14487.662 & \text { Yes }\end{array}$

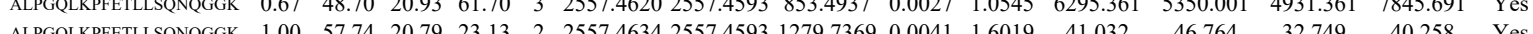

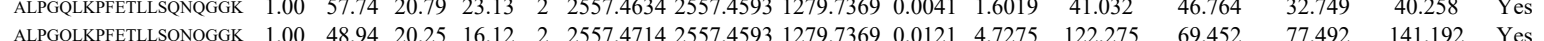

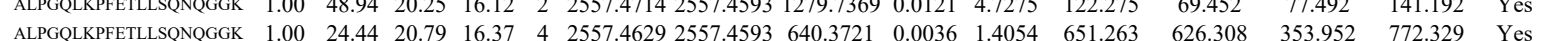

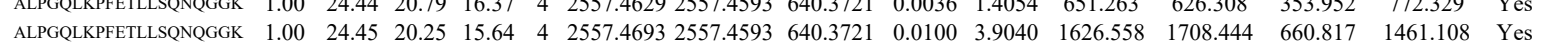
$\begin{array}{llllllllllllllll}\text { ALPQEAALVDMVNDGVEDLR } & 0.92 & 22.72 & 27.13 & 15.83 & 3 & 2260.0810 & 2260.0763 & 754.3660 & 0.0047 & 2.0768 & 26.307 & 6.670 & 5.209 & 11.792 & \text { No }\end{array}$

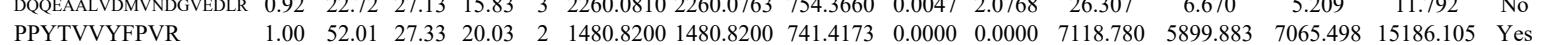
$\begin{array}{llllllllllllllll}\text { PPYTVVYFVR } & 1.00 & 40.28 & 27.39 & 53.28 & 2 & 1480.8208 & 1480.8200 & 741.4173 & 0.0008 & 0.5395 & 2198.469 & 2009.715 & 2399.245 & 4803.635 & \text { Yes }\end{array}$

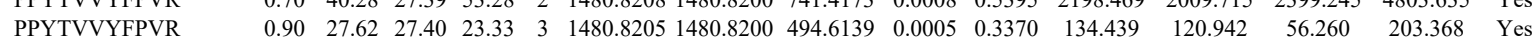
$\begin{array}{llllllllllllllll}\text { PPYTVVYFPVR } & 1.00 & 45.51 & 27.40 & 26.13 & 3 & 1480.8205 & 1480.8200 & 494.6139 & 0.0005 & 0.3370 & 118.246 & 143.025 & 55.620 & 205.428 & \text { Yes }\end{array}$

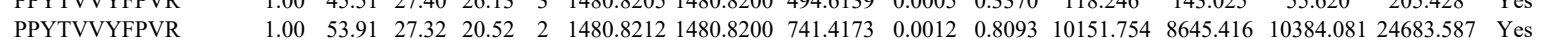

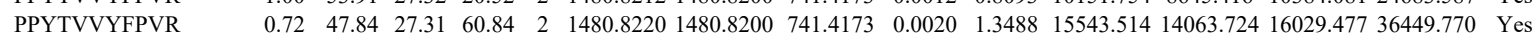
$\begin{array}{llllllllllllllll}\text { PPYTVVYFPVR } & 1.00 & 54.86 & 27.41 & 23.87 & 2 & 1480.8206 & 1480.8200 & 741.4173 & 0.0006 & 0.4046 & 7945.299 & 7416.486 & 9337.628 & 19169.625 & \text { Yes }\end{array}$ $\begin{array}{llllllllllll}\text { PPYTVVYFPVR } & 0.70 & 40.12 & 27.38 & 53.12 & 2 & 1480.8214 & 1480.8200 & 741.4173 & 0.0006 & 0.40\end{array}$ $\begin{array}{lllllllllllllllll}\text { DQQEAALVDMVNDGVEDLR } & 1.00 & 89.06 & 27.04 & 19.84 & 2 & 2260.0774 & 2260.0763 & 1131.0454 & 0.0011 & 0.4863 & 181.371 & 436.226 & 442.629 & 581.407 & \text { Yes }\end{array}$ $\begin{array}{lllllllllllllllll}\text { DQQEAALVDMVNDGVEDLR } & 1.00 & 31.01 & 27.03 & 16.50 & 3 & 2260.0780 & 2260.0763 & 754.3660 & 0.0017 & 0.7512 & 13.030 & 6.406 & 14.377 & 20.459 & \text { Yes }\end{array}$ $\begin{array}{lllllllllllllllll}\text { DQQEAALVDMVNDGVEDLR } & 1.00 & 92.82 & 27.12 & 23.93 & 2 & 2260.0794 & 2260.0763 & 1131.0454 & 0.0031 & 1.3704 & 425.061 & 174.376 & 599.878 & 618.644 & \text { Yes }\end{array}$ $\begin{array}{lllllllllllllllll}\text { DQQEAALVDMVNDGVEDLR } & 0.89 & 17.99 & 27.12 & 17.18 & 3 & 2260.0795 & 2260.0763 & 754.3660 & 0.0032 & 1.4140 & 23.507 & 12.549 & 38.242 & 74.609 & \text { Yes }\end{array}$ $\begin{array}{llllllllllllllll}\text { DQQEAALVDMVNDGVEDLR } & 0.93 & 23.04 & 27.05 & 16.41 & 3 & 2260.0813 & 2260.0763 & 754.3660 & 0.0050 & 2.2094 & 2.917 & 12.169 & 8.993 & 9.967 & \text { Yes }\end{array}$

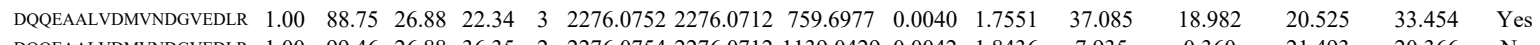
$\begin{array}{llllllllllllllll}\text { DQQEAALVDMVNDGVEDLR } & 1.00 & 99.46 & 26.88 & 36.35 & 2 & 2276.0754 & 2276.0712 & 1139.0429 & 0.0042 & 1.8436 & 7.935 & 0.360 & 21.493 & 20.366 & \text { No }\end{array}$

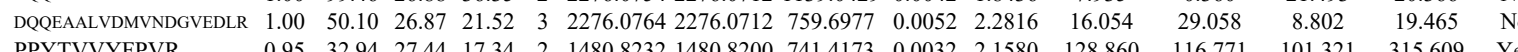

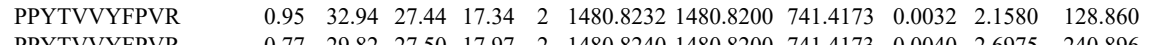
$\begin{array}{llllllllllll}\text { PPYTVVYFPVR } & 0.77 & 29.82 & 27.50 & 17.97 & 2 & 1480.8240 & 1480.8200 & 741.4173 & 0.0040 & 2.6975 & 240.896\end{array}$

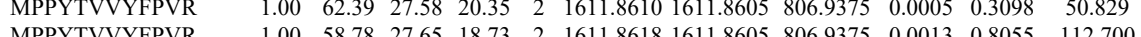

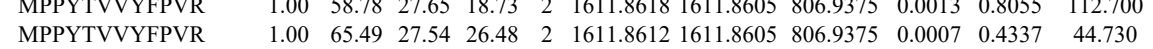

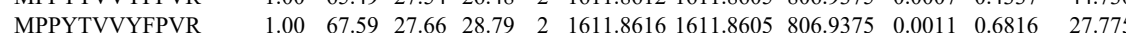
$\begin{array}{lllllllllllll}\text { DQQEAALVDMVNDGVEDLR } & 0.98 & 25.80 & 27.08 & 16.78 & 3 & 2260.0789 & 2260.0763 & 754.3660 & 0.0026 & 1.1489 & 34.531\end{array}$ 


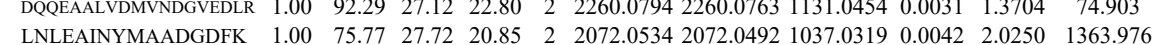

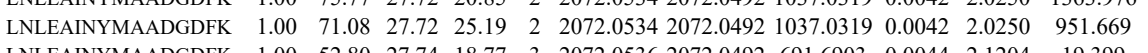
$\begin{array}{llllllllllll}\text { LNLEAINYMAADGDFK } & 1.00 & 52.80 & 27.74 & 18.77 & 3 & 2072.0536 & 2072.0492 & 691.6903 & 0.0044 & 2.1204 & 19.399\end{array}$

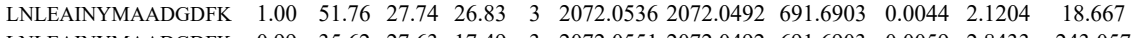
$\begin{array}{llllllllllll}\text { LNLEAINYMAADGDFK } & 0.99 & 35.62 & 27.63 & 17.49 & 3 & 2072.0551 & 2072.0492 & 691.6903 & 0.0059 & 2.8433 & 243.057\end{array}$ $\begin{array}{llllllllllll}\text { LNLEAINYMAADGDFK } & 1.00 & 54.41 & 27.63 & 21.24 & 3 & 2072.0551 & 2072.0492 & 691.6903 & 0.0059 & 2.8433 & 261.609\end{array}$

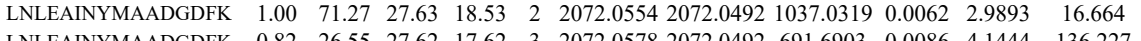
$\begin{array}{llllllllllll}\text { LNLEAINYMAADGDFK } & 0.82 & 26.55 & 27.62 & 17.62 & 3 & 2072.0578 & 2072.0492 & 691.6903 & 0.0086 & 4.1444 & 136.227\end{array}$ $\begin{array}{lllllllllllll}\text { LNLEAINYMAADGDFK } & 0.51 & 20.83 & 27.62 & 15.14 & 3 & 2072.0578 & 2072.0492 & 691.6903 & 0.0086 & 4.1444 & 136.245 & 107.153 \\ \text { LNLEAINYMAADGDFK } & 0.78 & 25.66 & 27.61 & 16.32 & 3 & 2072.0581 & 2072.0492 & 691.6903 & 0.0089 & 4.2890 & 139.563 & 130.163\end{array}$ $\begin{array}{lllllllllllll}\text { LNLEAINYMAADGDFK } & 1.00 & 82.66 & 27.72 & 19.16 & 2 & 2072.0534 & 2072.0492 & 1037.0319 & 0.0042 & 2.0250 & 1100.686 & 617.395\end{array}$ $\begin{array}{lllllllllllllll}\text { LNLEAINYMAADGDFK } & 1.00 & 67.05 & 27.74 & 18.25 & 3 & 2072.0536 & 2072.0492 & 691.6903 & 0.0044 & 2.1204 & 36.994\end{array}$

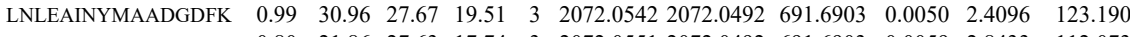
$\begin{array}{llllllllllll}\text { LNLEAINYMAADGDFK } & 0.80 & 21.86 & 27.63 & 17.74 & 3 & 2072.0551 & 2072.0492 & 691.6903 & 0.0059 & 2.8433 & 112.073\end{array}$ $\begin{array}{llllllllllll}\text { LNLEAINYMAADGDFK } & 1.00 & 45.84 & 27.63 & 20.68 & 3 & 2072.0551 & 2072.0492 & 691.6903 & 0.0059 & 2.8433 & 45.016\end{array}$ $\begin{array}{llllllllllllll} & \text { LNLEAINYMAADGDFK } & 0.99 & 36.74 & 27.63 & 16.43 & 3 & 2072.0560 & 2072.0492 & 691.6903 & 0.0068 & 3.2770 & 397.830 & 348.935\end{array}$ $\begin{array}{llllllllllll} & \end{array}$ $\begin{array}{lllllllllllll} & \text { LNLEANYMAADGDFK } & 1.00 & 79.49 & 27.72 & 20.34 & 2 & 2072.0534 & 2072.0492 & 1037.0319 & 0.0042 & 2.0250 & 56.465\end{array}$ $\begin{array}{llllllllllll} & \end{array}$

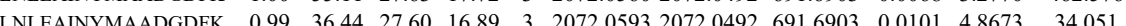

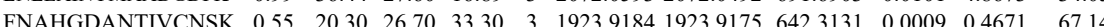
$\begin{array}{llllllllllllll}\text { FNAHGDANTIVCNSK } & 0.67 & 34.42 & 26.79 & 47.42 & 3 & 1923.9208 & 1923.9175 & 642.3131 & 0.0033 & 1.7126 & 29.031 & 17.019\end{array}$ $\begin{array}{llllllllllll} & \end{array}$

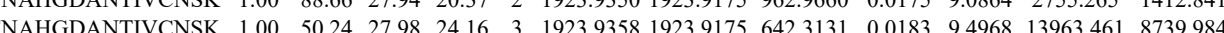
$\begin{array}{lllllllllllllll}\text { FNAHGDANTIVCNSK } & 1.00 & 51.66 & 27.95 & 22.47 & 3 & 1923.9361 & 1923.9175 & 642.3131 & 0.0186 & 9.6525 & 8871.234 & 5253.985 & 1154\end{array}$ $\begin{array}{lllllllllllll}\text { FNAHGDANTIVCNSK } & 1.00 & 49.41 & 27.98 & 24.69 & 3 & 1923.9358 & 1923.9175 & 642.3131 & 0.0183 & 9.4968 & 6772.222 & 3739.360\end{array}$ $\begin{array}{llllllllllllll}\text { FNAHGDANTIVCNSK } & 1.00 & 40.89 & 27.44 & 17.60 & 3 & 1923.9313 & 1923.9175 & 642.3131 & 0.0138 & 7.1616 & 2876.761 & 2590.081\end{array}$ $\begin{array}{llllllllllllll}\text { FNAHGDANTIVCNSK } & 1.00 & 43.21 & 27.54 & 17.91 & 3 & 1923.9325 & 1923.9175 & 642.3131 & 0.0150 & 7.7843 & 2425.582 & 1340.369\end{array}$

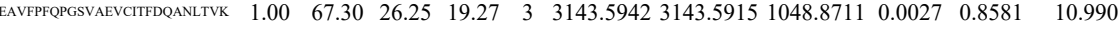
$\begin{array}{lllllllllllll} & \end{array}$ $\begin{array}{lllllllllllll} & \end{array}$ $\begin{array}{lllllllllllll} & \end{array}$

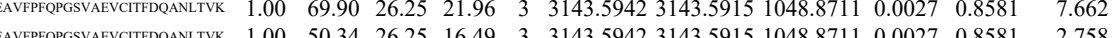
GEVAPDAK $\begin{array}{lllllllllllll}0.83 & 28.37 & 24.70 & 20.66 & 2 & 1164.7192 & 1164.7110 & 583.3628 & 0.0082 & 7.0282 & 56060.329 & 28420.260 & 4713 \\ 0.98 & 36.98 & 23.44 & 26.33 & 2 & 1164.7202 & 1164.7110 & 583.3628 & 0.0092 & 7.8853 & 37892.264 & 23268.971\end{array}$ $\begin{array}{llllllllllllll} & 0.97 & 39.27 & 28.84 & 30.14 & 2 & 1073.6000 & 1073.5961 & 537.8053 & 0.0035 & 3.2540 & 1418.824 & 712.563 \\ & 0 & 2.937 .8053 & 0.0039 & 3.6258 & 959.611 & 456.405\end{array}$

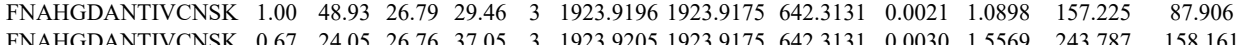

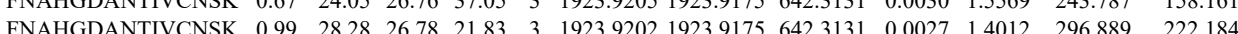

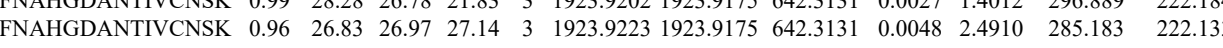



$\begin{array}{lllllllllllllllll}\text { GPDASVNFSEFSK } & 0.93 & 86.98 * & 2.18 & 43.11 & 2 & 175.8894 & 1751.8722 & 876.9434 & 0.0172 & 9.8067 & 1276.050 & 1043.708 & 2543.864 & 1077.436 & \text { No }\end{array}$

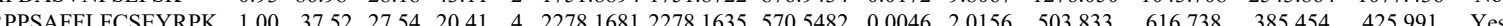

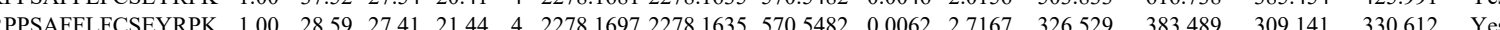

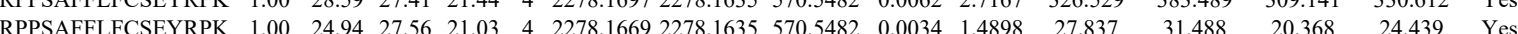
$\begin{array}{llllllllllllllll}\text { RPPSAFFLFCSEYRPK } & 0.97 & 16.38 & 27.54 & 18.38 & 4 & 2278.1701 & 2278.1635 & 570.5482 & 0.0066 & 2.8919 & 13.115 & 19.181 & 12.015 & 15.057 & \text { Yes }\end{array}$

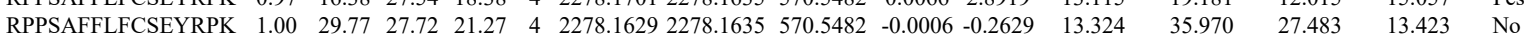

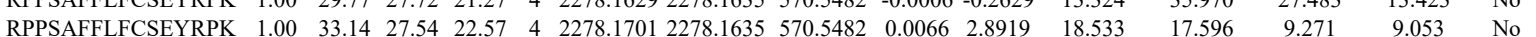

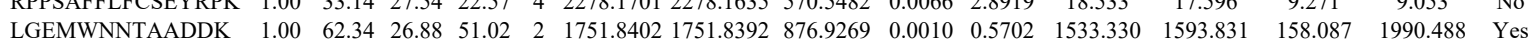

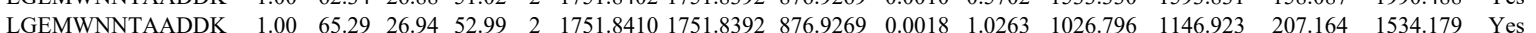
$\begin{array}{llllllllllllllll}\text { LGEMWNNTAADDK } & 0.99 & 60.43 & 27.06 & 47.87 & 2 & 1751.8440 & 1751.8392 & 876.9269 & 0.0048 & 2.7368 & 1484.161 & 1644.403 & 171.923 & 2007.247 & \text { Yes }\end{array}$ $\begin{array}{llllllllllllllllll}\text { LGEMWNNTAADDK } & 0.98 & 67.34 & 27.06 & 59.85 & 2 & 1751.8440 & 1751.8392 & 876.9269 & 0.0048 & 2.7368 & 4658.377 & 5745.916 & 659.013 & 6978.993 & \text { Yes }\end{array}$ $\begin{array}{llllllllllllllll}\text { GEHPGLSIGDVAK } & 0.50 & 17.48 & 27.75 & 15.36 & 3 & 1566.8602 & 1566.8609 & 523.2942 & -0.0007 & -0.4459 & 132.690 & 140.648 & 58.612 & 143.511 & \text { Yes }\end{array}$

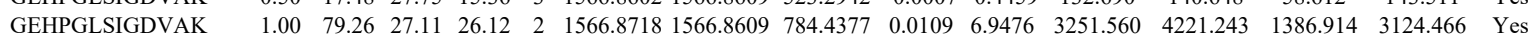
$\begin{array}{llllllllllllllll}\text { GEHPGLSIGDVAK } & 1.00 & 64.72 & 27.23 & 27.31 & 2 & 1566.8736 & 1566.8609 & 784.4377 & 0.0127 & 8.0949 & 5977.587 & 7312.359 & 2258.706 & 6847.318 & \text { Yes }\end{array}$

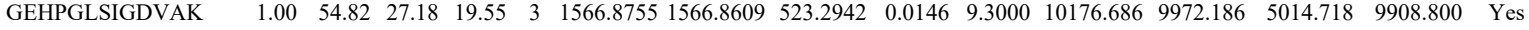
$\begin{array}{llllllllllllllll}\text { GEHPGLSIGDVAK } & 1.00 & 58.23 & 27.18 & 19.52 & 3 & 1566.8755 & 1566.8609 & 523.2942 & 0.0146 & 9.3000 & 11693.648 & 16075.650 & 6495.130 & 12532.883 & \text { Yes }\end{array}$

$\begin{array}{lllllllllllll}\text { CLCB_HUMAN } & \text { P09497 } & \text { CLTB } & \text { Clathrin light chai } 25.19 & 1.00 & 3 & 11.4 & -0.2429 & 0.1633 & 3.0407 & 0.2652 & 4 & \text { VAQLCDFNPK }\end{array}$

VAQLCDFNPK

VAQLCDFNPK

VAQLCDFNPK

SVLMSLK

SVLMSLK

LQELDAASK

LQELDAASK

FLTVLCSR

FLTVLCSR

FLTVLCSR

FLTVLCSR

FLTVLCSR

FLTVLCSR

FLTVLCSR

NLGLEELGIELDPR

NLGLEELGIELDPR
NLGLEELGIELDPR

NLGLEELGIELDPR

NLGLEELGIELDPR

VCHAHPTLSEAFR

VCHAHPTLSEAFR

IPNIYAIGDVVAGPMLAHK IPNIYAIGDVVAGPMLAH

ALTGGIAHLFK
ALTGGIAHLFK

EDSQRPGAHLTVK

EDSQRPGAHLTVK

GFAFVTFDDHDSVDK

GFAFVTFDDHDSVDK

EDSQRPGAHLTVK

EDSQRPGAHLTVK

NQGGYGGSSSSSSYGSGR
NQGGYGGSSSSSYGSGR

NQGGYGGSSSSSSYGSGR
NQGGYGGSSSSSYGSGR

IEVIEIMTDR

IEVIEIMTDR

IEVIEIMTDR

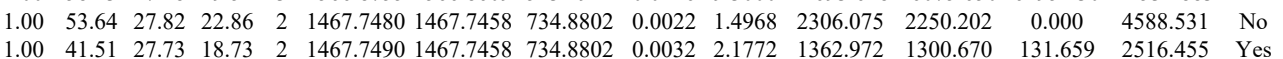
$\begin{array}{llllllllllllllll}1.00 & 41.51 & 27.73 & 18.73 & 2 & 1467.7490 & 1467.7458 & 734.8802 & 0.0032 & 2.1772 & 1362.972 & 1300.670 & 131.659 & 2516.455 & \text { Yes } \\ 0 & 0.97 & 43.64 & 27.61 & 21.45 & 2 & 1467.7466 & 1467.7458 & 734.8802 & 0.0008 & 0.5443 & 181.555 & 213.406 & 0.000 & 279.996 & \text { No }\end{array}$

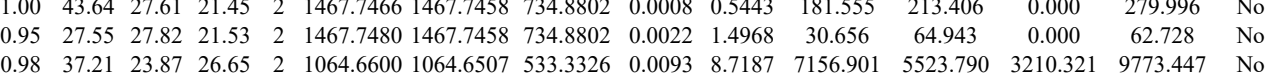

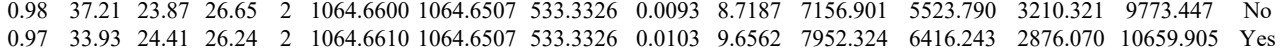

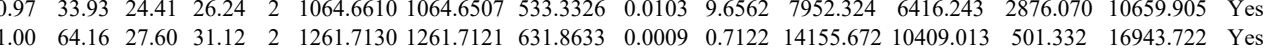
$\begin{array}{lllllllllllllll}1.00 & 64.16 & 27.60 & 31.12 & 2 & 1261.7130 & 1261.7121 & 631.8633 & 0.0009 & 0.7122 & 14155.672 & 10409.013 & 501.332 & 16943.722 & \text { Yes } \\ 1.00 & 63.81 & 27.75 & 30.51 & 2 & 1261.7142 & 1261.7121 & 631.8633 & 0.0021 & 1.6617 & 14688.502 & 13011.784 & 563.021 & 20687.576 & \text { Yes }\end{array}$

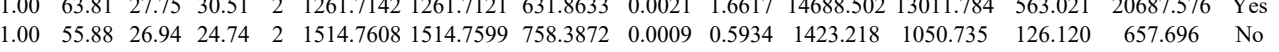

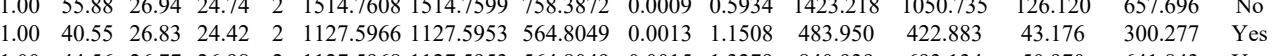
$\begin{array}{lllllllllllllll}1.00 & 40.55 & 26.83 & 24.42 & 2 & 1127.5966 & 1127.5953 & 564.8049 & 0.0013 & 1.1508 & 483.950 & 422.883 & 43.176 & 300.277 & \text { Yes } \\ 1.00 & 44.56 & 26.77 & 26.98 & 2 & 1127.5968 & 1127.5953 & 564.8049 & 0.0015 & 1.3279 & 840.939 & 693.134 & 50.970 & 641.843 & \text { Yes }\end{array}$ \begin{tabular}{llllllllllllllll}
1.00 & 44.56 & 26.77 & 26.98 & 2 & 1127.5968 & 1127.5953 & 564.8049 & 0.0015 & 1.3279 & 840.939 & 693.134 & 50.970 & 641.843 & Yes \\
1.00 & 47.37 & 26.83 & 25.37 & 2 & 1127.5966 & 1127.5953 & 564.8049 & 0.0013 & 1.1508 & 1090.170 & 986.730 & 90.301 & 811.582 & Yes \\
\hline
\end{tabular} \begin{tabular}{lllllllllllllll}
1.00 & 48.38 & 26.77 & 26.98 & 2 & 1127.5968 & 1127.5953 & 564.8049 & 0.0015 & 1.3279 & 2174.522 & 1738.431 & 89.021 & 1557.120 & Yes \\
\hline
\end{tabular}

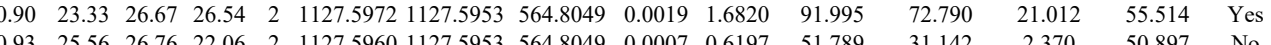

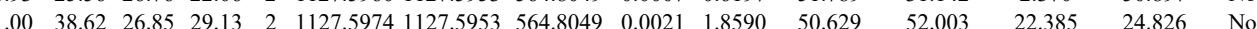

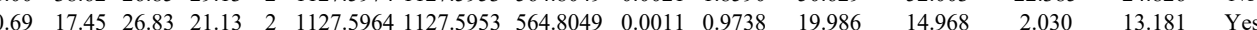
$\begin{array}{cccccccccccc}1.00 \text { \#\#\#\# 27.01 } 36.40 & 2 & 1710.9290 & 1710.9274 & 856.4710 & 0.0016 & 0.9341 & 65.872 & 51.330 & 0.000 & 130.276 & \text { No }\end{array}$ $\begin{array}{lllllllllllllll}1.00 & 91.18 & 27.01 & 32.59 & 2 & 1710.9292 & 1710.9274 & 856.4710 & 0.0018 & 1.0508 & 61.128 & 48.780 & 30.180 & 142.453 & \text { Yes } \\ 1.40\end{array}$

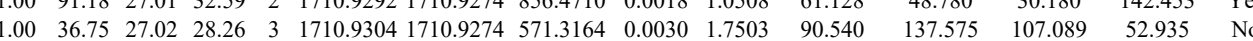

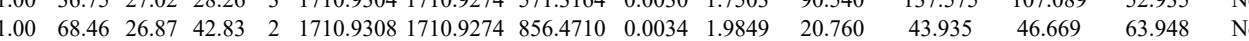
$\begin{array}{lllllllllllllll}1.00 & 74.15 & 26.85 & 35.08 & 2 & 1710.9310 & 1710.9274 & 856.4710 & 0.0036 & 2.1016 & 74.139 & 49.822 & 127.780 & 91.437 & \text { No }\end{array}$ $\begin{array}{lllllllllllllll}1.00 & 29.99 & 27.12 & 42.99 & 4 & 1656.8117 & 1656.7986 & 415.2069 & 0.0131 & 7.8876 & 3361.397 & 4616.730 & 1267.509 & 5227.861 & \text { Y }\end{array}$ $\begin{array}{lllllllllllllll}1.00 & 36.85 & 27.08 & 16.93 & 4 & 1656.8125 & 1656.7986 & 415.2069 & 0.0139 & 8.3693 & 3238.605 & 2786.808 & 1578.634 & 3814.589 & \text { Yes }\end{array}$

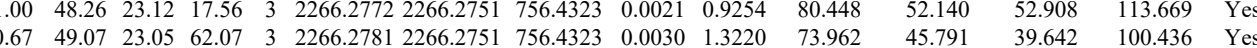
$\begin{array}{lllllllllllllll}1.00 & 57.78 & 22.94 & 29.64 & 3 & 1414.8667 & 1414.8540 & 472.6253 & 0.0127 & 8.9570 & 13654.044 & 17498.354 & 535.106 & 31506.334 & \text { Yes }\end{array}$ $\begin{array}{lllllllllllllll}1.00 & 62.66 & 22.97 & 33.37 & 3 & 1414.8676 & 1414.8540 & 472.6253 & 0.0136 & 9.5917 & 11559.731 & 13093.482 & 598.706 & 24828.801 & \text { Yes }\end{array}$

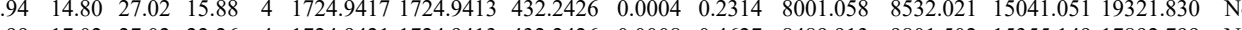
$\begin{array}{lllllllllllllll}0 & 0.061 .078 & \text { Yes }\end{array}$

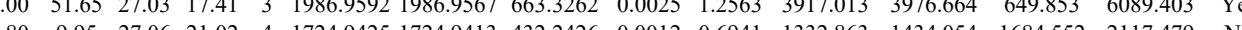
$\begin{array}{llllllllllllllll}0.96 & 1.95 & 2.06 & 21.02 & 4 & 1724.9425 & 1724.9413 & 432.2426 & 0.0012 & 0.6941 & 1332.863 & 1434.054 & 1684.552 & 2117.479 & \text { No }\end{array}$ $\begin{array}{llllllllllllll} & \end{array}$ $\begin{array}{lllllllllllll} & 74.07 \\ 22.67 & 30.08 & 3 & 1837.7962 & 1837.7949 & 6136056 & 0.0013 & 0.7892 & 86.383 & 76.541 & 2.825 & 103.102 & \text { Yes } \\ 1.00 & 67.394 & 14.431 & 2.811 & 20.347 & \text { No }\end{array}$ $\begin{array}{llllllllllllllll}1.00 & 67.39 & 22.62 & 21.43 & 3 & 1837.7965 & 1837.7949 & 613.6056 & 0.0016 & 0.8692 & 17.627 & 18.571 & 9.547 & 18.568 & \text { Yes }\end{array}$

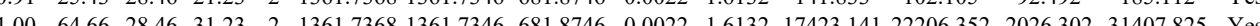
$\begin{array}{lllllllllllllllll}1.00 & 54.68 & 28.65 & 26.69 & 2 & 1361.7372 & 1361.7346 & 681.8746 & 0.0026 & 1.9065 & 10967.585 & 13590.439 & 188.202 & 18130.101 & \text { Yes }\end{array}$ 

$\begin{array}{lllllllllllllll}\text { NQGGYGGSSSSSSYGSGR } & 0.55 & 50.33 & 22.70 & 63.33 & 3 & 1837.7959 & 1837.7949 & 613.6056 & 0.0010 & 0.5432 & 10.491 & 6.516 & 2.88\end{array}$

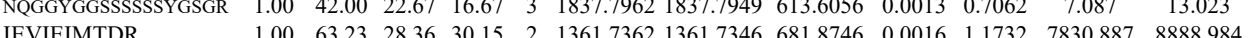

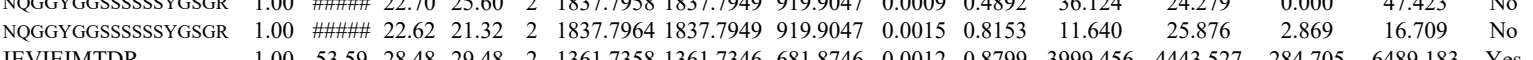

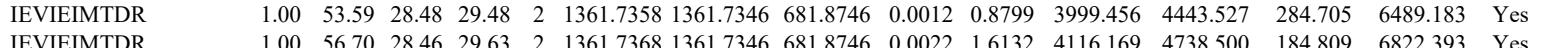
$\begin{array}{lllllllllllllllll} & \end{array}$

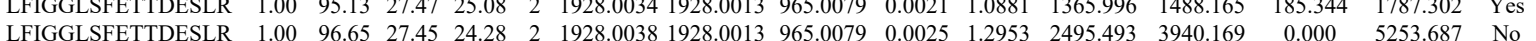
$\begin{array}{lllllllllllllll} & \end{array}$

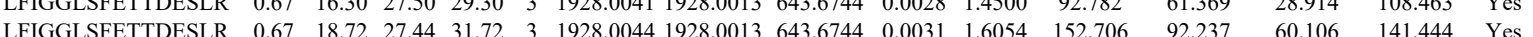
$\begin{array}{llllllllllllllll}\text { LFIGGLSFETTDESLR } & 1.00 & 94.66 & 27.69 & 29.45 & 2 & 1928.0022 & 1928.0013 & 965.0079 & 0.0009 & 0.4663 & 1855.754 & 2029.165 & 137.517 & 3571.482 & \text { Yes }\end{array}$

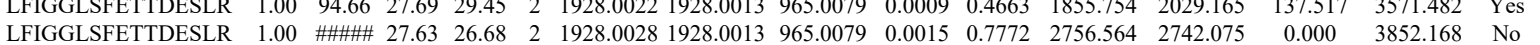

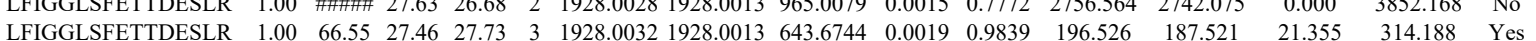
$\begin{array}{lllllllllllllllll}\text { LFIGGLSFETTDESLR } & 1.00 & 71.26 & 27.45 & 28.89 & 3 & 1928.0038 & 1928.0013 & 643.6744 & 0.0025 & 1.2946 & 206.505 & 172.882 & 42.652 & 256.833 & \text { Yes }\end{array}$ $\begin{array}{lllllllllllllllll}\text { LFIGGLSFETTDESLR } & 1.00 & 94.06 & 27.63 & 26.29 & 2 & 1928.0012 & 1928.0013 & 965.0079 & -0.0001 & -0.0518 & 600.924 & 607.700 & 21.803 & 913.333 & \text { Yes }\end{array}$ $\begin{array}{llllllllllllllll}\text { LFIGGLSFETTDESLR } & 1.00 & 87.81 & 27.49 & 42.81 & 2 & 1928.0042 & 1928.0013 & 965.0079 & 0.0029 & 1.5026 & 655.501 & 594.307 & 32.768 & 938.399 & \text { Yes }\end{array}$ $\begin{array}{llllllllllllllll}\text { SHFEQWGTLTDCVVMR } & 0.55 & 34.86 & 25.21 & 47.86 & 3 & 2097.9565 & 2097.9556 & 700.3258 & 0.0009 & 0.4284 & 110.764 & 81.974 & 41.637 & 102.832 & \text { Yes }\end{array}$ $\begin{array}{llllllllllllllll}\text { SHFEQWGTLTDCVVMR } & 0.55 & 35.52 & 25.21 & 48.52 & 3 & 2097.9565 & 2097.9556 & 700.3258 & 0.0009 & 0.4284 & 93.957 & 96.255 & 40.807 & 103.461 & \text { Yes }\end{array}$ $\begin{array}{llllllllllllllll}\text { SHFEQWGTLTDCVVMR } & 1.00 & 58.42 & 25.21 & 17.21 & 3 & 2097.9565 & 2097.9556 & 700.3258 & 0.0009 & 0.4284 & 5360.919 & 5796.650 & 294.941 & 6974.697 & \text { Yes }\end{array}$ \begin{tabular}{llllllllllllllll} 
SHFEQWGTLTDCVVMR & 1.00 & 56.57 & 25.20 & 19.76 & 3 & 2097.9577 & 2097.9556 & 700.3258 & 0.0021 & 0.9995 & 26.693 & 22.590 & 4.481 & 35.511 & Yes \\
\hline
\end{tabular}

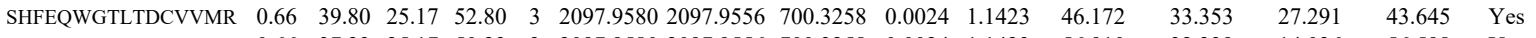

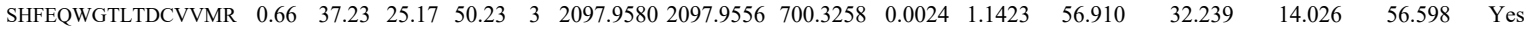

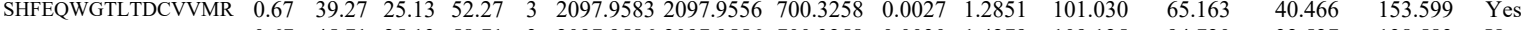

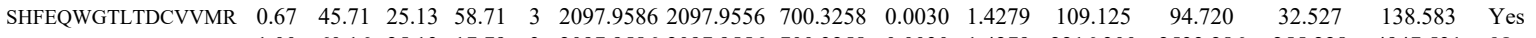

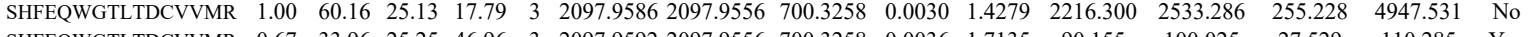

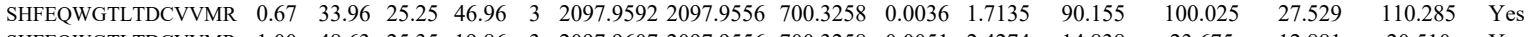

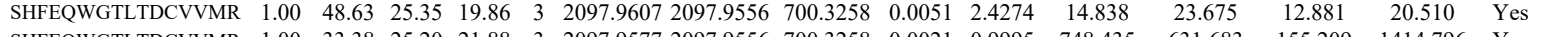
\begin{tabular}{llllllllllllllll} 
SHFEQWGTLTDCVVMR & 1.00 & 33.38 & 25.20 & 21.88 & 3 & 2097.9577 & 2097.9556 & 700.3258 & 0.0021 & 0.9995 & 748.435 & 631.683 & 155.209 & 1414.796 & Yes \\
\hline
\end{tabular} $\begin{array}{lllllllllllllllll}\text { SHFEQWGTLTDCVVMR } & 0.67 & 41.06 & 25.13 & 54.06 & 3 & 2097.9586 & 2097.9556 & 700.3258 & 0.0030 & 1.4279 & 1867.363 & 1980.973 & 297.762 & 3434.603 & \text { Yes }\end{array}$

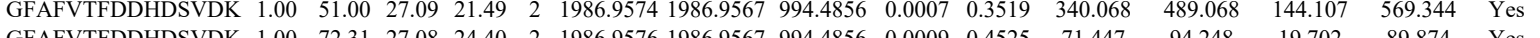
\begin{tabular}{llllllllllllllll} 
GFAFVTFDDHDSVDK & 1.00 & 72.31 & 27.08 & 24.40 & 2 & 1986.9576 & 1986.9567 & 994.4856 & 0.0009 & 0.4525 & 71.447 & 94.248 & 19.702 & 89.874 & Yes \\
\hline
\end{tabular} $\begin{array}{lllllllllllllll} & \end{array}$

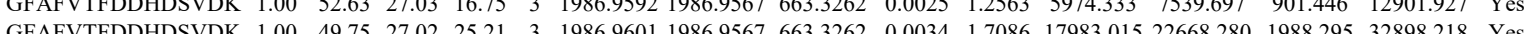

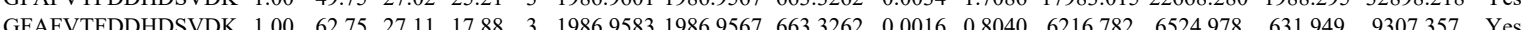

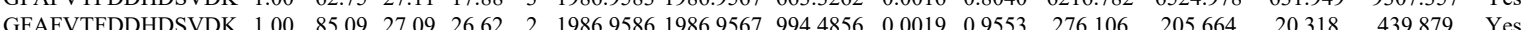

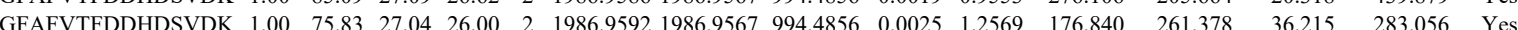
$\begin{array}{lllllllllllllllll} & \text { GFAFVTFDDHDSVDK } & 1.00 & 53.79 & 27.05 & 17.24 & 3 & 1986.9595 & 1986.9567 & 663.3262 & 0.0028 & 1.4070 & 10747.342 & 16665.504 & 488.285 & 21180.450 & \text { Yes }\end{array}$ $\begin{array}{lllllllllllllllll}\text { EDSQRPGAHLTVK } & 0.97 & 24.68 & 27.06 & 19.67 & 3 & 1724.9425 & 1724.9413 & 575.9877 & 0.0012 & 0.6945 & 6423.935 & 5488.111 & 11384.929 & 11267.243 & \text { No }\end{array}$

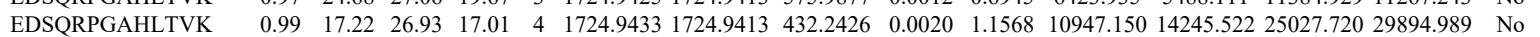

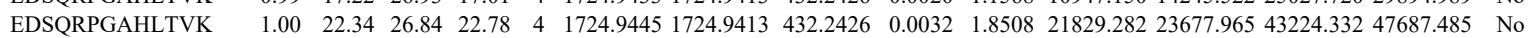

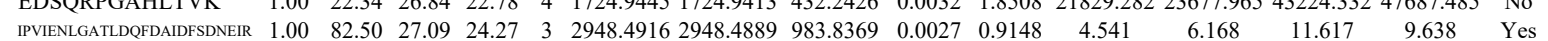

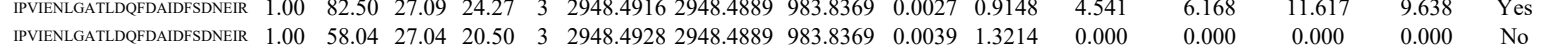

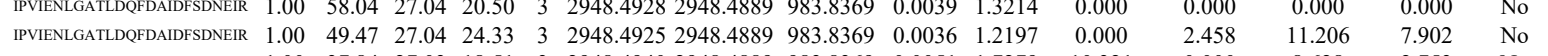
$\begin{array}{llllllllllllllll}\text { IPVIENLGATLDPFDAIDFSDNEIR } & 1.00 & 37.84 & 27.03 & 18.51 & 3 & 2948.4940 & 2948.4889 & 983.8369 & 0.0051 & 1.7279 & 10.321 & 0.000 & 8.628 & 2.753 & \text { No }\end{array}$

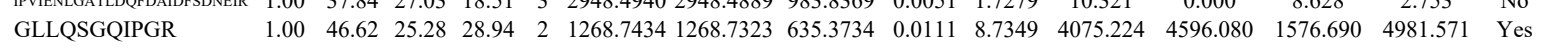
$\begin{array}{lllllllllllllllll}\text { GLLQSGQIPGR } & 1.00 & 49.87 & 25.13 & 26.18 & 2 & 1268.7440 & 1268.7323 & 635.3734 & 0.0117 & 9.2071 & 6065.627 & 6342.060 & 2188.962 & 7344.778 & \text { Yes }\end{array}$ $\begin{array}{llllllllllllllll}\text { GLLQSGQIPGR } & 1.00 & 55.16 & 25.11 & 27.58 & 2 & 1268.7446 & 1268.7323 & 635.3734 & 0.0123 & 9.6793 & 10707.649 & 12777.236 & 2304.371 & 13184.307 & \text { Yes }\end{array}$ $\begin{array}{llllllllllllllll}\text { GLLQSGQIPGR } & 1.00 & 53.69 & 25.11 & 27.46 & 2 & 1268.7446 & 1268.7323 & 635.3734 & 0.0123 & 9.6793 & 8819.450 & 10084.419 & 2309.809 & 12455.670 & \text { Yes }\end{array}$ SLTYLSILR SLTYLSILR SLTYLSILR SLTYLSILR SLTYLSILR GGPSPGDVEAIK

$\begin{array}{llllllllllll}\text { TACD2 HUMA] P09758 TACSTD2 Tumor-associated } & 35.709 & 1.00 & 3 & 10.2 & -0.0205 & 0.5016 & 3.2112 & 1.3788 & 4 & \text { MTVCSPDGPGGR }\end{array}$ MTVCSPDGPGGR CLLLK

CLLLLK

AGDVDIGDAAYYFE LEQMPSK (245.676 Y Y $\begin{array}{lllllllllllllll}1.00 & 42.33 & 25.67 & 24.07 & 2 & 1208.7262 & 1208.7250 & 605.3698 & 0.0008 & 0.6608 & 4448.729 & 4016.010 & 242.885 & 7761.766 & \text { Yes } \\ & 44.0012 & 0.9911 & 3207.761 & 2730.332 & 120.089 & 5901.211 & \text { Yes }\end{array}$ $\begin{array}{lllllllllllllll}0.99 & 44.11 & 24.64 & 23.48 & 2 & 1208.7236 & 1208.7250 & 605.3698 & -0.0014 & -1.1563 & 1277.521 & 1073.382 & 111.914 & 2025.171 & \text { Yes }\end{array}$ $\begin{array}{llllllllllllllll}1.00 & 45.51 & 24.64 & 24.53 & 2 & 1208.7240 & 1208.7250 & 605.3698 & -0.0010 & -0.8259 & 1438.494 & 1331.645 & 66.986 & 2145.738 & \text { Yes }\end{array}$ $\begin{array}{lllllllllllllll}0.99 & 38.78 & 25.73 & 23.73 & 2 & 1208.7252 & 1208.7250 & 605.3698 & 0.0002 & 0.1652 & 546.853 & 541.009 & 104.652 & 807.356 & \text { Yes }\end{array}$

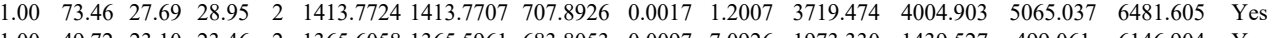
$\begin{array}{llllllllllllllll}1.00 & 49.72 & 23.10 & 23.46 & 2 & 1365.6058 & 1365.5961 & 683.8053 & 0.0097 & 7.0926 & 1973.330 & 1439.527 & 499.061 & 6146.904 & \text { Yes }\end{array}$ $\begin{array}{lllllllllllllll}1.00 & 47.90 & 23.14 & 22.31 & 2 & 1365.6060 & 1365.5961 & 683.8053 & 0.0099 & 7.2388 & 2004.977 & 2060.475 & 290.949 & 9437.788 & \text { Yes }\end{array}$

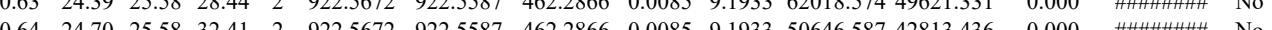

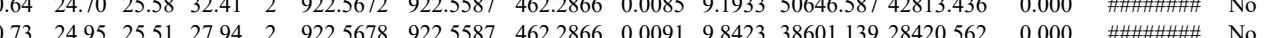

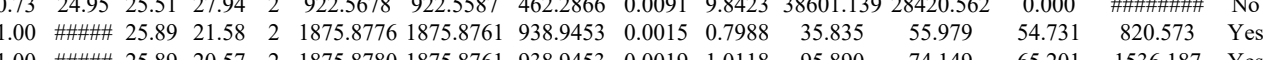

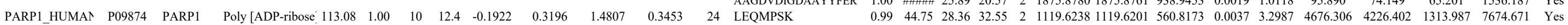

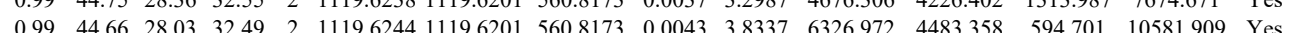



$\begin{array}{ccccccccccccccc}0.91 & 9.60 & 25.05 & 14.79 & 4 & 3478.7721 & 3478.7661 & 870.6988 & 0.0060 & 1.7228 & 4.488 & 4.011 & 8.467 & 18.801 & \text { Y }\end{array}$ $\begin{array}{ccccccccccccccc}0.99 & 39.76 & 27.62 & 21.26 & 3 & 1755.9352 & 1755.9262 & 586.3160 & 0.0090 & 5.1167 & 1865.496 & 1569.166 & 274.396 & 4691.128 & \text { Yes }\end{array}$

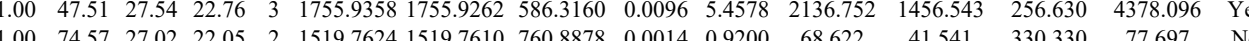

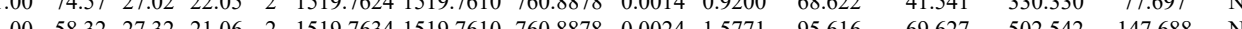

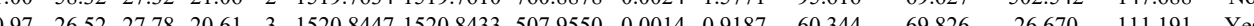

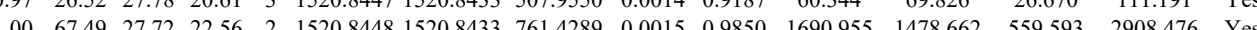
$\begin{array}{lllllllllllllll}100 & 33.73 & 27.71 & 1826 & 3 & 1520.8456 & 1520.8433 & 507.9550 & 0.0023 & 1.5093 & 43.089 & 81.700 & 26.808 & 96.368 & \text { No }\end{array}$ $\begin{array}{lllllllllllllll}1 & 68.62 & 27.72 & 23.28 & 2 & 1520.8456 & 1520.8433 & 761.4289 & 0.0023 & 1.5103 & 968.474 & 800.321 & 354.633 & 2169.821 & \text { Yes }\end{array}$

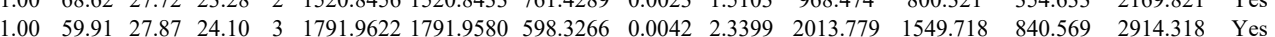
$\begin{array}{lllllllllllllll}1.00 & 61.41 & 27.87 & 23.26 & 3 & 1791.9622 & 1791.9580 & 598.3266 & 0.0042 & 2.3399 & 2690.433 & 2253.672 & 1293.698 & 4510.493 & \text { Yes }\end{array}$ $\begin{array}{lllllllllllllll}1.00 & 74.03 & 27.78 & 25.88 & 2 & 1520.8446 & 1520.8433 & 761.4289 & 0.0013 & 0.8537 & 880.375 & 759.541 & 192.743 & 1605.808 & \text { Yes }\end{array}$ $\begin{array}{lllllllllllllll}1.00 & 81.09 & 27.72 & 28.15 & 2 & 1520.8448 & 1520.8433 & 761.4289 & 0.0015 & 0.9850 & 1707.895 & 1543.151 & 981.492 & 4018.707 & \text { Yes }\end{array}$ $\begin{array}{lllllllllllllll}0.98 & 26.66 & 27.72 & 20.28 & 3 & 1520.8453 & 1520.8433 & 507.9550 & 0.0020 & 1.3125 & 56.167 & 61.508 & 15.583 & 90.276 & \text { Yes }\end{array}$ $\begin{array}{llllllllllllllll}0.92 & 19.91 & 27.73 & 19.60 & 3 & 1520.8459 & 1520.8433 & 507.9550 & 0.0026 & 1.7062 & 61.277 & 38.259 & 37.034 & 74.448 & \text { Yes }\end{array}$ $\begin{array}{llllllllllllllll}1.00 & 77.11 & 27.77 & 24.46 & 2 & 1520.8442 & 1520.8433 & 761.4289 & 0.0009 & 0.5910 & 717.196 & 623.967 & 276.649 & 1345.551 & \text { Yes } \\ \end{array}$

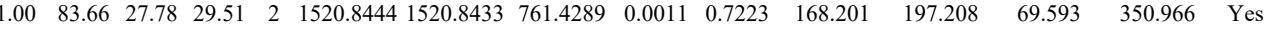

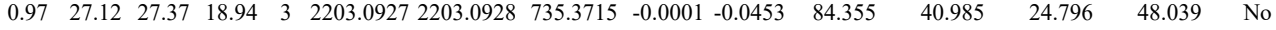
$\begin{array}{lllllllllllllll}1.00 & 51.26 & 27.18 & 31.28 & 2 & 1209.6848 & 1209.6839 & 605.8492 & 0.0009 & 0.7428 & 10208.912 & 9119.742 & 1656.904 & 16299.559 & \text { Yes }\end{array}$ $\begin{array}{lllllllllllllll}1.00 & 53.35 & 26.89 & 23.18 & 2 & 1209.6954 & 1209.6839 & 605.8492 & 0.0115 & 9.4907 & 8609.344 & 7344.968 & 959.727 & 13361.371 & \text { Yes }\end{array}$ \begin{tabular}{lllllllllllllll}
1.00 & 61.73 & 26.46 & 27.66 & 2 & 1607.9050 & 1607.9014 & 804.9580 & 0.0036 & 2.2361 & 504.637 & 224.458 & 5.841 & 65.337 & Yes \\
\hline
\end{tabular}

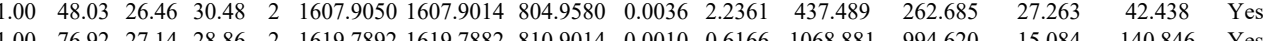
$\begin{array}{lllllllllllllll}1.00 & 76.92 & 27.14 & 28.86 & 2 & 1619.7892 & 1619.7882 & 810.9014 & 0.0010 & 0.6166 & 1068.881 & 994.620 & 15.084 & 140.846 & \text { Yes } \\ 1.00 & 71.48 & 27.31 & 2.92 & 2 & 1619.7898 & 1619.7882 & 81.9014 & 0.0016 & 0.9866 & 1187.064 & 1032.918 & 0.000 & 211.46 & \end{array}$ $\begin{array}{llllllllllllllll}1.00 & 71.48 & 27.31 & 28.92 & 2 & 1619.7898 & 1619.7882 & 810.9014 & 0.0016 & 0.9866 & 1187.064 & 1032.918 & 0.000 & 211.460 & \text { No }\end{array}$

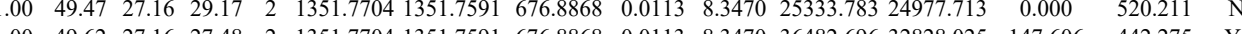

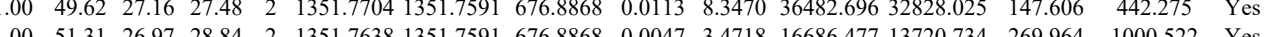

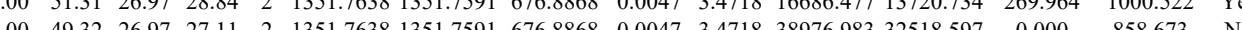

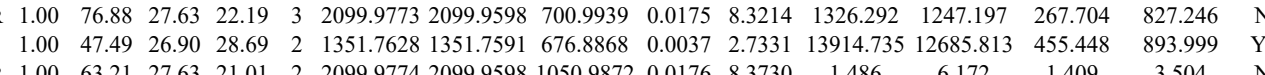
$\begin{array}{lllllllllllllllll} & \end{array}$

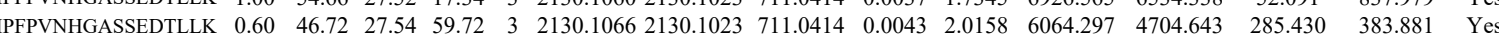
$\begin{array}{lllllllllllllllll} & \text { MPFPVNHGASSEDTLLK } & 1.00 & 50.71 & 27.50 & 17.52 & 3 & 2130.1075 & 2130.1023 & 711.0414 & 0.0052 & 2.4377 & 16030.847 & 12631.408 & 500.782 & 927.011 & \text { Yes }\end{array}$ $\begin{array}{lllllllllllllllll}\text { MPFPVNHGASSEDTLLK } & 1.00 & 56.58 & 27.54 & 24.42 & 3 & 2130.1078 & 2130.1023 & 711.0414 & 0.0055 & 2.5784 & 11109.323 & 9900.812 & 468.812 & 385.476 & \text { Yes } \\ \text { MQLKPMEINPEMLNK } & 0.96 & 28.71 & 25.73 & 21.09 & 3 & 2247.2224 & 2247.2154 & 750.0791 & 0.0070 & 3.1108 & 1470.427 & 1627.618 & 331.123 & 289.409 & \text { Yes }\end{array}$

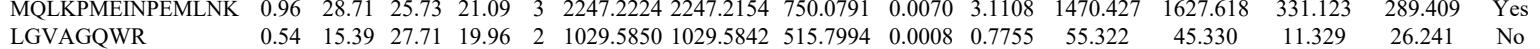

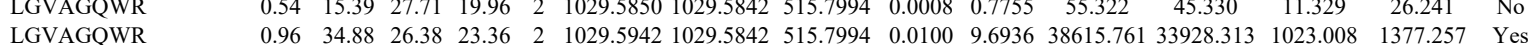

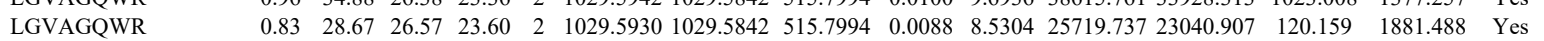

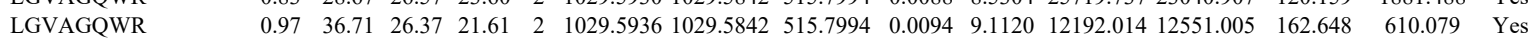

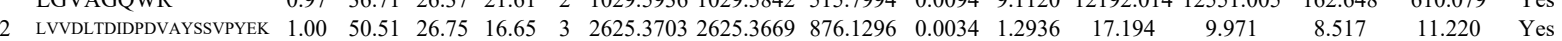

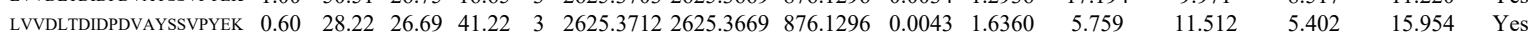
$\begin{array}{lllllllllllllllll}\text { LVVDLTDIDPDVAYSSVPYEK } & 0.55 & 26.88 & 26.87 & 39.88 & 3 & 2625.3682 & 2625.3669 & 876.1296 & 0.0013 & 0.4946 & 99.798 & 75.192 & 41.602 & 85.825 & \text { Yes }\end{array}$ $\begin{array}{llllllllllllllllll}\text { LVVDLTDIDPDVAYSSVPYEK } & 1.00 & 46.03 & 26.79 & 16.72 & 3 & 2625.3694 & 2625.3669 & 876.1296 & 0.0025 & 0.9512 & 51.710 & 62.882 & 37.824 & 42.526 & \text { Yes }\end{array}$ $\begin{array}{lllllllllllllllll}\text { GSPMEISLPIALSK } & 1.00 & 81.15 & 25.33 & 24.61 & 2 & 1729.9894 & 1729.9892 & 866.0019 & 0.0002 & 0.1155 & 353.177 & 306.988 & 204.866 & 557.670 & \text { Yes }\end{array}$ $\begin{array}{lllllllllllllllll}\text { GSPMEISLPIALSK } & 1.00 & 79.37 & 25.34 & 24.00 & 2 & 1729.9900 & 1729.9892 & 866.0019 & 0.0008 & 0.4619 & 439.623 & 395.106 & 232.208 & 584.633 & \text { Yes }\end{array}$ $\begin{array}{lllllllllllllllll}\text { GSPMEISLPIALSK } & 0.99 & 24.59 & 25.39 & 16.07 & 3 & 1729.9912 & 1729.9892 & 577.6703 & 0.0020 & 1.1541 & 169.977 & 175.556 & 79.552 & 266.496 & \text { Yes }\end{array}$ $\begin{array}{lllllllllllllllll}\text { GSPMEISLPIALSK } & 0.99 & 24.38 & 25.37 & 19.69 & 3 & 1729.9915 & 1729.9892 & 577.6703 & 0.0023 & 1.3272 & 151.728 & 124.166 & 62.071 & 290.392 & \text { Yes }\end{array}$ $\begin{array}{lllllllllllllllll}\text { DGETPDPEDPSR } & 0.98 & 28.16 & 22.67 & 20.29 & 2 & 1457.6398 & 1457.6392 & 729.8269 & 0.0006 & 0.4111 & 33.811 & 47.752 & 61.689 & 69.721 & \text { Yes }\end{array}$ $\begin{array}{lllllllllllllllll}\text { ASMHPVTAMLVGK } & 1.00 & 53.60 & 26.60 & 21.41 & 3 & 1628.9146 & 1628.8986 & 543.9735 & 0.0160 & 9.8043 & 6483.799 & 7077.440 & 954.085 & 8785.219 & \text { Yes }\end{array}$ \begin{tabular}{llllllllllllllll} 
EDDLNSFNATDLK & 1.00 & 78.77 & 27.69 & 27.86 & 2 & 1768.8734 & 1768.8723 & 885.4434 & 0.0011 & 0.6212 & 611.557 & 544.164 & 806.174 & 1026.326 & Yes \\
\hline
\end{tabular} $\begin{array}{llllllllllllllll}\text { EDDLNSFNATDLK } & 1.00 & 73.18 & 27.70 & 27.73 & 2 & 1768.8738 & 1768.8723 & 885.4434 & 0.0015 & 0.8470 & 630.651 & 370.387 & 719.202 & 846.324 & \text { Yes }\end{array}$ $\begin{array}{llllllllllllllll}\text { GVVPLAGTDGeTTTQGLDGLSER } & 1.00 & 79.04 & 27.40 & 21.73 & 2 & 2416.2214 & 2416.2204 & 1209.1175 & 0.0010 & 0.4135 & 32.719 & 12.355 & 57.577 & 118.452 & \text { No }\end{array}$

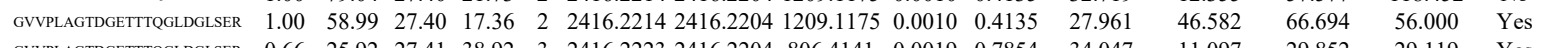

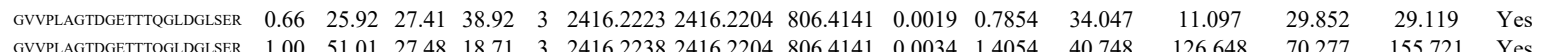

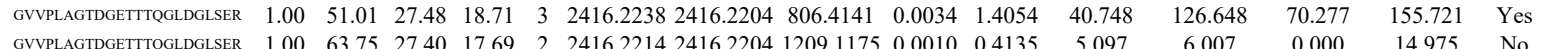

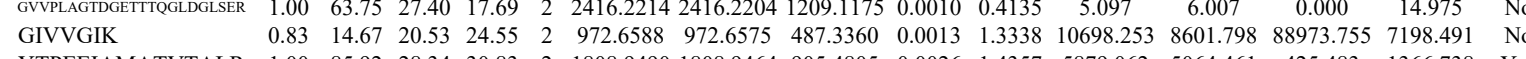
$\begin{array}{lllllllllllllllllll}\text { YTPEEIAMATVTALR } & 1.00 & 85.92 & 28.34 & 30.83 & 2 & 1808.9490 & 1808.9464 & 905.4805 & 0.0026 & 1.4357 & 5879.062 & 5064.461 & 425.483 & 1366.738 & \text { Yes }\end{array}$ $\begin{array}{llllllllllllllll}\text { YTPEIAMATVALR } & 1.00 & 83.56 & 28.33 & 22.14 & 2 & 1808.9496 & 1808.9464 & 905.4805 & 0.0032 & 1.7670 & 712.880 & 666.076 & 119.199 & 151.968 & \text { Yes } \\ \text { YTPEEIAMATVTALR } & 1.00 & 36.03 & 28.33 & 19.12 & 3 & 1808.9497 & 1808.9464 & 603.9894 & 0.0033 & 1.8212 & 233.420 & 265.651 & 105.450 & 118.293 & \text { Yes }\end{array}$ 
ATIAGGGVIPHIHK ATIAGGGVIPHIHK ATIAGGGVIPHIHK ATIAGGGVIPHIHK ATIAGGGVIPHIHK ATIAGGGVIPHIHK ATIAGGGVIPHIHK

\section{GGATAVYSAIIEYLTAEVELLAGNASK}

GDEELDSLIK

GDEELDSLIK

GDEELDSLIK

GDEELDSLIK

GDEELDSLIK

ALLQEMPLTALLR

ALLQEMPLTALLR

ALLQEMPLTALLR

IPTHLFTFIQFK

IPTHLFTFIQFK
IPTHLFTFIQFK

IPTHLFTFIQFK
IPTHLFTFIOFK

LDILDTAGQEEFGAM

LNVDEAFEQLVR

LNVDEAFEQLVR

LFTQILR

LFTQILR

LFTQILR

LFTQILR

LDILDTAGQEEFGAM LDILDT

10 KATGAATPK

KPAAAAGAK

KPAAAAGAK

KPAAAAGAK

KPAAAAGAK

KPAAAAGAK

KATGAATPK

KPAAAAGAK

KPAAAAGAK

ATGAATPK $\begin{array}{llllllllllll} & 1.00 \\ 1.00 & 73.30 & 27.40 & 20.04 & 2 & 2416.2214 & 2416.2204 & 1209.1175 & 0.0010 & 0.4135 & 5.706 & 1.801 \\ 1\end{array}$

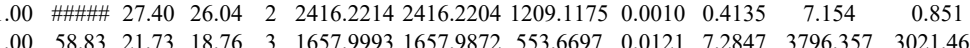
$\begin{array}{llllllllllll}1.00 & 58.83 & 21.73 & 18.76 & 3 & 1657.9993 & 657.9872 & 553.6697 & 0.0121 & 7.2847 & 3796.357 & 3021.463 \\ 1.00 & 77.72 & 21.73 & 22.75 & 3 & 1658.0005 & 1657.9872 & 553.6697 & 0.0133 & 8.0071 & 4339.564 & 4559.40\end{array}$ $\begin{array}{llllllllllll}1.00 & 55.66 & 21.73 & 19.61 & 4 & 1658.0005 & 1657.9872 & 415.5041 & 0.0133 & 8.0023 & 2448.042 & 2985.619 \\ 1.00 & 52.70 & 21.64 & 2.66 & 4 & 1658.0013 & 1657.9872 & 415.5041 & 0.0141 & 8.4836 & 1371.522 & 1774.973\end{array}$ $\begin{array}{llllllllllll}1.00 & 52.70 & 21.64 & 22.66 & 4 & 1658.0013 & 1657.9872 & 415.5041 & 0.0141 & 8.4836 & 1371.522 & 1774.973\end{array}$ $\begin{array}{llllllllllll}1.00 & 56.53 & 21.49 & 16.56 & 3 & 1657.9990 & 1657.9872 & 553.6697 & 0.0118 & 7.1041 & 5255.897 & 5935.431\end{array}$ $\begin{array}{llllllllllll}1.00 & 60.98 & 21.73 & 23.62 & 4 & 1657.9993 & 1657.9872 & 415.5041 & 0.0121 & 7.2803 & 3175.390 & 3875.394\end{array}$ $\begin{array}{llllllllllllll}1.00 & 43.61 & 21.73 & 21.39 & 4 & 1658.0001 & 1657.9872 & 415.5041 & 0.0129 & 7.7616 & 2603.929 & 3548.808 & \\ 1.00 & 54.57 & 21.73 & 23.67 & 4 & 1658.0005 & 1657.9872 & 415.5041 & 0.0133 & 8.0023 & 3364.434 & 3134.790\end{array}$ $\begin{array}{lllllllllll}0.77 & 3.88 & 22.20 & 16.88 & 4 & 3182.7357 & 3182.7318 & 796.6902 & 0.0039 & 1.2238 & 28.550\end{array}$ $\begin{array}{lllllllllll}1.00 & 31.81 & 22.20 & 15.52 & 4 & 3182.7357 & 3182.7318 & 796.6902 & 0.0039 & 1.2238 & 23.444 \\ 1.00 & 21.13 & 22.12 & 14.51 & 4 & 3182.7361 & 3182.7318 & 796.6902 & 0.0043 & 1.3493 & 20.701\end{array}$ $\begin{array}{lllllllllll}1.00 & 21.13 & 22.12 & 14.51 & 4 & 3182.7361 & 3182.7318 & 796.6902 & 0.0043 & 1.3493 & 20.701 \\ 1.00 & 70.78 & 28.66 & 29.12 & 2 & 1405.7550 & 1405.7544 & 703.8845 & 0.0006 & 0.4262 & 447.877\end{array}$ $\begin{array}{llllllllllll}1.00 & 70.78 & 28.66 & 29.12 & 2 & 1405.7550 & 1405.7544 & 703.8845 & 0.0006 & 0.4262 & 447.877 & 60 \\ 1.00 & 58.14 & 28.66 & 26.98 & 2 & 1405.7556 & 1405.7544 & 703.8845 & 0.0012 & 0.8524 & 312.170 & 36\end{array}$ $\begin{array}{lllllllllll}1.00 & 58.14 & 28.66 & 26.98 & 2 & 1405.7556 & 1405.7544 & 703.8845 & 0.0012 & 0.8524 & 312.170 \\ 1.00 & 40.40 & 28.66 & 23.90 & 3 & 1405.7557 & 1405.7544 & 469.5921 & 0.0013 & 0.9228 & 19.656\end{array}$ $\begin{array}{llllllllllll}1.00 & 40.40 & 28.66 & 23.90 & 3 & 1405.7557 & 1405.7544 & 469.5921 & 0.0013 & 0.9228 & 19.656 \\ 1.00 & 52.26 & 28.67 & 25.94 & 3 & 1405.7560 & 1405.7544 & 469.5921 & 0.0016 & 1.1357 & 29.509\end{array}$ $\begin{array}{lllllllllllll}1.00 & 52.26 & 28.67 & 25.94 & 3 & 1405.7560 & 140.7544 & 46.5921 & 0.0016 & 1.1357 & 29.509 & 25.632 & 5\end{array}$ $\begin{array}{lllllllllllll}1.00 & 66.52 & 28.58 & 27.90 & 2 & 1405.7546 & 405.7544 & 703.8845 & 0.0002 & 0.1421 & 3483.172 & 4607.075 & \\ 1.00 & 64.19 & 28.65 & 25.50 & 2 & 1405.7552 & 1405.7544 & 703.8845 & 0.0008 & 0.5683 & 4664.233 & 6452.287\end{array}$ $\begin{array}{llllllllllllll}1.00 & 73.01 & 23.16 & 35.83 & 2 & 1611.9506 & 1611.9503 & 806.9824 & 0.0003 & 0.1859 & 274.556 & 382.869\end{array}$

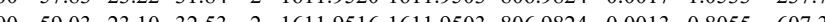
$\begin{array}{llllllllllllll}1.00 & 69.14 & 23.10 & 37.46 & 2 & 1611.9516 & 1611.9503 & 806.9824 & 0.0013 & 0.8055 & 541.913 & 592.178\end{array}$ $\begin{array}{llllllllllllll}0.97 & 37.70 & 23.50 & 39.76 & 3 & 1779.0361 & 17790327 & 594.0182 & 0.0034 & 1.9079 & 224.405 & 196.522\end{array}$ $\begin{array}{llllllllllllll}0.88 & 20.76 & 23.52 & 25.64 & 3 & 17790373 & 17790327 & 5940182 & 0.0046 & 25813 & 2247.733 & 287.264\end{array}$ $\begin{array}{llllllllllllll}1.00 & 32.51 & 23.44 & 24.59 & 3 & 1779.0358 & 1779.0327 & 594.0182 & 0.0031 & 1.7396 & 139.233 & 160.281\end{array}$ $\begin{array}{llllllllllll}1.00 & 81.90 & 27.22 & 22.06 & 2 & 1908.9382 & 1908.9373 & 955.4759 & 0.0009 & 0.4710 & 149.621 & 84.517\end{array}$ $\begin{array}{llllllllllll}1.00 & 72.58 & 28.21 & 25.56 & 2 & 1575.8398 & 1575.8378 & 788.9262 & 0.0020 & 1.2675 & 2395.249 & 1993.785\end{array}$ $\begin{array}{lllllllllllll}1.00 & 69.58 & 28.20 & 25.22 & 2 & 1575.8402 & 1575.8378 & 788.9262 & 0.0024 & 1.5211 & 3516.677 & 2679.580\end{array}$ $\begin{array}{lllllllllllllll}100 & 61.70 & 20.17 & 27.62 & 2 & 1228.7832 & 1228.7747 & 615.3946 & 0.0085 & 6.9061 & 4440.994 & 4138.829\end{array}$ $\begin{array}{llllllllllll}0.97 & 28.20 & 25.13 & 32.46 & 2 & 1033.6418 & 1033.6406 & 517.8276 & 0.0012 & 1.1587 & 5607.840 & 4935.647\end{array}$ $\begin{array}{llllllllllll}0.96 & 26.18 & 25.13 & 31.13 & 2 & 1033.6418 & 1033.6406 & 517.8276 & 0.0012 & 1.1587 & 7580.501 & 5246.024\end{array}$ $\begin{array}{lllllllllllll}0.93 & 29.21 & 25.75 & 32.98 & 2 & 1033.6408 & 1033.6406 & 517.8276 & 0.0002 & 0.1931 & 3379.417 & 3232.202\end{array}$ $\begin{array}{llllllllllll}0.94 & 30.90 & 25.67 & 34.45 & 2 & 1033.6410 & 1033.6406 & 517.8276 & 0.0004 & 0.3862 & 2990.987 & 2590.674\end{array}$ $\begin{array}{lllllllllllll}.00 & 84.23 & 27.19 & 22.07 & 2 & 1908.9380 & 1908.9373 & 955.4759 & 0.0007 & 0.3663 & 365.012 & 25 \\ .00 & 86.83 & 27.19 & 22.29 & 2 & 1908.9380 & 1908.9373 & 955.4759 & 0.0007 & 0.3663 & 293.670 & 23\end{array}$ $\begin{array}{lllllllllll}0.98 & 31.66 & 23.46 & 20.05 & 3 & 1275.7858 & 1275.7876 & 426.2698 & -0.0018 & -1.4076 & 53.146\end{array}$ $\begin{array}{llllllllllll}0.96 & 32.97 & 22.70 & 23.02 & 3 & 1215.7636 & 1215.7664 & 406.2627 & -0.0028 & -2.2974 & 161.860\end{array}$ $\begin{array}{llllllllllll}0.96 & 36.07 & 22.70 & 26.16 & 3 & 1215.7639 & 1215.7664 & 406.2627 & -0.0025 & -2.0512 & 108.050 \\ 0.99 & 31.26 & 22.70 & 19.83 & 3 & 1215.7651 & 1215.7664 & 406.2627 & -0.0013 & -1.0666 & 208.343\end{array}$ $\begin{array}{lllllllllllll}0.99 & 31.26 & 22.70 & 19.83 & 3 & 1215.7651 & 1215.7664 & 406.2627 & -0.0013 & -1.0666 & 208.343 \\ 1.00 & 38.87 & 22.70 & 23.40 & 3 & 1215.7651 & 1215.7664 & 406.2627 & -0.0013 & -1.0666 & 138.210 & 21\end{array}$ $\begin{array}{llllllllllll}1.00 & 38.87 & 22.70 & 23.40 & 3 & 1215.7651 & 1215.7664 & 406.2627 & -0.0013 & -1.0666 & 138.210 \\ 1.00 & 43.48 & 22.83 & 22.74 & 3 & 1215.7660 & 1215.7664 & 406.2627 & -0.0004 & -0.3282 & 151.947 & 2\end{array}$ $\begin{array}{llllllllllll}1.00 & 43.48 & 22.83 & 22.74 & 3 & 1215.7660 & 1215.7664 & 406.2627 & -0.0004 & -0.3282 & 151.947 \\ 0.73 & 20.57 & 23.46 & 16.85 & 3 & 1275.7858 & 1275.7876 & 426.2698 & -0.0018 & -1.4076 & 71.221\end{array}$ $\begin{array}{lllllllllll}0.73 & 20.57 & 23.46 & 16.85 & 3 & 1275.7858 & 1275.7876 & 426.2698 & -0.0018 & -1.4076 & 71.221 \\ 0.51 & 21.38 & 22.70 & 23.66 & 3 & 1215.7633 & 1215.7664 & 406.2627 & -0.0031 & -2.5435 & 158.618\end{array}$ $\begin{array}{llllllllllll}0.51 & 21.38 & 22.70 & 23.66 & 3 & 1215.7633 & 1215.7664 & 406.2627 & -0.0031 & -2.5435 & 158.618\end{array}$

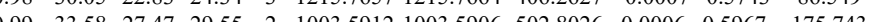
$\begin{array}{lllllllllllll}0.99 & 33.58 & 27.47 & 29.55 & 2 & 1003.5912 & 1003.5906 & 502.8026 & 0.0006 & 0.5967 & 175.743 & \\ 0.99 & 37.20 & 27.47 & 30.33 & 2 & 1003.5914 & 1003.5906 & 502.8026 & 0.0008 & 0.7955 & 294.508 & \end{array}$

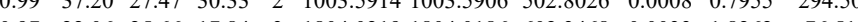

$\begin{array}{llllllllllllll}\text { GVETIANDVVSLATK } & 1.00 & 49.45 & 25.66 & 20.63 & 3 & 1804.0219 & 1804.0186 & 602.3468 & 0.0033 & 1.8262 & 76.194\end{array}$ $\begin{array}{lll}664.134 & 2603.715 & \text { No }\end{array}$ $\begin{array}{lll}627.575 & 6065.077 & \text { Yes } \\ 837.571 & 3554.527 & \text { Yes }\end{array}$

$\begin{array}{lll}10.113 & 20.935 & \text { Yes }\end{array}$ $\begin{array}{lll}14.904 & 13.382 & \text { No } \\ 11.918 & 2.875 & \text { Ye }\end{array}$ $\begin{array}{lll}11.918 & 20.875 & \text { Yes }\end{array}$ $508.879 \quad 481.430 \quad$ Yes $\begin{array}{lll}386.213 & 307.304 & \text { Yes }\end{array}$ $\begin{array}{llll}78.640 & 36.629 & \text { No } \\ 5889 & 38.923 & \text { Y }\end{array}$ $\begin{array}{lll}6.046 & 5713.002 & \text { Yes }\end{array}$ $\begin{array}{llll}35.734 & 369.976 & \text { Yes }\end{array}$ $\begin{array}{lll}1.663 & 291.375 & \text { Yes }\end{array}$ $\begin{array}{lll}16.177 & 638.111 & \text { Yes }\end{array}$ $\begin{array}{llll}24.944 & 578.903 & \text { Yes } \\ 151.419 & 236.751 & \text { Yes }\end{array}$ $\begin{array}{lll}237.695 & 340.391 & \text { Yes }\end{array}$ $\begin{array}{lll}117.275 & 197.895 & \text { Yes }\end{array}$ $\begin{array}{lll}2.150 & 289.685 & \text { No }\end{array}$ $\begin{array}{lll}74.675 & 1098.667 & \text { Yes }\end{array}$ $\begin{array}{lll}618.744 & 5244.166 & \text { Yes } \\ 360.383 & 3063.948 & \text { Yes }\end{array}$ $\begin{array}{lll}47.150 & 381.732 & \text { Yes }\end{array}$ $\begin{array}{lll}44.945 & 345.856 & \text { Yes } \\ 60.437 & 163.904 & Y a s\end{array}$ $\begin{array}{lll}60.437 & 163.904 & \text { Yes } \\ 177.196 & 3085492 & Y\end{array}$ $\begin{array}{lll}177.196 & 308.547 & \text { Yes } \\ 151.619 & 23.72 & Y e s\end{array}$ $\begin{array}{lll}177.196 & 308.547 & \text { Yes } \\ 212.792 & \text { Yes }\end{array}$ $\begin{array}{lll}212.196 & 333.715 & \text { Yes } \\ 307.652 & 34.931 & \text { Yes }\end{array}$

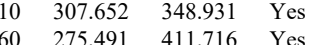
\begin{tabular}{llll}
23.460 & 275.491 & 411.716 & Yes \\
\hline 18.796 & 35.511 & 54.990 & No
\end{tabular} $\begin{array}{llll}18.806 & 119.254 & 215.066 & \text { Yes } \\ 90.871 & 78.408 & 111.813 & \text { Yes }\end{array}$ $\begin{array}{lllll}90.871 & 78.408 & 111.813 & \text { Yes }\end{array}$ $\begin{array}{lllll}653.161 & 563.143 & 655.348 & \text { Yes }\end{array}$ 
LEATINELV

LEATINELV

VGEFSGANK

TAFQEALDAAGDK

TAFQEALDAAGDK

CMPTFQFFK

CMPTFQFFK

CMPTFQFFK

CMPTFQFFK

CMPTFQFFK

CMPTFQFFK

CMPTFQFFK

CMPTFQFFK

CMPTFQFFK

CMPTFQFFK

CMPTFQFFK

CMPTFQFFK

CMPTFQFFK

CMPTFQFFK

CMPTFQFFK

CMPTFQFFK

CMPTFQFFK

CMPTFQFFK

CMPTFQFFK

CMPTFQFFK

CMPTFQFFK

CMPTFQFFK

CMPTFQFFK

CMPTFQFFK

CMPTFQFFK

CMPTFQFFK

CMPTFQFFK

CMPTFQFFK

TAFQEALDAAGDK

TAFQEALDAAGDK

TAFQEALDAAGDK

TAFQEALDAAGD

EKLEATINELV

TAFQEALDAAGDK

TAFQEALDAAGDK

TAFQEALDAAGDK

TAFQEALDAAGDK

TAFQEALDAAGDK

TAFQEALDAAGDK

TAFQEALDAAGDK

TAFQEALDAAG

LEATINELV

LEATINELV

VGEFSGANK

$\begin{array}{lllllllllllll}\text { COX5B_HUMA] P10606 } & \text { COX5B } & \text { Cytochrome c oxi } 13.696 & 1.00 & 3 & 24 & 0.0927 & 0.2083 & 0.8144 & 0.1899 & 7 & \text { GLDPYNVLAPK }\end{array}$ $\begin{array}{lllllllllll}25.89 & 25.06 & 2 & 18820492 & 18820468 & 942.0307 & 0.0024 & 12738 & 130.817\end{array}$

$\begin{array}{llllllllllll}1.00 & 46.65 & 28.16 & 35.18 & 2 & 11446476 & 11446461 & 573.3303 & 0.0015 & 13081 & 79.919 & 1\end{array}$

22.09

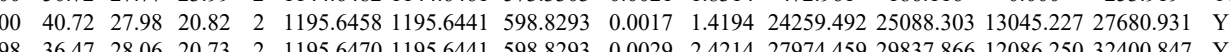

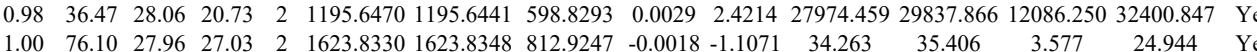

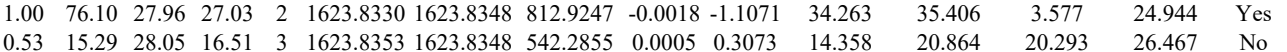
$\begin{array}{lllllllllllllll}0.60 & 14.36 & 28.01 & 27.36 & 3 & 1623.8386 & 1623.8348 & 542.2855 & 0.0038 & 2.3358 & 31.224 & 26.192 & 30.235 & 24.940 & \text { No }\end{array}$ $\begin{array}{llllllllllllllll}1.00 & 38.33 & 26.73 & 21.79 & 2 & 1481.7120 & 1481.7113 & 741.8629 & 0.0007 & 0.4718 & 9593.705 & 10637.861 & 84.604 & 16035.927 & \text { Yes }\end{array}$ $\begin{array}{llllllllllllllll}0.98 & 24.29 & 26.70 & 24.51 & 3 & 1481.7136 & 1481.7113 & 494.9110 & 0.0023 & 1.5491 & 635.082 & 572.434 & 0.000 & 792.566 & \text { No }\end{array}$ $\begin{array}{llllllllllllllll}1.00 & 38.35 & 26.71 & 20.62 & 2 & 1481.7136 & 1481.7113 & 741.8629 & 0.0023 & 1.5501 & 24681.940 & 26804.058 & 477.670 & 35877.838 & \text { Yes }\end{array}$ $\begin{array}{lllllllllllllllllll}0.95 & 20.72 & 26.63 & 24.44 & 3 & 1481.7142 & 1481.7113 & 494.9110 & 0.0029 & 1.9532 & 657.502 & 719.547 & 273.997 & 777.126 & \text { Yes }\end{array}$ $\begin{array}{llllllllllllllll}0.99 & 36.76 & 26.69 & 19.24 & 2 & 1481.7132 & 1481.7113 & 741.8629 & 0.0019 & 1.2806 & 31224.557 & 29631.763 & 0.000 & 43335.681 & \text { No }\end{array}$

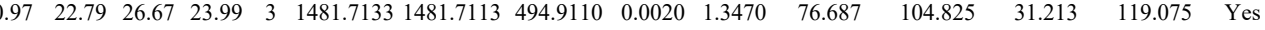
$\begin{array}{lllllllllllllll}0.52 & 9.58 & 26.70 & 21.17 & 3 & 1481.7136 & 1481.7113 & 494.9110 & 0.0023 & 1.5491 & 64.014 & 79.495 & 43.795 & 107.820 & \text { Yes }\end{array}$

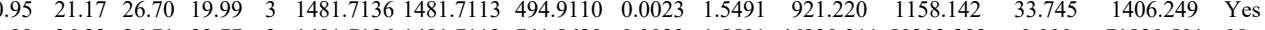
$\begin{array}{llllllllllllllll}0.99 & 36.22 & 26.71 & 22.77 & 2 & 1481.7136 & 1481.7113 & 741.8629 & 0.0023 & 1.5501 & 46930.311 & 50202.293 & 0.000 & 71820.501 & \text { No }\end{array}$

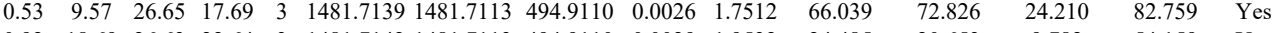

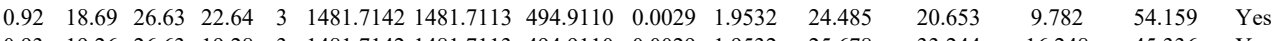

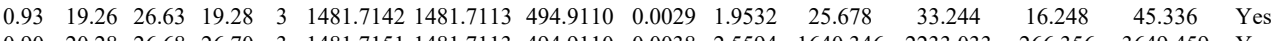
$\begin{array}{lllllllllllllll}0.90 & 20.28 & 26.68 & 26.70 & 3 & 1481.7151 & 1481.7113 & 494.9110 & 0.0038 & 2.5594 & 1640.346 & 2233.033 & 266.356 & 3649.459 & \text { Yes }\end{array}$ $\begin{array}{llllllllllllllll}0.94 & 33.79 & 25.97 & 19.73 & 2 & 1497.7054 & 1497.7062 & 749.8604 & -0.0008 & -0.5334 & 1988.254 & 2019.567 & 0.000 & 3383.201 & \text { No }\end{array}$ $\begin{array}{lllllllllllllll}0.99 & 35.01 & 26.12 & 17.31 & 2 & 1497.7068 & 4497.7062 & 749.8604 & 0.0006 & 0.4001 & 3004.662 & 3102.864 & 0.000 & 4816.950 & \text { No }\end{array}$ $\begin{array}{lllllllllllllll}0.99 & 27.29 & 26.67 & 25.79 & 3 & 1481.7133 & 1481.7113 & 494.9110 & 0.0020 & 1.3470 & 321.275 & 582.259 & 8.185 & 1048.375 & \text { Yes }\end{array}$ $\begin{array}{lllllllllllllll}1.00 & 40.34 & 26.67 & 25.07 & 2 & 1481.7134 & 1481.7113 & 741.8629 & 0.0021 & 1.4154 & 34385.221 & 58317.118 & 0.000 & 48630.480 & \text { No }\end{array}$ $\begin{array}{llllllllllllllllll}1.00 & 40.34 & 26.71 & 24.30 & 2 & 1481.7136 & 1481.7113 & 741.8629 & 0.0023 & 1.5501 & 19772.102 & 18914.489 & 188.631 & 27679.287 & \text { Yes }\end{array}$

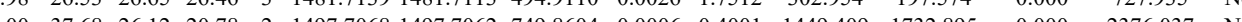
$\begin{array}{llllllllllllll} & 0.98 & 26.53 & 2.65 & 26.46 & 3 & 1481.7139 & 1481.7113 & 494.9110 & 0.0026 & 1.7512 & 302.954 & 197.574 & 0.000\end{array}$

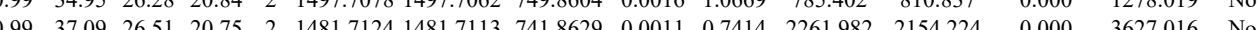

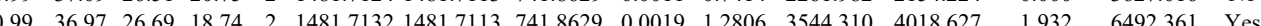

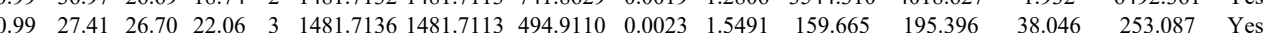
$\begin{array}{lllllllllllllll}0.75 & 15.54 & 26.69 & 19.31 & 3 & 1481.7124 & 1481.7113 & 494.9110 & 0.0011 & 0.7409 & 139.936 & 115.723 & 72.798 & 139.940 & \text { Yes }\end{array}$ $\begin{array}{llllllllllllllll}0.98 & 32.05 & 26.65 & 19.18 & 2 & 1481.7126 & 1481.7113 & 741.8629 & 0.0013 & 0.8762 & 805.127 & 737.207 & 0.000 & 1047.537 & \text { No }\end{array}$ $\begin{array}{llllllllllllllll}1.00 & 38.69 & 26.65 & 20.80 & 2 & 1481.7126 & 1481.7113 & 741.8629 & 0.0013 & 0.8762 & 1238.325 & 1219.749 & 0.000 & 1766.948 & \text { No }\end{array}$ $\begin{array}{lllllllllllllll}1.00 & 43.64 & 26.73 & 20.24 & 2 & 1481.7120 & 1481.7113 & 741.8629 & 0.0007 & 0.4718 & 444.151 & 398.568 & 0.000 & 640.011 & \text { No }\end{array}$ $\begin{array}{lllllllllllllll}1.00 & 38.02 & 26.71 & 20.66 & 2 & 1481.7128 & 1481.7113 & 741.8629 & 0.0015 & 1.0110 & 411.811 & 441.852 & 18.270 & 596.281 & \text { Yes }\end{array}$ $\begin{array}{lllllllllllllll}1.00 & 41.32 & 26.69 & 23.50 & 2 & 1481.7130 & 1481.7113 & 741.8629 & 0.0017 & 1.1458 & 330.315 & 361.986 & 5.186 & 444.837 & \text { Yes }\end{array}$ $\begin{array}{lllllllllllllll}1.00 & 87.42 & 28.01 & 33.34 & 2 & 1623.8360 & 1623.8348 & 812.9247 & 0.0012 & 0.7381 & 1934.555 & 2636.075 & 406.913 & 3398.166 & \text { Yes }\end{array}$ $\begin{array}{llllllllllllllll}1.00 & 91.89 & 28.03 & 33.30 & 2 & 1623.8364 & 1623.8348 & 812.9247 & 0.0016 & 0.9841 & 6769.598 & 7054.090 & 609.573 & 7940.141 & \text { Yes }\end{array}$

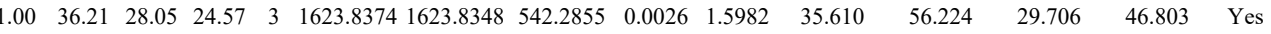

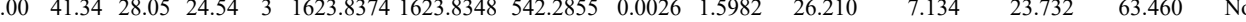
$\begin{array}{lllllllllllll} & \end{array}$ $\begin{array}{lllllllllllllll}1.00 & 99.29 & 28.01 & 33.49 & 2 & 1623.8360 & 1623.8348 & 812.9247 & 0.0012 & 0.7381 & 1820.652 & 1920.037 & 56.033 & 2668.605 & \text { Yes }\end{array}$ $\begin{array}{lllllllllllllll}1.00 & \text { man } 28.03 & 33.83 & 2 & 1623.8364 & 1623.8348 & 812.9247 & 0.0016 & 0.9841 & 6251.204 & 6774.262 & 1149.076 & 8676.402 & \text { Yes }\end{array}$ $\begin{array}{lllllllllllllll}.99 & 28.64 & 28.03 & 22.50 & 3 & 1623.8365 & 1623.8348 & 542.2855 & 0.0017 & 1.0450 & 171.474 & 207.856 & 55.725 & 245.173 & \text { Yes }\end{array}$ $\begin{array}{lllllllllllllll}1.00 & 63.17 & 28.05 & 28.74 & 3 & 1623.8374 & 1623.8348 & 542.2855 & 0.0026 & 1.5982 & 115.747 & 115.865 & 37.063 & 338.102 & \text { No }\end{array}$ $\begin{array}{lllllllllllllll}1.00 & \text { man 27.99 } & 35.08 & 2 & 1623.8358 & 1623.8348 & 812.9247 & 0.0010 & 0.6151 & 3295.878 & 3346.263 & 462.915 & 4537.248 & \text { Yes }\end{array}$

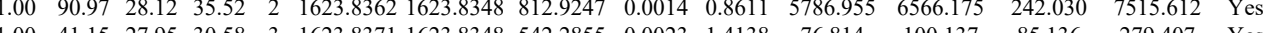

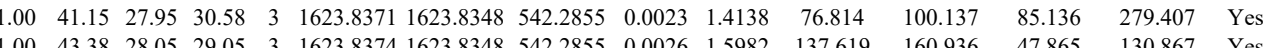
$\begin{array}{lllllllllllllll} & 3.38 & 28.05 & 29.05 & 3 & 1623.8374 & 1623.8348 & 542.2855 & 0.0026 & 1.5982 & 137.619 & 160.936 & 47.865 & 130.867 & \text { Yes } \\ 1.00 & 50.02 & 27.77 & 28.17 & 2 & 1144.6482 & 1144.6461 & 573.3303 & 0.0021 & 1.8314 & 87.387 & 74.066 & 53.747 & 170.721 & \text { Yes }\end{array}$

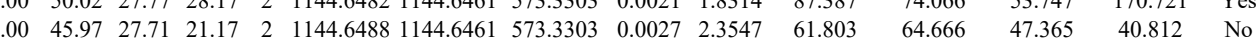
$\begin{array}{llllllllllllllll}0.99 & 42.47 & 27.74 & 19.66 & 2 & 1195.6482 & 1195.6441 & 598.8293 & 0.0041 & 3.4233 & 15222.231 & 18546.082 & 9906.573 & 18909.662 & \text { Yes }\end{array}$ $\begin{array}{lllllllllllllll}0.99 & 44.69 & 27.78 & 25.56 & 2 & 1195.6484 & 1195.6441 & 598.8293 & 0.0043 & 3.5903 & 20309.522 & 19875.641 & 12820.982 & 22563.768 & \text { Yes }\end{array}$ $\begin{array}{lllllllllllll}0.19 .142 & 20.984 & 40.095 & 69.175 & \text { No }\end{array}$

Table S-4 page 137 of 614 

24.243

LGPSDYFGEIALLMNRPR

$\begin{array}{lllllllllllllll}\text { LGPSDYFGEIALLMNRPR } & 0.60 & 38.36 & 27.04 & 18.52 & 3 & 2192.1571 & 2192.1534 & 731.7251 & 0.0037 & 1.6855 & 1410.911 & 1267.844 & 122 . & \end{array}$

ILMGSTLR

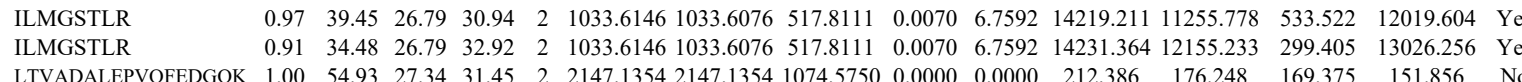

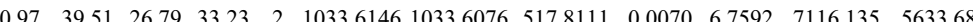

122.345

$\begin{array}{lccccccccccccccc}\text { ILMGSTLR } & 0.97 & 39.45 & 26.79 & 30.94 & 2 & 1033.6146 & 1033.6076 & 517.8111 & 0.0070 & 6.7592 & 14219.211 & 11255.778 & 533.522 & 12019.604 & \text { Yes } \\ \text { ILMGSTLR } & 0.91 & 34.48 & 26.79 & 32.92 & 2 & 1033.6146 & 1033.6076 & 517.8111 & 0.0070 & 6.7592 & 14231.364 & 12155.233 & 299.405 & 13026.256 & \text { Yes } \\ \text { LTVADALEPVOFEDGQK } & 1.00 & 54.93 & 27.34 & 31.45 & 2 & 2147.1354 & 2147.1354 & 1074.5750 & 0.0000 & 0.0000 & 212.386 & 176.248 & 169.375 & 151.856 & \text { No }\end{array}$

2 AYDATHLVK $\begin{array}{llllllllllllllll}0.99 & 32.80 & 27.35 & 32.64 & 2 & 2147.1374 & 2147.1354 & 1074.5750 & 0.0020 & 0.9306 & 198.726 & 136.746 & 217.479 & 304.915 & \text { No } & \end{array}$ $\begin{array}{lllllllllllllll}1.00 & 32.22 & 28.20 & 20.36 & 3 & 1304.7357 & 1304.7332 & 435.9183 & 0.0235 & 2.6763 & 21916.324 & 17453.823 & 149.719 & 20193.684 & \text { Yes }\end{array}$ $\begin{array}{llllllllllllllll}\text { SYPGSQLDILIDQGK } & 1.00 & 44.52 & 26.46 & 25.51 & 3 & 1921.0429 & 1921.0400 & 641.3539 & 0.0029 & 1.5072 & 491.496 & 375.142 & 298.913 & 405.408 & \text { Yes }\end{array}$ $\begin{array}{llllllllllllllll}\text { DDQFLLDGQLLPDNFIAACTEK } & 0.55 & 44.24 & 26.86 & 57.24 & 3 & 2799.3718 & 2799.3703 & 934.1307 & 0.0015 & 0.5353 & 24.707 & 16.148 & 16.345 & 21.608 & \text { Yes }\end{array}$

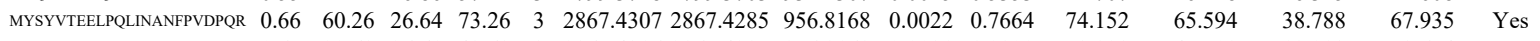
$\begin{array}{llllllllllllllll}\text { MYSYVTEELPQLNANFPVDPQR } & 0.67 & 29.63 & 26.61 & 42.63 & 3 & 2867.4316 & 2867.4285 & 956.8168 & 0.0031 & 1.0800 & 53.828 & 45.708 & 13.993 & 53.674 & \text { Yes }\end{array}$

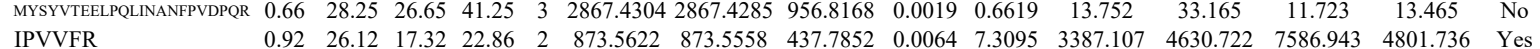

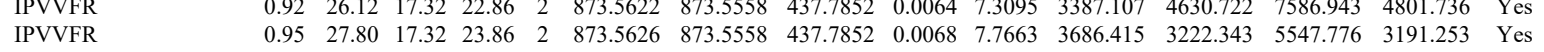
$\begin{array}{llllllllllllllll}\text { IPVVFR } & 0.90 & 23.11 & 16.72 & 23.20 & 2 & 873.5638 & 873.5558 & 437.7852 & 0.0080 & 9.1368 & 4837.286 & 5087.034 & 7676.649 & 4919.552 & \text { Yes } \\ \text { KIPVVFR } & 0.78 & 19.38 & 16.53 & 26.63 & 2 & 1145.568 & 1145.528 & 573.883 & 0.00 & 3.450 & 593.142 & 5747.139 & 721.434 & 933.76 & \text { No }\end{array}$ $\begin{array}{llllllllllllllllll}\text { KIPVVFR } & 0.78 & 19.38 & 16.53 & 26.63 & 2 & 1145.7568 & 1145.7528 & 573.8837 & 0.0040 & 3.4850 & 5923.142 & 5747.139 & 721.434 & 9336.761 & \text { No }\end{array}$

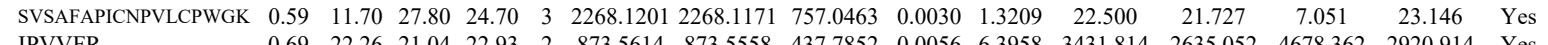
$\begin{array}{llllllllllllllll}\text { IPVVFR } & 0.69 & 22.26 & 21.04 & 22.93 & 2 & 873.5614 & 873.5558 & 437.7852 & 0.0056 & 6.3958 & 3431.814 & 2635.052 & 4678.362 & 2920.914 & \text { Yes }\end{array}$

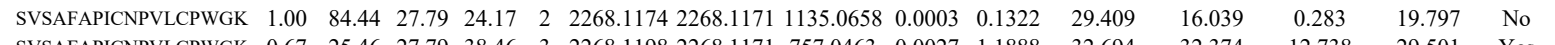

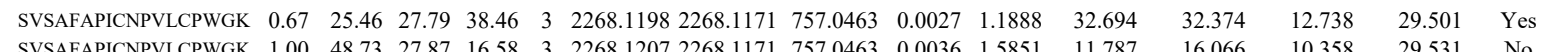

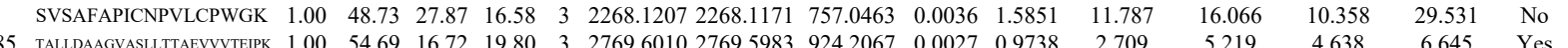

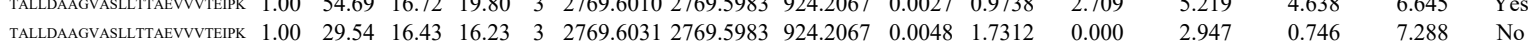

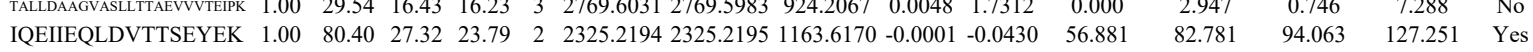

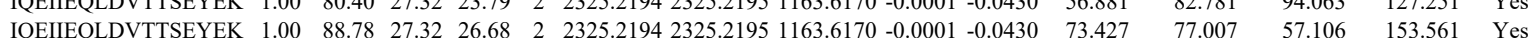
$\begin{array}{llllllllllllllll}\text { IQEIIEQLDVTTSEYEK } & 1.00 & 50.76 & 27.10 & 19.36 & 3 & 2325.2227 & 2325.2195 & 776.0804 & 0.0032 & 1.3744 & 16.728 & 71.160 & 104.638 & 28.557 & \text { No }\end{array}$

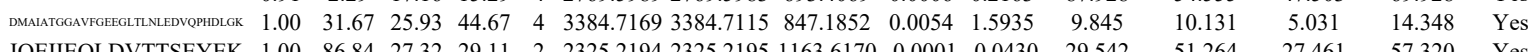
$\begin{array}{llllllllllllllll}\text { IQEIIEQLDVTTSEYEK } & 1.00 & 86.84 & 27.32 & 29.11 & 2 & 2325.2194 & 2325.2195 & 1163.6170 & -0.0001 & -0.0430 & 29.542 & 51.264 & 27.461 & 57.320 & \text { Yes } \\ \text { IQEIIEQLDVTTSEYEK } & 1.00 & 63.63 & 27.15 & 20.10 & 3 & 2325.2233 & 2325.2195 & 776.0804 & 0.0038 & 1.6321 & 12.181 & 14.777 & 0.000 & 0.000 & \text { No }\end{array}$

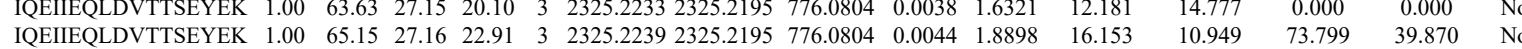

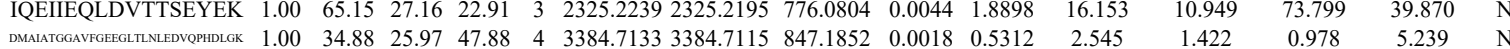

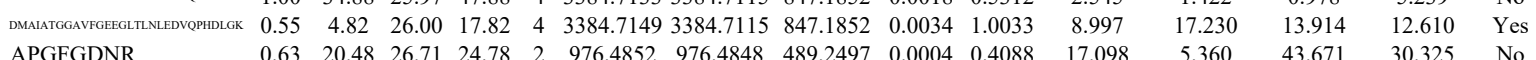
$\begin{array}{lllllllllllllllll}\text { APGGDNR } & 0.63 & 20.48 & 26.71 & 24.78 & 2 & 976.4852 & 976.4848 & 489.2497 & 0.0004 & 0.4088 & 17.098 & 5.360 & 43.671 & 30.325 & \text { No } \\ \text { APGFGDNR } & 0.90 & 27.58 & 26.71 & 24.21 & 2 & 976.4852 & 976.4848 & 4892497 & 0.0004 & 0.4088 & 9.623 & 7.560 & 31.755 & 36.654 & \text { Yes }\end{array}$

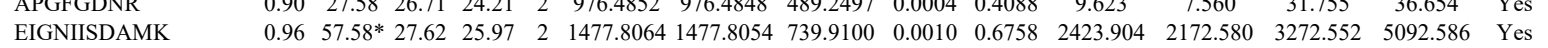
$\begin{array}{lllllllllllllll}\text { EIGNIISDAMK } & 0.95 & 55.36 * 27.66 & 25.63 & 2 & 1477.8068 & 1477.8054 & 739.9100 & 0.0014 & 0.9461 & 4370.653 & 4523.020 & 5619.916 & 10190.383 & \text { Yes }\end{array}$ $\begin{array}{lllllllllllllllll}\text { IQEIIEQLDVTTSEYEK } & 1.00 & 59.81 & 27.15 & 19.28 & 3 & 2325.2233 & 2325.2195 & 776.0804 & 0.0038 & 1.6321 & 14.671 & 21.498 & 5.368 & 17.649 & \text { Yes }\end{array}$

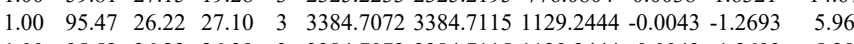

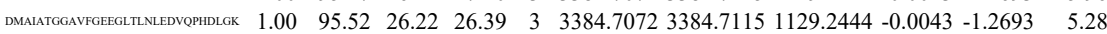
$\begin{array}{lllllllllllll}\text { DMAATGGAVGGEGLLTINLEDVPHDLGK } & 1.00 & 76.92 & 26.06 & 24.45 & 3 & 3384.7102 & 3384.7115 & 1129.2444 & -0.0013 & -0.3837 & 4.238\end{array}$ $\begin{array}{lllllllllllll} & 0.99 & 17.57 & 26.02 & 30.57 & 4 & 3384.7121 & 3384.7115 & 847.1852 & 0.0006 & 0.1771 & 18.095\end{array}$

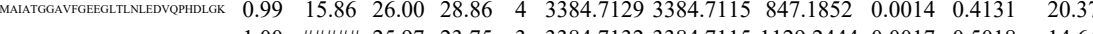
$\begin{array}{llllllllllll}1.00 & \text { man\# } 25.97 & 23.75 & 3 & 3384.7132 & 3384.7115 & 1129.2444 & 0.0017 & 0.5018 & 14.641\end{array}$ \begin{tabular}{llllllllllll}
1.00 & 0.66 & 95.29 & 25.97 & 23.75 & 3 & 3384.7132 & 3384.7115 & 1129.2444 & 0.0017 & 0.5018 & 14.641 \\
\hline & 3 & 384.7132 & 3384.7115 & 1129.2444 & 0.0017 & 0.5018 & 3.447
\end{tabular} $\begin{array}{llllllllllll} & \end{array}$

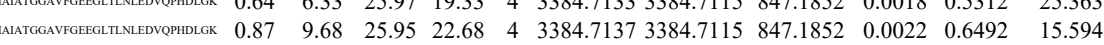

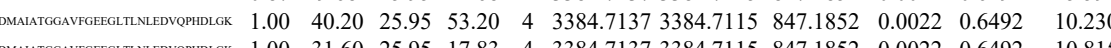

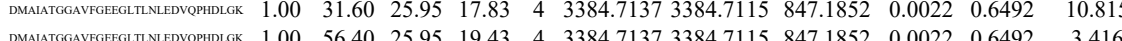




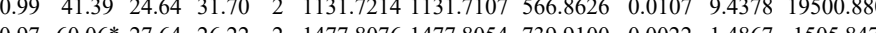
$\begin{array}{llllllllllll} & 1.00 & 55.61 & 27.36 & 27.11 & 2 & 1477.8080 & 1477.8054 & 739.9100 & 0.0026 & 1.7570 & 2343.424\end{array}$ $\begin{array}{lllllllllllll}\text { CIPALDSLTPANEDQK } & 1.00 & 82.62 & 27.54 & 21.68 & 2 & 2048.0174 & 2048.0162 & 1025.0154 & 0.0012 & 0.5854 & 338.341\end{array}$ $\begin{array}{llllllllllllll}\text { TALLDAGVVASLTTAEVVVTEIPK } & 0.67 & 13.24 & 16.72 & 26.24 & 3 & 2769.6010 & 2769.5983 & 924.2067 & 0.0027 & 0.9738 & 22.258\end{array}$ $\begin{array}{lllllllllllll}\text { INLDAGVASLTTAEVYVTEPKK } & 0.67 & 30.49 & 16.72 & 43.49 & 3 & 2769.6016 & 2769.5983 & 924.2067 & 0.0033 & 1.1902 & 15.2895\end{array}$ $\begin{array}{llllllllllll}\text { IALDAGVYSLTTAEYYTEPK } & 0.83 & 0.51 & 16.02 & 13.51 & 4 & 27696053 & 2769.5983 & 693.4069 & 0.0070 & 2.5238 & 62.677\end{array}$ $\begin{array}{llllllllllll}\text { IMESSSEVGYDAMAGDFVNMVEK } & 0.97 & 22.54 & 26.27 & 17.18 & 3 & 2795.3080 & 2795.3060 & 932.7759 & 0.0020 & 0.7147 & 5.053\end{array}$ $\begin{array}{llllllllllll} & 24.04 & 3384.7102 & 3384.7115 & 1129.2444 & -0.0013 & -0.3837 & 15.476\end{array}$

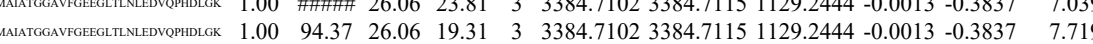

DMA

DMAAT

DMAIA

\section{DМА}

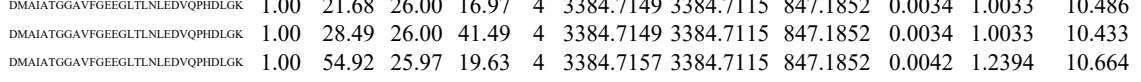
$\begin{array}{llllllllllll}\text { DMALATGGAVGEEGLIINLEDVPPHDLGK } & 1.00 & 19.35 & 25.97 & 15.51 & 4 & 3384.7157 & 3384.7115 & 847.1852 & 0.0042 & 1.2394 & 9.568\end{array}$

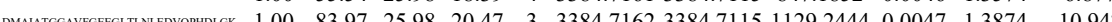
$\begin{array}{lllllllllllll}\text { DMALTGGAVGGEGLINILEDVPPDLCKK } & 1.00 & 98.72 & 25.98 & 19.49 & 3 & 3384.7162 & 3384.7115 & 1129.2444 & 0.0047 & 1.3874 & 6.941\end{array}$

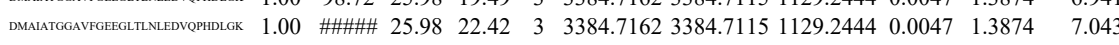
$\begin{array}{llllllllllll}\text { DMALATGGAVGGEGLLINLLEVVPHDLCKK } & 1.00 & \text { \#\#\#\# } 25.98 & 24.71 & 3 & 3384.7162 & 3384.7115 & 1129.2444 & 0.0047 & 1.3874 & 0.000\end{array}$

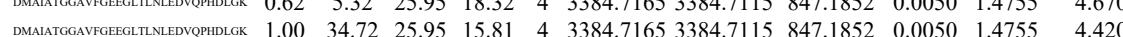
$\begin{array}{llllllllllll} & 3284.7177 & 384.71115 & 847.1852 & 0.0062 & 1.8296 & 13.525\end{array}$

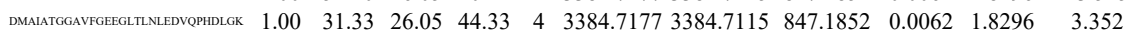
$\begin{array}{llllllllllll}\text { DMAAATGGAVIGEGGLITILEDVUPHDLGK } & 1.00 & 57.46 & 26.00 & 18.14 & 4 & 3384.7185 & 3384.7115 & 847.1852 & 0.0070 & 2.0657 & 7.980\end{array}$

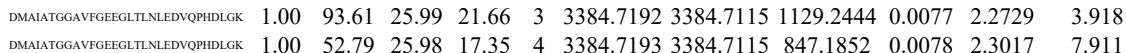
VGEVIVTK $\begin{array}{llllllllllll}1.00 & 52.79 & 25.98 & 17.35 & 4 & 3384.7193 & 3384.7115 & 847.1852 & 0.0078 & 2.3017 & 7 .\end{array}$ $\begin{array}{lllllllllllll} & 1.00 & 51.78 & 24.64 & 31.21 & 2 & 1131.7218 & 1131.7107 & 566.8626 & 0.0111 & 9.7906 & 22997.992\end{array}$

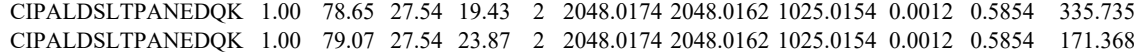
$\begin{array}{llllllllllllll}\text { CIPALDSLTPANEDQK } & 0.91 & 19.10 & 27.52 & 18.81 & 3 & 2048.0197 & 2048.0162 & 683.6793 & 0.0035 & 1.7065 & 3976.602\end{array}$ $\begin{array}{lllllllllllll}\text { TALLDAAGVASLLTAEVVVTEIPK } & 0.55 & 17.07 & 17.16 & 30.07 & 3 & 2769.5989 & 2769.5983 & 924.2067 & 0.0006 & 0.2164 & 10.729\end{array}$ $\begin{array}{llllllllllll}\text { IMQSSSEVGYDAMAGDFNNMVEK } & 0.71 & 19.44 & 26.21 & 14.29 & 3 & 2795.3047 & 2795.3060 & 932.7759 & -0.0013 & -0.4646 & 10.535\end{array}$

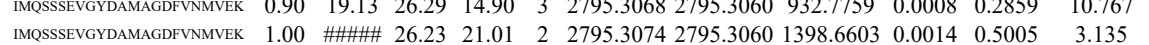

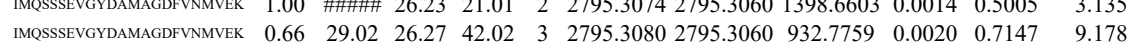
$\begin{array}{llllllllllll}\text { IMQSSSEVGYDAMAGDFVNMVEK } & 0.67 & 28.49 & 26.30 & 41.49 & 3 & 2795.3080 & 2795.3060 & 932.7759 & 0.0020 & 0.7147 & 9.178 \\ \end{array}$ $\begin{array}{llllllllllll}\text { IMQSSSEVGYDAMAGDFVNMVEK } & 1.00 & 33.85 & 26.30 & 19.87 & 3 & 2795.3092 & 2795.3060 & 932.7759 & 0.0032 & 1.1435 & 13.102\end{array}$ $\begin{array}{llllllllllll}\text { IMQSSSEVGYDAMAGDFVNMVK } & 1.00 & 94.66 & 26.32 & 24.24 & 3 & 2795.3098 & 2795.3060 & 932.7759 & 0.0038 & 1.3580 & 12.220\end{array}$

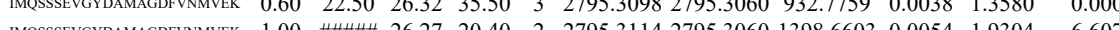

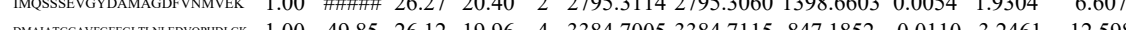

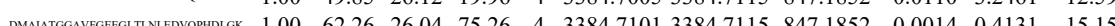

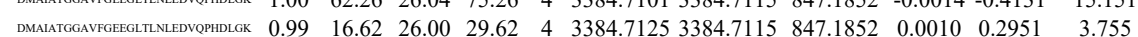




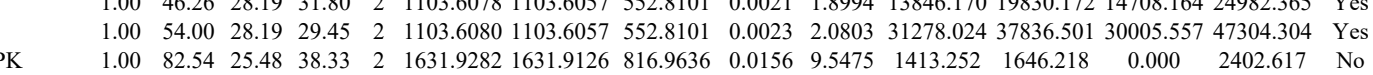
$\begin{array}{lllllllllllllllll} & 1.00 & 82.54 & 25.48 & 38.33 & 2 & 1631.9282 & 1631.9126 & 816.9636 & 0.0156 & 9.5475 & 1413.252 & 1646.218 & 0.000 & 2402.617 & \text { No }\end{array}$

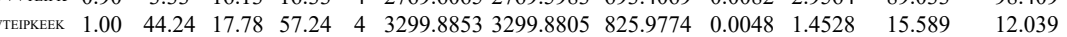
$\begin{array}{lllllllllllll} & \end{array}$

TVIIEQSWGSPK

$\begin{array}{llllllllllll} & \end{array}$

$\begin{array}{llllllllllll} & & 163.9288 & 1631.9126 & 816.9636 & 0.0162 & 9.9147 & 710.532\end{array}$

$\begin{array}{llllllllllll} & \end{array}$

$\begin{array}{lllllllllll}0.66 & 13.16 & 19.34 & 26.16 & 3 & 2652.5326 & 2652.5305 & 885.1841 & 0.0021 & 0.7908 & 10.403\end{array}$

MLVIIAEDVDGEALSTLVLNR $\begin{array}{lllllllllllll}0.66 & 55.35 & 19.40 & 68.35 & 3 & 2652.5329 & 2652.5305 & 885.1841 & 0.0024 & 0.9038 & 0.000\end{array}$

$\begin{array}{lllllllllllll}\text { KPLVIIAEDVDGEALSTLVLNR } & 0.67 & 9.07 & 19.29 & 22.07 & 3 & 2652.5335 & 2652.5305 & 885.1841 & 0.0030 & 1.1297 & 16.000\end{array}$

\begin{tabular}{llllllllllll} 
KPLVIIAEDVDGEALSTLVLNR & 0.67 & \#\#\#\# & 19.24 & \#\#\# & 3 & 2652.5338 & 2652.5305 & 885.1841 & 0.0033 & 1.2427 & 11.444 \\
\hline
\end{tabular}

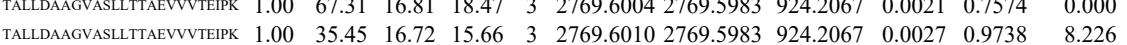
$\begin{array}{lllllllllllll}\text { TALDAAGVASLITAEVVVTEPRK } & 1.00 & 14.37 & 16.43 & 27.37 & 4 & 2769.6033 & 2769.5983 & 693.4069 & 0.0050 & 1.8027 & 64.760\end{array}$ $\begin{array}{llllllllllllll}\text { ALLDAGGVALLTTAEVVVTEIPK } & 1.00 & 32.67 & 16.02 & 45.67 & 4 & 2769.6057 & 2769.5983 & 693.4069 & 0.0074 & 2.6680 & 82.874\end{array}$ $\begin{array}{llllllllllllll}\text { MLDAAGVASLLTAEVVUTEPREFK } & 1.00 & 48.51 & 17.63 & 61.51 & 4 & 3299.8877 & 3299.8805 & 825.9774 & 0.0072 & 2.1792 & 25.775\end{array}$ $\begin{array}{lllllllllllll} & 30.47 & 17.32 & 43.47 & 4 & 3299.8965 & 3299.8805 & 825.9774 & 0.0760 & 4.8427 & 0.060\end{array}$

IGIEIIK

TVIIEQSWGSPK

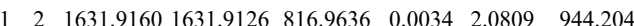

$\begin{array}{llllllllllll}1.00 & 73.32 & 25.84 & 32.36 & 2 & 1631.9172 & 1631.9126 & 816.9636 & 0.0046 & 2.8153 & 538.110\end{array}$

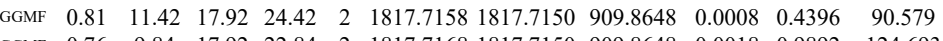
$\begin{array}{llllllllllll} & 0.7177168 & 1817.7150 & 909.8648 & 0.0018 & 0.9892 & 124.693\end{array}$ $\begin{array}{llllllllllll}\text { KPLVIIAEDVDGEALSTLVLNR } & 1.00 & 77.01 & 19.59 & 90.01 & 4 & 2652.5301 & 2652.5305 & 664.1399 & -0.0004 & -0.1506 & 72.366\end{array}$ $\begin{array}{lllllllllllll}\text { KPLVIIAEDVDGEALSTLVLNR } & 1.00 & 76.51 & 19.59 & 89.51 & 4 & 2652.5301 & 2652.5305 & 664.1399 & -0.0004 & -0.1506 & 78.950 \\ 8\end{array}$ \begin{tabular}{lllllllllllll} 
& CLLVIAEDVDGEALSTLVLNR & 1.00 & 30.79 & 19.54 & 43.79 & 4 & 2652.5309 & 2652.5305 & 664.1399 & 0.0004 & 0.1506 & 113.905 \\
\hline
\end{tabular}

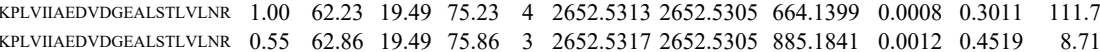
$\begin{array}{llllllllllll}\text { KPLVIIAEDVDGEALSTLVLNR } & 0.55 & 84.32 & 19.49 & 97.32 & 3 & 2652.5317 & 2652.5305 & 885.1841 & 0.0012 & 0.4519 & 5.772\end{array}$ $\begin{array}{lllllllllllll}\text { KPLVIIAEDVDGEALSTLVLNR } & 1.00 & 82.04 & 19.34 & 95.04 & 4 & 2652.5321 & 2652.5305 & 664.1399 & 0.0016 & 0.6023 & 18.551\end{array}$

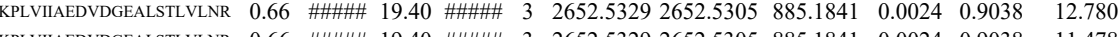

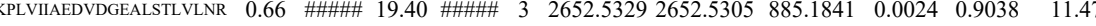
$\begin{array}{llllllllllll}\text { KPLVIIAEDVDGEALSTLVLNR } & 0.66 & 81.21 & 19.40 & 94.21 & 3 & 2652.5329 & 2652.5305 & 885.1841 & 0.0024 & 0.9038 & 2.290\end{array}$ $\begin{array}{lllllllllllll}\text { KPLVIIAEDVDGEALSTLVLNR } & 0.66 & 71.88 & 19.40 & 84.88 & 3 & 2652.5329 & 2652.5305 & 885.1841 & 0.0024 & 0.9038 & 2.976\end{array}$

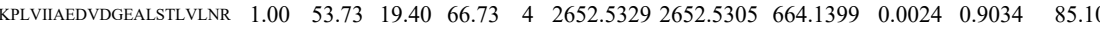
$\begin{array}{lllllllllllll}\text { KPLVIIAEDVDGEALSTLVLNR } & 0.67 & 86.70 & 19.40 & 99.70 & 3 & 2652.5332 & 2652.5305 & 885.1841 & 0.0027 & 1.0167 & 18.074\end{array}$ $\begin{array}{llllllllllll}\text { KPLVIIAEDVDGEALSTLVLNR } & 0.67 & 70.90 & 19.40 & 83.90 & 3 & 2652.5332 & 2652.5305 & 885.1841 & 0.0027 & 1.0167 & 6.604\end{array}$ $\begin{array}{lllllllllllll}\text { KPLVIIAEDVDGEALSTLVLNR } & 0.67 & 39.36 & 19.40 & 52.36 & 3 & 2652.5332 & 2652.5305 & 885.1841 & 0.0027 & 1.0167 & 6.35\end{array}$ $\begin{array}{lllllllllllll}\text { KPLVIIAEDVDGEALSTLVLNR } & 0.67 & 88.54 & 19.40 & \text { \#\#\#\# } & 3 & 2652.5332 & 2652.5305 & 885.1841 & 0.0027 & 1.0167 & 0.000 \\ \text { KPLVIIAEDVDGEALSTLVLNR } & 0.67 & 73.14 & 19.40 & 86.14 & 3 & 2652.5332 & 2652.5305 & 885.1841 & 0.0027 & 1.0167 & 1.61\end{array}$

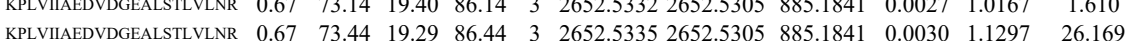
$\begin{array}{llllllllllll}\text { KPLVIIAEDVDGEALSTLVLNR } & 0.67 & 73.44 & 19.29 & 86.44 & 3 & 2652.5335 & 2652.5305 & 885.1841 & 0.0030 & 1.1297 & 26.169 \\ \text { KPLVIIAEDVDGEALSTLVLNR } & 1.00 & 50.90 & 19.29 & 63.90 & 4 & 2652.5337 & 2652.5305 & 664.1399 & 0.0032 & 1.2046 & 113.155\end{array}$ $\begin{array}{lllllllllllll}\text { KPLVIIAEDVDGEALSTLVLNR } & 0.67 & 58.14 & 19.24 & 71.14 & 3 & 2652.5338 & 2652.5305 & 885.1841 & 0.0033 & 1.2427 & 7.342\end{array}$ $\begin{array}{lllllllll} & 1.2427 & 9.764\end{array}$

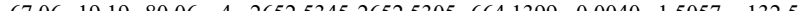
49.125

1194.660

\begin{tabular}{llll}
130.923 & No \\
\hline & 70.480 & 1540.535 & Yes
\end{tabular}

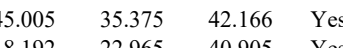

5.747

5.24

52.620

6.843

6.357
80.178

76.31

0.000

3686.686

562.017



$\begin{array}{llllllllllll}1 & \end{array}$

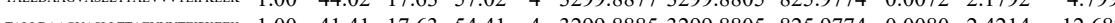
IGIEIIK

$\begin{array}{llllllllllll}0.89 & 32.34 & 19.44 & 34.61 & 2 & 1072.7194 & 1072.7099 & 537.3622 & 0.0095 & 8.8394 & 9180.519 & 996\end{array}$

$\begin{array}{ccccccccccc}0.89 & 32.34 & 19.44 & 34.61 & 2 & 1072.7194 & 1072.7099 & 537.3622 & 0.0095 & 8.8394 & 9180.519 \\ 0.94 & 33.50 & 19.44 & 34.42 & 2 & 1072.7196 & 1072.7099 & 537.3622 & 0.0097 & 9.0255 & 11915.336\end{array}$

$\begin{array}{llllllllllll}\text { GVMLAVDAVIAELK } & 0.98 & 24.57 & 23.14 & 21.10 & 3 & 1716.0100 & 1716.0099 & 573.0106 & 0.0001 & 0.0582 & 190.213 \\ \text { GVMLAVDAVIAELK } & 0.93 & 19.70 & 23.14 & 16.74 & 3 & 1716.0103 & 1716.0099 & 573.0106 & 0.0004 & 0.2327 & 81.552\end{array}$

$\begin{array}{llllllllllll}\text { GVMLAVDAVIAELK } & 0.78 & 12.53 & 23.07 & 15.88 & 3 & 1716.0109 & 1716.0099 & 573.0106 & 0.0010 & 0.5817 & 161.158\end{array}$

$\begin{array}{llllllllllll}\text { GVMLAVDAVIAELK } & 1.00 & 35.94 & 23.07 & 18.59 & 3 & 1716.0115 & 1716.0099 & 573.0106 & 0.0016 & 0.9308 & 119.510\end{array}$

$\begin{array}{lllllllllllll}\text { GVMLAVDAVIAELK } & 1.00 & 52.47 & 22.99 & 23.00 & 3 & 1716.0118 & 1716.0099 & 573.0106 & 0.0019 & 1.1053 & 91.435\end{array}$

$\begin{array}{llllllllllll}\text { GVMLAVDAVIAELK } & 1.00 & \text { \#\#\#\# } 23.12 & 33.87 & 2 & 1716.0122 & 1716.0099 & 859.0122 & 0.0023 & 1.3387 & 122.459\end{array}$ $\begin{array}{llllllllllll}\text { GVMLAVDAVIAELK } & 1.00 & 40.65 & 23.12 & 24.03 & 3 & 1716.0124 & 1716.0099 & 573.0106 & 0.0025 & 1.4543 & 81.118\end{array}$ $\begin{array}{llllllllllll}\text { GVMLAVDAVIAELK } & 1.00 & 51.07 & 23.12 & 30.16 & 3 & 1716.0124 & 1716.0099 & 573.0106 & 0.0025 & 1.4543 & 494.466 \\ \text { GVMLAVDAVIAELK } & 1.00 & \# \# \# \# 23.12 & 26.31 & 2 & 1716.0124 & 1716.0099 & 859.0122 & 0.0025 & 1.4552 & 236.061\end{array}$ $\begin{array}{lllllllllllll}\text { GVMLAVDAVIAELK } & 1.00 & 27.31 & 23.14 & 19.67 & 3 & 1716.0127 & 1716.0099 & 573.0106 & 0.0028 & 1.6288 & 170.060\end{array}$ $\begin{array}{lllllllllllll}\text { GVMLAVDAVIAELK } & 1.00 & 51.98 & 23.14 & 24.96 & 3 & 1716.0127 & 1716.0099 & 573.0106 & 0.0028 & 1.6288 & 129.977\end{array}$ $\begin{array}{llllllllllll}\text { GVMLAVDAVIAELK } & 0.91 & 15.81 & 23.42 & 22.54 & 3 & 1716.0130 & 1716.0099 & 573.0106 & 0.0031 & 1.8033 & 164.335\end{array}$

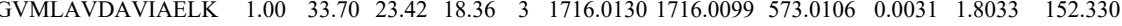
$\begin{array}{lllllllllllll}\text { GVMLAVDAVIAELK } & 0.94 & 16.31 & 23.34 & 18.21 & 3 & 1716.0133 & 1716.0099 & 573.0106 & 0.0034 & 1.9779 & 135.791\end{array}$

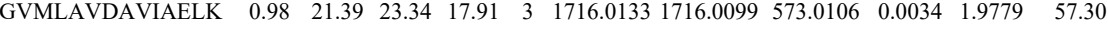
$\begin{array}{llllllllllll}\text { KPLVIIAEDVDGEALSTLVLNR } & 1.00 & 44.54 & 19.91 & 57.54 & 4 & 2652.5269 & 2652.5305 & 664.1399 & -0.0036 & -1.3551 & 40.547\end{array}$ $\begin{array}{llllllllllll}\text { KPLVIIAEDVDGEALSTLVLNR } & 1.00 & 32.61 & 19.59 & 45.61 & 4 & 2652.5297 & 2652.5305 & 664.1399 & -0.0008 & -0.3011 & 53.619\end{array}$ $\begin{array}{llllllllllll}\text { KPLVIIAEDVDGEALSTLVLNR } & 0.55 & 47.59 & 19.34 & 60.59 & 3 & 2652.5320 & 2652.5305 & 885.1841 & 0.0015 & 0.5649 & 32.835\end{array}$ $\begin{array}{lllllllllllll}\text { KPLVIIAEDVDGEALSTLVLNR } & 1.00 & 57.89 & 19.34 & 70.89 & 4 & 2652.5321 & 2652.5305 & 664.1399 & 0.0016 & 0.6023 & 68.482\end{array}$ $\begin{array}{lllllllllllll}\text { KPLVIIAEDVDGEALSILVINR } & 0.66 & 73.58 & 19.34 & 86.58 & 3 & 2652.5323 & 2652.5305 & 885.1841 & 0.0018 & 0.6778 & 15.388\end{array}$ $\begin{array}{lllllllllllll}\text { KPLVIIAEDVDGEALSTLVLNR } & 0.67 & 86.24 & 19.24 & 99.24 & 3 & 2652.5338 & 2652.5305 & 885.1841 & 0.0033 & 1.2427 & 6.385\end{array}$ $\begin{array}{llllllllllll}\text { KPLVIIAEDVDGEALSTLVLNR } & 1.00 & 70.08 & 18.75 & 83.08 & 4 & 2652.5377 & 2652.5305 & 664.1399 & 0.0072 & 2.7103 & 65.681 \\ \text { TALLDAAGVASLTTAEVVVTEIPK } & 0.96 & 2.11 & 16.43 & 15.11 & 4 & 2769.6033 & 2769.5983 & 693.4069 & 0.0050 & 1.8027 & 107.699\end{array}$

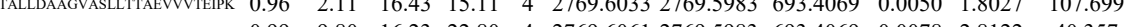
$\begin{array}{llllllllllll}\text { GVMLAVDAVIAELK } & 1.00 & 31.50 & 23.14 & 20.17 & 3 & 1716.0106 & 1716.0099 & 573.0106 & 0.0007 & 0.4072 & 145.384\end{array}$ $\begin{array}{lllllllllllll}\text { GVMLAVDAVIAELK } & 1.00 & 53.17 & 23.10 & 22.83 & 3 & 1716.0112 & 1716.0099 & 573.0106 & 0.0013 & 0.7562 & 41.295\end{array}$ $\begin{array}{llllllllllll}\text { GVMLAVDAVIAELK } & 1.00 & 92.35 & 22.99 & 27.91 & 2 & 1716.0116 & 1716.0099 & 859.0122 & 0.0017 & 0.9895 & 334.446\end{array}$ $\begin{array}{llllllllllll}\text { GVMLAVDAVIAELK } & 1.00 & 32.11 & 22.99 & 15.89 & 3 & 1716.0118 & 1716.0099 & 573.0106 & 0.0019 & 1.1053 & 177.035\end{array}$ $\begin{array}{lllllllllllll}\text { GVMLAVDAVIAELK } & 0.94 & 16.31 & 22.99 & 15.42 & 3 & 1716.0118 & 1716.0099 & 573.0106 & 0.0019 & 1.1053 & 147.410\end{array}$ $\begin{array}{llllllllllll}\text { GVMLAVDAVIAELK } & 1.00 & 48.14 & 22.99 & 20.07 & 3 & 1716.0118 & 1716.0099 & 573.0106 & 0.0019 & 1.1053 & 26.582 \\ \end{array}$ $\begin{array}{llllllllllll}\text { GVMLAVDAVIAELK } & 0.99 & 26.94 & 23.12 & 24.98 & 3 & 1716.0121 & 1716.0099 & 573.0106 & 0.0022 & 1.2798 & 109.652\end{array}$

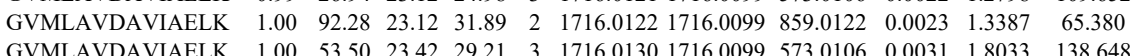

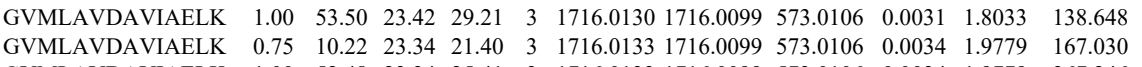
$\begin{array}{lllllllllllll}\text { GVMLAVDAVIAELK } & 1.00 & 52.48 & 23.34 & 25.41 & 3 & 1716.0133 & 1716.0099 & 573.0106 & 0.0034 & 1.9779 & 367.246\end{array}$

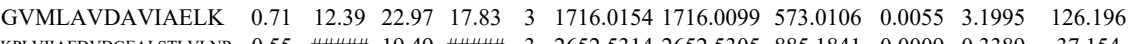

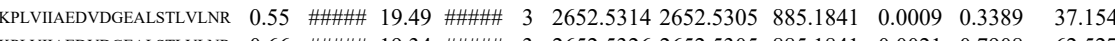

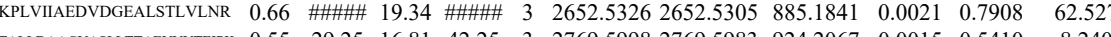
$\begin{array}{lllllllllllll}\text { TALLDAAGVASLLTTAEVVVTEIPK } & 0.55 & 29.25 & 16.81 & 42.25 & 3 & 2769.5998 & 2769.5983 & 924.2067 & 0.0015 & 0.5410 & 8.240\end{array}$

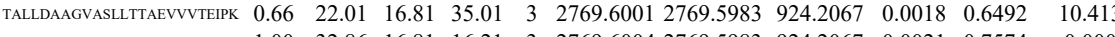

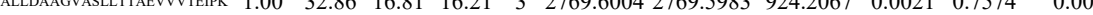

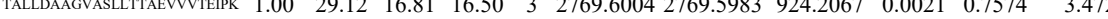
$\begin{array}{lllllllllllll}\text { TALLDAGGVASLLTTAEVVVTEIPK } & 0.96 & 23.08 & 16.72 & 26.23 & 3 & 2769.6007 & 2769.5983 & 924.2067 & 0.0024 & 0.8656 & 3.156\end{array}$ $\begin{array}{llllllllllll}\text { IALLDAAGVASLLTTAEVVVTEPKK } & 0.67 & 43.52 & 16.72 & 56.52 & 3 & 2769.6010 & 2769.5983 & 924.2067 & 0.0027 & 0.9738 & 9.727\end{array}$ $\begin{array}{llllllllllll}\text { TALLDAGGASLLTTAEVVVTEPKK } & 0.67 & 27.38 & 16.72 & 40.38 & 3 & 2769.6010 & 2769.5983 & 924.2067 & 0.0027 & 0.9738 & 9.637\end{array}$ $\begin{array}{cccccccccccc}\text { TALLDAAGVASLLTTAEVVVTEIPKK } & 0.60 & 43.09 & 16.72 & 56.09 & 3 & 2769.6019 & 2769.5983 & 924.2067 & 0.0036 & 1.2984 & 2.604 \\ \text { TUDAAGVALITAEVYVTEPKK } & 0.98 & 4.44 & 16.33 & 17.44 & 4 & 2769.6045 & 2769.5983 & 693.4069 & 0.0062 & 2.2353 & 102.119\end{array}$ $\begin{array}{lllllllllllll}\text { TALLDAGVASLLTAEVVVTEIPKK } & 0.98 & 4.44 & 16.33 & 17.44 & 4 & 2769.6045 & 2769.5983 & 693.4069 & 0.0062 & 2.2353 & 102.119 \\ \text { TALDAAGVASLITAEVVVTFIPK } & 1.00 & 13.91 & 16.13 & 14.10 & 4 & 2769.6065 & 2769.5983 & 693.4069 & 0.0082 & 2.9564 & 88.260\end{array}$ $\begin{array}{lllllllllllll}\text { GVMLAVDAVIAELK } & 1.00 & 38.31 & 23.14 & 20.38 & 3 & 1716.0103 & 1716.0099 & 573.0106 & 0.0004 & 0.2327 & 145.422\end{array}$

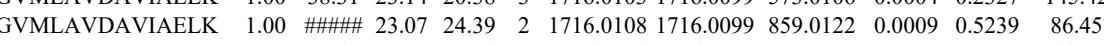
$\begin{array}{llllllllllllll} & \end{array}$

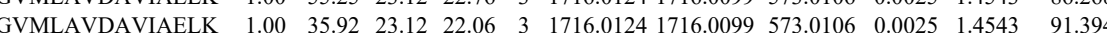
$\begin{array}{lllllllllllll}\text { AAVEEGIVLGGGCALLR } & 1.00 & 37.04 & 28.10 & 15.68 & 3 & 1816.9699 & 1816.9661 & 606.6626 & 0.0038 & 2.0879 & 35.970\end{array}$ 

$\begin{array}{lllllllllllll}\text { TALLDAAGVASLLTAAEVVVTEIPK } & 1.00 & 71.46 & 16.72 & 23.38 & 3 & 2769.6016 & 2769.5983 & 924.2067 & 0.0033 & 1.1902 & 3.016\end{array}$ $\begin{array}{llllllllllll}\text { TALLDAGGVASLITAEVVVTEIRK } & 0.92 & 1.29 & 16.72 & 14.29 & 4 & 2769.6017 & 2769.5983 & 693.4069 & 0.0034 & 1.2258 & 22.226\end{array}$ $\begin{array}{llllllllllll}\text { TALDAAGVASLLTTAEVVVTEPK } & 1.00 & 67.67 & 16.72 & 19.10 & 3 & 2769.6019 & 2769.5983 & 924.2067 & 0.0036 & 1.2984 & 3.932 \\ \text { TALDAGGVSLTTAEVYVTEPK } & 0.97 & 3.65 & 16.72 & 16.65 & 4 & 2769.6021 & 2769.5983 & 693.4069 & 0.0038 & 1.3700 & 21.980\end{array}$

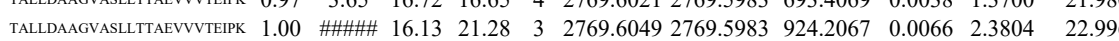

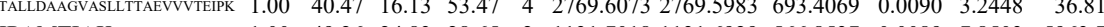
$\begin{array}{lllllllllllll}\text { TALLDAGVASLLTAEVVVTEPKK } & 1.00 & 59.94 & 16.72 & 23.24 & 3 & 2769.6007 & 2769.5983 & 924.2067 & 0.0024 & 0.8656 & 5.476\end{array}$

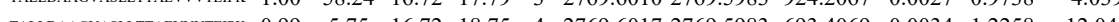
\begin{tabular}{llllllllllllll}
\hline & 1
\end{tabular} $\begin{array}{llllllllllll} & 2.862\end{array}$

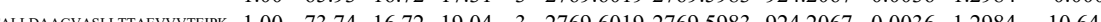
$\begin{array}{llllllllllllll}\text { TNDDAGVASLTTAEVYVTEPKK } & 0.97 & 3.20 & 16.43 & 16.20 & 4 & 2769.6037 & 2769.5983 & 693.4069 & 0.0054 & 1.9469 & 95.031\end{array}$

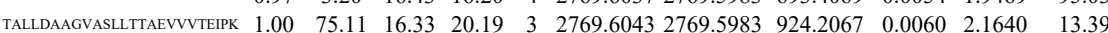

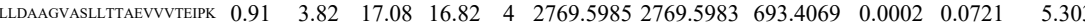
$\begin{array}{llllllllllll}\text { TALLDAGVASLLTAEVVVTEIPK } & 1.00 & 29.43 & 16.99 & 18.42 & 3 & 2769.5992 & 2769.5983 & 924.2067 & 0.0009 & 0.3246 & 11.139\end{array}$ $\begin{array}{lllllllllllll}\text { TALLDAGVASLITAEVVVTEIPK } & 1.00 & 50.51 & 16.81 & 19.71 & 3 & 2769.5998 & 2769.5983 & 924.2067 & 0.0015 & 0.5410 & 8.778\end{array}$ $\begin{array}{lllllllllllll} & \text { ALLDAGVASLLTTAEVVVTEPKK } & 0.99 & 20.41 & 16.81 & 19.59 & 3 & 2769.6001 & 2769.5983 & 924.2067 & 0.0018 & 0.6492 & 5.384\end{array}$ $\begin{array}{lllllllllllll}\text { MALDAAGVASLITAEVVVTEPKK } & 0.66 & 31.91 & 16.81 & 44.91 & 3 & 2769.6004 & 2769.5983 & 924.2067 & 0.0021 & 0.7574 & 5.76\end{array}$ $\begin{array}{lllllllllllll} & \text { MLDAAGVASLITAEVVVTEIPK } & 1.00 & 23.01 & 16.72 & 15.20 & 3 & 2769.6010 & 2769.5983 & 924.2067 & 0.0027 & 0.9738 & 16.526\end{array}$ $\begin{array}{lllllllllll}16.72 & 20.36 & 3 & 2769.6013 & 2769.5983 & 924.2067 & 0.0030 & 1.0820 & 2.469\end{array}$

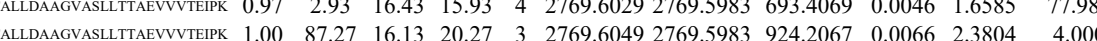
$\begin{array}{lllllllllllll} & \end{array}$ 

$\begin{array}{lllllllllllll}\text { LLMLQGVDLLADAVAVTMGPK } & 1.00 & 70.23 & 23.54 & 22.50 & 3 & 2400.3394 & 2400.3364 & 801.1194 & 0.0030 & 1.2483 & 14.83\end{array}$ $\begin{array}{lllllllllll} & \end{array}$ $\begin{array}{llllllllll} & 0.934\end{array}$ $\begin{array}{llllllllll} & \end{array}$ $\begin{array}{llllllllll} & 0.003\end{array}$ $\begin{array}{llllllllll} & \end{array}$ $\begin{array}{llllllllllll} & \end{array}$

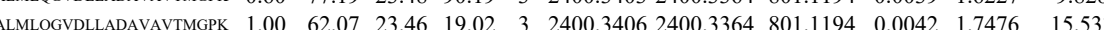

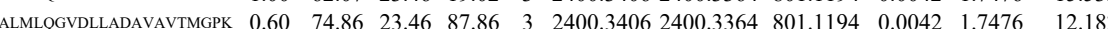
$\begin{array}{lllllllllllll}\text { ALMLQGVDLADAVAVTMGPK } & 1.00 & 62.15 & 23.38 & 19.15 & 3 & 2400.3409 & 2400.3364 & 801.1194 & 0.0045 & 1.8724 & 20.756\end{array}$

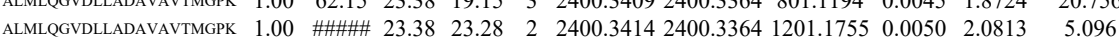
$\begin{array}{llllllllllllll}\text { aLMLQGVDLLADAVAVTMGPK } & 1.00 & 70.16 & 22.30 & 19.92 & 3 & 2400.3496 & 2400.3364 & 801.1194 & 0.0132 & 5.4923 & 1083.862\end{array}$

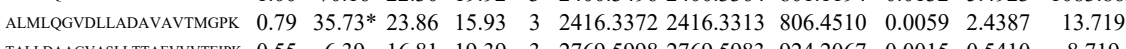
$\begin{array}{lllllllllllll}\text { TALLDAGVASLLTAEVVVTERKK } & 0.55 & 6.39 & 16.81 & 19.39 & 3 & 2769.5998 & 2769.5983 & 924.2067 & 0.0015 & 0.5410 & 8.719\end{array}$ $\begin{array}{lllllllllllll} & 16.81 & 19.39 & 3 & 269.598 & 2769.5983 & 924.2067 & 0.0015 & 0.5410 & 8.719\end{array}$

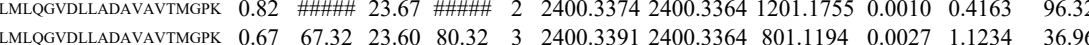
$\begin{array}{llllllllllll} & \end{array}$

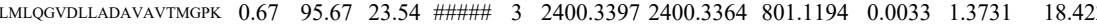

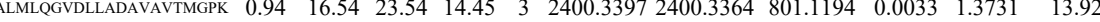
$\begin{array}{lllllllllllll}\text { ALMLQGVDLADAVAVTMGPK } & 1.00 & 73.83 & 23.48 & 21.34 & 3 & 2400.3403 & 2400.3364 & 801.1194 & 0.0039 & 1.6227 & 10.216\end{array}$ $\begin{array}{llllllllllll}\text { ALMLQGVDLLADAVAVTMGPK } & 1.00 & 70.73 & 23.48 & 24.99 & 3 & 2400.3403 & 2400.3364 & 801.1194 & 0.0039 & 1.6227 & 25.574\end{array}$ $\begin{array}{llllllllllll}\text { ALMLQGVDLLADAVAVTMGPK } & 1.00 & 51.27 & 23.48 & 18.70 & 3 & 2400.3403 & 2400.3364 & 801.1194 & 0.0039 & 1.6227 & 16.525\end{array}$ $\begin{array}{lllllllllllll}\text { ALMLQGVDLLADAVAVTMGPK } & 1.00 & 64.29 & 23.46 & 18.25 & 3 & 2400.3406 & 2400.3364 & 801.1194 & 0.0042 & 1.7476 & 19.152 \\ \text { ALMLQGVDLLADAVAVTMGPK } & 0.60 & 42.95 & 23.46 & 55.95 & 3 & 2400.3406 & 2400.3364 & 801.1194 & 0.0042 & 1.7476 & 7.795\end{array}$ $\begin{array}{llllllllllll}\text { ALMLGGVDLADAVAVTMGPK } & 0.60 & 42.95 & 23.46 & 55.95 & 3 & 2400.3406 & 2400.3364 & 801.1194 & 0.0042 & 1.7476 & 7.795 \\ \text { ALMLQGVDLLADAVAVTMGPK } & 1.00 & 88.99 & 23.46 & 23.02 & 3 & 2400.3406 & 2400.3364 & 801.1194 & 0.0042 & 1.7476 & 41.074\end{array}$ $\begin{array}{lllllllllllll}\text { ILMLQGVDLLADAVAVTMGPK } & 1.00 & 63.61 & 23.30 & 20.14 & 3 & 2400.3427 & 2400.3364 & 801.1194 & 0.0063 & 2.6213 & 5.829\end{array}$

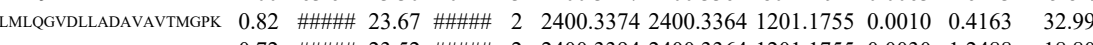
$\begin{array}{llllllllll} & \end{array}$ (1) $\begin{array}{lllllllll} & \end{array}$ $\begin{array}{lllllllllll} & 0.07\end{array}$ $\begin{array}{llllllllllll} & 1.00 & 73.89 & 23.38 & 27.26 & 3 & 24003409 & 24003364 & 801.1194 & 0.0045 & 1.8724 & 39.291\end{array}$ $\begin{array}{llllllllllll}\text { ISMLOGVDUADAVAYTMGPK } & 1.00 & 64.04 & 23.38 & 21.70 & 3 & 24003409 & 24003364 & 801.1194 & 0.0045 & 1.8724 & 33.595\end{array}$ $\begin{array}{llllllllllllll}\text { VTDALNATR } & 1.00 & 48.63 & 28.71 & 29.39 & 2 & 1103.6052 & 1103.6057 & 552.8101 & -0.0005 & 0.4522 & 582.938\end{array}$ $\begin{array}{lllllllllllll} & \text { ISSIOSIVPALEIANAHR } & 0.94 & 26.87 & 24.58 & 25.44 & 3 & 2062.1644 & 2062.1656 & 688.3958 & -0.0012 & -0.5811 & 25.175\end{array}$

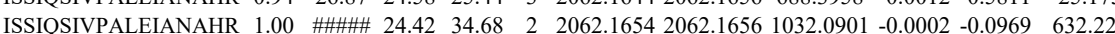

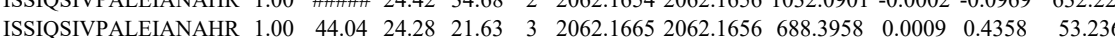
$\begin{array}{lllllllllllll}\text { ISSIQSIVPALEIANAHR } & 1.00 & 31.40 & 24.28 & 23.08 & 3 & 2062.1665 & 2062.1656 & 688.3958 & 0.0009 & 0.4358 & 45.292\end{array}$ $\begin{array}{llllllllllll}\text { ISSIQSIVPALEIANAHR } & 0.99 & 29.29 & 24.28 & 26.78 & 3 & 2062.1665 & 2062.1656 & 688.3958 & 0.0009 & 0.4358 & 42.772\end{array}$ $\begin{array}{llllllllllll}\text { ISSIQSIVPALEIANAHR } & 1.00 & 70.11 & 24.20 & 29.51 & 3 & 2062.1677 & 2062.1656 & 688.3958 & 0.0021 & 1.0169 & 1189.233\end{array}$

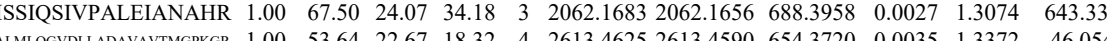
$\begin{array}{lllllllllllll} & \end{array}$ $\begin{array}{lllllllllllll} & \text { SLENDLADAVAVTMGPKGR } & 1.00 & 69.23 & 22.67 & 18.53 & 4 & 2613.4629 & 2613.4590 & 654.3720 & 0.0039 & 1.4900 & 31.949\end{array}$ $\begin{array}{llllllllllll} & \end{array}$ $\begin{array}{llllllllllll}\text { ISSLSIVPALEIANAHR } & 1.00 & 97.07 & 24.25 & 32.97 & 2 & 2062.1674 & 2062.1656 & 1032.0901 & 0.0018 & 0.8720 & 341.296 \\ \text { ISSIQSIVPALIANAHR } & 1.00 & \# \# \# \# & 24.25 & 40.57 & 2 & 2062.1674 & 2062.1656 & 1032.0901 & 0.0018 & 0.8720 & 203.813\end{array}$

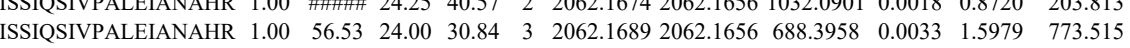
$\begin{array}{llllllllllll}\text { ISSIQSIVPALEIANAHR } & 1.00 & 60.64 & 24.49 & 32.38 & 3 & 2062.1650 & 2062.1656 & 688.3958 & -0.0006 & -0.2905 & 296.686\end{array}$ $\begin{array}{llllllllllll}\text { ISSIQSIVPALEIANAHR } & 1.00 & 63.57 & 24.20 & 27.13 & 3 & 2062.1677 & 2062.1656 & 688.3958 & 0.0021 & 1.0169 & 291.001 \\ \text { ISSIQSIVPALEIANAHR } & 1.00 & 70.33 & 24.42 & 29.30 & 3 & 2062.1656 & 2062.1656 & 688.3958 & 0.0000 & 0.0000 & 382.080\end{array}$ $\begin{array}{llllllllllll}\text { ISSIQSIVPALEIANAHR } & 1.00 & 70.33 & 24.42 & 29.30 & 3 & 2062.1656 & 2062.1656 & 688.3958 & 0.0000 & 0.0000 & 382.080 \\ \text { ISSIOSIVPALEIANAHR } & 1.00 & 70.35 & 24.07 & 28.36 & 3 & 2062.1683 & 2062.1656 & 688.3958 & 0.0027 & 1.3074 & 248.623\end{array}$ $\begin{array}{llllllllllll}\text { ISSIQSIVPALEIANAHR } & 1.00 & 70.35 & 24.07 & 28.36 & 3 & 2062.1683 & 2062.1656 & 688.3958 & 0.0027 & 1.3074 & 248.623 \\ \text { TALAAGVSLTTAEVVYTEFK } & 1.00 & 70.81 & 16.33 & 20.16 & 3 & 2769.6025 & 2769.5983 & 924.2067 & 0.0042 & 1.5148 & 16.241\end{array}$

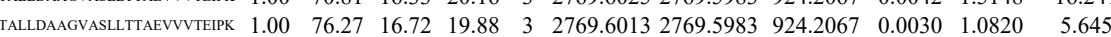
$\begin{array}{lllllllllllll} & \text { AILDAAGVASLLTTAEVVVTEIPK } & 0.60 & 75.63 & 16.72 & 88.63 & 3 & 2769.6019 & 2769.5983 & 924.2067 & 0.0036 & 1.2984 & 7.309\end{array}$

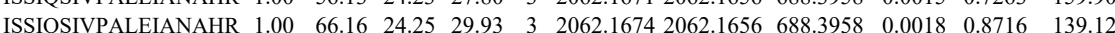
$\begin{array}{llllllllllll} & \end{array}$ 


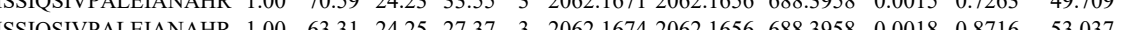
$\begin{array}{lllllllllll} & \end{array}$ $\begin{array}{llllll} & \end{array}$ $\begin{array}{lllllllllllll} & \end{array}$ $\begin{array}{llllllllll} & \end{array}$ $\begin{array}{llllllllllllll} & \text { ISSIOSIVPALEIANAHR } & 1.00 & 75.96 & 24.25 & 29.42 & 3 & 2062.1674 & 20621656 & 688.3958 & 0.0018 & 0.8716 & 66.471\end{array}$ $\begin{array}{llllllllllllll}\text { JMLOGVDLADAVAVTMGPK } & 0.55 & 60.27 & 23.75 & 73.27 & 3 & 2400.3373 & 2400.3364 & 801.1194 & 0.0009 & 0.3745 & 7.608\end{array}$ $\begin{array}{llllllllllllll} & \text { ALLDAAGYASUTTAEVVVTEIPK } & 1.00 & 82.50 & 16.72 & 19.36 & 3 & 2769.6013 & 2769.5983 & 924.2067 & 0.0030 & 1.0820 & 2.978\end{array}$

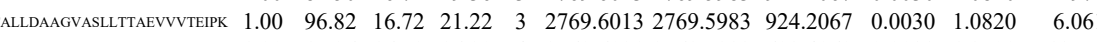

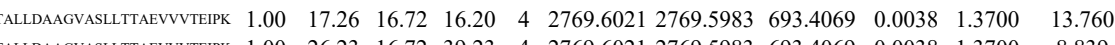

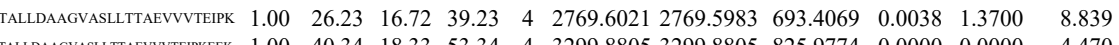

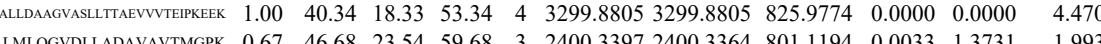
$\begin{array}{llllllllllllll} & & \end{array}$ \begin{tabular}{llllllllllll} 
TALLDAAGVASLLTTAEVVVTEIPK & 1.00 & 9.45 & 16.81 & 22.45 & 4 & 2769.6001 & 2769.5983 & 693.4069 & 0.0018 & 0.6490 & 7.528 \\
\hline
\end{tabular} $\begin{array}{llllllllllll}\text { TALLDAAGVASLLTTAEVVVTEIPK } & 1.00 & 89.04 & 16.72 & 24.52 & 3 & 2769.6013 & 2769.5983 & 924.2067 & 0.0030 & 1.0820 & 2.557\end{array}$

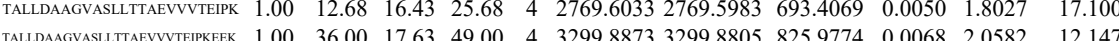
$\begin{array}{llllllllllllll}\text { RALDAAGVALLITAEVVTERREEK } & 1.00 & 36.00 & 17.63 & 49.00 & 4 & 3299.8873 & 3299.8805 & 825.9774 & 0.0068 & 2.0582 & 12.147\end{array}$ $\begin{array}{llllllllllll}\text { TALLAAGVASLLTAEVVITERPK } & 1.00 & 82.70 & 16.72 & 20.98 & 3 & 2769.6019 & 2769.5983 & 9934.2067 & 0.0036 & 1.2984 & 6.270\end{array}$

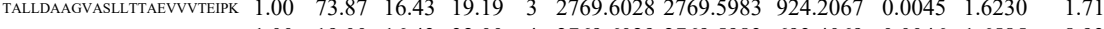
$\begin{array}{llllllllllll}\text { TALLDAAGVASLLTAAEVVVTEIPK } & 1.00 & 19.00 & 16.43 & 32.00 & 4 & 2769.6029 & 2769.5983 & 693.4069 & 0.0046 & 1.6585 & 8.935 \\ \text { ISSIOSIVPALEIANAHR } & 1.00 & 64.79 & 24.00 & 28.51 & 3 & 2062.1689 & 2062.1656 & 688.3958 & 0.0033 & 1.5979 & 289.239\end{array}$ $\begin{array}{llllllllllll}\text { ISSIQSIVPALEIANAHR } & 1.00 & 64.79 & 24.00 & 28.51 & 3 & 2062.1689 & 2062.1656 & 688.3958 & 0.0033 & 1.5979 & 289.239 \\ \text { TALDAAGVASLTTAEVVVTEIPK } & 1.00 & 80.99 & 16.72 & 18.82 & 3 & 2769.6010 & 2769.5983 & 924.2067 & 0.0027 & 0.9738 & 7.550\end{array}$

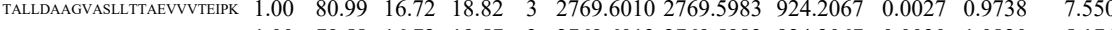

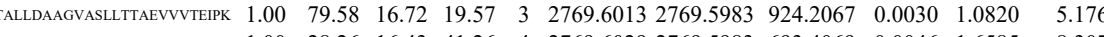
$\begin{array}{lllllllllllll}\text { IALDAAGVASLITAEVVVTEIPK } & 1.00 & 14.23 & 16.43 & 27.23 & 4 & 2769.6029 & 2769.5983 & 693.4069 & 0.0046 & 1.6585 & 6.089\end{array}$

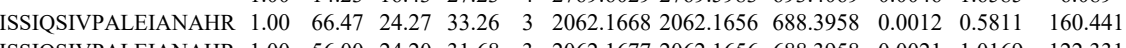
$\begin{array}{lllllllllllll}\text { ISSIQSIVPALEIANAHR } & 1.00 & 56.00 & 24.20 & 31.68 & 3 & 2062.1677 & 2062.1656 & 688.3958 & 0.0021 & 1.0169 & 122.33\end{array}$ \begin{tabular}{llllllllll}
\hline & 1.00
\end{tabular}

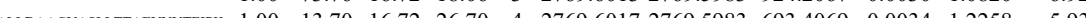
\begin{tabular}{llllllllllll}
\hline & 0.938
\end{tabular} $\begin{array}{llllllllllll} & 1.00 & 79.93 & 16.72 & 21.18 & 3 & 2769.6013 & 2769.593 & 924.2067 & 0.0030 & 1.0820 & 0.000\end{array}$ \begin{tabular}{lllllllllllllll}
\hline INDDAGVGSUTTEVYVTEPK & 1.00 & 79.49 & 16.72 & 18.78 & 3 & 2769.6013 & 2769.5983 & 9242067 & 0.0030 & 1.0820 & 1.209
\end{tabular} $\begin{array}{llllllllllllll}\text { TALLAAGYSLUTAEYVVTEPKK } & 1.00 & 33.56 & 16.43 & 15.27 & 4 & 2769.6029 & 2769.5983 & 693.4069 & 0.0046 & 1.6585 & 1.065\end{array}$ $\begin{array}{lllllllllllll}\text { TALDAGVASLTTAEVYVTEPK } & 0.94 & 6.12 & 16.13 & 19.12 & 4 & 2769.6069 & 2769.5983 & 693.4069 & 0.0086 & 3.1006 & 4.919\end{array}$

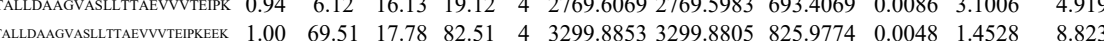
$\begin{array}{lllllllllllll}\text { ISSIQSIVPALEIANAHR } & 1.00 & 66.69 & 24.12 & 34.69 & 3 & 2062.1680 & 2062.1656 & 688.3958 & 0.0024 & 1.1621 & 8.574\end{array}$ $\begin{array}{llllllllllll}\text { ISSIQSIVPALEIANAHR } & 1.00 & 43.84 & 24.00 & 32.45 & 3 & 2062.1689 & 2062.1656 & 688.3958 & 0.0033 & 1.5979 & 9.696\end{array}$ $\begin{array}{llllllllllllll}\text { ALLDAAGVASLTTAEVVVTEEPK } & 1.00 & 25.30 & 16.43 & 38.30 & 4 & 2769.6037 & 2769.5983 & 693.4069 & 0.0054 & 1.9469 & 7.720\end{array}$ $\begin{array}{llllllllllllll}\text { TALLDAAGVASLLTTAEVVVTEPKK } & 1.00 & 69.08 & 16.13 & 17.45 & 3 & 2769.6049 & 2769.5983 & 924.2067 & 0.0066 & 2.3804 & 0.000\end{array}$

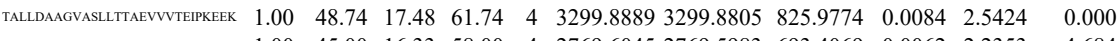

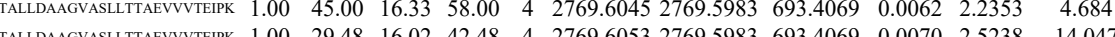
$\begin{array}{lllllllllllll}\text { TALLDAAGVASLLTTAEVVVTEIPK } & 1.00 & 29.48 & 16.02 & 42.48 & 4 & 2769.6053 & 2769.5983 & 693.4069 & 0.0070 & 2.5238 & 14.047\end{array}$ $\begin{array}{lllllllllllll} & \end{array}$ $\begin{array}{lllllllllllll}\text { NALDAAGVASLITAEVVTERRERKK } & 1.00 & 44.80 & 17.32 & 57.80 & 4 & 3299.8921 & 3299.8805 & 85.9794 & 0.0116 & 3.5110 & 3.514\end{array}$ $\begin{array}{llllllllllll}\text { VGGTSDVEVNEK } & 1.00 & 66.73 & 27.93 & 33.61 & 2 & 1520.7916 & 1520.7926 & 761.4036 & -0.0010 & -0.6567 & 3963.890\end{array}$ $\begin{array}{llllllllllll}\text { VGGTSDVEVNEK } & 1.00 & 70.19 & 27.99 & 33.74 & 2 & 1520.7924 & 1520.7926 & 761.4036 & -0.0002 & -0.1313 & 9130.762\end{array}$ $\begin{array}{lllllllllllll}\text { TALLDAGGASLLTTAEVVVTEIPK } & 0.60 & 53.32 & 16.43 & 66.32 & 3 & 2769.6028 & 2769.5983 & 924.2067 & 0.0045 & 1.6230 & 2.009 \\ \text { TILDAGVASLTTAEVYVTEPKK } & 1.00 & 45.08 & 16.02 & 17.23 & 3 & 2769.6058 & 2769.5983 & 924.2067 & 0.0075 & 2.7050 & 3.815\end{array}$ $\begin{array}{lllllllllllll}\text { TALLDAAGVASLLTAEVVVTEIPK } & 1.00 & 45.08 & 16.02 & 17.23 & 3 & 2769.6058 & 2769.5983 & 924.2067 & 0.0075 & 2.7050 & 3.815 \\ \text { ALMLOGVDLADAVAVTMGPK } & 1.00 & 65.73 & 23.46 & 17.38 & 3 & 2400.3406 & 2400.3364 & 801.1194 & 0.0042 & 1.7476 & 6.202\end{array}$ $\begin{array}{llllllllllllll}\text { ALMLQGVDLLADAVAVTMGPK } & 1.00 & 65.73 & 23.46 & 17.38 & 3 & 2400.3406 & 2400.3364 & 801.1194 & 0.0042 & 1.7476 & 6.202 \\ \text { TALDAAGVASLITAEVVTTEPK } & 1.00 & 69.08 & 16.13 & 17.45 & 3 & 2769.6049 & 2769.5983 & 924.2067 & 0.0066 & 2.3804 & 0.000\end{array}$

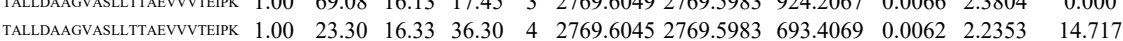
$\begin{array}{lllllllllllll}\text { IMLDAAGVASLITAEVVVTERKEEK } & 1.00 & 34.11 & 18.33 & 47.11 & 4 & 3299.8809 & 3299.8805 & 825.9774 & 0.0004 & 0.1211 & 3.290\end{array}$ $\begin{array}{lllllllllllll} & \text { TLLDAGVASLLTTAEVVVTERKEEK } & 1.00 & 31.73 & 17.78 & 15.79 & 4 & 3299.8853 & 3299.8805 & 825.9774 & 0.0048 & 1.4528 & 6.51\end{array}$

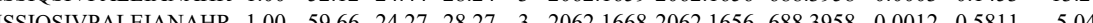

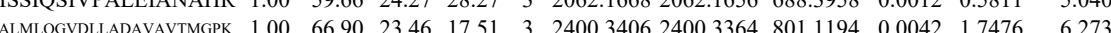

82.041
7.534

0.000

38.864

71.008

3.862

91.684

6.623

1.295

394

23.284

5.620

3.825
15.82

0.000

13.298

1.173

7.010

(1.069

0.000

14.202

31.147

1.897

12.916

1.681

12.233

9.855

0.000

5255.14 $\begin{array}{lll}4.232 & 71.403 \\ 4.615 & 77.709\end{array}$ $\begin{array}{ll}.471 & 7.403 \\ 5.118 & 4.950\end{array}$ $\begin{array}{ll}5.118 & 4.950 \\ 3 & \end{array}$ $5.118-408$
$37.753-60.044$ . $964 \quad 0.000$ $0.318 \quad 23.838$
$6.806 \quad-25.276$ $\begin{array}{lll}12.318 & 23.838 & \text { Yes } \\ 6.806 & 25.276 & \text { Y }\end{array}$ $\begin{array}{lll}6.806 & 25.276 & \text { Y } \\ 60.520 & 136.321 & \text { Y } \\ 1.992 & 4.312 & \text { Yes }\end{array}$

$\begin{array}{lll}1.992 & 4.612 \quad \mathrm{Yes}\end{array}$ $0.000 \quad 3.993$ No $.085 \quad 9.987$
8.674 $8.674 \quad 13.671$ $5.590 \quad 2.70$ $\begin{array}{ll}5.528 & 8.231 \\ 0.000 & 0.000\end{array}$ $0.000 \quad 19.39$ $5.053 \quad 2.836$
6.902

Table S-4 page 144 

$\begin{array}{llllllllllll}\text { ALMLQGVDLLADAVAVTMGPK } & 0.66 & 59.48 & 23.71 & 72.48 & 3 & 2400.3388 & 2400.3364 & 801.1194 & 0.0024 & 0.9986 & 13.478\end{array}$ $\begin{array}{lllllllllllll}\text { TALLDAGVASLLTTAEVVVTEPKK } & 0.60 & 83.85 & 16.72 & 96.85 & 3 & 2769.6019 & 2769.5983 & 924.2067 & 0.0036 & 1.2984 & 1.584 \\ \end{array}$

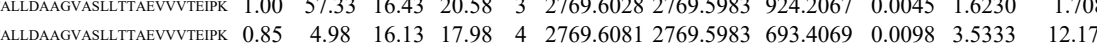

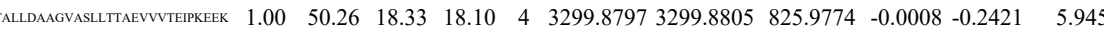
$\begin{array}{lllllllllllll} & 18.33 & 18.10 & 4 & 329.8797 & 329.8805 & 825.9774 & 0.0008 & 0.2421 & 5.945 \\ \end{array}$

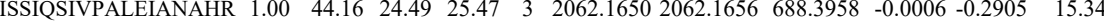

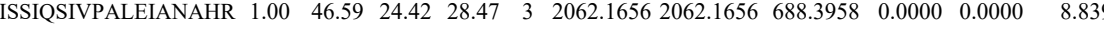
$\begin{array}{llllllllllll}\text { KPLVIIAEDVDGEALSTLVLNR } & 1.00 & 99.67 & 19.59 & 19.71 & 3 & 2652.5302 & 2652.5305 & 885.1841 & -0.0003 & -0.1130 & 3.207\end{array}$ $\begin{array}{llllllllllll}\text { TALLDAGGVASLLTAAEVVVTEIPK } & 1.00 & 73.79 & 16.72 & 19.26 & 3 & 2769.6016 & 2769.5983 & 924.2067 & 0.0033 & 1.1902 & 0.000 \\ \text { TALLDAGGVASLITAEVVVTEIPK } & 1.00 & 13.24 & 16.02 & 26.24 & 4 & 2769.6053 & 2769.5983 & 693.4069 & 0.0070 & 2.5238 & 7.677\end{array}$ $\begin{array}{lllllllllllll}\text { TALLDAAGVASLLTTAEVVVTEIPK } & 1.00 & 13.24 & 16.02 & 26.24 & 4 & 2769.6053 & 2769.5983 & 693.4069 & 0.0070 & 2.5238 & 7.677 \\ \end{array}$ $\begin{array}{lllllllllllll}\text { TALLDAAGVASLLTTAEVVVTEIPK } & 1.00 & 62.45 & 16.23 & 19.48 & 3 & 2769.6064 & 2769.5983 & 924.2067 & 0.0081 & 2.9214 & 0.000 \\ \text { TNLDAAGVALLTTAEVVTEIPKKEK } & 1.00 & 23.76 & 18.33 & 36.76 & 4 & 3299.8801 & 3299.8805 & 825.9774 & -0.0004 & -0.1211 & 6.524\end{array}$

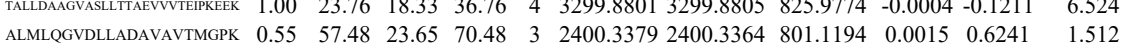
$\begin{array}{lllllllllllll}\text { ALMLQGVDLLADAVAVTMGPK } & 0.66 & 53.96 & 23.71 & 66.96 & 3 & 2400.3388 & 2400.3364 & 801.1194 & 0.0024 & 0.9986 & 4.377\end{array}$ $\begin{array}{llllllllllll}\text { KPLVIIAEDVDGEALSTLVLNR } & 0.60 & 91.45 & 19.24 & \text { \#\#\#\# } & 3 & 2652.5344 & 2652.5305 & 885.1841 & 0.0039 & 1.4686 & 4.236\end{array}$ $\begin{array}{lllllllllll}1.00 & 72.25 & 16.72 & 17.89 & 3 & 2769.6019 & 2769.5983 & 924.2067 & 0.0036 & 1.2984 & 10.546\end{array}$ $\begin{array}{llllllllllll} & \end{array}$

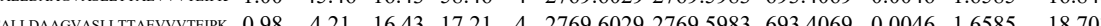

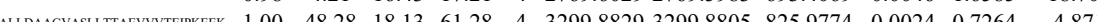
$\begin{array}{llllllllllll} & 1.28\end{array}$ $\begin{array}{llllllllllll}\text { GVMLAVDAVIAELK } & 0.59 & 17.22 & 23.14 & 27.37 & 3 & 1716.0103 & 1716.0099 & 573.0106 & 0.0004 & 0.2327 & 11.668\end{array}$ $\begin{array}{lllllllllllll}\text { LLMLOGVDLADAVATMGPK } & 1.00 & 63.44 & 23.60 & 18.36 & 3 & 2400.3391 & 2400.3364 & 801.1194 & 0.0027 & 1.1234 & 15.539\end{array}$ $\begin{array}{llllllllllll}\text { ALMLQGVDLADAVAVTMGPK } & 1.00 & 76.37 & 23.54 & 21.09 & 3 & 2400.3394 & 2400.3364 & 801.1194 & 0.0030 & 1.2483 & 18.882\end{array}$

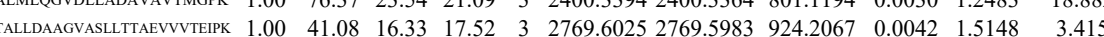

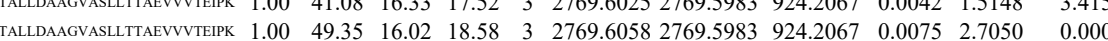
$\begin{array}{lllllllllllll}\text { TALDAAGVASLITAEVVVEEIRKEK } & 1.00 & 30.82 & 18.13 & 43.82 & 4 & 3299.8833 & 3299.8805 & 825.9774 & 0.0028 & 0.8475 & 5.219\end{array}$ $\begin{array}{llllllllllllll}\text { TALLDAGVASLITAEVVVTEPREEK } & 1.00 & 58.31 & 17.63 & 71.31 & 4 & 3299.8869 & 3299.8805 & 825.9774 & 0.0064 & 1.9371 & 7.250 \\ \text { GVMLAVDAVIAELK } & 0.79 & 21.68 & 23.40 & 15.64 & 3 & 1716.0082 & 1716.0099 & 573.0106 & -0.0017 & -0.9889 & 16.28\end{array}$ \begin{tabular}{lllllllllllll} 
ALMLQGVDLLADAVAVTMGPK & 0.66 & 82.88 & 23.75 & 55.64 & 3 & 1716.0082 & 1716.0099 & 573.0106 & -0.0017 & -0.9889 & 16.285 \\
\hline
\end{tabular} $\begin{array}{llllllllllll}\text { ALMLQGVDLLADAVAVTMGPK } & 1.00 & 70.18 & 23.54 & 20.51 & 3 & 2400.3397 & 2400.3364 & 801.1194 & 0.0033 & 1.3731 & 11.810\end{array}$ $\begin{array}{llllllllllll}\text { TALLDAGGASLLTTAEVVVTEIPKK } & 0.60 & 20.16 & 16.72 & 33.16 & 3 & 2769.6019 & 2769.5983 & 924.2067 & 0.0036 & 1.2984 & 3.054\end{array}$

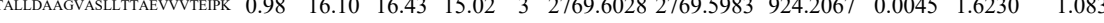

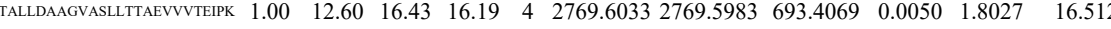
$\begin{array}{llllllllllllll} & 1.00\end{array}$ $\begin{array}{llllllllllllll}\text { TALDAGGVASLTAEWWTERKEKK } & 1.00 & 53.50 & 18.13 & 66.50 & 4 & 3299.8841 & 3299.8805 & 825.9774 & 0.0036 & 1.0896 & 7.863\end{array}$ $\begin{array}{llllllllllllll}\text { TALLDAGVASLITAEVVVTEPRKEKK K } & 1.00 & 49.87 & 17.48 & 62.87 & 4 & 3299.8897 & 3299.8805 & 825.9774 & 0.0092 & 2.7846 & 6.898\end{array}$ $\begin{array}{lllllllllllll}\text { TLNDELEIIEGMK } & 1.00 & 85.62 & 27.99 & 25.23 & 2 & 1791.9548 & 1791.9532 & 896.9839 & 0.0016 & 0.8919 & 735.105 \\ \text { TLNDELEIEGMK } & 0.99 & 27.13 & 28.11 & 20.70 & 3 & 1791.9553 & 1791.9532 & 598.3250 & 0.0021 & 1.1699 & 68.706\end{array}$ $\begin{array}{llllllllllll}\text { TLNDELEIIEGMK } & 0.99 & 27.13 & 28.11 & 20.70 & 3 & 1791.9553 & 1791.9532 & 598.3250 & 0.0021 & 1.1699 & 68.706 \\ \text { TLNDELEIIEGMK } & 1.00 & 81.40 & 27.95 & 22.55 & 2 & 1791.9562 & 1791.9532 & 896.9839 & 0.0030 & 1.6723 & 5168.458\end{array}$ TLNDELEIIEGMK $\begin{array}{lllllllllll}1.00 & 40.22 & 27.80 & 33.01 & 3 & 1791.9574 & 1791.9532 & 598.3250 & 0.0042 & 2.3399\end{array}$

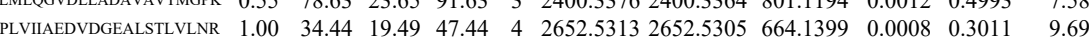
$\begin{array}{llllllllllll}1.00 & 12.99 & 19.34 & 25.99 & 4 & 2652.5325 & 2652.5305 & 664.1399 & 0.0020 & 0.7529 & 6.126\end{array}$ $\begin{array}{llllllllll} & 19.34 & \# \# \# \# \quad 3 & 2652.5326 & 2652.5305 & 885.1841 & 0.0021 & 0.750 & \end{array}$ 


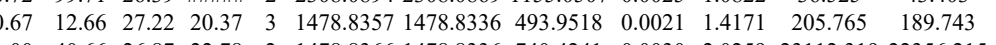

VYEGERPLTK $\begin{array}{lllllllllllllll}0.99 & 43.38 & 26.81 & 22.97 & 2 & 1478.8374 & 1478.8336 & 740.4241 & 0.0038 & 2.5661 & 27784.056 & 20867.172 & 2048.280 & 22497.220 & \text { Yes }\end{array}$

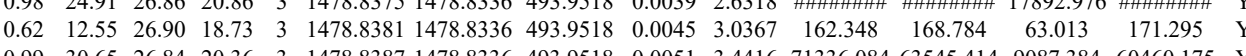
$\begin{array}{lllllllllllllll}0.99 & 30.65 & 26.84 & 20.36 & 3 & 1478.8387 & 1478.8336 & 493.9518 & 0.0051 & 3.4416 & 71336.084 & 63545.414 & 9087.384 & 60460.175 & \text { Yes } \\ 0.53 & 16.94 & 26.41 & 21.80 & 3 & 1488.8411 & 1478.8336 & 493.9518 & 0.0075 & 5.0612 & 183.840 & 169.071 & 51.807 & 195.167 & \text { Yes }\end{array}$

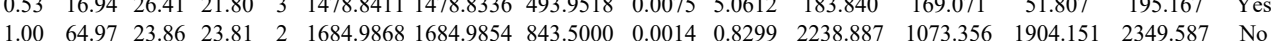
$\begin{array}{lllllllllllllll}1.00 & 92.20 & 23.80 & 25.84 & 2 & 1684.9874 & 1684.9854 & 843.5000 & 0.0020 & 1.1855 & 5601.808 & 2545.182 & 3645.018 & 5524.768 & \text { Yes }\end{array}$ $\begin{array}{lllllllllllllll}1.00 & 33.94 & 23.77 & 18.73 & 3 & 1684.9882 & 1684.9854 & 562.6691 & 0.0028 & 1.6588 & 414.187 & 75.640 & 114.363 & 178.013 & \text { No }\end{array}$ $\begin{array}{lllllllllllllll}1.00 & 29.20 & 23.77 & 17.83 & 3 & 1684.9882 & 1684.9854 & 562.6691 & 0.0028 & 1.6588 & 79.797 & 58.561 & 57.688 & 79.373 & \text { Yes }\end{array}$ $\begin{array}{llllllllllllllll}0.99 & 37.85 & 27.11 & 23.25 & 2 & 1478.8362 & 1478.8336 & 740.4241 & 0.0026 & 1.7557 & 24626.107 & 20784.130 & 2213.744 & 18418.037 & \text { Yes }\end{array}$ $\begin{array}{llllllllllllllll}1.00 & 43.75 & 26.87 & 22.79 & 2 & 1478.8368 & 1478.8336 & 740.4241 & 0.0032 & 2.1609 & 22678.020 & 20022.471 & 1956.752 & 17598.974 & \text { Yes }\end{array}$ $\begin{array}{lllllllllllllll}0.99 & 29.39 & 26.90 & 20.70 & 3 & 1478.8381 & 1478.8336 & 493.9518 & 0.0045 & 3.0367 & 58741.780 & 58513.092 & 7799.719 & 52607.281 & \text { Yes }\end{array}$

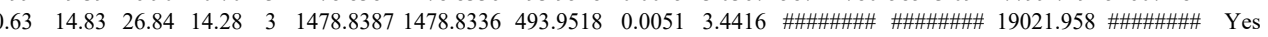
$\begin{array}{lllllllllllllll}1.00 & 66.79 & 28.12 & 30.44 & 2 & 1603.8352 & 1603.8337 & 802.9241 & 0.0015 & 0.9341 & 4932.398 & 4107.753 & 86.092 & 3146.486 & \text { Yes }\end{array}$ $\begin{array}{llllllllllllllll}1.00 & 73.69 & 28.30 & 30.91 & 2 & 1603.8362 & 1603.8337 & 802.9241 & 0.0025 & 1.5568 & 3821.680 & 3609.687 & 0.000 & 2381.472 & \text { No }\end{array}$ $\begin{array}{lllllllllllllll}1.00 & 62.72 & 23.89 & 20.90 & 2 & 1684.9872 & 1684.9854 & 843.5000 & 0.0018 & 1.0670 & 429.854 & 217.840 & 298.381 & 484.280 & \text { Yes }\end{array}$

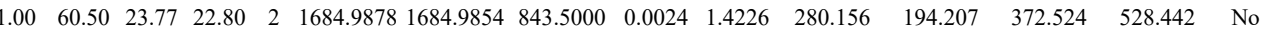
$\begin{array}{lllllllllllllll}1.00 & 31.28 & 23.50 & 18.01 & 3 & 1684.9888 & 1684.9854 & 562.6691 & 0.0034 & 2.0142 & 70.276 & 45.324 & 40.044 & 136.453 & \text { Yes }\end{array}$

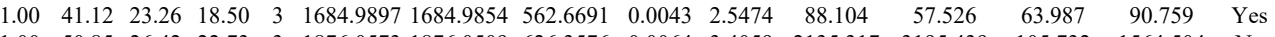
$\begin{array}{lllllllllllllll}1.00 & 50.85 & 26.42 & 22.73 & 3 & 1876.0573 & 1876.0509 & 626.3576 & 0.0064 & 3.4059 & 2135.317 & 3195.439 & 105.732 & 1564.504 & \text { No } \\ 0.95 & 23.42 & 2.3 & 20.78 & 3 & 148.8348 & 148.8336 & 493.958 & 0.0012 & 0.898 & 5828.827 & 71620.05 & 720.371 & 6252.064 & \text { Ye }\end{array}$ $\begin{array}{lllllllllllllll}0.95 & 23.42 & 27.30 & 20.78 & 3 & 1478.8348 & 1478.8336 & 493.9518 & 0.0012 & 0.8098 & 68828.827 & 71620.058 & 7209.371 & 62752.064 & \text { Yes }\end{array}$

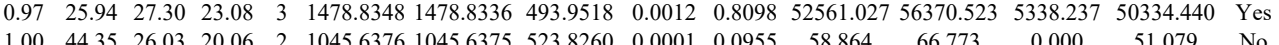

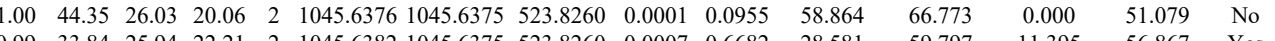

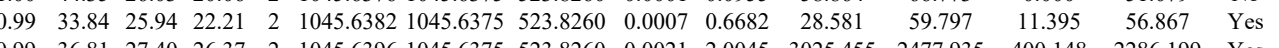
$\begin{array}{lllllllllllllll}0.99 & 36.81 & 27.40 & 26.37 & 2 & 1045.6396 & 1045.6375 & 523.8260 & 0.0021 & 2.0045 & 3025.455 & 2477.935 & 400.148 & 2286.199 & \text { Yes } \\ 0.99 & 36.65 & 27.41 & 20.15 & 2 & 1045.6406 & 1045.6375 & 523.8260 & 0.0031 & 2.9590 & 1934.115 & 1539.558 & 282.909 & 1590.687 & \text { Yes }\end{array}$ $\begin{array}{ccccccccccccccc}0.99 & 36.65 & 27.41 & 20.15 & 2 & 1045.6406 & 1045.6375 & 523.8260 & 0.0031 & 2.9590 & 1934.115 & 1539.558 & 282.909 & 1590.687 & \text { Yes } \\ 0.99 & 35.96 & 27.55 & 21.46 & 2 & 1045.6386 & 1045.6375 & 523.8260 & 0.0011 & 1.0500 & 49.589 & 44.717 & 0.000 & 53.557 & \text { No }\end{array}$ $\begin{array}{lllllllllllllll}0.99 & 35.96 & 27.55 & 21.46 & 2 & 1045.6386 & 1045.6375 & 523.8260 & 0.0011 & 1.0500 & 49.589 & 44.717 & 0.000 & 53.557 & \text { No } \\ 0.99 & 32.85 & 27.31 & 20.23 & 2 & 1045.6398 & 1045.6375 & 523.8260 & 0.0023 & 2.1954 & 48.561 & 56.945 & 7.187 & 34.810 & \text { Yes }\end{array}$

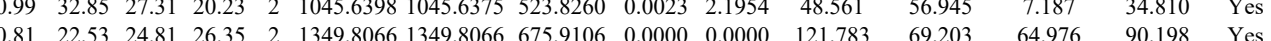

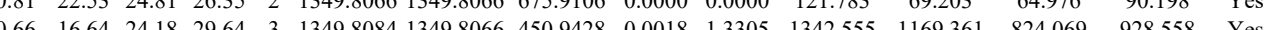


ITITNDQNR

ITITNDQNR

VTHAVVTVPAY

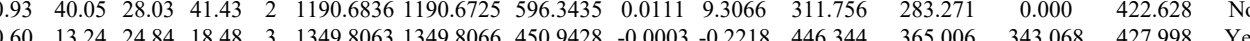

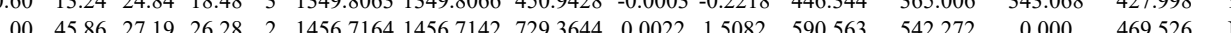

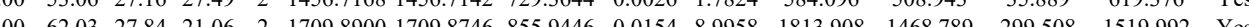

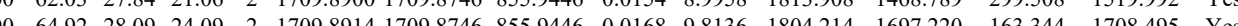

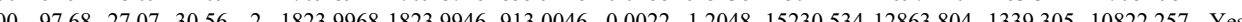
$\begin{array}{lllllllllllllll}100 & 93.04 & 27.06 & 29.00 & 2 & 1823.9970 & 1823.9946 & 913.0046 & 0.0024 & 1.3143 & 9886.822 & 8612.138 & 279.846 & 6930.056 & \text { Yes }\end{array}$ $\begin{array}{lllllllllllllll}100 & 49.76 & 27.10 & 25.96 & 3 & 1823.9974 & 1823.9946 & 609.0055 & 0.0028 & 1.5326 & 260.859 & 117.904 & 84.699 & 319.569 & \text { Yes }\end{array}$ $\begin{array}{lllllllllllllll}1.00 & 53.70 & 27.10 & 30.75 & 3 & 1823.9986 & 1823.9946 & 609.0055 & 0.0040 & 2.1894 & 422.461 & 327.193 & 15.392 & 311.216 & \text { Yes }\end{array}$ $\begin{array}{llllllllllllllll}00 & 88.65 & 27.10 & 25.31 & 2 & 1823.9974 & 1823.9946 & 913.0046 & 0.0028 & 1.5334 & 32.430 .603 & 2862.791 & 139.285 & 2248.281 & \text { Yes }\end{array}$

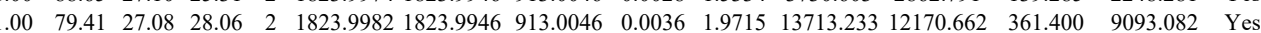
$\begin{array}{lllllllllllllll}1.00 & 55.98 & 27.13 & 29.18 & 3 & 1823.9995 & 1823.9946 & 609.0055 & 0.0049 & 2.6820 & 596.862 & 953.747 & 0.000 & 717.619 & \text { No }\end{array}$ $\begin{array}{lllllllllllllll}1.00 & 45.84 & 27.13 & 26.44 & 3 & 1823.9998 & 1823.9946 & 609.0055 & 0.0052 & 2.8462 & 344.459 & 270.337 & 74.936 & 279.668 & \text { Yes }\end{array}$ $\begin{array}{llllllllllllllll}0.84 & 24.38 & 22.30 & 23.77 & 3 & 2036.1814 & 2036.1632 & 679.7283 & 0.0182 & 8.9251 & 3801.976 & 3619.334 & 6975.390 & 5808.438 & \text { No }\end{array}$ $\begin{array}{llllllllllllll}1.00 & 27.17 & 33.06 & 2 & 1823.9952 & 1823.9946 & 913.0046 & 0.0006 & 0.3286 & 3033.926 & 2781.289 & 205.549 & 2278.750 & \text { Yes }\end{array}$

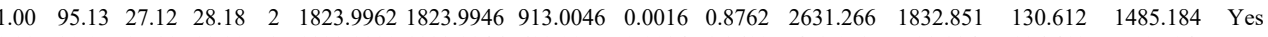
$\begin{array}{llllllllllllllll}0.99 & 30.05 & 27.11 & 19.20 & 3 & 1823.9980 & 1823.9946 & 609.0055 & 0.0034 & 1.8610 & 452.078 & 523.334 & 106.412 & 550.794 & \text { Yes }\end{array}$

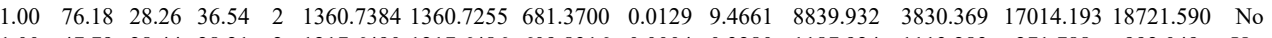
$\begin{array}{llllllllllllllll}1.00 & 47.79 & 28.44 & 28.21 & 2 & 1217.6490 & 1217.6486 & 609.8316 & 0.0004 & 0.3280 & 1187.924 & 1113.283 & 271.788 & 992.049 & \text { Yes }\end{array}$ $\begin{array}{llllllllllllllll}1.00 & 40.67 & 28.27 & 19.68 & 2 & 1217.6504 & 1217.6486 & 609.8316 & 0.0018 & 1.4758 & 1340.642 & 1149.866 & 391.403 & 1187.948 & \text { Yes }\end{array}$ $\begin{array}{lllllllllllllllll}0.88 & 25.93 & 20.76 & 28.91 & 2 & 938.5922 & 938.5833 & 470.2989 & 0.0089 & 9.4620 & 30632.199 & 22981.961 & 0.000 & \# \# \# \# \text { No }\end{array}$

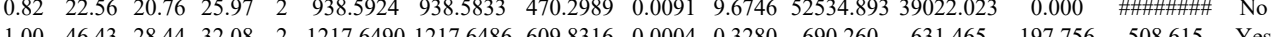

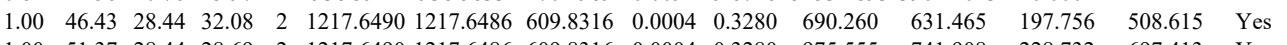
$\begin{array}{lllllllllllllll}1.00 & 51.37 & 28.44 & 28.69 & 2 & 1217.6490 & 1217.6486 & 609.8316 & 0.0004 & 0.3280 & 975.555 & 741.908 & 228.732 & 697.413 & \text { Yes }\end{array}$ $\begin{array}{lllllllllllllllll}0.78 & 25.94 & 20.76 & 32.13 & 2 & 938.5924 & 938.5833 & 470.2989 & 0.0091 & 9.6746 & 11746.906 & 10211.704 & 0.000 & 62637.866 & \text { No }\end{array}$ $\begin{array}{llllllllllllllll}1.00 & 47.59 & 28.45 & 28.83 & 2 & 1217.6486 & 1217.6486 & 609.8316 & 0.0000 & 0.0000 & 1211.489 & 932.370 & 213.340 & 837.064 & \text { Yes }\end{array}$ \begin{tabular}{lllllllllllllll}
1.00 & 53.13 & 28.44 & 25.23 & 2 & 1217.6488 & 1217.6486 & 609.8316 & 0.0002 & 0.1640 & 778.889 & 663.666 & 191.912 & 609.648 & Yes \\
\hline
\end{tabular} $\begin{array}{lllllllllllllll}0.99 & 49.77 & 27.99 & 37.34 & 2 & 1205.6842 & 1205.6747 & 603.8446 & 0.0095 & 7.8662 & 5089.243 & 4234.918 & 1272.041 & 5077.878 & \text { Yes } \\ 0.60 & 18.99 & 27.77 & 25.27 & 3 & 1297.7230 & 1297.7243 & 433.5820 & -0.0013 & -0.9994 & 2315.621 & 1975.481 & 358.868 & 2332.851 & \text { Yes }\end{array}$

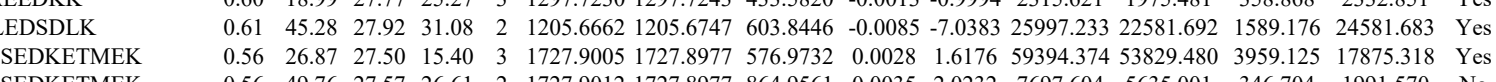
$\begin{array}{llllllllllllllll}0.56 & 49.876 & 27.57 & 26.41 & 2 & 1727.9012 & 1727.877 & 576.9732 & 0.028 & 1.6176 & 5939.374 & 53829.480 & 3.59 .125 & 17875.318 & \text { Yes }\end{array}$ $\begin{array}{lllllllllllllll} & 30.56 & 27.50 & 19.92 & 3 & 2262.1048 & 2262.1048 & 755.0422 & 0.0000 & 0.0000 & 23.537 & 27.277 & 19.793 & 41.583 & \text { Yes }\end{array}$

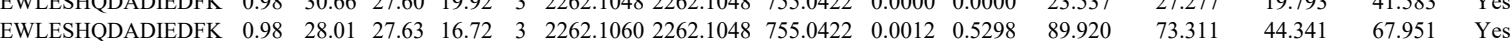
$\begin{array}{lllllllllllllllll}\text { IEWLESHQDADIEDFK } & 1.00 & 32.43 & 27.61 & 17.99 & 3 & 22621066 & 22621048 & 755.0422 & 0.0018 & 0.7947 & 81.662 & 82.393 & 28.661 & 77.986 & \text { Yes }\end{array}$

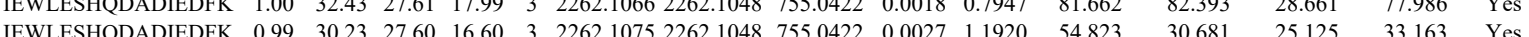

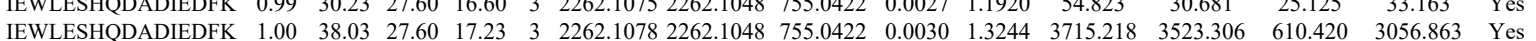

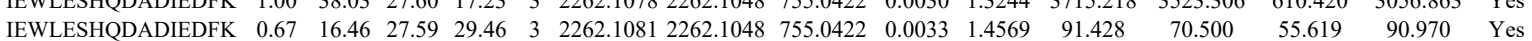

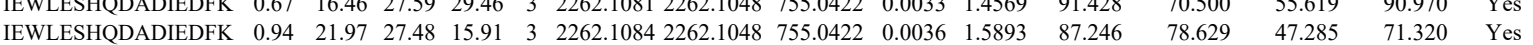

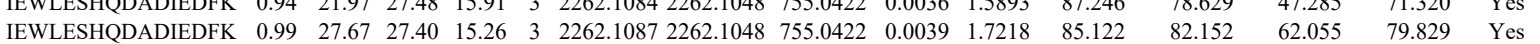
$\begin{array}{lllllllllllllllll}\text { IEWLESHQDADIEDFK } & 0.60 & 36.85 & 27.42 & 49.85 & 3 & 2262.1090 & 2262.1048 & 755.0422 & 0.0042 & 1.8542 & 12700.810 & 12380.570 & 804.281 & 11765.021 & \text { Yes }\end{array}$ $\begin{array}{lllllllllllllllll}\text { IEWLESHQDADIEDFK } & 0.97 & 24.89 & 27.42 & 17.75 & 3 & 2262.1090 & 2262.1048 & 755.0422 & 0.0042 & 1.8542 & 81.478 & 57.044 & 50.425 & 82.694 & \text { Yes }\end{array}$ $\begin{array}{llllllllllllllll}\text { IEWLESHQDADIEDFK } & 1.00 & 34.61 & 27.43 & 15.55 & 3 & 2262.1096 & 2262.1048 & 755.0422 & 0.0048 & 2.1191 & 70.270 & 70.060 & 49.120 & 84.310 & \text { Yes }\end{array}$ $\begin{array}{llllllllllllllll}\text { IEWLESHQDADIEDFK } & 0.98 & 29.39 & 27.43 & 16.03 & 3 & 2262.1096 & 2262.1048 & 755.0422 & 0.0048 & 2.1191 & 81.267 & 80.491 & 54.982 & 57.456 & \text { Yes }\end{array}$ $\begin{array}{llllllllllllllll}\text { IEWLESHQDADIEDFK } & 0.80 & 21.65 & 27.38 & 18.51 & 3 & 2262.1105 & 2262.1048 & 755.0422 & 0.0057 & 2.5164 & 91.994 & 48.265 & 39.089 & 67.202 & \text { Yes }\end{array}$

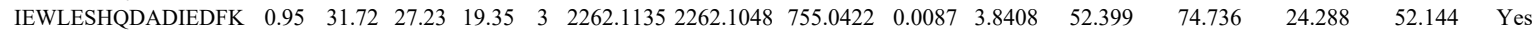
$\begin{array}{llllllllllllllll}\text { TWNDPSVQQDIK } & 1.00 & 51.90 & 27.72 & 26.36 & 2 & 1717.8908 & 1717.8879 & 859.9512 & 0.0029 & 1.6861 & 2747.438 & 2307.850 & 305.729 & 2269.012 & \text { Yes }\end{array}$ $\begin{array}{llllllllllllllllll}\text { TWNDPSVQQDIK } & 1.00 & 67.22 & 27.92 & 34.09 & 2 & 1717.8918 & 1717.8879 & 859.9512 & 0.0039 & 2.2676 & 5086.407 & 4836.442 & 188.635 & 3900.403 & \text { Yes }\end{array}$ $\begin{array}{llllllllllllllll}\text { IEWLESHQDADIEDFK } & 0.99 & 28.56 & 27.64 & 15.39 & 3 & 2262.1069 & 2262.1048 & 755.0422 & 0.0021 & 0.9271 & 2380.010 & 2105.340 & 455.772 & 1788.912 & \text { Yes }\end{array}$ $\begin{array}{llllllllllllllll}\text { IEWLESHQDADIEDFK } & 1.00 & 36.34 & 27.59 & 18.90 & 3 & 2262.1081 & 2262.1048 & 755.0422 & 0.0033 & 1.4569 & 2776.852 & 2995.409 & 340.626 & 2871.789 & \text { Yes }\end{array}$ $\begin{array}{llllllllllllllll}\text { SDIDEIVLVGGSTR } & 1.00 & 79.02 & 27.77 & 28.36 & 2 & 1603.8554 & 1603.8539 & 802.9342 & 0.0015 & 0.9341 & 947.152 & 591.303 & 167.986 & 484.783 & \text { Yes }\end{array}$

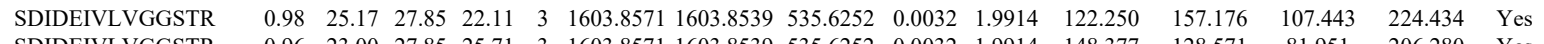
$\begin{array}{lllllllllllllllll}\text { SDIDEIVLVGGSTR } & 0.96 & 23.00 & 27.85 & 25.71 & 3 & 1603.8571 & 1603.8539 & 535.6252 & 0.0032 & 1.9914 & 148.377 & 128.571 & 81.951 & 206.280 & \text { Yes } \\ \text { TWNDPSVQQDIK } & 0.63 & 25.81 & 27.79 & 22.61 & 2 & 17178688 & 171.7879 & 859.951 & -0.0011 & 0.639 & 28.56 & 31.971 & 20.711 & 22.49 & \text { Yes }\end{array}$ \begin{tabular}{llllllllllllllll} 
TWNDPSVQQDIK & 0.63 & 25.81 & 27.79 & 22.61 & 2 & 1717.8868 & 1717.8879 & 859.9512 & -0.0011 & -0.6396 & 28.560 & 31.971 & 20.711 & 22.490 & Yes \\
\hline
\end{tabular}

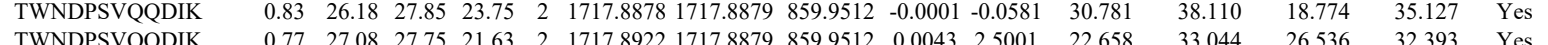
$\begin{array}{llllllllllllllll}\text { TWNDPSVQQDIK } & 0.77 & 27.08 & 27.75 & 21.63 & 2 & 1717.8922 & 1717.8879 & 859.9512 & 0.0043 & 2.5001 & 22.658 & 33.044 & 26.536 & 32.393 & \text { Yes } \\ \text { TWNDPSVQQDIK } & 0.87 & 34.05 & 27.67 & 27.39 & 2 & 1717.8942 & 1717.8879 & 859.9512 & 0.0063 & 3.6630 & 31.577 & 32.522 & 10.776 & 40.296 & \text { Yes }\end{array}$

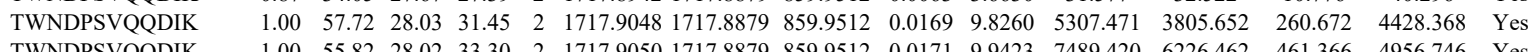

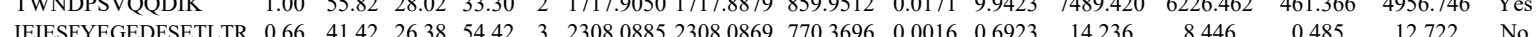



$\begin{array}{lllllllllllll} & \text { GUPOIEVTFIDANGILNVSAVDK } & 0.67 & 16.09 & 24.47 & 29.09 & 3 & 2801.5084 & 2801.5055 & 934.8424 & 0.0029 & 1.0340 & 1.729\end{array}$ $\begin{array}{llllllllllllll} & \end{array}$ $\begin{array}{lllllllllllll} & \end{array}$

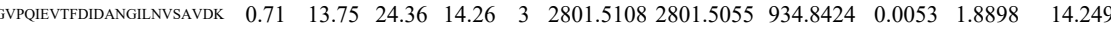
$\begin{array}{llllllllllllll}\text { SFYPEEVSSMVLTK } & 0.99 & 28.29 & 27.74 & 19.83 & 3 & 1903.9864 & 1903.9845 & 635.6688 & 0.0019 & 0.9963 & 360.660\end{array}$ $\begin{array}{lllllllllllll}\text { SFYPEEVSSMVLTK } & 1.00 & 74.45 & 27.71 & 19.89 & 2 & 1903.9866 & 1903.9845 & 952.9995 & 0.0021 & 1.1018 & 1343.965\end{array}$

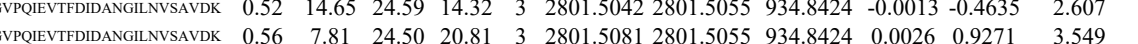

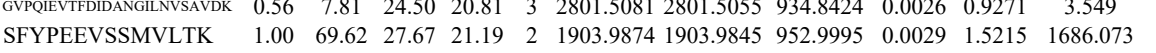
$\begin{array}{lllllllllllll}\text { SFYPEEVSSMVLTK } & 1.00 & 49.03 & 27.69 & 24.07 & 3 & 1903.9879 & 1903.9845 & 635.6688 & 0.0034 & 1.7829 & 365.322 & 13 \\ \text { SFYPEESSMVIT } & 1.00 & 49.24 & 27.69 & 23.46 & 3 & 1903.988 & 1903.9855 & 635.6688 & 0.043 & 2.2548 & 659.044 & 567\end{array}$ $\begin{array}{lllllllllllll}\text { SFYPEEVSSMVLTK } & 1.00 & 49.24 & 27.69 & 23.46 & 3 & 1903.9888 & 1903.9845 & 635.6688 & 0.0043 & 2.2548 & 659.014 \\ \text { GVPOIEVTFDIDANGLNVSAVDK } & 1.00 & 32.48 & 24.56 & 17.41 & 4 & 2801.5069 & 2801.5055 & 701.3837 & 0.0014 & 0.4990 & 48.438\end{array}$ $\begin{array}{lllllllllllll}\text { GVPPIEVTFDIDANGILNVSAVDK } & 1.00 & 32.48 & 24.56 & 17.41 & 4 & 2801.5069 & 2801.5055 & 701.3837 & 0.0014 & 0.4990 & 48.438 \\ \text { GVPIIEVTFIDANGLINVSAVDK } & 0.66 & 23.98 & 24.58 & 36.98 & 3 & 2801.5072 & 2801.5055 & 934.8424 & 0.0017 & 0.6062 & 11.136\end{array}$ $\begin{array}{lllllllllllll}\text { GVPRIEVTFDIDANGILNVSAVDK } & 0.67 & 25.85 & 24.47 & 38.85 & 3 & 2801.5084 & 2801.5055 & 934.8424 & 0.0029 & 1.0340 & 9.719\end{array}$ $\begin{array}{lllllllllllll}\text { GPQIEVTFDDANGLNSAVVKK } & 0.67 & 67.23 & 24.47 & 80.23 & 3 & 2801.5084 & 2801.5055 & 934.8424 & 0.0029 & 1.0340 & 3.275\end{array}$

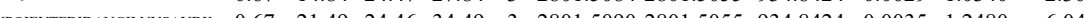
$\begin{array}{lllllllllll} & 0.304\end{array}$

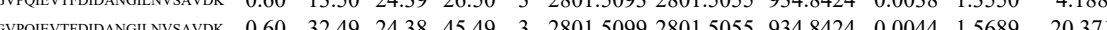

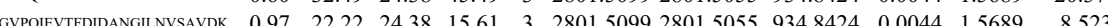

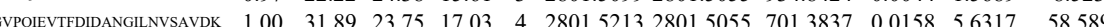
$\begin{array}{lllllllllllll}\text { SFYPEEVSSMVLTK } & 1.00 & 61.66 & 27.73 & 23.79 & 2 & 1903.9864 & 1903.9845 & 952.9995 & 0.0019 & 0.9969 & 705.265\end{array}$ $\begin{array}{llllllllllllll}\text { SFYPEEVSSMVLTK } & 1.00 & 70.56 & 27.74 & 18.43 & 2 & 1903.9872 & 1903.9845 & 952.9995 & 0.0027 & 1.4166 & 1472.795 & 218\end{array}$ $\begin{array}{lllllllllllll}\text { SFYPEEVSSMVLTK } & 0.72 & 15.27 & 27.82 & 14.41 & 3 & 1903.9882 & 1903.9845 & 635.6688 & 0.0037 & 1.9402 & 307.963\end{array}$ $\begin{array}{llllllllllllll}\text { SFYPEEVSSMVLTK } & 1.00 & 43.64 & 27.77 & 17.54 & 3 & 1903.9885 & 1903.9845 & 635.6688 & 0.0040 & 2.0975 & 528.507\end{array}$

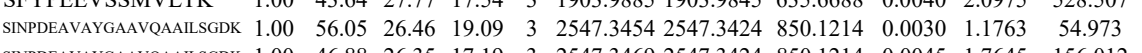
$\begin{array}{llllllllllll}\text { SINPDEAVAYGAAVQAAILSGDK } & 1.00 & 46.88 & 26.35 & 17.19 & 3 & 2547.3469 & 2547.3424 & 850.1214 & 0.0045 & 1.7645 & 156.012\end{array}$

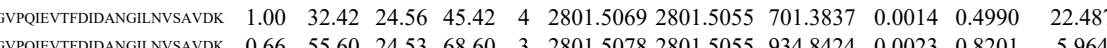
$\begin{array}{lllllllllllll} & \end{array}$

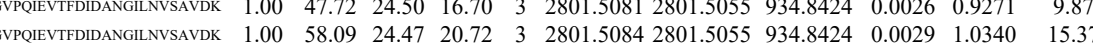

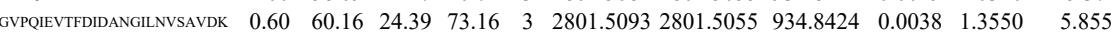

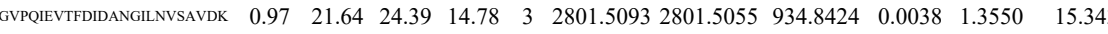
$\begin{array}{lllllllllllll}\text { GVPRIEVTFDIDANGLLNSADS } & 0.95 & 13.07 & 24.13 & 26.07 & 4 & 2801.5133 & 2801.5055 & 701.3837 & 0.0078 & 2.7802 & 33.648\end{array}$ CNEIINWLDK 
MVNHFIAEFK

MVNHFIAEFK

MVNHFIAEFK

$\begin{array}{llllllllllll}1.00 & 55.50 & 27.85 & 20.96 & 2 & 1522.8340 & 1522.8210 & 762.4178 & 0.0130 & 8.5254 & 5641.602 & 5785.034\end{array}$

MVNHFIAEFK

$\begin{array}{lllllllllllll}1.00 & 52.29 & 27.85 & 16.83 & 2 & 1522.8342 & 1522.8210 & 762.4178 & 0.0132 & 8.6566 & 6057.317 & 6792.544 & \\ 0.90 & 28.50 & 27.87 & 18.82 & 3 & 1522.8358 & 1522.8210 & 508.6143 & 0.0148 & 9.6995 & 10467.991 & 11040.246 & 0\end{array}$

CNEIINWLDK

CNEIINWLDK

$\begin{array}{llllllllllll}0.99 & 39.71 & 27.86 & 22.29 & 3 & 1522.8361 & 1522.8210 & 508.6143 & 0.0151 & 9.8961 & 8034.901 & 9415.520\end{array}$

CNEIINWLDK

$\begin{array}{llllllllllll}0.79 & 15.19 & 27.47 & 14.23 & 3 & 1580.7961 & 1580.7934 & 527.9384 & 0.0027 & 1.7047 & 98.945 & 86.737\end{array}$

$\begin{array}{llllllllllll}1.00 & 49.76 & 27.37 & 33.71 & 2 & 1580.7962 & 1580.7934 & 791.4040 & 0.0028 & 1.7690 & 6835.707 & 6936.316\end{array}$

$\begin{array}{llllllllllll}0.88 & 17.68 & 27.38 & 17.64 & 3 & 1580.7964 & 1580.7934 & 527.9384 & 0.0030 & 1.8942 & 101.725 & 113.183\end{array}$

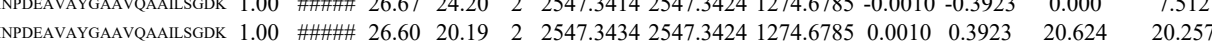

$\begin{array}{llllllllllll} & \end{array}$

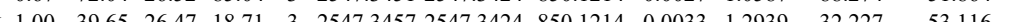

DAGTIAGLNVLR

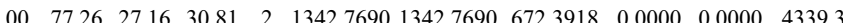

3.116

DAGTALATK

$\begin{array}{llllllllllllll}1.00 & 74.45 & 27.19 & 31.02 & 2 & 1342.7694 & 1342.7690 & 672.3918 & 0.0004 & 0.2974 & 4847.365 & 1936.740 & 1585\end{array}$

MVNHFIAEFK

MVNHFIAEFK

$\begin{array}{llllllllllll}1.00 & 50.83 & 27.69 & 20.15 & 2 & 1522.8210 & 1522.8210 & 762.4178 & 0.0000 & 0.0000 & 7614.499 & 11195.910 \\ 1.00 & 56.97 & 27.93 & 20.73 & 2 & 1522.8214 & 1522.8210 & 762.4178 & 0.0004 & 0.2623 & 11276.964 & 11885.854\end{array}$

$\begin{array}{lllllllllllll}1.00 & 56.97 & 27.93 & 20.73 & 2 & 1522.8214 & 1522.8210 & 762.4178 & 0.0004 & 0.2623 & 11276.964 & 11885.854 \\ 0.66 & 38.88 & 28.05 & 51.88 & 3 & 1522.8232 & 1522.8210 & 508.6143 & 0.0022 & 1.4418 & 8453.683 & 10841.743\end{array}$

CNEIINWLDK

CNEIINWLDK

$\begin{array}{llllllllllllll}1.00 & 42.05 & 27.41 & 28.26 & 2 & 1580.7950 & 1580.7934 & 791.4040 & 0.0016 & 1.0109 & 1899.008 & 2319.058\end{array}$

CNEIINWLDK

$\begin{array}{llllllllllllll}1.00 & 53.15 & 27.41 & 33.77 & 2 & 1580.7950 & 1580.7934 & 791.4040 & 0.0016 & 1.0109 & 595.975 & 552.484\end{array}$ $\begin{array}{llllllllllll}0.95 & 21.58 & 27.37 & 18.05 & 3 & 1580.7967 & 1580.7934 & 527.9384 & 0.0033 & 2.0836 & 72.111 & 92.078\end{array}$

QIHDIVLVGGSTR

$\begin{array}{llllllllllllll}1.00 & 81.45 & 26.55 & 18.39 & 2 & 1624.9122 & 1624.9019 & 813.4582 & 0.0103 & 6.3310 & 1963.563 & 1952.108\end{array}$

$\begin{array}{lllllllllllll}1.00 & 81.60 & 26.52 & 20.37 & 2 & 1624.9128 & 1624.9019 & 813.4582 & 0.0109 & 6.6997 & 2813.341 & 3228.288\end{array}$

$\begin{array}{lllllllllllll}1.00 & 82.92 & 26.56 & 35.15 & 3 & 1624.9135 & 1624.9019 & 542.6412 & 0.0116 & 7.1256 & 1789.370 & 2878.645\end{array}$

SQIHDIVLVGGSTR

SINPDEAVAYGAAVQAALSSCOK

DAGTIAGLNVLR

DAGTIAGLNVLR

MVNHFIAEFK

MVNHFIAEFK

SQIHDIVLVGGSTR

SQIHDIVLVGGSTR

SQIHDIVLVGGSTR

SQIHDIVLVGGSTR

SQIHDIVLVGGSTR

SQIHDIVLVGGSTR

SQIHDIVLVGGSTR

QQ

$\begin{array}{lllllllllllll}1.00 & 42.76 & 26.41 & 19.41 & 3 & 2547.3463 & 2547.3424 & 850.1214 & 0.0039 & 1.5292 & 105.205 & 79.030 & 136\end{array}$

$\begin{array}{lllllllllllllll} & \end{array}$ $\begin{array}{lllllllllllllll}1.00 & 74.51 & 26.97 & 31.10 & 2 & 1342.7812 & 1342.7690 & 672.3918 & 0.0122 & 9.0720 & 5787.089 & 2887.691 & 25936.637 & 24377.626 & \text { No }\end{array}$

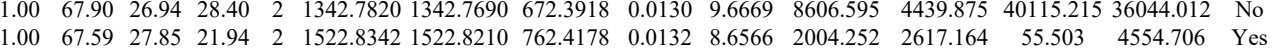

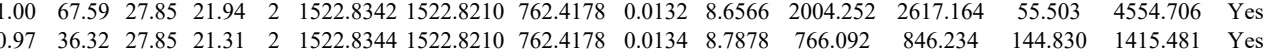

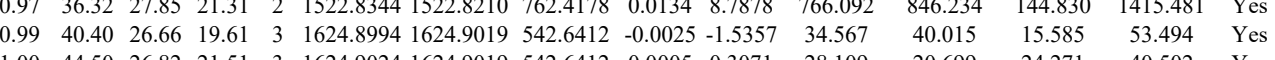

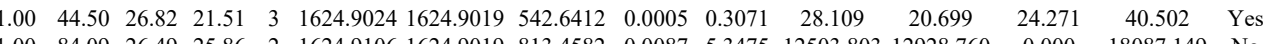

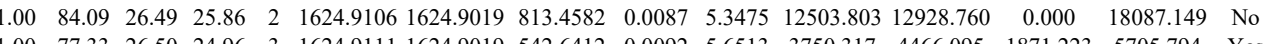
$\begin{array}{llllllllllllllll}1.00 & 77.33 & 26.50 & 24.96 & 3 & 1624.9111 & 1624.9019 & 542.6412 & 0.0092 & 5.6513 & 3750.317 & 4466.095 & 1871.223 & 5705.794 & \text { Yes }\end{array}$ \begin{tabular}{lllllllllllllll}
1.00 & 66.11 & 26.54 & 24.30 & 3 & 1624.9120 & 1624.9019 & 542.6412 & 0.0101 & 6.2042 & 2021.764 & 3624.566 & 1512.733 & 3803.933 & Yes \\
\hline
\end{tabular} $\begin{array}{lllllllllllllll}1.00 & 86.85 & 26.52 & 21.58 & 2 & 1624.9126 & 1624.9019 & 813.4582 & 0.0107 & 6.5768 & 11340.623 & 13221.578 & 512.186 & 16570.732 & \text { Yes } \\ 1.00 & 84.03 & 26.49 & 23.50 & 2 & 1624.9106 & 1624.9019 & 813.4582 & 0.0087 & 5.3475 & 5934.512 & 6162.599 & 32.681 & 9041.639 & \text { Yes }\end{array}$

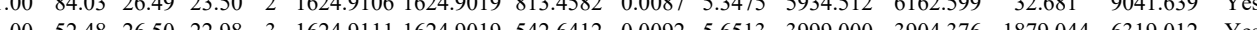

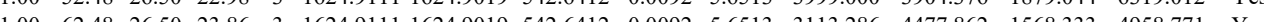
$\begin{array}{lllllllllllllll}1.00 & 93.12 & 26.46 & 19.81 & 2 & 1624.9114 & 1624.9019 & 813.4582 & 0.0095 & 5.8392 & 6145.050 & 6177.599 & 152.365 & 9554.677 & \text { Yes }\end{array}$ 


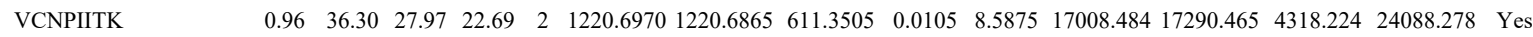

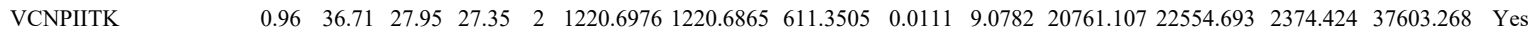
$\begin{array}{lllllllllllllllll}\text { GPAVGIDLGTTYSCVGVFOHGK } & 1.00 & 84.90 & 27.03 & 19.37 & 3 & 2539.2799 & 2539.2807 & 847.4342 & -0.0008 & -0.3147 & 13.473 & 20.630 & 16.142 & 10.972 & \text { Yes }\end{array}$

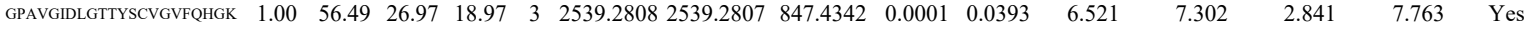

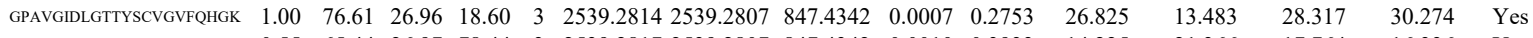
$\begin{array}{llllllllllllllll}\text { GPAVGIDLGTTYSCVGVFOHGK } & 0.55 & 65.44 & 26.97 & 78.44 & 3 & 2539.2817 & 2539.2807 & 847.4342 & 0.0010 & 0.3933 & 14.225 & 21.366 & 17.764 & 16.336 & \text { Yes }\end{array}$ $\begin{array}{lllllllllllllll}\text { GAAVGDLGTINSCVGVFOHGK } & 0.55 & 88.75 & 27.00 & \text { \#\#\#\# } 3 & 2539.2823 & 2539.2807 & 847.4342 & 0.0016 & 0.6294 & 150.926 & 166.030 & 200.569 & 210.862 & \text { Yes }\end{array}$ $\begin{array}{llllllllllllllllll}\text { CAAVGLLGTYSCVGVFPHGK } & 0.60 & 85.64 & 27.02 & 98.64 & 3 & 2539.2847 & 2539.2807 & 847.4342 & 0.0040 & 1.5734 & 96.916 & 75.871 & 106.371 & 193.075 & \text { Yes }\end{array}$

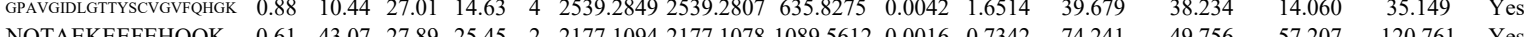

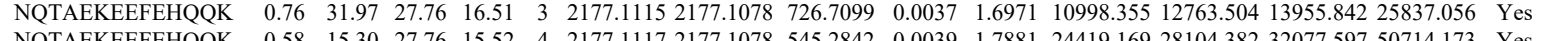

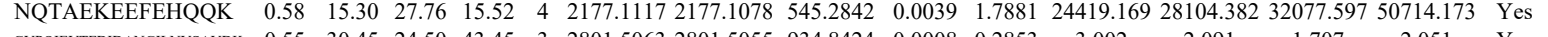

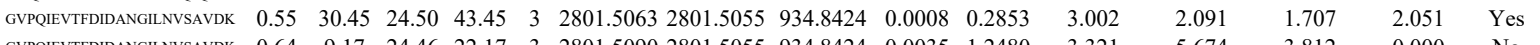
$\begin{array}{llllllllllllllll}\text { GVPQIEVTEDIDANGIINVSAVDK } & 0.64 & 9.17 & 24.46 & 22.17 & 3 & 2801.5090 & 2801.5055 & 934.8424 & 0.0035 & 1.2480 & 3.321 & 5.674 & 3.812 & 0.000 & \text { No }\end{array}$

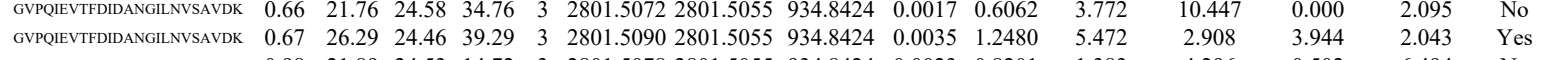

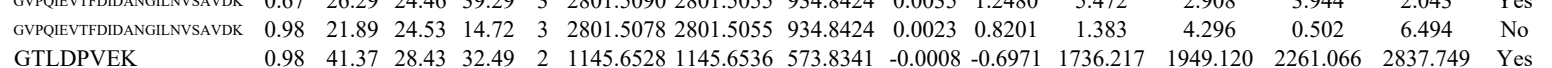

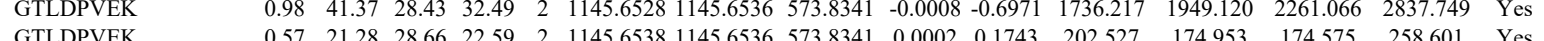
$\begin{array}{lllllllllllllllll} & \text { GTDPVE } & 0.57 & 21.28 & 28.66 & 22.59 & 2 & 1445.658 & 145.656 & 573.8341 & 0.002 & 0.1743 & 202.527 & 174.953 & 174.575 & 258.601 & \text { Yes }\end{array}$ $\begin{array}{llllllllllllllllllll}\text { NQTAEKFEFEHQQK } & 0.65 & 30.78 & 27.86 & 17.82 & 3 & 2177.1085 & 2177.1078 & 736.7099 & 0.0007 & 0.3211 & 9691.960 & 11762.640 & 15468.071 & 23646.215 & \text { Yes }\end{array}$

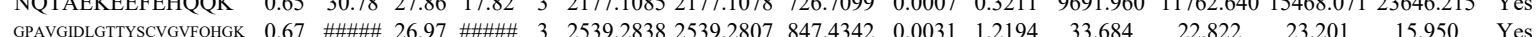

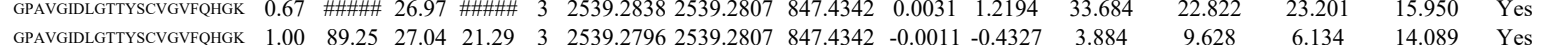

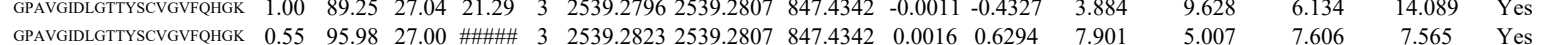

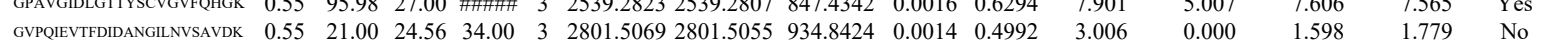

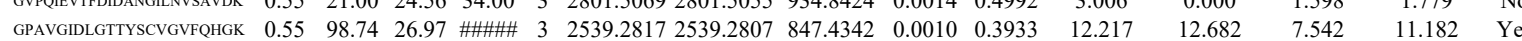

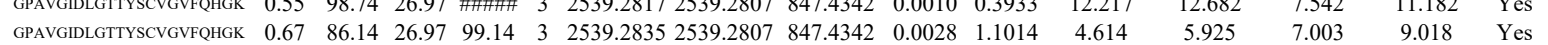

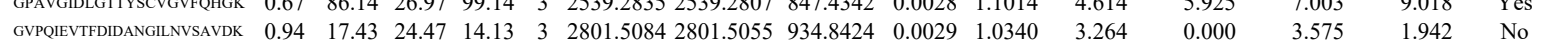

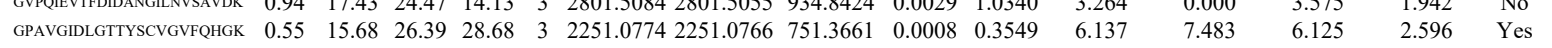

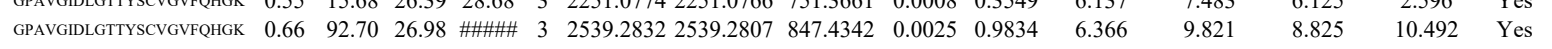

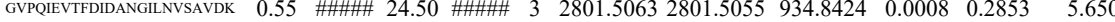
$\begin{array}{lllllllllllll} & \text { ONPIEVTFDIDANGILNVSAVDK } & 0.67 & 34.67 & 24.47 & 47.67 & 3 & 2801.5084 & 2801.5055 & 934.8424 & 0.0029 & 1.0340 & 0.050\end{array}$ $\begin{array}{llllllllllll}\text { GPAVGIDLGTTYSCVGVFOHGK } & 0.55 & \text { \#\#\#\# } 26.96 & \text { \#\#\#\# } & 3 & 2539.2814 & 2539.2807 & 847.4342 & 0.0007 & 0.2753 & 4.792\end{array}$ $\begin{array}{lllllllllllll}\text { GPAVGIDLGTTYSCVGVFOHGK } & 0.66 & 22.04 & 26.97 & 35.04 & 3 & 2539.2829 & 2539.2807 & 847.4342 & 0.0022 & 0.8654 & 14.056\end{array}$ $\begin{array}{llllllllllll}\text { GPAVGIDLGITYSCVGVFOHGK } & 0.60 & 96.09 & 27.02 & \# \# \# \text { 3 } & 2539.2844 & 2539.2807 & 847.4342 & 0.0037 & 1.4554 & 13.892 \\ \text { SINPDEAVAYGAAVQAAISGGDK } & 1.00 & 50.20 & 26.58 & 22.68 & 3 & 2547.3421 & 2547.3424 & 850.1214 & -0.0003 & -0.1176 & 7.596\end{array}$ $\begin{array}{lllllllllllll}\text { GVPRIEVTFDIDANGILNVSAVDK } & 0.59 & 12.76 & 24.53 & 14.00 & 3 & 2801.5057 & 2801.5055 & 934.8424 & 0.0002 & 0.0713 & 2.026\end{array}$ $\begin{array}{lllllllllllll}\text { GVPOIEVTFDIDANGILNVSAVDK } & 0.55 & 36.05 & 24.50 & 49.05 & 3 & 2801.5063 & 2801.5055 & 934.8424 & 0.0008 & 0.2853 & 2.667\end{array}$ $\begin{array}{llllllllllll}\text { GVPQIEVTFDIDANGLILVSAVDK } & 0.67 & 30.14 & 24.46 & 43.14 & 3 & 2801.5090 & 2801.5055 & 934.8424 & 0.0035 & 1.2480 & 1.538\end{array}$

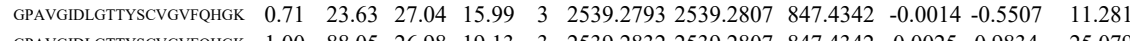

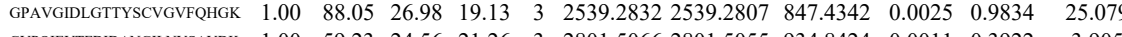
$\begin{array}{lllllllllllll}\text { GNOIEVFDDANGLNVSAVDK } & 1.00 & 59.23 & 24.56 & 21.26 & 3 & 2801.5066 & 2801.5055 & 934.8424 & 0.0011 & 0.3922 & 3.905\end{array}$ $\begin{array}{lllllllllllll}\text { GVPQIEVTFDIDANGILNVSAVDK } & 1.00 & 76.10 & 24.53 & 22.45 & 3 & 2801.5078 & 2801.5055 & 934.8424 & 0.0023 & 0.8201 & 5.152\end{array}$ $\begin{array}{lllllllllllll}\text { FDDAVVQSDMK } & 0.96 & 37.19 & 27.41 & 29.56 & 2 & 1541.7632 & 1541.7639 & 771.8892 & 0.0007 & 0.4534 & 31.581\end{array}$ 
FDDAVVQSDMK FDDAVVQSDMK FDDAVVQSDMK FDDAVVQSDMK FDDAVVQSDMK FDDAVVQSDMK FDDAVVQSDMK FDDAVVQSDMK FDDAVVQDMK TDAVQSDMK

DER

VPQIEVTFDIDANGILNVSAV

VPIIEVTFDIDANGILNVSAV

GPQIEVTFDIDANGLLNVSAVD

FDDAVVQSDMK

RFDDAVVQSDMK

RFDDAVVQSDMK

RFDDAVVQSDMK

TPEELFHPLGADSQ

VTILELFR

VTILELFR

VTILELFR

VTILELFR

FLLINR

FLLINR

FLLINR

FLLINR

GTADVTHDLQEMK

GTADVTHDLQEMK

TPEELFHPLGADSQ

MEGPAFNFLDAPAVR

TYYMSGGLQPVPIVE

TYYMSGGLQPVPIVFR

TYYMSGGLQPVPIVFR

40 VEDVEALDR

VEDVEALDR

$\begin{array}{lllllllllllll}\text { IVNGWQVEEADDWLR } & 0.72 & 78.35 & 27.73 & 19.33 & 2 & 1972.9788 & 1972.9765 & 987.4955 & 0.0023 & 1.1646 & 2223.397\end{array}$

$\begin{array}{llllllllllllllll} & \end{array}$

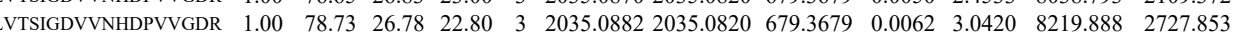
$\begin{array}{lllllllllllll}\text { IGEEFLTDLSQLK } & 0.99 & 37.18 & 26.62 & 22.47 & 3 & 1779.9931 & 1779.9862 & 594.3360 & 0.0069 & 3.8698 & 153.052 & 49.719\end{array}$ GEEFLTDLSQLK

$\begin{array}{lllllllllllll}1.00 & 52.77 & 26.62 & 28.14 & 3 & 1779.9931 & 1779.9862 & 594.3360 & 0.0069 & 3.8698 & 156.489\end{array}$

$\begin{array}{llllllllllll}1.00 & 75.90 & 26.72 & 21.87 & 3 & 2035.0864 & 2035.0820 & 679.3679 & 0.0044 & 2.1589 & 6043.486 & 1875.060\end{array}$ $\begin{array}{lllllllllllllll} & 2035.0864 & 2035.0820 & 679.3679 & 0.0044 & 2.1589 & 11948.638 & 4579.960\end{array}$

$\begin{array}{lllllllllllll}\text { IGEEFLTDLSQLK } & 1.00 & 75.22 & 26.68 & 30.11 & 2 & 1779.9918 & 1779.9862 & 891.0004 & 0.0056 & 3.1425 & 2392.213 & 493.634 \\ \text { IGEEFLTDLSQLK } & 1.00 & 72.77 & 26.68 & 30.22 & 2 & 1779.9918 & 1779.9862 & 891.0004 & 0.0056 & 3.1425 & 1732.610 & 348.774\end{array}$ GEEFLTDLSQLK

IGEEFLTDLSQL

IGEEFLTDLSQL

IGEEFLTDLSQLK

IGEEFLTDLSQLK

$\begin{array}{lllllllllllll}1.00 & 42.42 & 26.62 & 23.29 & 3 & 1779.9931 & 1779.9862 & 594.3360 & 0.0069 & 3.8698 & 545.488 & 219.866 \\ 1.00 & 52.38 & 26.62 & 29.65 & 3 & 1779.9931 & 1779.9862 & 594.3360 & 0.0069 & 3.8698 & 199.405 & 123.579\end{array}$

$\begin{array}{llllllllllll}1.00 & 52.38 & 26.62 & 29.65 & 3 & 1779.9931 & 1779.9862 & 594.3360 & 0.0069 & 3.8698 & 199.405 & 123.579\end{array}$

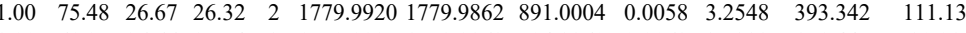

$\begin{array}{lllllllllllll}1.00 & 61.25 & 26.66 & 27.74 & 3 & 1779.9925 & 1779.9862 & 594.3360 & 0.0063 & 3.5333 & 151.447 & 80.013 \\ 1.00 & 58.53 & 26.60 & 24.45 & 2 & 1779.9928 & 1779.9862 & 891.0004 & 0.0066 & 3.7037 & 503.835 & 197.171\end{array}$

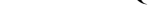

$\begin{array}{llllllllllll}1.00 & 58.53 & 26.60 & 24.45 & 2 & 1779.9928 & 1779.9862 & 891.0004 & 0.0066 & 3.7037 & 503.835 & 197.171 \\ 1.00 & 62.92 & 26.98 & 18.76 & 3 & 2734.4125 & 2734.4051 & 912.4756 & 0.0074 & 2.7033 & 58.162 & 32.712\end{array}$

IGEEFLTDLSQLK

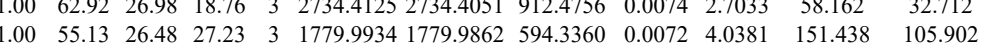

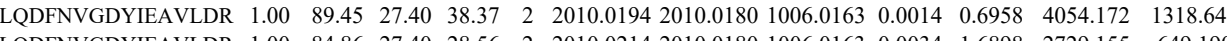

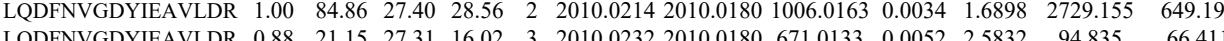

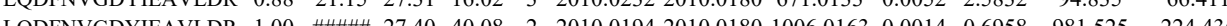
$\begin{array}{lllllllllllll}\text { LQDFNVGDYIEAVLDR } & 1.00 & 89.36 & 27.40 & 30.58 & 2 & 2010.0214 & 2010.0180 & 1006.0163 & 0.0034 & 1.6898 & 1271.162 & 279.187\end{array}$ $\begin{array}{llllllllllllllll}\text { LQDFNVGDYIEAVLDR } & 1.00 & 66.14 & 27.31 & 24.12 & 3 & 2010.0232 & 2010.0180 & 671.0133 & 0.0052 & 2.5832 & 111.112 & 161.103\end{array}$ $\begin{array}{lllllllllllllll}0.60 & 17.81 & 27.45 & 30.81 & 3 & 1541.7676 & 1541.7639 & 514.9286 & 0.0037 & 2.3951 & 260.201 & 229.492 & 91.764 & 295.125 & \text { Yes } \\ 0.99 & 44.31 & 27.69 & 28.12 & 2 & 1541.7716 & 1541.7639 & 771.8892 & 0.0077 & 4.9877 & 40.210 & 40.096 & 5.985 & 54.570 & \text { Yes }\end{array}$ $\begin{array}{ccc}5.985 & 54.570 & \text { Yes } \\ 3.514 & 1.637 & \text { No }\end{array}$ 


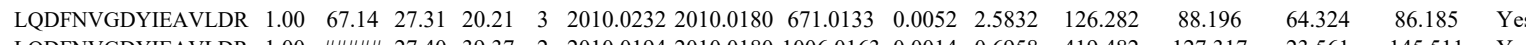
$\begin{array}{lllllllllllllll}\text { LQDFNVGDYIEAVLDR } & 1.00 & \text { \#\#\#\# } 27.40 & 39.37 & 2 & 2010.0194 & 2010.0180 & 1006.0163 & 0.0014 & 0.6958 & 419.482 & 127.317 & 23.561 & 145.511 & \text { Yes }\end{array}$

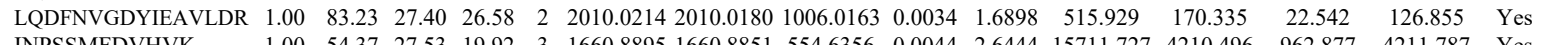
$\begin{array}{llllllllllllllll}\text { INPSSMFDVHVK } & 1.00 & 54.37 & 27.53 & 19.92 & 3 & 1660.8895 & 1660.8851 & 554.6356 & 0.0044 & 2.6444 & 15711.727 & 4210.496 & 962.877 & 4211.787 & \text { Yes } \\ \text { INPSSMFDVHVK } & 1.00 & 56.24 & 27.53 & 19.33 & 3 & 1603 & \end{array}$

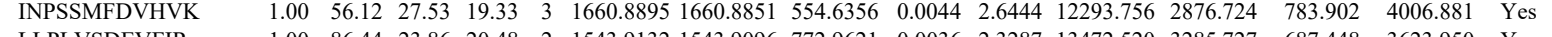
\begin{tabular}{lllllllllllllllll} 
LLPLVSDEVFIR & 1.00 & 86.44 & 23.86 & 20.48 & 2 & 1543.9132 & 1543.9096 & 772.9621 & 0.0036 & 2.3287 & 13472.520 & 3285.727 & 687.448 & 3623.950 & Yes \\
\hline LLPLVSDEVFIR & 1.0 & 6.13 & 24.23 & 20.54 & 2 & 1543.9138 & 1543.996 & 772.9621 & 0.042 & 2.7168 & 7533.810 & 1925.734 & 351.784 & 2047.717 & Yes
\end{tabular} \begin{tabular}{lllllllllllllllll} 
LLPLVSDEVFIR & 1.00 & 66.13 & 24.23 & 20.54 & 2 & 1543.9138 & 1543.9096 & 772.9621 & 0.0042 & 2.7168 & 7533.810 & 1925.734 & 351.784 & 2047.717 & Yes \\
\hline
\end{tabular}

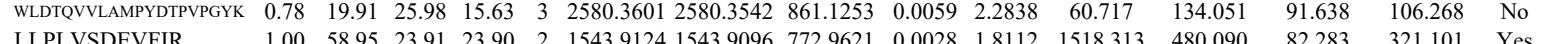

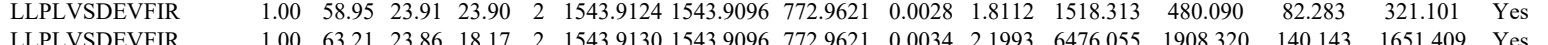
$\begin{array}{lllllllllllll} & \end{array}$

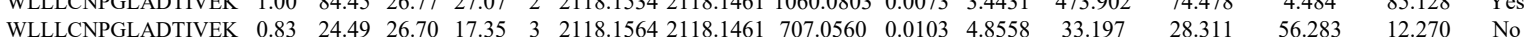

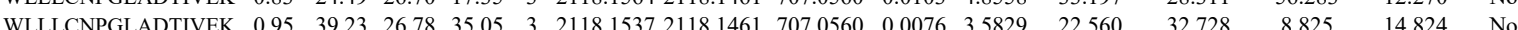

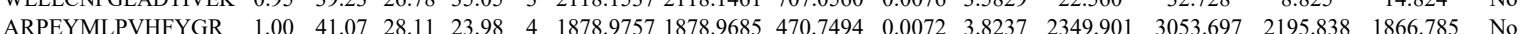

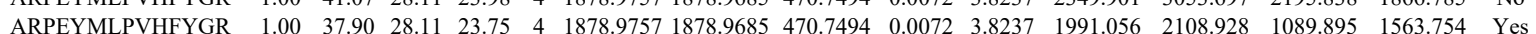
$\begin{array}{lllllllllllllllll} & \text { VRPEYLP } & 1.09 & 53.51 & 27.85 & 45.19 & 2 & 1188.6216 & 1188.6108 & 595.3127 & 0.0108 & 9.0708 & 6873.109 & 1871.811 & 916.509 & 2337.223 & \text { Yes }\end{array}$ $\begin{array}{lllllllllllllllll}\text { VEDVEALDR } & 0.99 & 53.51 & 27.85 & 45.19 & 2 & 1188.6216 & 1188.6108 & 595.3127 & 0.0108 & 9.0708 & 6873.109 & 1871.811 & 916.509 & 2337.223 & \text { Yes } \\ \text { VEDVEALDR } & 0.97 & 52.26 & 27.75 & 49.17 & 2 & 1188.6222 & 1188.6108 & 595.3127 & 0.0114 & 9.5747 & 4656.947 & 1361.469 & 654.716 & 1708.803 & \text { Yes }\end{array}$

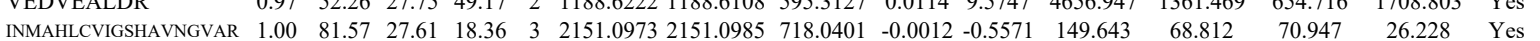
$\begin{array}{llllllllllllllll}\text { INMAHLCVIGSHAVNGVAR } & 1.00 & 78.00 & 27.68 & 19.17 & 3 & 2151.0991 & 2151.0985 & 718.0401 & 0.0006 & 0.2785 & 192.777 & 68.832 & 69.031 & 45.725 & \text { Yes }\end{array}$

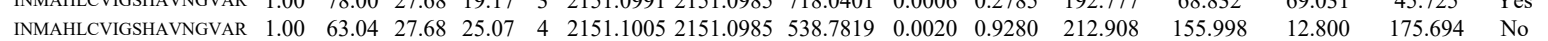
$\begin{array}{llllllllllllllll}\text { INMAHLCVIGSHAVNGVAR } & 1.00 & 86.42 & 27.64 & 31.31 & 4 & 2151.1009 & 2151.0985 & 538.7819 & 0.0024 & 1.1136 & 199.482 & 160.272 & 15.767 & 152.270 & \text { Yes }\end{array}$

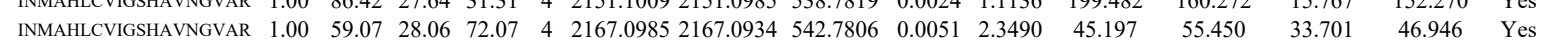
$\begin{array}{llllllllllllllll}\text { QLLNCLHVVTLYNR } & 1.00 & 67.01 & 27.11 & 22.25 & 3 & 1875.0022 & 1874.9981 & 626.0066 & 0.0041 & 2.1831 & 96.781 & 95.316 & 12.808 & 67.353 & \text { No }\end{array}$

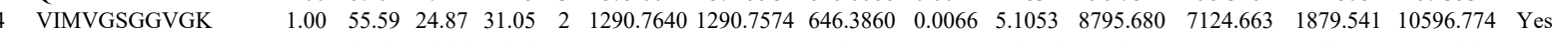
$\begin{array}{llllllllllllllll}\text { VFFDLMR } & 1.00 & 41.68 & 26.64 & 26.36 & 2 & 1070.5712 & 1070.5705 & 536.2925 & 0.0007 & 0.6526 & 2824.927 & 2535.083 & 266.059 & 8705.465 & \text { Yes }\end{array}$ VFFDLMR VFFDLMR VFFDLMR

22 QPEDDLFDR NLQLFMENK IMPEDIIINCSK IMPEDIIINCSK IMPEDIIINCSK LNTGILNK LNTGILNK IEPPGLFR

\section{LEEEEDGK} $\begin{array}{llllllllllllllllll}\text { KLEEEEDGK } & 0.99 & 34.11 & 28.25 & 19.89 & 3 & 1507.8094 & 1507.8095 & 03.6104 & -0.0001 & -0.0662 & 1402.173 & 1675.639 & 735.978 & 2797.992 & \text { Yes } \\ \text { KLEEEEDGK } & 1.00 & 41.62 & 28.33 & 22.89 & 3 & 1507.8103 & 1507.8095 & 503.6104 & 0.0008 & 0.5295 & 1847.142 & 2055.163 & 453.509 & 3995.952 & \text { Yes }\end{array}$ $\begin{array}{lllllllllllllll}0.99 & 36.23 & 26.84 & 25.20 & 2 & 1070.5730 & 1070.5705 & 536.2925 & 0.0025 & 2.3308 & 3097.501 & 2571.526 & 0.000 & 9859.072 & \text { No }\end{array}$

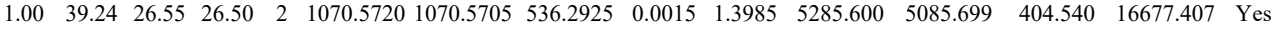
$\begin{array}{lllllllllllllll}1.00 & 39.06 & 26.55 & 25.42 & 2 & 1070.5720 & 1070.5705 & 536.2925 & 0.0015 & 1.3985 & 5432.087 & 6412.263 & 710.214 & 17941.950 & \text { Yes }\end{array}$

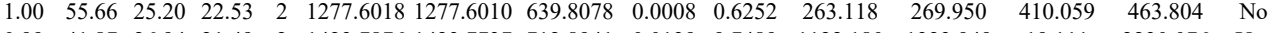
$\begin{array}{lllllllllllllll}0.99 & 41.87 & 26.94 & 21.49 & 2 & 1423.7876 & 1423.7737 & 712.8941 & 0.0139 & 9.7489 & 1122.180 & 1323.949 & 19.111 & 2230.076 & \text { Yes }\end{array}$ $\begin{array}{lllllllllllllll}0.97 & 24.68 & 28.13 & 14.88 & 3 & 1708.8832 & 1708.8805 & 570.6341 & 0.0027 & 1.5772 & 69.480 & 73.844 & 59.276 & 98.896 & \text { Yes }\end{array}$

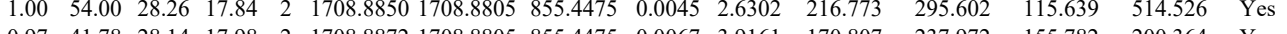
$\begin{array}{lllllllllllllll}0.97 & 41.78 & 28.14 & 17.98 & 2 & 1708.8872 & 1708.8805 & 855.4475 & 0.0067 & 3.9161 & 170.807 & 237.972 & 155.782 & 200.364 & \text { Yes }\end{array}$ $\begin{array}{llllllllllllllll}0.99 & 42.90 & 25.58 & 32.42 & 2 & 1159.7244 & 1159.7168 & 580.8657 & 0.0076 & 6.5419 & 16421.359 & 25011.123 & 7983.093 & 34958.605 & \text { Yes }\end{array}$ $\begin{array}{lllllllllllllllll}0.99 & 42.94 & 25.58 & 32.52 & 2 & 1159.7250 & 1159.7168 & 580.8657 & 0.0082 & 7.0584 & 15792.854 & 17062.844 & 1180.608 & 28127.005 & \text { Yes }\end{array}$ $\begin{array}{lllllllllllllllll}0.76 & 24.84 & 25.89 & 20.67 & 2 & 107.6296 & 1071.6199 & 536.8172 & 0.0097 & 9.0347 & 14396.098 & 15314.618 & 0.000 & 2591.715 & \text { No } \\ 0.99 & 41.00 & 27.24 & 29.02 & 2 & 1235.6128 & 1235.6125 & 618.8135 & 0.0003 & 0.2424 & 1080.787 & 1448.416 & 1247.103 & 1446.062 & \text { Yes }\end{array}$ $\begin{array}{llllllllllllllll}0.99 & 41.00 & 27.24 & 29.02 & 2 & 1235.6128 & 1235.6125 & 618.8135 & 0.0003 & 0.2424 & 1080.787 & 1448.416 & 1247.103 & 1446.062 & \text { Yes } \\ 0.99 & 34.11 & 28.25 & 19.89 & 3 & 1507.8094 & 1507.8095 & 503.6104 & 0.0001 & 0.062 & 1402.173 & 1675.639 & 735.978 & 2797.992 & \text { Yes }\end{array}$ $\begin{array}{lllllllllllll} & \end{array}$ YIMLNPSSR YIMLNPSSR YIMLNPSSR QPEDDLFDR AVAILCNHQR AVAILCNHQR AVAILCNHQR AVAILCNHQR AVAILCNHQR AVAILCNHQR AVAILCNHQR AVAILCNHQR AVAILCNHQR MLDHEYTTK

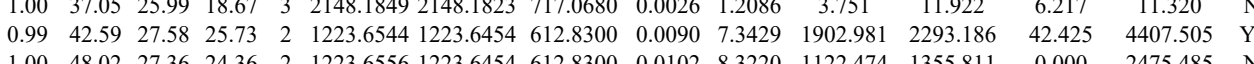
$\begin{array}{lllllllllllllll}0.99 & 43.70 & 27.58 & 32.95 & 2 & 1223.6544 & 1223.6454 & 6128300 & 0.0090 & 73429 & 2055.716 & 2655.074 & 125.287 & 4012.191 & \text { Yes }\end{array}$ $\begin{array}{llllllllllllllll}0.95 & 34.31 & 27.19 & 27.99 & 2 & 1223.6550 & 1223.6454 & 6128300 & 0.0096 & 7.8325 & 560.707 & 655.998 & 138.706 & 768.391 & \text { Yes }\end{array}$ $\begin{array}{lllllllllllllll}0.52 & 16.96 & 25.26 & 23.91 & 2 & 1277.6014 & 1277.6010 & 639.8078 & 0.0004 & 0.3126 & 849.368 & 827.757 & 1215.043 & 1283.630 & \text { No }\end{array}$ $\begin{array}{lllllllllllllll}1.00 & 63.63 & 27.08 & 26.60 & 2 & 1313.6864 & 1313.6818 & 657.8482 & 0.0046 & 3.4962 & 3382.500 & 4155.060 & 0.000 & 7137.885 & \text { No }\end{array}$ $\begin{array}{lllllllllllllll}1.00 & 65.07 & 27.08 & 25.62 & 2 & 1313.6866 & 1313.6818 & 657.8482 & 0.0048 & 3.6482 & 1436.258 & 1715.249 & 216.190 & 3013.143 & \text { Yes }\end{array}$ $\begin{array}{llllllllllllllll}1.00 & 49.25 & 26.89 & 27.32 & 3 & 1313.6872 & 1313.6818 & 438.9012 & 0.0054 & 4.1011 & 7220.440 & 7229.033 & 1213.475 & 16371.653 & \text { Yes }\end{array}$ $\begin{array}{lllllllllllllll}1.00 & 52.62 & 26.90 & 26.00 & 3 & 1313.6881 & 1313.6818 & 438.9012 & 0.0063 & 4.7847 & 9556.138 & 10864.645 & 882.735 & 17482.686 & \text { Yes }\end{array}$ $\begin{array}{llllllllllllllll}1.00 & 53.12 & 26.80 & 29.04 & 3 & 1313.6797 & 1313.6818 & 438.9012 & -0.0021 & -1.5949 & 4563.809 & 5145.742 & 689.840 & 9780.502 & \text { Yes }\end{array}$ $\begin{array}{lllllllllllllll}0.97 & 43.82 & 26.82 & 35.06 & 3 & 1313.6800 & 1313.6818 & 438.9012 & -0.0018 & -1.3671 & 5892.610 & 8306.120 & 1384.090 & 11698.565 & \text { Yes }\end{array}$ $\begin{array}{llllllllllllllll}1.00 & 55.49 & 26.79 & 22.77 & 2 & 1313.6806 & 1313.6818 & 657.8482 & -0.0012 & -0.9121 & 1530.282 & 1860.081 & 167.911 & 2899.091 & \text { Yes }\end{array}$

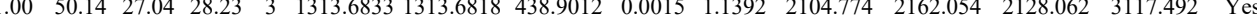
$\begin{array}{llllllllllllllll}1.00 & 43.74 & 26.82 & 24.56 & 3 & 1313.6842 & 1313.6818 & 438.9012 & 0.0024 & 1.8227 & 2074.407 & 2410.452 & 2539.340 & 3739.394 & \text { Yes }\end{array}$

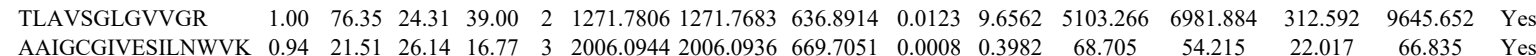
$\begin{array}{llllllllllllllll}0.67 & 16.38 & 27.49 & 29.38 & 3 & 1424.7247 & 1424.7213 & 475.9144 & 0.0034 & 2.3814 & 1281.876 & 1546.692 & 810.967 & 1745.068 & \text { Yes } & \\ \end{array}$ $\begin{array}{llllllllllllllll}\text { AAIGCGIVESILNWVK } & 0.94 & 21.51 & 26.14 & 16.77 & 3 & 2006.0944 & 2006.0936 & 669.7051 & 0.0008 & 0.3982 & 68.705 & 54.215 & 22.017 & 66.835 & \text { Yes }\end{array}$ $\begin{array}{llllllllllllllll}\text { AAIGCGVESILNWVK } & 0.98 & 23.40 & 25.97 & 18.24 & 3 & 2006.0953 & 2006.0936 & 669.7051 & 0.0017 & 0.8461 & 63.370 & 56.983 & 9.156 & 66.770 & \text { Yes }\end{array}$ $\begin{array}{lllllllllllllllll}\text { EDLATFIEELEAVEAK } & 1.00 & 37.09 & 27.52 & 22.41 & 3 & 2094.1003 & 2094.0976 & 699.0398 & 0.0027 & 1.2875 & 83.393 & 59.254 & 72.701 & 121.152 & \text { Yes }\end{array}$

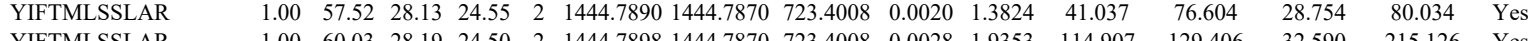

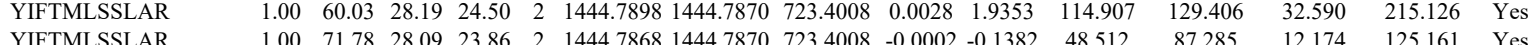

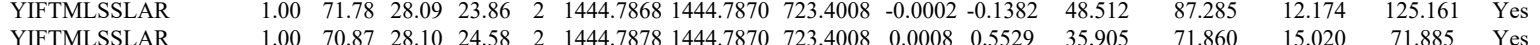

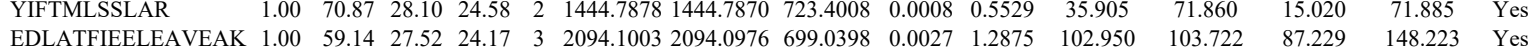

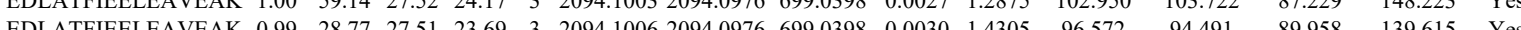

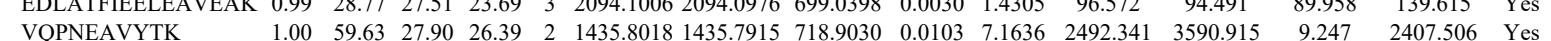




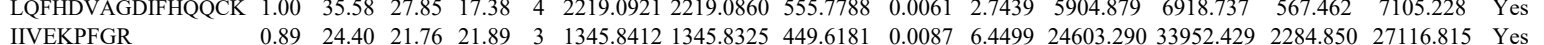

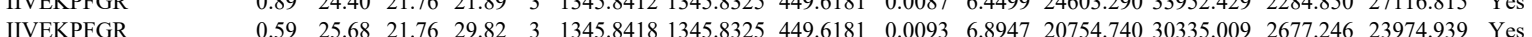
IIVEKPFGR $\quad \begin{array}{llllllllllllllll}0.75 & 23.40 & 21.11 & 25.35 & 3 & 1345.8436 & 13458325 & 449.6181 & 0.0111 & 82291 & 27004293 & 39433.530 & 1719.926 & 29551.330 & \text { Yes }\end{array}$

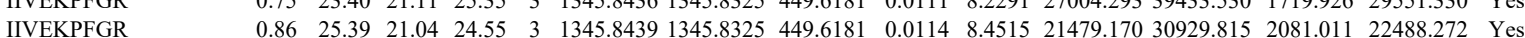

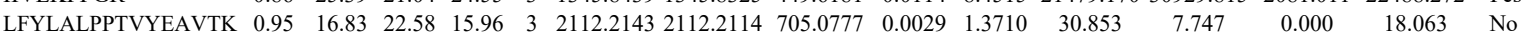

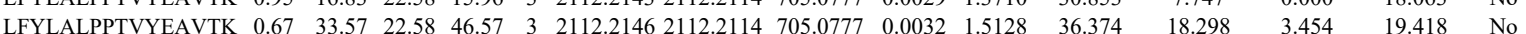
$\begin{array}{llllllllllllllll}\text { LNSHMNALHLGSQANR } & 0.99 & 25.73 & 27.85 & 20.78 & 4 & 1905.9889 & 1905.9713 & 477.5001 & 0.0176 & 9.2146 & 580.960 & 678.842 & 353.577 & 939.078 & \text { Yes }\end{array}$

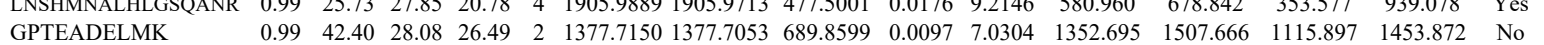

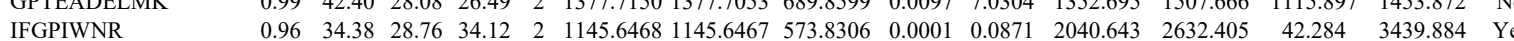

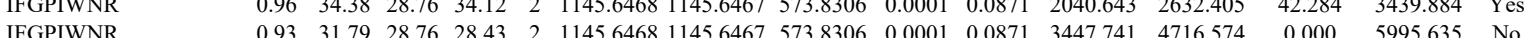
IFGPIWNR

GYLDDPTVPR $\begin{array}{llllllllllllllll}0.80 & 26.24 & 28.70 & 29.58 & 2 & 1145.6472 & 1145.6467 & 573.8306 & 0.0005 & 0.4357 & 2428.472 & 3234.248 & 128.674 & 3863.291 & \text { Yes }\end{array}$ $\begin{array}{lllllllllllllll}0.98 & 34.04 & 28.74 & 30.85 & 2 & 1145.6476 & 1145.6467 & 573.8306 & 0.0009 & 0.7842 & 2141.459 & 3240.174 & 0.000 & 3737.580 & \text { No }\end{array}$ $\begin{array}{lllllllllllllll}0.97 & 37.29 & 28.47 & 17.08 & 2 & 1275.6680 & 1275.6581 & 638.8363 & 0.0099 & 7.7484 & 2159.630 & 2918.951 & 796.707 & 2429.227 & \text { Yes }\end{array}$

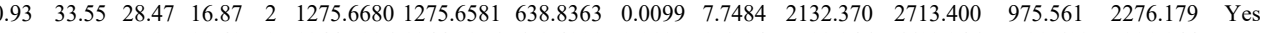
$\begin{array}{llllllllllllllll}1.00 & 52.50 & 25.15 & 20.42 & 2 & 1344.7986 & 1344.7856 & 673.4001 & 0.0130 & 9.6524 & 7522.246 & 6603.246 & 5039.608 & 7331.944 & \text { Yes }\end{array}$ $\begin{array}{lllllllllllllll}.99 & 39.07 & 25.74 & 22.03 & 2 & 1344.7964 & 1344.7856 & 673.4001 & 0.0108 & 8.0189 & 4241.895 & 3110.861 & 2392.119 & 3513.391 & \text { Yes }\end{array}$ $\begin{array}{llllllllllllllll}1.00 & 70.30 & 28.05 & 21.42 & 2 & 1629.8490 & 1629.8484 & 815.9315 & 0.0006 & 0.3677 & 1047.181 & 773.984 & 18.628 & 1713.772 & \text { Yes }\end{array}$

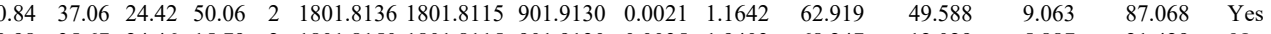
$\begin{array}{lllllllllllllll}0.98 & 35.67 & 24.46 & 15.79 & 2 & 1801.8150 & 1801.8115 & 901.9130 & 0.0035 & 1.9403 & 68.247 & 12.029 & 5.887 & 21.429 & \text { No }\end{array}$ $\begin{array}{lllllllllllllll}0.98 & 37.77 & 27.51 & 24.79 & 2 & 1446.8194 & 1446.8075 & 724.4110 & 0.0119 & 8.2135 & 960.396 & 806.371 & 1657.637 & 1887.986 & \text { Yes } \\ \end{array}$ $\begin{array}{llllllllllllllll}1.00 & 45.12 & 27.40 & 29.27 & 2 & 1446.8198 & 1446.8075 & 724.4110 & 0.0123 & 8.4896 & 3599.571 & 3024.174 & 6758.627 & 7286.912 & \text { Yes }\end{array}$ $\begin{array}{lcccccccccccccc} & \end{array}$ $\begin{array}{lllllllllllllll}1.00 & 57.85 & 24.03 & 17.47 & 4 & 4349.2029 & 4349.1984 & 1088.3069 & 0.0045 & 1.0337 & 11.374 & 18.501 & 39.312 & 10.824 & \text { No }\end{array}$

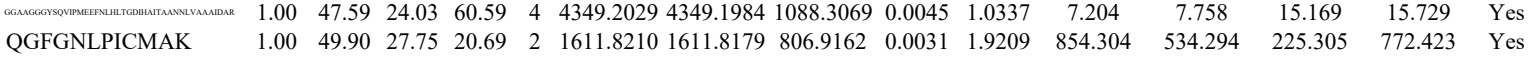
\begin{tabular}{llllllllllllllll} 
& \\
QGFGNLPICMAK & 1.00 & 49.90 & 27.75 & 20.69 & 2 & 1611.8210 & 1611.8179 & 806.9162 & 0.0031 & 1.9209 & 854.304 & 534.294 & 225.305 & 772.423 & Yes \\
\hline
\end{tabular} $\begin{array}{lllllllllllllll} & \text { Q }\end{array}$

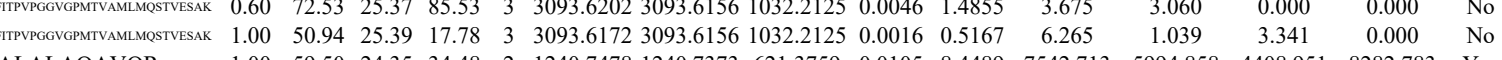
GALALAQAVQ $\begin{array}{lllllllllllllll}1.00 & 59.50 & 24.35 & 34.48 & 2 & 1240.7478 & 1240.7373 & 621.3759 & 0.0105 & 8.4489 & 7542.713 & 5994.858 & 4408.951 & 8282.783 & \text { Yes }\end{array}$ $\begin{array}{llllllllllllll} & \end{array}$

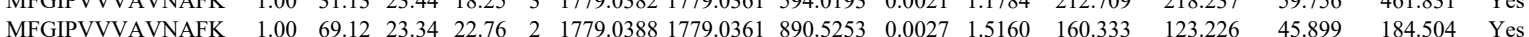
$\begin{array}{llllllllllllllll}\text { MFGIPVVVAVNAFK } & 1.00 & 69.12 & 23.34 & 22.76 & 2 & 1779.0388 & 1779.0361 & 890.5253 & 0.0027 & 1.5160 & 160.333 & 123.226 & 45.899 & 184.504 & \text { Yes } \\ \text { MFGIPVVVAVNAFK } & 0.60 & 15.99 & 23.42 & 28.99 & 3 & 1779.0397 & 1779.0361 & 594.0193 & 0.0036 & 2.0201 & 218.731 & 220.031 & 127.552 & 246.596 & \text { Yes }\end{array}$

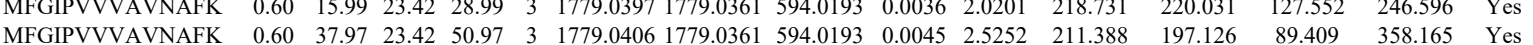

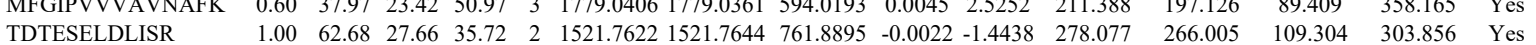
$\begin{array}{llllllllllllllll} & \\ \text { TDTESELDLISR } & 1.00 & 59.69 & 27.82 & 39.13 & 2 & 1521.7658 & 1521.7644 & 761.8895 & 0.0014 & 0.9188 & 212.563 & 227.507 & 140.678 & 290.568 & \text { Yes }\end{array}$

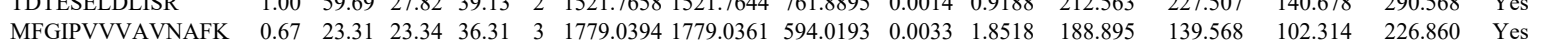
$\begin{array}{llllllllllllllll}\text { MFGIPVVVAVNAFK } & 0.99 & 25.88 & 23.42 & 14.65 & 3 & 1779.0397 & 1779.0361 & 594.0193 & 0.0036 & 2.0201 & 149.665 & 177.910 & 99.222 & 269.211 & \text { Yes }\end{array}$

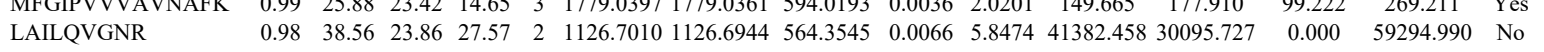

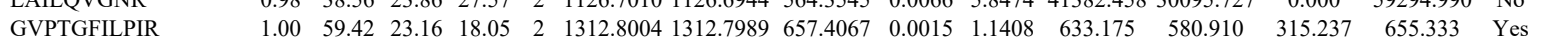
$\begin{array}{llllllllllllllll}\text { MFGIPVVVAVNAFK } & 0.65 & 8.24 & 23.34 & 16.28 & 3 & 1779.0388 & 1779.0361 & 594.0193 & 0.0027 & 1.5151 & 109.706 & 113.882 & 40.158 & 199.224 & \text { Yes }\end{array}$ $\begin{array}{lllllllllllllllll}\text { LAILQVGNR } & 1.00 & 49.38 & 23.87 & 30.74 & 2 & 1126.7008 & 1126.6944 & 564.3545 & 0.0064 & 5.6702 & 23327.926 & 17451.602 & 0.000 & 36843.814 & \text { No }\end{array}$ $\begin{array}{llllllllllllllll}\text { LAILQVGNR } & 1.00 & 49.21 & 23.71 & 28.38 & 2 & 1126.7020 & 1126.6944 & 564.3545 & 0.0076 & 6.7333 & 25082.421 & 20021.001 & 0.000 & 41170.725 & \text { No }\end{array}$ $\begin{array}{llllllllllllllll}\text { GVPTGFILPIR } & 0.82 & 51.09 & 23.05 & 64.09 & 2 & 1312.8000 & 1312.7989 & 657.4067 & 0.0011 & 0.8366 & 534.210 & 604.800 & 257.143 & 654.839 & \text { Yes }\end{array}$

LALQVGNR

LAILQVGNR

LAILQVGNR

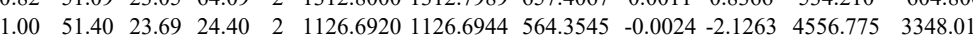
$\begin{array}{lllllllllllll}1.00 & 48.46 & 23.32 & 23.94 & 2 & 1126.6930 & 1126.6944 & 564.3545 & -0.0014 & -1.2404 & 4048.343 & 3288.195\end{array}$ $\begin{array}{llllllllllll}0.99 & 32.28 & 23.24 & 23.69 & 2 & 1126.6962 & 1126.6944 & 564.3545 & 0.0018 & 1.5947 & 67.146 & 85.101\end{array}$ $\begin{array}{llllllllllllllll} & 1.00 & 48.46 & 23.32 & 23.94 & 2 & 1126.6930 & 1126.6944 & 564.3545 & -0.0014 & -1.2404 & 4048.343 & 3288.195 & 115.850 & 5155.926 & \text { Yes } \\ & 0.99 & 32.28 & 23.24 & 23.69 & 2 & 1126.6962 & 1126.6944 & 564.3545 & 0.0018 & 1.5947 & 67.146 & 85.101 & 24.574 & 157.151 & \text { Yes } \\ \text { NR } & 1.00 & 84.00 & 27.34 & 29.44 & 2 & 1647.8198 & 1667.8073 & 824.9109 & 0.0125 & 7.5765 & 30.2681 & 202.037 & 38.787 & 354.766 & \text { Yes } \\ \text { NR } & 1.00 & 69.98 & 27.34 & 23.42 & 2 & 1647.8200 & 1647.8073 & 824.9109 & 0.0127 & 7.6977 & 74.333 & 81.658 & 31.967 & 92.916 & \text { Yes } \\ \text { EAQHK } & 1.00 & 52.82 & 27.09 & 19.65 & 3 & 2099.1178 & 2099.1142 & 700.7120 & 0.0036 & 1.7125 & 1409.453 & 1093.745 & 375.333 & 1875.892 & \text { Yes }\end{array}$ $\begin{array}{lllllllllllllll} & \end{array}$ $\begin{array}{lllllllllllll} & 1.00 & 57.59 & 22.65 & 17.46 & 2 & 1268.7596 & 1268.7584 & 635.3865 & 0.0012 & 0.9443 & 5163.268 & 3690.763\end{array}$ $\begin{array}{llllllllllllll} & 1.00 & 57.62 & 22.67 & 17.40 & 2 & 1268.7612 & 1268.7584 & 635.3865 & 0.0028 & 2.2034 & 4801.213 & 3759.958\end{array}$ $\begin{array}{lllllllllll} & 573.072 & \text { Yes } & \end{array}$ $\begin{array}{llllllllllllllllll}\text { IDPLAPLDK } & 1.00 & 57.70 & 22.81 & 17.70 & 2 & 1268.7610 & 1268.7584 & 635.3865 & 0.0026 & 2.0460 & 3594.379 & 2887.472 & 561.349 & 3134.024 & \text { Yes }\end{array}$ 

$\begin{array}{llllllllllllllll}\text { VDEAVAVLQAHQAK } & 1.00 & 58.37 & 24.28 & 21.45 & 3 & 1766.0077 & 1765.9930 & 589.6716 & 0.0147 & 8.3096 & 3539.835 & 3576.255 & 4032.064 & 6548.170 & \text { Yes }\end{array}$ $\begin{array}{llllllllllllllll}\text { VDEAVAVLQAHQAK } & 1.00 & 81.35 & 24.28 & 21.89 & 2 & 1766.0078 & 1765.9930 & 884.0038 & 0.0148 & 8.3709 & 429.259 & 412.548 & 535.639 & 826.830 & \text { Yes }\end{array}$

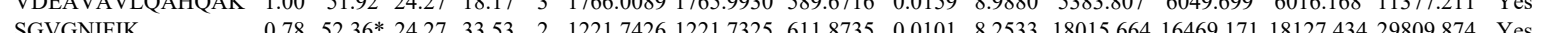

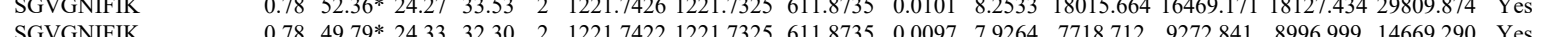

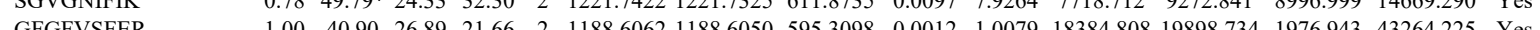
$\begin{array}{llllllllllllllllllll} & \text { GFGFVSFR } & 1.00 & 40.86 & 26.87 & 19.27 & 2 & 1188.6064 & 1188.6050 & 595.3098 & 0.0014 & 1.1759 & 10631.788 & 11993 & 202 & 1390213 & 25805.840 & \text { Yes }\end{array}$

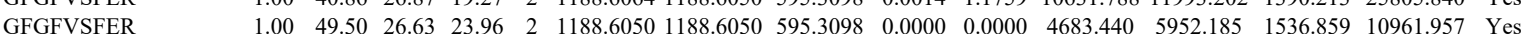
GFGFVSFER GFGFVSFER NLDDGIDDER NFDDGIDDER NFGEDMDDER NFGEDMDDER LFPLIQAMHPTLA $\begin{array}{llllllllllllllll}1.00 & 49.50 & 26.63 & 23.96 & 2 & 1188.6050 & 1188.6050 & 595.3098 & 0.0000 & 0.0000 & 4683.440 & 5952.185 & 1536.859 & 10961.957 & \text { Yes } \\ 1.00 & 51.50 & 26.88 & 21.97 & 2 & 1188.6058 & 1188.6050 & 595.3098 & 0.0008 & 0.6719 & 3328.154 & 3487.451 & 779.572 & 7518.516 & \text { Yes }\end{array}$ $\begin{array}{lllllllllllllllll}1.00 & 48.19 & 23.26 & 30.44 & 2 & 1304.5980 & 1304.5966 & 553.3056 & 0.0014 & 1.0715 & 2995.780 & 3570.774 & 480.616 & 8090.457 & \text { Yes }\end{array}$ $\begin{array}{lllllllllllllllll}1.00 & 57.28 & 23.34 & 31.10 & 2 & 1304.5988 & 13045966 & 653.3056 & 0.0022 & 1.6837 & 1499.297 & 1725.451 & 656.240 & 3676.315 & \text { Yes }\end{array}$ $\begin{array}{llllllllllllllllll}1.00 & 58.45 & 16.90 & 20.44 & 2 & 1370.5526 & 1370.5530 & 686.2838 & -0.0004 & -0.2914 & 1664.557 & 1509.049 & 716.171 & 3998.181 & \text { Yes }\end{array}$ $\begin{array}{llllllllllllllll}1.00 & 59.32 & 16.99 & 19.57 & 2 & 1370.5530 & 1370.5530 & 6862838 & 0.0000 & 0.0000 & 2038.058 & 2188.965 & 888.534 & 5639.046 & \text { Yes }\end{array}$ $\begin{array}{llllllllllllllll} & 0.84 & 28.98 & 16.53 & 41.98 & 2 & 1370.5554 & 1370.5530 & 686.2838 & 0.0024 & 1.7485 & 1421.922 & 1133.900 & 765.834 & 4147.521 & \text { No } \\ & 0.66 & 62.31 & 22.01 & 75.31 & 3 & 1924.1230 & 1924.1212 & 642.3810 & 0.0018 & 0.9340 & 2823.937 & 2654.936 & 1349.010 & 6142.667 & \text { Yes }\end{array}$ \begin{tabular}{lllllllllllllllll} 
& 1.00 & 46.33 & 26.19 & 26.15 & 2 & 1300.7632 & 1300.7625 & 651.3885 & 0.0007 & 0.5373 & 3238.017 & 2845.944 & 470.291 & 6976.679 & Yes \\
\hline
\end{tabular} $\begin{array}{llllllllllllllll}\text { LFPLIQAMHPTLAGK } & 1.00 & 84.76 & 22.33 & 24.38 & 2 & 1924.1212 & 1924.1212 & 963.0679 & 0.0000 & 0.0000 & 1217.165 & 975.413 & 661.805 & 2752.449 & \text { Yes }\end{array}$ \begin{tabular}{lllllllllllllllll} 
LFPLIQAMHPTLAGK & 1.00 & 89.30 & 22.36 & 24.78 & 2 & 1924.1214 & 1924.1212 & 963.0679 & 0.0002 & 0.1038 & 769.282 & 950.190 & 491.018 & 1876.133 & Yes \\
\hline
\end{tabular}

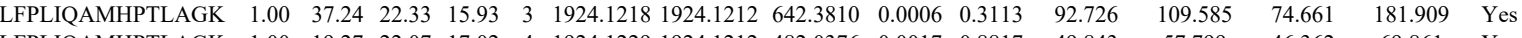
$\begin{array}{llllllllllllllll}\text { LFPLIQAMHPTLAGK } & 0.66 & 36.72 & 22.01 & 49.72 & 3 & 1924.1230 & 1924.1212 & 642.3810 & 0.0018 & 0.9340 & 54.963 & 55.530 & 38.491 & 84.014 & \text { Yes }\end{array}$ $\begin{array}{llllllllllllllll}\text { LFPLIQAMHPTLAGK } & 0.66 & 34.26 & 22.04 & 47.26 & 3 & 1924.1233 & 1924.1212 & 642.3810 & 0.0021 & 1.0897 & 64.013 & 77.927 & 54.661 & 125.547 & \text { Yes }\end{array}$

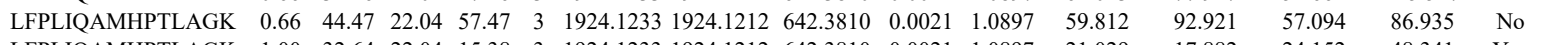

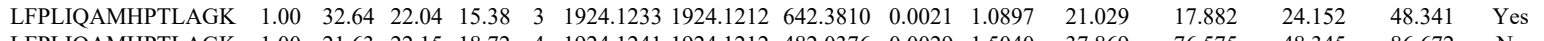
$\begin{array}{llllllllllllllll}\text { LFPLIQAMHPTLAGK } & 1.00 & 21.63 & 22.15 & 18.72 & 4 & 1924.1241 & 1924.1212 & 482.0376 & 0.0029 & 1.5040 & 37.869 & 76.575 & 48.345 & 86.672 & \text { No }\end{array}$

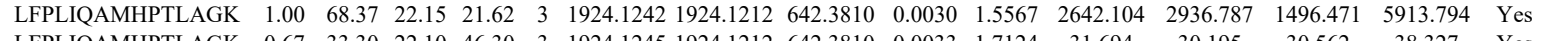

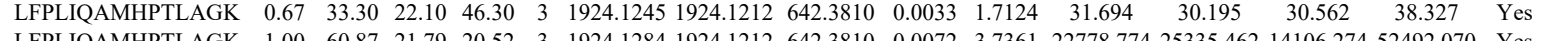

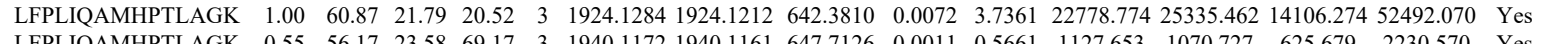
\begin{tabular}{llllllllllllllll} 
LFPLIQAMHPTLAGK & .555 & 56.17 & 23.58 & 69.17 & 3 & 1940.1172 & 1940.1161 & 647.7126 & 0.0011 & 0.5661 & 1127.653 & 1070.727 & 625.679 & 2230.570 & Yes \\
\hline LFPLIQAMHPTLAGK & 1.00 & 5.66 & 23.58 & 18.83 & 3 & 1940.1172 & 1940.1161 & 647.7126 & 0.0011 & 0.5661 & 655.021 & 736.295 & 436.660 & 1447.772 & Yes
\end{tabular} $\begin{array}{lllllllllllllllll}\text { LFPLIQAMHPTLAGK } & 1.00 & 59.66 & 23.58 & 18.83 & 3 & 1940.1172 & 1940.1161 & 647.7126 & 0.001 & 0.5661 & 655.021 & 736.295 & 436.660 & 1447.772 & \text { Yes } \\ \text { FSPAGPILSIR } & 1.00 & 52.78 & 26.7 & 23.96 & 2 & 1300.7624 & 1300.7625 & 651.3885 & 0.0001 & 0.0768 & 16718.154 & 19161.954 & 238.414 & 47787.746 & \text { Yes }\end{array}$

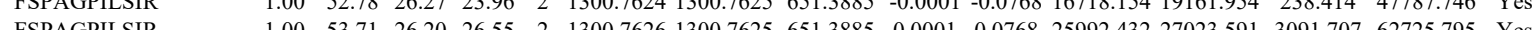

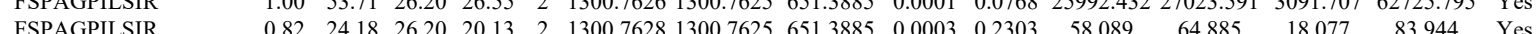

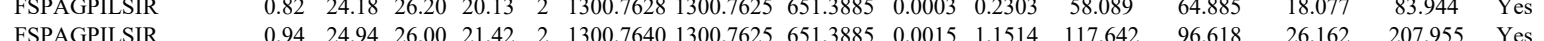

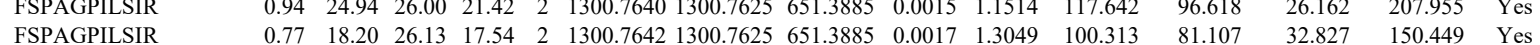

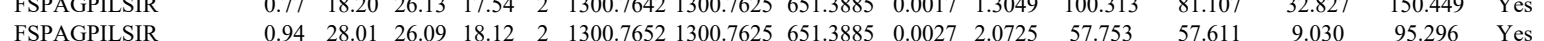

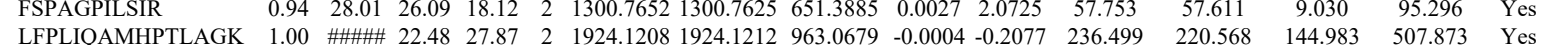

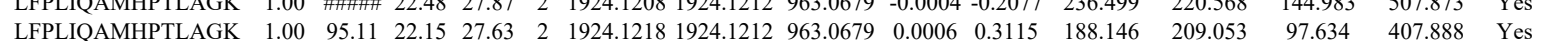
$\begin{array}{lllllllllllllllll}\text { LFPLIQAMHPTLAGK } & 1.00 & 22.22 & 22.04 & 15.89 & 4 & 1924.1233 & 1924.1212 & 482.0376 & 0.0021 & 1.0891 & 64.524 & 65.826 & 42.721 & 160.969 & \text { Yes }\end{array}$

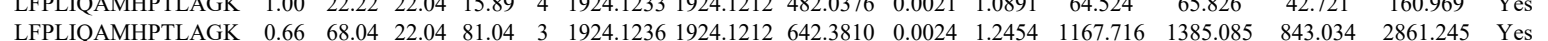
$\begin{array}{llllllllllllllll}\text { LFPLIQAMHPTLAGK } & 0.94 & 7.61 & 22.04 & 14.12 & 4 & 1924.1237 & 1924.1212 & 482.0376 & 0.0025 & 1.2966 & 59.050 & 63.174 & 30.365 & 108.615 & \text { Yes }\end{array}$ $\begin{array}{llllllllllllllll}\text { LFPLIQAMHPTLAGK } & 1.00 & 62.72 & 22.15 & 19.93 & 3 & 1924.1242 & 1924.1212 & 642.3810 & 0.0030 & 1.5567 & 2887.302 & 3085.440 & 2059.473 & 7173.525 & \text { Yes }\end{array}$

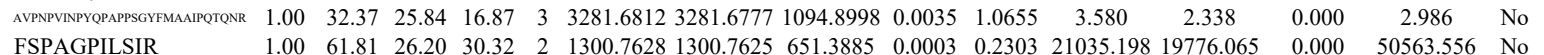

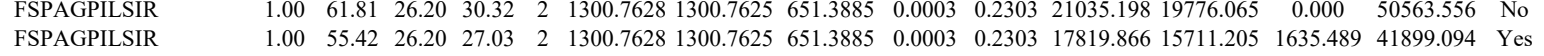
$\begin{array}{lllllllllllllllll}\text { LFPLIQAMHPTLAGK } & 0.66 & 57.78 & 22.01 & 70.78 & 3 & 1924.1230 & 1924.1212 & 642.3810 & 0.0018 & 0.9340 & 889.860 & 1073.579 & 688.247 & 2027.809 & \text { Yes }\end{array}$ $\begin{array}{lllllllllllllllll}\text { LFPLIQAMHPTLAGK } & 1.00 & 63.71 & 22.04 & 18.40 & 3 & 1924.1236 & 1924.1212 & 642.3810 & 0.0024 & 1.2454 & 1267.310 & 1435.766 & 766.495 & 3038.655 & \text { Yes }\end{array}$ $\begin{array}{llllllllllllllll}\text { FSPAGPILSIR } & 1.00 & 53.67 & 26.19 & 30.32 & 2 & 1300.7616 & 1300.7625 & 651.3885 & -0.0009 & -0.6908 & 3175.439 & 3406.161 & 312.000 & 8158.855 & \text { Yes }\end{array}$ $\begin{array}{llllllllllllllll}\text { FSPAGPILSIR } & 1.00 & 45.37 & 26.26 & 25.82 & 2 & 1300.7622 & 1300.7625 & 651.3885 & -0.0003 & -0.2303 & 3939.737 & 4016.137 & 199.449 & 8825.811 & \text { Yes }\end{array}$ $\begin{array}{lllllllllllllllll}\text { LFPLIQAMHPTLAGK } & 1.00 & 60.96 & 22.01 & 19.37 & 3 & 1924.1230 & 1924.1212 & 642.3810 & 0.0018 & 0.9340 & 310.798 & 349.729 & 172.871 & 699.820 & \text { Yes }\end{array}$ $\begin{array}{llllllllllllllll}\text { LFPLIQAMHPTLAGK } & 0.66 & 59.06 & 22.01 & 72.06 & 3 & 1924.1230 & 1924.1212 & 642.3810 & 0.0018 & 0.9340 & 230.924 & 311.672 & 149.079 & 511.136 & \text { Yes }\end{array}$ $\begin{array}{llllllllllllllll}\text { IVATKPLYVALAQR } & 0.64 & 63.93 & 16.13 & 76.93 & 2 & 1830.1336 & 1830.1335 & 916.0740 & 0.0001 & 0.0546 & 419.425 & 497.730 & 399.255 & 696.196 & \text { Yes }\end{array}$ $\begin{array}{lllllllllllllllll}\text { IVATKPLYVALAQR } & 0.55 & 38.36 & 16.02 & 51.36 & 3 & 1830.1345 & 1830.1335 & 611.0518 & 0.0010 & 0.5455 & 2378.957 & 2963.785 & 2693.696 & 4338.827 & \text { Yes }\end{array}$ $\begin{array}{llllllllllllllll}\text { IVATKPLYVALAQR } & 0.66 & 45.33 & 15.91 & 58.33 & 3 & 1830.1351 & 1830.1335 & 611.0518 & 0.0016 & 0.8728 & 1768.684 & 2093.952 & 1787.847 & 2887.944 & \text { Yes }\end{array}$

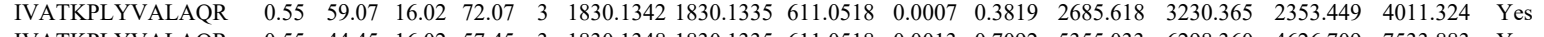
$\begin{array}{lllllllllllllllll}\text { IVATKPLYVALAQR } & 0.55 & 44.45 & 16.02 & 57.45 & 3 & 1830.1348 & 1830.1335 & 611.0518 & 0.0013 & 0.7092 & 5355.033 & 6298.360 & 4626.709 & 7533.883 & \text { Yes }\end{array}$ \begin{tabular}{llllllllllllllll} 
AAYYPPSQIAQLRPSPR & 0.88 & 21.49 & 27.16 & 14.54 & 3 & 2058.1135 & 2058.1132 & 687.0450 & 0.0003 & 0.1456 & 284.774 & 219.245 & 59.209 & 158.189 & No \\
\hline A YYYPPSQIAQLPPSPR & 0.55 & 23.71 & 27.14 & 36.71 & 3 & 2058.1141 & 2058.1132 & 687.0450 & 0.0009 & 0.4367 & 161.782 & 139.397 & 57.061 & 92.685 & No
\end{tabular}

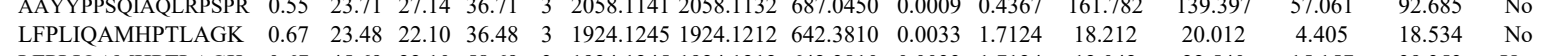

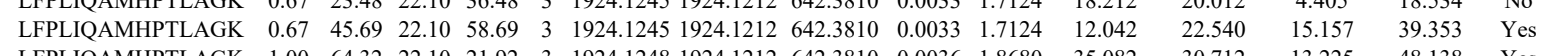

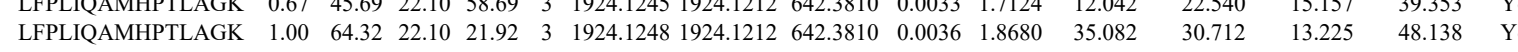

Table S-4 page 154 of 614 
LVQGSILK

LVQGSILK

YLNFFTK

YLNFFTK

YLNFFTK

YLNFFTK

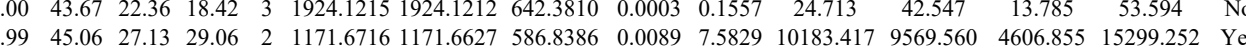

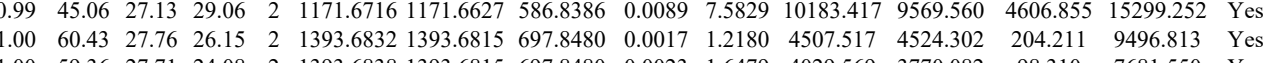
$\begin{array}{lllllllllllllll}1.00 & 59.36 & 27.71 & 24.08 & 2 & 1393.6838 & 1393.6815 & 697.8480 & 0.0023 & 1.6479 & 4029.569 & 3770.082 & 98.310 & 7681.550 & \text { Yes }\end{array}$ $\begin{array}{llllllllllllllll}1.00 & 67.91 & 27.68 & 28.07 & 2 & 1393.6822 & 1393.6815 & 697.8480 & 0.0007 & 0.5015 & 4189.836 & 4190.062 & 207.571 & 8335.789 & \text { Yes }\end{array}$ $\begin{array}{lllllllllllllll}1.00 & 66.20 & 27.68 & 24.48 & 2 & 1393.6822 & 1393.6815 & 697.8480 & 0.0007 & 0.5015 & 4733.896 & 4388.830 & 143.242 & 8692.390 & \text { Yes } \\ \end{array}$

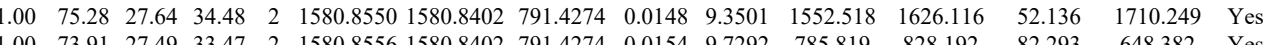

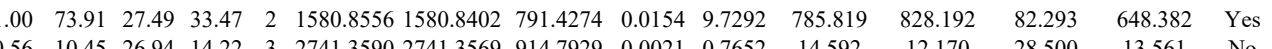

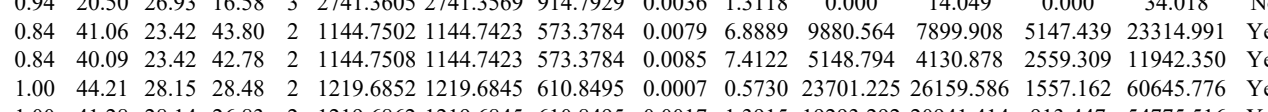

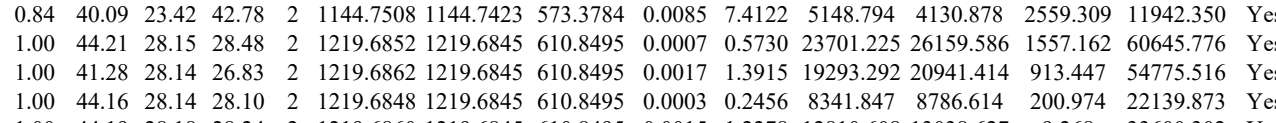
$\begin{array}{lllllllllllllll}1.00 & 44.16 & 28.14 & 28.10 & 2 & 1219.6848 & 1219.6845 & 610.8495 & 0.0003 & 0.2456 & 8341.847 & 8786.614 & 200.974 & 22159.516 & \text { Yes } \\ 1.00 & 44.19 & 28.18 & 28.24 & 2 & 1219.6860 & 1219.6845 & 610.8495 & 0.0015 & 1.2278 & 12810.608 & 13038.627 & 9.26 & 3360.302 & \text { Yes }\end{array}$ $\begin{array}{llllllllllllllll}\text { AEDNADTLALVFEAPNQEK } & 1.00 & 50.92 & 27.34 & 20.38 & 3 & 2362.1929 & 2362.1896 & 788.4038 & 0.0033 & 1.3952 & 13.352 & 88.186 & 7.890 & 94.990 & \text { No }\end{array}$ $\begin{array}{lllllllllllllllll}\text { AEDNADTLALVFEAPNOEK } & 1.00 & 42.25 & 27.38 & 20.62 & 3 & 2362.1938 & 2362.1896 & 788.4038 & 0.0042 & 1.7757 & 123.541 & 108.263 & 105.498 & 162.500 & \text { Yes }\end{array}$ $\begin{array}{lllllllllllllllll}\text { AEDNADTLALVFEAPNQEK } & 0.98 & 26.91 & 27.31 & 16.11 & 3 & 2362.1905 & 2362.1896 & 788.4038 & 0.0009 & 0.3805 & 39.092 & 39.562 & 48.973 & 37.305 & \text { Yes }\end{array}$

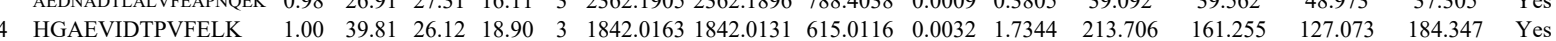
$\begin{array}{llllllllllllllllll}\text { YDGLVGMFDPK } & 1.00 & 69.84 & 27.92 & 26.31 & 2 & 1528.7862 & 1528.7840 & 765.3993 & 0.0022 & 1.4372 & 684.768 & 535.856 & 234.706 & 809.098 & \text { Yes }\end{array}$ $\begin{array}{llllllllllllllll}\text { LVSELWDAGIK } & 1.00 & 62.59 & 26.35 & 27.96 & 2 & 1517.8712 & 1517.8697 & 759.9421 & 0.0015 & 0.9869 & 903.721 & 792.141 & 0.000 & 1603.942 & \text { No }\end{array}$ $\begin{array}{lllllllllllllllll}\text { LVSELWDAGIK } & 1.00 & 60.46 & 26.24 & 31.26 & 2 & 1517.8718 & 1517.8697 & 759.9421 & 0.0021 & 1.3817 & 812.284 & 769.682 & 35.880 & 1723.504 & \text { Yes }\end{array}$ $\begin{array}{llllllllllllllll}\text { IGDYVQOHGGVSLVEQLLDPK } & 1.00 & 39.65 & 25.00 & 16.41 & 3 & 2710.4563 & 2710.4534 & 904.4917 & 0.0029 & 1.0687 & 74.379 & 131.196 & 134.033 & 111.396 & \text { Yes }\end{array}$ $\begin{array}{lllllllllllllllll}\text { IGDYVQQHGGVSLVEQLLQDPK } & 0.99 & 24.19 & 24.97 & 14.77 & 3 & 2710.4566 & 2710.4534 & 904.4917 & 0.0032 & 1.1793 & 38.104 & 32.002 & 66.697 & 57.349 & \text { Yes }\end{array}$ $\begin{array}{llllllllllllllll}\text { LLNQLQYCEEAGIPVVAIIGEQELK } & 1.00 & 41.11 & 23.56 & 23.77 & 3 & 3117.6742 & 3117.6697 & 1040.2305 & 0.0045 & 1.4420 & 3.170 & 0.000 & 6.207 & 4.477 & \text { No }\end{array}$ $\begin{array}{llllllllllllllll}\text { LLNQLQYCEEAGIPVAAIGEEELKK } & 1.00 & 60.32 & 23.56 & 19.41 & 3 & 3117.6742 & 3117.6697 & 1040.2305 & 0.0045 & 1.4420 & 10.727 & 0.000 & 36.344 & 11.978 & \text { No }\end{array}$ $\begin{array}{llllllllllllllll}\text { LLFEYLTLFGIDDK } & 0.99 & 28.01 & 25.76 & 18.27 & 3 & 1974.0994 & 1974.0957 & 659.0392 & 0.0037 & 1.8714 & 110.527 & 131.062 & 63.477 & 192.180 & \text { Yes }\end{array}$

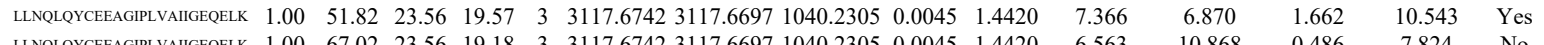
$\begin{array}{llllllllllllllll}\text { LLNQLQYCEEAGIPLVAIIGEQELKK } & 1.00 & 67.02 & 23.56 & 19.18 & 3 & 3117.6742 & 3117.6697 & 1040.2305 & 0.0045 & 1.4420 & 6.563 & 10.868 & 0.486 & 7.824 & \text { No }\end{array}$

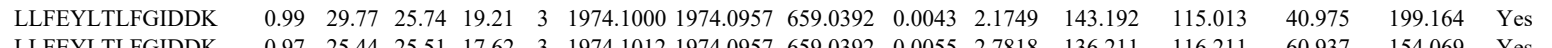

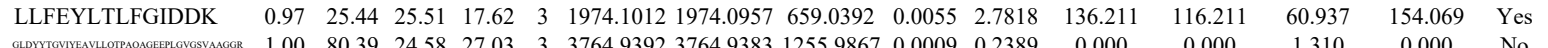

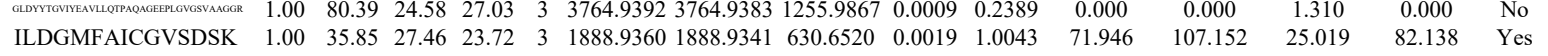

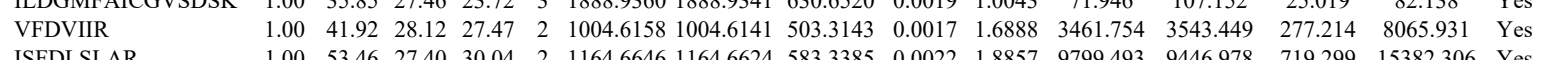

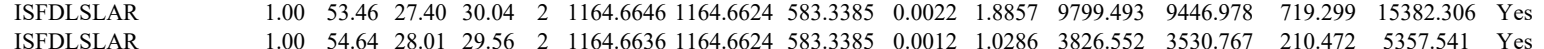

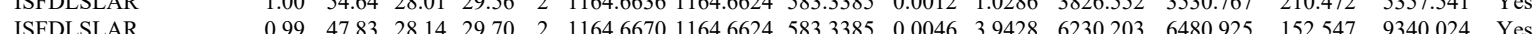

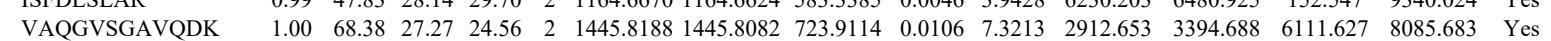

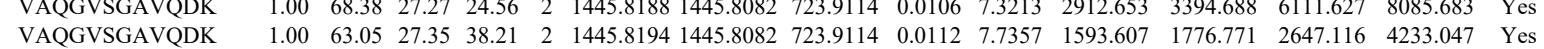
$\begin{array}{llllllllllllllll}\text { LPIVNEDDELVAIIAR } & 1.00 & 84.45 & 25.04 & 20.70 & 2 & 1923.0808 & 1923.0798 & 9625472 & 0.0010 & 0.5195 & 50.951 & 166.767 & 312.032 & 212.598 & \text { Yes }\end{array}$

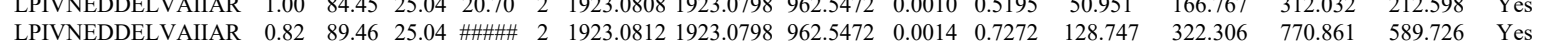

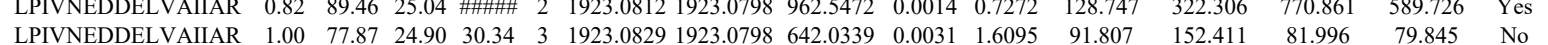
$\begin{array}{llllllllllllllll}\text { LPIVNEDDELVAIIAR } & 1.00 & 68.07 & 24.90 & 27.13 & 3 & 1923.0838 & 1923.0798 & 642.0339 & 0.0040 & 2.0767 & 74.457 & 130.478 & 92.953 & 49.690 & \text { No }\end{array}$ $\begin{array}{llllllllllllllll}\text { LPIVNEDDELVAIIAR } & 1.00 & 85.90 & 25.22 & 18.60 & 2 & 1923.0798 & 1923.0798 & 962.5472 & 0.0000 & 0.0000 & 370.989 & 368.994 & 1078.319 & 1012.473 & \text { Yes }\end{array}$ $\begin{array}{lllllllllllllllll}\text { LPIVNEDDELVAIIAR } & 1.00 & 89.23 & 25.22 & 20.84 & 2 & 1923.0802 & 1923.0798 & 962.5472 & 0.0004 & 0.2078 & 117.710 & 330.010 & 848.370 & 819.265 & \text { Yes }\end{array}$ $\begin{array}{llllllllllllllll}\text { LPIVNEDDELVAIIAR } & 1.00 & 60.60 & 24.90 & 23.27 & 3 & 1923.0829 & 1923.0798 & 642.0339 & 0.0031 & 1.6095 & 250.379 & 241.997 & 169.174 & 277.362 & \text { Yes }\end{array}$ $\begin{array}{llllllllllllllllll}\text { NLIDAGVDALR } & 1.00 & 44.37 & 27.51 & 35.31 & 2 & 1299.7276 & 1299.7268 & 650.8707 & 0.0008 & 0.6146 & 266.764 & 228.763 & 108.289 & 379.635 & \text { Yes }\end{array}$ $\begin{array}{llllllllllllllll}\text { NLIDAGVDALR } & 1.00 & 58.97 & 27.42 & 53.40 & 2 & 1299.7278 & 1299.7268 & 650.8707 & 0.0010 & 0.7682 & 3047.032 & 4018.771 & 356.408 & 10177.999 & \text { No }\end{array}$ $\begin{array}{lllllllllllllllll}\text { LPIVNEDDELVAIIAR } & 0.82 & 64.58 & 25.05 & 77.58 & 2 & 1923.0810 & 1923.0798 & 962.5472 & 0.0012 & 0.6233 & 214.226 & 332.703 & 722.962 & 705.547 & \text { Yes }\end{array}$ $\begin{array}{llllllllllllllll}\text { HGFCGIPITDTGR } & 0.57 & 13.75 & 25.87 & 17.35 & 2 & 1372.6582 & 1372.6558 & 687.3352 & 0.0024 & 1.7459 & 977.388 & 925.700 & 3271.032 & 353.198 & \text { No }\end{array}$ $\begin{array}{lllllllllllllllll}\text { FGVPVIADGGIQNVGHIAK } & 0.55 & 57.74 & 23.30 & 70.74 & 3 & 2179.2373 & 2179.2357 & 727.4192 & 0.0016 & 0.7332 & 1972.575 & 2798.099 & 5733.482 & 5618.828 & \text { Yes }\end{array}$

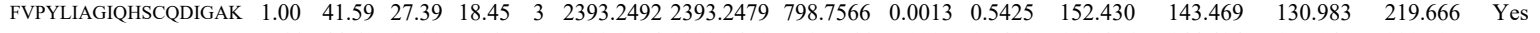
$\begin{array}{llllllllllllllll}\text { FVPYLIAGIQHSCQDIGAK } & 0.66 & 44.69 & 27.23 & 57.69 & 3 & 2393.2504 & 2393.2479 & 798.7566 & 0.0025 & 1.0433 & 129.416 & 144.434 & 155.040 & 232.020 & \text { Yes }\end{array}$ $\begin{array}{llllllllllllllll}\text { TSSAQVEGGVHSLHSYEK } & 0.99 & 17.79 & 26.91 & 15.43 & 4 & 1914.9089 & 1914.9072 & 479.7341 & 0.0017 & 0.8859 & 73.208 & 80.891 & 75.957 & 88.721 & \text { Yes }\end{array}$ $\begin{array}{llllllllllllllll}\text { VAQGVSGAVQDK } & 0.59 & 21.19 & 27.35 & 15.44 & 3 & 1445.8195 & 1445.8082 & 482.9433 & 0.0113 & 7.7993 & 1114.459 & 945.925 & 1362.581 & 1227.229 & \text { Yes } \\ \text { VAQGVGAVQDK } & 1.0 & & \end{array}$

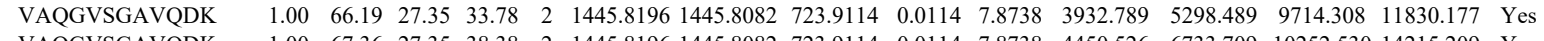
$\begin{array}{llllllllllllllll}\text { VAQGVSGAVQDK } & 1.00 & 67.36 & 27.35 & 38.38 & 2 & 1445.8196 & 1445.8082 & 723.9114 & 0.0114 & 7.8738 & 4450.526 & 6733.709 & 10252.530 & 14215.209 & \text { Yes }\end{array}$ $\begin{array}{llllllllllllllll}\text { VAQGVSGAVQDK } & 0.94 & 30.15 & 27.41 & 19.14 & 3 & 1445.8198 & 1445.8082 & 482.9433 & 0.0116 & 8.0064 & 1148.133 & 1559.706 & 1299.621 & 1507.394 & \text { Yes }\end{array}$ $\begin{array}{lllllllllll}1.00 & 30.99 & 26.43 & 25.41 & 3 & 2317.2478 & 2317.2442 & 773.4220 & 0.0036 & 1.5515 & 39.051\end{array}$ \begin{tabular}{lll}
3.688 & 29.968 & 38.385 \\
\hline & & 0
\end{tabular}

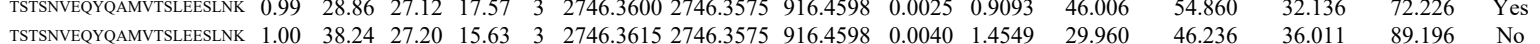
$\begin{array}{lllllllllllllllll}\text { LTELYNAYVETQDQLLLEK } & 1.00 & 35.04 & 25.48 & 15.20 & 3 & 2570.3740 & 2570.3723 & 857.7980 & 0.0017 & 0.6606 & 21.731 & 57.574 & 28.810 & 65.513 & \text { Yes }\end{array}$

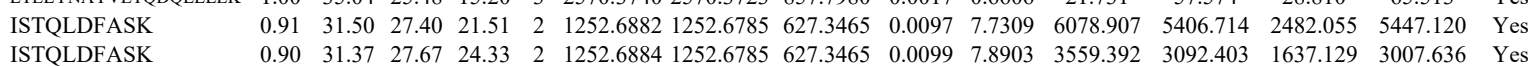



$\begin{array}{lllllllllllll}\text { GQNLLLTNLQTIQGILER } & 1.00 & 54.32 & 22.70 & 16.71 & 3 & 2167.2457 & 2167.2446 & 723.4221 & 0.0011 & 0.5068 & 9.283\end{array}$ $\begin{array}{llllllllllll}\text { GQNLLLTNLQTIQGILER } & 1.00 & 42.74 & 22.67 & 16.47 & 3 & 2167.2481 & 2167.2446 & 723.4221 & 0.0035 & 1.6127 & 18.288\end{array}$ $\begin{array}{llllllllllll}0.69 & 14.91 & 25.01 & 22.56 & 3 & 1209.7213 & 1209.7216 & 404.2478 & -0.0003 & -0.2474 & 23.435\end{array}$

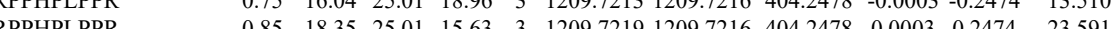

(1)

RPPHPLPPR

RPPHPLPPR

RPPHPLPPR
RPPHPLPPR

RPPHPLPPR

RPPPLLPPR

RPPHPLPPR

RPPHPLPPR

RPPHPLPPR

RPPHPLPPR
RPPHPLPPR

RPPHPLPPR

RPPHPLPPR

RPPHPLPPR

RPPHPLPPR

RPPHPLPPR

RPPHPLPPR

RPPHPLPPR

RPPHPLPPR

AIESMEQQLSELK

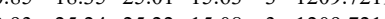

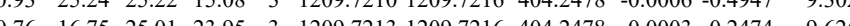
$\begin{array}{lllllllllll}1.00 & 38.40 & 25.01 & 16.02 & 3 & 1209.7213 & 1209.7216 & 404.2478 & -0.0003 & 0.2474 & 85.773\end{array}$

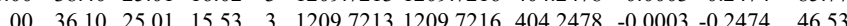
$\begin{array}{lllllllllll}1.00 & 36.31 & 25.01 & 15.79 & 3 & 1209.7213 & 12097216 & 404.2478 & -0.0003 & -0.2474 & 76.0285\end{array}$ $\begin{array}{lllllllllllll}1.00 & 50.57 & 25.01 & 25.90 & 3 & 1209.7213 & 1209.7216 & 404.2478 & -0.0003 & 0.2474 & 88.764\end{array}$ $\begin{array}{llllllllllll}0.64 & 19.33 & 25.01 & 32.33 & 2 & 12097220 & 12097216 & 605.8681 & 0.0004 & 0.3301 & 14.031\end{array}$ $\begin{array}{llllllllllll}1.00 & 32.86 & 25.01 & 15.33 & 3 & 12097213 & 12097216 & 404.2478 & -0.0003 & -0.2474 & 46.790\end{array}$ $\begin{array}{lllllllllll}1.00 & 41.13 & 25.01 & 2.442 & 3 & 1209.7213 & 1209.7216 & 404.2478 & 0.0003 & 0.2474 & 33.235\end{array}$ $\begin{array}{llllllllllll}0.00 & 38.41 & 25.01 & 15.85 & 3 & 1209.7213 & 1209.7216 & 404.2478 & -0.0003 & -0.2474 & 23.694\end{array}$ $\begin{array}{lllllllllllll}0.51 & 16.47 & 25.01 & 29.47 & 2 & 1209.7214 & 1209.7216 & 605.8681 & -0.0002 & -0.1651 & 12.425\end{array}$ $\begin{array}{llllllllllll}0.68 & 19.68 & 25.01 & 20.78 & 2 & 1209.7218 & 1209.7216 & 605.8681 & 0.0002 & 0.1651 & 4.442\end{array}$ $\begin{array}{llllllllllll}1.00 & 38.20 & 25.01 & 19.35 & 3 & 1209.7219 & 1209.7216 & 404.2478 & 0.0003 & 0.2474 & 16.919\end{array}$ $\begin{array}{lllllllllllll}0.82 & 20.93 & 25.01 & 33.93 & 2 & 1209.7224 & 1209.7216 & 605.8681 & 0.0008 & 0.6602 & 22.433\end{array}$ $\begin{array}{lllllllllllll}0.84 & 18.30 & 25.01 & 22.23 & 3 & 1209.7219 & 1209.7216 & 404.2478 & 0.0003 & 0.2474 & 11.970\end{array}$ $\begin{array}{lllllllllllll}0.65 & 14.14 & 25.01 & 16.71 & 3 & 1209.7219 & 1209.7216 & 404.2478 & 0.0003 & 0.2474 & 1.316\end{array}$ $\begin{array}{llllllllllll}1.00 & 40.68 & 25.01 & 20.33 & 3 & 1209.7219 & 1209.7216 & 404.2478 & 0.0003 & 0.2474 & 2.778\end{array}$ $\begin{array}{llllllllllll}0.55 & 12.56 & 25.01 & 17.04 & 3 & 1209.7222 & 1209.7216 & 404.2478 & 0.0006 & 0.4947 & 2.976\end{array}$

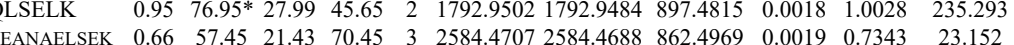
$\begin{array}{llllllllllll}\text { KLEDLELANAELSEK } & 0.66 & 57.45 & 21.43 & 70.45 & 3 & 2584.4707 & 2584.4688 & 862.4969 & 0.0019 & 0.7343 & 23.152 \\ \text { KLEDIPLOEANAELSEK } & 1.00 & 73.30 & 21.49 & 22.80 & 3 & 2584.4719 & 2584.4688 & 862.4969 & 0.0031 & 1.1981 & 50.511\end{array}$

\begin{tabular}{lllllllllllll} 
KLELDILPLQEANAELSEK & 1.00 & 73.30 & 21.49 & 22.80 & 3 & 2584.4719 & 2584.4688 & 862.4969 & 0.0031 & 1.1981 & 50.511 & 50.5 \\
\hline
\end{tabular} $\begin{array}{llllllllll} & \end{array}$ $\begin{array}{lllllllllll} & \end{array}$ $\begin{array}{lllllllllllll} & \text { LAVEAL }\end{array}$

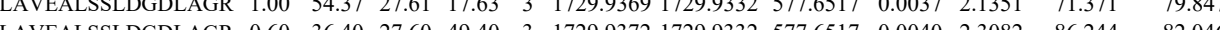
$\begin{array}{llllllllll} & \end{array}$

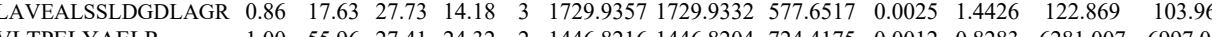

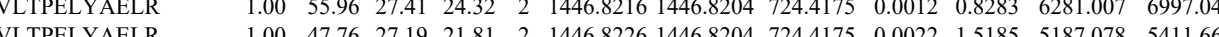
VLTPELYAELR

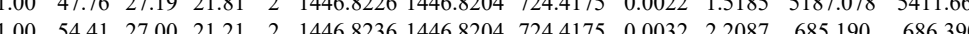

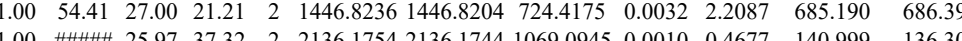

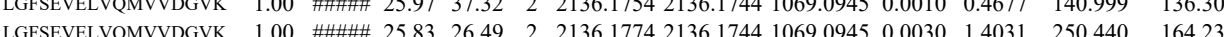

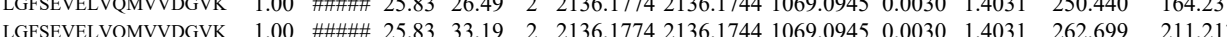
\begin{tabular}{lllllllllllll}
\hline LGFSEVELVQMVVDGVK & 1.00 & 25.83 & 33.19 & 2 & 2136.1774 & 2136.1744 & 1069.0945 & 0.0030 & 1.4031 & 262.699 & 211.213 \\
\hline
\end{tabular} FCTGLTQIETLFK FCTGLTQIETLFK FCTGLTQIETLFK FCTGLTQIETLFK FCTGLTQIETLFK FCTGLTQIETLFK FCTGLTQIETLFK FCTGLTQIETLFK FCTGLTQIETLFK GFCLPPHCSR
GFCLPPHCSR

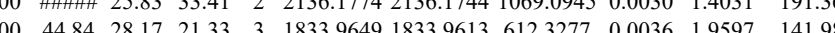
$\begin{array}{lllllllllll}1.00 & 80.34 & 28.17 & 29.55 & 2 & 1833.9650 & 1833.9613 & 917.9879 & 0.0037 & 2.0153 & 588.728\end{array}$ $\begin{array}{lllllllllll} & \end{array}$ $\begin{array}{llllllllllll}1.00 & 42.35 & 28.16 & 19.60 & 3 & 1833.9664 & 1833.9613 & 612.3277 & 0.0051 & 2.7763 & 135.327 & 111.701\end{array}$ $\begin{array}{lllllllllllll}1.00 & 67.28 & 28.27 & 22.77 & 2 & 1833.9636 & 1833.9613 & 917.9879 & 0.0023 & 1.2527 & 3179.813 & 3073.111\end{array}$ $\begin{array}{llllllllllllll}1.00 & 64.54 & 28.19 & 22.19 & 2 & 1833.9642 & 1833.9613 & 917.9879 & 0.0029 & 1.5795 & 1598.671 & 1250.363\end{array}$ $\begin{array}{lllllllllllll}1.00 & 49.55 & 28.14 & 24.98 & 3 & 1833.9658 & 1833.9613 & 612.3277 & 0.0045 & 2.4497 & 560.266 & 333.298\end{array}$ $\begin{array}{llllllllllllll}1.00 & 40.47 & 28.14 & 20.48 & 3 & 1833.9661 & 1833.9613 & 612.3277 & 0.0048 & 2.6130 & 189.840 & 189.634\end{array}$ $\begin{array}{lllllllllllll}1.00 & 41.29 & 28.14 & 27.85 & 3 & 1833.9661 & 1833.9613 & 612.3277 & 0.0048 & 2.6130 & 161.672 & 172.046\end{array}$ $\begin{array}{llllllllllll}0.67 & 26.88 & 21.27 & 39.88 & 3 & 1351.5808 & 1351.5780 & 451.5333 & 0.0028 & 2.0670 & 2639.206 & 3153.483\end{array}$ $\begin{array}{llllllllllll}1.00 & 35.06 & 21.27 & 17.20 & 3 & 1351.5817 & 1351.5780 & 451.5333 & 0.0037 & 2.7314 & 3103.440 & 3526.642 \\ 1.00 & 74.84 & 26.49 & 18.63 & 2 & 2661.2634 & 2661.2640 & 1331.6393 & 0.0006 & 0.2253 & 18352 & 7.281\end{array}$ $\begin{array}{llllllllllllll}\text { TDLNPDNLQGGDDLDPNYVLSSR } & 1.00 & 74.84 & 26.49 & 18.63 & 2 & 2661.2634 & 2661.2640 & 1331.6393 & -0.0006 & -0.2253 & 18.352 & 7.281 \\ \text { TDLNPDNLGGGDLDPNYVLSRR } & 0.66 & 18.49 & 26.36 & 31.49 & 3 & 2661.2662 & 2661.2640 & 888.0953 & 0.0022 & 0.8257 & 47.296 & 29.934\end{array}$ $\begin{array}{lllllllllllllll}\text { TDLNPDNLQGGDDLDPNYVLSSR } & 0.66 & 18.49 & 26.36 & 31.49 & 3 & 2661.2662 & 2661.2640 & 888.0953 & 0.0022 & 0.8257 & 47.296 & 29.934\end{array}$ $\begin{array}{llllllllllllll}\text { GAGTNEDALIEILTTR } & 1.00 & \text { \#\#\#\# } 28.18 & 32.23 & 2 & 1816.9668 & 1816.9652 & 909.4899 & 0.0016 & 0.8796 & 2272.389 & 847\end{array}$

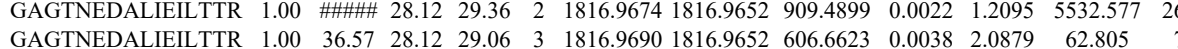

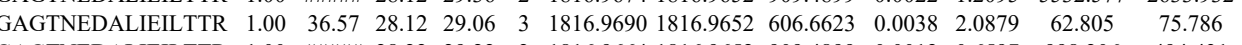

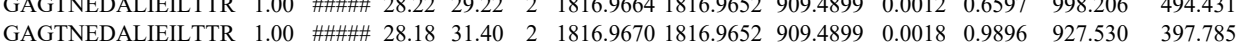
$\begin{array}{lllllllllllll}\text { GAGTNEDALIEILTTR } & 1.00 & 28.18 & 31.40 & 2 & 18616.9670 & 1816.9652 & 909.4899 & 0.0018 & 0.9896 & 927.530 & 397.785 \\ \text { GAGTNEDALIEILTTR } & 0.98 & 31.00 & 28.11 & 32.39 & 3 & 1816.9675 & 1816.9652 & 606.6623 & 0.0023 & 1.2637 & 116.529 & 125.465\end{array}$ $\begin{array}{lllllllllllll}\text { WGTDEDKFTEILCLR } & 0.93 & 37.59 & 27.45 & 21.56 & 3 & 2159.0674 & 2159.0635 & 720.6951 & 0.0039 & 1.8038 & 916.112 & 449.724\end{array}$ $\begin{array}{llllllllllllll} & \text { WGTDEDKFTELLCLR } & 0.86 & 34.33 & 27.49 & 19.90 & 3 & 2159.0680 & 2159.0635 & 720.6951 & 0.0045 & 2.0813 & 905.581 & 354.934\end{array}$ 


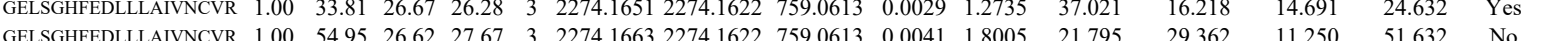

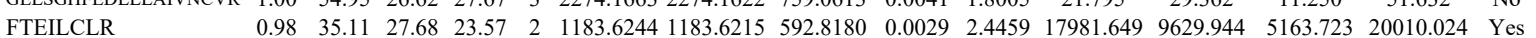
$\begin{array}{lllllllllllllllll} & \text { FTEILCLR } & 0.99 & 40.09 & 27.72 & 24.65 & 2 & 1183.6248 & 1183.6215 & 592.8180 & 0.0033 & 2.7833 & 18655.125 & 10969.707 & 7036.891 & 20508.276 & \text { Yes }\end{array}$

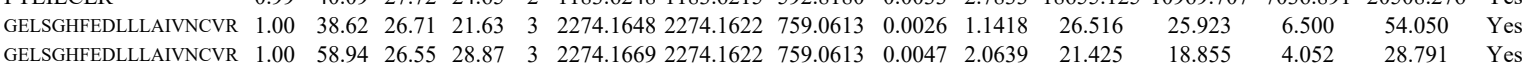

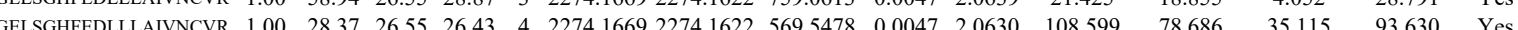

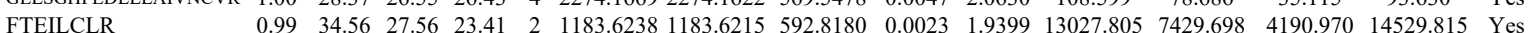
$\begin{array}{lllllllllllllllll} & \text { FTELCLR } & 0.99 & 34.56 & 27.56 & 23.41 & 2 & 1183.6238 & 1183.6215 & 52.8180 & 0.023 & 1.9399 & 13027.805 & 7429.698 & 4190.916 & 14529.815 & \text { Yes } \\ \text { FTEILCLR } & 0.98 & 35.15 & 27.68 & 23.65 & 2 & 1183.6246 & 1183.6215 & 5928180 & 0.0031 & 2.6146 & 12407.830 & 6887.935 & 4473.362 & 12218.246 & \text { Yes }\end{array}$

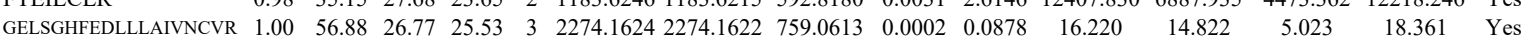

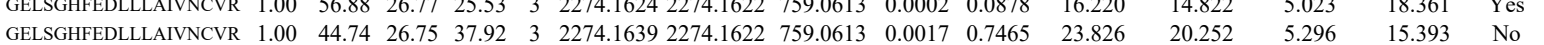

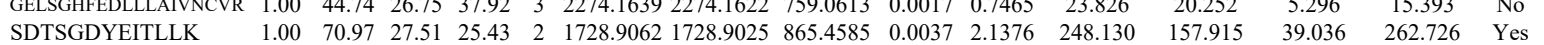
$\begin{array}{llllllllllllllll}\text { SEIDLLDIR } & 1.00 & 57.20 & 28.92 & 35.47 & 2 & 1216.6806 & 1216.6785 & 609.3465 & 0.0021 & 1.7232 & 5228.974 & 3136.682 & 100.979 & 8072.623 & \text { Yes }\end{array}$

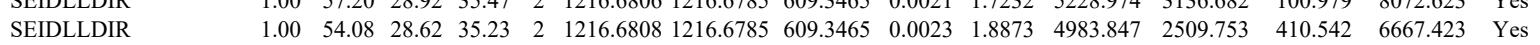

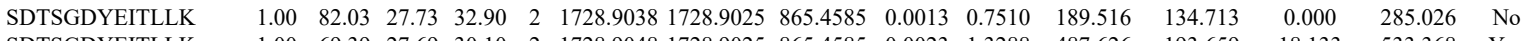
$\begin{array}{llllllllllllllll}\text { SDTSGDYEITLLK } & 1.00 & 69.39 & 27.69 & 30.10 & 2 & 1728.9048 & 1728.9025 & 865.4585 & 0.0023 & 1.3288 & 487.626 & 193.659 & 18.133 & 533.368 & \text { Yes }\end{array}$ $\begin{array}{llllllllllllllll}\text { DYPDFSPSVDAEAIQK } & 1.00 & 85.11 & 27.89 & 22.74 & 2 & 2069.0214 & 2069.0197 & 1035.5171 & 0.0017 & 0.8208 & 415.640 & 106.741 & 416.190 & 595.239 & \text { No }\end{array}$ $\begin{array}{lllllllllllllllll}\text { DYPDFSPSVDAEAIQK } & 1.00 & 53.41 & 27.89 & 23.05 & 3 & 2069.0236 & 2069.0197 & 690.6805 & 0.0039 & 1.8822 & 574.673 & 551.670 & 571.319 & 812.182 & \text { Yes }\end{array}$

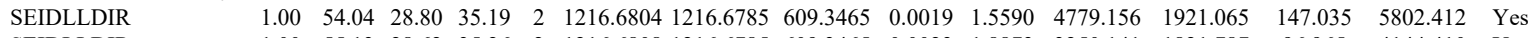

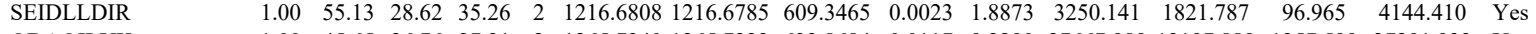
$\begin{array}{llllllllllllllll}\text { QDAQILYK } & 1.00 & 45.65 & 26.76 & 27.31 & 2 & 1265.7340 & 1265.7223 & 633.8684 & 0.0117 & 9.2290 & 27667.989 & 13197.889 & 1357.599 & 27291.933 & \text { Yes }\end{array}$ $\begin{array}{llllllllllllllll}\text { QDAQILYK } & 1.00 & 45.74 & 26.74 & 27.30 & 2 & 1265.7344 & 1265.7223 & 633.8684 & 0.0121 & 9.5445 & 28090.066 & 13422.331 & 1066.102 & 26759.711 & \text { Yes }\end{array}$ $\begin{array}{llllllllllllllll} & \end{array}$

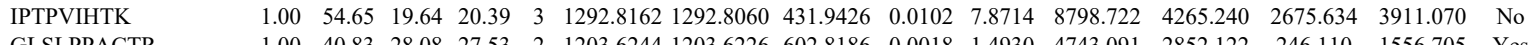

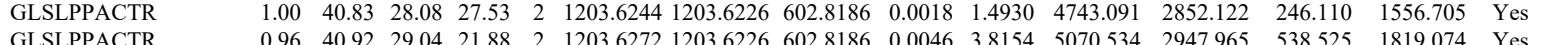
$\begin{array}{llllllllllllllll}\text { GLSLPPACTR } & 0.96 & 40.92 & 29.04 & 21.88 & 2 & 1203.6272 & 1203.6226 & 602.8186 & 0.0046 & 3.8154 & 5070.534 & 2947.965 & 538.525 & 1819.074 & \text { Yes } \\ \text { GLSLPPACTR } & 0.96 & 40.99 & 29.13 & 22.80 & 2 & 1203.6278 & 1203.6226 & 6028186 & 0.0052 & 43131 & 6473.873 & 3733.174 & 564.369 & 2638.081 & \text { Yes }\end{array}$

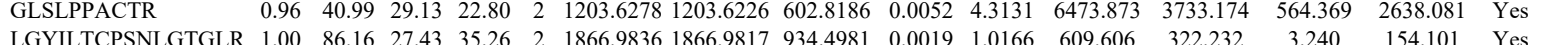
$\begin{array}{llllllllllllll} & \end{array}$ $\begin{array}{llllllllllllll} & \end{array}$

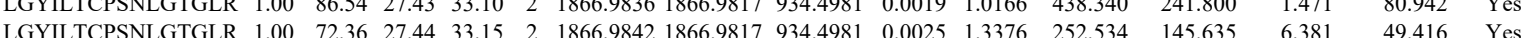

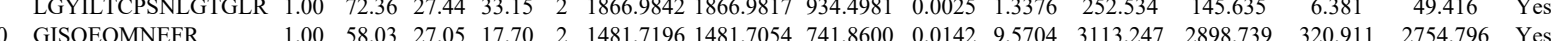

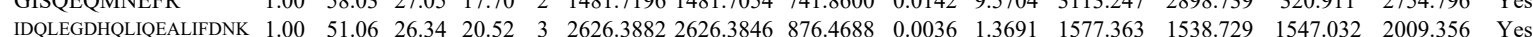

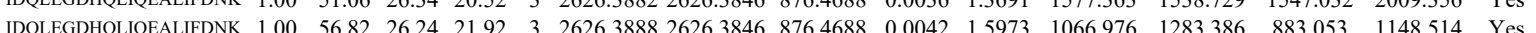

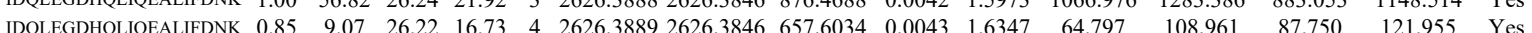

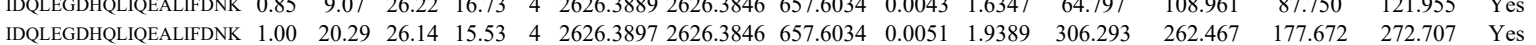

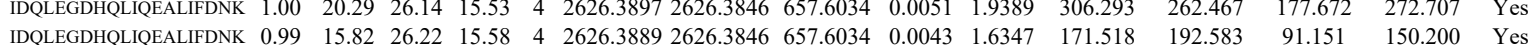

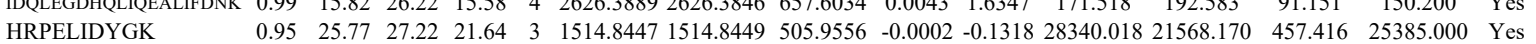
$\begin{array}{llllllllllllllll}\text { HRPELIDYGK } & 0.97 & 25.61 & 27.14 & 19.60 & 3 & 1514.8459 & 1514.8449 & 505.9556 & 0.0010 & 0.6588 & 17927.096 & 14265.751 & 759.317 & 17045.581 & \text { Yes }\end{array}$ $\begin{array}{lllllllllllllllll}\text { VPENTMHAMQQK } & 1.00 & 64.91 & 28.15 & 25.93 & 2 & 1700.8622 & 1700.8582 & 851.4364 & 0.0040 & 2.3490 & 4281.215 & 2565.189 & 4728.772 & 4665.537 & \text { Yes }\end{array}$ $\begin{array}{llllllllllllllllll}\text { VPENTMHAMQQK } & 1.00 & 60.00 & 28.16 & 24.03 & 2 & 1700.8628 & 1700.8582 & 851.4364 & 0.0046 & 2.7013 & 4408.431 & 2920.595 & 4700.156 & 4379.395 & \text { Yes }\end{array}$ $\begin{array}{llllllllllllllll}\text { VPENTMHAMQQK } & 1.00 & 36.47 & 28.03 & 21.80 & 3 & 1700.8633 & 1700.8582 & 567.9600 & 0.0051 & 2.9932 & 9988.405 & 9308.847 & 11788.621 & 13603.878 & \text { Yes }\end{array}$

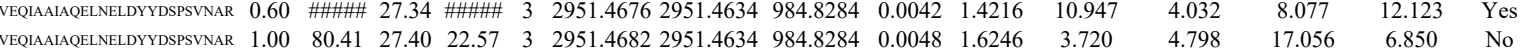

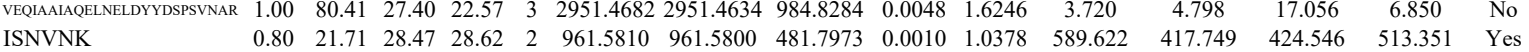
$\begin{array}{lllllllllllllllll} & 0.80 & 21.71 & 28.47 & 28.62 & 2 & 961.5810 & 961.5800 & 481.7973 & 0.0010 & 1.0378 & 589.622 & 417.749 & 424.546 & 5.350 & \text { Yes } \\ \text { VPENTMHAMQQK } & 1.00 & 49.73 & 27.93 & 20.64 & 3 & 1700.8642 & 1700.8582 & 567.9600 & 0.0060 & 3.5214 & 7678.586 & 5907.072 & 8831.848 & 9101.016 & \text { Yes }\end{array}$ $\begin{array}{llllllllllllllll}\text { VPENTMHAMQQK } & 0.98 & 34.17 & 28.04 & 18.38 & 3 & 1700.8654 & 1700.8582 & 567.9600 & 0.0072 & 4.2256 & 10099.873 & 7747.346 & 11278.821 & 11680.185 & \text { Yes }\end{array}$

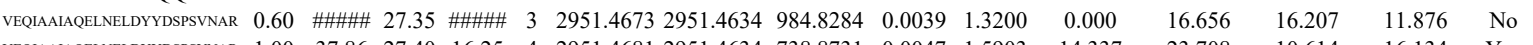

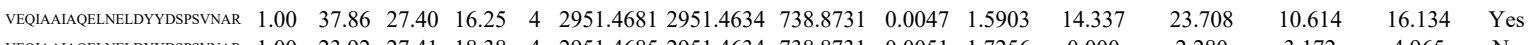

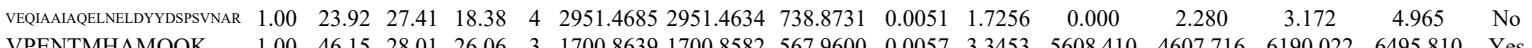
$\begin{array}{llllllllllllllll}\text { VPENTMHAMQQK } & 1.00 & 46.15 & 28.01 & 26.06 & 3 & 1700.8639 & 1700.8582 & 567.9600 & 0.0057 & 3.3453 & 5608.410 & 4607.716 & 6190.022 & 6495.810 & \text { Yes }\end{array}$

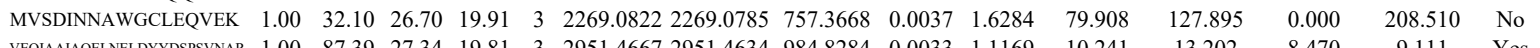

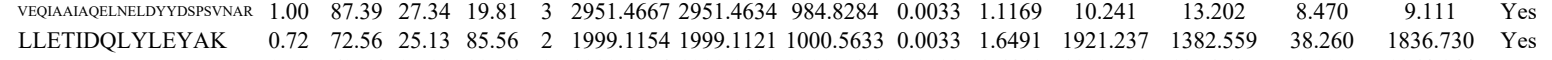
$\begin{array}{llllllllllllllll}\text { LLETIDQLYLEYAK } & 0.72 & 72.56 & 25.13 & 85.56 & 2 & 1999.1154 & 1999.1121 & 1000.5633 & 0.0033 & 1.6491 & 1921.237 & 1382.559 & 38.260 & 1836.730 & \text { Yes } \\ \text { LLETIDQLYLEYAK } & 0.72 & 69.56 & 25.13 & 82.56 & 2 & 1999.1154 & 1999.1121 & 1000.5633 & 0.0033 & 1.6491 & 1809.538 & 1376.625 & 0.000 & 1864.144 & \text { No }\end{array}$ $\begin{array}{lllllllllllllllll}\text { LLETIDQLYLEYAK } & 0.72 & 69.56 & 25.13 & 82.56 & 2 & 1999.1154 & 1999.1121 & 000.5633 & 0.0033 & 1.6491 & 1809.538 & 1376.625 & 0.000 & 1864.144 & \text { No } \\ \text { LLETIDQLYLEYAK } & 0.60 & 30.49 & 25.04 & 43.49 & 3 & 1999.1164 & 1999.1121 & 667.3780 & 0.0043 & 2.1477 & 681.804 & 713.918 & 22.594 & 604.604 & \text { Yes }\end{array}$

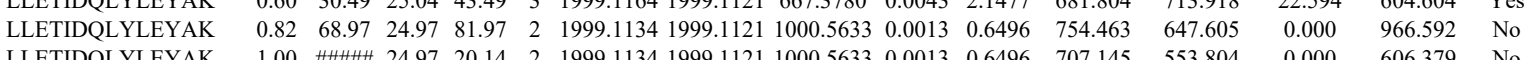



$\begin{array}{llllllllllllll}\text { DIISIAEDEDLR } & 1.00 & 68.14 & 28.18 & 26.00 & 2 & 1531.7864 & 1531.7851 & 766.8998 & 0.0013 & 0.8476 & 67.552\end{array}$

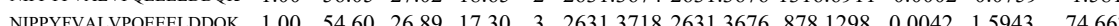

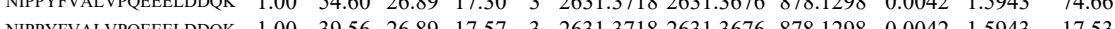
$\begin{array}{llllllllllllll} & \end{array}$ $\begin{array}{lllllllllllll}\text { NLEALALDLMEPEQAVDLTLPK } & 0.97 & 23.92 & 24.42 & 17.21 & 3 & 2710.4752 & 2710.4706 & 904.4975 & 0.0046 & 1.6952 & 43.942 \\ 3\end{array}$

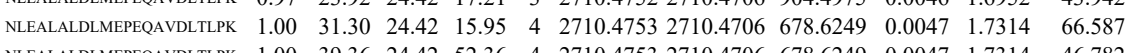

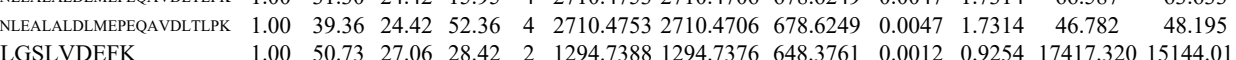
LGSLVDEFK

$\begin{array}{llllllllllll}1.00 & 44.82 & 27.21 & 29.61 & 2 & 1294.7390 & 1294.7376 & 648.3761 & 0.0014 & 1.0796 & 10803.611 & 9837.595\end{array}$

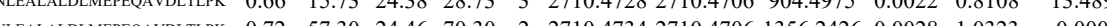
$\begin{array}{llllllllllll} & \end{array}$

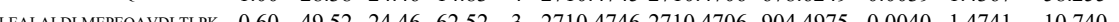

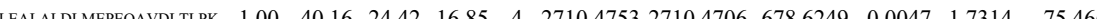

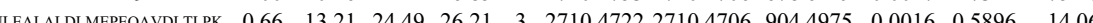



$\begin{array}{llllllllllll}.00 & 28.51 & 25.85 & 41.51 & 4 & 3603.7485 & 3603.7435 & 901.9432 & 0.0050 & 1.2750 & 0.000\end{array}$ $\begin{array}{llllllllllll}\text { QLNHFWEIVVDDGITLITK } & 0.98 & 20.54 & 22.83 & 15.82 & 3 & 2541.4216 & 2541.4199 & 848.1472 & 0.0017 & 0.6681 & 26.769\end{array}$ $\begin{array}{llllllllllllll} & \end{array}$ $\begin{array}{lllllllllllll}\text { EEASGSSVTAEEAK } & 0.60 & 11.54 & 27.37 & 17.66 & 3 & 1681.8277 & 1681.8250 & 561.6156 & 0.0027 & 1.6025 & 432.349 & 382\end{array}$ $\begin{array}{lllllllllllll}\text { QLNHFWEIVVQDGITLITK } & 1.00 & 52.96 & 22.67 & 16.73 & 3 & 2541.4234 & 2541.4199 & 848.1472 & 0.0035 & 1.3755 & 10.184 & 8\end{array}$ $\begin{array}{llllllllllllll}\text { QLNHFWEIVVQDGITLITK } & 1.00 & 43.45 & 22.60 & 56.45 & 4 & 2541.4237 & 2541.4199 & 636.3623 & 0.0038 & 1.4929 & 71.337 & & \end{array}$ $\begin{array}{lllllllllllll}\text { QLNHFWEIVVQDGITLITK } & 1.00 & 41.76 & 22.60 & 16.39 & 4 & 2541.4237 & 2541.4199 & 636.3623 & 0.0038 & 1.4929 & 61.258 & 88\end{array}$ \begin{tabular}{lllllll}
0.008 & 1.4929 & 61.258 & 83.448 & 27.716 & 73.137 & Y \\
\hline
\end{tabular} LTIGSNLSIR $\begin{array}{llllllllllllllll}1.00 & 55.36 & 26.90 & 35.81 & 2 & 1216.7264 & 1216.7261 & 609.3703 & 0.0003 & 0.2462 & 18336.193 & 18709.692 & 1504.464 & 25640.668 & \text { Yes } \\ 1.00 & 53.98 & 26.36 & 30.01 & 2 & 1216.7278 & 1216.7261 & 609.3703 & 0.0017 & 1.3949 & 38433.569 & 31850.177 & 2682.029 & 46955.919 & \text { Yes }\end{array}$ $\begin{array}{lllllllllllllll}1.00 & 56.64 & 25.95 & 31.41 & 2 & 1216.7258 & 1216.7261 & 609.3703 & -0.0003 & -0.2462 & 20784.118 & 20548.596 & 1482.744 & 25363.499 & \text { Yes } \\ 1.00 & 60.44 & 26.90 & 36.04 & 2 & 1216.7266 & 1216.7261 & 609.3703 & 0.0005 & 0.4103 & 18474.492 & 17982.692 & 1555.053 & 24035.796 & \text { Yes }\end{array}$

CFSVLGFCK $\begin{array}{llllllllllllllll}1.00 & 60.44 & 26.90 & 36.04 & 2 & 1216.7266 & 1216.7261 & 609.3703 & 0.0005 & 0.4103 & 18474.492 & 17982.692 & 1555.053 & 24035.796 & \text { Yes } \\ 1.00 & 45.45 & 25.73 & 21.09 & 2 & 1382.6466 & 1382.6463 & 692.3304 & 0.0003 & 0.2167 & 1889.834 & 1843.015 & 167.801 & 1914.530 & \text { Yes }\end{array}$ $\begin{array}{llllllllllllllll} & & & & \end{array}$ $\begin{array}{lllllllllllllll} & \\ 0.84 & 50.29 & 25.65 & 63.29 & 2 & 1382.6480 & 1382.6463 & 692.3304 & 0.0003 & 0.2167 & 1889.834 & 1843.015 & 167.801 & 1914.530 & \text { Yes } \\ 1.092 .3304 & 0.0017 & 1.2277 & 1829.359 & 1897.474 & 237.977 & 1872.193 & \text { Yes }\end{array}$ $\begin{array}{llllllllllllllll}\text { DQVTAQEIFDDNHEDGPTAK } & 0.60 & 40.55 & 26.99 & 53.55 & 3 & 2530.2217 & 2530.2180 & 844.4133 & 0.0037 & 1.4606 & 139.766 & 144.513 & 213.375 & 265.767 & \text { Yes } \\ \text { CFSVLGFCK } & 0.84 & 44.25 & 25.66 & 57.25 & 2 & 1382.6478 & 1382.6463 & 6923304 & 0.0015 & 1.0833 & 1411.740 & 1474.009 & 93.729 & 1492889 & \text { Yes }\end{array}$

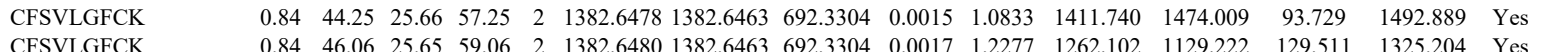
$\begin{array}{lllllllllllllllll} & 0.84 \\ \text { CFSVLGFCK } & 0.84 & 46.06 & 25.65 & 59.06 & 2 & 1382.6480 & 1382.6463 & 692.3304 & 0.0017 & 1.2277 & 1262.102 & 1129.222 & 129.511 & 1325.204 & \text { Yes } \\ \text { VITMFVQR } & 0.98 & 41.23 & 26.33 & 22.55 & 2 & 1136.6550 & 1136.6498 & 569.3322 & 0.0052 & 4.5667 & 7708.798 & 7464.887 & 805.790 & 9373.113 & \text { Yes }\end{array}$

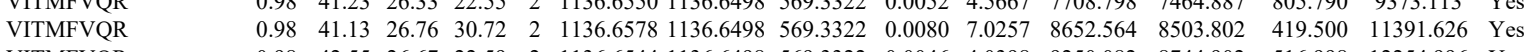

VITMFVQR

VITMFVQR

KVITMFVQR

VITMFVQR $\begin{array}{lllllllllllllllll}0.98 & 42.55 & 26.67 & 22.59 & 2 & 1136.6544 & 1136.6498 & 569.3322 & 0.0046 & 4.0398 & 9250.082 & 8744.902 & 516.998 & 12254.996 & \text { Yes }\end{array}$

VITMFVQR $\begin{array}{llllllllllllllll}0.96 & 37.96 & 26.67 & 21.46 & 2 & 1136.6546 & 1136.6498 & 569.3322 & 0.0048 & 4.2154 & 5669.564 & 5319.674 & 323.269 & 7415.056 & \text { Yes } & \\ 0.67 & 29.78 & 21.88 & 42.78 & 3 & 1408.8502 & 1408.8468 & 470.6229 & 0.0034 & 2.4082 & 3571.987 & 3663.504 & 138.358 & 596.859 & \text { Yes }\end{array}$ $\begin{array}{llllllllllllllll}0.99 & 41.47 & 27.27 & 21.08 & 2 & 1136.6500 & 1136.6498 & 569.3322 & 0.0002 & 0.1756 & 3737.390 & 3991.589 & 280.602 & 4956.059 & \text { Yes } \\ 1.00 & 40.95 & 27.43 & 20.98 & 2 & 1136.6506 & 1136.6498 & 569.3322 & 0.0008 & 0.7026 & 3522.821 & 3604.567 & 315.808 & 4494.169 & \text { Yes }\end{array}$ $\begin{array}{lllllllllllllll}1.00 & 41.14 & 27.32 & 24.64 & 2 & 1136.6508 & 1136.6498 & 569.3322 & 0.0010 & 0.8782 & 783.597 & 770.955 & 86.425 & 956.392 & \text { Yes }\end{array}$ $\begin{array}{lllllllllllllll} & 1.28 & 27.02 & 20.18 & 3 & 2530.2214 & 2530.2180 & 844.4133 & 0.0034 & 1.3422 & 1115.275 & 1083.316 & 1600.343 & 1894.313 & \text { Yes }\end{array}$

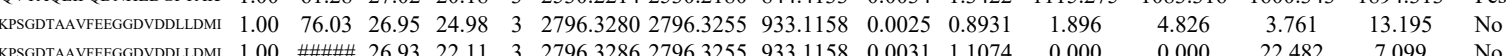

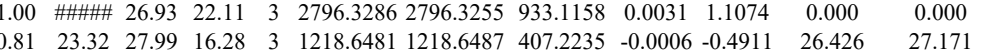

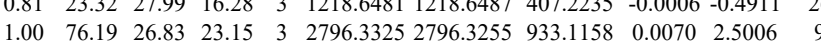
$\begin{array}{llllllllllll}1.00 & 76.19 & 26.83 & 23.15 & 3 & 2796.3325 & 2796.3255 & 933.1158 & 0.0070 & 2.5006 & 9.316 & 20.807 \\ 1.00 & 62.44 & 27.87 & 32.75 & 2 & 1667.8868 & 1667.8862 & 834.9504 & 0.0006 & 0.3593 & 1174.520 & 969.331\end{array}$ TDTLEDLFPTTK $\begin{array}{ll}8.051 & 19.767 \\ 8.302 & 2.992\end{array}$ $\begin{array}{llllllllllllllll} & \\ \text { TDTLEDLFPTK } & 0.97 & 24.23 & 27.85 & 26.89 & 3 & 1667.8882 & 1667.8862 & 556.9693 & 0.0020 & 1.1970 & 86.046 & 58.217 & 46.781 & 88.589 & \text { Yes } \\ \text { TDTLEDLFPTK } & 1.00 & 65.20 & 27.81 & 26.40 & 2 & 1667.8890 & 1667.8862 & 834.9504 & 0.0028 & 1.6767 & 2873.862 & 2467.721 & 197.590 & 35.770 & \text { Yes }\end{array}$

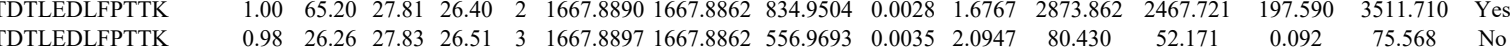
$\begin{array}{lllllllllllllll} & & \end{array}$ $\begin{array}{lllllllllllllllll}\text { HLMLPDFDLLEDIESK } & 1.00 & 36.83 & 27.08 & 23.76 & 3 & 2202.1522 & 2202.1486 & 735.0568 & 0.0036 & 1.6325 & 169.733 & 160.834 & 66.270 & 231.761 & \text { Yes }\end{array}$ $\begin{array}{llllllllllllllll}\text { DHPLPEVAHVK } & 1.00 & 54.77 & 26.16 & 22.61 & 3 & 1528.8736 & 1528.8606 & 510.6275 & 0.0130 & 8.4862 & 6883.816 & 5838.619 & 8059.769 & 9727.607 & \text { Yes }\end{array}$

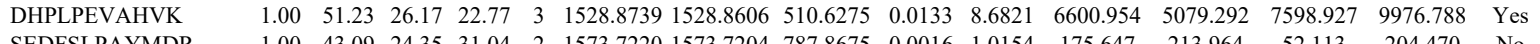

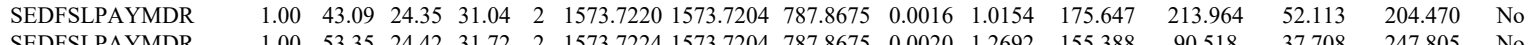

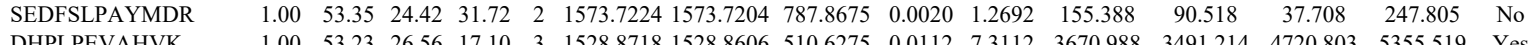

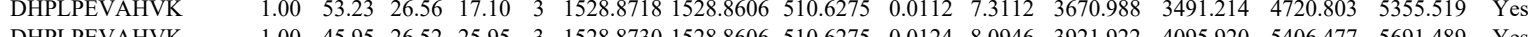

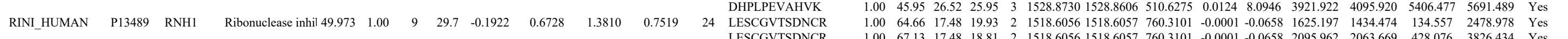
$\begin{array}{lccccccccccccccc}\text { LESCGVTSDNCR } & 1.00 & 67.13 & 17.48 & 18.81 & 2 & 1518.6056 & 1518.6057 & 760.3101 & -0.0001 & -0.0658 & 2095.962 & 2063.669 & 428.076 & 3826.434 & \text { Yes } \\ \text { ELDLSNNCLGDAGLLLVESVR } & 1.00 & 63.17 & 27.44 & 18.87 & 3 & 2547.2797 & 2547.2794 & 850.1004 & 0.0003 & 0.1176 & 13.901 & 21.681 & 15.025 & 18.213 & \text { Yes }\end{array}$ \begin{tabular}{llllllllllllllll} 
ELDLSNNCLGDAGLLLVESVR & 1.00 & 63.17 & 27.44 & 18.87 & 3 & 2547.2797 & 2547.2794 & 850.1004 & 0.0003 & 0.1176 & 13.901 & 21.681 & 15.025 & 18.213 & Yes \\
\hline ELDSNNCLGDAGLOLVESVR & 1.00 & 75.32 & 27.42 & 22.64 & 3 & 2547.2821 & 2547.2794 & 850.1004 & 0.0027 & 1.0587 & 12.894 & 7.518 & 0.000 & 29.805 & No
\end{tabular}

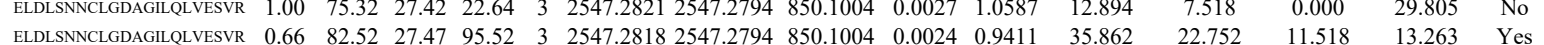



$\begin{array}{llllllllllllllllll}\text { ARPFPGLAEDIDKGEVSAR } & 0.95 & 47.18 & 26.31 & 17.88 & 3 & 2430.2830 & 2430.2747 & 811.0988 & 0.0083 & 3.4110 & 473.614 & 533.056 & 788.596 & 1102.646 & \text { Yes }\end{array}$ $\begin{array}{lllllllllllllllll}\text { ARPFPDGLAEDIDKGEVSAR } & 1.00 & 55.26 & 26.31 & 17.92 & 4 & 2430.2837 & 2430.2747 & 608.5760 & 0.0090 & 3.6971 & 4540.744 & 4831.205 & 7230.655 & 9449.405 & \text { Yes }\end{array}$ $\begin{array}{lllllllllllllllll} & 0.94 & 34.21 & 27.13 & 26.55 & 2 & 1198.6312 & 1198.6226 & 600.3186 & 0.0086 & 7.1628 & 13708.831 & 11488.603 & 4921.491 & 32648.197 & \text { Yes }\end{array}$

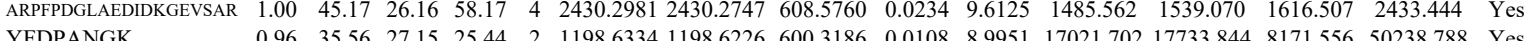
$\begin{array}{llllllllllllllll}\text { YFDPANGK } & 0.96 & 35.56 & 27.15 & 25.44 & 2 & 1198.6334 & 1198.6226 & 600.3186 & 0.0108 & 8.9951 & 17021.702 & 17733.844 & 8171.556 & 50238.788 & \text { Yes }\end{array}$ $\begin{array}{llllllllllllllll}\text { YFDPANGK } & 0.96 & 35.63 & 27.13 & 26.62 & 2 & 1198.6340 & 1198.6226 & 600.3186 & 0.0114 & 9.4949 & 19206.605 & 20322.425 & 6010.817 & 48715.421 & \text { Yes }\end{array}$

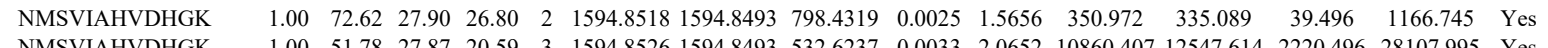

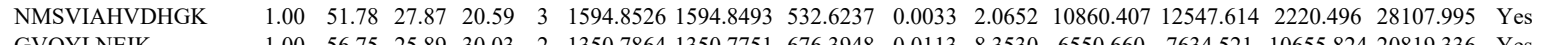

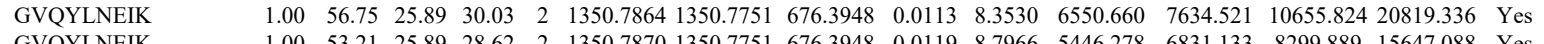
\begin{tabular}{llllllllllllllll} 
GVQYLNEIK & 1.00 & 53.21 & 25.89 & 28.62 & 2 & 1350.7870 & 1350.7751 & 676.3948 & 0.0119 & 8.7966 & 5446.278 & 6831.133 & 8299.889 & 15647.088 & Yes \\
\hline PFAEMYAK & 0.99 & 4.79 & 27.87 & 25.27 & 2 & 1373.7374 & 1373.7257 & 687.8701 & 0.0117 & 8.5044 & 2240.066 & 2191.505 & 335.988 & 5403.557 & Yes
\end{tabular}

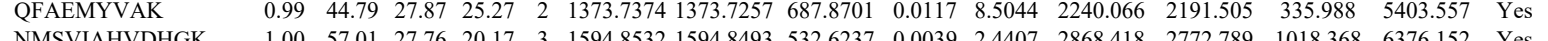

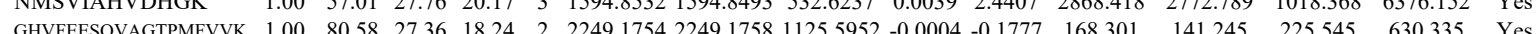
\begin{tabular}{llllllllllllllll} 
GHVFESQVAGPMFVK & 1.00 & 80.58 & 27.36 & 18.24 & 2 & 2249.1754 & 2249.1758 & 125.5952 & -0.0004 & -0.1777 & 168.301 & 141.245 & 225.545 & 630.335 & Yes \\
\hline
\end{tabular}

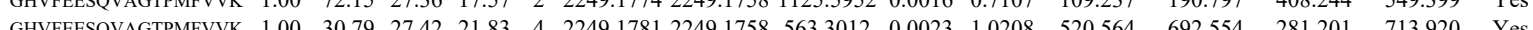

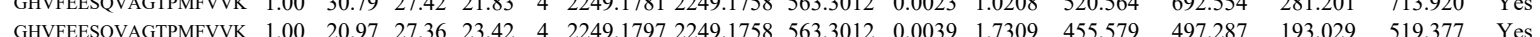

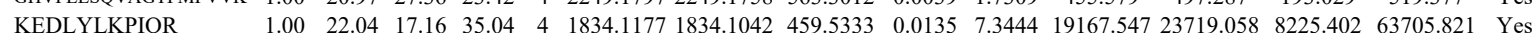
$\begin{array}{llllllllllllllll}\text { KEDLYLKPIQR } & 1.00 & 22.04 & 17.16 & 35.04 & 4 & 1834.1177 & 1834.1042 & 459.5333 & 0.0135 & 7.3444 & 19167.547 & 23719.058 & 8225.402 & 63705.821 & \text { Yes } \\ \text { KEDLYLKPIQR } & 1.00 & 23.93 & 17.16 & 36.93 & 4 & 1834.1189 & 1834.1042 & 459.5333 & 0.0147 & 7.9972 & 18561.363 & 22627.039 & 6217.226 & 60306.340 & \text { Yes }\end{array}$ $\begin{array}{llllllllllllllllll}\text { GHVFEESQVAGTPMFVVK } & 1.00 & 80.28 & 27.44 & 19.37 & 2 & 249.1794 & 2249.1758 & 1125.5952 & 0.0036 & 1.5992 & 110.746 & 120.044 & 182.932 & 273.343 & \text { Yes }\end{array}$

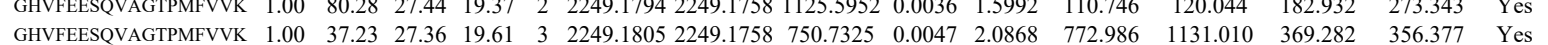

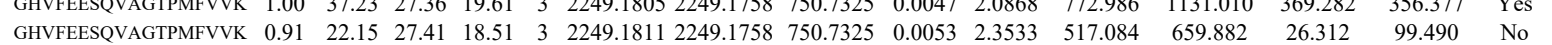

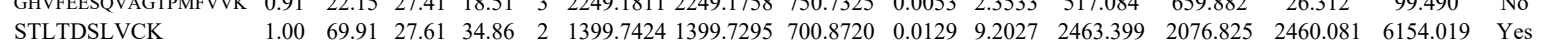

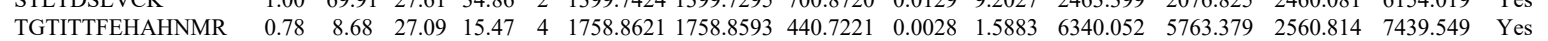
$\begin{array}{lllllllllllllllll}\text { KEDLYLKPIQR } & 1.00 & 32.92 & 17.16 & 45.92 & 4 & 1834.1161 & 1834.1042 & 459.5333 & 0.0119 & 6.4739 & 14627.281 & 17922.448 & 4151.441 & 48300.411 & \text { Yes }\end{array}$ $\begin{array}{llllllllllllllll}\text { ALLELQLEPEELYQTFQR } & 1.00 & 44.89 & 26.66 & 18.45 & 2 & 2363.2514 & 2363.2494 & 1182.6320 & 0.0020 & 0.8456 & 25.769 & 50.664 & 156.901 & 140.916 & \text { No }\end{array}$ $\begin{array}{lllllllllllllllll}\text { ALLELQLEPEELYQTFQR } & 0.84 & 44.42 & 26.66 & 57.42 & 2 & 2363.2514 & 2363.2494 & 1182.6320 & 0.0020 & 0.8456 & 32.533 & 60.006 & 162.970 & 196.855 & \text { Yes }\end{array}$ $\begin{array}{lllllllllllllllll}\text { TGTITTFEHAHNMR } & 1.00 & 27.12 & 27.15 & 40.12 & 4 & 1758.8593 & 1758.8593 & 440.7221 & 0.0000 & 0.0000 & 2216.161 & 2520.359 & 1443.373 & 5109.058 & \text { Yes }\end{array}$ $\begin{array}{llllllllllllllllll}\text { TGTITTFEHAHNMR } & 1.00 & 95.13 & 27.20 & 29.39 & 3 & 1758.8605 & 1758.8593 & 587.2937 & 0.0012 & 0.6811 & 1434.564 & 1415.903 & 1215.751 & 2909.900 & \text { Yes }\end{array}$ $\begin{array}{llllllllllllllll}\text { TGTITTFEHAHNMR } & 1.00 & 29.34 & 27.17 & 42.34 & 4 & 1758.8613 & 1758.8593 & 440.7221 & 0.0020 & 1.1345 & 2340.600 & 1990.868 & 2179.251 & 4646.098 & \text { Yes }\end{array}$ $\begin{array}{lllllllllllllllll}\text { TGTITTFEHAHNMR } & 1.00 & 64.69 & 27.03 & 21.30 & 3 & 1758.8620 & 1758.8593 & 587.2937 & 0.0027 & 1.5325 & 1612.730 & 2172.600 & 1644.958 & 4171.120 & \text { Yes }\end{array}$

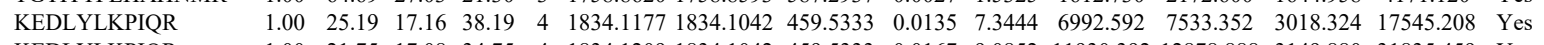

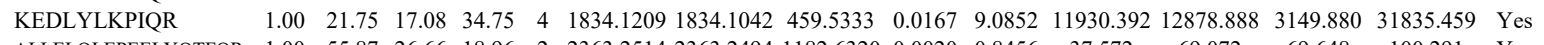

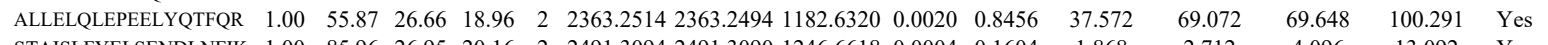

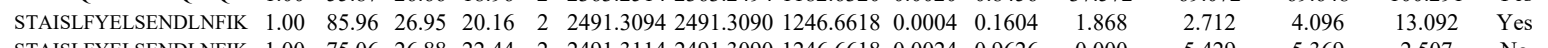

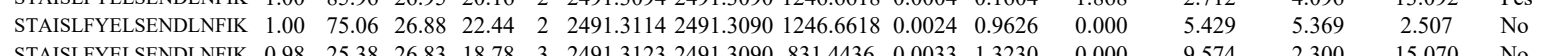

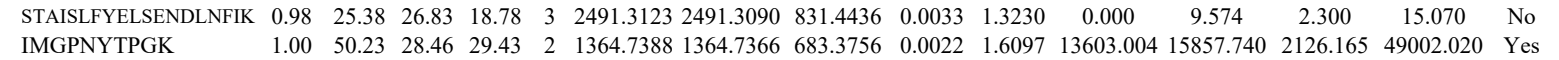
$\begin{array}{lllllllllllllllll}\text { IMGPNYTPK } & 1.00 & 50.23 & 28.46 & 29.43 & 2 & 1364.7388 & 1364.7366 & 683.3756 & 0.0022 & 1.6097 & 13603.004 & 15857.740 & 2126.165 & 49002.020 & \text { Yes } \\ \text { IMGPNYTPGK } & 1.00 & 47.89 & 28.88 & 32.31 & 2 & 1364.7402 & 1364.7366 & 683.3756 & 0.0036 & 2.6340 & 25166.936 & 28126.247 & 5939.946 & 89675.061 & \text { Yes }\end{array}$

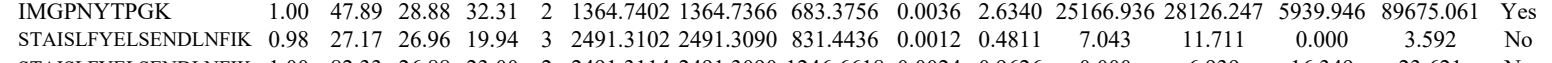
$\begin{array}{llllllllllllllll}\text { STAISLFYLLSENLNFK } & 0.98 & 27.17 & 26.96 & 19.94 & 3 & 2491.3102 & 2491.3090 & 831.4436 & 0.0012 & 0.481 & 7.043 & 11.711 & 0.00 & 3.52 & \text { N } \\ \text { STAISLFYELSENDLNFIK } & 1.00 & 82.33 & 26.88 & 23.00 & 2 & 2491.3114 & 2491.3090 & 1246.6618 & 0.0024 & 0.9626 & 0.000 & 6.939 & 16.349 & 23.621 & \text { No }\end{array}$

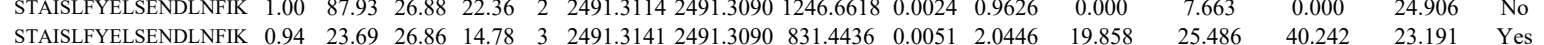

Table S-4 page 162 of 614 

$\begin{array}{lllllllllll}1.00 & 75.34 & 26.45 & 23.54 & 3 & 2944.5124 & 2944.5052 & 982.5090 & 0.0072 & 2.4427 & 13.947\end{array}$

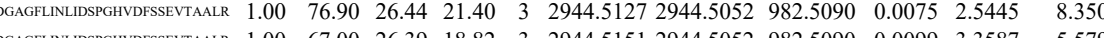

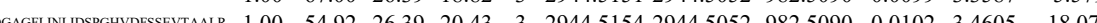

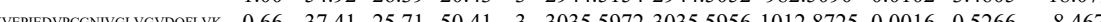
r. $\begin{array}{lllllllllll} & 1.00 & 24.36 & 25.73 & 27.16 & 4 & 3035.6009 & 3035.5956 & 759.9062 & 0.0053 & 1.7436\end{array}$

AYLPVNESFGFTADLI

$\begin{array}{lllllllllllllll} & \end{array}$

$\begin{array}{llllllllllll} & \end{array}$

0.000

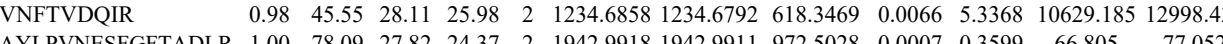

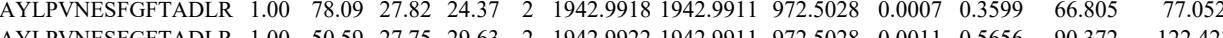

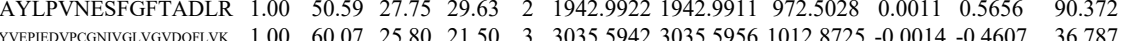

$\begin{array}{llllllllll} & 0.367\end{array}$

$\begin{array}{llllllllllll} & \end{array}$

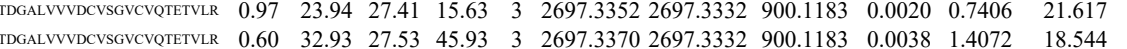
$\begin{array}{llllllllll}0.99 & 30.16 & 27.32 & 26.26 & 3 & 1371.7483 & 1371.7464 & 458.2561 & 0.0019 & 1.3820\end{array}$

$\begin{array}{lllllllllllll} & \end{array}$

$\begin{array}{lllllllllllll}0.67 & 33.50 & 27.48 & 46.50 & 3 & 2697.3361 & 2697.3332 & 900.1183 & 0.0029 & 1.0739 & 4.517\end{array}$

$\begin{array}{lllllllllllll}\text { TRGALVVVDCVGGVCVQTETVLR } & 1.00 & 84.84 & 27.53 & 20.55 & 3 & 2697.3379 & 2697.3332 & 900.1183 & 0.0047 & 1.7405 & 8.802\end{array}$

$\begin{array}{lllllllllllll}\text { VIR } & 0.67 & 34.92 & 27.48 & 47.92 & 3 & 2697.3361 & 2697.3332 & 900.1183 & 0.0029 & 1.0739 & 5.735\end{array}$

$\begin{array}{llll}0.0038 & 1.4072 & 20.447 \\ 0.0038 & 1.4072 & 2.167 & 0\end{array}$ 


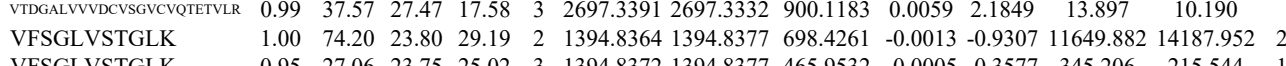

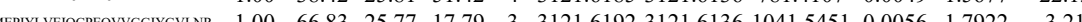
$\begin{array}{llllllllllll}1.00 & 30.40 & 25.77 & 17.54 & 4 & 3121.61973121 .6136 & 781.4107 & 0.0061 & 1.9516 & 5.594\end{array}$ $\begin{array}{lllllllllllllll}0.91 & 20.91 & 20.09 & 16.37 & 3 & 1504.9333 & 1504.9199 & 502.6472 & 0.0134 & 8.8862 & 18837.865 & 18695.227 & 14284.826 & 56524.406 & \text { Yes } \\ 0.99 & 35.73 & 19.96 & 21.05 & 2 & 1504.9340 & 1504.9199 & 753.4672 & 0.0141 & 9.3567 & 12005.423 & 15919.877 & 14156.809 & 36028.457 & \text { Yes } \\ 1.00 & 47.11 & 19.03 & 23.05 & 2 & 1504.9344 & 1504.9199 & 753.4672 & 0.0145 & 9.6221 & 1553.394 & 19377.540 & 15309.239 & 49256.386 & \text { Yes }\end{array}$ $\begin{array}{lllllllllllllllll}1.00 & 47.11 & 19.03 & 23.05 & 2 & 1504.9344 & 1504.9199 & 753.4672 & 0.0145 & 9.6221 & 15573.394 & 19377.540 & 15309.239 & 49256.386 & \text { Yes }\end{array}$

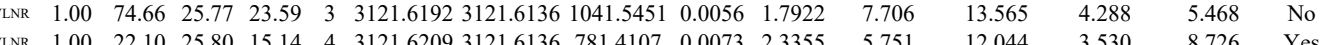
$\begin{array}{lllllllllllllll} & & & \end{array}$ $\begin{array}{lllllllllllllll}1.00 & 69.96 & 21.52 & 26.23 & 2 & 1394.8516 & 1394.8377 & 698.4261 & 0.0139 & 9.9508 & 9980.148 & 12487.805 & 379.733 & 30585.762 & \text { Yes } \\ 1.00 & 47.10 & 19.96 & 24.80 & 2 & 1504.9340 & 1504.9199 & 753.4672 & 0.0141 & 9.3567 & 1203.925 & 1281.728 & 1097.635 & 3567.473 & \text { Yes }\end{array}$

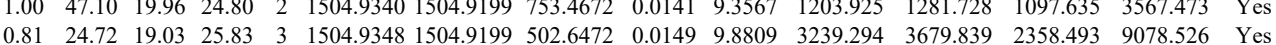
$\begin{array}{llllllllllllllll}\text { TFCQLILDPIFK } & 1.00 & 74.89 & 26.99 & 31.26 & 2 & 1770.9664 & 1770.9656 & 886.4901 & 0.0008 & 0.4512 & 845.379 & 566.383 & 134.471 & 2830.911 & \text { Yes }\end{array}$ $\begin{array}{llllllllllllllll}\text { TFCQLILDPIFK } & 1.00 & 71.73 & 27.15 & 26.72 & 2 & 1770.9674 & 1770.9656 & 886.4901 & 0.0018 & 1.0152 & 1794.749 & 1239.424 & 376.090 & 7191.455 & \text { Yes }\end{array}$ $\begin{array}{llllllllllllllll}\text { TFCQLILDPIFK } & 0.98 & 25.14 & 27.28 & 22.57 & 3 & 1770.9691 & 1770.9656 & 591.3291 & 0.0035 & 1.9730 & 27.831 & 20.028 & 3.218 & 80.865 & \text { Yes }\end{array}$ TFCQLILDPIFK

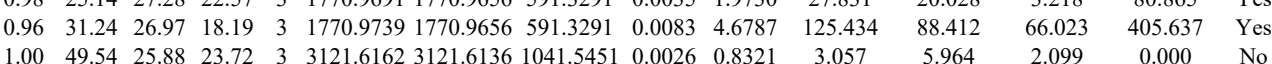

\section{(1)}

FSVSPVVR

TFCQLILDPIFK

TFCQLILDPIFK

FSVSPVVR

FSVSPVVR

TFCQLILDPIFK

TFCQLILDPIFK $\begin{array}{lllllllllll}1.00 & 66.57 & 25.88 & 21.62 & 3 & 3121.6162 & 3121.6136 & 1041.5451 & 0.0026 & 0.8321 & 3.057\end{array}$

0.000

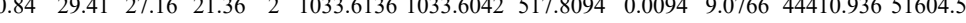

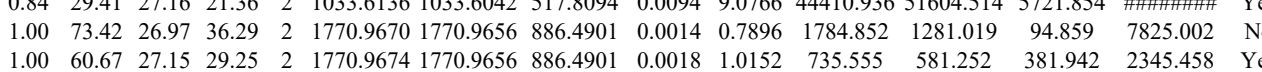

TIDGALVVVDCYGGVCVO

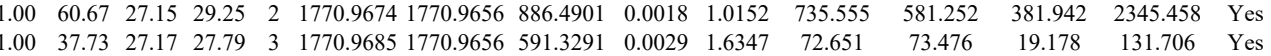

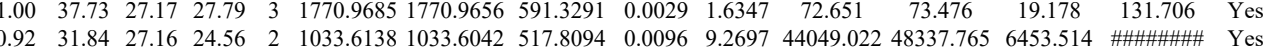

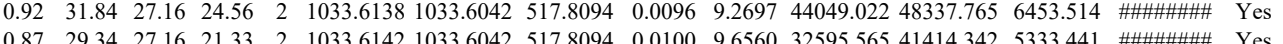

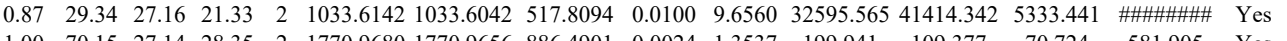

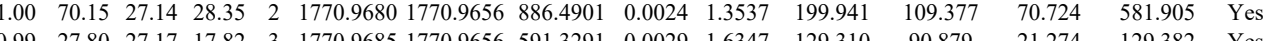

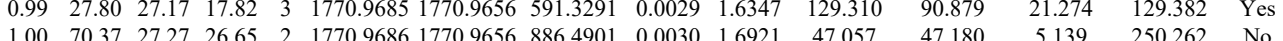

FSVSPVVR $\begin{array}{lllllllllll}1.00 & 7.37 & 27.27 & 26.65 & 2 & 1770.9686 & 1770.9656 & 886.4901 & 0.0030 & 1.6921 & 47.057\end{array}$

TFCQLILDPIFK $\begin{array}{llllllllllll}0.89 & 36.94 & 26.18 & 18.54 & 3 & 3365.6992 & 3365.6938 & 1122.9052 & 0.0054 & 1.6030 & 4.305\end{array}$

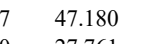
0.78 $\begin{array}{lllllllllllll}12.71 & 27.28 & 20.73 & 3 & 1770.9691 & 1770.9656 & 591.3291 & 0.0035 & 1.9730 & 85.256\end{array}$ 27.761

WLPAGDALLQMITHLPSPVTAO

WLPAGDALLQ

TILMMGR
TILMMGR

TILMMGR

TILMMGR

TILMMGR

TILMMGR

TILMMGR

TILMMGR $\begin{array}{lllllllllll}0.55 & 44.50 & 20.49 & 57.50 & 3 & 2903.6200 & 2903.6187 & 968.8802 & 0.0013 & 0.4473 & 72.085\end{array}$

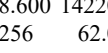
$\begin{array}{lllllllllll}0.93 & 5.45 & 20.57 & 18.45 & 4 & 2903.6217 & 2903.6187 & 726.9120 & 0.0030 & 1.0318 & 5.595\end{array}$ $\begin{array}{lllllllllllll}0.79 & 19.53 & 26.58 & 25.35 & 2 & 964.5328 & 964.5320 & 483.2733 & 0.0008 & 0.8277 & 76.795\end{array}$ $\begin{array}{lllllllllllll}0.58 & 15.04 & 26.58 & 23.30 & 2 & 964.5330 & 964.5320 & 483.2733 & 0.0010 & 1.0346 & 100.252 \\ 0.94 & 25.58 & 26.58 & 27.86 & 2 & 964.5330 & 964.5320 & 483.2733 & 0.0010 & 1.0346 & 75.530\end{array}$ $\begin{array}{lllllllllllll}0.96 & 15.58 & 26.58 & 27.86 & 2 & 964.5330 & 984.5320 & 483.2733 & 0.0010 & 1.0346 & 75.530\end{array}$ $\begin{array}{lllllllllllll}0.86 & 21.67 & 26.58 & 29.35 & 2 & 964.5334 & 964.5320 & 483.2733 & 0.0014 & 1.4485 & 81.704\end{array}$ $\begin{array}{llllllllllllll}0.71 & 17.65 & 26.58 & 24.32 & 2 & 964.5334 & 964.5320 & 483.2733 & 0.0014 & 1.4485 & 46.294\end{array}$ $\begin{array}{lllllllllllll}0.52 & 14.40 & 27.60 & 25.55 & 2 & 964.5336 & 964.5320 & 483.2733 & 0.0016 & 1.6554 & 95.534\end{array}$ $\begin{array}{llllllllllll}0.71 & 29.12 & 27.99 & 32.29 & 2 & 964.5394 & 964.5320 & 483.2733 & 0.0074 & 7.6561 & 34304.217\end{array}$

$\begin{array}{llll}62.070 & 21.201 & 152.174 & \text { Yes }\end{array}$

PAGDALLQMITHLPSPVTAC

WLPAGDALLQ

TILMMGR

TILMMGR

TILMMGR

TILMMGR

TILMMGR $\begin{array}{llllllllll}2.45 & 22.45 & 4 & 2903.6205 & 2903.6187 & 726.9120 & 0.0018 & 0.6191 & 1.425\end{array}$

TILOM $\begin{array}{llllllllllll}0.51 & 13.63 & 26.58 & 23.52 & 2 & 964.5328 & 964.5320 & 483.2733 & 0.0008 & 0.827 & 69.384 \\ 0.51 & 1.34 & 2 & 964.5328 & 964.5320 & 483.2733 & 0.0008 & 0.8277 & 25.157\end{array}$ $\begin{array}{llllllllllllll}0.69 & 17.28 & 26.58 & 27.99 & 2 & 964.5332 & 964.5320 & 483.2733 & 0.0012 & 1.2415 & 79.434\end{array}$ $\begin{array}{llllllllllllll}0.76 & 18.78 & 26.58 & 24.11 & 2 & 964.5334 & 964.5320 & 483.2733 & 0.0014 & 1.4485 & 60.821\end{array}$ $\begin{array}{llllllllllll}0.70 & 18.53 & 26.58 & 24.11 & 2 & 964.5334 & 964.5320 & 483.2733 & 0.0014 & 1.485 & 60.821\end{array}$ $\begin{array}{llllllllllll}0.76 & 19.41 & 27.63 & 28.78 & 2 & 964.5340 & 964.5320 & 483.2733 & 0.0020 & 2.0692 & 88.455\end{array}$

$\begin{array}{llll}67.673 & 21.333 & 154.250 & \text { Yes }\end{array}$
$\begin{array}{llllllllllll}0.88 & 35.18 & 27.99 & 35.25 & 2 & 964.5384 & 964.5320 & 483.2733 & 0.0064 & 6.6215 & 24233.556\end{array}$ 

$\begin{array}{llllllllllll}0.64 & 65.86 & 27.93 & 78.86 & 2 & 1510.7760 & 1510.7758 & 756.3952 & 0.0002 & 0.1322 & 5742.777 & 6193.127\end{array}$ $\begin{array}{llllllllllll}0.82 & 60.24 & 27.87 & 73.24 & 2 & 1510.7766 & 1510.7758 & 756.3952 & 0.0008 & 0.5288 & 33.007\end{array}$ $\begin{array}{lllllllllllll}0.82 & 61.26 & 27.90 & 74.26 & 2 & 1510.7770 & 1510.7758 & 756.3952 & 0.0012 & 0.7932 & 6.945\end{array}$ $\begin{array}{lllllllllllll}0.82 & 73.67 & 27.89 & 86.67 & 2 & 1510.7772 & 1510.7758 & 756.3952 & 0.0014 & 0.9254 & 12.409\end{array}$

CLYASVLTAQPR

CLYASVLTAQPR

CLYASVLTAQPR

CLYASVLTAQPR

CLYASVLTAQPR

VTDGALVVVDCYGGVCVQTETY $\begin{array}{llllllllllll}.00 & 59.91 & 27.89 & 19.02 & 2 & 1510.7774 & 1510.7758 & 756.3952 & 0.0016 & 1.0576 & 14.715 \\ 0.84 & 67.86 & 27.89 & 80.86 & 2 & 1510.7778 & 1510.7758 & 756.3952 & 0.0020 & 1.3221 & 28.749\end{array}$ $\begin{array}{llllllllllll}0.84 & 74.30 & 27.89 & 87.30 & 2 & 1510.7778 & 1510.7758 & 756.3952 & 0.0020 & 1.3221 & 20.293\end{array}$ $\begin{array}{llllllllllll}1.00 & 58.93 & 27.86 & 20.67 & 2 & 1510.7782 & 1510.7758 & 756.3952 & 0.0024 & 1.5865 & 12.943 & 31\end{array}$ $\begin{array}{llllllllllll}1.00 & 71.68 & 28.03 & 17.67 & 2 & 1510.7788 & 1510.7758 & 756.3952 & 0.0030 & 1.9831 & 11.897\end{array}$ $\begin{array}{lllllllllll}1.00 & 56.17 & 28.03 & 18.94 & 2 & 1510.7792 & 1510.7758 & 756.3952 & 0.0034 & 2.2475 & 17.756\end{array}$ TILMMGR

TILMMGR $\begin{array}{lllllllllll}1.00 & 88.73 & 27.53 & 19.14 & 3 & 2697.3370 & 2697.3332 & 900.1183 & 0.0035 & 1.2961 & 1.749 \\ 0.7332 & 900.1183 & 0.0038 & 1.4072 & 1.716\end{array}$ $\begin{array}{llllllllllll}0.71 & 17.72 & 26.58 & 23.67 & 2 & 964.5328 & 964.5320 & 483.2733 & 0.0008 & 0.8277 & 974.411\end{array}$ $\begin{array}{lllllllllllll}0.79 & 19.62 & 26.58 & 26.88 & 2 & 964.5330 & 964.5320 & 483.2733 & 0.0010 & 1.0346 & 845.857\end{array}$ $\begin{array}{lllllllllll}1.00 & 54.85 & 27.70 & 23.29 & 2 & 1510.7738 & 1510.7758 & 756.3952 & -0.0020 & -1.3221 & 10.001\end{array}$

CLYASVLTAQPR

CLYASTIAQR

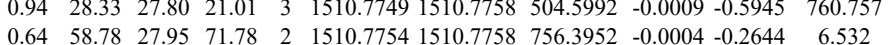
$\begin{array}{lllllllllll}1.00 & 37.51 & 27.92 & 24.22 & 3 & 1510.7758 & 1510.7758 & 504.5992 & 0.0000 & 0.0000 & 692.462\end{array}$ $\begin{array}{llllllllllll}1.00 & 69.65 & 27.92 & 18.37 & 2 & 1510.7758 & 1510.7758 & 756.3952 & 0.0000 & 0.0000 & 876.671\end{array}$

(1)

CLYASVLTAQPR $\begin{array}{llllllllllll}0.64 & 79.03 & 27.93 & 92.03 & 2 & 1510.7760 & 1510.7758 & 756.3952 & 0.0002 & 0.1322 & 4181.484\end{array}$ $\begin{array}{lllllllllllll}0.64 & 56.19 & 27.93 & 69.19 & 2 & 1510.7760 & 1510.7758 & 756.3952 & 0.0002 & 0.1322 & 22.178\end{array}$

CLYASVLTAQPR

CLYASVLTAQPR

CLYASVLTAQPR

CLYASVLTAQPR

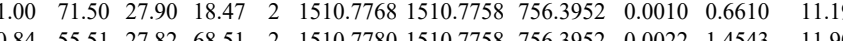
$\begin{array}{llllllllllll}1.84 & 55.51 & 27.82 & 68.51 & 2 & 1510.7780 & 1510.7758 & 756.3952 & 0.0022 & 1.4543 & 11.909 \\ 0.84 & 55.86 & 27.82 & 68.86 & 2 & 1510.7780 & 1510.7758 & 756.3952 & 0.0022 & 1.4543 & 11.269\end{array}$ $\begin{array}{lllllllllll}0.84 & 55.86 & 27.82 & 68.86 & 2 & 1510.7780 & 1510.7758 & 756.3952 & 0.0022 & 1.4543 & 11.269 \\ 0.72 & 37.62 & 28.03 & 50.62 & 2 & 1510.7788 & 1510.7758 & 756.3952 & 0.0030 & 1.9831 & 7.186\end{array}$ $\begin{array}{lllllllllll}0.72 & 58.41 & 2.03 & 71.41 & 2 & 1510.7792 & 1510.7758 & 756.3952 & 0.0034 & 2.2475 & 1.574\end{array}$ $\begin{array}{llllllllllll}\text { VTDGALVVVDCVGGVVQTETVLR } & 0.67 & 18.87 & 27.48 & 31.87 & 3 & 2697.3364 & 2697.3332 & 900.1183 & 0.0032 & 1.1850 & 2.987\end{array}$ VTDGALVVVDCV $\begin{array}{lllllllllllll}0.60 & 82.83 & 27.54 & 95.83 & 3 & 2697.3376 & 2697.3332 & 900.1183 & 0.0044 & 1.6294 & 0.000 \\ 0.75 & 18.60 & 26.58 & 27.23 & 2 & 964.5328 & 964.5320 & 483.2733 & 0.0008 & 0.8277 & 406.212\end{array}$

CLYASVLTAQPR $\begin{array}{llllllllllll}0.76 & 18.60 & 26.58 & 27.23 & 2 & 964.5328 & 964.5320 & 483.2733 & 0.0008 & 0.8277 & 406.212 \\ 0.96 & 33.07 & 27.70 & 17.23 & 3 & 1510.7737 & 1510.7758 & 504.5992 & -0.0021 & -1.3872 & 216.875\end{array}$

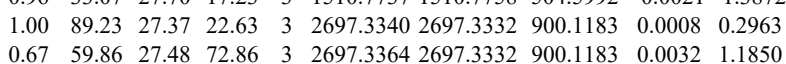

VTDGALVVVDCYGGVCVQTETV

\section{CLYASVLTAQPR}

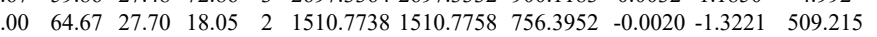
$\begin{array}{lllllllllllll}\text { CLYASVLTAQPR } & 1.00 & 81.96 & 27.70 & 18.74 & 2 & 1510.7738 & 1510.7758 & 756.3952 & -0.0020 & -1.3221 & 744.615\end{array}$ $\begin{array}{llllllllllllll} & \end{array}$ $\begin{array}{lllllllllllll} & \text { VIDGALVVDCVGGVCVQTETVLR } & 0.66 & 56.29 & 27.42 & 69.29 & 3 & 2697.3355 & 2697.3332 & 900.1183 & 0.0023 & 0.8517 & 2.38\end{array}$

CLYASVLTAQPR $\begin{array}{lllllllllll}1.00 & 51.28 & 27.54 & 16.98 & 3 & 2697.3376 & 2697.3332 & 900.1183 & 0.0044 & 1.6294 & 6.653\end{array}$ $\begin{array}{llllllllllllll} & \end{array}$ $\begin{array}{lllllllllllll}\text { CLYASVLTAQPR } & 0.82 & 80.47 & 27.90 & 93.47 & 2 & 1510.7764 & 1510.7758 & 756.3952 & 0.0006 & 0.3966 & 71.486\end{array}$ $\begin{array}{lllllllllllll}\text { VTDGALVVVDCVGGVCVQTETVIR } & 1.00 & 88.55 & 27.53 & 20.69 & 3 & 2697.3370 & 2697.3332 & 900.1183 & 0.0038 & 1.4072 & 1.999\end{array}$ $\begin{array}{lllllllllllll}\text { VTDGALVVVDCVSGVCVQTETVLR } & 0.56 & 20.03 & 27.53 & 15.24 & 3 & 2697.3409 & 2697.3332 & 900.1183 & 0.0077 & 2.8515 & 4.086\end{array}$ $\begin{array}{llllllllllll}1.00 & 75.03 & 27.90 & 19.28 & 2 & 1510.7770 & 1510.7758 & 756.3952 & 0.0012 & 0.7932 & 90.818 \\ 0.82 & 78.90 & 27.89 & 91.90 & 2 & 1510.7772 & 1510.7758 & 756.3952 & 0.0014 & 0.9254 & 91.168\end{array}$

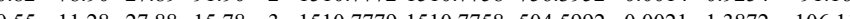


$\begin{array}{llllllllllll}\text { CLYASVLTAQPR } & 1.00 & 72.09 & 27.94 & 18.49 & 2 & 1510.7776 & 1510.7758 & 756.3952 & 0.0018 & 1.1899 & 84.125\end{array}$ $\begin{array}{lllllllllllll}\text { CLYASVLTAQPR } & 0.84 & 73.73 & 27.94 & 86.73 & 2 & 1510.7776 & 1510.7758 & 756.3952 & 0.0018 & 1.1899 & 53.843\end{array}$ $\begin{array}{lllllllllllll}\text { MTDGALVVVDCVSGVCVOTETVLR } & 0.55 & 36.26 & 27.40 & 49.26 & 3 & 2697.3346 & 2697.3332 & 900.1183 & 0.0014 & 0.5185 & 2.924\end{array}$ $\begin{array}{llllllllllllll} & \end{array}$

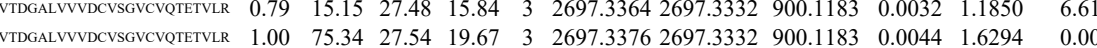
$\begin{array}{llllllllllllll}\text { VTDGALVVVDCVSGVCVPTETVLR } & 1.00 & 62.24 & 27.51 & 17.55 & 3 & 2697.3397 & 2697.3332 & 900.1183 & 0.0065 & 2.4071 & 0.000\end{array}$ CLYASVLTAQPR

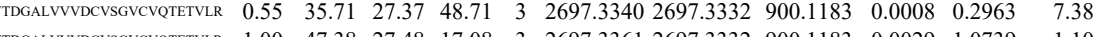
$\begin{array}{llllllllllllll} & \end{array}$ $\begin{array}{llllllllllllll} & \end{array}$ $\begin{array}{lllllllllllc} & \\ \text { CLYASVLTAAQPR } & 1.00 & 80.05 & 27.95 & 21.87 & 2 & 1510.7754 & 1510.7758 & 756.3952 & -0.0004 & -0.2644 & 99.329\end{array}$ $\begin{array}{lllllllllllll}\text { CLYASVLTAQPR } & 1.00 & 77.11 & 27.93 & 20.08 & 2 & 1510.7760 & 1510.7558 & 756.3952 & 0.0002 & 0.1322 & 63.187\end{array}$ $\begin{array}{llllllllllll}\text { VIDGALVVVDCVGGVVVOTETVRR } & 0.55 & 26.49 & 27.37 & 39.49 & 3 & 2697.3340 & 2697.3332 & 900.1183 & 0.0008 & 0.2963 & 5.719\end{array}$ $\begin{array}{lllllllllllll}\text { VIDGALVVVDCVGGVCVTETVIR R } & 0.55 & 29.88 & 27.40 & 42.88 & 3 & 2697.3346 & 2697.3332 & 900.1183 & 0.0014 & 0.5185 & 3.674\end{array}$ $\begin{array}{llllllllllll}\text { VTDGALVVDCUGGVVVOTETVLR } & 0.75 & 16.12 & 27.40 & 14.51 & 3 & 2697.3346 & 2697.3332 & 900.1183 & 0.0014 & 0.5185 & 1.390 \\ \text { VTDGALVVDDCVGGVVVTETVRR } & 0.66 & 47.22 & 27.41 & 60.22 & 3 & 2697.3352 & 2697.3332 & 900.1183 & 0.0020 & 0.7406 & 1.468\end{array}$ $\begin{array}{llllllllllll}\text { VTDGALVVDCVGGVCVTTETVR } & 0.66 & 47.22 & 27.41 & 60.22 & 3 & 2697.3352 & 2697.3332 & 900.183 & 0.0020 & 0.7406 & 1.468 \\ \text { VTDGALVVVDCVGGVVVTETVLR } & 0.86 & 18.94 & 27.37 & 17.73 & 3 & 2697.3340 & 2697.3332 & 900.1183 & 0.0008 & 0.2963 & 1.794\end{array}$

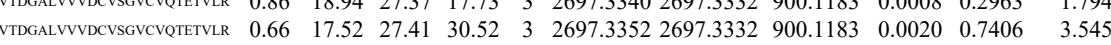

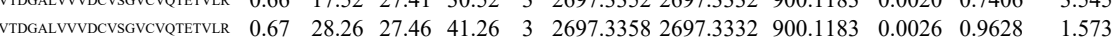

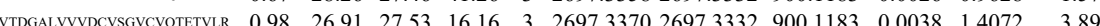

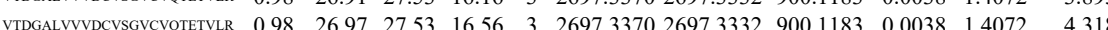

$\begin{array}{llllllllllll}\text { YEWDVAEAR } & 0.68 & 24.55 & 25.44 & 20.74 & 2 & 1281.6100 & 1281.6111 & 641.8128 & -0.0011 & -0.8569 & 186.673\end{array}$

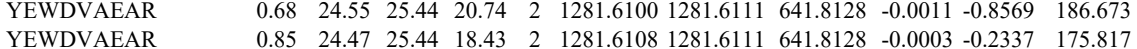

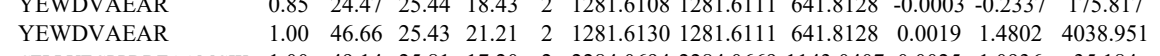
$\begin{array}{llllllllllll}\text { CELLYEGPPDDEAAMGIK } & 1.00 & 49.14 & 25.81 & 17.20 & 2 & 2284.0694 & 2284.0669 & 1143.0407 & 0.0025 & 1.0936 & 35.184\end{array}$ $\begin{array}{lllllllllllll}\text { CELLYEGPPDDEAAMGIK } & 1.00 & 67.17 & 25.81 & 18.53 & 3 & 2284.0702 & 2284.0669 & 762.3629 & 0.0033 & 1.4429 & 11.460\end{array}$ $\begin{array}{lllllllllllll}\text { CELLYEGPPDDEAAMGIK } & 1.00 & 77.11 & 25.84 & 19.87 & 2 & 2284.0714 & 2284.0669 & 1143.0407 & 0.0045 & 1.9684 & 59.381\end{array}$ $\begin{array}{llllllllllll}\text { VTDGALVVVDCVSGVCVQTETVLR } & 0.79 & 17.15 & 27.37 & 16.12 & 3 & 2697.3340 & 2697.3332 & 900.1183 & 0.0008 & 0.2963 & 4.038\end{array}$ $\begin{array}{lllllllllllll} & & \end{array}$ KVEDMMK $\begin{array}{llllllllllll}0.61 & 18.43 & 26.95 & 25.02 & 3 & 1311.7246 & 1311.7256 & 438.2491 & -0.0010 & -0.7606 & 94.105\end{array}$ $\begin{array}{llllllllllll} & 0.670 & 185.25 & 27.40 & 23.04 & 3 & 131.7270 & 1311.7256 & 438.2491 & 0.0014 & 1.0648 & 74.619 \\ \text { ARPFPDGLAEDIDK } & 0.99 & 35.77 & 27.81 & 27.78 & 2 & 1830.9728 & 1830.9719 & 916.4932 & 0.0009 & 0.4910 & 307.118\end{array}$ $\begin{array}{llllllllllllll}\text { ARPFPDGLAEDIDK } & 1.00 & 45.84 & 27.83 & 27.76 & 2 & 1830.9740 & 1830.9719 & 916.4932 & 0.0021 & 1.1457 & 297.239\end{array}$ ARPFPDGLAEDIDK $\quad \begin{array}{llllllllllll}1.00 & 44.33 & 27.79 & 30.39 & 3 & 1830.9742 & 1830.9719 & 611.3312 & 0.0023 & 1.2541 & 955.802\end{array}$ $\begin{array}{lllllllllllll}\text { ARPFPDGLAEDIDK } & 1.00 & 42.49 & 27.79 & 30.63 & 3 & 1830.9742 & 1830.9719 & 611.3312 & 0.0023 & 1.2541 & 940.696\end{array}$ $\begin{array}{lllllllllllll}\text { CELLYEGPPDDEAAMGIK } & 0.55 & 18.42 & 25.76 & 31.42 & 3 & 2284.0681 & 2284.0669 & 762.3629 & 0.0012 & 0.5247 & 18.138\end{array}$ $\begin{array}{lllllllllllll}\text { CELLYEGPPDDEAAMGIK } & 0.66 & 16.31 & 25.81 & 29.31 & 3 & 2284.0690 & 2284.0669 & 762.3629 & 0.0021 & 0.9182 & 36.67\end{array}$ $\begin{array}{llllllllllll}\text { CELLYEGPPDDEAAMGIK } & 0.57 & 9.44 & 25.81 & 22.44 & 3 & 2284.0690 & 2284.0669 & 762.3629 & 0.0021 & 0.9182 & 25.924\end{array}$ $\begin{array}{lllllllllllll}\text { CELLYEGPPDDEAAMGIK } & 0.66 & 20.76 & 25.83 & 33.76 & 3 & 2284.0693 & 2284.0669 & 762.3629 & 0.0024 & 1.0494 & 24.497\end{array}$

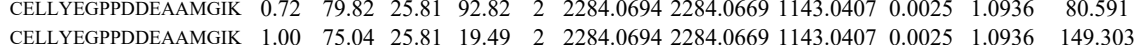
$\begin{array}{lllllllllllll}\text { CELLYEGPDDDEAAMGIK } & 1.00 & 75.04 & 25.81 & 19.49 & 2 & 2284.0694 & 2284.0669 & 143.0407 & 0.0025 & 1.0936 & 149.303 \\ \text { CELLYEGPDDEAAMGIK } & 0.56 & 9.13 & 25.83 & 22.13 & 3 & 2284.0699 & 2284.0669 & 762.3629 & 0.0030 & 1.3117 & 40.838\end{array}$ $\begin{array}{llllllllllll}\text { CELLYEGPDDDEAAMGIK } & 0.56 & 9.13 & 25.83 & 22.13 & 3 & 2284.0699 & 2284.0669 & 762.3629 & 0.0030 & 1.3117 & 40.838 \\ \text { CELLYEGPDDEAAMGIK } & 0.67 & 53.76 & 25.81 & 66.76 & 3 & 2284.0702 & 2284.0669 & 762.3629 & 0.0033 & 1.4429 & 11.321\end{array}$

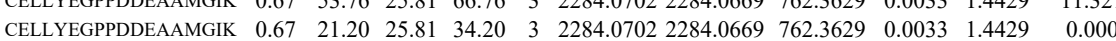
$\begin{array}{lllllllllllll}\text { CELLYEGPPDDEAAMGIK } & 0.67 & 25.64 & 25.83 & 38.64 & 3 & 2284.0699 & 2284.0669 & 762.3629 & 0.0030 & 1.3117 & 9.058\end{array}$ $\begin{array}{llllllllllllll}\text { ARPFPDGLAEDIDKGEVSAR } & 1.00 & 54.60 & 26.63 & 26.45 & 3 & 2430.2755 & 2430.2747 & 811.0988 & 0.0008 & 0.3288 & 682.780\end{array}$ $\begin{array}{llll}4.489 & 7.880 & 7.901 & \text { Yes } \\ 0.000 & 1.008 & 1.458 & \text { No }\end{array}$ $\begin{array}{llll}04.941 & 507.188 & 635.878 & \text { Yes }\end{array}$ $\begin{array}{llll}172.692 & 668.417 & 900.970 & \text { Yes }\end{array}$ $\begin{array}{llllll}1821.725 & 10501.356 & 14368.722 & \text { Yes }\end{array}$ $\begin{array}{llll}101.426 & 0.808 & 270.873 & \text { Yes }\end{array}$ $\begin{array}{llll}0.662 & 6.171 & 27.290 & \mathrm{No}\end{array}$ $\begin{array}{lllll}0.000 & 2.049 & 2.525 & \text { No }\end{array}$

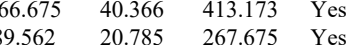
117 


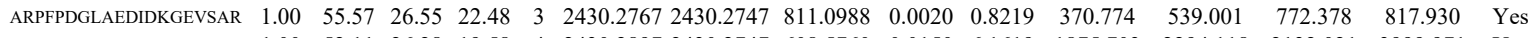
$\begin{array}{llllllllllllllll}\text { ARPFPDGLAEDIDKGEVSAR } & 1.00 & 52.11 & 26.28 & 19.58 & 4 & 2430.2897 & 2430.2747 & 608.5760 & 0.0150 & 6.1619 & 1875.703 & 2294.118 & 2132.021 & 3999.971 & \text { Yes }\end{array}$ $\begin{array}{lllllllllllllllll}\text { ARPFPDGLAEDIDKGEVSAR } & 1.00 & 47.36 & 26.19 & 19.21 & 4 & 2430.2965 & 2430.2747 & 608.5760 & 0.0218 & 8.9553 & 4198.644 & 4764.854 & 4643.763 & 8493.324 & \text { Yes }\end{array}$ $\begin{array}{lllllllllllllllll}\text { AQYEEIANR } & 0.67 & 41.89 * & 28.08 & 33.44 & 2 & 1236.6250 & 1236.6220 & 619.3183 & 0.0030 & 2.4220 & 5575.863 & 5206.312 & 2780.744 & 4887.960 & \text { Yes }\end{array}$ $\begin{array}{lllllllllllllllll}\text { YEELQQTAGR } & 1.00 & 58.98 & 27.69 & 24.07 & 2 & 1337.6770 & 1337.6697 & 669.8421 & 0.0073 & 5.4490 & 16315.148 & 15445.538 & 1238.294 & 17548.228 & \text { Yes }\end{array}$ (1) LAELEEALQK LAELEEALK LAELEEALK LAELEEALQK LELEEALQK LAELEEALQK LAELEEALQK LAELEEALQK LAELEEALQK LAELEEALQK LAELEEALQK LAELEEALQK LAELEEALQK LAELEEALQK LAELEEALQK TEAESWYQTK TTAENEFVMLK TTAENEFVMLK TTAENEFVMLK YEELQQTAGR LAELEEALQK

LAELEEALQK

LAELEEALQK

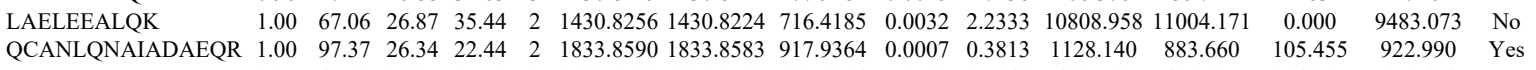
$\begin{array}{llllllllllllllll}1.00 & 74.62 & 27.65 & 31.90 & 2 & 1337.6776 & 1337.6697 & 669.8421 & 0.0079 & 5.8969 & 28710.095 & 31601.274 & 84.674 & 28079.163 & \text { Yes }\end{array}$

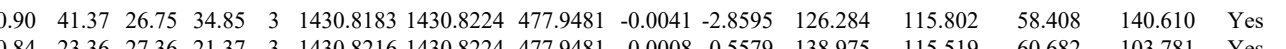

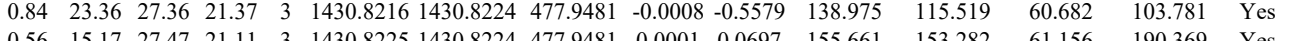

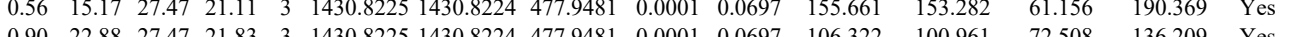

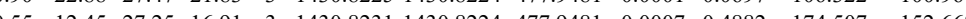

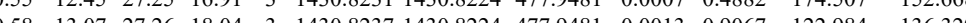

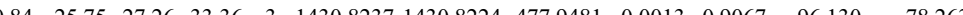
\begin{tabular}{lllllllllllllll}
0.93 & 21.55 & 27.26 & 22.90 & 3 & 1430.8237 & 1430.8224 & 477.9481 & 0.0013 & 0.9067 & 45.851 & 43.278 & 17.720 & 60.206 & Yes \\
\hline
\end{tabular} $72.508-136.209$ Yes $\begin{array}{llllllllllllllll}1.00 & 55.21 & 27.19 & 30.30 & 2 & 1430.8238 & 1430.8224 & 716.4185 & 0.0014 & 0.9771 & 20076.986 & 20179.194 & 538.131 & 20366.130 & \text { Yes }\end{array}$

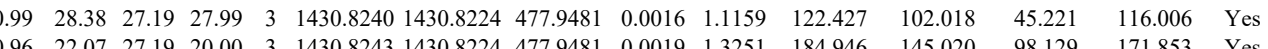

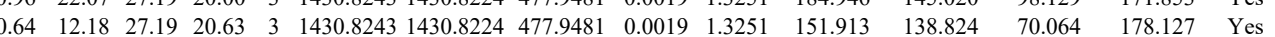
$\begin{array}{llllllllllllllll}1.00 & 44.94 & 26.88 & 36.33 & 3 & 1430.8249 & 1430.8224 & 477.9481 & 0.0025 & 1.7436 & 7324.773 & 10553.546 & 80.610 & 7608.244 & \text { Yes }\end{array}$ $\begin{array}{lllllllllllllll}0.99 & 49.45 & 26.88 & 46.90 & 3 & 1430.8252 & 1430.8224 & 477.9481 & 0.0028 & 1.9528 & 3717.910 & 5750.170 & 75.261 & 4301.341 & \text { Yes }\end{array}$ $\begin{array}{llllllllllllllll}1.00 & 74.31 & 26.88 & 37.76 & 2 & 1430.8252 & 1430.8224 & 716.4185 & 0.0028 & 1.9542 & 33775.964 & 33346.530 & 479.521 & 32883.638 & \text { Yes }\end{array}$ $\begin{array}{lllllllllllllll}0.92 & 22.05 & 26.46 & 24.61 & 3 & 1430.8270 & 1430.8224 & 477.9481 & 0.0046 & 3.2081 & 109.351 & 105.671 & 58.524 & 124.205 & \text { Yes }\end{array}$ $\begin{array}{lllllllllllllll}1.00 & 70.51 & 27.73 & 24.63 & 2 & 1529.7720 & 1529.7605 & 765.8875 & 0.0115 & 7.5076 & 1734.116 & 2039.492 & 45.130 & 1462.836 & \text { Yes }\end{array}$ $\begin{array}{lllllllllllllll}1.00 & 70.08 & 27.72 & 28.52 & 2 & 1569.8372 & 1569.8316 & 785.9231 & 0.0056 & 3.5627 & 5572.142 & 4216.708 & 534.023 & 9357.409 & \text { No }\end{array}$

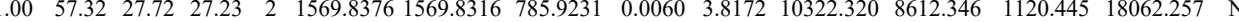
$\begin{array}{lllllllllllllll}0.56 & 17.54 & 27.69 & 17.39 & 3 & 1569.8380 & 1569.8316 & 524.2845 & 0.0064 & 4.0690 & 57.176 & 62.761 & 61.535 & 82.258 & \text { No }\end{array}$ $\begin{array}{lllllllllllllll}1.00 & 72.04 & 27.72 & 23.79 & 2 & 1337.6744 & 1337.6697 & 669.8421 & 0.0047 & 3.5083 & 10964.930 & 9574.783 & 1106.539 & 9262.434 & \text { Yes }\end{array}$ $\begin{array}{lllllllllllllll}1.00 & 63.78 & 27.19 & 34.71 & 2 & 1430.8242 & 1430.8224 & 716.4185 & 0.0018 & 1.2562 & 1906.984 & 2225.400 & 0.000 & 2457.476 & \text { No }\end{array}$

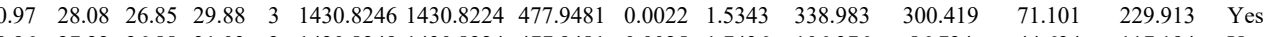
$\begin{array}{lllllllllllllll}0.96 & 27.22 & 26.88 & 31.03 & 3 & 1430.8249 & 1430.8224 & 477.9481 & 0.0025 & 1.7436 & 106.376 & 86.724 & 44.634 & 117.194 & \text { Yes }\end{array}$

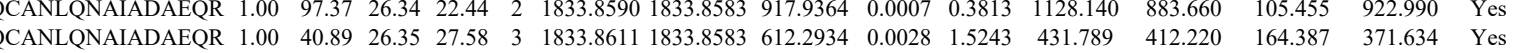

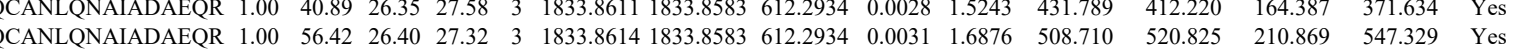
$\begin{array}{llllllllllllllll}\text { VDALMDEINFMK } & 1.00 & 54.03 & 28.06 & 17.09 & 2 & 1712.8734 & 1712.8721 & 857.4433 & 0.0013 & 0.7581 & 1995.391 & 1849.928 & 159.745 & 2917.207 & \text { Yes }\end{array}$ $\begin{array}{llllllllllllllll} & \\ \text { VDALMDEINFMK } & 1.00 & 57.11 & 28.07 & 16.60 & 2 & 171287361712.8721 & 857.4433 & 0.0015 & 0.8747 & 5257.024 & 5945.958 & 728.261 & 867.2924 & \text { No }\end{array}$

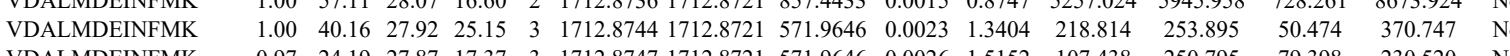

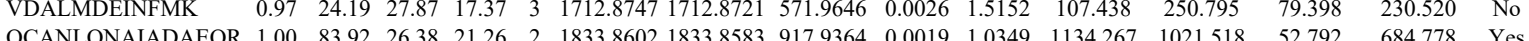
$\begin{array}{lllllllllllllll} & \end{array}$ $\begin{array}{lllllllllllllll} & \end{array}$

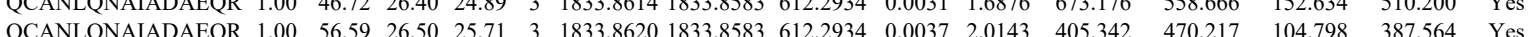

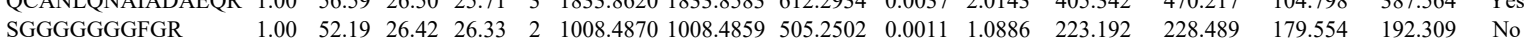

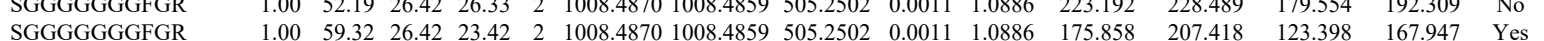
YEELQQTAGR YEELQQTAGR VDALMDEINFMK VDALMDEINFMK $\begin{array}{llllllllllll}1.00 & 59.32 & 26.42 & 23.42 & 2 & 1008.4870 & 1008.4859 & 505.2502 & 0.0011 & 1.0886 & 175.858 & 207.418 \\ 1.00 & 62.13 & 27.52 & 27.10 & 2 & 1337.6718 & 1337.6697 & 669.8421 & 0.002 & 1.5675 & 4293.714 & 3947.202\end{array}$ $\begin{array}{lllllllllllll}1.00 & 79.69 & 27.96 & 22.19 & 2 & 1712.8750 & 1712.8721 & 857.4433 & 0.0029 & 1.6911 & 7822.516 & 6981.2010 & 35\end{array}$

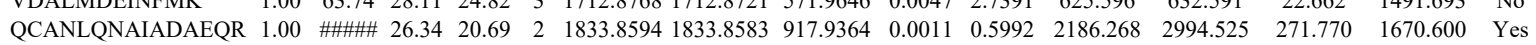
$\begin{array}{llllllllllllllll}\text { QCANLQNAIADAEQR } & 1.00 & 29.93 & 26.38 & 24.19 & 3 & 1833.8602 & 1833.8583 & 612.2934 & 0.0019 & 1.0344 & 397.379 & 281.964 & 86.041 & 522.583 & \text { No }\end{array}$

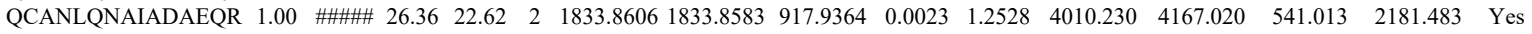
$\begin{array}{llllllllllllllll}\text { QCANLQNAIADAEQR } & 1.00 & 51.47 & 26.35 & 22.36 & 3 & 1833.8611 & 1833.8583 & 612.2934 & 0.0028 & 1.5243 & 379.640 & 407.737 & 221.203 & 561.834 & \text { Yes }\end{array}$ $\begin{array}{lllllllllllllllll}\text { VDALMDEINFMK } & 1.00 & 85.52 & 28.04 & 19.45 & 2 & 1712.8738 & 1712.8721 & 857.4433 & 0.0017 & 0.9913 & 2379.147 & 2910.950 & 248.457 & 4302.244 & \text { No }\end{array}$ $\begin{array}{lllllllllllllllll}\text { VDALMDEINFMK } & 1.00 & 80.35 & 27.90 & 18.86 & 2 & 1712.8744 & 1712.8721 & 857.4433 & 0.0023 & 1.3412 & 3467.915 & 3472.689 & 429.927 & 5303.165 & \text { No }\end{array}$ $\begin{array}{llllllllllllllll}\text { VDALMDEINFMK } & 1.00 & 40.00 & 27.96 & 24.75 & 3 & 1712.8750 & 1712.8721 & 571.9646 & 0.0029 & 1.6901 & 231.084 & 180.210 & 49.722 & 260.209 & \text { Yes }\end{array}$ $\begin{array}{llllllllllllllll}\text { VDALMDEINFMK } & 0.98 & 26.25 & 27.96 & 17.00 & 3 & 1712.8750 & 1712.8721 & 571.9646 & 0.0029 & 1.6901 & 135.488 & 166.321 & 48.721 & 126.487 & \text { Yes }\end{array}$ $\begin{array}{lllllllllllllllll}\text { QCANLQNAIADAEQR } & 1.00 & 80.81 & 26.32 & 23.09 & 2 & 1833.8584 & 1833.8583 & 917.9364 & 0.0001 & 0.0545 & 557.293 & 532.644 & 154.997 & 413.948 & \text { Yes }\end{array}$

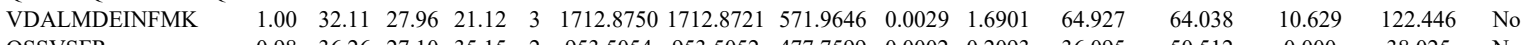
$\begin{array}{llllllllllllllll}\text { QSSVSFR } & 0.98 & 36.26 & 27.10 & 35.15 & 2 & 953.5054 & 953.5052 & 477.7599 & 0.0002 & 0.2093 & 36.095 & 50.512 & 0.000 & 38.025 & \text { No }\end{array}$

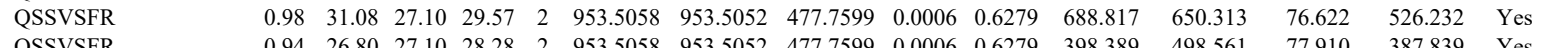

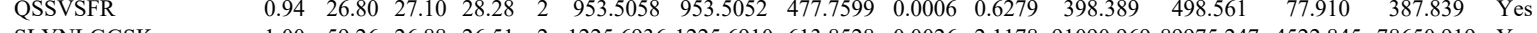
SLYNLGGSK SLYNLGGSK $\begin{array}{lllllllllllllll}1.00 & 59.26 & 26.88 & 26.51 & 2 & 1225.6936 & 1225.6910 & 613.8528 & 0.0026 & 2.1178 & 91090.969 & 89975.247 & 4522.845 & 78650.919 & \text { Yes }\end{array}$

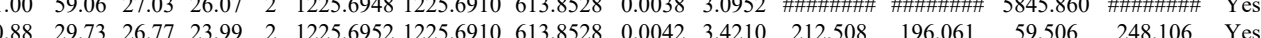
$\begin{array}{llllllllllllllll} & & & \end{array}$

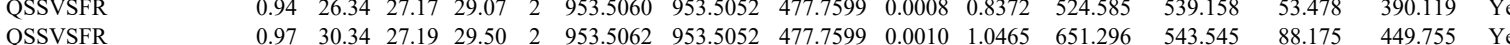



$\begin{array}{lllllllllllllll}\text { GLGVGFGSGGGSSSSVK } & 1.00 & \text { \#\#\#\# 27.54 } & 28.84 & 2 & 1726.9188 & 1726.9094 & 864.4620 & 0.0094 & 5.4369 & 15508.665 & 15363.524 & 6305.304 & 12572.116 & \text { Yes }\end{array}$ \begin{tabular}{lllllllllllllll} 
GLGVGFGSGGGSSSSVK & 1.00 & \#\#\#\# 27.54 & 27.99 & 2 & 1726.9204 & 1726.9094 & 864.4620 & 0.0110 & 6.3623 & 8571.103 & 8691.771 & 3336.266 & 6400.250 & Yes \\
\hline
\end{tabular}

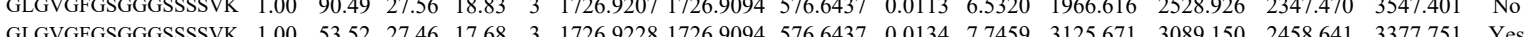
$\begin{array}{lllllllllllllllll} & \end{array}$

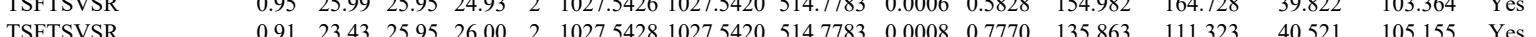

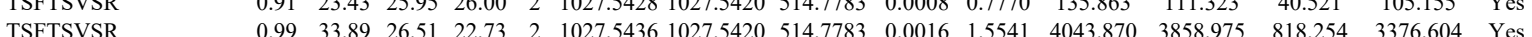

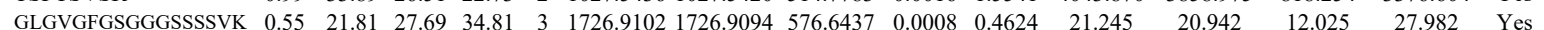

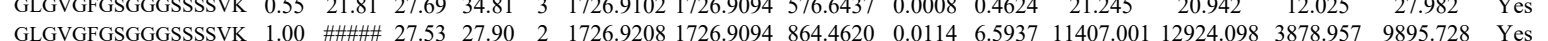
$\begin{array}{lllllllllllllllll}\text { GLGVGFGSGGGSSSSVK } & 0.80 & 24.55 & 27.39 & 27.05 & 3 & 1726.9219 & 1726.9094 & 576.6437 & 0.0125 & 7.2257 & 3429.411 & 3670.154 & 14741.589 & 5749.742 & \text { No }\end{array}$ $\begin{array}{lllllllllllllll}\text { GLGVGFGSGGGSSSVV } & 1.00 & \text { \#\#\#\# } 27.43 & 29.40 & 2 & 1726.9220 & 1726.9094 & 864.4620 & 0.0126 & 7.2877 & 6950.133 & 7312334 & 2431.630 & 4171.803 & \text { Yes }\end{array}$

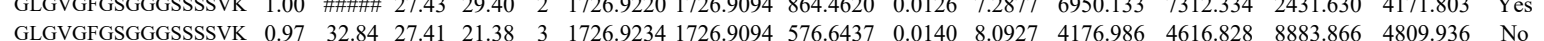
$\begin{array}{llllllllllllll} & \text { GLGVGVSS } & & \end{array}$

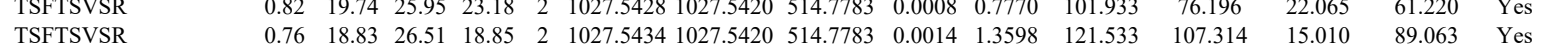

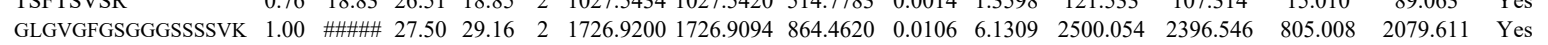
$\begin{array}{lllllllllllllll}\text { GLGVGFGSGGGSSSSVK } & 1.00 & \text { \#\#\# } 27.44 & 31.00 & 2 & 1726.9226 & 1726.9094 & 864.4620 & 0.0132 & 7.6347 & 2719.132 & 2200.262 & 1065.822 & 1857.824 & \text { Yes }\end{array}$

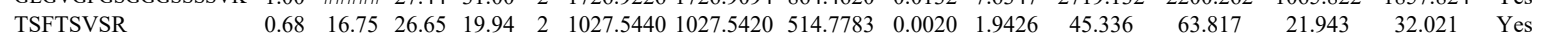
$\begin{array}{llllllllllllllll}\text { FVSTTSSSR } & 1.00 & 47.89 & 25.72 & 28.44 & 2 & 1114.5748 & 1114.5741 & 558.2943 & 0.0007 & 0.6269 & 111.428 & 164.024 & 7.612 & 149.371 & \text { Yes }\end{array}$ $\begin{array}{llllllllllllllllll}\text { FVSTTSSSR } & 0.96 & 26.63 & 25.84 & 27.42 & 2 & 1114.5752 & 1114.5741 & 558.2943 & 0.0011 & 0.9851 & 335.985 & 331.931 & 142.727 & 337.373 & \text { Yes }\end{array}$ $\begin{array}{llllllllllllllll}\text { FVSTTSSSR } & 1.00 & 45.78 & 26.25 & 28.95 & 2 & 1114.5746 & 1114.5741 & 558.2943 & 0.0005 & 0.4478 & 694.466 & 680.370 & 5.636 & 619.925 & \text { Yes }\end{array}$ $\begin{array}{llllllllllllllll}\text { FVSTTSSSR } & 1.00 & 40.70 & 25.80 & 30.33 & 2 & 1114.5750 & 1114.5741 & 558.2943 & 0.0009 & 0.8060 & 466.216 & 480.173 & 18.914 & 383.719 & \text { Yes }\end{array}$ $\begin{array}{llllllllllllllll}\text { FVSTTSSSR } & 0.99 & 37.00 & 26.25 & 27.76 & 2 & 1114.5746 & 1114.5741 & 558.2943 & 0.0005 & 0.4478 & 343.165 & 348.931 & 27.889 & 316.970 & \text { Yes } \\ \text { FVSTTSSSR } & 1.00 & 42.19 & 25.84 & 28.31 & 2 & 1114.5752 & 1114.5741 & 558.2943 & 0.0011 & 0.9851 & 457.321 & 516.980 & 51.949 & 370.548 & \text { Yes }\end{array}$ FVSTTSSSR SFSTASAITPSVSR
SFSTASAITPSVSR SLYNLGGSKR SFSTASAITPSVSR SFSTASAITPSVSR
SFSTASAITPSVSR SFSTASAITPSVSR
SFSTASAITPSVSR SFSTASAITPSVSR ISISTSGGSFR

ISISTSGGSFR

SFSTASAITPSVSR

ISISTSGGSFR

ISISTSGGSFR

ISISTSGGSFR

ISISTSGGSFR

ISISTSGGSFR

ISISTSGGSFR $\begin{array}{lllllllllllllllll}0.99 & 36.07 & 25.88 & 26.43 & 2 & 1144.5756 & 1114.5741 & 558.2943 & 0.0015 & 1.3434 & 189.237 & 213.209 & 63.621 & 165.176 & \text { Yes }\end{array}$ $\begin{array}{lllllllllllllll}1.00 & 99.88 & 27.28 & 30.10 & 2 & 1553.8308 & 1553.8171 & 777.9158 & 0.0137 & 8.8055 & 19637.271 & 17244.321 & 3163.648 & 11987.345 & \text { Yes }\end{array}$ $\begin{array}{llllllllllllllll}1.00 & \# \text { \#\#\# 27.40 } & 34.69 & 2 & 1553.8314 & 1553.8171 & 777.9158 & 0.0143 & 9.1911 & 20887.966 & 22473.604 & 3371.957 & 17086.292 & \text { Yes }\end{array}$ $\begin{array}{llllllllllllllll}0.94 & 18.61 & 25.42 & 22.39 & 3 & 1381.7956 & 1381.7921 & 461.6046 & 0.0035 & 2.5274 & 16763.475 & 17158.762 & 5732.919 & 10396.958 & \text { Yes }\end{array}$ $\begin{array}{llllllllllllllll}0.83 & 25.44 & 27.40 & 25.38 & 3 & 1553.8297 & 1553.8171 & 518.9463 & 0.0126 & 8.0933 & 1249.934 & 897.318 & 616.419 & 962.386 & \text { Yes } \\ 1\end{array}$

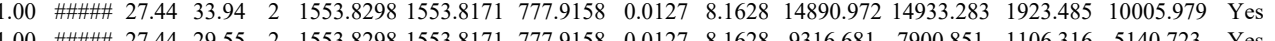

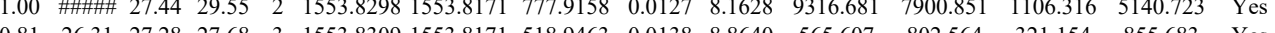

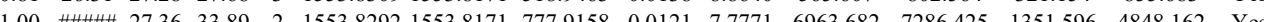
$\begin{array}{llllllllllllllll}1.07 & 17.732 & \text { Ne }\end{array}$

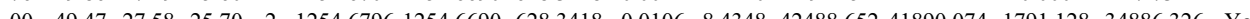

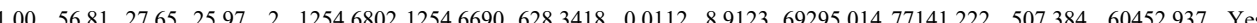
$\begin{array}{lllllllllllllll}1.00 & \text { \#\#\#\# } 27.28 & 29.56 & 2 & 1553.8308 & 1553.8171 & 777.9158 & 0.0137 & 8.8055 & 1991.725 & 2202.663 & 305.049 & 1245.210 & \text { Yes }\end{array}$ $\begin{array}{llllllllllllllll}1.00 & 56.87 & 27.58 & 26.09 & 2 & 1254.6794 & 1254.6690 & 6283418 & 0.0104 & 8.2757 & 51519.009 & 54943.596 & 2322.832 & 45498.263 & \text { Yes }\end{array}$

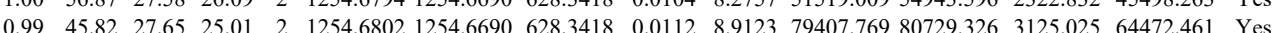
$\begin{array}{lllllllllllllll}0.00 & 53.82 & 27.58 & 26.36 & 2 & 1254.6794 & 1254.6690 & 628.3418 & 0.0104 & 8.92757 & 17938.013 & 20327.641 & 588.830 & 14834.151 & \text { Yes }\end{array}$ $\begin{array}{llllllllllllllll}1.00 & 57.40 & 27.65 & 26.51 & 2 & 1254.6802 & 1254.6690 & 628.3418 & 0.0112 & 8.9123 & 29351.517 & 31111.783 & 502.777 & 23565.992 & \text { Yes }\end{array}$ $\begin{array}{lllllllllllllllll}1.00 & 57.61 & 27.54 & 27.41 & 2 & 1254.6788 & 1254.6690 & 628.3418 & 0.0098 & 7.7982 & 5717.797 & 6690.204 & 992.947 & 4228.217 & \text { Yes }\end{array}$ $\begin{array}{lllllllllllllllll}1.00 & 54.58 & 27.66 & 25.19 & 2 & 1254.6792 & 1254.6690 & 628.3418 & 0.0102 & 8.1165 & 5251.143 & 6648.936 & 256.909 & 4503.817 & \text { Yes }\end{array}$ $\begin{array}{llllllllllllllll}1.00 & 57.90 & 27.56 & 26.13 & 2 & 1254.6780 & 1254.6690 & 628.3418 & 0.0090 & 7.1617 & 3800.672 & 4007.152 & 74.698 & 2660.322 & \text { Yes }\end{array}$ $\begin{array}{lllllllllllllllll}\text { VSLAGACGVGGYGSR } & 0.90 & 42.51 & 26.22 & 15.97 & 2 & 1542.7368 & 1542.7405 & 772.3775 & -0.0037 & -2.3952 & 24.675 & 28.944 & 0.000 & 24.244 & \text { No }\end{array}$ $\begin{array}{llllllllllllllll}\text { VSLAGACGVGGYGSR } & 1.00 & 90.77 & 26.34 & 21.35 & 2 & 1542.7396 & 1542.7405 & 772.3775 & -0.0009 & -0.5826 & 3697.166 & 4422.157 & 146.453 & 3301.082 & \text { Yes }\end{array}$ $\begin{array}{llllllllllllllll}\text { VSLAGACGVGGYGSR } & 1.00 & 89.75 & 26.27 & 22.52 & 2 & 1542.7404 & 1542.7405 & 772.3775 & -0.0001 & -0.0647 & 8109.785 & 6614.031 & 0.000 & 5928.962 & \text { No }\end{array}$

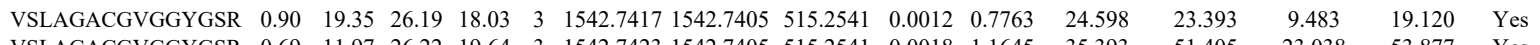
$\begin{array}{llllllllllllllll}\text { VSLAGACGVGGYGSR } & 0.69 & 11.97 & 26.22 & 19.64 & 3 & 1542.7423 & 1542.7405 & 515.2541 & 0.0018 & 1.1645 & 35.393 & 51.405 & 23.038 & 53.877 & \text { Yes }\end{array}$ $\begin{array}{llllllllllllllll}\text { VSLAGACGVGGYGSR } & 0.89 & 16.98 & 26.25 & 20.26 & 3 & 1542.7426 & 1542.7405 & 515.2541 & 0.0021 & 1.3586 & 53.520 & 60.392 & 11.435 & 60.247 & \text { Yes }\end{array}$ $\begin{array}{lllllllllllllllllll}\text { VSLAGACGVGGYGSR } & 0.76 & 13.43 & 26.25 & 19.82 & 3 & 1542.7426 & 1542.7405 & 515.2541 & 0.0021 & 1.3586 & 2458.053 & 2372.549 & 99.799 & 2702.552 & \text { Yes }\end{array}$

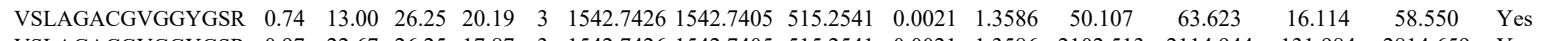

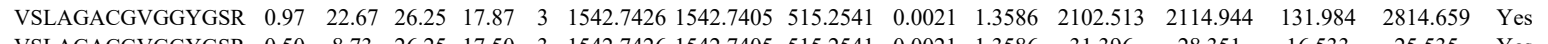

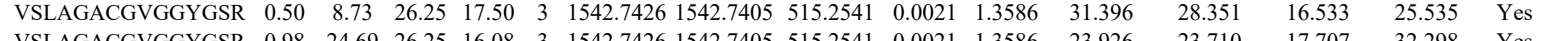
$\begin{array}{llllllllllllllll}\text { VSLAGACGVGGYGSR } & 0.98 & 24.69 & 26.25 & 16.08 & 3 & 1542.7426 & 1542.7405 & 515.2541 & 0.0021 & 1.3586 & 23.926 & 23.710 & 17.707 & 32.298 & \text { Yes } \\ \text { VSLAGACGVGGYGR } & 1.00 & 39.92 & 26.25 & 21.81 & 3 & 1542.7426 & 1542.7405 & 515.2541 & 0.0021 & 13586 & 14.617 & 19.148 & 15.955 & 9.746 & \mathrm{No}\end{array}$

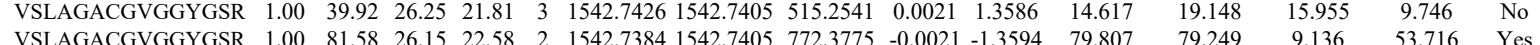

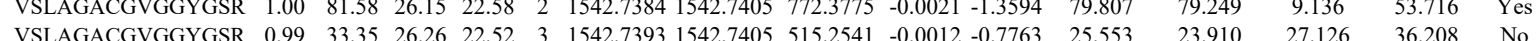

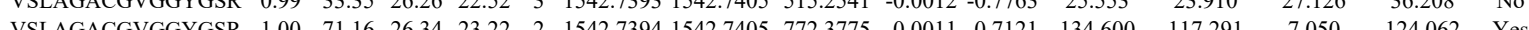
$\begin{array}{llllllllllllllll}\text { VSLAGACGVGGYGSR } & 1.00 & 71.16 & 26.34 & 23.22 & 2 & 1542.7394 & 1542.7405 & 772.3775 & -0.0011 & -0.7121 & 134.600 & 117.291 & 7.050 & 124.062 & \text { Yes } \\ \text { VSLAGACGVGGYGSR } & 1.00 & 74.43 & 26.34 & 20.23 & 2 & 1542.7396 & 1542.7405 & 772.3775 & -0.0009 & -0.5826 & 71.426 & 80.787 & 10.857 & 77.654 & \text { Yes }\end{array}$

Table S-4 page 168 of 614 
$\begin{array}{llllllllllllll}\text { VSLAGACGVGGYGSR } & 1.00 & 98.59 & 26.22 & 26.64 & 2 & 1542.7422 & 1542.7405 & 772.3775 & 0.0017 & 1.1005 & 15827.251 & 14888.605\end{array}$ $\begin{array}{llllllllllll}\text { VSLAGACGVGGYGSR } & 1.00 & 69.35 & 26.21 & 20.48 & 2 & 1542.7424 & 1542.7405 & 772.3775 & 0.0019 & 1.2300 & 92.516\end{array}$

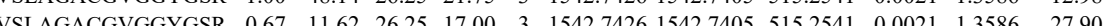
$\begin{array}{llllllllllllll}\text { VSLAGACGVGGGSR } & 0.95 & 20.66 & 26.37 & 15.80 & 3 & 1542.7429 & 1542.7405 & 515.2541 & 0.0024 & 1.5526 & 45.480\end{array}$

$\begin{array}{llllllllllllll}\text { VSLAGACGVGGYGSR } & 1.00 & \# \# \# \# 26.99 & 22.96 & 2 & 1542.7502 & 1542.7405 & 772.3775 & 0.0097 & 6.2793 & 11774.822 & 9960.82\end{array}$ $\begin{array}{lllllllllllllll}\text { VSLAGACGVGGYGSR } & 0.94 & 30.24 & 26.96 & 19.63 & 3 & 1542.7516 & 1542.7405 & 515.2541 & 0.0111 & 7.1809 & 1129.211 & 1204.489\end{array}$ $\begin{array}{lllllllllllll}\text { VSLAGACGVGGYGSR } & 1.00 & 69.20 & 26.22 & 19.85 & 2 & 1542.7368 & 1542.7405 & 772.3775 & -0.0037 & -2.3952 & 56.319 & 36.888\end{array}$ $\begin{array}{llllllllllllll}\text { VSLAGACGVGGYGSR } & 1.00 & 51.66 & 26.38 & 19.59 & 2 & 1542.7406 & 1542.7405 & 772.3775 & 0.0001 & 0.0647 & 50.254 & 47.309\end{array}$ $\begin{array}{llllllllllllll}\text { VSLAGACGVGGYGSR } & 0.88 & 18.49 & 26.38 & 16.11 & 3 & 1542.7411 & 1542.7405 & 515.2541 & 0.0006 & 0.3882 & 50.408 & 40.486\end{array}$ $\begin{array}{llllllllllllll}\text { VSLAGACGVGGYGSR } & 1.00 & 39.63 & 26.43 & 21.44 & 2 & 1542.7412 & 1542.7405 & 772.3775 & 0.0007 & 0.4531 & 63.325 & 65.498\end{array}$ $\begin{array}{lllllllllllllll}\text { VSLAGACGVGGYGSR } & 1.00 & 50.24 & 26.33 & 22.20 & 2 & 1542.7414 & 1542.7405 & 772.3775 & 0.0009 & 0.5826 & 94.619 & 77.087\end{array}$ $\begin{array}{llllllllllllll}\text { VSLAGACGVGGYGSR } & 1.00 & 49.10 & 26.33 & 23.24 & 2 & 1542.7414 & 1542.7405 & 772.3775 & 0.0009 & 0.5826 & 51.102 & 57.301\end{array}$ $\begin{array}{llllllllllllll}\text { VSLAGACGVGGYGSR } & 1.00 & 51.43 & 26.19 & 18.12 & 2 & 1542.7418 & 1542.7405 & 772.3775 & 0.0013 & 0.8416 & 72.851 & 85.544\end{array}$ $\begin{array}{lllllllllllll}\text { VSLAGACGVGGYGSR } & 1.00 & 59.94 & 26.22 & 22.34 & 2 & 1542.7422 & 1542.7405 & 772.3775 & 0.0017 & 1.1005 & 23.603 & 20.761\end{array}$ $\begin{array}{llllllllllllll}\text { VSLAGACGVGGYGSR } & 0.66 & 15.66 & 26.22 & 28.66 & 3 & 1542.7423 & 1542.7405 & 515.2541 & 0.0018 & 1.1645 & 35.205 & 52.236\end{array}$ $\begin{array}{lllllllllllll}\text { VSLAGACGVGGYGSR } & 1.00 & 52.57 & 26.38 & 18.21 & 2 & 1542.7428 & 1542.7405 & 772.3775 & 0.0023 & 1.4889 & 27.889 & 28.694 \\ \text { VSLAGACGVGGYGR } & 0.99 & 28.20 & 26.41 & 16.22 & 3 & 1542.7435 & 1542.7405 & 515.2541 & 0.0030 & 1.9408 & 6.405 & 15.207\end{array}$

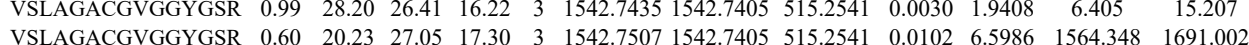

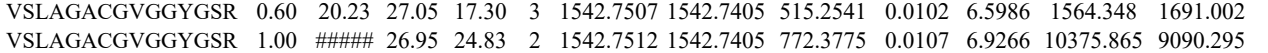
$\begin{array}{lllllllllllllll}\text { VSLAGACGVGGYGSR } & 1.00 & \text { \#\#\#\# } & 26.95 & 24.83 & 2 & 1542.7512 & 1542.7405 & 772.3775 & 0.0107 & 6.9266 & 10375.865 & 9090.295 \\ \text { VSLAGACGVGGYGSR } & 0.94 & 29.64 & 26.98 & 18.52 & 3 & 1542.7525 & 1542.7405 & 515.2541 & 0.0120 & 7.7631 & 1161.231 & 1226.571\end{array}$ $\begin{array}{lllllllllllll}\text { VSLAGACGVGGYGRR } & 0.94 & 29.64 & 26.98 & 18.52 & 3 & 1542.7525 & 1542.7405 & 515.2541 & 0.0120 & 7.7631 & 1161.231 & 1226.57 \\ \text { TSFTSVSR } & 0.85 & 20.94 & 26.51 & 20.50 & 2 & 1027.5436 & 1027.5420 & 514.7783 & 0.0016 & 1.5541 & 242.654 & 235.778\end{array}$

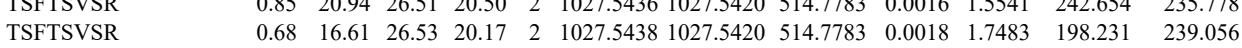
$\begin{array}{llllllllllllll} & 0.68 & 16.61 & 26.53 & 20.17 & 2 & 1027.5438 & 1027.5420 & 514.7783 & 0.0018 & 1.7483 & 198.231 & 239.056\end{array}$ $\begin{array}{llllllllllllll}\text { VSLAGACGVGGYGSR } & 1.00 & \# \# \# \# \frac{26.58}{20.23} & 2 & 1542.7474 & 1542.7405 & 772.3775 & 0.0069 & 4.4667 & 5686.141 & 4893.219\end{array}$ $\begin{array}{lllllllllllll}\text { TSFTSVSR } & 0.75 & 17.98 & 25.95 & 21.70 & 2 & 1027.5428 & 1027.5420 & 514.7783 & 0.0008 & 0.7770 & 241.744 & 269.183\end{array}$ $\begin{array}{lllllllllllll}1.00 & 58.20 & 27.66 & 25.81 & 2 & 1254.6686 & 1254.6690 & 628.3418 & -0.0004 & -0.3183 & 4113.818 & 4096.336\end{array}$

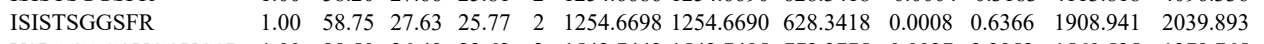
$\begin{array}{lllllllllllll}\text { VSLAGACGVGGYGSR } & 1.00 & 98.50 & 26.49 & 22.62 & 2 & 1542.7442 & 1542.7405 & 772.3775 & 0.0037 & 2.3952 & 1560.525 & 1379.765\end{array}$ TSFTSVSR AQYEEIANR $\begin{array}{llllllllllll}0.71 & 17.23 & 26.51 & 17.79 & 2 & 1027.5436 & 1027.5420 & 514.7783 & 0.0016 & 1.5541 & 141.104 & 167.537 \\ 0.60 & 33.92 * & 28.06 & 29.02 & 2 & 1236.6228 & 1236.6220 & 619.3183 & 0.0008 & 0.6459 & 88.980 & 78.938\end{array}$ ISISTSGGSFR $\begin{array}{llllllllllll}1.00 & 53.35 & 27.66 & 25.30 & 2 & 1254.6688 & 1254.6690 & 628.3418 & -0.0002 & -0.1591 & 2186.837 & 2061.257\end{array}$ $\begin{array}{lllllllllllllll} & & 1.00 & 51.78 & 27.66 & 25.24 & 2 & 1254.6692 & 1254.6690 & 628.3418 & 0.0002 & 0.1591 & 1929.988 & 2028.232 & 20 \\ \end{array}$

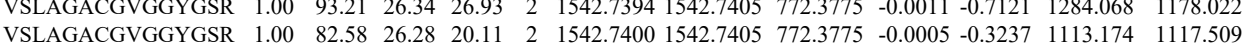
$\begin{array}{llllllllllllll}\text { GLGVGFGSGGGSSSSVK } & 0.55 & 56.97 & 27.70 & 69.97 & 3 & 1726.9108 & 1726.9094 & 576.6437 & 0.0014 & 0.8093 & 221.496 & 216.770\end{array}$ $\begin{array}{llllllllllllll}\text { GLGVGFGSGGGSSSSVK } & 1.00 & 54.69 & 27.70 & 16.88 & 3 & 1726.9108 & 1726.9094 & 576.6437 & 0.0014 & 0.8093 & 252.085 & 241.078\end{array}$ TSFTSVSR

FVSTTSSSR

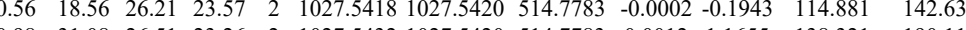

ISISTSGGSFR $\begin{array}{llllllllllll}0.98 & 31.08 & 26.51 & 23.26 & 2 & 1027.5432 & 1027.5420 & 514.7783 & 0.0012 & 1.1655 & 138.321 & 190.117\end{array}$ $\begin{array}{lllllllllllll} & \end{array}$ $\begin{array}{lllllllllllll} & \text { VSLAGACGVGGYGSR } & 1.00 & \text { \#\#册 } 26.43 & 24.21 & 2 & 1542.7412 & 1542.7405 & 772.3775 & 0.0007 & 0.4531 & 1184.705 & 861.233\end{array}$ $\begin{array}{llllllllllllll}\text { VSLAGACGVGGYGSR } & 0.91 & 19.86 & 26.18 & 21.73 & 3 & 1542.7420 & 1542.7405 & 515.2541 & 0.0015 & 0.9704 & 111.081 & 165.888\end{array}$ $\begin{array}{llllllllllllll}\text { SFSTASAITPSVSR } & 1.00 & \text { \#\#\# } 27.85 & 25.17 & 2 & 1553.8176 & 1553.8171 & 777.9158 & 0.0005 & 0.3214 & 226.260 & 231.643\end{array}$

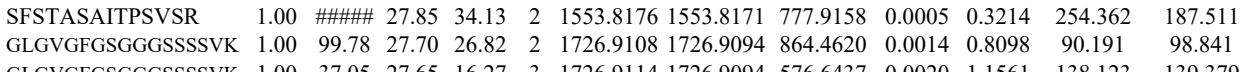
$\begin{array}{llllllllllllll}\text { GLGVGFGSGGGSSSSVK } & 1.00 & 37.05 & 27.65 & 16.27 & 3 & 1726.9114 & 1726.9094 & 576.6437 & 0.0020 & 1.1561 & 138.123 & 139.379\end{array}$ ISISTSGGSFR $\begin{array}{llllllllllll}1.00 & 60.05 & 27.63 & 25.64 & 2 & 1254.6696 & 1254.6690 & 628.3418 & 0.0006 & 0.4774 & 2213.646 & 2172.507\end{array}$ ISISTSGGSFR $\begin{array}{llllllllllll}1.00 & 52.91 & 27.63 & 27.02 & 2 & 1254.6696 & 1254.6690 & 628.3418 & 0.0006 & 0.4774 & 1459.453 & 1375.244 \\ 0.84 & 39.03 & 27.44 & 15.82 & 2 & 1409.7120 & 1409.7151 & 705.8648 & -0.0031 & -2.1959 & 34.955 & 32.093\end{array}$

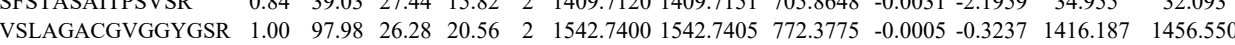
$\begin{array}{lllllllllllll}\text { VSLAGACGVGGYGSR } & 1.00 & 93.01 & 26.219 & 20.64 & 2 & 1542.7416 & 1542.7405 & 772.3775 & 0.0011 & 0.7121 & 1369.848 & 1143.594\end{array}$ $\begin{array}{lllllllllllll}\text { GLGVGFGSGGGSSSSVK } & 1.00 & 90.53 & 27.64 & 21.94 & 2 & 1726.9096 & 1726.9094 & 864.4620 & 0.0002 & 0.1157 & 67.752 & 61.944\end{array}$ 
$\begin{array}{llllllllllll}1.00 & 46.03 & 27.60 & 24.14 & 2 & 1254.6694 & 1254.6690 & 628.3418 & 0.0004 & 0.3183 & 323.297 & 3 \\ 0.64 & 86.91 & 27.79 & 99.91 & 2 & 1409.7148 & 1409.7151 & 705.8648 & 0.0003 & -0.2125 & 10.946 & \end{array}$

SFSTASAITPSVSR

$\begin{array}{llllllllll}0.64 & 91.96 & 27.72 & \# \# \# \# \quad 2 & 1409.7148 & 1409.7151 & 705.8648 & -0.0003 & -0.2125 & 10.946 \\ 1 & 2709.7151 & 705.8648 & 0.0001 & 0.0708 & 5.064\end{array}$

$\begin{array}{llllllllllll}\text { VSLAGACGVGGYGSR } & 1.00 & 91.57 & 26.34 & 19.03 & 2 & 1542.7430 & 1542.7405 & 772.3775 & 0.0025 & 1.6184 & 261.924 \\ \text { VSLAGACGVGGYGSR } & 1.00 & 43.49 & 26.35 & 24.06 & 3 & 1542.7432 & 1542.7405 & 515.2541 & 0.0027 & 1.7467 & 37.740\end{array}$

$\begin{array}{llllllllllll}\text { VSLAGACGVGGYGSR } & 1.00 & 43.49 & 26.35 & 24.06 & 3 & 1542.7432 & 1542.7405 & 515.2541 & 0.0027 & 1.7467 & 37.740 \\ \text { VSLAGACGVGGYGSR } & 1.00 & 46.76 & 26.41 & 23.89 & 3 & 1542.7435 & 1542.7405 & 515.2541 & 0.0030 & 1.9408 & 25.972\end{array}$ $\begin{array}{llllllllllll}\text { GLGVGFGSGGGSSSSVK } & 1.00 & 46.76 & 26.41 & 23.89 & 3 & 1542.7435 & 1542.7405 & 515.2541 & 0.0030 & 1.9408 & 25.972 \\ & 0.55 & 51.84 & 27.70 & 64.84 & 3 & 1726.9108 & 1726.9094 & 576.6437 & 0.0014 & 0.8093 & 46.692\end{array}$ TSFTSVSR

$\begin{array}{llllllllllll}1.00 & 46.11 & 27.60 & 23.76 & 2 & 1254.6694 & 1254.6690 & 628.3418 & 0.0004 & 0.3183 & 260.983\end{array}$

$\begin{array}{llllllllllll}\text { GLGVGFGSGGGSSSSVK } & .55 & 2.52 & 27.70 & 66.52 & 3 & 1726.9108 & 1726.9094 & 576.6437 & 0.0014 & 0.8093 & 79.289 \\ \text { GLGVGFGSGGGSSSSVK } & 1.00 & 43.04 & 27.70 & 18.28 & 3 & 1726.9108 & 1726.9094 & 576.6437 & 0.0014 & 0.8093 & 68.848\end{array}$ $\begin{array}{llllllllllll}\text { ISISTSGGSFR } & 1.00 & 50.18 & 27.66 & 25.28 & 2 & 1254.6686 & 1254.6690 & 628.3418 & -0.0004 & -0.3183 & 397.892\end{array}$

$\begin{array}{llllllllllll}\text { VSLAGACGVGGYGSR } & 1.00 & 95.67 & 26.33 & 19.58 & 2 & 1542.7414 & 1542.7405 & 772.3775 & 0.0009 & 0.5826 & 464.392\end{array}$ $\begin{array}{llllllllllll}\text { VSLAGACGVGGYGSR } & 1.00 & \text { \#\#\#\# } & 26.19 & 24.86 & 2 & 1542.7416 & 1542.7405 & 772.3775 & 0.0011 & 0.7121 & 673.668 \\ \text { VSLAGACGVGGYGSR } & 0.91 & 17.8 & 26.25 & 15.69 & 3 & 1542.7426 & 1542.7405 & 515.52541 & 0.0021 & 1.3586 & 33.875\end{array}$ $\begin{array}{llllllllllll}\text { VSLAGACGVGGYGSR } & 0.91 & 17.88 & 26.25 & 15.69 & 3 & 1542.7426 & 1542.7405 & 515.2541 & 0.0021 & 1.3586 & 33.875 \\ \text { SFSTASAITPSVSR } & 1.00 & \# \# \# \# 27.85 & 27.28 & 2 & 1553.8176 & 1553.8171 & 777.9158 & 0.0005 & 0.3214 & 131.371\end{array}$ $\begin{array}{llllllllllll}\text { SFSTASAITPSVSR } & 1.00 & \text { \#\#\#\# } 27.85 & 27.28 & 2 & 1553.8176 & 1553.8171 & 777.9158 & 0.0005 & 0.3214 & 131.371\end{array}$ $\begin{array}{lllllllllllll}\text { GLGVGFGSGGGSSSSVK } & 1.00 & 94.55 & 27.65 & 24.21 & 2 & 1726.9092 & 1726.9094 & 864.4620 & -0.0002 & -0.1157 & 90.730 \\ \text { GLGVGFGSGGGSSSVK } & 0.55 & 42.37 & 27.72 & 55.37 & 3 & 1726.9105 & 1726.9094 & 576.6437 & 0.0011 & 0.6359 & 76.673\end{array}$ $\begin{array}{lllllllllllll}\text { GLGVGFGSGGGSSSSVK } & 0.55 & 42.37 & 27.72 & 55.37 & 3 & 1726.9105 & 1726.9094 & 576.6437 & 0.0011 & 0.6359 & 76.673 \\ & 1.00 & 27.70 & 18.90 & 3 & 1726.9108 & 1726.9094 & 576.6437 & 0.0014 & 0.8093 & 71.712\end{array}$ TSFTSVSR $\begin{array}{lllllllllll}1.89 & 22.58 & 25.95 & 16.95 & 2 & 1027.5426 & 1027.5420 & 514.7783 & 0.0006 & 0.5828 & 159.508 \\ 1.00 & & 26.43 & 20.47 & 2 & 1542.7412 & 1542.7405 & 772.3775 & 0.0007 & 0.4531 & 332.445\end{array}$

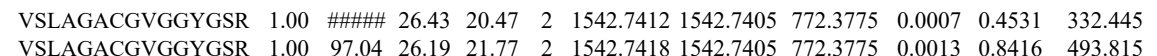
$\begin{array}{llllllllllll}\text { VSLAGACGVGGYGSR } & 1.00 & 97.04 & 26.19 & 21.77 & 2 & 1542.7418 & 1542.7405 & 772.3775 & 0.0013 & 0.8416 & 493.815 \\ \text { GLGVGFGSGGGSSSSVK } & 1.00 & 89.85 & 27.65 & 23.64 & 2 & 1726.9092 & 1726.9094 & 864.4620 & -0.0002 & -0.1157 & 80.632\end{array}$ $\begin{array}{lllllllllllll}\text { GLGVGFGSGGGSSSSVK } & 1.00 & 89.85 & 27.65 & 23.64 & 2 & 1726.9092 & 1726.9094 & 864.4620 & -0.0002 & -0.1157 & 80.632 \\ \text { GLGVGFGSGGGSSSSVK } & 0.66 & 47.85 & 27.67 & 60.85 & 3 & 1726.9111 & 1726.9094 & 576.6437 & 0.0017 & 0.9827 & 63.585\end{array}$ $\begin{array}{lllllllllllll}\text { GLGVGFGSGGGSSSSVK } & 0.66 & 47.85 & 27.67 & 60.85 & 3 & 1726.9111 & 1726.9094 & 576.6437 & 0.0017 & 0.9827 & 63.585 \\ \text { GLGVGFGSGGGSSSSVK } & 1.00 & 56.39 & 27.67 & 20.19 & 3 & 1726.9111 & 1726.9094 & 576.6437 & 0.0017 & 0.9827 & 57.891\end{array}$

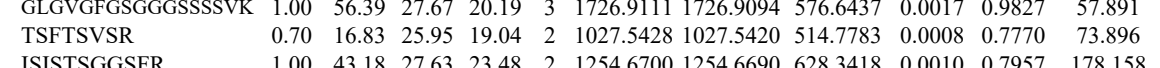
$\begin{array}{llllllllllll}0.70 & 16.83 & 25.95 & 19.04 & 2 & 1027.5428 & 1027.5420 & 514.7783 & 0.0008 & 0.7770 & 73.896 \\ 1.00 & 43.18 & 27.63 & 23.48 & 2 & 1254.6700 & 1254.6690 & 628.3418 & 0.0010 & 0.7957 & 178.158\end{array}$

$\begin{array}{lllllllllllll}\text { VSLAGACGVGGYGSR } & 1.00 & 96.68 & 26.38 & 20.58 & 2 & 1542.7406 & 1542.7405 & 772.3775 & 0.0001 & 0.0647 & 349.844\end{array}$ $\begin{array}{llllllllllll}\text { VSLAGACGVGGYGSR } & 1.00 & 87.96 & 26.43 & 19.27 & 2 & 1542.7412 & 1542.7405 & 772.3775 & 0.0007 & 0.4531 & 430.640\end{array}$ 

\begin{tabular}{llllllllllll} 
& VSLAGACGVGGYGSR & 1.00 & \#\#\#\# 26.38 & 25.79 & 2 & 1542.7408 & 1542.7405 & 772.3775 & 0.0003 & 0.1942 & 776.605 \\
\hline
\end{tabular}

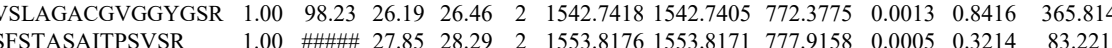
$\begin{array}{lllllllllllll}\text { GLGVGFGSGGGSSSSVK } & 1.00 & 98.82 & 27.69 & 23.99 & 2 & 1726.9102 & 1726.9094 & 864.4620 & 0.0008 & 0.4627 & 122.060\end{array}$ $\begin{array}{lllllllllllll}\text { GLGVGFGSGGGSSSSVK } & 1.00 & 55.58 & 27.65 & 17.68 & 3 & 1726.9114 & 1726.9094 & 576.6437 & 0.0020 & 1.1561 & 79.060\end{array}$ $\begin{array}{llllllllllllll} & \end{array}$ GLGVGFGSGGGSSSSVK $\begin{array}{lllllllllll}0.67 & 81.17 & 27.62 & 94.17 & 3 & 1726.9120 & 1726.9094 & 576.6437 & 0.0026 & 1.5029 & 79.452\end{array}$

ISISTSGGSFR $\begin{array}{lllllllllll}0.79 & 24.83 & 27.66 & 24.50 & 2 & 1254.6692 & 1254.6690 & 628.3418 & 0.0002 & 0.1591 & 67.700 \\ 1.00 & 91.27 & 26.43 & 19.75 & 2 & 1542.7412 & 1542.7405 & 772.3775 & 0.0007 & 0.4531 & 333.305\end{array}$

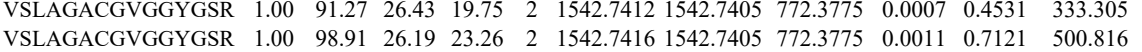
$\begin{array}{lllllllllllll}\text { SFSTASAITPSVSR } & 1.00 & \text { \#\#\#\# } 27.85 & 27.37 & 2 & 1553.8186 & 1553.8171 & 777.9158 & 0.0015 & 0.9641 & 103.088\end{array}$ $\begin{array}{lllllllllll}\text { SFSTASAITPSVSR } & 1.00 & \text { \#\#\# } 27.77 & 23.31 & 2 & 1553.8204 & 1553.8171 & 777.9158 & 0.0033 & 2.1210 & 143.962 \\ \text { GLGVGFGSGGGSSSSVK } & 1.00 & \text { \#\#\#\# } 27.72 & 27.89 & 2 & 1726.9118 & 1726.9094 & 864.4620 & 0.0024 & 1.3881 & 89.164\end{array}$ $\begin{array}{llllllllllll}\text { GLGVGFGSGGGSSSSVK } & 1.00 & \text { \#\#\# } & 27.72 & 27.89 & 2 & 1726.9118 & 1726.9094 & 864.4620 & 0.0024 & 1.3881 & 89.164 \\ \text { GLGVGFGSGGGSSSSVK } & 1.00 & 67.36 & 27.54 & 17.46 & 3 & 1726.9138 & 1726.9094 & 576.6437 & 0.0044 & 2.5434 & 49.473\end{array}$ $\begin{array}{llllllllllll}\text { GLGVGFGSGGGSSSSVK } & 1.00 & 67.36 & 27.54 & 17.46 & 3 & 1726.9138 & 1726.9094 & 576.6437 & 0.0044 & 2.5434 & 49.473 \\ \text { GLGVGFGSGGGSSSSVK } & 1.00 & 98.08 & 27.57 & 24.04 & 2 & 1726.9150 & 1726.9094 & 864.4620 & 0.0056 & 3.2390 & 72.800\end{array}$ $\begin{array}{llllllllllll}\text { GLGVGFGSGGGSSSSVK } & 1.00 & 98.08 & 27.57 & 24.04 & 2 & 1726.9150 & 1726.9094 & 864.4620 & 0.0056 & 3.2390 & 72.800 \\ \text { ISISTSGGSFR } & 1.00 & 38.75 & 27.63 & 21.13 & 2 & 1254.6696 & 1254.6690 & 628.3418 & 0.0006 & 0.4774 & 178.555\end{array}$

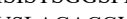
$\begin{array}{llllllllllllllll} & \text { VSLAGACGVGGYGSR } & 1.00 & 9.66 & 26.27 & 20.93 & 2 & 1542.7404 & 1542.7405 & 772.3775 & -0.0001 & -0.0647 & 626.240 & 55 \\ \end{array}$

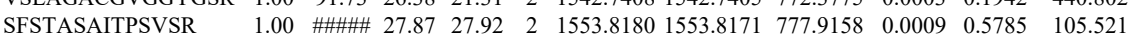

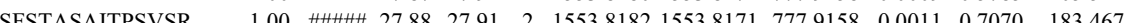

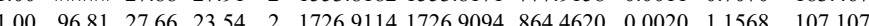
$\begin{array}{llllllllllllllll}\text { GLGVGFGSGGGSSSVK } & 1.00 & 96.81 & 27.68 & 27.54 & 2 & 1526.914 & 1553.8171 & 777.9158 & 0.0011 & 0.7070 & 183.467 & 23\end{array}$ $\begin{array}{llllllllllll}\text { GLGFTSVSR } & 0.51 & 17.61 & 26.03 & 21.05 & 2 & 1027.5422 & 1027.5420 & 514.7783 & 0.0002 & 0.1943 & 215.748\end{array}$

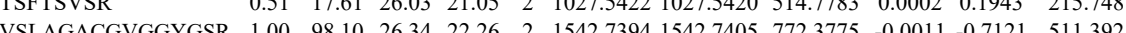
$\begin{array}{lllllllllllll}\text { VSLAGACGVGGYGSR } & 1.00 & 99.03 & 26.38 & 20.45 & 2 & 1542.7406 & 15427405 & 772.3775 & 0.0001 & 0.0647 & 388.151 & 514.285\end{array}$ $\begin{array}{llllllllllllll}\text { VSLAGACGVGGYGSR } & 0.50 & 10.65 & 26.19 & 23.55 & 3 & 1542.7417 & 1542.7405 & 515.2541 & 0.0012 & 0.7763 & 159.500 & 192.298\end{array}$

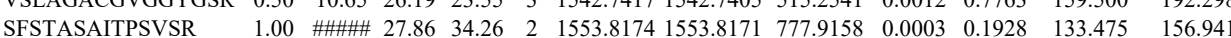

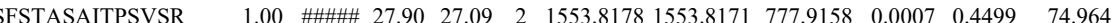

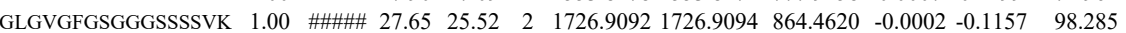
$\begin{array}{lllllllllllll}\text { GLGVGFGSGGGSSSSVK } & 1.00 & 74.33 & 27.66 & 18.50 & 3 & 1726.9126 & 1726.9094 & 576.6437 & 0.0032 & 1.8498 & 71.468\end{array}$ TEAESWYQTK

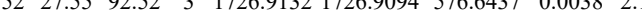
TEAESWYQTK AQYEEIANR

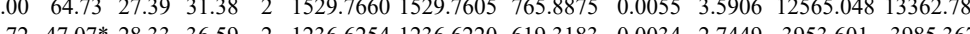
AQYEEIANR

YEELQQTAGR YEELQQTAGR NMQDLVEDFK TEAESWYQTK TEAESWYQTK TEAESWYQTK TEAESWYQTK TEAESWYQTK TEAESWYQTK

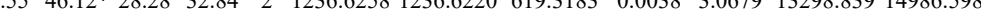
$\begin{array}{llllllllllll}1.00 & 74.82 & 27.67 & 28.89 & 2 & 1337.6782 & 1337.6697 & 669.8421 & 0.0085 & 6.3447 & 26854.133 & 29938.127 \\ 1.00 & 71.89 & 27.90 & 24.12 & 2 & 1337.6788 & 1337.6697 & 669.8421 & 0.0091 & 6.7926 & 47699.050 & 51495.706\end{array}$ $\begin{array}{lllllllllll}0.69 & 27.20 * 27.97 & 25.86 & 3 & 1525.7716 & 1525.7690 & 509.5969 & 0.0026 & 1.7007 & 26.565 & 67.924\end{array}$ $\begin{array}{lllllllllllll}1.00 & 61.23 & 27.19 & 24.97 & 2 & 1529.7620 & 1529.7605 & 765.8875 & 0.0015 & 0.9793 & 5134.268 & 5640.787 \\ 1.00 & 65.92 & 27.19 & 27.04 & 2 & 1529.7622 & 1529.7605 & 765.8875 & 0.0017 & 1.1098 & 13664.530 & 13286.253\end{array}$ $\begin{array}{llllllllllll}1.00 & 65.92 & 27.19 & 27.04 & 2 & 1529.7622 & 1529.7605 & 765.8875 & 0.0017 & 1.1098 & 13664.530 & 13286.25\end{array}$ $\begin{array}{lllllllllllll}0.88 & 22.60 & 27.18 & 32.06 & 2 & 1529.7624 & 1529.7605 & 765.8875 & 0.0019 & 1.2404 & 8.120 & 10.705 \\ 0.80 & 20.08 & 27.27 & 30.70 & 2 & 1529.7630 & 1529.7605 & 765.8875 & 0.0025 & 1.6321 & 75.560 & 59.105\end{array}$ $\begin{array}{llllllllllll}0.80 & 20.08 & 27.27 & 30.70 & 2 & 1529.7630 & 1529.7605 & 765.8875 & 0.0025 & 1.6321 & 75.560 & 59.105 \\ 0.80 & 33.32 & 27.14 & 44.46 & 2 & 1529.7640 & 1529.7605 & 765.8875 & 0.0035 & 2.2849 & 82.987 & 58.837\end{array}$ $\begin{array}{llllllllllll}0.80 & 33.32 & 27.14 & 44.46 & 2 & 1529.7640 & 1529.7605 & 765.8875 & 0.0035 & 2.2849 & 82.987 & 58.837 \\ 0.75 & 26.06 & 27.18 & 31.14 & 2 & 1529.7642 & 1529.7605 & 765.8875 & 0.0037 & 2.4155 & 80.317 & 60.484\end{array}$ $\begin{array}{lllllllllllll}0.61 & 27.07 & 27.12 & 37.98 & 2 & 1529.7646 & 1529.7605 & 765.8875 & 0.0041 & 2.6766 & 66.580 & 91.795\end{array}$ $\begin{array}{lllllllllllll}0.90 & 41.63 & 27.12 & 44.48 & 2 & 1529.7646 & 1529.7605 & 7658875 & 0.0041 & 2.6766 & 98.750 & 77.598\end{array}$ $\begin{array}{lllllllllllllll}0.79 & 26.92 & 27.12 & 23.35 & 2 & 1529.7646 & 1529.7605 & 765.8875 & 0.0041 & 2.6766 & 72.922\end{array}$ 


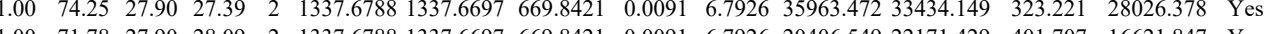
$\begin{array}{ccccccccccccccc}1.00 & 71.78 & 27.90 & 28.09 & 2 & 1337.6788 & 1337.6697 & 669.8421 & 0.0091 & 6.7926 & 20406.549 & 22171.429 & 401.707 & 16621.847 & \text { Yes } \\ 0.67 & 16.95 & 27.26 & 27.99 & 3 & 1430.8237 & 1430.8224 & 477.9481 & 0.0013 & 0.9067 & 204.137 & 170.502 & 75.864 & 209.185 & \text { Yes } \\ 1.00 & 55.25 & 27.19 & 28.15 & 2 & 1430.8238 & 1430.822 & 716.4185 & 0.0014 & 0.9771 & 829.089 & 865.839 & 30.240 & 109.499 & \text { Yes }\end{array}$

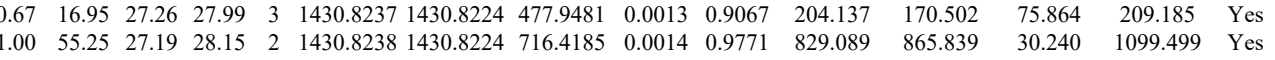
\begin{tabular}{llllllllllllllll}
0.96 & 26.41 & 27.19 & 29.96 & 3 & 1430.8243 & 1430.8224 & 477.9481 & 0.0019 & 1.371 & 829.089 & 290.328 & 283.800 & 21.343 & 177.602 & Yes \\
\hline
\end{tabular} $\begin{array}{lllllllllllllll}1.00 & 49.39 & 26.85 & 28.99 & 2 & 1430.8246 & 1430.8224 & 716.4185 & 0.0022 & 1.5354 & 5498.149 & 6281.478 & 130.003 & 5142.001 & \text { Yes }\end{array}$ $\begin{array}{llllllllllllllll}1.00 & 67.17 & 27.72 & 26.47 & 2 & 1529.7722 & 1529.7605 & 765.8875 & 0.0117 & 7.6381 & 9451.765 & 10263.344 & 47.920 & 8097.420 & \text { Yes }\end{array}$ $\begin{array}{llllllllllllllll}1.00 & 68.34 & 27.72 & 26.28 & 2 & 1529.7734 & 1529.7605 & 765.8875 & 0.0129 & 8.4215 & 8101.313 & 7368.922 & 54.866 & 6597.742 & \text { Yes } \\ 1.00 & 61.40 & 27.90 & 32.39 & 2 & 1337.6788 & 1337.6697 & 669.8421 & 0.0091 & 6.7926 & 7640.897 & 8015.621 & 1110.500 & 7990.616 & \text { Yes }\end{array}$

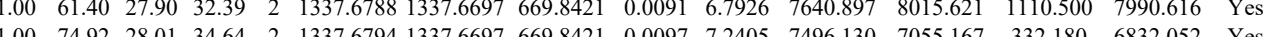

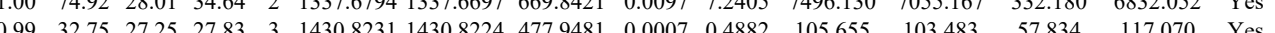

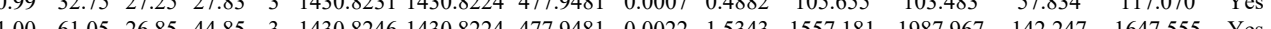

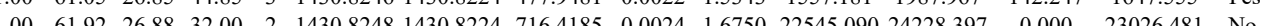

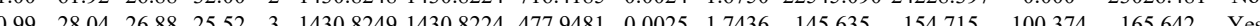
$\begin{array}{lllllllllllllll}100 & 42.42 & 6.88 & 31.20 & 3 & 1430.8252 & 1430.8224 & 477.9481 & 0.0028 & 1.9528 & 3197.988 & 3546.491 & 0.000 & 3067.527 & \text { No }\end{array}$ $\begin{array}{llllllllllllllll}1.00 & 59.20 & 26.85 & 33.33 & 2 & 1430.8254 & 1430.8224 & 716.4185 & 0.0030 & 2.0937 & 34192.844 & 35535.861 & 276.980 & 32065.113 & \text { Yes }\end{array}$

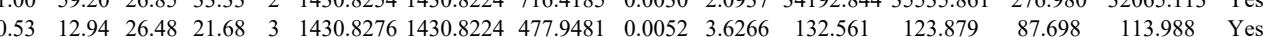
$\begin{array}{llllllllllllllll}0.91 & 26.52 & 26.17 & 23.60 & 3 & 1430.8306 & 1430.8224 & 477.9481 & 0.0082 & 5.7189 & 140.578 & 147.071 & 62.015 & 117.317 & \text { Yes }\end{array}$ $\begin{array}{lllllllllllllll}1.00 & 62.54 & 27.63 & 21.58 & 2 & 1569.8456 & 1569.8316 & 785.9231 & 0.0140 & 8.9066 & 2750.151 & 2605.083 & 267.534 & 4961.002 & \text { No }\end{array}$

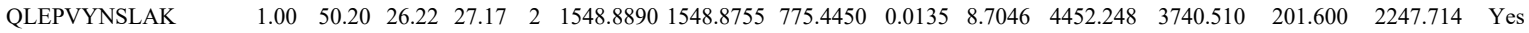
$\begin{array}{llllllllllllllll}\text { QLEPVYNSLAK } & 1.00 & 57.15 & 26.22 & 26.84 & 2 & 1548.8890 & 1548.8755 & 775.4450 & 0.0135 & 8.7046 & 3248.788 & 2759.900 & 48.873 & 1615.794 & \text { Yes }\end{array}$ $\begin{array}{llllllllllllllll}\text { VSQGQLVVMQPEK } & 1.00 & 83.78 & 26.07 & 25.27 & 2 & 1729.9794 & 1729.9640 & 865.9893 & 0.0154 & 8.8915 & 1072.356 & 768.919 & 249.818 & 473.008 & \text { Yes }\end{array}$ $\begin{array}{llllllllllllllll}\text { VSQGQLVVMQPEK } & 1.00 & 92.63 & 26.33 & 26.15 & 2 & 1729.9798 & 1729.9640 & 865.9893 & 0.0158 & 9.1224 & 1081.675 & 1030.832 & 303.377 & 434.797 & \text { Yes }\end{array}$ $\begin{array}{lllllllllllllllll}\text { EVSQPDWTPPPEVTLVLTK } & 0.99 & 25.90 & 24.89 & 16.72 & 3 & 2423.3233 & 2423.3192 & 808.7803 & 0.0041 & 1.6898 & 23.494 & 32.589 & 25.199 & 25.631 & \text { Yes }\end{array}$ $\begin{array}{llllllllllllllll}\text { EVSQPDWTPPPEVTLVLTK } & 1.00 & 61.89 & 24.89 & 18.42 & 2 & 2423.3234 & 2423.3192 & 1212.6669 & 0.0042 & 1.7317 & 31.375 & 13.008 & 10.899 & 16.916 & \text { Yes }\end{array}$ $\begin{array}{lllllllllllllllll}\text { EVSQPDWTPPPEVTLVLTK } & 1.00 & 61.46 & 24.89 & 18.37 & 2 & 2423.3234 & 2423.3192 & 1212.6669 & 0.0042 & 1.7317 & 30.707 & 9.024 & 4.875 & 15.644 & \text { Yes }\end{array}$ \begin{tabular}{llllllllllllllll} 
EVSQPDWTPPPEVTLVLTK & 0.91 & 17.37 & 24.89 & 15.68 & 3 & 2423.3236 & 2423.3192 & 808.7803 & 0.0044 & 1.8134 & 73.014 & 81.612 & 8.438 & 67.075 & Yes \\
\hline
\end{tabular}

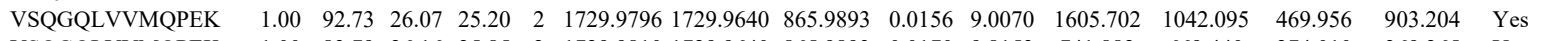
$\begin{array}{lllllllllllllllll}\text { VSQGQLVVMQPEK } & 1.00 & 83.79 & 26.16 & 25.85 & 2 & 1729.9810 & 1729.9640 & 865.9893 & 0.0170 & 9.8153 & 741.882 & 669.440 & 274.010 & 369.265 & \text { Yes }\end{array}$ $\begin{array}{llllllllllllllll}\text { YGIVDYMIEQSGPPSK } & 1.00 & 73.23 & 27.78 & 24.21 & 2 & 2071.0554 & 2071.0540 & 1036.5343 & 0.0014 & 0.6753 & 401.757 & 317.801 & 34.359 & 131.214 & \text { Yes }\end{array}$ $\begin{array}{llllllllllllllll}\text { YGIVDYMIEQSGPPSK } & 1.00 & 40.02 & 27.72 & 16.46 & 3 & 2071.0582 & 2071.0540 & 691.3586 & 0.0042 & 2.0250 & 595.634 & 459.571 & 85.339 & 662.116 & \text { Yes }\end{array}$ $\begin{array}{lllllllllllllllll}\text { YGIVDYMIEQSGPPSK } & 0.95 & 24.73 & 27.76 & 23.11 & 3 & 2071.0591 & 2071.0540 & 691.3586 & 0.0051 & 2.4589 & 461.685 & 448.472 & 349.051 & 615.076 & \text { Yes }\end{array}$ $\begin{array}{llllllllllllllll}\text { YGIVDYMIEQSGPPSK } & 1.00 & 52.65 & 27.76 & 22.61 & 3 & 2071.0591 & 2071.0540 & 691.3586 & 0.0051 & 2.4589 & 500.515 & 654.672 & 116.016 & 522.784 & \text { Yes }\end{array}$

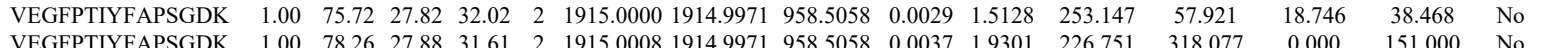

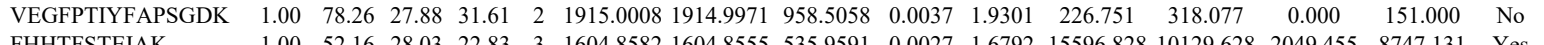

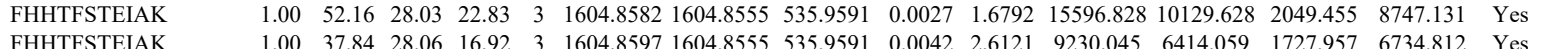
$\begin{array}{lllllllllllllllll} & 1.0 & 37.84 & 28.06 & 16.92 & 3 & 1604.8597 & 1604.8555 & 535.9591 & 0.0042 & 2.6121 & 9230.045 & 6414.059 & 1727.957 & 6734.812 & \text { Yes } \\ \text { VEGFPTIYFAPSGDK } & 1.00 & 77.10 & 27.89 & 31.57 & 2 & 1914.9990 & 1914.9971 & 958.5058 & 0.0019 & 0.9911 & 219.942 & 87.676 & 42.602 & 72.173 & \text { Yes }\end{array}$

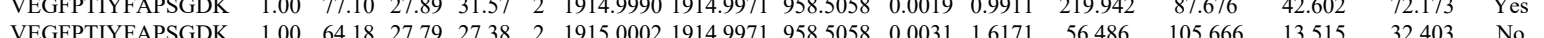

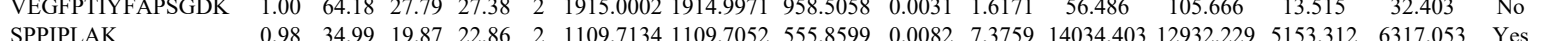

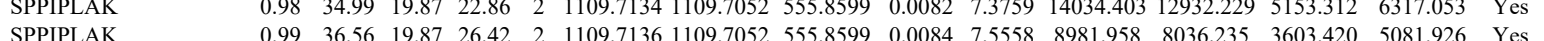

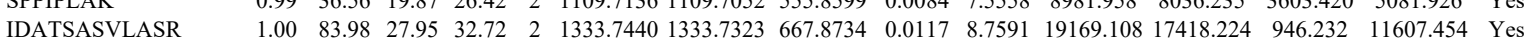
\begin{tabular}{llllllllllllllll} 
& \\
IDATSASVLASR & 1.00 & 83.98 & 27.95 & 32.72 & 2 & 1333.7440 & 1333.7323 & 667.8734 & 0.0117 & 8.7591 & 19169.108 & 17418.224 & 946.232 & 11607.454 & Yes \\
\hline
\end{tabular}

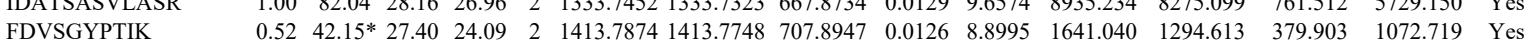

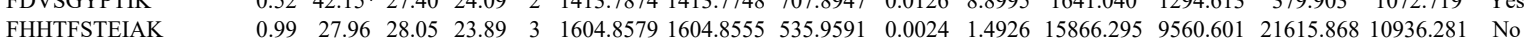
SPPIPLAK SPPIPLAK IDATSASVLASR IDATSASVLASR IDATSASVLASR IDATSASVLASR AATQFWR AATQFWR AATQFWR AATQFWR MDATANDVPSDR MDATANDVPSDR DLGLSESGEDVNAAILDE VDATAETDLAK
VDATAETDLAK VDATAETDLAK MDATANDVPSDR MDATANDVPSDR FAMEPEEFDSDTLR

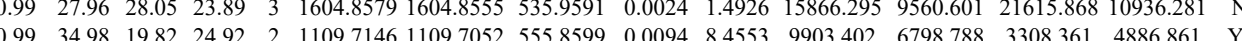
$\begin{array}{llllllllllllllll}0.99 & 34.98 & 19.82 & 24.92 & 2 & 1109.7146 & 1109.7052 & 555.8599 & 0.0094 & 8.4553 & 9903.402 & 6798.788 & 3308.361 & 4886.861 & \text { Yes } \\ 0.99 & 33.67 & 19.82 & 24.67 & 2 & 1109.7152 & 1109.7052 & 555.8599 & 0.0100 & 8.9950 & 9945.397 & 7768.232 & 3726.906 & 5187.273 & \text { Yes }\end{array}$ $\begin{array}{lllllllllllllllll}1.00 & 93.29 & 28.02 & 31.01 & 2 & 1333.7416 & 1333.7323 & 667.8734 & 0.0093 & 6.9623 & 23186.874 & 18967.227 & 1644.887 & 9659.271 & \text { Yes }\end{array}$ $\begin{array}{llllllllllllllll}1.00 & 94.85 & 27.98 & 31.94 & 2 & 1333.7420 & 1333.7323 & 667.8734 & 0.0097 & 7.2618 & 44834.859 & 34323.168 & 2472.202 & 18599.834 & \text { Yes }\end{array}$ $\begin{array}{llllllllllllllll}1.00 & 84.63 & 28.18 & 24.48 & 2 & 1333.7400 & 1333.7323 & 667.8734 & 0.0077 & 5.7645 & 15336.665 & 13861.250 & 1537.571 & 7980.998 & \text { Yes }\end{array}$ $\begin{array}{lllllllllllllll}1.00 & 86.86 & 27.93 & 30.89 & 2 & 1333.7406 & 1333.7323 & 667.8734 & 0.0083 & 6.2137 & 26074.984 & 20810.988 & 1322.494 & 12789.647 & \text { Yes }\end{array}$ $\begin{array}{lllllllllllllll}0.69 & 26.24 & 27.76 & 19.77 & 2 & 1022.5514 & 1022.5419 & 512.2782 & 0.0095 & 9.2722 & 3236.299 & 3404.405 & 650.789 & 2793.319 & \text { Yes }\end{array}$ $\begin{array}{llllllllllllllll}0.65 & 24.18 & 27.72 & 22.31 & 2 & 1022.5516 & 1022.5419 & 512.2782 & 0.0097 & 9.4674 & 3786.864 & 4094.798 & 622.271 & 3491.887 & \text { Yes }\end{array}$ $\begin{array}{llllllllllllllll}0.94 & 33.54 & 27.72 & 26.60 & 2 & 1022.5516 & 1022.5419 & 512.2782 & 0.0097 & 9.4674 & 5634.622 & 4651.465 & 654.949 & 3609.032 & \text { Yes }\end{array}$ $\begin{array}{lllllllllllllll}0.81 & 27.99 & 27.72 & 21.14 & 2 & 1022.5518 & 1022.5419 & 512.2782 & 0.0099 & 9.6626 & 7557.381 & 6036.086 & 1022.891 & 5688.659 & \text { Yes }\end{array}$ $\begin{array}{lllllllllllllllll}1.00 & 55.02 & 24.81 & 22.50 & 2 & 1434.6544 & 1434.6531 & 718.3338 & 0.0013 & 0.9049 & 17524.754 & 14110.112 & 396.829 & 9842.953 & \text { Yes }\end{array}$ $\begin{array}{llllllllllllllll}1.00 & 66.07 & 24.81 & 25.18 & 2 & 1434.6546 & 1434.6531 & 718.3338 & 0.0015 & 1.0441 & 7968.718 & 5706.070 & 553.387 & 4453.787 & \text { Yes }\end{array}$ $\begin{array}{lllllllllllllll}0.60 & 19.62 & 27.62 & 32.62 & 3 & 2406.2050 & 2406.2005 & 803.0741 & 0.0045 & 1.8678 & 13.495 & 14.051 & 26.873 & 10.824 & \text { No }\end{array}$

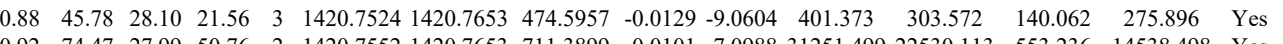

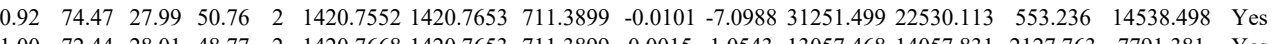
$\begin{array}{lllllllllllllllll}1.00 & 72.44 & 28.01 & 48.77 & 2 & 1420.7668 & 1420.7653 & 711.3899 & 0.0015 & 1.0543 & 13057.468 & 14057.831 & 2127.763 & 7791.381 & \text { Yes } \\ 1.00 & 46.27 & 24.86 & 27.67 & 2 & 1434.6558 & 1434.6531 & 718.3338 & 0.0027 & 1.8793 & 1720.920 & 13098.901 & 502.082 & 10465.298 & \text { Yes }\end{array}$ $\begin{array}{llllllllllllllll}1.00 & 46.27 & 24.86 & 27.67 & 2 & 1434.6558 & 1434.6531 & 718.3338 & 0.0027 & 1.8793 & 17209.920 & 13098.901 & 502.082 & 10465.298 & \text { Yes } & \\ 1.00 & 53.14 & 24.86 & 2.01 & 2 & 1434.6558 & 1434.6531 & 7183338 & 0.0027 & 1.8793 & 19199.541 & 16091.370 & 1519.243 & 9202.743 & \text { Yes }\end{array}$ $\begin{array}{llllllllllllllll}1.00 & 53.14 & 24.86 & 22.01 & 2 & 1434.6558 & 1434.6531 & 718.3338 & 0.0027 & 1.8793 & 19199.541 & 16091.370 & 1519.243 & 9202.743 & \text { Yes } & \\ 1.00 & 76.39 & 24.41 & 65.53 & 2 & 1829.8280 & 1829.8264 & 915.9205 & 0.0016 & 0.8734 & 211.960 & 266.013 & 0.000 & 216.988 & & \end{array}$ $\begin{array}{lllllllllllllll}1.00 & 76.39 & 24.41 & 65.53 & 2 & 1829.8280 & 1829.8264 & 915.9205 & 0.0016 & 0.8734 & 211.960 & 266.013 & 0.000 & 216.988 & \text { No } \\ 0.99 & 62.47 & 24.47 & 61.93 & 2 & 1829.8284 & 1829.8264 & 915.9205 & 0.0020 & 1.0918 & 2592.043 & 2037.916 & 0.000 & 1764.967 & \text { No }\end{array}$ $\begin{array}{llllllllllllllll}\text { FAMEPEEPSDTLR } & 0.99 & 62.47 & 24.47 & 61.93 & 2 & 1829.8284 & 1829.8264 & 95.9271 & 0.020 & 1.018 & 2592.043 & 2037.916 & 0.000 & 1764.967 & \text { No }\end{array}$

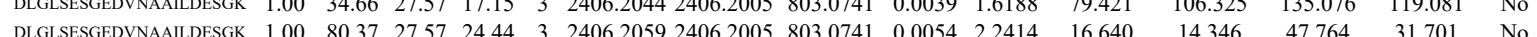

Table S-4 page 172 of 614 


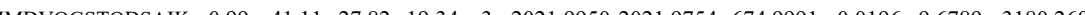

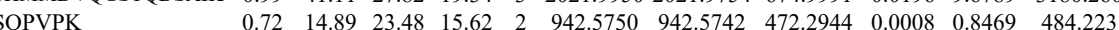

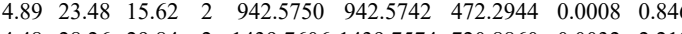

922.065

$\begin{array}{lllllllllllll}\text { TFDSIVMDPK } & 0.99 & 42.02 & 28.26 & 39.07 & 2 & 1439.7606 & 1439.7574 & 720.8860 & 0.0032 & 2.2195 & 313.030 & 204.000\end{array}$

$\begin{array}{llllllllllllllll}\text { SHMMDVQGSTQDSAIK } & 1.00 & 58.09 & 27.75 & 20.97 & 3 & 2021.9935 & 2021.9754 & 674.9991 & 0.0181 & 8.9382 & 2990.519 & 2451.356 & 13\end{array}$

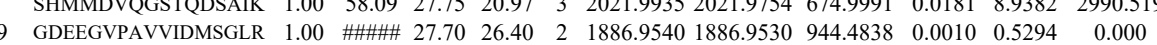
$\begin{array}{lllllllllll}\text { GDEEGVPAVVIDMSGLR } & 1.00 & \text { \#\#\#\# } 27.54 & 22.57 & 2 & 1886.9546 & 1886.9530 & 944.4838 & 0.0016 & 0.8470 & 123.435\end{array}$ $\begin{array}{llllllllllllll}\text { GDEEGVPAVVIDMSGLR } & 1.00 & 75.15 & 27.53 & 21.41 & 3 & 1886.9560 & 1886.9530 & 629.9916 & 0.0030 & 1.5873 & 55.040\end{array}$ $\begin{array}{llllllllllllll}\text { GDEEGVPAVVIDMSGLR } & 1.00 & 57.23 & 27.53 & 18.36 & 3 & 1886.9560 & 1886.9530 & 629.9916 & 0.0030 & 1.5873 & 44.319\end{array}$ $\begin{array}{llllllllllll}\text { AECMLQQAER } & 1.00 & 52.81 & 24.65 & 22.89 & 2 & 1367.6238 & 1367.6117 & 684.8131 & 0.0121 & 8.8344 & 463.002 \\ \text { AECMLQQAER } & 1.00 & 55.10 & 24.68 & 16.64 & 2 & 1367.6248 & 1367.6117 & 684.8131 & 0.0131 & 9.5646 & 641.942\end{array}$ $\begin{array}{lllllllllllll}\text { VYALPEDLVEVNPK } & 1.00 & 39.79 & 25.19 & 18.28 & 2 & 1873.0450 & 1873.0440 & 937.5293 & 0.0010 & 0.5333\end{array}$ $\begin{array}{lllllllllllll}\text { VYALPEDLVEVNPK } & 1.00 & 43.75 & 25.20 & 22.81 & 3 & 1873.0453 & 1873.0440 & 625.3553 & 0.0013 & 0.6929 & 86.108\end{array}$ $\begin{array}{llllllllllllll}\text { VYALPEDLVEVNPK } & 1.00 & 46.05 & 25.26 & 16.13 & 2 & 1873.0456 & 1873.0440 & 937.5293 & 0.0016 & 0.8533 & 0.000\end{array}$ $\begin{array}{llllllllllll}\text { VYALPEDLVEVNPK } & 1.00 & 37.42 & 25.25 & 20.70 & 3 & 1873.0459 & 1873.0440 & 625.3553 & 0.0019 & 1.0128 & 105.598\end{array}$ $\begin{array}{llllllllllllll}\text { YPALHKPENQDIDWGALEGETR } & 0.64 & 7.45 & 27.08 & 16.79 & 4 & 2826.4197 & 2826.4180 & 707.6118 & 0.0017 & 0.6006 & 46.488 \\ \text { PAHKENDE }\end{array}$ $\begin{array}{lllllllllllll}\text { YPALHKPENQDIDWGALEGETR } & 0.96 & 12.78 & 26.95 & 14.02 & 4 & 2826.4233 & 2826.4180 & 707.6118 & 0.0053 & 1.8725 & 44.548 & 62 . \\ \text { VYALPEDLVEVNPK } & 1.00 & 73.16 & 25.19 & 20.24 & 2 & 1873.0450 & 1873.0440 & 937.5293 & 0.0010 & 0.5333 & 9.573 & 0.13\end{array}$ $\begin{array}{llllllllllll}\text { VYALPEDLVEVNPK } & 1.00 & 73.16 & 25.19 & 20.24 & 2 & 1873.0450 & 1873.0440 & 937.5293 & 0.0010 & 0.5333 & 9.573 \\ \text { VYALPEDLVEVNK } & 1.00 & 48.54 & 25.19 & 24.34 & 2 & 1873.0450 & 1873.0440 & 937.5293 & 0.0010 & 0.5333 & 10.961\end{array}$ $\begin{array}{lllllllllllll}\text { VYALPEDLVEVNPK } & 1.00 & 48.54 & 25.20 & 20.50 & 3 & 1873.0453 & 1873.0440 & 625.3553 & 0.0013 & 0.6929 & 59.995 \\ \text { VYALPEDLVEVNPK } & 1.00 & 49.01 & 25.24 & 27.06 & 3 & 1873.0469 & 1873.040 & 62.3553 & 0.028 & 1.4925 & 117.258 & 105\end{array}$ $\begin{array}{llllllllllll}\text { VYALPEDLVEVNPK } & 1.00 & 49.01 & 25.24 & 27.06 & 3 & 1873.0468 & 1873.0440 & 625.3553 & 0.0028 & 1.4925 & 117.258\end{array}$ $\begin{array}{llllllllllll}\text { VDTDGNGYISFNELNDLFK } & 1.00 & 86.57 & 27.64 & 22.65 & 3 & 2448.2092 & 2448.2053 & 817.0757 & 0.0039 & 1.5910 & 39.468\end{array}$

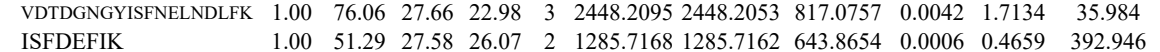
ISFDEFIK ISFDEFIK IGNFSTDIK IGNFSTDIK ISFDEFIK

IGNFSTIK

IGNFSTDIK

VPVDWNR

VPVDWNR
VPVDWNR $\begin{array}{lllllllllllll}1.00 & 48.23 & 27.58 & 26.15 & 2 & 1285.7168 & 1285.7162 & 643.8654 & 0.006 & 0.4659 & 149.822 & 15\end{array}$ $\begin{array}{llllllllllll}0.99 & 46.40 & 26.86 & 35.88 & 2 & 1281.7288 & 1281.7172 & 641.8659 & 0.0116 & 9.0361 & 1368.039 & 118 \\ 0.99 & 43.15 & 26.48 & 37.33 & 2 & 1281.7292 & 1281.7172 & 641.8659 & 0.0120 & 9.3477 & 1111.939 & 1276\end{array}$ $\begin{array}{llllllllllll}1.00 & 51.04 & 27.72 & 26.60 & 2 & 1285.7174 & 1285.7162 & 643.8654 & 0.0012 & 0.9319 & 575.042\end{array}$ $\begin{array}{llllllllllll}1.00 & 51.04 & 27.72 & 26.60 & 2 & 1285.7174 & 1285.7162 & 643.8654 & 0.0012 & 0.9319 & 575.042 \\ 1.00 & 47.92 & 27.62 & 25.59 & 2 & 1285.7176 & 1285.7162 & 643.8654 & 0.0014 & 1.0872 & 408.117\end{array}$ $\begin{array}{llllllllllll}0.92 & 32.04 & 26.37 & 25.52 & 2 & 1028.5616 & 1028.5525 & 515.2835 & 0.0091 & 8.8300 & 7054.446 & 6312\end{array}$ $\begin{array}{lllllllllllll}0.77 & 26.71 & 26.37 & 23.23 & 2 & 1028.5616 & 1028.5525 & 515.2835 & 0.0091 & 8.8300 & 7624.363 & 6707.01\end{array}$ $\begin{array}{lllllllllllll}0.85 & 31.11 & 26.73 & 24.92 & 2 & 1028.5604 & 1028.5525 & 515.2835 & 0.0079 & 7.6656 & 2760.570 & 234\end{array}$

\section{VPVDWNR} $\begin{array}{lllllllllllll}0.58 & 24.74 & 26.73 & 24.39 & 2 & 1028.5604 & 1028.5525 & 515.2835 & 0.0079 & 7.6656 & 4141.640 & 3949\end{array}$

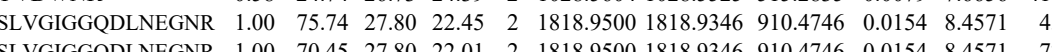
$\begin{array}{lllllllllllllll} & \end{array}$ \begin{tabular}{llllllllllllll}
\hline SLVGIGGQDLNEGNR & 0.69 & 23.40 & 27.87 & 17.34 & 3 & 1818.9511 & 1818.9346 & 607.3188 & 0.0165 & 9.0561 & 1787.230 & 1680.287
\end{tabular} $\begin{array}{lllllllllllll}\text { VNDDIIVNWVNETLR } & 1.00 & 86.10 & 27.37 & 35.66 & 2 & 1943.0244 & 1943.0234 & 972.5190 & 0.0010 & 0.5141 & 61.074\end{array}$

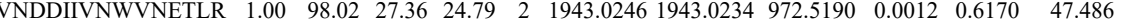
$\begin{array}{llllllllllll}\text { VNDDIIVNWVNETLR } & 1.00 & 44.65 & 27.35 & 16.54 & 3 & 1943.0251 & 1943.0234 & 648.6817 & 0.0017 & 0.8736 & 122.384\end{array}$ $\begin{array}{llllllllllllll}\text { VNDDIIVNWVNETLR } & 1.00 & 54.80 & 27.34 & 17.45 & 3 & 1943.0260 & 1943.0234 & 648.6817 & 0.0026 & 1.3360 & 69.543\end{array}$ VNDDIIVNWVNETLR $1.00 \quad 98.27 \begin{array}{llllllllll}27.29 & 29.25 & 2 & 1943.0232 & 1943.0234 & 972.5190 & -0.0002 & -0.1028 & 31.103\end{array}$ $\begin{array}{llllllllllll}\text { VNDDIIVNWVNETLR } & 1.00 & 98.41 & 27.36 & 27.45 & 2 & 1943.0242 & 1943.0234 & 972.5190 & 0.0008 & 0.4113 & 0.000\end{array}$

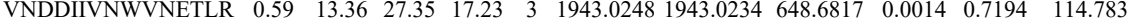
VNDDIIVNWVNETLR $1.00 \begin{array}{llllllllllll}46.68 & 27.35 & 22.05 & 3 & 1943.0251 & 1943.0234 & 648.6817 & 0.0017 & 0.8736 & 106.360\end{array}$ $\begin{array}{llllllllllllll}\text { VNDDIIVNWVNETLR } & 1.00 & 68.54 & 27.30 & 24.96 & 2 & 1943.0260 & 1943.0234 & 972.5190 & 0.0026 & 1.3367 & 21.631\end{array}$

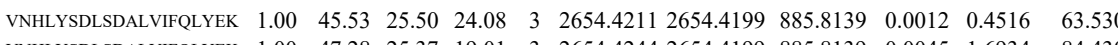

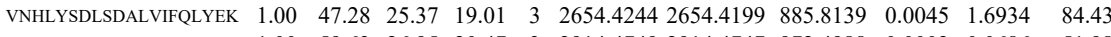

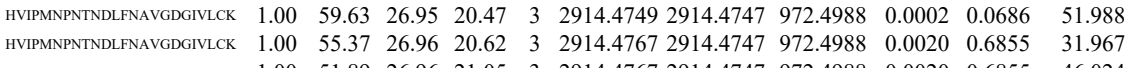

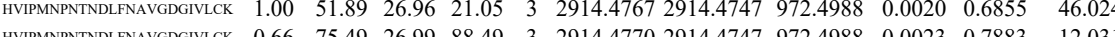
$\begin{array}{llllllllllllll} & \text { HIPMNPNTNDLFNAVGDGIVLCK } & 0.66 & 75.49 & 26.99 & 88.49 & 3 & 2914.4770 & 2914.4747 & 972.4988 & 0.0023 & 0.7883 & 12.031\end{array}$

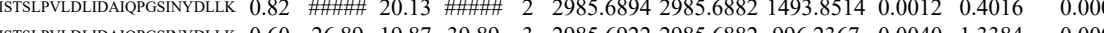

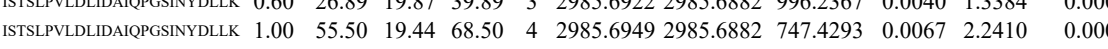

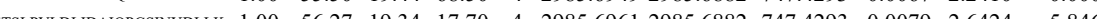




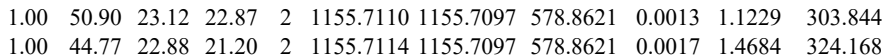

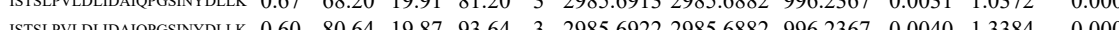

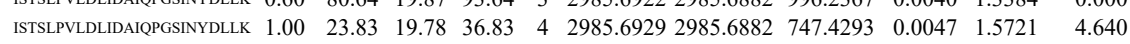
TENLNDDEK $\begin{array}{llllllllllll}1.00 & 49.54 & 27.41 & 29.15 & 2 & 1364.6660 & 1364.6663 & 683.3404 & -0.0003 & -0.2195 & 172.180\end{array}$ TENLNDDEK $\begin{array}{lllllllllllll}1.00 & 48.51 & 27.42 & 28.61 & 2 & 1364.6664 & 1364.6663 & 683.3404 & 0.0001 & 0.0732 & 151.326\end{array}$

NWMNSLGVNPR

NWMNSLGVNPR

NWMNSLGVNPR

NWMNSLGVNPR

AACLPLPGYR

AACLPLPGYR

AACLPLPGYR

AACLPLPGYR

AACLPLPGYR

TLTLALIWQLMR

TLTLALIWQLMR

TLTLALIWQLMR

TLTLALIWQLMR

TLTLALIWQLMR

TLTLALIWQLMR

TLTLALIWQLMR

LNLAFIANLFNR $\begin{array}{llllllllllll}\text { LNLAFIANLFNR } & 1.00 & 57.96 & 25.51 & 26.52 & 2 & 1548.8922 & 1548.8898 & 775.4522 & 0.0024 & 1.5475 & 1.098 \\ \text { GDEEGVPAVVIDMSGLR } & 1.00 & \text { \#\#\# } & 27.68 & 26.25 & 2 & 1886.9532 & 1886.9530 & 944.4838 & 0.0002 & 0.1059 & 24.504 \\ \text { GDEEGVPAVVIDMSGLR } & 1.00 & 91.77 & 27.68 & 24.53 & 2 & 1886.9532 & 1886.9530 & 944.4838 & 0.0002 & 0.1059 & 17.658\end{array}$ \begin{tabular}{llllllllllll} 
GDEEGVPAVVIDMSGLR & 1.00 & 41.44 & 27.68 & 24.53 & 2 & 1886.9532 & 1886.9530 & 944.4838 & 0.0002 & 0.1059 & 17.658 \\
\hline & 22.03 & 1886.9557 & 1886.9530 & 629.9916 & 0.0027 & 1.4286 & 88.023
\end{tabular} $\begin{array}{llllllllllllll}\text { GDEEGVPAVVIDMSGLR } & 1.00 & 96.45 & 27.70 & 26.26 & 2 & 1886.9536 & 1886.9530 & 944.4838 & 0.0006 & 0.3176 & 58.769\end{array}$ $\begin{array}{lllllllllllll}\text { GDEEGVPAVVIDMSGLR } & 1.00 & 92.98 & 27.55 & 24.66 & 2 & 1886.9542 & 1886.9530 & 944.4838 & 0.0012 & 0.6353 & 102.148 \\ \text { GDEEGVPAVVIDMSGLR } & 1.00 & 62.48 & 27.52 & 18.39 & 3 & 1886.9554 & 1886.9530 & 629.9916 & 0.0024 & 1.2699 & 80.947\end{array}$ $\begin{array}{llllllllllll}\text { GDEEGVPAVVIDMSGLR } & 1.00 & 62.48 & 27.52 & 18.39 & 3 & 1886.9554 & 1886.9530 & 629.9916 & 0.0024 & 1.2699 & 80.947 \\ \text { GDEEGVPAVVIDMSGLR } & 0.67 & 12.78 & 27.53 & 14.65 & 3 & 1886.9560 & 1886.9530 & 629.9916 & 0.0030 & 1.5873 & 120.824\end{array}$

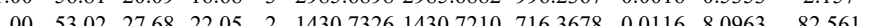
$\begin{array}{lllllllllll}100 & 57.87 & 27.91 & 20.42 & 2 & 1430.7348 & 1430.7210 & 716.3678 & 0.0138 & 9.6318 & 92.042\end{array}$ $\begin{array}{lllllllllllll}1.00 & 59.37 & 27.40 & 20.70 & 2 & 1430.7194 & 1430.7210 & 716.3678 & -0.0016 & -1.1167 & 217.129 & 49\end{array}$ $\begin{array}{llllllllllll}0.98 & 31.94 & 27.80 & 21.06 & 2 & 140.7200 & 1430.7210 & 716.3678 & -0.0010 & -0.6980 & 72.417 \\ 0.6438 .6433 & 625.8289 & 0.0005 & 0.3995 & 980.481\end{array}$ $\begin{array}{llllllllllll}1.00 & 39.00 & 27.80 & 19.88 & 2 & 1249.6440 & 1249.6433 & 625.8289 & 0.0007 & 0.5593 & 483.629\end{array}$ $\begin{array}{lllllllllllll}0.99 & 41.65 & 27.90 & 25.01 & 2 & 1249.6430 & 1249.6433 & 625.8289 & -0.0003 & -0.2397 & 478.397\end{array}$ $\begin{array}{lllllllllll}0.92 & 30.17 & 27.90 & 20.47 & 2 & 1249.6432 & 1249.6433 & 625.8289 & -0.0001 & -0.0799 & 847.170\end{array}$ $\begin{array}{lllllllllll}0.92 & 33.15 & 28.20 & 23.51 & 2 & 1249.6472 & 1249.6433 & 625.8289 & 0.0039 & 3.1159 & 5.18 \\ 1.00 & 75.09 & 24.55 & 24.14 & 2 & 1601.9444 & 1601.9449 & 801.9797 & -0.0005 & -0.3117 & 4.460\end{array}$ $\begin{array}{llllllllllll}1.00 & 63.98 & 24.44 & 20.71 & 2 & 1601.9466 & 1601.9449 & 801.9797 & 0.0017 & 1.0599 & 7.440\end{array}$ $\begin{array}{lllllllllll}1.00 & 74.88 & 24.20 & 21.91 & 2 & 1601.9464 & 1601.9449 & 801.9797 & 0.0015 & 0.9352 & 11.302\end{array}$ $\begin{array}{lllllllllll}1.00 & 71.96 & 24.44 & 20.37 & 2 & 1601.9468 & 1601.9449 & 801.9797 & 0.0019 & 1.1846 & 5.302\end{array}$ $\begin{array}{lllllllllll}1.00 & 11.90 & 24.55 & 24.44 & 2 & 1601.9442 & 1601.9449 & 801.9797 & -0.0007 & -0.4364 & 11.514\end{array}$ $\begin{array}{lllllllllll}1.00 & 76.13 & 24.42 & 19.81 & 2 & 1601.9470 & 1601.9449 & 801.9797 & 0.0021 & 1.3093 & 12.911\end{array}$ $\begin{array}{llllllllll}1.00 & 58.53 & 24.44 & 23.12 & 2 & 1601.9401601 .9478 & 80.9997 & 0.0021 & 1.3093 & 12.911\end{array}$ $\begin{array}{lllllllllllll}\text { DINMSGFNETDDLK } & 1.00 & 74.48 & 27.52 & 33.10 & 2 & 1998.9834 & 1998.9812 & 1000.4979 & 0.0022 & 1.0995 & 114.959\end{array}$

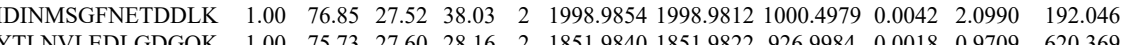
$\begin{array}{llllllllllll}\text { YTLNVLEDLGDGQK } & 1.00 & 80.70 & 27.60 & 28.16 & 2 & 1851.984 & 1851.9822 & 926.9984 & 0.0018 & 0.970 & 620.369\end{array}$ $\begin{array}{llllllllllllll}\text { YTLNVLEDLGDGQK } & 1.00 & 69.31 & 27.63 & 26.80 & 2 & 18519830 & 1851.9822 & 926.9984 & 0.0008 & 0.4315 & 129.580\end{array}$ $\begin{array}{lllllllllllll}\text { YTLNVLEDLGDGQK } & 1.00 & 73.19 & 27.63 & 29.28 & 2 & 1851.9850 & 1851.9822 & 926.9984 & 0.0028 & 1.5102 & 124.579 & 10\end{array}$ $\begin{array}{lllllllllllll}\text { YPALTKPENODIDWTLLEGETR } & 1.00 & 47.80 & 26.42 & 16.08 & 3 & 2876.4814 & 2876.4799 & 959.8339 & 0.0015 & 0.5209 & 946.611\end{array}$ $\begin{array}{lllllllllllll}\text { YPALTRPENDDDWTLLEGETR } & 0.67 & 42.86 & 26.43 & 55.86 & 3 & 2876.4826 & 2876.4799 & 959.8339 & 0.0027 & 0.9377 & 563.454\end{array}$ $\begin{array}{llllllllllll}\text { VYALPEDLVEVKPK } & 0.94 & 48.70 * 20.29 & 29.26 & 3 & 2031.2005 & 2031.1981 & 678.0733 & 0.0024 & 1.1798 & 1486.585 & 144\end{array}$ 
TISSSLAVVDLIDAIQPGCIN
DGETLEELMK

DGETLEELMK
LNLAFVANLFNK

LNLAFVANLFNK

LNLAFVANLFNK

LNLAFVANLFNK

LNLAFVANLFNK

LNLAFVANLFNK

LNLAFVANLFNK

MVMTVACLMR

MVMTVFACLMGR

MVMTVFACLMGR

MVMTVFACLMGR

MVMTVFACLMGR

MVMTVACLMGR

MVMTVFACLMGR

MVMTVFACLMGR

MVMTVFACLMGR

MVMTVFACLMGR

AESMLQQADK

AESMLQQADK

IDINMSGFNETDDLK

18 ASSTSPVEISEWLDQK
VVPEMTEILK

VLVAQHDVYK

DPEAPIFQVADYGIVADLFK

DPEAPIFQVADYGIVADLFK 098

DPEAPIFQVADYGIVADL
LEVAPISDIIAIK

LEVAPISDIIAIK

LEVAPISDIIAIK
LEVAPISDIIAIK

LEVAPISDIIAIK

VVVSGGR

VVVSGGR
GLLPEELTPLILATQK

GLLPEELTPLI

VVVSGGR

LLYDLADQLHAAVGAS

LLYDLADQLHAAVGAS

LLYDLADQLHAAVGASR
LLYDLADQLHAAVGASR

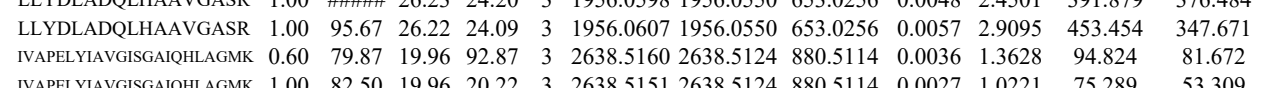

$\begin{array}{llllllllllllll}\text { IVAPELYIAVGISGAIQHLAGMK } & 1.00 & 82.50 & 19.96 & 20.22 & 3 & 2638.5151 & 2638.5124 & 880.5114 & 0.0027 & 1.0221 & 75.289 & 53.309\end{array}$

57 SWIEQEGVTVK

$\begin{array}{llllllllllllll} & 1562.8552 & 1562.8548 & 782.4347 & 0.0004 & 0.2556 & 276.614 & 269.421\end{array}$ $\begin{array}{lllllllllllll}\text { GIGTNEQAIIDVLTK } & 1.00 & \# \# \# \# 23.98 & 28.82 & 2 & 1859.0632 & 1859.0608 & 930.5377 & 0.0024 & 1.2896 & 1101.658 & 1221.033 & 111 \\ \text { GIGTNEQAIIDVLTK } & 1.00 & \# \# \# & 23.98 & 24.91 & 2 & 1859.0634 & 1859.0608 & 930.5377 & 0.0026 & 1.3970 & 1051.406 & 1010.602\end{array}$ GIGTNEQAIDVVLTK GIGTNEQAIIDVLTK GIGTNEQAIIDVLTK GIGTNEQAIIDVLTK

GIGTNEQAIIDVLTK

GIGTNEQAIIDVLTK

NALLSLVGSD

LIVALMYPPYR

LIVALMYPPYR

LIVALMYPPYR

LIVALMYPPYR

LIVALMYPPYR

LIVALMYPPYR

LIVALMYPPYR

FITILCTR

LIVALMYPPYR

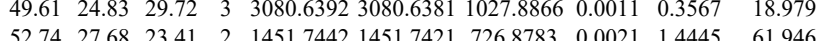

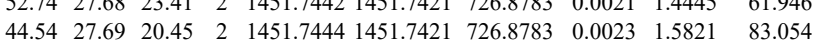
$\begin{array}{llllllllllll}1.00 & 64.73 & 22.60 & 39.23 & 2 & 1650.9714 & 1650.9701 & 826.4923 & 0.0013 & 0.7865 & 225.677 \\ 1.00 & 42.53 & 22.65 & 38.85 & 2 & 1650.9718 & 1650.9701 & 826.4923 & 0.0017 & 1.0284 & 484.108 & 3\end{array}$ $\begin{array}{lllllllllll}1.00 & 42.53 & 22.65 & 38.85 & 2 & 1650.9718 & 1650.9701 & 826.4923 & 0.0017 & 1.0284 & 484.108\end{array}$ $\begin{array}{lllllllllllll}0.67 & 42.68 & 22.65 & 55.68 & 3 & 1650.9733 & 1650.9701 & 551.3306 & 0.0032 & 1.9347 & 203.746\end{array}$ $\begin{array}{lllllllllllll}1.00 & 42.98 & 23.20 & 21.53 & 3 & 1650.9712 & 1650.9701 & 551.3306 & 0.0011 & 0.6651 & 169.614 \\ 1.00 & 60.80 & 23.20 & 26.53 & 2 & 1650.9712 & 1650.9701 & 826.4923 & 0.0011 & 0.6655 & 104.737\end{array}$ $\begin{array}{llllllllllll}61.70 & 23.20 & 28.27 & 2 & 1650.9712 & 1650.9701 & 826.4923 & 0.0011 & 0.6655 & 90.517\end{array}$ $\begin{array}{llllllllll}25.62 * 25.81 & 16.68 & 2 & 1563.7234 & 1563.7226 & 782.8686 & 0.0008 & 0.5109 & 14.012\end{array}$ $\begin{array}{lllllllllll} & 4.21 & 26.39 & 18.98 & 2 & 1547.7282 & 1547.7277 & 774.8711 & 0.0005 & 0.3226 & 34.999\end{array}$ $\begin{array}{lllllllllllll} & 0.82 & 52.72 & 26.27 & 65.72 & 2 & 1547.7286 & 1547.7277 & 774.8711 & 0.0009 & 0.5807 & 46.112\end{array}$ $\begin{array}{llllllllllll}1.00 & 66.58 & 26.24 & 19.89 & 2 & 1547.7284 & 1547.7277 & 774.8711 & 0.0007 & 0.4517 & 48.109\end{array}$ $\begin{array}{llllllllllll}1.00 & 60.95 & 26.27 & 18.58 & 2 & 1547.7286 & 1547.7277 & 774.8711 & 0.0009 & 0.5807 & 16.676\end{array}$ $\begin{array}{llllllllllll}1.00 & 45.82 & 26.28 & 17.62 & 2 & 1547.7274 & 1547.7277 & 774.8711 & -0.0003 & -0.1936 & 19.956\end{array}$ $\begin{array}{llllllllllll}1 & 64.03 & 26.38 & 20.14 & 2 & 1547.7306 & 1547.7277 & 774.8711 & 0.0029 & 1.8713 & 16.562\end{array}$ $\begin{array}{lllllllllll}1.00 & 55.49 & 26.24 & 18.73 & 2 & 1547.7312 & 1547.7277 & 774.8711 & 0.0035 & 2.2584 & 7.547 \\ 1.7277 & 774.8711 & 0.0007 & 0.4517 & 39.246\end{array}$ $\begin{array}{llllllllllll}1.00 & 71.79 & 26.33 & 17.67 & 2 & 1547.7314 & 1547.7277 & 774.8711 & 0.0037 & 2.3875 & 19.036\end{array}$ $\begin{array}{llllllllllll} & 42.64 & 27.75 & 28.76 & 2 & 1407.7310 & 1407.7271 & 704.8708 & 0.0039 & 2.7665 & 3869.228 & 2600.261\end{array}$ $\begin{array}{lllllllllllll}0 & 74.57 & 27.75 & 26.90 & 2 & 1407.7310 & 1407.7271 & 704.8708 & 0.0039 & 2.7665 & 1935.671 & 1904.637 \\ 1.00 & 72.95 & 27.67 & 28.21 & 2 & 1998.9814 & 1998.9812 & 1000.4979 & 0.0002 & 0.1000 & 98.711 & 68.891\end{array}$

$\begin{array}{llllllllll} & \end{array}$ $\begin{array}{lllllllllll}40.54 & 26.06 & 22.85 & 3 & 1458.8566 & 458.8438 & 487.2885 & 0.0128 & 8.7559 & 22235.865\end{array}$

14599.341

9.165 $\begin{array}{lllllllllllll}0.60 & 12.93 & 26.54 & 25.93 & 3 & 2495.3233 & 2495.3192 & 832.7803 & 0.0041 & 1.6411 & 0.000 & 24.043\end{array}$

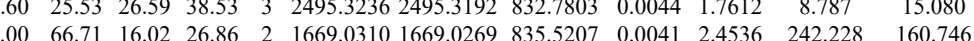
$\begin{array}{llllllllllll}1.00 & 66.71 & 16.02 & 26.86 & 2 & 1669.0310 & 1659.0269 & 835.5207 & 0.0041 & 2.4536 & 242.228 & 160.746\end{array}$

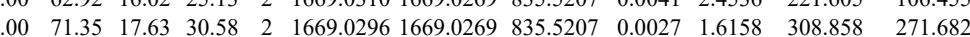

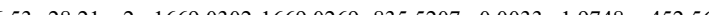
$\begin{array}{lllllllll}9.75 & 30.57 & 2 & 816.4938 & 816.4940 & 409.2543 & -0.0002 & -0.2443 & 123.099\end{array}$ $\begin{array}{llllllllllll}0.56 & 22.01 & 29.70 & 26.00 & 2 & 816.4944 & 816.4940 & 409.2543 & 0.0004 & 0.4887 & 39.437\end{array}$ $\begin{array}{llllllllllll}0.54 & 21.86 & 29.75 & 26.64 & 2 & 816.4938 & 816.4940 & 409.2543 & -0.0002 & -0.2443 & 49.807\end{array}$ $\begin{array}{llllllll} & 0.858\end{array}$ $\begin{array}{lllllllllll}1.00 & \# \# \# \text { 26.24 } & 24.07 & 3 & 1956.0574 & 1956.0550 & 653.0256 & 0.0024 & 1.2251 & 6771.375 & 660\end{array}$ $\begin{array}{lllllllllll} & 23.98 & 24.91 & 2 & 1859.0634 & 1859.0608 & 930.5377 & 0.0026 & 1.3970 & 1051.406 & 1010.602\end{array}$ $\begin{array}{lllllllllllll}1.00 & 37.42 & 23.87 & 15.91 & 3 & 1859.0638 & 1859.0608 & 620.6942 & 0.0030 & 1.6111 & 131.193 & 61.195 \\ 1.00 & 37.66 & 23.87 & 20.04 & 3 & 1859.0647 & 1859.0608 & 620.6942 & 0.0039 & 2.0944 & 84.751 & 105.774\end{array}$ $\begin{array}{lllllllllllll} & 94.12 & 24.03 & 22.43 & 2 & 1859.0624 & 1859.0608 & 930.5377 & 0.0016 & 0.8597 & 24.75 .408 & 2034.287\end{array}$ $\begin{array}{lllllllllllll}1.00 & 38.60 & 23.87 & 22.66 & 3 & 1859.0638 & 1859.0608 & 620.6942 & 0.0030 & 1.6111 & 87.650 & 105.352\end{array}$

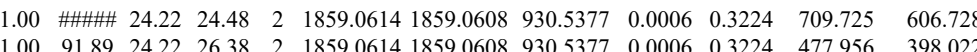
$\begin{array}{lllllllllllll}1.00 & 91.89 & 24.22 & 26.38 & 2 & 1859.0614 & 1859.0608 & 930.5377 & 0.0006 & 0.3224 & 477.956 & 398.022 \\ 0.53 & 17.94 & 27.64 & 21.19 & 2 & 1228.6810 & 1228.6785 & 615.3465 & 0.0025 & 2.0314 & 28.147 & 24.569\end{array}$ $\begin{array}{llllllllllll}0.53 & 17.94 & 27.64 & 21.19 & 2 & 1228.6810 & 1228.6785 & 615.3465 & 0.0025 & 2.0314 & 28.147 & 24.569 \\ 1.00 & 47.82 & 26.67 & 22.16 & 2 & 1478.8458 & 1478.8441 & 740.4293 & 0.0017 & 1.1480 & 113.902 & 115.354\end{array}$ $\begin{array}{lllllllllllll}1.00 & 47.82 & 26.67 & 22.16 & 2 & 1478.8458 & 1478.8441 & 740.4293 & 0.0017 & 1.1480 & 113.902 & 115.354 \\ 1.00 & 46.13 & 26.66 & 21.45 & 2 & 1478.8462 & 1478.8441 & 740.4293 & 0.0021 & 1.4181 & 92.089 & 93.499\end{array}$ $\begin{array}{rrrrrrrrrrrrr}1.00 & 46.13 & 26.66 & 21.45 & 2 & 1478.8462 & 1478.8441 & 740.4293 & 0.0021 & 1.4181 & 92.089 & 93.499 \\ 1.00 & 57.07 & 26.67 & 22.88 & 2 & 1478.8458 & 1478.8441 & 740.4293 & 0.0017 & 1.1480 & 142.009 & 112.244 \\ 1.00 & 49.42 & 26.67 & 22.35 & 2 & 1478.8466 & 1478.8441 & 740.4293 & 0.0025 & 1.6882 & 160.417 & 133.452\end{array}$ $\begin{array}{llllllllllll}1.00 & 57.07 & 26.67 & 22.88 & 2 & 1478.8458 & 1478.8441 & 740.4293 & 0.0017 & 1.1480 & 142.009 & 112.244 \\ 1.00 & 49.42 & 26.67 & 22.35 & 2 & 1478.8466 & 1478.8441 & 740.4293 & 0.0025 & 1.6882 & 160.417 & 133.452\end{array}$ $\begin{array}{llllllllllll}1.00 & 49.42 & 26.67 & 22.35 & 2 & 1478.8466 & 1478.8441 & 740.4293 & 0.0025 & 1.6882 & 160.417 & 133.452 \\ 0.57 & 10.19 & 26.65 & 14.58 & 3 & 1478.8468 & 1478.8441 & 493.9553 & 0.0027 & 1.8220 & 15.857 & 13.927\end{array}$

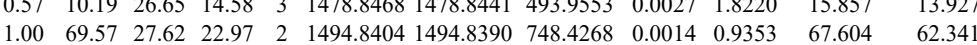

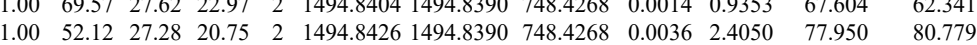
$\begin{array}{llllllllllll}0.99 & 37.57 & 27.72 & 22.22 & 2 & 1155.6274 & 1155.6266 & 578.8206 & 0.0008 & 0.6911 & 1151.692 & 1132.779\end{array}$ $\begin{array}{llllllllllll}1.00 & 40.02 & 27.70 & 22.58 & 2 & 1155.6278 & 1155.6266 & 578.8206 & 0.0012 & 1.0366 & 414.971 & 372.766\end{array}$ $\begin{array}{llllllllllll}1.00 & 60.27 & 26.65 & 23.42 & 2 & 1478.8460 & 1478.8441 & 740.4293 & 0.0019 & 1.2830 & 34.637 & 58.665\end{array}$ 181.860 43.149 59.800 75.720 25.266 43.796 18.657 13.277 38.259 -
0.259

50.673 $\begin{array}{lll}6.455 & 1631.657 & \text { Yes }\end{array}$ $\begin{array}{lll}9.946 & 190.437 & \text { Ye }\end{array}$ $\begin{array}{llll}1593.843 & 2021.292 & \text { No }\end{array}$ $\begin{array}{lll}112.160 & 87.499 & \text { No }\end{array}$ $\begin{array}{lll}689.525 & 876.773 & \text { No }\end{array}$ $\begin{array}{lll}343.195 & 500.595 & \text { Yes } \\ 30.867 & 33.843 & \text { No }\end{array}$ $\begin{array}{lll}30.867 & 33.843 & \text { No }\end{array}$ $\begin{array}{lll}17.761 & 166.011 & \text { Yes } \\ 19.213 & 12.653 & \text { Yes }\end{array}$ $10.814 \quad 124.653$ Yes $\begin{array}{lll}10.814 & 124.653 & \text { Yes } \\ 42.291 & 226.596 & \text { Yes }\end{array}$ $\begin{array}{lll}4.724 & 6.917 & \text { Yos }\end{array}$ $\begin{array}{lll}8.241 & 89.171 & \text { Yes }\end{array}$ $\begin{array}{llll}8.241 & 89.171 & \text { Yes } \\ 149.153 & 2425.736 & \text { Yes }\end{array}$ 917.434 Yes

No

Table S-4 page 175 of 614 
LIVALMYPPYR

ILVCLLQGSR

ILVCLLQGSR

FITILCTR

ILVCLLQGSR

FITILCTR

FITILCTR
ILVCLLQGS

ILVCLLQGSR

ILVCLLQGSR

ILVCLLQGSR

ILVCLLQGSR

TLSSMIMEDTSGDYK

DDVSFYDPGLALLDADDLYAAC
SETHGSLEEAMLTVYK

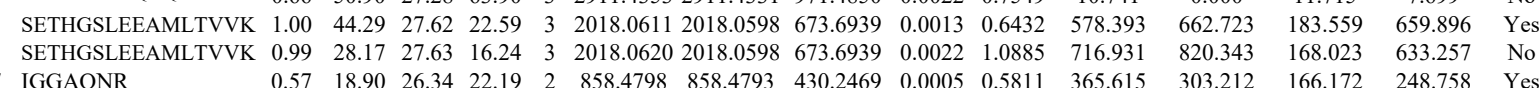
$\begin{array}{lllllllllllllll}0.99 & 36.90 & 27.72 & 21.76 & 2 & 1155.6280 & 1155.6266 & 578.8206 & 0.0014 & 1.2094 & 9462.695 & 9355.546 & 1543.147 & 17668.248 & \text { Yes }\end{array}$

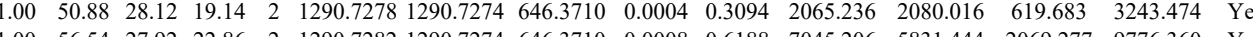

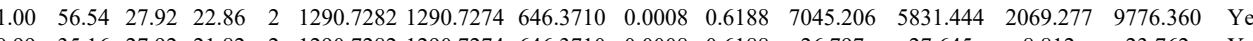

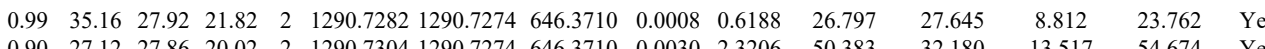

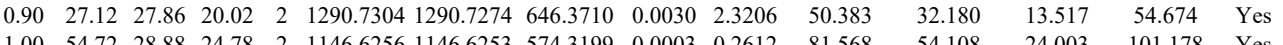
$\begin{array}{lllllllllllllll}1.00 & 54.72 & 28.88 & 24.78 & 2 & 1146.6256 & 1146.6253 & 574.3199 & 0.0003 & 0.2612 & 81.568 & 54.108 & 24.003 & 101.178 & \text { Yes } \\ 1.00 & 73.16 & 28.88 & 24.97 & 2 & 1146.6258 & 1146.6253 & 574.3199 & 0.0005 & 0.4353 & 45.298 & 63.967 & 38.560 & 74.073 & \text { Yes }\end{array}$

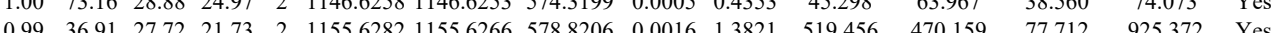

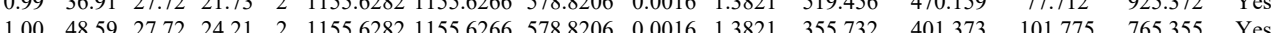

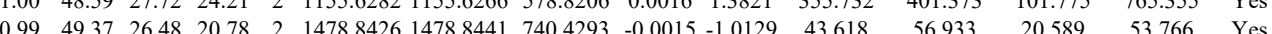

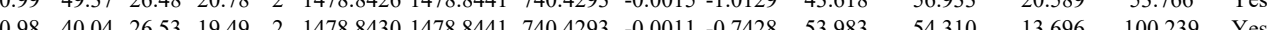

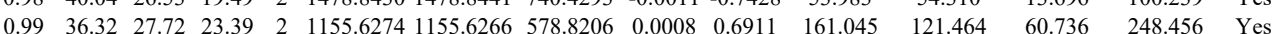

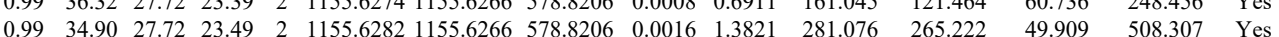

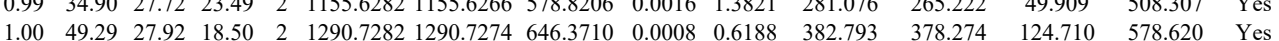

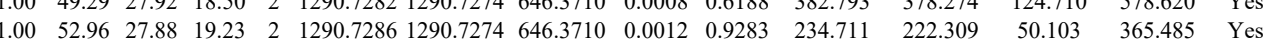
$\begin{array}{lllllllllllllll}1.00 & 44.80 & 26.79 & 20.29 & 2 & 1478.8448 & 1478.8441 & 740.4293 & 0.0007 & 0.4727 & 24.899 & 27.078 & 5.242 & 30.401 & \text { Yes }\end{array}$ $\begin{array}{lllllllllllllll}1.00 & 51.51 & 26.66 & 27.83 & 2 & 1478.8462 & 1478.8441 & 740.4293 & 0.0021 & 1.4181 & 26.163 & 25.746 & 2.491 & 28.531 & \text { Yes }\end{array}$

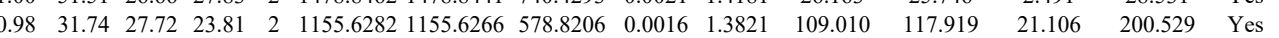
$\begin{array}{lllllllllllllll}1.00 & 54.43 & 27.92 & 20.22 & 2 & 1290.7282 & 1290.7274 & 646.3710 & 0.0008 & 0.6188 & 198.319 & 170.570 & 41.628 & 233.494 & \text { Yes }\end{array}$

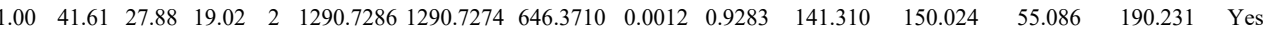

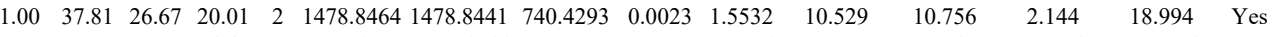

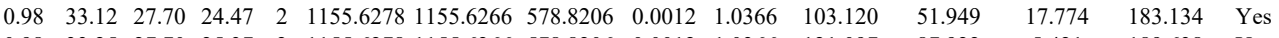
$\begin{array}{lllllllllllllll}0.98 & 33.25 & 27.70 & 25.37 & 2 & 1155.6278 & 1155.6266 & 578.8206 & 0.0012 & 1.0366 & 121.097 & 87.922 & 5.421 & 189.638 & \text { Yes }\end{array}$

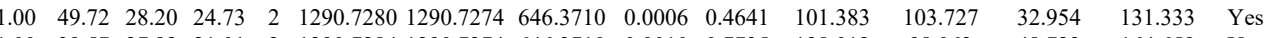
$\begin{array}{lllllllllllllll}1.00 & 39.57 & 27.92 & 21.01 & 2 & 1290.7284 & 1290.7274 & 646.3710 & 0.0010 & 0.7735 & 138.012 & 98.063 & 48.723 & 164.659 & \text { Yes }\end{array}$

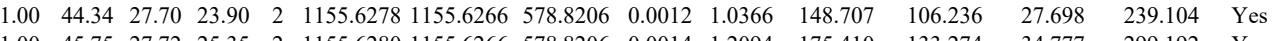

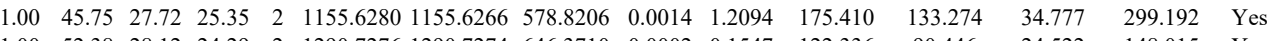
$\begin{array}{lllllllllllllll}1.00 & 52.38 & 28.12 & 24.29 & 2 & 1290.7276 & 1290.7274 & 646.3710 & 0.0002 & 0.1547 & 122.336 & 90.446 & 24.522 & 148.015 & \text { Yes }\end{array}$ $\begin{array}{lllllllllllllll}1.00 & 51.93 & 28.14 & 24.99 & 2 & 1290.7290 & 1290.7274 & 646.3710 & 0.0016 & 1.2377 & 155.420 & 127.791 & 70.461 & 229.316 & \text { Yes }\end{array}$ $\begin{array}{lllllllllllllll}0.99 & 37.75 & 27.70 & 23.70 & 2 & 1155.6278 & 1155.6266 & 578.8206 & 0.0012 & 1.0366 & 111.910 & 123.748 & 12.388 & 203.422 & \text { Yes } \\ 1.00 & 51.60 & 7.88 & 22.37 & 2 & 1290.7286 & 129.7274 & 4863710 & 0.0012 & 0.9283 & 119.109 & 137.144 & 38.484 & 191.307 & \text { Yes }\end{array}$

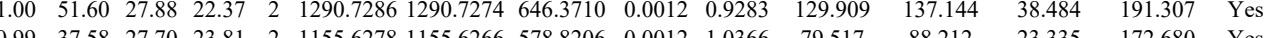
$\begin{array}{lllllllllllllll}0.99 & 37.58 & 27.70 & 23.81 & 2 & 1155.6278 & 1155.6266 & 578.8206 & 0.0012 & 1.0366 & 79.517 & 88.212 & 23.335 & 172.680 & \text { Yes } \\ 1.00 & 43.99 & 27.70 & 27.75 & 2 & 1155.6278 & 1155.6266 & 578.8206 & 0.0012 & 1.0366 & 90.293 & 70.046 & 19.854 & 129.751 & \text { Yes }\end{array}$ $\begin{array}{lllllllllllllll}1.00 & 43.99 & 27.70 & 27.75 & 2 & 1155.6278 & 1155.6266 & 578.8206 & 0.0012 & 1.0366 & 90.293 & 70.046 & 19.854 & 129.751 & \text { Yes } \\ 1.00 & 40.69 & 27.92 & 19.25 & 2 & 1290.7284 & 1290.7274 & 646.3710 & 0.0010 & 0.7735 & 122.966 & 138.157 & 42.262 & 140.560 & \text { Yes }\end{array}$ $\begin{array}{lllllllllllllll}1.00 & 40.69 & 27.92 & 19.25 & 2 & 1290.7284 & 1290.7274 & 646.3710 & 0.0010 & 0.7735 & 122.966 & 138.157 & 42.262 & 140.560 & \text { Yes } \\ 1.00 & 49.87 & 27.92 & 21.66 & 2 & 1290.7284 & 1290.7274 & 6463710 & 0.0010 & 0.7735 & 109.15 & 90.746 & 13.140 & 129.063 & Y e s\end{array}$

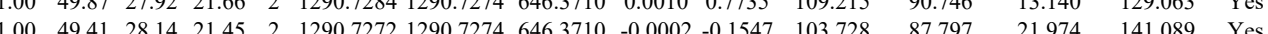

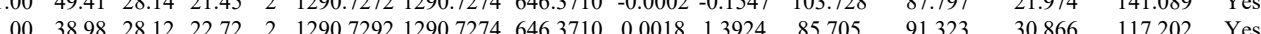

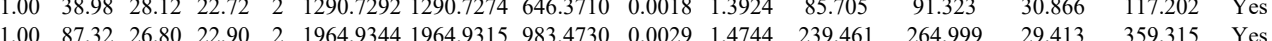

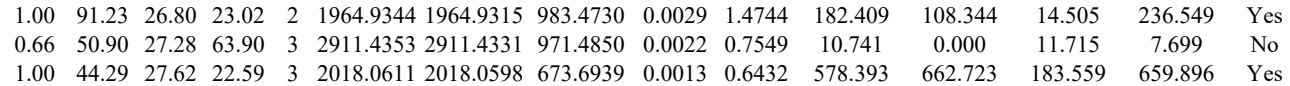

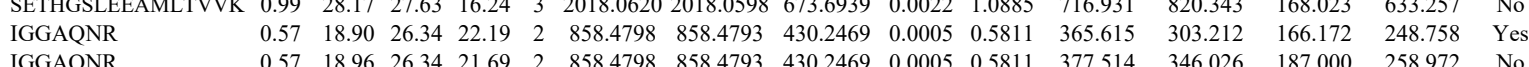
$\begin{array}{lllllllllllllllll} & \\ \text { GGAANR } & 0.57 & 18.96 & 26.34 & 21.69 & 2 & 858.4798 & 858.4793 & 430.2469 & 0.0005 & 0.5811 & 377.514 & 346.026 & 187.000 & 258.972 & \text { No } \\ \text { LLCGLLAER } & 0.92 & 26.60 & 28.43 & 30.65 & 2 & 1176.6488 & 1766.6480 & 589.3313 & 0.0008 & 0.6787 & 155.547 & 157.102 & 27.853 & 215.060 & \text { Yes }\end{array}$ LLCGLLAER LLCGLLAER LLCGLLAER LLCGLLAER

LLCGLLAER

LLCGLLAER

LLCGLLAER

LLCGLLAER

LLCGLLAER

LLCGLLAER

LLCGLLAER

LLCGLLAER

LLCGLLAER

LLCGLLAER

LLCGLLAER

LLCGLLAER

LLCGLLAER

LLCGLLAER

LLCGLLAER $\begin{array}{lllllllllllll}0.92 & 26.60 & 28.43 & 30.65 & 2 & 1176.6488 & 1176.6480 & 589.3313 & 0.0008 & 0.6787 & 155.547 & 157.102\end{array}$ $\begin{array}{lllllllllllll}0.93 & 26.83 & 28.43 & 23.20 & 2 & 1176.6488 & 1176.6480 & 589.3313 & 0.0008 & 0.6787 & 169.547 & 158.585 \\ 0.94 & 27.38 & 28.28 & 23.09 & 2 & 1176.6492 & 1176.6480 & 589.3313 & 0.0012 & 1.0181 & 182.562 & 119.495\end{array}$ $\begin{array}{llllllllllll}1.00 & 44.74 & 28.28 & 27.57 & 2 & 1176.6494 & 1176.6480 & 589.3313 & 0.0014 & 1.1878 & 47.732 & 14.354\end{array}$ $\begin{array}{llllllllllll}0.87 & 23.71 & 28.44 & 23.41 & 2 & 1176.6498 & 1176.6480 & 589.3313 & 0.0018 & 1.5272 & 263.385 & 23\end{array}$ 14.354 $\begin{array}{llllllllllll}0.97 & 30.54 & 28.33 & 23.07 & 2 & 1176.6502 & 1176.6480 & 589.3313 & 0.0022 & 1.8665 & 256.640 & 216.755\end{array}$ \begin{tabular}{llllllllllll} 
& \\
\hline
\end{tabular} $\begin{array}{lllllllllllllllll}0.99 & 36.94 & 28.33 & 33.08 & 2 & 1176.6504 & 1176.6480 & 589.3313 & 0.0024 & 2.0362 & 22770.532 & 18382.753 & 603.879 & 31634.134 & \text { Yes }\end{array}$ $\begin{array}{lllllllllllllllll}0.95 & 31.42 & 28.33 & 24.27 & 2 & 1176.6506 & 1176.6480 & 589.3313 & 0.0026 & 2.2059 & 166.656 & 121.513 & 37.783 & 227.078 & \text { Yes }\end{array}$ $\begin{array}{lllllllllllllll}0.98 & 36.19 & 28.44 & 32.88 & 2 & 1176.6478 & 1176.6480 & 589.3313 & -0.0002 & -0.1697 & 39320.491 & 32306.828 & 79.700 & 52617.962 & \text { Yes }\end{array}$

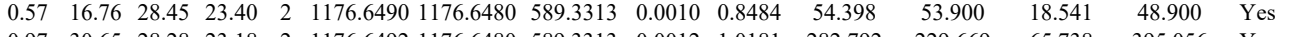

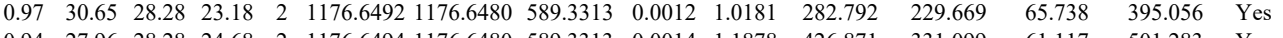
$\begin{array}{lllllllllllllll}0.94 & 27.96 & 28.28 & 24.68 & 2 & 1176.6494 & 1176.6480 & 589.3313 & 0.0014 & 1.1878 & 426.871 & 331.099 & 61.117 & 501.283 & \text { Yes }\end{array}$

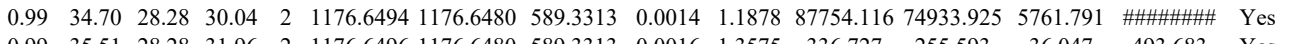
$\begin{array}{lllllllllllllll}0.99 & 35.51 & 28.28 & 31.96 & 2 & 1176.6496 & 1176.6480 & 589.3313 & 0.0016 & 1.3575 & 336.727 & 255.593 & 36.047 & 493.683 & \text { Yes } \\ 0.96 & 29.65 & 28.28 & 23.24 & 2 & 1176.6496 & 1176.6480 & 589.3313 & 0.0016 & 1.3575 & 285.928 & 227.862 & 41337 & 433.099 & \text { Yes }\end{array}$

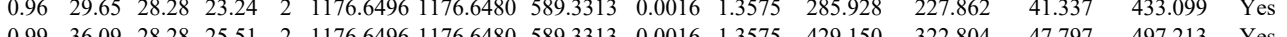

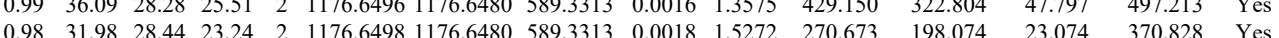

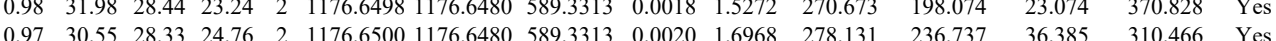

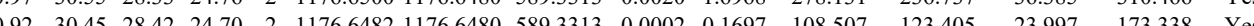
$\begin{array}{lllllllllllllll}0.92 & 30.45 & 28.42 & 24.70 & 2 & 1176.6482 & 1176.6480 & 589.3313 & 0.0002 & 0.1697 & 108.507 & 123.405 & 23.997 & 173.338 & \text { Yes } \\ 0.75 & 20.53 & 28.45 & 23.58 & 2 & 1176.6490 & 1176.6480 & 589.3313 & 0.0010 & 0.8484 & 139.701 & 152.586 & 33.708 & 170.503 & \text { Yes }\end{array}$

Table S-4 page 176 of 614 


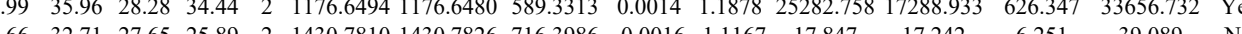

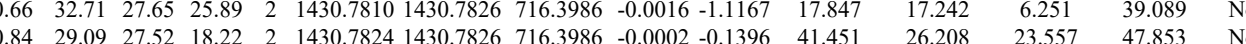
$\begin{array}{lllllllllllll} & 0.87 .853 & \text { No }\end{array}$

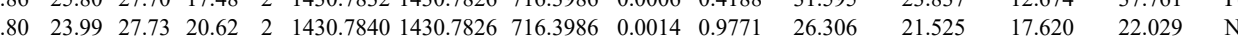

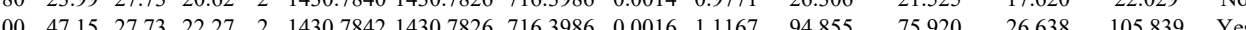
$\begin{array}{lllllllllllllll}0.99 & 41.10 & 27.73 & 18.13 & 2 & 1430.7842 & 1430.7826 & 716.3986 & 0.0016 & 1.1167 & 55.456 & 56.939 & 18.069 & 58.106 & \text { Yes }\end{array}$

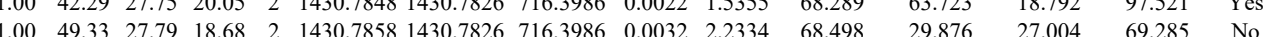
$\begin{array}{lllllllllllllll}1.00 & 39.11 & 28.28 & 32.90 & 2 & 1176.6496 & 1176.6480 & 589.3313 & 0.0016 & 13575 & 8209.499 & 6923.803 & 670.112 & 10353.812 & \text { Yes }\end{array}$

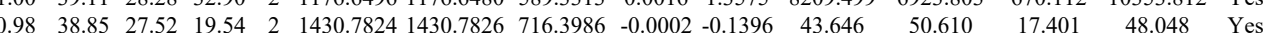
$\begin{array}{llllllllllllllll}1.00 & 55.18 & 27.47 & 27.13 & 2 & 1430.7826 & 1430.7826 & 7163986 & 0.0000 & 0.0000 & 39528.520 & 35025.458 & 8590.625 & 35787.807 & \text { Yes }\end{array}$ $\begin{array}{lllllllllllllllllll}1.00 & 54.86 & 27.47 & 24.55 & 2 & 1430.7828 & 1430.7826 & 716.3986 & 0.0002 & 0.1396 & 24658.547 & 23951.414 & 7170.826 & 29828.604 & \text { Yes }\end{array}$

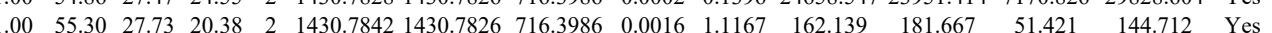
$\begin{array}{lllllllllllllll}1.00 & 55.30 & 27.73 & 20.38 & 2 & 140.7842 & 1430.7826 & 716.3986 & .0016 & 1.1167 & 162.139 & 181.667 & 51.421 & 144.712 & \text { Yes } \\ 1.00 & 56.11 & 27.73 & 21.01 & 2 & 1430.7842 & 1430.7826 & 716.3986 & 0.0016 & 1.1167 & 147.926 & 88.642 & 25.887 & 123.240 & \text { Yes }\end{array}$ $\begin{array}{llllllllllllllll}0.90 & 24.18 & 27.77 & 18.15 & 3 & 1430.7844 & 1430.7826 & 477.9348 & 0.0018 & 1.2554 & 329.794 & 270.137 & 228.050 & 275.312 & \text { No }\end{array}$ $\begin{array}{lllllllllllllll}1.00 & 51.81 & 27.77 & 22.08 & 2 & 1430.7844 & 1430.7826 & 716.3986 & 0.0018 & 1.2563 & 66.949 & 104.299 & 17.516 & 119.151 & \text { No }\end{array}$ $\begin{array}{lllllllllllllll}1.00 & 62.22 & 27.77 & 19.61 & 2 & 1430.7844 & 1430.7826 & 716.3986 & 0.0018 & 1.2563 & 121.545 & 66.936 & 30.451 & 75.237 & \mathrm{No}\end{array}$

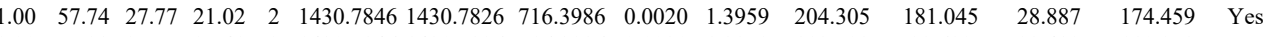
$\begin{array}{lllllllllllllll}1.00 & 57.23 & 27.77 & 27.41 & 2 & 1430.7846 & 1430.7826 & 716.3986 & 0.0020 & 1.3959 & 113.792 & 99.699 & 22.482 & 110.253 & \text { Yes }\end{array}$ $\begin{array}{lllllllllllllll}1.00 & 46.72 & 27.77 & 20.71 & 2 & 1430.7846 & 1430.7826 & 716.3986 & 0.0020 & 1.3959 & 68.497 & 48.829 & 24.289 & 49.293 & \text { Yes }\end{array}$

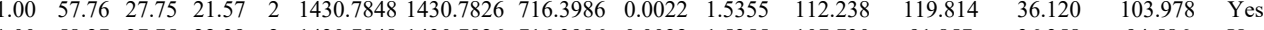

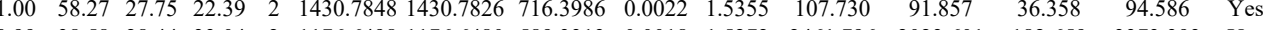
$\begin{array}{lllllllllllllll}0.99 & 38.58 & 28.44 & 33.04 & 2 & 1176.6498 & 1176.6480 & 589.3313 & 0.0018 & 1.5272 & 2461.796 & 2023.601 & 182.659 & 3373.393 & \text { Yes }\end{array}$

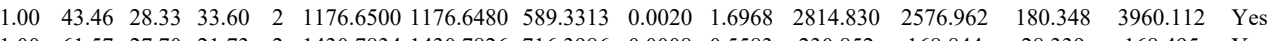
$\begin{array}{lllllllllllllll}1.00 & 61.57 & 27.70 & 21.73 & 2 & 1430.7834 & 1430.7826 & 716.3986 & 0.0008 & 0.5583 & 230.852 & 168.844 & 28.339 & 168.495 & \text { Yes }\end{array}$

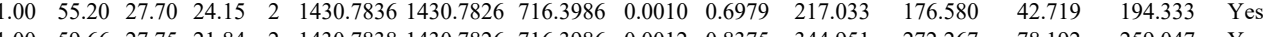

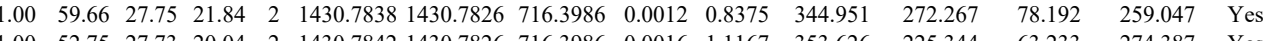
$\begin{array}{lllllllllllllll}1.00 & 52.75 & 27.73 & 20.04 & 2 & 1430.7842 & 1430.7826 & 716.3986 & 0.0016 & 1.1167 & 353.626 & 225.344 & 63.233 & 274.387 & \text { Yes }\end{array}$ $\begin{array}{lllllllllllllll}1.00 & 55.57 & 27.73 & 24.24 & 2 & 1430.7842 & 1430.7826 & 716.3986 & 0.0016 & 1.1167 & 226.115 & 173.690 & 62.892 & 149.372 & \text { Yes } \\ 1.00 & 58.46 & 27.73 & 24.74 & 2 & 1430.7842 & 1430.7826 & 716.3986 & 0.0016 & 1.1167 & 233.884 & 191.558 & 38.944 & 171.339 & \text { Yes }\end{array}$ $\begin{array}{lllllllllllllll}1.00 & 58.46 & 27.73 & 24.74 & 2 & 1430.7842 & 1430.7826 & 716.3986 & 0.0016 & 1.1167 & 233.884 & 191.558 & 38.944 & 171.339 & \text { Yes } \\ 1.00 & 51.47 & 27.73 & 23.36 & 2 & 1430.7842 & 1430.7826 & 716.3986 & 0.0016 & 1.1167 & 200.628 & 150.368 & 56.214 & 186.491 & \text { Yes }\end{array}$

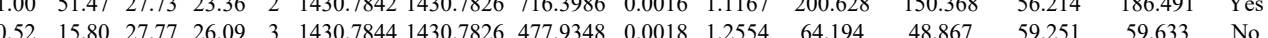

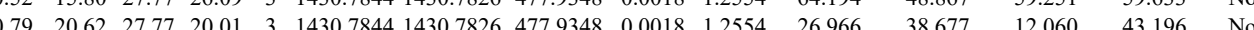

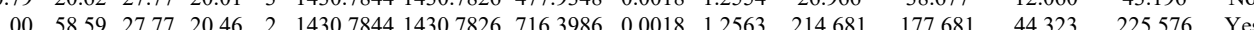

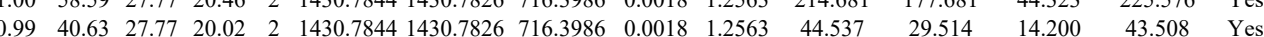

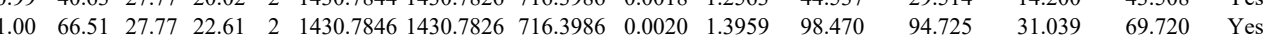

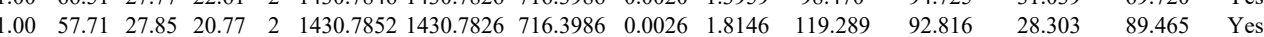

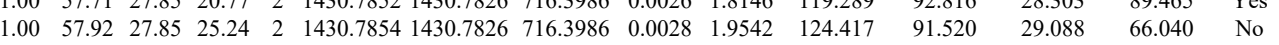

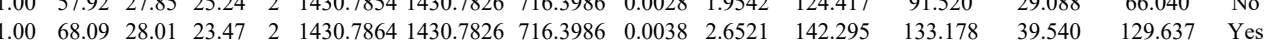

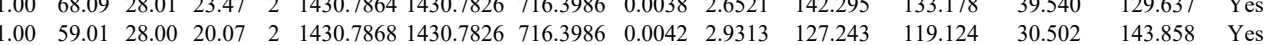

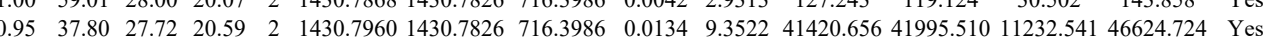

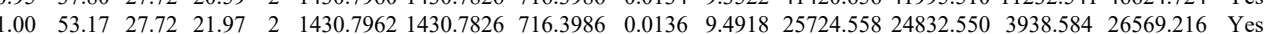
$\begin{array}{lllllllllllllll}0.99 & 48.19 & 28.85 & 23.01 & 2 & 1446.7872 & 1446.7775 & 724.3960 & 0.0097 & 6.6952 & 11208.824 & 10141.037 & 1100.203 & 9252.942 & \text { Yes }\end{array}$ $\begin{array}{lllllllllllllll}0.99 & 47.00 & 28.85 & 17.52 & 2 & 1446.7874 & 1446.7775 & 724.3960 & 0.0099 & 6.8332 & 689.636 & 681.005 & 117.758 & 542.419 & \text { Yes }\end{array}$ $\begin{array}{llllllllllllllll}1.00 & 52.39 & 28.84 & 17.97 & 2 & 1446.7878 & 1446.7775 & 724.3960 & 0.0103 & 7.1093 & 271.606 & 287.646 & 64.221 & 245.872 & \text { Yes }\end{array}$ $\begin{array}{llllllllllllllll}0.99 & 49.64 & 28.71 & 22.61 & 2 & 1446.7886 & 1446.7775 & 724.3960 & 0.0111 & 7.6615 & 11657.554 & 9546.244 & 2102.939 & 9610.190 & \text { Yes }\end{array}$ $\begin{array}{llllllllllllllll}0.99 & 36.34 & 28.33 & 33.04 & 2 & 1176.6502 & 1176.6480 & 589.3313 & 0.0022 & 1.8665 & 2518.589 & 1869.748 & 106.554 & 3369.910 & \text { Yes }\end{array}$

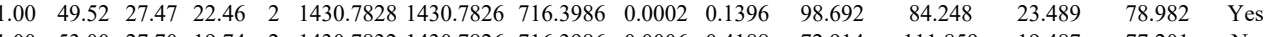

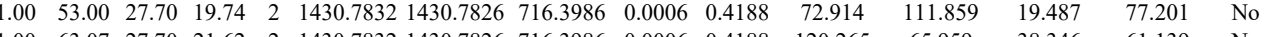

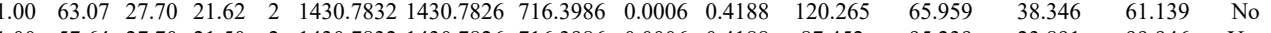

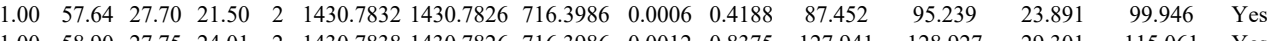
$\begin{array}{lllllllllllllll}1.00 & 58.90 & 27.75 & 24.01 & 2 & 1430.7838 & 1430.7826 & 716.3986 & 0.0012 & 0.8375 & 127.941 & 128.927 & 29.301 & 115.061 & \text { Yes }\end{array}$ $\begin{array}{lllllllllllllll}1.00 & 51.86 & 27.73 & 20.72 & 2 & 1430.7840 & 1430.7826 & 716.3986 & 0.0014 & 0.9771 & 134.116 & 134.350 & 19.880 & 122.405 & \text { Yes }\end{array}$

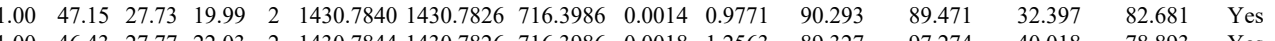
$\begin{array}{llllllllllllllll}1.00 & 46.43 & 27.77 & 22.03 & 2 & 1430.7844 & 1430.7826 & 716.3986 & 0.0018 & 1.2563 & 89.327 & 97.274 & 40.018 & 78.893 & \text { Yes } \\ 1.00 & 52.76 & 27.78 & 23.04 & 2 & 1430.7850 & 1430.7826 & 716.3986 & 0.0024 & 1.6750 & 11.657 & 67.653 & 32.079 & 7.69 & \text { Yes }\end{array}$ $\begin{array}{lllllllllllllll}1.00 & 52.76 & 27.78 & 23.04 & 2 & 1430.7850 & 1430.7826 & 716.3986 & 0.0024 & 1.6750 & 111.657 & 67.653 & 32.079 & 71.697 & \text { Yes } \\ 0.99 & 37.79 & 27.78 & 20.35 & 2 & 1430.7850 & 1430.7826 & 716.3986 & 0.0024 & 1.6750 & 77.976 & 58.352 & 18.982 & 34.511 & \text { No }\end{array}$ $\begin{array}{lllllllllllllll}0.99 & 37.79 & 27.78 & 20.35 & 2 & 1430.7850 & 1430.7826 & 716.3986 & 0.0024 & 1.6750 & 77.976 & 58.352 & 18.982 & 34.511 & \text { No } \\ 1.00 & 52.55 & 27.85 & 24.12 & 2 & 1430.7852 & 1430.7826 & 7163986 & 0.0026 & 1.8146 & 70.122 & 44.618 & 21.508 & 43.510 & Y\end{array}$

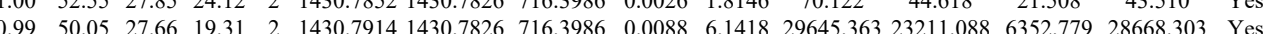

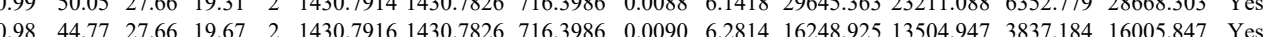

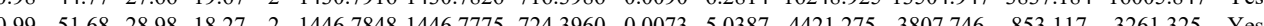
$\begin{array}{lllllllllllllll}0.99 & 46.47 & 28.80 & 18.76 & 2 & 1446.7864 & 1446.7775 & 724.3960 & 0.0089 & 6.1430 & 3658.837 & 3185.136 & 705.904 & 3355.257 & \text { Yes }\end{array}$

Table S-4 page 177 of 614 


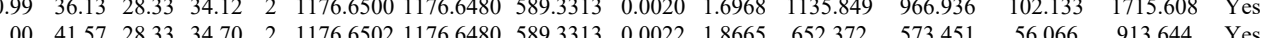

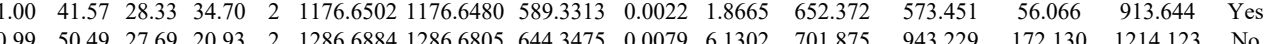

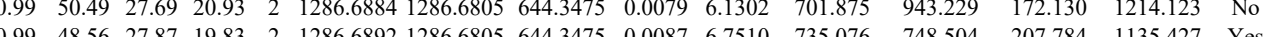

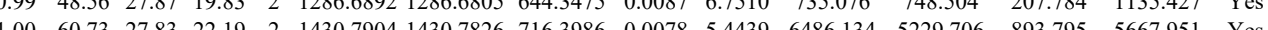

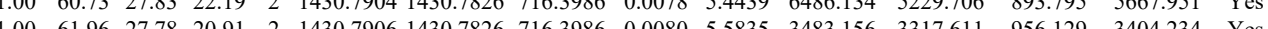

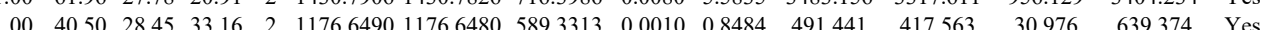

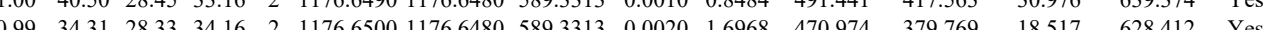
$\begin{array}{lllllllllllllll}100 & 60.21 & 27.47 & 24.25 & 2 & 1430.7828 & 1430.7826 & 7163986 & 0.0002 & 0.1396 & 2151.230 & 1817.852 & 574.811 & 1936630 & \text { Yes }\end{array}$

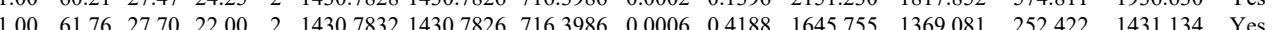

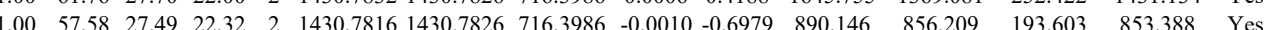

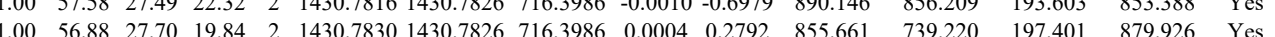

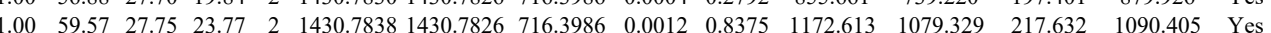

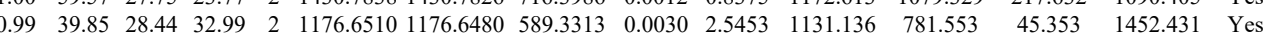

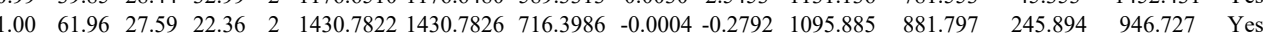
$\begin{array}{lllllllllllllll}1.00 & 61.98 & 27.70 & 23.57 & 2 & 1430.7832 & 1430.7826 & 716.3986 & 0.0006 & 0.4188 & 1078.647 & 864.780 & 240.737 & 880.845 & \text { Yes }\end{array}$ $\begin{array}{llllllllllllllll}0.99 & 39.15 & 28.84 & 16.21 & 2 & 1446.7792 & 1446.7775 & 724.3960 & 0.0017 & 1.1734 & 153.294 & 148.483 & 44.631 & 117.353 & \text { Yes } \\ \end{array}$ $\begin{array}{lllllllllllllll}1.00 & 58.53 & 27.70 & 21.96 & 2 & 1430.7834 & 1430.7826 & 716.3986 & 0.0008 & 0.5583 & 395.855 & 269.521 & 61.812 & 290.862 & \text { Yes }\end{array}$ $\begin{array}{lllllllllllllll}1.00 & 64.60 & 27.75 & 21.47 & 2 & 1430.7838 & 1430.7826 & 716.3986 & 0.0012 & 0.8375 & 257.968 & 243.933 & 47.044 & 247.333 & \text { Yes }\end{array}$

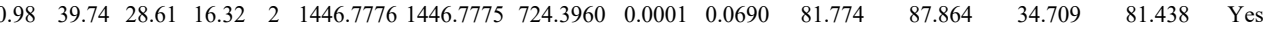

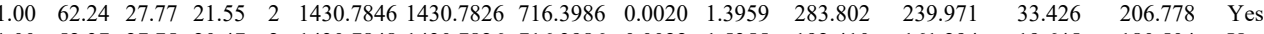

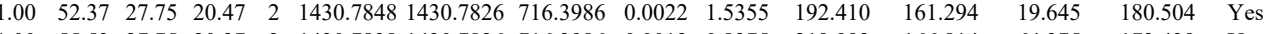

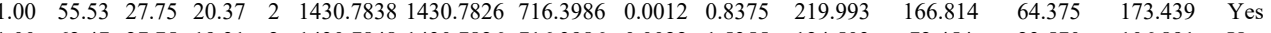

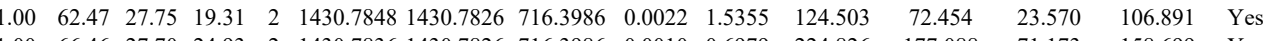
$\begin{array}{lllllllllllllll}1.00 & 66.46 & 27.70 & 24.93 & 2 & 1430.7836 & 1430.7826 & 716.3986 & 0.0010 & 0.6979 & 224.826 & 177.088 & 71.173 & 158.699 & \text { Yes }\end{array}$

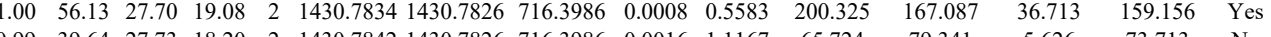
$\begin{array}{llllllllllllllll}0.99 & 39.64 & 27.73 & 18.20 & 2 & 1430.7842 & 1430.7826 & 716.3986 & 0.0016 & 1.1167 & 65.724 & 79.341 & 5.626 & 73.713 & \text { No }\end{array}$

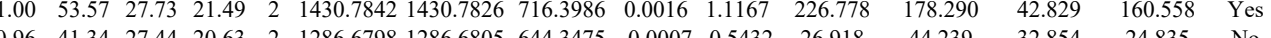
$\begin{array}{lllllllllllllll}0.96 & 41.34 & 27.44 & 20.63 & 2 & 1286.6798 & 1286.6805 & 644.3475 & -0.0007 & -0.5432 & 26.918 & 44.239 & 32.854 & 24.835 & \text { No } \\ 0.98 & 34.84 & 27.73 & 20.73 & 2 & 1430.7842 & 1430.7826 & 7163986 & 0.0016 & 1.1167 & 83.519 & 92.611 & 20.447 & 58.566 & \text { No }\end{array}$

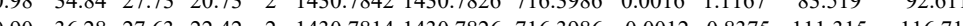

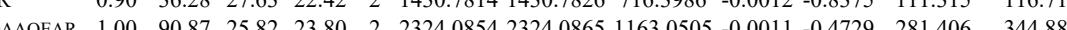

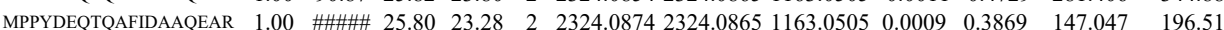
\begin{tabular}{llllllllllllll}
\hline MPYDEOTOAFIDAPOARR & 1.00 & 55.60 & 25.77 & 26.47 & 3 & 23240881 & 23240865 & 775.7028 & 0.0016 & 0.6875 & 512.421 & 537.417
\end{tabular} $\begin{array}{llllllllllllll}\text { MPPYDEOTQAFIDASOEAR } & 0.67 & 20.84 & 25.80 & 33.84 & 3 & 2324.0893 & 2324.0865 & 775.7028 & 0.0028 & 1.2032 & 87.026 & 105.528\end{array}$ $\begin{array}{lllllllllllll}\text { LWEEQLAAAK } & 1.00 & 51.72 & 27.51 & 30.00 & 2 & 1445.8202 & 1445.8122 & 723.9134 & 0.0080 & 5.5255 & 548.403 & 932.716\end{array}$

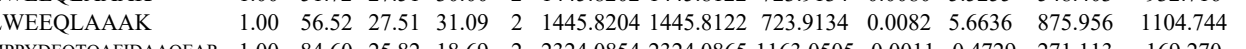

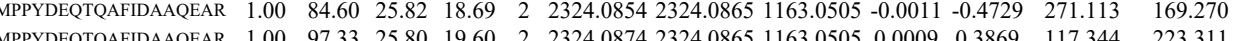

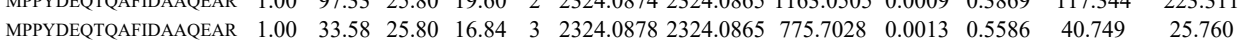

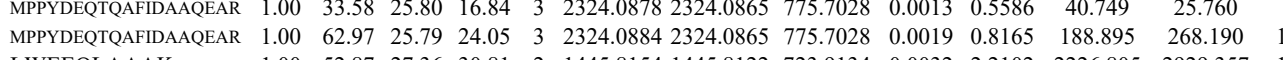

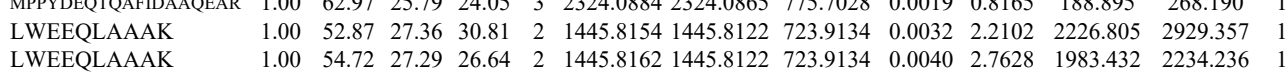
$\begin{array}{llllllllllll}1.00 & 52.87 & 27.36 & 30.81 & 2 & 1445.8154 & 1445.8122 & 723.9134 & 0.0032 & 2.2102 & 2226.805 & 2929.357 \\ 1.00 & 54.72 & 27.29 & 26.64 & 2 & 1445.8162 & 1445.8122 & 723.9134 & 0.0040 & 2.7628 & 1983.432 & 2234.236\end{array}$ $\begin{array}{lllllllllllll}\text { MMPYDEOTQAFIDAAQEAR } & 1.00 & \text { \#\#\#\# } 25.80 & 21.58 & 2 & 2324.0874 & 2324.0865 & 1163.0505 & 0.0009 & 0.3869 & 41.529 & 78.856\end{array}$ $\begin{array}{lllllllllllllll}\text { MPPYDEQTQAFIDAAQEAR } & 0.97 & 22.35 & 25.79 & 15.73 & 3 & 2324.0884 & 2324.0865 & 775.7028 & 0.0019 & 0.8165 & 18.671 & 24.878\end{array}$ $\begin{array}{llllllllllllll}\text { MPPYDEQTQAFIDAAOFAR } & 0.78 & 13.47 & 25.76 & 16.90 & 3 & 2324.0890 & 2324.0865 & 775.7028 & 0.0025 & 1.0743 & 35.398 & 37.291\end{array}$ $\begin{array}{lllllllllllll}\text { ILIEDWK } & 0.86 & 30.86 & 27.02 & 24.91 & 2 & 1203.7096 & 1203.7107 & 602.8626 & -0.0011 & -0.9123 & 570.636 & 552.153 \\ \text { ILIEDWK } & 0.99 & 38.51 & 27.23 & 28.49 & 2 & 1203.7106 & 1203.7107 & 602.8626 & -0.0001 & -0.0829 & 2371.480 & 3250.988\end{array}$

LIEDWK $\begin{array}{llllllllllll}0.99 & 41.36 & 27.29 & 29.76 & 2 & 1203.7104 & 1203.7107 & 602.8626 & -0.0003 & -0.2488 & 6882.487 & 8909.48\end{array}$

ILIEDWK $\begin{array}{llllllllllll}1.00 & 38.23 & 27.26 & 28.23 & 2 & 1203.7112 & 1203.7107 & 602.8626 & 0.0005 & 0.4147 & 7876.641 & 10930.910\end{array}$ $\begin{array}{lllllllllllll}\text { LGGSPTSLGTWGSWIGPDHDK } & 1.00 & 77.46 & 27.40 & 19.00 & 3 & 2455.2436 & 2455.2376 & 819.4198 & 0.0060 & 2.4407 & 125.356 & 316.517\end{array}$ $\begin{array}{llllllllllllll}\text { LGGSPTSLGTWGSWIGPDHDK } & 1.00 & 53.38 & 27.51 & 22.98 & 3 & 2455.2454 & 2455.2376 & 819.4198 & 0.0078 & 3.1730 & 232.368 & 950.513 & 152.1 \\ \text { LGGSPTSLGTWGSWIGPDHDK } & 1.00 & 70.79 & 27.15 & 23.67 & 3 & 2455.2502 & 2455.2376 & 819.4198 & 0.0126 & 5.1256 & 287.107 & 337.147 & 2.25\end{array}$ $\begin{array}{llllllllllllll}\text { LGGSPTSLGTWGSWIGPDHDK } & 1.00 & 70.79 & 27.15 & 23.67 & 3 & 2455.2502 & 2455.2376 & 819.4198 & 0.0126 & 5.1256 & 287.107 & 337.147\end{array}$ $\begin{array}{lllllllllllll}\text { LGGSPTSLGTWGSWIGPDHDK } & 1.00 & 74.06 & 27.18 & 21.49 & 3 & 2455.2508 & 2455.2376 & 819.4198 & 0.0132 & 5.3696 & 198.009 & 294.161\end{array}$ CPFK $\begin{array}{lllllllllllll}0.63 & 25.49 & 26.60 & 27.48 & 2 & 940.5196 & 940.5118 & 471.2632 & 0.0078 & 8.2756 & 32937.924 & 35027.930\end{array}$ AQQEQELAADAFK $\begin{array}{llllllllllll}1.00 & 77.51 & 28.26 & 24.08 & 2 & 1735.8998 & 1735.8984 & 868.9565 & 0.0014 & 0.8056 & 1336.219 & 1683.584\end{array}$ AQQEQELAADAFK $\begin{array}{llllllllllll}1.00 & 79.07 & 28.17 & 31.44 & 2 & 1735.8996 & 1735.8984 & 868.9565 & 0.0012 & 0.6905 & 1718.452 & 1633.624\end{array}$ $\begin{array}{lllllllllllll}1.00 & 79.07 & 28.17 & 31.44 & 2 & 1735.8996 & 1735.8984 & 868.9565 & 0.0012 & 0.6905 & 1718.452 & 1633.624 \\ 1.00 & 69.71 & 27.92 & 28.93 & 2 & 1362.6952 & 1362.6935 & 682.3540 & 0.0017 & 1.2457 & 18640.710 & 27190.468\end{array}$ 
$\begin{array}{lllllllllll} & \end{array}$

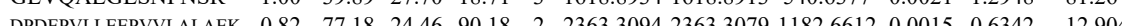
$\begin{array}{llllllllllll}\text { DPDEPVLLEEPVVLALAEK } & 0.72 & 64.51 & 24.46 & 77.51 & 2 & 2363.3114 & 2363.3079 & 1182.6612 & 0.0035 & 1.4797 & 50.011\end{array}$ $\begin{array}{llllllllllllll}\text { DPDEPVLLEEPVVLALAEK } & 1.00 & 48.53 & 24.35 & 19.36 & 3 & 2363.3122 & 2363.3079 & 788.7766 & 0.0043 & 1.8172 & 38.373\end{array}$ $\begin{array}{llllllllllll} & \end{array}$

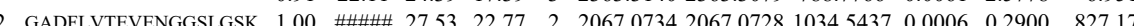

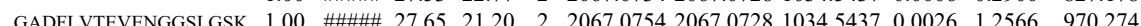

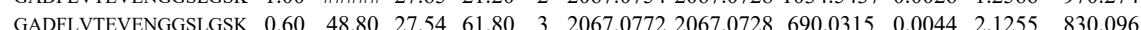
$\begin{array}{lllllllllllll}\text { GADFLVTEVENGGSLGSK } & 1.00 & 34.99 & 27.55 & 16.08 & 3 & 2067.0775 & 2067.0728 & 690.0315 & 0.0047 & 2.2704 & 199.909\end{array}$

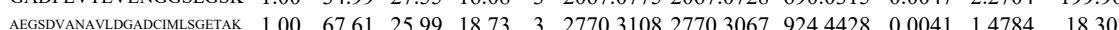
$\begin{array}{llllllllllll}\text { AEGSDVANAVIDGADCIMLSGETAK } & 0.99 & 14.82 & 25.98 & 15.82 & 4 & 2770.3109 & 2770.3067 & 693.5840 & 0.0042 & 1.5139 & 50.404\end{array}$ $\begin{array}{lllllllllllll}\text { AEGSDVANAVIDGADCIMLSGETAK } & 1.00 & 43.92 & 25.98 & 16.86 & 3 & 2786.3050 & 2786.3016 & 929.7745 & 0.0034 & 1.2189 & 53.215\end{array}$

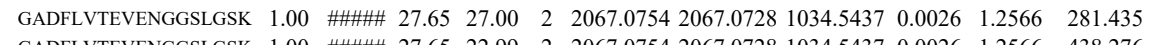
$\begin{array}{llllllllllll}\text { GADFLVTEVENGGSLGSK } & 1.00 & \text { \#\#\# } 27.65 & 22.99 & 2 & 2067.0754 & 2067.0728 & 1034.5437 & 0.0026 & 1.2566 & 438.276\end{array}$ $\begin{array}{llllllllllll}\text { GADFLVTEVENGGSLGSK } & 1.00 & 46.59 & 27.54 & 18.77 & 3 & 2067.0772 & 2067.0728 & 690.0315 & 0.0044 & 2.1255 & 830.033\end{array}$ $\begin{array}{lllllllllllll}\text { GADFLVTEVENGGSLGSK } & 1.00 & 55.98 & 27.55 & 22.92 & 3 & 2067.0775 & 2067.0728 & 690.0315 & 0.0047 & 2.2704 & 588.066 & \\ \end{array}$

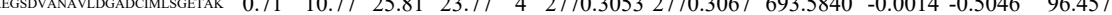
$\begin{array}{lllllllllllll} & \end{array}$ $\begin{array}{lllllllllllll} & \end{array}$ $\begin{array}{llllllllllll} & 1.00 & 22.67 & 25.93 & 14.65 & 4 & 2770.3085 & 2770.3067 & 693.5840 & 0.0018 & 0.6488 & 84.718\end{array}$

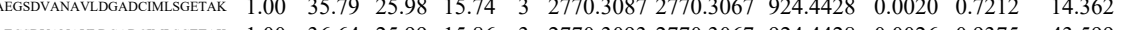
$\begin{array}{lllllllllllll} & 1.00 & 36.64 & 25.99 & 15.86 & 3 & 2770.3093 & 2770.3067 & 924.4428 & 0.0026 & 0.9375 & 43.599\end{array}$ $\begin{array}{llllllllllll}\text { EGgDVANAVIDGADCIMLSGETAK } & 0.51 & 4.33 & 25.99 & 13.42 & 4 & 2770.3093 & 2770.3067 & 693.5840 & 0.0026 & 0.9372 & 94.412\end{array}$ $\begin{array}{lllllllllll} & \end{array}$

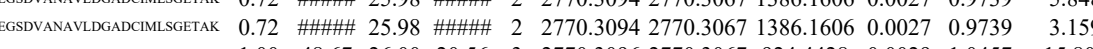

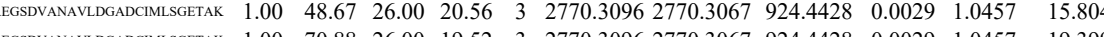
$\begin{array}{lllllllllllll}1.00 & 48.67 & 26.00 & 20.56 & 3 & 2770.3096 & 2770.3067 & 924.4428 & 0.029 & 1.0457 & 15.804\end{array}$

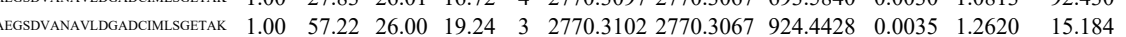

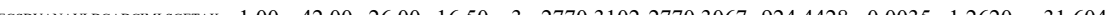

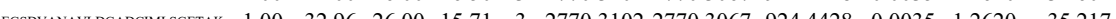

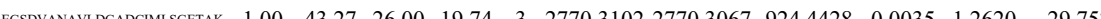
$\begin{array}{llllllllllll} & \text { EGSDVANAVDG }\end{array}$ $\begin{array}{llllllllllllll}\text { EEGSDVANAVDGADCIMISGETAK } & 1.00 & 49.66 & 26.00 & 16.24 & 3 & 2770.3102 & 2770.3067 & 924.4428 & 0.0035 & 1.2620 & 28.951\end{array}$ $\begin{array}{lllllllllllllll}\text { AEGSDVANAVLDGACIMISGETAK } & 1.00 & 80.40 & 26.00 & 19.49 & 3 & 2770.3102 & 2770.3067 & 924.4428 & 0.0035 & 1.2620 & 48.9614\end{array}$ $\begin{array}{lllllllllllll}\text { EEGSDANAVDGDCIMUGETAK } & 1.00 & 62.54 & 25.99 & 19.03 & 3 & 2770.3108 & 2770.3067 & 924.4428 & 0.0041 & 1.4784 & 14.019\end{array}$ $\begin{array}{lllllllllllll} & \text { EESDVANAVLGGDCIMLGETAK } & 0.60 & 66.15 & 25.99 & 79.15 & 3 & 2770.3108 & 2770.3067 & 924.4428 & 0.0041 & 1.4784 & 8.192\end{array}$ $\begin{array}{lllllllllllll}\text { AEGSDVANAVIDGADCIMLSGETAK } & 1.00 & 23.29 & 25.98 & 36.29 & 4 & 2770.3109 & 2770.3067 & 693.5840 & 0.0042 & 1.5139 & 72.723\end{array}$ $\begin{array}{lllllllllllll} & \text { AEGSDVANAVLDGADCILSGEETAK } & 0.97 & 12.93 & 26.02 & 25.93 & 4 & 2770.3113 & 2770.3067 & 693.5840 & 0.0046 & 1.6581 & 78.942\end{array}$ $\begin{array}{llllllllllll}\text { AEGSDVANAVLDGADCIMLSGETAK } & 1.00 & 94.57 & 26.01 & 19.15 & 2 & 2770.3114 & 2770.3067 & 1386.1606 & 0.0047 & 1.6953 & 8.452\end{array}$

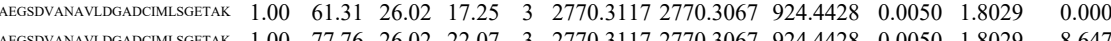
$\begin{array}{lllllllllllll}\text { AEGSDVANAVLDGADCIMLSGETAK } & 1.00 & 77.76 & 26.02 & 22.07 & 3 & 2770.3117 & 2770.3067 & 924.4428 & 0.0050 & 1.8029 & 8.647\end{array}$

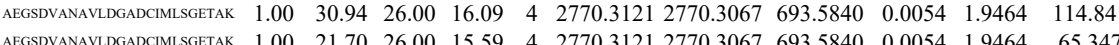

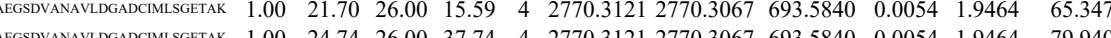
$\begin{array}{lllllllllllll} & \text { AGSDVANAVLDGADCIMLSGETAK } & 1.00 & 24.74 & 26.00 & 37.74 & 4 & 2770.3121 & 2770.3067 & 693.5840 & 0.0054 & 1.9464 & 79.940\end{array}$

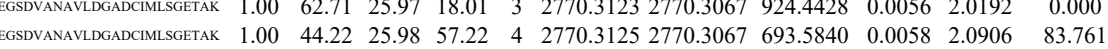
$\begin{array}{llllllllllllll}\text { AEGSDVANAVLDGADCMLLGGETAK } & 1.00 & 36.62 & 25.98 & 17.19 & 4 & 2770.3125 & 2770.3067 & 693.5840 & 0.0058 & 2.0906 & 81.490\end{array}$

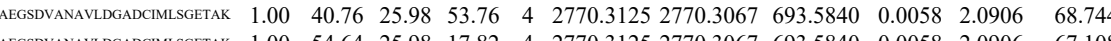
$\begin{array}{llllllllllll}\text { AEGSDVANAVLDGADCIMLSGETTKK } & 1.00 & 54.64 & 25.98 & 17.82 & 4 & 2770.3125 & 2770.3067 & 693.5840 & 0.0058 & 2.0906 & 67.108\end{array}$

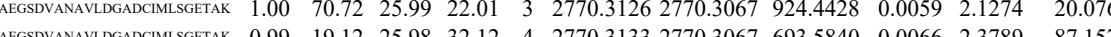

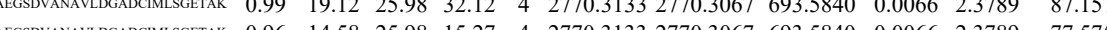
$\begin{array}{llllllllllll}\text { AEGSDVANAVDGADCMLSGGEAKK } & 0.96 & 14.58 & 25.98 & 15.27 & 4 & 2770.3133 & 2770.3067 & 693.5840 & 0.0066 & 2.3789 & 77.575 \\ \text { AEGSDVANAVLGGADCIMLSGETAK } & 0.98 & 15.76 & 25.98 & 16.00 & 4 & 2770.3133 & 2770.3067 & 693.5840 & 0.0066 & 2.3789 & 64.640\end{array}$

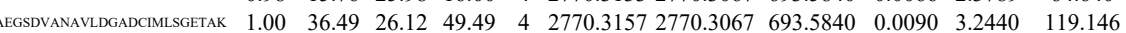
$\begin{array}{lllllllllllll} & 1.00 & 72.16 & 26.18 & 24.73 & 3 & 2770.3186 & 2770.3067 & 924.4428 & 0.0119 & 42909 & 141.043\end{array}$ 


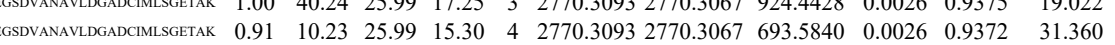

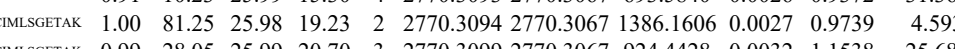
$\begin{array}{llllllllllll}\text { AEGSDVANAVLDGADCIMLSGETAK } & 0.99 & 28.05 & 25.99 & 20.70 & 3 & 2770.3099 & 2770.3067 & 924.4428 & 0.0032 & 1.1538 & 25.681 \\ \text { AEGSDVANAVLDGADCIMLLGGTAK } & 1.00 & 51.47 & 26.00 & 16.47 & 3 & 2770.3102 & 2770.3067 & 924.4428 & 0.0035 & 1.2620 & 33.201\end{array}$

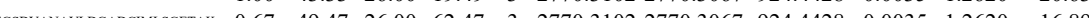

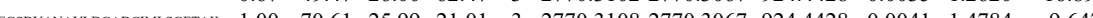
$\begin{array}{llllllllll} & 0.640\end{array}$

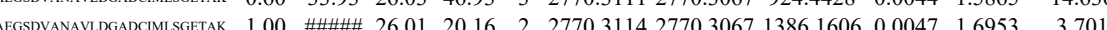

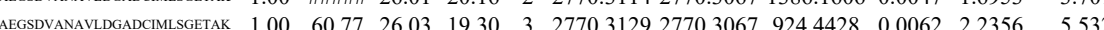
$\begin{array}{lllllllllllll} & \text { EGSDVANAVDGADCMUSGETAK } & 0.98 & 32.07 & 26.01 & 19.40 & 3 & 2770.3141 & 2770.3067 & 924.4428 & 0.0074 & 2.6683 & 13.077\end{array}$ $\begin{array}{lllllllllllll} & \text { EEGSVANAVDGADCIMSGETAK } & 1.00 & 62.64 & 26.01 & 21.18 & 3 & 2770.3141 & 2770.3067 & 924.4428 & 0.0074 & 2.6683 & 62.993\end{array}$ $\begin{array}{llllllllllll}\text { EGSDVANAVLDGADCIMLSGETAK } & 1.00 & 29.61 & 26.01 & 16.47 & 4 & 2770.3141 & 2770.3067 & 693.5840 & 0.0074 & 2.6673 & 72.060\end{array}$ $\begin{array}{llllllllllll} & 28.06 & 26.05 & 17.60 & 3 & 27703147 & 2770.3067 & 924.4428 & 0.0080 & 2.8846 & 21.939\end{array}$ AEGSDVANAVLD $\begin{array}{llllllllllll}0.98 & 33.66 & 25.50 & 35.50 & 2 & 911.5064 & 911.5059 & 456.7602 & 0.0005 & 0.5473 & 49.824\end{array}$ 


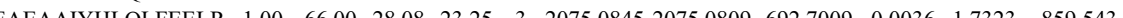

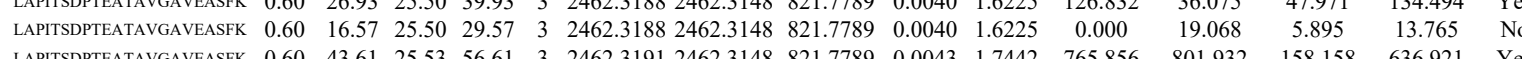

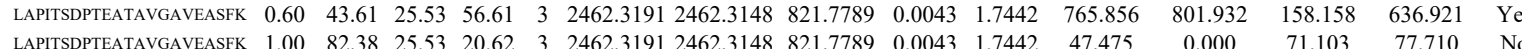

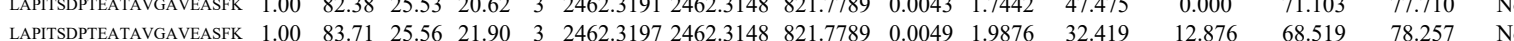

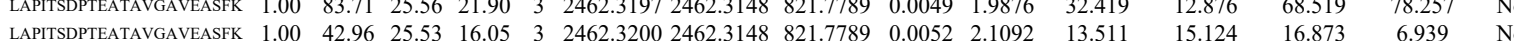

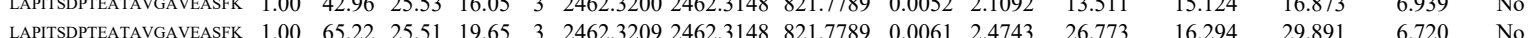
$\begin{array}{llllllllllllllll}\text { SGMNVAR } & 0.84 & 22.40 & 27.88 & 25.38 & 2 & 877.4574 & 877.4562 & 439.7354 & 0.0012 & 1.3645 & 155.341 & 110.991 & 72.974 & 150.136 & \text { Yes }\end{array}$

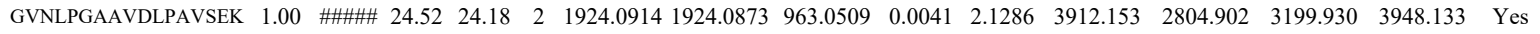
$\begin{array}{llllllllllllllll}\text { GVNLPGAAVDLPAVSEK } & 0.98 & 29.41 & 24.58 & 23.16 & 3 & 1924.0930 & 1924.0873 & 642.3697 & 0.0057 & 2.9578 & 645.434 & 451.872 & 126.487 & 642.121 & \text { Yes }\end{array}$ $\begin{array}{llllllllllllllll}\text { GVNLPGAAVDLPAVSEK } & 0.94 & 24.21 & 24.53 & 23.08 & 3 & 1924.0936 & 1924.0873 & 642.3697 & 0.0063 & 3.2691 & 304.722 & 229.273 & 35.431 & 315.257 & \text { Yes }\end{array}$

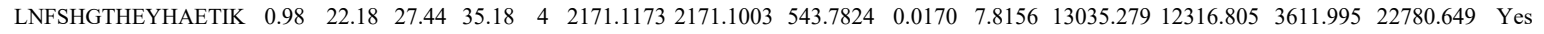
$\begin{array}{llllllllllllllll}\text { LNFSHGTHEYHAETIK } & 1.00 & 35.74 & 27.25 & 15.57 & 4 & 2171.1189 & 2171.1003 & 543.7824 & 0.0186 & 8.5511 & 21817.809 & 19402.546 & 6501.687 & 35684.584 & \text { Yes }\end{array}$ $\begin{array}{lllllllllllllllll}\text { LAPITDPTEATAVGAVEASFK } & 1.00 & 70.33 & 25.62 & 17.75 & 3 & 2462.3143 & 2462.3148 & 821.7789 & -0.0005 & -0.2028 & 64.856 & 37.541 & 83.870 & 77.672 & \text { Yes }\end{array}$ $\begin{array}{llllllllllllllll}\text { LAPISDPTEATAVGAVEASFK } & 0.66 & 22.42 & 25.72 & 35.42 & 3 & 2462.3167 & 2462.3148 & 821.7789 & 0.0019 & 0.7707 & 11.781 & 24.214 & 11.051 & 23.864 & \text { Yes }\end{array}$

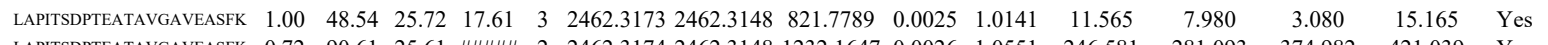

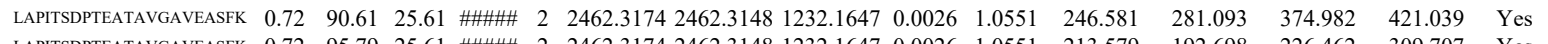

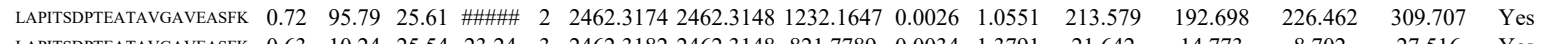

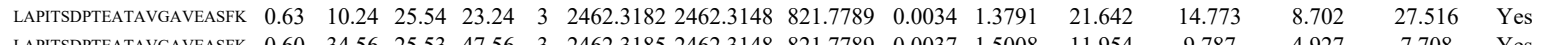

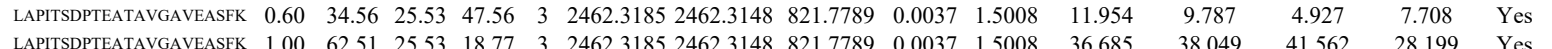
\begin{tabular}{llllllllllllllll} 
LAPITDPTEATAVGAVEASFK & 1.00 & 62.51 & 25.53 & 18.77 & 3 & 2462.3185 & 2462.3148 & 821.7789 & 0.0037 & 1.5008 & 36.685 & 38.049 & 41.562 & 28.199 & Yes \\
\hline
\end{tabular}

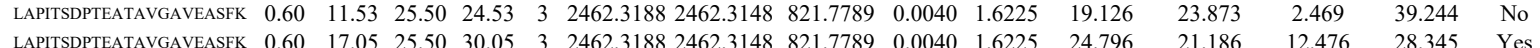

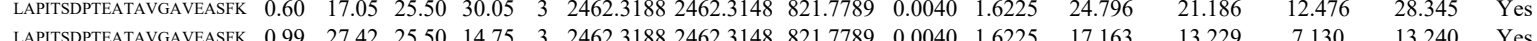

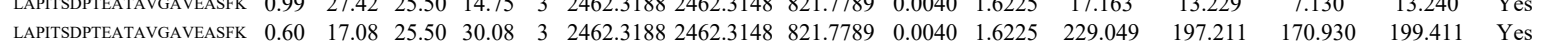


$\begin{array}{llllllllllllll}\text { RFDEILEASDGIMVAR } & 1.00 & 69.05 & 28.36 & 25.62 & 3 & 1965.0157 & 1965.0111 & 656.0110 & 0.0046 & 2.3374 & 1970.076\end{array}$

(2).507. $\begin{array}{llllllllllllllllll} & \end{array}$ $\begin{array}{lllllllllllllllllll}\text { LNFSHGTHEYHAETIK } & 0.97 & 20.42 & 27.25 & 20.77 & 4 & 2171.1189 & 2171.1003 & 543.7824 & 0.0186 & 8.5511 & 16695.080 & 15335.332 & 2654.140 & 20119.057 & \text { Yes }\end{array}$ $\begin{array}{llllllllllllll} & \end{array}$

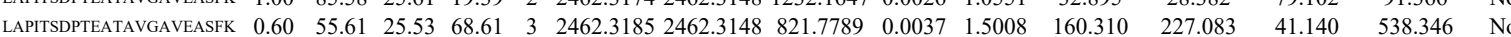

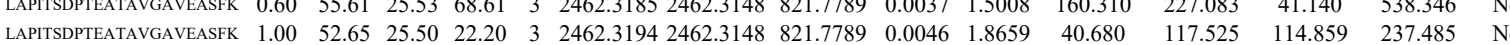
$\begin{array}{lllllllllllllllll}\text { LAPITDPTEATAVGAVEASFK } & 1.00 & 54.76 & 25.53 & 16.76 & 3 & 2462.3200 & 2462.3148 & 821.7789 & 0.0052 & 2.1092 & 14.599 & 3.690 & 0.000 & 9.784 & \text { No }\end{array}$

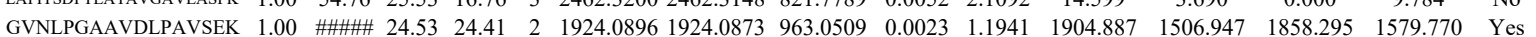
$\begin{array}{lllllllllllllll}\text { GVNLPGAAVDLPAVSEK } & 1.00 & \text { \#\#\#\# } 24.53 & 22.82 & 2 & 1924.0896 & 1924.0873 & 963.0509 & 0.0023 & 1.1941 & 3119.899 & 1984.134 & 1918.301 & 2784.433 & \text { Yes }\end{array}$ $\begin{array}{llllllllllllllll}\text { GVNLPGAAVDLPAVSEK } & 0.99 & 26.36 & 24.53 & 15.80 & 3 & 1924.0915 & 1924.0873 & 642.3697 & 0.0042 & 2.1794 & 450.524 & 919.660 & 70.410 & 512.416 & \text { No }\end{array}$ $\begin{array}{llllllllllllllll}\text { GVNLPGAAVDLPAVSEK } & 0.99 & 27.27 & 24.50 & 17.79 & 3 & 1924.0918 & 1924.0873 & 642.3697 & 0.0045 & 2.3351 & 997.990 & 553.167 & 320.652 & 830.503 & \text { Yes }\end{array}$ $\begin{array}{llllllllllllllll}\text { RFDEILEASDGIMVAR } & 1.00 & 71.98 & 28.28 & 24.25 & 3 & 1965.0136 & 1965.0111 & 656.0110 & 0.0025 & 1.2703 & 710.243 & 905.167 & 99.390 & 1072.591 & \text { Yes }\end{array}$ $\begin{array}{llllllllllllllll}\text { RFDEILEASDGIMVAR } & 1.00 & 67.47 & 28.38 & 27.08 & 3 & 1965.0154 & 1965.0111 & 656.0110 & 0.0043 & 2.1849 & 669.172 & 462.632 & 153.629 & 755.481 & \text { Yes }\end{array}$ $\begin{array}{lllllllllllllllll} & \text { LNFSHGTHEYHAETK } & 1.00 & 41.44 & 27.36 & 17.99 & 4 & 2171.1177 & 2171.1003 & 543.7824 & 0.0174 & 7.9995 & 15967.432 & 12089.668 & 1989.240 & 19637.934 & \text { Yes }\end{array}$

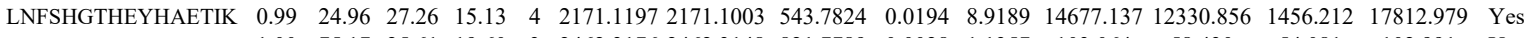
$\begin{array}{llllllllllllllll}\text { LAPTSDPTEATAVGAVEASFK } & 1.00 & 75.17 & 25.61 & 19.60 & 3 & 2462.3176 & 2462.3148 & 821.7789 & 0.0028 & 1.1357 & 103.064 & 58.430 & 54.081 & 102.991 & \text { Yes }\end{array}$ $\begin{array}{llllllllllllllll}\text { GVNLPGAAVDLPAVSEK } & 1.00 & 93.92 & 24.50 & 19.66 & 2 & 1924.0900 & 1924.0873 & 963.0509 & 0.0027 & 1.4018 & 587.126 & 367.953 & 480.725 & 750.169 & \text { Yes }\end{array}$

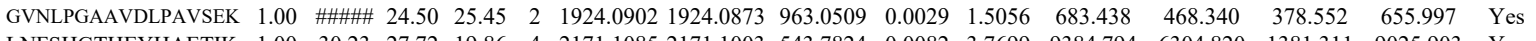
$\begin{array}{llllllllllllllll}\text { LNFSHGTHEYHAETIK } & 1.00 & 30.23 & 27.72 & 19.86 & 4 & 2171.1085 & 2171.1003 & 543.7824 & 0.0082 & 3.7699 & 9384.794 & 6304.820 & 1381.311 & 9025.903 & \text { Yes }\end{array}$

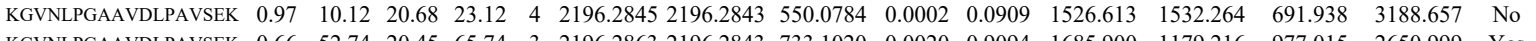

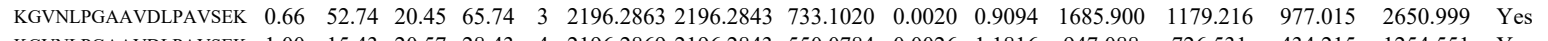
$\begin{array}{lllllllllllllllll}\text { KGVNLPGAAVDLPAVSEK } & 1.00 & 15.43 & 20.57 & 28.43 & 4 & 2196.2869 & 2196.2843 & 550.0784 & 0.0026 & 1.1816 & 947.088 & 726.531 & 434.215 & 1254.551 & \text { Yes }\end{array}$

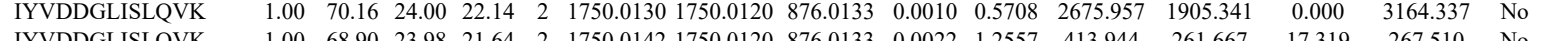

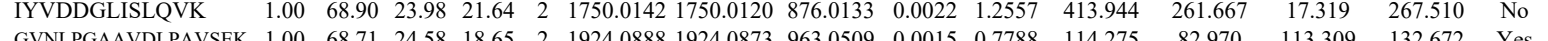
$\begin{array}{llllllllllllllll}\text { GNNLPAAVDLPAVSK } & 1.00 & 68.71 & 24.58 & 18.65 & 2 & 1924.0888 & 1924.0873 & 96.050 & 0.0014 & 0.7788 & 144.275 & 82.970 & 173.309 & 132.672 & \text { Yes }\end{array}$

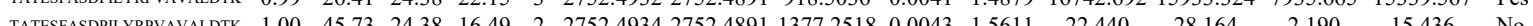
$\begin{array}{llllllllllllllll} & 12.190 & 15.436 & \text { No }\end{array}$ $\begin{array}{lllllllllllllllll} & & \end{array}$

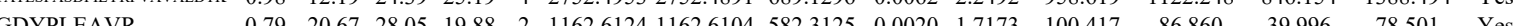
$\begin{array}{lllllllllllllll} & & \end{array}$

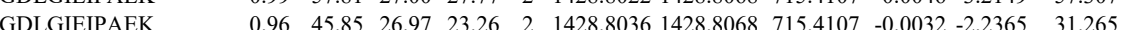
$\begin{array}{llllllllllll}\text { DPVQEAWAEDVDLR } & 0.55 & 23.59 & 26.93 & 20.55 & 2 & 1785.8644 & 1785.8655 & 893.9400 & -0.0011 & -0.6153 & 7.158\end{array}$ $\begin{array}{llllllllllll}\text { DPVQEAWAEDVDLR } & 1.00 & 84.76 & 26.77 & 24.07 & 2 & 1785.8668 & 1785.8655 & 893.9400 & 0.0013 & 0.7271 & 22.287\end{array}$ $\begin{array}{lllllllllllll}\text { DPVQEAWAEDVDLR } & 0.76 & 18.98 & 26.78 & 31.98 & 2 & 1785.8670 & 1785.8655 & 893.9400 & 0.0015 & 0.8390 & 11.894\end{array}$

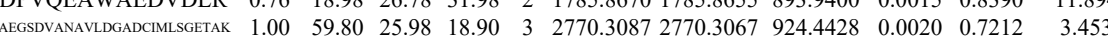

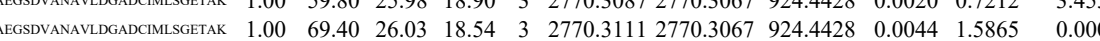

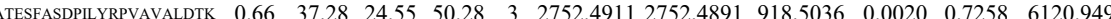
$\begin{array}{llllllllllllll} & \text { TATESFASDPILYRPVAVALDTK } & 0.67 & 39.20 & 24.50 & 52.20 & 3 & 2752.4920 & 2752.4891 & 918.5036 & 0.0029 & 1.0524 & 13562.077 & 90\end{array}$

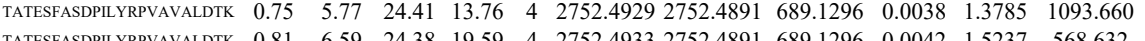
$\begin{array}{lllllllllllll}\text { TATESFASDPLYRPVAVALDTK } & 0.81 & 6.59 & 24.38 & 19.59 & 4 & 2752.4933 & 2752.4891 & 689.1296 & 0.0042 & 1.5237 & 568.632 \\ \text { TAS } & & \end{array}$ $\begin{array}{llllllllllllll}\text { TATESFASDPILYRPVAVALDTK } & 0.55 & 36.89 & 24.62 & 49.89 & 3 & 2752.4905 & 2752.4891 & 918.5036 & 0.0014 & 0.5081 & 5628.932 & 3413.133 \\ \text { TATESFASDPILYRPVAVALDTK } & 1.00 & 38.26 & 24.50 & 17.42 & 3 & 2752.4917 & 2752.4891 & 918.5036 & 0.0026 & 0.9436 & 3792.436 & 3298.288\end{array}$ $\begin{array}{llllllllllllll}\text { TATESFASDPILYRPVAVALDTK } & 0.97 & 11.06 & 24.42 & 23.15 & 4 & 2752.4925 & 2752.4891 & 689.1296 & 0.0034 & 1.2334 & 350.815 & 328.043\end{array}$ $\begin{array}{llllllllllllll}\text { FGVEQDVDMVFASFIR } & 1.00 & 84.55 & 27.94 & 20.41 & 2 & 2002.9934 & 2002.9945 & 1002.5045 & -0.0011 & -0.5486 & 23.620 & 15.361\end{array}$

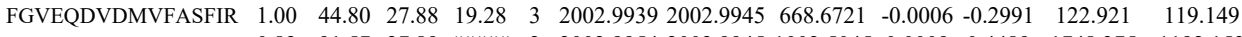

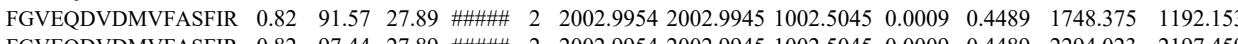
$\begin{array}{lllllllllllll}\text { FGVEQDVDMVFASFIR } & 0.82 & 97.44 & 27.89 & \# \# \# \# \quad 2 & 2002.9954 & 2002.9945 & 1002.5045 & 0.0009 & 0.4489 & 2294.023 & 2197.45\end{array}$

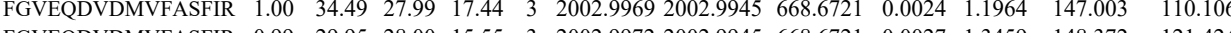
$\begin{array}{llllllllllllll} & \text { FGVQDVDMVASFR } & 0.99 & 29.95 & 28.00 & 15.55 & 3 & 2002.9972 & 2002.9945 & 668.6721 & 0.0027 & 1.3459 & 148.372 & 121.424\end{array}$

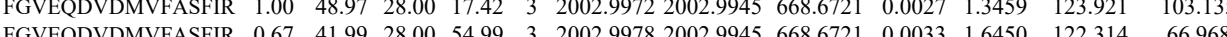
$\begin{array}{lllllllllllll} & 0.068\end{array}$

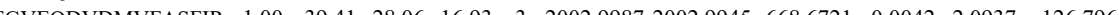

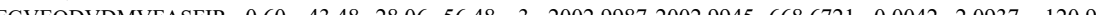


$\begin{array}{lllllllllllll}\text { FGVEQDVDMVFASFIR } & 0.60 & 18.12 & 28.06 & 31.12 & 3 & 2002.9987 & 2002.9945 & 668.6721 & 0.0042 & 2.0937 & 68.909\end{array}$

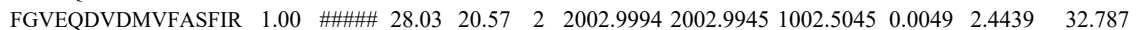

$\begin{array}{llllllllllll}\text { FGVEQDVDMVFASFIR } & 1.00 & 60.00 & 27.34 & 17.41 & 2 & 2018.9854 & 2018.9894 & 1010.5020 & -0.0040 & -1.9792 & 54.339\end{array}$

VFLAQK

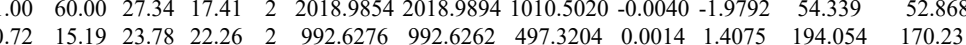
VNFAMNVGK

VNFAMNVGK

VNFAMNVGK

VNFAMNVGK

VNFAMNVGK

VNFAMNVGK

GIFPVLCK

VNFAMNVGK $\begin{array}{llllllllllll}1.00 & 53.10 & 27.40 & 28.95 & 2 & 1266.6986 & 1266.6998 & 634.3572 & -0.0012 & -0.9458 & 43.009\end{array}$ 168.750

VNFAMNVGK

$\begin{array}{lllllllllllll}1.00 & 53.10 & 27.40 & 28.95 & 2 & 1266.696 & 1266.698 & 634.3572 & 0.012 & 0.948 & 43.009\end{array}$

92.381

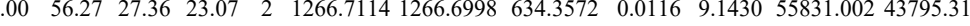

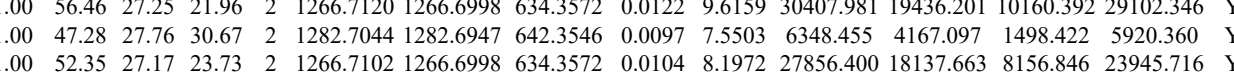

$\begin{array}{llllllllllllllllll}1.00 & 60.87 & 27.18 & 22.21 & 2 & 1266.7112 & 1266.6998 & 634.3572 & 0.0114 & 8.9854 & 28985.087 & 17831.077 & 6400.015 & 27706.323 & \text { Yes }\end{array}$ $\begin{array}{lllllllllllllll}0.97 & 29.92 & 27.06 & 20.09 & 2 & 1209.6880 & 1209.6857 & 605.8501 & 0.0023 & 1.8982 & 179.727 & 171.107 & 72.692 & 200.588 & \text { Yes }\end{array}$ $\begin{array}{lllllllllllllll}1.00 & 58.78 & 27.25 & 21.05 & 2 & 1266.7118 & 1266.6998 & 634.3572 & 0.0120 & 9.4583 & 13346.458 & 7315.566 & 2438.424 & 12480.284 & \text { Yes }\end{array}$ $\begin{array}{llllllllllllllll} & \end{array}$ $\begin{array}{cccccccccccccccc} & \end{array}$ $\begin{array}{lllllllllllllllll} & \\ \text { DPVEAWAEDVDLR } & 0.99 & 47.94 & 26.87 & 23.49 & 2 & 1785.8706 & 1785.8655 & 893.9400 & 0.0051 & 2.8525 & 6.854 & 10.949 & 3.226 & 8.530 & \text { No }\end{array}$ $\begin{array}{llllllllllllllll} & \end{array}$

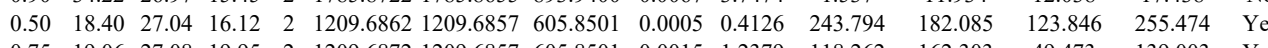

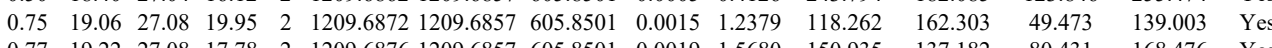
$\begin{array}{llllllllllllll}0.750 .935 & 162.303\end{array}$

APIAVTR $\begin{array}{llllllllllll}1.00 & 41.69 & 27.04 & 24.98 & 2 & 1209.6878 & 1209.6857 & 605.8501 & 0.0021 & 1.7331 & 243.419 \\ 0.82 & 13.31 & 19.29 & 26.31 & 2 & 983.6256 & 983.6249 & 4928197 & 0.0007 & 0.7102 & 97.077\end{array}$

GIFPVLCK

GIFPVLCK

GIFPVLCK

GIFPVLCK $\begin{array}{llllllllllllllll}0.75 & 27.90 & 27.19 & 20.18 & 2 & 1209.6850 & 1209.6857 & 605.8501 & -0.0007 & -0.5777 & 124.208\end{array}$ $\begin{array}{llllllllllll}0.63 & 20.77 & 27.04 & 16.93 & 2 & 1209.6862 & 1209.6857 & 605.8501 & 0.0005 & 0.4126 & 43.588 & 31.725\end{array}$ $\begin{array}{lllllllllll}0.97 & 29.74 & 26.97 & 22.82 & 2 & 1209.6866 & 1209.6857 & 605.8501 & 0.0009 & 0.7428 & 148.667\end{array}$

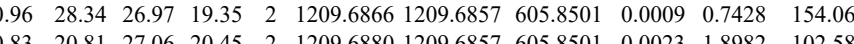
$\begin{array}{lllllllllllll}0.83 & 20.81 & 27.06 & 20.45 & 2 & 1209.6880 & 1209.6857 & 605.8501 & 0.0023 & 1.8982 & 102.587\end{array}$

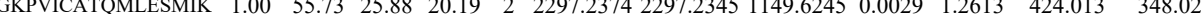
$\begin{array}{llllllllllllll} & \text { AGRPVICATQMLESMIK } & 1.00 & 43.11 & 25.77 & 23.17 & 3 & 2297.2384 & 2297.2345 & 766.7521 & 0.0039 & 1.6955 & 3744.699 & 2587.727\end{array}$ $\begin{array}{llllllllllllll}\text { AGKPVICATQMLESMIK } & 1.00 & 48.19 & 25.77 & 23.77 & 3 & 2297.2384 & 2297.2345 & 766.7521 & 0.0039 & 1.6955 & 2146.489 & 1052 . \\ \text { AGKPVICATQMLESMIK } & 1.00 & 35.34 & 25.79 & 19.21 & 4 & 2297.2401 & 2297.2345 & 575.3159 & 0.0056 & 2.4334 & 436.549 & 322 .\end{array}$ AGKPVICATQMLESMIK

APIIAVTR

APIIAVTR

APIIAVTR

APIIAVTR

APIIAVTR

APIIAVTR

APIIAVTR

APIIAVTR

MQHLIAR

MQHLIAR

GIFVLCK

GIFPVLCK $\begin{array}{llllllllllll}0.97 & 21.23 & 19.14 & 16.02 & 2 & 983.6258 & 983.6249 & 492.8197 & 0.0009 & 0.9131 & 120.263\end{array}$ $\begin{array}{llllllllllll}0.99 & 28.37 & 19.14 & 16.65 & 2 & 983.6258 & 983.6249 & 492.8197 & 0.0009 & 0.9131 & 86.756 \\ 0.82 & 19.39 & 18.63 & 32.39 & 2 & 983.6260 & 983.6249 & 4928197 & 0.0011 & 1.1160 & 106.345\end{array}$ $\begin{array}{llllllllllll}0.82 & 19.39 & 18.63 & 32.39 & 2 & 983.6260 & 983.6249 & 492.8197 & 0.0011 & 1.1160 & 106.345 & 8 \\ 0.82 & 19.43 & 18.63 & 32.43 & 2 & 983.6260 & 983.6249 & 492.8197 & 0.0011 & 1.1160 & 50.699\end{array}$ $\begin{array}{lllllllllllll}0.82 & 19.43 & 18.63 & 32.43 & 2 & 983.6260 & 983.6249 & 492.8197 & 0.0011 & 1.1160 & 50.699\end{array}$ $\begin{array}{lllllllllllll}0.98 & 22.72 & 18.63 & 16.35 & 2 & 983.6262 & 983.6249 & 492.8197 & 0.0013 & 1.3189 & 135.683 \\ 0.84 & 19.29 & 19.19 & 32.29 & 2 & 983.6268 & 983.6249 & 492.8197 & 0.0019 & 1.9277 & 32.230\end{array}$ \begin{tabular}{lllllllll} 
& \\
\hline
\end{tabular} 


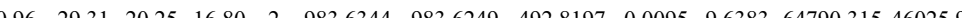
$\begin{array}{llllllllllllll} & \end{array}$

$\begin{array}{llllllllllllllllllll} & 0.99 & 36.49 & 27.05 & 23.88 & 2 & 1209.6886 & 1209.6857 & 605.8501 & 0.0029 & 2.3933 & 21682.898 & 14444.138 & 11359.619 & 17792.891 & \text { Yes }\end{array}$

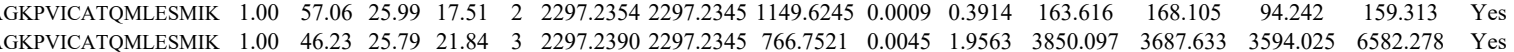
$\begin{array}{llllllllllllllll} & \end{array}$

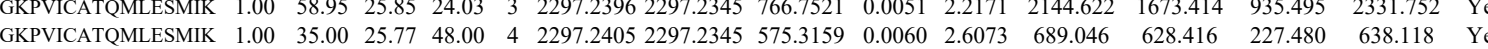
$\begin{array}{lllllllllllllll} & \end{array}$

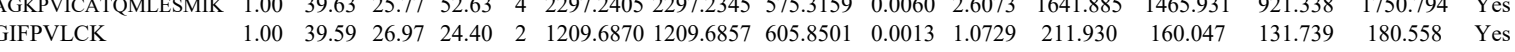
$\begin{array}{llllllllllllll} & & & \end{array}$ $\begin{array}{llllllllllllllll}\text { GIFPVLCK } & 0.67 & 16.71 & 27.05 & 29.65 & 3 & 1209.6874 & 1209.6857 & 404.2358 & 0.0017 & 1.4018 & 247.108 & 182.643 & 263.522 & 390.870 & \text { Yes } \\ \text { GIFPVLCK } & 0.96 & 25.18 & 27.05 & 29.13 & 3 & 1209.6874 & 1209.6857 & 404.2358 & 0.0017 & 1.4018 & 366.484 & 269.759 & 390.924 & 475.874 & \text { Yes }\end{array}$ GIFPVLCK GIFPVLCK GIFPVICK $\begin{array}{lllllllllll}1.00 & 46.07 & 27.08 & 23.49 & 2 & 1209.6874 & 1209.6857 & 605.8501 & 0.0017 & 1.4030 & 495.625\end{array}$ $\begin{array}{llllllllllll}1.00 & 46.15 & 27.08 & 23.73 & 2 & 1209.6874 & 1209.6857 & 605.8501 & 0.0017 & 1.4030 & 583.099 & 3 \\ 16.42 & 2.08 & 23.51 & 2 & 1209.6874 & 1209.6857 & 605.8501 & 0.0017 & 1.4030 & 440.152\end{array}$ $23.25 \quad 2 \quad 1209.6874$ $\begin{array}{llllllllllll}1.00 & 43.99 & 27.08 & 25.55 & 2 & 1209.6876 & 1209.6857 & 605.8501 & 0.0019 & 1.5680 & 522.780 \\ 0.99 & 36.53 & 27.08 & 2.21 & 2 & 12096876 & 1209.6857 & 605.8501 & 0.0019 & 1.5680 & 156.930\end{array}$ 131.436 $\begin{array}{lllllllll}0 & 36.53 & 27.08 & 22.21 & 2 & 1209.6876 & 1209.68\end{array}$

GIFPVLCK

GIFPVLCK

GIFPVLCK

GIFPVLCK

GIFPVLCK

GIFPVLCK

GIFPVLCK

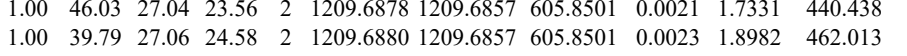

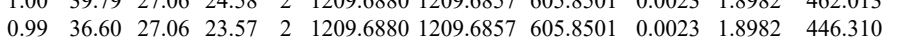
$\begin{array}{llllllllllll}0.99 & 32.45 & 27.06 & 20.58 & 2 & 1209.6880 & 1209.6857 & 605.8501 & 0.0023 & 1.8982 & 430.293\end{array}$

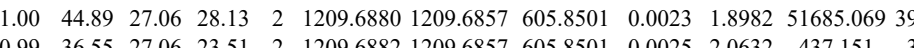
$\begin{array}{lllllllllllll}0.99 & 36.59 & 27.06 & 22.94 & 2 & 1209.6884 & 1209.6857 & 605.8501 & 0.0027 & 2.2283 & 396.501 & \end{array}$ $\begin{array}{lllllllllll}0.97 & 32.10 & 27.05 & 20.92 & 2 & 1209.6886 & 1209.6857 & 605.8501 & 0.0029 & 2.3933 & 215.803\end{array}$

6.427 $\begin{array}{llll}254.961 & 454.012 & \text { Yes }\end{array}$

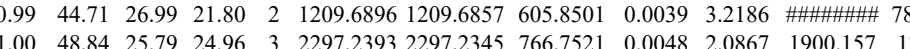

GIFPVLCK

GFPLCK

GIFPVCK

GIFPVLCK

GIFPVLCK

GIFPLCK

GIFPVCK

GIFPVCK

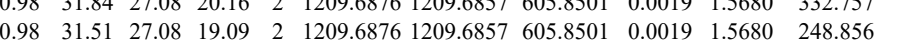
$\begin{array}{llllllllllll}0.95 & 26.88 & 27.06 & 17.55 & 2 & 1209.6882 & 1209.6857 & 605.8501 & 0.0025 & 2.0632 & 226.924 & 170\end{array}$ $\begin{array}{lllllllllll}1.00 & 50.74 & 27.35 & 22.03 & 2 & 1486.7616 & 1486.7623 & 744.3884 & -0.0007 & -0.4702 & 59.216\end{array}$ $\begin{array}{llllllllllll}1.00 & 52.39 & 27.50 & 23.05 & 2 & 1486.7634 & 1486.7623 & 744.3884 & 0.0011 & 0.7389 & 63.174 \\ 0.69 & 15.21 & 27.47 & 18.02 & 3 & 1486.7638 & 1486.7623 & 496.5947 & 0.0015 & 1.0069 & 19.794\end{array}$ 

$\begin{array}{lllllllllllllll}1.00 & 49.32 & 27.50 & 23.53 & 2 & 1486.7636 & 486.7623 & 744.3884 & 0.001 & 0.8732 & 1784.550 & 1438.693 & 41.845 & 185.463 & \text { Yes } \\ 1.00 & 55.25 & 27.42 & 27.15 & 2 & 1486.7646 & 1486.7623 & 744.3884 & 0.0023 & 1.5449 & 7107.328 & 4364.347 & 744.833 & 7255.572 & \text { Yes }\end{array}$ $\begin{array}{lllllllllllllll}1.00 & 76.56 & 28.37 & 24.12 & 2 & 1491.7668 & 1491.7659 & 746.8902 & 0.0009 & 0.6025 & 15320.165 & 11860.051 & 2900.835 & 14113.597 & \text { Yes }\end{array}$ $\begin{array}{llllllllllllllll}1.00 & 64.14 & 28.36 & 26.17 & 2 & 1491.7672 & 1491.7659 & 746.8902 & 0.0013 & 0.8703 & 47918.374 & 38397.174 & 9358.224 & 46248.873 & \text { Yes }\end{array}$ $\begin{array}{lllllllllllllll}1.00 & 55.04 & 28.36 & 23.73 & 2 & 1491.7672 & 1491.7659 & 746.8902 & 0.0013 & 0.8703 & 24.856 & 25.008 & 5.423 & 52.361 & \text { No }\end{array}$

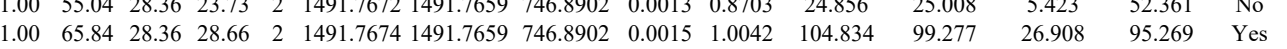
$\begin{array}{lllllllllllllll}0.97 & 26.43 & 28.36 & 16.48 & 3 & 1491.7675 & 1491.7659 & 498.2626 & 0.0016 & 1.0704 & 111.849 & 104.147 & 94.405 & 122.454 & \text { Yes }\end{array}$ $\begin{array}{llllllllllllllll}1.00 & 65.12 & 28.33 & 23.07 & 2 & 1491.7676 & 1491.7659 & 746.8902 & 0.0017 & 1.1381 & 97.774 & 123.322 & 11.049 & 92.754 & \text { No }\end{array}$ $\begin{array}{lllllllllllllll}1.00 & 41.07 & 28.48 & 28.18 & 3 & 1491.7693 & 1491.7659 & 498.2626 & 0.0034 & 2.2746 & 150.256 & 348.113 & 0.000 & 134.386 & \text { No }\end{array}$ $\begin{array}{lllllllllllllll}1.00 & 57.36 & 28.43 & 26.82 & 2 & 1491.7696 & 1491.7659 & 746.8902 & 0.0037 & 2.4769 & 40.523 & 33.450 & 3.057 & 41.160 & \text { Yes }\end{array}$

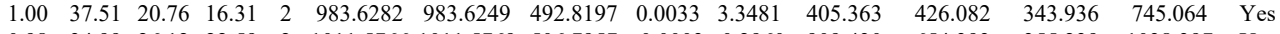

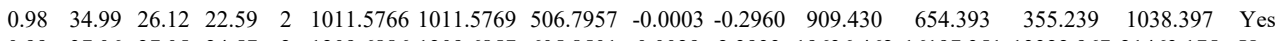

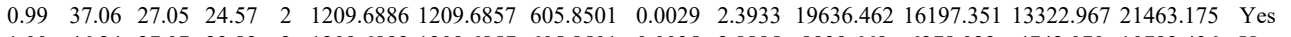

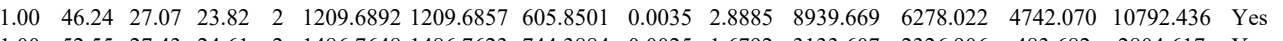
$\begin{array}{lllllllllllllll}1.00 & 52.55 & 27.43 & 24.61 & 2 & 1486.7648 & 1486.7623 & 744.3884 & 0.0025 & 1.6792 & 3133.607 & 2326.906 & 483.682 & 2804.617 & \text { Yes }\end{array}$ $\begin{array}{llllllllllllllll}1.00 & 48.43 & 27.45 & 22.86 & 2 & 1486.7650 & 1486.7623 & 744.3884 & 0.0027 & 1.8136 & 2287.334 & 1991.164 & 538.309 & 2636.008 & \text { Yes }\end{array}$

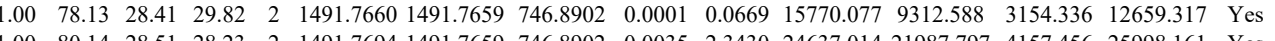
$\begin{array}{lllllllllllllll}1.00 & 80.14 & 28.51 & 28.23 & 2 & 1491.7694 & 1491.7659 & 746.8902 & 0.0035 & 2.3430 & 24637.014 & 21987.797 & 4157.456 & 25998.161 & \text { Yes }\end{array}$ $\begin{array}{llllllllllllllll}0.90 & 23.15 & 28.55 & 18.51 & 3 & 1491.7708 & 1491.7659 & 498.2626 & 0.0049 & 3.2780 & 230.778 & 68.942 & 0.000 & 239.747 & \text { No }\end{array}$

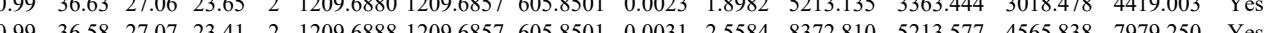
$\begin{array}{llllllllllllllll}0.99 & 36.58 & 27.07 & 23.41 & 2 & 1209.6888 & 1209.6857 & 605.8501 & 0.0031 & 2.5584 & 8372.810 & 5213.577 & 4565.838 & 7979.250 & \text { Yes } \\ 1.00 & 45.30 & 27.45 & 22.94 & 2 & 1486.7650 & 1486.7623 & 74.3884 & 0.0027 & 1.8136 & 551.976 & 547.391 & 109.133 & 601.278 & \text { Yes }\end{array}$ TTGHCTIGPASR

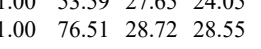

EDVD

DPVQEAWAEDVDLR

DPVQEAWAEDVDLR

$\begin{array}{lllllllllll} & 175.8658 & 1785.8655 & 893.9400 & 0.0003 & 0.1678 & 21.419\end{array}$

$\begin{array}{llllllllllll}\text { DPVQEAWAEDVDLR } & 1.00 & 95.63 & 26.85 & 25.03 & 2 & 1785.8660 & 1785.8655 & 893.9400 & 0.0005 & 0.2797 & 46.382\end{array}$

$\begin{array}{lllllllllllll}\text { DPVEAWAEVDLR } & 1.00 & 66.23 & 26.87 & 20.66 & 2 & 1785.8662 & 1785.8655 & 893.9400 & 0.0007 & 0.3915 & 21.67 \\ \text { DPVEAWAEDVDLR } & 1.00 & 92.09 & 26.87 & 25.45 & 2 & 1785.8662 & 1785.865 & 893.9400 & 0.0007 & 0.3915 & 10.644\end{array}$ \begin{tabular}{lllllllllllll} 
DPVQEAWAEDVDLR & 1.00 & 63.86 & 26.81 & 24.29 & 2 & 1785.8666 & 1785.86555 & 893.9400 & 0.0007 & 0.3915 & 10.644 \\
\hline
\end{tabular} $\begin{array}{lllllllllllll}\text { DPVQEAWAEDVDLR } & 1.00 & 91.84 & 26.81 & 25.53 & 2 & 1785.8666 & 1785.8655 & 893.9400 & 0.0011 & 0.6153 & 26.914\end{array}$ $\begin{array}{llllllllllll}\text { DPVQEAWAEDVDLR } & 1.00 & 92.62 & 26.81 & 26.94 & 2 & 1785.8666 & 1785.8655 & 893.9400 & 0.0011 & 0.6153 & 35.806\end{array}$ $\begin{array}{llllllllllll}\text { DPVQEAWAEDVDLR } & 1.00 & 86.80 & 26.81 & 24.98 & 2 & 1785.8666 & 1785.8655 & 893.9400 & 0.0011 & 0.6153 & 19.274\end{array}$ $\begin{array}{llllllllllll}\text { DPVQEAWAEDVDLR } & 1.00 & 81.15 & 26.81 & 23.35 & 2 & 1785.8666 & 1785.8655 & 893.9400 & 0.0011 & 0.6153 & 31.939\end{array}$ $\begin{array}{llllllllllllll}\text { DPVQEAWAEDVDLR } & 1.00 & 87.88 & 26.77 & 23.28 & 2 & 1785.8668 & 1785.8655 & 893.9400 & 0.0013 & 0.7271 & 38.670\end{array}$ $\begin{array}{lllllllllllllll}\text { DPVQEAWAEDVDLR } & 1.00 & 70.39 & 26.77 & 24.87 & 2 & 1785.8668 & 1785.8655 & 893.9400 & 0.0013 & 0.7271 & 61.550\end{array}$ $\begin{array}{lllllllllllll}\text { DPVQEAWAEDVDLR } & 1.00 & 74.27 & 26.78 & 23.21 & 2 & 1785.8670 & 1785.8655 & 893.9400 & 0.0015 & 0.8390 & 25.26\end{array}$ $\begin{array}{lllllllllllll}\text { DPVQEAWAEDVDLR } & 1.00 & 70.53 & 26.83 & 27.07 & 2 & 1785.8672 & 1785.8655 & 893.9400 & 0.0017 & 0.9508 & 55.362\end{array}$ $\begin{array}{llllllllllll}\text { DPVQEAWAEDVDLR } & 1.00 & 60.45 & 26.83 & 19.05 & 2 & 1785.8672 & 1785.8655 & 893.9400 & 0.0017 & 0.9508 & 13.376\end{array}$ $\begin{array}{llllllllllll}\text { DPVQEAWAEDVDLR } & 0.80 & 15.06 & 26.83 & 17.39 & 3 & 1785.8674 & 1785.8655 & 596.2958 & 0.0019 & 1.0621 & 104.082\end{array}$ $\begin{array}{llllllllllll}\text { DPVQEAWAEDVDLR } & 1.00 & 63.85 & 26.83 & 19.52 & 3 & 1785.8674 & 1785.8655 & 596.2958 & 0.0019 & 1.0621 & 108.488\end{array}$ $\begin{array}{lllllllllllll}\text { DPVQEAWAEDVDLR } & 0.66 & 55.74 & 26.83 & 68.74 & 3 & 1785.8674 & 1785.8655 & 596.2958 & 0.0019 & 1.0621 & 77.647 \\ \text { DPVQEAWAEDVDLR } & 1.00 & 36.54 & 26.83 & 15.40 & 3 & 1785.8674 & 1785.8655 & 596.2958 & 0.0019 & 1.0621 & 26.145\end{array}$ $\begin{array}{llllllllllll}\text { DPVQEAWAEDVDLR } & 1.00 & 36.54 & 26.83 & 15.40 & 3 & 1785.8674 & 1785.8655 & 596.2958 & 0.0019 & 1.0621 & 26.145 \\ \text { DPVQEAWAEDVDLR } & 1.00 & 70.36 & 26.84 & 24.02 & 2 & 1785.8674 & 1785.8655 & 893.9400 & 0.0019 & 1.0627 & 900.763\end{array}$ $\begin{array}{llllllllllll}\text { DPVQEAWAEDVDLR } & 1.00 & 70.36 & 26.84 & 24.02 & 2 & 1785.8674 & 1785.8655 & 893.9400 & 0.0019 & 1.0627 & 900.763 \\ \text { DPVQEAWAEDVDLR } & 1.00 & 66.85 & 26.87 & 22.59 & 2 & 1785.8676 & 1785.8655 & 893.9400 & 0.0021 & 1.1746 & 86.651\end{array}$

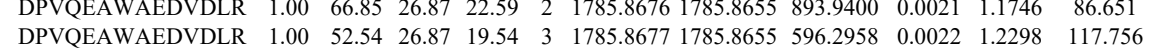
$\begin{array}{llllllllllll}\text { DPVQEAWAEDVDLR } & 1.00 & 52.54 & 26.87 & 19.54 & 3 & 1785.8677 & 1785.8655 & 596.2958 & 0.0022 & 1.2298 & 117.756 \\ \text { DPVQEAWAEDVDLR } & 1.00 & 80.74 & 26.88 & 24.84 & 2 & 1785.8678 & 1785.8655 & 893.9400 & 0.0023 & 1.2864 & 58.920\end{array}$

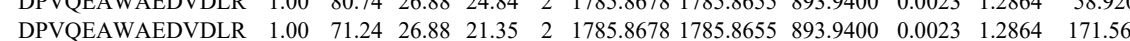
$\begin{array}{llllllllllll}\text { DPVQEAWAEDVDLR } & 0.84 & 70.43 & 26.88 & 83.43 & 2 & 1785.8678 & 1785.8655 & 893.9400 & 0.0023 & 1.2864 & 11.723\end{array}$ $\begin{array}{llllllllllll}\text { DPVQEAWAEDVDLR } & 1.00 & 76.60 & 26.89 & 25.35 & 2 & 1785.8680 & 1785.8655 & 893.9400 & 0.0025 & 1.3983 & 39.275\end{array}$

$\begin{array}{cccc}1606.107 & 399.527 & 2000.481 & \text { Yes } \\ 7.671 & 13.855 & 6.080 & \text { No } \\ 22.564 & 48.251 & 55.737 & \text { Yes } \\ 14.644 & 23.988 & 29.225 & \text { Yes } \\ 34.532 & 78.944 & 86.856 & \text { Yes } \\ 40.382 & 81.641 & 73.685 & \text { Yes } \\ 11.218 & 25.995 & 40.234 & \text { Yes } \\ 15.939 & 11.630 & 7.614 & \text { Yes } \\ 30.977 & 25.900 & 47.854 & \text { Yes } \\ 23.280 & 21.584 & 39.189 & \text { Yes } \\ 32.391 & 24.183 & 29.486 & \text { Yes } \\ 30.404 & 31.166 & 35.342 & \text { Yes } \\ 18.713 & 23.215 & 38.639 & \text { Yes } \\ 17.275 & 42.357 & 37.171 & \text { Yes } \\ 39.199 & 55.650 & 54.205 & \text { Yes } \\ 39.784 & 43.166 & 37.185 & \text { Yes } \\ 40.826 & 42.980 & 39.542 & \text { Yes } \\ 12.227 & 14.152 & 12.767 & \text { Yes } \\ 100.639 & 30.864 & 110.982 & \text { Yes } \\ 98.353 & 43.414 & 144.540 & \text { Yes } \\ 104.796 & 59.384 & 128.274 & \text { Yes } \\ 49.178 & 17.841 & 71.056 & \text { Yes } \\ 589.761 & 926.517 & 844.484 & \text { Yes } \\ 50.162 & 88.318 & 71.482 & \text { Yes } \\ 97.012 & 57.365 & 168.504 & \text { Yes } \\ 69.115 & 127.207 & 115.060 & \text { No } \\ 119.978 & 224.428 & 187.369 & \text { Yes } \\ 12.067 & 5.227 & 10.053 & \text { Yes } \\ 21.105 & 35.048 & 46.296 & \text { Yes }\end{array}$

Table S-4 page 185 of 614 
GDVVIVLTGWRPGSGFTN

GDVVIVLTGWRPGSGFTN
NTGIICTIGPASR

$\begin{array}{llllllllllll}1.00 & 78.10 & 28.36 & 22.87 & 2 & 1491.7672 & 1491.7659 & 746.8902 & 0.0013 & 0.8703 & 1005.548\end{array}$

GDVVIVLTGWRPGSGFTNTMR $\left.\begin{array}{lllllllllllll}0.73 & 13.25 & 26.63 & 15.82 & 3 & 2406.2623 & 2406.2600 & 803.0939 & 0.0023 & 0.9546 & 435.133 & 354.549\end{array}\right)$ $\begin{array}{llllllllllllll}\text { KGDVVIVLIORPGSGFNTMR } & 0.55 & 18.70 & 24.13 & 31.70 & 3 & 2678.4586 & 2678.4570 & 893.8263 & 0.0016 & 0.5967 & 549.972 & 438.068\end{array}$ $\begin{array}{llllllllllllll}\text { KGDVVIVLTGWRPGSGFTNTMR } & 1.00 & 20.63 & 24.01 & 17.17 & 4 & 2678.4593 & 2678.4570 & 670.6215 & 0.0023 & 0.8574 & 487.137 & 602.989 \\ \text { KGDVVIVLTGWRPGSGFTNMR } & 1.00 & 27.76 & 24.01 & 18.54 & 4 & 2678.4605 & 2678.4570 & 670.6215 & 0.0035 & 1.3048 & 620.214 & 902.161\end{array}$ $\begin{array}{llllllllllllll}\text { KGDVVIVLTGWRPGGGFTNTMR } & 0.99 & 15.25 & 24.96 & 14.88 & 4 & 2694.4537 & 2694.4520 & 674.6203 & 0.0035 & 1.3048 & 620.214 & 902.161 \\ \end{array}$

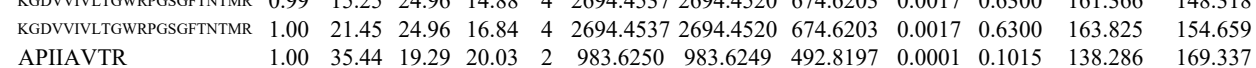
APIIAVTR $\begin{array}{llllllllllllll}\text { APIIAVTR } & 1.00 & 34.86 & 19.29 & 17.84 & 2 & 983.6252 & 983.6249 & 492.8197 & 0.0003 & 0.3044 & 102.420 & 10 \\ \text { NTGICTIGPASR } & 1.00 & 90.65 & 28.36 & 26.26 & 2 & 1491.7672 & 1491.7659 & 746.8902 & 0.0013 & 0.8703 & 411.969 & 26\end{array}$ \begin{tabular}{llllllllllll} 
& 1.00 & 0.65 & 28.36 & 26.26 & 2 & 1491.8672 & 1491.8659 & 746.8902 & 0.0013 & 0.8783 & 41.969 \\
\hline
\end{tabular} $\begin{array}{llllllllllllll}\text { KGDVVIVLTGWRPGSGFTNTMR } & 0.99 & 17.15 & 24.86 & 16.06 & 4 & 2694.4517 & 2694.4520 & 674.6203 & -0.0003 & -0.1112 & 53.328\end{array}$ KGDVVIVLTGWRPGSGFTNTMR $\begin{array}{lllllllllll}0.95 & 20.92 & 24.94 & 18.57 & 3 & 2694.4531 & 2694.4520 & 899.1579 & 0.0011 & 0.4078 & 79.095\end{array}$ $\begin{array}{lllllllllllll}0.97 & 26.77 & 19.73 & 26.80 & 2 & 983.6248 & 983.6249 & 492.8197 & -0.0001 & -0.1015 & 65.215 \\ 0.97 & 26.84 & 19.29 & 26.22 & 2 & 983.6250 & 983.6249 & 492.8197 & 0.0001 & 0.1015 & 63.652\end{array}$ $\begin{array}{llllllllllll}0.97 & 26.84 & 19.29 & 26.22 & 2 & 983.6250 & 983.6249 & 492.8197 & 0.0001 & 0.1015 & 63.652 \\ 1.00 & 46.85 & 27.08 & 23.99 & 2 & 1209.6874 & 1209.6857 & 605.8501 & 0.0017 & 1.4030 & 242.916\end{array}$

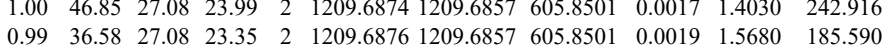
$\begin{array}{lllllllllll}1.00 & 70.51 & 28.33 & 22.98 & 2 & 1491.7676 & 1491.7659 & 746.8902 & 0.0017 & 1.1381 & 175.758\end{array}$ $\begin{array}{lllllllllll}1.00 & 90.45 & 28.31 & 26.45 & 2 & 1491.7678 & 1491.7659 & 746.8902 & 0.0019 & 1.2719 & 275.480 \\ 0.50 & 10.71 & 28.37 & 19.93 & 3 & 1491.7687 & 1491.7659 & 498.2626 & 0.0028 & 1.8732 & 36.351\end{array}$ $\begin{array}{lllllllllll}0.50 & 10.71 & 28.37 & 19.93 & 3 & 1491.7687 & 1491.7659 & 498.2626 & 0.0028 & 1.8732 & 36.351 \\ 0.68 & 18.64 & 28.10 & 17.34 & 2 & 1162.6110 & 1162.6104 & 582.3125 & 0.0006 & 0.5152 & 64.725\end{array}$

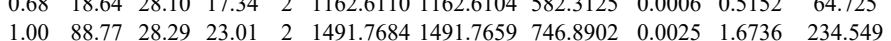
$\begin{array}{llllllllllll}1.00 & 88.77 & 28.29 & 23.01 & 2 & 1491.7684 & 1491.7659 & 746.8902 & 0.0025 & 1.6736 & 234.549 & 17 \\ 1.00 & 79.44 & 28.62 & 23.38 & 2 & 1491.7698 & 1491.7659 & 746.8902 & 0.0039 & 2.6108 & 300.896 & \end{array}$ $\begin{array}{llllllllllll}1.00 & 79.44 & 28.62 & 23.38 & 2 & 1491.7698 & 1491.7659 & 746.8902 & 0.0039 & 2.6108 & 300.896 \\ 0.71 & 27.84 & 28.11 & 25.52 & 2 & 1277.7058 & 1277.7071 & 639.8608 & -0.0013 & -1.0158 & 181.336\end{array}$ $\begin{array}{llllllllllll}1.00 & 65.92 & 28.00 & 38.01 & 2 & 1277.7080 & 1277.7071 & 639.8608 & 0.0009 & 0.7033 & 30527.083 & 2285\end{array}$ $\begin{array}{llllllllllll}1.00 & 69.66 & 28.05 & 42.95 & 2 & 1277.7082 & 1277.7071 & 639.8608 & 0.0011 & 0.8596 & 27880.728 & \end{array}$ 

$\begin{array}{llllllllllll}\text { DPVQEAWAEDVDLR } & 0.99 & 56.59 & 26.96 & 19.49 & 2 & 1785.8628 & 1785.8655 & 893.9400 & -0.0027 & -1.5102 & 25.853\end{array}$ $\begin{array}{lllllllllllll}\text { DPVQEAWAEDVDLR } & 1.00 & 68.70 & 26.83 & 19.43 & 2 & 1785.8658 & 1785.8655 & 893.9400 & 0.0003 & 0.1678 & 24.726 \\ \text { DPVQEAWAEDVDLR } & 1.00 & 61.98 & 26.84 & 18.52 & 2 & 1785.8674 & 1785.8655 & 893.9400 & 0.0019 & 1.0627 & 25.965\end{array}$

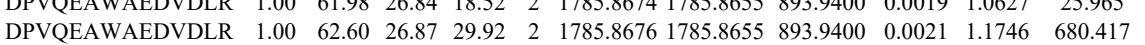

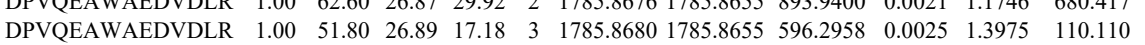
$\begin{array}{llllllllllll}\text { DPVQEAWAEDVDLR R } & 1.00 & 73.66 & 26.89 & 25.91 & 2 & 1785.8680 & 1785.8655 & 893.9400 & 0.0025 & 1.3983 & 393.778\end{array}$ $\begin{array}{lllllllllllll}\text { DPVQEAWAEDVDLR } & 1.00 & 63.72 & 26.88 & 21.43 & 2 & 1785.8682 & 1785.8655 & 893.9400 & 0.0027 & 1.5102 & 4.463\end{array}$ $\begin{array}{lllllllllllll}\text { DPVQEAWAEDVDLR } & 1.00 & 77.13 & 26.91 & 26.23 & 2 & 1785.8688 & 1785.8655 & 893.9400 & 0.0033 & 1.8458 & 31.14\end{array}$ $\begin{array}{llllllllllll}\text { DPVQEAWAEDVDLR } & 1.00 & 41.13 & 26.92 & 20.77 & 3 & 1785.8689 & 1785.8655 & 596.2958 & 0.0034 & 1.9006 & 105.662\end{array}$

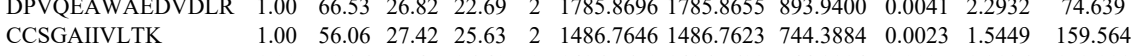
$\begin{array}{llllllllllll}\text { CCSGAIIVLTK } & 1.00 & 59.36 & 27.45 & 26.40 & 2 & 1486.7650 & 1486.7623 & 744.3884 & 0.0027 & 1.8136 & 172.988\end{array}$ $\begin{array}{lllllllllllll}\text { KGDVVIVLTGWRPGSGTNTMR } & 1.00 & 23.88 & 23.75 & 17.51 & 4 & 2678.4629 & 2678.4570 & 670.6215 & 0.0059 & 2.1994 & 134.352\end{array}$ $\begin{array}{llllllllllll}\text { CCSGAIIVLTK } & 1.00 & 56.05 & 27.47 & 26.45 & 2 & 1486.7644 & 1486.7623 & 744.3884 & 0.0021 & 1.4106 & 198.620 \\ \text { CCSGAIVLTK } & 1.00 & 55.62 & 27.72 & 27.49 & 2 & 1486.7646 & 1486.7623 & 744.3884 & 0.0023 & 1.5449 & 268.933\end{array}$ CCSGAIIVLTK NTGIICTIGPASR NTGIICTIGPASR GIFPVLCK GIFPVLCK

VNFAMNVGK $\begin{array}{llllllllll} & \end{array}$ $\begin{array}{llllllllllll}1.00 & 74.80 & 28.33 & 23.75 & 2 & 1491.7670 & 1491.7659 & 746.8902 & 0.0011 & 0.7364 & 511.610 & \end{array}$ $\begin{array}{llllllllllll}0.99 & 42.11 & 27.18 & 18.89 & 2 & 1209.6848 & 1209.6857 & 605.8501 & -0.0009 & -0.7428 & 150.387\end{array}$

CCSGAIIVLTK

CCSGAIIVLTK

NTGIICTIGPASR

NTGIICTIGPASR LAPITSDPTEATAV GAV
GIFPVLCK

GIFPVLCK

CCSGAIIVLTK $\begin{array}{lllllllllll}1.00 & 53.63 & 27.20 & 28.13 & 2 & 1266.7008 & 1266.6998 & 634.3572 & 0.0010 & 0.7882 & 143.2\end{array}$ $\begin{array}{lllllllllllll}1.00 & 53.98 & 27.47 & 26.01 & 2 & 1486.7644 & 1486.7623 & 744.3884 & 0.0021 & 1.4106 & 257.246 \\ 1.00 & 56.22 & 27.45 & 25.41 & 2 & 1486.7650 & 1486.7623 & 744.3884 & 0.0027 & 1.8136 & 169.709\end{array}$ $\begin{array}{lllllllllllll}1.00 & 56.22 & 27.45 & 25.41 & 2 & 1486.7650 & 1486.7623 & 744.3884 & 0.0027 & 1.8136 & 169.709 \\ 1.00 & 77.02 & 28.37 & 27.13 & 2 & 1491.7666 & 1491.7659 & 746.8902 & 0.0007 & 0.4686 & 286.164\end{array}$ $\begin{array}{llllllllllll}1.00 & 77.02 & 28.37 & 27.13 & 2 & 1491.7666 & 1491.7659 & 746.8902 & 0.0007 & 0.4686 & 286.164 \\ 1.00 & 80.44 & 28.37 & 22.47 & 2 & 1491.7668 & 1491.7659 & 746.8902 & 0.0009 & 0.6025 & 379.661\end{array}$ $\begin{array}{lllllllllll}1.00 & 59.21 & 25.66 & 17.05 & 3 & 2462.3155 & 2462.3148 & 821.7789 & 0.0007 & 0.2839 & 11.992\end{array}$ $\begin{array}{lllllllllll}1.00 & 59.21 & 25.66 & 17.05 & 3 & 2462.3156 & 2462.3148 & 82.7789 & 0.0007 & 0.2839 & 11.992 \\ 0.94 & 30.75 & 27.10 & 18.43 & 2 & 1209.6860 & 1209.6857 & 605.8501 & 0.0003 & 0.2476 & 116.167\end{array}$ CCSGAIIVLTK $\begin{array}{lllllllllll}1.00 & 72.68 & 27.43 & 24.88 & 2 & 1486.7638 & 1486.7623 & 744.3884 & 0.0015 & 1.0075 & 75.209\end{array}$ $\begin{array}{lllllllllllll}1.00 & 54.67 & 27.47 & 24.60 & 2 & 1486.7644 & 1486.7623 & 744.3884 & 0.0021 & 1.4106 & 132.988\end{array}$ NTGIICTIGPASR $\begin{array}{llllllllllll}0.79 & 15.32 & 27.45 & 22.17 & 3 & 1486.7650 & 1486.7623 & 496.5947 & 0.0027 & 1.8123 & 21.691 \\ 1.00 & 79.01 & 28.37 & 27.94 & 2 & 1491.7666 & 1491.7659 & 746.8902 & 0.0007 & 0.4686 & 312.293\end{array}$ NTGIICTIGPASR GIFPVLCK $\begin{array}{llllllllllll}1.00 & 79.01 & 28.37 & 27.94 & 2 & 1491.7666 & 1491.7659 & 746.8902 & 0.0007 & 0.4686 & 312.293 \\ 1.00 & 77.07 & 28.37 & 26.06 & 2 & 1491.7668 & 1491.7659 & 746.8902 & 0.0009 & 0.6025 & 239.171\end{array}$ $\begin{array}{llllllllllll}1.00 & 77.07 & 28.37 & 26.06 & 2 & 1491.7668 & 1491.7659 & 746.8902 & 0.0009 & 0.6025 & 239.171 \\ 0.76 & 28.24 & 27.44 & 22.99 & 2 & 1209.6844 & 1209.6857 & 605.8501 & -0.0013 & -1.0729 & 78.861\end{array}$

\section{CCSGAIVITK} $\begin{array}{lllllllllll}1.00 & 42.70 & 27.08 & 21.75 & 2 & 1209.6876 & 1209.6857 & 605.8501 & 0.0019 & 1.5680 & 127.776\end{array}$

CCSGAIIVLTK

CCSGAIVLTK

CCSGAIIVLTK

NTGIICTIGPASR

NTGIICTIGPASR

$\begin{array}{llllllllllll}1.00 & 51.76 & 27.50 & 21.92 & 2 & 1486.7636 & 1486.7623 & 744.3884 & 0.0013 & 0.8732 & 57.774\end{array}$ $\begin{array}{llllllllllll}0.95 & 21.66 & 27.46 & 16.17 & 3 & 1486.7644 & 1486.7623 & 496.5947 & 0.0021 & 1.4096 & 12.161\end{array}$ $\begin{array}{llllllllllll}1.00 & 54.54 & 27.43 & 24.85 & 2 & 1486.7648 & 1486.7623 & 744.3884 & 0.0025 & 1.6792 & 132.160\end{array}$ $\begin{array}{llllllllllll}0.65 & 12.58 & 27.58 & 25.58 & 3 & 1486.7656 & 1486.7623 & 496.5947 & 0.0033 & 2.2151 & 13.666\end{array}$ $\begin{array}{lllllllllll}1.00 & 76.58 & 28.36 & 26.38 & 2 & 1491.7672 & 1491.7659 & 746.8902 & 0.0013 & 0.8703 & 283.193\end{array}$ $\begin{array}{lllllllllll}1.00 & 90.51 & 28.36 & 24.88 & 2 & 1491.7674 & 1491.7659 & 746.8902 & 0.0015 & 1.0042 & 343.423\end{array}$

LAPISDPTEATAVGAVEASFK

GIFPVLCK

CCSGAIIVLTK $\begin{array}{lllllllllllll}1.00 & 72.76 & 25.53 & 19.08 & 3 & 2462.3185 & 2462.3148 & 821.7789 & 0.0037 & 1.5008 & 2.863 \\ 0.59 & 4.55 & 27.18 & 8.83 & 2 & 20.648 & 20.657 & 65.8501 & 0.000 & 0.7428 & 12.923\end{array}$ CSGGAIIVLTK $\begin{array}{rrrrrrrrrrr}0.58 & 24.55 & 27.18 & 18.83 & 2 & 1209.6848 & 1209.6857 & 605.8501 & -0.0009 & -0.7428 & 122.923 \\ 0.98 & 31.38 & 26.97 & 19.07 & 2 & 1209.6866 & 1209.6857 & 605.8501 & 0.0009 & 0.7428 & 131.775\end{array}$ $\begin{array}{llllllllllll}1.00 & 54.09 & 27.47 & 23.73 & 2 & 1486.7644 & 1486.7623 & 744.3884 & 0.0021 & 1.4106 & 184.078\end{array}$

NTGIICTIGPASR $\begin{array}{lllllllllllll}1.00 & 56.20 & 27.45 & 26.13 & 2 & 1486.7650 & 1486.7623 & 744.3884 & 0.0027 & 1.8136 & 170.734\end{array}$

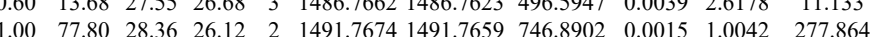
$\begin{array}{lllllllllll}1.00 & 80.77 & 28.33 & 28.50 & 2 & 1491.7676 & 1491.7659 & 746.8902 & 0.0017 & 1.1381 & 208.998\end{array}$

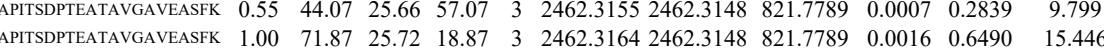
GGDVIVLTGWRPGSGFTNTMR $\begin{array}{llllllllllll} & 0.66 & 14.82 & 24.01 & 27.82 & 3 & 2678.4592 & 2678.4570 & 893.8263 & 0.0022 & 0.8204 & 33.496\end{array}$ $\begin{array}{llllllllllll}\text { KGDVVIVLTGWRPGSGFTNTMR } & 1.00 & 23.59 & 24.01 & 19.10 & 4 & 2678.4593 & 2678.4570 & 670.6215 & 0.0023 & 0.8574 & 22.83\end{array}$ $\begin{array}{lllllllllllll}\text { KGDVVIVLTGWRPGSGFTNTMR } & 1.00 & 24.59 & 24.01 & 20.19 & 4 & 2678.4597 & 2678.4570 & 670.6215 & 0.0027 & 1.0065 & 35.143 \\ \text { APIIAVTR } & 0.99 & 26.21 & 18.63 & 20.45 & 2 & 983.6260 & 983.6249 & 492.8197 & 0.0011 & 1.1160 & 159.895\end{array}$ APIIAVTR $\begin{array}{llllllllllll}0.99 & 42.39 & 27.63 & 20.45 & 2 & 983.6260 & 983.6249 & 492.8157 & 0.0011 & 1.1160 & 159.895\end{array}$ $\begin{array}{lllllllllll}0.99 & 42.39 & 27.10 & 20.83 & 2 & 1209.6860 & 1209.6857 & 605.8501 & 0.0003 & 0.2476 & 106.017 \\ 0.99 & 34.83 & 27.08 & 21.85 & 2 & 1209.6872 & 1209.6857 & 605.8501 & 0.0015 & 1.2379 & 145.715\end{array}$ $\begin{array}{lllllllllllll}1.00 & 50.77 & 27.54 & 25.13 & 2 & 14867652 & 14867623 & 744.3884 & 0.0029 & 1.9479 & 224.509\end{array}$ $\begin{array}{lllllllllll}1.00 & 53.50 & 27.54 & 24.04 & 2 & 1486.7652 & 1486.7623 & 744.3884 & 0.0029 & 1.9479 & 175.961\end{array}$

Table S-4 page 187 of 614 

$\begin{array}{lllllllllll}0.94 & 26.08 & 26.97 & 20.65 & 2 & 1209.6870 & 1209.6857 & 605.8501 & 0.0013 & 1.0729 & 79.923\end{array}$ $\begin{array}{llllllllllll}1.00 & 55.03 & 27.46 & 24.64 & 2 & 1486.7642 & 1486.7623 & 744.3884 & 0.0019 & 1.2762 & 233.831\end{array}$ $\begin{array}{lllllllllllll}0.97 & 39.65 & 26.39 & 20.55 & 2 & 1428.8116 & 1428.8068 & 715.4107 & 0.0048 & 3.3547 & 41.527 \\ 0.64 & 27.92 & 19.29 & 40.92 & 2 & 983.6252 & 983.6249 & 492.8197 & 0.0003 & 0.3044 & 14.388\end{array}$ $\begin{array}{lllllllllllll}0.64 & 27.92 & 19.29 & 40.92 & 2 & 983.6252 & 983.6249 & 492.8197 & 0.0003 & 0.3044 & 14.388 \\ 0.64 & 21.05 & 19.29 & 34.05 & 2 & 983.6254 & 983.6249 & 492.8197 & 0.0005 & 0.5073 & 15.914\end{array}$ $\begin{array}{lllllllllll}0.64 & 21.05 & 19.29 & 34.05 & 2 & 983.6254 & 983.6249 & 492.8197 & 0.0005 & 0.5073 & 15.914 \\ 0.98 & 31.38 & 28.19 & 23.77 & 2 & 1277.7090 & 1277.7071 & 639.8608 & 0.0019 & 1.4847 & 3.908\end{array}$

NPQTAR

GDYPLEAVR

GDYPLEAVR

GDYPLEAVR

GDYPLEAVR

GDYPLEAVR

GDYPLEAVR

GDYPLEAVR

DDYPLEAVR

GDYPLEAVR

GDYPLEAVR

GDYPLEAVR

GDYPLEAVR

GDYPLEAVR

GDYPLEAVR

GDYPLEAVR

GDYPLEAVR $\begin{array}{lllllllllll}0.85 & 22.71 & 27.98 & 19.72 & 2 & 1162.6116 & 1162.6104 & 582.3125 & 0.0012 & 1.0304 & 232.504\end{array}$ $\begin{array}{lllllllllll}0.74 & 19.64 & 27.98 & 19.92 & 2 & 1162.6116 & 1162.6104 & 582.3125 & 0.0012 & 1.0304 & 178.816\end{array}$ $\begin{array}{llllllllllll}0.89 & 24.62 & 28.09 & 22.59 & 2 & 1162.6118 & 1162.6104 & 582.3125 & 0.0014 & 1.2021 & 258.688\end{array}$ $\begin{array}{lllllllllll}1.00 & 40.46 & 28.09 & 30.98 & 2 & 1162.6118 & 1162.6104 & 582.3125 & 0.0014 & 1.2021 & 10575.010\end{array}$

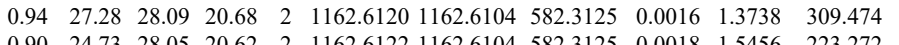
$\begin{array}{lllllllllll}0.90 & 24.73 & 28.05 & 20.62 & 2 & 1162.6122 & 1162.6104 & 582.3125 & 0.0018 & 1.5456 & 223.272\end{array}$ $\begin{array}{llllllllllll}1.00 & 43.62 & 28.05 & 25.19 & 2 & 1162.6124 & 1162.6104 & 582.3125 & 0.0020 & 1.7173 & 2859.159 \\ 0.95 & 28.15 & 28.05 & 21.44 & 2 & 116.6124 & 1162.6104 & 582.3125 & 0.0020 & 1.7173 & 258.287\end{array}$ $\begin{array}{llllllllllll}0.95 & 28.15 & 28.05 & 21.44 & 2 & 1162.6124 & 1162.6104 & 582.3125 & 0.0020 & 1.7173 & 258.287 & 28\end{array}$ $\begin{array}{lllllllllll}0.86 & 22.91 & 28.05 & 18.52 & 2 & 1162.6124 & 1162.6104 & 582.3125 & 0.0020 & 1.7173 & 25.206 \\ 0.95 & 27.88 & 28.03 & 19.05 & 2 & 1162.6128 & 1162.6104 & 582.3125 & 0.0024 & 2.0607 & 210.163\end{array}$ $\begin{array}{lllllllllll}0.95 & 27.88 & 28.03 & 19.05 & 2 & 1162.6128 & 1162.6104 & 582.3125 & 0.0024 & 2.0607 & 210.163\end{array}$ $\begin{array}{llllllllllll}0.99 & 37.01 & 28.03 & 23.75 & 2 & 1162.6128 & 1162.6104 & 582.3125 & 0.0024 & 2.0607 & 7038.606 \\ 1.00 & 42.17 & 28.03 & 27.27 & 2 & 1162.6130 & 1162.6104 & 582.3125 & 0.0026 & 2.2325 & 3228.169\end{array}$ $\begin{array}{llllllllllll}1.00 & 42.17 & 28.03 & 27.27 & 2 & 1162.6130 & 1162.6104 & 582.3125 & 0.0026 & 2.2325 & 3228.169 \\ 0.91 & 28.59 & 28.39 & 18.44 & 2 & 1162.6136 & 1162.6104 & 582.3125 & 0.0032 & 2.7477 & 78.724\end{array}$ $\begin{array}{lllllllllll}0.91 & 28.59 & 28.39 & 18.44 & 2 & 1162.6136 & 1162.6104 & 582.3125 & 0.0032 & 2.7477 & 78.724 \\ 0.84 & 25.62 & 28.39 & 20.66 & 2 & 1162.6138 & 1162.6104 & 582.3125 & 0.0034 & 2.9194 & 212.817 \\ 0.92 & 42.16 & 27.13 & 20.87 & 2 & 1428.8034 & 1428.868 & 75.4107 & 0.0030 & -2.067 & \end{array}$ $\begin{array}{llllllllllll}0.84 & 25.62 & 28.39 & 20.66 & 2 & 1162.6138 & 1162.6104 & 582.3125 & 0.0034 & 2.9194 & 212.817 \\ 0.92 & 42.16 & 27.13 & 20.87 & 2 & 1428.8038 & 1428.8068 & 715.4107 & -0.0030 & -2.0967 & 40.795\end{array}$ $\begin{array}{llllllllllll}0.98 & 45.67 & 27.13 & 21.31 & 2 & 1428.8044 & 1428.8068 & 715.4107 & -0.0024 & -1.6774 & 52.950\end{array}$ $\begin{array}{lllllllllll}0.92 & 37.24 & 27.20 & 23.30 & 2 & 1428.8046 & 1428.8068 & 715.4107 & -0.0022 & -1.5376 & 53.364 \\ 0.86 & 34.0 & 27.23 & 24.66 & 2 & 1428.8050 & 1428.8068 & 715.4107 & -0.0018 & -1.2580 & 72.427\end{array}$

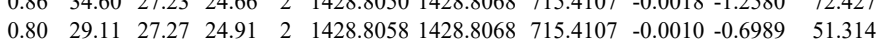
$\begin{array}{lllllllllll}1.00 & 49.54 & 27.27 & 28.18 & 2 & 1428.8060 & 1428.8068 & 715.4107 & -0.0008 & -0.5591 & 52.174\end{array}$ $\begin{array}{llllllllllll}0.86 & 26.71 & 27.39 & 21.83 & 2 & 1428.8068 & 1428.8068 & 715.4107 & 0.0000 & 0.0000 & 38.036\end{array}$ 

$\begin{array}{lllllllllllll}\text { GADFLVTEVENGGSLGSK } & 0.99 & 28.33 & 27.46 & 18.30 & 3 & 2067.0766 & 2067.0728 & 690.0315 & 0.0038 & 1.8357 & 852.448\end{array}$ $\begin{array}{lllllllllllll}\text { GADFLVTEVENGGSLGSK } & 1.00 & 35.85 & 27.54 & 25.52 & 3 & 2067.0772 & 2067.0728 & 690.0315 & 0.0044 & 2.1255 & 72.295 \\ \text { GADFVTEVENGSLGSK } & 1.00 & 43.46 & 27.55 & 17.05 & 3 & 2067.0775 & 2067.0728 & 690.0315 & 0.0047 & 2.2704 & 77.624\end{array}$ $\begin{array}{llllllllllllll}\text { GADFLVTEVENGGSLGSK } & 0.99 & 34.30 & 27.55 & 18.42 & 3 & 2067.0775 & 2067.0728 & 690.0315 & 0.0047 & 2.2704 & 67.420\end{array}$ $\begin{array}{llllllllllll}\text { GADFLVTEVENGGSLGSK } & 1.00 & 58.46 & 27.50 & 19.24 & 3 & 2067.0790 & 2067.0728 & 690.0315 & 0.0062 & 2.9950 & 88.670\end{array}$ $\begin{array}{llllllllllll}\text { GADFLVTEVENGGSLGSK } & 0.99 & 33.15 & 27.50 & 15.49 & 3 & 2067.0790 & 2067.0728 & 690.0315 & 0.0062 & 2.9950 & 602.485\end{array}$

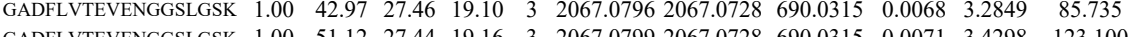
$\begin{array}{llllllllllll}\text { GADFLVTEVENGGSLGSK } & 1.00 & 51.12 & 27.44 & 19.16 & 3 & 2067.0799 & 2067.0728 & 690.0315 & 0.0071 & 3.4298 & 123.100\end{array}$ $\begin{array}{lllllllllll} & \end{array}$

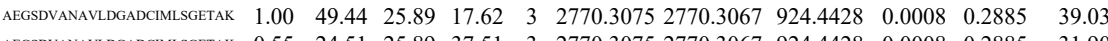

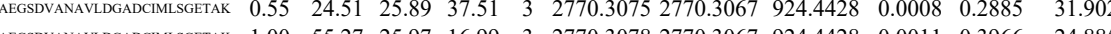

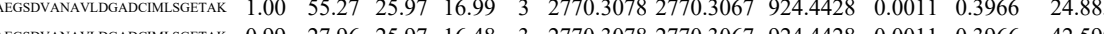

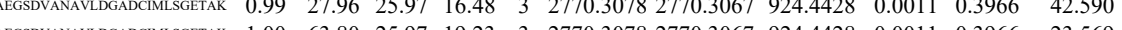
\begin{tabular}{llllllllllll}
\hline EGSDVANAVIDGADCIMLSGETAK & 0.55 & 55.92 & 25.94 & 68.92 & 3 & 2770.3081 & 2770.3067 & 924.4428 & 0.0014 & 0.5048 & 52.804
\end{tabular}

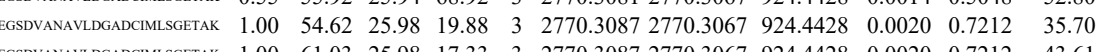

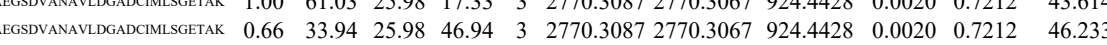

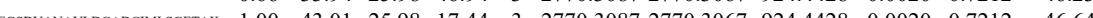
$\begin{array}{lllllllllllll}\text { AEGSDVANAVLDGADCIMLSGETAK } & 1.00 & 24.15 & 25.98 & 37.15 & 4 & 2770.3089 & 2770.3067 & 693.5840 & 0.0022 & 0.7930 & 78.788\end{array}$

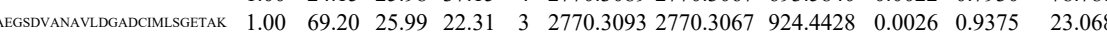
$\begin{array}{lllllllllllll}\text { AEGSDVANAVLDGADCIMLSGEtaK } & 1.00 & 94.78 & 25.99 & 19.85 & 3 & 2770.3093 & 2770.3067 & 924.4428 & 0.0026 & 0.9375 & 98.504\end{array}$ $\begin{array}{llllllllllll}\text { AEGSDVANAVLDGADCIMLSGEFTAK } & 1.00 & 39.47 & 25.99 & 18.26 & 4 & 2770.3093 & 2770.3067 & 693.5840 & 0.0026 & 0.9372 & 42.161\end{array}$

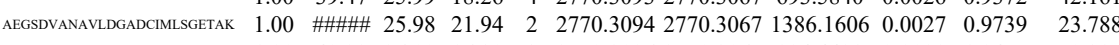

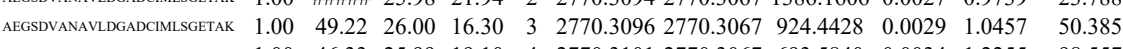

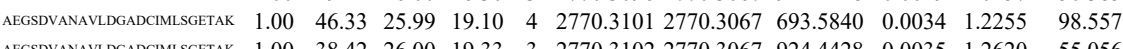

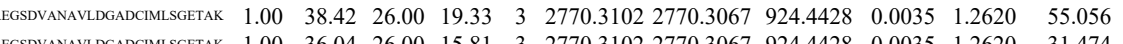

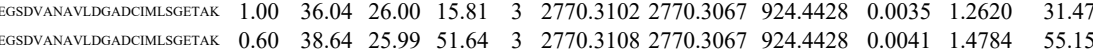

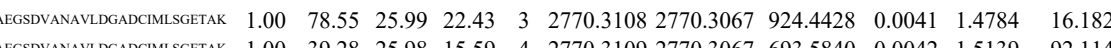

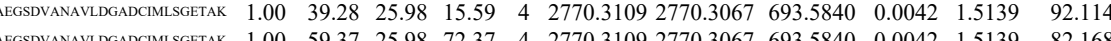
$\begin{array}{llllllllllll} & \end{array}$ $\begin{array}{llllllllllllll} & \end{array}$

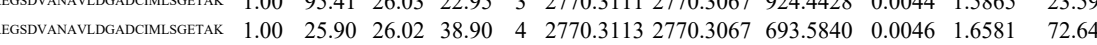

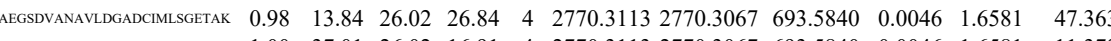
$\begin{array}{lllllllllllll}\text { AEGSDVANAVLDGADCIMLSGETAK } & 1.00 & 37.01 & 26.02 & 16.91 & 4 & 2770.3113 & 2770.3067 & 693.5840 & 0.0046 & 1.6581 & 11.373 \\ \text { IEGSDVANAVLDGADCIMLSGETAK } & 1.00 & 34.97 & 26.02 & 21.95 & 3 & 2770.3117 & 2770.3067 & 924.4428 & 0.0050 & 1.8029 & 52.887\end{array}$ $\begin{array}{llllllllllll}\text { AEGSDVANAVIDGADCIMLSGETAK } & 1.00 & 34.97 & 26.02 & 21.95 & 3 & 2770.3117 & 2770.3067 & 924.4428 & 0.0050 & 1.8029 & 52.887 \\ \text { AEGSDVANAVIDGADCIMLSGETAK } & 0.59 & 4.99 & 26.02 & 13.93 & 4 & 2770.3117 & 2770.3067 & 693.5840 & 0.0050 & 1.8022 & 100.909\end{array}$ $\begin{array}{lllllllllllll}\text { AEGSDVANAVLDGADCIMLSGETAK } & 0.59 & 4.99 & 26.02 & 13.93 & 4 & 2770.3117 & 2770.3067 & 693.5840 & 0.0050 & 1.8022 & 100.909 \\ \text { AEGSDVANAVIDGADCIMLSGETAK } & 1.00 & 30.94 & 26.02 & 43.94 & 4 & 2770.3117 & 2770.3067 & 693.5840 & 0.0050 & 1.8022 & 89.028\end{array}$ $\begin{array}{lllllllllllll}\text { AEGSDVANAVLDGADCIMLSGETAK } & 1.00 & 30.94 & 26.02 & 43.94 & 4 & 2770.3117 & 2770.3067 & 693.5840 & 0.0050 & 1.8022 & 89.028 \\ \text { IEGSDVANAVLDGADCIMLSGETAK } & 0.73 & 6.75 & 26.00 & 19.75 & 4 & 2770.3121 & 2770.3067 & 693.5840 & 0.0054 & 1.9464 & 56.446\end{array}$

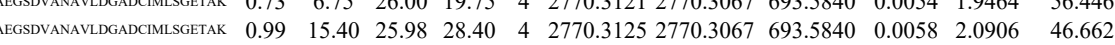
$\begin{array}{llllllllllllll} & \end{array}$

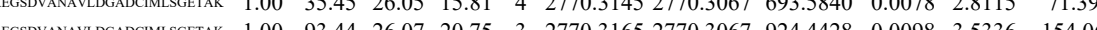
$\begin{array}{llllllllll} & 154.064\end{array}$ 

$\begin{array}{llllllllllllllll}1.00 & 42.61 & 27.47 & 19.27 & 2 & 1153.6344 & 1153.6335 & 577.8240 & 0.0009 & 0.7788 & 493.217 & 553.968 & 20.585 & 425.313 & \text { Yes }\end{array}$ $\begin{array}{llllllllllllllllll}0.99 & 46.39 & 27.57 & 30.21 & 2 & 1269.6902 & 1269.6808 & 635.8477 & 0.0094 & 7.3917 & 21693.638 & 23762.964 & 11853.087 & 19276.971 & \text { Yes }\end{array}$ $\begin{array}{lllllllllllllllll}1.00 & 45.96 & 27.69 & 29.82 & 2 & 1269.6908 & 1269.6808 & 635.8477 & 0.0100 & 7.8635 & 29689.629 & 32133.234 & 14370.986 & 23044.221 & \text { Yes }\end{array}$ $\begin{array}{lllllllllllllll}1.00 & 59.89 & 26.80 & 27.10 & 2 & 1372.7926 & 1372.7805 & 687.3975 & 0.0121 & 8.8012 & 14082.862 & 16293.005 & 2564.353 & 14210.043 & \text { Yss }\end{array}$ DISTNYYASQK $\begin{array}{llllllllllllllll}1.00 & 78.16 & 27.59 & 31.55 & 2 & 1576.8072 & 1576.7977 & 789.4061 & 0.0095 & 6.0171 & 2188.144 & 1317.756 & 3708.457 & 4452.041 & \text { No } & \\ 1.00 & 62.07 & 27.5 & 23.59 & 2 & 1576872 & & \end{array}$

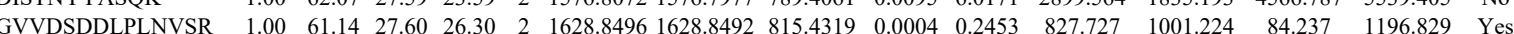
$\begin{array}{lllllllllllllllll}\text { GVVDSDDLPLNVSR } & 1.00 & 84.05 & 27.88 & 32.39 & 2 & 1628.8644 & 1628.8492 & 815.4319 & 0.0152 & 9.3201 & 584.165 & 534.908 & 135.866 & 501.256 & \text { Yes }\end{array}$ AQAYQTGK AQAYQTGK SGTSEFLNK SGTSEFLNK LSLNIDPDAK LSLNIDPDAK $\begin{array}{lllllllllllllll}0.84 & 30.71 & 27.62 & 19.33 & 2 & 1153.6330 & 1153.6335 & 577.8240 & -0.0005 & -0.4327 & 165.457 & 174.194 & 23.542 & 129.712 & \text { Yes }\end{array}$

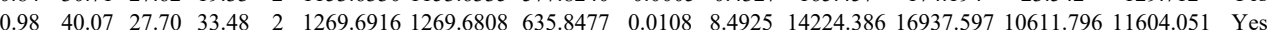
$\begin{array}{lllllllllllllll}0.98 & 38.19 & 27.48 & 24.64 & 2 & 1269.6926 & 1269.6808 & 635.8477 & 0.0118 & 9.2789 & 14710.830 & 17597.356 & 16023.315 & 14762.490 & \text { Yes }\end{array}$ $\begin{array}{lllllllllllllll}1.00 & 59.21 & 27.23 & 26.81 & 2 & 1372.7830 & 1372.7805 & 687.3975 & 0.0025 & 1.8184 & 19666.355 & 22420.270 & 1299.934 & 19174.538 & \text { Yes }\end{array}$ $\begin{array}{llllllllllllllll}1.00 & 60.57 & 27.12 & 26.34 & 2 & 1372.7834 & 1372.7805 & 687.3975 & 0.0029 & 2.1094 & 15512.186 & 17825.755 & 80.781 & 14911.767 & \text { Yes }\end{array}$ $\begin{array}{lllllllllllllllll}0.79 & 27.01 & 26.22 & 22.10 & 2 & 1007.6022 & 1007.5929 & 504.8037 & 0.0093 & 9.2114 & 4831.735 & 5051.761 & 757.658 & 6393.964 & \text { Yes }\end{array}$ $\begin{array}{llllllllllllllll}0.86 & 28.63 & 26.59 & 22.03 & 2 & 1007.6028 & 1007.5929 & 504.8037 & 0.0099 & 9.8057 & 4945.978 & 5052.634 & 946.201 & 6750.551 & \text { Yes }\end{array}$ LSLNIDPDAK $\begin{array}{lllllllllllllll} & \end{array}$

VFITDDFHDMMMPK

VFITDDFHDMMPK

VFITDDFHDMMPK

VFITDDFHDMMPK $\begin{array}{llllllllllll}0.98 & \end{array}$ EDEDDKTVLDLAVVLFETA

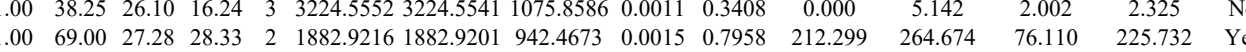

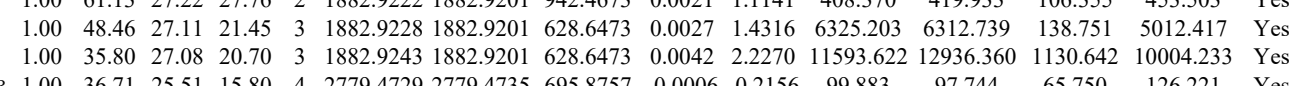
\begin{tabular}{|llllllllllllllllll} 
&
\end{tabular}

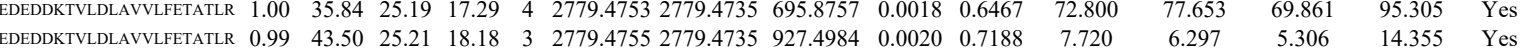

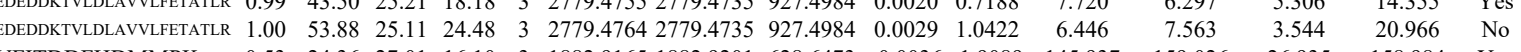

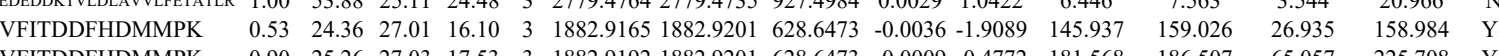
\begin{tabular}{llllllllllllllllll} 
VFITDDFHDMMPK & 0.90 & 25.26 & 27.03 & 17.53 & 3 & 1882.9192 & 1882.9201 & 628.6473 & -0.0009 & -0.4772 & 181.568 & 186.507 & 65.057 & 225.708 & Ys \\
\hline
\end{tabular}

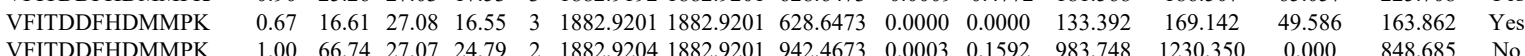

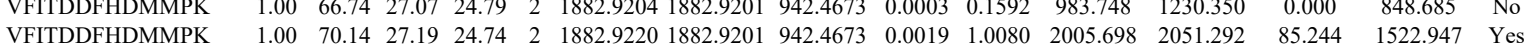

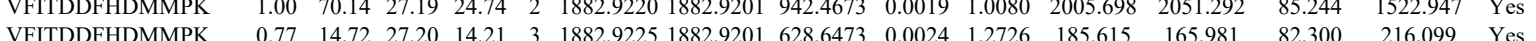

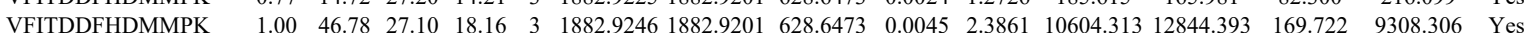
$\begin{array}{lllllllllllllllll}\text { FQSSHHPTDITSLDQYVER } & 0.67 & 52.91 & 27.14 & 65.91 & 3 & 2403.1609 & 2403.1577 & 802.0598 & 0.0032 & 1.3299 & 1570.153 & 1629.553 & 531.011 & 1532.025 & \text { Yes }\end{array}$

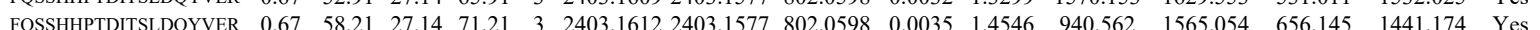
\begin{tabular}{llllllllllllllll} 
EDEDDKTVLDLAVVLFETATLR & 1.00 & 39.86 & 25.02 & 17.91 & 4 & 2779.4769 & 2779.4735 & 695.8757 & 0.0034 & 1.2215 & 74.926 & 71.310 & 62.126 & 101.866 & Yes \\
\hline
\end{tabular} $\begin{array}{llllllllllllllll}\text { EDEDDKTLDLAVVLFETATLR } & 1.00 & 30.95 & 25.01 & 15.61 & 4 & 2779.4777 & 2779.4735 & 695.8757 & 0.0042 & 1.5089 & 93.299 & 101.889 & 36.092 & 90.374 & \text { Yes }\end{array}$ $\begin{array}{llllllllllllllll}\text { VFITDDFHDMMPK } & 1.00 & 72.92 & 27.06 & 30.01 & 2 & 1882.9210 & 1882.9201 & 942.4673 & 0.0009 & 0.4775 & 767.088 & 714.268 & 0.000 & 481.519 & \text { No }\end{array}$

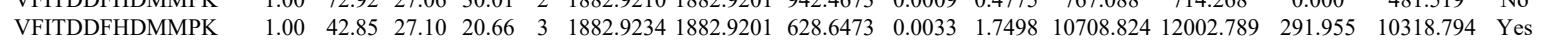
$\begin{array}{llllllllllllllll}\text { VFITDDFHDMMPK } & 1.00 & 41.00 & 27.09 & 21.91 & 3 & 1882.9240 & 1882.9201 & 628.6473 & 0.0039 & 2.0679 & 8836.551 & 9457.423 & 75.451 & 7439.078 & \text { Yes }\end{array}$ $\begin{array}{llllllllllllllllll}\text { EDEDDKTVLDLAVVLFETATLR } & 1.00 & 40.88 & 25.24 & 53.88 & 4 & 2779.4757 & 2779.4735 & 695.8757 & 0.0022 & 0.7904 & 137.935 & 92.844 & 58.710 & 130.023 & \text { Yes }\end{array}$

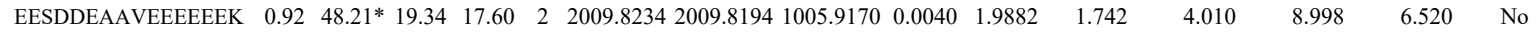
$\begin{array}{lllllllllllllllll}\text { EESDDEAAVEEEEEEK } & 0.59 & 10.40 & 22.17 & 15.37 & 3 & 2153.9215 & 2153.9215 & 718.9811 & 0.0000 & 0.0000 & 17.482 & 5.439 & 4.503 & 9.021 & \text { No }\end{array}$

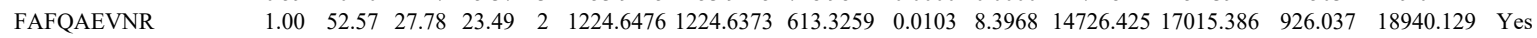
FAFQAEVNR

FAFQAEVNR

FAFQAEVNR

FAFQAEVNR

$\begin{array}{lllllllllllllllll}1.00 & 50.27 & 27.78 & 26.63 & 2 & 1224.6478 & 1224.6373 & 613.3259 & 0.0105 & 8.5598 & 14850.982 & 15375.591 & 12.204 & 22398.896 & \text { Yes }\end{array}$ $\begin{array}{lllllllllllllllll}0.99 & 44.36 & 27.56 & 23.64 & 2 & 1224.6450 & 1224.6373 & 613.3259 & 0.0077 & 6.2772 & 16683.696 & 17899.386 & 1154.610 & 25528.378 & \text { Yes }\end{array}$ $\begin{array}{lllllllllllllllll}1.00 & 53.91 & 27.56 & 22.92 & 2 & 1224.6450 & 1224.6373 & 613.3259 & 0.0077 & 6.2772 & 18198.007 & 22979.050 & 363.300 & 28341.317 & \text { Yes }\end{array}$ $\begin{array}{lllllllllllllll}0.98 & 40.81 & 27.56 & 23.69 & 2 & 1224.6452 & 1224.6373 & 613.3259 & 0.0079 & 6.4403 & 6454.048 & 7691.550 & 364.433 & 10038.889 & \text { Yes }\end{array}$ $\begin{array}{llllllllllllllllll}0.99 & 41.72 & 27.40 & 21.79 & 2 & 1224.6460 & 1224.6373 & 613.3259 & 0.0087 & 7.0924 & 9692.257 & 9759.718 & 478.173 & 13867.825 & \text { Yes }\end{array}$

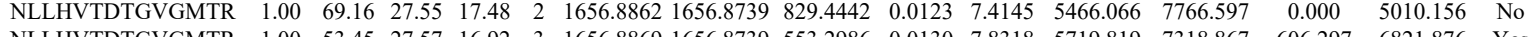
$\begin{array}{llllllllllllllll}\text { NLLHVTDTGVGMTR } & 1.00 & 53.45 & 27.57 & 16.92 & 3 & 1656.8869 & 1656.8739 & 553.2986 & 0.0130 & 7.8318 & 5719.819 & 7318.867 & 606.297 & 6821.876 & \text { Yes }\end{array}$ $\begin{array}{llllllllllllllll}\text { NLLHVTDTGVGMTR } & 1.00 & 70.81 & 27.60 & 26.00 & 2 & 1656.8890 & 1656.8739 & 829.4442 & 0.0151 & 9.1024 & 9615.673 & 10417.490 & 0.000 & 7002.024 & \text { No }\end{array}$

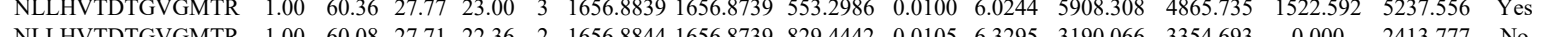

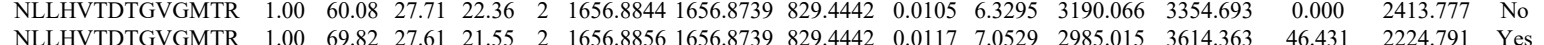

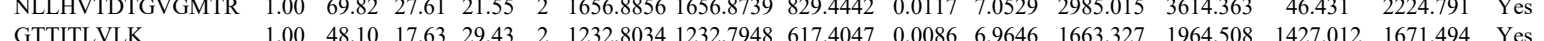
$\begin{array}{llllllllllllllll}\text { GTTITLVK } & 1.00 & 48.10 & 17.63 & 29.43 & 2 & 1232.8034 & 1232.7948 & 617.4047 & 0.008 & 6.9646 & 1363.327 & 1964.508 & 1427.012 & 167.494 & \text { Yes } \\ \text { GTTITLVLK } & 1.00 & 57.02 & 20.21 & 30.09 & 2 & 1232.8068 & 1232.7948 & 617.4047 & 0.0120 & 9.7180 & 3058.844 & 3500.616 & 2312.150 & 2515.279 & \text { Yes }\end{array}$ $\begin{array}{lllllllllllllllll}\text { GTTILV } & 1.00 & 57.02 & 20.21 & 30.09 & 2 & 1232.8068 & 1232.7948 & 617.4047 & 0.0120 & 9.7180 & 3058.844 & 3500.616 & 2312.150 & 2515.279 & \text { Yes } \\ \text { YLNFVK } & 0.88 & 27.00 & 24.50 & 31.09 & 2 & 1070.6472 & 1070.6368 & 536.3257 & 0.0104 & 9.6955 & 50951.517 & 46655.799 & 3603.599 & 77560.604 & \text { Yes }\end{array}$ 

$\begin{array}{llllllllllllllll}\text { LTESPCALVASQYGWSGNMER } & 0.82 & 64.16 & 24.76 & 77.16 & 2 & 2488.1314 & 2488.1307 & 1245.0726 & 0.0007 & 0.2811 & 19.173 & 81.792 & 19.329 & 31.437 & \text { No } \\ \text { LTESPCALVASQYGWSGNMER } & 0.82 & 79.14 & 24.76 & 92.14 & 2 & 2488.1314 & 2488.1307 & 1245.0726 & 0.0007 & 0.2811 & 18.382 & 32.245 & 1.358 & 51.887 & \text { No }\end{array}$

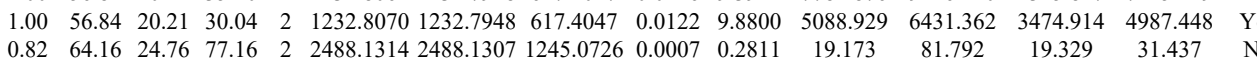

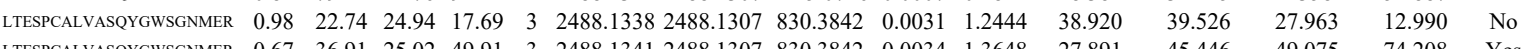
$\begin{array}{llllllllllllllll}\text { LTESPCALVASQYGWSGNMER } & 0.67 & 36.91 & 25.02 & 49.91 & 3 & 2488.1341 & 2488.1307 & 830.3842 & 0.0034 & 1.3648 & 27.891 & 45.446 & 49.075 & 74.208 & \text { Yes }\end{array}$

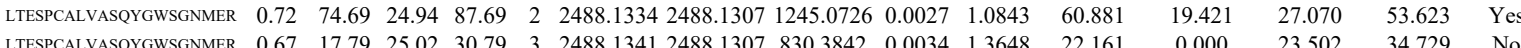
\begin{tabular}{lllllllllllllll} 
& LTESPCALVASQYGWSGMMER \\
\hline
\end{tabular}

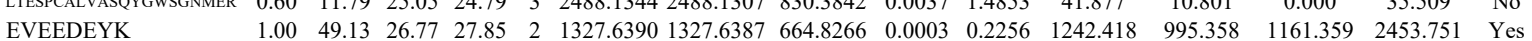

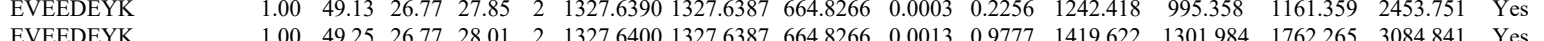

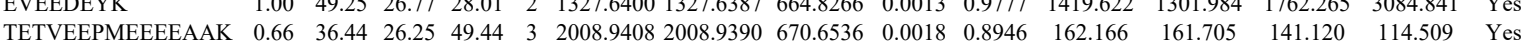
$\begin{array}{lllllllllllllll} & \end{array}$

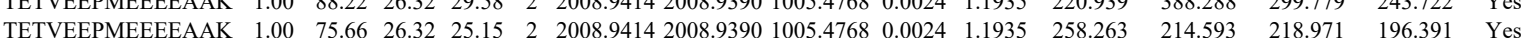
$\begin{array}{llllllllllllllll}\text { TETVEEPMEEEEAAK } & 0.67 & 40.67 & 6.640 & 53.67 & 3 & 2008.9423 & 2008.9390 & 670.6536 & 0.0033 & 1.6402 & 70.985 & 37.558 & 79.126 & 47.757 & \text { No }\end{array}$

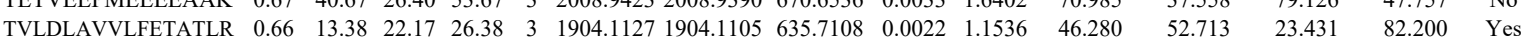
$\begin{array}{llllllllllllllll}\text { TVLDLAVVLFETATLR } & 0.67 & 15.86 & 21.99 & 28.86 & 3 & 1904.1139 & 1904.1105 & 635.7108 & 0.0034 & 1.7828 & 56.356 & 6.279 & 25.228 & 97.621 & \text { Yes }\end{array}$ $\begin{array}{llllllllllllllll}\text { TVLDLAVVLFETATLR } & 0.68 & 9.68 & 22.23 & 14.02 & 3 & 1904.1118 & 1904.1105 & 635.7108 & 0.0013 & 0.6817 & 71.194 & 59.294 & 14.299 & 74.387 & \text { Yes }\end{array}$ $\begin{array}{llllllllllllll}\text { TVLDLAVVLFETATLR } & 1.00 & \# \# \# \# \frac{22.23}{30.65} & 2 & 1904.1122 & 1904.1105 & 953.0625 & 0.0017 & 0.8919 & 62.173 & 120.997 & 23.827 & 77.587 & \text { Yes }\end{array}$ $\begin{array}{lllllllllllllllll}\text { TVLDLAVVLFETATLR } & 0.66 & 20.31 & 22.17 & 33.31 & 3 & 1904.1127 & 1904.1105 & 635.7108 & 0.0022 & 1.1536 & 45.386 & 57.647 & 14.401 & 82.488 & \text { Yes }\end{array}$ $\begin{array}{lllllllllllllllll}\text { TVLDLAVVLFETATLR } & 0.67 & 23.73 & 22.20 & 36.73 & 3 & 1904.1133 & 1904.1105 & 635.7108 & 0.0028 & 1.4682 & 53.914 & 49.855 & 20.594 & 45.460 & \text { Yes }\end{array}$ \begin{tabular}{lllllllllllllllll} 
TVLDLAVVLFETATLR & 0.67 & 19.73 & 22.01 & 32.73 & 3 & 1904.1136 & 1904.1105 & 635.7108 & 0.0031 & 1.6255 & 37.628 & 46.833 & 14.488 & 56.937 & Yes \\
\hline
\end{tabular} $\begin{array}{lllllllllllllll}\text { TVLDLAVVLFETATLR } & 1.00 & \text { \#\#\#\# } 22.01 & 33.25 & 2 & 1904.1136 & 1904.1105 & 953.0625 & 0.0031 & 1.6263 & 57.635 & 68.239 & 24.636 & 74.430 & \text { Yes }\end{array}$ $\begin{array}{llllllllllllllll}\text { TVLDLAVVLFETATLR } & 0.51 & 6.79 & 22.12 & 14.09 & 3 & 1904.1112 & 1904.1105 & 635.7108 & 0.0007 & 0.3670 & 39.248 & 47.440 & 20.690 & 61.733 & \text { Yes }\end{array}$ $\begin{array}{llllllllllllllll}\text { TVLDLAVVLFETATLR } & 0.66 & 34.60 & 22.23 & 47.60 & 3 & 1904.1124 & 1904.1105 & 635.7108 & 0.0019 & 0.9963 & 44.693 & 57.905 & 25.327 & 64.190 & \text { Yes }\end{array}$ $\begin{array}{lllllllllllllll}\text { TVLDLAVVLFETATLR } & 1.00 & \text { \#\#\#\# } 22.23 & 29.63 & 2 & 1904.1124 & 1904.1105 & 953.0625 & 0.0019 & 0.9968 & 49.610 & 59.483 & 19.154 & 37.638 & \text { Yes }\end{array}$ $\begin{array}{lllllllllllllll}\text { TVLDLAVVLFETATLR } & 1.00 & \text { \#\#\# } 22.17 & 30.64 & 2 & 1904.1128 & 1904.1105 & 953.0625 & 0.0023 & 1.2066 & 53.940 & 75.091 & 34.458 & 66.077 & \text { Yes }\end{array}$ $\begin{array}{llllllllllllllll}\text { TVLDLAVVLFETATLR } & 0.67 & 27.51 & 22.01 & 40.51 & 3 & 1904.1136 & 1904.1105 & 635.7108 & 0.0031 & 1.6255 & 49.258 & 60.755 & 24.744 & 51.975 & \text { Yes }\end{array}$ $\begin{array}{llllllllllllllll}\text { TVLDLAVVLFETATLR } & 1.00 & \text { 22.20 } & 33.28 & 2 & 1904.1106 & 1904.1105 & 953.0625 & 0.0001 & 0.0525 & 59.390 & 71.592 & 45.324 & 98.785 & \text { Yes }\end{array}$

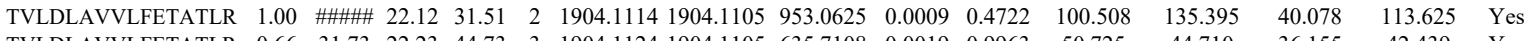
$\begin{array}{llllllllllllllll}\text { TVLDLAVVLFETATLR } & 0.66 & 31.73 & 22.23 & 44.73 & 3 & 1904.1124 & 1904.1105 & 635.7108 & 0.0019 & 0.9963 & 50.725 & 44.710 & 36.155 & 42.439 & \text { Yes }\end{array}$ \begin{tabular}{llllllllllllllll} 
TVLDLAVVLFETATLR & 0.66 & 13.10 & 22.17 & 26.10 & 3 & 1904.1127 & 1904.1105 & 635.7108 & 0.0022 & 1.1536 & 51.934 & 32.544 & 13.501 & 35.281 & Yes \\
\hline
\end{tabular}

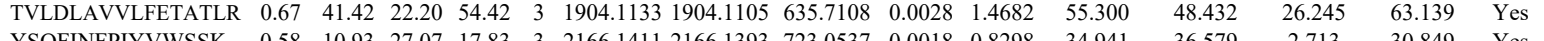

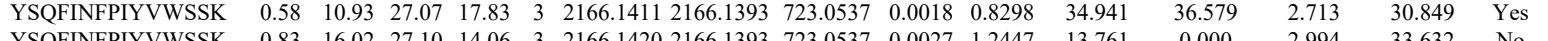

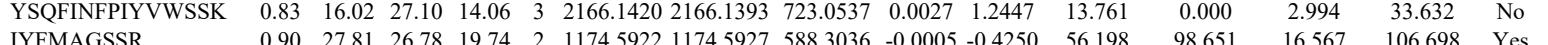

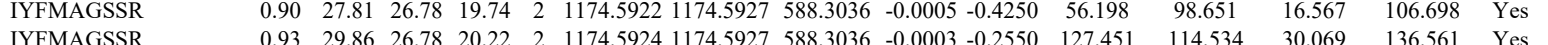

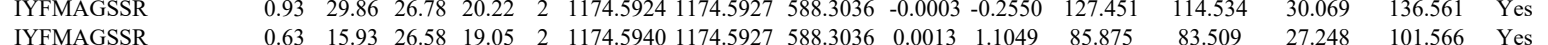

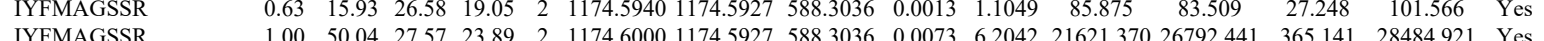

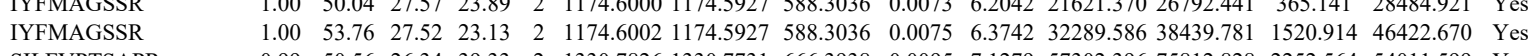

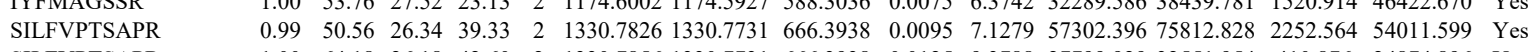

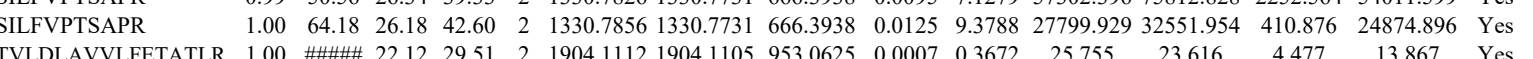
\begin{tabular}{lllllllllllllll} 
TVLDLAVVLFETATLR & 1.00 & $\# \# \# \#$ 22.12 & 29.51 & 2 & 1904.1112 & 1904.1105 & 953.0625 & 0.0007 & 0.3672 & 25.755 & 23.616 & 4.477 & 13.867 & Yes \\
\hline
\end{tabular}

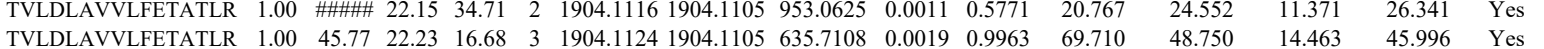

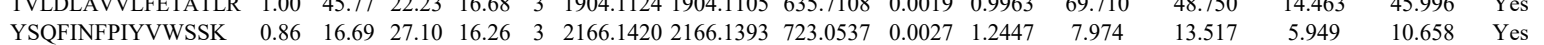

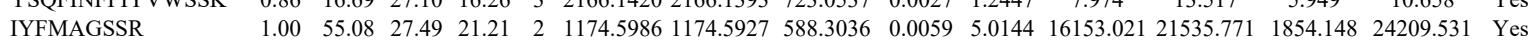

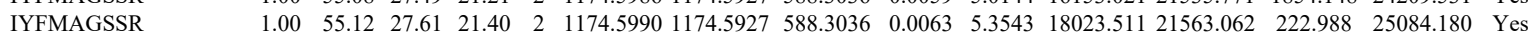

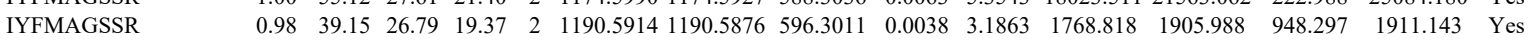
$\begin{array}{lllllllllllllllll}\text { SILFVPTSAPR } & 1.00 & 60.29 & 26.34 & 46.00 & 2 & 1330.7824 & 1330.7731 & 666.3938 & 0.0093 & 6.9778 & 11744.023 & 14855.312 & 12.376 & 12144.818 & \text { Yes }\end{array}$ $\begin{array}{llllllllllllllll}\text { SILFVPTSAPR } & 1.00 & 62.52 & 26.16 & 46.24 & 2 & 1330.7842 & 1330.7731 & 666.3938 & 0.0111 & 8.3283 & 19241.613 & 25791.210 & 0.000 & 20637.666 & \text { No }\end{array}$ $\begin{array}{lllllllllllllllll}\text { IYFMAGSSR } & 1.00 & 46.95 & 26.85 & 19.76 & 2 & 1174.5944 & 1174.5927 & 588.3036 & 0.0017 & 1.4448 & 4867.874 & 5440.553 & 365.376 & 6387.055 & \text { Yes }\end{array}$ $\begin{array}{lllllllllllllllll}\text { IYFMAGSSR } & 1.00 & 48.70 & 27.19 & 20.41 & 2 & 1174.5950 & 1174.5927 & 588.3036 & 0.0023 & 1.9548 & 6335.497 & 6371.546 & 964.720 & 8293.852 & \text { Yes }\end{array}$

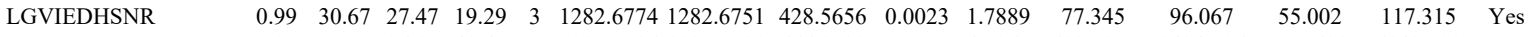

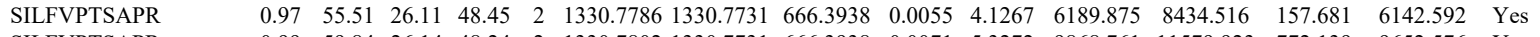
$\begin{array}{llllllllllllllll}\text { SILFVPTSAPR } & 0.99 & 59.84 & 26.14 & 48.24 & 2 & 1330.7802 & 1330.7731 & 666.3938 & 0.0071 & 5.3272 & 9868.761 & 11579.923 & 772.139 & 9652.576 & \text { Yes }\end{array}$ $\begin{array}{llllllllllllllll}\text { IYFMAGSSR } & 1.00 & 45.65 & 26.58 & 18.95 & 2 & 1174.5942 & 1174.5927 & 588.3036 & 0.0015 & 1.2749 & 2721.102 & 3184.406 & 539.767 & 4020.343 & \text { Yes }\end{array}$ $\begin{array}{lllllllllllllllll} & \text { SILFVPTSAPR } & 1.00 & 56.03 & 26.64 & 38.31 & 2 & 1330.7756 & 1330.7731 & 666.3938 & 0.0025 & 1.8758 & 3316.843 & 3851.724 & 233.278 & 2658.974 & \text { Yes } \\ \text { SILFVPTSAPR } & 1.00 & 56.09 & 26.54 & 38.30 & 2 & 1330.7766 & 1330.7731 & 666.3938 & 0.0035 & 2.6261 & 3261.511 & 4273.835 & 243.772 & 3124.813 & \text { Yes }\end{array}$ $\begin{array}{lllllllllllllllll} & \\ \text { SILFVPTSAPR } & 1.00 & 56.09 & 26.54 & 38.30 & 2 & 1330.7766 & 1330.7731 & 666.3938 & 0.0035 & 2.6261 & 3261.511 & 4273.835 & 243.772 & 3124.813 & \text { Yes } \\ \text { IYFMAGSSR } & 1.00 & 54.95 & 26.78 & 23.84 & 2 & 1174.5926 & 1174.5927 & 588.3036 & -0.0001 & -0.0850 & 1111.682 & 1157.252 & 250.865 & 1254.151 & \text { Yes }\end{array}$ $\begin{array}{lccccccccccccccc}\text { IYFMAGSSR } & 1.00 & 54.95 & 26.78 & 23.84 & 2 & 1174.5926 & 1174.5927 & 588.3036 & -0.0001 & -0.0850 & 1111.682 & 1157.252 & 250.865 & 1254.151 & \text { Yes } \\ \text { TVLDLAVVLFETATLR } & 1.00 & 32.64 & 22.12 & 15.95 & 3 & 1904.1112 & 1904.1105 & 635.7108 & 0.0007 & 0.3670 & 7.068 & 19.971 & 5.014 & 18.999 & \text { Yes }\end{array}$

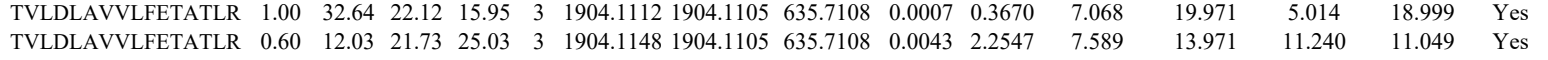
$\begin{array}{llllllllllllllll}\text { TVLDLAVVLFETATLR } & 0.60 & 12.03 & 21.73 & 25.03 & 3 & 1904.1148 & 1904.1105 & 635.7108 & 0.0043 & 2.2547 & 7.589 & 13.971 & 11.240 & 11.049 & \text { Yes } \\ \text { TVLDLAVVLFETATLR } & 0.55 & 35.30 & 22.12 & 48.30 & 3 & 1904.1115 & 1904.1105 & 635.7108 & 0.0010 & 0.5243 & 18.732 & 26.450 & 11.320 & 18.088 & \text { Yes }\end{array}$ $\begin{array}{llllllllllllllll}\text { TVLDLAVVLFETATLR } & 0.55 & 35.30 & 22.12 & 48.30 & 3 & 1904.1115 & 1904.1105 & 635.7108 & 0.0010 & 0.5243 & 18.732 & 26.450 & 11.320 & 18.088 & \text { Ycs } \\ \text { TVLDLAVVLFETATLR } & 1.00 & 83.67 & 22.17 & 19.32 & 2 & 1904.1128 & 1904.1105 & 953.0625 & 0.0023 & 1.2066 & 12.328 & 25.718 & 1.744 & 11.165 & \text { No }\end{array}$

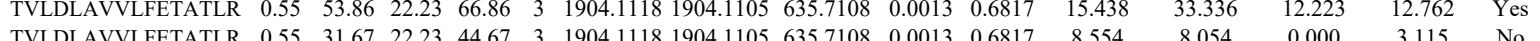
$\begin{array}{llllllllllllllll}\text { TVLDLAVVLFETATLR } & 0.55 & 31.67 & 22.23 & 44.67 & 3 & 1904.1118 & 1904.1105 & 635.7108 & 0.0013 & 0.6817 & 8.554 & 8.054 & 0.000 & 3.115 & \text { No } \\ \text { TVLDLAVVLFETATLR } & 0.67 & 21.32 & 22.01 & 34.32 & 3 & 1904.1136 & 1904.1105 & 635.7108 & 0.0031 & 1.6255 & 4.485 & 8.680 & 8.442 & 3.561 & \text { No }\end{array}$

Table S-4 page 191 of 614 

$\begin{array}{llllllllllllllll}\text { GLFDEYGSK } & 0.99 & 41.20 & 28.09 & 17.31 & 2 & 1302.6824 & 1302.6700 & 652.3423 & 0.0124 & 9.5041 & 11402.253 & 16394.629 & 817.179 & 11076.723 & \text { Yes }\end{array}$

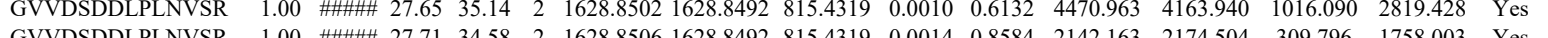

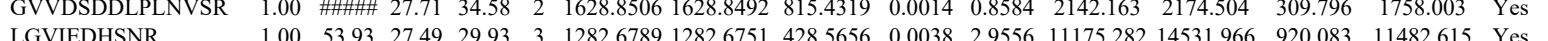

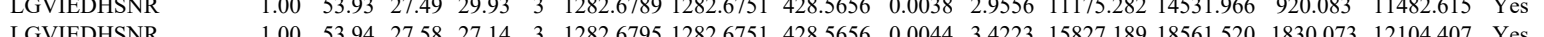
$\begin{array}{lllllllllllllllll} & 1.00 & 53.94 & 27.58 & 27.14 & 3 & 1282.674 & 1282.6751 & 28.5656 & 0.0044 & 3.4223 & 15827.189 & 18561.520 & 1830.073 & 1282.6407 & \text { Yes }\end{array}$

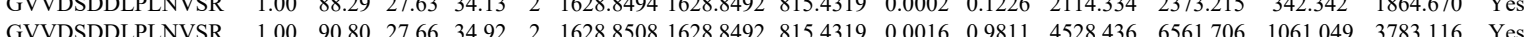
$\begin{array}{llllllllllllll} & \end{array}$ $\begin{array}{lllllllllllll} & \end{array}$

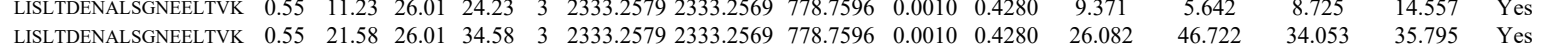

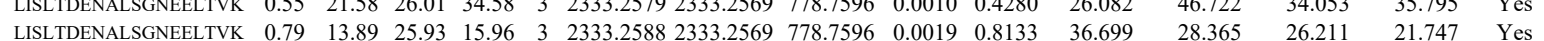
$\begin{array}{lllllllllllllllll}\text { LISIDENASGNEEITVK } & 1.00 & 74.18 & 25.89 & 20.67 & 3 & 2333.2591 & 2333.2569 & 778.7596 & 0.0022 & 0.9417 & 94.735 & 73.183 & 62.589 & 144.752 & \text { Yes }\end{array}$ $\begin{array}{llllllllllllllll}\text { LISLTDENALSGNFELTVK } & 1.00 & 54.32 & 25.89 & 18.14 & 3 & 2333.2591 & 2333.2569 & 778.7596 & 0.0022 & 0.9417 & 26.736 & 29.131 & 6.381 & 30.965 & \text { Yes }\end{array}$ $\begin{array}{llllllllllllllll}\text { LISLTDENALSGNEFLTVK } & 1.00 & 37.33 & 25.83 & 20.26 & 3 & 2333.2594 & 2333.2569 & 778.7596 & 0.0025 & 1.0701 & 141.924 & 124.199 & 41.912 & 200.081 & \text { Yes }\end{array}$ $\begin{array}{llllllllllllllll}\text { LISLTDENALSGNEELTVK } & 0.66 & 23.53 & 25.83 & 36.53 & 3 & 2333.2594 & 2333.2569 & 778.7596 & 0.0025 & 1.0701 & 32.319 & 27.050 & 19.622 & 28.792 & \text { Yes }\end{array}$

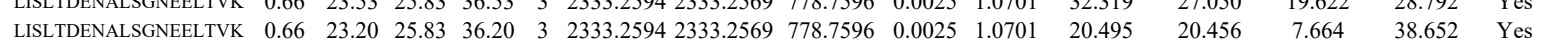

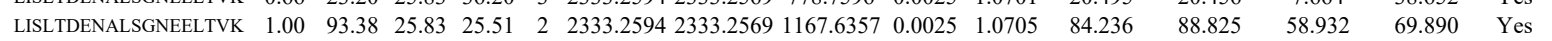
$\begin{array}{llllllllllllllll}\text { LISLTDENALSGNEELTVK } & 0.99 & 28.08 & 25.85 & 20.15 & 3 & 2333.2603 & 2333.2569 & 778.7596 & 0.0034 & 1.4553 & 21.395 & 14.019 & 21.945 & 27.752 & \text { Yes }\end{array}$

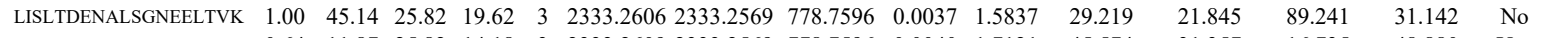
$\begin{array}{llllllllllllllll}\text { LISLTDENALSGNEELTVK } & 0.64 & 11.87 & 25.82 & 14.18 & 3 & 2333.2609 & 2333.2569 & 778.7596 & 0.0040 & 1.7121 & 45.574 & 31.357 & 16.735 & 48.880 & \text { Yes }\end{array}$

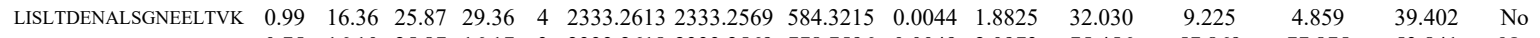
$\begin{array}{lllllllllllllllll}\text { LISLTDENALSGNEELTVK } & 0.75 & 16.10 & 25.87 & 16.17 & 3 & 2333.2618 & 2333.2569 & 778.7596 & 0.0049 & 2.0973 & 75.456 & 57.869 & 77.875 & 53.841 & \text { No }\end{array}$

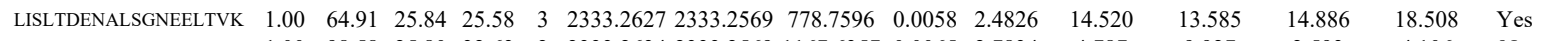
$\begin{array}{llllllllllllllll}\text { LISLTDENALSGNEELTVK } & 1.00 & 98.58 & 25.80 & 32.63 & 2 & 2333.2634 & 2333.2569 & 1167.6357 & 0.0065 & 2.7834 & 4.787 & 9.927 & 2.593 & 4.106 & \text { No }\end{array}$ $\begin{array}{lllllllllllllll}\text { LISLTDENALSGNEELTVK } & 1.00 & \text { \#\#\#\# } 24.89 .69 & 2 & 2333.2794 & 2333.2569 & 1167.6357 & 0.0225 & 9.6348 & 19.239 & 6.643 & 15.877 & 11.619 & \text { No }\end{array}$

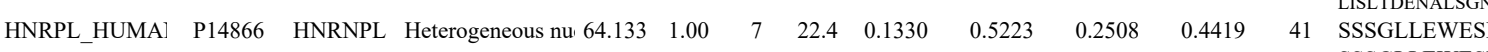
SSSGLLEWES FSTPEQAAK
FSTPEQAAK

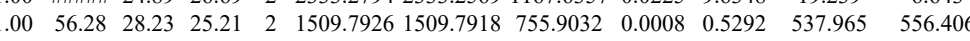
$\begin{array}{lllllllllllllllll}1.00 & 52.40 & 28.60 & 27.83 & 2 & 1265.6898 & 1265.6859 & 633.8502 & 0.0039 & 3.0764 & 41358.127 & 43059.382 & 6213.121 & 57780.995 & \text { Yes } \\ 1.00 & 51.13 & 28.62 & 32.58 & 2 & 1265.6902 & 1265.6859 & 633.8502 & 0.0043 & 3.3920 & 25445.621 & 23575.228 & 3435.057 & 34532.742 & \text { Yes } \\ & 1.00 & 99.53 & 20.57 & 25.46 & 4 & 3268.3997 & 32683995 & 818.1072 & 0.0002 & 0.0611 & 77.526 & 95.442 & 112529 & 105.968 & \text { Yes }\end{array}$ $\begin{array}{llllllllllllllll}\text { FSTPEQAAK } & 1.00 & 52.72 & 28.62 & 31.57 & 2 & 1265.6884 & 1265.6859 & 633.8502 & 0.0025 & 1.9721 & 25587.692 & 25904.475 & 4326.924 & 34278.634 & \text { Yes } \\ \text { FSTPEQAAK } & 1.00 & 52.78 & 28.70 & 29.81 & 2 & 1265.6890 & 1265.6859 & 633.8502 & 0.0031 & 2.4454 & 25231.488 & 28506.703 & 3563.140 & 39196.113 & \text { Yes }\end{array}$

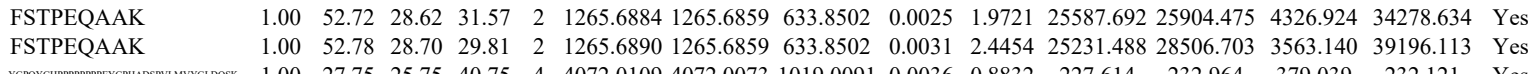
$\begin{array}{lllllllllllllll} & \end{array}$

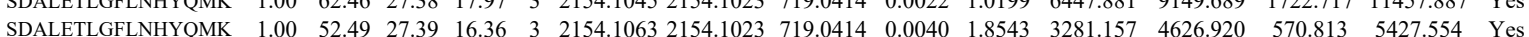

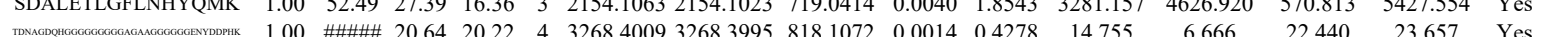

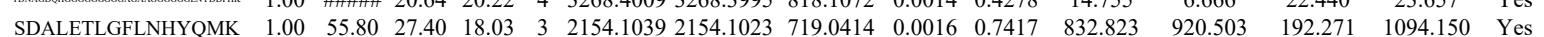
$\begin{array}{llllllllllllllll}\text { SDALETLGFLNHYQMK } & 1.00 & 46.24 & 27.38 & 15.97 & 3 & 2154.1045 & 2154.1023 & 719.0414 & 0.0022 & 1.0199 & 3572.296 & 4617.285 & 261.852 & 5715.325 & \text { Yes }\end{array}$

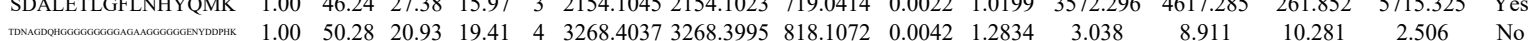
$\begin{array}{lllllllllllllll}1.00 & 50.28 & 20.93 & 19.41 & 4 & 3268.4037 & 3268.3995 & 818.1072 & 0.0042 & 1.2834 & 3.038 & 8.911 & 10.281 & 2.506 & \text { No } \\ 1.00 & 8835 & 20.64 & 21.32 & 4 & 3268.4005 & 3268.3995 & 818.1072 & 0.0010 & 0.3056 & 32.839 & 29.148 & 43.630 & 41.050 & \text { Yes }\end{array}$

MGPPVGGHR MGPPVGGHR

MGPPVGGHR MGPPVGGHR MGPPVGGHR

TPASPVVHIR TPASPVVHIR
TPASPVVHIR

\section{TPASPVVHIR}

TPASPVVHIR

TPASPVVHIR

TPASPVITR

TPASPVVHIR

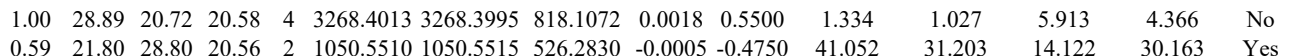
$\begin{array}{lllllllllllllll}0.96 & 30.06 & 29.14 & 19.75 & 2 & 1050.5522 & 1050.5515 & 526.2830 & 0.0007 & 0.6650 & 42.110 & 67.984 & 30.426 & 53.015 & \text { Yes }\end{array}$

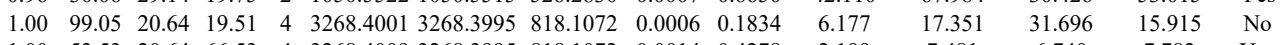
$\begin{array}{lllllllllllllll}1.00 & 53.53 & 20.64 & 66.53 & 4 & 3268.4009 & 3268.3995 & 818.1072 & 0.0014 & 0.4278 & 2.199 & 7.481 & 6.740 & 7.782 & \text { Yes }\end{array}$

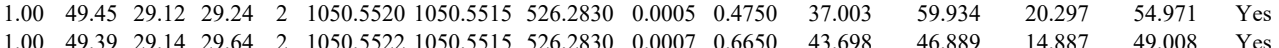

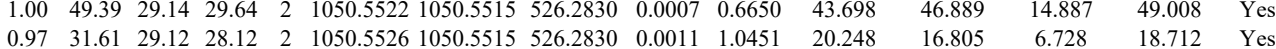

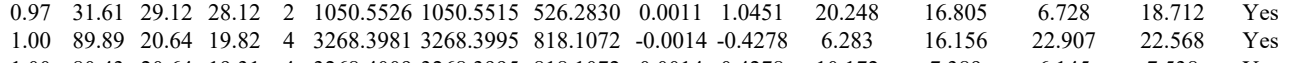

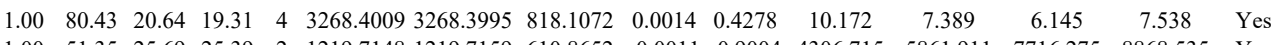

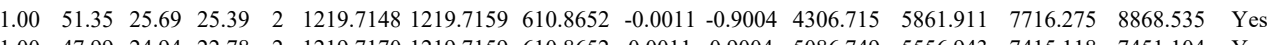
$\begin{array}{lllllllllllllll}1.00 & 47.99 & 24.94 & 22.78 & 2 & 1219.7170 & 1219.7159 & 610.8652 & 0.0011 & 0.9004 & 5086.749 & 5556.943 & 7415.118 & 7451.104 & \text { Yes }\end{array}$ $\begin{array}{lllllllllllllll}0.55 & 65.95 & 24.94 & 78.95 & 3 & 1219.7173 & 1219.7159 & 407.5792 & 0.0014 & 1.1450 & 7700.265 & 7524.839 & 9914.098 & 9580.564 & \text { Yes } \\ 1.00 & 55.95 & 2.0 & 68.95 & 4 & 3268.40413268 .3995 & 818.1072 & 0.0046 & 1.457 & 4.355 & 6.968 & 9.713 & 8.272 & \text { Yes }\end{array}$

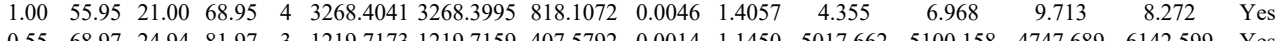
$\begin{array}{lllllllllllllll}0.55 & 68.97 & 24.94 & 81.97 & 3 & 1219.7173 & 1219.7159 & 407.5792 & 0.0014 & 1.1450 & 5017.662 & 5100.158 & 4747.689 & 6142.599 & \text { Yes } \\ 0.66 & 66.28 & 25.17 & 79.28 & 3 & 1219.7179 & 1219.7159 & 407.5792 & 0.0020 & 1.6357 & 4160.430 & 4494.640 & 3653.794 & 4376.548 & \text { Yes }\end{array}$

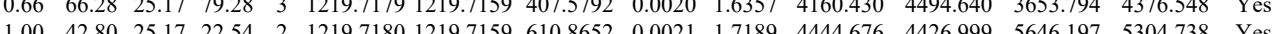

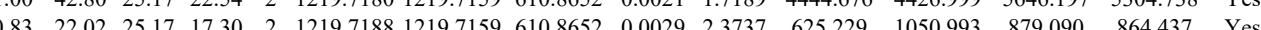

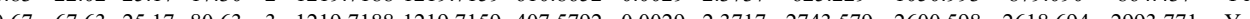
$\begin{array}{lllllllllllllll}0.67 & 78.79 & 25.20 & 91.79 & 3 & 1219.7191 & 1219.7159 & 407.5792 & 0.0032 & 2.6171 & 2472.499 & 2800.198 & 2527.018 & 2677.464 & \text { Yes }\end{array}$ 
SSSGLLEWESK

$\begin{array}{lllllllllllll}\text { SYDC HUMAN } & \text { P14868 } & \text { DARS } & \text { Aspartyl-tRNA sy } 57.136 & 1.00 & 12 & 25.7 & 0.0513 & 0.2772 & 1.0656 & 0.3738 & 50 & \text { YDTDFYILDK }\end{array}$

QFPCEPFK

FLEPTLR

FGAPPHAGGGIGLER

FGAPPHAGGGIGLE

FGAPPHAGGGIGLER

LEYCEALAMLR

LEYCEALAML

IYVISLAEPR

QCFLVLR

QCFLVLR

QCFLVLR

VFSIGPVFR

VFSIGPVFR

VFSIGPVFR

VFSIGPVFR

VFSIGPVFR

VFSIGPVFR

VFSIGPVFR

VFSIGPVFR

VFSIGPVFR

LQSGICHLFR

LQSGICHLFR
VTMLFLGLHNVR

VTMLFLGLHNVR

VTMLFLGLHNVR

VTMLFLGLHNVR

LPLQLDDAVRPEAEGEEEG

LPLQLDDAVRPEAEGEEE

VTMLFLGLHNVR

VTMLFLGLHNVR

VTMLFLGLHNVR

VTMLFLGLHNVR

VTMLFLGLHNVR

VTMLFLGLHNVR

VTMLFLGLHNVR

VTMLFLGLHNVR

VTMLFLGLHNVR

VTMLFLGLHNVR

VTMLFLGLHNVR

VTMLFLGLHNVR

VTMLFLGLHNVR

VTMLFLGLHNVR

VTMLFLGLHNVR

VTMLFLGLHNVR

VTMLFLGLHNVR

VTMLFLGLHNVR

VTMLFLGLHNVR

VTMLFLGLHNVR

VTMLFLGLHNVR

VTMLFLGLHNVR

VTMLFGLHNVR

VTMLFLGLHNVR
VTMLFLGLHNVR \begin{tabular}{cc}
9.125 & 6.276 \\
0.000 & 11.301 \\
389.141 & 444.458 \\
\hline 9.831 & 262.655
\end{tabular} $\begin{array}{lllllllll} & \end{array}$ $\begin{array}{llllllllllllll} & \end{array}$

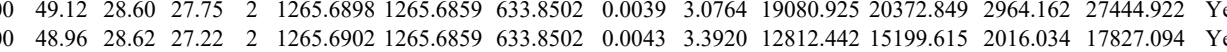

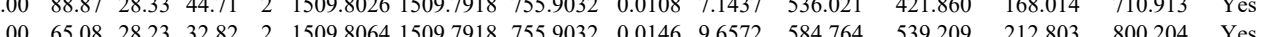
$\begin{array}{lllllllllllllll} & \end{array}$

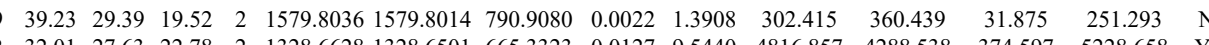

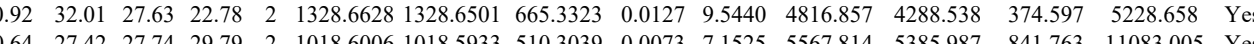

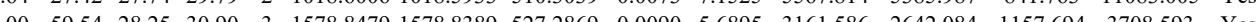
$\begin{array}{llllllllllllllll}1.00 & 63.59 & 28.54 & 31.95 & 3 & 1578.8500 & 1578.8389 & 527.2869 & 0.0111 & 7.0170 & 3536.534 & 3059.388 & 1785.574 & 3143.561 & \text { Yes }\end{array}$ $\begin{array}{llllllllllllllll}1.00 & 69.98 & 28.52 & 31.77 & 3 & 1578.8488 & 1578.8389 & 527.2869 & 0.0099 & 62584 & 5126.513 & 4745.025 & 3943.308 & 6601.991 & \text { Yes }\end{array}$ $\begin{array}{lllllllllllllll}.00 & 58.86 & 28.44 & 30.54 & 3 & 1578.8506 & 1578.8389 & 527.2869 & 0.0117 & 7.3963 & 5613.881 & 5788.806 & 1843.216 & 8483.897 & \text { Yes }\end{array}$ $\begin{array}{llllllllllllllll}1.00 & 61.91 & 26.20 & 22.32 & 2 & 1500.7284 & 1500.7260 & 751.3703 & 0.0024 & 1.5971 & 629.946 & 674.150 & 0.000 & 763.594 & \mathrm{No} \\ 0.84 & 59.46 & 26.20 & 72.46 & 2 & 1500.7284 & 1500.7260 & 751.3703 & 0.024 & 1.5971 & 246.059 & 108.450 & 12.906 & 348.782 & \mathrm{No}\end{array}$ $\begin{array}{lllllllllllllll}1.00 & 50.75 & 26.65 & 25.10 & 2 & 1303.7636 & 1303.7621 & 652.8883 & 0.0015 & 1.1487 & 11494.312 & 11411.751 & 551.818 & 13944.960 & \text { Yes }\end{array}$

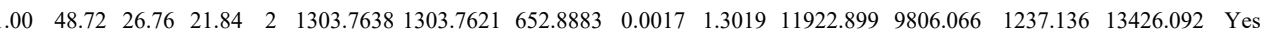
$\begin{array}{lllllllllllllllll}0.90 & 24.58 & 27.80 & 24.87 & 2 & 1067.5756 & 1067.5742 & 534.7944 & 0.0014 & 1.3089 & 3383.394 & 3119.175 & 389.172 & 5658.362 & \text { Yes }\end{array}$ $\begin{array}{llllllllllllllll}0.91 & 24.68 & 27.70 & 26.93 & 2 & 1067.5760 & 1067.5742 & 534.7944 & 0.0018 & 1.6829 & 3947.411 & 4112.232 & 90.282 & 7130.193 & \text { Yes }\end{array}$ $\begin{array}{lllllllllllllll}0.92 & 25.90 & 27.78 & 25.80 & 2 & 1067.5754 & 1067.5742 & 534.7944 & 0.0012 & 1.1219 & 1430.037 & 1372.888 & 104.496 & 2404.992 & \text { Yes }\end{array}$ $\begin{array}{lllllllllllllll}0.87 & 23.45 & 27.78 & 23.84 & 2 & 1067.5754 & 1067.5742 & 534.7944 & 0.0012 & 1.1219 & 1081.422 & 1247.725 & 108.603 & 1919.983 & \text { Yes }\end{array}$ $\begin{array}{lllllllllllllll}1.00 & 48.84 & 26.86 & 28.19 & 2 & 1164.6774 & 1164.6777 & 583.3461 & -0.0003 & -0.2571 & 6248.507 & 5947.001 & 0.000 & 11961.569 & \text { No }\end{array}$

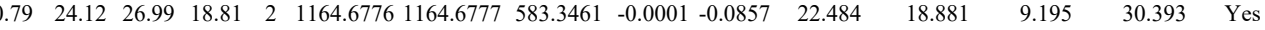

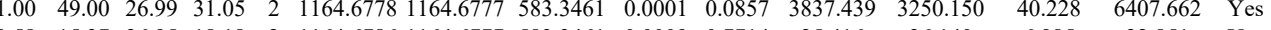
$\begin{array}{lllllllllllll}0.58 & 15.37 & 26.95 & 18.18 & 2 & 1164.6786 & 1164.6777 & 583.3461 & 0.0009 & 0.7714 & 25.416 & 26.140 & 6.8\end{array}$ $\begin{array}{lllllllllllll}0.53 & 14.50 & 26.96 & 18.34 & 2 & 1164.6790 & 1164.6777 & 583.3461 & 0.0013 & 1.1143 & 21.157 & 20.058\end{array}$ $\begin{array}{lllllllllllll}0.99 & 34.69 & 26.96 & 20.78 & 2 & 1164.6792 & 1164.6777 & 583.3461 & 0.0015 & 1.2857 & 23.546 & 26.575\end{array}$ $\begin{array}{cccccccccccc}0.90 & 23.55 & 26.96 & 18.16 & 2 & 1164.6794 & 1164.6777 & 583.3461 & 0.0017 & 1.4571 & 11.038 & 20.856 \\ 0.99 & 41.13 & 26.86 & 26.52 & 2 & 1164.6774 & 1164.6777 & 583.3461 & -0.0003 & -0.2571 & 2203.197 & 1805.389\end{array}$ $\begin{array}{lllllllllllll}0.99 & 41.13 & 26.86 & 26.52 & 2 & 1164.6774 & 1164.6777 & 583.3461 & -0.0003 & -0.2571 & 2203.197 & 1805.389\end{array}$ $\begin{array}{llllllllllllll}1.00 & 48.69 & 26.95 & 26.58 & 2 & 1164.6786 & 1164.6777 & 583.3461 & 0.0009 & 0.7714 & 1760.545 & 1909.725\end{array}$ $\begin{array}{lllllllllllllll}1.00 & 39.62 & 27.96 & 24.16 & 3 & 1362.7033 & 1362.7022 & 455.2413 & 0.0011 & 0.8054 & 1237.792 & 1424.641\end{array}$ $\begin{array}{lllllllllllll}1.00 & 44.81 & 27.98 & 25.87 & 3 & 1362.7036 & 1362.7022 & 455.2413 & 0.0014 & 1.0251 & 1425.784 & 1699.489\end{array}$ $\begin{array}{llllllllllllll}1.00 & 44.81 & 27.98 & 25.87 & 3 & 1362.7036 & 1362.7022 & 455.2413 & 0.0014 & 1.0251 & 1425.784 & 1699.489\end{array}$

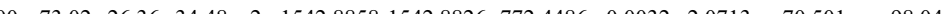
$\begin{array}{lllllllll} & \end{array}$ $\begin{array}{lllllllllllll} & \end{array}$

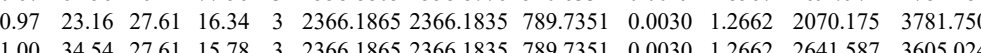
$\begin{array}{llllllllllllll}1.00 & 71.16 & 26.28 & 34.59 & 2 & 1542.8846 & 1542.8826 & 772.4486 & 0.0020 & 1.2946 & 320.212 & 286.123\end{array}$ $\begin{array}{lllllllllllll}1.00 & 62.90 & 26.28 & 25.12 & 3 & 1542.8848 & 1542.8826 & 515.3015 & 0.0022 & 1.4231 & 1681.783 & 1455.686 & 8 \\ 1.00 & 60.28 & 6.36 & 25.17 & 3 & 1542.8854 & 1542.8826 & 5153015 & 0.0028 & 1.8112 & 528.177 & 602.59 & 2\end{array}$ $\begin{array}{lllllllllllll}1.00 & 60.28 & 26.36 & 25.17 & 3 & 1542.8854 & 1542.8826 & 515.3015 & 0.0028 & 1.8112 & 528.177 & 602.594\end{array}$ $\begin{array}{lllllllllllll}1.00 & 71.41 & 26.47 & 34.68 & 2 & 1542.8860 & 1542.8826 & 772.4486 & 0.0034 & 2.2008 & 506.196 & 482.59\end{array}$ $\begin{array}{lllllllllll}1.00 & 85.79 & 26.35 & 27.60 & 2 & 1542.8834 & 1542.8826 & 772.4486 & 0.0008 & 0.5178 & 134.475\end{array}$ $\begin{array}{llllllllllll}1.00 & 73.51 & 26.27 & 33.18 & 2 & 1542.8838 & 1542.8826 & 772.4486 & 0.0012 & 0.7768 & 98.653\end{array}$ $\begin{array}{lllllllllllll}1.00 & 85.79 & 26.35 & 27.60 & 2 & 1542.8834 & 1542.8826 & 772.4486 & 0.008 & 0.5178 & 134.475 & 138.216 \\ 1.00 & 66.13 & 26.31 & 26.31 & 3 & 1542.8845 & 152882826 & 515.3015 & 0.012 & 0.7768 & 98.653 & 127.781\end{array}$ $\begin{array}{llllllllllll}1.00 & 70.12 & 26.31 & 28.47 & 3 & 1542.8845 & 1542.8826 & 515.3015 & 0.0019 & 1.2291 & 164.411 & 410.866\end{array}$ $\begin{array}{lllllllllll}1.00 & 89.62 & 26.43 & 28.76 & 2 & 1542.8824 & 1542.8826 & 772.4486 & -0.0002 & -0.1295 & 63.368\end{array}$ $\begin{array}{llllllllllll}1.00 & 62.59 & 26.30 & 28.32 & 3 & 1542.8830 & 1542.8826 & 515.3015 & 0.0004 & 0.2587 & 74.259\end{array}$ $\begin{array}{lllllllllll}1.00 & 6.59 & 26.30 & 28.32 & 3 & 1542.8830 & 1542.8826 & 515.3015 & 0.0004 & 0.2587 & 74.259\end{array}$

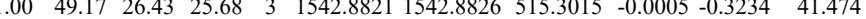
$\begin{array}{lllllllllll}1.00 & 57.15 & 26.43 & 25.78 & 2 & 1542.8822 & 1542.8826 & 772.4486 & -0.0004 & -0.2589 & 44.202\end{array}$ $\begin{array}{lllllllllll}1.00 & 48.99 & 26.34 & 25.53 & 3 & 1542.8833 & 1542.8826 & 515.3015 & 0.0007 & 0.4528 & 41.707\end{array}$ $\begin{array}{lllllllllll}0.99 & 47.44 & 26.84 & 26.49 & 3 & 1542.8773 & 1542.8826 & 515.3015 & -0.0053 & -3.4284 & 41.566\end{array}$ $\begin{array}{lllllllllll}1.00 & 59.88 & 26.41 & 29.12 & 3 & 1542.8827 & 1542.8826 & 515.3015 & 0.0001 & 0.0647 & 34.594\end{array}$ $\begin{array}{lllllllllll}1.00 & 53.36 & 26.30 & 27.02 & 3 & 1542.8830 & 1542.8826 & 515.3015 & 0.0004 & 0.2587 & 69.813\end{array}$ $\begin{array}{llllllllllll}1.00 & 61.49 & 26.34 & 23.59 & 3 & 1542.8836 & 1542.8826 & 515.3015 & 0.0010 & 0.6469 & 69.527\end{array}$

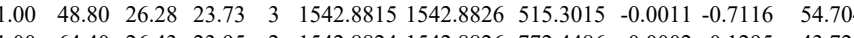

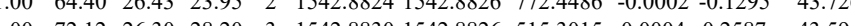
$\begin{array}{lllllllllll}1.00 & 72.12 & 26.30 & 28.20 & 3 & 1542.8830 & 1542.8826 & 515.3015 & 0.0004 & 0.2587 & 43.595\end{array}$

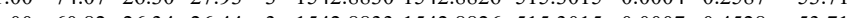

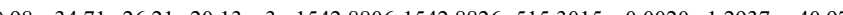
$\begin{array}{llllllllllll}1.00 & 60.69 & 26.29 & 31.23 & 2 & 15428810 & 15428826 & 772.4486 & -0.0016 & -1.0357 & 35.080\end{array}$ $\begin{array}{lllllllllll}1.00 & 62.79 & 26.30 & 24.85 & 3 & 1542.8830 & 1542.8826 & 515.3015 & 0.0004 & 0.2587 & 49.625\end{array}$

78.428

$\begin{array}{lcc}6.985 & 22.851 & \text { Yes } \\ 6.035 & 31.881 & \text { Yes }\end{array}$ $8.035 \quad 31.881$ Yes $\begin{array}{lll}8.244 & 40.705 & \text { Yes }\end{array}$ $\begin{array}{llll}57.473 & 87.809 & \text { Y }\end{array}$ $\begin{array}{lll}94.874 & 113.066 & \text { Yes }\end{array}$ $\begin{array}{lll}52.157 & 97.854 & \text { Yes } \\ 80.488 & 99.318 & \text { Yes }\end{array}$ \begin{tabular}{rrr}
15.133 & 305.640 & Yes \\
\hline 893.927 & 1623.942 & Yes
\end{tabular} $\begin{array}{lll}592.260 & 592.736 & \text { Yes }\end{array}$ 0.602
$499.551 \quad$ Yes \begin{tabular}{lll}
.716 & 129.098 & Yes \\
\hline
\end{tabular} $\begin{array}{lll}4.488 & 113.037 & \text { Yes }\end{array}$ $\begin{array}{lll}047 & 182.818 \quad \mathrm{~N}\end{array}$

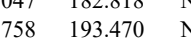
$\begin{array}{ccc}157.148 & \text { No } \\ 0.525 & 49.670 & \text { Yes }\end{array}$ $\begin{array}{llll}36.785 & 45.625 & 49.670 & \text { Yes } \\ & 11.406 & 32317 & \text { Yes }\end{array}$

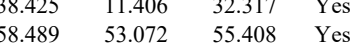
$\begin{array}{llll}51.286 & 62.494 & 37.037 & \text { No }\end{array}$ $\begin{array}{llll}80.525 & 65.746 & 69.827 & \text { Yes }\end{array}$ 56.793 36.268 73.708 56.520 $\begin{array}{llll}31.177 & 51.285 & 36.538 & \text { No }\end{array}$ $\begin{array}{llll}80.525 & 65.746 & 69.827 & \text { Yes }\end{array}$

Table S-4 page 193 of 614 

$\begin{array}{llllllllllllllll}0.96 & 29.80 & 26.19 & 17.90 & 3 & 1419.8155 & 1419.8078 & 474.2765 & 0.0077 & 5.4117 & 9185.341 & 8969.336 & 1228.286 & 11104.223 & \text { Yes } & \\ 0.96 & 30.71 & 26.58 & 20.49 & 3 & 1419.8161 & 1419.8078 & 474.2765 & 0.0083 & 5.8334 & 9869.995 & 8844.808 & 1539.277 & 10693.578 & \text { Yes }\end{array}$ $\begin{array}{lllllllllllllllll}1.00 & 55.57 & 19.54 & 20.56 & 2 & 1398.5712 & 1398.5699 & 700.2922 & 0.0013 & 0.9282 & 266.365 & 225.895 & 77.606 & 691.265 & \text { Yes }\end{array}$ $\begin{array}{llllllllllllllll}1.00 & 57.98 & 19.59 & 20.12 & 2 & 1398.5720 & 1398.5699 & 700.2922 & 0.0021 & 1.4994 & 216.642 & 179.479 & 104.211 & 518.652 & \text { Yes } & \end{array}$

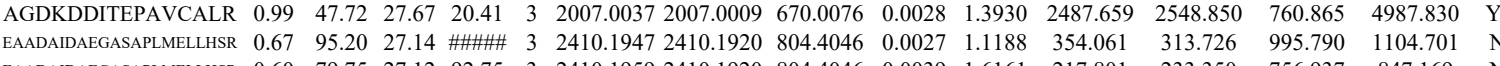
\begin{tabular}{llllllllllllllllll} 
& BAADIDAEGASAPLMELLHSR & 0.60 & 79.75 & 27.12 & 92.75 & 3 & 2410.1959 & 2410.1920 & 804.4046 & 0.0039 & 1.6161 & 217.801 & 233.350 & 756.937 & 847.169 & $\mathrm{~N} 0$ \\
\hline
\end{tabular}

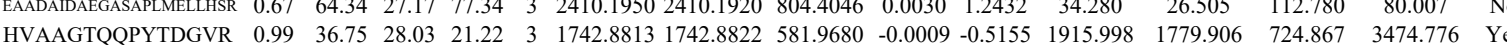

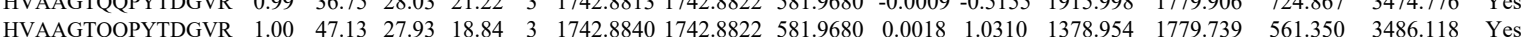
$\begin{array}{lllllllllllllll} & \text { SVANG }\end{array}$ $\begin{array}{lllllllllllllllll} & \text { VSVELTNSLFK } & 1.00 & 57.26 & 25.89 & 26.16 & 2 & 1523.8838 & 1523.8803 & 762.9474 & 0.0035 & 2.2937 & 807.086 & 569.374 & 72.261 & 1511.858 & \text { Yes }\end{array}$

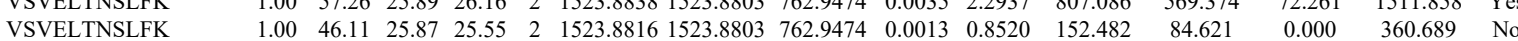

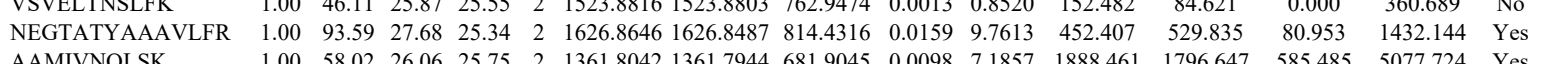

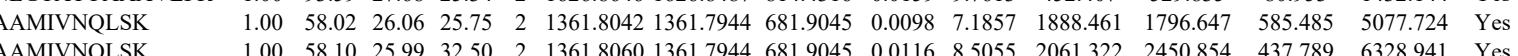
AAMIVNQLSK
MVPLLNK MVPLLNK MVPLLNK LNYGIPAIVK LNYGIPAIVK

LNYGIPAIVK

VLSVCPSNKPAIVEAGGMQALGK

SGGIPALVR

SGGIPALVR

LLNQPNQWPLVK

LLNQPNQWPLVK

LLNQPNQWPLVK

ATIGLIR $\begin{array}{llllllllllllllll}1.00 & 58.10 & 25.99 & 32.50 & 2 & 1361.8060 & 1361.7944 & 681.9045 & 0.0116 & 8.5055 & 2061.322 & 2450.854 & 437.789 & 6328.941 & \text { Yes } & \\ 0.97 & 33.67 & 24.33 & 24.40 & 2 & 1101.6922 & 1101.6824 & 551.8485 & 0.0098 & 8.8792 & 5132.913 & 5558.624 & 661.692 & 17557.124 & \text { Yes } & \end{array}$ $\begin{array}{lllllllllllllll}1.00 & 45.88 & 24.22 & 29.44 & 2 & 1101.6918 & 1101.6824 & 551.8485 & 0.0094 & 8.5168 & 9677.221 & 10062.667 & 2031.611 & 32020.109 & \text { Yes }\end{array}$ $\begin{array}{lllllllllllllll}1.00 & 46.39 & 23.78 & 29.84 & 2 & 1101.6924 & 1101.6824 & 551.8485 & 0.0100 & 9.0604 & 8261.125 & 8054.828 & 2267.268 & 21753.328 & \text { Yes }\end{array}$ $\begin{array}{lllllllllllllll}1.00 & 51.74 & 22.60 & 21.39 & 2 & 1374.8490 & 1374.8478 & 688.4312 & 0.0012 & 0.8715 & 8512.183 & 8497.509 & 1562.449 & 24633.386 & \text { Yes }\end{array}$

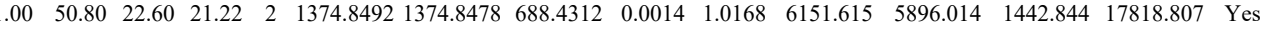
$\begin{array}{llllllllllllllll}1.00 & 50.81 & 22.60 & 21.21 & 2 & 1374.8492 & 1374.8478 & 688.4312 & 0.0014 & 1.0168 & 8239.527 & 7843.664 & 2044.618 & 24923.195 & \text { Yes }\end{array}$

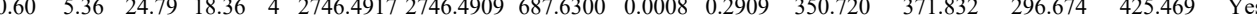

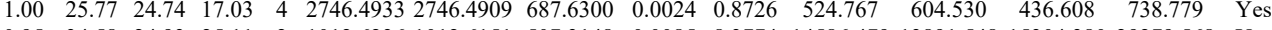

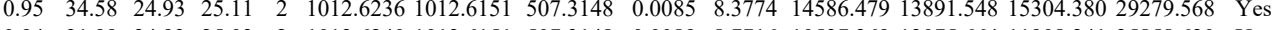
$\begin{array}{llllllllllllllll}0.94 & 31.99 & 24.93 & 25.03 & 2 & 1012.6240 & 1012.6151 & 507.3148 & 0.0089 & 8.7716 & 10537.269 & 12075.664 & 11908.241 & 25858.620 & \text { Yes }\end{array}$ $\begin{array}{llllllllllllllll}1.00 & 45.30 & 23.67 & 22.85 & 2 & 1737.0196 & 1737.0181 & 869.5163 & 0.0015 & 0.8625 & 960.560 & 1054.340 & 206.056 & 3410.224 & \text { Yes }\end{array}$ \begin{tabular}{lllllllllllllll}
1.00 & 46.11 & 23.67 & 22.77 & 2 & 1737.0196 & 1737.0181 & 869.5163 & 0.0015 & 0.8625 & 2122.341 & 2819.531 & 264.660 & 8709.412 & Yes \\
\hline
\end{tabular} $\begin{array}{lllllllllllllll}0.66 & 13.33 & 23.73 & 26.33 & 3 & 1737.0202 & 1737.0181 & 580.0133 & 0.0021 & 1.2069 & 480.369 & 519.026 & 171.534 & 609.892 & \text { Yes }\end{array}$

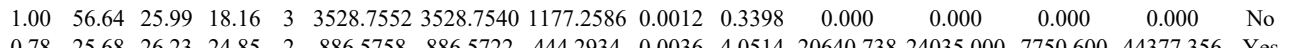
$\begin{array}{llllllllllllllll}0.78 & 25.68 & 26.23 & 24.85 & 2 & 886.5758 & 886.5722 & 444.2934 & 0.0036 & 4.0514 & 20640.738 & 24035.000 & 7750.600 & 44377.356 & \text { Yes }\end{array}$ $\begin{array}{llllllllllllllll}\text { ATIGLIR } & 0.70 & 27.20 & 26.25 & 25.95 & 2 & 886.5770 & 886.5722 & 444.2934 & 0.0048 & 5.4018 & 23033.839 & 24014.885 & 8981.742 & 51169.842 & \text { Yes }\end{array}$

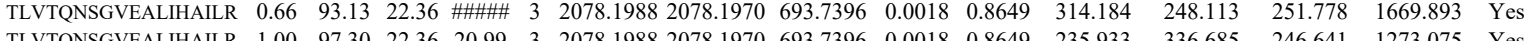
$\begin{array}{llllllllllllllll}\text { TLVTQNSGVEALIHAILR } & 1.00 & 97.30 & 22.36 & 20.99 & 3 & 2078.1988 & 2078.1970 & 693.7396 & 0.0018 & 0.8649 & 235.933 & 336.685 & 246.641 & 1273.075 & \text { Yes } \\ \text { ALMGSPQLVAAVVVR } & 1.00 & 90.92 & 24.84 & 23.92 & 2 & 1554.9048 & 1554.9038 & 778.4592 & 0.0010 & 0.6423 & 2376.310 & 2798.943 & 742.239 & 9025.517 & \text { Yes }\end{array}$ $\begin{array}{llllllllllllllll} & \end{array}$

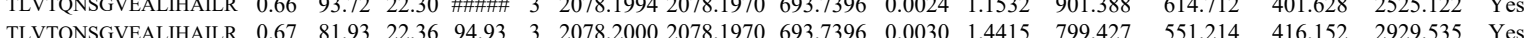
$\begin{array}{lllllllllllllll} & \end{array}$ $\begin{array}{lllllllllllllllll} & \end{array}$

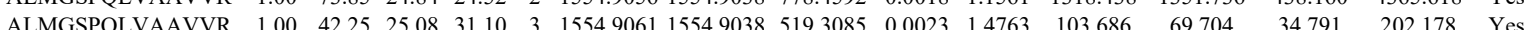

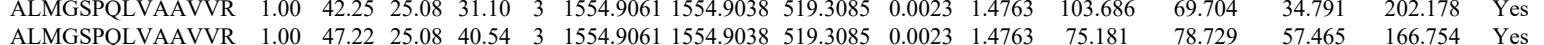
$\begin{array}{llllllllllllllll}\text { TLVTQNGGVEALIHAILR } & 1.00 & 95.85 & 22.30 & 21.06 & 3 & 2078.1994 & 2078.1970 & 693.7396 & 0.0024 & 1.1532 & 274.887 & 261.018 & 240.400 & 916.479 & \text { Yes }\end{array}$ $\begin{array}{llllllllllllllll}\text { TLVTQNSGVEALIHAILR } & 0.67 & 84.54 & 22.33 & 97.54 & 3 & 2078.1997 & 2078.1970 & 693.7396 & 0.0027 & 1.2973 & 273.691 & 215.275 & 215.118 & 1132.647 & \text { Yes }\end{array}$

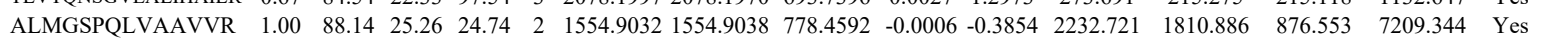
$\begin{array}{llllllllllllllllll}\text { ALMGSPQLVAAVVR } & 1.00 & 75.52 & 25.12 & 23.65 & 2 & 1554.9044 & 1554.9038 & 778.4592 & 0.0006 & 0.3854 & 1739.910 & 2375.586 & 2008.081 & 6557.246 & \text { Yes }\end{array}$ $\begin{array}{llllllllllllllll}\text { CTTSILHNLSHHR } & 1.00 & 40.38 & 27.63 & 21.49 & 4 & 1707.8469 & 1707.8419 & 427.9678 & 0.0050 & 2.9208 & 1751.226 & 1598.211 & 540.589 & 3898.942 & \text { Yes }\end{array}$ $\begin{array}{lllllllllllllllll}\text { CTTSILHNLSHHR } & 1.00 & 38.36 & 27.64 & 18.26 & 4 & 1707.8473 & 1707.8419 & 427.9678 & 0.0054 & 3.1544 & 1970.045 & 2122.163 & 941.659 & 4912.960 & \text { Yes }\end{array}$ $\begin{array}{lllllllllllllllllll}\text { TLVTQNSGVEALIHAILR } & 1.00 & 89.94 & 22.43 & 18.67 & 3 & 2078.1979 & 2078.1970 & 693.7396 & 0.0009 & 0.4324 & 65.406 & 53.785 & 51.797 & 214.690 & \text { Yes }\end{array}$ $\begin{array}{llllllllllllllllll}\text { CTTSILHNLSHHR } & 1.00 & 36.45 & 27.40 & 16.05 & 4 & 1707.8401 & 1707.8419 & 427.9678 & -0.0018 & -1.0515 & 1788.745 & 2093.497 & 403.697 & 4546.072 & \text { Yes }\end{array}$

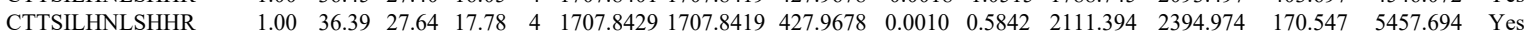
$\begin{array}{lllllllllllllllll}\text { LNTIPLFVQLLYSSVENIQR } & 1.00 & \text { \#\#\#\# } 22.74 & 23.66 & 2 & 2490.3974 & 2490.3968 & 1246.2057 & 0.0006 & 0.2407 & 0.000 & 5.093 & 9.254 & 15.546 & \text { No }\end{array}$ $\begin{array}{lllllllllllllllll}\text { LNTIPLFVQLLYSSVENIQR } & 1.00 & 52.41 & 22.72 & 16.40 & 3 & 2490.3991 & 2490.3968 & 831.1395 & 0.0023 & 0.9224 & 12.205 & 10.976 & 14.003 & 0.950 & \text { No }\end{array}$ $\begin{array}{llllllllllllllllll}\text { LNTIPLFVLLYSSVENIQR } & 1.00 & 88.34 & 22.74 & 22.99 & 2 & 2490.3974 & 2490.3968 & 1246.2057 & 0.0006 & 0.2407 & 8.788 & 5.477 & 5.840 & 34.282 & \text { Yes }\end{array}$ $\begin{array}{llllllllllllllll}\text { LNTIPLFVQLLYSSVENIQR } & 0.66 & 47.74 & 22.72 & 60.74 & 3 & 2490.3991 & 2490.3968 & 831.1395 & 0.0023 & 0.9224 & 2.745 & 4.727 & 3.132 & 6.041 & \text { Yes }\end{array}$

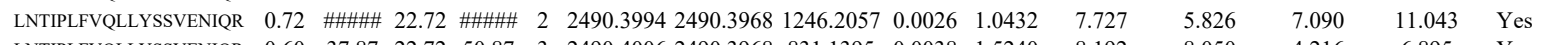
$\begin{array}{llllllllllllllll}\text { LNTIPLFVQLLYSSVENIQR } & 0.60 & 37.87 & 22.72 & 50.87 & 3 & 2490.4006 & 2490.3968 & 831.1395 & 0.0038 & 1.5240 & 8.192 & 8.050 & 4.216 & 6.895 & \text { Yes }\end{array}$ $\begin{array}{lllllllllllllll}\text { LIILANGGPQALVQIMR } & 1.00 & \text { \#\#\#\# } 19.82 & 54.28 & 2 & 1950.1568 & 1950.1570 & 976.0858 & -0.0002 & -0.1025 & 19.450 & 22.151 & 27.138 & 54.035 & \text { Yes }\end{array}$

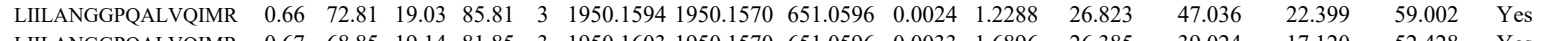
\begin{tabular}{llllllllllllllll} 
LIILANGGPQALVQIMR & 0.67 & 68.85 & 19.14 & 81.85 & 3 & 1950.1603 & 1950.1570 & 651.0596 & 0.0033 & 1.6896 & 26.385 & 39.024 & 17.120 & 52.428 & Yes \\
\hline
\end{tabular}

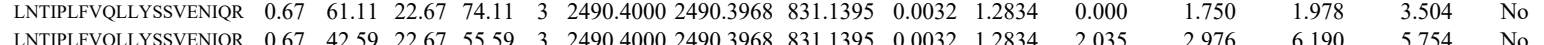

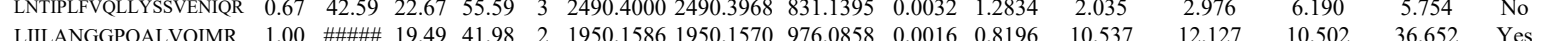

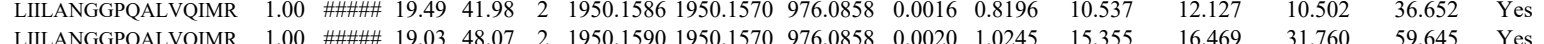

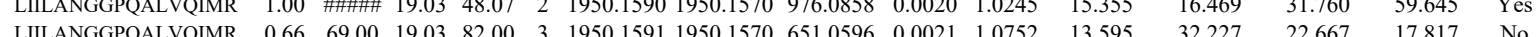
$\begin{array}{llllllllllllllll}\text { LIILANGGPALVQIMR } & 0.66 & 69.00 & 19.03 & 82.00 & 3 & 1950.1591 & 1950.1570 & 651.0596 & 0.0021 & 1.0752 & 13.595 & 32.227 & 22.667 & 17.817 & \text { No } \\ \text { LIILANGGPQALVQIMR } & 1.00 & 59.24 & 19.03 & 18.11 & 3 & 1950.1597 & 1950.1570 & 651.0596 & 0.0027 & 1.3824 & 8.876 & 15.950 & 5.576 & 11.648 & \text { No }\end{array}$ 
$\begin{array}{lllllllllll}1.00 & 60.97 & 25.95 & 21.24 & 2 & 1628.9224 & 1628.9229 & 815.4687 & -0.0005 & -0.3066 & 367.925\end{array}$

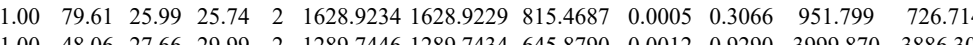

IAENFK
IAENFK

IAENFK

IAENFK $\begin{array}{llllllllllllll}0.59 & 15.43 & 26.75 & 24.25 & 2 & 1008.5856 & 1008.5847 & 505.2996 & 0.0009 & 0.8906 & 513.059 & 54 & \\ 0.59 & 15.50 & 26.75 & 21.50 & 2 & 10085856 & 1008.5847 & 505.2996 & 0.0009 & 0.8906 & 348.574 & 45 & \\ 0.54 & 1.98 & 26.74 & 17.05 & 2 & 008.586 & 008.587 & 505.2996 & 0.007 & 1.6822 & 262.15 & 24\end{array}$

IAENFK

IAENFK

NLVVIPK

$\begin{array}{llllllllllll}0.54 & 13.98 & 26.74 & 17.05 & 2 & 1008.5864 & 1008.5847 & 505.2996 & 0.0017 & 1.6822 & 262.115 \\ 0.54 & 13.89 & 26.77 & 18.82 & 2 & 1008.5866 & 1008.5847 & 505.2996 & 0.0019 & 1.8801 & 195.374\end{array}$

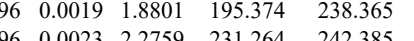

NLVVTK

MPILGLGTWK

MPILGLGTWK

MPILGLGTWK

VCALLSCTSHK

VCALLSCTSHK

VCALLSCTSHK

VCALLSCTSHK

SPPGQVTEAVK

$\begin{array}{lllllllllllll}\text { ERF3A_HUMAR } & \text { P15170 } & \text { GSPT1 } & \text { Eukaryotic peptid } 55.756 & 1.00 & 6 & 17.4 & 0.0653 & 0.3441 & 1.0787 & 0.4192 & 12 & \begin{array}{l}\text { SPPVQVPPGAPK } \\ \text { SVVAPAPG }\end{array}\end{array}$

$\begin{array}{llllllllllllllll} & \end{array}$ $\begin{array}{lllllllllllllllll}1.00 & 35.18 & 21.82 & 48.18 & 4 & 2707.5149 & 2707.5103 & 677.8849 & 0.0046 & 1.6965 & 2845.678 & 3036.083 & 2106.600 & 3627.689 & \text { Yes }\end{array}$ $\begin{array}{lllllllllllllllll}0.91 & 46.56 & 25.89 & 33.15 & 2 & 1402.8268 & 1402.8250 & 702.4198 & 0.0018 & 1.2813 & 832.614 & 887.461 & 1390.528 & 1626.307 & \text { Yes }\end{array}$ $\begin{array}{lllllllllllllll}0.75 & 44.22 * & 25.88 & 32.69 & 2 & 1402.8254 & 1402.8250 & 702.4198 & 0.0004 & 0.2847 & 2499.364 & 2264.400 & 6468.263 & 7296.107 & \text { No }\end{array}$ $\begin{array}{llllllllllllllll}0.82 & 44.11 * & 25.69 & 32.56 & 2 & 1402.8276 & 1402.8250 & 702.4198 & 0.0026 & 1.8507 & 1978.856 & 2270.355 & 3728.825 & 4415.726 & \text { Yes }\end{array}$

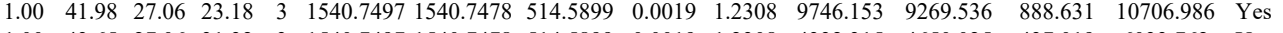
$\begin{array}{lllllllllllllll}1.00 & 43.65 & 27.06 & 31.32 & 3 & 1540.7497 & 1540.7478 & 514.5899 & 0.0019 & 1.2308 & 4332.315 & 4650.025 & 437.019 & 6033.762 & \text { Yes }\end{array}$ $\begin{array}{lllllllllllllll}1.00 & 44.70 & 27.06 & 22.42 & 3 & 1540.7497 & 1540.7478 & 514.5899 & 0.0019 & 1.2308 & 2253.245 & 2385.409 & 236.184 & 2971.118 & \text { Yes }\end{array}$ $\begin{array}{llllllllllllllll}1.00 & 31.81 & 27.05 & 21.11 & 3 & 1540.7509 & 1540.7478 & 514.5899 & 0.0031 & 2.0081 & 1431.624 & 1845.940 & 189.146 & 1698.823 & \text { Yes }\end{array}$ $\begin{array}{llllllllllllllll}1.00 & 59.20 & 26.86 & 24.00 & 2 & 1399.8016 & 1399.7915 & 700.9030 & 0.0101 & 7.2049 & 3268.137 & 4684.327 & 5370.023 & 5582.737 & \text { Yes }\end{array}$

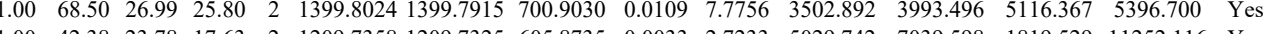
\begin{tabular}{llllllllllllllll}
1.00 & 42.38 & 23.78 & 17.63 & 2 & 1209.7358 & 1209.7325 & 605.8735 & 0.0033 & 2.7233 & 5029.742 & 7039.598 & 1819.529 & 11252.116 & Yes \\
\hline
\end{tabular} SVVAPPGAPK SVVAPPGAPK $\begin{array}{llllllllllllllll}1.00 & 45.32 & 24.07 & 22.34 & 2 & 1209.7360 & 1209.7325 & 605.8735 & 0.0035 & 2.8884 & 8217.207 & 9631.064 & 2533.544 & 18352.889 & \text { Yes } \\ 1.00 & 57.97 & 23.80 & 23.42 & 2 & 1209.735 & 1209.7325 & 605.835 & 0.002 & 2.631 & 4779.112 & 4037.101 & 2001.465 & 703.32 & \text { Yes }\end{array}$ SVVAPPGAPK $\begin{array}{lllllllllllllll}1.00 & 45.94 & 23.80 & 20.42 & 2 & 1209.7350 & 1209.7325 & 605.8735 & 0.0025 & 2.0631 & 4779.112 & 4037.101 & 2001.465 & 7035.232 & \text { Yes }\end{array}$ GQQLVMMPNK $\quad \begin{array}{lllllllllllllllll} & 1.00 & 50.26 & 27.72 & 22.59 & 2 & 1432.7878 & 1432.7774 & 717.3960 & 0.0104 & 7.2484 & 1600.700 & 2434.341 & 2328.819 & 3782292 & \text { Yes }\end{array}$

HLIVLINK $\begin{array}{llllllllllllllll}\text { KGEFETGFEK } & 1.00 & 43.80 & 27.97 & 19.16 & 3 & 1602.8752 & 1602.8619 & 535.2946 & 0.0133 & 8.2820 & 11055.310 & 9808.449 & 1101.243 & 21671.315 & \text { Yes } \\ \text { KGEFETGFEK } & 1.00 & 43.85 & 27.80 & 25.53 & 3 & 16028779 & 1602.8619 & 5352946 & 0.0160 & 9.9633 & 15344.790 & 17079.936 & 1148.398 & 33692.766 & \text { Yes }\end{array}$

$\begin{array}{llllllllllllllll}1.00 & 50.26 & 27.72 & 22.59 & 2 & 1432.7878 & 1432.7774 & 717.3960 & 0.0104 & 7.2484 & 1600.700 & 2434.341 & 2328.819 & 3782.292 & \text { Yes } \\ 0.89 & 20.76 & 11.14 & 19.15 & 3 & 1236.8269 & 1236.8161 & 413.2793 & 0.0108 & 8.7107 & 2237.463 & 1657.227 & 590.614 & 3066.396 & \text { Yes }\end{array}$ $\begin{array}{lllllllllllllll}0.84 & 26.55 & 1.14 & 26.11 & 3 & 1236.8272 & 1236.8161 & 413.2793 & 0.0111 & 8.9527 & 1900.025 & 1835.392 & 311.894 & 4247.047 & \text { Yes }\end{array}$

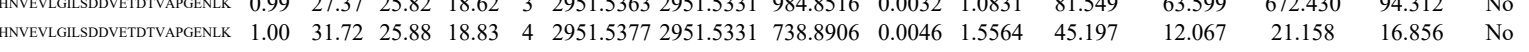

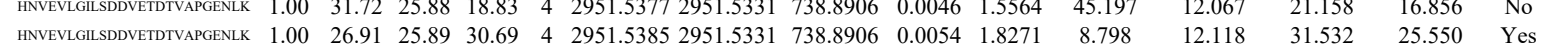

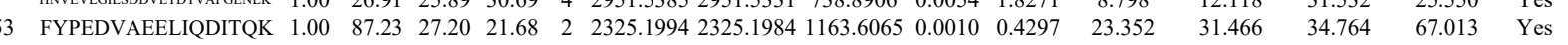
$\begin{array}{lllllllllllllllll}\text { FYPEDVAEELIQDITQK } & 1.00 & 57.61 & 27.09 & 22.73 & 3 & 2325.2011 & 2325.1984 & 776.0734 & 0.0027 & 1.1597 & 41.279 & 36.887 & 13.913 & 42.214 & \text { Yes }\end{array}$ $\begin{array}{llllllllllllllll}\text { FYPEDVAEELIQDITQK } & 1.00 & 90.19 & 27.04 & 25.89 & 2 & 2325.2014 & 2325.1984 & 1163.6065 & 0.0030 & 1.2891 & 22.975 & 16.601 & 32.928 & 47.867 & \text { Yes }\end{array}$ $\begin{array}{lllllllllllllllll}\text { FYPEDVAEELIQDITQK } & 1.00 & 48.15 & 27.02 & 32.05 & 3 & 2325.2020 & 2325.1984 & 776.0734 & 0.0036 & 1.5462 & 39.741 & 73.483 & 26.717 & 41.656 & \text { No }\end{array}$ $\begin{array}{llllllllllllllll}\text { SQEQLAAELAEYTAK } & 1.00 & 95.73 & 27.76 & 22.67 & 2 & 1939.0154 & 1939.0142 & 970.5144 & 0.0012 & 0.6182 & 733.559 & 686.620 & 629.288 & 1567.209 & \text { Yes }\end{array}$ $\begin{array}{lllllllllllllllll}\text { SQEQLAAELAEYTAK } & 1.00 & 42.37 & 27.60 & 19.94 & 3 & 1939.0159 & 1939.0142 & 647.3453 & 0.0017 & 0.8754 & 453.200 & 258.478 & 368.062 & 604.038 & \text { Yes }\end{array}$

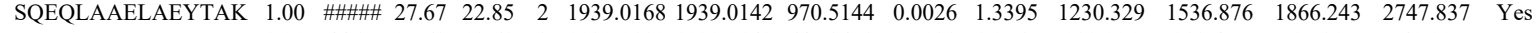
$\begin{array}{llllllllllllllll}\text { SQEQLAAELAEYTAK } & 1.00 & 44.37 & 27.63 & 18.68 & 3 & 1939.0180 & 1939.0142 & 647.3453 & 0.0038 & 1.9567 & 282.221 & 313.477 & 537.395 & 549.995 & \text { Yes }\end{array}$

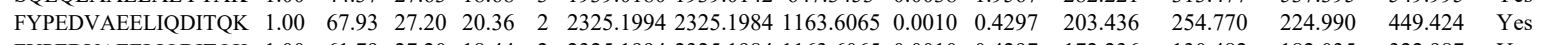
$\begin{array}{llllllllllllllll}\text { FYPEDVAEELIQDITQK } & 1.00 & 61.79 & 27.20 & 18.44 & 2 & 2325.1994 & 2325.1984 & 1163.6065 & 0.0010 & 0.4297 & 172.236 & 130.482 & 182.035 & 322.987 & \text { Yes }\end{array}$ $\begin{array}{llllllllllllllll}\text { FYPEDVAEELIQDITQK } & 1.00 & 52.07 & 27.09 & 26.30 & 3 & 2325.2011 & 2325.1984 & 776.0734 & 0.0027 & 1.1597 & 107.465 & 83.031 & 30.809 & 169.700 & \text { Yes }\end{array}$

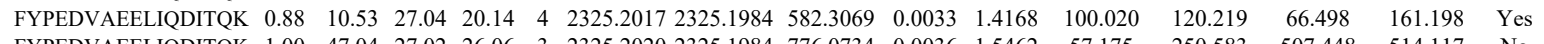

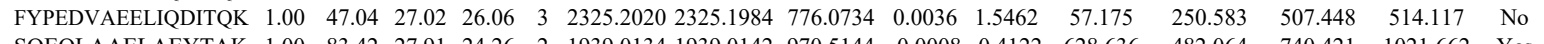

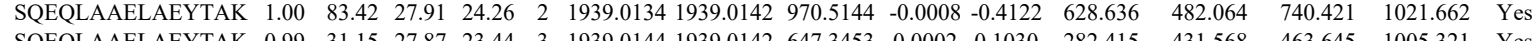
\begin{tabular}{llllllllllllllll} 
SQEQLAAELAEYTAK & 0.99 & 31.15 & 27.87 & 23.44 & 3 & 1939.0144 & 1939.0142 & 647.3453 & 0.0002 & 0.1030 & 282.415 & 431.568 & 463.645 & 1005.321 & Yes \\
\hline SQEQLA
\end{tabular} $\begin{array}{llllllllllllllll}\text { SQEQLAAELAEYTAK } & 1.00 & 93.31 & 27.82 & 23.59 & 2 & 1939.0146 & 1939.0142 & 970.5144 & 0.0004 & 0.2061 & 761.361 & 667.496 & 617.119 & 963.038 & \text { Yes } \\ \text { SQEQLAAELAEYTAK } & 1.00 & 36.50 & 27.60 & 18.12 & 3 & 1939.0159 & 1939.0142 & 647.3453 & 0.0017 & 0.8754 & 418307 & 332500 & 254.943 & 658.631 & \text { Yes }\end{array}$ $\begin{array}{llllllllllllllll}\text { SQEQLAAELAEYTAK } & 1.00 & 36.50 & 27.60 & 18.12 & 3 & 1939.0159 & 1939.0142 & 647.3453 & 0.0017 & 0.8754 & 418.307 & 332.500 & 254.943 & 658.631 & \text { Yes } \\ \text { FYPEDVAEELIQDITQK } & 1.00 & 72.03 & 27.20 & 18.57 & 2 & 2325.1994 & 2325.1984 & 1163.6065 & 0.0010 & 0.4297 & 102.122 & 56.833 & 98.852 & 191.658 & \text { Yes }\end{array}$

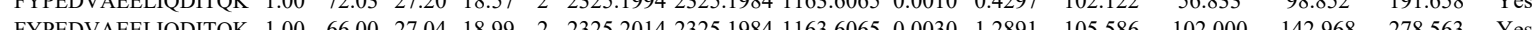

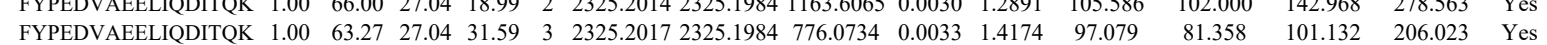



$\begin{array}{lllllllllllll} & & 0.96 & 54.87 & 26.29 & 32.64 & 2 & 1057.6276 & 1057.6253 & 529.8199 & 0.0023 & 2.1705 & 4065.665 \\ \text { IAQDLEMYGINYFEIK } & 1.00 & 68.61 & 27.34 & 26.48 & 2 & 2234.1554 & 2234.1536 & 1118.0841 & 0.0018 & 0.8049 & 203.076\end{array}$

$\begin{array}{llllllllllll}\text { QLLTLSSELSQAR } & 1.00 & 92.60 & 27.28 & 25.66 & 2 & 1588.8914 & 1588.8906 & 795.4526 & 0.0008 & 0.5029 & 12195.361\end{array}$ $\begin{array}{llllllllllll}\text { QTISNACGTIGLIHAIANNK } & 1.00 & 54.81 & 26.65 & 18.09 & 3 & 2372.2543 & 2372.2548 & 791.7589 & -0.0005 & -0.2105 & 833.845 \\ \text { OTISNACGTIGLLAIANNK } & 1.00 & 54.63 & 26.56 & 22.72 & 3 & 2372.2561 & 2372.2548 & 791.7589 & 0.0013 & 0.5473 & 2713.134\end{array}$ $\begin{array}{llllllllllllll}\text { QTISNACGTIGLIHAIANNK } & 1.00 & 54.63 & 26.56 & 22.72 & 3 & 2372.2561 & 2372.2548 & 791.7589 & 0.0013 & 0.5473 & 2713.134 \\ \text { QTISNACGTIGLIHAIANNKK } & 0.66 & 57.23 & 26.54 & 70.23 & 3 & 2372.2564 & 2372.2548 & 791.7589 & 0.0016 & 0.6736 & 617.314\end{array}$ $\begin{array}{lllllllllllll}\text { RIISNACGTIGLLHAIANNK } & 0.66 & 57.23 & 26.54 & 70.23 & 3 & 2372.2564 & 2372.2548 & 791.7589 & 0.0016 & 0.6736 & 617.314 & 642.241 \\ \text { QTISNACGTIGLLHAIANNK } & 0.66 & 45.38 & 26.54 & 58.38 & 3 & 2372.2567 & 2372.2548 & 791.7589 & 0.0019 & 0.7999 & 570.998 & 429.059\end{array}$ $\begin{array}{lllllllllllll}\text { QTISNACGTIGLIHAIANNK } & 0.66 & 55.66 & 26.59 & 68.66 & 3 & 2372.2570 & 2372.2548 & 791.7589 & 0.0022 & 0.9262 & 137.204 \\ \text { VTHETSAHEGQTEAPSIDEK } & 1.00 & 22.32 & 27.02 & 14.89 & 4 & 2453.1953 & 2453.1914 & 614.3051 & 0.0039 & 1.5872 & 1075.627\end{array}$ $\begin{array}{llllllllllll}1.00 & 51.20 & 23.69 & 37.36 & 2 & 1115.7164 & 1115.7158 & 558.8652 & 0.0006 & 0.5368 & 303.361 \\ 1.00 & 36.55 & 23.69 & 31.85 & 2 & 1115.7168 & 1115.7158 & 558.8652 & 0.0010 & 0.8947 & 251.404\end{array}$ $\begin{array}{llllllllllll}1.00 & 51.20 & 23.69 & 37.36 & 2 & 11 & 15.7164 & 1115.7158 & 558.8652 & 0.0006 & 0.5368 & 303.361\end{array}$ $\begin{array}{lllllllllll}0.99 & 31.28 & 23.69 & 29.54 & 2 & 1115.7168 & 1115.7158 & 558.8652 & 0.0010 & 0.8947 & 183.815\end{array}$ $\begin{array}{llllllllllll}1.00 & 52.48 & 23.58 & 40.76 & 2 & 1115.7170 & 1115.7158 & 558.8652 & 0.0012 & 1.0736 & 314.796 \\ 1.00 & 50.26 & 23.42 & 37.73 & 2 & 1115.7172 & 1115.7158 & 558.8652 & 0.0014 & 1.2525 & 262.559\end{array}$ $\begin{array}{llllllllllll}1.00 & 50.26 & 23.42 & 37.73 & 2 & 1115.7172 & 1115.7158 & 558.8652 & 0.0014 & 1.2525 & 262.559 \\ 1.00 & 50.06 & 23.42 & 37.43 & 2 & 1115.7174 & 1115.7158 & 558.8652 & 0.0016 & 1.4315 & 266.115\end{array}$ $\begin{array}{llllllllllll}1.00 & 50.06 & 23.42 & 37.43 & 2 & 1115.7174 & 1115.7158 & 558.8652 & 0.0016 & 1.4315 & 266.115 \\ 0.99 & 36.61 & 23.28 & 36.73 & 2 & 1115.7180 & 1115.7158 & 558.8652 & 0.0022 & 1.9683 & 324.263\end{array}$ $\begin{array}{llllllllllll}0.99 & 36.61 & 23.28 & 36.73 & 2 & 1115.7180 & 1115.7158 & 558.8652 & 0.0022 & 1.9683 & 324.263 \\ 0.75 & 36.79 & 23.34 & 41.51 & 2 & 1115.7208 & 1115.7158 & 558.8652 & 0.0050 & 4.4733 & 273.106\end{array}$ 


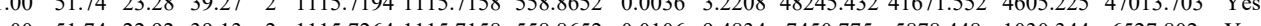
\begin{tabular}{llllllllllllllll}
1.00 & 51.74 & 22.92 & 39.13 & 2 & 1115.7264 & 1115.7158 & 558.8652 & 0.0106 & 9.4834 & 7450.775 & 5878.448 & 1030.344 & 6527.802 & Yes \\
\hline
\end{tabular}

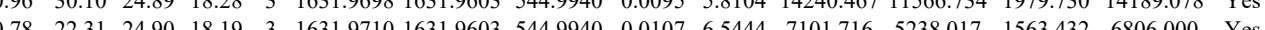
$\begin{array}{lllllllllllllll}0.84 & 16.51 & 25.59 & 15.59 & 3 & 1631.9611 & 1631.9603 & 544.9940 & 0.0008 & 0.4893 & 558.909 & 415.318 & 153.348 & 586.005 & \text { Yes }\end{array}$

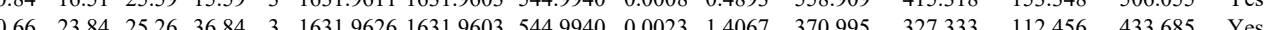
$\begin{array}{lllllllllllll} & \end{array}$

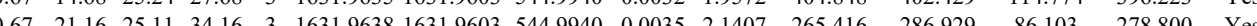

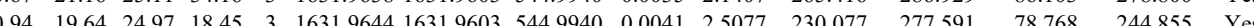

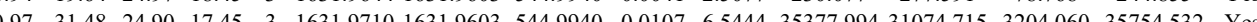
$\begin{array}{llllllllllllllllll}100 & 52.76 & 24.79 & 16.64 & 2 & 1631.9720 & 1631.9603 & 816.9874 & 0.0117 & 7.1604 & 12896356 & 9347.419 & 273.158 & 10941.551 & \text { Yes }\end{array}$ $\begin{array}{llllllllllllllll}100 & 5.90 & 24.77 & 20.46 & 2 & 1631.9734 & 1631.9603 & 8169874 & 0.0131 & 8.0172 & 15061672 & 12441.074 & 931.583 & 12649.633 & \text { Yes }\end{array}$ $\begin{array}{llllllllllllllll}1.00 & 51.52 & 24.77 & 16.47 & 2 & 1631.9728 & 1631.9603 & 816.9874 & 0.0125 & 7.6500 & 10287.659 & 6617.186 & 339.216 & 8013.857 & \text { No }\end{array}$ $\begin{array}{lllllllllllllllll}100 & 56.15 & 24.50 & 20.65 & 2 & 1631.9736 & 1631.9603 & 816.9874 & 0.0133 & 8.1396 & 8134.833 & 7928.568 & 253.712 & 8777.003 & \text { Yes }\end{array}$ $\begin{array}{lllllllllllllll}1.00 & 40.48 & 24.86 & 17.13 & 3 & 1631.9713 & 1631.9603 & 544.9940 & 0.0110 & 6.7279 & 25448.692 & 21616.320 & 1444.396 & 33712.191 & \text { Yes }\end{array}$ $\begin{array}{llllllllllllllll} & & \end{array}$ $\begin{array}{llllllllllllllll}\text { YMHSGPVVAMVWEGLNVVK } & 1.00 & 36.63 & 26.13 & 19.59 & 3 & 2403.2710 & 2403.2687 & 802.0968 & 0.0023 & 0.9558 & 72.347 & 77.560 & 42.266 & 36.630 & \text { No }\end{array}$ $\begin{array}{llllllllllllllll}\text { YMHSGPVVAMVWEGLNVVK } & 1.00 & 53.94 & 26.19 & 22.14 & 4 & 2403.2721 & 2403.2687 & 601.8245 & 0.0034 & 1.4124 & 229.562 & 120.285 & 135.223 & 399.952 & \text { No }\end{array}$ \begin{tabular}{llllllllllllllll} 
YMHSGPVVAMVWEGLNVVK & 1.00 & 64.48 & 26.10 & 24.58 & 4 & 2403.2737 & 2403.2687 & 601.8245 & 0.0050 & 2.0770 & 199.405 & 149.743 & 65.606 & 139.947 & Yes \\
\hline
\end{tabular}

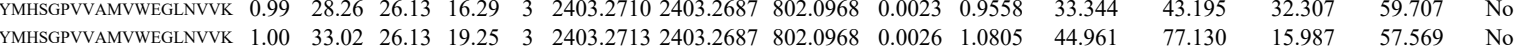
$\begin{array}{lllllllllllllllll}\text { YMHSGPVVAMVWEGLNVVK } & 1.00 & 63.80 & 26.19 & 18.39 & 4 & 2403.2721 & 2403.2687 & 601.8245 & 0.0034 & 1.4124 & 322.006 & 224.339 & 122.487 & 465.303 & \text { Yes }\end{array}$

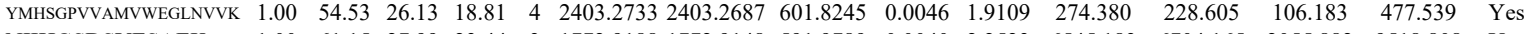

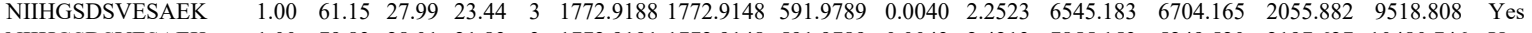
$\begin{array}{llllllllllllllll}\text { NIIHGSDSVESAEK } & 1.00 & 79.83 & 28.01 & 21.83 & 3 & 1772.9191 & 1772.9148 & 591.9789 & 0.0043 & 2.4213 & 7855.153 & 5249.520 & 2197.627 & 10480.746 & \text { Yes }\end{array}$ TFIAIKPDGVQR NIIHGSDSVESAEK NIIHGSDSVESAEK NIIHGSDSVESAEK

47 SPYQEFTDHLVK

SPYQEFTDHLVK

SPYQEFTDHLVK

SPYQEFTDHLVK

ATFDAISK

ATFDAISK

ATFDAISK

SPYQEFTDHLVK

GTGIVSAPVPK

GTGIVSAPVPK

GTGIVSAPVPK

GTGIVSAPVPK

GTGIVSAPVPK

GTGIVSAPVPK

GTGIVSAPVPK

GTGIVSAPVPK

GTGIVSAPVPK

TYSYLTPDLWK

TYSYLTPDLWK

TYSYLTPDLWK

TYSLIFDLWK

SLEEIYLFSLPIK
SLEEIYLFSLPIK $\begin{array}{lllllllllllllll}0.97 & 28.05 & 24.89 & 23.87 & 3 & 1631.9674 & 1631.9603 & 544.9940 & 0.0071 & 4.3425 & 11784.961 & 10210.627 & 1707.193 & 10956.823 & \text { Yes }\end{array}$ $\begin{array}{llllllllllllllll}1.00 & 94.38 & 27.95 & 24.50 & 2 & 1772.9142 & 1772.9148 & 887.4647 & -0.0006 & -0.3380 & 1786.910 & 927.032 & 168.764 & 2621.084 & \text { Yes }\end{array}$ $\begin{array}{lllllllllllllll}1.00 & 71.16 & 27.92 & 22.07 & 3 & 1772.9161 & 1772.9148 & 591.9789 & 0.0013 & 0.7320 & 5688.208 & 4109.105 & 1354.644 & 7765.924 & \text { Yes }\end{array}$ \begin{tabular}{llllllllllllllll}
1.00 & 62.81 & 27.94 & 20.57 & 3 & 1772.9164 & 1772.9148 & 591.9789 & 0.0016 & 0.9009 & 11003.641 & 7544.303 & 3461.606 & 17163.117 & Yes \\
\hline
\end{tabular}

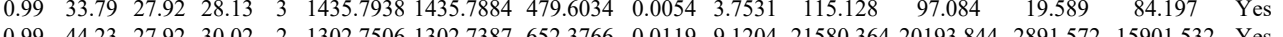
$\begin{array}{llllllllllllllll}0.99 & 44.23 & 27.92 & 30.02 & 2 & 1302.7506 & 1302.7387 & 652.3766 & 0.0119 & 9.1204 & 21580.364 & 20193.844 & 2891.572 & 15901.532 & \text { Yes } \\ 0.98 & 37.59 & 27.54 & 25.24 & 2 & 1302.7514 & 1302.7387 & 6523766 & 0.0127 & 9.7335 & 17240.895 & 15000533 & 1613.674 & 11043.076 & \text { Yes }\end{array}$ $\begin{array}{lllllllllllllllll}0.98 & 37.59 & 27.54 & 25.24 & 2 & 1302.7514 & 1302.7387 & 652.3766 & 0.0127 & 9.7335 & 17240.895 & 1500.533 & 1613.674 & 11043.076 & \text { Yes } \\ 0.91 & 36.08 & 27.70 & 25.32 & 2 & 1302.7442 & 1302.7387 & 652.3766 & 0.0055 & 42153 & 11208.306 & 9647.463 & 1580.492 & 9318.883 & \text { Yes }\end{array}$ $\begin{array}{ccccccccccccccc}.91 & 6.08 & 27.10 & 25.32 & 2 & 1302.7442 & 1302.7387 & 652.3766 & 0.0055 & 4.2153 & 1208.306 & 9647.463 & 1580.492 & 9318.883 & \text { Yes } \\ 1.00 & 62.13 & 27.50 & 46.14 & 3 & 2483.2291 & 2483.2277 & 828.7498 & 0.0014 & 0.5631 & 44.033 & 16.173 & 30.070 & 41.862 & \text { No }\end{array}$ $\begin{array}{lllllllllllllllll}1.00 & 47.43 & 25.30 & 34.75 & 2 & 1273.7664 & 1273.7638 & 637.8892 & 0.0026 & 2.0380 & 9163.477 & 7012.637 & 166.405 & 8559.948 & \text { Y }\end{array}$ $\begin{array}{llllllllllllllll}0.99 & 36.57 & 24.56 & 24.79 & 3 & 1438.8424 & 1438.8289 & 480.6169 & 0.0135 & 9.3629 & 15760.384 & 14905.223 & 296.688 & 11155.821 & \text { Yes }\end{array}$ $\begin{array}{lllllllllllllll}0.99 & 37.10 & 24.62 & 23.88 & 3 & 1438.8430 & 1438.8289 & 480.6169 & 0.0141 & 9.7790 & 15574.922 & 14788.571 & 1613.684 & 10378.976 & \text { Yes }\end{array}$ $\begin{array}{lllllllllllllllll}0.94 & 27.42 & 24.58 & 21.50 & 3 & 1438.8421 & 1438.8289 & 480.6169 & 0.0132 & 9.1548 & 807.568 & 818.396 & 236.480 & 838.649 & \text { Yes }\end{array}$ $\begin{array}{lllllllllllllll}0.58 & 22.89 & 27.60 & 30.31 & 2 & 1302.7494 & 1302.7387 & 652.3766 & 0.0107 & 82007 & 17186.008 & 16952.112 & 4061.302 & 18370.846 & \text { Yes }\end{array}$ $\begin{array}{lllllllllllllll}1.00 & 43.93 & 28.64 & 24.25 & 2 & 1750.9162 & 1750.9134 & 876.4640 & 0.0028 & 1.5973 & 48.402 & 50.914 & 136.844 & 114.799 & \text { No }\end{array}$

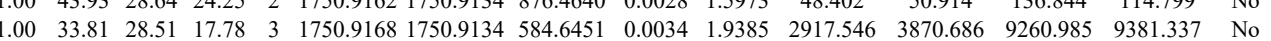
$\begin{array}{lllllllllllllll}0.54 & 12.93 & 28.64 & 14.50 & 3 & 1750.9177 & 1750.9134 & 584.6451 & 0.0043 & 2.4516 & 179.990 & 174.297 & 111.220 & 219.467 & \text { Yes }\end{array}$ $\begin{array}{llllllllllllllll}1.00 & 44.14 & 28.64 & 16.41 & 3 & 1750.9180 & 1750.9134 & 584.6451 & 0.0046 & 2.6227 & 3764.957 & 3969.651 & 9779.280 & 11445.294 & \text { No }\end{array}$

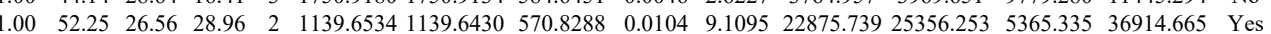
$\begin{array}{lllllllllllllll}1.00 & 60.40 & 26.33 & 26.20 & 2 & 1139.6542 & 1139.6430 & 570.8288 & 0.0112 & 9.8102 & 32459.705 & 34855.965 & 10302.977 & 46932.561 & \text { Yes }\end{array}$ $\begin{array}{lllllllllllllll}1.00 & 60.45 & 26.79 & 29.37 & 2 & 1139.6512 & 1139.6430 & 570.8288 & 0.0082 & 7.1825 & 31045.918 & 31926.995 & 8392.074 & 48313.250 & \text { Yes }\end{array}$ $\begin{array}{lllllllllllllll}1.00 & 52.76 & 26.55 & 29.67 & 2 & 1139.6530 & 1139.6430 & 570.8288 & 0.0100 & 8.7591 & 28710.992 & 31544.119 & 7914.792 & 45751.314 & \text { Yes }\end{array}$ $\begin{array}{lllllllllllllll}1.00 & 36.98 & 28.55 & 18.26 & 3 & 1750.9153 & 1750.9134 & 584.6451 & 0.0019 & 1.0833 & 2508.248 & 2558.139 & 1542.754 & 2964.503 & \text { Yes }\end{array}$ $\begin{array}{lllllllllllllll}1.00 & 62.29 & 22.72 & 20.80 & 2 & 1312.8042 & 1312.7958 & 657.4052 & 0.0084 & 6.3887 & 5024.102 & 4353.119 & 6594.160 & 7274.157 & \text { Yes }\end{array}$

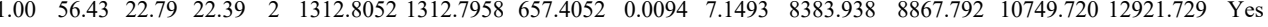
$\begin{array}{lllllllllllllll}0.99 & 32.22 & 22.79 & 15.95 & 3 & 1312.8055 & 1312.7958 & 438.6059 & 0.0097 & 7.3718 & 1037.106 & 1169.009 & 663.959 & 900.417 & \text { Yes }\end{array}$ $\begin{array}{llllllllllllllll}0.89 & 22.78 & 22.79 & 19.00 & 3 & 1312.8055 & 1312.7958 & 438.6059 & 0.0097 & 7.3718 & 910.795 & 1172.515 & 895.430 & 988.578 & \text { Yes }\end{array}$

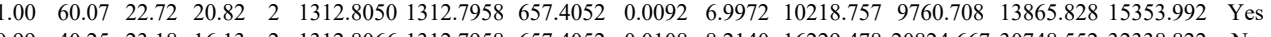
$\begin{array}{lllllllllllllll}0.99 & 40.25 & 23.18 & 16.13 & 2 & 1312.8066 & 1312.7958 & 657.4052 & 0.0108 & 8.2140 & 16229.478 & 20824.667 & 30748.552 & 32338.822 & \text { No }\end{array}$ $\begin{array}{llllllllllllllll}0.58 & 17.48 & 23.77 & 16.20 & 3 & 1312.8070 & 1312.7958 & 438.6059 & 0.0112 & 8.5117 & 1458.553 & 1108.797 & 1083.433 & 1535.438 & \text { Yes }\end{array}$

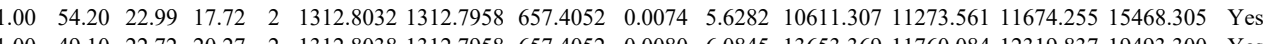
\begin{tabular}{llllllllllllllllll}
1.00 & 49.10 & 22.72 & 20.27 & 2 & 1312.8038 & 1312.7958 & 657.4052 & 0.0080 & 6.0845 & 13653.369 & 11760.084 & 12319.837 & 19493.300 & Yes \\
\hline
\end{tabular} $\begin{array}{lllllllllllllll}1.00 & 58.74 & 27.31 & 20.29 & 2 & 1673.9062 & 1673.8908 & 837.9527 & 0.0154 & 9.1890 & 2137.290 & 2265.385 & 47.259 & 3931.824 & \text { Yes } \\ 1.00 & 49.71 & 27.31 & 19.50 & 2 & 1673.9070 & 1673.8908 & 837.9527 & 0.0162 & 9.6663 & 2876.212 & 2498.941 & 235.009 & 5571.439 & \text { Yes }\end{array}$

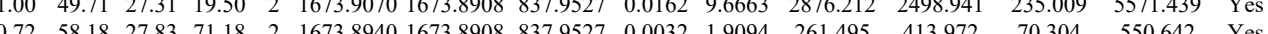

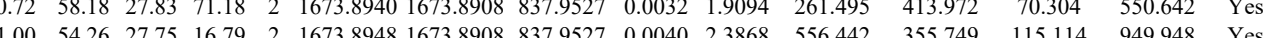

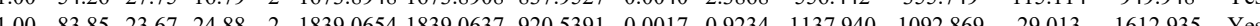

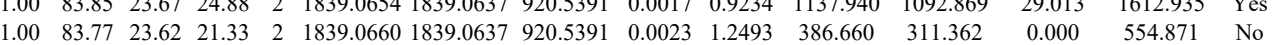

Table S-4 page 197 of 6 
SLEEIYLFSLPIK SLEEIYLFSLPIK SLEEIYLFSLPIK SLEEIYLFSLPIK SLEEIYLFSLPIK SLEEIYLFSLPIK SLEEIYLFSLPIK SLEEIYLFSLPIK SLEEIYLFSLPIK LLMMAGIDDCYTS GCTATLGNFAK GCIATTVPCK

IGKPHTVPCK

LLMMAGIDDCYTSA

IGKPHTVPCK
LIPAPR

LIPAPR

LIPAPR

CGSVLVR

CGSVLVR
CGSVLVR

CGSVLVR

LSIVPVR

LSIVPVR

LSIVPVR

LSIVPVR

LSIVPVR

LSIVPVR

IGKPHTVPCKVTGR

IGKPHTVPCKVTGR

LSIVPVR

LSIVPVRR
LSIVPVRR
TVSVSEAIK GLIDYETFK

VQYDLQK

KVSYVQLK $\begin{array}{lllllllllllllllll}0.84 & 15.40 & 26.28 & 18.91 & 3 & 1556.8921 & 1556.8896 & 519.9705 & 0.0025 & 1.6027 & 18875.521 & 19384.080 & 19558.384 & 31593.834 & \text { Yes }\end{array}$ $\begin{array}{llllllllllllllllll}0.92 & 19.83 & 26.14 & 25.45 & 3 & 1556.8939 & 1556.8896 & 519.9705 & 0.0043 & 2.7566 & 10507.490 & 12009.293 & 11281.297 & 20076.258 & \text { Yes }\end{array}$ $\begin{array}{llllllllllllllll}0.70 & 29.93 * & 21.49 & 21.59 & 2 & 8095270 & 809.5245 & 405.7695 & 0.0025 & 3.0806 & 23950.971 & 28919666 & 737.696 & 51187.568 & \text { Yes }\end{array}$ $\begin{array}{lllllllllllllll}0.62 & 26.84 * 21.49 & 20.57 & 2 & 809.5272 & 809.5245 & 405.7695 & 0.0027 & 3.3270 & 27229.687 & 32006.031 & 862.780 & 59906.583 & \text { Yes }\end{array}$ $\begin{array}{llllllllllllllll}0.55 & 30.17 * 24.46 & 24.30 & 2 & 809.5276 & 809.5245 & 405.7695 & 0.0031 & 3.8199 & 9644.372 & 12857.691 & 1578.719 & 23090.391 & \text { Yes }\end{array}$ $\begin{array}{lllllllllllllll}0.91 & 34.56 & 29.33 & 36.06 & 2 & 922.4936 & 922.4850 & 462.2498 & 0.0086 & 9.3022 & 43847.021 & 52151.796 & 44066.366 & 96287.174 & \text { Yes }\end{array}$

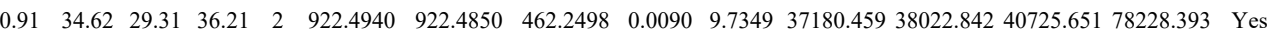

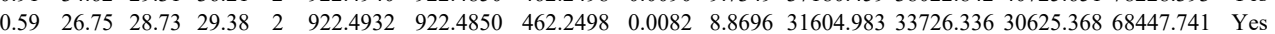
$\begin{array}{lllllllllllllllll}0.89 & 25.96 & 17.92 & 26.14 & 2 & 926.6084 & 926.6035 & 464.3090 & 0.0049 & 5.2766 & 5739.535 & 6280.190 & 1841.502 & 8726.499 & \text { Yes }\end{array}$ $\begin{array}{llllllllllllllll}0.90 & 27.57 & 17.92 & 26.70 & 2 & 926.6096 & 926.6035 & 464.3090 & 0.0061 & 6.5689 & 13322.983 & 13173.992 & 3972.398 & 21632.439 & \text { Yes }\end{array}$ $\begin{array}{lllllllllllllll}0.97 & 31.39 & 17.92 & 20.33 & 2 & 926.6090 & 926.6035 & 464.3090 & 0.005 & 5.9227 & 24276.841 & 27456.099 & 2686.577 & 43626.726 & \text { Yes }\end{array}$ $\begin{array}{llllllllllllllll}0.87 & 24.15 & 17.92 & 16.78 & 2 & 926.6092 & 926.6035 & 464.3090 & 0.0057 & 6.1381 & 16899.417 & 20209.451 & 4938.926 & 30759.193 & \text { Yes }\end{array}$ $\begin{array}{lllllllllllllll}0.98 & 33.43 & 17.92 & 20.79 & 2 & 926.6092 & 926.6035 & 464.3090 & 0.0057 & 6.1381 & 32996.483 & 38135.023 & 1773.320 & 67522.769 & \text { Yes }\end{array}$ $\begin{array}{lllllllllllllllll}0.96 & 34.14 & 17.92 & 28.26 & 2 & 926.6094 & 926.6035 & 464.3090 & 0.0059 & 6.3535 & 35596.317 & 35030.671 & 3326.804 & 67426.662 & \text { Yes }\end{array}$ $\begin{array}{llllllllllllllll}0.97 & 19.71 & 23.48 & 32.71 & 4 & 1970.1293 & 1970.1283 & 493.5394 & 0.0010 & 0.5065 & 1830.233 & 2175.283 & 929.523 & 1451.156 & \text { Yes }\end{array}$ $\begin{array}{lllllllllllllll}0.79 & 14.35 & 23.48 & 27.35 & 4 & 1970.1289 & 1970.1283 & 493.5394 & 0.0006 & 0.3039 & 402.167 & 353.287 & 164.767 & 334.899 & \text { Yes }\end{array}$ $\begin{array}{lllllllllllllllll}0.58 & 8.62 & 15.91 & 21.62 & 2 & 926.6032 & 926.6035 & 464.3090 & -0.0003 & -0.3231 & 422.664 & 514.710 & 215.426 & 789.760 & \text { Yes } \\ 0.93 & 21.75 & 15.31 & 25.54 & 2 & 1282.7050 & 1282.704 & 542.350 & 0.0004 & 0.368 & 302.810 & 268.815 & 173.802 & 105.382 & \text { No }\end{array}$

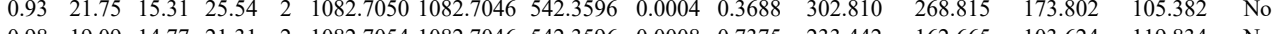
$\begin{array}{lllllllllllllll}0.98 & 19.09 & 14.77 & 21.31 & 2 & 1082.7054 & 1082.7046 & 542.3596 & 0.0008 & 0.7375 & 233.442 & 162.665 & 103.624 & 119.834 & \text { No } \\ 0.99 & 44.36 & 25.72 & 33.66 & 2 & 1220.7292 & 120.7220 & 6 & \end{array}$ $\begin{array}{lllllllllllllllll}0.99 & 44.36 & 25.72 & 33.66 & 2 & 1220.7292 & 122.7220 & 611.3683 & 0.0072 & 5.8884 & 11765.457 & 9944.924 & 13071.030 & 16032.200 & \text { Yes }\end{array}$ $\begin{array}{lllllllllllllll}0.5 & 1.93 & 27.87 & 24.47 & 2 & 1372.7512 & 1372.7482 & 687.3814 & 0.0030 & 2.1822 & 3355.112 & 3377.586 & 230.693 & 5319.894 & \text { Yes }\end{array}$ \begin{tabular}{llllllllllllllll}
0.55 & 4.50 & 16.09 & 15.30 & 2 & 1395.684118 .696 & 591.3421 & 0.0108 & 9.1317 & 24624.245 & 22760.852 & 10349.003 & 23250.569 & Yes \\
\hline
\end{tabular} $\begin{array}{lllllllllllllllll} & \end{array}$ $\begin{array}{llllllllllllllll}\text { GFFDPNTERNLTYLLLK } & 1.00 & 62.94 & 27.62 & 18.14 & 3 & 2316.1939 & 2316.1881 & 773.0700 & 0.0058 & 2.5008 & 205.304 & 118.577 & 43.627 & 138.827 & \text { Yes }\end{array}$

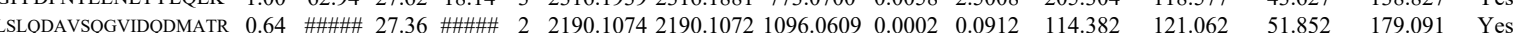

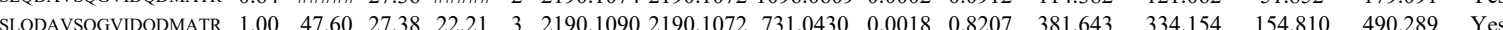

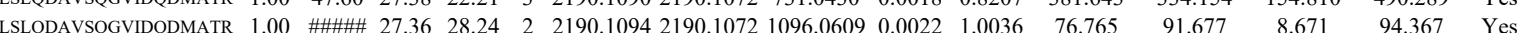

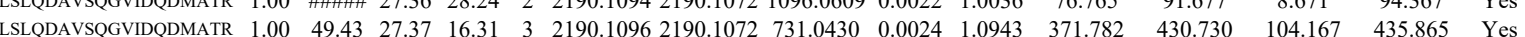

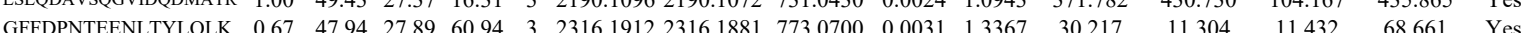

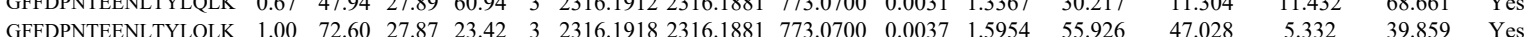

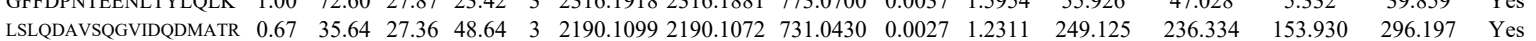
$\begin{array}{llllllllllllllll}\text { GFFDPNTEENLTYLOLK } & 1.00 & 59.68 & 27.87 & 25.54 & 3 & 2316.1918 & 2316.1881 & 773.0700 & 0.0037 & 1.5954 & 99.359 & 189.539 & 84.033 & 127.940 & \text { Yes }\end{array}$ $\begin{array}{llllllllllllllll}\text { SVQNDSQAIAEVLNQLK } & 1.00 & 94.90 & 26.19 & 23.47 & 2 & 2144.1694 & 2144.1681 & 1073.0913 & 0.0013 & 0.6057 & 164.337 & 104.869 & 206.463 & 171.162 & \text { No }\end{array}$

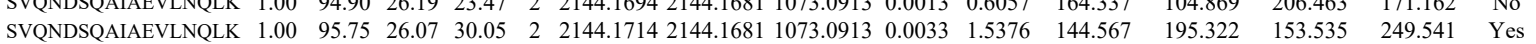

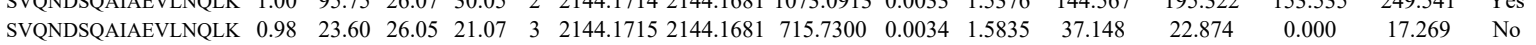
$\begin{array}{llllllllllllllll}\text { SVQNDSQAIAEVLNQLK } & 1.00 & 36.91 & 25.94 & 22.22 & 3 & 2144.1736 & 2144.1681 & 715.7300 & 0.0055 & 2.5615 & 66.052 & 28.868 & 115.509 & 52.310 & \text { No }\end{array}$

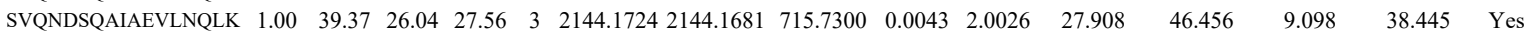
$\begin{array}{llllllllllllllll}\text { AEMDMVAWGVLLASVEOHINSHR } & 1.00 & 57.52 & 26.44 & 17.43 & 4 & 2738.3053 & 2738.3026 & 685.5829 & 0.0027 & 0.9846 & 323.764 & 405.149 & 111.642 & 482.507 & \text { Yes }\end{array}$ $\begin{array}{lllllllllllllll} & \end{array}$

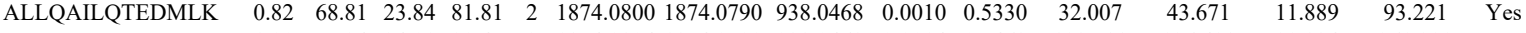

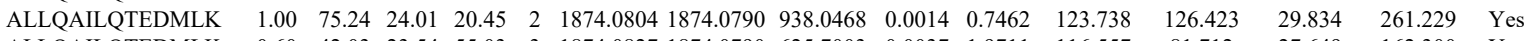
$\begin{array}{llllllllllllllll}\text { ALLQAILQTEDMLK } & 0.60 & 42.03 & 23.54 & 55.03 & 3 & 1874.0827 & 1874.0790 & 625.7003 & 0.0037 & 1.9711 & 116.557 & 81.712 & 27.649 & 162.300 & \text { Yes }\end{array}$

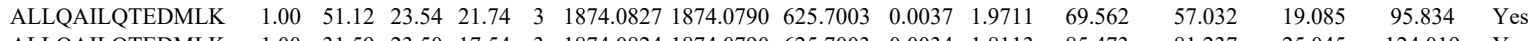

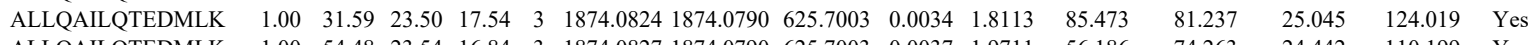

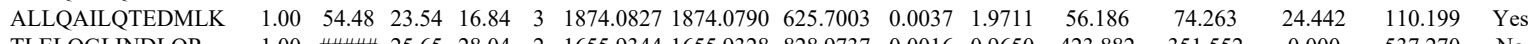

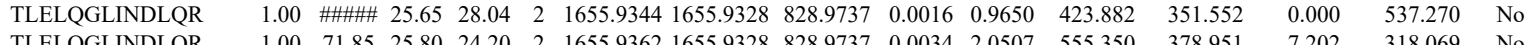
$\begin{array}{lrllllllllllllll}\text { TLELQGLINDLQR } & 1.00 & 71.85 & 25.80 & 24.20 & 2 & 1655.9362 & 1655.9328 & 828.9737 & 0.0034 & 2.0507 & 555.350 & 378.951 & 7.202 & 318.069 & \text { No }\end{array}$ $\begin{array}{lllllllllllllll} & & \end{array}$ \begin{tabular}{llllllllllllllll} 
& FLEFQYLTGGLVDPEVHGR \\
FLEFOYLTGGLVDPEVHGR & 1.00 & 68.05 & 27.28 & 81.05 & 3 & 2320.1989 & 2320.1974 & 774.4064 & 0.0015 & 0.6457 & 647.784 & 343.329 & 316.110 & 961.001 & Yes \\
\hline
\end{tabular} $\begin{array}{lllllllllllllll} & \end{array}$

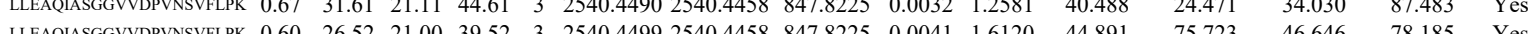
$\begin{array}{llllllllllllllll}\text { LLQLOEQMR } & 0.99 & 42.76 & 27.58 & 24.61 & 2 & 1301.7364 & 1301.7247 & 651.8696 & 0.0117 & 8.9741 & 8370.087 & 8434.774 & 264.700 & 14748.423 & \text { Yes }\end{array}$

Table S4 page 198 of 614 
$\begin{array}{llllllllllllllll}0.55 & 17.99 & 19.34 & 30.99 & 3 & 1227.7921 & 1227.7906 & 410.2708 & 0.0015 & 1.2187 & 31531.098 & 28922.702 & 20770.990 & 39462.340 & \text { Yes }\end{array}$ $\begin{array}{llllllllllllllll}\text { SNKPIILR } & 1.00 & 34.24 & 19.34 & 24.89 & 2 & 1227.7926 & 1227.7906 & 614.9026 & 0.0020 & 1.6263 & 3357.879 & 4019.583 & 2629.061 & 5266.535 & \text { Yes }\end{array}$ $\begin{array}{llllllllllllllll}0.96 & 14.64 & 19.34 & 15.57 & 3 & 1227.7927 & 1227.7906 & 410.2708 & 0.0021 & 1.7062 & 24448.040 & 23034.265 & 15009.755 & 30020.443 & \text { Yes }\end{array}$ $\begin{array}{lllllllllllllllll} & \text { SNKPIILR } & 1.00 & 31.17 & 19.34 & 24.66 & 2 & 1227.7928 & 1227.7906 & 614.9026 & 0.0022 & 1.7889 & 2514.692 & 2515.642 & 1738.214 & 3532.728 & \text { Yes }\end{array}$ $\begin{array}{llllllllllllllll}\text { YCYLQNEVFGLFQK } & 1.00 & 31.95 & 27.35 & 19.45 & 3 & 2085.0337 & 2085.0307 & 696.0175 & 0.0030 & 1.4367 & 107.353 & 60.992 & 38.076 & 63.905 & \text { Yes }\end{array}$

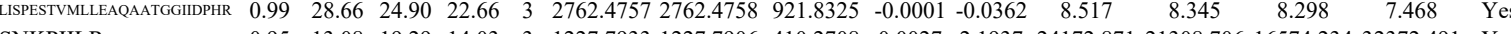

SNKPIILR

SNKPIILR

SNKPIILR

SNKPIILR

QLQNIIQATSR $\begin{array}{llllllllllllllll}0.95 & 13.08 & 19.29 & 14.03 & 3 & 1227.7933 & 1227.7906 & 410.2708 & 0.0027 & 2.1937 & 24172.871 & 21308.706 & 16574.234 & 32372.491 & \text { Yes } & \end{array}$ $\begin{array}{lllllllllllllll}0.99 & 19.82 & 19.29 & 15.01 & 3 & 1227.7933 & 1227.7906 & 410.2708 & 0.0027 & 2.1937 & 30952.476 & 34056.198 & 26911.035 & 46148.475 & \text { Yes }\end{array}$ $\begin{array}{llllllllllllllll}0.99 & 28.82 & 19.29 & 23.58 & 2 & 1227.7936 & 1227.7906 & 614.9026 & 0.0030 & 2.4394 & 4962.268 & 5260.165 & 3709.359 & 7295.369 & \text { Yes }\end{array}$ $\begin{array}{llllllllllllllll}0.64 & 4.16 & 19.29 & 17.16 & 3 & 1227.7939 & 1227.7906 & 410.2708 & 0.0033 & 2.6811 & 12206.919 & 12777.983 & 11324.266 & 17140.724 & \text { Yes }\end{array}$ $\begin{array}{lllllllllllllll} & 23.59 & 2623.1593 & 2623.1555 & 875.3924 & 0.0038 & 1.4470 & 0.000 & 0.000 & 0.000 & 2.388 & \text { No }\end{array}$

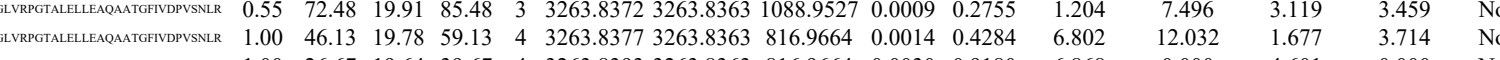

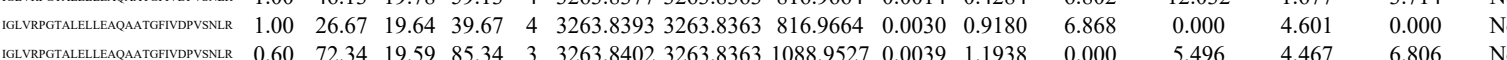

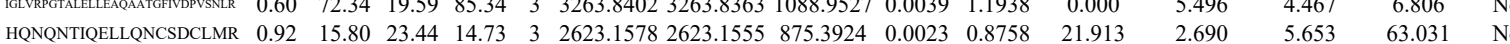

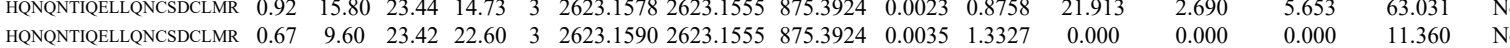
$\begin{array}{lllllllllllll} & \end{array}$

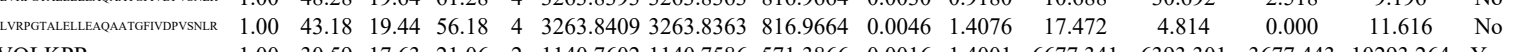

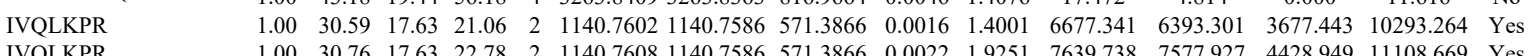

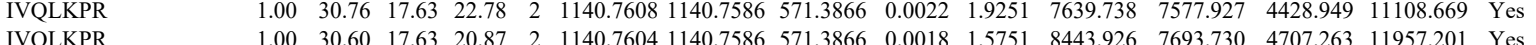

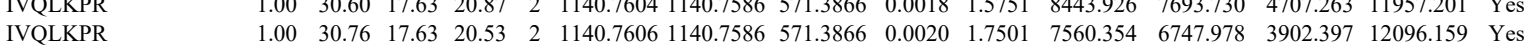
$\begin{array}{llllllllllllllll}\text { IVQLKPR } & 0.99 & 26.08 & 16.99 & 24.10 & 2 & 1140.7594 & 1140.7586 & 571.3866 & 0.0008 & 0.7001 & 2874.798 & 2721.160 & 1598.351 & 4227.487 & \text { Yes }\end{array}$ $\begin{array}{llllllllllllllll}1.00 & 30.46 & 16.90 & 19.83 & 2 & 1140.7598 & 1140.7586 & 571.3866 & 0.0012 & 1.0501 & 1865.703 & 1764.902 & 856.606 & 2685.541 & \text { Yes }\end{array}$ $\begin{array}{llllllllllllllll}1.00 & 62.33 & 27.95 & 36.65 & 2 & 12727058 & 1272.7047 & 637.3596 & 0.0011 & 0.8629 & 392.642 & 337.702 & 24.004 & 603.998 & \text { Yes }\end{array}$

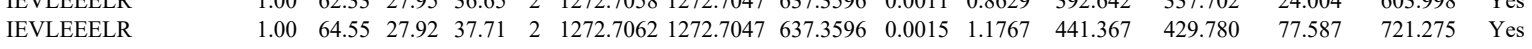
$\begin{array}{llllllllllllllll}\text { IEVLEEELR } & 1.00 & 53.83 & 27.95 & 31.02 & 2 & 1272.7060 & 1272.7047 & 637.3596 & 0.0013 & 1.0198 & 2367.824 & 2522.611 & 0.000 & 5084.326 & \text { No }\end{array}$ $\begin{array}{llllllllllllllll}\text { IEVLEEELR } & 1.00 & 57.01 & 28.10 & 32.44 & 2 & 1272.7064 & 1272.7047 & 637.3596 & 0.0017 & 1.3336 & 2970.616 & 3147.412 & 232.917 & 6295.549 & \text { Yes }\end{array}$ $\begin{array}{llllllllllllllll}\text { TGSQYDIQDAIDK } & 1.00 & 71.68 & 27.47 & 31.59 & 2 & 1740.8794 & 1740.8774 & 871.4460 & 0.0020 & 1.1475 & 606.099 & 553.211 & 160.673 & 720.644 & \text { Yes }\end{array}$

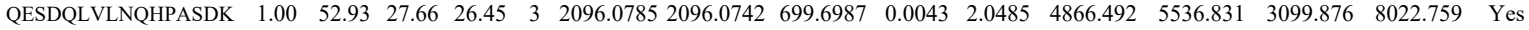

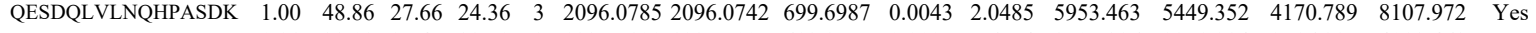
$\begin{array}{llllllllllllllll}\text { LPVEEAYK } & 0.91 & 33.02 & 27.47 & 33.79 & 2 & 1235.7100 & 1235.7005 & 618.8575 & 0.0095 & 7.6754 & 2707.396 & 2351.284 & 2516.295 & 4018.468 & \text { Yes }\end{array}$ $\begin{array}{llllllllllllllll}\text { LPVEEAYK } & 0.93 & 32.94 & 27.47 & 33.69 & 2 & 1235.7102 & 1235.7005 & 618.8575 & 0.0097 & 7.8370 & 2383.194 & 1639.844 & 1697.210 & 2966.929 & \text { Yes }\end{array}$

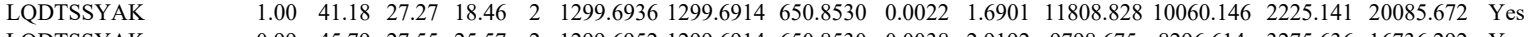
$\begin{array}{llllllllllllllll}\text { LQDTSSYAK } & 0.99 & 45.79 & 27.55 & 25.57 & 2 & 1299.6952 & 1299.6914 & 650.8530 & 0.0038 & 2.9192 & 9798.675 & 8296.614 & 3275.636 & 16736.292 & \text { Yes }\end{array}$

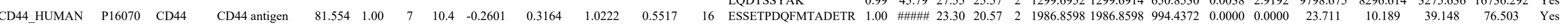

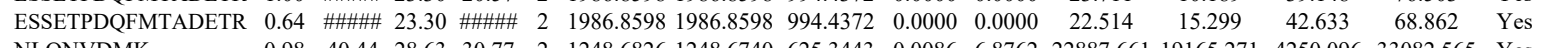

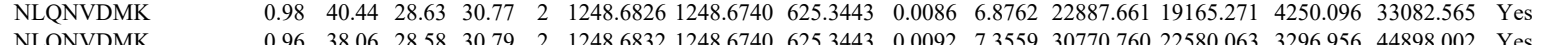
$\begin{array}{lllllllllllllllll}\text { NLQNVDMK } & 0.96 & 38.06 & 28.58 & 30.79 & 2 & 1248.6832 & 1248.6740 & 625.3443 & 0.0092 & 7.3559 & 30770.760 & 22580.063 & 3296.956 & 44898.002 & \text { Yes } \\ \text { LVINSGNGAVEDR } & 1.00 & 71.24 & 27.95 & 32.78 & 2 & 14867988 & 1486.7861 & 744.4003 & 0.0127 & 8.5303 & 2961250 & 2632.745 & 180.479 & 2453.180 & \text { No }\end{array}$ $\begin{array}{llllllllllllllll}\text { LVINSGNGAVEDR } & 1.00 & 71.24 & 27.95 & 32.78 & 2 & 1486.7988 & 1486.7861 & 744.4003 & 0.0127 & 8.5303 & 2961.250 & 2632.745 & 180.479 & 2453.180 & \text { No } \\ \text { LVINSGNGAVEDR } & 1.00 & 80.97 & 27.95 & 31.30 & 2 & 14867994 & 1486.7861 & 744.4003 & 0.0133 & 8.9333 & 5382.728 & 4991.382 & 296.116 & 5082.756 & \text { Yes }\end{array}$

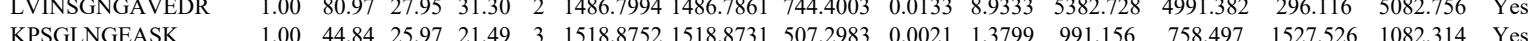

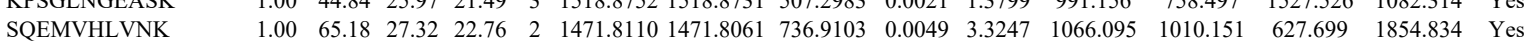
SQEMVHLVNK

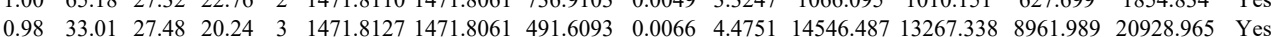




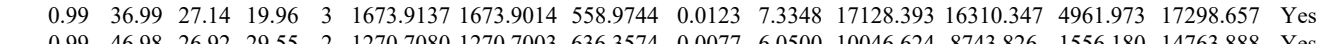
$\begin{array}{llllllllllllllllllll} & & & \end{array}$ \begin{tabular}{lllllllllllllllll} 
& \\
LELQVDSLLR & 1.00 & 75.37 & 25.58 & 34.47 & 2 & 1570.9070 & 1570.9052 & 786.4599 & 0.0018 & 1.1444 & 1469.866 & 1361.863 & 76.530 & 2278.175 & Yes \\
\hline
\end{tabular} $\begin{array}{llllllllllllllll} & 1.00 & 93.35 & 25.53 & 33.43 & 2 & 1570.9074 & 1570.9052 & 786.4599 & 0.0022 & 1.3987 & 594.331 & 712.234 & 55.871 & 1013394 & \text { Yes }\end{array}$ LLELQEVDSLLR $\begin{array}{lllllllllllllll}1.00 & 89.79 & 25.72 & 32.58 & 2 & 1570.9062 & 1570.9052 & 786.4599 & 0.0010 & 0.6358 & 346.472 & 508.124 & 42.709 & 854.566 & \text { Yes } \\ 1.00 & 88.10 & 25.50 & 31.45 & 2 & 1570.9072 & 1570.952 & 786.459 & 0.0020 & 1.2715 & 676.272 & 787.407 & 54.352 & 1246.825 & \text { Yes }\end{array}$

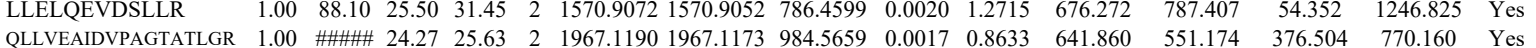

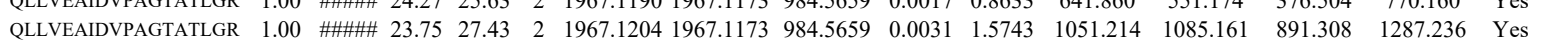
$\begin{array}{lllllllllllllllll}\text { FHVQLSNPK } & 0.99 & 37.20 & 26.21 & 30.66 & 3 & 1356.7804 & 1356.7758 & 453.2659 & 0.0046 & 3.3828 & 9127.735 & 8523.669 & 2328.113 & 12504.090 & \text { Yes }\end{array}$ $\begin{array}{lllllllllllllll}\text { CNTQAELLAAGCQR } & 1.00 & \text { \#\#\#\# } 24.22 & 20.67 & 2 & 1712.7718 & 1712.7588 & 857.3867 & 0.0130 & 7.5811 & 1371.452 & 1135.096 & 174.647 & 1801.017 & \text { Yes }\end{array}$

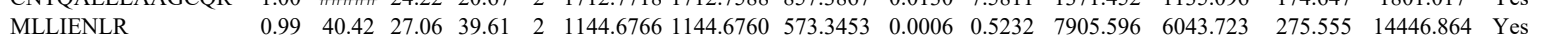
\begin{tabular}{llllllllllllllll} 
MLLIENLR & 1.00 & 46.92 & 27.13 & 40.05 & 2 & 1144.6782 & 1144.6760 & 573.3453 & 0.0022 & 1.9186 & 7273.151 & 6605.744 & 324.075 & 13846.379 & Yes \\
\hline
\end{tabular}

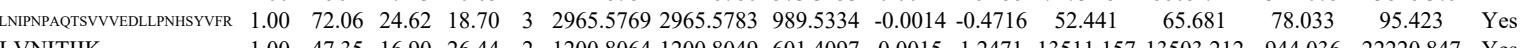

LVNITIIK

VLSTSSTLTR $036 \quad 22220.847$ Yes $\begin{array}{llllllllllllllll} & 1.00 & 65.49 & 26.36 & 28.78 & 2 & 1207.6994 & 1207.6894 & 604.8520 & 0.0100 & 8.2664 & 19949.569 & 17354.921 & 0.000 & 26869.503 & \text { No }\end{array}$ $\begin{array}{lllllllllllllllll} & \end{array}$ \begin{tabular}{lllllllllllllll}
\hline & &
\end{tabular} LVFSALGPTSLR LVFSALGPTSLR LVFSALGPTSLR LVFSALGPTSLR LVFSALGPTSLR LVTALGPTSR ACLALPCCNR

ACLALLPCCNR

NVISLTEDVDEFR

VPLFIRPEDDDEK

VPLFIRPEDDDEK

\section{SPEEGAETPYLALLPPDAEGPHCOFV}

SCSPELQQK

SCSPELQQK

TNFFGTR

TNFFGTR

TNFFGTR

GIGLAIVR

GIGLAIVR

VVNVSSIMSVR

VVNVSSIMSVR

VVNVSSIMSVR

VVNVSSIMSVR

VVNVSSIMSVR

ILLNACCPGWVR

ILLNACCPGWVR

VVNVSSIMSVR

VVNVSSIMSVR

SETITEEELVGLM

SETITEEELVGLMNK

SETITEEELVGLMNK $\begin{array}{lllllllllllll}1.00 & 77.76 & 26.84 & 18.94 & 3 & 2869.3825 & 2869.3795 & 957.4671 & 0.0030 & 1.0444 & 24.742 & 27.048 & 15.13\end{array}$ $\begin{array}{lllllllllllll}1.00 & 78.28 & 25.61 & 31.39 & 2 & 1403.8268 & 1403.8258 & 702.9202 & 0.0010 & 0.7113 & 3193.412 & 2689.967 & \\ 1.00 & 89.42 & 25.30 & 34.33 & 2 & 1403.8270 & 1403.8258 & 702.9202 & 0.0012 & 0.8536 & 2402.629 & 2135.057 & 0.006\end{array}$ $\begin{array}{lllllllllllll}1.00 & 89.42 & 25.30 & 34.33 & 2 & 1403.8270 & 1403.8258 & 702.9202 & 0.0012 & 0.8536 & 2402.629 & 2135.057 & 0.00 \\ 1.00 & 84.97 & 25.30 & 34.42 & 2 & 1403.8270 & 1403.8258 & 702.9202 & 0.0012 & 0.8536 & 1852.565 & 1931.801 & 60.6\end{array}$ $\begin{array}{llllllllllllllll}14.42 & 2 & 1403.8270 & 1403.8258 & 702.9202 & 0.0012 & 0.8536 & 1852.565 & 1931.801 & 60.656 & 3404.905 & \text { Yo }\end{array}$

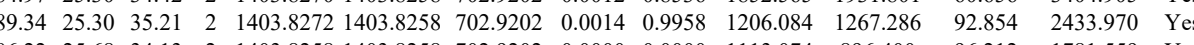

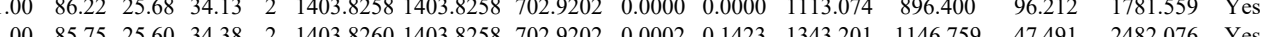
$\begin{array}{lllllllllllllll} & \end{array}$

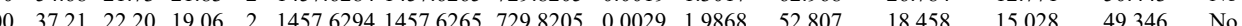
$\begin{array}{lllllllllllllll}1.00 & 71.59 & 28.00 & 18.76 & 2 & 1679.8506 & 1679.8488 & 840.9317 & 0.0018 & 1.0702 & 165.264 & 214.720 & 6.540 & 368.549 & \text { Yes }\end{array}$ $\begin{array}{lllllllllllllll}0.96 & 2239 & 27.33 & 19.50 & 3 & 1859.9896 & 1859.9873 & 621.0030 & 0.0023 & 1.2346 & 3218.752 & 33.68 .704 & 6219.370 & 5547.105 & \text { No }\end{array}$ $\begin{array}{lllllllllllllll}0.92 & 19.35 & 27.33 & 14.59 & 3 & 1859.9896 & 18599873 & 621.0030 & 0.0023 & 1.2346 & 3490.178 & 3103.126 & 5702.546 & 6538.548 & \mathrm{No}\end{array}$

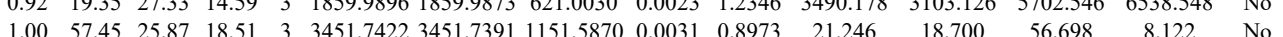

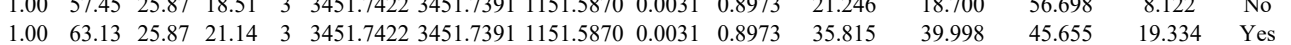

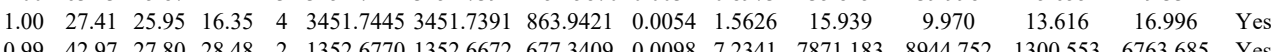
\begin{tabular}{lllllllllllllll}
0.99 & 42.97 & 27.80 & 28.48 & 2 & 1352.6770 & 1352.6672 & 677.3409 & 0.0098 & 7.2341 & 7871.183 & 8944.752 & 1300.553 & 6763.685 & Yes \\
\hline
\end{tabular} $\begin{array}{lllllllllllllllll}0.99 & 42.82 & 27.96 & 23.20 & 2 & 1352.6782 & 1352.6672 & 677.3409 & 0.0110 & 8.1199 & 8475.976 & 9840.050 & 1420.286 & 6962.175 & \text { Yes } \\ 0.57 & 22.08 & 25.92 & 24.32 & 2 & 98.5190 & 98.5103 & 49.7624 & 0.0087 & 8.8098 & 19442.673 & 21257.860 & 1386.116 & 17278.152 & \text { Yes }\end{array}$ $\begin{array}{llllllllllllllll}0.57 & 22.08 & 25.92 & 24.32 & 2 & 985.5190 & 985.5103 & 493.7624 & 0.0087 & 8.8098 & 19442.673 & 21257.860 & 1386.116 & 17278.152 & \text { Yes } \\ 0.61 & 22.03 & 26.09 & 24.40 & 2 & 985.5144 & 985.5103 & 493.7624 & 0.0041 & 4.1518 & 16164.025 & 18636.652 & 403.575 & 15090.608 & \text { Yes }\end{array}$ $\begin{array}{lllllllllllllllll}0.86 & 27.93 & 26.09 & 24.82 & 2 & 985.5146 & 985.5103 & 493.7624 & 0.0043 & 4.3543 & 19922.116 & 21967.006 & 1026.806 & 18023.614 & \text { Yes }\end{array}$ $\begin{array}{lllllllllllllllll}0.98 & 41.45 & 20.53 & 33.95 & 2 & 941.6228 & 941.6144 & 471.8145 & 0.0084 & 8.9017 & 16033.972 & 18591.977 & 6456.909 & 16342.728 & \text { Yes }\end{array}$ $\begin{array}{lllllllllllllll}1.00 & 41.73 & 20.53 & 24.75 & 2 & 941.6234 & 941.6144 & 471.8145 & 0.0090 & 9.5376 & 13688.567 & 18141.476 & 4408.436 & 14987.077 & \text { Yes }\end{array}$ $\begin{array}{llllllllllllllll}1.00 & 66.41 & 27.74 & 23.58 & 2 & 1333.7514 & 1333.7510 & 667.8828 & 0.0004 & 0.2995 & 5807.371 & 7504.400 & 576.583 & 5343.735 & \text { Yes }\end{array}$ $\begin{array}{lllllllllllllll}1.00 & 62.35 & 27.75 & 23.39 & 2 & 1333.7518 & 1333.7510 & 667.8828 & 0.0008 & 0.5989 & 12168.153 & 16059.477 & 1035.947 & 11225.309 & \text { Yes }\end{array}$ $\begin{array}{lllllllllllllll}1.00 & 62.42 & 27.79 & 23.22 & 2 & 1333.7510 & 1333.7510 & 667.8828 & 0.0000 & 0.0000 & 8615.598 & 10502.591 & 840.015 & 9308.938 & \text { Yes }\end{array}$

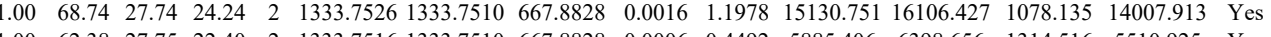
$\begin{array}{lllllllllllllll}1.00 & 62.38 & 27.75 & 22.40 & 2 & 1333.7516 & 1333.7510 & 667.8828 & 0.0006 & 0.4492 & 5885.406 & 6398.656 & 1314.516 & 5510.925 & \text { Yes }\end{array}$ $\begin{array}{lllllllllllllll}1.00 & 66.25 & 27.75 & 23.36 & 2 & 1333.7518 & 1333.7510 & 667.8828 & 0.0008 & 0.5989 & 7500.481 & 8936.727 & 453.269 & 8074.392 & \text { Yes }\end{array}$

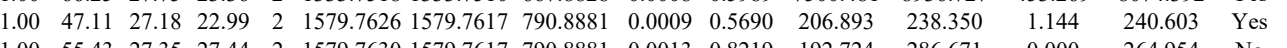

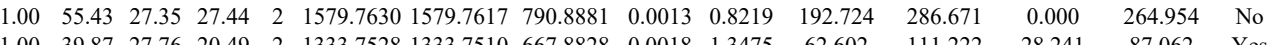

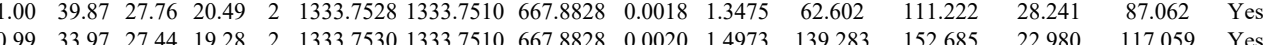
\begin{tabular}{lllllllllllllll}
1.90 & 39.41 & 27.44 & 19.28 & 2 & 1333.7530 & 1333.7510 & 667.8828 & 0.0020 & 1.4973 & 139.283 & 152.685 & 22.980 & 117.059 & Yes \\
\hline
\end{tabular}

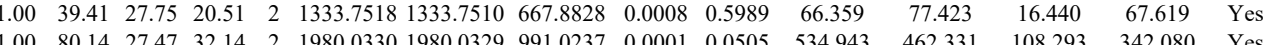
$\begin{array}{lllllllllllllll}1.00 & 85.86 & 27.46 & 32.37 & 2 & 1980.0334 & 1980.0329 & 991.0237 & 0.0005 & 0.2523 & 327.822 & 434.571 & 185.406 & 390.902 & \text { Yes }\end{array}$

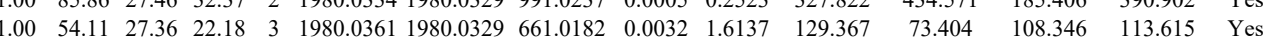

Table S-4 page 200 of 614 


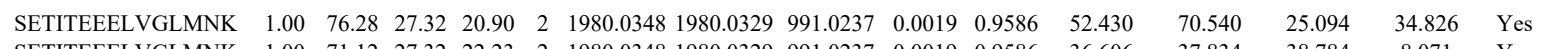
$\begin{array}{llllllllllllllll}\text { SETITEEELVGLMNK } & 1.00 & 71.12 & 27.32 & 22.23 & 2 & 1980.0348 & 1980.0329 & 991.0237 & 0.0019 & 0.9586 & 36.606 & 37.834 & 38.784 & 8.071 & \text { Yes }\end{array}$

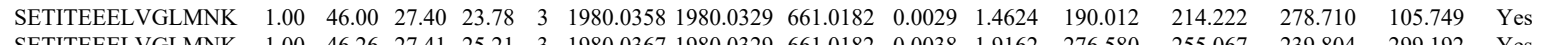

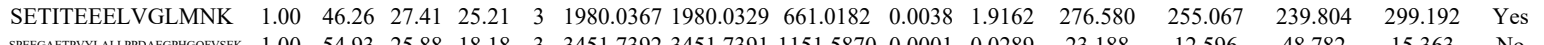

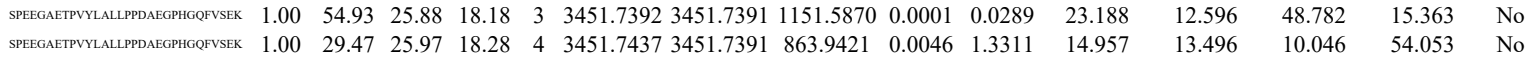
$\begin{array}{llllllllllllllll} & \end{array}$

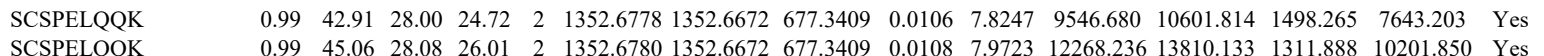

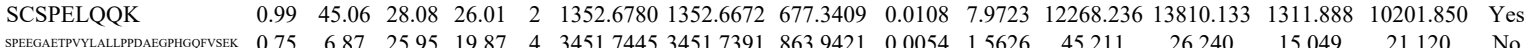

$\begin{array}{llllllllllll}15 & & & & & \end{array}$ ALAAGGYDVEK ALAAGGYDVEK

SPAKPK

SPAKPK

KPAGATPK

KPAGATPK

KPAGATPK

KPAGATPK

KPAGATPK

KPAGATPK

KPAGATPK

KPAGATPK

KPAGATPK

KPAAAGVK

KPAAAGVK

KPAGATPK

KPAGATPK

ATGPPVSELITK

KPAAAGVK

KPAAAGVK

ATGPPVSELITK

ATGPPVSELITK

NGLSLAALK

NGLSLAALK

NGLSLAALK

NGLSLAALK

SETAPAETATPAPVEK

ALAAGGYDVEK

ALAAGGYDVEK

ALAAGGYDVEK

ALAAGGYDVEK

ALAAGGYDVEK

AAGAGAAK

ALAAGGYDVEK

H13_HUMAN P16402 HIST1H1D Histone H1.3

$\begin{array}{llllllll}22.35 & 1.00 & 4 & 42.1 & 0.4838 & 0.2941 & 0.1796 & 0.3966\end{array}$

VAGAATPK

VAGAATPK

KPATAAGTK

KPATAAGTK

VAGAATPK

KPATAAGTK

AASGEGKPK

AGATAGK

2 KPAAATVTK

KPAAATVTK

KPAAATVTK

KPAAATVTK

KPAAATVTK

KPAAATVTK

KPAAATVTK

KPAAATVTK

AAGGATPK $\begin{array}{lllllllllllllll}0.75 & 6.87 & 25.95 & 19.87 & 4 & 3451.7445 & 3451.7391 & 863.9421 & 0.0054 & 1.5626 & 45.211 & 26.240 & 15.049 & 21.120 & \text { No }\end{array}$

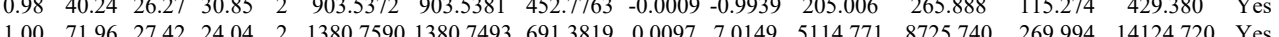

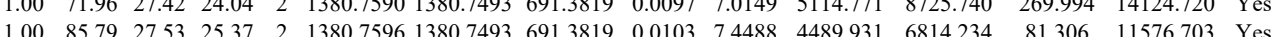

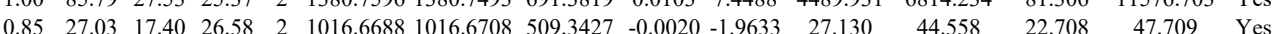

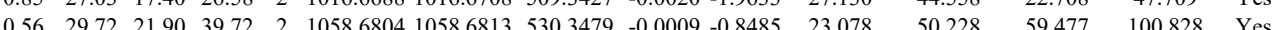
$\begin{array}{lllllllllllllll}0.56 & 18.89 & 21.85 & 28.95 & 2 & 1058.6808 & 1058.6813 & 5303479 & -0.0005 & -0.4714 & 18.954 & 9.037 & 22.169 & 22.623 & \text { Yes }\end{array}$

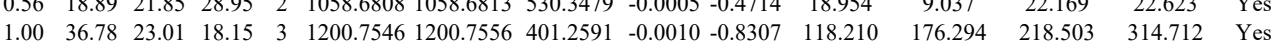

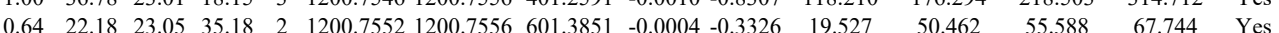

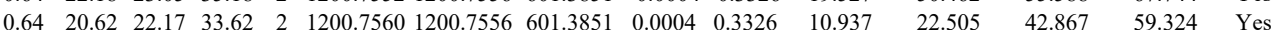
$\begin{array}{lllllllllllllll}1.00 & 31.78 & 22.17 & 19.05 & 3 & 1200.7561 & 1200.7556 & 401.2591 & 0.0005 & 0.4154 & 195.960 & 233.422 & 366.527 & 406.379 & \text { Yes }\end{array}$ $\begin{array}{lllllllllllllll}0.88 & 24.15 & 23.10 & 17.07 & 3 & 1200.7537 & 1200.7556 & 401.2591 & -0.0019 & -1.5784 & 95.172 & 170.683 & 158.147 & 173.932 & \text { Yes }\end{array}$ $\begin{array}{lllllllllllllll}0.67 & 19.11 & 23.10 & 15.98 & 3 & 1200.7540 & 1200.7556 & 401.2591 & -0.0016 & -1.3292 & 117.443 & 121.086 & 149.979 & 204.724 & \text { Yes }\end{array}$ $\begin{array}{lllllllllllllll}1.00 & 37.65 & 23.10 & 20.39 & 3 & 1200.7543 & 1200.7556 & 401.2591 & -0.0013 & -1.0799 & 79.327 & 127.740 & 205.274 & 218.234 & \text { Yes }\end{array}$

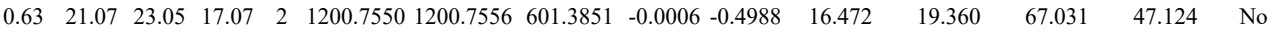

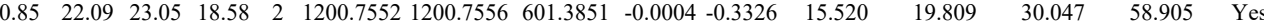

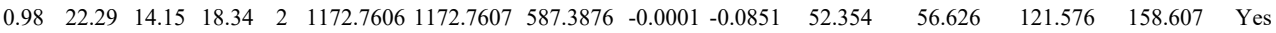

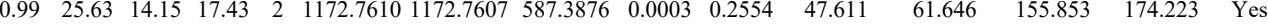
$\begin{array}{lllllllllllllll}0.79 & 17.90 & 23.01 & 16.50 & 3 & 1200.7546 & 1200.7556 & 401.2591 & -0.0010 & -0.8307 & 78.316 & 71.332 & 84.500 & 82.775 & \text { Yes }\end{array}$

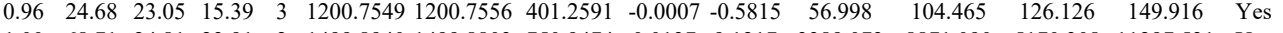

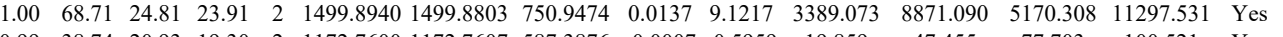

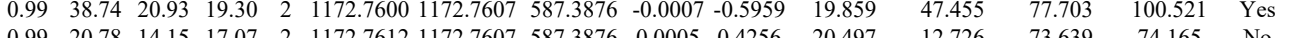
$\begin{array}{lllllllllllllll}0.99 & 20.78 & 14.15 & 17.07 & 2 & 1172.7612 & 1172.7607 & 587.3876 & 0.0005 & 0.4256 & 20.497 & 12.726 & 73.639 & 74.165 & \text { No }\end{array}$ $\begin{array}{lllllllllllllll}1.00 & 64.96 & 24.83 & 21.00 & 2 & 1499.8942 & 1499.8803 & 750.9474 & 0.0139 & 9.2549 & 1771.441 & 3157.572 & 2516.206 & 4681.137 & \text { Yes }\end{array}$ $\begin{array}{lllllllllllllllll}1.00 & 65.38 & 23.96 & 22.74 & 2 & 1499.8944 & 1499.8803 & 750.9474 & 0.0141 & 9.3881 & 3337.600 & 5985.130 & 4354.674 & 8642.287 & \text { Yes }\end{array}$ $\begin{array}{lllllllllllllllll}0.97 & 38.20 & 25.04 & 22.21 & 2 & 1173.7384 & 1173.7325 & 587.8735 & 0.0059 & 5.0181 & 8956.920 & 15137.609 & 2357.459 & 15201.221 & \text { Yes } \\ 0.99 & 42.24 & 24.94 & 24.13 & 2 & 1173.7402 & 1173.7325 & 587.8735 & 0.0077 & 6.5490 & 14927.804 & 23834.789 & 4789.834 & 24224.865 & \text { Yes }\end{array}$ \begin{tabular}{lllllllllllllllll}
0.99 & 42.24 & 24.94 & 24.13 & 2 & 1173.7402 & 173.7325 & 587.8735 & 0.0077 & 6.5490 & 14927.804 & 23834.789 & 4789.834 & 24224.865 & Yes \\
\hline
\end{tabular} $\begin{array}{llllllllllllllll}1.00 & 52.23 & 24.94 & 23.86 & 2 & 1173.7412 & 1173.7325 & 587.8735 & 0.0087 & 7.3995 & 23549.414 & 35845.271 & 5899.010 & 35722.695 & \text { Yes } \\ 0.98 & 38.83 & 24.94 & 22.07 & 2 & 1173.7412 & 1173.7325 & 587.8735 & 0.0087 & 7.3995 & 8291.035 & 12170.019 & 3423.001 & 13238.190 & \text { Yes }\end{array}$

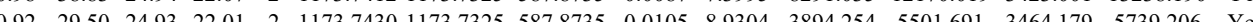
$\begin{array}{llllllllllllll} & \end{array}$ $\begin{array}{lllllllllllllll}1.00 & 74.32 & 27.52 & 24.38 & 2 & 1380.7512 & 1380.7493 & 691.3819 & 0.0019 & 1.3741 & 5642.719 & 10654.885 & 54.140 & 18485.721 & \text { Yes }\end{array}$ $\begin{array}{lllllllllllllll}1.00 & 85.86 & 27.54 & 23.50 & 2 & 1380.7516 & 1380.7493 & 691.3819 & 0.0023 & 1.6633 & 12138.055 & 21313.659 & 0.000 & 42947.069 & \text { No }\end{array}$ $\begin{array}{llllllllllllllll}0.98 & 24.71 & 27.45 & 18.57 & 3 & 1380.7522 & 1380.7493 & 461.2570 & 0.0029 & 2.0957 & 334.062 & 296.677 & 166.564 & 414.394 & \text { No } \\ 0.99 & 28.66 & 27.45 & 16.32 & 3 & 1380.7522 & 1380.7493 & 461.2570 & 0.0029 & 2.0957 & 297.261 & 282.737 & 108.501 & 425.242 & \text { Yes }\end{array}$ $\begin{array}{lllllllllllllll}1.00 & 74.28 & 27.41 & 24.29 & 2 & 1380.7612 & 1380.7493 & 691.3819 & 0.0119 & 8.6059 & 12886.745 & 23932.880 & 0.000 & 41957.938 & \text { No }\end{array}$ $\begin{array}{llllllllllllllll}1.00 & 74.24 & 27.39 & 24.36 & 2 & 1380.7614 & 1380.7493 & 691.3819 & 0.0121 & 8.7505 & 14895.929 & 25825.139 & 0.000 & 47620.749 & \text { No }\end{array}$ $\begin{array}{lllllllllllllll}0.70 & 28.94 & 26.06 & 19.23 & 2 & 903.5364 & 903.5381 & 452.7763 & -0.0017 & -1.8773 & 45.354 & 54.504 & 28.362 & 72.442 & \text { Yes }\end{array}$

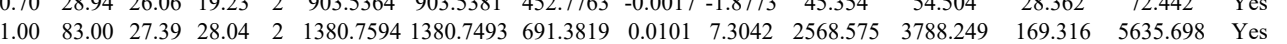
$\begin{array}{lllllllllllllll}0.95 & 35.01 & 25.66 & 25.45 & 2 & 1001.6106 & 1001.6113 & 501.8129 & -0.0007 & -0.6975 & 187.091 & 270.450 & 115.934 & 340.527 & \text { Yes }\end{array}$ $\begin{array}{lllllllllllllll}0.98 & 35.23 & 25.60 & 27.10 & 2 & 1001.6116 & 1001.6113 & 501.8129 & 0.0003 & 0.2989 & 181.173 & 319.152 & 135.137 & 357.826 & \text { Yes }\end{array}$ $\begin{array}{lllllllllllllll}0.95 & 33.89 & 23.52 & 31.86 & 3 & 1275.7867 & 1275.7876 & 426.2698 & -0.0009 & -0.7038 & 109.085 & 140.978 & 117.007 & 243.555 & \text { Yes }\end{array}$

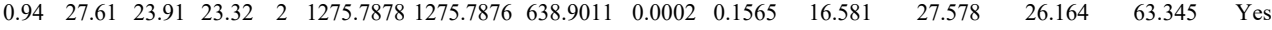

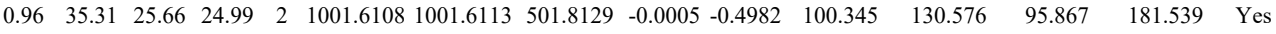

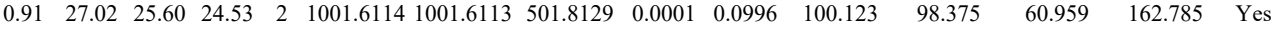

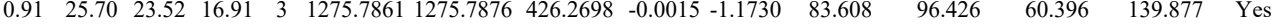

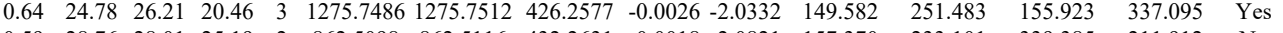
$\begin{array}{lllllllllllllllll}0.59 & 28.76 & 28.01 & 25.19 & 2 & 862.5098 & 862.5116 & 432.2631 & -0.0018 & -2.0821 & 157.370 & 233.101 & 339.385 & 211.912 & \text { No }\end{array}$

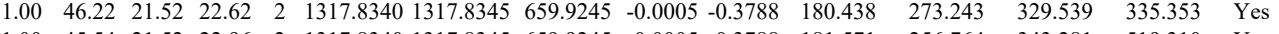

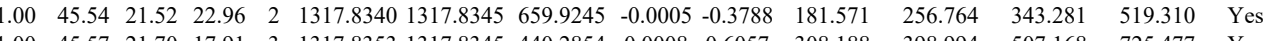
$\begin{array}{lllllllllllllll}1.00 & 45.57 & 21.70 & 17.91 & 3 & 1317.8353 & 1317.8345 & 440.2854 & 0.0008 & 0.6057 & 308.188 & 398.994 & 507.168 & 725.477 & \text { Yes }\end{array}$

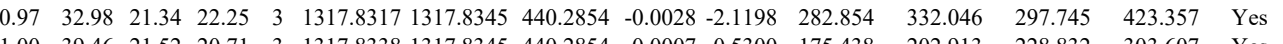

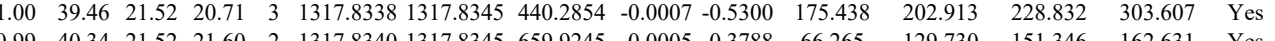

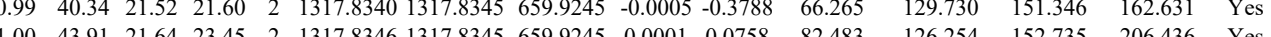

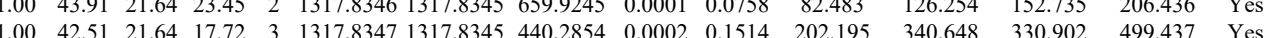

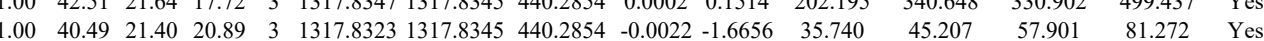

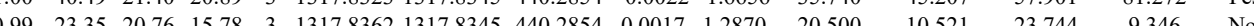
$\begin{array}{llllllllllllllll}0.73 & 40.69 & 26.60 & 47.42 & 2 & 959.5634 & 959.5644 & 480.7895 & -0.0010 & -1.0400 & 106.892 & 122.319 & 85.814 & 155.258 & \text { Yes }\end{array}$

Table S-4 page 201 of 6 
QTLTSSVR

QTLTSSVR

IQTLTSSVR

NPFLAAVTTNR

NPFLAAVTTNR

NPFLAAVTTNR

NPFLAAVTTNR

NPFLAAVTTNR $\begin{array}{llllllllllll}0.95 & 22.88 & 27.52 & 15.73 & 3 & 2178.0766 & 2178.0724 & 727.0314 & 0.0042 & 1.9256 & 23.761 & 42.643 \\ 1.0 & 85.83 * 26.23 & 19.36 & 3 & 3227.6062 & 3227.6052 & 1076.8757 & 0.010 & 0.305 & 37.55 & 3.96\end{array}$

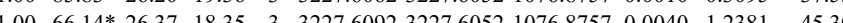

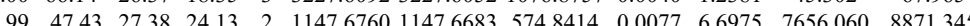
$106.487 \quad 77.016 \quad$ Y

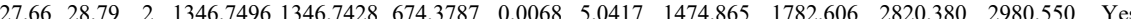
$\begin{array}{lllllllllllllll}54.64 & 27.66 & 39.30 & 2 & 1346.7496 & 1346.7428 & 674.3787 & 0.0068 & 5.0417 & 2597.547 & 3469.400 & 5581.533 & 5925.781 & \text { Yes } & \\ \end{array}$ $\begin{array}{llllllllllllllll}1.00 & 57.51 & 28.13 & 42.24 & 2 & 1346.7458 & 1346.7428 & 674.3787 & 0.0030 & 2.2243 & 1221.174 & 1444.144 & 2571.343 & 2860.175 & \text { Ycs } & \\ 1.00 & 61.16 & 28.13 & 34.89 & 2 & 1346.7458 & 1346.7428 & 674.3787 & 0.0030 & 2.2243 & 1264.724 & 1554.921 & 2603.931 & 2822.834 & \text { Y s } & \\ 0 & 7.55 & 71.07 & 26.96 & 84.07 & 3 & 2568.2509 & 2568.2499 & 857.090 & 0.0010 & 0.3889 & 2.540 & 1.696 & 16.925 & 2.292 & \end{array}$

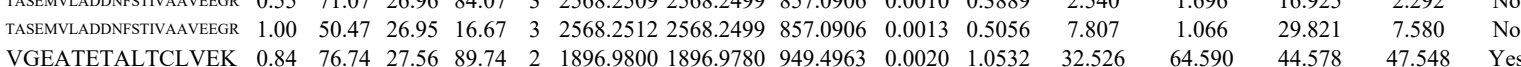
$\begin{array}{llllllllllllllll}\text { VGEATETALTCLVEK } & 1.00 & 42.81 & 27.53 & 25.09 & 3 & 1896.9805 & 1896.9780 & 633.3333 & 0.0025 & 1.3158 & 291.097 & 305.870 & 201.931 & 449.552 & \text { Yes }\end{array}$ $\begin{array}{llllllllllllllll}\text { VGEATETALTCLVEK } & 0.99 & 30.57 & 27.55 & 19.57 & 3 & 1896.9817 & 1896.9780 & 633.3333 & 0.0037 & 1.9474 & 328.540 & 366.186 & 232.110 & 557.482 & \text { Yes }\end{array}$ $\begin{array}{llllllllllllllll}\text { VIMITGDNK } & 1.00 & 45.69 & 27.23 & 30.03 & 2 & 1277.7380 & 1277.7257 & 639.8701 & 0.0123 & 9.6112 & 3819.817 & 3931.972 & 4477.120 & 4549.889 & \text { Yes }\end{array}$ $\begin{array}{lllllllllllllllll}\text { VDQSILTGESVSVIK } & 1.00 & 69.28 & 24.18 & 20.90 & 2 & 1862.0616 & 1862.0604 & 932.0375 & 0.0012 & 0.6438 & 26.029 & 56.650 & 35.564 & 45.721 & \text { Yes }\end{array}$ $\begin{array}{lllllllllllllll} & 15.96 & 26.73 & 15.60 & 3 & 3068.5642 & 3068.5620 & 1023.8613 & 0.0022 & 0.7162 & 1.389 & 1.994 & 0.000 & 5.903 & \text { No }\end{array}$ $\begin{array}{llllllllllllll} & \end{array}$ $\begin{array}{llllllllllllllll} & \text { Yes }\end{array}$ $\begin{array}{llllllllllllllll} & \end{array}$

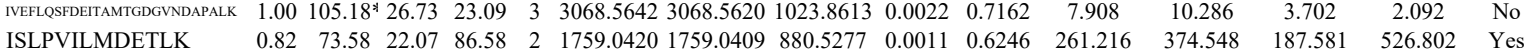

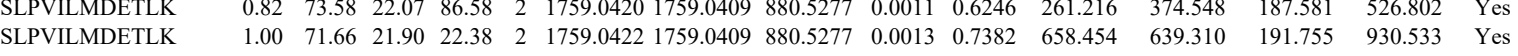
$\begin{array}{lllllllllllllllll} & \text { ISLPVILMDETLK } & 0.67 & 55.13 & 22.15 & 68.13 & 3 & 1759.0435 & 1759.0409 & 587.3542 & 0.0026 & 1.4755 & 166.274 & 226.212 & 31.374 & 262.420 & \text { Yes }\end{array}$ $\begin{array}{lllllllllllllllllll} & \end{array}$ $\begin{array}{lllllllllllllllll} & \\ \text { ISLPVILMDETLK } & 0.82 & 57.16 & 22.12 & 70.16 & 2 & 1759.0416 & 1759.0409 & 880.5277 & 0.0007 & 0.3975 & 275.491 & 331.398 & 65.492 & 346.771 & \text { Yes }\end{array}$ $\begin{array}{llllllllllllll} & \end{array}$ $\begin{array}{lllllllllllll} & \end{array}$ $\begin{array}{llllllllllllll} & & \end{array}$

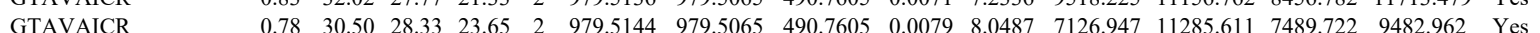
$\begin{array}{llllllllllllllll}\text { CLALATHDNPLR } & 1.00 & 57.84 & 27.88 & 21.20 & 3 & 1512.7789 & 1512.7663 & 505.2627 & 0.0126 & 8.3124 & 3372.660 & 2764.667 & 1036.328 & 4249.811 & \text { Yes }\end{array}$ CLALATHDNPLR
GTAVAICR GTAVAICR VSFYQLSHFLQCK VSFYQLSHFLQCK VSFYQLSHFLQCK WGSNELPAEEGK WGSNELPAEEGK IRDEMVATEQER IRDEMVATEQER

NAENAIEALK

LDEFGEQLSK

LDEFGEQLSK

IGIFGQDEDVTSK

DIVPGDIVEIAVGDK

DIVPGDIVEIAVGDK DIVPGDIVEIAVGD IGIFGQDEDVTSK IGIFGQDEDVTSK $\begin{array}{lllllllllllllll}1.00 & 57.84 & 27.88 & 21.20 & 3 & 1512.7789 & 1512.7663 & 505.2627 & 0.0126 & 8.3124 & 3372.660 & 2764.667 & 1036.328 & 4249.811 & \text { Yes } \\ 0.88 & 33.20 & 27.77 & 26.90 & 2 & 979.5140 & 979.5065 & 490.7605 & 0.0075 & 7.6411 & 6418756 & 8483.760 & 9447.608 & 10118.066 & \text { Yes }\end{array}$ $\begin{array}{lllllllllllllllll}0.97 & 39.94 & 27.84 & 25.44 & 2 & 979.5142 & 979.5065 & 490.7605 & 0.0077 & 7.8449 & 6668.604 & 7191.483 & 8398.189 & 9043.703 & \text { Yes }\end{array}$ $\begin{array}{lllllllllllllll}1.00 & 35.08 & 27.95 & 18.19 & 3 & 1932.9856 & 1932.9834 & 645.3351 & 0.0022 & 1.1364 & 2588.644 & 2757.664 & 196.230 & 3280.989 & \text { Yes }\end{array}$ $\begin{array}{lllllllllllllll}1.00 & 39.44 & 27.95 & 18.73 & 3 & 1932.9856 & 1932.9834 & 645.3351 & 0.0022 & 1.1364 & 437.670 & 565.576 & 71.068 & 701.416 & \text { Yes }\end{array}$

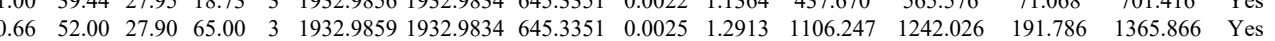
$\begin{array}{lllllllllllllll}1.00 & 75.94 & 28.30 & 24.84 & 2 & 1603.8208 & 1603.8085 & 802.9115 & 0.0123 & 7.6596 & 906.909 & 912.677 & 84.868 & 1202.576 & \text { Yes }\end{array}$ $\begin{array}{llllllllllllllll}1.00 & 66.44 & 28.31 & 21.12 & 2 & 1603.8210 & 1603.8085 & 802.9115 & 0.0125 & 7.7841 & 1179.294 & 925.461 & 140.613 & 1678.361 & \text { Yes }\end{array}$ $\begin{array}{lllllllllllllll}0.95 & 61.00 & 27.84 & 28.49 & 2 & 1619.8054 & 1619.8059 & 810.9102 & -0.0005 & -0.3083 & 1584.988 & 3002.082 & 1945.729 & 2687.149 & \text { Yes }\end{array}$ $\begin{array}{lllllllllllllll}0.86 & 55.24 & 27.84 & 23.64 & 2 & 1619.8054 & 1619.8059 & 810.9102 & -0.0005 & -0.3083 & 883.521 & 804.724 & 729.786 & 538.466 & \text { Yes }\end{array}$ $\begin{array}{lllllllllllllllll}1.00 & 56.88 & 31.38 & 23.55 & 2 & 1359.7644 & 1359.7601 & 680.8873 & 0.0043 & 3.1576 & 16198.707 & 17166.741 & 5905.664 & 18340.231 & \text { Yes }\end{array}$ $\begin{array}{llllllllllllllll}1.00 & 51.02 & 28.20 & 34.72 & 2 & 1452.7828 & 1452.7704 & 727.3925 & 0.0124 & 8.5235 & 365.907 & 493.086 & 23.486 & 702.332 & \text { Yes }\end{array}$ $\begin{array}{lllllllllllllll}.98 & 38.32 & 28.03 & 30.64 & 2 & 1452.7840 & 1452.7704 & 727.3925 & 0.0136 & 9.3484 & 483.663 & 557.852 & 190.873 & 809.016 & \text { Yes }\end{array}$

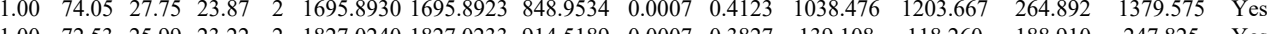
$\begin{array}{lllllllllllllll}1.00 & 72.53 & 25.99 & 23.22 & 2 & 1827.0240 & 1827.0233 & 914.5189 & 0.0007 & 0.3827 & 139.108 & 118.260 & 188.910 & 247.825 & \text { Yes } \\ 1.00 & 62.6 & 25.98 & 2.17 & 2 & 1827.0254 & 8227.0233 & 91.5189 & 0.0021 & 1.1481 & 75.667 & 32.051 & 142.92 & 116.754 & \end{array}$

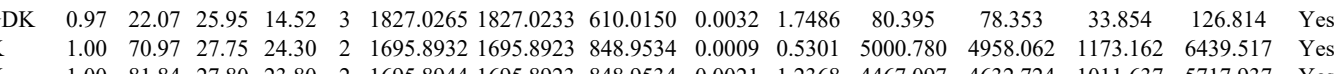
$\begin{array}{llllllllllllllll} & \\ & 1.00 & 81.84 & 27.80 & 23.80 & 2 & 1695.8944 & 1695.8923 & 848.9534 & 0.0021 & 1.2368 & 4467.097 & 4632.724 & 1011.637 & 5717.937 & \text { Yes } \\ \end{array}$

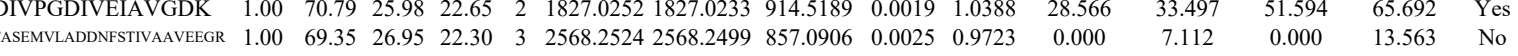

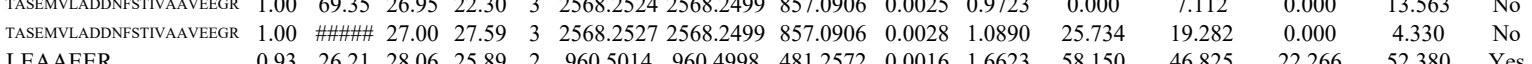

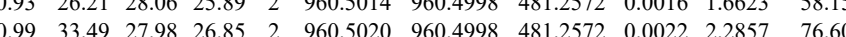
$\begin{array}{lllllllllllll} & \end{array}$

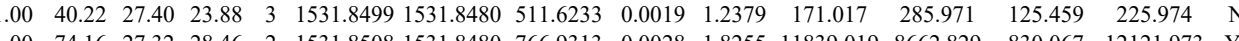


ASGQAFELILSPR ASGQAFELILSPR ASGQAFELILSPR ASGQAFELILSP

GEAANYTGPDGYPVEGS GAEAANVTGPDGVPVEGSR

$\begin{array}{lllllllllllll}\text { HMGA1_HUMA } & \text { P17096 } & \text { HMGA1 } & \text { High mobility gro 11.676 } & 1.00 & 6 & 51.4 & -0.5691 & 0.2955 & -0.611 & 0.5813 & 27 & \text { TTTTPGR }\end{array}$

TTTTPGR
TTTTPGR

TTTTPGR

TTTTPGR

SSQPLASK

TTTPGGR

SSQPLASK

SSQPLASK

EEEEGISQESSEEEQ

QEEGISQESSEEEQ

$\begin{array}{lllllllll} & 7.786 & \end{array}$

$\begin{array}{lllllllllllllllll} & & \end{array}$ $\begin{array}{llllllllllllllll}\text { QPPVSPGTALVGSQK } & 0.71 & 20.71 & 24.05 & 20.55 & 3 & 1753.0153 & 1752.9978 & 585.3399 & 0.0175 & 9.9656 & 2383.429 & 2291.869 & 1735.052 & 1735.664 & \text { Yes }\end{array}$ $\begin{array}{llllllllllllllllll}\text { QPPVSPGTALVGSQK } & 1.00 & 95.51 & 24.38 & 26.45 & 2 & 1753.0098 & 1752.9978 & 877.5062 & 0.0120 & 6.8375 & 4709.837 & 2450.861 & 3429.450 & 1690.096 & \text { Yes }\end{array}$ $\begin{array}{llllllllllllllll}\text { QPPVSPGTALVGSQK } & 0.85 & 22.98 & 24.38 & 18.62 & 3 & 1753.0099 & 1752.9978 & 585.3399 & 0.0121 & 6.8905 & 2327.156 & 1818.268 & 1007.165 & 1399.182 & \text { Yes }\end{array}$ \begin{tabular}{lllllllllllllllll} 
QPPVSPGTALVGSQK & 1.00 & 82.07 & 24.31 & 27.24 & 2 & 1753.0114 & 1752.9978 & 877.5062 & 0.0136 & 7.7492 & 5332.757 & 3449.255 & 5858.798 & 4113.356 & Yes \\
\hline QPPVSPGTALGSQK & 1.0 & 39.81 & 24.28 & 18.73 & 3 & 1753.123 & 1752.9978 & 585.339 & 0.0145 & 8.2572 & 2497.04 & 185.929 & 762.651 & 128.51 & Yes
\end{tabular} \begin{tabular}{llllllllllllllll} 
QPPVSPGTALVGSQK & 1.00 & 39.81 & 24.28 & 18.73 & 3 & 1753.0123 & 1752.9978 & 585.3399 & 0.0145 & 8.2572 & 2497.104 & 1805.929 & 762.661 & 1288.051 & Yes \\
\hline QPPVSPGTALVGSQK & 1.00 & 91.56 & 24.36 & 26.97 & 2 & 1753.0082 & 1752.9978 & 877.5062 & 0.0104 & 5.9258 & 1213.771 & 814.181 & 1019.761 & 1204.960 & Yes
\end{tabular}

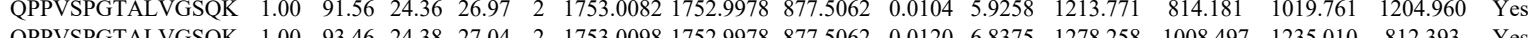

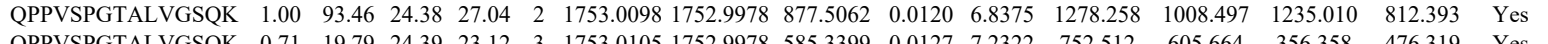

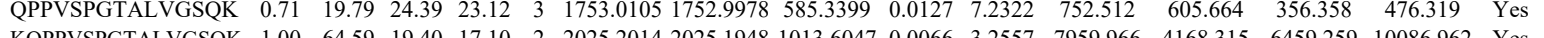
\begin{tabular}{llllllllllllllll} 
KQPPVSPGTALVGSQK & 1.00 & 64.59 & 19.40 & 17.10 & 2 & 2025.2014 & 2025.1948 & 1013.6047 & 0.0066 & 3.2557 & 7959.966 & 4168.315 & 6459.259 & 10086.962 & Yes \\
\hline KQPPVSPGTALVGSQK & 1.00 & 75.71 & 19.40 & 18.13 & 2 & 2025.2014 & 2025.1948 & 1013.6047 & 0.0066 & 3.2557 & 4972.806 & 2905.972 & 4303.947 & 7159.850 & Yes
\end{tabular} $\begin{array}{llllllllllllllll}\text { KQPPVSPGTALVGSK } & 1.00 & 75.71 & 19.40 & 18.13 & 2 & 2025.2014 & 2025.1948 & 1013.6047 & 0.0066 & 3.2557 & 4972.806 & 2905.912 & 4303.947 & 7159.850 & \text { Yes }\end{array}$ $\begin{array}{lllllllllllllllll}\text { KQPPVSPGTALVGSQK } & 1.00 & 29.63 & 19.19 & 26.49 & 4 & 2025.2045 & 2025.1948 & 507.3060 & 0.0097 & 4.7801 & 10543.041 & 6771.194 & 9538.316 & 18937.565 & \text { Yes } \\ \text { KQPPVSPGTALVGSQK } & 1.00 & 21.68 & 18.06 & 34.68 & 4 & 2025.2113 & 2025.1948 & 507.3060 & 0.0165 & 8.1311 & 3122.063 & 2977.883 & 2135.671 & 5316.795 & \text { Yes }\end{array}$

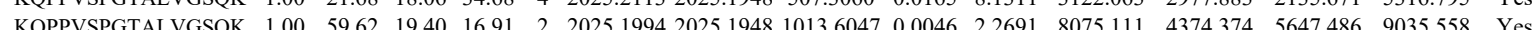

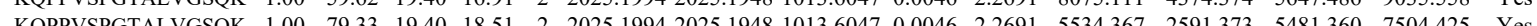

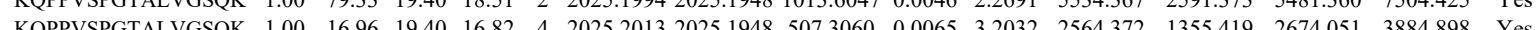

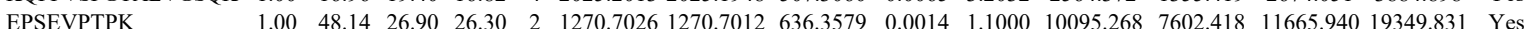
EPSEVPTPK

EPSEVPTPK

EPSEVPTPK

28 LALGDDSPALK

LALGDDSPALK

EPESILQVLSQMEK

EPESILQVLSQMEK

EPESILQVLSQMEK

EPESILQVLSQMEK

EPESILQVLSQMEK

EPESILQVLSQMEK

TDDCHPWVLPVVK

IVASTLSNPELFEEWTGNVK

VGNLTVVGK

VGNLTVVGK

ANDNSLNHEYLPILGLAEFR

IANDNSLNHEYLPLGLALEFR

IANDNSLNHEYL

INVSGLTTK

$\begin{array}{llllllllllllllll}1.00 & 48.14 & 26.90 & 26.30 & 2 & 1270.7026 & 1270.7012 & 636.3579 & 0.0014 & 1.1000 & 10095.268 & 7602.418 & 11665.940 & 19349.831 & \text { Yes } \\ 0.99 & 37.45 & 27.20 & 21.84 & 2 & 1270.7030 & 1270.7012 & 6363579 & 0.0018 & 1.4143 & 13259.447 & 8863.255 & 15930.055 & 20364.216 & \text { Yes }\end{array}$ $\begin{array}{llllllllllllllll}0.99 & 37.26 & 27.16 & 22.56 & 2 & 1270.7038 & 1270.7012 & 636.3579 & 0.0026 & 2.0429 & 380.383 & 441.451 & 828.972 & 593.371 & \text { No }\end{array}$ $\begin{array}{llllllllllllllll}0.97 & 32.34 & 27.12 & 25.83 & 2 & 1270.7042 & 1270.7012 & 636.3579 & 0.0030 & 2.3572 & 349.462 & 350.737 & 400.311 & 386.977 & \text { Yes }\end{array}$

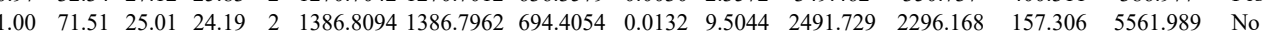
$\begin{array}{lllllllllllllll}1.00 & 76.53 & 25.13 & 25.32 & 2 & 1386.8096 & 1386.7962 & 694.4054 & 0.0134 & 9.6484 & 2534.773 & 2510.476 & 257.909 & 5765.124 & \text { No }\end{array}$ $\begin{array}{lllllllllllllll}1.00 & 32.22 & 27.39 & 15.89 & 3 & 1918.0354 & 1918.0325 & 640.3514 & 0.0029 & 1.5096 & 143.094 & 183.504 & 119.417 & 158.875 & \text { Yes }\end{array}$ $\begin{array}{lllllllllllllll}1.00 & 73.36 & 27.52 & 21.35 & 2 & 1918.0342 & 1918.0325 & 960.0235 & 0.0017 & 0.8854 & 7.707 & 22.977 & 22.175 & 45.146 & \text { Yes }\end{array}$

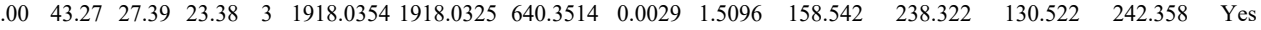
$\begin{array}{lllllllllllllll}1.00 & 36.38 & 27.41 & 20.59 & 3 & 1918.0357 & 1918.0325 & 640.3514 & 0.0032 & 1.6657 & 153.414 & 149.094 & 261.261 & 249.828 & \text { Yes }\end{array}$

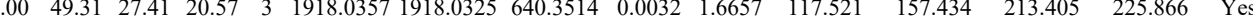
$\begin{array}{lllllllllllllll}0.98 & 25.88 & 27.26 & 14.74 & 3 & 1841.9440 & 1841.9412 & 614.9877 & 0.0028 & 1.5176 & 739.628 & 581.571 & 62.085 & 690.809 & \text { Yes }\end{array}$ $\begin{array}{ccccccccccccc} & \end{array}$ $\begin{array}{lllllllllllllll}0.99 & 43.36 & 24.94 & 22.00 & 2 & 1173.7408 & 1173.7325 & 587.8735 & 0.0083 & 7.0593 & 11793.642 & 11799.201 & 8692.538 & 12687.463 & \text { Yes }\end{array}$ $\begin{array}{lllllllllllllllll}1.00 & 3.12 & 24.94 & 21.55 & 2 & 1173.7412 & 1173.7325 & 587.8735 & 0.0087 & 7.3995 & 13374.244 & 16850.282 & 11378.128 & 20607.001 & \text { Yes }\end{array}$ $\begin{array}{llllllllllllllll}1.00 & 39.03 & 26.55 & 16.71 & 3 & 2542.3357 & 2542.3301 & 848.4506 & 0.0056 & 2.2001 & 316.338 & 299.947 & 239.500 & 327.176 & \text { Yes } \\ 1.00 & 37.41 & 26.76 & 17.73 & 3 & 2542.3318 & 2542.3301 & 848.4506 & 0.0017 & 0.6679 & 219.907 & 238.186 & 210.414 & 245.960 & \text { Yes }\end{array}$ $\begin{array}{lllllllllllllll}1.00 & 47.45 & 24.52 & 23.34 & 2 & 1219.7462 & 1219.7380 & 610.8763 & 0.0082 & 6.7116 & 3990.805 & 4801.364 & 2395.183 & 5570.954 & \text { Yes }\end{array}$

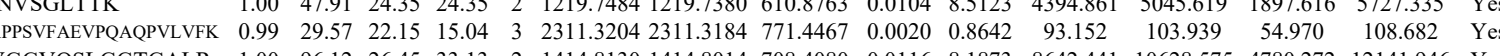
$\begin{array}{lllllllllllllllll} & & \end{array}$ $\begin{array}{llllllllll}1.00 & 94.07 & 26.51 & 32.48 & 2 & 1414.8136 & 1414.8014 & 708.4080 & 0.0122 & 8.6108\end{array}$ 
VNLGVGAYR

ITWSNPPAQGAR

TWSNPPAQGAR

ITWSNPPAQGAR

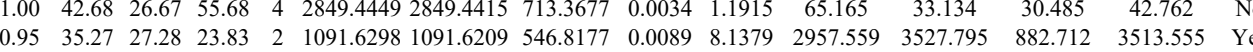
$\begin{array}{lllllllllllllll}1.00 & 46.74 & 27.28 & 25.48 & 2 & 1091.6300 & 1091.6209 & 546.8177 & 0.00091 & 8.3379 & 2957.559 & 3527.795 & 882.712 & 3513.555 & \text { Yes } \\ & & \\ 1 & 5645.962 & 7167.764 & 966.017 & 8427.638 & \text { Yes }\end{array}$ $\begin{array}{llllllllllllllll}1.00 & 56.18 & 27.97 & 20.58 & 2 & 1440.7718 & 1440.7595 & 721.3870 & 0.0123 & 8.5252 & 1564.360 & 1888.873 & 1841.986 & 2360.317 & \text { Yes }\end{array}$ $\begin{array}{lllllllllllllll}1.00 & 62.11 & 27.99 & 21.13 & 2 & 1440.7720 & 1440.7595 & 721.3870 & 0.0125 & 8.6638 & 4550.619 & 4930.595 & 4774.142 & 5658.570 & \text { Yes }\end{array}$

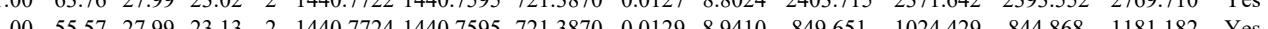
VDISENPGTSPALEAYSET

SVACDVGYPALK

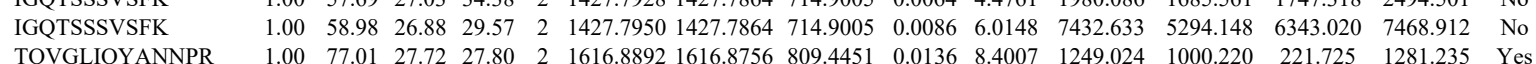

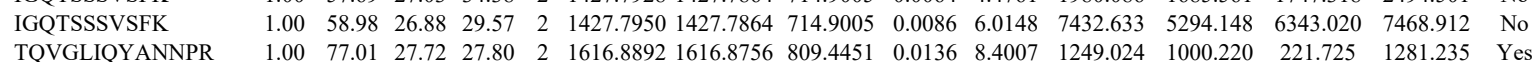

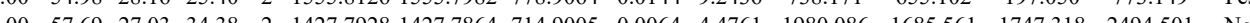
$\begin{array}{llllllllllllllll} & \end{array}$

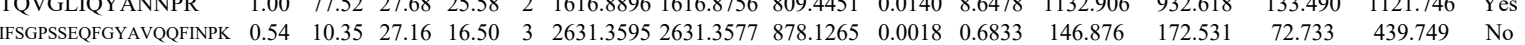
$\begin{array}{lllllllllllllllll}\text { IFSGPSSEPFGYAVQOFINPK } & 0.66 & 17.76 & 27.16 & 30.76 & 3 & 2631.3595 & 2631.3577 & 878.1265 & 0.0018 & 0.6833 & 138.078 & 87.216 & 92.667 & 222.851 & \text { No }\end{array}$

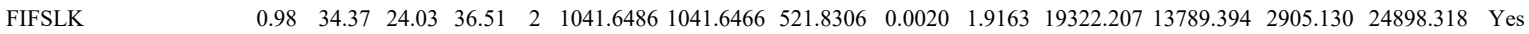

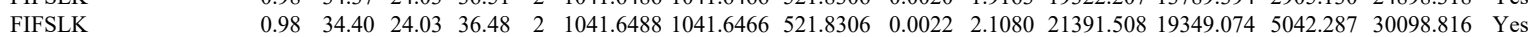
$\begin{array}{lllllllllllllllll}\text { FGIAVLGYLNR } & 1.00 & 54.56 & 25.97 & 24.54 & 2 & 1365.7900 & 1365.7890 & 683.9018 & 0.0010 & 0.7311 & 1044.625 & 894.061 & 215.123 & 1116.330 & \text { Yes }\end{array}$ $\begin{array}{llllllllllllllll}\text { FGIAVLGYLNR } & 1.00 & 54.70 & 25.97 & 24.57 & 2 & 1365.7900 & 1365.7890 & 683.9018 & 0.0010 & 0.7311 & 963.583 & 876.226 & 216.071 & 1137.636 & \text { Yes }\end{array}$ $\begin{array}{llllllllllllllll}\text { FGIAVLGYLNR } & 1.00 & 59.10 & 25.97 & 25.28 & 2 & 1365.7902 & 1365.7890 & 683.9018 & 0.0012 & 0.8773 & 519.738 & 517.887 & 97.326 & 589.300 & \text { Yes }\end{array}$ $\begin{array}{llllllllllllllll}\text { FGIAVLGYLNR } & 1.00 & 54.37 & 25.97 & 24.41 & 2 & 1365.7904 & 1365.7890 & 683.9018 & 0.0014 & 1.0235 & 733.907 & 566.246 & 136.476 & 778.776 & \text { Yes }\end{array}$

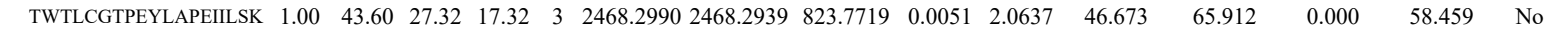
$\begin{array}{lllllllllllllllll}\text { TWTLCGTPEYLAPEIILSK } & 1.00 & 37.56 & 27.25 & 17.64 & 3 & 2468.3002 & 2468.2939 & 823.7719 & 0.0063 & 2.5492 & 49.431 & 7.066 & 38.879 & 21.666 & \text { Yes }\end{array}$ $\begin{array}{llllllllllllllll}\text { TWTLCGTPEYLAPEIILSK } & 0.60 & 28.80 & 27.36 & 41.80 & 3 & 2468.2975 & 2468.2939 & 823.7719 & 0.0036 & 1.4567 & 49.400 & 72.558 & 18.273 & 38.790 & \text { Yes }\end{array}$

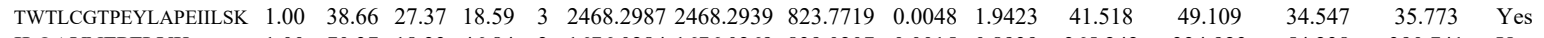
$\begin{array}{llllllllllllllll}\text { ILQAVNFPFLVK } & 1.00 & 70.37 & 18.33 & 46.84 & 2 & 1676.0284 & 1676.0269 & 839.0207 & 0.0015 & 0.8939 & 365.242 & 334.923 & 54.238 & 390.741 & \text { Yes }\end{array}$ $\begin{array}{llllllllllllllll}\text { ILQAVNFPFLVK } & 1.00 & 72.08 & 18.69 & 53.74 & 2 & 1676.0298 & 1676.0269 & 839.0207 & 0.0029 & 1.7282 & 235.507 & 164.479 & 38.614 & 214.367 & \text { Yes }\end{array}$ YLNQDYEALR NPWGEVEWTGR

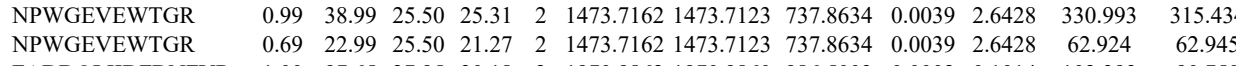
$\begin{array}{llllllllllllll} & \end{array}$ $\begin{array}{llllllllllll} & \end{array}$ $\begin{array}{llllllllllll}\text { FADDQLIIDFDNFVR } & 1.00 & 97.42 & 27.90 & 30.84 & 2 & 1970.9872 & 1970.9860 & 986.5003 & 0.0012 & 0.6082 & 213.151\end{array}$ $\begin{array}{lllllllllllll} & \text { FADDQLIDANFR } & 1.00 & 93.14 & 27.94 & 27.81 & 2 & 1970.9878 & 1970.9860 & 986.5003 & 0.0018 & 0.9123 & 670.726\end{array}$

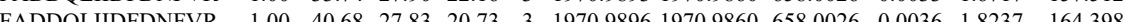
FADDQLIIDFDNFVR

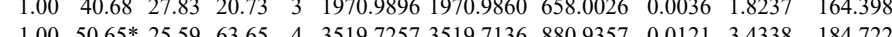
$\begin{array}{llllllllll}1.00 & 50.65 * 25.59 & 63.65 & 4 & 3519.7257 & 3519.7136 & 880.9357 & 0.0121 & 3.4338 & 184.72\end{array}$ $\begin{array}{lllllllllllll}\text { FADDQLIIDFDNFVR } & 1.00 & 89.28 & 27.92 & 27.97 & 2 & 1970.9874 & 1970.9860 & 986.5003 & 0.0014 & 0.7096 & 148.027 & 52\end{array}$

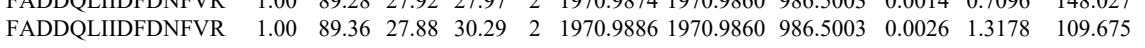
\begin{tabular}{lllllllllllll} 
FADDQLIIDFDNFVR & 0.99 & 30.29 & 27.83 & 21.87 & 3 & 1970.9896 & 1970.9860 & 658.0026 & 0.0036 & 1.8237 & 134.231 & \\
\hline
\end{tabular} $\begin{array}{llllllllllllll} & \end{array}$ $\begin{array}{llllllllllllll}\text { LEICNLTPDTLTSDTYK } & 1.00 & 43.47 & 27.73 & 20.16 & 3 & 2260.1233 & 2260.1210 & 7543809 & 0.0023 & 1.0163 & 131.327 & 103.425\end{array}$ $\begin{array}{llllllllllllll} & \text { LEICNLTPDTLTSTYK } & 1.00 & 68.79 & 27.72 & 19.21 & 2 & 2260.1234 & 2260.1210 & 1131.0678 & 0.0024 & 1.0609 & 522.344 & 293.65\end{array}$ \begin{tabular}{lllllllllllllll}
\hline EICNLTPDTLTSDTYK & 1.00 & 70.15 & 27.72 & 23.86 & 2 & 2260.1234 & 2260.1210 & 1131.0678 & 0.0024 & 1.0609 & 371.959 & 312.394
\end{tabular}

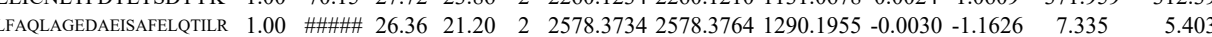
$\begin{array}{llllllllllllll}\text { LFAQLAGEDAEISAFELQTILR } & 1.00 & 41.97 & 25.98 & 19.40 & 3 & 2578.3792 & 2578.3764 & 860.4661 & 0.0028 & 1.0847 & 21.933 & 26.164\end{array}$ $\begin{array}{llllllllllllll} & \text { LFAQLAGEDAEISAFELQTILR } & 0.67 & 43.83 & 25.90 & 56.83 & 3 & 2578.3798 & 2578.3764 & 860.4661 & 0.0034 & 1.3171 & 11.927 & 5.088\end{array}$ $\begin{array}{lllllllllllll}\text { NECLEAGTLFPDPSPAAPSALGFK } & 0.66 & 30.57 & 26.58 & 43.57 & 3 & 2985.4879 & 2985.4860 & 996.1693 & 0.0019 & 0.6358 & 136.596 & 9\end{array}$ $\begin{array}{llllllllllll}\text { NECLEAGTLFDPSFPAIPSALGFK } & 0.67 & 25.26 & 26.63 & 38.26 & 3 & 2985.4888 & 2985.4860 & 996.1693 & 0.0028 & 0.9369 & 20.059\end{array}$

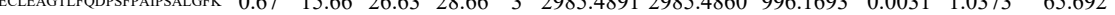
$\begin{array}{llllllllllll}\text { NECLEAGTLFEDPSPAIPSALGFK } & 0.97 & 15.95 & 26.65 & 25.95 & 4 & 2985.4913 & 2985.486 & 747.3788 & 0.0053 & 1.7729 & 33.515\end{array}$ KPPPNLFK $\begin{array}{lllllllllllll}1.00 & 28.61 & 19.24 & 15.13 & 3 & 1371.8629 & 1371.8604 & 458.2941 & 0.0025 & 1.8183 & 34998.896 & 23687.052\end{array}$ $\begin{array}{lllllllllllllll} & & & \end{array}$

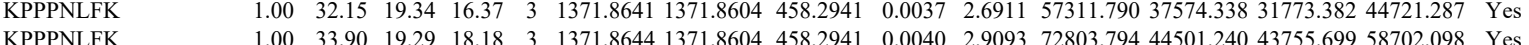

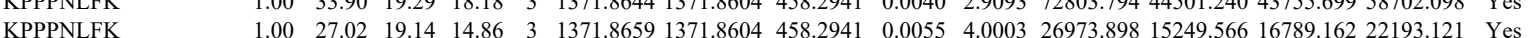
$\begin{array}{llllllllllllllllll} & 1.00 & 27.02 & 19.14 & 14.86 & 3 & 1371.8659 & 1371.8604 & 458.2941 & 0.0055 & 4.0003 & 26973.898 & 15249.566 & 16789.162 & 22193.121 & \text { Yes }\end{array}$ $\begin{array}{llllllllllllllllll} & \end{array}$ $\begin{array}{llllllllllllllll}\text { RPTEICADPQFIIGGATR } & 0.99 & 33.39 & 27.49 & 20.96 & 3 & 2134.0840 & 2134.0785 & 712.3668 & 0.0055 & 2.5736 & 534.751 & 2823.933 & 368.836 & 614.010 & \text { No }\end{array}$ $\begin{array}{lllllllllllllllll}\text { RPTEICADPQFIIGGATR } & 1.00 & 31.97 & 27.50 & 1679 & 3 & 2134.0822 & 134.0785 & 712.3668 & 0.0037 & 1.7313 & 55.233 & 330.219 & 120.229 & 219.194 & \text { No }\end{array}$ 


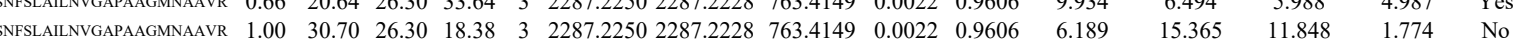
$\begin{array}{llllllllllllllll}\text { SNFLAILNVGAPAGGNAAVR } & 0.99 & 29.67 & 26.49 & 21.44 & 3 & 2287.2262 & 2287.2228 & 763.4149 & 0.0034 & 1.4846 & 2.964 & 7.632 & 12.979 & 6.042 & \text { No }\end{array}$ $\begin{array}{llllllllllllllll} & \end{array}$

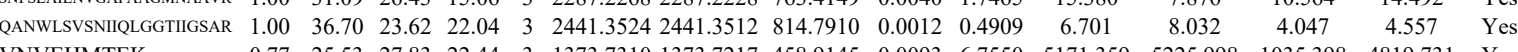
VNVEHMTEK

VNVEHMTEK
IQVLVEPDHFK

IQVLVEPDHFK
IQVLVEPDHFK IQVLVEPDHFK IQVLVEPDHFK GNDVAFHFNPR GNDVAFHFNPR IALDFQR $\begin{array}{lllllllllllllll}0.77 & 25.53 & 27.83 & 22.44 & 3 & 1373.7310 & 1373.7217 & 458.9145 & 0.0093 & 6.7550 & 5171.359 & 5225.998 & 1035.398 & 4819.731 & \text { Yes }\end{array}$ $\begin{array}{lllllllllllllllll}1.00 & 47.40 & 24.74 & 22.34 & 3 & 1611.9253 & 1611.9228 & 538.3149 & 0.0025 & 1.5480 & 2772.350 & 1827.520 & 186297 & 1838.153 & \text { Yes }\end{array}$ $\begin{array}{llllllllllllllll}0.67 & 39.31 & 24.71 & 52.31 & 3 & 1611.9259 & 1611.9228 & 538.3149 & 0.0031 & 1.9196 & 2916.490 & 2178.013 & 230.623 & 2029.321 & \text { Yes }\end{array}$ $\begin{array}{lllllllllllllll}1.00 & 46.64 & 25.11 & 16.90 & 3 & 1611.9232 & 1611.9228 & 538.3149 & 0.0004 & 0.2477 & 4860.429 & 4743.001 & 119.621 & 3669.748 & \text { No }\end{array}$ $\begin{array}{llllllllllllllll}1.00 & 49.27 & 24.79 & 22.15 & 3 & 1611.9247 & 1611.9228 & 538.3149 & 0.0019 & 1.1765 & 6207.337 & 4360.380 & 354.852 & 4079.818 & \text { Yes }\end{array}$ $\begin{array}{llllllllllllllll}1.00 & 69.20 & 27.02 & 27.84 & 3 & 1416.7153 & 1416.7020 & 473.2413 & 0.0133 & 9.3679 & 15495.989 & 10383.446 & 6432.323 & 11441.343 & \text { Yes }\end{array}$ $\begin{array}{llllllllllllllll}\text { MLITILGTVKPNANR } & 1.00 & 65.73 & 20.41 & 19.72 & 3 & 1928.1520 & 1928.1485 & 643.7234 & 0.0035 & 1.8124 & 153.542 & 132.568 & 75.527 & 116.309 & \text { Yes }\end{array}$ $\begin{array}{llllllllllllllll}\text { MLITILGTVKPNANR } & 1.00 & 52.53 & 20.41 & 22.34 & 3 & 1928.1529 & 1928.1485 & 643.7234 & 0.0044 & 2.2784 & 249.697 & 148.344 & 76.910 & 149.813 & \text { Yes }\end{array}$ \begin{tabular}{lllllllllllllllll} 
MLITILGTVKPNANR & 1.00 & 62.02 & 20.33 & 22.22 & 3 & 1928.1517 & 1928.1485 & 643.7234 & 0.0032 & 1.6570 & 1474.357 & 996.443 & 463.718 & 905.582 & Yes \\
\hline
\end{tabular} $\begin{array}{llllllllllllllll}\text { MLITILGTVKPNANR } & 1.00 & 58.10 & 19.96 & 21.35 & 3 & 1928.1505 & 1928.1485 & 643.7234 & 0.0020 & 1.0356 & 135.028 & 129.967 & 57.173 & 125.805 & \text { Yes }\end{array}$ $\begin{array}{llllllllllllllll}\text { MLITILGTVKPNANR } & 1.00 & 50.45 & 19.78 & 17.85 & 3 & 1928.1499 & 1928.1485 & 643.7234 & 0.0014 & 0.7249 & 90.130 & 78.589 & 32.834 & 80.388 & \text { Yes }\end{array}$ $\begin{array}{llllllllllllllll}\text { MLITILGTVKPNANR } & 1.00 & 54.67 & 20.33 & 20.96 & 3 & 1928.1517 & 1928.1485 & 643.7234 & 0.0032 & 1.6570 & 78.243 & 76.081 & 25.726 & 43.886 & \text { Yes }\end{array}$

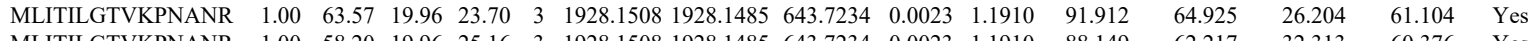

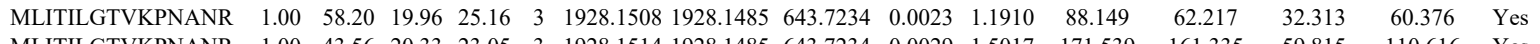
$\begin{array}{llllllllllllllll}\text { MLITILGTVKPNANR } & 1.00 & 43.56 & 20.33 & 23.05 & 3 & 1928.1514 & 1928.1485 & 643.7234 & 0.0029 & 1.5017 & 171.539 & 161.335 & 59.815 & 110.616 & \text { Yes } \\ \text { MLIILGTVRNANR } & 1.00 & 61.56 & 20.33 & 20.96 & 3 & 1928.1517 & 1928.1485 & 643.7234 & 0.0032 & 1.6570 & 174.903 & 91.32 & 53.29 & 115.228 & \mathrm{~N}\end{array}$

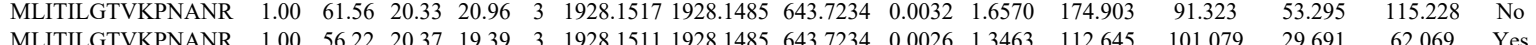

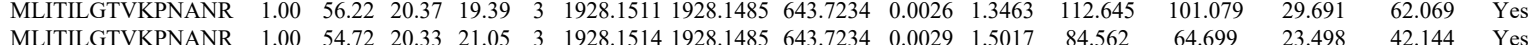

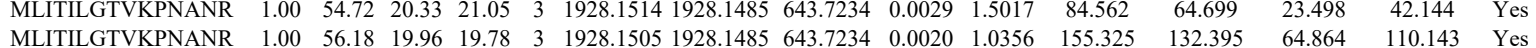

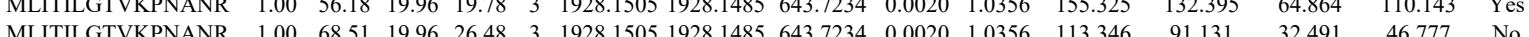
$\begin{array}{lllllllllllllllll}\text { MLITILGTVKPNANR } & 1.00 & 51.56 & 19.96 & 22.69 & 3 & 1928.1505 & 1928.1485 & 643.7234 & 0.0020 & 1.0356 & 175.976 & 121.764 & 75.038 & 96.610 & \text { Yes }\end{array}$ 

$\begin{array}{lllllllllllllll} & \end{array}$

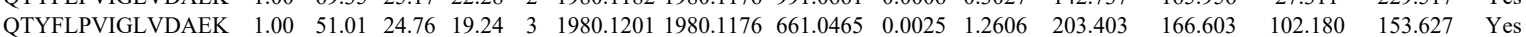

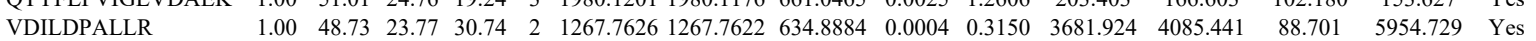

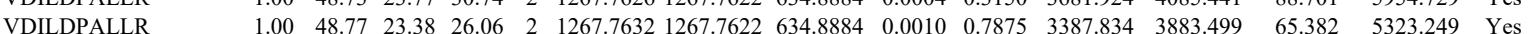
$\begin{array}{llllllllllllllll}\text { LKPGDLVGVNK } & 0.97 & 29.73 & 17.40 & 22.34 & 3 & 1570.9864 & 1570.9772 & 524.6663 & 0.0092 & 5.8450 & 6441.047 & 6940.707 & 3881.250 & 9229.460 & \text { Yes }\end{array}$

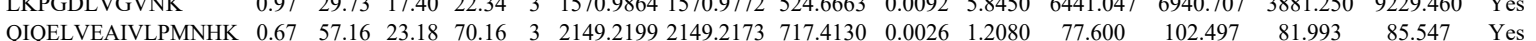

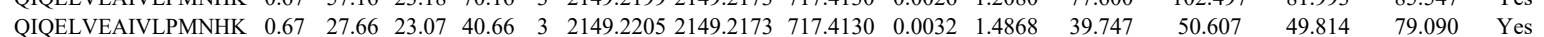

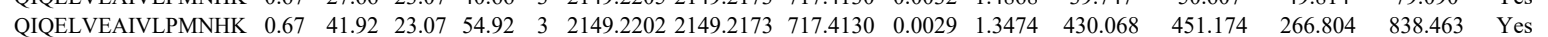

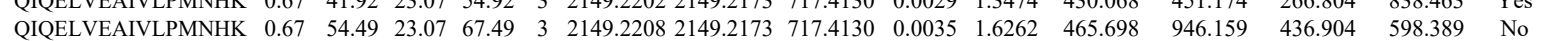
$\begin{array}{llllllllllllllll}\text { TMLELLNQLDGFOPNTQVK } & 0.60 & 34.85 & 25.11 & 47.85 & 3 & 2476.3276 & 2476.3239 & 826.4486 & 0.0037 & 1.4923 & 4.294 & 28.358 & 17.641 & 30.923 & \text { Yes }\end{array}$

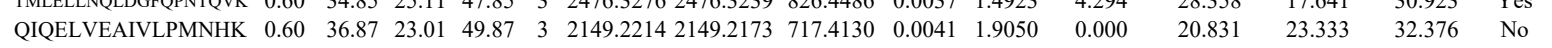

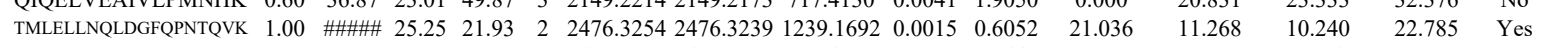
$\begin{array}{llllllllllllllll}\text { MATVWDEAEQDGIGEEVLK } & 1.00 & 38.27 & 26.72 & 23.22 & 3 & 2407.1851 & 2407.1821 & 803.4013 & 0.0030 & 1.2447 & 3.371 & 9.038 & 6.084 & 5.179 & \text { No }\end{array}$

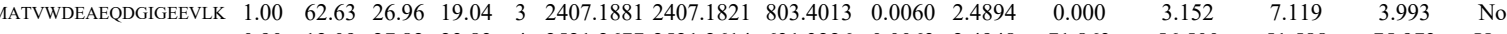
$\begin{array}{llllllllllllllll}\text { GATELTHEDYMEGLEVQAK } & 0.90 & 12.09 & 27.82 & 23.83 & 4 & 2521.2677 & 2521.2614 & 631.3226 & 0.0063 & 2.4948 & 71.863 & 56.500 & 51.588 & 75.973 & \text { Yes }\end{array}$

$\begin{array}{lllllllllllll}\text { TCPA_HUMAN } & \text { P17987 } & \text { TCP1 } & \text { T-complex proteir } 60.344 & 1.00 & 23 & 57.4 & 0.2103 & 0.4849 & 0.9773 & 0.4964 & 73 & \text { LLEVEHPAAK }\end{array}$
LLEVEHPAAK

LLEVEHPAAK

ICDDELILIK

ICDDELILIK

VLCELADLQDK

VLCELADLQDK

VLCELADLQDK ICDDELILIK

ICDDELILIK

VLCELADLQDK

VLCLLADLQDK

TCCELADLQDK

(1)

LGVQVVITDPEK

(1)

MLVDDIGDVTITNDATILK

\begin{tabular}{|llllllllllll} 
& 26.27 & 25.71 & 2 & 2391.2834 & 2391.2811 & 1196.6478 & 0.0023 & 0.9610 & 149.243 \\
IILK & 1.00 & 95.02 & 26.27 & 28.41 & 2 & 2391.2834 & 2391.2811 & 1196.6478 & 0.0023 & 0.9610 & 115.901
\end{tabular}

$\begin{array}{llllllllllllll} & 23.91\end{array}$

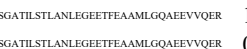

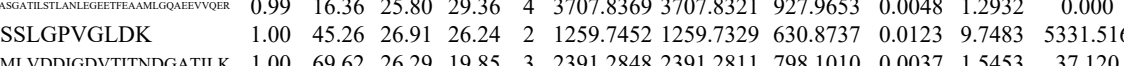

$\begin{array}{lllllllllll}1.00 & 38.84 & 25.74 & 51.84 & 4 & 3707.8345 & 3707.8321 & 927.9653 & 0.0024 & 0.6466 & 1.648\end{array}$ $\begin{array}{lllllllllllll}\text { MLVDDIGDVIITNDGATILK } & 1.00 & 69.62 & 26.29 & 19.85 & 3 & 2391.2848 & 2391.2811 & 798.1010 & 0.0037 & 1.5453 & 37.120 \\ \text { MLVDIGDVTITNDGATILK } & 1.00 & 54.68 & 26.29 & 17.36 & 3 & 2391.2848 & 2391.2811 & 798.1010 & 0.0037 & 1.5453 & 6.935\end{array}$

YINENLIVNTDELG

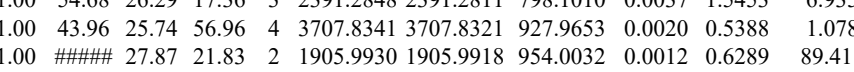

DELGR

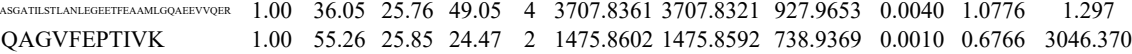
$\begin{array}{llllllllllll}1.00 & 17.71 & 25.74 & 14.90 & 4 & 3707.8345 & 3707.8321 & 927.9653 & 0.0024 & 0.6466 & 3.466\end{array}$ $\begin{array}{lllllllllllll} & & 1.00 & 55.26 & 25.85 & 24.47 & 2 & 1475.8602 & 1475.8592 & 738.9369 & 0.0010 & 0.6766 & 3046.370\end{array}$ $\begin{array}{lllllllllll}1.00 & 52.75 & 22.25 & 21.79 & 3 & 2102.2105 & 2102.2078 & 701.7432 & 0.0027 & 1.2825 & 63.703\end{array}$ QAGVFEPTIVK

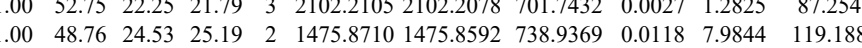
$\begin{array}{llllllllllll}\text { EVGDGTTSVVIIAAELLK } & 1.00 & \text { \#\#\#\# } 22.38 & 21.25 & 2 & 2102.2094 & 2102.2078 & 1052.1112 & 0.0016 & 0.7604 & 117.986\end{array}$ $\begin{array}{lllllllllll}\text { EVGDGTTSVVIIAAELLK } & 1.00 & \text { \#\#\# } 22.38 & 22.31 & 2 & 2102.2094 & 2102.2078 & 1052.1112 & 0.0016 & 0.7604 & 18.704\end{array}$

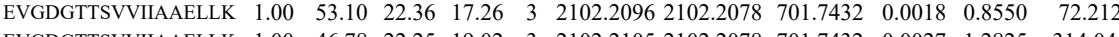
$\begin{array}{llllllllllll} & \end{array}$

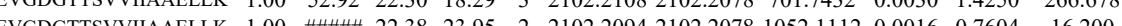
$\begin{array}{llllllllllll} & \end{array}$ $\begin{array}{lllllllll} & 0.3515\end{array}$

$\begin{array}{lllllllllllll}\text { EVGDGTTSVVIIAAELLK } & 0.60 & 50.58 & 21.99 & 63.58 & 3 & 2102.2120 & 2102.2078 & 701.7432 & 0.0042 & 1.9950 & 76.306 & 81.356 \\ \text { SLHDALCVVK } & 1.00 & 53.90 & 27.90 & 25.57 & 2 & 1417.7792 & 1417.7665 & 709.8905 & 0.0127 & 8.9450 & 373.929 & 409.379\end{array}$

$3720.596 \quad 1042.447 \quad 4505.638 \quad$ Yes $\begin{array}{llllllllllllllll}.07 & 30.70 & 24.70 & 18.99 & 3 & 1393.8292 & 1393.8173 & 465.6130 & 0.0119 & 8.5192 & 19703.798 & 25320.603 & 2458.000 & 28990.452 & \text { Yes }\end{array}$

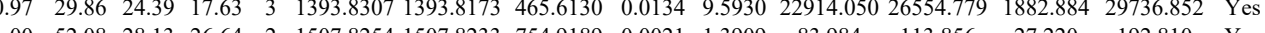
$\begin{array}{llllllllllll}1 & \end{array}$ $\begin{array}{llll}13.856 & 27.220 & 192.810 & \text { Yes } \\ 109.953 & 4.949 & 104.46 & Y \text { Yes }\end{array}$ $\begin{array}{lll}298.112 & 6119.658 & \text { Yes } \\ 551.327 & 2791.707 & Y e s\end{array}$

$\begin{array}{rr}.678 & 96.32 \\ .799 & 0.000 \\ 193 & 16.82\end{array}$

0.00
-19.8

$\begin{array}{lc}-163.193 & 161.82 \\ 0.475 & 0.000 \\ 6.215 & 0.000\end{array}$

$\begin{array}{ll}6.215 & 0.000 \\ 4.022 & 19.51\end{array}$

$\begin{array}{ll}174.022 & 19.51 \\ 291.844 & 607.30 \\ 32.346 & 468.57\end{array}$

132.346

40.908

25.864
0.000
5.285

0.000
5.285
5.809

30.469

26.219
1.776

1.776

.706

0.000

3211.571
58.999

87.104

94.700
132.042

132.042
28.668

28.668
71.918

472.857

155.371
8.096

S-4 page 206 of 614 

$\begin{array}{llllllllllllllll} & \end{array}$

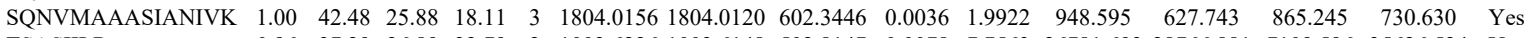

TSASIILR

WIGLDLSNGKPR

WIGLDLSNGKPR

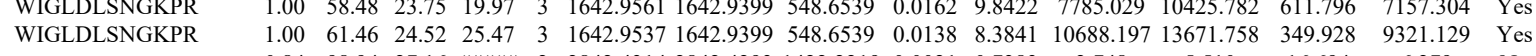
$\begin{array}{lllllllllllllll}0.96 & 37.29 & 26.89 & 32.79 & 2 & 1003.6226 & 1003.6148 & 502.8147 & 0.0078 & 7.7563 & 26781.693 & 28766.881 & 7109.596 & 35626.524 & \text { Yes }\end{array}$ $\begin{array}{lllllllllllllllll}0.97 & 37.14 & 27.13 & 32.77 & 2 & 1003.6240 & 1003.6148 & 502.8147 & 0.0092 & 9.1484 & 28401.067 & 34791.738 & 9667.122 & 38756.512 & \text { Yes }\end{array}$ $\begin{array}{llllllllllllllll}1.00 & 51.85 & 24.52 & 21.88 & 3 & 1642.9537 & 1642.9399 & 548.6539 & 0.0138 & 8.3841 & 2430.550 & 2385.601 & 582.425 & 1988.596 & \text { Yes }\end{array}$

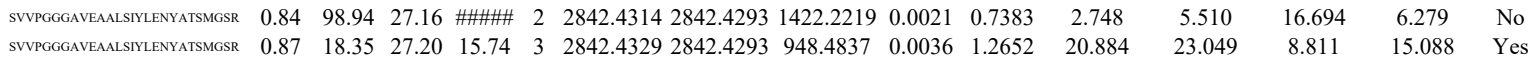

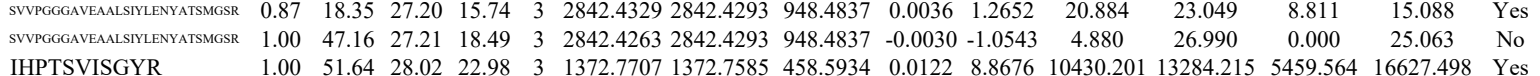
IHPTSVISGYR IHPTSVISGYR IHPTSVISGYR GANDFMCDEMER $\begin{array}{lllllllllllllll}1.00 & 53.13 & 27.83 & 21.63 & 2 & 1372.7712 & 1372.7585 & 687.3865 & 0.0127 & 9.8378 & 8791.766 & 10950.024 & 1876.142 & 13650.235 & \text { Ycs }\end{array}$

\section{HGSYEDAVHSGALND}

IDDLIK

IDDLIK

LLEVEHPAAK

$\begin{array}{lllllllllllll}\text { PTN1_HUMAN } & \text { P18031 } & \text { PTPN1 } & \text { Tyrosine-protein } \mathrm{r} 49.967 & 1.00 & 4 & 9.7 & 0.4092 & 0.3112 & 0.7827 & 0.2562 & 8 & \text { GAQAASPAK }\end{array}$ KDPSSVDIK KDPSSVDIK MGLIQTADQLR QLELENLTTQETR QLELENLTTQETR

GAQAASPAK

$\begin{array}{lllllllllllll}\text { RL35A HUMAR } & \text { P18077 } & \text { RPL35A } & \text { 60S ribosomal pro } 12.538 & 1.00 & 5 & 41.8 & 0.1330 & 0.1996 & 1.5052 & 0.3342 & 21 & \text { NNTVTPGGKPNK }\end{array}$

NNTVTPGGKPNK

NNTVTPGGKPNK

NNTVTPGGKPNK

NNTVTPGGKPNK

NNTVTPGGKPNK

NNTVTPGGKPNK

AIFAGYK

AIFAGYK

AIFAGYK

AIFAGYK

SNLPAKAIG

VMLYPSR $\begin{array}{lllllllllllllllll} & \end{array}$

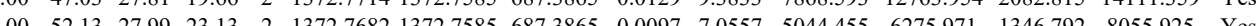
$\begin{array}{llllllllllllllll}1.00 & 52.31 & 15.19 & 21.82 & 2 & 1606.6018 & 1606.6006 & 804.3076 & 0.0012 & 0.7460 & 199.551 & 150.129 & 24.847 & 354.234 & \text { Yes }\end{array}$

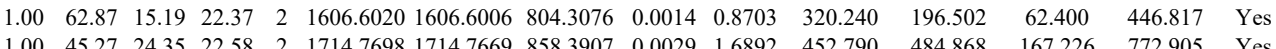
$\begin{array}{llllllllllllllll}0.85 & 30.38 & 26.68 & 34.53 & 2 & 1003.6250 & 1003.6157 & 502.8151 & 0.0093 & 9.2478 & 5844.474 & 6086.973 & 2657.032 & 7536376 & \text { Yes }\end{array}$ $\begin{array}{llllllllllllllll}0.82 & 30.38 & 26.68 & 35.43 & 2 & 1003.6252 & 1003.6157 & 5028151 & 0.0095 & 9.4467 & 7067.620 & 7259.774 & 3267.774 & 8052211 & \text { Yes }\end{array}$ $\begin{array}{llllllllllllllll}0.61 & 17.81 & 24.38 & 16.38 & 3 & 1393.8274 & 1393.8173 & 465.6130 & 0.0101 & 7.2306 & 41317.473 & 51353.823 & 1625.715 & 58294.837 & \text { Yes }\end{array}$ $\begin{array}{lllllllllllllll}0.91 & 26.18 & 24.49 & 16.41 & 3 & 1393.8283 & 1393.8173 & 465.6130 & 0.0110 & 7.8749 & 29478.007 & 33381.318 & 2126.530 & 39497.155 & \text { Yes }\end{array}$ $\begin{array}{llllllllllllllll}1.00 & 45.16 & 26.86 & 28.02 & 2 & 1087.6230 & 1087.6229 & 544.8187 & 0.0001 & 0.0918 & 84.366 & 80.279 & 81.832 & 96.498 & \text { Yes }\end{array}$

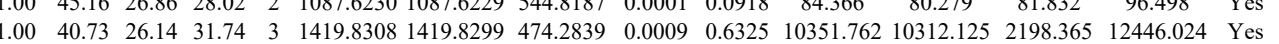
$\begin{array}{llllllllllllllll}0.99 & 31.37 & 26.20 & 26.98 & 3 & 1419.8311 & 1419.8299 & 474.2839 & 0.0012 & 0.8434 & 6619.347 & 8201.734 & 2463.695 & 9921.946 & \text { Yes }\end{array}$ $\begin{array}{lllllllllllllll}1.00 & 71.25 & 27.24 & 30.03 & 2 & 1388.7706 & 1388.7568 & 695.3857 & 0.0138 & 9.9225 & 2228.365 & 3347.747 & 205.827 & 3613.996 & \text { Yes }\end{array}$ $\begin{array}{llllllllllllllll}1.00 & 69.10 & 27.69 & 30.49 & 2 & 1717.8972 & 1717.8968 & 859.9557 & 0.0004 & 0.2326 & 695.546 & 1041.650 & 162.707 & 1005.137 & \text { Yes }\end{array}$

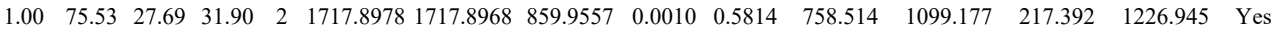

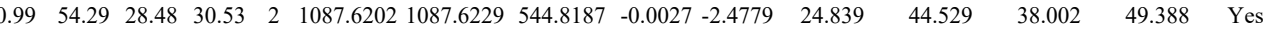

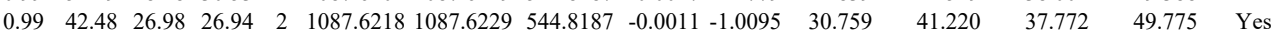

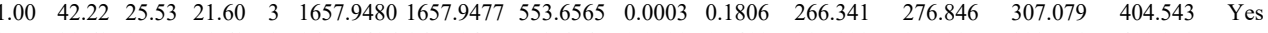
$\begin{array}{lllllllllllllll}0.55 & 38.63 & 25.59 & 51.63 & 3 & 1657.9486 & 1657.9477 & 553.6565 & 0.0009 & 0.5419 & 287.823 & 279.985 & 333.751 & 402.252 & \text { Yes }\end{array}$

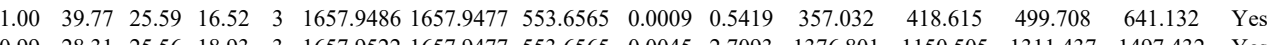
$\begin{array}{lllllllllllllll}0.99 & 28.31 & 25.56 & 18.93 & 3 & 1657.9522 & 1657.9477 & 553.6565 & 0.0045 & 2.7093 & 1376.801 & 1150.505 & 1311.437 & 1497.432 & \text { Yes }\end{array}$ $\begin{array}{lllllllllllllll}1.00 & 40.49 & 25.56 & 17.33 & 3 & 1657.9522 & 1657.9477 & 553.6565 & 0.0045 & 2.7093 & 1513.601 & 1401.857 & 1876.996 & 2038.740 & \text { Yes }\end{array}$ $\begin{array}{lllllllllllllll}0.99 & 32.73 & 25.53 & 19.19 & 3 & 1657.9480 & 1657.9477 & 553.6565 & 0.0003 & 0.1806 & 266.724 & 255.717 & 339.594 & 412.976 & \text { Yes } \\ 1.00 & 34.86 & 5.59 & 17.26 & 3 & 167.9507 & 157.9477 & 553.656 & 0.0030 & 1.062 & 573.483 & 545.758 & 637.885 & 749.670 & \text { Yes }\end{array}$

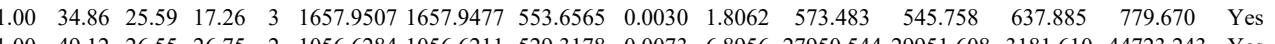
$\begin{array}{llllllllllllllll}1.00 & 49.12 & 26.55 & 26.75 & 2 & 1056.6284 & 1056.6211 & 529.3178 & 0.0073 & 6.8956 & 27950.544 & 29951.608 & 3181.610 & 44723.243 & \text { Yes } \\ 0.96 & 36.48 & 26.07 & 25.69 & 2 & 1056.6294 & 1056.6211 & 529.3178 & 0.0083 & 7.8402 & 31446.867 & 40857.397 & 3200.746 & 64619.902 & \text { Yes }\end{array}$ $\begin{array}{llllllllllllllll}0.96 & 36.48 & 26.07 & 25.69 & 2 & 1056.6294 & 1056.6211 & 529.3178 & 0.0083 & 7.8402 & 31446.867 & 40857.397 & 3200.746 & 64619.902 & \text { Yes } \\ 1.00 & 49.62 & 27.06 & 25.99 & 2 & 1056.6272 & 1056.6211 & 529.3178 & 0.0061 & 5.7621 & 11067.319 & 12372.393 & 761.371 & 1867.106 & \text { Yes }\end{array}$ $\begin{array}{llllllllllllllll}1.00 & 49.62 & 27.06 & 25.99 & 2 & 1056.6272 & 1056.6211 & 529.3178 & 0.006 & 5.7621 & 11067.319 & 12372.393 & 761.371 & 18674.106 & \text { Yes } \\ 1.00 & 49.56 & 26.07 & 27.17 & 2 & 1056.6286 & 1056.6211 & 529.3178 & 0.0075 & 7.0845 & 15581.201 & 17474.197 & 1798.689 & 24415.968 & \text { Yes }\end{array}$ $\begin{array}{lllllllllllllllll}1.00 & 49.56 & 26.07 & 27.17 & 2 & 1056.6286 & 056.6211 & 529.3178 & 0.0075 & 7.0845 & 15581.201 & 17474.197 & 1798.689 & 24415.968 & \text { Yes } \\ 0.53 & 27.48 & 24.35 & 15.77 & 3 & 1450.8613 & 1450.8612 & 484.6277 & 0.0001 & 0.0688 & 812.248 & 897.930 & 854.043 & 778.854 & \text { Yes }\end{array}$

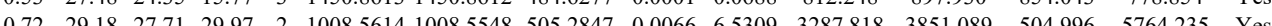

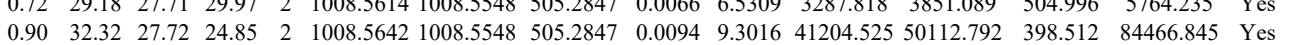

6.845 Yes

Table S-4 page 207 of 614 

$\begin{array}{lllllllllllllll} & \end{array}$ $\begin{array}{lllllllllllllll}1.00 & 44.46 & 28.53 & 38.25 & 2 & 1131.6460 & 1131.6443 & 566.8294 & 0.0017 & 1.4996 & 3986.937 & 4508.881 & 475.376 & 9677.112 & \text { Yes }\end{array}$

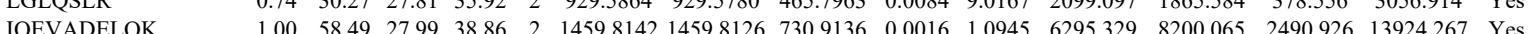

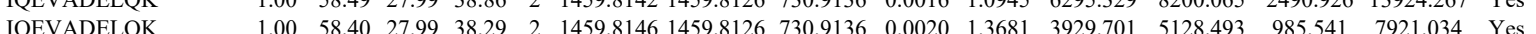

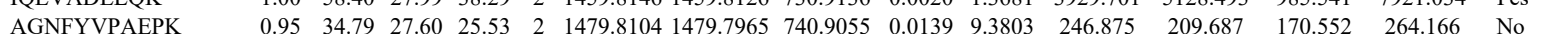
SVNELIYK

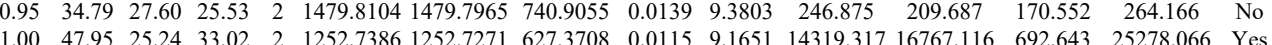
$\begin{array}{llllllllllllllllll}\text { SVNELIYK } & 1.00 & 47.95 & 25.24 & 33.02 & 2 & 1252.7386 & 1252.7271 & 627.3708 & 0.0115 & 9.1651 & 14319.317 & 16767.116 & 692.643 & 25278.066 & \text { Yes } \\ \text { YGIICMEDLIHEIYTVGK } & 0.67 & 56.21 & 27.68 & 69.21 & 3 & 2430.2275 & 2430.2241 & 811.082 & 0.0034 & 1.3973 & 3547.361 & 4850.955 & 1773.441 & 7109.858 & \text { Yes }\end{array}$ $\begin{array}{lllllllllllllllll}\text { YGIICMEDLIHEIYTVGK } & 0.67 & 56.21 & 27.68 & 69.21 & 3 & 2430.2275 & 2430.2241 & 811.0820 & 0.0034 & 1.3973 & 3547.361 & 4850.955 & 1773.441 & 7109.858 & \text { Yes } \\ \text { YGIICMEDLIHEIYTVGK } & 0.60 & 43.71 & 27.62 & 56.71 & 3 & 2430.2284 & 2430.2241 & 811.0820 & 0.0043 & 1.7672 & 2667.353 & 4458.604 & 763.866 & 7783.540 & \text { Yes }\end{array}$ $\begin{array}{llllllllllllllll}\text { YGIICMEDLIHEIYTVGK } & 1.00 & 21.95 & 27.57 & 19.90 & 4 & 2430.2289 & 2430.2241 & 608.5633 & 0.0048 & 1.9719 & 91.001 & 59.755 & 41.600 & 77.474 & \text { Yes }\end{array}$ $\begin{array}{llllllllllllllll}\text { YGIICMEDLIHEIYTVGK } & 1.00 & 84.10 & 27.75 & 22.86 & 2 & 2430.2254 & 2430.2241 & 1216.1193 & 0.0013 & 0.5345 & 47.342 & 48.395 & 34.099 & 40.888 & \text { No }\end{array}$

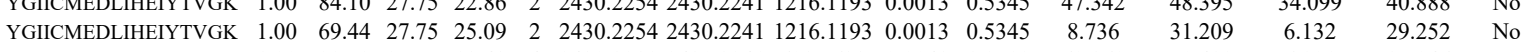

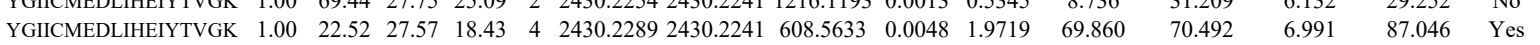
$\begin{array}{llllllllllllllll}\text { YGIICMEDLIHEIYTVGK } & 1.00 & 55.38 & 27.57 & 23.44 & 3 & 2430.2290 & 2430.2241 & 811.0820 & 0.0049 & 2.0138 & 5512.112 & 5617.524 & 1108.236 & 11228.123 & \text { Yes }\end{array}$ $\begin{array}{llllllllllllllll}\text { YGIICMEDLIHEIYTVGK } & 0.66 & 38.48 & 27.73 & 51.48 & 3 & 2430.2263 & 2430.2241 & 811.0820 & 0.0022 & 0.9041 & 1052.136 & 1331.827 & 163.042 & 2524.712 & \text { Yes }\end{array}$

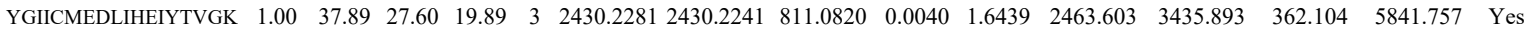
$\begin{array}{llllllllllllllll}\text { IALTDNALIAR } & 1.00 & 53.33 & 25.04 & 27.50 & 2 & 1313.7914 & 1313.7789 & 657.8967 & 0.0125 & 9.4999 & 13262.030 & 14578.004 & 432.811 & 21203.949 & \text { Yes }\end{array}$ $\begin{array}{lllllllllllllllll}\text { QIFNGTFVK } & 0.98 & 40.05 & 26.18 & 18.92 & 2 & 1340.7788 & 1340.7696 & 671.3921 & 0.0092 & 6.8514 & 29180.985 & 35340.949 & 0.000 & 37235.432 & \text { No }\end{array}$ $\begin{array}{llllllllllllllll}\text { QIFNGTFVK } & 1.00 & 44.55 & 25.60 & 18.76 & 2 & 1340.7804 & 1340.7696 & 671.3921 & 0.0108 & 8.0429 & 19127.414 & 20938.086 & 93.525 & 19842.201 & \text { Yes }\end{array}$

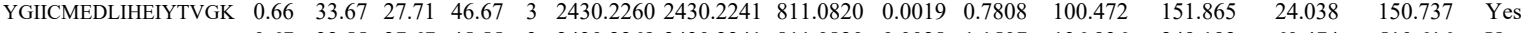

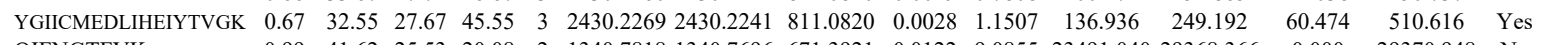
$\begin{array}{llllllllllllllll}\text { QIFNGTFVK } & 0.99 & 41.62 & 25.53 & 20.08 & 2 & 1340.7818 & 1340.7696 & 671.3921 & 0.0122 & 9.0855 & 23491.040 & 29368.366 & 0.000 & 29370.948 & \text { No }\end{array}$

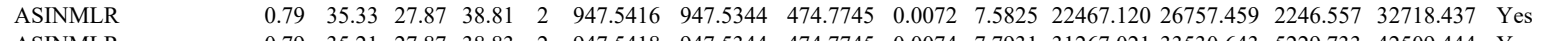

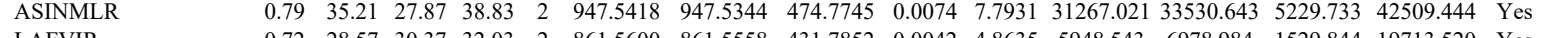

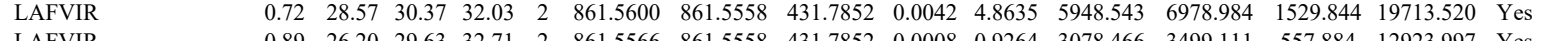
$\begin{array}{llllllllllllllll}\text { LAFVIR } & 0.89 & 26.20 & 29.63 & 32.71 & 2 & 861.5566 & 861.5558 & 431.7852 & 0.0008 & 0.9264 & 3078.466 & 3499.111 & 557.884 & 12923.997 & \text { Yes }\end{array}$ \begin{tabular}{llllllllllllllll} 
LAFVIR & 0.76 & 26.03 & 29.70 & 32.37 & 2 & 861.5562 & 861.5558 & 431.7852 & 0.0004 & 0.4632 & 829.092 & 952.037 & 206.206 & 3400.873 & Yes \\
\hline LAFVIR & 0.88 & 25.84 & 29.70 & 30.20 & 2 & 861.5564 & 861.5558 & 431.7852 & 0.0006 & 0.6948 & 954.169 & 1097.147 & 212.741 & 3749.879 & Yes
\end{tabular} $\begin{array}{llllllllllllllll}\text { LAFVIR } & 0.88 & 25.84 & 29.70 & 30.20 & 2 & 861.5564 & 861.5558 & 431.7852 & 0.0006 & 0.6948 & 954.169 & 1097.147 & 212.741 & 3749.879 & \text { Yes } \\ \text { LAFVIR } & 0.96 & 30.48 & 29.70 & 33.15 & 2 & 861.5564 & 861.5558 & 431.7852 & 0.0006 & 0.6948 & 817.658 & 926.224 & 276.958 & 2549.465 & \text { Yes }\end{array}$ $\begin{array}{llllllllllllllll}\text { LAFVR } & 0.96 & 30.48 & 29.10 & 33.15 & 2 & 861.5564 & 861.5558 & 431.7852 & 0.0006 & 0.6948 & 817.658 & 926.224 & 276.958 & 2549.465 & \text { Yes }\end{array}$

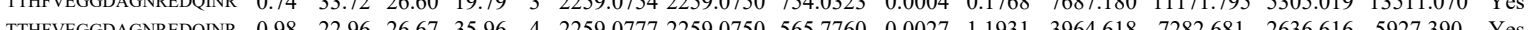

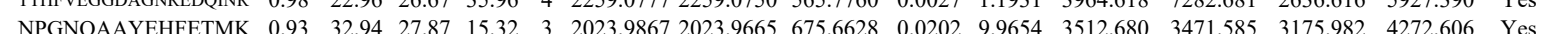

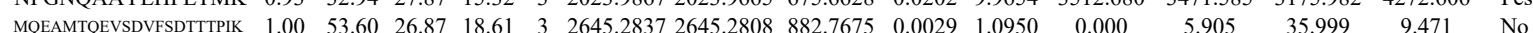

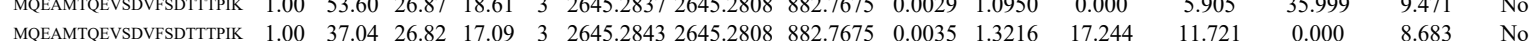

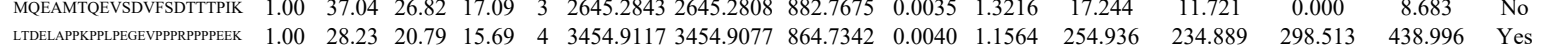

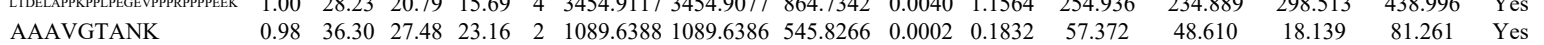

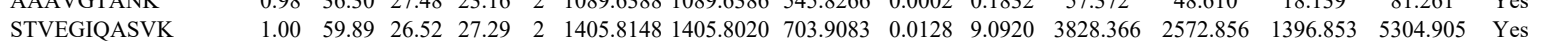

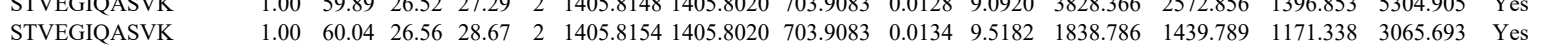

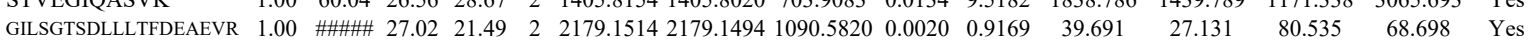
$\begin{array}{llllllllllllllll}\text { GILSGTSDLLLTFDEAEVR } & 0.95 & 22.41 & 27.01 & 17.30 & 3 & 2179.1533 & 2179.1494 & 727.3904 & 0.0039 & 1.7872 & 24.502 & 24.248 & 14.025 & 7.390 & \text { No }\end{array}$ $\begin{array}{llllllllllllllll}\text { GILSGTSDLLLTFDEAEVR } & 1.00 & 34.36 & 27.01 & 15.93 & 3 & 2179.1533 & 2179.1494 & 727.3904 & 0.0039 & 1.7872 & 27.090 & 0.000 & 27.117 & 7.976 & \text { No }\end{array}$

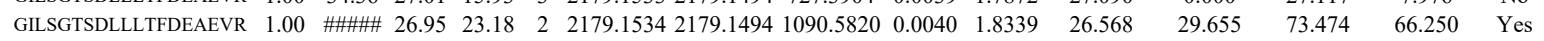
$\begin{array}{llllllllllllllll}\text { VLQLTSWDEDAWASK } & 0.97 & 23.64 & 27.94 & 18.58 & 3 & 2036.0494 & 2036.0458 & 679.6892 & 0.0036 & 1.7655 & 286.657 & 150.550 & 125.700 & 216.207 & \text { Yes }\end{array}$ $\begin{array}{lllllllllllllllll}\text { VLQLTSWDEDAWASK } & 0.97 & 26.98 & 27.93 & 19.73 & 3 & 2036.0512 & 2036.0458 & 679.6892 & 0.0054 & 2.6483 & 223.106 & 235.973 & 116.976 & 261.518 & \text { Yes }\end{array}$ $\begin{array}{lllllllllllllll}\text { GILSGTSDLLLTFDEAEVR } & 1.00 & \text { \#\#\#\# } 27.02 & 24.82 & 2 & 2179.1514 & 2179.1494 & 1090.5820 & 0.0020 & 0.9169 & 38.079 & 33.268 & 64.410 & 71.040 & \text { Yes }\end{array}$ $\begin{array}{llllllllllllllll}\text { GILSGTSDLLLTFDEAEVR } & 0.85 & 16.28 & 27.05 & 17.56 & 3 & 2179.1524 & 2179.1494 & 727.3904 & 0.0030 & 1.3748 & 9.928 & 10.624 & 1.140 & 17.439 & \text { Yes }\end{array}$ $\begin{array}{llllllllllllllll}\text { GiLSGTSDLLLTFDEAEVR } & 1.00 & \text { \#\#\#\# } 26.95 & 23.65 & 2 & 2179.1534 & 2179.1494 & 1090.5820 & 0.0040 & 1.8339 & 46.793 & 72.007 & 85.546 & 92.036 & \text { Yes }\end{array}$

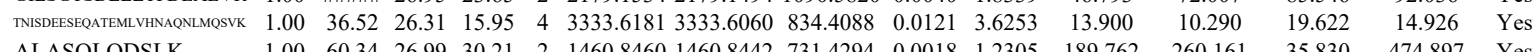

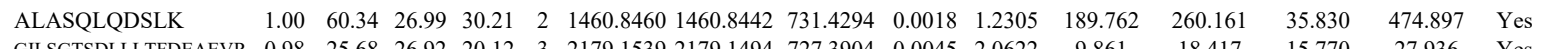

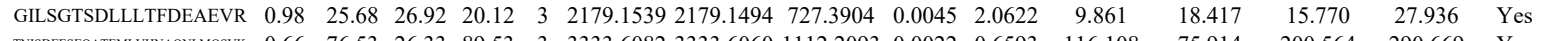

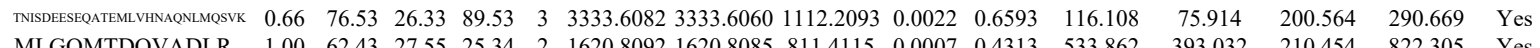

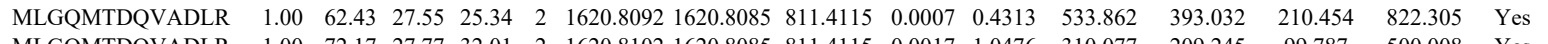

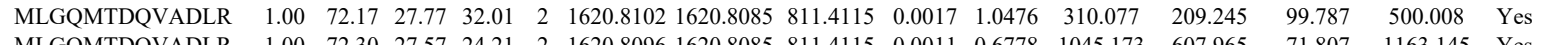

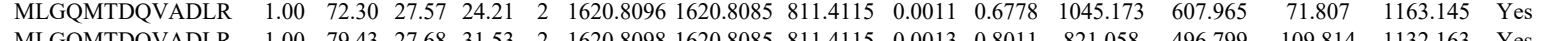
\begin{tabular}{lllllllllllllllll} 
MLGQMTDQVADLR & 1.00 & 79.43 & 27.68 & 31.53 & 2 & 1620.8098 & 1620.8085 & 811.4115 & 0.0013 & 0.8011 & 821.058 & 496.799 & 109.814 & 1132.163 & Yes \\
\hline TIESU PPV & &
\end{tabular}

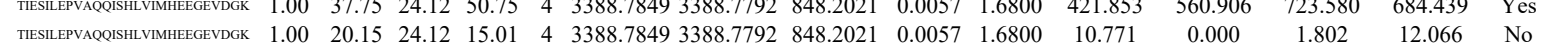
$\begin{array}{llllllllllllllll}\text { TIESILEPVAeOSHLVIMHEEGEVDGK } & 1.00 & 32.14 & 24.15 & 45.14 & 4 & 3388.7841 & 3388.7792 & 848.2021 & 0.0049 & 1.4442 & 259.568 & 193.187 & 444.158 & 388.355 & \text { Yes }\end{array}$

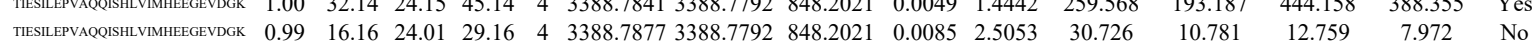

Table S-4 page 208 of 614 


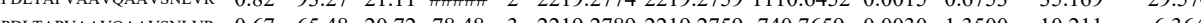
$\begin{array}{lllllllllll} & \end{array}$ $\begin{array}{lllllllllll} & 0.003 & 1.7549 & 24.900\end{array}$ $\begin{array}{lllllllllll} & 0.753\end{array}$ $\begin{array}{lllllllll} & \end{array}$ $\begin{array}{lllllllllll} & \end{array}$

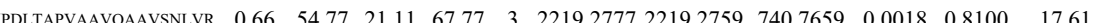
$\begin{array}{llllllllllll} & 0.06 & 20.61 & 17.58 & 3 & 2219.2792 & 2219.2759 & 740.7659 & 0.0033 & 1.4849 & 16.734\end{array}$ $\begin{array}{llllllllllllll}\text { DPSASPGDAGEQAIR } & 1.00 & 84.81 & 26.56 & 22.22 & 2 & 1613.7758 & 1613.7767 & 807.8956 & -0.0009 & -0.5570 & 994.182\end{array}$ $\begin{array}{llllllllllllll}\text { DPSASPGDAGEQAIR } & 1.00 & 75.17 & 26.54 & 21.70 & 2 & 1613.7760 & 1613.7767 & 807.8956 & -0.0007 & -0.4332 & 635.250\end{array}$

$\begin{array}{lllllllllllllll} & \end{array}$

$\begin{array}{lllllllllllll} & 23.31 & 2066.1631 & 2066.1615 & 689.7278 & 0.0016 & 0.7733 & 1138.027\end{array}$ $\begin{array}{lllllllllllll} & \end{array}$ $\begin{array}{lllllllllllllll}\text { GLDVDSLVIEHIQVNK } & 1.00 & 49.39 & 23.84 & 16.24 & 3 & 2066.1640 & 2066.1615 & 689.7278 & 0.0025 & 1.2082 & 176.623 & 194.315 & 234.5 \\ \text { GLDVDSLVIEHIQVNK } & 1.00 & 49.77 & 23.82 & 21.74 & 3 & 2066.1643 & 2066.1615 & 689.7278 & 0.0028 & 1.3532 & 1050.000 & 1049.087 & \end{array}$

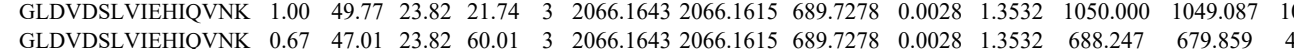
$\begin{array}{lllllllllllllll}\text { GLDVDSLVIEHIQVNK } & 0.67 & 47.01 & 23.82 & 60.01 & 3 & 2066.1643 & 2066.1615 & 689.7278 & 0.0028 & 1.3532 & 688.247 & 679.859 & 454.6 \\ \text { GLDVDSLVIEHIQVNK } & 0.67 & 53.71 & 23.69 & 66.71 & 3 & 2066.1649 & 2066.1615 & 689.7278 & 0.0034 & 1.6432 & 94.301 & 125.071 & \end{array}$

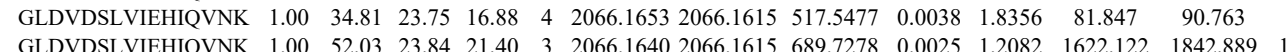

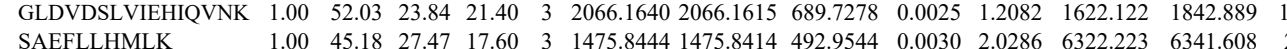



\begin{tabular}{lllllllllllllllll} 
FSGWYDADLSPAGHEEAK & 1.00 & 56.07 & 26.32 & 16.52 & 3 & 2267.0776 & 2267.0738 & 756.6985 & 0.0038 & 1.6739 & 3547.253 & 2235.225 & 398.017 & 3207.265 & Yes \\
\hline
\end{tabular} \begin{tabular}{llllllllllllllll} 
AMEAVAAQGK & 0.99 & 27.62 & 28.14 & 17.48 & 3 & 1262.6923 & 1262.6896 & 421.9038 & 0.0027 & 2.1332 & 2850.366 & 2356.389 & 1346.082 & 1742.369 & Yes \\
\hline AMEAVAAQGK & 1.00 & 71.80 & 28.12 & 31.60 & 2 & 1262.6926 & 1262.6896 & 632.3521 & 0.0030 & 23721 & 19391.799 & 11369.372 & 2435.055 & 12052.481 & Yes
\end{tabular} $\begin{array}{llllllllllllllll} & & & \end{array}$ $\begin{array}{llllllllllllllll} & 1.00 & 62.81 & 28.10 & 28.13 & 2 & 1262.6934 & 1262.689 & 632.3521 & 0.0038 & 3.0046 & 2455.262 & 14911.126 & 2746.576 & 15294.203 & \text { Yes }\end{array}$

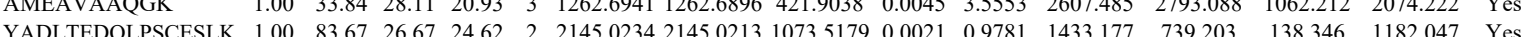

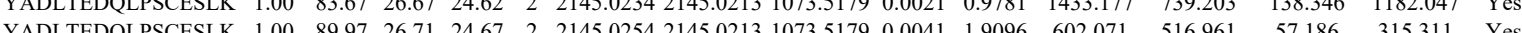

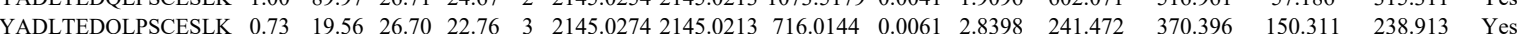
$\begin{array}{llllllllllllllll}\text { YADLTEDQLPCESLK } & 1.00 & 67.51 & 26.67 & 17.94 & 2 & 2145.0234 & 2445.0213 & 1073.5179 & 0.0021 & 0.9781 & 473.340 & 417.135 & 15.192 & 383.924 & \text { Yes }\end{array}$

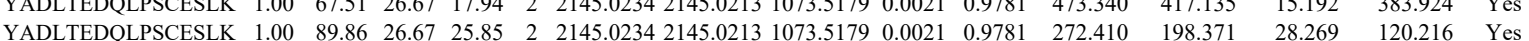
$\begin{array}{llllllllllllllll}\text { YADLTEDOLPSCESLK } & 0.51 & 10.41 & 26.68 & 23.41 & 3 & 2145.0253 & 2145.0213 & 716.0144 & 0.0040 & 1.8622 & 22.521 & 66.574 & 23.343 & 21.793 & \text { No }\end{array}$

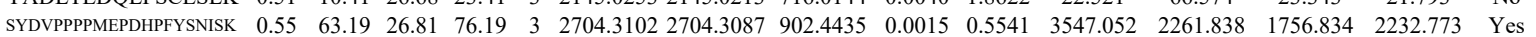
$\begin{array}{llllllllllllllllll}\text { SYDVPPPPMEPDHPFYSNISK } & 0.66 & 48.77 & 26.80 & 61.77 & 3 & 2704.3108 & 2704.3087 & 902.4435 & 0.0021 & 0.7757 & 4058.622 & 2662.527 & 1805.398 & 3034.793 & \text { Yes }\end{array}$ $\begin{array}{lllllllllllllllll}\text { SYDVPPPPMEPDHPFYSNISK } & 1.00 & 51.06 & 26.83 & 17.45 & 3 & 2704.3126 & 2704.3087 & 902.4435 & 0.0039 & 1.4405 & 3330.801 & 3502.506 & 1099.912 & 2112.032 & \text { Yes }\end{array}$ $\begin{array}{lllllllllllllllll}\text { SYDVPPPPMEPDHPFYSNISK } & 1.00 & 46.62 & 26.81 & 16.28 & 3 & 2704.3102 & 2704.3087 & 902.4435 & 0.0015 & 0.5541 & 1484.580 & 1513.457 & 723.406 & 1167.198 & \text { Yes }\end{array}$ $\begin{array}{lllllllllllllllll}\text { SYDVPPPPMEPDHPFYSNISK } & 0.66 & 44.69 & 26.81 & 57.69 & 3 & 2704.3111 & 2704.3087 & 902.4435 & 0.0024 & 0.8865 & 1018.772 & 581.586 & 360.525 & 616.493 & \text { Yes }\end{array}$

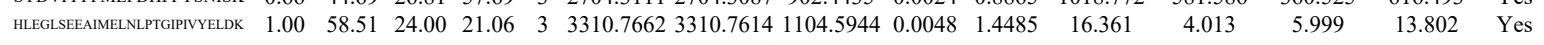

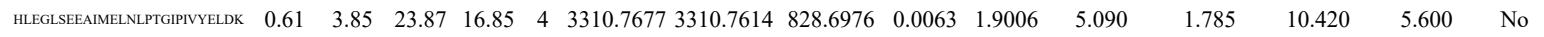
$\begin{array}{llllllllllllllll}\text { HLEGLSEAIMELNLPTGIPIYYEDK } & 0.98 & 15.71 & 23.78 & 14.07 & 4 & 3310.7693 & 3310.7614 & 828.6976 & 0.0079 & 2.3833 & 3.387 & 0.000 & 0.000 & 13.577 & \text { No }\end{array}$

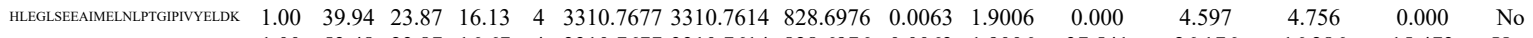
$\begin{array}{llllllllllllllll}\text { HLEGLSEAAMELNLPTGIPIYYLDK } & 1.00 & 53.48 & 23.87 & 16.67 & 4 & 3310.7677 & 3310.7614 & 828.6976 & 0.0063 & 1.9006 & 37.541 & 26.176 & 16.286 & 15.473 & \text { Yes }\end{array}$

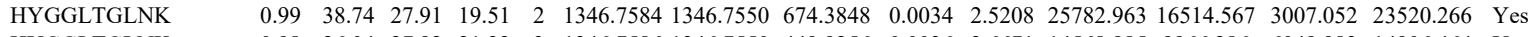
$\begin{array}{lllllllllllllllll}\text { HYGGLTGLNK } & 0.98 & 26.04 & 27.92 & 21.32 & 3 & 1346.7586 & 1346.7550 & 449.9256 & 0.0036 & 2.6671 & 14568.985 & 9966.286 & 6049.983 & 14906.464 & \text { Yes }\end{array}$ $\begin{array}{llllllllllllllll}\text { HYGGLTGLNK } & 0.98 & 27.83 & 27.91 & 21.94 & 3 & 1346.7592 & 1346.7550 & 449.9256 & 0.0042 & 3.1116 & 34996.680 & 25017.592 & 7217.273 & 37173.967 & \text { Yes }\end{array}$ $\begin{array}{lllllllllllllllll}\text { ALPFWNEEIVPQIK } & 0.66 & 19.39 & 24.65 & 32.39 & 3 & 1971.1090 & 1971.1073 & 658.0430 & 0.0017 & 0.8611 & 76.011 & 49.869 & 24.753 & 84.936 & \text { Yes }\end{array}$ ALPFWNEEIVPQIK ALPFWNEEIVPQIK ALPFWNEEIVPQIK ALPFWNEEIVPQIK ALPFWNEEIVPQIK ALPFWNEEIVPQIK ALPFWNEEIVPQIK ALPWNEEIVPQIK ALPFNEEIVPQIK ALPFWNEEIVPQIK ALPFWNEEIVPQIK ALPFWNEEIVPQIK ALPFWNEEIVPQIK VLIAAHGNSLR VLIAAAGNSLR VLIAAHGNSLR VLIAAHGNSLR VLIAAHGNSLR VLIAAHGNSLR $\begin{array}{llllllllllllllll}1.00 & 59.76 & 24.55 & 17.19 & 2 & 1971.1094 & 1971.1073 & 986.5609 & 0.0021 & 1.0643 & 9585.588 & 6509.150 & 370.478 & 8226.728 & \text { Yes }\end{array}$ $\begin{array}{lllllllllllllll}0.76 & 11.70 & 24.52 & 16.45 & 3 & 1971.1105 & 1971.1073 & 658.0430 & 0.0032 & 1.6210 & 131.057 & 94.854 & 49.077 & 108.675 & \text { Yes }\end{array}$ $\begin{array}{lllllllllllllll}1.00 & 1.27 & 24.25 & 18.51 & 2 & 1971.1110 & 1971.1073 & 986.5609 & 0.0037 & 1.8752 & 7633.451 & 4403.386 & 0.000 & 5291.485 & \text { No } \\ 0.88 & 15.80 & 24.25 & 14.93 & 3 & 19711111 & 1971.1073 & 568.0430 & 0.038 & 1.9249 & 66.962 & 577.930 & 102.092 & 497.589 & \text { Yos }\end{array}$

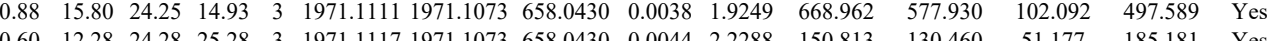

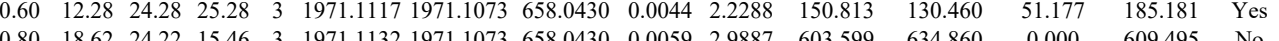

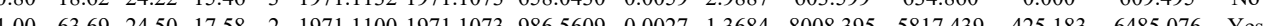

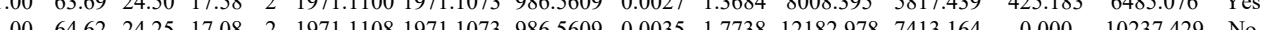

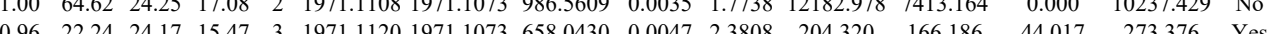

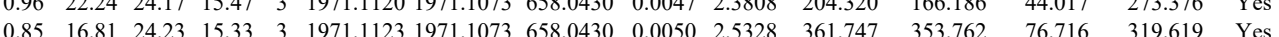
$\begin{array}{llllllllllllllll}0.84 & 55.80 & 24.62 & 68.80 & 2 & 1971.1092 & 1971.1073 & 986.5609 & 0.0019 & 0.9629 & 2906.098 & 2060.410 & 84.757 & 2905.977 & \text { Yes }\end{array}$

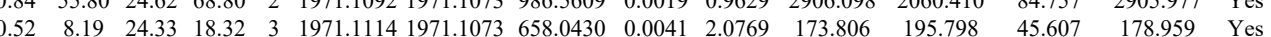
$\begin{array}{llllllllllllllll}0.52 & 54.53 & 24.33 & 21.51 & 2 & 1971.1116 & 1971.1073 & 986.5609 & 0.0043 & 2.1793 & 2436.061 & 1667.429 & 0.000 & 2131.128 & \text { No }\end{array}$ $\begin{array}{rrrrrrrrrrrrrrr}0.83 & 19.19 & 24.22 & 14.36 & 3 & 1971.1132 & 1971.1073 & 658.0430 & 0.0059 & 2.9887 & 259.004 & 136.345 & 100.629 & 285.508 & \text { Yes }\end{array}$ $\begin{array}{llllllllllllllll}1.00 & 59.35 & 25.47 & 26.98 & 2 & 1293.7684 & 1293.7639 & 647.8892 & 0.0045 & 3.4728 & 3836.203 & 3033.407 & 174.547 & 2871.553 & \text { Yes }\end{array}$ $\begin{array}{llllllllllllllll}1.00 & 57.97 & 25.47 & 29.94 & 2 & 1293.7686 & 1293.7639 & 647.8892 & 0.0047 & 3.6272 & 3000.102 & 2212.006 & 149.681 & 2043.658 & \text { Yes }\end{array}$ $\begin{array}{lllllllllllllll}1.00 & 58.08 & 25.47 & 23.69 & 3 & 1293.7687 & 1293.7639 & 432.2619 & 0.0048 & 3.7014 & 16978.801 & 16787.764 & 1319.518 & 13310.404 & \text { Yes }\end{array}$ $\begin{array}{llllllllllllllll}1.00 & 57.35 & 24.74 & 23.58 & 3 & 1293.7711 & 1293.7639 & 432.2619 & 0.0072 & 5.5522 & 10412.040 & 8596.196 & 1410.360 & 9817.610 & \text { Yes }\end{array}$ $\begin{array}{llllllllllllllll} & & \end{array}$

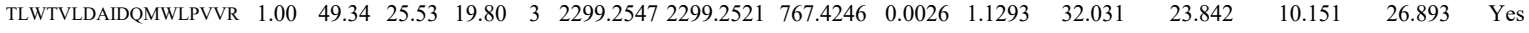

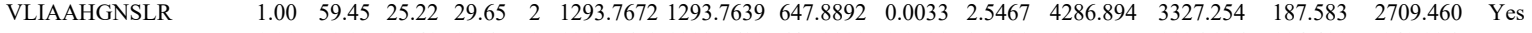
$\begin{array}{llllllllllllllll}\text { VLIAAHGNSLR } & 1.00 & 58.80 & 25.48 & 29.65 & 2 & 1293.7678 & 1293.7639 & 647.8892 & 0.0039 & 3.0098 & 1587.207 & 1196.116 & 194.490 & 949.936 & \text { Yes } \\ \text { VLIAAHGNSLR } & 1.00 & 50.29 & 24.74 & 26.49 & 3 & 1293.7711 & 1293.7639 & 432.2619 & 0.0072 & 5.5522 & 22741.792 & 18451.001 & 1970.029 & 16137.993 & \text { Yes }\end{array}$

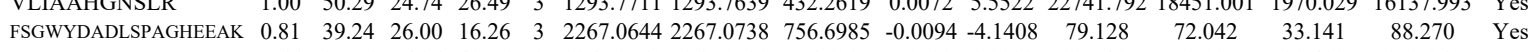

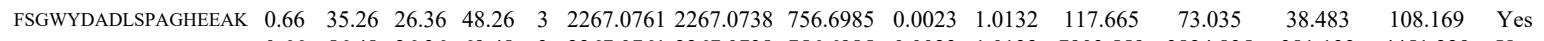

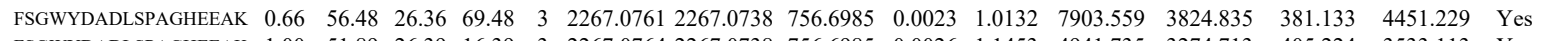
$\begin{array}{llllllllllllllll}\text { FSGWYDADLSPAGHEEAK } & 1.00 & 51.89 & 26.39 & 16.39 & 3 & 2267.0764 & 2267.0738 & 756.6985 & 0.0026 & 1.1453 & 4941.735 & 3274.713 & 405.224 & 3533.113 & \text { Yes }\end{array}$

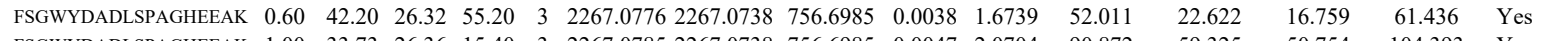

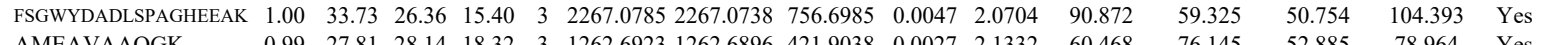

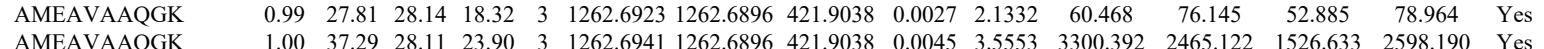

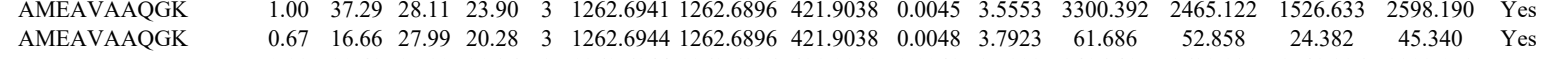

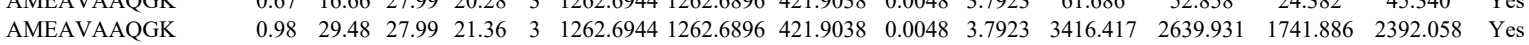

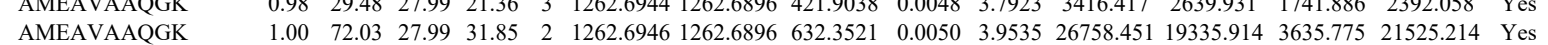




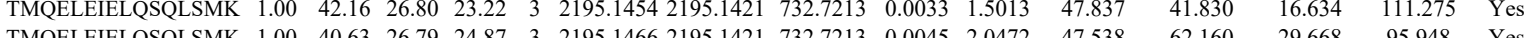

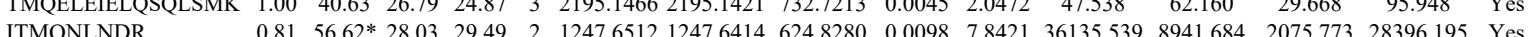

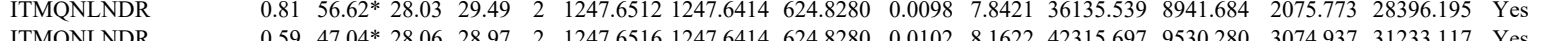

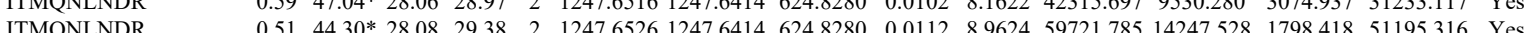

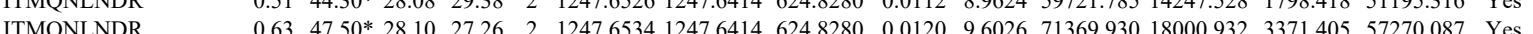

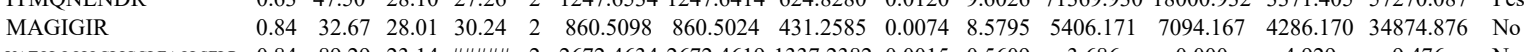

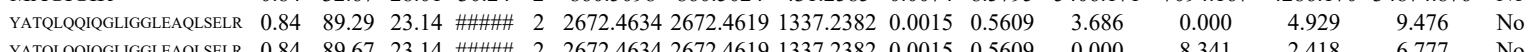

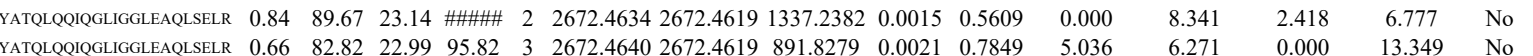

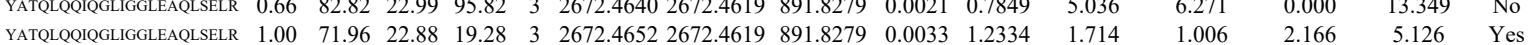

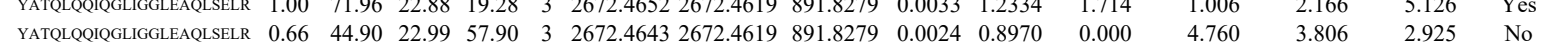

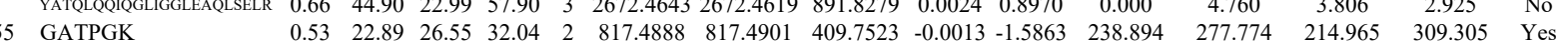

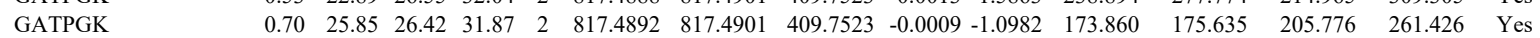
$\begin{array}{llllllllllllllll}\text { AAATPAK } & 0.72 & 22.20 & 26.63 & 21.66 & 2 & 916.5584 & 916.5585 & 459.2865 & -0.0001 & -0.1089 & 242.196 & 226.675 & 49.992 & 311.471 & \text { Yes }\end{array}$ $\begin{array}{llllllllllllllllll}\text { AAATPAK } & 0.80 & 24.22 & 26.63 & 26.46 & 2 & 916.5584 & 916.5585 & 459.2865 & -0.0001 & -0.1089 & 328.063 & 332.100 & 48.418 & 463.696 & \text { Yes }\end{array}$ $\begin{array}{llllllllllllllll}\text { VPQNQNGK } & 0.78 & 23.82 & 27.01 & 22.32 & 2 & 1171.6556 & 1171.6553 & 586.8349 & 0.0003 & 0.2556 & 14.910 & 31.284 & 12.689 & 19.907 & \text { Yes }\end{array}$ $\begin{array}{llllllllllllllll}\text { AAVTPGK } & 0.83 & 33.66 & 25.21 & 37.52 & 2 & 930.5730 & 930.5742 & 466.2944 & -0.0012 & -1.2867 & 180.022 & 135.257 & 80.914 & 247.199 & \text { Yes }\end{array}$ $\begin{array}{lllllllllllllllll}\text { AAVTPGK } & 0.61 & 28.22 & 25.21 & 37.30 & 2 & 930.5732 & 930.5742 & 466.2944 & -0.0010 & -1.0723 & 243.448 & 258.657 & 50.112 & 317.401 & \text { Yes }\end{array}$ $\begin{array}{lllllllllllllllll}\text { AVTTPGK } & 0.73 & 22.58 & 26.89 & 22.52 & 2 & 960.5844 & 960.5848 & 481.2997 & -0.0004 & -0.4155 & 164.700 & 143.696 & 116.180 & 198.217 & \text { Yes }\end{array}$

AVTTPGK

TVTPAK

AAVTPGK

AVTTPK GYAFIEFASFEDAK GAAIPAK GAAIPAK

GAAIPAK

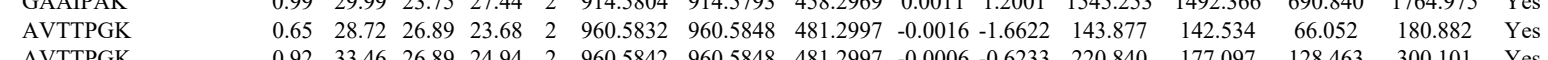
$\begin{array}{llllllllllllllll}0.91 & 28.36 & 26.89 & 23.32 & 2 & 960.5844 & 960.5848 & 481.2997 & -0.0004 & -0.4155 & 163.716 & 186.320 & 115.596 & 184.337 & \text { Yes }\end{array}$ $\begin{array}{llllllllllllllll}0.65 & 21.25 & 27.18 & 18.04 & 2 & 903.5630 & 903.5633 & 452.7889 & -0.0003 & -0.3313 & 185.094 & 185.404 & 124.141 & 203.412 & \text { Yes }\end{array}$ $\begin{array}{llllllllllllllll}0.90 & 37.75 & 25.21 & 38.59 & 2 & 930.5732 & 930.5742 & 466.2944 & -0.0010 & -1.0723 & 412.538 & 427.430 & 66.824 & 562.166 & \text { Yes }\end{array}$ $\begin{array}{lllllllllllllll}0.96 & 37.98 & 25.00 & 38.66 & 2 & 930.5744 & 930.5742 & 466.2944 & 0.0002 & 0.2145 & 531.974 & 545.261 & 101.537 & 647.690 & \text { Yes }\end{array}$ $\begin{array}{llllllllllllllll}0.99 & 33.82 & 26.36 & 25.24 & 2 & 960.5854 & 960.5848 & 481.2997 & 0.0006 & 0.6233 & 627.705 & 602.556 & 329.338 & 804.059 & \text { Yes }\end{array}$ $\begin{array}{lllllllllllllll}1.00 & 38.77 & 26.27 & 28.35 & 2 & 960.5862 & 960.5848 & 481.2997 & 0.0014 & 1.4544 & 883.590 & 964.783 & 415.232 & 1252.278 & \text { Yes }\end{array}$ $\begin{array}{lllllllllllllll}1.00 & 57.21 & 27.37 & 22.11 & 3 & 1881.9418 & 1881.9392 & 628.3203 & 0.0026 & 1.3793 & 150.958 & 183.239 & 58.895 & 238.930 & \text { Yes } \\ \end{array}$

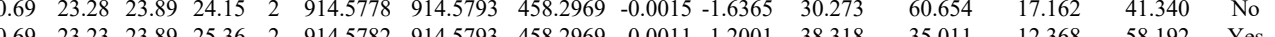

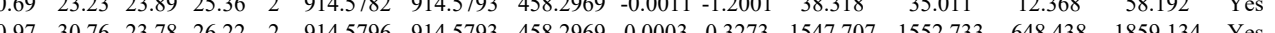
$\begin{array}{lllllllllllllll}0.97 & 30.76 & 23.78 & 26.22 & 2 & 914.5796 & 914.5793 & 458.2969 & 0.0003 & 0.3273 & 1547.707 & 1552.733 & 648.438 & 1859.134 & \text { Yes } \\ \end{array}$

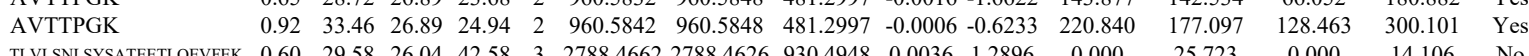

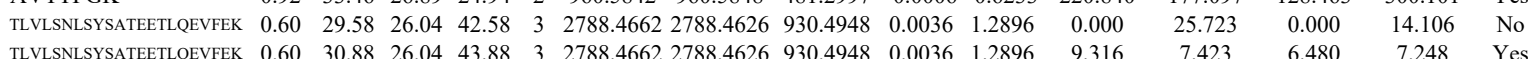
$\begin{array}{lllllllllllllllll} & \text { GAAIPAK } & 0.80 & 25.84 & 23.89 & 22.69 & 2 & 914.5778 & 914.5793 & 458.2969 & -0.0015 & -1.6365 & 53.680 & 43.497 & 13.496 & 61.351 & \text { Yes }\end{array}$

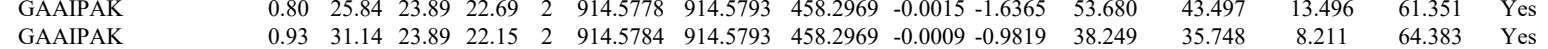

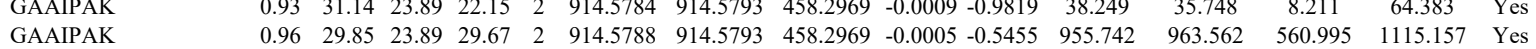

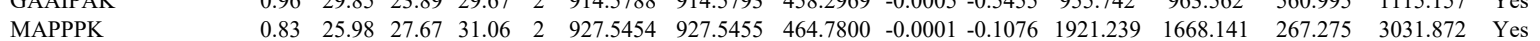
$\begin{array}{llllllllllllllll}\text { MAPPPK } & 0.92 & 25.95 & 27.76 & 31.00 & 2 & 927.5462 & 927.5455 & 464.7800 & 0.0007 & 0.7530 & 1888.991 & 1833.572 & 229.187 & 3188.817 & \text { Yes }\end{array}$ $\begin{array}{llllllllllllllll}\text { TLVLSNLSYSATEETLQEVFEK } & 0.60 & 62.71 & 26.06 & 75.71 & 3 & 2788.4668 & 2788.4626 & 930.4948 & 0.0042 & 1.5046 & 37.913 & 0.000 & 0.000 & 28.374 & \text { No }\end{array}$ $\begin{array}{llllllllllllll}\text { TLVLSNLSYSATEETLOEVFEK } & 0.60 & \text { \#\#\#\# } 26.10 \text { \#\#\#\# } 33 & 2788.4671 & 2788.4626 & 930.4948 & 0.0045 & 1.6120 & 34.369 & 0.000 & 29.284 & 20.513 & \text { No }\end{array}$

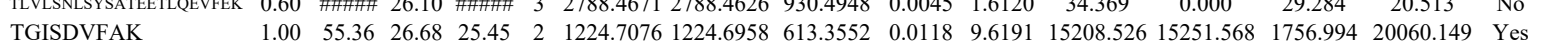

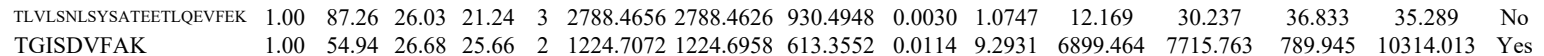

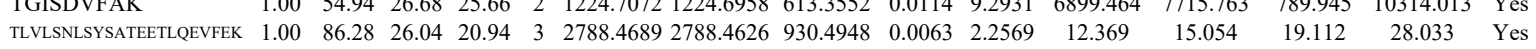

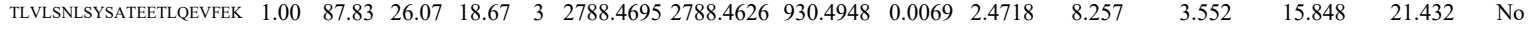
$\begin{array}{llllllllllllllll}\text { VAVATPAK } & 1.00 & 48.86 & 21.58 & 23.25 & 2 & 1043.6584 & 1043.6583 & 522.8364 & 0.0001 & 0.0956 & 11515.993 & 11702.770 & 2111.636 & 15456.096 & \text { Yes }\end{array}$ $\begin{array}{llllllllllllllll}\text { ALVATPGK } & 0.89 & 31.21 & 22.12 & 41.67 & 2 & 1043.6590 & 1043.6583 & 522.8364 & 0.0007 & 0.6694 & 5826.206 & 6066.099 & 1396.173 & 7536.854 & \text { Yes }\end{array}$ GIAYIEFK VAVATPAK ALELTGLK ALELTGLK GIAYIEFK
GIAYIEFK $\begin{array}{llllllllllllllll}1.00 & 63.21 & 25.98 & 35.94 & 2 & 1227.7126 & 1227.7107 & 614.8626 & 0.0019 & 1.5451 & 21265.634 & 18956.225 & 270.442 & 29026.632 & \text { Yes }\end{array}$ $\begin{array}{llllllllllllllll}1.00 & 48.69 & 21.58 & 26.70 & 2 & 1043.6580 & 1043.6583 & 522.8364 & -0.0003 & -0.2869 & 6032.006 & 5688.198 & 1489.563 & 7605.546 & \text { Yes }\end{array}$ GIAYIEF $\begin{array}{llllllllllllllll}0.99 & 42.22 & 24.64 & 28.64 & 2 & 1131.7218 & 1131.7107 & 566.8626 & 0.0111 & 9.7906 & 10198.615 & 10271.371 & 1017.386 & 15544.337 & \text { Yes }\end{array}$ $\begin{array}{lllllllllllllll}1.00 & 46.53 & 25.73 & 34.20 & 2 & 1227.7216 & 1227.7107 & 614.8626 & 0.0109 & 8.8637 & 12072.235 & 13573.631 & 3698.499 & 17201.465 & \text { Yes }\end{array}$

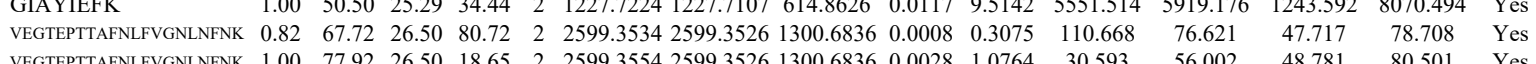
\begin{tabular}{lllllllllllll}
\hline &
\end{tabular} $\begin{array}{lllllllllllllllll}\text { EAMEDGEIDGNK } & 1.00 & 65.30 & 25.33 & 21.97 & 2 & 1594.7388 & 1594.7388 & 798.3767 & 0.0000 & 0.0000 & 1361.261 & 928.072 & 585.594 & 3740.198 & \text { No }\end{array}$ 
AAATPAK

FNTSDVSAIEK LSDETLIDIMTR LSDETLIDIMTR LSDETLIDIMTR LSDETLIDIMTR ITPELLTR TVCGVVSR TVCGVVSR TVCGVVSR GAALITAVGVR

\section{GAALITAVGVR}

Table S-4 page 212 of 614 

$\begin{array}{llllllllllll}1.00 & 40.48 & 23.01 & 16.90 & 2 & 1371.6058 & 1371.6042 & 686.8094 & 0.0016 & 1.1648 & 150.905\end{array}$

6 ALQEALVLSDR

$\begin{array}{lllllllllll}1.00 & 48.78 & 21.37 & 23.28 & 3 & 1691.0152 & 1691.0113 & 564.6777 & 0.0039 & 2.3022 & 79.958\end{array}$ $\begin{array}{lllllllllllll}1.00 & 57.40 & 24.73 & 23.16 & 2 & 1436.8502 & 1436.8483 & 719.4314 & 0.0019 & 1.3205 & 1445.649 & 1240.711\end{array}$ $\begin{array}{llllllllllllll} & \end{array}$ $\begin{array}{lllllllllllll} & 1.00 & 66.36 & 27.76 & 25.19 & 2 & 1357.7712 & 1357.7687 & 679.8916 & 0.0025 & 1.8385 & 8495.458 & 7395.447\end{array}$ $\begin{array}{llllllllllll} & & & \end{array}$

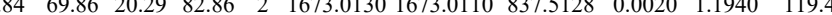

$\begin{array}{lllllllllllllll} & & \end{array}$ $\begin{array}{lllllllllllll}\text { TLVGVGASLGLR } & 0.97 & 45.54 & 24.44 & 49.14 & 2 & 1285.7854 & 1285.7840 & 643.8993 & 0.0014 & 1.0871 & 21806.654 & 15657.818\end{array}$ $\begin{array}{lllllllllllll}\text { ALPLALVLHELGAGR } & 0.84 & 93.60 & 20.29 & \text { \#\#\#\# } & 2 & 1673.0126 & 1673.0110 & 837.5128 & 0.0016 & 0.9552 & 342.758 & 281.424\end{array}$ $\begin{array}{lllllllllllll}\text { ALPLALVLHELGAGR } & 0.84 & 93.07 & 20.29 & \text { \#\#\#\# } & 2 & 1673.0132 & 1673.0110 & 837.5128 & 0.0022 & 1.3134 & 284.776 & 258.55\end{array}$ $\begin{array}{lllllllllllll}\text { VSLVLAPALAACGCK } & 1.00 & 80.30 & 28.01 & 30.55 & 2 & 1794.9490 & 1794.9472 & 898.4809 & 0.0018 & 1.0017 & 53.483 & 77.024\end{array}$ $\begin{array}{llllllllllll}\text { VSLVLAPALAACGCK } & 1.00 & 76.00 & 28.13 & 29.25 & 2 & 1794.9496 & 1794.9472 & 898.4809 & 0.0024 & 1.3356 & 111.655\end{array}$ $\begin{array}{llllllllllll}\text { VSLVLAPALAACGCK } & 1.00 & 67.85 & 28.11 & 19.35 & 3 & 1794.9505 & 1794.9472 & 599.3230 & 0.0033 & 1.8354 & 66.607\end{array}$ $\begin{array}{lllllllllllll}\text { VSLVLAPALAACGCK } & 1.00 & 61.45 & 28.12 & 23.29 & 3 & 1794.9511 & 1794.9472 & 599.3230 & 0.0039 & 2.1691 & 66.126\end{array}$ $\begin{array}{lllllllllllll}\text { TLVGVGASLGLR } & 0.71 & 15.80 & 24.64 & 27.12 & 2 & 1285.7846 & 1285.7840 & 643.8993 & 0.0006 & 0.4659 & 411.613 & 30 \\ \text { TLVGVGASLGLR } & 0.67 & 14.71 & 24.44 & 27.13 & 2 & 1285.7852 & 1285.7840 & 643.8993 & 0.0012 & 0.9318 & 385.515 & 25\end{array}$ $\begin{array}{llllllllllll}\text { TLVGVGASLGLR } & 0.67 & 14.71 & 24.44 & 27.13 & 2 & 1285.7852 & 1285.7840 & 643.8993 & 0.0012 & 0.9318 & 385.515 \\ \text { ALPLALVLHELGAGR } & 0.66 & 42.07 & 20.29 & 55.07 & 3 & 1673.0131 & 1673.0110 & 558.6776 & 0.0021 & 1.2530 & 25.714\end{array}$ $\begin{array}{llllllllllll}\text { ALPLALVLHELGAGR } & 0.66 & 42.07 & 20.29 & 55.07 & 3 & 1673.0131 & 1673.0110 & 558.6776 & 0.0021 & 1.2530 & 25.714\end{array}$

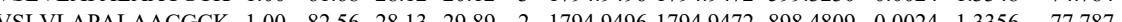

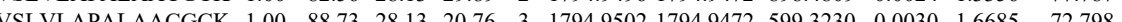
$\begin{array}{llllllllllll}\text { VSLVLAPALAACGCK } & 1.00 & 72.55 & 28.13 & 31.47 & 2 & 1794.9502 & 1794.9472 & 898.4809 & 0.0030 & 1.6695 & 79.096\end{array}$ $\begin{array}{lllllllllllll} & \text { TLVGVGASLGLR } & 0.52 & 16.49 & 24.76 & 28.47 & 2 & 1285.7838 & 1285.7840 & 6438993 & -0.0002 & -0.1553 & 335.269\end{array}$ $\begin{array}{lllllllllllll}\text { VSLVLAPALAACGCK } & 1.00 & 54.84 & 28.12 & 18.63 & 3 & 1794.9496 & 1794.9472 & 599.3230 & 0.0024 & 1.3348 & 53.407\end{array}$ $\begin{array}{llllllllllllll}\text { VSLVLAPALAACGCK } & 1.00 & 69.00 & 28.13 & 20.17 & 3 & 1794.9502 & 1794.9472 & 599.3230 & 0.0030 & 1.6685 & 101.506 & 107\end{array}$ $\begin{array}{lllllllllllll}\text { VSLVLAPALAACGCK } & 1.00 & 75.98 & 28.13 & 27.34 & 2 & 1794.9502 & 1794.9472 & 898.4809 & 0.0030 & 1.6695 & 19.785\end{array}$ $\begin{array}{lllllllllllll}\text { VSLVLAPALAACGCK } & 1.00 & 59.21 & 28.10 & 28.95 & 2 & 1794.9508 & 1794.9472 & 898.4809 & 0.0036 & 2.0034 & 36.187\end{array}$ $\begin{array}{lllllllllllll}\text { ALPLALVLHELGAGR } & 0.66 & 76.79 & 20.29 & 89.79 & 3 & 1673.0131 & 1673.0110 & 558.6776 & 0.0021 & 1.2530 & 127.346\end{array}$ $\begin{array}{llllllllllll}\text { ALPLALVLHELGAGR } & 0.67 & 87.21 & 19.54 & \text { \#\#\#\# } 3 & 1673.0137 & 1673.0110 & 558.6776 & 0.0027 & 1.6109 & 88.041\end{array}$ $\begin{array}{llllllllllllll}\text { VSLVLAPALAACGCK } & 1.00 & 57.63 & 28.14 & 27.01 & 2 & 1794.9498 & 1794.9472 & 898.4809 & 0.0026 & 1.4469 & 45.869\end{array}$ $\begin{array}{lllllllllllll}\text { VSLVLAPALAACGCK } & 0.60 & 46.73 & 28.10 & 59.73 & 3 & 1794.9508 & 1794.9472 & 599.3230 & 0.0036 & 2.0023 & 30.212\end{array}$ $\begin{array}{lllllllllllll}\text { VSLVLAPALAACGCK } & 0.60 & 47.30 & 28.10 & 60.30 & 3 & 1794.9508 & 1794.9472 & 599.3230 & 0.0036 & 2.0023 & 44.658\end{array}$ $\begin{array}{llllllllllll}\text { DLVTLGGALLISGHAGTPAGAAR } & 0.66 & 84.48 & 24.64 & 97.48 & 3 & 2707.4545 & 2707.4528 & 903.4915 & 0.0017 & 0.6272 & 158.108\end{array}$

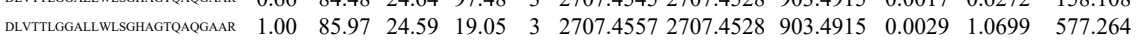
$\begin{array}{llllllllllllll} & \text { DNTLGGALLLLGHAGTRQGAAR } & 1.00 & 55.76 & 24.39 & 17.83 & 4 & 2707.4577 & 2707.4528 & 677.8705 & 0.0049 & 1.8071 & 12.817\end{array}$ $\begin{array}{llllllllllllll} & \text { DNTLOGALWLAHAGRARGAAR } & 1.00 & 46.02 & 24.39 & 17.07 & 4 & 2707.4577 & 2707.4528 & 677.8705 & 0.0049 & 1.8071 & 17.194\end{array}$

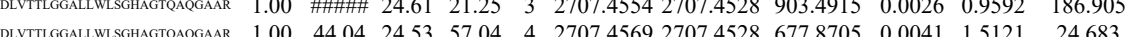

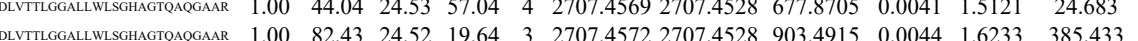

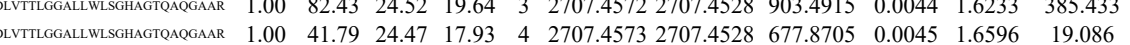

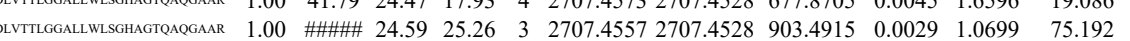

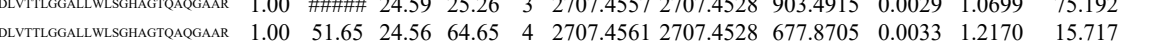
$\begin{array}{lllllllllllll} & \end{array}$

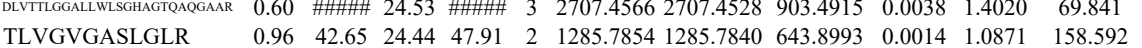
$\begin{array}{lllllllllll}0.96 & 42.65 & 24.44 & 47.91 & 2 & 1285.7854 & 1285.7840 & 643.8993 & 0.0014 & 1.0871 & 158.592 \\ 0.99 & 46.16 & 23.50 & 47.50 & 2 & 1285.7856 & 1285.7840 & 643.8993 & 0.0016 & 1.2424 & 183.461\end{array}$ $\begin{array}{llllllllllll}0.99 & 46.16 & 23.50 & 47.50 & 2 & 1285.7856 & 1285.7840 & 643.8993 & 0.0016 & 1.2424 & 183.461 \\ 0.99 & 37.60 & 24.44 & 37.09 & 2 & 1285.7854 & 1285.7840 & 643.8993 & 0.0014 & 1.0871 & 145.261\end{array}$

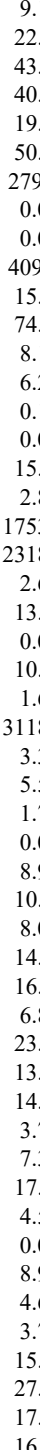


$\begin{array}{llllllllllllllll} & & & \end{array}$

$\begin{array}{llllllllllllllll} & 0.83 & 17.48 & 28.63 & 14.15 & 3 & 1503.8869 & 1503.8839 & 502.3019 & 0.0030 & 1.9908 & 5394.200 & 5692.858 & 4988.682 & 6784.428 & \text { Yes }\end{array}$

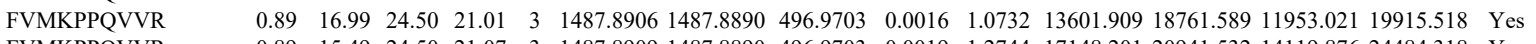

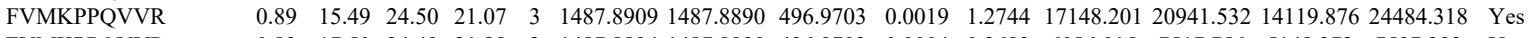

$\begin{array}{llllllllllllllll} & & & \end{array}$

$\begin{array}{llllllllllllllll} & 0.97 & 22.89 & 24.53 & 22.48 & 3 & 1487.8903 & 1487.8890 & 496.9703 & 0.0013 & 0.8719 & 5118.359 & 5790.499 & 3813.379 & 6023.256 & \text { Yes }\end{array}$

\begin{tabular}{llllllllllllllll} 
& \\
FVMKPPQVVR & 0.79 & 14.20 & 24.53 & 18.20 & 3 & 1487.8897 & 1487.8890 & 496.9703 & 0.0007 & 0.4695 & 1860.577 & 1982.318 & 2368.152 & 2275.460 & Yes \\
\hline
\end{tabular} \begin{tabular}{llllllllllllllll} 
& \\
FNMKPPQVR & 0.85 & 15.86 & 24.53 & 21.14 & 3 & 1487.8900 & 1487.8890 & 496.9703 & 0.0010 & 0.6707 & 1294.102 & 1529.154 & 1628.028 & 1721.983 & Yes \\
\hline
\end{tabular}

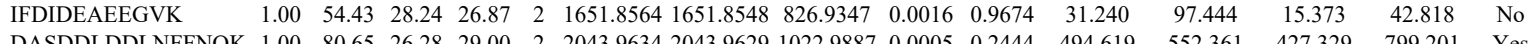
$\begin{array}{llllllllllllllll}\text { DASDDLDDLNFFNQK } & 1.00 & 80.65 & 26.28 & 29.00 & 2 & 2043.9634 & 2043.9629 & 1022.9887 & 0.0005 & 0.2444 & 494.619 & 552.361 & 427.329 & 799.201 & \text { Yes }\end{array}$

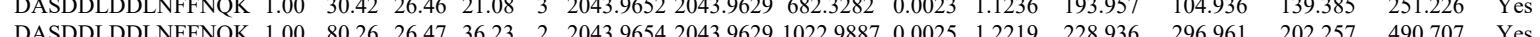
$\begin{array}{lllllllllllllll} & \end{array}$ $\begin{array}{llllllllllllllll}\text { DASDDLDDLNFFNQK } & 1.00 & 50.81 & 26.54 & 18.82 & 3 & 2043.9670 & 2043.9629 & 682.3282 & 0.0041 & 2.0029 & 179.785 & 186.416 & 142.340 & 250.122 & \text { Yes } \\ \text { IISDYEPTEPEDDDDMLGNK } & 0.85 & 35.37 * & 27.28 & 16.50 & 3 & 2774.3449 & 2774.3411 & 925.7876 & 0.0038 & 1.3682 & 4.585 & 13.686 & 0.000 & 5.503 & \text { No }\end{array}$

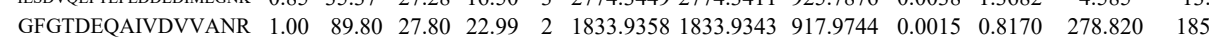

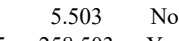

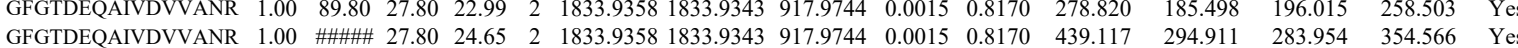

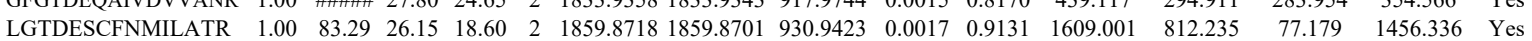

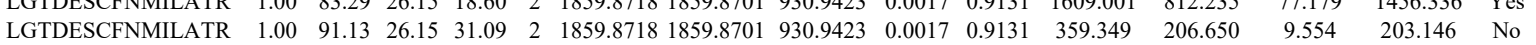

LLLAIVGQ

LLLAIVGQ

VLIEILCTR
VLIEILCTR

VLIEILCTR

VLIEILCTR

$\begin{array}{lllllllllllllll}1.00 & 91.13 & 26.15 & 31.09 & 2 & 1859.8718 & 1859.8701 & 930.9423 & 0.0017 & 0.9131 & 359.349 & 206.650 & 9.554 & 203.146 & \mathrm{No} \\ 0.95 & 18.18 & 18.39 & 18.90 & 2 & 969.6358 & 969.6344 & 485.8245 & 0.0014 & 1.4408 & 91.136 & 122.492 & 32.819 & 138.447 & \mathrm{~N}\end{array}$

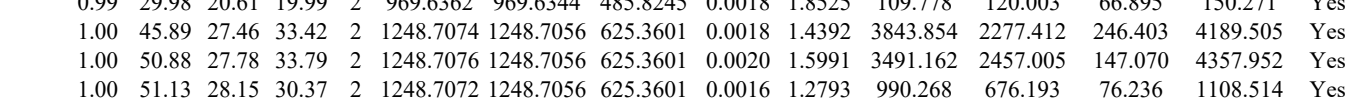
$\begin{array}{llllllllllllllll}1.00 & 51.13 & 28.15 & 30.37 & 2 & 1248.7072 & 1248.7056 & 625.3601 & 0.0016 & 1.2793 & 990.268 & 676.193 & 76.236 & 1108.514 & \text { Yes } \\ 1.00 & 4.34 & 27.69 & 30.26 & 2 & 124.7982 & \end{array}$ \begin{tabular}{lllllllllllllllll} 
& 1.00 & 49.34 & 27.69 & 30.26 & 2 & 1248.7082 & 1248.7056 & 625.3601 & 0.0026 & 2.0788 & 1269.679 & 722.110 & 44.802 & 1318.251 & Yes \\
\hline
\end{tabular}

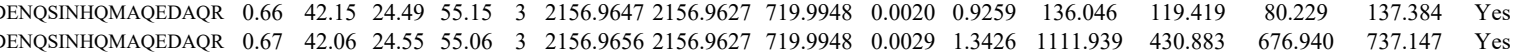
$\begin{array}{llllllllllllllllll} & \\ \text { LLVSMCQGNR } & 1.00 & 51.51 & 26.68 & 22.83 & 2 & 1309.6426 & 1309.6427 & 655.8286 & -0.0001 & -0.0762 & 2237.888 & 1262.642 & 69.953 & 1850.717 & \text { Yes }\end{array}$ $\begin{array}{llllllllllllllll}1.00 & 46.23 & 26.67 & 21.92 & 2 & 1309.6428 & 1309.6427 & 655.8286 & 0.0001 & 0.0762 & 2564.529 & 1595.494 & 69.606 & 2609.602 & \text { Yes }\end{array}$ $\begin{array}{lllllllllllllllll} & 1.00 & 48.74 & 26.65 & 24.31 & 2 & 1309.6434 & 1309.6427 & 655.8286 & 0.0007 & 0.5337 & 2050.946 & 1092.671 & 93.462 & 1976.486 & \text { Yes }\end{array}$ $\begin{array}{llllllllllllllll} & 1.00 \\ \text { LLVSMCQGNR } & 1.00 & 44.69 & 26.59 & 22.84 & 2 & 1309.6436 & 1309.6427 & 655.8286 & 0.0009 & 0.6862 & 2660.270 & 1629.962 & 140.812 & 2698.976 & \text { Yes }\end{array}$

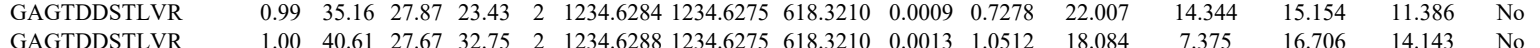
$\begin{array}{lllllllllllllllll}0.94 & 41.46 & 25.01 & 38.21 & 2 & 1028.6540 & 1028.6473 & 515.3309 & 0.0067 & 6.5006 & 14393.492 & 14428.448 & 10204.060 & 36947.869 & \text { Yes }\end{array}$ $\begin{array}{llllllllllllllll}\text { LAEALPK } & 0.97 & 43.72 & 24.80 & 38.49 & 2 & 1028.6554 & 1028.6473 & 515.3309 & 0.0081 & 7.8590 & 5439.108 & 5858.821 & 3037.479 & 14644.557 & \text { Yes }\end{array}$ $\begin{array}{llllllllllllllll}\text { LAEALPK } & 0.95 & 32.76 & 24.56 & 31.26 & 2 & 1028.6562 & 1028.6473 & 515.3309 & 0.0089 & 8.6352 & 2549.918 & 2642.905 & 2399.617 & 5693.703 & \text { Yes }\end{array}$ $\begin{array}{lllllllllllllll} & \text { LAEALE }\end{array}$ $\begin{array}{llllllllllllllll} & \end{array}$

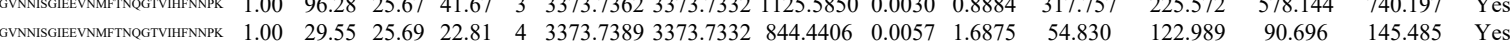
$\begin{array}{lllllllllllllllll} & 37.00 & 37.43 & 25.63 & 37.91 & 3 & 3373.7332 & 3373.7332 & 1125.5850 & 0.0000 & 0.0000 & 61.977 & 64.415 & 47.401 & 116.273 & \text { Yes }\end{array}$

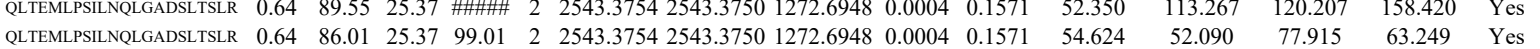


$\begin{array}{llllllllllll} & \end{array}$

$\begin{array}{llllllllllll}\text { YGVDIPEDENEK } & 0.64 & 31.33 & 27.28 & 44.33 & 2 & 1694.8240 & 1694.8243 & 848.4194 & -0.0003 & -0.1768 & 68.011\end{array}$

$\begin{array}{lllllllllllll} & \end{array}$ $\begin{array}{lllllllllllllll} & \end{array}$ $\begin{array}{lllllllllllllll}\text { LGVEODLALPAIAVIGDQSSGK } & 1.00 & 58.06 & 23.75 & 23.40 & 3 & 2539.4143 & 2539.4101 & 847.4773 & 0.0042 & 1.6520 & 29.338 & 23.419 & 45.661\end{array}$

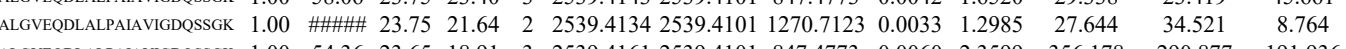
$\begin{array}{llllllllllllll}\text { ALGVEODLALPAIAVIGDQSSGK } & 1.00 & 54.36 & 23.65 & 18.91 & 3 & 2539.4161 & 2539.4101 & 847.4773 & 0.0060 & 2.3599 & 356.178 & 290.877 & 191.936 \\ \text { TIGILTKPDDLVDK } & 0.84 & 58.44 & 17.48 & 71.44 & 2 & 1844.1366 & 1844.1348 & 923.0747 & 0.0018 & 0.9750 & 2336.125 & 2303.918 & 26.593\end{array}$ $\begin{array}{lllllll} & \end{array}$ $\begin{array}{lllllllllllll}1.00 & 53.32 & 23.86 & 20.35 & 2 & 1280.7694 & 1280.7584 & 641.3865 & 0.0110 & 8.5751 & 1715.308 & 1161.332 & 0.000\end{array}$

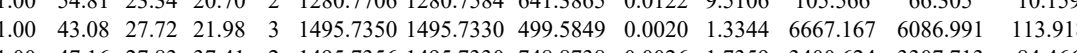

NFEEFFNLHR

NFEEFFNLHR

LTSELITHICK

LTSELITHICK

LTSELITHICK

SSVLEALSGVALPR

SSVLEALSGVALPR

SSVLEALSGVALPR

SSVLEALSGVALPR

SSVLEALSGVALPR

SSVLEALSGVALPR

SSVLEALSGVALPR

SSVLEALSGVALPR

SSVLEALSGVALPR

SSVLEALSGVALPR

SSVLEALSGVALPR
SSVLEALSGVALPR

VRPCIDLIDSLR

VRPCIDLIDSLR

VRPCIDLIDSLR

SSVLEALSGVALPR

SSVLEALSGVALP

VRPCIDLIDSLR

VRPCTDLIDSLR

$\begin{array}{lllllllllllll}1.00 & 4.08 & 27.72 & 1.98 & 3 & 145.7350 & 1495.7330 & 49.5849 & 0.020 & 1.334 & 6667.167 & 086.991\end{array}$

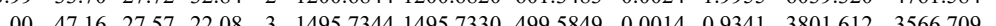

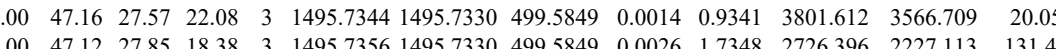

$\begin{array}{llllllllllllll}1.00 & 48.90 & 28.16 & 28.30 & 3 & 1590.8755 & 1590.8717 & 531.2978 & 0.0038 & 2.3841 & 5044.307 & 5706.640 & 59.257\end{array}$

$\begin{array}{lllllllllllll}1.00 & 40.85 & 28.02 & 23.08 & 3 & 1590.8776 & 1590.8717 & 531.2978 & 0.0059 & 3.7016 & 4862.888 & 5079.161 & 0.000\end{array}$

$\begin{array}{lllllllllllll}1.00 & 49.08 & 28.20 & 24.98 & 3 & 1590.8749 & 1590.8717 & 531.2978 & 0.0032 & 2.0077 & 10708.130 & 9615.743 & 82.565 \\ 1.00 & 52.28 & 28.10 & 28.18 & 3 & 1590.8764 & 1590.8717 & 531.2978 & 0.0047 & 2.9487 & 10631.378 & 8357.756 & 78.738\end{array}$

$\begin{array}{lllllllllllll}1.00 & 88.85 & 25.72 & 20.91 & 3 & 1541.8909 & 1541.8899 & 514.9706 & 0.0010 & 0.6473 & 171.595 & 136.665 & 76.575\end{array}$

$\begin{array}{lllllllllllll}1.00 & 85.56 & 25.65 & 25.89 & 2 & 1541.8914 & 1541.8899 & 771.9522 & 0.0015 & 0.9716 & 1546.360 & 1722.069 & 0.000\end{array}$

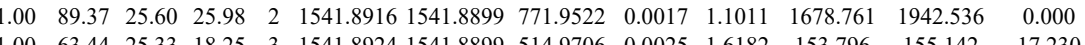

$\begin{array}{llllllllllllll}1.00 & 63.44 & 25.33 & 18.25 & 3 & 1541.8924 & 1541.8899 & 514.9706 & 0.0025 & 1.6182 & 153.796 & 155.142 & 17.230 \\ 1.00 & 90.32 & 25.68 & 25.63 & 2 & 1541.8906 & 1541.8899 & 771.9522 & 0.0007 & 0.4534 & 13310.853 & 12170.208 & 247.122\end{array}$

$\begin{array}{llllllllllllll}1.00 & 96.61 & 25.65 & 26.13 & 2 & 1541.8914 & 1541.8899 & 771.9522 & 0.0015 & 0.9716 & 11285.668 & 10634.814 & 0.000\end{array}$

$\begin{array}{lllllllllllll}0.66 & 74.92 & 25.33 & 87.92 & 3 & 1541.8924 & 1541.8899 & 514.9706 & 0.0025 & 1.6182 & 541.436 & 687.025 & 116.117 \\ 0.67 & 66.57 & 25.33 & 79.57 & 3 & 1541.8930 & 1541.8899 & 514.9706 & 0.0031 & 2.0066 & 567.748 & 832.082 & 27.006\end{array}$

$\begin{array}{lllllllllllll}1.00 & 85.80 & 25.48 & 26.39 & 2 & 1541.8874 & 1541.8899 & 771.9522 & -0.0025 & -1.6193 & 2948.740 & 3358.698 & 0.000 \\ 1.00 & 89.23 & 25.37 & 24.86 & 2 & 1541.8892 & 1541.8899 & 771.9522 & -0.0007 & -0.4534 & 5603.952 & 5104.321 & 121.839\end{array}$

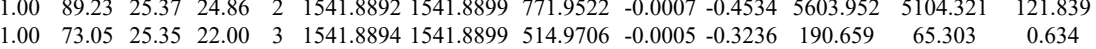

$\begin{array}{lllllllllllll}1.00 & 76.04 & 25.35 & 21.59 & 3 & 1541.8897 & 1541.8899 & 514.9706 & -0.0002 & -0.1295 & 327.350 & 292.673 & 37.708\end{array}$

$\begin{array}{lllllllllllll}1.00 & 50.52 & 27.93 & 33.01 & 2 & 1588.8558 & 1588.8551 & 795.4348 & 0.0007 & 0.4400 & 3572.642 & 4590.893 & 369.086 \\ 1.00 & 47.48 & 28.22 & 29.52 & 3 & 1588.8586 & 1588.8551 & 530.6256 & 0.0035 & 2.1987 & 7574.304 & 14184.732 & 1928.906\end{array}$

$\begin{array}{llllllllllllll}1.00 & 47.48 & 28.22 & 29.52 & 3 & 1588.8586 & 1588.8551 & 530.6256 & 0.0035 & 2.1987 & 7574.304 & 14184.732 & 1928.906 \\ 1.00 & 49.17 & 28.19 & 28.83 & 2 & 1588.8588 & 1588.8551 & 795.4348 & 0.0037 & 2.3258 & 3632.972 & 4334.466 & 417.586\end{array}$ $\begin{array}{lllllllllllll}1.00 & 49.17 & 28.19 & 28.83 & 2 & 1588.8588 & 1588.8551 & 795.4348 & 0.0037 & 2.3258 & 3632.972 & 4334.466 & 417.586 \\ 1.00 & 39.12 & 28.06 & 27.41 & 3 & 1588.8595 & 1588.8551 & 530.6256 & 0.0044 & 2.7640 & 11892.230 & 14926.090 & 1084.918\end{array}$ $\begin{array}{lllllllllllll}1.00 & 39.12 & 28.06 & 27.41 & 3 & 1588.8595 & 1588.8551 & 530.6256 & 0.0044 & 2.7640 & 11892.230 & 4926.090 & 1084.918 \\ 1.00 & 47.53 & 25.60 & 23.74 & 3 & 1541.8921 & 1541.8899 & 514.9706 & 0.0022 & 1.4240 & 101.989 & 167.186 & 20.331\end{array}$ $\begin{array}{lllllllllllll}1.00 & 47.53 & 25.60 & 23.74 & 3 & 1541.8921 & 1581.8899 & 514.9706 & 0.0022 & 1.4240 & 101.989 & 167.186 & 20.331 \\ 1.00 & 56.34 & 25.33 & 21.26 & 3 & 1541.8930 & 1541.8899 & 514.9706 & 0.0031 & 2.0066 & 79.130 & 140.811 & 46.040\end{array}$ $\begin{array}{lllllllllllll}1.00 & 56.34 & 25.33 & 21.26 & 3 & 1541.8930 & 1541.8899 & 514.9706 & 0.0031 & 2.0066 & 79.130 & 140.811 & 46.040 \\ 1.00 & 42.24 & 27.90 & 31.07 & 2 & 1588.8568 & 1588.8551 & 795.4348 & 0.0017 & 1.0686 & 1020.396 & 1411.235 & 138.464\end{array}$

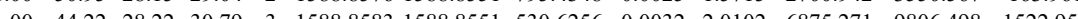

VRPCIDLIDSLR 

$\begin{array}{llllllllllllllllll} & \end{array}$ $\begin{array}{lllllllllll}3 & 2291.2225 & 2291.2187 & 764.7468 & 0.0038 & 1.6563 & 250.834 & 355.872 & 286.662 & 82.513 & \text { Yes }\end{array}$ $\begin{array}{lllllllllllllllll}\text { DNNQVGFK } & 1.00 & 85.58 & 26.31 & 18.59 & 2 & 2291.2274 & 2291.2187 & 1146.6166 & 0.0087 & 3.7938 & 134.042 & 88.021 & 142.727 & 143.801 & \text { Yes }\end{array}$ $\begin{array}{llllllllllllllll} & 0.81 & 25.47 & 25.26 & 25.32 & 2 & 1009.6008 & 1009.5908 & 505.8027 & 0.0100 & 9.8852 & 33810.620 & 35578.511 & 1709.349 & 56240.266 & \text { Yes }\end{array}$ $\begin{array}{llllllllllllllll} & 0.81 & & \end{array}$ $\begin{array}{llllllllllllllll}\text { ICIVTK } & 0.97 & 34.87 & 25.26 & 25.99 & 2 & 1009.6006 & 1009.5908 & 505.8027 & 0.0098 & 9.6875 & 17990.318 & 14663.538 & 1503.924 & 25182.502 & \text { Yes }\end{array}$ $\begin{array}{lllllllllllllllll}0.82 & 25.91 & 25.26 & 27.64 & 2 & 1009.6006 & 1009.5908 & 505.8027 & 0.0098 & 9.6875 & 4669.124 & 3894.478 & 1068.751 & 5149.221 & \text { Yes }\end{array}$

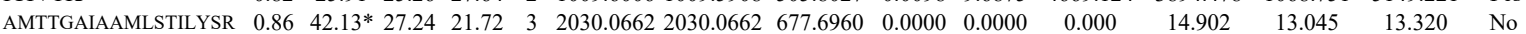
$\begin{array}{lllllllllllllll} & 26.52 & 23.76 & 2 & 2014.0734 & 2014.0713 & 1008.0429 & 0.0021 & 1.0416 & 3.957 & 12.941 & 11.159 & 8.985 & \text { Yes }\end{array}$ $\begin{array}{llllllllllllllll}\text { AMTTGAIAAMLSTILYSR } & 1.00 & 37.51 & 26.62 & 16.43 & 3 & 2014.0738 & 2014.0713 & 672.3644 & 0.0025 & 1.2394 & 9.962 & 5.950 & 4.940 & 2.009 & \text { Yes }\end{array}$ $\begin{array}{llllllllllllllll}\text { AMTTGAIAAMLSTILYSR } & 0.99 & 29.06 & 26.54 & 17.09 & 3 & 2014.0729 & 2014.0713 & 672.3644 & 0.0016 & 0.7932 & 16.371 & 8.060 & 6.512 & 5.319 & \text { Yes }\end{array}$ $\begin{array}{lllllllllllllll} & 26.52 & 30.44 & 2 & 2014.0734 & 2014.0713 & 1008.0429 & 0.0021 & 1.0416 & 27.920 & 19.043 & 5.862 & 11.503 & \text { Yes }\end{array}$ $\begin{array}{llllllllllllllll}\text { AMTTGAIAAMLSTILYSR } & 0.66 & 42.62 & 26.52 & 55.62 & 3 & 2014.0735 & 2014.0713 & 672.3644 & 0.0022 & 1.0907 & 11.200 & 17.989 & 12.158 & 6.063 & \text { Yes }\end{array}$ \begin{tabular}{llllllllllllllll} 
AMTIGAIAAMLSTILYSR & 1.00 & 46.47 & 26.79 & 19.59 & 3 & 2014.0681 & 2014.0713 & 672.3644 & -0.0032 & -1.5864 & 6.573 & 22.883 & 12.399 & 12.901 & Yes \\
\hline
\end{tabular}

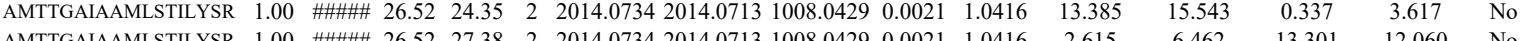
$\begin{array}{lllllllllllll} & \end{array}$

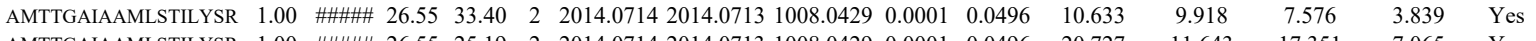

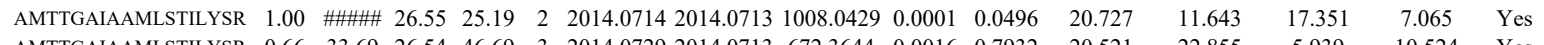

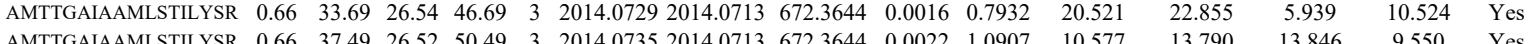

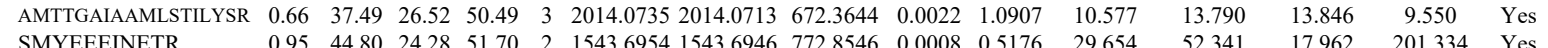

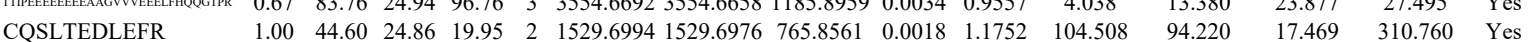
$\begin{array}{llllllllllllllll}\text { CQSLTEDLEFR } & 1.00 & 70.72 & 24.86 & 22.57 & 2 & 1529.6994 & 1529.6976 & 765.8561 & 0.0018 & 1.1752 & 117.866 & 133.894 & 48.168 & 401.015 & \text { Yes }\end{array}$

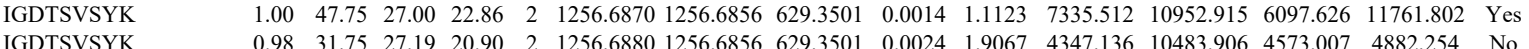

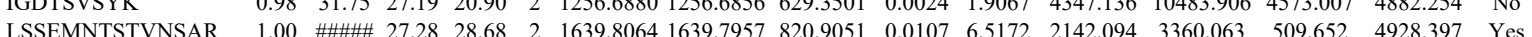
$\begin{array}{lllllllllllllll} & \text { LSSEMNTSTVNSAR } & 1.00 & \# \# \# \# \frac{27.28}{28.69} & 2 & 1639.8064 & 1639.7957 & 820.9051 & 0.0107 & 6.5172 & 507.602 & 726.728 & 142.578 & 1198.467 & \text { Yes }\end{array}$ $\begin{array}{llllllllllllllll}\text { AGGPTPLSPTR } & 1.00 & 57.53 & 27.88 & 23.32 & 2 & 1297.7116 & 1297.7112 & 649.8629 & 0.0004 & 0.3078 & 6479.975 & 9098.311 & 8803.684 & 10051.523 & \text { Yes }\end{array}$ $\begin{array}{lllllllllllllllll}\text { AGGPTPLSPTR } & 1.00 & 52.71 & 27.83 & 21.64 & 2 & 1297.7104 & 1297.7112 & 649.8629 & -0.0008 & -0.6155 & 1108.139 & 1564.747 & 2010.576 & 1782.447 & \text { Yes }\end{array}$

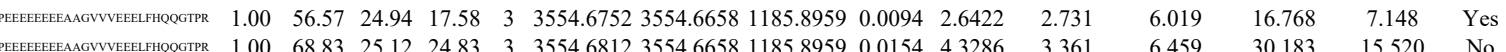
$\begin{array}{lllllllllllllll} & & & \end{array}$

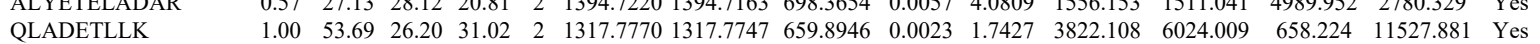

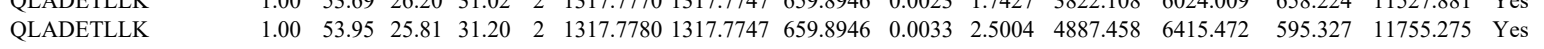
$\begin{array}{llllllllllllllll}\text { DQMQQQLNDYEQLLDVK } & 0.98 & 25.67 & 27.18 & 16.71 & 3 & 2395.1959 & 2395.1933 & 799.4050 & 0.0026 & 1.0841 & 46.456 & 41.912 & 43.073 & 83.269 & \text { Yes }\end{array}$ $\begin{array}{llllllllllllllll}\text { DQMQQQLNDYEQLLDVK } & 0.67 & 18.34 & 27.18 & 31.34 & 3 & 2395.1965 & 2395.1933 & 799.4050 & 0.0032 & 1.3343 & 24.408 & 24.983 & 31.668 & 6.330 & \text { No }\end{array}$

$\begin{array}{lllllllllllllllll}37 & \text { DLDDALDK } & 1.00 & 43.77 & 27.60 & 23.67 & 2 & 1191.6240 & 1191.6227 & 596.8186 & 0.0013 & 1.0891 & 430.848 & 274.918 & 273.378 & 300.625 & \text { Yes }\end{array}$ $\begin{array}{lllllllllllllllll}\text { SESELIDELSEDFDR } & 1.00 & 88.88 & 26.46 & 21.00 & 2 & 1926.8824 & 1926.8816 & 964.4481 & 0.0008 & 0.4147 & 75.434 & 93.381 & 32.938 & 164.103 & \text { Yes }\end{array}$ $\begin{array}{llllllllllllllllll}\text { SESELIDELSEDFDR } & 1.00 & 99.20 & 26.41 & 21.87 & 2 & 1926.8832 & 1926.8816 & 964.4481 & 0.0016 & 0.8295 & 88.645 & 172.604 & 53.511 & 218.886 & \text { Yes }\end{array}$

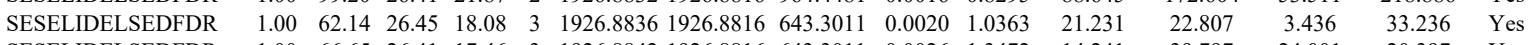
$\begin{array}{llllllllllllllll}\text { SESELIDELSEDFDR } & 1.00 & 66.65 & 26.41 & 17.46 & 3 & 1926.8842 & 1926.8816 & 643.3011 & 0.0026 & 1.3472 & 14.241 & 39.797 & 24.001 & 20.397 & \text { Yes }\end{array}$

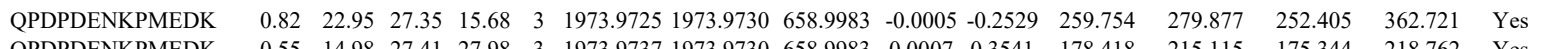
$\begin{array}{lllllllllllllllll}\text { QPDPDENKPMEDK } & 0.55 & 14.98 & 27.41 & 27.98 & 3 & 1973.9737 & 1973.9730 & 658.9983 & 0.0007 & 0.3541 & 178.418 & 215.115 & 175.344 & 218.762 & \text { Yes }\end{array}$ $\begin{array}{llllllllllllllll}\text { DTSQSDKDLDDALDK } & 0.84 & 32.59 & 27.43 & 22.65 & 3 & 2097.0466 & 2097.0439 & 700.0219 & 0.0027 & 1.2857 & 257.108 & 218.168 & 276.986 & 368.505 & \text { Yes }\end{array}$ $\begin{array}{llllllllllllllll}\text { EKPSKPTEK } & 0.73 & 7.53 & 22.43 & 20.53 & 4 & 1618.9733 & 1618.9741 & 405.7508 & -0.0008 & -0.4929 & 406.485 & 319.465 & 563.798 & 694.364 & \text { Yes }\end{array}$ $\begin{array}{llllllllllllllll}\text { GTVPDDAVEALADSLGK } & 1.00 & 83.04 & 27.43 & 19.09 & 2 & 1945.0268 & 1945.0248 & 973.5197 & 0.0020 & 1.0272 & 66.227 & 34.719 & 43.678 & 79.779 & \text { Yes } \\ \text { GTVPDAVEALADSLGK } & 1.00 & 82.25 & 27.55 & 22.30 & 2 & 1945.0272 & 1945.0248 & 973.5197 & 0.0024 & 1.2326 & 43.233 & 26.238 & 16.480 & 21.074 & \text { Yes }\end{array}$

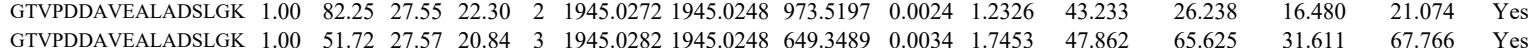

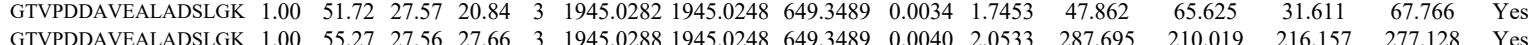

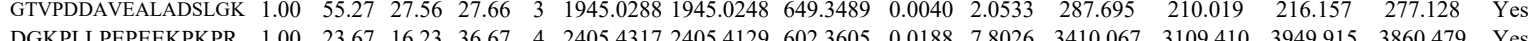

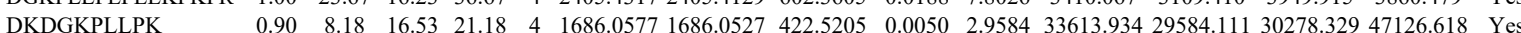
$\begin{array}{lllllllllllllllllll}\text { DKDGKPLLPK } & 0.90 & 8.18 & 16.53 & 21.18 & 4 & 1686.0577 & 1686.0527 & 422.520 & 0.0050 & 2.9584 & 33613.934 & 29584.111 & 30278.329 & 47126.618 & \text { Yes }\end{array}$

Table S-4 page 216 of 614 
$\begin{array}{llllllllllll} & 25.73 & 20.45 & 2 & 2466.3234 & 2466.3200 & 1234.1673 & 0.0034 & 1.3774 & 0.000\end{array}$

$\begin{array}{lllllllllllll}\text { LAAISEVVSQTPASTTQAGAPPR } & 0.55 & 46.39 & 25.82 & 59.39 & 3 & 2466.3214 & 2466.3200 & 823.1139 & 0.0014 & 0.5670 & 20.694\end{array}$

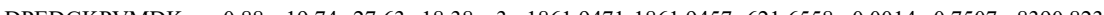

$\begin{array}{llllllllllllll}\text { EADPEDGKPVMDK } & 0.85 & 16.86 & 27.57 & 19.13 & 3 & 1861.9489 & 1861.9457 & 621.6558 & 0.0032 & 1.7158 & 7686.231 & 52\end{array}$ $\begin{array}{lllllllllllll}1.00 & 39.74 & 26.67 & 23.74 & 2 & 1298.7338 & 1298.7324 & 650.3735 & 0.0014 & 1.0763 & 291.461 & 278.269\end{array}$ $\begin{array}{llllllllllll}1.00 & 40.50 & 17.99 & 19.71 & 2 & 1142.7522 & 1142.7509 & 572.3827 & 0.0013 & 1.1356 & 154.549 & 134.897 \\ 0.82 & 54.68 & 17.99 & 67.68 & 2 & 1142.7522 & 1142.7509 & 572.3827 & 0.0013 & 1.1356 & 119.845 & 133.736\end{array}$

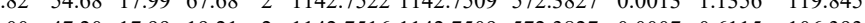
$\begin{array}{lllllllllll}1.00 & 47.20 & 17.99 & 19.21 & 2 & 1142.7516 & 142.7509 & 572.3827 & 0.0007 & 0.6115 & 106.393\end{array}$

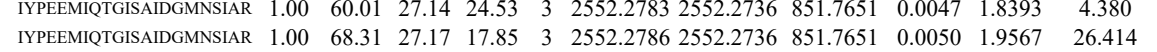
$\begin{array}{llllllllllll}\text { IYPEEMIQTGISAIDGMNSIIAR } & 1.00 & 68.31 & 27.17 & 17.85 & 3 & 2552.2786 & 2552.2736 & 851.7651 & 0.0050 & 1.9567 & 26.414 \\ \text { IYPEEMIQTGISAIDGMNSIAR } & 1.00 & 57.79 & 27.19 & 19.01 & 3 & 2552.2789 & 2552.2736 & 851.7651 & 0.0053 & 2.0741 & 14.117\end{array}$ $\begin{array}{lllllllllllll}\text { IYPEEMIQTGISAIDGMNSIAR } & 1.00 & 57.79 & 27.19 & 19.01 & 3 & 2552.2789 & 2552.2736 & 851.7651 & 0.0053 & 2.0741 & 14.117 \\ \text { TVFETLDIGWQLLR } & 1.00 & 52.77 & 26.36 & 27.14 & 2 & 1834.0120 & 1834.0111 & 918.0128 & 0.0009 & 0.4902 & 629.224\end{array}$ $\begin{array}{lllllllllllll}\text { TVFETLDIGWQLLR } & 0.92 & 19.32 & 26.21 & 14.31 & 3 & 1834.0156 & 1834.0111 & 612.3443 & 0.0045 & 2.4496 & 47.618\end{array}$ $\begin{array}{lllllllllllll}\text { IVIFSAAGLPHNEIAAQICR } & 0.66 & 63.39 & 26.97 & 76.39 & 3 & 2310.2119 & 2310.2098 & 771.0772 & 0.0021 & 0.9078 & 974.500\end{array}$ 

$\begin{array}{llllllllllll}\text { GLVEPVDVVDNADGTOTVNYVPSR } & 1.00 & \text { \#\#\#\# } 27.41 & 24.27 & 2 & 2687.3534 & 2687.3525 & 1344.6835 & 0.0009 & 0.3347 & 7.106 \\ \text { GLVEPDVVDNADGTQTVNYVPSR } & 1.00 & \text { \#\#\#\#\# } 27.41 & 22.80 & 2 & 2687.3534 & 2687.3525 & 1344.6835 & 0.0009 & 0.3347 & 1.767\end{array}$ 1.767

$\begin{array}{llllllllllllllllll}\text { VEPGLGADNSVVR } & 1.00 & 57.05 & 27.29 & 35.67 & 2 & 1373.7810 & 1373.7758 & 687.8952 & 0.0052 & 3.7796 & 23214.246 & 17814.861 & 8539.359 & 19258.685 & \text { Yes }\end{array}$ $\begin{array}{llllllllllllllll}\text { DKGEYTLVVK } & 0.62 & 33.27 & 23.28 & 20.60 & 3 & 1582.9378 & 1582.9296 & 528.6505 & 0.0082 & 5.1704 & 11275.707 & 7051.866 & 11676.527 & 12169.533 & \text { Yes }\end{array}$

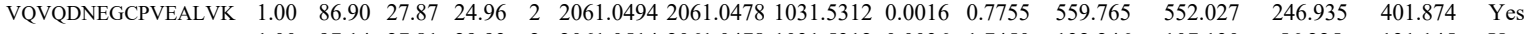
$\begin{array}{llllllllllllll} & \end{array}$

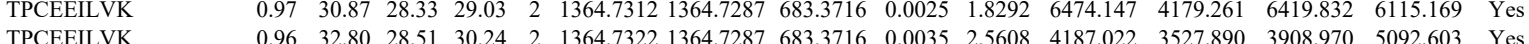
$\begin{array}{llllllllllllllll}\text { TPCEEILVK } & 0.96 & 32.80 & 28.51 & 30.24 & 2 & 1364.7322 & 1364.7287 & 683.3716 & 0.0035 & 2.5608 & 4187.022 & 3527.890 & 3908.970 & 5092.603 & \text { Yes }\end{array}$

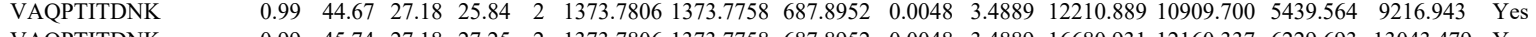
\begin{tabular}{llllllllllllllllll} 
VAQPTITDNK & 0.99 & 45.74 & 27.18 & 27.25 & 2 & 1373.7806 & 1373.7758 & 687.8952 & 0.0048 & 3.4889 & 16680.931 & 12160.337 & 6229.693 & 13043.479 & Yes \\
\hline
\end{tabular} $\begin{array}{llllllllllllllll}\text { VEPGLGADNSVVR } & 1.00 & 71.01 & 28.22 & 34.61 & 2 & 1455.7938 & 1455.7804 & 728.8975 & 0.0134 & 9.1919 & 1674.863 & 1559.886 & 0.000 & 1298.718 & \text { No }\end{array}$ $\begin{array}{lllllllllllllllll}\text { VEPGLGADNSVVR } & 1.00 & 74.97 & 28.20 & 28.18 & 2 & 1455.7944 & 1455.7804 & 728.8975 & 0.0140 & 9.6035 & 1532.134 & 1285.923 & 107.870 & 1068.782 & \text { Yes } \\ \text { VANPSGNTETYVQDR } & 1.00 & 94.41 & 28.07 & 26.22 & 2 & 1906.9696 & 1906.9507 & 954.482 & 0.0189 & 9.9006 & 2760.929 & 2235.491 & 441.500 & 2361.991 & \text { Yes }\end{array}$

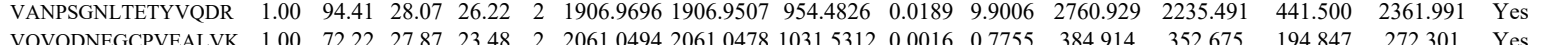
$\begin{array}{llllllllllllllll}\text { VQVQDNEGCPVEALVK } & 1.00 & 72.22 & 27.87 & 23.48 & 2 & 2061.0494 & 2061.0478 & 1031.5312 & 0.0016 & 0.7755 & 384.914 & 352.675 & 194.847 & 272.301 & \text { Yes } \\ \text { VQVQDNEGCPVEALVK } & 1.00 & 76.33 & 27.81 & 22.67 & 2 & 2061.0514 & 2061.0478 & 1031.5312 & 0.0036 & 1.7450 & 548.211 & 490.924 & 288.979 & 417.590 & \text { Yes }\end{array}$

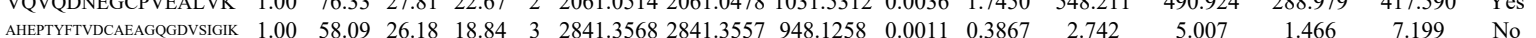
$\begin{array}{lllllllllllllll} & \end{array}$

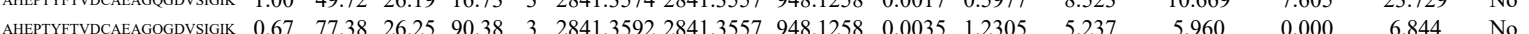

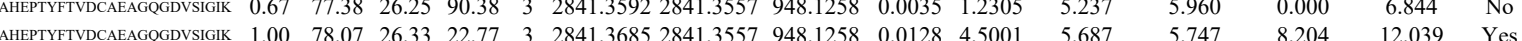

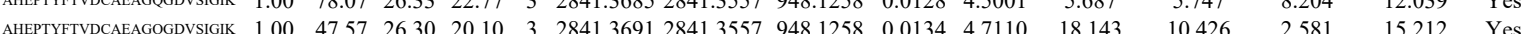

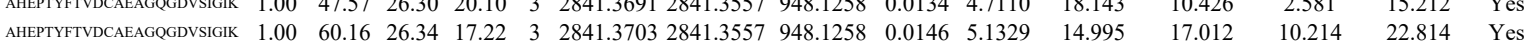

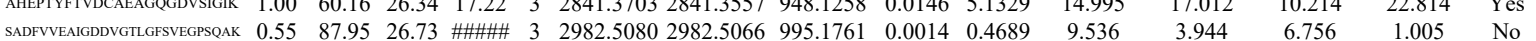

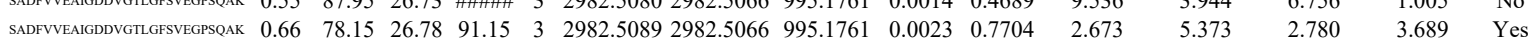

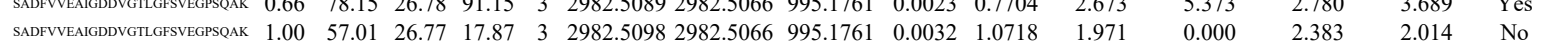
$\begin{array}{llllllllllllllll}\text { SADFVVEAGDDVGTLGFVEGPSOAK } & 0.67 & 80.15 & 26.79 & 93.15 & 3 & 2982.5101 & 2982.5066 & 995.1761 & 0.0035 & 1.1723 & 3.287 & 2.696 & 7.028 & 10.603 & \text { No }\end{array}$ $\begin{array}{lllllllllllllllll}\text { SADFVVEAGDDVGTLGFVEGPSQAK } & 0.67 & 52.36 & 26.79 & 65.36 & 3 & 2982.5101 & 2982.5066 & 995.1761 & 0.0035 & 1.1723 & 0.000 & 0.000 & 6.042 & 16.748 & \text { No }\end{array}$ $\begin{array}{llllllllllllllll}\text { SADFVVEAGDDVGTLGFSVEGPSAK } & 1.00 & 94.72 & 26.80 & 20.89 & 3 & 2982.5104 & 2982.5066 & 995.1761 & 0.0038 & 1.2728 & 0.000 & 0.000 & 2.892 & 3.435 & \text { No }\end{array}$ $\begin{array}{llllllllllllllll}\text { SADFVVEAIGDDGGLGFSVEGPSQAK } & 1.00 & 98.66 & 26.84 & 21.40 & 3 & 2982.5119 & 2982.5066 & 995.1761 & 0.0053 & 1.7752 & 12.237 & 2.342 & 3.138 & 5.971 & \text { No } \\ \text { SADFVVEAGDDVGTLGFVEGPSQAK } & 1.00 & 91.63 & 26.84 & 20.76 & 3 & 2982.5119 & 2982.5066 & 995.1761 & 0.0053 & 1.7752 & 8.431 & 0.000 & 0.000 & 2.480 & \text { No }\end{array}$ $\begin{array}{lllllllllllll}\text { SADNVEAGDDVGLGFSVEGPSAAK } & 1.00 & 91.63 & 26.84 & 20.76 & 3 & 2982.5119 & 2982.5066 & 995.1761 & 0.0053 & 1.7752 & 8.431\end{array}$

TPCEEILVK $\begin{array}{llllllllllllllll}\text { ATCAPQHGAPGPGPADASK } & 1.00 & 47.42 & 26.86 & 17.06 & 3 & 2065.9921 & 2065.9917 & 689.6712 & 0.0004 & 0.1933 & 10373.272 & 8971.112 & 9262.472 & 8245.003 & \text { Yes }\end{array}$ $\begin{array}{lllllllllllllllll}\text { ATCAPQHGAPGPGPADASK } & 1.00 & 48.17 & 26.87 & 21.43 & 3 & 2065.9942 & 2065.9917 & 689.6712 & 0.0025 & 1.2083 & 16007.798 & 19443.624 & 11581.612 & 11669.095 & \text { Yes }\end{array}$ $\begin{array}{llllllllllllllll}\text { AHEPTYADCAEAGGDVSIGKK } & 0.66 & 70.33 & 26.19 & 83.33 & 3 & 2841.3580 & 2841.3557 & 948.1258 & 0.0023 & 0.8086 & 9.463 & 14.516 & 6.620 & 19.613 & \text { Yes }\end{array}$ $\begin{array}{llllllllllllllll}\text { AHEPTFTVCAEAGQGDVSIGIK } & 1.00 & 69.68 & 26.19 & 21.60 & 3 & 2841.3580 & 2841.3557 & 948.1258 & 0.0023 & 0.8086 & 6.664 & 9.900 & 5.986 & 14.430 & \text { Yes } \\ \text { AHEPTYFTVDCES }\end{array}$

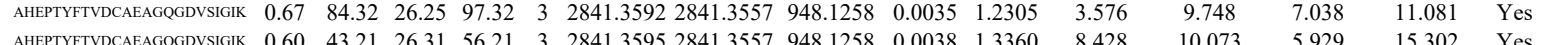

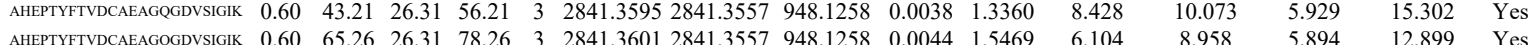
$\begin{array}{lllllllllllllllll} & \end{array}$

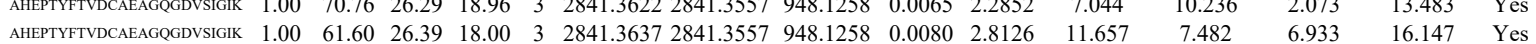
SADFVVENDE $\begin{array}{llllllll} & \end{array}$ $\begin{array}{llllllllllllll}\text { SADFVVEAGDDVGTLGFSVEGPSQAK } & 1.00 & 42.19 & 26.80 & 17.40 & 3 & 2982.5104 & 2982.5066 & 995.1761 & 0.0038 & 1.2728 & 4.924\end{array}$ 


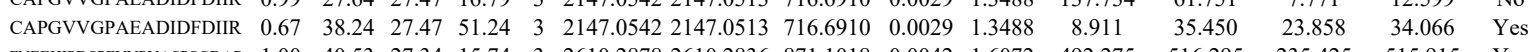
$\begin{array}{llllllllllllllll} & & & \end{array}$

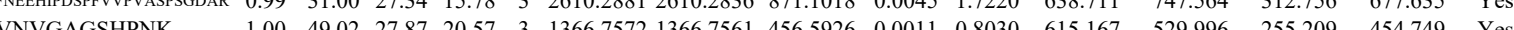

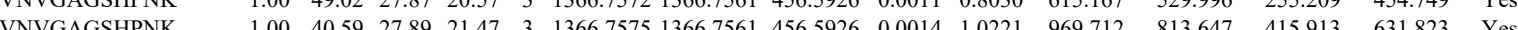
$\begin{array}{llllllllllllllll} & \end{array}$

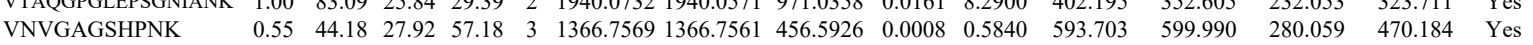

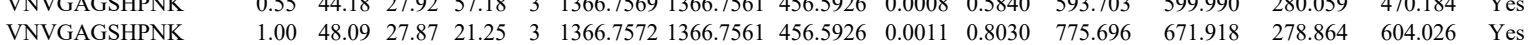

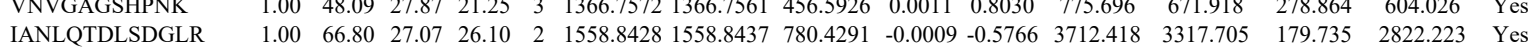
$\begin{array}{lllllllllllllllll}\text { IANLQTDLSDGLR } & 1.00 & 64.32 & 27.23 & 26.71 & 2 & 1558.8438 & 1558.8437 & 780.4291 & 0.0001 & 0.0641 & 6084.300 & 4322.077 & 171.630 & 4474.855 & \text { Yes }\end{array}$ $\begin{array}{lllllllllllllllll}\text { VHGPGIQSGTTNKPNK } & 1.00 & 21.40 & 23.84 & 34.40 & 4 & 2066.1641 & 2066.1598 & 517.5472 & 0.0043 & 2.0771 & 1712.735 & 1448.726 & 1287.761 & 1346.482 & \text { Yes }\end{array}$ $\begin{array}{llllllllllllllll}\text { AWGPGLEGGVVGK } & 1.00 & 92.95 & 26.22 & 36.25 & 2 & 1513.8646 & 1513.8497 & 757.9321 & 0.0149 & 9.8293 & 1221.970 & 992.563 & 450.514 & 962.555 & \text { Yes }\end{array}$ \begin{tabular}{llllllllllllllll} 
IANLQTDLSDGLR & 0.99 & 42.22 & 27.07 & 22.16 & 2 & 1558.8430 & 1558.8437 & 780.4291 & -0.0007 & -0.4485 & 1298.127 & 1362.236 & 546.737 & 1440.807 & Yes \\
\hline
\end{tabular} $\begin{array}{llllllllllllllll}\text { VHGPGIQSGTTNKPNK } & 1.00 & 86.21 & 24.13 & 20.05 & 2 & 2066.1614 & 2066.1598 & 1034.0872 & 0.0016 & 0.7736 & 234.553 & 167.560 & 110.426 & 120.786 & \text { Yes }\end{array}$ $\begin{array}{lllllllllllllllll}\text { YTPVQQGPVGVNVTYGGDPIPK } & 1.00 & 57.61 & 24.98 & 18.22 & 2 & 2573.3974 & 2573.3734 & 1287.6940 & 0.0240 & 9.3189 & 62.506 & 56.057 & 28.818 & 12.173 & \text { Yes }\end{array}$ $\begin{array}{llllllllllllllll}\text { AGVAPLQVK } & 1.00 & 41.44 & 21.21 & 16.34 & 2 & 1169.7420 & 1169.7376 & 585.8761 & 0.0044 & 3.7550 & 33699.394 & 26811.364 & 8990.261 & 20098.277 & \text { Yes }\end{array}$ $\begin{array}{llllllllllllllll}\text { LTVSSLQESGLK } & 1.00 & 67.29 & 25.01 & 46.86 & 2 & 1548.9032 & 1548.8967 & 775.4556 & 0.0065 & 4.1911 & 7966.637 & 6145.994 & 388.675 & 6009.814 & \text { Yes }\end{array}$ $\begin{array}{llllllllllllllll}\text { LTVSSLQESGLK } & 1.00 & 74.41 & 24.91 & 48.77 & 2 & 1548.9044 & 1548.8967 & 775.4556 & 0.0077 & 4.9648 & 8553.597 & 5929.351 & 593.623 & 5555.417 & \text { Yes }\end{array}$ \begin{tabular}{llllllllllllllll} 
AEAGVPAEFSIWTR & 1.00 & 74.46 & 27.95 & 29.51 & 2 & 1676.8666 & 1676.8644 & 839.4395 & 0.0022 & 1.3104 & 3096.879 & 2297.440 & 169.649 & 2928.497 & Yes \\
\hline
\end{tabular} $\begin{array}{llllllllllllllll}\text { AEAGVPAEFSIWTR } & 1.00 & 79.63 & 27.85 & 29.45 & 2 & 1676.8668 & 1676.8644 & 839.4395 & 0.0024 & 1.4295 & 4639.438 & 3928.508 & 211.629 & 3206.874 & \text { Yes }\end{array}$ $\begin{array}{llllllllllllllll}\text { YNEQHVPGSPFTAR } & 1.00 & 73.16 & 27.72 & 20.30 & 2 & 1745.8740 & 1745.8607 & 873.9376 & 0.0133 & 7.6092 & 1221.315 & 1236.225 & 667.942 & 725.692 & \text { Yes }\end{array}$ $\begin{array}{llllllllllllllll}\text { YNEQHVPGSPFTAR } & 0.97 & 32.96 & 27.74 & 22.92 & 3 & 1745.8762 & 1745.8607 & 582.9608 & 0.0155 & 8.8627 & 2980.218 & 3002.302 & 1688.074 & 2197.604 & \text { Yes }\end{array}$ $\begin{array}{llllllllllllllll}\text { YNEQHVPGSPFTAR } & 0.98 & 36.72 & 27.69 & 27.99 & 3 & 1745.8771 & 1745.8607 & 582.9608 & 0.0164 & 9.3773 & 3487.915 & 2866.696 & 2037.172 & 1847.696 & \text { Yes }\end{array}$ \begin{tabular}{llllllllllllllll} 
VHGPGIQSGTTNKPNK & 1.00 & 61.05 & 24.13 & 18.70 & 2 & 2066.1614 & 2066.1598 & 1034.0872 & 0.0016 & 0.7736 & 160.308 & 122.284 & 89.938 & 106.771 & Yes \\
\hline
\end{tabular}

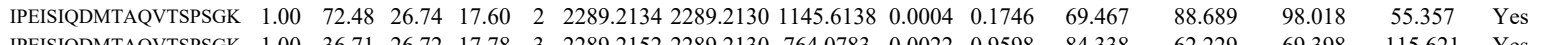

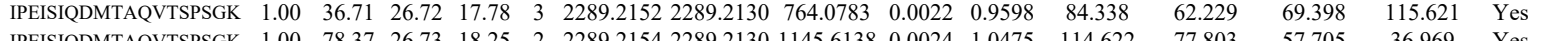

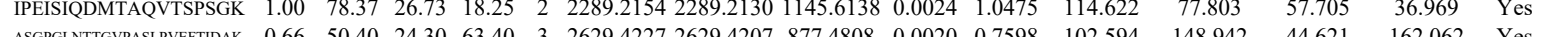

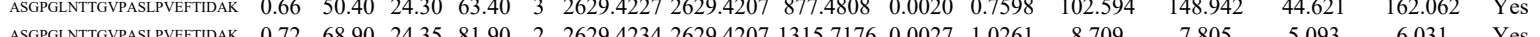
\begin{tabular}{lllllllllllllll}
\hline & S
\end{tabular}

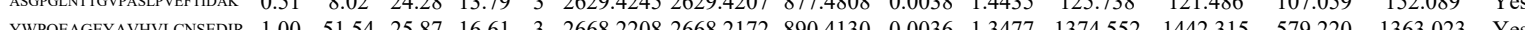

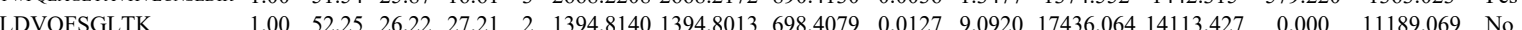

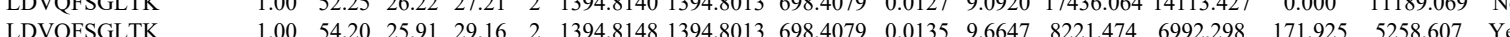
$\begin{array}{llllllllllllllll}\text { APSVANVGSHCDLSLK } & 1.00 & 71.47 & 28.17 & 17.90 & 3 & 1931.0026 & 1930.9848 & 644.6689 & 0.0178 & 9.2036 & 3624.540 & 3612.111 & 1102.121 & 4194.049 & \text { Yes }\end{array}$ $\begin{array}{llllllllllllllll}\text { IPEISIQDMTAQVTSPSGK } & 1.00 & 51.86 & 26.88 & 17.13 & 3 & 2289.2167 & 2289.2130 & 764.0783 & 0.0037 & 1.6141 & 58.193 & 46.532 & 50.912 & 57.016 & \text { Yes }\end{array}$

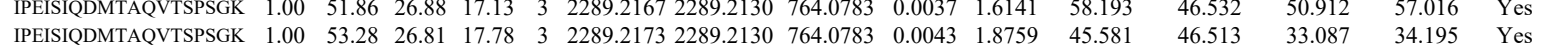

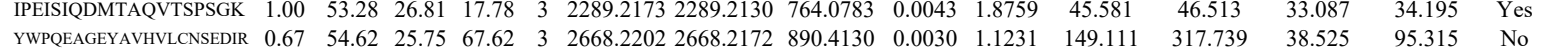

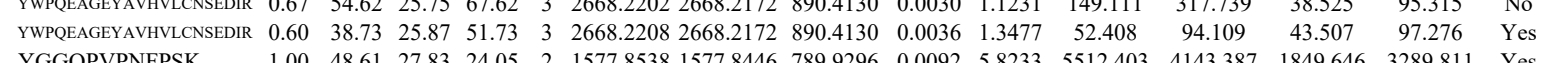

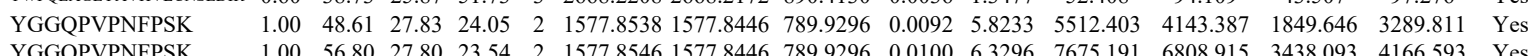
$\begin{array}{lllllllllllllllll}\text { FVPAEMGTHTVSVK } & 1.00 & 56.80 & 27.80 & 23.54 & 2 & 1577.8546 & 1577.8446 & 789.9296 & 0.0100 & 6.3296 & 7675.191 & 6808.915 & 3438.093 & 4166.593 & \text { Yes } \\ \text { FVPAEM } & 1.00 & 27.13 & 20.56 & 3 & 1789.9765 & 1789.9641 & 597.6620 & 0.0124 & 6.9158 & 24051.722 & 17133.255 & 3361.086 & 12948.081 & \text { Yes }\end{array}$ $\begin{array}{llllllllllllllll}\text { FVPAEMGTHTVSVK } & 1.00 & 52.15 & 27.14 & 21.76 & 3 & 1789.9771 & 1789.9641 & 597.6620 & 0.0130 & 7.2504 & 22403.667 & 17141.992 & 3994.511 & 12868.893 & \text { Yes }\end{array}$ $\begin{array}{lllllllllllllllll}\text { SPFSVAVSPSLDLSK } & 1.00 & 78.73 & 25.92 & 19.59 & 2 & 1821.0146 & 1821.0128 & 911.5137 & 0.0018 & 0.9874 & 210.156 & 190.970 & 154.491 & 195.337 & \text { Yes }\end{array}$ $\begin{array}{lllllllllllllllll}\text { SPFSVAVSPSLDLSK } & 1.00 & 99.03 & 25.68 & 23.93 & 2 & 1821.0164 & 1821.0128 & 911.5137 & 0.0036 & 1.9747 & 306.040 & 315.822 & 319.876 & 252.562 & \text { Yes }\end{array}$

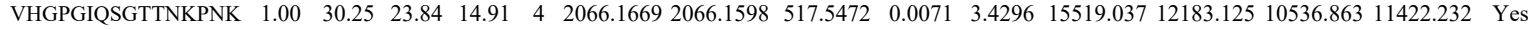
$\begin{array}{lllllllllllllllll}\text { YGGQPVPNFPSK } & 1.00 & 49.41 & 27.81 & 21.81 & 2 & 1577.8542 & 1577.8446 & 789.9296 & 0.0096 & 6.0765 & 2259.821 & 1869.990 & 1164.916 & 1633.922 & \text { Yes }\end{array}$ $\begin{array}{llllllllllllllll}\text { YGGQPVPNFPSK } & 1.00 & 56.11 & 27.80 & 22.49 & 2 & 1577.8548 & 1577.8446 & 789.9296 & 0.0102 & 6.4562 & 5864.997 & 4839.229 & 2523.467 & 3547.956 & \text { Yes }\end{array}$

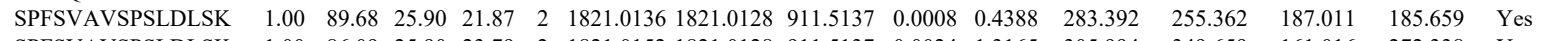

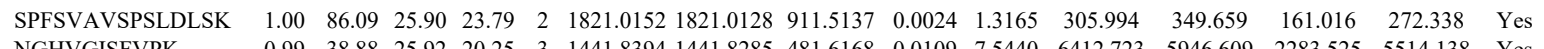
$\begin{array}{llllllllllllllll}\text { NGHVGISFVPK } & 0.99 & 38.88 & 25.92 & 20.25 & 3 & 1441.8394 & 1441.8285 & 481.6168 & 0.0109 & 7.5440 & 6412.723 & 5946.609 & 2283.525 & 5514.138 & \text { Yes }\end{array}$ $\begin{array}{lllllllllllllllll}\text { TFSVWYVPEVTGTHK } & 0.60 & 43.61 & 27.60 & 56.61 & 3 & 2038.0813 & 2038.0768 & 680.3662 & 0.0045 & 2.2047 & 2938.331 & 2679.913 & 144.229 & 1950.982 & \text { Yes }\end{array}$

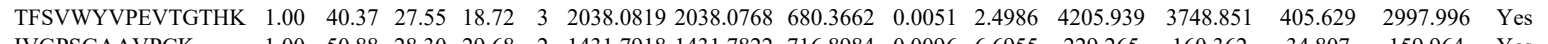

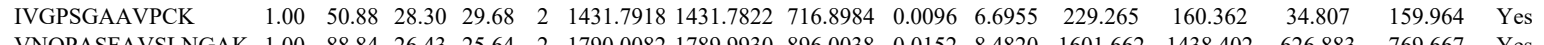

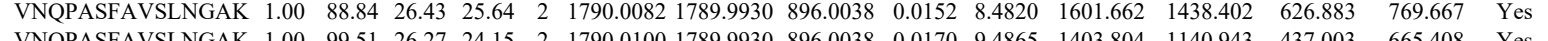

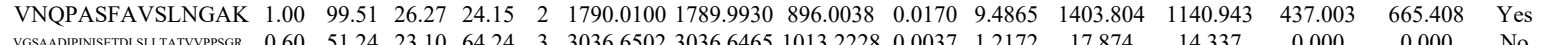

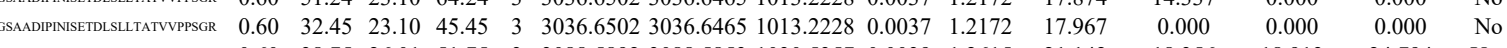
\begin{tabular}{lllllllllllllll}
\hline & & &
\end{tabular}

Table S- 4 page 219 of 614 
$\begin{array}{lllllllllll} & \end{array}$ $\begin{array}{lllllllllll}1.00 & 40.50 & 22.99 & 16.67 & 4 & 3036.650 & 3036.6465 & 760.1689 & 0.0044 & 1.447 & 5.453\end{array}$

$\begin{array}{llllllllllll} & \end{array}$

\section{AFGPGLQGGSAGS}

$\begin{array}{lllll}1.00 & 96.73 & 27.77 & 39.62 \\ 1.00 & \# \# \# \# 2 & 27.77 & 39.57 \\ 0.97 & 33.38 & 27.95 & 24.86 & 3\end{array}$

$\begin{array}{lllll}1572.8268 & 1572.8130 & 787.4138 & 0.0138 & 8.7 \\ 1572.8268 & 15728130 & 787.4138 & 0.0138 & 8.7628\end{array}$

$\begin{array}{lllll}0.78 & 27.40 & 27.90 & 29.23 & 3 \\ 0.93 & 17.89 & 23.36 & 14.47 & 3 \\ 0.60 & 12.49 & 23.10 & 25.49 & 3\end{array}$

588.873915888 .8606

AFGPGLQGGSAGSPAI

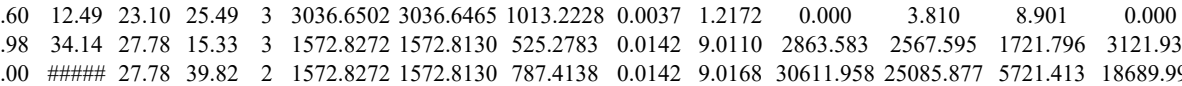

AFGPGLQGGSAGSPAR

FNGTHIPGSPFK

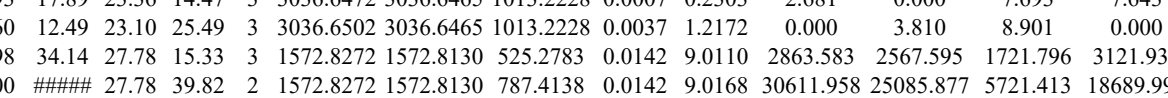

$\begin{array}{lllllllllllllll}1.00 & 96.71 & 27.71 & 39.35 & 2 & 1572.8280 & 1572.8130 & 787.4138 & 0.0150 & 9.5248 & 22716.964 & 19089296 & 4876.521 & 13383.448 & Y \text { Gs }\end{array}$

$\begin{array}{llllllllllllllll} & \end{array}$ $\begin{array}{llllllllllllllll}\text { AFGPGLQGGSAGSPAR } & 1.00 & 94.93 & 27.60 & 32.73 & 2 & 1572.8254 & 1572.8130 & 787.4138 & 0.0124 & 7.8738 & 6854.938 & 5777.130 & 1067.486 & 4000.036 & \text { Yes }\end{array}$ $\begin{array}{llllllllllllllll}\text { AFGPGLQGGSAGSPAR } & 1.00 & 99.87 & 27.77 & 32.27 & 2 & 1572.8262 & 1572.8130 & 787.4138 & 0.0132 & 8.3818 & 16577.624 & 14227.713 & 2641.133 & 10524.245 & \text { Yes }\end{array}$

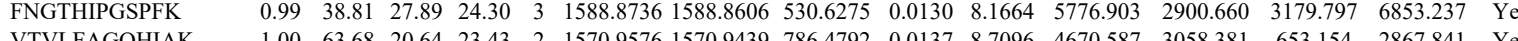

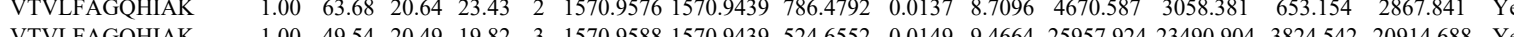

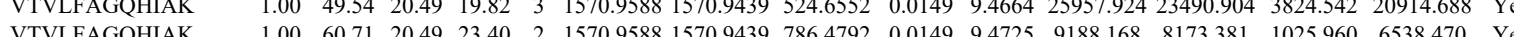

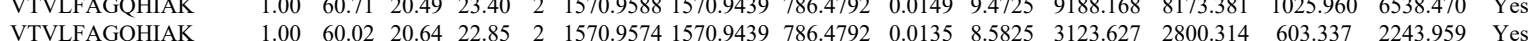
$\begin{array}{llllllllllllllll}\text { VTVLFAGQHIK } & 1.00 & 60.02 & 20.64 & 22.85 & 2 & 1570.9574 & 1570.9439 & 786.472 & 0.0135 & 8.5825 & 3123.627 & 2800.314 & 603.337 & 2243.959 & \text { Yes }\end{array}$

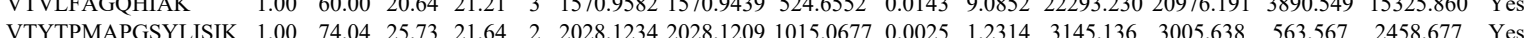

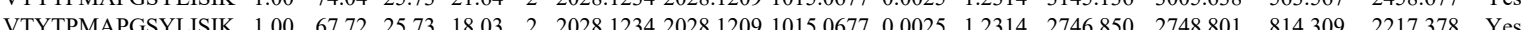

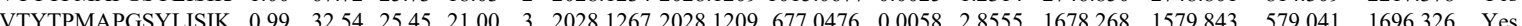

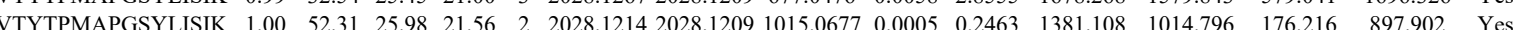

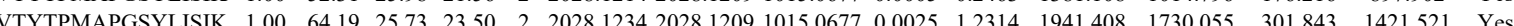
$\begin{array}{llllllllllllllll}\text { VTYTPMAPGSYLISIK } & 1.00 & 37.75 & 25.45 & 20.34 & 3 & 2028.1252 & 2028.1209 & 677.0476 & 0.0043 & 21170 & 1612.112 & 1428.865 & 394.674 & 1275.471 & \text { Yes }\end{array}$ $\begin{array}{llllllllllllllll}\text { VTYTPMAPGSYLISIK } & 1.00 & 40.03 & 25.44 & 20.06 & 3 & 2028.1255 & 2028.1209 & 677.0476 & 0.0046 & 22647 & 711.258 & 762.481 & 194.354 & 927.457 & \text { Yes }\end{array}$

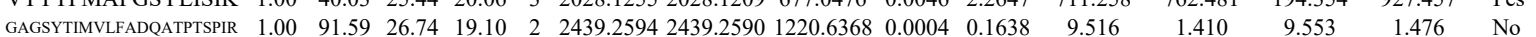
$\begin{array}{llllllllllllllll}\text { GAGSYTIMVLFADQATPTSPIR } & 0.67 & 29.41 & 26.67 & 42.41 & 3 & 2439.2617 & 2439.2590 & 814.0936 & 0.0027 & 1.1055 & 19.855 & 19.657 & 0.000 & 40.686 & \text { No }\end{array}$ \begin{tabular}{lllllllllllllllll} 
GAGSYTIMVLFADQATPTSPIR & 0.67 & 19.88 & 26.67 & 32.88 & 3 & 2439.2623 & 2439.2590 & 814.0936 & 0.0033 & 1.3512 & 23.126 & 7.889 & 7.588 & 23.926 & Yes \\
\hline
\end{tabular}

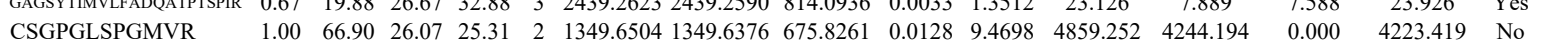
$\begin{array}{llllllllllllllll}\text { VTYTPMAPGSYLISIK } & 1.00 & 67.79 & 25.98 & 23.18 & 2 & 2028.1214 & 2028.1209 & 1015.0677 & 0.0005 & 0.2463 & 150.044 & 100.166 & 30.093 & 81.388 & \text { Yes }\end{array}$ \begin{tabular}{llllllllllllllll} 
VTYTPMAPGSYLISIK & 1.00 & 43.15 & 25.73 & 25.45 & 3 & 2028.1228 & 2028.1209 & 677.0476 & 0.0019 & 0.9354 & 353.210 & 425.293 & 196.632 & 383.492 & Yes \\
\hline
\end{tabular} $\begin{array}{lllllllllllllllll}\text { VTYTPMAPGSYLISIK } & 1.00 & 37.15 & 25.79 & 18.68 & 3 & 2028.1231 & 2028.1209 & 677.0476 & 0.0022 & 1.0831 & 393.086 & 471.007 & 213.658 & 457.341 & \text { Yes }\end{array}$ $\begin{array}{lllllllllllllllll}\text { GAGSYTIMVLFADQATPTSPIR } & 0.55 & 36.18 & 26.75 & 49.18 & 3 & 2439.2599 & 2439.2590 & 814.0936 & 0.0009 & 0.3685 & 52.144 & 42.281 & 0.000 & 142.491 & \text { No }\end{array}$ $\begin{array}{llllllllllllllll}\text { GAGSYTIMVLFADQATPTSPIR } & 0.55 & 32.80 & 26.72 & 45.80 & 3 & 2439.2605 & 2439.2590 & 814.0936 & 0.0015 & 0.6142 & 84.168 & 51.212 & 26.443 & 60.571 & \text { Yes }\end{array}$ $\begin{array}{lllllllllllllllllll}\text { CSYQPTMEGVHTVHVTFAGVPIPR } & 1.00 & 28.55 & 26.73 & 41.55 & 4 & 2815.3753 & 2815.3730 & 704.8505 & 0.0023 & 0.8158 & 762.851 & 838.871 & 230.132 & 859.276 & \text { Yes }\end{array}$

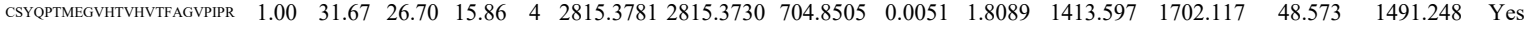
$\begin{array}{llllllllllllllll}\text { CSGPGLSPGMVR } & 1.00 & 60.17 & 26.13 & 30.53 & 2 & 1349.6484 & 1349.6376 & 675.8261 & 0.0108 & 7.9902 & 5074.460 & 4028.805 & 134.917 & 3683.040 & \text { Yes }\end{array}$

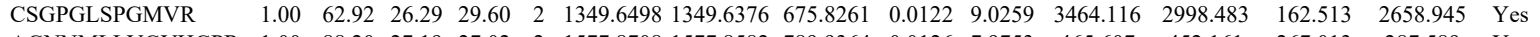

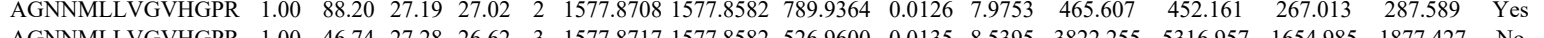
$\begin{array}{lllllllllllllllll}\text { AGNNMLLVGVHGPR } & 1.00 & 46.74 & 27.28 & 26.62 & 3 & 1577.8717 & 1577.8582 & 526.9600 & 0.0135 & 8.5395 & 3822.255 & 5316.957 & 1654.985 & 1877.427 & \text { No }\end{array}$ $\begin{array}{llllllllllllllll}\text { AGNNMLLVGVHGPR } & 1.00 & 75.28 & 27.34 & 28.84 & 2 & 1577.8724 & 1577.8582 & 789.9364 & 0.0142 & 8.9880 & 1256.158 & 1075.701 & 601.435 & 729.411 & \text { Yes }\end{array}$

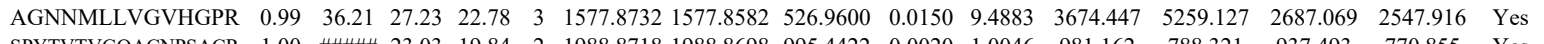

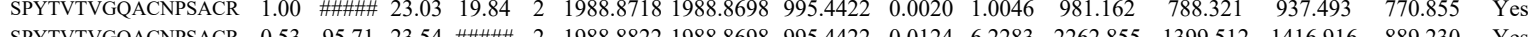
\begin{tabular}{lllllllllllllllll} 
SPYTVTVGQACNPAACR & 0.53 & 95.71 & 23.54 & \#\#\# & 2 & 1988.8822 & 1988.8698 & 995.4422 & 0.0124 & 6.2283 & 2262.855 & 1399.512 & 1416.916 & 889.230 & Yes \\
\hline
\end{tabular} $\begin{array}{llllllllllllllll}\text { CSYQPTMEGVHTVHVTFAGVPIPR } & 1.00 & 44.29 & 26.74 & 16.65 & 4 & 2815.3761 & 2815.3730 & 704.8505 & 0.0031 & 1.0995 & 590.781 & 1205.733 & 531.528 & 578.888 & \text { No }\end{array}$

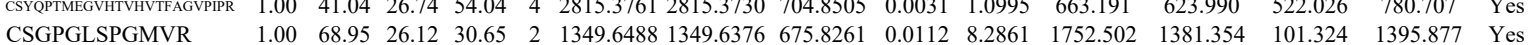

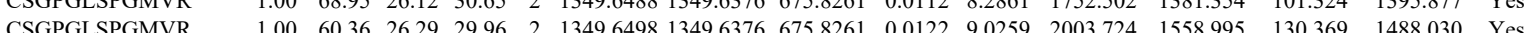
$\begin{array}{llllllllllllllll}\text { CSGPGLSPGMVR } & 1.00 & 60.36 & 26.29 & 29.96 & 2 & 1349.6498 & 1349.6376 & 675.8261 & 0.0122 & 9.0259 & 2003.724 & 1558.995 & 130.369 & 1488.030 & \text { Yes } \\ \text { AGNNMLLVGVHGPR } & 1.00 & 79.06 & 27.19 & 26.67 & 2 & 1577.8706 & 1577.8582 & 789.9364 & 0.0124 & 7.8487 & 1166.259 & 1113.515 & 525.996 & 802.399 & \text { Yes }\end{array}$

Yes

Table S-4 page 220 of 614 
$\begin{array}{llllllllllllllll}\text { AGNNMLLVGVHGPR } & 1.00 & 43.00 & 27.25 & 26.88 & 3 & 1577.8711 & 1577.8582 & 526.9600 & 0.0129 & 8.1599 & 3104.909 & 2080.117 & 526.631 & 1719.060 & \text { Yes }\end{array}$

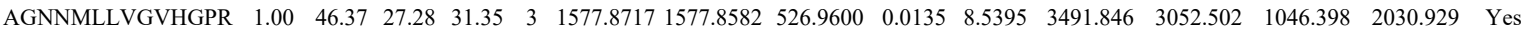

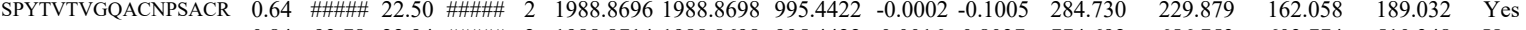

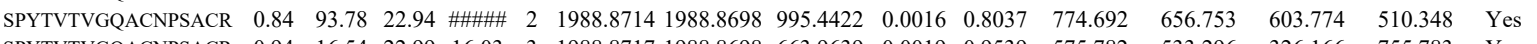
$\begin{array}{llllllllllllllll}\text { SPYTVTVGQACNPSACR } & 0.94 & 16.54 & 22.99 & 16.03 & 3 & 1988.8717 & 1988.8698 & 663.9639 & 0.0019 & 0.9539 & 575.782 & 533.296 & 326.166 & 755.783 & \text { Yes }\end{array}$ $\begin{array}{lllllllllllllllll}\text { SPYTVTVGQACNPSACR } & 1.00 & 29.82 & 22.99 & 15.06 & 3 & 1988.8735 & 1988.8698 & 663.9639 & 0.0037 & 1.8575 & 1766.398 & 1550.538 & 689.936 & 1628.267 & \text { Yes }\end{array}$

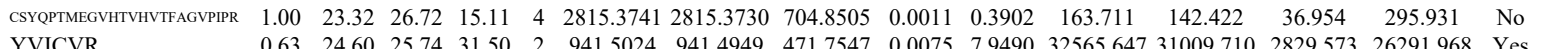

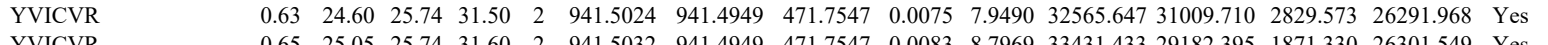
\begin{tabular}{llllllllllllllll} 
& 0.63 & 24.60 & 25.74 & 31.50 & 2 & 941.5024 & 941.494 & 471.7547 & 0.0075 & 7.9490 & 32565.647 & 31009.710 & 2829.573 & 26291.968 & Yes \\
AGNNMLLVGVHGPR & 1.00 & 46.55 & 25.73 & 31.60 & 2 & 941.5032 & 941.4949 & 471.7547 & 0.0083 & 8.7969 & 33431.433 & 29182.395 & 1871.330 & 26301.549 & Yes \\
\hline
\end{tabular}

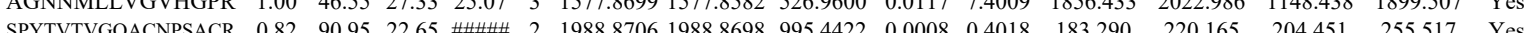
$\begin{array}{lllllllllllllll} & \end{array}$

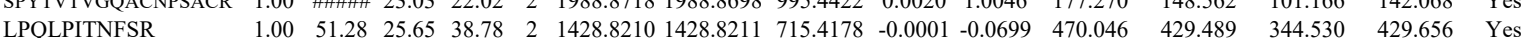
$\begin{array}{llllllllllllllll}\text { LPQLPITNFSR } & 1.00 & 51.28 & 25.65 & 38.78 & 2 & 1428.8210 & 1428.8211 & 715.4178 & -0.0001 & -0.0699 & 470.046 & 429.489 & 344.530 & 429.656 & \text { Yes } \\ \text { LPQLPITNFSR } & 0.99 & 42.85 & 25.59 & 41.36 & 2 & 1428.8218 & 1428.8211 & 715.4178 & 0.0007 & 0.4892 & 361.686 & 307.541 & 300.813 & 373.828 & \text { Yes }\end{array}$

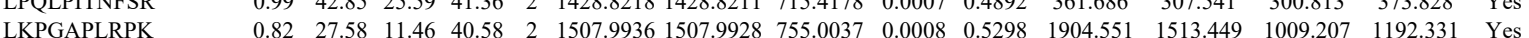
$\begin{array}{lllllllllllllllll} & \text { LKPGAPLRPK } & 0.82 & 27.66 & 11.46 & 40.66 & 2 & 1507.9940 & 1507.9928 & 755.0037 & 0.0012 & 0.7947 & 2128.062 & 1634.479 & 1122299 & 1273.571 & \text { Yes }\end{array}$ $\begin{array}{lllllllllllllllll} & \text { LKPGAPLRPK } & 0.82 & 20.33 & 11.46 & 33.33 & 3 & 1507.9948 & 1507.9928 & 503.6715 & 0.0020 & 1.3236 & 12234.719 & 10685.145 & 70257726 & 9076.639 & \text { Yes }\end{array}$ $\begin{array}{llllllllllllllll}\text { LKPGAPLRPK } & 0.67 & 19.66 & 11.14 & 32.66 & 3 & 1507.9957 & 1507.9928 & 503.6715 & 0.0029 & 1.9192 & 3955.869 & 3316.036 & 1989.265 & 3151.211 & \text { Yes }\end{array}$

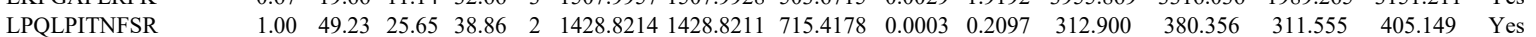
$\begin{array}{llllllllllllllll}\text { LPQLPITNFSR } & 1.00 & 50.73 & 25.60 & 39.02 & 2 & 1428.8216 & 1428.8211 & 715.4178 & 0.0005 & 0.3494 & 828.296 & 910.780 & 669.477 & 919.268 & \text { Yes }\end{array}$ $\begin{array}{llllllllllllllll}\text { LKPGAPLRPK } & 0.64 & 27.91 & 11.46 & 40.91 & 2 & 1507.9932 & 1507.9928 & 755.0037 & 0.0004 & 0.2649 & 3785.874 & 3153.122 & 1790.153 & 2402.056 & \text { Yes }\end{array}$ $\begin{array}{llllllllllllllll}\text { LKPGAPLRPK } & 0.66 & 17.56 & 11.46 & 30.56 & 3 & 1507.9948 & 1507.9928 & 503.6715 & 0.0020 & 1.3236 & 15922.778 & 16270.844 & 8204.072 & 11045.022 & \text { Yes }\end{array}$ $\begin{array}{llllllllllllllll}\text { LKPGAPLRPK } & 0.84 & 27.97 & 11.46 & 40.97 & 2 & 1507.9948 & 1507.9928 & 755.0037 & 0.0020 & 1.3245 & 3877.268 & 3534.356 & 1992.535 & 2596.216 & \text { Yes }\end{array}$ $\begin{array}{llllllllllllllll}\text { LKPGAPLRPK } & 0.67 & 21.17 & 11.14 & 34.17 & 3 & 1507.9957 & 1507.9928 & 503.6715 & 0.0029 & 1.9192 & 28210.014 & 26723.117 & 15387.467 & 20268.528 & \text { Yes }\end{array}$ $\begin{array}{llllllllllllllll}\text { HTAMVSWGGVSIPNSPFR } & 1.00 & 83.63 & 27.75 & 23.88 & 2 & 2086.0554 & 2086.0540 & 1044.0343 & 0.0014 & 0.6705 & 179.876 & 154.059 & 16.761 & 123.415 & \text { Yes }\end{array}$ $\begin{array}{llllllllllllllll}\text { HTAMVSWGGVSIPNSPFR } & 1.00 & 41.36 & 27.69 & 22.12 & 3 & 2086.0576 & 2086.0540 & 696.3586 & 0.0036 & 1.7232 & 314.847 & 331.665 & 325.635 & 482.308 & \text { Yes }\end{array}$ $\begin{array}{lllllllllllllllll}\text { HTAMVSWGGVSIPNSPFR } & 1.00 & 42.65 & 27.73 & 28.89 & 3 & 2086.0588 & 2086.0540 & 696.3586 & 0.0048 & 2.2977 & 310.760 & 285.231 & 268.675 & 282.873 & \text { Yes }\end{array}$ $\begin{array}{llllllllllllllll}\text { LKPGAPLRPK } & 0.54 & 9.88 * & 13.98 & 20.03 & 3 & 1363.8925 & 1363.8907 & 455.6375 & 0.0018 & 1.3168 & 957.941 & 981.306 & 769.030 & 744.375 & \text { Yes }\end{array}$ $\begin{array}{llllllllllllllll}\text { LPQLPITNFSR } & 1.00 & 60.48 & 25.61 & 38.91 & 2 & 1428.8220 & 1428.8211 & 715.4178 & 0.0009 & 0.6290 & 199.614 & 189.017 & 136.933 & 242.477 & \text { Yes }\end{array}$ $\begin{array}{lllllllllllllllll}\text { LPQLPITNFSR } & 1.00 & 46.59 & 25.49 & 40.26 & 2 & 1428.8232 & 1428.8211 & 715.4178 & 0.0021 & 1.4677 & 432.063 & 384.890 & 331.476 & 406.775 & \text { Yes }\end{array}$ $\begin{array}{llllllllllllllll}\text { LKPGAPLRPK } & 0.84 & 27.95 & 11.46 & 40.95 & 2 & 1507.9946 & 1507.9928 & 755.0037 & 0.0018 & 1.1920 & 2902.543 & 2271.162 & 1479.737 & 1824.853 & \text { Yes }\end{array}$ $\begin{array}{llllllllllllllllll}\text { LKPGAPLRPK } & 0.84 & 27.75 & 11.46 & 40.75 & 2 & 1507.9952 & 1507.9928 & 755.0037 & 0.0024 & 1.5894 & 2657.511 & 2349.924 & 1492.932 & 1769.694 & \text { Yes }\end{array}$

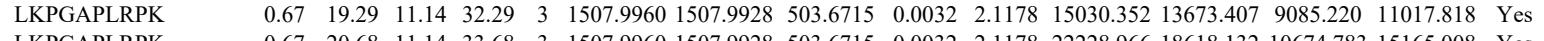
\begin{tabular}{lllllllllllllllll}
\hline LKPGAPLRK & 0.67 & 2.68 & 11.14 & 33.68 & 3 & 1507.9960 & 1507.9928 & 503.6715 & 0.0032 & 2.1178 & 22228.966 & 18618.132 & 10674.783 & 15165.008 & Yes
\end{tabular} $\begin{array}{llllllllllllllll}\text { HTAMVSWGGVSIPNSPFR } & 1.00 & 36.96 & 27.72 & 22.46 & 3 & 2086.0582 & 2086.0540 & 696.3586 & 0.0042 & 2.0105 & 323.473 & 396.866 & 188.563 & 437.933 & \text { Yes } \\ \text { LKPGAPLRPK } & 0.84 & 25.82 & 1 & 38.82 & 2 & 1507.9946 & 1507.9928 & 755.0037 & 0.0018 & 1.1920 & 601.032 & 469.838 & 262.747 & 309.159 & \text { Yes }\end{array}$

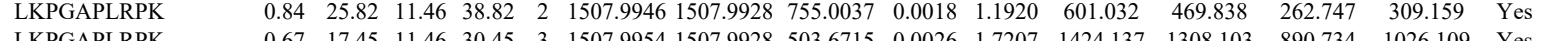

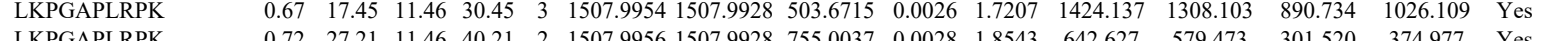
$\begin{array}{llllllllllllllll}\text { LKPGAPLRK } & 0.72 & 27.21 & 1.46 & 40.21 & 2 & 1507.996 & 1507.928 & 755.0037 & 0.028 & 1.8543 & 642.627 & 579.473 & 301.520 & 374.977 & \text { Yes } \\ \text { LKPGAPLRPK } & 0.60 & 21.50 & 11.14 & 34.50 & 3 & 1507.9966 & 1507.9928 & 503.6715 & 0.0038 & 2.5149 & 4082.482 & 3580.345 & 2139.063 & 2881.999 & \text { Yes }\end{array}$ $\begin{array}{llllllllllllllll}\text { LKPGAPLRPK } & 0.60 & 21.50 & 11.14 & 34.50 & 3 & 1507.9966 & 1507.9928 & 503.6715 & 0.0038 & 2.5149 & 4082.482 & 3580.345 & 2139.063 & 2881.999 & \text { Yes } \\ \text { VLPTHDASK } & 0.55 & 25.23 & 25.73 & 38.23 & 3 & 12547189 & 12547176 & 419.2465 & 0.0013 & 1.0336 & 361.462 & 397.995 & 77.379 & 215.419 & \text { Yes }\end{array}$

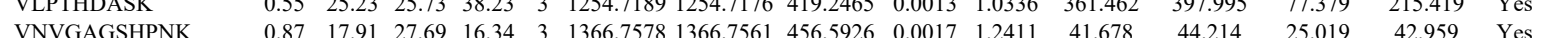

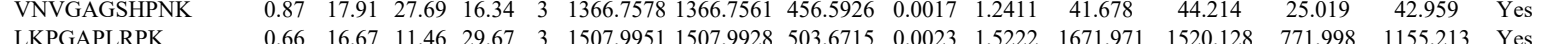
LKPGAPLRPK

LKPGAPLRPK

VLPTHDASK

VLPTHDASK

VNVGAGSHPNK

VNVGAGSHPNK

LKPGAPLRPK $\begin{array}{lllllllllllllll}0.66 & 16.67 & 11.46 & 29.67 & 3 & 1507.9951 & 1507.9928 & 503.6715 & 0.0023 & 1.5222 & 1671.971 & 1520.128 & 771.998 & 1155.213 & \text { Yes } \\ 0.67 & 20.22 & 11.14 & 33.22 & 3 & 1507.9957 & 1507.9928 & 503.6715 & 0.0029 & 1.9192 & 1355347 & 1272.723 & 681.420 & 963.874 & \text { Yes }\end{array}$ $\begin{array}{llllllllllllllll}0.55 & 22.85 & 26.05 & 35.85 & 3 & 1254.7186 & 1254.7176 & 419.2465 & 0.0010 & 0.7951 & 251.478 & 309.736 & 68.144 & 151.667 & \text { Yes }\end{array}$ $\begin{array}{llllllllllllllll}0.66 & 26.63 & 25.66 & 39.63 & 3 & 1254.7192 & 1254.7176 & 4192465 & 0.0016 & 1.2721 & 370.713 & 326.877 & 64.043 & 221.069 & \text { Yes }\end{array}$ $\begin{array}{lllllllllllllll}0.96 & \end{array}$ $\begin{array}{llllllllllllllll}1.00 & 49.33 & 27.96 & 20.07 & 3 & 1366.7566 & 1366.7561 & 456.5926 & 0.0005 & 0.3650 & 44.159 & 17.916 & 22.666 & 21.797 & \text { Yes }\end{array}$ $\begin{array}{llllllllllllllll}1.00 & 38.42 & 27.92 & 19.48 & 3 & 1366.7569 & 1366.7561 & 456.5926 & 0.0008 & 0.5840 & 45.177 & 59.357 & 31.097 & 20.488 & \text { Yes }\end{array}$ $\begin{array}{llllllllllllllll}0.67 & 20.90 & 11.14 & 33.90 & 3 & 1507.9960 & 1507.9928 & 503.6715 & 0.0032 & 2.1178 & 802.924 & 705.882 & 386.483 & 515.501 & \text { Yes }\end{array}$ $\begin{array}{llllllllllllllll} & & & \end{array}$ \begin{tabular}{|llllllllllllllll} 
&
\end{tabular} $\begin{array}{llllllllllllllll}\text { VNVGAGSHPNK } & 1.00 & 39.52 & 27.87 & 20.23 & 3 & 1366.7572 & 1366.7561 & 456.5926 & 0.0011 & 0.8030 & 22.230 & 18.946 & 6.580 & 8.492 & \text { Yes }\end{array}$ $\begin{array}{llllllllllllllll}\text { VDINTEDLEDGTCR } & 1.00 & 63.65 & 23.73 & 20.65 & 2 & 1768.7740 & 1768.7729 & 885.3937 & 0.0011 & 0.6212 & 179.222 & 197.162 & 65.897 & 153.862 & \text { Yes }\end{array}$ $\begin{array}{llllllllllllllll}\text { VNVGAGSHPNK } & 1.00 & 45.05 & 27.96 & 28.93 & 3 & 1366.7566 & 1366.7561 & 456.5926 & 0.0005 & 0.3650 & 57.843 & 56.802 & 15.817 & 39.854 & \text { Yes }\end{array}$ $\begin{array}{lllllllllllllllll}\text { VNVGAGSHPNK } & 1.00 & 33.58 & 27.87 & 18.29 & 3 & 1366.7572 & 1366.7561 & 456.5926 & 0.0011 & 0.8030 & 93.910 & 81.702 & 41.376 & 35.515 & \text { Yes }\end{array}$ $\begin{array}{lllllllllllllllll}\text { VSGQGLHEGHTFEPAEFIDTR } & 0.55 & 49.99 & 26.96 & 62.99 & 3 & 2439.1825 & 2439.1819 & 814.0679 & 0.0006 & 0.2457 & 6.160 & 9.635 & 2.135 & 10.857 & \text { Yes }\end{array}$ $\begin{array}{llllllllllllllll}\text { CSYQPTMEGVHTVHVTFAGVPIPR } & 1.00 & 26.96 & 26.70 & 39.96 & 4 & 2815.3729 & 2815.3730 & 704.8505 & -0.0001 & -0.0355 & 27.466 & 21.426 & 4.403 & 17.026 & \text { Yes }\end{array}$ $\begin{array}{llllllllllllllll}\text { CSYPPTMEGVHTVHVTFAGVPPRR } & 1.00 & 53.17 & 26.79 & 66.17 & 4 & 2815.3773 & 2815.3730 & 704.8505 & 0.0043 & 1.5251 & 11.903 & 28.419 & 6.546 & 13.977 & \text { No }\end{array}$ $\begin{array}{llllllllllllllll}\text { CSYQPTMEGVHTVHVTFAGVPIPR } & 1.00 & 33.90 & 26.74 & 46.90 & 4 & 2815.3737 & 2815.3730 & 704.8505 & 0.0007 & 0.2483 & 22.543 & 25.875 & 5.741 & 24.553 & \text { Yes }\end{array}$

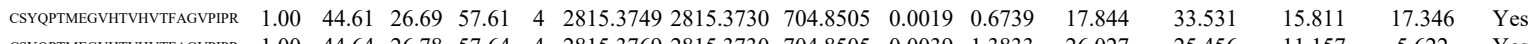

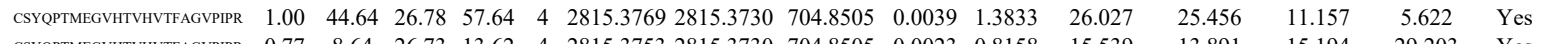

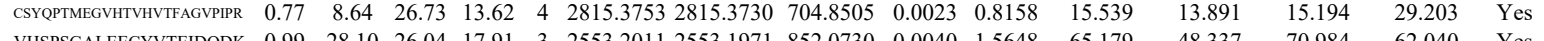

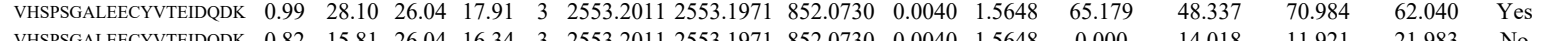

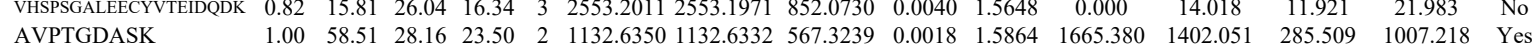

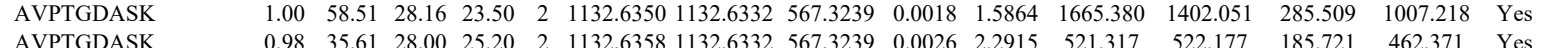
$\begin{array}{llllllllllllllll}\text { AVPTGDASK } & 0.98 & 35.61 & 28.00 & 25.20 & 2 & 1132.6358 & 132.6332 & 567.3239 & 0.026 & 2.2915 & 521.317 & 522.177 & 185.721 & 462.371 & \text { Yes }\end{array}$

$\begin{array}{llllllllllllllll}\text { VPVHDVIDASK } & 1.00 & 65.53 & 27.08 & 24.46 & 2 & 1454.8040 & 1454.7973 & 728.4059 & 0.0067 & 4.5991 & 5304.356 & 3536.851 & 5675.373 & 6030.732 & \text { Yes } \\ \text { VPVHDVTDASK } & 1.00 & 59.62 & 27.13 & 17.85 & 2 & 1454.8052 & 1454.7973 & 728.4059 & 0.0079 & 5.4228 & 4694.353 & 3330.964 & 3747.320 & 5259.614 & \text { Yes }\end{array}$ 

$\begin{array}{llllllllllllllll}\text { AGQSAAGAAPGGGVDTR } & 1.00 & 86.83 & 27.47 & 23.15 & 2 & 1585.7956 & 1585.7930 & 793.9038 & 0.0026 & 1.6375 & 1665.377 & 859.288 & 501.692 & 406.323 & \text { Yes }\end{array}$ $\begin{array}{llllllllllllllll}\text { SPFEVYVDK } & 1.00 & 57.35 & 27.48 & 25.13 & 2 & 1370.7462 & 1370.7326 & 68.3736 & 0.0136 & 9.9070 & 3128.849 & 2570.394 & 3905.129 & 3534504 & \text { Yes }\end{array}$

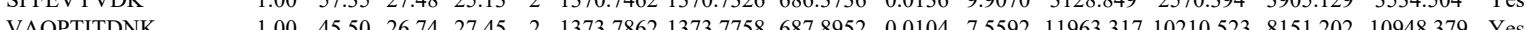

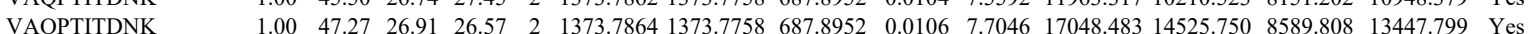
$\begin{array}{llllllllllllllll}\text { VEPGLGADNSVVR } & 1.00 & 75.52 & 28.20 & 26.06 & 2 & 1455.7942 & 1455.7804 & 728.8975 & 0.0138 & 9.4663 & 18503.138 & 12964.085 & 312.555 & 11955.175 & \text { Yes }\end{array}$ $\begin{array}{lllllllllllllll}\text { AGQSAAGAAPGGGVDTR } & 1.00 & \text { \#\#\#\# } 27.48 & 22.65 & 2 & 1585.7944 & 1585.7930 & 793.9038 & 0.0014 & 0.8817 & 109.315 & 52.099 & 42.337 & 30.581 & \text { Yes }\end{array}$ $\begin{array}{lllllllllllllll}\text { AGOSAAGAAPGGGDTR } & 1.00 & \# \# \# \# 27.44 & 26.89 & 2 & 1585.7948 & 1585.7930 & 793.9038 & 0.0018 & 1.1336 & 308.988 & 182.904 & 44.257 & 111.466 & \text { Yes }\end{array}$ $\begin{array}{lllllllllllllll}\text { GAGTGGLGLAVEGSEAK } & 1.00 & \text { \#\#\#\# } 26.50 & 27.38 & 2 & 1858.0210 & 1858.0040 & 930.0093 & 0.0170 & 9.1396 & 591.318 & 491.537 & 432.189 & 433.158 & \text { Yes }\end{array}$

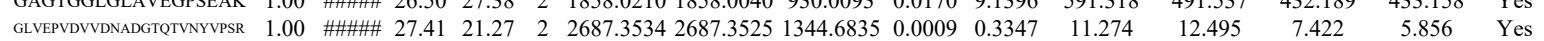
$\begin{array}{llllllllllllllll}\text { GLVEPVDVDNADGTTTVNYVPSR } & 0.66 & 70.14 & 27.44 & 83.14 & 3 & 2687.3545 & 2687.3525 & 896.7914 & 0.0020 & 0.7434 & 66.768 & 47.637 & 28.976 & 4.152 & \text { No }\end{array}$ $\begin{array}{lllllllllllllllll}\text { GLVEPVDVVDNADGTTVNNYVPSR } & 0.67 & 54.48 & 27.41 & 67.48 & 3 & 2687.3551 & 2687.3525 & 896.7914 & 0.0026 & 0.9664 & 49.364 & 46.906 & 14.581 & 37.716 & \text { Yes }\end{array}$

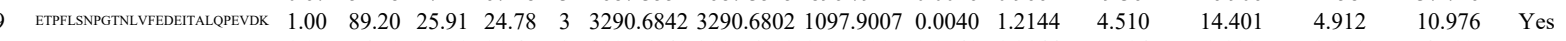
$\begin{array}{llllllllllllllll}\text { ETPFLSNPGTNLVFDEITALPPEVDK } & 1.00 & 76.71 & 25.91 & 21.47 & 3 & 3290.6842 & 3290.6802 & 1097.9007 & 0.0040 & 1.2144 & 7.594 & 2.829 & 3.179 & 4.510 & \text { Yes }\end{array}$

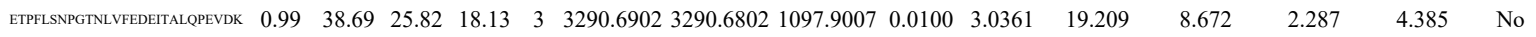
$\begin{array}{llllllllllllllll}\text { YDAMALGNHEFDNGVEGLIEPLLK } & 1.00 & 20.79 & 27.20 & 33.79 & 4 & 2932.4949 & 2932.4884 & 734.1294 & 0.0065 & 2.2135 & 40.555 & 45.339 & 25.168 & 16.193 & \text { Yes }\end{array}$

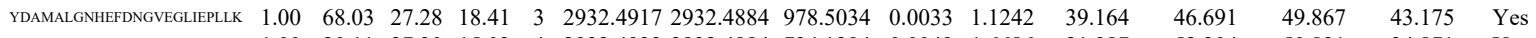
$\begin{array}{llllllllllllllll}\text { YDAMALGNHEDNGVEGLIEPLLK } & 1.00 & 20.11 & 27.30 & 15.03 & 4 & 2932.4933 & 2932.4884 & 734.1294 & 0.0049 & 1.6686 & 21.987 & 52.304 & 50.831 & 34.871 & \text { Yes }\end{array}$

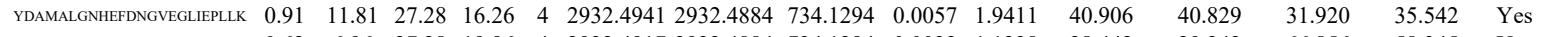

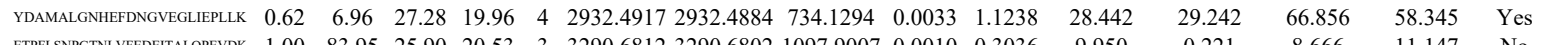

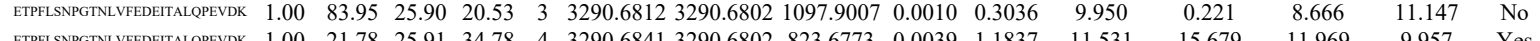
$\begin{array}{llllllllllllllll}\text { ETPFLSNPGNLNDEALLPEVDK } & 1.00 & 21.78 & 25.91 & 34.78 & 4 & 3290.6841 & 3290.6802 & 823.6773 & 0.0039 & 1.1837 & 11.531 & 15.679 & 11.969 & 9.957 & \text { Yes }\end{array}$

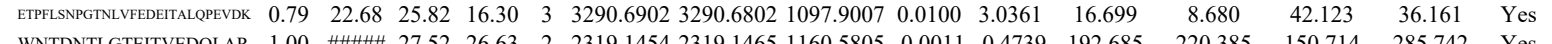

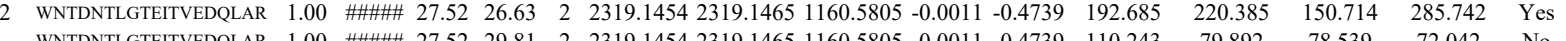

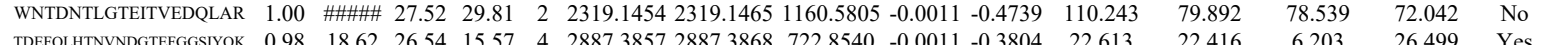

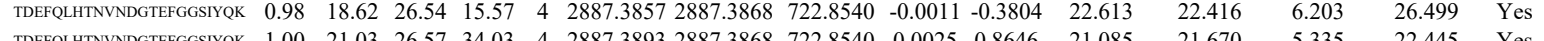

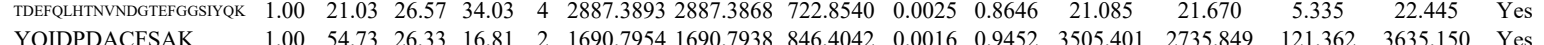

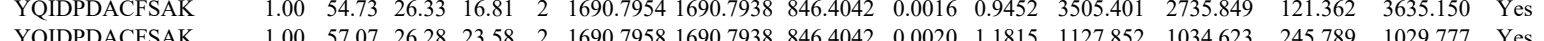

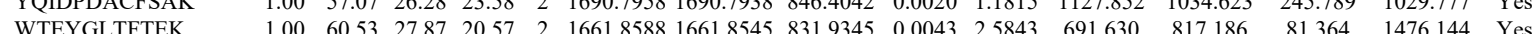

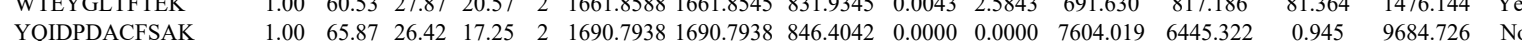

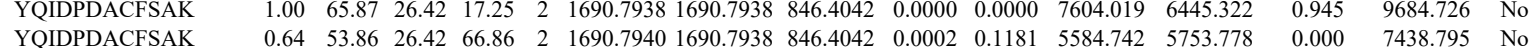
$\begin{array}{lllllllllllllllll}\text { YQIDPDACFSAK } & 0.77 & 17.90 & 26.40 & 15.62 & 3 & 1690.7944 & 1690.7938 & 564.6052 & 0.0006 & 0.3542 & 156.741 & 155.355 & 121.145 & 135.593 & \text { Yes }\end{array}$ \begin{tabular}{lllllllllllllllll} 
YQIDPDACFSAK & 1.00 & 36.76 & 26.28 & 18.92 & 3 & 1690.7956 & 1690.7938 & 564.6052 & 0.0018 & 1.0627 & 101.383 & 124.976 & 90.612 & 127.699 & Yes \\
\hline
\end{tabular} $\begin{array}{lllllllllllllllll}\text { WTEYGLTFTEK } & 1.00 & 60.38 & 27.90 & 22.51 & 2 & 1661.8564 & 1661.8545 & 831.9345 & 0.0019 & 1.1419 & 1331.998 & 1502.533 & 151.787 & 2902.577 & \text { No }\end{array}$ $\begin{array}{llllllllllllllll}\text { YQIDPDACFSAK } & 0.82 & 63.72 & 26.38 & 76.72 & 2 & 1690.7948 & 1690.7938 & 846.4042 & 0.0010 & 0.5907 & 403.376 & 300.361 & 36.269 & 364.142 & \text { No }\end{array}$ $\begin{array}{llllllllllllllll}\text { YQIDPDACFSAK } & 1.00 & 48.45 & 26.25 & 16.26 & 2 & 1690.7960 & 1690.7938 & 846.4042 & 0.0022 & 1.2996 & 148.049 & 243.528 & 25.525 & 207.325 & \text { No }\end{array}$ $\begin{array}{llllllllllllllll}\text { LTFDSSFSPNTGK } & 1.00 & 79.15 & 28.24 & 28.93 & 2 & 1687.8750 & 1687.8661 & 844.9403 & 0.0089 & 5.2666 & 3209.838 & 3718.177 & 266.781 & 5149.328 & \text { Yes }\end{array}$ $\begin{array}{llllllllllllllll}\text { LTFDSSFSPNTGK } & 1.00 & 78.43 & 28.24 & 29.22 & 2 & 1687.8814 & 1687.8661 & 844.9403 & 0.0153 & 9.0538 & 2827.218 & 2931.154 & 0.000 & 4181.584 & \text { No }\end{array}$ $\begin{array}{llllllllllllllll}\text { LTFDSSFSPNTGK } & 1.00 & 74.67 & 28.18 & 26.60 & 2 & 1687.8822 & 1687.8661 & 844.9403 & 0.0161 & 9.5272 & 2720.081 & 2423.261 & 212.011 & 3390.216 & \text { Yes }\end{array}$ $\begin{array}{llllllllllllllll}\text { VTQSNFAVGYK } & 1.00 & 61.70 & 27.18 & 23.00 & 2 & 1500.8258 & 1500.8180 & 751.4163 & 0.0078 & 5.1902 & 4181.735 & 5345.750 & 1725.555 & 5651.145 & \text { Yes }\end{array}$ $\begin{array}{llllllllllllllll}\text { VTQSNFAVGYK } & 1.00 & 67.52 & 27.45 & 24.29 & 2 & 1500.8274 & 1500.8180 & 751.4163 & 0.0094 & 6.2548 & 7090.826 & 8085.995 & 2366.622 & 9356.323 & \text { Yes }\end{array}$ $\begin{array}{llllllllllllllll}\text { VTQSNFAVGYK } & 1.00 & 66.38 & 27.34 & 27.49 & 2 & 1500.8280 & 1500.8180 & 751.4163 & 0.0100 & 6.6541 & 8655.256 & 9279.801 & 3214.091 & 11412.771 & \text { Yes }\end{array}$ $\begin{array}{lllllllllllllllll}\text { VTQSNFAVGYK } & 1.00 & 66.18 & 27.30 & 26.14 & 2 & 1500.8286 & 1500.8180 & 751.4163 & 0.0106 & 7.0533 & 9096.881 & 9640.265 & 3751.011 & 12898.612 & \text { Yes }\end{array}$

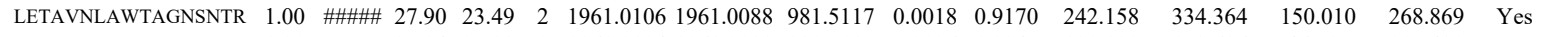

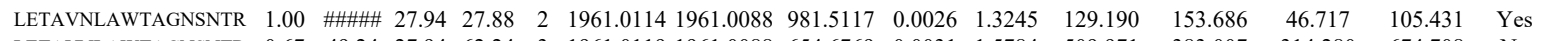
$\begin{array}{lllllllllllllllll}\text { LETAVNLAWTAGNSNTR } & 0.67 & 49.24 & 27.94 & 62.24 & 3 & 1961.0119 & 1961.0088 & 654.6769 & 0.0031 & 1.5784 & 509.971 & 383.007 & 314.280 & 674.708 & \text { No }\end{array}$ $\begin{array}{llllllllllllllll}\text { LETAVNLAWTAGNSNTR } & 1.00 & 41.50 & 27.88 & 20.98 & 3 & 1961.0095 & 1961.0088 & 654.6769 & 0.0007 & 0.3564 & 608.371 & 569.176 & 202.828 & 788.274 & \text { Yes }\end{array}$ $\begin{array}{lllllllllllllllll}\text { LETAVNLAWTAGNSNTR } & 1.00 & 64.45 & 27.93 & 21.77 & 3 & 1961.0098 & 1961.0088 & 654.6769 & 0.0010 & 0.5092 & 436.564 & 647.900 & 267.604 & 622.049 & \text { Yes }\end{array}$ $\begin{array}{llllllllllllllll}\text { KLETAVNLAWTAGNSNTR } & 1.00 & 72.67 & 25.26 & 26.15 & 3 & 2233.2250 & 2233.2058 & 745.4092 & 0.0192 & 8.5858 & 553.953 & 682.114 & 273.144 & 604.213 & \text { Yes }\end{array}$ $\begin{array}{llllllllllllllll}\text { KLETAVNLAWTAGNSNTR } & 1.00 & 61.22 & 25.20 & 22.72 & 3 & 2233.2259 & 2233.2058 & 745.4092 & 0.0201 & 8.9883 & 614.197 & 538.427 & 308.535 & 1364.923 & \text { No }\end{array}$

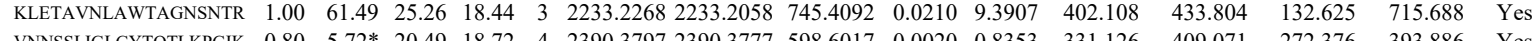

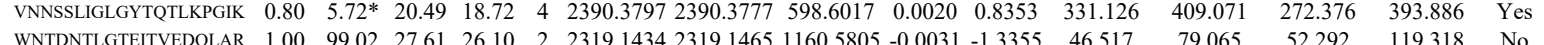

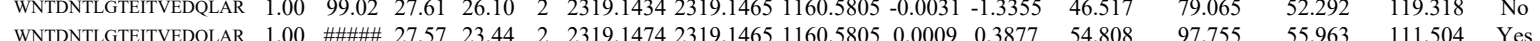

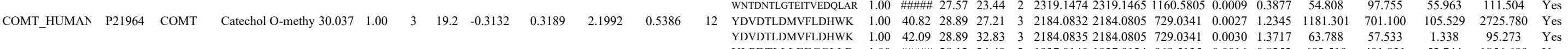

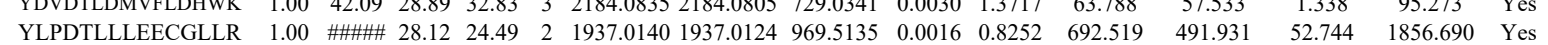

Table S- 4 page 222 of 614 
$\begin{array}{lllllllllllll} & 0.364 .346\end{array}$

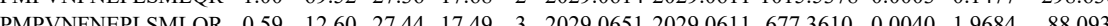
$\begin{array}{lllllllllllll} & 17.35\end{array}$ $\begin{array}{lllllllllllll} & \text { IPMPVNFNEPLSMLQR } & 1.00 & 84.00 & 27.36 & 21.05 & 2 & 2029.0614 & 20290611 & 1015.5378 & 0.0003 & 0.81477 & 75.014\end{array}$ $\begin{array}{lllllllllllll} & \text { IPMPVNFNEPSSMLQR } & 0.97 & 24.12 & 27.40 & 16.25 & 3 & 2029.0627 & 2029.0611 & 677.3610 & 0.0016 & 0.7874 & 75.1146\end{array}$ $\begin{array}{lllllllllllll}\text { IPMPVNFNEPLSMLQR } & 0.51 & 11.25 & 27.42 & 16.51 & 3 & 2029.0648 & 2029.0611 & 677.3610 & 0.0037 & 1.8208 & 71.897\end{array}$ $\begin{array}{lllllllllllll}\text { IPMPVNFNEPLSMLQR } & 1.00 & 70.48 & 27.40 & 21.30 & 2 & 2029.0654 & 2029.0611 & 1015.5378 & 0.0043 & 2.1171 & 55.197\end{array}$

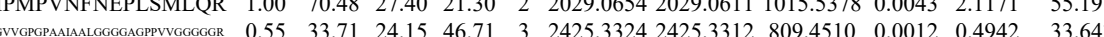
$\begin{array}{llllllllllll}\text { GVVGGCPAAAALGGGGAGPPVGGGGGR } & 0.64 & 94.56 & 24.20 & \text { \#\#\#\# } & 2 & 2425.3314 & 2425.3312 & 1213.6729 & 0.0002 & 0.0824 & 17.219\end{array}$ $\begin{array}{lllllllllll} & \end{array}$

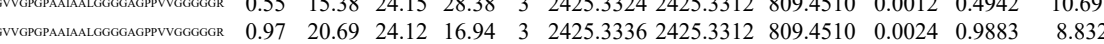
LEETLEQLLAK $\begin{array}{rrrrrrrrrrrr}0.55 & 10.18 & 24.13 & 23.18 & 3 & 2425.3321 & 2425.3312 & 809.4510 & 0.0009 & 0.3706 & 2.833 \\ 1.00 & 53.14 & 27.11 & 30.75 & 2 & 1460.8348 & 1460.8330 & 731.4238 & 0.0018 & 1.2305 & 495.566\end{array}$

$\begin{array}{llllllllllllll}\text { LILPVGPAGGNQMLEQYDK } & 1.00 & 41.60 & 25.83 & 17.97 & 3 & 2330.2549 & 2330.2548 & 777.7589 & 0.0001 & 0.0429 & 148.226\end{array}$ $\begin{array}{llllllllllll}\text { LILPVGPAGGNQMLEQYDK } & 1.00 & 74.13 & 25.49 & 22.75 & 3 & 2330.2600 & 2330.2548 & 777.7589 & 0.0052 & 2.2286 & 227.847\end{array}$ $\begin{array}{lllllllllllll}\text { LILPVGPAGGNQMLEQYDK } & 0.55 & 43.27 & 25.74 & 56.27 & 3 & 2330.2561 & 2330.2548 & 777.7589 & 0.0013 & 0.5572 & 326.357\end{array}$

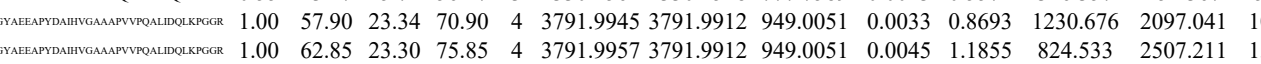

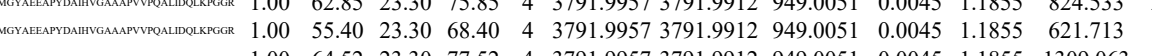
$\begin{array}{lllllllllll}1.00 & 64.52 & 23.30 & 77.52 & 4 & 3791.9957 & 3791.9912 & 949.0051 & 0.0045 & 1.1855 & 1309.063\end{array}$

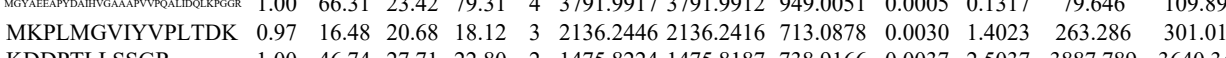
KDDPTLLSSGR KDDPTLLSSGR KDDPTLSSGR $\begin{array}{llllllllllll}1.00 & 46.74 & 27.71 & 22.80 & 2 & 1475.8224 & 1475.8187 & 738.9166 & 0.0037 & 2.5037 & 3887.789 & 3640.344\end{array}$ LLSSG $\begin{array}{llllllllllll}0.99 & 44.03 & 27.81 & 27.46 & 2 & 1475.8232 & 1475.8187 & 738.9166 & 0.0045 & 3.0450 & 2710.287 & 2451.521 \\ 1.00 & 40.47 & 27.80 & 23.84 & 3 & 1475.8237 & 1475.8187 & 492.9468 & 0.0050 & 3.3810 & 6993.990 & 7809.467\end{array}$

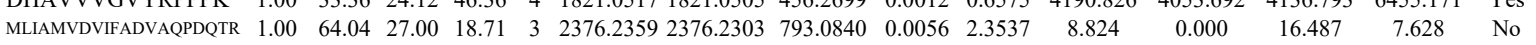
$\begin{array}{llllllllllllllll}\text { MLIAMVDVIFADVAQPDQTR } & 0.67 & 43.68 & 26.95 & 56.68 & 3 & 2376.2335 & 2376.2303 & 793.0840 & 0.0032 & 1.3450 & 2.070 & 12.774 & 0.000 & 15.579 & \text { No }\end{array}$ $\begin{array}{llllllllllllllll}\text { MLIAMVDVIFADVAQPDQTR } & 1.00 & 72.02 & 27.00 & 20.70 & 3 & 2376.2359 & 2376.2303 & 793.0840 & 0.0056 & 2.3537 & 6.413 & 6.293 & 1.286 & 5.736 & \text { Yes }\end{array}$ $\begin{array}{llllllllllllllll}\text { LAAAILGGVDQIHIKPGAK } & 0.90 & 2.24 & 14.31 & 15.24 & 4 & 2303.4041 & 2303.4054 & 576.8586 & -0.0013 & -0.5634 & 81.659 & 58.146 & 252.228 & 70.064 & \text { No }\end{array}$

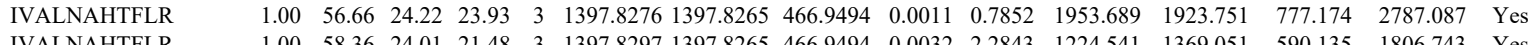
$\begin{array}{lllllllllllllllll}\text { IVALNAHTFLR } & 1.00 & 58.36 & 24.01 & 21.48 & 3 & 1397.8297 & 1397.8265 & 466.9494 & 0.0032 & 2.2843 & 1224.541 & 1369.051 & 590.135 & 1806.743 & \text { Yes }\end{array}$ $\begin{array}{llllllllllllllll}\text { NLVPGESVYGEK } & 1.00 & 60.22 & 28.38 & 25.32 & 2 & 1578.8518 & 1578.8497 & 790.4321 & 0.0021 & 1.3284 & 868.535 & 831.825 & 118.394 & 1454.943 & \text { Yes }\end{array}$ $\begin{array}{llllllllllllllll}\text { NLVPGESVYGEK } & 1.00 & 58.29 & 28.38 & 26.86 & 2 & 1578.8518 & 1578.8497 & 790.4321 & 0.0021 & 1.3284 & 223.348 & 226.451 & 39.423 & 399.218 & \text { Yes }\end{array}$

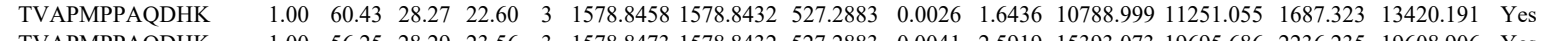
$\begin{array}{llllllllllllllll}\text { TVAPMPPAQDHK } & 1.00 & 56.25 & 28.29 & 23.56 & 3 & 1578.8473 & 1578.8432 & 527.2883 & 0.0041 & 2.5919 & 15393.073 & 19695.686 & 2236.235 & 19608.906 & \text { Yes }\end{array}$ $\begin{array}{llllllllllllllll}\text { TVAPMPPAQDHK } & 1.00 & 55.02 & 28.23 & 23.86 & 3 & 1578.8449 & 1578.8432 & 527.2883 & 0.0017 & 1.0747 & 7655.753 & 8618.406 & 2709.867 & 8861.668 & \text { Yes }\end{array}$ $\begin{array}{llllllllllllllll}\text { TVAPMPPAQDHK } & 1.00 & 49.34 & 28.27 & 20.04 & 3 & 1578.8455 & 1578.8432 & 527.2883 & 0.0023 & 1.4540 & 7546.429 & 9385.889 & 7164.453 & 9058.425 & \text { Yes }\end{array}$

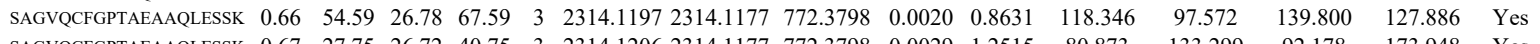

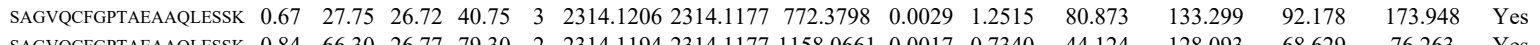

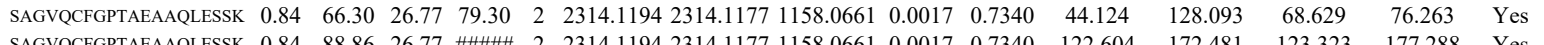

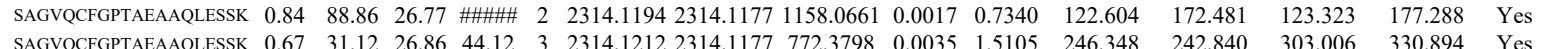
$\begin{array}{llllllllllllllll}\text { SAGVCFGPAEAACLSS } & 0.67 & 31.12 & 26.86 & 44.12 & 3 & 2314.1212 & 2314.1177 & 772.3798 & 0.0035 & 1.5105 & 246.348 & 242.840 & 303.006 & 330.894 & \text { Yes } \\ \text { SAGVQCFGPTAEAQLESSK } & 0.67 & 34.35 & 26.86 & 47.35 & 3 & 2314.1212 & 2314.1177 & 772.3798 & 0.0035 & 1.5105 & 32.700 & 68.482 & 113.667 & 131.171 & \text { No }\end{array}$

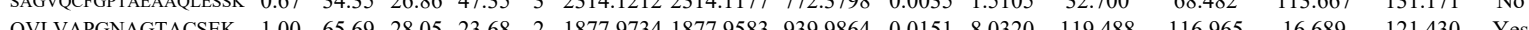

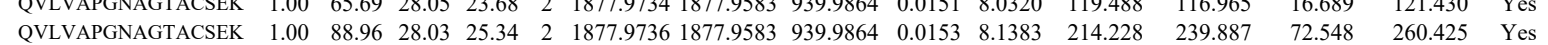

Table S-4 page 223 of 614 
MLNIHPSLLPSF

$\begin{array}{llllllllll} & 0.0012 & 0.6622 & 2090.032 & 2234.373 & 388.046 & 2838.783 & \text { Ys } & \\ 0\end{array}$

MLNIHPSLLPSFK

$\begin{array}{llllllllllll}1.00 & 39.85 & 23.38 & 29.33 & 3 & 1784.0260 & 1784.0262 & 595.6827 & -0.0002 & -0.1119 & 7268.522 & 8069.286 \\ 1.00 & 35.50 & 23.48 & 26.46 & 3 & 1784.0266 & 1784.0262 & 595.6827 & 0.0004 & 0.2238 & 10437.562 & 11858.139\end{array}$

$\begin{array}{lllllllllllll}\text { VAVLISGTGSNLQALIDSTR } & 1.00 & \text { \#\#\#\# } 24.39 & 26.08 & 2 & 2158.2094 & 2158.2079 & 1080.1112 & 0.0015 & 0.6944 & 250.216 & 223.537\end{array}$

VAVLISGTGSNLQALIDSTR

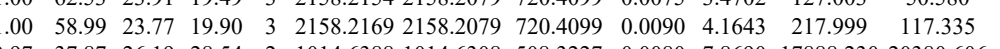



\begin{tabular}{lllllllllllllll}
1.00 & 28.95 & 23.48 & 20.13 & 3 & 1784.0269 & 1784.0262 & 595.6827 & 0.0007 & 0.3917 & 563.284 & 481.833 & 192.997 & 668.952 & Yes \\
\hline
\end{tabular}

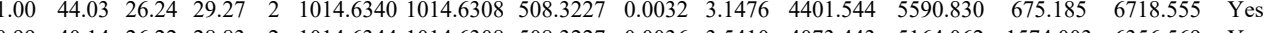
$\begin{array}{llllllllllllllll}0.99 & 40.14 & 26.22 & 28.83 & 2 & 1014.6344 & 1014.6308 & 508.3227 & 0.0036 & 3.5410 & 4073.443 & 5164.062 & 1574.003 & 6356.569 & \text { Yes }\end{array}$ \begin{tabular}{llllllllllllllll}
1.00 & 49.79 & 26.02 & 22.93 & 2 & 1186.7024 & 1186.6944 & 594.3545 & 0.0080 & 6.7299 & 10875.003 & 14299.216 & 296.370 & 14648.564 & Yes \\
\hline
\end{tabular} $\begin{array}{llllllllllllllll}1.00 & 49.29 & 26.02 & 23.46 & 2 & 1186.7026 & 1186.6944 & 594.3545 & 0.0082 & 6.8982 & 12637.866 & 15965.369 & 0.000 & 18961.306 & \text { No } \\ 0.99 & 24.72 & 23.73 & 17.65 & 3 & 1440.8596 & 1440.8575 & 481.2931 & 0.0021 & 1.4544 & 1497.346 & 1679.754 & 501.276 & 2271.775 & \text { Yos }\end{array}$

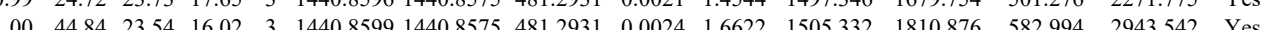

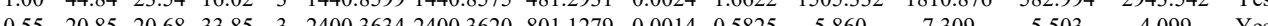

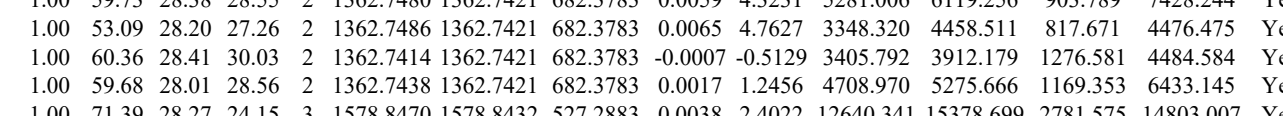
$\begin{array}{llllllllllllllllll}1.00 & 59.68 & 28.01 & 28.56 & 2 & 1362.7438 & 1362.7421 & 682.3783 & 0.0017 & 1.2456 & 4708.970 & 5275.666 & 1169.353 & 6433.145 & \text { Yes } \\ 1.00 & 71.39 & 28.27 & 24.15 & 3 & 1578.8470 & 1578.8432 & 527.2883 & 0.0038 & 2.4022 & 12640.341 & 15378.699 & 2781.575 & \\ 1.00 & 65.29 & 28.38 & 24.16 & 3 & 1578.8453 & 5788432 & 527.288 & 0.053 & 3.355 & & \end{array}$ $\begin{array}{lllllllllllllllllll} & \end{array}$ $\begin{array}{lllllllllllllllll}\text { AEYEGDGIPTVFVAVAGR } & 1.00 & 75.83 & 28.27 & 24.11 & 2 & 1994.0246 & 1994.0231 & 998.0188 & 0.0015 & 0.7515 & 123.251 & 89.515 & 49.368 & 108.381 & \text { Yes }\end{array}$ $\begin{array}{llllllllllllllll}\text { AEYEGDGIPTVFVAVAGR } & 1.00 & 69.40 & 28.27 & 38.18 & 2 & 1994.0254 & 1994.0231 & 998.0188 & 0.0023 & 1.1523 & 71.418 & 105.413 & 37.574 & 106.342 & \text { Yes }\end{array}$

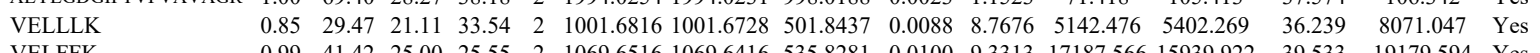

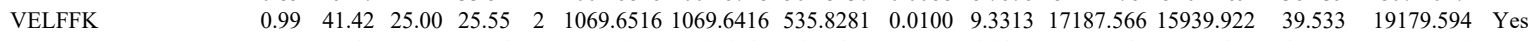

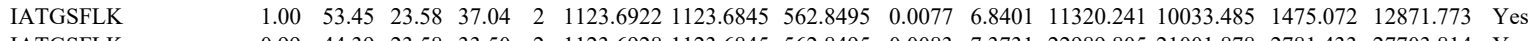

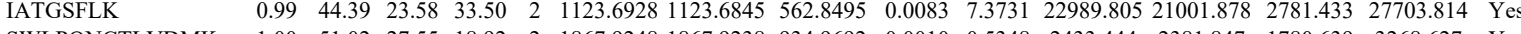
$\begin{array}{llllllllllllllll}\text { SWLPQNCTLVDMK } & 1.00 & 51.02 & 27.55 & 18.92 & 2 & 1867.9248 & 1867.9238 & 934.9692 & 0.0010 & 0.5348 & 2433.444 & 2381.847 & 1780.639 & 3268.627 & \text { Yes }\end{array}$ IATGSFLK

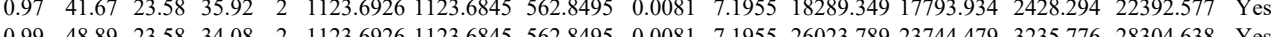
$\begin{array}{lllllllllllllll}0.99 & 48.89 & 23.58 & 34.08 & 2 & 1123.6926 & 1123.6845 & 562.8495 & 0.0081 & 7.1955 & 26023.789 & 23744.479 & 3235.776 & 28304.638 & \text { Yes }\end{array}$ $\begin{array}{lllllllllllllll}1.00 & 63.43 & 27.59 & 18.78 & 2 & 1867.9314 & 1867.9238 & 934.9692 & 0.0076 & 4.0643 & 2659.274 & 2941.903 & 2396.109 & 3318.149 & \text { Yes }\end{array}$

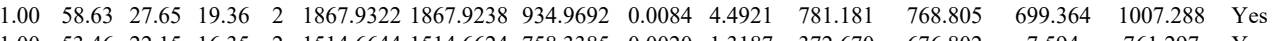
$\begin{array}{lllllllllllllll}1.00 & 53.46 & 22.15 & 16.35 & 2 & 1514.6644 & 1514.6624 & 758.3385 & 0.0020 & 1.3187 & 372.670 & 676.802 & 7.594 & 761.297 & \text { Yes }\end{array}$

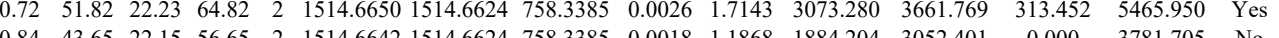
$\begin{array}{lllllllllllllll}0.84 & 43.65 & 22.15 & 56.65 & 2 & 1514.6642 & 1514.6624 & 758.3385 & 0.0018 & 1.1868 & 1884.204 & 3052.401 & 0.000 & 3781.705 & \text { No } \\ 0.84 & 44.87 & 22.01 & 57.87 & 2 & 1514.6646 & 1514.6624 & 758.3385 & 0.0022 & 1.4505 & 5272.335 & 4761.099 & 0.000 & 7225.539 & \text { No }\end{array}$

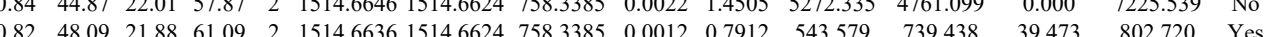

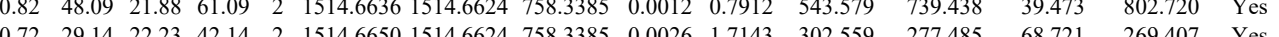
$\begin{array}{lllllllllllll} & 0.725 .407 & \text { Yes }\end{array}$ \begin{tabular}{llllllllllllllll} 
ASILNTWISLK & 1.00 & 73.20 & 23.05 & 24.83 & 2 & 1532.9188 & 1532.9170 & 767.4658 & 0.0018 & 1.1727 & 5669.675 & 5424.729 & 93.765 & 5651.547 & Yes \\
\hline & 1.00 & 26.51 & 23.05 & 15.31 & 3 & 1532.9191 & 1532.9170 & 511.9796 & 0.0021 & 1.3672 & 111.165 & 85.724 & 25.118 & 130.564 & Y
\end{tabular}

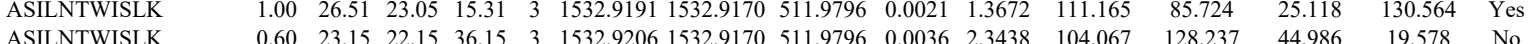

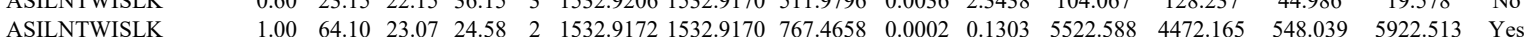

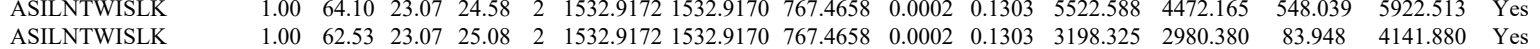

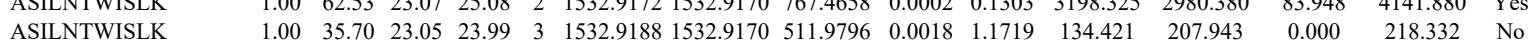
$\begin{array}{llllllllllllllll}\text { ASILNTWISLK } & 1.00 & 35.70 & 23.05 & 23.99 & 3 & 1532.9188 & 532.9170 & 511.9796 & 0.0018 & 1.1719 & 134.421 & 207.943 & 0.000 & 218.332 & \text { No } \\ \text { ASILNTWISLK } & 1.00 & 33.79 & 22.10 & 20.00 & 3 & 1532.9203 & 1532.9170 & 511.9796 & 0.0033 & 2.1485 & 162.438 & 190.200 & 36.943 & 229.904 & \text { Yes }\end{array}$

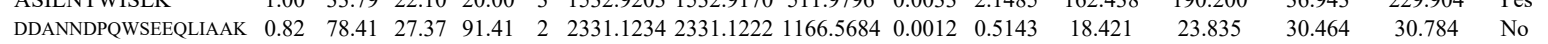
$\begin{array}{llllllllllllllll}\text { DDANNDPQWSEEQLIAAK } & 1.00 & 77.16 & 27.37 & 20.33 & 2 & 2331.1234 & 2331.1222 & 1166.5684 & 0.0012 & 0.5143 & 8.836 & 14.452 & 23.948 & 8.210 & \text { No }\end{array}$

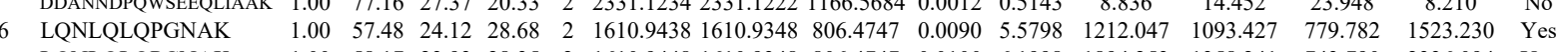
$\begin{array}{llllllllllllllll}\text { LQNLQLQPGNAK } & 1.00 & 58.17 & 23.93 & 28.35 & 2 & 1610.9448 & 1610.9348 & 806.4747 & 0.0100 & 6.1998 & 1894.253 & 1358.241 & 743.790 & 2336.094 & \text { Yes }\end{array}$ $\begin{array}{llllllllllllllll}\text { IGGIFAFK } & 0.98 & 28.13 & 23.56 & 26.15 & 2 & 1139.6960 & 1139.6947 & 570.8546 & 0.0013 & 1.1386 & 32830.851 & 26607.023 & 2006.855 & 46170.881 & \text { Yes }\end{array}$ $\begin{array}{llllllllllllllll}\text { IGGIFAFK } & 1.00 & 38.29 & 23.58 & 26.99 & 2 & 1139.6968 & 1139.6947 & 570.8546 & 0.0021 & 1.8393 & 36541.837 & 27617.954 & 2222.139 & 47567.753 & \text { Yes }\end{array}$

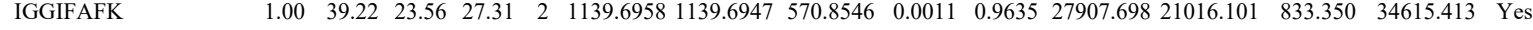

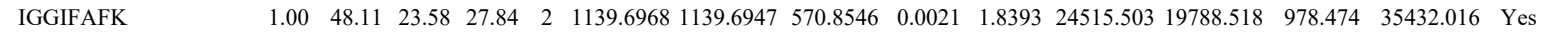

$\begin{array}{llllllllllllllll}\text { QPAENVNQYLTDPK } & 1.00 & 63.69 & 27.71 & 28.25 & 2 & 1904.0068 & 1903.9883 & 953.0014 & 0.0185 & 9.7061 & 203.619 & 217.659 & 219.384 & 280.965 & \text { Yes }\end{array}$

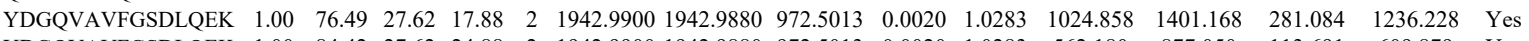
$\begin{array}{lllllllllllllllll}\text { YDGQVAVFGSDLQEK } & 1.00 & 84.42 & 27.62 & 24.88 & 2 & 1942.9900 & 1942.9880 & 972.5013 & 0.0020 & 1.0283 & 562.180 & 877.050 & 113.691 & 609.879 & \text { Yes }\end{array}$

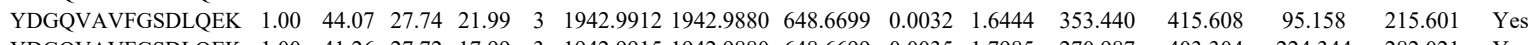

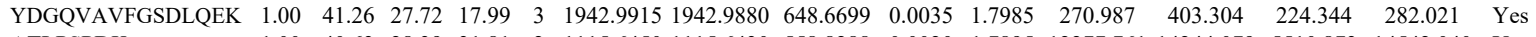

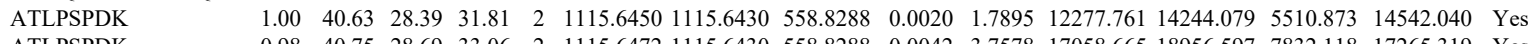

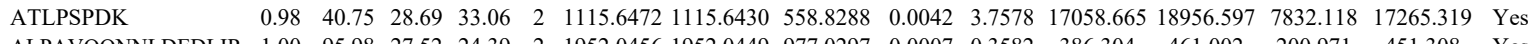
$\begin{array}{llllllllllllllll}\text { ALPAVQQNNLDEDLIR } & 1.00 & 95.98 & 27.52 & 24.39 & 2 & 1952.0456 & 1952.0449 & 977.0297 & 0.0007 & 0.3582 & 386.304 & 461.002 & 200.971 & 451.308 & \text { Yes }\end{array}$

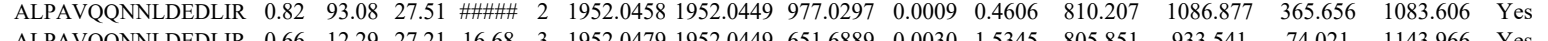
\begin{tabular}{llllllllllllllll} 
ALPAVQQNNLDEDLIR & 0.66 & 12.29 & 27.21 & 16.68 & 3 & 1952.0479 & 1952.0449 & 651.6889 & 0.0030 & 1.5345 & 805.851 & 933.541 & 74.021 & 1143.966 & Yes \\
\hline
\end{tabular}

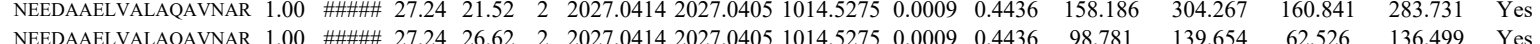

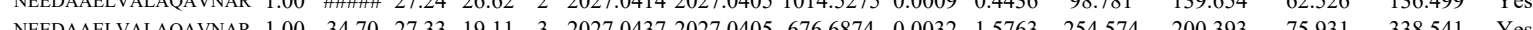

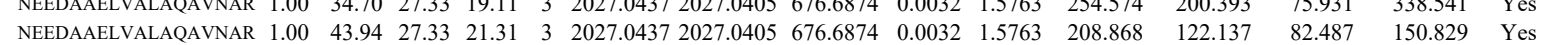


$\begin{array}{llllllllllll}1.00 & 70.78 & 17.08 & 19.30 & 2 & 1675.0384 & 1675.0245 & 838.5195 & 0.0139 & 8.2883 & 2598.736 & 2905.215\end{array}$

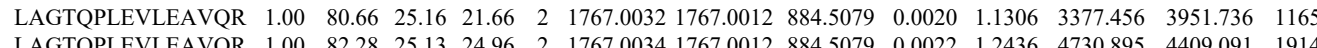

$\begin{array}{lllllllllllll} & \end{array}$

$\begin{array}{lllllllllllll}\text { LAGTQPLEVLEAVQR } & 1.00 & 88.02 & 25.28 & 22.41 & 2 & 1767.0018 & 1767.0012 & 884.5079 & 0.0006 & 0.3392 & 2315.630 & 2280.202\end{array}$

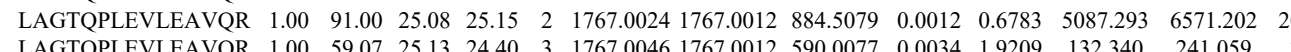

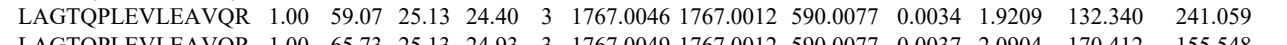

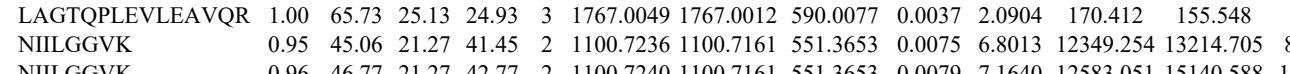

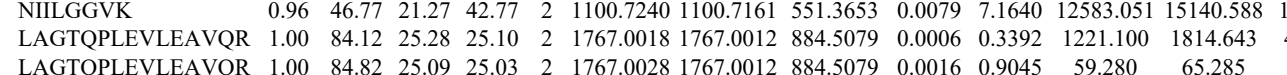

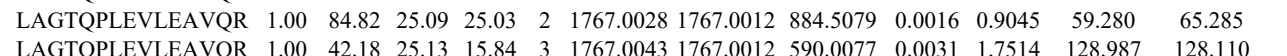

$\begin{array}{lllllllllllll}\text { LAGTQPLEVLEAVQR } & 1.00 & 42.18 & 25.13 & 15.84 & 3 & 1767.0043 & 1767.0012 & 590.0077 & 0.0031 & 1.7514 & 128.987 & 128.110 \\ \text { NIILGGVK } & 0.86 & 41.05 & 21.27 & 41.90 & 2 & 1100.7224 & 1100.7161 & 551.3653 & 0.0063 & 5.7131 & 10808.619 & 11840.923\end{array}$

$\begin{array}{llllllllllll}0.86 & 41.05 & 21.27 & 41.90 & 2 & 1100.7224 & 1100.7161 & 551.3653 & 0.0063 & 5.7131 & 10808.619 & 11840.923 \\ 0.93 & 38.71 & 21.27 & 36.55 & 2 & 1100.7236 & 1100.7161 & 551.3653 & 0.0075 & 6.8013 & 9660.457 & 9217.432\end{array}$ $\begin{array}{lllllllllllll}\text { AVTLHDQGTAQWADLSSQFYLR } & 1.00 & 64.67 & 27.03 & 23.00 & 3 & 2650.3276 & 2650.3262 & 884.4493 & 0.0014 & 0.5276 & 99.701 & 89.773\end{array}$

$\begin{array}{lllllllllll} & \end{array}$

$\begin{array}{llllllllll} & \text { AAVATC }\end{array}$

$\begin{array}{lllllllllll} & \end{array}$

SIPICTLK

$\begin{array}{lllllllllllll}1.00 & 40.45 & 27.24 & 25.62 & 2 & 1207.6932 & 1207.6912 & 604.8529 & 0.0020 & 1.6533 & 21623.928 & 24794.241 & 0\end{array}$.

SIPICTLK

$\begin{array}{llllllllllllll}\text { NFPNAIEHTLQWAR } & 1.00 & 74.07 & 27.73 & 25.94 & 3 & 1839.9559 & 1839.9502 & 614.3240 & 0.0057 & 3.0928 & 13435.182 & 19372.981 & 1567.2\end{array}$

$\begin{array}{llllllllllllllllll} & \end{array}$

$\begin{array}{lllllllllllllll}\text { AAVATFLQSVQVPEFTPK } & 1.00 & \text { \#\#\#\# } 24.55 & 19.92 & 2 & 2220.2394 & 2220.2398 & 1111.1272 & -0.0004 & -0.1800 & 34.097 & 73.554 & 29.803 & 118.013 & \text { Yes }\end{array}$ $\begin{array}{llllllllllllllll} & \\ \text { AIVACTLQSVVPEFTPK } & 0.64 & 89.53 & 24.55 & \text { \#\#\#\# } & 2 & 2220.2394 & 2220.2398 & 111.1272 & -0.0004 & -0.1800 & 44.514 & 126.479 & 20.064 & 75.477 & \text { Yes } \\ \text { SIPICTLK } & 0.99 & 35.27 & 27.25 & 25.79 & 2 & 1207.6926 & 1207.6912 & 604.8529 & 0.0014 & 1.1573 & 20575.157 & 19253.732 & 0.000 & 18530.248 & \text { No }\end{array}$ $\begin{array}{lllllllllllllllll}\text { NFPNAIEHTLQWAR } & 1.00 & 66.30 & 27.66 & 30.06 & 3 & 1839.9508 & 1839.9502 & 614.3240 & 0.0006 & 0.3256 & 8241.472 & 6671.086 & 1220.433 & 8688.320 & \text { Yes }\end{array}$ $\begin{array}{lllllllllllllllll}\text { NFPNAIEHTLQWAR } & 1.00 & 70.10 & 27.69 & 25.34 & 3 & 1839.9520 & 1839.9502 & 614.3240 & 0.0018 & 0.9767 & 8814.619 & 12574.770 & 270.000 & 11563.766 & \text { Yes }\end{array}$ $\begin{array}{llllllllllllllll}\text { YFLVGAGAIGCELLK } & 0.97 & 27.01 & 27.17 & 22.80 & 3 & 1887.0247 & 1887.0242 & 630.0153 & 0.0005 & 0.2645 & 44.498 & 43.472 & 9.231 & 83.366 & \text { Yes }\end{array}$ $\begin{array}{llllllllllllllll}\text { AAVATFLQSVQVPEFTPK } & 1.00 & 74.86 & 24.55 & 22.19 & 2 & 2220.2394 & 2220.2398 & 1111.1272 & -0.0004 & -0.1800 & 104.320 & 78.921 & 16.216 & 77.236 & \text { Yes }\end{array}$ $\begin{array}{llllllllllllllll}\text { AAVATFLQSVQVPEFTPK } & 0.64 & 94.49 & 24.55 & \text { \#\#\#\# } 2 & 2 & 2220.2394 & 2220.2398 & 1111.1272 & -0.0004 & -0.1800 & 90.756 & 97.881 & 27.896 & 79.195 & \text { Yes }\end{array}$ $\begin{array}{llllllllllllllllll}\text { AAVATFLQSVQVPEFTPK } & 1.00 & 35.83 & 24.38 & 19.24 & 3 & 2220.2413 & 2220.2398 & 741.0872 & 0.0015 & 0.6747 & 81.206 & 49.188 & 22.864 & 109.479 & \text { Yes }\end{array}$ $\begin{array}{llllllllllllllll}\text { AAVATFLQSVQVPEFTPK } & 0.66 & 13.76 & 24.38 & 26.76 & 3 & 2220.2416 & 2220.2398 & 741.0872 & 0.0018 & 0.8096 & 38.322 & 34.059 & 0.000 & 84.836 & \text { No }\end{array}$

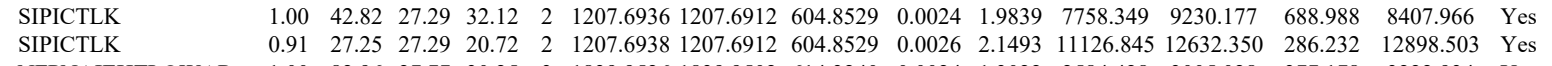
$\begin{array}{llllllllllllllll}\text { NFPNAIEHTLQWAR } & 1.00 & 82.96 & 27.77 & 30.25 & 3 & 1839.9526 & 1839.9502 & 614.3240 & 0.0024 & 1.3022 & 2584.428 & 3005.028 & 377.178 & 3222.934 & \text { Yes }\end{array}$

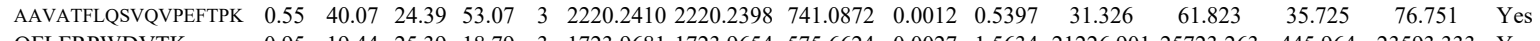

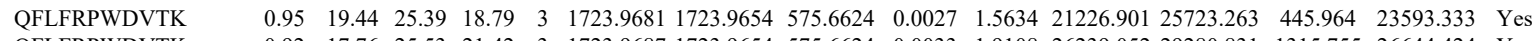
QFLFRPWDVTK QFLFRPWDVTK $\begin{array}{llllllllllllllllll}0.92 & 17.76 & 25.53 & 21.42 & 3 & 1723.9687 & 1723.9654 & 575.6624 & 0.0033 & 1.9108 & 26239.052 & 29280.831 & 1315.755 & 26644.424 & \text { Yes }\end{array}$ $\begin{array}{lllllllllllllllll}0.92 & 21.72 & 25.65 & 17.00 & 3 & 1723.9654 & 1723.9654 & 575.6624 & 0.0000 & 0.0000 & 35189.774 & 45826.529 & 955.388 & 38906.884 & \text { Yes } & \end{array}$

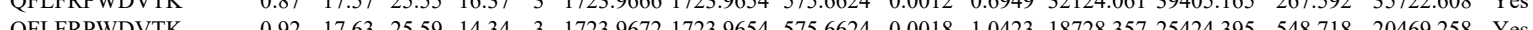

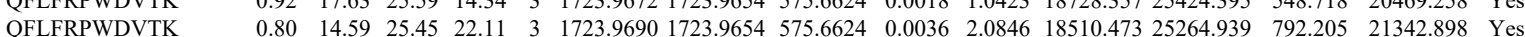
$\begin{array}{lllllllllllllllllll}\text { LQTSSVLVSGLR } & 1.80 & 74.59 & 25.45 & 22.11 & 3 & 1723.9690 & 1723.9654 & 575.6624 & 0.0036 & 2.0846 & 18510.473 & 25264.939 & 782.205 & 21342.898 & \text { Yes }\end{array}$

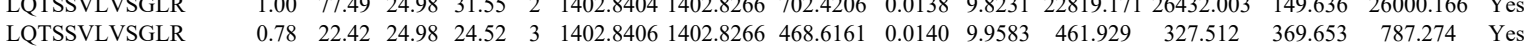
$\begin{array}{llllllllllllllll}\text { LQTSSVLSLR } & 0.78 & 22.42 & 24.98 & 24.52 & 3 & 1402.8406 & 402.8266 & 468.6161 & 0.0140 & 9.9583 & 461.929 & 327.512 & 369.653 & 787.274 & \text { Yes } \\ \text { LQTSSVLVGLR } & 1.00 & 78.31 & 25.89 & 38.56 & 2 & 1402.8274 & 1402.8266 & 702.4206 & 0.0008 & 0.5695 & 19341.286 & 21743.215 & 46.322 & 23498.071 & \text { Yes }\end{array}$ 


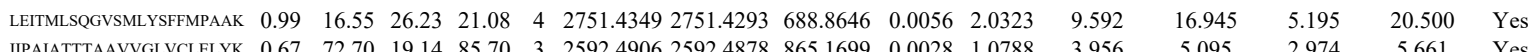

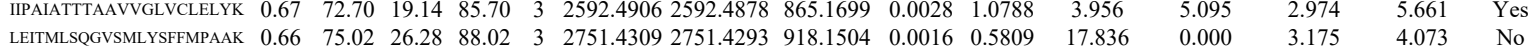

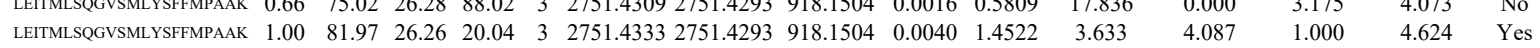

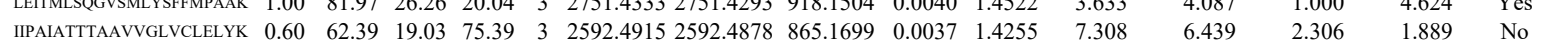
$\begin{array}{lllllllllllllllllll} & \text { AENYDIPSADR } & 1.00 & 56.59 & 26.51 & 23.28 & 2 & 1393.6604 & 1393.6595 & 697.8370 & 0.0009 & 0.6448 & 11.266728 & 15203.353 & 978.290 & 13001.823 & \text { Yes }\end{array}$ $\begin{array}{lllllllllllllllllll}\text { AENYDIPSADR } & 1.00 & 56.59 & 26.51 & 23.28 & 2 & 1393.6604 & 1393.6595 & 697.837 & 0.0009 & 0.6448 & 11266.728 & 15203.353 & 978.290 & 13001.823 & \text { Yes } \\ \text { AENYDIPSADR } & 1.00 & 53.07 & 26.50 & 22.70 & 2 & 1393.6606 & 1393.6595 & 697.8370 & 0.0011 & 0.7881 & 14300.759 & 17645.283 & 759.166 & 14871.571 & \text { Yes }\end{array}$

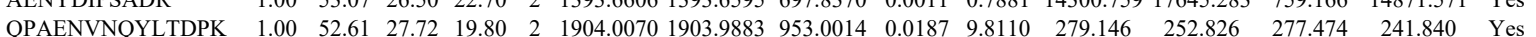

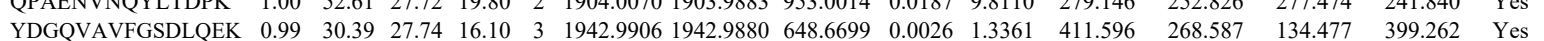
$\begin{array}{llllllllllllllll}\text { YDGQVAVFGSDLQEK } & 1.00 & 42.45 & 27.75 & 23.09 & 3 & 1942.9918 & 1942.9880 & 648.6699 & 0.0038 & 1.9527 & 290.722 & 288.921 & 131.325 & 450.021 & \text { Yes }\end{array}$

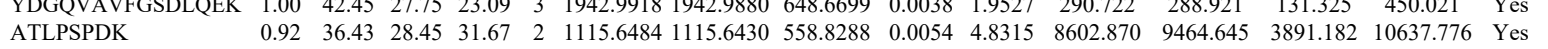
$\begin{array}{lllllllllllllllll}\text { ATLPSPDK } & 0.92 & 36.66 & 28.45 & 30.69 & 2 & 1115.6484 & 1115.6430 & 558.8288 & 0.0054 & 4.8315 & 9481.431 & 11055.764 & 5755.041 & 13041.172 & \text { Yes }\end{array}$ $\begin{array}{lllllllllllllllll}\text { NEEDAAELVALAQAVNAR } & 0.82 & 16.01 & 27.36 & 15.45 & 3 & 2027.0434 & 2027.0405 & 676.6874 & 0.0029 & 1.4285 & 201.026 & 198.272 & 89.844 & 388.955 & \text { Yes }\end{array}$

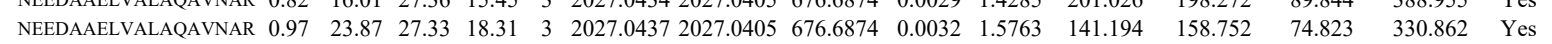
$\begin{array}{llllllllllllllll}\text { EESGKPGAHVTVK } & 0.97 & 13.00 & 26.01 & 20.96 & 4 & 1770.0021 & 1770.0001 & 443.5073 & 0.0020 & 1.1274 & 5440.876 & 5195.320 & 11930.888 & 15080.737 & \text { No }\end{array}$ $\begin{array}{lllllllllllllllll}\text { GFGFVTFDDHDPVDK } & 1.00 & 36.91 & 27.41 & 16.61 & 3 & 1982.9644 & 1982.9618 & 661.9945 & 0.0026 & 1.3092 & 9241.196 & 8697.139 & 2604.633 & 18715.171 & \text { Yes }\end{array}$ $\begin{array}{lllllllllllllllll}\text { GFGFVTFDDHDPVDK } & 1.00 & 35.90 & 27.50 & 18.16 & 3 & 1982.9653 & 1982.9618 & 661.9945 & 0.0035 & 1.7623 & 6443.771 & 8414.082 & 1956.667 & 16321.891 & \text { Yes }\end{array}$ $\begin{array}{lllllllllllllllll}1.00 & 57.72 & 28.25 & 25.35 & 2 & 1331.7434 & 1331.7418 & 666.8782 & 0.0016 & 1.1996 & 4309.777 & 5665.273 & 343.573 & 10348.521 & \text { Yes }\end{array}$ $\begin{array}{llllllllllllllll}1.00 & 60.04 & 28.25 & 25.74 & 2 & 1331.7436 & 1331.7418 & 666.8782 & 0.0018 & 1.3496 & 11117.085 & 12622.377 & 972.787 & 26189.327 & \text { Yes }\end{array}$ $\begin{array}{lllllllllllllllll}\text { IDTIEIITDR } & 1.00 & 57.67 & 28.33 & 38.12 & 2 & 1331.7440 & 1331.7418 & 666.8782 & 0.0022 & 1.6495 & 3116.190 & 4272.423 & 703.979 & 7143.769 & \text { Yes }\end{array}$ $\begin{array}{llllllllllllllll}\text { IDTIEIITDR } & 1.00 & 59.87 & 28.33 & 35.86 & 2 & 1331.7440 & 1331.7418 & 666.8782 & 0.0022 & 1.6495 & 6275.226 & 6328.424 & 530.173 & 11720.946 & \text { Yes }\end{array}$ \begin{tabular}{llllllllllllllll} 
NYYEQWGK & 0.96 & 35.85 & 27.56 & 23.16 & 2 & 1374.6948 & 1374.6812 & 688.3479 & 0.0136 & 9.8786 & 4122.005 & 3926.313 & 446.262 & 9209.709 & Yes \\
\hline
\end{tabular}

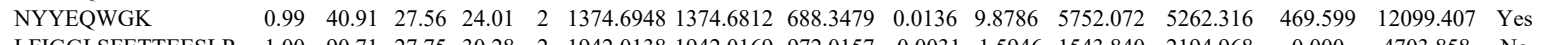

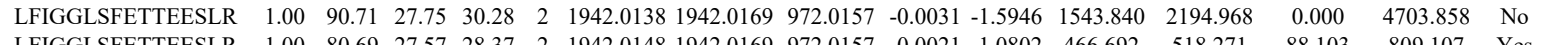

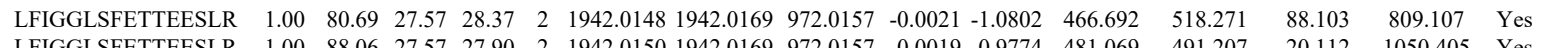

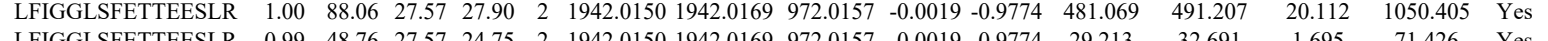

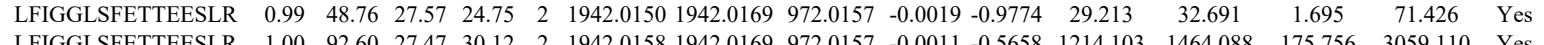

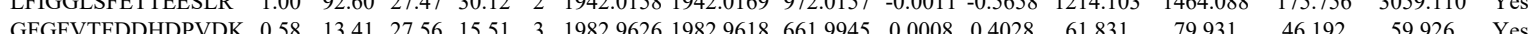

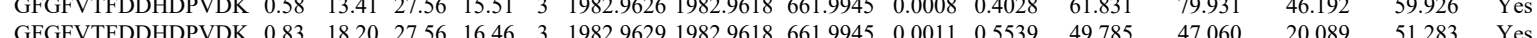

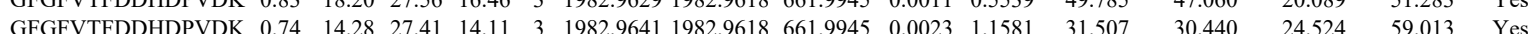
$\begin{array}{llllllllllllllll}\text { GFGFVTFDDHDPVDK } & 0.81 & 15.80 & 27.48 & 15.47 & 3 & 1982.9650 & 1982.9618 & 61.9945 & 0.0232 & 1.6113 & 37.052 & 39.707 & 23.257 & 52.551 & \text { Yes }\end{array}$ $\begin{array}{lllllllllllllllll}\text { GFGFVTFDDHDPVDK } & 0.54 & 10.45 & 27.50 & 15.31 & 3 & 1982.9653 & 1982.9618 & 661.9945 & 0.0035 & 1.7623 & 52.469 & 49.210 & 20.643 & 46.905 & \text { Yes }\end{array}$

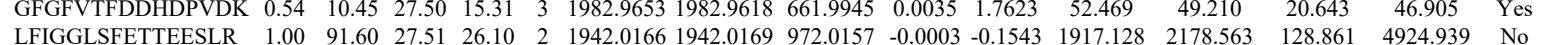
$\begin{array}{llllllllllllllll}\text { LFFGGLSFETTESLR } & 1.00 & 96.03 & 27.53 & 28.56 & 2 & 1942.0168 & 1942.0169 & 972.0157 & -0.0001 & -0.0514 & 142.461 & 102.132 & 13.848 & 222.412 & \text { Yes }\end{array}$

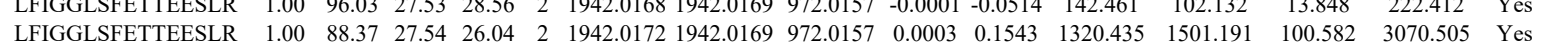
$\begin{array}{lllllllllllllllll}\text { LFIGGLSFETTEESLR } & 1.00 & 51.93 & 27.62 & 17.07 & 3 & 1942.0189 & 1942.0169 & 648.3462 & 0.0020 & 1.0283 & 231.684 & 320.309 & 146.424 & 413.092 & \text { Yes }\end{array}$ $\begin{array}{llllllllllllllll}\text { LFIGGLSFETTEESLR } & 1.00 & 57.38 & 27.60 & 20.07 & 3 & 1942.0192 & 1942.0169 & 648.3462 & 0.0023 & 1.1825 & 315.441 & 225.552 & 93.556 & 409.128 & \text { Yes }\end{array}$

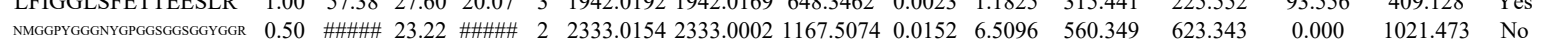

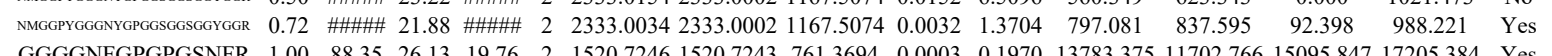
$\begin{array}{lllllllllllllllll}\text { GGGGNFGPGPGSNFR } & 1.00 & 88.35 & 26.13 & 19.76 & 2 & 1520.7246 & 1520.7243 & 761.3694 & 0.0003 & 0.1970 & 13783.375 & 11702.766 & 15095.847 & 17205.384 & \text { Yes }\end{array}$ $\begin{array}{llllllllllllllll}\text { GGGGNFGPGPGSNFR } & 1.00 & 91.14 & 26.06 & 22.06 & 2 & 1520.7248 & 1520.7243 & 761.3694 & 0.0005 & 0.3284 & 9297.273 & 10154.308 & 12582.720 & 16042.600 & \text { Yes } \\ \text { LTDCVVMR } & 0.97 & 35.34 & 26.33 & 28.40 & 2 & 1125.5576 & 1125.546 & 563.7806 & 0.0110 & 9.7555 & 7050.547 & 8657.163 & 1050.092 & 16505.122 & \text { Yes }\end{array}$

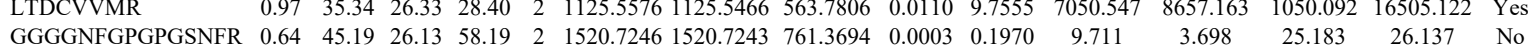

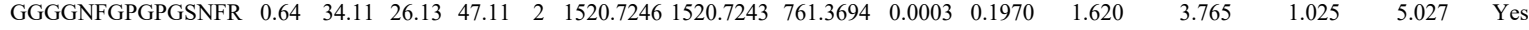
$\begin{array}{lllllllllllllllll}\text { GGGGNFGPGPGSNFR } & 1.00 & 86.59 & 26.37 & 22.48 & 2 & 1520.7268 & 1520.7243 & 761.3694 & 0.0025 & 1.6418 & 8242.669 & 12005.886 & 15656.913 & 15293.788 & \text { Yes }\end{array}$

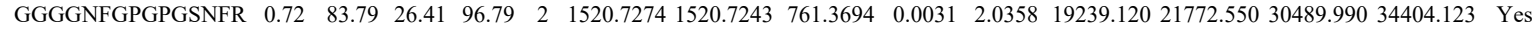
$\begin{array}{llllllllllllllll}\text { GGGGNFGPGPGSNFR } & 0.60 & 13.23 & 26.29 & 26.23 & 3 & 1520.7280 & 1520.7243 & 507.9154 & 0.0037 & 2.4282 & 1714.814 & 1565.171 & 1047.763 & 1203.852 & \text { Yes }\end{array}$

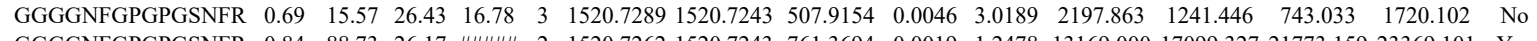
$\begin{array}{llllllllllllllllll}\text { GGGGNFGPGPGSNFR } & 0.84 & 88.73 & 26.17 & \text { \#\#\# } & 2 & 1520.7262 & 1520.7243 & 761.3694 & 0.0019 & 1.2478 & 13169.000 & 17099.327 & 21773.159 & 23369.101 & \text { Yes }\end{array}$ $\begin{array}{llllllllllllllll}\text { GGGGNFGPGPGSNFR } & 0.67 & 13.86 & 26.41 & 26.86 & 3 & 1520.7274 & 1520.7243 & 507.9154 & 0.0031 & 2.0345 & 2622.607 & 2158.556 & 1060.934 & 1333.372 & \text { No }\end{array}$

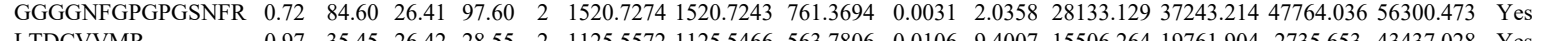
\begin{tabular}{llllllllllllllll} 
LTDCVVMR & 0.97 & 35.45 & 26.42 & 28.55 & 2 & 1125.5572 & 1125.5466 & 563.7806 & 0.0106 & 9.4007 & 15506.264 & 19761.904 & 2735.653 & 43437.028 & Yes \\
\hline
\end{tabular} $\begin{array}{lllllllllllllllll}\text { GGGGNFGPGPGSNFR } & 1.00 & 91.67 & 26.43 & 30.08 & 2 & 1520.7288 & 1520.7243 & 761.3694 & 0.0045 & 2.9552 & 3583.807 & 4281.795 & 5246.333 & 6237.205 & \text { Yes }\end{array}$ $\begin{array}{llllllllllllllllll}\text { GGGGNFGPGPGSNFR } & 1.00 & 98.16 & 26.40 & 29.90 & 2 & 1520.7296 & 1520.7243 & 761.3694 & 0.0053 & 3.4806 & 7565.793 & 7061.899 & 8169.852 & 11210.094 & \text { Yes }\end{array}$

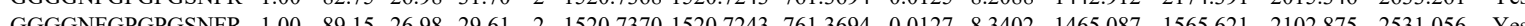

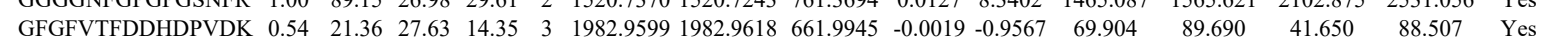

Table S-4 page 227 of 614 


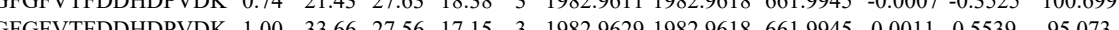
\begin{tabular}{llllllllllll} 
GFGFFVDDDDPV & 1.00 & 33.66 & 27.56 & 17.15 & 3 & 1982.9629 & 1982.9618 & 661.9945 & 0.0011 & 0.5539 & 95.073 \\
\hline
\end{tabular} $\begin{array}{llllllllllll}\text { GFGFVTFDDHDPVDK } & 0.92 & 19.58 & 27.41 & 15.83 & 3 & 1982.9644 & 1982.9618 & 661.9945 & 0.0026 & 1.3092 & 106.879\end{array}$

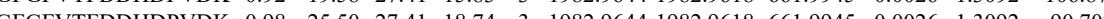

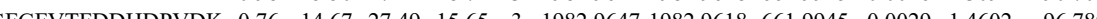

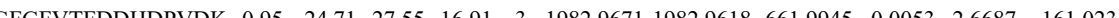

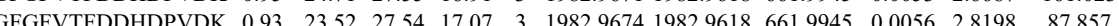
$\begin{array}{llllllllllll}\text { GGGGNFGPGPGSNFR } & 1.00 & 81.62 & 23.38 & 22.73 & 2 & 1376.6190 & 1376.6222 & 689.3184 & -0.0032 & -2.3211 & 16.8440\end{array}$

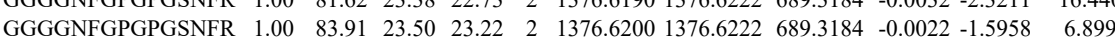
$\begin{array}{llllllllllll}\text { GGGGNFGPGPGSNFR } & 1.00 & 74.96 & 23.52 & 19.24 & 2 & 1376.6206 & 1376.6222 & 689.3184 & -0.0016 & -1.1606 & 18.745\end{array}$ $\begin{array}{llllllllllll}\text { GFGFVTFDDHDPVDK } & 0.95 & 28.88 & 27.63 & 18.33 & 3 & 1982.9611 & 1982.9618 & 661.9945 & -0.0007 & -0.3525 & 133.207\end{array}$ $\begin{array}{llllllllllll}\text { GFGFVTFDDHDPVDK } & 0.98 & 29.31 & 27.57 & 15.02 & 3 & 1982.9623 & 1982.9618 & 661.9945 & 0.0005 & 0.2518 & 143.579\end{array}$ $\begin{array}{lllllllllllll}\text { GFGFVTFDDHDPVDK } & 0.92 & 23.60 & 27.57 & 15.53 & 3 & 1982.9623 & 1982.9618 & 661.9945 & 0.0005 & 0.2518 & 90.358\end{array}$ $\begin{array}{llllllllllll}\text { GFGFVTFDDHDPVDK } & 0.96 & 22.80 & 27.40 & 15.13 & 3 & 1982.9635 & 1982.9618 & 661.9945 & 0.0017 & 0.8560 & 136.271\end{array}$ $\begin{array}{llllllllllll}\text { GFGFVTFDDHDPVDK } & 0.66 & 20.97 & 27.41 & 33.97 & 3 & 1982.9644 & 1982.9618 & 661.9945 & 0.0026 & 1.3092 & 153.393\end{array}$ $\begin{array}{llllllllllll}\text { GFGFVTFDDHDPVDK } & 0.96 & 22.54 & 27.50 & 14.89 & 3 & 1982.9653 & 1982.9618 & 661.9945 & 0.0035 & 1.7623 & 122.904 \\ \text { GFGVTFD }\end{array}$ $\begin{array}{llllllllllll}\text { GFGFVTFDDHDPVDK } & 0.92 & 23.12 & 27.54 & 17.15 & 3 & 1982.9668 & 1982.9618 & 661.9945 & 0.0050 & 2.5176 & 105.431\end{array}$ $\begin{array}{lllllllllllll}\text { GFGFVTFDDHDPVDK } & 0.93 & 26.54 & 27.54 & 15.77 & 3 & 1982.9677 & 1982.9618 & 661.9945 & 0.0059 & 2.9708 & 168.143\end{array}$ $\begin{array}{llllllllllllll}\text { GFGFVTFDDHDPVDK } & 0.92 & 26.97 & 27.54 & 18.87 & 3 & 1982.9686 & 1982.9618 & 661.9945 & 0.0068 & 3.4240 & 125.237\end{array}$ $\begin{array}{lllllllllllll}\text { EESGKPGAHVTVK } & 0.98 & 14.09 & 26.01 & 19.25 & 4 & 1770.0021 & 1770.0001 & 443.5073 & 0.0020 & 1.1274 & 9243.691 \\ \text { EESGKPGAHVTVK } & 0.95 & 11.61 & 25.91 & 15.99 & 4 & 1770.0033 & 1770.0001 & 443.5073 & 0.0032 & 1.8038 & 8968.139\end{array}$ $\begin{array}{lllllllllllll}\text { EESGKPGAHVTVK } & 0.95 & 11.61 & 25.91 & 15.99 & 4 & 1770.0033 & 1770.0001 & 443.5073 & 0.0032 & 1.8038 & 8968.139 \\ \text { GFGFVTFDDHDPVDK } & 0.97 & 31.57 & 27.68 & 19.00 & 3 & 1982.9614 & 1982.9618 & 661.9945 & -0.0004 & -0.2014 & 168.256\end{array}$ $\begin{array}{lllllllllllll}\text { GFGFVTFDDHDPVDK } & 0.99 & 34.51 & 27.68 & 22.96 & 3 & 1982.9617 & 1982.9618 & 661.9945 & -0.0001 & -0.0504 & 140.673\end{array}$ $\begin{array}{lllllllllllll}\text { GFGFVTFDDHDPVDK } & 1.00 & 37.21 & 27.68 & 15.62 & 3 & 1982.9620 & 1982.9618 & 661.9945 & 0.0002 & 0.1007 & 199.435 \\ \text { GFGFVTFDDHDPVDK } & 1.00 & 38.69 & 27.57 & 21.28 & 3 & 1982.9623 & 1982.9618 & 661.9945 & 0.0005 & 0.2518 & 156.996\end{array}$ $\begin{array}{lllllllllllll}\text { GFGFVTFDDHDPVDK } & 1.00 & 38.69 & 27.57 & 21.28 & 3 & 1982.9623 & 1982.9618 & 661.9945 & 0.0005 & 0.2518 & 156.996 \\ \text { GFGFVTFDDHDPVDK } & 1.00 & 41.64 & 27.56 & 20.53 & 3 & 1982.9626 & 1982.9618 & 661.9945 & 0.0008 & 0.4028 & 169.340\end{array}$ $\begin{array}{lllllllllllll}\text { GFGFVTFDDHDPVDK } & 1.00 & 41.64 & 27.56 & 20.53 & 3 & 1982.9626 & 1982.9618 & 661.9945 & 0.0008 & 0.4028 & 169.340 \\ \text { GFGFVTFDDHDPVDK } & 0.99 & 29.45 & 27.56 & 20.83 & 3 & 1982.9626 & 1982.9618 & 661.9945 & 0.0008 & 0.4028 & 75.384\end{array}$ $\begin{array}{llllllllllll}\text { GFGFVTFDDHDPVDK } & 0.99 & 29.45 & 27.56 & 20.83 & 3 & 1982.9626 & 1982.9618 & 661.9945 & 0.0008 & 0.4028 & 75.384 \\ \text { GFGFVTFDDHDPVDK } & 1.00 & 37.24 & 27.56 & 16.26 & 3 & 1982.9629 & 1982.9618 & 661.9945 & 0.0011 & 0.5539 & 189.322\end{array}$ $\begin{array}{llllllllllll}\text { GFGFVTFDDHDPVDK } & 1.00 & 38.22 & 27.57 & 20.30 & 3 & 1982.9632 & 1982.9618 & 661.9945 & 0.0014 & 0.7049 & 188.036\end{array}$ $\begin{array}{llllllllllll}\text { GFGFVTFDDHDPVDK } & 1.00 & 37.89 & 27.40 & 22.43 & 3 & 1982.9635 & 1982.9618 & 661.9945 & 0.0017 & 0.8560 & 201.282\end{array}$ $\begin{array}{llllllllllll}\text { GFGFVTFDDHDPVDK } & 1.00 & 36.99 & 27.40 & 21.84 & 3 & 1982.9635 & 1982.9618 & 661.9945 & 0.0017 & 0.8560 & 151.076\end{array}$ $\begin{array}{llllllllllll}\text { GFGFVTFDDHDPVDK } & 1.00 & 85.22 & 27.41 & 22.31 & 2 & 1982.9636 & 1982.9618 & 992.4882 & 0.0018 & 0.9068 & 193.308\end{array}$ $\begin{array}{llllllllllllll}\text { GFGFVTFDDHDPVDK } & 1.00 & 36.10 & 27.41 & 23.43 & 3 & 1982.9638 & 1982.9618 & 661.9945 & 0.0020 & 1.0071 & 170.494\end{array}$ $\begin{array}{llllllllllll}\text { GFGFVTFDDHDPVDK } & 1.00 & 31.01 & 27.41 & 15.85 & 3 & 1982.9638 & 1982.9618 & 661.9945 & 0.0020 & 1.0071 & 186.321\end{array}$ $\begin{array}{llllllllllll}\text { GFGFVTFDDHDPVDK } & 1.00 & 52.98 & 27.41 & 21.36 & 3 & 1982.9638 & 1982.9618 & 661.9945 & 0.0020 & 1.0071 & 220.635\end{array}$ $\begin{array}{lllllllllllll}\text { GFGFVTFDDHDPVDK } & 1.00 & 48.43 & 27.41 & 17.49 & 3 & 1982.9638 & 1982.9618 & 661.9945 & 0.0020 & 1.0071 & 165.553 & 17\end{array}$ $\begin{array}{llllllllllllll}\text { GFGFVTFDDHDPVDK } & 1.00 & 33.90 & 27.41 & 18.03 & 3 & 1982.9638 & 1982.9618 & 661.9945 & 0.0020 & 1.0071 & 157.350 & 19\end{array}$ $\begin{array}{llllllllllllll}\text { GFGFVTFDDHDPVDK } & 1.00 & 40.72 & 27.41 & 23.66 & 3 & 1982.9638 & 1982.9618 & 661.9945 & 0.0020 & 1.0071 & 75.653\end{array}$ $\begin{array}{llllllllllll}\text { GFGFVTFDDHDPVDK } & 0.98 & 24.80 & 27.41 & 15.82 & 3 & 1982.9638 & 1982.9618 & 661.9945 & 0.0020 & 1.0071 & 59.125\end{array}$ $\begin{array}{llllllllllllll}\text { GFGFVTFDDHDPVDK } & 1.00 & 41.36 & 27.49 & 15.73 & 3 & 1982.9647 & 1982.9618 & 661.9945 & 0.0029 & 1.4602 & 7700.757 & 76\end{array}$ $\begin{array}{lllllllllllll}\text { GFGFVTFDDHDPVDK } & 1.00 & 34.19 & 27.48 & 15.84 & 3 & 1982.9650 & 1982.9618 & 661.9945 & 0.0032 & 1.6113 & 133.476\end{array}$ $\begin{array}{llllllllllllll}\text { GFGFVTFDDHDPVDK } & 1.00 & 35.06 & 27.50 & 19.24 & 3 & 1982.9653 & 1982.9618 & 661.9945 & 0.0035 & 1.7623 & 120.156\end{array}$ $\begin{array}{llllllllllllll}\text { GFGFVTFDDHDPVDK } & 0.99 & 26.42 & 27.50 & 18.01 & 3 & 1982.9653 & 1982.9618 & 661.9945 & 0.0035 & 1.7623 & 99.220\end{array}$ $\begin{array}{llllllllllllll} & \text { VIFDD }\end{array}$ $\begin{array}{llllllllllllll}\text { EESGKPGAHVTVK } & 0.94 & 11.29 & 25.91 & 19.14 & 4 & 1770.0037 & 1770.0001 & 443.5073 & 0.0036 & 2.0293 & 10804.024 & 9727.290\end{array}$ $\begin{array}{llllllllllll}\text { GFGFVTFDDHDPVDK } & 0.99 & 32.1 & 27.68 & 19.89 & 3 & 1982.9617 & 1982.9618 & 661.9945 & -0.0001 & -0.0504 & 178.699\end{array}$ $\begin{array}{llllllllllll}\text { GFGFVTFDDHDPVDK } & 0.99 & 28.68 & 27.56 & 15.28 & 3 & 1982.9626 & 1982.9618 & 661.9945 & 0.0008 & 0.4028 & 169.685\end{array}$ $\begin{array}{lllllllllllll}\text { GFGFVTFDDHDPVDK } & 0.98 & 28.08 & 27.56 & 19.05 & 3 & 1982.9626 & 1982.9618 & 661.9945 & 0.0008 & 0.4028 & 143.731\end{array}$ $\begin{array}{lllllllllllll}\text { GFGFVTFDDHDPVDK } & 0.99 & 29.20 & 27.56 & 15.48 & 3 & 1982.9626 & 1982.9618 & 661.9945 & 0.0008 & 0.4028 & 87.863 \\ \text { GFGFVTFDDHDPVDK } & 1.00 & 80.60 & 27.56 & 24.99 & 2 & 1982.9628 & 1982.9618 & 992.4882 & 0.0010 & 0.5038 & 784.577\end{array}$ $\begin{array}{lllllllllllll}\text { GFGFVTFDDHDPVDK } & 1.00 & 80.60 & 27.56 & 24.99 & 2 & 1982.9628 & 1982.9618 & 992.4882 & 0.0010 & 0.5038 & 784.577 & 78 \\ \text { GFGFVTFDDHDPVDK } & 1.00 & 36.13 & 27.56 & 20.41 & 3 & 1982.9629 & 1982.9618 & 661.9945 & 0.0011 & 0.5539 & 104.720 & 13\end{array}$ $\begin{array}{llllllllllll}\text { GFGFVTFDDHDPVDK } & 1.00 & 36.13 & 27.56 & 20.41 & 3 & 1982.9629 & 1982.9618 & 661.9945 & 0.0011 & 0.5539 & 104.720 \\ \text { GFGFVTFDDHDPVDK } & 1.00 & 34.73 & 27.56 & 26.53 & 3 & 1982.9629 & 1982.9618 & 661.9945 & 0.0011 & 0.5539 & 161.938\end{array}$ $\begin{array}{llllllllllll}\text { GFGFVTFDDHDPVDK } & 1.00 & 34.73 & 27.56 & 26.53 & 3 & 1982.9629 & 1982.9618 & 661.9945 & 0.0011 & 0.5539 & 161.938\end{array}$ $\begin{array}{llllllllllll}\text { GFGFVTFDDHDPVDK } & 1.00 & 36.00 & 27.57 & 19.38 & 3 & 1982.9632 & 1982.9618 & 661.9945 & 0.0014 & 0.7049 & 160.314 \\ \text { GFGFVTFDDHDPVDK } & 1.00 & 35.54 & 27.57 & 27.54 & 3 & 1982.9632 & 1982.9618 & 661.9945 & 0.0014 & 0.7049 & 145.190\end{array}$ $\begin{array}{llllllllllll}\text { GFGFVTFDDHDPVDK } & 1.00 & 38.98 & 27.40 & 22.61 & 3 & 1982.9635 & 1982.9618 & 661.9445 & 0.0017 & 0.8560 & 124.806\end{array}$ $\begin{array}{llllllllllll}\text { GFGFVTFDDHDPVDK } & 1.00 & 34.54 & 27.41 & 18.66 & 3 & 1982.9638 & 1982.9618 & 661.9945 & 0.0020 & 1.0071 & 165.024\end{array}$ $\begin{array}{lllllllllllll}\text { GFGFVTFDDHDPVDK } & 1.00 & 33.71 & 27.41 & 20.07 & 3 & 1982.9638 & 1982.9618 & 661.9945 & 0.0020 & 1.0071 & 109.787\end{array}$

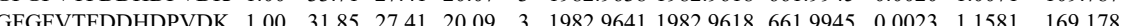

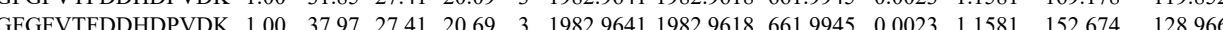




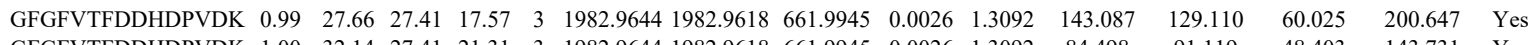
$\begin{array}{llllllllllllllll}\text { GFGFVTFDDHDPVDK } & 1.00 & 32.14 & 27.41 & 21.31 & 3 & 1982.9644 & 1982.9618 & 661.9945 & 0.0026 & 1.3092 & 84.498 & 91.119 & 48.403 & 143.731 & \text { Yes }\end{array}$

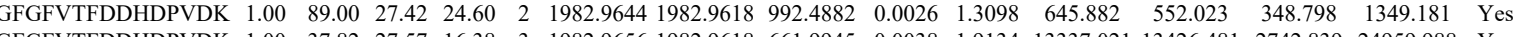
$\begin{array}{llllllllllllllll}\text { GFGFVTFDDHDPVDK } & 1.00 & 37.82 & 27.57 & 16.38 & 3 & 1982.9656 & 1982.9618 & 661.9945 & 0.0038 & 1.9134 & 13337.021 & 13426.481 & 2742.839 & 24959.988 & \text { Yes }\end{array}$ $\begin{array}{lllllllllllllllll}\text { GFGFVTFDDHDPVDK } & 0.99 & 31.33 & 27.53 & 22.24 & 3 & 1982.9662 & 1982.9618 & 661.9945 & 0.0044 & 2.2155 & 168.524 & 167.021 & 71.479 & 246.226 & \text { Yes }\end{array}$ $\begin{array}{llllllllllllllll}\text { GFGFVTFDDHDPVDK } & 1.00 & 39.89 & 27.53 & 17.24 & 3 & 1982.9662 & 1982.9618 & 661.9945 & 0.0044 & 2.2155 & 7779.249 & 8123.127 & 1957.596 & 16144.603 & \text { Yes }\end{array}$

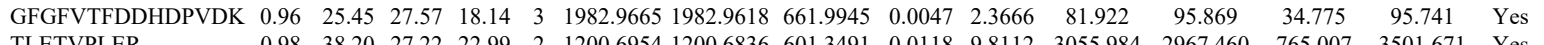

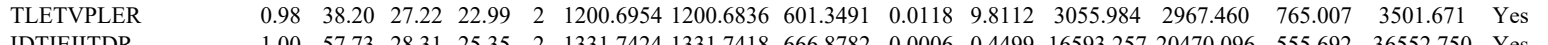

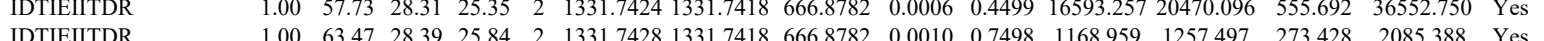

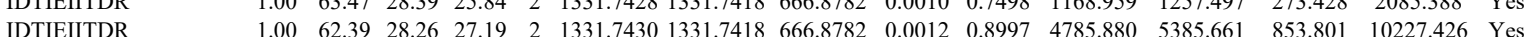
$\begin{array}{llllllllllllll} & 1.025 .426 & \text { Yes }\end{array}$

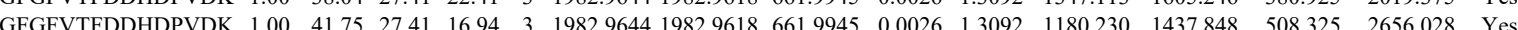
$\begin{array}{lllllllllllllllll}\text { NCTYTQVQTR } & 1.00 & 62.02 & 25.48 & 26.87 & 2 & 1402.6454 & 1402.645 & 7023300 & -0.0001 & -0.0712 & 13994.783 & 10971.593 & 871.992 & 24097.767 & \text { Yes }\end{array}$

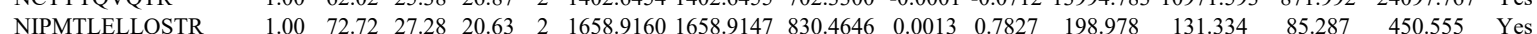

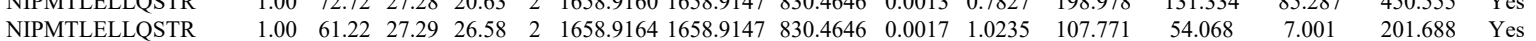

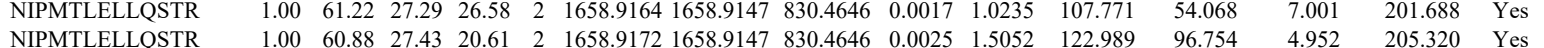

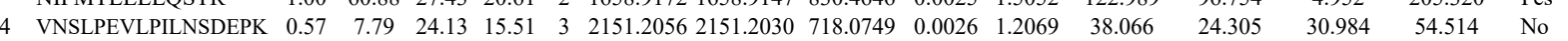

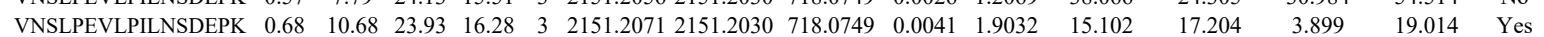

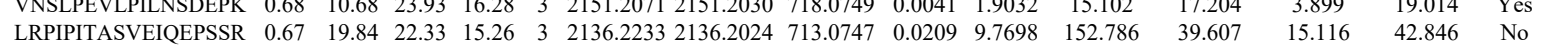
$\begin{array}{llllllllllllllll}\text { LRPIPITASVEIOEPSSR } & 1.00 & 67.44 & 24.28 & 21.44 & 3 & 2136.2029 & 2136.2024 & 713.0747 & 0.0005 & 0.2337 & 288.887 & 321.281 & 90.733 & 175.728 & \text { No }\end{array}$ $\begin{array}{llllllllllllllll}\text { LSYLPIQK } & 0.97 & 33.09 & 24.35 & 22.28 & 2 & 1282.7646 & 1282.7529 & 642.3837 & 0.0117 & 9.1066 & 10600.629 & 12165.495 & 1171.246 & 13394.417 & \text { Yes }\end{array}$ $\begin{array}{llllllllllllllll}\text { SRPVINIQK } & 0.95 & 27.91 & 20.53 & 22.95 & 2 & 1341.8374 & 1341.8336 & 671.9241 & 0.0038 & 2.8277 & 2018.262 & 2788.402 & 2868.646 & 3261.130 & \text { No }\end{array}$ $\begin{array}{llllllllllllllll}\text { SRPVINIQK } & 0.68 & 20.83 & 20.37 & 22.69 & 2 & 1341.8382 & 1341.8336 & 671.9241 & 0.0046 & 3.4230 & 2081.347 & 2487.770 & 2215.422 & 3033.825 & \text { Yes }\end{array}$ $\begin{array}{llllllllllllllll}\text { SRPVINIQK } & 0.93 & 17.31 & 20.37 & 20.14 & 3 & 1341.8386 & 1341.8336 & 448.2851 & 0.0050 & 3.7179 & 5630.064 & 7210.839 & 6360.504 & 8269.242 & \text { Yes }\end{array}$ $\begin{array}{llllllllllllllll}\text { SRPVINIQK } & 0.82 & 14.52 & 20.09 & 21.29 & 3 & 1341.8389 & 1341.8336 & 448.2851 & 0.0053 & 3.9409 & 12798.831 & 16706.147 & 16062.128 & 20761.965 & \text { Yes }\end{array}$

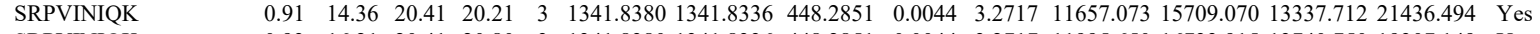

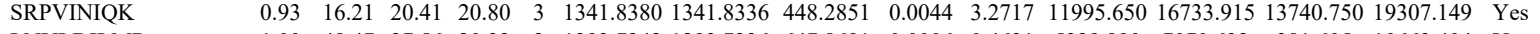
$\begin{array}{llllllllllllllll}\text { LNYLDILMR } & 1.00 & 48.47 & 27.56 & 20.32 & 2 & 1293.7242 & 1293.7236 & 647.8691 & 0.0006 & 0.4631 & 5329.990 & 7070.632 & 381.605 & 10663.404 & \text { Yes } \\ \text { LNYLDILMR } & 1.00 & 38.83 & 27.47 & 19.60 & 2 & 1293.7252 & 1293.7236 & 647.8691 & 0.0016 & 1.2348 & 4820.313 & 7595.376 & 65.809 & 12411.230 & \text { Yes }\end{array}$ LNYLDILMR LNYLDILMR WNNVKPIR WNNVKPIR WNNVKPIR WNNVKPIR WNNVKPIR WLLYLVK WLLYLVK WLLYLVK
WLLYLVK

WLLYLVK

LLLVGAPR

LLLVGAPR
LLLVGAPR

LLLLVGAPR

LLLVGAPR

LLLVGAPR

QGPGPGGPK QGPGPGGPK $\begin{array}{lllllllllllllll}1.00 & 47.21 & 27.56 & 19.96 & 2 & 1293.7240 & 1293.7236 & 647.8691 & 0.0004 & 0.3087 & 1610.935 & 2599.027 & 369.451 & 3225.030 & \text { Yes }\end{array}$ $\begin{array}{lllllllllllllll}1.00 & 47.21 & 27.56 & 19.96 & 2 & 1293.7240 & 1293.7236 & 647.861 & 0.0004 & 0.3087 & 1610.935 & 2599.027 & 369.451 & 3225.030 & \text { Yes }\end{array}$

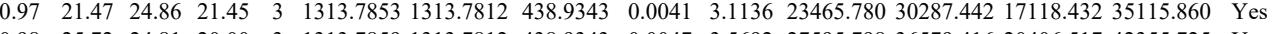

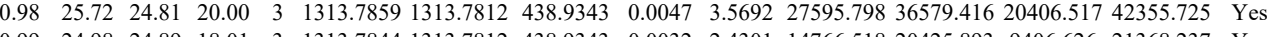
$\begin{array}{llllllllllllllllll}0.99 & 24.98 & 24.8 & 18.01 & 3 & 1313.7844 & 1313.7812 & 438.9343 & 0.0032 & 2.4301 & 14766.518 & 20425.893 & 9406.626 & 21368.237 & \text { Yes }\end{array}$

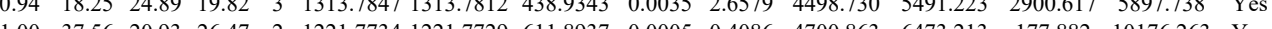

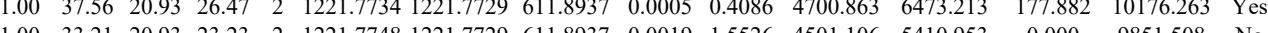

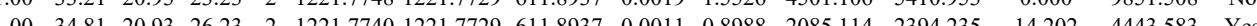

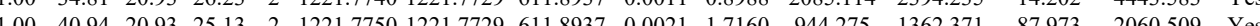

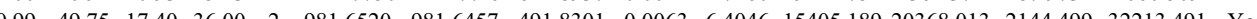

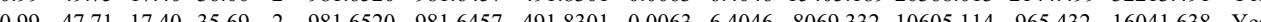
$\begin{array}{llllllllllllllll}1.00 & 45.63 & 16.13 & 32.85 & 2 & 981.6462 & 981.6457 & 491.8301 & 0.0005 & 0.5083 & 5155.656 & 7275.166 & 901.099 & 10605.868 & \text { Yes }\end{array}$ $\begin{array}{lllllllllllllllll}100 & 4540 & 16.13 & 28.86 & 2 & 981.6470 & 981.6457 & 4918301 & 0.0013 & 1.3216 & 11390641 & 18229356 & 3522.007 & 28542398 & \text { Yes }\end{array}$ $\begin{array}{llllllllllllllll}1.00 & 4560 & 16.13 & 29.14 & 2 & 981.6454 & 981.6457 & 491.8301 & -0.0003 & -03050 & 2678.136 & 4696.655 & 433.830 & 6793269 & \text { Yes }\end{array}$ $\begin{array}{llllllllllllllll}1.00 & 45.60 & 6.13 & 29.14 & 2 & 981.6454 & 981.6457 & 491.8301 & -0.0003 & -0.3050 & 2678.136 & 4696.655 & 433.830 & 6793.269 & \text { Yes } \\ 1.00 & 45.57 & 16.13 & 29.17 & 2 & 981.6458 & 981.6457 & 491.8301 & 0.0001 & 0.1017 & 3607.843 & 4817.820 & 492.034 & 7711.992 & \text { Yes }\end{array}$ $\begin{array}{lllllllllllllll}1.00 & 38.51 & 26.76 & 23.04 & 2 & 1081.6140 & 1081.6124 & 541.8135 & 0.0016 & 1.4765 & 261.211 & 95.880 & 103.379 & 280.344 & \text { Yes }\end{array}$

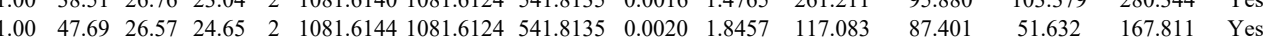
$\begin{array}{lllllllllllllll}0.99 & 44.41 & 27.33 & 25.30 & 2 & 1539.8330 & 1539.8177 & 770.9161 & 0.0153 & 9.9232 & 336.609 & 220.688 & 308.628 & 341.595 & \text { Yes }\end{array}$ $\begin{array}{llllllllllllllllll}\text { LFVGNLPADITEDEFK } & 1.00 & 86.34 & 27.86 & 23.52 & 2 & 2095.1094 & 2095.1081 & 1048.5613 & 0.0013 & 0.6199 & 1078.172 & 679.845 & 534.252 & 2123.145 & \text { Yes }\end{array}$ $\begin{array}{lllllllllllllllll}\text { LFVGNLPADITEDEFK } & 1.00 & 76.20 & 27.74 & 23.01 & 2 & 2095.1114 & 2095.1081 & 1048.5613 & 0.0033 & 1.5736 & 1708.015 & 747.716 & 443.670 & 2806.596 & \text { Yes }\end{array}$ $\begin{array}{llllllllllllllll}\text { LFVGNLPADITEDEFK } & 0.99 & 28.65 & 27.77 & 18.50 & 3 & 2095.1125 & 2095.1081 & 699.3766 & 0.0044 & 2.0971 & 71.562 & 134.915 & 122.099 & 145.295 & \text { Yes }\end{array}$ $\begin{array}{lllllllllllllllll}\text { LFVGNLPADITEDEFK } & 1.00 & 57.53 & 27.77 & 19.60 & 3 & 2095.1125 & 2095.1081 & 699.3766 & 0.0044 & 2.0971 & 626.144 & 359.006 & 297.489 & 952.752 & \text { Yes }\end{array}$ $\begin{array}{lllllllllllllllll}\text { LFVGNLPADITEDEFK } & 1.00 & 49.50 & 27.72 & 17.83 & 3 & 2095.1119 & 2095.1081 & 699.3766 & 0.0038 & 1.8111 & 170.162 & 105.990 & 107.616 & 145.523 & \text { Yes }\end{array}$ $\begin{array}{lllllllllllllllll}\text { LFVGNLPADITEDEFK } & 1.00 & 58.81 & 27.77 & 20.28 & 3 & 2095.1122 & 2095.1081 & 699.3766 & 0.0041 & 1.9541 & 136.751 & 138.623 & 148.586 & 297.683 & \text { Yes }\end{array}$ $\begin{array}{lllllllllllllllll}\text { GMGPGTPAGYGR } & 1.00 & 43.80 & 26.74 & 21.55 & 2 & 1263.6178 & 1263.6152 & 632.8149 & 0.0026 & 2.0543 & 1141.927 & 705.631 & 466.808 & 905.741 & \text { Yes }\end{array}$ $\begin{array}{llllllllllllllll}\text { NLSPYVSNELLEEAFSQFGPIER } & 0.55 & 35.44 & 27.36 & 48.44 & 3 & 2782.3951 & 2782.3935 & 928.4718 & 0.0016 & 0.5744 & 21.096 & 43.910 & 108.655 & 25.694 & \text { No }\end{array}$

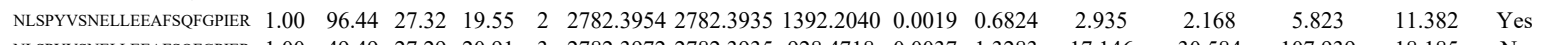

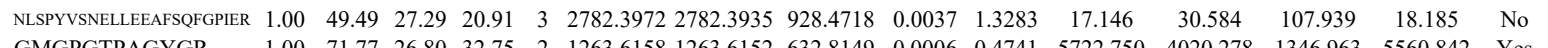
$\begin{array}{llllllllllllllll}\text { GMGPGTPAGYGR } & 1.00 & 71.77 & 26.80 & 32.75 & 2 & 1263.6158 & 1263.6152 & 632.8149 & 0.0006 & 0.4741 & 5722.750 & 4020.278 & 1346.963 & 5560.842 & \text { Yes }\end{array}$

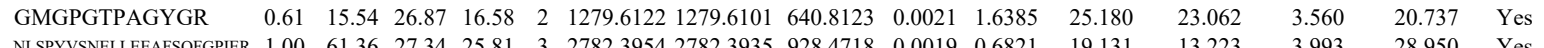

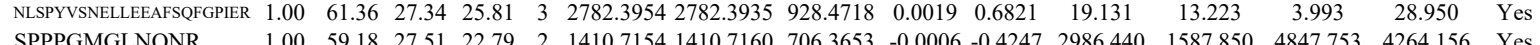

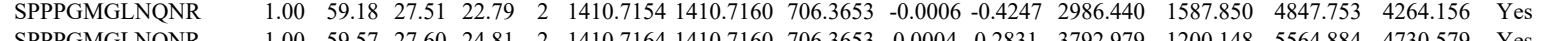

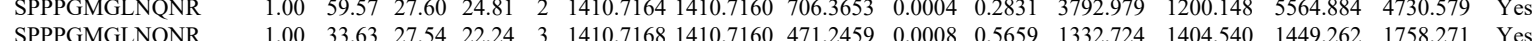

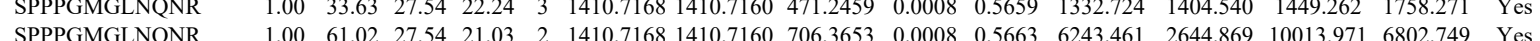

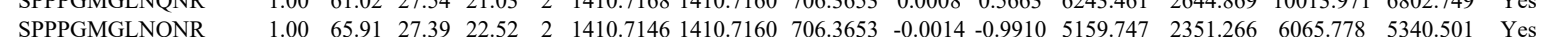

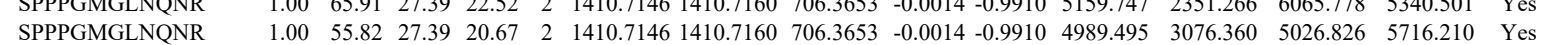




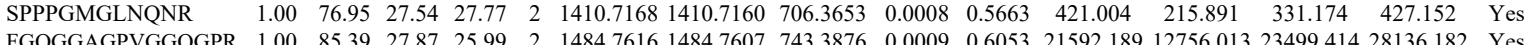

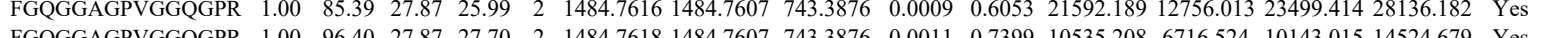
$\begin{array}{lllllllllllllllll} & \text { FGQGGAGPVGGQGPR } & 1.00 & 96.40 & 27.87 & 27.70 & 2 & 1484.7618 & 1484.7607 & 743.3876 & 0.0011 & 0.7399 & 15535.208 & 6716.524 & 10143.015 & 14524.679 & \text { Yes } \\ \text { FGQGGAGPGGQGPR } & 1.00 & 35.08 & 27.75 & 16.05 & 3 & 1484.7625 & 1484.7607 & 495.9275 & 0.0018 & 1.2099 & 1000.450 & 1049.228 & 778.745 & 1108.091 & \text { Yes }\end{array}$ $\begin{array}{lllllllllllllllll} & \end{array}$ $\begin{array}{llllllllllllllll} & \end{array}$

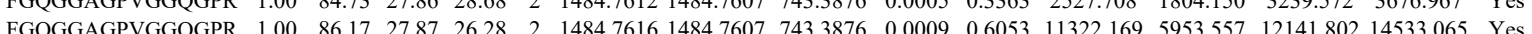
$\begin{array}{lllllllllllllllll} & \text { FQQGGAGPVGGQGPR } & 0.99 & 31.92 & 27.73 & 17.73 & 3 & 1484.7622 & 1484.7607 & 495.9275 & 0.0015 & 1.0082 & 1086.693 & 1234.953 & 920.870 & 1240575 & \text { Yes }\end{array}$

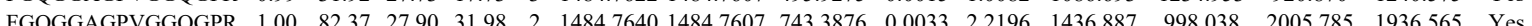

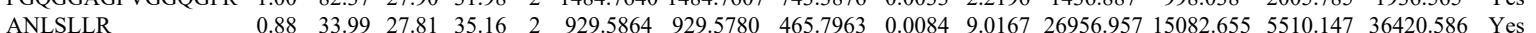

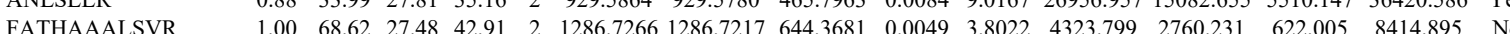
$\begin{array}{llllllllllllllll}\text { FATHAAALSVR } & 1.00 & 63.35 & 27.35 & 29.10 & 3 & 1286.7271 & 12867217 & 429.9145 & 0.0054 & 4.1869 & 11116.962 & 10179.835 & 3127.249 & 15729.244 & \text { Yes }\end{array}$ $\begin{array}{lllllllllllllllll}\text { FATHAAALSVR } & 1.00 & 48.37 & 27.30 & 24.71 & 3 & 1286.7274 & 1286.7217 & 429.9145 & 0.0057 & 4.4195 & 9424.710 & 10207.909 & 4090.001 & 15075.221 & \text { Yes }\end{array}$ $\begin{array}{llllllllllllllll}\text { FATHAAALSVR } & 1.00 & 48.99 & 27.35 & 24.64 & 3 & 12867271 & 12867217 & 429.9145 & 0.0054 & 4.1869 & 5601.571 & 6425.925 & 2695.816 & 11603.667 & \text { Yes }\end{array}$ $\begin{array}{lllllllllllllllll}\text { FATHAAALSVR } & 1.00 & 51.90 & 27.35 & 26.42 & 3 & 1286.7271 & 1286.7217 & 429.9145 & 0.0054 & 4.1869 & 7034.693 & 7832.887 & 3457.853 & 11444.909 & \text { Yes }\end{array}$ $\begin{array}{llllllllllllllll}\text { FATHAAALSVR } & 1.00 & 43.17 & 27.54 & 24.53 & 3 & 1286.7256 & 1286.7217 & 429.9145 & 0.0039 & 3.0238 & 4150.493 & 4900.703 & 1678.061 & 6437.978 & \text { Yes }\end{array}$

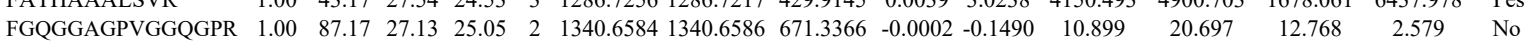
$\begin{array}{lllllllllllllllll}\text { FGQGGAGPVGGQGPR } & 1.00 & 79.70 & 27.08 & 29.01 & 2 & 1340.6620 & 1340.6586 & 671.3366 & 0.0034 & 2.5323 & 2.450 & 12.370 & 14.707 & 4.449 & \text { No }\end{array}$

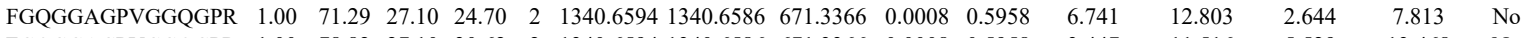

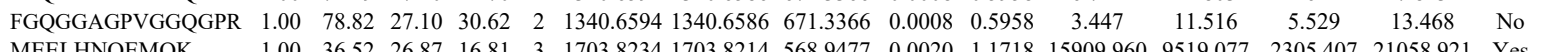
\begin{tabular}{llllllllllllllll} 
MEELHNQEMQK & 1.00 & 36.52 & 26.87 & 16.81 & 3 & 1703.8234 & 1703.8214 & 568.9477 & 0.0020 & 1.1718 & 15909.960 & 9519.077 & 2305.407 & 21058.921 & Yes \\
\hline
\end{tabular}

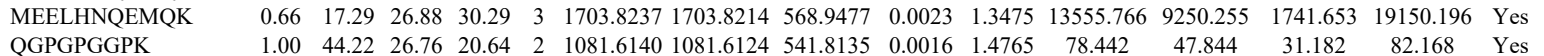

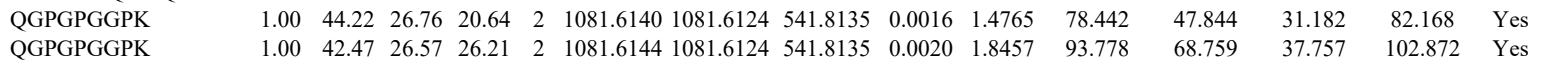

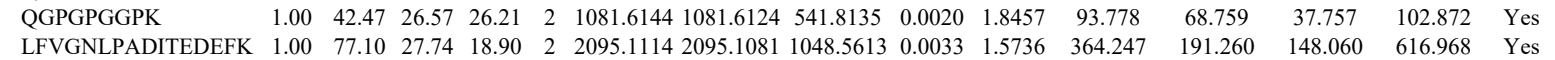
$\begin{array}{lllllllllllllllll}\text { LFVGNLPADITEDEFK } & 1.00 & 77.10 & 27.74 & 18.90 & 2 & 2095.1114 & 2095.1081 & 1048.5613 & 0.0033 & 1.5736 & 364.247 & 191.260 & 148.060 & 616.968 & \text { Yes } \\ \text { LFVGNLPADITEDEFK } & 1.00 & 90.21 & 27.74 & 24.80 & 2 & 2095.1114 & 2095.1081 & 1048.5613 & 0.0033 & 1.5736 & 683.717 & 353.260 & 264.844 & 809.398 & \text { Yes }\end{array}$ $\begin{array}{lllllllllllllllll}\text { LFVGNLPADITEDEFK } & 1.00 & 46.58 & 27.77 & 16.95 & 3 & 2095.1114 & 2095.1081 & 1048.5613 & 0.0033 & 1.5736 & 683.717 & 353.260 & 264.844 & 809.398 & \text { Yes } \\ \text { LFVGNLPADITEDEFK } & 1.00 & 46.1081 & 2599.3766 & 0.0047 & 2.2401 & 975.530 & 468.415 & 445.973 & 979.363 & \text { Yes }\end{array}$ $\begin{array}{lllllllllllllllll}\text { LFVGNLPADITEDEFK } & 1.00 & 46.58 & 27.77 & 16.95 & 3 & 2095.1128 & 2095.1081 & 699.3766 & 0.0047 & 2.240 & 975.530 & 468.415 & 445.973 & 979.363 & \text { Yes } \\ \text { QLCAEHIIPEGIIEEFATEGTDR } & 1.00 & 53.91 & 25.39 & 18.23 & 3 & 2777.2786 & 2777.2758 & 926.7659 & 0.0028 & 1.0071 & 22.192 & 16.718 & 16.196 & 24.725 & \text { Yes }\end{array}$

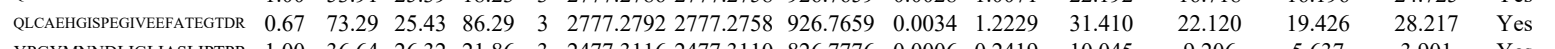

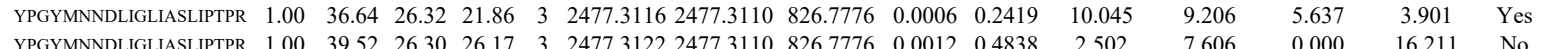

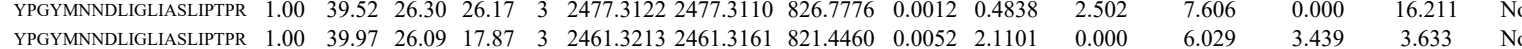
$\begin{array}{lllllllllllll} & \text { No }\end{array}$

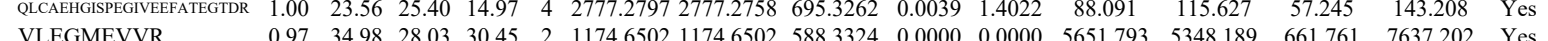
$\begin{array}{llllllllllllllllll}\text { VLEGMEVVR } & 0.97 & 34.98 & 28.03 & 30.45 & 2 & 1174.6502 & 1174.6502 & 588.3324 & 0.0000 & 0.0000 & 5651.793 & 5348.189 & 661.761 & 7637.202 & \text { Yes } \\ \text { VLEGMEVVR } & 1.00 & 43.87 & 28.06 & 33.57 & 2 & 1174.6504 & 1174.6502 & 588.3324 & 0.0002 & 0.1700 & 4470.163 & 3960.181 & 285.173 & 6003.693 & \text { Yes }\end{array}$

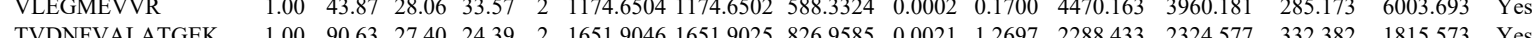
$\begin{array}{llllllllllllllll}\text { TVDNFVALATGEK } & 1.00 & 96.66 & 27.33 & 25.28 & 2 & 1651.9054 & 1651.9025 & 826.9585 & 0.0029 & 1.7534 & 541.162 & 507.118 & 103.253 & 481.706 & \text { Yes }\end{array}$ $\begin{array}{llllllllllllllll} & \\ \text { TVDNFVALATGEK } & 0.67 & 30.66 & 27.28 & 43.66 & 3 & 1651.9060 & 1651.9025 & 551.6414 & 0.0035 & 2.149 & 224.698 & 91.244 & 39.784 & 251.321 & \text { Yes }\end{array}$ $\begin{array}{llllllllllllllll}\text { TVDNFVALATGEK } & 0.98 & 26.41 & 27.06 & 15.80 & 3 & 1651.9069 & 1651.9025 & 551.6414 & 0.0044 & 2.6587 & 145.757 & 94.405 & 50.291 & 192.620 & \text { Yes }\end{array}$

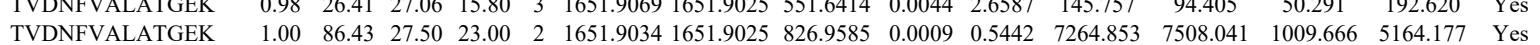
$\begin{array}{llllllllllllllll}\text { TVDNFVALATGEK } & 1.00 & 90.24 & 27.50 & 24.64 & 2 & 1651.9034 & 1651.9025 & 826.9585 & 0.0009 & 0.5442 & 9695.709 & 9383.396 & 476.980 & 8721.985 & \text { Yes }\end{array}$ $\begin{array}{lllllllllllllllll}\text { TVDNFVALATGEK } & 0.96 & 22.18 & 27.33 & 23.23 & 3 & 1651.9051 & 1651.9025 & 551.6414 & 0.0026 & 1.5711 & 242.655 & 124.981 & 120.952 & 522.396 & \text { No }\end{array}$ $\begin{array}{llllllllllllllll}\text { TVDNFVALATGEK } & 1.00 & 83.60 & 27.51 & 19.92 & 2 & 1651.9040 & 1651.9025 & 826.9585 & 0.0015 & 0.9069 & 2666.450 & 2831.223 & 360.055 & 2930.671 & \text { Yes }\end{array}$ $\begin{array}{lllllllllllllllll}\text { TVDNFVALATGEK } & 1.00 & 88.58 & 27.46 & 21.85 & 2 & 1651.9044 & 1651.9025 & 826.9585 & 0.0019 & 1.1488 & 3137.416 & 2793.453 & 469.212 & 3307.273 & \text { Yes }\end{array}$ $\begin{array}{llllllllllllllll}\text { TVDNFVALATGEK } & 1.00 & 36.46 & 27.33 & 21.01 & 3 & 1651.9057 & 1651.9025 & 551.6414 & 0.0032 & 1.9336 & 173.366 & 165.823 & 66.392 & 301.221 & \text { Yes }\end{array}$ $\begin{array}{llllllllllllllll}\text { TVDNFVALATGEK } & 1.00 & 37.98 & 27.28 & 20.28 & 3 & 1651.9060 & 1651.9025 & 551.6414 & 0.0035 & 2.1149 & 180.051 & 111.538 & 71.814 & 315.409 & \text { No }\end{array}$ $\begin{array}{llllllllllllllll}\text { IEVEKPFAIAK } & 0.95 & 21.73 & 18.81 & 17.46 & 3 & 1676.0314 & 1676.0238 & 559.6819 & 0.0076 & 4.5264 & 22049.295 & 20389.716 & 7468.976 & 21938.573 & \text { Yes }\end{array}$ $\begin{array}{llllllllllllllll}\text { HYGPGWVSMANAGK } & 0.98 & 34.65 & 27.51 & 21.75 & 3 & 1761.8992 & 1761.8864 & 588.3027 & 0.0128 & 7.2524 & 2526.873 & 3270.923 & 1060.022 & 3588.045 & \text { Yes }\end{array}$

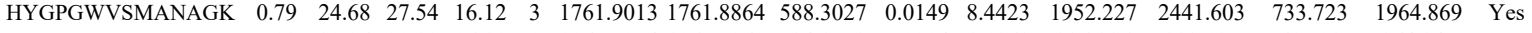
VIFGLFGK

VIFGLFGK

VIFGLFGK

VIFGLFGK

VIFGLFGK

VIFGLFGK

VIFGLFGK

VIFGLFGK
VIFGLFGK

VIFGLFGK

VIFGLFGK

VIFGLFGK

VIFGLFGK $\begin{array}{llllllllllll}0.99 & 30.26 & 21.99 & 16.81 & 2 & 1167.7274 & 1167.7260 & 584.8703 & 0.0014 & 1.1968 & 336.336 & 283.195\end{array}$ $\begin{array}{llllllllllll}0.99 & 30.25 & 21.99 & 19.57 & 2 & 1167.7276 & 1167.7260 & 584.8703 & 0.0016 & 1.3678 & 318.979 & 282.850\end{array}$

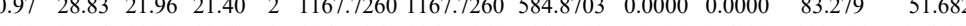
$\begin{array}{llllllllllll}0.99 & 30.54 & 21.99 & 22.63 & 2 & 1167.7268 & 1167.7260 & 584.8703 & 0.0008 & 0.6839 & 189.798 & 174.191\end{array}$ $\begin{array}{ccccccccccccc}0.99 & 32.10 & 21.99 & 21.18 & 2 & 1167.7270 & 1167.7260 & 584.8703 & 0.0010 & 0.8549 & 162.294 & 122.443 \\ 1.00 & 38.51 & 21.99 & 18.42 & 2 & 1167.7278 & 1167.7260 & 584.8703 & 0.0018 & 1.5388 & 29393.642 & 26556.624 \\ 1.00 & 37.01 & 21.9 & 21.50 & 2 & 1167.278 & 1167.7260 & 584.8703 & 0.018 & 1.538 & 65507.808 & 58759.732\end{array}$ $\begin{array}{lllllllllllll}1.00 & 37.01 & 1.9 & 21.50 & 2 & 1167.7278 & 1167.7260 & 584.8703 & 0.0018 & 1.5388 & 65507.808 & 58759.732\end{array}$ $\begin{array}{lllllllllllll}0.99 & 29.63 & 21.99 & 20.85 & 2 & 1167.7280 & 1167.7284 & 1167.7260 & 584.8703 & 0.0020 & 1.7098 & 136.532 & 136.7103 \\ 0.987 .0024 & 2.0517 & 210.199 & 182.779\end{array}$ $\begin{array}{llllllllllll}0.99 & 29.63 & 1.99 & 20.55 & 2 & 1167.7284 & 167.726 & 584.8703 & 0.0024 & 2.0517 & 210.199 & 182.779 \\ 0.97 & 27.23 & 21.99 & 26.43 & 2 & 1167.7290 & 1167.7260 & 584.8703 & 0.0030 & 2.5647 & 177.773 & 122.818\end{array}$ $\begin{array}{llllllllllll}1.00 & 37.31 & 21.99 & 21.73 & 2 & 1167.7280 & 1167.7260 & 584.8703 & 0.0020 & 1.7098 & 28144.957 & 24462.944\end{array}$ $\begin{array}{llllllllllll}1.00 & 44.75 & 21.99 & 23.46 & 2 & 1167.7284 & 1167.7260 & 584.8703 & 0.0024 & 2.0517 & 35911.018 & 29880.387\end{array}$

$\begin{array}{llll}61.709 & 364.947 & \text { Yes } & 0 \\ 0\end{array}$

$46.031 \quad 376.862 \quad$ Yes

$\begin{array}{lll}15.906 & 70.994 & \text { Yes } \\ 37.445 & 290.327 & \text { Yes }\end{array}$ $\begin{array}{lll}37.445 & 290.327 & \text { Yes } \\ 22.507 & 160.783 & \text { Yes }\end{array}$ $\begin{array}{ccc}22.507 & 160.783 & \text { Yes } \\ 8.594 & 34176.408 & \text { Yes }\end{array}$ $\begin{array}{ccc}8.594 & 34176.408 & \text { Yes } \\ 714.179 & 73895.719 & \text { Yes }\end{array}$ $\begin{array}{lll}179.079 & \text { Yes }\end{array}$

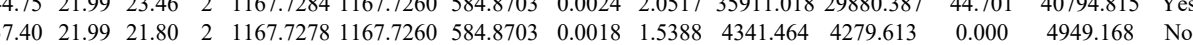



\begin{tabular}{lllllllllllllll}
1.00 & 49.82 & 21.99 & 21.47 & 2 & 1167.7280 & 1167.7260 & 584.8703 & 0.0020 & 1.7098 & 1006.006 & 801.972 & 29.789 & 946.845 & Yes \\
\hline .97 & 3.27 & 27.18 & 1.35 & 2 & 1183.6122 & 1183.6117 & 5928131 & 0.0005 & 0.4217 & 6833.514 & 5512.913 & 1121433 & 12469.027 & No
\end{tabular} \begin{tabular}{lllllllllllllll}
1.00 & 38.95 & 27.14 & 33.37 & 2 & 18.63 .6134 & 1183.6117 & 592.8131 & 0.0005 & 0.4217 & 6833.514 & 5512.913 & 11214.333 & 12469.027 & No \\
\hline
\end{tabular} \begin{tabular}{|llllllllllllllll} 
& \\
& 1.00 & 38.95 & 27.14 & 33.37 & 2 & 1183.6134 & 1183.6117 & 592.8131 & 0.0017 & 1.4358 & 9360.824 & 6493.879 & 15845.951 & 16464.866 & No
\end{tabular}

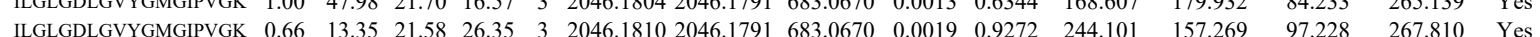
$\begin{array}{lllllllllllllllll} & \text { GKPLMLNPR } & 0.94 & 16.89 & 23.30 & 17.98 & 3 & 131.7914 & 1312.7893 & 438.6037 & 0.0021 & 1.5960 & 16619.079 & 24537.677 & 9076.595 & 1454.847 & \text { Yes }\end{array}$ $\begin{array}{llllllllllllllll} & 0.97 & 16.832 & 23.30 & 19.10 & 3 & 13127917 & 13127893 & 4386037 & 0.0024 & 1.8240 & 15201760 & 28301.586 & 7374473 & 14640.285 & \text { Yes }\end{array}$ $\begin{array}{llllllllllllllll}\text { GKPLMLNPR } & 0.97 & 20.85 & 23.28 & 22.77 & 3 & 1312.7923 & 1312.7893 & 438.6037 & 0.0030 & 22800 & 9964615 & 14218.755 & 6905.898 & 9900.833 & \text { Yes }\end{array}$ $\begin{array}{lllllllllllllllll}\text { GKPLMLNPR } & 0.96 & 19.31 & 23.28 & 18.14 & 3 & 1312.7929 & 1312.7893 & 4386037 & 0.0036 & 2.7359 & 10193.606 & 13734.077 & 6011.657 & 8918.787 & \text { Yes }\end{array}$

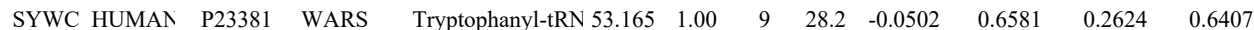

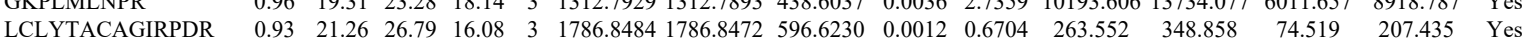

MSASDPNSSIFLTDTAK

GIFGFTDSDCIGK

GIFGFTDSDCIGK

GIFGFTDSDCIGK

GIFGFTDSDCIGK

PNSEPASLLELFNSIATQGEL

NSEPASLLELFNSIATQGELVR

ALIEVLQPLIAEHQAR

PNSEPASLLELFNSIATQGE

NSEPASLLELFNSIATQGELVR

PNSEPASLLELELFSIATQGELVR

NSEPASLL

GIFFSHR

GIFFSHR

GIFFSHR

ATGQRPHHFLR

ATGQRPHHFLR

ATGQRPHHFLR

STAMATS

ISFPAIQAAPSFSNSFPQI

ISFPAIQAAPSFSNSFPQI

SFPAIQAAPSFSNSFPQIFR

ISFPAIQA

GIDYDK

46 ELTAVVQK

FGFPEGSVELYAEK FGFPEGSVELYAEK

ELTAVVQK

GCEVVVSGK

GCEVVVSGK

FGFPEGSVELYAEK

KPLPDHVSIVEPK

KPLPDHVSIVEPK

FIMESGAK

GCEVVVSGK

GCEVVVSGK

AELNEFLTR

KPLPDHVSIVEPK

AELNEFLTR

GGKPEPPAMPQPVPT

KPLPDHVSIVEPK

KPLPDHVSIVEPK

KPLPDHVSIVER

$\begin{array}{llllllllllllll}1.00 & 87.56 & 27.66 & 41.05 & 2 & 2072.0314 & 2072.0340 & 1037.0243 & 0.0026 & 0.6704 & 263.552 & 348.858 \\ 1.00 & 71.21 & 27.23 & 2.66 & 2 & 1692.810 & 1692.805 & 847.4120 & 0.0015 & 0.8850 & 327.736 & 242.792\end{array}$

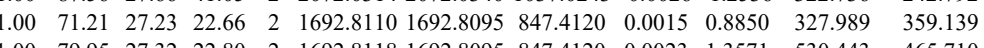

$\begin{array}{llllllllllll}1.00 & 79.95 & 27.32 & 22.80 & 2 & 1692.8118 & 1692.8095 & 847.4120 & 0.0023 & 1.3571 & 530.443 & 465.710\end{array}$

$\begin{array}{llllllllllll}1.00 & 68.93 & 27.23 & 22.89 & 2 & 1692.8110 & 1692.8095 & 847.4120 & 0.0015 & 0.8850 & 387.123 & 270.440\end{array}$

\begin{tabular}{ll}
74.519 & 207.435 \\
34.641 & 304.511 \\
\hline & 37.414
\end{tabular}

$\begin{array}{ll}34.641 & 304.511 \\ 49.414 & 371.915\end{array}$

$\begin{array}{ll}36.229 & 468.652 \\ 87.332 & 317.193\end{array}$ $\begin{array}{lllllllllll}12.77 & 26.72 & 14.98 & 3 & 2577.3427 & 2577.3393 & 860.1204 & 0.0034 & 1.3176 & 27.640\end{array}$

$\begin{array}{lll}72.950 & 138.742 & 215.543 \\ 23.662 & 4.273 & 44.505\end{array}$

23.662

4.449

8.171

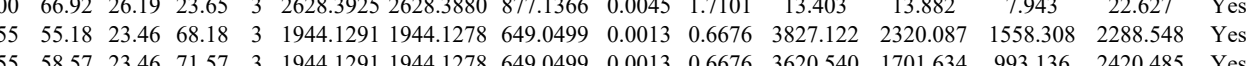

$\begin{array}{r}92.627 \\ \hline\end{array}$

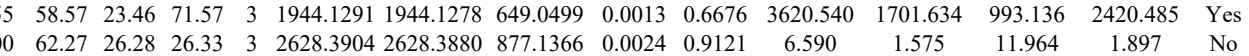

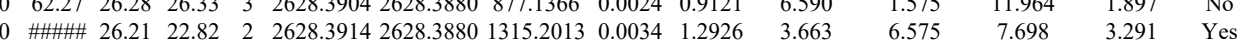
$\begin{array}{llllllllllllllll}37.84 & 26.22 & 22.36 & 3 & 2628.3919 & 2628.3880 & 877.1366 & 0.0039 & 1.4821 & 4.414 & 0.000 & 3.581 & 8.865 & \text { No }\end{array}$

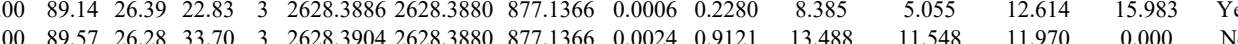

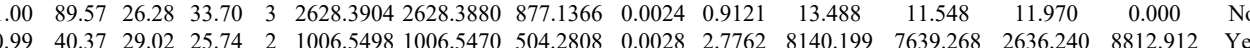

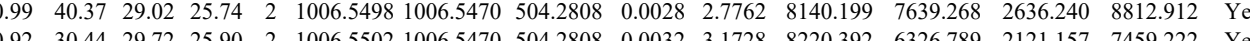

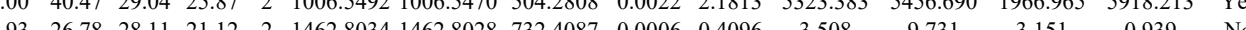
$\begin{array}{cccccccccccccc}0.9 & 26.78 & 28.11 & 21.12 & 2 & 1462.8034 & 1462.8028 & 732.4087 & 0.0006 & 0.4096 & 3.508 & 9.731 & 3.151 & 0.939 \\ \mathrm{~N}\end{array}$ $\begin{array}{lllllllllll} & \end{array}$

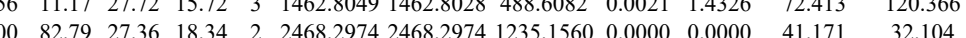
$\begin{array}{llllllllllllllll}62.60 & 27.23 & 17.22 & 3 & 2468.3008 & 2468.2974 & 823.7731 & 0.0034 & 1.3758 & 3.944 & 9.684 & 8.742 & 10.684 & \text { Y }\end{array}$ $\begin{array}{lllllllllllllll}1.00 & 66.36 & 27.20 & 21.45 & 3 & 2468.3011 & 2468.2974 & 823.7731 & 0.0037 & 1.4972 & 15.925 & 1.024 & 4.982 & 11.150 & \text { No }\end{array}$ $\begin{array}{llllllllllllll} & \end{array}$

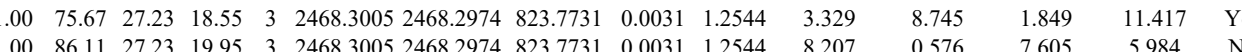

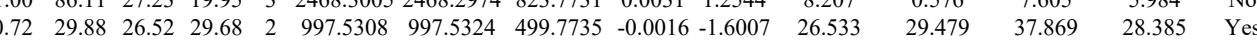
$\begin{array}{llllllllllllllll}0.99 & 33.87 & 26.98 & 31.83 & 2 & 997.5332 & 997.5324 & 499.7735 & 0.0008 & 0.8004 & 29.528 & 42.840 & 29.729 & 47.464 & \text { Yes }\end{array}$ $\begin{array}{lllllllllllllll}0.99 & 40.36 & 25.59 & 30.54 & 2 & 1174.7280 & 1174.7165 & 588.3655 & 0.0115 & 9.7727 & 4134.105 & 3500.816 & 6414.984 & 9540.245 & \text { No }\end{array}$ $\begin{array}{lllllllllllllll}1.00 & 66.65 & 28.20 & 24.69 & 2 & 1859.9570 & 1859.9549 & 930.9847 & 0.0021 & 1.1278 & 175.647 & 289.714 & 10.761 & 290.777 & \text { No }\end{array}$

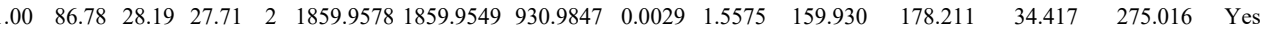
$\begin{array}{llllllllllllllll}1.92 & 30.53 & 25.59 & 25.78 & 2 & 1174.7280 & 1174.7165 & 588.3655 & 0.0115 & 9.7727 & 478.459 & 457.141 & 438.501 & 600.854 & \text { Yes }\end{array}$

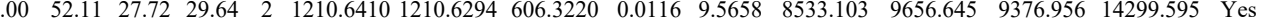
$\begin{array}{lllllllllllllll}.00 & 64.56 & 27.72 & 29.43 & 2 & 1210.6412 & 1210.6294 & 606.3220 & 0.0118 & 9.7307 & 9002.092 & 8778.087 & 8265.801 & 12522.949 & \text { Yes }\end{array}$

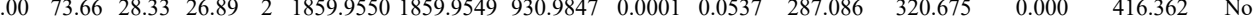

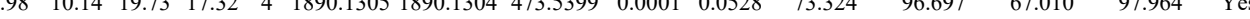

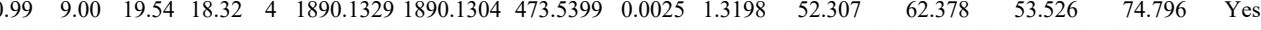
$\begin{array}{llllllllllllllll}.96 & 39.70 & 27.17 & 37.32 & 2 & 1169.6444 & 1169.6358 & 585.8252 & 0.0086 & 7.3400 & 21251.216 & 21921.494 & 1746.782 & 41638.477 & \text { Yes }\end{array}$

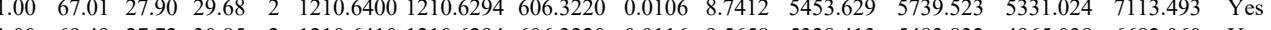
$\begin{array}{llllllllllllllll}1.00 & 69.49 & 27.72 & 30.85 & 2 & 1210.6410 & 1210.6294 & 606.3220 & 0.0116 & 9.5658 & 5328.413 & 5483.832 & 4965.038 & 6682.060 & \text { Yes }\end{array}$ $\begin{array}{lllllllllllllll}1.00 & 50.61 & 27.95 & 32.31 & 2 & 1235.6644 & 1235.6632 & 618.8389 & 0.0012 & 0.9696 & 7307.004 & 8256.487 & 362.828 & 11677.526 & \text { Yes }\end{array}$

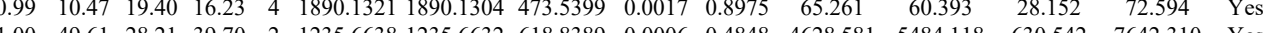
$\begin{array}{lllllllllllllll}1.00 & 49.61 & 28.21 & 39.70 & 2 & 1235.6638 & 1235.6632 & 618.8389 & 0.0006 & 0.4848 & 4628.581 & 5484.118 & 630.542 & 7642.310 & \text { Yes } \\ 0.57 & 23.32 & 26.98 & 20.82 & 2 & 1861.0178 & 1861.0011 & 931.5078 & 0.0167 & 8.9639 & 597.744 & 465.146 & 128.504 & 428.309 & \text { No }\end{array}$ $\begin{array}{llllllllllllllll}0.57 & 23.32 & 26.98 & 20.82 & 2 & 1861.0178 & 1861.0011 & 931.5078 & 0.0167 & 8.9639 & 597.744 & 465.146 & 128.504 & 428.309 & \text { No } \\ 1.00 & 45.07 & 18.92 & 22.05 & 3 & 1890.1462 & 1890.1304 & 63.0507 & 0.0158 & 8.3458 & 29.735 & 2546.330 & 2697.506 & 4382.989 & \text { Yes }\end{array}$ $\begin{array}{llllllllllllllll}1.00 & 45.07 & 18.92 & 22.05 & 3 & 1890.1462 & 1890.1304 & 631.0507 & 0.0158 & 8.3458 & 2964.735 & 2546.330 & 2697.506 & 4382.989 & \text { Yes }\end{array}$ $\begin{array}{lllllllllllllll}1.00 & 29.23 & 18.57 & 19.44 & 4 & 1890.1493 & 1890.1304 & 473.5399 & 0.0189 & 9.9779 & 2289.698 & 2383.042 & 3424.921 & 3386.922 & \text { No }\end{array}$ $\begin{array}{llllllllllllllll} & \end{array}$ $\begin{array}{llllllllllllllll}\text { FVADGIFK } & 1.00 & 56.26 & 25.60 & 24.55 & 2 & 1183.6950 & 1183.6845 & 592.8495 & 0.0105 & 8.8555 & 9574.922 & 8907.777 & 1711.803 & 15109.882 & \text { Yes }\end{array}$ $\begin{array}{lllllllllllllllllll} & \text { FVADGIFK } & 1.00 & 56.26 & 25.60 & 24.55 & 2 & 1183.6950 & 1183.6845 & 592.8495 & 0.0105 & 8.8555 & 9574.922 & 8907.777 & 1711.803 & 15109.882 & \text { Yes } \\ & 1.00 & 56.29 & 25.51 & 24.87 & 2 & 1183.6960 & 1183.6845 & 592.8495 & 0.0115 & 9.6988 & 19364.596 & 17607.611 & 1389.201 & 35384.097 & \text { Yes }\end{array}$ 


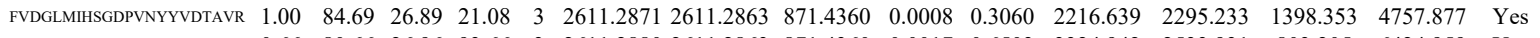

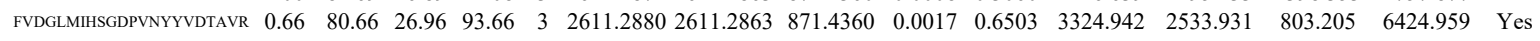
$\begin{array}{llllllllllllllll}\text { FVDGLMIHSGDPVNYYVDIAVR } & 0.67 & 80.38 & 26.95 & 93.38 & 3 & 2611.2889 & 2611.2863 & 871.4360 & 0.0026 & 0.9945 & 1947.478 & 2285.959 & 1689.759 & 4325.600 & \text { Yes }\end{array}$

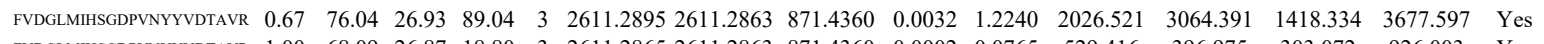

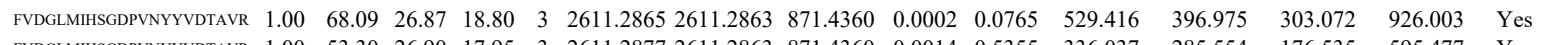
$\begin{array}{llllllllllllllll}\text { FVDGLMIHSGDPVNYYVDTAVR } & 1.00 & 53.30 & 26.90 & 17.95 & 3 & 2611.2877 & 2611.2863 & 871.4360 & 0.0014 & 0.5355 & 336.037 & 285.554 & 176.535 & 595.477 & \text { Yes } \\ \text { TEIILATR } & 1.00 & 46.75 & 23.42 & 30.19 & 2 & 1172.7250 & 1172.7250 & 587.3698 & 0.0000 & 0.0000 & 25.774 & 42.49 & 2.030 & 27.30 & \text { No }\end{array}$

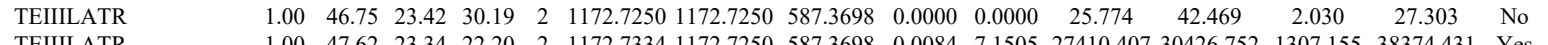
TEIIILATR

TEIIILATR IMLPWDPTGK TELTLATR

TEIIILATR

IMLPWDPTGK

IMLPWDPTGK

IMLPWDPTGK
IMLPWDPTGK

IMLPWDPTGK

GLCAIAQAESLR

GLCAIAQAESLR
GLCAIAQAESLR

IMLPWDPTGK

GLCAIAQAESLR

GLCAIAQAESLR

ACYGVLR

ACYGVLR

ACYGVLR

ACYGVLR

ALGGLAVR

LLGGLAVR

LLGGLAVR

LLGGLAVR

LLGGLAVR

LLGGLAVR

LLGGLAVR

LLGGLAVR

LLGGLAVR

DEILPTTPISEQK

DEILPTTPISEQK

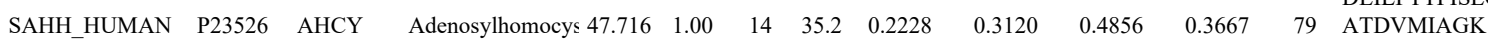

ATDVMIAGK

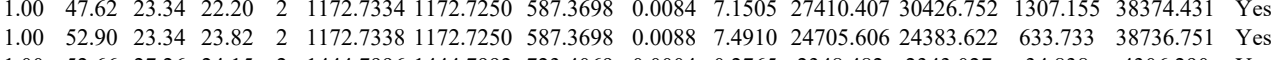
$\begin{array}{llllllllllllllll}1.00 & 52.66 & 27.26 & 24.15 & 2 & 1444.7996 & 1444.7992 & 723.4069 & 0.0004 & 0.2765 & 2348.482 & 2343.027 & 34.838 & 4306.290 & \text { Yes }\end{array}$

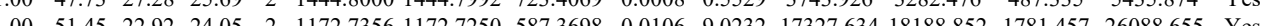

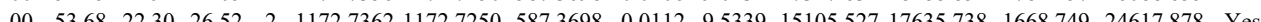
$\begin{array}{lllllllllllllll}1.00 & 58.64 & 27.28 & 25.92 & 2 & 1444.8000 & 1444.7992 & 723.4069 & 0.0008 & 0.5529 & 6798.317 & 6751.470 & 207.962 & 12750.571 & \text { YeS }\end{array}$ $\begin{array}{lllllllllllllll}1.00 & 53.20 & 27.28 & 23.87 & 2 & 1444.8000 & 1444.7992 & 723.4069 & 0.0008 & 0.5529 & 2201.351 & 2230.062 & 0.000 & 4284.359 & \text { No }\end{array}$

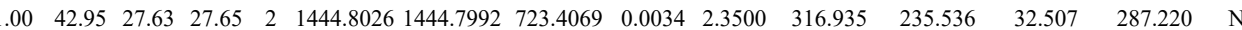
$\begin{array}{lllllllllllllll}1.00 & 56.10 & 27.52 & 23.18 & 2 & 1444.8032 & 1444.7992 & 723.4069 & 0.0040 & 2.7647 & 1112.150 & 1094.665 & 243.034 & 2266.967 & \text { Yes }\end{array}$ $\begin{array}{lllllllllllllll}1.00 & 64.47 & 28.74 & 24.41 & 2 & 1420.7302 & 1420.7288 & 711.3717 & 0.0014 & 0.9840 & 5657.481 & 7330.451 & 509.332 & 10283.543 & \text { Yes }\end{array}$ $\begin{array}{lllllllllllllll}1.00 & 69.44 & 28.75 & 25.51 & 2 & 1420.7306 & 1420.7288 & 711.3717 & 0.0018 & 1.2652 & 3345.114 & 3471.478 & 279.073 & 5798.013 & \text { Yes } \\ 1.00 & 42.81 & 27.59 & 22.20 & 2 & 144.8016 & 14447992 & 723.4069 & 0.0024 & 1.6588 & 248.344 & 125.829 & 0.000 & 307.203 & \text { No }\end{array}$

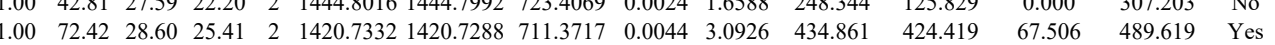
$\begin{array}{lllllllllllllll}1.00 & 79.56 & 28.71 & 24.13 & 2 & 1420.7338 & 1420.7288 & 711.3717 & 0.0050 & 3.5143 & 509.871 & 1255.602 & 122.231 & 1142.546 & \text { No }\end{array}$ $\begin{array}{lllllllllllllll}0.97 & 39.85 & 26.67 & 30.87 & 2 & 970.4932 & 970.4850 & 486.2498 & 0.0082 & 8.4318 & 17582.391 & 21021.770 & 2224.038 & 31101.727 & \text { Yes }\end{array}$ $\begin{array}{llllllllllllllll}0.95 & 34.63 & 26.67 & 25.89 & 2 & 970.4942 & 970.4850 & 486.2498 & 0.0092 & 9.4601 & 18214.508 & 21407.374 & 2219.122 & 32854.056 & \text { Yes }\end{array}$

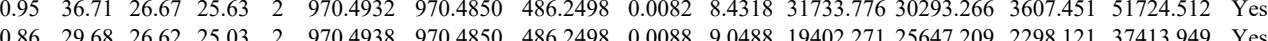
$\begin{array}{llllllllllllllll}0.86 & 29.68 & 26.62 & 25.03 & 2 & 970.4938 & 970.4850 & 486.2498 & 0.0088 & 9.0488 & 19402.271 & 25647.209 & 2298.121 & 37413.949 & \text { Yes } \\ 0.81 & 29.41 & 26.48 & 23.26 & 2 & 970.4928 & 970.4850 & 486.2498 & 0.0078 & 8.0205 & 12825.194 & 14398.151 & 1190.788 & 23619.464 & \text { Yes }\end{array}$ $\begin{array}{lllllllllllllllll}0.81 & 29.41 & 26.48 & 23.26 & 2 & 970.4928 & 970.4850 & 486.2498 & 0.0078 & 8.0205 & 12825.194 & 14398.151 & 1190.788 & 23619.464 & \text { Yes } \\ 0.55 & 9.90 & 17.71 & 22.90 & 2 & 941.646 & 941.6144 & 471.8145 & 0.0002 & 0.2119 & 92.381 & 84.161 & 16318 & 141.845 & \text { Y S }\end{array}$ $\begin{array}{ccccccccccccccc}0.75 & 9.65 & 17.71 & 22.54 & 2 & 941.6146 & 941.6144 & 471.8145 & 0.0002 & 0.2119 & 92.381 & 84.161 & 16.318 & 141.845 & \text { Yes } \\ 0 & 941.6144 & 471.8145 & 0.0006 & 0.6358 & 139.037 & 137.180 & 44.698 & 216.353 & \text { Yes }\end{array}$ $\begin{array}{lllllllllllllll}0.78 & 10.42 & 17.56 & 15.87 & 2 & 941.6156 & 941.6144 & 471.8145 & 0.0012 & 1.2717 & 87.947 & 62.837 & 17.893 & 143.559 & \text { Yes }\end{array}$ $\begin{array}{lllllllllllllll}0.77 & 9.52 & 17.48 & 22.52 & 2 & 941.6160 & 941.6144 & 471.8145 & 0.0016 & 1.6956 & 79.384 & 71.686 & 36.318 & 115.305 & \text { Yes }\end{array}$

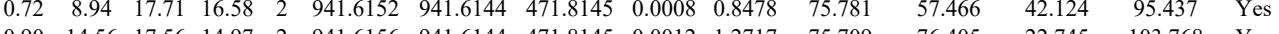

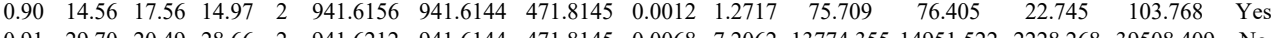
$\begin{array}{lllllllllllllllll}0.91 & 29.70 & 20.49 & 28.66 & 2 & 941.6212 & 941.6144 & 471.8145 & 0.0068 & 7.2062 & 13774.355 & 14951.522 & 2228.268 & 39508.409 & \text { No }\end{array}$ $\begin{array}{lllllllllllllllll}0.96 & 34.42 & 20.49 & 29.36 & 2 & 941.6216 & 941.6144 & 471.8145 & 0.0072 & 7.6301 & 18297.367 & 21633.901 & 2057.378 & 54756.745 & \text { No }\end{array}$ $\begin{array}{llllllllllllll}1.00 & 41.66 & 17.48 & 30.27 & 2 & 941.6158 & 941.6144 & 471.8145 & 0.0014 & 1.4856 & 5351.492 & 5172.149 & 465.169 & 12525.010\end{array}$ $\begin{array}{llllllllllllllll}1.00 & 63.38 & 26.67 & 36.46 & 2 & 1757.9670 & 1757.9655 & 879.9900 & 0.0015 & 0.8523 & 2003.770 & 2408.573 & 2580.937 & 4035.971 & \text { Yes }\end{array}$ $\begin{array}{lllllllllllllll}.00 & 66.91 & 26.65 & 31.30 & 2 & 1757.9674 & 1757.9655 & 879.9900 & 0.0019 & 1.0796 & 902.104 & 656.289 & 1269.865 & 1559.769 & \mathrm{No}\end{array}$ $\begin{array}{lllllllllllllll}1.00 & 64.35 & 27.17 & 33.04 & 2 & 1192.6814 & 1192.6729 & 597.3437 & 0.0085 & 7.1148 & 14704.952 & 16315.197 & 6038.464 & 21386.013 & \text { Yes }\end{array}$

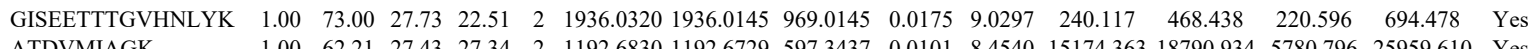
ATDVMIAGK

ALDIAENEMPGLMR ALDIAENEMPGLMR GISEETTTGVHNLYK GISEETTTGVHNLYK ATDVMIAGK
ATDVMIAGK

$\begin{array}{lllllllllllllll}1.00 & 62.21 & 27.43 & 27.34 & 2 & 1192.6830 & 1192.6729 & 597.3437 & 0.0101 & 8.4540 & 15174.363 & 18790.934 & 5780.796 & 25959.610 & \text { Yes } \\ \end{array}$

$\begin{array}{ccccccccccccccc}1.00 & 64.32 & 27.82 & 21.83 & 3 & 1702.8529 & 1702.8504 & 568.6241 & 0.0025 & 1.4655 & 63.116 & 49.859 & 43.086 & 100.630 & \text { Yes } \\ 1.00 & 27.82 & 25.19 & 2 & 1702.8536 & 1702.8504 & 852.4325 & 0.0032 & 1.8770 & 2434.103 & 2935.906 & 130.181 & 4368.172 & \text { Yes }\end{array}$

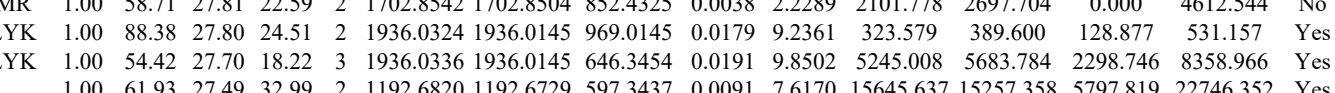

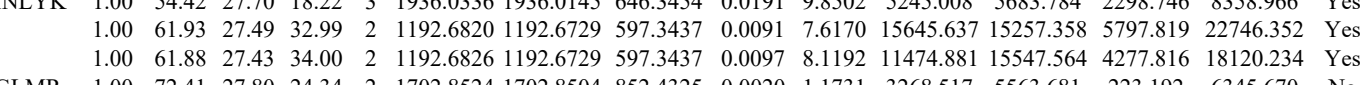
$\begin{array}{lllllllllllllllll} & & \end{array}$

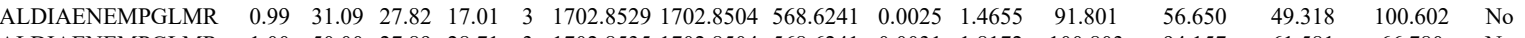

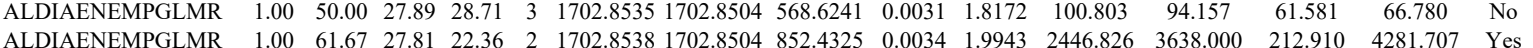
$\begin{array}{lllllllllllllllll}\text { ALDAENEMPGLMR } & 1.00 & 61.67 & 27.81 & 22.36 & 2 & 1702.8538 & 1702.8504 & 852.4325 & 0.0034 & 1.9943 & 2446.826 & 3638.000 & 212.910 & 4281.707 & \text { Yes } \\ \text { ALDIAENEMPGLMR } & 1.00 & 75.54 & 27.80 & 24.95 & 2 & 1702.8524 & 1702.8504 & 852.4325 & 0.0020 & 1.1731 & 371.422 & 521.496 & 73.228 & 899.967 & \text { Yes }\end{array}$ $\begin{array}{llllllllllllllll}\text { ALDIAENEMPGLMR } & 1.00 & 69.03 & 27.80 & 23.64 & 2 & 1702.8524 & 1702.8504 & 852.4325 & 0.0020 & 1.1731 & 202.086 & 575.177 & 11.556 & 727.212 & \text { No }\end{array}$

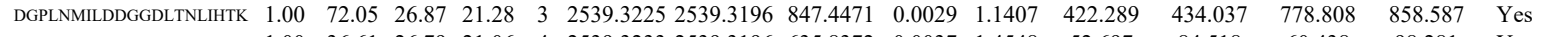
$\begin{array}{llllllllllllllll}\text { DGPLNMILDDGGDLTNLHHTK } & 1.00 & 36.61 & 26.79 & 21.06 & 4 & 2539.3233 & 2539.3196 & 635.8372 & 0.0037 & 1.4548 & 52.697 & 84.518 & 60.438 & 98.281 & \text { Yes }\end{array}$ $\begin{array}{lllllllllllllll}\text { DGPLNMILDDGGDLTNLIHTK } & 1.00 & 26.79 & 23.32 & 3 & 2539.3234 & 2539.3196 & 847.4471 & 0.0038 & 1.4947 & 1615.173 & 2337.501 & 2193.517 & 3214.196 & \text { Yes }\end{array}$

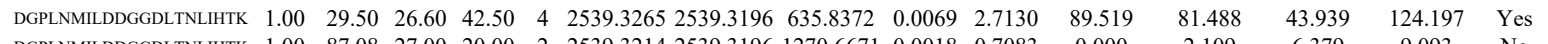

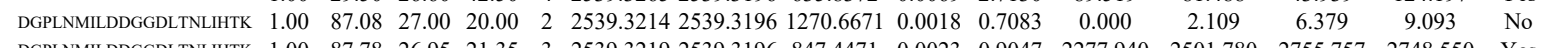

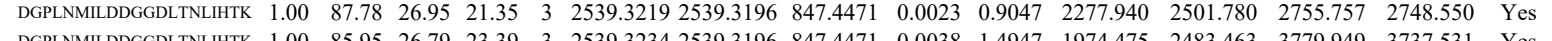
$\begin{array}{llllllllllllllll}\text { DGPLNMILDDGGDLINLIHTK } & 1.00 & 85.95 & 26.79 & 23.39 & 3 & 2539.3234 & 2539.3196 & 847.4471 & 0.0038 & 1.4947 & 1974.475 & 2483.463 & 3779.949 & 3737.531 & \text { Yes }\end{array}$ $\begin{array}{llllllllllllllll}\text { DGPLNMILDDGGDLTNLIHTK } & 1.00 & 46.70 & 26.83 & 19.39 & 3 & 2539.3243 & 2539.3196 & 847.4471 & 0.0047 & 1.8487 & 36.886 & 24.245 & 46.641 & 70.955 & \text { Yes }\end{array}$

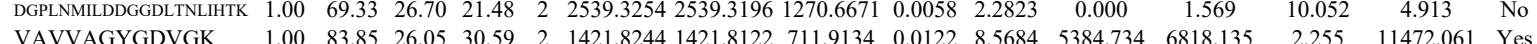

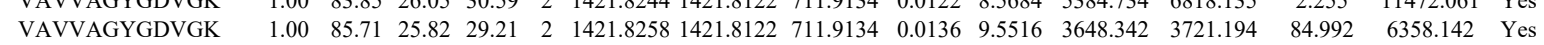

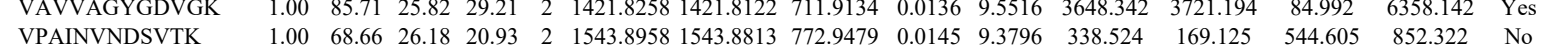




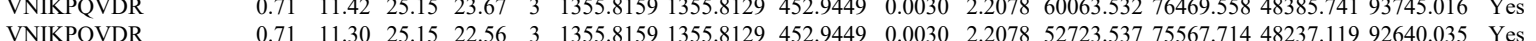
$\begin{array}{lllllllllllllll}0.71 & 11.30 & 25.15 & 22.56 & 3 & 1355.8159 & 1355.8129 & 452.9449 & 0.0030 & 2.2078 & 52723.537 & 75567.714 & 48237.119 & 92640.035 & \text { Yes }\end{array}$

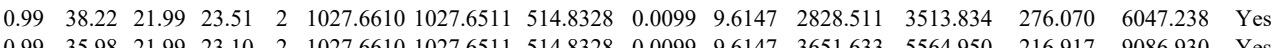

$\begin{array}{llllllllllllllll} & & & & & \end{array}$

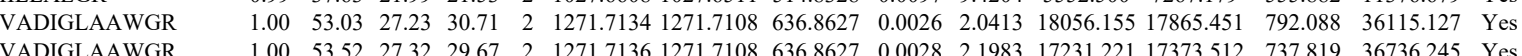

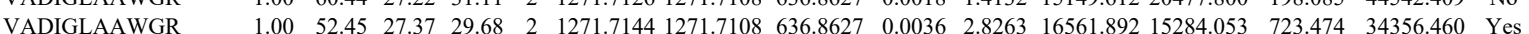

$\begin{array}{llllllllllllllll}\text { VADIGLAAWGR } & 1.00 & 61.48 & 27.28 & 34.30 & 2 & 1271.7116 & 1271.7108 & 636.8627 & 0.0008 & 0.6281 & 6638.125 & 8355.921 & 598.841 & 15499.552 & \text { Yes }\end{array}$

YPVGVHFLPK

YPVGVHFLPK

$\begin{array}{llllllllllllllll}1.00 & 58.13 & 27.29 & 31.05 & 2 & 1271.7140 & 1271.7108 & 636.8627 & 0.00032 & 2.5123 & 6168.723 & 6239.892 & 282.171 & 13515.481 & \text { Yes } \\ \end{array}$ $\begin{array}{lllllllllllllll}0.99 & 39.34 & 24.64 & 22.07 & 2 & 1443.8580 & 1443.8482 & 722.9314 & 0.0098 & 6.7779 & 1509.633 & 1435.337 & 2638.357 & 2969.275 & \text { Yes }\end{array}$ $\begin{array}{llllllllllllllll}0.98 & 37.04 & 24.33 & 21.31 & 2 & 1443.8588 & 1443.8482 & 722.9314 & 0.0106 & 7.3312 & 1565.680 & 1957.893 & 4329.593 & 4790.614 & \text { Yes } \\ 0.97 & 29.09 & 24.00 & 20.73 & 3 & & 443.8617 & 1434.8482 & 482.290 & 0.03 & 9.3304 & 6356.764 & 7287.808 & 11564.826 & 12458.038 & \text { Yes }\end{array}$

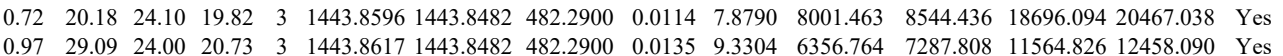
$\begin{array}{llllllllllllllll}0.97 & 29.09 & 24.00 & 20.73 & 3 & 1443.8617 & 1443.8482 & 482.2900 & 0.0135 & 9.3304 & 6356.764 & 7287.808 & 11564.826 & 12458.090 & \text { Yes } \\ 0.99 & 36.76 & 24.12 & 21.07 & 2 & 1443.8602 & 1443.8482 & 722.9314 & 0.0120 & 8.2995 & 1025.618 & 1052.934 & 2251.051 & 2208.029 & \text { Yes }\end{array}$ $\begin{array}{llllllllllllllll}0.99 & 36.76 & 24.12 & 21.07 & 2 & 1443.8602 & 1443.8482 & 722.9314 & 0.0120 & 8.2995 & 1025.618 & 1052.934 & 2251.051 & 2208.029 & \text { Yes } \\ 0.99 & 37.44 & 2.05 & 22.36 & 2 & 1443.8608 & 1443.8482 & 722.9314 & 0.0126 & 8.7144 & 1768.699 & 1677.875 & 3467.336 & 3608.399 & \text { Yes }\end{array}$

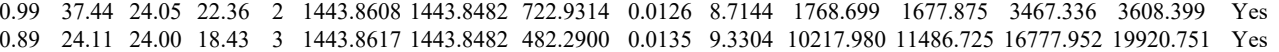
$\begin{array}{llllllllllllllll}0.93 & 26.12 & 24.07 & 19.52 & 3 & 1443.8626 & 1443.8482 & 482.2900 & 0.0144 & 9.9524 & 8013.140 & 10049.500 & 17867.753 & 20538.925 & \text { Yes }\end{array}$ $\begin{array}{llllllllllllllllll}0.75 & 19.89 & 24.07 & 18.96 & 3 & 1443.8623 & 1443.8482 & 482.2900 & 0.0141 & 9.7451 & 5322.364 & 5000.855 & 8332.583 & 8980.762 & \text { Yes }\end{array}$ $\begin{array}{lllllllllllllll}0.99 & 33.03 & 25.55 & 15.26 & 2 & 1199.7156 & 1199.7148 & 600.8647 & 0.0008 & 0.6657 & 65.632 & 84.540 & 65.871 & 89.676 & \text { Yes }\end{array}$ $\begin{array}{lllllllllllllll}0.93 & 24.07 & 25.63 & 17.71 & 2 & 1199.7158 & 1199.7148 & 600.8647 & 0.0010 & 0.8321 & 82.886 & 65.584 & 45.659 & 81.673 & \text { No }\end{array}$ $\begin{array}{lllllllllllllll}0.66 & 15.74 & 25.63 & 17.83 & 2 & 1199.7160 & 1199.7148 & 600.8647 & 0.0012 & 0.9986 & 45.395 & 73.030 & 37.612 & 53.820 & \text { No }\end{array}$

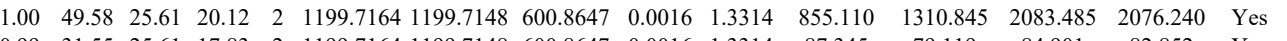
$\begin{array}{llllllllllllllll}0.99 & 31.55 & 25.61 & 17.83 & 2 & 1199.7164 & 1199.7148 & 600.8647 & 0.0016 & 1.3314 & 87.345 & 79.119 & 84.901 & 82.852 & \text { Yes }\end{array}$ $\begin{array}{lllllllllllllll}0.69 & 15.90 & 25.61 & 14.36 & 2 & 1199.7164 & 1199.7148 & 600.8647 & 0.0016 & 1.3314 & 35.604 & 45.562 & 43.324 & 74.628 & \text { Yes }\end{array}$ $\begin{array}{lllllllllllllll}0.86 & 20.42 & 25.61 & 16.46 & 2 & 1199.7168 & 1199.7148 & 600.8647 & 0.0020 & 1.6643 & 54.501 & 82.938 & 52.548 & 116.224 & \text { Yes } \\ 0.99 & 6.01 & 25.42 & 16.67 & 2 & 11997174 & 1199.7148 & 600.8647 & 0.022 & 2.1635 & 1726.552 & 2161.215 & 3539.088 & 452.673 & \text { Yes }\end{array}$

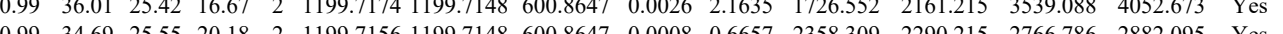
$\begin{array}{lllllllllllllll}0.99 & 34.69 & 25.55 & 20.18 & 2 & 1199.7156 & 1199.7148 & 600.8647 & 0.0008 & 0.6657 & 2358.309 & 2290.215 & 2766.786 & 2882.095 & \text { Yes } \\ 0.99 & 35.05 & 25.55 & 17.21 & 2 & 1199.7156 & 1199.7148 & 600.8647 & 0.0008 & 0.6657 & 5470.589 & 6531.346 & 8741.750 & 8150.456 & \text { Yes }\end{array}$

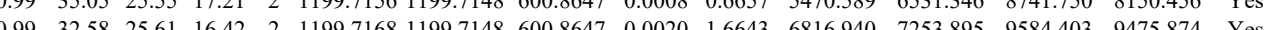

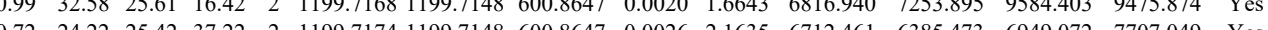

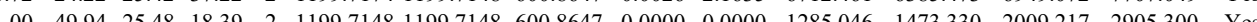

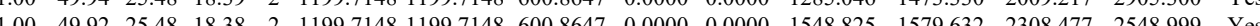

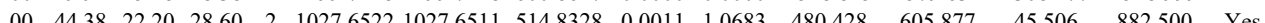

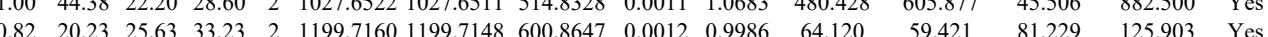

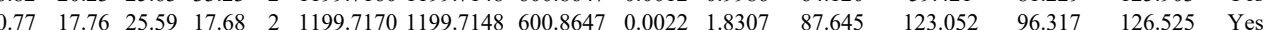

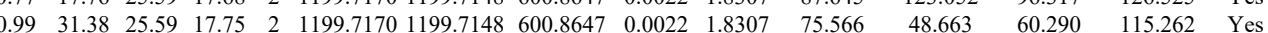

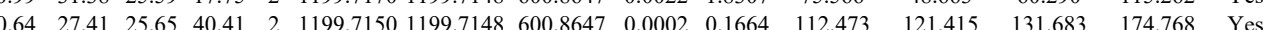
$\begin{array}{lllllllllllllll}0.64 & 27.41 & 25.65 & 40.41 & 2 & 1199.7150 & 199.7148 & 600.8647 & 0.0002 & 0.1664 & 112.475 & 121.415 & 131.683 & 174.768 & \text { Yes } \\ 0.97 & 27.75 & 25.55 & 17.75 & 2 & 1199.7156 & 1199.7148 & 600.8647 & 0.0008 & 0.6657 & 107.053 & 84.495 & 116.316 & 133.209 & \text { Yes }\end{array}$ $\begin{array}{lllllllllllllll}0.97 & 27.36 & 25.61 & 22.11 & 2 & 1199.7164 & 1199.7148 & 600.8647 & 0.0016 & 1.3314 & 67.885 & 83.224 & 55.584 & 116.469 & \text { Yes }\end{array}$

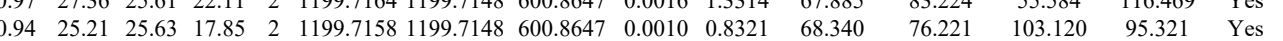
$\begin{array}{llllllllllllllll}0.96 & 26.81 & 25.61 & 22.32 & 2 & 1199.7164 & 1199.7148 & 600.8647 & 0.0016 & 1.3314 & 47.450 & 55.911 & 64.324 & 117.240 & \text { Yes }\end{array}$ $\begin{array}{lllllllllllllll}0.90 & 22.39 & 25.55 & 17.31 & 2 & 1199.7156 & 1199.7148 & 600.8647 & 0.0008 & 0.6657 & 43.312 & 60.957 & 116.589 & 107.237 & \text { Yes }\end{array}$ $\begin{array}{lllllllllllllll}0.96 & 27.22 & 25.63 & 18.16 & 2 & 1199.7160 & 1199.7148 & 600.8647 & 0.0012 & 0.9986 & 65.836 & 53.979 & 85.887 & 77.276 & \text { Yes }\end{array}$ $\begin{array}{lllllllllllllll}0.82 & 27.33 & 25.63 & 40.33 & 2 & 1199.7162 & 1199.7148 & 600.8647 & 0.0014 & 1.1650 & 74.038 & 70.892 & 93.146 & 121.278 & \text { Yes }\end{array}$

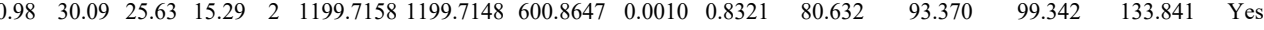

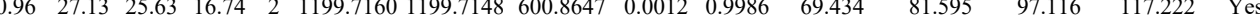
$\begin{array}{lllllllllllllll}0.95 & 29.98 & 25.65 & 18.43 & 2 & 1199.7152 & 1199.7148 & 600.8647 & 0.0004 & 0.3329 & 44.173 & 97.036 & 92.848 & 110.846 & \text { Yes }\end{array}$

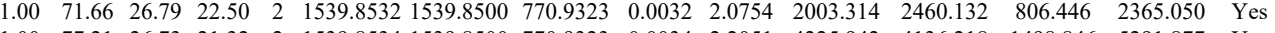
$\begin{array}{lllllllllllllll}1.00 & 77.21 & 26.73 & 21.32 & 2 & 1539.8534 & 1539.8500 & 770.9323 & 0.0034 & 2.2051 & 4225.942 & 4136.218 & 1498.846 & 5291.877 & \text { Yes }\end{array}$ $\begin{array}{lllllllllllllll}1.00 & 59.84 & 26.60 & 26.41 & 3 & 1539.8548 & 1539.8500 & 514.2906 & 0.0048 & 3.1111 & 18929.849 & 23753.371 & 11544.054 & 24338.815 & \text { Yes }\end{array}$ $\begin{array}{lllllllllllllll}1.00 & 59.85 & 26.60 & 18.76 & 3 & 1539.8548 & 1539.8500 & 514.2906 & 0.0048 & 3.1111 & 13064.103 & 15039.321 & 6239.284 & 16004.146 & \text { Yes }\end{array}$ $\begin{array}{lllllllllllllll}1.00 & 66.99 & 26.28 & 19.87 & 3 & 1539.8647 & 1539.8500 & 514.2906 & 0.0147 & 9.5276 & 3754.968 & 4601.169 & 1671.267 & 4552.935 & \text { Yes }\end{array}$

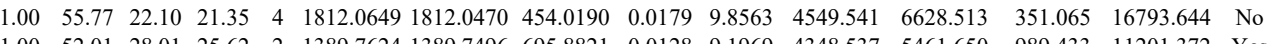

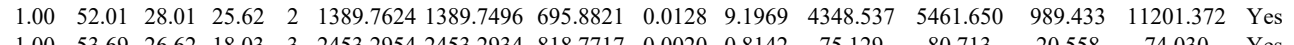




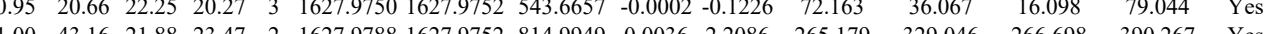

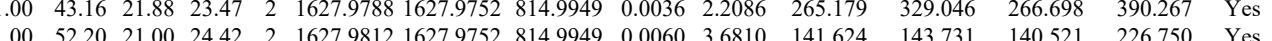

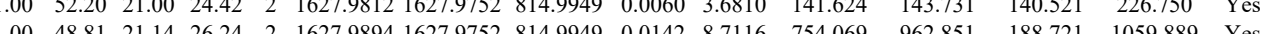

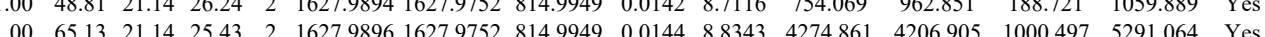

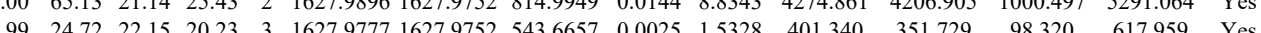
$\begin{array}{lllllllllllllll}1.00 & 55.80 & 2.15 & 24.04 & 2 & 1627.9784 & 1627.9752 & 814.9949 & 0.0032 & 1.9632 & 3255.254 & 2174.051 & 845.444 & 4036.192 & \text { Yes }\end{array}$ $\begin{array}{llllllllllllllll} & 0139.568 & \text { Y }\end{array}$

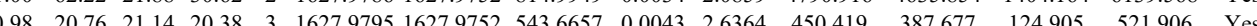

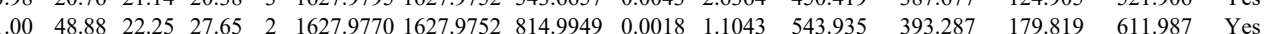
$\begin{array}{lllllllllllllll}1.00 & 54.65 & 22.15 & 26.77 & 2 & 1627.9782 & 1627.9752 & 814.9949 & 0.0030 & 1.8405 & 532.149 & 309.760 & 139.604 & 555.474 & \text { Yes }\end{array}$

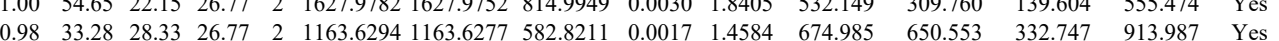
$\begin{array}{lllllllllllllll}0.55 & 9.67 & 22.25 & 22.67 & 3 & 1627.9765 & 1627.9752 & 543.6657 & 0.0013 & 0.7971 & 28.706 & 44.094 & 25.323 & 39.169 & \text { Yes }\end{array}$

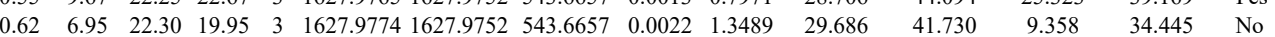
$\begin{array}{llllllllllllllll}1.00 & 41.60 & 22.25 & 25.85 & 2 & 1627.9768 & 1627.9752 & 814.9949 & 0.0016 & 0.9816 & 35.715 & 43.204 & 14.254 & 57.648 & \text { Yes }\end{array}$

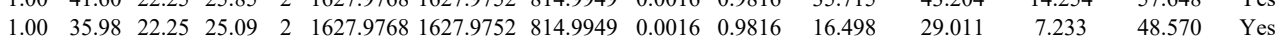
$\begin{array}{lllllllllllllll}0.55 & 8.23 & 22.28 & 21.23 & 3 & 1627.9759 & 1627.9752 & 543.6657 & 0.0007 & 0.4292 & 18.066 & 35.917 & 12.141 & 31.848 & \text { No }\end{array}$ $\begin{array}{lllllllllllllll}1.00 & 49.11 & 22.25 & 24.56 & 2 & 1627.9764 & 1627.9752 & 814.9949 & 0.0012 & 0.7362 & 31.413 & 28.458 & 10.223 & 46.595 & \text { Yes }\end{array}$ $\begin{array}{lllllllllllllll}0.85 & 11.85 & 22.30 & 17.58 & 3 & 1627.9774 & 1627.9752 & 543.6657 & 0.0022 & 1.3489 & 33.809 & 6.053 & 10.281 & 19.992 & \text { No }\end{array}$

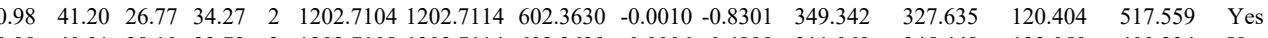
$\begin{array}{llllllllllllllll}0.98 & 40.91 & 28.10 & 33.72 & 2 & 1202.7108 & 1202.7114 & 602.3630 & -0.0006 & -0.4980 & 311.069 & 245.448 & 123.050 & 400.234 & \text { Yes }\end{array}$

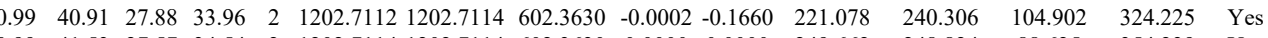
$\begin{array}{lllllllllllllll}0.99 & 41.53 & 27.57 & 34.54 & 2 & 1202.7114 & 1202.7114 & 602.3630 & 0.0000 & 0.0000 & 249.662 & 248.824 & 88.625 & 354.239 & \text { Yes }\end{array}$ $\begin{array}{lllllllllllllll}0.99 & 38.81 & 27.57 & 32.19 & 2 & 1202.7114 & 1202.7114 & 602.3630 & 0.0000 & 0.0000 & 271.855 & 220.695 & 101.513 & 402.299 & \text { Yes }\end{array}$

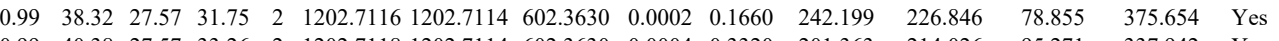
$\begin{array}{lllllllllllllll}0.99 & 40.38 & 27.57 & 33.26 & 2 & 1202.7118 & 1202.7114 & 602.3630 & 0.0004 & 0.3320 & 201.363 & 214.026 & 95.271 & 337.942 & \text { Yes }\end{array}$ $\begin{array}{llllllllllllllll}1.00 & 39.59 & 27.54 & 33.24 & 2 & 1202.7122 & 1202.7114 & 602.3630 & 0.0008 & 0.6641 & 262.484 & 280.693 & 77.471 & 409.199 & \text { Yes }\end{array}$

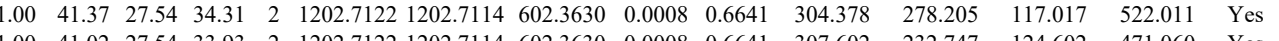

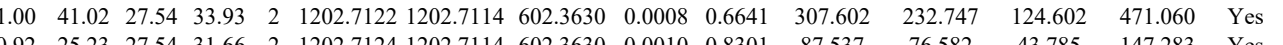
$\begin{array}{lllllllllllllll}0.92 & 25.23 & 27.54 & 31.66 & 2 & 1202.7124 & 1202.7114 & 602.3630 & 0.0010 & 0.8301 & 87.537 & 76.582 & 43.785 & 147.283 & \text { Yes }\end{array}$ $\begin{array}{lllllllllllllll}1.00 & 40.83 & 27.44 & 33.72 & 2 & 1202.7126 & 1202.7114 & 602.3630 & 0.0012 & 0.9961 & 304.415 & 266.213 & 104.467 & 396.225 & \text { Yes } \\ 1.00 & 41.40 & 27.44 & 34.56 & 2 & 1202.7126 & 12027114 & 602.3630 & 0.0012 & 0.9961 & 262.024 & 263.740 & 91.180 & 303.422 & \text { Yes }\end{array}$

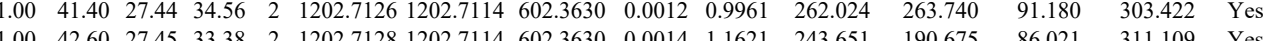

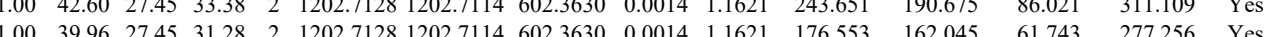

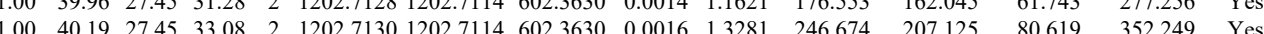

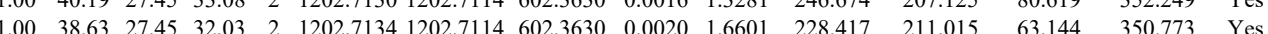
$\begin{array}{lllllllllllllll}100 & 4691 & 27.38 & 37.68 & 2 & 12027140 & 1202.7114 & 6023630 & 0.0026 & 2.1582 & 2569.384 & 2364.273 & 1646.479 & 4274405 & \text { Yes }\end{array}$ $\begin{array}{llllllllllllllll}0.99 & 41.13 & 27.28 & 34.19 & 2 & 1202.7146 & 1202.7114 & 6023630 & 0.0032 & 2.6562 & 367.219 & 296.715 & 104.770 & 450.090 & \text { Yes }\end{array}$ $\begin{array}{lllllllllllllll}0.94 & 36.71 & 27.27 & 30.13 & 2 & 1202.7160 & 1202.7114 & 602.3630 & 0.0046 & 3.8183 & 12786.069 & 10984.457 & 1989.695 & 31161.292 & \text { No }\end{array}$ $\begin{array}{llllllllllllllll}0.98 & 47.44 & 27.05 & 38.05 & 2 & 1202.7174 & 1202.7114 & 602.3630 & 0.0060 & 4.9804 & 15007.050 & 12899.898 & 980.205 & 32670.546 & \text { Yes } \\ 1.00 & 83.04 & 26.63 & 18.62 & 2 & 2453.2954 & 2453.2934 & 1227.6540 & 0.0020 & 0.8146 & 95.761 & 105.410 & 50.673 & 186.279 & \text { Yes }\end{array}$

NIILEEGK

NIILEEGK

NIILEEGK

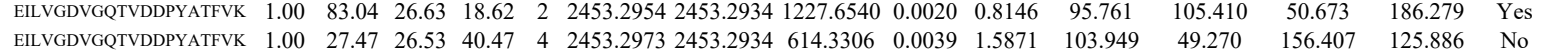

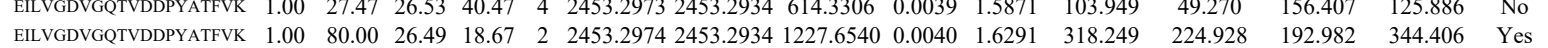
$\begin{array}{lllllllllllllllll}\text { ELVGDVGQTVDDPYATFVK } & 0.99 & 32.55 & 26.45 & 25.92 & 3 & 2453.2981 & 2453.2934 & 818.7717 & 0.0047 & 1.9134 & 84.204 & 108.970 & 55.459 & 194.646 & \text { Yes }\end{array}$

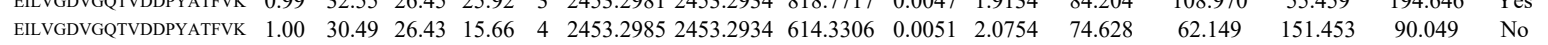
$\begin{array}{lllllllllllllllll}\text { EILVGDVGQTVDDPYATFVK } & 1.00 & 81.43 & 26.46 & 19.35 & 3 & 2453.2987 & 2453.2934 & 818.7717 & 0.0053 & 2.1577 & 168.444 & 473.885 & 304.259 & 156.729 & \text { No }\end{array}$ $\begin{array}{lllllllllllllll}1.00 & 45.99 & 25.35 & 36.27 & 2 & 1123.6682 & 1123.6667 & 562.8406 & 0.0015 & 1.3325 & 18495.025 & 19591.936 & 804.268 & 32320.208 & \text { Yes }\end{array}$ $\begin{array}{lllllllllllllll}1.00 & 46.02 & 25.35 & 36.17 & 2 & 1123.6686 & 1123.6667 & 562.8406 & 0.0019 & 1.6879 & 20019.652 & 18964.880 & 0.000 & 36874.769 & \text { No }\end{array}$ $\begin{array}{lllllllllllllll}0.98 & 44.15 & 27.55 & 34.31 & 2 & 972.5910 & 972.5838 & 487.2992 & 0.0072 & 7.3876 & 13426.686 & 17204.520 & 7377.399 & 23418.111 & \text { Yes }\end{array}$ $\begin{array}{llllllllllllllll}0.99 & 45.40 & 27.60 & 35.79 & 2 & 972.5914 & 972.5838 & 487.2992 & 0.0076 & 7.7980 & 13728.696 & 16637.957 & 8441.260 & 24683.878 & \text { Yes }\end{array}$ $\begin{array}{lllllllllllllll}0.99 & 41.41 & 24.61 & 25.96 & 2 & 997.6122 & 997.6042 & 499.8094 & 0.0080 & 8.0030 & 15825.867 & 21063.266 & 2646.032 & 26618.520 & \text { Yes }\end{array}$ $\begin{array}{llllllllllllllll}0.98 & 38.89 & 24.50 & 24.41 & 2 & 997.6126 & 997.6042 & 499.8094 & 0.0084 & 8.4031 & 13147.211 & 14387.767 & 1905.636 & 18160.738 & \text { Yes }\end{array}$ $\begin{array}{llllllllllllllll}0.92 & 37.17 & 27.60 & 35.32 & 2 & 972.5912 & 972.5838 & 487.2992 & 0.0074 & 7.5928 & 12076.840 & 44478.641 & 5062.453 & 18063.096 & \text { Yes }\end{array}$

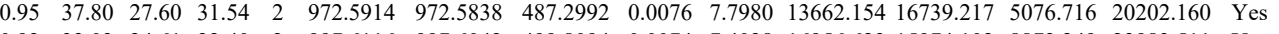
$\begin{array}{lllllllllllllllll}0.92 & 33.03 & 24.61 & 22.40 & 2 & 997.6116 & 997.6042 & 499.8094 & 0.0074 & 7.4028 & 16956.623 & 15974.102 & 8873.249 & 23983.511 & \text { Yes }\end{array}$

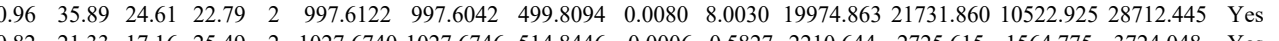

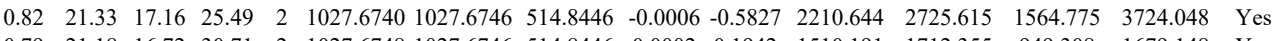

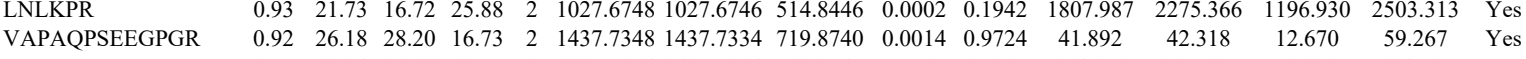



$\begin{array}{lllllllllllllllll}\text { SAGGIGVAVSCIR } & 1.00 & 68.37 & 27.94 & 22.50 & 2 & 1378.7182 & 1378.7183 & 690.3664 & -0.0001 & -0.0724 & 106.091 & 114.132 & 60.287 & 195.957 & \text { Yes }\end{array}$

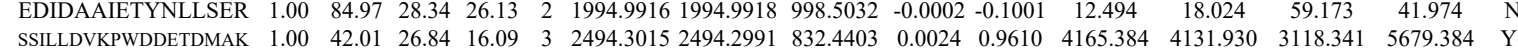

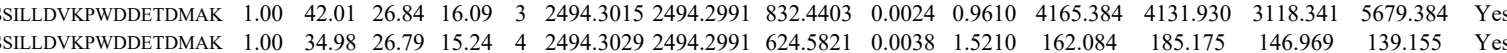
$\begin{array}{lllllllllllllllll}\text { SSILLDVKPWDDETDMAK } & 1.00 & 36.29 & 26.79 & 15.43 & 3 & 2494.3030 & 2494.2991 & 832.4403 & 0.0039 & 1.5617 & 4966.757 & 5855.769 & 5747.690 & 8172.232 & \text { Yes }\end{array}$

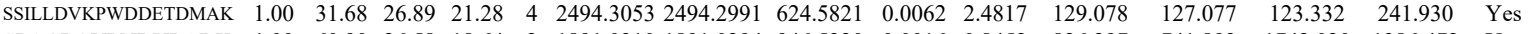

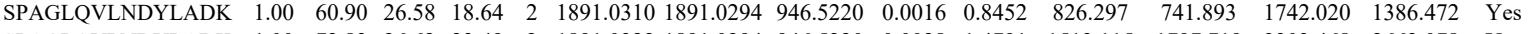
$\begin{array}{llllllllllllllll}\text { SPAGLQVLNDYLADK } & 1.00 & 72.83 & 26.62 & 23.49 & 2 & 1891.0322 & 1891.0294 & 946.5220 & 0.0028 & 1.4791 & 1513.115 & 1797.719 & 3303.468 & 2662.078 & \text { Yes }\end{array}$ $\begin{array}{llllllllllllllll}\text { SPAGLQVLNDYLADK } & 1.00 & 61.11 & 26.62 & 23.00 & 3 & 1891.0324 & 1891.0294 & 631.3504 & 0.0030 & 1.5839 & 275.491 & 200.968 & 289.160 & 442.337 & \text { Yes }\end{array}$ $\begin{array}{llllllllllllllll}\text { SPAGLQVLNDYLADK } & 1.00 & 39.57 & 26.60 & 23.03 & 3 & 1891.0339 & 1891.0294 & 631.3504 & 0.0045 & 2.3759 & 266.311 & 150.749 & 163.327 & 477.600 & \text { Yes }\end{array}$ $\begin{array}{lllllllllllllllll}\text { SIQADGLVWGSSK } & 1.00 & 55.24 & 27.32 & 23.70 & 2 & 1634.9034 & 1634.8872 & 818.4509 & 0.0162 & 9.8966 & 914.391 & 912.052 & 624.006 & 1352.306 & \text { Yes }\end{array}$ \begin{tabular}{llllllllllllllll} 
SPAGLQVLNDYLADK & 1.00 & 70.73 & 26.73 & 21.28 & 2 & 1891.0296 & 1891.0294 & 946.5220 & 0.0002 & 0.1056 & 1259.379 & 1361.080 & 2326.902 & 1823.175 & Yes \\
\hline
\end{tabular} \begin{tabular}{llllllllllllllll} 
SPAGLQVLNDYLADK & 1.00 & 60.79 & 26.58 & 18.42 & 2 & 1891.0310 & 1891.0294 & 946.5220 & 0.0016 & 0.8452 & 714.151 & 550.224 & 1336.369 & 1057.629 & Yes \\
\hline
\end{tabular} \begin{tabular}{llllllllllllllll} 
SPAGLQVLNDYLADK & 1.00 & 40.89 & 26.57 & 17.24 & 3 & 1891.0315 & 1891.0294 & 631.3504 & 0.0021 & 1.1087 & 385.027 & 281.778 & 215.916 & 443.837 & Yes \\
\hline
\end{tabular}

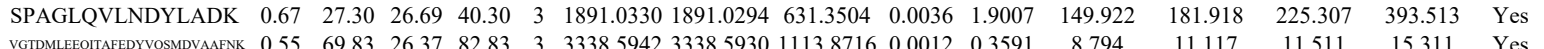

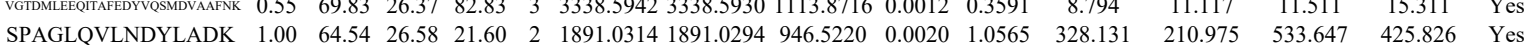
$\begin{array}{lllllllllllll} & \end{array}$

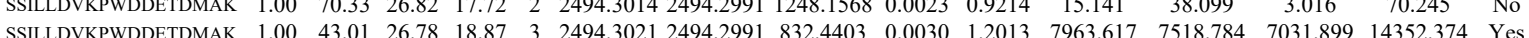

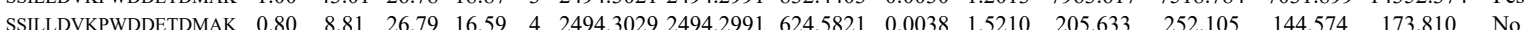
$\begin{array}{llllllllllllllll} & \end{array}$ $\begin{array}{llllllllllllllll}\text { SSILLDVKPWDDETDMAK } & 0.96 & 13.04 & 26.86 & 14.29 & 4 & 2494.3041 & 24942991 & 624.5821 & 0.0050 & 2.0013 & 231.296 & 220.223 & 179.865 & 268.602 & \text { Yes }\end{array}$

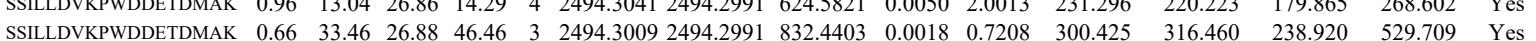
$\begin{array}{llllllllllllllll}\text { SSILDDVKPWDDETDMAK } & 1.00 & 37.37 & 26.84 & 18.50 & 3 & 2444.3015 & 2494.2991 & 832.4403 & 0.0024 & 0.9610 & 2027.601 & 1975.958 & 1505.529 & 3123.411 & \text { Yes }\end{array}$

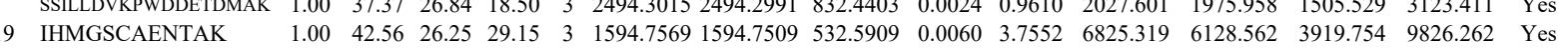
$\begin{array}{llllllllllllllll}\text { ENGTVAANASTINDGAALVILTADAAK } & 1.00 & 58.85 & 26.60 & 17.80 & 3 & 3048.5632 & 3048.5641 & 1017.1953 & -0.0009 & -0.2949 & 22.683 & 15.521 & 20.522 & 10.011 & \text { No }\end{array}$

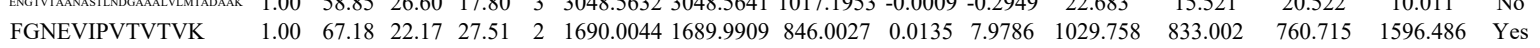
$\begin{array}{llllllllllllllll}\text { FGNEVIPVTVTVK } & 1.00 & 44.05 & 21.99 & 25.62 & 2 & 1690.0052 & 1689.9909 & 846.0027 & 0.0143 & 8.4514 & 670.180 & 792.175 & 367.345 & 1225.827 & \text { Yes }\end{array}$

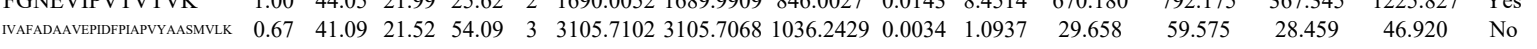
$\begin{array}{llllllllllllllll}\text { NNAFADANEFDPFIAPVYASSMVLK } & 0.67 & 16.61 & 21.52 & 29.61 & 3 & 3105.7102 & 3105.7068 & 1036.2429 & 0.0034 & 1.0937 & 15.916 & 0.000 & 13.706 & 7.789 & \text { No }\end{array}$ $\begin{array}{llllllllllllllll}\text { NAFADAAVM } & 3105.7102 & 3105.7068 & 1036.2429 & 0.0034 & 1.0937 & 13.694 & 2.589 & 7.080 & 15.366 & \text { Yes }\end{array}$

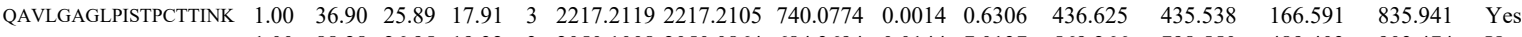
$\begin{array}{llllllllllllllll}\text { TPIGSFLGSLSLLPATK } & 0.82 & 80.81 & 19.49 & 93.81 & 2 & 1989.1764 & 1989.1754 & 995.5950 & 0.0010 & 0.5022 & 44.265 & 69.742 & 102.742 & 153.164 & \text { Yes }\end{array}$ $\begin{array}{llllllllllllllll}\text { TPIGSFLGSLSLLPATK } & 0.67 & 34.31 & 19.49 & 47.31 & 3 & 1989.1780 & 1989.1754 & 664.0657 & 0.0026 & 1.3051 & 114.681 & 101.570 & 137.791 & 196.463 & \text { Yes }\end{array}$ $\begin{array}{llllllllllllllll}\text { TPIGSLGSLSLLPATK } & 1.00 & 36.62 & 19.49 & 15.38 & 3 & 1989.1783 & 1989.1754 & 664.0657 & 0.0029 & 1.4557 & 85.412 & 93.989 & 113.043 & 155.029 & \text { Yes }\end{array}$ $\begin{array}{llllllllllll}15.45 & \end{array}$ $\begin{array}{llllllllllll} & 121.950 & 187.950 & \text { Yes }\end{array}$

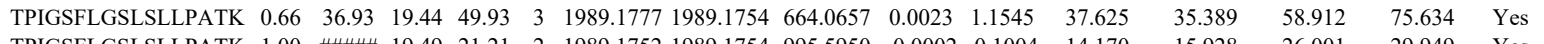

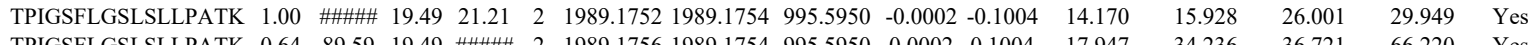

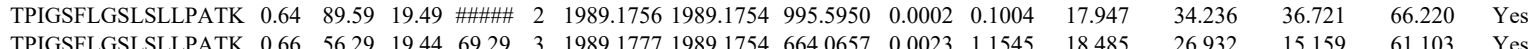

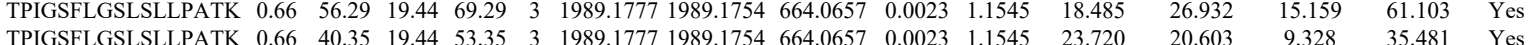

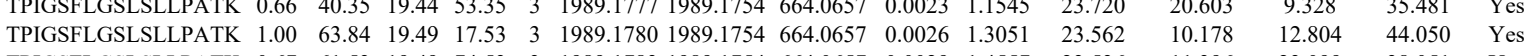

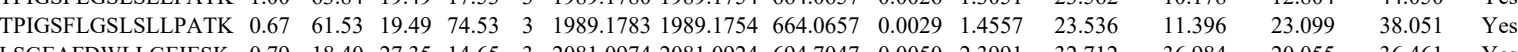



$\begin{array}{llllllllllllllll}\text { FDLLFIMLDQMDPEQDR } & 0.95 & 21.05 & 26.83 & 17.26 & 3 & 2269.0906 & 2269.0881 & 757.3700 & 0.0025 & 1.1003 & 16.206 & 3.966 & 4.161 & 17.413 & \text { No }\end{array}$

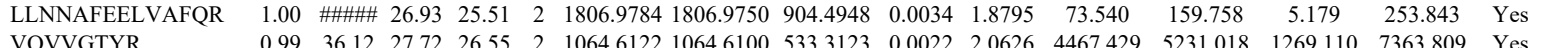

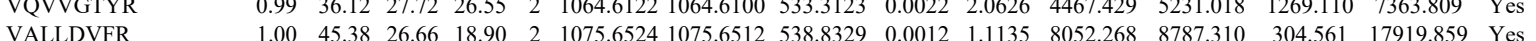

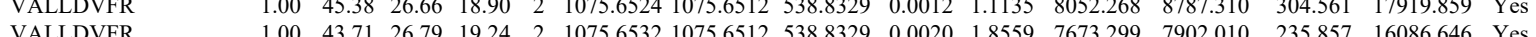

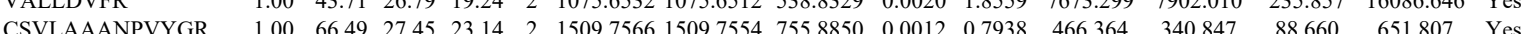

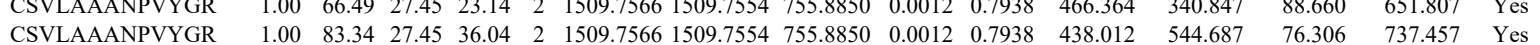

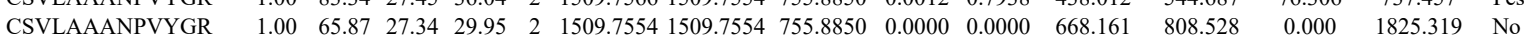
$\begin{array}{llllllllllllllll}\text { CSVLAAANPVYGR } & 1.00 & 85.47 & 27.44 & 31.14 & 2 & 1509.7564 & 1509.7554 & 755.8850 & 0.0010 & 0.6615 & 822.026 & 859.338 & 27.398 & 1297.453 & \text { Yes }\end{array}$

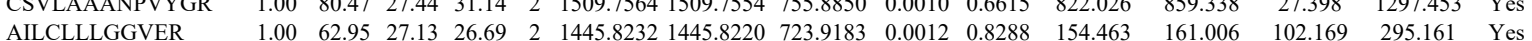

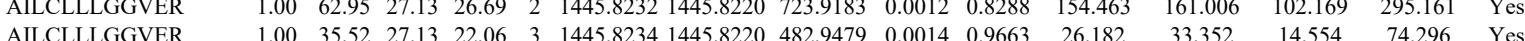
$\begin{array}{llllllllllllllll}\text { AILCLLLGGVER } & 1.00 & 56.46 & 27.14 & 23.43 & 2 & 1445.8236 & 1445.8220 & 723.9183 & 0.0016 & 1.1051 & 113.066 & 137.100 & 106.091 & 222952 & \text { Yes }\end{array}$ $\begin{array}{llllllllllllllll}\text { AILCLLLGGVER } & 1.00 & 59.21 & 27.12 & 26.81 & 2 & 1445.8228 & 1445.8220 & 723.9183 & 0.0008 & 0.5525 & 101.097 & 122.546 & 94.988 & 188.587 & \text { Yes }\end{array}$

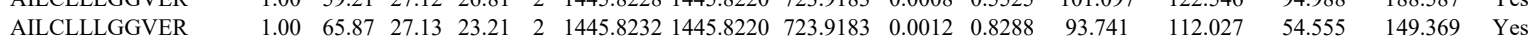

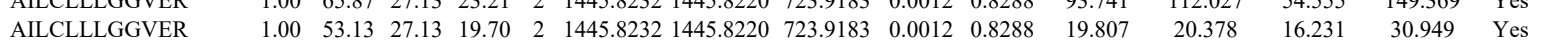
AILCLLLGGVER

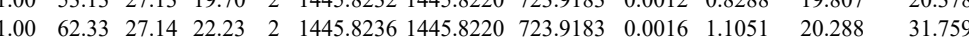

\section{GVVCIDEFDK} $\begin{array}{lllllllllll} & \end{array}$

HLCVLASNCDEPMYVK

\begin{tabular}{llllllllllllllll} 
& 24.03 \\
LVEALCAEHQINLIK & 1.00 & 76.93 & 26.11 & 29.51 & 2 & 2027.1154 & 2027.1151 & 1014.5648 & 0.0003 & 0.1478 & 1888.817 & 1959.090 & 249.500 & 2403.715 & Yes \\
\hline
\end{tabular} $\begin{array}{llllllllllllllll}\text { LVEALCAEHQINLIK } & 1.00 & 76.37 & 26.11 & 28.77 & 2 & 2027.1154 & 2027.1151 & 1014.5648 & 0.0003 & 0.1478 & 1593.763 & 2167.797 & 525.536 & 2659.457 & \text { Yes } \\ \text { Les } & 45.91 & 28.49 & 3 & 2027.1169 & 2027.1151 & 676.7123 & 0.0018 & 0.8866 & 10116.617 & 13854.587 & 3881.345 & 18354.844 & \text { Yes }\end{array}$

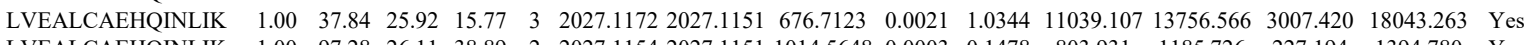

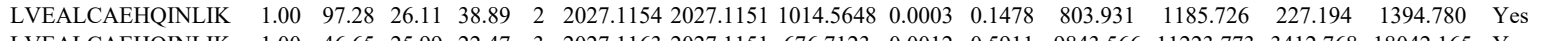

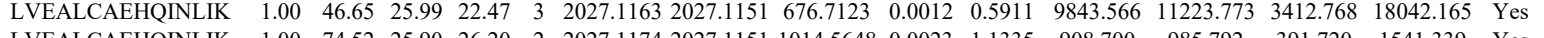

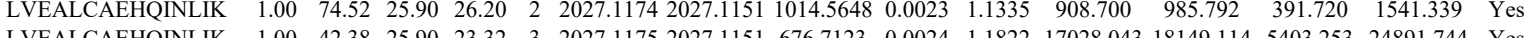

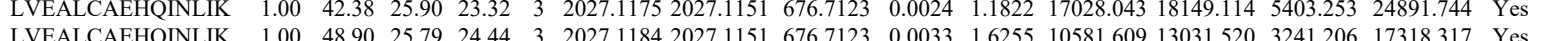
\begin{tabular}{lllllllllllllllll} 
LVEALCAEHQINLIK & 1.00 & 48.90 & 25.79 & 24.44 & 3 & 2027.1184 & 2027.1151 & 676.7123 & 0.0033 & 1.6255 & 10581.609 & 13031.520 & 3241.206 & 17318.317 & Yes \\
\hline
\end{tabular}

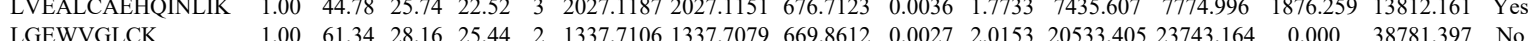

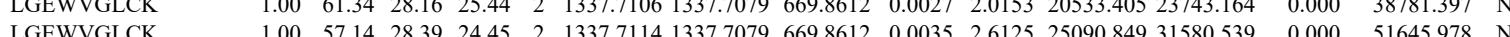

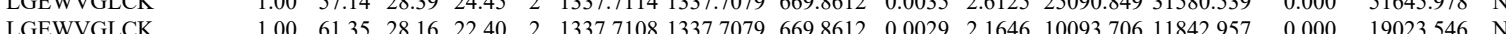

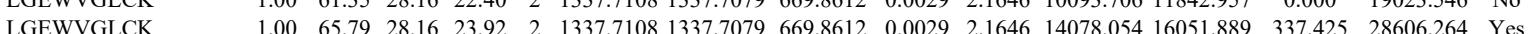

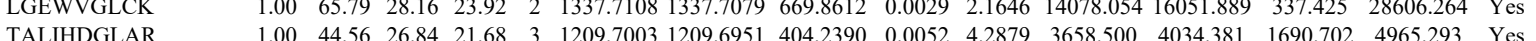

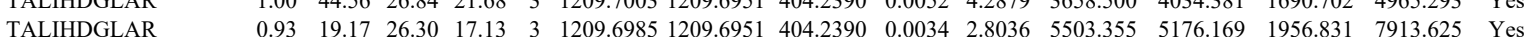

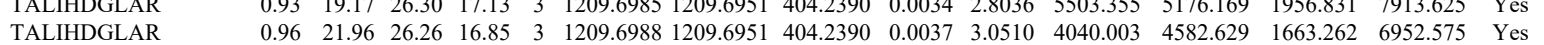
$\begin{array}{llllllllllllllll}\text { TALIHDGLAR } & 0.92 & 21.94 & 27.26 & 22.25 & 3 & 1209.6931 & 12096951 & 404.2390 & -0.0020 & -1.6492 & 232.555 & 276.092 & 74.071 & 201.069 & \text { No }\end{array}$

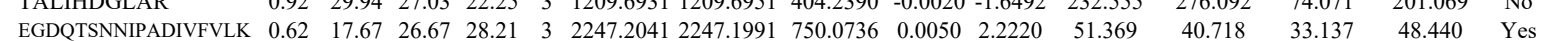

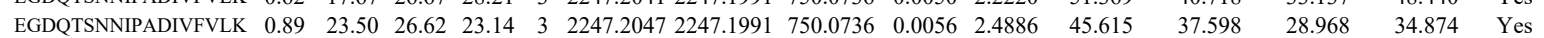
$\begin{array}{llllllllllllllll}\text { TVLEQVLPI } & 1.00 & 40.97 & 23.80 & 26.67 & 2 & 1154.7052 & 1154.7033 & 578.3589 & 0.0019 & 1.6426 & 80.991 & 65.120 & 17.664 & 97.291 & \text { Yes }\end{array}$

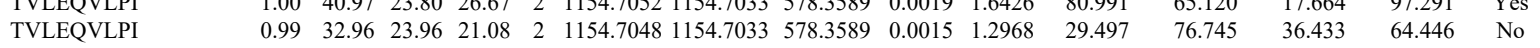

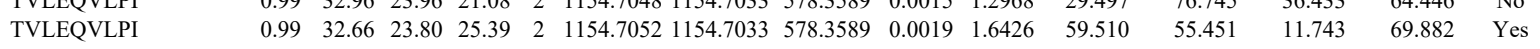
$\begin{array}{llllllllllllllll}\text { VSLEEIYSGCTK } & 1.00 & 74.85 & 28.23 & 42.91 & 2 & 1661.8268 & 1661.8248 & 831.9197 & 0.0020 & 1.2020 & 1170.652 & 1419.177 & 88.970 & 1266.985 & \text { Yes }\end{array}$ $\begin{array}{lllllllllllllllll}\text { NPFDTFFGQR } & 0.99 & 47.06 & 26.71 & 18.09 & 2 & 1371.6748 & 1371.6694 & 686.8420 & 0.0054 & 3.9310 & 12054.707 & 9199.765 & 8426.619 & 9505.259 & \text { Yes }\end{array}$ $\begin{array}{llllllllllllllll}\text { NPFDTFFGQR } & 0.96 & 38.37 & 26.68 & 17.20 & 2 & 1371.6750 & 1371.6694 & 686.8420 & 0.0056 & 4.0766 & 10002.149 & 7419.719 & 6953.816 & 9229.488 & \text { Yes }\end{array}$ $\begin{array}{lllllllllllllllll}\text { NPFDTFFGQR } & 0.99 & 35.26 & 26.46 & 17.22 & 2 & 1371.6722 & 1371.6694 & 686.8420 & 0.0028 & 2.0383 & 8066.480 & 6026.956 & 4927.197 & 7082.084 & \text { Yes }\end{array}$

FNDGSDEK EPMQTGIK $\begin{array}{lccccccccccccccc}\text { EPMQTGIK } & 0.99 & 39.91 & 28.00 & 29.14 & 2 & 1190.6598 & 1190.6573 & 596.3359 & 0.0025 & 2.0961 & 5519.184 & 4324.992 & 6201.375 & 5318.746 & \text { No } \\ \text { EPMQTGIK } & 0.98 & 35.44 & 27.92 & 25.33 & 2 & 1190.6602 & 1190.6573 & 596.3359 & 0.0029 & 2.4315 & 3792.928 & 3423.870 & 5822.069 & 4368.118 & \text { No }\end{array}$ $\begin{array}{llllllllllllllll} & & & \end{array}$

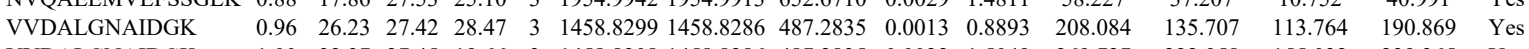

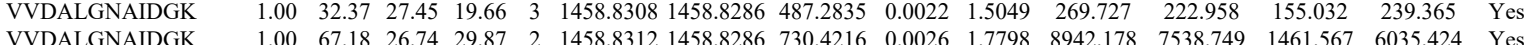

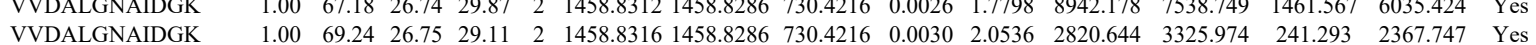

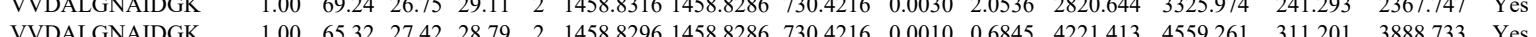

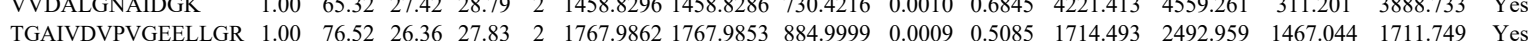

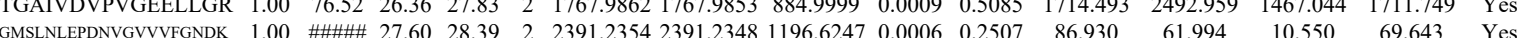

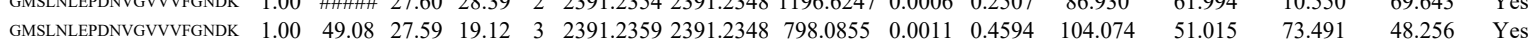

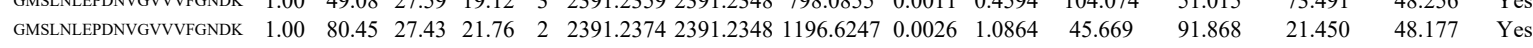

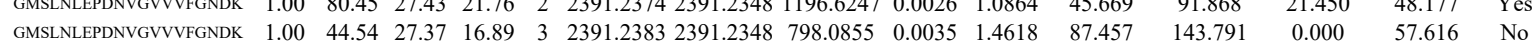

Table S-4 page 236 of 6 

$\begin{array}{lllllllllllllll}1.00 & 45.80 & 26.50 & 28.81 & 2 & 1143.6830 & 1143.6734 & 572.8440 & 0.0096 & 8.3792 & 18450.391 & 15928.357 & 1857.816 & 16695.421 & \text { Yes }\end{array}$ $\begin{array}{llllllllllllllll}1.00 & 46.53 & 26.48 & 28.80 & 2 & 1143.6832 & 1143.6734 & 572.8440 & 0.0098 & 8.5537 & 17622.104 & 17839.011 & 1892.513 & 17061.525 & \text { Yes } & \end{array}$ $\begin{array}{lllllllllllllllll}0.99 & 41.85 & 24.55 & 23.47 & 2 & 1169.6986 & 1169.6890 & 585.8518 & 0.0096 & 8.1931 & 12640.800 & 12409.644 & 2625.745 & 10229.320 & \text { Yes } \\ 0.99 & 38.67 & 2.55 & 25.42 & 2 & 1169.6986 & 1169.6890 & 585.8518 & 0.0096 & 8.1931 & 18628352 & 18673.076 & 184.160 & 14285.607 & \text { Yes }\end{array}$

VLSIGDGIAR $\begin{array}{lllllllllllllllll}0.99 & 38.67 & 24.55 & 25.42 & 2 & 1169.6986 & 1169.6890 & 585.8518 & 0.0096 & 8.1931 & 18628.352 & 18673.076 & 1814.160 & 14285.607 & \text { Yes } & \\ 1.00 & 59.05 & 26.48 & 30.21 & 2 & 1436.6832 & 1143.6734 & 572.840 & 0.0098 & 8.5537 & 11042968 & 8663.195 & 636.105 & 10419.769 & \text { Yes }\end{array}$

VLSIGDGIAR $\begin{array}{llllllllllllllll}1.00 & 59.05 & 26.48 & 30.21 & 2 & 1143.6832 & 1143.6734 & 572.8440 & 0.0098 & 8.5537 & 11042.968 & 8663.195 & 636.105 & 10419.769 & \text { Yes } & \\ 1.00 & 53.43 & 26.48 & 29.70 & 2 & 1143.6832 & 1143.6734 & 572.8440 & 0.0098 & 8.5537 & 18506.182 & 16865.351 & 406.038 & 16365.923 & \text { Yes }\end{array}$

\begin{tabular}{llllllllllllllll} 
AVDSLVPIGR & 1.00 & 45.27 & 24.28 & 23.16 & 2 & 1169.6998 & 1169.6890 & 585.8518 & 0.0108 & 9.2173 & 9886.467 & 10420.310 & 1605.068 & 9280.291 & Yes \\
AVDSLVPIGR & 0.99 & 41.90 & 24.27 & 20.75 & 2 & 1169.7004 & 1169.6890 & 585.8518 & 0.0114 & 9.7293 & 8941.699 & 8919.802 & 1446.624 & 7397.553 & Yes \\
\hline
\end{tabular} $\begin{array}{lllllllllllllll}1.00 & 53.43 & 26.48 & 29.70 & 2 & 1433.6832 & 143.6734 & 572.8440 & 0.0098 & 8.5337 & 18506.182 & 16865.351 & 406.038 & 16365.923 & \text { Yes }\end{array}$

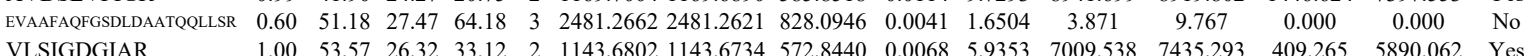
VLSIGDGIAR $\begin{array}{lllllllllllllll}1.00 & 53.57 & 26.32 & 33.12 & 2 & 1143.6802 & 1143.6734 & 572.8440 & 0.0068 & 5.9353 & 7009.538 & 7435.293 & 409.265 & 5890.062 & \text { Yes } \\ 1.00 & 50.89 & 26.32 & 32.82 & 2 & 1143.6804 & 1143.6734 & 572.8440 & 0.0070 & 6.1098 & 6501.111 & 5473.355 & 658.916 & 4917.411 & \text { Yes }\end{array}$ $\begin{array}{lllllllllllllll} & \\ \text { EVAAFAQFGSDLDAATQQLLSR } & 1.00 & \text { \#\#\#\# } 27.52 & 22.65 & 3 & 2481.2659 & 2481.2621 & 828.0946 & 0.0038 & 1.5296 & 5.725 & 15.937 & 6.017 & 17.963 & \text { No }\end{array}$

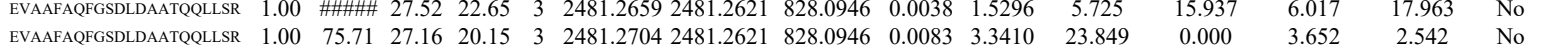

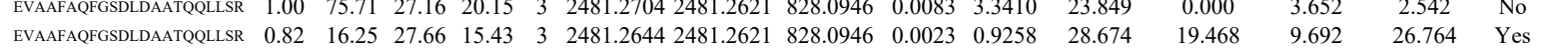

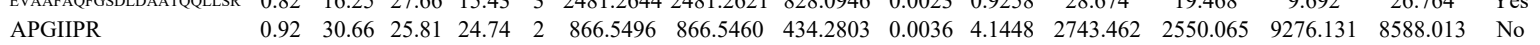
$\begin{array}{lllllllllllllllll}\text { APGIIPR } & 0.51 & 30.12 & 25.90 & 39.54 & 2 & 866.5506 & 866.5460 & 434.2803 & 0.0046 & 5.2961 & 2138.650 & 2140.489 & 4418.916 & 5051.670 & \text { No }\end{array}$ $\begin{array}{lllllllllllllllll}\text { QMSLLLR } & 0.85 & 33.85 & 26.62 & 37.95 & 2 & 1003.6056 & 1003.5970 & 502.8058 & 0.0086 & 8.5519 & 21798.391 & 23890.267 & 6936.905 & 27873.648 & \text { Yes }\end{array}$ $\begin{array}{llllllllllllllll}\text { QMSLLLR } & 0.68 & 28.54 & 26.97 & 37.14 & 2 & 1003.6062 & 1003.5970 & 502.8058 & 0.0092 & 9.1486 & 20680.549 & 20455.058 & 7521.709 & 28372.181 & \text { Yes }\end{array}$ $\begin{array}{lllllllllllllllll}\text { FENAFLSHVVSQHQALLGTIR } & 1.00 & 84.05 & 25.72 & 20.55 & 3 & 2510.3530 & 2510.3516 & 837.7911 & 0.0014 & 0.5570 & 1275.993 & 1143.717 & 357.350 & 1093.455 & \text { Yes }\end{array}$

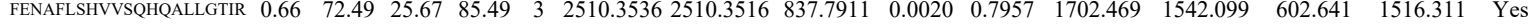

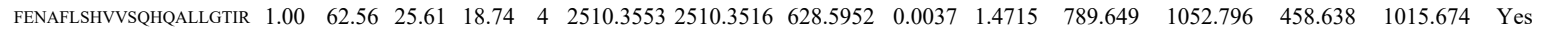

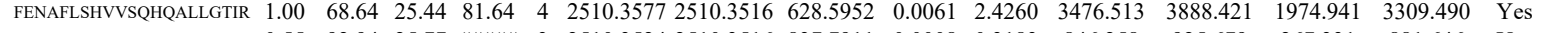

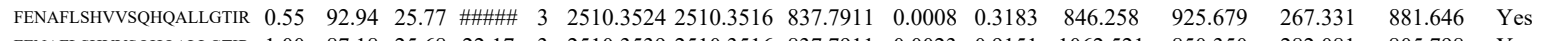
$\begin{array}{llllllllllllllll}\text { FENAFLSHVVSQHQALLGTIR } & 1.00 & 87.18 & 25.68 & 22.17 & 3 & 2510.3539 & 2510.3516 & 837.7911 & 0.0023 & 0.9151 & 1062.521 & 850.350 & 282.081 & 805.798 & \text { Yes }\end{array}$

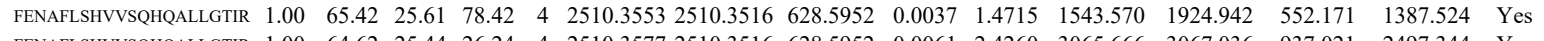

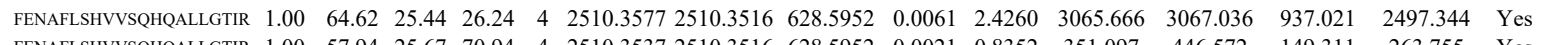

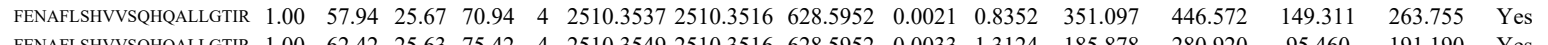

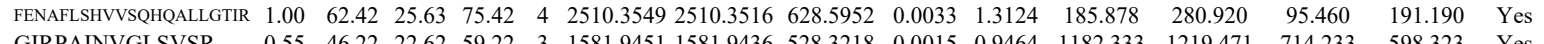

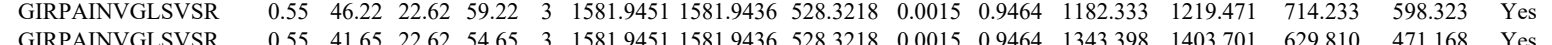
$\begin{array}{llllllllllllllll}\text { GIRPAINVGLSVR } & 0.55 & 41.65 & 22.62 & 54.65 & 3 & 1581.9451 & 1581.9436 & 528.3218 & 0.0015 & 0.9464 & 1343.398 & 1403.701 & 629.810 & 471.168 & \text { Yes } \\ \text { GIRPAINVGLSVSR } & 1.00 & 43.08 & 22.60 & 17.70 & 3 & 1581.9442 & 1581.9436 & 5283218 & 0.0006 & 0.3786 & 575.375 & 734.708 & 317.414 & 180.232 & \text { Yes }\end{array}$ $\begin{array}{llllllllllllllll}\text { GIRPANVGLSVSR } & 1.00 & 70.08 & 22.60 & 17.74 & 3 & 1581.9442 & 1581.9436 & 528.3218 & 0.006 & 0.3786 & 575.375 & 74.708 & 317.414 & 180.232 & \text { Yes }\end{array}$

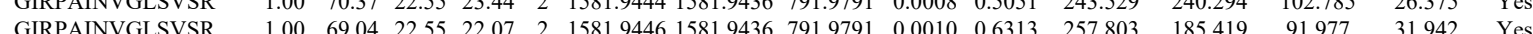

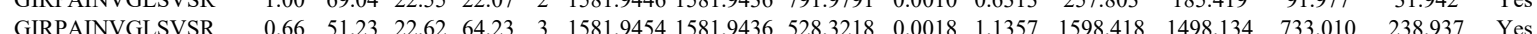

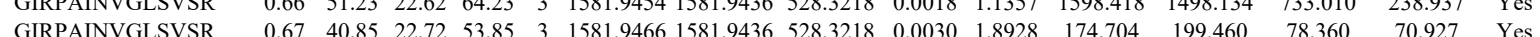

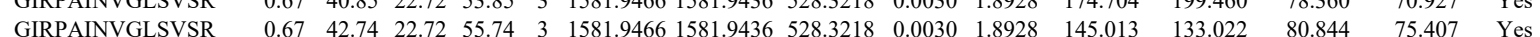

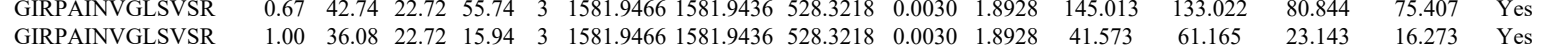
$\begin{array}{lllllllllllllllll}\text { GIRPAINVGLSVSR } & 0.66 & 35.81 & 22.76 & 48.81 & 3 & 1581.9460 & 1581.9436 & 528.3218 & 0.0024 & 1.5142 & 76.428 & 89.805 & 34.785 & 24.190 & \text { Yes }\end{array}$ $\begin{array}{llllllllllllllll}\text { GRPAINVGLSVSR } & 1.00 & 32.47 & 22.62 & 15.54 & 3 & 1581.9457 & 1581.9436 & 528.3218 & 0.0021 & 1.3249 & 80.037 & 113.510 & 84.853 & 39.256 & \text { Yes } \\ \text { GIRPAI }\end{array}$ $\begin{array}{llllllllllllllll}\text { TGTAEMSSILEER } & 1.00 & 76.68 & 26.85 & 22.18 & 2 & 1566.7700 & 1566.7681 & 784.3913 & 0.0019 & 1.2111 & 517.447 & 458.651 & 110.031 & 503.560 & \text { Yes }\end{array}$ $\begin{array}{llllllllllllllll}\text { ILGADTSVDLEETGR } & 1.00 & 88.11 & 27.63 & 23.43 & 2 & 1718.8818 & 1718.8808 & 860.4477 & 0.0010 & 0.5811 & 197.519 & 227.211 & 0.000 & 180.115 & \text { No }\end{array}$ $\begin{array}{llllllllllllllll}\text { TGTAEMSSILEER } & 1.00 & 73.47 & 26.96 & 27.13 & 2 & 1566.7690 & 1566.7681 & 784.3913 & 0.0009 & 0.5737 & 2867.373 & 3861.648 & 1108.645 & 2471.337 & \text { Yes }\end{array}$ $\begin{array}{llllllllllllllll}\text { TGTAEMSSILEER } & 1.00 & 73.60 & 27.04 & 23.80 & 2 & 1566.7712 & 1566.7681 & 784.3913 & 0.0031 & 1.9761 & 558.157 & 449.405 & 234.561 & 524.646 & \text { Yes }\end{array}$

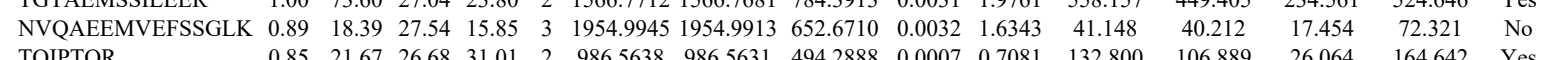

29 TQIPTQR

TQIPTQR

\section{TQIPTQR}

TQIPTQR

NVSIGIVGK

THAVLVALK

THAVLVALK

THAVLVALK

THAVLVALK

THAVLVALK

THAVLVALK

THAVLVALK

LVSLIGSK

LVSLIGSK

FVFDRPLPVSR

FVFDRPLPVSR $\begin{array}{llllllllllllll}0.85 & 21.67 & 26.68 & 31.01 & 2 & 986.5638 & 986.5631 & 494.2888 & 0.0007 & 0.7081 & 132.800\end{array}$ $\begin{array}{lllllllllllllll}0.57 & 14.81 & 26.62 & 25.70 & 2 & 986.5642 & 986.5631 & 494.2888 & 0.0011 & 1.1127 & 116.139 & 100.093 & 38.612 & 122.995 & \text { Yes } \\ 0.87 & 22.07 & 26.62 & 31.43 & 2 & 986.5640 & 9865631 & 494.2888 & 0.0009 & 0.9104 & 57.012 & 50.774 & 17.849 & 65.087 & \text { Yes }\end{array}$ $\begin{array}{lllllllllllllllll}0.77 & 19.04 & 26.62 & 25.89 & 2 & 986.5640 & 986.5631 & 494.2888 & 0.0009 & 0.9104 & 49.582 & 29.550 & 14.048 & 45.344 & \text { No }\end{array}$

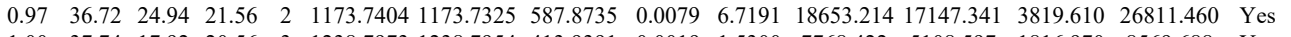
$\begin{array}{llllllllllllllll}1.00 & 37.74 & 17.92 & 20.56 & 3 & 1238.7973 & 1238.7954 & 413.9391 & 0.0019 & 1.5300 & 7768.422 & 5108.597 & 1816.970 & 8569.688 & \text { Yes }\end{array}$ \begin{tabular}{llllllllllllllll}
1.00 & 59.41 & 17.71 & 17.40 & 2 & 1238.7980 & 1238.7954 & 620.4050 & 0.0026 & 2.0954 & 12526.096 & 6483.322 & 2831.898 & 15496.746 & Yes \\
\hline
\end{tabular} $\begin{array}{llllllllllllllll}1.00 & 39.74 & 17.56 & 20.95 & 3 & 1238.8036 & 1238.7954 & 413.9391 & 0.0082 & 6.6032 & 9092.686 & 6955.143 & 1170.770 & 10308.570 & \text { Yes }\end{array}$ $\begin{array}{lllllllllllllll}1.00 & 59.22 & 17.56 & 19.81 & 2 & 1238.8052 & 1238.7954 & 620.4050 & 0.0098 & 7.8980 & 10270.572 & 6378.571 & 2464.504 & 14964.997 & \text { Yes }\end{array}$

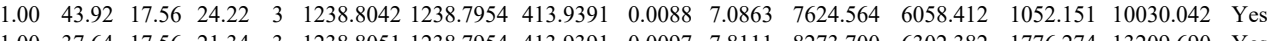
\begin{tabular}{lllllllllllllllll}
1.00 & 37.64 & 17.56 & 21.34 & 3 & 1238.8051 & 1238.7954 & 413.9391 & 0.0097 & 7.8111 & 8273.700 & 6302.382 & 1776.274 & 13209.690 & Yes \\
\hline
\end{tabular} $\begin{array}{lllllllllllllll}1.00 & 56.52 & 17.56 & 18.56 & 2 & 1238.8052 & 1238.7954 & 62.4050 & 0.0098 & 7.8980 & 5331.792 & 3301.450 & 1456.094 & 7133.232 & \text { Yes }\end{array}$ $\begin{array}{lllllllllllllll}0.94 & 4.12 & 21.58 & 46.40 & 2 & 103.7262 & 103.7158 & 552.8652 & 0.0104 & 9.4055 & 25302.612 & 18994.852 & 640.526 & 40008.306 & \text { Yes } \\ 0.95 & 45.87 & 21.58 & 45.99 & 2 & 1103.7258 & 1103.7158 & 552.8652 & 0.0100 & 9.0437 & 14339.590 & 14562.303 & 653.684 & 23823.998 & \text { Yes }\end{array}$

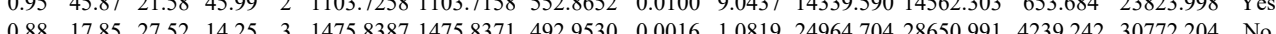

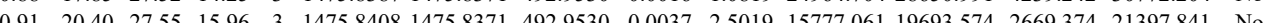
$\begin{array}{lllllllllllllll}0.69 & 13.28 & 27.54 & 19.82 & 3 & 1475.8408 & 1475.8371 & 492.9530 & 0.0037 & 2.5019 & 15777.061 & 19693.574 & 2669.374 & 21397.841 & \text { No } \\ & & & & & & & & \end{array}$ 
FVFDRPLPVSR VFDRPLPVSR AQPAQPADEPAEK AQPAQPADEPAEK AQPAQPADEPAEK FVFDRPLPVSR THAVLVALKR THAVLVALKR FVFDRPLPV LLCNFMR

LLCNFMR

LLCNFR

LLCNFMR

LLCNFMR
LLCNFMR

LLCNFMR

LLCNFMR

LLCNFMR

LLCNFMR

AQPAQPADEPAEK

$\begin{array}{lllllllllllll}\text { PSA2_HUMAN } & \text { P25787 } & \text { PSMA2 } & \text { Proteasome subun 25.899 } & 1.00 & 6 & 42.7 & -0.1274 & 0.7263 & -0.0438 & 0.6018 & 40 & \text { AANGVVLATEK } \\ & & & & & & & & & & & & \text { AANGVVLATEK }\end{array}$

AANGVVLATEK

YNEDLELEDAIHTAILTLK

YNEDLELEDAIHTAILTLK

YNEDLELEDAIHTAILTLK

YNEDLELEDAIHTAILTLK

YNEDLELEDAIHTAILTLK

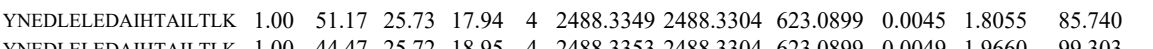

$\begin{array}{lllllllllllllll} & \text { YNEDLELEDAIHTAILTLK } & 1.00 & 44.47 & 25.72 & 18.95 & 4 & 2488.3353 & 2488.3304 & 623.0899 & 0.0049 & 1.9660 & 99.303 & 62.03\end{array}$

$\begin{array}{lllllllllllll}\text { NADLELDAIHTAILTLK } & 0.66 & 56.22 & 25.79 & 69.22 & 3 & 2488.3324 & 2488.3304 & 830.4507 & 0.0020 & 0.8028 & 298.511 & 25\end{array}$

$\begin{array}{llllllllllllll}\text { NEDLELEDAIHTAILTLK } & 0.66 & 63.85 & 25.77 & 76.85 & 3 & 2488.3327 & 2488.3304 & 830.4507 & 0.0023 & 0.9232 & 265.365 & 251\end{array}$

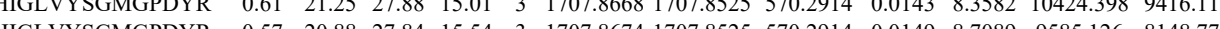

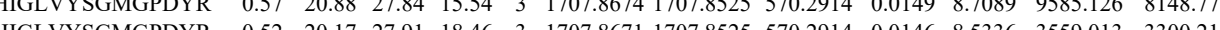

$\begin{array}{llllllllllllll}\text { GYSFSLTTFSPSGK } & 1.00 & 92.92 & 28.29 & 23.05 & 2 & 1765.9148 & 1765.9131 & 883.9638 & 0.0017 & 0.9616 & 1468.918 & 1039.093 & \end{array}$

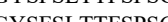

GYQPYTYYOSPSC

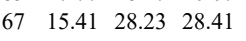
1765.9159

$\begin{array}{llllllllllllll} & \end{array}$

$\begin{array}{llllllllllll} & 22.16 & 2 & 2664.4434 & 2664.4397 & 1333.2271 & 0.0037 & 1.3876 & 6.856 & 10.516\end{array}$

$\begin{array}{llllllllllllll}\text { LAQQYYLVYQEPITTAQLVQR } & 1.00 & 30.27 & 24.49 & 16.36 & 3 & 2664.4438 & 2664.4397 & 889.1538 & 0.0041 & 1.5370 & 50.482 & 25.537\end{array}$

$\begin{array}{llllllllllllll}\text { LAQQYYLVYQEPIPTAQLVQR } & 1.00 & \text { \#\#\#\# } 24.47 & 26.64 & 2 & 2664.4434 & 2664.4397 & 1333.2271 & 0.0037 & 1.3876 & 1.113 & 0.000\end{array}$

$\begin{array}{lllllllllllll}\text { LVOIEYALAAVAGGAPSVGIK } & 1.00 & 38.86 & 19.64 & 16.84 & 3 & 2314.3510 & 2314.3504 & 772.4574 & 0.0006 & 0.2589 & 24.527 & 6.869\end{array}$

$\begin{array}{llllllllllll}\text { LVIEYALAAVAGGAPSVGIK } & 0.82 & \text { \#\#\#\# } & 19.64 & \text { \#\#\#\# } & 2 & 2314.3514 & 2314.3504 & 1158.1825 & 0.0010 & 0.4317 & 16.544 \\ \text { VQIEYALAAVAGGAPSVGIK } & 0.66 & 14.29 & 19.34 & 27.29 & 3 & 2314.3528 & 2314.3504 & 772.4574 & 0.0024 & 1.0357 & 35.776\end{array}$

$\begin{array}{llllllllllll}\text { LVIIEYALAAVAGGAPSVGIK } & 1.00 & 59.76 & 19.34 & 19.49 & 3 & 2314.3531 & 2314.3504 & 772.4574 & 0.0027 & 1.1651 & 3.946\end{array}$

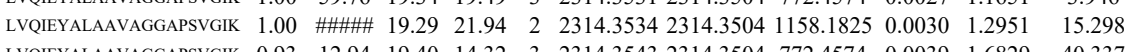

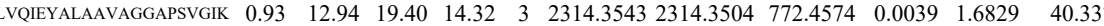

$\begin{array}{lllllllllllll}\text { LVIIEYALAAVAGGAPSVGIK } & 1.00 & 61.82 & 19.40 & 20.58 & 3 & 2314.3567 & 2314.3504 & 772.4574 & 0.0063 & 2.7186 & 0.000\end{array}$

\begin{tabular}{lllllllllllll} 
EVQIEYALAAVAGGAPSVGIK & 1.00 & 37.70 & 19.49 & 16.75 & 3 & 2314.3519 & 2314.3504 & 772.4574 & 0.0015 & 0.6473 & 16.393 \\
\hline
\end{tabular}

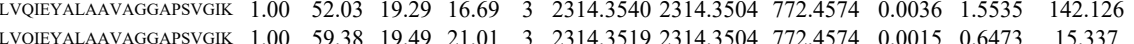

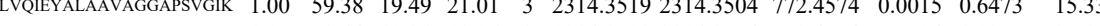

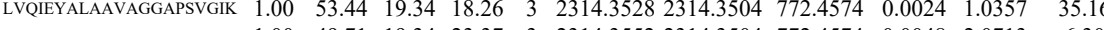

$\begin{array}{llllllllllllll} & \end{array}$

$\begin{array}{llllllllllllll} & \end{array}$

$\begin{array}{lllllllllllllll} & \text { LVIVALAVAGAPSGIK } & 1.00 & 62.54 & 19.40 & 18.06 & 3 & 2314.3525 & 2314.3504 & 772.4574 & 0.0021 & 0.9062 & 7.340\end{array}$

$\begin{array}{llllllllllll}\text { LVIEYALAAVAGGAPSVGIK } & 1.00 & 45.06 & 19.34 & 27.38 & 3 & 2314.3528 & 2314.3504 & 772.4574 & 0.0024 & 1.0357 & 9.015 \\ \text { LVIEYALAAVAGGAPSGGIK } & 1.00 & 72.88 & 19.34 & 24.78 & 3 & 2314.3531 & 2314.3504 & 772.4574 & 0.0027 & 1.1651 & 13.105\end{array}$ $\begin{array}{lllllllllllll}\text { LVIIEYALAAVAGGAPSVGIK } & 1.00 & 51.86 & 19.29 & 21.79 & 3 & 2314.3540 & 2314.3504 & 772.4574 & 0.0036 & 1.5535 & 13.459\end{array}$

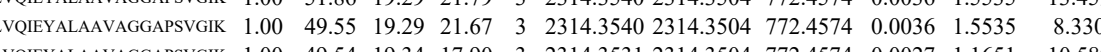
$\begin{array}{llllllllllll}\text { LVQIEYALAAVAGGAPSVGIK } & 1.00 & 49.54 & 19.34 & 17.90 & 3 & 2314.3531 & 2314.3504 & 772.4574 & 0.0027 & 1.1651 & 10.580 \\ \text { LVQIEYALAAVAGGAPSVGIK } & 1.00 & 58.34 & 19.34 & 22.53 & 3 & 2314.3552 & 2314.3504 & 772.4574 & 0.0048 & 2.0713 & 4.025\end{array}$

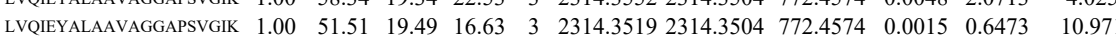
$\begin{array}{lllllllllllll}\text { LVOIEYALAAVAGGAPSVGIK } & 0.55 & 12.09 & 19.49 & 25.09 & 3 & 2314.3519 & 2314.3504 & 72.4574 & 0.0015 & 0.6473 & 8.644\end{array}$ $\begin{array}{llllllllllllll}\text { LVOIEYALAAVAGGAPSVGIK } & 1.00 & 42.86 & 19.49 & 16.84 & 3 & 2314.3519 & 2314.3504 & 772.4574 & 0.0015 & 0.6473 & 15.847\end{array}$

1519.181
552.920
624.055

624.055

168.859

74.344
130.622 7.961 14.051 1.112

Yes $\begin{array}{ll}30.622 & 19.766 \\ 58.264 & 72.406\end{array}$

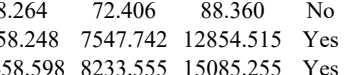
$\begin{array}{llll} & \\ 67.419 & 4249.681 & 9175.555 & \text { Yes } \\ & 3.747 & 11.888 & Y e s\end{array}$ \begin{tabular}{cccc}
6.714 & 11.888 & Yes \\
8 & 924.174 & 1316.982 & Yes \\
\hline 4.778 & 16.724 & 3.748 &
\end{tabular} \begin{tabular}{llll}
0.778 & 16.724 & 3.748 & No \\
\hline .756 & 65.347 & 106.920 & Y
\end{tabular} \begin{tabular}{llll}
8.792 & 65.347 & 106.920 & Yes \\
\hline 92 & 84.839 & 84.220 & Yes
\end{tabular} $\begin{array}{llll}652 & 476.461 & 544.350 & \text { Yes }\end{array}$ $\begin{array}{llll}971.269 & 1163.868 & \text { Yes }\end{array}$ $\begin{array}{lll}58.843 & 121.869 & \text { Yes } \\ 48.098 & 120.226 & \text { Yes }\end{array}$ $\begin{array}{lll}48.098 & 120.226 & \text { Yes } \\ 370.139 & 592.477 & \text { Yes }\end{array}$ $\begin{array}{lll}370.139 & 592.477 & \text { Yes } \\ 217.591 & 379.768 & \text { Yes }\end{array}$ \begin{tabular}{|lll}
7.789 & 100.694 & Yes \\
\hline
\end{tabular}

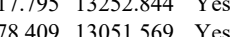
$\begin{array}{lll}1628.370 & \text { Yes }\end{array}$ $\begin{array}{lll}7.288 & 540.636 & \text { Yes }\end{array}$ $\begin{array}{lll}21.198 & 23.959 & \text { Yes }\end{array}$ $\begin{array}{lll}21.051 & 14.561 & \text { No }\end{array}$ $80.768 \quad 131.405$ Yes $\begin{array}{lll}8.699 & 9.219 & \text { No }\end{array}$ $\begin{array}{lll}0.379 & 11.817 \quad \text { No }\end{array}$ $25.961 \quad 19.621 \quad$ Yes $24.479 \quad 39.654$ Yes $\begin{array}{lll}0.000 & 4.480 & \text { No }\end{array}$ $\begin{array}{lll}13.934 & 12.374 & \text { Yes }\end{array}$ $11.078 \quad 38.623 \quad$ Yes $\begin{array}{llll}27 & 29.893 & 53.170 & \text { No }\end{array}$ \begin{tabular}{llll}
6.804 & 26.053 & 67.378 & No \\
8.012 & 30.872 & 74.376 & Yes \\
\hline 7.228 & 9.794 & 15.988 & Yes
\end{tabular} $\begin{array}{llll}17.228 & 9.794 & 15.988 & \text { Yes }\end{array}$ $\begin{array}{llll}1.078 & 2.612 & 49.867 & \text { Yes } \\ 1.683 & 1.436 & 3.76 & \text { Ye }\end{array}$ 

$\begin{array}{llllllllllllllll} & \end{array}$ LLDEVFFSEK $\begin{array}{lllllllllllllll}0.99 & 29.50 & 27.26 & 17.47 & 3 & 1513.8292 & 1513.8272 & 505.6163 & 0.0020 & 1.3185 & 157.972 & 138.462 & 91.747 & 200.982 & \text { Yes }\end{array}$ $\begin{array}{lllllllllllllll}1.00 & 37.33 & 27.36 & 18.88 & 3 & 1513.8298 & 1513.8272 & 505.6163 & 0.0026 & 1.7141 & 152.810 & 113.206 & 32.202 & 180.704 & \text { Y ses } \\ 1.00 & 3.86 & 27.36 & 27.6 & 2 & 1513.8298 & 1513.8272 & 757.929 & 0.0026 & 1.7152 & 929.765 & 1365.547 & 0.00 & & \end{array}$ LDEVFFSEK $\begin{array}{lllllll}1.00 & 61.07 & 27.36 & 27.61 & 2\end{array}$ TEDMGSVAGITSDANVLTNELR 0.8

VEIATLTR

VEIATLTR

VEIATLTR

SALALAIK

SALALAIK 61.07 27.1624 .12 2 215 $0.000 \quad 1894.930 \quad \mathrm{~N}$

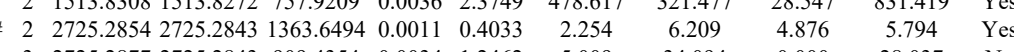

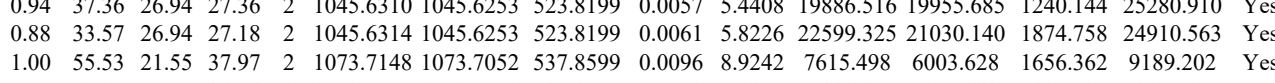
$\begin{array}{lllllllllllllll}0.99 & 40.69 & 21.55 & 34.04 & 2 & 1073.7150 & 1073.7052 & 537.8599 & 0.0096 & 8.9242 & 7615.498 & 6003.628 & 1656.362 & 9189.202 & \text { Yes } \\ 0.1101 & 10826.459 & 9395.648 & 2885.535 & 12120.869 & \text { Yes }\end{array}$

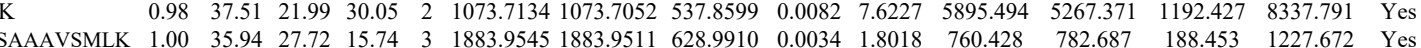

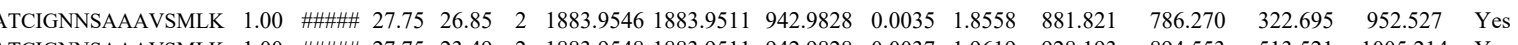

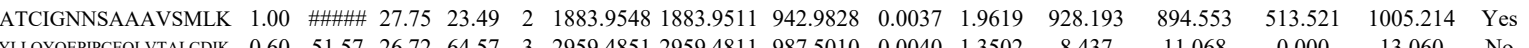
$\begin{array}{llllllllllllllll} & & & \end{array}$ $\begin{array}{llllllllllllllll} & \end{array}$ $\begin{array}{llllllllllllllll}\text { MLLQYQEPIPCEQLVTALCDIK } & 0.81 & 8.58 & 26.69 & 15.04 & 4 & 2959.4865 & 2959.4811 & 740.8776 & 0.0054 & 1.8222 & 11.619 & 2.548 & 8.279 & 7.212 & \text { Yes }\end{array}$

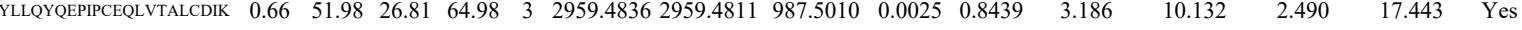

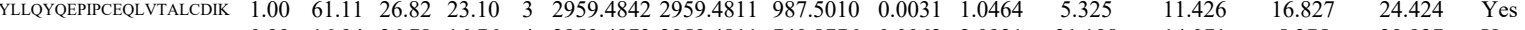
$\begin{array}{lllllllllllllll} & 26.375 & 29.927 & \text { Yes }\end{array}$

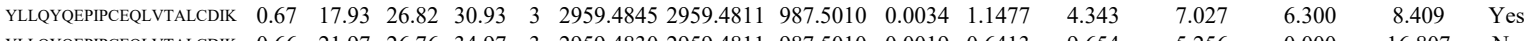

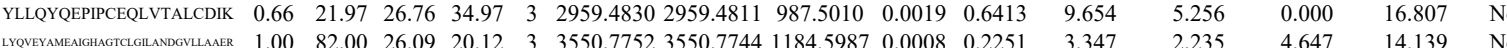
$\begin{array}{llllllllllllllll} & \text { No }\end{array}$

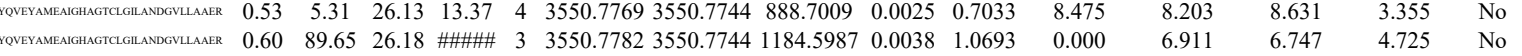

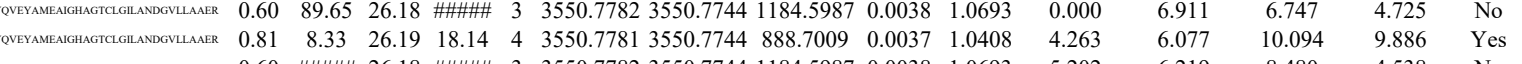
$\begin{array}{lllllllllllllll} & \end{array}$

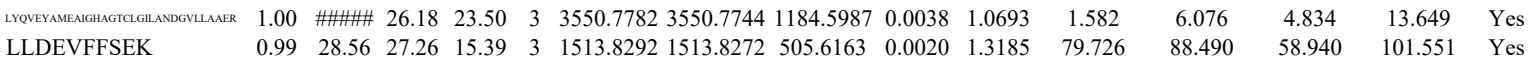
$\begin{array}{lllllllllllll} & \end{array}$

$\begin{array}{llllllllllllll}\text { ITA3_HUMAN } & \text { P26006 } & \text { ITGA3 } & \text { Integrin alpha-3 } & 118.76 & 1.00 & 3 & 2.4 & -0.2258 & 0.1766 & 2.2245 & 0.4421 & 9 & \text { VLVCAHR }\end{array}$ VLVCAHR VLVCAHR
YLLLAGAPR YLLLAGAPR
YLLLAGAPR YLLLAGAPR YLLLAGAPR VNGWATLFLR VNGWATLFLR VNGWATLFLR

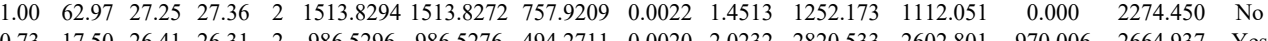
$\begin{array}{llllllllllllllll}0.92 & 24.66 & 2.88 & 27.21 & 2 & 986.5282 & 986.5276 & 494.2711 & 0.0006 & 0.6070 & 1685.518 & 1588.224 & 1246.212 & 1901.871 & \text { No }\end{array}$ $\begin{array}{lllllllllllllllll}0.97 & 28.39 & 26.54 & 31.02 & 2 & 986.5286 & 986.5276 & 494.2711 & 0.0010 & 1.0116 & 4772.711 & 4485.524 & 1145.098 & 5053.160 & \text { Yes }\end{array}$

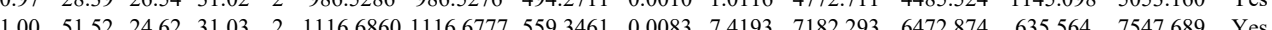
$\begin{array}{llllllllllllllll}1.00 & 49.93 & 24.59 & 30.66 & 2 & 116.6866 & 116.6777 & 559.3461 & 0.0089 & 7.9557 & 8963.262 & 8486.651 & 565.948 & 10312.174 & \text { Yes }\end{array}$ $\begin{array}{lllllllllllllllll}1.00 & 50.25 & 26.44 & 30.96 & 2 & 11166.6844 & 1116.6777 & 559.3461 & 0.0067 & 5.9891 & 7687.684 & 7289.237 & 482.538 & 8351.998 & \text { Yes }\end{array}$ $\begin{array}{lllllllllllllll}0.98 & 40.66 & 26.09 & 30.46 & 2 & 1116.6854 & 1116.6777 & 559.3461 & 0.0077 & 6.8830 & 8333.719 & 7227.407 & 103.702 & 8561.810 & \text { Yes }\end{array}$

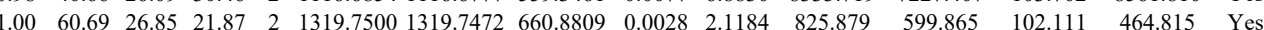
$\begin{array}{lllllllllllllll}100 & 59.50 & 26.82 & 28.68 & 2 & 1319.7502 & 1319.7472 & 660.8809 & 0.0030 & 2.2697 & 1389.844 & 1051.488 & 109.360 & 763.196 & \text { Yes }\end{array}$ $\begin{array}{llllllllllllllll}1.00 & 69.25 & 26.82 & 24.95 & 2 & 1319.7502 & 1319.7472 & 660.8809 & 0.0030 & 2.2697 & 1328.829 & 930.940 & 119.666 & 823.883 & \text { Yes }\end{array}$ $\begin{array}{lllllllllllllllll}0.87 & 23.75 & 28.23 & 28.74 & 2 & 931.5218 & 931.5209 & 466.7677 & 0.0009 & 0.9641 & 631.793 & 533.005 & 139.704 & 519.786 & \text { Yes }\end{array}$ $\begin{array}{lllllllllllllllll}0.96 & 29.08 & 28.23 & 31.96 & 2 & 931.5218 & 931.5209 & 466.7677 & 0.0009 & 0.9641 & 820.846 & 656.610 & 167.655 & 783.361 & \text { Yes }\end{array}$ VTAQDVR TANDMIHAENM $\begin{array}{lllllllllllllllll}1.00 & 84.75 & 25.37 & 31.83 & 3 & 1545.7249 & 1545.7150 & 516.2456 & 0.0099 & 6.3923 & 13399.289 & 12149.140 & 1854.613 & 8268.341 & \text { Yes }\end{array}$ $\begin{array}{lllllllllllllllll}\text { TANDMIHAENMR } & 1.00 & 59.13 & 25.47 & 31.69 & 3 & 1545.7255 & 1545.7150 & 516.2456 & 0.0105 & 6.7797 & 9550.350 & 7633.448 & 2342.005 & 6348.294 & \text { Yes }\end{array}$

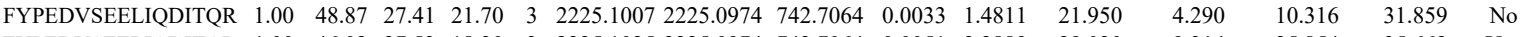

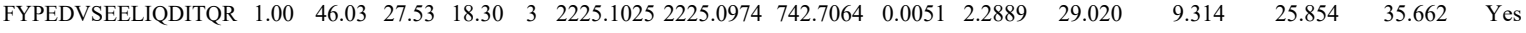

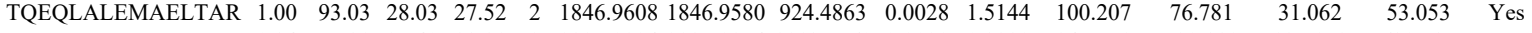

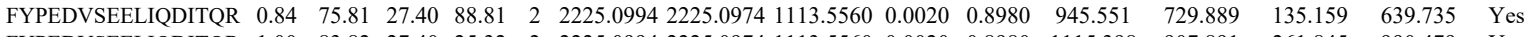

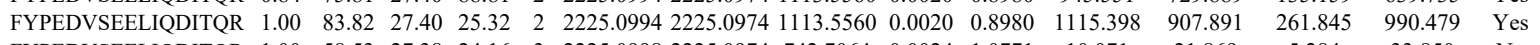

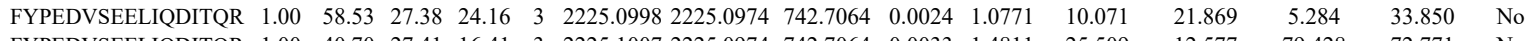
$\begin{array}{llllllllllllllll}\text { FYPEDVSEELIQDITQR } & 1.00 & 40.70 & 27.41 & 16.41 & 3 & 2225.1007 & 2225.0974 & 742.7064 & 0.0033 & 1.4811 & 25.509 & 12.577 & 79.428 & 72.771 & \text { No }\end{array}$ $\begin{array}{lllllllllllllll}\text { TQEQLALEMAELTAR } & 1.00 & \text { 28.05 } & 31.71 & 2 & 1846.9594 & 1846.9580 & 924.4863 & 0.0014 & 0.7572 & 4030.700 & 2617.801 & 840.955 & 2320.405 & \text { Yes }\end{array}$

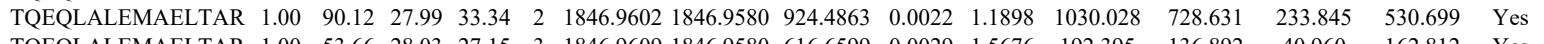

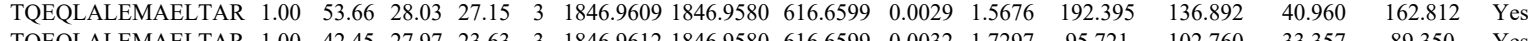

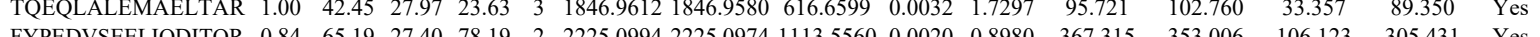

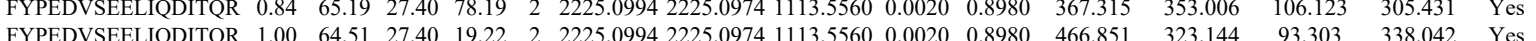
$\begin{array}{lllllllllllllll} & \end{array}$

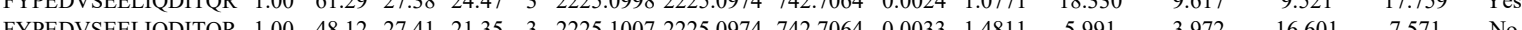

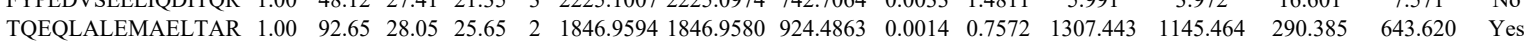


$\begin{array}{lllllllllllllll}\text { TQEQLALEMAELTAR } & 1.00 & \text { \#\#.04 } & 28.73 & 2 & 1846.9598 & 1846.9580 & 924.4863 & 0.0018 & 0.9735 & 3860.797 & 3267.400 & 610.769 & 2402.369 & \text { Yes }\end{array}$ $\begin{array}{lllllllllllllllll}\text { TQEQLALEMAELTAR } & 1.00 & 56.22 & 28.03 & 27.12 & 3 & 1846.9606 & 1846.9580 & 616.6599 & 0.0026 & 1.4054 & 120.172 & 52.153 & 47.921 & 172.434 & \text { Yes }\end{array}$ $\begin{array}{lllllllllllllllll}\text { TQEQLALEMAELTAR } & 1.00 & 52.17 & 27.97 & 26.08 & 3 & 1846.9624 & 1846.9580 & 616.6599 & 0.0044 & 2.3784 & 88.505 & 69.979 & 71.199 & 177.076 & \text { Yes }\end{array}$ $\begin{array}{llllllllllllllll}\text { FYPEDVSEELIQDITQR } & 1.00 & 43.75 & 27.37 & 17.71 & 3 & 2225.1004 & 2225.0974 & 742.7064 & 0.0030 & 1.3464 & 20.952 & 23.610 & 12.295 & 52.367 & \text { No }\end{array}$

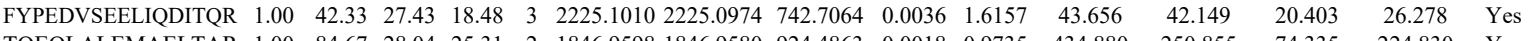

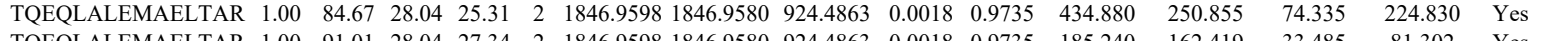

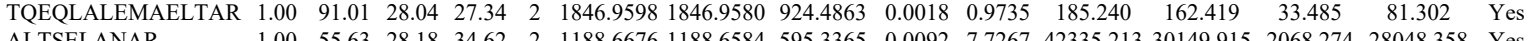

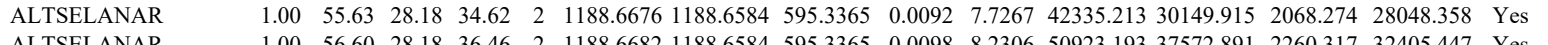
$\begin{array}{llllllllllllllll} & 1.0 & 55.63 & 28.18 & 34.62 & 2 & 1188.6676 & 1188.6584 & 55.336 & 0.002 & 7.7267 & 42335.213 & 30149.915 & 2068.274 & 28048.358 & \text { Yes } \\ \text { ALTSELANAR } & 1.00 & 56.60 & 28.18 & 36.46 & 2 & 1188.6682 & 1188.6584 & 595.3365 & 0.0098 & 8.2306 & 50923.193 & 37572.891 & 2260.317 & 32405.447 & \text { Yes }\end{array}$

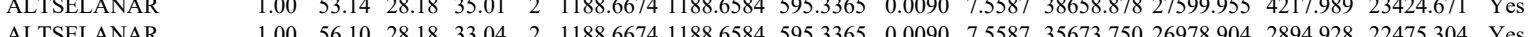

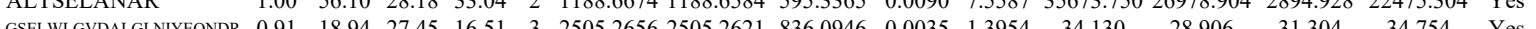

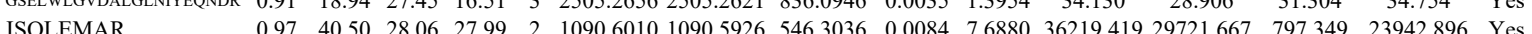

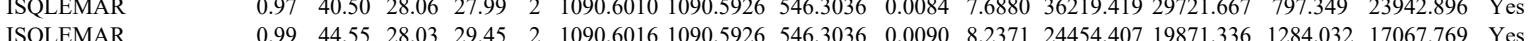

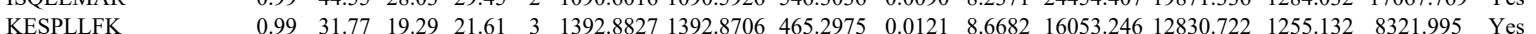
$\begin{array}{llllllllllllllll}\text { KESPLLFK } & 0.99 & 32.97 & 19.29 & 21.74 & 3 & 132.88830 & 1392.8706 & 465.2975 & 0.0124 & 8.8831 & 11958.805 & 9523.753 & 720.930 & 7766.393 & \text { Yes }\end{array}$ $\begin{array}{llllllllllllllll}\text { KEINDIYCPETAVLAAYAVOSK } & 1.90 & 25.73 & 26.273 & 14.67 & 4 & 31425845 & 3142.5810 & 786.6525 & 0.0035 & 1.1123 & 14.528 & 16.169 & 7.773 & 19.630 & \text { Yes }\end{array}$

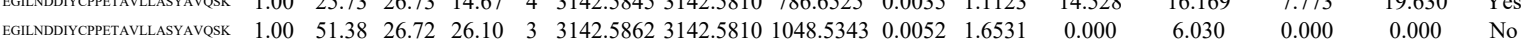

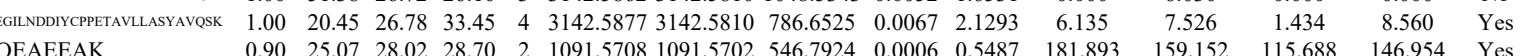
$\begin{array}{llllllllllllllll} & 0.90 & 25.07 & 28.02 & 28.70 & 2 & 1091.5708 & 1091.5702 & 546.7924 & 0.0006 & 0.5487 & 181.893 & 759.152 & 1.434 .688 & 8.560 .934 & \text { Yes } \\ \text { ISQLEMAR } & 0.98 & 39.86 & 28.14 & 29.63 & 2 & 1090.6018 & 1090.5926 & 546.3036 & 0.0092 & 8.4202 & 33998.397 & 27452.070 & 1414.908 & 23494.738 & \text { Yes }\end{array}$

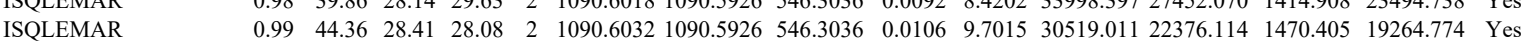
$\begin{array}{llllllllllllllll}\text { EGLNDIYCPPETAVLLASYAVQSK } & 0.99 & 30.21 & 26.72 & 16.54 & 3 & 3142.5862 & 3142.5810 & 1048.5343 & 0.0052 & 1.6531 & 0.000 & 0.000 & 4.227 & 3.707 & \text { No }\end{array}$ $\begin{array}{llllllllllllllll}\text { EGLNDDIYCPEETAVLLASYAVQSK } & 1.00 & 21.05 & 26.78 & 34.05 & 4 & 3142.5885 & 3142.5810 & 786.6525 & 0.0075 & 2.3835 & 16.086 & 10.254 & 19.850 & 22.731 & \text { Yes }\end{array}$ $\begin{array}{lllllllllllllllll} & & & \end{array}$

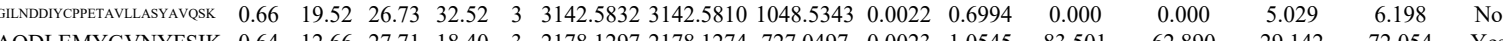

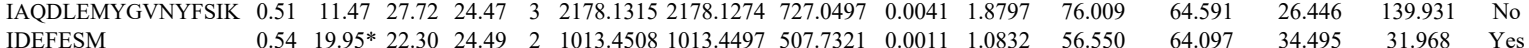

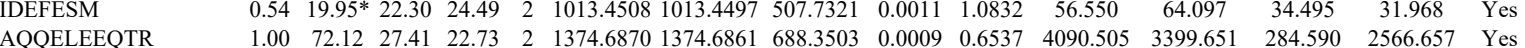

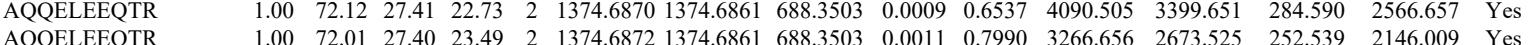

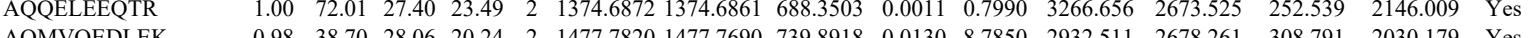
$\begin{array}{lllllllllllllllll} & \text { AQMVEDLEK } & 0.98 & 38.70 & 28.06 & 20.24 & 2 & 1477.7820 & 1477.7690 & 739.8918 & 0.0130 & 8.7850 & 2932.511 & 2678.261 & 308.791 & 2030.179 & \text { Yes }\end{array}$

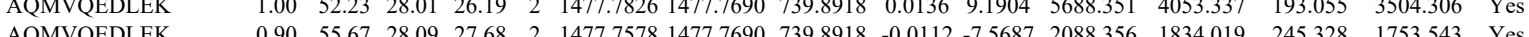
TANDMHAENMR TANDMIHAENMR TANDMIHAENMR

TANDMHAENMR

TANDMHAENMR

TANDMIHAENMR

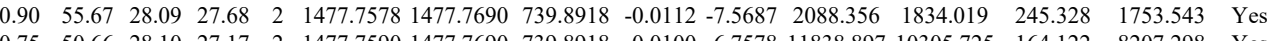
\begin{tabular}{llllllllllllllll}
0.75 & 50.66 & 28.10 & 27.17 & 2 & 1477.750 & 1477.7690 & 739.8918 & -0.0100 & -6.7578 & 11838.897 & 10305.725 & 164.122 & 8207.298 & Yes \\
\hline
\end{tabular} $\begin{array}{llllllllllllllll}1.00 & 61.12 & 25.37 & 30.81 & 3 & 1545.7249 & 1545.7150 & 516.2456 & 0.0099 & 6.3923 & 13093.481 & 11032.579 & 1192.136 & 8494.823 & \text { Yes } \\ 1.00 & 63.80 & 25.51 & 37.25 & 3 & 1545.7261 & 1545.7150 & 516.2456 & 0.0111 & 7.1671 & 14302.345 & 12338.551 & 1827.029 & 7252.885 & \text { Yes }\end{array}$

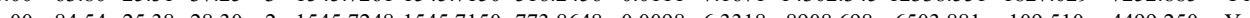

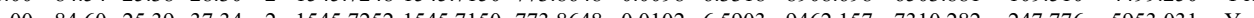

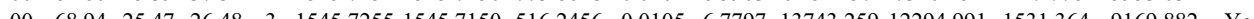
$\begin{array}{lllllllllllllll}1.00 & 67.83 & 25.55 & 32.54 & 3 & 1545.7270 & 1545.7150 & 516.2456 & 0.0120 & 7.7482 & 16542.796 & 14785.476 & 2467.151 & 10898.698 & \text { Yes }\end{array}$ $\begin{array}{lllllllllllllll}1.00 & 50.36 & 25.47 & 25.91 & 3 & 1545.7255 & 1545.7150 & 516.2456 & 0.0105 & 6.7797 & 7878.099 & 6106.369 & 2816.925 & 6014.578 & \text { YeS }\end{array}$ $\begin{array}{llllllllllllllll} & & \end{array}$

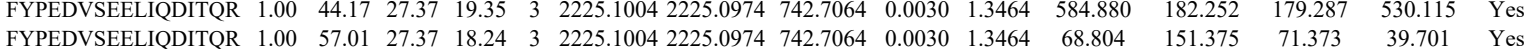

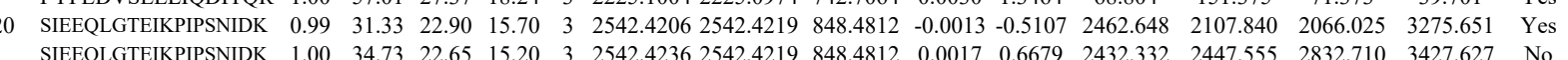
\begin{tabular}{llllllllllllllll} 
SIEEQLGTEIKPIPSNIDK & 1.00 & 34.73 & 22.65 & 15.20 & 3 & 2542.4236 & 2542.4219 & 848.4812 & 0.0017 & 0.6679 & 2432.332 & 2447.555 & 2832.710 & 3427.627 & No \\
\hline
\end{tabular}

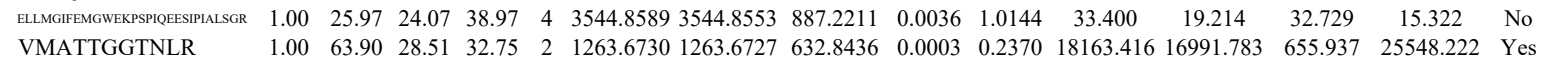

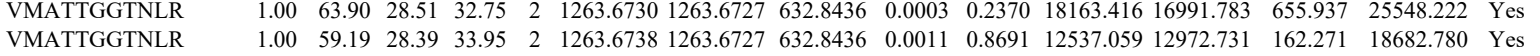
$\begin{array}{llllllllllllllll}\text { SGAYLIPLLER } & 1.00 & 49.34 & 26.88 & 23.75 & 2 & 1374.8002 & 1374.7993 & 688.4069 & 0.0009 & 0.6537 & 2666.787 & 2806.788 & 188.113 & 3702.735 & \text { Yes }\end{array}$ $\begin{array}{lllllllllllllllll} & \text { SGAYLIPLLER } & 1.00 & 47.11 & 26.88 & 24.80 & 2 & 1374.8004 & 1374.7993 & 688.4069 & 0.0011 & 0.7989 & 2475.818 & 2953.700 & 117.840 & 3925.142 & \text { Yes }\end{array}$

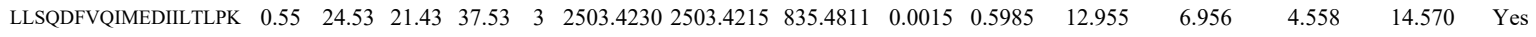
$\begin{array}{llllllllllllllll}\text { VMATTGGTNLR } & 1.00 & 56.70 & 28.48 & 35.46 & 2 & 1263.6734 & 1263.6727 & 632.8436 & 0.0007 & 0.5531 & 6962.415 & 6849.852 & 22.955 & 11279.416 & \text { Yes }\end{array}$ $\begin{array}{llllllllllllllll}\text { VMATTGGTNLR } & 1.00 & 62.56 & 28.06 & 29.80 & 2 & 1263.6746 & 1263.6727 & 632.8436 & 0.0019 & 1.5012 & 2396.474 & 2033.853 & 174.166 & 3301.470 & \text { Yes }\end{array}$ $\begin{array}{lllllllllllllllll}\text { SGAYLIPLLER } & 1.00 & 45.01 & 26.81 & 23.62 & 2 & 1374.8008 & 1374.7993 & 688.4069 & 0.0015 & 1.0895 & 2167.345 & 2186.113 & 125.201 & 3038.307 & \text { Yes }\end{array}$

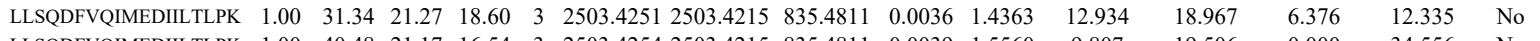
$\begin{array}{llllllllllllllll}\text { LLSQDFVQIMEDIILTLPK } & 1.00 & 40.48 & 21.17 & 16.54 & 3 & 2503.4254 & 2503.4215 & 835.4811 & 0.0039 & 1.5560 & 9.807 & 19.506 & 0.000 & 34.556 & \text { No }\end{array}$ $\begin{array}{llllllllllllllll}\text { LLSQDFVQIMEDIILTLPK } & 0.60 & 45.38 & 21.17 & 58.38 & 3 & 2503.4254 & 2503.4215 & 835.4811 & 0.0039 & 1.5560 & 27.054 & 17.031 & 4.433 & 22.996 & \text { No }\end{array}$

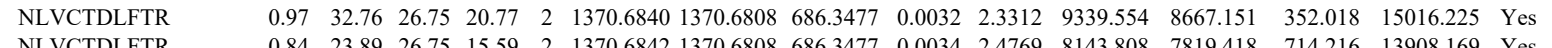

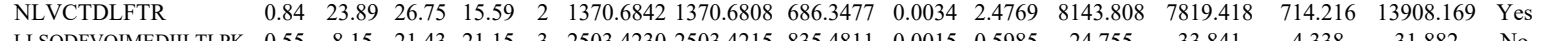

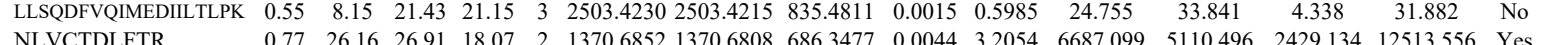

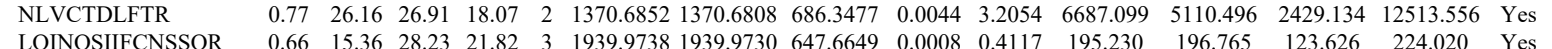
$\begin{array}{llllllllllllllll}\text { LQINQSIIFCNSSQR } & 0.66 & 15.36 & 28.23 & 21.82 & 3 & 1939.9738 & 1939.9730 & 647.6649 & 0.0008 & 0.4117 & 195.230 & 196.765 & 123.626 & 224.020 & \text { Yes } \\ \text { VHCLNTLFSR } & 0.55 & 29.81 & 27.61 & 42.81 & 3 & 1378.6984 & 1378.6971 & 460.5730 & 0.0013 & 0.9409 & 1157.160 & 1061.409 & 590.163 & 1734576 & \text { Yes }\end{array}$ $\begin{array}{llllllllllllllll}\text { VHCLNTLFSR } & 1.00 & 38.61 & 27.59 & 19.23 & 2 & 1378.6992 & 1378.6971 & 690.03558 & 0.0021 & 1.5210 & 1413.613 & 1022.034 & 398.518 & 1809.566 & \text { Yes }\end{array}$ $\begin{array}{llllllllllllllll}\text { VHCLNTLFS } & 1.06 & 38.61 & 27.59 & 19.23 & 2 & 1378.6992 & 1378.6971 & 690.3558 & 0.0021 & 1.521 & 1413.613 & 1022.034 & 398.518 & 1809.566 & \text { Yes } \\ \text { VHCLNTLFSR } & 0.66 & 34.03 & 27.62 & 47.03 & 3 & 1378.6996 & 1378.6971 & 460.5730 & 0.0025 & 1.8093 & 646.510 & 694.230 & 438.336 & 961.364 & \text { Yes }\end{array}$

Table S- 4 page 240 of 614 
43 VITEEEK

VITEEEK

VITEEEK

STESLQANVQR

STESLQANVQ

GFSLEELR

GFSLEELR

STESLQANVQR

STESLQANVQR

STESLQANVQR

TIGISVDPR

TIGISVDPR
NGMVLKPHFHK

NGMVLKPHFHK

NGMVLKPHFH

EAAEQDVEK

EAAEQDVEK

LATQLTGPVMPVR

LATQLTPMMPR

LATQLTGPYMPVR

LATQLTGPVMPVR

LATOLTGPVMPVR

LATOLTGPVMPVR

VATWFNQPAR

VATWFNQPAR
VATWFNOPAR

LATOLTGPVMPVR

LATQLTGPVMPVR

LATQLTGPVMPVR

LATQLTGPVMPVR

VATWFNQPAR

VATWFNQPAR

LATQLTGPVMPVR

LATQLTGPVMPVR

VATWFNQPAR

VATWFNQPAR

LATQLTGPVMPVR

LATQLTGPVMPVR

VATWFNQPAR

VATWFNQPAR

LILFPR

LILFPR
LILFPR

LILFPR
LILFPR

LILFPR

LILFPR
LILFPR

LILFPR
LILFPR

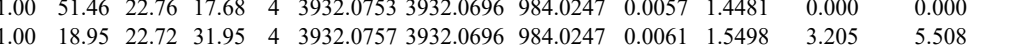

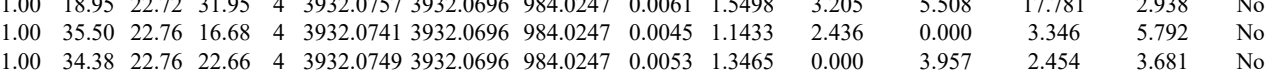

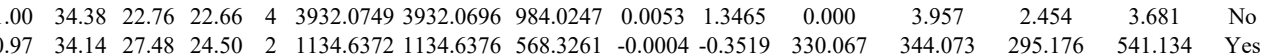
$\begin{array}{lllllllllllll} & \end{array}$ $\begin{array}{llllllllllllllll}0.95 & 32.34 & 28.35 & 25.16 & 2 & 1134.6380 & 1134.6376 & 568.3261 & 0.0004 & 0.3519 & 335.632 & 397.463 & 282.605 & 523.011 & \text { Yes }\end{array}$ $\begin{array}{lllllllllllllll}0.77 & 25.15 & 28.35 & 27.97 & 2 & 1134.6380 & 1134.6376 & 568.3261 & 0.0004 & 0.3519 & 316.829 & 375.150 & 221.607 & 530.128 & \text { Yes }\end{array}$ $\begin{array}{lllllllllllllll}1.00 & 68.46 & 28.08 & 32.70 & 2 & 1375.7184 & 1375.7177 & 688.8661 & 0.0007 & 0.5081 & 8460.660 & 7632.896 & 10405.395 & 10104.378 & \text { No }\end{array}$ $\begin{array}{llllllllllllllll}1.00 & 68.48 & 28.30 & 34.09 & 2 & 1375.7192 & 1375.7177 & 688.8661 & 0.0015 & 1.0887 & 16031.564 & 16581.690 & 22726.468 & 22233.376 & \text { No }\end{array}$ $\begin{array}{lllllllllllllll}1.00 & 41.59 & 28.05 & 26.59 & 2 & 1093.5914 & 1093.5889 & 547.8017 & 0.0025 & 2.2818 & 9308.601 & 11561.933 & 1401.332 & 13034.492 & \text { Yes }\end{array}$

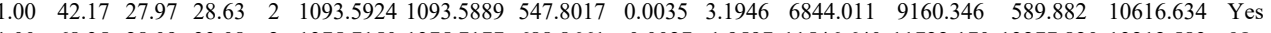

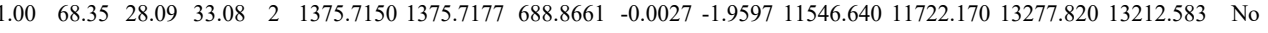
$\begin{array}{llllllllllllllll}1.00 & 66.49 & 27.99 & 31.75 & 2 & 1375.7156 & 1375.7177 & 688.8661 & -0.0021 & -1.5242 & 12510.832 & 14465.062 & 15956.184 & 17426.358 & \text { No }\end{array}$ $\begin{array}{llllllllllllllll}1.00 & 70.94 & 28.06 & 29.92 & 2 & 1375.7176 & 1375.7177 & 688.8661 & -0.0001 & -0.0726 & 1946.406 & 2156.658 & 2367.894 & 2481.422 & \text { No }\end{array}$ $\begin{array}{llllllllllllllll}0.94 & 33.54 & 27.23 & 21.72 & 2 & 1100.6410 & 1100.6312 & 551.3229 & 0.0098 & 8.8876 & 2815.367 & 2691.243 & 1075.242 & 4377.165 & \text { Yes }\end{array}$ $\begin{array}{lllllllllllllll}0.98 & 38.78 & 27.01 & 24.96 & 2 & 1100.6414 & 1100.6312 & 551.3229 & 0.0102 & 9.2504 & 2124.714 & 2282.681 & 860.257 & 3630.468 & \text { Yes }\end{array}$ \begin{tabular}{llllllllllllllllll}
1.00 & 21.14 & 23.44 & 22.63 & 4 & 1739.0077 & 1739.0030 & 435.7580 & 0.0047 & 2.6964 & 18756.808 & 23442.966 & 8967.392 & 22723.505 & Yes \\
\hline
\end{tabular} $\begin{array}{lllllllllllllll}1.00 & 14.85 & 23.44 & 18.19 & 4 & 1739.0081 & 1739.0030 & 455.7580 & 0.0051 & 2.9259 & 21604.092 & 24612.206 & 7099.592 & 21496.680 & \text { Yes }\end{array}$

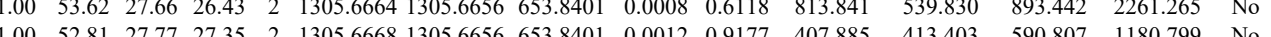

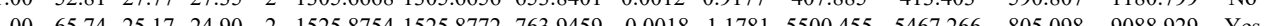

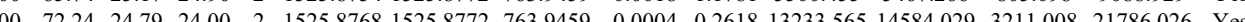

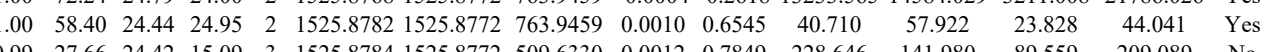

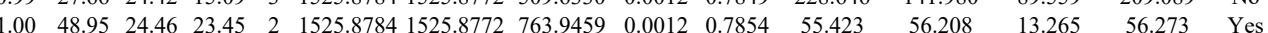

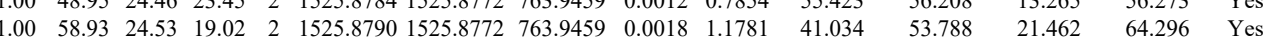
$\begin{array}{lllllllllllllll}1.00 & 57.56 & 24.52 & 21.86 & 2 & 1525.8794 & 1525.8772 & 763.9459 & 0.0022 & 1.4399 & 32.214 & 24.788 & 21.462 & 64.296 & \text { Yes } \\ 0\end{array}$ $\begin{array}{ccccccccccccccc}1.09 & 57.56 & 24.52 & 21.86 & 2 & 1525.8794 & 1525.8772 & 763.9459 & 0.0022 & 1.4399 & 36.214 & 24.330 & 15.702 & 55.396 & \text { Yes } \\ 0.99 & 47.76 & 27.54 & 23.10 & 2 & 1332.7142 & 1332.7061 & 667.3603 & 0.0081 & 6.0686 & 16689.675 & 19785.039 & 727.544 & 29614.669 & \text { Yes }\end{array}$ $\begin{array}{llllllllllllllll}1.00 & 48.57 & 27.67 & 22.79 & 2 & 1332.7150 & 1332.7061 & 6673603 & 0.0089 & 6.6680 & 11678.725 & 13692.332 & 381.202 & 18926.329 & \text { Yes }\end{array}$ $\begin{array}{llllllllllllllll}1.00 & 66.13 & 24.53 & 20.99 & 2 & 1525.8788 & 1525.8772 & 763.9459 & 0.0016 & 1.0472 & 3137.731 & 3543.842 & 1139.725 & 6203.336 & \text { Yes }\end{array}$ $\begin{array}{lllllllllllllllll}1.00 & 73.17 & 24.47 & 21.28 & 2 & 1525.8820 & 1525.8772 & 763.9459 & 0.0048 & 3.1416 & 10399.520 & 13865.300 & 2628.480 & 19982.386 & \text { Yes }\end{array}$

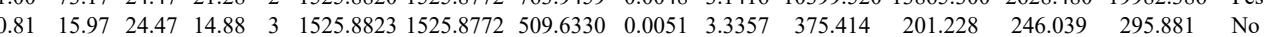

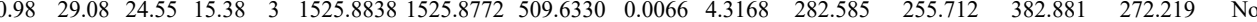
$\begin{array}{llllllllllllllll}0.99 & 45.30 & 27.87 & 22.25 & 2 & 1332.7138 & 1332.7061 & 667.3603 & 0.0077 & 5.7690 & 10474.048 & 11873.102 & 389.302 & 17918.573 & \text { Yes }\end{array}$ $\begin{array}{lllllllllllllll}1.00 & 49.01 & 27.54 & 22.49 & 2 & 1332.7146 & 1332.7061 & 667.3603 & 0.0085 & 6.3683 & 23187.367 & 30036.184 & 144.130 & 40517.369 & \text { Yes }\end{array}$ $\begin{array}{lllllllllllllll}1.00 & 64.84 & 23.38 & 19.26 & 2 & 1525.8904 & 1525.8772 & 763.9459 & 0.0132 & 8.6393 & 6241.756 & 7045.205 & 1330.409 & 9303.198 & \text { Yes }\end{array}$ $\begin{array}{lllllllllllllll}1.00 & 67.16 & 23.80 & 20.06 & 2 & 1525.8910 & 1525.8772 & 763.9459 & 0.0138 & 9.0320 & 7003.142 & 8432.971 & 1621.109 & 11955.762 & \text { Yes }\end{array}$ $\begin{array}{llllllllllllllll}0.99 & 48.46 & 27.63 & 24.98 & 2 & 1332.7126 & 1332.7061 & 667.3603 & 0.0065 & 4.8699 & 8034.946 & 8943.882 & 331.626 & 12331.297 & \text { Yes }\end{array}$ $\begin{array}{llllllllllllllll}0.99 & 47.82 & 27.58 & 22.60 & 2 & 1332.7134 & 1332.7061 & 667.3603 & 0.0073 & 5.4693 & 16089.785 & 17954.282 & 300.044 & 26986.194 & \text { Yes }\end{array}$

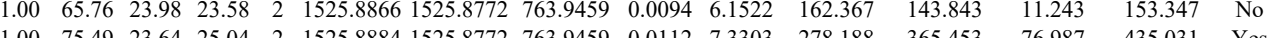
$\begin{array}{llllllllllllllll}1.00 & 75.49 & 23.64 & 25.04 & 2 & 1525.8884 & 1525.8772 & 763.9459 & 0.0112 & 7.3303 & 278.188 & 365.453 & 76.987 & 435.031 & \text { Yes } \\ 1.00 & 45.05 & 27.47 & 21.48 & 2 & 1332.7092 & 1332.706 & 63.3603 & 0.031 & 2.3226 & 5548.287 & 7701.723 & 133.09 & 1014523 & \text { Yes }\end{array}$ $\begin{array}{lllllllllllllll}1.00 & 45.05 & 27.47 & 21.48 & 2 & 1332.7092 & 1332.7061 & 667.3603 & 0.0031 & 2.3226 & 5548.287 & 7701.723 & 133.099 & 10145.923 & \text { Yes } \\ 0.99 & 46.42 & 27.63 & 22.89 & 2 & 1332.7128 & 1332.7061 & 667.3603 & 0.0067 & 5.0198 & 7259.404 & 7623.593 & 528.610 & 13146.28 & \text { Yes }\end{array}$

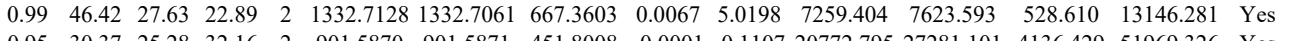
$\begin{array}{lllllllllllllll}0.95 & 30.37 & 25.28 & 32.16 & 2 & 901.5870 & 901.5871 & 451.8008 & -0.0001 & -0.1107 & 725772.795 & 27281.101 & 4136.429 & 51969.326 & \text { Yes } \\ 0.51 & 16.76 & 25.26 & 28.99 & 2 & 901.5874 & 901.5871 & 451.800 & 0.0003 & 0.3320 & 74.811 & 60.477 & 24.46 & 108.816 & \text { Yes }\end{array}$

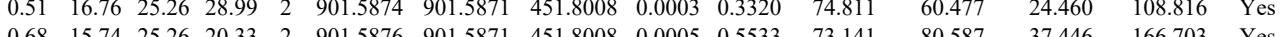
$\begin{array}{lllllllllllllll}0.68 & 15.74 & 25.26 & 20.33 & 2 & 901.5876 & 901.5871 & 451.8008 & 0.0005 & 0.5533 & 73.141 & 80.587 & 37.446 & 166.703 & \text { Yes } \\ 0.77 & 17.76 & 25.26 & 30.33 & 2 & 901.5880 & 901.5871 & 451.8008 & 0.0009 & 0.9960 & 2726.979 & 2033.447 & 156.404 & 3268.080 & \text { No }\end{array}$ $\begin{array}{lllllllllllllll}0.77 & 17.76 & 25.26 & 30.33 & 2 & 901.5880 & 91.5871 & 451.8008 & 0.0009 & 0.9960 & 2726.979 & 2033.447 & 156.404 & 3268.080 & \text { No } \\ 0.96 & 26.31 & 25.26 & 32.06 & 2 & 901.5880 & 901.5871 & 451.8008 & 0.0009 & 0.9960 & 690.173 & 8875.950 & 1825.322 & 15879.566 & \text { Yes }\end{array}$

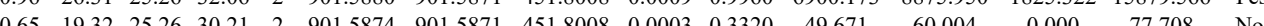
$\begin{array}{lllllllllllllll}0.65 & 19.32 & 25.26 & 30.21 & 2 & 901.5874 & 901.5871 & 451.8008 & 0.0003 & 0.3320 & 49.671 & 60.004 & 0.000 & 77.708 & \text { No } \\ 0.92 & 23.05 & 25.26 & 29.75 & 2 & 901.5876 & 901.5871 & 451.8008 & 0.0005 & 0.5533 & 12.098 & 32.144 & 2.837 & 43.733 & \text { No }\end{array}$

Table S-4 page 241 of 614 

$\begin{array}{llllllllllll}\text { AIPGLAGAGNSVLLVSNLNPER } & 0.66 & 35.44 & 21.61 & 48.44 & 3 & 2418.3733 & 2418.3716 & 807.1311 & 0.0017 & 0.7021 & 16.259\end{array}$ $\begin{array}{lllllllllllll}\text { AIPGLAGAGNSVLLVSNLNPER } & 0.84 & 80.04 & 21.55 & 93.04 & 2 & 2418.3734 & 2418.3716 & 1210.1931 & 0.0018 & 0.7437 & 126.086\end{array}$ $\begin{array}{lllllllllllll} & & \end{array}$

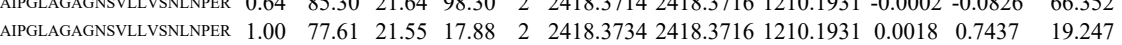

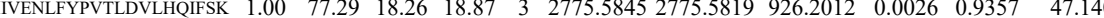

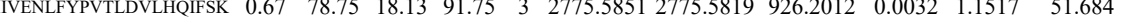
HQNVQLPR $\begin{array}{lllllllllllll}0.64 & 28.00 & 28.04 & 41.00 & 2 & 1134.6384 & 1134.6380 & 568.3263 & 0.0004 & 0.3519 & 307.885\end{array}$ $\begin{array}{lllllllllll}0.84 & 26.57 & 28.04 & 15.21 & 2 & 1134.6384 & 1134.6380 & 568.3263 & 0.0004 & 0.3519 & 319.446\end{array}$

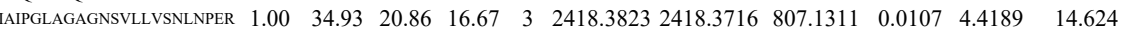

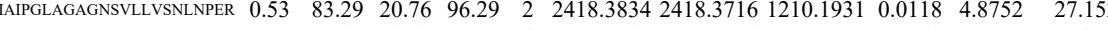

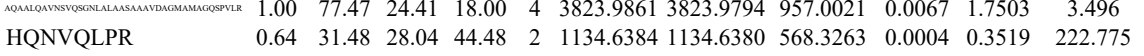
\begin{tabular}{llllllllllll} 
& 0.64 & 31.48 & 28.04 & 44.48 & 2 & 134.6384 & 134.6380 & 568.3263 & 0.0004 & 0.3519 & 222.775 \\
& 0.82 & 34.07 & 28.04 & 47.07 & 2 & 1134.6388 & 1134.6380 & 568.3263 & 0.0008 & 0.7038 & 265.167 \\
\hline
\end{tabular} $\begin{array}{lllllllllll}1.00 & 54.60 & 21.55 & 17.81 & 3 & 2418.3727 & 2418.3716 & 807.1311 & 0.0011 & 0.4543 & 5.262 \\ 1.00 & 70.46 & 24.50 & 83.46 & 4 & 3823.9837 & 3823.9794 & 957.0021 & 0.0043 & 1.1233 & 0.000\end{array}$

$\begin{array}{llllllllllll} & & \end{array}$ $\begin{array}{lllllllllll}0.82 & 32.01 & 28.04 & 45.01 & 2 & 1134.6386 & 1134.6380 & 568.3263 & 0.0006 & 0.5279 & 211.819 \\ 0.82 & 27.67 & 28.04 & 40.67 & 2 & 1134.6388 & 1134.638 & 5683263 & 0.0008 & 0.7038 & 350.976\end{array}$ $\begin{array}{llllllllllll}1.00 & 84.13 & 24.49 & 19.90 & 4 & 3823.9853 & 3823.9794 & 957.0021 & 0.0059 & 1.5413 & 9.888\end{array}$ 

$\begin{array}{llllllllllll}1.00 & 58.39 & 2.51 & 17.52 & 3 & 2418.3733 & 2418.3716 & 807.1311 & 0.0017 & 0.7521 & 18.663\end{array}$

LNLSTRPEK

AELNPWPEYIYTR

AELNPWPEYIYT
LNLSTRPEK

LNLSTRPEK

IYGISFPDPK

IYGISFPDPK

LNLSTRPEK

NELSGALTGLTR

NELSGALTGLTR

IYGISFPDPK

IYGISFPDPK

MIAILTENYGGK

MIAILTENYGGK

VNTPTTTVYR

VNTPTTTVYR

NELSGALTGLTR

NELSGALTGLTR

VNTPTTTVYR

LADFGVLHR

LADFGVLHR

ISGTVNIR

ISGTVNIR

GCLDFLR

TTPYQIACGISQ

GCLDFLR $\begin{array}{lllllllllllllll}0.99 & 24.34 & 25.28 & 21.62 & 3 & 1344.7987 & 344.7969 & 49.2729 & 0.0018 & 1.3355 & 48283.017 & 39425.576 & 30552.635 & 83957.221 & \text { Yes } \\ 1.00 & 44.78 & 27.72 & 30.90 & 2 & 1794.9084 & 1794.9062 & 898.4604 & 0.0022 & 1.2243 & 1450.909 & 934.806 & 298.877 & 2267.903 & \text { Yes }\end{array}$ $\begin{array}{lllllllllllllllll}1.00 & 44.78 & 27.72 & 30.90 & 2 & 1794.9084 & 1794.9062 & 898.460 & 0.0022 & 1.2243 & 140.954 & 934.806 & 258.877 & 2267.903 & \text { Yes } \\ 1.00 & 51.31 & 27.77 & 25.81 & 2 & 1794.9090 & 1794.9062 & 898.4604 & 0.0028 & 1.5582 & 1064.524 & 784.490 & 248.299 & 1828.498 & \text { Yes }\end{array}$

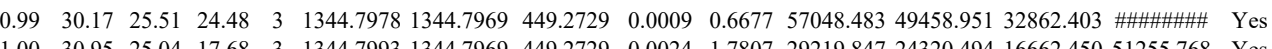
$\begin{array}{llllllllllllllllllll}1.00 & 30.95 & 25.04 & 17.68 & 3 & 1344.7993 & 1344.7969 & 449.2729 & 0.0024 & 1.7807 & 29219.847 & 24320.494 & 16662.450 & 51255.768 & \text { Yes }\end{array}$ \begin{tabular}{lllllllllllllll}
0.85 & 27.64 & 26.44 & 26.65 & 2 & 1423.8082 & 1423.7955 & 712.9050 & 0.0127 & 8.9071 & 2411.976 & 2414.295 & 220.673 & 4204.349 & Yes \\
\hline
\end{tabular} \begin{tabular}{llllllllllllllll}
0.96 & 33.81 & 26.44 & 32.49 & 2 & 1423.8084 & 1423.7955 & 712.9050 & 0.0129 & 9.0474 & 2267.352 & 2314.074 & 482.849 & 3921.569 & Yes \\
\hline
\end{tabular}

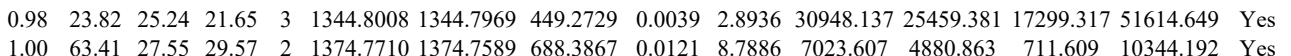
$\begin{array}{lllllllllllllll}1.00 & 63.41 & 27.55 & 29.57 & 2 & 1374.7710 & 1374.7589 & 688.3867 & 0.0121 & 8.7886 & 7023.607 & 4880.863 & 711.609 & 10344.192 & \text { Yes } \\ 1.00 & 66.64 & 2.55 & 29.73 & 2 & 13747710 & 1374.7589 & 688.3867 & 0.0121 & 8.7886 & 6375.113 & 4434.413 & 557.148 & 862.254 & \text { Yes }\end{array}$ $\begin{array}{ccccccccccccccc}1.00 & 66.64 & 27.55 & 29.73 & 2 & 1374.7710 & 1374.7589 & 688.3867 & 0.0121 & 8.7886 & 6375.113 & 4434.413 & 557.148 & 8623.254 & \text { Yes } \\ 0.92 & 31.16 & 26.65 & 24.92 & 2 & 1423.8052 & 1423.7955 & 712.9050 & 0.0097 & 6.8031 & 2087.967 & 1661.720 & 0.000 & 4527.821 & \text { No }\end{array}$

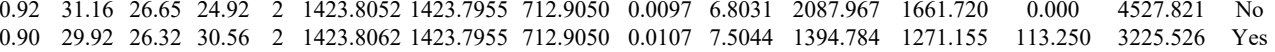
$\begin{array}{llllllllllllllll}1.00 & 71.48 & 27.09 & 29.14 & 2 & 1596.8814 & 1596.8789 & 799.4467 & 0.0025 & 1.5636 & 384.178 & 262.385 & 45.833 & 530.022 & \text { Yes }\end{array}$

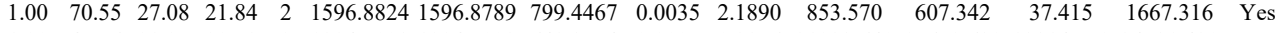
$\begin{array}{lllllllllllllll}1.00 & 45.76 & 28.27 & 20.78 & 2 & 1294.7008 & 1294.7003 & 648.3574 & 0.0005 & 0.3856 & 21933.640 & 17659.630 & 13814.759 & 34531.430 & \text { Yes }\end{array}$ $\begin{array}{lllllllllllllll}1.00 & 57.05 & 28.26 & 19.21 & 2 & 1294.7010 & 1294.7003 & 648.3574 & 0.0007 & 0.5398 & 47291.715 & 36661.426 & 32044.557 & 79179.724 & \text { Yes }\end{array}$

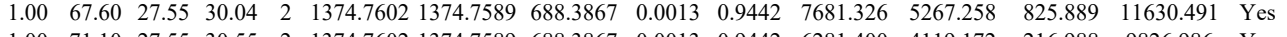

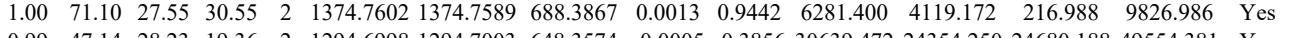

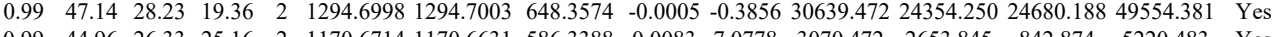
$\begin{array}{llllllllllllllll}0.99 & 44.96 & 26.33 & 25.16 & 2 & 1170.6714 & 1170.6631 & 586.3388 & 0.0083 & 7.0778 & 3070.472 & 2653.845 & 842.874 & 5220.483 & \text { Yes }\end{array}$ $\begin{array}{lllllllllllllll}0.99 & 43.85 & 26.11 & 22.82 & 2 & 1170.6732 & 1170.6631 & 586.3388 & 0.0101 & 8.6127 & 3283.860 & 3130.927 & 898.060 & 6953.580 & \text { Yes }\end{array}$ $\begin{array}{llllllllllllllll}0.93 & 45.60 & 27.86 & 46.56 & 2 & 1002.5986 & 1002.5944 & 502.3045 & 0.0042 & 4.1807 & 9994.792 & 9670.423 & 9348.318 & 25181.407 & \text { Yes } \\ 0.90 & 41.45 & 27.77 & 40.26 & 2 & 1002.6000 & 1002.5944 & 502.3045 & 0.0056 & 5.5743 & 8660.971 & 6786.882 & 6070.145 & 16637.170 & \text { Yes }\end{array}$ $\begin{array}{lllllllllllllll}1.00 & 37.13 & 26.15 & 24.83 & 2 & 1012.4970 & 1012.4956 & 507.2551 & 0.0014 & 1.3800 & 4356.235 & 4338.876 & 417.119 & 9117.866 & \text { Yes }\end{array}$ $\begin{array}{lllllllllllllll}1.00 & 37.31 & 26.15 & 23.66 & 2 & 1012.4970 & 1012.4956 & 507.2551 & 0.0014 & 1.3800 & 10106.851 & 8153.374 & 1593.975 & 20279.450 & \text { Yes }\end{array}$ $\begin{array}{lllllllllllllll}1.00 & 37.31 & 26.15 & 23.66 & 2 & 1012.4970 & 1012.4956 & 507.2551 & 0.0014 & 1.3800 & 106.851 & 8153.374 & 1593.975 & 20279.450 & \text { Yes } \\ 1.00 & 31.71 & 27.08 & 15.01 & 3 & 2597.3482 & 2597.3437 & 8667885 & 0.0045 & 1.7305 & 139.323 & 182.835 & 49.017 & 64.441 & N^{2}\end{array}$

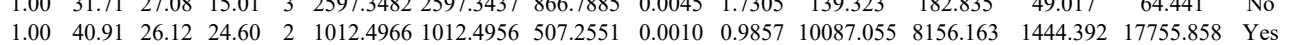




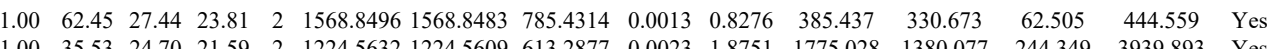
$\begin{array}{lllllllllllllll}1.00 & 35.53 & 24.70 & 21.59 & 2 & 1224.5632 & 1224.5609 & 613.2877 & 0.0023 & 1.8751 & 1775.028 & 1380.077 & 244.349 & 3939.893 & \text { Yes }\end{array}$

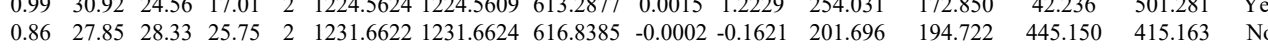

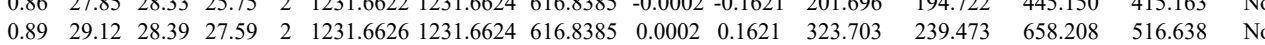

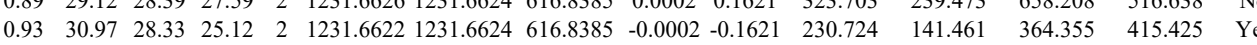

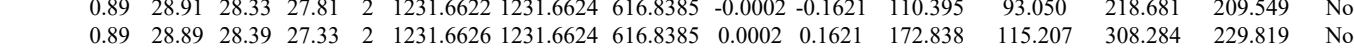

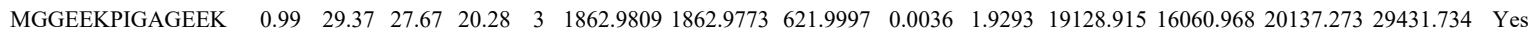

WPFWLSPR

WPFWLSPR

WPFWLSPR

WPFWLSPR

QLENSLNEFGEK

QLENSLNEFGEK

FLGDIEVWDQAEK

FLGDIEVWDQAEK

$\begin{array}{llllllllllllllll}0.99 & 31.51 & 27.66 & 18.79 & 3 & 186.9812 & 1862.9773 & 621.9997 & 0.0039 & 2.0900 & 23228.566 & 20140.850 & 27651.026 & 38201.696 & \text { Yes }\end{array}$ $\begin{array}{lllllllllllllll}0.78 & 21.09 & 28.43 & 28.36 & 2 & 1231.6632 & 1231.6624 & 616.8385 & 0.0008 & 0.6485 & 58.060 & 100.050 & 97.165 & 122.442 & \text { Yes }\end{array}$

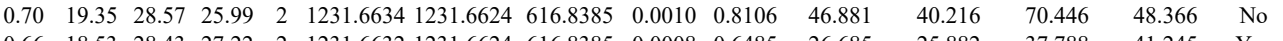

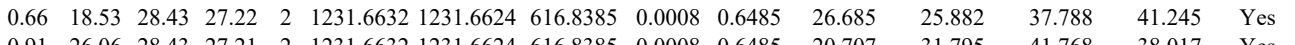

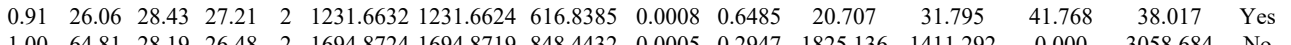

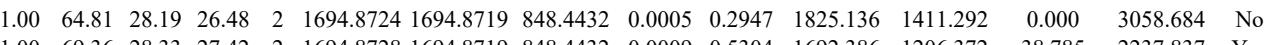
$\begin{array}{lllllllllllllll}1.00 & 69.36 & 28.33 & 27.42 & 2 & 1694.8728 & 1694.8719 & 848.4432 & 0.0009 & 0.5304 & 1692.386 & 1206.372 & 38.785 & 2237.837 & \text { Yes }\end{array}$ $\begin{array}{lllllllllllllll}1.00 & 64.67 & 27.80 & 39.22 & 2 & 1836.9524 & 1836.9501 & 919.4823 & 0.0023 & 1.2507 & 1192.779 & 615.120 & 0.000 & 2081.226 & \text { No }\end{array}$

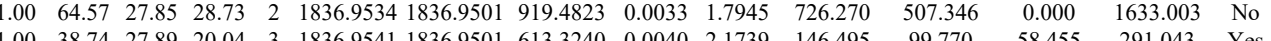
FLGDIEVWDQAEK $\begin{array}{llllll}9501 & 613.3240 & 0.0040 & 2.1739 & 146.495 & 99.770\end{array}$ $\begin{array}{lllllllllllll} & \text { Q }\end{array}$ $\begin{array}{lllllllllll} & \end{array}$

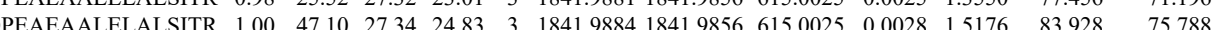

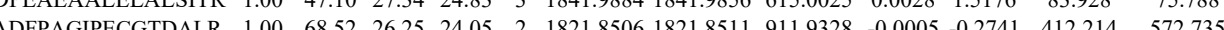

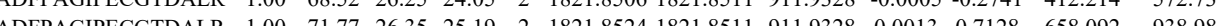
$\begin{array}{llllllllllll} & \text { ADPACE }\end{array}$

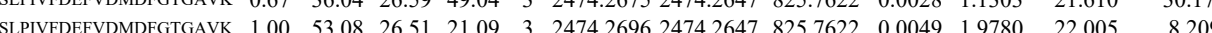
$\begin{array}{llllllllllllll}\text { IETMLGDVAVAVHPK } & 1.00 & 60.69 & 25.51 & 26.07 & 3 & 1867.0513 & 1867.0481 & 623.3566 & 0.0032 & 1.7112 & 912.616 & 932.005\end{array}$ $\begin{array}{llllllllllllll}\text { GIEDNPMVVPLCNR } & 0.82 & 77.60 & 26.78 & 90.60 & 2 & 1745.8392 & 1745.8385 & 873.9265 & 0.0007 & 0.4005 & 115.894 & 138.585\end{array}$ $\begin{array}{lllllllllllll}\text { ALSPLEEWLR } & 1.00 & 64.72 & 27.90 & 33.44 & 2 & 1356.7500 & 1356.7523 & 679.3834 & -0.0023 & -1.6927 & 1228.204 & 1372.898 \\ \text { ALSPLEEWLR } & 0.99 & 46.61 & 27.80 & 31.01 & 2 & 1356.7506 & 1356.7523 & 679.3834 & -0.0017 & -1.2511 & 2120.695 & 2646.224\end{array}$

$\begin{array}{llllllllllll}1.00 & 64.72 & 27.90 & 33.44 & 2 & 1356.7500 & 1356.7523 & 679.3834 & -0.0023 & -1.6927 & 1228.204 & 1372.898 \\ 0.99 & 46.61 & 27.80 & 31.01 & 2 & 1356.7506 & 1356.7523 & 679.3834 & -0.0017 & -1.2511 & 2120.695 & 2646.224\end{array}$

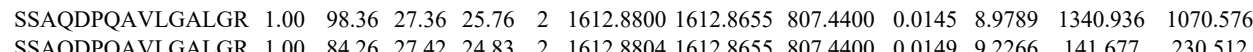

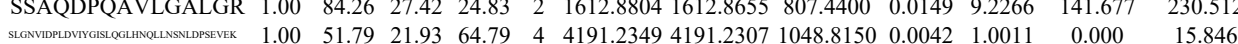
$\begin{array}{llllllllllllll}\text { CGEMAQAASAAVTR } & 1.00 & 90.84 & 25.54 & 20.76 & 2 & 1554.7224 & 1554.7074 & 778.3610 & 0.0150 & 9.6355 & 2740.781 & 2755.707 & 52\end{array}$ CGEMAQAASAAVTR

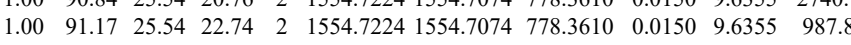
$\begin{array}{lllllllllll}1.00 & 62.35 & 21.99 & 75.35 & 4 & 4191.2309 & 4191.2307 & 1048.8150 & 0.0002 & 0.0477 & 22.900\end{array}$

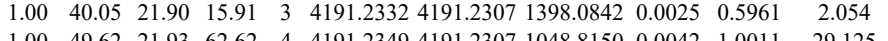

IWNNVTR IWNNVTR $\begin{array}{lllllllllll}1.00 & 76.20 & 21.93 & 89.20 & 4 & 4191.2349 & 4191.2307 & 1048.8150 & 0.0042 & 1.0011 & 12.904\end{array}$

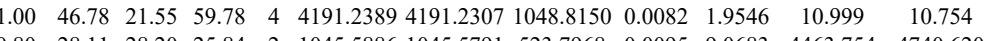
$\begin{array}{llllllllllllllll}0.94 & 38.62 & 28.79 & 32.58 & 2 & 1045.5838 & 1045.5791 & 523.7968 & 0.0047 & 4.4865 & 3865.889 & 4882.467 & 2831.825 & 4601.787 & \text { Yes }\end{array}$

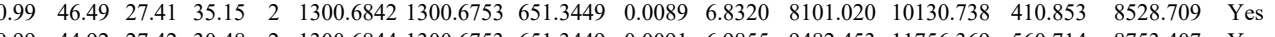

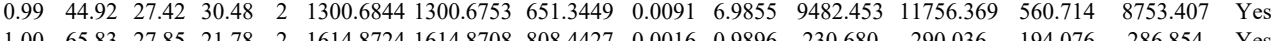
$\begin{array}{llllllllllllllll} & \end{array}$ 

$\begin{array}{lllllllllll}0.90 & 24.93 & 26.58 & 21.31 & 3 & 1211.6893 & 1211.6906 & 404.9041 & -0.0013 & -1.0702 & 106.853\end{array}$ $\begin{array}{lllllllllll}0.58 & 17.28 & 26.39 & 21.24 & 3 & 1211.6899 & 1211.6906 & 404.9041 & -0.0007 & -0.5763 & 109.306\end{array}$ $\begin{array}{lllllllllll}1.00 & 36.57 & 26.39 & 25.82 & 3 & 1211.6905 & 1211.6906 & 404.9041 & -0.0001 & -0.0823 & 144.721\end{array}$ $\begin{array}{llllllllllll}0.89 & 21.94 & 26.39 & 25.57 & 3 & 1211.6905 & 1211.6906 & 404.9041 & -0.0001 & -0.0823 & 109.444\end{array}$

73.137
102.760

DPFAHLPK $\begin{array}{llllllllllll}0.93 & 24.55 & 26.05 & 26.31 & 3 & 1211.6911 & 1211.6906 & 404.9041 & 0.0005 & 0.4116 & 78.537\end{array}$

DPFAHLPK

DPFAHLPK $\begin{array}{llllllllllll}0.98 & 25.65 & 26.11 & 24.54 & 3 & 1211.6917 & 1211.6906 & 404.9041 & 0.0011 & 0.9056 & 156.214\end{array}$ $\begin{array}{llllllllllll}0.98 & 24.51 & 26.13 & 22.12 & 3 & 1211.6926 & 1211.6906 & 404.9041 & 0.0020 & 1.6465 & 108.185\end{array}$

$\begin{array}{llllllllllll}1.00 & 34.00 & 26.13 & 27.56 & 3 & 1211.6926 & 1211.6906 & 404.9041 & 0.0020 & 1.6465 & 90.296\end{array}$

$86.511 \quad 88.30$

DPFAHLPK

DPFAHLPK

DPFAHLPK

DPFAHLPK

DPFAHLPK

DPFAHLPK

DPFAHLPK

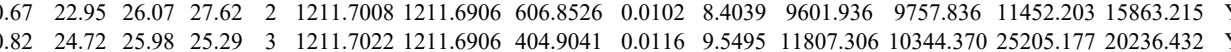

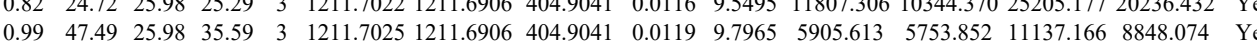
$\begin{array}{lllllllllllllll}0.74 & 20.21 & 26.39 & 21.88 & 3 & 1211.6902 & 1211.6906 & 404.9041 & -0.0004 & -0.3293 & 132.116 & 63.032 & 115.323 & 168.171 & \text { Yes } \\ 0.88 & 20.75 & 26.12 & 18.82 & 3 & 1211.6908 & 1211.6906 & 404.9041 & 0.0002 & 0.1646 & 89.676 & 93.688 & 77.467 & 129.478 & \text { Yes }\end{array}$ $\begin{array}{ccccccccccccccc}0.88 & 20.75 & 26.12 & 18.82 & 3 & 1211.6908 & 1211.6906 & 404.9041 & 0.0002 & 0.1646 & 89.676 & 93.688 & 77.467 & 129.478 & \text { Yes } \\ 0.87 & 35.22 & 26.05 & 33.55 & 3 & 1211.7001 & 1211.6906 & 404.9041 & 0.0095 & 7.8207 & 9023.177 & 9140.861 & 18855.762 & 16507.836 & \text { Yes } \\ 0.57 & 21.04 & 26.07 & 27.30 & 2 & 1211.7008 & 1211.6906 & 606.8526 & 0.0102 & 8.4039 & 8932.030 & 10478.790 & 9482.164 & 14877.576 & \text { Yes }\end{array}$

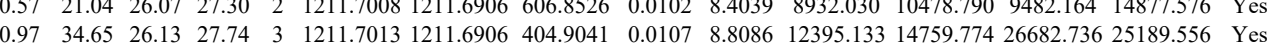
$\begin{array}{lllllllllllllll}0.97 & 3.65 & 26.13 & 27.74 & 3 & 1211.7013 & 1211.6906 & 404.9041 & 0.0107 & 8.8086 & 12395.133 & 14759.774 & 26682.736 & 25189.556 & \text { Yes } \\ 0.85 & 34.10 & 25.98 & 33.80 & 3 & 1211.7019 & 1211.6906 & 404.9041 & 0.0113 & 9.3025 & 2727.495 & 2618.707 & 5351.661 & 4788.973 & \text { Yes }\end{array}$ $\begin{array}{lllllllllllllllll}0.85 & 34.10 & 25.98 & 33.80 & 3 & 1211.7019 & 1211.6906 & 404.9041 & 0.0113 & 9.3025 & 2727.495 & 2618.707 & 5351.661 & 4788.973 & \text { Yes } \\ 0.92 & 34.45 & 25.98 & 31.91 & 3 & 1211.7025 & 1211.6906 & 404.9041 & 0.0119 & 9.7965 & 5182.861 & 4460.680 & 9043.788 & 8829.768 & \text { Yes }\end{array}$

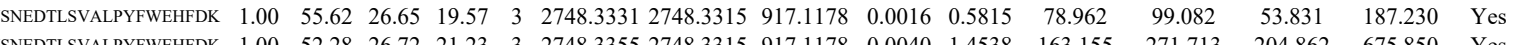
$\begin{array}{llllllllllllllll} & \end{array}$

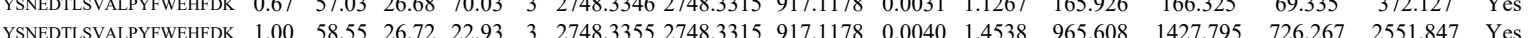
$\begin{array}{lllllllllllllllll}\text { STFVLDEFKR } & 0.98 & 34.33 & 26.45 & 15.96 & 3 & 1528.8640 & 1528.8493 & 510.6237 & 0.0147 & 9.5960 & 4662841 & 5560.138 & 3188.237 & 9467.269 & \text { Yes }\end{array}$

STFVLDEFKR

QAFPNTNR

STFVLDEFKR

STFVLDEFKR
STFVLDEFKR $\begin{array}{llllllllllllllll}0.98 & 34.33 & 26.45 & 15.68 & 3 & 1528.8640 & 1528.8493 & 510.6237 & 0.0147 & 9.5960 & 4662.841 & 5560.138 & 3188.237 & 9467.269 & \text { Yes } \\ 0.75 & 24.10 & 27.90 & 24.28 & 2 & 1090.5642 & 1090.5641 & 546.2893 & 0.0001 & 0.0915 & 191.687 & 192.452 & 46.000 & 383.752 & \text { Yes }\end{array}$

GQELAFPLSPDWQ QAFPNTNR QAFPLLDAYLK ILGLLDAYLK ILGLLDAYLK

ILGLLDAYLK

ILGLLDAYLK

ILGLLDAYLK

ILGLLDAYLK

ILGLLDAYLK

ILGLLDAYLK

ILGLLDAYLK

ILGLLDAYLK

ILGLLDAYLK

ALIAAQYSGAQVR

ALIAAQYSGAQVR

ALIAAQYSGAQVR

ILGLLDAYLK

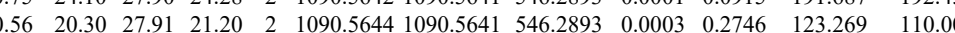

$\begin{array}{lllllllllllllll}0.56 & 37.93 & 27.02 & 19.52 & 3 & 1528.8556 & 1528.8493 & 510.6237 & 0.0063 & 4.1126 & 4858.868 & 6075.966 & 33.352 & 246.599 & \text { Yes }\end{array}$ $\begin{array}{lllllllllllllll}1.99 & 33.78 & 26.88 & 21.04 & 3 & 1528.8562 & 1528.8493 & 510.6237 & 0.0069 & 4.5043 & 2603.118 & 3003.837 & 1447.943 & 4750.102 & \text { Yes }\end{array}$

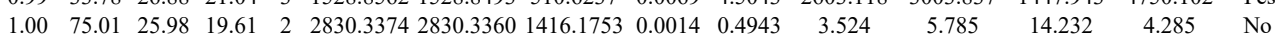

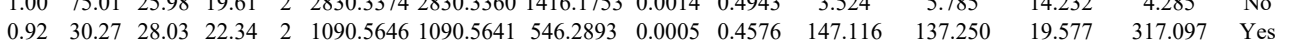
$\begin{array}{lllllllllllllll}0.63 & 17.56 & 28.08 & 23.08 & 2 & 1090.5650 & 1090.5641 & 546.2893 & 0.0009 & 0.8237 & 247.685 & 229.513 & 60.135 & 432.406 & \text { Yes }\end{array}$ $\begin{array}{llllllllllllllll}1.00 & 30.67 & 18.51 & 21.59 & 3 & 1405.8805 & 1405.8788 & 469.6335 & 0.0017 & 1.2066 & 151.693 & 195.237 & 0.000 & 335.645 & \text { No }\end{array}$ $\begin{array}{llllllllllllllll}1.00 & 21.79 & 17.99 & 14.52 & 3 & 1405.8811 & 1405.8788 & 469.6335 & 0.0023 & 1.6325 & 442.948 & 454.781 & 17.860 & 1193.236 & \text { Yes }\end{array}$ $\begin{array}{lllllllllllllll}1.00 & 51.18 & 17.99 & 22.10 & 2 & 1405.8818 & 1405.8788 & 703.9467 & 0.0030 & 2.1308 & 7597.660 & 9877.255 & 0.000 & 30739.215 & \text { No }\end{array}$ $\begin{array}{lllllllllllllll}1.00 & 54.14 & 17.92 & 23.05 & 2 & 1405.8822 & 1405.8788 & 703.9467 & 0.0034 & 2.4149 & 11533.238 & 12603.353 & 0.000 & 42559.287 & \text { No }\end{array}$ $\begin{array}{lllllllllllllllll}0.97 & 17.49 & 18.51 & 18.51 & 3 & 1405.8802 & 1405.8788 & 469.6335 & 0.0014 & 0.9937 & 151.900 & 118.797 & 32.531 & 167.147 & \text { Yes }\end{array}$ $\begin{array}{llllllllllllllll}1.00 & 37.65 & 18.51 & 24.17 & 3 & 1405.8802 & 4405.8788 & 469.6335 & 0.0014 & 0.9937 & 228.092 & 360.037 & 47.441 & 815.934 & \text { Yes }\end{array}$ $\begin{array}{lllllllllllllll}1.00 & 53.88 & 17.99 & 22.22 & 2 & 1405.8814 & 1405.8788 & 703.9467 & 0.0026 & 1.8467 & 7060.743 & 8392.962 & 0.000 & 25539.267 & \text { No }\end{array}$

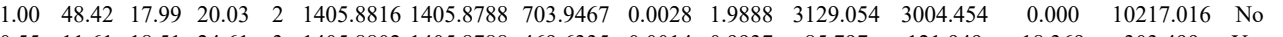
$\begin{array}{lllllllllllllll}0.55 & 11.61 & 18.51 & 24.61 & 3 & 1405.8802 & 1405.8788 & 469.6335 & 0.0014 & 0.9937 & 85.797 & 121.949 & 18.369 & 303.499 & \text { Yes }\end{array}$ $\begin{array}{llllllllllllllll}1.00 & 55.81 & 18.51 & 23.57 & 2 & 1405.8806 & 1405.8788 & 703.9467 & 0.0018 & 1.2785 & 113.864 & 65.933 & 7.835 & 337.245 & \text { Yes }\end{array}$

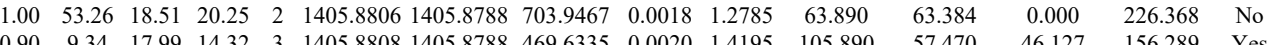
$\begin{array}{lllllllllllllll}0.90 & 9.34 & 17.99 & 14.32 & 3 & 1405.8808 & 1405.8788 & 469.6335 & 0.0020 & 1.4195 & 105.890 & 57.470 & 46.127 & 156.289 & \text { Yes } \\ 1.00 & 80.79 & 27.38 & 25.90 & 2 & 1490.8440 & 1490.8327 & 746.4236 & 0.0113 & 7.5694 & 6359.934 & 7588.812 & 0.000 & 14744.711 & \text { No }\end{array}$ $\begin{array}{llllllllllllllll}1.00 & 80.79 & 27.38 & 25.90 & 2 & 1490.8440 & 1490.8327 & 746.4236 & 0.0113 & 7.5694 & 6359.934 & 7588.812 & 0.000 & 14744.711 & \text { No } \\ 1.00 & 69.27 & 27.40 & 23.19 & 2 & 14908444 & 1490.8327 & 746.4236 & 0.0117 & 7.8373 & 10740.374 & 12061.342 & 524.233 & 25872.834 & \text { Yes }\end{array}$ \begin{tabular}{lllllllllllllllll}
1.00 & 6.27 & 27.40 & 23.19 & 2 & 1490.8444 & 1490.8327 & 746.4236 & 0.0117 & 7.8373 & 10740.374 & 12061.342 & 524.233 & 25872.834 & Yes \\
\hline
\end{tabular}

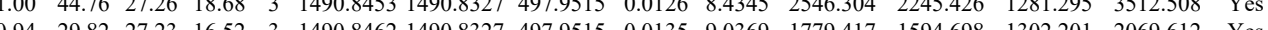

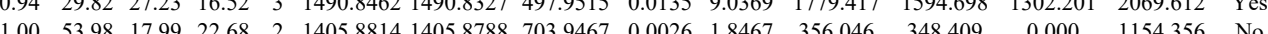


$\begin{array}{llllllllllll} & \text { VLSAPPIFHFQTNR }\end{array}$ $\begin{array}{llllllllllllllll} & \end{array}$ $\begin{array}{lllllllllllllllll} & \end{array}$ $\begin{array}{lllllllllllll} & \end{array}$ $\begin{array}{llllllllllllllll}\text { AAAPAPEEEMDECEOALAAEPK } & 1.00 & 17.78 & 24.79 & 24.50 & 4 & 2633.1937 & 2633.1902 & 659.3048 & 0.0035 & 1.3272 & 44.063 & 67.745 & 73.880 & 101.973 & \text { Yes }\end{array}$ $\begin{array}{lllllllllllllllll}\text { AAAPAPEFEMDECEQALAAEPK } & 1.00 & 20.41 & 24.79 & 21.12 & 4 & 2633.1949 & 2633.1902 & 659.3048 & 0.0047 & 1.7822 & 53.882 & 44.827 & 69.517 & 111.720 & \text { Yes }\end{array}$

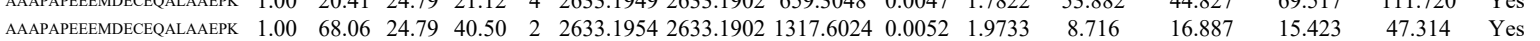

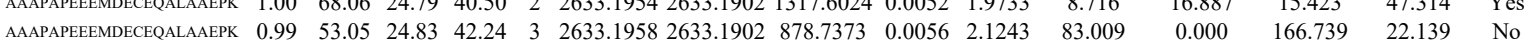
$\begin{array}{llllllllllllllll}\text { AAAPAPEEEMDECEAALAAEPK } & 1.00 & 60.97 & 24.80 & 48.94 & 3 & 2633.1964 & 2633.1902 & 878.7373 & 0.0062 & 2.3519 & 0.000 & 0.000 & 57.466 & 0.000 & \text { No }\end{array}$ $\begin{array}{llllllllllllllll}\text { VLSAPPHFHFGQTNR } & 1.00 & 67.74 & 28.33 & 19.02 & 3 & 1850.9752 & 1850.9662 & 617.9960 & 0.0090 & 4.8544 & 6063.714 & 7125.193 & 1187.534 & 14371.879 & \text { Yes }\end{array}$ $\begin{array}{llllllllllllllll}\text { VLSAPPHFHFGQTNR } & 1.00 & 35.82 & 28.08 & 48.82 & 4 & 1850.9765 & 1850.9662 & 463.7488 & 0.0103 & 5.5525 & 11641.481 & 15818.192 & 1479.241 & 29649.249 & \text { Yes }\end{array}$ $\begin{array}{llllllllllllllll}\text { VLSAPPHFHFGQTNR } & 1.00 & 49.08 & 28.02 & 18.08 & 3 & 1850.9776 & 1850.9662 & 617.9960 & 0.0114 & 6.1489 & 5173.856 & 5903.616 & 815.443 & 16136.329 & \text { Yes }\end{array}$ $\begin{array}{llllllllllllllll}\text { VLSAPPHFHFGQTNR } & 1.00 & 93.95 & 27.97 & 31.03 & 2 & 1850.9790 & 1850.9662 & 926.4904 & 0.0128 & 6.9077 & 301.933 & 367.871 & 12.226 & 832.598 & \text { Yes }\end{array}$

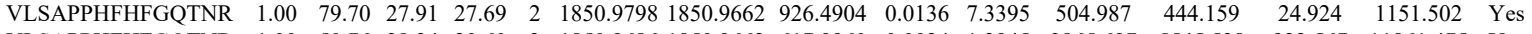

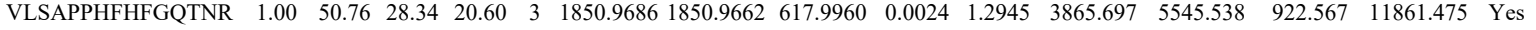
$\begin{array}{llllllllllllllll}\text { VLSAPPHFHFGQTNR } & 1.00 & 33.65 & 28.36 & 46.65 & 4 & 1850.9689 & 1850.9662 & 463.7488 & 0.0027 & 1.4555 & 5464.991 & 6272.939 & 1442.696 & 14101.006 & \text { Yes }\end{array}$ $\begin{array}{llllllllllllllll}\text { VLSAPPHFHFGQTNR } & 1.00 & 40.42 & 28.26 & 29.93 & 4 & 1850.9693 & 1850.9662 & 463.7488 & 0.0031 & 1.6712 & 8482.339 & 8656.110 & 1459.900 & 19361.406 & \text { Yes }\end{array}$ $\begin{array}{llllllllllllllll}\text { VLSAPPHFHFGQTNR } & 1.00 & 56.74 & 28.18 & 19.25 & 3 & 1850.9704 & 1850.9662 & 617.9960 & 0.0042 & 2.2654 & 3698.832 & 4432.151 & 1115.363 & 8860.045 & \text { Yes }\end{array}$ $\begin{array}{llllllllllllllllll}\text { VLSAPPHFHFGQTNR } & 1.00 & 42.65 & 28.34 & 17.90 & 3 & 1850.9662 & 1850.9662 & 617.9960 & 0.0000 & 0.0000 & 828.734 & 1077.490 & 293.554 & 2142.603 & \text { Yes }\end{array}$

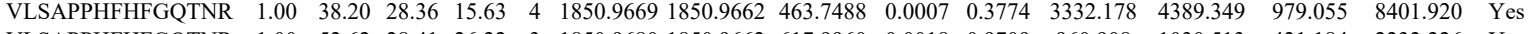
$\begin{array}{lllllllllllllllll}\text { VLSAPPHFFGQTNR } & 1.00 & 52.62 & 28.41 & 26.22 & 3 & 1850.9680 & 1850.9662 & 617.9960 & 0.0018 & 0.9709 & 960.908 & 1030.513 & 421.184 & 2232.226 & \text { Yes }\end{array}$

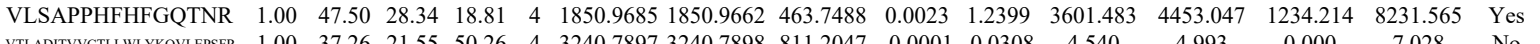
$\begin{array}{lllllllllllllll}\text { VLADITVCTLLWLYKQVEEPSR } & 1.00 & 37.26 & 21.55 & 50.26 & 4 & 3240.7897 & 3240.7898 & 811.2047 & -0.0001 & -0.0308 & 4.540 & 4.993 & 0.000 & 7.028\end{array}$ $\begin{array}{llllllllll} & \end{array}$ $\begin{array}{llllllllll} & \end{array}$

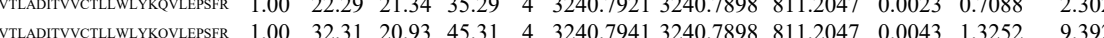

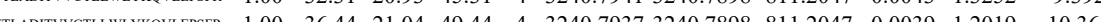
$\begin{array}{lllllllllllll}0.97 & 33.53 & 26.12 & 31.58 & 3 & 1211.6908 & 1211.6906 & 404.9041 & 0.0002 & 0.1646 & 1610.477 \\ 0.97 & 35.61 & 26.05 & 33.93 & 3 & 1211.6911 & 1211.6006 & 4049041 & 0.0005 & 0.4116 & 1633.071 & 15\end{array}$

DPFAHLPK

ALIAAQYSGAQVR

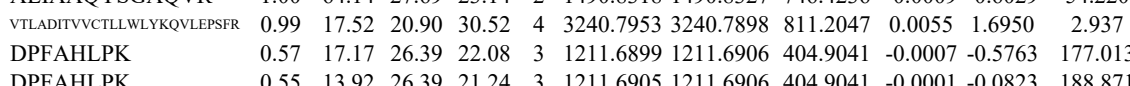

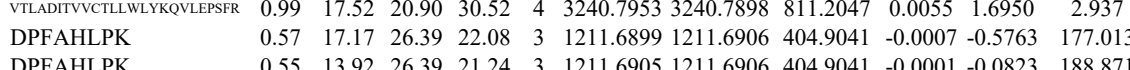
$\begin{array}{lllllllllll}0.97 & 35.61 & 26.05 & 33.93 & 3 & 1211.6911 & 1211.6906 & 404.9041 & 0.0005 & 0.4116 & 1633.071 \\ 1.00 & 64.14 & 27.69 & 23.14 & 2 & 1490.8318 & 1490.8327 & 746.4236 & -0.0009 & -0.6029 & 54.220\end{array}$ $\begin{array}{llllllllllll} & 0.55 & 13.92 & 26.39 & 21.24 & 3 & 1211.6905 & 1211.6906 & 404.9041 & -0.0001 & -0.0823 & 188.871\end{array}$ $\begin{array}{llllllllllll}\text { VTLADTTVCTLLWLYKOVLEPSFR } & 1.00 & 32.02 & 2.04 & 45.02 & 4 & 3240.7937 & 3240.7898 & 811.2047 & 0.0039 & 1.2019 & 4.482\end{array}$ $\begin{array}{llllllllllll} & \end{array}$ $\begin{array}{lrllllllllll} & \end{array}$ $\begin{array}{llllllllllll}\text { ALIAAQYSGAQVR } & 1.00 & 59.29 & 27.70 & 22.81 & 2 & 1490.8322 & 1490.8327 & 746.4236 & -0.0005 & -0.3349 & 11.190\end{array}$ $\begin{array}{lllllllllllll} & \text { AAAPAPEEEMDECEQALAAEPK } & 1.00 & 87.87 & 24.84 & 45.45 & 2 & 2633.1914 & 2633.1902 & 1317.6024 & 0.0012 & 0.4554 & 8.110\end{array}$ $\begin{array}{llllllllllllll} & & \end{array}$

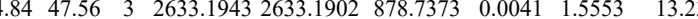
$\begin{array}{lllllllllllll}\text { AAAPAPEEEMDECEAALAAEPK } & 1.00 & 17.77 & 24.84 & 26.43 & 4 & 2633.1953 & 2633.1902 & 659.3048 & 0.0051 & 1.9339 & 68.889\end{array}$ $\begin{array}{lllllllllllll} & & \end{array}$ AAAPAPEEEMDECEQALAAEK WFLTCINQPQFR WFLTCINQPQFR WFLTCINQPQFR WFLTCINQPQFR WFLTCINQPQFR ALIAAQYSGAQVR

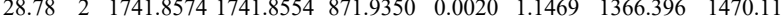

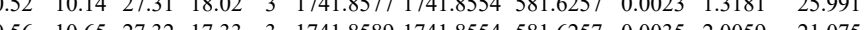
$\begin{array}{llllllllll} & \end{array}$ $\begin{array}{llllllllllll}0.56 & 10.65 & 27.32 & 17.33 & 3 & 1741.8589 & 1741.8554 & 581.6257 & 0.0035 & 2.0059 & 21.075 & 18.868 \\ 1.00 & 63.270 & 27.29 & 17.32 & 3 & 1741.8592 & 1741.8554 & 581.6257 & 0.0038 & 2.1778 & 17.696 & 16.722\end{array}$ $\begin{array}{lllllllll} & \end{array}$ $\begin{array}{lllllllllllll}1.00 & 83.36 & 27.61 & 22.42 & 2 & 1490.8326 & 14908327 & 74.4236 & 0.0001 & 0.0670 & 58.228\end{array}$ $\begin{array}{lllllllllllll}1.00 & 79.45 & 27.51 & 23.47 & 2 & 1741.8562 & 1741.8554 & 871.9350 & 0.0008 & 0.4587 & 61.994\end{array}$ $\begin{array}{llllllllllll}0.51 & 12.11 & 27.53 & 25.11 & 3 & 1490.8336 & 1490.8327 & 497.9515 & 0.0009 & 0.6025 & 111.231\end{array}$
(3.132

6.430

1495.659

\subsection{9}

2.710
168.723

168.723

63.817
11.437

4.294

5.192
21.084

33.423

2.933

4.135

2.533 $\begin{array}{rr}1.720 & 5.116 \\ 44.038 & 249.490\end{array}$

$4.965 \quad 3.248$
5.583

(9.6.64
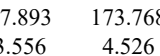

166.421

174.567

8.168
5.078

6.186

18.412

8.864
27.825

19.7

68.686

Table S-4 page 246 of 614 

$\begin{array}{lllllllllllll}0.88 & 1.58 & 27.56 & 17.59 & 3 & 1741.8568 & 1741.8554 & 581.6257 & 0.0014 & 0.8023 & 35.388 & 30.235\end{array}$ $\begin{array}{llllllllllll}0.98 & 2.35 & 27.32 & 17.31 & 3 & 1741.8589 & 1741.8554 & 581.6257 & 0.0035 & 2.0059 & 25.726 & 33.121 \\ 1.55 & 1.82 & 27.48 & 2.82 & 3 & 1741.8565 & 1741.8554 & 581.6257 & 0.0011 & 0.6304 & 43.182 & 14.944\end{array}$ $\begin{array}{lllllllllllll}0.55 & 15.82 & 27.48 & 28.82 & 3 & 1741.8565 & 1741.854 & 581.6257 & 0.0011 & 0.6304 & 43.182 & & 14.944\end{array}$ \begin{tabular}{lllllllllllll}
1.00 & 62.79 & 27.39 & 21.27 & 2 & 1741.8570 & 1741.854 & 581.6257 & 0.0011 & 0.6304 & 43.182 & 14.944 \\
1.00 & 38.85 & 27.31 & 19.22 & 3 & 1741.8577 & 1741.8554 & 581.6257 & 0.016 & 0.9175 & 21.695 & 15.061 \\
\hline
\end{tabular}

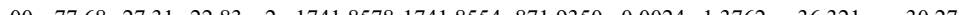

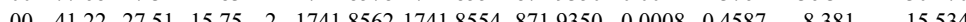

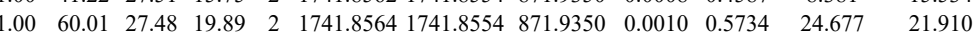

$\begin{array}{lllllllllllll}1.00 & 60.01 & 27.48 & 19.8 & 2 & 1741.8564 & 1741.8554 & 871.9350 & 0.0010 & 0.5734 & 24.677 & 21.91 .338 & 9755.333\end{array}$

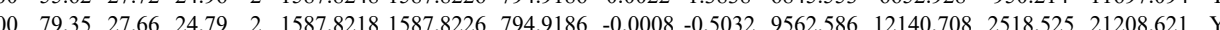

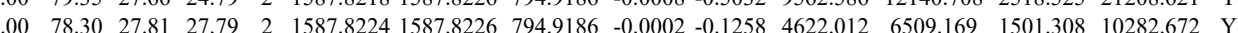
AVTEQGAELSNEER $\begin{array}{llllllllllll}1.00 & 57.89 & 28.04 & 24.76 & 2 & 1587.8382 & 1587.8226 & 794.9186 & 0.0156 & 9.8122 & 537.960 & 423.095\end{array}$ AVTEQGAELSNEER $\begin{array}{lllllllllllll}1.00 & 85.95 & 26.93 & 26.84 & 2 & 1675.8146 & 1675.8135 & 838.9140 & 0.0011 & 0.6556 & 263.191 & 22 & \end{array}$ $\begin{array}{llllllllllll}1.00 & 87.14 & 26.95 & 36.40 & 2 & 1675.8148 & 1675.8135 & 838.9140 & 0.0013 & 0.7748 & 413.975\end{array}$ AVTEQGAELSNEER TIDNSQGAYQEAFDISK $\begin{array}{lllllllllll}0.93 & 19.93 & 27.02 & 20.94 & 3 & 1675.8151 & 1675.8135 & 559.6118 & 0.0016 & 0.9530 & 65.219\end{array}$ $\begin{array}{lllllllllllll} & \end{array}$ $\begin{array}{lllllllllllll}1.00 & 76.81 & 27.09 & 25.31 & 2 & 1667.9106 & 1667.9081 & 834.9613 & 0.0025 & 1.4971 & 10973.891 & 9022.266\end{array}$ $\begin{array}{lllllllllllll}1.00 & 74.48 & 27.06 & 24.59 & 2 & 1667.9110 & 1667.9081 & 834.9613 & 0.0029 & 1.7366 & 5879.981 & 4438.992\end{array}$ $\begin{array}{lllllllllllll}0.50 & 9.31 & 26.97 & 20.53 & 3 & 1667.9116 & 1667.9081 & 556.9766 & 0.0035 & 2.0946 & 54.290 & 53.864 \\ 1.00 & 35.66 & 26.93 & 26.88 & 3 & 1667.9119 & 1667.9081 & 556.9766 & 0.0038 & 22742 & 281.125 & 114.816 & 1\end{array}$ $\begin{array}{llllllllllll}1.00 & 35.66 & 26.93 & 26.88 & 3 & 1667.9119 & 1667.9081 & 556.9766 & 0.0038 & 2.2742 & 281.125 & 114.816\end{array}$ $\begin{array}{llllllllllll}1.00 & 61.54 & 27.06 & 22.98 & 2 & 1667.9110 & 1667.9081 & 834.9613 & 0.0029 & 1.7366 & 2464.954 & 1882.732\end{array}$ $\begin{array}{lllllllllllll}.00 & 62.69 & 27.06 & 22.81 & 2 & 1667.9110 & 1667.9081 & 834.9613 & 0.0029 & 1.7366 & 994.430 & 9\end{array}$ $\begin{array}{lllllllllllll}.99 & 31.06 & 26.93 & 23.30 & 3 & 1667.9119 & 1667.9081 & 556.9766 & 0.0038 & 2.2742 & 67.779\end{array}$

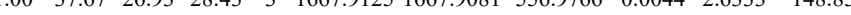

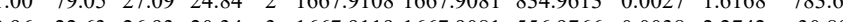
$\begin{array}{llllllllllllll}1.00 & 79.05 & 27.09 & 24.84 & 2 & 1667.9108 & 1667.9081 & 834.9613 & 0.027 & 1.6168 & 783.635\end{array}$

\section{AVTEQGAESSNEER} $\begin{array}{llllllllllll}0.96 & 22.63 & 26.93 & 2.34 & 3 & 1667.919 & 1667.9081 & 556.9766 & 0.0038 & 2.2742 & 30.897\end{array}$ $\begin{array}{llllllll}0.963 & \end{array}$

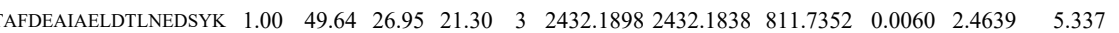

$\begin{array}{llllllllllll}0.72 & 70.33 & 23.12 & 83.33 & 2 & 1400.6212 & 1400.6186 & 701.3166 & 0.0026 & 1.8537 & 12520.443 & 10838.693\end{array}$ $\begin{array}{llllllllllllll}\text { YLAEVACGDDR } & 1.00 & 63.41 & 23.12 & 18.27 & 2 & 1400.6212 & 1400.6186 & 701.3166 & 0.0026 & 1.8537 & 13505.940 & 12442.357 & 47\end{array}$ $\begin{array}{llllllllllllll}\text { QTIDNSQGAYQEAFDISK } & 1.00 & 95.06 & 27.41 & 29.18 & 2 & 2302.1334 & 2302.1321 & 1152.0733 & 0.0013 & 0.5642 & 748.911 & 381.147\end{array}$ $\begin{array}{llllllllllllll}\text { QTIDNSQGAYQEAFDISK } & 0.76 & 22.00 & 27.60 & 15.78 & 3 & 2302.1389 & 2302.1321 & 768.3846 & 0.0068 & 2.9499 & 390.597 & 199.58\end{array}$ QTIDNSQGAYQEAFDISK

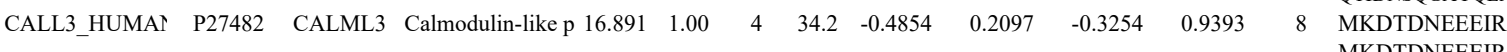
MKDTDNEEEIR SLGQNPTEAELR LSDEEVDEMIR LSDEEVDEMIR AADTDGDGQVNYEEFVR
AADTDGDGQVNYEEFVR LSDEEVDEMI AADTDGDGQVNYEEFVR SLGQNPTEAELR SLGQNPTEAELR $\begin{array}{lllllllllllll}1.00 & 63.52 & 27.43 & 23.48 & 3 & 2302.1359 & 2302.1321 & 768.3846 & 0.0038 & 1.6485 & 75.664 & 105.274 \\ 0 & 33.13 & 26.94 & 15.73 & 3 & 1666.888 & 1666076 & 556.608 & 0.0012 & 0.7186 & 162.275 & 155.84\end{array}$ $\begin{array}{llllllllllllll}0.81 & 33.13 & 26.94 & 15.73 & 3 & 1666.8088 & 1666.8076 & 556.6098 & 0.0012 & 0.7186 & 162.275 & 155.814\end{array}$ $\begin{array}{lllllllllllll}0.84 & 32.32 & 27.08 & 17.82 & 3 & 1666.8103 & 1666.8076 & 556.6098 & 0.0027 & 1.6169 & 186.910 & 140.653 \\ 0.89 & 46.59 & 27.44 & 50.21 & 2 & 1457.7706 & 1457.7596 & 729.8871 & 0.0110 & 7.5354 & 11834.612 & 6982.518 \\ 1.00 & 69.70 & 26.52 & 27.97 & 2 & 1478.7062 & 1478.7044 & 740.3595 & 0.0018 & 1.2156 & 671.478 & 559.621\end{array}$ $\begin{array}{llllllllllll}.80 & 69.70 & 26.42 & 50.21 & 2 & 1457.7706 & 1457.7596 & 729.8871 & 0.0110 & 7.5354 & 11834.612 & 6982.518 \\ 1.00 & 27.97 & 2 & 1478.7062 & 1478.7044 & 740.3595 & 0.0018 & 1.2156 & 671.478 & 559.621\end{array}$ $\begin{array}{llllllllllll}1.00 & 56.13 & 26.57 & 35.66 & 2 & 1478.7064 & 1478.7044 & 740.3595 & 0.0020 & 1.3507 & 2193.477 & 1699.535\end{array}$ $\begin{array}{lllllllllllll}1.00 & 90.97 & 26.33 & 20.40 & 2 & 2028.9174 & 2028.9147 & 1015.4646 & 0.0027 & 1.3294 & 582.745 & 502.644 \\ 1.00 & 89.73 & 26.33 & 20.89 & 2 & 2028.9174 & 2028.9147 & 1015.4646 & 0.0027 & 1.3294 & 184.830 & 163.244\end{array}$ $\begin{array}{llllllllllll}1.00 & 88.17 & 26.25 & 20.32 & 2 & 2028.9154 & 2028.9147 & 1015.4646 & 0.0007 & 0.3447 & 1461.903 & 1085.210\end{array}$ 

$\begin{array}{llllllllllllllll}1.00 & 49.40 & 27.32 & 21.93 & 2 & 1475.8458 & 1475.8452 & 738.9299 & 0.0006 & 0.4060 & 2851.876 & 4104.077 & 4260.635 & 5303.388 & \text { Yes }\end{array}$ $\begin{array}{llllllllllllllll}1.00 & 53.70 & 27.21 & 20.11 & 3 & 1475.8468 & 1475.8452 & 492.9557 & 0.0016 & 1.0819 & 14299.771 & 15791.422 & 20918.486 & 24582.855 & \text { Yes }\end{array}$ $\begin{array}{lllllllllllllll}1.00 & 53.08 & 2.23 & 20.95 & 2 & 1475.8470 & 1475.8452 & 738.9299 & 0.0018 & 1.2180 & 2051.592 & 2543.846 & 2865.013 & 3386.532 & \text { Yes }\end{array}$

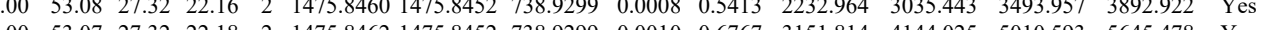
$\begin{array}{lllllllllllllll}1.0 & 53.08 & 27.32 & 22.16 & 2 & 1475.8460 & 1475.8452 & 738.9299 & 0.000 & 0.5413 & 2232.964 & 3035.443 & 3493.957 & 3892.922 & \text { Yes }\end{array}$ $\begin{array}{llllllllllllllll}1.00 & 53.07 & 27.32 & 22.18 & 2 & 1475.8462 & 1475.8452 & 738.929 & 0.0010 & 0.6767 & 3151.814 & 4144.025 & 5010.593 & 5645.478 & \text { Yes }\end{array}$ $\begin{array}{lllllllllllllll} & \end{array}$

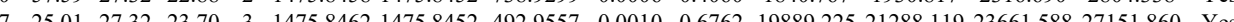
$\begin{array}{lllllllllllllllll}1.00 & 53.51 & 27.32 & 21.70 & 2 & 1475.8462 & 1475.8452 & 738.9299 & 0.0010 & 0.6767 & 1655.774 & 2239.237 & 2411.425 & 2373.405 & \text { Yes }\end{array}$ $\begin{array}{lllllllllllllll}0.99 & 27.10 & 27.22 & 15.81 & 3 & 1475.8480 & 1475.8452 & 492.9557 & 0.0028 & 1.8933 & 28912.238 & 31155.877 & 42251.735 & 44633.938 & \text { Yes }\end{array}$ $\begin{array}{lllllllllllllll}0.99 & 45.60 & 27.52 & 22.40 & 2 & 1475.8446 & 1475.8452 & 738.9299 & -0.0006 & -0.4060 & 179.008 & 251.231 & 165.525 & 263.531 & \text { Yes }\end{array}$ $\begin{array}{lllllllllllllll}1.00 & 35.21 & 27.36 & 20.01 & 3 & 1475.8453 & 1475.8452 & 492.9557 & 0.0001 & 0.0676 & 4385.610 & 5271.321 & 6044.968 & 6326.471 & \text { Yes }\end{array}$ $\begin{array}{lllllllllllllll}0.91 & 24.81 & 27.36 & 27.99 & 3 & 1475.8450 & 1475.8452 & 492.9557 & -0.0002 & -0.1352 & 4278.545 & 4370.736 & 4596.295 & 6258.790 & \text { Yes }\end{array}$ $\begin{array}{lllllllllllllll}0.99 & 33.84 & 27.29 & 17.50 & 2 & 1161.6912 & 1161.6893 & 581.8519 & 0.0019 & 1.6327 & 3523.798 & 4173.300 & 584.249 & 4512.820 & \text { Yes }\end{array}$ $\begin{array}{lllllllllllllll}0.99 & 33.74 & 27.32 & 20.44 & 2 & 1161.6916 & 1161.6893 & 581.8519 & 0.0023 & 1.9764 & 3588.475 & 4208.985 & 557.534 & 4333.410 & \text { Yes }\end{array}$

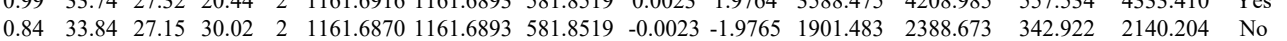

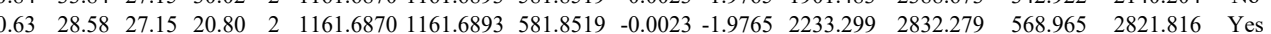
$\begin{array}{llllllllllllllll}0.85 & 34.36 & 27.32 & 21.46 & 2 & 1161.6876 & 1161.6893 & 581.8519 & -0.0017 & -1.4609 & 594.878 & 704.075 & 157.172 & 780.250 & \text { Yes }\end{array}$ $\begin{array}{llllllllllllllll}1.00 & 48.18 & 24.73 & 18.17 & 3 & 1395.8146 & 1395.8142 & 466.2787 & 0.0004 & 0.2860 & 1466.858 & 2489.794 & 511.369 & 2734.102 & \text { Yes }\end{array}$

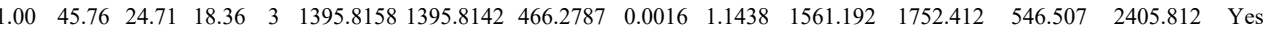
$\begin{array}{lllllllllllllll}0.84 & 66.23 & 24.68 & 79.23 & 2 & 1395.8162 & 1395.8142 & 698.9144 & 0.0020 & 1.4308 & 1437.581 & 1260.154 & 230.404 & 2184.677 & \text { Yes }\end{array}$ $\begin{array}{llllllllllllllll}0.82 & 68.03 & 24.73 & 81.03 & 2 & 1395.8148 & 1395.8142 & 698.9144 & 0.0006 & 0.4292 & 2399.756 & 1839.497 & 341.635 & 3557.337 & \text { Yes }\end{array}$ $\begin{array}{lllllllllllllll}1.00 & 47.97 & 24.73 & 18.03 & 3 & 1395.8152 & 1395.8142 & 466.2787 & 0.0010 & 0.7149 & 898.967 & 1022.209 & 394.923 & 1365.037 & \text { Yes }\end{array}$ $\begin{array}{lllllllllllllll}0.82 & 62.98 & 24.71 & 75.98 & 2 & 1395.8154 & 1395.8142 & 698.9144 & 0.0012 & 0.8585 & 2709.587 & 2261.384 & 367.431 & 4459.590 & \text { Yes }\end{array}$ $\begin{array}{llllllllllllllll}1.00 & 50.51 & 24.70 & 18.54 & 3 & 1395.8161 & 1395.8142 & 466.2787 & 0.0019 & 1.3583 & 2363.196 & 2406.866 & 614.237 & 2958.647 & \text { Yes }\end{array}$

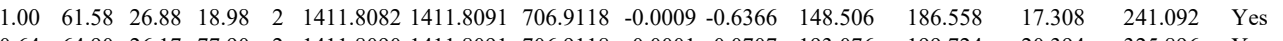
$\begin{array}{lllllllllllllll}0.64 & 64.90 & 26.17 & 77.90 & 2 & 1411.8090 & 1411.8091 & 706.9118 & -0.0001 & -0.0707 & 193.076 & 199.724 & 20.394 & 325.896 & \text { Yes }\end{array}$ $\begin{array}{lllllllllllllll}0.99 & 27.50 & 26.01 & 22.46 & 3 & 1411.8106 & 1411.8091 & 471.6103 & 0.0015 & 1.0602 & 486.110 & 547.613 & 180.002 & 655.150 & \text { Yes }\end{array}$ \begin{tabular}{llllllllllllllll}
1.00 & 64.36 & 24.84 & 19.38 & 2 & 1395.8142 & 1395.8142 & 698.9144 & 0.0000 & 0.0000 & 4926.171 & 3990.207 & 825.106 & 7492.915 & Yes \\
\hline
\end{tabular} $\begin{array}{llllllllllllllll}0.82 & 55.33 & 24.73 & 68.33 & 2 & 1395.8148 & 1395.8142 & 698.9144 & 0.0006 & 0.4292 & 2813.160 & 2883.766 & 530.945 & 5275.599 & \text { Yes }\end{array}$ $\begin{array}{lllllllllllllllll}1.00 & 49.20 & 24.71 & 17.37 & 3 & 1395.8155 & 1395.8142 & 466.2787 & 0.0013 & 0.9293 & 1280.664 & 1670.862 & 579.425 & 2854.360 & \text { Yes }\end{array}$

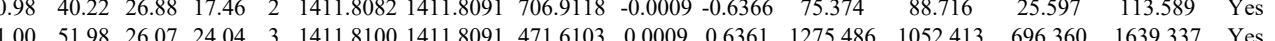

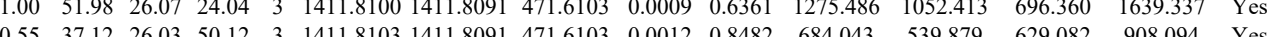

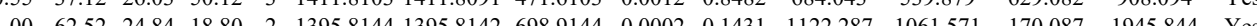

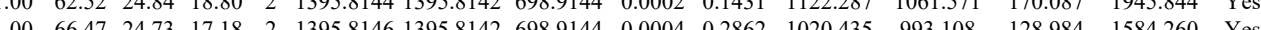

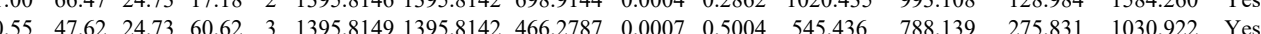
$\begin{array}{lllllllllllllll}1.00 & 38.26 & 24.73 & 16.07 & 3 & 1395.8152 & 1395.8142 & 466.2787 & 0.0010 & 0.7149 & 503.754 & 525.329 & 223.367 & 870.270 & \text { Yes }\end{array}$ $\begin{array}{lllllllllllllll}0.55 & 38.95 & 24.71 & 51.95 & 3 & 13958158 & 1395.8142 & 466.2787 & 0.0016 & 1.1438 & 76.558 & 103.069 & 29.040 & 119.143 & \text { Yes }\end{array}$ $\begin{array}{lllllllllllllll}0.66 & 52.10 & 24.68 & 65.10 & 3 & 1395.8164 & 1395.8142 & 466.2787 & 0.0022 & 1.5727 & 99.911 & 98.861 & 49.128 & 130.530 & \text { Yes }\end{array}$ $\begin{array}{lllllllllllllll}1.00 & 70.49 & 26.05 & 21.84 & 2 & 1831.8558 & 1831.8542 & 916.9344 & 0.0016 & 0.8725 & 4915.857 & 4628.445 & 435.213 & 8462.302 & \text { Yes }\end{array}$

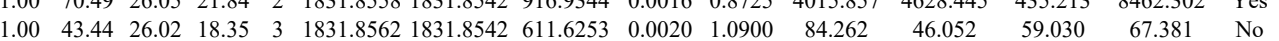
$\begin{array}{llllllllllllllll}1.00 & 74.26 & 26.01 & 26.09 & 2 & 1831.8564 & 1831.8542 & 916.9344 & 0.0022 & 1.1996 & 5626.178 & 6822.203 & 635.601 & 9007.622 & \text { Yes }\end{array}$ $\begin{array}{lllllllllllllll}0.67 & 39.70 & 26.10 & 52.70 & 3 & 1831.8571 & 1831.8542 & 611.6253 & 0.0029 & 1.5805 & 109.972 & 151.414 & 42.445 & 380.677 & \text { No }\end{array}$

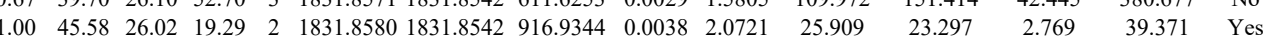
$\begin{array}{lllllllllllllll}0.99 & 26.80 & 24.73 & 15.38 & 3 & 1395.8149 & 1395.8142 & 466.2787 & 0.0007 & 0.5004 & 114.109 & 110.891 & 62.595 & 155.921 & \text { Yes }\end{array}$ $\begin{array}{lllllllllllllll}0.67 & 12.01 & 24.71 & 15.15 & 3 & 1395.8158 & 1395.8142 & 466.2787 & 0.0016 & 1.1438 & 93.431 & 102.819 & 52.428 & 142.616 & \text { Yes }\end{array}$ $\begin{array}{lllllllllllllll}0.55 & 38.92 & 24.73 & 51.92 & 3 & 1395.8152 & 1395.8142 & 466.2787 & 0.0010 & 0.7149 & 54.576 & 80.559 & 39.340 & 85.401 & \text { Yes }\end{array}$

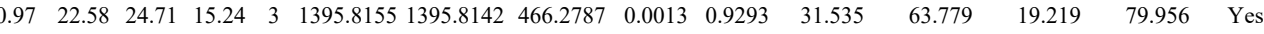

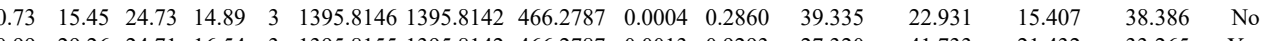

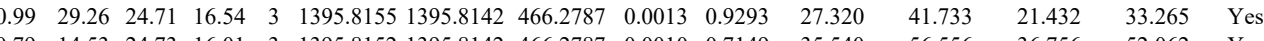
$\begin{array}{lllllllllllllll}0.79 & 14.53 & 24.73 & 16.01 & 3 & 1395.8152 & 1395.8142 & 466.2787 & 0.0010 & 0.7149 & 35.540 & 56.556 & 36.756 & 52.062 & \text { Yes }\end{array}$ $\begin{array}{lllllllllllllll}1.00 & 34.22 & 24.71 & 16.24 & 3 & 1395.8155 & 1395.8142 & 466.2787 & 0.0013 & 0.9293 & 34.429 & 44.427 & 12.964 & 62.439 & \text { Yes }\end{array}$

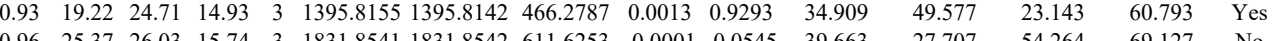

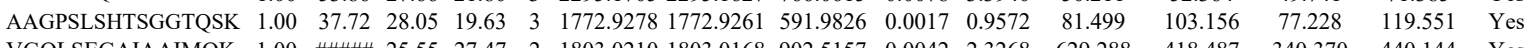

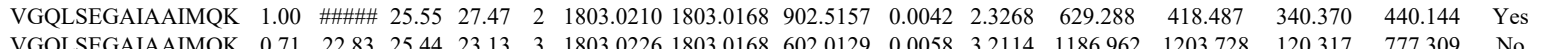

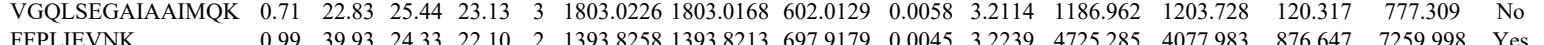
$\begin{array}{llllllllllllllll}\text { FFPLIEVNK } & 0.99 & 39.93 & 24.33 & 22.10 & 2 & 1393.8258 & 1393.8213 & 697.9179 & 0.0045 & 3.2239 & 4725.285 & 4077.983 & 876.647 & 7259.998 & \text { Yes } \\ \text { FFPLIEVNK } & 1.00 & 47.74 & 24.30 & 23.18 & 2 & 1393.8264 & 1393.8213 & 697.9179 & 0.0051 & 3.6537 & 5468.594 & 5380.074 & 560.108 & 8735.917 & \text { Yes }\end{array}$ $\begin{array}{lllllllllllllllll} & 1.50 & 22.96 & 26.39 & 21.13 & 2 & 938.4672 & 938.4588 & 470.2367 & 0.0084 & 8.9316 & 10283.656 & 9858.219 & 833.081 & 16445.376 & \text { Yes }\end{array}$

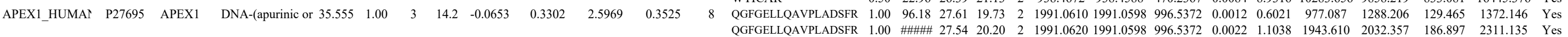




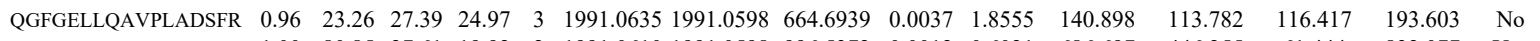
$\begin{array}{llllllllllllllllll}\text { QGFGELLQAVPLADSFR } & 1.00 & 80.85 & 27.61 & 19.92 & 2 & 1991.0610 & 1991.0598 & 996.5372 & 0.0012 & 0.6021 & 686.697 & 446.25 & 61.444 & 832.077 & \text { Yes }\end{array}$ $\begin{array}{llllllllllllllll}\text { ICSWNVDGLR } & 1.00 & 47.36 & 26.38 & 21.22 & 2 & 1351.6528 & 1351.6499 & 676.8322 & 0.0029 & 2.1423 & 2524.876 & 2359.166 & 406.360 & 4163.408 & \text { Yes }\end{array}$

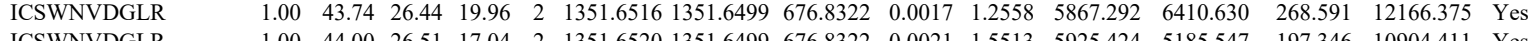
$\begin{array}{llllllllllllllll}\text { ICSWNVDGLR } & 1.00 & 44.00 & 26.51 & 17.04 & 2 & 1351.6520 & 1351.6499 & 676.8322 & 0.0021 & 1.5513 & 5925.424 & 5185.547 & 197.346 & 10904.411 & \text { Yes }\end{array}$ $\begin{array}{llllllllllllllll}\text { LDYFLLSHSLLPALCDSK } & 1.00 & 26.50 & 26.76 & 16.64 & 4 & 2368.2445 & 2368.2414 & 593.0676 & 0.0031 & 1.3068 & 64.682 & 71.771 & 26.526 & 80.236 & \text { Yes }\end{array}$ \begin{tabular}{llllllllllllllll} 
LDYFLLSHSLLPALCDSK & 1.00 & 41.54 & 26.70 & 20.46 & 4 & 2368.246 & 2368.2414 & 593.0676 & 0.0047 & 1.9812 & 86.056 & 64.634 & 18.339 & 87.718 & Yes \\
\hline
\end{tabular} $\begin{array}{llllllllllllllll}\text { GEEDNSLSVR } & 0.92 & 33.27 & 26.55 & 28.47 & 2 & 1248.6058 & 1248.6068 & 625.3107 & -0.0010 & -0.7996 & 53.376 & 64.046 & 76.584 & 83.797 & \text { Yes } \\ \text { GEEDNSLSVR } & 1.00 & 48.35 & 26.91 & 28.02 & 2 & 1248.6086 & 1248.6068 & 625.3107 & 0.0018 & 1.4393 & 67.048 & 45.068 & 74.708 & 66.584 & \text { Yes }\end{array}$

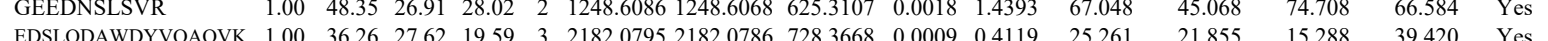

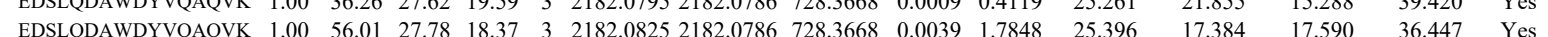

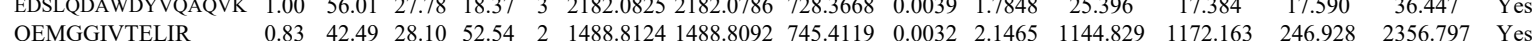
$\begin{array}{llllllllllllllll} & \end{array}$ $\begin{array}{lllllllllllllllll}\text { HPQPGAVELAAK } & 1.00 & 45.57 & 25.98 & 20.97 & 3 & 1504.8643 & 1504.8605 & 502.6274 & 0.0038 & 2.5201 & 1821.355 & 2278.743 & 2132.276 & 2176.831 & \text { No }\end{array}$ $\begin{array}{llllllllllllllll}\text { VIMGEVEPVGLMTGGGVGGVK } & 0.67 & 63.13 & 25.13 & 76.13 & 3 & 2474.3398 & 2474.3368 & 825.7862 & 0.0030 & 12110 & 119.402 & 156.708 & 186.072 & 211.259 & \text { No }\end{array}$ $\begin{array}{lllllllllllllllll} & \text { LSLDDLLQR } & 1.00 & 53.63 & 27.92 & 30.91 & 2 & 1215.6960 & 1215.6945 & 608.8545 & 0.0015 & 1.2318 & 3081.580 & 2900.180 & 296.936 & 4217.129 & \text { Yes }\end{array}$

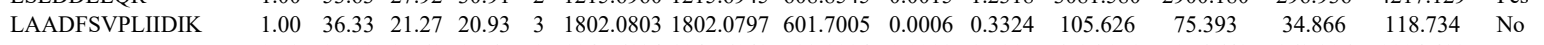
\begin{tabular}{llllllllllllllll} 
YVAPPSLR & 0.73 & 25.09 & 25.69 & 15.65 & 2 & 1045.6134 & 1045.6042 & 523.8094 & 0.0092 & 8.7817 & 6786.151 & 7076.643 & 863.306 & 9904.432 & Yes \\
\hline
\end{tabular} $\begin{array}{llllllllllllllll}\text { VFNTGGAPR } & 1.00 & 54.25 & 27.97 & 28.23 & 2 & 1061.5748 & 1061.5740 & 531.7943 & 0.0008 & 0.7522 & 4023.551 & 4985.777 & 549.839 & 6377.877 & \text { Yes }\end{array}$ $\begin{array}{llllllllllllllll}\text { VFNTGGAPR } & 1.00 & 53.67 & 27.97 & 25.63 & 2 & 1061.5754 & 1061.5740 & 531.7943 & 0.0014 & 1.3163 & 2682.996 & 2979.211 & 355.152 & 4228.706 & \text { Yes }\end{array}$ \begin{tabular}{|lllllllllllllllll} 
PAQALDIFTRR & 1.00 & 45.93 & 23.01 & 58.93 & 4 & 2832.5425 & 2832.5368 & 709.1415 & 0.0057 & 2.0095 & 72.184 & 90.810 & 0.000 & 175.653 & No
\end{tabular}

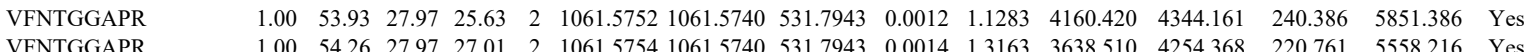
$\begin{array}{llllllllllllllll}\text { VFNTGGAPR } & 1.00 & 54.26 & 27.97 & 27.01 & 2 & 1061.5754 & 1061.5740 & 531.7943 & 0.0014 & 1.3163 & 3638.510 & 4254.368 & 220.761 & 5558.216 & \text { Yes }\end{array}$

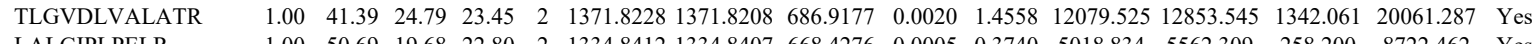
$\begin{array}{llllllllllllllll}\text { LALGIPLPELR } & 1.00 & 50.69 & 19.68 & 22.80 & 2 & 1334.8412 & 1334.8407 & 668.4276 & 0.0005 & 0.3740 & 5018.834 & 5562.309 & 258.200 & 8722.462 & \text { Yes }\end{array}$

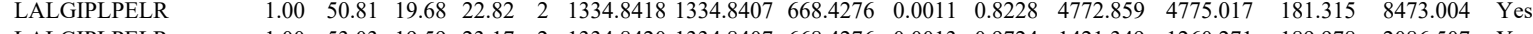
$\begin{array}{lllllllllllllllll}\text { LALGIPLPELR } & 1.00 & 53.03 & 19.59 & 23.17 & 2 & 1334.8420 & 1334.8407 & 668.4276 & 0.0013 & 0.9724 & 1421.349 & 1260.271 & 189.978 & 2086.507 & \text { Yes }\end{array}$ \begin{tabular}{llllllllllllllll} 
LCPPGIPTPGSGLPPPR & 1.00 & 71.02 & 27.83 & 23.57 & 2 & 1844.9758 & 1844.9763 & 923.4954 & -0.0005 & -0.2707 & 105.985 & 118.210 & 56.882 & 128.470 & Yes \\
\hline LCPPS
\end{tabular}

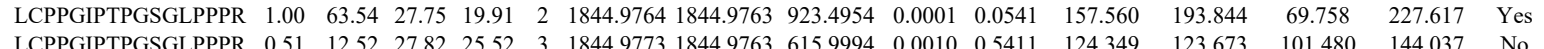
$\begin{array}{llllllllllllllll}\text { LCPPGIPTPGSGLPPPR } & 0.51 & 12.52 & 27.82 & 25.52 & 3 & 1844.9773 & 1844.9763 & 615.9994 & 0.0010 & 0.5411 & 124.349 & 123.673 & 101.480 & 144.037 & \text { No }\end{array}$ \begin{tabular}{llllllllllllllll} 
MALLATVLGR & 1.00 & 53.16 & 24.94 & 25.15 & 2 & 1187.7196 & 1187.7182 & 594.8664 & 0.0014 & 1.1767 & 156.115 & 208.637 & 11.707 & 311.718 & Yes \\
\hline MALLATVLR & 1.00 & 56.3 & 2.94 & 24.99 & 2 & 1187.7196 & 1187.7182 & 594.8664 & 0.0014 & 1.1767 & 194.915 & 146.748 & 26.827 & 325.822 & Yes
\end{tabular}

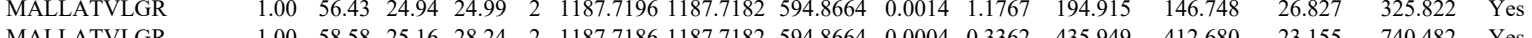

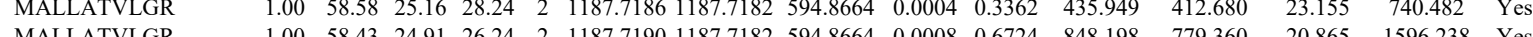

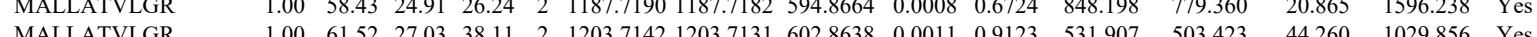

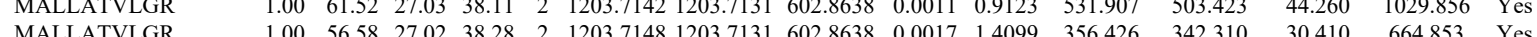

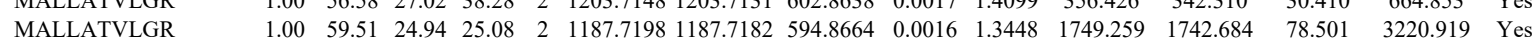

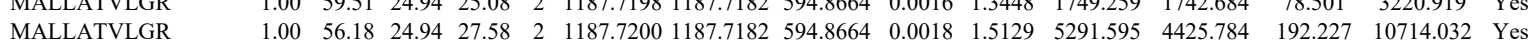

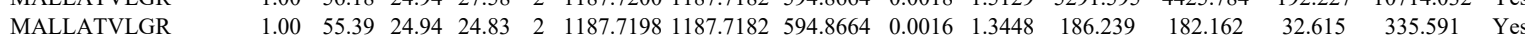

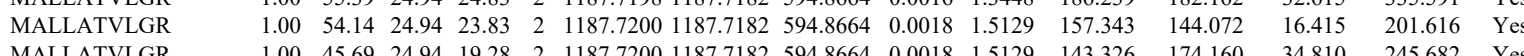

62 DPDASKPEDWDER DPDASKPEDWDER HEQNIDCGGGYVK HEQNIDCGGGYVK HEQNIDCGGGYVK HEONIDCGGGYVK HEQNIDCGGGYVK HEQNIDCGGGYVK HEQNIDCGGGYVK $\begin{array}{llllllllllllllll}\text { HEQNIDCGGGYVK } & 1.00 & 46.47 & 26.22 & 19.81 & 3 & 1752.8329 & 1752.8167 & 585.2795 & 0.0162 & 9.2263 & 2990.405 & 3021.382 & 477.136 & 2495.060 & Y \\ \text { HEQNIDCGGGYVK } & 1.00 & 68.63 & 26.30 & 28.66 & 2 & 1752.8330 & 1752.8167 & 877.4156 & 0.0163 & 9.2886 & 15387.652 & 14014.464 & 0.000 & 7948.558 & N\end{array}$

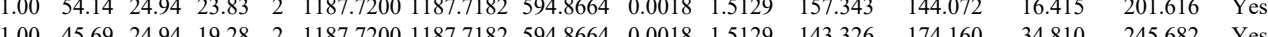

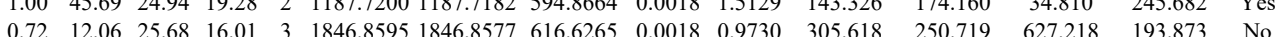

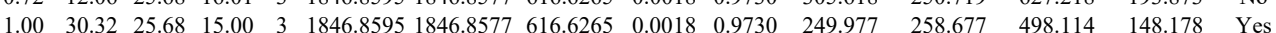
$\begin{array}{lllllllllllllll}0.91 & 27.66 & 25.20 & 18.33 & 3 & 1752.8143 & 1752.8167 & 585.2795 & -0.0024 & -1.3669 & 80.274 & 81.143 & 51.806 & 109.990 & \text { Yes }\end{array}$

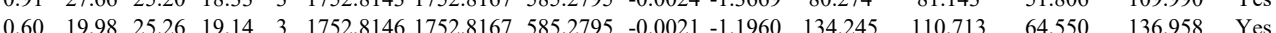

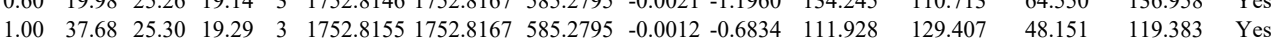
$\begin{array}{lllllllllllllll}0.73 & 18.88 & 25.38 & 16.95 & 3 & 1752.8158 & 1752.8167 & 585.2795 & -0.0009 & -0.5126 & 157.847 & 108.791 & 83.033 & 132.003 & \text { Yes }\end{array}$ $\begin{array}{lllllllllllllll}0.75 & 16.34 & 25.37 & 14.77 & 3 & 1752.8167 & 1752.8167 & 585.2795 & 0.0000 & 0.0000 & 174.510 & 172.038 & 83.041 & 175.464 & \text { Yes }\end{array}$ $\begin{array}{llllllllllllllll}0.63 & 11.95 & 25.33 & 18.51 & 3 & 1752.8176 & 1752.8167 & 585.2795 & 0.0009 & 0.5126 & 141.680 & 122.383 & 63.747 & 146.402 & \text { Yes }\end{array}$ $\begin{array}{llllllllllllllll}0.67 & 23.62 & 25.60 & 36.62 & 3 & 1752.8197 & 1752.8167 & 585.2795 & 0.0030 & 1.7086 & 160.425 & 137.556 & 71.604 & 189.286 & \text { Yes }\end{array}$ $\begin{array}{llllllllllllllll}0.59 & 9.56 & 25.60 & 22.56 & 3 & 1752.8197 & 1752.8167 & 585.2795 & 0.0030 & 1.7086 & 161.587 & 153.489 & 93.215 & 142.049 & \text { Yes }\end{array}$ $\begin{array}{llllllllllllllll}\text { HEQNIDCGGGYVK } & 0.99 & 37.52 & 26.42 & 16.67 & 3 & 1752.8335 & 1752.8167 & 585.2795 & 0.0168 & 9.5680 & 10447.265 & 8132.274 & 956.537 & 5205.648 & \text { Yes }\end{array}$

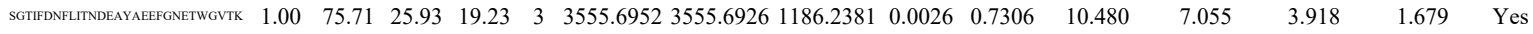

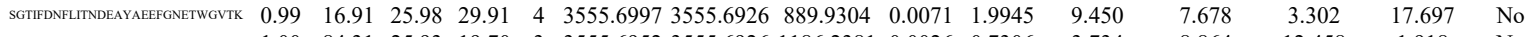
$\begin{array}{llllllllllllllll}\text { SGTFDNFUTNDEAXAEFGNEETWGVTK } & 1.00 & 84.31 & 25.93 & 19.70 & 3 & 3555.6952 & 3555.6926 & 1186.2381 & 0.0026 & 0.7306 & 3.734 & 8.864 & 12.458 & 1.918 & \text { No }\end{array}$ $\begin{array}{lllllllllllllll}\text { SGTIPDNFLITDEEAYAEFGNEETWGVTK } & 1.00 & \text { \#\#\#\# } 25.93 & 21.92 & 3 & 3555.6952 & 3555.6926 & 1186.2381 & 0.0026 & 0.7306 & 2.778 & 0.000 & 7.800 & 3.444 & \text { No }\end{array}$

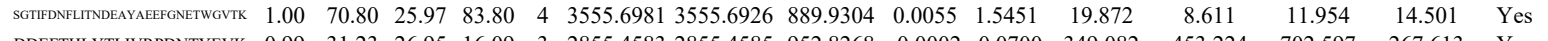

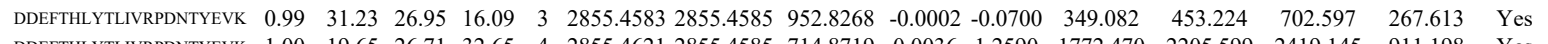

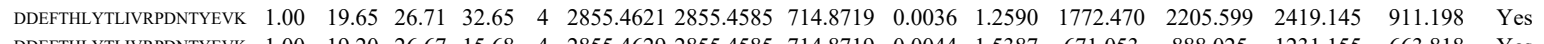

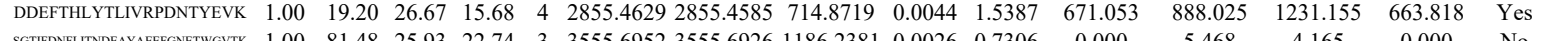

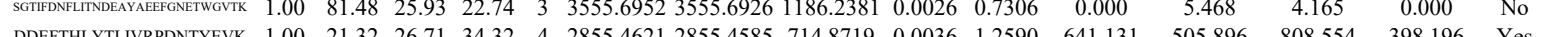

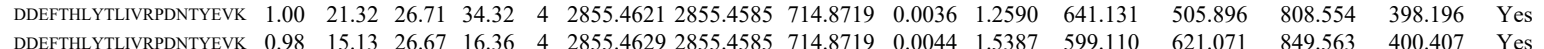

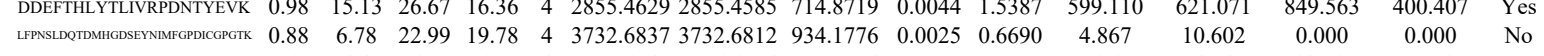
$\begin{array}{llllllllllllllll}\text { CKDDEFTHLYTLIVRDNTYEVK } & 0.62 & 14.47 & 26.19 & 16.80 & 4 & 3276.6541 & 3276.6524 & 820.1704 & 0.0017 & 0.5182 & 116.675 & 54.549 & 64.969 & 35.362 & \text { Yes } \\ \text { LPNSLDPTMHGDERNMMFGPDICGPCTK } & 0.99 & 19.05 & 23.20 & 32.05 & 4 & 3732.6905 & 3732.6812 & 934.1776 & 0.0093 & 2.4888 & 27.885 & 13.332 & 10.133 & 22.083 & \text { Yes }\end{array}$

Table S-4 page 249 of 614 

$\begin{array}{lllllllllllllllll}1.00 & 47.18 & 25.11 & 22.80 & 2 & 1306.7770 & 1306.7641 & 654.3893 & 0.0129 & 9.8564 & 37735.584 & 29674.978 & 1948.465 & 22460.625 & \text { Yes }\end{array}$ $\begin{array}{llllllllllllllll}0.67 & 11.57 & 25.31 & 24.57 & 3 & 1306.7668 & 1306.7641 & 436.5953 & 0.0027 & 2.0614 & 27.682 & 33.228 & 21.505 & 31.301 & \text { Yes }\end{array}$ \begin{tabular}{llllllllllllll} 
& \\
\hline
\end{tabular}

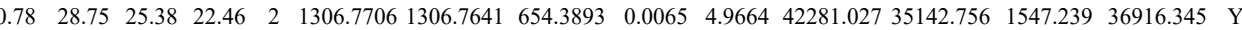

DPDASKPEDWDER $\begin{array}{llllllllllllllll}0.96 & 29.34 & 25.11 & 16.99 & 3 & 1306.7767 & 1306.7641 & 436.5953 & 0.0126 & 9.6198 & 17106.792 & 15226.488 & 398.048 & 9000.911 & \text { Yes } \\ 0.93 & 21.72 & 25.93 & 17.27 & 3 & 1846.8631 & 1846.8577 & 616.6265 & 0.0054 & 2.9191 & 2829.029 & 3373.601 & 5910.921 & 2253.711 & \text { Yes }\end{array}$

\section{FVLSSGK}

$\begin{array}{lccc}1773.601 & 5910.921 & 2253.711 & \text { Yes } \\ 162.151 & 27.849 & 117.562 & \text { Yes } \\ 2.679 & 2.772 & 9.660 & \text { Yes }\end{array}$

VISSGK $\begin{array}{llllllllllll}1.00 & 24.31 & 25.21 & 37.31 & 4 & 3391.5965 & 3391.5920 & 848.9053 & 0.0045 & 1.3252 & 11.349 \\ 3391.5920 & 848.9053 & 0.0053 & 1.5608 & 18.367\end{array}$ $\begin{array}{lllllllllllll} & \end{array}$

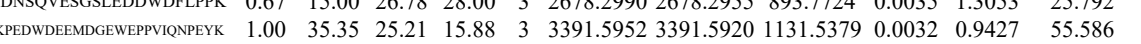
$\begin{array}{lllllllllllll} & \end{array}$ $\begin{array}{llllllllllll}1.00 & 39.25 & 27.16 & 28.77 & 2 & 1118.5810 & 1118.5802 & 560.2974 & 0.0008 & 0.7139 & 402.897 & \\ 1.00 & 46.00 & 27.19 & 28.12 & 2 & 1118.5812 & 1118.5802 & 560.2974 & 0.0010 & 0.8924 & 560.866 & 41\end{array}$ $\begin{array}{llllllllll} & 0.405\end{array}$

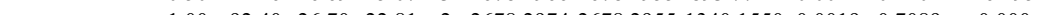
$\begin{array}{llllllllll} & 0.000\end{array}$ $\begin{array}{llllllllllll}\text { IDNSOVEGGSLEDDWDFPPK } & 1.00 & 68.47 & 26.81 & 19.65 & 2 & 2678.2994 & 26782955 & 1340.1550 & 0.0039 & 1.4551 & 3.324\end{array}$ $\begin{array}{lllllllllllll}\text { GLQTSQDAR } & 0.99 & 34.57 & 27.19 & 26.99 & 2 & 1118.5812 & 1118.5802 & 560.2974 & 0.0010 & 0.8924 & 214.296 & 157\end{array}$ $\begin{array}{lllllllllllll} & 1.00 & 43.56 & 27.13 & 29.18 & 2 & 1118.5816 & 1118.5802 & 560.2974 & 0.0014 & 1.2493 & 211.987 & 18\end{array}$ $\begin{array}{llllllllllll}\text { DNSQVSGLEDDWDFLPPK } & 0.60 & 48.61 & 26.79 & 61.61 & 3 & 2678.2993 & 2678.2955 & 893.7724 & 0.0038 & 1.4172 & 57.671 \\ \text { INSQESGLEDWDFLPPK } & 1.00 & 89.80 & 26.81 & 20.43 & 2 & 2678.2994 & 2678.2955 & 1340.1550 & 0.0039 & 1.4551 & 5.798\end{array}$

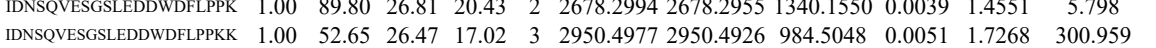
$\begin{array}{llllllllllll}\text { IDNSQVESGSLEDDWDFLPPKK } & 1.00 & 25.44 & 26.47 & 38.44 & 4 & 2950.4977 & 2950.4926 & 738.6304 & 0.0051 & 1.7262 & 67.964\end{array}$

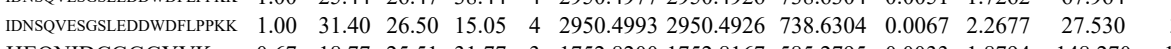
$\begin{array}{lllllllllllll}\text { HEQNIDCGGGYVK } & 0.67 & 18.77 & 25.51 & 31.77 & 3 & 1752.8200 & 1752.8167 & 585.2795 & 0.0033 & 1.8794 & 148.270 & 123.089\end{array}$ HEQNIDCGGGYVK

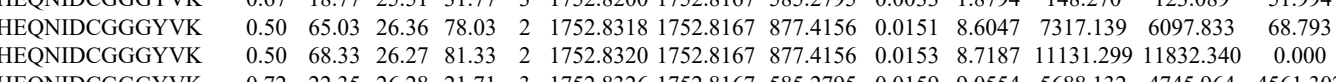




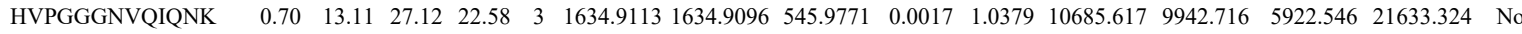
$\begin{array}{llllllllllllllll}\text { HVPGGGNVQIQNK } & 0.84 & 20.32 & 27.23 & 24.20 & 3 & 1634.9095 & 1634.9096 & 545.9771 & -0.0001 & -0.0611 & 3473.681 & 3087.863 & 1576.854 & 4955.847 & \text { Yes }\end{array}$ $\begin{array}{lllllllllllllllll}\text { HVPGGGNVQIQNK } & 0.97 & 30.21 & 27.19 & 31.18 & 3 & 1634.9107 & 1634.9096 & 545.9771 & 0.0011 & 0.6716 & 5721.676 & 4536.347 & 2180.964 & 7001.612 & \text { Yes }\end{array}$

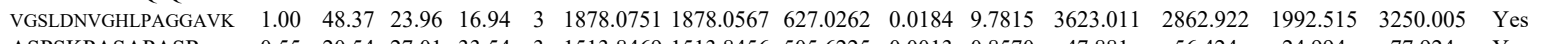
ASPSKPASAPAS ASPSKPASAPASR

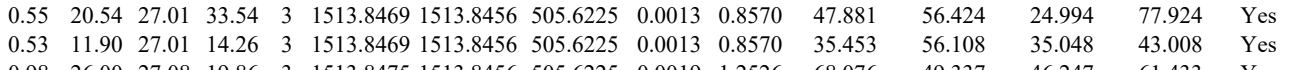
$\begin{array}{llllllllllllllll}0.98 & 26.00 & 27.08 & 19.86 & 3 & 1513.8475 & 1513.8456 & 505.6225 & 0.0019 & 1.2526 & 68.076 & 49.337 & 46.247 & 61.433 & \text { Yes } \\ 0.73 & 13.49 & 27.06 & 18.91 & 3 & 1513.8484 & 1513.8456 & 505.6225 & 0.0028 & 1.8459 & 67.908 & 68.915 & 67.132 & 6.899 & \text { Yes }\end{array}$ $\begin{array}{llllllllllllllll} & \text { Y }\end{array}$ $\begin{array}{llllllllllllllll}\text { TTTAAAVASTGPSSR } & 0.51 & 10.61 & 27.99 & 14.31 & 3 & 1520.7937 & 1520.7916 & 507.9378 & 0.0021 & 1.3781 & 132.092 & 152.167 & 86.254 & 131.551 & \text { Yes } \\ \text { VGSLDNVGHLPAGGAVK } & 1.00 & 39.04 & 25.80 & 22.69 & 3 & 1878.0589 & 1878.0567 & 627.0262 & 0.0022 & 1.1695 & 1102.547 & 1191.100 & 731.735 & 1269.506 & \text { Yes }\end{array}$

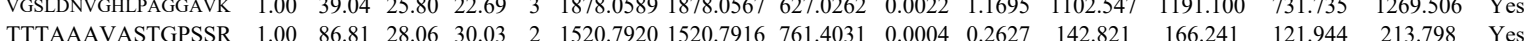

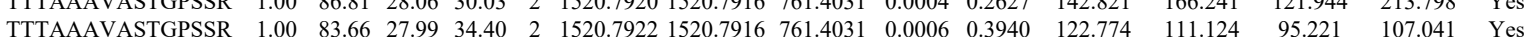

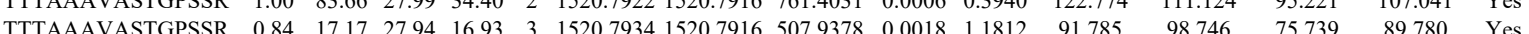
$\begin{array}{lllllllllllllllll} & \text { TTTAAAVASTGPSSR } & 1.00 & 74.24 & 27.93 & 29.40 & 2 & 1520.7916 & 1520.7916 & 761.4031 & 0.0000 & 0.000 & 1655.850 & 1712.472 & 1448.637 & 1574.720 & \text { Yes }\end{array}$ $\begin{array}{lllllllllllllllll}\text { TTTAAAVASTGPSSR } & 1.00 & 83.44 & 28.10 & 28.31 & 2 & 1520.7928 & 1520.7916 & 761.4031 & 0.0012 & 0.7880 & 1088.918 & 1071.499 & 977.273 & 1328.646 & \text { Yes }\end{array}$

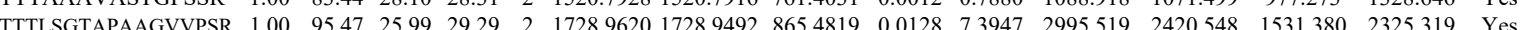
$\begin{array}{llllllllllllllll}\text { TTILSGTAPAAGVVPSR } & 1.00 & 84.91 & 25.99 & 20.37 & 2 & 1728.9620 & 1728.9492 & 865.481 & 0.0128 & 73947 & 1531.850 & 1357.449 & 1052.669 & 1576.569 & \text { Yes }\end{array}$ $\begin{array}{llllllllllllllll}\text { KPTSAKPSSTTPR } & 0.66 & 16.65 & 23.36 & 29.65 & 3 & 1789.0441 & 1789.0423 & 597.3547 & 0.0018 & 1.0044 & 29.195 & 21.450 & 29.588 & 18.776 & \text { Yes }\end{array}$ $\begin{array}{llllllllllllllll}\text { KPTSAKPSSTTPR } & 1.00 & 35.48 & 23.58 & 15.31 & 3 & 1789.0420 & 1789.0423 & 597.3547 & -0.0003 & -0.1674 & 27.318 & 42.489 & 30.684 & 35.562 & \text { Yes }\end{array}$

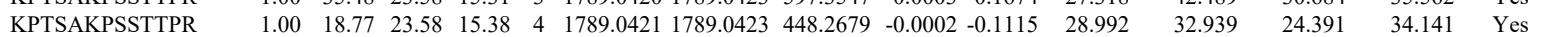
$\begin{array}{llllllllllllllll}\text { KPTSAKPSSTTPR } & 0.55 & 40.07 & 23.50 & 53.07 & 3 & 1789.0429 & 1789.0423 & 597.3547 & 0.0006 & 0.3348 & 142.057 & 127.320 & 81.412 & 97.788 & \text { Yes }\end{array}$ $\begin{array}{llllllllllllllll}\text { KPTSAKPSSTTPR } & 0.55 & 14.20 & 23.50 & 27.20 & 3 & 1789.0429 & 1789.0423 & 597.3547 & 0.0006 & 0.3348 & 24.209 & 48.314 & 18.781 & 48.444 & \text { Yes }\end{array}$ $\begin{array}{lllllllllllllllll}\text { KPTSAKPSSTTPR } & 1.00 & 19.64 & 23.58 & 16.08 & 4 & 1789.0421 & 1789.0423 & 448.2679 & -0.0002 & -0.1115 & 40.182 & 69.397 & 40.386 & 50.913 & \text { Yes }\end{array}$ $\begin{array}{llllllllllllllll}\text { KPTSAKPSSTTPR } & 0.57 & 5.59 & 23.58 & 18.59 & 4 & 1789.0421 & 1789.0423 & 448.2679 & -0.0002 & -0.1115 & 31.134 & 46.666 & 20.469 & 34.389 & \text { Yes }\end{array}$

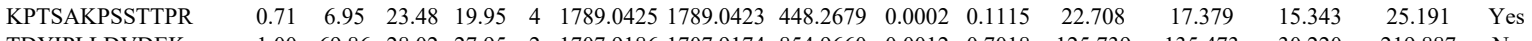

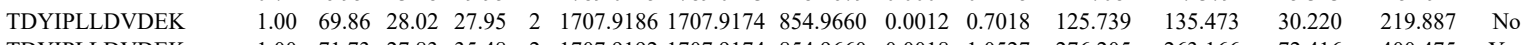
$\begin{array}{llllllllllllllll}\text { TDYIPLLDVDEK } & 1.00 & 71.73 & 27.83 & 35.48 & 2 & 1707.9192 & 1707.9174 & 854.9660 & 0.0018 & 1.0527 & 276.205 & 263.166 & 72.416 & 400.475 & \text { Yes }\end{array}$ $\begin{array}{llllllllllllllll}\text { DFIATLEAEAFDDVVGETVGK } & 1.00 & 38.85 & 27.11 & 22.71 & 3 & 2513.2777 & 2513.2781 & 838.7666 & -0.0004 & -0.1590 & 17.254 & 18.302 & 7.764 & 5.680 & \text { No }\end{array}$

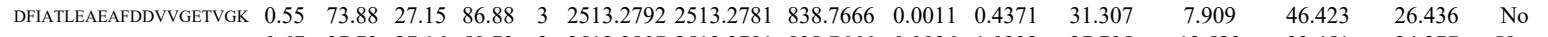

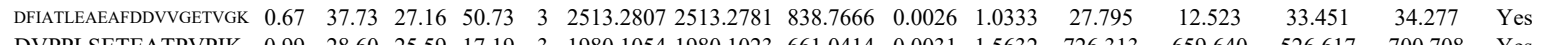
$\begin{array}{llllllllllllllll}\text { DVPPLSETEATPVPIK } & 0.99 & 28.60 & 25.59 & 17.19 & 3 & 1980.1054 & 1980.1023 & 661.0414 & 0.0031 & 1.5632 & 726.313 & 659.640 & 526.617 & 700.708 & \text { Yes }\end{array}$

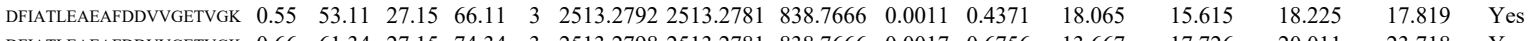

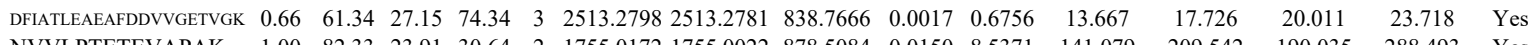

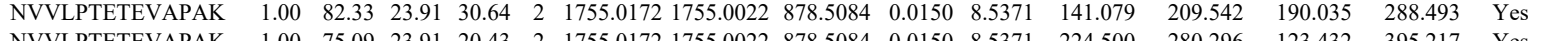
$\begin{array}{llllllllllllllll}\text { NVVLPTETEVAPAK } & 1.00 & 75.09 & 23.91 & 20.43 & 2 & 1755.0172 & 1755.0022 & 878.5084 & 0.0150 & 8.5371 & 224.500 & 280.296 & 123.432 & 395.217 & \text { Yes } \\ \text { AEEDEILNR } & 1.00 & 48.55 & 26.82 & 31.20 & 2 & 1231.6166 & 1231.6166 & 616.8156 & 0.0000 & 0.0000 & 524.689 & 713.845 & 189.678 & 709.748 & \text { Yes }\end{array}$

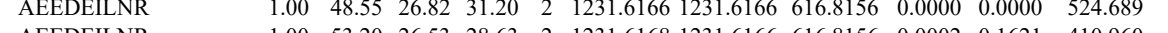
AEEDEILNR KDDTDDIAK

TELNLDQFHDK

TPELNDQHAK

TPELNLDQFHD

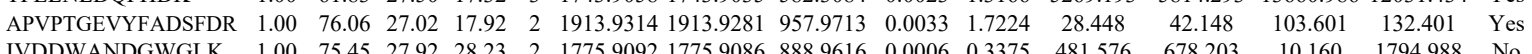
$\begin{array}{lllllllllll}1.00 & 53.20 & 26.53 & 28.63 & 2 & 1231.6168 & 1231.6166 & 616.8156 & 0.0002 & 0.1621 & 410.960\end{array}$

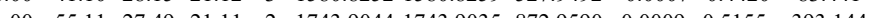
97.455 101.429 164.892

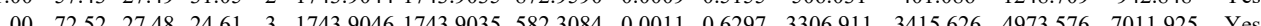
$\begin{array}{lllllllllllllll}1.00 & 61.83 & 27.50 & 17.32 & 3 & 1743.9058 & 1743.9035 & 5823084 & 0.0023 & 1.3166 & 5269.193 & 5814.293 & 13660.986 & 12031.434 & \text { Yes }\end{array}$

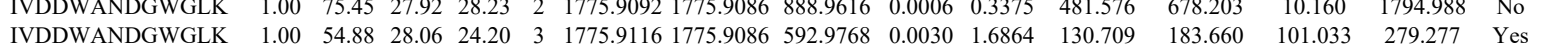
$\begin{array}{llllllllllllllll}\text { IVDDWANDGWGLK } & 1.00 & 56.25 & 28.13 & 38.34 & 3 & 1775.9125 & 1775.9086 & 592.9768 & 0.0039 & 2.1923 & 201.246 & 209.263 & 61.458 & 267.014 & \text { Yes }\end{array}$ $\begin{array}{lllllllllllllllll}\text { APVPTGEVYFADSFDR } & 0.84 & 83.14 & 26.79 & 96.14 & 2 & 1913.9298 & 1913.9281 & 957.9713 & 0.0017 & 0.8873 & 683.792 & 664.008 & 3538.717 & 2278.577 & \text { Yes }\end{array}$ $\begin{array}{llllllllllllllll}\text { APVPTGEVYFADSFDR } & 0.72 & 81.02 & 27.02 & 94.02 & 2 & 1913.9314 & 1913.9281 & 957.9713 & 0.0033 & 1.7224 & 888.427 & 903.387 & 3917.612 & 3182.897 & \text { Yes }\end{array}$ $\begin{array}{llllllllllllllll}\text { IVDDWANDGWGLK } & 1.00 & 62.33 & 27.94 & 22.34 & 2 & 1775.9090 & 1775.9086 & 888.9616 & 0.0004 & 0.2250 & 2924.038 & 2761.348 & 422.100 & 5674.893 & \text { Yes }\end{array}$ $\begin{array}{lllllllllllllllll}\text { IVDDWANDGWGLK } & 1.00 & 66.95 & 28.06 & 26.33 & 2 & 1775.9114 & 1775.9086 & 888.9616 & 0.0028 & 1.5749 & 4332.097 & 5069.897 & 288.248 & 9398.317 & \text { Yes }\end{array}$ $\begin{array}{llllllllllllllll}\text { IPNPDFFEDLEPFR } & 1.00 & 78.11 & 27.72 & 25.82 & 2 & 1878.9276 & 1878.9274 & 940.4710 & 0.0002 & 0.1063 & 637.288 & 1351.874 & 2612.606 & 1584.351 & \text { Yes }\end{array}$ $\begin{array}{llllllllllllllllll}\text { IPNPDFFEDLEPFR } & 1.00 & 60.99 & 27.58 & 20.30 & 2 & 1878.9294 & 1878.9274 & 940.4710 & 0.0020 & 1.0633 & 1688.923 & 1230.184 & 4305.706 & 3786.623 & \text { Yes }\end{array}$ $\begin{array}{llllllllllllllll}\text { IPNPDFFEDLEPFR } & 1.00 & 73.33 & 27.58 & 28.00 & 3 & 1878.9295 & 1878.9274 & 627.3164 & 0.0021 & 1.1159 & 44.220 & 56.041 & 33.156 & 88.297 & \text { Yes }\end{array}$ $\begin{array}{llllllllllllllllll}\text { IPNPDFFEDLEPFR } & 1.00 & 36.76 & 27.64 & 20.11 & 3 & 1878.9298 & 1878.9274 & 627.3164 & 0.0024 & 1.2753 & 43.365 & 110.711 & 93.127 & 88.776 & \text { Yes }\end{array}$ $\begin{array}{llllllllllllllll}\text { APVPTGEVYFADSFDR } & 0.82 & 61.14 & 26.87 & 74.14 & 2 & 1913.9292 & 1913.9281 & 957.9713 & 0.0011 & 0.5741 & 62.804 & 43.147 & 108.171 & 97.507 & \text { Yes } \\ \text { IPNPDFFEDLEPFR } & 1.00 & 59.66 & 27.69 & 19.20 & 2 & 1878.9270 & 1878.9274 & 940.4710 & -0.0004 & -0.2127 & 233.696 & 436.12 & 1292759 & 687.849 & \text { Yes }\end{array}$ IPNPDFFEDLEPFR IPNPDFFEDLEPFR IPNPDFFEDLEPFR IPNPDFFEDLEPFR IPNPDFFEDLEPFR IPNPDFFEDLEPFR KIPNPDFFEDLEPFR KIPNPDFFEDLEPFR KIPPDFEDLERR KIPNPDFFEDLEPRR DEEEKEEK $\begin{array}{lllllllllll}1.00 & 59.66 & 27.69 & 19.20 & 2 & 1878.9270 & 1878.9274 & 940.4710 & -0.0004 & -0.2127 & 233.696 \\ 1.00 & 73.55 & 27.53 & 25.46 & 2 & 1878.9280 & 1878.9274 & 940.4710 & 0.0006 & 0.3190 & 357.993\end{array}$ $\begin{array}{llllllllllll}1.00 & 34.33 & 27.62 & 18.41 & 3 & 1878.9304 & 1878.9274 & 627.3164 & 0.0030 & 1.5941 & 86.756\end{array}$ $\begin{array}{lllllllllllll}1.00 & 47.65 & 27.62 & 19.90 & 3 & 1878.9304 & 1878.9274 & 627.3164 & 0.0030 & 1.5941 & 107.814 \\ 1.00 & 43.53 & 27.71 & 16.50 & 2 & 1878.9272 & 1878.9274 & 940.4710 & -0.0002 & -0.1063 & 25.957\end{array}$ $\begin{array}{llllllllllll}1.00 & 43.53 & 27.71 & 16.50 & 2 & 1878.9272 & 1878.9274 & 940.4710 & -0.0002 & -0.1063 & 25.957 \\ 1.00 & 53.67 & 27.54 & 17.03 & 2 & 1878.9286 & 1878.9274 & 940.4710 & 0.0012 & 0.6380 & 165.370\end{array}$ $\begin{array}{lllllllllll}1.00 & 53.67 & 27.54 & 17.03 & 2 & 1878.9286 & 1878.9274 & 940.4710 & 0.0012 & 0.6380 & 165.370 \\ 0.67 & 46.68 & 27.40 & 59.68 & 3 & 2151.1273 & 2151.1244 & 718.0487 & 0.0029 & 1.3462 & 655.700\end{array}$ $\begin{array}{llllllllllll}0.67 & 46.68 & 27.40 & 59.68 & 3 & 2151.1273 & 2151.1244 & 718.0487 & 0.0029 & 1.3462 & 655.700 \\ 1.00 & 46.06 & 27.40 & 16.17 & 3 & 2151.1273 & 2151.1244 & 718.0487 & 0.0029 & 1.3462 & 441.923\end{array}$ $\begin{array}{lllllllllll}1.00 & 45.83 & 27.40 & 16.96 & 3 & 2151.1270 & 2151.1244 & 718.0487 & 0.0026 & 1.2070 & 116.294\end{array}$ $\begin{array}{llllllllllll}1.00 & 51.92 & 27.40 & 18.35 & 3 & 2151.1273 & 2151.1244 & 718.0487 & 0.0029 & 1.3462 & 101.865\end{array}$

DKGDEEEEGEEK $\begin{array}{llllllllllll}0.88 & 54.89 & 26.44 & 28.94 & 2 & 1824.8588 & 1824.8590 & 913.4368 & -0.0002 & -0.1095 & 50.461\end{array}$ 
$\begin{array}{llllllllllll}1.00 & 41.09 & 23.34 & 26.28 & 2 & 1145.5330 & 1145.5322 & 573.7734 & 0.0008 & 0.6971 & 1032.538\end{array}$

$\begin{array}{lllllllllllllll}1.00 & 51.00 & 24.05 & 64.00 & 4 & 2644.4509 & 2644.4313 & 662.1151 & 0.0196 & 7.4005 & 6124.458 & 8052.862 & 3718.196 & 9382.964 & \text { Yes }\end{array}$ $\begin{array}{lllllllllllllllll} & \end{array}$ $\begin{array}{llllllllllllllllll} & \end{array}$ $\begin{array}{llllllllllllllllll} & & \end{array}$ GLVLMSR AEEDEILNR AEEDEILNR LHFIFR

WEVEEMK $\begin{array}{llllllllllllllll}1.00 & 50.96 & 24.64 & 17.88 & 4 & 2644.4349 & 2644.4313 & 662.1151 & 0.0036 & 1.3593 & 2051.067 & 2403.404 & 1160.367 & 3309.853 & \text { Yes }\end{array}$ WEVEEMK

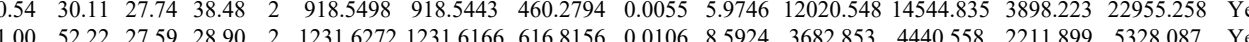
$\begin{array}{llllllllllllllll}1.00 & 52.22 & 27.59 & 28.90 & 2 & 1231.6272 & 1231.6166 & 616.8156 & 0.0106 & 8.5924 & 3682.853 & 4440.558 & 2211.899 & 5328.087 & \text { Yes }\end{array}$ $\begin{array}{lllllllllllllllll}0.99 & 45.22 & 27.59 & 28.70 & 2 & 1231.6278 & 1231.6166 & 616.8156 & 0.0112 & 9.0788 & 3241.835 & 3720.786 & 1776.233 & 4530.861 & \text { Yes }\end{array}$ $\begin{array}{lllllllllllllllll}0.58 & 17.14 & 28.76 & 26.19 & 2 & 975.5784 & 975.5776 & 488.7961 & 0.0008 & 0.8183 & 589.707 & 554.871 & 247.046 & 1636.241 & \text { Yes } \\ \end{array}$ $\begin{array}{llllllllllllll} & \end{array}$ $\begin{array}{llllllllllllllllll} & 0.03\end{array}$

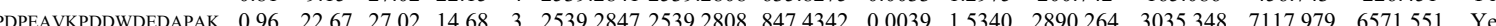
$\begin{array}{lllllllllllllllllll}\text { KPEDWDERPK } & 1.00 & 29.95 & 27.94 & 19.08 & 4 & 1730.9333 & 1730.9317 & 433.7402 & 0.0016 & 0.9222 & 966.971 & 1197.589 & 3345.097 & 3272.807 & \text { Yes }\end{array}$

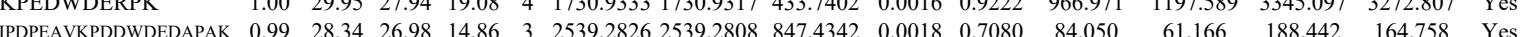
$\begin{array}{lllllllllllllllll}\text { TPELNLDQFHDK } & 1.00 & 60.46 & 27.36 & 26.78 & 2 & 1743.9196 & 1743.9035 & 872.9590 & 0.0161 & 9.2214 & 593.729 & 531.462 & 1052.185 & 964.219 & \text { Yes }\end{array}$ TPELNLDQFHDK TPELNLDQFHDK TPELNLDQFHDK $\begin{array}{ccccccccccccccc}1.00 & 60.46 & 27.36 & 26.78 & 2 & 1743.9196 & 1743.9035 & 872.9590 & 0.0161 & 9.2214 & 593.729 & 531.462 & 1052.185 & 964.219 & \text { Yes } \\ 1.00 & 57.56 & 27.50 & 25.03 & 2 & 1743.9204 & 1743.9035 & 872.9590 & 0.0169 & 9.6796 & 453.389 & 489.300 & 783.201 & 964.340 & \text { Yes }\end{array}$ EELEEVIK EELEEVIKDI ITSPLMEPSSIEK ITSPLMEPSSIEK LFQVEYAIEAIK LFQVEYAIEAIK

LFQVEYAIEAIK

LFQVEYAIEAIK $\begin{array}{llllllllllllllll}\text { LFQVEYAIEAIK } & 0.99 & 34.59 & 24.93 & 31.63 & 3 & 1710.9838 & 1710.9800 & 571.3339 & 0.0038 & 2.2170 & 27.398 & 39.854 & 4.492 & 50.868 & \text { Yes } \\ \text { LFQVEYAIEAIK } & 1.00 & 67.18 & 24.97 & 30.65 & 2 & 1710.9828 & 1710.9800 & 856.4973 & 0.0028 & 1.6346 & 343.577 & 270.481 & 67.439 & 371.888 & \text { Yes }\end{array}$ $\begin{array}{lllllllllllllllll}1.00 & 57.56 & 27.50 & 25.03 & 2 & 1743.9204 & 1743.9035 & 872.9590 & 0.0169 & 9.6796 & 453.389 & 489.300 & 783.201 & 964.340 & \text { Yes } \\ 1.00 & 61.83 & 27.54 & 17.63 & 3 & 1743.9208 & 1743.9035 & 582.3084 & 0.0173 & 9.9030 & 2948.976 & 3784.715 & 7048.145 & 6610.732 & \text { Yes }\end{array}$ \begin{tabular}{lllllllllllllll}
1.00 & 58.72 & 27.54 & 19.42 & 3 & 1743.9208 & 1743.9035 & 582.3084 & 0.0173 & 9.9030 & 1576.734 & 1798.245 & 3324.151 & 3623.742 & Yes \\
\hline
\end{tabular} $\begin{array}{lllllllllllllll}0.98 & 33.21 & 28.05 & 29.08 & 2 & 1275.7176 & 1275.7165 & 638.8655 & 0.0011 & 0.8609 & 284.258 & 216.361 & 470.847 & 626.440 & \text { Yes } \\ 0.87 & 47.86 & 27.96 & 24.97 & 2 & 1275.726 & 1275.715 & 63.855 & 0.02 & 1.645 & 332.48 & 202.747 & 457.015 & 620.979 & \text { Yes }\end{array}$ \begin{tabular}{llllllllllllllll}
1.00 & 44.69 & 27.90 & 31.85 & 2 & 1275.7186 & 1275.7165 & 638.8655 & 0.0021 & 1.6435 & 332.488 & 202.747 & 457.015 & 620.979 & Yes \\
\hline
\end{tabular}

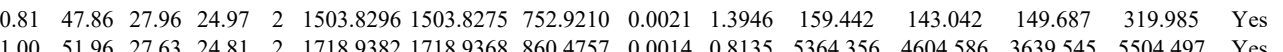

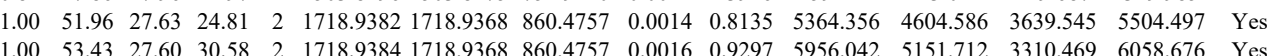
$\begin{array}{lllllllllllllll}1.00 & 53.43 & 27.60 & 30.58 & 2 & 1718.9384 & 1718.9368 & 860.4757 & 0.0016 & 0.9297 & 5956.042 & 5151.712 & 3310.469 & 6058.676 & \text { Yes } \\ 1.00 & 70.15 & 24.97 & 30.32 & 2 & 1710.9826 & 1710.9800 & 856.4973 & 0.002 & 1.5178 & 113.951 & 964.887 & 78.96 & 184.047 & \text { Yes }\end{array}$ $\begin{array}{llllllllllllllll}1.00 & 70.15 & 24.97 & 30.32 & 2 & 1710.9826 & 1710.9800 & 856.4973 & 0.0026 & 1.5178 & 1113.951 & 964.887 & 78.960 & 1849.047 & \text { Yes } \\ \end{array}$

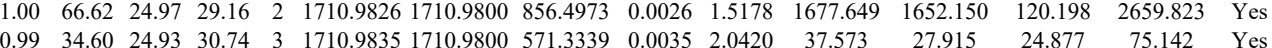
$\begin{array}{lllllllllllllllll} & & & \end{array}$

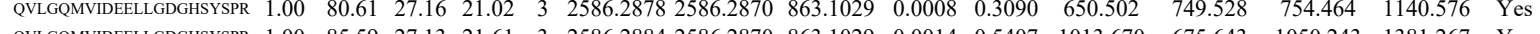
$\begin{array}{llllllllllllllll}\text { QVLGQMVIDEELLGDGHSYSPR } & 1.00 & 85.59 & 27.13 & 21.61 & 3 & 2586.2884 & 2586.2870 & 863.1029 & 0.0014 & 0.5407 & 1013.670 & 675.643 & 1050.243 & 1381.267 & \text { Yes }\end{array}$

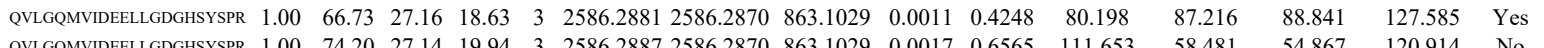

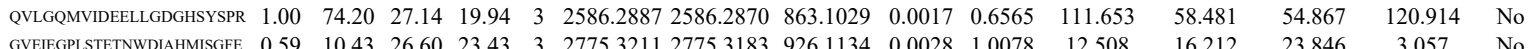

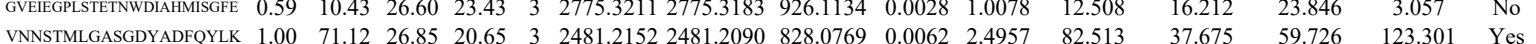

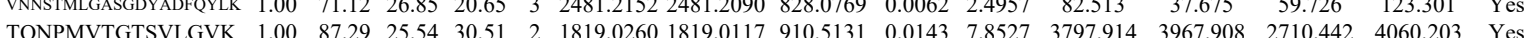
$\begin{array}{llllllllllllll} & \text { TQNPMVGTSE }\end{array}$

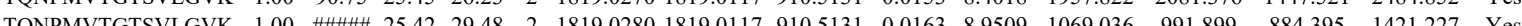

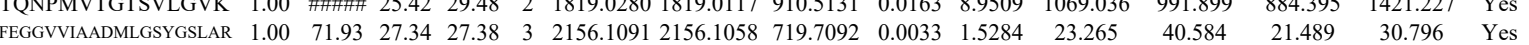

Table S- 4 page 252 of 614 


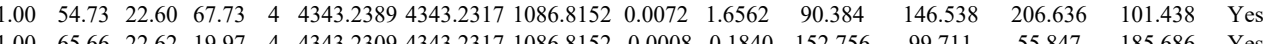
$\begin{array}{lllllllllllllll}1.00 & 63.27 & 22.74 & 76.27 & 4 & 4343.2349 & 4343.2317 & 1086.8152 & 0.0032 & 0.7361 & 82.626 & 112.715 & 157.686 & 111.672 & \text { Yes }\end{array}$ $\begin{array}{llllllllllllllll}\text { IFCCR } & 0.57 & 9.60 * & 16.53 & 14.57 & 2 & 876.3610 & 876.3600 & 439.1873 & 0.0010 & 1.1385 & 22.394 & 34.430 & 26.375 & 91.136 & \text { Yes }\end{array}$

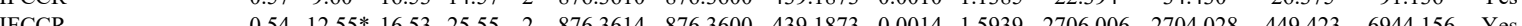

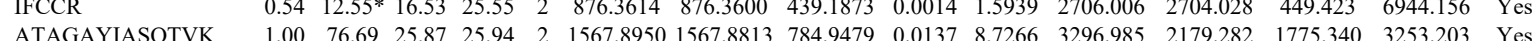
$\begin{array}{lllllllllllllllll}\text { VSSDNVADLHEK } & 1.00 & 55.57 & 28.18 & 23.26 & 3 & 1600.8325 & 1600.8300 & 534.6173 & 0.0025 & 1.5587 & 5609.682 & 3694.177 & 1591.642 & 8324.124 & \text { Yes }\end{array}$ $\begin{array}{llllllllllllllll}\text { VSSDNVADLHEK } & 1.00 & 59.69 & 28.21 & 31.37 & 3 & 1600.8328 & 1600.8300 & 534.6173 & 0.0028 & 1.7458 & 10493.780 & 8366.737 & 1699.687 & 15940.071 & \text { Yes }\end{array}$ $\begin{array}{lllllllllllllllll}\text { NDGAAILAAVSSIAQK } & 0.60 & 25.71 & 24.74 & 38.71 & 3 & 1816.0339 & 1816.0298 & 6063505 & 0.004 & 22539 & 214.621 & 200.115 & 75.147 & 274.516 & \text { Yes }\end{array}$

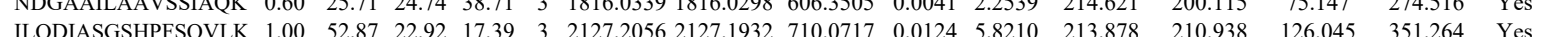
$\begin{array}{lllllllllllllllll}\text { VAVTPPGLAR } & 0.96 & 33.93 & 23.58 & 19.30 & 2 & 1123.6920 & 1123.6835 & 562.8490 & 0.0085 & 7.5508 & 3496.701 & 3369.511 & 867.162 & 4965.123 & \text { Yes }\end{array}$ $\begin{array}{lllllllllllllllll}\text { VAVTPPGLAR } & 0.98 & 35.28 & 23.58 & 17.21 & 2 & 1123.6926 & 1123.6835 & 562.8490 & 0.0091 & 8.0838 & 9304.299 & 8897.550 & 1435.236 & 12826.926 & \text { Yes }\end{array}$ $\begin{array}{llllllllllllllll}\text { KPMVVLGSSALQR } & 1.00 & 58.04 & 20.86 & 19.08 & 3 & 1673.0005 & 1672.9902 & 558.6707 & 0.0103 & 6.1455 & 1679.866 & 1511.145 & 1371.076 & 1879.163 & \text { Yes }\end{array}$ $\begin{array}{lllllllllllllllll}\text { KPMVVLGSSALQR } & 0.55 & 36.05 & 22.20 & 49.05 & 3 & 1672.9915 & 1672.9902 & 558.6707 & 0.0013 & 0.7757 & 1123.528 & 1219.447 & 1898.804 & 1532.622 & \text { Yes }\end{array}$ $\begin{array}{llllllllllllllllll}\text { IIVEEALAAPYIEOYYPPSDEPAEAPFK } & 1.00 & 96.88 & 25.39 & 22.27 & 3 & 3649.8112 & 3649.8071 & 1217.6096 & 0.0041 & 1.1224 & 0.000 & 11.871 & 12.861 & 18.569 & \text { No }\end{array}$ $\begin{array}{lllllllllllllllllll}\text { IIVVEQLLAAPYLEYYDPSDEPALAAPFK } & 1.00 & 17.19 & 25.42 & 15.85 & 4 & 3649.8121 & 3649.8071 & 913.4591 & 0.0050 & 1.3684 & 12.430 & 24.583 & 42.690 & 3.642 & \text { No }\end{array}$

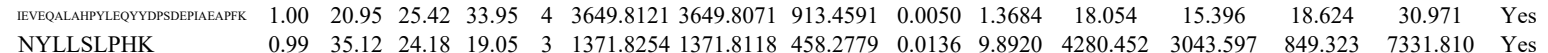

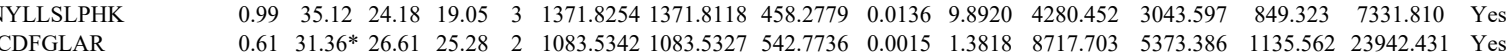
$\begin{array}{lllllllllllllll} & \\ \text { ICDFGLAR } & 0.61 & 31.36 * 26.61 & 25.28 & 2 & 1083.5342 & 1083.5327 & 542.7736 & 0.0015 & 1.3818 & 8717.703 & 5373.386 & 135.562 & 123120.49 & \text { Yes }\end{array}$ $\begin{array}{lllllllllllllllll} & \text { FDMELDDLPK } & 1.00 & 60.54 & 27.66 & 27.04 & 2 & 1509.7640 & 1509.7629 & 755.8887 & 0.0011 & 0.7276 & 687.085 & 474.259 & 79.171 & 1346.384 & \text { Yes }\end{array}$ $\begin{array}{lllllllllllllllll}\text { FDMELDDLPK } & 1.00 & 60.49 & 27.66 & 36.13 & 2 & 1509.7642 & 1509.7629 & 755.8887 & 0.0013 & 0.8599 & 508.724 & 371.421 & 62.628 & 844.491 & \text { Yes }\end{array}$

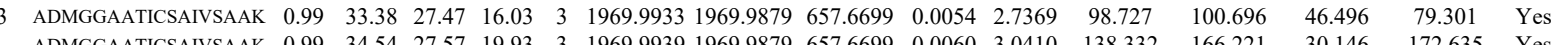
$\begin{array}{lllllllllllllllll}\text { ADMGGAATICSAIVSAAK } & 0.99 & 34.54 & 27.57 & 19.93 & 3 & 1969.9939 & 1969.9879 & 657.6699 & 0.0060 & 3.0410 & 138.332 & 166.221 & 30.146 & 172.635 & \text { Yes }\end{array}$

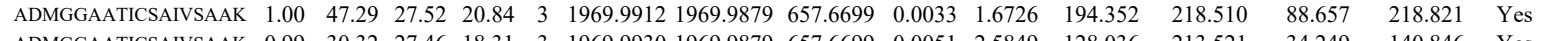

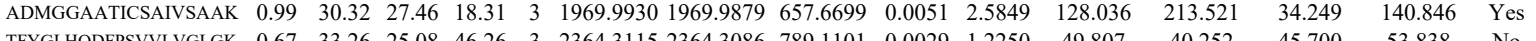

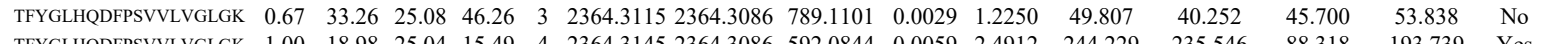
\begin{tabular}{llllllllllllllll} 
TFYGLHQDFPSVVLVGLGK & 1.00 & 18.98 & 25.04 & 15.49 & 4 & 2364.3145 & 2364.3086 & 592.0844 & 0.0059 & 2.4912 & 244.229 & 235.546 & 88.318 & 193.739 & Yes \\
\hline
\end{tabular} $\begin{array}{llllllllllllll} & \end{array}$

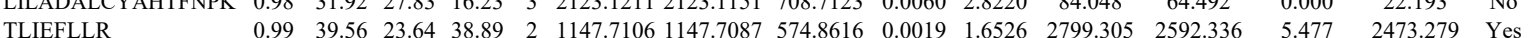

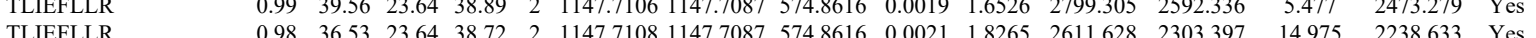

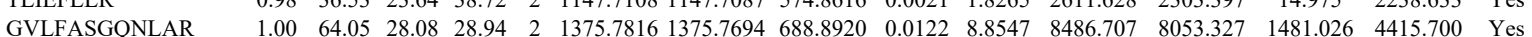

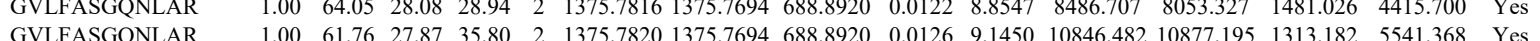

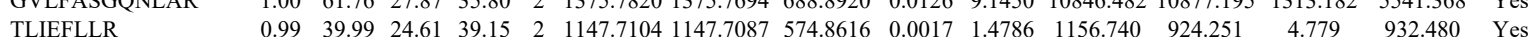

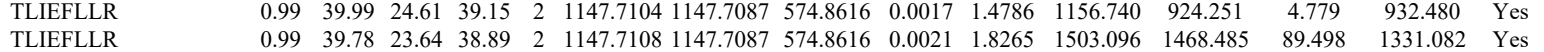

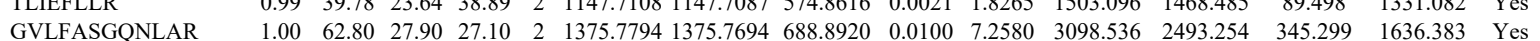
\begin{tabular}{llllllllllllllll} 
SILTDNPTWIIPPIDGTTNFVHR & 1.00 & 56.66 & 26.64 & 22.06 & 3 & 2768.4280 & 2768.4256 & 923.8158 & 0.0024 & 0.8660 & 34.975 & 93.382 & 23.090 & 88.195 & Yes \\
\hline
\end{tabular}

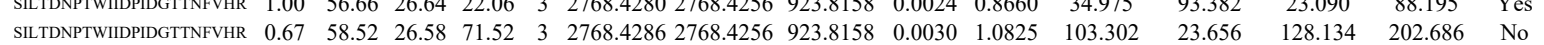
$\begin{array}{llllllllllllllll}\text { LFCIPVHGIR } & 1.00 & 34.74 & 27.67 & 17.81 & 3 & 1343.7343 & 1343.7328 & 448.9182 & 0.0015 & 1.1138 & 37.860 & 63.821 & 6.140 & 90.402 & \text { Yes }\end{array}$ $\begin{array}{lllllllllllllllll}\text { LFCIPVHGIR } & 0.55 & 37.35 & 27.66 & 50.35 & 3 & 1343.7340 & 1343.7328 & 448.9182 & 0.0012 & 0.8910 & 85.930 & 75.365 & 20.946 & 138.202 & \text { Yes }\end{array}$ $\begin{array}{lllllllllllllllll} & \text { LFCIPVHGIR } & 1.00 & 59.42 & 27.66 & 19.71 & 3 & 1343.7346 & 1343.7328 & 448.9182 & 0.0018 & 1.3365 & 100.570 & 99.905 & 29.739 & 138.587 & \text { Yes }\end{array}$ $\begin{array}{llllllllllllllll}\text { LFCIPVHGIR } & 0.89 & 26.50 & 27.69 & 20.13 & 2 & 1343.7354 & 1343.7328 & 672.8737 & 0.0026 & 1.9320 & 119.722 & 62.038 & 30.957 & 166.539 & \text { Yes }\end{array}$ $\begin{array}{llllllllllllllll}\text { LFCIPVHGIR } & 0.84 & 24.82 & 27.63 & 15.24 & 2 & 1343.7356 & 1343.7328 & 672.8737 & 0.0028 & 2.0806 & 79.457 & 108.728 & 20.806 & 122.985 & \text { Yes }\end{array}$

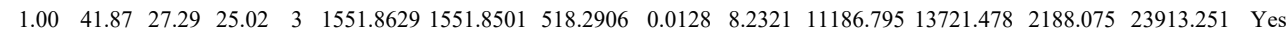
$\begin{array}{llllllllllllllll}\text { ISSDLDGHPVPK } & 0.94 & 34.00 & 27.23 & 30.43 & 3 & 1551.8641 & 1551.8501 & 518.2906 & 0.0140 & 9.0039 & 9634.606 & 13998.306 & 3127.372 & 17925.664 & \text { Yes }\end{array}$

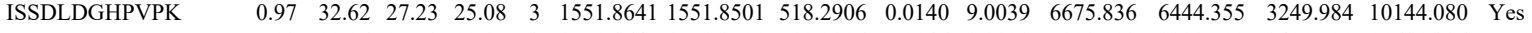

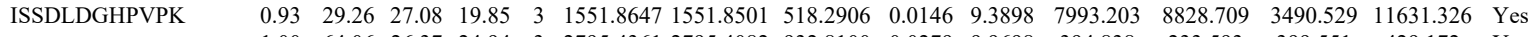
$\begin{array}{lllllllllllllllll}\text { TSRPENAIIYNNNEDFQVGQAK } & 1.00 & 64.06 & 26.37 & 24.94 & 3 & 2795.4361 & 2795.4082 & 932.8100 & 0.0279 & 9.9698 & 394.838 & 233.593 & 399.551 & 429.172 & \text { Yes }\end{array}$ $\begin{array}{llllllllllllllll}\text { SVPTSTVFYPSDGVATEK } & 1.00 & 71.18 & 27.58 & 22.33 & 2 & 2172.1214 & 2172.1194 & 1087.0670 & 0.0020 & 0.9199 & 613.704 & 1006.314 & 757.405 & 1402.894 & \text { Yes }\end{array}$ $\begin{array}{lllllllllllllllll}\text { SVPTSTVFYPSDGVATEK } & 1.00 & 67.21 & 27.58 & 19.68 & 2 & 2172.1214 & 2172.1194 & 1087.0670 & 0.0020 & 0.9199 & 524.189 & 1183.483 & 964.036 & 1204.444 & \text { Yes }\end{array}$ $\begin{array}{llllllllllllllll}\text { ILATPPQEDAPSVDIANIR } & 0.64 & 98.57 & 26.16 & 2 & 2163.1654 & 2163.1657 & 1082.5901 & -0.0003 & -0.1386 & 833.153 & 1077.929 & 820.531 & 1621.274 & \text { Yes }\end{array}$

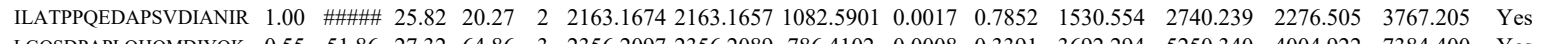

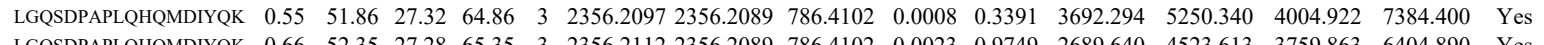

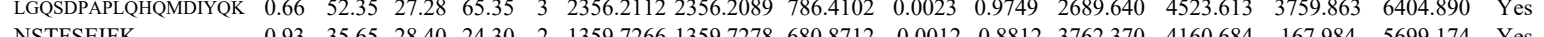

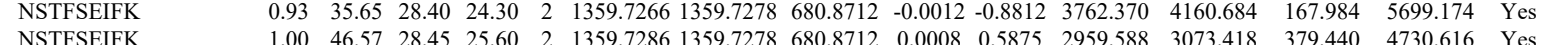
$\begin{array}{lllllllllllllllll}\text { NSTFEIFK } & 1.00 & 46.57 & 28.45 & 25.60 & 2 & 1359.7286 & 1359.7278 & 680.8712 & 0.0008 & 0.5875 & 2959.588 & 3073.418 & 379.440 & 4730.616 & \text { Yes }\end{array}$

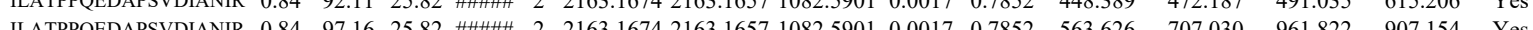
$\begin{array}{llllllllllllllll}\text { DDQVTVIGAGUTLHEALAAakLLK } & 0.99 & 15.74 & 22.28 & 16.96 & 4 & 2721.5149 & 2721.5156 & 681.3862 & -0.0007 & -0.2568 & 87.746 & 101.693 & 44.058 & 118.484 & \text { Yes }\end{array}$ 


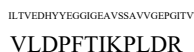

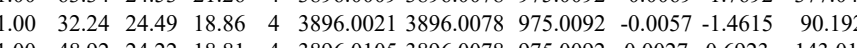

$\begin{array}{llllllllllll}1.00 & 48.92 & 24.22 & 18.81 & 4 & 3896.0105 & 3896.0078 & 975.0092 & 0.0027 & 0.6923 & 143.014 & 9 \\ 0.60 & 32.32 & 22.67 & 45.32 & 3 & 1701.0106 & 1701.0069 & 568.0096 & 0.0037 & 2.1713 & 2785.527 & 46\end{array}$ $\begin{array}{llllllllllll}0.99 & 43.73 & 27.15 & 20.57 & 2 & 1209.6770 & 1209.6671 & 605.8408 & 0.0099 & 8.1704 & 2959.110 & 2851 \\ 1.00 & 34.44 & 22.74 & 20.55 & 3 & 1701.0094 & 1701.0069 & 568.0096 & 0.0025 & 1.4671 & 3260.828 & 46963.2\end{array}$

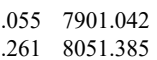

$\begin{array}{lllllllllllll}1.00 & 32.80 & 22.70 & 16.68 & 3 & 1701.0097 & 1701.0069 & 568.0096 & 0.0028 & 1.4671 & 3260.828 & 4696 \\ 0.0432 & 5495.764 & 7397\end{array}$

NMAEQIIQEIYSQIQSK

NMAEQIIQEIYSQIQSK

LDNLVAILDINR 99 76.45*26.88 28.58

$\begin{array}{llllllllllll}\text { LDNLVAILDINR } & 1.00 & 72.91 & 24.70 & 39.05 & 2 & 1511.8816 & 1511.8793 & 756.9469 & 0.0023 & 1.5193 & 533.802 \\ \text { LDNLVAILDINR } & 1.00 & 45.31 & 24.70 & 25.10 & 3 & 1511.8822 & 1511.8793 & 504.9670 & 0.0029 & 1.9143 & 63.839\end{array}$

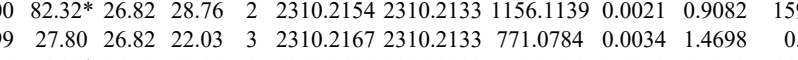

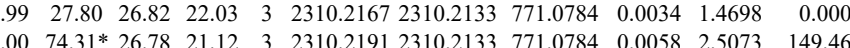

$\begin{array}{lllllllllll}1.00 & 38.32 & 25.11 & 25.60 & 3 & 1511.8810 & 1511.8793 & 504.9670 & 0.0017 & 1.1222 & 79.109\end{array}$

$\begin{array}{llllllllllll}\text { NMAEQIIQEIYSQIQSK } & 0.99 & 73.82 * 26.82 & 27.28 & 2 & 2310.2154 & 2310.2133 & 1156.1139 & 0.0021 & 0.9082 & 122.411\end{array}$

$\begin{array}{llllllllllll}\text { NMAEQIIQEIYSQIQSK } & 1.00 & 77.46 * & 26.82 & 31.77 & 2 & 2310.2154 & 2310.2133 & 1156.1139 & 0.0021 & 0.9082 & 116.910\end{array}$

$\begin{array}{llllllllllll}\text { NMAEQIIQEIYSQIQSK } & 1.00 & 32.01 & 26.79 & 16.60 & 3 & 2310.2161 & 2310.2133 & 771.0784 & 0.0028 & 1.2104 & 26.951\end{array}$

NMAEQIIQEIYSQIQSK

LDNLVAILDINR

$\begin{array}{llll}1.00 & 50.09 & 26.75 & 26.24\end{array}$

LDNLVAILDINR

$\begin{array}{lllllllllll}1.00 & 40.01 & 25.11 & 24.86 & 3 & 1511.8810 & 1511.8793 & 504.9670 & 0.0017 & 1.1222 & 49.680\end{array}$

LDNLVAILDINR

$\begin{array}{llllllllllll}1.00 & 41.55 & 25.11 & 27.38 & 3 & 1511.8810 & 1511.8793 & 504.9670 & 0.0017 & 1.1222 & 65.564 & 56.155\end{array}$

$\begin{array}{lll}8051.385 & 9034.940 & \text { Yes } \\ 1008.484 & 5846.715 & \text { Yes } \\ 1781.371 & 10046.562 & \text { Yes }\end{array}$

NMAEQIIQEIYSQIQ

$\begin{array}{lllllllllllll} & 1.00 & 78.53 & 25.11 & 37.55 & 2 & 1511.8810 & 1511.8793 & 756.9469 & 0.0017 & 1.1229 & 754.963\end{array}$

$\begin{array}{lllllllllllll} & 18.88 & 3 & 2310.2173 & 2310.2133 & 771.0784 & 0.0040 & 1.7292 & 0.000\end{array}$

$\begin{array}{lllllllllllll} & \end{array}$

\begin{tabular}{llllllllllll}
\hline & a
\end{tabular}

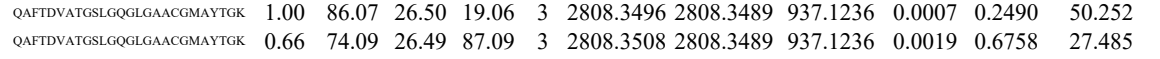

$\begin{array}{lllllllllllll}\text { QAATDVATGSLGQGLGAACGMAYTGK } & 1.00 & 85.26 & 26.58 & 18.53 & 3 & 2808.3517 & 2808.3489 & 937.1236 & 0.0028 & 0.9960 & 42.243\end{array}$

GICFIR

GICFR

\begin{tabular}{lll}
61.230 \\
$\quad 36.691$ \\
\hline
\end{tabular}

GICFIR

ISSDLDGHPVPK

TVPFCSTFAPK

TVPFCSTFAAFFTR

IIALDGDTK

IIALDGDTK

IIALDGDTK

IIALDGDTKK

ISSDLDGHPVPK

ISSDLDGHPVPK

ISSDLDGHPVPK

ISSDLDGHPVPK

$\begin{array}{llllllllllll}\text { PML_HUMAN P29590 } & \text { PML } & \text { Probable transcrip 97.551 } & 1.00 & 3 & 3.7 & -0.2258 & 0.2187 & -0.4803 & 0.2382 & 8 & \text { DPIDVDLPEEAER } \\ & & & & & & & & & & & \end{array}$

DPIDVDLPEEAER

TPTLTSIYCR

TPTLTSIYCR

TPTLTSIYCR
TPTLTSIYCR

TPTLTSIYCR

SAMAAVLAMR

$\begin{array}{llllllllllllllll} & \end{array}$

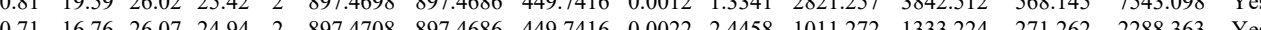

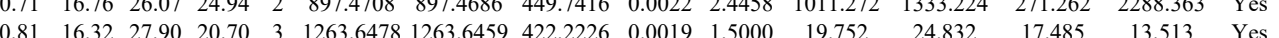

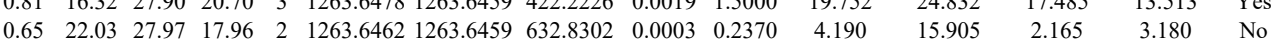

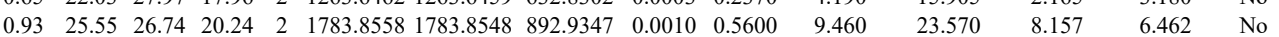

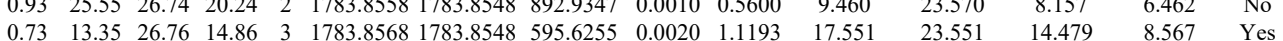
$\begin{array}{lllllllllllllll}0.90 & 44.46 & 27.29 & 47.51 & 2 & 1232.7334 & 1232.7220 & 617.3683 & 0.0114 & 9.2327 & 10052.560 & 12634.495 & 999.925 & 20264.134 & \text { Yes }\end{array}$ $\begin{array}{llllllllllllllll}0.90 & 44.46 & 27.29 & 47.51 & 2 & 1232.7334 & 1232.7220 & 617.368 & 0.0114 & .2327 & 17.552 .560 & 12634.495 & 999.925 & 20264.134 & \text { Yes } \\ 0.94 & 46.25 & 27.29 & 47.09 & 2 & 1232.7336 & 1232.7220 & 617.3683 & 0.0116 & 9.3946 & 9820.257 & 12418.793 & 724.148 & 19563.477 & \text { Yes }\end{array}$ $\begin{array}{lllllllllllllll}0.95 & 46.49 & 27.32 & 46.59 & 2 & 1232.7338 & 1232.7220 & 617.3683 & 0.0118 & 9.5566 & 1775.168 & 1853.472 & 564.324 & 2960.792 & \text { Yes }\end{array}$ $\begin{array}{llllllllllllllll}0.96 & 63.08 & 27.40 & 62.40 & 2 & 1232.7340 & 1232.7220 & 617.3683 & 0.0120 & 9.7186 & 2884.965 & 3749.827 & 633.724 & 5808.501 & \text { Yes }\end{array}$ $\begin{array}{llllllllllllllll}0.85 & 25.89 & 27.23 & 20.95 & 3 & 1551.8620 & 1551.8501 & 518.2906 & 0.0119 & 7.6533 & 11940.885 & 15472.620 & 4399.397 & 21705.650 & \text { Yes }\end{array}$ $\begin{array}{lllllllllllllll}1.00 & 56.59 & 27.23 & 38.08 & 2 & 1551.8622 & 1551.8501 & 776.9323 & 0.0121 & 7.7870 & 1343.259 & 1109.089 & 501.367 & 1658.330 & \text { Yes }\end{array}$ $\begin{array}{lllllllllllllll}1.00 & 60.19 & 27.23 & 38.27 & 2 & 1551.8634 & 1551.8501 & 776.9323 & 0.0133 & 8.5592 & 2442.973 & 2019.125 & 599.128 & 3182.989 & \text { Yes }\end{array}$

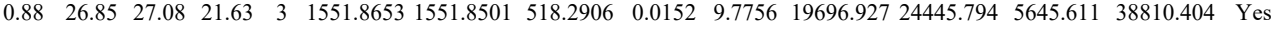
$\begin{array}{lllllllllllllll}1.00 & 62.18 & 26.97 & 24.30 & 2 & 1640.8022 & 1640.8015 & 821.4080 & 0.0007 & 0.4261 & 90.605 & 82.668 & 79.594 & 69.004 & \text { Yes }\end{array}$

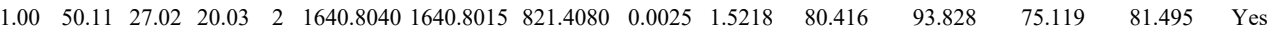
$\begin{array}{lllllllllllllll}1.00 & 43.34 & 26.78 & 22.43 & 2 & 1343.6714 & 1343.6699 & 672.8422 & 0.0015 & 1.1147 & 1683.914 & 1254.128 & 1353.286 & 1555.921 & \text { Yes }\end{array}$ $\begin{array}{lllllllllllllll}1.00 & 43.38 & 26.74 & 23.77 & 2 & 1343.6722 & 1343.6699 & 672.8422 & 0.0023 & 1.7092 & 2791.633 & 1985.477 & 1941.189 & 2179.042 & \text { Yes }\end{array}$ $\begin{array}{llllllllllllllll}0.99 & 37.52 & 26.81 & 20.77 & 2 & 1343.6710 & 1343.6699 & 672.8422 & 0.0011 & 0.8174 & 1281.286 & 1071.294 & 682.129 & 1045.520 & \text { Yes }\end{array}$ $\begin{array}{lllllllllllllll}0.98 & 30.87 & 26.78 & 21.08 & 2 & 1343.6714 & 1343.6699 & 672.8422 & 0.0015 & 1.1147 & 1077.416 & 849.167 & 728.989 & 1044.187 & \text { Yes }\end{array}$

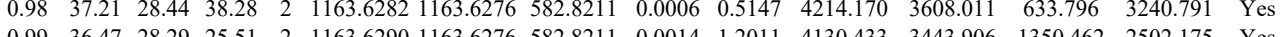
$\begin{array}{lllllllllllllll}0.99 & 36.47 & 28.29 & 25.51 & 2 & 1163.6290 & 1163.6276 & 582.8211 & 0.0014 & 1.2011 & 4130.433 & 3443.906 & 1350.462 & 2502.175 & \text { Yes }\end{array}$

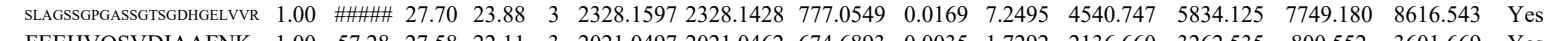

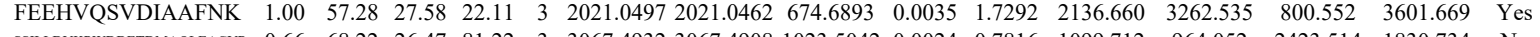
$\begin{array}{llllllllllllllll}\text { SSILLDVKPWDDETDMAQLEACVR } & 0.66 & 68.22 & 27.47 & 81.22 & 3 & 3067.4932 & 3067.4908 & 1023.5042 & 0.0024 & 0.7816 & 1099.712 & 964.052 & 2423.514 & 1830.734 & \text { No } \\ \text { LNVLEK } & 0.90 & 37.58 & 26.15 & 39.46 & 2 & 1002.6408 & 1002.6317 & 502.3231 & 0.0091 & .0578 & 7459.538 & 8055.634 & 1022.977 & 14555.456 & \text { Yes }\end{array}$ $\begin{array}{lllllllllllllllll}\text { LNVLEK } & 0.90 & 37.58 & 26.15 & 39.46 & 2 & 1002.6408 & 1002.6317 & 502.3231 & 0.0091 & 9.0578 & 7459.538 & 8055.634 & 1022.977 & 14555.456 & \text { Yes } \\ \text { IASLEVENQSLR } & 0.95 & 57.10 & 27.48 & 39.40 & 2 & 1501.8176 & 1501.8222 & 751.9184 & 0.0046 & -3.0589 & 2234.765 & 2530.470 & 330.342 & 5122.615 & \text { Yes }\end{array}$ $\begin{array}{llllllllllllllll}\text { TASLEVENQSLR } & 0.95 & 57.10 & 27.48 & 39.40 & 2 & 1501.8176 & 1501.8222 & 751.9184 & -0.0046 & -3.0589 & 2234.765 & 2530.470 & 330.342 & 5122.615 & \text { Yes } \\ \text { SSIUDVKPWDDETMAQLACYR } & 0.66 & 59.95 & 26.47 & 72.95 & 3 & 3067.4932 & 3067.4908 & 1023.5042 & 0.0024 & 0.7816 & 442.239 & 637.320 & 974.492 & 1225.978 & \text { Yes }\end{array}$

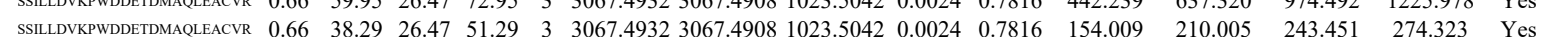


GVVQELQQAISK GVVQELQQAISK GVVQELQQAISK GVVQELQQAISK GVVQELQQAISK GVVQELQQAISK GVVQELQQAISK GVVQELQQAISK WFDK

GVVQELQQAISK GVVQELQAISK GVVQLQISK

GTVELQAISK

ATAPQTQHVSPMR

FYEQMNGPVAGAS

FYEQMNGPVAGASR ATAPQTQHVSPMR ATAPQTOHVSPMR ATAPQTQHVSPMR ATAPQTOHVSPMR ATAPQTQHVSPMR FYEQMNGPVAGASR ATAPQTQHVSPMR ATAPQTQHVSPMR ATAPQTQHVSPMR SIQLDGLVWGASK SIQLDGLVWGASK ATAPQTQHVSPMR ATAPQTQHVSPMR LVPVGYGIR LVPVGYGIR LVPVGYGIR LVPVGYGIR LVPVGYGIR ATAPQTQHVSPM VGTDLLEEEITK VGTDLLEEEITK

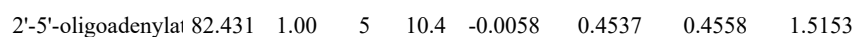

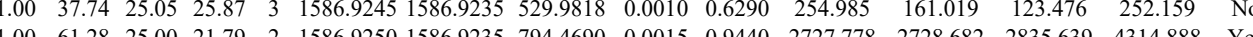
$\begin{array}{llllllllllllllll}1.00 & 70.70 & 25.00 & 23.38 & 2 & 1586.9252 & 1586.9235 & 794.4690 & 0.0017 & 1.0699 & 1009.070 & 1865.564 & 2030.025 & 2208.281 & \text { Yes }\end{array}$ $\begin{array}{ccccccccccccccc}1.00 & 53.75 & 25.00 & 24.83 & 3 & 1586.9254 & 1586.9235 & 529.9818 & 0.0019 & 1.1950 & 227.973 & 237.642 & 107.983 & 142.599 & \text { No } \\ 1.00 & 69.14 & 25.00 & 24.52 & 2 & 158.9252 & 15869235 & 794.4690 & 0.017 & 1.0699 & 4570.689 & 5463.488 & 5995.943 & 8437.698 & \text { Y }\end{array}$

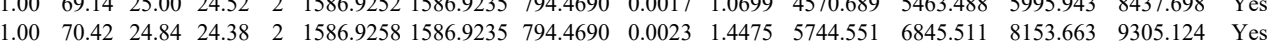
$\begin{array}{llllllllllllllll}1.00 & 51.28 & 24.91 & 26.19 & 3 & 1586.9263 & 1586.9235 & 529.9818 & 0.0028 & 1.7611 & 219.959 & 339.399 & 279.198 & 226.749 & \text { Yes }\end{array}$ $\begin{array}{lllllllllllllll}1.00 & 44.59 & 25.04 & 28.64 & 3 & 1586.9266 & 1586.9235 & 529.9818 & 0.0031 & 1.9497 & 249.464 & 279.067 & 324.112 & 382.429 & \text { Yes } \\ 0.61 & 28.97 * & 25.93 & 27.79 & 2 & 595.5708 & 595.5684 & 498.7915 & 0.0024 & 2.4058 & 6289.232 & 6517.879 & 5236.751 & 1154.905 & \text { Yes }\end{array}$ $\begin{array}{llllllllllllllllll}0.61 & 28.97 & 25.93 & 27.79 & 2 & 985.5708 & 995.5684 & 498.7915 & 0.0024 & 2.4058 & 6289.232 & 6517.879 & 5236.751 & 11514.905 & \text { Yes }\end{array}$

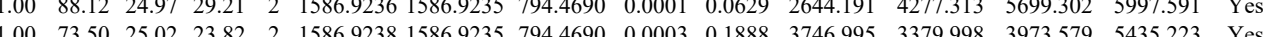

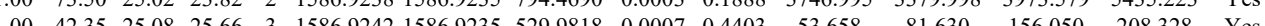

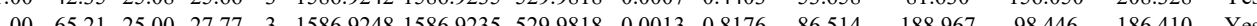

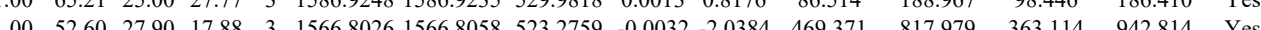
$\begin{array}{lllllllllllllll}1.00 & 47.98 & 27.91 & 17.41 & 3 & 1566.8056 & 1566.8058 & 523.2759 & -0.0002 & -0.1274 & 591.872 & 714.613 & 475.823 & 903.571 & \text { Yes }\end{array}$ $\begin{array}{llllllllllllll}1.00 & \# \# \# \# 26.79 & 24.22 & 2 & 1669.8142 & 1669.8004 & 835.9075 & 0.0138 & 8.2544 & 1215.082 & 1706.343 & 17.657 & 1283.708 & \text { No- }\end{array}$ $\begin{array}{lllllllllllllll}1.00 & 83.49 & 26.81 & 22.74 & 2 & 1669.8146 & 1669.8004 & 835.9075 & 0.0142 & 8.4937 & 2370.878 & 2678.883 & 132.076 & 2832.772 & \text { Yes }\end{array}$

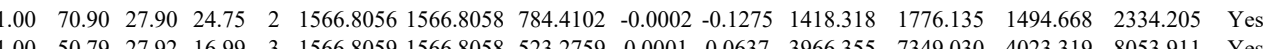
$\begin{array}{lllllllllllllllll}1.00 & 50.79 & 27.92 & 16.99 & 3 & 1566.8059 & 1566.8058 & 523.2759 & 0.0001 & 0.0637 & 3966.355 & 7349.030 & 4023.319 & 8053.911 & \text { Yes } \\ 1.00 & 64.70 & 27.75 & 24.43 & 2 & 1566.8070 & 1566.8058 & 784.4102 & 0.0012 & 0.7649 & 361.668 & 552.942 & 406.366 & 607.959 & \text { Yes }\end{array}$ $\begin{array}{lllllllllllllll}1.00 & 50.18 & 27.76 & 17.91 & 3 & 1566.8086 & 1566.8058 & 523.2759 & 0.0028 & 1.7836 & 13638.920 & 22827.706 & 17418.127 & 25309.302 & \text { Yes }\end{array}$

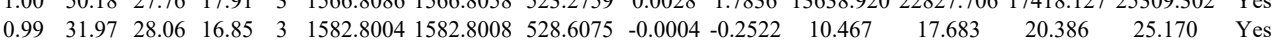

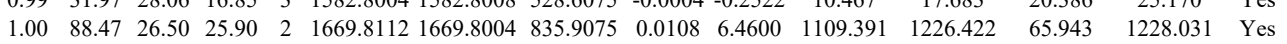
$\begin{array}{lllllllllllllll}1.00 & 48.39 & 27.69 & 16.50 & 3 & 1566.8074 & 1566.8058 & 523.2759 & 0.0016 & 1.0192 & 499.526 & 859.519 & 511.751 & 959.193 & \text { Yes }\end{array}$

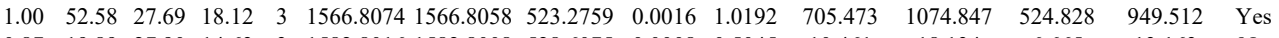
$\begin{array}{llllllllllllll}27.90 & 14.63 & 3 & 1582.8016 & 1582.8008 & 528.6075 & 0.0008 & 0.5045 & 10.461 & 18.134 & 6.665 & 13.163 & \text { No } \\ \end{array}$

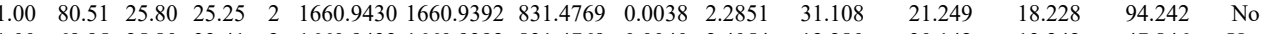

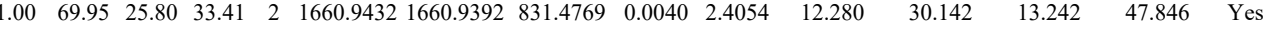

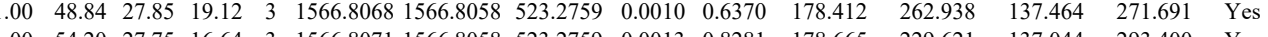
$\begin{array}{lllllllllllllll}1.00 & 54.20 & 27.75 & 16.64 & 3 & 1566.8071 & 1566.8058 & 523.2759 & 0.0013 & 0.8281 & 178.665 & 229.621 & 137.044 & 293.400 & \text { Yes }\end{array}$ $\begin{array}{lllllllllllllllll}0.50 & 19.61 & 24.59 & 23.76 & 2 & 1116.6866 & 1116.6777 & 559.3461 & 0.0089 & 7.9557 & 12991.413 & 18003.680 & 2584.443 & 31334.329 & \text { Yes }\end{array}$ $\begin{array}{lllllllllllllll}0.82 & 26.44 & 24.76 & 20.81 & 2 & 1116.6870 & 116.6777 & 559.3461 & 0.0093 & 8.3132 & 16890.633 & 22697.452 & 1131.536 & 37558.465 & \text { Yes }\end{array}$

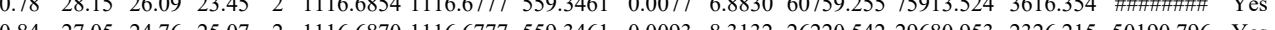
$\begin{array}{llllllllllllllll}0.84 & 27.05 & 24.76 & 25.07 & 2 & 1116.6870 & 1116.6777 & 559.3461 & 0.0093 & 8.3132 & 26220.542 & 29680.953 & 2326.215 & 50190.796 & \text { Yes }\end{array}$

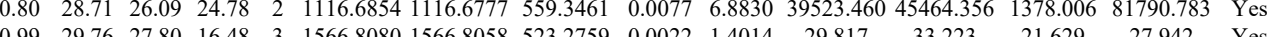
$\begin{array}{ccccccccccccccc}0.99 & 29.76 & 27.80 & 16.48 & 3 & 1566.8080 & 1566.8058 & 523.2759 & 0.0022 & 1.4014 & 29.817 & 33.223 & 21.629 & 27.942 & \text { Yes } \\ 1.00 & 65.10 & 27.90 & 31.08 & 2 & 1633.9032 & 1633.9018 & 817.9582 & 0.0014 & 0.8558 & 3379.821 & 4416.222 & 5647.163 & 7404.199 & \text { Yes }\end{array}$

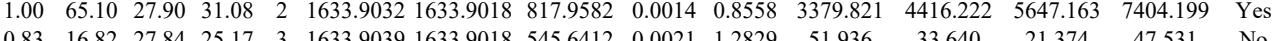

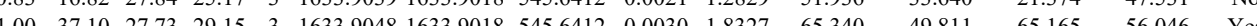
\begin{tabular}{|lllllllllllllllll} 
&
\end{tabular}

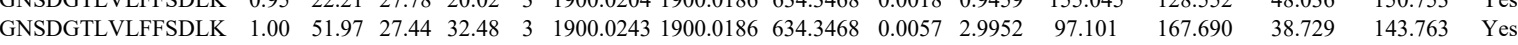
$\begin{array}{lllllllllllllllll}\text { TNASPGEFAVCFTELQQK } & 0.67 & 20.61 & 27.19 & 33.61 & 3 & 2303.1202 & 2303.1170 & 768.7129 & 0.0032 & 13876 & 16.134 & 49.782 & 0.000 & 59.599 & \text { No }\end{array}$

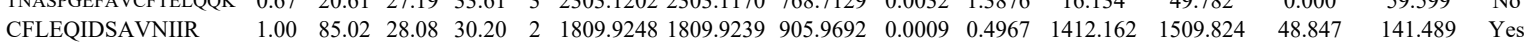

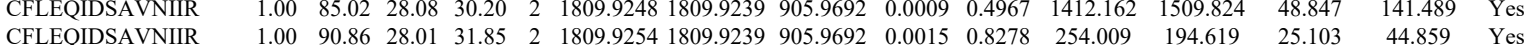

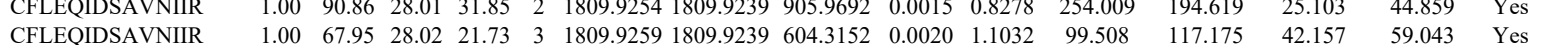

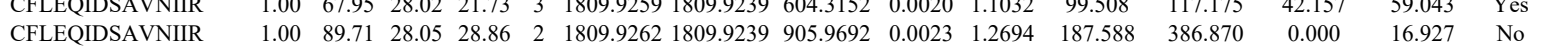

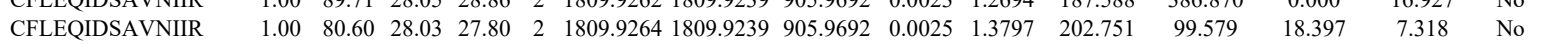
$\begin{array}{llllllllllllllll}\text { CFLEQIDSAVNIIR } & 1.00 & 63.28 & 27.99 & 22.49 & 3 & 1809.9271 & 1809.9239 & 604.3152 & 0.0032 & 1.7651 & 148.384 & 106.313 & 45.225 & 76.270 & \text { Yes }\end{array}$ $\begin{array}{lllllllllllllll}\text { CFLEQIDSAVNIIR } & 1.00 & \text { \#\#\# } 28.04 & 33.41 & 2 & 1809.9266 & 1809.9239 & 905.9692 & 0.0027 & 1.4901 & 302.541 & 301.120 & 8.851 & 138.041 & \text { Yes }\end{array}$

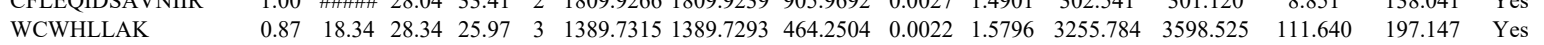
$\begin{array}{lllllllllllllllll}\text { TRPVILDPAEPTGDVGGGDR } & 1.00 & 48.59 & 27.47 & 16.73 & 3 & 2165.1232 & 2165.1199 & 722.7139 & 0.0033 & 1.5220 & 1533.849 & 925.524 & 445.338 & 1008.377 & \text { Yes }\end{array}$ $\begin{array}{lllllllllllllllll}\text { TRPVILDPAEPTGDVGGGDR } & 0.98 & 25.02 & 27.47 & 14.61 & 3 & 2165.1232 & 2165.1199 & 722.7139 & 0.0033 & 1.5220 & 681.641 & 903.966 & 159.094 & 667.843 & \text { Yes }\end{array}$

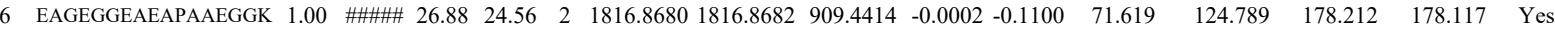

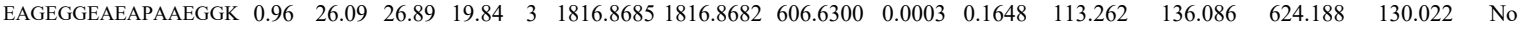
$\begin{array}{lllllllllllllll}\text { EAGEGGEAEAPAAEGGK } & 1.00 & 26.85 & 25.55 & 2 & 1816.8698 & 1816.8682 & 909.4414 & 0.0016 & 0.8797 & 90.284 & 99.764 & 221.224 & 122.561 & \text { Yes }\end{array}$ $\begin{array}{lllllllllllllllll}\text { AAEEPSKVEEK } & 0.58 & 27.18 & 27.40 & 21.02 & 3 & 1647.9061 & 1647.9044 & 550.3087 & 0.0017 & 1.0297 & 2881.619 & 5137.063 & 3139.962 & 4731.932 & \text { Yes }\end{array}$ $\begin{array}{llllllllllllllll}\text { AEDGATPSPSNETPK } & 0.67 & 14.31 & 26.95 & 14.73 & 3 & 1787.8789 & 1787.8781 & 596.9666 & 0.0008 & 0.4467 & 195.624 & 129.484 & 215.159 & 222.967 & \text { Yes }\end{array}$ $\begin{array}{llllllllllllllll}\text { EAGEGGEAEAPAAEGGK } & 0.97 & 24.66 & 26.84 & 17.98 & 3 & 1816.8694 & 1816.8682 & 606.6300 & 0.0012 & 0.6594 & 141.381 & 91.728 & 162.247 & 148.126 & \text { Yes }\end{array}$ $\begin{array}{cccccccccccccc} & \end{array}$ $\begin{array}{lllllllllllllllll} & \end{array}$

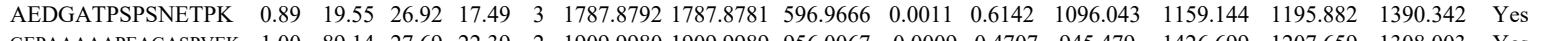
\begin{tabular}{llllllllllllllll} 
GEPAAAAAPEAGASPVEK & 1.00 & 89.14 & 27.69 & 22.39 & 2 & 1909.9980 & 1909.9989 & 956.0067 & -0.0009 & -0.4707 & 945.479 & 1426.699 & 1207.659 & 1308.003 & Yes \\
\hline
\end{tabular} \begin{tabular}{llllllllllllllll} 
GEPAAAAAPEAGASPVEK & 1.00 & 97.00 & 27.81 & 20.79 & 2 & 1909.9990 & 1909.9989 & 956.0067 & 0.0001 & 0.0523 & 790.827 & 1277.411 & 1078.015 & 1291.734 & Yes \\
\hline
\end{tabular} \begin{tabular}{llllllllllllllllll} 
& GEPAAAAAPEAGASPVEK & 1.00 & 34.08 & 27.63 & 19.72 & 3 & 1910.0011 & 1909.9989 & 637.6736 & 0.0022 & 1.1500 & 948.243 & 1212.819 & 2634.865 & 854.419 & Yes \\
\hline
\end{tabular}

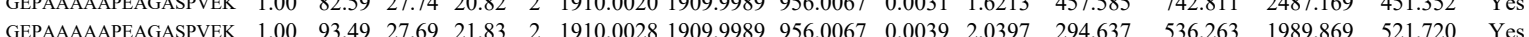

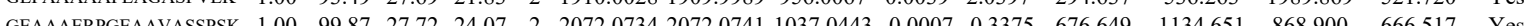
$\begin{array}{llllllllllllllllll}\text { GEAAAERPGEAAVASSPSK } & 1.00 & 58.40 & 27.56 & 21.43 & 3 & 2072.0770 & 2072.0741 & 691.6986 & 0.0029 & 1.3975 & 14942.888 & 26868.247 & 24233.939 & 20381.647 & \text { Yes }\end{array}$ 


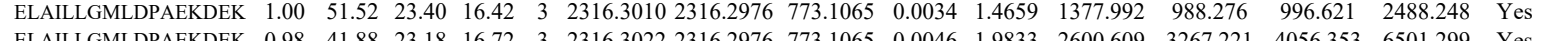
\begin{tabular}{lllllllllllllllll} 
& ELAILLGMLDPAEKDEK \\
\hline
\end{tabular} \begin{tabular}{llllllllllllllll}
\hline ELALLGMLDPAKDEK & 1.00 & 31.55 & 23.20 & 19.17 & 4 & 2316.303 & 2316.2976 & 580.0817 & 0.0057 & 2.1565 & 949.964 & 852.245 & 1082.144 & 1823.914 & Yes
\end{tabular}

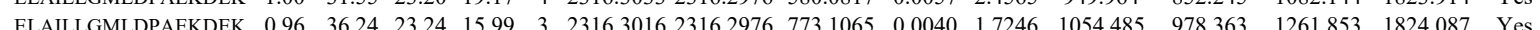
$\begin{array}{lllllllllllllll} & 13.363 & 126.858 & 1824.087 & \text { Yes }\end{array}$

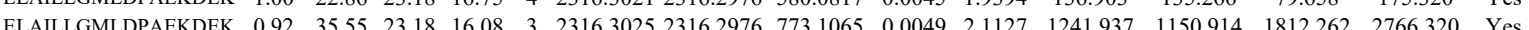

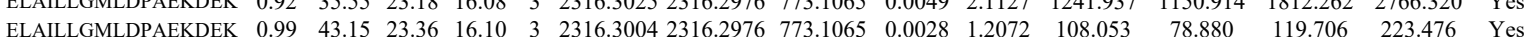
$\begin{array}{lllllllllllllllll} & \text { ELAILLGMLDPAEKDEK } & 1.00 & 27.85 & 23.32 & 15.52 & 4 & 23163005 & 23162976 & 580.0817 & 0.0029 & 1.2498 & 134.632 & 155.915 & 77.783 & 185.856 & \text { Yes }\end{array}$

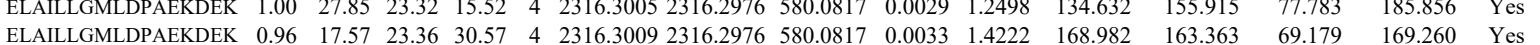

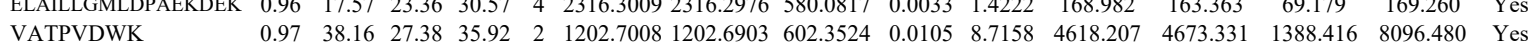

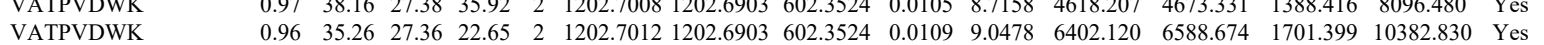

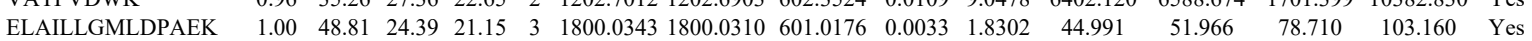
$\begin{array}{lllllllllllllllll}\text { ELAILLGMLDPAEK } & 1.00 & 47.85 & 24.35 & 20.22 & 3 & 1800.0349 & 1800.0310 & 601.0176 & 0.0039 & 2.1630 & 130.926 & 139.293 & 241.671 & 318.863 & \text { Yes }\end{array}$ $\begin{array}{llllllllllllllllll}\text { ELAILLGMLDPAEK } & 1.00 & 44.65 & 24.42 & 16.92 & 3 & 1800.0340 & 1800.0310 & 601.0176 & 0.0030 & 1.6638 & 135.185 & 140.349 & 203.904 & 266.083 & \text { Yes }\end{array}$ $\begin{array}{llllllllllllllll}\text { ELAILLGMLDPAEK } & 1.00 & 92.96 & 24.39 & 32.59 & 2 & 1800.0342 & 1800.0310 & 901.0228 & 0.0032 & 1.7758 & 13.193 & 7.345 & 12.559 & 39.717 & \text { Yes }\end{array}$ $\begin{array}{llllllllllllllll}\text { ELAILLGMLDPAEK } & 1.00 & 40.43 & 24.42 & 18.67 & 3 & 1800.0346 & 1800.0310 & 601.0176 & 0.0036 & 1.9966 & 120.351 & 106.778 & 110.479 & 214.704 & \text { Yes }\end{array}$ $\begin{array}{llllllllllllllll}\text { ELAILLGMLDPAEK } & 1.00 & 65.62 & 24.42 & 40.01 & 2 & 1800.0346 & 1800.0310 & 901.0228 & 0.0036 & 1.9977 & 12.256 & 1.780 & 12.967 & 3.969 & \text { No }\end{array}$ $\begin{array}{llllllllllllllll}\text { LIALSIDSVEDHLAWSK } & 0.60 & 56.00 & 25.02 & 69.00 & 3 & 2184.2077 & 2184.2034 & 729.0751 & 0.0043 & 1.9660 & 1787.800 & 2355.816 & 496.758 & 3889.916 & \text { Yes }\end{array}$

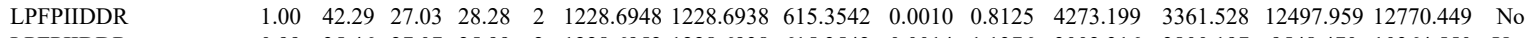
$\begin{array}{llllllllllllllll}\text { LPFPIIDDR } & 0.99 & 35.46 & 27.07 & 25.99 & 2 & 1228.6952 & 1228.6938 & 615.3542 & 0.0014 & 1.1376 & 3002.316 & 3800.197 & 9548.470 & 10364.550 & \text { Yes }\end{array}$ $\begin{array}{llllllllllllllll}\text { LIALSIDSVEDHLAWSK } & 1.00 & 60.62 & 25.17 & 16.96 & 3 & 2184.2059 & 2184.2034 & 729.0751 & 0.0025 & 1.1430 & 3196.756 & 2894.970 & 318.088 & 6017.275 & \text { Yes }\end{array}$ $\begin{array}{lllllllllllllllll}\text { LIALSIDSVEDHLAWSK } & 0.60 & 53.05 & 25.08 & 66.05 & 3 & 2184.2071 & 2184.2034 & 729.0751 & 0.0037 & 1.6916 & 4302.123 & 4870.631 & 1244.188 & 8662.179 & \text { Yes }\end{array}$ $\begin{array}{llllllllllllllll}\text { GMPVTAR } & 0.68 & 23.83 & 29.24 & 31.17 & 2 & 874.4816 & 874.4817 & 438.2481 & -0.0001 & -0.1141 & 221.920 & 260.311 & 77.167 & 305.064 & \text { Yes }\end{array}$

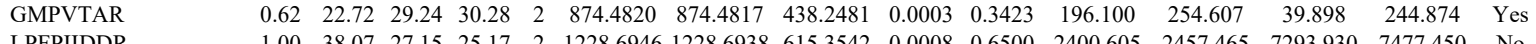

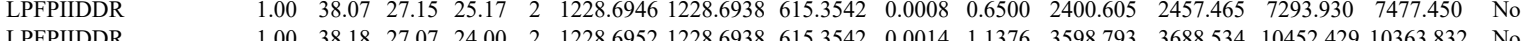
$\begin{array}{llllllllllllllll}\text { LPFPIIDDR } & 1.00 & 38.18 & 2.157 & 25.00 & 2 & 1228.6952 & 1228.6938 & 615.3542 & 0.0014 & 1.1376 & 3598.793 & 3688.534 & 10452.429 & 10363.832 & \text { No }\end{array}$

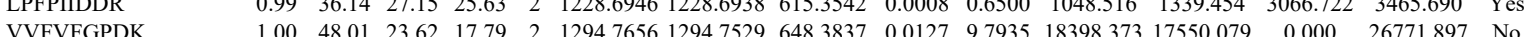
$\begin{array}{llllllllllllllllll} & \text { VVFVFGPK } & 1.00 & 48.01 & 23.62 & 17.79 & 2 & 1294.7656 & 1294.7529 & 648.3837 & 0.0127 & 9.7935 & 18398.373 & 17550.079 & 0.000 & 26771.897 & \text { No }\end{array}$

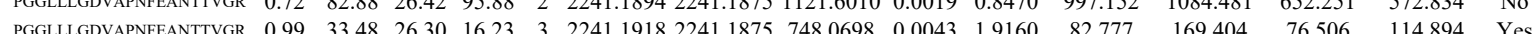

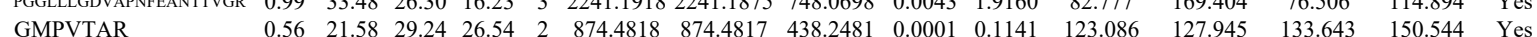

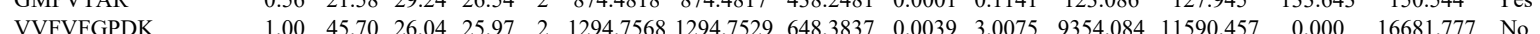

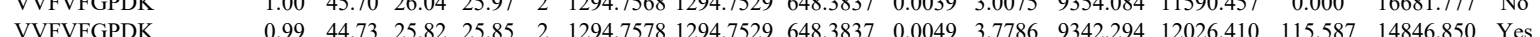

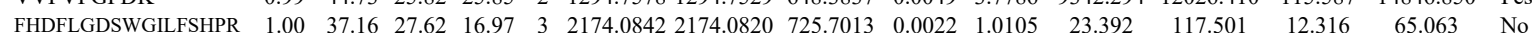

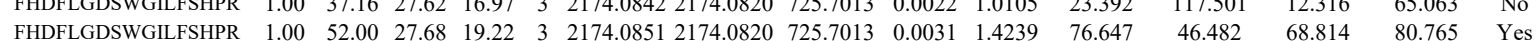
$\begin{array}{llllllllllllllll}\text { FHDFLGDSWGILFSHPR } & 1.00 & 55.57 & 27.69 & 68.57 & 4 & 2174.0857 & 2174.0820 & 544.5278 & 0.0037 & 1.6987 & 645.669 & 877.513 & 221.352 & 1174.191 & \text { Yes }\end{array}$

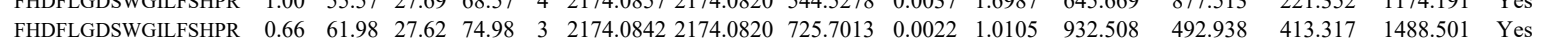
$\begin{array}{llllllllllllllll}\text { FHDFLGDSWGILFSHPR } & 0.67 & 69.47 & 27.66 & 82.47 & 3 & 2174.0848 & 2174.0820 & 725.7013 & 0.0028 & 1.2861 & 1655.839 & 1188.379 & 438.628 & 2353.857 & \text { Yes }\end{array}$ $\begin{array}{llllllllllllllll}\text { FHDFLGDSWGILFSHPR } & 1.00 & 51.43 & 27.65 & 21.04 & 4 & 2174.0853 & 2174.0820 & 544.5278 & 0.0033 & 1.5151 & 2732.000 & 2232.736 & 717.451 & 5245.884 & \text { Yes }\end{array}$ $\begin{array}{llllllllllllllll}\text { FHDFLGDSWGILFSHPR } & 1.00 & 48.68 & 27.67 & 20.17 & 4 & 2174.0869 & 2174.0820 & 544.5278 & 0.0049 & 2.2497 & 3573.988 & 3184.212 & 1251.625 & 3788.198 & \text { Yes }\end{array}$

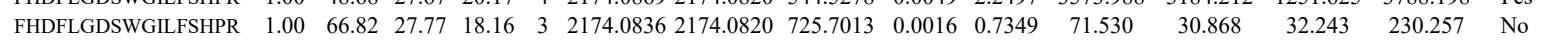
$\begin{array}{lllllllllllllllll}\text { FHDFLGDSWGILFSHPR } & 1.00 & 52.95 & 27.63 & 16.67 & 4 & 2174.0845 & 2174.0820 & 544.5278 & 0.0025 & 1.1478 & 1935.131 & 1886.561 & 698.121 & 3031.759 & \text { Yes }\end{array}$ $\begin{array}{lllllllllllllllll}\text { FHDFLGDSWGILFSHPR } & 1.00 & 45.11 & 27.70 & 16.60 & 4 & 2174.0861 & 2174.0820 & 544.5278 & 0.0041 & 1.8824 & 1243.840 & 1589.211 & 665.211 & 2180.469 & \text { Yes }\end{array}$ $\begin{array}{lllllllllllllllll}\text { LSILYPATTGR } & 0.99 & 48.73 & 26.46 & 37.46 & 2 & 1334.7770 & 1334.7680 & 668.3913 & 0.0090 & 6.7325 & 18769.647 & 24125.126 & 0.000 & 33404.223 & \text { No }\end{array}$ $\begin{array}{llllllllllllllll}\text { LSILYPATTGR } & 0.98 & 42.63 & 26.39 & 37.21 & 2 & 1334.7802 & 1334.7680 & 668.3913 & 0.0122 & 9.1263 & 10203.021 & 11800.148 & 0.000 & 18121.839 & \text { No }\end{array}$ $\begin{array}{llllllllllllllll}\text { LSILYPATTGR } & 0.99 & 51.56 & 26.53 & 38.04 & 2 & 1334.7748 & 1334.7680 & 668.3913 & 0.0068 & 5.0868 & 7023.224 & 8578.475 & 0.000 & 10557.578 & \text { No }\end{array}$ $\begin{array}{llllllllllllllll}\text { LSILYPATTGR } & 1.00 & 56.18 & 26.53 & 36.14 & 2 & 1334.7748 & 1334.7680 & 668.3913 & 0.0068 & 5.0868 & 16662.933 & 18143.683 & 0.000 & 24536.561 & \text { No }\end{array}$ $\begin{array}{llllllllllllllll}\text { LSILYPATTGR } & 0.99 & 49.20 & 26.69 & 37.86 & 2 & 1334.7730 & 1334.7680 & 668.3913 & 0.0050 & 3.7403 & 5316.435 & 5393.643 & 236.292 & 9323.231 & \text { Yes }\end{array}$ $\begin{array}{llllllllllllllllll}\text { LSILYPATTGR } & 0.98 & 47.41 & 26.57 & 37.59 & 2 & 1334.7740 & 1334.7680 & 668.3913 & 0.0060 & 4.4884 & 2598.147 & 3223.965 & 379.958 & 4268.041 & \text { Yes }\end{array}$

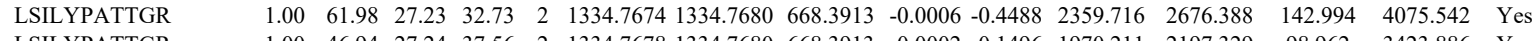

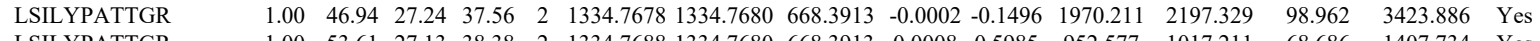
$\begin{array}{llllllllllllllll}\text { LSILYPATTGR } & 1.00 & 53.61 & 27.13 & 38.38 & 2 & 1334.7688 & 1334.7680 & 668.3913 & 0.0008 & 0.5985 & 952.577 & 1017.211 & 68.686 & 1407.734 & \text { Yes } \\ \text { LSLYPATTGR } & 1.00 & 46.32 & 27.02 & 35.42 & 2 & 1334.768 & 1334.780 & 688.3913 & 0.0018 & 13465 & 527.191 & 620.83 & 134.42 & 817.621 & \text { Yes }\end{array}$

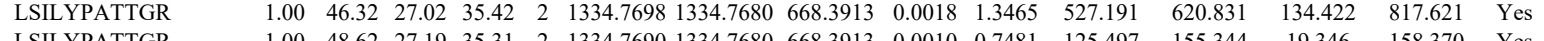

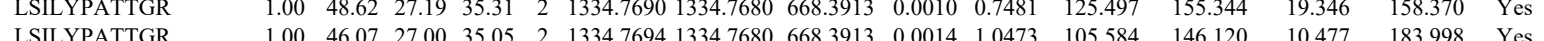

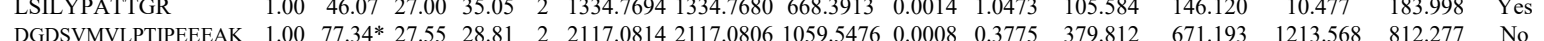

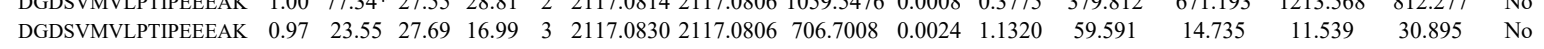

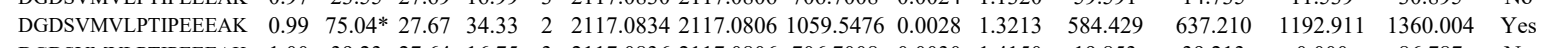

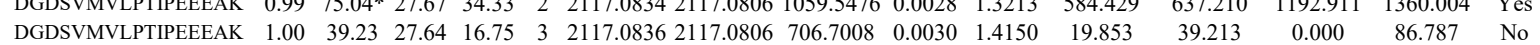

Table S-4 page 256 of 614 


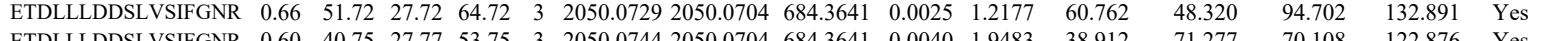

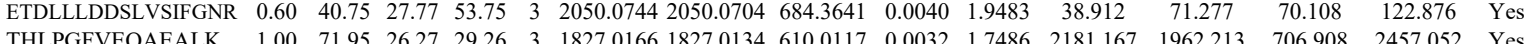

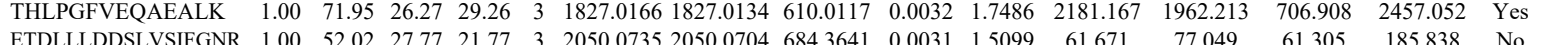
$\begin{array}{llllllllllllll} & \end{array}$ $\begin{array}{lllllllllllllll} & \end{array}$

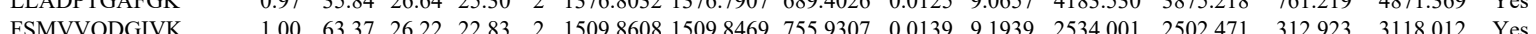

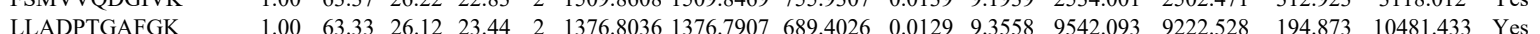
$\begin{array}{llllllllllllllll}\text { LLADPTGAFGK } & 1.00 & 61.53 & 26.18 & 23.58 & 2 & 1376.8038 & 1376.7907 & 689.4026 & 0.0131 & 9.5009 & 15083.856 & 14851.667 & 293.309 & 16547.797 & \text { Yes }\end{array}$ $\begin{array}{lllllllllllllllll}\text { FSMVVQDGIVK } & 1.00 & 63.81 & 26.02 & 21.92 & 2 & 1509.8598 & 1509.8469 & 755.9307 & 0.0129 & 8.5325 & 821.692 & 915.237 & 66.522 & 1067.876 & \text { Yes }\end{array}$

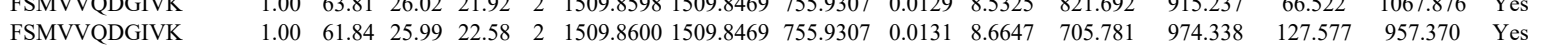
$\begin{array}{llllllllllllllll}\text { LLADPTGAFGK } & 1.00 & 63.25 & 26.18 & 23.80 & 2 & 1376.8038 & 13767907 & 689.4026 & 0.0131 & 9.5009 & 10549.309 & 9524.209 & 262.578 & 10275.704 & \text { Yes }\end{array}$ $\begin{array}{llllllllllllllll}\text { ILNVEPDGTGLTCSLAPNISQL } & 0.88 & 32.01 & 27.21 & 21.61 & 2 & 2515.2774 & 2515.2784 & 1258.6465 & -0.0010 & -0.3973 & 1.983 & 0.000 & 3.943 & 1.258 & \text { No }\end{array}$

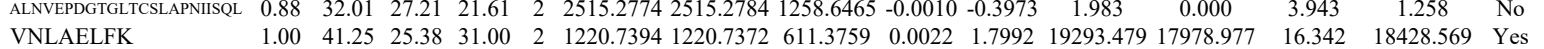

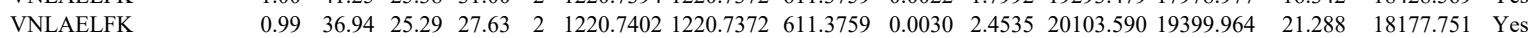

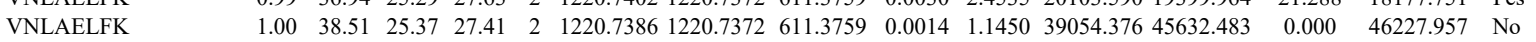

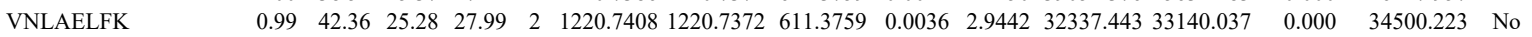

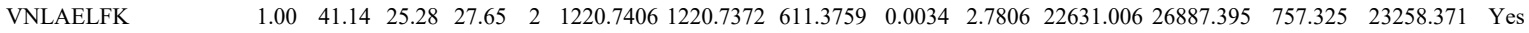
$\begin{array}{lllllllllllllllll}0.99 & 39.92 & 25.28 & 27.71 & 2 & 1220.7408 & 1220.7372 & 611.3759 & 0.0036 & 2.9442 & 24947.825 & 25967.437 & 763.051 & 26181.889 & \text { Yes }\end{array}$ $\begin{array}{llllllllllllllll}\text { VNLAELFK } & 1.00 & 36.80 & 25.37 & 27.29 & 2 & 1220.7390 & 1220.7372 & 611.3759 & 0.0018 & 1.4721 & 5512.120 & 5989.693 & 35.032 & 6165.061 & \text { Yes }\end{array}$ $\begin{array}{llllllllllllllll}\text { GVLFGVPGAFTPGCSK } & 1.00 & 84.28 & 27.23 & 25.59 & 2 & 1869.9740 & 1869.9725 & 935.9935 & 0.0015 & 0.8013 & 946.551 & 1453.419 & 333.287 & 946.769 & \text { Yes }\end{array}$ $\begin{array}{lllllllllllllllll}\text { GVLFGVPGAFTPGCSK } & 1.00 & 89.49 & 27.23 & 25.67 & 2 & 1869.9740 & 1869.9725 & 935.9935 & 0.0015 & 0.8013 & 2113.533 & 3295.222 & 505.548 & 1967.283 & \text { Yes }\end{array}$ $\begin{array}{llllllllllllllllll}\text { GVLFGVPGAFTPGCSK } & 1.00 & 45.01 & 27.17 & 17.59 & 3 & 1869.9751 & 1869.9725 & 624.3314 & 0.0026 & 1.3881 & 1210.025 & 1092.371 & 311.820 & 1305.330 & \text { Yes }\end{array}$ $\begin{array}{llllllllllllllll}\text { GVLFGVPGAFTPGCSK } & 0.60 & 45.20 & 27.10 & 58.20 & 3 & 1869.9769 & 1869.9725 & 624.3314 & 0.0044 & 2.3492 & 662.942 & 457.447 & 351.195 & 882.301 & \text { Yes }\end{array}$ $\begin{array}{llllllllllllllll}\text { GVLFGVPGAFTPGCSK } & 1.00 & 94.74 & 27.33 & 24.99 & 2 & 1869.9698 & 1869.9725 & 935.9935 & -0.0027 & -1.4423 & 410.277 & 458.219 & 65.764 & 433.546 & \text { Yes }\end{array}$

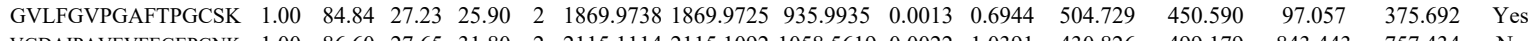
$\begin{array}{llllllllllllllll}\text { VGDAIPAVEVFEGEPGNK } & 1.00 & 86.60 & 27.65 & 31.80 & 2 & 2115.1114 & 2115.1092 & 1058.5619 & 0.0022 & 1.0391 & 430.826 & 499.179 & 843.443 & 757.434 & \text { No }\end{array}$

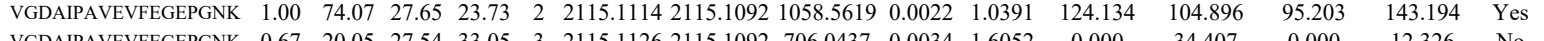

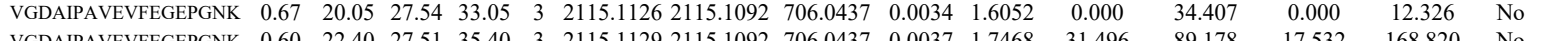

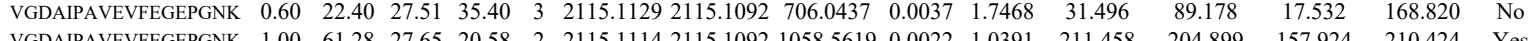

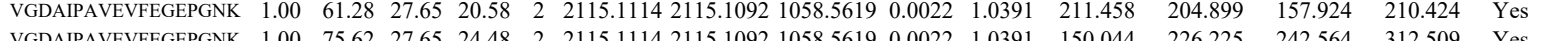
VGDAIPAVEVEFGEPGN

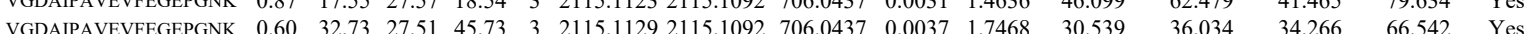

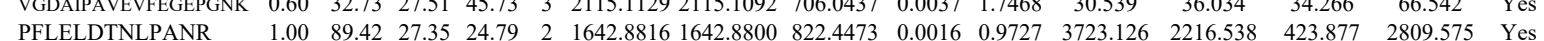

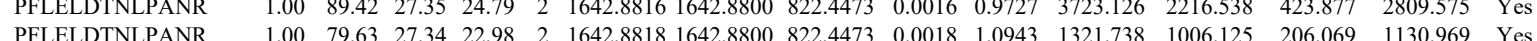

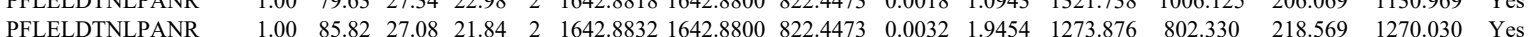
FFPLESWQIGK FFPLESWQIGK FFPLESWQIGK FFPLESWQIGK FFPLESWQIGK FFPLESWQIGK IGTVMTFL IGTVMTFL

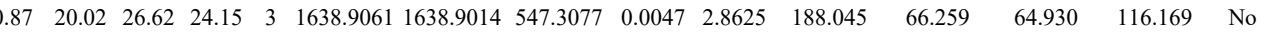

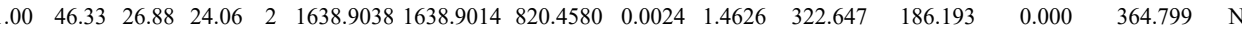
$\begin{array}{lllllllllllllll}0.99 & 40.33 & 26.80 & 21.05 & 2 & 1638.9040 & 1638.9014 & 820.4580 & 0.0026 & 1.5845 & 247.415 & 157.726 & 43.421 & 379.357 & \text { Yes }\end{array}$

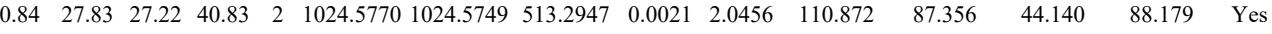

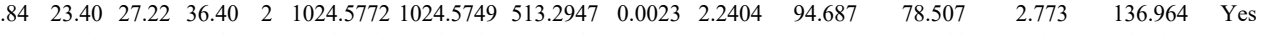

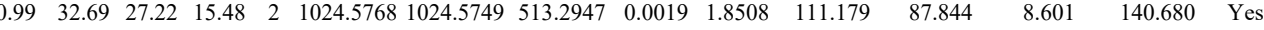
$\begin{array}{lllllllllllllll}0.93 & 25.90 & 27.44 & 18.30 & 2 & 1024.5764 & 1024.5749 & 513.2947 & 0.0015 & 1.4611 & 71.886 & 81.934 & 27.884 & 111.360 & \text { Yes }\end{array}$ $\begin{array}{lllllllllllllll}0.84 & 29.19 & 27.44 & 42.19 & 2 & 1024.5766 & 1024.5749 & 513.2947 & 0.0017 & 1.6560 & 85.311 & 63.715 & 46.028 & 89.811 & \text { No }\end{array}$ $\begin{array}{lllllllllllllll}1.00 & 49.11 & 27.08 & 30.30 & 2 & 1308.7390 & 1308.7281 & 655.3713 & 0.0109 & 8.3158 & 17147.026 & 12156.495 & 7444.873 & 13064.000 & \text { Yes }\end{array}$ $\begin{array}{llllllllllllllll}1.00 & 52.45 & 27.32 & 31.89 & 2 & 1308.7392 & 1308.7281 & 655.3713 & 0.0111 & 8.4684 & 15397.195 & 9253.586 & 5625.388 & 10777.205 & \text { Yes }\end{array}$ $\begin{array}{lllllllllllllll}0.99 & 39.83 & 27.14 & 24.11 & 2 & 1308.7410 & 1308.7281 & 655.3713 & 0.0129 & 9.8417 & 11992.051 & 10986.662 & 4307.960 & 10184.252 & \text { Yes }\end{array}$

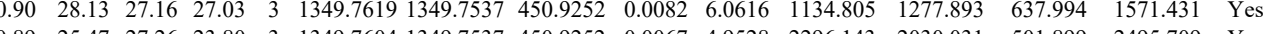
$\begin{array}{lllllllllllllll}0.89 & 25.47 & 27.26 & 23.80 & 3 & 1349.7604 & 1349.7537 & 450.9252 & 0.0067 & 4.9528 & 2296.143 & 2030.031 & 501.899 & 2495.709 & \text { Yes }\end{array}$ $\begin{array}{lllllllllllllll}1.00 & 65.51 & 21.34 & 27.87 & 2 & 1572.9530 & 1572.9483 & 787.4814 & 0.0047 & 2.9842 & 712.144 & 530.652 & 108.356 & 756.523 & \text { Yes }\end{array}$ $\begin{array}{llllllllllllllll}1.00 & 59.99 & 21.70 & 27.40 & 2 & 1572.9510 & 1572.9483 & 787.4814 & 0.0027 & 1.7143 & 725.279 & 697.743 & 220.814 & 651.407 & \text { Yes }\end{array}$ $\begin{array}{lllllllllllllll} & 1.01 .269 & 919.597 & \text { Yes }\end{array}$ $\begin{array}{llllllllllll} & \end{array}$

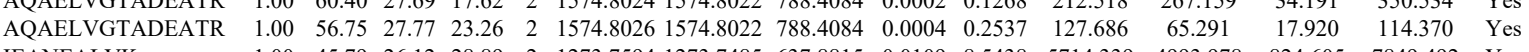
$\begin{array}{lllllllllllllllll} & \text { IEANEALVK } & 1.00 & 45.79 & 26.12 & 28.89 & 2 & 1273.7594 & 1273.7485 & 637.8815 & 0.0109 & 8.5438 & 5714.339 & 4993.978 & 824.605 & 7849.492 & \text { Yes }\end{array}$

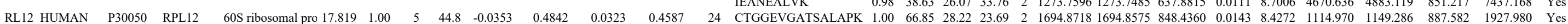




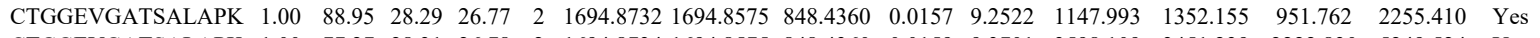
$\begin{array}{lllllllllllllllll}\text { CTGGEVGATSALAPK } & 1.00 & 77.27 & 28.31 & 26.78 & 2 & 1694.8734 & 1694.8575 & 848.4360 & 0.0159 & 9.3701 & 3598.109 & 3451.239 & 2222.830 & 5249.524 & \text { Yes } \\ \text { CTGGEVGATSALAPK } & 1.00 & 81.31 & 28.23 & 27.11 & 2 & 1694.8744 & 1694.8575 & 848.4360 & 0.0169 & 9.9594 & 2769.675 & 2662.847 & 1885.835 & 4193.879 & \text { Yes }\end{array}$ $\begin{array}{llllllllllllllll}\text { CTGGEVGATSALAPK } & 1.00 & 81.31 & 28.23 & 27.11 & 2 & 1694.8744 & 1694.8575 & 848.4360 & 0.0169 & 9.9594 & 2769.675 & 2662.847 & 1885.835 & 4193.879 & \text { Yes } \\ \text { HSGNITFDEIVNIAR } & 0.99 & 38.08 & 27.60 & 19.29 & 3 & 1828.9726 & 1828.9553 & 610.6590 & 0.0173 & 9.4433 & 612.776 & 569.108 & 266.011 & 643.082 & \text { Yes }\end{array}$ $\begin{array}{lllllllllllllllll}\text { HSGNITFDEIVNIAR } & 1.00 & 52.27 & 27.52 & 25.63 & 3 & 1828.9729 & 1828.9553 & 610.6590 & 0.0176 & 9.6070 & 404.778 & 397.944 & 188.865 & 523.872 & \text { Yes }\end{array}$ $\begin{array}{llllllllllllllll}\text { QAQIEVVPSASALIIK } & 1.00 & 63.96 & 17.56 & 18.08 & 2 & 1954.1708 & 1954.1706 & 978.0926 & 0.0002 & 0.1022 & 1389.484 & 2129.275 & 1183.981 & 2981.622 & \text { Yes }\end{array}$

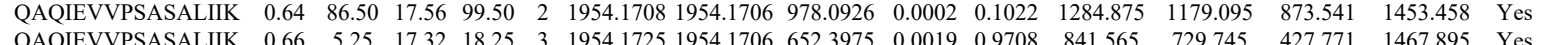
\begin{tabular}{lllllllllllllllll} 
QAQIEVVPSASALIIK & 0.66 & 5.25 & 17.32 & 18.25 & 3 & 1954.1725 & 1954.1706 & 652.3975 & 0.0019 & 0.9708 & 841.565 & 729.745 & 427.771 & 1467.895 & Yes \\
\hline QAQIEVVPSASALIK & 1.00 & 49.69 & 17.32 & 23.02 & 3 & 1954.1731 & 1954.1706 & 652.3975 & 0.0025 & 1.2773 & 1559.805 & 1137.574 & 1139.850 & 1437.65 & Yes
\end{tabular} $\begin{array}{llllllllllllllll}\text { QAQIEVVPSASALIIK } & 1.00 & 49.69 & 17.32 & 23.02 & 3 & 1954.1731 & 1954.1706 & 652.3975 & 0.0025 & 1.2773 & 1559.805 & 1137.574 & 1139.850 & 1437.605 & \text { Yes } \\ \text { HSGNITFDEIVNIAR } & 0.98 & 32.66 & 27.63 & 21.07 & 3 & 1828.9546 & 1828.9553 & 610.6590 & -0.0007 & 0.3821 & 1165.922 & 1169.072 & 300.072 & 2741.847 & \text { No }\end{array}$

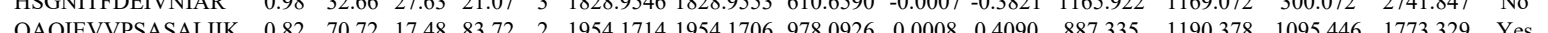

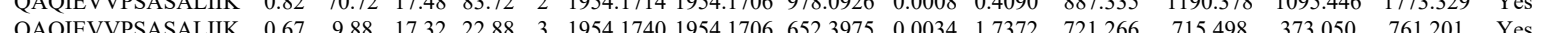
$\begin{array}{llllllllllllllll} & \end{array}$

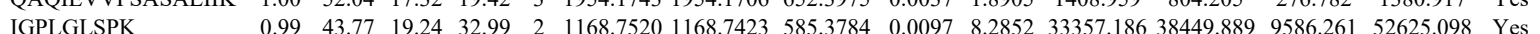

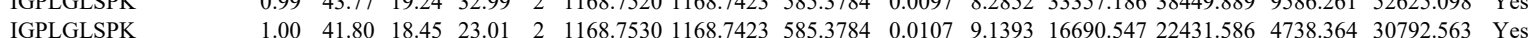

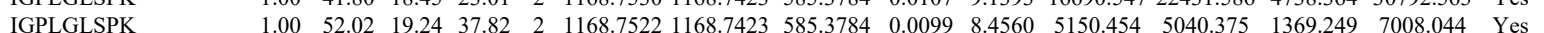
$\begin{array}{lllllllllllllllll}\text { IGPLGLSPK } & 1.00 & 46.85 & 17.78 & 26.22 & 2 & 1168.7532 & 1168.7423 & 585.3784 & 0.0109 & 9.3101 & 11802.789 & 13537.289 & 1990.192 & 15382.966 & \text { Yes }\end{array}$

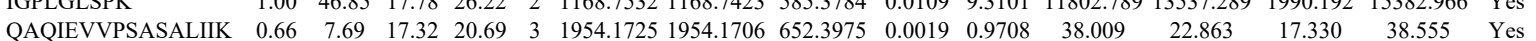
$\begin{array}{llllllllllllllll}\text { QAQIEVVPSASALIIK } & 0.55 & 16.57 & 17.48 & 29.57 & 3 & 1954.1713 & 1954.1706 & 652.3975 & 0.0007 & 0.3577 & 19.340 & 2.596 & 17.116 & 27.752 & \text { Yes }\end{array}$ \begin{tabular}{llllllllllllllll} 
HPHDIIDDINSGAVECPAS & 1.00 & 99.43 & 24.33 & 19.64 & 2 & 2178.9814 & 2178.9796 & 1090.4971 & 0.0018 & 0.8253 & 184.428 & 145.946 & 298.752 & 310.720 & Yes \\
\hline
\end{tabular} $\begin{array}{lllllllllllllllll}\text { HPHDIIDDINSGAVECPAS } & 1.00 & 92.56 & 24.33 & 19.65 & 2 & 2178.9814 & 2178.9796 & 1090.4971 & 0.0018 & 0.8253 & 204.661 & 82.852 & 295.116 & 250.728 & \text { Yes }\end{array}$ $\begin{array}{llllllllllllllll}\text { HPHDIIDDINSGAVECPAS } & 0.67 & 22.01 & 24.36 & 35.01 & 3 & 2178.9823 & 2178.9796 & 727.3338 & 0.0027 & 1.2374 & 38.729 & 7.758 & 35.344 & 0.000 & \text { No }\end{array}$ $\begin{array}{lllllllllllllllll}\text { HPHDIIDDINSGAVECPAS } & 1.00 & 50.21 & 24.38 & 18.09 & 3 & 2178.9826 & 2178.9796 & 727.3338 & 0.0030 & 1.3749 & 118.690 & 138.595 & 368.817 & 449.882 & \text { Yes }\end{array}$ $\begin{array}{llllllllllllllll}\text { HPHDIIDDINSGAVECPAS } & 1.00 & 69.89 & 24.35 & 18.50 & 3 & 2178.9814 & 2178.9796 & 727.3338 & 0.0018 & 0.8249 & 175.680 & 140.021 & 289.697 & 192.000 & \text { Yes }\end{array}$ \begin{tabular}{llllllllllllllll} 
HPHDIIDDINSGAVECPAS & 1.00 & 81.71 & 24.33 & 19.54 & 2 & 2178.9814 & 2178.9796 & 1090.4971 & 0.0018 & 0.8253 & 40.929 & 84.127 & 144.339 & 65.016 & Yes \\
\hline
\end{tabular} $\begin{array}{llllllllllllllll}\text { HPHDIIDDINSGAVECPAS } & 0.84 & 73.88 & 24.33 & 86.88 & 2 & 2178.9814 & 2178.9796 & 1090.4971 & 0.0018 & 0.8253 & 31.065 & 21.861 & 120.503 & 64.810 & \text { No }\end{array}$

$\begin{array}{llllllllllllll}27.05 & 35.77 & 2 & 2247.1874 & 2247.1846 & 1124.5996 & 0.0028 & 1.2449 & 46.822 & 7.052 & 25.696 & 29.469 & \text { No }\end{array}$

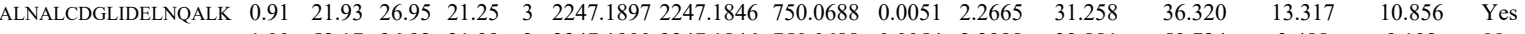

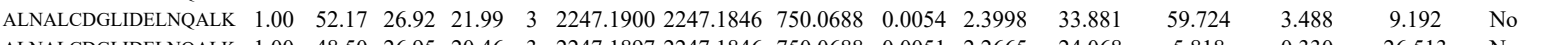

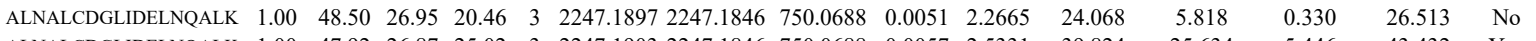

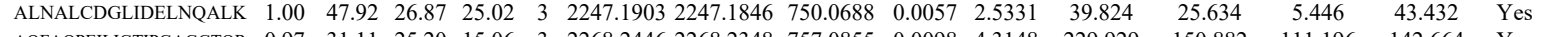

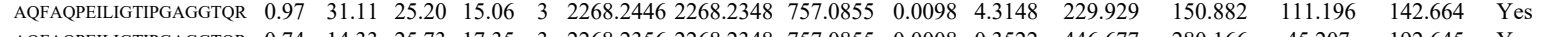

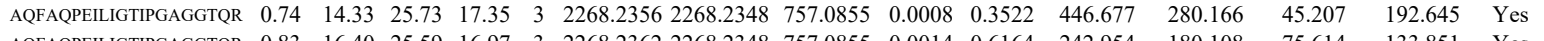

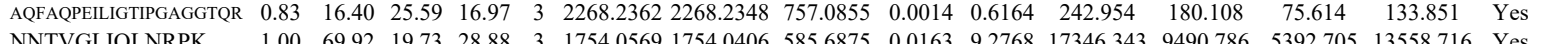
$\begin{array}{lllllllllllllllll}\text { NNTVGLIQLNRPK } & 1.00 & 69.92 & 19.73 & 28.88 & 3 & 1754.0569 & 1754.0406 & 585.6875 & 0.0163 & 9.2768 & 17346.343 & 9490.786 & 5392.705 & 13558.716 & \text { Yes }\end{array}$ $\begin{array}{lllllllllllllll} & \end{array}$ $\begin{array}{llllllllllllllll}\text { NNTVGLIQLNRPK } & 1.00 & 69.79 & 19.82 & 28.63 & 3 & 1754.0554 & 1754.0406 & 585.6875 & 0.0148 & 8.4231 & 2524.892 & 1727.240 & 1112.648 & 2080.344 & \text { Yes } \\ \text { SVDEVFDEVVQIFDK } & 1.00 & 77.38 & 27.49 & 19.11 & 2 & 2056.0614 & 2056.0609 & 1029.0377 & 0.0005 & 0.2429 & 191.490 & 113.052 & 58.468 & 281.556 & \text { Yes }\end{array}$ $\begin{array}{llllllllllllllll}\text { SVDEVFDEVVQIFDK } & 1.00 & 48.01 & 27.40 & 30.94 & 3 & 2056.0630 & 2056.0609 & 6863609 & 0.002 & 1.0199 & 74.060 & 73.696 & 57.105 & 14.411 & \text { Yes }\end{array}$

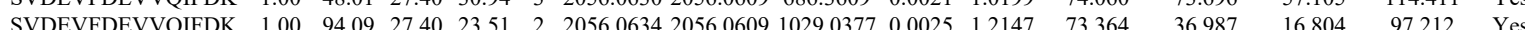
$\begin{array}{lllllllllllllll} & \end{array}$

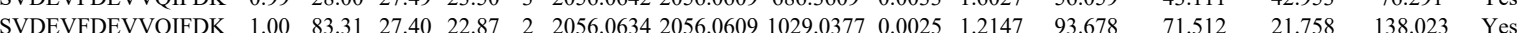

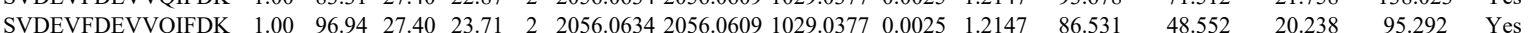

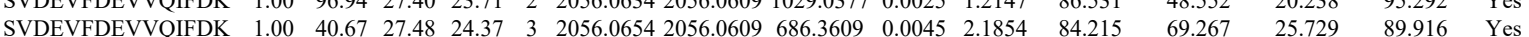

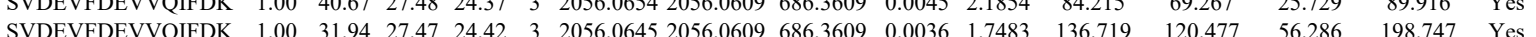

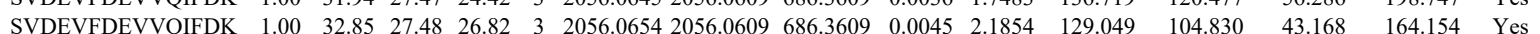
$\begin{array}{lllllllllllllllll}\text { IOTYLOSTKPIDLYEFMGK } & 0.67 & 47.33 & 23.50 & 60.33 & 3 & 2801.5276 & 2801.5250 & 934.8489 & 0.0026 & 0.9271 & 183.136 & 138.470 & 131.569 & 277.623 & \text { Yes }\end{array}$ $\begin{array}{lllllllllllllllll}\text { MKPLVVFVLGGPGAGK } & 0.67 & 17.64 & 16.33 & 30.64 & 3 & 2001.2209 & 2001.2175 & 668.0798 & 0.0034 & 1.6964 & 203.996 & 165.711 & 69.926 & 271.084 & \text { Yes }\end{array}$ $\begin{array}{llllllllllllllll}\text { MKPLVVFVLGGPGAGK } & 0.60 & 18.87 & 16.33 & 31.87 & 3 & 2001.2215 & 2001.2175 & 668.0798 & 0.0040 & 1.9958 & 207.623 & 218.715 & 36.770 & 328.818 & \text { Yes }\end{array}$ \begin{tabular}{lllllllllllllllll} 
MKPLVVFVLGGPGAGK & 1.00 & 19.26 & 15.91 & 14.87 & 4 & 2001.2225 & 2001.2175 & 501.3117 & 0.0050 & 2.4935 & 27.389 & 30.609 & 28.748 & 42.623 & Yes \\
\hline
\end{tabular} $\begin{array}{llllllllllllllll}\text { MKPLVVFVLGGPGAGK } & 1.00 & 40.68 & 15.80 & 19.15 & 4 & 2001.2229 & 2001.2175 & 501.3117 & 0.0054 & 2.6929 & 43.381 & 74.246 & 51.939 & 34.141 & \text { No }\end{array}$

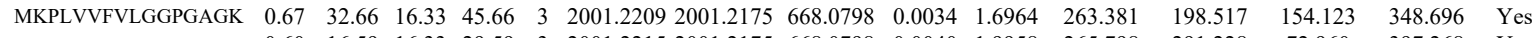

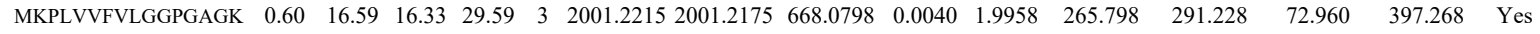

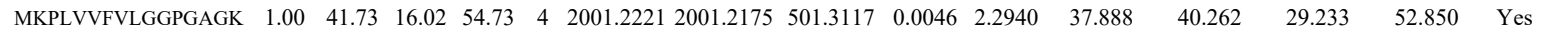

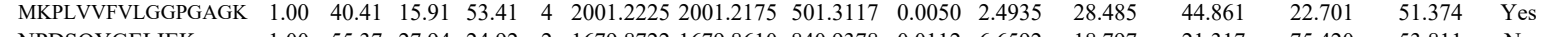

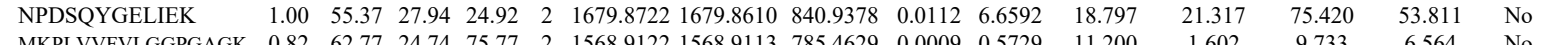

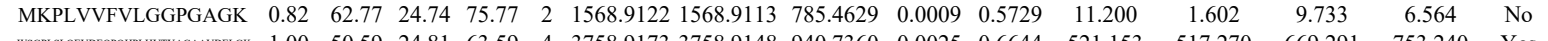

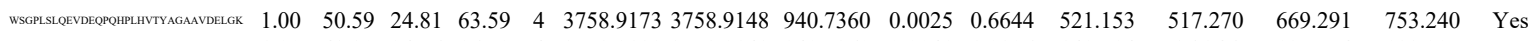

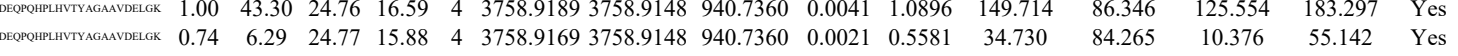
\begin{tabular}{llllllllllllllll} 
LYTLVLTDPDAPSR & 1.00 & 78.74 & 27.60 & 22.57 & 2 & 1703.9214 & 1703.9216 & 852.9681 & -0.0002 & -0.1172 & 476.073 & 454.983 & 167.592 & 823.725 & Yes \\
\hline
\end{tabular}

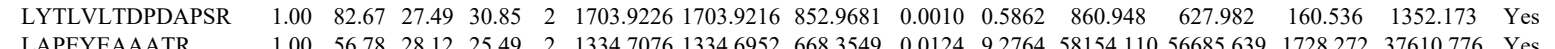

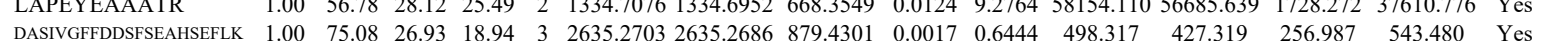

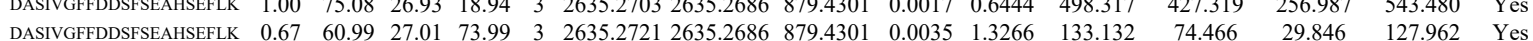
$\begin{array}{llllllllllllllll}\text { DPNIVIAK } & 0.86 & 23.35 & 24.00 & 24.84 & 2 & 1156.7056 & 1156.7059 & 579.3602 & -0.0003 & -0.2589 & 229.937 & 164.373 & 83.612 & 171.452 & \text { Yes }\end{array}$ $\begin{array}{llllllllllllllll}1.00 & 49.07 & 22.65 & 19.34 & 2 & 1156.7174 & 11567059 & 579.3602 & 0.0115 & 9.9246 & 14185.968 & 14188.409 & 8980.962 & 9867.910 & \text { Yes } & \end{array}$ 

$\begin{array}{llllllllllllllll}\text { TADGIVSHLK } & 1.00 & 42.74 & 26.05 & 23.24 & 3 & 1327.7815 & 1327.7703 & 443.5974 & 0.0112 & 8.4160 & 34140.275 & 29573.424 & 1097.199 & 23458.670 & \text { Yes }\end{array}$

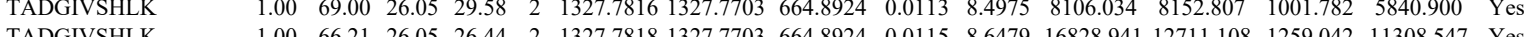
$\begin{array}{llllllllllllllllll}1.00 & 66.21 & 26.05 & 26.44 & 2 & 1327.7818 & 1327.7703 & 664.8924 & 0.0115 & 8.6479 & 16828.941 & 12711.108 & 1259.042 & 11308.547 & \text { Yes }\end{array}$ $\begin{array}{llllllllllllllll} & \end{array}$

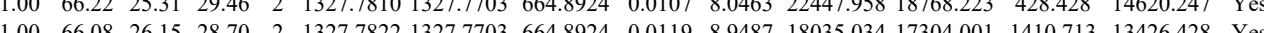

TADGIVSHLK $\begin{array}{llllllllllllllll}1.00 & 66.08 & 26.15 & 28.70 & 2 & 1327.7822 & 1327.7703 & 664.8924 & 0.0119 & 8.9487 & 18035.034 & 17304.001 & 1410.713 & 13426.428 & \text { Yes } \\ 1.00 & 51.94 & 6.15 & 29.06 & 3 & 1327.7824 & 1327.7703 & 443.5974 & 0.0121 & 9.0922 & 33891.085 & 29854.766 & 684.061 & 24960.366 & \text { Yes }\end{array}$

TADGIVSHLK $\begin{array}{lllllllllllllll}1.00 & 51.94 & 26.15 & 29.06 & 3 & 1327.7824 & 1327.7703 & 443.5974 & 0.0121 & 9.0922 & 33891.085 & 29854.766 & 684.061 & 24960.366 & \text { Yes } \\ 1.00 & 66.37 & 25.20 & 26.37 & 2 & 1327.7798 & 1327.7703 & 664.8924 & 0.0095 & 7.1440 & 7749.121 & 6170.793 & 290.435 & 5645.994 & \text { Yes }\end{array}$ $\begin{array}{llllllllllllllllll}1.00 & 58.60 & 25.20 & 26.17 & 3 & 1327.7800 & 1327.7703 & 443.5974 & 0.0097 & 7.2888 & 15928.319 & 14506.148 & 468.668 & 11618.540 & \text { Yes }\end{array}$ $\begin{array}{lllllllllllllllllll}1.00 & 65.82 & 25.31 & 27.26 & 3 & 1327.7806 & 1327.7703 & 443.5974 & 0.0103 & 7.7397 & 18614.017 & 18842.711 & 314.500 & 14487.831 & \text { Yes }\end{array}$ $\begin{array}{lllllllllllllllll}100 & 6089 & 28.08 & 32.91 & 2 & 1646.8568 & 1646.8548 & 824.4347 & 0.0020 & 1.2130 & 10184.555 & 9957.112 & 211.604 & 7903.806 & \text { Yes }\end{array}$ $\begin{array}{llllllllllllllll}\text { FLQDYFDGNLK } & 1.00 & 60.89 & 28.08 & 32.91 & 2 & 1646.8568 & 1646.8548 & 824.4347 & 0.0020 & 1.2130 & 10184.555 & 9957.112 & 211.604 & 7903.806 & \text { Yes } \\ \text { FLQDYFDGNLK } & 1.00 & 72.01 & 28.02 & 25.34 & 2 & 1646.8574 & 1646.8548 & 824.4347 & 0.0026 & 1.5768 & 15728.489 & 14161.272 & 0.000 & 14232.106 & \text { No } \\ \text { FLQDYFDGNLK } & 1.00 & 53.72 & 27.97 & 24.73 & 3 & 1646.8582 & 1646.8548 & 549.9589 & 0.0034 & 2.0608 & 238.250 & 265.166 & 55.727 & 354.356 & \text { No } \\ \text { FLQDYFDGNLK } & 1.00 & 54.45 & 27.90 & 20.58 & 3 & 1646.8585 & 1646.8548 & 549.9589 & 0.0037 & 2.2426 & 464.813 & 281.686 & 107.684 & 238.120 & \text { Yes }\end{array}$ $\begin{array}{llllllllllllllll}\text { FLQDYFDGNLK } & 1.00 & 60.89 & 28.08 & 32.91 & 2 & 1646.8568 & 1646.8548 & 824.4347 & 0.0020 & 1.2130 & 10184.555 & 9957.112 & 211.604 & 7903.806 & \text { Yes } \\ \text { FLQDYFDGNLK } & 1.00 & 72.01 & 28.02 & 25.34 & 2 & 1646.8574 & 1646.8548 & 824.4347 & 0.0026 & 1.5768 & 15728.489 & 14161.272 & 0.000 & 14232.106 & \text { No } \\ \text { FLQDYFDGNLK } & 1.00 & 53.72 & 27.97 & 24.73 & 3 & 1646.8582 & 1646.8548 & 549.9589 & 0.0034 & 2.0608 & 238.250 & 265.166 & 55.727 & 354.356 & \text { No } \\ \text { FLQDYFDGNLK } & 1.00 & 54.45 & 27.90 & 20.58 & 3 & 1646.8585 & 1646.8548 & 549.9589 & 0.0037 & 2.2426 & 464.813 & 281.686 & 107.684 & 238.120 & \text { Yes }\end{array}$

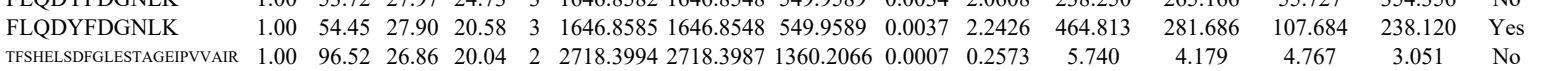

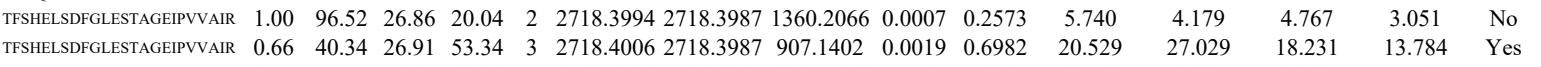

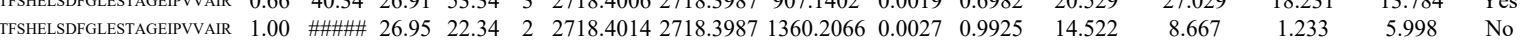
$\begin{array}{llllllllllllllll}\text { TFSHELSDFGLESTAGEIPVVAIR } & 0.67 & 70.30 & 26.94 & 83.30 & 3 & 2718.4018 & 2718.3987 & 907.1402 & 0.0031 & 1.1391 & 67.923 & 188.848 & 150.224 & 168.029 & \text { No }\end{array}$

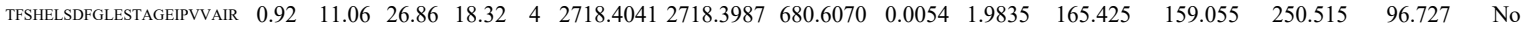
$\begin{array}{llllllllllllllll}\text { FLQDYFDGNLK } & 1.00 & 39.62 & 27.99 & 23.76 & 3 & 1646.8570 & 1646.8548 & 549.9589 & 0.0022 & 1.3334 & 225.801 & 228.313 & 63.692 & 249.752 & \text { Yes }\end{array}$ $\begin{array}{llllllllllllllll}\text { FLQDYFDGNLK } & 1.00 & 55.13 & 28.03 & 24.17 & 2 & 1646.8572 & 1646.8548 & 824.4347 & 0.0024 & 1.4555 & 12980.201 & 12492.482 & 0.000 & 10545.929 & \text { No }\end{array}$ $\begin{array}{llllllllllllllll}\text { FLQDYFDGNLK } & 1.00 & 49.58 & 28.03 & 24.27 & 2 & 1646.8572 & 1646.8548 & 824.4347 & 0.0024 & 1.4555 & 8965.741 & 8336.208 & 0.000 & 8218.164 & \text { No }\end{array}$ $\begin{array}{llllllllllllllll}\text { FLQDYFDGNLK } & 1.00 & 46.11 & 27.90 & 27.22 & 3 & 1646.8585 & 1646.8548 & 549.9589 & 0.0037 & 2.2426 & 210.687 & 187.692 & 11.119 & 192.461 & \text { Yes }\end{array}$ \begin{tabular}{lllllllllllllllll} 
TFSHELSDFGLESTAGEIPVVAIR & 1.00 & 69.28 & 26.89 & 17.76 & 3 & 2718.4009 & 2718.3987 & 907.1402 & 0.0022 & 0.8084 & 138.793 & 86.516 & 40.766 & 79.383 & Yes \\
\hline
\end{tabular}

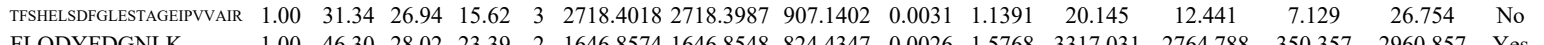
$\begin{array}{llllllllllllllll}\text { FLQDYFDGNLK } & 1.00 & 46.30 & 28.02 & 23.39 & 2 & 1646.8574 & 1646.8548 & 824.4347 & 0.0026 & 1.5768 & 3317.031 & 2764.788 & 350.357 & 2960.857 & \text { Yes }\end{array}$ $\begin{array}{llllllllllllllll}\text { FLQDYFDGNLK } & 1.00 & 60.36 & 28.01 & 24.01 & 2 & 1646.8578 & 1646.8548 & 824.4347 & 0.0030 & 1.8194 & 2733.200 & 2305.911 & 596.728 & 2010.644 & \text { Yes }\end{array}$

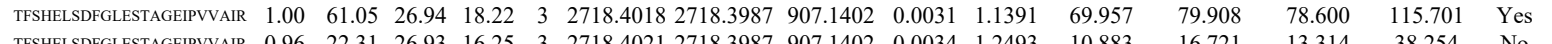
$\begin{array}{llllllllllllllll}\text { TFSHELSDFGLESTAGEIPVVAIR } & 0.96 & 22.31 & 26.93 & 16.25 & 3 & 2718.4021 & 2718.3987 & 907.1402 & 0.0034 & 1.2493 & 10.883 & 16.721 & 13.314 & 38.254 & \text { No } \\ \text { GIVPLAK } & 0.62 & 16.48 & 18.57 & 20.33 & 2 & 984.6566 & 984.6575 & 493.3360 & -0.0009 & -0.9122 & 82.474 & 74.409 & 59.109 & 64378 & \text { Yes }\end{array}$

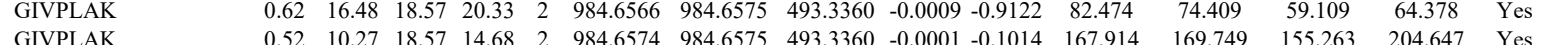

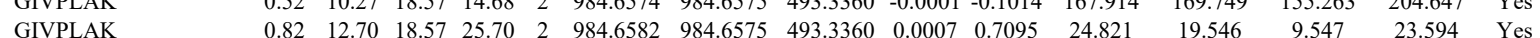
GIVPLAK

GIVPLAK

QAGPASVPL

QAGPASVPLR

QAGPASVPLR

YGVSGYPTLK

GIVPLAK

YGVSGYPTLK

YGVSGYPTLK

YGVSGYPTLK

YGVSGYPTLK

YGVSGYPTLK

GFPTIYFSPANK

GFPTIYFSPANK

GFPTIYFSPANK

GFPTIYFSPANK

GFPTIYFSPANK

GFPTIYFSPANK

GFPTIYFSPANK

GFPTIYFSPANK

GFPTIYFSPANK

LNFAVASR

LNFAVASR

$\begin{array}{lllllllllllllll}0.82 & 12.70 & 18.57 & 25.70 & 2 & 984.6582 & 984.6575 & 493.3360 & 0.0007 & 0.7095 & 24.821 & 19.546 & 9.547 & 23.594 & \text { Yes } \\ 0.66 & 19.77 & 19.59 & 19.37 & 2 & 984.6630 & 984.6575 & 493.3360 & 0.0055 & 5.5743 & 50521.372 & 46317.378 & 9723.315 & 40256.911 & \text { Yes }\end{array}$ $\begin{array}{lllllllllllllllll}0.92 & 28.14 & 19.59 & 17.85 & 2 & 984.6640 & 984.6575 & 493.3360 & 0.0065 & 6.5878 & 64320.123 & 55443.190 & 10226.764 & 42720.681 & \text { Yes }\end{array}$ $\begin{array}{llllllllllllllll}0.99 & 33.16 & 26.47 & 20.81 & 2 & 1138.6590 & 1138.6580 & 570.3363 & 0.0010 & 0.8767 & 95740.570 & \# \# \# \# \# \text { 451.150 } & 61019.680 & \text { Yes }\end{array}$ $\begin{array}{llllllllllllllll}0.99 & 32.76 & 26.24 & 20.35 & 2 & 1138.6600 & 1138.6580 & 570.3363 & 0.0020 & 1.7533 & \text { \#\#\#\#\#\#\#\#\#\# } 4876.682 & 79890.619 & \text { Yes }\end{array}$ \begin{tabular}{lllllllllllllll}
0.99 & 46.16 & 29.56 & 22.90 & 2 & 1371.7728 & 1371.7642 & 686.8894 & 0.0086 & 6.2601 & 9644.205 & 8601.705 & 470.113 & 6160.999 & Yes \\
\hline
\end{tabular} $\begin{array}{lllllllllllllllll}0.99 & 48.57 & 29.45 & 22.34 & 2 & 1371.7730 & 1371.7642 & 686.8894 & 0.0088 & 6.4056 & 25162.302 & 21627.087 & 190.655 & 14842.567 & \text { Yes } \\ 0.93 & 28.48 & 19.4 & 20.00 & 2 & 984.6550 & 984.6575 & 93.3360 & 0.075 & 7.603 & 2264.258 & 21406.935 & 18932290 & 15116.507 & \text { Yes }\end{array}$

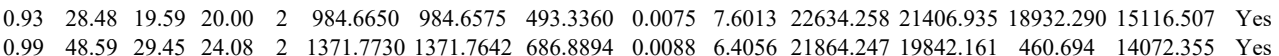
$\begin{array}{llllllllllllllll}0.99 & 48.59 & 29.45 & 24.08 & 2 & 1371.7730 & 1371.7642 & 686.8894 & 0.0088 & 6.4056 & 21864.247 & 19842.161 & 460.694 & 14072.355 & \text { Yes } \\ 0.99 & 47.31 & 29.4 & 24.16 & 2 & 1371.7734 & 1371.7642 & 686.8894 & 0.0092 & 6.6968 & 26449.011 & 27304.028 & 522.903 & 18597.716 & \text { Yes }\end{array}$

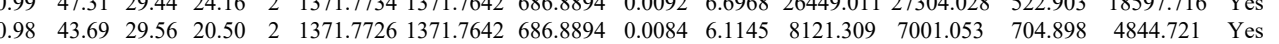
$\begin{array}{llllllllllllllll}0.97 & 40.84 & 29.45 & 23.76 & 2 & 1371.7730 & 1371.7642 & 686.8894 & 0.0088 & 6.4056 & 4622.488 & 4415.820 & 759.336 & 4663.026 & \text { Yes }\end{array}$ $\begin{array}{lllllllllllllll}0.98 & 41.80 & 29.44 & 24.45 & 2 & 1371.7734 & 1371.7642 & 686.8894 & 0.0092 & 6.6968 & 1584.658 & 1534.532 & 103.659 & 966.486 & \text { Yes }\end{array}$ $\begin{array}{lllllllllllllll}0.97 & 37.67 & 29.41 & 24.22 & 2 & 1371.7764 & 1371.7642 & 686.8894 & 0.0122 & 8.8805 & 548.303 & 420.532 & 29.707 & 327.139 & \text { Yes }\end{array}$

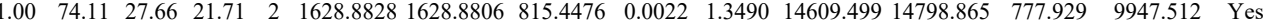
$\begin{array}{lllllllllllllll}1.00 & 71.62 & 27.66 & 19.86 & 2 & 1628.8828 & 1628.8806 & 815.4476 & 0.0022 & 1.3490 & 9193.074 & 8468.749 & 229.006 & 5910.478 & \text { Yes }\end{array}$ $\begin{array}{lllllllllllllll}0.98 & 29.20 & 27.52 & 24.52 & 3 & 1628.8852 & 1628.8806 & 543.9675 & 0.0046 & 2.8188 & 471.188 & 342.098 & 124.055 & 588.876 & \text { No }\end{array}$ $\begin{array}{lllllllllllllll}0.99 & 30.78 & 27.52 & 23.78 & 3 & 1628.8852 & 1628.8806 & 543.9675 & 0.0046 & 2.8188 & 742.034 & 902.665 & 122.501 & 619.264 & \text { Yes }\end{array}$

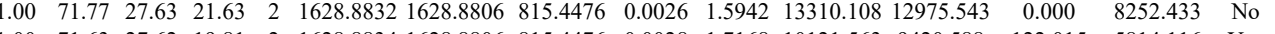
$\begin{array}{llllllllllllllll}1.00 & 71.63 & 27.62 & 19.81 & 2 & 1628.8834 & 1628.8806 & 815.4476 & 0.0028 & 1.7168 & 10121.563 & 9420.588 & 122.015 & 5814.116 & \text { Yes }\end{array}$ $\begin{array}{llllllllllllllll}0.97 & 27.23 & 27.62 & 23.18 & 3 & 1628.8855 & 1628.8806 & 543.9675 & 0.0049 & 3.0026 & 679.310 & 455.312 & 274.500 & 666.131 & \text { Yes }\end{array}$ \begin{tabular}{llllllllllllllll}
0.85 & 24.08 & 27.63 & 30.05 & 3 & 1628.8858 & 1628.8806 & 543.9675 & 0.0052 & 3.1865 & 547.084 & 404.746 & 98.828 & 431.183 & Yes \\
\hline
\end{tabular}

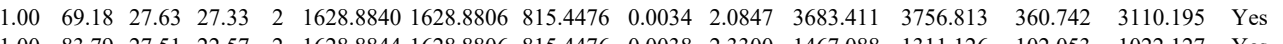

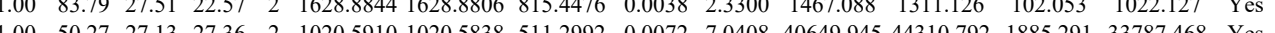
$\begin{array}{llllllllllllllll}1.00 & 50.27 & 27.13 & 27.36 & 2 & 1020.5910 & 1020.5838 & 511.2992 & 0.0072 & 7.0408 & 40649.945 & 4431.0792 & 1825.291 & 33787.468 & \text { Yes }\end{array}$ $\begin{array}{lllllllllllllll}1.00 & 48.88 & 27.09 & 26.73 & 2 & 1020.5920 & 1020.5838 & 51.2992 & 0.0082 & 8.0187 & 30388.336 & 28183.280 & 2755.770 & 22175.441 & \text { Yes }\end{array}$ $\begin{array}{llllllllllllllll}1.00 & 4.14 & 27.13 & 26.69 & 2 & 1020.5914 & 1020.5838 & 511.292 & 0.0076 & 7.4320 & 25177.552 & 26410.515 & 1216.950 & 2175.561 & \text { Yes }\end{array}$

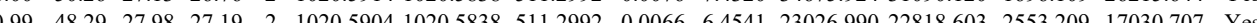
$\begin{array}{llllllllllllllll}1.00 & 50.16 & 28.01 & 26.46 & 2 & 1020.5906 & 1020.5838 & 511.2992 & 0.0068 & 6.6497 & 22685.104 & 21102.215 & 2202.911 & 15808.020 & \text { Yes }\end{array}$ 
SEPIPESNDGPVK SEPIPESNDGPVK LNFAVASR LNFAVASR LNFAVASR LNFAVASR

SEPIPESNDGPVK SEPIPESNDGPVK SETPSDVGK

EATN

EATNPVIQEK

EAT PPVILEKPK

EATNPPVIOEEKPK

EATNPPVIQEEKPK

EATNPPVIQEEKPK

VVVAENFDEIVNNENK

VVVAENFDEIVNNENK 0.62

MDATANDVPSPYEVR

VVVAENFDEIVIVNNENK 1.00

VVVAENFDEIVNNENK

VVVAENFDEIVN

LAPEYEAAAT

LAPEYEAAATR

MAGEYEAAATR

MAGDPVANV

PILDNSTLQSEVKPILEK

IGPILDNSTLQSEVKPILEK

IGPILDNSTLQSEVKPILEK
IGPIDDNSTLQSEVKPLEK

\section{IGPILDNSTLQSEVKPILE}

TDLVPAFQNLMK

TDLVPAFQNLMK

TDLVPAFQNLMK

TDLVPAFQNLMK

TDLVPAFQNLMK

TDLVPAFQNLMK

TDLVPAFQNLMK

DNTIEHLLPLFLAQLK

DNTIEHLLPLFLAQLK

DNTIEHLLPLFLAQLK
DNTIEHLLPLFLAQLK
DNTIEHLLPLFLAQLK

DNTIEHLLP

LTQDQDVDVK

LTQDQDVDVK

ALASVIMGLSPILGK

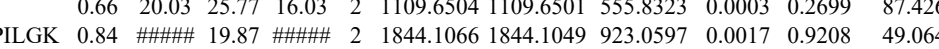

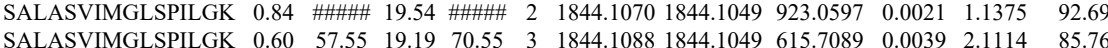

$\begin{array}{lllllllllllll}\text { SALASVIMGLSPILGK } & 0.60 & 57.55 & 19.19 & 70.55 & 3 & 1844.1088 & 1844.1049 & 615.7089 & 0.0039 & 2.1114 & 85.767 \\ \text { SALASVIMGLSPILGK } & 0.84 & \# \# \# \# \quad 21.88 & \text { \#\#\#\# } & 2 & 1860.1016 & 1860.0998 & 931.0572 & 0.0018 & 0.9666 & 33.403\end{array}$

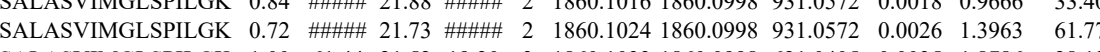

$\begin{array}{lllllllllllll}\text { SALASVIMGLSPILGK } & 1.00 & 61.44 & 21.52 & 19.30 & 3 & 1860.1033 & 1860.0998 & 621.0405 & 0.0035 & 1.8786 & 28.123 \\ \text { SALASVIMGLSPILGK } & 0.60 & 50.68 & 21.52 & 63.68 & 3 & 1860.1036 & 1860.0998 & 621.0405 & 0.0038 & 2.0396 & 49.145\end{array}$ $\begin{array}{llllllllllllll}\text { SALASVIMGLSPILGK } & 0.60 & 50.68 & 21.52 & 63.68 & 3 & 1860.1036 & 1860.0998 & 621.0405 & 0.0038 & 2.0396 & 49.145 \\ \text { SALASVIMGLSPILGK } & 0.82 & \# \# \# & 20.09 & \# \# \# \# & 2 & 1844.1058 & 1844.1049 & 923.0597 & 0.0009 & 0.4875 & 87.583\end{array}$

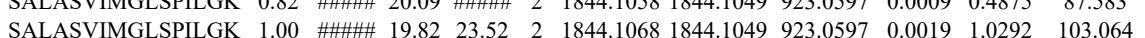
$\begin{array}{llllllllllll}\text { SALASVIMGLSILGK } & 1.00 & \ldots & 19.82 & 23.52 & 2 & 1844.1068 & 1844.1049 & 923.0597 & 0.0019 & 1.0292 & 103.064 \\ \text { SALASVIMGLSILGK } & 0.67 & 66.30 & 19.64 & 79.30 & 3 & 1844.1076 & 1844.1049 & 615.7089 & 0.0027 & 1.4617 & 50.323\end{array}$ $\begin{array}{lllllllllllll}\text { SALASVIMGLSPILGK } & 0.67 & 66.30 & 19.64 & 79.30 & 3 & 1844.1076 & 1844.1049 & 615.7089 & 0.0027 & 1.4617 & 50.323 \\ \text { SALASVIMGLSILGK } & 0.67 & 45.60 & 19.19 & 58.60 & 3 & 1844.1082 & 1844.1049 & 615.7089 & 0.0033 & 1.7866 & 23.146\end{array}$

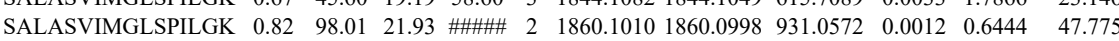
$\begin{array}{llllllllllllll}\text { SALASVIMGLSPILGK } & 0.67 & 12.18 & 21.73 & 25.18 & 3 & 1860.1024 & 1860.0998 & 621.0405 & 0.0026 & 1.3955 & 25.204\end{array}$ SALASVIMGLSPILGK 0.72 \#\#\#\# 21.73 \#\#\#\# 2 1860.1024 $1860.0998 \begin{array}{lllllll}931.0572 & 0.0026 & 1.3963 & 2.7 .762\end{array}$ \begin{tabular}{lllllllllllllll} 
& 31.98 & 28.18 & 17.17 & 2 & 1655.8740 & 1655.8610 & 828.9378 & 0.0130 & 7.8413 & 6606.090 & 5959.097 & 892.035 & 3824.568 & Yes \\
\hline
\end{tabular} $\begin{array}{lllllllllllll} & \end{array}$ \begin{tabular}{llllllllllllll}
43.32 & 28.15 & 25.23 & 2 & 1020.5848 & 1020.5838 & 5112992 & 0.000 & 0.000 & 1649.571 & 1621.927 & 635.367 & 1151.247 & Yes \\
\hline
\end{tabular} $\begin{array}{lllllllllllllllll}0.98 & 33.02 & 27.97 & 24.39 & 2 & 1020.5846 & 1020.5838 & 511.2992 & 0.0008 & 0.7823 & 562.549 & 603.967 & 197.591 & 595.294 & \text { Yes }\end{array}$ \begin{tabular}{lllllllllllll} 
& 189.294 & Yes \\
\hline
\end{tabular} $\begin{array}{lllllllllllllll}27.93 & 14.73 & 3 & 1655.8627 & 1655.8610 & 552.9609 & 0.0017 & 1.0248 & 1879.056 & 1439.320 & 970.100 & 1612.539 & \text { Yes }\end{array}$

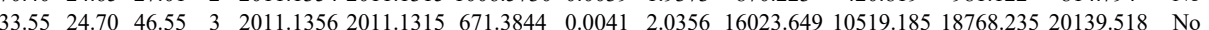
$\begin{array}{lllllllllllllll}39.55 & 24.79 & 52.55 & 4 & 2011.1365 & 2011.1315 & 503.7902 & 0.0050 & 2.4812 & 3691.136 & 2309.195 & 4292.960 & 3949.790 & \text { No }\end{array}$

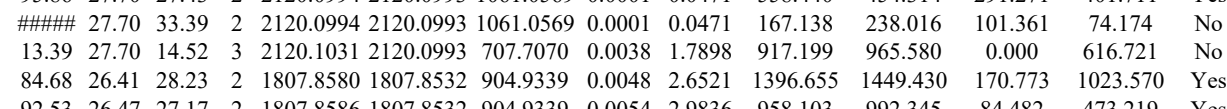

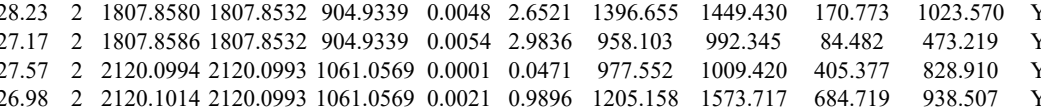
$\begin{array}{cccccccccccccc}38.54 & 27.04 & 24.98 & 2 & 1347.7064 & 1334.6952 & 668.3549 & 0.0112 & 8.3787 & 33804.189 & 37025.691 & 0.000 & 27501.119 & \text { No } \\ \end{array}$ $\begin{array}{llllllllllllllll}0.99 & 39.04 & 27.04 & 27.64 & 2 & 1172.6122 & 1172.6094 & 587.3120 & 0.0028 & 2.3837 & 18557.455 & 17546.644 & 1200.332 & 15754.527 & \text { Yes }\end{array}$

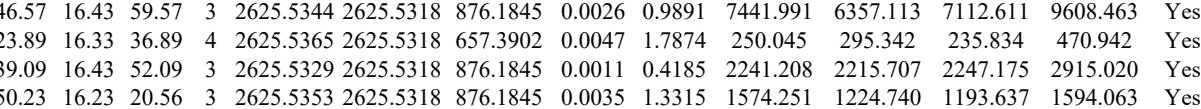
$\begin{array}{lllllllllllll}58.72 & 3 & 2625.5329 & 2625.5318 & 876.1845 & 0.0011 & 0.4185 & 1518.067 & 1264.353 & 1379.637 & 1894.063 & \text { Yes } \\ 33.96 & 2 & 1663.920 & 6630.9211 & 82.5678 & 0.001 & -0.6603 & 5366.924 & 4963.815 & 432.227 & 4458.757 & \text { Yes }\end{array}$ $867 \quad 94.008 \quad 2199.471 \quad Y$ Y $\begin{array}{llll}88.056 & 133.391 & \text { Yes }\end{array}$

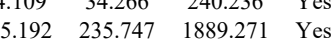
$\begin{array}{lllll}87.785 & 198.732 & 763.345 & \text { Yes }\end{array}$ $\begin{array}{lllll}164.785 & 112.034 & 1230.763 & \text { No }\end{array}$ $\begin{array}{llll}1.558 & 113.186 & 882.172 & \text { No }\end{array}$ $\begin{array}{llll}13.640 & 20.961 & 20.886 & \text { No }\end{array}$ $\begin{array}{llll}1.766 & 29.437 & 28.438 & \text { Yes }\end{array}$ $\begin{array}{llll}30.250 & 0.000 & 15.895 & \text { No }\end{array}$ $\begin{array}{llll}170.545 & 298.908 & 307.777 & \text { Yes }\end{array}$ $\begin{array}{llll}59.293 & 46.293 & 87.054 & \text { Yes } \\ 0.757 & 0.000 & 113008 & \text { No }\end{array}$ $\begin{array}{ccccc}1035.757 & 0.000 & 1143.008 & \text { No } \\ 469.814 & 359.103 & 726.275 & \text { Yes }\end{array}$ $\begin{array}{llll}575.072 & 547.875 & 716.592 & \text { Yes }\end{array}$ $\begin{array}{llll}48.939 & 80.071 & 123.563 & \text { Yes }\end{array}$ $\begin{array}{llll}41.471 & 5.833 & 47.747 & \text { Yes }\end{array}$ $\begin{array}{llll}81.933 & 11.448 & 58.299 & \text { Yes }\end{array}$ $\begin{array}{llll}89.874 & 28.322 & 86.445 & \text { Yes }\end{array}$ 43.552 3.417 70.320 95.741 52.554 8.280
51214 51.214 28.771
17.816

24.139

34.142
22.359

18.174

33.022
19.514

9.858

Table S-4 page 260 of 614 


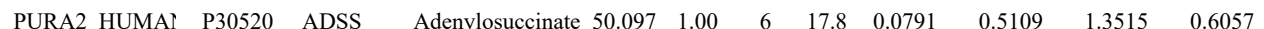
FIEDELQIPVK $\begin{array}{llllllllllll}\text { FIEDELQIPVK } & 1.00 & 61.03 & 26.03 & 34.82 & 2 & 1617.9238 & 1617.9221 & 809.9683 & 0.0017 & 1.0494 & 45.844 \\ \text { FIEDELQIPVK } & 0.74 & 29.94 & 25.82 & 41.54 & 3 & 1617.9247 & 1617.9221 & 540.3146 & 0.0026 & 1.6040 & 68.73 \\ \text { FIEDELQIPVK } & 0.97 & 22.42 & 25.73 & 24.00 & 3 & 1617.9253 & 1617.9221 & 540.3146 & 0.0032 & 1.9742 & 74.043\end{array}$ $\begin{array}{lllllllllllll} & 0.97 & 22.42 & 25.73 & 24.00 & 3 & 1617.9253 & 1617.9221 & 540.3146 & 0.0032 & 1.9742 & 74.043\end{array}$ $\begin{array}{llllllllllll} & \end{array}$

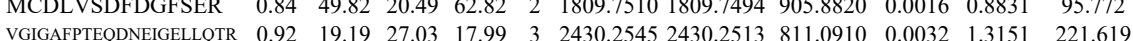
$\begin{array}{llllllllllll}\text { VGIGAFPTEODNEIGELLOTR } & 1.00 & 42.59 & 26.95 & 16.11 & 3 & 2430.2548 & 2430.2513 & 811.0910 & 0.0032 & 1.31584 & 221.619\end{array}$ $\begin{array}{lllllllllllll}\text { VGIGAFPTEQDNEIGELLQTR } & 1.00 & 42.59 & 26.95 & 16.11 & 3 & 2430.2548 & 2430.2513 & 811.0910 & 0.0035 & 1.4384 & 92.274 \\ \text { VVDLLAQDADIVCR } & 1.00 & 93.84 & 27.94 & 24.15 & 2 & 1718.8832 & 1718.8817 & 860.4481 & 0.0015 & 0.8716 & 84.769\end{array}$ $\begin{array}{llllllllllll}\text { VVDLLAQDADIVCR } & 1.00 & 32.84 & 27.92 & 15.89 & 3 & 1718.8846 & 1718.8817 & 573.9678 & 0.0029 & 1.6842 & 56.874\end{array}$ $\begin{array}{llllllllllll}\text { LDILDMFTEIK } & 0.99 & 36.61 & 26.59 & 33.44 & 3 & 1624.9006 & 1624.8990 & 542.6403 & 0.0016 & 0.9828 & 42.769 \\ \text { LDILDMFTEIK } & 0.99 & 27.42 & 26.92 & 23.10 & 3 & 1624.9009 & 1624.8990 & 542.6403 & 0.0019 & 1.1671 & 72.107\end{array}$ LDILDMFTEIK

LDILDMFTEIK

VVDLLAQDADIVCR LDILDMFTEIK LDILDMFTEIK LDILDMFTEIK LDILDMFTEIK CGWLDLVLLK CGWLDLVLLK

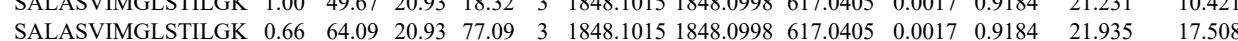
$\begin{array}{lllllllllllll} & \text { SALASVIMGLSTLGK } & 0.66 & 64.09 & 20.93 & 77.09 & 3 & 1848.1015 & 1848.0998 & 617.0405 & 0.0017 & 0.9184 & 21.935\end{array}$ $\begin{array}{llllllllllllll} & \text { SALASVIMLSTILGK } & 0.55 & 32.25 & 21.58 & 45.25 & 3 & 1864.0960 & 1864.0947 & 622.3722 & 0.0013 & 0.6963 & 42.896 & 4 \\ & 1.00 & 34.16 & 21.49 & 21.30 & 3 & 1864.0972 & 1864.0947 & 622.3722 & 0.0025 & 1.3390 & 39.667 & 3\end{array}$ $\begin{array}{llllllllllll} & \end{array}$

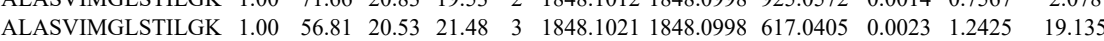

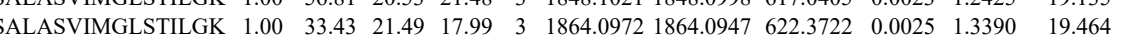
$\begin{array}{llllllllllll}\text { VVDLLAQDADIVCR } & 1.00 & 44.21 & 27.95 & 19.95 & 3 & 1718.8843 & 1718.8817 & 573.9678 & 0.0026 & 1.5100 & 57.777\end{array}$ $\begin{array}{lllllllllllll}1.00 & 51.93 & 26.92 & 34.25 & 2 & 1624.9012 & 1624.8990 & 813.4568 & 0.0022 & 1.3523 & 296.013 & 362.508\end{array}$

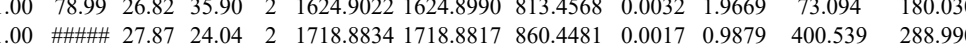
$\begin{array}{lllllllllll}1.00 & \text { \#\#.91 } & 28.41 & 2 & 1718.8856 & 1718.8817 & 860.4481 & 0.0039 & 2.2663 & 133.493 & 97.510\end{array}$ $\begin{array}{lllllllllllll}1.00 & 78.47 & 26.92 & 30.47 & 2 & 1624.9012 & 1624.8990 & 813.4568 & 0.0022 & 1.3523 & 116.684 & 95.161\end{array}$ $\begin{array}{llllllllllllll}1.00 & 57.92 & 26.92 & 35.43 & 2 & 1624.9012 & 1624.8990 & 813.4568 & 0.0022 & 1.3523 & 166.377 & 127.24 \mathrm{I}\end{array}$ $\begin{array}{llllllllllll}0.99 & 30.81 & 26.75 & 27.86 & 3 & 1624.9015 & 1624.8990 & 542.6403 & 0.0025 & 1.5357 & 111.179 & 95.015\end{array}$ $\begin{array}{llllllllllll}0.93 & 25.87 & 26.73 & 31.97 & 3 & 1624.9018 & 1624.8990 & 542.6403 & 0.0028 & 1.7200 & 69.690 & 64.014 \\ 1.00 & 40.55 & 26.90 & 22.69 & 2 & 14928418 & 14928389 & 747.4267 & 0.0029 & 1.9400 & 11.872 & 5.343\end{array}$ $\begin{array}{llllllllllll}1.00 & 40.55 & 26.90 & 22.69 & 2 & 1492.8418 & 1492.8389 & 747.4267 & 0.0029 & 1.9400 & 11.872 & 5.343 \\ 1.00 & 50.84 & 26.90 & 25.19 & 2 & 14928420 & 14928389 & 747.4267 & 0.0031 & 2.0738 & 43.196 & 53.943\end{array}$ $\begin{array}{llllllllllll}1.00 & 50.84 & 26.90 & 25.19 & 2 & 1492.8420 & 1492.8389 & 747.4267 & 0.0031 & 2.0738 & 43.196 & 53.943 \\ 1.00 & 63.90 & 24.17 & 21.53 & 2 & 1414.8470 & 1414.8387 & 708.4266 & 0.0083 & 5.8580 & 9492.071 & 9939.688\end{array}$ $\begin{array}{lllllllllllllllll}1.00 & 74.15 & 24.17 & 24.03 & 2 & 1414.8480 & 1414.8387 & 708.4266 & 0.0093 & 6.5638 & 11949.935 & 12969.256 & 4843.489 & 14767.282 & \text { Yes }\end{array}$ $\begin{array}{lllllllllllll}79 & 2 & 1039.5688 & 1039.5606 & 520.7876 & 0.0082 & 7.8726 & 4689.335 & 4909.369 & 654.575 & 7970.353 & \text { Yes }\end{array}$

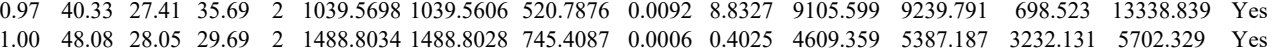



$\begin{array}{llllllllllllllll}0.98 & 27.71 & 28.38 & 18.36 & 3 & 1678.8745 & 1678.8735 & 560.6318 & 0.0010 & 0.5946 & 258.702 & 294.250 & 20.894 & 273.512 & \text { Yes }\end{array}$ $\begin{array}{llllllllllllllll}0.96 & 44.42 & 16.72 & 45.23 & 2 & 969.6460 & 969.6457 & 485.8301 & 0.0003 & 0.3087 & 4665.596 & 5509.777 & 362.085 & 10018.616 & \text { Yes } \\ 0.96 & 44.30 & 16.72 & 45.42 & 2 & 969.6460 & 969.6457 & 485.8301 & 0.0003 & 0.3087 & 5234.812 & 5087.942 & 153.584 & 10885.950 & \text { Yes }\end{array}$

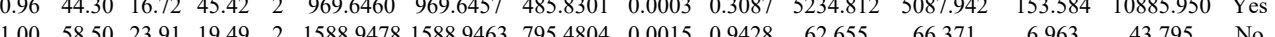

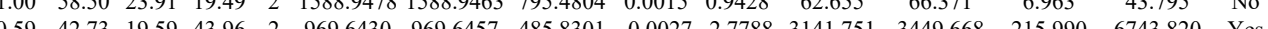

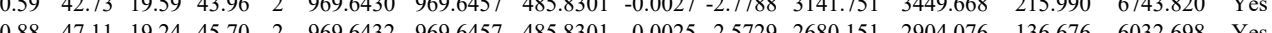

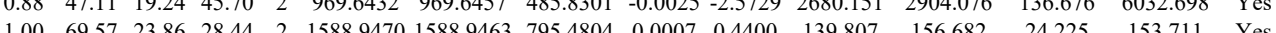

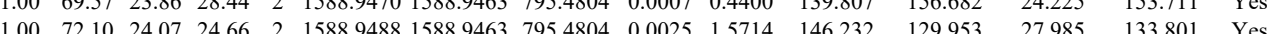

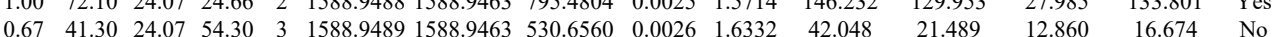
$\begin{array}{llllllllllllllll}0.73 & 29.95 & 16.72 & 41.14 & 2 & 969.6458 & 969.6457 & 485.8301 & 0.0001 & 0.1029 & 309.992 & 336.500 & 61.422 & 665.425 & \text { Yes }\end{array}$

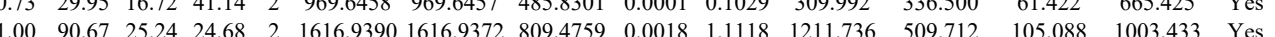
$\begin{array}{lllllllllllllll}1.00 & 87.43 & 25.16 & 26.10 & 2 & 1616.9396 & 1616.9372 & 809.4759 & 0.0024 & 1.4824 & 1197.281 & 474.353 & 72.747 & 890.860 & \text { Yes }\end{array}$

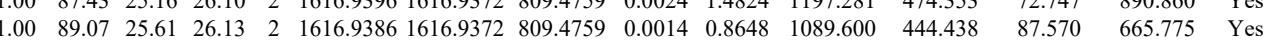

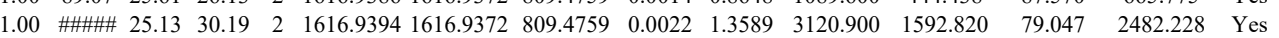

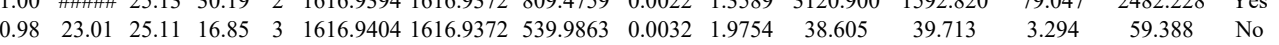
$\begin{array}{llllllllllllllll} & 0.67 & 32.12 & 25.12 & 45.12 & 3 & 1616.9407 & 1616.9372 & 539.9863 & 0.0035 & 2.1605 & 31.261 & 33.558 & 16.849 & 46.358 & \text { No } \\ \text { LGANSLLDLVVFGR } & 1.00 & 98.71 & 25.16 & 28.18 & 2 & 1616.9398 & 1616.9372 & 809.4759 & 0.0026 & 1.6060 & 1165.150 & 670.379 & 37.906 & 857.954 & \text { Y }\end{array}$ \begin{tabular}{lllllllllllllllll} 
LGANSLLDLVVFGR & 1.00 & 90.82 & 25.16 & 28.23 & 2 & 1616.9398 & 1616.9372 & 809.4759 & 0.0026 & 1.6060 & 1297.098 & 681.562 & 65.321 & 916.708 & Yes \\
\hline
\end{tabular} $\begin{array}{llllllllllllllll}\text { LGANSLLDLVVFGR } & 1.00 & 86.88 & 25.60 & 26.90 & 2 & 1616.9382 & 1616.9372 & 809.4759 & 0.0010 & 0.6177 & 328.010 & 150.910 & 52.158 & 226.848 & \text { Yes }\end{array}$ $\begin{array}{llllllllllllllll}\text { GEGGILINSQGER } & 1.00 & 81.28 & 25.16 & 26.79 & 2 & 1616.9398 & 1616.9372 & 809.4759 & 0.0026 & 1.6060 & 82.597 & 41.649 & 12.645 & 73.078 & \text { Yes }\end{array}$ GEGGILINSQGER

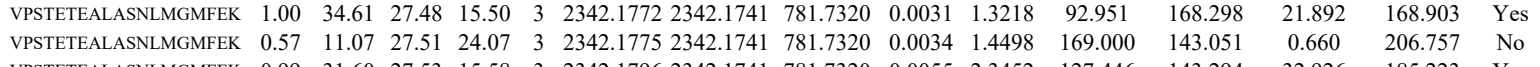

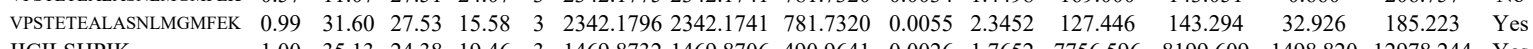

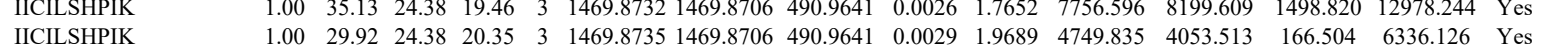

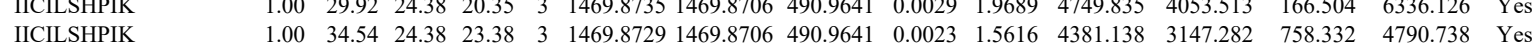

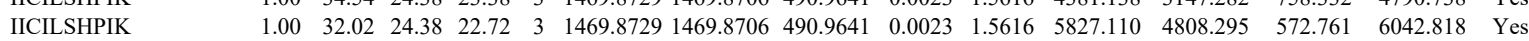

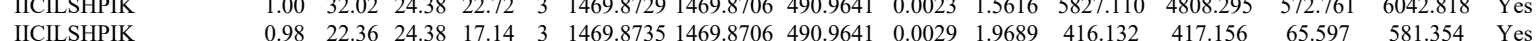
$\begin{array}{llllllllllllllll}\text { EVEPALELLEPIDQK } & 1.90 & 47.51 & 4.94 & 17.38 & 3 & 2010.1138 & 2010.1128 & 671.0449 & 0.0010 & 0.4967 & 59.554 & 45.956 & 73.401 & 95.584 & \text { Yes }\end{array}$

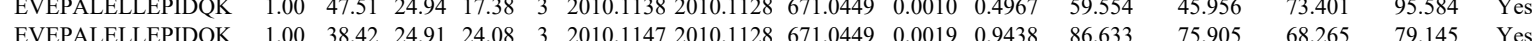
$\begin{array}{llllllllllllllll}\text { EVEPALELLEPIDQK } & 1.00 & 31.00 & 24.91 & 15.43 & 3 & 2010.1159 & 2010.1128 & 671.0449 & 0.0031 & 1.5399 & 94.077 & 110.466 & 116.536 & 132.810 & \text { Yes }\end{array}$

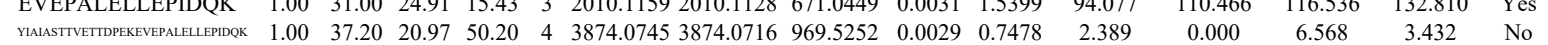

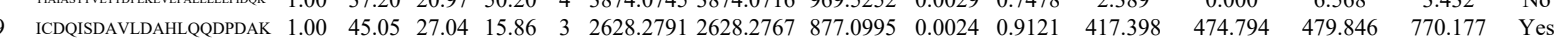
$\begin{array}{llllllllllllllll}\text { ICDQISDAVLDAHLQODPDAK } & 0.66 & 48.24 & 27.04 & 61.24 & 3 & 2628.2791 & 2628.2767 & 877.0995 & 0.0024 & 0.9121 & 222.029 & 275.823 & 452.179 & 497.128 & \text { Yes }\end{array}$

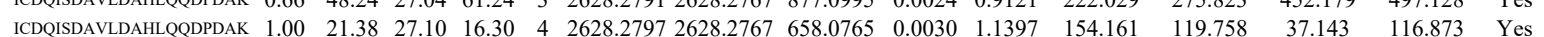

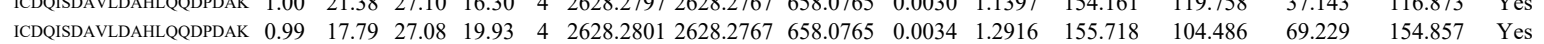
$\begin{array}{llllllllllllllll}\text { TCNVLVALEQQSPDIAQGVHLDR } & 0.66 & 72.94 & 27.10 & 85.94 & 3 & 2695.3564 & 2695.3544 & 899.4587 & 0.0020 & 0.7412 & 0.000 & 42.401 & 29.238 & 79.219 & \text { No }\end{array}$

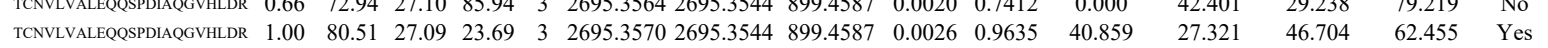
$\begin{array}{llllllllllllllll}\text { TCNVLVALEQQSPDIAQGVHLDR } & 1.00 & 77.23 & 27.10 & 25.28 & 3 & 2695.3564 & 2695.3544 & 899.4587 & 0.0020 & 0.7412 & 181.885 & 245.691 & 147.174 & 300.900 & \text { Yes }\end{array}$ $\begin{array}{lllllllllllllllll}\text { TCNVLVALEQQSPDIAQGVHLDR } & 1.00 & 85.01 & 27.30 & 24.98 & 3 & 2695.3579 & 2695.3544 & 899.4587 & 0.0035 & 1.2971 & 217.502 & 436.565 & 330.454 & 400.142 & \text { Yes }\end{array}$ $\begin{array}{lllllllllllllllll}\text { TCNVLVALEQSPDIAQGVHLDR } & 1.00 & 56.40 & 27.26 & 23.28 & 4 & 2695.3589 & 2695.3544 & 674.8459 & 0.0045 & 1.6670 & 120.182 & 119.248 & 102.928 & 189.766 & \text { Yes }\end{array}$ $\begin{array}{llllllllllllllllll}\text { FVIGGPQGDAGLTGR } & 1.00 & 87.83 & 27.53 & 26.81 & 2 & 1587.8646 & 1587.8491 & 794.9318 & 0.0155 & 9.7492 & 2788.053 & 3242.996 & 381.595 & 4224.803 & \text { Yes }\end{array}$ \begin{tabular}{llllllllllllllll}
\hline ETEVIDPQDLLEGR & 1.00 & 81.30 & 27.41 & 21.16 & 2 & 1756.8984 & 1756.8965 & 879.4555 & 0.0019 & 1.0802 & 10.400 & 20.612 & 76.402 & 87.035 & Yes
\end{tabular} $\begin{array}{llllllllllllllll}\text { ETEVIDPQDLLEGR } & 1.00 & 73.31 & 27.40 & 20.46 & 2 & 1756.8990 & 1756.8965 & 879.4555 & 0.0025 & 1.4213 & 11.623 & 45.921 & 101.319 & 97.203 & \text { Yes }\end{array}$ $\begin{array}{llllllllllllllll}\text { ETEVIDPQDLLEGR } & 1.00 & 79.37 & 27.37 & 22.11 & 2 & 1756.8978 & 1756.8965 & 879.4555 & 0.0013 & 0.7391 & 41.356 & 38.414 & 170.069 & 167.483 & \text { Yes }\end{array}$

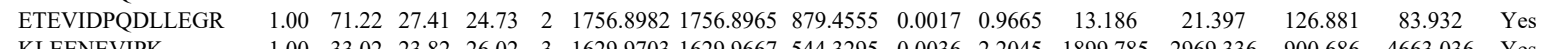
KLEENEVIPK $\begin{array}{lllllllllll}1.00 & 57.56 & 22.72 & 52.18 & 3 & 2809.2385 & 2809.2358 & 937.4192 & 0.0027 & 0.9601 & 1.322\end{array}$ $\begin{array}{llllllllllllll} & \\ \text { QISQAYEVLSDAK } & 0.95 & 63.99 & 22.94 & 61.99 & 3 & 2809.2421 & 2809.2358 & 937.4192 & 0.0063 & 2.2402 & 4.565 & 3 & \\ \end{array}$ VNFPENGFLSPDK $\begin{array}{llllllllllllllllll}\text { NVVHOLSVTLEDLYNGATR } & 1.00 & 64.36 & 18.57 & 25.52 & 3 & 1680.0274 & 1680.0178 & 561.0132 & 0.0096 & 5.7039 & 8804.140 & 10796.116 & 5929.001 & 15014.739 & \text { Yes }\end{array}$ $\begin{array}{lllllllllllllll} & & \end{array}$

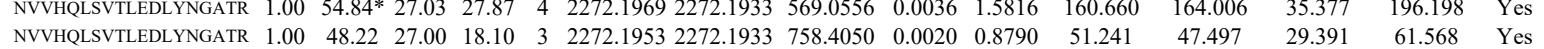




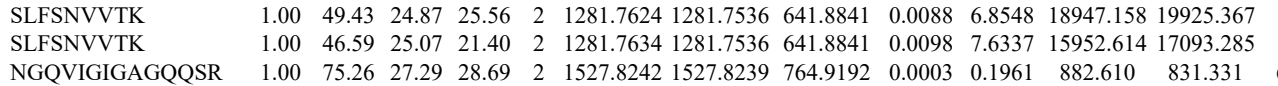
$\begin{array}{llllllllllll} & & \end{array}$ $\begin{array}{lllllllllllll}\text { VIEACDELGIILAHTNLR } & 1.00 & 68.05 & 26.42 & 17.61 & 3 & 2268.2116 & 2268.2092 & 757.0770 & 0.0024 & 1.0567 & 214.131 & 230.344 \\ \text { VIFA }\end{array}$

WEACDELGIILAHTNLR

LDFNLIR

LDFNLIR

LDFNLIR

LDFNLIR

TLTPISAAYAR

TLFGLHLSQK

TLFGLHLSQK

TLFGLHLSQK

TLFGLHLSQK

TITSAYYR

$\begin{array}{llllllllll} & \end{array}$

1506.0121104 .832

$\begin{array}{llllll}0.00 & 72.53 & 26.42 & 19.98 & 3 & 22 \\ 0.99 & 33.64 & 27.62 & 24.42 & 2 & 10\end{array}$

$\begin{array}{lllllllllllll}0.99 & 33.64 & 27.62 & 24.42 & 2 & 1033.6050 & 1033.6042 & 517.8094 & 0.0008 & 0.7725 & 19622.936 & 19023.157 & 46.3\end{array}$ $\begin{array}{llllllllllllllll}0.93 & 26.91 & 27.96 & 25.98 & 2 & 1033.6054 & 1033.6042 & 517.8094 & 0.0012 & 1.1587 & 14167.816 & 15001.863 & 1014.115 & 16262.935 & \text { Yes }\end{array}$ $\begin{array}{llllllllllllllll}0.99 & 33.59 & 28.21 & 24.43 & 2 & 1033.6064 & 1033.6042 & 517.8094 & 0.0022 & 2.1243 & 12569.869 & 13106.363 & 739.255 & 16818.987 & \text { Yes }\end{array}$ $\begin{array}{lllllllllllllllll}0.90 & 34.94 & 27.27 & 28.26 & 2 & 1306.7428 & 1306.7367 & 654.3756 & 0.0061 & 4.6609 & 42831.039 & 36849.266 & 1581.519 & 36507.607 & \text { Yes }\end{array}$ $\begin{array}{llllllllllllllll}0.98 & 38.21 & 24.12 & 30.82 & 3 & 1430.8606 & 1430.8489 & 477.9569 & 0.0117 & 8.1597 & 17097.923 & 20379.344 & 0.000 & 26991.646 & \text { No }\end{array}$ $\begin{array}{lllllllllllllll}0.95 & 35.90 & 23.60 & 30.91 & 3 & 1430.8624 & 1430.8489 & 477.9569 & 0.0135 & 9.4150 & 16382.127 & 19144.028 & 0.000 & 26383.792 & \mathrm{No} \\ 1.00 & 48.36 & 24.12 & 33.71 & 3 & 1430.8609 & 1430.8489 & 477.9569 & 0.0120 & 8.3689 & 14071.582 & 15583.851 & 432.756 & 21571.038 & \text { Yes }\end{array}$ $\begin{array}{lllllllllllllll}1.00 & 48.36 & 24.12 & 33.71 & 3 & 1430.8609 & 1430.8489 & 477.9569 & 0.0120 & 8.3689 & 14071.582 & 15583.851 & 432.756 & 21571.038 & \text { Yes } \\ 0.98 & 38.74 & 23.60 & 30.45 & 3 & 1430.8624 & 1430.8489 & 477.9569 & 0.0135 & 9.4150 & 3413.863 & 3176.663 & 62.199 & 3988.859 & \text { Yes }\end{array}$

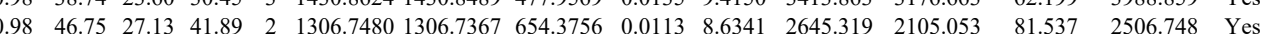
\begin{tabular}{|lllllllllllllllll} 
&
\end{tabular} $\begin{array}{llllllllllllllll} & \\ \text { TLHPAVHAGILAR } & 0.66 & 61.09 & 24.33 & 74.09 & 3 & 1498.8874 & 1498.8854 & 500.6357 & 0.0020 & 1.3316 & 532.258 & 485.206 & 333.047 & 594.203 & \text { Yes }\end{array}$ $\begin{array}{lllllllllllllllll}\text { NIPEDNADMAR } & 1.00 & 49.43 & 25.42 & 26.60 & 2 & 1388.6488 & 1388.6476 & 695.3311 & 0.0012 & 0.8629 & 6123.343 & 6491.294 & 1205.541 & 8483.874 & \text { Yes }\end{array}$ $\begin{array}{lllllllllllllllll} & & & \end{array}$ \begin{tabular}{lllllllllllllll} 
& 22.90 & 20.09 & 3 & 1887.1039 & 1887.1033 & 630.0417 & 0.0006 & 0.3174 & 53.518 & 50.747 & 19.412 & 68.424 & Yes \\
\hline
\end{tabular}

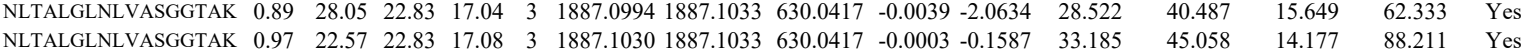

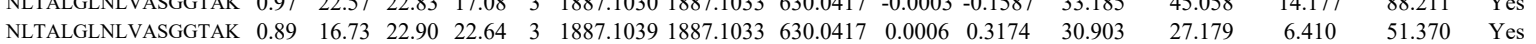
$\begin{array}{llllllllllllllll}\text { NLTALGLNLVASGGTAK } & 0.98 & 23.47 & 22.90 & 14.78 & 3 & 1887.1039 & 1887.1033 & 630.0417 & 0.0006 & 0.3174 & 25.791 & 36.251 & 9.566 & 41.861 & \text { Yes }\end{array}$ $\begin{array}{lllllllllllllllll}\text { ALFEEVPELLTEAEK } & 0.65 & 16.05 & 26.15 & 20.86 & 2 & 2005.0874 & 2005.0863 & 1003.5504 & 0.0011 & 0.5481 & 5.470 & 2.154 & 7.046 & 8.413 & \text { Yes }\end{array}$ $\begin{array}{lllllllllllllllll}\text { ALFEEVPELLTEAEK } & 0.99 & 36.23 & 26.15 & 17.83 & 2 & 2005.0874 & 2005.0863 & 1003.5504 & 0.0011 & 0.5481 & 30.072 & 30.890 & 43.618 & 26.346 & \text { Yes }\end{array}$ $\begin{array}{llllllllllllllll}\text { ALFEEVPELLTEAEK } & 0.97 & 29.10 & 26.15 & 18.55 & 2 & 2005.0874 & 2005.0863 & 1003.5504 & 0.0011 & 0.5481 & 42.094 & 14.228 & 11.548 & 52.247 & \text { Yes }\end{array}$ $\begin{array}{llllllllllllllll}\text { ALFEEVPELLTEAEK } & 0.66 & 19.21 & 26.43 & 32.21 & 3 & 2005.0879 & 2005.0863 & 669.3694 & 0.0016 & 0.7968 & 43.696 & 26.663 & 14.777 & 33.628 & \text { Yes }\end{array}$ $\begin{array}{lllllllllllllllll}\text { ALFEEVPELLTEAEK } & 1.00 & 55.34 & 26.67 & 25.88 & 3 & 2005.0888 & 2005.0863 & 669.3694 & 0.0025 & 1.2450 & 119.662 & 198.948 & 80.349 & 212.070 & \text { Yes }\end{array}$ $\begin{array}{lllllllllllllllll}\text { ALFEEVPELLTEAEK } & 1.00 & 56.08 & 26.67 & 21.83 & 3 & 2005.0894 & 2005.0863 & 669.3694 & 0.0031 & 1.5437 & 41.282 & 54.501 & 25.187 & 78.929 & \text { Yes }\end{array}$ $\begin{array}{llllllllllllllll}\text { ALFEEVPELLTEAEK } & 0.56 & 17.49 & 26.67 & 15.87 & 2 & 2005.0894 & 2005.0863 & 1003.5504 & 0.0031 & 1.5445 & 3.385 & 2.240 & 9.758 & 8.437 & \text { No }\end{array}$

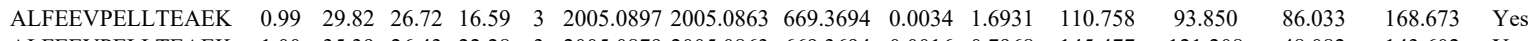

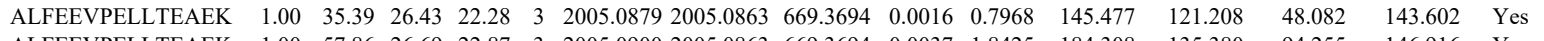
$\begin{array}{llllllllllllllll}\text { ALFEEVPELLTEAEK } & 1.00 & 57.86 & 26.69 & 22.87 & 3 & 2005.0900 & 2005.0863 & 669.3694 & 0.0037 & 1.8425 & 184.308 & 135.380 & 94.255 & 146.916 & \text { Yes }\end{array}$

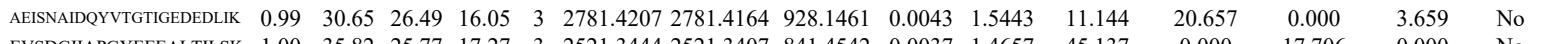
$\begin{array}{llllllllllllllll}\text { EVSDGIIAPGYEEEALTILSK } & 1.00 & 35.82 & 25.77 & 17.27 & 3 & 2521.3444 & 2521.3407 & 841.4542 & 0.0037 & 1.4657 & 45.137 & 0.000 & 17.706 & 0.000 & \text { No }\end{array}$

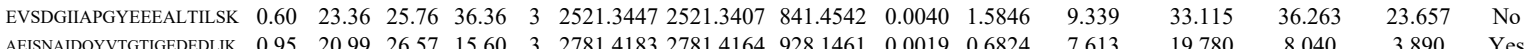

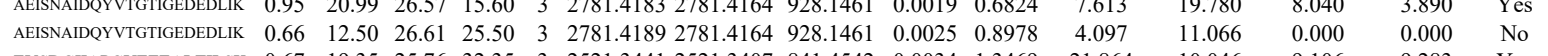
$\begin{array}{llllllllllllllll}\text { EVSDGIIAPGYEEEALTILSK } & 0.67 & 19.35 & 25.76 & 32.35 & 3 & 2521.3441 & 2521.3407 & 841.4542 & 0.0034 & 1.3469 & 21.864 & 10.046 & 9.106 & 9.283 & \text { Yes } \\ \text { EVSDGIIAPGYEEEALTISK } & 0.60 & 19.25 & 25.77 & 32.25 & 3 & 2521.3444 & 2521.3407 & 841.4542 & 0.0037 & 1.4657 & 7.471 & 22.361 & 0.000 & 12.125 & \text { No }\end{array}$

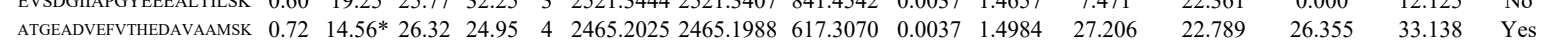
$\begin{array}{ccccccccccccccc}\text { ATENDIANFFSPLNPIR } & 1.00 & \text { \#\#\#\# } 28.06 & 29.13 & 2 & 2062.0614 & 2062.0605 & 1032.0375 & 0.0009 & 0.4360 & 1295.637 & 1368.847 & 1210.234 & 1292.132 & \text { Yes }\end{array}$ 
$\begin{array}{lllllllllllll}\text { AVIEQGHELSNEER } & 1.00 & 81.32 & 26.45 & 32.31 & 2 & 1741.8354 & 1741.8353 & 871.9249 & 0.0001 & 0.0573 & 18.748 \\ \text { AVTEQGHELSNEER } & 1.00 & 60.26 & 26.45 & 18.90 & 3 & 1741.8355 & 1741.8353 & 581.6190 & 0.0002 & 0.1146 & 137.458 & \\ \text { AVTEQGS }\end{array}$

\section{GEELSCEER} $\begin{array}{rrrrrrrrrrr}1.00 & 45.90 & 19.03 & 23.45 & 2 & 1240.5200 & 1240.5185 & 621.2665 & 0.0015 & 1.2072 & 731.157\end{array}$ $\begin{array}{llllllllllllll} & \text { GELILWTADAGEEGGEAPQEPQS } & 0.99 & 27.05 & 24.00 & 14.96 & 3 & 2672.1979 & 2672.1960 & 891.7393 & 0.0019 & 0.7102 & 5.998 & 2.117\end{array}$ $\begin{array}{lllllllllllll} & \end{array}$ ITFDEAMADLHTLSEDSYK $\begin{array}{lllllllllll}0.60 .29 & 26.61 & 69.29 & 3 & 2461.1602 & 2461.1563 & 821.3927 & 0.0039 & 1.5827 & 603.186 \\ 0.50 & 21.61 & 30.28 & 33.59 & 2 & 817.4778 & 817.4779 & 409.7462 & -0.0001 & -0.1220 & 37.374\end{array}$ $\begin{array}{llllllllllllll}1.00 & 54.75 & 26.82 & 22.07 & 2 & 1392.6690 & 1392.6661 & 697.3403 & 0.0029 & 2.0793 & 8208.420 & 6298.665 & 102\end{array}$ $\begin{array}{lllllllllllll}1.00 & 56.27 & 26.70 & 23.04 & 2 & 1392.6694 & 1392.6661 & 697.3403 & 0.0033 & 2.3661 & 1122.6101 & 9205.243 & 677.3 \\ 0.99 & 38.57 & 26.42 & 20.62 & 3 & 2461.1548 & 2461.1563 & 821.3927 & -0.0015 & -0.6087 & 383.070 & 265.705 & \end{array}$ $\begin{array}{llllllllllllll}0.99 & 38.57 & 26.42 & 20.62 & 3 & 2461.1548 & 2461.1563 & 821.3927 & -0.0015 & -0.6087 & 383.070 & 265.705 & 144.7 \\ 0.83 & 28.55 & 30.16 & 29.90 & 2 & 817.4780 & 817.4779 & 409.7462 & 0.0001 & 0.1220 & 49.801 & 34.037 & \end{array}$ $\begin{array}{llllllllllllll}0.83 & 28.55 & 30.16 & 29.90 & 2 & 817.4780 & 817.4779 & 409.7462 & 0.0001 & 0.1220 & 49.801 & 34.037 \\ 0.91 & 31.64 & 30.16 & 34.05 & 2 & 817.4784 & 817.4779 & 409.7462 & 0.0005 & 0.6101 & 21.592 & 22.143\end{array}$ $\begin{array}{lllllllllllll}1.00 & 54.65 & 26.81 & 21.13 & 2 & 1392.6692 & 1392.6661 & 697.3403 & 0.00031 & 2.2227 & 16755.538 & 13981.905 & 40.35 \\ 1.00 & 54.74 & 26.70 & 22.85 & 2 & 1392.6694 & 1392.6661 & 697.3403 & 0.0033 & 2.3661 & 15078.357 & 12116.542 & 1057.7\end{array}$ $\begin{array}{llllllllllllll}1.00 & 54.74 & 26.70 & 22.85 & 2 & 1392.6694 & 1392.6661 & 697.3403 & 0.0033 & 2.3661 & 15078.357 & 12116.542 & 1052.7 \\ 0.88 & 30.37 & 30.16 & 36.98 & 2 & 817.4780 & 817.4779 & 409.7462 & 0.0001 & 0.1220 & 31.526 & 19.732 & 17.73 \\ 0.88 & 30.27 & 30.16 & 36.67 & 2 & 817.4782 & 17.4779 & 09.7462 & 0.003 & 0.3661 & 30.786 & 36.325 & 1\end{array}$ $\begin{array}{lllllllllllll}0.88 & 30.27 & 30.16 & 36.67 & 2 & 817.4782 & 817.4779 & 409.7462 & 0.0003 & 0.3661 & 30.726 & 36.325 \\ 0.73 & 18.09 & 26.50 & 18.54 & 2 & 872.4962 & 872.4950 & 437.2548 & 0.0012 & 1.3722 & 401.829 & 247.637\end{array}$ $\begin{array}{lllllllllllll}0.73 & 18.09 & 26.50 & 18.54 & 2 & 872.4962 & 872.4950 & 437.2548 & 0.0012 & 1.3722 & 401.829 & 247.637 \\ 0.87 & 21.35 & 26.30 & 19.81 & 2 & 872.4966 & 872.4950 & 437.2548 & 0.0016 & 1.8296 & 566.216 & 294.807 \\ 0.94 & 33.19 & 26.59 & 20.18 & 2 & 1392.6698 & 1392.6661 & 697.3403 & 0.0037 & 2.6529 & 3299.201 & 363.763\end{array}$ 

$\begin{array}{llllllllllll} & \text { EKVETELQGVCDTVLGLLDSHLIK } & 1.00 & \text { \#\#\#\#\# } 23.58 & 29.57 & 3 & 3116.6872 & 3116.6827 & 1039.9015 & 0.0045 & 1.4424 & 82.826 \\ \text { KVVETELQGVCDTVLGLDSHLK } & 1.00 & 53.34 & 23.58 & 25.44 & 4 & 3116.6873 & 3116.6827 & 780.1780 & 0.0046 & 1.4740 & 897.183\end{array}$ $\begin{array}{llllllllllllll}\text { VETELOGVCDTVLGLLDSHLIK } & 1.00 & 72.38 & 24.94 & 22.45 & 3 & 2715.4450 & 2715.4431 & 906.1550 & 0.0019 & 0.6989 & 36.329\end{array}$

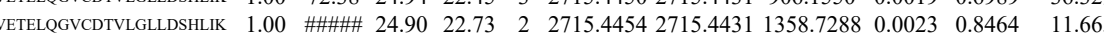

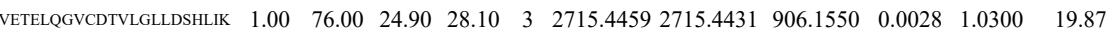
$\begin{array}{llllllllllllll}\text { VETELQGVCDTVLGLLDSHLK } & 1.00 & 89.68 & 24.93 & 22.65 & 3 & 2715.4465 & 2715.4431 & 906.1550 & 0.0034 & 1.2507 & 35.644\end{array}$

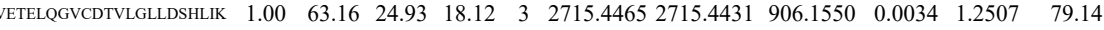

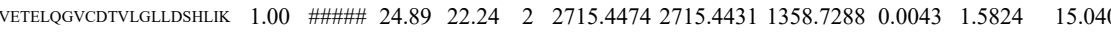
$\begin{array}{lllllllllllll}\text { NETELQGVCDTVLGLLDSHLIK } & 1.00 & 34.89 & 24.90 & 19.94 & 4 & 2715.4477 & 2715.4431 & 679.8681 & 0.0046 & 1.6915 & 74.569\end{array}$ $\begin{array}{llllllllllll}\text { VETELQGVCDTVLGLLDSHLIK } & 1.00 & 73.22 & 24.91 & 23.55 & 3 & 2715.4483 & 2715.4431 & 906.1550 & 0.0052 & 1.9128 & 91.580 \\ \text { VETELOGYDTLLLDSLIK } & 1.00 & 22.69 & 24.91 & 14.76 & 4 & 2715.4501 & 2715.4431 & 679.8681 & 0.0070 & 2.5740 & 55.623\end{array}$ $\begin{array}{llllllllllll}\text { VETELQGVCDTVLGLLDSHLIK } & 1.00 & 22.69 & 24.91 & 14.76 & 4 & 2715.4501 & 2715.4431 & 679.8681 & 0.0070 & 2.5740 & 55.623 \\ \text { VETELOGVDTVLGLDSHLK } & 1.00 & 75.86 & 24.36 & 23.75 & 3 & 2715.4615 & 27154431 & 906.1550 & 0.0184 & 67685 & 9982.939\end{array}$ $\begin{array}{lllllllllllll}\text { VETELQGVCDTVLGLLDSHLIK } & 1.00 & 75.86 & 24.36 & 23.75 & 3 & 2715.4615 & 2715.4431 & 906.1550 & 0.0184 & 6.7685 & 9982.939 \\ \text { VETELQGVCDTVLGLDSHLIK } & 1.00 & 77.26 & 24.33 & 20.00 & 3 & 2715.4621 & 2715.4431 & 906.1550 & 0.0190 & 6.9892 & 9010.458\end{array}$ $\begin{array}{llllllllllll}\text { VETELQGVCDTVLGLLDSHLIK } & 1.00 & 77.26 & 24.33 & 20.00 & 3 & 2715.4621 & 2715.4431 & 906.1550 & 0.0190 & 6.9892 & 9010.458 \\ \text { EKVETELQGVCDTVLGLDSHLIK } & 1.00 & 48.65 & 23.69 & 16.06 & 4 & 3116.6861 & 3116.6827 & 780.1780 & 0.0034 & 1.0895 & 117.782\end{array}$

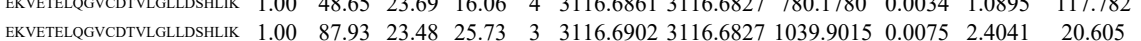

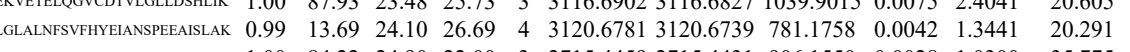
$\begin{array}{llllllllllll}\text { VETELQGVCDIVLGLDSHLIK } & 1.00 & 84.22 & 24.90 & 22.00 & 3 & 2715.4459 & 2715.4431 & 906.1550 & 0.0028 & 1.0300 & 35.775\end{array}$ $\begin{array}{lllllllllll} & 0\end{array}$

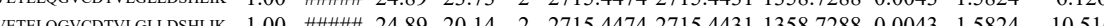

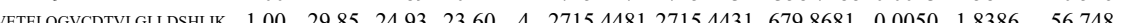
$\begin{array}{lllllllllllll} & \text { V. }\end{array}$ $\begin{array}{lllllllllllll}\text { VETELQGVCDTVLGLDDSLLIK } & 1.00 & 77.16 & 24.36 & 18.05 & 3 & 2715.4618 & 2715.4431 & 906.1550 & 0.0187 & 6.8788 & 8262.673\end{array}$ $\begin{array}{llllllllllllll}\text { EKVETELQGVCDTVLGLLDSHLIK } & 1.00 & 51.82 & 23.42 & 64.82 & 4 & 3116.6913 & 3116.6827 & 780.1780 & 0.0086 & 2.7558 & 41.779\end{array}$ \begin{tabular}{llllllllllll} 
LGLLLNFSVFHYEIANSPEEAISLAK & 1.00 & 62.17 & 24.20 & 18.10 & 3 & 3120.6772 & 3120.6739 & 1041.2319 & 0.0033 & 1.0564 & 87.886 \\
\hline
\end{tabular} $\begin{array}{llllllllllll} & \text { (1.03 }\end{array}$

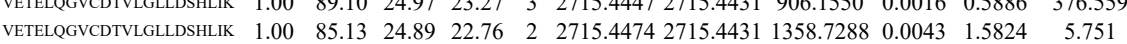
$\begin{array}{llllllllllllll}\text { VETELQGVCDTVLGLLDSHLIK } & 1.00 & 28.32 & 24.93 & 19.26 & 4 & 2715.4481 & 2715.4431 & 679.8681 & 0.0050 & 1.8386 & 67.890\end{array}$ $\begin{array}{llllllllllllll}\text { VETELQGVCDTVLGLLDSHLIK } & 1.00 & 21.01 & 24.91 & 24.75 & 4 & 2715.4493 & 2715.4431 & 679.8681 & 0.0062 & 2.2798 & 16.168\end{array}$ $\begin{array}{llllllllllll}\text { VETELQGVCDTVLGLLDHLIK } & 1.00 & 84.90 & 24.71 & 24.94 & 3 & 2715.4531 & 2715.4431 & 906.1550 & 0.0100 & 3.6785 & 4234.034\end{array}$ $\begin{array}{lllllllllllll}\text { VETELQGVCDTVLGLLDSLIK } & 1.00 & 85.18 & 24.93 & 20.94 & 3 & 2715.4465 & 2715.4431 & 906.1550 & 0.0034 & 1.2507 & 249.856 \\ \text { VETELQGVCDTVLGLDSHUK } & 1.00 & 42.4 & 24.93 & 17.56 & 4 & 2715.4481 & 2715.4431 & 679.8681 & 0.0050 & 1.8386 & 76.109\end{array}$ $\begin{array}{lllllllllllll} & \end{array}$

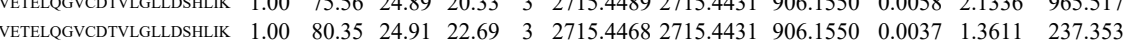
$\begin{array}{lllllllllllll} & \text { EETELQGVCDTVLGLLDSHLIK } & 1.00 & 83.41 & 24.91 & 18.71 & 3 & 2715.4483 & 275.4431 & 906.1550 & 0.0052 & 1.9128 & 129.959\end{array}$ $\begin{array}{lllllllllllll}0.94 & 18.60 & 18.92 & 15.60 & 2 & 1240.5198 & 1240.5185 & 621.2665 & 0.0013 & 1.0462 & 84.408\end{array}$ $\begin{array}{lllllllllll}1.00 & 50.83 & 19.29 & 23.21 & 2 & 1240.5210 & 1240.5185 & 621.2665 & 0.0025 & 2.0120 & 512.529\end{array}$ 
$\begin{array}{llllllllllllll} & \text { THE }\end{array}$

TTDSPEDVK

DPQALSEHLK

DPQALSEHLK

DPQASEHLK

NKPSDLGTK

NKPSDLGTK

DPQALSEHLK

DPQALSEHLK

LAYINPDLALEEK

LAYINPDLALEEK

LAYINPDLALEEK

LAYINPDLALEEK

AMADPEVQQIMSDPAM

NKPSDLGTK

LAYINPDLALEEK

AYINPDLALEEK

NPVIAQK

NPVIAQK

PVIAQ

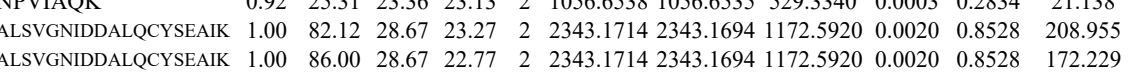

$\begin{array}{lllllllllllll}\text { ALSVGNIDDALQCYSEAIK } & 1.00 & 82.12 & 28.67 & 23.27 & 2 & 2343.1714 & 2343.1694 & 1172.5920 & 0.0020 & 0.8528 & 2.08 .955 \\ \text { ALSVGNIDDALQCYSEAIK } & 1.00 & 86.00 & 28.67 & 22.77 & 2 & 2343.1714 & 2343.1694 & 1172.5920 & 0.0020 & 0.8528 & 172.229 & 15\end{array}$

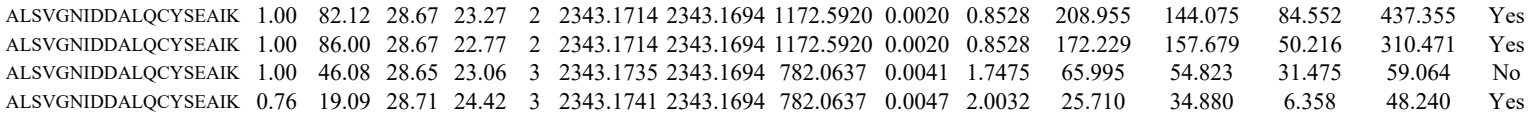

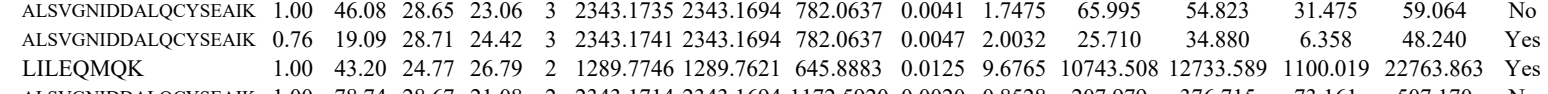

$\begin{array}{lllllllllllll}0.60 & 44.30 & 26.61 & 57.30 & 3 & 2461.1602 & 2461.1563 & 821.3927 & 0.0039 & 1.5827 & 3343.474 & 2990.635 \\ 0.63 & 16.04 & 27.15 & 25.53 & 3 & 1213.6180 & 1213.6183 & 405.5467 & -0.0003 & -0.2466 & 81.244 & 76.677\end{array}$

$\begin{array}{llllllllllll} & 88.87 & 01.111 & \text { Yes }\end{array}$

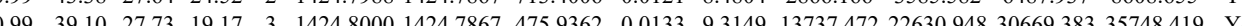

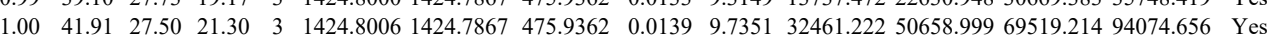

$\begin{array}{lllllllllllllll}0.99 & 27.48 & 25.79 & 2.5 .58 & 3 & 1390.8154 & 1390.8145 & 464.6121 & 0.0009 & 0.6457 & 1164.944 & 1372.004 & 788.735 & 2198.003 & \text { Yes }\end{array}$

$\begin{array}{llllllllllllllll}0.99 & 27.97 & 25.76 & 16.48 & 3 & 1390.8157 & 1390.8145 & 464.6121 & 0.0012 & 0.8609 & 1097.504 & 1465.256 & 803.507 & 2342.170 & \text { Yes }\end{array}$

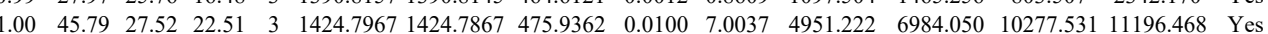
$\begin{array}{lllllllllllllll}1.00 & 45.00 & 27.49 & 20.33 & 3 & 1424.7976 & 1424.7867 & 475.9362 & 0.0109 & 7.6340 & 5185.893 & 8324.456 & 10335.477 & 12363.417 & \text { Yes }\end{array}$ \begin{tabular}{lllllllllllllll}
1.00 & 80.08 & 26.38 & 22.86 & 2 & 1775.9922 & 1775.9912 & 889.0029 & 0.0010 & 0.5624 & 819.859 & 1646.616 & 129.838 & 3841.323 & Yes \\
\hline
\end{tabular} $\begin{array}{lllllllllllllll}1.00 & 37.22 & 26.29 & 18.38 & 3 & 1775.9938 & 1775.9912 & 593.0043 & 0.0026 & 1.4615 & 163.936 & 161.475 & 98.381 & 303.293 & \text { Yes }\end{array}$ $\begin{array}{lllllllllllllll}0.99 & 29.28 & 26.28 & 19.32 & 3 & 1775.9941 & 1775.9912 & 593.0043 & 0.0029 & 1.6301 & 174.844 & 147.927 & 91.663 & 134.163 & \text { No }\end{array}$ $\begin{array}{llllllllllllll}86.53 & 25.93 & 21.36 & 2 & 2032.9534 & 2032.9502 & 1017.4824 & 0.0032 & 1.5725 & 118.154 & 79.676 & 31.934 & 228.227 & \text { Yes } \\ \end{array}$ $\begin{array}{lllllllllllllll}0.95 & 24.07 & 25.75 & 19.24 & 3 & 1390.8136 & 1390.8145 & 464.6121 & -0.0009 & -0.6457 & 531.128 & 638.435 & 461.614 & 93.564 & \text { Yes } \\ 0.95 & 1390.4145 & 1390.8145 & 464.6121 & 0.0000 & 0.0000 & 553.257 & 683.347 & 611.176 & 938.085 & \text { Yes }\end{array}$ $\begin{array}{lllllllllllllll}1.00 & 63.33 & 26.30 & 24.17 & 2 & 1775.9934 & 1775.9912 & 889.0029 & 0.0022 & 1.2373 & 928.441 & 950.624 & 54.529 & 3199.799 & \text { No }\end{array}$

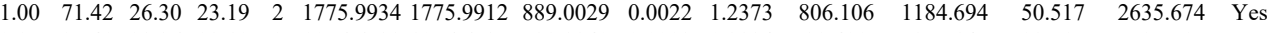
$\begin{array}{lllllllllllllll}0.95 & 27.41 & 23.36 & 23.19 & 2 & 1056.6538 & 1056.6535 & 529.3340 & 0.0003 & 0.2834 & 32.490 & 35.714 & 22.715 & 52.751 & \text { Yes }\end{array}$

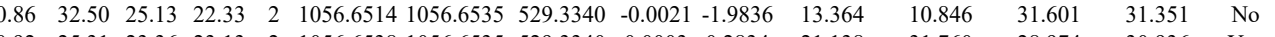
$\begin{array}{llllllllllllllll} & 1.00 & 78.74 & 28.67 & 21.08 & 2 & 2343.1714 & 2343.1694 & 1172.5920 & 0.0020 & 0.8528 & 207.979 & 376.715 & 73.161 & 22763.863 & \text { Yes } \\ \text { ALSVGNIDDALQCYSEAIK } & 1.070 & \text { No }\end{array}$

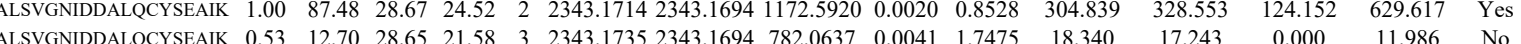

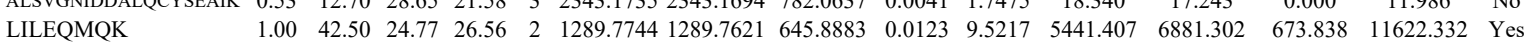

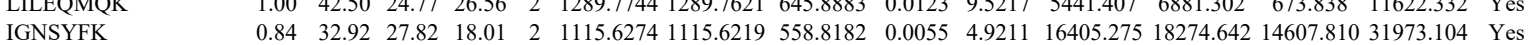


IGNSYFK

LDPHNHVLYSNR

LDPHNHVLYSN

AAALEFLNR

LLEFQLALK

LLEFQLALK

LMDVGLIAIR

LMDVGLIAIR

LMDVGLIAIR

LMDVGLIAIR

THDIR

TTKPEMDPENK

NKPSDLGTK

DPQLATK

DPQALSEHLK

DPQALSEHLK

AMADPEVQQIMSDPA

AMADPEVQQIMSDPAMR

AMADPEVQQIMSDPAMR

6 AVPSQK

AVPSOK

DGYNYTLSK

DGYNYTLSK

AVPSQK

AVPSQK

AVPSQK

AVPSQK

AVPSQK

AVPSQK

TEFLSFMNTELAAFTK

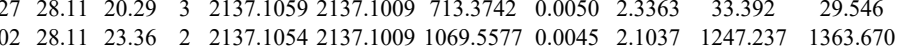

$\begin{array}{lllllllllllll}\text { TELSMNELAAFTK } & 1.00 & \text { \#\#\#\# } 28.11 & 33.08 & 2 & 2137.1054 & 2137.1009 & 1069.5577 & 0.0045 & 2.1037 & 2324.149 & 2249.461\end{array}$

$\begin{array}{lllllllllllll}\text { TELSTMNELAAFTK } & 1.00 & 45.46 & 28.11 & 21.13 & 3 & 2137.1059 & 2137.1009 & 713.3742 & 0.0050 & 2.3363 & 394.093 & 218.708\end{array}$

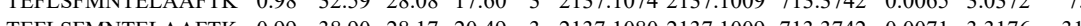

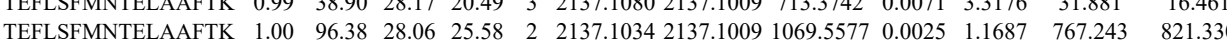

$\begin{array}{lllllllll} & \end{array}$

$\begin{array}{lllllllllllll}\text { TEFLSFMNTELAAFTK } & 1.00 & 89.59 & 28.06 & 23.33 & 2 & 2137.1034 & 2137.1009 & 1069.5577 & 0.0025 & 1.1687 & 543.258 & 533.376\end{array}$

$\begin{array}{llllllllllllllll} & & 234.355\end{array}$

$\begin{array}{llllllllllllll} & \text { TEFLFPMTELAAFTK } & 1.00 & 97.14 & 28.11 & 27.14 & 2 & 2137.1054 & 2137.1009 & 1069.5577 & 0.0045 & 2.1037 & 135.136 & 147.047\end{array}$

$\begin{array}{llllllllllllll} & \text { TEFLSFMNTELAAFTK } & 1.00 & 64.78 & 28.05 & 18.62 & 3 & 2137.1044 & 2137.1009 & 713.3742 & 0.0035 & 1.6354 & 28.829 & 29.788\end{array}$

$\begin{array}{lllllllllllllll} & \text { TEFLSFMNTELAAFTK } & 1.00 & 66.88 & 28.18 & 20.64 & 3 & 2137.1029 & 2137.1009 & 713.3742 & 0.0020 & 0.9345 & 36.601 & 44.422\end{array}$

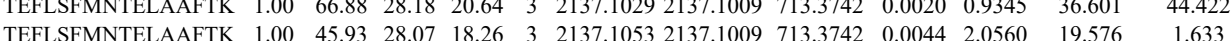

$\begin{array}{llllllllllllll}\text { TEFLSFMNTELAAFTK } & 1.00 & 50.48 & 28.10 & 23.74 & 3 & 2137.1017 & 2137.1009 & 713.3742 & 0.0008 & 0.3738 & 45.103 & 32.666\end{array}$

$\begin{array}{llllllllllllll}\text { TEFLSFMNTELAAFK } & 1.00 & 69.45 & 28.10 & 22.25 & 3 & 2137.1041 & 2137.1009 & 713.3742 & 0.0032 & 1.4952 & 40.978 & 34.840\end{array}$

CIESLIAVFQK

CIESLIAVFQK

CIESLIAVFQK

CIESLIAVFQK

CIESLIAVFQK

CIESLIAVFQK

CIESLIAVFQK

CIESLIAVFQK

CIESLIAVFQK

CIESLIAVFQK

CIESLIAVFQK

CIESLIAVFQK

CIESLIAVFQK

CIESLIAVFQK

CIESLIAVFQK

CIESLIAVFQK

CIESLIAVFQK

CIESLIAVFQK

CIESLIAVFQK $\begin{array}{llllllll}19.52 & 3 & 1583.8672 & 1583.8659 & 528.9626 & 0.0013 & 0.8192 & 108.494\end{array}$ $\begin{array}{llllllllllll}0.72 & 13.81 & 27.47 & 17.51 & 3 & 1583.8690 & 1583.8659 & 528.9626 & 0.0031 & 1.9535 & 45.304\end{array}$ $\begin{array}{llllllllllll}0.96 & 21.92 & 27.44 & 20.41 & 3 & 1583.8693 & 1583.8659 & 528.9626 & 0.0034 & 2.1426 & 38.001\end{array}$ $\begin{array}{lllllllll} & \end{array}$ $\begin{array}{llllllllllll}0.99 & 33.89 & 27.35 & 21.26 & 3 & 1583.8708 & 1583.8659 & 528.9626 & 0.0045 & 2.8375 & 2375.734 & 2147.336 \\ 1.0048 & & 1587.311 & 923.897\end{array}$ $\begin{array}{llllllllllll}1.00 & 79.65 & 27.29 & 34.28 & 2 & 1583.8714 & 1583.8659 & 792.9402 & 0.0055 & 3.4681 & 3013.235 & 1936.764\end{array}$

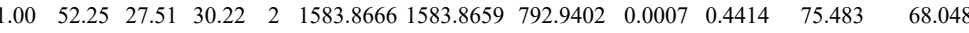
$\begin{array}{llllllllllllll}0.86 & 19.13 & 27.59 & 19.41 & 3 & 1583.8672 & 1583.8659 & 528.9626 & 0.0013 & 0.8192 & 70.429 & 68.651\end{array}$ $\begin{array}{lllllllllllll}0.98 & 26.60 & 27.59 & 16.91 & 3 & 1583.8672 & 1583.8659 & 528.9626 & 0.0013 & 0.8192 & 35.498 & 37.803\end{array}$ $\begin{array}{llllllllllll}0.87 & 17.87 & 27.59 & 14.96 & 3 & 1583.8675 & 1583.8659 & 528.9626 & 0.0016 & 1.0083 & 85.760 & 72.801\end{array}$ $\begin{array}{lllllllllllll}0.71 & 13.71 & 27.55 & 20.97 & 3 & 1583.8678 & 1583.8659 & 528.9626 & 0.0019 & 1.1973 & 79.321 & 83.138\end{array}$

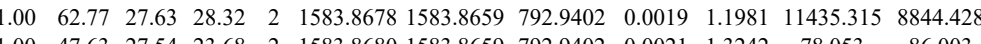
$\begin{array}{llllllllllll}1.00 & 47.63 & 27.54 & 23.68 & 2 & 1583.8680 & 1583.8659 & 792.9402 & 0.0021 & 1.3242 & 78.053 & 86.003\end{array}$ $\begin{array}{llllllllllllll}1.00 & 57.05 & 27.54 & 23.04 & 2 & 1583.8684 & 1583.8659 & 792.9402 & 0.0025 & 1.5764 & 76.974 & 47.790\end{array}$ $\begin{array}{lllllllllllll}1.96 & 57.05 & 27.54 & 23.04 & 2 & 1583.8684 & 1583.865 & 792.9402 & 0.025 & 1.5764 & 76.974 & 47.790 \\ 0.98 & 25.80 & 27.51 & 26.13 & 3 & 1583.8687 & 1583.8659 & 528.9626 & 0.0028 & 1.7645 & 2597.509 & 1713.532\end{array}$

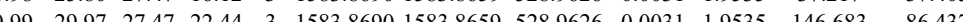
$\begin{array}{llllllllllll}0.97 & 36.84 & 27.36 & 20.67 & 2 & 1583.8696 & 1583.8659 & 792.9402 & 0.0037 & 2.3331 & 52.249 & 49.030\end{array}$

$\begin{array}{llllllllllll}1.00 & 69.42 & 27.36 & 26.60 & 2 & 1583.8696 & 1583.8659 & 792.9402 & 0.0037 & 2.3331 & 17555.206 & 15927.625\end{array}$ 

$\begin{array}{llllllllllllll}0.78 & 24.29 & 27.39 & 19.19 & 2 & 1162.5956 & 11625952 & 582.3049 & 0.0004 & 0.3435 & 51.146 & 47.742\end{array}$ $\begin{array}{lllllllllllll}0.99 & 27.95 & 27.54 & 19.77 & 3 & 1583.8681 & 1583.8659 & 528.9626 & 0.0022 & 1.3864 & 60.501 & 48.796\end{array}$ $\begin{array}{lllllllllllll}0.67 & 21.51 & 27.36 & 33.35 & 3 & 1583.8699 & 1583.8659 & 528.9626 & 0.0040 & 2.5207 & 59.472 & 35.819\end{array}$ $\begin{array}{llllllllllll}0.91 & 19.46 & 27.54 & 17.16 & 3 & 1583.8681 & 1583.8659 & 528.9626 & 0.0022 & 1.3864 & 24.354 & 17.362 \\ 1.00 & 62.72 & 27.63 & 27.95 & 2 & 1583.8676 & 1583.869 & 782.9402 & 0.0017 & 1.0720 & 89.324 & 79.115\end{array}$ $\begin{array}{llllllllllll}1.00 & 62.72 & 27.63 & 27.95 & 2 & 1583.8676 & 1583.8659 & 792.9402 & 0.0017 & 1.0720 & 89.324 & 79.115 \\ 1.00 & 7229 & 27.54 & 26.61 & 2 & 1583.8680 & 1583.8659 & 792.9402 & 0.0021 & 1.3242 & 62.556 & 41.594\end{array}$ $\begin{array}{lllllllllllll}1.00 & 72.29 & 27.54 & 26.61 & 2 & 1583.8680 & 1583.8659 & 792.9402 & 0.0021 & 1.3242 & 62.556 & 41.594 \\ 100 & 40.92 & 27.54 & 27.66 & 3 & 1583.8684 & 1583.8659 & 528.9626 & 0.0025 & 1.5754 & 27.963 & 34.215\end{array}$

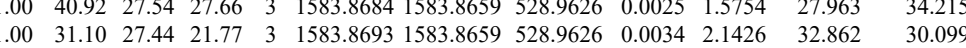
$\begin{array}{lllllllllllll}1.00 & 77.41 & 27.63 & 33.21 & 2 & 1583.8678 & 1583.8659 & 792.9402 & 0.0019 & 1.1981 & 366.584 & 316.019\end{array}$ $\begin{array}{lllllllllllll}1.00 & 77.44 & 27.63 & 33.32 & 2 & 1583.8678 & 1583.8659 & 792.9402 & 0.0019 & 1.1981 & 331.554 & 284.720\end{array}$ $\begin{array}{llllllllllll}1.00 & 37.32 & 27.47 & 23.35 & 3 & 1583.8690 & 1583.8659 & 528.9626 & 0.0031 & 1.9535 & 42.757 & 54.703\end{array}$ $\begin{array}{llllllllllll}0.98 & 25.79 & 27.54 & 22.23 & 3 & 1583.8684 & 1583.8659 & 528.9626 & 0.0025 & 1.5754 & 57.191 & 48.732\end{array}$ $\begin{array}{lllllllllllll}1.00 & 71.82 & 27.44 & 28.83 & 2 & 1583.8692 & 1583.8659 & 792.9402 & 0.0033 & 2.0809 & 147.144 & 108.303\end{array}$ $\begin{array}{llllllllllll}1.00 & 44.38 & 27.44 & 25.97 & 3 & 1583.8693 & 1583.8659 & 528.9626 & 0.0034 & 2.1426 & 38.261 & 29.260\end{array}$ $\begin{array}{llllllllllll}1.00 & 65.36 & 27.36 & 27.27 & 2 & 1583.8696 & 1583.8659 & 792.9402 & 0.0037 & 2.3331 & 118.778 & 108.88\end{array}$

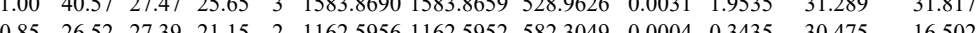

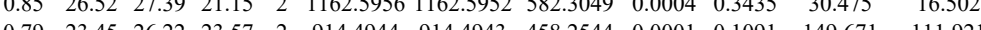
$\begin{array}{llllllllllll}0.61 & 15.23 & 26.22 & 23.58 & 2 & 914.4950 & 914.4943 & 458.2544 & 0.0007 & 0.7638 & 58.952 & 34.677\end{array}$

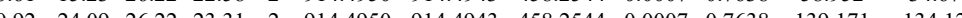

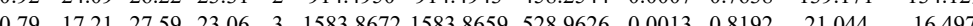
$\begin{array}{lllllllllllll}0.76 & 17.78 & 27.32 & 18.73 & 3 & 1583.8711 & 1583.8659 & 528.9626 & 0.0052 & 3.8768 & 13.0465 & 25.555\end{array}$ $\begin{array}{lllllllllllllll}0.94 & 25.75 & 26.322 & 24.87 & 2 & 914.4952 & 914.4943 & 458.2544 & 0.0009 & 0.9820 & 116.566 & 103.169\end{array}$ $\begin{array}{lllllllllllll}0.52 & 19.27 & 27.64 & 19.65 & 2 & 1162.5952 & 1162.5952 & 582.3049 & 0.0000 & 0.0000 & 27.082 & 34.469\end{array}$ $\begin{array}{lllllllllllll}1.00 & 42.80 & 27.39 & 26.50 & 2 & 11625956 & 11625952 & 582.34049 & 0.0004 & 0.3435 & 28.306 & 34.469\end{array}$ $\begin{array}{llllllllllll}0.99 & 33.89 & 27.47 & 28.12 & 2 & 11625960 & 11625952 & 582.3049 & 0.0008 & 0.6869 & 28.306 & 22.941 \\ 1.00 & 45.36 & 27.47 & 29.87 & 2 & 162.5964 & 162.5952 & 582.349 & 0.001 & 1.0304 & 922.617 & 351.352\end{array}$

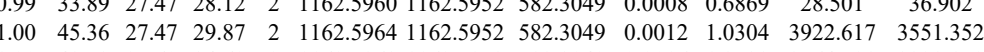
$\begin{array}{llllllllllllll}1.00 & 48.73 & 27.60 & 34.69 & 2 & 1162.5968 & 1162.5952 & 582.3049 & 0.0016 & 1.3738 & 3764.591 & 3328.159 & 29\end{array}$ IGKPAPDFK IGKPAPDFK

GKPAPDFK

IGKPAPDFK $\begin{array}{lllllllllll}45.99 & 27.02 & 28.75 & 2 & 1310.7454 & 1310.7325 & 656.3735 & 0.0129 & 9.8266 & 16981.385 & 14547.532\end{array}$ $\begin{array}{lllllllllllllll} & \end{array}$

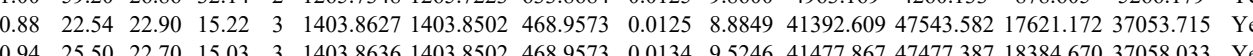

\section{GLFIIDGK} $\begin{array}{llllllllllllllll}0.94 & 25.50 & 22.70 & 15.03 & 3 & 1403.8636 & 1403.8502 & 468.9573 & 0.0134 & 9.5246 & 41477.867 & 47477.387 & 18384.670 & 37058.033 & \text { Yes } & \\ 0\end{array}$ $\begin{array}{lllllllllllllll}0.90 & 19.61 & 22.30 & 14.37 & 3 & 1403.8567 & 1403.8502 & 468.9573 & 0.0065 & 4.6202 & 39062.879 & 40058.479 & 15582.344 & 33922.830 & \text { Yes } \\ 0.89 & 19.16 & 22.30 & 14.47 & 3 & 1403.8567 & 1403.8502 & 468.9573 & 0.0065 & 4.6202 & 52589.965 & 55771.000 & 20818.722 & 40418.191 & \text { Yes }\end{array}$ $\begin{array}{lllllllllllllllll}0.88 & 26.64 & 23.78 & 22.60 & 2 & 1149.7114 & 1149.7001 & 575.8573 & 0.0113 & 9.8114 & 13192.733 & 11686.569 & 162.056 & 12487.727 & \text { Yes }\end{array}$ $\begin{array}{llllllllllllllll} & 24.59 & 21.33 & 2 & 1878.0714 & 1878.0696 & 940.0421 & 0.0018 & 0.9574 & 4038.861 & 4463.197 & 3245.580 & 3411.210 & \text { Yes }\end{array}$ $\begin{array}{llllllllllllllll} & 24.50 & 27.41 & 2 & 1878.0716 & 1878.0696 & 940.0421 & 0.0020 & 1.0638 & 2480.748 & 3061.658 & 2400.575 & 1700.024 & \text { Yes }\end{array}$

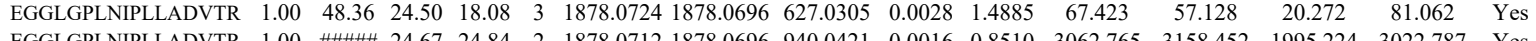
$\begin{array}{lllllllllllllll} & 24.67 & 24.84 & 2 & 1878.0712 & 1878.0696 & 940.0421 & 0.0016 & 0.8510 & 3062.765 & 3158.452 & 1995.224 & 3022.787 & \text { Yes }\end{array}$

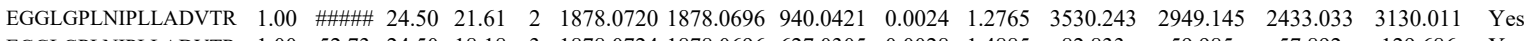

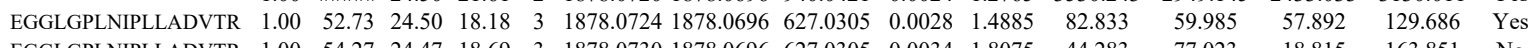

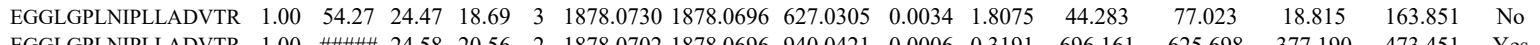

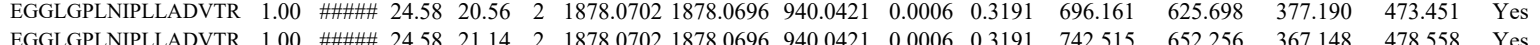
$\begin{array}{lllllllllllllll} & \end{array}$ $\begin{array}{llllllllllllllll}\text { EGGLGPLNPLLADVTR } & 0.99 & 28.73 & 24.50 & 26.91 & 3 & 1878.0721 & 1878.0696 & 627.0305 & 0.0025 & 1.3290 & 191.494 & 180.040 & 81.264 & 192.542 & \text { Yes } \\ \text { KEGGLGPNIPLLDVTR } & 1.00 & 36.22 & 19.34 & 15.44 & 3 & 2150.2690 & 21502667 & 717.7628 & 0.0023 & 1.0681 & 385.815 & 283.812 & 239.154 & 538.025 & \text { Yes }\end{array}$ $\begin{array}{llllllllllllll} & \text { KGGLGNALA }\end{array}$ $\begin{array}{lllllllllllllll}\text { LGCEVLGVSVDSOFTHLAWINTPR } & 0.66 & \text { \#\#\#\# } 27.11 & \text { \#\#\#\# } & 3 & 2831.4238 & 2831.4221 & 944.8146 & 0.0017 & 0.5998 & 565.115 & 457.061 & 332.622 & 474.391 & \text { Yes }\end{array}$

Table S-4 page 268 of 614 


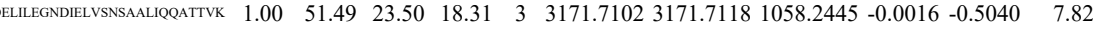
$\begin{array}{llllllllllllll} & \end{array}$

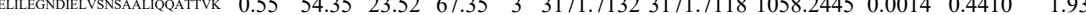
$\begin{array}{llllllllllll} & 0.35 .04 & 23.52 & 68.04 & 3 & 3171.7132 & 3171.7118 & 1058.2445 & 0.0014 & 0.4410 & 6.056\end{array}$

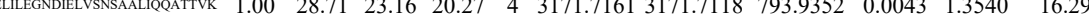

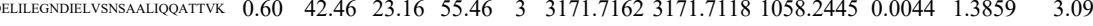

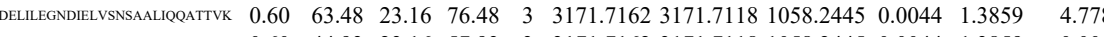

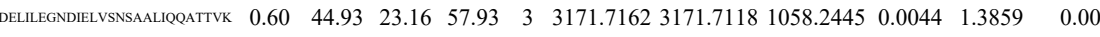
$\begin{array}{llllllllllll}\text { DELILEGNDELVSNSAALQQATTVK } & 0.60 & 63.89 & 23.16 & 76.89 & 3 & 3171.7162 & 3171.7118 & 1058.2445 & 0.0044 & 1.3859 & 0.000\end{array}$ $\begin{array}{llllllllllll}\text { DELLEGNDIELVNSAALQQATTVK } & 1.00 & 29.76 & 23.10 & 42.76 & 4 & 3171.7173 & 3171.7118 & 793.9352 & 0.0055 & 1.7319 & 0.000 \\ \text { TILSNOTVDIPENVDITLK } & 0.55 & 36.19 & 23.73 & 49.19 & 3 & 2400.3370 & 2400.3355 & 801.1191 & 0.0015 & 0.6241 & 180.507\end{array}$

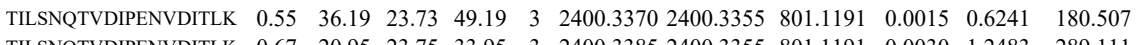
$\begin{array}{llllllllllll}\text { TILSNQTVDIPENVDITLK } & 0.67 & 20.95 & 23.75 & 33.95 & 3 & 2400.3385 & 2400.3355 & 801.1191 & 0.0030 & 1.2483 & 289.111 \\ \text { DELLEGNDELVSNAALLQQATVK } & 1.00 & 29.67 & 23.28 & 42.67 & 4 & 3171.7149 & 3171.7118 & 793.9352 & 0.0031 & 0.9761 & 21.969\end{array}$

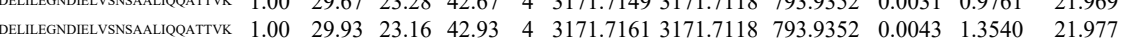
$\begin{array}{lllllllllll} & \end{array}$ $\begin{array}{llllllllllllll} & 1.00 & 85.19 & 23.16 & 21.33 & 3 & 3171.7162 & 3171.7118 & 1058.2445 & 0.0044 & 1.3859 & 18.397\end{array}$ $\begin{array}{llllllll} & 0.828\end{array}$

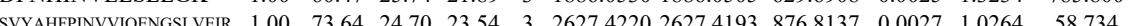
$\begin{array}{lllllllllllll} & \text { DFV }\end{array}$

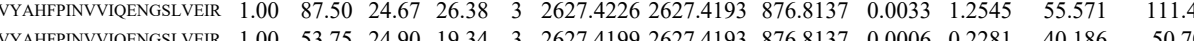

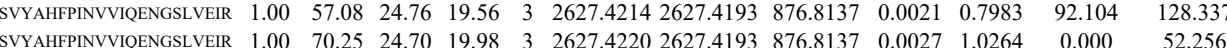

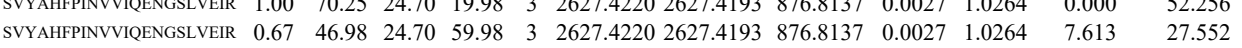

TICSHVQNMIK TICSHVQNMIK TICSHVQNMIK TICSHVQNMIK TICSHVQNMIK TICSHVQNMIK MRPGVACSVSQAQK GVTLGFR $\begin{array}{llllllllllll}1.00 & 51.56 & 28.32 & 23.28 & 2 & 1606.8380 & 1606.8237 & 804.4191 & 0.0143 & 8.8883 & 1224.781 & 1352.029\end{array}$ $\begin{array}{lllllllllllll}1.00 & 45.50 & 28.31 & 17.50 & 3 & 1606.8382 & 1606.8237 & 536.6152 & 0.0145 & 9.0070 & 8945.870 & 10670.190 & 85\end{array}$

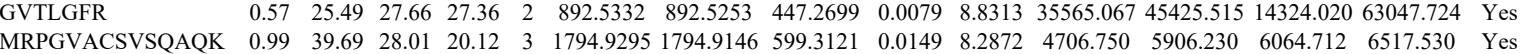
$\begin{array}{lllllllllllll} & \end{array}$ $\begin{array}{llllllllllll} & \end{array}$ $\begin{array}{lllllllllllllll}1.00 & 65.22 & 28.34 & 25.23 & 2 & 1606.8384 & 1606.8237 & 804.4191 & 0.0147 & 9.1369 & 1586.276 & 1387.633 & 123.858 & 2678.241 & \text { Y ses }\end{array}$ $\begin{array}{llllllllllllllllll}1.00 & 42.04 & 28.27 & 26.43 & 3 & 1606.8388 & 1606.8237 & 536.6152 & 0.0151 & 9.3797 & 12888.108 & 12303.966 & 1172.681 & 21819.871 & \text { Yes } \\ 1.00 & 44.56 & 28.27 & 25.58 & 3 & 1606.8388 & 1606.8237 & 5366152 & 0.0151 & 93797 & 6906336 & 5573.361 & 403.121 & 9855.042 & \text { Yes }\end{array}$ $\begin{array}{llllllllllllllll}0.70 & 27.93 & 27.66 & 28.14 & 2 & 892.5332 & 892.5253 & 447.2699 & 0.0079 & 8.8313 & 36735.148 & 51661.946 & 15896.507 & 73057.331 & \text { Yes }\end{array}$ $\begin{array}{llllllllllllllllll} & \end{array}$ $\begin{array}{llllllllllllllll} & \end{array}$

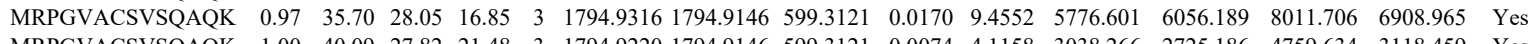
\begin{tabular}{llllllllllllllll} 
MRPGVACSVSQAQK & 1.00 & 40.09 & 27.82 & 21.48 & 3 & 1794.9220 & 1794.9146 & 599.3121 & 0.0074 & 4.1158 & 3038.266 & 2725.186 & 4759.634 & 3118.459 & Yes \\
\hline
\end{tabular}

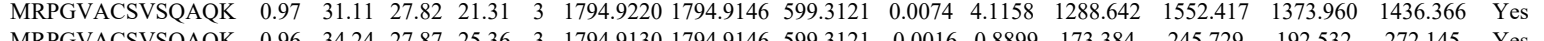

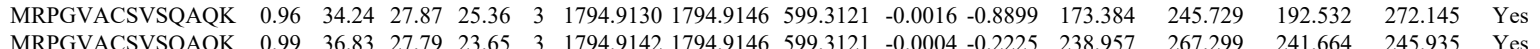
$\begin{array}{llllllllllllllll}\text { MRPGVACSVSQAQK } & 0.99 & 36.83 & 27.79 & 23.65 & 3 & 1794.9142 & 1794.9146 & 599.3121 & -0.0004 & -0.2225 & 238.957 & 267.299 & 241.664 & 245.935 & \text { Yes } \\ \text { MRPGVACSVSQAQK } & 0.96 & 37.19 & 27.80 & 25.33 & 3 & 1794.9115 & 1794.9146 & 599.3121 & -0.0031 & -1.7242 & 178.250 & 234.764 & 205.222 & 221.088 & \text { Yes }\end{array}$ $\begin{array}{lllllllllllllllll} & \text { MRPGVACSVSQAQK } & 0.92 & 33.67 & 27.80 & 25.40 & 3 & 1794.9118 & 1794.9146 & 599.3121 & 0.0028 & 1.5573 & 204.861 & 287.572 & 239.677 & 262.742 & \text { Yes }\end{array}$ $\begin{array}{lllllllllllllllll}\text { MRPGVACSVSQAQK } & 0.92 & 33.67 & 27.80 & 20.40 & 3 & 1794.9118 & 1794.9146 & 599.3121 & -0.0028 & -1.5573 & 204.861 & 287.572 & 239.677 & 262.742 & \text { Yes } \\ \text { MRPGVACSVSQAQK } & 0.90 & 33.18 & 27.87 & 25.05 & 3 & 1794.9121 & 1794.9146 & 599.3121 & -0.0025 & -1.3905 & 154.551 & 137.647 & 152.461 & 165.189 & \text { Yes }\end{array}$ 

\begin{tabular}{llllllllllllllll} 
EVLQALEELAVNYDQK & 0.91 & 19.32 & 26.39 & 18.46 & 3 & 2149.1548 & 2149.1510 & 717.3909 & 0.0038 & 1.7657 & 38.609 & 51.535 & 20.568 & 62.452 & Yes \\
\hline
\end{tabular}

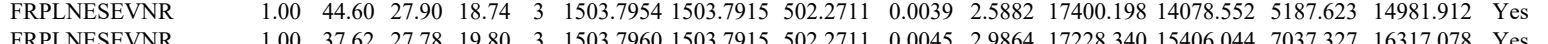
$\begin{array}{lllllllllllllllll} & \text { FRPLNESEVNR } & 1.00 & 37.62 & 27.78 & 19.80 & 3 & 1503.7960 & 1503.7915 & 502.2711 & 0.0045 & 2.9864 & 17228.340 & 15406.044 & 7037.327 & 16317.078 & \text { Yes } \\ \text { ISFLENNLEQLTK } & 0.88 & 18.10 & 25.97 & 18.70 & 3 & 1836.0247 & 1836.0236 & 613.0151 & 0.0011 & 0.5981 & 259.321 & 141.638 & 55.613 & 179.670 & \text { Yes }\end{array}$

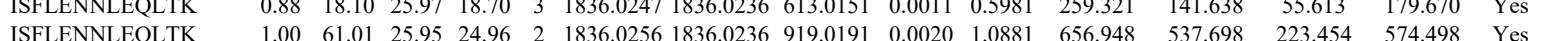
$\begin{array}{llllllllllllll} & \end{array}$ $\begin{array}{llllllllllllllll} & \end{array}$

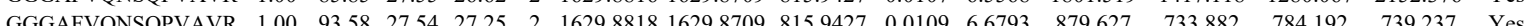
$\begin{array}{llllllllllllllll}\text { STLLFGQR } & 0.95 & 40.60 & 27.97 & 36.70 & 2 & 10646166 & 10646100 & 533.3123 & 0.0066 & 6.1877 & 13567.028 & 10174.854 & 2793.747 & 11666.064 & \text { Yes }\end{array}$ $\begin{array}{llllllllllllllll} & 1.9606064 & \text { Yes }\end{array}$

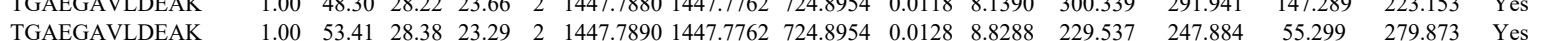

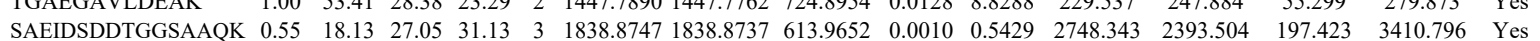
$\begin{array}{llllllllllllllll}\text { FVCSPDEVMDTIDEGK } & 0.60 & 27.55 & 24.81 & 40.55 & 3 & 2117.9608 & 2117.9563 & 706.9927 & 0.0045 & 2.1217 & 48.604 & 22.337 & 45.015 & 38.937 & \text { No }\end{array}$

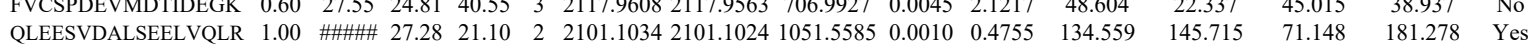

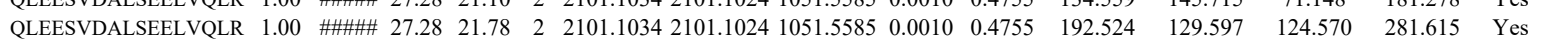
$\begin{array}{llllllllllllllll}\text { QLEESVDALSEELVQLR } & 1.00 & 75.26 & 27.16 & 26.14 & 3 & 2101.1059 & 2101.1024 & 701.3747 & 0.0035 & 1.6634 & 123.647 & 99.172 & 80.001 & 103.113 & \text { Yes }\end{array}$

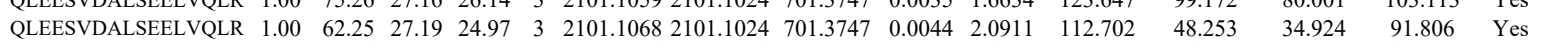
$\begin{array}{llllllllllllllll}\text { QLEESVDALSEELVQLR } & 1.00 & 96.04 & 27.28 & 25.01 & 2 & 2101.1034 & 2101.1024 & 1051.5585 & 0.0010 & 0.4755 & 18.906 & 24.907 & 18.589 & 43.225 & \text { No }\end{array}$ $\begin{array}{lllllllllllllllll}\text { QLEESVDALSEELVQLR } & 0.94 & 20.38 & 27.20 & 19.41 & 3 & 2101.1044 & 2101.1024 & 701.3747 & 0.0020 & 0.9505 & 84.565 & 104.868 & 45.508 & 81.663 & \text { Yes }\end{array}$

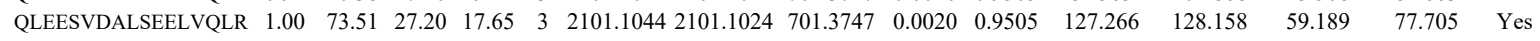

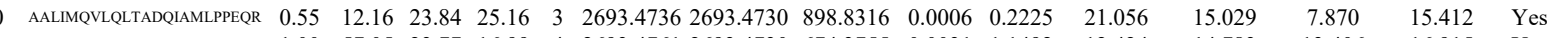

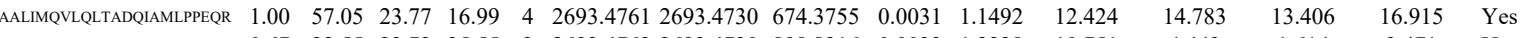
$\begin{array}{llllllllllllllll}\text { AALIMQVLQLTADQIAMLPFEQR } & 0.67 & 22.55 & 23.73 & 35.55 & 3 & 2693.4763 & 2693.4730 & 898.8316 & 0.0033 & 1.2238 & 10.751 & 4.443 & 1.614 & 3.471 & \text { Yes }\end{array}$

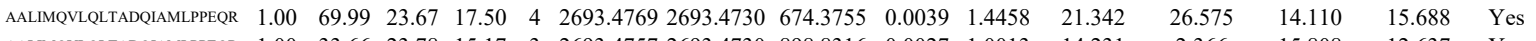
\begin{tabular}{llllllllllllllll} 
AALIMQVLQLTADPIAMLPPEQR & 1.00 & 33.66 & 23.78 & 15.17 & 3 & 2693.4757 & 2693.4730 & 898.8316 & 0.0027 & 1.0013 & 14.231 & 2.366 & 15.808 & 12.637 & Yes \\
\hline
\end{tabular}

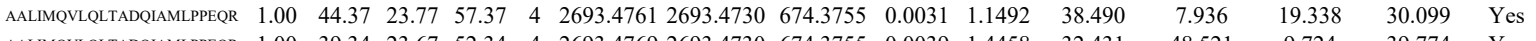

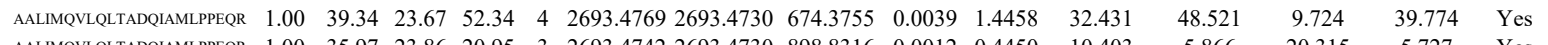

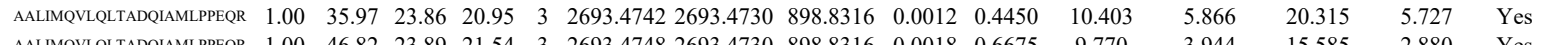

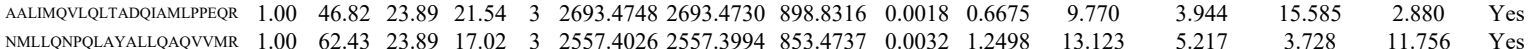

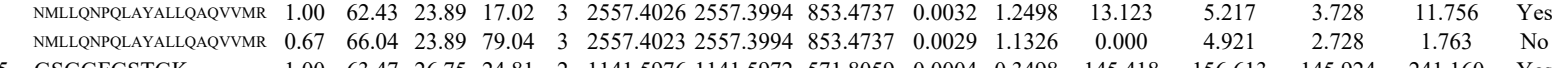

LSEHATAPTR $\begin{array}{llllllllllll}100 & 63.47 & 26.75 & 24.81 & 2 & 1141.5976 & 1141.5972 & 571.8059 & 0.0004 & 0.3498 & 145.418 & 156.613\end{array}$

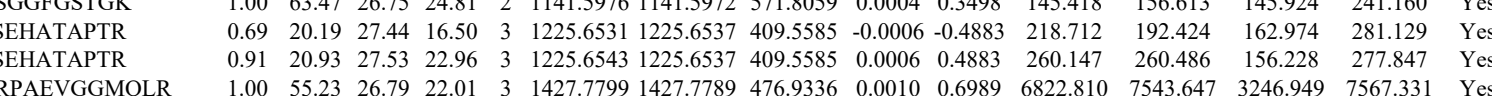
$\begin{array}{llllllllllllllll}1.00 & 51.24 & 26.79 & 20.67 & 3 & 1427.7799 & 1427.7789 & 476.9336 & 0.0010 & 0.6989 & 7976.934 & 10039.848 & 3868.941 & 9459.806 & \text { Yes }\end{array}$ $\begin{array}{llllllllllllllll} & 1.00 & 52.56 & 26.73 & 20.56 & 3 & 1427.7805 & 1427.7789 & 476.9336 & 0.0016 & 1.1183 & 7242.305 & 11266.321 & 4205.956 & 10604.201 & \text { Yes }\end{array}$ $\begin{array}{llllllllllllllll} & \end{array}$

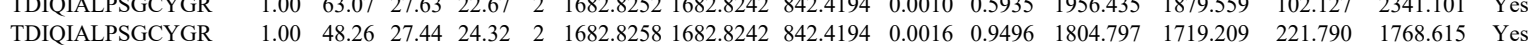
$\begin{array}{llllllllllllllll}\text { TDIQIALPSGCYGR } & 1.00 & 57.76 & 27.43 & 28.93 & 2 & 1682.8268 & 1682.8242 & 842.4194 & 0.0026 & 1.5432 & 3552.526 & 3199.252 & 265.485 & 3612.375 & \text { Yes }\end{array}$ $\begin{array}{lllllllllllllllll}\text { TDIQIALPSGCYGR } & 0.98 & 39.84 & 27.36 & 28.93 & 2 & 1682.8278 & 1682.8242 & 842.4194 & 0.0036 & 2.1367 & 3507.062 & 3432.419 & 700.132 & 3974.041 & \text { Yes }\end{array}$ $\begin{array}{lllllllllllllllll}\text { GNVGVVLFNFGK } & 1.00 & 64.61 & 25.28 & 23.72 & 2 & 1537.8878 & 1537.8861 & 769.9503 & 0.0017 & 1.1040 & 2342.164 & 2339.838 & 1709.945 & 3012.899 & \text { Yes }\end{array}$ $\begin{array}{lllllllllllllllll}\text { GNVGVVLFNFGK } & 0.67 & 38.21 & 25.24 & 51.21 & 3 & 1537.8892 & 1537.8861 & 513.6360 & 0.0031 & 2.0118 & 238.168 & 230.223 & 223.593 & 624.019 & \text { No }\end{array}$ $\begin{array}{llllllllllllllll}\text { GNVGVVLFNFGK } & 1.00 & 38.39 & 24.80 & 19.15 & 3 & 1537.8895 & 1537.8861 & 513.6360 & 0.0034 & 2.2065 & 454.206 & 184.567 & 315.325 & 291.897 & \text { No }\end{array}$

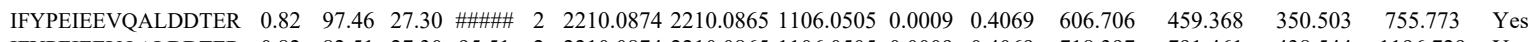
$\begin{array}{llllllllllllllll}\text { IFYPEIEEVQALDDTER } & 0.82 & 82.51 & 27.30 & 95.51 & 2 & 2210.0874 & 2210.0865 & 1106.0505 & 0.0009 & 0.4069 & 718.397 & 791.461 & 438.544 & 1196.729 & \text { Yes }\end{array}$

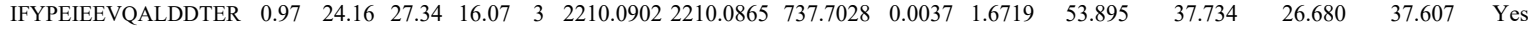

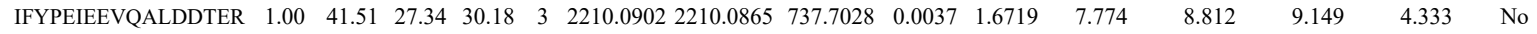

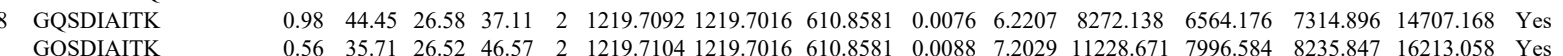
$\begin{array}{llllllllllllllll}\text { GQSDIAITK } & 0.56 & 35.71 & 26.52 & 46.57 & 2 & 1219.7104 & 1219.7016 & 610.8581 & 0.0088 & 7.2029 & 11228.671 & 7996.584 & 8235.847 & 16213.058 & \text { Yes } \\ \text { QRPDLGSAQK } & 0.55 & 35.96 & 27.62 & 48.96 & 3 & 1386.7837 & 1386.7823 & 4632680 & 0.0014 & 1.0073 & 549.768 & 578.392 & 286.704 & 747.902 & \text { Yes }\end{array}$ $\begin{array}{llllllllllllllll}\text { QRPDLGSAQK } & 0.55 & 35.96 & 27.62 & 48.96 & 3 & 1386.7837 & 1386.7823 & 463.2680 & 0.0014 & 1.0073 & 549.768 & 578.392 & 286.704 & 747.902 & \text { Yes } \\ \text { LGEINVIGEPFLNVNCEHIK } & 1.00 & 59.01 & 26.05 & 24.75 & 3 & 2571.3475 & 2571.3433 & 858.1217 & 0.0042 & 1.6315 & 350.828 & 369.504 & 278.349 & 697.565 & \text { Yes }\end{array}$ $\begin{array}{llllllllllllllll}\text { LGEINVIGEPFENVNCEHIK } & 1.00 & 59.01 & 26.05 & 24.75 & 3 & 2571.3475 & 2571.3433 & 858.1217 & 0.0042 & 1.6315 & 350.828 & 369.504 & 278.349 & 697.565 & \text { Yes } \\ \text { LGEINVIGEPFLNVNCEHIK } & 1.00 & 53.47 & 26.05 & 18.38 & 3 & 2571.3475 & 2571.3433 & 858.1217 & 0.0042 & 1.6315 & 311.409 & 332.835 & 197.401 & 561.874 & \text { Yes }\end{array}$ $\begin{array}{llllllllllllllll}\text { LGEINVIGEPFLNVNCEHIK K } & 1.00 & 53.47 & 26.05 & 18.38 & 3 & 2571.3475 & 2571.3433 & 858.1217 & 0.0042 & 1.6315 & 311.409 & 332.835 & 197.401 & 561.874 & \text { Yes } \\ \text { LGEINVIGEPFLNVNCEHIK } & 1.00 & 55.26 & 26.12 & 19.36 & 3 & 2571.3460 & 2571.3433 & 858.1217 & 0.0027 & 1.0488 & 73.495 & 149.152 & 51.740 & 109.103 & \text { No }\end{array}$

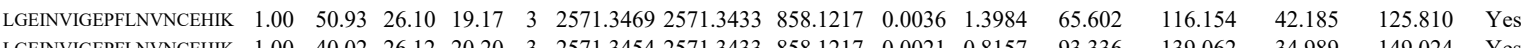
\begin{tabular}{llllllllllllllll} 
LGEINVIGEPFLNVNCEHIK & 1.00 & 40.02 & 26.12 & 20.20 & 3 & 2571.3454 & 2571.3433 & 858.1217 & 0.0021 & 0.8157 & 93.336 & 139.062 & 34.989 & 149.024 & Yes \\
\hline
\end{tabular} $\begin{array}{llllllllllllll}\text { NLNPDIDQLITSGMVIR } & 0.84 & \ldots & 26.38 & \ldots & \end{array}$

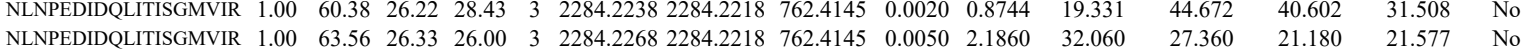

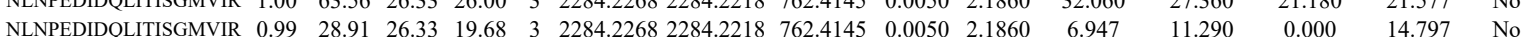

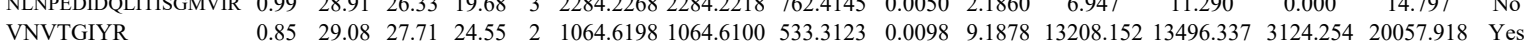


TGIVDISILTTGMSATSR 1.00 TGIVDISILTTGMSATSR
VEAIDVEEAK LHGLDEEAEQK SQLLQYVYNLVPR
SQLLQYVYNLVPR SQLLQYVYNLVP
GILLQLFGGTR GILLQLFGGTR GILLQLFGGTR GILLQLFGGTR GLLLLFGTR GILLQLFGGTR GLLQLGTR GILLOLFGGTR

GILLQLFGGTR

GILLQLFGGTR

GILLQLFGGTR

GILLQLFGGTR GILLQLFGGTR GILLQLFGGTR GILLQLFGGTR GILLQLFGGTR GILLQLFGGTR GILLQLFGGTR GILLQLFGGTR GILLQLFGGTR GILLQLFGGTR GILLQLFGGTR

ALADDDFLTVTGK
ALADDDFLTVTGK

$\begin{array}{lllllllllllll}\text { MCM5_HUMAN } & \text { P33992 } & \text { MCM5 } & \text { DNA replication 1 } 82.286 & 1.00 & 10 & 18.7 & 0.0653 & 0.3169 & 1.0323 & 0.4283 & 31 & \text { LQPFATEADVEEALR } \\ & & & & & & & & & & & & \end{array}$

LQPFATEADVEEALR

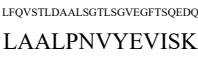

LAALPNVYEVISK

GSSAAGLTASVMR

FGLTSR

VLQLMLR

PGIIAASAVR

IPGIIIAASAVR
IPGIIIAASAVR

IPGIIIAASAVR

IPGIIIAASAVR

IPGIIIAASAVR

CSVLAAANSVFGR

CSVLAAANSVFGR

IPGIIIAASAVR

IPGIIIAASAVR

CSVLAAANSVFGR

CSVLAAANSVFGR

CSVLAAANSVFG

AIACLLFGGSR

AIACLLFGGSR

AIACLLFGGSR

AIACLLFGGSR

AIACLLFGGSR

AIACLLFGGSR

AIACLLFGGSR

AIACLLFGGSR

AIACLLFGGSR

AIACLLFGGSR

AIACLLFGGSR

AIACLLFGGSR

AICLLGGSR

AIACLLFGGSR

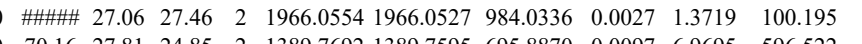

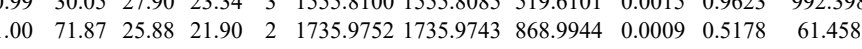

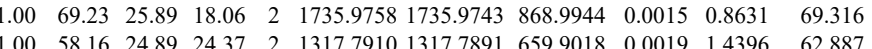
$\begin{array}{lllllllllllll}1.00 & 58.16 & 24.89 & 24.37 & 2 & 1317.7910 & 1317.7891 & 659.9018 & 0.0019 & 1.4396 & 62.887\end{array}$

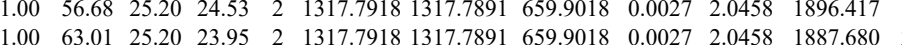

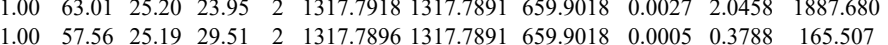
$\begin{array}{lllllllllllll}1.00 & 57.56 & 25.19 & 29.51 & 2 & 1317.7896 & 1317.7891 & 659.9018 & 0.0005 & 0.3788 & 165.507 \\ 1.00 & 60.99 & 25.13 & 29.93 & 2 & 1317.7900 & 1317.7891 & 659.9018 & 0.0009 & 0.6819 & 191.378\end{array}$ $\begin{array}{lllllllllllll}.00 & 55.01 & 25.09 & 30.85 & 2 & 1317.7902 & 1317.7891 & 659.9018 & 0.0011 & 0.8335 & 98.496\end{array}$ $\begin{array}{lllllllllllll}1.00 & 42.62 & 25.019 & 26.35 & 2 & 1317.7894 & 1317.7891 & 659.9018 & 0.0003 & 0.8335 & 65.331\end{array}$ $\begin{array}{lllllllllllll}1.00 & 54.74 & 25.09 & 27.86 & 2 & 1317.7902 & 131777891 & 659.9018 & 0.0011 & 0.8335 & 59.619\end{array}$ $\begin{array}{llllllllllll}1.00 & 50.94 & 25.09 & 28.48 & 2 & 1317.7904 & 1317.7891 & 659.9018 & 0.0013 & 0.9850 & 58.136\end{array}$ $\begin{array}{llllllllllll}1.00 & 55.04 & 25.09 & 30.64 & 2 & 1317.7904 & 1317.7891 & 659.9018 & 0.0013 & 0.9850 & 50.690\end{array}$ $\begin{array}{llllllllllll}1.00 & 51.04 & 25.09 & 29.11 & 2 & 1317.7904 & 1317.7891 & 659.9018 & 0.0013 & 0.9850 & 85.755\end{array}$ $\begin{array}{llllllllllll}1.00 & 52.66 & 25.20 & 23.19 & 2 & 1317.7916 & 1317.7891 & 659.9018 & 0.0025 & 1.8942 & 44.706\end{array}$ $\begin{array}{lllllllllll}1.00 & 53.73 & 25.09 & 29.21 & 2 & 1317.7904 & 1317.7891 & 659.9018 & 0.0013 & 0.9850 & 54.562\end{array}$ $\begin{array}{lllllllllllll}1.00 & 50.87 & 24.89 & 23.83 & 2 & 1317.7910 & 1317.7891 & 659.9018 & 0.0019 & 1.4396 & 34.396\end{array}$ $\begin{array}{llllllllllll}100 & 49.03 & 25.09 & 27.22 & 2 & 1317.7904 & 1317.7891 & 659.9018 & 0.0013 & 0.9850 & 79.048\end{array}$ $\begin{array}{lllllllllllll}1.00 & 51.53 & 25.21 & 29.12 & 2 & 1317.7898 & 1317.7891 & 659.9018 & 0.0007 & 0.5304 & 47.289\end{array}$ $\begin{array}{llllllllllll}1.00 & 51.20 & 25.09 & 28.88 & 2 & 1317.7902 & 1317.7891 & 659.9018 & 0.0011 & 0.8335 & 62.822\end{array}$ $\begin{array}{llllllllllll}1.00 & 5.20 & 25.09 & 28.88 & 2 & 1317.7902 & 1317.7891 & 659.9018 & 0.0011 & 0.8335 & 62.822\end{array}$ $\begin{array}{llllllllllll}1.00 & 54.23 & 25.09 & 27.89 & 2 & 1317.7902 & 1317.7891 & 659.9018 & 0.0011 & 0.8335 & 85.584\end{array}$ $\begin{array}{llllllllllll}1.00 & 39.47 & 25.21 & 24.26 & 2 & 1317.7898 & 1317.7891 & 659.9018 & 0.0007 & 0.5304 & 14.256\end{array}$ $\begin{array}{llllllllllll}.00 & 36.15 & 25.09 & 18.88 & 2 & 1317.7904 & 1317.7891 & 659.9018 & 0.0013 & 0.9850 & 15.347\end{array}$ $\begin{array}{lllllllllll} & & & \end{array}$ $\begin{array}{llllllllllllll}1.00 & 89.21 & 27.75 & 24.85 & 2 & 1652.8882 & 1652.8865 & 827.4505 & 0.0017 & 1.0273 & 2452.431 & 2310.387\end{array}$

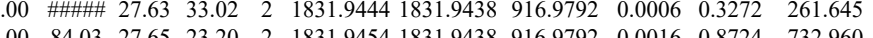

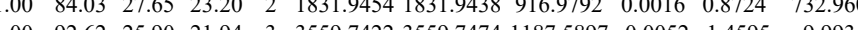
$\begin{array}{llllllllll} & \end{array}$ $\begin{array}{llllllllll} & \end{array}$ $\begin{array}{lllllllllll} & \end{array}$ $\begin{array}{llllllllllll}1.96 & \end{array}$

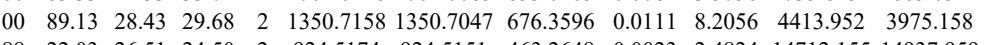

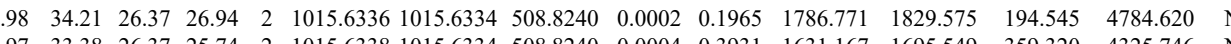

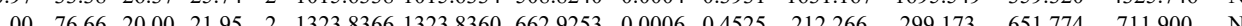
$\begin{array}{lllllllllllllll}1.00 & 67.48 & 20.00 & 22.55 & 2 & 1323.8368 & 1323.8360 & 662.9253 & 0.0008 & 0.6034 & 279.026 & 267.054 & 434.917 & 512.836 & \text { Yes }\end{array}$ $\begin{array}{lllllllllllllll}0.99 & 25.07 & 18.86 & 19.62 & 3 & 1323.8374 & 1323.8360 & 4422859 & 0.0014 & 1.0551 & 49.067 & 52.006 & 9.112 & 48.694 & \text { Yes }\end{array}$ $\begin{array}{llllllllllll}1.00 & 76.35 & 20.00 & 18.51 & 2 & 1323.8364 & 1323.8360 & 662.9253 & 0.0004 & 0.3017 & 307.468 & 4\end{array}$ $\begin{array}{llllllllllll} & 0.007\end{array}$ $\begin{array}{lllllllllll}1.00 & 69.41 & 20.00 & 22.44 & 2 & 1323.8368 & 1323.8360 & 662.9253 & 0.0008 & 0.6034 & 542.070 \\ 1.00 & 78.77 & 26.99 & 22.76 & 2 & 1483.7400 & 1483.7397 & 742.8771 & 0.0003 & 0.2019 & 64.080\end{array}$ $\begin{array}{llllllllllll}1.00 & 76.77 & 27.11 & 25.75 & 2 & 1483.7404 & 1483.7397 & 742.8771 & 0.0007 & 0.4711 & 58.063\end{array}$ $\begin{array}{lllllllllllll}1.00 & 59.92 & 20.00 & 17.80 & 2 & 1323.8364 & 1323.8360 & 662.9253 & 0.0004 & 0.3017 & 338.805\end{array}$ $\begin{array}{llllllllllll}1.00 & 59.10 & 20.00 & 17.23 & 2 & 1323.8364 & 1323.8360 & 662.9253 & 0.0004 & 0.3017 & 474.477\end{array}$ $\begin{array}{lllllllllll}1.00 & 80.24 & 27.11 & 25.18 & 2 & 1483.7404 & 1483.7397 & 742.8771 & 0.0007 & 0.4711 & 229.427\end{array}$ $\begin{array}{llllllllllll}1.00 & 83.06 & 27.18 & 23.94 & 2 & 1483.7414 & 1483.7397 & 742.8771 & 0.0017 & 1.1442 & 543.865 & 4\end{array}$ $\begin{array}{llllllllllll}1.00 & 84.22 & 26.99 & 31.87 & 2 & 1483.7400 & 1483.7397 & 742.8771 & 0.0003 & 0.2019 & 161.500 & \end{array}$ $\begin{array}{llllllllllll}1.00 & 66.37 & 27.10 & 21.34 & 2 & 1483.7408 & 1483.7397 & 742.8771 & 0.0011 & 0.7404 & 178.960\end{array}$ $\begin{array}{lllllllllll}1.00 & 43.72 & 27.99 & 22.14 & 2 & 1296.6814 & 1296.6804 & 649.3475 & 0.0010 & 0.7700 & 5.564 \\ 0.99 & 40.75 & 27.89 & 18.97 & 2 & 12966832 & 1296.6804 & 649.3475 & 0.0028 & 2.1560 & 37.037\end{array}$ $\begin{array}{llllllllllll}0.99 & 40.75 & 27.89 & 18.97 & 2 & 1296.6832 & 1296.6804 & 649.3475 & 0.0028 & 2.1560 & 37.037 \\ 1.00 & 46.38 & 28.25 & 27.01 & 2 & 1296.6810 & 1296.6804 & 649.3475 & 0.0006 & 0.4620 & 536.830\end{array}$

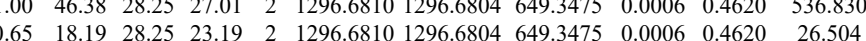
$\begin{array}{lllllllllll}1.00 & 49.57 & 28.10 & 24.95 & 2 & 1296.6820 & 1296.6804 & 649.3475 & 0.0016 & 1.2320 & 301.272\end{array}$ $\begin{array}{lllllllllllll}1.00 & 50.88 & 28.25 & 27.32 & 2 & 1296.6810 & 1296.6804 & 649.3475 & 0.0006 & 0.4620 & 379.040\end{array}$ $\begin{array}{lllllllllll}1.00 & 58.15 & 27.99 & 28.88 & 2 & 1296.6814 & 1296.6804 & 649.3475 & 0.0010 & 0.7700 & 471.166\end{array}$ $\begin{array}{llllllllllll}1.00 & 48.59 & 28.21 & 20.80 & 2 & 1296.6812 & 1296.6804 & 649.3475 & 0.0008 & 0.6160 & 105.858 \\ 1.00 & 51.35 & 27.99 & 25.71 & 2 & 12966814 & 12966804 & 649.3475 & 0.0010 & 0.7700 & 161.087\end{array}$ $\begin{array}{lllllllllllll}1.00 & 51.35 & 27.99 & 25.71 & 2 & 1296.6814 & 1296.6804 & 649.3475 & 0.0010 & 0.7700 & 161.087 \\ 1.00 & 41.46 & 27.99 & 19.58 & 2 & 1296.6814 & 1296.6804 & 649.3475 & 0.0010 & 0.7700 & 67.032\end{array}$ $\begin{array}{lllllllllll}1.00 & 41.46 & 27.99 & 19.58 & 2 & 1296.6814 & 1296.6804 & 649.3475 & 0.0010 & 0.7700 & 67.032 \\ 1.00 & 39.38 & 27.99 & 20.27 & 2 & 1296.6816 & 1296.6804 & 649.3475 & 0.0012 & 0.9240 & 87.092\end{array}$ $\begin{array}{llllllllllll}1.00 & 39.38 & 27.99 & 20.27 & 2 & 1296.6816 & 1296.6804 & 649.3475 & 0.0012 & 0.9240 & 87.092 \\ 1.00 & 44.39 & 28.18 & 19.43 & 2 & 1296.6804 & 1296.6804 & 649.3475 & 0.0000 & 0.0000 & 40.355\end{array}$ $\begin{array}{llllllllllll}1.00 & 44.39 & 28.18 & 19.43 & 2 & 1296.6804 & 1296.6804 & 649.345 & 0.0000 & 0.0000 & 47.355 \\ 1.00 & 55.55 & 28.18 & 23.75 & 2 & 1296.6804 & 1296.6804 & 649.3475 & 0.0000 & 0.0000 & 37.137\end{array}$ $\begin{array}{llllllllllll}1.00 & 50.71 & 27.99 & 23.90 & 2 & 12966816 & 12966804 & 649.3475 & 0.0012 & 0.9240 & 60.893\end{array}$ $\begin{array}{lllllllllllll}1.00 & 41.33 & 27.94 & 3.15 & 2 & 12966824 & 12966804 & 649.3475 & 0.0020 & 1.5400 & 56.775\end{array}$ $59.557 .259 \quad 975.699$ 4. 18.122

9

217

Table S-4 page 271 of 614 


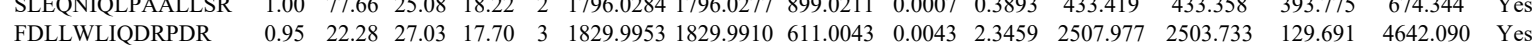
$\begin{array}{llllllllllllllll}\text { FDLLWLIQDRPDR } & 0.95 & 22.28 & 27.03 & 17.70 & 3 & 1829.9953 & 1829.9910 & 611.0043 & 0.0043 & 2.3459 & 2507.977 & 2503.733 & 129.691 & 4642.090 & \text { Yes } \\ \text { SEDDESGAGELTR } & 1.00 & 74.86 & 23.75 & 21.73 & 2 & 1508.6710 & 1508.6712 & 755.3429 & -0.0002 & 0.1324 & 176.876 & 265.107 & 78.684 & 447.226 & \text { Yes }\end{array}$

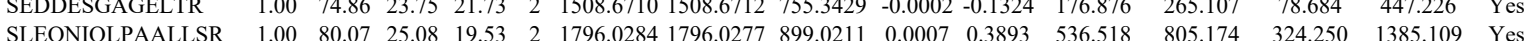

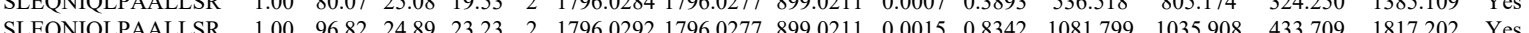

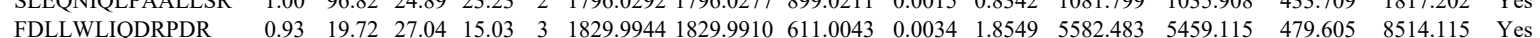
$\begin{array}{lllllllllllllllll}\text { GSSGVGLTAAVLR } & 1.00 & 8522 & 26.61 & 29.72 & 2 & 1330.7816 & 13307691 & 666.3918 & 0.0125 & 9.3788 & 2930.062 & 33233653 & 2762296 & 4548.731 & \text { Yes }\end{array}$ $\begin{array}{llllllllllllllllll}\text { FDLLWLIQDRPDR } & 0.95 & 21.27 & 27.06 & 15.50 & 3 & 1829.9938 & 1829.9910 & 611.0043 & 0.0028 & 1.5275 & 3675.600 & 3522.560 & 272.581 & 5478.680 & \text { Yes }\end{array}$ $\begin{array}{llllllllllllllll}\text { FDLLWLIQDRPDR } & 0.96 & 22.10 & 27.06 & 17.11 & 3 & 1829.9938 & 1829.9910 & 611.0043 & 0.0028 & 1.5275 & 1527.817 & 1843.788 & 26.596 & 2707.706 & \text { Yes }\end{array}$ $\begin{array}{lllllllllllllllll}\text { FDLLWLIQDRPDR } & 0.96 & 22.10 & 27.06 & 17.11 & 3 & 1829.9938 & 1829.9910 & 611.0043 & 0.0028 & 1.5275 & 1527.817 & 1843.788 & 26.596 & 2707.706 & \text { Yes } \\ \text { GSSGVGLTAAVLR } & 1.00 & 85.33 & 26.14 & 26.73 & 2 & 1330.7798 & 1330.7691 & 666.3918 & 0.0107 & 8.0282 & 2167.666 & 2133.635 & 1987.451 & 3856.559 & \text { Yes }\end{array}$

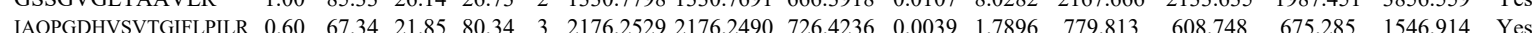

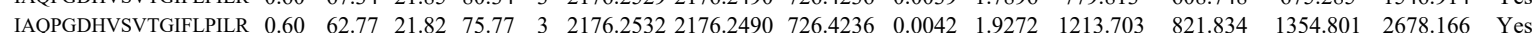
$\begin{array}{llllllllllllllll}\text { IAQPGDHVSVTGIFLPILR } & 0.99 & 24.60 & 22.12 & 18.42 & 3 & 2176.2502 & 2176.2490 & 726.4236 & 0.0012 & 0.5506 & 254.624 & 224.607 & 667.893 & 731.340 & \text { No }\end{array}$

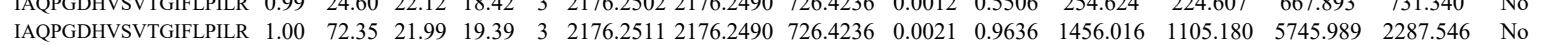
$\begin{array}{llllllllllllllll}\text { ALLLLLVGGVDQSPR } & 0.55 & 62.09 & 20.93 & 75.09 & 3 & 1694.0224 & 1694.0212 & 565.6810 & 0.0012 & 0.7071 & 36.032 & 19.343 & 14.659 & 46.078 & \text { Yes }\end{array}$ $\begin{array}{llllllllllllllll}\text { ALLLLLVGGVDQSPR } & 0.67 & 51.96 & 20.97 & 64.96 & 3 & 1694.0239 & 1694.0212 & 565.6810 & 0.0027 & 1.5910 & 30.564 & 53.611 & 19.382 & 44.895 & \text { Yes }\end{array}$ $\begin{array}{lllllllllllll}\text { ALLLLLVGGVDQSPR } & 0.82 & \text { \#\#\#\# } 20.93 \text { \#\#\#\# } 2 & 1694.0224 & 1694.0212 & 848.0179 & 0.0012 & 0.7075 & 7.563 & 25.579 & 4.169 & 17.547 & \text { No }\end{array}$ $\begin{array}{lllllllllllll}\text { ALLLLLVGGVDQSPR } & 0.82 & \text { \#\#\#\# } 20.93 \text { \#\#\#\# } 2 & 1694.0226 & 1694.0212 & 848.0179 & 0.0014 & 0.8255 & 3.231 & 2.483 & 6.324 & 7.603 & \text { No }\end{array}$

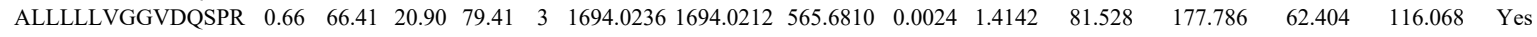
$\begin{array}{llllllllllllllll}\text { ALLLLLVGGVDQSPR } & 0.66 & 57.80 & 20.90 & 70.80 & 3 & 1694.0236 & 1694.0212 & 565.6810 & 0.0024 & 1.4142 & 85.354 & 23.520 & 9.942 & 51.701 & \text { No }\end{array}$

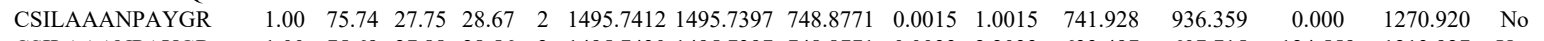

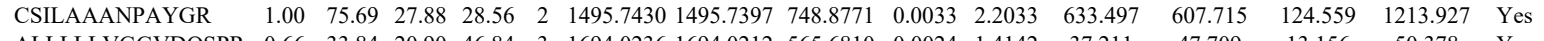
$\begin{array}{lllllllllllllllll}\text { ALLLLVGGVDQSPR } & 0.66 & 33.84 & 20.90 & 46.84 & 3 & 1694.0236 & 1694.0212 & 565.6810 & 0.0024 & 1.4142 & 37.211 & 47.709 & 13.156 & 50.378 & \text { Yes }\end{array}$ $\begin{array}{llllllllllllllll}\text { ALLLLLVGGVDQSPR } & 1.00 & 27.16 & 20.90 & 15.10 & 3 & 1694.0236 & 1694.0212 & 565.6810 & 0.0024 & 1.4142 & 59.886 & 51.282 & 26.821 & 48.526 & \text { Yes }\end{array}$ $\begin{array}{llllllllllllllll}\text { TLLAILR } & 0.96 & 22.79 & 21.88 & 25.01 & 2 & 942.6360 & 942.6348 & 472.3247 & 0.0012 & 1.2703 & 1944.747 & 2122.925 & 0.000 & 5536.764 & \text { No }\end{array}$

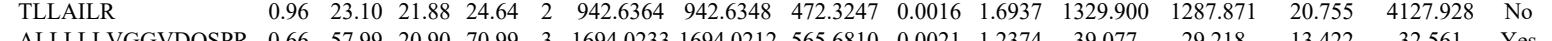

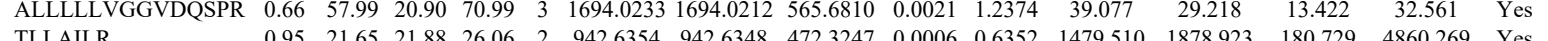
$\begin{array}{llllllllllllllll}\text { TLLAILR } & 0.95 & 21.65 & 21.88 & 26.06 & 2 & 942.6354 & 942.6348 & 472.3247 & 0.0006 & 0.6352 & 1479.510 & 1878.923 & 180.729 & 4860.269 & \text { Yes }\end{array}$

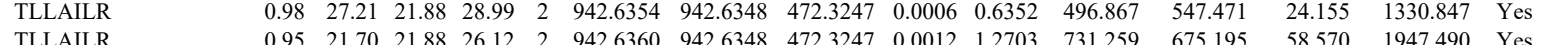

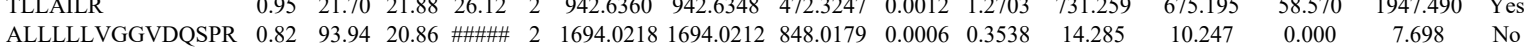

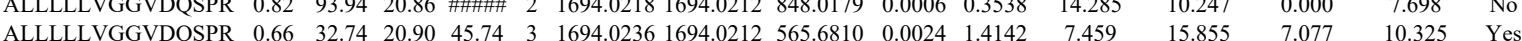

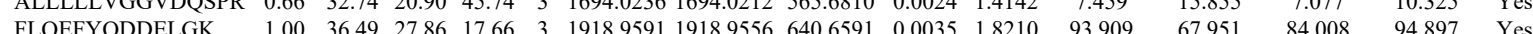

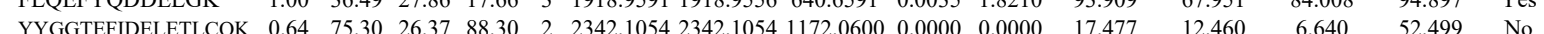
$\begin{array}{lllllllllllllllll}\text { YYGGTEFIDELETLCOK } & 1.00 & 35.09 & 26.47 & 19.52 & 3 & 2342.1100 & 2342.1054 & 781.7091 & 0.0046 & 1.9615 & 8.266 & 16.994 & 9.509 & 24.737 & \text { Yes }\end{array}$

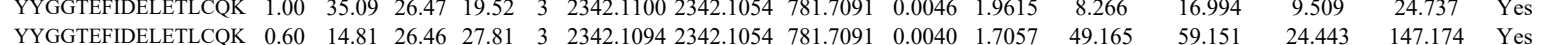

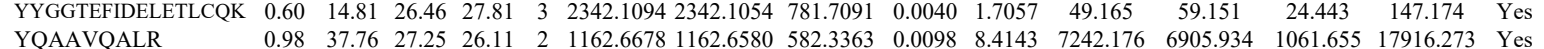
$\begin{array}{llllllllllllllll}\text { YQAAVQALR } & 0.98 & 37.76 & 27.25 & 2.11 & 2 & 1162.6678 & 162.658 & 582.3363 & 0.0098 & 8.4143 & 7242.176 & 6905.934 & 1061.655 & 17916.273 & \text { Yes } \\ \text { AVLEALGSCLNNK } & 1.00 & 56.87 & 28.03 & 20.56 & 3 & 1664.8858 & 1664.8833 & 555.9684 & 0.0025 & 1.4989 & 249.349 & 186.506 & 58.295 & 305.511 & \text { No }\end{array}$ $\begin{array}{llllllllllllllll}\text { AVLEALGSCLNNK } & 0.97 & 24.62 & 28.03 & 15.90 & 3 & 1664.8858 & 1664.8833 & 555.9684 & 0.0025 & 1.4989 & 133.782 & 111.699 & 34.066 & 165.764 & \text { Yes }\end{array}$

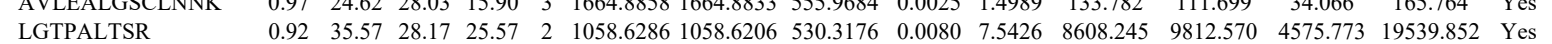

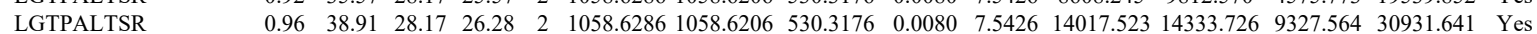

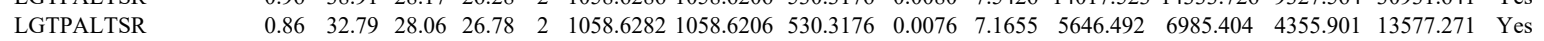
$\begin{array}{llllllllllllllll}\text { LGTPALTSR } & 0.90 & 34.17 & 28.06 & 29.01 & 2 & 1058.6284 & 1058.6206 & 530.3176 & 0.0078 & 7.3540 & 5473.108 & 5944.121 & 3531.763 & 11899.014 & \text { Yes }\end{array}$

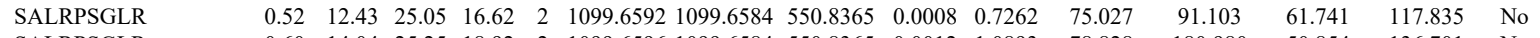

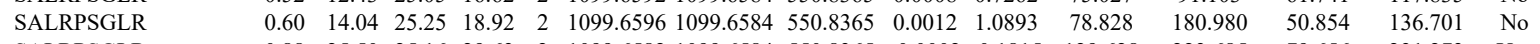

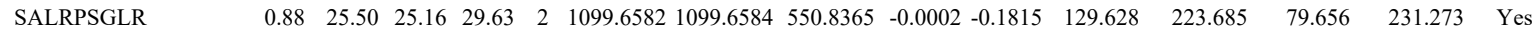
$\begin{array}{lllllllllllllllll}\text { SALRPSGLR } & 0.99 & 32.11 & 25.05 & 22.66 & 2 & 1099.6592 & 1099.6584 & 550.8365 & 0.0008 & 0.7262 & 168.877 & 310.586 & 65.897 & 346.382 & \text { Yes }\end{array}$ $\begin{array}{lllllllllllllllll} & \text { AFPMPGFDEH } & 0.64 & 42.72 & 23.75 & 55.72 & 2 & 1290.5826 & 1290.5825 & 646.2985 & 0.0001 & 0.0774 & 2570.904 & 2544.051 & 114.546 & 5092.584 & \text { Yes }\end{array}$ $\begin{array}{lllllllllllllllll}\text { AFPMPGFDEH } & 1.00 & 45.16 & 23.80 & 16.00 & 2 & 1290.5840 & 1290.5825 & 646.2985 & 0.0015 & 1.1605 & 2418.736 & 2371.315 & 42.927 & 4434.939 & \text { Yes }\end{array}$ $\begin{array}{llllllllllllllll}\text { VVDFIDEGVNIGLEVK } & 1.00 & 45.73 & 25.04 & 22.12 & 3 & 2033.1322 & 2033.1289 & 678.7169 & 0.0033 & 1.6207 & 141.132 & 98.170 & 71.540 & 163.549 & \text { Yes }\end{array}$ $\begin{array}{llllllllllllllll}\text { VVDFIDEGVNIGLEVK } & 1.00 & 56.79 & 25.08 & 22.11 & 3 & 2033.1328 & 2033.1289 & 678.7169 & 0.0039 & 1.9154 & 124.504 & 150.342 & 82.871 & 192.845 & \text { Yes }\end{array}$ $\begin{array}{llllllllllllllll}\text { VVDFIDEGVNIGLEVK } & 1.00 & 38.15 & 25.07 & 16.76 & 3 & 2033.1331 & 2033.1289 & 678.7169 & 0.0042 & 2.0627 & 91.253 & 66.789 & 58.291 & 129.143 & \text { Yes }\end{array}$

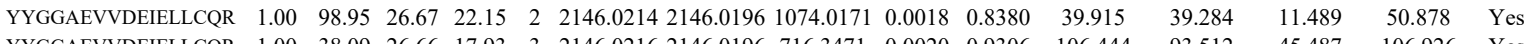
$\begin{array}{llllllllllllllll}\text { YYGGAEVVDEIELLCQR } & 1.00 & 38.09 & 26.66 & 17.93 & 3 & 2146.0216 & 2146.0196 & 716.3471 & 0.0020 & 0.9306 & 106.444 & 93.512 & 45.487 & 106.926 & \text { Yes }\end{array}$

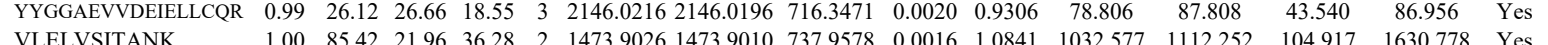

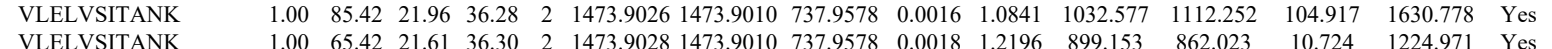

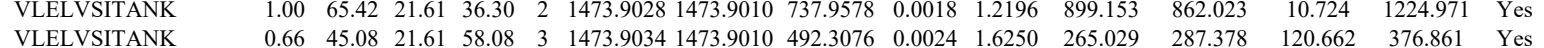

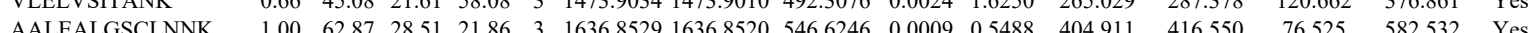
$\begin{array}{llllllllllllllll}\text { AALEALGSCLNNK } & 1.00 & 62.87 & 28.51 & 21.86 & 3 & 1636.8529 & 1636.8520 & 546.6246 & 0.0009 & 0.5488 & 404.911 & 416.550 & 76.525 & 582.532 & \text { Yes } \\ \text { AALEALGSCLNNK } & 1.00 & 70.67 & 28.51 & 36.42 & 2 & 1636.8530 & 1636.8520 & 819.4333 & 0.0010 & 0.6102 & 317.767 & 372.643 & 2.484 & 594.542 & \text { Yes }\end{array}$

Table S-4 page 272 of 614 
AALEALGSCLNNK AALEALGSCLNNK AALEALGSCLNNK AALEALGSCLNNK TGLIDYNQLALTAR TGLIDYNQLALTAR LGAPALTSR

LGAPALTSR

LGAPALTSR

LGAPALTSR

LGAPALTSR

LIIAGTSAYAR

GWTGQESLSDSDPEMWELLOR

GWTGQESLSDSDPEMWELLO

AESEEMETSQAGSK AESEEMETSQAGSK AESEEMETSQAGSK LEDTENWLYEDGEDQPK LEDTENWLYEDGEDQPK LEDTENWLYEDGEDQPK

\section{LEDTENW}

STNEAMEWMNNK

SIGAAAK

SQVISNAK

SQVISNAK

SQVISNAK

DEVLVNHFCEEFGK

KFDEVLVNHFCEEGK 0.55

$\begin{array}{llllllllllllll} & \end{array}$

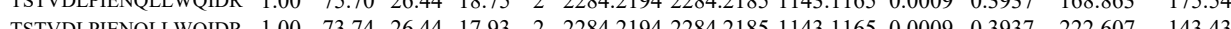

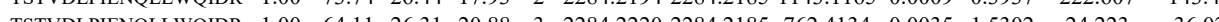

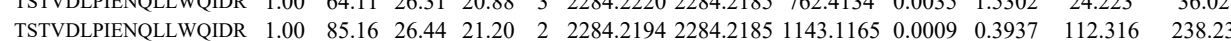

$\begin{array}{lllllllllllllll}\text { TSTVDLPIENQLLWQIDR } & 1.00 & 82.64 & 26.44 & 19.67 & 2 & 2284.2194 & 2284.2185 & 1143.1165 & 0.0009 & 0.3937 & 166.881 & 218.241\end{array}$

$\begin{array}{llllllllllll}\text { TSTVDLPIENQLLWQIDR } & 1.00 & 86.81 & 26.43 & 25.47 & 2 & 2284.2174 & 2284.2185 & 1143.1165 & -0.0011 & -0.4811 & 86.763\end{array}$

$\begin{array}{llllllllllll}\text { TSTVDLPIENQLLWQIDR } & 1.00 & 93.32 & 26.44 & 22.93 & 2 & 2284.2194 & 2284.2185 & 1143.1165 & 0.0009 & 0.3937 & 107.455\end{array}$

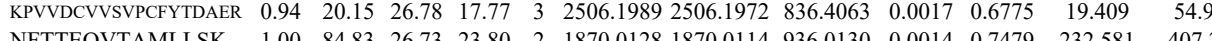

$\begin{array}{lllllllllllll}\text { NFTTEQVTAMLLSK } & 0.89 & 17.52 & 26.67 & 19.24 & 3 & 1870.0138 & 1870.0114 & 624.3444 & 0.0024 & 1.2813 & 125.142 & 104.463\end{array}$

$\begin{array}{llllllllllllll}\text { NFTTEOVTAMLLSK } & 1.00 & 87.37 & 26.670 & 21.23 & 2 & 1870.0142 & 1870.0114 & 92.360130 & 0.0028 & 1.4957 & 523.223 & 609.141\end{array}$

$\begin{array}{llllllllllllll}\text { NFTTEOVTAMLLSK } & 0.77 & 14.97 & 26.59 & 15.78 & 3 & 1870.0156 & 1870.0114 & 624.3444 & 0.0042 & 2.2423 & 148.885 & 197 .\end{array}$

$\begin{array}{llllllllllllll}\text { NFTTEQVTAMLSK } & 1.00 & 93.72 & 26.61 & 20.74 & 2 & 1870.0146 & 1870.0114 & 936.0130 & 0.0032 & 1.7094 & 471.009 & 4\end{array}$

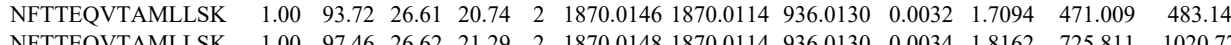

$\begin{array}{llllllllllllll}\text { NFTTEQVTAMLLSK } & 0.99 & 29.52 & 26.62 & 15.54 & 3 & 1870.0165 & 1870.0114 & 624.3444 & 0.0051 & 2.7228 & 201.417 & 201.904\end{array}$

$\begin{array}{llllllllllllll}\text { NFTTEQVTAMLLSK } & 0.98 & 27.26 & 26.66 & 17.54 & 3 & 1870.0168 & 1870.0114 & 624.3444 & 0.0054 & 2.8830 & 243.618 & 160.053\end{array}$

$\begin{array}{llllllllllllll}\text { VLATAFDTTLGGR } & 1.00 & 76.09 & 27.69 & 29.15 & 2 & 1464.8112 & 1464.8058 & 733.4102 & 0.0054 & 3.6814 & 8961.500 & 9844.731\end{array}$ $\begin{array}{lllllllllllll}\text { VLATAFDTTLGGR } & 1.00 & 66.90 & 27.69 & 25.44 & 2 & 1464.8112 & 1464.8058 & 733.4102 & 0.0054 & 3.6814 & 236.646 & 163.880\end{array}$ $\begin{array}{llllllllllllll}\text { SNLAYDIVQLPTGLTGIK } & 0.82 & 84.27 & 21.73 & 97.27 & 2 & 2190.2514 & 2190.2504 & 1096.1325 & 0.0010 & 0.4561 & 242.151 & 531.749\end{array}$

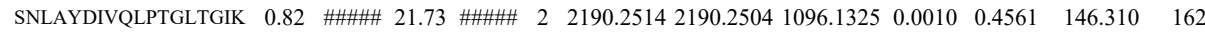

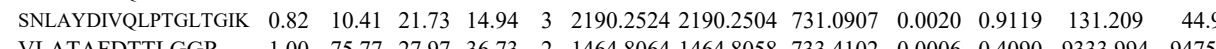

$\begin{array}{lllllllllllll}\text { VLATAFDTTLGGR } & 1.00 & 75.77 & 27.97 & 36.73 & 2 & 1464.8064 & 1464.8058 & 733.4102 & 0.0006 & 0.4090 & 9333.994 & 9475.061\end{array}$ $\begin{array}{llllllllllllll}\text { VLATAFDTTLGGR } & 1.00 & 76.40 & 28.03 & 38.05 & 2 & 1464.8080 & 1464.8058 & 733.4102 & 0.0022 & 1.4998 & 7623.891 & 10200.837\end{array}$

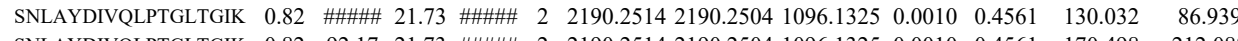

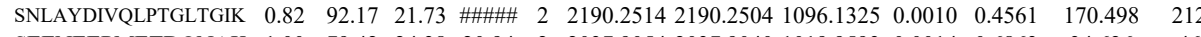
$\begin{array}{llllllllllllll}\text { SEENEEPMETDQNAK } & 1.00 & 79.42 & 24.38 & 20.94 & 2 & 2037.9054 & 2037.9040 & 1019.9593 & 0.0014 & 0.6863 & 34.626 & 46.573\end{array}$ $\begin{array}{llllllllllllll}\text { FLEMCNDLLAR } & 1.00 & 65.57 & 25.99 & 27.57 & 2 & 1513.7230 & 1513.7213 & 757.8679 & 0.0017 & 1.1216 & 790.338 & 1039.638\end{array}$

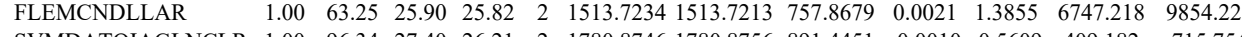

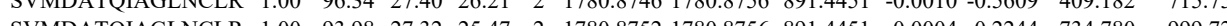

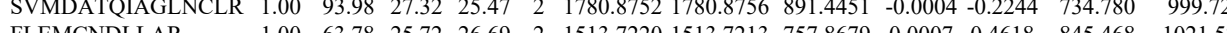
$\begin{array}{lllllllllllll}\text { FLEMCNDLLAR } & 1.00 & 63.78 & 25.72 & 26.69 & 2 & 1513.7220 & 1513.7213 & 757.8679 & 0.0007 & 0.4618 & 845.468 & 1021.526 \\ \text { FLEMCNDLLAR } & 1.00 & 61.97 & 25.85 & 22.45 & 2 & 1513.7224 & 1513.7213 & 757.8679 & 0.0011 & 0.7257 & 2545.979 & 2731.137\end{array}$ $\begin{array}{lllllllllllll}\text { SVMDATQIAGLNCLR } & 1.00 & 89.52 & 27.45 & 21.49 & 2 & 1780.8762 & 1780.8756 & 891.4451 & 0.0006 & 0.3365 & 1910.204 & 2234.871\end{array}$ 
$\begin{array}{llllllllllllllll}\text { KLPEMDID } & 0.91 & 30.67 & 28.91 & 18.32 & 2 & 1247.6670 & 1247.6675 & 624.8410 & -0.0005 & -0.4001 & 1624.908 & 2237.620 & 152.817 & 2948.567 & \text { Yes }\end{array}$

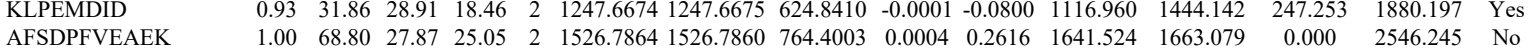

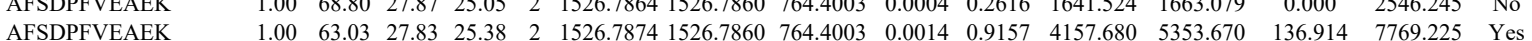

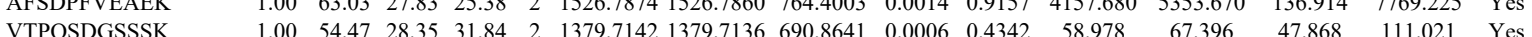
$\begin{array}{llllllllllllllllll} & \text { QDLPALEERPR } & 1.00 & 45.14 & 26.43 & 27.25 & 3 & 1582.8919 & 1582.8922 & 528.6380 & 0.0003 & 0.1892 & 12697.543 & 14863.660 & 1862138 & 21716.075 & \text { Yes }\end{array}$

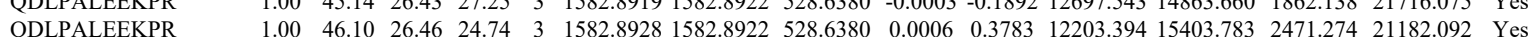

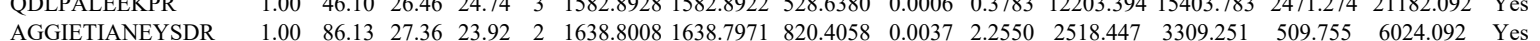

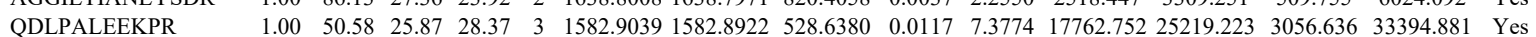
$\begin{array}{lllllllllllllllll}\text { QDLPALEEKPR } & 1.00 & 52.92 & 25.87 & 26.76 & 3 & 1582.9039 & 1582.8922 & 528.6380 & 0.0117 & 7.3774 & 13000.181 & 17375.463 & 3426.834 & 23773.812 & \text { Yes }\end{array}$

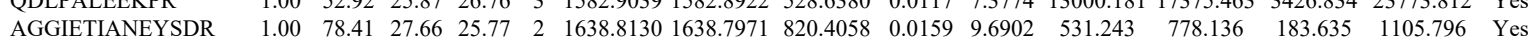
$\begin{array}{lllllllllllllllll}\text { AGGIETIANEYSDR } & 1.00 & 75.44 & 27.69 & 25.44 & 2 & 1638.8132 & 1638.7971 & 820.4058 & 0.0161 & 9.8121 & 407.287 & 437.353 & 176.388 & 619.332 & \text { Yes }\end{array}$

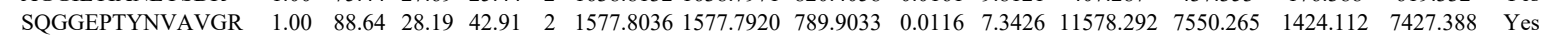
$\begin{array}{llllllllllllllllll}\text { SQGGEPTYNVAVGR } & 1.00 & 93.60 & 28.44 & 37.73 & 2 & 1577.8052 & 1577.7920 & 789.9033 & 0.0132 & 8.3554 & 15663.131 & 10554.075 & 2484.629 & 9309.031 & \text { Yes }\end{array}$ $\begin{array}{llllllllllllllll}\text { VLVFVMGK } & 1.00 & 48.88 & 23.07 & 26.23 & 2 & 1179.7316 & 1179.7293 & 590.8719 & 0.0023 & 1.9463 & 12619.588 & 8823.246 & 1035.019 & 12502.785 & \text { Yes }\end{array}$ VLVFVMGK

48 NTSDVISAAK NTSDVISAAK ALKPEVDK $\begin{array}{lllllllllllllllll}1.00 & 48.84 & 23.07 & 26.78 & 2 & 1179.7322 & 1179.7293 & 590.8719 & 0.0029 & 2.4540 & 4642.614 & 2968.966 & 1040.795 & 3562.148 & \text { Yes }\end{array}$ $\begin{array}{lllllllllllllllll}1.00 & 57.15 & 27.64 & 29.11 & 2 & 1792.7260 & 1292.7180 & 647.3663 & 0.0080 & 6.1788 & 41336.274 & 10242.943 & 2957.424 & 16401.429 & \text { Yes } & & \\ \end{array}$ $\begin{array}{llllllllllllllll}1.00 & 56.32 & 27.40 & 28.38 & 2 & 1292.7266 & 1292.7180 & 647.3663 & 0.0086 & 6.6423 & 10986.136 & 9536.429 & 3482.660 & 14179.965 & \text { Yes } & \\ 0.75 & 10.89 & 22.81 & 22.44 & 3 & 1330.8217 & 1330.8186 & 44.6135 & 0.0031 & 2.3241 & 9277.492 & 9477.184 & 1384.633 & 14604.853 & \text { Y }\end{array}$

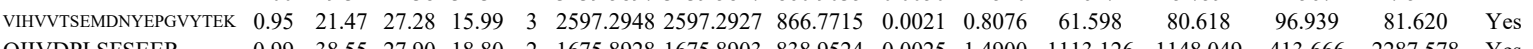
$\begin{array}{llllllllllllllll}\text { QIIVDPLSFSEER } & 0.99 & 38.55 & 27.90 & 18.80 & 2 & 1675.8928 & 1675.8903 & 838.9524 & 0.0025 & 1.4900 & 1113.126 & 1148.049 & 413.666 & 2287.578 & \text { Yes }\end{array}$ QIIVDPLSFSEER AHVLAASVEQATENFLE LLILADMADVYK LLILADMADVYK $\begin{array}{llllllllllllll}0.9 & 38.19 & 27.79 & 15.96 & 2 & 1675.8932 & 1675.8903 & 838.9524 & 0.0029 & 1.7283 & 1417.719 & 1522.976 & 389\end{array}$ \begin{tabular}{|lllllllllllllllll} 
& 1.00 & 87.67 & 25.04 & 22.87 & 2 & 1651.9502 & 1651.9462 & 826.9804 & 0.0040 & 2.4184 & 356.194 & 405.091 & 68.377 & 674.083 & Yes
\end{tabular} $\begin{array}{llllllllllllllllll} & \end{array}$

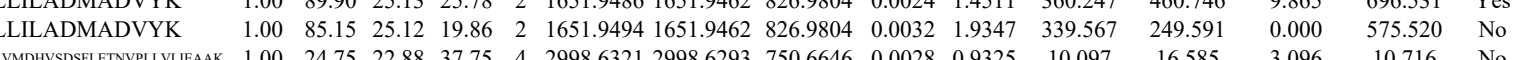
$\begin{array}{llllllllllllll} & & 10.716 & N 0 & N\end{array}$ $\begin{array}{lllllllllllll} & \end{array}$ $\begin{array}{llllllllllllllll} & 0.75 & 62.68 & 22.81 & 1.01 & 3 & 2988.6342 & 2988.6293 & 1000.5504 & 0.004 & 1.6324 & 25.651 & 39.352 & 37.599 & 21.874 & \text { Yes }\end{array}$

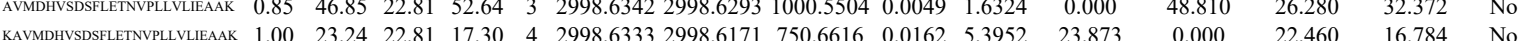

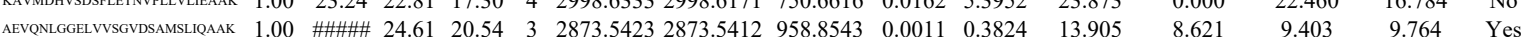

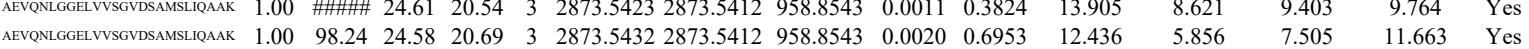

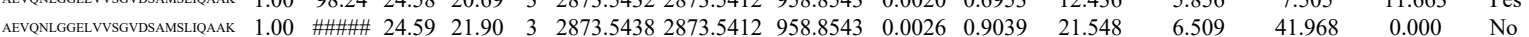

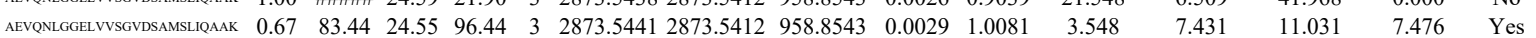
$\begin{array}{llllllllllllllll}\text { AEVQNLGGELVVSGVDSAMSLIAAK } & 1.00 & 18.38 & 24.47 & 31.38 & 4 & 2873.5457 & 2873.5412 & 719.3926 & 0.0045 & 1.5638 & 32.319 & 4.304 & 31.889 & 12.356 & \text { No }\end{array}$ $\begin{array}{llllllllllllllll}\text { AEVNNLGGELVSGVDSAMSLLAAK } & 0.99 & 13.80 & 24.42 & 26.80 & 4 & 2873.5461 & 2873.5412 & 719.3926 & 0.0049 & 1.7028 & 31.608 & 40.733 & 8.453 & 30.273 & \text { Yes }\end{array}$ $\begin{array}{lllllllllllllllll}\text { AEVQNLGGELVSGVDSAMSLQAAK } & 1.00 & 95.20 & 24.55 & 21.47 & 3 & 2873.5435 & 2873.5412 & 958.8543 & 0.0023 & 0.7996 & 0.000 & 20.022 & 0.000 & 30.597 & \text { No }\end{array}$ $\begin{array}{llllllllllllllll}\text { AEVQNGGGELVSGVDSAMSLIQAAK } & 1.00 & 77.13 & 24.50 & 21.94 & 3 & 2873.5456 & 2873.5412 & 958.8543 & 0.0044 & 1.5296 & 14.608 & 25.067 & 9.914 & 67.319 & \text { Yes }\end{array}$

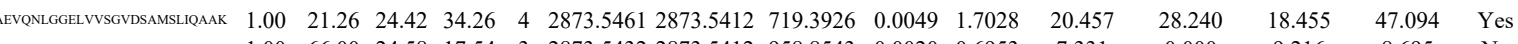
$\begin{array}{llllllllllllllll} & 8.695 & \text { No }\end{array}$

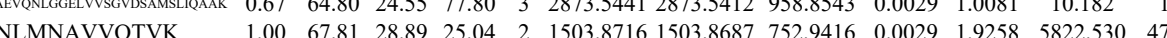

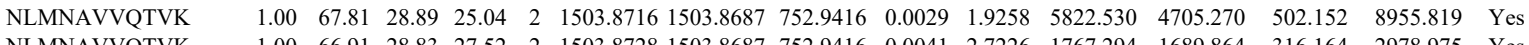

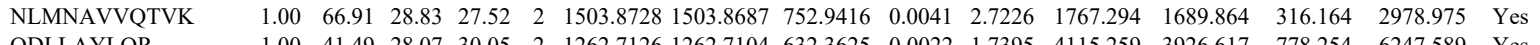
$\begin{array}{lllllllllllllllll} & \text { QDLLAYLQR } & 1.00 & 41.49 & 28.07 & 30.05 & 2 & 1262.7126 & 1262.7104 & 632.3625 & 0.0022 & 1.7395 & 4115.259 & 3926.617 & 778.254 & 6247.589 & \text { Yes }\end{array}$ $\begin{array}{llllllllllllllll}\text { NLMNAVVQTVK } & 1.00 & 65.06 & 28.88 & 24.23 & 2 & 1503.8694 & 1503.8687 & 752.9416 & 0.0007 & 0.4648 & 503.210 & 481.297 & 49.268 & 607.432 & \text { Yes }\end{array}$ \begin{tabular}{llllllllllllllll} 
& 1.00 & 46.91 & 28.87 & 17.85 & 2 & 1503.8700 & 1503.8687 & 752.9416 & 0.0013 & 0.8633 & 241.905 & 295.852 & 82.324 & 340.364 & Yes \\
\hline
\end{tabular} $\begin{array}{llllllllllllllll} & \end{array}$ $\begin{array}{llllllllllllllll} & 27.30 & 17.24 & 3 & 2735.4046 & 2735.4018 & 912.8079 & 0.0028 & 1.0225 & 1088.869 & 1338.563 & 806.282 & 2086.187 & \text { Yes }\end{array}$

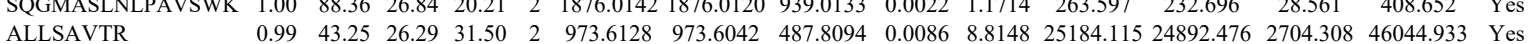

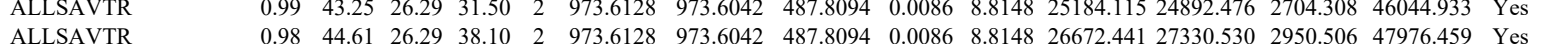

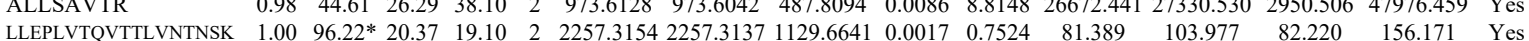

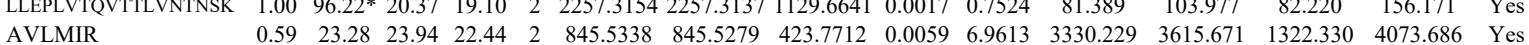
$\begin{array}{llllllllllllllll}\text { ALLSAVTR } & 0.93 & 37.00 & 26.29 & 35.21 & 2 & 973.6126 & 973.6042 & 487.8094 & 0.0084 & 8.6098 & 19092.142 & 19529.920 & 2674.830 & 35754.029 & \text { Yes }\end{array}$ 


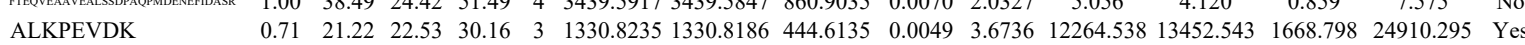
$\begin{array}{llllllllllllllll}\text { ALKPEVDK } & 0.92 & 18.74 & 22.53 & 22.17 & 3 & 1330.8235 & 1330.8186 & 44.6135 & 0.0049 & 3.6736 & 22875.531 & 23816.575 & 2589.588 & 41167.640 & \text { Yes }\end{array}$ $\begin{array}{lllllllllllllll} & & & \end{array}$ $\begin{array}{llllllllllllllll} & \\ \text { NTSDVISAAK } & 1.00 & 72.00 & 27.66 & 32.36 & 2 & 1292.7254 & 1292.7180 & 647.3663 & 0.0074 & 5.7154 & 8038.894 & 7654.146 & 3770.466 & 13840.970 & \text { Yes } \\ \text { NTSDISAAK } & 1.00 & 64.87 & 27.66 & 29.88 & 2 & 1292.7256 & 1292.7180 & 647.3663 & 0.0076 & 5.8699 & 7776.956 & 6709.880 & 3321.411 & 11820.756 & \text { Yes }\end{array}$ $\begin{array}{llllllllllllllll}\text { VIHVVTSEMDNYEPGVYTEK } & 1.00 & 43.97 & 27.18 & 16.03 & 3 & 2597.2960 & 2597.2927 & 866.7715 & 0.0033 & 1.2691 & 137.930 & 59.226 & 35.227 & 147.149 & \text { Yes }\end{array}$ $\begin{array}{llllllllllllllll} & 1.00 & 50.79 & 28.14 & 31.38 & 2 & 1230.6984 & 1230.6876 & 616.3511 & 0.0108 & 8.7612 & 1618.119 & 1383.078 & 3573.183 & 4472.227 & \text { Yes } \\ \text { FLAITTDCLQILAYGNQESK } & 0.77 & 30.34 * 27.71 & 17.94 & 3 & 2561.3134 & 2561.3113 & 854.7777 & 0.0021 & 0.8189 & 4.481 & 10.087 & 4.360 & 0.000 & \text { Ne }\end{array}$ $\begin{array}{llllllllllllll}0.77 & 30.34 * 27.71 & 17.94 & 3 & 2561.3134 & 2561.3113 & 854.7777 & 0.0021 & 0.8189 & 4.481 & 10.087 & 4.360 & 0.000 & \text { No }\end{array}$

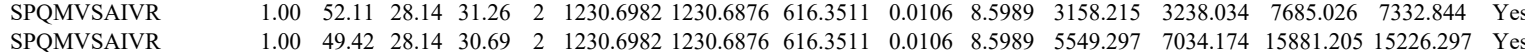

$\begin{array}{lllllllllllllllll}\text { LSVELTSSLFR } & 1.00 & 52.51 & 27.14 & 26.85 & 2 & 1394.7898 & 1394.7891 & 698.4018 & 0.0007 & 0.5011 & 614.325 & 548.014 & 99.334 & 1673.455 & \text { Yes }\end{array}$

$\begin{array}{llllllllllllllll}\text { LLHPPSHWPLIK } & 1.00 & 25.36 & 20.68 & 24.28 & 4 & 1725.0341 & 1725.0334 & 432.2656 & 0.0007 & 0.4048 & 5020.721 & 4324.842 & 874.726 & 11872.756 & \text { Yes }\end{array}$

$\begin{array}{llllllllllllllll}\text { LLHPPSHWPLIK } & 1.00 & 28.68 & 20.53 & 18.05 & 4 & 1725.0373 & 1725.0334 & 432.2656 & 0.0039 & 2.2556 & 2733.857 & 2198.990 & 99.379 & 7712.609 & \text { Yes }\end{array}$

$\begin{array}{llllllllllllllll}\text { LLHPPSHWPLIK } & 1.00 & 30.83 & 20.64 & 15.98 & 4 & 1725.0345 & 1725.0334 & 432.2656 & 0.0011 & 0.6362 & 1025.706 & 1115.204 & 167.921 & 2815.457 & \text { Yes }\end{array}$

$\begin{array}{llllllllllllllll}\text { LLHPPSHWPLIK } & 1.00 & 29.04 & 20.64 & 22.05 & 4 & 1725.0349 & 1725.0334 & 432.2656 & 0.0015 & 0.8675 & 1095.086 & 1137.156 & 208.111 & 3002.242 & \text { Yes }\end{array}$

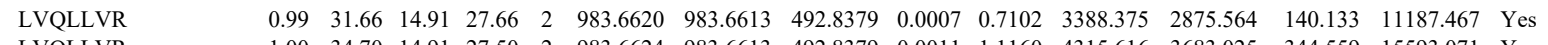

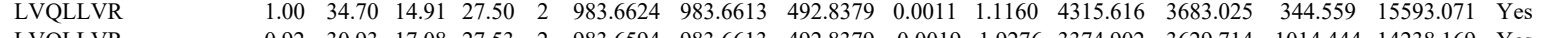

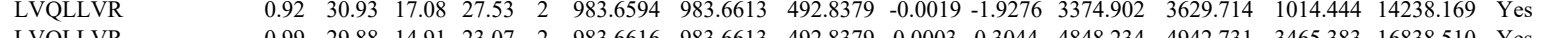
\begin{tabular}{llllllllllllllll} 
LVQLLVR & 0.99 & 29.88 & 14.91 & 23.07 & 2 & 983.6616 & 983.6613 & 492.8379 & 0.0003 & 0.3044 & 4848.234 & 4942.731 & 3465.383 & 16838.510 & Yes \\
\hline
\end{tabular}

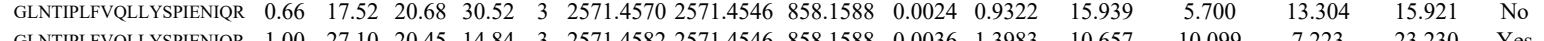

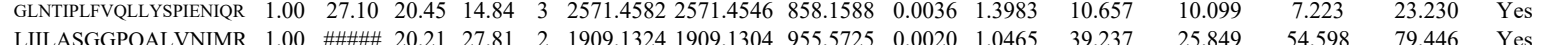

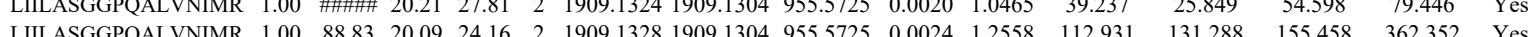

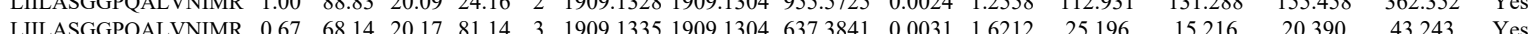
$\begin{array}{llllllllllllll} & \end{array}$

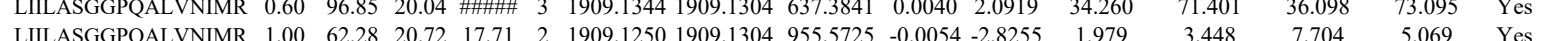

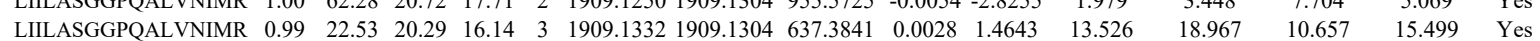

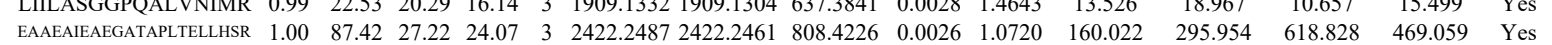
$\begin{array}{llllllllllllllll}\text { EAAEAIEAEGATAPLELLHSR } & 1.00 & 87.42 & 27.22 & 24.07 & 3 & 2422.2489 & 2422.246 & 808.4226 & 0.0026 & 1.0720 & 160.022 & 295.954 & 618.828 & 469.059 & \text { Yes } \\ \text { EAAEAIEAEGATAPTTLLHSR } & 1.00 & 71.37 & 27.19 & 17.99 & 3 & 2422.2490 & 2422.2461 & 808.4226 & 0.0029 & 1.1957 & 20.967 & 60.989 & 125.234 & 165.188 & \text { No }\end{array}$

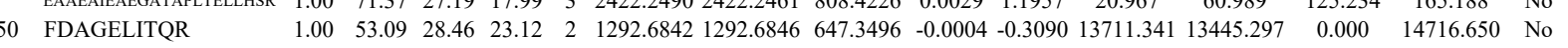

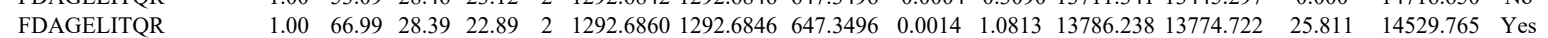

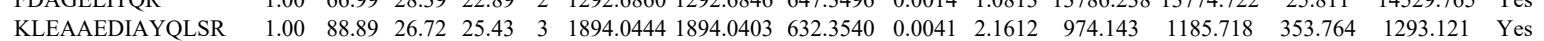
$\begin{array}{llllllllllllllll}\text { KLEAAEDIAYQLSR } & 0.97 & 24.09 & 26.72 & 20.12 & 3 & 1894.0444 & 1894.0403 & 632.3540 & 0.0041 & 2.1612 & 102.188 & 103.539 & 78.133 & 121.917 & \text { Yes }\end{array}$ $\begin{array}{llllllllllllllll}\text { KLEAAEDIAYQLSR } & 0.91 & 19.49 & 26.73 & 17.57 & 3 & 1894.0441 & 1894.0403 & 632.3540 & 0.0038 & 2.0031 & 326.167 & 258.729 & 130.636 & 289.104 & \text { Yes }\end{array}$

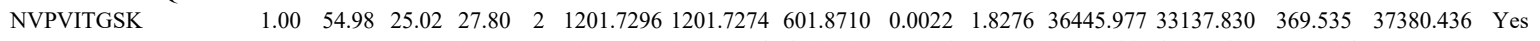

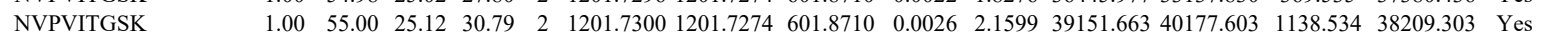
$\begin{array}{llllllllllllllll}\text { NVPVITGSK } & 1.00 & 59.57 & 25.12 & 22.09 & 2 & 1201.7300 & 1201.7274 & 601.8710 & 0.0026 & 2.1599 & 10269.016 & 10399.048 & 925.136 & 9556.235 & \text { Yes }\end{array}$ $\begin{array}{lllllllllllllllll}\text { NVPVITGSK } & 1.00 & 57.15 & 25.12 & 26.24 & 2 & 1201.7302 & 1201.7274 & 601.8710 & 0.0028 & 2.3261 & 19704.062 & 22782.283 & 54.916 & 21957.471 & \text { Yes }\end{array}$ $\begin{array}{llllllllllllllll}\text { DLQNVNITLR } & 0.99 & 56.66 & 28.36 & 48.30 & 2 & 1328.7654 & 1328.7534 & 665.3840 & 0.0120 & 9.0173 & 9641.846 & 8634.335 & 6646.778 & 8984.795 & \text { Yes }\end{array}$ $\begin{array}{llllllllllllllllll}\text { DLQNVNITLR } & 0.98 & 48.69 & 28.37 & 44.87 & 2 & 1328.7656 & 1328.7534 & 665.3840 & 0.0122 & 9.1676 & 8037.042 & 7658.761 & 6012.027 & 8745.390 & \text { Yes }\end{array}$

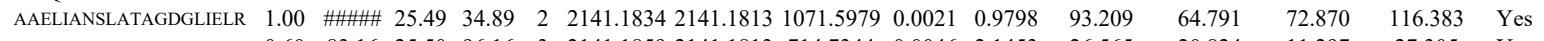

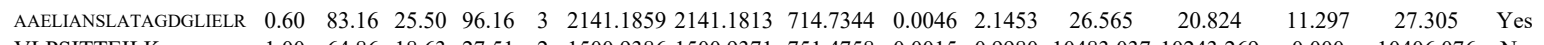
$\begin{array}{llllllllllllllll}\text { VLPSITTEILK } & 1.00 & 64.86 & 18.63 & 27.51 & 2 & 1500.9386 & 1500.9371 & 751.4758 & 0.0015 & 0.9980 & 10483.037 & 10243.269 & 0.000 & 10406.076 & \text { No }\end{array}$ $\begin{array}{llllllllllllllll}\text { VLPSITTEILK } & 1.00 & 57.10 & 18.63 & 25.44 & 2 & 1500.9388 & 1500.9371 & 751.4758 & 0.0017 & 1.1311 & 6347.629 & 6203.688 & 0.000 & 6756.154 & \text { No }\end{array}$

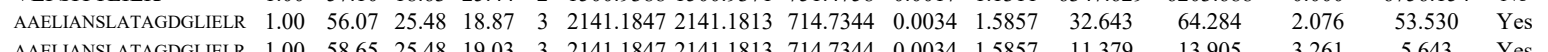

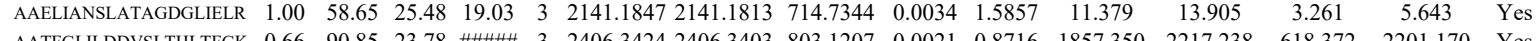

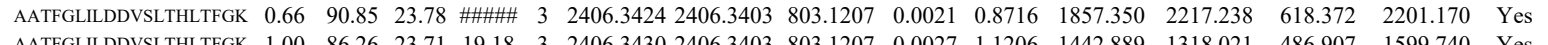
\begin{tabular}{llllllllllllllll} 
AATFGLILDDVSLTHLTFGK & 1.00 & 86.26 & 23.71 & 19.18 & 3 & 2406.3430 & 2406.3403 & 803.1207 & 0.0027 & 1.1206 & 1442.889 & 1318.021 & 486.907 & 1599.740 & Yes \\
\hline NITYLPGQSVLLQLPQ & 0.97 & 27.53 & 24.71 & 19.19 & 2 & 1998.1294 & 1998.1272 & 1000.0709 & 0.0022 & 1.0999 & 82.082 & 37.374 & 47.011 & 74.995 & Yes
\end{tabular} $\begin{array}{llllllllllllllll}\text { NITYLPAGQSVLQLPQ } & 0.97 & 27.53 & 24.71 & 19.19 & 2 & 1998.1294 & 1998.1272 & 1000.0709 & 0.0022 & 1.0999 & 82.082 & 37.374 & 47.011 & 74.995 & \text { Yes }\end{array}$

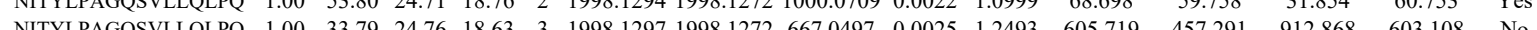

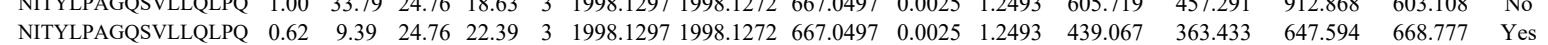




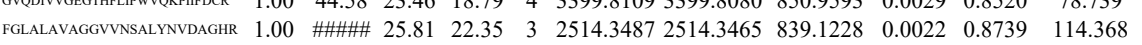
$\begin{array}{lllllllllllll}\text { AALAVAGGVVNSALYNVDAGHR } & 0.67 & 84.73 & 25.75 & 97.73 & 3 & 2514.3493 & 2514.3465 & 839.1228 & 0.0028 & 1.1123 & 333.004\end{array}$

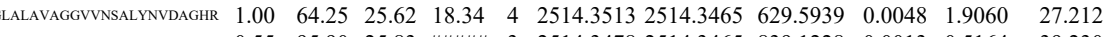

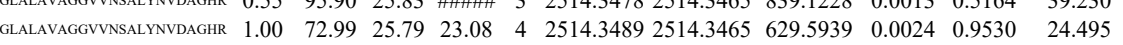
$\begin{array}{llllllll} & 0\end{array}$

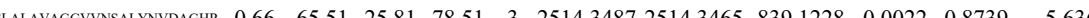
$\begin{array}{lllllllllll} & 0.67\end{array}$ $\begin{array}{llllllllllll} & 0.30\end{array}$

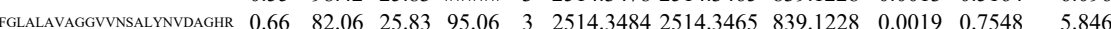

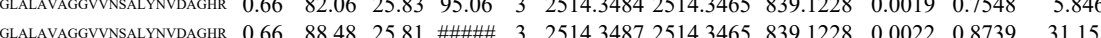
$\begin{array}{lllllllllllll}\text { FGLALAVAGGVVNSALYNVDAGHR } & 0.66 & 71.68 & 25.81 & 84.68 & 3 & 2514.3487 & 2514.3465 & 839.1228 & 0.0022 & 0.8739 & 27.058\end{array}$ $\begin{array}{lllllllllllll}\text { ILFRPVASQLPR } & 0.87 & 15.61 & 23.82 & 16.31 & 3 & 1395.8362 & 1395.8350 & 466.2856 & 0.0012 & 0.8578 & 90.073\end{array}$ $\begin{array}{lllllllllllll}\text { ILFRPVASQLPR } & 0.99 & 27.53 & 24.27 & 16.56 & 3 & 1395.8356 & 1395.8350 & 466.2856 & 0.0006 & 0.4289 & 67.233\end{array}$ $\begin{array}{lllllllllllll}\text { ILFRPVASQLPR } & 0.94 & 19.00 & 23.82 & 15.04 & 3 & 1395.8362 & 1395.8350 & 466.2856 & 0.0012 & 0.8578 & 95.548\end{array}$ $\begin{array}{lllllllllllll}\text { ILFRPVASQLPR } & 0.82 & 43.20 & 21.46 & 56.20 & 2 & 1539.9386 & 1539.9371 & 770.9758 & 0.0015 & 0.9728 & 545.747 & 435\end{array}$ $\begin{array}{lllllllllllll}\text { ILFRPVASQLPR } & 0.82 & 43.20 & 21.46 & 56.20 & 2 & 1539.9386 & 1539.9371 & 770.9758 & 0.0015 & 0.9728 & 545.747 & 435.796 \\ \text { ILFRPVASQLPR } & 0.84 & 51.59 & 21.40 & 64.59 & 2 & 1539.9390 & 1539.9371 & 770.9758 & 0.0019 & 1.2322 & 637.459 & 548.838 \\ \text { ILFRPVASQLPR } & 0.67 & 23.63 & 21.11 & 36.63 & 3 & 1539.9397 & 1539.9371 & 514.3196 & 0.0026 & 1.6851 & 2973.827 & 3213.493\end{array}$ \begin{tabular}{lllll}
9.9371 & 514.3196 & 0.0026 & 1.6851 & 2973.827 \\
\hline
\end{tabular} $\left.\begin{array}{llllllllllll}0.67 & 28.16 & 21.07 & 41.16 & 3 & 1539.9403 & 1539.9371 & 514.3196 & 0.0032 & 2.0739 & 1060.694 & 1\end{array}\right)$

Lervase $\begin{array}{llllllllllll}1.00 & 95.96 & 25.83 & 19.07 & 3 & 2514.3478 & 2514.3465 & 839.1228 & 0.0013 & 0.5164 & 4.565\end{array}$

ILFRPVASQLPR $\begin{array}{llllllllllll}0.82 & 44.72 & 21.99 & 57.72 & 2 & 1539.9378 & 1539.9371 & 770.9758 & 0.0007 & 0.4540 & 653.717 & 638.059 \\ 0.82 & 51.84 & 21.99 & 64.84 & 2 & 1539.9378 & 1539.9371 & 770.9758 & 0.0007 & 0.4540 & 700.090 & 580.315\end{array}$

ILFPVASQLPR $\begin{array}{llllllllllllll}0.82 & 51.84 & 21.99 & 64.84 & 2 & 1539.9378 & 1539.9371 & 770.9758 & 0.0007 & 0.4540 & 700.090 & 580.315\end{array}$

ILFRPVASQLPR $\begin{array}{llllllllllll}0.67 & 26.26 & 21.40 & 39.26 & 3 & 1539.9391 & 1539.9371 & 514.3196 & 0.0020 & 1.2962 & 1173.614 & 1235.717 \\ 0.67 & 23.21 & 21.11 & 36.21 & 3 & 1539.9397 & 1539.9371 & 514.3196 & 0.0026 & 1.6851 & 2672.289 & 2831.107\end{array}$ $\begin{array}{lllllllllll} & 25.53 & 3 & 2544.3457 & 2514.3465 & 839.1228 & -0.0008 & -0.3178 & 2.239\end{array}$

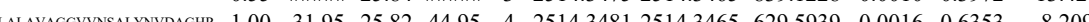

$\begin{array}{llllllllllll} & \end{array}$ $\begin{array}{lllllllllllllllll}\text { LVLVNAVYFR } & 1.00 & 47.42 & 24.01 & 19.53 & 2 & 1336.8008 & 1336.7989 & 669.4067 & 0.0019 & 1.4192 & 3762.581 & 3266.371 & 313.475 & 3260.799 & \text { Yes }\end{array}$ $\begin{array}{lllllllllllllllll}\text { LVLVNAVYFR } & 1.00 & 50.54 & 24.01 & 21.47 & 2 & 1336.8008 & 1336.7989 & 669.4067 & 0.0019 & 1.4192 & 4857.085 & 4271.480 & 377.371 & 4629.859 & \text { Yes }\end{array}$ $\begin{array}{lllllllllllllllll}\text { LVLVNAVYFR } & 1.00 & 50.85 & 24.01 & 18.28 & 2 & 1336.8004 & 1336.7989 & 669.4067 & 0.0015 & 1.1204 & 1581.898 & 1382.397 & 180.244 & 1193.623 & \text { Yes }\end{array}$

$\begin{array}{lllllllllllllllll}\text { LVLVNAVYFR } & 1.00 & 40.62 & 24.27 & 17.69 & 2 & 1336.7992 & 1336.7989 & 669.4067 & 0.0003 & 0.2241 & 336.158 & 268.958 & 56.729 & 295.218 & \text { Yes }\end{array}$ (16.121 Yes $\begin{array}{lllllllllllllll}\text { NQEQLAAELAEFTAK } & 1.00 & \text { \#\#\#\#\# } 27.47 & 27.20 & 2 & 1950.0314 & 1950.0302 & 976.0224 & 0.0012 & 0.6147 & 324.965 & 188.469 & 269.039 & 389.097 & \text { Yes }\end{array}$ $\begin{array}{llllllllllllllll}\text { NQEQLAAELAEFTAK } & 1.00 & 55.13 & 27.36 & 24.58 & 3 & 1950.0325 & 1950.0302 & 651.0173 & 0.0023 & 1.1776 & 385.567 & 254.653 & 83.094 & 179.478 & \text { Yes }\end{array}$

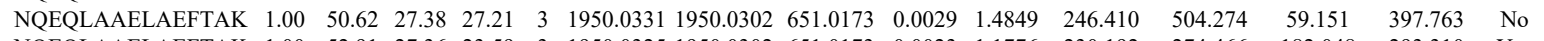

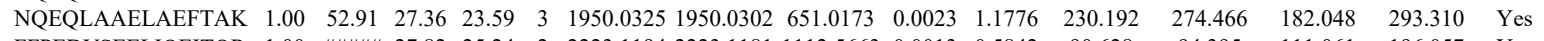

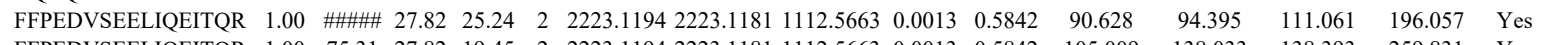

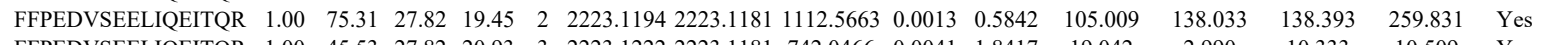

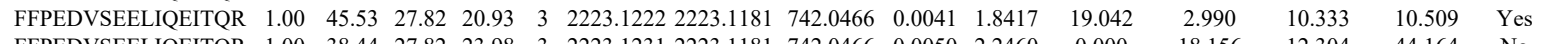

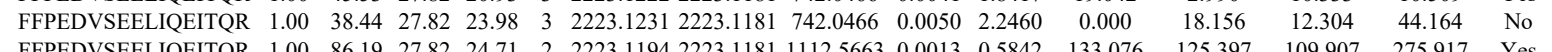

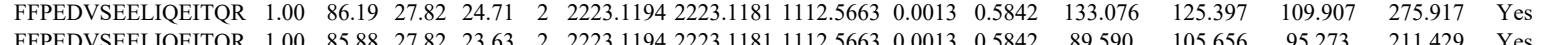

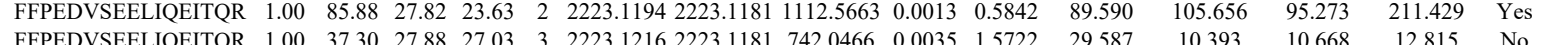

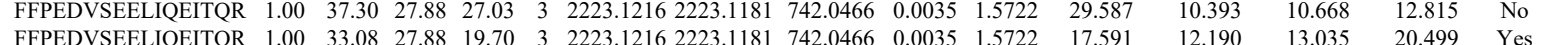

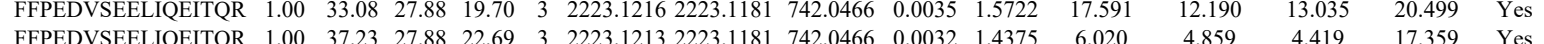
$\begin{array}{llllllllllllll} & \end{array}$

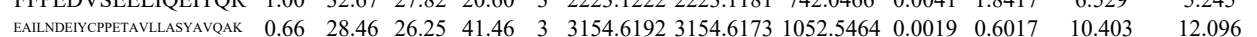


QLQALSSELAQAR AFAAQEDLEK

KTQNDVLHAENVK NTALTNGSR ATTQSATR FCLICNYVSR FCLICNYVSR

IIILDEADSMTDGAQQAL

TTSILCLAR

TTSILCLAR

VVANSK ITVTSEVPFSK ITVTSEVPFSK AVCLLTGASR

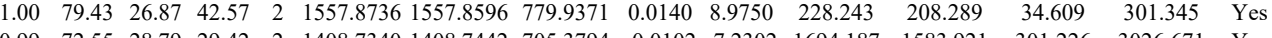

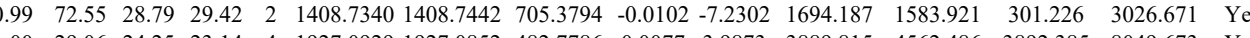
NTAQLTVSSARAAL IILDEADSMTDGAQQAL PYTDDGLEAIFTAQGDMR 1.00

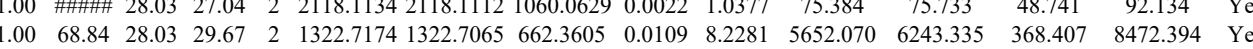
$\begin{array}{lllllllllllllll}1.00 & 68.84 & 28.03 & 29.67 & 2 & 1322.7174 & 1322.7065 & 662.3605 & 0.0109 & 8.2281 & 5652.070 & 6243.335 & 368.407 & 8472.394 & \text { Yes } \\ 1.00 & 68.91 & 27.92 & 29.73 & 2 & 1322.7180 & 1322.7065 & 6623605 & 0.0115 & 8.6810 & 4742.722 & 5453.321 & 171.565 & 7250.837 & \text { Y S S }\end{array}$ $\begin{array}{lllllllllllllll}0.84 & 31.27 & 27.28 & 20.77 & 2 & 1250.7186 & 1250.7105 & 626.3625 & 0.0081 & 6.4659 & 7363.020 & 8559.118 & 1162.278 & 10664.630 & \text { Yes }\end{array}$ $\begin{array}{lllllllllllllllll}0.88 & 31.25 & 27.27 & 17.51 & 2 & 1250.7192 & 1250.7105 & 626.3625 & 0.0087 & 6.9448 & 7167.664 & 7722.090 & 935.915 & 9526.086 & \text { Yes }\end{array}$ $\begin{array}{lllllllllllllll}0.64 & 45.52 & 23.94 & 58.52 & 2 & 1452.6512 & 1452.6508 & 727.3327 & 0.0004 & 0.2750 & 205.601 & 227.919 & 77.196 & 251.798 & \text { Yes } \\ 0.64 & 45.89 & 23.94 & 58.89 & 2 & 1452.6512 & 1452.6508 & 727.3327 & 0.0004 & 0.2750 & 174.966 & 200.081 & 90.286 & 246.866 & \text { Yes }\end{array}$ $\begin{array}{llllllllllll}0.64 & 45.52 & 23.94 & 58.52 & 2 & 1452.6512 & 1452.6508 & 727.3327 & 0.0004 & 0.2750 & 205.601 & 27.919\end{array}$ $\begin{array}{llllllllll}1 & 0.432\end{array}$

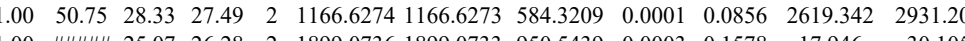

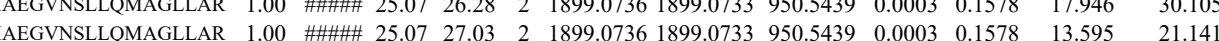

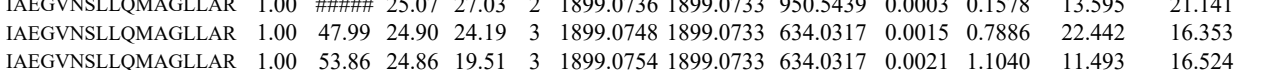

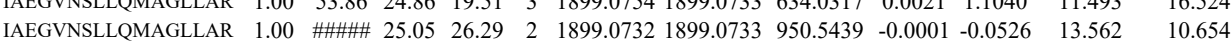
$\begin{array}{lllllllllllll}\text { IAEGVNSLLQMAGLLAR } & 1.00 & 46.22 & 24.87 & 20.59 & 3 & 1899.0751 & 1899.0733 & 634.0317 & 0.0018 & 0.9463 & 10.864 & 14.155\end{array}$ $\begin{array}{lllllllllllll}\text { IAEGVNSLLQMAGLLAR } & 1.00 & 58.38 & 24.77 & 20.51 & 3 & 1899.0760 & 1899.0733 & 634.0317 & 0.0027 & 1.4195 & 13.077 & 11.174\end{array}$ $\begin{array}{lllllllllllll}\text { IAEGVNSLLQMAGLLAR } & 1.00 & \text { \#\#\# } 24.98 & 31.35 & 2 & 1899.0738 & 1899.0733 & 950.5439 & 0.0005 & 0.2630 & 17.116 & 15.650\end{array}$ $\begin{array}{llllllllllll}\text { IAEGVNSLLQMAGLLAR } & 1.00 & \text { \#\#\#\# } & 25.00 .17 & 2 & 1899.0740 & 1899.0733 & 950.5439 & 0.0007 & 0.3682 & 8.804 & 10.723\end{array}$ $\begin{array}{lllllllllllll}\text { IAEGVNSLLQMAGLLAR } & 1.00 & 66.14 & 25.04 & 19.50 & 3 & 1899.0745 & 1899.0733 & 634.0317 & 0.0012 & 0.6309 & 10.883\end{array}$

$\begin{array}{lllllllllllll}\text { IAEGVNSLLQMAGLLAR } & 1.00 & 64.72 & 24.87 & 21.58 & 3 & 1899.0751 & 1899.0733 & 634.0317 & 0.0018 & 0.9463 & 15.647 & 17.910\end{array}$

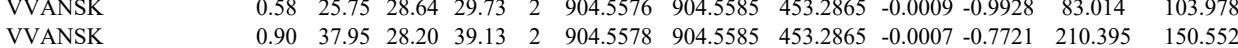
$\begin{array}{llllllllllll} & \text { VVANSK }\end{array}$ $\begin{array}{lllllllllllll}\text { TLDCTHPVEDGIMDAANEEQFLEER } & 1.00 & 62.28 & 23.84 & 75.28 & 4 & 3215.4525 & 3215.4484 & 804.8694 & 0.0041 & 1.2735 & 6.056\end{array}$ $\begin{array}{lllllllllllll}\text { FTLCTHPVEDGMDAANFEFFLEER } & 1.00 & 36.20 & 23.87 & 49.20 & 4 & 3215.4537 & 3215.4484 & 804.8694 & 0.0053 & 1.6462 & 71.272\end{array}$ $\begin{array}{llllllllllll}\text { KTLCTHPVEDGMDAANFEOFLLER } & 0.66 & 87.41 & 23.87 & \text { \#\#\#\# } & 3 & 3215.4502 & 3215.4484 & 1072.8234 & 0.0018 & 0.5593 & 24.048\end{array}$

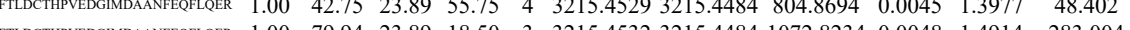
$\begin{array}{lllllllllllll}\text { FTLCTHPVEDGIMDAANEEFLLER } & 1.00 & 79.94 & 23.89 & 18.50 & 3 & 3215.4532 & 3215.4484 & 1072.8234 & 0.0048 & 1.4914 & 283.004 \\ \text { FTLDCTHPVDGIMDAANFEFLOER } & 1.00 & 53.66 & 23.93 & 17.72 & 4 & 3215.4549 & 3215.4484 & 804.8694 & 0.0065 & 20190 & 20.412\end{array}$ $\begin{array}{lllllllllllll} & \text { AGNLGGVVTIER } & 1.00 & 53.66 & 23.93 & 17.72 & 4 & 3215.459 & 3215.4484 & 804.8694 & 0.0065 & 2.0190 & 20.412\end{array}$

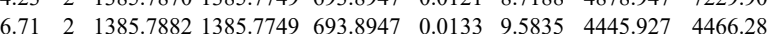
$\begin{array}{llllllllllllll}\text { LERR } & 1.00 & 35.46 & 23.84 & 48.46 & 4 & 3215.4525 & 3215.4484 & 804.8694 & 0.0041 & 1.2735 & 16.222\end{array}$ $\begin{array}{lllllllllllll}\text { FLDCTHPVEDGIMDANAFEFLLEER } & 1.00 & 49.96 & 23.89 & 16.25 & 4 & 3215.4529 & 3215.4484 & 804.8694 & 0.0045 & 1.3977 & 2.379 & 21.455 \\ \text { AGNLGGGGVTIER } & 1.00 & 72.44 & 26.10 & 30.30 & 2 & 1385.7848 & 1385.7749 & 693.8947 & 0.0099 & 7.1336 & 1594.774 & 1805.576\end{array}$ $\begin{array}{lllllllllllll}\text { AGNLGGGVVTIER } & 1.00 & 74.18 & 25.99 & 30.62 & 2 & 1385.7852 & 1385.7749 & 693.8947 & 0.0103 & 7.4218 & 1514.783 & 1944.261\end{array}$

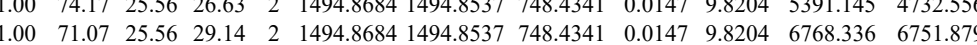
$\begin{array}{llllllllllll}\text { FTLDCTHPVDGIMDAANFEQFLLER } & 1.00 & \text { \#\#\#\#\# } 23.87 & 28.81 & 3 & 3215.4502 & 3215.4484 & 1072.8234 & 0.0018 & 0.5593 & 14.758 & 17.356\end{array}$ $\begin{array}{lllllllllllllll}\text { FTLDCTHPVEDIMDAANFEFLLER } & 1.00 & 86.98 & 23.87 & 21.90 & 3 & 3215.4502 & 3215.4484 & 1072.8234 & 0.0018 & 0.5593 & 50.594 & 30.439\end{array}$

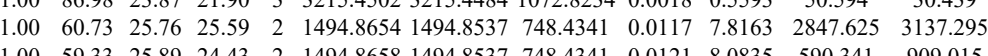

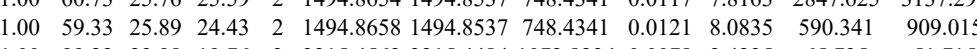
$\begin{array}{lllllllllllll} & 1.00 & 99.22 & 23.98 & 19.76 & 3 & 3215.4562 & 3215.4484 & 1072.8234 & 0.0078 & 2.4235 & 65.735\end{array}$

$\begin{array}{llllllllllllll}\text { VPADLGAEAGLOQLLGALR } & 0.51 & 10.54 & 23.64 & 13.69 & 3 & 2035.1551 & 2035.1548 & 679.3922 & 0.0003 & 0.1472 & 45.923\end{array}$ $\begin{array}{lllllll} & & & \end{array}$

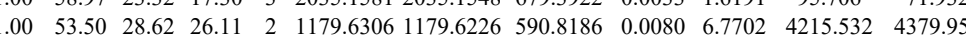
$\begin{array}{llllllllllll} & \end{array}$ $\begin{array}{lllllllllllll}\text { TLAPLLASLLSPGSVLVLSAR } & 0.60 & 24.33 & 12.30 & 37.33 & 3 & 2221.3573 & 2221.3531 & 741.4583 & 0.0042 & 1.8882 & 9.692 \\ \text { TLAPLASLSPGSVLVLSAR } & 0.66 & 23.95 & 12.30 & 36.95 & 3 & 2221.3552 & 2221.3531 & 741.4583 & 0.0021 & 0.9441 & 4.243\end{array}$

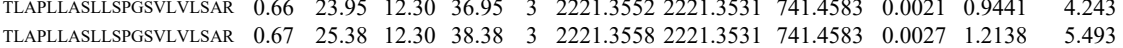
$\begin{array}{lllllllllllll}\text { SGGGGGGGGGGGGSIR } & 1.00 & 58.72 & 25.44 & 26.90 & 2 & 1231.5912 & 1231.5906 & 616.8026 & 0.0006 & 0.4864 & 8.139\end{array}$ $\begin{array}{llllllllllll}\text { SGGGGGGGLGSGGSIR } & 1.00 & 60.55 & 25.20 & 27.20 & 2 & 1231.5900 & 1231.5906 & 616.8026 & -0.0006 & -0.4864 & 19.01\end{array}$

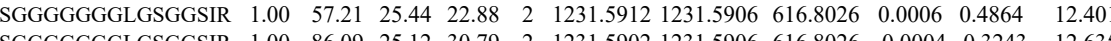

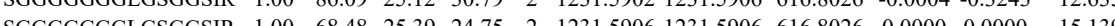
$\begin{array}{llllllllll} & \end{array}$

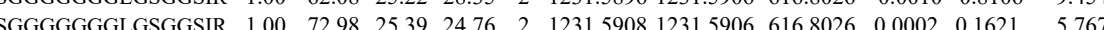


35 EEELVK $\begin{array}{llllllllll}0.82 & \# \# \# \text { 17.71 \#\#\#\# } 2 \quad 1790.72101790 .7205 \quad 896.3675 & 0.0005 & 0.2789\end{array}$ $\begin{array}{llllllllll}0.82 & \# \# \# 17.71 & \text { \#\#\#\# } 2 & 1790.7210 & 1790.7205 & 896.3675 & 0.0005 & 0.2789 & 0.000\end{array}$

TLEEEAK $\begin{array}{lllllllllll}0.92 & 27.51 & 27.99 & 36.10 & 2 & 1033.5912 & 1033.5899 & 517.8022 & 0.0013 & 1.2553 & 793.255 \\ 0.96 & 28.74 & 27.99 & 33.65 & 2 & 1033.5914 & 1033.5899 & 517.8022 & 0.0015 & 1.4484 & 902.802\end{array}$

TIEEEAK $\begin{array}{lllllllllll}0.96 & 28.74 & 27.99 & 33.65 & 2 & 1033.5914 & 1033.5899 & 517.8022 & 0.0015 & 1.4484 & 902.802 \\ 0.84 & 22.78 & 28.27 & 26.47 & 2 & 1106.6076 & 1106.6063 & 554.3104 & 0.0013 & 1.1726 & 289.151\end{array}$ $\begin{array}{llllllllllll}0.62 & 20.03 & 28.22 & 20.63 & 2 & 1106.6090 & 1106.6063 & 554.3104 & 0.0027 & 2.4355 & 216.761\end{array}$

VEEEAAQK $\begin{array}{lllllllllll}0.62 & 20.03 & 28.22 & 20.63 & 2 & 1106.6090 & 1106.6063 & 554.3104 & 0.0027 & 2.4355 & 216.76 \\ 0.97 & 34.04 & 28.92 & 28.04 & 2 & 1106.6096 & 1106.6063 & 554.3104 & 0.0033 & 2.9767 & 279.038\end{array}$

VEEEAAQK $\begin{array}{llllllllllll}0.97 & 34.04 & 28.92 & 28.04 & 2 & 1106.6096 & 1106.6063 & 554.3104 & 0.0033 & 2.9767 & 279.038\end{array}$

ADGAEAKPAE

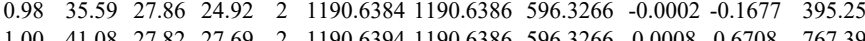
$\begin{array}{llllllllllll}1.00 & 41.08 & 27.82 & 27.69 & 2 & 1190.6394 & 1190.6386 & 596.3266 & 0.0008 & 0.6708 & 767.394 \\ 0.99 & 37.60 & 27.80 & 18.69 & 2 & 1245.6464 & 1245.6444 & 623.8295 & 0.0020 & 1.6030 & 739.501\end{array}$

QEEEMMAK $\begin{array}{lllllllllllll}0.99 & 37.60 & 27.80 & 18.69 & 2 & 1245.6464 & 1245.6444 & 623.8295 & 0.0020 & 1.6030 & 739.501 \\ 0.99 & 34.72 & 27.69 & 15.25 & 2 & 1245.6466 & 1245.6444 & 623.8295 & 0.0022 & 1.7633 & 772.126\end{array}$ $\begin{array}{lllllllllll}1.00 & 44.03 & 25.81 & 25.71 & 2 & 1282.6164 & 1282.6141 & 642.3143 & 0.0023 & 1.7904 & 620.999\end{array}$

ELEDATETADAMNR VMQEQGTHPK VMQEQGTHPK KEEELQAALAR $\begin{array}{llllllllllll}1.00 & 81.93 & 25.17 & 18.13 & 2 & 1708.7704 & 1708.7695 & 855.3920 & 0.0009 & 0.5261 & 232.514 \\ 1.00 & 89.39 & 25.38 & 23.19 & 2 & 1708.7712 & 1708.7695 & 855.3920 & 0.0017 & 0.9937 & 190.314\end{array}$ LKDVLLQVDDER $\begin{array}{llllllllllllll}1.00 & 39.45 & 27.58 & 23.28 & 3 & 1441.7617 & 1441.7591 & 481.5936 & 0.0026 & 1.7996 & 915.627 & 6 & \\ 1.00 & 45.31 & 7.54 & 19.89 & 3 & 141.7623 & 144.7591 & 48.5936 & 0.0032 & 2.2149 & 406.772 & 3 & \end{array}$

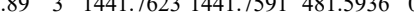
LKDVLLQVDDER $\begin{array}{llllllllllll}.00 & 62.83 & 26.15 & 35.56 & 2 & 1544.8912 & 1544.8765 & 773.4455 & 0.0147 & 9.5028 & 27461.305\end{array}$ \begin{tabular}{lllllllllllll} 
& 30.15 & 27.18 & 17.03 & 3 & 1878.8989 & 1878.8985 & 627.3068 & 0.0004 & 0.2125 & 290.294 \\
\hline
\end{tabular} $\begin{array}{lllllllllll} & \end{array}$ $\begin{array}{lllllllllllll}\text { KQELEEICHDLEAR } & 1.00 & 51.10 & 26.95 & 18.54 & 4 & 2046.0145 & 2046.0117 & 512.5102 & 0.0028 & 1.3658 & 4434.480\end{array}$

$\begin{array}{lllllllllllll}\text { KQELEEICHDLEAR } & 1.00 & 38.50 & 27.06 & 51.50 & 4 & 2046.0157 & 2046.0117 & 512.5102 & 0.0040 & 1.9512 & 3695.368 & 22.1 . \\ \text { KQELEEICHDLEAR } & 1.00 & 67.81 & 27.08 & 23.88 & 3 & 2046.0163 & 2046.0117 & 683.0112 & 0.0046 & 2.2450 & 1338.703 & 8\end{array}$

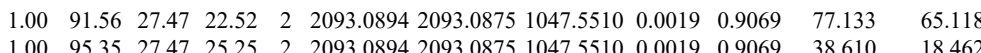
$\begin{array}{lllllllllllll}\text { LQQELDDLLVDLDHQR } & 1.00 & 95.35 & 27.47 & 25.25 & 2 & 2093.0894 & 2093.0875 & 1047.5510 & 0.0019 & 0.9069 & 38.610 & 18.462\end{array}$ $\begin{array}{llllllllllllll}\text { LQQELDDLLVDLDHQR } & 0.67 & 61.67 & 27.52 & 74.67 & 3 & 2093.0902 & 2093.0875 & 698.7031 & 0.0027 & 1.2881 & 682.224 & 282.954\end{array}$

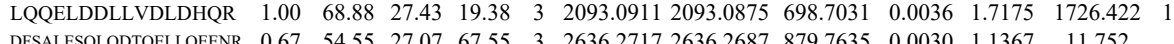
RSALESQLQDTQELLQEEN 1742.628 KLEMDLK

TDLLLEPYNK $\begin{array}{lllllllllllll}0.55 & 18.05 & 23.26 & 25.10 & 2 & 1307.7886 & 1307.7848 & 654.8997 & 0.0038 & 2.9012 & 12966.643 & 7624.983 \\ 1.00 & 57.52 & 26.68 & 30.66 & 2 & 1492.8508 & 1492.8381 & 747.4263 & 0.0127 & 8.4957 & 2045.344 & 1085.651\end{array}$

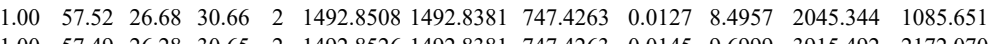
LQLQEQLQAETELCAEAE $\begin{array}{lllllllllll}1.00 & 57.49 & 26.28 & 30.65 & 2 & 1492.8526 & 1492.8381 & 747.4263 & 0.0145 & 9.6999 & 3915.49\end{array}$

2172.070

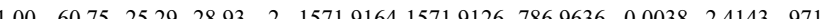

5796.269

NLPIYSEEIVEMYK $\begin{array}{lllllllllllll}1.00 & 51.72 & 25.22 & 24.44 & 2 & 1571.9172 & 1571.9126 & 786.9636 & 0.0046 & 2.922 & 2762.117 & 175.437 & 527\end{array}$

NLPIYSEEIVEMYK

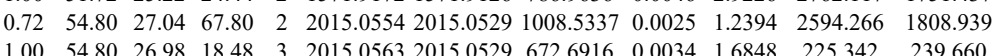
$\begin{array}{lllllllllllll}1.00 & 54.80 & 26.98 & 18.48 & 3 & 2015.0563 & 2015.0529 & 672.6916 & 0.0034 & 1.6848 & 225.342 & 239.660 \\ 1.00 & 37.04 & 27.02 & 15.67 & 3 & 2015.0581 & 2015.0529 & 672.6916 & 0.0052 & 25767 & 1304.487 & 525.716\end{array}$ LQQELDDLLVDLDHQR ALELDSNLYR ALELDSNLYR VEAQLQELQVK $\begin{array}{llllllllllll}1.00 & 70.05 & 27.52 & 20.45 & 3 & 2093.0902 & 2093.0875 & 698.7031 & 0.0027 & 1.2881 & 210.075 & 139.027\end{array}$

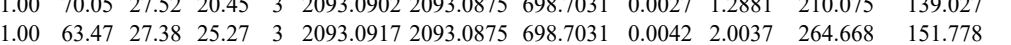
VEAQLQELQVK $\begin{array}{llllllllllll}1.00 & 46.24 & 28.44 & 29.50 & 2 & 1336.7110 & 1336.7108 & 669.3627 & 0.0002 & 0.1494 & 5832.955 & 4149.701\end{array}$ $\begin{array}{llllllllllll}1.00 & 45.30 & 28.39 & 29.00 & 2 & 1336.7120 & 1336.7108 & 669.3627 & 0.0012 & 0.8964 & 4042.567 & 3283.072\end{array}$ $\begin{array}{lllllllllllll}1.00 & 66.10 & 25.66 & 42.49 & 2 & 1571.9140 & 1571.9126 & 786.9636 & 0.0014 & 0.8895 & 7459.115 & 5134.897\end{array}$ $\begin{array}{lllllllllllll}1.00 & 59.75 & 25.62 & 34.40 & 2 & 1571.9148 & 1571.9126 & 786.9636 & 0.0022 & 1.3978 & 2078.894 & 1395.390\end{array}$ NLPIYSEEIVEMYK MYK $\begin{array}{lllllllllllll}0.72 & 59.37 & 27.04 & 72.37 & 2 & 2015.0554 & 20150529 & 1008.5337 & 0.0025 & 1.2394 & 2384.834 & 1554.403\end{array}$

NLPIYSEEIVEMYK
NLPIYSEEIVEMYK $\begin{array}{lllllllllllll}0.72 & 67.16 & 27.04 & 80.16 & 2 & 2015.0554 & 2015.0529 & 1008.5337 & 0.0025 & 1.2394 & 2168.651 & 1518.673\end{array}$

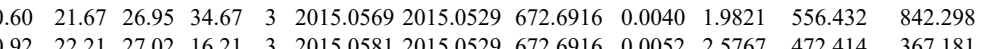

LTEMETLQSQLMAEK $\begin{array}{lllllllllllll}0.92 & 22.21 & 27.02 & 16.21 & 3 & 2015.0581 & 2015.0529 & 672.6916 & 0.0052 & 2.5767 & 472.414 & 367.181 \\ 0.99 & 2837 & 27.38 & 16.91 & 3 & 20390554 & 20390522 & 680.6913 & 0.0032 & 1.5670 & 302899 & 349.246\end{array}$

$\begin{array}{lllllllllllll}\text { LTEMETLQSQLMAEK } & 1.00 & 97.87 & 27.38 & 26.90 & 2 & 2039.0554 & 2039.0522 & 1020.5334 & 0.0032 & 1.5678 & 417.057 & 312.995\end{array}$

$\begin{array}{lllllllllllllll}\text { LTEMETLQSQLMAEK } & 0.97 & 24.82 & 27.45 & 20.48 & 3 & 2039.0566 & 2039.0522 & 680.6913 & 0.0044 & 2.1547 & 277.816 & 257.232\end{array}$ $\begin{array}{lllllllllllll} & \text { LQELDDLLVDLDIVR } & 1.00 & 69.83 & 27.40 & 21.06 & 3 & 2093.0908 & 2093.0875 & 698.7031 & 0.0033 & 1.5743 & 242.665\end{array}$ $\begin{array}{lllllllllllll} & \end{array}$ $\begin{array}{lllllllllll} & \end{array}$

13768.364 $\begin{array}{lllllllllllllllll}\text { ANLQIDQINTDLNLER } & 1.00 & 89.83 & 27.72 & 25.04 & 2 & 2013.0634 & 2013.0612 & 1007.5379 & 0.0022 & 1.0918 & 3304.209 & 2336.459 & 808.810 & 2792.416 & \text { Y }\end{array}$

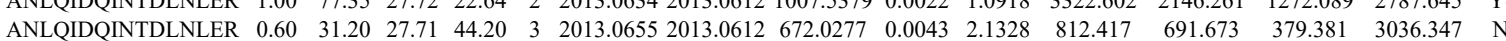

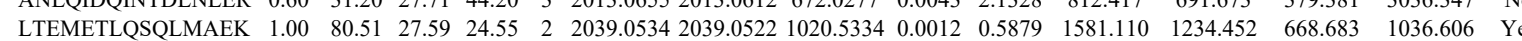

Table S-4 page 278 of 614 
$\begin{array}{llllllllllllllll} & \text { LTEMETLQSQLMAEK } & 1.00 & \text { 27.38 } & 28.31 & 2 & 2039.0554 & 2039.0522 & 1020.5334 & 0.0032 & 1.5678 & 595.971 & 324.005 & 138.333 & 388.087 & \text { Yes }\end{array}$ $\begin{array}{llllllllllllllll}\text { LTEMETLQSQLMAEK } & 1.00 & 50.98 & 27.40 & 20.84 & 3 & 2039.0572 & 2039.0522 & 680.6913 & 0.0050 & 2.4485 & 391.382 & 234.327 & 81.068 & 344.855 & \text { Yes }\end{array}$ $\begin{array}{lllllllllllllllll}\text { NMDPLNDNIATLLHQSSDK } & 1.00 & 38.09 & 27.76 & 15.78 & 3 & 2413.2208 & 2413.2151 & 805.4123 & 0.0057 & 2.3590 & 9835.654 & 6740.588 & 6667.346 & 8499.948 & \text { Yes }\end{array}$

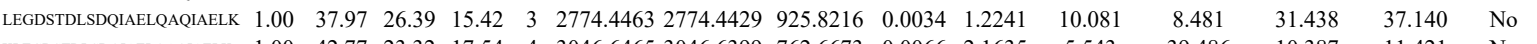

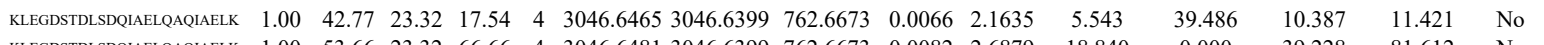

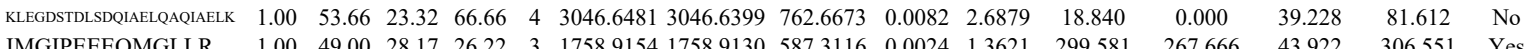

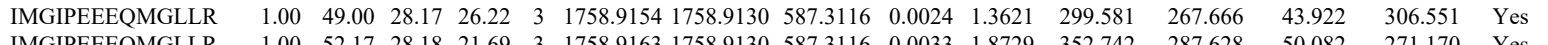

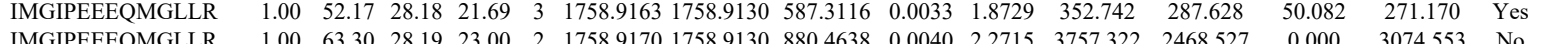

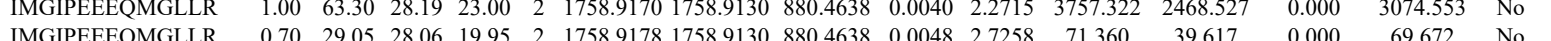
$\begin{array}{llllllllllllll} & 0.000 & 69.672 & \text { No }\end{array}$ $\begin{array}{lllllllllllll} & \end{array}$ $\begin{array}{llllllllllllllll} & \end{array}$ $\begin{array}{lllllllllllll} & \end{array}$ $\begin{array}{llllllllllllll} & 21.38 & 65.267 & \text { Yes }\end{array}$ $\begin{array}{lllllllllllllllll}\text { NMDPLNDNIATLLHOSSDK } & 1.00 & 49.68 & 27.69 & 19.94 & 3 & 24132172 & 2413.2151 & 805.4123 & 0.0021 & 0.8691 & 3777.177 & 2630.777 & 1727.463 & 3503.858 & \text { Yes }\end{array}$ $\begin{array}{llllllllllllllllll}\text { KLEGDSTDISDOAELOAOAELK } & 0.98 & 13.61 & 23.34 & 26.61 & 4 & 3046.6473 & 3046.6399 & 762.6673 & 0.0074 & 2.4257 & 0.000 & 21.844 & 15.606 & 15.054 & \text { No }\end{array}$

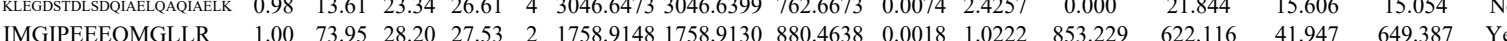
$\begin{array}{llllllllllllllll}\text { IMGIPEEEQMGLLR } & 1.00 & 63.45 & 28.19 & 26.05 & 2 & 1758.9170 & 1758.9130 & 880.4638 & 0.0040 & 2.2715 & 1032.318 & 627.580 & 15.095 & 467.036 & \text { Yes }\end{array}$ $\begin{array}{llllllllllllllll}\text { ANLQIDQINTDLNLER } & 1.00 & 77.24 & 27.72 & 23.39 & 2 & 2013.0634 & 2013.0612 & 1007.5379 & 0.0022 & 1.0918 & 1001.740 & 653.200 & 307.892 & 764.585 & \text { Yes }\end{array}$ $\begin{array}{llllllllllllllll}\text { ANLQIDQINTDLNLER } & 1.00 & 75.59 & 27.72 & 21.91 & 2 & 2013.0634 & 2013.0612 & 1007.5379 & 0.0022 & 1.0918 & 956.236 & 607.086 & 334.879 & 622.924 & \text { Yes }\end{array}$

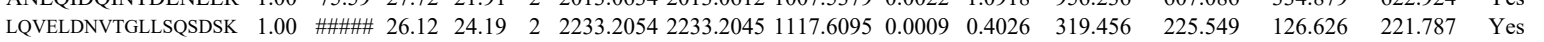
$\begin{array}{llllllllllllllll}\text { LQVELDNVTGLLSQSDSK } & 1.00 & 91.35 & 26.07 & 23.04 & 2 & 2233.2074 & 2233.2045 & 1117.6095 & 0.0029 & 1.2974 & 427.542 & 233.561 & 226.156 & 267.221 & \text { Yes }\end{array}$ $\begin{array}{llllllllllllllll}\text { LQVELDNVTGLLSQSDSK } & 1.00 & 58.34 & 25.79 & 18.39 & 3 & 2233.2106 & 2233.2045 & 745.4088 & 0.0061 & 2.7278 & 85.671 & 22.185 & 13.932 & 28.992 & \text { No }\end{array}$ $\begin{array}{lllllllllllllllll}\text { IMGIPEEEQMGLLR } & 0.56 & 15.83 & 28.16 & 18.14 & 2 & 1758.9150 & 1758.9130 & 880.4638 & 0.0020 & 1.1358 & 77.080 & 48.330 & 0.000 & 42.961 & \text { No }\end{array}$ $\begin{array}{llllllllllllllll}\text { IMGIPEEEQMGLLR } & 0.59 & 19.55 & 28.16 & 19.84 & 2 & 1758.9162 & 1758.9130 & 880.4638 & 0.0032 & 1.8172 & 70.665 & 26.343 & 0.000 & 39.280 & \text { No }\end{array}$ $\begin{array}{llllllllllllllll}\text { LQVELDNVTGLLSQSDSK } & 1.00 & 88.39 & 26.07 & 24.48 & 2 & 2233.2074 & 2233.2045 & 1117.6095 & 0.0029 & 1.2974 & 821.111 & 974.601 & 462.600 & 849.616 & \text { Yes }\end{array}$ $\begin{array}{llllllllllllllll}\text { LQVELDNVTGLLSQSDSK } & 1.00 & 94.70 & 26.07 & 22.09 & 2 & 2233.2074 & 2233.2045 & 1117.6095 & 0.0029 & 1.2974 & 1844.588 & 995.808 & 418.673 & 1557.320 & \text { Yes }\end{array}$

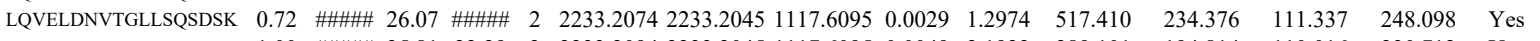
$\begin{array}{lllllllllllllll}\text { LQVELDNVTGLLSQSDSK } & 1.00 & \text { 25.81 } & 22.29 & 2 & 2233.2094 & 2233.2045 & 1117.6095 & 0.0049 & 2.1922 & 289.101 & 194.814 & 110.016 & 230.712 & \text { Yes }\end{array}$ $\begin{array}{llllllllllllllll}\text { QIATLHAQVADMK } & 0.99 & 37.23 & 25.74 & 18.75 & 3 & 1712.9647 & 1712.9487 & 571.9902 & 0.0160 & 9.3241 & 3374.019 & 2244.427 & 893.052 & 2611.947 & \text { Yes }\end{array}$

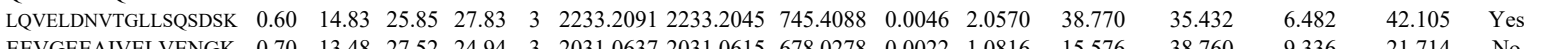

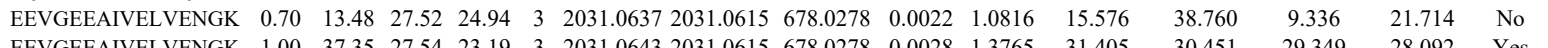

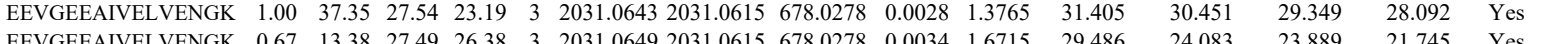

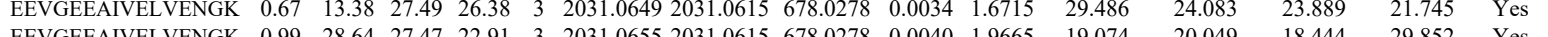

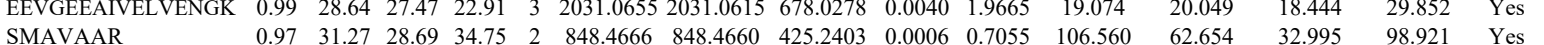

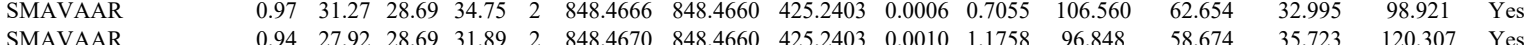

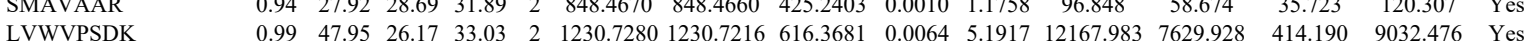

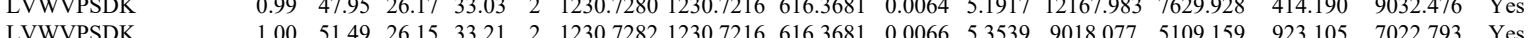
$\begin{array}{llllllllllllll} & & \end{array}$

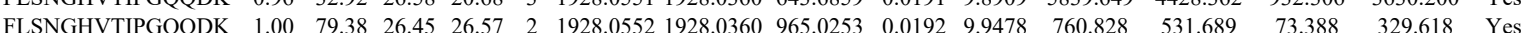

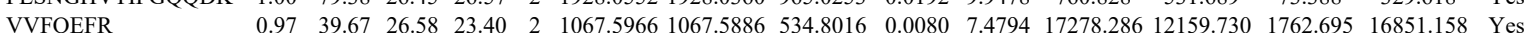

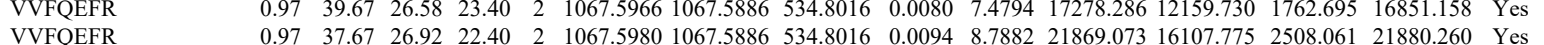
$\begin{array}{lllllllllllllllll}\text { FLSNGHVTIPGQQDK } & 0.98 & 33.64 & 26.99 & 22.09 & 3 & 1928.0494 & 1928.0360 & 6436859 & 0.0134 & 6.9392 & 6021.150 & 3769.099 & 1620.280 & 3708.490 & \text { Yes }\end{array}$ $\begin{array}{lllllllllllllllll}\text { FLSNGHVTIPGQQDK } & 0.99 & 37.90 & 26.93 & 20.82 & 3 & 1928.0497 & 1928.0360 & 643.6859 & 0.0137 & 7.0945 & 4501.037 & 2822.938 & 991.067 & 3004.852 & \text { Yes }\end{array}$ $\begin{array}{lllllllllllllllll}\text { NFINNPLAQADWAAK } & 1.00 & 80.09 & 27.18 & 30.94 & 2 & 1960.0446 & 1960.0410 & 981.0278 & 0.0036 & 1.8348 & 3642078 & 2260.106 & 214.703 & 2539.872 & \text { Yes }\end{array}$ $\begin{array}{llllllllllllllll}\text { NVFQEFR } & 0.97 & 37.49 & 26.68 & 27.43 & 2 & 1067.5974 & 1067.5886 & 534.8016 & 0.0088 & 8.2273 & 31269.219 & 23589.530 & 1952.271 & 34622.222 & \text { Yes }\end{array}$

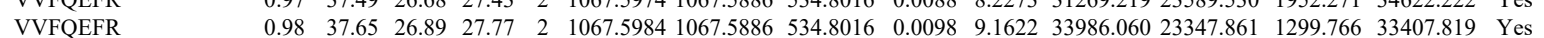

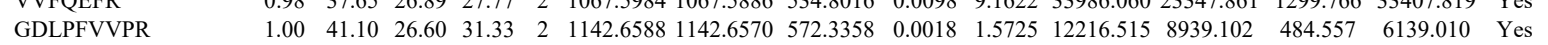
$\begin{array}{llllllllllllllll}\text { GDLPFVVPR } & 1.00 & 47.07 & 26.60 & 31.89 & 2 & 1142.6594 & 1142.6570 & 572.3358 & 0.0024 & 2.0967 & 17216.493 & 13121.039 & 588.326 & 7802.000 & \text { Yes }\end{array}$ $\begin{array}{llllllllllllllll}\text { NFINNPLAQADWAAK } & 1.00 & 80.68 & 27.28 & 23.26 & 2 & 1960.0436 & 1960.0410 & 981.0278 & 0.0026 & 1.3251 & 6231.734 & 2628.524 & 0.000 & 3620.378 & \text { No }\end{array}$ $\begin{array}{lllllllllllllllll}\text { NFINNPLAQADWAAK } & 1.00 & 83.87 & 27.27 & 25.64 & 2 & 1960.0438 & 1960.0410 & 981.0278 & 0.0028 & 1.4271 & 6533.166 & 4351.699 & 672.558 & 3544.032 & \text { Yes }\end{array}$ $\begin{array}{lllllllllllllllll}\text { NFINNPLAQADWAAK } & 0.99 & 30.40 & 27.20 & 21.21 & 3 & 1960.0447 & 1960.0410 & 654.3543 & 0.0037 & 1.8848 & 1900.726 & 1800.683 & 536.282 & 3144.116 & \text { Yes }\end{array}$ $\begin{array}{llllllllllllllll}\text { NFINNPLAQADWAAK } & 1.00 & 76.76 & 27.21 & 27.89 & 2 & 1960.0444 & 1960.0410 & 981.0278 & 0.0034 & 1.7329 & 1780.726 & 1322.734 & 46.463 & 1543.621 & \text { Yes }\end{array}$ $\begin{array}{llllllllllllllll}\text { NFINNPLAQADWAAK } & 1.00 & 98.59 & 27.28 & 26.28 & 2 & 1960.0464 & 1960.0410 & 981.0278 & 0.0054 & 2.7522 & 1086.781 & 701.876 & 32.904 & 755.541 & \text { Yes }\end{array}$

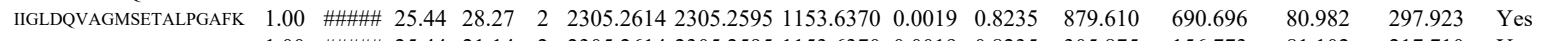

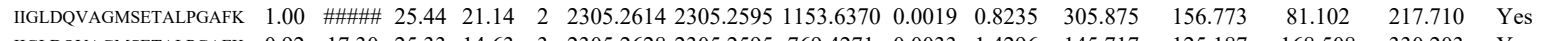
$\begin{array}{llllllllllllllll}\text { IIGLDQVAGMSETALPGAFK } & 0.92 & 17.30 & 25.33 & 14.63 & 3 & 2305.2628 & 2305.2595 & 769.4271 & 0.0033 & 1.4296 & 145.717 & 125.187 & 168.508 & 330.203 & \text { Yes }\end{array}$

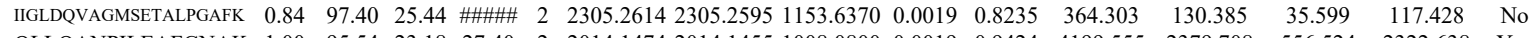

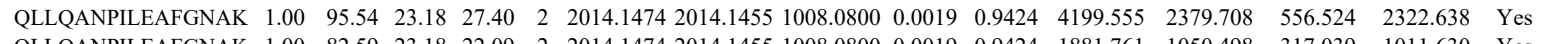

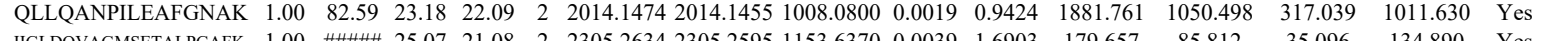

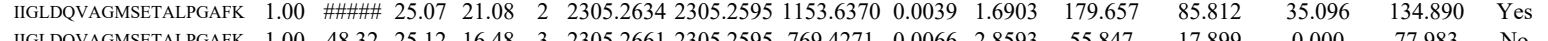
$\begin{array}{lllllllllllllll} & \end{array}$

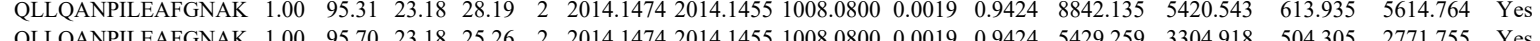

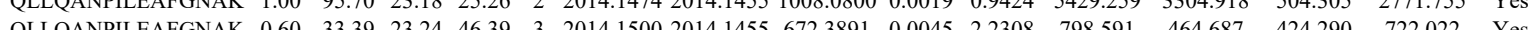

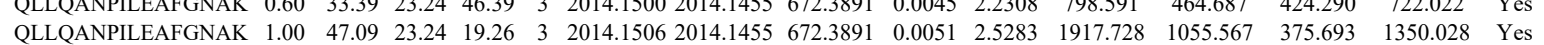

Table S-4 page 279 of 614 

$\begin{array}{lllllllllllllll}0.98 & 33.45 & 28.33 & 35.85 & 2 & 1106.6070 & 1106.6063 & 554.3104 & 0.0007 & 0.6314 & 2791.208 & 1870.909 & 287.668 & 2367.414 & \text { Yes }\end{array}$

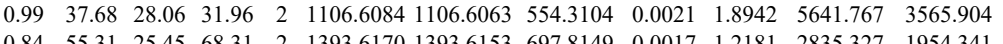

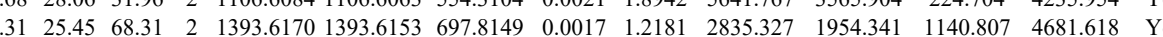
$\begin{array}{lllllllllll}0.71 & 22.46 & 27.44 & 18.13 & 3 & 2031.0694 & 2031.0615 & 678.0278 & 0.0079 & 3.8838 & 37.795 \\ 0.57 & 10.90 & 25.21 & 20.10 & 3 & 1298.7592 & 1298.7581 & 433.9266 & 0.0011 & 0.8450 & 24.239\end{array}$ $\begin{array}{lllllllllllll}1.00 & 43.16 & 24.47 & 26.60 & 3 & 1298.7703 & 1298.7581 & 433.9266 & 0.0122 & 9.3717 & 4018.794 & 5930.766\end{array}$ $\begin{array}{lllllllllllllll}1.00 & 4.16 & 24.47 & 26.60 & 3 & 1298.7703 & 1288.7581 & 433.9266 & 0.022 & 9.3717 & 40.8 .794 & 5930.766 & 13\end{array}$

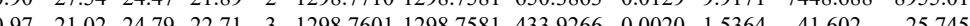
$\begin{array}{llllllllllllll}0.89 & 15.55 & 24.79 & 20.20 & 3 & 1298.7601 & 1298.7581 & 433.9266 & 0.0020 & 1.5364 & 32.280 & 26.416\end{array}$ $\begin{array}{lllllllllllll}0.81 & 23.96 & 24.03 & 19.65 & 2 & 1298.7698 & 1298.7581 & 650.3863 & 0.0117 & 8.9946 & 1588.850 & 1454.222\end{array}$ $\begin{array}{lllllllllllll}0.90 & 27.76 & 24.47 & 17.02 & 2 & 1298.7708 & 1298.7581 & 650.3863 & 0.0127 & 9.7633 & 943.903 & 987.238\end{array}$ $\begin{array}{llllllllllllll}1.00 & 79.90 & 26.90 & 46.08 & 2 & 1714.9486 & 1714.9488 & 858.4817 & -0.0002 & -0.1165 & 9443.457 & 6636.768 & 351.3\end{array}$ $\begin{array}{llllllllllll}1.00 & 80.17 & 26.62 & 46.40 & 2 & 1714.9508 & 1714.9488 & 858.4817 & 0.0020 & 1.1648 & 8052.426 & 5445.383 \\ 0.95 & 21.13 & 26.67 & 16.24 & 3 & 1714.9513 & 1714.9488 & 572.6569 & 0.0025 & 1.4552 & 62.051 & 73.134\end{array}$

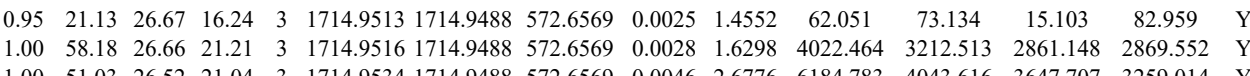
$\begin{array}{llllllllllllllllll}1.00 & 51.03 & 26.52 & 21.04 & 3 & 1714.9534 & 1714.9488 & 572.6569 & 0.0046 & 2.6776 & 6184.783 & 4043.616 & 3647.707 & 3259.014 & \text { Yes }\end{array}$ $\begin{array}{lllllllllllllll}1.00 & 85.30 & 26.90 & 46.36 & 2 & 1714.9488 & 1714.9488 & 858.4817 & 0.0000 & 0.0000 & 6600.573 & 3923.054 & 124.584 & 4204.263 & \text { Yes } \\ 1.00 & 64.26 & 26.82 & 6.37 & 2 & 174.948 & 1714.948 & 85.417 & 0.001 & 0.5824 & 978.160 & 421.268 & 523638 & 560.55 & \text { Yes }\end{array}$ $\begin{array}{lllllllllllllll}1.00 & 84.46 & 26.84 & 46.67 & 2 & 1714.9498 & 1714.9488 & 858.4817 & 0.0010 & 0.5824 & 9718.160 & 4921.268 & 523.638 & 5610.455 & \text { Yes } \\ 1.00 & 64.26 & 6.82 & 26.37 & 3 & 1714.9507 & 1714.9488 & 572.659 & 0.0019 & 1.1060 & 5364.699 & 3774.256 & 956.909 & 4257.748 & \text { Yes }\end{array}$ $\begin{array}{lllllllllllllll}1.00 & 64.26 & 26.82 & 26.37 & 3 & 1714.9507 & 1714.9488 & 572.6569 & 0.0019 & 1.1060 & 5364.699 & 3774.256 & 956.909 & 4257.748 & \text { Yes } \\ 1.00 & 51.61 & 26.66 & 20.83 & 3 & 1714.9516 & 1714.9488 & 572.6569 & 0.0028 & 1.6298 & 4082.944 & 3900.107 & 802.022 & 6140.150 & \text { Yes }\end{array}$ $\begin{array}{lllllllllllllll}1.00 & 51.95 & 24.23 & 27.10 & 3 & 1298.7694 & 1298.7581 & 433.9266 & 0.0113 & 8.6803 & 1248.827 & 1598.064 & 1012.633 & 1112.795 & \text { Yes }\end{array}$ SHLLGINVTDFTR VSHLLGINVTDFTR VSHLLGINVTDFTR VSHLLGINVTDFTR VIQYLAYVASSHK VMQEQGTHPK $\begin{array}{llllllllllll}.99 & 39.42 & 24.47 & 26.52 & 3 & 1298.7706 & 1298.7581 & 433.9266 & 0.0125 & 9.6021 & 1095.387 & 1551.555 \\ 1.00 & 80.65 & 26.87 & 42.07 & 2 & 1714.9504 & 1714.9488 & 858.4817 & 0.0016 & 0.9319 & 1117.528 & 602.250\end{array}$ $\begin{array}{llllllllllll}1.00 & 73.46 & 26.63 & 25.87 & 3 & 1714.9522 & 1714.9488 & 572.6569 & 0.0034 & 1.9791 & 2918.188 & 1953.071 \\ 0.97 & 23.24 & 26.62 & 16.86 & 3 & 1714.9510 & 1714.9488 & 572.6569 & 0.0022 & 1.2806 & 271.750 & 319.268\end{array}$ $\begin{array}{llllllllllll}0.97 & 23.24 & 26.62 & 16.86 & 3 & 1714.9510 & 1714.9488 & 572.6569 & 0.0022 & 1.2806 & 271.750 & 319.268 \\ 1.00 & 51.15 & 26.63 & 22.33 & 3 & 1714.9522 & 1714.9488 & 572.6569 & 0.0034 & 1.9791 & 773.452 & 682.138\end{array}$ $\begin{array}{lllllllllllll}1.00 & 61.77 & 25.07 & 16.91 & 3 & 1765.9993 & 1765.9970 & 589.6729 & 0.0023 & 1.3002 & 6441.399 & 5065.086\end{array}$ $\begin{array}{llllllllllllll}0.99 & 27.62 & 27.60 & 18.01 & 3 & 1441.7608 & 1441.7591 & 481.5936 & 0.0017 & 1.1766 & 73.284 & 66.705\end{array}$ $\begin{array}{llllllllllll}0.95 & 21.92 & 27.63 & 15.11 & 3 & 1441.7620 & 1441.7591 & 481.5936 & 0.0029 & 2.0072 & 53.876 & 42.329 \\ 1.00 & 37.58 & 26.52 & 23.11 & 3 & 1714.9531 & 1714.9488 & 572.6569 & 0.0043 & 2.5029 & 41.644 & 30.191\end{array}$ $\begin{array}{llllllllllll}1.00 & 71.43 & 24.94 & 22.83 & 3 & 1766.0002 & 1765.9970 & 589.6729 & 0.0032 & 1.8089 & 1922.045 & 1515.412\end{array}$ $\begin{array}{llllllllllllll}1.00 & 65.26 & 24.91 & 18.47 & 3 & 1766.0005 & 1765.9970 & 589.6729 & 0.0035 & 1.9785 & 1775.166 & 1386.849\end{array}$ $\begin{array}{llllllllllllll}1.00 & 90.10 & 18.20 & 19.78 & 2 & 1774.0990 & 1774.0960 & 888.0553 & 0.0030 & 1.6891 & 1067.164 & 768.070\end{array}$ $\begin{array}{lllllllllllll}0.67 & 46.64 & 18.20 & 5.64 & 3 & 1774.0996 & 1774.0960 & 592.3726 & 0.0036 & 20257 & 525.082 & 576.127\end{array}$ $\begin{array}{llllllllllll}0.68 & 21.66 & 27.02 & 23.75 & 2 & 1118.5536 & 1118.5532 & 560.2839 & 0.0004 & 0.3570 & 143.142 & 103.644\end{array}$ $850.669 \quad 646.964 \quad$ No $79.640 \quad 672.597 \quad$ Yes

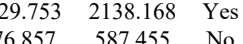
$\begin{array}{lll}76.857 & 587.455 & \text { No }\end{array}$ $\begin{array}{lll}152.705 & 888.839 & \text { Yes }\end{array}$ $\begin{array}{llll}107.076 & 2102.896 & \text { Yes }\end{array}$

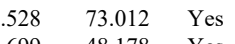
$\begin{array}{lll}40.451 & 913.307 & \text { Yes }\end{array}$ $\begin{array}{lll}1.552 & 1048.823 & \text { Yes } \\ & 1024.186 & \text { Yes }\end{array}$ 
$\begin{array}{llllllll} & \end{array}$

$\begin{array}{llllllllllllll} & & \end{array}$

IAEFTTNLTEEEEK

$\begin{array}{lllllllllll}1.00 & 86.35 & 27.86 & 22.37 & 2 & 1940.9856 & 1940.9822 & 971.4984 & 0.0034 & 1.7499 & 148.101\end{array}$

$\begin{array}{llllllllllll} & \end{array}$

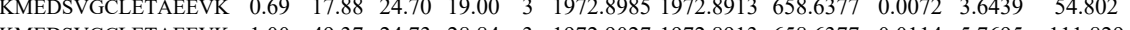

$\begin{array}{llllllllllll}\text { KMEDSVGCLETAEEVK } & 1.00 & 49.37 & 24.73 & 28.84 & 3 & 1972.9027 & 1972.8913 & 658.6377 & 0.0114 & 5.7695 & 111.829 \\ \text { KMEDSVGCLETAEEVK } & 1.00 & 53.20 & 24.94 & 23.40 & 3 & 1972.9057 & 1972.8913 & 658.6377 & 0.0144 & 7.2877 & 88.433\end{array}$

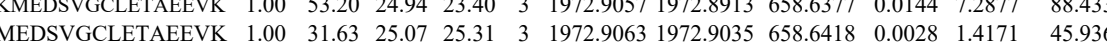

$\begin{array}{llllllllllll}\text { KMEDSVGCLETAEEVK } & 0.94 & 27.70 & 24.98 & 18.42 & 3 & 1972.9069 & 1972.8913 & 658.6377 & 0.0156 & 7.8950 & 112.487\end{array}$ $\begin{array}{llllllllllllll}\text { KMEDSVGCLETAEEVK } & 0.98 & 34.74 & 25.09 & 25.94 & 3 & 1972.9078 & 1972.8913 & 658.6377 & 0.0165 & 8.3505 & 68.183 \\ \text { KMEDSVGCLETAEEVK } & 0.97 & 32.64 & 25.26 & 19.16 & 3 & 1972.9099 & 1972.8913 & 658.6377 & 0.0186 & 9.4133 & 67.660\end{array}$

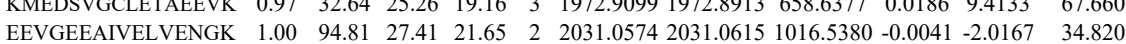
$\begin{array}{llllllllllll}\text { EEVGEEAIVELVENGK } & 1.00 & 94.81 & 27.41 & 21.65 & 2 & 2031.0574 & 2031.0615 & 1016.5380 & -0.0041 & -2.0167 & 34.820\end{array}$ $\begin{array}{llllllllll} & \end{array}$ $\begin{array}{llllllllllll} & 0.0329 & 1.549\end{array}$

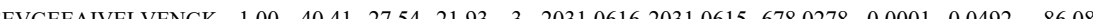

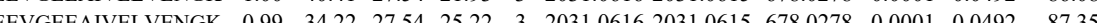
$\begin{array}{lllllllllllll}\text { EEVGEEAIVELVENGK } & 0.99 & 32.02 & 27.53 & 24.32 & 3 & 2031.0625 & 2031.0615 & 678.0278 & 0.0010 & 0.4916 & 84.795\end{array}$ $\begin{array}{llllllllllllll} & \text { EEVGEEAIVELVENGK } & 1.00 & 38.63 & 27.54 & 23.73 & 3 & 2031.0643 & 2031.0615 & 678.0278 & 0.0028 & 1.3765 & 74.7986\end{array}$

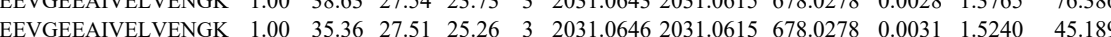
$\begin{array}{lllllllllllll}\text { EEVGEEAIVELVENGK } & 0.99 & 30.88 & 27.46 & 19.18 & 3 & 2031.0652 & 2031.0615 & 678.0278 & 0.0037 & 1.8190 & 62.852\end{array}$

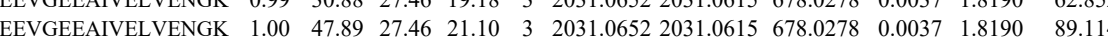
$\begin{array}{lllllllllllll}\text { EEVGEEAIVELVENGK } & 1.00 & 93.43 & 27.49 & 22.65 & 2 & 2031.0654 & 2031.0615 & 1016.5380 & 0.0039 & 1.9183 & 29.1100\end{array}$

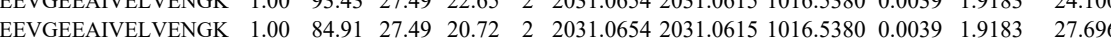
$\begin{array}{lllllllllllll}\text { EEVGEEAIVELVENGK } & 1.00 & 45.63 & 27.47 & 24.15 & 3 & 2031.0655 & 2031.0615 & 678.0278 & 0.0040 & 1.9665 & 84.367\end{array}$

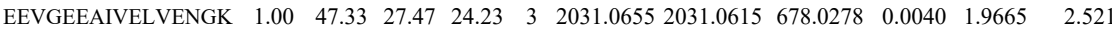

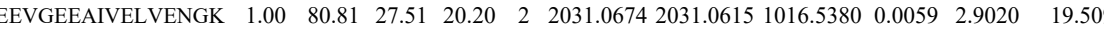
$\begin{array}{lllllllllllll}\text { EEVGEEAIVELVENGK } & 0.87 & 23.81 & 27.51 & 17.80 & 3 & 2031.0676 & 2031.0615 & 678.0278 & 0.0061 & 2.9989 & 69.181\end{array}$

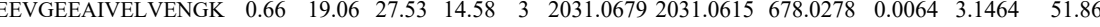
$\begin{array}{llllllllllll}\text { EEVGEEAIVELVENGK } & 0.99 & 37.07 & 27.44 & 21.44 & 3 & 2031.0682 & 2031.0615 & 678.0278 & 0.0067 & 3.2939 & 82.694\end{array}$

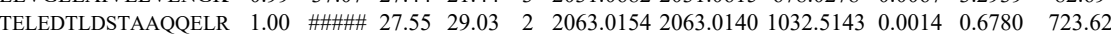
$\begin{array}{llllllllllll}\text { TELEDTLDSTAAQQELR } & 1.00 & \text { \#\#\#\# } 27.55 & 27.85 & 2 & 2063.0154 & 2063.0140 & 1032.5143 & 0.0014 & 0.6780 & 861.372\end{array}$ $\begin{array}{lllllllllllll}\text { TELEDTLDSTAAQQELR } & 1.00 & 58.78 & 27.61 & 25.90 & 3 & 2063.0161 & 2063.0140 & 688.6786 & 0.0021 & 1.0164 & 675.962\end{array}$ $\begin{array}{lllllllllllll}\text { ELESQISELQEDLESER } & 0.99 & 30.00 & 26.89 & 19.65 & 3 & 2177.0512 & 2177.0457 & 726.6892 & 0.0055 & 2.5229 & 5.286\end{array}$

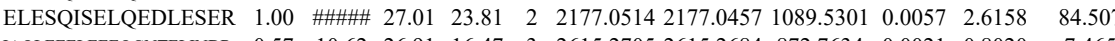
$\begin{array}{lllllllllllll}\text { IAQLEEELEEEQGNTELINDR } & 0.57 & 10.62 & 26.91 & 16.47 & 3 & 2615.2705 & 2615.2684 & 872.7634 & 0.0021 & 0.8020 & 7.465\end{array}$ $\begin{array}{llllllllllll}\text { IAQLEEELEELQGNELINDR } & 0.98 & 31.19 & 27.03 & 17.64 & 3 & 2615.2741 & 2615.2684 & 872.7634 & 0.0057 & 2.1770 & 11.577\end{array}$ $\begin{array}{lllllllllllll}\text { IAQLEEELEEEQGNTELINDR } & 0.73 & 20.86 & 27.00 & 17.93 & 3 & 2615.2753 & 2615.2684 & 872.7634 & 0.0069 & 2.6353 & 9.042\end{array}$ $\begin{array}{llllllllllll}\text { IAQLEELEEEGNTELLNDR } & 1.00 & 72.27 & 27.08 & 19.11 & 3 & 2615.2774 & 2615.2684 & 872.7634 & 0.0090 & 3.4373 & 0.000\end{array}$

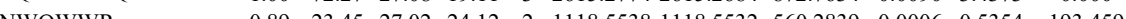


$\begin{array}{llllllllllll} & & \end{array}$

$\begin{array}{llllllllllllll} & 125.907 & 1972.8913 & 658.6377 & 0.0162 & 8.1987 & 125.363 & 101.971\end{array}$

$\begin{array}{llllllllllllll}\text { EEVGEEAIVELVENGK } & 1.00 & 48.72 & 27.50 & 23.43 & 3 & 2031.0661 & 2031.0615 & 678.0278 & 0.0046 & 2.2615 & 126.371 & 115.458\end{array}$

$\begin{array}{llllllllllllllll} & \end{array}$

$\begin{array}{lllllllllllll}\text { LEEEQIILEDQNCK } & 0.99 & 37.81 & 27.75 & 17.67 & 2 & 2037.0014 & 2037.0002 & 1019.5074 & 0.0012 & 0.5885 & 28.922 & 38\end{array}$

$\begin{array}{llllllllllll}\text { LEEEQIILEDQNCK } & 0.99 & 37.96 & 27.73 & 18.42 & 2 & 2037.0034 & 2037.0002 & 1019.5074 & 0.0032 & 1.5694 & 107.237\end{array}$

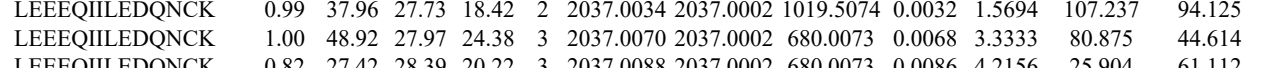

TELEDTLDSTAAQQELR

TELEDTLDSTAAQQELR 0.9

TELEDTLDSTAAQQELR
TELEDTLDSTAAQQELR
VSHLLGINVTDFTR

VSHLLGINVTD

EEELQAALAR

EEELQAALAR

LQEMEGTVK

LQEMEGTVK

TEMEDLMSSK

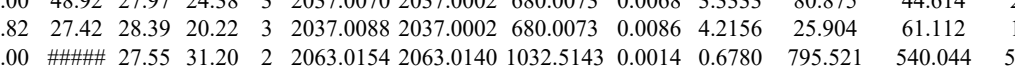

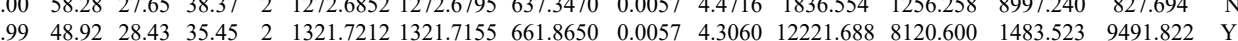
$\begin{array}{llllllllllllll} & \end{array}$ $\begin{array}{lllllllllllllll}1.00 & 55.47 & 25.95 & 19.69 & 2 & 1457.7026 & 1457.6985 & 729.8565 & 0.0041 & 2.882 & 14386.862 & 8825.158 & 1387.020 & 11301.218 & \text { Yes }\end{array}$

Table S-4 page 282 of 614 
$\begin{array}{llllllllllllllll}\text { NTDQASMPDNTAAQK } & 1.00 & 96.43 & 27.21 & 30.62 & 2 & 1878.9030 & 1878.8985 & 940.4565 & 0.0045 & 2.3924 & 8522.905 & 5965.156 & 4605.849 & 5729.100 & \text { Yes }\end{array}$ $\begin{array}{llllllllllllllll}\text { NTDQASMPDNTAAQK } & 1.00 & 98.22 & 27.28 & 25.14 & 2 & 1878.9038 & 1878.8985 & 940.4565 & 0.0053 & 2.8178 & 3767.000 & 3294.961 & 2423.942 & 2128.843 & \text { Yes }\end{array}$ $\begin{array}{llllllllllllllll}\text { NTDQASMPDNTAAQK } & 1.00 & 57.52 & 27.44 & 22.74 & 3 & 1878.9049 & 1878.8985 & 627.3068 & 0.0064 & 3.4008 & 599.367 & 308.657 & 441.071 & 632.911 & \text { Yes }\end{array}$

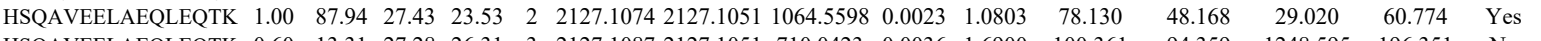
$\begin{array}{llllllllllllllll}\text { HSQAVEELAEQLEQTK } & 0.60 & 13.31 & 27.28 & 26.31 & 3 & 2127.1087 & 2127.1051 & 710.0423 & 0.0036 & 1.6900 & 100.361 & 94.359 & 1248.595 & 196.351 & \text { No }\end{array}$

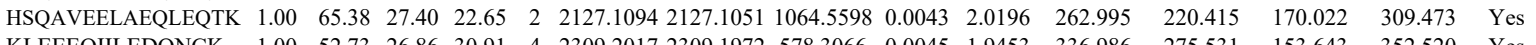
$\begin{array}{llllllllllllllll}\text { KLEEEQIILEDQNCK } & 1.00 & 52.73 & 26.86 & 30.91 & 4 & 2309.2017 & 2309.1972 & 578.3066 & 0.0045 & 1.9453 & 336.986 & 275.531 & 153.643 & 352.520 & \text { Yes }\end{array}$ $\begin{array}{llllllllllllllll}\text { KLEEEQIILEDQNCK } & 0.99 & 31.99 & 26.86 & 21.54 & 3 & 2309.2024 & 2309.1972 & 770.7397 & 0.0052 & 2.2489 & 519.456 & 262.853 & 391.810 & 440.310 & \text { Yes }\end{array}$

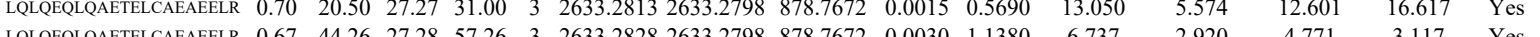

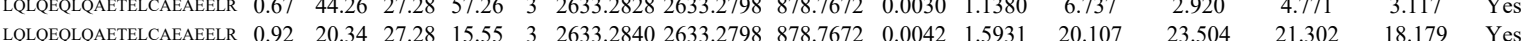

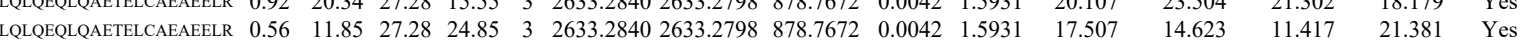
$\begin{array}{llllllllllll} & 11.417 & 21.381 & \text { YeS }\end{array}$ $\begin{array}{llllllllllllllllll} & \text { LQEMEGTVK } & 1.00 & 46.78 & 28.37 & 34.79 & 2 & 1321.7178 & 1321.7155 & 661.8650 & 0.0023 & 17375 & 16651.957 & 11097.458 & 1615.906 & 13628.427 & \text { Yes }\end{array}$

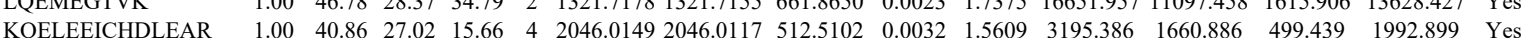
$\begin{array}{lllllllllllllllll}\text { KOELEEICHDLEAR } & 1.00 & 73.16 & 27.06 & 25.15 & 3 & 2046.0157 & 2046.0117 & 683.0112 & 0.0040 & 1.9521 & 2131.145 & 1624.692 & 457.608 & 1740.471 & \text { Yes }\end{array}$ $\begin{array}{llllllllllllllll}\text { KQELEEICHDLEAR } & 1.00 & 35.86 & 27.05 & 15.36 & 4 & 20460169 & 20460117 & 512.5102 & 0.0052 & 25365 & 1165.793 & 713.465 & 215.574 & 744.772 & \text { Yes }\end{array}$ $\begin{array}{lllllllllllllllll}\text { KQELEEICHDLEAR } & 1.00 & 58.21 & 27.11 & 23.18 & 3 & 2046.0172 & 2046.0117 & 683.0112 & 0.0055 & 2.6842 & 1835.651 & 1562.871 & 199.484 & 1607.961 & \text { Yes }\end{array}$ $\begin{array}{lllllllllllllll}\text { LQQELDDLLVDLDHQR } & 1.00 & \text { \#\#\#\# } 27.41 & 25.92 & 2 & 2093.0874 & 2093.0875 & 1047.5510 & -0.0001 & -0.0477 & 25.610 & 49.013 & 11.834 & 17.895 & \text { No }\end{array}$

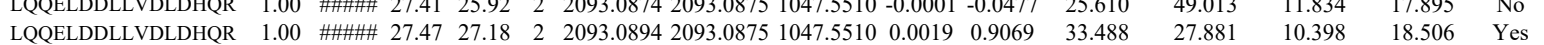

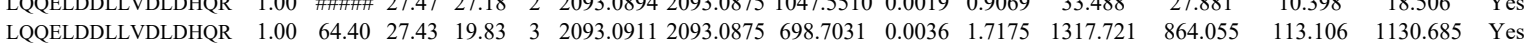
$\begin{array}{lllllllllllllllll}\text { LQQELDDLLVDLDHQR } & 1.00 & 58.62 & 27.38 & 18.76 & 3 & 2093.0917 & 2093.0875 & 698.7031 & 0.0042 & 2.0037 & 555.648 & 476.360 & 208.785 & 445.863 & \text { Yes }\end{array}$ $\begin{array}{llllllllllllllll}\text { HSQAVEELAEQLEQTK } & 0.84 & 71.85 & 27.43 & 84.85 & 2 & 2127.1074 & 2127.1051 & 1064.5598 & 0.0023 & 1.0803 & 538.523 & 415.104 & 324.411 & 558.773 & \text { Yes }\end{array}$ $\begin{array}{llllllllllllllll}\text { HSQAVEELAEQLEQTK } & 0.93 & 12.38 & 27.32 & 22.70 & 4 & 2127.1089 & 2127.1051 & 532.7836 & 0.0038 & 1.7831 & 225.518 & 179.596 & 71.164 & 329.347 & \text { Yes }\end{array}$ $\begin{array}{llllllllllllllll}\text { HSQAVEELAEQLEQTK } & 1.00 & 28.10 & 27.36 & 18.41 & 4 & 2127.1093 & 2127.1051 & 532.7836 & 0.0042 & 1.9708 & 531.915 & 661.951 & 320.397 & 792.410 & \text { Yes }\end{array}$

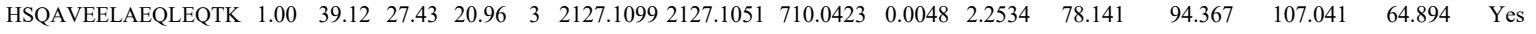
$\begin{array}{llllllllllllllll}\text { HSQAVEELAEQLEQTK } & 0.83 & 19.46 & 27.43 & 19.53 & 3 & 2127.1099 & 2127.1051 & 710.0423 & 0.0048 & 2.2534 & 381.576 & 234.449 & 73.286 & 120.291 & \text { Yes }\end{array}$ $\begin{array}{llllllllllllllll}\text { LQLQEQLQAETELCAEAEELR } & 1.00 & 81.61 & 27.35 & 24.97 & 3 & 2633.2873 & 2633.2798 & 878.7672 & 0.0075 & 2.8449 & 1.036 & 1.691 & 8.301 & 13.228 & \text { No }\end{array}$

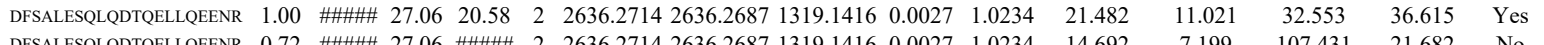

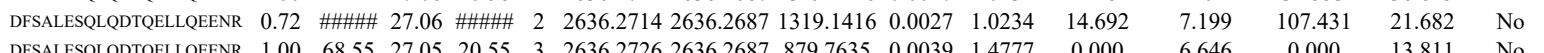

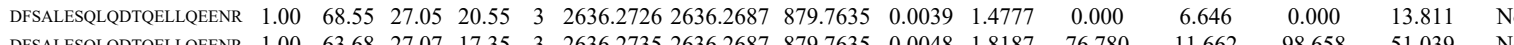

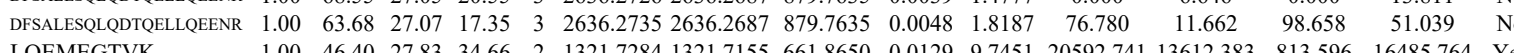

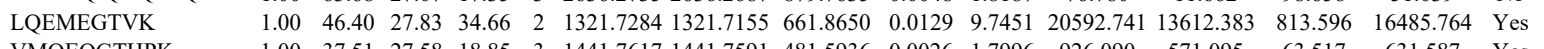

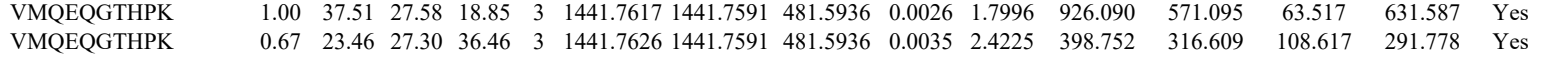
$\begin{array}{lrllllllllllllll}\text { VMQEQGTHPK } & 0.67 & 23.46 & 27.30 & 36.46 & 3 & 1441.7626 & 1441.7591 & 481.5936 & 0.0035 & 2.4225 & 398.752 & 316.609 & 108.617 & 291.778 & \text { Yes } \\ \text { KQELEEICHDLEAR } & 1.00 & 41.48 & 27.06 & 20.53 & 4 & 2046.0157 & 2046.0117 & 512.5102 & 0.0040 & 1.9512 & 8033.460 & 5513.110 & 1065.419 & 6395.418 & \text { Yes }\end{array}$ $\begin{array}{lllllllllllllllll}\text { KQELEEICHDLEAR } & 1.00 & 41.48 & 27.06 & 20.53 & 4 & 2046.0157 & 2046.0117 & 512.5102 & 0.0040 & 1.9512 & 8033.460 & 5513.110 & 1065.419 & 6395.418 & \text { Yes } \\ \text { KQELEEICHDLEAR } & 1.00 & 70.56 & 27.03 & 19.48 & 3 & 2046.0160 & 2046.0117 & 683.0112 & 0.0043 & 2.0985 & 6588.623 & 4306.618 & 1206.904 & 4512.027 & \text { Yes }\end{array}$ $\begin{array}{lllllllllllllllll}\text { KQELEEICHDLEAR } & 1.00 & 38.57 & 27.05 & 20.20 & 4 & 2046.0161 & 2046.0117 & 512.5102 & 0.0044 & 2.1463 & 7722.929 & 3952.581 & 1836.911 & 4024.516 & \text { Yes }\end{array}$ $\begin{array}{llllllllllllll} & \end{array}$ $\begin{array}{llllllllllllll} & \end{array}$ $\begin{array}{lllllllllllllll} & \end{array}$

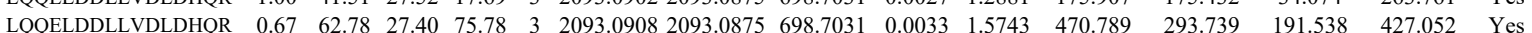

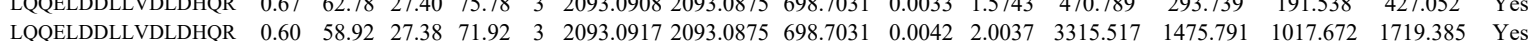
$\begin{array}{lllllllllllllllll}\text { HSQAVEELAEQLEQTK } & 1.00 & 22.91 & 27.37 & 18.46 & 4 & 2127.1097 & 2127.1051 & 532.7836 & 0.0046 & 2.1585 & 261.186 & 261.599 & 116.981 & 300.076 & \text { Yes }\end{array}$

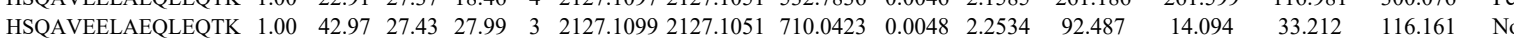

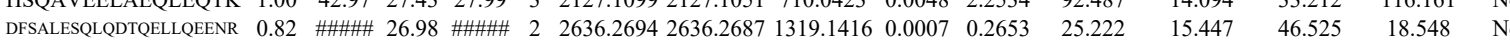

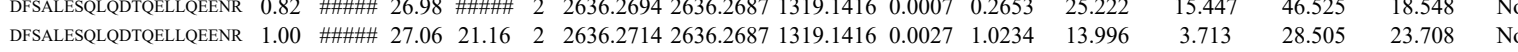
$\begin{array}{lllllllllllllll}\text { DFSALESQLQDTQELLQEENR } & 1.00 & \text { \#\#\#\# } 27.07 & 22.86 & 3 & 2636.2717 & 2636.2687 & 879.7635 & 0.0030 & 1.1367 & 7.681 & 0.000 & 0.000 & 34.293 & \text { No }\end{array}$ $\begin{array}{llllllllllllllll}\text { DFSALESQLQDTQELLQEENR } & 1.00 & 89.29 & 27.07 & 22.68 & 3 & 2636.2735 & 2636.2687 & 879.7635 & 0.0048 & 1.8187 & 51.419 & 35.476 & 26.066 & 10.985 & \mathrm{~N} 0\end{array}$ $\begin{array}{llllllllllllllll}\text { KLEMDLK } & 0.66 & 35.20 & 21.76 & 38.33 & 3 & 1307.7940 & 1307.7848 & 436.9355 & 0.0092 & 7.0185 & 31931.047 & 21502.642 & 0.000 & 30489.388 & \text { No }\end{array}$ $\begin{array}{llllllllllllllll} & 0.98 & 25.28 & 27.55 & 19.05 & 3 & 1441.7611 & 1441.7591 & 481.5936 & 0.0020 & 1.3843 & 346.100 & 283.170 & 99.434 & 297.234 & \text { Yes } \\ \text { VMQEQGTHPK } & 0.99 & 31.03 & 27.26 & 17.55 & 3 & 1441.7632 & 144.7591 & 48.5936 & 0.004 & 2.8378 & 357.902 & 264.204 & 216.738 & 380.796 & \text { Yes }\end{array}$ $\begin{array}{llllllllllllllll} & \\ \text { KMQEQGTHPK } & 0.99 & 31.03 & 27.26 & 17.55 & 3 & 1441.7632 & 1441.7591 & 481.5936 & 0.0041 & 2.8378 & 357.902 & 264.204 & 216.738 & 380.796 & \text { Yes } \\ \text { KEEELAALAR } & 1.00 & 48.77 & 26.11 & 26.59 & 3 & 15448918 & 1544.8765 & 515.9661 & 0.0153 & 9.8843 & 19859.119 & 12973.105 & 3340.905 & 13848.112 & \text { Yes }\end{array}$

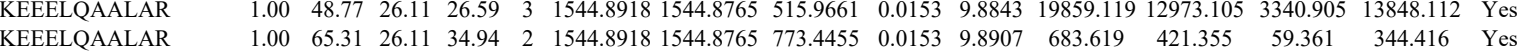
$\begin{array}{llllllllllllllll}\text { LQQELDDLLVDLDHQR } & 1.00 & 56.88 & 27.52 & 17.86 & 3 & 2093.0902 & 2093.0875 & 698.7031 & 0.0027 & 1.2881 & 870.035 & 469.995 & 272.730 & 408.451 & \text { Yes }\end{array}$ $\begin{array}{lllllllllllllllll}\text { LQQELDDLLVDLDHQR } & 1.00 & 57.76 & 27.43 & 17.11 & 3 & 2093.0911 & 2093.0875 & 698.7031 & 0.0036 & 1.7175 & 665.449 & 514.746 & 257.690 & 671.506 & \text { Yes }\end{array}$

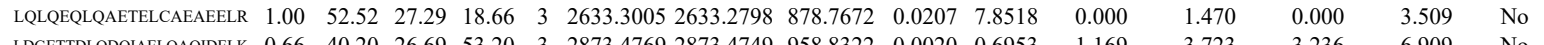

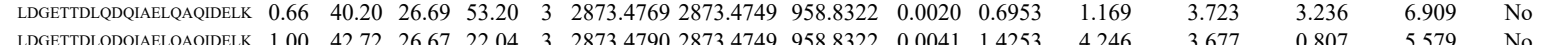

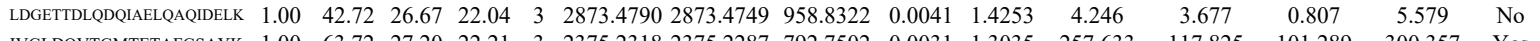

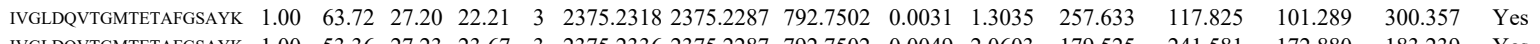

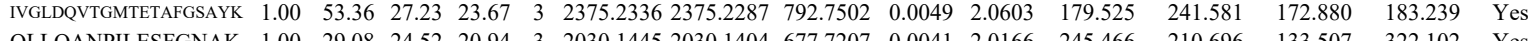

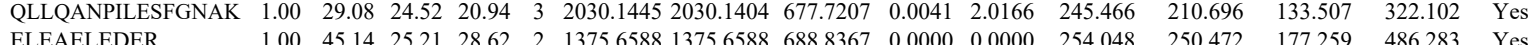

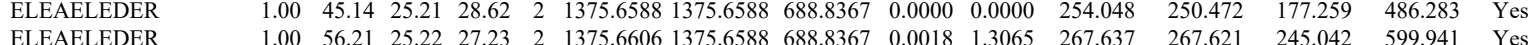

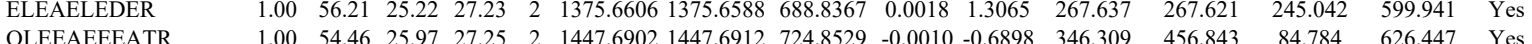

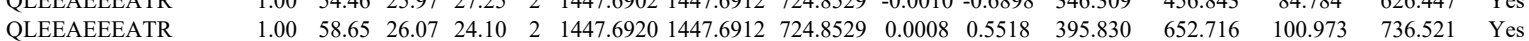

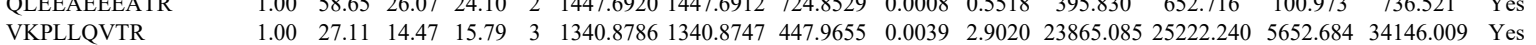

Table S-4 page 283 of 614 
$\begin{array}{llllllllllllllll}0.60 & 27.20 & 14.47 & 40.20 & 3 & 1340.8786 & 1340.8747 & 447.9655 & 0.0039 & 2.9020 & 13718.063 & 17517.382 & 2930.743 & 17394.683 & \text { Yes }\end{array}$ $\begin{array}{llllllllllllll} & & & \end{array}$ $\begin{array}{llllllllllllllll}1.00 & 70.76 & 27.54 & 36.15 & 2 & 1727.9242 & 1727.9225 & 864.9685 & 0.0017 & 0.9827 & 29.445 & 41.552 & 33.895 & 46.955 & \text { Yos }\end{array}$ $\begin{array}{llllllllllllll} & \end{array}$ $\begin{array}{lllllllllll} & & \end{array}$

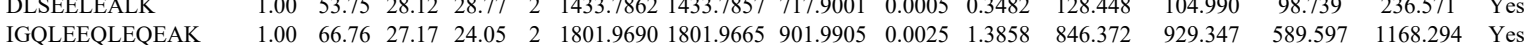

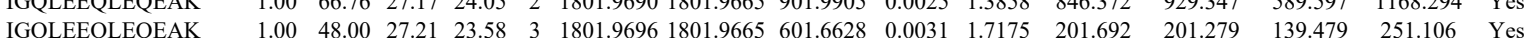
\begin{tabular}{lllllllllllllllll} 
& \\
LQQELDDLTVDLDHQR & 1.00 & 82.22 & 27.87 & 33.30 & 3 & 2081.0545 & 2081.0511 & 694.6910 & 0.0034 & 1.6314 & 410.019 & 526.434 & 153.231 & 644.440 & Yes \\
\hline
\end{tabular}

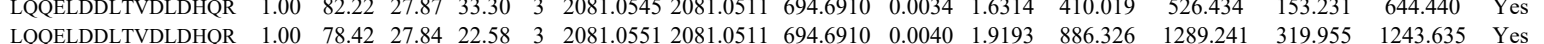

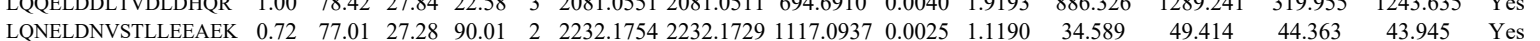

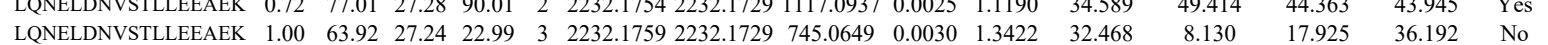

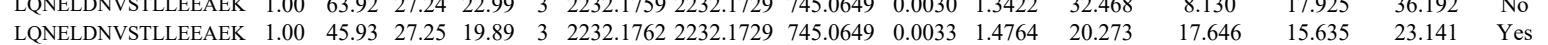
$\begin{array}{llllllllllllllll}\text { DAASLESQLQDTQELLQEETR } & 1.00 & \text { \#\#\#\# } 27.28 & 19.95 & 2 & 2547.2434 & 2547.2422 & 1274.6284 & 0.0012 & 0.4707 & 10.333 & 10.527 & 9.273 & 8.513 & \text { Yes }\end{array}$

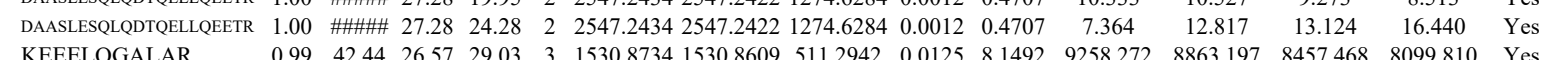

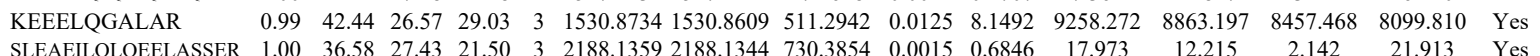

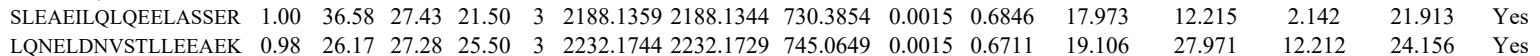

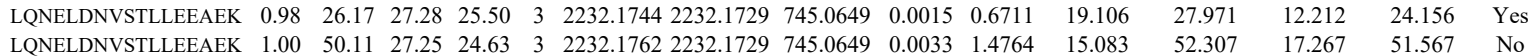

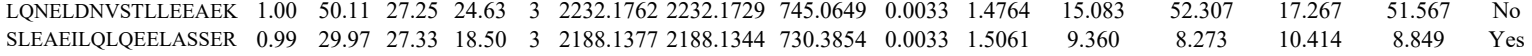

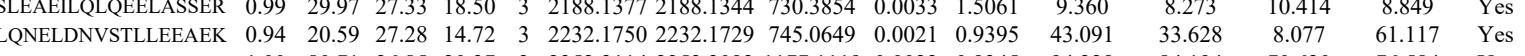

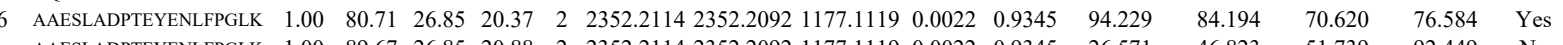

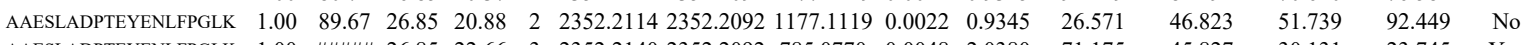

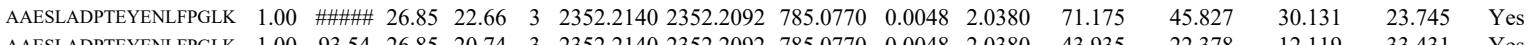

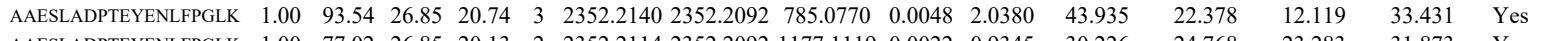

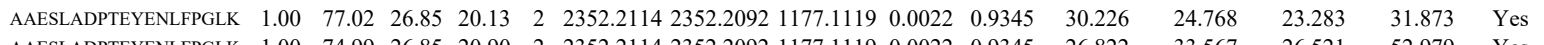

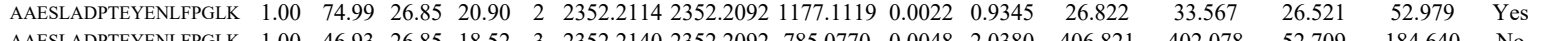
$\begin{array}{llllllllllllllll}\text { AAESLADPTEYENLFPGLK } & 1.00 & 46.93 & 26.85 & 18.52 & 3 & 2352.2140 & 2352.2092 & 785.0770 & 0.0048 & 2.0380 & 406.821 & 402.078 & 52.709 & 184.640 & \text { No }\end{array}$

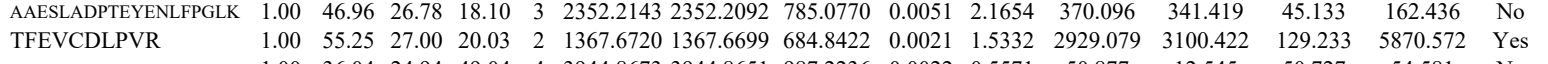
$\begin{array}{cccc}10.422 & 129.233 & 5870.572 & \text { Yes } \\ 12.545 & 50.727 & 5.581 & \text { No }\end{array}$

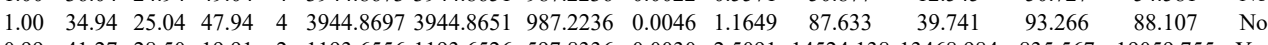

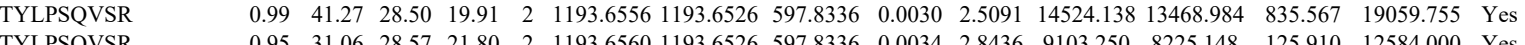

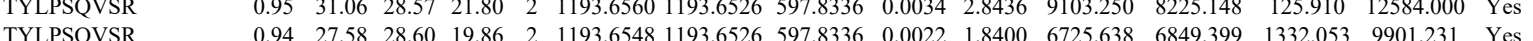
$\begin{array}{llllllllllllllll}\text { TMYLLGYIPK } & 1.00 & 48.09 & 26.78 & 19.13 & 2 & 1485.8514 & 1485.8509 & 743.9327 & 0.0005 & 0.3361 & 1117.263 & 1126.032 & 167.755 & 2341.181 & \text { Yes }\end{array}$ TMYLLGYIPK TMYLLGYIPK VWCVASLR VWCVASLR VWCVASLR VWCVASLR $\begin{array}{lllllllllllllll}1.00 & 48.09 & 26.78 & 19.13 & 2 & 1485.8514 & 1485.8509 & 743.9327 & 0.0005 & 0.3361 & 1117.263 & 1126.032 & 167.755 & 2341.181 & \text { Yes } \\ 0.99 & 36.21 & 26.79 & 16.05 & 2 & 1485.8520 & 14858509 & 743.9327 & 0.0011 & 0.7393 & 1090.704 & 734.355 & 249.630 & 1535.588 & Y e s\end{array}$ $\begin{array}{lllllllllllllll}1.00 & 44.14 & 27.80 & 28.11 & 2 & 11225798 & 1122.5800 & 5622973 & -0.0002 & -0.1778 & 586.921 & 543.178 & 77.680 & 1100807 & \text { Yes }\end{array}$ $\begin{array}{lllllllllllllll}1.09 & 44.14 & 27.80 & 28.11 & 2 & 1122.5798 & 1122.5800 & 562.2973 & -0.0002 & -0.1778 & 586.921 & 543.178 & 71.680 & 1100.807 & \text { Yes } \\ 0.99 & 35.08 & 27.87 & 25.08 & 2 & 1122.5806 & 1122.5800 & 562.2973 & 0.0006 & 0.5335 & 841.933 & 839.182 & 171.113 & 1666.609 & \text { Yes }\end{array}$ $\begin{array}{lllllllllllllllll}0.99 & 36.51 & 27.94 & 25.24 & 2 & 1122.5808 & 1122.5800 & 562.2973 & 0.0008 & 0.7114 & 2040.397 & 2114.334 & 519.270 & 4586.503 & \text { Yes }\end{array}$ $\begin{array}{lllllllllllllll}0.99 & 35.33 & 27.99 & 22.04 & 2 & 1122.5810 & 1122.5800 & 562.2973 & 0.0010 & 0.8892 & 3296.113 & 3405.029 & 639.605 & 7331.628 & \text { Yes }\end{array}$ $\begin{array}{lllllllllllllll}1.00 & 46.58 & 27.93 & 26.98 & 2 & 1122.5804 & 1122.5800 & 562.2973 & 0.0004 & 0.3557 & 924.396 & 981.991 & 142.820 & 1965.804 & \text { Yes }\end{array}$

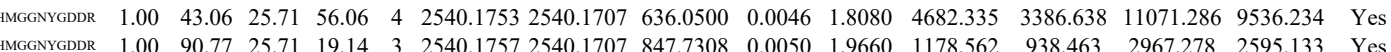
$\begin{array}{lllllllllllllllll}\text { ARPDGPGGGPGSHMGGNYGDDR } & 1.00 & 26.30 & 25.05 & 39.30 & 4 & 2556.1673 & 2556.1656 & 640.0487 & 0.0017 & 0.6640 & 898.716 & 1069.607 & 3328.614 & 2373.233 & \text { Yes }\end{array}$ $\begin{array}{lllllllllllllllll} & \end{array}$ $\begin{array}{lllllllllllllllll} & 30.13 & 24.96 & 43.13 & 4 & 2556.1657 & 2556.1656 & 640.0487 & 0.0001 & 0.0391 & 190.892 & 191.602 & 434.414 & 382.584 & \text { Yes }\end{array}$ $\begin{array}{lllllllllllllllll}\text { ARRPDGPGGGPGGSHMGGNYGDDR } & 1.00 & 48.02 & 25.48 & 61.02 & 4 & 2540.1681 & 2540.1707 & 636.0500 & -0.0026 & -1.0219 & 4062.957 & 4442.121 & 5536.446 & 7094.083 & \text { Yes }\end{array}$ $\begin{array}{llllllllllllllll}\text { TGQPMINLYTDR } & 1.00 & 68.94 & 27.85 & 23.84 & 2 & 1551.7884 & 1551.7837 & 776.8991 & 0.0047 & 3.0248 & 692.163 & 619.253 & 943.997 & 1593.782 & \text { Yes }\end{array}$

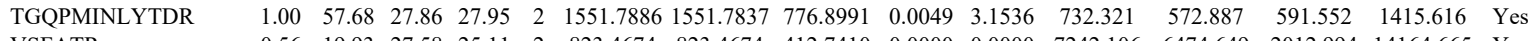
$\begin{array}{llllllllllllllll}\text { VSFATR } & 0.56 & 19.93 & 27.58 & 25.11 & 2 & 823.4674 & 823.4674 & 412.7410 & 0.0000 & 0.0000 & 7242.106 & 6474.649 & 2012.994 & 14164.665 & \text { Yes }\end{array}$ $\begin{array}{llllllllllllllllll}\text { VSFATR } & 0.70 & 18.30 & 27.36 & 22.83 & 2 & 823.4682 & 823.4674 & 412.7410 & 0.0008 & 0.9691 & 9217.585 & 7093.113 & 2349.235 & 16402.560 & \text { Yes }\end{array}$

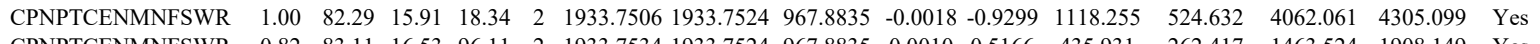
\begin{tabular}{lllllllllllllllll} 
CPNPTCENMNFSWR & 0.82 & 83.11 & 16.53 & 96.11 & 2 & 1933.7534 & 1933.7524 & 967.8835 & 0.0010 & 0.5166 & 435.931 & 262.417 & 1463.524 & 1908.149 & Yes \\
\hline
\end{tabular}

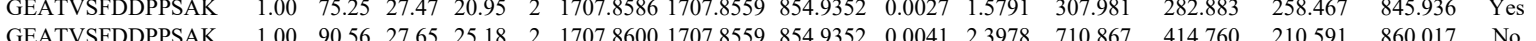
\begin{tabular}{lllllllllllllllll} 
GEATVSFDDPPSAK & 1.00 & 90.56 & 27.65 & 25.18 & 2 & 1707.8600 & 1707.8559 & 854.9352 & 0.0041 & 2.3978 & 710.867 & 414.760 & 210.591 & 860.017 & No \\
\hline
\end{tabular}

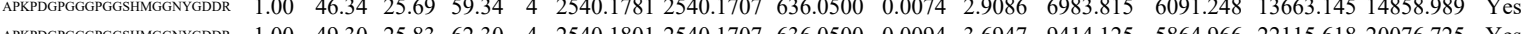

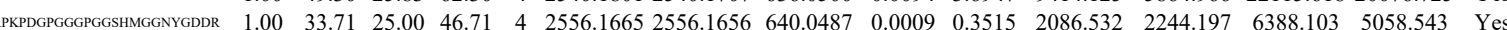
$\begin{array}{llllllllllllllllll}\text { APRPDGPGGGGGSHMGGNYGDDR } & 1.00 & 45.82 & 25.66 & 16.82 & 4 & 2540.1765 & 2540.1707 & 636.0500 & 0.0058 & 2.2797 & 3712.044 & 4116.414 & 10814.944 & 10142.724 & \text { Yes }\end{array}$ 
APRPDGPGGGFGGSHMC SICEVLDLER SICEVLDLER SICEVLDLER SICEVLDLER SICEVLDLER LTMQVSSLQR LTMQVSSLQR LTMQVSSLQR LTMQVSSLQR

LTMQVSSLR

LLYNRPGTVSSLK

FDDGAGGDNEVQR

FDDGAGGDNEVQR

IDPTVTMMQVEEKPDVTYSDVGG

IEFSLPDLEGR

TMLELINQLDGFDP TMLELINQLDGFDPR ACLIFFDEIDAIGGAR ACLIFFDEIDAIGGAR TMLELINQLDGFDPR TMLELINQLDGFDPR TMLELINQLDGFDPR ACLIFFDEIDAIGGAR
SVCTEAGMFAIR

IINADSEDPK

IINADSEDPK

FDDGAGGDNEVQR
QVEDDIQQLLK

QVEDDIQQLLK
ALDEGDIALLK

ALDEGDIALLK
ALDEGDIALLK

ALDEGDIALLK

QVEDDIQQLLK
QVEDDIQQLLK

QVEDDIQQLLK

ALDEGDIALLK

FVVDLSDQVAPTDIE

LSCVPVLIFANK

LSCVPVLIFANK

LSCVPVLIFANK

LSCVPVLIFANK

LSCVPVLIFANK
LSCVPVLIFANK

GLLSILR

GLLSILR
GLLSILR
LSCVPVLIFANK

GLLSILR

GLLSILR

10 AEEIDAK

AEEIDAK

GALFGANANR

IQMSNLMNQAR

IQMSNLMNQAR

IQMSNLMNQAR

IQMSNLMNQAR

ARDDLITDLLNEAK
ARDDLITDLLNEAK

107 GPCIIYNEDNGIIK

GPCIIYNEDNGIIK
GPCIIYNEDNGIIK

MINTDLSR

MINTDLSR
MINTDLSR

KPVVGK

KPVVGK
KPVVGK

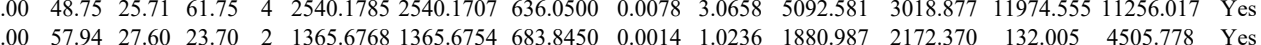

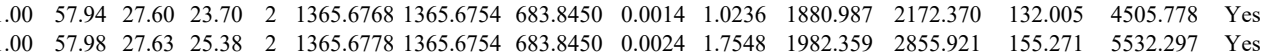
\begin{tabular}{llllllllllllllll}
1.00 & 59.25 & 27.65 & 26.13 & 2 & 1365.6772 & 1365.6754 & 683.8450 & 0.0018 & 1.3161 & 3552.500 & 4163.978 & 76.303 & 9751.602 & Yes \\
\hline
\end{tabular} $\begin{array}{lllllllllllllll}1.00 & 59.21 & 27.65 & 26.12 & 2 & 1365.6772 & 1365.6754 & 683.8450 & 0.0018 & 1.3161 & 3494.978 & 5068.381 & 110.083 & 11003.612 & \text { Yes }\end{array}$ $\begin{array}{lllllllllllllll}1.00 & 59.31 & 27.65 & 26.38 & 2 & 1365.6770 & 1365.6754 & 683.8450 & 0.0016 & 1.1699 & 1363.076 & 1647.115 & 177.864 & 3609.738 & \text { Yes } \\ 1.00 & 62.62 & 28.1 & 27.12 & 2 & 1305.7320 & 135.7197 & 533.8671 & 0.0123 & 9.405 & 1529.13 & 1978.035 & 571.594 & 3167.832 & \text { No }\end{array}$ $\begin{array}{lllllllllllllll}1.00 & 62.62 & 28.19 & 27.12 & 2 & 1305.7320 & 1305.7197 & 653.8671 & 0.0123 & 9.4055 & 1529.133 & 1978.035 & 571.594 & 3167.832 & \text { No } \\ 1.00 & 4.13 & 28.09 & 25.18 & 2 & 1305.7300 & 1305.7197 & 553.8671 & 0.0103 & 7.8762 & 2211.849 & 2678.969 & 556.942 & 4932.922 & \text { Yos }\end{array}$ $\begin{array}{lllllllllllllll}1.00 & 64.13 & 28.09 & 25.18 & 2 & 1305.7300 & 1305.7197 & 653.8671 & 0.0103 & 7.8762 & 2211.849 & 2678.969 & 556.942 & 4932.922 & \text { Yes } \\ 1.00 & 62.03 & 27.93 & 25.98 & 2 & 1305.7306 & 1305.7197 & 653.8671 & 0.0109 & 83350 & 4977.898 & 5412.590 & 1214.427 & 10543.484 & \text { Yes }\end{array}$ $\begin{array}{lllllllllllllll}1.00 & 62.03 & 27.93 & 25.98 & 2 & 1305.7306 & 1305.7197 & 653.8671 & 0.0109 & 8.3350 & 4977.898 & 5412.590 & 1214.427 & 10543.484 & \text { Yes } \\ 1.00 & 59.13 & 27.93 & 26.94 & 2 & 1305.7294 & 1305.7197 & 653.8671 & 0.0097 & 7.4174 & 2040.215 & 2118.054 & 396.024 & 4008.509 & \text { Yes }\end{array}$ $\begin{array}{lllllllllllllll}1.00 & 59.13 & 27.93 & 26.94 & 2 & 1305.7294 & 1305.7197 & 653.8671 & 0.0097 & 7.4174 & 2040.215 & 212.5054 & 396.024 & 4008.509 & \text { Yes }\end{array}$

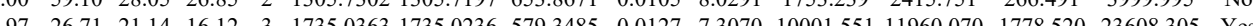

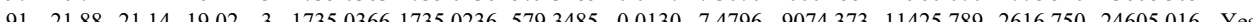

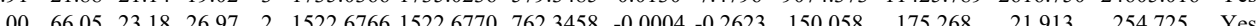

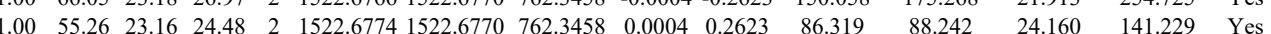

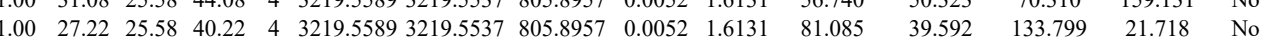

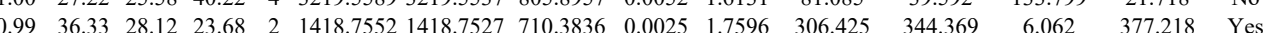
$\begin{array}{lllllllllllllll}0 & 89.37 & 27.60 & 27.16 & 2 & 1904.9804 & 1904.9788 & 953.4967 & 0.0016 & 0.8390 & 50.175 & 74.690 & 26.950 & 68.691 & \text { Yes }\end{array}$

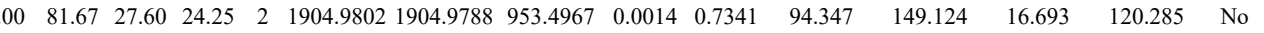

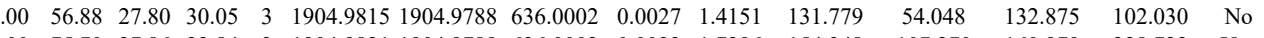
$\begin{array}{lllllllllllll} & \end{array}$

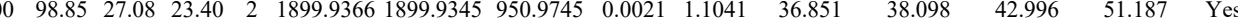
$\begin{array}{lllllllllllllll}1.00 & 53.69 & 24.96 & 23.81 & 2 & 1473.6946 & 1473.6900 & 737.8523 & 0.0046 & 3.1171 & 147.316 & 141.780 & 24.516 & 221.063 & \text { Yes }\end{array}$ $\begin{array}{lllllllllllllll}0.98 & 34.91 & 28.30 & 34.06 & 2 & 1388.7416 & 1388.7391 & 695.3768 & 0.0025 & 1.7976 & 3489.871 & 3103.371 & 1421.512 & 4482.115 & \text { Yes }\end{array}$ $\begin{array}{lllllllllllllll}0.91 & 32.46 & 28.24 & 28.58 & 2 & 1388.7428 & 1388.7391 & 695.3768 & 0.0037 & 2.6604 & 4144.187 & 3840.874 & 1972.835 & 4599.486 & \text { Yes }\end{array}$ \begin{tabular}{lllllllllllllll}
1.00 & 64.61 & 23.12 & 25.37 & 2 & 1522.6788 & 1522.6770 & 762.3458 & 0.0018 & 1.1806 & 349.416 & 394.917 & 63.707 & 460.046 & Yes \\
\hline
\end{tabular} \begin{tabular}{lllllllllllllll}
1.00 & 60.89 & 26.73 & 31.31 & 2 & 1615.9048 & 1615.9025 & 808.9585 & 0.0023 & 1.4216 & 183.279 & 207.051 & 27.881 & 243.910 & Yes \\
\hline
\end{tabular}

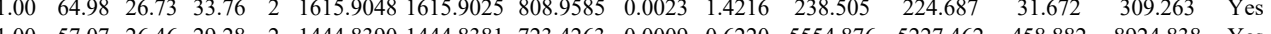

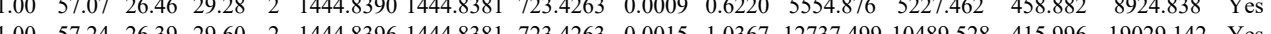
\begin{tabular}{llllllllllllllll}
1.00 & 57.24 & 26.39 & 29.60 & 2 & 1444.8396 & 1444.8381 & 723.4263 & 0.0015 & 1.0367 & 12737.499 & 10489.528 & 415.996 & 19029.142 & Yes \\
\hline
\end{tabular}

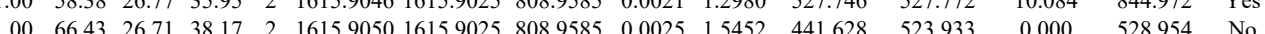
$\begin{array}{lllllllllllllll}1.00 & 47.47 & 26.46 & 23.95 & 2 & 1444.8392 & 1444.8381 & 723.4263 & 0.0011 & 0.7603 & 643.138 & 573.913 & 0.000 & 936766 & N 0\end{array}$ $\begin{array}{lllllllllllllll} & \\ 1.00 & 53.00 & 26.39 & 23.88 & 2 & 1444.8396 & 1444.8381 & 723.4263 & 0.0015 & 1.0367 & 64.18288 & 634.021 & 11.862 & 913.994 & \text { Y }\end{array}$

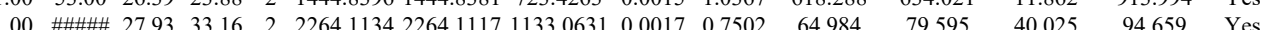
$\begin{array}{lllllllllllllll}0.77 & 13.08 & 25.69 & 18.02 & 3 & 1636.9309 & 1636.9288 & 546.6502 & 0.0021 & 12805 & 172.201 & 129.306 & 53.735 & 216.768 & \text { No }\end{array}$ $\begin{array}{lllllllllllllll}0.70 & 12.47 & 25.40 & 18.13 & 3 & 1636.9330 & 1636.9288 & 546.6502 & 0.0042 & 25610 & 197.434 & 228.979 & 65.163 & 248.267 & \text { Yes }\end{array}$ $\begin{array}{lllllllllllllll}0.80 & 13.86 & 25.69 & 19.17 & 3 & 1636.9309 & 1636.9288 & 546.6502 & 0.0021 & 12805 & 85.686 & 96.170 & 34.986 & 102.163 & \text { Yes }\end{array}$ $\begin{array}{lllllllllllllll}0.66 & 11.00 & 25.69 & 21.32 & 3 & 1636.9309 & 1636.9288 & 546.6502 & 0.0021 & 1.2805 & 93.157 & 95.419 & 54.504 & 107.034 & \text { No }\end{array}$

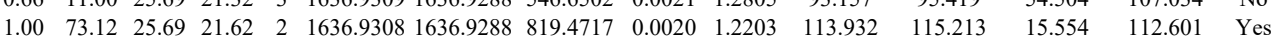
$\begin{array}{lllllllllllllll}0.95 & 22.26 & 25.43 & 25.79 & 3 & 1636.9324 & 1636.9288 & 546.6502 & 0.0036 & 2.1952 & 68.251 & 82.911 & 25.572 & 105.715 & \text { Yes }\end{array}$ $\begin{array}{lllllllllllllllll}0.91 & 37.08 & 23.84 & 39.36 & 2 & 914.6036 & 914.6035 & 458.3090 & 0.0001 & 0.1091 & 1820.762 & 2018.712 & 166.603 & 2481.206 & \text { Yes }\end{array}$ $\begin{array}{lllllllllllllllll}0.91 & 26.82 & 23.80 & 33.58 & 2 & 914.6050 & 914.6035 & 458.3090 & 0.0015 & 1.6364 & 3542.525 & 3622.043 & 414.912 & 4522.927 & \text { Yes }\end{array}$ $\begin{array}{llllllllllllllll}0.88 & 17.99 & 25.72 & 18.31 & 3 & 1636.9300 & 1636.9288 & 546.6502 & 0.0012 & 0.7317 & 61.385 & 63.144 & 10.652 & 81.251 & \text { Yes }\end{array}$ $\begin{array}{llllllllllllllll}0.93 & 30.33 & 23.84 & 35.16 & 2 & 914.6042 & 914.6035 & 458.3090 & 0.0007 & 0.7637 & 1278.728 & 1361.619 & 218.043 & 1731.781 & \text { Yes }\end{array}$ $\begin{array}{lllllllllllllllll}0.90 & 26.81 & 23.80 & 33.55 & 2 & 914.6046 & 914.6035 & 458.3090 & 0.0011 & 1.2001 & 1220.959 & 1493.617 & 187.991 & 1833.957 & \text { Yes }\end{array}$ $\begin{array}{lllllllllllllll}0.94 & 35.70 & 27.70 & 39.20 & 2 & 1062.5800 & 1062.5800 & 532.2973 & 0.0000 & 0.0000 & 138.728 & 100.298 & 119.998 & 138.534 & \text { Yes }\end{array}$ $\begin{array}{lllllllllllllll}0.90 & 25.57 & 28.46 & 32.37 & 2 & 1062.5808 & 1062.5800 & 532.2973 & 0.0008 & 0.7515 & 161.991 & 134.408 & 132.633 & 155.908 & \text { Yes }\end{array}$ $\begin{array}{lllllllllllllll}1.00 & 52.41 & 28.23 & 29.16 & 2 & 1133.6100 & 1133.6063 & 567.8104 & 0.0037 & 3.2581 & 5210.647 & 4685.539 & 979.305 & 6187.315 & \text { Yes }\end{array}$

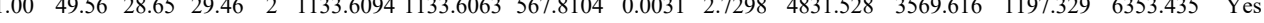
$\begin{array}{lllllllllllllll}1.00 & 62.01 & 28.14 & 26.64 & 2 & 1448.7464 & 1448.7350 & 725.3748 & 0.0114 & 7.8579 & 2443.894 & 2131.120 & 358.963 & 3668.527 & \text { Yes }\end{array}$

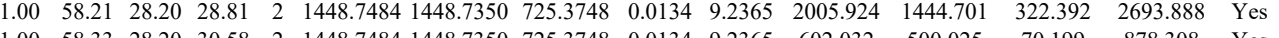

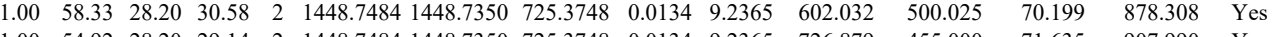

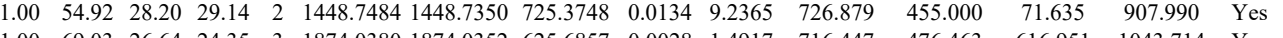

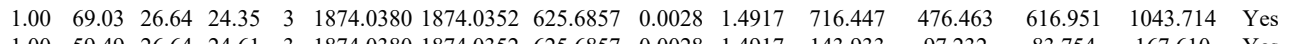

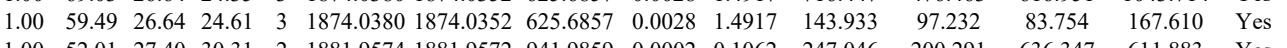

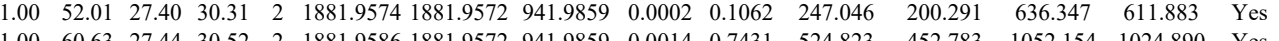
$\begin{array}{llllllllllllllll}1.00 & 60.63 & 27.44 & 30.52 & 2 & 1881.9586 & 1881.9572 & 941.9859 & 0.0014 & 0.7431 & 524.823 & 452.783 & 1052.154 & 1024.890 & \text { Yes } \\ 0.67 & 24.74 & 27.54 & 37.74 & 3 & 1881.9607 & 1881.9572 & 628.3263 & 0.0035 & 1.8568 & 406.389 & 219.731 & 129.672 & 230.968 & \text { No }\end{array}$

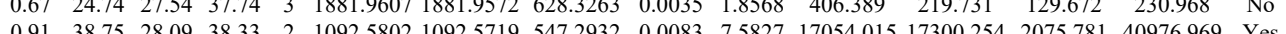
$\begin{array}{llllllllllllllll}0.91 & 38.75 & 28.09 & 38.33 & 2 & 1092.5802 & 1092.5719 & 547.2932 & 0.0083 & 7.5827 & 17054.015 & 17300.254 & 2075.781 & 40976.969 & \text { Yes } \\ 0.92 & 37.46 & 28.06 & 38.13 & 2 & 1092.5810 & 1092.5719 & 547.2932 & 0.0091 & 8.3136 & 18534.329 & 19861.040 & 3103.514 & 43703.489 & \text { Yes }\end{array}$

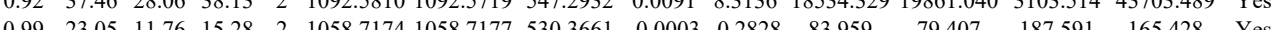

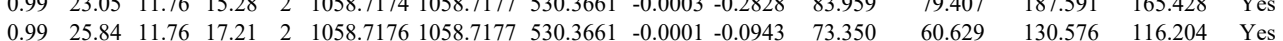

Table S-4 page 285 of 614 
$\begin{array}{lllllllllllllll}0.99 & 36.17 & 28.14 & 19.22 & 2 & 1380.7286 & 1390.7271 & 696.3708 & 0.0015 & 1.0770 & 13324.732 & 13159.387 & 14691.132 & 18961.788 & \text { Yes }\end{array}$ $\begin{array}{llllllllllllllll} & 1.00 & 41.11 & 28.00 & 24.36 & 2 & 1390.7292 & 1390.7271 & 696.3708 & 0.0021 & 1.5078 & 10784.340 & 13859.203 & 13738.658 & 18212.384 & \text { Yes }\end{array}$ $\begin{array}{llllllllllllllll}0.99 & 29.99 & 28.12 & 19.98 & 3 & 1390.7299 & 1390.7271 & 464.5830 & 0.0028 & 2.0090 & 31125.079 & 35510.856 & 43151.164 & 49244.589 & \text { Yes }\end{array}$

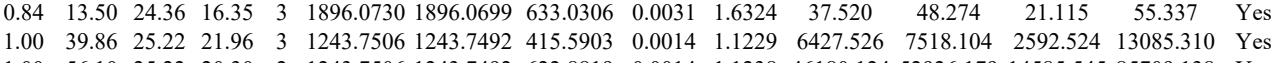
$\begin{array}{lllllllllllllll}1.00 & 39.86 & 25.22 & 21.96 & 3 & 1243.7506 & 1243.7492 & 415.5903 & 0.0014 & 1.1229 & 6427.526 & 7518.104 & 2592.524 & 13085.310 & \text { Yes } \\ 1.00 & 56.10 & 25.22 & 20.30 & 2 & 1243.7506 & 1243.7492 & 622.8819 & 0.0014 & 1.1238 & 46180.124 & 52926.179 & 14585.545 & 85709.138 & \text { Yes }\end{array}$ AAAAAAALQAK $\begin{array}{llllllllllllllllll}1.00 & 50.18 & 25.24 & 16.22 & 2 & 1243.7514 & 1243.7492 & 622.8819 & 0.0022 & 1.7660 & 85654.279 & 96847.446 & 19412.411 & \text { \#\#\#\#\# Yes }\end{array}$

AAAAAALQAK $\begin{array}{lllllllllllllll}1.00 & 31.37 & 25.24 & 22.64 & 3 & 1243.7515 & 1243.7492 & 415.5903 & 0.0023 & 1.8448 & 3207.508 & 3184.325 & 1095.507 & 6216.679 & \text { Yes } \\ 0.98 & 30.07 & 27.97 & 21.41 & 3 & 1390.7275 & 1390.7271 & 464.583 & 0.0004 & 0.2870 & & \end{array}$

AAAAAAALQAK

AAAAAAALQAK

AAAAAALQK

SNYNLPMHK

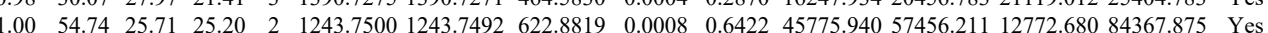

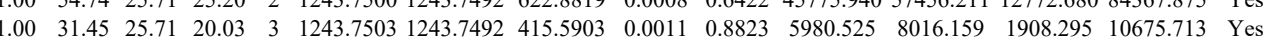
$\begin{array}{lllllllllllllll}1.00 & 33.90 & 25.22 & 19.41 & 3 & 1243.7506 & 1243.7492 & 415.5903 & 0.0014 & 1.1229 & 7603.194 & 8116.386 & 2555.860 & 14327.246 & \text { Yes }\end{array}$ $\begin{array}{lllllllllllllllllll}1.00 & 57.53 & 25.21 & 22.23 & 2 & 1243.7508 & 1243.7492 & 6228819 & 0.0016 & 1.2844 & 34396.202 & 34126.406 & 9378.247 & 54771.798 & \text { Yes }\end{array}$ $\begin{array}{lllllllllllllll}1.00 & 42.30 & 27.94 & 24.26 & 3 & 1390.7269 & 1390.7271 & 464.5830 & -0.0002 & -0.1435 & 7289.442 & 10783.294 & 9009.351 & 11625.864 & \text { Yes }\end{array}$ AAAAAAALQAK AAAAAAALQAK

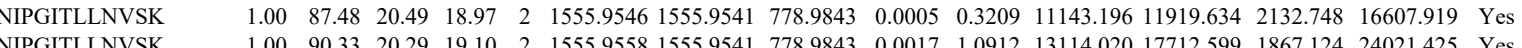
$\begin{array}{llllllllllllllll}1.00 & 42.30 & 27.94 & 24.26 & 3 & 1390.7269 & 1390.7271 & 464.5830 & -0.0002 & -0.1435 & 7289.442 & 10783.294 & 9009.351 & 11625.864 & \text { Yes } \\ 1.00 & 78.41 & 25.30 & 23.64 & 2 & 1243.7524 & 1243.7492 & 6228819 & 0.0032 & 25687 & 9989.785 & 9054.934 & 2476.003 & 12698.626 & \text { Yes }\end{array}$ $\begin{array}{lllllllllllllllll}1.00 & 75.88 & 25.30 & 22.04 & 2 & 1243.7524 & 1243.7492 & 622.8819 & 0.0032 & 2.5687 & 13420.404 & 14685.775 & 3361.811 & 19156.197 & \text { Yes }\end{array}$ $\begin{array}{llllllllllllllll}0.77 & 23.18 & 26.62 & 22.39 & 2 & 1006.5798 & 1006.5794 & 504.2970 & 0.0004 & 0.3966 & 45.660 & 49.271 & 6.927 & 103.589 & \text { Yes }\end{array}$

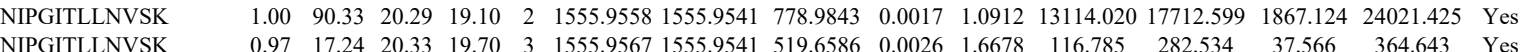
NIPGITLLNVSK

NIPGITLLNVSK

NIPGITLLNVSK $\begin{array}{llllllllllllllll}0.67 & 29.29 & 19.29 & 42.29 & 3 & 1555.9576 & 1555.9541 & 519.6586 & 0.0035 & 2.2451 & 609.298 & 756.283 & 122.940 & 540.912 & \text { No }\end{array}$

NIPGITLLNVSK $\begin{array}{llllllllllllllll}1.00 & 84.37 & 20.45 & 18.76 & 2 & 1555.9544 & 1555.9541 & 778.9843 & 0.0003 & 0.1926 & 9929.863 & 11383.974 & 2781.634 & 15125.250 & \text { Yes }\end{array}$ $\begin{array}{llllllllllllllll}1.00 & 83.22 & 20.29 & 18.32 & 2 & 1555.9560 & 1555.9541 & 778.9843 & 0.0019 & 1.2195 & 14839.826 & 14794.169 & 3381.500 & 23789.023 & \text { Yes }\end{array}$

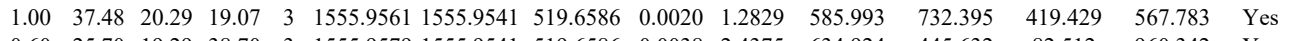
$\begin{array}{lllllllllllllll}0.60 & 25.70 & 19.29 & 38.70 & 3 & 1555.9579 & 1555.9541 & 519.6586 & 0.0038 & 2.4375 & 634.924 & 445.632 & 82.512 & 960.342 & \text { Yes }\end{array}$

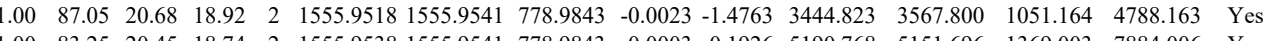
$\begin{array}{lllllllllllllll}1.00 & 83.25 & 20.45 & 18.74 & 2 & 1555.9538 & 1555.9541 & 778.9843 & -0.0003 & -0.1926 & 5190.768 & 5151.696 & 1369.003 & 7884.006 & \text { Yes }\end{array}$ $\begin{array}{lllllllllllllll}1.00 & 30.91 & 20.49 & 15.34 & 3 & 1555.9555 & 1555.9541 & 519.6586 & 0.0014 & 0.8980 & 319.522 & 367.293 & 150.987 & 522.170 & \text { Yes }\end{array}$ $\begin{array}{lllllllllllllll}0.99 & 38.75 & 24.97 & 18.35 & 2 & 1448.6702 & 1448.6703 & 725.3424 & -0.0001 & -0.0689 & 19.568 & 23.623 & 10.275 & 48.498 & \text { Yes }\end{array}$

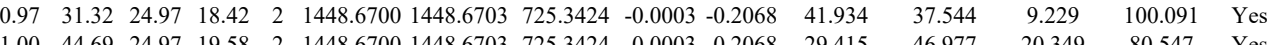

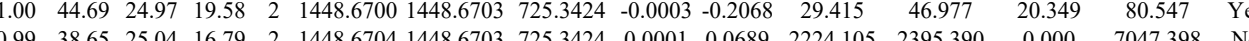

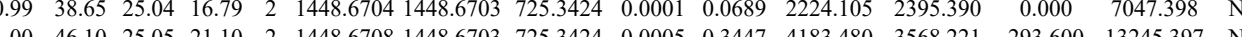

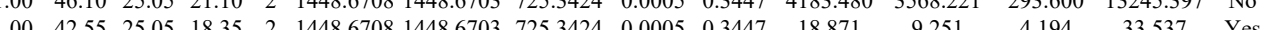

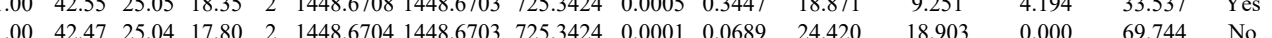

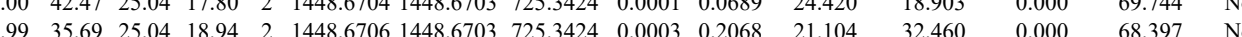

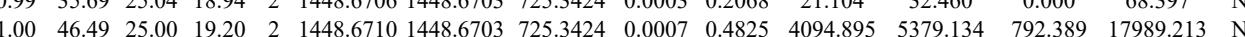
$\begin{array}{lllllllllllllll}1.00 & 42.19 & 25.04 & 19.29 & 2 & 1448.6712 & 1448.6703 & 725.3424 & 0.0009 & 0.6204 & 25.541 & 34.012 & 14.965 & 57.957 & \mathrm{Y} s \mathrm{~s}\end{array}$ $\begin{array}{lllllllllllllll}1.00 & 43.73 & 25.05 & 20.45 & 2 & 1448.6716 & 1448.6703 & 725.3424 & 0.0013 & 0.8961 & 2647.945 & 3199.986 & 0.000 & 10495.788 & \text { No }\end{array}$

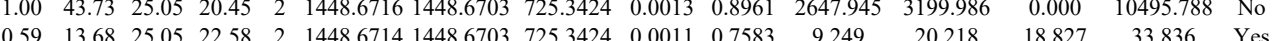
NIPGITLLNVSK NIPGITLLNVSK FCIWTESAFR FCIWTESAFR FCIWTESAF

FCIWTESAF

FCIWTESAFR

FCIWTESAFR

FCIWTESAFR

FCIWTESAFR

FCIWTESAFR $\begin{array}{llllllllllll}0.59 & 13.68 & 25.05 & 22.58 & 2 & 1448.6714 & 1448.6703 & 725.3424 & 0.0011 & 0.7583 & 9.249 \\ 1.00 & 21.26 & 2.00 & 34.26 & 4 & 2005.1349 & 2005.1343 & 502.2909 & 0.0006 & 0.2986 & 59.012\end{array}$ $\begin{array}{llllllllllll}\text { APIRPDIVNFVHTNLR } & 1.00 & 21.26 & 24.00 & 34.26 & 4 & 2005.1349 & 2005.1343 & 502.2909 & 0.0006 & 0.2986 & 59.012 \\ \text { APIRPDIVNFVHTNLR } & 1.00 & 19.20 & 24.00 & 14.39 & 4 & 2005.1349 & 2005.1343 & 502.2909 & 0.0006 & 0.2986 & 51.052\end{array}$ $\begin{array}{llllllllllll}\text { APIRPDIVNFVHTNLR } & 0.99 & 13.67 & 23.78 & 15.72 & 4 & 2005.1357 & 2005.1343 & 502.2909 & 0.0014 & 0.6968 & 43.451\end{array}$ $\begin{array}{lllllllllllll}\text { APIRPDIVNFVHTNLR } & 0.99 & 13.06 & 23.75 & 17.44 & 4 & 2005.1361 & 2005.1343 & 502.2909 & 0.0018 & 0.8959 & 63.781\end{array}$ $\begin{array}{lllllllllllll}\text { APIRPDIVNFVHTNLR } & 1.00 & 17.85 & 23.75 & 30.85 & 4 & 2005.1361 & 2005.1343 & 502.2909 & 0.0018 & 0.8959 & 54.147\end{array}$

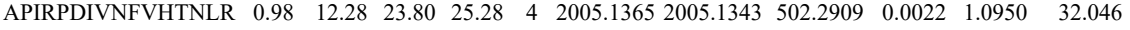

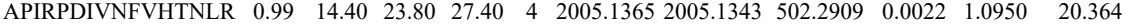
$\begin{array}{llllllllllll}\text { APIRPDIVNFVHTNLR } & 1.00 & 28.83 & 23.82 & 41.83 & 4 & 2005.1369 & 2005.1343 & 502.2909 & 0.0026 & 1.2941 & 2632.669\end{array}$ $\begin{array}{lllllllllllll}\text { APIRPDIVNFVHTNLR } & 1.00 & 16.09 & 23.82 & 19.57 & 4 & 2005.1369 & 2005.1343 & 502.2909 & 0.0026 & 1.2941 & 52.333 \\ \text { APIRPDIVNFVHTNLR } & 1.00 & 15.79 & 23.78 & 28.79 & 4 & 2005.1373 & 2005.1343 & 502.2909 & 0.0030 & 1.4932 & 33.878\end{array}$

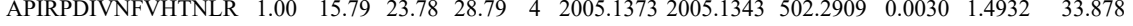

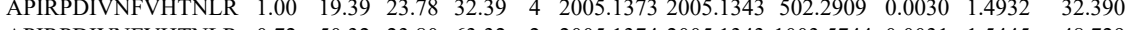
$\begin{array}{lllllllllllll}\text { APIRPDIVNFVHTNLR } & 0.72 & 50.32 & 23.80 & 63.32 & 2 & 2005.1374 & 2005.1343 & 1003.5744 & 0.0031 & 1.5445 & 48.729\end{array}$ $\begin{array}{lllllllllllll}\text { APIRPDIVNFVHTNLR } & 1.00 & 24.57 & 23.62 & 37.57 & 4 & 2005.1397 & 2005.1343 & 502.2909 & 0.0054 & 2.6877 & 3551.111 & 56 \\ \text { APIRPDIVNFVHTNLR } & 1.00 & 21.72 & 24.07 & 34.72 & 4 & 2005.1333 & 2005.1343 & 502.2909 & -0.0010 & -0.4977 & 32.579 & 2\end{array}$ APIRPDIVNFVHTNLR $1.00 \quad 21.72 \begin{array}{lllllllllll}34.07 & 34.72 & 4 & 2005.1333 & 2005.1343 & 502.2909 & -0.0010 & -0.4977 & 32.579\end{array}$ $\begin{array}{llllllllllll}\text { APIRPDIVNFVHTNLR } & 0.98 & 14.09 & 24.07 & 27.09 & 4 & 2005.1341 & 2005.1343 & 502.2909 & -0.0002 & -0.0995 & 33.115 \\ \text { APIRPDIVNFVHTNLR } & 0.99 & 14.28 & 23.77 & 27.28 & 4 & 2005.1353 & 2005.1343 & 502.2909 & 0.0010 & 0.4977 & 39.762\end{array}$ $\begin{array}{lllllllllllll}\text { APIRPDIVNFVHTNLR } & 0.99 & 14.28 & 23.77 & 27.28 & 4 & 2005.1353 & 2005.1343 & 502.2909 & 0.0010 & 0.4977 & 39.762 & 3\end{array}$ $\begin{array}{lllllllllllll}\text { APIRPDIVNFVHTNLR } & 1.00 & 22.62 & 23.80 & 17.62 & 4 & 2005.1365 & 2005.1343 & 502.2909 & 0.0022 & 1.0950 & 39.769\end{array}$

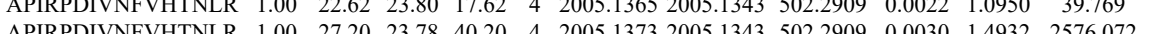
64.158 46.552 


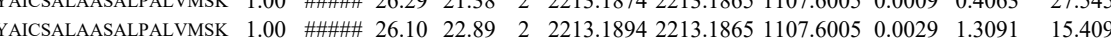
$\begin{array}{lllllllllllll}\text { YAICSALAASALPALVMSK } & 1.00 & 56.33 & 26.01 & 21.34 & 3 & 2213.1898 & 2213.1865 & 738.7361 & 0.0033 & 1.4890 & 22.168\end{array}$ $\begin{array}{lllllllllllll}\text { YACSLAASSALPALVMSK } & 1.00 & 47.97 & 26.02 & 19.00 & 3 & 2213.1907 & 2213.1865 & 738.7361 & 0.0042 & 1.8951 & 75.381\end{array}$

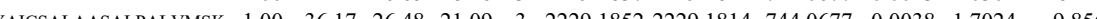

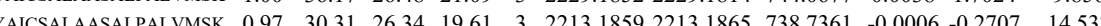
$\begin{array}{llllllllllll} & \text { YAICSALAASALPAVYMSK } & 1.00 & \text { \#\#\#\# } 26.10 & 24.34 & 2 & 2213.1894 & 2213.1865 & 1107.6005 & 0.0029 & 1.3091 & 11.474\end{array}$ YAICSALAASALPALVMSK $\begin{array}{lllllllllllll}0.99 & 28.70 & 26.10 & 19.55 & 3 & 2213.1895 & 2213.1865 & 738.7361 & 0.0030 & 1.3537 & 9.710\end{array}$

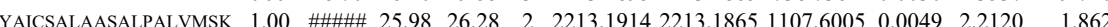
$\begin{array}{llllllllllll}\text { YAICSALAASALPALVMSK } & 1.00 & 37.04 & 26.65 & 18.55 & 3 & 2229.1837 & 2229.1814 & 744.0677 & 0.0023 & 1.0304 & 11.051\end{array}$ $\begin{array}{llllllllllllll}\text { YAICSALAASALPALVMSK } & 1.00 & 39.37 & 26.53 & 20.95 & 3 & 2229.1843 & 2229.1814 & 744.0677 & 0.0029 & 1.2992 & 19.786\end{array}$ $\begin{array}{llllllllllllll}\text { YAICSALAASALPALVMSK } & 1.00 & 55.66 & 26.16 & 23.60 & 3 & 2213.1889 & 2213.1865 & 738.7361 & 0.0024 & 1.0829 & 1.756\end{array}$ $\begin{array}{llllllllllllllll}\text { YAICSALAASALPALVMSK } & 0.81 & 14.96 & 26.65 & 18.55 & 3 & 2229.1837 & 2229.1814 & 744.0677 & 0.0023 & 1.0304 & 0.000\end{array}$ $\begin{array}{lllllllllllll}\text { YAICSALAASALPALVMSK } & 1.00 & 57.38 & 26.02 & 24.63 & 3 & 2213.1910 & 2213.1865 & 738.7361 & 0.0045 & 2.0305 & 7.502\end{array}$ $\begin{array}{llllllllllll}\text { APIRPDIVNFVHTNLR } & 1.00 & 21.47 & 23.82 & 34.47 & 4 & 2005.1369 & 2005.1343 & 502.2909 & 0.0026 & 1.2941 & 61.213 \\ \text { APIRPDIVNFVHTNL R } & 1.00 & 2.49 & 23.75 & 42.49 & 4 & 2005.1361 & 2005.1343 & 5022009 & 0.0018 & 0.8959 & 32.199\end{array}$ $\begin{array}{llllllllllllll}\text { APIRPDIVNFVHTNLR } & 1.00 & 29.49 & 23.75 & 42.49 & 4 & 2005.1361 & 2005.1343 & 502.2909 & 0.0018 & 0.8959 & 32.199\end{array}$ $\begin{array}{lllllllllllll}\text { APIRPDIVNFVHTNLR } & 1.00 & 26.83 & 23.82 & 39.83 & 4 & 2005.1369 & 2005.1343 & 502.2909 & 0.0026 & 1.2941 & 40.406 \\ \text { APIRPDIVNFVHTNLR } & 1.00 & 33.04 & 23.78 & 15.25 & 3 & 2005.1377 & 2005.1343 & 669.3854 & 0.0034 & 1.6931 & 40.711\end{array}$ $\begin{array}{lllllllllllll}\text { APIRPDIVNFVHTNLR } & 1.00 & 27.63 & 23.80 & 40.63 & 4 & 2005.1365 & 2005.1343 & 502.2909 & 0.0022 & 1.0950 & 27.837\end{array}$

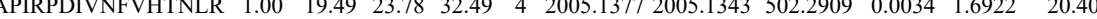

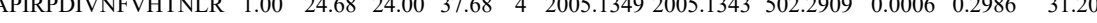
$\begin{array}{llllllllllllll}\text { APIRPDIVNFVHTNLR } & 1.00 & 31.85 & 23.75 & 44.85 & 4 & 2005.1361 & 2005.1343 & 502.2909 & 0.0018 & 0.8959 & 39.362\end{array}$

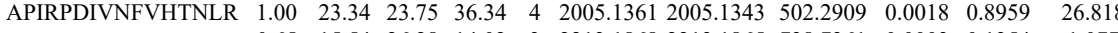
$\begin{array}{llllllllllllll}\text { YAICSALAASALPALVMSK } & 0.65 & 15.54 & 26.28 & 14.02 & 3 & 2213.1868 & 2213.1865 & 738.7361 & 0.0003 & 0.1354 & 1.077\end{array}$ $\begin{array}{llllllllllll}\text { APIRPDIVNFVHTNLR } & 1.00 & 23.07 & 23.75 & 36.07 & 4 & 2005.1361 & 2005.1343 & 502.2909 & 0.0018 & 0.8959 & 45.658\end{array}$ $\begin{array}{llllllllllll}\text { APIRPDIVNFVHTNLR } & 1.00 & 23.98 & 23.75 & 36.98 & 4 & 2005.1361 & 2005.1343 & 502.2909 & 0.0018 & 0.8959 & 32.538\end{array}$ $\begin{array}{llllllllllll}\text { APIRPDIVNFVHTNLR } & 1.00 & 43.72 & 23.64 & 15.95 & 3 & 2005.1398 & 2005.1343 & 669.3854 & 0.0055 & 2.7388 & 47.230\end{array}$ $\begin{array}{lllllllllllll} & \text { YAICSALAASALALVMSK } & 0.91 & 19.84 & 26.27 & 17.48 & 3 & 2213.1877 & 2213.1865 & 788.7361 & 0.0012 & 0.5415 & 4.747\end{array}$ $\begin{array}{llllllllllllll} & \text { APIRPDIVNFVHNLR } & 1.00 & 36.48 & 23.78 & 16.22 & 4 & 2005.1357 & 2005.1343 & 502.2909 & 0.0014 & 0.6968 & 17.853\end{array}$

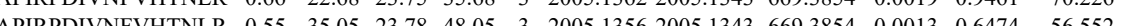
$\begin{array}{lllllllllllll}\text { APIRPDIVNFVHTNLR } & 1.00 & 24.27 & 23.75 & 15.02 & 4 & 2005.1361 & 2005.1343 & 502.2909 & 0.0018 & 0.8959 & 22.983\end{array}$ $\begin{array}{lllllllllllll}\text { APIRPDIVNFVHTNLR } & 1.00 & 29.62 & 23.75 & 42.62 & 4 & 2005.1361 & 2005.1343 & 502.2909 & 0.0018 & 0.8959 & 36.836\end{array}$ $\begin{array}{llllllllllllll}\text { APIRPDIVNFVHTNLR } & 1.00 & 24.63 & 23.75 & 37.63 & 4 & 2005.1361 & 2005.1343 & 502.2909 & 0.0018 & 0.8959 & 73.963\end{array}$ $\begin{array}{llllllllllllll}\text { APIRPDIVNFVHTNLR } & 1.00 & 21.80 & 23.75 & 34.80 & 4 & 2005.1361 & 2005.1343 & 502.2909 & 0.0018 & 0.8959 & 59.658\end{array}$ $\begin{array}{lllllllllllll}\text { YAICSALAASALPALVMSK } & 1.00 & 44.16 & 26.12 & 22.21 & 3 & 2213.1892 & 2213.1865 & 738.7361 & 0.0027 & 1.2183 & 6.724\end{array}$ $\begin{array}{llllllllllllll}\text { YAICSALAASALPALVMSK } & 0.56 & 9.36 & 26.01 & 22.36 & 3 & 2213.1898 & 2213.1865 & 738.7361 & 0.0033 & 1.4890 & 0.802\end{array}$

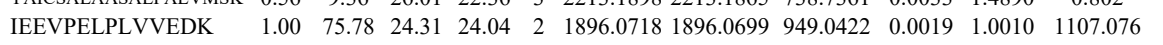
$\begin{array}{llllllllllllll}\text { IEEVPELPLVVEDK } & 1.00 & 76.20 & 24.50 & 24.00 & 2 & 1896.0726 & 1896.0699 & 949.0422 & 0.0027 & 1.4225 & 2159.125 & 2541 & \end{array}$ $\begin{array}{llllllllllllll}\text { IEEVPELPLVVEDK } & 1.00 & 56.90 & 24.31 & 16.75 & 3 & 1896.0733 & 1896.0699 & 633.0306 & 0.0034 & 1.7903 & 552.063 & 36 & \end{array}$ $\begin{array}{llllllllllll}\text { IEEVPELPLVVEDK } & 1.00 & 55.98 & 24.47 & 28.99 & 3 & 1896.0739 & 1896.0699 & 633.0306 & 0.0040 & 2.1063 & 351.540\end{array}$ $\begin{array}{llllllllllllll}\text { IEEVPELPLVVEDK } & 1.00 & 60.22 & 24.30 & 23.41 & 2 & 1896.0704 & 1896.0699 & 949.0422 & 0.0005 & 0.2634 & 47.545\end{array}$ $\begin{array}{lllllllllllll}\text { IEEVPELPLVVEDK } & 1.00 & 72.63 & 24.31 & 21.60 & 2 & 1896.0712 & 1896.0699 & 949.0422 & 0.0013 & 0.6849 & 523.324 & 6 \\ \end{array}$ $\begin{array}{llllllllllll}\text { IEEVPELPLVVEDK } & 1.00 & 41.53 & 24.31 & 23.67 & 3 & 1896.0718 & 1896.0699 & 633.0306 & 0.0019 & 1.0005 & 170.583\end{array}$ $\begin{array}{lllllllllllll}\text { IEEVPELPLVVEDK } & 1.00 & 48.27 & 24.33 & 23.70 & 3 & 1896.0721 & 1896.0699 & 633.0306 & 0.0022 & 1.1584 & 159.980 & 21\end{array}$

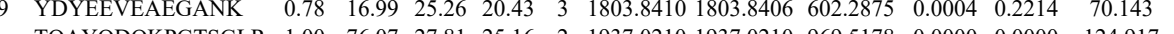

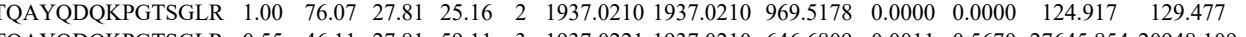
$\begin{array}{lllllllllllll}\text { TQAYQDQKPGTSGLR } & 0.55 & 46.11 & 27.81 & 59.11 & 3 & 1937.0221 & 1937.0210 & 646.6809 & 0.0011 & 0.5670 & 27645.854 & 20948 .\end{array}$ $\begin{array}{lllllllllllll}\text { TQAYQDQKPGTSGLR } & 1.00 & 85.94 & 27.75 & 23.85 & 2 & 1937.0228 & 1937.0210 & 969.5178 & 0.0018 & 0.9283 & 770.733 & 5 \\ \text { TQAYQDQKPGTSGR } & 1.00 & 36.60 & 27.81 & 19.74 & 3 & 1937.0221 & 1937.0210 & 646.680 & 0.0011 & 0.5670 & 16669.29 & 1088 .\end{array}$ $\begin{array}{llllllllllllllll}\text { TQAYQDQKPGTSGLR } & 0.60 & 40.25 & 27.48 & 53.25 & 3 & 1937.0248 & 1937.0210 & 646.6809 & 0.0038 & 1.9587 & 24646.548 & 16563.685 & 7229.342 & 28458.885 & \text { Y }\end{array}$ $\begin{array}{lllllllllllllllll} & \end{array}$ $\begin{array}{lllllllllllll}\text { INQDPQVMLAPLISIALK } & 1.00 & 46.70 & 16.72 & 18.07 & 3 & 2251.3270 & 2251.3217 & 751.4478 & 0.0053 & 2.3510 & 0.000\end{array}$ $\begin{array}{lllllllllllll} & \text { NQDPQVMLAPLSIALK } & 1.00 & 54.78 & 16.72 & 24.86 & 3 & 2251.3270 & 2251.3217 & 751.4478 & 0.0053 & 2.3510 & 21.324\end{array}$ $\begin{array}{lllllllllllll} & \end{array}$ $\begin{array}{llllllllllll} & \end{array}$

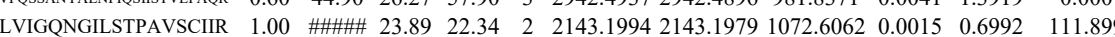

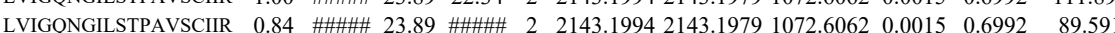
$\begin{array}{llllllllllllll}\text { LVIGQNGILSTPAVSCIIR } & 0.66 & 27.66 & 23.87 & 40.66 & 3 & 2143.1998 & 2143.1979 & 715.4066 & 0.0019 & 0.8853 & 4.738\end{array}$ 

$\begin{array}{lllllllllll} & \end{array}$

$\begin{array}{lllllllllllll} & \end{array}$

$\begin{array}{llllllllllll}\text { LVIGQNGILSTPAVSCIIR } & 1.00 & \text { \#\#\#\# } 24.08 & 28.16 & 2 & 2143.1974 & 2143.1979 & 1072.6062 & -0.0005 & -0.2331 & 157.423\end{array}$

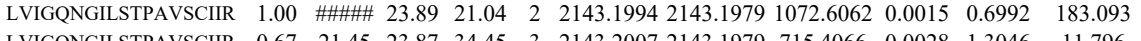
$\begin{array}{llllllllllll}\text { LVIGQNGILSTPAVSCIR } & 0.67 & 21.45 & 23.87 & 34.45 & 3 & 2143.2007 & 2143.1979 & 715.4066 & 0.0028 & 1.3046 & 11.796\end{array}$ $\begin{array}{lllllllllllll}\text { LVIGQNGILSTPAVSCIR } & 0.67 & 20.22 & 23.93 & 33.22 & 3 & 2143.2013 & 2143.1979 & 715.4066 & 0.0034 & 1.5842 & 17.175\end{array}$ $\begin{array}{lllllllllllll} & 0.62\end{array}$

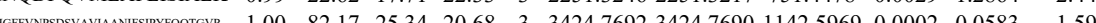

LNQQPSQGLGPR

LNQQPSQGLGPR

SSLINGLVGR

IPVQALLHLR

IPVQALLHLR

IPVQALLHLR

IPVQALLHLR $\begin{array}{lllllllllll}1.00 & 55.99 & 27.78 & 31.04 & 2 & 1437.7806 & 1437.7810 & 719.8978 & -0.0004 & -0.2778 & 4345.368\end{array}$

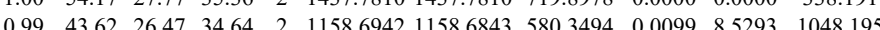
$\begin{array}{lllllllllll}0.55 & 54.09 & 20.29 & 67.09 & 3 & 1302.8269 & 1302.8258 & 435.2825 & 0.0011 & 0.8424 & 91.051\end{array}$ $\begin{array}{llllllllllll}1.00 & 47.60 & 20.29 & 18.84 & 3 & 1302.8269 & 1302.8258 & 435.2825 & 0.0011 & 0.8424 & 100.663 & 9\end{array}$ $\begin{array}{llllllllllll}1.00 & 57.80 & 20.57 & 22.40 & 3 & 1302.8266 & 1302.8258 & 435.2825 & 0.0008 & 0.6126 & 196.152\end{array}$ $\begin{array}{lllllllllllll}1.00 & 64.48 & 20.29 & 20.08 & 3 & 1302.8269 & 1302.8258 & 435.2825 & 0.0011 & 0.8424 & 474.212 & 45\end{array}$

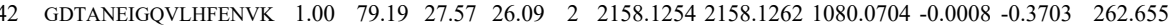
$\begin{array}{llllllllllll}\text { GDTANEIGQVLHFENVK } & 1.00 & 81.24 & 27.57 & 29.57 & 2 & 2158.1254 & 2158.1262 & 1080.0704 & -0.0008 & -0.3703 & 433.887\end{array}$

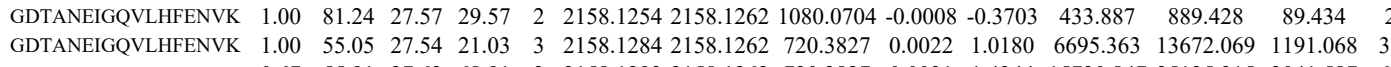
$\begin{array}{lllllllllllllllll}\text { GDTANEIGQVLHFENVK } & 0.67 & 55.91 & 27.63 & 68.91 & 3 & 2158.1293 & 2158.1262 & 720.3827 & 0.0031 & 1.4344 & 15730.847 & 25135.315 & 3041.587 & 6817.573 & \text { Yes }\end{array}$

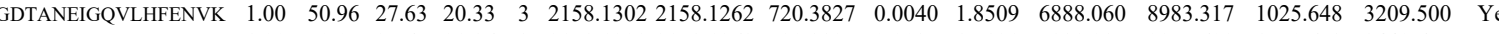
$\begin{array}{lllllllllllllllll} & & \end{array}$ $\begin{array}{lllllllllllllll}0.98 & 41.90 & 28.24 & 31.98 & 2 & 1160.6748 & 1160.6757 & 581.3451 & -0.0009 & -0.7741 & 50.419 & 80.046 & 8.677 & 21.484 & \text { Yes } \\ \end{array}$ $\begin{array}{lllllllllllllllll} & & & \end{array}$ $\begin{array}{llllllllllllllll}\text { ACLENLGLK } & 1.00 & 58.88 & 27.79 & 28.74 & 2 & 1293.7116 & 1293.7028 & 647.8587 & 0.0088 & 6.7916 & 4234.866 & 6292.469 & 505.767 & 2175.188 & \text { Yes }\end{array}$ $\begin{array}{lllllllllllllllll} & 1.00 & 58.93 & 27.80 & 23.80 & 2 & 1293.7130 & 1293.7028 & 647.8587 & 0.0102 & 7.8720 & 14385.100 & 20481.199 & 506.476 & 6420.190 & \text { Yes }\end{array}$

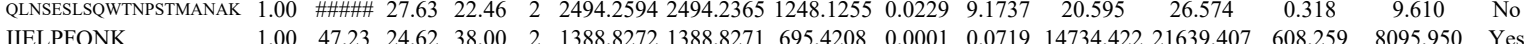

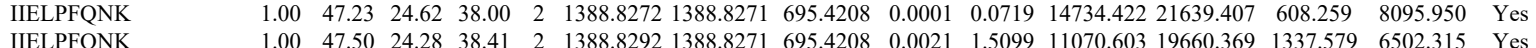
$\begin{array}{llllllllllllllllll} & 1.00 & 47.50 & 24.28 & 38.41 & 2 & 1388.8292 & 1388.8271 & 695.4208 & 0.0021 & 1.5099 & 11070.603 & 19660.369 & 1337.579 & 6502.315 & \text { Yes }\end{array}$ $\begin{array}{llllllllllllllll}\text { LLNSLLSQWTNSTMANAK } & 0.96 & 35.42 & 27.55 & 15.65 & 3 & 2494.2562 & 2494.2365 & 832.4194 & 0.0197 & 7.8886 & 56.600 & 77.592 & 64.114 & 67.583 & \text { Yes } \\ \text { IIELPFQNK } & 1.00 & 44.33 & 24.67 & 36.44 & 2 & 1388.8284 & 1388.8271 & 65.4208 & 0.0013 & 0.9347 & 19730.216 & 26894.272 & 1263.209 & 11499.267 & \text { Yes }\end{array}$ $\begin{array}{lllllllllllllllll} & \end{array}$ $\begin{array}{llllllllllllllllll} & 1.00 & 47.11 & 24.31 & 37.93 & 2 & 1388.8298 & 1388.8271 & 695.4208 & 0.027 & 1.9413 & 27388.248 & 37500.051 & 1413.675 & 15668.351 & \text { Yes }\end{array}$

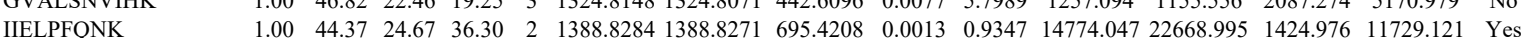

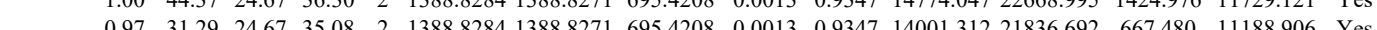

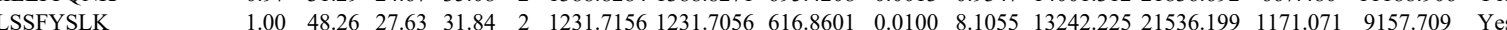

LSSFYLK

LSSFYSLK

DVEDESTGLEK

DVEDESTGLEK

DVEDESTGLEK

DVEDESTGLEK

ILVVNAAYFVGK

ILVVNAAYFVGK

LVVNAAYFVGK

ILVVNAAYFVGK

$\begin{array}{llllllllllllllll}1.00 & 48.26 & 27.63 & 31.84 & 2 & 1231.7156 & 1231.7056 & 616.8601 & 0.0100 & 8.105 & 13242.225 & 21536.199 & 1171.071 & 9157.709 & \text { Yes }\end{array}$ $\begin{array}{lllllllllllllll}1.00 & 46.51 & 27.52 & 3.806 & 2 & 1231.7162 & 1231.7056 & 616.8601 & 0.0106 & 85918 & 19148.660 & 24209.711 & 456.659 & 15409.316 & \text { Yes }\end{array}$ $\begin{array}{lllllllllllllllll}0.99 & 41.03 & 27.52 & 25.82 & 2 & 1231.7164 & 1231.7056 & 616.8601 & 0.0108 & 8.7539 & 12588.589 & 15978.551 & 620.731 & 10383.591 & \text { Yes }\end{array}$ $\begin{array}{lllllllllllllll}1.00 & 62.47 & 27.12 & 30.96 & 2 & 1508.7436 & 1508.7450 & 755.3798 & -0.0014 & -0.9267 & 643.833 & 824.732 & 547.875 & 564.416 & \text { Yes }\end{array}$

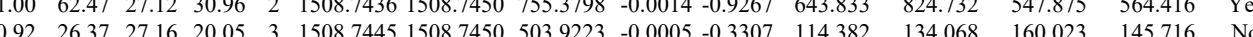

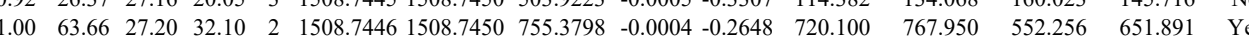

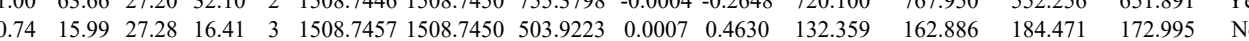

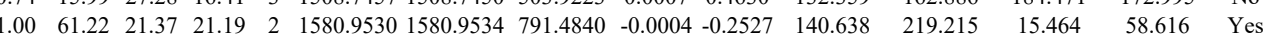

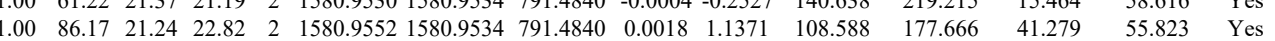
$\begin{array}{lllllllllllllll}1.00 & 83.18 & 21.52 & 23.77 & 2 & 1580.9536 & 1580.9534 & 791.4840 & 0.0002 & 0.1263 & 2590.272 & 3486.933 & 242.684 & 1132.997 & \text { Yes }\end{array}$

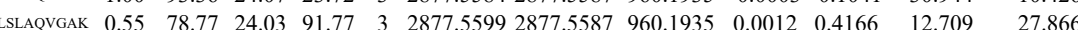

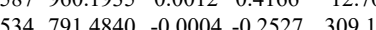
$\begin{array}{lllllllllll}1 & 8.22 & 1.37 & 23.06 & 2 & 1580.9530 & 1580.9534 & 791.4840 & -0.0004 & -0.2527 & 309.182\end{array}$ 383.358

DTh $\begin{array}{llllllllllll}0.66 & 40.16 & 23.93 & 53.16 & 3 & 2877.5611 & 2877.5587 & 960.1935 & 0.0024 & 0.8332 & 18.340\end{array}$

HLSMFILLPK

HLSMFILLPK

HLSMFILLPK $\begin{array}{llllllllllll}0.51 & 19.12 & 23.14 & 25.45 & 2 & 1485.8976 & 1485.8985 & 743.9565 & -0.0009 & -0.6049 & 137.173\end{array}$

HLSMFILLPK $\begin{array}{lllllllllll}0.91 & 29.47 & 23.10 & 18.74 & 2 & 1485.8978 & 1485.8985 & 743.9565 & -0.0007 & -0.4705 & 345.115\end{array}$

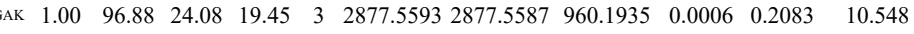
$\begin{array}{llllllllllll} & 0.67\end{array}$

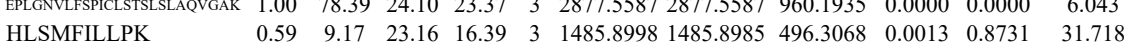

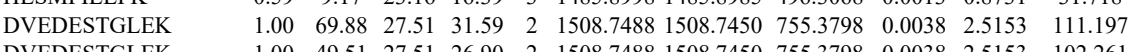
DVEDESTGLEK $\begin{array}{llllllllllll}1.00 & 4.51 & 27.51 & 26.90 & 2 & 1508.7488 & 1508.7450 & 755.3798 & 0.0038 & 2.5153 & 102.261\end{array}$ $\begin{array}{llllllllllll}0.53 & 10.26 & 23.07 & 19.42 & 3 & 1485.8989 & 1485.8985 & 496.3068 & 0.0004 & 0.2687 & 41.134\end{array}$ 
DLTDGHFENL $N$ N

AKPAEAPAAAAPK AKPAEAPAAAAPK AKPAEAPAAAAPK AKPAEAPAAAAPK KXPAPAAAR AKPAEAPAAAAPK AKPAEAPAAAAPK AKPAEAPAAAAPK AKPAEAPAAAAPK ASAFALQEQPVVNAVIDDT ASAFALQEQPVVNAVIDDTTK AKPAEAPAAAAPK AKPAEAPAAAAPK GLVVPVIR

GLVVPVIR

TPAFAESVTEGDVR

TPAFAESVTEGDVR

NVEAMNFADIER

NVEAMNFADIER

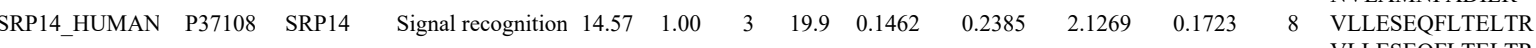

VLLESEQFLTELTR

VLLESEQFLTELTR

VLLESEQFLTELTR

VLLESEQFLTELTR

VLLESEQFLTELTR

GTVEGFEPADNK

KGTVEGFEPADNK

GTEGPADN

KGTVEGFEPADNK

KGIGMAEFLDK

MGIGMAEFLDK

QVLEDFPTISLEFR

QVLEDFPTISLEFR

SFAAVIQALDGEMR

YQTVIADICR

YQTVIADICR

YQTVIADICR

TQNLPNCQLISR

$\begin{array}{llllllllllll}0.99 & 18.16 & 27.32 & 14.56 & 4 & 2633.2845 & 2633.2813 & 659.3276 & 0.0032 & 1.2134 & 206.277\end{array}$ $\begin{array}{llllllllllll}.76 & 23.45 & 26.96 & 24.64 & 2 & 902.5424 & 902.5429 & 452.2787 & -0.0005 & -0.5528 & 120.684\end{array}$ $\begin{array}{llllllllllll} & 0.071 & 0.6765 & 1181.695 & 967.297\end{array}$

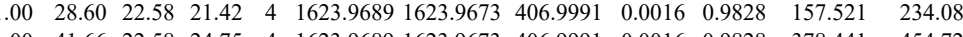
$\begin{array}{lllllllllllll}0.99 & 31.69 & 22.53 & 22.96 & 2 & 1623.9698 & 1623.9673 & 812.9909 & 0.0025 & 1.5375 & 1238.874 & 587.649\end{array}$ $\begin{array}{lllllllllllll}1.00 & 46.58 & 22.23 & 22.17 & 3 & 1623.9715 & 1623.9673 & 542.3297 & 0.0042 & 2.5814 & 20144.498 & 16692.401\end{array}$ $\begin{array}{llllllllllllll}1.00 & 32.80 & 22.58 & 20.42 & 4 & 1623.9689 & 1623.9673 & 406.9991 & 0.0016 & 0.9828 & 292.782 & 244.366\end{array}$

$\begin{array}{lllllllllllllll}1.00 & 34.49 & 22.53 & 18.98 & 4 & 1623.9697 & 1623.9673 & 406.9991 & 0.024 & 1.4742 & 195.713 & 234.932\end{array}$ $\begin{array}{llllllllllllll}1.00 & 43.34 & 22.41 & 18.84 & 3 & 1623.9709 & 1623.9673 & 5423297 & 0.0036 & 2.4127 & 4326.041 & 3010.968\end{array}$ $\begin{array}{llllllllllll}0.96 & 20.98 & 26.34 & 17.04 & 3 & 2504.3386 & 2504.3366 & 835.7861 & 0.0020 & 0.7977 & 44.294 & 57.7\end{array}$ $\begin{array}{llllllllllll}0.66 & 20.72 & 26.32 & 33.72 & 3 & 2504.3389 & 2504.3366 & 835.7861 & 0.0023 & 0.9173 & 72.951 & 26.197\end{array}$ $\begin{array}{lllllllllllll}1.00 & 29.95 & 22.53 & 15.18 & 3 & 1623.9700 & 1623.9673 & 542.3297 & 0.0027 & 1.6595 & 1665.978 & 1065.334\end{array}$ $\begin{array}{llllllllllllll}0.67 & 39.00 & 22.41 & 52.00 & 3 & 1623.9706 & 1623.9673 & 542.3297 & 0.0033 & 2.0283 & 801.645 & 839.399\end{array}$ $\begin{array}{llllllllllll}.96 & 21.61 & 26.24 & 14.37 & 3 & 2504.3398 & 2504.3366 & 835.7861 & 0.0032 & 1.2762 & 27.745 & 41.578 \\ 0.97 & 33.61 & 11.76 & 30.93 & 2 & 995.6712 & 995.6613 & 498.8379 & 0.009 & 9.9230 & 3713.809 & 3229.382\end{array}$ $\begin{array}{lllllllllllll}0.99 & 41.01 & 13.01 & 31.56 & 2 & 995.6690 & 995.6613 & 498.8379 & 0.0077 & 7.7179 & 2289.607 & 1951.636 \\ 0.97 & 37.26 & 13.01 & 13.35 & 2 & 995.6694 & 995.6613 & 498.8379 & 0.0081 & 8.1188 & 2534.611 & 2002.741\end{array}$ $\begin{array}{llllllllllllll}0.97 & 37.26 & 13.01 & 31.35 & 2 & 995.6694 & 995.6613 & 498.8379 & 0.0081 & 8.1188 & 2534.611 & 2002.741 \\ 0.97 & 50.37 & 27.45 & 26.09 & 2 & 1621.8032 & 1621.8070 & 81.9108 & -0.0038 & -23402 & 3716.930 & 4065.819 & 248 \\ 1.00 & 61.98 & 27.80 & 26.27 & 2 & 1621.8054 & 1621.870 & 811.9108 & -0.0016 & -0.9853 & 477.113 & 473.275 & 40\end{array}$ $\begin{array}{llllllllllll}0.97 & 50.37 & 27.45 & 26.09 & 2 & 1621.8032 & 1621.8000 & 811.9108 & -0.0038 & -2.3402 & 3716.930 & 4065.819 \\ 1.00 & 61.98 & 27.80 & 26.27 & 2 & 1621.8054 & 1621.8070 & 811.9108 & -0.0016 & -0.9853 & 477.113 & 473.275\end{array}$ $\begin{array}{lllllllllllll}1.00 & 70.25 & 26.77 & 26.12 & 2 & 1551.7486 & 1551.7473 & 776.8809 & 0.0013 & 0.8367 & 365.473 & 283.051 \\ 1.00 & 62.58 & 26.87 & 24.75 & 2 & 1551.7494 & 1551.7473 & 776.8809 & 0.0021 & 1.3516 & 441.058 & 377.040\end{array}$ $\begin{array}{llllllllllll}1.00 & 62.58 & 26.87 & 24.75 & 2 & 1551.7494 & 1551.7473 & 776.8809 & 0.0021 & 1.3516 & 441.058 & 377.040\end{array}$ $\begin{array}{llllllllllll}1.00 & 26.57 & 29.00 & 2 & 1821.0016 & 1821.0005 & 911.5075 & 0.0011 & 0.6034 & 2172.497 & 3627.493\end{array}$ $\begin{array}{lllllllllllll}1.00 & 98.26 & 26.58 & 35.63 & 2 & 1821.0018 & 1821.0005 & 911.5075 & 0.0013 & 0.7131 & 1258.853 & 1983.308\end{array}$ $\begin{array}{llllllllllll}1.00 & 47.61 & 26.60 & 20.68 & 3 & 1821.0034 & 1821.0005 & 608.0074 & 0.0029 & 1.5899 & 129.269 & 118.788\end{array}$ $\begin{array}{llllllllllll}1.00 & 92.42 & 26.57 & 31.28 & 2 & 1821.0016 & 1821.0005 & 911.5075 & 0.0011 & 0.6034 & 937.574 & 955.073\end{array}$

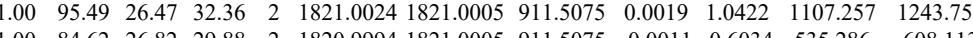

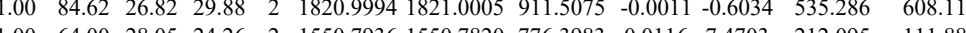
$\begin{array}{llllllllllllll}1.00 & 64.00 & 28.05 & 24.26 & 2 & 1550.7936 & 1550.7820 & 716.3983 & 0.0116 & 7.4703 & 212.095 & 111.886\end{array}$

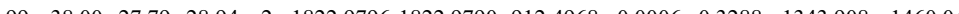
$\begin{array}{lllllllllllll}1.00 & 32.77 & 27.71 & 20.88 & 3 & 1822.9822 & 1822.9790 & 608.6669 & 0.0032 & 1.7525 & 6825.937 & 7636.814\end{array}$

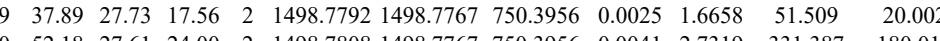
$\begin{array}{llllllllllll}1.00 & 52.18 & 27.61 & 24.00 & 2 & 1498.7808 & 1498.7767 & 750.3956 & 0.0041 & 2.7319 & 331.387 & 180.019 \\ 1.00 & 58.03 & 27.17 & 27.64 & 2 & 1836.9800 & 1836.9744 & 919.4945 & 0.005 & 3.0451 & 285.147 & 233.523\end{array}$ $\begin{array}{lllllllllllll}1.00 & 58.03 & 27.17 & 27.64 & 2 & 1836.9800 & 1836.9744 & 919.4945 & 0.0056 & 3.0451 & 285.147 & 233.523 \\ 0.99 & 45.62 & 27.15 & 17.53 & 2 & 1836.9824 & 1836.9744 & 919.4945 & 0.0080 & 4.3502 & 329.119 & 208.439\end{array}$ $\begin{array}{llllllllllll}0.90 & \text { \#\#\#\# 28.68 } & 28.03 & 2 & 1836.924 & 1836.9744 & 919.4945 & 0.0080 & 4.3502 & 329.119 & 208.439 \\ 1.00 & 9.5650 .8521 & 826.4333 & 0.0031 & 1.8755 & 418.664 & 264.935\end{array}$ $\begin{array}{lllllllllllll}1.00 & 59.59 & 26.76 & 20.81 & 2 & 1370.6848 & 1370.6808 & 686.3477 & 0.0040 & 2.9140 & 7343.428 & 5406.889\end{array}$ $\begin{array}{lllllllllllll}1.00 & 59.62 & 26.68 & 22.09 & 2 & 1370.6814 & 1370.6808 & 686.3477 & 0.0006 & 0.4371 & 4734.395 & 3242.318\end{array}$ $\begin{array}{lllllllllllll}1.00 & 46.80 & 26.80 & 19.63 & 2 & 1370.6822 & 1370.6808 & 6863477 & 0.0014 & 1.0199 & 6170.782 & 4351.24\end{array}$ $\begin{array}{lllllllllllll}1.00 & 50.73 & 27.54 & 28.90 & 2 & 1575.8006 & 1575.7983 & 788.9064 & 0.0023 & 1.4577 & 4892.853 & 4555.089\end{array}$ $\begin{array}{lllllllllllllll}1.00 & 54.24 & 27.64 & 28.14 & 2 & 1575.8014 & 1575.7983 & 788.9064 & 0.0031 & 1.9647 & 3865.713 & 2709.389\end{array}$

DDGLFSGDPNWFPK

DDGLFSGDPNWFPK DDGLFSGDPNWFPK DDGLFSGDPNWF

DVGRPQPR

DDGLFSGDPNWFPK

$\begin{array}{llllllllllllll}1.00 & 81.99 & 27.49 & 26.81 & 2 & 1881.9166 & 1881.9141 & 941.9643 & 0.0025 & 1.3270 & 1595.532 & 1016.907\end{array}$

$\begin{array}{llllllllllll}1.00 & 77.30 & 27.48 & 22.51 & 2 & 1881.9164 & 1881.9141 & 941.9643 & 0.0023 & 1.2209 & 1781.054 & 1067.838 \\ 1.00 & 5809 & 27.48 & 22.53 & 3 & 188.19187 & 1881.9141 & 6283120 & 0.0046 & 2.4404 & 153.06 & 120.880\end{array}$

$\begin{array}{llllllllllll}1.00 & 58.09 & 27.48 & 22.53 & 3 & 1881.9187 & 1881.9141 & 628.3120 & 0.0046 & 2.4404 & 153.206 & 120.680\end{array}$

$\begin{array}{lllllllllllll}1.00 & 68.05 & 27.60 & 24.09 & 3 & 1881.9190 & 1881.9141 & 628.3120 & 0.0049 & 2.5996 & 196.281 & 158.979\end{array}$

DDGLFSGDPNWFPK

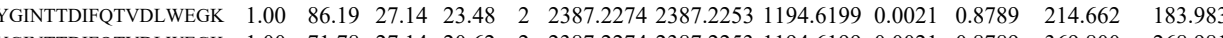

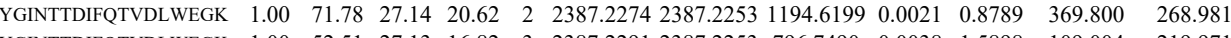
$\begin{array}{lllllllllllll} & \text { YGN }\end{array}$

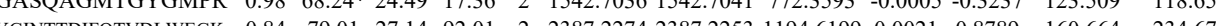
$\begin{array}{llllllllllll} & \text { YASQA }\end{array}$

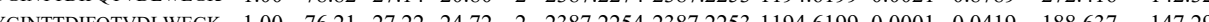
$\begin{array}{lllllllllllll} & 6026 & 27.19 & 20.32 & 3 & 2387.2309 & 2387.2253 & 796.7490 & 0.0056 & 2.3428 & 24.606 & 21.279\end{array}$

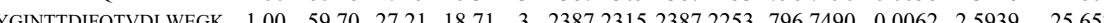

Yes 
$\begin{array}{llllllllllllllll}\text { QMEQISQFLQAAER } & 1.00 & 87.07 & 28.15 & 31.88 & 2 & 1821.9180 & 1821.9165 & 911.9655 & 0.0015 & 0.8224 & 8081.082 & 7086.013 & 562.400 & 7924.981 & \text { Yes }\end{array}$

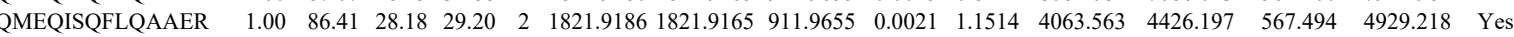

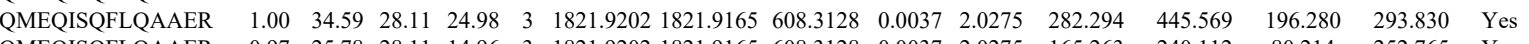

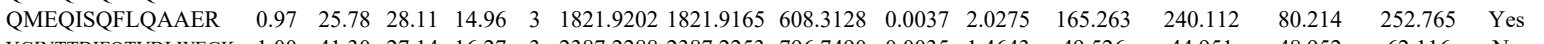
$\begin{array}{llllllllllllllll}\text { YGINTTDIFQTVDLWEGK } & 1.00 & 41.30 & 27.14 & 16.27 & 3 & 2387.2288 & 2387.2253 & 796.7490 & 0.0035 & 1.4643 & 49.526 & 44.951 & 48.952 & 62.116 & \text { No }\end{array}$

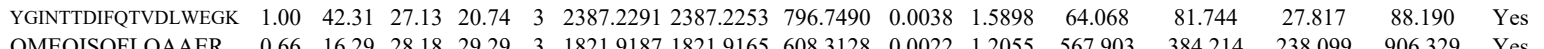
\begin{tabular}{llllllllllllllll} 
QMEQISQFLQAAER & 0.66 & 16.29 & 28.18 & 29.29 & 3 & 1821.9187 & 1821.9165 & 608.3128 & 0.0022 & 1.2055 & 567.903 & 384.214 & 238.099 & 906.329 & Yes \\
\hline
\end{tabular}

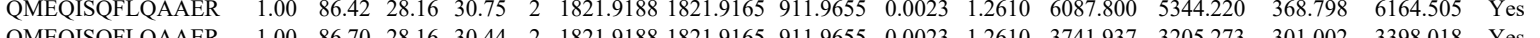

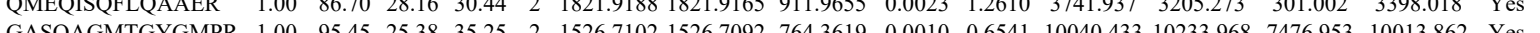

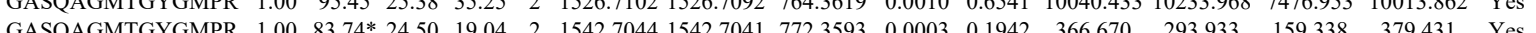
$\begin{array}{lllllllllllllll} & \end{array}$ $\begin{array}{llllllllllll} & \end{array}$ $\begin{array}{lllllllllllll} & \end{array}$

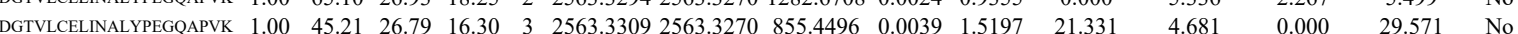

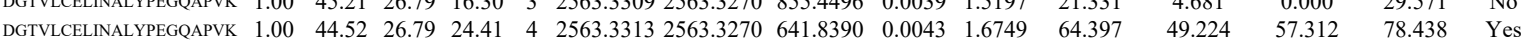

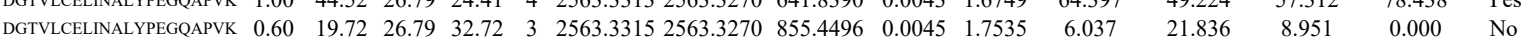
$\begin{array}{llllllllllllllll}\text { DGTVLCELINALYPEGQAPVK } & 1.00 & 40.04 & 26.79 & 16.17 & 4 & 2563.3325 & 2563.3270 & 641.8390 & 0.0055 & 2.1423 & 79.822 & 47.588 & 31.219 & 81.608 & \text { Yes }\end{array}$ $\begin{array}{llllllllllllllll}\text { IQASTMAFK } & 1.00 & 56.65 & 26.85 & 33.92 & 2 & 1283.7238 & 1283.7151 & 642.8648 & 0.0087 & 6.7665 & 37429.122 & 33757.032 & 2824.077 & 36908.441 & \text { Yes }\end{array}$

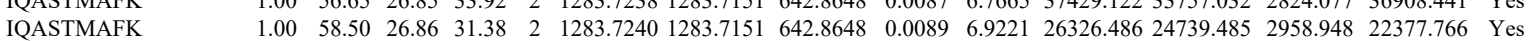
$\begin{array}{llllllllllllllll}\text { GASQAGMTGYGMPR } & 1.00 & 99.87 & 25.30 & 34.96 & 2 & 1526.7098 & 1526.7092 & 764.3619 & 0.0006 & 0.3925 & 9929.190 & 11366.242 & 3790.810 & 8401.208 & \text { Yes }\end{array}$

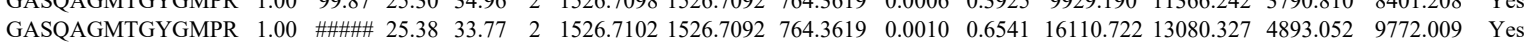

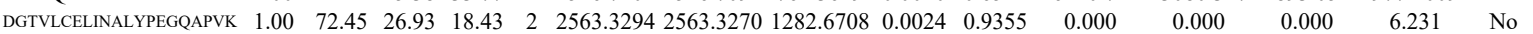

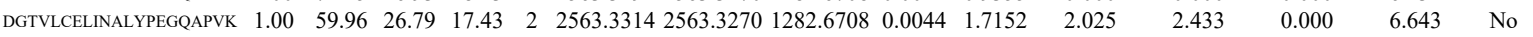
$\begin{array}{lllllllllllllllll}\text { DGTVLCELINALYPEGQAPVK } & 0.99 & 29.90 & 26.79 & 17.04 & 3 & 2563.3315 & 2563.3270 & 855.4496 & 0.0045 & 1.7535 & 66.351 & 31.846 & 35.649 & 60.201 & \text { Yes }\end{array}$ $\begin{array}{llllllllllllllll}\text { DGTVLCELINALYPEGQAPVK } & 1.00 & 45.69 & 26.79 & 17.33 & 4 & 2563.3321 & 2563.3270 & 641.8390 & 0.0051 & 1.9865 & 72.481 & 54.512 & 45.526 & 90.082 & \text { Yes }\end{array}$

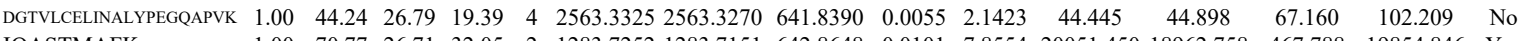
IQASTMAFK $\begin{array}{lllllllllllll}1.00 & 70.77 & 26.71 & 32.05 & 2 & 1283.7252 & 1283.7151 & 642.8648 & 0.0101 & 7.8554 & 20051.450 & 18962.758\end{array}$ $\begin{array}{ccc}67.160 & 102.209 & \mathrm{No} \\ 467.788 & 19854.846 & \text { Yes }\end{array}$ IQASTMAFK $\begin{array}{llllllllllll}1.00 & 72.13 & 26.92 & 18.95 & 2 & 2563.3274 & 2563.3270 & 1282.6708 & 0.0004 & 0.1559 & 0.000 & 1.910\end{array}$ NVIGLQMGTNR NVIGLQMGTNR NVIGLQMGTNR NVIGLQMGTNR NVIGLQMGTNR NVIGLQMGTNR NVLLMTNR NIGLQMTR NVIGLQMGTNR NVIGLQMGTNR TLMNLGGLAVAR TLMNLGGLAVAR TLMNLGGLAVAR TLMNLGGLAVAR TLMNLGGLAVAR TLMNLGGLAVAR TLMNLGGLAVAR TLMNLGGLAVAR TLMNLGGLAVAR TLMNLGGLAVAR TLMNLGGLAVAR TLMNLGGLAVAR TLMNLGGLAVAR TLMNLGGLAVAR TLMNLGGLAVAR TLMNLGGLAVAR TLMNLGGLAVAR TLMNLGGLAVAR TLMNLGGLAVAR TLMNLGGLAVAR TLMNLGGLAVAR TLMNLGGLAVAR TLMNLGGLAVAR TLMNGGLAVAR

TLMNLGGLAVAR $\begin{array}{lllllllllllllll}1.00 & 55.33 & 26.88 & 30.58 & 2 & 1283.7242 & 1283.7151 & 642.8648 & 0.0091 & 7.0776 & 5594.106 & 4300.187 & 632.520 & 4789.268 & \text { Yes } \\ 1.00 & 59.45 & 26.88 & 31.01 & 2 & 1283.7242 & 1283.7151 & 642.8648 & 0.0091 & 7.0776 & 8487.870 & 7089.908 & 582.264 & 7484.555 & \text { Yes }\end{array}$ $\begin{array}{llllllllllllllll}1.00 & 55.19 & 28.03 & 21.10 & 2 & 1345.7372 & 1345.7258 & 673.8702 & 0.0114 & 8.4585 & 29700.017 & 28854.221 & 525.279 & 28422.264 & \text { Yes }\end{array}$ $\begin{array}{lllllllllllllllll}1.00 & 53.80 & 28.03 & 21.29 & 2 & 1345.7374 & 1345.7258 & 673.8702 & 0.0116 & 8.6069 & 20080.054 & 18907.278 & 442.281 & 19755.133 & \text { Yes }\end{array}$ $\begin{array}{lllllllllllllll}1.00 & 53.34 & 28.03 & 25.97 & 2 & 1345.7372 & 1345.7258 & 673.8702 & 0.0114 & 8.4585 & 36630.280 & 32415.265 & 0.000 & 33149.147 & \text { No }\end{array}$ $\begin{array}{lllllllllllllll}0.96 & 32.44 & 28.20 & 26.45 & 3 & 1345.7377 & 1345.7258 & 449.5825 & 0.0119 & 8.8229 & 1357.850 & 1474.791 & 330.752 & 1424.537 & \text { Yes } \\ 1.00 & 53.52 & 28.20 & 27.51 & 2 & 1345.7378 & 1345.7258 & 673.8702 & 0.0120 & 8.9037 & 25636.508 & 25438.535 & 49.097 & 22977.069 & \text { Yes }\end{array}$ $\begin{array}{llllllllllllllll}1.00 & 53.52 & 28.20 & 27.51 & 2 & 1345.7378 & 1345.7258 & 673.8702 & 0.0120 & 8.9037 & 25636.508 & 25438.535 & 49.097 & 22977.069 & \text { Yes }\end{array}$ $\begin{array}{lllllllllllllll}1.00 & 50.20 & 28.26 & 25.23 & 3 & 1345.7392 & 1345.7258 & 449.5825 & 0.0134 & 9.9350 & 1362.905 & 1384.098 & 366.342 & 1206.837 & \text { Yes } \\ 1.00 & 55.23 & 28.06 & 27.84 & 2 & 1361.7254 & 1361.7207 & 681.8676 & 0.0047 & 3.4464 & 1529.854 & 1540.642 & 69.949 & 1627.533 & \text { Yes }\end{array}$

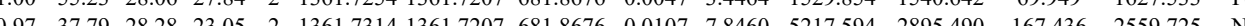

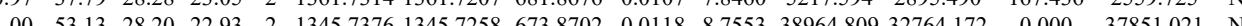
$\begin{array}{lllllllllllllll}1.00 & 55.23 & 28.20 & 28.23 & 2 & 1345.7378 & 1345.7258 & 673.8702 & 0.0120 & 8.9037 & 27233.857 & 25840.496 & 0.000 & 26389.064 & \end{array}$ $\begin{array}{lllllllllllllll}1.00 & 71.73 & 26.42 & 30.66 & 2 & 1358.7832 & 1358.7826 & 680.3986 & 0.0006 & 0.4409 & 9856.387 & 7179.136 & 127.538 & 9574.541 & \text { Yes }\end{array}$

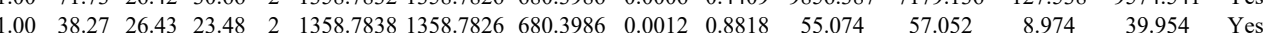

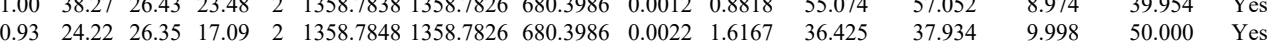

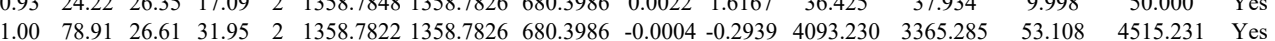

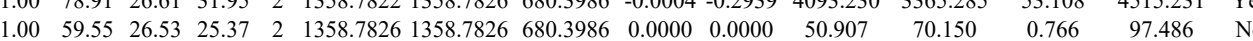
$\begin{array}{llllllllllllllll}1.00 & 37.80 & 26.43 & 21.57 & 3 & 1358.7838 & 1358.7826 & 453.9348 & 0.0012 & 0.8812 & 173.882 & 206.674 & 75.417 & 241.773 & \text { Yes }\end{array}$

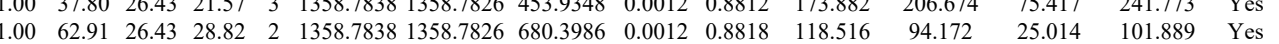
$\begin{array}{lllllllllllllll}1.00 & 56.42 & 26.43 & 31.79 & 2 & 1358.7838 & 1358.7826 & 680.3986 & 0.0012 & 0.8818 & 79.958 & 102.128 & 15.870 & 89.351 & \text { Yes }\end{array}$ $\begin{array}{lllllllllllllll}1.00 & 60.17 & 26.43 & 26.70 & 2 & 1358.7838 & 1358.7826 & 680.3986 & 0.0012 & 0.8818 & 81.002 & 60.112 & 13.713 & 72.012 & \text { Yes }\end{array}$ $\begin{array}{llllllllllllllll}1.00 & 56.67 & 26.41 & 27.24 & 2 & 1358.7842 & 1358.7826 & 680.3986 & 0.0016 & 1.1758 & 75.440 & 71.259 & 4.000 & 87.811 & \text { Yes }\end{array}$ $6 \begin{array}{lllll}680.3986 & 0.0016 & 1.1758 & 61.183 & 51.752\end{array}$ $\begin{array}{llllllllllll}1.00 & 51.03 & 26.41 & 24.87 & 2 & 1358.7842 & 1358.7826 & 680.3986 & 0.0016 & 1.1758 & 61.183 & 1.752\end{array}$ $\begin{array}{llllllllllll}1.00 & 53.57 & 26.41 & 30.94 & 2 & 1358.7844 & 1358.7826 & 680.3986 & 0.0018 & 1.3228 & 61.051 & 72.054\end{array}$ $\begin{array}{lllllllllllll}1.00 & 41.72 & 26.18 & 27.41 & 3 & 1358.7850 & 1358.7826 & 453.9348 & 0.0024 & 1.7624 & 673.418 & 453.733\end{array}$ $\begin{array}{llllllllllll}1.00 & 72.50 & 27.48 & 29.12 & 2 & 1374.7876 & 1374.7775 & 688.3960 & 0.0101 & 7.3358 & 5156.159 & 4557.691\end{array}$ $\begin{array}{lllllllllllll}1.00 & 70.08 & 27.29 & 29.01 & 2 & 1374.7898 & 1374.7775 & 688.3960 & 0.0123 & 8.9337 & 4893.024 & 4102.568 \\ 1.00 & 85.76 & 26.75 & 20.20 & 2 & 1358.7798 & 1358.7826 & 680.3986 & -0.0028 & -2.0576 & 1158.154 & 1158.625\end{array}$ $\begin{array}{llllllllllllll}1.00 & 85.76 & 26.75 & 20.20 & 2 & 1358.7798 & 1358.7826 & 680.3986 & -0.0028 & -2.0576 & 1158.154 & 1158.625 \\ 1.00 & 76.16 & 26.57 & 31.68 & 2 & 1358.7820 & 1358.7826 & 680.3986 & -0.0006 & -0.4409 & 4578.697 & 4219.645\end{array}$ $\begin{array}{lllllllllllll}1.00 & 76.16 & 26.57 & 31.68 & 2 & 1358.7820 & 1358.7826 & 680.3986 & -0.0006 & -0.4409 & 4578.697 & 4219.645 \\ 1.00 & 38.19 & 26.45 & 22.44 & 3 & 1358.7832 & 1358.7826 & 453.9348 & 0.0006 & 0.4406 & 67.115 & 56.218\end{array}$ $\begin{array}{llllllllllll}1.00 & 38.19 & 26.45 & 22.44 & 3 & 1358.7832 & 1358.7826 & 453.9348 & 0.0006 & 0.4406 & 67.115 & 56.218\end{array}$ $\begin{array}{lllllllllllll}0.99 & 28.49 & 26.45 & 16.64 & 3 & 1358.7832 & 1358.7826 & 453.9348 & 0.0006 & 0.4406 & 130.132 & 136.048\end{array}$ $\begin{array}{lllllllllllllll}1.00 & 40.24 & 26.43 & 19.61 & 2 & 1358.7836 & 3588.7826 & 680.3986 & 0.0010 & 0.7349 & 32.162 & 36.622\end{array}$ $\begin{array}{llllllllllllll}1.00 & 42.81 & 26.37 & 2.41 & 2 & 1358.7836 & 1358.7826 & 680.3986 & 0.001 & 0.7349 & 32.162 & 36.622\end{array}$

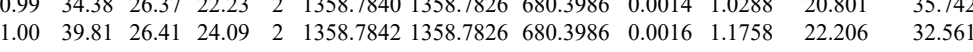
$\begin{array}{llllllllllll}1.00 & 41.04 & 26.18 & 21.54 & 2 & 1358.7850 & 1358.7826 & 680.3986 & 0.0024 & 1.7587 & 40.223 & 45.73\end{array}$

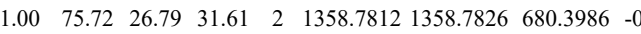




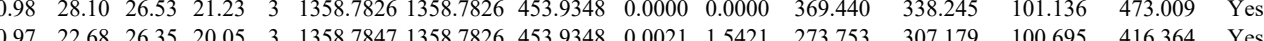

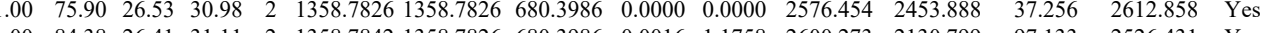
$\begin{array}{llllllllllllllll}1.00 & 84.38 & 26.41 & 31.11 & 2 & 1358.7842 & 1358.7826 & 680.3986 & 0.0016 & 1.1758 & 2600.273 & 2130.799 & 97.133 & 2526.431 & \text { Yes }\end{array}$ $\begin{array}{lllllllllllllll}1.00 & 55.60 & 28.47 & 26.12 & 2 & 1345.7256 & 1345.7258 & 673.8702 & -0.0002 & -0.1484 & 404.101 & 393.327 & 21.033 & 392.936 & \text { Yes }\end{array}$

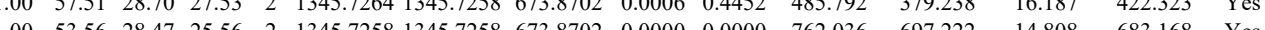

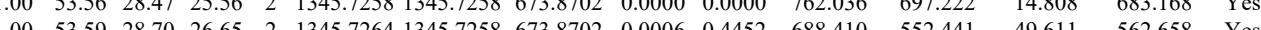
$\begin{array}{llllllllllllll} & \end{array}$ $\begin{array}{llllllllllllllll}1.00 & 53.92 & 28.47 & 29.85 & 2 & 1345.7258 & 1345.7258 & 673.8702 & 0.0000 & 0.0000 & 1030.560 & 736.172 & 19.311 & 792.208 & \text { Yes }\end{array}$ \begin{tabular}{llllllllllllllll}
1.00 & 77.19 & 26.61 & 31.59 & 2 & 1358.7822 & 1358.7826 & 680.3986 & -0.0004 & 0.2939 & 1241.183 & 971.377 & 49.551 & 1282.428 & Yes \\
\hline
\end{tabular}

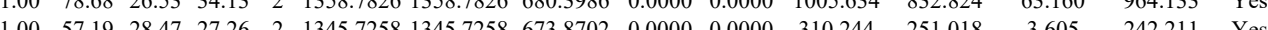

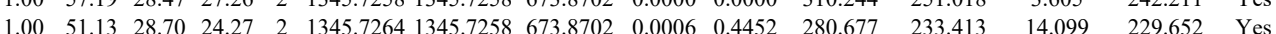
$\begin{array}{lllllllllllllll}0.96 & 25.75 & 28.69 & 22.71 & 3 & 1345.7266 & 1345.7258 & 449.5825 & 0.0008 & 0.5931 & 37.171 & 43.297 & 20.984 & 58.515 & \text { Yes }\end{array}$

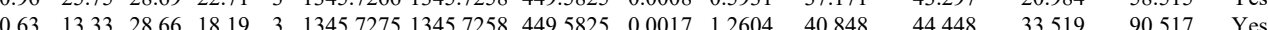

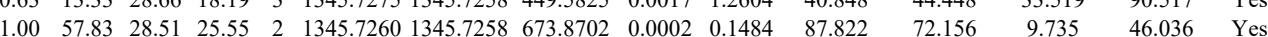

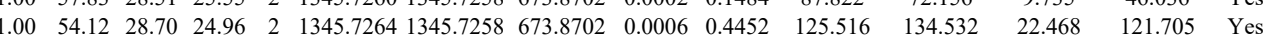
$\begin{array}{lllllllllllllll}1.00 & 53.74 & 26.18 & 28.61 & 2 & 1358.7850 & 1358.7826 & 680.3986 & 0.0024 & 1.7637 & 266.900 & 235.555 & 22.086 & 273.184 & \text { Yes }\end{array}$ $\begin{array}{llllllllllllllll}1.00 & 60.02 & 26.24 & 32.08 & 2 & 1358.7854 & 1358.7826 & 680.3986 & 0.0028 & 2.0576 & 355.723 & 304.576 & 33.358 & 288.905 & \text { Yes }\end{array}$

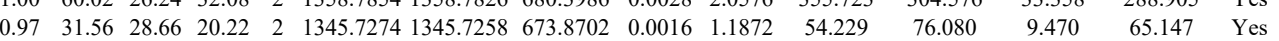
$\begin{array}{lllllllllllllllll}1.00 & 69.22 & 27.75 & 31.31 & 2 & 1566.7914 & 1566.7882 & 784.4014 & 0.0032 & 2.0398 & 27806.566 & 20464.116 & 0.000 & 24949.522 & \text { No }\end{array}$ $\begin{array}{llllllllllllllll}1.00 & 63.21 & 27.63 & 26.29 & 2 & 1566.7926 & 1566.7882 & 784.4014 & 0.0044 & 2.8047 & 18061.913 & 17684.673 & 1054.648 & 19472.628 & \text { Yes }\end{array}$ $\begin{array}{llllllllllllllll}1.00 & 50.38 & 25.73 & 37.12 & 2 & 1500.8768 & 1500.8755 & 751.4450 & 0.0013 & 0.8650 & 666.354 & 395.213 & 0.000 & 861.942 & \text { No }\end{array}$ $\begin{array}{lllllllllllllll}0.95 & 42.53 & 25.73 & 45.32 & 3 & 1500.8770 & 1500.8755 & 501.2991 & 0.0015 & 0.9974 & 190.232 & 156.657 & 44.725 & 274.200 & \text { Yes }\end{array}$ $\begin{array}{llllllllllllllll}1.00 & 52.71 & 25.73 & 33.59 & 2 & 1500.8770 & 1500.8755 & 751.4450 & 0.0015 & 0.9981 & 1313.159 & 1184.126 & 91.068 & 2090.534 & \text { Yes }\end{array}$

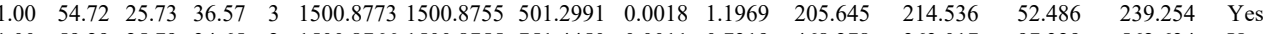
$\begin{array}{lllllllllllllll}1.00 & 59.29 & 25.79 & 34.65 & 2 & 1500.8766 & 1500.8755 & 751.4450 & 0.0011 & 0.7319 & 468.278 & 363.017 & 97.329 & 562.634 & \text { Yes }\end{array}$

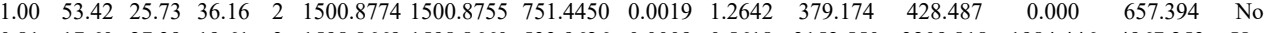

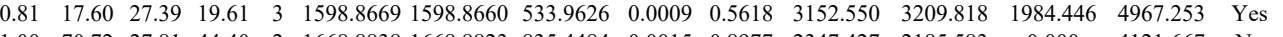
$\begin{array}{llllllllllllllll}1.00 & 70.72 & 27.81 & 44.40 & 2 & 1668.8838 & 1668.8823 & 835.4484 & 0.0015 & 0.8977 & 2347.427 & 2185.583 & 0.000 & 4121.667 & \text { No } \\ 1.09 & 1.26 & 27.77 & 41.67 & 2 & 1668.884 & 1668.823 & 85.4484 & 0.021 & 1.2568 & 94.86 & 883.970 & 0.000 & 1233.977 & \text { No }\end{array}$ $\begin{array}{lllllllllllllll}1.00 & 61.26 & 27.77 & 41.67 & 2 & 1668.8844 & 1668.8823 & 835.4484 & 0.0021 & 1.2568 & 944.186 & 883.970 & 0.000 & 1943.977 & \text { No }\end{array}$ $\begin{array}{lllllllllllllll}0.97 & 23.19 & 27.69 & 19.44 & 3 & 1668.8854 & 1668.8823 & 557.3014 & 0.0031 & 1.8542 & 118.689 & 123.681 & 39.898 & 127.855 & \text { Yes } \\ 1.00 & 45.15 & 17.71 & 25.03 & 2 & 113.7466 & 113.7365 & 557.875 & 0.05 & 9.521 & 19288.905 & 0854378 & 1407.890 & 23340.324 & \text { Yes }\end{array}$ $\begin{array}{lllllllllllllllllll}1.00 & 45.15 & 17.71 & 25.03 & 2 & 1113.7466 & 1113.7365 & 557.8755 & 0.0101 & 9.0521 & 19288.905 & 20854.378 & 1407.890 & 28340.324 & \text { Yes }\end{array}$ $\begin{array}{llllllllllllllll}1.00 & 45.10 & 1.71 & 25.05 & 2 & 1113.7466 & 1113.7365 & 557.8755 & 0.0101 & 9.0521 & 14383.669 & 14087.465 & 631.898 & 23781.911 & \text { Yes }\end{array}$ $\begin{array}{llllllllllllllll}1.00 & 35.26 & 16.53 & 16.82 & 2 & 1113.7470 & 1113.7365 & 557.8755 & 0.0105 & 9.4106 & 15837.300 & 15714.098 & 1526.828 & 22709.135 & \text { Yes } \\ 1.00 & 61.60 & 18.51 & 2257 & 2 & 1536.9538 & 1536.9523 & 769.4834 & 0.0015 & 0.9747 & 172872 & 118.766 & 0.000 & 288.701 & \text { No }\end{array}$ $\begin{array}{llllllllllllllll}1.00 & 61.60 & 18.51 & 22.57 & 2 & 1536.9538 & 1536.9523 & 769.4834 & 0.0015 & 0.9747 & 172.872 & 118.766 & 0.000 & 288.701 & \text { No } \\ 1.00 & 63.79 & 18.51 & 27.80 & 2 & 1536.9540 & 1536.9523 & 769.4834 & 0.0017 & 1.1046 & 92.954 & 54.191 & 9.110 & 171.737 & Y\end{array}$ $\begin{array}{lllllllllllllll}1.00 & 63.79 & 18.51 & 27.80 & 2 & 1536.9540 & 1536.923 & 769.4834 & 0.0017 & 1.1046 & 92.944 & 54.191 & 9.110 & 171.737 & \text { Yes } \\ 1.00 & 33.88 & 18.45 & 15.72 & 3 & 1536.9553 & 1536.9523 & 513.3247 & 0.0030 & 1.9481 & 28.445 & 23.118 & 18.840 & 31.070 & N_{0}\end{array}$ $\begin{array}{lllllllllllllll}1.00 & 25.83 & 18.33 & 15.00 & 3 & 1536.9559 & 1536.9523 & 513.3247 & 0.0036 & 2.3777 & 17.309 & 21.969 & 21.116 & 44.726 & \text { No }\end{array}$

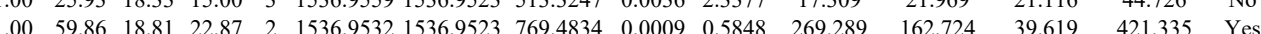

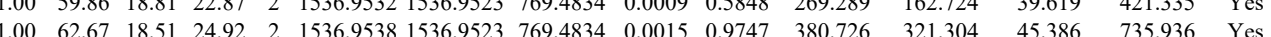

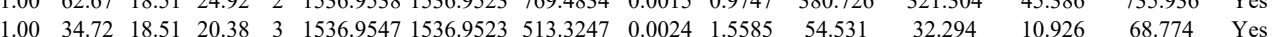

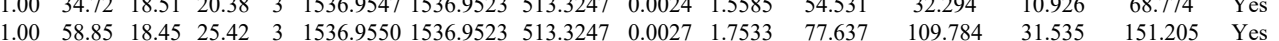
$\begin{array}{lllllllllllllll}1.086 & 34.82 & 27.65 & 36.24 & 2 & 1124.6212 & 1124.6134 & 563.3140 & 0.0078 & 6.9233 & 4821.366 & 4370.527 & 74.281 & 7600.848 & \text { Yes }\end{array}$ $\begin{array}{lllllllllllllll}0.94 & 35.92 & 27.51 & 36.23 & 2 & 1124.6230 & 1124.6134 & 563.3140 & 0.0096 & 8.5209 & 8589.566 & 6448.476 & 483.712 & 12705.726 & \text { Yes }\end{array}$ $\begin{array}{lllllllllllllll}0.66 & 34.39 & 27.38 & 41.76 & 2 & 1124.6216 & 1124.6134 & 563.3140 & 0.0082 & 7.2783 & 311.611 & 172.286 & 61.192 & 391.740 & \text { Yes }\end{array}$ $\begin{array}{lllllllllllllll}0.69 & 27.35 & 27.40 & 32.51 & 2 & 1124.6218 & 1124.6134 & 563.3140 & 0.0084 & 7.4558 & 153.640 & 170.987 & 20.018 & 200.058 & \text { Yes }\end{array}$ $\begin{array}{llllllllllllllll}0.88 & 27.98 & 27.97 & 33.11 & 2 & 1124.6132 & 1124.6134 & 563.3140 & -0.0002 & -0.1775 & 130.941 & 183.658 & 24.221 & 245.160 & \text { Yes }\end{array}$ $\begin{array}{lllllllllllllll}0.95 & 31.81 & 27.63 & 31.31 & 2 & 1124.6136 & 1124.6134 & 563.3140 & 0.0002 & 0.1775 & 96.274 & 85.921 & 19.601 & 155.169 & \text { Yes }\end{array}$ $\begin{array}{lllllllllllllll}0.55 & 19.81 & 27.63 & 25.12 & 2 & 1124.6134 & 1124.6134 & 563.3140 & 0.0000 & 0.0000 & 62.257 & 49.433 & 9.606 & 100.302 & \text { Yes }\end{array}$

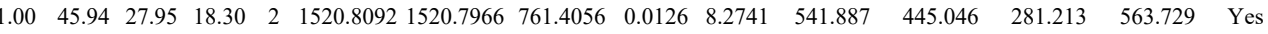

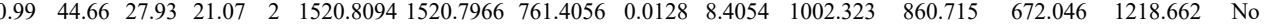
$\begin{array}{lllllllllllllll}1.00 & 62.72 & 27.41 & 24.68 & 2 & 1786.8926 & 1786.8916 & 894.4531 & 0.0010 & 0.5590 & 1209.724 & 1570.536 & 127.753 & 2203.887 & \text { Yes }\end{array}$ $\begin{array}{llllllllllllllll}1.00 & 45.11 & 27.63 & 20.87 & 3 & 1786.8952 & 1786.8916 & 596.6378 & 0.0036 & 2.0113 & 5080.593 & 4359.473 & 1028.165 & 5072.613 & \text { Yes }\end{array}$ $\begin{array}{lllllllllllllll}1.00 & 53.30 & 27.69 & 23.39 & 3 & 1786.8961 & 1786.8916 & 596.6378 & 0.0045 & 2.5141 & 7383.654 & 6248.698 & 1040.466 & 9816.084 & \text { Yes }\end{array}$ $\begin{array}{lllllllllllllll}1.00 & 63.81 & 28.27 & 24.89 & 2 & 1722.9146 & 1722.9144 & 862.4645 & 0.0002 & 0.1159 & 1240.344 & 1075.293 & 299.814 & 1829.746 & \text { Yes }\end{array}$

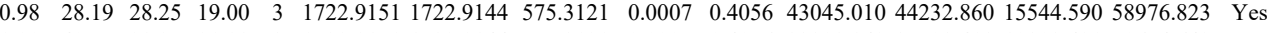
$\begin{array}{lllllllllllllll}1.00 & 40.57 & 28.25 & 21.98 & 3 & 1722.9151 & 1722.9144 & 575.3121 & 0.0007 & 0.4056 & 33308.842 & 37708.418 & 10803.421 & 50654.642 & \text { Yes }\end{array}$

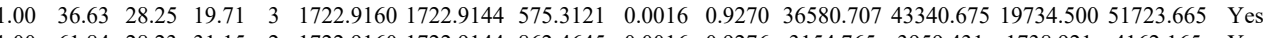

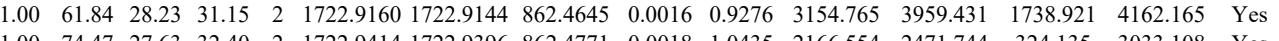

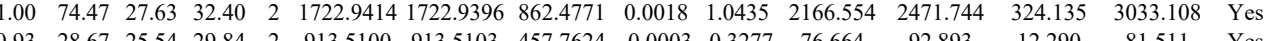
$\begin{array}{lllllllllllllll}0.93 & 28.67 & 25.54 & 29.84 & 2 & 913.5100 & 913.5103 & 457.7624 & -0.0003 & -0.3277 & 76.664 & 92.893 & 12.290 & 81.511 & \text { Yes } \\ 0.55 & 17.67 & 25.54 & 25.71 & 2 & 913.5106 & 913.5103 & 457.7624 & 0.0003 & 0.3277 & 64.853 & 65.541 & 19.608 & 88.539 & \text { Yes }\end{array}$ $\begin{array}{lllllllllllllll}0.55 & 17.67 & 25.54 & 25.71 & 2 & 913.5106 & 913.5103 & 457.7624 & 0.0003 & 0.3277 & 64.853 & 65.541 & 19.608 & 88.539 & \text { Yes } \\ 0.98 & 25.92 & 28.16 & 19.23 & 3 & 1722.9172 & 1722.9144 & 575.312 & 0.0028 & 1.623 & 13000.016 & 13214.816 & 11027.347 & 15423.088 & \text { Yes }\end{array}$ $\begin{array}{llllllllllllllllll}0.98 & 25.92 & 28.16 & 19.23 & 3 & 1722.9172 & 1722.9144 & 575.3121 & 0.0028 & 1.6223 & 13000.016 & 13214.816 & 11027.347 & 15423.088 & \text { Yes } \\ 1.00 & 79.18 & 27.31 & 40.78 & 2 & 1722.9424 & 1722.9396 & 862.4771 & 0.0028 & 1.6232 & 1929.232 & 1949.878 & 217.593 & 3041.397 & \text { Yes }\end{array}$

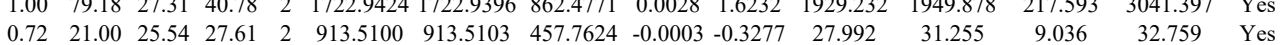
$\begin{array}{lllllllllllllll}0.72 & 21.00 & 25.54 & 27.61 & 2 & 913.5100 & 913.5103 & 457.7624 & -0.0003 & -0.3277 & 27.992 & 31.255 & 9.036 & 32.759 & \text { Yes } \\ 0.55 & 13.24 & 25.31 & 23.17 & 2 & 913.5114 & 913.5103 & 457.7624 & 0.0011 & 1.2015 & 26.084 & 40.946 & 12.482 & 38.170 & \text { Yes }\end{array}$

Table S-4 page 291 of 614 


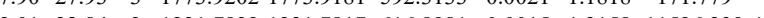
$\begin{array}{lllllllllllllll}0.92 & 26.23 & 28.10 & 32.92 & 2 & 1031.6260 & 1031.6249 & 516.8197 & 0.0011 & 1.0642 & 14258.426 & 13867.669 & 11828.857 & 28157.738 & \text { Yes }\end{array}$ $\begin{array}{lllllllllllllll}0.94 & 40.68 & 28.02 & 43.88 & 2 & 1031.6254 & 1031.6249 & 516.8197 & 0.0005 & 0.4837 & 5389.200 & 4160.034 & 4065.749 & 9739.047 & \text { Yes }\end{array}$

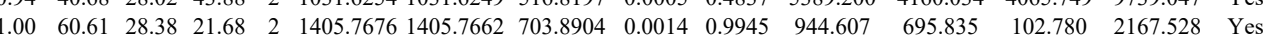
$\begin{array}{llllllllllllllll}1.00 & 63.07 & 28.36 & 22.57 & 2 & 1405.7682 & 1405.7662 & 703.8904 & 0.0020 & 1.4207 & 1484.812 & 1008.416 & 49.604 & 3143.495 & \text { Yes }\end{array}$ $\begin{array}{llllllllllllllll}1.00 & 56.95 & 28.38 & 21.78 & 2 & 1405.7676 & 1405.7662 & 703.8904 & 0.0014 & 0.9945 & 1775.321 & 1374.083 & 110.856 & 4135.918 & \text { Yes } \\ 1.00\end{array}$

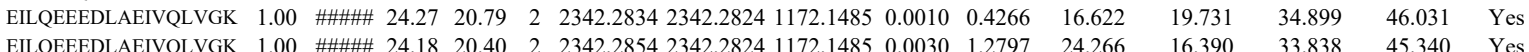

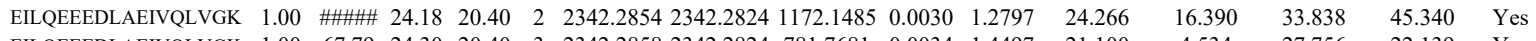
$\begin{array}{llllllllllllllll}\text { ELLEEEDLAEIVQLVGK } & 1.00 & 67.79 & 24.30 & 20.40 & 3 & 2342.2858 & 2342.2824 & 781.7681 & 0.0034 & 1.4497 & 21.100 & 4.534 & 27.756 & 22.139 & \text { Yes }\end{array}$ $\begin{array}{llllllllllllllll}\text { EILQEEEDLAEIVQLVGK } & 1.00 & 30.77 & 24.25 & 18.12 & 3 & 2342.2837 & 2342.2824 & 781.7681 & 0.0013 & 0.5543 & 10.675 & 8.595 & 7.310 & 7.617 & \text { Yes }\end{array}$

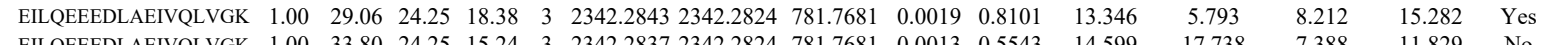

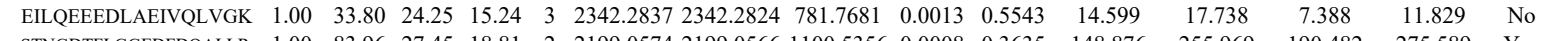

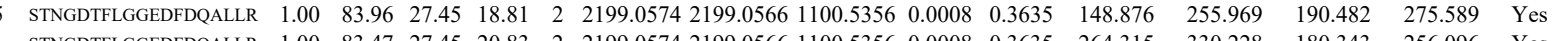

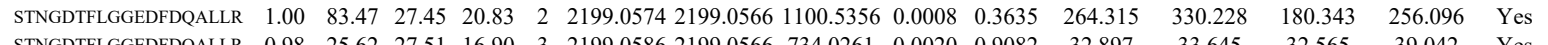

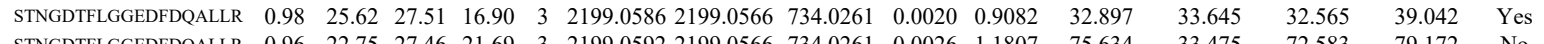
$\begin{array}{llllllllllllllll}\text { STNGDTFLGGEDFDQALLR } & 0.96 & 22.75 & 27.46 & 21.69 & 3 & 2199.0592 & 2199.0566 & 734.0261 & 0.0026 & 1.1807 & 75.634 & 33.475 & 72.583 & 79.172 & \text { No }\end{array}$

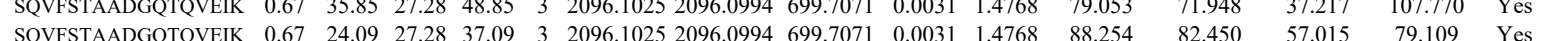

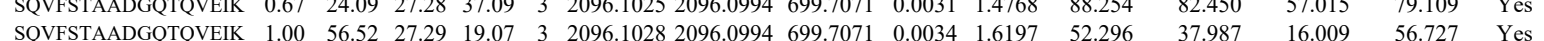

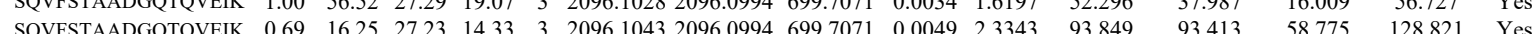

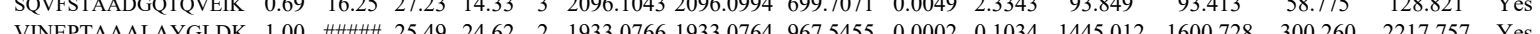

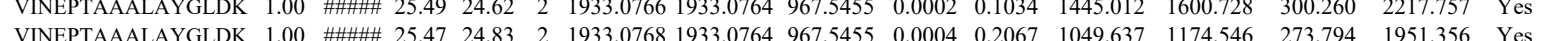
$\begin{array}{lllllllllllllllllll} & \text { VAASSLQQASLK } & 1.00 & 67.97 & 26.19 & 23.18 & 2 & 1518.8634 & 1518.8609 & 760.4377 & 0.0025 & 1.6438 & 11895.196 & 12899.863 & 2050.549 & 20719.148 & \text { Yes }\end{array}$ $\begin{array}{lllllllllllllllll}\text { QAASSLQQASLK } & 1.00 & 67.97 & 26.19 & 23.18 & 2 & 1518.8634 & 1518.8609 & 760.4377 & 0.025 & 1.6438 & 11895.196 & 12899.863 & 2050.549 & 20719.148 & \text { Yes } \\ \text { QAASSLQQASLK } & 1.00 & 68.02 & 26.07 & 25.48 & 2 & 1518.8652 & 1518.8609 & 760.4377 & 0.0043 & 2.8273 & 16065.558 & 19876.570 & 2315.879 & 34000.729 & \text { Yes }\end{array}$

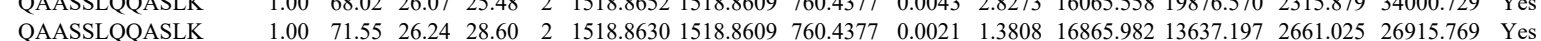
$\begin{array}{lllllllllllllllll}\text { QAASSLQQASLK } & 1.00 & 71.55 & 26.24 & 28.60 & 2 & 1518.8630 & 1518.8609 & 760.4377 & 0.0021 & 1.3808 & 16865.982 & 13637.197 & 2661.025 & 26915.769 & \text { Yes } \\ \text { QAASSLQQASLK } & 1.00 & 67.95 & 26.14 & 28.86 & 2 & 1518.8640 & 1518.8609 & 760.4377 & 0.0031 & 2.0383 & 14500.316 & 17759.731 & 1475.173 & 28311.416 & \text { Yes }\end{array}$

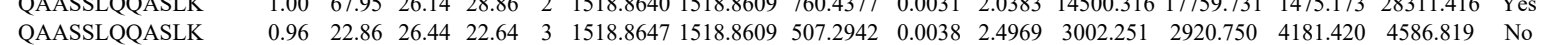
$\begin{array}{llllllllllllllll}\text { QAVTNPNNTFYATK } & 1.00 & 83.41 & 27.61 & 23.15 & 2 & 1855.9810 & 1855.9672 & 928.9909 & 0.0138 & 7.4274 & 5610.069 & 6452.412 & 539.119 & 8187.539 & \text { Yes }\end{array}$

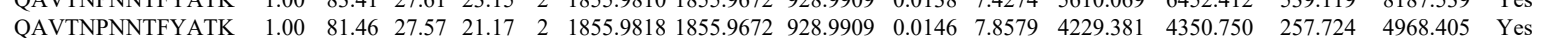
$\begin{array}{llllllllllllllll}\text { QAASSLQQASLK } & 1.00 & 66.21 & 26.24 & 29.07 & 2 & 1518.8628 & 1518.8609 & 760.4377 & 0.0019 & 1.2493 & 2392.714 & 2361.029 & 499.784 & 3731.336 & \text { Yes }\end{array}$ $\begin{array}{llllllllllllllll}\text { SDIGEVILVGGMTR } & 1.00 & 62.23 & 27.98 & 24.83 & 2 & 1589.8578 & 1589.8569 & 795.9357 & 0.0009 & 0.5654 & 2079.436 & 2208.151 & 84.419 & 3864.881 & \text { Yes }\end{array}$ $\begin{array}{lllllllllllllllll}\text { SDIGEVILVGGMTR } & 1.00 & 65.38 & 27.98 & 27.30 & 2 & 1589.8578 & 1589.8569 & 795.9357 & 0.0009 & 0.5654 & 1697.178 & 1619.421 & 312.392 & 2665.354 & \text { Yes }\end{array}$ $\begin{array}{lllllllllllllllll}\text { QAVTNPNNTFYATK } & 1.00 & 86.13 & 27.72 & 20.37 & 2 & 1855.9784 & 1855.9672 & 928.9909 & 0.0112 & 6.0280 & 1161.949 & 1472.943 & 85.847 & 1874.219 & \text { Yes }\end{array}$

LFEMAYK

AQFEGIVTDLIR AQFEGIVTDLIR AQFEGIVTDLIR AQFEGIVTDLIR LVGMPAK LVGMPAK
AQFEGIVTDLIR AQFEGIVTDLIR AQFEGIVTDLIR $\begin{array}{lllllllllllllll}0.96 & 39.04 & 28.10 & 26.81 & 2 & 1188.6532 & 1188.6456 & 595.3301 & 0.0076 & 6.3830 & 6607.722 & 5778.406 & 1278.148 & 21390.224 & \text { No }\end{array}$ $\begin{array}{lllllllllllllll}1.00 & 86.04 & 27.54 & 20.15 & 3 & 2354.1898 & 2354.1888 & 785.7369 & 0.0010 & 0.4242 & 16.511 & 6.287 & 3.184 & 3.105 & \text { No }\end{array}$ $\begin{array}{lllllllllllllll}1.00 & 67.00 & 27.18 & 19.44 & 2 & 1504.8396 & 1504.8371 & 753.4258 & 0.0025 & 1.6591 & 502.990 & 451.164 & 31.820 & 821.027 & \text { Yes }\end{array}$ $\begin{array}{lllllllllllllll}1.00 & 65.17 & 27.19 & 20.67 & 2 & 1504.8398 & 1504.8371 & 753.4258 & 0.0027 & 1.7918 & 5212.095 & 5724.932 & 0.000 & 9235.229 & \text { No }\end{array}$ $\begin{array}{lllllllllllllll}1.00 & 63.35 & 27.47 & 21.60 & 2 & 1504.8382 & 1504.8371 & 753.4258 & 0.0011 & 0.7300 & 869.742 & 1117.244 & 0.000 & 2168.300 & \text { No }\end{array}$

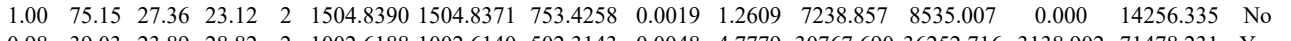
$\begin{array}{lllllllllllllll}0.98 & 39.03 & 23.89 & 28.82 & 2 & 1002.6188 & 1002.6140 & 502.3143 & 0.0048 & 4.7779 & 30767.690 & 36252.716 & 3138.902 & 71478.231 & \text { Yes }\end{array}$ $\begin{array}{llllllllllllllll}0.97 & 37.59 & 25.87 & 26.92 & 2 & 1002.6224 & 1002.6140 & 502.3143 & 0.0084 & 8.3612 & 35716.948 & 33323.263 & 2434.501 & 79428.390 & \text { Yes }\end{array}$

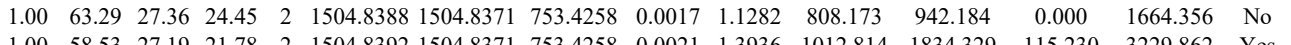

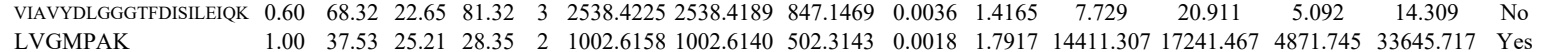

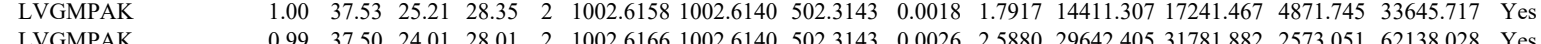

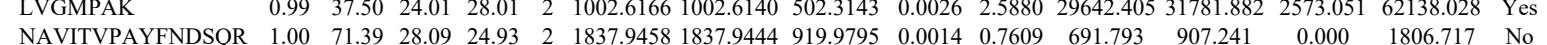




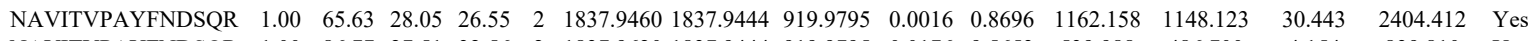

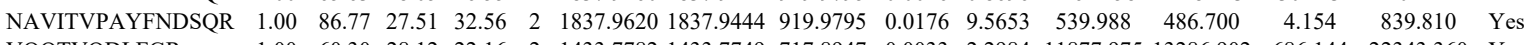

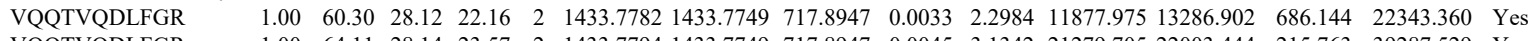
$\begin{array}{lllllllllllllllll}\text { VQQTVQDLFGR } & 1.00 & 64.11 & 28.14 & 23.57 & 2 & 1433.7794 & 1433.7749 & 717.8947 & 0.0045 & 3.1342 & 21279.705 & 22003.444 & 215.763 & 39287.529 & \text { Yes }\end{array}$ $\begin{array}{lllllllllllllllll}\text { VQQTVQDLFGR } & 1.00 & 61.00 & 28.39 & 24.66 & 2 & 1433.7764 & 1433.7749 & 717.8947 & 0.0015 & 1.0447 & 16147.607 & 20400.727 & 81.980 & 25635.166 & \text { Yes }\end{array}$ VQQTVQDLFGR VQQTVQDLFGR

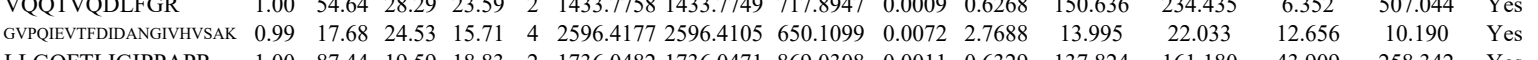
$\begin{array}{lllllllllllllll}1.00 & 60.04 & 28.29 & 24.06 & 2 & 1433.7774 & 1433.7749 & 717.8947 & 0.0025 & 1.7412 & 11223.540 & 10731.794 & 1050.675 & 17760.365 & \text { Yes }\end{array}$ $\begin{array}{llllllllllllllll}1.00 & 59.20 & 28.26 & 27.41 & 2 & 1433.7756 & 1433.7749 & 717.8947 & 0.0007 & 0.4875 & 828.931 & 1093.498 & 19.586 & 1685.992 & \text { Yes }\end{array}$ $\begin{array}{llllllllllllllll} & \end{array}$ $\begin{array}{llllllllllllllll}\text { LLGQFTLIGIPPAPR } & 1.00 & 96.33 & 19.24 & 19.57 & 2 & 1736.0484 & 1736.0471 & 869.0308 & 0.0013 & 0.7480 & 165.453 & 160.157 & 18.967 & 300.499 & \text { Yes } \\ \text { LLGQFTLIGIPPAPR } & 0.67 & 33.56 & 19.19 & 46.56 & 3 & 1736.0500 & 1736.0471 & 579.6896 & 0.0029 & 1.6676 & 23.622 & 78.916 & 12.149 & 68.046 & \text { No } \\ \text { LLGQFTLGIPPAPR } & 1.00 & 38.51 & 19.19 & 18.86 & 3 & 1736.0500 & 1736.0471 & 579.6896 & 0.0029 & 1.6676 & 8.935 & 26.986 & 0.000 & 18.503 & \text { No }\end{array}$ $\begin{array}{llllllllllllll} & \end{array}$

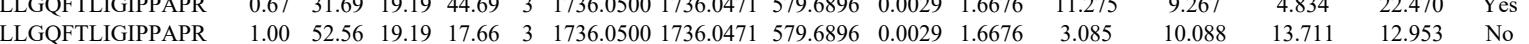
\begin{tabular}{lllllllllllllllll} 
LLGQFTLGIPPAPR & 1.00 & 92.74 & 19.96 & 22.48 & 2 & 1736.0472 & 1736.0471 & 869.0308 & 0.0001 & 0.0575 & 58.202 & 75.049 & 18.000 & 125.251 & Yes \\
\hline
\end{tabular}

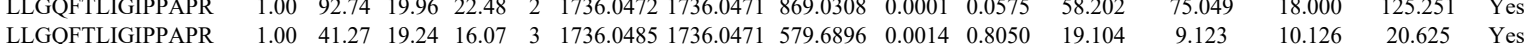

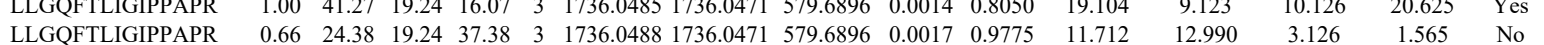

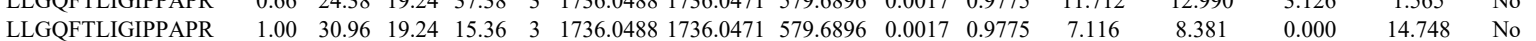

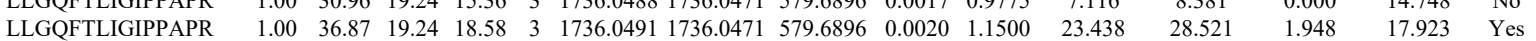
$\begin{array}{llllllllllllllll}\text { LLGQFTLIGIPPAPR } & 0.84 & 95.08 & 19.14 & \# \# \# \# & 2 & 1736.0492 & 1736.0471 & 869.0308 & 0.0021 & 1.2082 & 74.934 & 58.453 & 4.836 & 136.094 & \text { Yes }\end{array}$ $\begin{array}{llllllllllllllll}\text { LLGQFTLIGIPPAPR } & 0.66 & 18.87 & 19.14 & 31.87 & 3 & 1736.0494 & 1736.0471 & 579.6896 & 0.0023 & 1.3225 & 11.073 & 14.847 & 9.434 & 13.196 & \text { Yes }\end{array}$ $\begin{array}{llllllllllllllll}\text { LLGQFTLIGIPPAPR } & 0.67 & 31.79 & 19.14 & 44.79 & 3 & 1736.0497 & 1736.0471 & 579.6896 & 0.0026 & 1.4951 & 8.332 & 17.519 & 3.267 & 14.298 & \text { Yes }\end{array}$ $\begin{array}{lllllllllllllllll}\text { YDDPEVQK } & 0.85 & 22.45 & 27.63 & 26.53 & 2 & 1280.6502 & 1280.6492 & 641.3319 & 0.0010 & 0.7796 & 10471.662 & 11198.551 & 8015.992 & 11291.271 & \text { Yes }\end{array}$

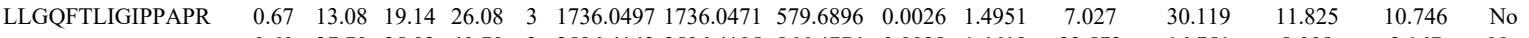
$\begin{array}{llllllllllllllll}\text { GVPIIEVTFDIDANGIVHVSAK } & 0.60 & 27.70 & 25.02 & 40.70 & 3 & 2596.4143 & 2596.4105 & 866.4774 & 0.0038 & 1.4619 & 23.572 & 16.751 & 8.098 & 3.167 & \text { No }\end{array}$ $\begin{array}{llllllllllllllll}\text { ASNGDAWVEAHGK } & 1.00 & 52.65 & 27.76 & 22.04 & 3 & 1628.8195 & 1628.8150 & 543.9456 & 0.0045 & 2.7576 & 5105.374 & 6113.196 & 1171.082 & 6691.631 & \text { Yes }\end{array}$

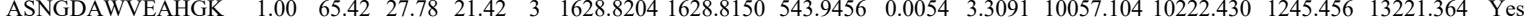
$\begin{array}{lllllllllllllll}\text { VEAVNMAEGIIHDTETK } & 1.00 & \text { \#\#\#\# } 27.52 & 26.57 & 2 & 2144.1034 & 2144.1027 & 1073.0586 & 0.0007 & 0.3262 & 357.178 & 400.764 & 379.722 & 830.817 & \text { Yes }\end{array}$

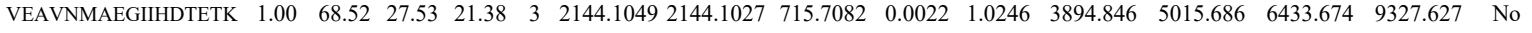

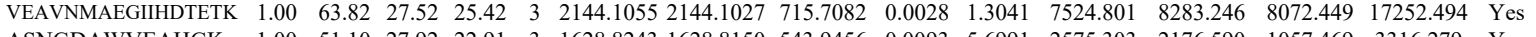

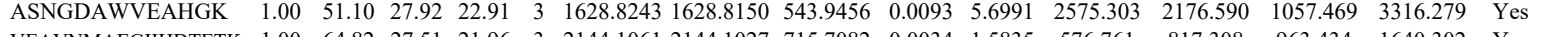

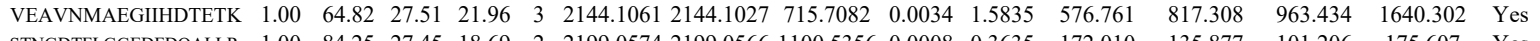
$\begin{array}{llllllllllllllll}\text { STNGDTFLGGEDFDQALLR } & 1.00 & 84.25 & 27.45 & 18.69 & 2 & 2199.0574 & 2199.0566 & 1100.5356 & 0.0008 & 0.3635 & 172.010 & 135.877 & 101.206 & 175.607 & \text { Yes }\end{array}$

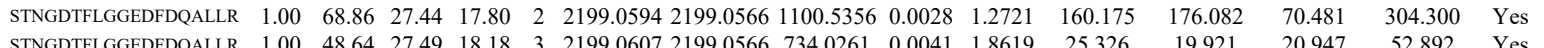

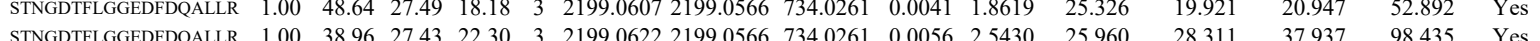

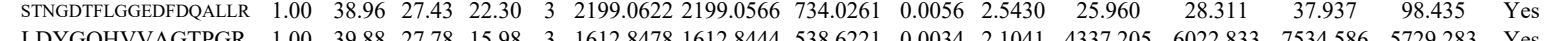
$\begin{array}{llllllllllllllllll} & \end{array}$ $\begin{array}{lllllllllllllllll} & \text { KLDYGQHK } \\ \text { GVAINFVK } & 1.00 & 51.20 & 22.92 & 23.15 & 2 & 1134.7102 & 1134.7005 & 568.3575 & 0.0097 & 8.5333 & 7666.551 & 7215.441 & 4319.530 & 9843.142 & \text { Yes }\end{array}$

GVAINFVK

VLISTDVWAR

VLISTDVWAR

VLISTDVWAR

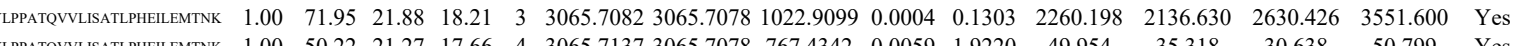

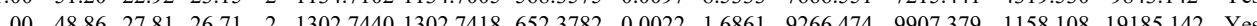
$\begin{array}{llllllllllllllll}10 & 51.51 & 27.85 & 25.67 & 2 & 1302.7444 & 13027418 & 6523782 & 0.0026 & 1.9927 & 6081.990 & 6149.819 & 644.553 & 12339.690 & \text { Yes }\end{array}$ $\begin{array}{llllllllllllllll}1.00 & 46.21 & 27.85 & 28.15 & 2 & 13027444 & 13027418 & 652.3782 & 0.0026 & 1.9927 & 5807.250 & 4512.610 & 293.810 & 10149.569 & \text { Yes }\end{array}$ $\begin{array}{lllllllllllllllll}1.00 & 51.30 & 27.85 & 25.50 & 2 & 1302.7450 & 1302.7418 & 652.3782 & 0.0032 & 2.4526 & 5736.132 & 5453.661 & 658.894 & 11638.263 & \text { Yes }\end{array}$

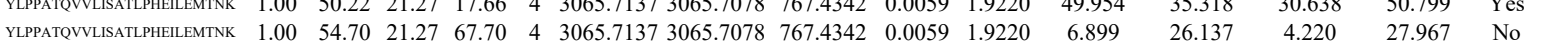

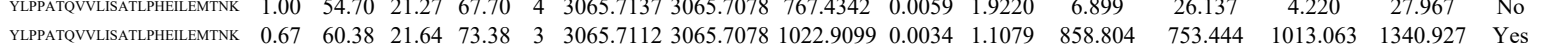
$\begin{array}{llllllllllllllll}\text { YLPPATQVVLISATLPHELIEMTNKK } & 1.00 & 32.80 & 21.40 & 45.80 & 4 & 3065.7129 & 3065.7078 & 767.4342 & 0.0051 & 1.6614 & 19.371 & 8.555 & 23.860 & 17.859 & \text { No }\end{array}$

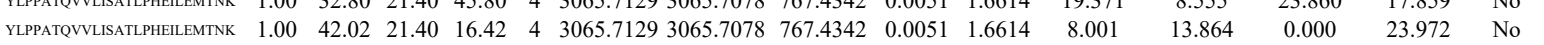
$\begin{array}{llllllllllllllll}\text { YLPPATQVVLISATLPHELLMTNK } & 0.67 & 59.91 & 21.64 & 72.91 & 3 & 3065.7112 & 3065.7078 & 1022.9099 & 0.0034 & 1.1079 & 532.468 & 497.552 & 847.805 & 1176.569 & \text { Yes }\end{array}$ $\begin{array}{lllllllllllllllll}\text { YLPATQVVLISATLPHELEMTNK } & 0.67 & 45.03 & 21.64 & 58.03 & 3 & 3065.7112 & 3065.7078 & 1022.9099 & 0.0034 & 1.1079 & 348.303 & 505.822 & 747.803 & 691.600 & \text { Yes }\end{array}$ $\begin{array}{llllllllllllllll}\text { YLPPATQVULISATLPHELEMTNKK } & 1.00 & 60.70 & 21.40 & 17.47 & 4 & 3065.7129 & 3065.7078 & 767.4342 & 0.0051 & 1.6614 & 15.558 & 16.803 & 0.000 & 19.479 & \text { No }\end{array}$ $\begin{array}{lllllllllllllllll}\text { MLPATQVVLSATLPHELEMTNKK } & 1.00 & 40.23 & 21.27 & 15.55 & 4 & 3065.7137 & 3065.7078 & 767.4342 & 0.0059 & 1.9220 & 17.779 & 0.000 & 5.632 & 19.427 & \text { No }\end{array}$ $\begin{array}{llllllllllllllll}\text { MLVLDEADEMLNK } & 1.00 & 64.05 & 28.06 & 26.01 & 2 & 1807.9312 & 1807.9303 & 904.9724 & 0.0009 & 0.4973 & 584.786 & 805.063 & 114.458 & 1421.142 & \text { Yes }\end{array}$ $\begin{array}{lllllllllllllllll}\text { MLVLDEADEMLNK } & 1.00 & 75.58 & 28.14 & 24.10 & 2 & 1807.9316 & 1807.9303 & 904.9724 & 0.0013 & 0.7183 & 1012.564 & 1312.199 & 238.279 & 2342.295 & \text { Yes }\end{array}$

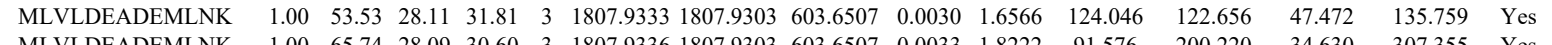

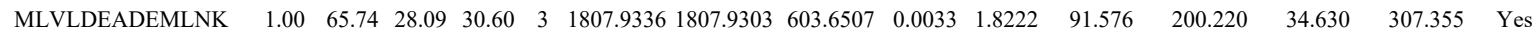
$\begin{array}{llllllllllllllll}\text { MLVLDEADEMLNK } & 1.00 & 76.01 & 28.06 & 22.79 & 2 & 1807.9312 & 1807.9303 & 904.9724 & 0.0009 & 0.4973 & 489.923 & 523.656 & 80.374 & 872.520 & \text { Yes }\end{array}$ $\begin{array}{llllllllllllllll}\text { MLVLDEADEMLNK } & 1.00 & 95.52 & 28.14 & 29.60 & 2 & 1807.9314 & 1807.9303 & 904.9724 & 0.0011 & 0.6078 & 378.153 & 349.748 & 77.110 & 641.847 & \text { Yes }\end{array}$

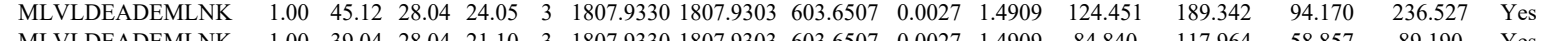

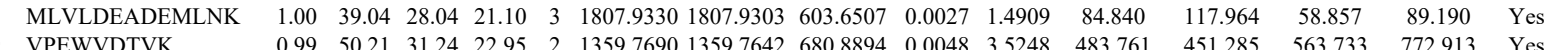
GGAGVGSMTK VPEWVDTVK

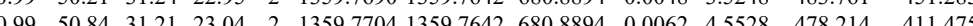
$\begin{array}{lllllllllllll}1.00 & 60.69 & 28.62 & 30.59 & 2 & 1151.6202 & 1151.6212 & 576.8179 & -0.0010 & -0.8668 & 428.144 & 610.807\end{array}$ $\begin{array}{llll}563.733 & 772.913 & \text { Yes } \\ 732.860 & 842.424 & \text { Yes }\end{array}$

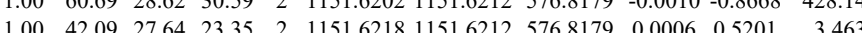
$\begin{array}{lllllllllllll}\text { RS19_HUMAN } & \text { P39019 } & \text { RPS19 } & \text { 40S ribosomal pro 16.061 } & 1.00 & 6 & 35.9 & 0.1592 & 0.3135 & 0.1426 & 0.3844 & 19 & \begin{array}{l}\text { VPEWVDTVK } \\ \text { VPEWVDTVK }\end{array} \\ & & & & & & & & & & & & \\ \text { GGAGVGSMTK }\end{array}$ $\begin{array}{llllllllll} & & & & & & & & & \\ \text { VPEWVDTVK } & \text { GGAGVSMTK }\end{array}$ 

$\begin{array}{llllllllllllllll}0.73 & 21.96 & 26.22 & 25.83 & 2 & 942.5370 & 942.5369 & 472.2757 & 0.0001 & 0.1059 & 105.194 & 105.209 & 34.686 & 94.699 & \text { Yes } \\ 0.70 & 17.14 & 26.17 & 28.57 & 2 & 942.5378 & 9425369 & 4722757 & 0.0009 & 0.9528 & 78.374 & 117.337 & 37.322 & 104.167 & \text { Yes }\end{array}$

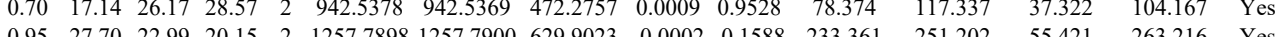

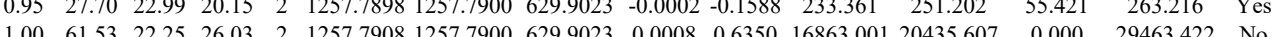
$\begin{array}{lllllllllllllll}1.00 & 62.17 & 21.64 & 23.03 & 2 & 1257.7908 & 1257.790 & 629.9023 & 0.0008 & 0.6350 & 16863.01 & 25435.607 & 0.000 & 29363.422 & \text { No }\end{array}$

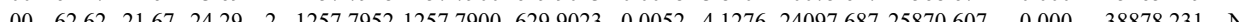

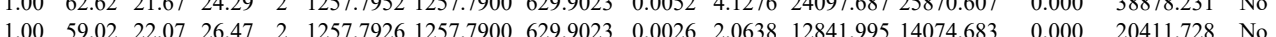
$\begin{array}{llllllllllllll}1.00 & 61.51 & 22.07 & 24.66 & 2 & 1257.7926 & 1257.7900 & 629.9023 & 0.0026 & 2.0638 & 13461.548 & 14948.277 & 0.000 & 22197.349\end{array}$ $\begin{array}{lllllllllllllll}0.98 & 28.01 & 26.07 & 19.09 & 3 & 1274.6308 & 1274.6312 & 425.8843 & -0.0004 & -0.3131 & 2141.140 & 3005.048 & 15080.369 & 2758.302 & \text { No }\end{array}$ $\begin{array}{lllllllllllllll}0.97 & 25.97 & 26.12 & 19.57 & 3 & 1274.6314 & 1274.6312 & 425.8843 & 0.0002 & 0.1565 & 1616.876 & 1978.515 & 4224.937 & 1915.489 & \text { Yes }\end{array}$ $\begin{array}{llllllllllllllll}0.99 & 41.66 & 24.17 & 24.32 & 2 & 1020.6656 & 1020.6575 & 511.3360 & 0.0081 & 7.9204 & 8945.195 & 11438.158 & 582.772 & 18752.056 & \text { Yes }\end{array}$ $\begin{array}{llllllllllllllll}100 & 49.14 & 24.10 & 25.88 & 2 & 1020.6674 & 1020.6575 & 511.3360 & 0.0099 & 9.6804 & 15044.766 & 17757.967 & 532.205 & 26143.513 & \text { Yes }\end{array}$ $\begin{array}{lllllllllllllllll}1.00 & 49.12 & 24.17 & 25.70 & 2 & 1020.6660 & 1020.6575 & 511.3360 & 0.0085 & 8.3115 & 9015.120 & 9969.859 & 4141.615 & 14928.321 & \text { Yes }\end{array}$ $\begin{array}{lllllllllllllll}100 & 44.11 & 24.10 & 23.98 & 2 & 1020.6674 & 1020.6575 & 511.3360 & 0.0099 & 9.6804 & 11463.250 & 11834.091 & 4381.325 & 19927.776 & \text { Yes }\end{array}$ $\begin{array}{lllllllllllllllll} & \\ \text { N } & 0.60 & 56.52 & 26.36 & 69.52 & 3 & 1711.8190 & 1711.8153 & 571.6124 & 0.0037 & 2.1576 & 1528.444 & 1749.159 & 242.777 & 2786.689 & \text { Yes }\end{array}$ $\begin{array}{llllllllllllllll}\text { LEQQVPVNQVFGQDEMIDVIGVTK } & 0.66 & 53.87 & 25.01 & 66.87 & 3 & 2973.5749 & 2973.5725 & 992.1981 & 0.0024 & 0.8063 & 14.362 & 0.000 & 10.902 & 44.124 & \text { No }\end{array}$ $\begin{array}{lllllllllllllllll} & 38.82 & 17.574 & 2973.5725 & 992.1981 & 0.0024 & 0.8063 & 31.803 & 0.000 & 70.343 & 31.188 & \text { No }\end{array}$ $\begin{array}{lllllllllllllll}\text { LEQQVPVNQVFGQDEMIDVIGVTK } & 1.00 & \text { \#\#\# } 25.04 & 19.82 & 2 & 2973.5754 & 2973.5725 & 1487.7935 & 0.0029 & 0.9746 & 3.287 & 7.552 & 6.477 & 2.867 & \text { No }\end{array}$ $\begin{array}{llllllllllll} & \end{array}$

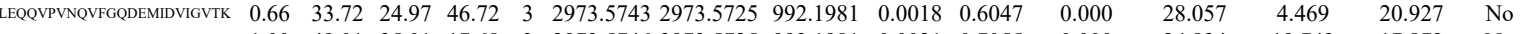
$\begin{array}{llllllllllllllll} & 25.01 & 17.68 & 3 & 2973.5746 & 2973.5725 & 992.1981 & 0.0021 & 0.7055 & 0.000 & 24.824 & 19.743 & 17.873 & \text { No }\end{array}$ $\begin{array}{lllllllllllllll} & 79.60 & 25.04 & 18.82 & 2 & 2973.5754 & 2973.5725 & 1487.7935 & 0.0029 & 0.9746 & 5.092 & 0.000 & 3.010 & 3.418 & \text { No }\end{array}$ $\begin{array}{llllllllllllllll}\text { LEQRANAQVFGDEMDVGGVK } & 0.66 & 16.93 & 24.97 & 29.93 & 3 & 2973.5743 & 2973.5725 & 992.1981 & 0.0018 & 0.6047 & 5.784 & 5.370 & 5.122 & 24.558 & \text { No }\end{array}$ $\begin{array}{llllllllllllllll} & \end{array}$

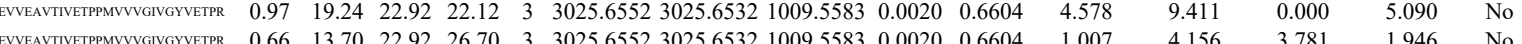
$\begin{array}{lllllllllllllll} & \end{array}$

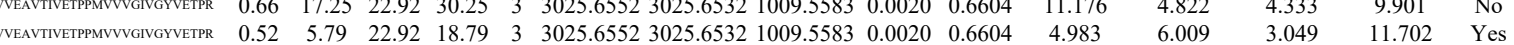
$\begin{array}{lllllllllllllll} & \text { AVEATIVETPPYVYGGVGYVEPR } \\ 0.66 & 8.63 & 22.92 & 21.63 & 3 & 3025.6552 & 3025.6532 & 1009.5583 & 0.0020 & 0.6604 & 1.762 & 4.417 & 1.721 & 12.934 & \text { No }\end{array}$ $\begin{array}{llllllllllllllll} & & \end{array}$

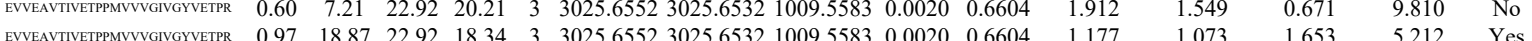

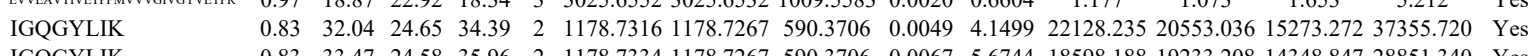

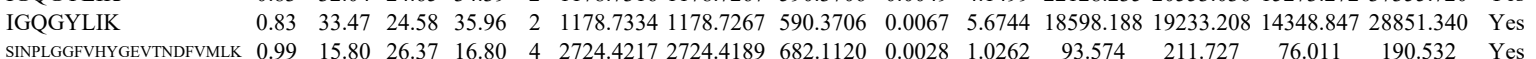

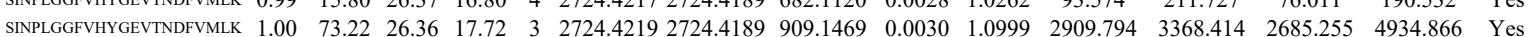

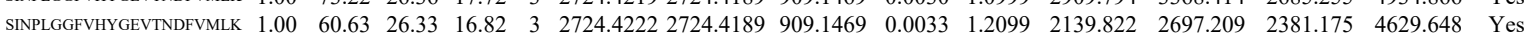

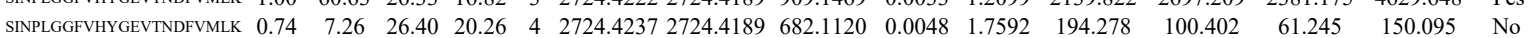

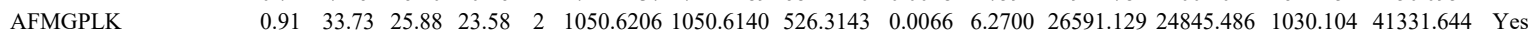

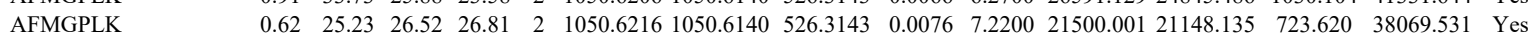

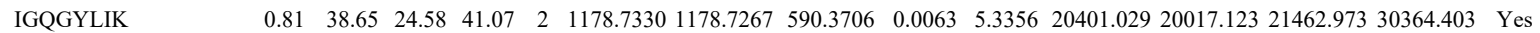

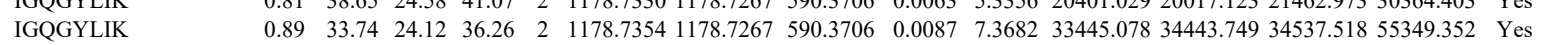

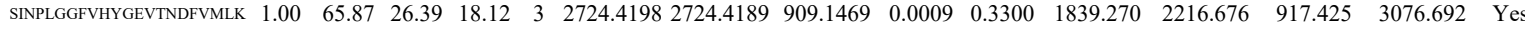

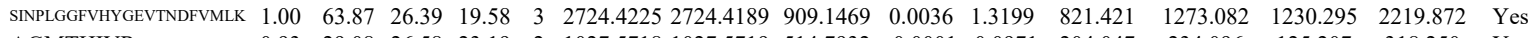

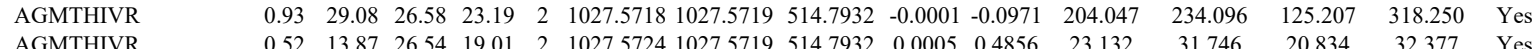

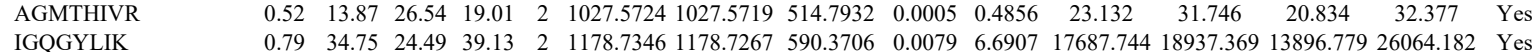
$\begin{array}{lllllllllllllllll}\text { IGQGYLIK } & 0.79 & 34.75 & 24.49 & 39.13 & 2 & 1178.7346 & 1178.7267 & 590.3706 & 0.0079 & 6.6907 & 17687.744 & 18937.369 & 13896.779 & 26064.182 & \text { Yes } \\ \text { IGQGYLIK } & 0.85 & 34.90 & 24.49 & 37.49 & 2 & 1178.7350 & 1178.7267 & 590.3706 & 0.0083 & 7.0294 & 17402 & 180 & 17670.253 & 17555.963 & 27949.278 & \text { Yes }\end{array}$

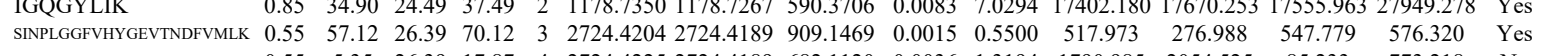

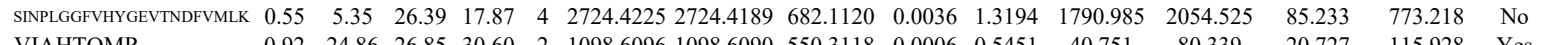

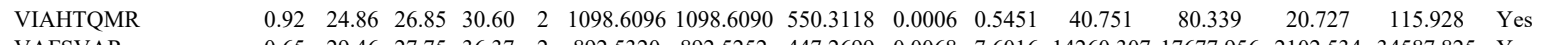

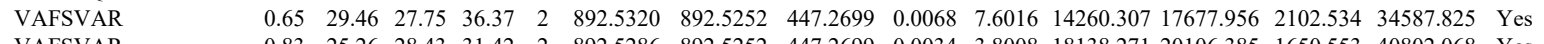
$\begin{array}{lllllllllllllllll}\text { VAFSVAR } & 0.83 & 25.26 & 28.43 & 31.42 & 2 & 892.5286 & 892.5252 & 447.2699 & 0.0034 & 3.8008 & 18138.271 & 20106.385 & 1650.553 & 40802.068 & \text { Yes } \\ \text { VAFSVAR } & 0.81 & 27.39 & 28.29 & 38.9 & 2 & 82.5282 & 82.5252 & 47.269 & 0.0030 & 3.357 & 0185.137 & 0116512 & 1977.483 & 1912.291 & \text { Yes }\end{array}$ VAFSVAR $\begin{array}{lllllllllllllll}0.81 & 27.39 & 28.29 & 38.19 & 2 & 892.5282 & 892.5252 & 447.2699 & 0.0030 & 3.3537 & 10185.137 & 10116.512 & 1977.483 & 19112.291 & \text { Yes } \\ 0.09\end{array}$ $\begin{array}{llllllllllllllll}0.89 & 25.72 & 25.49 & 15.42 & 2 & 1126.6462 & 1126.6369 & 564.3257 & 0.0093 & 8.2399 & 7117.312 & 9068.065 & 410.855 & 12447.583 & \text { Yes }\end{array}$

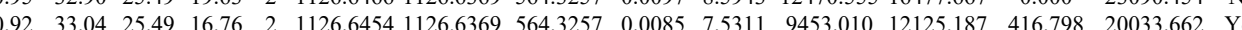
$\begin{array}{llllllllllllllll}0.92 & 33.04 & 25.49 & 16.76 & 2 & 1126.6454 & 1126.6369 & 564.3257 & 0.0085 & 7.5311 & 9453.010 & 12125.187 & 416.798 & 20033.662 & \text { Yes } \\ 0.93 & 32.38 & 25.77 & 19.48 & 2 & 1126.64561126 .6369 & 564.3257 & 0.0087 & 7.7083 & 4310.451 & 5053.626 & 341.286 & 8911.651 & \text { Yes }\end{array}$

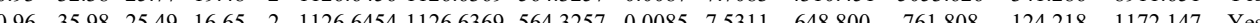

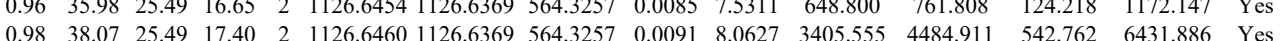




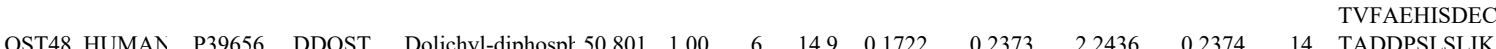

VACIGAWHPAR

TVFAEHISDECK

TVFAEHISDECK

TVFAEHISDECK

TVFAEHISDECK

TVFAEHISDECK

TVFAEHISDECK

TVFAEHISDECK

$\begin{array}{lllllllllll}75.35 & 26.14 & 25.57 & 2 & 1629.7728 & 1629.7726 & 815.8936 & 0.0002 & 0.1226 & 3931.787 & 3667.672\end{array}$ $\begin{array}{llllllllllll} & 26.12 & 24.50 & 2 & 1629.7732 & 1629.7726 & 815.8936 & 0.0006 & 0.3677 & 3817.025 & 3416.522\end{array}$

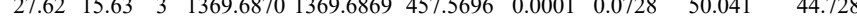
$\begin{array}{lllllllllllll}0.55 & 19.6 & 27.62 & 15.68 & 3 & 1369.6870 & 1369.6869 & 457.5696 & 0.0001 & 0.0728 & 19.523\end{array}$ $\begin{array}{llllllllll} & \end{array}$ $\begin{array}{llllllllllll}1.00 & 38.93 & 27.57 & 16.17 & 3 & 1369.6885 & 1369.6869 & 457.5696 & 0.0016 & 1.1656 & 79.184\end{array}$ $\begin{array}{llllllllllll}0.88 & 18.05 & 27.56 & 15.52 & 3 & 1369.6891 & 1369.6869 & 457.5696 & 0.0022 & 1.6027 & 23.763\end{array}$ $\begin{array}{lllllllllllll}1.00 & 45.71 & 27.88 & 16.29 & 3 & 1369.6957 & 1369.6869 & 457.5696 & 0.0088 & 6.4106 & 2646.709 & 25\end{array}$

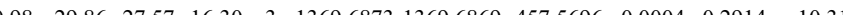
$\begin{array}{llllllllllllll}0.99 & 31.44 & 27.57 & 16.13 & 3 & 3 & 1369.6873 & 1369.6869 & 457.5696 & 0.0004 & 0.2914 & 45.3157\end{array}$ $\begin{array}{lllllllllllll}1.00 & 36.86 & 27.57 & 18.90 & 3 & 1369.6876 & 1369.6869 & 457.5696 & 0.0007 & 0.5099 & 47.216\end{array}$ $\begin{array}{llllllllllll}0.98 & 28.18 & 27.57 & 15.99 & 3 & 1369.6876 & 1369.6869 & 457.5696 & 0.0007 & 0.5099 & 40.386\end{array}$ $\begin{array}{lllllllllll}0.77 & 16.83 & 27.57 & 14.83 & 3 & 1369.6876 & 1369.6869 & 457.5696 & 0.0007 & 0.5099 & 22.129\end{array}$ $\begin{array}{lllllllllll}0.99 & 30.30 & 27.57 & 15.68 & 3 & 1369.6876 & 1369.6869 & 457.5696 & 0.0007 & 0.5099 & 36.450 \\ 1.00 & 33.52 & 27.56 & 15.31 & 3 & 1369.6879 & 1369.6869 & 457.5696 & 0.0010 & 0.7285 & 58.689\end{array}$ $\begin{array}{llllllllllll}0.98 & 28.34 & 27.56 & 16.71 & 3 & 1369.6879 & 1369.6869 & 457.5696 & 0.0010 & 0.7285 & 58.689\end{array}$ $\begin{array}{lllllllllll}1.00 & 39.19 & 27.56 & 16.95 & 3 & 1369.6879 & 1369.6869 & 457.5696 & 0.0010 & 0.7285 & 37.089\end{array}$ $\begin{array}{lllllllllllll}0.98 & 26.79 & 27.56 & 15.91 & 3 & 1369.6879 & 1369.6869 & 457.5696 & 0.0010 & 0.7285 & 27.673\end{array}$ $\begin{array}{lllllllllll}0.99 & 29.80 & 27.57 & 18.55 & 3 & 1369.6885 & 1369.6869 & 457.5696 & 0.0016 & 1.1656 & 23.262\end{array}$ $\begin{array}{llllllllllll}0.99 & 28.44 & 27.57 & 16.85 & 3 & 1369.6885 & 1369.6869 & 457.5696 & 0.0016 & 1.1656 & 21.811\end{array}$ $\begin{array}{llllllllllll} & \end{array}$ $\begin{array}{lllllllllll}48.02 & 27.86 & 19.93 & 3 & 1369.6897 & 1369.6869 & 457.5696 & 0.0028 & 2.0398 & 6386.414 & 7054.202 \\ 69.31 & 27.86 & 19.77 & 2 & 1369.6898 & 1369.6869 & 685.8507 & 0.0029 & 2.1142 & 4776.017 & 5146.346\end{array}$ $\begin{array}{lllllllllllll}1.00 & 46.93 & 27.79 & 19.80 & 3 & 1369.6912 & 1369.6869 & 457.5696 & 0.0043 & 3.1325 & 13811.838 & 16184.956\end{array}$ $\begin{array}{lllllllllllll}1.00 & 28.79 & 27.48 & 21.87 & 4 & 1641.8841 & 1641.8839 & 411.4783 & 0.0002 & 0.1215 & 1804.211 & 2012.011 & \\ 1.00 & 41.41 & 27.36 & 16.90 & 4 & 1641.8857 & 1641.8839 & 411.4783 & 0.0018 & 1.0936 & 1579.293 & 1993.534\end{array}$ $\begin{array}{lllllllllllll}0.84 & 20.74 & 27.57 & 14.47 & 3 & 1369.6867 & 1369.6869 & 457.5696 & -0.0002 & -0.1457 & 20.804 & 19.443\end{array}$ $\begin{array}{llllllllllll}1.00 & 49.31 & 27.57 & 22.79 & 3 & 1369.6876 & 1369.6869 & 457.5696 & 0.0007 & 0.5099 & 6300.727 & 6027.470\end{array}$ $\begin{array}{llllllllllll}0.89 & 20.24 & 27.57 & 14.40 & 3 & 1369.6876 & 1369.6869 & 457.5696 & 0.0007 & 0.5099 & 25.056\end{array}$ $\begin{array}{llllllllllll}0.94 & 22.53 & 27.57 & 15.36 & 3 & 1369.6876 & 1369.6869 & 457.5696 & 0.0007 & 0.5099 & 9.553\end{array}$

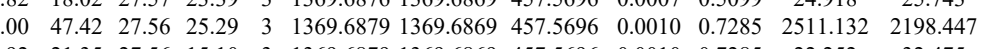
$\begin{array}{lllllllllllll}1.00 & 47.42 & 27.56 & 25.29 & 3 & 1369.6879 & 1369.6869 & 457.5696 & 0.0010 & 0.7285 & 2511.132\end{array}$ $\begin{array}{lllllllllll}1.00 & 41.57 & 27.54 & 18.25 & 2 & 1369.6860 & 1369.6869 & 685.8507 & -0.0009 & 0.6561 & 21.7 .748\end{array}$

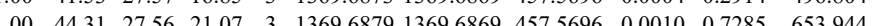

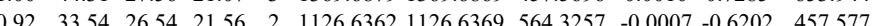

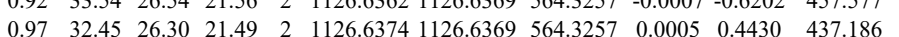
$\begin{array}{lllllllllllll}1.00 & 45.76 & 27.56 & 21.16 & 3 & 1369.6879 & 1369.6869 & 457.5696 & 0.0010 & 0.7285 & 844.008\end{array}$ $\begin{array}{lllllllllllll}0.99 & 42.02 & 26.54 & 21.85 & 2 & 1126.6362 & 1126.6369 & 564.3257 & -0.0007 & -0.6202 & 414.458\end{array}$ $\begin{array}{llllllllllll}0.96 & 32.69 & 26.72 & 21.30 & 2 & 1126.6368 & 1126.6369 & 564.3257 & -0.0001 & -0.0886 & 381.443\end{array}$ $\begin{array}{lllllllllllll}1.00 & 49.13 & 27.57 & 18.28 & 3 & 1369.6867 & 1369.6869 & 457.5696 & -0.0002 & -0.1457 & 524.630\end{array}$ $\begin{array}{lllllllllllll}0.67 & 21.18 & 26.71 & 15.32 & 2 & 1126.6366 & 1126.6369 & 564.3257 & -0.0003 & -0.2658 & 80.958\end{array}$ $\begin{array}{llllllllllll}1.00 & 36.73 & 27.57 & 20.51 & 3 & 1369.6876 & 1369.6869 & 457.5696 & 0.0007 & 0.5099 & 83.393\end{array}$ $\begin{array}{llllllllllll}0.96 & 31.68 & 26.30 & 15.40 & 2 & 1126.6374 & 1126.6369 & 564.3257 & 0.0005 & 0.4430 & 123.222\end{array}$ $\begin{array}{lllllllllllll}0.96 & 31.68 & 26.30 & 15.40 & 2 & 1126.6374 & 1126.6369 & 564.3257 & 0.0005 & 0.4430 & 123.226 & 1 \\ 0.64 & 34.85 & 26.30 & 47.85 & 2 & 1126.6374 & 1126.6369 & 564.3257 & 0.0005 & 0.4430 & 145.468 & 1\end{array}$ $\begin{array}{lllllllllllll}0.64 & 34.85 & 6.30 & 47.85 & 2 & 1126.6374 & 126.6369 & 564.3257 & 0.0005 & 0.443 & 14.468 & 1\end{array}$ $\begin{array}{lllllllllllll}1.00 & 73.25 & 26.09 & 23.45 & 2 & 1629.7734 & 1629.7726 & 815.8936 & 0.0008 & 0.4903 & 800.493 & 73 \\ .00 & 38.44 & 27.62 & 17.04 & 3 & 1369.6870 & 1369.6869 & 457.5696 & 0.0001 & 0.0728 & 48.315 & \end{array}$ $\begin{array}{llllllllllll}0.66 & 13.73 & 26.38 & 26.73 & 3 & 1711.8169 & 1711.8153 & 571.6124 & 0.0016 & 0.9330 & 171.544\end{array}$ $\begin{array}{lllllllllllll}0.64 & 11.28 & 26.38 & 17.19 & 3 & 1711.8169 & 1711.8153 & 571.6124 & 0.0016 & 0.9330 & 117.307 & 121.9\end{array}$ $\begin{array}{llllllllllllll}0.66 & 19.30 & 26.28 & 32.30 & 3 & 1711.8172 & 1711.8153 & 571.6124 & 0.0019 & 1.1080 & 172.778 & 165.098\end{array}$ $\begin{array}{llllllllllll}0.66 & 22.28 & 26.26 & 35.28 & 3 & 1711.8175 & 1711.8153 & 571.6124 & 0.0022 & 1.2829 & 193.003 & 150.258\end{array}$ $\begin{array}{lllllllllllll}0.60 & 15.52 & 26.36 & 28.52 & 3 & 1711.8190 & 1711.8153 & 571.6124 & 0.0037 & 2.1576 & 158.842 & 156.062 \\ 1.00 & 53.16 & 26.80 & 20.88 & 2 & 1711.8286 & 1711.8153 & 856.9149 & 0.0133 & 7.7603 & 1445.256 & 1677.373\end{array}$ $\begin{array}{lllllllllllll}1.00 & 53.16 & 26.80 & 20.88 & 2 & 1711.8286 & 1711.8153 & 856.9149 & 0.0133 & 7.7603 & 1445.256 & 1677.373\end{array}$ $\begin{array}{lllllllllllll}1.00 & 66.95 & 26.81 & 19.95 & 2 & 1711.8292 & 1711.8153 & 856.9149 & 0.0139 & 8.1104 & 1681.710 & 1773.450\end{array}$ $\begin{array}{lllllllllllll}1.00 & 70.96 & 26.88 & 19.30 & 3 & 1711.8307 & 1711.8153 & 571.6124 & 0.0154 & 8.9804 & 5717.423 & 6474.448 \\ 1.00 & 66.67 & 26.78 & 22.60 & 2 & 1711.8318 & 1711.8153 & 856.9149 & 0.0165 & 9.6275 & 580.548 & 727.009\end{array}$ $\begin{array}{llllllllllll}1.00 & 66.67 & 26.78 & 22.60 & 2 & 1711.8318 & 1711.8153 & 856.9149 & 0.0165 & 9.6275 & 580.548 & 727.009 \\ 1.00 & 47.63 & 27.54 & 20.84 & 2 & 1446.8180 & 1446.8173 & 724.4159 & 0.0007 & 0.4831 & 166.138 & 202.025\end{array}$

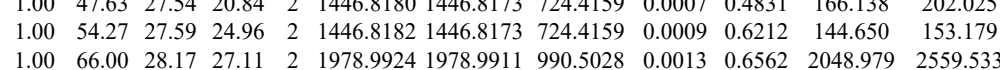
TADDPSLSLIK $\begin{array}{lllllllllllll}\text { WVPFDGDDIQLEFVR } & 1.00 & 72.82 & 28.25 & 29.37 & 2 & 1978.9928 & 1978.9911 & 990.5028 & 0.0017 & 0.8581 & 657.103 & 1083.202\end{array}$ $\begin{array}{llllllllllllll}\text { WVPFDGDDILLEFVR } & 1.00 & 57.12 & 28.14 & 28.34 & 2 & 1978.9920 & 1978.9911 & 990.5028 & 0.0009 & 0.4543 & 162.584 & 161.214\end{array}$ 


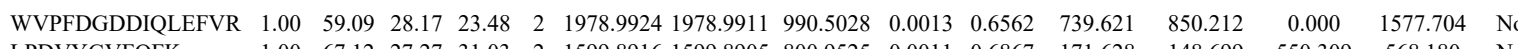
$\begin{array}{lllllllllllllllll}\text { LPDVYGVFQFK } & 1.00 & 67.12 & 27.27 & 31.03 & 2 & 1599.8916 & 1599.8905 & 800.9525 & 0.0011 & 0.6867 & 171.628 & 148.699 & 550.309 & 568.180 & \text { No }\end{array}$

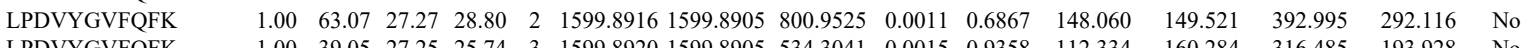
$\begin{array}{lllllllllllllllll}\text { LPDVYGVFQFK } & 1.00 & 39.05 & 27.25 & 25.74 & 3 & 1599.8920 & 1599.8905 & 534.3041 & 0.0015 & 0.9358 & 112.334 & 160.284 & 316.485 & 193.928 & \text { No }\end{array}$ $\begin{array}{llllllllllllllll}\text { LPDVYGVFQF } & 1.00 & 30.98 & 27.22 & 22.02 & 3 & 1599.8935 & 1599.8905 & 534.3041 & 0.0030 & 1.8716 & 129.969 & 150.063 & 242.452 & 234.968 & \text { Yes }\end{array}$

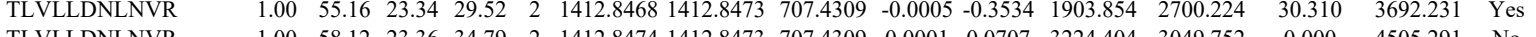

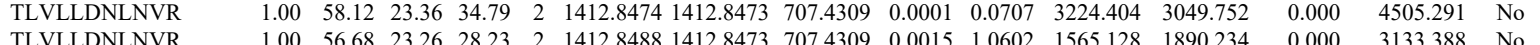

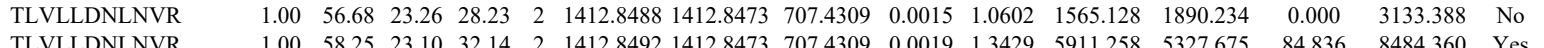

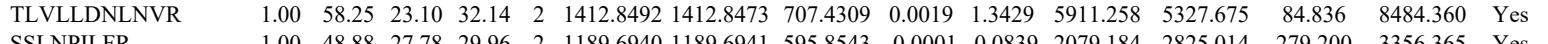
SSLNPILFR SSLNPILFR $\begin{array}{lllllllllllllll}1.00 & 48.88 & 27.78 & 29.96 & 2 & 1189.6940 & 1189.6941 & 595.8543 & -0.0001 & -0.0839 & 2079.184 & 2825.014 & 279.200 & 3356.365 & \text { Yes }\end{array}$ $\begin{array}{llllllllllllll}1.00 & 52.24 & 28.01 & 32.35 & 2 & 189.6940 & 1189.694 & 595.8543 & 0.001 & 0.0839 & 2079.184 & 2825.014 & 279.200 & 3356.365\end{array}$ $\begin{array}{lllllllllllllllll}1.00 & 31.49 & 23.30 & 24.95 & 3 & 1312.7974 & 1312.7948 & 438.6055 & 0.0026 & 1.9760 & 293.313 & 220.221 & 175.806 & 329.208 & \text { Y }\end{array}$ $\begin{array}{lllllllllllllll}1.00 & 53.20 & 23.30 & 31.27 & 2 & 132.7978 & 1312.7948 & 657.404 & 0.0030 & 2.9817 & 9745.460 & 12268.272 & 2781.097 & 14970.424 & \text { Yes }\end{array}$ $\begin{array}{lllllllllllllllll}1.00 & 56.05 & 23.44 & 33.53 & 2 & 13127980 & 1312.7948 & 657.4047 & 0.0032 & 2.4338 & 12576.333 & 14176.432 & 3792.172 & 18539.746 & \text { Yes }\end{array}$ $\begin{array}{llllllllllllllll}0.99 & 34.24 & 23.36 & 29.59 & 3 & 13127986 & 1312.7948 & 438.6055 & 0.0038 & 2.8879 & 372.506 & 408.913 & 155.906 & 653.622 & \text { Yes }\end{array}$ $\begin{array}{llllllllllllllll}1.00 & 62.11 & 27.09 & 27.70 & 2 & 1446.8314 & 1446.8173 & 724.4159 & 0.0141 & 9.7319 & 2223.393 & 2210.451 & 114.238 & 3970.567 & \text { Yes }\end{array}$

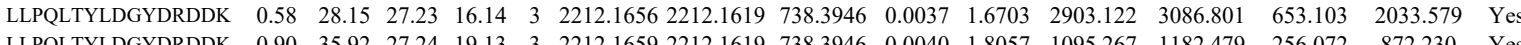

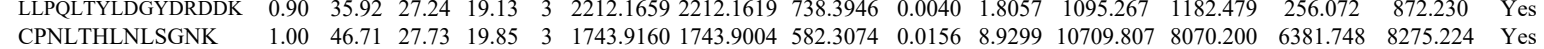
$\begin{array}{lllllllllllllllll}\text { CPNLTHLNLSGNK } & 1.00 & 52.21 & 27.69 & 19.92 & 3 & 1743.9175 & 1743.9004 & 582.3074 & 0.0171 & 9.7885 & 6340.783 & 6378.151 & 4759.334 & 4885.225 & \text { Yes }\end{array}$ $\begin{array}{llllllllllllllll}\text { CPNLTHLNLSGNK } & 1.00 & 49.43 & 27.73 & 20.67 & 3 & 1743.9160 & 1743.9004 & 582.3074 & 0.0156 & 8.9299 & 8957.227 & 7557.838 & 6677.231 & 7925.498 & \text { Yes }\end{array}$ $\begin{array}{lllllllllllllllllll}\text { CPNLTHLNLSGNK } & 1.00 & 68.13 & 27.66 & 26.48 & 2 & 1743.9164 & 1743.9004 & 872.9575 & 0.0160 & 9.1642 & 916.926 & 873.132 & 632.441 & 856.098 & \text { Yes }\end{array}$ $\begin{array}{llllllllllllllll}\text { CPNLTHLNLSGNK } & 1.00 & 45.05 & 27.69 & 21.12 & 3 & 1743.9172 & 1743.9004 & 582.3074 & 0.0168 & 9.6168 & 14325.543 & 13209.840 & 10932.838 & 11448.161 & \text { Yes }\end{array}$ $\begin{array}{lllllllllllllllll}\text { CPNLTHLNLSGNK } & 0.98 & 36.69 & 27.66 & 20.21 & 3 & 1743.9163 & 1743.9004 & 582.3074 & 0.0159 & 9.1016 & 10106.444 & 10386.205 & 6791.963 & 9834.907 & \text { Yes }\end{array}$

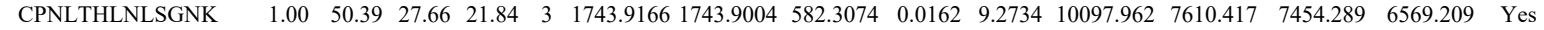

6 WSEPNEEELIK $\begin{array}{lllllllllllllll}1.00 & 48.34 & 28.16 & 25.39 & 2 & 1660.8564 & 1660.8551 & 831.4348 & 0.0013 & 0.7818 & 60.566 & 73.761 & 13.544 & 132.850 & \text { Yes }\end{array}$ $\begin{array}{llllllllllllllll}\text { QLQQAQAAGAEQEVEK } & 0.75 & 13.95 & 26.96 & 16.37 & 3 & 2015.0551 & 2015.0527 & 672.6915 & 0.0024 & 1.1893 & 641.293 & 536.171 & 1212.941 & 816.604 & \text { Yes }\end{array}$ $\begin{array}{llllllllllllllll}\text { EAHQLFLEPEVLDPESVELK } & 0.60 & 42.46 & 26.07 & 55.46 & 3 & 2609.3869 & 2609.3832 & 870.8017 & 0.0037 & 1.4163 & 24.824 & 19.102 & 16.008 & 80.710 & \text { Yes }\end{array}$

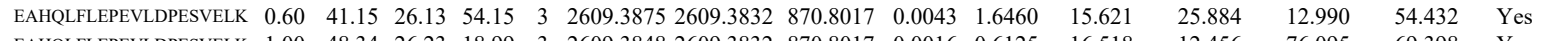
$\begin{array}{llllllllllllllll}\text { EAHQLFLEPEVLDPESVELK } & 1.00 & 48.34 & 26.23 & 18.99 & 3 & 2609.3848 & 2609.3832 & 870.8017 & 0.0016 & 0.6125 & 16.518 & 12.456 & 76.095 & 69.398 & \text { Yes }\end{array}$ $\begin{array}{llllllllllllllll}\text { EAHQLFLEPEVLDPESVELK } & 0.66 & 33.96 & 26.23 & 46.96 & 3 & 2609.3848 & 2609.3832 & 870.8017 & 0.0016 & 0.6125 & 0.000 & 19.798 & 11.206 & 35.139 & \text { No }\end{array}$ $\begin{array}{llllllllllllllll}\text { EAHQLFLEPEVLDPESVELK } & 0.64 & 15.25 & 26.32 & 14.25 & 3 & 2609.3830 & 2609.3832 & 870.8017 & -0.0002 & -0.0766 & 32.268 & 16.037 & 16.127 & 17.482 & \text { No }\end{array}$

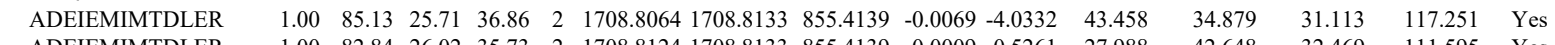
\begin{tabular}{llllllllllllllll} 
ADEIEMIMTDLER & 1.00 & 82.84 & 26.02 & 35.73 & 2 & 1708.8124 & 1708.8133 & 855.4139 & -0.0009 & -0.5261 & 27.988 & 42.648 & 32.469 & 111.595 & Yes \\
\hline PPGSLPAPPPSQLP & 1.00 & 45.73 & 24.93 & 19.67 & 3 & 1712.9818 & 1712908 & 572.0009 & 0.0010 & 0.5827 & 21.713 & 48.499 & 15.031 & 16.513 & Yes
\end{tabular}

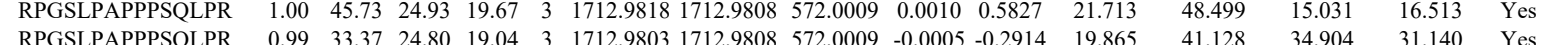

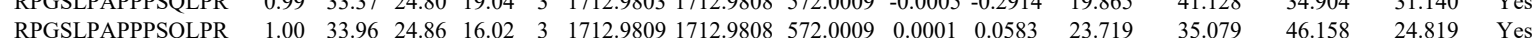

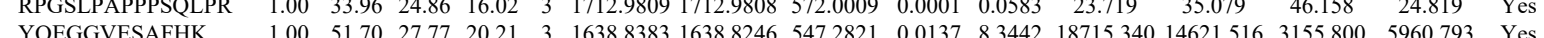
TSTGAPAK TSTGAPAAIK QAALQVAEGFISR QAALQVAEGFISR QAALQVAEGFISR EGNPEEDLTADK EGNPEEDLTADK

06 TNLGPK

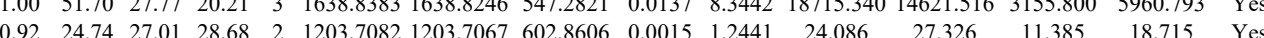

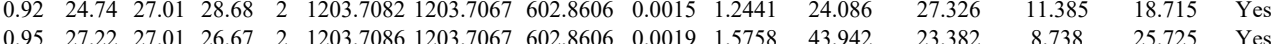

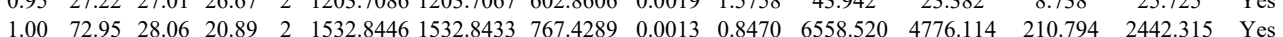
$\begin{array}{llllllllllllllll}1.00 & 74.11 & 27.88 & 24.49 & 2 & 1532.8458 & 1532.8433 & 767.4289 & 0.0025 & 1.6288 & 21187.537 & 13070.495 & 531.237 & 4294.322 & \text { Yes }\end{array}$ $\begin{array}{llllllllllllllll}0.60 & 18.94 & 27.79 & 31.94 & 3 & 1532.8471 & 1532.8433 & 511.9550 & 0.0038 & 2.4742 & 205.412 & 156.612 & 142.774 & 286.654 & \text { No }\end{array}$ $\begin{array}{lllllllllllllll}1.00 & 44.27 & 26.46 & 20.33 & 2 & 1604.7802 & 1604.7773 & 803.3959 & 0.0029 & 1.8048 & 62.651 & 40.730 & 18.524 & 26.923 & \text { Yes }\end{array}$

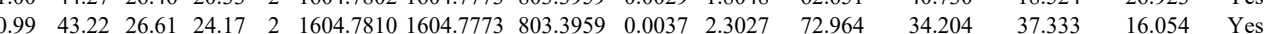
$\begin{array}{llllllllllllllll}0.60 & 24.17 & 26.63 & 23.81 & 2 & 916.5580 & 916.5585 & 459.2865 & -0.0005 & -0.5443 & 394.353 & 456.674 & 198.287 & 435.302 & \text { Yes }\end{array}$ \begin{tabular}{|llllllllllllllll} 
& 93.531 .5396 & 2831.5372 & 944.8530 & 0.0024 & 0.8467 & 20.066 & 14.468 & 10.729 & 32.711 & Yes
\end{tabular}

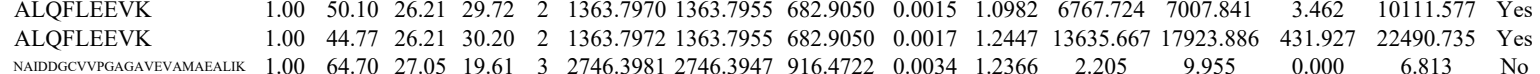
$\begin{array}{lllllllllllllll}0.87 & 28.60 & 26.88 & 26.69 & 2 & 1277.7384 & 1277.7257 & 639.8701 & 0.0127 & 9.9238 & 5068.590 & 4959.498 & 2631.584 & 6357.922 & \text { Yes } \\ 1.00 & 50.10 & 26.21 & 29.72 & 2 & 1363.7970 & 1363.7955 & 68.9050 & 0.0015 & 1.0982 & 6767.724 & 7007.841 & 3.462 & 10111.577 & \text { Yes }\end{array}$ $\begin{array}{llllllllllllllll}\text { VATAQDDTGDGGTAMAELLK } & 1.00 & 64.70 & 27.05 & 19.61 & 3 & 2746.3981 & 2746.3947 & 916.4722 & 0.0034 & 1.2366 & 2.205 & 9.955 & 0.000 & 6.813 & \text { No }\end{array}$ $\begin{array}{llllllllllllllll}\text { VATAQDDITGDGTTSUIGELLK } & 1.00 & 42.54 & 23.52 & 23.51 & 3 & 2831.5387 & 2831.5372 & 944.8530 & 0.0015 & 0.5292 & 27.420 & 38.102 & 12.293 & 9.622 & \text { No }\end{array}$

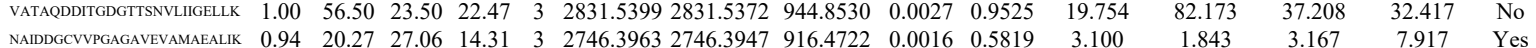
$\begin{array}{llllllllllllllll}\text { NADDDE } & 0.94 & 20.27 & 27.06 & 14.31 & 3 & 2746.3963 & 2746.3947 & 916.4722 & 0.0016 & 0.5819 & 3.100 & 1.843 & 3.167 & 7.917 & \text { Yes }\end{array}$ $\begin{array}{lllllllllllllllll}\text { NARDAREVAMAELLKK } & 0.98 & 25.81 & 27.10 & 16.93 & 3 & 2746.3966 & 2746.3947 & 916.4722 & 0.0019 & 0.6911 & 11.362 & 0.000 & 0.000 & 6.286 & \text { No }\end{array}$

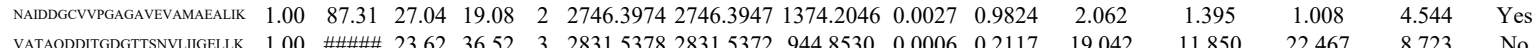

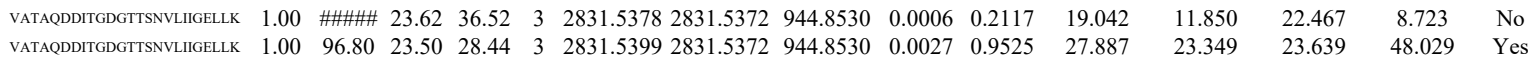
$\begin{array}{cccccccccccccc} & \end{array}$ $\begin{array}{llllllllllllllll}\text { MLVSGAGDIK } & 0.89 & 30.36 & 27.13 & 24.14 & 2 & 1277.7356 & 1277.7257 & 639.8701 & 0.0099 & 7.7359 & 6886.463 & 6360.454 & 5956.443 & 9342.441 & \text { Yes }\end{array}$

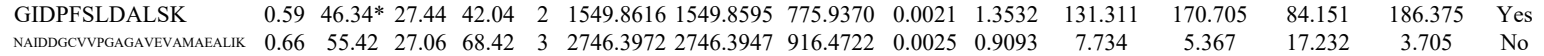

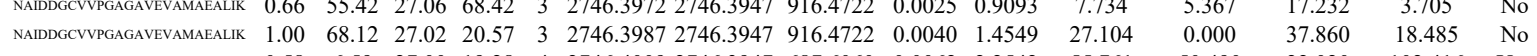
$\begin{array}{llllllllll} & & & \end{array}$ 

\begin{tabular}{llllllllllllllll} 
DGNVLLEMOIOHPTASLIAK & 1.00 & 49.24 & 24.96 & 56.24 & 3 & 26302.4161 & 2632.4145 & 868.4788 & 0.0016 & 0.6141 & 276.562 & 275.984 & 349.848 & 409.111 & Yes \\
\hline
\end{tabular} $\begin{array}{llllllllllllllll} & \end{array}$

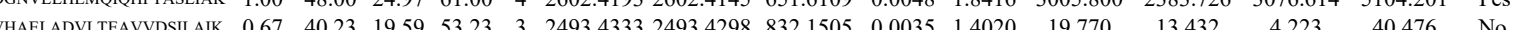
$\begin{array}{llllllllllllll} & \end{array}$

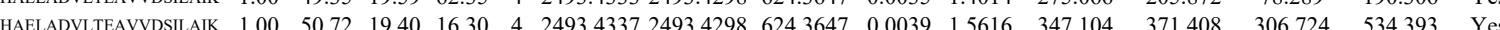

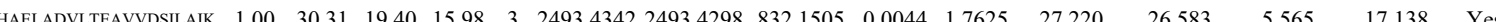
$\begin{array}{lllllllllllllllll}\text { DGNVLHEMOIOHPTASLAK } & 1.00 & 55.77 & 23.71 & 68.77 & 4 & 2402.4397 & 2602.4145 & 651.6109 & 0.0252 & 9.6683 & 1223.474 & 1228.213 & 1141.604 & 1966.713 & \text { Yes }\end{array}$

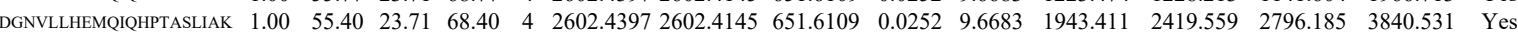
$\begin{array}{lllllllllllllllll}\text { GFVVINQK } & 0.92 & 34.31 & 25.55 & 19.60 & 2 & 1191.7282 & 1191.7219 & 596.8682 & 0.0063 & 5.2775 & 13888.713 & 15935.261 & 8107.975 & 21519.151 & \text { Yes }\end{array}$

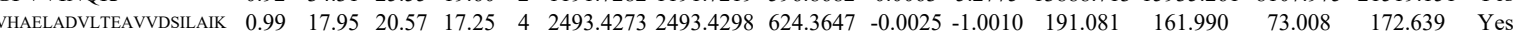
$\begin{array}{llllllllllllllll}\text { VHAELADVLTEAVVDSLLAIK } & 1.00 & 89.91 & 20.00 & 21.92 & 2 & 2493.4294 & 2493.4298 & 1247.7222 & -0.0004 & -0.1603 & 7.042 & 6.942 & 5.575 & 3.508 & \text { Yes }\end{array}$ $\begin{array}{llllllllllllllll}\text { VHAELADVLTEAVVDSILAIK } & 1.00 & 54.65 & 19.68 & 67.65 & 4 & 2493.4305 & 2493.4298 & 624.3647 & 0.0007 & 0.2803 & 34.548 & 16.835 & 6.261 & 31.306 & \text { Yes }\end{array}$ \begin{tabular}{llllllllllllllllll} 
VHAELADVLTEAVVDSILAIK & 1.00 & 49.03 & 19.73 & 62.03 & 4 & 2493.4309 & 2493.4298 & 624.3647 & 0.0011 & 0.4404 & 140.200 & 145.953 & 79.297 & 156.782 & Yes \\
\hline
\end{tabular} $\begin{array}{llllllllllllllllll}\text { VHAELADVLTEAVVDSILAIK } & 1.00 & 54.51 & 19.73 & 17.75 & 4 & 2493.4309 & 2493.4298 & 624.3647 & 0.0011 & 0.4404 & 157.969 & 195.447 & 55.761 & 167.065 & \text { Yes }\end{array}$ $\begin{array}{llllllllllllllll}\text { VHAELADVLTEAVVDSILAIK } & 1.00 & 96.95 & 19.68 & 22.87 & 2 & 2493.4314 & 2493.4298 & 1247.7222 & 0.0016 & 0.6412 & 4.296 & 3.532 & 8.812 & 7.672 & \text { No } \\ \text { VHAELADVLTEAVVDSLAIK } & 0.92 & 4.71 & 19.68 & 15.36 & 4 & 2493.4317 & 2493.4298 & 624.3647 & 0.0019 & 0.7608 & 152892 & 190.242 & 88.749 & 206.008 & \text { Yes }\end{array}$ $\begin{array}{llllllllllllllll}\text { VHAELADVLTEAVVDSILAIK } & 1.00 & 85.51 & 19.78 & 21.68 & 3 & 2493.4324 & 2493.4298 & 832.1505 & 0.0026 & 1.0415 & 41.925 & 39.662 & 34.751 & 81.100 & \text { Yes }\end{array}$

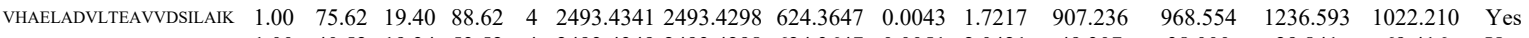
$\begin{array}{llllllllllllllll}\text { VHAELADVLTEAVVDSILAIK } & 1.00 & 40.52 & 19.34 & 53.52 & 4 & 2493.4349 & 2493.4298 & 624.3647 & 0.0051 & 2.0421 & 49.307 & 38.000 & 29.841 & 69.416 & \text { Yes }\end{array}$

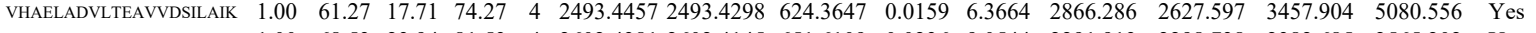

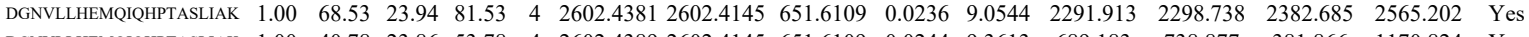

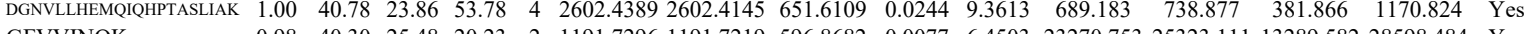

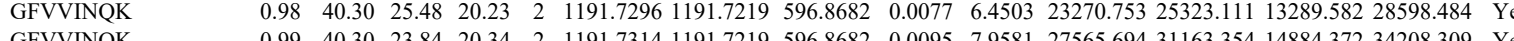

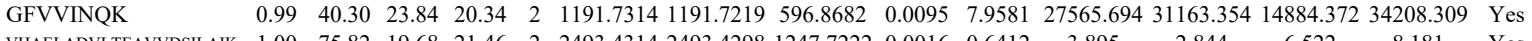

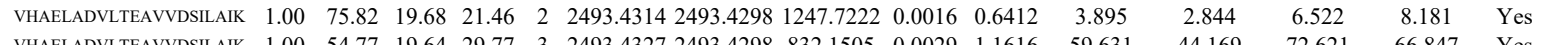

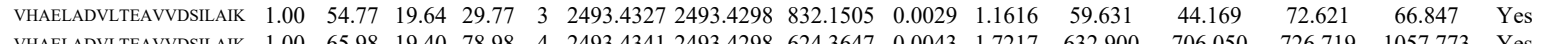
$\begin{array}{llllllllllllllll}\text { HHAELADVLTEAVVDSLAAIK } & 1.00 & 65.98 & 19.40 & 78.98 & 4 & 2493.4341 & 2493.4298 & 624.3647 & 0.0043 & 1.7217 & 632.900 & 706.050 & 726.719 & 1057.773 & \text { Yes }\end{array}$

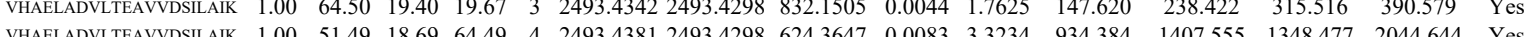

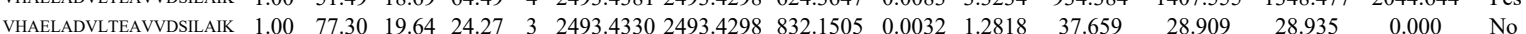

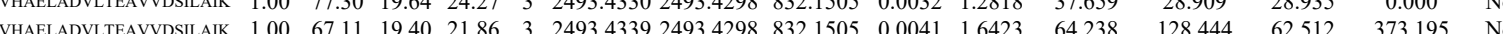
$\begin{array}{llllllllllllll} & & & \end{array}$

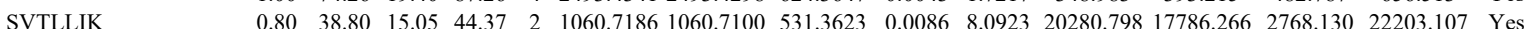

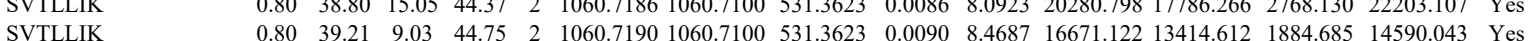
$\begin{array}{llllllllllllllll}\text { VHAELADVLTEAVVDSLAIK } & 1.80 & 73.38 & 19.6 & 23.86 & 3 & 2493.4312 & 2493.4298 & 832.1505 & 0.0014 & 0.5608 & 21.902 & 30.874 & 8.003 & 23.831 & \text { Yes }\end{array}$

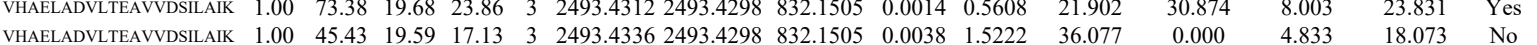

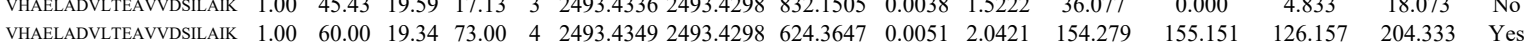
$\begin{array}{lllllllllllllllll}\text { VHAELADVLTEAVVDSILAIK } & 1.00 & 57.87 & 19.24 & 70.87 & 4 & 2493.4353 & 2493.4298 & 624.3647 & 0.0055 & 2.2022 & 337.849 & 298.843 & 242.210 & 338.499 & \text { Yes }\end{array}$ $\begin{array}{llllllllllllllll}\text { SVTLLIK } & 0.96 & 48.45 & 9.03 & 47.46 & 2 & 1060.7200 & 1060.7100 & 531.3623 & 0.0100 & 9.4097 & 8848.016 & 8005.277 & 3623.031 & 9827.033 & \text { Yes }\end{array}$ $\begin{array}{lllllllllllllllll}\text { SVTLLIK } & 0.91 & 31.80 & 9.03 & 34.42 & 2 & 1060.7204 & 1060.7100 & 531.3623 & 0.0104 & 9.7861 & 2479.547 & 1958.898 & 610.745 & 2133.469 & \text { Yes }\end{array}$ $\begin{array}{llllllllllllllll}\text { AQLGVQAFADALLIIPK } & 0.55 & 59.39 & 17.16 & 72.39 & 3 & 2055.2350 & 2055.2336 & 686.0851 & 0.0014 & 0.6802 & 116.064 & 135.422 & 26.988 & 106.100 & \text { Yes }\end{array}$ $\begin{array}{llllllllllllllll}\text { AQLGVQAFADALLIIPK } & 0.66 & 28.77 & 17.16 & 41.77 & 3 & 2055.2359 & 2055.2336 & 686.0851 & 0.0023 & 1.1174 & 80.176 & 68.126 & 27.514 & 106.472 & \text { Yes }\end{array}$ $\begin{array}{lllllllllllllllll}\text { AQLGVQAFADALLIIPK } & 0.67 & 68.84 & 17.16 & 81.84 & 3 & 2055.2362 & 2055.2336 & 686.0851 & 0.0026 & 1.2632 & 73.410 & 74.898 & 58.542 & 121.633 & \text { Yes }\end{array}$

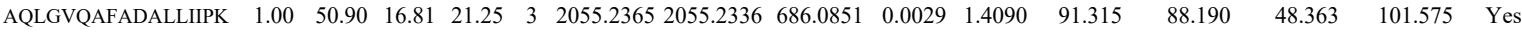

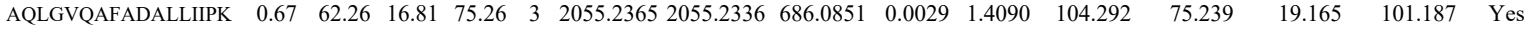

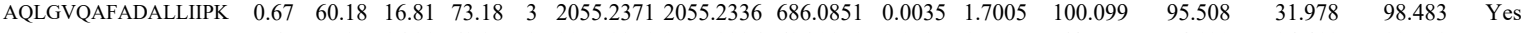
$\begin{array}{llllllllllllllll}\text { AQLGVQAFADALLIIPK } & 0.67 & 55.35 & 16.81 & 68.35 & 3 & 2055.2371 & 2055.2336 & 686.0851 & 0.0035 & 1.7005 & 64.577 & 74.120 & 24.419 & 89.528 & \text { Yes }\end{array}$

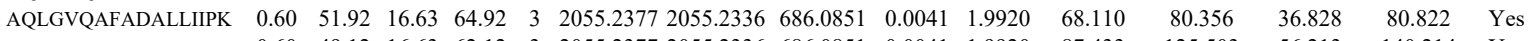
$\begin{array}{llllllllllllllll}\text { AQLGVQAFADALLIIPK } & 0.60 & 49.12 & 16.63 & 62.12 & 3 & 2055.2377 & 2055.2336 & 686.0851 & 0.0041 & 1.9920 & 87.433 & 125.503 & 56.213 & 140.214 & \text { Yes }\end{array}$ $\begin{array}{llllllllllllllll}\text { AQLGVQAFADALLIIPK } & 0.60 & 63.94 & 16.63 & 76.94 & 3 & 2055.2380 & 2055.2336 & 686.0851 & 0.0044 & 2.1377 & 93.348 & 152.071 & 53.115 & 153.815 & \text { Yes }\end{array}$ $\begin{array}{llllllllllllllll}\text { AQLGVQAFADALLIIPK } & 1.00 & 49.77 & 17.16 & 20.45 & 3 & 2055.2350 & 2055.2336 & 686.0851 & 0.0014 & 0.6802 & 118.869 & 60.148 & 48.666 & 104.661 & \text { Yes } \\ \text { AQLGVQAFADALLIIPK } & 1.00 & 91.92 & 17.16 & 22.86 & 2 & 2055.2354 & 2055.2336 & 1028.6241 & 0.0018 & 0.8750 & 23.443 & 14.962 & 13.171 & 18321 & \text { Yes }\end{array}$

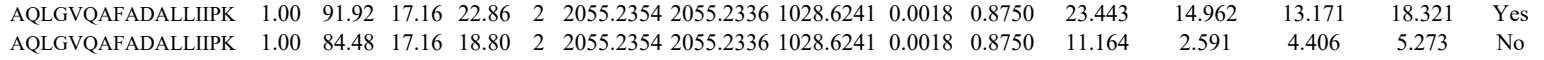

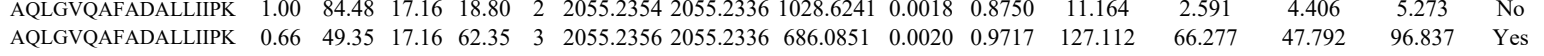

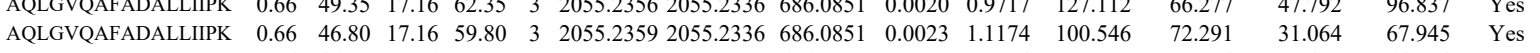

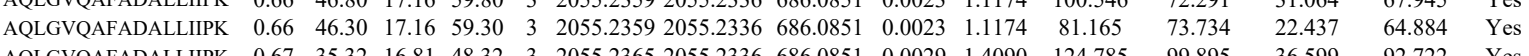
$\begin{array}{lllllllllllllll} & & 0.82 .722 & \text { Yes }\end{array}$ $\begin{array}{llllllllllllllll}\text { AQLGVQAFADALLIIPK } & 0.67 & 32.53 & 16.81 & 45.53 & 3 & 2055.2365 & 2055.2336 & 866.0851 & 0.0029 & 1.4090 & 96.192 & 94.570 & 38.448 & 98.040 & \text { Yes } \\ \text { AQLGVQAFADALLIIPK } & 0.67 & 39.39 & 16.81 & 52.39 & 3 & 2055.2365 & 2055.2336 & 686.0851 & 0.0029 & 1.4090 & 84.445 & 117.629 & 21.580 & 117.813 & \text { Yes }\end{array}$

Table S-4 page 297 of 614 
$\begin{array}{lllllllllll}0.51 & 93.35 & 16.02 & \# \# \# \text { 2 } & 2 & 2055.2434 & 2055.2336 & 1028.6241 & 0.0098 & 4.7636\end{array}$

8.325

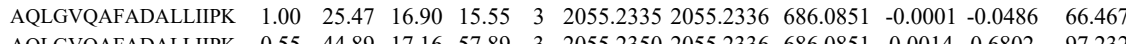

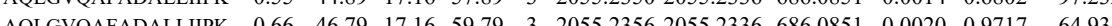

\begin{tabular}{llllllllllllll}
\hline AQLGVQAFADALLIPK & 0.66 & 30.44 & 17.16 & 43.44 & 3 & 2055.2356 & 2055.2336 & 686.0851 & 0.0020 & 0.9717 & 55.563
\end{tabular}

$\begin{array}{llllllllllllll}\text { QLLHSCTVIATNILLVDEIMR } & 1.00 & 79.45 & 25.56 & 22.63 & 3 & 2571.3703 & 2571.3708 & 858.1309 & -0.0005 & -0.1942 & 18.029\end{array}$

$\begin{array}{llllllllllll}\text { EGIVALRR } & 0.91 & 49.54 & 24.42 & 48.71 & 2 & 1056.6578 & 1056.6525 & 529.3335 & 0.0053 & 5.0063 & 504.793\end{array}$

EGIVALRR

$\begin{array}{lllllllllll}0.97 & 49.36 & 24.42 & 43.33 & 2 & 1056.6578 & 1056.6525 & 529.3335 & 0.0053 & 5.0063 & 769.729 \\ 1.00 & 87.63 & 26.12 & 21.62 & 2 & 1398.8062 & 1398.8065 & 700.4105 & -0.003 & 0.2142 & 201.918\end{array}$

$\begin{array}{lllllllllll}1.00 & 87.63 & 26.12 & 21.62 & 2 & 1398.8062 & 1398.8065 & 700.4105 & -0.0003 & -0.2142 & 201.918 \\ 1.00 & 85.51 & 26.33 & 27.14 & 2 & 1398.8066 & 1398.8065 & 700.4105 & 0.0001 & 0.0714 & 330.416\end{array}$

AQAALAVNISAAR

$\begin{array}{lllllllllll}1.00 & 85.51 & 26.33 & 27.14 & 2 & 1398.8066 & 1398.8065 & 700.4105 & 0.0001 & 0.0714 & 330.416 \\ 0.66 & 49.96 & 17.16 & 62.96 & 3 & 2055.2359 & 2055.2336 & 686.0851 & 0.0023 & 1.1174 & 10.574\end{array}$

AQLGVQAFADALLIIPK

EGIVALRR

EGIVALRR

$\begin{array}{llllllllllll}0.67 & 58.47 & 16.81 & 71.47 & 3 & 2055.2365 & 2055.2336 & 686.0851 & 0.0029 & 1.4090 & 15.761 \\ 0.81 & 16.87 & 23.40 & 26.82 & 2 & 1056.6534 & 1056.6525 & 529.3335 & 0.0009 & 0.8501 & 20.793\end{array}$

EGIVALRR

$\begin{array}{lllllllllllll}0.97 & 48.49 & 24.42 & 42.40 & 2 & 1056.6576 & 1056.6525 & 529.3335 & 0.0051 & 4.8174 & 2053.961 & 26\end{array}$

AQAALAVNISAAR

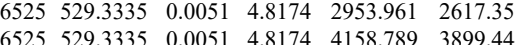

$\begin{array}{llllllllllll}1.00 & 83.01 & 26.28 & 26.97 & 2 & 1398.8070 & 1398.8065 & 700.4105 & 0.0005 & 0.3569 & 373.993\end{array}$

$\begin{array}{lllllllllll}0.67 & 59.46 & 16.81 & 72.46 & 3 & 2055.2368 & 2055.2336 & 686.0851 & 0.0032 & 1.5547 & 21.678\end{array}$

EGIVALRR

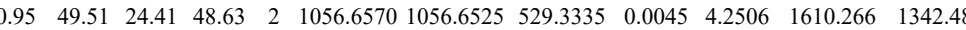

AQLGVQAFADALLIIPK

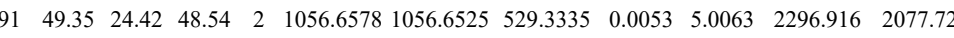

$\begin{array}{llllllllllll} & \end{array}$

AQAALAVNISAAR

AQAALAVNISAAR

AQAALAVNISAAR

$\begin{array}{lllllllllllll}17.60 & 6.09 & 3 & 2055.2374 & 2055.2336 & 686.0851 & 0.0038 & 1.8462 & 13.087 & 17.898\end{array}$

AQAALAVNISAAR

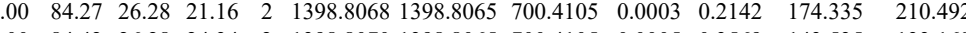
$\begin{array}{llllllllllll}1.00 & 84.42 & 26.28 & 24.34 & 2 & 1398.8070 & 1398.8065 & 700.4105 & 0.0005 & 0.3569 & 143.535\end{array}$ $\begin{array}{lllllllllllll}1.00 & 84.42 & 26.28 & 24.34 & 2 & 1398.8070 & 1398.8065 & 700.4105 & 0.005 & 0.3569 & 143.535\end{array}$ $\begin{array}{llllllllllll}0.65 & 15.38 & 26.27 & 16.61 & 3 & 1398.8068 & 1398.8065 & 467.2761 & 0.0003 & 0.2140 & 86.678\end{array}$

QQAALAVISAAR $\begin{array}{lllllllllllll}1.00 & 71.70 & 26.28 & 23.21 & 2 & 1398.8070 & 1398.8065 & 700.4105 & 0.0005 & 0.3569 & 81.753\end{array}$

AQAALAVNISAAR $\begin{array}{lllllllllll}.00 & 87.08 & 26.43 & 19.80 & 2 & 1398.8078 & 1398.8065 & 700.4105 & 0.0013 & 0.9280 & 75.869\end{array}$ $\begin{array}{lllllllllll} & \end{array}$ $\begin{array}{llllllllllll} & 0.05\end{array}$

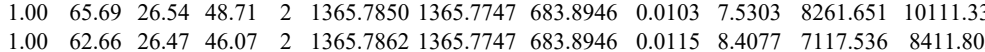

$\begin{array}{lllllllllllll}1.00 & 66.12 & 26.73 & 30.71 & 2 & 1539.8534 & 1539.8388 & 770.9267 & 0.0146 & 9.4690 & 2658.913 & 3831.910\end{array}$

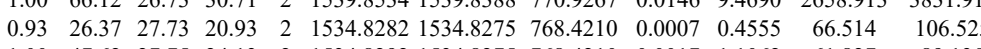
$\begin{array}{lllllllllllll}1.00 & 47.62 & 27.75 & 24.13 & 2 & 1534.8292 & 1534.8275 & 768.4210 & 0.0017 & 1.1062 & 61.827 & 89.135\end{array}$ $\begin{array}{llllllllllll}0.78 & 24.20 & 27.19 & 27.11 & 2 & 962.4730 & 962.4725 & 482.2435 & 0.0005 & 0.5184 & 56.460\end{array}$ $\begin{array}{llllllllllllll}0.80 & 20.49 & 27.30 & 24.67 & 2 & 962.4736 & 962.4725 & 482.2435 & 0.0011 & 1.1405 & 31.949 & 40.749\end{array}$

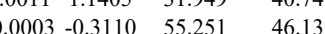

MNTNPSR

LAAIVAK $\begin{array}{llllllllllll}0.57 & 19.80 & 27.19 & 26.00 & 2 & 962.4728 & 962.4725 & 482.2435 & 0.0003 & 0.3110 & 36.622 & 66.826 \\ 0.74 & 2.93 & 27.01 & 27.71 & 2 & 962.4724 & 962.4725 & 482.2435 & 0.0001 & 0.1037 & 11.862 & 24.950\end{array}$

LAAIVAK

LAAIVAK

MVVAALK

LAAIVAK

CEGINISGNFYR

CEGINISGNFYR

CEGINISGNFY
FAYLGR

FAYLGR $\begin{array}{lllllllllllll}0.74 & 22.93 & 27.01 & 27.71 & 2 & 962.4724 & 962.4725 & 482.2435 & -0.0001 & -0.1037 & 11.862 & 24.950\end{array}$ $\begin{array}{lllllllllllllll}1.00 & 44.86 & 21.55 & 25.19 & 2 & 972.6626 & 972.6575 & 487.3360 & 0.0051 & 5.2325 & 29698.994 & 32606.663 & 1657.938 & 66810.599 & \text { Yes }\end{array}$ $\begin{array}{lllllllllllllll}0.98 & 37.27 & 23.14 & 17.80 & 2 & 1115.7048 & 1115.6980 & 558.8563 & 0.0068 & 6.0838 & 8787.535 & 10289.496 & 713.265 & 14172.555 & \text { Yes }\end{array}$ $\begin{array}{lllllllllllllll}0.98 & 36.99 & 23.07 & 16.35 & 2 & 1115.7062 & 1115.6980 & 558.8563 & 0.0082 & 7.3364 & 12433.404 & 12858.615 & 1026.371 & 17347.220 & \text { Yes }\end{array}$ $\begin{array}{lllllllllllllll}0.99 & 42.98 & 21.55 & 21.96 & 2 & 972.6638 & 972.6575 & 487.3360 & 0.0063 & 6.4637 & 16265.228 & 17372.273 & 1952.149 & 29538.492 & \text { Yes }\end{array}$ $\begin{array}{llllllllllllllll}0.85 & 24.39 & 22.97 & 17.80 & 2 & 1115.7082 & 115.6980 & 558.8563 & 0.0102 & 9.1257 & 12319.709 & 12703.746 & 1185.300 & 17815.813 & \text { Yes } \\ 1.00 & 0.60 & 2.35 & 20.09 & 2 & 1561.7152 & 1561.7139 & 781.8642 & 0.0013 & 0.8313 & 3974.571 & 471.934 & 0.000 & 942.890 & \text { No }\end{array}$ $\begin{array}{llllllllllllllll}1.00 & 6.60 & 24.35 & 20.09 & 2 & 1561.7152 & 1561.7139 & 781.8642 & 0.0013 & 0.8313 & 3974.571 & 4711.934 & 0.000 & 9425.990 & \text { No } \\ 1.00 & 55.39 & 24.38 & 20.35 & 2 & 1561.7156 & 15617139 & 781.8642 & 0.0017 & 1.0871 & 4220.707 & 4499.758 & 0.000 & 10683.19 & \text { No }\end{array}$ $\begin{array}{lllllllllllllll}1.00 & 55.39 & 24.38 & 20.35 & 2 & 1561.7156 & 1561.7139 & 781.8642 & 0.0017 & 1.0871 & 4220.707 & 4499.758 & 0.000 & 10683.219 & \text { No } \\ 1.00 & 54.54 & 24.38 & 18.65 & 2 & 1561.7148 & 1561.7139 & 781.8642 & 0.0009 & 0.5755 & 1006.429 & 756363 & 228.193 & 1898.200 & \text { Yes }\end{array}$

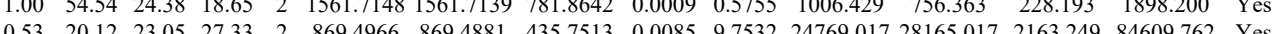
$\begin{array}{llllllllllllllll}0.53 & 20.12 & 23.05 & 27.33 & 2 & 869.4966 & 869.4881 & 435.713 & 0.0085 & 9.7532 & 24769.017 & 286165.017 & 2163.249 & 84609.762 & \text { Yes } \\ 0.86 & 26.23 & 27.03 & 23.21 & 2 & 925510 & 925.5507 & 463.7826 & 0.003 & 0.323 & 9278.424 & 13174.286 & 2033.704 & 68250.551 & \text { Yes }\end{array}$

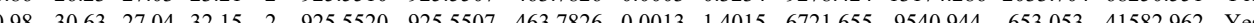
$\begin{array}{lllllllllllllllll}0.98 & 30.63 & 27.04 & 32.15 & 2 & 925.5520 & 925.5507 & 463.7826 & 0.0013 & 1.4015 & 6721.655 & 9540.944 & 653.053 & 41582.962 & \text { Yes } \\ 0.85 & 26.16 & 27.02 & 22.65 & 2 & 925.5512 & 925.5507 & 463.7826 & 0.0005 & 0.5390 & 5099.843 & 6907.727 & 1120.763 & 33646.158 & \text { Yes }\end{array}$ 


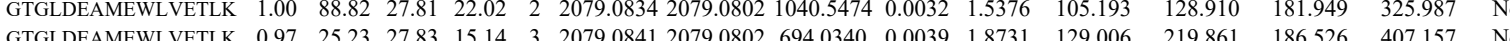
$\begin{array}{llllllllllllllll}\text { GTGLDEAMEWLVETLK } & 0.99 & 30.30 & 27.76 & 20.71 & 3 & 2079.0847 & 2079.0802 & 694.0340 & 0.0045 & 2.1613 & 74.019 & 128.398 & 52.051 & 407.157 & \text { No }\end{array}$ $\begin{array}{lllllllllllllll} & \text { G }\end{array}$ $\begin{array}{llllllllllllllll}\text { GTGLDEAMEWLVETLK } & 1.00 & 76.34 & 27.87 & 21.38 & 2 & 2079.0814 & 2079.0802 & 1040.5474 & 0.0012 & 0.5766 & 15.149 & 3.141 & 7.260 & 18.126 & \text { No }\end{array}$

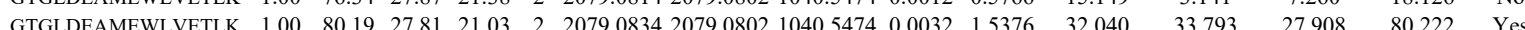

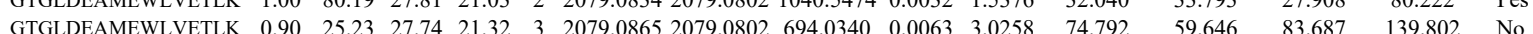
$\begin{array}{llllllllllllllll}\text { GTGLDEAMEWLVETLK } & 0.98 & 33.62 & 27.72 & 28.08 & 3 & 2079.0871 & 2079.0802 & 694.0340 & 0.0069 & 3.3139 & 69.479 & 74.338 & 31.266 & 106.108 & \text { Yes }\end{array}$ $\begin{array}{lllllllllllllll}\text { GTGDEAMEWLVETLK } & 0.62 & 15.60 & 27.75 & 14.60 & 3 & 2079.08562079 .0802 & 694.0340 & 0.0054 & 2.5935 & 35.129 & 27.250 & 12.975 & 26.788 & \text { Yes } \\ \text { GTGLDEAME } & \text { Yes }\end{array}$ $\begin{array}{llllllllllllllll}\text { GTGLDEAMEWLVETLK } & 0.92 & 26.22 & 27.76 & 16.75 & 3 & 2079.0859 & 2079.0802 & 694.0340 & 0.0057 & 2.7376 & 60.516 & 50.734 & 55.108 & 94.073 & \text { No }\end{array}$

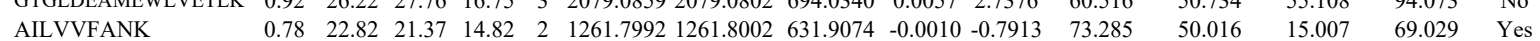

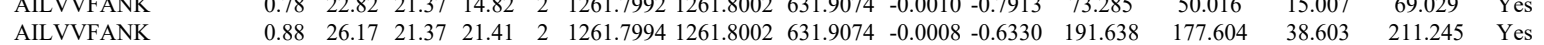
$\begin{array}{llllllllllllllll}\text { AILVVFANK } & 0.98 & 25.82 & 20.79 & 21.91 & 2 & 1261.8010 & 1261.8002 & 631.9074 & 0.0008 & 0.6330 & 285.887 & 221.989 & 37.793 & 245.969 & \text { Yes }\end{array}$ $\begin{array}{llllllllllllllll}\text { AILVVFANK } & 0.98 & 26.23 & 20.79 & 21.97 & 2 & 1261.8012 & 1261.8002 & 631.9074 & 0.0010 & 0.7913 & 196.932 & 188.330 & 23.687 & 233.995 & \text { Yes }\end{array}$ $\begin{array}{llllllllllllllll}\text { AILVVFANK } & 0.55 & 20.73 & 20.68 & 33.73 & 3 & 1261.8016 & 1261.8002 & 421.6073 & 0.0014 & 1.1069 & 4628.491 & 4606.822 & 138.976 & 4320.277 & \text { Yes }\end{array}$

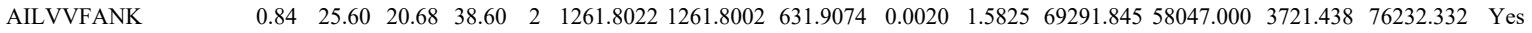
$\begin{array}{llllllllllllllll}\text { AILVVFANK } & 0.67 & 29.13 & 20.68 & 42.13 & 3 & 1261.8031 & 1261.8002 & 421.6073 & 0.0029 & 2.2928 & 1968.639 & 2599.672 & 85.171 & 2969.454 & \text { Yes }\end{array}$ AILVVFANK AILVVFANK AILVVFANK

AILVVFANK

AILVVFANK

AILVVFANK

AILVVFANK

AILVVFANK AILVVFANK AILVVFANK AILVVFANK AILVVFANK AILVVFANK

AILVVANK

AILVVFANK

SELVAMLEEEELR

AILVVFANK

AILVVFANK

AILVVFANK

AILVVFANK

AILVVFANK

AILVVFANK

AILVVFANK

AILVVFANK

AILVVFANK

AILVVFANK

AILVVFANK

AILVVFANK $\begin{array}{llllllllllllll}\text { STAT3_HUMAR } & \text { P40763 } & \text { STAT3 } & \text { Signal transducer : } 88.068 & 1.00 & 6 & 11.9 & 0.1330 & 0.5022 & 0.8144 & 0.5301 & 17 & \text { KLEELQQK } \\ \text { KLEELQQK }\end{array}$

$\begin{array}{lllllllllllllll}0.98 & 31.48 & 20.86 & 18.44 & 2 & 1261.8038 & 1261.8002 & 631.9074 & 0.0036 & 2.8485 & 48238.036 & 39776.890 & 3459.520 & 49784.431 & \text { Yes }\end{array}$

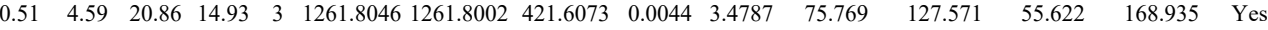
$\begin{array}{lllllllllllllll}0.55 & 29.38 & 20.68 & 42.38 & 3 & 1261.8016 & 1261.8002 & 421.6073 & 0.0014 & 1.1069 & 2679.532 & 2388.267 & 207.845 & 3035.937 & \text { Yes }\end{array}$

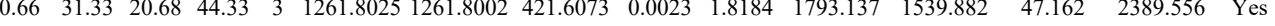
$\begin{array}{llllllllllllllll}0.97 & 25.62 & 20.68 & 15.48 & 2 & 1261.8030 & 1261.8002 & 631.9074 & 0.0028 & 2.2155 & 42721.887 & 39470.521 & 933.458 & 41597.668 & \text { Yes }\end{array}$

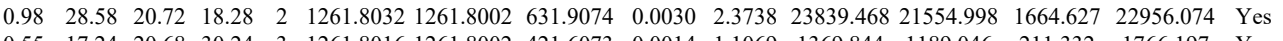
$\begin{array}{lllllllllllllllll}0.55 & 17.24 & 20.68 & 30.24 & 3 & 1261.8016 & 1261.8002 & 421.6073 & 0.0014 & 1.1069 & 1369.844 & 1189.046 & 211.332 & 1766.197 & \text { Yes }\end{array}$

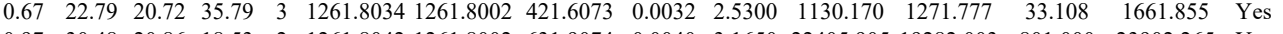
$\begin{array}{lllllllllllllll}0.97 & 30.48 & 20.86 & 18.53 & 2 & 1261.8042 & 1261.8002 & 631.9074 & 0.0040 & 3.1650 & 22405.905 & 19282.003 & 801.000 & 23902.265 & \text { Yes }\end{array}$

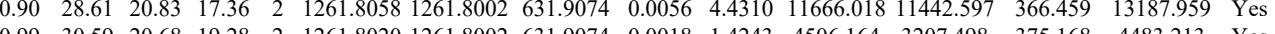

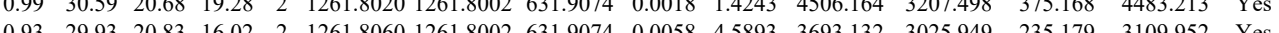

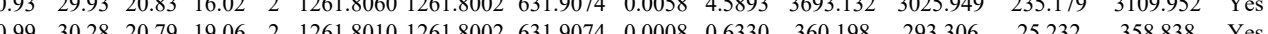

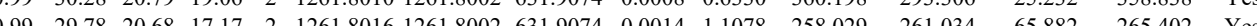

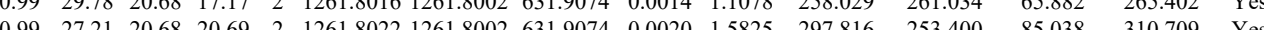

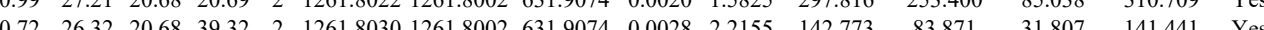

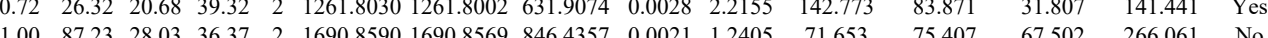

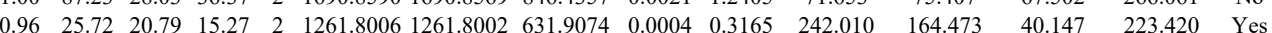

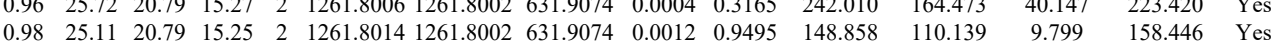
$\begin{array}{lllllllllllllll}0.99 & 26.12 & 20.68 & 20.00 & 2 & 1261.8026 & 1261.8002 & 631.9074 & 0.0024 & 1.8990 & 118.800 & 77.511 & 17.291 & 98.972 & \text { Yes }\end{array}$

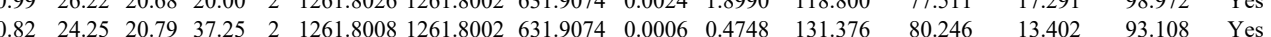
$\begin{array}{lllllllllllllll}0.98 & 24.35 & 20.79 & 15.73 & 2 & 1261.8014 & 1261.8002 & 631.9074 & 0.0012 & 0.9495 & 105.921 & 87.418 & 14.523 & 99.980 & \text { Yes }\end{array}$ $\begin{array}{lllllllllllllll}0.98 & 26.15 & 20.79 & 15.77 & 2 & 1261.8008 & 1261.8002 & 631.9074 & 0.0006 & 0.4748 & 80.051 & 67.466 & 26.709 & 70.663 & \text { Yes }\end{array}$ $\begin{array}{lllllllllllllll}0.82 & 23.95 & 20.68 & 36.95 & 2 & 1261.8016 & 1261.8002 & 631.9074 & 0.0014 & 1.1078 & 105.151 & 90.232 & 3.377 & 88.649 & \text { Yes }\end{array}$ $\begin{array}{lllllllllllllll}0.72 & 24.53 & 20.72 & 37.53 & 2 & 1261.8034 & 1261.8002 & 631.9074 & 0.0032 & 2.5320 & 72.770 & 98.101 & 22.328 & 60.737 & \text { No }\end{array}$ $\begin{array}{lllllllllllllllll}0.64 & 26.14 & 21.21 & 39.14 & 2 & 1261.8004 & 1261.8002 & 631.9074 & 0.0002 & 0.1583 & 72.820 & 83.279 & 17.828 & 79.551 & \text { Yes }\end{array}$

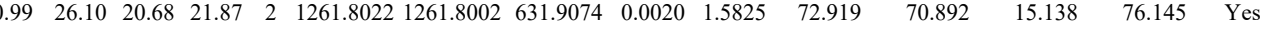
$\begin{array}{lllllllllllllll}0.97 & 25.58 & 20.68 & 15.62 & 2 & 1261.8030 & 1261.8002 & 631.9074 & 0.0028 & 2.2155 & 69.473 & 49.724 & 13.468 & 55.379 & \text { Yes }\end{array}$

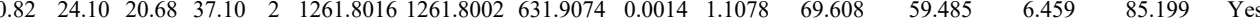
$\begin{array}{llllllllllllllll}0.84 & 22.39 & 20.68 & 35.39 & 2 & 1261.8022 & 1261.8002 & 631.9074 & 0.0020 & 1.5825 & 86.914 & 57.681 & 20.314 & 67.853 & \text { Yes } & \\ \end{array}$ $\begin{array}{llllllllllllllll}0.85 & 28.88 & 22.10 & 32.03 & 3 & 1446.8830 & 1446.8771 & 483.2996 & 0.0059 & 4.0692 & 13204.399 & 11425.126 & 1818.030 & 13606.087 & \text { Yes } & \\ 0.93 & 35.50 & 21.73 & 32.29 & 3 & 14468872 & 1446.8771 & 483.2996 & 0.0101 & 6.9660 & 10417.602 & 8343.652 & 1265.110 & 10695.080 & \text { Yes }\end{array}$ $\begin{array}{lccccccccccccccc} & 0.93 & 35.50 & 21.73 & 32.29 & 3 & 1446.8872 & 1446.8771 & 483.2996 & 0.0101 & 6.9660 & 10417.602 & 8343.652 & 1265.110 & 10695.080 & \text { Yes } \\ \text { SIVSELAGLLSAMEYVQK } & 1.00 & 92.53 & 25.05 & 30.09 & 2 & 2225.2234 & 2225.2221 & 1113.6183 & 0.0013 & 0.5837 & 8.252 & 9.605 & 8.596 & 20.006 & \text { Yes }\end{array}$ $\begin{array}{llllllllllllllll}\text { SIVSELAGLLSAMEYVQK } & 1.00 & 63.43 & 24.81 & 21.05 & 3 & 2225.2267 & 2225.2221 & 7113.6183 & 0.0013 & 0.5837 & 8.252 & 9.605 & 8.596 & 20.006 & \text { Yes } \\ \text { S } & 74.0046 & 0.0644 & 16.165 & 41.236 & 34.126 & 30.125 & \text { Yes }\end{array}$

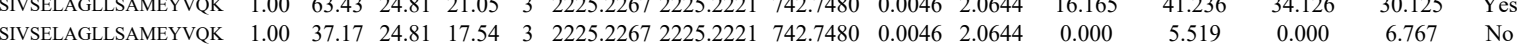

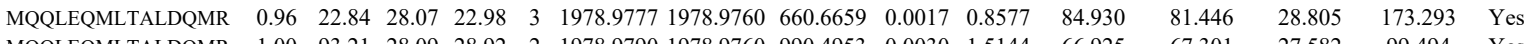
\begin{tabular}{llllllllllllllll} 
MQQLEQMLTALDQMR & 1.00 & 93.21 & 28.09 & 28.92 & 2 & 1978.9790 & 1978.9760 & 990.4953 & 0.0030 & 1.5144 & 66.925 & 67.301 & 27.582 & 99.494 & Yes \\
\hline
\end{tabular}

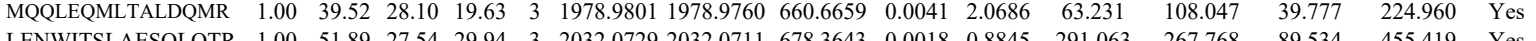
\begin{tabular}{lllllllllllllllll} 
& LENWITSLAESQLQTR & 1.00 & 51.89 & 27.54 & 29.94 & 3 & 2032.0729 & 2032.0711 & 678.3643 & 0.0018 & 0.8845 & 291.063 & 267.768 & 89.534 & 455.419 & Yes \\
\hline
\end{tabular}

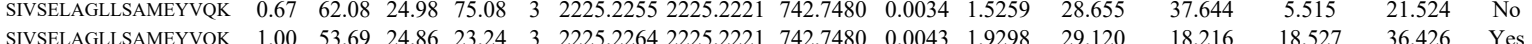
$\begin{array}{lllllllllllllll} & \end{array}$

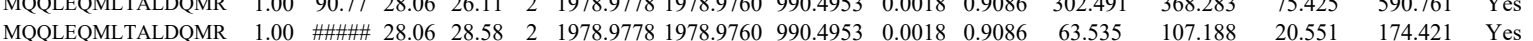

Table S-4 page 299 of 614 
$\begin{array}{llllllllllllllll}.8 .61 & 36.33 & 21.88 & 36.43 & 3 & 1446.8860 & 1446.8771 & 483.2996 & 0.0089 & 6.1383 & 14715.124 & 13610.980 & 1942.470 & 18600.667 & \text { Yes }\end{array}$ GEFVTTVQQR $\begin{array}{llllllllllll} & \end{array}$ $\begin{array}{lllllllllllllll}1.00 & 57.85 & 28.49 & 28.58 & 2 & 1307.6996 & 1307.6956 & 654.8551 & 0.0040 & 3.0541 & 18048.093 & 16770.076 & 3104.354 & 21933.518 & \text { Yes } \\ 1.00 & 59.92 & 28.49 & 28.69 & 2 & 1307.6996 & 1307.6956 & 6548551 & 0.0040 & 3.0541 & 20380.877 & 16542788 & 3318.907 & \end{array}$

GEFVTTVQQR

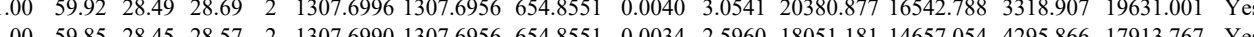
$\begin{array}{lllllllllllllll}1.00 & 58.19 & 28.49 & 28.44 & 2 & 1307.6996 & 1307.6956 & 654.8551 & 0.0040 & 3.0541 & 20168.766 & 15324.947 & 3843.181 & 21628.191 & \text { Yes } \\ 1.00 & 5.55 & 28.45 & 8.69 & 2 & 1307.692 & 1307.656 & 654.8551 & 0.036 & 2.748 & 8222.646 & 577.199 & 1917.36 & 8779.528 & \text { Yes }\end{array}$ $\begin{array}{llllllllllllll} & & & \end{array}$

6 MISDAIPELK

MISDAIPELK MISDAIPELK

ANTFVAELK

ANTFVAELK

GYLGPEQLPDCLK

GYLGPEQLPDCLK

GYLGPEQLPDCLK

GYLGPEQLPDCLK

GYLGPEQLPDCLK

GYLGPEQLPDCLK

GYLGPEQLPDCLK

GYLGPEQLPDCLK

SQETECTYFSTPLLLGK

LTLYDIAHTPGVAADLSHIETK

LILYDIAHTPGVAADLSHIETK
LTLDIAHTPGVAADLSHIETK
NSPLVSR $\begin{array}{llllllllllllllll}\text { NSPLVSR } & 0.74 & 22.31 & 26.29 & 18.55 & 2 & 915.5262 & 915.5260 & 458.7703 & 0.0002 & 0.2180 & 165.443 & 163.470 & 68.355 & 190.424 & \text { Yes } \\ \text { NSPLVSR } & 0.78 & 23.14 & 26.29 & 24.77 & 2 & 915.5262 & 915.5260 & 458.7703 & 0.0002 & 0.2180 & 100.107 & 120.939 & 13.188 & 170.191 & \text { Yes } \\ \text { LTLYDIAHTPGVAALSHIETK } & 0.66 & 75.02 & 24.76 & 88.02 & 3 & 2652.4387 & 2652.4366 & 885.1528 & 0.0021 & 0.7908 & 1278.453 & 1452.816 & 1487.829 & 2117.285 & \text { Yes }\end{array}$ $\begin{array}{lllllllllll}0.60 & 91.97 & 21.73 & \text { \# } & 2872.5982 & 2872.5942 & 958.5387 & 0.0040 & 1.3910 & 3.761 \\ 0.60 & 66.73 & 21.64 & 79.73 & 3 & 2872.5988 & 2872.5942 & 958.5387 & 0.0046 & 1.5997 & 1.853\end{array}$ $\begin{array}{lllllllllllllll}1.00 & 55.72 & 27.19 & 28.68 & 2 & 1403.7956 & 1403.7937 & 702.9041 & 0.0019 & 1.3515 & 6380.711 & 7733.529 & 89.103 & 0.000 & \text { No }\end{array}$ $\begin{array}{llllllllllllll}1 & & \end{array}$

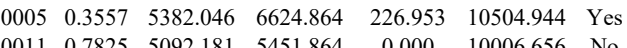
$\begin{array}{llll} & 1865.306 & \text { Yes }\end{array}$ $\begin{array}{lllllllllllllll}1.00 & 64.60 & 28.12 & 37.17 & 2 & 1765.9016 & 1765.8986 & 883.9566 & 0.0030 & 1.6969 & 2442.424 & 2984.448 & 747.362 & 3640.037 & \text { Yes }\end{array}$

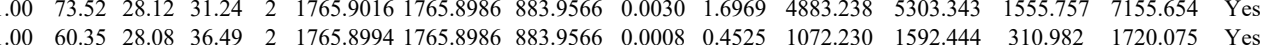

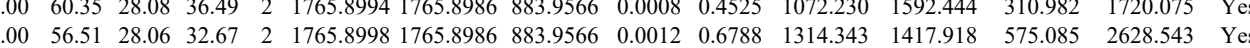
$\begin{array}{lllllllllllllll}0.93 & 20.99 & 28.09 & 21.51 & 3 & 1765.9015 & 1765.8986 & 589.6401 & 0.0029 & 1.6394 & 293.348 & 254.342 & 50.320 & 454.938 & \text { Yes }\end{array}$

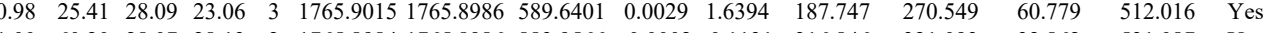

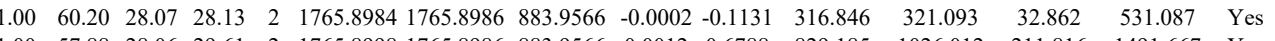
$\begin{array}{lllllllllllllll}1.00 & 57.88 & 28.06 & 29.61 & 2 & 1765.8998 & 1765.8986 & 883.9566 & 0.0012 & 0.6788 & 829.185 & 1026.012 & 211.816 & 1491.667 & \text { Yes }\end{array}$ $\begin{array}{ccccccccccccccc}1.00 & 56.34 & 24.73 & 69.34 & 4 & 2652.4377 & 2652.4366 & 664.1164 & 0.0011 & 0.4141 & 4194.461 & 4980.511 & 4798.029 & 8259.970 & \text { Y } \\ 0.74 & 22.31 & 26.29 & 18.55 & 2 & 915.5262 & 915.5260 & 458.7703 & 0.0002 & 0.2180 & 165.443 & 163.470 & 68.355 & 19.24 & Y \\ 0.78 & 23.14 & 26 & 24.77 & 2 & 915.5262 & 915.5260 & 4587703 & 0.0002 & 0.2180 & 10.107 & 12.939 & 13.188 & 170.191 & Y\end{array}$ \begin{tabular}{|lllllllllllllllllll} 
& 1.00 & 51.52 & 24.74 & 64.52 & 4 & 2652.4389 & 2652.4366 & 664.1164 & 0.0023 & 0.8658 & 1479.946 & 2358.658 & 2093.350 & 3667.759 & Yes
\end{tabular}

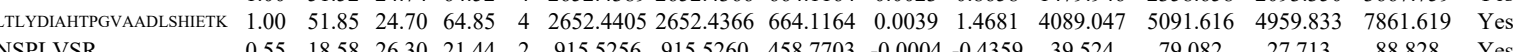
$\begin{array}{llllllllllllll} & & & \end{array}$ $\begin{array}{llllllllllllllll}\text { VDFPQDQLTALTGR } & 1.00 & 85.20 & 28.11 & 27.07 & 2 & 1703.8962 & 1703.8965 & 852.9555 & -0.0003 & -0.1759 & 2249.930 & 3037.813 & 652.838 & 4517.844 & \text { Yes }\end{array}$ $\begin{array}{llllllllllllllll}\text { LTLYDIAHTPGVADL SHETK } & 1.00 & 57.08 & 24.71 & 70.08 & 4 & 2652.4401 & 2652.4366 & 664.1164 & 0.0035 & 1.3175 & 1706.547 & 2437.331 & 2075.665 & 3670.237 & \text { Yes }\end{array}$ $\begin{array}{llllllllllllllllll}\text { LTLYDIAHTPGVAADLSHETK } & 1.00 & 61.66 & 24.58 & 74.66 & 4 & 2652.4413 & 2652.4366 & 664.1164 & 0.0047 & 1.7693 & 1077.180 & 1658.770 & 1590.059 & 2310.431 & \text { Yes }\end{array}$ $\begin{array}{lllllllllllllllll}\text { VDFPQDQLTALTGR } & 1.00 & 86.25 & 28.25 & 24.63 & 2 & 1703.8954 & 1703.8965 & 852.9555 & -0.0011 & -0.6448 & 4360.441 & 6115.083 & 1369.993 & 6781.069 & \text { Yes }\end{array}$ $\begin{array}{llllllllllllllll}\text { VDFPODQLTALTGR } & 1.00 & 82.28 & 28.11 & 21.94 & 2 & 1703.8960 & 1703.8965 & 852.9555 & -0.0005 & -0.2931 & 2579.712 & 3180.368 & 728.146 & 4688.289 & \text { Yes }\end{array}$ $\begin{array}{lllllllllllllllll}\text { VDFPQDQLTALTGR } & 1.00 & 78.30 & 28.10 & 24.71 & 2 & 1703.8968 & 1703.8965 & 852.955 & 0.0003 & 0.1759 & 1341.291 & 1509.722 & 203.677 & 2178.641 & \text { Yes }\end{array}$ $\begin{array}{lllllllllllllllll}\text { VDFPQDQLTALTGR } & 1.00 & 78.49 & 28.09 & 21.59 & 2 & 1703.8974 & 1703.8965 & 852.9555 & 0.0009 & 0.5276 & 2316.742 & 2731.726 & 522.167 & 3620.781 & \text { Yes }\end{array}$ $\begin{array}{lllllllllllllllll}\text { VNVPVIGGHAGK } & 0.51 & 74.36 & 22.25 & 87.36 & 2 & 1434.8650 & 1434.8551 & 718.4348 & 0.0099 & 6.8899 & 2149.531 & 3010.857 & 1526.310 & 3825.607 & \text { Yes }\end{array}$ $\begin{array}{lllllllllllllllll}\text { GCDVVVIPAGVPR } & 1.00 & 54.97 & 27.41 & 17.83 & 2 & 1470.7818 & 1470.7809 & 736.3977 & 0.0009 & 0.6111 & 3297.577 & 4675.278 & 2720.035 & 5310.324 & \text { Yes }\end{array}$ $\begin{array}{llllllllllllllll}\text { GCDVVVIPAGVPR } & 0.82 & 55.54 & 27.43 & 68.54 & 2 & 1470.7820 & 1470.7809 & 736.3977 & 0.0011 & 0.7469 & 2112.786 & 3302.630 & 2473.338 & 3516.197 & \text { Yes }\end{array}$ $\begin{array}{lllllllllllllllll}\text { GCDVVVIPAGVPR } & 0.99 & 44.79 & 27.28 & 16.90 & 2 & 1470.7850 & 1470.7809 & 736.3977 & 0.0041 & 2.7838 & 2064.164 & 2072.604 & 5221.876 & 2825.906 & \mathrm{No}\end{array}$ $\begin{array}{lllllllllllllllll}\text { GCDVVVIPAGVPR } & 1.00 & 46.20 & 27.28 & 19.23 & 2 & 1470.7852 & 1470.7809 & 736.3977 & 0.0043 & 2.9196 & 1049.187 & 1143.890 & 2999.409 & 1566.606 & \text { No }\end{array}$ $\begin{array}{lllllllllllllll}\text { AGAGSATLSMAYAGAR } & 0.53 & \text { \#\#\# } 27.28 & \text { \#\#\#\# } & 2 & 1597.8136 & 1597.8004 & 799.9075 & 0.0132 & 8.2509 & 1603.325 & 1751.565 & 1412.063 & 2369.220 & \text { Yes }\end{array}$ $\begin{array}{lllllllllllllllll} & \text { FVFSLVDAMNGK } & 1.00 & 70.11 & 27.69 & 19.77 & 2 & 1614.8694 & 1614.8683 & 808.4414 & 0.0011 & 0.6803 & 2585.700 & 3304.260 & 156.063 & 3913.343 & \text { Yes }\end{array}$

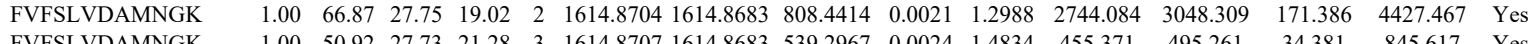

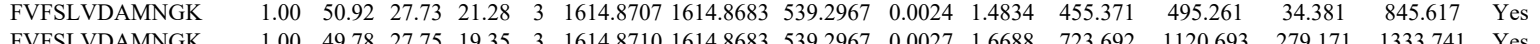

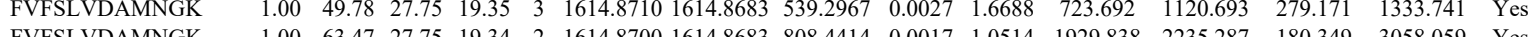
$\begin{array}{llllllllllllllllll} & \text { FVISLDAMNGK } & 1.00 & 63.47 & 27.75 & 19.34 & 2 & 1614.8700 & 1614.8683 & 808.4414 & 0.0017 & 1.0514 & 1929.838 & 2235.287 & 180.349 & 3058.059 & \text { Yes }\end{array}$

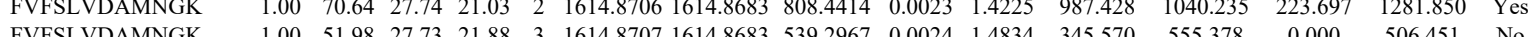

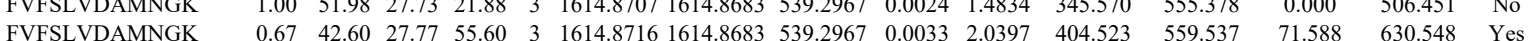

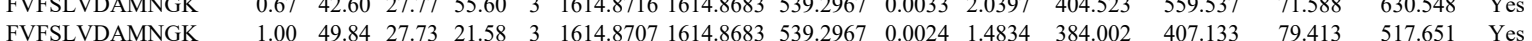
$\begin{array}{lllllllllllllllll}\text { FVFSLVDAMNGK } & 1.00 & 48.92 & 27.75 & 16.91 & 3 & 1614.8710 & 1614.8683 & 539.2967 & 0.0027 & 1.6688 & 324.144 & 295.491 & 113.663 & 463.743 & \text { Yes }\end{array}$

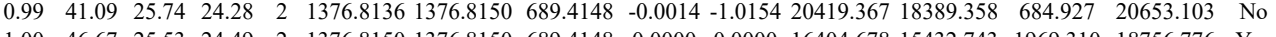

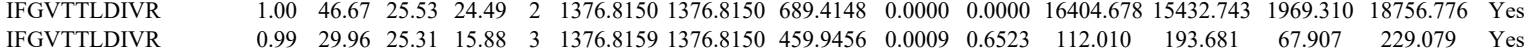




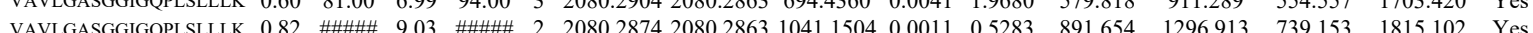

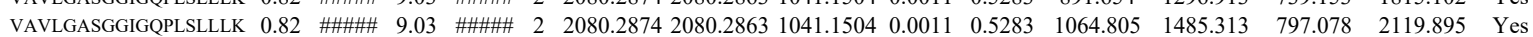

$\begin{array}{llllllllllllllll}\text { VAVLGASGGIGPISLLKK } & 0.67 & 30.58 & 7.78 & 43.58 & 3 & 208.2892 & 20802863 & 694.4360 & 0.0029 & 13920 & 19.465 & 28.131 & 29.794 & 61.119 & \text { Yes }\end{array}$

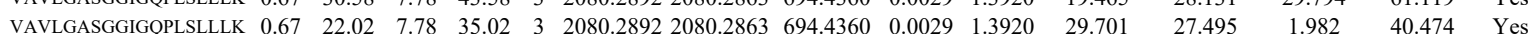

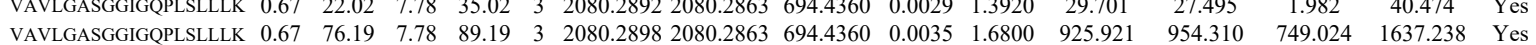

$\begin{array}{llllllllllllllll}\text { VAVLGASGGIGOPISLLLK } & 0.60 & 24.93 & 7.78 & 37.93 & 3 & 2080.2901 & 2080.2863 & 694.4360 & 0.0038 & 1.8240 & 14.411 & 35.592 & 9.064 & 36.898 & \text { Yes }\end{array}$

$\begin{array}{lllllllllllllllll}\text { VAVLGASGGIGOPLSLLLK } & 0.60 & 34.42 & 6.99 & 47.42 & 3 & 2080.2904 & 2080.2863 & 694.4360 & 0.0041 & 1.9680 & 35.318 & 33.552 & 19.233 & 39.337 & \text { Yes }\end{array}$

$\begin{array}{lllllllllllllllll}\text { VAVLGASGGIGQPL SLLLK } & 0.82 & \text { \#\#\#\#\# } & 9.03 & \text { \#\#\#\# } & 2 & 2080.2874 & 2080.2863 & 1041.1504 & 0.0011 & 0.5283 & 432.497 & 461.472 & 356.971 & 978.351 & \text { Yes }\end{array}$

$\begin{array}{lllllllllllllllll}\text { VAVLGASGGIGQPLSLLLK } & 0.67 & 73.18 & 7.78 & 86.18 & 3 & 2080.2898 & 2080.2863 & 694.4360 & 0.0035 & 1.6800 & 421.873 & 427.081 & 496.997 & 1278.381 & \text { Yes }\end{array}$

$\begin{array}{lllllllllllllllll}\text { VAVLGASGGIGQPLSLLLK } & 0.82 & \text { \#\#\#\# } & 9.03 & \text { \#\#\#\# } 2 & 2080.2874 & 2080.2863 & 1041.1504 & 0.0011 & 0.5283 & 61.288 & 97.786 & 53.144 & 145.335 & \text { Yes }\end{array}$ $\begin{array}{lllllllllllllllll}\text { VAVLGASGGIGQPLSLLLK } & 0.66 & 58.28 & 7.78 & 71.28 & 3 & 2080.2883 & 2080.2863 & 694.4360 & 0.0020 & 0.9600 & 197.470 & 251.094 & 99.089 & 711.731 & \text { No }\end{array}$ $\begin{array}{llllllllllllllll}\text { VAVLGASGGIGQPLSLLLK } & 0.66 & 64.83 & 7.78 & 77.83 & 3 & 2080.2880 & 2080.2863 & 694.4360 & 0.0017 & 0.8160 & 44.774 & 55.329 & 22.723 & 66.656 & \text { Yes } \\ \text { VAVGGASGGGQPLSL } & 0.66 & 77.22 & 7.78 & 90.22 & 3 & 2080.2880 & 2002863 & 694.436 & 0.0017 & 0.8160 & 43.574 & 43.580 & 29.836 & 82500 & \text { Yes }\end{array}$ $\begin{array}{llllllllllllllll}\text { VAVLGASGGIGQPLSLLLK } & 0.66 & 77.22 & 7.78 & 90.22 & 3 & 2080.2880 & 2080.2863 & 694.4360 & 0.0017 & 0.8160 & 43.574 & 43.580 & 29.836 & 82.500 & \text { Yes } \\ \text { VAVLGASGGIGQPLSLLK } & 0.66 & 77.46 & 7.78 & 90.46 & 3 & 2080.2880 & 2080.2863 & 694.4360 & 0.0017 & 0.8160 & 35.778 & 44.883 & 12.879 & 42.973 & \text { Yes }\end{array}$

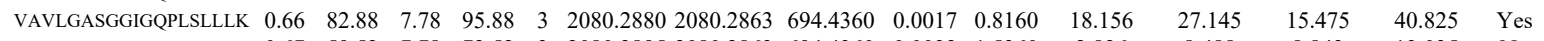
$\begin{array}{llllllllllllllll}\text { VAVLGASGGIGQPLSLLLK } & 0.67 & 59.52 & 7.78 & 72.52 & 3 & 2080.2895 & 2080.2863 & 694.4360 & 0.0032 & 1.5360 & 2.826 & 8.488 & 8.843 & 13.035 & \text { No }\end{array}$

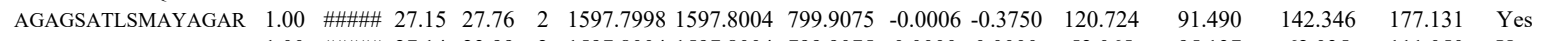

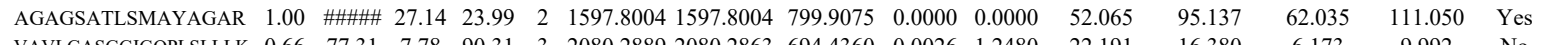

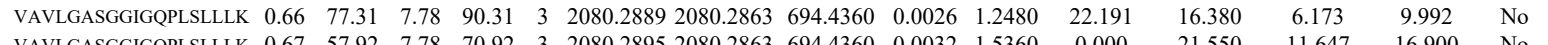
$\begin{array}{llllllllllllllll}\text { VAVLGASGGIGQPLSLLLK } & 0.67 & 57.92 & 7.78 & 70.92 & 3 & 2080.2895 & 2080.2863 & 694.4360 & 0.0032 & 1.5360 & 0.000 & 21.550 & 11.647 & 16.900 & \text { No }\end{array}$

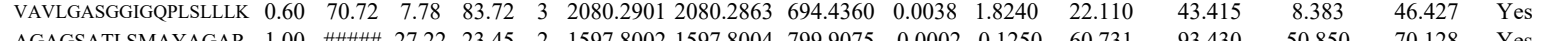

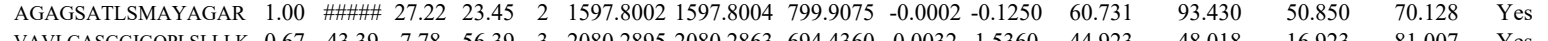

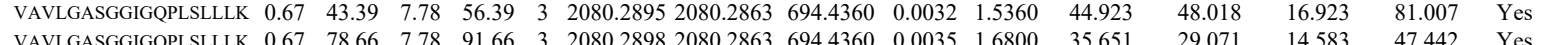

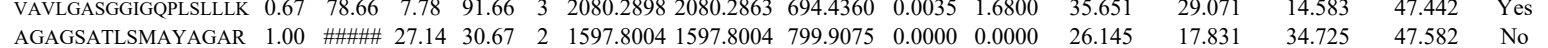

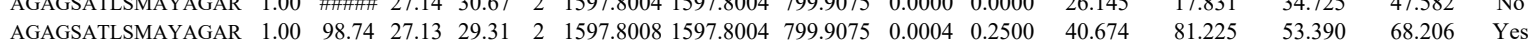

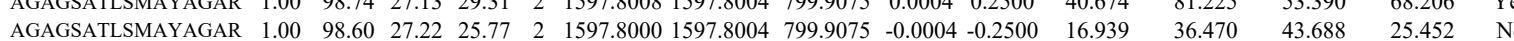

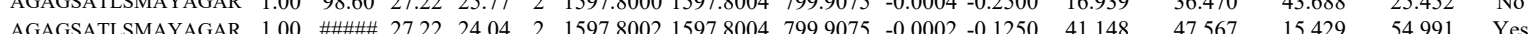

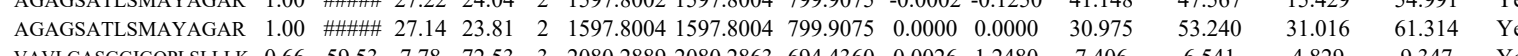
$\begin{array}{llllllllllllll} & \end{array}$

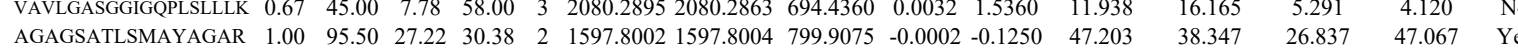

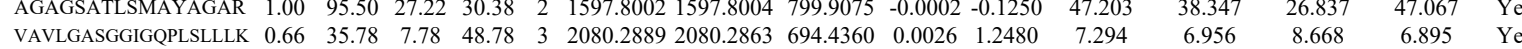
$\begin{array}{lllllllllllllll}\text { AGAGSATLSMAYAGAR } & 1.00 & \text { \#\#\#\# } 27.22 & 26.07 & 2 & 1597.8042 & 1597.8004 & 799.9075 & 0.0038 & 2.3753 & 48.728 & 59.916 & 56.509 & 82.099 & \text { Yes }\end{array}$ $\begin{array}{lllllllllllllll}\text { AGAGSATLSMAYAGAR } & 1.00 & \text { \#\#\# } 27.00 & 19.70 & 2 & 1597.8058 & 1597.8004 & 799.9075 & 0.0054 & 3.3754 & 54.473 & 52.896 & 64.023 & 82.681 & \text { Yes }\end{array}$ $\begin{array}{llllllllllllllll}\text { VAVLGASGGIGQPLSLLLK } & 0.66 & 20.60 & 7.78 & 33.60 & 3 & 2080.2880 & 2080.2863 & 694.4360 & 0.0017 & 0.8160 & 13.557 & 13.339 & 2.513 & 9.884 & \text { No }\end{array}$ $\begin{array}{lllllllllllllllll}\text { VAVLGASGGIGQPLSLLLK } & 0.66 & 10.25 & 7.78 & 23.25 & 3 & 2080.2883 & 2080.2863 & 694.4360 & 0.0020 & 0.9600 & 9.138 & 19.270 & 6.436 & 3.308 & \text { No }\end{array}$

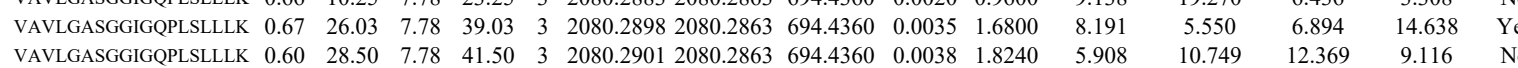
$\begin{array}{lllllllllllll}\text { VAVLGASGGIGQPLSLLLK } & 0.60 & 28.50 & 7.78 & 41.50 & 3 & 2080.2901 & 2080.2863 & 694.4360 & 0.0038 & 1.8240 & 5.908 & 10\end{array}$

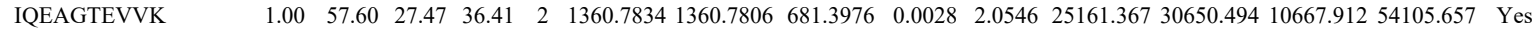

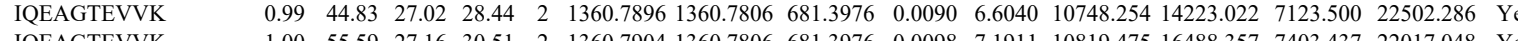
$\begin{array}{lllllllllllllllll}\text { IQEAGTEVVK } & 1.00 & 55.59 & 27.16 & 30.51 & 2 & 1360.7904 & 1360.7806 & 681.3976 & 0.0098 & 7.1911 & 10819.475 & 16488.357 & 7403.437 & 22017.048 & \text { Yes }\end{array}$

$\begin{array}{lllllllllllllll}\text { LVILDEADAMTQDAQNALR } & 1.00 & \text { \#\#\#\# } 27.78 & 27.75 & 2 & 2230.1394 & 2230.1385 & 1116.0765 & 0.0009 & 0.4032 & 81.440 & 95.334 & 72.865 & 126.506 & \text { Yes }\end{array}$

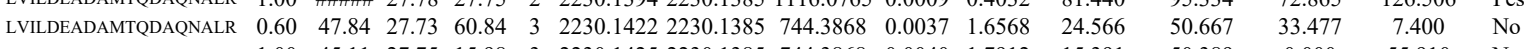

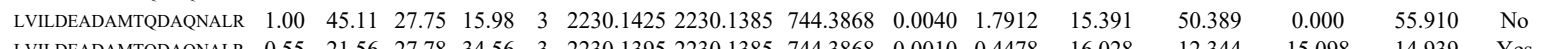

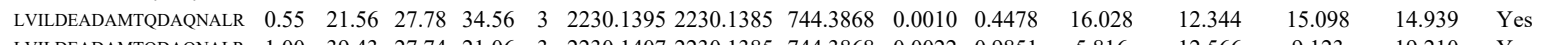
$\begin{array}{llllllllllllllll}\text { LVILDEADAMTQDAQNALR } & 1.00 & 39.43 & 27.74 & 21.06 & 3 & 2230.1407 & 2230.1385 & 744.3868 & 0.0022 & 0.9851 & 5.816 & 12.566 & 9.123 & 19.210 & \text { Yes }\end{array}$

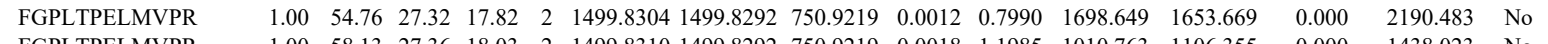

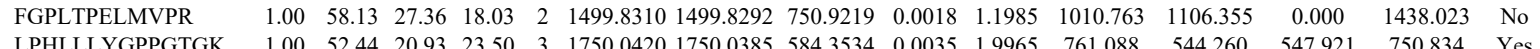

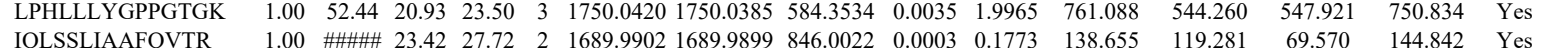

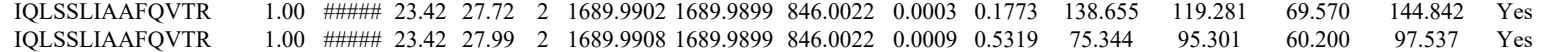

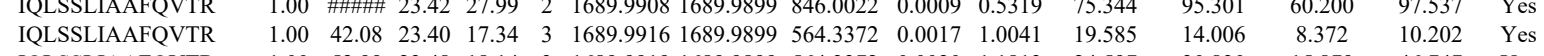

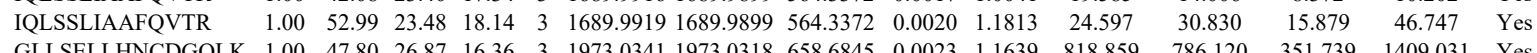

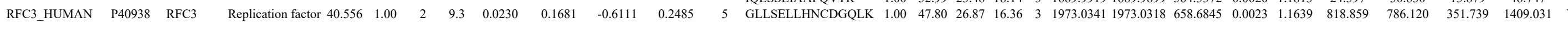

Table S-4 page 301 of 614 

$\begin{array}{llllllllllll}\text { GQQQVFK } & 0.55 & 15.02 & 27.67 & 21.71 & 2 & 1121.6454 & 1121.6437 & 561.8291 & 0.0017 & 1.5129 & 29.975 \\ \text { ADMVIEAVFEDLSLK } & 1.00 & 79.29 & 27.01 & 26.24 & 2 & 1967.0540 & 1967.0529 & 984.5337 & 0.0011 & 0.5586 & 187.761\end{array}$

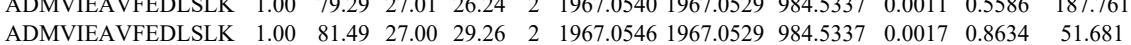
$\begin{array}{lllllllllllll}\text { ADMVIEAVFEDLSLK } & 1.00 & 81.49 & 27.00 & 29.26 & 2 & 1967.0546 & 1967.0529 & 984.5337 & 0.0017 & 0.8634 & 51.681 & \\ \text { ADMVIEAVFEDLSLK } & 1.00 & 40.19 & 27.07 & 21.63 & 3 & 1967.0566 & 1967.0529 & 656.6916 & 0.0037 & 1.8781 & 93.844 & \end{array}$ $\begin{array}{llllllllllll}\text { ADMVIEAVFEDLSLK } & 1.00 & 40.19 & 27.07 & 21.63 & 3 & 1967.0566 & 1967.0529 & 656.6916 & 0.0037 & 1.8781 & 93.844 \\ \text { ADMVIEAVFEDLSLK } & 1.00 & 43.56 & 27.10 & 20.48 & 3 & 1967.0569 & 1967.0529 & 656.6916 & 0.0040 & 2.0304 & 78.472\end{array}$ $\begin{array}{llllllllllll}\text { ADMVIEAVFEDLSLK } & 1.00 & 97.38 & 27.02 & 28.01 & 2 & 1967.0554 & 1967.0529 & 984.5337 & 0.0025 & 1.2696 & 18.122\end{array}$ $\begin{array}{llllllllllllll}\text { ADMVIEAVFEDLSLK } & 1.00 & 53.62 & 27.07 & 25.14 & 3 & 1967.0566 & 1967.0529 & 656.6916 & 0.0037 & 1.8781 & 78.429\end{array}$ $\begin{array}{llllllllllllll}\text { ADMVIEAVFEDLSLK } & 0.97 & 24.75 & 27.10 & 21.20 & 3 & 1967.0569 & 1967.0529 & 656.6916 & 0.0040 & 2.0304 & 106.673\end{array}$ $\begin{array}{lllllllllllll}\text { TLQEVTQLSQEAQR } & 1.00 & 93.35 & 27.69 & 31.23 & 2 & 1773.9354 & 1773.9343 & 887.9744 & 0.0011 & 0.6194 & 1298.060\end{array}$ $\begin{array}{llllllllllll}\text { TLQEVTQLSQEAQR } & 1.00 & \text { \#\#\#\# } 27.69 & 27.28 & 2 & 1773.9356 & 1773.9343 & 887.9744 & 0.0013 & 0.7320 & 1207.592\end{array}$ $\begin{array}{llllllllllll}\text { TLQEVTQLSQEAQR } & 1.00 & 78.97 & 27.85 & 28.60 & 2 & 1773.9316 & 1773.9343 & 887.9744 & -0.0027 & -1.5203 & 277.570\end{array}$

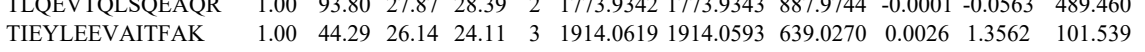
$\begin{array}{lllllllllllll}\text { KMGLVDQLVEPLGPGLKPPEER } & 1.00 & 22.62 & 23.89 & 14.77 & 4 & 2561.4185 & 2561.4009 & 641.3575 & 0.0176 & 6.8604 & 274.712\end{array}$ $\begin{array}{lllllllllllll}\text { KMGLVDQLVEPLGPGLKPPEER } & 1.00 & 64.80 & 23.93 & 17.18 & 3 & 2561.4172 & 2561.4009 & 854.8076 & 0.0163 & 6.3562 & 51.606\end{array}$ $\begin{array}{lllllllllllll}\text { MQLLEIITTEK } & 1.00 & 74.36 & 25.25 & 26.27 & 2 & 1605.9264 & 1605.9255 & 803.9700 & 0.0009 & 0.5597 & 624.610\end{array}$

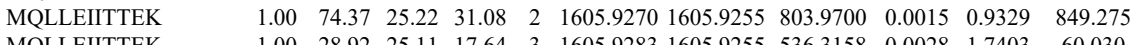
$\begin{array}{llllllllllll}\text { MQLLEIITTEK } & 1.00 & 28.92 & 25.11 & 17.64 & 3 & 1605.9283 & 1605.9255 & 536.3158 & 0.0028 & 1.7403 & 60.030\end{array}$ $\begin{array}{llllllllllll}\text { MQLLEITTEK } & 0.99 & 25.83 & 25.19 & 15.97 & 3 & 1605.9298 & 1605.9255 & 536.3158 & 0.0043 & 2.6725 & 116.736\end{array}$ MQLLEIITTEK $\begin{array}{lllllllllll}1.00 & 70.46 & 25.16 & 30.89 & 2 & 1605.9286 & 1605.9255 & 803.9700 & 0.0031 & 1.9279 & 688.639 \\ 0.93 & 27.42 & 27.17 & 14.86 & 3 & 1865 & \end{array}$ $\begin{array}{llllllllllll}\text { FGGGNPELLTQMVSK } & 0.93 & 27.42 & 27.17 & 14.86 & 3 & 1865.0035 & 1864.9961 & 622.6726 & 0.0074 & 3.9614 & 797.732\end{array}$ \begin{tabular}{llllllllllll} 
TVLGTPEVLLGALPGAGGTOR & 1.00 & \#\#\#\# 23.38 & 19.85 & 2 & 2150.2194 & 2150.2181 & 1076.1163 & 0.0013 & 0.6040 & 652.863 \\
\hline
\end{tabular}

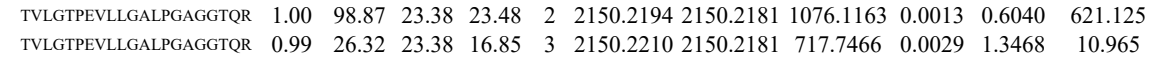
$\begin{array}{lllllllllllll}\text { TVLGTPEVLLGALPGAGGTQR } & 1.00 & 54.59 & 23.30 & 22.25 & 3 & 2150.2222 & 2150.2181 & 717.7466 & 0.0041 & 1.9041 & 6.319\end{array}$ $\begin{array}{lllllllllllll}\text { MVGVPAALDMMLTGR } & 1.00 & 70.53 & 27.98 & 20.12 & 2 & 1704.8864 & 1704.8847 & 853.4496 & 0.0017 & 0.9960 & 76.106 \\ \text { MVGVPAALDMMLTGR } & 1.00 & 70.26 & 27.96 & 19.68 & 2 & 1704.8866 & 1704.8847 & 853.4496 & 0.0019 & 1.1131 & 214.471\end{array}$ $\begin{array}{lllllllllllll}\text { MVGVPAALDMMLTGR } & 1.00 & 70.26 & 27.96 & 19.68 & 2 & 1704.8866 & 1704.8847 & 853.4496 & 0.0019 & 1.1131 & 214.471 \\ \text { TVLGTPEVLLGLPGAGGTOR } & 0.82 & 91.04 & 23.38 & \# \# \# \# & 2 & 2150.2194 & 2150.2181 & 1076.1163 & 0.0013 & 0.6040 & 381.502\end{array}$ $\begin{array}{llllllllllll}\text { TVLGTPEVLLGALPGAGGTQR } & 0.82 & 91.04 & 23.38 & \# \# \# \# & 2 & 2150.2194 & 2150.2181 & 1076.1163 & 0.0013 & 0.6040 & 381.502 \\ \text { TVLGTPEVLGGLPGAGGTQR } & 1.00 & 40.10 & 23.34 & 19.99 & 3 & 2150.2213 & 2150.2181 & 717.7466 & 0.0032 & 1.4861 & 96.409\end{array}$ $\begin{array}{llllllllllll}\text { TVLGTPEVLLGALPGAGGTQR } & 1.00 & 40.10 & 23.34 & 19.99 & 3 & 2150.2213 & 2150.2181 & 717.7466 & 0.0032 & 1.4861 & 96.409 \\ \text { TVLGTPEVLLGALPGAGGTOR } & 0.99 & 25.99 & 23.30 & 17.61 & 3 & 2150.2222 & 2150.2181 & 717.7466 & 0.0041 & 1.9041 & 18.865\end{array}$ $\begin{array}{llllllllllll}\text { TVLGTPEVLLGALPGAGGTTR } & 0.99 & 25.99 & 23.30 & 17.61 & 3 & 2150.2222 & 2150.2181 & 717.7466 & 0.0041 & 1.9041 & 18.865 \\ \text { MVGVPAALDMMLTGR } & 1.00 & 70.52 & 28.00 & 21.30 & 2 & 1704.8868 & 1704.8847 & 853.4496 & 0.0021 & 1.2303 & 311.301\end{array}$ $\begin{array}{llllllllllll}\text { MVGVPALDMMLTGR } & 1.00 & 70.52 & 28.00 & 21.30 & 2 & 1704.8868 & 1704.8847 & 853.4496 & 0.0021 & 1.2303 & 311.301 \\ \text { MVGVPALDMMLTGR } & 1.00 & 76.81 & 28.00 & 23.17 & 2 & 1704.8868 & 1704.8847 & 853.4496 & 0.0021 & 1.2303 & 225.483\end{array}$

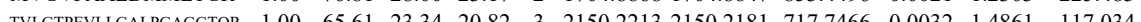
$\begin{array}{llllllllllll}\text { TVLGTPEVLLGALPGAGGTQR } & 1.00 & 54.78 & 23.28 & 20.04 & 3 & 2150.2228 & 2150.2181 & 717.7466 & 0.0047 & 2.1828 & 138.051\end{array}$ $\begin{array}{lllllllllllll}\text { TVLGTPEVLGALPGAGGTQR } & 1.00 & 54.78 & 23.28 & 20.04 & 3 & 2150.2228 & 2150.2181 & 717.7466 & 0.0047 & 2.1828 & 138.051 \\ \text { MVGVPAALDMMLTGR } & 1.00 & 57.86 & 28.05 & 19.81 & 2 & 1704.8860 & 1704.8847 & 853.4496 & 0.0013 & 0.7616 & 35.747\end{array}$ $\begin{array}{lllllllllllll}\text { MVGVPAALDMMLTGR } & 1.00 & 67.56 & 27.96 & 23.77 & 2 & 1704.8866 & 1704.8847 & 853.4496 & 0.0019 & 1.1131 & 62.008\end{array}$ $\begin{array}{lllllllllllll}\text { TVLGTPEVLLGALPGAGGTQR } & 0.55 & 27.08 & 23.38 & 40.08 & 3 & 2150.2195 & 2150.2181 & 717.7466 & 0.0014 & 0.6502 & 16.517\end{array}$ $\begin{array}{llllllllllll}\text { MVLGTPEVLGALPGAGGTQR } & 0.55 & 27.08 & 23.38 & 40.08 & 3 & 2150.2195 & 2150.2181 & 717.7466 & 0.0014 & 0.6502 & 16.517 \\ \text { MVGVPAALDMMLTGR } & 1.00 & 65.65 & 28.01 & 21.94 & 2 & 1704.8862 & 1704.8847 & 853.4496 & 0.0015 & 0.8788 & 50.457\end{array}$ $\begin{array}{llllllllllllll}\text { TVLGTPEVLLGALPGAGGTQR } & 0.99 & 25.90 & 23.38 & 16.15 & 3 & 2150.2210 & 2150.2181 & 717.7466 & 0.0029 & 1.3468 & 8.488\end{array}$ $\begin{array}{lllllllllllll}\text { TVLGTPEVLLGALPGAGGTQR } & 0.98 & 21.01 & 23.34 & 14.67 & 3 & 2150.2213 & 2150.2181 & 717.7466 & 0.0032 & 1.4861 & 6.298\end{array}$ $\begin{array}{lllllllllllll}\text { MVGVPAALDMMLTGR } & 0.99 & 36.93 & 28.00 & 17.08 & 2 & 1704.8868 & 1704.8847 & 853.4496 & 0.0021 & 1.2303 & 18.302\end{array}$ $\begin{array}{lllllllllllll}\text { TVLGTPEVLLGALPGAGGTQR } & 1.00 & 42.35 & 23.30 & 18.07 & 3 & 2150.2204 & 2150.2181 & 717.7466 & 0.0023 & 1.0682 & 9.850\end{array}$ $\begin{array}{lllllllllllll}\text { TVLGTPEVLLGALPGAGGTQR } & 1.00 & 53.45 & 23.38 & 21.86 & 3 & 2150.2210 & 2150.2181 & 717.7466 & 0.0029 & 1.3468 & 9.798\end{array}$

$\begin{array}{llllllllllllll} & \text { IVLTNPVCTEVGEK } & 1.00 & 77.19 & 27.92 & 28.21 & 2 & 1834.9790 & 1834.9776 & 918.4961 & 0.0014 & 0.7621 & 243.177 & 5.21\end{array}$

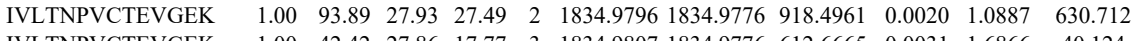

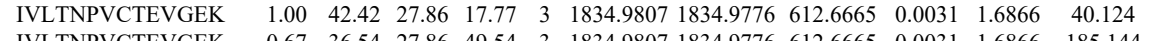
$\begin{array}{llllllllllllll}\text { IVLTNPVCTEVGEK } & 0.67 & 36.54 & 27.86 & 49.54 & 3 & 1834.9807 & 1834.9776 & 612.6665 & 0.0031 & 1.6866 & 185.144 & 135 \\ \text { IVTIS }\end{array}$ $\begin{array}{lllllllllllll}1.07 & 6.55 & 26.29 & 20.98 & 3 & 1394.8108 & 1394.8003 & 465.9407 & 0.0105 & 7.5116 & 5281.696 & 681827\end{array}$ LTPLSHEVISR $\begin{array}{llllllllllllll}1.00 & 48.85 & 26.29 & 26.32 & 3 & 1394.8111 & 1394.8003 & 465.9407 & 0.0108 & 7.7262 & 5282.344 & 53 \\ 1.00 & 53.93 & 26.13 & 18.41 & 3 & 1394.8081 & 1394.8003 & 465.9407 & 0.0078 & 5.5801 & 4088.014 & 43\end{array}$ $\begin{array}{llllllllllll}\text { WSLFAEHNDLQYAAPGGLGVGTK } & 1.00 & 52.95 & 23.52 & 17.72 & 3 & 2857.5610 & 2857.5582 & 953.5267 & 0.0028 & 0.9788 & 45.196\end{array}$ $\begin{array}{llllllllllll}\text { IVSLFAEHNDLQYAAPGGLGVGTK } & 1.00 & 21.31 & 23.44 & 20.10 & 4 & 2857.5617 & 2857.5582 & 715.3968 & 0.0035 & 1.2231 & 167.837 \\ \text { IVSLAAHNDLOYAAPGGLGVGTK } & 1.00 & 73.98 & 23.44 & 17.89 & 3 & 2857.5622 & 2857.5582 & 953.5267 & 0.0040 & 1.3983 & 52.884\end{array}$ $\begin{array}{llllllllllll}\text { IVSLFAEHNDLQYAAPGGLIGVGTKK } & 1.00 & 73.98 & 23.44 & 17.89 & 3 & 2857.5622 & 2857.5582 & 953.5267 & 0.0040 & 1.3983 & 52.884\end{array}$ $\begin{array}{llllllllllll}\text { IVSLFAEHNDLQYAAPGGLGVGTK } & 1.00 & 15.98 & 23.40 & 16.92 & 4 & 2857.5625 & 2857.5582 & 715.3968 & 0.0043 & 1.5027 & 164.901 \\ \text { IVSLFAEHNDLYYAAPGGLGVGTK } & 1.00 & 15.02 & 23.52 & 28.02 & 4 & 2857.5609 & 2857.5582 & 715.3968 & 0.0027 & 0.9435 & 38.607\end{array}$ $\begin{array}{llllllllllll}\text { IVSLFAFHNDLQYAAPGGLGVGTK } & 1.00 & 15.02 & 23.52 & 28.02 & 4 & 2857.5609 & 2857.5582 & 715.3968 & 0.0027 & 0.9435 & 38.607 \\ \text { IVISFAFHNDLQYAAPGGLGVGTK } & 1.00 & 18.70 & 23.52 & 31.70 & 4 & 2857.5613 & 2857.5582 & 7153968 & 0.0031 & 1.0833 & 71.808\end{array}$ $\begin{array}{lllllllllllll}\text { IVSLFAEHNDLQYAAPGGLIGUGK } & 1.00 & 18.70 & 23.52 & 31.70 & 4 & 2857.5613 & 2857.5582 & 715.3968 & 0.0031 & 1.0833 & 71.808\end{array}$ IVSLFAEHNDLQ $\begin{array}{lllllllllll}0.67 & 59.71 & 23.52 & 72.71 & 3 & 2857.5616 & 2857.5582 & 953.5267 & 0.0034 & 1.1886 & 21.854 \\ 0.99 & 35.00 & 17.48 & 22.48 & 3 & 1265.8150 & 1265.8063 & 422.9427 & 0.0087 & 6.8567 & 8877.933\end{array}$ $\begin{array}{lllllllllllll}\text { EQYEQILAFVQGTVAEGAPIIISAQLKK } & 1.00 & 34.20 & 20.93 & 17.28 & 4 & 3300.8273 & 3300.8213 & 826.2126 & 0.0060 & 1.8155 & 15.126\end{array}$ 
$\begin{array}{llllllllllllllll}\text { SFDVNKPGCEVDDLK } & 0.60 & 24.07 & 27.95 & 37.07 & 3 & 2143.0693 & 2143.0655 & 715.3624 & 0.0020 & 1.7707 & 9727.085 & 11049.169 & 9239.249 & 17207.124 & \text { Yes }\end{array}$

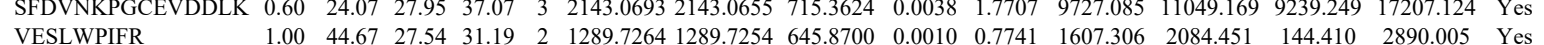

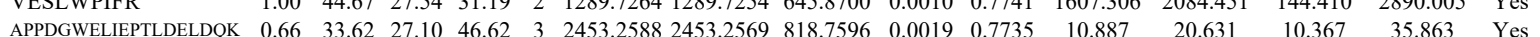
$\begin{array}{llllllllllllllll}\text { APPDGWELEPTLDELDOK } & 0.93 & 19.72 & 27.12 & 1524 & 3 & 2453.2594 & 24532569 & 818.7596 & 0.0025 & 10178 & 75.741 & 25.360 & 21.906 & 5.773 & \text { Yes }\end{array}$

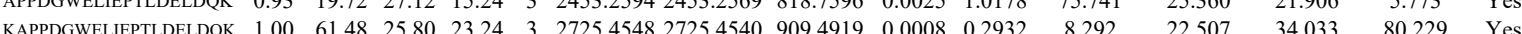

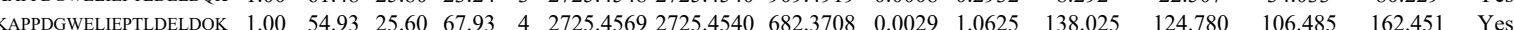

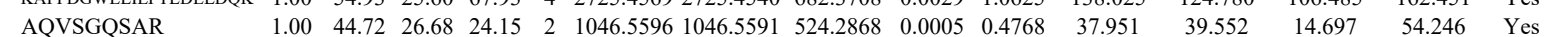

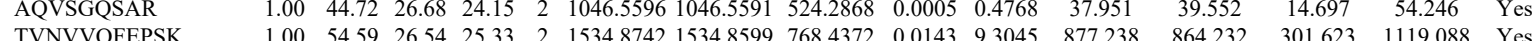
$\begin{array}{llllllllllllllll}\text { AEISELPSIVODLANGNITWADVEAR } & 0.67 & 32.30 & 26.33 & 45.30 & 3 & 2954.5141 & 2954.5107 & 985.8442 & 0.0034 & 1.1496 & 14.386 & 21.108 & 7.240 & 5.466 & \text { No- }\end{array}$

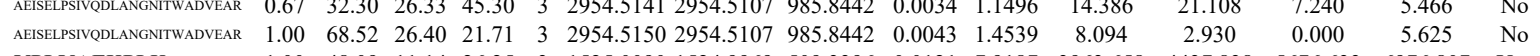
$\begin{array}{llllllllllllllll}\text { VPLVAEKPLK } & 1.00 & 48.09 & 11.14 & 26.25 & 3 & 1525.0090 & 1524.9969 & 509.3396 & 0.0121 & 7.9187 & 3963.658 & 4437.838 & 5676.633 & 6976.807 & \text { Yes }\end{array}$ $\begin{array}{lllllllllllllllll}\text { VPLVAEKPLK } & 1.00 & 38.26 & 11.14 & 22.72 & 3 & 1525.0096 & 1524.9969 & 509.3396 & 0.0127 & 8.3113 & 3520.935 & 4040.295 & 7084.282 & 6321.024 & \text { Yes }\end{array}$

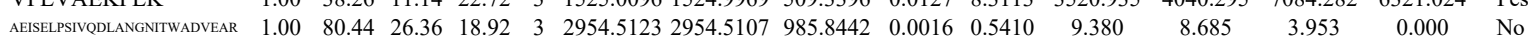

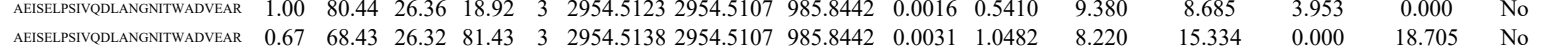

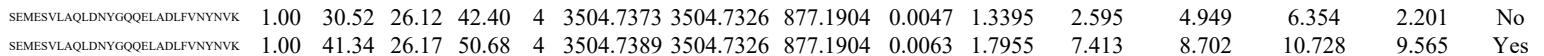

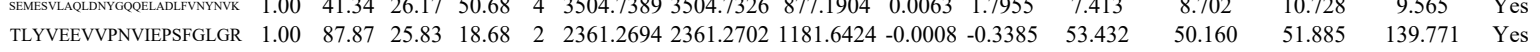
$\begin{array}{lllllllllllllllll}\text { TLYVEEVVPNVIEPSFGLGR } & 1.00 & 86.81 & 25.76 & 19.96 & 2 & 2361.2714 & 2361.2702 & 1181.6424 & 0.0012 & 0.5078 & 96.920 & 31.440 & 55.570 & 67.326 & \text { Yes }\end{array}$ $\begin{array}{lllllllllllllllll}\text { SPITGNDLSPPVSFNLMFK } & 0.87 & 16.85 & 26.85 & 15.18 & 3 & 2351.2471 & 2351.2439 & 784.7552 & 0.0032 & 1.3592 & 94.234 & 99.720 & 46.454 & 177.470 & \text { Yes }\end{array}$ $\begin{array}{llllllllllllllll}\text { NNIIQTWR } & 0.97 & 38.47 & 28.46 & 31.77 & 2 & 1187.6628 & 1187.6533 & 594.8339 & 0.0095 & 7.9854 & 19519.614 & 18109.003 & 1645.690 & 24645.128 & \text { Yes }\end{array}$ $\begin{array}{llllllllllllllll}\text { NNIIQTWR } & 0.97 & 38.29 & 28.25 & 32.14 & 2 & 1187.6630 & 1187.6533 & 594.8339 & 0.0097 & 8.1535 & 18002.540 & 18962.791 & 1307.799 & 23533.141 & \text { Yes }\end{array}$ $\begin{array}{llllllllllllllll}\text { NNIIQTWR } & 0.96 & 36.22 & 28.51 & 31.72 & 2 & 1187.6636 & 1187.6533 & 594.8339 & 0.0103 & 8.6578 & 9272.687 & 8989.591 & 278.568 & 12555.425 & \text { Yes }\end{array}$

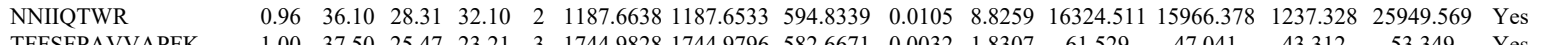

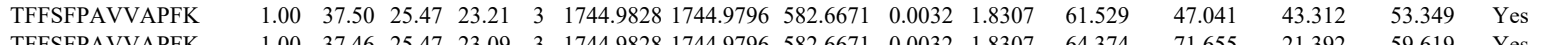

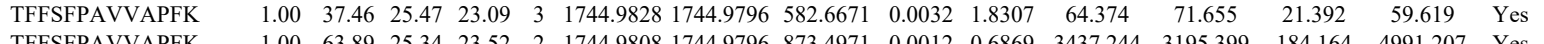

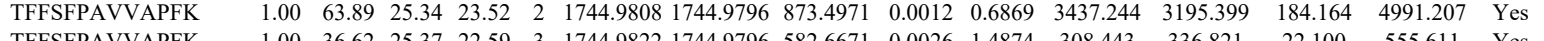

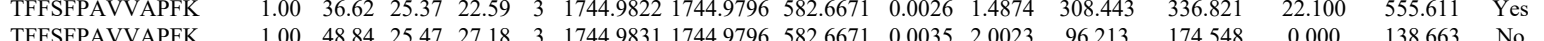

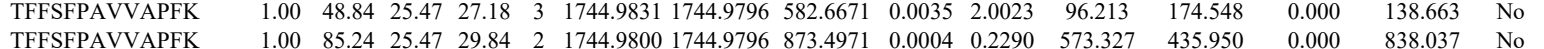

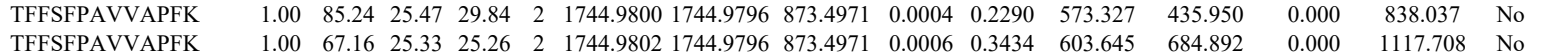

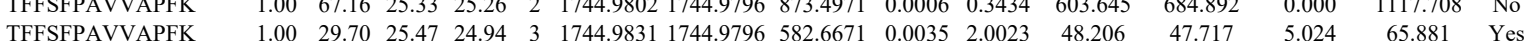

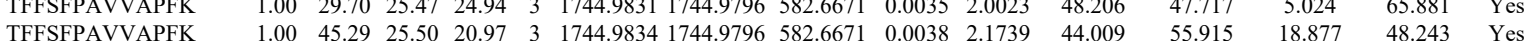

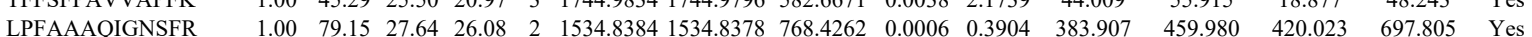
$\begin{array}{llllllllllllllll}\text { LPFAAAQIGNSFR } & 1.00 & 79.15 & 27.64 & 26.08 & 2 & 1534.8384 & 1534.8378 & 768.4262 & 0.0006 & 0.3904 & 383.907 & 459.980 & 420.023 & 697.805 & \text { Yes } \\ \text { LPFAAAQIGNSFR } & 1.00 & 72.46 & 27.52 & 28.81 & 2 & 1534.8392 & 1534.8378 & 768.4262 & 0.0014 & 0.9110 & 466.134 & 311.655 & 603.803 & 795.684 & \text { Yes }\end{array}$ $\begin{array}{llllllllllllllll}\text { LPFAAAQIGNSR } & 1.00 & 72.46 & 27.52 & 28.81 & 2 & 1534.8342 & 1534.8378 & 768.4262 & 0.0014 & 0.9110 & 466.134 & 311.655 & 603.803 & 795.684 & \text { Yes } \\ \text { LPFAAAQIGNSFR } & 0.60 & 15.99 & 27.46 & 28.99 & 3 & 1534.8418 & 1534.8378 & 512.6199 & 0.0040 & 2.6010 & 124.052 & 124.492 & 58.062 & 182.515 & \text { Yes }\end{array}$ $\begin{array}{llllllllllllllll}\text { LPFAAAQIGNSFR } & 0.60 & 15.99 & 27.46 & 28.99 & 3 & 1534.8418 & 534.8378 & 512.6199 & 0.0040 & 2.6010 & 124.052 & 124.492 & 58.062 & 182.515 & \text { Yes } \\ \text { LPFAAAQIGNSFR } & 0.91 & 20.23 & 27.46 & 17.07 & 3 & 1534.8418 & 1534.8378 & 512.6199 & 0.0040 & 2.6010 & 112.924 & 155.451 & 65.528 & 202.620 & \text { Yes }\end{array}$

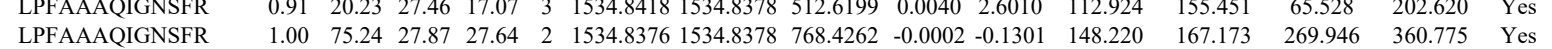

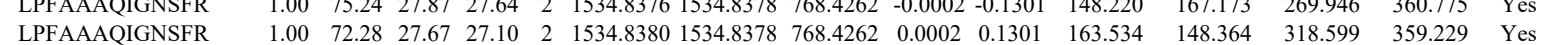

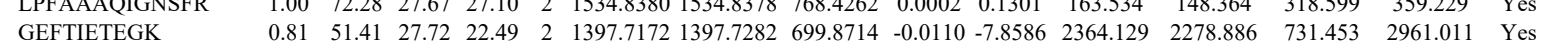

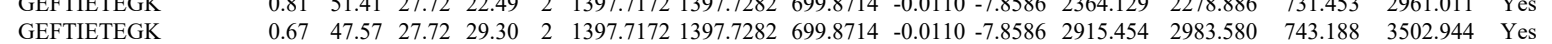
$\begin{array}{lllllllllllllllll}\text { EFTMAEIEHFVDPSEK } & 1.00 & 34.91 & 27.04 & 16.38 & 3 & 2196.0673 & 2196.0652 & 733.0290 & 0.0021 & 0.9549 & 157.304 & 145.540 & 169.772 & 197.398 & \text { Yes }\end{array}$ $\begin{array}{lllllllllllllllll}\text { EFTMAEIEHFVDPSEK } & 1.00 & 33.67 & 27.09 & 17.81 & 3 & 2196.0685 & 2196.0652 & 733.0290 & 0.0033 & 1.5006 & 205.928 & 122.405 & 305.997 & 295.283 & \text { Yes }\end{array}$ $\begin{array}{llllllllllllllll}\text { YPLFEGQETGK } & 1.00 & 54.53 & 27.81 & 28.80 & 2 & 1555.8270 & 1555.8126 & 778.9136 & 0.0144 & 9.2436 & 1426.707 & 1665.692 & 1845.298 & 2894.226 & \text { Yes }\end{array}$

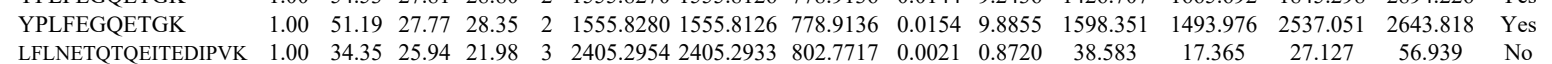
$\begin{array}{llllllllllllllll}\text { LFLNETOTOEITEDIPVK } & 0.91 & 17.61 & 25.85 & 16.33 & 3 & 2405.2960 & 2405.2933 & 802.7717 & 0.0027 & 1.1211 & 42.239 & 20.004 & 5.771 & 11.554 & \text { No }\end{array}$ $\begin{array}{llllllllllllllll}\text { FGWDCHGLPVEYEIDK } & 1.00 & 32.65 & 26.54 & 16.24 & 3 & 2241.0520 & 2241.0478 & 748.0232 & 0.0042 & 1.8716 & 0.000 & 58.904 & 0.000 & 66.634 & \text { No }\end{array}$ $\begin{array}{lllllllllllllllll}\text { FGWDCHGLPVEYEIDK } & 0.96 & 27.61 & 26.65 & 24.20 & 3 & 2241.0535 & 2241.0478 & 748.0232 & 0.0057 & 2.5400 & 59.501 & 49.756 & 17.266 & 86.485 & \text { Yes }\end{array}$

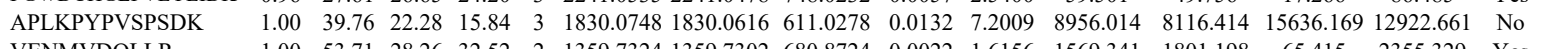
$\begin{array}{llllllllllllllll}\text { VENMVDQLLR } & 1.00 & 53.71 & 28.26 & 32.52 & 2 & 1359.7324 & 1359.7302 & 680.8724 & 0.0022 & 1.6156 & 1569.341 & 1801.198 & 65.415 & 2355.329 & \text { Yes }\end{array}$ $\begin{array}{lllllllllllllllll}\text { VENMVDQLLR } & 1.00 & 69.35 & 28.22 & 29.64 & 2 & 1359.7318 & 1359.7302 & 680.8724 & 0.0016 & 1.1750 & 3262.664 & 3989.024 & 13.865 & 4661.962 & \text { Yes } \\ \text { VENMVDQLLR } & 1.00 & 66.80 & 28.26 & 29.48 & 2 & 1359.7324 & 1359.732 & 90.894 & 0.022 & 1.615 & 2871.432 & 3443.60 & 63.427 & 4194.625 & \text { Yes }\end{array}$

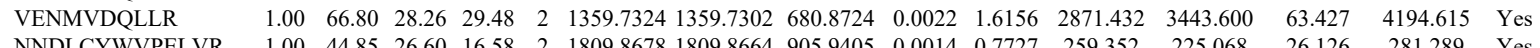

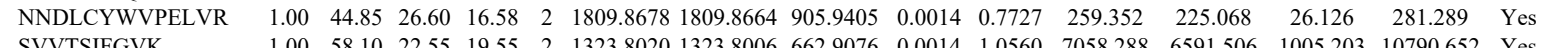

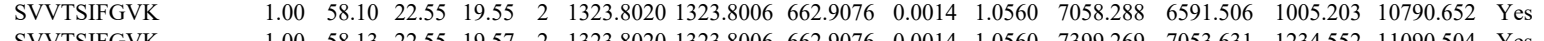
SVVTSIFGVK $\begin{array}{llllllllllllllll}1.00 & 58.13 & 22.55 & 19.57 & 2 & 1323.8020 & 1323.8006 & 662.9076 & 0.0014 & 1.0560 & 7399.269 & 7053.631 & 1234.552 & 11090.504 & \text { Yes } \\ 1.00 & 38.80 & 25.29 & 28.71 & 2 & 1101.6714 & 101.6702 & 55.824 & 0.001 & 1.0873 & 4732.043 & 473.490 & 52.035 & 1008.366 & \text { Yes }\end{array}$

$\begin{array}{llllllllllllllll}1.00 & 44.35 & 25.29 & 32.49 & 2 & 1101.6720 & 1101.6702 & 51.8424 & 0.0018 & 1.6309 & 5572.635 & 5914.743 & 343.262 & 11770.985 & \text { Yes }\end{array}$

LYTVVPR $\quad \begin{array}{lllllllllllllllll}0.86 & 29.51 & 26.62 & 25.02 & 2 & 990.6076 & 990.5984 & 4963065 & 0.0092 & 9.2684 & 15817.177 & 20098.264 & 11167.520 & 25674.016 & \text { Yes }\end{array}$ 
LYTVVPR

YRPLFDYFLK

YRPLFDYFLK

FVDILTNWYVR

AVPSWFVR

AVPSWFVR

AVPSWFVR
LYLINSPVVR

LYLINSPVVR
LYLINSPVVR

LYLINSPVVR
LYLINSPVVR

FLIQNVLR

FLIQNVLR

FLIQNVLR

FLIQNVLR

FLIQNVLR

FLIQNVLR

LESDYEILER

LLVATTFTHSYPF

LLVATTFTHSYPFCWR

LFLNETQTQEITEDIPIX

GDDLLPAGTEDY

NICQFLVEIGLAK

TLTTVQGIADDYDK

38 YTYEHDPITK

YTYEHDPITK

QTTDNLLPMSPEEFDEVSR

LQTTDNLLPMSPEEFDEVSR

LQTTDNLLPMSPE
YTYEHDPITK

YTYEHDPITK QDWEHAANDVSFATIR

VMAAENIPENPLK

VMAAENIPENPLK

VMAAENIPENPLK

GLNVDQLNMLGEK

GLNVDQLNMLGE

QYLAQWLEK

FNILGTHTK

FNILGTHTK

LLGPNASPDGLIPWTR

$\begin{array}{lllllllllllll}\text { LLGPNASPDGLIPWTR } & 1.00 & 77.75 & 26.66 & 24.92 & 2 & 1850.0168 & 1850.0172 & 926.0159 & -0.0004 & -0.2160 & 2661.079 & 1913.966 \\ \text { LLGPNASPDGLIPWTR } & 1.00 & 73.62 & 26.54 & 26.36 & 2 & 1850.0194 & 1850.0172 & 926.0159 & 0.0022 & 1.1879 & 9296.804 & 6347.555 \\ \text { LLGPNSPDGLIPWTR } & 1.00 & 81.13 & 26.57 & 28.74 & 2 & 1550.0182 & 1850.0172 & 926.0159 & 0.0010 & 0.5399 & 7650204 & 5042.194\end{array}$

$\begin{array}{llllllllllllll}0 & \end{array}$

$\begin{array}{lllllllllllll}\text { WAPLSEVLSWOFSSVTK } & 1.00 & 35.96 & 26.43 & 29.18 & 2 & 1850.0192 & 1850.0172 & 926.0159 & 0.0020 & 1.0799 & 13328.840 & 9049.372 \\ \text { WA } & 2283.2185 & 2283.2143 & 762.0787 & 0.0042 & 1.8371 & 37.136 & 28.822\end{array}$

$\begin{array}{llllllllllllll}\text { WAQLSEVLSWQFSSVTK } & 1.00 & 38.08 & 26.46 & 16.51 & 3 & 2283.2194 & 2283.2143 & 762.0787 & 0.0051 & 2.2307 & 29.696 & 17.049\end{array}$

$\begin{array}{llllllllllllll}\text { LLGPNASPDGLIPWTR } & 1.00 & 68.02 & 26.57 & 23.70 & 2 & 1850.0182 & 1850.0172 & 926.0159 & 0.0010 & 0.5399 & 4066.922 & 2943.53\end{array}$

$\begin{array}{llllllllllllll}\text { LLGPNASPDGLIPWTR } & 1.00 & 77.30 & 26.54 & 27.57 & 2 & 1850.0190 & 1850.0172 & 926.0159 & 0.0018 & 0.9719 & 225.200 & 176.246\end{array}$

$\begin{array}{lllllllllllll}\text { WAQLSEVLSWQFSSVTK } & 0.94 & 19.60 & 26.43 & 23.86 & 3 & 2283.2173 & 2283.2143 & 762.0787 & 0.0030 & 1.3122 & 64.572 & 27.550\end{array}$

$\begin{array}{lllllllllllllll}\text { QPCMPTHPQRPLVLK } & 0.95 & 18.89 & 25.91 & 15.45 & 4 & 2078.1349 & 2078.1195 & 520.5372 & 0.0154 & 7.3962 & 6078.523 & 4198.742 & 129\end{array}$

$\begin{array}{lllllllllllllll}\text { QPCMPTHPQRPLVLK } & 0.92 & 17.38 & 25.77 & 17.21 & 4 & 2078.1361 & 2078.1195 & 520.5372 & 0.0166 & 7.9725 & 6403.841 & 5748.550 & 1710.59\end{array}$

$\begin{array}{lllllllllllllll}\text { QPCMPTHPQRPLVLK } & 0.99 & 24.44 & 25.98 & 18.10 & 4 & 2078.1341 & 2078.1195 & 520.5372 & 0.0146 & 7.0119 & 7404.637 & 6251.690 & 1027.588\end{array}$

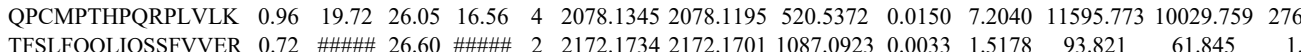

$\begin{array}{lllllllllllll}\text { TFSLFQQLIQSSFVVER } & 1.00 & 37.32 & 26.49 & 15.36 & 3 & 2172.1750 & 2172.1701 & 725.0640 & 0.0049 & 2.2527 & 1.061\end{array}$

$\begin{array}{llllllllllll}\text { TFSLFQQLIQSSFVVER } & 0.67 & 12.73 & 26.60 & 25.73 & 3 & 2172.1735 & 2172.1701 & 725.0640 & 0.0034 & 1.5631 & 76.850\end{array}$

NLSFFLTPPCAR

NLSFFLTPPCAR

NLSFFLTPPCAR

NLSFFTPPCAR

NLSTTPCAR

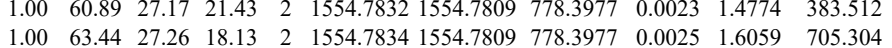

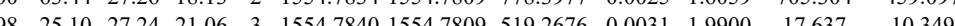
$\begin{array}{llllllllllllll}0.97 & 24.73 & 27.27 & 26.99 & 3 & 1554.7843 & 1554.7809 & 519.2676 & 0.0034 & 2.1826 & 14.304 & 8.022\end{array}$ $\begin{array}{llllllllllll}1.00 & 61.51 & 27.13 & 18.77 & 2 & 1554.7824 & 1554.7809 & 778.3977 & 0.0015 & 0.9635 & 178.422 & 118.653\end{array}$

NLSFFLTPPCAR
1.060

Yes $\begin{array}{ccccccc}0.9549 & 58.182 & 1697.615 & 277.714 & 2605.779 & \text { Yes } \\ 03.201 & 2.921 & 103.966 & \text { Yes }\end{array}$

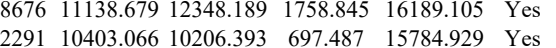
$\begin{array}{lll}18.068 & 11.277 & \text { Yes } \\ 147.231 & \text { Yes }\end{array}$ \begin{tabular}{lll}
14.668 & 147.231 & Yes \\
72.600 & 735.752 & Yes \\
\hline 56.805 & 142.685 & Yes
\end{tabular} $\begin{array}{rrr}56.805 & 142.685 & \text { Yes } \\ 4 & 14.459 & \text { Yes }\end{array}$ $\begin{array}{lll}4.936 & 14.459 & \text { Yes } \\ & & \end{array}$ $21.881 \quad 21.976$ No $0.640 \quad 929.379 \quad$ Yes $8095 \quad 765.737$ Yes $\begin{array}{lll}102 & 62.717 & \text { Yes }\end{array}$ $\begin{array}{lll}4.365 & 1171.220 & \text { Yes } \\ 546 & 566.864 & \text { Yes }\end{array}$

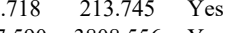
$\begin{array}{lll}3808.556 & \text { Yes }\end{array}$ $\begin{array}{lll}4.413 & \text { Yes } \\ 0.000 & 8.956 & \text { No }\end{array}$ $\begin{array}{lll}0.963 & \text { No }\end{array}$ $\begin{array}{lll}2296.291 & \text { Yes }\end{array}$ $\begin{array}{lll}3479.352 & \text { Yes }\end{array}$ $\begin{array}{llll} & 217 & 352.301 & \text { Yes }\end{array}$ $\begin{array}{lll}90.553 & \text { Yes }\end{array}$ $\begin{array}{lll}0.032 & 9541.273 & \mathrm{No}\end{array}$ $\begin{array}{lll}656.905 & 11392.243 & \text { Yes }\end{array}$ $\begin{array}{lll}13.645 & 11476.835 & \text { Yes } \\ 0.668 .657 & \text { Yes }\end{array}$ $0.000 \quad 492.053 \quad$ No $\begin{array}{lll}0.000 & 1642.060 & \mathrm{~N}\end{array}$ $\begin{array}{lll}0.000 & 1692.023 \quad \mathrm{~N}\end{array}$ $.000 \quad 2486.896 \quad \mathrm{~N}$ $\begin{array}{lll}.062 & 19.245 \quad \text { No }\end{array}$ $826 \quad 21.125 \quad$ Yes \begin{tabular}{lll}
902.268 & No \\
& 73.048 & Yes \\
\hline
\end{tabular} $\begin{array}{lll}780 & 60.272 & \text { No }\end{array}$ $\begin{array}{lll} & -1 \\ 8 & 2285.461 & \text { Yes }\end{array}$ $\begin{array}{lll}1.813 & 14.320 & \text { Yes }\end{array}$ $\begin{array}{llll}1.27 & -1.000 & \text { No } \\ 1.240 & 1127.459 & \text { No }\end{array}$ $\begin{array}{lll}84.378 & \text { Yes } \\ & 8.226 & -1 \\ \end{array}$ $\begin{array}{lll}15.754 & 151.383 & \text { Yes } \\ 5.874 & 6.910 & \text { Yes }\end{array}$

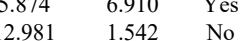
$\begin{array}{lll}6.004 & 42.441 & \text { Yes }\end{array}$ $\begin{array}{ccc}6.004 & 42.699 & \text { No } \\ .790 & 9.549 & \text { Ye }\end{array}$

Table S-4 page 304 of 614 
NLSFFLTPPCAR NLSFFLTPPCAR NLSFFLTPPCAR KLEELEQK KLEELEQK SLEDLQDEYDFK SLEDLQDEYDFK YTYEHDPITK YTYEHDPITK
YTYEHDPITK $\begin{array}{lllllllllllll}. & \end{array}$ $\begin{array}{lllllllllllll}1.00 & 57.82 & 27.26 & 18.12 & 2 & 1554.7840 & 1554.7809 & 778.3977 & 0.0031 & 1.9913 & 106.971 & 59.831 & 5.7\end{array}$

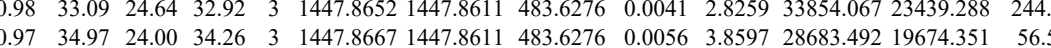

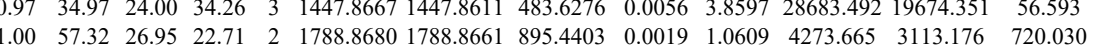
$\begin{array}{llllllllllll} & \end{array}$ $\begin{array}{llllllllllllll}1.00 & 50.27 & 26.94 & 22.57 & 2 & 1788.8692 & 1788.8661 & 895.4403 & 0.0031 & 1.7310 & 3831.433 & 2854.181 & 766.491 & 1096.764\end{array}$

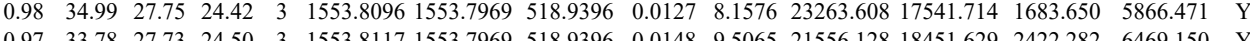

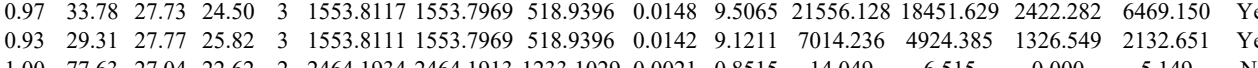

$\begin{array}{lllllllllll}\text { SK2L2 HUMAN P42285 } & \text { SKIV2L2 } & \text { Superkiller viralic } & 117.8 & 1.00 & 6 & 10.5 & 0.3306 & 0.7977 & -0.6868 & 0.6257\end{array}$

$\begin{array}{lllllllllll}\text { FRAP_HUMAN } & \text { P42345 } & \text { FRAP1 } & \text { Serine/threonine-p } 288.89 & 1.00 & 5 & 3.9 & -0.5059 & 0.7439 & 0.4507 & 1.0166\end{array}$

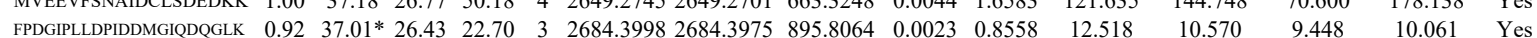

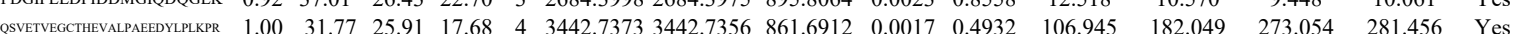
$\begin{array}{llllllllllllllll} & \end{array}$ $\begin{array}{llllllllllllllllll}\text { LPQVEHVLPLLK } & 1.00 & 36.53 & 16.13 & 18.93 & 3 & 1673.0512 & 1673.0483 & 558.6900 & 0.0029 & 1.7302 & 642.770 & 858.189 & 1134.634 & 1580.319 & \text { Yes }\end{array}$ $\begin{array}{lllllllllllllllll}\text { TVLFTNAR } & 1.00 & 47.11 & 27.65 & 25.84 & 2 & 1064.6206 & 1064.6100 & 533.3123 & 0.0106 & 9.9378 & 4919.859 & 6057.496 & 199.158 & 9066.319 & \text { No- }\end{array}$ $\begin{array}{llllllllllllllll}\text { GEMQVVPVLVHLLSAISSVR } & 0.66 & 80.64 & 22.01 & 93.64 & 3 & 2277.3022 & 2277.3001 & 760.1073 & 0.0021 & 0.9209 & 19.710 & 22.780 & 33.946 & 37.808 & \text { Yes }\end{array}$ \begin{tabular}{llllllllllllllll} 
GEMQVVPVLVHLLSAISSVR & 0.67 & 79.93 & 21.88 & 92.93 & 3 & 2277.3031 & 2277.3001 & 760.1073 & 0.0030 & 1.3156 & 41.067 & 42.356 & 49.793 & 42.854 & Yes \\
\hline
\end{tabular} $\begin{array}{lllllllllllllllll}\text { GEMQVVPVLVHLLSAISSVR } & 1.00 & 77.46 & 23.01 & 19.03 & 3 & 2293.2967 & 2293.2950 & 765.4389 & 0.0017 & 0.7403 & 7.535 & 29.941 & 15.702 & 14.816 & \text { No }\end{array}$

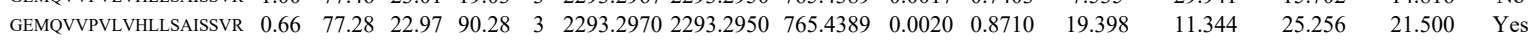
$\begin{array}{llllllllllllllll}\text { GEMQVVPVLVHLLSAISSVR } & 0.67 & 77.75 & 21.88 & 90.75 & 3 & 2277.3031 & 2277.3001 & 760.1073 & 0.0030 & 1.3156 & 20.107 & 19.271 & 31.094 & 41.457 & \text { Yes }\end{array}$ \begin{tabular}{llllllllllllllll} 
GEMQVVPVLVHLLSAISSVR & 1.00 & 45.77 & 21.88 & 16.60 & 4 & 2277.3033 & 2277.3001 & 570.3323 & 0.0032 & 1.4027 & 9.670 & 16.911 & 7.362 & 18.837 & Yes \\
\hline
\end{tabular}

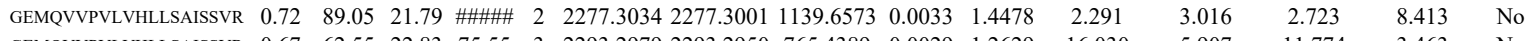

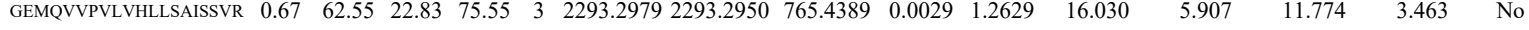
$\begin{array}{llllllllllllllll}\text { GEMQVVPVLVHLLSAISSVR } & 0.67 & 75.01 & 21.90 & 88.01 & 3 & 2277.3028 & 2277.3001 & 760.1073 & 0.0027 & 1.1840 & 18.318 & 11.235 & 20.899 & 11.647 & \text { Yes }\end{array}$ $\begin{array}{llllllllllllllll}\text { GEMQVVPVLVHLLSAISSVR } & 0.60 & 69.16 & 21.73 & 82.16 & 3 & 2277.3046 & 2277.3001 & 760.1073 & 0.0045 & 1.9734 & 6.740 & 20.341 & 14.980 & 14.144 & \text { Yes }\end{array}$ $\begin{array}{llllllllllllllll}\text { GEMQVVPVLVHLLSAISSVR } & 0.55 & 82.28 & 22.99 & 95.28 & 3 & 2293.2964 & 2293.2950 & 765.4389 & 0.0014 & 0.6097 & 2.902 & 13.941 & 9.929 & 8.546 & \text { Yes }\end{array}$ $\begin{array}{llllllllllllllllll}\text { MVEVFSNAIDCLSDEDKK } & 1.00 & 58.81 & 26.79 & 19.97 & 3 & 2649.2710 & 2649.2701 & 884.0973 & 0.0009 & 0.3393 & 58.091 & 76.708 & 62.282 & 91.829 & \text { Yes }\end{array}$ $\begin{array}{lllllllllllll} & \end{array}$

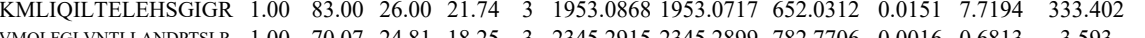
$\begin{array}{llllllllllll} & \text { MULE }\end{array}$ $\begin{array}{lllllllllllll}\text { SLAVMSMVGYILGLGDR } & 0.97 & 24.75 & 27.08 & 16.43 & 3 & 1925.0251 & 1925.0236 & 642.6818 & 0.0015 & 0.7780 & 20.391\end{array}$ $\begin{array}{llllllllllllll} & \text { GLVNTLLANDPTSLR } & 1.00 & 41.71 & 24.96 & 23.00 & 3 & 2345.2966 & 2345.2899 & 782.7706 & 0.0067 & 2.8531 & 8.045\end{array}$ $\begin{array}{lllllllllllll} & & \end{array}$

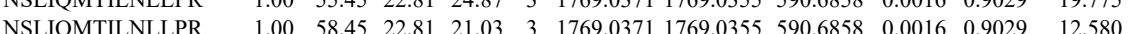
$\begin{array}{lllllllllllll}\text { NSLLQMTILNLLPR } & 1.00 & 87.69 & 22.83 & 21.49 & 2 & 1769.0374 & 1769.0355 & 885.5250 & 0.0019 & 1.0728 & 21.588\end{array}$

IQEENVIPR TVLDQQQTPSR $\begin{array}{llllllllllll}1.00 & 87.69 & 22.83 & 21.49 & 2 & 1769.0374 & 1769.0355 & 885.5250 & 0.0019 & 1.0728 & 21.188 & 10.424\end{array}$ $\begin{array}{llllllllllll}1.00 & 51.83 & 26.68 & 22.25 & 2 & 1240.7010 & 1240.6897 & 621.3521 & 0.0113 & 9.0930 & 4578.783 & 3880.130\end{array}$ $\begin{array}{llllllllllll}\text { NNNIDAAIENIENMLTSENK } & 1.00 & 86.75 & 27.60 & 23.43 & 3 & 2534.2576 & 2534.2525 & 845.7581 & 0.0051 & 2.0100 & 14.483\end{array}$

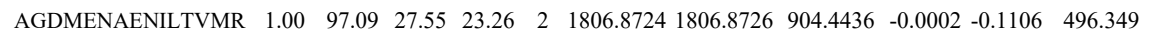

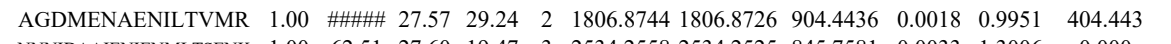
$\begin{array}{lllllllllllll}\text { NNNIDAAIENIENMLTSENK } & 1.00 & 62.51 & 27.60 & 19.47 & 3 & 2534.2558 & 2534.2525 & 845.7581 & 0.0033 & 1.3006 & 0.000 & 23 \\ \text { NNNIDAAIENIENMLTSENK } & 1.00 & 64.70 & 27.54 & 18.75 & 3 & 2534.2570 & 2534.2525 & 845.7581 & 0.0045 & 1.7736 & 18681 & 5.4\end{array}$ $\begin{array}{lllllllllllll}\text { SVLELIPELNEK } & 1.00 & 67.13 & 24.17 & 18.69 & 2 & 1670.9712 & 1670.9698 & 836.4922 & 0.0014 & 0.8368 & 268.488\end{array}$

SVLELIPELNEK $\begin{array}{llllllllllll}1.00 & 71.37 & 23.67 & 19.26 & 2 & 1670.9726 & 1670.9698 & 836.4922 & 0.0028 & 1.6737 & 914.801\end{array}$ SVLELIPELNEK $\begin{array}{lllllllllll}1.00 & 42.22 & 23.67 & 17.05 & 3 & 1670.9728 & 1670.9698 & 557.9972 & 0.0030 & 1.7921 & 131.002\end{array}$ $\begin{array}{llllllllllll}0.93 & 17.61 & 23.73 & 15.63 & 3 & 1670.9734 & 1670.9698 & 557.9972 & 0.0036 & 2.1505 & 115.651\end{array}$ $\begin{array}{llllllllllll}\text { TVQLTSSELESTLETLK } & 1.00 & 96.53 & 25.25 & 26.08 & 2 & 2166.1894 & 2166.1875 & 1084.1010 & 0.0019 & 0.8763 & 188.000\end{array}$ $\begin{array}{lllllllllllllll}\text { TVQLTSSELESTLETLK } & 1.00 & 94.25 & 25.25 & 25.80 & 2 & 2166.1894 & 2166.1875 & 1084.1010 & 0.0019 & 0.8763 & 176.061 & 107.438\end{array}$

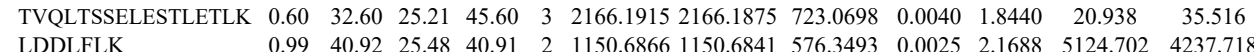

$\begin{array}{lllllllllllll}\text { LDDLFLK } & 0.99 & 40.92 & 25.48 & 40.91 & 2 & 1150.6866 & 1150.6841 & 576.3493 & 0.0025 & 2.1688 & 5124.702 & 4237.718 \\ \text { LDDLFLK } & 0.95 & 40.84 & 25.84 & 40.83 & 2 & 1150.6880 & 1150.6841 & 576.3493 & 0.0039 & 3.3834 & 6212.317 & 5033.392\end{array}$ $\begin{array}{lllllllllllll}\text { TVQLTSSELESTLETLK } & 0.98 & 23.31 & 25.20 & 17.63 & 3 & 2166.1918 & 2166.1875 & 723.0698 & 0.0043 & 1.9823 & 11.329 & 6.206\end{array}$ $\begin{array}{llllllllllllll}\text { LLMSEDYFTQAMEVK } & 1.00 & 66.39 & 27.76 & 21.50 & 2 & 2092.0494 & 2092.0464 & 1047.0305 & 0.0030 & 1.4326 & 115.748 & 90.162 \\ \text { LLMSEDYFTQAMEVK } & 1.00 & 49.47 & 27.76 & 19.77 & 3 & 2092.0495 & 2092.0464 & 698.3561 & 0.0031 & 1.4797 & 191.544 & 193.499\end{array}$

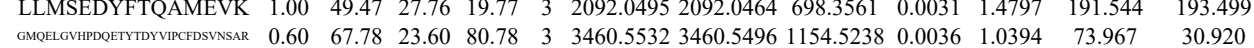

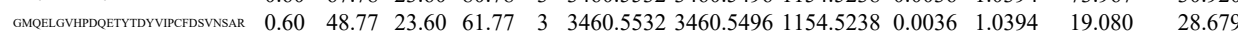
$\begin{array}{lllllllllll} & \end{array}$

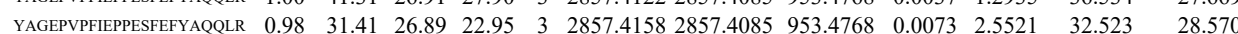


LQDAINILK
SCGSLLPELK

LQDAINILK

LQDAINILK

SCGSLLPELK

\section{GPTEAVGYFLYNLID}

NVQGIIEILK

NVQGIIEILK

GEAANGAVYFLYNLIDSMSDSEVQAK

\section{LLAEILR}

LLAEILR

LLAEILR

ISNQFDWALMR

ISNQFDWALMR
YIPDAMNLILLLVTEK

YIPDAMNLILLLV
SNTLPISLQSIR

SNTLPISLQSIR

SNTLPISLQSIR

SNTLPISLQSIR

MVFINNIALAQIK

MVFINNIALAQIK

MVFINNIALAQIK

MVFINNIALAQIK

LIITQVR

SNTLPISLQSIR

SNTLPISLQSIR

MVFINNIALAQIK

VIEPQYFGLAYLFR
VIEPOYFGLAYLFR

VIEPQYFGLAYLFR
VIEEQLEPAVEK

VIEEQLEPAVEK

SSLLLGFR

SSLLLGFR

CGAIAEQTPILLLFLL

CGAIAEQTPILLLFLLR

CGAIAEQTPILLLFLL

CGAIAEQTPILLLFLL

CGAIAEQTPILLLFLL

CGAIAEQTPILLLFLLR

GDAIAEQTPILLLL

VIEEQLEPAVEK

VIEEQLEPAVEK

MEEANIQPNR

17 VTGGAASK

VTGGAASK

VTGGAASK

VELSQLR

VELSQLR
VELSQLR

VELSQLR
VLTVINQTQK

VLTVINQTQK

YKPLDLRPK

YKPLDLRPK

YKPLDLRPK

YKPLDLRPK

VLTVINQTQK

VLTVINQTQK

YKPLDLRPK

YKPLDLRPK

YKPLDLRPK
YKPLDLRPK

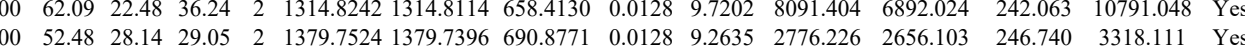
$\begin{array}{lllllllllllllll}1.00 & 25.89 & 26.95 & 38.89 & 4 & 3021.4925 & 3021.4885 & 756.3794 & 0.0040 & 1.3221 & 24.244 & 40.535 & 14.199 & 32.421 & \text { Yes }\end{array}$ $\begin{array}{lllllllllllllll}1.00 & 60.18 & 23.18 & 36.43 & 2 & 1314.8132 & 1314.8114 & 658.4130 & 0.0018 & 1.3669 & 4754.844 & 3530.074 & 457.232 & 5529.731 & \text { Yes } \\ 1.00 & 61.98 & 23.05 & 36.07 & 2 & 1314.8152 & 1314.8114 & 658.4130 & 0.0038 & 2.8857 & 9396.612 & 7051.838 & 293.544 & 10009.950 & \text { Yes }\end{array}$

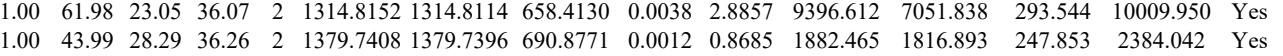
$\begin{array}{lllllllllllllll}1.00 & 43.99 & 28.29 & 36.26 & 2 & 1379.7408 & 1379.7396 & 690.8771 & 0.0012 & 0.8685 & 1882.465 & 1816.893 & 247.853 & 2384.042 & \text { Yes } \\ 1.00 & 73.00 & 26.99 & 20.99 & 3 & 3021.4912 & 3021.4885 & 1008.1701 & 0.0027 & 0.8927 & 2.467 & 5.736 & 9.381 & 7.033 & \text { No } \\ 1.00 & 70.06 & 26.99 & 21.68 & 3 & 3021.4912 & 3021.4885 & 1008.1701 & 0.0027 & 0.8927 & 14.982 & 7.376 & 5.596 & 9.761 & \text { Yes }\end{array}$

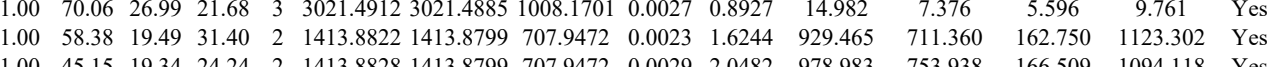
$\begin{array}{lllllllllllllll}1.00 & 45.15 & 19.34 & 24.24 & 2 & 1413.8828 & 1413.8799 & 707.9472 & 0.0029 & 2.0482 & 978.983 & 753.938 & 166.509 & 1094.118 & \text { Yes } \\ 1.00 & 42.06 & 2.95 & 20.11 & 3 & 3021.4942 & 3021.4885 & 10081701 & 0.0057 & 1.8846 & 1.232 & 3.706 & 0.000 & 2.194 & \text { No }\end{array}$

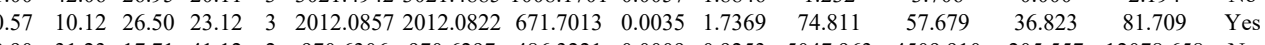
$\begin{array}{llllllllllllllll}0.90 & 31.23 & 17.71 & 41.12 & 2 & 970.6306 & 970.6297 & 486.3221 & 0.0009 & 0.9253 & 5047.963 & 4509.910 & 205.557 & 12.78 .658 & \text { No } \\ 0.97 & 31.14 & 17.71 & 35.39 & 2 & 970.602 & 970.627 & 486.321 & 0.0005 & 0.5141 & 5722.089 & 5022.255 & 321.625 & 12014.721 & \text { No }\end{array}$ $\begin{array}{lllllllllllllll}0.87 & 31.09 & 17.71 & 42.54 & 2 & 970.6310 & 970.6297 & 486.3221 & 0.0013 & 1.5366 & 4925.381 & 4985299 & 231.567 & 11016.286 & \text { No }\end{array}$ $\begin{array}{llllllllllllllll}1.00 & 65.38 & 27.77 & 23.76 & 2 & 1523.7690 & 1523.7677 & 762.8911 & 0.0013 & 0.8520 & 3737.389 & 2637.873 & 101.670 & 4785.336 & \text { Yes }\end{array}$ $\begin{array}{lllllllllllllll}1.00 & 71.44 & 27.85 & 24.85 & 2 & 1523.3700 & 1523.7677 & 762.8911 & 0.0023 & 1.5074 & 4041.032 & 3121.223 & 9.943 & 5406.583 & \text { Yes }\end{array}$

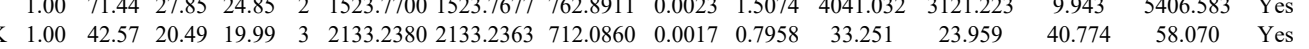
$\begin{array}{lllllllllllllll}0.67 & 25.99 & 20.29 & 38.99 & 3 & 2133.2392 & 2133.2363 & 712.0860 & 0.0029 & 1.3575 & 33.427 & 51.493 & 28.606 & 45.252 & \text { Yes }\end{array}$

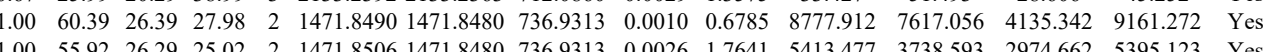
$\begin{array}{llllllllllllllll}1.00 & 55.92 & 26.29 & 25.02 & 2 & 1471.8506 & 1471.8480 & 736.9313 & 0.0026 & 1.7641 & 5413.477 & 3738.593 & 2974.662 & 5395.123 & \text { Yes } \\ 100 & 55.78 & 26.39 & 23.26 & 2 & 1471.8490 & 1471.8480 & 736.9313 & 0.0010 & 0.6785 & 350.808 & 296.537 & 264.232 & 433.837 & \text { Yes }\end{array}$ $\begin{array}{lllllllllllllll}1.00 & 51.30 & 26.39 & 22.49 & 2 & 1471.8494 & 1471.8480 & 736.9313 & 0.0014 & 0.9499 & 769.926 & 816.415 & 361.360 & 1116.093 & \text { Yes }\end{array}$ $\begin{array}{llllllllllllllll}1.00 & 80.20 & 21.93 & 24.82 & 2 & 1762.0434 & 1762.0419 & 882.0282 & 0.0015 & 0.8503 & 2010.833 & 1454.020 & 395.662 & 1698.474 & \text { Yes }\end{array}$ $\begin{array}{llllllllllllll}1.00 & \text { \#\#\# } 21.93 & 31.25 & 2 & 1762.0438 & 1762.0419 & 882.0282 & 0.0019 & 1.0771 & 1421.735 & 1252.031 & 48.399 & 1726.180 & \text { Yes }\end{array}$ $\begin{array}{lllllllllllllll}1.00 & 38.35 & 21.46 & 17.71 & 3 & 1762.0456 & 1762.0419 & 588.3546 & 0.0037 & 2.0962 & 370.890 & 454.768 & 99.594 & 492.034 & \text { Yes }\end{array}$ $\begin{array}{llllllllllllllll}1.00 & 34.82 & 21.46 & 18.63 & 3 & 1762.0459 & 1762.0419 & 588.3546 & 0.0040 & 2.2662 & 731.324 & 861.343 & 182.225 & 1278.770 & \text { Yes }\end{array}$ $\begin{array}{llllllllllllllll}0.77 & 36.67 & 24.00 & 40.78 & 2 & 985.6476 & 985.6406 & 493.8276 & 0.0070 & 7.0874 & 19678.446 & 16881.540 & 2045.433 & 27631.719 & \text { Yes }\end{array}$

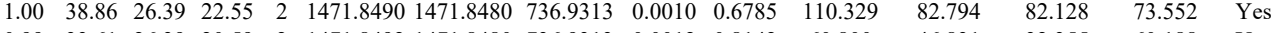

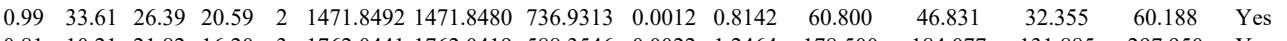
$\begin{array}{lllllllllllllll}0.81 & 10.21 & 21.82 & 16.20 & 3 & 1762.0441 & 1762.0419 & 588.3546 & 0.0022 & 1.2464 & 178.500 & 184.077 & 131.885 & 297.950 & \text { Yes }\end{array}$ $\begin{array}{llllllllllllllll}1.00 & 77.32 & 27.01 & 20.91 & 2 & 1859.0122 & 1859.0103 & 930.5124 & 0.0019 & 1.0209 & 106.495 & 100.424 & 0.028 & 132.097 & \text { No }\end{array}$

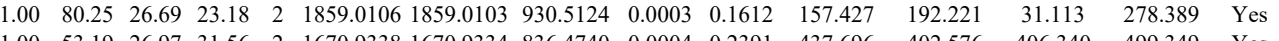
$\begin{array}{lllllllllllllll}1.00 & 53.19 & 26.97 & 31.56 & 2 & 1670.9338 & 1670.9334 & 836.4740 & 0.0004 & 0.2391 & 437.696 & 402.576 & 406.340 & 499.349 & \text { Yes }\end{array}$

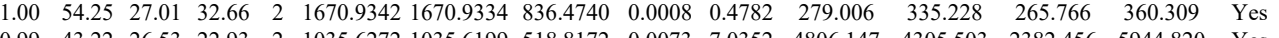

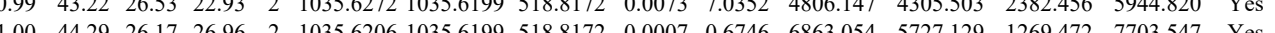
$\begin{array}{lllllllllllllll}1.00 & 44.29 & 26.17 & 26.96 & 2 & 1035.6206 & 1035.6199 & 518.8172 & 0.0007 & 0.6746 & 6863.054 & 5727.129 & 1269.472 & 7703.547 & \text { Yes }\end{array}$

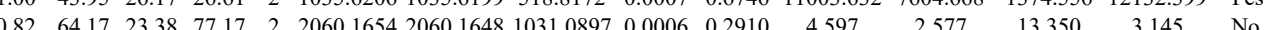

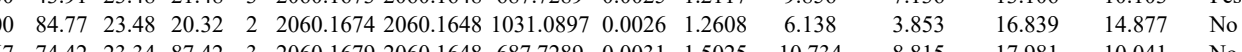

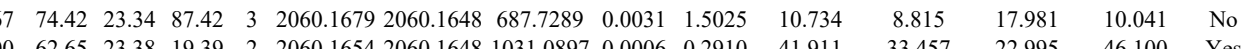
$\begin{array}{lllllllllllllll}1.00 & 61.51 & 23.38 & 23.34 & 2 & 2060.1654 & 2060.1648 & 1031.0897 & 0.0006 & 0.2910 & 33.026 & 14.374 & 25.485 & 28.266 & \text { Yes }\end{array}$

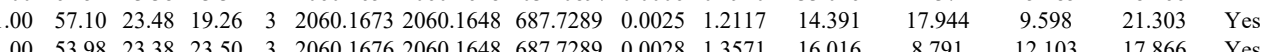

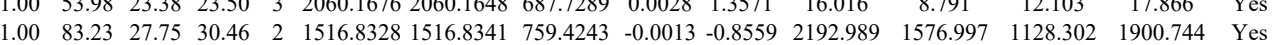

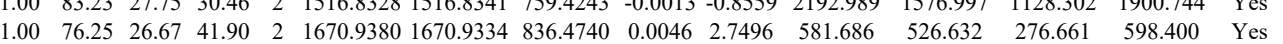

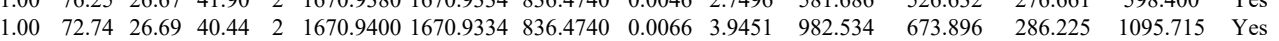
$\begin{array}{lllllllllllllll}1.00 & 48.36 & 27.26 & 22.58 & 2 & 1344.6584 & 1344.6577 & 673.3361 & 0.0007 & 0.5198 & 2866.544 & 2427.296 & 584.839 & 3847.387 & \text { Yes }\end{array}$ $\begin{array}{lllllllllllllll}0.96 & 33.54 & 28.02 & 26.91 & 2 & 977.5750 & 977.5749 & 489.7947 & 0.0001 & 0.1021 & 110.500 & 135.392 & 99.467 & 129.609 & \text { No }\end{array}$ $\begin{array}{llllllllllllllll}0.95 & 36.98 & 28.20 & 27.85 & 2 & 977.5742 & 977.5749 & 489.7947 & -0.0007 & -0.7146 & 162.043 & 147.107 & 166.021 & 218.873 & \text { No }\end{array}$ $\begin{array}{lllllllllllllll}0.99 & 40.02 & 28.16 & 27.59 & 2 & 977.5746 & 977.5749 & 489.7947 & -0.0003 & -0.3063 & 144.422 & 183.241 & 153.483 & 177.792 & \text { No }\end{array}$

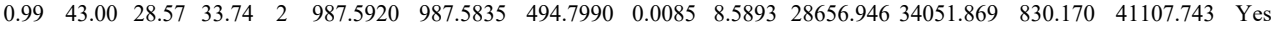
$\begin{array}{llllllllllllllll}0.67 & 28.23 & 28.59 & 26.62 & 2 & 987.5914 & 987.5835 & 494.7990 & 0.0079 & 7.9830 & 4735.058 & 5180.528 & 419.236 & 4830.752 & \text { Yes }\end{array}$ $\begin{array}{lllllllllllllllll}0.95 & 37.13 & 28.76 & 28.94 & 2 & 987.5928 & 987.5835 & 494.7990 & 0.0093 & 9.3977 & 5441.937 & 5427.636 & 411.969 & 5847.355 & \text { Yes }\end{array}$ $\begin{array}{lllllllllllllll}1.00 & 55.20 & 21.70 & 22.10 & 2 & 1430.8796 & 1430.8701 & 716.4423 & 0.0095 & 6.6299 & 11292.078 & 12362.786 & 712.383 & 14509.912 & \text { Yes }\end{array}$ $\begin{array}{lllllllllllllll}1.00 & 53.95 & 22.15 & 30.84 & 2 & 1430.8810 & 4430.8701 & 716.4423 & 0.0109 & 7.6070 & 13041.173 & 14041.118 & 640.554 & 16978.507 & \text { Yes }\end{array}$ $\begin{array}{lllllllllllllll}0.98 & 22.18 & 17.16 & 15.44 & 2 & 1560.9734 & 1560.9717 & 781.4931 & 0.0017 & 1.0877 & 2914.398 & 3520.291 & 1420.086 & 4428.848 & \text { Yes }\end{array}$ $\begin{array}{lllllllllllllll}0.98 & 22.36 & 17.16 & 15.67 & 2 & 1560.9736 & 1560.9717 & 781.4931 & 0.0019 & 1.2156 & 2385.947 & 2604.739 & 1027.072 & 3147.281 & \text { Yes }\end{array}$

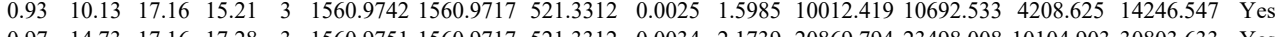
$\begin{array}{llllllllllllllll}0.97 & 14.73 & 17.16 & 15.28 & 3 & 1560.9751 & 1560.9717 & 521.3312 & 0.0034 & 2.1739 & 20869.194 & 23498.008 & 10104.903 & 30803.633 & \text { Yes }\end{array}$ $\begin{array}{llllllllllllllllll}1.00 & 55.17 & 21.76 & 23.67 & 2 & 1430.8806 & 1430.8701 & 716.4423 & 0.0105 & 7.3278 & 13008.386 & 15433.421 & 1101.785 & 16158.127 & \text { Yes } \\ 1.00 & 56.05 & 21.82 & 21.03 & 2 & 1430.8808 & 1430.8701 & 716.4423 & 0.0107 & 7.4674 & 11067.013 & 13620.115 & 190.375 & 14354.705 & \text { Yes }\end{array}$ $\begin{array}{lllllllllllllll}1.00 & 56.05 & 21.82 & 21.03 & 2 & 1430.8808 & 1430.8701 & 716.4423 & 0.0107 & 7.4674 & 11067.013 & 13620.115 & 190.375 & 14354.705 & \text { Yes } \\ 0.98 & 22.43 & 17.16 & 15.66 & 2 & 1560.9740 & 1560.9717 & 781.4931 & 0.0023 & 1.4715 & 12700.354 & 12910.412 & 4914065 & 20770.767 & \text { Yes }\end{array}$

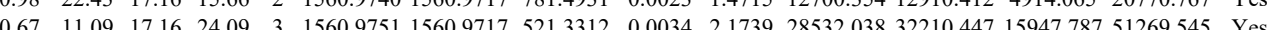

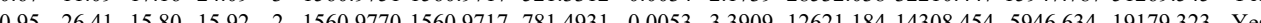
$\begin{array}{lllllllllllllll}0.86 & 14.29 & 16.13 & 17.01 & 3 & 1560.9775 & 1560.9717 & 521.3312 & 0.0058 & 3.7084 & 31890.343 & 36622.832 & 13610.266 & 59198.095 & \text { Yes }\end{array}$

Table S-4 page 306 of 614 

$\begin{array}{lllllllllllllllll} & \end{array}$

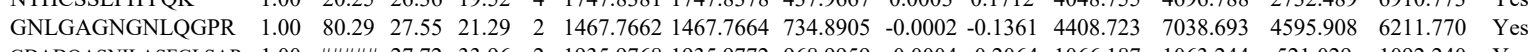

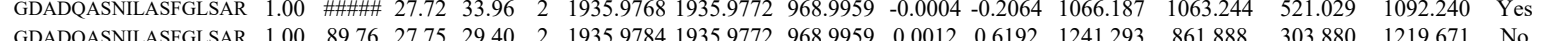

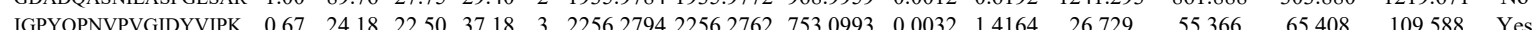

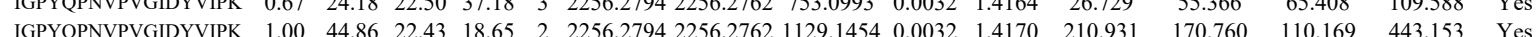
$\begin{array}{llllllllllllllll}\text { IGPYOPNYPVGIDYVIPK } & 0.72 & 33.88 & 22.43 & 46.88 & 2 & 256.2794 & 2562762 & 1129.1454 & 0.0032 & 1.4170 & 159.826 & 266.123 & 212.715 & 351.990 & \text { Yes }\end{array}$

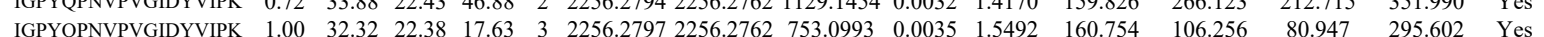
$\begin{array}{llllllllllllllll}\text { IGPYPQPNVPVGIDYVIPK } & 0.60 & 23.98 & 22.36 & 36.98 & 3 & 2256.2806 & 2256.2762 & 753.0993 & 0.0044 & 1.9475 & 149.439 & 99.396 & 103.454 & 174.734 & \text { Yes }\end{array}$

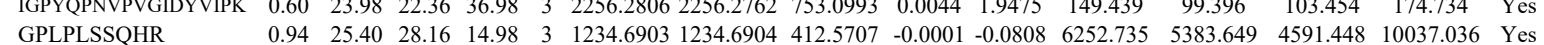
$\begin{array}{llllllllllllllllll}\text { GPLPSSSQHR } & 0.98 & 27.13 & 28.12 & 15.56 & 3 & 1234.6912 & 1234.6904 & 4125707 & 0.0008 & 0.6464 & 2824.054 & 2702.052 & 2331.883 & 5590.165 & \text { Yes }\end{array}$

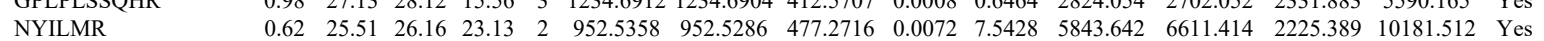
NYILMR

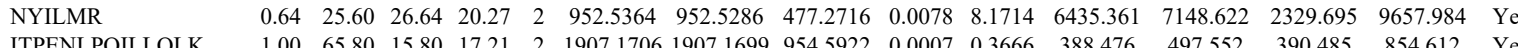
$\begin{array}{lllllllllllllllll}\text { ITYNLPQILLQLK } & 1.00 & 65.80 & 15.80 & 17.21 & 2 & 1907.1706 & 1907.1699 & 954.5922 & 0.0007 & 0.3666 & 388.476 & 497.552 & 390.485 & 854.612 & \text { Yes }\end{array}$ \begin{tabular}{lllllllllllllllll} 
ITPENLPQILLQLK & 0.84 & 59.40 & 15.19 & 72.40 & 2 & 1907.1720 & 1907.1699 & 954.5922 & 0.0021 & 1.0999 & 2139.768 & 3017.812 & 2153.752 & 3781.851 & Yes \\
\hline
\end{tabular} $\begin{array}{lllllllllllllllll}\text { ITPENLPQILLQLK } & 1.00 & 45.54 & 14.77 & 17.80 & 3 & 1907.1751 & 1907.1699 & 636.7306 & 0.0052 & 2.7222 & 577.490 & 875.729 & 485.858 & 980.412 & \text { Yes } \\ \end{array}$ $\begin{array}{llllllllllllllll}\text { ITPENLPQILLQLK } & 0.82 & 63.74 & 15.80 & 76.74 & 2 & 1907.1710 & 1907.1699 & 954.5922 & 0.0011 & 0.5762 & 1308.698 & 1257.394 & 1089.386 & 1935.828 & \text { Yes } \\ \text { IT } & 0.83 .77 & 15.19 & 76.77 & 2 & 1907.1716 & 1907.1699 & 954.5922 & 0.0017 & 0.8904 & 1081.738 & 1449.846 & 875.766 & 1997.683 & \text { Yes }\end{array}$ $\begin{array}{lllllllllllllllll}\text { YQLLQLVEPFGVISNHLILNK } & 0.55 & 58.46 & 16.72 & 71.46 & 3 & 2725.5787 & 2725.5774 & 909.5331 & 0.0013 & 0.4764 & 212.027 & 399.284 & 370.855 & 622.845 & \text { Yes }\end{array}$ $\begin{array}{llllllllllllllll}\text { YQLLQLVEPFGVISNHLILNK } & 0.67 & 71.82 & 16.33 & 84.82 & 3 & 2725.5805 & 2725.5774 & 909.5331 & 0.0031 & 1.1361 & 582.028 & 834.333 & 701.555 & 1221.743 & \text { Yes }\end{array}$

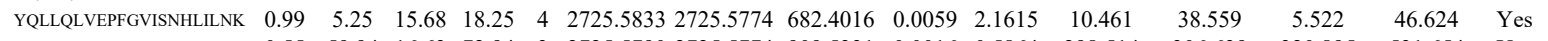
$\begin{array}{llllllllllllllllll}\text { YQLLQLVEPFGVISNHLILNK } & 0.55 & 59.94 & 16.63 & 72.94 & 3 & 2725.5790 & 2725.5774 & 909.5331 & 0.0016 & 0.5864 & 298.514 & 306.639 & 320.895 & 531.654 & \text { Yes }\end{array}$

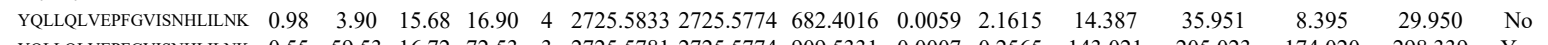
$\begin{array}{llllllllllllllll}\text { YQLLQLVEPFGVISNHLLLNK } & 0.55 & 59.53 & 16.72 & 72.53 & 3 & 2725.5781 & 2725.5774 & 909.5331 & 0.0007 & 0.2565 & 143.021 & 205.023 & 174.020 & 298.339 & \text { Yes }\end{array}$ $\begin{array}{llllllllllllllll}\text { YQLLQLVEPFGVISNHLLLNK } & 0.55 & 73.65 & 16.72 & 86.65 & 3 & 2725.5784 & 2725.5774 & 909.5331 & 0.0010 & 0.3665 & 163.871 & 215.040 & 138.756 & 306.243 & \text { Yes }\end{array}$

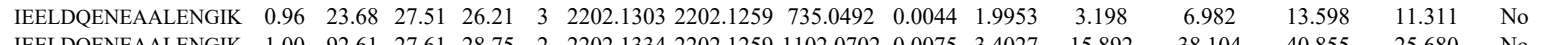

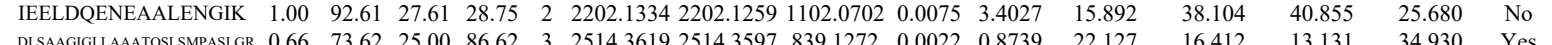

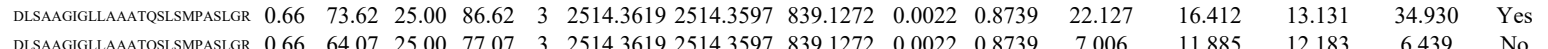

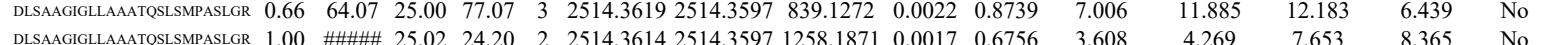
$\begin{array}{lllllllllllll} & \text { DLSAAGLA }\end{array}$

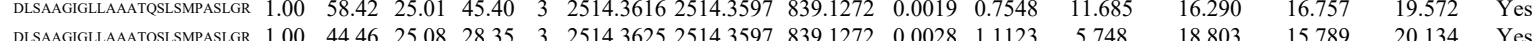
$\begin{array}{llllllllllllll}D & 16.515 & \text { YeS }\end{array}$ $\begin{array}{lllllllllllllllll}\text { DLSAGGIGLAATOSLSMPASLGR } & 1.00 & 96.07 & 25.58 & 20.04 & 3 & 2530.3564 & 2530.3546 & 844.4588 & 0.0018 & 0.7105 & 6.598 & 5.966 & 6.253 & 9.062 & \text { Yes }\end{array}$ $\begin{array}{llllllllllllllll}\text { ITPENLPQILLQLK } & 0.66 & 22.86 & 15.19 & 35.86 & 3 & 1907.1721 & 1907.1699 & 636.7306 & 0.0022 & 1.1517 & 74.621 & 98.539 & 19.414 & 104.792 & \text { Yes }\end{array}$ $\begin{array}{lllllllllllll} & \end{array}$

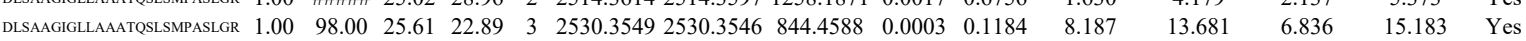

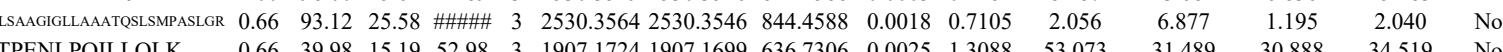

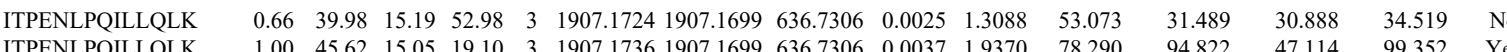
$\begin{array}{llllllllllllllll}\text { ITPENLPQILLQLK } & 1.00 & 45.62 & 15.05 & 19.10 & 3 & 1907.1736 & 1907.1699 & 636.7306 & 0.0037 & 1.9370 & 78.290 & 94.822 & 47.114 & 99.352 & \text { Yes }\end{array}$ $\begin{array}{lllllllllllllllll} & & & \end{array}$ $\begin{array}{lllllllllllll}\text { VDIEELDQENEAALENGIK } & 1.00 & 59.63 & 25.79 & 21.23 & 3 & 2688.4189 & 2688.4183 & 897.1467 & 0.0006 & 0.2229 & 92.488 & 12\end{array}$

$\begin{array}{lllllllllllllll}\text { SQAFIEMETR } & 1.00 & 55.51 & 27.23 & 24.42 & 2 & 1354.6802 & 1354.6673 & 678.3409 & 0.0129 & 9.5084 & 1662.616 & & & \\ \end{array}$

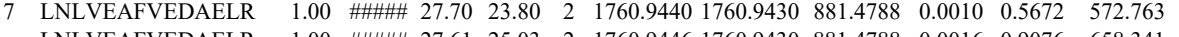

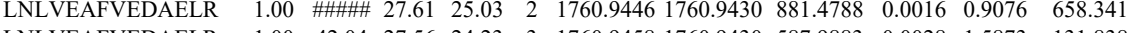

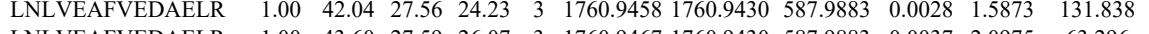

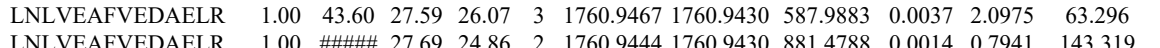

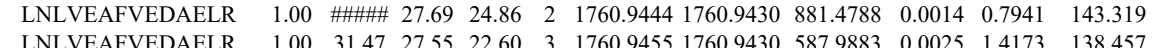
$\begin{array}{lllllllllllll}\text { LNLVEAFVEDAELR } & 1.00 & 31.47 & 27.55 & 22.60 & 3 & 1760.9455 & 1760.9430 & 587.9883 & 0.0025 & 1.4173 & 138.457 & 123.709 \\ \text { LNLVEAFVEDAELR } & 0.72 & 14.00 & 27.55 & 22.73 & 3 & 1760.9455 & 1760.9430 & 587.9883 & 0.0025 & 1.4173 & 121.772 & 126.90\end{array}$ LNLVEAFVEDAELR MQSTLISAAR MQSTLISAAR $\begin{array}{llllllllllll}1.00 & 61.35 & 28.31 & 33.15 & 2 & 1220.6770 & 1220.6669 & 611.3407 & 0.0101 & 8.2605 & 4109.668 & 2840.701 \\ 1.00 & 51.77 & 28.29 & 32.24 & 2 & 1220.6774 & 1220.6669 & 611.3407 & 0.0105 & 8.5876 & 3683.077 & 2930.296\end{array}$ LLLAVFVTPLTDLR $\begin{array}{llllllllllll}1.00 & 51.77 & 28.29 & 32.24 & 2 & 1220.6774 & 1220.6669 & 611.3407 & 0.0105 & 8.5876 & 3683.077 & 2930.296\end{array}$ $\begin{array}{llllllllllll}0.82 & 79.02 & 18.69 & 92.02 & 2 & 1714.0522 & 1714.0515 & 858.0330 & 0.0007 & 0.4079 & 64.414\end{array}$ $\begin{array}{llllllllllll}00 & 32.82 & 18.57 & 15.91 & 3 & 1714.0531 & 1714.0515 & 572.3578 & 0.0016 & 0.9318 & 19.565\end{array}$ $\begin{array}{lllllllllll}1.00 & 49.15 & 18.45 & 21.75 & 3 & 1714.0540 & 1714.0515 & 572.3578 & 0.0025 & 1.4560 & 27.26 \\ 1.00 & 8.59 & 18.69 & 25.76 & 2 & 17140520 & 17140515 & 858.033 & 0.0005 & 0.2914 & 38.754\end{array}$

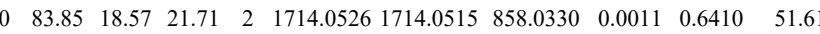
$\begin{array}{llllllllllll}1.00 & 49.16 & 18.45 & 17.39 & 3 & 1714.0540 & 1714.0515 & 572.3578 & 0.0025 & 1.4560 & 24.133\end{array}$ 


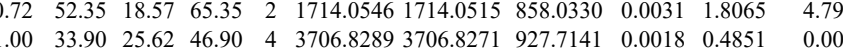
$\begin{array}{llllllllllllll} & \end{array}$

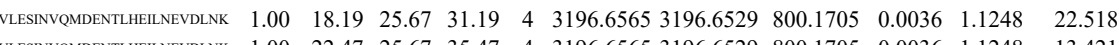
$\begin{array}{llllllllllll}\text { ULESINVQMDENTLHELLNEVLLK } & 1.00 & 22.47 & 25.67 & 35.47 & 4 & 3196.6565 & 3196.6529 & 800.1705 & 0.0036 & 1.1248 & 13.421 \\ \text { ANLLEIAPHLSAPLPIMLPVYK } & 0.55 & 52.06 & 15.80 & 65.06 & 3 & 2687.5705 & 2687.5691 & 896.8636 & 0.0014 & 0.5203 & 77.812\end{array}$ $\begin{array}{llllllllllll}\text { ANLLEIAPHLSAPLPIMLPVYK } & 0.55 & 52.06 & 15.80 & 65.06 & 3 & 2687.5705 & 2687.5691 & 896.8636 & 0.0014 & 0.5203 & 77.812 \\ \text { ANLLEIAPHLSAPLPIMLPVYK } & 0.66 & 53.30 & 15.80 & 66.30 & 3 & 2687.5708 & 2687.5691 & 896.8636 & 0.0017 & 0.6318 & 224.302\end{array}$ $\begin{array}{lllllllllllll}\text { ANLLEIAPHLSAPLPIMLPVYK } & 0.66 & 53.30 & 15.80 & 66.30 & 3 & 2687.5708 & 2687.5691 & 896.8636 & 0.0017 & 0.6318 & 224.302 & 17 \\ \text { WPIVGVR } & 0.68 & 25.57 & 24.98 & 28.23 & 2 & 96.5054 & 96.5882 & 48.5014 & 0.0072 & 7.4104 & 8476.02 & 592\end{array}$ WPIVGVR VIFFLPWQK

VIFFLPWQK

VIFFLPWQK

VIFFLPWQK

WPIVGVR

VIFFLPWQK

VIFFLPWQK

MNLAIALTAAR

MNLAIALTAAR

$\begin{array}{lllllllllllllll}0.68 & 25.57 & 24.98 & 28.23 & 2 & 969.5954 & 969.5882 & 485.8014 & 0.0072 & 7.4104 & 8476.026 & 5922.431 & 65.4\end{array}$ $\begin{array}{llllllllllllll}0.75 & 24.36 & 24.46 & 25.52 & 2 & 969.5972 & 969.5882 & 485.8014 & 0.0090 & 9.2630 & 7007.301 & 6000.546 \\ 1.00 & 45.43 & 23.10 & 25.70 & 2 & 1464.8760 & 1464.8737 & 733.4441 & 0.0023 & 1.5679 & 1237.211 & 826260\end{array}$

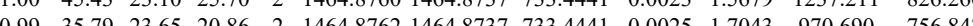

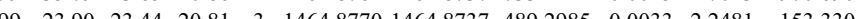
$\begin{array}{llllllllllllll}0.94 & 18.00 & 23.44 & 18.45 & 3 & 1464.8773 & 1464.8737 & 489.2985 & 0.0036 & 2.4525 & 145.445\end{array}$

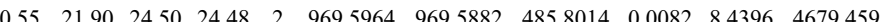

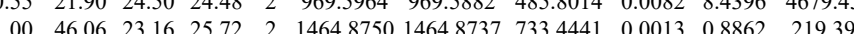

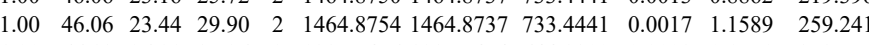
$\begin{array}{lllllllllll}1.00 & 66.13 & 26.91 & 35.26 & 2 & 1287.7456 & 1287.7454 & 644.8800 & 0.0002 & 0.1551 & 353.777\end{array}$ $\begin{array}{lllllllllll}1.00 & 63.00 & 27.00 & 36.51 & 2 & 1287.7466 & 1287.7454 & 644.8800 & 0.0012 & 0.9304 & 334.351\end{array}$ GTEDFIVESLDASFR GTEDFIVESLDASFR FLVGFTNK FLVGFTNK GEDFPANNIVK

GEDFPANNIVK

GEDFPANNIVK

GTEDFIVESLDASFR

$\begin{array}{lllllllllllll}\text { RANG_HUMAN } & \text { P43487 } & \text { RANBP1 } & \text { Ran-specific GTP: } 23.31 & 1.00 & 5 & 31.8 & 0.0927 & 0.2653 & 2.0771 & 0.4698 & 18 & \text { TLEEDEEELFK }\end{array}$

TLEEDEEELFK

TLEEDEEELFK

TLEEDEEELFK

FASENDLPEWK

FASENDLPEW

FLNAENAQK

TLNAENAQK

FLNAENAQK

$\begin{array}{llllllllllll}1.00 & 89.31 & 27.54 & 27.55 & 2 & 1828.8984 & 1828.8965 & 915.4555 & 0.0019 & 1.0377 & 245.438\end{array}$

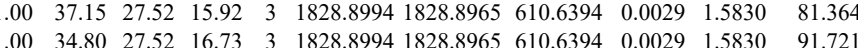
$\begin{array}{lllllllllll}1.00 & 99.24 & 27.49 & 26.93 & 2 & 1828.8998 & 1828.8965 & 915.4555 & 0.0033 & 1.8024 & 212.923\end{array}$ $\begin{array}{lllllllll}1.00 & 45.72 & 24.44 & 23.03 & 2 & 1212.7224 & 1212.7110 & 60\end{array}$

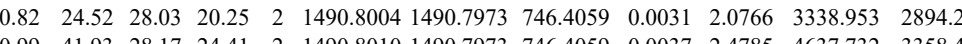
$\begin{array}{lllllllllllll}0.99 & 41.93 & 28.17 & 24.41 & 2 & 1490.8010 & 1490.7973 & 746.4059 & 0.0037 & 2.4785 & 4637.732 & 3358.478 \\ 0.84 & 29.26 & 2.19 & 29.29 & 2 & 1490.8118 & 1490.7973 & 746.4059 & 0.0145 & 9.7131 & 272.459 & 155.124\end{array}$ $\begin{array}{llllllllllll}0.84 & 29.26 & 28.19 & 29.29 & 2 & 1490.8118 & 1490.7973 & 746.4059 & 0.0145 & 9.7131 & 272.459 & 155.124 \\ 1.00 & 91.76 & 27.51 & 29.71 & 2 & 1828.8986 & 1828.8965 & 915.4555 & 0.0021 & 1.1470 & 97.325 & 73.142\end{array}$ $\begin{array}{llllllllllll}1.00 & 27.49 & 32.67 & 2 & 1828.8990 & 1828.8965 & 915.4555 & 0.0025 & 1.3654 & 68.173\end{array}$ $\begin{array}{lllllllllll}0.96 & 24.93 & 28.06 & 26.34 & 3 & 1668.8350 & 1668.8338 & 557.2852 & 0.0012 & 0.7178 & 30.168\end{array}$ $\begin{array}{lllllllllll}0.89 & 18.87 & 28.01 & 21.32 & 3 & 1668.8356 & 1668.8338 & 557.2852 & 0.0018 & 1.0766 & 34.134\end{array}$ $\begin{array}{lllllllllllll}1.00 & 63.11 & 27.96 & 27.05 & 2 & 1668.8362 & 1668.8338 & 835.4242 & 0.0024 & 1.4364 & 661.738 & 838.492\end{array}$ $\begin{array}{llllllllllll}1.00 & 62.77 & 27.89 & 26.89 & 2 & 1668.8368 & 1668.8338 & 835.4242 & 0.0030 & 1.7955 & 378.221 & 425.050\end{array}$ $\begin{array}{lllllllllllll}1.00 & 65.50 & 28.24 & 25.25 & 2 & 1622.8190 & 1622.8184 & 812.4165 & 0.0006 & 0.3693 & 1187.333 & 1210.211 \\ 1.00 & 62.87 & 28.18 & 25.09 & 2 & 16228196 & 1622.8184 & 812.4165 & 0.0012 & 0.7385 & 4151.794 & 4114.701\end{array}$

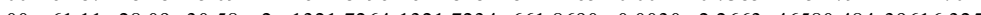
$\begin{array}{llllllllllllllllll}0.53 & 41.92 & 27.85 & 27.74 & 2 & 1638.8326 & 1638.8313 & 820.4229 & 0.0013 & 0.7923 & 248.795 & 220.268 & 309.258 & 369.812 & \mathrm{No}\end{array}$

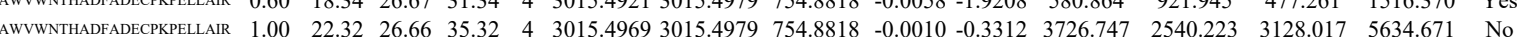
$\begin{array}{lllllllllllllllll}\text { AWVWNTHADFADECPKPELLAIR } & 1.00 & 22.95 & 26.67 & 35.95 & 4 & 3015.4993 & 3015.4979 & 754.8818 & 0.0014 & 0.4636 & 1430.139 & 1896.972 & 1380.602 & 2505.402 & \text { Y }\end{array}$ $\begin{array}{llllllllllllllll}\text { AWVWNTHADFADECPKPELAIR } & 1.00 & 25.59 & 26.67 & 38.59 & 4 & 3015.5013 & 3015.4979 & 754.8818 & 0.0034 & 1.1260 & 2554.438 & 2778.696 & 2309.429 & 3629.794 & \text { Yes }\end{array}$ $\begin{array}{llllllllllllllll}\text { TLEEDEEELFK } & 1.00 & 64.31 & 28.00 & 29.89 & 2 & 1668.8338 & 1668.8338 & 835.4242 & 0.0000 & 0.0000 & 308.840 & 382.926 & 57.716 & 505.652 & \text { Yes }\end{array}$ $\begin{array}{llllllllllllllll} & \\ \text { TLEEDEEELFK } & 1.00 & 67.47 & 28.10 & 31.09 & 2 & 1668.8348 & 1668.8338 & 835.4242 & 0.0010 & 0.5985 & 736.639 & 898.689 & 143.046 & 1322.155 & \text { Yes }\end{array}$ $\begin{array}{llllllllllllllll}\text { TLEEDEEELFK } & 0.69 & 13.64 & 27.88 & 23.56 & 3 & 1668.8368 & 1668.8338 & 557.2852 & 0.0030 & 1.7944 & 34.428 & 34.545 & 18.731 & 31.702 & \text { Yes }\end{array}$ $\begin{array}{llllllllllllllll}\text { TLEEDEEELFK } & 1.00 & 58.47 & 28.01 & 27.55 & 2 & 1668.8340 & 1668.8338 & 835.4242 & 0.0002 & 0.1197 & 554.643 & 599.263 & 132.142 & 1222.668 & \text { Yes }\end{array}$

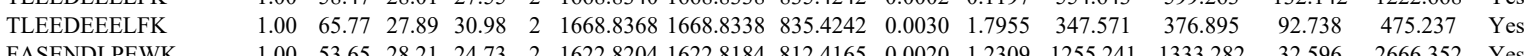
FASENDLPEWK FASENDLPEWK

$\begin{array}{lllllllllll}\text { NAMPT_HUMA } & \text { P43490 } & \text { NAMPT } & \text { Nicotinamide pho: } 55.521 & 1.00 & 13 & 31.6 & 0.8726 & 0.7602 & -0.1700 & 0.7885\end{array}$

EEGK $\begin{array}{lllllllllllll}.00 & 53.65 & 28.21 & 24.73 & 2 & 1622.8204 & 1622.8184 & 812.4165 & 0.0020 & 1.2309 & 1255.241 & 1333.282\end{array}$

TPAGNFVTLEEGK $\begin{array}{lllllllll}-28.22 & 23.59 & 2 & 1622.8216 & 1622.8184 & 812.4165 & 0.0032 & 1.9694 & 9\end{array}$ TPAGNFTLEEK $\begin{array}{llllllllllllllll}1.00 & 80.98 & 27.63 & 28.79 & 2 & 1649.8866 & 1649.8868 & 825.9507 & -0.0002 & -0.1211 & 486.109 & 838.723 & 2109.377 & 1545.478 & \text { Yes } & \\ 1.00 & 75.48 & 27.63 & 25.45 & 2 & 1649.8868 & 1649.8868 & 825.9507 & 0.0000 & 0.0000 & 724.692 & 1071.319 & 2516.250 & 2043.161 & \text { Yes }\end{array}$ $32.596 \quad 2666.352$ Yes

\section{FPVTENSK} $\begin{array}{lllllllllllllllllll} & \end{array}$ $\begin{array}{lllllllllllllllll}0.98 & 35.34 & 27.72 & 22.38 & 2 & 1208.6678 & 1208.6645 & 605.3395 & 0.0033 & 2.7257 & 3143.181 & 4099.793 & 21934.466 & 5063.614 & \text { No }\end{array}$ $\begin{array}{lllllllllllllll} & & & \end{array}$ $\begin{array}{lllllllllllll}\text { GDLEEYGQDLLHTVKK } & 1.00 & 47.69 & 27.64 & 16.01 & 3 & 2151.1126 & 2151.1092 & 718.0437 & 0.0034 & 1.5784 & 126.474\end{array}$ $\begin{array}{lllllllllllll} & \end{array}$

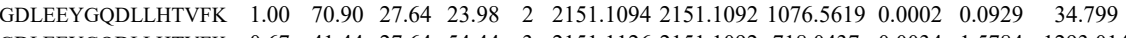
$\begin{array}{llllllllllll}\text { GDLEEYGQDLLHTVFK } & 0.67 & 41.44 & 27.64 & 54.44 & 3 & 2151.1126 & 2151.1092 & 718.0437 & 0.0034 & 1.5784 & 1293.014 \\ \text { GDLEEYGQLLHTVFK } & 1.00 & 43.04 & 27.72 & 16.03 & 3 & 2151.1132 & 2151.1092 & 718.0437 & 0.0040 & 1.8569 & 431.473\end{array}$ 
$\begin{array}{lllllllllll} & \\ 0\end{array}$

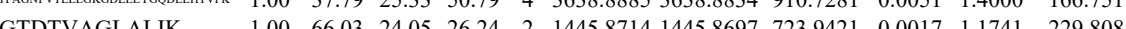

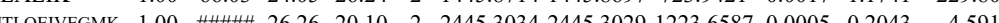

$\begin{array}{llllllllllll}0 & 26.26 & 20.10 & 2 & 2445.3034 & 2445.3029 & 1223.6587 & 0.0005 & 0.2043\end{array}$

$\begin{array}{lllllllllll}0.91 & 34.03 & 26.53 & 36.21 & 2 & 1309.7382 & 1309.7274 & 655.8710 & 0.0108 & 8.2333 & 1363.814 \\ 1.00 & 68.36 & 23.22 & 32.09 & 2 & 1445.8834 & 1445.8697 & 723.9421 & 0.0137 & 9.4620 & 64.717\end{array}$

40.926

GTDTVAGLALIK

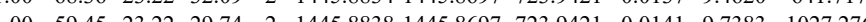

IQGDGVDINTLQEIVE

$\begin{array}{llllllllllll}1.00 & 59.45 & 23.22 & 29.74 & 2 & 1445.8838 & 1445.8697 & 723.9421 & 0.0141 & 9.7383 & 1027.276\end{array}$

1381326

$\begin{array}{llllllllllll}0.99 & 5.15 & 23.22 & 44.02 & 2 & 1445.8840 & 1445.8697 & 723.9421 & 0.0143 & 9.8764 & 517.648 & \end{array}$

VLEILGK

AVPEGFVIPR

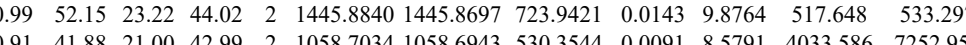

AVPEGFVVIPR

$\begin{array}{llllllllllllll}0.91 & 41.90 & 21.00 & 43.03 & 2 & 1058.7034 & 1058.6943 & 530.3544 & 0.0091 & 8.5791 & 3928.644 & 6962.887\end{array}$

TQAPLIIRPDSGNPLDTVLK

$\begin{array}{lllllllllllll}34.51 & 25.66 & 19.32 & 2 & 1227.7206 & 1227.7097 & 614.8621 & 0.0109 & 8.8637 & 727.416 & 988.493\end{array}$

AVPEGFVIP $\begin{array}{lllllllllllllllll} & 2522.4346 & 2522.4312 & 841.8177 & 0.0034 & 1.3463 & 1695.575 & 2541.297 & 4907.840 & 4141.927 & \text { Yes }\end{array}$

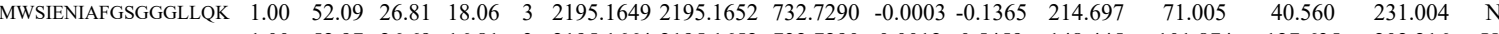

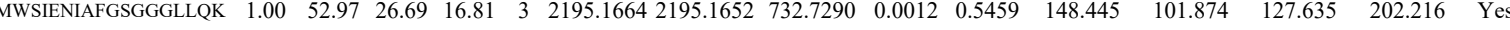
$\begin{array}{llllllllllllllll} & 29.51 & 2 & 2195.1674 & 2195.1652 & 1098.5899 & 0.0022 & 1.0013 & 68.355 & 150.026 & 61.030 & 240.105 & \text { Yes }\end{array}$ $\begin{array}{llllllllllllll}\text { MWSIENAFGSGGGLLQK } & 0.66 & 25.24 & 26.64 & 38.24 & 3 & 2195.1673 & 2195.1652 & 732.7290 & 0.0021 & 0.9553 & 37.083 & 33.682 & \end{array}$

LLPPYLR

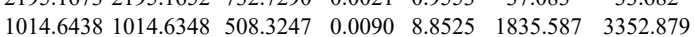

\section{LLPYTR}

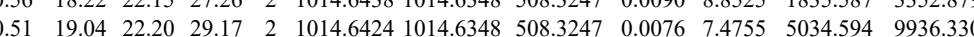

$12.981 \quad 80.509 \quad$ Yes $\begin{array}{lllllllllll}1.00 & 72.52 & 27.04 & 27.78 & 2 & 1649.8990 & 1649.8868 & 825.9507 & 0.0122 & 7.3854 & 65.124\end{array}$

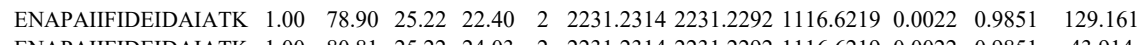
$\begin{array}{llllllllllll}\text { ENAPAIIFIDEIDAIATK } & 1.00 & 40.81 & 25.22 & 24.03 & 2 & 2231.2314 & 2231.2292 & 1116.6219 & 0.0022 & 0.9851 & 43.914 \\ & 25.21 & 20.21 & 3 & 2231.2321 & 2231.2292 & 744.7503 & 0.0029 & 1.2980 & 6.993\end{array}$

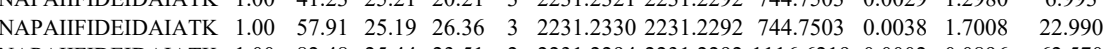
$\begin{array}{llllllllllll}\text { ENAPAIIFIDEIDAIATK } & 1.00 & 82.48 & 25.44 & 23.51 & 2 & 2231.2294 & 2231.2292 & 1116.6219 & 0.0002 & 0.0896 & 62.570\end{array}$

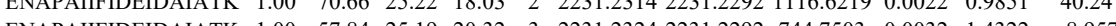
$\begin{array}{llllllllll} & \end{array}$

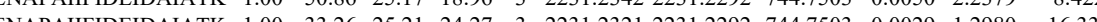
$\begin{array}{llllllllllll} & 0.03 .25\end{array}$ $\begin{array}{lllllllllll} & \end{array}$

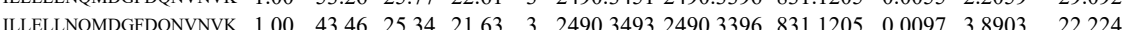
$\begin{array}{llllllllllll}\text { ILLELLNQMDGFDQNVNVK } & 0.97 & 23.21 & 25.88 & 19.44 & 3 & 2490.3439 & 2490.3396 & 831.1205 & 0.0043 & 1.7246 & 0.000\end{array}$ $\begin{array}{llllllllllll}\text { ILLELLNQMDGFDQNVNK } & 0.97 & 23.21 & 25.88 & 1.44 & 3 & 2490.3439 & 2490.3396 & 831.1205 & 0.0043 & 1.7246 & 0.000 \\ \text { AVAHHTTAAFIR } & 0.96 & 26.68 & 27.29 & 16.26 & 3 & 1437.7963 & 1437.7963 & 480.2727 & 0.0000 & 0.0000 & 1106.285\end{array}$ $\begin{array}{lllllllllllll} & & \end{array}$

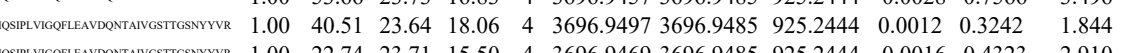

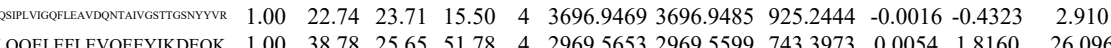
$\begin{array}{lllllllllllll}\text { MNLSEEVDLEDYVDERPKK } & 1.00 & 38.78 & 25.65 & 51.78 & 4 & 2969.5653 & 2969.5599 & 743.3973 & 0.0054 & 1.8160 & 26.096 \\ & 52.92 & 27.17 & 19.11 & 3 & 2410.1950 & 2410.1929 & 804.4049 & 0.0021 & 0.8702 & 1944.759\end{array}$ $\begin{array}{lllllllllllll}\text { MNLSEEVDLEDYVARPDK } & 0.66 & 52.29 & 27.13 & 65.29 & 3 & 2410.1953 & 2410.1929 & 804.4049 & 0.0024 & 0.9945 & 2518.138 & 2638.7\end{array}$

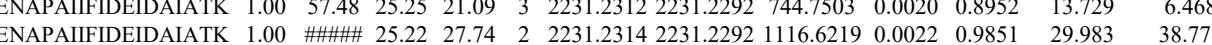

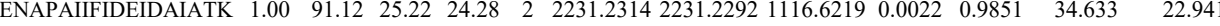

$\begin{array}{llllllllllllll} & \text { WNABNLGIEAIEDQICQGLK } & 1.00 & 82.94 & 26.65 & 24.18 & 2 & 2795.3714 & 2795.3713 & 1398.6929 & 0.0001 & 0.0357 & 3.505 & 4.000\end{array}$ $\begin{array}{llllllllllllll}\text { WNTDNTLGTEIAIEDQICQGLK } & 1.00 & \text { \#\#\#\# } 26.58 & 23.17 & 2 & 2795.3734 & 2795.3713 & 1398.6929 & 0.0021 & 0.7507 & 2.824 & 19.132\end{array}$ $\begin{array}{lllllllllllll}\text { WNTDNTLGTEIAIEDQICQGLK } & 0.56 & 13.45 & 26.57 & 19.14 & 3 & 2795.3761 & 2795.3713 & 932.7977 & 0.0048 & 1.7153 & 31.744 & 9.315\end{array}$

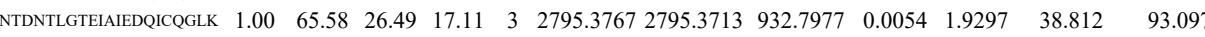
$\begin{array}{lllllllllllll}\text { WNTDNTLGTEAIEDQICQGLK } & 0.67 & 19.66 & 26.62 & 32.66 & 3 & 2795.3749 & 2795.3713 & 932.7977 & 0.0036 & 1.2865 & 10.293 & 18.35\end{array}$ $\begin{array}{lllllllllllll}\text { WNTDNTLGTEAAIEDQICQGLK } & 1.00 & 50.99 & 26.62 & 16.57 & 3 & 2795.3734 & 2795.3713 & 932.7977 & 0.0021 & 0.7504 & 35.252 & 16.757\end{array}$

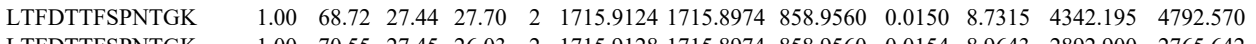
(1) LTLSALVDGK $\begin{array}{lllllllllllll}1.00 & 70.55 & 27.45 & 26.03 & 2 & 1715.9128 & 1715.8974 & 858.9560 & 0.0154 & 8.9643 & 2892.900 & 2765.642\end{array}$ LTFDTTFSPNT $\begin{array}{llllllllllll}1.00 & 62.02 & 23.42 & 26.19 & 2 & 1303.7988 & 1303.7955 & 652.9050 & 0.0033 & 2.5272 & 15307.538 & 14403.343 \\ 1.00 & 66.53 & 27.41 & 25.45 & 2 & 1715.9114 & 1715.8974 & 858.9560 & 0.0140 & 8.1494 & 120.209 & 88.941\end{array}$ $\begin{array}{llllllllllll}1.00 & 66.53 & 27.41 & 25.45 & 2 & 1715.9114 & 1715.8974 & 858.9560 & 0.0140 & 8.1494 & 120.209 & 88.941 \\ 1.00 & 82.09 & 27.47 & 28.69 & 2 & 1715.9132 & 1715.8974 & 858.9560 & 0.0158 & 9.1971 & 1533.249 & 1235.179\end{array}$ $\begin{array}{lllllllllllll}1.00 & 58.07 & 23.42 & 25.57 & 2 & 1303.7990 & 1303.7955 & 652.9050 & 0.0035 & 2.6803 & 9854.240 & 7744.002 & 1\end{array}$

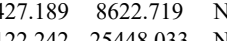
LTLSALVDGK

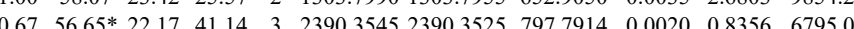


UBP5_HUMAN P45974 USP5

$\begin{array}{llllllll}\text { Ubiquitin carboxy } 95.786 & 1.00 & 5 & 9.9 & 0.0653 & 0.5343 & -0.0798 & 0.4137\end{array}$

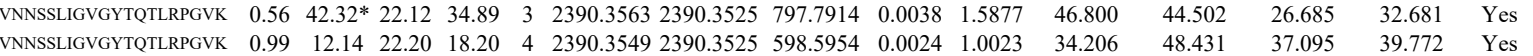

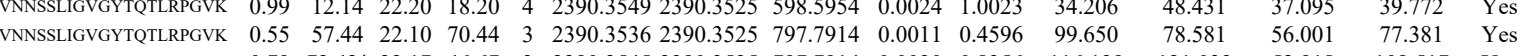

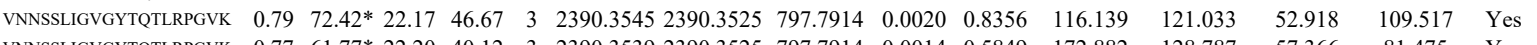
$\begin{array}{lllllllllllllll}\text { NNSSLIGVGYTQTLRPGVK } & 0.77 & 61.77 * 22.20 & 40.12 & 3 & 2390.3539 & 2390.3525 & 797.7914 & 0.0014 & 0.5849 & 172.882 & 128.787 & 57.366 & 81.475 & \text { Yes }\end{array}$ \begin{tabular}{llllllllllllllll} 
NNSSLIGVGTCILRPGVK & 0.64 & $56.96 *$ & 22.17 & 41.87 & 3 & 2390.3545 & 2390.3525 & 797.7914 & 0.0020 & 0.8356 & 93.988 & 63.955 & 42.164 & 47.403 & Yes \\
\hline
\end{tabular} $\begin{array}{llllllllllllllll} & \end{array}$ $\begin{array}{lllllllllllllll} & \text { VDYMQLPVPMDAALNK } & 0.96 & 22.07 & 27.03 & 14.65 & 3 & 2205.1813 & 2205.1781 & 736.0666 & 0.0032 & 1.4491 & 40.677 & 33.547 & 40\end{array}$ $\begin{array}{llllllllllllllll} & \end{array}$ $\begin{array}{llllllllllll} & \end{array}$ $\begin{array}{llllllllllll} & \end{array}$ $\begin{array}{lllllllllll} & \end{array}$

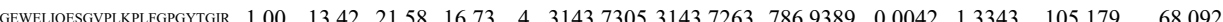

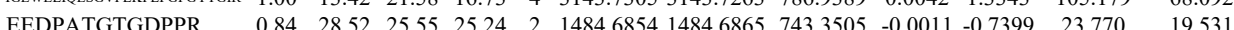

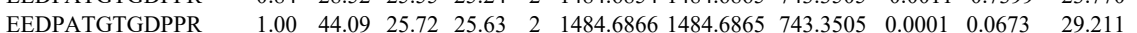

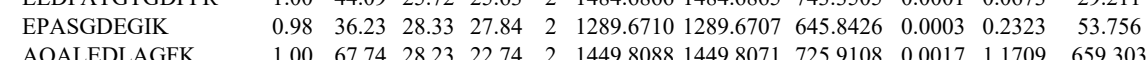
AQALEDLAGKK $\begin{array}{lllllllllllll}\text { AQALEDLAGFK } & 1.00 & 67.74 & 28.23 & 22.74 & 2 & 1449.8088 & 1449.8071 & 725.9108 & 0.0017 & 1.1709 & 659.303 & 60 \\ \text { TPVQYSQQQNSPQK } & 0.67 & 36.01 & 27.88 & 49.01 & 3 & 1919.9971 & 1919.9945 & 641.0054 & 0.0026 & 1.3520 & 944.373 & 78\end{array}$ $\begin{array}{llllllllllllllll} & \end{array}$ $\begin{array}{llllllllllllll}\text { LTQTSGETTHTHTEPTGDGK } & 1.00 & 32.17 & 27.33 & 45.17 & 4 & 2385.1685 & 2385.1652 & 597.2986 & 0.0033 & 1.3812 & 1750.056 & 1154.715 & 48\end{array}$

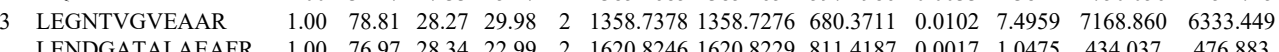

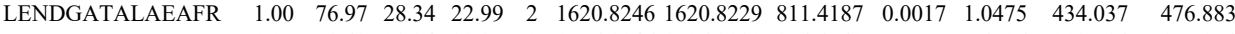

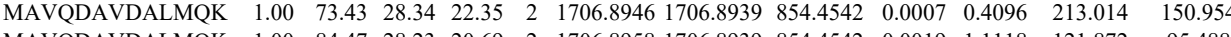

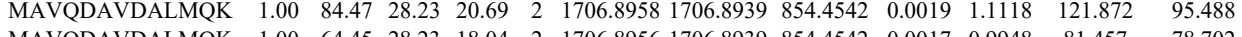
$\begin{array}{lllllllllllllll}\text { MAVQDAVDALMQK } & 1.00 & 64.45 & 28.23 & 18.04 & 2 & 1706.8956 & 1706.8939 & 854.4542 & 0.0017 & 0.9948 & 81.457 & 78.702\end{array}$

QVEVINFGDCLVR

ILAAALTECHR

ILAAALTECHR

LLVHMGLLK

LLVHMGLLK

LLVHMGLLK $\begin{array}{lllllllllllll}\text { AFNSSSFNSNTFLTR } & 1.00 & 78.27 & 28.16 & 29.12 & 2 & 1835.8952 & 1835.8924 & 918.9535 & 0.0028 & 1.5235 & 729.412 & 607.690 \\ \text { AFNSSSFNSNTFLTR } & 1.00 & 98.87 & 28.14 & 27.68 & 2 & 1835.8954 & 1835.8924 & 918.9535 & 0.0030 & 1.6323 & 994.797 & 1071.388\end{array}$ $\begin{array}{llllllllllll}0.99 & 24.14 & 24.08 & 18.15 & 3 & 3577.8832 & 3577.8800 & 1193.6339 & 0.0032 & 0.8936 & 8.099\end{array}$ $\begin{array}{llllllllllll}0.84 & 6.31 & 23.98 & 19.31 & 4 & 3577.8849 & 3577.8800 & 895.4773 & 0.0049 & 1.3680 & 77.846\end{array}$

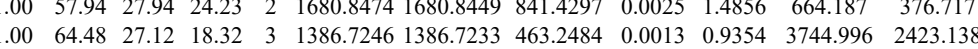
$\begin{array}{lllllllllllll}1.00 & 62.69 & 27.12 & 17.56 & 3 & 1386.7246 & 1386.7233 & 463.2484 & 0.0013 & 0.9354 & 3793.262 & 3756.407\end{array}$ $\begin{array}{llllllllllllll}1.00 & 35.46 & 16.33 & 18.75 & 3 & 1310.8438 & 1310.8352 & 437.9523 & 0.0086 & 6.5456 & 2722.292 & 3041.33\end{array}$

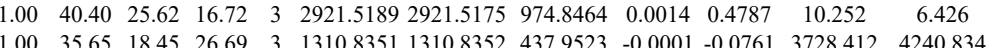
$\begin{array}{llllllllllll}1.00 & 35.65 & 18.45 & 26.69 & 3 & 1310.8351 & 1310.8352 & 437.9523 & -0.0001 & -0.0761 & 3728.412 & 4240.834 \\ 1.00 & 38.67 & 18.26 & 29.48 & 3 & 1310.8372 & 1310.8352 & 437.9523 & 0.0020 & 1.5222 & 2578.607 & 3589.271\end{array}$ $\begin{array}{llllllllllllll} & \end{array}$ $\begin{array}{llllllllllllll}\text { AFNSSSFNSNTFLTR } & 1.00 & 91.33 & 28.10 & 31.57 & 2 & 1835.8930 & 1835.8924 & 918.9535 & 0.0006 & 0.3265 & 1113.110 & 1172.055 & 0.6\end{array}$ $\begin{array}{lllllllllllll}\text { ALAPLLLAFVTKPNSALESCSAAR } & 0.66 & 57.38 & 23.71 & 70.38 & 3 & 2852.5561 & 2852.5536 & 951.8585 & 0.0025 & 0.8755 & 80.806 & 96.025\end{array}$ $\begin{array}{lllllllllllllllllllll} & \end{array}$

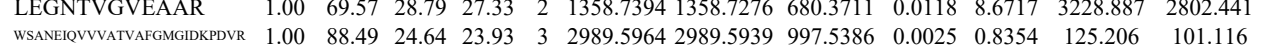
$\begin{array}{lll}46.488 & 319.127 & \text { Yes }\end{array}$ 25.106 56.406 Yes $29.647 \quad$ Yes 78.249 No $281.301 \quad 4884.768$ Yes

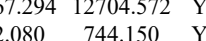
0.000 $272.883 \quad \mathrm{No}$

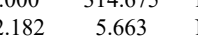
$57.904 \quad 47.336 \quad \mathrm{No}$ 21.0293094 .878 Yes $904.014 \quad 8644.252$ Y $198.426 \quad 8614.553 \quad$ Yes (1.8.280 1868.834 Yes $2077.694 \quad \mathrm{No}$ $\begin{array}{lll}93.454 & \text { No }\end{array}$ $\begin{array}{lllllllllll}\text { RECQ1 HUMAI P46063 } & \text { RECQL } & \text { ATP-dependent D 73.457 } & 1.00 & 4 & 10.3 & 0.0927 & 0.2608 & 0.1917 & 0.2121\end{array}$

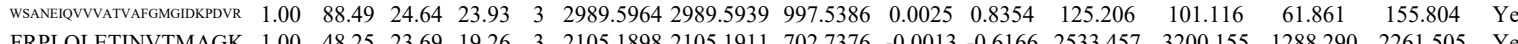
$\begin{array}{lllllllllllllllll}\text { FRPLQLETINVTMAGK } & 0.55 & 42.50 & 23.86 & 55.50 & 3 & 2105.1922 & 2105.1911 & 702.7376 & 0.0011 & 0.5218 & 5037.021 & 5700.179 & 3073.713 & 5522.220 & \text { Yes }\end{array}$ $\begin{array}{lllllllllllllllll}\text { VAGVVAPTLPR } & 1.00 & 51.21 & 21.85 & 28.94 & 2 & 1222.7638 & 1222.7520 & 612.3833 & 0.0118 & 9.6344 & 18372.475 & 22095.702 & 1509.183 & 20460.848 & \text { Yes }\end{array}$ $\begin{array}{llllllllllllllllll}\text { FRPLQLETINVTMAGK } & 0.66 & 43.09 & 23.71 & 56.09 & 3 & 2105.1928 & 2105.1911 & 702.7376 & 0.0017 & 0.8064 & 3099.429 & 3861.404 & 1652.293 & 3772.983 & \text { Yes }\end{array}$ $\begin{array}{lllllllllllllllll} & \text { FRPLQLETINVTMAGK } & 0.66 & 45.11 & 23.71 & 58.11 & 3 & 2105.1928 & 2105.1911 & 702.7376 & 0.0017 & 0.8064 & 4084.121 & 4008.961 & 1926.828 & 3636.866 & \text { Yes }\end{array}$ $\begin{array}{llllllllllllllll}\text { QKPSNTEDFIEDIVK } & 1.00 & 36.34 & 26.35 & 19.72 & 3 & 2194.1866 & 2194.1847 & 732.4022 & 0.0019 & 0.8647 & 277.280 & 241.158 & 259.189 & 252.344 & \text { Yes }\end{array}$ \begin{tabular}{llllllllllllllll}
\hline IQDIVGILR & 1.00 & 46.65 & 21.90 & 26.43 & 2 & 1169.7304 & 1169.7254 & 585.8700 & 0.0050 & 4.2671 & 4353.659 & 5159.934 & 75.418 & 7766.521 & Yes
\end{tabular} $\begin{array}{llllllllllllllll} & 1 & & 1\end{array}$ $\begin{array}{lllllllllllllllll}\text { IQDIVGILR } & 1.00 & 42.64 & 21.82 & 28.19 & 2 & 1169.7274 & 1169.7254 & 585.8700 & 0.0020 & 1.7069 & 5954.099 & 7309.195 & 2478.853 & 10421.552 & \text { Yes }\end{array}$ $\begin{array}{llllllllllllllll}\text { GPQSLFNAPR } & 1.00 & 57.79 & 27.99 & 23.98 & 2 & 1229.6744 & 1229.6638 & 615.8392 & 0.0106 & 8.6061 & 2411.667 & 2428.994 & 5124.055 & 2835.308 & \text { Yes }\end{array}$ $\begin{array}{llllllllllllllllll}\text { TQASSSFQDSSQPAGK } & 0.99 & 27.95 & 26.94 & 17.82 & 3 & 1912.9381 & 1912.9370 & 638.6529 & 0.0011 & 0.5741 & 665.122 & 660.586 & 721.680 & 651.917 & \text { Yes }\end{array}$ $\begin{array}{llllllllllllllll}\text { TQASSSFQDSSQPAGK } & 0.67 & 20.29 & 27.03 & 33.29 & 3 & 1912.9399 & 1912.9370 & 638.6529 & 0.0029 & 1.5136 & 1349.598 & 1544.811 & 4955.677 & 1088.528 & \text { Yes }\end{array}$

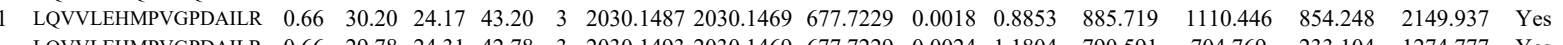
$\begin{array}{lllllllllllllllll}\text { LQVVLEHMPVGPDAILR } & 0.66 & 29.78 & 24.31 & 42.78 & 3 & 2030.1493 & 2030.1469 & 677.7229 & 0.0024 & 1.1804 & 790.591 & 704.769 & 233.104 & 1274.777 & \text { Yes }\end{array}$ $\begin{array}{llllllllllllllll}\text { LQVVLEHMPVGPDAILR } & 1.00 & 39.55 & 24.20 & 18.64 & 3 & 2030.1490 & 2030.1469 & 677.7229 & 0.0021 & 1.0329 & 1019.606 & 1389.200 & 925.268 & 1861.951 & \text { Yes }\end{array}$ $\begin{array}{llllllllllllllll}\text { LQVVLEHMPVGPDALR } & 1.00 & 65.55 & 23.96 & 31.17 & 3 & 2030.1508 & 2030.1469 & 677.7229 & 0.0039 & 1.9182 & 1075.719 & 940.347 & 1153.484 & 2069.280 & \text { Yes }\end{array}$

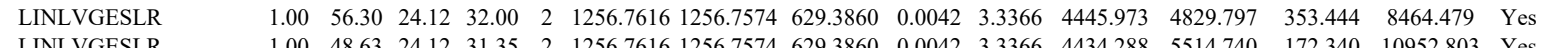

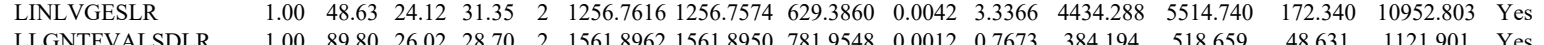

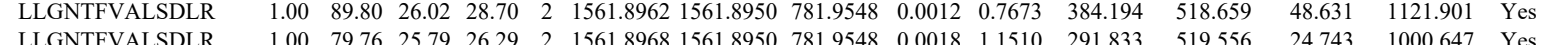

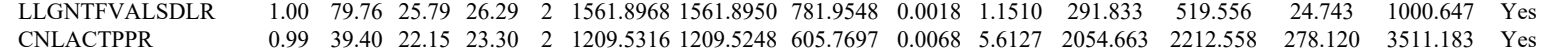
CNLACTPPR $\begin{array}{llllllllllllllll}.99 & 39.40 & 22.15 & 23.30 & 2 & 1209.5316 & 1209.5248 & 605.7697 & 0.0068 & 5.6127 & 2054.663 & 2212.558 & 278.120 & 3511.183 & \text { Yes }\end{array}$

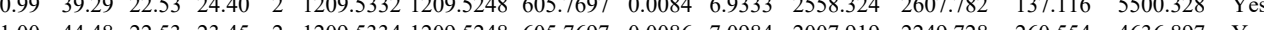
$\begin{array}{llllllllllllllll}1.00 & 42.58 & 27.85 & 23.95 & 2 & 1164.5018 & 1164.6009 & 583.3077 & 0.0009 & 0.7715 & 56.266 & 60.494 & 82.044 & 107.003 & & \end{array}$ 


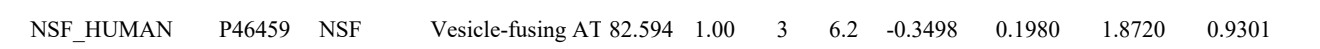
$\begin{array}{llllllllllll}\text { RL27A_HUMAI } & \text { P46776 } & \text { RPL27A } & \text { 60S ribosomal pro } 16.561 & 1.00 & 4 & 27.7 & 0.1977 & 0.1520 & 2.6374 & 0.2107 & 1\end{array}$

\section{LLIIGTTSR}

FLALLR

FLALLR

TGAAPIIDVVR

NQSFCPTVNLDK

TGAAPIIDVVR

TGAAPIIDVVR

NQSFCPTVNLDK

TGAAPIIDVVR

TGAAPIIDVVR

YHPGYFGK
YHPGYFGK

YHPGYFGK
YHPGYFGK

YHPGYFGK

YHPGYFGK

YHPGYFGK

YHPGYFGK

LWTLVSEQTR

LWTLVSEQTR

LWTLVSEQTR

LWTLVSEQTR

LWTLVSEQTR

LWTLVSEQTR

YLMEEDEDAYK
YLMEEDEDAYK

RFPGYDSESK

RFPGYDSESK

RFPGYDSESK

RFPGYDSESK

GAVDGGLSIPHSTK

GAVDGGLSIPHSTK
GAVDGGLSIPHSTK

GAVDGGLSIPHSTK
GAVDGGLSIPHSTK

GAVDGGLSIPHSTK
GAVDGGLSIPHSTK

GAVDGGLSIPHSTK

GAVDGGLSIPHSTK

IEGDMIVCAAYAHELP

IEGDMIVCAAYAHELPK
IEGDMIVCAAYAHELPK

IEGDMIVCAA

QFSQYIK

HIMGQNVADYMR

HIMGQNVADYMR

HIMGQNVADYMR

VGLTNYAAAYCTGLLLAR

VGLTNYAAAYCTGLLLAR \begin{tabular}{lllllllllllllll}
1.80 & 24.15 & 21.20 & 2 & 1254.7536 & 1254.7418 & 628.3782 & 0.0118 & 9.3892 & 9749.729 & 12044.793 & 2898.949 & 14749.451 & Yes \\
\hline
\end{tabular} $\begin{array}{llllllllllllllll}0.97 & 29.71 & 27.36 & 19.95 & 2 & 1255.6614 & 1255.6593 & 628.8369 & 0.0021 & 1.6697 & 19753.791 & 20643.356 & 0.000 & 39071.575 & \text { No }\end{array}$ $\begin{array}{llllllllllllllll}0.67 & 24.12 & 27.36 & 37.12 & 3 & 1255.6627 & 1255.6593 & 419.5604 & 0.0034 & 2.7012 & 49729.787 & 53467.320 & 5502.753 & \text { \#\#\#\#\#\# Yes } \\ 0.60 & 23.23 & 27.57 & 36.23 & 3 & 1255.6633 & 1255.6593 & 4195604 & 0.0040 & 3.1779 & 3862.304 & 47370.526 & 4562.195 & 55007.909 & \text { Yes }\end{array}$ $\begin{array}{lllllllllllllll}0.55 & 32.81 & 27.34 & 45.81 & 3 & 1255.6603 & 1255.6593 & 419.5604 & 0.0010 & 0.7945 & 16423.363 & 19243.123 & 992.917 & 37704.173 & \text { Yes }\end{array}$ $\begin{array}{llllllllllllllll}0.60 & 27.85 & 27.55 & 40.85 & 3 & 1255.6630 & 1255.6593 & 419.5604 & 0.0037 & 2.9396 & 12921.362 & 15301.902 & 818.806 & 26998.301 & \text { Yes }\end{array}$ $\begin{array}{lllllllllllllll}0.55 & 21.79 & 27.34 & 34.79 & 3 & 1255.6603 & 1255.6593 & 419.5604 & 0.0010 & 0.7945 & 7143.946 & 9062.118 & 1372.081 & 11772.966 & \text { Yes }\end{array}$ $\begin{array}{lllllllllllllllll}1 & 5.72 & 28.12 & 28.12 & 2 & 1375.7602 & 1375.7581 & 688.8863 & 0.0021 & 1.5242 & 10660.070 & 10709.557 & 1070.812 & 21816.051 & \text { Yes } \\ 1.00 & 58.24 & 28.22 & 29.24 & 2 & 1375.7580 & 1375.7581 & 688.8863 & -0.0001 & -0.0726 & 7391.948 & 7313.564 & 1327.808 & 13762.388 & \text { Yes }\end{array}$ $\begin{array}{llllllllllllllll}1.00 & 58.11 & 28.12 & 24.99 & 2 & 1375.7596 & 1375.7581 & 688.8863 & 0.0015 & 1.0887 & 5268.638 & 6471.509 & 266.329 & 12356.622 & \text { Yes }\end{array}$

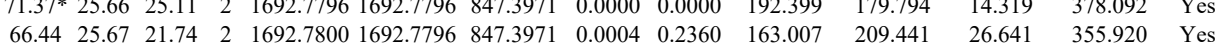
$\begin{array}{lllllllllllllll}1.00 & 32.17 & 27.33 & 23.29 & 3 & 1472.7538 & 1472.7503 & 491.9240 & 0.0035 & 2.3716 & 16854.503 & 16640.186 & 827.243 & 39820.700 & \text { No }\end{array}$ $\begin{array}{llllllllllllllll}.99 & 31.39 & 27.36 & 22.56 & 3 & 1472.7550 & 1472.7503 & 491.9240 & 0.0047 & 3.1848 & 17865.210 & 15653.935 & 1043.989 & 37572.101 & \text { No }\end{array}$

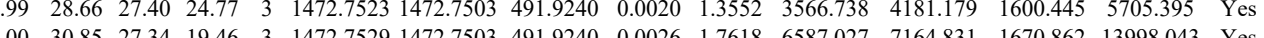

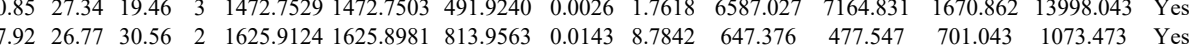
$\begin{array}{llllllllllllll} & \end{array}$ $\begin{array}{llllllllllllllll}16.1625 & 83.39 & 26.71 & 26.44 & 2 & 1625.9122 & 1625.8981 & 813.9563 & 0.0141 & 8.6613 & 1969.235 & 1322.022 & 2322.191 & 2284.887 & \text { Yes }\end{array}$

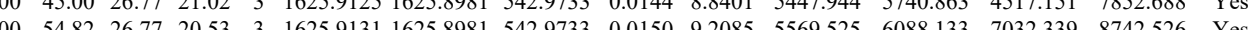
$\begin{array}{llllllllllll} & \end{array}$ $\begin{array}{lllllllllllllll} & \end{array}$ $\begin{array}{lllllllllllllll}.98 & 40.86 & 27.80 & 24.29 & 2 & 1200.6832 & 1200.6746 & 601.3446 & 0.0086 & 7.1506 & 8530.082 & 8256.522 & 1270.419 & 14410.967 & \text { Yes }\end{array}$ $\begin{array}{llllllllllllllll}1.00 & 64.59 & 26.44 & 21.59 & 2 & 1577.7638 & 1577.7564 & 789.8855 & 0.0074 & 4.6842 & 3877.194 & 4000.846 & 402.594 & 5566.255 & \text { Yes } \\ 1.00 & 43.35 & 2.4 & 20.95 & 3 & 1577.636 & 157.7564 & 26.926 & 0.082 & 5.1873 & 5264.42 & 384.483 & 107.819 & 6370.596 & \text { Yes }\end{array}$ $\begin{array}{llllllllllllllll}43.35 & 26.48 & 20.95 & 3 & 1577.7646 & 1577.7564 & 526.9261 & 0.0082 & 5.1873 & 5264.428 & 6384.483 & 1097.819 & 6370.596 & \text { Yes } \\ \end{array}$ 


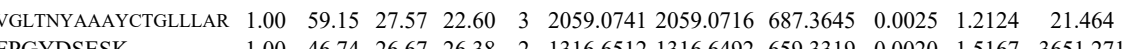

FPGYDSESK

$\begin{array}{lllllllllll}44.63 & 26.74 & 27.99 & 2 & 1316.6516 & 1316.6492 & 659.3319 & 0.0024 & 1.8200 & 4693.852\end{array}$

FPGYDSES

$\begin{array}{lllllllllll}0.99 & 72.19 * & 25.56 & 25.44 & 2 & 1861.8514 & 1861.8504 & 931.9325 & 0.0010 & 0.5365 & 904.436 \\ 1.00 & 54.35 & 27.10 & 24.64 & 2 & 1316.6568 & 1316.6492 & 659.3319 & 0.0076 & 5.7634 & 5090.187\end{array}$

\begin{tabular}{cc}
52 & 4653.561 \\
\hline 36 & 667.654
\end{tabular}

$\begin{array}{lllllllllllllllll}0.99 & 47.34 & 27.09 & 25.05 & 2 & 1316.6570 & 1316.6492 & 659.3319 & 0.0078 & 5.9150 & 7173.310 & 6515.067 & 42067.359 & 15937.395 & \end{array}$

PGYDSESK

NSVTPDMMEEMYK

FPGYDSESK

FPGYDSESK

26 KGDIVDIK

KGDIVDIK

KGDIVDIK

KGDIVDIK

KGDIVDIK

KGDIVDIK

GMGTVQK

GMGTVQK

GMGTVQK

GMGTVQK

GTWVQLK

GTWVQLK

GTWVQLK

VYNVTQHAVGIVVNK

HGVVPLATYMR

HGVVPLATYMR

HGVLATYMR

GUVATM

HGVVPLATYMR

HGVVPLATYMR

HGVVPLATYMR

HGVVPLATYMR

EPELLEPIPYEFM

EPELLEPIPYEFMA

EPELLEPIPYEFMA

EPELLEPIPYEFMA

EPELLEPIPYEFMA

KGDIVDIK

KGDIVDIK

KGDIVDIK

KGDIVDIK

$\begin{array}{lllllllllllll}\text { RL28 HUMAN } & \text { P46779 } & \text { RPL28 } & \text { 60S ribosomal pro } 15.748 & 1.00 & 7 & 39.4 & 0.1330 & 0.1706 & 0.0323 & 0.2999 & 25 & \text { QTYSTEPNNLK }\end{array}$

QTYSTEPNNLK

SQKPVMVK

SQKPVMVK

SQKPVMVK

GVVVVIK

GVVVVIK

KPATSYVR

KPATSYVR

KPATSYVR

KPATSYVR

KPATSYVR

KPATSYVR

KPATSYR

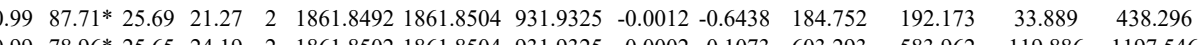

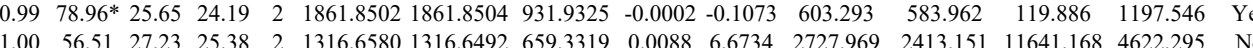
$\begin{array}{llllllllllllllll}0.98 & 38.39 & 26.71 & 23.42 & 2 & 1316.6592 & 1316.6492 & 659.3319 & 0.0100 & 7.5834 & 4755.142 & 3875.953 & 17673.037 & 7577.087 & \text { No }\end{array}$ $\begin{array}{lllllllllllllll}0.52 & 13.16 & 23.10 & 19.37 & 3 & 1318.8178 & 1318.8186 & 440.6135 & -0.0008 & -0.6052 & 104.278 & 87.096 & 32.353 & 128.303 & \text { Yes }\end{array}$ $\begin{array}{lllllllllllllll}0.78 & 14.87 & 23.10 & 14.70 & 3 & 1318.8190 & 1318.8186 & 440.6135 & 0.0004 & 0.3026 & 38.421 & 53.866 & 21.202 & 85.629 & \text { Yes }\end{array}$ $\begin{array}{lllllllllllllll}0.99 & 40.50 & 21.04 & 27.81 & 2 & 1318.8264 & 1318.8186 & 660.4166 & 0.0078 & 5.9053 & 24923.714 & 26635.921 & 0.000 & 46322.251 & \text { No }\end{array}$ $\begin{array}{llllllllllllllll}0.95 & 28.85 & 20.97 & 24.35 & 3 & 1318.8268 & 1318.8186 & 440.6135 & 0.0082 & 6.2034 & 20814.915 & 20888.494 & 938.670 & 33648.137 & \text { Yes }\end{array}$ $\begin{array}{lllllllllllllllll}0.94 & 26.10 & 20.90 & 22.36 & 3 & 1318.8271 & 1318.8186 & 440.6135 & 0.0085 & 6.4304 & 43303.549 & 51767.313 & 0.000 & 96563.584 & \mathrm{No}\end{array}$ $\begin{array}{lllllllllllllll}0.94 & 32.61 & 20.90 & 24.50 & 2 & 1318.8276 & 1318.8186 & 660.4166 & 0.0090 & 6.8138 & 28840.282 & 29729.523 & 0.000 & 56155.442 & \text { No }\end{array}$ $\begin{array}{llllllllllllllll}0.96 & 24.84 & 20.90 & 15.48 & 3 & 1318.8283 & 1318.8186 & 440.6135 & 0.0097 & 7.3382 & 9900.148 & 9228.566 & 5834.334 & 16843.055 & \text { Yes }\end{array}$

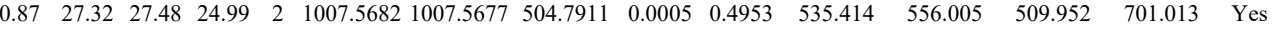

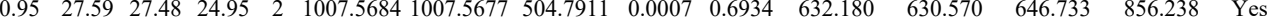

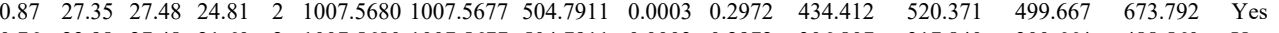
$\begin{array}{lllllllllllllll}0.76 & 23.98 & 27.48 & 21.60 & 2 & 1007.5680 & 1007.5677 & 504.7911 & 0.0003 & 0.2972 & 306.807 & 317.840 & 300.664 & 488.560 & \text { Yes }\end{array}$

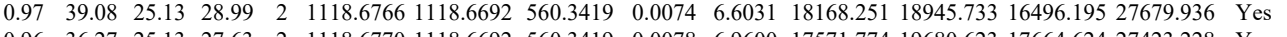

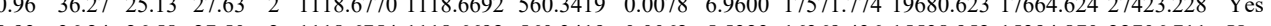

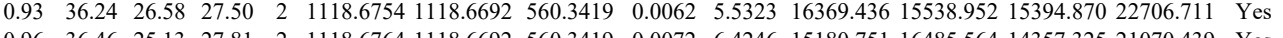

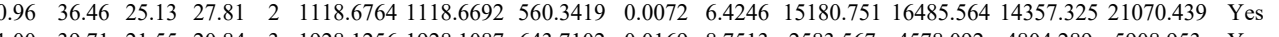

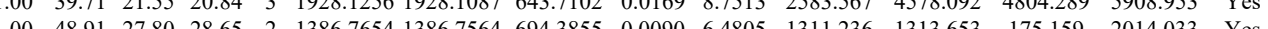

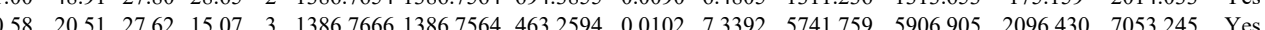
$\begin{array}{llllllllllllll} & \end{array}$ $\begin{array}{llllllllll} & 0.982 .626 & \text { Yes }\end{array}$

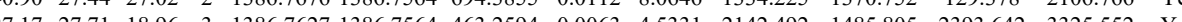
$\begin{array}{llllllllllllllll} & \end{array}$

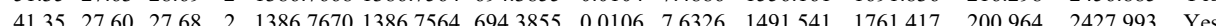
$\begin{array}{lllllllllllllllll}0.86 & 24.71 & 27.63 & 16.18 & 3 & 1386.7630 & 1386.7564 & 463.2594 & 0.0066 & 4.7489 & 762.189 & 668.494 & 781.853 & 1692.095 & \text { Yes }\end{array}$ $\begin{array}{llllllllllllllll}0.85 & 24.51 & 27.63 & 15.99 & 3 & 1386.7636 & 1386.7564 & 463.2594 & 0.0072 & 5.1807 & 1241.925 & 1163.038 & 1225.647 & 2502.418 & \text { Yes }\end{array}$ $\begin{array}{lllllllllllllll}0.97 & 30.23 & 27.94 & 17.61 & 2 & 1820.9046 & 1820.9028 & 911.4587 & 0.0018 & 0.9874 & 6.837 & 7.629 & 62.800 & 10.729 & \text { No }\end{array}$

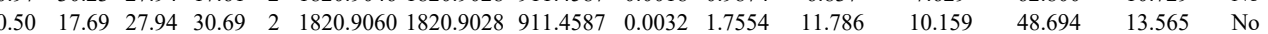

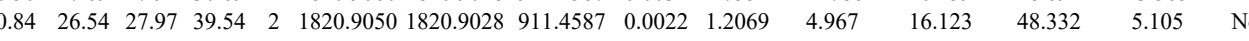
$\begin{array}{lllllllllllllll}0.84 & 61.04 & 27.94 & 74.04 & 2 & 1820.9044 & 1820.9028 & 911.4587 & 0.0016 & 0.8777 & 3.818 & 0.000 & 3.217 & 2.010 & \text { No }\end{array}$

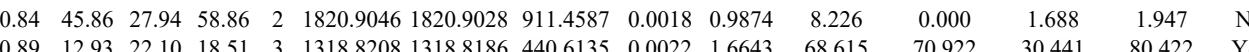

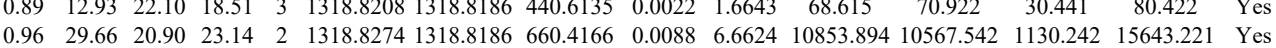
$\begin{array}{lllllllllllllll}0.96 & 29.68 & 20.90 & 24.78 & 2 & 1318.8278 & 1318.8186 & 660.4166 & 0.0092 & 6.9653 & 11905.188 & 15229.671 & 345.842 & 22125.569 & \text { Yes }\end{array}$ $\begin{array}{lllllllllllllll}0.95 & 26.93 & 21.04 & 21.65 & 3 & 1318.8292 & 1318.8186 & 440.6135 & 0.0106 & 8.0191 & 9764.549 & 11219.363 & 861.565 & 18317.428 & \text { Yes }\end{array}$ $\begin{array}{lllllllllllllll}1.00 & 49.06 & 27.99 & 26.31 & 2 & 1581.8278 & 1581.8242 & 791.9194 & 0.0036 & 2.2730 & 3800.578 & 4284.996 & 1375.872 & 6522.375 & \text { Yes }\end{array}$

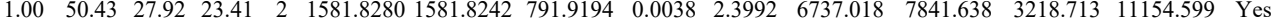
$\begin{array}{llllllllllllllll}0.98 & 21.08 & 22.28 & 14.76 & 3 & 1347.8293 & 1347.8274 & 450.2831 & 0.0019 & 1.4065 & 4822.839 & 5513.521 & 4954.299 & 7681.251 & \text { Yes }\end{array}$ $\begin{array}{lllllllllllllll}0.98 & 24.48 & 22.62 & 14.90 & 3 & 1347.8275 & 1347.8274 & 450.2831 & 0.0001 & 0.0740 & 1908.850 & 2263.335 & 1875.877 & 3034.547 & \text { Yes }\end{array}$ $\begin{array}{lllllllllllllll}0.55 & 22.88 & 22.62 & 35.88 & 3 & 1347.8281 & 1347.8274 & 450.2831 & 0.0007 & 0.5182 & 1039.230 & 1183.366 & 901.837 & 1445.858 & \text { Yes }\end{array}$ $\begin{array}{llllllllllllllll}0.98 & 41.92 & 17.71 & 33.55 & 2 & 1000.6952 & 1000.6889 & 501.3517 & 0.0063 & 6.2830 & 13252.620 & 14206.210 & 10934.130 & 22663.707 & \text { Yes }\end{array}$ $\begin{array}{lllllllllllllll}0.99 & 45.57 & 17.71 & 33.91 & 2 & 1000.6968 & 1000.6889 & 501.3517 & 0.0079 & 7.8786 & 10603.397 & 11229.689 & 7948.524 & 42589.649 & \text { No }\end{array}$ $\begin{array}{lllllllllllllll}0.59 & 14.73 & 26.53 & 15.87 & 3 & 1208.7118 & 1208.7121 & 403.9113 & -0.0003 & -0.2476 & 114.492 & 117.317 & 207.600 & 244.738 & \text { Yes }\end{array}$

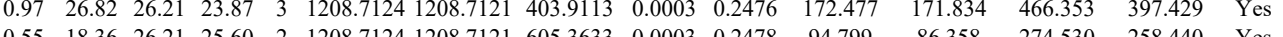

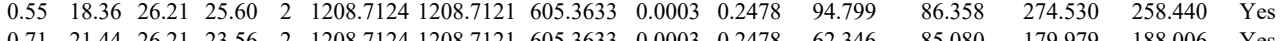

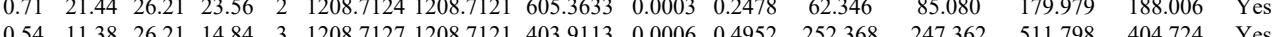

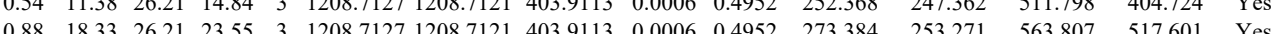

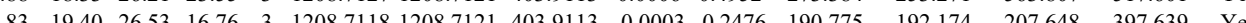

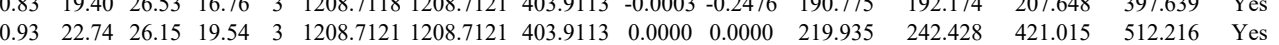

Table S-4 page 312 of 614 

$\begin{array}{llllllllllllllll}1.00 & 6.45 & 27.99 & 30.00 & 2 & 1330.7334 & 1330.7336 & 666.3741 & -0.0002 & -0.1501 & 9049.580 & 11168.668 & 1814.880 & 18825.000 & \text { Yes }\end{array}$

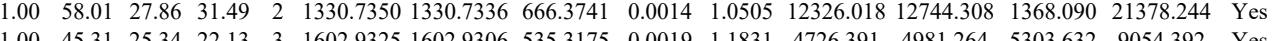
\begin{tabular}{lllllllllllllllll}
1.00 & 52.74 & 27.73 & 24.37 & 2 & 1581.8326 & 1581.824 & 791.9194 & 0.0084 & 5.3035 & 235.523 & 2929.942 & 769.013 & 4555.774 & $Y e s$ \\
\hline
\end{tabular}

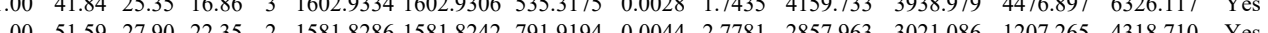
$\begin{array}{llllllllllllllll}1.00 & 51.85 & 27.66 & 24.37 & 2 & 1581.8294 & 1581.8242 & 791.9194 & 0.0052 & 3.2832 & 3983.589 & 3532.798 & 1434.045 & 5412.525 & \text { Yes }\end{array}$

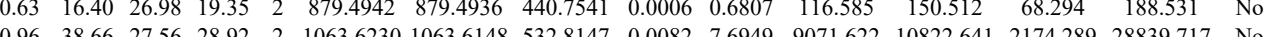

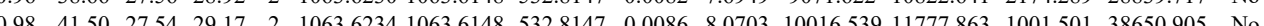

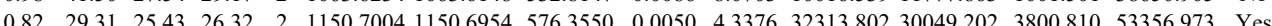

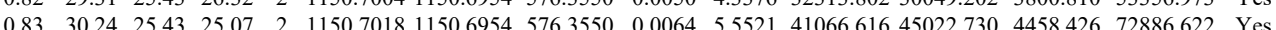

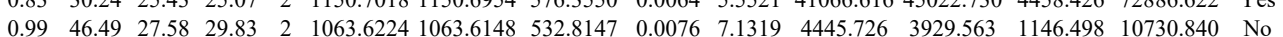

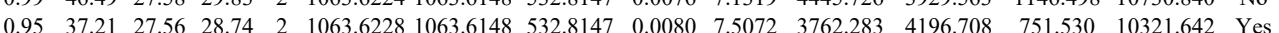
$\begin{array}{llllllllllllllll}0.96 & 37.89 & 25.43 & 27.28 & 2 & 1150.7018 & 1150.6954 & 576.3550 & 0.0064 & 5.521 & 23995.107 & 30918.288 & 6338.312 & 46875.701 & \text { Yes }\end{array}$ $\begin{array}{llllllllllllllll}1.00 & 54.46 & 21.96 & 25.24 & 2 & 1221.7596 & 1221.7576 & 611.8861 & 0.0020 & 1.6343 & 56759.619 & 55964.705 & 1924.477 & 91825.160 & \text { Yes }\end{array}$

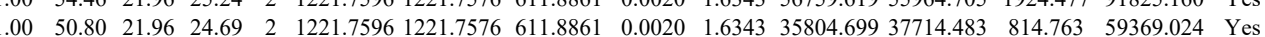
$\begin{array}{lllllllllllllll}1.00 & 50.86 & 20.76 & 24.73 & 2 & 1221.7606 & 1221.7576 & 611.8861 & 0.0030 & 2.4514 & 23600.766 & 26392.721 & 752.728 & 39443.285 & \text { Yes }\end{array}$ $\begin{array}{llllllllllllllll}1.00 & 54.66 & 20.83 & 25.51 & 2 & 1221.7608 & 1221.7576 & 611.8861 & 0.0032 & 2.6149 & 34644.026 & 37419.914 & 0.000 & 54951.666 & \text { No }\end{array}$

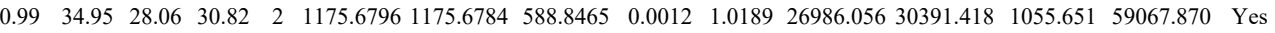

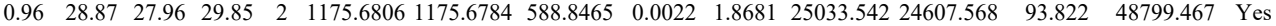
$\begin{array}{lllllllllllllll}1.00 & 50.89 & 22.10 & 29.43 & 2 & 1221.7586 & 1221.7576 & 611.8861 & 0.0010 & 0.8171 & 7030.672 & 7967.537 & 321.622 & 11645.161 & \text { Yes }\end{array}$

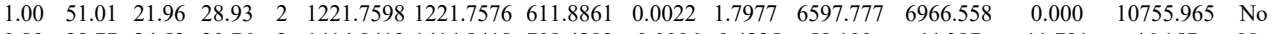

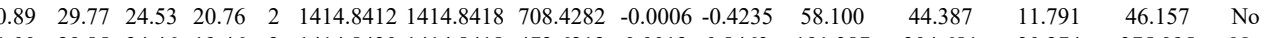
$\begin{array}{lllllllllllllll}1.00 & 29.85 & 24.46 & 19.46 & 3 & 1414.8430 & 1414.8418 & 472.6212 & 0.0012 & 0.8463 & 191.387 & 304.681 & 30.274 & 375.095 & \text { No }\end{array}$

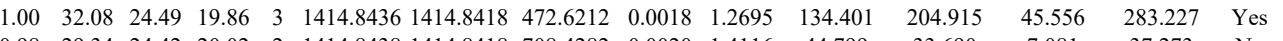
$\begin{array}{lllllllllllllll}0.98 & 29.34 & 24.42 & 20.02 & 2 & 1414.8438 & 1414.8418 & 708.4282 & 0.0020 & 1.4116 & 44.799 & 33.690 & 7.081 & 37.273 & \text { No }\end{array}$ $\begin{array}{lllllllllllllll}1.00 & 49.83 & 24.44 & 27.29 & 2 & 1414.8440 & 1414.8418 & 708.4282 & 0.0022 & 1.5527 & 22314.627 & 23466.686 & 1048.777 & 35118.034 & \text { Yes }\end{array}$ $\begin{array}{lllllllllllllll}0.99 & 33.41 & 24.46 & 21.53 & 2 & 1414.8442 & 1414.8418 & 708.4282 & 0.0024 & 1.6939 & 42.769 & 42.063 & 11.991 & 67.793 & \text { Yes }\end{array}$ \begin{tabular}{lllllllllllllll}
0.98 & 29.23 & 24.46 & 19.87 & 2 & 1414.8442 & 1414.8418 & 708.4282 & 0.0024 & 1.6939 & 22.857 & 35.432 & 7.053 & 66.042 & Yes \\
\hline
\end{tabular} \begin{tabular}{lllllllllllllll}
1.00 & 54.12 & 24.46 & 27.21 & 2 & 1414.8444 & 1414.8418 & 708.4282 & 0.0026 & 1.8350 & 8781.002 & 10074.466 & 295.417 & 17224.575 & Yes \\
\hline
\end{tabular} $\begin{array}{llllllllllllllll}1.00 & 50.05 & 24.46 & 26.27 & 2 & 1414.8426 & 1414.8418 & 708.4282 & 0.0008 & 0.5646 & 3938.869 & 4190.645 & 69.450 & 6885.142 & \text { Yes } \\ 1.00 & 43.54 & 24.46 & 22.53 & 2 & 14148426 & 1414.818 & 708.4282 & 0.008 & 0.5646 & 1142.184 & 1036.483 & 113.021 & 1806.794 & \text { Yes }\end{array}$ $\begin{array}{lllllllllllllll}1.00 & 43.54 & 24.46 & 22.53 & 2 & 1414.8426 & 1414.8418 & 708.4282 & 0.0008 & 0.5646 & 1142.184 & 1036.483 & 113.021 & 1806.794 & \text { Yes } \\ 0.99 & 29.40 & 24.49 & 18.89 & 3 & 1414.8433 & 1414.8418 & 472.6212 & 0.0015 & 1.0579 & 105.140 & 143.339 & 40.774 & 140.171 & \text { No }\end{array}$

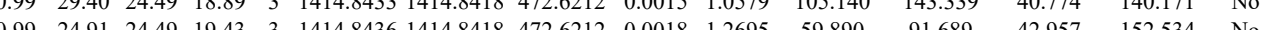

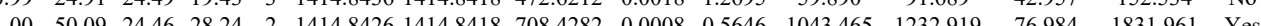
$\begin{array}{lllllllllllllll}1.00 & 50.09 & 24.46 & 28.24 & 2 & 1414.8426 & 1414.8418 & 708.4282 & 0.008 & 0.5646 & 1043.465 & 1232.919 & 76.984 & 1831.961 & \text { Yes } \\ 1.00 & 50.11 & 24.46 & 27.36 & 2 & 1414.8426 & 1414.8418 & 708.4282 & 0.0008 & 0.5646 & 1952.939 & 2179.316 & 269.665 & 3479.762 & \text { Yes }\end{array}$

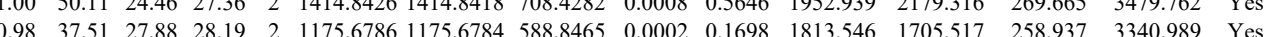

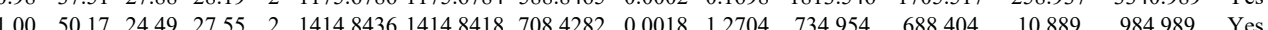

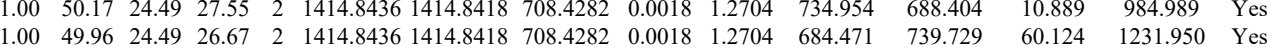

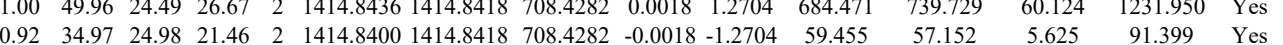

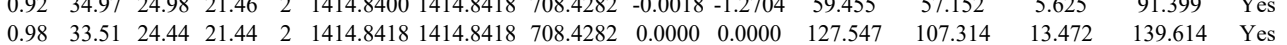
$\begin{array}{lllllllllllllll}0.98 & 35.20 & 28.41 & 36.57 & 2 & 1064.5632 & 1064.5624 & 533.2885 & 0.0008 & 0.7501 & 10885.703 & 12231.558 & 886.435 & 20490.738 & \text { Yes }\end{array}$ $\begin{array}{lllllllllllllll}0.95 & 31.99 & 27.82 & 31.65 & 2 & 1117.6590 & 1117.6587 & 559.8366 & 0.0003 & 0.2679 & 359.637 & 416.297 & 130.012 & 523.336 & \text { Yes }\end{array}$ $\begin{array}{llllllllllllllll}0.99 & 37.02 & 27.70 & 32.16 & 2 & 1117.6604 & 1117.6587 & 559.8366 & 0.0017 & 1.5183 & 19533.806 & 18650.329 & 7596.784 & 28137.729 & \text { Yes }\end{array}$ $\begin{array}{lllllllllllllll}0.99 & 34.51 & 27.70 & 28.55 & 2 & 1117.6606 & 1117.6587 & 559.8366 & 0.0019 & 1.6969 & 17197.258 & 13949.674 & 8288.660 & 24186.852 & \text { No }\end{array}$ $\begin{array}{lllllllllllllll}0.98 & 33.28 & 28.36 & 26.37 & 2 & 1064.5636 & 1064.5624 & 533.2885 & 0.0012 & 1.1251 & 5801.672 & 7069.099 & 1053.060 & 12219.061 & \text { Yes }\end{array}$ $\begin{array}{lllllllllllllll}0.98 & 32.21 & 28.36 & 34.51 & 2 & 1064.5636 & 1064.5624 & 533.2885 & 0.0012 & 1.1251 & 9482.213 & 10600.184 & 1266.405 & 20000.562 & \text { Yes }\end{array}$ $\begin{array}{lllllllllllllll}1.00 & 44.33 & 27.50 & 35.15 & 2 & 1213.6548 & 1213.6546 & 607.8346 & 0.0002 & 0.1645 & 15.079 & 15.674 & 10.791 & 29.965 & \text { Yes }\end{array}$ $\begin{array}{llllllllllllllll}0.99 & 44.54 & 26.95 & 30.01 & 2 & 1127.6502 & 1127.6421 & 564.8283 & 0.0081 & 7.1703 & 25011.677 & 27870.222 & 1886.822 & 41777.945 & \text { Yes }\end{array}$

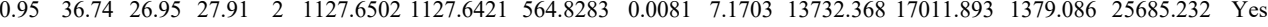
$\begin{array}{llllllllllllllll}0.94 & 34.80 & 27.13 & 27.57 & 2 & 1127.6506 & 1127.6421 & 564.8283 & 0.0085 & 7.5244 & 15907.978 & 17692.413 & 534.715 & 27495.847 & \text { Yes }\end{array}$ $\begin{array}{lllllllllllllllll}0.99 & 42.89 & 27.09 & 32.21 & 2 & 1127.6510 & 1127.6421 & 564.8283 & 0.0089 & 7.8784 & 10842.743 & 11197.580 & 1002.840 & 17934.841 & \text { Yes }\end{array}$

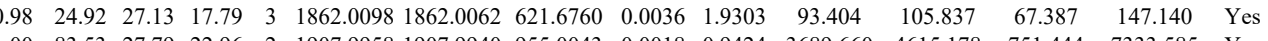
$\begin{array}{llllllllllllllll} & \end{array}$

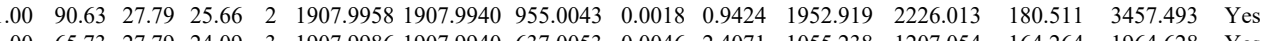
$\begin{array}{lllllllllllllll} & & \end{array}$

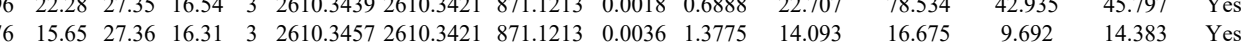
$\begin{array}{lllllllllllll} & \end{array}$

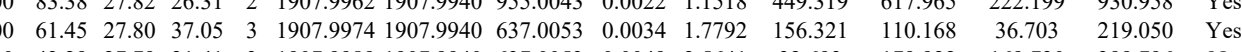




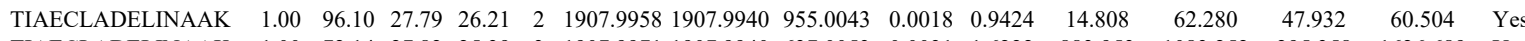

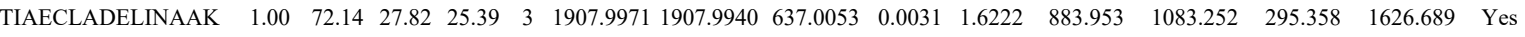
$\begin{array}{llllllllllllllll}\text { TIAECLADELINAAK } & 1.00 & 69.73 & 27.85 & 28.64 & 3 & 1907.9983 & 1907.9940 & 637.0053 & 0.0043 & 2.2501 & 335.824 & 231.547 & 53.944 & 310.476 & \text { Yes }\end{array}$

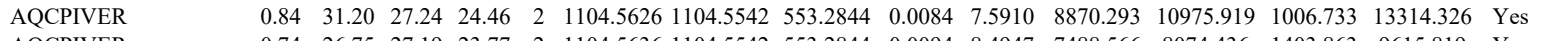
$\begin{array}{lllllllllllllll}0.74 & 26.75 & 27.19 & 23.77 & 2 & 1104.5636 & 1104.5542 & 553.2844 & 0.0094 & 8.4947 & 7488.566 & 8074.436 & 1403.863 & 9615.819 & \text { Yes }\end{array}$

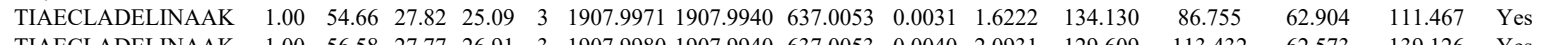
$\begin{array}{llllllllllllllll}\text { TIAECLADELINAAK } & 1.00 & 56.58 & 27.77 & 26.91 & 3 & 1907.9980 & 1907.9940 & 637.0053 & 0.0040 & 2.0931 & 129.609 & 113.432 & 62.573 & 139.126 & \text { Yes }\end{array}$

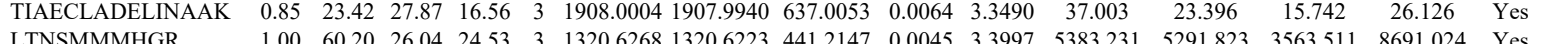
LTNSMMMHGR $\begin{array}{llllllllllllllll}1.00 & 60.20 & 26.04 & 24.53 & 3 & 1320.6268 & 1320.6223 & 441.2147 & 0.0045 & 3.3997 & 5383.231 & 5291.823 & 3563.511 & 8691.024 & \text { Yes } & \end{array}$ LTNSMMMHGR $\begin{array}{lllllllllllllll}1.00 & 54.48 & 26.02 & 24.51 & 3 & 1320.6259 & 1320.6223 & 441.2147 & 0.0036 & 2.7198 & 4847.516 & 6107.581 & 1860.284 & 7808.364 & \text { Yes } \\ 1.00 & 55.63 & 26.24 & 24.96 & 3 & 1320.6271 & 1320.6223 & 44.2147 & 0.0048 & 3.6263 & 5531.774 & 8116.610 & 1887.130 & 9088.485 & \text { Yes }\end{array}$ LTNSMMMHGR $\begin{array}{lllllllllllllll}1.00 & 55.63 & 26.24 & 24.96 & 3 & 1320.6271 & 1320.6223 & 41.2147 & 0.0048 & 3.6283 & 5531.774 & 811.6810 & 1887.130 & 9088.485 & \text { Yes }\end{array}$

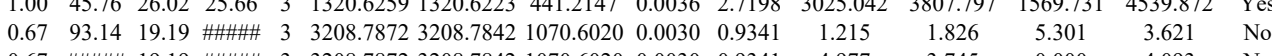

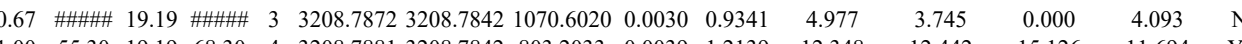

EIHHLTGENPLVLLNAIIN $\begin{array}{llllllllllll}.00 & 52.45 & 19.08 & 65.45 & 4 & 3208.7885 & 3208.7842 & 803.2033 & 0.0043 & 1.3384 & 6.841 & 17.715\end{array}$

HAFEIHLLT

HАFЕІнLL

VNQAIWLLCTGAR $\begin{array}{lllllllllll}1.00 & 20.61 & 19.19 & 23.08 & 4 & 32087881 & 32087842 & 803.2033 & 0.0039 & 12139 & 2.720\end{array}$ $\begin{array}{lllllllllll}1.00 & 40.35 & 19.19 & 53.35 & 4 & 3208.7853 & 3208.7842 & 803.2033 & 0.0011 & 0.3424 & 0.000\end{array}$

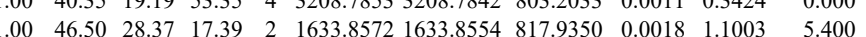
$\begin{array}{llllllllllll}0.97 & 30.50 & 28.36 & 15.43 & 2 & 1633.8578 & 1633.8554 & 817.9350 & 0.0024 & 1.4671 & 2.640\end{array}$

VNQAIWLLCTGAR

VNQAIWLLCTGAR

VNQAIWLLCTGAR

VNQAIWLLCTGAR

VNQAIWLLCTGAR

VNQAIWLLCTGAR

VNQAIWLLCTGAR

VNQAIWLLCTGAR

VNQAIWLLCTGAR

VNQAIWLLCTGAR

VNQAIWLLCTGAR

VNQAIWLLCTGAR

VNQAFLLCTGAR

VNQAIWLLCTGAR

VNQAWLLCTGAR

VNQAWLLCTGAR

VNQAIWLLCTGAR

VNQAIWLLCTGAR

VNQAIWLLCTGAR

VNQAIWLLCTGAR

VNQAIWLLCTGAR

VNQAIWLLCTGAR

VNQAIWLLCTGAR

VNQAIWLLCTGAR

VNQAIWLLCTGAR

VNQAIWLLCTGAR

VNQAIWLLCTGAR

VNQAIWLLCTGAR

VNQAIWLLCTGA

$\begin{array}{lllllllllllll}\text { RS10_HUMAN } & \text { P46783 } & \text { RPS10 } & \text { 40S ribosomal pro } 18.898 & 1.00 & 2 & 10.9 & 0.0927 & 0.1386 & 3.6026 & 0.3527 & 13 & \text { NVPNLHVMK } \\ & & & & & & & & & & & & \end{array}$

NVPNLHVMK

NVPNLHVMK

NVPNLHVMK

NVPNLHVMK

NVPNLHVMK

NVPNLHVMK

NVPNLHVMK

IAIYELLFK

IAIYELLFK

IAIYELLFK

IAIYLLIK

IAIYELLFK $\begin{array}{llllllllll}28.49 & 63.93 & 2 & 1633.8556 & 1633.8554 & 817.9350 & 0.0002 & 0.1223 & 26.710 & 30.660\end{array}$

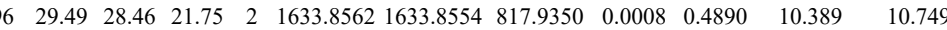
$\begin{array}{llllllllllll}0.96 & 29.49 & 28.46 & 21.75 & 2 & 1633.8562 & 1633.855 & 817.9350 & 0.008 & 0.4890 & 10.389\end{array}$ $\begin{array}{llllllllllll}.00 & 69.33 & 28.32 & 20.74 & 2 & 1633.8584 & 1633.8554 & 817.9350 & 0.0030 & 1.8339 & 16.562\end{array}$ $\begin{array}{lllllllllll}1.00 & 50.47 & 28.21 & 18.04 & 2 & 1633.8600 & 1633.8554 & 817.9350 & 0.0046 & 2.8120 & 17.441\end{array}$ $\begin{array}{lllllllllll}1.00 & 49.88 & 28.47 & 18.63 & 2 & 1633.8548 & 1633.8554 & 817.9350 & -0.0006 & -0.3668 & 25.486\end{array}$ $\begin{array}{lllllllllll}0.64 & 45.14 & 28.46 & 58.14 & 2 & 1633.8554 & 1633.8554 & 817.9350 & 0.0000 & 0.0000 & 22.005 \\ 0.98 & 25.58 & 28.33 & 19.42 & 3 & 1633.8577 & 1633.8554 & 545.6257 & 0.0023 & 1.4051 & 15.184\end{array}$ $\begin{array}{lllllllllll}1.00 & 68.37 & 28.36 & 22.77 & 2 & 1633.8580 & 1633.8554 & 817.9350 & 0.0026 & 1.5894 & 4849.780\end{array}$ $\begin{array}{llllllllllll}1.00 & 50.17 & 28.32 & 25.32 & 2 & 1633.8583 & 1633.8554 & 545.6257 & 0.0029 & 1.7717 & 18.341 & 6.361 \\ 1.00 & 80.92 & 28.25 & 2.72 & 2 & 16338 & 1633.8554 & 817.9350 & 0.0030 & 1.8339 & 14.895 & 26.344\end{array}$

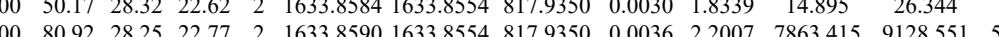
$\begin{array}{llllllllllll}1.0128 .517 & 5\end{array}$

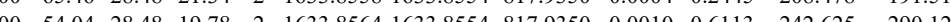
$\begin{array}{llllllllllll}.00 & 71.87 & 28.48 & 24.73 & 2 & 1633.8558 & 1633.8554 & 817.9350 & 0.0004 & 0.2445 & 150.134 & 194.195\end{array}$

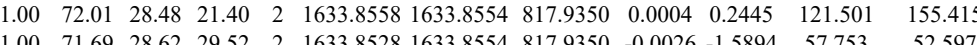

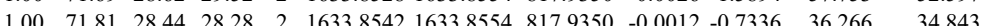
$\begin{array}{llllllllllll}1.00 & 68.04 & 28.43 & 21.58 & 2 & 1633.8536 & 1633.8554 & 817.9350 & -0.0018 & -1.1003 & 57.717 & 73.984\end{array}$

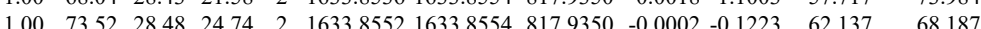
$\begin{array}{lllllllllll}1.00 & 60.79 & 28.48 & 21.14 & 2 & 1633.8564 & 1633.8554 & 817.9350 & 0.0010 & 0.6113 & 161.388\end{array}$

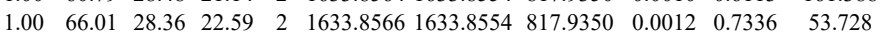
$\begin{array}{llllllllllll}1.00 & 69.41 & 28.48 & 23.95 & 2 & 1633.8564 & 1633.8554 & 817.9350 & 0.0010 & 0.6113 & 76.394\end{array}$ $\begin{array}{llllllllllll}1.00 & 67.89 & 28.48 & 24.50 & 2 & 1633.8564 & 1633.8554 & 817.9350 & 0.0010 & 0.6113 & 66.998\end{array}$ $\begin{array}{lllllllllll}1.00 & 71.54 & 28.49 & 21.82 & 2 & 1633.8560 & 1633.8554 & 817.9350 & 0.0006 & 0.3668 & 52.654\end{array}$ $\begin{array}{lllllllllll}1.00 & 70.69 & 28.46 & 22.34 & 2 & 1633.8562 & 1633.8554 & 817.9350 & 0.0008 & 0.4890 & 69.411\end{array}$ $\begin{array}{llllllllllll}1.00 & 73.19 & 28.46 & 23.87 & 2 & 1633.8562 & 1633.8554 & 817.9350 & 0.0008 & 0.4890 & 46.804\end{array}$ $\begin{array}{llllllllllll}1.00 & 67.10 & 28.48 & 22.12 & 2 & 1633.8564 & 1633.8554 & 817.9350 & 0.0010 & 0.6113 & 52.301\end{array}$ $\begin{array}{lllllllllllll}1.00 & 67.80 & 28.36 & 29.60 & 2 & 1633.8566 & 1633.8554 & 817.9350 & 0.0012 & 0.7336 & 90.476 \\ 1.00 & 74.49 & 28.36 & 22.55 & 2 & 1633.8566 & 1633.8554 & 817.9350 & 0.0012 & 0.7336 & 72.975\end{array}$ $\begin{array}{llllllllllll}1.00 & 74.49 & 28.36 & 22.55 & 2 & 1633.8566 & 1633.8554 & 817.9350 & 0.0012 & 0.7336 & 72.975 & 109.416\end{array}$ $\begin{array}{llllllllllllllll}0.99 & 43.90 & 25.91 & 21.19 & 2 & 1338.7784 & 1338.7686 & 670.3916 & 0.0098 & 7.3091 & 16843.843 & 18274.794 & 1305.202 & 27321.942 & \text { Yes }\end{array}$ $\begin{array}{lllllllllllllll}0.98 & 33.74 & 25.88 & 18.14 & 3 & 1338.7786 & 1338.7686 & 447.2635 & 0.0100 & 7.4527 & 53754.142 & 60046.573 & 2657.017 & 95621.833 & \text { Yes }\end{array}$ $\begin{array}{llllllllllllllll}0.97 & 1.35 & 25.77 & 18.23 & 3 & 1338.7789 & 1338.7686 & 447.2635 & 0.0103 & 7.6763 & 34564.940 & 33054.699 & 4327.021 & 55109.061 & \text { Yes }\end{array}$ $\begin{array}{lllllllllllllll}0.66 & 42.95 & 25.72 & 55.95 & 3 & 1388.7711 & 1338.7686 & 447.2635 & 0.0025 & 1.8632 & 31609.378 & 32057.892 & 3226.234 & 51081.691 & \text { Yes }\end{array}$

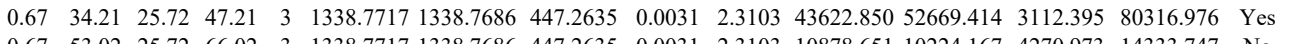
$\begin{array}{llllllllllllllll}1.60 & 58.02 & 25.72 & 66.02 & 3 & 1338.7717 & 1338.7686 & 447.2635 & 0.0031 & 2.3103 & 10878.651 & 10224.167 & 4270.973 & 14333.747 & \text { No }\end{array}$ $\begin{array}{lllllllllllllll}1.00 & 58.84 & 20.17 & 18.24 & 2 & 1396.8592 & 1396.8573 & 699.4359 & 0.0019 & 1.3582 & 1247.256 & 1237.204 & 73.530 & 2759.727 & \text { Yes }\end{array}$ $\begin{array}{lllllllllllllll}1.00 & 58.52 & 20.17 & 22.69 & 2 & 1396.8604 & 1396.8573 & 699.4359 & 0.0031 & 2.2161 & 647.098 & 575.263 & 40.588 & 1125.115 & \text { Yes } \\ 1.00 & 33.74 & 2.17 & 20.94 & 3 & 1396.8592 & 1396.5573 & 466.6264 & 0.0019 & 1.3573 & 160.543 & 233.127 & 0.000 & 340.740 & \text { No }\end{array}$

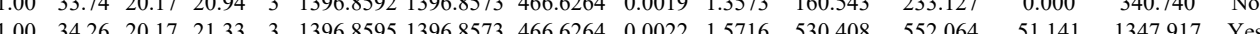

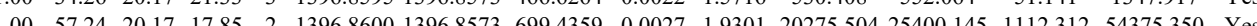
$\begin{array}{llllllllllllllll}1.00 & 50.99 & 20.17 & 22.54 & 2 & 1396.8602 & 1396.8573 & 699.4359 & 0.0029 & 2.0731 & 16388.325 & 17287.224 & 536.751 & 43274.274 & \text { Yes }\end{array}$

Table S-4 page 314 of 614 
129 LTAEEMDER $\begin{array}{ccccccccccccc}1.00 & 53.73 & 22.10 & 66.73 & 4 & 3677.9657 & 3677.9611 & 920.4976 & 0.0046 & 1.2493 & 52.221 & 30.631 \\ 1.00 & 37.49 & 24.31 & 32.28 & 2 & 1236.5792 & 1236.5778 & 619.2962 & 0.0014 & 1.1303 & 477.758 & 394.962\end{array}$ 


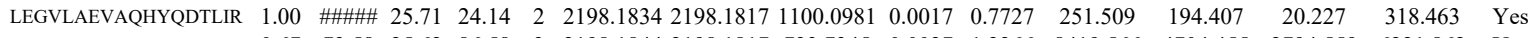

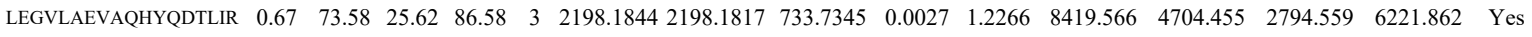

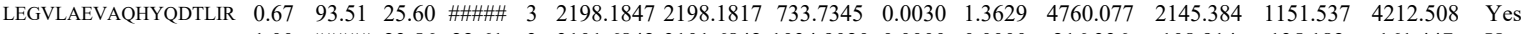

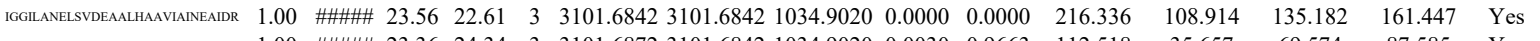

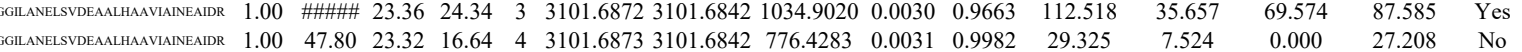

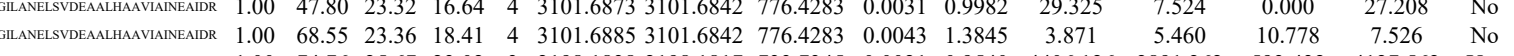
$\begin{array}{llllllllllllllll}\text { LEGVLAEVAQHYQDTLIR } & 1.00 & 74.76 & 25.67 & 23.02 & 3 & 2198.1838 & 2198.1817 & 733.7345 & 0.0021 & 0.9540 & 4406.126 & 2891.262 & 593.432 & 4127.562 & \text { Yes }\end{array}$

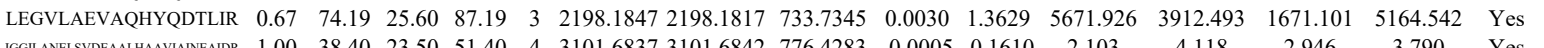
$\begin{array}{llllllllllll} & \text { Yes }\end{array}$

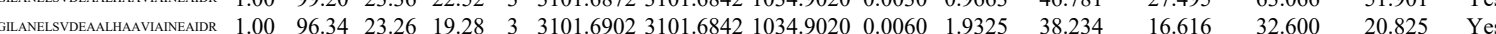
$\begin{array}{lllllllllllllll} & \end{array}$ $\begin{array}{lllllllllllllll} & \text { Res }\end{array}$

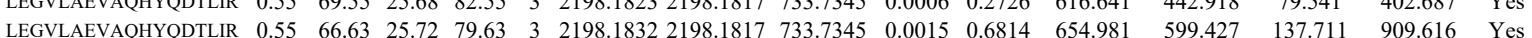

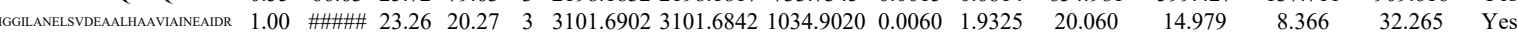

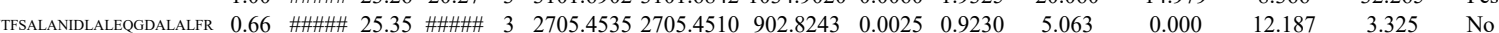

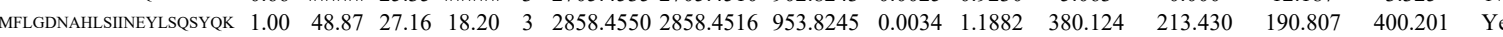
$\begin{array}{llllllllllllllll}\text { MFLGDNAHLSIINEYLSOSYQK } & 1.00 & 56.59 & 27.20 & 17.87 & 3 & 2858.4565 & 2858.4516 & 953.8245 & 0.0049 & 1.7124 & 100.852 & 116.272 & 68.455 & 112.436 & \text { Yes }\end{array}$

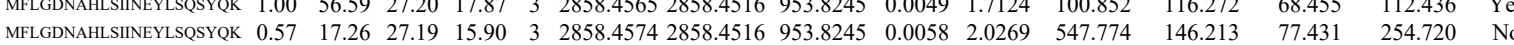
$\begin{array}{lllllllllllllllll}\text { LGNFFSPK } & 0.97 & 36.14 & 26.58 & 27.95 & 2 & 1196.6908 & 1196.6797 & 599.3471 & 0.0111 & 9.2600 & 14528.007 & 8663.135 & 435.425 & 13545.901 & \text { Yes }\end{array}$ $\begin{array}{llllllllllllllll}\text { ALQSPALGLR } & 1.00 & 48.25 & 23.58 & 22.86 & 2 & 1168.7158 & 1168.7050 & 585.3598 & 0.0108 & 9.2250 & 33920.739 & 24437.900 & 0.000 & 31721.945 & \text { No }\end{array}$ $\begin{array}{llllllllllllllll}\text { ALQSPALGLR } & 0.99 & 38.45 & 24.00 & 20.16 & 2 & 1168.7152 & 1168.7050 & 585.3598 & 0.0102 & 8.7125 & 37105.557 & 25081.810 & 1355.698 & 33765.724 & \text { Yes }\end{array}$ $\begin{array}{llllllllllllllll}\text { ALQSPALGLR } & 1.00 & 53.17 & 23.64 & 24.65 & 2 & 1168.7156 & 1168.7050 & 585.3598 & 0.0106 & 9.0542 & 37642.945 & 27228.720 & 525.987 & 37886.364 & \text { Yes }\end{array}$ $\begin{array}{llllllllllllllll}\text { LEAYQHLFYLLQTNPTYLAK } & 1.00 & 39.25 & 24.41 & 17.94 & 3 & 2713.4755 & 2713.4723 & 905.4980 & 0.0032 & 1.1780 & 36.362 & 25.672 & 6.364 & 14.232 & \text { Yes }\end{array}$ $\begin{array}{llllllllllllllll}\text { LEAYQHLFYLLQTNPTYLAK } & 1.00 & 42.33 & 24.38 & 19.20 & 3 & 2713.4773 & 2713.4723 & 905.4980 & 0.0050 & 1.8406 & 44.992 & 29.444 & 13.868 & 67.824 & \text { Yes }\end{array}$

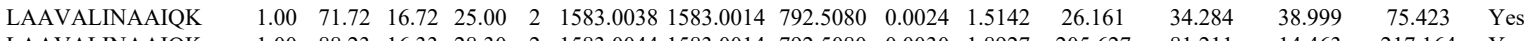
$\begin{array}{llllllllllllllll}\text { LAAVALINAAIQK } & 1.00 & 88.23 & 16.33 & 28.30 & 2 & 1583.0044 & 1583.0014 & 792.5080 & 0.0030 & 1.8927 & 205.627 & 81.211 & 14.463 & 217.164 & \text { Yes }\end{array}$ $\begin{array}{llllllllllllllll}\text { LAAVALINAAIQK } & 1.00 & 52.96 & 15.44 & 22.58 & 3 & 1583.0062 & 1583.0014 & 528.6744 & 0.0048 & 3.0264 & 355.685 & 238.191 & 32.595 & 218.812 & \text { Yes }\end{array}$ $\begin{array}{lllllllllllllll}\text { LAAVALINAAIQK } & 1.00 & 16.72 & 36.46 & 2 & 1583.0036 & 1583.0014 & 792.5080 & 0.0022 & 1.3880 & 774.499 & 296.217 & 136.023 & 540.480 & \text { Yes }\end{array}$ $\begin{array}{lllllllllllllllll}\text { LAAVALINAAIQK } & 1.00 & 95.87 & 16.72 & 33.82 & 2 & 1583.0038 & 1583.0014 & 792.5080 & 0.0024 & 1.5142 & 639.814 & 297.067 & 147.394 & 550.354 & \text { Yes }\end{array}$

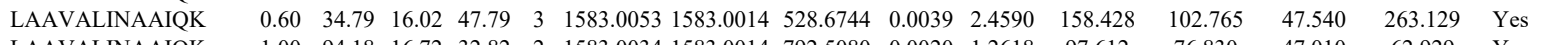

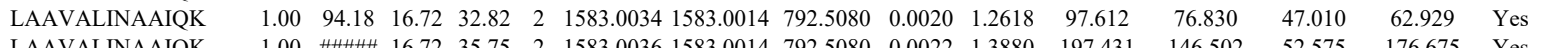

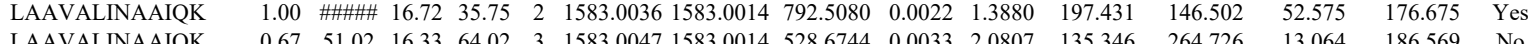
$\begin{array}{llllllllllllllll}\text { LAAVALINAAIQK } & 0.67 & 51.02 & 16.33 & 64.02 & 3 & 1583.0047 & 1583.0014 & 528.6744 & 0.0033 & 2.0807 & 135.346 & 264.726 & 13.064 & 186.569 & \text { No } \\ \text { LAAVALINAAIQK } & 1.00 & 39.45 & 16.02 & 17.88 & 3 & 1583.0053 & 1583.0014 & 528.6744 & 0.0039 & 2.4590 & 137.885 & 95.085 & 38.343 & 198.537 & \text { Yes }\end{array}$ LAAVALINAAIQK FPDAGEDELLK $\begin{array}{llllllllllll}1.00 & 48.83 & 28.12 & 34.61 & 2 & 1520.7994 & 1520.7966 & 761.4056 & 0.0028 & 1.8387 & 170.4\end{array}$

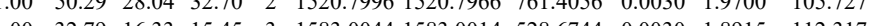
95.085 LAAVALINAAIQK $\begin{array}{lllllllllll}0.60 & 41.80 & 16.02 & 54.80 & 3 & 1583.0053 & 1583.0014 & 528.6744 & 0.0039 & 2.4590 & 312.211\end{array}$ $\begin{array}{lllllllllllll}\text { FMDSVIFTLYNYASNQR } & 0.85 & 16.29 & 27.04 & 20.38 & 3 & 2212.0771 & 2212.0745 & 738.3654 & 0.0026 & 1.1738 & 7.356\end{array}$ $\begin{array}{llllllllllll}\text { FMDSVIFTLYNYASNQR } & 0.90 & 18.03 & 27.00 & 19.95 & 3 & 2212.0777 & 2212.0745 & 738.3654 & 0.0032 & 1.4446 & 7.128\end{array}$ LAAVALINAAIQK LAAVALINAAIQK QIPAITCIQSQWR OIPAITCIOSQWR QIPAITCIQSQWR QIPAITCIQSQWR QIPAITCIQSQWR QIPAITCIQSQWR QIPAITCIQSQWR TALQEEIK

FPDAGEDELLK

FPDAGEDELLK

LAAVALINAAIQK

LAAVALINAAIQK

LAAVALINAAIQK

LAAVALINAAIQK

LAAVALINAAIQK LAAVALINAAIQK LAAVALINAAIQK LAAVALINAAIQK LAAVALINAAIQK LAAVALINAAIQK $\begin{array}{lllllllllllll}0.67 & 16.90 & 16.33 & 29.90 & 3 & 1583.0047 & 1583.0014 & 528.6744 & 0.0033 & 2.0807 & 52.304\end{array}$ $\begin{array}{llllllllllll}1.00 & 60.80 & 28.18 & 21.57 & 2 & 1732.8884 & 1732.8875 & 867.4510 & 0.0009 & 0.5188 & 210.602\end{array}$ $\begin{array}{lllllllllllll}1.00 & 61.78 & 28.20 & 21.26 & 2 & 1732.8888 & 1732.8875 & 867.4510 & 0.0013 & 0.7493 & 679.588\end{array}$ $\begin{array}{llllllllllll}1.00 & 34.35 & 28.09 & 22.56 & 3 & 1732.8910 & 1732.8875 & 578.6364 & 0.0035 & 2.0162 & 59.962\end{array}$ $\begin{array}{llllllllllll}1.00 & 62.19 & 28.09 & 33.59 & 3 & 1732.8910 & 1732.8875 & 578.6364 & 0.0035 & 2.0162 & 70.019\end{array}$ $\begin{array}{lllllllllll}1.00 & 58.54 & 28.20 & 25.19 & 2 & 1732.8888 & 1732.8875 & 867.4510 & 0.0013 & 0.7493 & 391.826\end{array}$ $\begin{array}{llllllllllll}0.96 & 23.53 & 28.09 & 20.97 & 3 & 1732.8907 & 1732.8875 & 578.6364 & 0.0032 & 1.8434 & 47.171\end{array}$ $\begin{array}{llllllllllll}0.99 & 29.45 & 28.09 & 20.01 & 3 & 1732.8910 & 1732.8875 & 578.6364 & 0.0035 & 2.0162 & 30.423\end{array}$

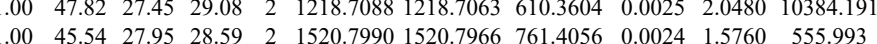
$\begin{array}{llllllllllll}1.00 & 49.16 & 28.04 & 30.96 & 2 & 1520.7996 & 1520.7966 & 761.4056 & 0.0030 & 1.9700 & 625.013\end{array}$ $\begin{array}{llllllllllll}0.67 & 18.93 & 16.33 & 31.93 & 3 & 1583.0044 & 1583.0014 & 528.6744 & 0.0030 & 1.8915 & 39.084\end{array}$

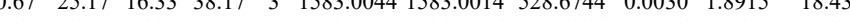
$\begin{array}{llllllllllll}0.60 & 26.38 & 16.33 & 39.38 & 3 & 1583.0050 & 1583.0014 & 528.6744 & 0.0036 & 2.2698 & 10.620 \\ 1.00 & 74.35 & 16.72 & 28.89 & 2 & 1583.0034 & 1583.0014 & 792.5080 & 0.0020 & 1.2618 & 18.452\end{array}$ $\begin{array}{llllllllllll}1.00 & 74.35 & 16.72 & 28.89 & 2 & 1583.0034 & 1583.0014 & 792.5080 & 0.0020 & 1.2618 & 18.452\end{array}$ $\begin{array}{llllllllllll}1.00 & 56.03 & 16.72 & 22.15 & 2 & 1583.0042 & 1583.0014 & 792.5080 & 0.0028 & 1.7665 & 13.861\end{array}$ $\begin{array}{lllllllllll}1.00 & 7.02 & 16.72 & 2 . .44 & 2 & 1583.0042 & 1583.0014 & 792.5080 & 0.0028 & 1.7665 & 13.861\end{array}$ $\begin{array}{llllllllllll}1.00 & 70.02 & 16.72 & 29.44 & 2 & 1583.0034 & 1583.0014 & 792.5080 & 0.020 & 1.2618 & 15.097\end{array}$ $\begin{array}{lllllllllllll}0.60 & 31.15 & 16.02 & 44.15 & 3 & 1583.0053 & 1583.0014 & 528.6744 & 0.0039 & 2.4590 & 18.117\end{array}$ $\begin{array}{lllllllllllll}0.55 & 30.36 & 16.99 & 43.36 & 3 & 1583.0023 & 1583.0014 & 528.6744 & 0.0009 & 0.5675 & 14.503\end{array}$ $\begin{array}{lllllllllll}0.67 & 21.76 & 16.33 & 34.76 & 3 & 1583.0047 & 1583.0014 & 528.6744 & 0.0033 & 2.0807 & 13.308\end{array}$ $\begin{array}{llllllllllll}0.67 & 32.40 & 16.33 & 45.40 & 3 & 15830047 & 1583.0014 & 528.6744 & 0.0033 & 2.0807 & 18.654\end{array}$ 

$\begin{array}{lllllllllllll} & \text { NQPGEITELLETPATSEEEAEHOR } & 1.00 & 70.14 & 26.45 & 17.55 & 3 & 2984.4511 & 2984.4485 & 995.8234 & 0.0026 & 0.8703 & 400.445 \\ \text { OQPGETLTELETPATSEOEAEHOR } & 0.67 & 72.53 & 26.45 & 85.53 & 3 & 2984.4511 & 2984.4485 & 995.8234 & 0.0026 & 0.8703 & 703.248\end{array}$

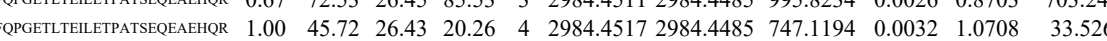

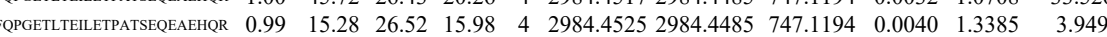
$\begin{array}{llllllllllll}\text { SNQQLENDLNLMDIK } & 1.00 & 88.17 & 27.90 & 32.70 & 2 & 2062.0594 & 2062.0608 & 1032.0377 & -0.0014 & -0.6783 & 546.136\end{array}$ $\begin{array}{lllllllllllll}\text { SNQQLENDLNLMDIK } & 1.00 & 87.47 & 28.06 & 31.08 & 2 & 2062.0614 & 2062.0608 & 1032.0377 & 0.0006 & 0.2907 & 149.499\end{array}$ $\begin{array}{llllllllllll}\text { SNQQLENDLNLMDIK } & 0.99 & 36.71 & 27.75 & 26.36 & 3 & 2062.0669 & 2062.0608 & 688.3609 & 0.0061 & 2.9539 & 306.637\end{array}$

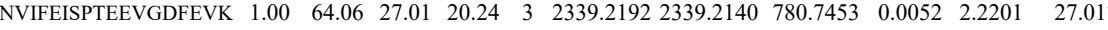

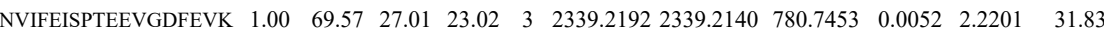
$\begin{array}{lllllllllllll}\text { FVHLLDQSDQDFQEELDLMK } & 1.00 & 69.99 & 27.57 & 21.42 & 3 & 2737.3546 & 2737.3513 & 913.4577 & 0.0033 & 1.2042 & 45.020\end{array}$ $\begin{array}{llllllllllll}\text { FVHLLDQSDQDFQEELDLMK } & 1.00 & 58.16 & 27.65 & 19.14 & 3 & 2737.3555 & 2737.3513 & 913.4577 & 0.0042 & 1.5326 & 65.460 \\ \text { FVHLLDQSDQDFQFELDLMK } & 1.00 & 25.04 & 27.63 & 38.04 & 4 & 2737.3565 & 2737.3513 & 685.3451 & 0.0052 & 1.8969 & 56.803\end{array}$ \begin{tabular}{llllllllllllll} 
FHLLDQSDQDFQEELDLMK & 1.00 & 25.04 & 27.63 & 38.04 & 4 & 2737.3565 & 2737.3513 & 685.3451 & 0.0052 & 1.8969 & 56.803 \\
\hline
\end{tabular}

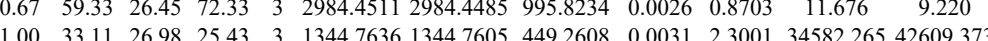
$\begin{array}{llllllllllllllllll} & \end{array}$

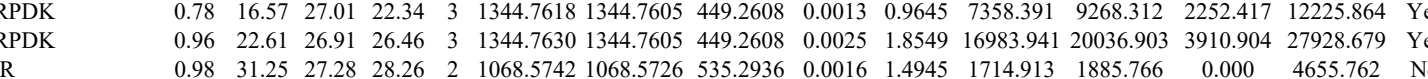

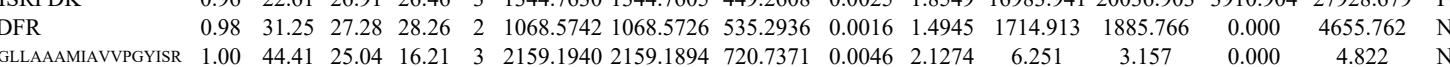
$\begin{array}{lllllllllllll} & 4.822 & N o & \end{array}$ $\begin{array}{lllllllllllllllll} & & & \end{array}$ $\begin{array}{llllllllllllll}\text { DAGAGLLAAAMIAVVPGYISR } & 1.00 & 44.14 & 24.91 & 22.51 & 3 & 2159.1946 & 2159.1894 & 720.7371 & 0.0052 & 2.4049 & 2.382 & 1.95\end{array}$

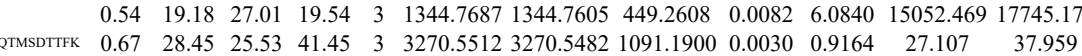

$\begin{array}{lllllllllll}1 & 0.67 & 20.64 & 21.14 & 3 & 1892.1292 & 1892.1227 & 631.7148 & 0.0065 & 3.4298 & 863.303\end{array}$

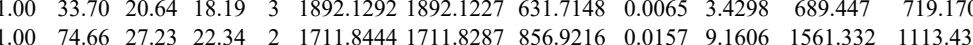

$\begin{array}{lllllllllllll}0.87 & 20.71 & 27.51 & 20.27 & 3 & 1961.9629 & 1961.9583 & 654.9934 & 0.0046 & 2.3410 & 1215.423 & 909.753\end{array}$

$\begin{array}{llllllllllll}1.00 & 78.11 & 26.83 & 26.49 & 2 & 1711.8290 & 1711.8287 & 856.9216 & 0.0003 & 0.1750 & 642.422 & 393.373\end{array}$

\section{SGSGTMNLGGSLTR}

SGSGTMNLGGSLTR

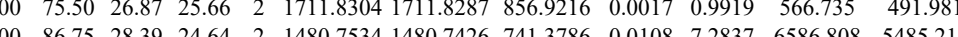

4.613 7.338

SGSGTMNLGGSLTR

STSTVMLWLOTNK

LTSTVMLWLQTNK

LTSTVMLWLQTNK

LVEDMENK

$\begin{array}{llllllllllllllll}1.00 & 79.07 & 28.59 & 26.78 & 2 & 1480.7544 & 1480.7426 & 741.3786 & 0.0118 & 7.9581 & 5723.763 & 4658.534 & 5013.212 & 5594.372 & \text { Yes }\end{array}$

$\begin{array}{llllllllllllllll}1.00 & 95.54 & 28.59 & 24.75 & 2 & 1480.7544 & 1480.7426 & 741.3786 & 0.0118 & 7.9581 & 2324.627 & 1866.525 & 2336.004 & 2697.155 & \text { Yes } \\ 1.00 & 76.91 & 28.57 & 25.81 & 2 & 1480.7550 & 1480.7426 & 741.3786 & 0.0124 & 8.3627 & 1920.855 & 1546.687 & 1575.815 & 1826.609 & \text { Yes }\end{array}$

$\begin{array}{ccccccccccccccc}1.00 & 35.72 & 26.09 & 19.56 & 3 & 1822.0297 & 1822.0266 & 608.3495 & 0.0031 & 1.6986 & 274.539 & 227.038 & 106.241 & 243.129 & \text { Yes }\end{array}$

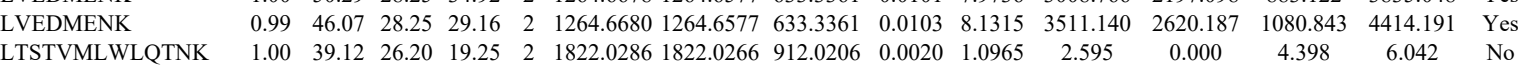

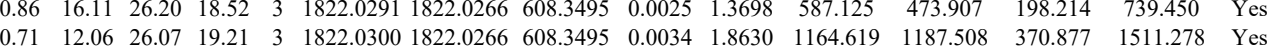
$\begin{array}{lllllllllllllll}0.71 & 12.06 & 26.07 & 19.21 & 3 & 1822.0300 & 1822.0266 & 608.3495 & 0.0034 & 1.8630 & 1164.619 & 1187.508 & 370.877 & 1511.278 & \text { Yes } \\ 1.00 & 50.29 & 28.25 & 34.92 & 2 & 1264.6678 & 1264.6577 & 633.3361 & 0.0101 & 7.9736 & 3008.766 & 2197.098 & 883.122 & 3835.048 & \text { Yes }\end{array}$

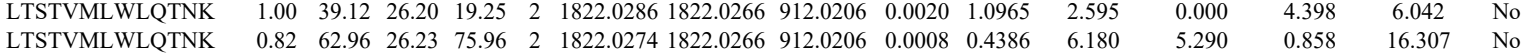
\begin{tabular}{llllllllllllllll} 
YDPPLEDGAMPSAR & 1.00 & 51.22 & 25.62 & 24.60 & 2 & 1661.7848 & 1661.7841 & 831.8993 & 0.0007 & 0.4207 & 114.699 & 186.378 & 97.965 & 140.558 & Yes \\
\hline
\end{tabular}

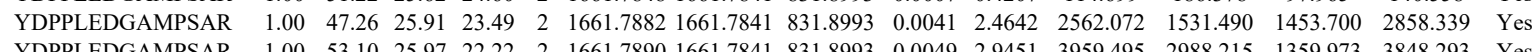
$\begin{array}{llllllllllllllll}\text { YDPPLEDGAMPSAR } & 1.00 & 53.10 & 25.97 & 22.22 & 2 & 1661.7890 & 1661.7841 & 831.8993 & 0.0049 & 2.9451 & 3959.495 & 2988.215 & 1359.973 & 3848.293 & \text { Yes } \\ \text { LEVEANNAFDQYR } & 1.00 & 69.66 & 26.83 & 24.74 & 2 & 1711.8290 & 1711.8287 & 856.9216 & 0.0003 & 0.1750 & 1090.376 & 817.683 & 98.554 & 719.703 & \text { Yes }\end{array}$ 


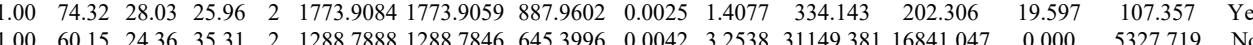
$\begin{array}{lllllllllllllllll}1.00 & 60.15 & 24.36 & 35.31 & 2 & 1288.7888 & 1288.7846 & 645.3996 & 0.0042 & 3.2538 & 31149.381 & 16841.047 & 0.000 & 5327.719 & \mathrm{No}\end{array}$ $\begin{array}{lllllllllllllllll}1.00 & 62.02 & 24.38 & 36.23 & 2 & 1288.7898 & 1288.7846 & 645.3996 & 0.0052 & 4.0285 & 24954.803 & 12433.564 & 0.000 & 4057.177 & \text { No } \\ 0.75 & 1855 & 22.67 & 18.37 & 3 & 1689.0043 & 1688.9939 & 564.0052 & 0.0104 & 6.1465 & 63008.950 & 29298.740 & 5021.434 & 10034313 & \text { Yos }\end{array}$

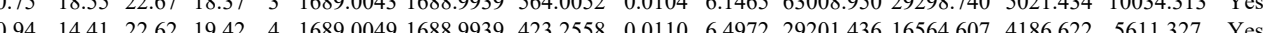

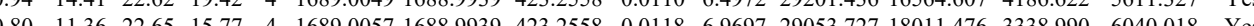

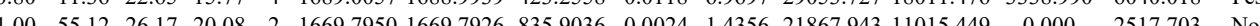

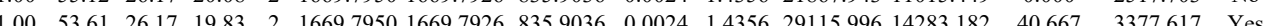
$\begin{array}{lllllllllllllll}0.99 & 17.75 & 22.76 & 22.71 & 4 & 1689.0033 & 1688.9939 & 423.2558 & 0.0094 & 5.5522 & 6463.222 & 5080.522 & 2101.881 & 3321205 & \text { No }\end{array}$ $\begin{array}{llllllllllllllll}0.93 & 13.84 & 22.65 & 17.43 & 4 & 1689.0045 & 1688.9939 & 423.2558 & 0.0106 & 6.2610 & 5184.365 & 3196.811 & 2040.732 & 3420.779 & \text { No }\end{array}$ $\begin{array}{lllllllllllllll}100 & 58.59 & 26.03 & 21.38 & 2 & 16697986 & 1669.7926 & 83559036 & 0.0060 & 3.5889 & 13820770 & 8204.569 & 233.977 & 1677.427 & \text { Yes }\end{array}$ $\begin{array}{lllllllllllllllll}1.00 & 60.93 & 26.06 & 20.24 & 2 & 1669.7990 & 1669.7926 & 835.9036 & 0.0064 & 3.8282 & 16447.092 & 7483.999 & 135.679 & 2318.278 & \text { Yes }\end{array}$ $\begin{array}{llllllllllllllll}1.00 & 84.66 & 28.31 & 28.55 & 2 & 1332.7380 & 1332.7272 & 667.3709 & 0.0108 & 8.0914 & 26616.074 & 15760.305 & 873.118 & 7298.607 & \text { Yes }\end{array}$ $\begin{array}{lllllllllllllll}1.00 & 82.08 & 28.27 & 29.13 & 2 & 1332.7384 & 1332.7272 & 667.3709 & 0.0112 & 8.3911 & 35489.286 & 20337.576 & 1625.763 & 5970.148 & \text { Yes }\end{array}$ $\begin{array}{lllllllllllllllll}1.00 & 62.25 & 27.86 & 25.02 & 2 & 1332.7336 & 1332.7272 & 667.3709 & 0.0064 & 4.7949 & 9928.734 & 5438.152 & 958.633 & 5525.982 & \text { No }\end{array}$ $\begin{array}{lllllllllllllll}1.00 & 73.79 & 28.02 & 26.82 & 2 & 1332.7356 & 1332.7272 & 667.3709 & 0.0084 & 6.2933 & 22779.320 & 10931.078 & 1620.958 & 4999.052 & \text { Yes }\end{array}$ $\begin{array}{lllllllllllllllll}1.00 & 47.42 & 25.47 & 24.57 & 2 & 1449.8450 & 1449.8425 & 725.9285 & 0.0025 & 1.7219 & 1442.587 & 511.317 & 43.571 & 544.866 & \text { Yes }\end{array}$ $\begin{array}{llllllllllllllll}1.00 & 46.27 & 25.15 & 22.60 & 2 & 1449.8466 & 1449.8425 & 725.9285 & 0.0041 & 2.8240 & 1176.195 & 669.688 & 58.293 & 426.722 & \text { Yes }\end{array}$

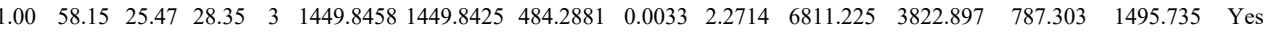
$\begin{array}{llllllllllllllll}1.00 & 50.22 & 25.13 & 24.55 & 2 & 1449.8460 & 1449.8425 & 725.9285 & 0.0035 & 2.4107 & 8713.989 & 4279.397 & 239.704 & 1805.041 & \text { Yes }\end{array}$ $\begin{array}{lllllllllllllll}1.00 & 52.58 & 25.13 & 22.17 & 3 & 1449.8461 & 1449.8425 & 484.2881 & 0.0036 & 2.4779 & 8695.450 & 4492.332 & 972.483 & 1476.981 & \text { Yes }\end{array}$ $\begin{array}{lllllllllllllll}1.00 & 39.54 & 25.53 & 23.42 & 2 & 1449.8434 & 1449.8425 & 725.9285 & 0.0009 & 0.6199 & 1029.951 & 651.008 & 48.079 & 322.034 & \text { Yes }\end{array}$

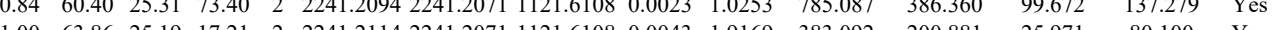

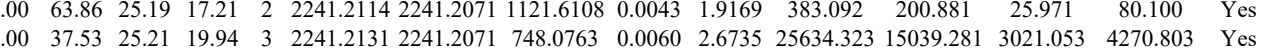
$\begin{array}{lllllllllllllll}1.00 & 42.31 & 25.21 & 18.60 & 3 & 2241.2152 & 2241.2071 & 748.0763 & 0.0081 & 3.6092 & 7587.219 & 3976.941 & 1012.848 & 1821.513 & \text { Yes }\end{array}$

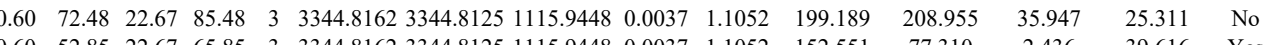
$\begin{array}{ccccccccccccccc}0.94 & 8.07 & 22.38 & 21.07 & 4 & 3344.8189 & 3344.8125 & 837.2104 & 0.0064 & 1.9111 & 169.003 & 23.843 & 49.257 & 179.647 & \text { No }\end{array}$ $\begin{array}{lllllllllllllll}1.00 & 44.97 & 24.58 & 24.46 & 2 & 1185.5508 & 1185.5392 & 593.7769 & 0.0116 & 9.7679 & 25070.551 & 10653.407 & 44.291 & 4393.785 & \text { Yes }\end{array}$

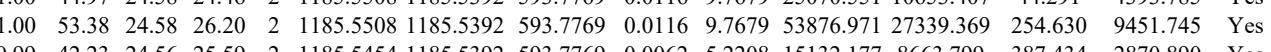

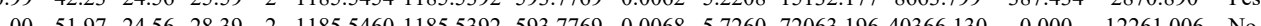
$\begin{array}{lllllllllllllll}0.99 & 41.80 & 24.67 & 25.92 & 2 & 1185.5452 & 1185.5392 & 593.7769 & 0.0060 & 5.5524 & 41769.485 & 20601.440 & 1392.110 & 6473.757 & \text { Yes }\end{array}$

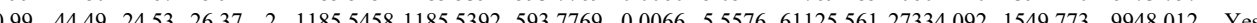

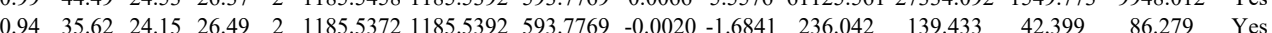

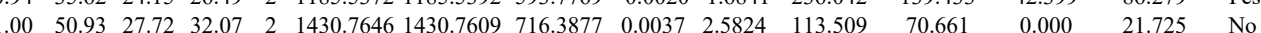

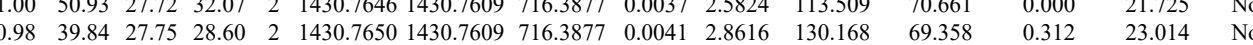
$\begin{array}{lllllllllllllll}1.00 & 57.23 & 23.84 & 25.87 & 2 & 1472.6638 & 1472.6553 & 737.3349 & 0.0085 & 5.7640 & 14873.236 & 6361.471 & 2360.186 & 2199.560 & \text { Yes }\end{array}$

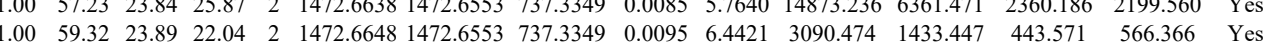
$\begin{array}{lllllllllllllll}1.00 & 59.32 & 23.89 & 22.04 & 2 & 1472.6648 & 1472.6553 & 737.3349 & 0.0095 & 6.4421 & 3090.474 & 1433.447 & 443.571 & 566.366 & \text { Yes } \\ 0.67 & 54.45 & 27.33 & 67.45 & 3 & 2615.3083 & 2615.3056 & 872.7758 & 0.0027 & 1.0312 & 9.448 & 3.042 & 3.830 & 15.359 & \text { No }\end{array}$ $\begin{array}{lllllllllllllll}0.67 & 26.65 & 27.38 & 39.65 & 3 & 2615.3086 & 2615.3056 & 872.7758 & 0.0030 & 1.1458 & 5.741 & 0.000 & 5.930 & 3.975 & \mathrm{No}\end{array}$

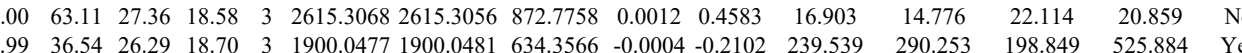
$\begin{array}{llllllllllllllll}1.00 & 36.94 & 26.16 & 22.49 & 3 & 1900.0483 & 1900.0481 & 634.3566 & 0.0002 & 0.1051 & 337.429 & 567.782 & 344.847 & 915.182 & \text { Yes }\end{array}$ $\begin{array}{llllllllllllllll}0.99 & 41.85 & 24.80 & 27.85 & 2 & 1239.7328 & 1239.7210 & 620.8678 & 0.0118 & 9.5027 & 2499.778 & 2979.568 & 216.991 & 9120.755 & \text { Yes }\end{array}$ $\begin{array}{lllllllllllllll}0.99 & 40.91 & 25.02 & 23.96 & 2 & 1239.7296 & 1239.7210 & 620.8678 & 0.0086 & 6.9257 & 2518.730 & 3128.538 & 159.094 & 9067.126 & \text { Yes }\end{array}$ $\begin{array}{lllllllllllllll}1.00 & 69.30 & 26.22 & 27.86 & 2 & 1377.8102 & 1377.8102 & 689.9124 & 0.0000 & 0.0000 & 685.992 & 864.387 & 329.589 & 1405.544 & \text { Yes }\end{array}$

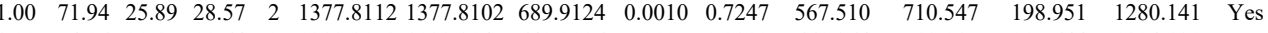
$\begin{array}{lllllllllllllll}1.00 & 54.06 & 22.17 & 29.64 & 2 & 1283.8052 & 1283.8047 & 642.9096 & 0.0005 & 0.3889 & 661.364 & 713.015 & 117.644 & 1804.130 & \text { Yes }\end{array}$ $\begin{array}{llllllllllllllll}1.00 & 3.07 & 22.01 & 31.44 & 2 & 1283.8056 & 1283.8047 & 642.9096 & 0.0009 & 0.6999 & 1439.944 & 1637.435 & 126.677 & 3810.259 & \text { Yes }\end{array}$ $\begin{array}{lllllllllllllll}1.00 & 72.68 & 26.22 & 30.80 & 2 & 1377.8102 & 1377.8102 & 689.9124 & 0.0000 & 0.0000 & 1112.858 & 1359.877 & 392.092 & 2142.371 & \text { Yes } \\ 1.00 & 73.21 & 26.19 & 30.78 & 2 & 1377.8108 & 1377.8102 & 689.9124 & 0.0006 & 0.4348 & 964.659 & 1096.770 & 387.748 & 1908.488 & \text { Yes }\end{array}$ $\begin{array}{lllllllllllllll}1.00 & 73.21 & 26.19 & 30.78 & 2 & 1377.8108 & 1377.8102 & 689.9124 & 0.0006 & 0.4348 & 964.659 & 1096.770 & 387.748 & 1908.488 & \text { Yes } \\ 1.00 & 43.46 & 26.02 & 24.68 & 2 & 1077.6680 & 1077.6668 & 539.8407 & 0.0012 & 1.1114 & 845.911 & 1261.256 & 0.000 & 4016.306 & \text { No }\end{array}$ $\begin{array}{rrrrrrrrrrrrrrrr}1.00 & 43.06 & 26.36 & 24.44 & 2 & 1077.6686 & 1077.6668 & 539.8407 & 0.0018 & 1.6672 & 845.911 & 1261.256 & 0.000 & 4016.306 & \text { No } \\ & 1027.067 & 125.308 & 3494.965 & \text { Yes }\end{array}$ $\begin{array}{lllllllllllllll}1.00 & 58.12 & 22.10 & 27.55 & 2 & 1283.8044 & 1283.8047 & 642.9096 & -0.0003 & -0.2333 & 1189.028 & 1297.150 & 74.596 & 3269.674 & \text { Yes } \\ 1.00 & 59.41 & 22.10 & 29.81 & 2 & 1283 & & \end{array}$ $\begin{array}{llllllllllllllll}1.00 & 59.41 & 22.10 & 29.81 & 2 & 1283.8048 & 1283.8047 & 642.9096 & 0.0001 & 0.0778 & 1778.173 & 2247.257 & 78.978 & 5060.894 & \text { Yes } \\ 1.00 & 70.12 & 26.22 & 27.57 & 2 & 1377.8102 & 1377.8102 & 689.9124 & 0.0000 & 0.0000 & 336518 & 480346 & 148.747 & 732.374 & \text { Yes }\end{array}$ $\begin{array}{llllllllllllllll}1.00 & 70.12 & 26.22 & 27.57 & 2 & 1377.8102 & 1377.8102 & 689.9124 & 0.0000 & 0.0000 & 336.518 & 480.346 & 148.747 & 732.374 & \text { Yes } \\ 1.00 & 37.80 & 26.36 & 23.48 & 2 & 1077.6686 & 1077.6668 & 539.8407 & 0.0018 & 1.6672 & 220.122 & 2878.134 & 239.633 & 9370.472 & \text { Yes }\end{array}$

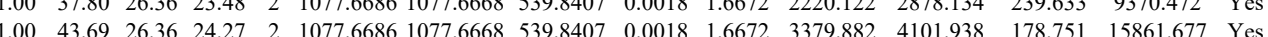

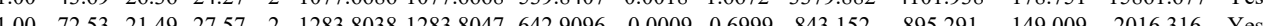

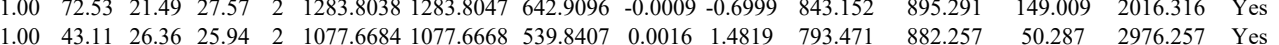




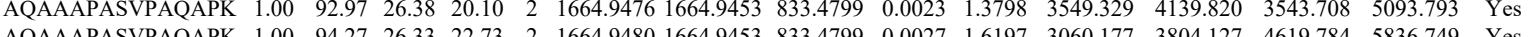
$\begin{array}{llllllllllllllll}\text { AQAAAPASVPAQAPK } & 1.00 & 94.27 & 26.33 & 22.73 & 2 & 1664.9480 & 1664.9453 & 833.4799 & 0.0027 & 1.6197 & 3060.177 & 3804.127 & 4619.784 & 5836.749 & \text { Yes }\end{array}$

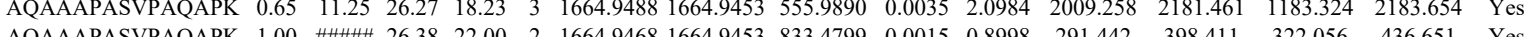
$\begin{array}{lllllllllllll} & \end{array}$

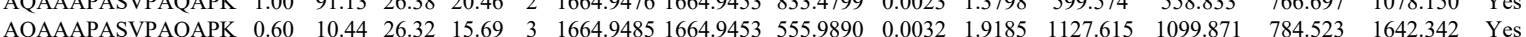

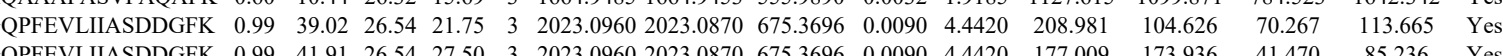
$\begin{array}{llllllllllllllll} & & & \end{array}$

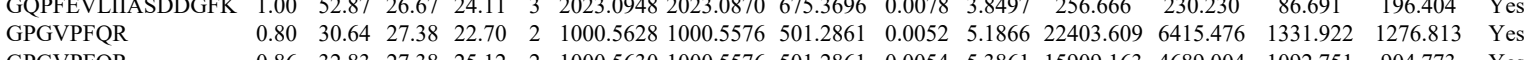
$\begin{array}{lllllllllllllllll}\text { GPGVPFQR } & 0.86 & 32.83 & 27.38 & 25.12 & 2 & 1000.5630 & 1000.5576 & 501.2861 & 0.0054 & 5.3861 & 15909.163 & 4689.004 & 1092.751 & 904.773 & \text { Yes }\end{array}$ $\begin{array}{llllllllllllllll}\text { SSLPEGIRPGTVLR } & 0.91 & 25.28 & 24.13 & 21.80 & 3 & 1624.9534 & 1624.9382 & 542.6533 & 0.0152 & 9.3368 & 36318.226 & 12362.497 & 1612.774 & 4165.555 & \text { Yes }\end{array}$ $\begin{array}{llllllllll}\text { UCRI_HUMAN } & \text { P47985 } & \text { UQCRFS1 Cytochrome b-c1 1 29.668 } & 1.00 & 4 & 18.2 & 0.2103 & 0.4210 & -0.3693 & 0.3011\end{array}$ DPQHDLDR $\begin{array}{llllllllllllllll}\text { DPQHDLDR } & 0.58 & 14.01 & 26.04 & 22.94 & 2 & 1138.5508 & 1138.5489 & 570.2817 & 0.0019 & 1.6658 & 44.821 & 37.032 & 50.692 & 71.782 & \text { Yes } \\ \text { NAVTOFVSSMSASADVLALAK } & 1.00 & 97.71 & 25.66 & 26.68 & 3 & 2397.2860 & 2397.2817 & 800.1012 & 0.0043 & 1.7914 & 35.817 & 19.910 & 22.181 & 27.874 & \text { No }\end{array}$ $\begin{array}{lllllllllllllll}0.95 & 25.72 & 26.01 & 22.72 & 2 & 1138.5504 & 1138.5489 & 570.2817 & 0.0015 & 1.3151 & 47.742 & 46.832 & 70.565 & 57.639 & \text { Yes } \\ 0\end{array}$

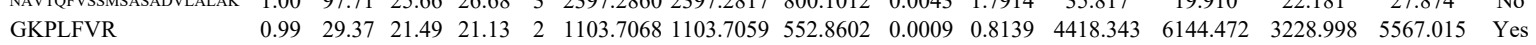
$\begin{array}{llllllllllllllll}\text { GKPLFVR } & 0.90 & 22.21 & 22.50 & 20.22 & 2 & 1103.7084 & 1103.7059 & 552.8602 & 0.0025 & 2.2610 & 2705.581 & 3583.993 & 1871.185 & 3650.372 & \text { Yes }\end{array}$ $\begin{array}{llllllllllllllll}\text { GKPLFVR } & 0.99 & 29.62 & 22.50 & 21.42 & 2 & 1103.7082 & 1103.7059 & 552.8602 & 0.0023 & 2.0801 & 6133.791 & 8977.281 & 3322.583 & 8955.557 & \text { Yes }\end{array}$ $\begin{array}{llllllllllllllll}\text { GKPLFVR } & 0.99 & 32.33 & 21.49 & 22.41 & 2 & 1103.7058 & 1103.7059 & 552.8602 & -0.0001 & -0.0904 & 2637.539 & 4110.838 & 1705.514 & 3943.867 & \text { Yes }\end{array}$ $\begin{array}{lllllllllllllll}\text { EIEQEAAVELSQLR } & 1.00 & \text { \#\#\#\# } 27.83 & 40.28 & 2 & 1757.9294 & 1757.9281 & 879.9713 & 0.0013 & 0.7387 & 140.179 & 106.765 & 260.025 & 316.805 & \text { Yes }\end{array}$ $\begin{array}{lllllllllll}\text { ATPO_HUMAN } & \text { P48047 } & \text { ATP5O } & \text { ATP synthase sub 23.277 } & 1.00 & 2 & 18.3 & -0.0502 & 0.1966 & 0.4856 & 0.3964\end{array}$ $\begin{array}{llllllllllllll} & \\ \text { NEALEK } & 1.00 & 75.30 & 27.71 & 20.34 & 3 & 2594.3092 & 2594.3063 & 865.7760 & 0.0029 & 1.1165 & 7.848 & 27.315 \\ \end{array}$ $\begin{array}{llllllllllll}\text { FSPLTTNLINLLAENGR } & 1.00 & \# \# \# \# \quad 25.17 & 24.42 & 2 & 2016.1134 & 2016.1125 & 1009.0635 & 0.0009 & 0.4460 & 1309.551 & 1473.069\end{array}$

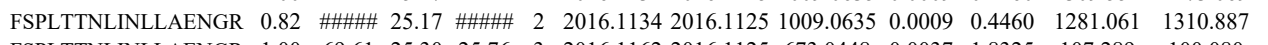
$\begin{array}{lllllllllllll}\text { FSPLTTNLINLLAENGR } & 1.00 & 69.61 & 25.30 & 25.76 & 3 & 2016.1162 & 2016.1125 & 673.0448 & 0.0037 & 1.8325 & 107.289 & 100.080\end{array}$ $\begin{array}{lllllllllllll}\text { FSPLTTNLINLLAENGR } & 1.00 & 45.79 & 25.35 & 23.80 & 3 & 2016.1165 & 2016.1125 & 673.0448 & 0.0040 & 1.9810 & 83.165 & 144.498\end{array}$ $\begin{array}{llllllllllll}\text { FSPLTTNLINLLAENGR } & 0.82 & \text { \#\#\#\# } 25.17 & \text { \#\#\# } & 2 & 2016.1134 & 2016.1125 & 1009.0635 & 0.0009 & 0.4460 & 237.776 & 189.971 \\ \text { FSPLTTNLINLLAENGR } & 1.00 & \text { \#\#\#\# } 25.17 & 23.67 & 2 & 2016.1134 & 2016.1125 & 1009.0635 & 0.0009 & 0.4460 & 212.859 & 232.753\end{array}$ $\begin{array}{llllllllllllll}\text { FSPLTTNLINLLAENGR } & 1.00 & \# \# \# \text { 25.17 } & 23.67 & 2 & 2016.1134 & 2016.1125 & 1009.0635 & 0.0009 & 0.4460 & 212.859 & 232.753 & 3.0 \\ \text { FSPLTTNLINLLAENGR } & 1.00 & 65.02 & 25.28 & 24.15 & 3 & 2016.1153 & 2016.1125 & 673.0448 & 0.0028 & 1.3867 & 87.717 & 92.489 & \end{array}$

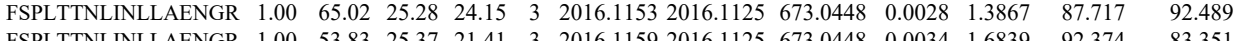
\begin{tabular}{lllllllllllll} 
ISPLTTNLINLLAENGR & 1.00 & 53.83 & 25.37 & 21.41 & 3 & 2016.1159 & 2016.1125 & 673.0448 & 0.0034 & 1.6839 & 92.374 & 83.351 \\
\hline CDLCQEVLADIGFVK & 1.00 & 38.47 & 26.65 & 17.31 & 3 & 2031.9763 & 2031.9745 & 678.3321 & 0.0018 & 0.8845 & 145.466 & 149.084
\end{tabular}

$\begin{array}{lllllllllllll} & \end{array}$ $\begin{array}{llllllllllllllll} & \text { MGVPICGACR } & 1.00 & 34.90 & 20.17 & 16.10 & 2 & 1241.5344 & 1241.5333 & 621.7739 & 0.0011 & 0.8846 & 1314.731 & 1566.729 & 6\end{array}$ $\begin{array}{llllllllllllllllll}\text { MGVPICGACR } & 0.99 & 29.19 & 20.29 & 16.57 & 2 & 124.5344 & 1241.5333 & 621.7739 & 0.0011 & 0.8846 & 1074.947 & 1094.355 & 2\end{array}$ $\begin{array}{llllllllllllll} & \text { MGVVICGACR } & 0.99 & 29.19 & 20.29 & 16.57 & 2 & 1241.5344 & 1241.5333 & 621.7739 & 0.0011 & 0.8846 & 1074.947 & 1094.355 \\ 16 & \text { LPEADDIQYPSMLLLTADHDDR } & 0.67 & 70.51 & 26.64 & 83.51 & 3 & 2671.2949 & 2671.2921 & 891.4380 & 0.0028 & 1.0470 & 29.153 & 42.842 \\ & \text { LPEADDIYYPSMLLTADHDDR } & 0.67 & 60.41 & 26.73 & 73.41 & 3 & 2671.2955 & 2671.2921 & 891.4380 & 0.0034 & 1.2714 & 36.332 & 44.510\end{array}$ $\begin{array}{lllllllllllll}\text { LPEADDIQYPSMLLLTADHDDR } & 0.67 & 60.41 & 26.73 & 73.41 & 3 & 2671.2955 & 2671.2921 & 891.4380 & 0.0034 & 1.2714 & 36.332 & 44.510 \\ \text { LPEADDIQYSSMLLLTADHDDR } & 1.00 & 89.23 & 26.70 & 21.88 & 3 & 2671.2961 & 2671.2921 & 891.4380 & 0.0040 & 1.4957 & 47.992 & 18.538\end{array}$ $\begin{array}{lllllllllllllllllll} & \end{array}$ $\begin{array}{llllllllllllllllll} & 20.90 & 3 & 1937.1601 & 1937.1553 & 646.7257 & 0.0048 & 2.4740 & 4937.667 & 3174.991 & 1361.077 & 4986.192 & \text { Yes } \\ \text { NILQLHDLTTGALLK } & 1.00 & 65.67 & 18.69 & 2.03 & \end{array}$ $\begin{array}{lllllllllllllll}1.00 & 55.83 & 28.22 & 19.00 & 2 & 1604.8552 & 1604.8540 & 803.4343 & 0.0012 & 0.7468 & 1530.665 & 1457.597 & 63.079 & 140.030 & \text { Yes } \\ 1.153 & \text { Yes }\end{array}$ $\begin{array}{lllllllllllllllll} & \text { ITVPFLEQCPIR } & 1.00 & 71.42 & 28.22 & 20.45 & 2 & 1604.8552 & 1604.8540 & 803.4343 & 0.0012 & 0.7468 & 2264.476 & 2020.870 & 98.850 & 2172.922 & \text { Yes }\end{array}$ $\begin{array}{llllllllllllllll}\text { ITVPFLEQCPIR } & 1.00 & 55.57 & 28.23 & 19.35 & 2 & 1604.8550 & 1604.8540 & 803.4343 & 0.0010 & 0.6223 & 489.149 & 552.688 & 0.000 & 553.152 & \text { No }\end{array}$ $\begin{array}{llllllllllllllll}\text { ITVPFLEQCPIR } & 1.00 & 71.20 & 28.16 & 21.88 & 2 & 1604.8554 & 1604.8540 & 803.4343 & 0.0014 & 0.8713 & 1067.929 & 836.081 & 32.994 & 1011.917 & \text { Yes }\end{array}$ $\begin{array}{lllllllllllllllll}\text { ITVPFLEQCPIR } & 0.57 & 20.73 & 28.14 & 23.48 & 2 & 1604.8544 & 1604.8540 & 803.4343 & 0.0004 & 0.2489 & 2391.535 & 3113.432 & 52.662 & 1399.708 & \text { No }\end{array}$ $\begin{array}{lllllllllllllllll}\text { YVLLSIR } & 1.00 & 34.98 & 23.05 & 28.05 & 2 & 1006.6310 & 1006.6297 & 504.3221 & 0.0013 & 1.2889 & 5744.747 & 4728.732 & 438.865 & 6215.594 & \text { Yes }\end{array}$

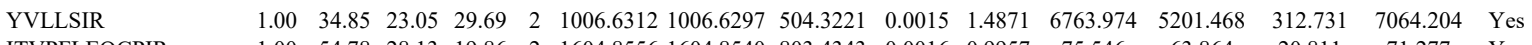

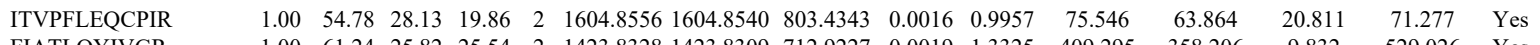

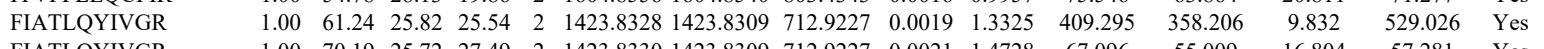

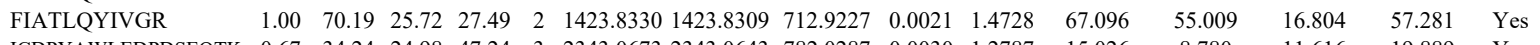

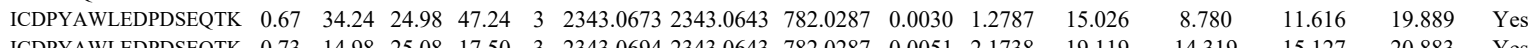

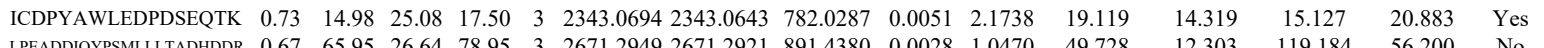

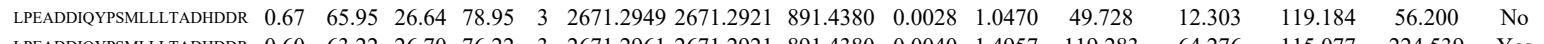

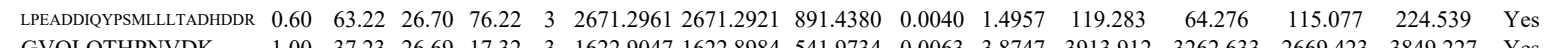
$\begin{array}{llllllllllllllll}1.00 & 37.23 & 26.69 & 17.32 & 3 & 1622.9047 & 1622.8984 & 541.9734 & 0.0063 & 3.8747 & 3913.912 & 3262.633 & 2669.423 & 3849.227 & \text { Yes }\end{array}$ VTQVDGNSPVR

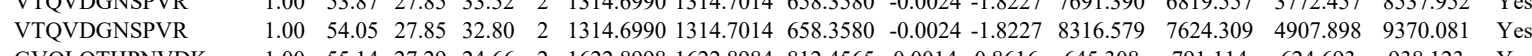
$\begin{array}{llllllllllllllll}0.99 & 34.52 & 26.73 & 17.09 & 3 & 1622.9056 & 1622.8984 & 541.9734 & 0.0072 & 4.4282 & 5281.071 & 5634.467 & 4563.975 & 5518.851 & \text { Yes } \\ 1.00 & 53.87 & 27.85 & 33.52 & 2 & 1314.6990 & 1314.7014 & 658.3580 & -0.0024 & -1.8227 & 7691.390 & 6819.557 & 3772.457 & 8537.952 & \text { Yes }\end{array}$

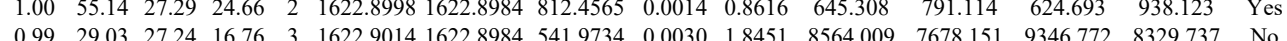


GVQLQTHPNVDK GVQLQTHPNVDKK GVQLQTHPNVDKK NTLEWCLPVIDAK NTLEWCLPVIDAK NTLEWCLPVIDAK VAPAPARPSGPSK VAPAPARPSGPSK VAPAPARSGGSK VAPAPARSGGSK AAPAPARSGCPK VAPAPARSGSK VAPAPARPSGPSK IEGLLAAFPK IEGLLAAFPK LFTAESLIGLK LFTAESLIGLK LFTAESLIGLK VAPAPARPSGPSK VAPAPARPSGPSK VAPAPARPSGPSK VAPAPARPSGPSK VAPAPARPSGPSK VAPAPARPSGPSK VLLAAAVCTK

VLLAAAVCTK

VLLAAAVCTK

VLLAAAVCTK

LYMVLITTK

LYMVLITTK

ITLTCGR

ITLTCGR

ITLTCGR

(17)

SEGETMSSSMGK

NSNILEDLETLR

STVFGTALNYVSL

STVFGTALNYVSLR

STVFGTALNYVSLR

STVFGTALNYVSLR

LCDAVAVLLNM

LCDAVAVLLNMR

LCDAVAVLLNMR

NIFPIWALGR

NIFPIWALG

$\begin{array}{llllllllll}\text { Glutathione synthr } 52.385 & 1.00 & 5 & 11.2 & 0.4309 & 0.2558 & 0.8493 & 0.1063 & 12 & \text { AIENELLAR } \\ \text { CPDIATOLAGT }\end{array}$

CPDIATQLAGTK

GLALGIAK
GLALGIAK

QIEINTISASFGGLASR

QIEINTISASFGGLASR

PIEINTISA

FVLKPQR

FVLKPQR

FVLKPQR

FVLKPQR

FULKPQR

AIENELLAR
FSELTAEK

TCPE HUMAN P48643 CCT

$\begin{array}{llllllll}\text { T-complex proteir } 59.671 & 1.00 & 23 & 56.4 & 0.1722 & 0.2976 & 1.6550 & 0.3825\end{array}$ $\begin{array}{llllllllllllll}34.42 & 27.24 & 17.83 & 3 & 1622.9017 & 1622.8984 & 541.9734 & 0.0033 & 2.0296 & 6039.081 & 6432.234 & 5046.963 & 6971.692 & \text { Yes }\end{array}$ $\begin{array}{lllllllllllllll} & \end{array}$

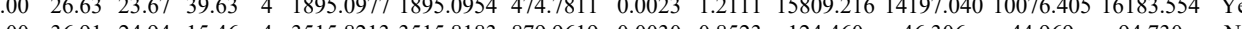

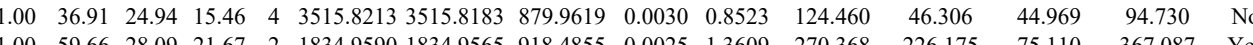
$\begin{array}{lllllllllllllll}1.00 & 59.66 & 28.09 & 21.67 & 2 & 1834.9590 & 1834.9565 & 918.4855 & 0.0025 & 1.360 & 270.368 & 226.175 & 75.110 & 367.087 & \text { Yes } \\ 1.00 & 50.32 & 28.08 & 1.90 & 2 & 1834.9596 & 1834.9565 & 918.4855 & 0.0031 & 1.6876 & 133.515 & 127.657 & 21.774 & 172.500 & \text { Yes }\end{array}$

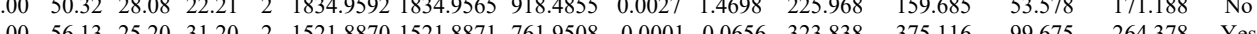

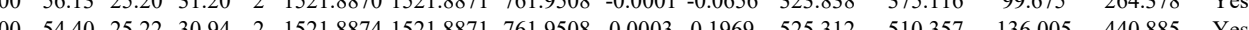

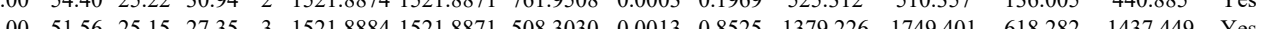

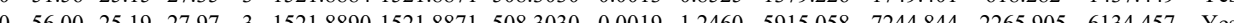

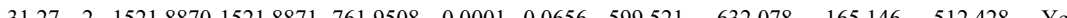
$\begin{array}{lllllllllllll} & \end{array}$ $\begin{array}{lllllllllllllll} & \end{array}$

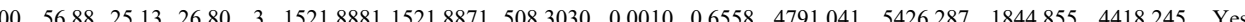
$\begin{array}{llllllllllllllll}1.00 & 31.45 & 24.01 & 21.66 & 3 & 1345.8238 & 1345.8213 & 449.6144 & 0.0025 & 1.8534 & 105.731 & 96.796 & 42.909 & 171.175 & \text { Yes }\end{array}$

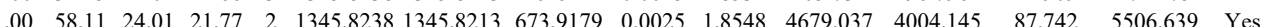
$\begin{array}{llllllllllllllll}100 & 52.34 & 20.64 & 19.97 & 2 & 1478.9000 & 1478.8952 & 740.4549 & 0.0048 & 3.2412 & 2770.979 & 3613.385 & 2508.934 & 4723.816 & \text { No }\end{array}$ $\begin{array}{llllllllllllllll}1.00 & 72.04 & 19.54 & 30.05 & 2 & 1478.9012 & 1478.8952 & 740.4549 & 0.0060 & 4.0515 & 4809.374 & 4056.531 & 1852.187 & 5516.343 & \text { Yes }\end{array}$

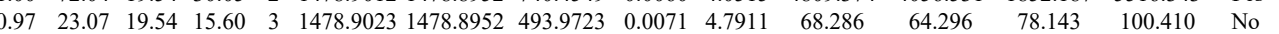
$\begin{array}{lllllllllllllll}1.00 & 58.65 & 25.13 & 23.85 & 3 & 1521.8881 & 1521.8871 & 508.3030 & 0.0010 & 0.6558 & 1465.884 & 1657.177 & 653.994 & 1407.302 & \text { Yes }\end{array}$ $\begin{array}{lllllllllllllll} & & & \end{array}$ $\begin{array}{lllllllllllllll} & \end{array}$ $\begin{array}{llllllllllllllll}1 & 0.71 .75 & 25.22 & 32.49 & 3 & 1521.8875 & 1521.8871 & 508.3030 & 0.0004 & 0.2623 & 898.885 & 1111.546 & 411.423 & 996.454 & \text { Yes }\end{array}$

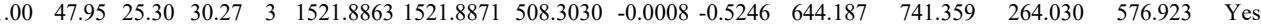
$\begin{array}{lllllllllllll} & \end{array}$

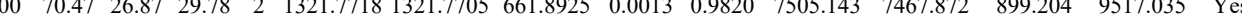
$\begin{array}{lllllllllllllll}1.00 & 76.19 & 26.87 & 29.99 & 2 & 1321.7718 & 1321.7705 & 661.8925 & 0.0013 & 0.9820 & 6174.312 & 5671.235 & 580.716 & 8140.719 & \text { Yes }\end{array}$ \begin{tabular}{llllllllllllllll}
1.00 & 70.29 & 26.36 & 29.81 & 2 & 1321.7716 & 1321.7705 & 661.8925 & 0.0011 & 0.8309 & 8028.031 & 8175.328 & 881.623 & 11640.627 & Yes \\
\hline
\end{tabular} \begin{tabular}{llllllllllllllll}
1.00 & 72.76 & 26.55 & 29.92 & 2 & 1321.7728 & 1321.7705 & 661.8925 & 0.0023 & 1.7374 & 9127.139 & 8575.235 & 1263.755 & 11833.625 & Yes \\
\hline
\end{tabular} $\begin{array}{llllllllllllllll}1.00 & 57.83 & 21.99 & 17.33 & 2 & 1368.8308 & 1368.8294 & 685.4220 & 0.0014 & 1.0213 & 8628.900 & 7442.499 & 1519.276 & 8934.386 & \text { Yes }\end{array}$ $\begin{array}{llllllllllllllll}1.00 & 50.38 & 21.93 & 17.95 & 2 & 1368.8292 & 1368.8294 & 685.4220 & -0.0002 & -0.1459 & 2895.062 & 3281.252 & 876.342 & 4240.160 & \text { Yes }\end{array}$ $\begin{array}{llllllllllllllll}0.76 & 30.71 & 27.80 & 27.91 & 2 & 952.5018 & 952.4956 & 477.2551 & 0.0062 & 6.4954 & 23340.750 & 23235.359 & 2853.933 & 29846.588 & \text { Yes }\end{array}$ $\begin{array}{lllllllllllllllll}0.63 & 27.37 & 27.80 & 25.66 & 2 & 952.5024 & 952.4956 & 477.2551 & 0.0068 & 7.1240 & 14824.146 & 15690.772 & 2448.288 & 18353.519 & \text { Yes }\end{array}$

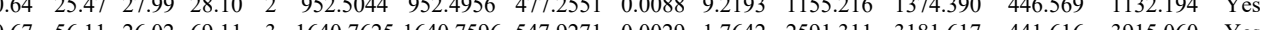

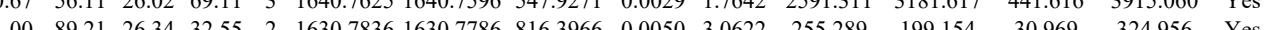
$\begin{array}{lllllllllllll} & 324.946 & \text { Yes }\end{array}$ $\begin{array}{lllllllllllllll}1.00 & 74.09 & 27.80 & 32.64 & 2 & 1559.8296 & 15598277 & 780.9211 & 0.0019 & 1.2165 & 461.773 & 805.774 & 22.952 & 1287.937 & \text { No }\end{array}$ $\begin{array}{lllllllllllllll}1.00 & 87.42 & 27.86 & 29.74 & 2 & 1670.9126 & 1670.9114 & 836.4630 & 0.0012 & 0.7173 & 577.523 & 635.765 & 100.011 & 693.122 & \text { Yes }\end{array}$

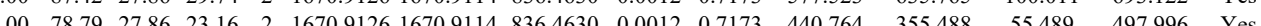
$\begin{array}{lllllllllllllll}1.00 & 85.36 & 27.86 & 22.90 & 2 & 1670.9124 & 1670.9114 & 836.4630 & 0.0010 & 0.5978 & 174.244 & 100.025 & 9.488 & 193.247 & \text { Yes }\end{array}$ $\begin{array}{lllllllllllllll}1.00 & 84.59 & 27.64 & 23.03 & 2 & 1670.9138 & 1670.9114 & 8364630 & 0.0024 & 1.4346 & 69.911 & 80.750 & 24.756 & 70.765 & \text { No- }\end{array}$

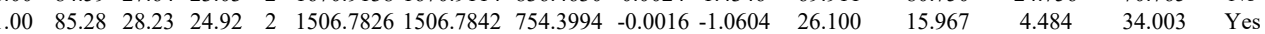
$\begin{array}{lllllllllllllll}100 & 50.77 & 28.18 & 20.90 & 2 & 1506.7860 & 1506.7842 & 754.3994 & 0.0018 & 1.1930 & 20.939 & 16.288 & 0.000 & 28.835 & \text { No }\end{array}$

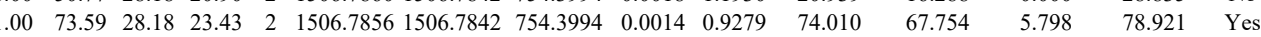
$\begin{array}{llllllllllllllll}1.00 & 78.62 & 28.13 & 24.58 & 2 & 1506.7864 & 1506.7842 & 754.3994 & 0.0022 & 1.4581 & 70.538 & 48.600 & 5.218 & 81.631 & \text { Yes }\end{array}$ $\begin{array}{lllllllllllllll}1.00 & 50.20 & 26.98 & 35.71 & 2 & 1329.7700 & 1329.7679 & 665.8912 & 0.0021 & 1.5768 & 1614.648 & 1367.903 & 16.252 & 2144.045 & \text { Yes }\end{array}$ $\begin{array}{lllllllllllllll}1.00 & 49.40 & 26.99 & 35.57 & 2 & 1329.7702 & 1329.7679 & 665.8912 & 0.0023 & 1.7270 & 1765.880 & 1812.211 & 69.376 & 2236.199 & \text { Yes }\end{array}$ $\begin{array}{llllllllllllllll}0.98 & 37.93 & 27.01 & 26.76 & 2 & 1171.6794 & 1171.6682 & 586.8414 & 0.0112 & 9.5425 & 869.009 & 765.194 & 140.361 & 906.254 & \text { Yes }\end{array}$

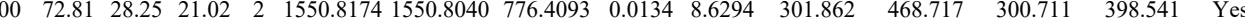

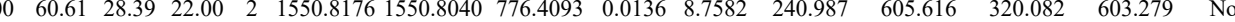
$\begin{array}{lllll}32.82 & 2 & 1029.6842 & 1029.679\end{array}$ $\begin{array}{lllllllllllllll}0.98 & 42.52 & 21.67 & 32.72 & 2 & 1029.6848 & 1029.6790 & 515.8468 & 0.0058 & 5.6218 & 8195.716 & 11304.341 & 2029.353 & 10586.402 & \text { Yes }\end{array}$

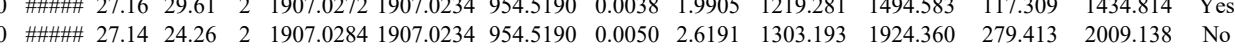

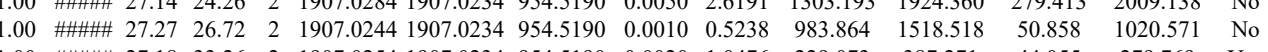

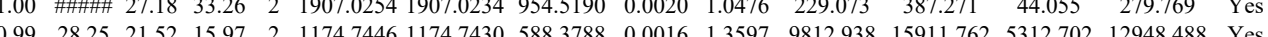
$\begin{array}{lllllllllllllll}0.99 & 28.25 & 21.52 & 15.97 & 2 & 1174.7446 & 1174.7430 & 588.3788 & 0.0016 & 1.3597 & 9812.938 & 15911.762 & 5312.702 & 12948.488 & \text { Yes }\end{array}$ $\begin{array}{llllllllllllllll}0.99 & 30.54 & 21.52 & 18.17 & 2 & 1174.7452 & 1774.7430 & 588.3788 & 0.0022 & 1.8695 & 15287.799 & 20426.359 & 6531.281 & 17738.365 & \text { Yes }\end{array}$ $\begin{array}{lllllllllllllllll}0.97 & 28.43 & 21.99 & 18.91 & 2 & 1174.7432 & 1174.7430 & 588.3788 & 0.0002 & 0.1700 & 10572.223 & 14452.751 & 4864.005 & 13439.913 & \text { Yes } \\ 0.99 & 30.44 & 2.49 & 17.44 & 2 & 1174.7440 & 1174.740 & 588.3788 & 0.0010 & 0.849 & 2946.116 & 3792.516 & 1534.93 & 351.529 & \text { Yes }\end{array}$ $\begin{array}{lllllllllllllll}0.99 & 30.44 & 21.49 & 17.44 & 2 & 1174.7440 & 1174.7430 & 588.3788 & 0.0010 & 0.8498 & 2946.116 & 3792.516 & 1534.938 & 3551.529 & \text { Yes }\end{array}$

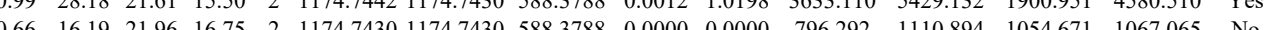

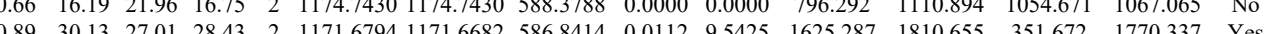

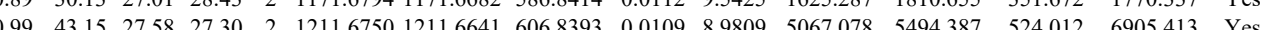

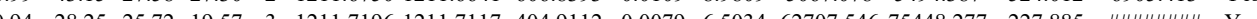
$\begin{array}{lllllllllllllllllll}1.00 & 49.94 & 25.72 & 28.92 & 2 & 1211.7200 & 1211.7117 & 606.8631 & 0.0083 & 6.8384 & 11462.916 & 11565.871 & 1181.370 & 16289.356 & \text { Yes }\end{array}$

Table S-4 page 320 of 614 


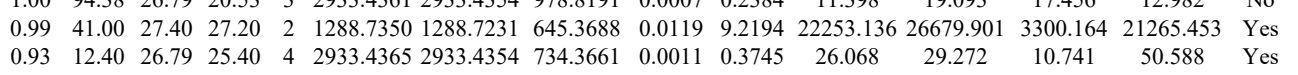

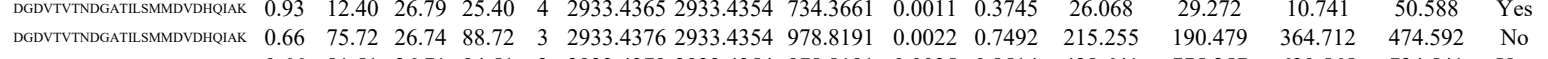
$\begin{array}{llllllllllllllll}\text { DGDVTVTNDGATILSMMDVDHOIAK } & 0.66 & 81.51 & 26.71 & 94.51 & 3 & 2933.4379 & 2933.4354 & 978.8191 & 0.0025 & 0.8514 & 428.641 & 775.257 & 630.565 & 724.541 & \text { Yes } \\ \text { TSLGPNGLDK } & 1.0 & 55.02 & 27.46 & 30.37 & 2 & 128.3756 & 128.7231 & 645.368 & 0.025 & 9.643 & 25571.884 & 27726.334 & 473.720 & 21175.549 & \text { Yes }\end{array}$

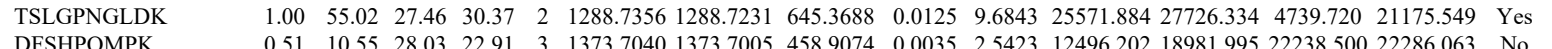

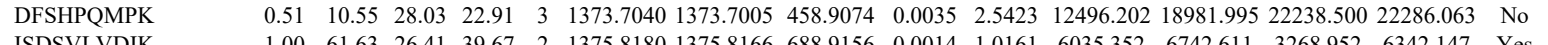
$\begin{array}{llllllllllllllll}\text { ISDSVLVDIK } & 1.00 & 61.63 & 26.41 & 39.67 & 2 & 1375.8180 & 1375.8166 & 688.9156 & 0.0014 & 1.0161 & 6035.352 & 6742.611 & 3268.952 & 6342.147 & \text { Yes } \\ \text { ISDSVLVDIK } & 1.00 & 60.37 & 26.43 & 37.91 & 2 & 1375.8184 & 1375.8166 & 688.9156 & 0.0018 & 1.3064 & 5924.117 & 6692.503 & 3608.394 & 7152.365 & \text { Yes }\end{array}$

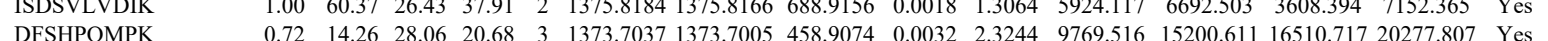
$\begin{array}{llllllllllllllll}\text { DFSHPQMPK } & 0.72 & 14.26 & 28.06 & 20.68 & 3 & 1373.7037 & 1373.7005 & 458.9074 & 0.0032 & 2.3244 & 9769.516 & 15200.611 & 16510.717 & 20277.807 & \text { Yes } \\ \text { ISDSVLVDIK } & 1.00 & 59.80 & 26.40 & 39.43 & 2 & 1375.8190 & 1375.8166 & 688.9156 & 0.0024 & 1.7419 & 1573.913 & 1425.222 & 582.937 & 1121.941 & \text { Yes }\end{array}$ $\begin{array}{lllllllllllllllll}\text { ISDSVLVDIK } & 1.00 & 59.80 & 26.40 & 39.43 & 2 & 1375.8190 & 1375.8166 & 688.9156 & 0.0024 & 1.7419 & 1573.913 & 1425.222 & 582.937 & 1121.941 & \text { Yes } \\ \text { VVYGGGAFISCALAVSEAADK } & 0.98 & 26.43 & 27.67 & 14.98 & 3 & 2471.2297 & 2471.2280 & 824.7499 & 0.0017 & 0.6871 & 10.410 & 11.646 & 4.121 & 13.678 & \text { Yes }\end{array}$ $\begin{array}{llllllllllllllll}\text { VVYGGGAAEISCALAVSOEADK } & 0.67 & 15.78 & 27.65 & 28.78 & 3 & 2471.2309 & 24712280 & 824.7499 & 0.0029 & 1.1721 & 17.745 & 23.279 & 16.872 & 31.424 & \text { Yes }\end{array}$

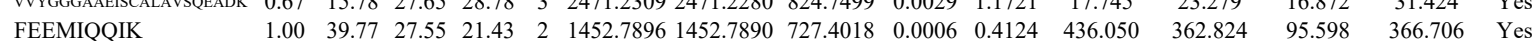

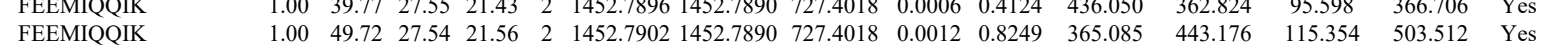

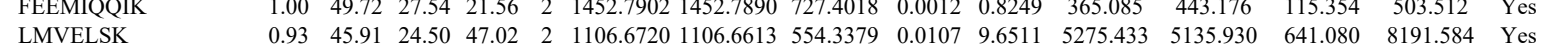

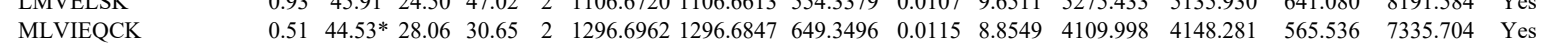
$\begin{array}{llllllllllllllll}\text { QQHVIETLIGK } & 0.99 & 39.81 & 22.88 & 16.09 & 2 & 1552.9216 & 1552.9181 & 777.4663 & 0.0035 & 2.2509 & 1314.240 & 1484.528 & 217.173 & 1251.779 & \text { Yes }\end{array}$ $\begin{array}{llllllllllllllll}\text { QQHVIETLIGK } & 1.00 & 54.48 & 22.88 & 20.48 & 2 & 1552.9216 & 1552.9181 & 777.4663 & 0.0035 & 2.2509 & 3805.206 & 4149.766 & 701.791 & 4763.733 & \text { Yes } \\ \text { QQHVIETLIGK } & 0.60 & 15 & 23.05 & 28 & & \end{array}$ $\begin{array}{llllllllllllllll}\text { QQHVIETLIGK } & 0.60 & 15.86 & 23.05 & 28.86 & 3 & 1552.9222 & 1552.9181 & 518.6466 & 0.0041 & 2.6351 & 685.353 & 912.994 & 353.788 & 962.530 & \text { Yes }\end{array}$ $\begin{array}{llllllllllllllll} & \\ \text { QQHVIETLIGK } & 1.00 & 40.89 & 22.55 & 18.14 & 3 & 1552.9228 & 1552.9181 & 518.6466 & 0.0047 & 3.0207 & 1753.540 & 1410.331 & 373.550 & 1664.297 & \text { Yes }\end{array}$ $\begin{array}{llllllllllllllll}\text { LMGLEALK } & 1.00 & 52.01 & 23.34 & 36.41 & 2 & 1161.7142 & 1161.7035 & 581.8590 & 0.0107 & 9.1946 & 2832.036 & 2711.440 & 115.008 & 4949.225 & \text { Yes }\end{array}$ $\begin{array}{llllllllllllllll}\text { QMAEIAVNAVLTVADMER } & 1.00 & 80.25 & 27.94 & 21.62 & 2 & 2104.0794 & 2104.0778 & 1053.0462 & 0.0016 & 0.7597 & 26.923 & 29.950 & 9.461 & 24.245 & \text { Yes } \\ \text { QMAEIAVNAVLTVADMER } & 1.00 & 42.02 & 27.83 & 19.65 & 3 & 2104.0813 & 2104.0778 & 702.3665 & 0.0035 & 1.6610 & 130.501 & 162.321 & 99.490 & 127.532 & \text { Yes }\end{array}$ $\begin{array}{lllllllllllllll}\text { QMAEIAVNAVLTVADMER } & 1.00 & \text { \#\#\#\# } 27.82 & 28.56 & 2 & 2104.0814 & 2104.0778 & 1053.0462 & 0.0036 & 1.7093 & 21.442 & 58.247 & 37.358 & 64.962 & \text { No }\end{array}$ $\begin{array}{llllllllllllllll}\text { QMAEIAVNAVLTVADMER } & 0.60 & 34.15 & 27.74 & 47.15 & 3 & 2104.0822 & 2104.0778 & 702.3665 & 0.0044 & 2.0882 & 84.988 & 102.609 & 37.019 & 131.985 & \text { Yes } \\ \text { LMGLEALK } & 1.00 & 51.87 & 23.78 & 36.71 & 2 & 1161.7130 & 1161.7035 & 581.8590 & 0.0095 & 8.1634 & 5455.141 & 5483.732 & 0.000 & 8744.632 & \text { No }\end{array}$

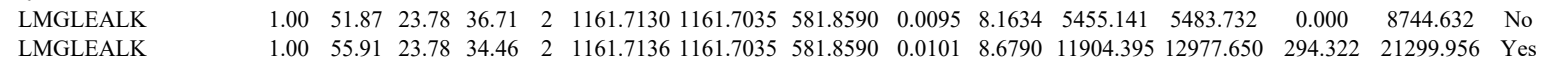
$\begin{array}{llllllllllllllll} & 1.00 & 55.91 & 23.78 & 34.46 & 2 & 1161.7136 & 1161.7035 & 581.8590 & 0.0101 & 8.6790 & 11904.395 & 12977.650 & 294.322 & 214.632 & \\ \text { QMAEIAVNAVLTVADMER } & 0.97 & 31.66 & 28.01 & 16.20 & 3 & 2104.0771 & 2104.0778 & 702.3665 & -0.0007 & -0.3322 & 81.409 & 97.619 & 43.583 & 86.155 & \text { Yes }\end{array}$

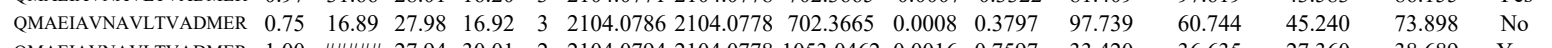

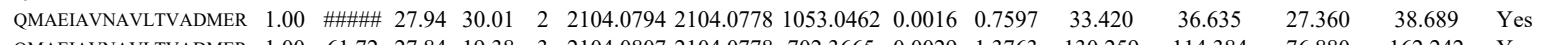

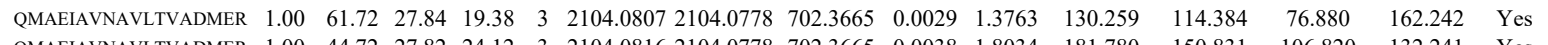

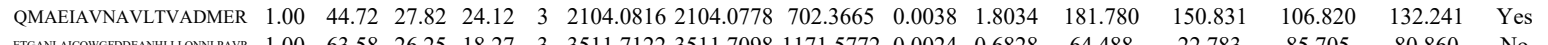

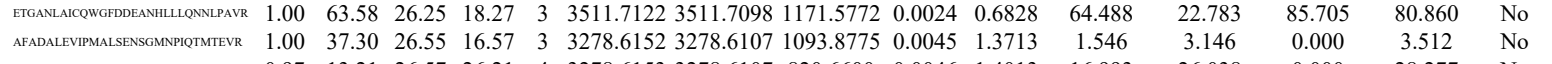

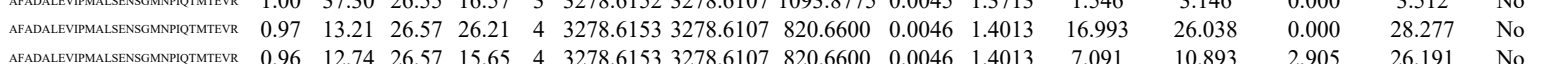

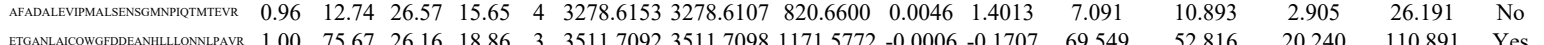

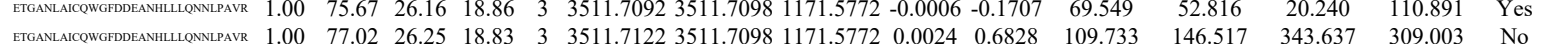

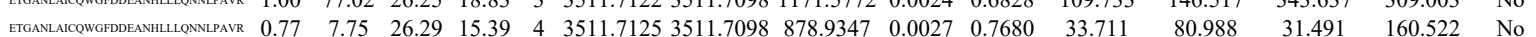

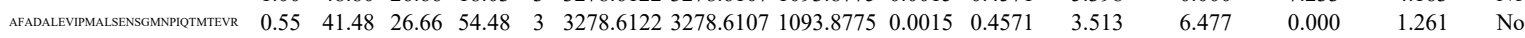

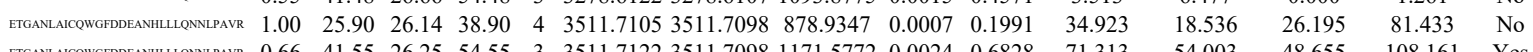

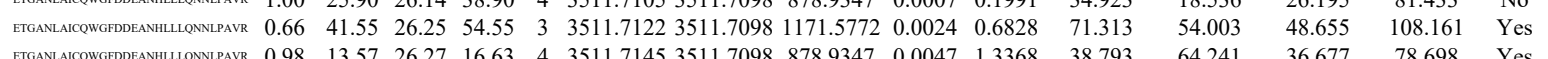

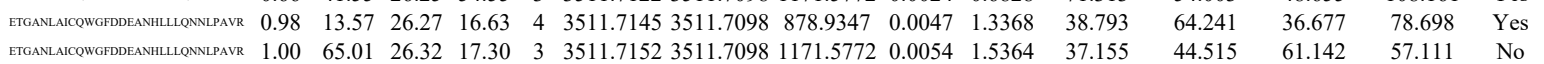

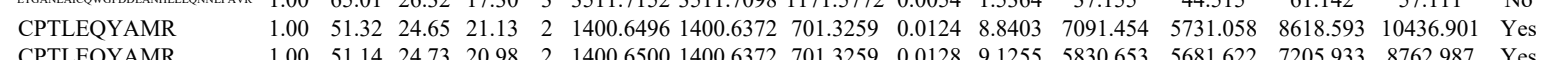
$\begin{array}{llllllllllllllll}\text { CPTLEQYAMR } & 1.00 & 51.14 & 24.73 & 20.98 & 2 & 1400.6500 & 1400.6372 & 701.3259 & 0.0128 & 9.1255 & 5830.653 & 5681.622 & 7205.933 & 8762.987 & \text { Yes } \\ \text { WVGGPEIELIAIATGGR } & 1.00 & 77.17 & 25.90 & 18.40 & 2 & 1882.0436 & 1882.0434 & 942.0290 & 0.0002 & 0.1062 & 315.886 & 227.818 & 82.181 & 386.789 & \text { Yes }\end{array}$ $\begin{array}{lllllllllllllll}\text { WVGGPEIELIAIATGGR } & 1.00 & \text { \#\#\#\# } 25.93 & 22.09 & 2 & 1882.0448 & 1882.0434 & 942.0290 & 0.0014 & 0.7431 & 7838.967 & 10632.161 & 1132.285 & 11788.129 & \text { Yes }\end{array}$

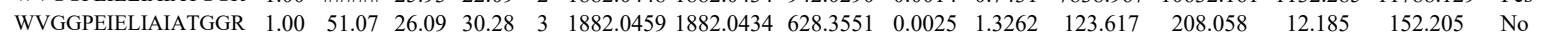
$\begin{array}{llllllllllllllll}\text { LGFAGLVQEISFGTTK } & 1.00 & 90.58 & 24.23 & 27.10 & 2 & 1955.1002 & 1955.0972 & 978.5559 & 0.0030 & 1.5329 & 477.615 & 665.337 & 235.106 & 752.226 & \text { Yes }\end{array}$ $\begin{array}{llllllllllllllllll}\text { LGFAGLVQEISFGTTK } & 1.00 & 90.27 & 23.93 & 32.43 & 2 & 1955.1046 & 1955.0972 & 978.5559 & 0.0074 & 3.7811 & 806.398 & 846.994 & 204.591 & 1695.113 & \text { Yes }\end{array}$ $\begin{array}{lllllllllllllllll}\text { LGFAGLVQEISFGTTK } & 1.00 & 40.38 & 23.75 & 21.66 & 3 & 1955.1097 & 1955.0972 & 652.7063 & 0.0125 & 6.3836 & 251.891 & 292.225 & 148.726 & 309.330 & \text { Yes }\end{array}$ $\begin{array}{llllllllllllllllll}\text { LGFAGLVQEISFGTTK } & 0.97 & 31.38 & 23.86 & 17.13 & 3 & 1955.1142 & 1955.0972 & 652.7063 & 0.0170 & 8.6817 & 100.805 & 113.684 & 40.497 & 126.523 & \text { Yes }\end{array}$ $\begin{array}{llllllllllllllll}\text { WVGGPEIELIAIATGGR } & 1.00 & 90.48 & 25.97 & 20.50 & 2 & 1882.0442 & 1882.0434 & 942.0290 & 0.0008 & 0.4246 & 3445.858 & 4456.144 & 153.792 & 5981.524 & \text { Yes }\end{array}$ $\begin{array}{lllllllllllllll}\text { WVGGPEIELIAIATGGR } & 1.00 & \text { \#\#\#\# } 21.80 & 2 & 1882.0450 & 1882.0434 & 942.0290 & 0.0016 & 0.8492 & 8471.855 & 11587.120 & 199.500 & 13932.545 & \text { Yes }\end{array}$

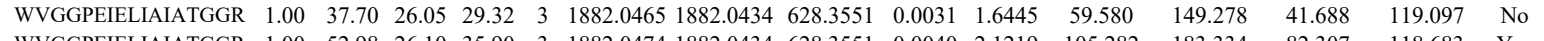
$\begin{array}{llllllllllllllll}\text { WVGGPEIELIAIATGGR } & 1.00 & 52.98 & 26.10 & 35.90 & 3 & 1882.0474 & 1882.0434 & 628.3551 & 0.0040 & 2.1219 & 105.282 & 183.334 & 82.307 & 118.683 & \text { Yes }\end{array}$ $\begin{array}{lllllllllllllll}\text { LGFAGLVQEISFGTTK } & 1.00 & \text { \#\#\#\# } 24.18 .51 & 2 & 1955.1004 & 1955.0972 & 978.5559 & 0.0032 & 1.6351 & 1471.365 & 1481.893 & 417.636 & 2186.045 & \text { Yes }\end{array}$

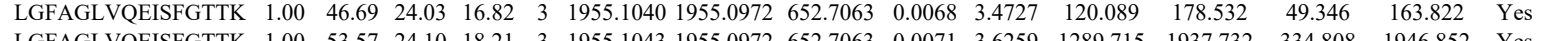

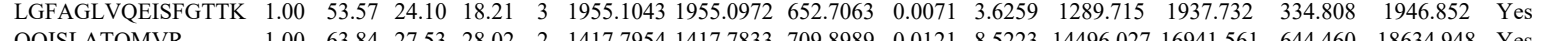

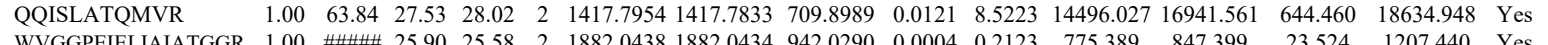

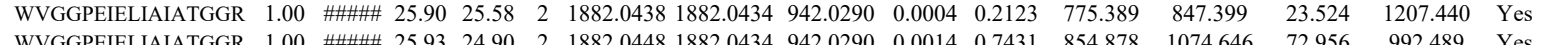

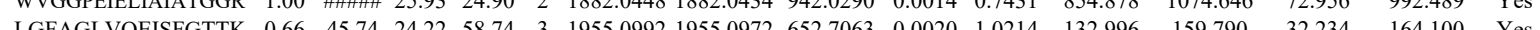
$\begin{array}{lllllllllllllllll}\text { LGFAGLVQEISFGTTK } & 1.00 & 45.74 & 24.22 & 58.74 & 3 & 1955.0992 & 1955.0972 & 652.7063 & 0.0020 & 1.0214 & 132.996 & 159.790 & 32.234 & 164.100 & \text { Yes } \\ \text { L } & & & & & & & \end{array}$ 
IAILTCPFEPPKPK IAILTCPFEPPKPK AILTCPFEPPKPK IAILTCPFEPPKPK QQISLATQMVR IAILTCPFEPPKPK IAILTCPFEPPKPK IAILTCPFEPPKPK QQISLATQMVR IAILTCPFEPPKPK AILTCPFPPKK IALTCPEPTK AVTIFIR

AVTIFIR

MIIEEAKR

MIIEEEAKR

MIIEEAKR
MIIEEAKR

MIIEEAKR

MIIEEAKR

MIIEEAKR

MIIEEAKR

MIIEEAKR

MIIEEAKR

MIIEEAKR

MIIEEAKR

MIIEEAKR

MIIEEAKR

MIIEEAKR

MIIEEAKR

MIIEEAKR

MIIEEAKR

MIIEEAKR

MIIEEAKR

MIIEEAKR

MIIEEAKR

MIIEEAKR

LGFAGLVOEISFGTTK

FSELTAEK

LDVTSVEDYK

LDVTSVEDYK

FSELTAEK

VAIEHLDK

VAIEHLDK

VAIEHLDK

:DVTVTNDGATLSMMDVDHO

$\begin{array}{lllllllllllll}\text { PTSS1_HUMAN } & \text { P48651 } & \text { PTDSS1 } & \text { Phosphatidylserin } 55.528 & 1.00 & 2 & 5.7 & -0.5908 & 0.2177 & 2.6681 & 0.4932 & 5 & \text { AVLQFTPASWTYVR }\end{array}$

ILFIGGITAPTVR

ILFIGGITAPTVR

ILFIGGITAPTVR

ILFIGGITAPTVR

$\begin{array}{llllllllll}\text { KC1A_HUMAN } & \text { P48729 } & \text { CSNK1A1 Casein kinase I isc } 38.915 & 1.00 & 4 & 15.4 & -0.0806 & 0.7012 & 0.3569 & 0.4808\end{array}$

AAQQAASSSGQGQQAQTPTGK

AAQQAASSSGQGQQAQTPTGK

AAQQAASSGQGQQAQTPTGK

TSLPWQGLK

LFLIDFGLAK

LFLIDFGLAK

LFLIDFGLAK

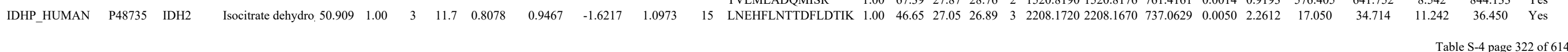

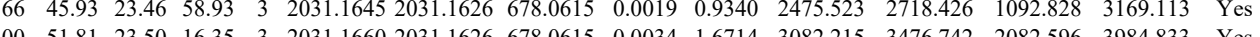

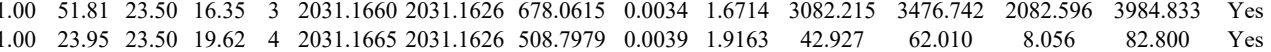
$\begin{array}{lllllllllllllll}1.00 & 23.61 & 23.32 & 15.12 & 4 & 2031.1673 & 2031.1626 & 508.7979 & 0.0047 & 2.3094 & 171.252 & 249.112 & 283.564 & 366.830 & \text { Yes }\end{array}$ $\begin{array}{lllllllllllllll}1.00 & 60.99 & 27.47 & 27.77 & 2 & 1417.7966 & 1417.7833 & 709.8989 & 0.0133 & 9.3674 & 17456.442 & 19456.949 & 1362.669 & 24728.424 & \text { Yes }\end{array}$ $\begin{array}{lllllllllllllll}1.00 & 36.22 & 23.50 & 49.22 & 4 & 2031.1661 & 2031.1626 & 508.7979 & 0.0035 & 1.7197 & 990.939 & 1515.221 & 704.346 & 2120.661 & \text { Yes }\end{array}$

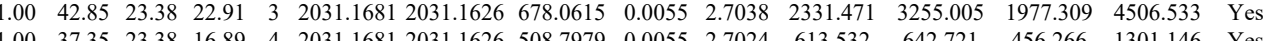
$\begin{array}{lllllllllllllll}1.00 & 37.35 & 23.38 & 16.89 & 4 & 2031.1681 & 2031.1626 & 508.7979 & 0.0055 & 2.7024 & 613.532 & 642.721 & 456.266 & 1301.146 & \text { Yes } \\ 1.00 & 57.67 & 27.47 & 27.82 & 2 & 1417.7966 & 1417.7833 & 709.8989 & 0.0133 & 9.3674 & 1586.564 & 1979.411 & 213.441 & 2895.700 & \text { Yes }\end{array}$

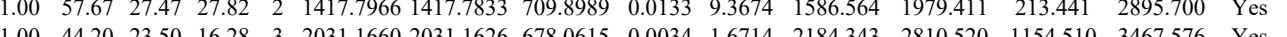

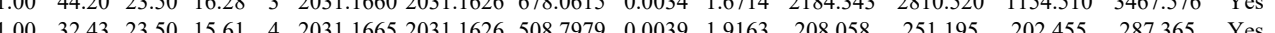

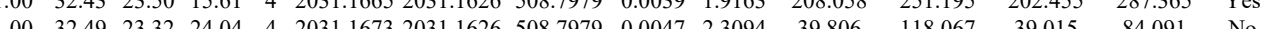

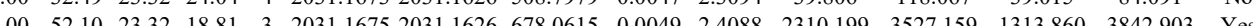

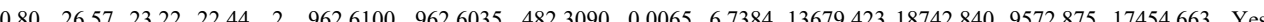
$\begin{array}{lllllllllllllllll}0.72 & 23.68 & 22.30 & 21.28 & 2 & 962.6104 & 962.6035 & 482.3090 & 0.0069 & 7.7530 & 13893.170 & 17157.153 & 10135.849 & 15361.702 & \text { Yes }\end{array}$ $\begin{array}{lllllllllllllll}0.96 & 30.58 & 26.97 & 26.35 & 2 & 12927396 & 1292.7366 & 647.3756 & 0.0030 & 23170 & 4413.971 & 4654.603 & 152.243 & 7823.642 & \text { Yes }\end{array}$

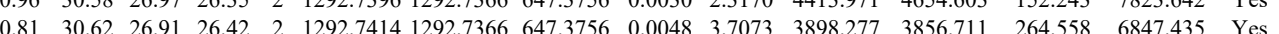

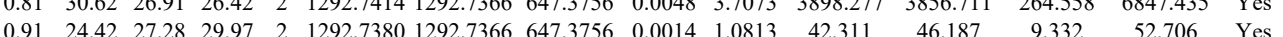
$\begin{array}{lllllllllllllll}0.98 & 30.64 & 27.28 & 32.21 & 2 & 1292.7382 & 1292.7366 & 647.3756 & 0.0016 & 1.2358 & 51.958 & 57.899 & 4.064 & 85.451 & \text { Yes }\end{array}$

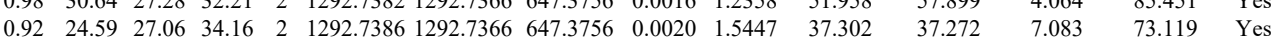
$\begin{array}{llllllllllllllll}0.96 & 29.19 & 27.06 & 35.11 & 2 & 1292.7386 & 1292.7366 & 647.3756 & 0.0020 & 1.5447 & 45.421 & 44.751 & 0.000 & 54.508 & \text { No }\end{array}$ $\begin{array}{lllllllllllllll}0.93 & 29.19 & 27.07 & 34.66 & 2 & 1292.7392 & 1292.7366 & 647.3756 & 0.0026 & 2.0081 & 28.318 & 35.968 & 15.662 & 63.652 & \text { Yes }\end{array}$

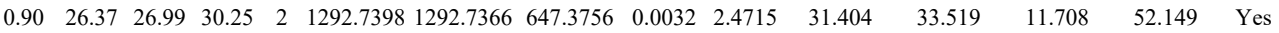

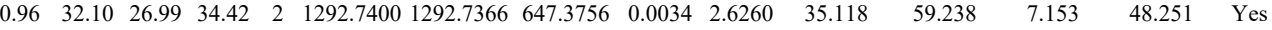
$\begin{array}{lllllllllllllll}0.93 & 32.78 & 26.99 & 28.47 & 2 & 1292.7402 & 1292.7366 & 647.3756 & 0.0036 & 2.7804 & 5235.757 & 5257.631 & 138.965 & 8073.989 & \text { Yes }\end{array}$ $\begin{array}{lllllllllllllll}0.77 & 26.39 & 26.99 & 31.53 & 2 & 1292.7402 & 1292.7366 & 647.3756 & 0.0036 & 2.7804 & 47.011 & 38.252 & 15.720 & 54.223 & \text { Yes }\end{array}$

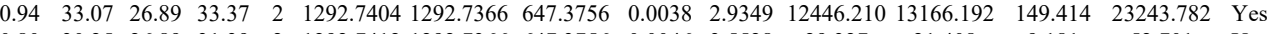
$\begin{array}{lllllllllllllll}0.80 & 30.25 & 26.89 & 31.39 & 2 & 1292.7412 & 1292.7366 & 647.3756 & 0.0046 & 3.5528 & 29.327 & 21.408 & 9.181 & 52.701 & \text { Yes }\end{array}$

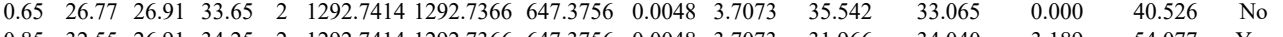

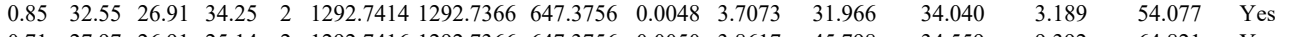
$\begin{array}{lllllllllllllll}0.71 & 27.97 & 26.91 & 25.14 & 2 & 1292.7416 & 1292.7366 & 647.3756 & 0.0050 & 3.8617 & 45.798 & 34.559 & 9.392 & 64.821 & \text { Yes } \\ 0.67 & 2.9 & 2.9 & 31.56 & 2 & 1292.746 & 292.736 & 64.3756 & 0.050 & 3.8617 & 41.694 & 25.967 & 13.255 & 4.26 & \text { Yes }\end{array}$

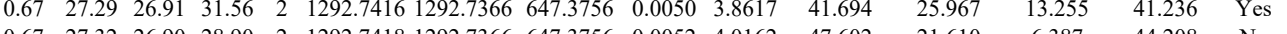

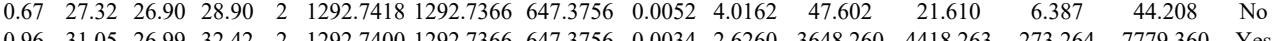

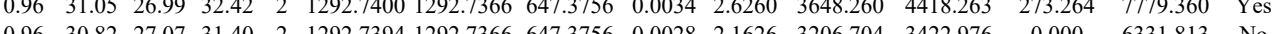

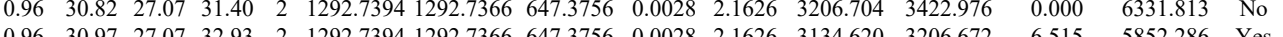

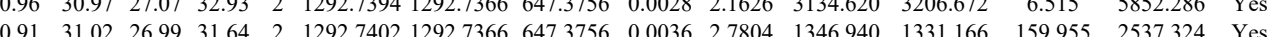

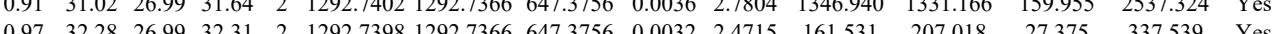

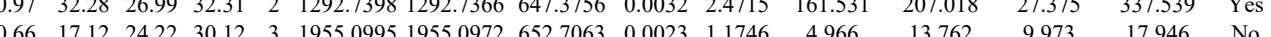

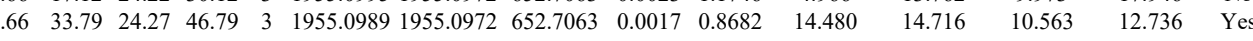
$\begin{array}{lllllllllllllll}0.95 & 36.22 & 27.66 & 27.59 & 2 & 1211.6730 & 1211.6641 & 606.8393 & 0.0089 & 7.3330 & 7429.972 & 7233.829 & 1245.140 & 15262.492 & \text { Yes }\end{array}$ $\begin{array}{lllllllllllllll}1.00 & 55.49 & 28.01 & 22.63 & 2 & 141.65730 & 1211.6641 & 606.8393 & 0.0089 & 7.3330 & 7583.252 & 8562.506 & 1615.251 & 146.4 .172 & \text { Yes } \\ 1.00 & 59.35 & 28.15 & 35.61 & 2 & 1455.7698 & 1455.7701 & 728.8923 & -0.0007 & -0.4802 & 12269.076 & 13855.306 & 0.000 & 16924.471 & \text { No }\end{array}$

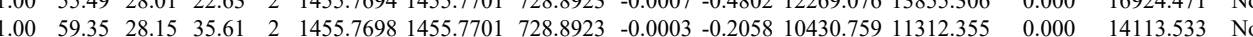
$\begin{array}{lllllllllllllll}0.98 & 37.78 & 27.44 & 28.37 & 2 & 1211.6758 & 1211.6641 & 606.8393 & 0.0117 & 9.6400 & 16512071 & 17060743 & 1557.620 & 26027.712 & \text { Yes }\end{array}$ $\begin{array}{lllllllllllllll}1.00 & 41.92 & 25.84 & 25.77 & 3 & 1211.7187 & 1211.7117 & 404.9112 & 0.0070 & 5.7625 & 23456.048 & 27186.827 & 68.758 & 35650.071 & \text { Yes }\end{array}$ $\begin{array}{lllllllllllllll}1.00 & 45.97 & 25.81 & 27.87 & 3 & 1211.7190 & 1211.7117 & 404.9112 & 0.0073 & 6.0095 & 18378.393 & 20619.864 & 0.000 & 30283.976 & \text { No }\end{array}$ $\begin{array}{lllllllllllllll}1.00 & 50.13 & 25.81 & 29.06 & 2 & 1211.7190 & 1211.7117 & 606.8631 & 0.0073 & 6.0145 & 4945.002 & 5608.442 & 974.031 & 6111.704 & \text { Yes }\end{array}$

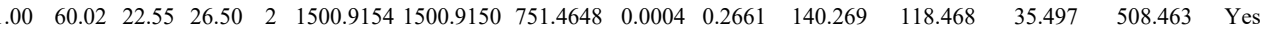

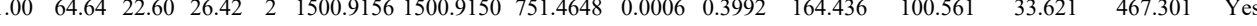
$\begin{array}{llllllllllllllll}1.00 & 64.64 & 22.60 & 26.42 & 2 & 1500.9156 & 1500.9150 & 751.4648 & 0.0006 & 0.3992 & 164.436 & 100.561 & 33.621 & 467.301 & \text { Yes } \\ 1.06 & 49.65 & 21.96 & 6.88 & 3 & 1500.9181 & 1500.9150 & 501.3123 & 0.0031 & 2.0613 & 12.717 & 39.471 & 11.680 & 52.361 & \text { No }\end{array}$

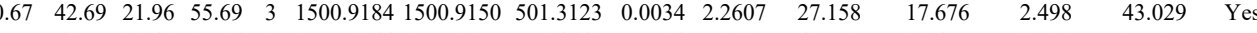

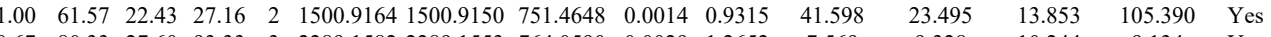

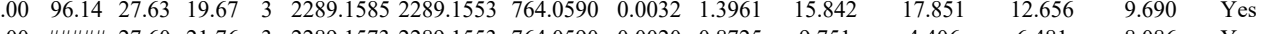
\begin{tabular}{llllllllllllll}
1.76 & 3 & 2289.1573 & 2289.1553 & 764.0590 & 0.0020 & 0.8725 & 9.751 & 4.406 & 6.481 & 8.086 & Yes \\
\hline
\end{tabular}

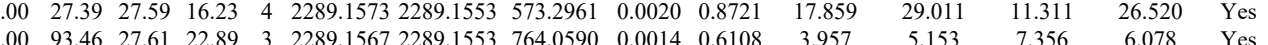

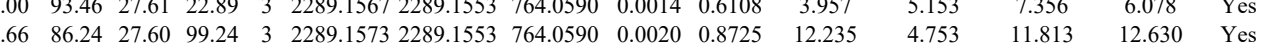

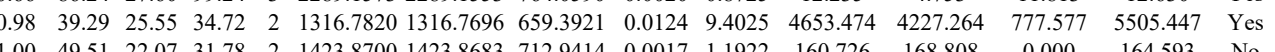
$\begin{array}{lllllllllllllll}1.00 & 49.51 & 25.07 & 31.78 & 2 & 1423.8700 & 1423.8683 & 712.9414 & 0.0017 & 1.1922 & 160.726 & 168.808 & 0.000 & 164.593 & \text { No } \\ 1.00 & 53.95 & 22.07 & 27.54 & 2 & 1423.8694 & 1423.8683 & 712.9414 & 0.0011 & 0.7715 & 63.833 & 71.977 & 19.270 & 110.344 & Y=5\end{array}$ $\begin{array}{llllllllllll} & \end{array}$

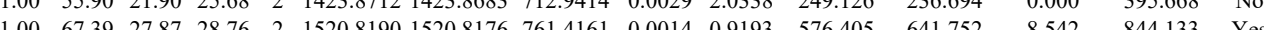

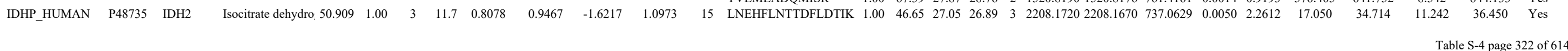




\section{KPIAGQVVTAMGK} KPIAGQVVTAMGK

4 AYGGSMCAK

AYGGSMCAK

IVYLYTK

SACGVCPGR

SACGVCPGR

SACGVCPGR

SACGVCPGR

SACGVCPGR

SACGVCPGR

SACGVCPGR

AQAQSQK

AQAQSQK
AFLIEEQK

AFLIEEQK

AFLIEEQK

AFLIEEQK

AFLIEEQK

$\begin{array}{lllllllllll}\text { NASP HUMAN } & \text { P49321 } & \text { NASP } & \text { Nuclear autoantigr 85.238 } & 1.00 & 3 & 5.6 & 0.1462 & 0.4566 & 0.0524 & 0.7223\end{array}$ $\begin{array}{llllllllllll}1.00 & 50.52 & 27.19 & 16.41 & 3 & 2018.0833 & 2018.0819 & 673.7012 & 0.0014 & 0.6927 & 4.427 \\ 1.00 & 28.97 & 24.41 & 41.97 & 4 & 4292.1629 & 4292.1604 & 1074.0474 & 0.0025 & 0.5819 & 8.847 \\ 1.00 & 40.53 & 24.33 & 53.53 & 4 & 4292.1669 & 4292.1604 & 1074.0474 & 0.0065 & 1.5130 & 2.508\end{array}$ $\begin{array}{llllll}1.00 & 47.99 & 18.33 & 24.23 & 3 & 1\end{array}$

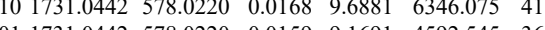
$\begin{array}{lllllllllllll} & \end{array}$ $\begin{array}{llllllllllllllll}1.00 & 61.20 & 25.00 & 17.24 & 2 & 1220.5626 & 1220.5595 & 611.2870 & 0.0031 & 2.5356 & 26008.461 & 30569.599 & 442.486 & 39957.972 & \text { Yes }\end{array}$ $\begin{array}{lllllllllllllll}1.00 & 49.37 & 24.96 & 23.07 & 2 & 1220.5628 & 1220.5595 & 611.2870 & 0.0033 & 2.6992 & 22313.204 & 26539.922 & 668.127 & 39421.562 & \text { Yes } \\ 0.99 & 41.86 & 2.27 & 21.69 & 2 & 1186.7306 & 1186.7205 & 594.3675 & 0.0101 & 8.4964 & 11939.100 & 12745.047 & 976.849 & 24300.449 & \text { Yes }\end{array}$ $\begin{array}{llllllllllllllll}0.99 & 41.86 & 24.27 & 21.69 & 2 & 1186.7306 & 1186.7205 & 594.3675 & 0.0101 & 8.4964 & 11939.100 & 12745.047 & 976.849 & 24300.449 & \text { Yes } \\ 1.98 & 33.23 & 1.63 & 26.49 & 2 & 108.4498 & 1084.4408 & 543.2277 & 0.0090 & 8.2838 & 17324.137 & 21396.467 & 648.491 & 21719.220 & \text { Yes }\end{array}$ $\begin{array}{lllllllllllllllll}0.98 & 33.23 & 18.63 & 26.49 & 2 & 1084.4498 & 1084.4408 & 543.2277 & 0.0090 & 8.2838 & 17324.137 & 21396.467 & 6048.491 & 21719.220 & \text { Yes } \\ 1.00 & 42.97 & 18.69 & 23.35 & 2 & 1084.4506 & 1084.4408 & 5432277 & 0.0098 & 9.0201 & 21483.007 & 26806.697 & 5708.694 & 32290.802 & \text { Yes }\end{array}$ $\begin{array}{llllllllllllllllll}1.00 & 42.97 & 18.69 & 23.35 & 2 & 1084.4506 & 1084.4408 & 543.2277 & 0.0098 & 9.0201 & 21483.007 & 26806.697 & 5708.694 & 32290.802 & \text { Yes } \\ 1.00 & 43.23 & 18.69 & 20.64 & 2 & 1084.4504 & 1084.4408 & 5432277 & 0.0096 & 8.8360 & 10415.828 & 13029.485 & 2392899 & 16026.903 & \text { Yes }\end{array}$ $\begin{array}{llllllllllllllll}1.00 & 43.23 & 18.69 & 20.64 & 2 & 1084.4504 & 1084.4408 & 543.2277 & 0.0096 & 8.8360 & 10415.828 & 13029.485 & 2392.899 & 16026.903 & \text { Yes } \\ 1.00 & 43.39 & 18.75 & 21.79 & 2 & 1084.4508 & 1084.4408 & 543.2277 & 0.0100 & 9.2042 & 17351.013 & 20538.698 & 3979.073 & 25184.678 & \text { Yes }\end{array}$ $\begin{array}{llllllllllllllll}1.00 & 46.24 & 18.69 & 16.14 & 2 & 1084.4504 & 1084.4408 & 543.2277 & 0.0096 & 8.8360 & 12472.257 & 11224.771 & 1259.991 & 16569.466 & \text { Yes }\end{array}$

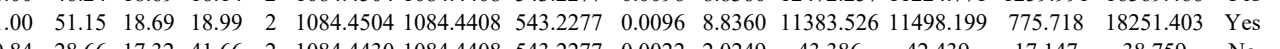

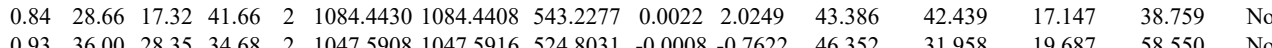

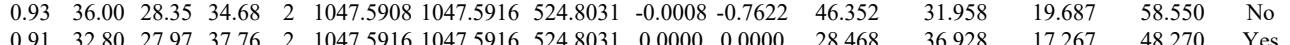

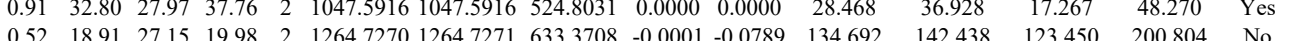

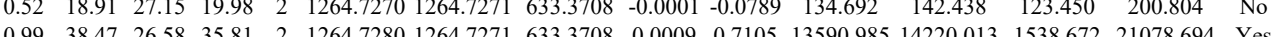

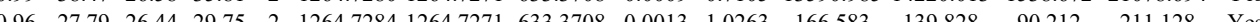
$\begin{array}{lllllllllllllll}1.00 & 39.71 & 26.44 & 29.75 & 2 & 1264.7284 & 1264.727 & 633.3708 & 0.0013 & 1.0263 & 166.583 & 139.828 & 90.212 & 211.128 & \text { Yes }\end{array}$

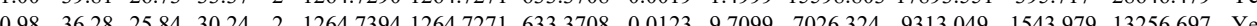

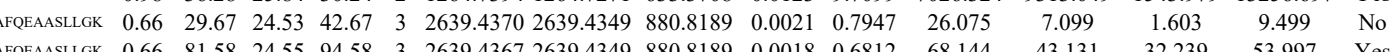
$\begin{array}{lllllllllllllll} & \end{array}$ $\begin{array}{lllllllllllllllll} & \end{array}$ $\begin{array}{lllllllllllll}\text { SLLGGK } & 0.56 & 3.39 & 24.44 & 16.39 & 4 & 2639.4381 & 2639.4349 & 660.8660 & 0.0032 & 1.2105 & 59.953\end{array}$

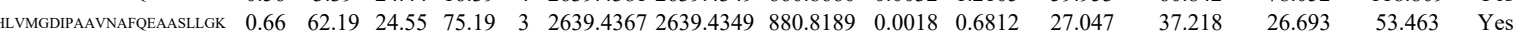
$\begin{array}{lllllllllllllllll}\text { HLVMGDIPAAVNAFFEAASLLGK } & 0.66 & 51.42 & 24.55 & 64.42 & 3 & 2639.4367 & 2639.4349 & 880.8189 & 0.0018 & 0.6812 & 25.971 & 26.722 & 4.157 & 44.777 & \text { Yes }\end{array}$ $\begin{array}{lllllllllllllllll}\text { HLVMGDIPAAVAAFEEAASLLGK } & 0.84 & 7.59 & 24.53 & 20.59 & 4 & 2639.4369 & 2639.4349 & 660.8660 & 0.0020 & 0.7566 & 62.631 & 94.014 & 96.582 & 103.298 & \text { Yes }\end{array}$ $\begin{array}{lllllllllllllllll}\text { HLVMGDIPAAVNAFOEAASLLGK } & 0.67 & 61.07 & 24.52 & 74.07 & 3 & 2639.4376 & 2639.4349 & 880.8189 & 0.0027 & 1.0218 & 31.513 & 26.282 & 41.350 & 53.674 & \text { Yes }\end{array}$ $\begin{array}{llllllllllllllllll}\text { HLVMGDIPAAVNAFFEAASLLGK } & 0.67 & 67.61 & 24.52 & 80.61 & 3 & 2639.4376 & 2639.4349 & 880.8189 & 0.0027 & 1.0218 & 21.886 & 34.482 & 12.507 & 34.754 & \text { Yes }\end{array}$ \begin{tabular}{llllllllllllllll} 
& 269.4405 & 2639.4349 & 660.8660 & 0.0056 & 2.1184 & 49.054 & 90.866 & 44.185 & 119.849 & Yes \\
\hline
\end{tabular} $\begin{array}{lllllllllllllllll} & & \end{array}$ $\begin{array}{llllllllllllllll}\text { QGEVIVSIEEKPK } & 1.00 & 42.66 & 22.74 & 18.92 & 3 & 1887.1054 & 1887.1042 & 630.0420 & 0.0012 & 0.6349 & 2843.369 & 2892.056 & 924.243 & 1319.301 & \text { Yes }\end{array}$ TGYQAK

VGDPQELNGITR VGDPQELNGITR SDEAVKPFGLK GVDLVLNSLAEEK GVDLVLNSLAEEK $\begin{array}{lccccccccccccccc}\text { GVDLVLNSLAEEK } & 1.00 & 61.59 & 26.43 & 35.07 & 3 & 1673.9482 & 1673.9443 & 558.9887 & 0.0039 & 2.3256 & 144.217 & 80.915 & 129.190 & 66.970 & \text { Yes } \\ \text { EDGLAQQQTOLNLR } & 1.00 & 83.70 & 27.77 & 32.12 & 2 & 1756.9348 & 1756.9189 & 879.4667 & 0.0159 & 9.0395 & 554.941 & 385.962 & 430.005 & 836.448 & \text { Yes }\end{array}$ $\begin{array}{llllllllllllllll}0.78 & 31.21 & 28.09 & 38.58 & 2 & 1102.6212 & 1102.6104 & 552.3125 & 0.0108 & 9.7770 & 6971.646 & 7388.677 & 2017.540 & 8264.721 & \text { Yes }\end{array}$ $\begin{array}{lllllllllllllll}0.84 & 20.44 & 25.88 & 18.11 & 2 & 954.5384 & 954.5378 & 478.2762 & 0.0006 & 0.6273 & 147.147 & 155.151 & 98.942 & 193.873 & \text { Yes }\end{array}$ $\begin{array}{lllllllllllllll}1.00 & 53.96 & 27.47 & 26.76 & 2 & 1441.7766 & 1441.7647 & 721.8896 & 0.0119 & 8.2422 & 1959.596 & 1396.680 & 670.932 & 1656.437 & \text { Yes }\end{array}$ $\begin{array}{lllllllllllllll}1.00 & 62.97 & 27.56 & 37.97 & 2 & 1441.7772 & 1441.7647 & 721.8896 & 0.0125 & 8.6578 & 8127.588 & 5509.583 & 2271.209 & 5415.544 & \text { Yes }\end{array}$ $\begin{array}{lllllllllllllll}0.87 & 25.17 & 22.70 & 24.05 & 3 & 1621.9567 & 1621.9405 & 541.6541 & 0.0162 & 9.9694 & 16329.977 & 10891.379 & 11488.957 & 15466.737 & \text { Yes }\end{array}$ $\begin{array}{lllllllllllllll}1.00 & 41.72 & 26.47 & 25.84 & 3 & 1673.9473 & 1673.9443 & 558.9887 & 0.0030 & 1.7889 & 102.415 & 108.128 & 104.937 & 161.968 & \text { Yes }\end{array}$ $\begin{array}{lllllllllllllll}1.00 & 73.84 & 26.48 & 25.82 & 2 & 1673.9476 & 1673.9443 & 837.9794 & 0.0033 & 1.9690 & 307.294 & 351.994 & 238.754 & 367.686 & \text { Yes } \\ 1.00 & 1.59 & 25.93 & 35.07 & 3 & 163.9482 & \end{array}$

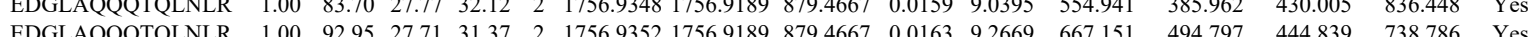

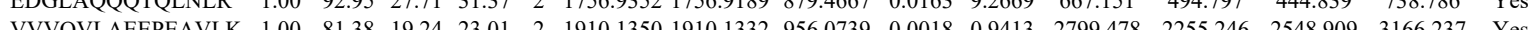

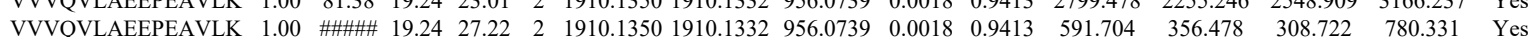
$\begin{array}{llllllllllllllllll}\text { VVVQVLAEEPEAVLK } & 1.00 & 66.07 & 19.29 & 28.73 & 3 & 1910.1358 & 1910.1332 & 637.7183 & 0.0026 & 1.3590 & 685.072 & 637.704 & 539.495 & 1090.770 & \text { Yes }\end{array}$ $\begin{array}{llllllllllllllll}\text { VVVQVLAEEPEAVLK } & 1.00 & 39.56 & 19.24 & 20.72 & 3 & 1910.1361 & 1910.1332 & 637.7183 & 0.0029 & 1.5158 & 392.170 & 12.312 & 49.344 & 461.319 & \text { No }\end{array}$ 

$\begin{array}{llllllllllll}0.93 & 26.13 & 27.55 & 30.65 & 2 & 1060.6498 & 1060.6484 & 531.3315 & 0.0014 & 1.3174 & 535.841\end{array}$

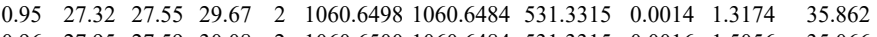
$\begin{array}{lllllllllll}0.96 & 27.95 & 27.59 & 30.08 & 2 & 1060.6500 & 1060.6484 & 531.3315 & 0.0016 & 1.5056 & 35.066 \\ 0.95 & 27.49 & 27.59 & 30.64 & 2 & 1060.6502 & 1060.6484 & 531.3315 & 0.0018 & 1.6939 & 664.825\end{array}$ 

$\begin{array}{lllllllllllllllll}\text { RPTPQDSPIFLPVDDTSFR } & 1.00 & 47.25 & 26.72 & 22.48 & 3 & 2331.1999 & 2331.1981 & 778.0733 & 0.0018 & 0.7711 & 213.674 & 435.007 & 378.985 & 486.111 & \text { Yes }\end{array}$ $\begin{array}{lllllllllllllllll}\text { RPTPQDSPIFLPVDDTSFR } & 1.00 & 45.82 & 26.79 & 16.49 & 3 & 2331.2005 & 2331.1981 & 778.0733 & 0.0024 & 1.0282 & 59.501 & 707.194 & 630.788 & 469.607 & \text { No }\end{array}$ $\begin{array}{llllllllllllllllll}\text { LLLEVTYEAIVDGGINPDSLR } & 0.60 & 17.24 & 25.47 & 30.24 & 3 & 2430.3169 & 2430.3128 & 811.1115 & 0.0041 & 1.6849 & 17.405 & 2.721 & 6.103 & 20.415 & \text { Yes }\end{array}$ $\begin{array}{llllllllllllllllll}\text { LLEVTYEAIVDGGINPDSLR } & 1.00 & 44.61 & 25.47 & 19.38 & 3 & 2430.3169 & 2430.3128 & 811.1115 & 0.0041 & 1.6849 & 5.925 & 0.550 & 8.844 & 2.491 & \text { No }\end{array}$ $\begin{array}{lllllllllllllllll}\text { LLLEVTYEAIVDGGINPDSLR } & 1.00 & 63.16 & 25.48 & 21.29 & 3 & 2430.3172 & 2430.3128 & 811.1115 & 0.0044 & 1.8082 & 12.992 & 9.428 & 2.464 & 8.427 & \text { Yes }\end{array}$ $\begin{array}{llllllllllllllll}\text { LLEEVTYEAIVDGGINPDSLR } & 1.00 & 57.81 & 25.48 & 27.24 & 3 & 2430.3172 & 2430.3128 & 811.1115 & 0.0044 & 1.8082 & 14.424 & 3.466 & 8.054 & 3.136 & \text { No }\end{array}$

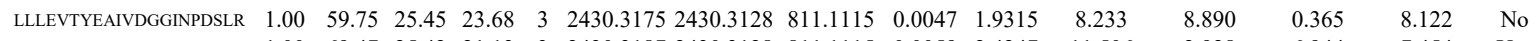
$\begin{array}{llllllllllllllll}\text { LLLEVTYEAIVDGGINPDSLR } & 1.00 & 69.47 & 25.42 & 21.13 & 3 & 2430.3187 & 2430.3128 & 811.1115 & 0.0059 & 2.4247 & 11.506 & 2.928 & 6.944 & 7.454 & \text { Yes }\end{array}$

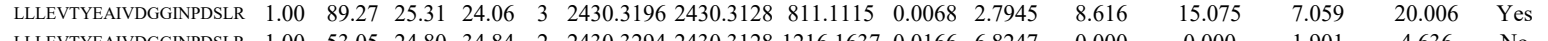

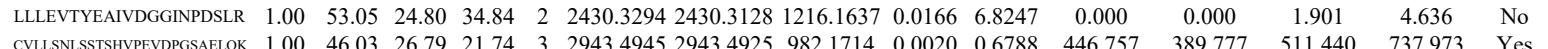

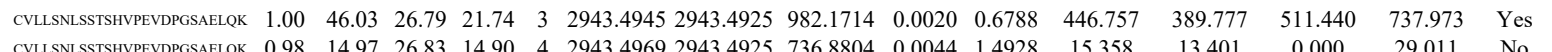

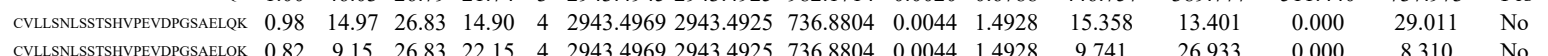

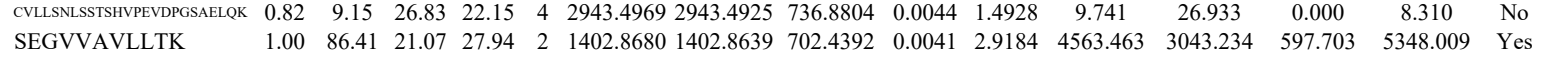

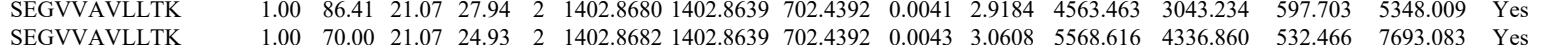

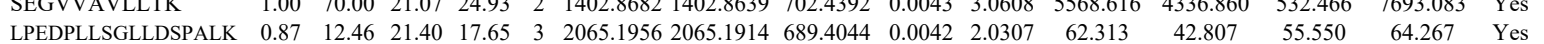
$\begin{array}{llllllllllllllll}\text { LPEDPLLSGLDDSPALK } & 1.00 & 54.49 & 21.40 & 19.09 & 3 & 2065.1959 & 2065.1914 & 689.4044 & 0.0045 & 2.1758 & 67.347 & 102.906 & 49.019 & 129.283 & \text { Yes }\end{array}$ $\begin{array}{llllllllllllllll} & \text { RPTPQDSPIFLPVDDTSFR } \\ 0.99 & 37.80 & 26.81 & 16.44 & 3 & 2331.2053 & 2331.1981 & 778.0733 & 0.0072 & 3.0845 & 722.573 & 146.233 & 403.243 & 309.323 & \mathrm{No}\end{array}$ $\begin{array}{llllllllllll} & 032345 & 339.753 & \text { Yes }\end{array}$ $\begin{array}{llllllllllllllll}\text { DTVIISGPQAPVFEFVEOLR } & 0.82 & 91.42 & 26.83 & \text { \#\#\#\# } & 2 & 237.62454 & 23762447 & 1189.1296 & 0.0007 & 02943 & 38.440 & 18.328 & 113.493 & 133.200 & \text { No }\end{array}$ $\begin{array}{llllllllllllllll}\text { DTVTISGPQAPVFEFVEOLR } & 1.00 & 68.15 & 26.82 & 19.93 & 3 & 2376.2473 & 2376.2447 & 793.0888 & 0.0026 & 1.0928 & 3.367 & 16.404 & 40.065 & 17.190 & \text { No }\end{array}$ $\begin{array}{llllllllllllllll}\text { DTVTISGPOAPVFFFVFELR } & 0.72 & 92.20 & 26.85 & \text { \#\#\#\# } & 2 & 2376.2474 & 2376.2447 & 1189.1296 & 0.0027 & 1.1353 & 45.990 & 34.763 & 142.402 & 108.951 & \text { No }\end{array}$ $\begin{array}{llllllllllllllll}\text { LLLEVTYEAIVDGGNPDSLR } & 1.00 & 55.16 & 25.54 & 23.85 & 3 & 2430.3154 & 2430.3128 & 811.1115 & 0.0026 & 1.0685 & 13.953 & 20.166 & 14.706 & 13.000 & \text { Yes }\end{array}$

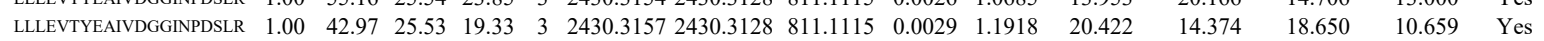
$\begin{array}{lllllllllllllllll}\text { LLLEVTYEAIVDGGINPDSLR } & 1.00 & 61.74 & 25.48 & 25.22 & 3 & 2430.3163 & 2430.3128 & 811.1115 & 0.0035 & 1.4384 & 9.120 & 17.046 & 23.622 & 27.286 & \text { Yes }\end{array}$ $\begin{array}{lllllllllllllllll}\text { LLLEVTYEAIVDGGINPDSLR } & 1.00 & 46.67 & 25.47 & 18.85 & 3 & 2430.3169 & 2430.3128 & 811.1115 & 0.0041 & 1.6849 & 13.403 & 3.572 & 3.658 & 20.877 & \text { Yes }\end{array}$ \begin{tabular}{llllllllllllllll} 
CVLLSNLSSTSHYPEVDPGSAELQK & 1.00 & 50.36 & 26.83 & 17.15 & 3 & 2943.4930 & 2943.4925 & 982.1714 & 0.0005 & 0.1697 & 477.817 & 276.290 & 559.702 & 484.425 & Yes \\
\hline
\end{tabular}

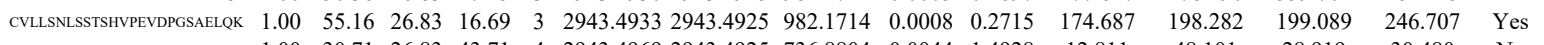

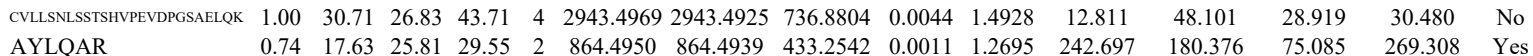

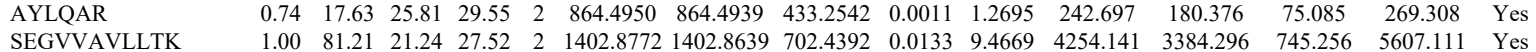

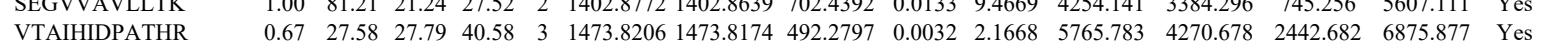

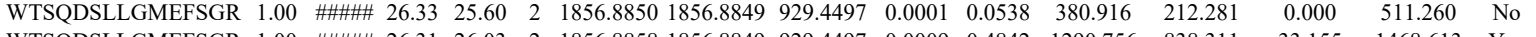

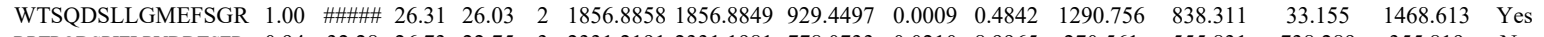
$\begin{array}{llllllllllllllll}\text { RPTPQDSPIFLPVDDTSFR } & 0.94 & 32.28 & 26.73 & 22.75 & 3 & 2331.2191 & 2331.1981 & 778.0733 & 0.0210 & 8.9965 & 270.561 & 555.831 & 738.289 & 355.819 & \text { No }\end{array}$

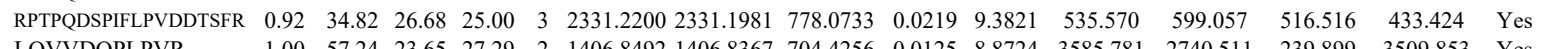
$\begin{array}{llllllllllllllll}\text { LQVVDQPLPVR } & 1.00 & 57.24 & 23.65 & 27.29 & 2 & 1406.8492 & 1406.8367 & 704.4256 & 0.0125 & 8.8724 & 3585.781 & 2740.511 & 239.899 & 3509.853 & \text { Yes }\end{array}$ \begin{tabular}{llllllllllllllll} 
LQVVDQPLPVR & 1.00 & 61.49 & 23.65 & 23.62 & 2 & 1406.8494 & 1406.8367 & 704.4256 & 0.0127 & 9.0144 & 407.685 & 283.403 & 61.900 & 323.731 & Yes \\
\hline
\end{tabular} $\begin{array}{llllllllllllllll}\text { VTAIHIDPATHR } & 1.00 & 41.77 & 27.53 & 16.38 & 3 & 1473.8212 & 1473.8174 & 492.2797 & 0.0038 & 2.5731 & 11443.849 & 10124.192 & 1280.350 & 13477.919 & \text { Yes } \\ \text { VTAIHPATR } & 1.00 & 48.36 & 27.55 & 16.13 & 3 & 1473.828 & 1473.8174 & 42.2797 & 0.044 & 2.9793 & 13055.211 & 12091.021 & 264.642 & 1521.514 & \text { Yes }\end{array}$ \begin{tabular}{lllllllllllllllllll} 
VIAIHIDPATHR & 1.00 & 48.36 & 27.55 & 16.13 & 3 & 1473.8218 & 1473.8174 & 492.2797 & 0.0044 & 2.9793 & 13055.241 & 12091.021 & 2684.642 & 15211.514 & Yes \\
\hline CTVFHGAQVEDAFR & 1.00 & 64.92 & 25.93 & 18.72 & 3 & 1768.8310 & 1768.8147 & 590.6122 & 0.0163 & 9.1994 & 2578.010 & 2764.988 & 388.081 & 3160.958 & Yes
\end{tabular} $\begin{array}{llllllllllllllll}\text { CTVFHGAQVEDAFR } & 1.00 & 64.92 & 25.93 & 18.72 & 3 & 1768.8310 & 1768.8147 & 590.6122 & 0.0163 & 9.1994 & 2578.010 & 2764.988 & 388.081 & 3160.958 & \text { Yes }\end{array}$

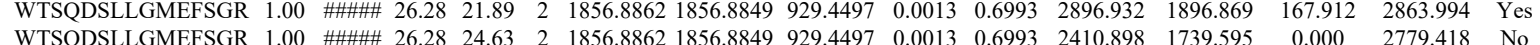

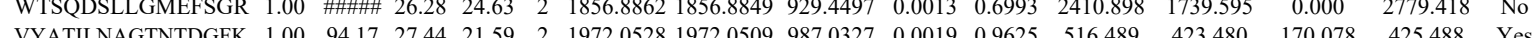

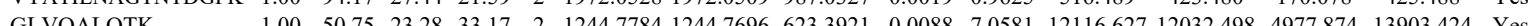

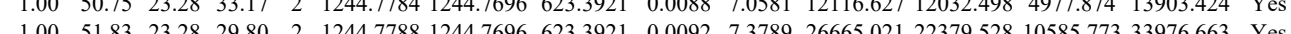



$\begin{array}{lllllllllllllllll} & \\ \text { LMSAISK } & 0.98 & 40.63 & 24.86 & 31.82 & 2 & 1036.6268 & 1036.6194 & 519.3170 & 0.0074 & 7.1247 & 31575.019 & 23868.733 & 11712.432 & 51115.998 & \text { Yes }\end{array}$ $\begin{array}{llllllllllllllllllll} & \text { GLVQALQTK } & 1.97 & 35.65 & 25.17 & 25.67 & 2 & 1036.6282 & 1036.6194 & 519.3170 & 0.0088 & 8.4726 & 24704.045 & 19322.297 & 15081.813 & 35910.926 & \text { Yes }\end{array}$

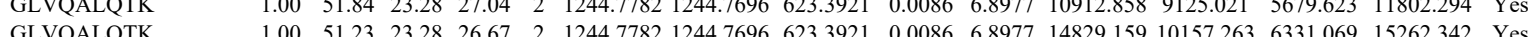

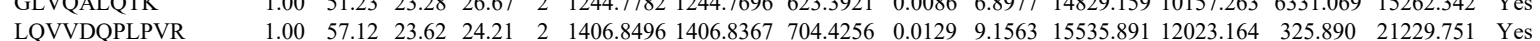

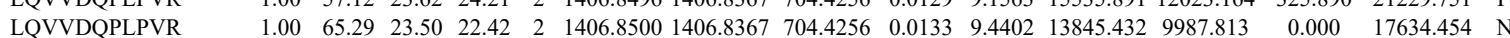

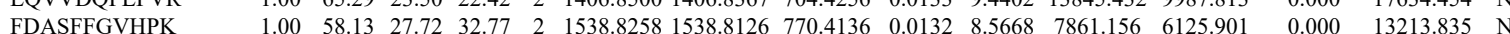

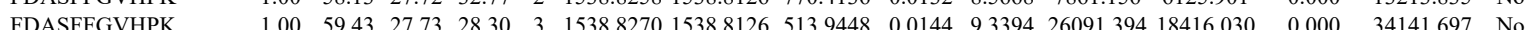

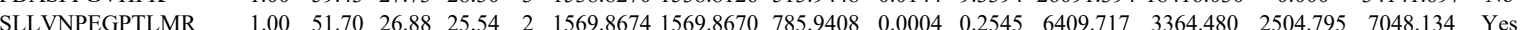
$\begin{array}{llllllllllllllll}\text { SLLVNPEGPTLMR } & 1.00 & 42.43 & 26.95 & 25.52 & 2 & 1569.8678 & 1569.8670 & 785.9408 & 0.0008 & 0.5089 & 5987.534 & 4068.643 & 2331.742 & 6154.810 & \text { Yes }\end{array}$ $\begin{array}{lllllllllllllllll}\text { ALGLGVEOPYVFEDYVHOATIPKK } & 0.66 & 52.43 & 16.02 & 65.43 & 3 & 3072.7852 & 3072.7831 & 1025.2683 & 0.0021 & 0.6827 & 461.558 & 192.674 & 544.640 & 738.769 & \text { Yes }\end{array}$ $\begin{array}{lllllllllllllllll}\text { ALGLGVEgLPVVFEDVLLHQATLPK } & 1.00 & 40.98 & 16.02 & 53.98 & 4 & 3072.7893 & 3072.7831 & 769.2031 & 0.0062 & 2.0151 & 31.261 & 3.421 & 7.721 & 24.209 & \text { No }\end{array}$ $\begin{array}{lllllllllllllllll}\text { ALGLGVEQLPVVFEVVLHQATILPK } & 1.00 & 59.34 & 15.68 & 72.34 & 4 & 3072.7933 & 3072.7831 & 769.2031 & 0.0102 & 3.3151 & 0.000 & 20.371 & 21.773 & 61.675 & \text { No }\end{array}$ $\begin{array}{llllllllllllllll}\text { VLEALLPLK } & 1.00 & 59.86 & 13.01 & 23.55 & 2 & 1282.8484 & 1282.8468 & 642.4307 & 0.0016 & 1.2453 & 21391.668 & 15181.191 & 884.097 & 36064.347 & \text { Yes }\end{array}$ $\begin{array}{llllllllllllllll}\text { VLEALLPLK } & 1.00 & 53.71 & 13.01 & 25.87 & 2 & 1282.8488 & 1282.8468 & 642.4307 & 0.0020 & 1.5566 & 14450.197 & 11386.020 & 10.211 & 24917.166 & \text { Yes }\end{array}$ $\begin{array}{llllllllllllllll}\text { SLLVNPEGPTLMR } & 1.00 & 54.59 & 26.73 & 23.70 & 2 & 1569.8788 & 1569.8670 & 785.9408 & 0.0118 & 7.5069 & 10599.804 & 7842.519 & 374.536 & 12149.859 & \text { Yes }\end{array}$ $\begin{array}{lllllllllllllllll}\text { SLLVNPEGPTLMR } & 1.00 & 57.83 & 26.73 & 30.79 & 2 & 1569.8788 & 1569.8670 & 785.9408 & 0.0118 & 7.5069 & 6463.400 & 4755.375 & 348.892 & 8114.548 & \text { Yes }\end{array}$ $\begin{array}{llllllllllllllllll}\text { FPQLDSTSFANSR } & 1.00 & 75.12 & 27.23 & 26.67 & 2 & 1612.8120 & 1612.7967 & 807.4056 & 0.0153 & 9.4747 & 5071.963 & 3497.724 & 7761.524 & 7456.549 & \text { Yes }\end{array}$ $\begin{array}{lllllllllllllllll}\text { EATLPK } & 1.00 & 47.55 & 15.68 & 16.22 & 4 & 3072.7921 & 3072.7831 & 769.2031 & 0.0090 & 2.9251 & 0.000 & 12.496 & 15.828 & 0.000 & \text { No }\end{array}$

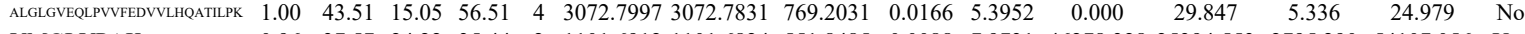
$\begin{array}{llllllllllllllll}\text { VMGLVPAK } & 0.96 & 37.57 & 24.22 & 35.44 & 2 & 1101.6912 & 1101.6824 & 551.8485 & 0.0088 & 7.9731 & 46278.328 & 25394.553 & 2795.290 & 54107.056 & \text { Yes }\end{array}$

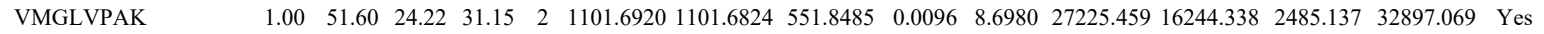
$\begin{array}{lllllllllllllllll}\text { VLEALLPLK } & 1.00 & 38.96 & 13.01 & 23.34 & 2 & 1282.8502 & 1282.8468 & 642.4307 & 0.0034 & 2.6462 & 14193.840 & 11243.411 & 1329.772 & 23595.755 & \text { Yes }\end{array}$

VLEALLPLK

VLEALLPLK

VLEALLPLK SLLVNPEGPTLMR

VMGLVPAK VMGLVPAK VLEALLPLK

$\begin{array}{lllllllllllllll}0.60 & 19.53 & 13.01 & 32.53 & 3 & 1282.8511 & 2828.846 & 428.6229 & 0.0043 & 3.3440 & 164.344 & 129.812 & 29.953 & 209.024 & \text { Yes }\end{array}$ $\begin{array}{llllllllllllllllll}1.00 & 52.94 & 13.01 & 26.10 & 2 & 1282.8512 & 1282.8468 & 642.4307 & 0.0044 & 3.4245 & 17081.040 & 14819.839 & 1952.387 & 30141.153 & \text { Yes }\end{array}$ $\begin{array}{lllllllllllllll}0.99 & 19.85 & 13.01 & 15.69 & 3 & 1282.8514 & 1282.8468 & 428.6229 & 0.0046 & 3.5773 & 174.515 & 124.394 & 9.263 & 209.027 & \text { Yes }\end{array}$

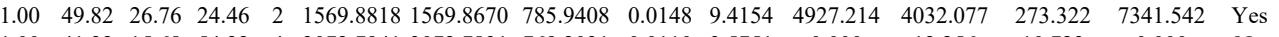

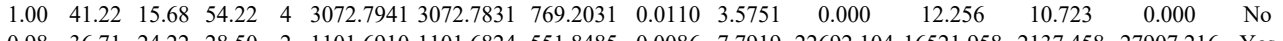
$\begin{array}{lllllllllllllll}0.98 & 36.71 & 24.22 & 28.50 & 2 & 1101.6910 & 1101.6824 & 551.8485 & 0.0086 & 7.7919 & 22692.104 & 16521.958 & 2137.458 & 27907.216 & \text { Yes }\end{array}$ $\begin{array}{lllllllllllllllll}0.98 & 36.94 & 24.22 & 30.44 & 2 & 1101.6920 & 101.6824 & 551.8485 & 0.0096 & 8.6980 & 35381.907 & 22682.691 & 2641.507 & 43402.594 & \text { Yes }\end{array}$ $\begin{array}{llllllllllllllll}1.00 & 56.20 & 13.01 & 26.05 & 2 & 1282.8496 & 1282.8468 & 642.4307 & 0.0028 & 2.1792 & 14104.316 & 10710.529 & 0.000 & 23881.614 & \text { No }\end{array}$ $\begin{array}{lllllllllllllll}1.00 & 39.08 & 13.01 & 20.74 & 2 & 1282.8502 & 1282.8468 & 642.4307 & 0.0034 & 2.6462 & 11595.876 & 7885.039 & 324.780 & 19434.773 & \text { Yes }\end{array}$

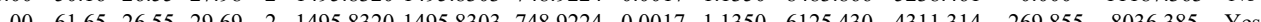

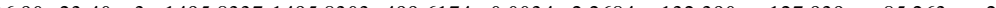

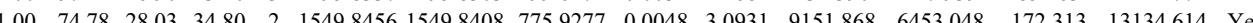
$\begin{array}{llllllllllllllll}1.00 & 76.58 & 28.06 & 34.51 & 2 & 1549.8458 & 1549.8408 & 775.9277 & 0.0050 & 3.2219 & 15465.107 & 9776.913 & 629.732 & 19795.245 & \text { Yes }\end{array}$

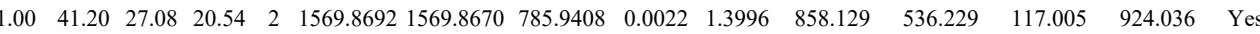

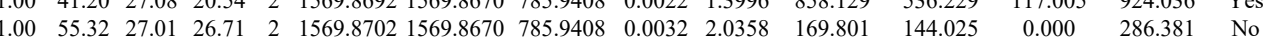
$\begin{array}{lllllllllllllll}1.00 & 47.21 & 26.95 & 24.61 & 2 & 1569.8708 & 1569.8670 & 785.9408 & 0.0038 & 2.4175 & 405.054 & 3399.962 & 58.347 & 604.938 & \text { Y }\end{array}$

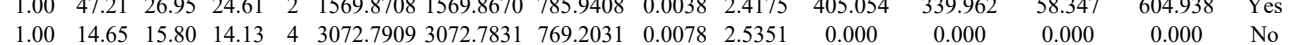

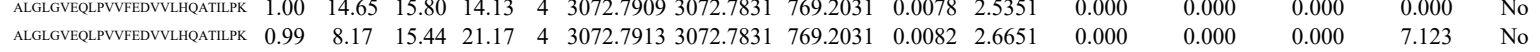
\begin{tabular}{|lllllllllllllllll} 
Nontrastror & 0.67 & 4.36 & 23.75 & 17.36 & 4 & 4075.1229 & 4075.1170 & 1019.7865 & 0.0059 & 1.4464 & 7.058 & 2.459 & 3.302 & 2.058 & No
\end{tabular}

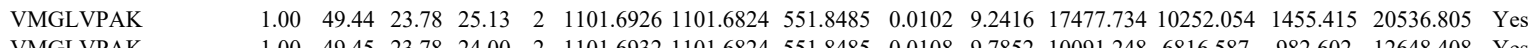

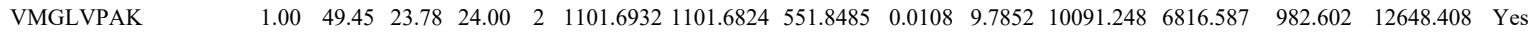
$\begin{array}{llllllllllllllll}\text { MVVPGLDGAQIPR } & 1.00 & 55.98 & 26.50 & 27.60 & 2 & 1495.8312 & 1495.8303 & 748.9224 & 0.0009 & 0.6009 & 1253.285 & 933.628 & 0.000 & 1880.070 & \text { No }\end{array}$ $\begin{array}{llllllllllllllll}\text { MVVPGLDGAQIPR } & 1.00 & 58.51 & 26.50 & 29.69 & 2 & 1495.8314 & 1495.8303 & 748.9224 & 0.0011 & 0.7344 & 1826.823 & 1680.083 & 54.874 & 2286.539 & \text { Yes }\end{array}$ $\begin{array}{llllllllllllllll}\text { VLQGDLVMNVYR } & 1.00 & 82.58 & 27.97 & 27.67 & 2 & 1549.8424 & 1549.8408 & 775.9277 & 0.0016 & 1.0310 & 6804.893 & 4694.636 & 25.385 & 8776.407 & \text { Yes }\end{array}$ $\begin{array}{llllllllllllllll}\text { VVEVLAGHGHLYSR } & 1.00 & 54.81 & 26.87 & 67.81 & 4 & 1679.9361 & 1679.9229 & 420.9880 & 0.0132 & 7.8386 & 9186.135 & 8103.057 & 1043.275 & 12379.637 & \text { Yes }\end{array}$ $\begin{array}{llllllllllllllllll} & \text { VVEVLAGHGHLYSR } & 1.00 & 41.06 & 26.58 & 15.86 & 4 & 1679.9373 & 1679.9229 & 420.9880 & 0.0144 & 8.5512 & 5457.337 & 6404.631 & 784.827 & 7982.702 & \text { Yes }\end{array}$ $\begin{array}{llllllllllllllll}\text { ALGLGVELLPVVFEDVLHQATILPK } & 1.00 & 23.44 & 16.02 & 36.44 & 4 & 3072.7889 & 3072.7831 & 769.2031 & 0.0058 & 1.8851 & 15.077 & 13.472 & 4.943 & 14.189 & \text { Yes }\end{array}$

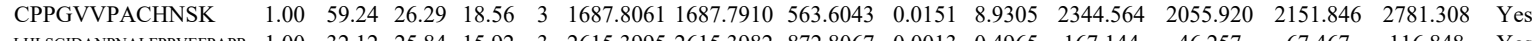
$\begin{array}{lllllllllllllllll}\text { L } & 1.00 & 32.12 & 25.84 & 15.92 & 3 & 2615.3995 & 2615.3982 & 872.8067 & 0.0013 & 0.4965 & 167.144 & 46.257 & 67.467 & 116.848 & \text { Yes }\end{array}$ $\begin{array}{llllllllllllll} & \end{array}$ $\begin{array}{llllllllllllllllll} & \text { LQLNGNLQLLAPVLAQERPK } & 0.66 & 88.71 & 18.13 & \text { \#\#\# } & 3 & 2662.5391 & 2662.5373 & 888.5197 & 0.0018 & 0.6753 & 1170.917 & 910.423 & 798.979 & 1161.031 & \text { Yes }\end{array}$ \begin{tabular}{llllllllllllllll} 
& \\
AGLYGLPR & 0.95 & 35.82 & 18.13 & 95.82 & 3 & 2662.5394 & 2662.5373 & 888.5197 & 0.0021 & 0.7878 & 1262.316 & 696.770 & 838.712 & 953.449 & Yes \\
\hline
\end{tabular}

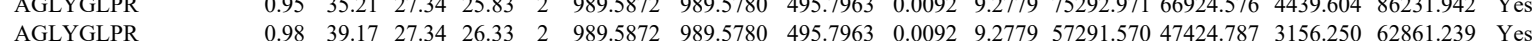

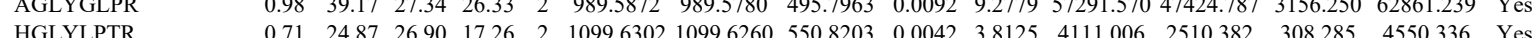
$\begin{array}{llllllllllllll} & \end{array}$

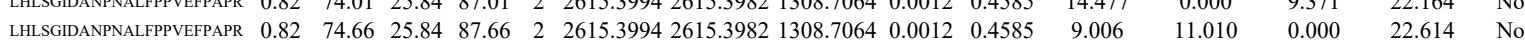

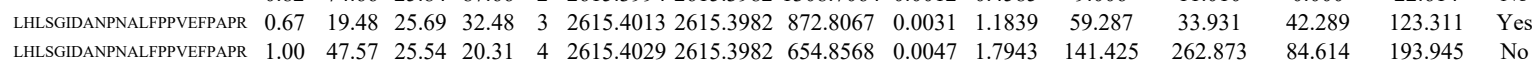

Table S-4 page 326 of 614 
$\begin{array}{llllllllllllllll}\text { LHLSGIDANPNALFPPVEFPAPR } & 1.00 & 44.84 & 25.59 & 16.51 & 3 & 2615.4031 & 2615.3982 & 872.8067 & 0.0049 & 1.8714 & 453.993 & 265.874 & 165.013 & 419.561 & \text { Yes }\end{array}$

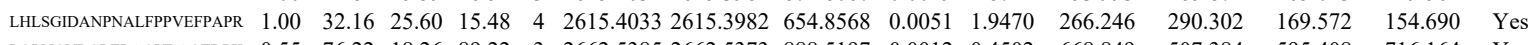

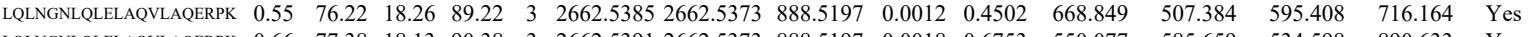
$\begin{array}{lllllllllllllllll}\text { LQLNGNLQLELAQVLAQERPK } & 0.66 & 77.38 & 18.13 & 90.38 & 3 & 2662.5391 & 2662.5373 & 888.5197 & 0.0018 & 0.6753 & 550.077 & 585.659 & 534.598 & 890.633 & \text { Yes } \\ \text { VLLSLHGLWAPNLHFHSNPEFPLLDGR } & 1.00 & 44.03 & 22.81 & 57.03 & 4 & 3485.8733 & 3485.8694 & 872.4746 & 0.0039 & 1.1175 & 125.329 & 96.157 & 220.802 & 422.160 & \text { Yes }\end{array}$

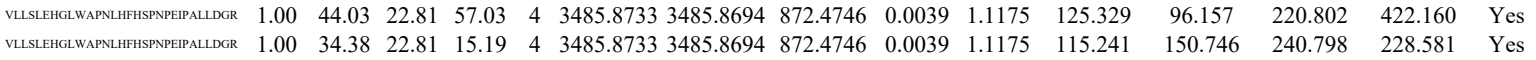

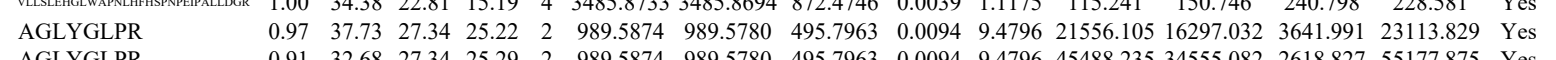

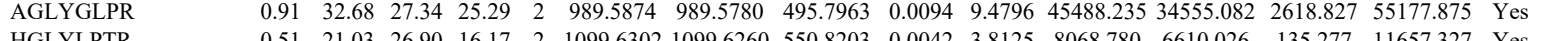
\begin{tabular}{lllllllllllllllll} 
HGLYLPTR & 0.51 & 21.03 & 26.90 & 16.17 & 2 & 1099.6302 & 1099.6260 & 550.8203 & 0.0042 & 3.8125 & 8068.780 & 6610.026 & 135.277 & 11657.327 & Yes \\
\hline FDLSQNHPLGMAIFLK & 0.66 & 36.88 & 26.66 & 49.88 & 3 & 2118.1561 & 2118.1539 & 707.0586 & 0.0022 & 1.0372 & 5196.963 & 3631.986 & 1172.756 & 5524240 & Yes
\end{tabular} $\begin{array}{lllllllllllllll} & \end{array}$ $\begin{array}{lllllllllllllll} & \text { DLSQNAPGMAR }\end{array}$ $\begin{array}{llllllllllllll} & \end{array}$ \begin{tabular}{llllllllllllllll}
\hline LLSGILANPNALPPYEFPAPR & 1.00 & 41.14 & 25.59 & 17.23 & 4 & 2615.4021 & 2615.3982 & 654.8568 & 0.0039 & 1.4889 & 180.659 & 159.637 & 190.212 & 153.833 & Yes
\end{tabular} \begin{tabular}{llllllllllllllll}
\hline LHSGIDANPNALPPVEFPAPR & 1.00 & 21.77 & 25.54 & 15.47 & 4 & 2615.4029 & 26153982 & 654.8568 & 0.0047 & 1.7943 & 204.913 & 151.209 & 223.039 & 140.445 & Yes
\end{tabular}

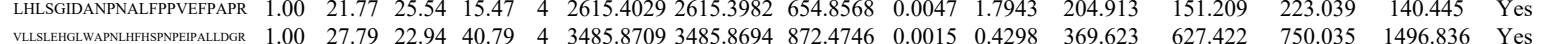

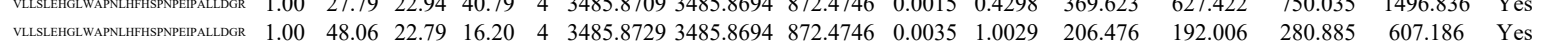
$\begin{array}{lllllllllllllllll}\text { AGLYGLPR } & 0.96 & 36.43 & 27.51 & 25.22 & 2 & 989.5868 & 989.5780 & 495.7963 & 0.0088 & 8.8745 & 21412.444 & 18656.959 & 1802.746 & 25323.563 & \text { Yes }\end{array}$

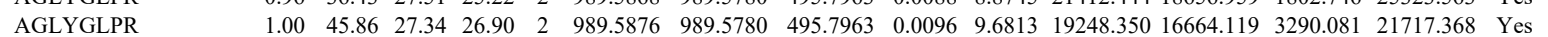
$\begin{array}{llllllllllllllll}\text { HGLYLPTR } & 0.72 & 25.02 & 26.99 & 17.42 & 2 & 1099.6298 & 1099.6260 & 550.8203 & 0.0038 & 3.4494 & 4239.539 & 3038.872 & 278.628 & 5510.209 & \text { Yes }\end{array}$ $\begin{array}{llllllllllllllll}\text { FDLSQNHPLGMAIFLK } & 0.96 & 22.50 & 26.81 & 24.04 & 3 & 2118.1579 & 2118.1539 & 707.0586 & 0.0040 & 1.8857 & 1811.942 & 1428.050 & 526.657 & 2223.929 & \text { Yes }\end{array}$

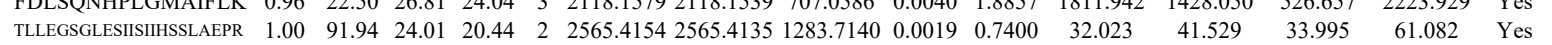

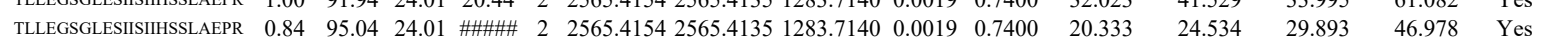
\begin{tabular}{llllllllllllllll} 
TLLEGSGLESIISIIHSSLAEPR & 1.00 & 36.97 & 23.86 & 49.97 & 4 & 2565.4165 & 2565.4135 & 642.3607 & 0.0030 & 1.1676 & 77.897 & 60.696 & 46.783 & 117.461 & Yes \\
\hline
\end{tabular} $\begin{array}{llllllllllllllll}\text { TLLEGSGLESIISIHSSSLAEPR } & 1.00 & 40.22 & 23.84 & 53.22 & 4 & 2565.4185 & 2565.4135 & 642.3607 & 0.0050 & 1.9459 & 72.386 & 119.640 & 97.344 & 134.938 & \text { Yes }\end{array}$ $\begin{array}{llllllllllllllll}\text { LHLSGIDANPNALFPVVEFPAPR } & 1.00 & 55.67 & 25.75 & 19.10 & 3 & 2615.4010 & 2615.3982 & 872.8067 & 0.0028 & 1.0693 & 220.563 & 196.341 & 50.356 & 296.806 & \text { Yes }\end{array}$

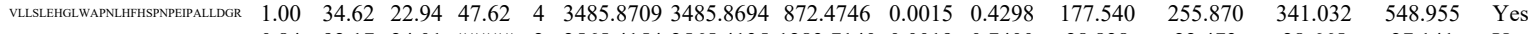

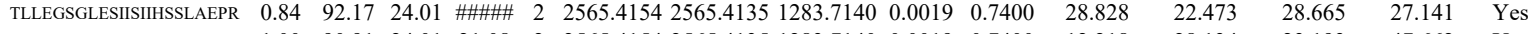
$\begin{array}{llllllllllllllll}\text { ILLEGSGLESISIIHSSLAEPR } & 1.00 & 50.34 & 23.80 & 63.34 & 4 & 2565.4177 & 2565.4135 & 642.3607 & 0.0042 & 1.6346 & 58.802 & 56.087 & 20.656 & 97.717 & \text { Yes }\end{array}$ $\begin{array}{llllllllllllllll}\text { TLLEGSGLESIISIIHSSLAEPR } & 1.00 & 45.57 & 23.80 & 58.57 & 4 & 2565.4181 & 2565.4135 & 642.3607 & 0.0046 & 1.7903 & 66.501 & 77.845 & 59.499 & 160.896 & \text { Yes }\end{array}$ $\begin{array}{llllllllllllllll}\text { YHGNVMLLR } & 0.98 & 34.98 & 27.86 & 22.35 & 3 & 1245.6889 & 1245.6774 & 416.2331 & 0.0115 & 9.2095 & 10188.448 & 10224.301 & 5150.910 & 15338.797 & \text { Yes }\end{array}$ $\begin{array}{lllllllllllllllllll}\text { YHGNVMLLR } & 0.99 & 41.64 & 27.86 & 27.57 & 3 & 1245.6889 & 1245.6774 & 416.2331 & 0.0115 & 9.2095 & 11174.237 & 10489.564 & 4648.903 & 13691.338 & \text { Yes }\end{array}$ \begin{tabular}{llllllllllllllll} 
ANDSBHLAAYYICIR & 1.00 & 62.71 & 27.80 & 17.80 & 3 & 2281.1407 & 2281.1357 & 761.3858 & 0.0050 & 2.1890 & 4061.332 & 2338.943 & 752.050 & 4112.582 & Yes \\
\hline
\end{tabular} $\begin{array}{llllllllllllll} & \text { TIESGG }\end{array}$

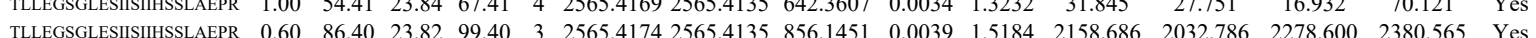

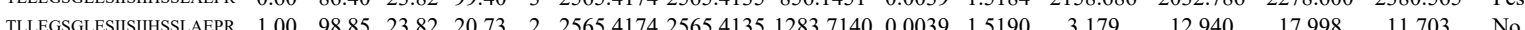

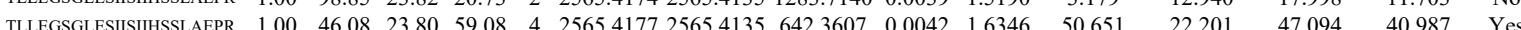

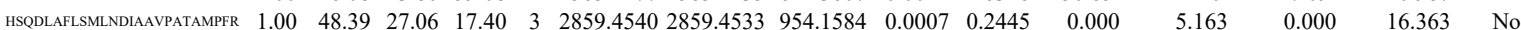

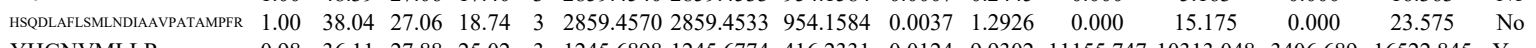
$\begin{array}{llllllllllllllllll}\text { YHGNVMLLR } & 0.98 & 36.11 & 27.88 & 25.02 & 3 & 1245.6898 & 1245.6774 & 416.2331 & 0.0124 & 9.9302 & 11155.747 & 10313.048 & 3406.689 & 16522.845 & \text { Yes } \\ \text { YHGNVMLLR } & 0.97 & 32.88 & 27.88 & 23.89 & 3 & 12456989 & 1245.6774 & 4162331 & 0.0124 & 9.9302 & 9961766 & 10619.461 & 3236972 & 13379.494 & \text { Yes }\end{array}$ $\begin{array}{lllllllllllllllll} & \text { AAPLDSHSLAYYIDCIR } & 1.00 & 63.70 & 27.87 & 17.53 & 3 & 2281.1389 & 2281.1357 & 761.3858 & 0.0032 & 1.401 & 1687.193 & 1120.659 & 115.680 & 2012.409 & \text { Yes }\end{array}$ $\begin{array}{llllllllllllllll}\text { AAAPLDSIHSLAAYYIDCIR } & 1.00 & 49.31 & 27.82 & 16.22 & 3 & 2281.1395 & 2281.1357 & 761.3858 & 0.0038 & 1.6636 & 584.142 & 602.166 & 271.141 & 1027.747 & \text { Yes }\end{array}$ \begin{tabular}{llllllllllllllll} 
ALLEGSGLESIISIIHSSLAEPR & 0.66 & 75.82 & 24.00 & 88.82 & 3 & 2565.4153 & 2565.4135 & 856.1451 & 0.0018 & 0.7008 & 415.475 & 511.008 & 318.893 & 578.971 & Yes \\
\hline
\end{tabular} $\begin{array}{llllllllllllllll}\text { TLLEGSGLESIISIIHSSLAEPR } & 0.67 & 67.38 & 23.84 & 80.38 & 3 & 2565.4168 & 2565.4135 & 856.1451 & 0.0033 & 1.2848 & 554.212 & 556.484 & 608.117 & 749.460 & \text { Yes }\end{array}$

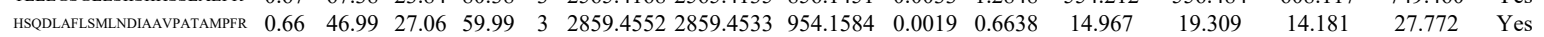

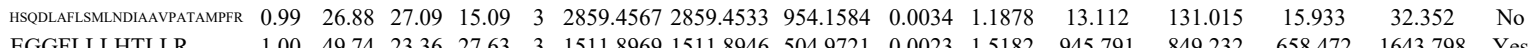

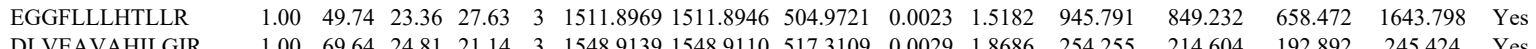

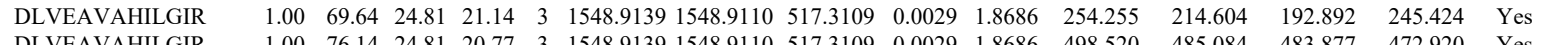
$\begin{array}{lllllllllllllllll}\text { DLVEAVAHILGIR } & 1.00 & 76.14 & 24.81 & 20.77 & 3 & 1548.9139 & 1548.9110 & 517.3109 & 0.0029 & 1.8686 & 498.520 & 485.084 & 483.877 & 472.920 & \text { Yes } \\ \text { AAPLDSIHSLAYYYIDCIR } & 0.67 & 43.25 & 27.87 & 56.25 & 3 & 2281.1389 & 2281.1357 & 761.3858 & 0.0032 & 1.4010 & 106.468 & 53.335 & 38.633 & 101.459 & \text { Yes }\end{array}$ $\begin{array}{lllllllllllllllll}\text { TLLEGSGLESIISIHSSLAEPR } & 1.00 & 91.84 & 23.82 & 22.04 & 3 & 2565.4174 & 2565.4135 & 856.1451 & 0.0039 & 1.5184 & 105.944 & 70.128 & 99.269 & 168.085 & \text { Yes }\end{array}$

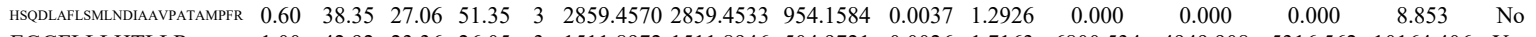

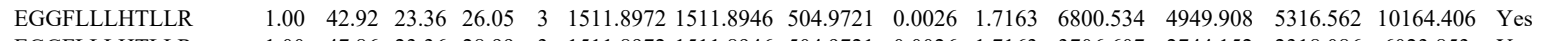
$\begin{array}{llllllllllllllll}\text { EGGFLLLHTLLR } & 1.00 & 47.86 & 23.36 & 28.99 & 3 & 1511.8972 & 1511.8946 & 504.9721 & 0.0026 & 1.7163 & 3706.607 & 2744.152 & 2318.086 & 6023.853 & \text { Yes }\end{array}$ $\begin{array}{llllllllllllllll}\text { IPGLLSPHPLLQLSYTATDR } & 1.00 & 58.52 & 24.03 & 19.09 & 3 & 2335.3021 & 2335.3022 & 779.4413 & -0.0001 & -0.0428 & 2122.995 & 985.073 & 1511.908 & 1907.090 & \text { Yes }\end{array}$ $\begin{array}{llllllllllllllll}\text { GGREVQQVPAGERPLWFICSGMGTOWR } & 1.00 & 47.42 & 26.05 & 16.74 & 3 & 3175.5292 & 3175.5276 & 1059.5165 & 0.0016 & 0.5034 & 151.573 & 102.972 & 66.804 & 162.050 & \text { Yes }\end{array}$

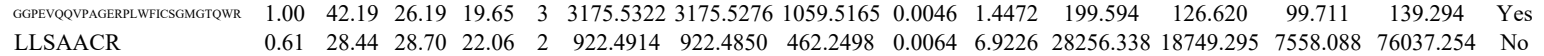

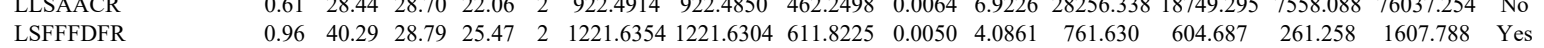

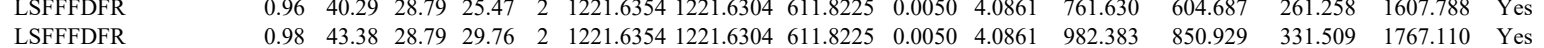

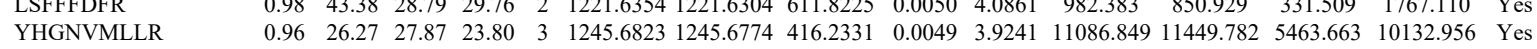
$\begin{array}{llllllllllllllll}0.96 & 26.27 & 27.87 & 23.80 & 3 & 1245.6823 & 1245.6774 & 416.2331 & 0.0049 & 3.9241 & 11086.849 & 11449.782 & 5463.663 & 10132.956 & \text { Yes }\end{array}$

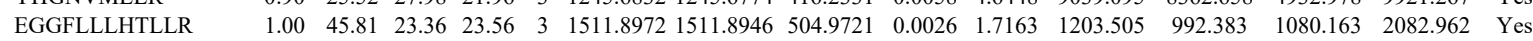

$\begin{array}{llllllllllllllll}\text { EGGFLLLHTLLR } & 1.00 & 66.49 & 23.36 & 25.32 & 3 & 1511.8975 & 1511.8946 & 504.9721 & 0.0029 & 1.9143 & 1638.762 & 1730.859 & 1215.290 & 2650.359 & \text { Yes }\end{array}$

Table S-4 page 327 of 614 


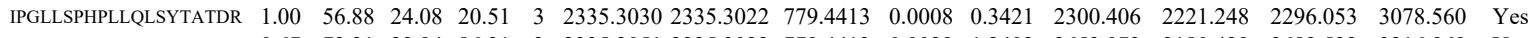
$\begin{array}{lllllllllllllllll}\text { PGLLSPHPLLQLSYTATDR } & 0.67 & 73.31 & 23.94 & 86.31 & 3 & 2335.3051 & 2335.3022 & 779.4413 & 0.0029 & 1.2402 & 3653.073 & 3180.429 & 3682.532 & 3216.969 & \text { Yes }\end{array}$

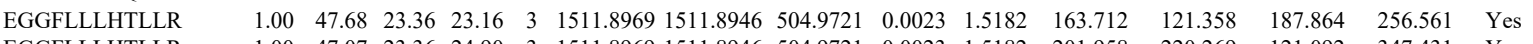

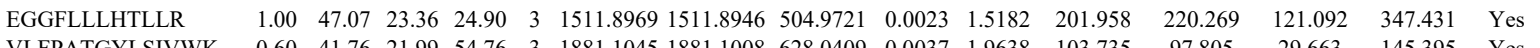
$\begin{array}{llllllllllllllll}\text { VLFPATGYLSIVWK } & 0.60 & 41.76 & 21.99 & 54.76 & 3 & 1881.1045 & 1881.1008 & 628.0409 & 0.0037 & 1.9638 & 103.735 & 97.805 & 29.663 & 145.395 & \text { Yes }\end{array}$ $\begin{array}{llllllllllllllll}\text { IPGLLSPHPLLQLSYTATDR } & 1.00 & 66.55 & 24.08 & 18.92 & 3 & 2335.3030 & 2335.3022 & 779.4413 & 0.0008 & 0.3421 & 278.796 & 287.022 & 256.642 & 264.229 & \text { Yes }\end{array}$ \begin{tabular}{llllllllllllllll} 
EGGFLLLHTLLR & 1.00 & 53.48 & 23.46 & 28.19 & 3 & 1511.8966 & 1511.8946 & 504.9721 & 0.0020 & 1.3202 & 118.997 & 89.137 & 76.043 & 200.654 & Yes \\
\hline
\end{tabular}

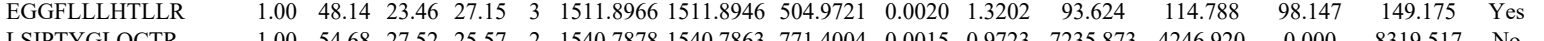

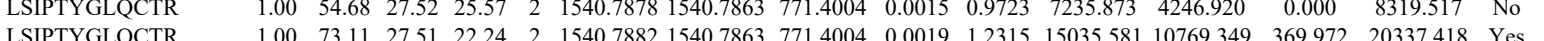

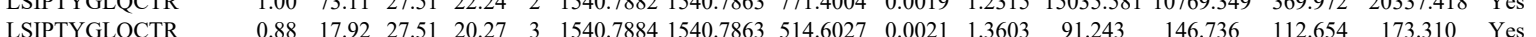
$\begin{array}{llllllllllllllll} & 1.88 & 17.92 & 27.51 & 20.27 & 3 & 1540.7884 & 1540.7863 & 514.6027 & 0.0021 & 1.3603 & 91.243 & 146.736 & 112.654 & 17.310 & \text { Yes } \\ \text { LSIPTYGLQCTR } & 0.95 & 21.82 & 27.68 & 17.61 & 3 & 1540.7890 & 1540.7863 & 514.6027 & 0.0027 & 1.7489 & 131.580 & 132.273 & 106.692 & 140.128 & \text { Yes }\end{array}$

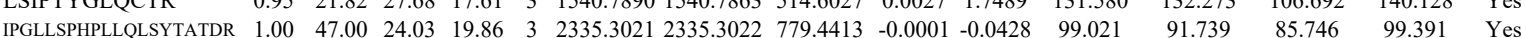

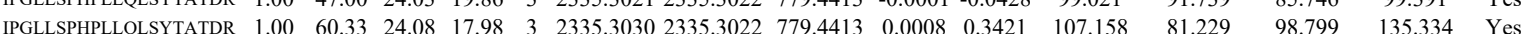

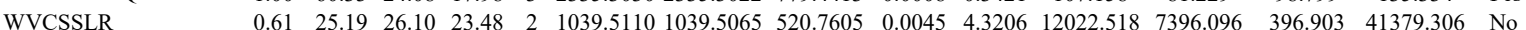
$\begin{array}{llllllllllllllll}\text { WVCSSLR } & 0.66 & 26.49 & 26.41 & 22.06 & 2 & 1039.5138 & 1039.5065 & 520.7605 & 0.0073 & 7.0089 & 14630.778 & 10897.756 & 1808.447 & 54429.449 & \text { No }\end{array}$ $\begin{array}{llllllllllllllll}\text { LSIPTYGLQCTR } & 1.00 & 53.79 & 27.53 & 21.93 & 2 & 1540.7872 & 15407863 & 771.4004 & 0.0009 & 0.5834 & 2329.899 & 1611.734 & 297.574 & 2237.285 & \text { Yes }\end{array}$

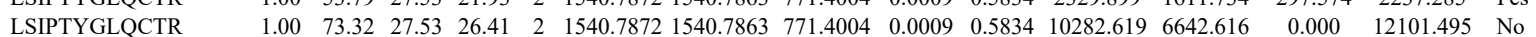
WVCSSLR LSIPTYGLQCTR $\begin{array}{llllllllllllll}0.71 & 27.36 & 26.10 & 20.25 & 2 & 1039.5110 & 1039.5065 & 520.7605 & 0.0045 & 4.3206 & 6989.029 & 5003.472 & 513\end{array}$ $\begin{array}{lllllllllllll}0.63 & 25.41 & 25.92 & 23.65 & 2 & 1039.5118 & 1039.5065 & 520.7605 & 0.0053 & 5.0887 & 5192.836 & 3987.737 & 336\end{array}$ LSIPTYGLQCT $\begin{array}{llllllllllll}1.00 & 57.61 & 27.59 & 21.25 & 2 & 1540.7868 & 1540.7863 & 771.4004 & 0.0005 & 0.3241 & 968.879 & 876.208\end{array}$ SFYGSTLFLCR $\begin{array}{llllllllllll}1.00 & 56.68 & 27.53 & 20.53 & 2 & 1540.7872 & 1540.7863 & 771.4004 & 0.0009 & 0.5834 & 2219.111 & 1550.711\end{array}$ $\begin{array}{llllllllllll}0.82 & 55.37 & 26.96 & 68.37 & 2 & 1482.7134 & 1482.7121 & 742.3633 & 0.0013 & 0.8756 & 1063.653 & 757.879\end{array}$ $3.803 \quad 24291.352$ No SFYGSTLFLCR $\begin{array}{llllllllllll}1.00 & 57.43 & 26.97 & 17.50 & 2 & 1482.7136 & 1482.7121 & 742.3633 & 0.0015 & 1.0103 & 899.810 & 580.079 \\ 1.00 & 76.71 & 27.40 & 20.50 & 3 & 2103.1051 & 2103.1042 & 702.0420 & 0.0009 & 0.4273 & 27.228 & 54.499\end{array}$ 1.00 $\begin{array}{llllllllllll}\text { AINCATSGVVGLVNCLR } & 1.00 & \# \# \# \# \text { 28.06 } 22.41 & 2 & 1924.9504 & 1924.9477 & 963.4811 & 0.0027 & 1.4012 & 170.757 & 136.635\end{array}$ $\begin{array}{llllllllll} & \end{array}$

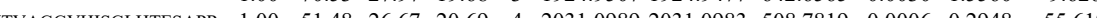

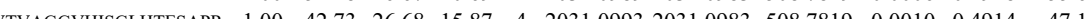

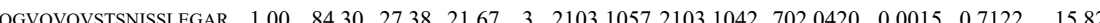

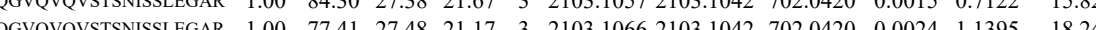
\begin{tabular}{lllllllllllll}
\hline & 0.0019 & 0.7882 & 3.889
\end{tabular}

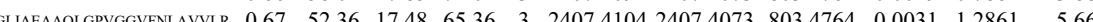
$\begin{array}{llllllllllllll}\text { LLLEVTYEAIVDGGINPDSLR } & 0.99 & 29.48 & 25.47 & 19.75 & 3 & 2430.3181 & 2430.3128 & 811.1115 & 0.0053 & 2.1781 & 2.739\end{array}$ $\begin{array}{lllllllllllll}\text { LSIPTYGLQCTR } & 1.00 & 56.55 & 27.54 & 21.89 & 2 & 1540.7886 & 1540.7863 & 771.4004 & 0.0023 & 1.4908 & 102.055\end{array}$ $\begin{array}{llllllllllllll}\text { LSIPTYGLQCTR } & 1.00 & 72.36 & 27.53 & 23.43 & 2 & 1540.7910 & 1540.7863 & 771.4004 & 0.0047 & 3.0464 & 80.076\end{array}$

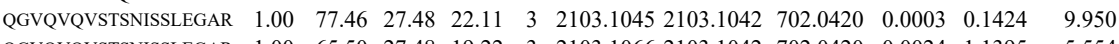

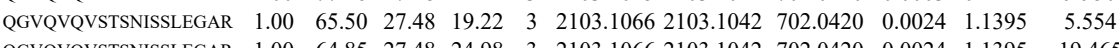
$\begin{array}{llllllllllll}\text { QGVQVQVSTSNISSLEGAR } & 1.00 & 64.85 & 27.48 & 24.98 & 3 & 2103.1066 & 2103.1042 & 702.0420 & 0.0024 & 1.1395 & 19.465\end{array}$

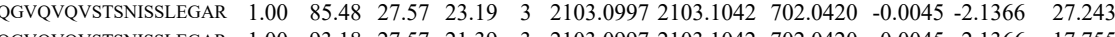

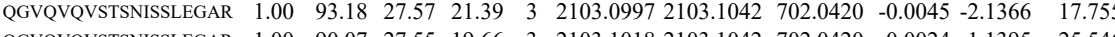

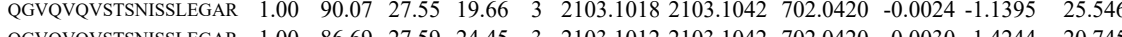
$\begin{array}{llllllllllll}\text { QGVQVQVSTSNISSLEGAR } & 1.00 & 86.69 & 27.59 & 24.45 & 3 & 2103.1012 & 2103.1042 & 702.0420 & -0.0030 & -1.4244 & 20.745\end{array}$ $\begin{array}{lllllllllllll}\text { AINCATSGVVGLVNCLR } & 1.00 & 98.78 & 27.87 & 19.20 & 2 & 1924.9482 & 1924.9477 & 963.4811 & 0.0005 & 0.2595 & 14.141\end{array}$

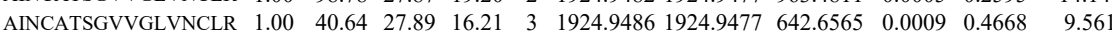
AINCATSGVVGLVNCLR 1.00 \#\#\#\# $27.83 \quad 20.34 \quad 2 \quad 1924.94921924 .9477 \begin{array}{llllllll}963.4811 & 0.0015 & 0.7784 & 19.170\end{array}$ $\begin{array}{llllllllllll}\text { AINCATSGVVGLVNCLR } & 0.99 & 27.03 & 28.00 & 16.80 & 3 & 1924.9501 & 1924.9477 & 642.6565 & 0.0024 & 1.2448 & 7.363\end{array}$ $\begin{array}{lllllllllllll}\text { SFYGSTLFLCR } & 0.74 & 21.09 & 26.77 & 14.72 & 2 & 1482.7156 & 1482.7121 & 742.3633 & 0.0035 & 2.3573 & 48.66\end{array}$

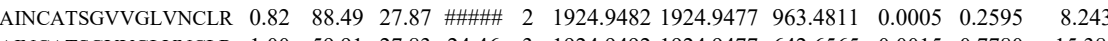
$\begin{array}{llllllllllll}\text { AINCATSGVGGVNCLR } & 1.00 & 59.91 & 27.83 & 24.46 & 3 & 1924.9492 & 1924.9477 & 642.6565 & 0.0015 & 0.7780 & 15.386\end{array}$ $\begin{array}{lllllllllllllll} & \text { AINCATSGVVGLVNCLR } & 1.00 & 48.22 & 27.97 & 17.78 & 3 & 1924.9507 & 1924.9477 & 642.6565 & 0.0030 & 1.5560 & 27.086\end{array}$ $\begin{array}{llllllllllllll} & \text { STYGSTLCR } & 0.86 & 22.26 & 26.97 & 14.77 & 2 & 1482.7136 & 1482.7121 & 742.3633 & 0.0015 & 1.0103 & 69.030\end{array}$ $\begin{array}{lllllllllllll} & \end{array}$ $\begin{array}{llllllllllllllll}\text { AINCATSGVVGLVNCLR } & 0.64 & \# \# \# \# 27.88 \text { \#\#\#\# } & 2 & 1924.9478 & 1924.9477 & 963.4811 & 0.0001 & 0.0519 & 20.494\end{array}$ $\begin{array}{lllllllllllll}\text { AINCATSGVVGLVNCLR } & 0.82 & 79.62 & 27.86 & 92.62 & 2 & 1924.9488 & 1924.9477 & 963.4811 & 0.0011 & 0.5708 & 27.273\end{array}$ 
$\begin{array}{llllllllllll}\text { LLLEVTYEAIVDGGINPDSLR } & 0.67 & 23.77 & 25.48 & 36.77 & 3 & 2430.3163 & 2430.3128 & 811.1115 & 0.0035 & 1.4384 & 6.218\end{array}$

$\begin{array}{lllllllllllll} & 240.3172 & 2430.3128 & 811.1115 & 0.0044 & 1.8082 & 10.289\end{array}$

$\begin{array}{lllllllllllll}\text { ADEASELACPTPK } & 1.00 & 71.53 & 26.77 & 17.54 & 2 & 1664.8012 & 1664.7993 & 833.4069 & 0.0019 & 1.1399 & 2132.943 & 1715.142\end{array}$

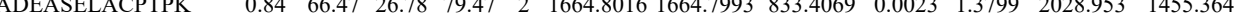

QQEQQVPILEK

ADEASELACPTPK

QQEQQVPILEK

GVDLVLNSLAEEK

$\begin{array}{llllllllllllll}1.00 & 58.12 & 26.44 & 31.71 & 2 & 1626.9208 & 1626.9184 & 814.4665 & 0.0024 & 1.4734 & 2725.829 & 2145.690\end{array}$

VDLVLNSLAEEK

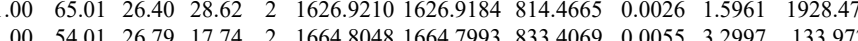

$\begin{array}{llllllllllll}1.00 & 63.79 & 25.54 & 28.22 & 2 & 1626.9336 & 1626.9184 & 814.4665 & 0.0152 & 9.3312 & 1018.422 & \end{array}$

GVDLVLNSLAEEK

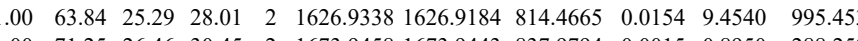

GVDLVLNSLAEEK

$\begin{array}{lllllllllll}1.00 & 71.25 & 26.46 & 30.45 & 2 & 1673.9458 & 1673.9443 & 837.9794 & 0.0015 & 0.8950 & 288.259\end{array}$

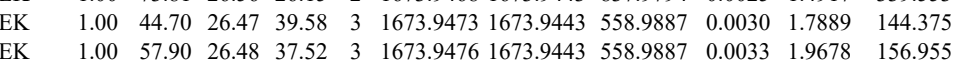

$\begin{array}{lllllllllllll} & \end{array}$

$\begin{array}{lllllllllllll}\text { VVVQVLAEEPEAVLK } & 1.00 & 48.95 & 19.14 & 20.64 & 3 & 1910.1355 & 1910.1332 & 637.7183 & 0.0023 & 1.2022 & 104.375 & 116.036\end{array}$

$\begin{array}{lllllllllllll} & 91.29 & 24.93 & 2 & 1910.1356 & 1910.1332 & 956.0739 & 0.0024 & 1.2551 & 18.681 & 13.92\end{array}$

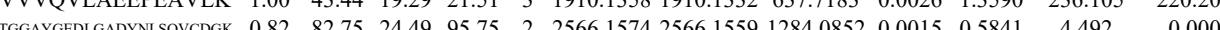

$\begin{array}{lllllllll} & 0.000\end{array}$

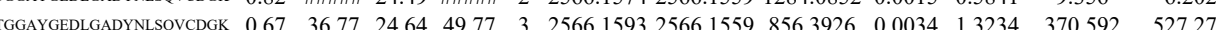

$\begin{array}{llllllllllllll}\text { TGGAYGEDLGADYNLSQVCDGK } & 0.67 & 36.77 & 24.64 & 49.77 & 3 & 2566.1593 & 2566.1559 & 856.3926 & 0.0034 & 1.3234 & 370.592 & 527.278 \\ \text { TGGAYGEDLGADYNISOVCDGK } & 0.60 & 36.73 & 24.70 & 49.73 & 3 & 2566.1605 & 2566.1559 & 856.3926 & 0.0046 & 1.7905 & 376.377 & 112.313\end{array}$

IDDIVSGHAYNLQVCDGK 
IPGGIIEDSCVLR IPGGIIEDSCVLR AMTGVEQWPYR AMTGVEQWPYR IPGGIIEDSCVLR IPGGIIEDSCVLR AVAQALEVIPR AVAQALEVIPR NLQDAMQVCR
NLQDAMQVCR AVAQALEVIPR AVAQALEVIPR MLLDPMGGIVMTNDGNAILR MLLDPMGGIVMTNDGNAILR

MLLDPMGGIVMTNDGNAIL MLLDPMGGIVMTNDGNAI ISIPVDISDSDMMLNINSSITTK ISIPVDISDSDMMLNIINSSITTK SIIPVDISDSDMMLNIIISSITTK MLLDPMGGIVMTNDGNAILR MLLDPMGGIVMTNDGNAIL WSSLACNIALDAVK WSSLACNIALDAVK

TAVETAVLLLR

GISDLAQHYLMR

TAVETAVLLLR

GISDLAQHYLMR

TAVETAVLLLR

TAVETAVLLLR

TLIQNCG
LLTSLR

TLIQNCGASTIR

TLIQNCGASTIR

TLIQNCGASTIR

ACTILLR

ACTILLR

ACTILLR

ACTILLR

ACTILLR

ACTILLR

ACTILLR
ACTILLR

ACTILLR

ACTILLR
ACTILLR

ACTILLR

ACTILLR

EDDVGT

EDDVGTGAGLLEIK

ANITAIRR

ANITAIRR

ANITAIRR

IDDIVSGHK

IDDIVSGHK

IDDIVSGHK

AEAGDNLGALVR

AEAGDNLGALVR

TIGTGLVTNTLAMTEEEK 1.0

TIGTGLVINTLAMTEEEK

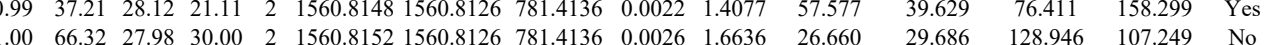

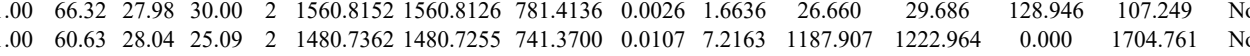

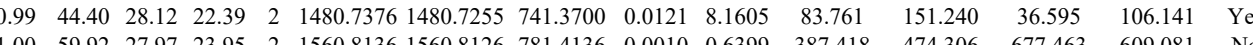
$\begin{array}{lllllllllllllll}1.00 & 59.92 & 27.97 & 23.95 & 2 & 1560.8136 & 1560.8126 & 781.4136 & 0.0010 & 0.6399 & 387.418 & 474.306 & 677.463 & 609.081 & \text { No }\end{array}$

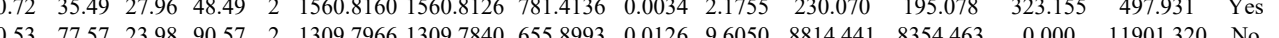

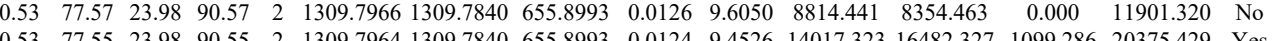
\begin{tabular}{llllllllllllllllll}
0.53 & 77.55 & 23.98 & 90.55 & 2 & 1309.7964 & 1309.7840 & 655.8993 & 0.0124 & 9.4526 & 14017.323 & 16482.327 & 1099.286 & 20375.429 & Yes \\
\hline
\end{tabular} $\begin{array}{lllllllllllllllll}1.00 & 51.95 & 25.72 & 22.36 & 2 & 1366.6402 & 1366.6277 & 684.3211 & 0.0125 & 9.1331 & 12945.613 & 14031.790 & 0.000 & 18755.507 & \text { No } \\ 1.00 & 50.05 & 25.71 & 22.48 & 2 & 1366.6406 & 13666277 & 684.3211 & 0.0129 & 9.4253 & 18401845 & 19043.607 & 450.785 & 25085.292 & \text { Yes }\end{array}$

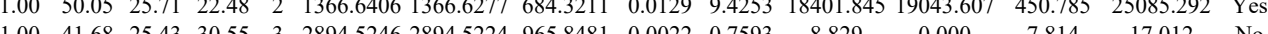

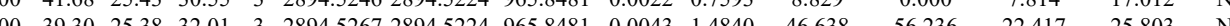
$\begin{array}{lllllllllllll} & \end{array}$

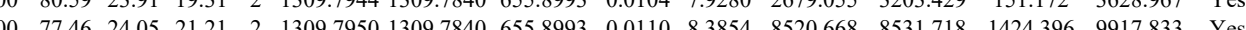

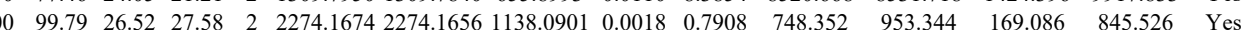
$\begin{array}{llllllllllllll}1.00 & \# \# \# \# 26.52 & 24.33 & 2 & 2274.1674 & 2274.1656 & 1138.0901 & 0.0018 & 0.7908 & 699.697 & 955.727 & 281.245 & 931.011 & \text { Yes }\end{array}$

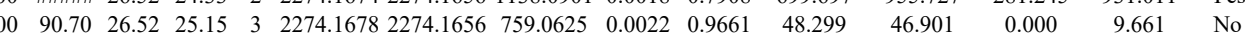

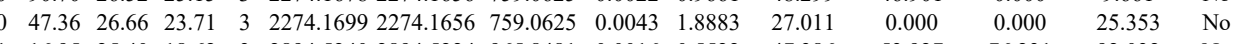

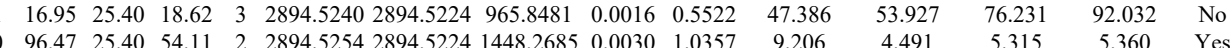

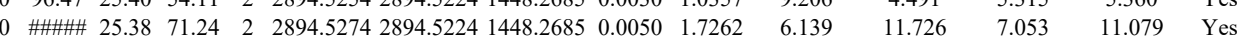
$\begin{array}{lllllllllllll}26.52 & 24.01 & 2 & 2274.1674 & 2274.1656 & 1138.0901 & 0.0018 & 0.7908 & 293.550 & 335.568 & 95.429 & 334.223 & \text { Yes }\end{array}$

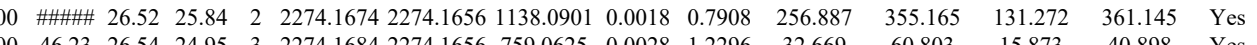

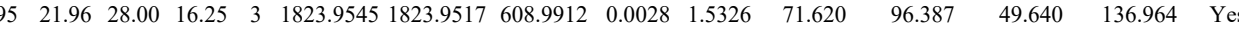

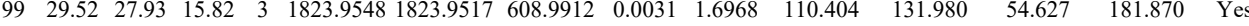

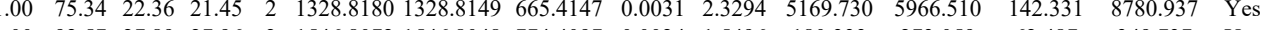

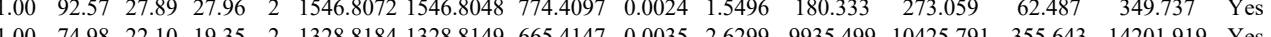
\begin{tabular}{lllllllllllllll}
1.00 & 74.98 & 2.10 & 19.35 & 2 & 1328.8184 & 1328.8149 & 665.4147 & 0.0035 & 2.6299 & 9935.499 & 10425.791 & 355.643 & 14201.919 & Yes \\
\hline
\end{tabular} $\begin{array}{lllllllllllllllll}1.00 & 65.80 & 27.91 & 27.85 & 3 & 1546.8082 & 1546.8048 & 516.6089 & 0.0034 & 2.1938 & 4174.332 & 3776.078 & 931.459 & 5230.428 & \text { Yes }\end{array}$ $\begin{array}{lllllllllllllll}1.00 & 67.76 & 27.80 & 26.05 & 3 & 1546.8094 & 1546.8048 & 516.6089 & 0.0046 & 2.9681 & 3804.550 & 4855.025 & 816.424 & 6035.486 & \text { Yes }\end{array}$ $\begin{array}{llllllllllllllll}1.00 & 62.92 & 23.18 & 19.31 & 2 & 1328.8152 & 1328.8149 & 665.4147 & 0.0003 & 0.2254 & 5220.027 & 5806.943 & 351.926 & 7707.996 & \text { Yes }\end{array}$

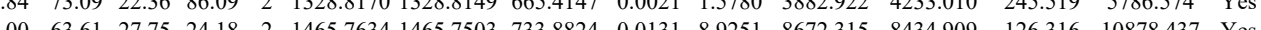

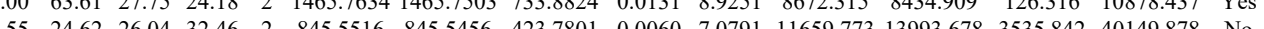

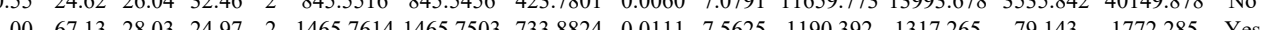

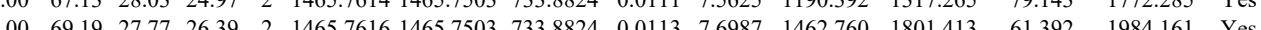

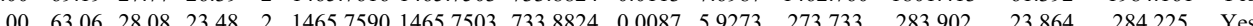
$\begin{array}{llllllllllllll} & 176516 & \text { Yes }\end{array}$ $\begin{array}{llllllllllllllll}0.58 & 20.76 & 27.98 & 17.92 & 2 & 978.5474 & 978.5476 & 490.2811 & -0.0002 & 0.02040 & 71.596 & 82.061 & 18.820 & 133.398 & \text { Yes }\end{array}$ $\begin{array}{llllllllllllllll}0.55 & 20.08 & 27.78 & 20.64 & 2 & 9785480 & 978.5476 & 490.2811 & 0.0004 & 0.4079 & 48.200 & 58.572 & 32.104 & 85.061 & \text { Yes }\end{array}$ $\begin{array}{lllllllllllllll}0.88 & 27.77 & 27.78 & 20.73 & 2 & 978.5480 & 978.5476 & 490.2811 & 0.0004 & 0.4079 & 45.890 & 45.315 & 29.982 & 59.372 & \text { Yes }\end{array}$ $\begin{array}{lllllllllllllll}0.57 & 15.84 & 27.51 & 17.41 & 2 & 978.5484 & 978.5476 & 490.2811 & 0.0008 & 0.8159 & 55.998 & 81.887 & 23.581 & 119.406 & \text { Yes }\end{array}$ $\begin{array}{llllllllllllllll}0.99 & 35.69 & 27.54 & 23.38 & 2 & 978.5490 & 978.5476 & 490.2811 & 0.0014 & 1.4278 & 15515.559 & 19036.002 & 1826.396 & 29269.417 & \text { Yes }\end{array}$ $\begin{array}{llllllllllllllll}0.67 & 28.64 & 28.28 & 25.43 & 2 & 978.5542 & 978.5476 & 490.2811 & 0.0066 & 6.7308 & 10434.078 & 11477.076 & 535.820 & 19801.401 & \text { Yes }\end{array}$ $\begin{array}{lllllllllllllllll}0.98 & 34.83 & 28.19 & 22.58 & 2 & 978.5506 & 978.5476 & 490.2811 & 0.0030 & 3.0595 & 6765.912 & 8067.283 & 473.212 & 12155.233 & \text { Yes }\end{array}$ $\begin{array}{llllllllllllllll}0.99 & 36.94 & 28.19 & 23.68 & 2 & 978.5506 & 978.5476 & 490.2811 & 0.0030 & 3.0595 & 10802.446 & 11917.962 & 1202.952 & 17955.162 & \text { Yes }\end{array}$ $\begin{array}{llllllllllllllll}0.98 & 36.66 & 27.98 & 23.87 & 2 & 978.5474 & 978.5476 & 490.2811 & -0.0002 & -0.2040 & 4784.793 & 5906.820 & 775.412 & 6823.470 & \text { Yes }\end{array}$ $\begin{array}{llllllllllllllll}0.81 & 25.40 & 27.78 & 22.61 & 2 & 978.5478 & 978.5476 & 490.2811 & 0.0002 & 0.2040 & 6275.919 & 6563.871 & 1213.005 & 8799.717 & \text { Yes }\end{array}$

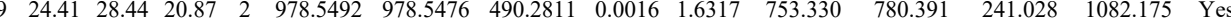
$\begin{array}{lllllllllllllll}0.69 & 22.75 & 27.94 & 21.50 & 2 & 978.5472 & 978.5476 & 490.2811 & -0.0004 & -0.4079 & 187.936 & 223.178 & 86.427 & 216.595 & \text { Yes }\end{array}$ $\begin{array}{lllllllllllllll}1.00 & 94.03 & 27.68 & 30.30 & 2 & 1703.9200 & 1703.9185 & 852.9665 & 0.0015 & 0.8793 & 1931.415 & 1821.795 & 2770.879 & 2077.997 & \text { No }\end{array}$ $\begin{array}{lllllllllllllll}.0 & 84.87 & 27.70 & 32.10 & 2 & 1703.9202 & 1703.9185 & 852.9665 & 0.0017 & 0.9965 & 3002.072 & 2888.357 & 3099.843 & 3304.116 & \text { Yes }\end{array}$

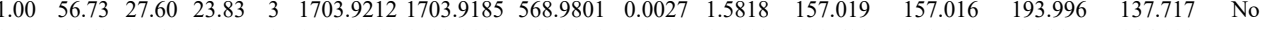

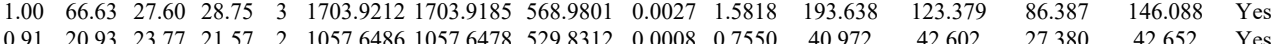
$\begin{array}{lllllllllllllll}0.91 & 20.93 & 23.77 & 21.57 & 2 & 1057.6486 & 1057.6478 & 529.8312 & 0.0008 & 0.7550 & 40.972 & 42.602 & 27.380 & 42.652 & \text { Yes } \\ 0.59 & 1.3 & 24.33 & 2.76 & 2 & 057.6476 & 057.647 & 529.812 & 0.0002 & -0.187 & 51.709 & -7.968 & 47.538 & 6.132 & \text { Yes }\end{array}$

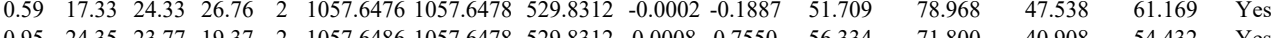
\begin{tabular}{lllllllllllllllll}
1.00 & 42.56 & 26.42 & 27.28 & 3 & 1270.7209 & 1270.7125 & 424.5781 & 0.0084 & 6.5947 & 13794.433 & 17260.981 & 8028.375 & 19924.724 & Yes \\
\hline
\end{tabular} \begin{tabular}{lllllllllllllllll}
1.00 & 42.56 & 26.4 & 27.28 & 3 & 1270.720 & 1270.7125 & 424.5781 & 0.0084 & 6.5947 & 13794.433 & 17260.981 & 8028.375 & 1924.724 & Yes \\
\hline
\end{tabular}

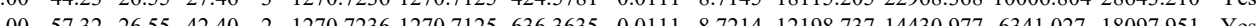

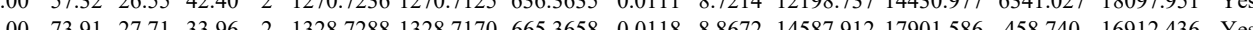

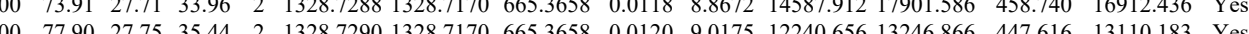
$\begin{array}{llllllllllllll}1.00 & \# \# \# \# 26.88 & 29.56 & 2 & 2195.1594 & 2195.1599 & 1098.5872 & -0.0005 & -0.2276 & 251.585 & 260.589 & 224.243 & 252.161 & \text { Yes }\end{array}$

Table S-4 page 330 of 614 


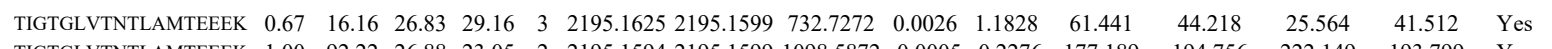

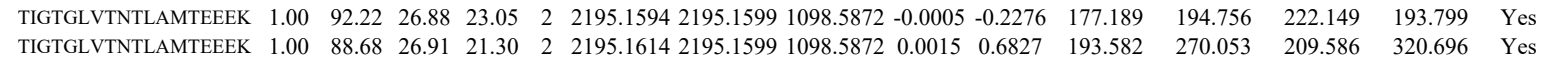

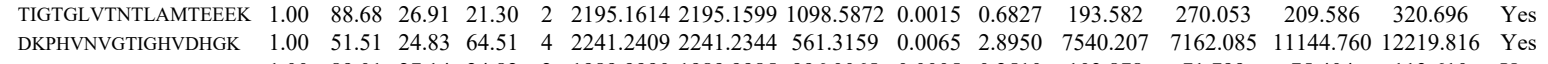
$\begin{array}{llllllllllllllll}\text { DKPHVNVGTIGHVDHGK } & 1.00 & 51.51 & 24.83 & 64.51 & 4 & 2241.2409 & 2241.2344 & 561.3159 & 0.0065 & 2.8950 & 7540.207 & 7162.085 & 11144.760 & 12219.816 & \text { Yes } \\ \text { GEETPVIVGSALCALEGR } & 1.00 & 89.01 & 27.14 & 24.82 & 2 & 1989.9990 & 1989.9985 & 996.0065 & 0.0005 & 0.2510 & 103.878 & 71.799 & 75.404 & 113.610 & \text { Yes }\end{array}$

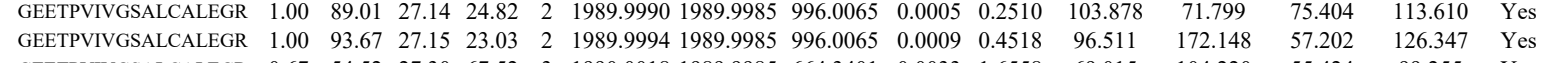

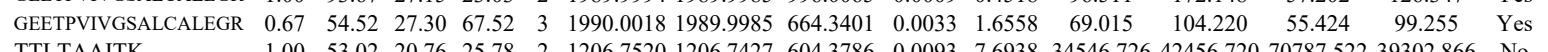

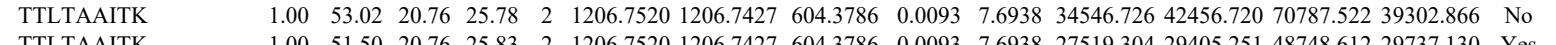

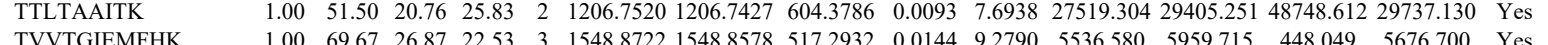

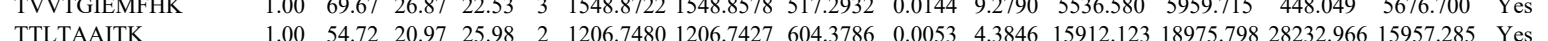
\begin{tabular}{llllllllllllllll} 
TTLTAAITK & 1.00 & 54.72 & 20.97 & 25.98 & 2 & 1206.7480 & 1206.7427 & 604.3786 & 0.0053 & 4.3846 & 15912.123 & 18975.798 & 28232.966 & 15957.285 & Yes \\
\hline TTLTAAITK & 1.00 & 53.86 & 20.57 & 22.95 & 2 & 1206.7486 & 1206.7427 & 604.3786 & 0.0059 & 4.8810 & 14842.634 & 20333.282 & 27410.930 & 17732.853 & Yes
\end{tabular} $\begin{array}{llllllllllllllllll}\text { TILTAAITK } & 1.00 & 53.86 & 20.57 & 22.95 & 2 & 1206.7486 & 1206.7427 & 04.3786 & 0.050 & 4.8810 & 14842.634 & 20353.282 & 27410.930 & 17732.853 & \text { Yes }\end{array}$

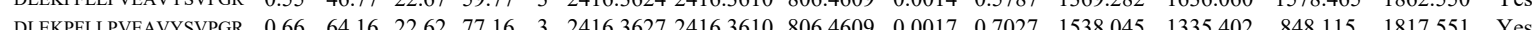

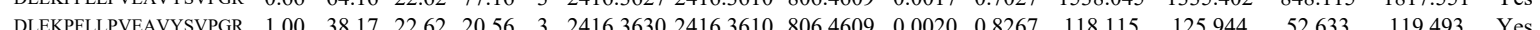

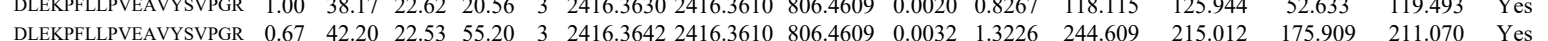

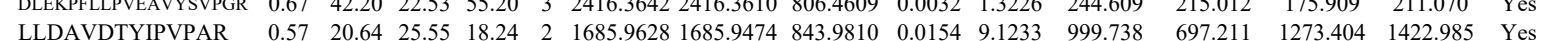

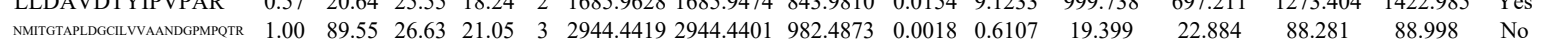
$\begin{array}{llllllllllllllll}\text { NMITGTAPDGGLIVVAANGGPMPTR } & 1.00 & 80.45 & 26.66 & 20.17 & 3 & 2944.4422 & 2944.4401 & 982.4873 & 0.0021 & 0.7125 & 0.000 & 4.866 & 0.000 & 5.103 & \text { No }\end{array}$

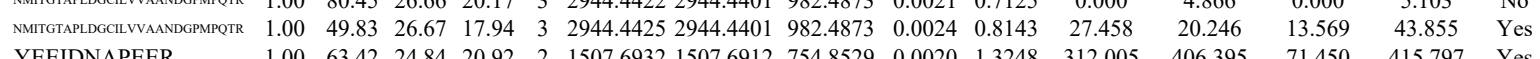
$\begin{array}{llllllllllllllll}\text { YEEIDNAPEER } & 1.00 & 63.42 & 24.84 & 20.92 & 2 & 1507.6932 & 1507.6912 & 754.8529 & 0.0020 & 1.3248 & 312.005 & 406.395 & 71.450 & 415.797 & \text { Yes } \\ \text { YEEIDNAPER }\end{array}$ $\begin{array}{llllllllllllllll}\text { YEEIDNAPEER } & 1.00 & 61.18 & 24.84 & 18.74 & 2 & 1507.6934 & 1507.6912 & 754.8529 & 0.0022 & 1.4572 & 365.621 & 550.083 & 122.827 & 621.174 & \text { Yes } \\ \text { KYEEDNAPR } & 1.0 & 58.6 & 27.92 & 27.5 & & & \end{array}$ FNLILR FNLILR

FNLILR

FNLILR

FNLILR

FNLILR

FNLILR

FNLILR
FNLILR

$\begin{array}{llllllllll}\text { AL7A1_HUMAI } & \text { P49419 } & \text { ALDH7A1 Alpha-aminoadipi } 58.487 & 1.00 & 7 & 19.7 & -0.2601 & 0.4374 & 0.5482 & 0.3525\end{array}$

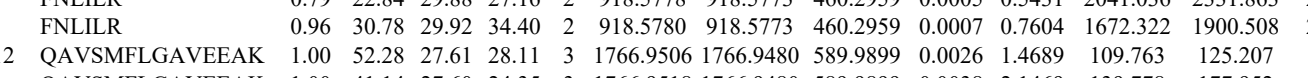
$\begin{array}{llllllllllllll}\text { QAVSMFLGAVEEAK } & 1.00 & 41.14 & 27.61 & 28.11 & 3 & 1766.9506 & 1766.9480 & 589.9899 & 0.0026 & 1.4689 & 109.763 & 125.207 & 63 .\end{array}$ $\begin{array}{lllllllllllllll}\text { GEVITTYCPANNEPIAR } & 0.82 & 69.41 & 26.63 & 82.41 & 2 & 2036.9794 & 2036.9781 & 1019.4963 & 0.0013 & 0.6376 & 347.036 & 262.995 & 146 .\end{array}$ $\begin{array}{llllllllllllll}\text { GEVITTYCPANNEPIAR } & 0.72 & 71.68 & 27.40 & 84.68 & 2 & 2036.9814 & 2036.9781 & 1019.4963 & 0.0033 & 1.6184 & 264.769 & 219.335 & 74 .\end{array}$ IWADIPAPK $\begin{array}{lllllllllllllllll}0.59 & 18.16 & 29.96 & 25.01 & 2 & 918.5796 & 918.5773 & 460.2959 & 0.0023 & 2.4984 & 48455.392 & 63903.680 & 2121.281 & 69524.842 & \text { Yes } \\ 0.57 & 18.24 & 29.88 & 26.72 & 2 & 918.5778 & 918.5773 & 460.2959 & 0.0005 & 0.5431 & 25964.390 & 29800.858 & 4454.627 & 33188.108 & \text { Yes } & \\ 0.65 & 19.33 & 29.85 & 25.17 & 2 & 918.5788 & 918.5773 & 460.2959 & 0.0015 & 1.6294 & 29512.896 & 36825.764 & 2259.879 & 37813.249 & \text { Yes } & \\ 0.79 & 22.82 & 29.92 & 27.10 & 2 & 918.5782 & 918.5773 & 460.2959 & 0.0009 & 0.9776 & 3991.561 & 4527.023 & 428.386 & 4430.449 & \text { Yes }\end{array}$ $\begin{array}{llllllllllllllll}0.79 & 22.82 & 29.92 & 27.10 & 2 & 918.5782 & 918.5773 & 460.295 & 0.0009 & 0.9776 & 3991.561 & 4527.023 & 428.386 & 4430.449 & \text { Yes }\end{array}$ $\begin{array}{lllllllllllllllll}0.61 & 19.01 & 29.93 & 24.54 & 2 & 918.5784 & 918.5773 & 460.2959 & 0.0011 & 1.1949 & 3374.041 & 4131.114 & 285.679 & 4280.706 & \text { Yes }\end{array}$ $\begin{array}{llllllllllllllll}0.61 & 18.98 & 29.85 & 26.37 & 2 & 918.5786 & 918.5773 & 460.2959 & 0.0013 & 1.4121 & 2975.014 & 3315.590 & 241.990 & 3634.417 & \text { Yes }\end{array}$ $\begin{array}{lllllllllllllll}0.88 & 25.27 & 29.85 & 30.38 & 2 & 918.5792 & 918.5773 & 460.2959 & 0.0019 & 2.0639 & 3175.030 & 3616.082 & 508.692 & 3686.524 & \text { Yes }\end{array}$

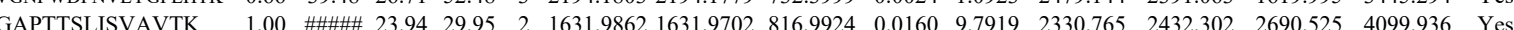
$\begin{array}{llllllllllllllll}\text { IQVLGSLVSLEMGK } & 1.00 & 53.11 & 23.69 & 17.68 & 3 & 1761.0346 & 1761.0314 & 588.0177 & 0.0032 & 1.8140 & 389.037 & 190.025 & 93.690 & 565.271 & \text { Yes }\end{array}$ $\begin{array}{lllllllllllllllll}\text { IQVLGSLVSLEMGK } & 1.00 & 55.88 & 23.73 & 20.49 & 3 & 1761.0328 & 1761.0314 & 588.0177 & 0.0014 & 0.7936 & 340.890 & 160.459 & 194.032 & 360.941 & \text { Yes }\end{array}$ $\begin{array}{llllllllllllllll}\text { IQVLGSLVSLEMGK } & 0.99 & 29.25 & 23.71 & 25.22 & 3 & 1761.0340 & 1761.0314 & 588.0177 & 0.0026 & 1.4739 & 118.162 & 161.615 & 148.561 & 97.774 & \text { No }\end{array}$ $\begin{array}{llllllllllllllll}\text { IQVLGSLVSLEMGK } & 1.00 & 96.53 & 23.73 & 27.45 & 2 & 1761.0318 & 1761.0314 & 881.5230 & 0.0004 & 0.2269 & 259.282 & 229.864 & 124.948 & 360.055 & \text { Yes }\end{array}$

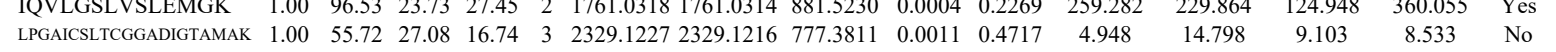

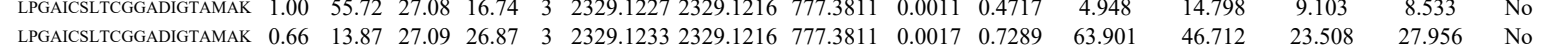

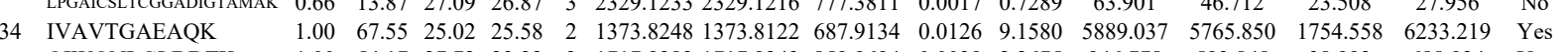
$\begin{array}{lllllllllllllllll}\text { QIWQNLGLDDTK } & 1.00 & 54.17 & 27.72 & 23.22 & 2 & 1717.9282 & 1717.9243 & 859.9694 & 0.0039 & 2.2675 & 946.778 & 593.848 & 38.992 & 688.924 & \text { Yes }\end{array}$ $\begin{array}{llllllllllllllll}\text { QIWQNLGLDDTK } & 1.00 & 66.66 & 27.66 & 25.15 & 2 & 1717.9286 & 1717.9243 & 859.9694 & 0.0043 & 2.5001 & 945.606 & 851.275 & 0.000 & 616.497 & \text { No }\end{array}$ $\begin{array}{llllllllllllllll}\text { VGDQVWLFIDEPR } & 0.99 & 38.62 & 28.38 & 24.18 & 2 & 1716.8986 & 1716.8957 & 859.4551 & 0.0029 & 1.6871 & 1826.569 & 1504.915 & 161.135 & 1904.624 & \text { Yes }\end{array}$ $\begin{array}{lllllllllllllllll}\text { AVYTQDCPLAAAK } & 0.72 & 51.62 & 27.99 & 64.62 & 2 & 1683.8596 & 1683.8568 & 842.9357 & 0.0028 & 1.6609 & 996.191 & 1055.021 & 143.567 & 964.600 & \text { Yes }\end{array}$ $\begin{array}{llllllllllllllll}\text { TITVALADGGRPDNTGR } & 1.00 & 41.13 & 27.24 & 22.45 & 3 & 1856.9968 & 1856.9826 & 620.0015 & 0.0142 & 7.6343 & 5322.697 & 7072.150 & 1740.760 & 5479.657 & \text { Yes }\end{array}$ $\begin{array}{llllllllllllllll}\text { TITVALADGGRPDNTGR } & 0.96 & 32.15 & 27.20 & 23.45 & 3 & 1856.9980 & 1856.9826 & 620.0015 & 0.0154 & 8.2795 & 3931.989 & 3904.556 & 1110.391 & 3359.977 & \text { Yes }\end{array}$

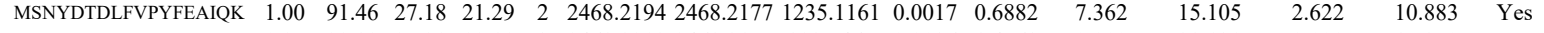

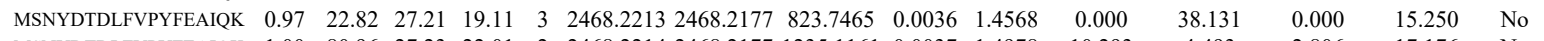

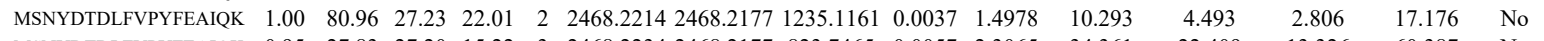
$\begin{array}{llllllllllllllll}\text { MSNYDTDLFVPYFEAIQK } & 0.95 & 27.83 & 27.20 & 15.22 & 3 & 2468.2234 & 2468.2177 & 823.7465 & 0.0057 & 2.3065 & 34.361 & 22.409 & 13.326 & 60.387 & \text { No }\end{array}$

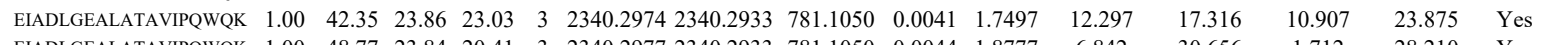

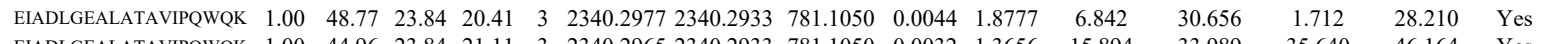

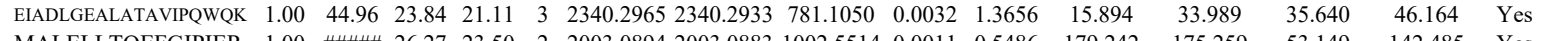

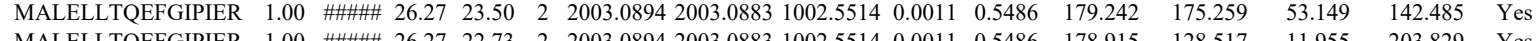
\begin{tabular}{llllllllllllll} 
MALELLTQEFGIPIER & 1.00 & 2003.829 & Yes \\
\hline
\end{tabular}

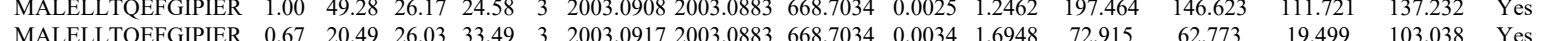

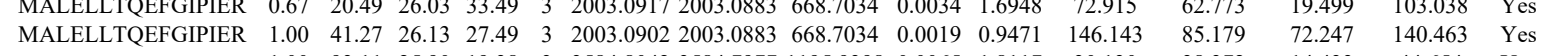

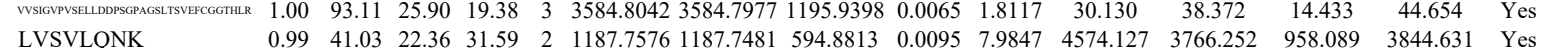


LVSVLQNK EADGILKPLPK GLEVTDDSPK GLEVTDDSPK ITCLCQVPQNAANR ITCLCQVPQNAANR
ITCLCQVPQNAANR ITCLCQVPQNAANR TCLCQVPQNAANR ITCLCQVPNAANR UCLELLTSR ITCLCQVPQNAANR ITCLCQVPQNAANR ITCLCQVPQNAANR GLEVTDDSPK

VGAEDADGIDMAY AEEIANEMIEAAK AVFDETYPDPVR

VPEILQLSDALR SYISFDILR LAFLMHSWK LAFLMHSWK

LLIDEAILK TTCLCQVPQNAANR

$\begin{array}{lllllllllllllll}0.99 & 41.13 & 22.36 & 31.60 & 2 & 1187.7580 & 1187.7481 & 594.8813 & 0.0099 & 8.3209 & 5483.993 & 4512.890 & 1050.723 & 4565.938 & \text { Yes }\end{array}$ $\begin{array}{lllllllllllllll}0.54 & 8.76 & 21.14 & 20.30 & 2 & 1467.8916 & 1467.8904 & 734.9525 & 0.0012 & 0.8164 & 12214.830 & 8487.213 & 0.000 & 59.814 & \text { No } \\ 1.00 & 47.46 & 28.54 & 30.03 & 2 & 1347.7166 & 1347.7126 & 674.8636 & 0.0040 & 2.9636 & 3615.476 & 3442580 & 2777.401 & 3526.163 & \text { Y }\end{array}$ \begin{tabular}{lllllllllllllll}
0.98 & 40.12 & 28.54 & 24.29 & 2 & 1347.7166 & 1347.7126 & 674.8636 & 0.0040 & 2.9636 & 3615.476 & 3442.580 & 2777.401 & 3526.163 & Yes \\
\hline
\end{tabular} $\begin{array}{lllllllllllllll}1.00 & 88.23 & 25.69 & 20.03 & 2 & 1765.8218 & 1765.8217 & 883.9181 & 0.0001 & 0.0566 & 311.695 & 270.657 & 65.845 & 231.969 & \text { Yes } \\ 1.00 & 0.25 & 25.82 & 21.85 & 2 & 1765.820 & 1765.8277 & 83.9181 & 0.0013 & 0.7354 & 674.154 & 528.772 & 128.92 & 600.782 & \text { Yes }\end{array}$ $\begin{array}{lllllllllllllll}1.00 & 90.28 & 25.82 & 21.85 & 2 & 1765.8230 & 1765.8217 & 883.9181 & 0.0013 & 0.7354 & 674.154 & 528.772 & 128.922 & 600.782 & \text { Yes }\end{array}$

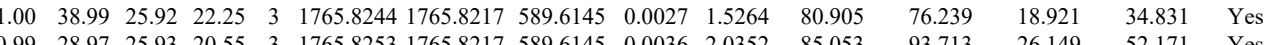

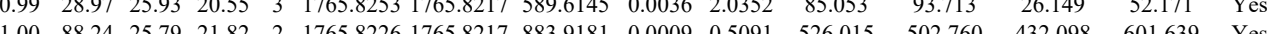

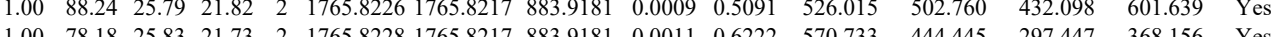

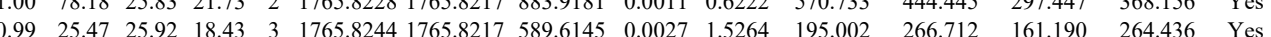

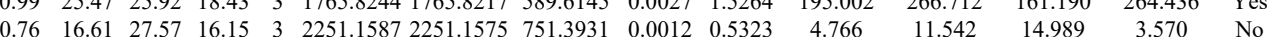

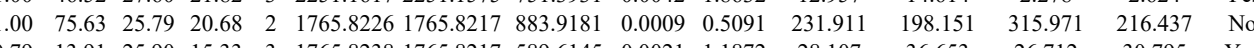
$\begin{array}{llllllllllllll}0.75 .91 & 25.90 & 15.33 & 3 & 1765.8238 & 1765.8217 & 589.6145 & 0.0021 & 1.1872 & 28.107 & 36.653 & 26.712 & 30.795 & \text { Yes }\end{array}$

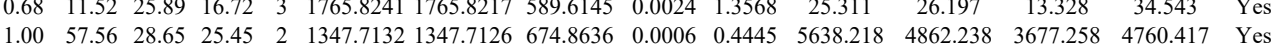

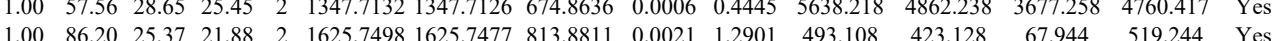

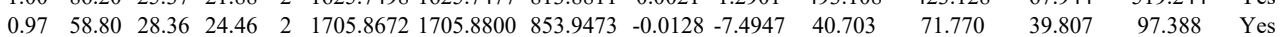
$\begin{array}{lllllllllllllll}1.00 & 52.12 & 24.98 & 21.77 & 2 & 1496.8696 & 1496.8684 & 749.4415 & 0.0012 & 0.8006 & 49.273 & 61.321 & 55.408 & 95.568 & \text { Yes }\end{array}$ $\begin{array}{lllllllllllllll}1.00 & 64.96 & 25.01 & 20.55 & 2 & 1496.8700 & 1496.8684 & 749.4415 & 0.0016 & 1.0675 & 32.741 & 39.014 & 65.045 & 51.482 & \text { Yes }\end{array}$

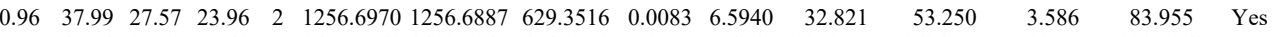
$\begin{array}{lllllllllllllll}1.00 & 43.04 & 27.33 & 20.42 & 3 & 1419.7963 & 1419.7940 & 474.2719 & 0.0023 & 1.6165 & 1939.203 & 1624.372 & 111.935 & 2283.263 & \text { Yes }\end{array}$ $\begin{array}{lllllllllllllllll}1.00 & 44.51 & 27.33 & 24.03 & 3 & 1419.7963 & 1419.7940 & 474.2719 & 0.0023 & 1.6165 & 2207.440 & 2435.455 & 194.845 & 3068.394 & \text { Yes } & \\ 1.00 & 62.58 & 19.14 & 37.97 & 2 & 1314.8392 & 1314.8366 & 658.4256 & 0.0026 & 1.9744 & 2808.212 & 2302.642 & 15.132 & 4765.661 & \text { Yes }\end{array}$

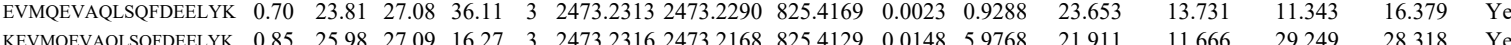

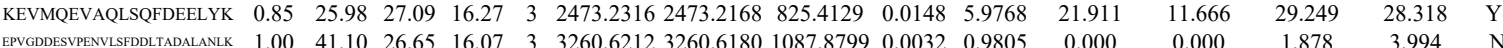
$\begin{array}{llllllllllllllll} & \end{array}$ $\begin{array}{llllllllllllll} & \end{array}$

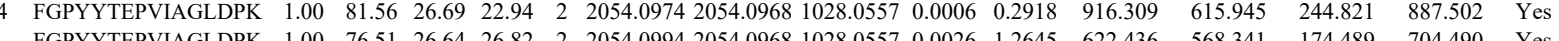
$\begin{array}{llllllllllllllll}\text { FGPYYTPVIAGLDPK } & 1.00 & 76.51 & 26.64 & 26.82 & 2 & 2054.0994 & 2054.0968 & 1028.0557 & 0.0026 & 1.2645 & 622.436 & 568.341 & 174.489 & 704.490 & \text { Yes }\end{array}$ \begin{tabular}{llllllllllllllll} 
FGPYYTEPVIAGLDPK & 0.99 & 28.57 & 26.70 & 17.77 & 3 & 2054.1001 & 2054.0968 & 685.7062 & 0.0033 & 1.6042 & 809.172 & 1090.235 & 91.534 & 2213.984 & Yes \\
\hline
\end{tabular} $\begin{array}{lllllllllllllll}195.117 & 4171.161 & \text { No }\end{array}$ $\begin{array}{llllllllllllll} & \end{array}$

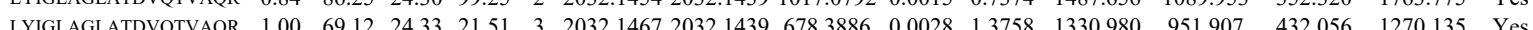

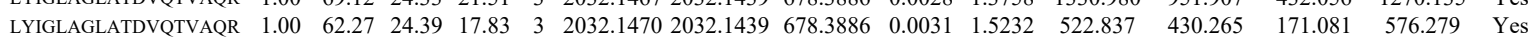

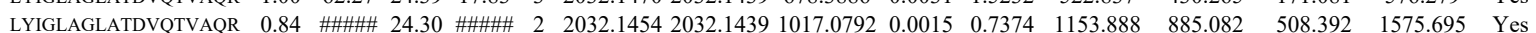

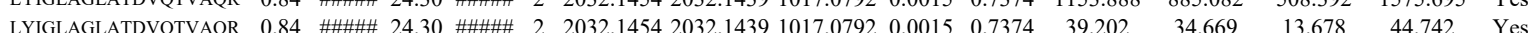

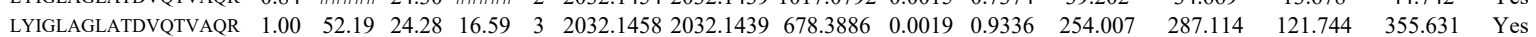
$\begin{array}{llllllllllllllll}\text { LYIGLAGLATDVQTVAQR } & 0.67 & 68.07 & 24.33 & 81.07 & 3 & 2032.1467 & 2032.1439 & 678.3886 & 0.0028 & 1.3758 & 750.610 & 864.098 & 402.504 & 1237.462 & \text { Yes }\end{array}$ $\begin{array}{llllllllllllllll}\text { LYIGLAGLATDVQTVAQR } & 1.00 & 58.49 & 24.33 & 18.85 & 3 & 2032.1464 & 2032.1439 & 678.3886 & 0.0025 & 1.2284 & 350.805 & 279.342 & 106.200 & 533.113 & \text { Yes }\end{array}$ $\begin{array}{llllllllllllllllll}\text { LYIGLAGLATDVQTVAOR } & 0.60 & 43.86 & 24.30 & 56.86 & 3 & 2032.1476 & 2032.1439 & 678.3886 & 0.0037 & 1.8180 & 471.095 & 329.195 & 148.589 & 568.813 & \text { Yes }\end{array}$ $\begin{array}{llllllllllllllll}\text { LYIGLAGLATDVQTVAQR } & 1.00 & 38.36 & 24.39 & 17.30 & 3 & 2032.1470 & 2032.1439 & 678.3886 & 0.0031 & 1.5232 & 13.332 & 19.225 & 7.777 & 21.223 & \text { No }\end{array}$

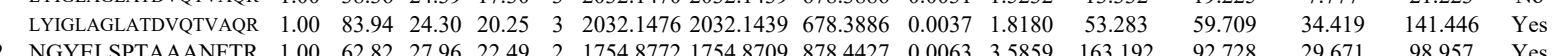

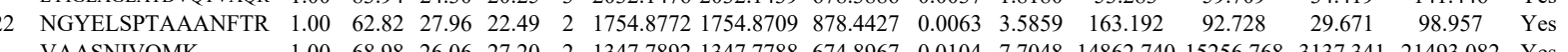
$\begin{array}{llllllllllllllll}\text { VAASNIVQMK } & 1.00 & 68.98 & 26.06 & 27.20 & 2 & 1347.7892 & 1347.7788 & 674.8967 & 0.0104 & 7.7048 & 14862.740 & 15256.768 & 3137.341 & 21493.082 & \text { Yes }\end{array}$ $\begin{array}{llllllllllllllll}\text { VAASNIVQMK } & 1.00 & 68.87 & 26.11 & 27.29 & 2 & 1347.7896 & 1347.7788 & 674.8967 & 0.0108 & 8.0012 & 7924.940 & 7676.705 & 3172.055 & 12869.841 & \text { Yes }\end{array}$ $\begin{array}{lllllllllllllllll}\text { VAASNIVQMK } & 1.00 & 61.85 & 26.67 & 26.93 & 2 & 1347.7868 & 1347.7788 & 674.8967 & 0.0080 & 5.9268 & 11222.652 & 8478.425 & 1831.026 & 12587.792 & \text { Yes }\end{array}$ FILNLPTFSVR FILNLPTFSVR FILNLPTFSVR FILNLPTFSVR FILNLPTFSVR FILNLPTFSVR FILNLPTFSVR FILNLPTFSVR FILNLPTFSVR FILNLPTFSVR FILNLPTFSVR FILNLPTFSVR (1)

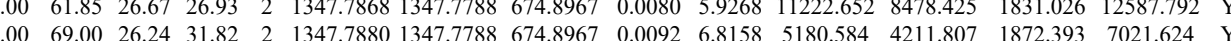
$\begin{array}{lllllllllllllll}1.00 & 53.02 & 25.00 & 42.33 & 2 & 1449.8484 & 1449.8466 & 725.9306 & 0.0018 & 1.2398 & 644.433 & 610.759 & 39.603 & 1002.424 & \text { Yes }\end{array}$

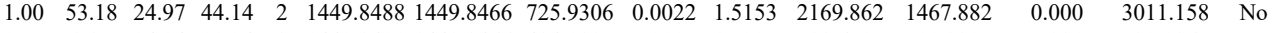
\begin{tabular}{lllllllllllllll}
0.55 & 8.25 & 24.94 & 19.24 & 3 & 1449.8491 & 1449.8466 & 484.2895 & 0.0025 & 1.7207 & 18.659 & 10.339 & 7.931 & 30.136 & Yes \\
\hline
\end{tabular}

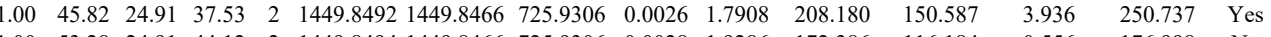

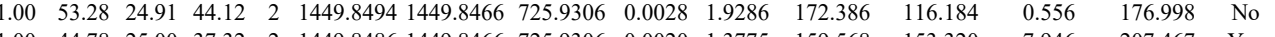
$\begin{array}{lllllllllllllll}1.00 & 44.78 & 25.00 & 37.32 & 2 & 1449.8486 & 1449.8466 & 725.9306 & 0.0020 & 1.3775 & 159.568 & 153.320 & 7.946 & 207.467 & \text { Yes }\end{array}$

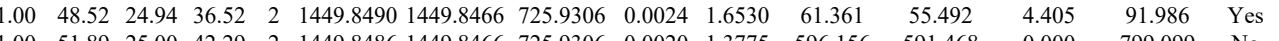

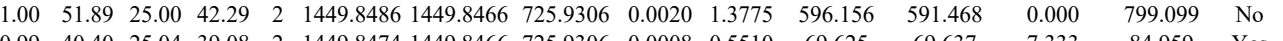
$\begin{array}{lllllllllllllll}0.99 & 40.40 & 25.04 & 39.08 & 2 & 1449.8474 & 1449.8466 & 725.9306 & 0.0008 & 0.5510 & 69.625 & 69.637 & 7.333 & 84.959 & \text { Yes } \\ 1.00 & 48.97 & 25.08 & 41.40 & 2 & 1449.8478 & 1449.8466 & 725.9306 & 0.0012 & 0.8265 & 63.318 & 101.176 & 14.234 & 127.109 & \text { No }\end{array}$

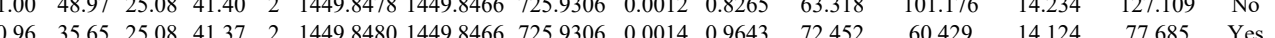
$\begin{array}{lllllllllllllll}0.96 & 35.65 & 25.08 & 41.37 & 2 & 1449.8480 & 1449.8466 & 725.9306 & 0.0014 & 0.9643 & 72.452 & 60.429 & 14.124 & 77.685 & \text { Yes } \\ 0.94 & 28.87 & 25.08 & 36.05 & 2 & 1449.8480 & 1449.8466 & 725.9306 & 0.0014 & 0.9643 & 37.261 & 48.624 & 11.586 & 70.097 & \text { Yes }\end{array}$

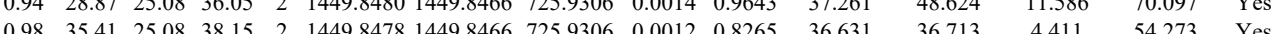

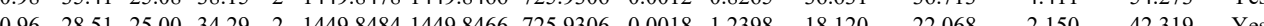
$\begin{array}{llllllllllll}0.97 & 30.85 & 25.00 & 35.94 & 2 & 1449.8484 & 1449.8466 & 725.9306 & 0.0018 & 1.2398 & 62.579 & 34.982\end{array}$

S 4 page 332 of 614 


\section{AGIVTSLQAR}

AGIVTSLQAR

AGIVTSLQAR

AGIVTSLQAR

AGIVTSLQAR

FDILCVVR

FDILCVVR

FDILCVVR

VAVGELTDEDVK

VAVGELTDEDVK

VAVGELTDEDVK

GVCLIDEFDK

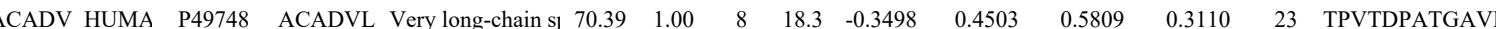

\section{TPVTDPATGAVK}

GFGGITHGPPEK

GFGGITHGPPEK

GQLTTDQVFPYPSVLNEEQTQFLK

NPFGNAGLLLGEAGK

AGLGSGLSLSGLVHPELSR

VAMHILNNGR

VAMHILNNGR

VAMHILNNGR

FGMAAALAGTMR

FGMAAALAGTMR

FGMAAALAGTMR

FGMAAALAGTMR

FGMAAALAGTMR

FGMAAALAGTMR

FGMAAALAGTMR

FGMAAALAGTMR

FGMAAALAGTMR

FGMAAALAGTMR

NDALEMVEETTWQGLK

NDALEMVEETTWQG

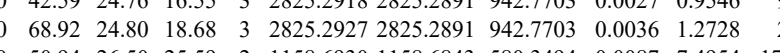
$\begin{array}{lllllllllllllll}100 & 56.42 & 26.48 & 24.51 & 2 & 11586938 & 1158.6843 & 580.3494 & 0.0095 & 8.1847 & 6084.256 & 6278.368\end{array}$ $\begin{array}{llllllllllllll}1.00 & 53.81 & 26.47 & 25.12 & 2 & 1158.6946 & 1158.6843 & 580.3494 & 0.0103 & 8.8739 & 10971.033 & 11512.088\end{array}$ $\begin{array}{lllllllllllllll}1.00 & 51.32 & 26.47 & 24.43 & 2 & 1158.6942 & 1158.6843 & 580.3494 & 0.0099 & 8.5293 & 1355.813 & 1396.317\end{array}$ $\begin{array}{lllllllllllll}1.00 & 57.65 & 26.47 & 27.14 & 2 & 1158.6942 & 1158.6843 & 580.3494 & 0.0099 & 8.5293 & 1983.431 & 1746.945 & 561.0\end{array}$ $\begin{array}{llllllllllll}0.99 & 35.46 & 27.99 & 26.71 & 2 & 1153.6122 & 1153.6110 & 577.8128 & 0.0012 & 1.0384 & 3575.387 & 3644.344 \\ 0\end{array}$ $\begin{array}{llllllllllll}1.00 & 39.73 & 27.99 & 27.05 & 2 & 1153.6124 & 1153.6110 & 577.8128 & 0.0014 & 1.2115 & 3462.811 & 3979.986 \\ 0.96 & 28.29 & 23.67 & 15.89 & 3 & 1277.7787 & 1277.7690 & 426.9303 & 0.0097 & 7.5734 & 1389.235 & 1420.299\end{array}$ $\begin{array}{llllllllllll}1.00 & 66.33 & 26.48 & 26.10 & 3 & 2154.1579 & 2154.1555 & 719.0591 & 0.0024 & 1.1126 & 34.991 & 19.796\end{array}$ $\begin{array}{lllllllllllll}1.00 & 79.50 & 27.38 & 46.12 & 2 & 1561.8462 & 1561.8443 & 781.9294 & 0.0019 & 1.2149 & 96.576 & 114.739\end{array}$ $\begin{array}{llllllllllll}0.99 & 49.10 & 27.60 & 44.23 & 2 & 1561.8472 & 1561.8443 & 781.9294 & 0.0029 & 1.8544 & 78.528 & 125.035\end{array}$ $\begin{array}{llllllllllll}0.95 & 29.08 & 27.39 & 36.16 & 2 & 1561.8460 & 1561.8443 & 781.9294 & 0.0017 & 1.0871 & 1307.001 & 1445.783\end{array}$ $\begin{array}{llllllllllll}.00 & 42.38 & 27.93 & 22.30 & 2 & 1471.7318 & 1471.7295 & 736.8720 & 0.0023 & 1.5606 & 224.699 & 270.006\end{array}$ $\begin{array}{lllllllllllll}1.00 & 64.53 & 26.54 & 25.47 & 2 & 1443.8274 & 1443.8177 & 722.9161 & 0.0097 & 6.7089 & 4533.419 & 3363.429 & 2\end{array}$ $\begin{array}{llllllllllllll}1.00 & 64.79 & 26.52 & 24.24 & 2 & 1443.8282 & 1443.8177 & 722.9161 & 0.0105 & 7.2622 & 4225.393 & 3365.288 & 2 \\ 1.00 & 39.21 & 27.34 & 28.47 & 3 & 1483.8082 & 1483.8027 & 495.6082 & 0.0055 & 3.6991 & 18509.645 & 13640.890 & 7236 .\end{array}$ $\begin{array}{lllllllllllllllll}0.99 & 35.65 & 27.36 & 28.14 & 3 & 1483.8085 & 1483.8027 & 495.6082 & 0.0058 & 3.9009 & 14910.391 & 9653.658 & 6436.126 & 10292.018 & \text { Ye }\end{array}$ TPVTDPATGAVK

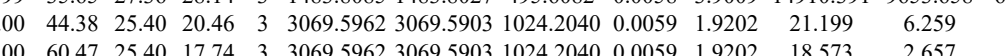

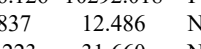
TPVTDPATAVK

$\begin{array}{lllllllllll}\text { TMEDA_HUMA } & \text { P49755 } & \text { TMED10 } & \text { Transmembrane el 24.976 } & 1.00 & 2 & 12.3 & -0.3872 & 0.4201 & 0.0524 & 0.6218\end{array}$

LEDLSESIVNDFAYMK

LEDLSESIVNDFAYMK

LEDLSESIVNDFA

IPDQLVILDMK

IPDQLVILDMK

IPDQLVILDMK

IPDQLVILDMK

IPDQLVILDMK

IPDQLVILDMK

$\begin{array}{lllllllllll}\text { RBM25 HUMAl P49756 } & \text { RBM25 } & \text { RNA-binding prot 100.19 } & 1.00 & 5 & 8.5 & -0.1116 & 0.4876 & -0.5594 & 0.6071\end{array}$

$\begin{array}{llllllllllllll}6.47 & 25.40 & 17.74 & 3 & 3069.5962 & 3069.5903 & 1024.2040 & 0.0059 & 1.9202 & 18.573 & 2.657 & 16.223 & 31.660 & \text { No }\end{array}$

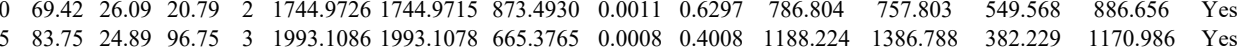
$\begin{array}{lllllllllllllll}98.89 & 24.89 & 24.08 & 3 & 1993.1089 & 1993.1078 & 665.3765 & 0.0011 & 0.5511 & 1373.420 & 1122.779 & 531.071 & 1298.959 & \text { Yes } \\ \end{array}$ $\begin{array}{lllllllllllllllll}1.00 & 36.74 & 27.75 & 30.84 & 3 & 1267.6975 & 1267.6941 & 423.5720 & 0.0034 & 2.6756 & 5114.594 & 4750.041 & 1469.817 & 7366.774 & \text { Yes }\end{array}$ $\begin{array}{llllllllllllll} & 1267.6993 & 1267.6941 & 423.5720 & 0.0052 & 4.0922 & 4161.756 & 4465.673 & 1461.727 & 6205.375 & \text { Yes }\end{array}$

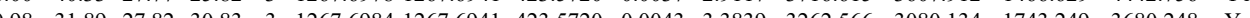
$\begin{array}{lllllllllllllll}1.00 & 64.04 & 27.67 & 28.07 & 2 & 1339.6860 & 1339.6862 & 670.8504 & 0.0002 & -0.1491 & 3042.881 & 1973322 & 264.265 & 2341.164 & \text { Yes }\end{array}$

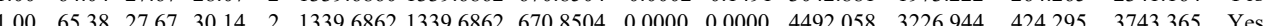
$\begin{array}{lllllllllllllll}0.85 & 21.86 & 27.61 & 17.87 & 2 & 1339.6880 & 1339.6862 & 670.8504 & 0.0018 & 1.3416 & 19.222 & 25.354 & 4.376 & 20.547 & \text { Yes }\end{array}$

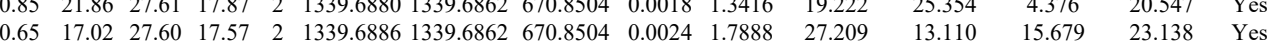

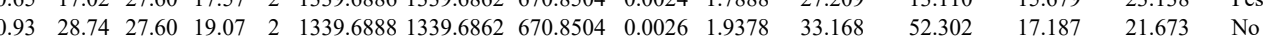

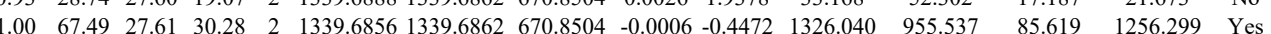
$\begin{array}{lllllllllllllll}1.00 & 67.72 & 27.67 & 30.09 & 2 & 1339.6860 & 1339.6862 & 670.8504 & -0.0002 & -0.1491 & 2442.311 & 1801.159 & 219.707 & 2080.145 & \text { Yes }\end{array}$

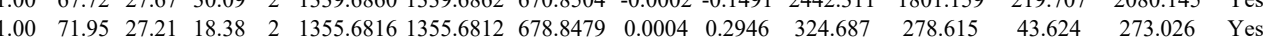
$\begin{array}{lllllllllllllll}1.00 & 82.46 * 27.38 & 21.80 & 2 & 1355.6820 & 1355.6812 & 678.8479 & 0.0008 & 0.5892 & 505.831 & 313.620 & 58.608 & 342.244 & \text { Yes }\end{array}$

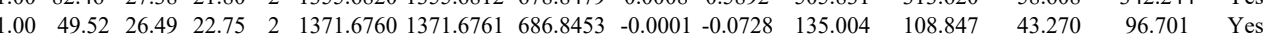

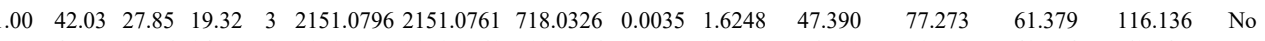

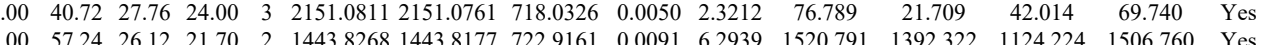

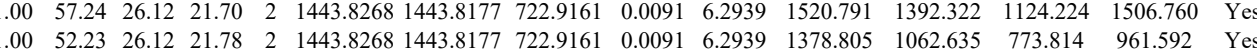
DREEDEEDAYER $\begin{array}{lllll}-1 & 0 \\ 0\end{array}$ $\begin{array}{llll}9.840 & 51.427 & \text { Yes }\end{array}$ \begin{tabular}{llllllllllll} 
& 21.81 .0894 & 2161.0856 & 1081.5501 & 0.0038 & 1.7567 & 110.201 & 97.315 & 15.298 & 62.686 & Yes \\
\hline
\end{tabular}

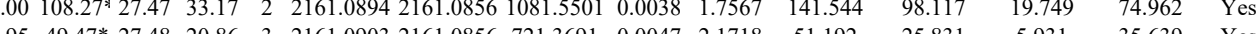

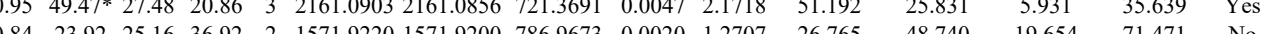

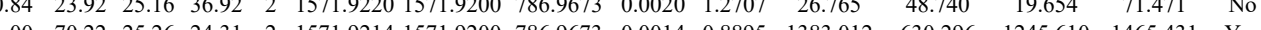
$\begin{array}{llllllllllllllll}1.00 & 0.22 & 25.26 & 24.31 & 2 & 1571.9214 & 1571.9200 & 786.9673 & 0.0014 & 0.8895 & 1383.012 & 630.296 & 1245.610 & 1465.431 & \text { Yes } \\ \end{array}$ $\begin{array}{lllllllllllllll}1.00 & 75.73 & 25.16 & 23.34 & 2 & 1571.9220 & 1571.9200 & 786.9673 & 0.0020 & 1.2707 & 2582.508 & 2106.529 & 3380.006 & 2907.187 & \text { Yes } \\ \end{array}$ $\begin{array}{lllllllllllllll}1.00 & 45.24 & 25.16 & 19.27 & 3 & 1571.9221 & 1571.9200 & 524.9806 & 0.0021 & 1.3334 & 136.149 & 145.164 & 147.831 & 261.391 & \text { Yes } \\ 1.00 & 37.93 & 25.09 & 17.73 & 3 & 1571.9233 & 1571.9200 & 524.9806 & 0.0033 & 2.0953 & 140.648 & 116.912 & 125.358 & 130.414 & \text { Yes }\end{array}$ $\begin{array}{lllllllllllllll}1.00 & 37.93 & 25.09 & 17.73 & 3 & 1571.9233 & 1571.9200 & 524.9806 & 0.0033 & 2.0953 & 140.648 & 116.912 & 125.358 & 130.414 & \text { Yes } \\ & & \end{array}$

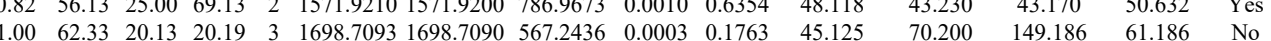

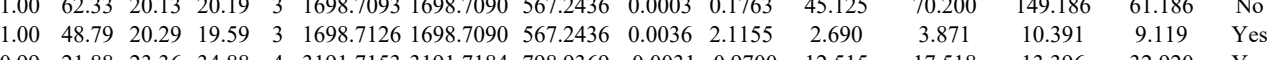
$\begin{array}{llllllllllllllll}\text { EFLEDYDDDRDDPK } & 0.68 & 28.38 & 25.79 & 17.55 & 3 & 2058.9301 & 2058.9262 & 687.3160 & 0.0039 & 1.8914 & 416.490 & 371.138 & 253.633 & 706.967 & \text { Yes }\end{array}$ 
$\begin{array}{lllllllllllllll}0.83 & 11.91 & 22.99 & 17.20 & 3 & 1213.7557 & 1213.7539 & 405.5919 & 0.0018 & 1.4893 & 18362.263 & 20140.018 & 11918.860 & 24901.773 & \text { Ycs }\end{array}$

PPVAPLIPYPLITK

$\begin{array}{llllllllllll}0.74 & 9.82 & 22.99 & 15.74 & 3 & 1213.7560 & 1213.7539 & 405.5919 & 0.0018 & 1.4793 & 18362.263 & 20.80 \\ 0.66 & 29.78 & 16.33 & 42.78 & 3 & 1856.1439 & 9991.969 & 10827\end{array}$ $\begin{array}{llllllllllll}0.66 & 29.78 & 16.33 & 42.78 & 3 & 1856.1439 & 1856.1419 & 619.7212 & 0.0020 & 1.0758 & 42.269\end{array}$

\section{SDESDQQESLHK}

$\begin{array}{llllllllllll}0.67 & 4.22 & 15.91 & 17.22 & 3 & 1856.1448 & 1856.1419 & 619.7212 & 0.0029 & 1.5598 & 44.331 \\ 1.00 & 36.54 & 25.92 & 19.68 & 3 & 1689.8053 & 1689.8049 & 564.2756 & 0.0004 & 0.2363 & 25.757\end{array}$

$\begin{array}{lllllllllllll}\text { FVAPEEVLPFTEGDILEK } & 1.00 & 46.40 & 26.15 & 26.47 & 3 & 2320.2466 & 2320.2446 & 774.4221 & 0.0020 & 0.8609 & 13.693\end{array}$

$\begin{array}{lllllllllllll}\text { FVAPEEVLPFTEGDILEK } & 1.00 & 45.65 & 26.11 & 17.41 & 3 & 2320.2487 & 2320.2446 & 774.4221 & 0.0041 & 1.7648 & 6.596 & 31\end{array}$

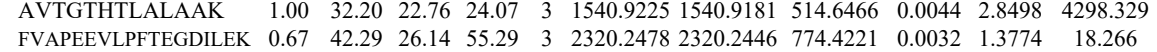

FVAPEEVLPFTEGDIL

VELVTGEEDEK

$\begin{array}{lllllllllll}0.67 & 42.29 & 26.14 & 55.29 & 3 & 2320.2478 & 2320.2446 & 774.4221 & 0.0032 & 1.3774 & 18.266 \\ 0.99 & 26.82 & 26.18 & 24.55 & 3 & 2320.2481 & 2320.2446 & 774.4221 & 0.0035 & 1.5065 & 17.137 \\ 1.00 & 51.22 & 28.38 & 28.52 & 2 & 1534.7986 & 1534.7970 & 768.4058 & 0.0016 & 1.0411 & 52.434\end{array}$

$\begin{array}{lllllllllll}1.00 & 51.22 & 28.38 & 28.52 & 2 & 1534.7986 & 1534.7970 & 768.4058 & 0.0016 & 1.0411 & 52.434\end{array}$

$\begin{array}{llllllllllll}\text { FLGLLYELEENTDK } & 1.00 & 50.64 & 27.08 & 24.82 & 3 & 1971.0481 & 1971.0444 & 658.0221 & 0.0037 & 1.8743 & 132.031\end{array}$

ATNTDLLLAYANLMLLTLSTR

TPELAEEFK

TPELAEEFK

36 SGNIVAGIANESK

VICAEEPYICK

VICAEEPYICK $\begin{array}{lllllllllll}0 & 5.12 & 23.96 & 21.20 & 3 & 2451.3544 & 2451.3528 & 818.1249 & 0.0016 & 0.6519 \\ 1.00 & 59.72 & 23.93 & 16.78 & 3 & 2451.3553 & 2451.3528 & 818.1249 & 0.0025 & 1.0186\end{array}$ $\begin{array}{lllllllllllll}0.9 & 39.02 & 29.10 & 32.48 & 2 & 1350.7290 & 1350.7274 & 676.3710 & 0.0016 & 1.1828 & 682.296 & \end{array}$ $\begin{array}{llllllllllll}0.99 & 39.38 & 29.08 & 32.66 & 2 & 1350.7296 & 1350.7274 & 676.3710 & 0.0022 & 1.6263 & 740.317 & 72\end{array}$ $\begin{array}{lllllllllllll}1.00 & 72.46 & 26.81 & 29.68 & 2 & 1546.8706 & 1546.8558 & 774.4352 & 0.0148 & 9.5553 & 1496.361 & 728\end{array}$ $\begin{array}{lllllllllllll}0.89 & 27.26 & 26.84 & 26.12 & 2 & 1646.7780 & 1646.7784 & 824.3965 & -0.0004 & -0.2426 & 319.608 \\ 0.92 & 24.25 & 26.83 & 21.80 & 2 & 1646.7808 & 1646.7784 & 824.3965 & 0.0024 & 1.4556 & 548.526\end{array}$ $\begin{array}{llllllllllll}0.92 & 24.25 & 26.83 & 21.80 & 2 & 1646.7808 & 1646.7784 & 824.3965 & 0.0024 & 1.4556 & 548.526 \\ 0.66 & 22.63 & 24.10 & 35.63 & 3 & 3063.6472 & 3063.6446 & 1022.2221 & 0.0026 & 0.8478 & 5.723\end{array}$

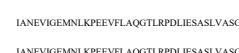

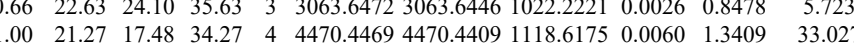
$\begin{array}{lllllllllll}1.00 & 21.27 & 17.48 & 34.27 & 4 & 4470.4469 & 4470.4409 & 1118.6175 & 0.0060 & 1.3409 & 33.027 \\ 0.98 & 5.79 & 17.48 & 18.79 & 4 & 4470.4469 & 4470.4409 & 1118.6175 & 0.0060 & 1.3409 & 70.566\end{array}$

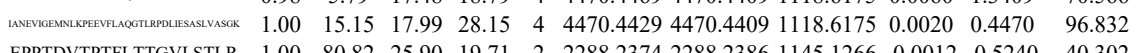

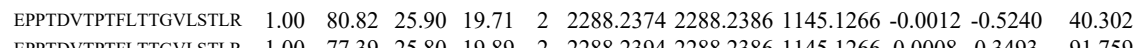
$\begin{array}{lllllllllllll}\text { EPPTDVTPTFLTTGVLSTLR } & 1.00 & 77.39 & 25.80 & 19.89 & 2 & 2288.2394 & 2288.2386 & 1145.1266 & 0.0008 & 0.3493 & 91.759\end{array}$ $\begin{array}{llllllllllllll}\text { EPTDVPTLTTGLSTLR } & 1.00 & 7.16 & 25.90 & 19.64 & 2 & 2288.2374 & 2288.2386 & 1145.1266 & 0.0012 & -0.5240 & 82.702\end{array}$

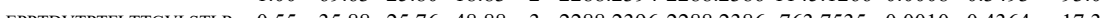

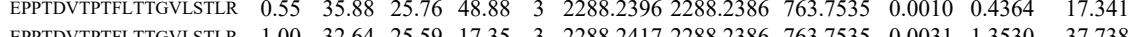

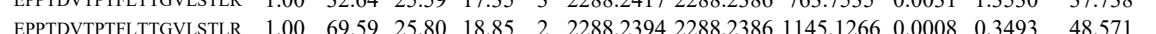
$\begin{array}{llllllllllll}\text { EPPTDVTPTFLTTGVISTLR } & 0.66 & 33.25 & 25.56 & 46.25 & 3 & 2288.2411 & 2288.2386 & 763.7535 & 0.0025 & 1.0911 & 116.910\end{array}$ $\begin{array}{llllllllllll}\text { EPPTDVTTELTTGVLSTLR } & 0.60 & 43.95 & 25.59 & 56.95 & 3 & 2288.2423 & 2288.2386 & 763.7535 & 0.0037 & 1.6148 & 43.416\end{array}$ 
$\begin{array}{lllllllllllllll} & \end{array}$ $\begin{array}{llllllllllllllll}1.00 & 55.40 & 28.19 & 40.52 & 2 & 1316.7340 & 1316.7220 & 659.3683 & 0.0120 & 9.0995 & 5236.226 & 5064.816 & 2685.527 & 6873.305 & \text { Yes } \\ 0.99 & 52.93 & 27.99 & 42.51 & 2 & 1316.7350 & 1316.7220 & 659.3683 & 0.0130 & 9.8578 & 7094.093 & 6022.522 & 3337.969 & 9063.527 & \text { Yes }\end{array}$ $\begin{array}{llllllllllllllllll}\text { IPGSPPESMGR } & 0.99 & 40.78 & 27.23 & 31.44 & 2 & 1270.6566 & 1270.6461 & 636.3303 & 0.0105 & 8.2504 & 5046.736 & 3698.348 & 8473.081 & 10614.220 & \text { Yes }\end{array}$ $\begin{array}{lllllllllllllllll}\text { QLICDPSYVK } & 0.99 & 37.06 & 27.72 & 15.90 & 2 & 1498.7778 & 1498.7767 & 750.3956 & 0.0011 & 0.7329 & 1696.264 & 1448.146 & 1043.857 & 2258.821 & \text { Yes }\end{array}$ $\begin{array}{llllllllllllllll}\text { QLICDPSYVK } & 0.79 & 27.64 & 27.75 & 27.63 & 2 & 1498.7882 & 1498.7767 & 750.3956 & 0.0115 & 7.6626 & 2506.715 & 2037.635 & 446.766 & 2901.114 & \text { Yes }\end{array}$

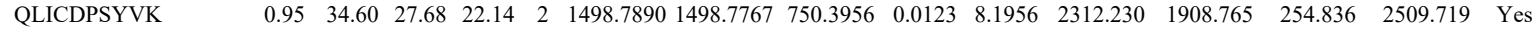
$\begin{array}{llllllllllllllll}\text { QLICDPSYVK } & 0.97 & 37.42 & 27.76 & 24.48 & 2 & 1498.7888 & 1498.7767 & 750.3956 & 0.0121 & 8.0623 & 1214.568 & 1191.810 & 241.852 & 1520.941 & \text { Yes }\end{array}$ $\begin{array}{llllllllllllllll}\text { VPSTEAEALASSLMGLFEK } & 0.82 & 76.91 & 27.35 & 89.91 & 2 & 2267.1974 & 2267.1962 & 1134.6054 & 0.0012 & 0.5288 & 42.772 & 18.602 & 78.904 & 72.972 & \text { No }\end{array}$

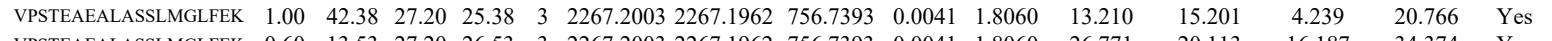

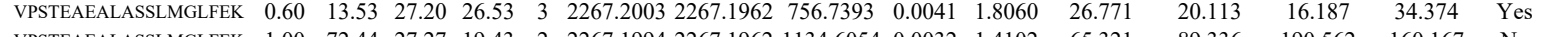

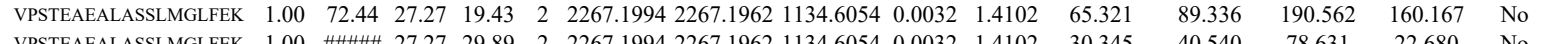

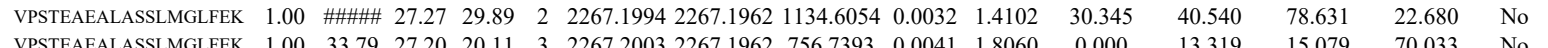

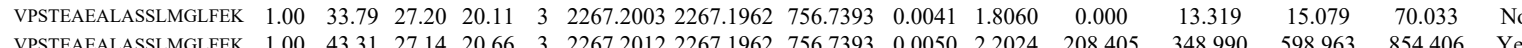
$\begin{array}{llllllllllllllll}\text { VPSTEAEALASSLMGLFEK } & 1.00 & 43.31 & 27.14 & 20.66 & 3 & 2267.2012 & 2267.1962 & 756.7393 & 0.0050 & 2.2024 & 208.405 & 348.990 & 598.963 & 854.406 & \text { Yes } \\ \text { VPSTEAEALASSLMGLFEK } & 1.00 & 41.02 & 27.28 & 26.16 & 3 & 2267.1991 & 2267.1962 & 756.7393 & 0.0029 & 1.2774 & 0.000 & 16.745 & 10.758 & 4.924 & \text { No }\end{array}$

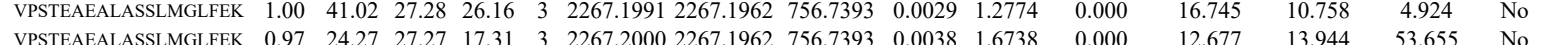

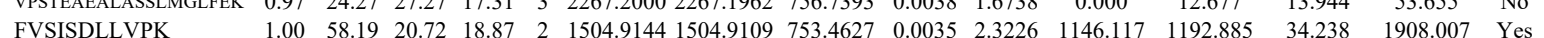

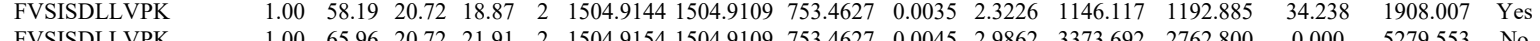

FVSISDLLVPK

FVSISDLLVPK

FVSISDLVYPK

FVSISDLLVPK

FVSISDLLVPK

FVSISDLLVPK

FVSISDLLVPK

VICILSHPIK

VICILSHPIK

VICILSHPIK

VICILSHPIK

VICILSHPIK

VICILSHPIK

VICILSHPIK

VICILSHPIK

TFEGIDPK

TFEGIDPK

MTGSEFDFEEMK

$\begin{array}{lllllllllllll}1.00 & 65.96 & 20.72 & 21.91 & 2 & 1504.9154 & 1504.9109 & 753.4627 & 0.0045 & 2.9862 & 3373.692 & 2762.800\end{array}$

$\begin{array}{lllllllllllll}1.00 & 45.99 & 21.61 & 18.60 & 2 & 1504.9118 & 15049109 & 753.4627 & 0.0009 & 0.5972 & 260.297 & 350.203\end{array}$

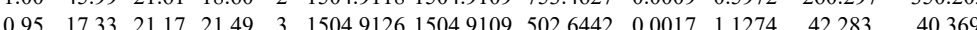
$\begin{array}{lllllllllllll}1.00 & 56.09 & 21.17 & 20.00 & 2 & 1504.9126 & 1504.9109 & 753.4627 & 0.0017 & 1.1281 & 928.510 & 669.697\end{array}$

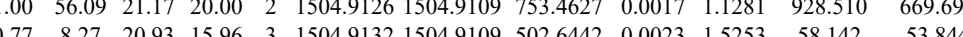
$\begin{array}{llllllllllll}1.00 & 49.72 & 20.93 & 22.68 & 2 & 1504.9136 & 1504.9109 & 753.4627 & 0.0027 & 1.79253 & 58.142 & 53.844 \\ 138.500 & 348.482\end{array}$

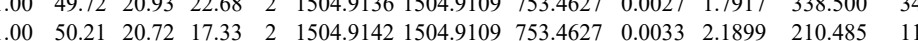
$\begin{array}{lllllllllllllll}0.21 & 20.72 & 17.33 & 2 & 1504.9142 & 1504.9109 & 753.4627 & 0.0033 & 2.1899 & 210.485 & 110.730 & 62.026 & 273.154 & \text { Yes } \\ 0.99 & 36.57 & 23.86 & 19.28 & 3 & 1455.8641 & 1455.8549 & 4862922 & 0.0092 & 6.3062 & 9172.810 & 6268.451 & 624.552 & 1350.226 & \text { Yes }\end{array}$ $\begin{array}{llllllllllllllll} & \end{array}$ $\begin{array}{lllllllllllllll}1.00 & 53.59 & 24.49 & 21.84 & 2 & 1455.8572 & 1455.8549 & 728.9347 & 0.0023 & 1.5776 & 755.614 & 696.497 & 10.216 & 1414.652 & \text { Yes }\end{array}$

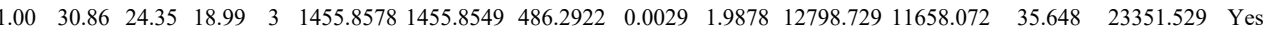

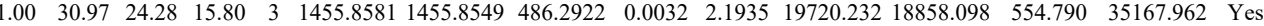
$\begin{array}{lllllllllllllll}1.00 & 45.52 & 23.98 & 19.75 & 2 & 1455.8588 & 1455.8549 & 728.9347 & 0.0039 & 2.6751 & 735.900 & 650.909 & 0.000 & 1119.795 & \text { No }\end{array}$ $\begin{array}{lllllllllllllll}0.99 & 33.76 & 24.97 & 31.20 & 3 & 1455.8557 & 1455.8549 & 486.2922 & 0.0008 & 0.5484 & 11255.789 & 9555.920 & 281.894 & 16541.915 & \text { Yes }\end{array}$ $\begin{array}{lllllllllllllll}1.00 & 29.53 & 24.23 & 16.15 & 3 & 1455.8584 & 1455.8549 & 486.2922 & 0.0035 & 2.3991 & 10854.866 & 10086.507 & 615.924 & 17903.595 & \text { Yes }\end{array}$ $\begin{array}{lllllllllllllll}0.92 & 39.42 & 28.54 & 47.99 & 2 & 1193.6550 & 1193.6536 & 597.8341 & 0.0014 & 1.1709 & 4543.611 & 3137.418 & 480.389 & 6875.931 & \text { Yes }\end{array}$ $\begin{array}{lllllllllllll}\text { MTGSEFDFEEMK } & 1.00 & 56.07 & 24.68 & 16.79 & 2 & 1737.7854 & 1737.7833 & 869.8989 & 0.0021 & 1.2070 & 1670.908 & 1802.254 \\ \text { MTGSEFDFEEMK } & 1.00 & 57.23 & 24.68 & 16.61 & 2 & 1737.7856 & 1737.7833 & 869.8989 & 0.0023 & 1.3220 & 1227.881 & 972.577\end{array}$ $\begin{array}{llllllllllllll} & 2034.8794 & 2034.8785 & 1018.4465 & 0.0009 & 0.4418 & 38.447 & 39.453 & 5.3\end{array}$ TYDATTHFETTCDDIK 0. 
CVDLVIQELINTVR

CVLVIQELINTVR

CVDLVIQELINTVR

CVDLVIQELINTVR

CVDLVIQELINTVR

CVDLVIQELINTVR

FFLSHPAYR

FFLSHPAYR

RPLILQLIFSK

RPLILQLIFSK

RPLILQLIFSK

RPLILQLIFSK

RPLILQLIFSK

RPLILQLIFSK

RPLILQLIFSK

$\begin{array}{lllllllllll}\text { AMPM2_HUMA } & \text { P50579 } & \text { METAP2 } & \text { Methionine amino } 52.892 & 1.00 & 4 & 12.1 & 0.3982 & 0.5419 & 0.3243 & 0.6278\end{array}$

\section{DEDDEDGDGDGDGA}

DEDDEDGDGDGDGATGK DEDDEDGDGDGDGATGK NFDVGHVPIR

ALDQASEEIWNDFR ALDQASEEIWNDFR ALDQASEEIWNDFR ALDQASEEIWNDF

SPPYQLDSQGR

AGAAGTAEATAR

$\begin{array}{lllllllllll}\text { BCAM_hUMAN } & \text { P50895 } & \text { BCAM } & \text { Basal cell adhesio } 67.405 & 1.00 & 2 & 3.7 & 0.3306 & 0.2516 & -0.6431 & 0.1857\end{array}$

$\begin{array}{lllllllllllll}\text { RL14_HUMAN } & \text { P50914 } & \text { RPL14 } & \text { 60S ribosomal pro 23.432 } & 1.00 & 5 & 23.7 & 0.2352 & 0.2550 & 2.9129 & 0.4176 & 20 & \text { ITAASK }\end{array}$

ITAASK

ALVDGPCTQVR

ALVDGPCTQVR

LVAIVDVIDQNR

ALVDGPCTQVR

ALVDGPCTQVR

LVAIVDVIDQNR

LVAIVDVIDQNR

ALVDGPCTQVR

ALVDGPCTQVR

LVAIVDVIDQNR

LVAIVDVIDQNR

VAYVSFGPHAGK

VAYVSFGPHAGK

VAYVSFGPHAGK

VAYVSFGPHAGK

CMQLTDFILK

CMQLTDFILK

CMQLTDFILK

CMQLTDFILK

CMLIDFLK

CMQLTDFILK

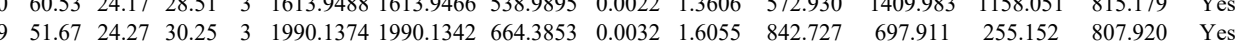
$\begin{array}{lllllllllllllll}09 & 56.41 & 24.36 & 35.75 & 3 & 1990.1383 & 1990.1342 & 664.3853 & 0.0041 & 2.0570 & 709.843 & 625.483 & 295.161 & 611.149 & \text { Yes }\end{array}$

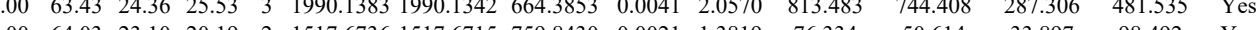

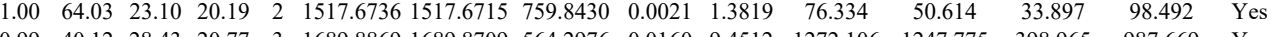

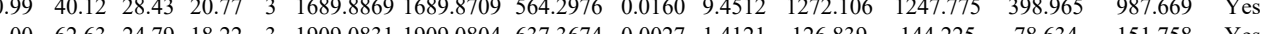

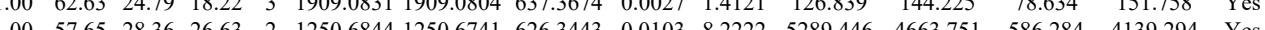

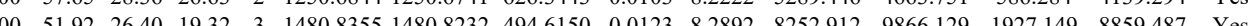

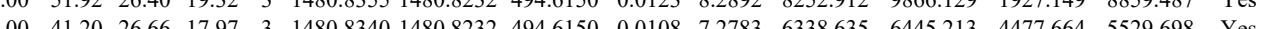
$\begin{array}{lllllllllllllll}0.55 & 10.18 & 23.75 & 23.18 & 3 & 183.83050 & 183.0252 & 494.6150 & 0.0108 & 7.2783 & 6338.635 & 6445.213 & 447.664 & 5529.698 & \text { Yes }\end{array}$

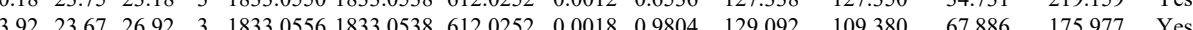
$\begin{array}{llllllllllllllll}1.00 & 90.87 & 27.20 & 28.05 & 2 & 1803.9724 & 1803.9709 & 902.9927 & 0.0015 & 0.8306 & 319.627 & 197.066 & 26.417 & 231.814 & \text { Yes }\end{array}$ $\begin{array}{llllllllllllll} & & \end{array}$ $\begin{array}{lllllllllllllll}100 & 30.96 & 27.05 & 19.51 & 3 & 1803.9742 & 1803.9709 & 6023309 & 0.0033 & 1.8262 & 32.498 & 85.902 & 33.557 & 62.326 & \text { Yes }\end{array}$

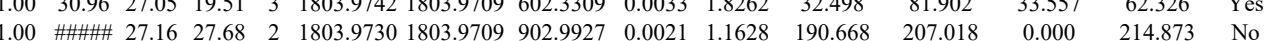

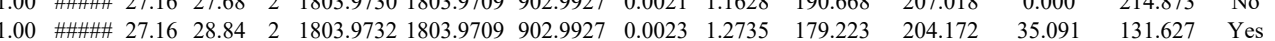

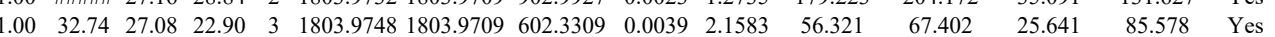

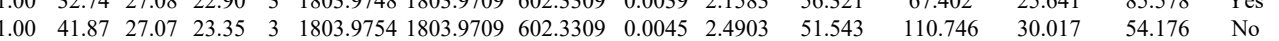
$\begin{array}{lllllllllllllll}0.99 & 31.75 & 28.31 & 19.31 & 3 & 1280.6788 & 1280.6788 & 427.9002 & 0.0000 & 0.0000 & 3209.364 & 3699.642 & 595.298 & 4568.050 & \text { Yes }\end{array}$ $\begin{array}{lllllllllllllll}1.00 & 39.58 & 28.34 & 16.86 & 3 & 1280.6806 & 1280.6788 & 427.9002 & 0.0018 & 1.4022 & 6510.396 & 6071.021 & 403.983 & 8415.642 & \text { Yes }\end{array}$ $\begin{array}{llllllllllllllll}0.55 & 31.67 & 13.22 & 44.67 & 3 & 1615.0441 & 1615.0428 & 539.3549 & 0.0013 & 0.8034 & 126.428 & 122.326 & 115.980 & 121.954 & \text { Yes }\end{array}$

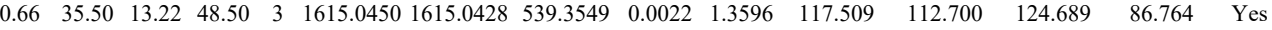

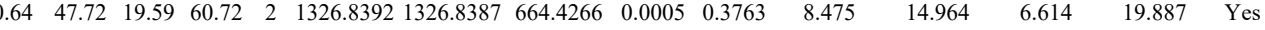

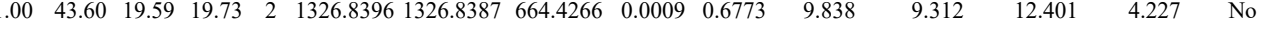

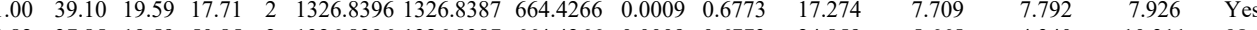

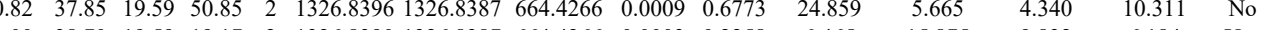

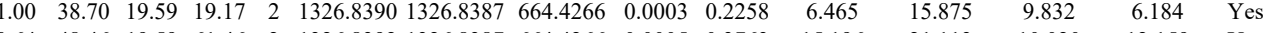

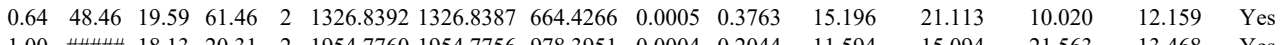

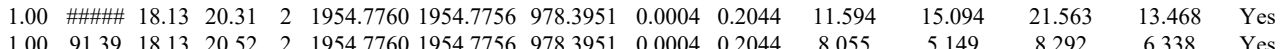

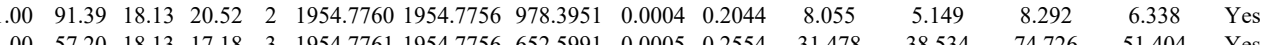

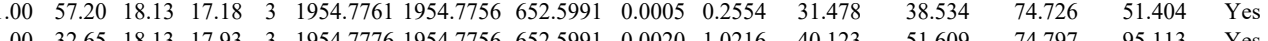

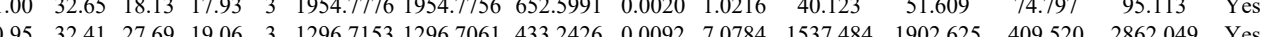

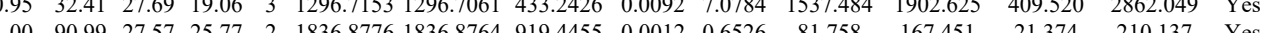

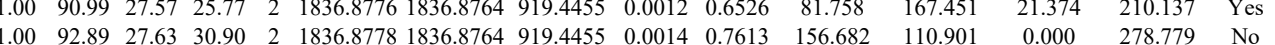
$\begin{array}{lllllllllllllll}1.00 & 32.34 & 26.87 & 18.26 & 3 & 2135.0365 & 2135.0336 & 712.6851 & 0.0029 & 1.3564 & 43.703 & 74.893 & 68.906 & 59.599 & \text { Yes }\end{array}$ $\begin{array}{lllllllllllllll}1.00 & 72.26 & 27.54 & 29.36 & 2 & 1836.8774 & 1836.8764 & 919.4455 & 0.0010 & 0.5438 & 33.496 & 71.646 & 3.051 & 105.634 & \text { Yes }\end{array}$ $\begin{array}{lllllllllllllll}1.00 & 51.08 & 27.62 & 19.98 & 2 & 183.8782 & 1836.8764 & 919.4455 & 0.0018 & 0.9788 & 50.969 & 49.069 & 16.525 & 112.219 & \text { Yes } \\ 1.00 & 3.87 & 27.63 & 24.93 & 2 & 1390.690 & 1390.6963 & 6963554 & 0.0007 & 0.5026 & 1130.927 & 1208.232 & 3339.914 & 3690.281 & \text { Yes }\end{array}$

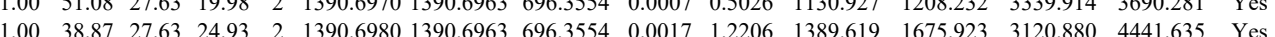
$\begin{array}{lllllllllllllll}1.00 & 57.73 & 28.27 & 25.85 & 2 & 1189.6172 & 1189.6173 & 595.8159 & -0.0001 & -0.0839 & 56.154 & 84.599 & 94.160 & 145.208 & \text { Yes }\end{array}$ $\begin{array}{llllllllllllllll}0.62 & 24.88 & 26.98 & 28.63 & 2 & 877.5470 & 877.5476 & 439.7811 & -0.0006 & -0.6822 & 377.952 & 383.937 & 401.110 & 530.940 & \text { No }\end{array}$ $\begin{array}{llllllllllllllll}0.57 & 24.00 & 26.98 & 27.17 & 2 & 877.5470 & 877.5476 & 439.7811 & -0.0006 & -0.6822 & 390.323 & 428.296 & 445.674 & 534.075 & \text { No }\end{array}$

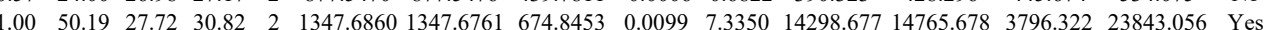
$\begin{array}{llllllllllllllll}1.00 & 56.36 & 27.86 & 31.25 & 2 & 1347.6870 & 1347.6761 & 674.8453 & 0.0109 & 8.0759 & 15001.889 & 15028.661 & 2021.096 & 24542.614 & \text { Yes }\end{array}$ $\begin{array}{llllllllllllllll}1.00 & 74.79 & 25.51 & 34.00 & 2 & 1497.8646 & 1497.8637 & 749.9391 & 0.0009 & 0.6000 & 7521.031 & 9969.306 & 402.300 & 15510.408 & \text { Yes }\end{array}$ $\begin{array}{lllllllllllllll}1.00 & 72.77 & 25.49 & 33.47 & 2 & 1497.8650 & 1497.8637 & 749.9391 & 0.0013 & 0.8667 & 3116.748 & 2801.397 & 681.399 & 6112.315 & \text { Yes }\end{array}$ $\begin{array}{llllllllllllllll}1.00 & 55.04 & 27.67 & 31.05 & 2 & 1347.6852 & 1347.6761 & 674.8453 & 0.0091 & 6.7422 & 15108.148 & 19476.229 & 2932.479 & 28361.467 & \text { Yes }\end{array}$ $\begin{array}{lllllllllllllll}1.00 & 59.31 & 27.62 & 31.55 & 2 & 1347.6866 & 1347.6761 & 674.8453 & 0.0105 & 7.7795 & 11721.949 & 16715.925 & 2814.169 & 21701.119 & \text { No }\end{array}$ $\begin{array}{llllllllllllllll}1.00 & 72.72 & 25.49 & 26.55 & 2 & 1497.8650 & 1497.8637 & 749.9391 & 0.0013 & 0.8667 & 2706.309 & 2840.062 & 565.795 & 4777.417 & \text { Yes }\end{array}$

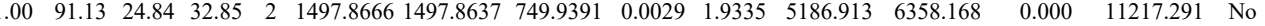
$\begin{array}{lllllllllllllll}1.00 & 60.64 & 27.86 & 30.06 & 2 & 1347.6870 & 1347.6761 & 674.8453 & 0.0109 & 8.0759 & 6374.605 & 6532.720 & 655.736 & 11767.562 & \text { Yes }\end{array}$

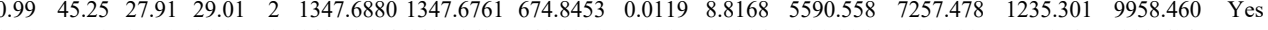
$\begin{array}{lllllllllllllll}1.00 & 75.78 & 25.50 & 31.87 & 2 & 1497.8654 & 1497.8637 & 749.9391 & 0.0017 & 1.1334 & 321.216 & 190.998 & 75.154 & 333.694 & \text { No }\end{array}$ $\begin{array}{lllllllllllllll}1.00 & 82.36 & 25.50 & 37.84 & 2 & 1497.8654 & 1497.8637 & 749.9391 & 0.0017 & 1.1334 & 155.000 & 143.508 & 37.342 & 216.705 & \text { Yes }\end{array}$

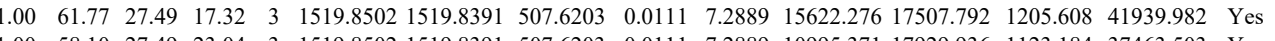
$\begin{array}{lllllllllllllll}1.00 & 58.10 & 27.49 & 23.04 & 3 & 1519.8502 & 1519.8391 & 507.6203 & 0.0111 & 7.2889 & 10995.371 & 17929.936 & 1123.184 & 37463.503 & \text { Yes }\end{array}$ $\begin{array}{lllllllllllllll}1.00 & 80.73 & 27.49 & 18.96 & 3 & 1519.8502 & 1519.8391 & 507.6203 & 0.0111 & 7.2889 & 5621.190 & 6285.251 & 1352.955 & 11310.066 & \text { Yes }\end{array}$

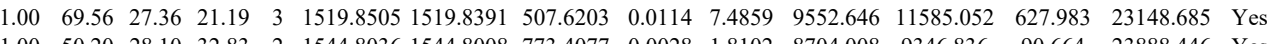
$\begin{array}{lllllllllllllll}1.00 & 50.20 & 28.10 & 32.83 & 2 & 1544.8036 & 1544.8008 & 773.4077 & 0.0028 & 1.8102 & 8704.008 & 9346.836 & 90.664 & 23888.446 & \text { Yes } \\ 1.00 & 4.69 & 28.09 & 31.37 & 2 & 1544.8038 & 1544.800 & 773.4077 & 0.0030 & 1.9395 & 13832.684 & 15936.724 & 0.000 & 32783.856 & \mathrm{No}\end{array}$ $\begin{array}{llllllllllllllll}1.00 & 43.69 & 28.09 & 31.37 & 2 & 1544.8038 & 1544.8008 & 773.4077 & 0.0030 & 1.9395 & 13832.684 & 15936.724 & 0.000 & 32783.856 & \text { No }\end{array}$

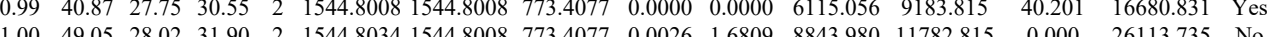
$\begin{array}{lllllllllllllll}1.00 & 49.05 & 28.02 & 31.90 & 2 & 1544.8034 & 1544.8008 & 773.4077 & 0.0026 & 1.6809 & 884.980 & 11782.815 & 0.000 & 26813.735 & \text { No } \\ 0.98 & 26.36 & 28.04 & 27.03 & 3 & 1544.8036 & 1544.8008 & 515.9409 & 0.0028 & 1.8090 & 144.180 & 124.584 & 117.732 & 250.786 & \text { No }\end{array}$

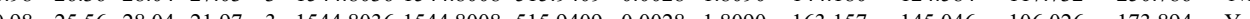

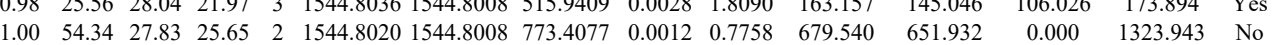

Table S-4 page 337 of 614 
$\begin{array}{llllllllllll}1.00 & 67.50 & 28.20 & 38.52 & 2 & 1316.7446 & 1316.7422 & 659.3784 & 0.0024 & 1.8199 & 8440.381\end{array}$

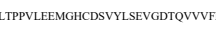

\section{$\begin{array}{lllllllllllll}1.00 & 60.23 & 24.53 & 31.89 & 2 & 1641.9554 & 1641.9545 & 821.9845 & 0.0009 & 0.5475 & 458.161 & 62\end{array}$} $\begin{array}{llllllllllll}0.60 & 12.72 & 27.39 & 25.72 & 3 & 2334.1516 & 2334.1479 & 779.0566 & 0.0037 & 1.5831 & 384.049 & 38\end{array}$

LTPPVLEMGGCDSVYLSEVGDT $\begin{array}{lllll}.00 & 46.41 & 25.93 & 17.12 & 4 \\ 0.97 & 12.97 & 25.81 & 19.32 & 4 \\ 4 & 0\end{array}$

FAEAFEAIPR

FAEAFEAIPR $\begin{array}{lllllllllll}0.97 & 12.97 & 25.81 & 19.32 & 4 & 3524.7545 & 3524.7485 & 882.1944 & 0.0060 & 1.7003\end{array}$ $\begin{array}{lllllllllllll}0.54 & 0.96 & 25.82 & 14.00 & 4 & 3524.7581 & 3524.7485 & 882.1944 & 0.0096 & 2.7205 & 3.188\end{array}$

$\begin{array}{lllll}1.00 & 62.08 & 27.60 & 24.52 & 2\end{array}$

FAEAFEAIPR $\begin{array}{lllllllllllll} & \end{array}$

VADMALHYANK $\begin{array}{llllllllllllllll}1.00 & 61.57 & 27.79 & 25.44 & 2 & 1293.6870 & 1293.6839 & 647.8492 & 0.0031 & 2.3925 & 8453.695 & 7357.866 & 983.958 & 19587.419 & \mathrm{No}\end{array}$

IGLSVSEVIEGYEIAC IGLSVSEVIEGYEIACR
APGFAQMLK

APGFAQMLK

LFVTNDAATILR

LFVTNDAATILR

LFVTNDAATILR

LFVTNDAATILR

YNIMLVR

ILGSGISSSSVLHGMVF

YNIMLVR $\begin{array}{lllllllllllll} & 77.53 & 28.48 & 23.64 & 2 & 1519.8186 & 1519.8060 & 760.9103 & 0.0126 & 8.2795 & 512.321 & 615 .\end{array}$

$\begin{array}{llllllllll}1.00 & \# \# \# \# 27.19 & 25.97 & 2 & 2027.0194 & 2027.0189 & 1014.5167 & 0.0005 & 0.2464 & 168.942\end{array}$

$\begin{array}{llll}6.443 & 67.477 & 948.353 & \text { Yes } \\ 1 & 4.704 & 107.08 & \end{array}$ $\begin{array}{llllllllllllllll}0.97 & 39.43 & 27.08 & 36.71 & 2 & 1249.7214 & 1249.7096 & 625.8621 & 0.0118 & 9.4269 & 2699.962 & 2864.994 & 15356.169 & 14744.820 & \text { Yes }\end{array}$ $\begin{array}{lllllllllllllll}1.00 & 56.68 & 27.08 & 37.90 & 2 & 1249.7214 & 1249.7096 & 625.8621 & 0.0118 & 9.4269 & 3441.335 & 2940.250 & 16957.457 & 19857.080 & \text { No }\end{array}$ $\begin{array}{llllllllllllllll}00 & 68.19 & 27.06 & 27.00 & 2 & 1476.8430 & 1476.8422 & 739.4284 & 0.0008 & 0.5410 & 15274.419 & 19983.346 & 317.646 & 24216.50 & \text { No }\end{array}$ $\begin{array}{lllllllllllllllll}1.00 & 65.60 & 27.01 & 31.63 & 2 & 1476.8434 & 1476.8422 & 739.4284 & 0.0012 & 0.8114 & 12017.142 & 15389.920 & 158.064 & 18039.317 & Y \text { Yes }\end{array}$ $\begin{array}{llllllllll} & 0\end{array}$

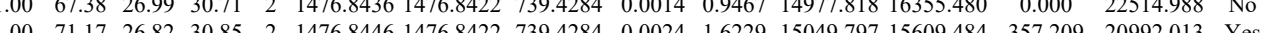

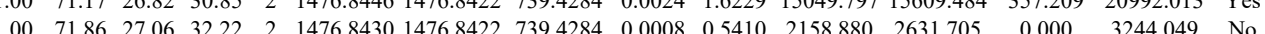
$\begin{array}{lllllllllllllll}1.00 & 71.86 & 27.06 & 32.22 & 2 & 1476.8430 & 1476.8422 & 739.4284 & 0.0008 & 0.5410 & 2158.880 & 2631.705 & 0.000 & 3244.049 & \text { No } \\ 1.00 & 66.78 & 26.69 & 29.27 & 2 & 1476.8456 & 1476.8422 & 739.4284 & 0.0034 & 22991 & 457.813 & 517.718 & 47.532 & 529.765 & \text { Yes }\end{array}$

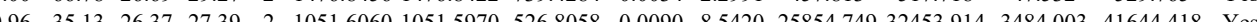

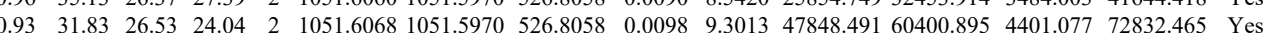

YNIMLVR

GEENLMDAQVK

GEENLMDAQVK

LFVTNDAATILR

LATNAAVTVLR

LATNAAVTVLR

LYAVHQEGNK

LYAVHQEGNK

LATNAAVTVLR

LATNAAVTVLR

LATNAAVTVLR

GSTDNLMDDIER

GSTDNLMDDIER

GEENLMDAQVK

GEENLMDAQVK

$\begin{array}{lllllllllllllll}0.93 & 31.83 & 26.53 & 24.04 & 2 & 1051.6068 & 1051.5970 & 526.8058 & 0.0098 & 9.3013 & 47848.491 & 60400.895 & 4401.077 & 72832.465 & \text { Yes }\end{array}$

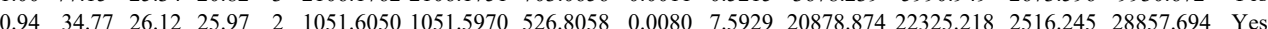
$\begin{array}{lllllllllllllll}0.88 & 31.85 & 26.35 & 23.09 & 2 & 1051.6052 & 1051.5970 & 526.8058 & 0.0082 & 7.7827 & 23774.279 & 27471.621 & 2098.623 & 32739.899 & \text { Yes }\end{array}$ $\begin{array}{lllllllllllllll}1.00 & 61.84 & 24.83 & 25.50 & 2 & 1508.6900 & 1508.6899 & 755.3522 & 0.0001 & 0.0662 & 416.595 & 380.945 & 143.076 & 554.094 & \text { Yes }\end{array}$

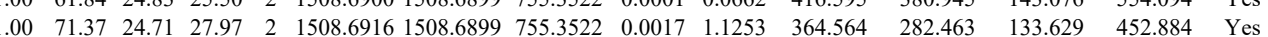
$\begin{array}{lllllllllllllll}1.00 & 65.29 & 28.22 & 26.74 & 2 & 1520.7846 & 1520.7748 & 761.3947 & 0.0098 & 6.4355 & 450.606 & 635.570 & 524.667 & 709.746 & \text { Yes }\end{array}$

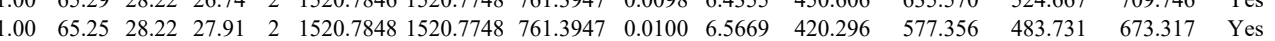
$\begin{array}{lllllllllllllll}1.00 & 65.20 & 26.94 & 28.01 & 2 & 1476.8424 & 1476.8422 & 739.4284 & 0.0002 & 0.1352 & 241.488 & 339.131 & 9.885 & 332.125 & \text { Yes }\end{array}$ $\begin{array}{llllllllllllllll}1.00 & 63.91 & 26.01 & 29.47 & 2 & 1271.7678 & 1271.7683 & 636.8914 & -0.0005 & -0.3925 & 432.791 & 467.428 & 64.885 & 677.489 & \text { Yes }\end{array}$ $\begin{array}{llllllllllllllll}1.00 & 59.81 & 26.01 & 28.21 & 2 & 1271.7678 & 1271.7683 & 636.8914 & -0.0005 & -0.3925 & 478.823 & 582.323 & 85.085 & 745.374 & \text { Yes }\end{array}$

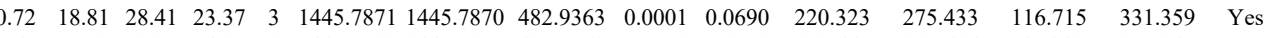
$\begin{array}{lllllllllllllll}0.69 & 15.93 & 28.31 & 14.39 & 3 & 1445.7883 & 1445.7870 & 482.9363 & 0.0013 & 0.8973 & 173.667 & 217.616 & 65.461 & 250.347 & \text { Yes }\end{array}$ $\begin{array}{lllllllllllllll}1.00 & 66.61 & 25.63 & 28.17 & 2 & 1271.7684 & 1271.7683 & 636.8914 & 0.0001 & 0.0785 & 321.238 & 354.525 & 69.318 & 452.419 & \text { Yes }\end{array}$ $\begin{array}{lllllllllllllll}1.00 & 57.65 & 25.65 & 29.64 & 2 & 1271.7688 & 1271.7683 & 636.8914 & 0.0005 & 0.3925 & 300.554 & 322.145 & 76.095 & 461.621 & \text { Yes }\end{array}$ $\begin{array}{lllllllllllllll}1.00 & 67.65 & 25.51 & 28.18 & 2 & 1271.7692 & 1271.7683 & 636.8914 & 0.0009 & 0.7066 & 250.292 & 285.195 & 45.967 & 378.435 & \text { Yes }\end{array}$ $\begin{array}{lllllllllllllll}1.00 & 63.52 & 25.51 & 26.56 & 2 & 1271.7694 & 1271.7683 & 636.8914 & 0.0011 & 0.8636 & 198.654 & 205.243 & 23.302 & 275.920 & \text { Yes }\end{array}$ $\begin{array}{lllllllllllllll}1.00 & 73.84 & 24.83 & 25.39 & 2 & 1508.6900 & 1508.6899 & 755.3522 & 0.0001 & 0.0662 & 1429.896 & 1393.930 & 302.461 & 1266.495 & \text { Yes }\end{array}$ $\begin{array}{lllllllllllllll}1.00 & 72.07 & 24.70 & 24.46 & 2 & 1508.6904 & 1508.6899 & 755.3522 & 0.0005 & 0.3310 & 1179.756 & 1364.634 & 336.150 & 1146.485 & \text { Yes }\end{array}$ $\begin{array}{lllllllllllllllll}1.00 & 78.04 & 27.79 & 28.10 & 2 & 1520.7616 & 1520.7748 & 761.3947 & -0.0132 & -8.6684 & 1723.823 & 1884.066 & 1125.348 & 1770.572 & \text { Yes } \\ \end{array}$

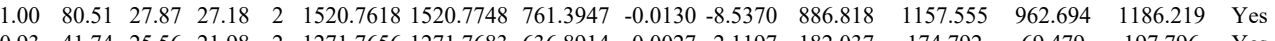

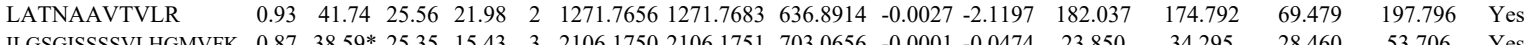
$\begin{array}{lllllllllllll} & \end{array}$

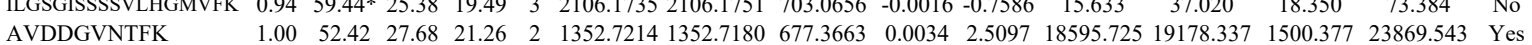

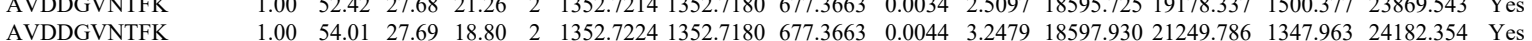

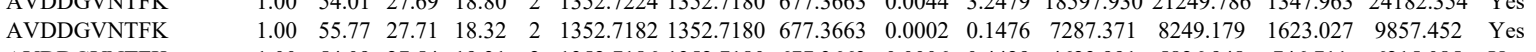
$\begin{array}{llllllllllllllll} & & & \end{array}$ 


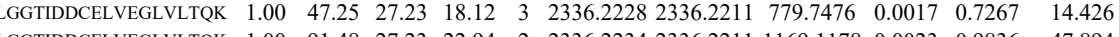

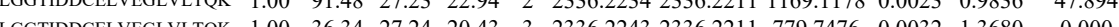
$\begin{array}{llllllllllll}\text { VIDPATATSVDLR } & 1.00 & 69.70 & 27.30 & 26.25 & 2 & 1500.8286 & 1500.8270 & 751.4208 & 0.0016 & 1.0646 & 2222.711\end{array}$ $\begin{array}{llllllllllllll}\text { LGGTIDDCELVEGLVLTOK } & 0.64 & 80.13 & 27.19 & 93.13 & 2 & 2336.2214 & 23362211 & 1169.1178 & 0.0003 & 0.1283 & 39.824\end{array}$ $\begin{array}{lllllllllllll}\text { LGGTIDDCELVEGLVLTOK } & 1.00 & 81.65 & 27.23 & 21.42 & 2 & 23362234 & 23362211 & 1169.1178 & 0.0023 & 0.9836 & 47.825\end{array}$

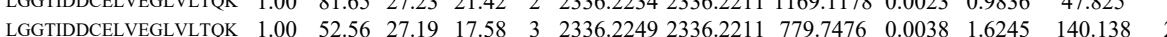

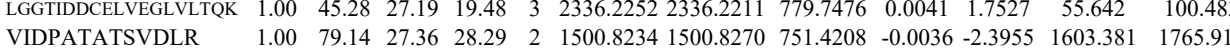

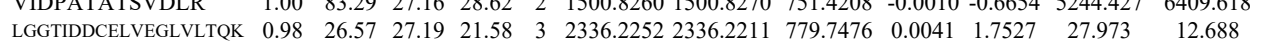
$\begin{array}{llllllllllllll}\text { LGGTIDDCELVEGLVLTQK } & 1.00 & 33.88 & 27.20 & 16.76 & 3 & 2336.2255 & 2336.2211 & 779.7476 & 0.0044 & 1.8809 & 13.361 & 0.000\end{array}$ $\begin{array}{llllllllllllll}\text { GIEILTDMSRPVELSDR } & 0.98 & 36.07 & 27.45 & 20.98 & 2 & 23674.0854 & 2074.0850 & 1038.0498 & 0.0004 & 0.1927 & 71.899 & 49.123\end{array}$ $\begin{array}{llllllllllll}\text { LGGTIDDCELVEGLVLTQK } & 1.00 & 41.20 & 27.23 & 19.10 & 3 & 2336.2228 & 2336.2211 & 779.7476 & 0.0017 & 0.7267 & 22.889\end{array}$ $\begin{array}{lllllllllllll}\text { LGGTIDDCELVEGLVLTQK } & 1.00 & 39.85 & 27.23 & 31.55 & 3 & 2336.2228 & 2336.2211 & 779.7476 & 0.0017 & 0.7267 & 11.702\end{array}$

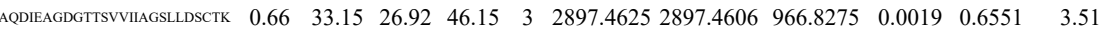

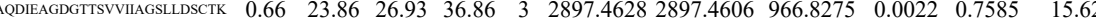

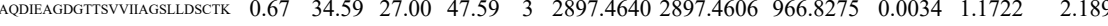
AQDIEAGDGTTSVIIAGSLLDSCTK $\begin{array}{lllllllllllllll}0.60 & 45.75 & 26.95 & 58.75 & 3 & 2897.4643 & 2897.4606 & 966.8275 & 0.0037 & 1.2756 & 13.88\end{array}$ $\begin{array}{llllllllllll}\text { AQDIEAGDGTSVVVIIAGSLLDSCTK } & 1.00 & 68.75 & 26.95 & 17.69 & 3 & 2897.4643 & 2897.4606 & 966.8275 & 0.0037 & 1.2756 & 6.185\end{array}$

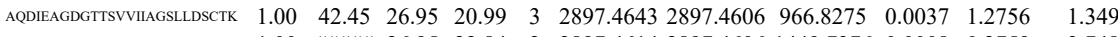

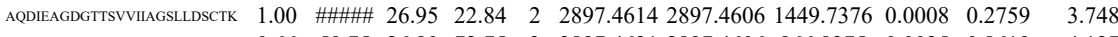
$\begin{array}{llllllllllllll}\text { AQDIEAGDGTTSVVIAGSLLDSCTK } & 0.66 & 59.75 & 26.90 & 72.75 & 3 & 2897.4631 & 2897.4606 & 966.8275 & 0.0025 & 0.8619 & 4.127 \\ \text { MQDIEAGDGTSVVIAGSLDSCTK } & 0.60 & 20.87 & 26.95 & 33.87 & 3 & 2897.4643 & 2897.4606 & 966.8275 & 0.0037 & 1.2756 & 20.898\end{array}$

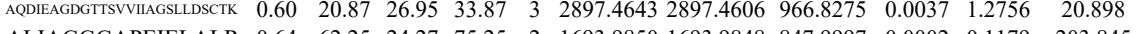
$\begin{array}{llllllllllll}\text { ALIAGGGAPELLALR } & 0.64 & 62.25 & 24.27 & 75.25 & 2 & 1693.9850 & 1693.9848 & 847.9997 & 0.0002 & 0.1179 & 203.845\end{array}$ $\begin{array}{llllllllllll}\text { ALIAGGGAPEIELALR } & 1.00 & 77.59 & 24.25 & 18.00 & 2 & 1693.9862 & 1693.9848 & 847.9997 & 0.0014 & 0.8255 & 460.516\end{array}$

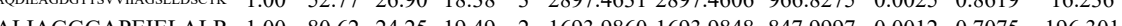

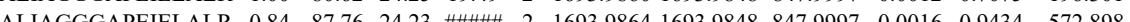

ITGCASPGK $\begin{array}{lllllllllllll}0.99 & 35.87 & 26.27 & 26.44 & 2 & 1124.6462 & 1124.6433 & 563.3289 & 0.0029 & 2.5740 & 20621.114 & 20501.169\end{array}$

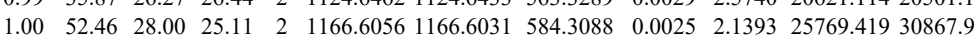
$\begin{array}{llllllllllll} & \end{array}$ $\begin{array}{lllllllllllll}\text { GIAPTISESFOK } & 1.00 & 45.12 & 26.11 & 18.65 & 3 & 1743.9883 & 1743.9763 & 5823327 & 0.0120 & 6.8689 & 45.029 & 42.711\end{array}$ GIHPTIISESFQK $\begin{array}{lllllllllllll}1.00 & 45.12 & 26.11 & 18.65 & 3 & 1743.9883 & 1743.9763 & 582.3327 & 0.0120 & 6.8689 & 4697.475 & 621 \\ 1.00 & 41.24 & 25.75 & 17.03 & 3 & 1743.9901 & 1743.9763 & 582.3327 & 0.0138 & 7.8992 & 4170.904 & & \\ \end{array}$

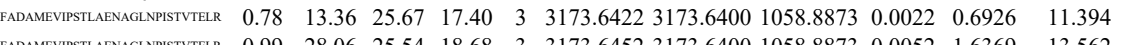
$\begin{array}{llllllllllll}\text { AFADAMEVPSTLAENAGLNPISTVTELR } & 0.99 & 28.06 & 25.54 & 18.68 & 3 & 3173.6452 & 3173.6400 & 1058.8873 & 0.0052 & 1.6369 & 13.562\end{array}$

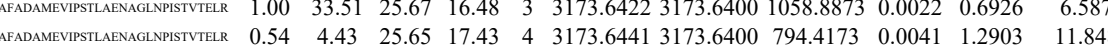
$\begin{array}{lllllllllllll}\text { AFADAMEVPSTLAENAGLPPSTVTELR } & 1.00 & 34.62 & 25.54 & 15.87 & 3 & 3173.6452 & 3173.6400 & 1058.8873 & 0.0052 & 1.6369 & 6.301\end{array}$ $\begin{array}{lllllllllllll} & \end{array}$ $\begin{array}{lllllllllll}0.66 & 25.23 & 25.67 & 38.23 & 3 & 3173.6422 & 3173.6400 & 10588.8873 & 0.0022 & 0.626 & 0.626\end{array}$ $\begin{array}{llllllllllll}1.00 & 77.22 & 25.77 & 24.68 & 2 & 1704.9668 & 1704.9502 & 853.4824 & 0.0166 & 9.7248 & 83.986\end{array}$ $\begin{array}{llllllllllllll}\text { LGGTIDDCELVEGLVLTQK } & 1.00 & 45.58 & 27.19 & 19.48 & 3 & 2336.2252 & 2336.2211 & 779.7476 & 0.0041 & 1.7527 & 55.642 & 100.483\end{array}$ $\begin{array}{llllllllllllll}\text { VIDPATATSVDLR } & 1.00 & 83.29 & 27.16 & 28.62 & 2 & 1500.8260 & 1500.8270 & 751.4208 & -0.0010 & -0.6654 & 5244.427 & 6409.618\end{array}$

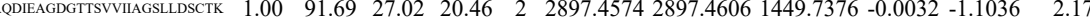

$\begin{array}{lllllllllllll}\text { ALIAGGGAPEIELALR } & 0.84 & 87.76 & 24.23 & \text { \#\#\#\# } & 2 & 1693.9864 & 1693.9848 & 847.9997 & 0.0016 & 0.9434 & 572.898 & 516.865 \\ \text { GIHPTIISESFQK } & 1.00 & 56.53 & 25.62 & 17.17 & 2 & 1743.9928 & 1743.9763 & 872.9954 & 0.0165 & 9.4501 & 1402.451 & 1481.485\end{array}$

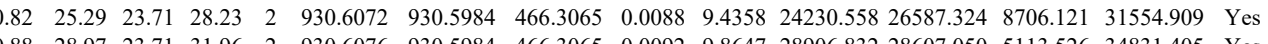

373.6

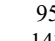

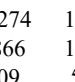

143.305 $\begin{array}{lllllllllllllll}0.88 & 28.97 & 23.71 & 31.96 & 2 & 930.6076 & 930.5984 & 466.3065 & 0.0092 & 9.8647 & 28906.832 & 28607.050 & 5113.526 & 34831.405 & \text { Yes }\end{array}$ $\begin{array}{lllllllllllllll}0 & 40.09 & 27.81 & 28.55 & 3 & 1293.7102 & 1293.7097 & 432.2438 & 0.0005 & 0.3856 & 5045.173 & 5544.796 & 1457.854 & 4248.841 & \text { Yes } \\ 0.75 & 55.31 * & 27.80 & 33.13 & 3 & 1293.7105 & 1293.7097 & 432.2438 & 0.0008 & 0.6169 & 3435.041 & 3536.452 & 897.004 & 3085.037 & \text { Yes }\end{array}$ $\begin{array}{lllllllllllllll}1.00 & 40.09 & 27.81 & 22.13 & 3 & 1293.7105 & 1293.7097 & 432.2438 & 0.0008 & 0.6169 & 3435.041 & 3536.452 & 897.004 & 3085.037 & \text { Yes }\end{array}$ $\begin{array}{llllllllllllllll}0.75 & 55.31 & 27.80 & 33.94 & 2 & 1315.6952 & 1315.6862 & 658.8504 & 0.0090 & 6.8300 & 3449.832 & 3553.870 & 270.014 & 4725.852 & \text { Yes } \\ 0.93 & 65.06 & 27.85 & 30.64 & 2 & 1315.6978 & 1315.682 & 658.8504 & 0.016 & 8.8031 & 4688.370 & 5364.003 & 318.285 & 7313.797 & \text { Yes }\end{array}$ \begin{tabular}{lllllllllllllll}
0.93 & $65.06 * 27.85$ & 30.64 & 2 & 1315.6978 & 1315.6862 & 658.8504 & 0.0116 & 8.8031 & 4688.370 & 5364.003 & 318.285 & 7313.797 & Yes \\
\hline
\end{tabular} \begin{tabular}{lllllllllllllll}
0.78 & $53.24 * 28.06$ & 29.64 & 2 & 1315.6974 & 1315.6862 & 658.8504 & 0.0112 & 8.4996 & 5321.056 & 5415.048 & 433.034 & 8200.639 & Yes \\
\hline
\end{tabular} $\begin{array}{lllllllllllllll}0.88 & 54.85 * 27.86 & 24.11 & 3 & 1315.6984 & 1315.6862 & 439.5693 & 0.0122 & 9.2514 & 1323.159 & 2241.627 & 1221.671 & 2523.159 & \text { Yes } \\ 1.00 & 47.42 & 20.83 & 20.32 & 2 & 1250.7734 & 1220.7736 & 311.3941 & 0.0002 & -0.1636 & 29812.752 & 30730.368 & 4742.667 & 38566.650 & \text { Yes }\end{array}$ \begin{tabular}{llllllllllllllll}
1.00 & 47.42 & 20.83 & 20.32 & 2 & 1220.7734 & 1220.7736 & 611.3941 & -0.0002 & -0.1636 & 29842.752 & 30730.368 & 4742.667 & 38566.650 & Yes \\
\hline
\end{tabular} $\begin{array}{llllllllllllllll}1.00 & 50.99 & 20.61 & 21.43 & 2 & 1220.7750 & 1220.7736 & 611.3941 & 0.0014 & 1.1449 & 22185.050 & 24916.202 & 1024.106 & 32116.534 & \text { Yes } \\ 0.81 & 50.85 * & 27.82 & 20.80 & 3 & 1315.6993 & 1315.6862 & 439.5693 & 0.0131 & 9.9339 & 1379.225 & 1367.966 & 648.637 & 2203.533 & \text { Yes }\end{array}$

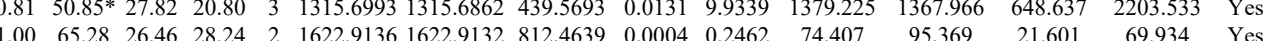
$\begin{array}{lllllllllllllll}1.00 & 65.28 & 26.46 & 28.24 & 2 & 1622.9136 & 1622.9132 & 812.4639 & 0.0004 & 0.2462 & 74.407 & 95.369 & 21.601 & 69.934 & \text { Yes } \\ 1.00 & 51.63 & 26.43 & 25.14 & 2 & 1622.9138 & 1622.9132 & 812.4639 & 0.0006 & 0.3692 & 36.228 & 66.420 & 14.653 & 30.298 & \text { Yes }\end{array}$

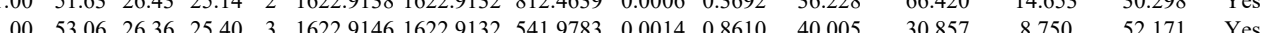

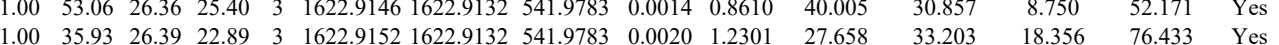


IGLIQFCLSAPK IGLIQFCLSAPK IDDVVNTR SGATAGAAGGR SGATAGAAGGR IDDVVNTR GDVTITNDGATILK GDVTITNDGATILK

QVPFNEVR GFLEFVEDFIQVPR GFLEFVEDFIQVPR GFLEFVEDFIQVPR GFLEFVEDFIQVPR GFLEFVEDFIQVPR GFLEFVEDFIQVPR

GFLEFVEDFIQVPR

PPGVTAIELDEDTGT

VPGVTAIELDEDTGTFR

$\begin{array}{lllllllllll}\text { RAB5C_HUMAl } & \text { P51148 } & \text { RAB5C } & \text { Ras-related protei } 23.483 & 1.00 & 5 & 34.7 & -0.3314 & 0.3463 & 0.5197 & 0.6469\end{array}$

\section{AVEFEEAQAYADDNSLLFETS}

QAEFPEAQAYADDNSLLFMETSA QASPNIVIALAGNK TAMNVNEIFMAIAK TAMNVNEIFMAIAK TAMNVNEIFMAIAK GVDLQENNPASR GVDLQENNPASR GVDLQENNPASR GVDLQENNPASR FEIWDTAGQER

8 DPENFPFVVLGNK DPENFPFVVLGNK DPENFPFVVLGNK DPENFPFVVLGNK ATIGADFLTK ATIGADFLTK VIILGDSGVGK DPENFPFVVLGNK DPENFPFVVLGNK DPENFPFVVLGNK DPENFPFVVLGNK TSLMNQYVNK

TSLMNQYVNK

TSLMNQYVNK

TSLMNQYVNK

FQSLGVAFYR FQSLGVAFYR FQSLGVAFYR $\begin{array}{llllllllllllll}\text { FQSLGVAFYR } & 0.54 & 25.86 & 27.93 & 27.82 & 2 & 1330.7202 & 1330.7156 & 666.3651 & 0.0046 & 3.4515 & 1451.384 & 1236.358 & 2737.3 \\ \text { QETEVELYNEFPEPIK } & 0.98 & 27.78 & 28.07 & 22.87 & 3 & 2252.1463 & 2252.1456 & 751.7225 & 0.0007 & 0.3104 & 10.995 & 20.667 & 22.0 \\ \text { QETEVELYNEFPEPIK } & 1.00 & 71.43 & 28.13 & 27.31 & 2 & 2252.1474 & 2252.1456 & 1127.0801 & 0.0018 & 0.7985 & 98.900 & 93.947 & 9\end{array}$ $\begin{array}{lllllllllllll} & \end{array}$ LAYLLQQTDEYVANLTELVR

$\begin{array}{lllllllll}26.46 & 18.69 & 3 & 1622.9134 & 1622.9132 & 541.9783 & 0.0002 & 0.1230 & 10.758\end{array}$ $\begin{array}{llllllllllll}1.00 & 51.19 & 28.11 & 32.43 & 2 & 1074.5898 & 1074.5791 & 538.2968 & 0.0107 & 9.9387 & 15568.364\end{array}$ $\begin{array}{llllllllllll}1.00 & 67.02 & 26.79 & 26.72 & 2 & 1018.5284 & 1018.5278 & 510.2712 & 0.0006 & 0.5879 & 71.267\end{array}$ 22.62 \begin{tabular}{|lllllll} 
& \\
\hline
\end{tabular} $\begin{array}{lllllllllllll}26.33 & 2 & 1704.9652 & 1704.9502 & 853.4824 & 0.0150 & 8.7875 & 3055.165 & 3565.590 & 1247.914 & 3435.476 & \text { Ycs } & \\ \end{array}$

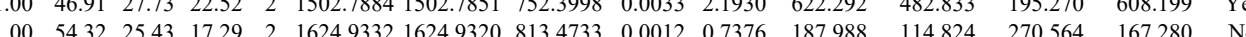
$\begin{array}{llllllllllllll} & \end{array}$

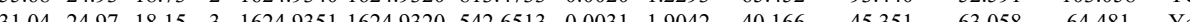
$\begin{array}{lllllllllllllll}1.00 & 30.45 & 25.08 & 21.10 & 3 & 1624.9360 & 1624.9320 & 542.6513 & 0.0040 & 2.4571 & 84.097 & 74.186 & 21.417 & 72.536 & \text { Yes }\end{array}$ $\begin{array}{llllllllllllllll}1.00 & 53.01 & 25.69 & 33.04 & 2 & 1243.7428 & 1243.7370 & 622.8758 & 0.0058 & 4.658 & 18656.445 & 11986.777 & 12.615 & 21628.473 & \text { Yes }\end{array}$ $\begin{array}{lllllllllllllllll}1.00 & 51.30 & 25.90 & 27.59 & 2 & 1243.7434 & 1243.7370 & 622.8758 & 0.0064 & 5.1374 & 6150.584 & 3672.139 & 147.047 & 6310.216 & \text { Yes }\end{array}$ $\begin{array}{llllllllllllllll}1.00 & 60.13 & 25.77 & 29.27 & 2 & 1243.7440 & 1243.7370 & 622.8758 & 0.0070 & 5.6191 & 8654.148 & 4583.055 & 43.925 & 9556.212 & \text { Yes }\end{array}$ $\begin{array}{llllllllllllllll}0.59 & 24.16 & 27.66 & 29.58 & 2 & 1131.6252 & 1131.6158 & 566.8152 & 0.0094 & 8.2919 & 10419.665 & 10348.053 & 1325.838 & 18218.847 & \text { Yes }\end{array}$ $\begin{array}{llllllllllllllll}1.00 & 75.62 & 27.69 & 23.95 & 2 & 1838.9700 & 1838.9689 & 920.4917 & 0.0011 & 0.5975 & 383.599 & 282.219 & 0.000 & 741.192 & \text { No }\end{array}$

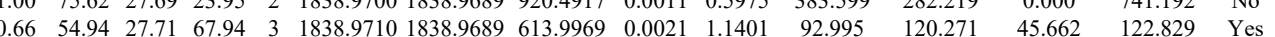
\begin{tabular}{lllllllllllllll}
1.00 & 64.66 & 27.68 & 21.94 & 2 & 1838.9712 & 1838.9689 & 920.4917 & 0.0023 & 1.2493 & 734.269 & 789.122 & 118.219 & 1381.205 & Yes \\
\hline
\end{tabular}

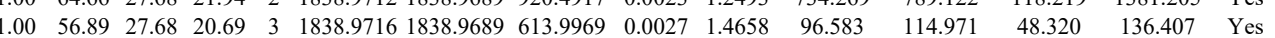
$\begin{array}{llllllllllllllll}1.00 & 81.09 & 27.64 & 29.11 & 2 & 1838.9698 & 1838.9689 & 920.4917 & 0.0009 & 0.4889 & 420.967 & 378.553 & 12.134 & 600.253 & \text { Yes }\end{array}$ $\begin{array}{llllllllllllllll}1.00 & 69.68 & 27.66 & 22.18 & 2 & 1838.9704 & 1838.9689 & 920.4917 & 0.0015 & 0.8148 & 639.412 & 713.071 & 0.000 & 1127.611 & \text { No }\end{array}$

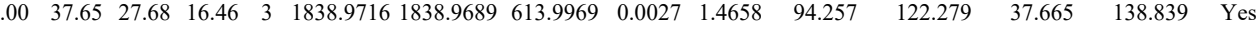
$\begin{array}{lllllllllllll} & \end{array}$ $\begin{array}{lllllllllllllll}.00 & 73.18 & 27.68 & 19.40 & 2 & 1838.9702 & 1838.9689 & 920.4917 & 0.0013 & 0.7061 & 71.722 & 79.516 & 13.131 & 114.596 & \text { Yes }\end{array}$

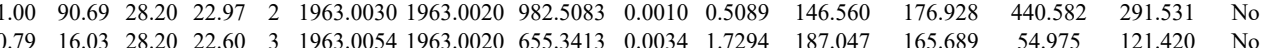

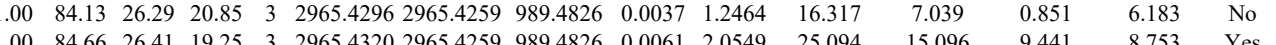
\begin{tabular}{lllllllllllllll}
1.06 & 84.66 & 26.41 & 19.25 & 3 & 2965.4320 & 2965.4259 & 989.4826 & 0.0061 & 2.0549 & 25.094 & 15.096 & 9.441 & 8.753 & Yes \\
\hline .61 & 20.25 & 26.59 & 15.55 & 3 & 2965.4413 & 2965.4259 & 989.4826 & 0.0154 & 5.1879 & 4.350 & 0.000 & 5.857 & 15.152 & No
\end{tabular}

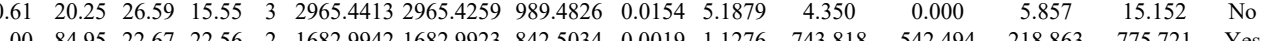

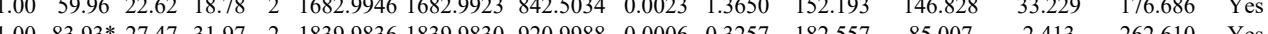

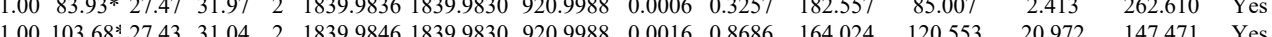
$\begin{array}{llllllllllllll}0.98 & 51.58 * 27.49 & 20.75 & 3 & 1839.9850 & 1839.9830 & 614.3349 & 0.0020 & 0.8686 & 164.024 & 120.553 & 20.972 & 147.471 & \text { Yes } \\ 0.9852 & 70.714 & 137.790 & 70.525 & 95.706 & \text { No }\end{array}$

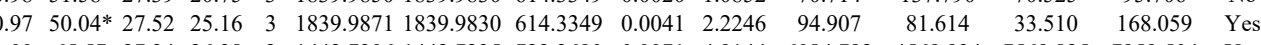
$\begin{array}{lllllllllllllll}1.00 & 65.57 & 27.34 & 26.38 & 2 & 1442.7306 & 1442.7235 & 722.3690 & 0.0071 & 4.9144 & 6084.792 & 4569.934 & 7569.825 & 7959.504 & \text { Yes }\end{array}$

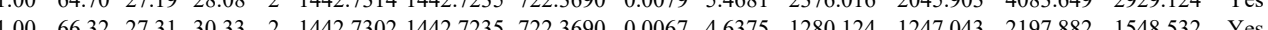
$\begin{array}{llllllllllllllll}1.00 & 63.71 & 27.28 & 32.96 & 2 & 14427318 & 1442.7235 & 722.3690 & 0.0083 & 5.7450 & 657.752 & 541.245 & 1201.500 & 575.557 & \text { Yes }\end{array}$ $\begin{array}{lllllllllllllll}0.99 & 40.32 & 26.83 & 29.54 & 2 & 1494.7254 & 1494.7225 & 748.3685 & 0.0029 & 1.9375 & 2522.025 & 2770.004 & 444.260 & 4535.957 & \text { Yes }\end{array}$

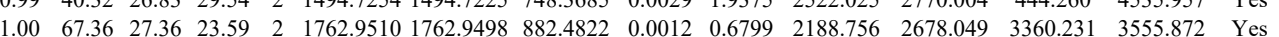
$\begin{array}{lllllllllllllll}1.00 & 77.24 & 27.30 & 23.79 & 2 & 1762.9514 & 1762.9498 & 882.4822 & 0.0016 & 0.9065 & 324.810 & 461.149 & 474.404 & 492.903 & \text { Yes }\end{array}$

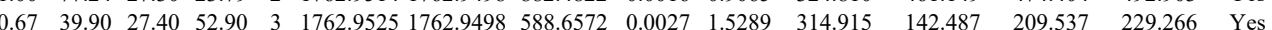
$\begin{array}{lllllllllllllll}0.98 & 25.80 & 27.52 & 19.99 & 3 & 1762.9534 & 1762.9498 & 588.6572 & 0.0036 & 2.0385 & 135.170 & 129.744 & 154.029 & 141.759 & \text { Yes }\end{array}$ $\begin{array}{llllllllllllllll}1.00 & 62.59 & 25.20 & 24.85 & 2 & 1323.7766 & 1323.7642 & 662.8894 & 0.0124 & 9.3529 & 8205.563 & 6715.362 & 3147.189 & 11382.548 & \text { Yes }\end{array}$ $\begin{array}{llllllllllllllll}1.00 & 59.48 & 25.20 & 24.81 & 2 & 1323.7772 & 1323.7642 & 662.8894 & 0.0130 & 9.8055 & 6498.091 & 5786.551 & 2549.527 & 10069.913 & \text { Yes }\end{array}$ $\begin{array}{lllllllllllllll}0.84 & 53.80 * 23.52 & 33.04 & 2 & 1344.8352 & 1344.8221 & 673.4183 & 0.0131 & 9.7264 & 5659.905 & 5050.200 & 1336.194 & 6708.728 & \text { Yes }\end{array}$ $\begin{array}{llllllllllllllll}1.00 & 65.45 & 27.26 & 26.23 & 2 & 1762.9502 & 1762.9498 & 882.4822 & 0.0004 & 0.2266 & 257.098 & 340.110 & 549.828 & 506.593 & \text { Yes }\end{array}$ $\begin{array}{lllllllllllllll}0.82 & 66.26 & 27.36 & 79.26 & 2 & 1762.9508 & 1762.9498 & 882.4822 & 0.0010 & 0.5666 & 335.353 & 250.383 & 361.870 & 467.754 & \text { Yes }\end{array}$ $\begin{array}{lllllllllllllll}0.92 & 19.34 & 27.33 & 15.14 & 3 & 1762.9519 & 1762.9498 & 588.6572 & 0.0021 & 1.1891 & 239.405 & 198.715 & 97.722 & 280.164 & \text { Yes }\end{array}$

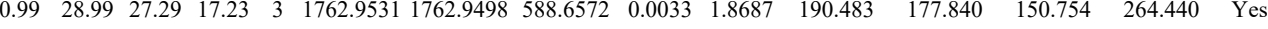
$\begin{array}{lllllllllllllll}.00 & 56.18 & 27.99 & 21.98 & 2 & 1484.8000 & 1484.7901 & 743.4023 & 0.0099 & 6.6585 & 7797.564 & 6277.535 & 399.757 & 9522.812 & \text { Yes }\end{array}$ $\begin{array}{lllllllllllllll}1.00 & 54.62 & 27.83 & 21.99 & 2 & 1484.8010 & 1484.7901 & 743.4023 & 0.0109 & 7.3311 & 9564.731 & 7583.378 & 191.254 & 12143.200 & \text { Yes }\end{array}$ $\begin{array}{lllllllllllllll}1.00 & 54.49 & 27.95 & 21.65 & 2 & 1484.8002 & 1484.7901 & 743.4023 & 0.0101 & 6.7930 & 2005.107 & 1688.150 & 37.463 & 2702.368 & \text { Yes }\end{array}$ $\begin{array}{llllllllllllllll}1.00 & 56.56 & 27.78 & 23.96 & 2 & 1484.8016 & 1484.7901 & 743.4023 & 0.0115 & 7.7346 & 570.618 & 552.795 & 26.489 & 665.813 & \text { Yes }\end{array}$ \begin{tabular}{llllllllllllllllll}
1.00 & 49.35 & 27.79 & 23.66 & 2 & 1330.7164 & 1330.7156 & 666.3651 & 0.0008 & 0.6003 & 8811.238 & 7708.375 & 230.031 & 16267.291 & Yes \\
\hline
\end{tabular} $\begin{array}{llllllllllllllll}1.00 & 50.21 & 27.81 & 21.48 & 2 & 1330.7168 & 1330.7156 & 666.3651 & 0.0012 & 0.9004 & 6942.632 & 5727.261 & 0.000 & 12987.151 & \text { No }\end{array}$

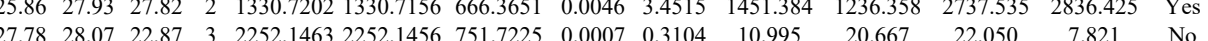

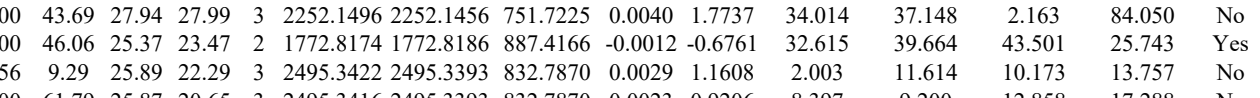
$\begin{array}{lllllllllllllllll}1.00 & 42.13 & 19.96 & 20.75 & 3 & 1239.7915 & 1239.7907 & 414.2708 & 0.0008 & 0.6437 & 14678.201 & 19803.660 & 7940.577 & 19561.122 & \text { Yes }\end{array}$ 

$\begin{array}{llllllllllllllll}0.99 & 29.39 & 19.34 & 19.59 & 2 & 1239.7926 & 1239.7907 & 620.9026 & 0.0019 & 1.5300 & 1617.878 & 2072.455 & 1004.160 & 1936.884 & \text { Yes }\end{array}$ $\begin{array}{lllllllllllllll}1.00 & 42.80 & 19.68 & 21.45 & 3 & 1239.7912 & 1239.7907 & 414.2708 & 0.0005 & 0.4023 & 8543.954 & 11374.359 & 5278.081 & 10786.138 & \text { Yes }\end{array}$ \begin{tabular}{llllllllllllllll} 
& 1.00 & 42.00 & 19.68 & 21.45 & 3 & 1239.7912 & 1239.7907 & 414.2708 & 0.000 & 0.4023 & 8543.954 & 11374.359 & 5278.081 & 10786.138 & Yes \\
\hline
\end{tabular} $\begin{array}{lllllllllllllllllll}1.00 & 42.57 & 1.96 & 21.31 & 3 & 1239.7915 & 1239.7907 & 414.2708 & 0.0008 & 0.6437 & 11496.039 & 14404.979 & 6245.832 & 14034.185 & \text { Yes }\end{array}$ $\begin{array}{llllllllllllllll}1.00 & 59.65 & 26.41 & 21.23 & 3 & 1654.9396 & 1654.9277 & 552.6498 & 0.0119 & 7.1775 & 6512.455 & 6469.953 & 1356.238 & 7700.813 & \text { Yes } \\ 1.00 & 52.24 & 28.48 & 31.19 & 2 & 136.7450 & 1363.7437 & 682.8791 & 0.013 & 0.9519 & 1493.422 & 2148.530 & 0.000 & 3070.292 & \mathrm{No}\end{array}$ $\begin{array}{lllllllllllllll}1.00 & 52.24 & 28.48 & 31.19 & 2 & 1363.7450 & 1363.7437 & 682.8791 & 0.0013 & 0.9519 & 1493.422 & 2148.530 & 0.000 & 3070.292 & \text { No }\end{array}$ $\begin{array}{llllllllllllllll}\text { FFDEESYSLLR } & 1.00 & 48.70 & 27.02 & 27.21 & 2 & 1548.7594 & 1548.7582 & 775.3864 & 0.0012 & 0.7738 & 613.713 & 830.729 & 22.437 & 1666.753 & \text { Yes } \\ \text { FFDEESYSLLR } & 1.00 & 48.06 & 27.15 & 26.92 & 2 & 1548.7598 & 1548.7582 & 775.3864 & 0.0016 & 1.0317 & 798.012 & 698.782 & 26.868 & 2012.556 & \text { Yes }\end{array}$ $\begin{array}{lllllllllllllll}1.00 & 59.93 & 28.48 & 32.95 & 2 & 1363.7450 & 1363.7437 & 682.8791 & 0.0013 & 0.9519 & 1793.794 & 2602.607 & 20.675 & 3724.123 & \text { Yes } \\ 1.00 & 48.70 & 7 . .7 & 27.21 & 2 & 158.7594 & 158.7582 & 775.384 & 0.0012 & 0.7738 & 613.713 & 830.729 & 22.437 & 166.753 & \text { Yes }\end{array}$ $\begin{array}{llllllllllllll} & \end{array}$ $\begin{array}{llllllllllll} & 0.000 & 49.790 & \text { No }\end{array}$

$\begin{array}{llllllllllll} & & \end{array}$

$\begin{array}{lllllllllllll}\text { BAP31_HUMAR } & \text { P51572 } & \text { BCAP31 } & \text { B-cell receptor-as: 27.992 } & 1.00 & 7 & 26 & -0.0353 & 0.1132 & 2.1062 & 0.1217 & 12 & \text { LKDELASTK }\end{array}$

LKDELASTK

LKDELASTK

AENQVLAMR

AENQVLAMR

AENQVLAMR

AENQVLAMR

YMLENPGALK

KYMEENDQLK

LDVGNAEVK

LDVGNAEVK

LQAAVDGPMDK

IDVVVNNAGILR
IDVVVNNAGILR

VVAPRRPDALLTDTSLINO

LGLLGLLANSLAIEGR LGLLGLANSLAIEGR VVLVTGAGAGLGR VVLVTGAGAGLGR VVLVTGAGAGLGR VVANYSVEEGK VVLVTGAAGLGR

VVLVTGAGAGLGR

VVLVTGAGAGLGR

25 SVVALHNLINNK

SVVALHNLINNK

SVVALHNLINNK

SVVALHNLINNK

VVGVLLGSWQK

VVGVLLGSWQK

VVGVLLGSWQK

VVGVLLGSWQK

$\begin{array}{llllllllllllll}\text { TNDQMVVVYLASLIR } & 1.00 & 75.37 & 26.83 & 19.29 & 2 & 1865.0212 & 1865.0202 & 933.5174 & 0.0010 & 0.5356 & 647.872 & 593.945 \\ \text { TNDQMVVVYLASLIR } & 1.00 & 53.63 & 26.90 & 27.02 & 3 & 1865.0221 & 1865.0202 & 622.6807 & 0.0019 & 1.0171 & 43.896 & 58.621\end{array}$

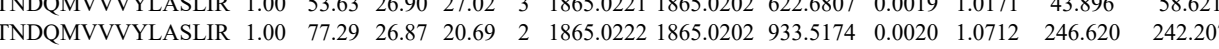
$\begin{array}{lllllllllllllll}\text { TNDQMVVVYLASLIR } & 1.00 & 43.86 & 26.78 & 21.70 & 3 & 1865.0239 & 1865.0202 & 622.6807 & 0.0037 & 1.9807 & 50.844 & 30.467\end{array}$ VVGVLLGSWQK

VVGVLLGSWQK

$\begin{array}{lllllllllll}1.00 & 48.61 & 21.90 & 21.68 & 3 & 1472.8984 & 1472.8959 & 491.9726 & 0.0025 & 1.6939 & 378.568\end{array}$

$\begin{array}{lllllllllllll}\text { VVGVLLGSWQK } & 1.00 & 49.52 & 21.55 & 34.84 & 2 & 1472.8984 & 1472.8959 & 737.4552 & 0.0025 & 1.6950 & 246.456 & 171.524 \\ \text { TNDQMVVVYLASLIR } & 1.00 & 81.17 & 26.90 & 21.97 & 2 & 1865.0220 & 1865.0202 & 933.5174 & 0.0018 & 0.9641 & 101.584 & 67.709\end{array}$ $\begin{array}{lllllllllllll}\text { TNDQMVVVYLASLIR } & 1.00 & 80.54 & 26.89 & 22.86 & 2 & 1865.0224 & 1865.0202 & 933.5174 & 0.0022 & 1.1783 & 95.267 & 67.709\end{array}$ $\begin{array}{lllllllllllll}\text { TNDQMVVVYLASLIR } & 0.99 & 28.49 & 26.88 & 21.04 & 3 & 1865.0227 & 1865.0202 & 622.6807 & 0.0025 & 1.3383 & 50.294 \\ \end{array}$ $\begin{array}{lllllllllllll}\text { TNDQMVVVYLASLIR } & 1.00 & 35.98 & 26.82 & 21.03 & 3 & 1865.0233 & 1865.0202 & 622.6807 & 0.0031 & 1.6595 & 95.236 \\ \text { VWVPVVLS }\end{array}$ $\begin{array}{llllllllllll}\text { VVVHPLVLLSVVDHFNR } & 1.00 & 57.20 & 21.30 & 33.17 & 4 & 2086.2193 & 2086.2173 & 522.5616 & 0.0020 & 0.9568 & 293.678\end{array}$ \begin{tabular}{llllllllllll} 
& WVIFLVLSVDNNR \\
\hline
\end{tabular} $\begin{array}{llllllllllll}\text { VVVHPLVLLSVVDHFNR } & 1.00 & 70.24 & 21.14 & 24.53 & 3 & 2086.2202 & 2086.2173 & 696.4130 & 0.0029 & 1.3881 & 94.118 \\ \text { VVVHPLVLSVVDHFNR } & 1.00 & 66.39 & 20.86 & 34.70 & 4 & 2086.2213 & 2086.2173 & 522.5616 & 0.0040 & 1.9136 & 493.423\end{array}$ $\begin{array}{llllllllllll}\text { VVVHPLVLLSVVDHFNR } & 1.00 & 64.15 & 21.14 & 24.75 & 3 & 2086.2199 & 2086.2173 & 696.4130 & 0.0026 & 1.2445 & 76.505\end{array}$ $\begin{array}{llllllllllll}\text { VVVHPLVLLSVVDHFNR } & 1.00 & 63.63 & 21.14 & 33.65 & 4 & 2086.220 & 2086.2173 & 522.5616 & 0.0028 & 1.3396 & 301.010\end{array}$

$\begin{array}{llllllllllllll}\text { VVVHPLVLLSVVDHFNR } & 1.00 & 62.73 & 21.14 & 35.74 & 4 & 2086.2201 & 2086.2173 & 522.5616 & 0.0028 & 1.3396 & 140.095\end{array}$ $\begin{array}{llllllllll} & & & \end{array}$

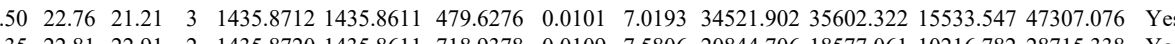

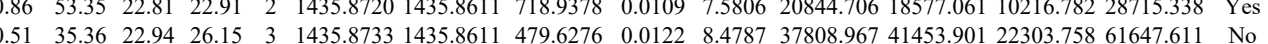
$\begin{array}{llllllllllllll}52.47 & 28.40 & 31.32 & 2 & 1174.6290 & 1174.6250 & 588.3198 & 0.0040 & 3.3995 & 19388.323 & 19501.691 & 1473.169 & 24498.618 & \text { Yes }\end{array}$

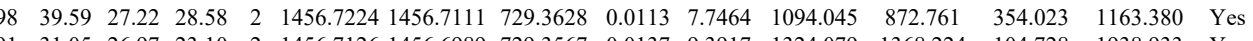
\begin{tabular}{lllllllllllllll}
1.00 & 74.39 & 24.79 & 31.11 & 2 & 1425.8436 & 1425.8425 & 713.9285 & 0.0011 & 0.7704 & 1014.271 & 803.465 & 225.965 & 1018.854 & Yes \\
\hline
\end{tabular} $\begin{array}{llllllllllllll} & \end{array}$ $\begin{array}{llllllllllllll} & \end{array}$ $\begin{array}{lllllllllllllll}1.00 & 89.41 & 22.72 & 32.89 & 2 & 13128042 & 1312.7949 & 657.4047 & 0.0093 & 7.0732 & 6358.064 & 7285.297 & 42.203 & 10429.789 & \text { Yes }\end{array}$ $42.203 \quad 10429.789$ Yes \begin{tabular}{rrr}
4.444 & 115.232 & Yes \\
\hline & 72.637 & Yes
\end{tabular}

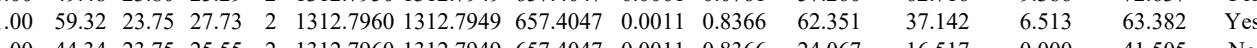
\begin{tabular}{lllllllllllllll}
1.00 & 54.16 & 23.75 & 26.07 & 2 & 1312.7966 & 1312.7949 & 657.4047 & 0.0017 & 1.2930 & 59.755 & 51.772 & 4.959 & 72.962 & Yes \\
\hline
\end{tabular} $\begin{array}{lllllllllllllllll}1.00 & 46.12 & 21.64 & 17.28 & 3 & 1608.9712 & 1608.9555 & 537.3258 & 0.0157 & 9.7395 & 13529.065 & 13368.412 & 3611.144 & 22712220 & \text { Yes }\end{array}$ $\begin{array}{lllllllllllllll}1.00 & 51.93 & 21.82 & 20.58 & 3 & 1608.9703 & 1608.9555 & 537.3258 & 0.0148 & 9.1812 & 12094.459 & 12699.710 & 2921.920 & 17516.679 & \text { Yes }\end{array}$ $\begin{array}{llllllllllllllll}1.00 & 46.71 & 21.64 & 23.67 & 3 & 1608.9706 & 1608.9555 & 537.3258 & 0.0151 & 9.3673 & 6835.124 & 4534.105 & 1716.177 & 8245.464 & \text { Yes } \\ 1 & 1608.9715 & 1608.9555 & 537.3258 & 0.0160 & 9.9256 & 6680.773 & 6229.091 & 1545.447 & 9311.435 & \text { Yes }\end{array}$ $\begin{array}{lllllllllllllll}1.00 & 55.17 & 21.90 & 35.30 & 2 & 1472.8980 & 1472.8959 & 737.4552 & 0.0021 & 1.4238 & 311.079 & 319.832 & 131.748 & 455.102 & \text { Yes }\end{array}$ $\begin{array}{llllllllllllllll}1.00 & 53.48 & 21.90 & 34.52 & 2 & 1472.8982 & 1472.8959 & 737.4552 & 0.0023 & 1.5594 & 2327.131 & 1715.920 & 15.786 & 4651.981 & \text { No }\end{array}$ $86.417 \quad 546.287 \quad$ Yes $\begin{array}{lll}112.988 & 532.445 & \text { Yes } \\ 226.885 & 764.460 & \text { Yes }\end{array}$ $\begin{array}{lll}62.140 & 66.428 & \text { Yes }\end{array}$ $70.636 \quad 346.023 \quad$ Yes $31.797 \quad 47.818 \quad$ Yes $33.288 \quad 598.603 \quad$ Yes $0.000 \quad 346.349$ No $22.067 \quad 106.274 \quad$ Yes $\begin{array}{llll}77.820 & 35.332 & 135.404 & \text { Yes }\end{array}$ \begin{tabular}{llll}
53.128 & 28.933 & 62.420 & Yes \\
\hline 5.650 & 49.194 & 36.67 & Ve
\end{tabular} $\begin{array}{rrrr}45.650 & 49.194 & 36.607 & \text { No }\end{array}$ $\begin{array}{llll}280.944 & 115.053 & 315.968 & \text { Yes } \\ 101.823 & 49.951 & 178.776 & \text { Yes }\end{array}$ $\begin{array}{llll}101.823 & 49.951 & 178.776 & \text { Yes } \\ 131.636 & 42.801 & 170.257 & \text { Yes }\end{array}$ $\begin{array}{llll}131.636 & 42.801 & 178.7767 & \text { Yes } \\ 511.626 & 249.282 & 609.992 & \text { Yes }\end{array}$ $\begin{array}{llll}102.175 & 53.692 & 121.789 & \text { Yes }\end{array}$ 


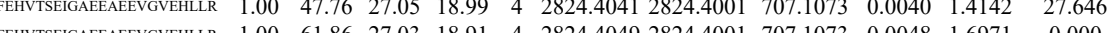

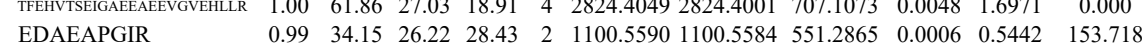
EDAEAPGIR $\begin{array}{lccccccccccc}\text { ASGYQSSQK } & 0.99 & 35.81 & 27.23 & 22.36 & 2 & 1242.6460 & 1242.6448 & 622.3297 & 0.0012 & 0.9641 & 34.899 \\ \text { GFSEGLWEIENNPTVK } & 1.00 & 48.18 & 28.08 & 19.56 & 3 & 2107.0846 & 2107.0829 & 703.3682 & 0.0017 & 0.8056 & 681.529\end{array}$ $\begin{array}{llllllllllll}0.99 & 34.15 & 26.22 & 28.43 & 2 & 1100.5590 & 1100.5584 & 551.2865 & 0.0006 & 0.5442 & 153.718\end{array}$ $\begin{array}{llllllllllll}\text { GFSEGLWEIENNPTVK } & 1.00 & 50.35 & 28.08 & 18.10 & 3 & 2107.0852 & 2107.0829 & 703.3682 & 0.0023 & 1.0900 & 686.976\end{array}$ $\begin{array}{lllllllllllllll} & \text { GFSEGLWEIENNPTVK } & 1.00 & \# \# \# \# 28.01 & 25.18 & 2 & 2107.0854 & 2107.0829 & 1054.5487 & 0.023 & 1.1853 & 356.919\end{array}$

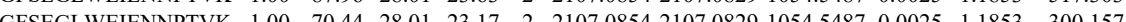

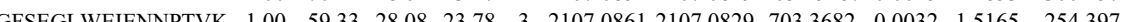
$\begin{array}{llllllllllll}\text { GFSEGLWEIENNPTVK } & 0.99 & 27.81 & 28.16 & 23.78 & 3 & 2107.0864 & 2107.0829 & 703.3682 & 0.0035 & 1.6587 & 230.189\end{array}$ $\begin{array}{llllllllllll}\text { GFSEGLWEIENNPTVK } & 1.00 & 75.88 & 28.12 & 21.71 & 2 & 2107.0874 & 2107.0829 & 1054.5487 & 0.0045 & 2.1336 & 340.344\end{array}$ $\begin{array}{lllllllllllll}\text { GFSEGLWEIENNPTVK } & 1.00 & 36.40 & 28.11 & 22.11 & 3 & 2107.0843 & 2107.0829 & 703.3682 & 0.0014 & 0.6635 & 233.119\end{array}$ $\begin{array}{lllllllllllll}\text { GFSEGLWEIENNPTVK } & 1.00 & 36.72 & 28.08 & 23.44 & 3 & 2107.0846 & 2107.0829 & 703.3682 & 0.0017 & 0.8056 & 230.530\end{array}$

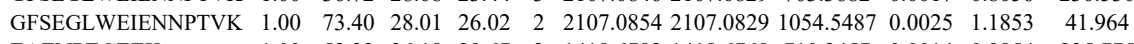
$\begin{array}{llllllllllll}\text { EAENPEGEEK } & 1.00 & 52.33 & 26.18 & 29.67 & 2 & 1418.6782 & 1418.6768 & 710.3457 & 0.0014 & 0.9854 & 225.775 \\ \text { EAENPEGEEK } & 1.00 & 31.72 & 26.19 & 20.38 & 3 & 1418.6785 & 1418.6768 & 473.8995 & 0.0017 & 1.1958 & 84.165\end{array}$ EAENPEGEEK EAENPEGEEK $\begin{array}{lllllllllll}1.00 & 31.72 & 26.19 & 20.38 & 3 & 1418.6785 & 1418.6768 & 473.8995 & 0.0017 & 1.1958 & 84.165\end{array}$ $\begin{array}{llllllllllll}0.99 & 27.78 & 26.19 & 26.11 & 3 & 1418.6788 & 1418.6768 & 473.8995 & 0.0020 & 1.4068 & 57.940\end{array}$ IDEMPEAAVK $\begin{array}{lllllllllll}1.00 & 53.92 & 26.13 & 25.66 & 2 & 1418.6788 & 1418.6768 & 710.3457 & 0.0020 & 1.4078 & 549.973 \\ 1.00 & 78.89 & 22.17 & 27.06 & 2 & 2320.993 & 2320.999 & 4161.5032 & 0.0015 & 0.6457 & 18.199\end{array}$ IDEMPEAAVK \begin{tabular}{cc}
21.512 \\
954 & 9633.508 \\
\hline
\end{tabular} EAATLEVERPLPMEVEK $\begin{array}{llllllllll} & \end{array}$

LVIDEPAK LVIDEPAK

EDSVKPGAHLTVK EDSVKPGAHLTVK EDSVKPGAHLTVK

\section{SSGSPYGGGYGSTG}

SSGSPYGGGYGSGGGSGGYGSR

SSGSPYGGGYGSGGGSGGYGSR

SSGSPYGGGYGSGGGSGGYGSR SSGSPYGGGYGSGGGSGGYGSR

$\begin{array}{lllllllllllll}\text { SSGSPYGGGYGSGGGSGGYGSR } & 0.82 & \text { \#\#\#\# } & 22.30 & \text { \#\#\#\# } & 2 & 2053.8854 & 2053.8848 & 1027.9497 & 0.0006 & 0.2918 & 561.847 & 459.446 \\ \text { SSGSPYGGGYGGGGSGGYGSR } & 1.00 & \text { \#\#\#\# } 22.30 & 30.66 & 2 & 2053.8854 & 2053.8848 & 1027.9497 & 0.0006 & 0.2918 & 272.411 & 202.022 \\ \text { SSGSPYGGGYGSGGGSGGYGSR } & 0.66 & 94.99 & 22.41 & \text { \#\#\#\# } & 3 & 2053.8865 & 2053.8848 & 685.6355 & 0.0017 & 0.8265 & 312.770 & 151.308\end{array}$

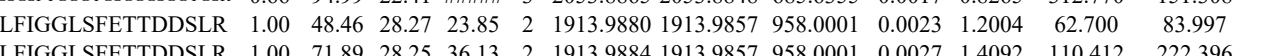

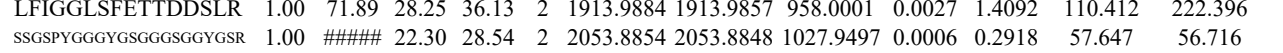

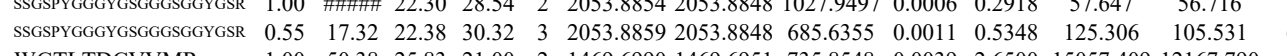
WGTLTDCVVMR WGTLTDCVVMR WGTLTDCVVMR WGTLTDCVVMR WGTLTDCVVMR IETIEVMEDR IETIEVMEDR

IETIEVMEDR $\begin{array}{lllllllllllllll}0.94 & 31.85 & 25.40 & 20.45 & 2 & 1171.7154 & 1171.7056 & 586.8601 & 0.0098 & 8.3495 & 4313100 & 3793968 & 120.624 & 4196.461 & \text { Yes }\end{array}$ $\begin{array}{llllllllllllllll}0.98 & 35.93 & 25.40 & 22.41 & 2 & 1171.7154 & 1171.7056 & 586.8601 & 0.0098 & 8.3495 & 9435.329 & 8854.020 & 1414.105 & 8751.752 & \text { Yes }\end{array}$ $\begin{array}{llllllllllllllll}1.00 & 59.93 & 23.12 & 23.14 & 2 & 1812.0538 & 1812.0471 & 907.0308 & 0.0067 & 3.6934 & 895.390 & 558.159 & 1040.001 & 1075.356 & \text { Yes }\end{array}$ $\begin{array}{lllllllllllllll}1.00 & 17.91 & 22.97 & 30.91 & 4 & 1812.0545 & 1812.0471 & 454.0191 & 0.0074 & 4.0747 & 18787.219 & 13295.204 & 22604.387 & 25659.035 & \text { Yes }\end{array}$ $\begin{array}{lllllllllllllllll}.5 & 13.52 & 23.48 & 26.52 & 4 & 1812.0517 & 1812.0471 & 454.0191 & 0.0046 & 2.5329 & 21569.889 & 14445.818 & 24857.622 & 31171.272 & \text { Yes }\end{array}$ $\begin{array}{lllllllllllll}\text { nes } & 23.54 & 2 & 2053.8854 & 2053.8848 & 1027.9497 & 0.0006 & 0.2918 & 820.803 & 803.237 & 53.816 & 939.492 & \text { Yes }\end{array}$ $\begin{array}{lllllllllllll} & \end{array}$

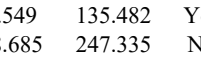

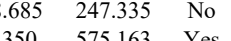

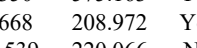
(17.985 $\begin{array}{lllllllllllllllll}\text { GFAFVTFDDHDTVDK } & 1.00 & 57.84 & 27.29 & 17.15 & 3 & 2000.9752 & 2000.9724 & 667.9981 & 0.0028 & 1.3972 & 5149.808 & 3864.278 & 529.253 & 6330.173 & \text { Yes }\end{array}$ $\begin{array}{llllllllllllllll}\text { GFAFVTFDDHDTVDK } & 0.88 & 24.93 & 27.35 & 15.02 & 3 & 2000.9794 & 2000.9724 & 667.9981 & 0.0070 & 3.4930 & 178.185 & 144.058 & 52.757 & 169.284 & \text { Yes }\end{array}$ $\begin{array}{lllllllllllllllll}\text { EDSVKPGAHLTVK } & 0.98 & 16.34 & 22.60 & 29.34 & 4 & 1812.0573 & 1812.0471 & 454.0191 & 0.0102 & 5.6165 & 31720.470 & 24494.290 & 40224.163 & 47287.325 & \text { Yes }\end{array}$ $\begin{array}{lllllllllllllllll} & \text { EDSVKPGAHLTKK } & 1.00 & 21.07 & 22.53 & 34.07 & 4 & 1812.0577 & 1812.0471 & 454.0191 & 0.0106 & 5.8367 & 23610.782 & 20063.745 & 30335.261 & 28915.697 & \text { Yes }\end{array}$

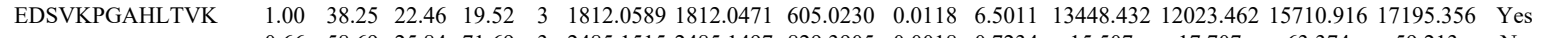
$\begin{array}{lllllllllllllll} & \end{array}$ $\begin{array}{llllllllllllllll}\text { DVLGMAQDEMAQAFEDWNK } & 0.53 & 8.71 & 25.79 & 21.71 & 3 & 2485.1521 & 2485.1497 & 829.3905 & 0.0024 & 0.9646 & 30.124 & 14.150 & 6.297 & 12.527 & \text { No }\end{array}$

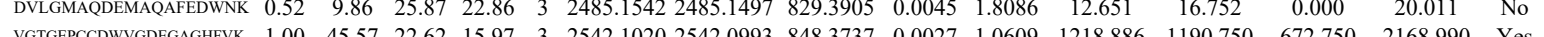
$\begin{array}{llllllllllllllll} & \end{array}$ $\begin{array}{llllllllllllllll}\text { VGTGEPCCDWVGDEGAGHFV } & 1.00 & 64.24 & 22.62 & 17.69 & 3 & 2542.1017 & 2542.093 & 848.3737 & 0.024 & 0.9430 & 1561.624 & 1357.119 & 758.026 & 2030.456 & \text { Yes }\end{array}$ \begin{tabular}{lllllllllllllll}
\hline & LVPLDTGG
\end{tabular} $\begin{array}{llllllllllllllll}\text { LVPLLDTGDIIIDGGNSEYR } & 1.00 & \# \# \# \# \text { 27.01 } & 22.65 & 2 & 2303.2134 & 2303.2131 & 1152.6138 & 0.0003 & 0.1301 & 463.218 & 418.203 & 231.186 & 566.145 & \text { Yes }\end{array}$

Table S-4 page 342 of 614 

$\begin{array}{llllllllllllllll} & \\ \text { TIFQGIAAK } & 0.99 & 38.93 & 24.55 & 23.63 & 2 & 1235.7572 & 1235.7481 & 618.8813 & 0.0091 & 7.3519 & 18457.543 & 16463.435 & 1868.201 & 26787.663 & \text { Yes }\end{array}$

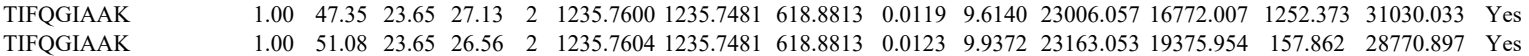
$\begin{array}{llllllllllllllll} & \\ \text { TIFQGIAAK } & 1.00 & 46.11 & 23.93 & 24.34 & 2 & 1235.7590 & 1235.7481 & 618.8813 & 0.0109 & 8.8061 & 8162.608 & 7427.623 & 2715.671 & 11016.180 & \text { Yes }\end{array}$

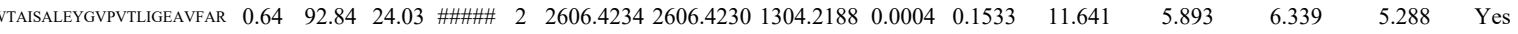
$\begin{array}{llllllllllllllll}\text { WTAISALEYGVPVTLIGEAVFAR } & 1.00 & 97.39 & 24.03 & 20.77 & 2 & 2606.4234 & 2606.4230 & 1304.2188 & 0.0004 & 0.1533 & 0.000 & 17.164 & 13.791 & 5.648 & \text { No }\end{array}$ $\begin{array}{llllllllllllllll}\text { WTAISALEYGVPVTLIGEAVFAR } & 0.66 & 25.77 & 23.82 & 38.77 & 3 & 2606.4250 & 2606.4230 & 869.8149 & 0.0020 & 0.7664 & 0.000 & 4.750 & 7.394 & 7.028 & \text { No }\end{array}$

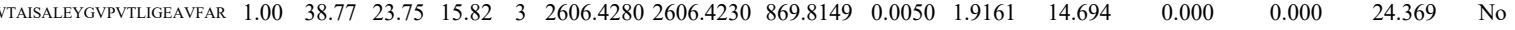

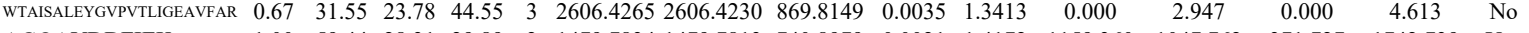
$\begin{array}{llllllllllllllll}\text { AGQAVDDFIEK } & 1.00 & 59.44 & 28.31 & 29.89 & 2 & 1479.7834 & 1479.7813 & 740.8979 & 0.0021 & 1.4172 & 1159.360 & 1047.762 & 371.727 & 1742.739 & \text { Yes }\end{array}$ $\begin{array}{llllllllllllllll}\text { AGQAVDDFIEK } & 1.00 & 61.85 & 28.09 & 30.56 & 2 & 1479.7862 & 1479.7813 & 740.8979 & 0.0049 & 3.3068 & 1806.167 & 1591.998 & 422.568 & 2100.953 & \text { Yes }\end{array}$ $\begin{array}{llllllllllllllll}\text { VDDFLANEAK } & 1.00 & 54.12 & 28.96 & 26.76 & 2 & 1408.7458 & 1408.7442 & 705.3794 & 0.0016 & 1.1341 & 372.088 & 369.612 & 39.556 & 412.484 & \text { Yes }\end{array}$

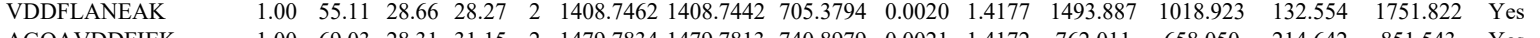

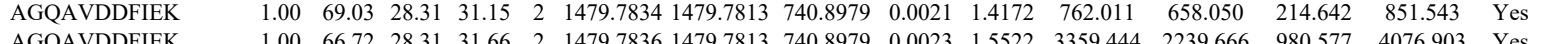
$\begin{array}{llllllllllllllll}\text { AGQAVDDFIEK } & 1.00 & 66.72 & 28.31 & 31.66 & 2 & 1479.7836 & 1479.7813 & 740.8979 & 0.0023 & 1.5522 & 3359.444 & 2239.666 & 980.577 & 4076.903 & \text { Yes }\end{array}$

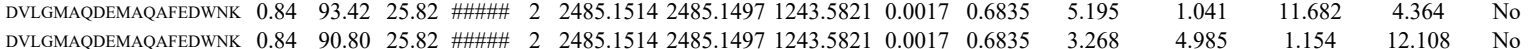

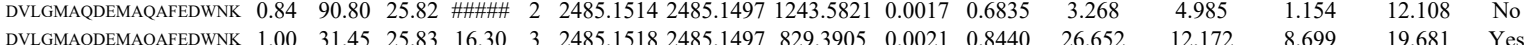
$\begin{array}{lllllllllllll} & 1.68 & \text { Yes }\end{array}$

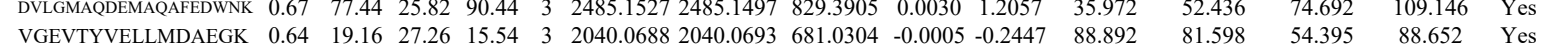

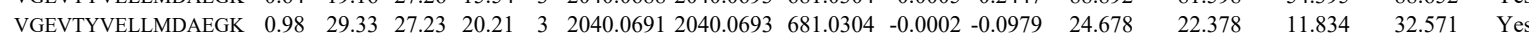

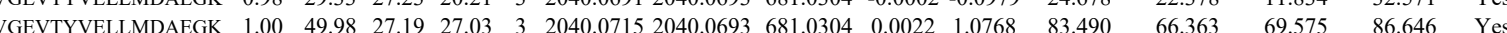
\begin{tabular}{llllllllllllllll} 
VGEVTYELLMDAEGK & 1.00 & 45.78 & 27.21 & 22.54 & 3 & 2040.0721 & 2040.0693 & 681.0304 & 0.0028 & 1.3705 & 207.124 & 107.646 & 102.602 & 179.596 & Yes \\
\hline
\end{tabular}

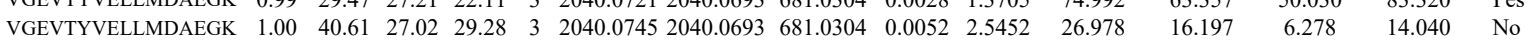

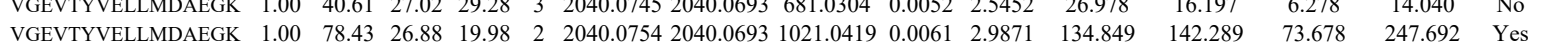

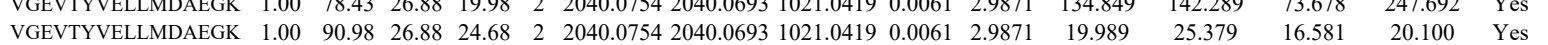

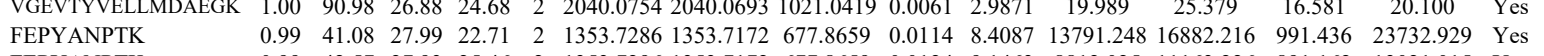

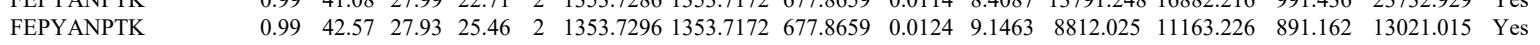
$\begin{array}{lllllllllllllll}\text { MGGMEGPFGGGMENMGR } & 1.00 & \text { \#\#\#\# } 22.04 & 19.84 & 2 & 1857.7786 & 1857.7752 & 929.8949 & 0.0034 & 1.8282 & 2096.674 & 1610.149 & 175.349 & 2686.137 & \text { Yes }\end{array}$ $\begin{array}{lllllllllllllll}\text { MGGMEGPFGGGMENMGR } & 1.00 & \text { \#\#\#\# } 22.07 & 21.30 & 2 & 1857.7788 & 1857.7752 & 929.8949 & 0.0036 & 1.9357 & 1847.754 & 1715.414 & 300.395 & 2546.057 & \text { Yes }\end{array}$ $\begin{array}{llllllllllllllll}\text { MGPLGLDHMASSIER } & 1.00 & 77.42 & 27.54 & 20.44 & 2 & 1756.8878 & 1756.8722 & 879.4434 & 0.0156 & 8.8692 & 152.996 & 193.947 & 36.448 & 254.668 & \text { Yes }\end{array}$ $\begin{array}{llllllllllllllll}\text { MGPLGLDHMASSIER } & 1.00 & 89.13 & 27.48 & 25.53 & 2 & 1756.8886 & 1756.8722 & 879.4434 & 0.0164 & 9.3240 & 166.360 & 255.118 & 1.184 & 253.610 & \text { No }\end{array}$

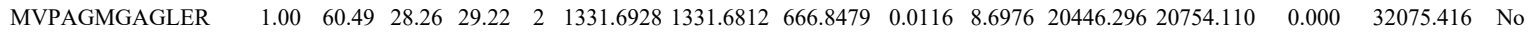

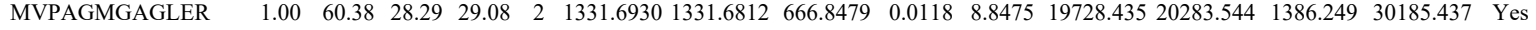

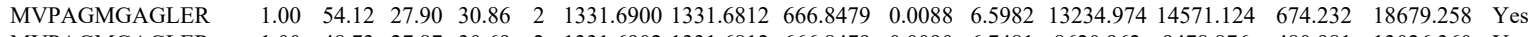
$\begin{array}{lllllllllllllllll}\text { MVPAGMGAGLER } & 1.00 & 48.73 & 27.87 & 30.69 & 2 & 1331.6902 & 1331.6812 & 666.8479 & 0.0090 & 6.7481 & 8620.962 & 9478.876 & 480.981 & 13026.360 & \text { Yes }\end{array}$ $\begin{array}{llllllllllllllll}\text { MGPAMGPALGAGIER } & 1.00 & 68.29 & 27.90 & 24.82 & 2 & 1570.8216 & 1570.8081 & 786.4113 & 0.0135 & 8.5832 & 674.397 & 585.412 & 99.824 & 1181.711 & \text { Yes }\end{array}$

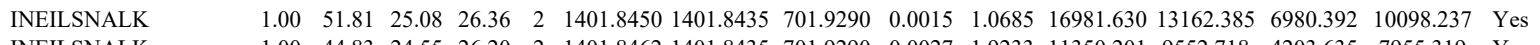
$\begin{array}{llllllllllllllll}\text { INEILSNALK } & 1.00 & 44.83 & 24.55 & 26.20 & 2 & 1401.8462 & 1401.8435 & 701.9290 & 0.0027 & 1.9233 & 11350.201 & 9552.718 & 4203.635 & 7955.319 & \text { Yes }\end{array}$ $\begin{array}{llllllllllllllll}\text { MGPAMGPALGAGIER } & 1.00 & 60.43 & 27.92 & 19.52 & 2 & 1570.8224 & 1570.8081 & 786.4113 & 0.0143 & 9.0919 & 8004.938 & 8511.256 & 1343.062 & 12050.691 & \text { Yes }\end{array}$ $\begin{array}{llllllllllllllll}\text { MGAGMGFGLER } & 1.00 & 62.43 & 26.76 & 23.32 & 2 & 1268.6236 & 1268.6127 & 635.3136 & 0.0109 & 8.5784 & 8768.646 & 8675.654 & 754.819 & 14612.883 & \text { Yes }\end{array}$ $\begin{array}{lllllllllllllllll}\text { MGAGMGFGLER } & 1.00 & 61.78 & 26.98 & 22.95 & 2 & 1268.6244 & 1268.6127 & 635.3136 & 0.0117 & 9.2080 & 5807.991 & 6294.797 & 723.467 & 10530.282 & \text { Yes }\end{array}$

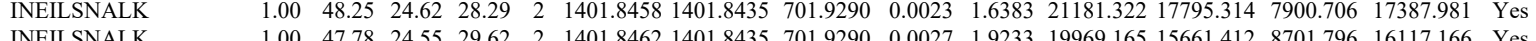
$\begin{array}{lllllllllllllllll}\text { INEILSNALK } & 1.00 & 47.78 & 24.55 & 29.62 & 2 & 1401.8462 & 1401.8435 & 701.9290 & 0.0027 & 1.9233 & 19969.165 & 15661.412 & 8701.796 & 16117.166 & \text { Yes } \\ \text { AFITNIPFDVK } & 1.00 & 60.31 & 25.63 & 24.24 & 2 & 1551.8902 & 1551.8905 & 776.9525 & -0.0003 & -0.1931 & 5820.668 & 6691.633 & 0.000 & 8530223 & \text { No }\end{array}$

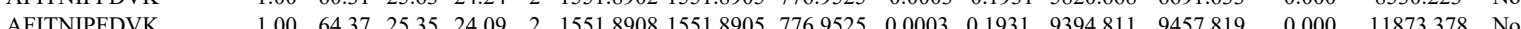




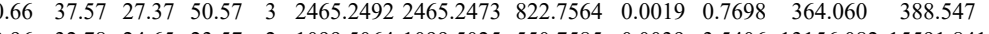

13 TGVVPQLVK $\begin{array}{llllllllllllllll}\text { TGVVPLVK } & 0.99 & 38.89 & 21.61 & 19.85 & 2 & 1227.7904 & 1227.7795 & 614.8970 & 0.0109 & 8.8632 & 2014.002 & 2265.860 & 1013.636 & 2893.401 & \text { Yes } \\ \text { TGVVPQLVK } & 0.96 & 32.93 & 21.52 & 26.20 & 2 & 1227.7864 & 1227.7795 & 614.8970 & 0.0069 & 5.6107 & 5893.393 & 5909.123 & 2676.768 & 7048.554 & \text { Yes } \\ \text { TGVVPQLVK } & 0.97 & 34.29 & 21.40 & 22.73 & 2 & 1227.7874 & 1227.7795 & 614.8970 & 0.0079 & 6.4238 & 3569.151 & 3106.578 & 1126.491 & 3972.264 & \text { Yes }\end{array}$ \begin{tabular}{llllllllllllllll} 
NPAPPIDAVEQILPTLVR & 1.00 & 92.23 & 23.86 & 20.13 & 2 & 2086.1914 & 2086.1908 & 1044.1027 & 0.0006 & 0.2873 & 212.849 & 249.143 & 599.464 & 4972.264 & Yes \\
\hline
\end{tabular}

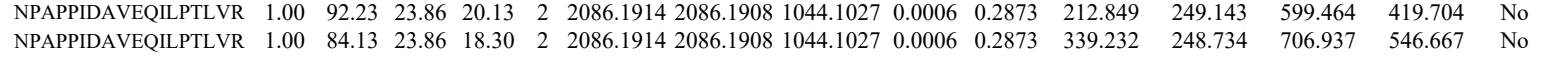
$\begin{array}{lllllllllllllllll}\text { NPAPPIDAVEQILPTLVR } & 0.55 & 11.06 & 23.73 & 24.06 & 3 & 2086.1923 & 2086.1908 & 696.4042 & 0.0015 & 0.7180 & 61.709 & 55.236 & 58.210 & 115.299 & \text { Yes }\end{array}$ $\begin{array}{lllllllllllllllll}\text { NPAPPIDAVEQILPTLVR } & 0.60 & 26.57 & 23.65 & 39.57 & 3 & 2086.1944 & 2086.1908 & 696.4042 & 0.0036 & 1.7231 & 91.598 & 63.976 & 100.016 & 98.800 & \text { Yes }\end{array}$ $\begin{array}{llllllllllllllll}\text { LLGASELPIVTPALR } & 0.67 & 32.97 & 20.13 & 45.97 & 3 & 1693.0288 & 1693.0260 & 565.3493 & 0.0028 & 1.6509 & 212.027 & 278.551 & 90.768 & 682.042 & \text { Yes } \\ \text { LLGASELPIVTPALR } & 0.67 & 35.53 & 19.78 & 48.53 & 3 & 1693.0291 & 1693.0260 & 565.3493 & 0.0031 & 1.8278 & 159.915 & 223533 & 0.000 & 570.878 & \text { No }\end{array}$ $\begin{array}{llllllllllllllll}\text { LLGASELPIVTPALR } & 0.67 & 35.53 & 19.78 & 48.53 & 3 & 1693.0291 & 1693.0260 & 565.3493 & 0.0031 & 1.8278 & 159.915 & 223.533 & 0.000 & 570.578 & \text { No }\end{array}$

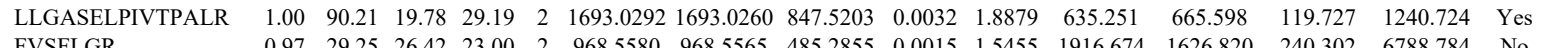
$\begin{array}{llllllllllllllll} & \end{array}$

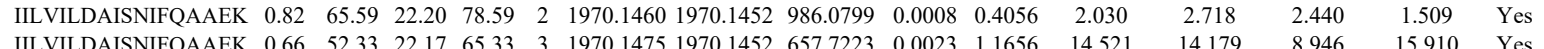

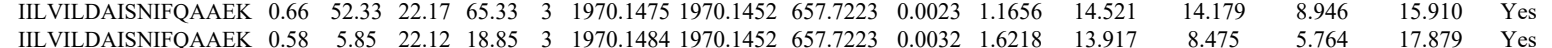

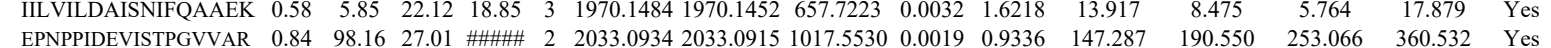
$\begin{array}{llllllllllllllll}\text { EPNPPIDEVISTPGVVAR } & 1.00 & \# \# \# & 27.01 & 20.41 & 2 & 2033.0934 & 2033.0915 & 1017.5530 & 0.0019 & 0.9336 & 244.668 & 208.702 & 305.904 & 366.972 & \text { Yes }\end{array}$

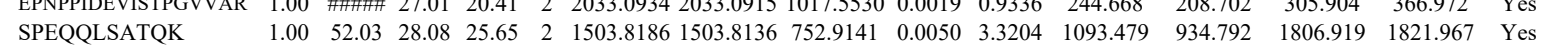

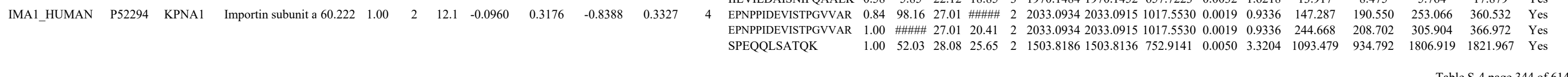



$\begin{array}{llllllllllll}\text { AEEYEFLTPVEEAPK } & 1.00 & 59.96 & 27.64 & 19.47 & 3 & 2039.0449 & 2039.0342 & 680.6853 & 0.0107 & 5.2398 & 175.490\end{array}$

$\begin{array}{lllllllllllll} & \end{array}$

TEMDWVLK

$\begin{array}{llllllllllllllllll}0.75 & 27.98 & 28.18 & 22.72 & 2 & 1193.6626 & 1193.6536 & 597.8341 & 0.0090 & 7.5271 & 7485.221 & 6880.784 & 1019.992 & 9990.190 & \text { Yes } & \\ 1.00 & 47.52 & 27.99 & 38.42 & 2 & 1308.7000 & 1308.691 & 555.3568 & 0.0009 & 0.6866 & 12132.952 & 11078.852 & 237.550 & 17875.520 & \text { Ycs }\end{array}$

$\begin{array}{lllllllllllllllll}\mathrm{K} & 1.00 & 45.57 & 28.08 & 37.01 & 2 & 1308.7006 & 1308.6991 & 655.3568 & 0.0015 & 1.1444 & 11197.371 & 11406.097 & 920.762 & 18264.908 & \text { Yes }\end{array}$

$\begin{array}{llllllllllllllll}\text { ITGEAFVQFASQELAEK } & 0.72 & 13.29 & 27.10 & 15.82 & 3 & 2155.1434 & 2155.1405 & 719.3874 & 0.0029 & 1.3437 & 7.646 & 22.201 & 5.344 & 0.000 & \text { No }\end{array}$

$\begin{array}{lllllllllllllllll}\text { ITGEAFVQFASQELAEK } & 0.98 & 24.34 & 27.09 & 23.01 & 3 & 2155.1437 & 2155.1405 & 719.3874 & 0.0032 & 1.4827 & 27.174 & 6.907 & 3.719 & 10.249 & \mathrm{~N}\end{array}$

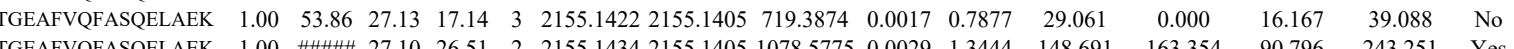

$\begin{array}{lllllllllllllll}\text { ITGEAFVQFASQELAEK } & 1.00 & \text { \#\#\#\# } 27.10 & 26.51 & 2 & 2155.1434 & 2155.1405 & 1078.5775 & 0.0029 & 1.3444 & 148.691 & 163.354 & 90.796 & 243.251 & \text { Yes }\end{array}$

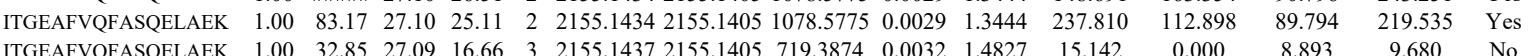
$\begin{array}{llllllllllll}\text { ITGEAFVQFASQELAEK } & 1.00 & 32.85 & 27.09 & 16.66 & 3 & 2155.1437 & 2155.1405 & 719.3874 & 0.0032 & 1.4827 & 15.142\end{array}$ $\begin{array}{lllllllllllll}\text { ITGEAFVQFASQELAEK } & 1.00 & 68.79 & 27.09 & 20.68 & 3 & 2155.1443 & 2155.1405 & 719.3874 & 0.0038 & 1.7608 & 26.017\end{array}$ $\begin{array}{lllllllllllll} & \text { EEVQFFGLLEIVNGGTLPVDPEGK } & 1.00 & 44.22 & 23.73 & 17.47 & 3 & 3114.6772 & 3114.6733 & 1039.2317 & 0.0039 & 1.2509 & 39.077\end{array}$ $\begin{array}{llllllllllll} & \end{array}$

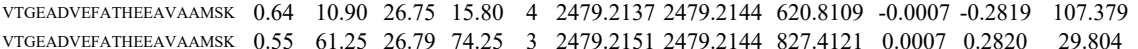
$\begin{array}{llllllllllllll}\text { VTGEADVEFATHEEAVAAMSK } & 1.00 & 62.75 & 26.93 & 17.27 & 3 & 2479.2157 & 2479.2144 & 827.4121 & 0.0013 & 0.5237 & 40.715\end{array}$ $\begin{array}{llllllllllllll}\text { VTGEADVEFATHEEAVAAMSK } & 0.65 & 7.36 & 26.88 & 16.54 & 4 & 2479.2169 & 2479.2144 & 620.8109 & 0.0025 & 1.0067 & 188.162 & & \\ \text { (n) }\end{array}$ $\begin{array}{lllllllllllll}\text { VTGEADVEFATHEEAVAAMSK } & 1.00 & 56.63 & 26.89 & 22.27 & 3 & 2479.2172 & 2479.2144 & 827.4121 & 0.0028 & 1.1280 & 36.033\end{array}$ $\begin{array}{lllllllllllll}\text { VTGEADVEFATHEEAVAAMSK } & 0.67 & 40.31 & 26.89 & 53.31 & 3 & 2479.2172 & 2479.2144 & 827.4121 & 0.0028 & 1.1280 & 6.526\end{array}$ $\begin{array}{llllllllllll}\text { VTGEADVEFATHEEAVAAMSK } & 0.67 & 68.42 & 26.91 & 81.42 & 3 & 2479.2175 & 2479.2144 & 827.4121 & 0.0031 & 1.2489 & 52.979 \\ \text { VTGEADVEFATHEEAVAAMSK } & 1.00 & 50.20 & 26.95 & 17.49 & 3 & 2479.2178 & 2479.2144 & 827.4121 & 0.0034 & 1.3697 & 8.739\end{array}$ $\begin{array}{llllllllllll}\text { VTGEADVEFATHEEAVAAMSK } & 1.00 & 50.20 & 26.95 & 17.49 & 3 & 2479.2178 & 2479.2144 & 827.4121 & 0.0034 & 1.3697 & 8.739 \\ \text { VTGEADVEFATHEFAVAMMSK } & 0.83 & 9.52 & 26.95 & 16.38 & 4 & 2479.2181 & 2479.2144 & 620.8109 & 0.0037 & 1.4900 & 263.721\end{array}$ $\begin{array}{lllllllllllll}\text { VTGEADVEFATHEEAVAAMSK } & 0.83 & 9.52 & 26.95 & 16.38 & 4 & 2479.2181 & 2479.2144 & 620.8109 & 0.0037 & 1.4900 & 263.721 \\ \text { VTGEADVEFATHEEAVAAMSK } & 0.60 & 62.74 & 27.10 & 75.74 & 3 & 2479.2187 & 2479.2144 & 827.4121 & 0.0043 & 1.7323 & 58.694\end{array}$

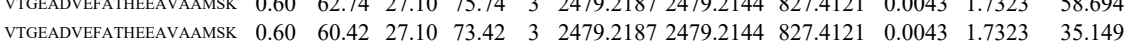
$\begin{array}{lllllllllllll}\text { VTGEADVEFATHEEAVAAMSK } & 1.00 & 65.16 & 27.07 & 17.76 & 3 & 2479.2190 & 2479.2144 & 827.4121 & 0.0046 & 1.8532 & 48.830\end{array}$ $\begin{array}{lllllllllllll}\text { VTGEADVEFATHEEAVAAMSK } & 1.00 & 64.96 & 27.08 & 17.79 & 3 & 2479.2196 & 2479.2144 & 827.4121 & 0.0052 & 2.0949 & 45.621\end{array}$

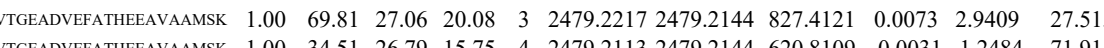

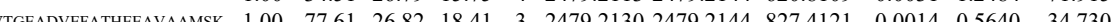

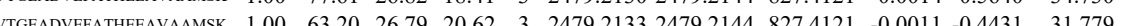

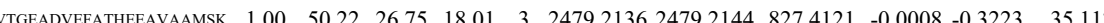

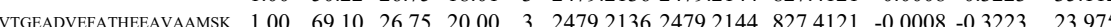
$\begin{array}{llllllllllllll}\text { VTGEADVEFATHEFVAMSK } & 1.00 & 76.74 & 26.81 & 22.25 & 3 & 2479.2154 & 24792144 & 827.4121 & 0.0010 & 0.4029 & 45.560\end{array}$ $\begin{array}{llllllllllllll}\text { VTGEADVEFATHEFAVAMSSK } & 1.00 & 61.71 & 26.93 & 16.87 & 3 & 2479.2157 & 2479.2144 & 827.4121 & 0.0013 & 0.5237 & 8.815\end{array}$ $\begin{array}{lllllllllllll}\text { VTGEADVEFATHEEAVAAMSK } & 0.66 & 78.89 & 26.92 & 91.89 & 3 & 2479.2163 & 2479.2144 & 827.4121 & 0.0019 & 0.7654 & 62.38\end{array}$ $\begin{array}{lllllllllllll}\text { VTGEADVFFATHEEAVAAMSK } & 1.00 & 68.64 & 26.92 & 22.08 & 3 & 2479.2163 & 2479.2144 & 827.4121 & 0.0019 & 0.7654 & 25.232\end{array}$ $\begin{array}{lllllllllllll}\text { VTGEADVEFATHEEAVAAMSK } & 1.00 & 22.40 & 26.93 & 35.40 & 4 & 2479.2173 & 2479.2144 & 620.8109 & 0.0029 & 1.1678 & 115.542\end{array}$ $\begin{array}{lllllllllllll}\text { VTGEADVEFATHEEAVAAMSK } & 1.00 & 18.10 & 26.93 & 16.42 & 4 & 2479.2173 & 2479.2144 & 620.8109 & 0.0029 & 1.1678 & 60.360\end{array}$ $\begin{array}{llllllllllll}\text { VTGEADVEFATHEEAVAAMSK } & 0.67 & 63.78 & 26.95 & 76.78 & 3 & 2479.2178 & 2479.2144 & 827.4121 & 0.0034 & 1.3697 & 50.206\end{array}$ $\begin{array}{lllllllllllll}\text { VTGEADVEFATHEEAVAAMSK } & 0.60 & 70.16 & 26.95 & 83.16 & 3 & 2479.2181 & 2479.2144 & 827.4121 & 0.0037 & 1.4906 & 53.448\end{array}$ $\begin{array}{llllllllllll}\text { VTGEADVEFATHEEAVAAMSK } & 0.60 & 78.81 & 27.10 & 91.81 & 3 & 2479.2187 & 2479.2144 & 827.4121 & 0.0043 & 1.7323 & 60.939\end{array}$ $\begin{array}{llllllllllll}\text { VTGEADVEFATHEEAVAAMSK } & 0.60 & 87.62 & 27.10 & \text { \#\#\#\# } & 3 & 2479.2187 & 2479.2144 & 827.4121 & 0.0043 & 1.7323 & 19.914\end{array}$ $\begin{array}{llllllllllll}\text { VTGEADVEFATHEEAVAAMSK } & 1.00 & 44.92 & 27.08 & 15.86 & 3 & 2479.2196 & 2479.2144 & 827.4121 & 0.0052 & 2.0949 & 6.808\end{array}$ $\begin{array}{lllllllllllll}\text { VTGEADVEFATHEEAVAAMSK } & 1.00 & 60.63 & 27.18 & 18.03 & 3 & 2479.2208 & 2479.2144 & 827.4121 & 0.0064 & 2.5783 & 19.508\end{array}$ SYSDPPLK

$\left.\begin{array}{llllllllllll}0.66 & 28.70 & 28.60 & 27.87 & 2 & 1193.6606 & 1193.6536 & 597.8341 & 0.0070 & 5.8544 & 28434.294 & 27\end{array}\right)$ $\begin{array}{lllllllllllll} & 0.85 & 31.07 & 28.31 & 21.53 & 2 & 1193.6622 & 1193.6536 & 597.8341 & 0.0086 & 7.1926 & 26924.641 \\ \text { VISGEADVEFATHEEAVAAMSK } & 0.95 & 13.06 & 27.07 & 17.22 & 4 & 2479.2189 & 2479.2144 & 620.8109 & 0.0045 & 1.8121 & 48.851\end{array}$ 
$\begin{array}{lllllllllllll}\text { ICQIVSTR } & 0.65 & 28.08 & 28.11 & 25.75 & 2 & 1108.5922 & 1108.5855 & 555.3000 & 0.0067 & 6.0327 & 4352.572 & 4964.433\end{array}$

$\begin{array}{llllllllllllll}1.00 & 62.33 & 28.84 & 28.24 & 2 & 1234.6660 & 1234.6648 & 618.3397 & 0.0012 & 0.9703 & 1457.093 & 1431.061\end{array}$ $\begin{array}{lllllllllllll}\text { SASLCAATLAAVLQR } & 0.53 & 10.90 & 27.98 & 23.90 & 3 & 1663.8904 & 1663.8871 & 555.6363 & 0.0033 & 1.9797 & 5.157\end{array}$ $\begin{array}{lllllllllllll}\text { SASLCAATLAAVLQR } & 0.55 & 23.52 & 27.83 & 36.52 & 3 & 1663.8880 & 1663.8871 & 555.6363 & 0.0009 & 0.5399 & 16.330\end{array}$ $\begin{array}{llllllllllll}\text { SASLCAATLAAVLQR } & 0.66 & 16.16 & 27.94 & 29.16 & 3 & 1663.8895 & 1663.8871 & 555.6363 & 0.0024 & 1.4398 & 10.33\end{array}$ $\begin{array}{llllllllllll}\text { SASLCAATLAAVLQR } & 0.66 & 23.35 & 27.82 & 36.35 & 3 & 1663.8889 & 1663.8871 & 555.6363 & 0.0018 & 1.0798 & 6.46\end{array}$

$\begin{array}{lllllllllllll} & \end{array}$ $\begin{array}{lllllllll} & \end{array}$

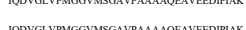
$\begin{array}{lllllllllll} & 0.962 .90 & 3 & 3620.9062 & 3620.9037 & 1207.9752 & 0.0025 & 0.6899 & 4.115\end{array}$ $\begin{array}{lllllllllll}0.98 & 23.45 & 24.50 & 14.71 & 4 & 3620.9093 & 3620.9037 & 906.2332 & 0.0056 & 1.5449 & 12.997 \\ 0.95 & 15.17 & 3 & 3620.9062 & 3620.9037 & 1207.9752 & 0.0025 & 0.6899 & 101.321\end{array}$ $\begin{array}{llllllllll} & \end{array}$

NYIQGINLVQAK $\begin{array}{lllllllllll}0.93 & 20.66 & 24.52 & 16.10 & 3 & 3620.9092 & 3620.9037 & 1207.9752 & 0.0055 & 1.5177 & 144.211\end{array}$

\subsection{6}

10.417

0.000

90.745

LTEAKPVDK $\begin{array}{llllllllll} & \end{array}$

LTEAKPVDK $\begin{array}{llllllllll} & \end{array}$ $\begin{array}{llllllllllllllll}\text { ISDTTFK } & 1.00 & 95.81 & 25.66 & 20.18 & 3 & 3327.5722 & 3327.5696 & 1110.1971 & 0.0026 & 0.7806 & 3.947 & 6.036 & 5.231 & 6.072 & \mathrm{~N}\end{array}$

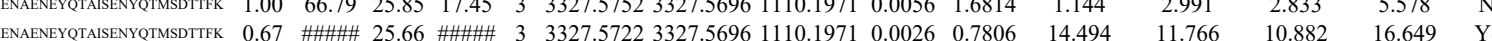

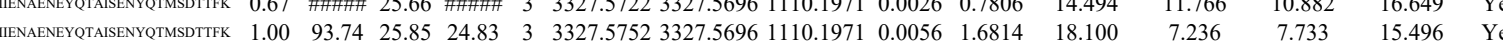

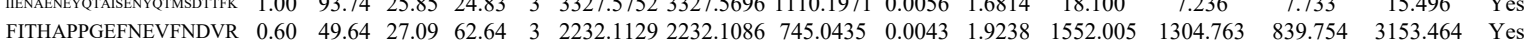

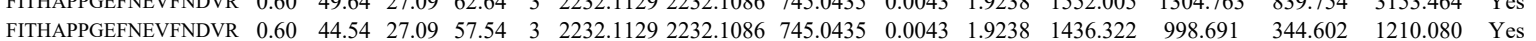
$\begin{array}{llllllllllllllll}\text { TIDGQQTIIACIESHOFOPK } & 0.60 & 40.87 & 27.21 & 53.87 & 3 & 2590.3168 & 2590.3127 & 864.4448 & 0.0041 & 1.5810 & 5210.854 & 2968.239 & 5148.461 & 8060.505 & \text { Yes }\end{array}$

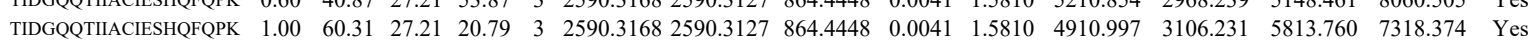
$\begin{array}{lllllllllllllllll}\text { TIDGQQTIIACIESHQFQPK } & 0.67 & 53.81 & 27.11 & 66.81 & 3 & 2590.3153 & 2590.3127 & 864.4448 & 0.0026 & 1.0026 & 2660.244 & 1963.249 & 2786.679 & 3189.685 & \text { Yes }\end{array}$ $\begin{array}{llllllllllllllll}\text { TIDGQQTIIACIESHQFPPK } & 1.00 & 57.60 & 27.12 & 18.95 & 3 & 2590.3159 & 2590.3127 & 864.4448 & 0.0032 & 1.2339 & 3392.468 & 1654.981 & 2841.323 & 4781.841 & \text { Yes }\end{array}$ $\begin{array}{llllllllllllllll}\text { TIDGQQTIIACIESHQFQPK } & 1.00 & 48.66 & 27.11 & 24.76 & 3 & 2590.3144 & 2590.3127 & 864.4448 & 0.0017 & 0.6555 & 107.174 & 63.668 & 49.887 & 138.737 & \text { Yes }\end{array}$ $\begin{array}{lllllllllllllllll}\text { EASDPQPEEADGGLK } & 1.00 & 58.86 & 26.91 & 25.27 & 2 & 1829.8888 & 1829.8887 & 915.9516 & 0.0001 & 0.0546 & 29.638 & 26.362 & 31.523 & 51.583 & \text { Yes }\end{array}$ $\begin{array}{llllllllllllllll}\text { FTITPPTAQVVGVLK } & 1.00 & 64.28 & 19.64 & 20.06 & 2 & 1858.1196 & 1858.1172 & 930.0659 & 0.0024 & 1.2902 & 3894.750 & 2231.761 & 2950.705 & 3826.981 & \text { Yes }\end{array}$ $\begin{array}{lllllllllllllllll}\text { FTITPPTAQVVGVLK } & 0.64 & 62.73 & 20.04 & 75.73 & 2 & 1858.1176 & 1858.1172 & 930.0659 & 0.0004 & 0.2150 & 573.718 & 357.328 & 464.121 & 813.605 & \text { Yes }\end{array}$ $\begin{array}{llllllllllllllll}\text { FTITPPTAQVVGVLK } & 0.84 & 58.94 & 19.82 & 71.94 & 2 & 1858.1188 & 1858.1172 & 930.0659 & 0.0016 & 0.8602 & 670.640 & 329.526 & 560.180 & 695.358 & \text { Yes }\end{array}$ $\begin{array}{lllllllllllllllll}\text { FTITPPTAQVVGVLK } & 0.60 & 37.74 & 19.34 & 50.74 & 3 & 1858.1212 & 1858.1172 & 620.3797 & 0.0040 & 2.1492 & 24.226 & 33.053 & 9.755 & 56.636 & \text { Yes }\end{array}$

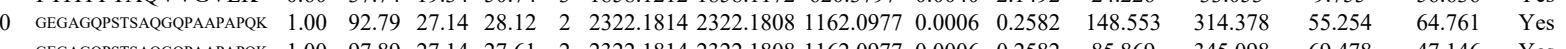

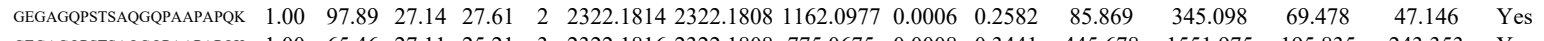

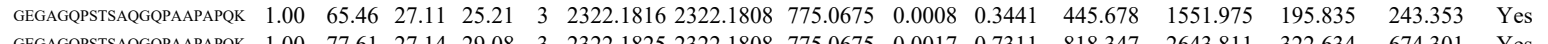

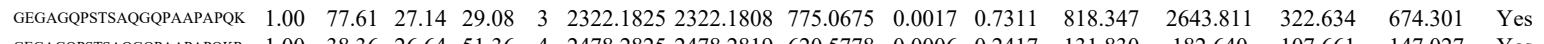

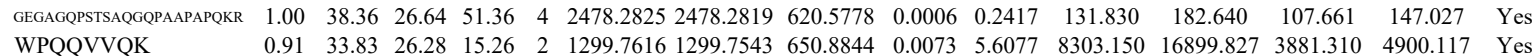

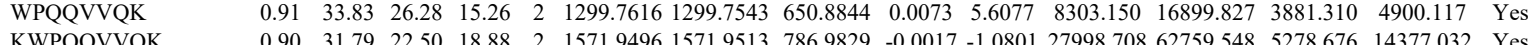

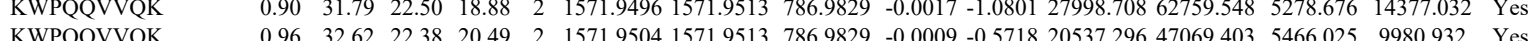

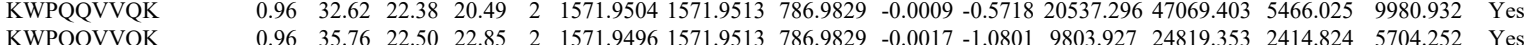

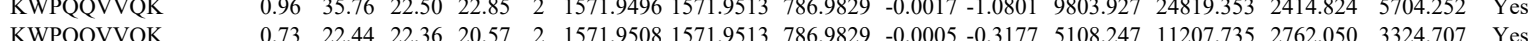

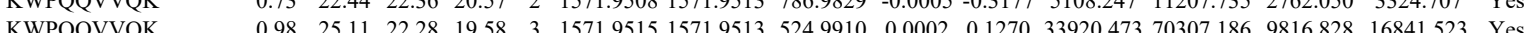

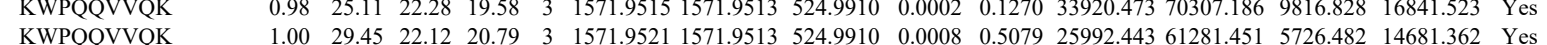


KWPQQVVQK QQQEPTGEPSPK

QQQEPTGEPSPK

GEGAGQPSTSAQGQPAAPAP

GEGAGQPSTSAQGQPAAPAPQK

GEGAGQPSTSAQGQPAAPAPQK

RQLGLVPR

NSPVEAVR

LALLLSQFVGSQSVR

LALLLSQFVGSQSVR

LALLLSQFVGSQSVR

LALLLSQFVGSQSVR

LALLLSQFVGSQSVR

LALLLSQFVGSQSV

$\begin{array}{lllllllllll}\text { BIEA_HUMAN } & \text { P53004 } & \text { BLVRA } & \text { Biliverdin reducta } 33.428 & 1.00 & 4 & 21.3 & 0.4629 & 0.6222 & 0.8261 & 0.5846\end{array}$

1 HY

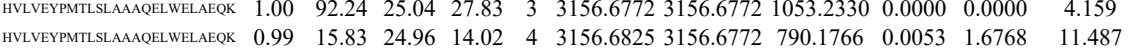

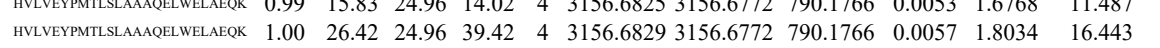
FGVVVVGVGR FGVVVVGVGR FGVVVVGVGR FGFPAFSGISR FGFPAFSGISR FGFPAFSGISR FGFPAFSGISR FIHDQTSPNPK GLSSLLYGSIPK

FGMFEFLSNHMR FFVMTSLR FFVMTSLR

ARFP1_HUMAR P53367 ARFIP1 Arfaptin-1 $\begin{array}{lllllll}41.738 & 1.00 & 3 & 13.7 & -0.1594 & 0.6534 & 0.0323\end{array}$ 0.4128
GEGAGQPSTSAQGQPAAPAPOK NPHPSSAFLNLIGFVSR NPHPSSAFLNLIGFVSR

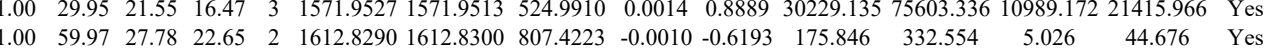

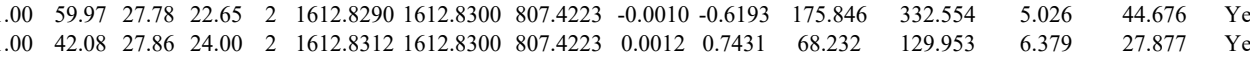

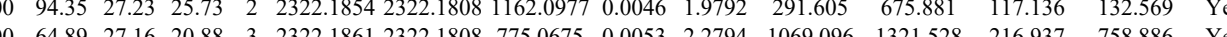
$\begin{array}{lllllllllllllll} & \end{array}$ $\begin{array}{rlllllllllllll} & \end{array}$

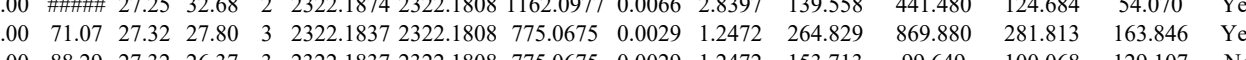
$\begin{array}{lllllllllllllll} & 3.37 & 2322.1837 & 2322.1808 & 775.0675 & 0.0029 & 1.2472 & 153.713 & 99.649 & 100.068 & 129.107 & \text { No }\end{array}$ $\begin{array}{llllllllllllll}1.00 & \text { \#\#\#\# } 24.05 & 29.14 & 2 & 1761.0276 & 1761.0271 & 881.5208 & 0.0005 & 0.2836 & 40.213 & 52.619 & 7.400 & 104.376 & \text { Yes }\end{array}$

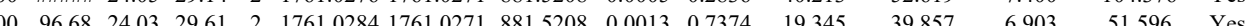
$\begin{array}{llllllllllllll}10.840 & \text { Yes }\end{array}$ $\begin{array}{lllllllllllllll}1.00 & 44.27 & 24.03 & 18.56 & 3 & 1761.0286 & 17610271 & 588.0163 & 0.0015 & 0.8503 & 38.059 & 24.160 & 14.179 & 52.046 & \text { Yes }\end{array}$ $\begin{array}{lllllllllllllll}1.00 & 73.82 & 24.05 & 26.05 & 2 & 1761.0272 & 1761.0271 & 881.5208 & 0.0001 & 0.0567 & 10.0311 & 8.1602 & 14.179 & 52.046 & \text { Yes } \\ 1.386 & 8.703 & \text { Yes }\end{array}$

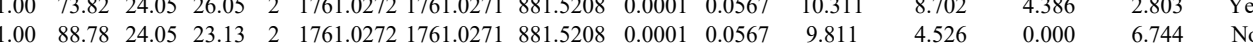

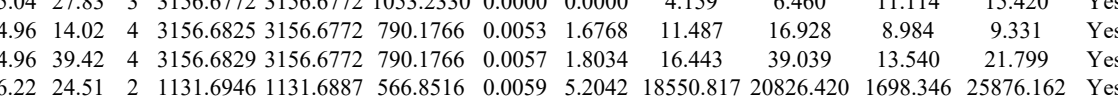

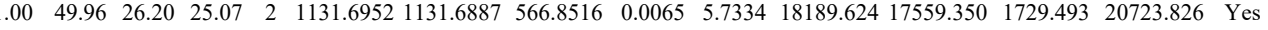
\begin{tabular}{lllllllllllllll}
1.00 & 49.96 & 26.20 & 25.07 & 2 & 1131.6952 & 1131.6887 & 566.8516 & 0.0065 & 5.734 & 18189.624 & 1759.350 & 1729.493 & 20723.826 & Yes \\
\hline
\end{tabular} $\begin{array}{lllllllllllllll}.00 & 47.03 & 27.66 & 24.16 & 2 & 1328.7008 & 1328.6999 & 665.3572 & 0.0009 & 0.6763 & 1680.926 & 1571.556 & 437.570 & 2109.700 & \text { Yes }\end{array}$ $\begin{array}{lllllllllllllll}1.00 & 39.64 & 27.61 & 23.78 & 2 & 1328.7012 & 1328.6999 & 665.3572 & 0.0013 & 0.9769 & 1540.178 & 1967.290 & 333.857 & 2243.182 & \text { Yes }\end{array}$

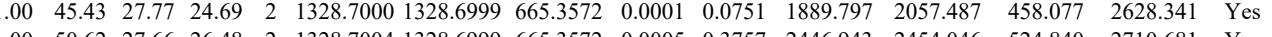
\begin{tabular}{llllllllllllllll}
1.00 & 50.62 & 27.66 & 26.48 & 2 & 1328.7004 & 1328.6999 & 665.3572 & 0.0005 & 0.3757 & 2446.943 & 2454.046 & 524.840 & 2710.681 & Yes \\
\hline
\end{tabular}

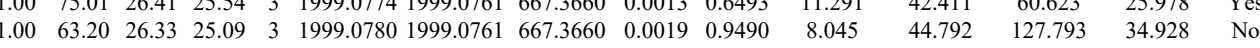
$\begin{array}{lllllllllllllll}0.83 & 20.70 & 27.70 & 23.57 & 3 & 1570.8352 & 1570.8347 & 524.6188 & 0.0005 & 0.3177 & 5837.121 & 4598.301 & 2059.921 & 5653.990 & \text { Yes }\end{array}$

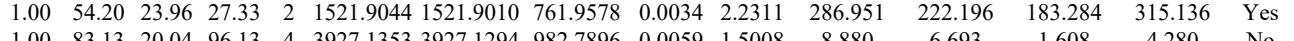

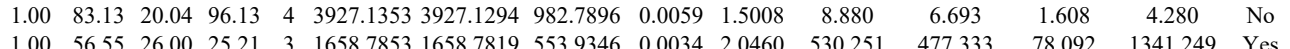

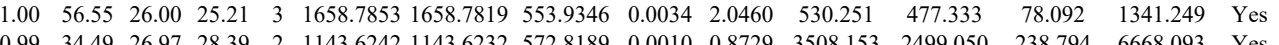

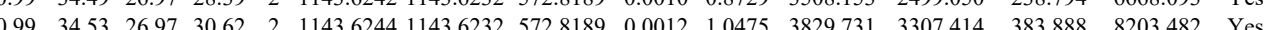
$\begin{array}{lllllllllllllll}0.92 & 34.59 & 27.69 & 30.64 & 2 & 1143.6218 & 1143.6232 & 572.8189 & 0.0014 & 1.2220 & 2531.146 & 1773.664 & 286.102 & 5252.710 & \text { Yes }\end{array}$

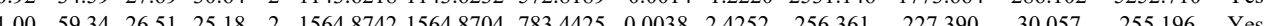

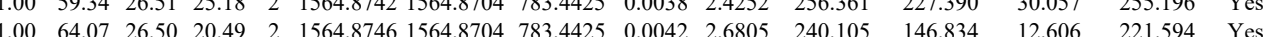
QLGDAFADLSLK

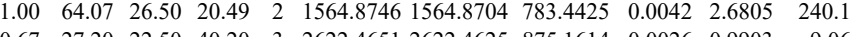
$\begin{array}{lllllllllllll} & \\ \text { L }\end{array}$

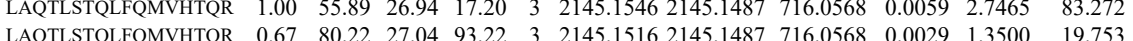
$\begin{array}{lllllllllllll}\text { LAQTLSTQLFOMVHTQR } & 1.00 & 66.85 & 27.04 & 18.55 & 3 & 2145.1516 & 2145.1487 & 716.0568 & 0.0029 & 1.3500 & 22.541\end{array}$ $\begin{array}{llllllllllll}\text { LAQTLSTQLFQMVHTQR } & 0.55 & 52.17 & 27.15 & 65.17 & 3 & 2161.1449 & 2161.1436 & 721.3885 & 0.0013 & 0.6007 & 39.881\end{array}$ $\begin{array}{llllllllllll}\text { LAQTLSTQLFQMVHTQR } & 0.66 & 56.92 & 27.13 & 69.92 & 3 & 2161.1452 & 2161.1436 & 721.3885 & 0.0016 & 0.7393 & 36.679\end{array}$

VT VTPDTDWAR VTPDTDWAR VTPDTDWAR FGGALDAAAK

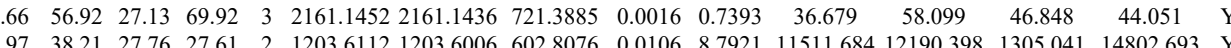
$\begin{array}{lllllllllllllllll}0.99 & 40.78 & 27.82 & 28.03 & 2 & 1203.6124 & 1203.6006 & 602.8076 & 0.0118 & 9.7874 & 13864.727 & 14338.647 & 589.009 & 17671.953 & \text { Yes }\end{array}$ $\begin{array}{llllllllllllllll}0.96 & 35.44 & 27.82 & 25.13 & 2 & 1203.6122 & 1203.6006 & 602.8076 & 0.0116 & 9.6216 & 4846.380 & 4302.229 & 2064.739 & 4316.649 & \text { Yes }\end{array}$ $\begin{array}{lllllllllllllllll}\text { HPWDDISYVLPEHMSM } & 1.00 & 52.79 & 26.70 & 30.93 & 2 & 1207.6918 & 1207.6805 & 604.8475 & 0.0113 & 9.3411 & 14454.676 & 13744.408 & 5503.577 & 15856.238 & \text { Yes } \\ \text { Hes } & 0.62 & 25.99 & 42.62 & 3 & 2099.9602 & 2099.9567 & 700.9928 & 0.0035 & 1.6643 & 179.326 & 149.894 & 61.646 & 194.568 & \text { Yes }\end{array}$ $\begin{array}{llllllllllllllll}\text { QHFPATPLLDYALEVEK } & 1.00 & 33.88 & 26.12 & 15.81 & 3 & 2258.2243 & 2258.2190 & 753.7469 & 0.0053 & 2.3438 & 23.398 & 55.770 & 14.033 & 13.116 & \text { No }\end{array}$

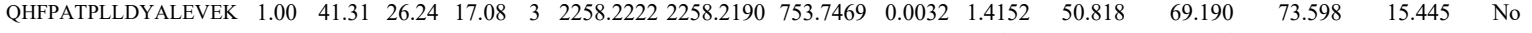

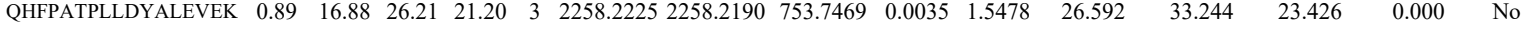
$\begin{array}{llllllllllllllll}\text { QHFPATPLLDYALEVEK } & 1.00 & 58.84 & 26.20 & 24.92 & 3 & 2258.2207 & 2258.2190 & 753.7469 & 0.0017 & 0.7518 & 392.093 & 352.170 & 234.960 & 594.872 & \text { Yes }\end{array}$

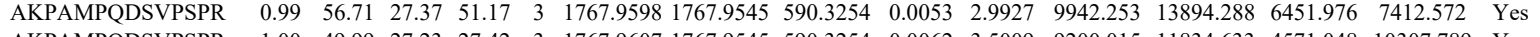
$\begin{array}{lllllllllllllllll}\text { AKPAMPQDSVPSPR } & 1.00 & 49.99 & 27.23 & 27.42 & 3 & 1767.9607 & 1767.9545 & 590.3254 & 0.0062 & 3.5009 & 9200.015 & 11834.633 & 4571.048 & 10307.789 & \text { Yes }\end{array}$

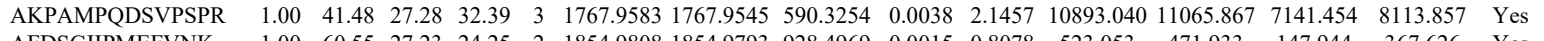

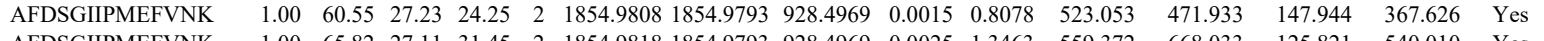
$\begin{array}{llllllllllllllll}\text { AFDSGIIPMEFVNK } & 1.00 & 65.82 & 27.11 & 31.45 & 2 & 1854.9818 & 1854.9793 & 928.4969 & 0.0025 & 1.3463 & 559.372 & 668.033 & 125.821 & 540.010 & \text { Yes } \\ \text { AKPAMPQDSVPSR } & 0.92 & 39.30 & 27.36 & 43.98 & 3 & 1767.9553 & 1767.9545 & 590.3254 & 0.0008 & 0.4517 & 7081.157 & 10708.326 & 5633.483 & 5957.638 & \text { Yes }\end{array}$ \begin{tabular}{lllllllllllllllll} 
AKPAMPQDSVPSR & 0.92 & 39.30 & 27.36 & 43.98 & 3 & 1767.9553 & 1767.9545 & 590.3254 & 0.0008 & 0.4517 & 7081.157 & 10708.326 & 5633.483 & 5957.638 & Yes \\
\hline AKPAMPQDSVPSR & 1.00 & 34.12 & 27.28 & 22.91 & 3 & 1767.9583 & 1767.9545 & 590.3254 & 0.0038 & 2.1457 & 5581.753 & 5032584 & 29331.215 & 5116.902 & $\mathrm{No}$
\end{tabular}

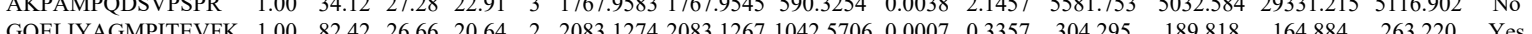
$\begin{array}{llllllllllllllll}\text { GQELIYAGMPITEVFK } & 1.00 & 82.42 & 26.66 & 20.64 & 2 & 2083.1274 & 2083.1267 & 042.5706 & 0.0007 & 0.3357 & 304.295 & 189.818 & 164.884 & 263.220 & \text { Yes } \\ \text { GQELYYAGMPTEVFK } & 0.92 & 19.93 & 26.52 & 14.30 & 3 & 2083.1308 & 2083.1267 & 695.3828 & 0.0041 & 1.9653 & 117.008 & 162.391 & 46.901 & 164.827 & \text { Yes }\end{array}$

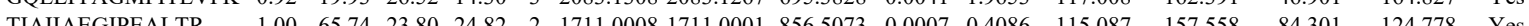
$\begin{array}{lllllllllllllllll}\text { TIAIIAEGIPEALTR } & 1.00 & 72.09 & 23.82 & 23.67 & 2 & 1711.0022 & 1711.0001 & 856.5073 & 0.0021 & 1.2259 & 1223.957 & 1130.266 & 376.852 & 952.341 & \text { Yes }\end{array}$ 


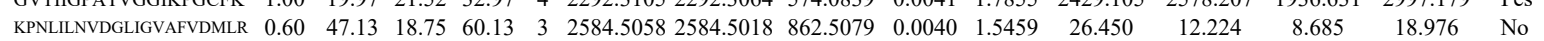
$\begin{array}{llllllllllllllll}\text { GVTIIGPATVGGIKPGCFK } & 1.00 & 52.30 & 21.85 & 18.91 & 3 & 2292.3079 & 2292.3064 & 765.1094 & 0.0015 & 0.6535 & 2991.811 & 3350.752 & 2159.668 & 3255.487 & \text { Yes }\end{array}$ $\begin{array}{lllllllllllllllll}\text { GVTIIGPATVGGIKPGCFK } & 1.00 & 45.50 & 21.58 & 16.27 & 3 & 2292.3097 & 2292.3064 & 765.1094 & 0.0033 & 1.4377 & 4256.491 & 4206.177 & 2770.372 & 3518.302 & \text { Yes }\end{array}$ $\begin{array}{lllllllllllllllll}\text { GVTIIGPATVGGIKPGCFK } & 1.00 & 24.03 & 21.52 & 37.03 & 4 & 2292.3097 & 2292.3064 & 574.0839 & 0.0033 & 1.4371 & 628.954 & 739.846 & 915.798 & 817.894 & \text { Yes }\end{array}$ $\begin{array}{llllllllllllllll}\text { GVTIIGPATVGGIKPGCFK } & 1.00 & 33.93 & 21.52 & 19.90 & 4 & 2292.3125 & 2292.3064 & 574.0839 & 0.0061 & 2.6564 & 695.349 & 683.195 & 687.888 & 593.124 & \text { Yes }\end{array}$ $\begin{array}{llllllllllllllll}\text { TIAIIAEGIPEALTRK } & 0.82 & 5.57 & 16.99 & 14.84 & 3 & 1983.1996 & 1983.1972 & 662.0730 & 0.0024 & 1.2083 & 51.904 & 111.383 & 52.734 & 157.546 & \text { No }\end{array}$ $\begin{array}{llllllllllllllll}\text { GVTIIGPATVGGIKPGCFK } & 1.00 & 53.26 & 21.76 & 22.73 & 3 & 2292.3082 & 2292.3064 & 765.1094 & 0.0018 & 0.7842 & 1002.468 & 1080.677 & 485.198 & 978.369 & \text { Yes }\end{array}$ $\begin{array}{llllllllllllllll}\text { AIVWGMQTR } & 0.97 & 41.41 & 28.54 & 29.19 & 2 & 1204.6590 & 1204.6508 & 603.3327 & 0.0082 & 6.7955 & 20589.830 & 20209.772 & 439.523 & 23621.311 & \text { Yes }\end{array}$ $\begin{array}{llllllllllllllll}\text { AIVWGMQTR } & 0.98 & 41.76 & 28.54 & 29.27 & 2 & 1204.6590 & 1204.6508 & 603.3327 & 0.0082 & 6.7955 & 20376.629 & 21305.747 & 659.208 & 24532.372 & \text { Yes }\end{array}$

LIMGIGHR

LIMGIGHR

AIVWGMQTR
FICTTSAIQNR

FICTTSAIQNR
FICTTSAIQNR

FICTTSAIQNR
FICTTSAIQNR

FICTTSAIQNR

TILSLMTR

FICTTSAIQNR

FICTISAIQNR

TILSLMTR

TILSLMTR

TILSLMTR

TILSLMLMTR

TIAIIAEGIPEALTRK

TIAIIAEGIPEALTRK

LYRPGSVAYVSR

LYRPGSVAYVSR

LYRPGSVAYVSR

LGQEATVGK

$\begin{array}{lllllllllllllllll}0.96 & 28.87 & 25.40 & 19.26 & 2 & 1039.6114 & 1039.6082 & 520.8114 & 0.0032 & 3.0721 & 9674.293 & 8590.212 & 551.984 & 14891.699 & \text { Yes }\end{array}$

$\begin{array}{lllllllllllllll}0.98 & 32.92 & 25.40 & 20.45 & 2 & 1039.6114 & 1039.6082 & 520.8114 & 0.0032 & 3.0721 & 15834.456 & 15071.663 & 870.297 & 24170.992 & \text { Yes }\end{array}$

$\begin{array}{llllllllllllllll}0.99 & 43.33 & 28.88 & 29.64 & 2 & 1204.6616 & 1204.6508 & 603.3327 & 0.0108 & 8.9502 & 2602.020 & 3036.699 & 121.064 & 3627.503 & \text { Yes }\end{array}$ $\begin{array}{llllllllllllllll}1.00 & 78.81 & 26.91 & 29.36 & 2 & 1442.7198 & 1442.7132 & 722.3639 & 0.0066 & 4.5683 & 14737.760 & 13221.087 & 262.863 & 16535.182 & \text { Yes }\end{array}$ \begin{tabular}{llllllllllllllll}
1.00 & 76.44 & 27.33 & 27.94 & 2 & 1442.7234 & 1442.7132 & 722.3639 & 0.0102 & 7.0601 & 15671.645 & 13482.105 & 580.086 & 14571.676 & Yes \\
\hline
\end{tabular} $\begin{array}{lllllllllllllllll}1.00 & 74.11 & 27.09 & 26.89 & 2 & 1442.7210 & 1442.7132 & 722.3639 & 0.0078 & 5.3989 & 16888.903 & 14652.438 & 598.228 & 18764.474 & \text { Yes } \\ 1.00 & 74.19 & 27.33 & 28.39 & 2 & 1442.7234 & 1442.7132 & 722.3639 & 0.0102 & 7.0601 & 10762.001 & 11382.177 & 0.000 & 14273.421 & \text { No }\end{array}$

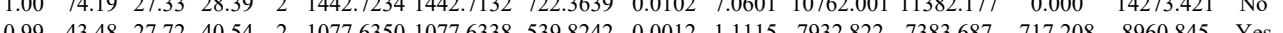
$\begin{array}{lllllllllllllll}0.99 & 43.48 & 27.72 & 40.54 & 2 & 1077.6350 & 1077.6338 & 539.8242 & 0.0012 & 1.1115 & 7932.822 & 7383.687 & 717.208 & 8960.845 & \text { Yes } \\ 0.99 & 43.26 & 28.10 & 40.77 & 2 & 1077.6360 & 1077.6338 & 539.8242 & 0.0022 & 2.0377 & 4119.252 & 2985.759 & 270.250 & 4043.438 & \text { Yes }\end{array}$

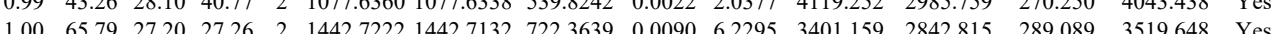

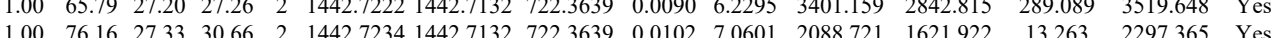

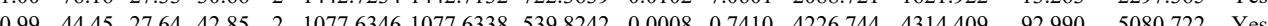

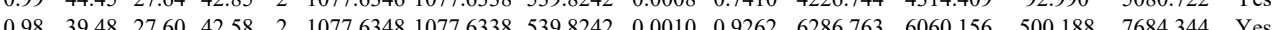

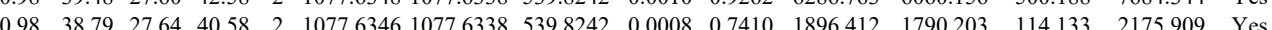
$\begin{array}{lllllllllllllll}0.98 & 38.79 & 27.64 & 40.58 & 2 & 1077.6346 & 1077.6338 & 539.8242 & 0.0008 & 0.7410 & 1866.412 & 1700.215 & 114.133 & 2175.909 & \text { Yes } \\ 0.98 & 37.46 & 27.64 & 40.01 & 2 & 1077.6346 & 1077.6338 & 539.8242 & 0.0008 & 0.7410 & 1871.687 & 1964.171 & 235.102 & 2138.956 & \text { Yes }\end{array}$ $\begin{array}{ccccccccccccccc}0.98 & 37.46 & 27.64 & 40.01 & 2 & 1077.6346 & 1077.6338 & 539.8242 & 0.0008 & 0.7410 & 1871.687 & 1964.171 & 235.102 & 2138.956 & \text { Yes } \\ 0.73 & 3.57 & 16.99 & 14.84 & 3 & 1983.1993 & 1983.1972 & 662.0730 & 0.0021 & 1.0573 & 19.359 & 24.279 & 11.452 & 32.613 & \text { Yes }\end{array}$

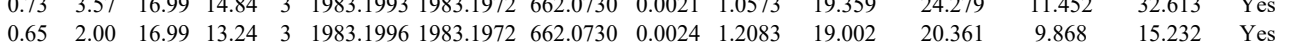

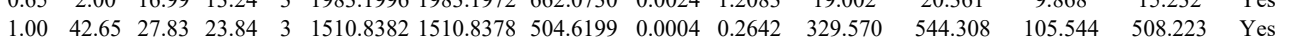
$\begin{array}{lllllllllllllll}1.00 & 37.93 & 27.51 & 15.47 & 3 & 1510.8397 & 1510.8378 & 504.6199 & 0.0019 & 1.2551 & 455.945 & 682.585 & 149.912 & 646.890 & \text { Yes }\end{array}$ $\begin{array}{lllllllllllllll}1.00 & 40.74 & 27.51 & 16.28 & 3 & 1510.8388 & 1510.8378 & 504.6199 & 0.0010 & 0.6606 & 296.141 & 444.745 & 78.111 & 454.079 & \text { Yes }\end{array}$ $\begin{array}{llllllllllllllll}1.00 & 51.24 & 27.83 & 28.49 & 2 & 1189.6952 & 1189.6910 & 595.8528 & 0.0042 & 3.5243 & 4377.651 & 4190.208 & 1562.193 & 4531.387 & \text { Yes }\end{array}$ $\begin{array}{llllllllllllllll}0.99 & 45.44 & 27.83 & 27.61 & 2 & 1189.6954 & 1189.6910 & 595.8528 & 0.0044 & 3.6922 & 9052.732 & 7635.955 & 1470.981 & 8013.157 & \text { Yes }\end{array}$

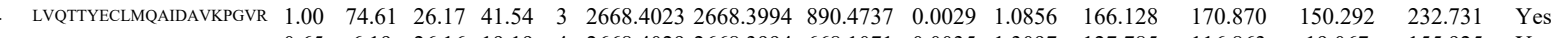
$\begin{array}{llllllllllllllll}\text { LVQTTYECLMQAIDAVKPGVR } & 0.65 & 6.19 & 26.16 & 19.19 & 4 & 2668.4029 & 2668.3994 & 668.1071 & 0.0035 & 1.3097 & 127.785 & 116.863 & 19.067 & 155.925 & \text { Yes }\end{array}$ $\begin{array}{lllllllllllllllll}\text { LVQTTYECLMQAIDAVKPGVR } & 1.00 & 19.43 & 26.18 & 32.43 & 4 & 2668.4037 & 2668.3994 & 668.1071 & 0.0043 & 1.6090 & 125.844 & 142.244 & 32.203 & 169.412 & \text { Yes }\end{array}$

$\begin{array}{llllllllllllllll}\text { LLSSEDIEGMR } & 1.00 & 45.33 & 27.97 & 25.10 & 2 & 1392.7052 & 1392.7040 & 697.3593 & 0.0012 & 0.8604 & 2401.029 & 2238.011 & 485.021 & 2910.537 & \text { Yes } \\ \text { SLGEIPIVESEIK } & 1.00 & 56.44 & 24.36 & 27.55 & 2 & 1700.9814 & 1700.9804 & 851.4975 & 0.0010 & 0.5872 & 336.928 & 527.772 & 34.046 & 378.906 & \text { Yes }\end{array}$

SLGEIPIVESEIK

SLGEIPIVESEIK

SLGEIPIVESEIK

SLGEIPIVESEIK

$\begin{array}{lllllllllll}1.00 & 50.54 & 24.36 & 23.17 & 2 & 1700.9818 & 1700.9804 & 851.4975 & 0.0014 & 0.8221 & 62.007\end{array}$

$\begin{array}{lllllllllll}1.00 & 48.06 & 24.25 & 30.21 & 3 & 1700.9830 & 1700.9804 & 568.0007 & 0.0026 & 1.5258 & 181.053 \\ 1.00 & 50.49 & 23.98 & 28.13 & 3 & 1700.9836 & 1700.9804 & 568.0007 & 0.0032 & 1.8779 & 133.159\end{array}$ $\begin{array}{lllllllllllll} & \text { SEHLPDAPELIHDFLVNEK } & 1.00 & 36.17 & 25.88 & 15.44 & 4 & 2777.4681 & 2777.4632 & 695.3731 & 0.0049 & 1.7616 & 142.402\end{array}$ $\begin{array}{llllllllllll}\text { NFEHLIPDAPELLHDFLVNEK } & 1.00 & 33.58 & 25.82 & 16.15 & 4 & 2777.4669 & 2777.4632 & 695.3731 & 0.0037 & 1.3302 & 430.620\end{array}$ $\begin{array}{llllllllllll}\text { NFEHLIPDAPELLHDFLVNEK } & 1.00 & 40.91 & 25.80 & 19.51 & 4 & 2777.4673 & 2777.4632 & 695.3731 & 0.0041 & 1.4740 & 489.085\end{array}$ $\begin{array}{llllllllllll}\text { NFEHLIPDAPELIHDFLVNEK } & 1.00 & 40.41 & 25.98 & 16.26 & 4 & 2777.4705 & 2777.4632 & 695.3731 & 0.0073 & 2.6245 & 73.448 \\ \text { NFEHLIPDAPELIHDFLVNEK } & 1.00 & 48.74 & 25.88 & 18.15 & 4 & 2777.4665 & 2777.4632 & 695.3731 & 0.0033 & 1.1864 & 245.017\end{array}$ $\begin{array}{llllllllllllll}\text { NFEHLIPDAPELIHDLUNEK } & 1.00 & 48.74 & 25.88 & 18.15 & 4 & 2777.4665 & 2777.4632 & 695.3731 & 0.0033 & 1.1864 & 245.017\end{array}$

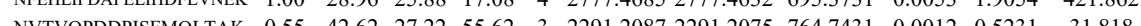

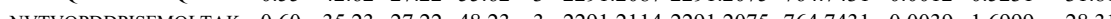
$\begin{array}{lllllllllllll}\text { VLSECSPLMNDIFNK } & 1.00 & 39.36 & 27.51 & 16.98 & 3 & 2043.0118 & 2043.0083 & 682.0100 & 0.0035 & 1.7106 & 387.126\end{array}$
527.772

44.469 121.798 
$\begin{array}{llllllllllll}1.00 & 77.81 & 26.02 & 36.23 & 2 & 1457.8416 & 1457.8398 & 729.9272 & 0.0018 & 1.2330 & 1168.623 & 1092.177\end{array}$ $\begin{array}{llllllllllll}1.00 & 80.38 & 26.11 & 36.22 & 2 & 1457.8434 & 1457.8398 & 729.9272 & 0.0036 & 2.4660 & 5715.760 & 5654.243\end{array}$

$\begin{array}{llllllllllll}0.82 & 68.80 & 26.58 & 81.80 & 2 & 1458.8536 & 1458.8528 & 730.4337 & 0.0008 & 0.5476 & 6384.230 & 7055.207\end{array}$

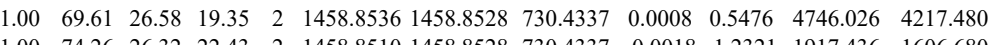
$\begin{array}{lllllllllllll}1.00 & 74.26 & 26.32 & 22.43 & 2 & 1458.8510 & 1458.8528 & 730.4337 & -0.0018 & -1.2321 & 1917.436 & 1606.680\end{array}$

NAVLAIYTIYR

$\begin{array}{lllllllllll}18.81 & 37.25 & 3 & 1644.0292 & 1644.0258 & 549.0159 & 0.0034 & 2.0643 & 14.797 & 47.387\end{array}$

NAVLAIYTIYR

LPGLLMTIIR

LPGLLMTIIR

LPGLLMTIIR

$\begin{array}{llllllllllll}1.00 & 56.79 & 25.73 & 17.57 & 2 & 1439.8264 & 1439.8258 & 720.9202 & 0.0006 & 0.4161 & 486.184 & 394.812 \\ 1.00 & 58.38 & 25.75 & 18.72 & 2 & 1439.8268 & 1439.8258 & 720.9202 & 0.0010 & 0.6936 & 408.453 & 392.682\end{array}$

$\begin{array}{llllllllllll}1.00 & 58.38 & 25.75 & 18.72 & 2 & 1439.8268 & 1439.8258 & 720.9202 & 0.0010 & 0.6936 & 408.453 & 392.682 \\ 1.00 & 54.97 & 20.29 & 22.68 & 2 & 1269.7974 & 1269.7964 & 635.9055 & 0.0010 & 0.7863 & 7.697 & 10.037\end{array}$

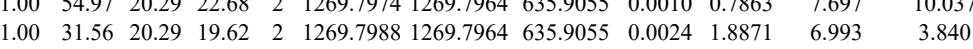

LPGLLMTIIR

VLTIDPTEFK

$\begin{array}{llllllllllll}1.00 & 4.14 & 20.29 & 25.91 & 2 & 1269.7982 & 1269.7964 & 635.9055 & 0.0018 & 1.4153 & 246.574 & 190.724\end{array}$

$\begin{array}{llllllllllll}1.00 & 47.01 & 25.00 & 23.73 & 2 & 1234.7494 & 1234.7377 & 618.3761 & 0.0117 & 9.4602 & 5743.552 & 5008.674 \\ 1.00 & 61.54 & 25.00 & 23.84 & 2 & 1234.7498 & 1234.7377 & 618.3761 & 0.0121 & 9.7836 & 6725.997 & 6241.461\end{array}$

$\begin{array}{lllllllllllll}1.00 & 62.37 & 26.29 & 26.65 & 2 & 1449.8334 & 1449.8323 & 725.9234 & 0.0011 & 0.7577 & 1144.394 & 1215.473\end{array}$

12.807 39.764 Yes

$32.034 \quad 465.561$ Yes

$15.423 \quad 216.662$ Yes

LLELGPKPEVAQQTR

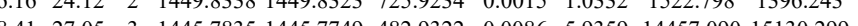

$0.000 \quad 33.442 \quad \mathrm{No}$

$8.118 \quad 245.084$ Yes 


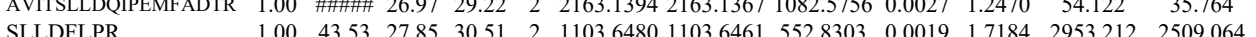
$\begin{array}{llllllllllllll}\text { SLLDLLPR } & 1.00 & 43.53 & 27.85 & 30.51 & 2 & 1103.6480 & 1103.6461 & 552.8303 & 0.0019 & 1.7184 & 2953.212 & 2509.064 & 4.78 \\ \text { SLLDFLPR } & 1.00 & 4357 & 27.73 & 35.14 & 2 & 1103.6484 & 1103.6461 & 5528303 & 0.0023 & 2.0802 & 2724.905 & 2493.290 & 2.82\end{array}$

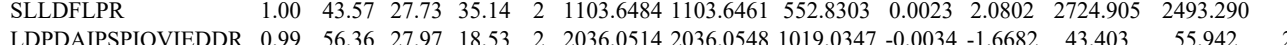

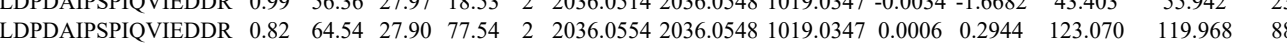

QVAPEKPVK

GISLNPEQWSOLK

GISLNEQWSQLK

GISLNPEQWSQLK

GISLNPEQWSQLK

GISLNPEQWSOLK

GISLNPEQWSQLK

GISLNPEQWSQLK

$\begin{array}{llllllllllllll}0.67 & 26.01 & 19.59 & 39.01 & 3 & 1426.8901 & 1426.8873 & 476.6364 & 0.0028 & 1.9582 & 21962.912 & 14613.646 & 5465.88\end{array}$

$\begin{array}{lllllllllllllll}1.00 & 17.18 & 11.14 & 30.18 & 4 & 1699.0857 & 1699.0843 & 425.7784 & 0.0014 & 0.8220 & 990.733 & 929.724 & 965.05 \\ 1.00 & 64.01 & 26.42 & 22.66 & 2 & 1786.9832 & 1786.9821 & 894.4983 & 0.0011 & 0.6149 & 501.535 & 353.604 & 47.24\end{array}$

$\begin{array}{lllllllllllllll}1.00 & 64.01 & 26.42 & 22.66 & 2 & 1786.9832 & 1786.9821 & 894.4983 & 0.0011 & 0.6149 & 501.535 & 353.604 & 47.245 \\ 1.00 & 66.12 & 26.44 & 27.63 & 2 & 1786.9828 & 1786.9821 & 894.4983 & 0.0007 & 0.3913 & 1666.876 & 1575.676 & 298.42 \\ 1.00 & 68.85 & 26.6 & 22.99 & 2 & 1786.9840 & 1786.9821 & 894.4983 & 0.0019 & 1.0620 & 4250.519 & 2537.650 & 973.63\end{array}$

$\begin{array}{lllllllllllll}1.00 & 68.85 & 26.26 & 22.99 & 2 & 1786.9840 & 1786.9821 & 894.4983 & 0.0019 & 1.0620 & 4250.519 & 2537.650 & 973.63 \\ 1.00 & 48.52 & 26.25 & 21.35 & 3 & 1786.9849 & 1786.9821 & 596.6680 & 0.0028 & 1.5642 & 424.039 & 407.274 & 105.09\end{array}$

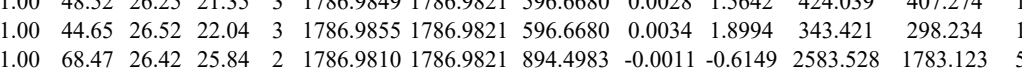
$\begin{array}{llllllllllll}1.00 & 68.47 & 26.42 & 25.84 & 2 & 1786.9810 & 1786.9821 & 894.4983 & -0.0011 & -0.6149 & 2583.528 & 1783.123 \\ 1.00 & 71.29 & 26.42 & 23.62 & 2 & 1786.9816 & 1786.9821 & 894.4983 & -0.0005 & -0.2795 & 1617.631 & 805.452\end{array}$

NCGCLG

AAYPDLENPPLLVTPSQQ $\begin{array}{llllllllllll}1.00 & 11.29 & 26.42 & 23.62 & 2 & 1786.9816 & 1786.9821 & 894.4893 & -0.0005 & -0.2795 & 1617.631 & 805.452 \\ 0.66 & 17.94 & 25.47 & 30.94 & 3 & 2539.1803 & 2539.1782 & 847.4000 & 0.0021 & 0.8261 & 33.771 & 93.646\end{array}$

$\begin{array}{lllllllllllll}.53 & 7.73 & 24.81 & 20.73 & 3 & 2439.3271 & 2439.3253 & 814.1157 & 0.0018 & 0.7370 & 39.244 & 27.159\end{array}$

(5.355

\section{LMDLLGEGLK}

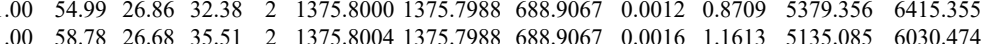

$\begin{array}{lllllllllllll}1.00 & 63.97 & 26.86 & 34.10 & 2 & 1375.8000 & 1375.7988 & 688.9067 & 0.0012 & 0.8709 & 2362.195 & 2973.210 & 113 .\end{array}$

LMDLLGEGLK

$\begin{array}{llllllllllll}1.00 & 62.39 & 26.67 & 34.36 & 2 & 1375.8008 & 1375.7988 & 688.9067 & 0.0020 & 1.4516 & 3214.508 & 4002.572 \\ 1.00 & 58.30 & 25.81 & 19.96 & 2 & 24863354 & 24863341 & 1244.1743 & 0.0013 & 0.5224 & 10.560 & 8.240\end{array}$

$\begin{array}{llllllllllllll}\text { FPDYLTVSPPIGDLQVFYK } & 0.67 & 4.118 & 25.68 & 54.18 & 2 & 2486.3354 & 2486.334 & 1244.1743 & 0.0013 & 0.5224 & 10.560 & 8.240 \\ \text { FP. }\end{array}$

$\begin{array}{lllllllllllllll}\text { FPDYLTVSPPIGDLQVFYK } & 1.00 & 33.95 & 25.60 & 15.15 & 3 & 2486.3380 & 2486.3341 & 829.7853 & 0.0039 & 1.5667 & 62.774 & 106.670 & 63 .\end{array}$

VEIAGPGFINVHLR

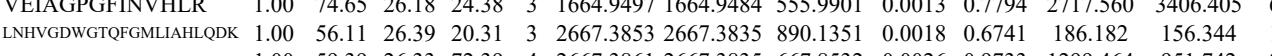

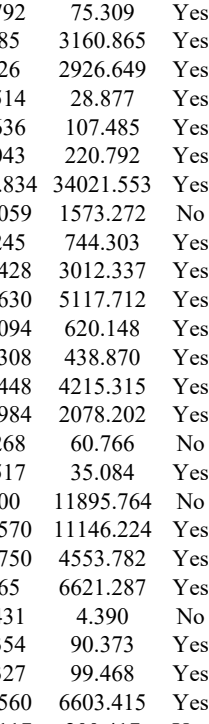

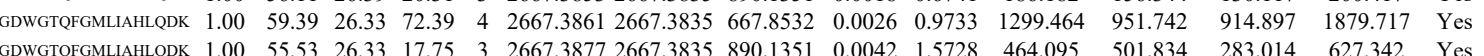

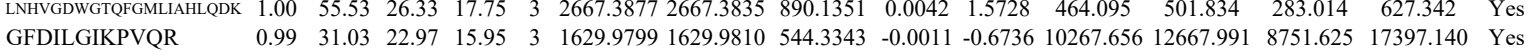
$\begin{array}{llllllllllllllllll} & \end{array}$ $\begin{array}{lllllllllllllllll} & \end{array}$ \begin{tabular}{llllllllllllllll} 
& \\
\hline
\end{tabular} $\begin{array}{llllllllllllllll} & \end{array}$ 

$\begin{array}{llllllllllll}1.00 & 36.13 & 27.96 & 23.78 & 3 & 1682.8864 & 1682.8835 & 561.9684 & 0.0029 & 1.7201 & 47.227\end{array}$ $\begin{array}{llllllllllllllll}.90 & 21.33 & 23.50 & 31.31 & 2 & 895.5734 & 895.5725 & 448.7935 & 0.0009 & 1.0027 & 4699.625 & 3675.936 & 2539.131 & 5142.971 & \text { Yes } \\ 1.00 & 42.39 & 18.75 & 17.04 & 3 & 1831.1188 & 1831.1153 & 611.3790 & 0.0035 & 1.9083 & 1163.032 & 1058.549 & 880.558 & 871.194 & \text { Yes }\end{array}$ $\begin{array}{llllllllllllllll}1.00 & 30.35 & 18.63 & 15.91 & 3 & 1831.1191 & 1831.1153 & 611.3790 & 0.0038 & 2.0718 & 1335.571 & 1033.651 & 965.498 & 916.336 & \text { Yes }\end{array}$ $\begin{array}{llllllllllllllll}1.00 & 33.79 & 18.75 & 16.29 & 3 & 1831.1170 & 1831.1153 & 611.3790 & 0.0017 & 0.9269 & 1206.544 & 1036.373 & 1051.893 & 980.376 & \text { Yes }\end{array}$

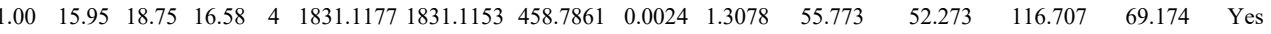

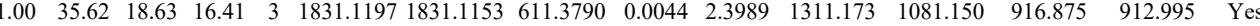
$\begin{array}{lllllllllllllll}0.99 & 31.24 & 18.33 & 16.03 & 3 & 1831.1233 & 1831.1153 & 611.3790 & 0.0080 & 4.3617 & 141.248 & 101.330 & 95.759 & 103.445 & \text { Yes }\end{array}$ $\begin{array}{lllllllllllllll}1.00 & 47.18 & 26.43 & 27.10 & 2 & 1128.5906 & 1128.5897 & 565.3021 & 0.0009 & 0.7960 & 4454.738 & 3908.867 & 1035.027 & 3351.409 & \text { Yes } \\ 1.00 & 41.85 & 26.67 & 28.82 & 2 & 1128.5916 & 1128.5897 & 565.3021 & 0.0019 & 1.6805 & 5053.378 & 4865.963 & 856.130 & 3539.482 & \text { Yes }\end{array}$ $\begin{array}{lllllllllllllll}1.00 & 41.85 & 26.67 & 28.82 & 2 & 1128.5916 & 1128.5897 & 565.3021 & 0.0019 & 1.6805 & 5053.378 & 4865.963 & 856.130 & 3539.482 & \text { Yes } \\ 1.00 & 45.81 & 28.25 & 31.50 & 2 & 1445.8002 & 1445.7969 & 723.9057 & 0.0033 & 2.2793 & 615.653 & 541.406 & 142.335 & 442.660 & \text { Yes }\end{array}$

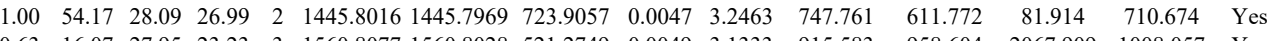

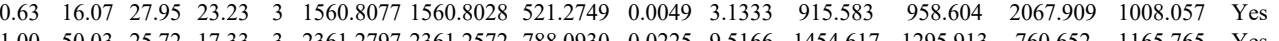

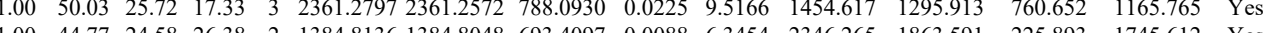
$\begin{array}{lllllllllllllll}1.00 & 44.77 & 24.58 & 26.38 & 2 & 1384.8136 & 1384.8048 & 693.4097 & 0.0088 & 6.3454 & 2346.265 & 1863.591 & 225.893 & 1745.612 & \text { Yes }\end{array}$ $\begin{array}{lllllllllllllll}0.94 & 30.23 & 24.55 & 24.51 & 2 & 1384.8176 & 1384.8048 & 693.4097 & 0.0128 & 9.2297 & 2034.759 & 1708.650 & 68.369 & 1645.992 & \text { Yes } \\ 0.93 & 32.35 & 24.33 & 21.64 & 2 & 1384.8130 & 1384.8048 & 693.4097 & 0.0082 & 5.9128 & 1426.898 & 1404.271 & 158.461 & 1493.571 & \text { Yes }\end{array}$

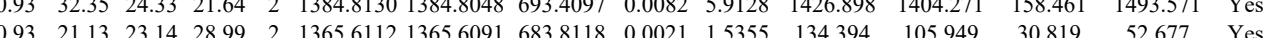

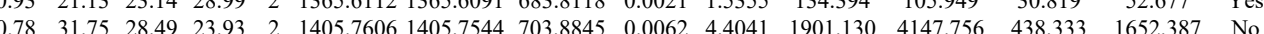
$\begin{array}{llllllllllllllll}0.91 & 32.05 & 28.01 & 25.06 & 2 & 1405.7650 & 1405.7544 & 703.8845 & 0.0106 & 7.5296 & 1787.369 & 3416.834 & 246.859 & 1332.817 & \mathrm{~N} 0\end{array}$

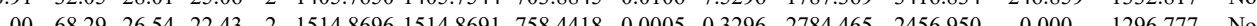
$\begin{array}{lllllllllllllll}1.00 & 85.67 & 26.34 & 23.32 & 2 & 1514.8702 & 1514.8691 & 758.4418 & 0.0011 & 0.7252 & 6387.849 & 5097.084 & 144.121 & 3120.390 & \text { Yes }\end{array}$ 
AQLFALTGVQPAR AQLFALTGVQPAR AQLFALTGVQPAR AQLFALTGVQPAR LPAYLTIQMVR LPAYLTIQMVR AQLFALTGVQPAR LPAYLTIQMVR LPAYLTIQMVR LPAYLTIQMVR

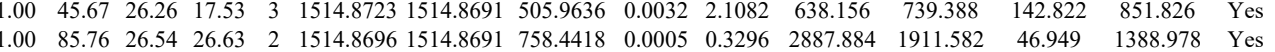

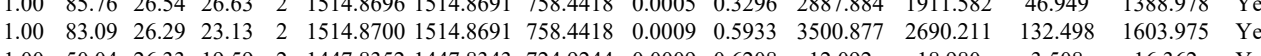

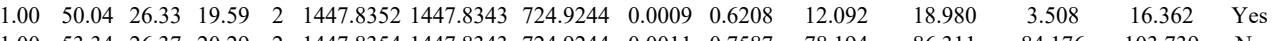
$\begin{array}{lllllllllllllll}1.00 & 53.34 & 26.37 & 20.29 & 2 & 1447.8354 & 1447.8343 & 724.9244 & 0.0011 & 0.7587 & 78.194 & 86.311 & 84.176 & 103.739 & \text { No }\end{array}$ $\begin{array}{lllllllllllllll}1.00 & 86.00 & 26.38 & 29.35 & 2 & 1514.8694 & 1514.8691 & 758.4418 & 0.0003 & 0.1978 & 1166.957 & 1098.160 & 4.410 & 477.610 & \text { Yes }\end{array}$

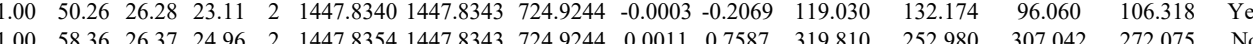
$\begin{array}{lllllllllllllll}1.00 & 58.36 & 26.37 & 24.96 & 2 & 1447.8354 & 1447.8343 & 724.9244 & 0.0011 & 0.7587 & 319.810 & 252.980 & 307.042 & 272.075 & \text { No } \\ 1.00 & 53.72 & 26.33 & 22.75 & 2 & 1447.8350 & 1447.8343 & 724.9244 & 0.0007 & 0.4828 & 39.722 & 36.897 & 29.418 & 35.166 & \text { Yes }\end{array}$ $\begin{array}{lllllllllllllll}1.00 & 53.72 & 26.33 & 22.75 & 2 & 1447.8350 & 1447.8343 & 724.9244 & 0.0007 & 0.4828 & 39.722 & 36.897 & 29.418 & 35.166 & \text { Yes } \\ 1.00 & 52.31 & 26.37 & 16.86 & 2 & 1447.8356 & 1447.8343 & 724.9244 & 0.0013 & 0.8966 & 37.333 & 31.221 & 11.438 & 29.107 & \text { Yes } \\ 1.00 & 62.29 & 17.71 & 24.88 & 3 & 2200.2961 & 2200.2922 & 734.4380 & 0.0039 & 1.7701 & 3.015 & 3.154 & 0.000 & 0.000 & \text { No }\end{array}$ $\begin{array}{llllllllllllll}\text { GIVSLSDILQALVLTGGEK } & 1.00 & 62.29 & 17.71 & 24.88 & 3 & 2200.296 & 220.2922 & 74.484 & 0.0013 & 0.8966 & 37.333 & 31.221 & 11.4\end{array}$

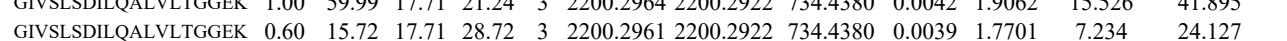
$\begin{array}{lllllllllllllll}\text { GIVSLSDILOALVLTGGEK } & 0.60 & 17.34 & 17.71 & 30.34 & 3 & 2200.2961 & 2200.2922 & 734.4380 & 0.0039 & 1.7701 & 10.225 & 10.024 & -5.96\end{array}$ $\begin{array}{llllllllllllll}\text { AFFALVTNGVR } & 1.00 & 67.02 & 27.04 & 20.55 & 2 & 1337.7582 & 1337.7578 & 669.8862 & 0.0004 & 0.2986 & 1256.148 & 1536.465 & 99.33\end{array}$ $\begin{array}{llllllllllllll}\text { AFFALVTNGVR } & 1.00 & 67.02 & 27.04 & 20.55 & 2 & 1337.7582 & 1337.7578 & 669.8862 & 0.0004 & 0.2986 & 1256.148 & 1536.465 & 9.93 \\ \text { AFFALVTNGVR } & 0.82 & 50.01 & 27.06 & 63.01 & 2 & 1337.7588 & 1337.7578 & 669.8862 & 0.0010 & 0.7464 & 975.371 & 1190.944 & 120.6\end{array}$ $\begin{array}{llllllllllllllll}\text { SDPTSYAGYIEDLKK } & 1.00 & 47.13 & 27.63 & 16.01 & 3 & 2118.1237 & 2118.1210 & 707.0476 & 0.0027 & 12729 & 2193.365 & 2275.872 & 2841.696 & 6325.742 & \text { Yes }\end{array}$ $\begin{array}{llllllllllllllll}\text { IIGLKPEGVPR } & 0.99 & 31.57 & 16.13 & 18.39 & 3 & 1465.9324 & 1465.9224 & 489.6481 & 0.0100 & 6.8076 & 15183.474 & 23877.808 & 9552.052 & 31569.038 & \text { Yes }\end{array}$

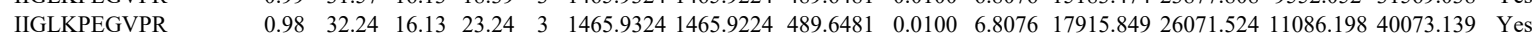
$\begin{array}{llllllllllllllll}\text { IIGLKPEGVPR } & 0.99 & 35.99 & 15.91 & 23.57 & 3 & 1465.9318 & 1465.9224 & 489.6481 & 0.0094 & 6.3991 & 15110.995 & 16220.066 & 5742.665 & 26063.956 & \text { Yes }\end{array}$ $\begin{array}{llllllllllllllll}\text { LFIYNPTTGEFLGR } & 1.00 & 79.66 & 27.54 & 25.69 & 2 & 1770.9426 & 1770.9427 & 886.4786 & -0.0001 & -0.0564 & 5173.138 & 5507.143 & 177.337 & 11244.869 & \text { Yes }\end{array}$ $\begin{array}{llllllllllllllll}\text { LFIYNPTTGEFLGR } & 1.00 & 76.56 & 27.45 & 25.13 & 2 & 1770.9434 & 1770.9427 & 886.4786 & 0.0007 & 0.3948 & 6947.880 & 8288.479 & 213.281 & 14907.325 & \text { Yes }\end{array}$

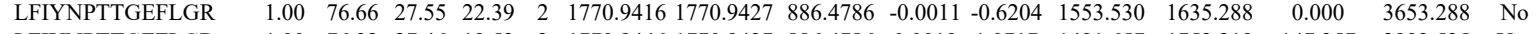
$\begin{array}{lllllllllllllllll}\text { LFIYNPTTGEFLGR } & 1.00 & 76.32 & 27.46 & 19.53 & 2 & 1770.9446 & 1770.9427 & 886.4786 & 0.0019 & 1.0717 & 1491.657 & 1752.219 & 147.357 & 2992.535 & \text { Yes }\end{array}$ $\begin{array}{lllllllllllllllll} & \end{array}$

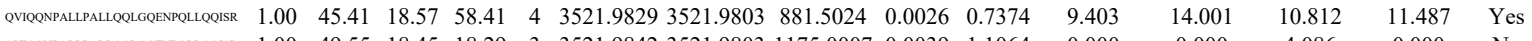

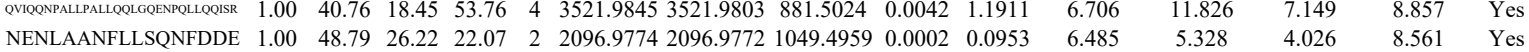

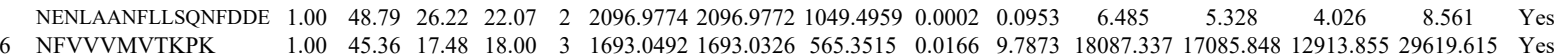
$\begin{array}{llllllllllllllll} & \\ \text { NDIDPEETVK } & 1.00 & 45.36 & 17.48 & 18.00 & 3 & 1693.0492 & 1693.0326 & 565.3515 & 0.0166 & 9.7873 & 18087.337 & 17085.848 & 12913.855 & 29619.615 & \text { Yes }\end{array}$

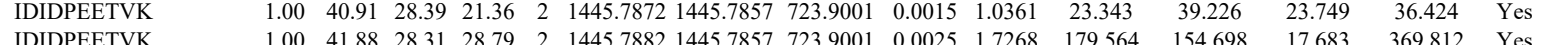

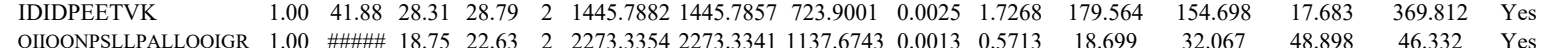
$\begin{array}{lllllllllllllll}\text { QIIQQNPSLLPALLQQIGR } & 1.00 & \text { \#\#\# } 18.75 & 22.63 & 2 & 2273.3354 & 2273.3341 & 1137.6743 & 0.0013 & 0.5713 & 18.699 & 32.067 & 48.898 & 46.332 & \text { Yes } \\ \text { QIIQQNPSLPALQQIGR } & 1.00 & 18.75 & 20.59 & 2 & 2273.3354 & 2273.3341 & 1137.6743 & 0.0013 & 0.5713 & 62.594 & 50.259 & 90.946 & 95.376 & \text { Yes }\end{array}$

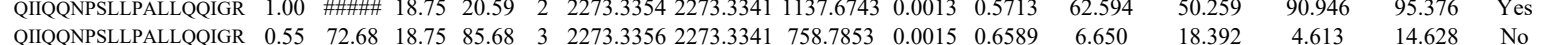

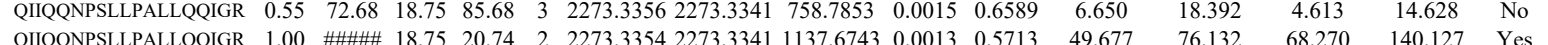

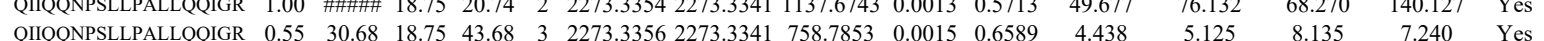

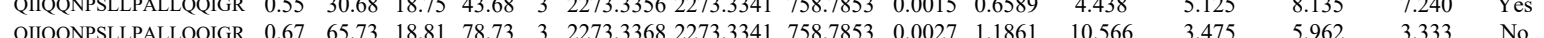

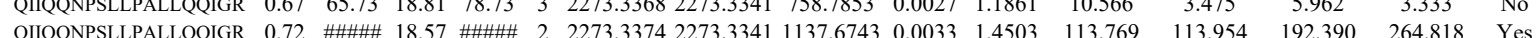

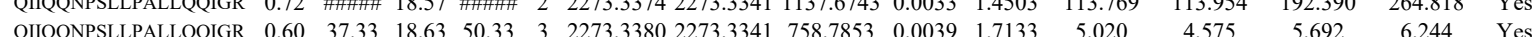

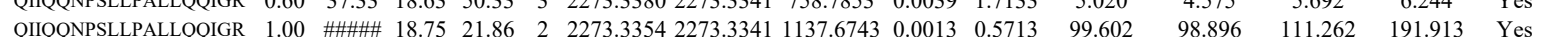

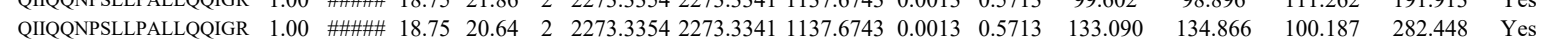
$\begin{array}{llllllllllllllll}\text { QIIQQNPSLLPALLQQIGR } & 0.66 & 30.50 & 18.81 & 43.50 & 3 & 2273.3365 & 2273.3341 & 758.7853 & 0.0024 & 1.0543 & 10.232 & 15.418 & 11.900 & 23.794 & \text { Yes }\end{array}$

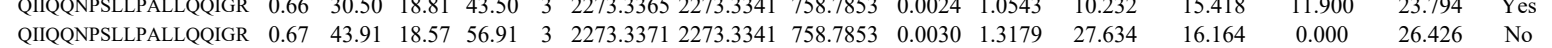

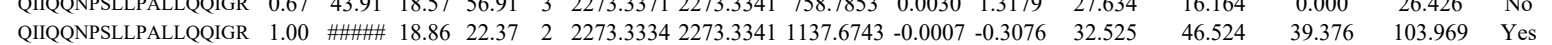

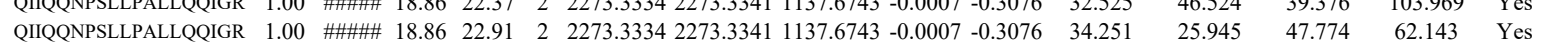

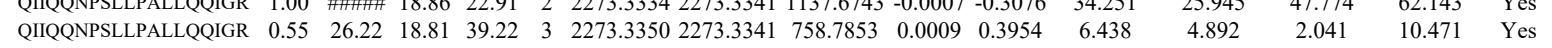

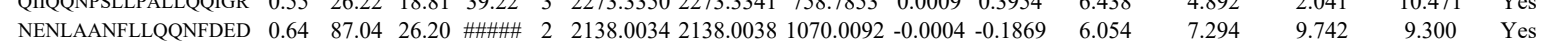

\begin{tabular}{llllllllllllllllll}
\hline & AVLLGPPGAGK & 1.00 & 66.53 & 19.68 & 22.14 & 2 & 1266.7994 & 1266.7903 & 634.4024 & 0.0091 & 7.1721 & 7808.172 & 8250.438 & 1678.876 & 6698.517 & Yes
\end{tabular} $\begin{array}{llllllllllllllll}\text { AVLLGPPGAGK } & 1.00 & 66.84 & 19.49 & 23.15 & 2 & 1266.8000 & 1266.7903 & 634.4024 & 0.0097 & 7.6449 & 5366.330 & 5466.805 & 1067.283 & 5452.283 & \text { Yes }\end{array}$ $\begin{array}{lllllllllllllllll}\text { AVLLGPPGAGK } & 1.00 & 68.74 & 19.68 & 22.22 & 2 & 1266.7972 & 1266.7903 & 634.4024 & 0.0069 & 5.4382 & 6921.809 & 6234.024 & 1972.384 & 6852.858 & \text { Yes }\end{array}$ $\begin{array}{llllllllllllllll}\text { QAEMLDDLMEK } & 1.00 & 71.05 & 27.85 & 35.43 & 2 & 1609.7928 & 1609.7935 & 805.9040 & -0.0007 & -0.4343 & 769.724 & 777.226 & 99.039 & 796.148 & \text { Yes }\end{array}$ $\begin{array}{lllllllllllllllll}\text { QAEMLDDLMEK } & 1.00 & 76.12 & 27.94 & 27.47 & 2 & 1609.7942 & 1609.7935 & 805.9040 & 0.0007 & 0.4343 & 1795.228 & 1639.962 & 134.877 & 1969.212 & \text { Yes }\end{array}$ $\begin{array}{llllllllllllllll}\text { QAEMLDDLMEK } & 0.99 & 30.29 & 28.10 & 24.63 & 3 & 1609.7965 & 1609.7935 & 537.6051 & 0.0030 & 1.8601 & 58.660 & 49.925 & 30.654 & 58.889 & \text { Yes }\end{array}$ $\begin{array}{llllllllllllllll}\text { LVSDEMVVELIEK } & 0.98 & 23.86 & 25.99 & 24.82 & 3 & 1790.9968 & 1790.9943 & 598.0054 & 0.0025 & 1.3935 & 98.726 & 78.901 & 24.956 & 92.417 & \text { Yes }\end{array}$ $\begin{array}{llllllllllllllll}\text { LVSDEMVVELIEK } & 0.94 & 22.12 & 25.99 & 27.46 & 3 & 1790.9968 & 1790.9943 & 598.0054 & 0.0025 & 1.3935 & 86.892 & 85.290 & 47.711 & 119.440 & \text { Yes }\end{array}$ $\begin{array}{llllllllllllllll}\text { LVSDEMVVELIEK } & 1.00 & 63.49 & 26.05 & 20.83 & 2 & 1790.9978 & 1790.9943 & 896.5044 & 0.0035 & 1.9520 & 77.169 & 93.551 & 12.076 & 99.760 & \text { Yes }\end{array}$

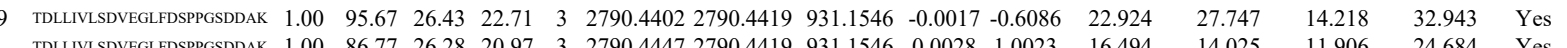

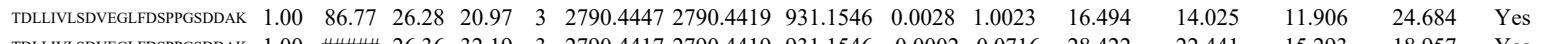

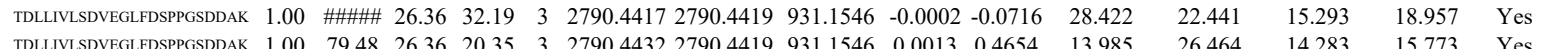

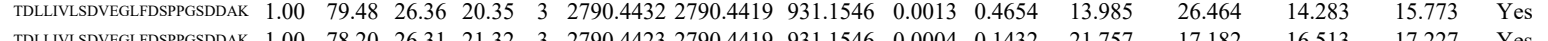
$\begin{array}{lllllllllllll} & \end{array}$

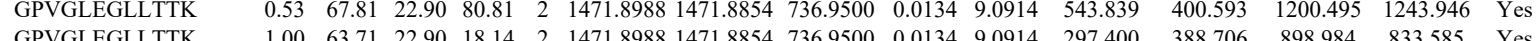

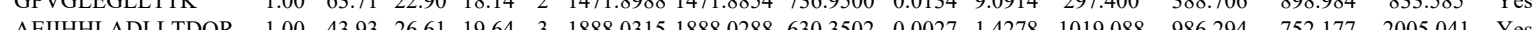

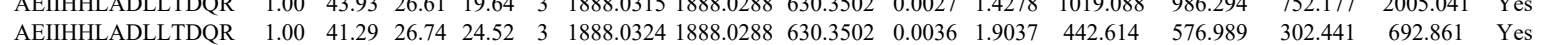




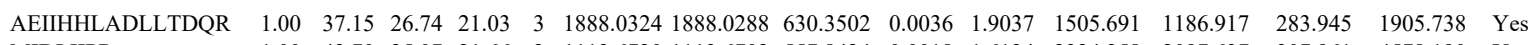

AADEEAFEDNSEEYIR

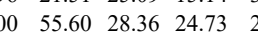

AADEEAFEDNSEEYIR SNELWTEIK

SNELWTEIK

IIIPEIQK

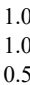

$\begin{array}{lllllll}303.7120 & 1303.7105 & 652.8625 & 0.0015 & 1.1488 & 3056.163\end{array}$ $4098.955 \quad 423.7 .0$ $\begin{array}{llllllllll}64.93 & 23.98 & 2 & 2030.8874 & 2030.8826 & 1016.4486 & 0.0048 & 2.3612 & 21.521\end{array}$

ALTLPGSSENEYIMK $\begin{array}{llllllllll}4 & 0\end{array}$ 41.488

NLFEDQNTLTSICEK NLFEDQNTLTSICEK NLFEDQNTLTSICEK $\begin{array}{llllllll} & \end{array}$

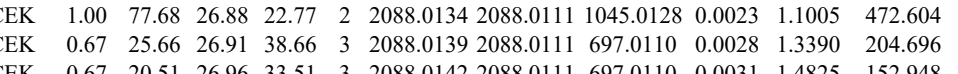
$\begin{array}{lllllllllllllll} & \\ \end{array}$ $\begin{array}{llllllllllll}\text { LLECPMMDTEYTK } & 1.00 & 73.97 & 26.10 & 26.00 & 2 & 2104.9794 & 2104.9797 & 1053.4971 & -0.0003 & -0.1424 & 220.179 \\ \text { LLTECPPMMD } & 2 & 2104.9814 & 2104.9797 & 1053.4971 & 0.0017 & 0.8068 & 244.778\end{array}$ $\begin{array}{llllllllllllll}\text { LLTECPPMMDTEYTK } & 0.60 & 48.37 & 26.39 & 61.37 & 3 & 2104.9834 & 2104.9797 & 702.6672 & 0.0037 & 1.7552 & 135.226\end{array}$ $\begin{array}{llllllllllllll}\text { ALTLPGSSENEYIMK } & 1.00 & 70.27 & 27.28 & 25.30 & 2 & 1940.0174 & 1940.0168 & 971.0157 & 0.0006 & 0.3090 & 548.140 & 60\end{array}$ $\begin{array}{llllllllllllll}\text { NLFEDQNTLTSICEK } & 0.66 & 39.12 & 26.88 & 52.12 & 3 & 2088.0133 & 2088.0111 & 697.0110 & 0.0022 & 1.0521 & 73.313 & 4\end{array}$ $\begin{array}{llllllllllll}\text { NLFEDQNTLTSICEK } & 0.67 & 31.22 & 27.00 & 44.22 & 3 & 2088.0145 & 2088.0111 & 697.0110 & 0.0034 & 1.6260 & 29.554\end{array}$ $\begin{array}{lllllllllllll}\text { LLTECPPMMDTEYTK } & 1.00 & 59.59 & 26.21 & 19.06 & 2 & 2104.9814 & 2104.9797 & 1053.4971 & 0.0017 & 0.8068 & 49.265 & 87 .\end{array}$

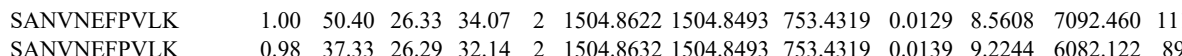

IIIPEIQK $\begin{array}{lllllllllll}0.98 & 37.33 & 26.29 & 32.14 & 2 & 1504.8632 & 1504.8493 & 753.4319 & 0.0139 & 9.2244 & 6082.122 \\ 0.70 & 19.87 * & 1.59 & 21.58 & 2 & 1240.8018 & 1240.7998 & 621.4072 & 0.0020 & 1.692 & 194.301\end{array}$

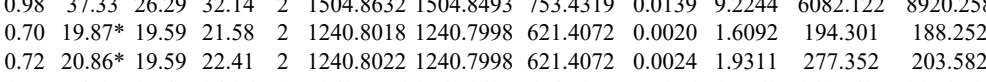

ATIELCSTHANDASALR

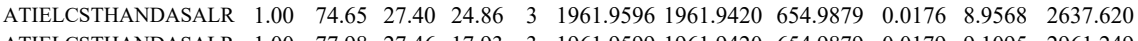
$\begin{array}{llllllllllll}\text { AADEEAFEDNSEEYIR } & 1.00 & 88.42 & 23.46 & 17.93 & 3 & 1961.9599 & 1961.9420 & 654.9879 & 0.0179 & 9.1095 & 2961.249 \\ \text { AGALALE } & 2030.8914 & 2030.8826 & 1016.4486 & 0.0088 & 4.3288 & 1.089\end{array}$ $\begin{array}{llllllllllll}\text { YGALALQEIFDGIQPK } & 1.00 & 68.42 & 23.62 & 20.02 & 2 & 2030.8914 & 2030.8826 & 1016.4486 & 0.0088 & 4.3288 & 1.089 \\ \text { YGALA } & 3 & 2050.1359 & 2050.1342 & 684.3853 & 0.0017 & 0.8280 & 133.347\end{array}$ $\begin{array}{llllllllllllll}\text { YGALALQEIFDGIQPK } & 1.00 & 61.56 & 25.25 & 21.84 & 3 & 2050.1374 & 2050.1342 & 684.3853 & 0.0032 & 1.5586 & 234.448\end{array}$ $\begin{array}{llllllllllll}\text { YGALALQEIFDGIQPK } & 1.00 & 80.36 & 25.26 & 22.41 & 2 & 2050.1334 & 2050.1342 & 1026.0744 & -0.0008 & -0.3898 & 33.903\end{array}$ $\begin{array}{llllllllllll}\text { YGALALQEFDGIQPK } & 1.00 & 59.78 & 25.30 & 25.87 & 3 & 2050.1353 & 2050.1342 & 684.3853 & 0.0011 & 0.5358 & 168.924 \\ \text { YGALALQEIFDGIQPK } & 1.00 & 81.43 & 25.30 & 29.26 & 2 & 2050.1354 & 2050.1342 & 1026.0744 & 0.0012 & 0.5848 & 31.891\end{array}$ $\begin{array}{llllllllllll}\text { WPDLLTEMVNR } & 1.00 & 54.25 & 27.68 & 24.50 & 2 & 1516.7854 & 1516.7830 & 759.3988 & 0.0024 & 1.5802 & 220.389\end{array}$

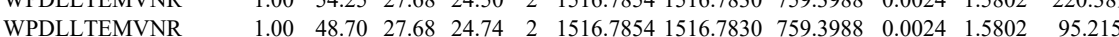
$\begin{array}{llll}173.603 & 69.794 & 263.430 & \text { Yes }\end{array}$ $\begin{array}{lllll}414.654 & 20.297 & 405.484 & \text { Y }\end{array}$ $\begin{array}{llll}640.503 & 105.958 & 708.663 & \text { Yes }\end{array}$

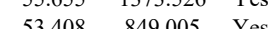
$\begin{array}{llll}10.691 & 59.930 & 181.630 & \text { Yes }\end{array}$ $\begin{array}{llll}0.345 & 122.690 & 144.079 & \text { No }\end{array}$ $\begin{array}{lllll}390.874 & 8.005 & 487.566 & \text { Yes }\end{array}$ $\begin{array}{llll}95.603 & 29.680 & 478.877 & \text { Yes }\end{array}$ $\begin{array}{lccc}105.092 & 184.008 & \text { Yes } \\ 606.558 & 0.000 & 1175.602 & \text { No }\end{array}$ \begin{tabular}{rrrr}
49.623 & 43.726 & 68.123 & Yes \\
\hline 7.706 & 18.241 & 40.622 & Yes
\end{tabular} \begin{tabular}{llll}
37.706 & 18.241 & 40.622 & Yes \\
\hline & 133.887 & Yes
\end{tabular} $\begin{array}{llll}133.830 .130 & \text { Yes }\end{array}$ $\begin{array}{llll}497.791 & 10412.682 & \text { Yes }\end{array}$ $39.051 \quad 275.424$ Yes $\begin{array}{lll}68.412 & 392.696 & \text { Yes }\end{array}$ $1647.410 \quad 3826.023$ Yes $\begin{array}{lll}738.686 & 4344.635 & \text { Yes }\end{array}$ $\begin{array}{lll}0.000 & 11.468 & \text { No }\end{array}$ $\begin{array}{lll}0.1192 & 21.548 & \text { Yes } \\ 59.192 & 2474 & \end{array}$ $\begin{array}{lll}59.192 & 247.454 & \text { No } \\ 38.881 & 103.125 & \text { Yes }\end{array}$ $\begin{array}{lll}139.310 & 271.314 & \text { Yes }\end{array}$ $\begin{array}{lll}67.378 & 88.159 & \text { Yes }\end{array}$ $\begin{array}{lll}52.048 & 260.511 & \text { No }\end{array}$

Table S-4 page 353 of 614 


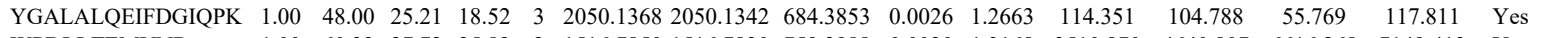
$\begin{array}{lllllllllllllll}1.00 & 60.33 & 27.72 & 25.82 & 2 & 1516.7850 & 1516.7830 & 759.3988 & 0.0020 & 1.3168 & 3510.970 & 4640.807 & 6616.268 & 7149.413 & \text { Yes }\end{array}$ $\begin{array}{lllllllllllllllll}\text { WPDLLTEMVNR } & 1.00 & 64.11 & 27.78 & 26.20 & 2 & 1516.7860 & 1516.7830 & 759.3988 & 0.0030 & 1.9752 & 2070.373 & 3361.159 & 4850.948 & 4389.996 & \text { Yes }\end{array}$ $\begin{array}{llllllllllllllll}\text { VIVPNMEFR } & 0.97 & 37.32 & 28.55 & 29.47 & 2 & 1247.6938 & 1247.6818 & 624.8482 & 0.0120 & 9.6022 & 6760.057 & 11757.755 & 613.328 & 13225.906 & \text { Yes }\end{array}$ VIVPNMEFR IHLAQSLHK $\begin{array}{llllllllllllllll}\text { IHLAQSLHK } & 1.00 & 39.31 & 24.23 & 22.38 & 2 & 1333.8080 & 1333.8074 & 667.9110 & 0.0006 & 0.4492 & 5379.649 & 5383.445 & 2091.304 & 8694.121 & \text { Yes } \\ \text { WPDLLTEMVNR } & 1.00 & 63.87 & 27.64 & 23.34 & 2 & 1516.7844 & 1516.7830 & 759.3988 & 0.0014 & 0.9218 & 1145.806 & 1273.485 & 1822.713 & 1999.173 & \text { Yes }\end{array}$ $\begin{array}{lllllllllllllllll}0.89 & 31.19 & 28.54 & 29.17 & 2 & 1247.6940 & 1247.6818 & 624.8482 & 0.0122 & 9.7623 & 9266.626 & 13304.399 & 923.633 & 15250.568 & \text { Yes } & \end{array}$ FLESVEGNONYPLULTLEK

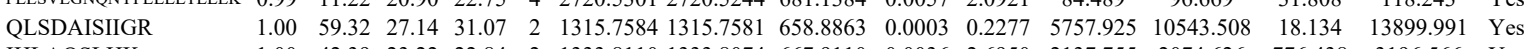
$\begin{array}{llllllllllllllll} & 1.00 & 4239 & 23.22 & 22.84 & 2 & 1333.8110 & 1333.8074 & 667.9110 & 0.0036 & 26950 & 2137.755 & 2074.626 & 776.438 & 3196.566 & \text { Yes }\end{array}$

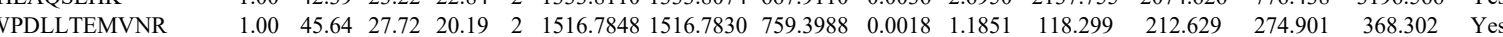
$\begin{array}{lllllllllllllll} & \end{array}$

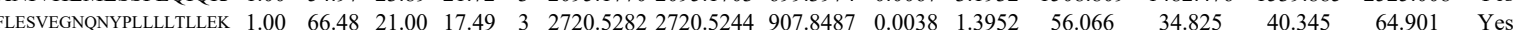

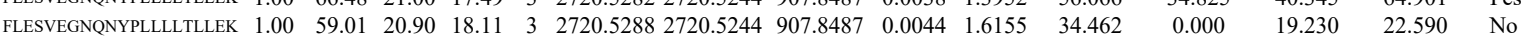

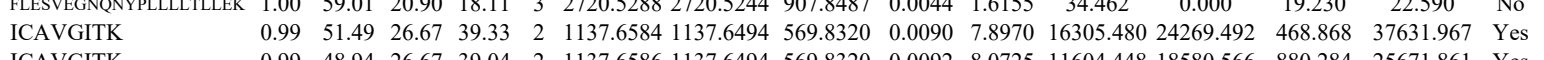
$\begin{array}{lllllllllllllllll}0.99 & 48.94 & 26.67 & 39.04 & 2 & 1137.6586 & 1137.6494 & 569.8320 & 0.0092 & 8.0725 & 11604.448 & 18580.566 & 880.284 & 25671.861 & \text { Yes }\end{array}$

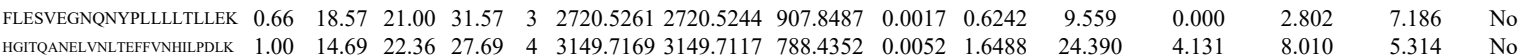

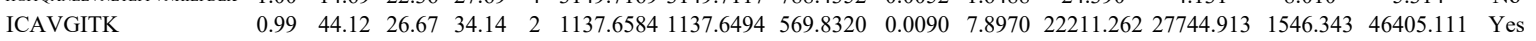

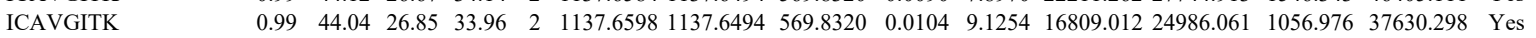
$\begin{array}{llllllllllllllll}\text { HGITPANELVNLTEFFVNHLPDLK } & 0.66 & 64.91 & 22.67 & 77.91 & 3 & 3149.7142 & 3149.7117 & 1050.9112 & 0.0025 & 0.7930 & 359.631 & 581.575 & 560.508 & 605.406 & \text { Yes }\end{array}$

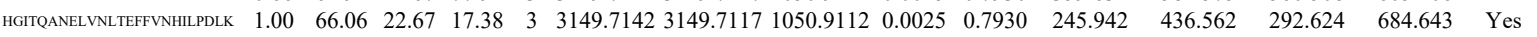
$\begin{array}{llllllllllllllll}\text { HGITQANELVNLTEFVVNHLPDLK } & 1.00 & 23.91 & 22.41 & 15.32 & 4 & 3149.7165 & 3149.7117 & 788.4352 & 0.0048 & 1.5220 & 6.289 & 15.961 & 11.104 & 31.220 & \text { Yes }\end{array}$

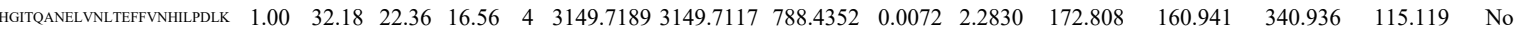

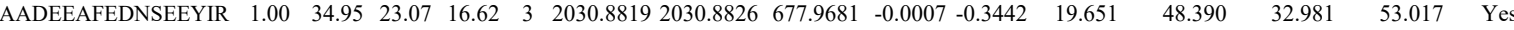

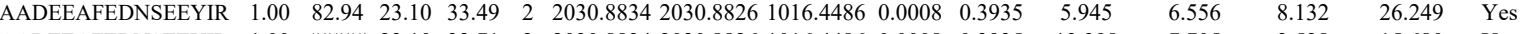

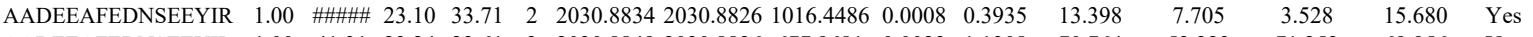
$\begin{array}{llllllllllllllll}\text { AADEEAFEDNSEEYIR } & 1.00 & 41.31 & 23.24 & 23.61 & 3 & 2030.8849 & 2030.8826 & 677.9681 & 0.0023 & 1.1308 & 70.764 & 52.323 & 71.253 & 69.956 & \text { Yes }\end{array}$

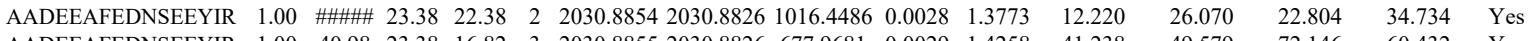

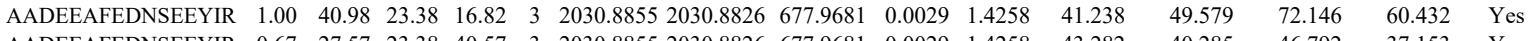

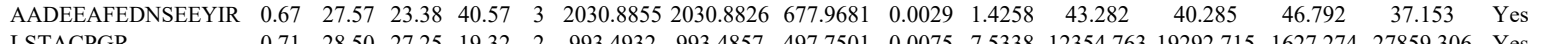

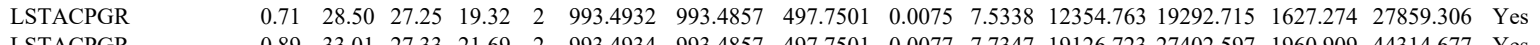
$\begin{array}{llllllllllllllllllll} & 0.71 & 28.50 & 27.25 & 19.32 & 2 & 993.4932 & 993.4857 & 497.7501 & 0.0075 & 7.5338 & 12354.763 & 19292.715 & 1627.274 & 27859.306 & \text { Yes } \\ \text { LSTACPGR } & 0.89 & 33.01 & 27.33 & 21.69 & 2 & 993.4934 & 99.4857 & 497.7501 & 0.0077 & 7.7347 & 19126.723 & 27402.597 & 1960.909 & 44314.677 & \text { Yes }\end{array}$

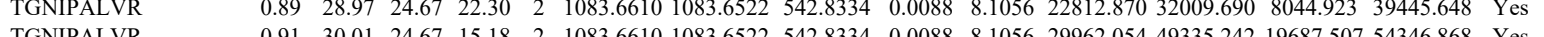

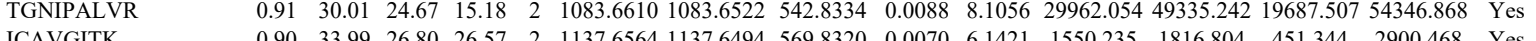

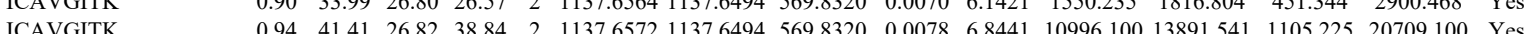

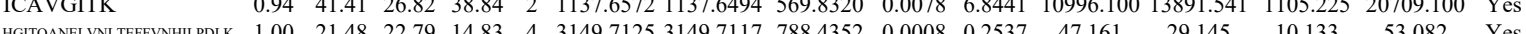
$\begin{array}{llllllllllllllll} & 128.448 & 160.007 & Y & Y\end{array}$

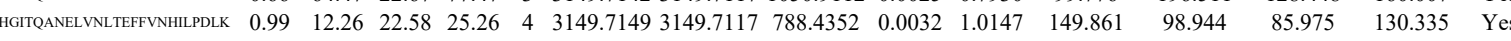

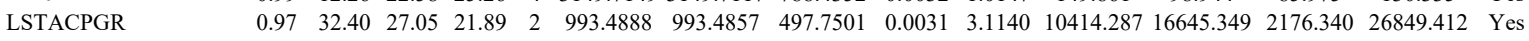
$\begin{array}{lllllllllllllllll} & \text { LSTACPGR } & 0.95 & 33.91 & 27.16 & 27.89 & 2 & 993.4894 & 993.4857 & 497.7501 & 0.0037 & 3.7167 & 13437.787 & 21409.997 & 2218.461 & 29901.384 & \text { Yes }\end{array}$ $\begin{array}{llllllllllllllll}\text { TGNIPALVR } & 0.83 & 28.12 & 24.67 & 23.10 & 2 & 1083.6606 & 1083.6522 & 542.8334 & 0.0084 & 7.7371 & 17810.169 & 31379.525 & 7760.253 & 38301.600 & \text { Yes }\end{array}$ $\begin{array}{llllllllllllllllll}0.93 & 32.46 & 24.67 & 20.41 & 2 & 1083.6606 & 1083.6522 & 542.8334 & 0.0084 & 7.7371 & 20326.359 & 35241.344 & 11684.423 & 43536.057 & \text { Yes } \\ \end{array}$ $\begin{array}{lllllllllllllllll} & \\ \text { HGITQANELVNLTEFFVNHLPDLK } & 0.66 & 68.65 & 22.67 & 81.65 & 3 & 3149.7142 & 3149.7117 & 1050.9112 & 0.0025 & 0.7930 & 28.663 & 71.099 & 56.554 & 52.092 & \text { Yes } \\ \text { HGITELEVLTEFFVNHLPDLK } & 1.00 & 44.01 & 22.50 & 57.01 & 4 & 3149.7157 & 3149.7117 & 788.4352 & 0.0040 & 1.2683 & 1.949 & 9.477 & 16.664 & 15.705 & \text { Yes }\end{array}$

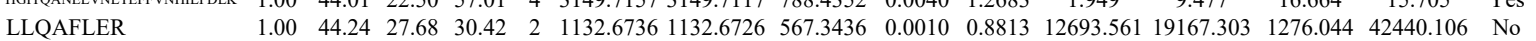

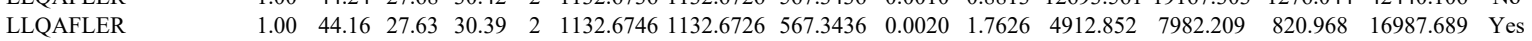
$\begin{array}{lllllllllllllll} & & & \end{array}$

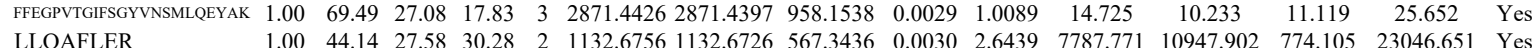
$\begin{array}{llllllllllllllll} & \\ \text { LLQAFER } & 1.00 & 44.14 & 27.58 & 30.28 & 2 & 1132.6756 & 1132.6726 & 567.3436 & 0.0030 & 2.6439 & 7787.771 & 10947.902 & 774.105 & 23046.651 & \text { Yc } \\ \text { LLQAFLR } & 1.00 & 44.41 & 27.57 & 28.65 & 2 & 1132.6758 & 1132.6726 & 567.3436 & 0.0032 & 2.8202 & 2961.547 & 5333.312 & 319.454 & 13574.912 & \text { No }\end{array}$

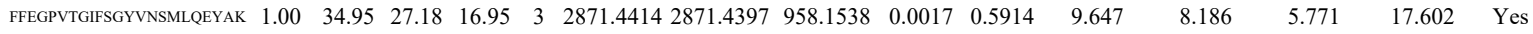
$\begin{array}{llllllllllllllll}\text { NDIPSSYMALFPHLLPVLWER } & 0.66 & 38.35 & 26.10 & 51.35 & 3 & 2769.4453 & 2769.4434 & 924.1551 & 0.0019 & 0.6853 & 128.437 & 138.266 & 116.502 & 252.646 & \text { Yes }\end{array}$

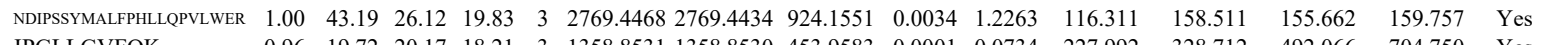
$\begin{array}{llllllllllllllll}\text { IPGLLGVFQK } & 0.96 & 19.72 & 20.17 & 18.21 & 3 & 1358.8531 & 1358.8530 & 453.9583 & 0.0001 & 0.0734 & 227.992 & 328.712 & 492.066 & 704.750 & \text { Yes }\end{array}$

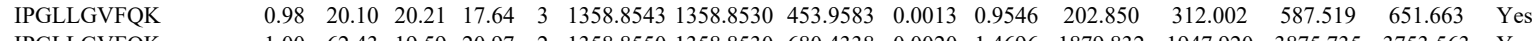
$\begin{array}{lllllllllllllllll}\text { IPGLLGVFQK } & 1.00 & 62.43 & 19.59 & 20.97 & 2 & 1358.8550 & 1358.8530 & 680.4338 & 0.0020 & 1.4696 & 1879.832 & 1947.920 & 3875.735 & 3753.563 & \text { Yes }\end{array}$

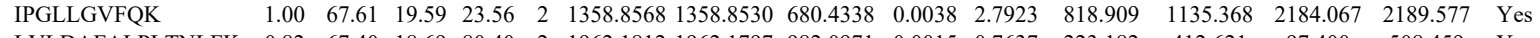
$\begin{array}{lllllllllllllllll}\text { LVLDAFALPLTNLFK } & 0.82 & 67.40 & 18.69 & 80.40 & 2 & 1962.1812 & 1962.1797 & 982.0971 & 0.0015 & 0.7637 & 223.182 & 412.621 & 97.400 & 508.459 & \text { Yes }\end{array}$ \begin{tabular}{llllllllllllllll} 
LVLDAFALPLTNLFK & 0.60 & 48.20 & 18.13 & 61.20 & 3 & 1962.1843 & 1962.1797 & 655.0672 & 0.0046 & 2.3407 & 61.862 & 72.609 & 13.751 & 131.248 & Yes \\
\hline
\end{tabular} $\begin{array}{llllllllllllllll} & \end{array}$

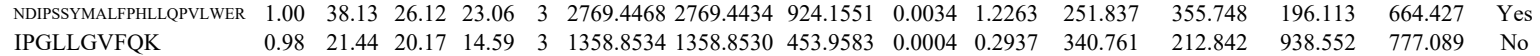

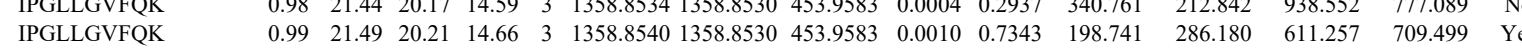

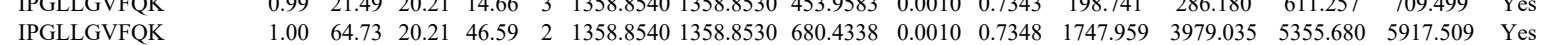

Table S-4 page 354 of 614 

FVTAIWNLVVTTGQEVK 0.60 $\begin{array}{lllllllllll}0.92 & 17.61 & 22.07 & 15.57 & 3 & 2206.264 & 22062605 & 736.4274 & 0.0041 & 1.8558 & 50.058\end{array}$

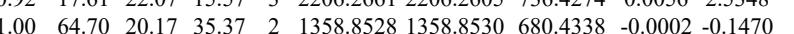
44.186 115.989

97
126.66
1137.94 22.0610

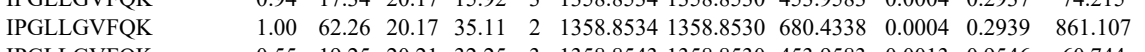
$\begin{array}{llllllllllll}0.55 & 19.25 & 20.21 & 32.25 & 3 & 1358.8543 & 1358.8530 & 453.9583 & 0.0013 & 0.9546 & 60.744\end{array}$ $\begin{array}{llllllllllllll}\text { IPGLLGVFQK } & 0.55 & 19.25 & 20.21 & 32.25 & 3 & 1358.8543 & 1358.8530 & 453.9583 & 0.0013 & 0.9546 & 60.744 \\ & \text { LVLDAFALP } & & \end{array}$ $\begin{array}{llllllllllll}\text { LVLDAFALPLTNLFK } & 0.67 & 35.82 & 18.33 & 48.82 & 3 & 1962.1831 & 1962.1797 & 65.56872 & 0.0034 & 1.7301 & 56.497 \\ \text { LVLDAFALPLTNLFK } & 1.00 & 49.61 & 17.99 & 18.49 & 3 & 1962.1834 & 1962.1797 & 655.0672 & 0.0037 & 1.8828 & 66.185\end{array}$ $\begin{array}{llllllllllllll}\text { LVTAIWNLLVTTGQEVK } & 1.00 & \# \# \# \text { 22.25 } & 28.44 & 2 & 2206.2614 & 2206.2605 & 1104.1375 & 0.0009 & 0.4076 & 14.664\end{array}$ $\begin{array}{llllllllllll}\text { FVTAIWNLLVTTGQEVK } & 0.67 & 57.61 & 22.10 & 70.61 & 3 & 2206.2640 & 2206.2605 & 736.4274 & 0.0035 & 1.5842 & 5.193 \\ \text { FVTAIWNLLVTTGQEVK } & 1.00 & 55.65 & 22.12 & 19.14 & 3 & 2206.2646 & 2206.2605 & 736.4274 & 0.0041 & 1.8558 & 43.788\end{array}$ FFTM LFTMR $\begin{array}{llllllllllll}0.77 & 18.23 & 23.26 & 23.61 & 2 & 810.4570 & 810.4544 & 406.2345 & 0.0026 & 3.2001 & 5749.889 \\ 0.85 & 20.68 & 23.26 & 24.65 & 2 & 810.4576 & 810.4544 & 406.2345 & 0.0032 & 3.9386 & 4808.332\end{array}$

$\begin{array}{lll}1.054 & 151.272 \\ 57.832 & 20.600 & -1\end{array}$

$\begin{array}{rrr}77.832 & 20.600 & 92.52 \\ 78.263 & 20.506 & 79.50 \\ 33.373 & 24.964 & 44.07\end{array}$

IPGLLGVFQK

$\begin{array}{ccc}0.000 & 1.663 & 0.000 \\ 263.329 & 305.798 & 445.62\end{array}$

IPGLLGVFQK
SFSLLQEAIIPYIPTLITQLTOK
YIMLR $\begin{array}{llllllllllll}1.00 & 54.71 & 20.21 & 34.12 & 2 & 1358.8540 & 1358.8530 & 680.4338 & 0.0010 & 0.7348 & 260.861 & 22\end{array}$

YIMIFR

YIMIFR

YIMIFR

YIMIFR

IPGLLGVFQK

IPGLLGVFQK

QIFILLFQR

QIFILLFQR

QIFLFR

QIFILPR

QIFLLFR

QIFILLFQR
QIFILLFQR

QIFILLFQR

KQIFILLFQR

KQIFILLFQR

QIFILLFQR

QIFILLFQR

QIFILLFQR
QIFILLFQR

QIFILLFQR

QIFILLFQR

QIFILLFQR

QIFILLFQR

QIFILLFQR

QIFILLFQR

QIFILLFQR

QIFILLFQR

ILFSSLILISK

QIFILLFQR

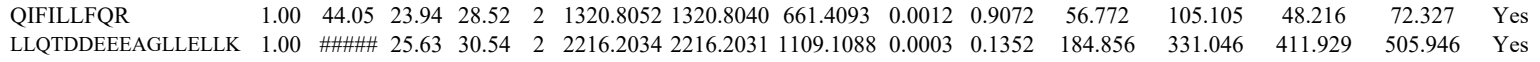
$\begin{array}{llllllllllll}1.00 & 39.73 & 17.24 & 15.64 & 3 & 2904.6841 & 2904.6819 & 969.2346 & 0.0022 & 0.7566 & 1.229\end{array}$

$\begin{array}{lll}226.700 & 332.523 & 381.9\end{array}$

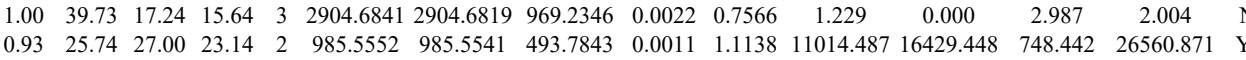
$\begin{array}{llllllllllllllll}0.93 & 25.26 & 26.96 & 23.88 & 2 & 985.5564 & 985.5541 & 493.7843 & 0.0023 & 2.3289 & 5055.143 & 7781.093 & 192.304 & 14251.734 & \text { Yes }\end{array}$ $\begin{array}{lllllllllllllll}0.93 & 25.57 & 27.00 & 22.96 & 2 & 985.5552 & 985.5541 & 493.7843 & 0.0011 & 1.1138 & 7189.577 & 11218.557 & 433.335 & 20399.113 & \text { Yes }\end{array}$ $\begin{array}{llllllllllllllll}0.94 & 25.60 & 26.92 & 23.36 & 2 & 985.5558 & 985.5541 & 493.7843 & 0.0017 & 1.7214 & 10746.577 & 14521.401 & 1709.179 & 28613.597 & \text { Yes }\end{array}$

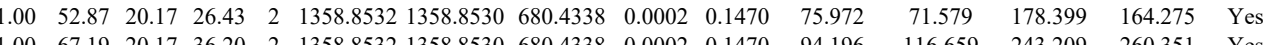

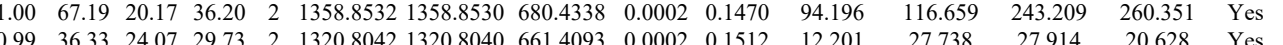

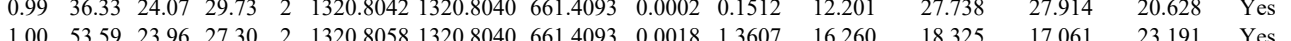

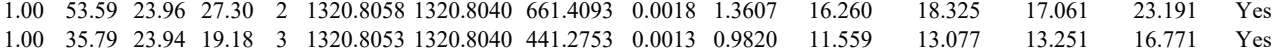

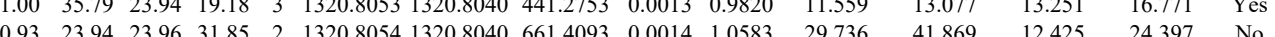
$\begin{array}{lllllllllllllll}1.00 & 45.96 & 23.87 & 26.88 & 2 & 1320.8064 & 1320.8040 & 661.403 & 0.0024 & 1.8143 & 1651.524 & 2689.074 & 1354.426 & 3126.165 & \text { Yes }\end{array}$

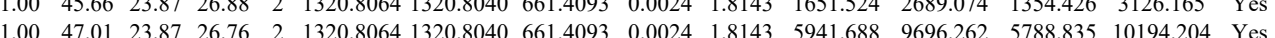
$\begin{array}{lllllllllllllll}1.00 & 47.01 & 23.87 & 26.76 & 2 & 1320.8064 & 1320.8040 & 661.4093 & 0.0024 & 1.8143 & 541.688 & 969.262 & 5788.835 & 10194.204 & \text { Yes } \\ 0.99 & 36.16 & 24.07 & 24.57 & 2 & 1320.8044 & 1320.8040 & 661.4093 & 0.0004 & 0.3024 & 418.458 & 629.847 & 464.765 & 800.032 & \text { Yes }\end{array}$ $\begin{array}{lllllllllllllll}1.00 & 43.67 & 24.01 & 25.40 & 2 & 1320.8048 & 1320.8040 & 661.4093 & 0.0008 & 0.6048 & 380.866 & 474.549 & 360.768 & 596.846 & \text { Yes }\end{array}$ $\begin{array}{llllllllllllllll}1.00 & 43.67 & 24.01 & 25.40 & 2 & 1320.8048 & 1320.8040 & 661.4093 & 0.0008 & 0.6048 & 380.866 & 474.549 & 360.768 & 596.846 & \text { Yes } \\ 1.00 & 47.35 & 15.68 & 21.10 & 3 & 1593.0025 & 1593.0010 & 532.0076 & 0.0015 & 0.9398 & 47.555 & 65.239 & 43.863 & 58.807 & \text { Yes }\end{array}$ $\begin{array}{llllllllllllllll}0.66 & 40.64 & 15.19 & 53.64 & 3 & 1593.0028 & 1593.0010 & 532.0076 & 0.0018 & 1.1278 & 47.606 & 78.967 & 55.811 & 54.289 & \text { Yes }\end{array}$ $\begin{array}{lllllllllllllll}1.00 & 44.29 & 24.07 & 29.67 & 2 & 1320.8044 & 1320.8040 & 661.4093 & 0.0004 & 0.3024 & 53.779 & 84.031 & 67.077 & 96.262 & \text { Yes }\end{array}$ $\begin{array}{lllllllllllllll}1.00 & 41.64 & 24.12 & 29.77 & 2 & 1320.8036 & 1320.8040 & 661.4093 & -0.0004 & -0.3024 & 64.445 & 60.865 & 22.675 & 95.481 & \text { Yes }\end{array}$

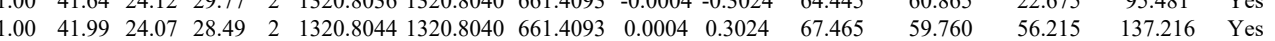
$\begin{array}{lllllllllllllll}1.00 & 45.42 & 24.01 & 27.73 & 2 & 1320.8048 & 1320.8040 & 661.4093 & 0.0008 & 0.6048 & 81.551 & 156.657 & 61.785 & 128.005 & \text { Yes }\end{array}$ $\begin{array}{lllllllllllllll}1.00 & 41.51 & 23.96 & 26.69 & 2 & 1320.8058 & 1320.8040 & 661.4093 & 0.0018 & 1.3607 & 68.198 & 79.512 & 56.661 & 90.301 & \text { Yes }\end{array}$

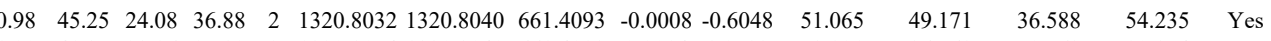

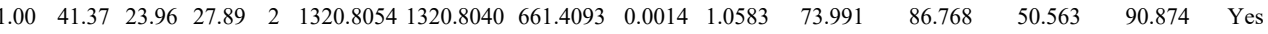
\begin{tabular}{lllllllllllllll}
1.00 & 43.07 & 24.07 & 29.24 & 2 & 1320.8042 & 1320.8040 & 661.4093 & 0.0002 & 0.1512 & 71.458 & 88.787 & 71.076 & 108.725 & Yes \\
\hline
\end{tabular} $\begin{array}{lllllllllllllll}0.99 & 36.81 & 24.07 & 31.83 & 2 & 1320.8044 & 1320.8040 & 661.4093 & 0.0004 & 0.3024 & 43.183 & 59.734 & 49.028 & 55.830 & \text { Yes }\end{array}$

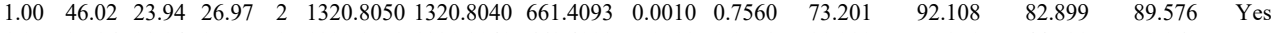

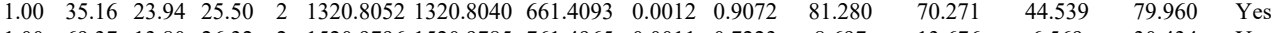

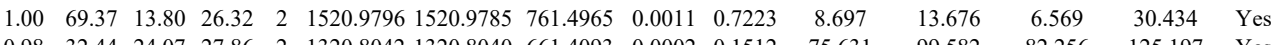

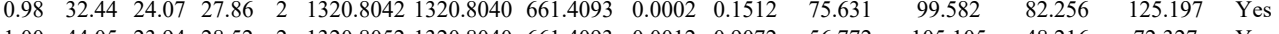

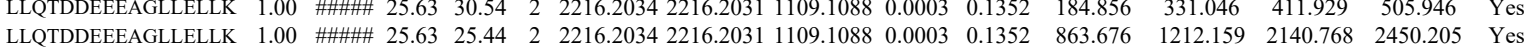

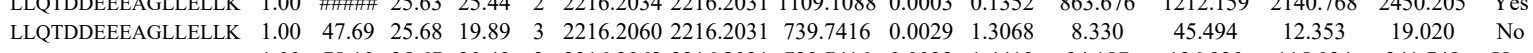

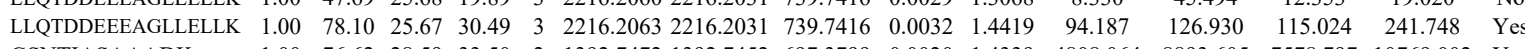
\begin{tabular}{llllllllllllllll} 
GSNTIASAAADK & 1.00 & 76.62 & 28.59 & 33.50 & 2 & 1392.7472 & 1392.7452 & 697.3799 & 0.0020 & 1.4339 & 4808.064 & 8893.605 & 7578.797 & 10769.002 & Yes \\
\hline
\end{tabular}

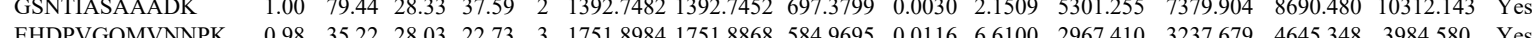

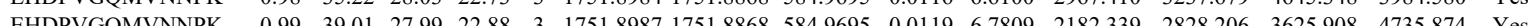
$\begin{array}{llllllllllllllll}\text { ESDPIAQMNNK } & 0.99 & 39.01 & 27.99 & 22.88 & 3 & 1751.8987 & 1751.8868 & 584.9695 & 0.0119 & 6.7809 & 2182.339 & 2828.206 & 3625.908 & 4735.874 & \text { Yes } \\ \text { GSNIIASAAADK } & 1.00 & 78.81 & 28.37 & 35.23 & 2 & 1392.7494 & 1392.7452 & 697.3799 & 0.0042 & 3.0113 & 2504.950 & 4101.013 & 3949.591 & 4387.289 & \text { Yes }\end{array}$ 

$\begin{array}{llllllllllll}\text { NAPAIIIDELDAIAPK } & 0.67 & 65.96 & 23.22 & 78.96 & 3 & 2098.1950 & 2098.1917 & 700.4045 & 0.0033 & 1.5705 & 99.354 \\ \text { NAPAIIIDEDAIAPK } & 0.97 & 19.04 & 23.18 & 17.55 & 3 & 2098.1953 & 2098.1917 & 700.4045 & 0.0036 & 1.7133 & 127.734\end{array}$ $\begin{array}{lllllllllllll}\text { NAPAIIFIDELDAIAPK } & 1.00 & 58.45 & 23.10 & 17.04 & 3 & 2098.1959 & 2098.1917 & 700.4045 & 0.0042 & 1.9988 & 413.218\end{array}$ $\begin{array}{llllllllllll}\text { LDQLIYIPLPDEK } & 1.00 & 42.55 & 24.50 & 27.28 & 3 & 1844.0566 & 1844.0539 & 615.6919 & 0.0027 & 1.4618 & 144.978\end{array}$ $\begin{array}{llllllllllll}\text { NAPAITDELDAIAPK } & 0.67 & 62.11 & 23.22 & 75.11 & 3 & 2098.1947 & 2098.1917 & 700.4045 & 0.0030 & 1.4277 & 132.623\end{array}$ $\begin{array}{lllllllllllll}\text { QAAPCLFFDEDSIAK } & 0.64 & 80.47 & 27.62 & 93.47 & 2 & 2200.1154 & 2200.1152 & 1101.0649 & 0.0002 & 0.0908 & 85.464\end{array}$ $\begin{array}{llllllllllll}\text { QAAPCVLFFDELDSIAK } & 1.00 & 80.70 & 27.62 & 25.36 & 2 & 2200.1154 & 2200.1152 & 1101.0649 & 0.0002 & 0.0908 & 71.117\end{array}$ $\begin{array}{llllllllllll}\text { QAAPCVLFFDELDSIAK } & 0.71 & 13.82 & 27.72 & 15.89 & 3 & 2200.1179 & 2200.1152 & 734.3790 & 0.0027 & 1.2255 & 9.480 \\ \text { QAAPCVLFFDELDSIAK } & 1.00 & 35.80 & 27.72 & 17.10 & 3 & 2200.1179 & 2200.1152 & 734.3790 & 0.0027 & 1.2255 & 37.442\end{array}$

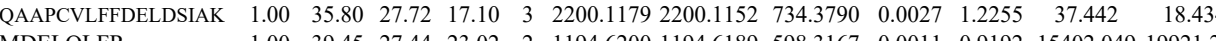



$\begin{array}{lllllllllllllllll}1.00 & 52.98 & 20.21 & 22.17 & 3 & 1381.8646 & 1381.8537 & 461.6252 & 0.0109 & 7.8707 & 9834.318 & 12454.557 & 30.990 & 12940.455 & \text { Yes }\end{array}$

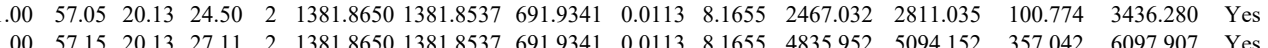

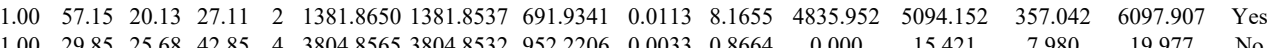

LEILQIHTK $\begin{array}{lllllllllllll}0.86 & 8.70 & 25.62 & 21.70 & 4 & 3804.8577 & 3804.8532 & 952.2206 & 0.0045 & 1.1814 & 15.335 & 28.677\end{array}$

\section{MTNGFSGADLT}

$\begin{array}{lllllllllll} & \end{array}$

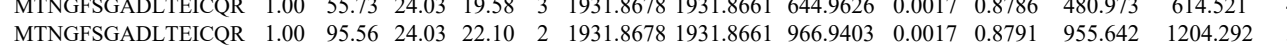

$\begin{array}{llllllllllll}\text { MTNGFSGADLTEICQR } & 0.66 & 24.18 & 24.03 & 37.18 & 3 & 1931.8681 & 1931.8661 & 644.9626 & 0.0020 & 1.0337 & 405.580\end{array}$

$\begin{array}{lllllllllllll}\text { MTNGFSGADLTEICQR } & 1.00 & 99.68 & 24.00 & 22.49 & 2 & 1931.8684 & 1931.8661 & 966.9403 & 0.0023 & 1.1893 & 64.739\end{array}$

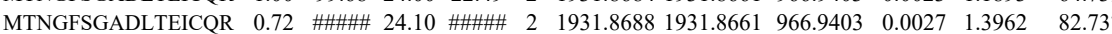

$\begin{array}{llllllllllllll}\text { AVANETGAFFFLINGPEIMSK } & 1.00 & 61.80 & 26.15 & 20.62 & 3 & 2543.3365 & 2543.3338 & 848.7852 & 0.0027 & 1.0603 & 82.912 & 9\end{array}$

$\begin{array}{lllllllllllll}\text { AVANETGAFFFLINGPEIMSK } & 0.60 & 35.57 & 26.17 & 48.57 & 3 & 2543.3374 & 2543.3338 & 848.7852 & 0.0036 & 1.4138 & 82.549 & 8 \\ \text { AVANETGAFFLLNGPEIMSK } & 0.60 & 23.18 & 26.17 & 36.18 & 3 & 2543.3374 & 2543.3338 & 848.7852 & 0.0036 & 1.4138 & 31.55 & 2\end{array}$

GILLYGPPGTGK

$\begin{array}{lllllllllll}0.60 & 23.18 & 26.17 & 36.18 & 3 & 2543.3374 & 2543.3338 & 848.7852 & 0.0036 & 1.4138 & 31.653 \\ 0.98 & 6.88 * & 23.87 & 24.37 & 2 & 1459.8778 & 1459.8642 & 730.9394 & 0.0136 & 9.3030 & 415.650\end{array}$

KYEMFAQTLQQSR $\begin{array}{llll}1.00 & 82.51 & 27.58 & 30.04\end{array}$

EDEEESLNEVGYDDIGGCR

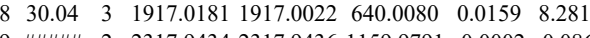

415.650
776.471
9.654

GVLFYGPPGCGK

\begin{tabular}{cc}
9.654 & 8.583 \\
\hline .547 & 11.588
\end{tabular}

$\begin{array}{rrrr}7.980 & 19.977 & \text { No } \\ 7.082 & 32.416 & \text { Yes }\end{array}$

GVLFYGPPGCGK

GVLFYGPPGCGK

GVLFYGPPGCGK

GVLFYGPPGCGK

GVLFYGPPGCGK

GVLFYGPPGCGK

GVLFYTH

UVSQLTTMDGL

STELTTLMDGLK

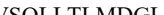

VSQLLTLMDGLK

VSQLLTLMDGLK

$\begin{array}{lllllllllllll}66.01 & 27.77 & 23.22 & 2 & 1527.7840 & 1527.7822 & 764.8984 & 0.0018 & 1.1766 & 7186.543 & 6\end{array}$

$\begin{array}{lllllllllll}1.98 & 25.36 & 27.63 & 19.56 & 3 & 1527.7846 & 1527.7822 & 510.2680 & 0.0024 & 1.5678 & 468.689\end{array}$

$\begin{array}{llllllllllll}1.00 & 57.43 & 27.63 & 29.86 & 2 & 1527.7836 & 1527.7822 & 764.8984 & 0.0014 & 0.9152 & 1739.719 & 2220.817\end{array}$

$\begin{array}{lllllllllllll}1.00 & 57.61 & 27.77 & 29.68 & 2 & 1527.7842 & 1527.7822 & 764.8984 & 0.0020 & 1.3074 & 4336.086 & 5183.886 & \end{array}$

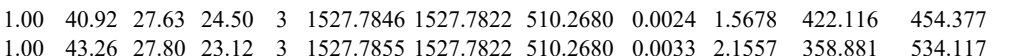

$\begin{array}{llllllllllll}1.00 & 43.26 & 27.80 & 23.12 & 3 & 1527.7855 & 1527.7822 & 510.2680 & 0.0033 & 2.1557 & 358.881 & 534.117 \\ 1.00 & 44.72 & 27.69 & 18.13 & 2 & 1527.7830 & 1527.7822 & 764.8984 & 0.0008 & 0.5229 & 1586.452 & 1405.375\end{array}$

$\begin{array}{llllllllllllll}1.00 & 44.75 & 27.66 & 20.66 & 2 & 1527.7834 & 1527.7822 & 764.8984 & 0.0012 & 0.7844 & 1003.034 & 1200.596\end{array}$

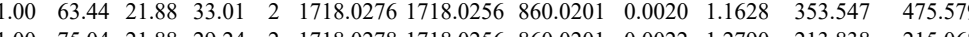

$\begin{array}{lllllllllllll}1.00 & 75.04 & 21.88 & 29.24 & 2 & 1718.0278 & 1718.0256 & 860.0201 & 0.0022 & 1.2790 & 213.838 & 2\end{array}$

37.743

$\begin{array}{llllllllllll}1.00 & 52.93 & 22.07 & 23.71 & 3 & 17180287 & 17180256 & 573.6825 & 0.0031 & 1.8012 & 113.895 & 139.64\end{array}$

$\begin{array}{lllllllllllll}1.00 & 66.14 & 21.79 & 25.32 & 2 & 1718.0272 & 1718.0256 & 860.0201 & 0.0016 & 0.9302 & 2134.390 & 2357.393 & 501.86\end{array}$

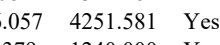

VSQLLTLMDGLK

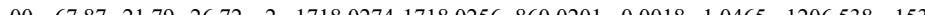

$\begin{array}{lllllllllllll}0.99 & 24.15 & 21.88 & 16.78 & 3 & 1718.0284 & 1718.0256 & 573.6825 & 0.0028 & 1.6269 & 26.579 & 51.333\end{array}$

IVSQLLTLMDGLK

IVSQLLTLMDGLK
IVSQLLTLMDGLK

WALSQSNPSALR

WALSQSNPSALR

IVSQLLTLMDGLK

IVSQLLTLMDGLK

IVSQLLTLMDGLK

WALSQSNPSALR

$\begin{array}{lllllllllllll}1.00 & 58.72 & 22.04 & 24.19 & 3 & 1718.0290 & 1718.0256 & 573.6825 & 0.0024 & 1.9755 & 565.603 & 645.643\end{array}$

$\begin{array}{llllllllllll}1.00 & 53.67 & 21.88 & 1.332 & 3 & 1718.0284 & 1718.0256 & 573.6825 & 0.0028 & 1.6269 & 90.346 & 92.048\end{array}$

$\begin{array}{llllllllllll}1.00 & 72.66 & 22.04 & 32.48 & 2 & 1718.0288 & 1718.0256 & 860.0201 & 0.0032 & 1.8604 & 272.720 & 272.213\end{array}$

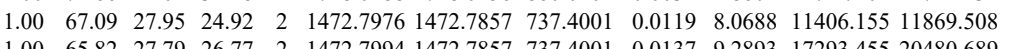

$\begin{array}{lllllllllllll}1.00 & 65.82 & 27.79 & 26.77 & 2 & 1472.7994 & 1472.7857 & 737.4001 & 0.0137 & 9.2893 & 17293.455 & 20480.689\end{array}$ $\begin{array}{lllllllllllll}1.00 & 54.17 & 22.01 & 20.55 & 2 & 1718.0270 & 1718.0256 & 860.0201 & 0.0014 & 0.8139 & 11.953 & 12.887\end{array}$ $\begin{array}{lllllllllllll}1.00 & 65.22 & 21.79 & 27.26 & 2 & 1718.0274 & 1718.0256 & 860.0201 & 0.0018 & 1.0465 & 96.956 & 112.129\end{array}$

$\begin{array}{llllllllllll}1.00 & 41.55 & 21.88 & 21.56 & 3 & 1718.0278 & 1718.0256 & 573.6825 & 0.0022 & 1.2783 & 28.627 & 25.936 \\ 1.00 & 39.51 & 21.88 & 22.21 & 3 & 1718.0278 & 1718.0256 & 573.6825 & 0.0022 & 1.2783 & 34.721 & 41.968\end{array}$

$\begin{array}{lllllllllllll}1.00 & 39.51 & 21.88 & 22.21 & 3 & 1718.0278 & 1718.0256 & 573.6825 & 0.0022 & 1.2783 & 34.721 & 41.968 \\ 1.00 & 82.67 & 27.96 & 27.01 & 2 & 1472.7946 & 1472.7857 & 737.4001 & 0.0089 & 6.0347 & 2674.436 & 3292.563 \\ 1.00 & 79.16 & 27.97 & 27.58 & 2 & 1472.7960 & 1472.7857 & 737.4001 & 0.0103 & 6.9839 & 5051.167 & 5589.626\end{array}$

$\begin{array}{llllllllllll}1.00 & 79.16 & 27.97 & 27.58 & 2 & 1472.7960 & 1472.7857 & 737.4001 & 0.0103 & 6.9839 & 5051.167 & 5589.626\end{array}$

$\begin{array}{llllllllllll}0.99 & 23.95 & 25.00 & 23.12 & 4 & 2289.2705 & 2289.2497 & 573.3197 & 0.0208 & 9.0699 & 536.622\end{array}$

$\begin{array}{llllllllllllll}\text { AHVIVMAATNRPNSIDPALR } & 0.99 & 23.85 & 25.12 & 15.81 & 4 & 2289.2709 & 2289.2497 & 573.3197 & 0.0212 & 9.2443 & 518.190 & 187.989 & \\ \text { QTNPSAMEVEDDDPVPEIR } & 1.00 & 81.76 & 26.50 & 24.91 & 2 & 2299.0774 & 2299.0760 & 1150.5453 & 0.0014 & 0.6084 & 72.024 & 120.493 & 130\end{array}$

$\begin{array}{llllllllllllll}\text { AHVIVMAATNRPNSIDPALR } & 1.00 & 27.97 & 25.45 & 17.32 & 4 & 2289.2649 & 2289.2497 & 573.3197 & 0.0152 & 6.6280 & 279.448\end{array}$

$\begin{array}{llllllllllllll}\text { AHVIVMAATNRPNSDFAR } & 0.94 & 17.58 & 25.30 & 17.68 & 4 & 2289.2677 & 2289.2497 & 573.3197 & 0.0180 & 7.8490 & 450.783\end{array}$

$\begin{array}{lllllllllllll}\text { NVFIIGATNRPDIIDPAILRPGR } & 0.67 & 30.06 & 20.33 & 43.06 & 3 & 2661.5233 & 2661.5200 & 888.1806 & 0.0033 & 1.2385 & 738.831 & 90 .\end{array}$

$\begin{array}{lllllllllllll}\text { NVFIIGATNRPDIIDPALRPGR } & 0.60 & 20.00 & 20.25 & 33.00 & 3 & 2661.5242 & 2661.5200 & 888.1806 & 0.0042 & 1.5763 & 452.002 & 955.897\end{array}$

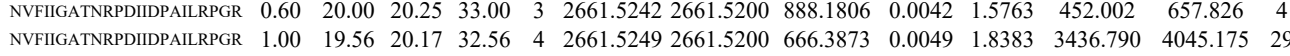

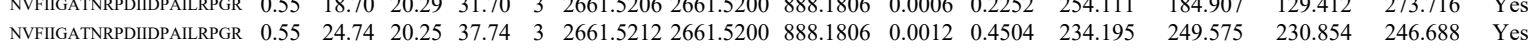
$\begin{array}{llllllllllllllllll}\text { NVFIIGATNRPDIIDPALRPGR } & 1.00 & 17.10 & 20.33 & 30.10 & 4 & 2661.5229 & 2661.5200 & 666.3873 & 0.0029 & 1.0880 & 962.726 & 1394.071 & 787.455 & 1228.024 & \text { Yes }\end{array}$ $\begin{array}{llllllllllllllll}\text { NVFIIGATNRPDIIDPAILRPGR } & 1.00 & 19.12 & 20.33 & 32.12 & 4 & 2661.5237 & 2661.5200 & 666.3873 & 0.0037 & 1.3881 & 2484.946 & 3113.737 & 2353.151 & 2807.190 & \text { Yes }\end{array}$ 


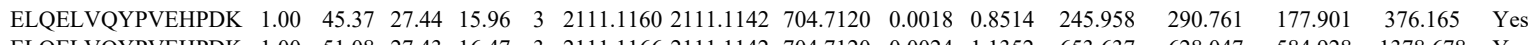
$\begin{array}{llllllllllllllll}\text { ELQELVQYPVEHPDK } & 1.00 & 51.08 & 27.43 & 16.47 & 3 & 2111.1166 & 2111.1142 & 704.7120 & 0.0024 & 1.1352 & 653.637 & 628.047 & 584.928 & 1378.678 & \text { Yes }\end{array}$ $\begin{array}{llllllllllllllll}\text { LIVDEAINEDNSVVSLSQPK } & 1.00 & 36.99 & 25.51 & 20.81 & 3 & 2457.3223 & 2457.3206 & 820.1141 & 0.0017 & 0.6910 & 31.611 & 18.806 & 7.693 & 76.262 & \text { No }\end{array}$

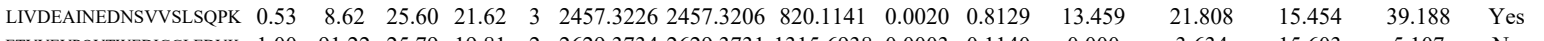

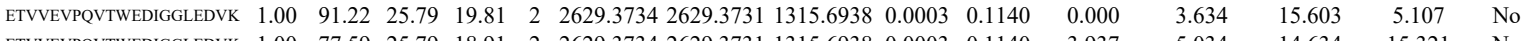
$\begin{array}{llllllllllllll} & \end{array}$ $\begin{array}{llllllllllllllll}\text { ETVVEVPQVTWEDIGGLEDVK } & 1.00 & 21.61 & 25.68 & 15.81 & 4 & 2629.3765 & 2629.3731 & 658.3506 & 0.0034 & 1.2911 & 68.853 & 65.908 & 53.107 & 88.223 & \text { Yes }\end{array}$

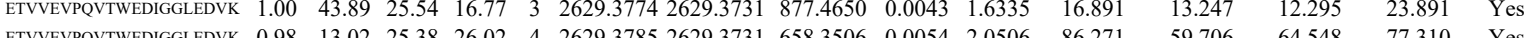
$\begin{array}{llllllllllllllll}\text { ETVEVPQVTWEDIGGLEDVK } & 0.98 & 13.02 & 25.38 & 26.02 & 4 & 2629.3785 & 2629.3731 & 658.3506 & 0.0054 & 2.0506 & 86.271 & 59.706 & 64.548 & 77.310 & \text { Yes } \\ \text { ETVYEVPQVTWEDIGGEDDVK } & 1.00 & 82.67 & 25.35 & 21.26 & 3 & 2629.3789 & 2629.3731 & 877.4650 & 0.0058 & 2.033 & 14.201 & 37.832 & 29.540 & 30.544 & \text { Yes }\end{array}$

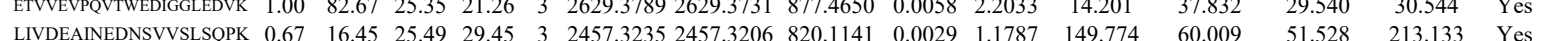

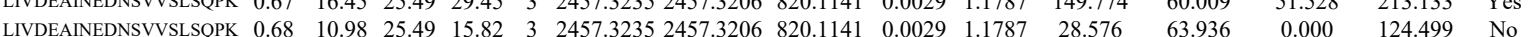

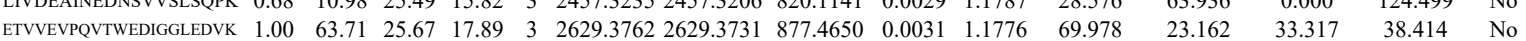

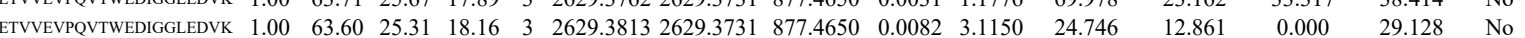

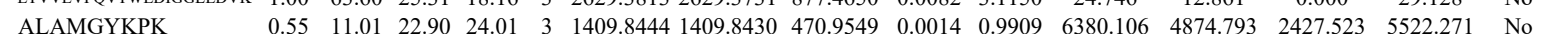
$\begin{array}{llllllllllllllll}\text { ALAMGYKPK } & 1.00 & 28.66 & 23.18 & 22.81 & 3 & 1409.8459 & 1409.8430 & 470.9549 & 0.0029 & 2.0526 & 64597.417 & 55355.167 & 2701.044 & 51885.500 & \text { Yes }\end{array}$

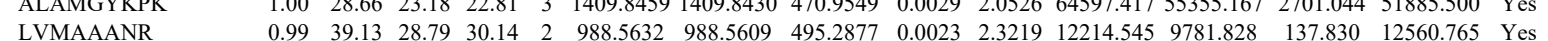
$\begin{array}{llllllllllllllll}\text { LVMAAANR } & 0.99 & 39.20 & 28.33 & 28.19 & 2 & 988.5638 & 988.5609 & 495.2877 & 0.0229 & 2.9276 & 11300.644 & 9957.525 & 383.728 & 11846.441 & \text { Yes }\end{array}$ $\begin{array}{lllllllllllllllll}\text { LVMAAANR } & 0.99 & 37.26 & 28.33 & 30.73 & 2 & 988.5638 & 988.5609 & 495.2877 & 0.0029 & 2.9276 & 5433.177 & 4423.094 & 452.274 & 5483.911 & \text { Yes }\end{array}$ $\begin{array}{llllllllllllllll}\text { AALTGLLHR } & 0.82 & 28.45 & 25.33 & 21.09 & 2 & 1094.6762 & 1094.6682 & 548.3414 & 0.0080 & 7.2947 & 13049.716 & 12922.165 & 1411.052 & 18774.024 & \text { Yes }\end{array}$ $\begin{array}{llllllllllllllll}\text { AALTGLLHR } & 0.96 & 35.90 & 25.33 & 21.48 & 2 & 1094.6764 & 1094.6682 & 548.3414 & 0.0082 & 7.4770 & 14057.256 & 12622.858 & 2696.628 & 18012.830 & \text { Yes }\end{array}$ $\begin{array}{llllllllllllllll}\text { AALTGLLHR } & 1.00 & 51.11 & 25.48 & 23.90 & 2 & 1094.6750 & 1094.6682 & 548.3414 & 0.0068 & 6.2005 & 7859.004 & 6643.675 & 406.510 & 9013.344 & \text { Yes }\end{array}$ $\begin{array}{lllllllllllllllll}\text { AALTGLLHR } & 0.99 & 45.14 & 25.33 & 23.83 & 2 & 1094.6758 & 1094.6682 & 548.3414 & 0.0076 & 6.9299 & 7010.249 & 5369.223 & 265.200 & 6400.037 & \text { Yes }\end{array}$ $\begin{array}{llllllllllllllll}\text { AQDEGLLSDVVPFK } & 0.96 & 26.10 & 27.02 & 29.66 & 3 & 1804.9846 & 1804.9815 & 602.6678 & 0.0031 & 1.7146 & 73.202 & 92.809 & 28.852 & 116.285 & \text { No }\end{array}$ $\begin{array}{llllllllllllllll}\text { AQDEGLLSDVVPFK } & 1.00 & 37.73 & 27.05 & 20.44 & 3 & 1804.9855 & 1804.9815 & 602.6678 & 0.0040 & 2.2124 & 131.021 & 100.465 & 43.925 & 127.853 & \text { Yes }\end{array}$

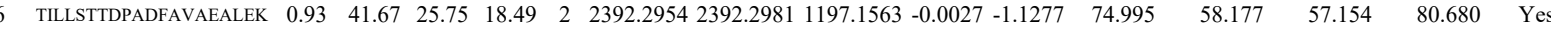

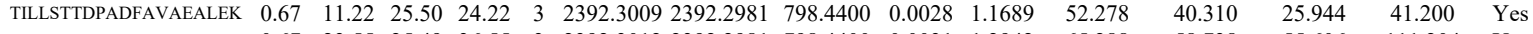

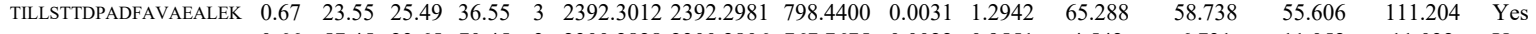
\begin{tabular}{llllllllllllllll} 
ITDAQDVLAHLVQMAFK & 0.66 & 57.45 & 23.65 & 70.45 & 3 & 2300.2828 & 2300.2806 & 767.7675 & 0.0022 & 0.9551 & 4.542 & 6.731 & 11.052 & 11.032 & Yes \\
\hline
\end{tabular}

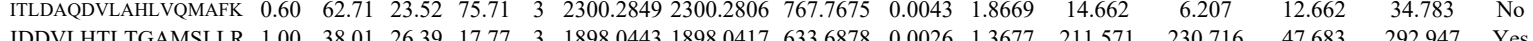
$\begin{array}{llllllllllllllll} & \\ \text { IDDVLHILTGAMSLLR } & 1.00 & 38.01 & 26.39 & 17.77 & 3 & 1898.0443 & 1898.0417 & 633.6878 & 0.0026 & 1.3677 & 211.571 & 230.716 & 47.683 & 292.947 & \text { Yes }\end{array}$ $\begin{array}{llllllllllllllll}\text { IDDVLHTLTGAMSLLR } & 0.67 & 49.46 & 26.28 & 62.46 & 3 & 1898.0452 & 1898.0417 & 633.6878 & 0.0035 & 1.8411 & 172.565 & 165.667 & 33.605 & 184.853 & \text { Yes }\end{array}$ $\begin{array}{lllllllllllllllll}\text { NVDLSDMVQEIDEPILK } & 1.00 & 45.63 & 27.06 & 21.01 & 3 & 2382.2374 & 2382.2344 & 795.0854 & 0.0030 & 1.2577 & 1547.180 & 1759.713 & 2010.208 & 2636.379 & \text { Yes }\end{array}$ $\begin{array}{lllllllllllllllllll} & \text { LDGLVDMVQUDEPILK } & 1.00 & 63.10 & 27.06 & 21.19 & 3 & 2382.2374 & 2382.2344 & 795.0854 & 0.0030 & 1.2577 & 989.807 & 1093.589 & 1123.158 & 1320.961 & \text { Yes }\end{array}$ $\begin{array}{llllllllllllllll} & \end{array}$ $\begin{array}{lllllllllllllll} & \text { LDGLE }\end{array}$

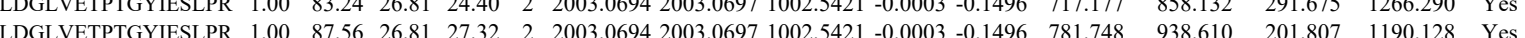
$\begin{array}{lllllllllllllllll} & \text { LDGLVETPTGYIESLPR } & 0.55 & 25.95 & 26.80 & 38.95 & 3 & 20033.0704 & 2003.0697 & 668.6972 & 0.0007 & 0.3489 & 432.786 & 400.861 & 173.329 & 485.409 & \text { Yes }\end{array}$ $\begin{array}{llllllllllllllll} & 1.00 & 70.22 & 26.81 & 23.66 & 2 & 2003.0714 & 2003.0697 & 10025421 & 0.0017 & 0.8478 & 513.569 & 499.309 & 184.035 & 721244 & \text { YeS }\end{array}$

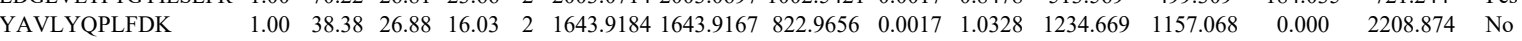
$\begin{array}{llllllllllllllll}\text { YAVLYQPLFDK } & 1.00 & 42.53 & 26.94 & 16.43 & 2 & 1643.9188 & 1643.9167 & 822.9656 & 0.0021 & 1.2759 & 795.955 & 1630.944 & 38.304 & 2078.688 & \text { Yes }\end{array}$

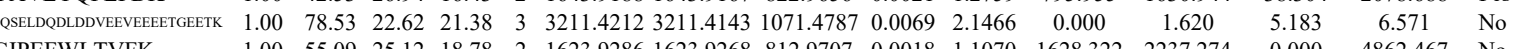
$\begin{array}{llllllllllllllll}\text { GIPEFWLTVFK } & 1.00 & 55.09 & 25.12 & 18.78 & 2 & 1623.9286 & 1623.9268 & 812.9707 & 0.0018 & 1.1070 & 1628.322 & 2237.274 & 0.000 & 4862.467 & \text { No }\end{array}$

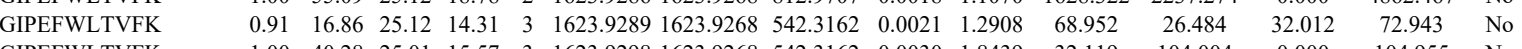

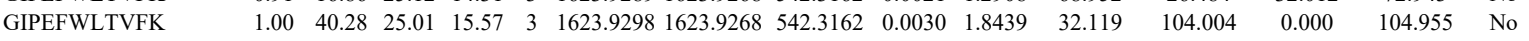
$\begin{array}{llllllllllllllll}\text { GIPEFWLTVFK } & 1.00 & 53.28 & 25.12 & 16.45 & 2 & 1623.9286 & 1623.9268 & 812.9707 & 0.0018 & 1.1070 & 2490.330 & 2996.768 & 35.217 & 5298.607 & \text { Yes }\end{array}$ $\begin{array}{llllllllllllllll}\text { GIPEFWLTVFK } & 1.00 & 51.66 & 25.12 & 18.25 & 2 & 1623.9286 & 1623.9268 & 812.9707 & 0.0018 & 1.1070 & 1481.058 & 1671.098 & 121.668 & 3686.795 & \text { Yes }\end{array}$ $\begin{array}{llllllllllllllll}\text { GIPEFWLTVFK } & 0.67 & 25.74 & 25.02 & 38.74 & 3 & 1623.9295 & 1623.9268 & 542.3162 & 0.0027 & 1.6595 & 92.110 & 66.229 & 24.762 & 89.495 & \text { No }\end{array}$ $\begin{array}{lllllllllllllllll}\text { QLTVQMMQNPQILAALQER } & 1.00 & 84.53 & 26.31 & 19.15 & 2 & 2355.2534 & 2355.2524 & 1178.6335 & 0.0010 & 0.4242 & 180.772 & 249.180 & 177.753 & 342.548 & \text { Yes }\end{array}$ $\begin{array}{llllllllllllllll}\text { QLTVQMMQNPQILAALQER } & 0.82 & 81.73 & 26.31 & 94.73 & 2 & 2355.2534 & 2355.2524 & 1178.6335 & 0.0010 & 0.4242 & 208.508 & 240.360 & 237.598 & 315.592 & \text { Yes }\end{array}$ $\begin{array}{llllllllllllllll}\text { QLTVQMMQNPQILAALQER } & 0.67 & 13.84 & 26.30 & 26.84 & 3 & 2355.2551 & 2355.2524 & 786.0914 & 0.0027 & 1.1449 & 44.476 & 25.965 & 89.653 & 143.653 & \text { No }\end{array}$ $\begin{array}{llllllllllllllll}\text { QLTVQMMQNPQILAALQER } & 0.67 & 56.22 & 26.34 & 69.22 & 3 & 2355.2557 & 2355.2524 & 786.0914 & 0.0033 & 1.3993 & 105.106 & 191.327 & 44.121 & 79.693 & \text { No }\end{array}$ $\begin{array}{llllllllllllllll}\text { GIPEFWLTVFK } & 1.00 & 68.31 & 25.04 & 18.20 & 2 & 1623.9272 & 1623.9268 & 812.9707 & 0.0004 & 0.2460 & 547.400 & 577.736 & 38.966 & 1338.495 & \text { Yes }\end{array}$

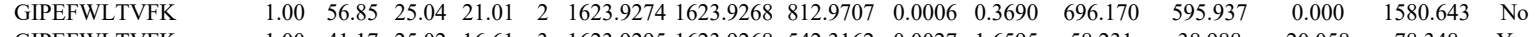
\begin{tabular}{llllllllllllllll} 
GIPEFWLTVFK & 1.00 & 41.17 & 25.02 & 16.61 & 3 & 1623.9295 & 1623.9268 & 542.3162 & 0.0027 & 1.6595 & 58.231 & 38.988 & 20.058 & 78.348 & Yes \\
\hline
\end{tabular} $\begin{array}{lllllllllllllllll}\text { GIPEFWLTVFK } & 0.67 & 32.06 & 25.05 & 45.06 & 3 & 1623.9301 & 1623.9268 & 542.3162 & 0.0033 & 2.0283 & 43.795 & 80.206 & 14.945 & 69.141 & \text { Yes }\end{array}$ $\begin{array}{lllllllllllllllllll}\text { QLTVQMMQNPQILAALQER } & 0.66 & 36.68 & 26.23 & 49.68 & 3 & 2355.2548 & 2355.2524 & 786.0914 & 0.0024 & 1.0177 & 13.779 & 13.802 & 11.626 & 5.039 & \text { No }\end{array}$ $\begin{array}{llllllllllllllll}\text { QLTVQMMQNPQLLAALQER } & 0.96 & 22.74 & 26.29 & 19.62 & 3 & 2355.2566 & 2355.2524 & 786.0914 & 0.0042 & 1.7810 & 9.561 & 9.098 & 8.260 & 14.564 & \text { Yes }\end{array}$

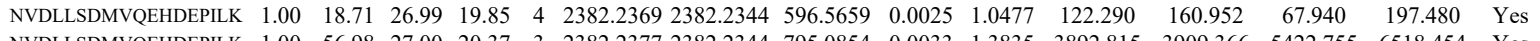

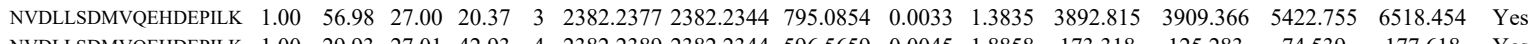

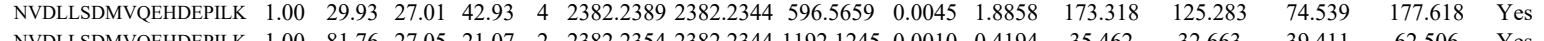

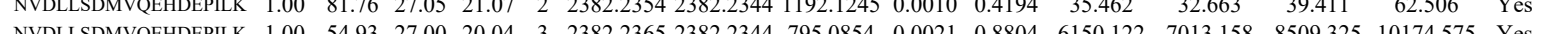

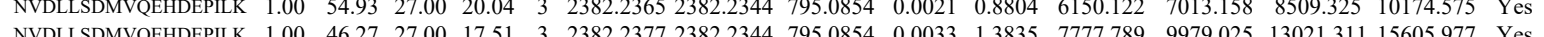

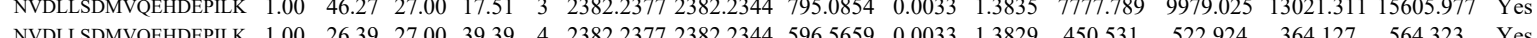

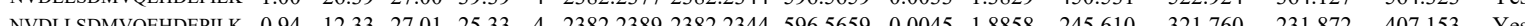
$\begin{array}{llllllllllllllll}\text { NVDLLSDMVQEHDEPILK } & 0.66 & 47.83 & 27.00 & 60.83 & 3 & 2382.2365 & 2382.2344 & 795.0854 & 0.0021 & 0.8804 & 3877.550 & 5233.257 & 5190.043 & 8088.088 & \text { Yes }\end{array}$ 


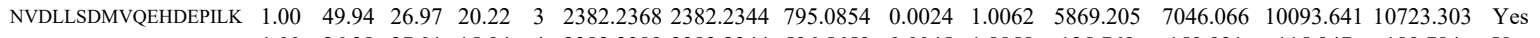
$\begin{array}{llllllllllllllll}\text { NVDLLSDMVQEHDEPILK } & 1.00 & 26.38 & 27.01 & 15.94 & 4 & 2382.2389 & 2382.2344 & 596.5659 & 0.0045 & 1.8858 & 125.769 & 159.921 & 115.947 & 189.784 & \text { Yes }\end{array}$

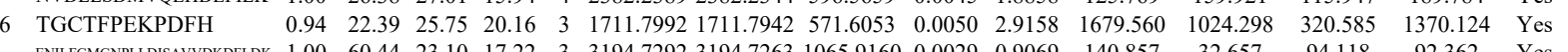
\begin{tabular}{lllllllllllllllll} 
& ENLFGMGNPLDDISAVVDKDFLDK & 1.00 & 60.44 & 23.10 & 17.22 & 3 & 3194.7292 & 3194.7263 & 1065.9160 & 0.0029 & 0.9069 & 140.857 & 32.657 & 94.118 & 92.362 & Yes \\
\hline
\end{tabular}

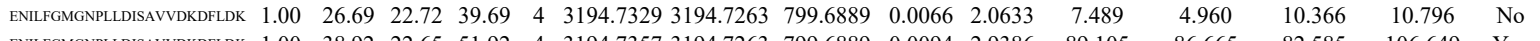

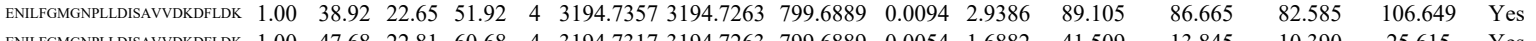

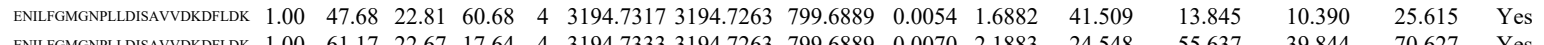

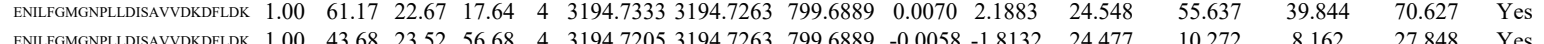

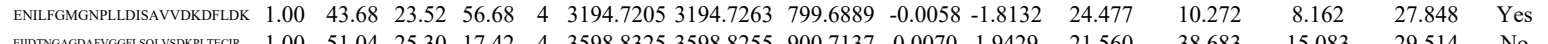

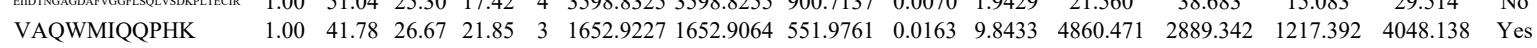

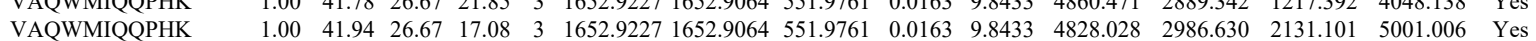
$\begin{array}{llllllllllllllll}\text { VAQWMIQQPHK } & 0.99 & 37.92 & 26.78 & 16.99 & 3 & 165.92215 & 16529064 & 551.9761 & 0.0151 & 9.1187 & 9100.634 & 6744.197 & 1899252 & 7993.683 & \text { Yes }\end{array}$

IVIFTQGR

IVIFTQGR

IVIFTQGR

IVIFTQGR

IVIFTQGR

IVIFTQGR

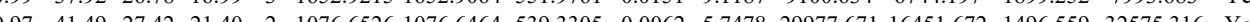
$\begin{array}{lllllllllllllll}0.97 & 39.89 & 27.42 & 19.87 & 2 & 1076.6530 & 1076.6464 & 539.3305 & 0.0056 & 6.1187 & 30225.388 & 17212.168 & 1815.545 & 34893.983 & \text { Yes }\end{array}$ $\begin{array}{lllllllllllllll}0.98 & 38.68 & 26.97 & 19.70 & 2 & 1076.6500 & 1076.6464 & 539.3305 & 0.0036 & 3.3375 & 16391.590 & 9440.157 & 122.557 & 17098.101 & \text { Yes }\end{array}$

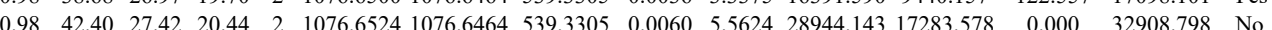
$\begin{array}{lllllllllllllllll}1.00 & 40.82 & 26.96 & 19.67 & 2 & 1076.6494 & 1076.6464 & 539.3305 & 0.0030 & 2.7812 & 13464.805 & 7584.734 & 530.936 & 12793.682 & \text { Yes }\end{array}$ $\begin{array}{lllllllllllllll}0.99 & 37.08 & 26.96 & 19.31 & 2 & 1076.6496 & 1076.6464 & 539.3305 & 0.0032 & 2.9666 & 10160.865 & 5770.234 & 802.698 & 10568.963 & \text { Yes }\end{array}$ $\begin{array}{lllllllllllllll}0.99 & 37.42 & 26.80 & 28.31 & 2 & 1076.6476 & 1076.6464 & 539.3305 & 0.0012 & 1.1125 & 1801.230 & 1127.319 & 358.799 & 1785.903 & \text { Yes }\end{array}$

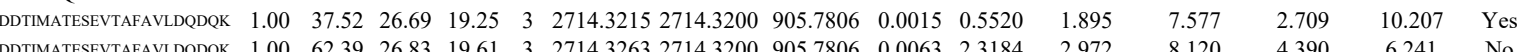

SPVTTLLECMHK

SPVTTLLECMHK SPVTTLLECMHK

SPVTTLLECMHK

$\begin{array}{llllllllllllllll}1.00 & 93.83 & 27.92 & 21.75 & 3 & 1691.8744 & 1691.8652 & 564.9623 & 0.0092 & 5.4281 & 929.255 & 783.666 & 1070.940 & 1292.855 & \text { Yes }\end{array}$ $\begin{array}{lllllllllllllllll} & \end{array}$ $\begin{array}{llllllllllllllll}\text { TLPLTGSTFHDQIAMLSHR } & 1.00 & 41.62 & 27.40 & 16.73 & 4 & 2268.1829 & 2268.1807 & 568.0525 & 0.0022 & 0.9682 & 2742.624 & 2756.513 & 1915.735 & 2148.228 & \text { Yes } \\ \text { TLPLTGSTFHDOLAMLSHR } & 1.00 & 43.55 & 27.43 & 56.55 & 4 & 2268.1825 & 2268.1807 & 568.0525 & 0.0018 & 0.7922 & 2614.544 & 2581.611 & 851.426 & 2238.426 & \text { Yes }\end{array}$ $\begin{array}{llllllllllllllll} & \\ \text { TLPLTGSTFHDQIAMLSHR } & 1.00 & 52.32 & 27.43 & 56.55 & 4 & 2268.1825 & 2268.1807 & 568.0525 & 0.0018 & 0.7922 & 2614.544 & 2581.611 & 851.426 & 2238.426 & \text { Yes } \\ & 1.0 & 46.11 & 2268.1845 & 2268.1807 & 568.0525 & 0.0038 & 1.6724 & 2112.999 & 1649.889 & 853.739 & 1975.961 & \text { Yes }\end{array}$ $\begin{array}{llllllllllllllll}\text { ILAAIIMK } & 1.00 & 46.11 & 20.57 & 21.83 & 2 & 1159.7618 & 1159.7606 & 580.8876 & 0.0012 & 1.0329 & 1980.707 & 1480.713 & 369.909 & 2060.661 & \text { Yes }\end{array}$

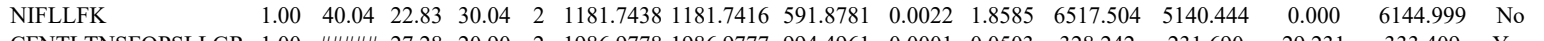

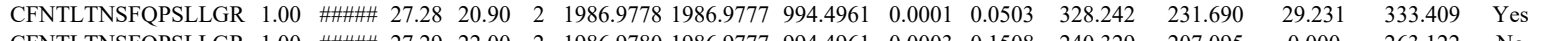

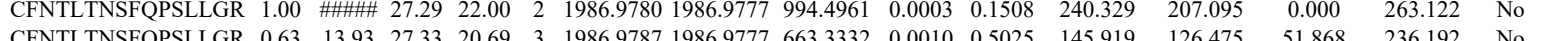

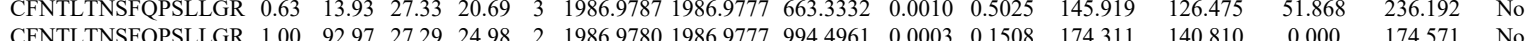

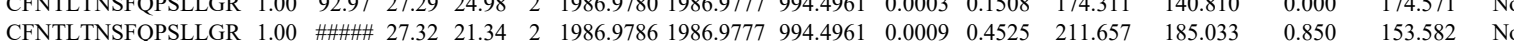

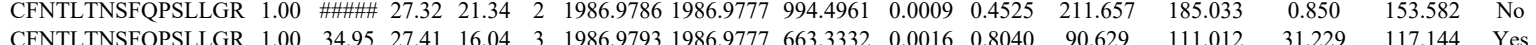

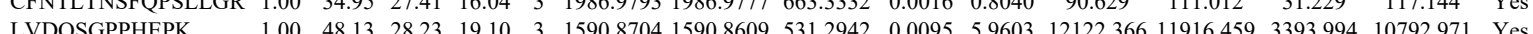
$\begin{array}{llllllllllllllll} & \end{array}$ $\begin{array}{llllllllllllllll}\text { VEEEIQTLSQVLAAK } & 1.00 & 94.81 & 25.02 & 24.94 & 2 & 1945.1000 & 1945.0975 & 973.5560 & 0.0025 & 1.2840 & 71.842 & 20.665 & 115.505 & 143.694 & \text { Yes }\end{array}$ $\begin{array}{llllllllllllllll}\text { VEEEIQTLSQVLAAK } & 1.00 & 58.67 & 25.07 & 21.32 & 3 & 1945.1011 & 1945.0975 & 649.3731 & 0.0036 & 1.8479 & 299.109 & 236.497 & 483.841 & 543.476 & \text { Yes }\end{array}$

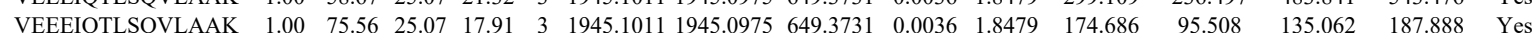
$\begin{array}{lllllllllllllllll}\text { VEEEIQTLSOVLAAK } & 1.00 & 61.27 & 25.07 & 22.90 & 3 & 1945.1008 & 1945.0975 & 649.3731 & 0.0033 & 1.6939 & 192.982 & 230.413 & 521.388 & 407.087 & \text { Yes }\end{array}$ $\begin{array}{llllllllllllllll}\text { VEEEIOTLSOVLAAK } & 1.00 & 43.64 & 25.07 & 17.69 & 3 & 1945.1008 & 1945.0975 & 649.3731 & 0.0033 & 1.6939 & 140.328 & 178.246 & 145.952 & 261.598 & \text { Yes }\end{array}$

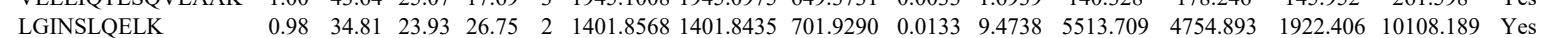

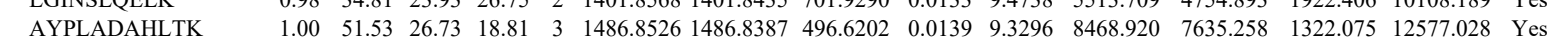
$\begin{array}{llllllllllllllll}\text { QQIQSIQQSIER } & 1.00 & 67.01 & 27.46 & 21.46 & 2 & 1600.8794 & 1600.8654 & 801.4400 & 0.0140 & 8.7342 & 1212.931 & 1435.342 & 274.927 & 1940.201 & \text { Yes }\end{array}$

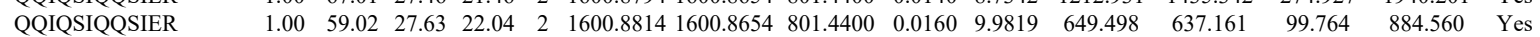
$\begin{array}{llllllllllllllll}\text { LLDLVQQSCNYK } & 1.00 & 49.98 & 27.53 & 22.97 & 3 & 1756.9123 & 1756.9095 & 586.6438 & 0.0028 & 1.5910 & 284.864 & 445.793 & 50.268 & 655.986 & \text { Yes }\end{array}$ $\begin{array}{llllllllllllllll}\text { NVPYVFVR } & 0.91 & 30.59 & 26.75 & 16.15 & 2 & 1136.6562 & 1136.6464 & 569.3305 & 0.0098 & 8.6065 & 5174.044 & 4881.568 & 704.400 & 7019.710 & \text { Yes }\end{array}$ NVPYVFVR

1 AFFESHPAPSAER $\begin{array}{llllllllllllllll}0.87 & 28.94 & 26.75 & 21.79 & 2 & 1136.6562 & 1136.6464 & 569.3305 & 0.0098 & 8.6065 & 5174.044 & 4881.568 & 704.400 & 7019.710 & \text { Yes } & \\ 0\end{array}$ $\begin{array}{llllllllllllllll}0.84 & 25.86 & 27.42 & 22.14 & 3 & 1588.7890 & 1588.7756 & 530.5991 & 0.0134 & 8.4181 & 7661.672 & 5534.770 & 1981.672 & 9149.206 & \text { Yes }\end{array}$ NVKPDQWVK AFPCWDEPAIK AGIISTVEVLK AGIISTVEVLK

VLGATLLPDLIQK

VLGATLLPDLIQK

VLGATLLPDLIQK VLGATLLPDLIQK VLGATLLPDLIQK LGLQNDLFSLAR LGLQNDLFSLAR $\begin{array}{lllllllllllllll}0.96 & 28.59 & 24.50 & 19.96 & 3 & 1544.9164 & 1544.9040 & 515.9753 & 0.0124 & 8.0107 & 28281.188 & 14332.037 & 6452.408 & 42852.337 & \text { Yes }\end{array}$ $\begin{array}{lllllllllllllll}1.00 & 42.32 & 27.47 & 18.70 & 2 & 1609.7886 & 1609.7876 & 805.9011 & 0.0010 & 0.6204 & 343.749 & 207.575 & 80.781 & 453.198 & \text { Yes }\end{array}$

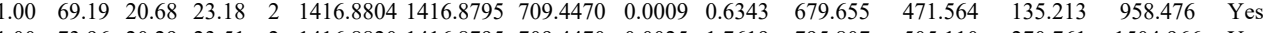
$\begin{array}{lllllllllllllll}1.00 & 73.96 & 20.29 & 23.51 & 2 & 1416.8820 & 1416.8795 & 709.4470 & 0.0025 & 1.7619 & 795.807 & 505.110 & 270.761 & 1504.966 & \text { Yes }\end{array}$

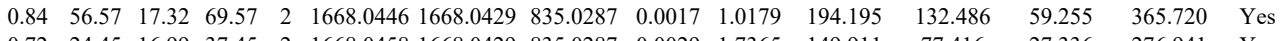
$\begin{array}{lllllllllllllll}0.72 & 24.45 & 16.99 & 37.45 & 2 & 1668.0458 & 1668.0429 & 835.0287 & 0.0029 & 1.7365 & 149.911 & 77.416 & 27.336 & 276.941 & \text { Yes }\end{array}$ $\begin{array}{lllllllllllllll}0.67 & 36.64 & 16.99 & 49.64 & 3 & 1668.0460 & 1668.0429 & 557.0216 & 0.0031 & 1.8551 & 211.147 & 142.562 & 94.370 & 175.787 & \text { Yes }\end{array}$ $\begin{array}{lllllllllllllll}1.00 & 26.25 & 15.68 & 17.71 & 3 & 1668.0481 & 1668.0429 & 557.0216 & 0.0052 & 3.1118 & 144.834 & 92.911 & 78.008 & 187.932 & \text { Yes } \\ 1.67 & 4.15 & 16.99 & 17.15 & 3 & 668.0463 & 1668.042 & 557.0216 & 0.003 & 2.0346 & 283.038 & 241.675 & 6.510 & 614.860 & \text { Yes }\end{array}$ $\begin{array}{lllllllllllllll}0.67 & 4.15 & 1.99 & 17.15 & 3 & 1668.0463 & 1668.0429 & 557.0216 & 0.0034 & 2.0346 & 283.038 & 241.675 & 65.510 & 614.860 & \text { Yes } \\ 1.00 & 72.02 & 27.39 & 32.32 & 2 & 1489.8386 & 1489.8374 & 745.9260 & 0.0012 & 0.8044 & 1180.083 & 686573 & 0.000 & 1889.546 & \text { No }\end{array}$ $\begin{array}{lllllllllllllll}1.00 & 7.02 & 27.39 & 32.32 & 2 & 1489.8386 & 1489.8374 & 745.9260 & 0.0012 & 0.8044 & 1180.083 & 686.573 & 0.000 & 1889.546 & \text { No }\end{array}$ $\begin{array}{lllllllllllllll}1.00 & 69.03 & 27.12 & 30.99 & 2 & 1489.8412 & 1489.8374 & 745.9260 & 0.0038 & 2.5472 & 4696.972 & 2719.872 & 0.000 & 8123.732 & \text { No } \\ 1.00 & 69.63 & 27.18 & 31.21 & 2 & 1489.8422 & 1489.8374 & 745.9260 & 0.0048 & 32175 & 7116.596 & 3937.660 & 341.668 & 10785.684 & Y\end{array}$ $\begin{array}{lllllllllllllllll}\text { VTLSFPSTLQTGTGTLK } & 0.64 & 86.82 & 23.64 & 99.82 & 2 & 2038.1554 & 2038.1554 & 1020.0850 & 0.0000 & 0.0000 & 1403.796 & 446.941 & 895.760 & 1870.349 & \text { Yes }\end{array}$ $\begin{array}{lllllllllllllllll}\text { VTLSFPSTLQTGTCTLK } & 1.00 & 27.85 & 23.50 & 20.96 & 3 & 2038.1590 & 2038.1554 & 6803924 & 0.0036 & 1.7637 & 946.153 & 1099.202 & 673.709 & 1525.191 & \text { Y }\end{array}$ 


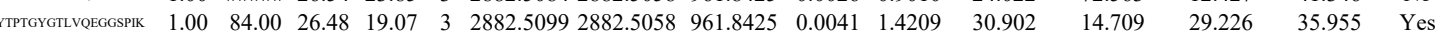
$\begin{array}{lllllllllllllll} & 26.58 .5 & 21.64 & 3 & 288.5072 & 2882.5058 & 961.8425 & 0.0014 & 0.4852 & 60.630 & 46.359 & 62.177 & 68.552 & \text { Yes }\end{array}$ $\begin{array}{llllllllllllll} & 25.15 & 35.09 & 2 & 2244.2374 & 2244.2348 & 1123.1247 & 0.0026 & 1.1575 & 114.858 & 66.452 & 70.599 & 106.329 & \text { Yes }\end{array}$ $\begin{array}{llllllllllllll} & 25.15 & 35.40 & 2 & 2244.2374 & 2244.2348 & 1123.1247 & 0.0026 & 1.1575 & 83.275 & 30.004 & 48.625 & 68.814 & \text { Yes }\end{array}$

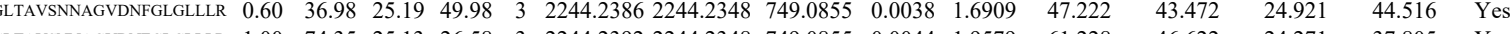

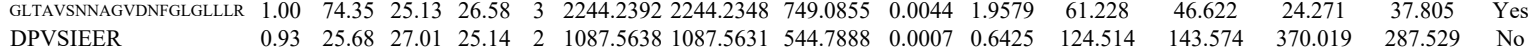

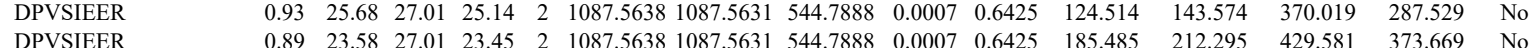
$\begin{array}{lrllllllllllllll} & 0.89 & 23.58 & 27.01 & 23.45 & 2 & 1087.5638 & 1087.5631 & 544.7888 & 0.0007 & 0.6425 & 185.485 & 212.295 & 429.581 & 373.669 & \text { No }\end{array}$

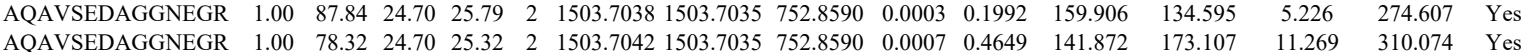
$\begin{array}{llllllllllllllll} & \\ \text { AQAVSEDAGGNEGR } & 1.00 & 78.32 & 24.70 & 25.32 & 2 & 1503.7042 & 1503.7035 & 752.8590 & 0.0007 & 0.4649 & 141.872 & 173.107 & 11.269 & 310.074 & \text { Yes } \\ \text { AQAVSEDAGGNEGR } & 1.00 & 52.77 & 24.71 & 27.56 & 3 & 1503.7048 & 1503.7035 & 5022418 & 0.0013 & 0.8628 & 19.487 & 18.520 & 44.030 & 33.596 & \text { Nes }\end{array}$ $\begin{array}{llllllllllllll} & \end{array}$

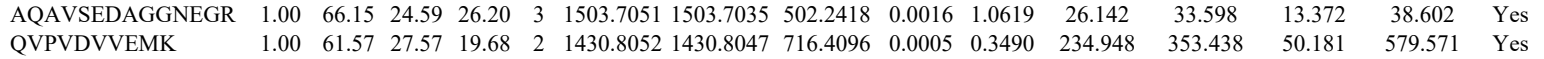

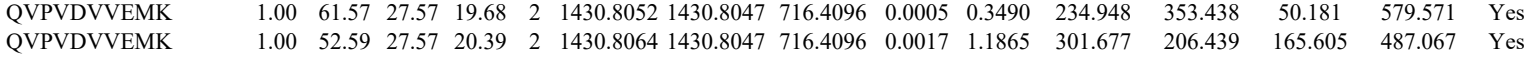

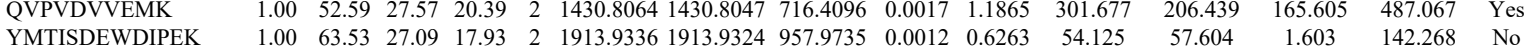
\begin{tabular}{lllllllllllll} 
& YMTISDEWDIPEK \\
\hline
\end{tabular}

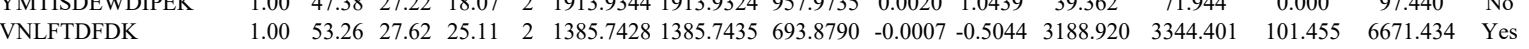
$\begin{array}{lllllllllllllll}\text { MTLDTLSIYETPSMGLDK } & 1.00 & 65.93 * 26.91 & 17.32 & 3 & 24152557 & 24152521 & 806.0913 & 0.0036 & 1.4887 & 43.401 & 45.834 & 39.966 & 107.102 & \text { Yes }\end{array}$

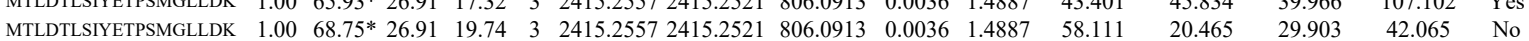

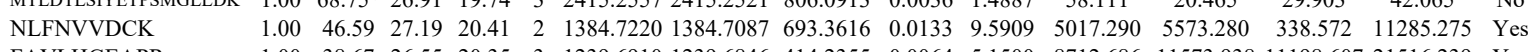

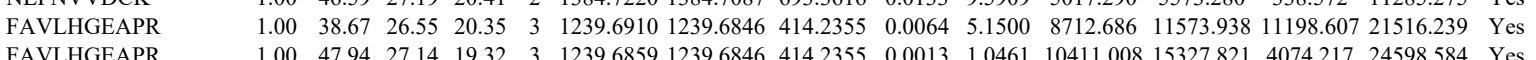
$\begin{array}{llllllllllllllllll} & \\ \text { FAVLHGEAPR } & 1.00 & 47.94 & 27.14 & 19.32 & 3 & 1239.6859 & 1239.6846 & 414.2355 & 0.0013 & 1.0461 & 10411.008 & 15327.821 & 4074.217 & 24598.584 & \text { Yes } \\ \text { FAVLHGEAPR } & 1.00 & 39.37 & 27.08 & 19.85 & 3 & 1239.6865 & 1239.6846 & 414.2355 & 0.0019 & 1.5289 & 13508.309 & 16156337 & 4665.739 & 30557.323 & \text { Yes }\end{array}$

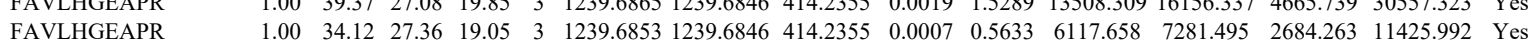

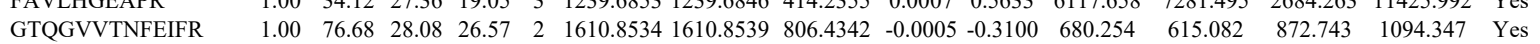

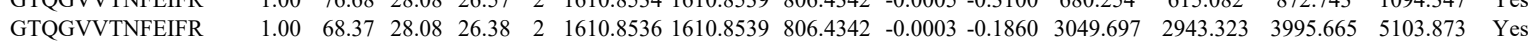
GTYLATFHQR GTYLATFHQR GTYLATFHQR GTYLATFHQR GTYLATFHQR GTYLATFHQR GTYLATFHQR GTYLATFHQR GTYLATFHQR VDNAYWLWTFQGR ITNDFYPEEDGK ITNDFYPEEDG VTLMQLPTR VTLMQLPTR

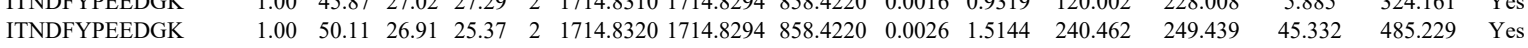

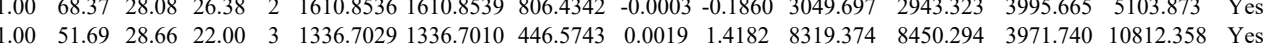
$\begin{array}{lllllllllllllll}1.00 & 54.17 & 28.37 & 19.99 & 3 & 1336.7038 & 1336.7010 & 446.5743 & 0.0028 & 2.0900 & 8663.935 & 10165.812 & 3166.556 & 13676.204 & \text { Yes }\end{array}$ $\begin{array}{llllllllllllllll}0.99 & 49.58 & 28.60 & 24.49 & 2 & 1336.7062 & 1336.7010 & 669.3578 & 0.0052 & 3.8843 & 1035.887 & 1043.217 & 777.000 & 2486.465 & \text { Yes }\end{array}$ $\begin{array}{llllllllllllllll}1.00 & 52.00 & 28.76 & 16.81 & 3 & 1336.7023 & 1336.7010 & 446.5743 & 0.0013 & 0.9703 & 1086.222 & 1151.603 & 661.519 & 1903.888 & \text { Yes }\end{array}$ $\begin{array}{llllllllllllllll}1.00 & 46.66 & 28.66 & 20.75 & 3 & 1336.7029 & 1336.7010 & 446.5743 & 0.0019 & 1.4182 & 1775.761 & 2018.445 & 989.513 & 3328.146 & \text { Yes }\end{array}$ $\begin{array}{lllllllllllllll}1.00 & 55.36 & 28.59 & 26.16 & 2 & 1336.7058 & 1336.7010 & 669.3578 & 0.0048 & 3.5855 & 363.102 & 378.763 & 221.895 & 744.327 & \text { Yes }\end{array}$

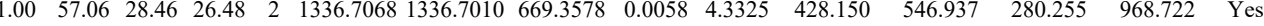

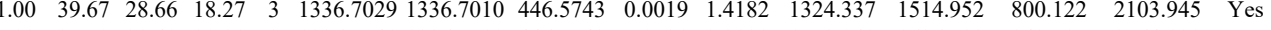
$\begin{array}{llllllllllllllll}0.98 & 25.79 & 28.49 & 20.81 & 3 & 1336.7041 & 1336.7010 & 446.5743 & 0.0031 & 2.3139 & 1553.949 & 1636.083 & 842.595 & 2764.120 & \text { Yes }\end{array}$ $\begin{array}{lllllllllllllll}1.00 & 71.90 & 27.32 & 25.05 & 2 & 1798.8910 & 1798.8913 & 900.4529 & -0.0003 & -0.1666 & 133.389 & 105.842 & 18.752 & 259.270 & \text { Yes }\end{array}$

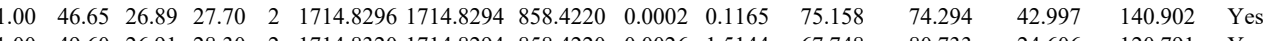

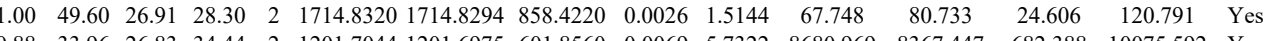
$\begin{array}{llllllllllllllll}0.88 & 33.96 & 26.83 & 34.44 & 2 & 1201.7044 & 1201.6975 & 601.8560 & 0.0069 & 5.7322 & 8680.969 & 8367.447 & 682.388 & 10075.592 & \text { Yes }\end{array}$ $\begin{array}{lllllllllllllll}0.99 & 48.72 & 26.83 & 27.57 & 2 & 1201.7044 & 1201.6975 & 601.8560 & 0.0069 & 5.7322 & 9007.388 & 11399.738 & 1182.932 & 15841.902 & \text { Yes }\end{array}$ $\begin{array}{llllllllllllllll} & \end{array}$

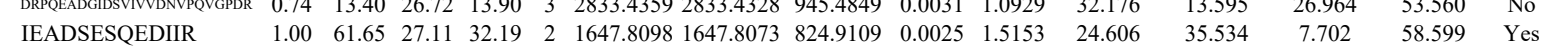

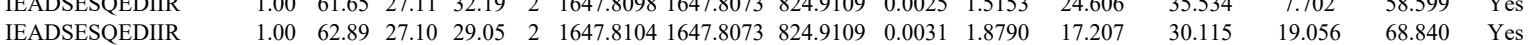


$\begin{array}{llllllllllll} & & & \end{array}$

$\begin{array}{llllllllll} & \\ 0\end{array}$ \begin{tabular}{llllllllllllllll} 
LFVSDGVPGCLPVLAAAGR & 1.00 & 69.81 & 27.23 & 27.37 & 2 & 2031.0794 & 2031.0767 & 1016.5456 & 0.0027 & 1.3280 & 626.427 & 909.715 & 292.932 & 935.832 & Yes \\
\hline
\end{tabular} $\begin{array}{llllllllllllllll}\text { LFVSDGVPGCLPVLAAAGR } & 0.96 & 26.18 & 27.42 & 19.89 & 3 & 2031.0817 & 2031.0767 & 678.0328 & 0.0050 & 2.4581 & 26.946 & 29.898 & 18.993 & 38.917 & \text { Yes }\end{array}$ $\begin{array}{llllllllllllllll}\text { LFVSDGVPGCLPVLAAAGR } & 1.00 & 43.09 & 27.23 & 16.29 & 3 & 2031.0835 & 2031.0767 & 678.0328 & 0.0068 & 3.3430 & 57.193 & 45.047 & 18.444 & 83.208 & \text { Yes }\end{array}$ $\begin{array}{llllllllllllllll}\text { UPVLQLDSGNYLFSTSAICR } & 1.00 & 46.55 & 27.33 & 22.76 & 3 & 2372.2021 & 2372.1990 & 791.7403 & 0.0031 & 1.3051 & 28.662 & 25.579 & 2.552 & 17.618 & \text { No }\end{array}$ $\begin{array}{llllllllllllllll}\text { LFVSDGVPGCLPVLAAAGR } & 1.00 & 94.38 & 27.18 & 26.07 & 2 & 2031.0774 & 2031.0767 & 1016.5456 & 0.0007 & 0.3443 & 468.768 & 319.533 & 88.704 & 533.636 & \text { Yes }\end{array}$

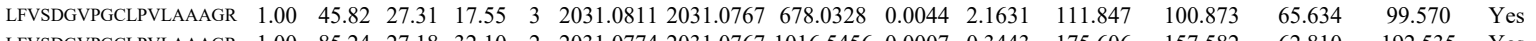

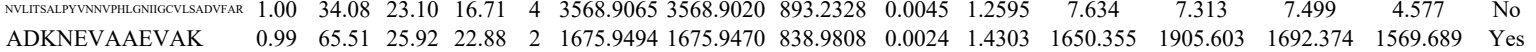
$\begin{array}{llllllllllllllll}\text { ADKNEVAAEVAK } & 0.99 & 65.51 & 25.92 & 22.88 & 2 & 1675.9494 & 1675.9470 & 838.9808 & 0.0024 & 1.4303 & 1650.355 & 1905.603 & 1692.374 & 1569.689 & \text { Yes } \\ \text { ADE } & 31.81 & 25.83 & 20.45 & 3 & 1675.9501 & 1675.9470 & 559.6563 & 0.0031 & 1.8464 & 10587.008 & 10917.934 & 7820.156 & 12150.412 & \text { Yes }\end{array}$

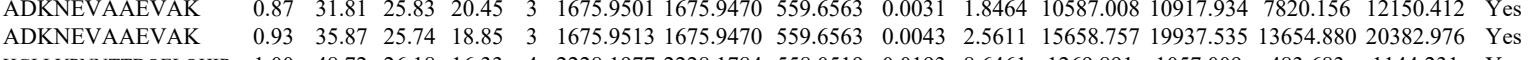
$\begin{array}{lllllllllllllllll} & \text { HGLLVNNTTDQELQHIR } & 1.00 & 48.72 & 26.18 & 16.33 & 4 & 2228.1977 & 2228.1784 & 558.0519 & 0.0193 & 8.6461 & 1269.891 & 1057.009 & 483.683 & 1144.231 & \text { Yes }\end{array}$

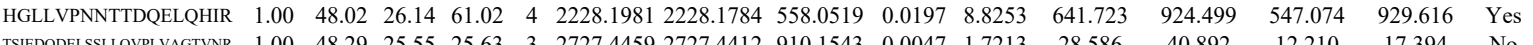

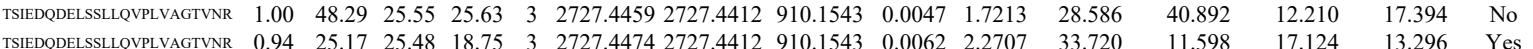

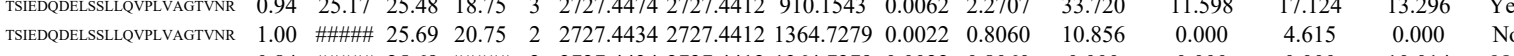

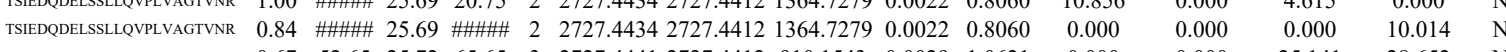

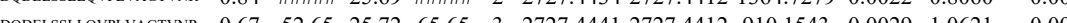




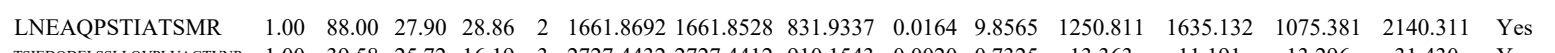

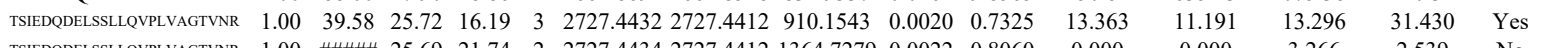
$\begin{array}{lllllllllllllll}\text { TSIEDQDELSSLLVPLVAGTVNR } & 1.00 & \text { \#\#\#\# } 25.69 & 21.74 & 2 & 2727.4434 & 2727.4412 & 1364.7279 & 0.0022 & 0.8060 & 0.000 & 0.000 & 3.266 & 2.539 & \text { No }\end{array}$

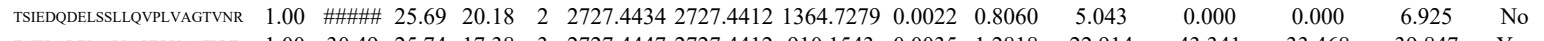

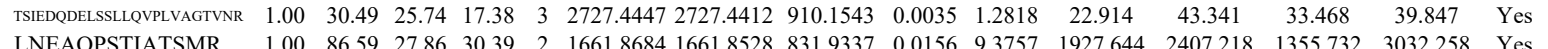

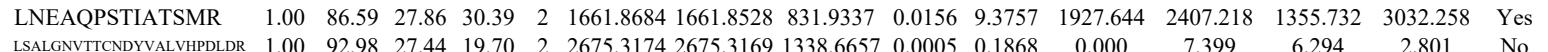

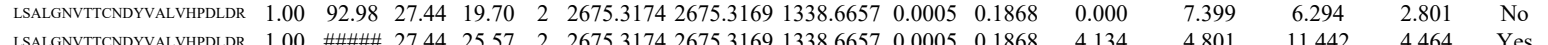

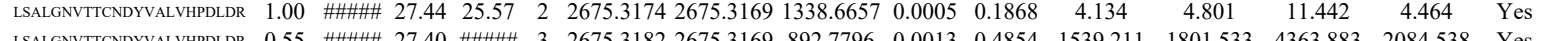

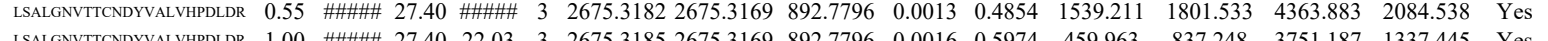
$\begin{array}{llllllllllllll} & \end{array}$

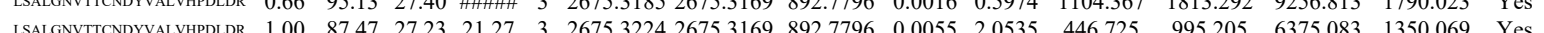

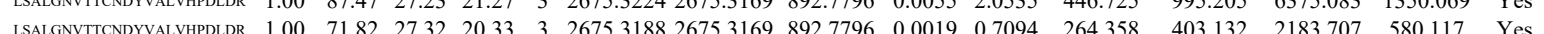
$\begin{array}{llllllllllllllllll}\text { LSALGNVTTCNDYVALVHPDDRR } & 0.67 & 77.58 & 27.28 & 90.58 & 3 & 2675.3200 & 26753169 & 892.7796 & 0.0031 & 1.1574 & 390.277 & 283.648 & 2544.801 & 416272 & \text { Yes }\end{array}$

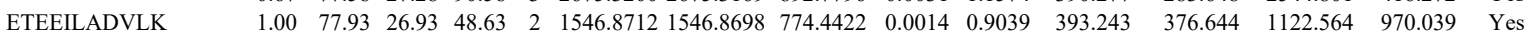

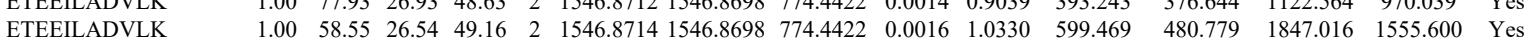

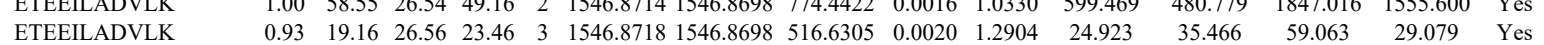

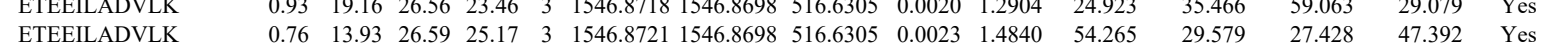

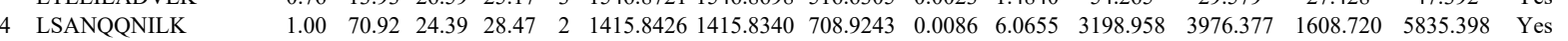

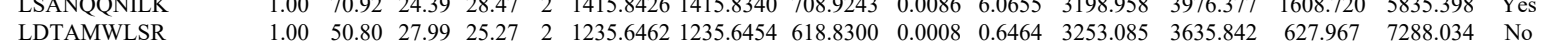

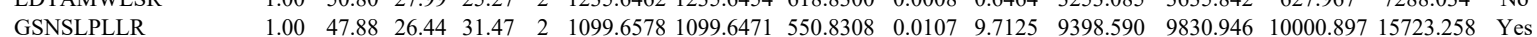

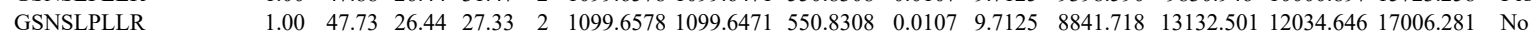
$\begin{array}{llllllllllllllllll}\text { GSNSLPLLR } & 1.00 & 49.49 & 26.32 & 30.78 & 2 & 1099.6544 & 1099.6471 & 550.8308 & 0.0073 & 6.6263 & 4420.657 & 4418.176 & 4889.071 & 6794.512 & \text { No }\end{array}$

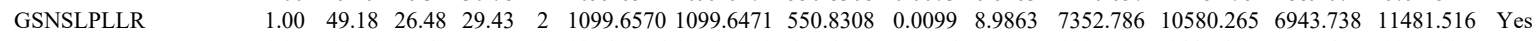
$\begin{array}{llllllllllllllll}\text { ALLANALTSALR } & 1.00 & 66.56 & 23.62 & 25.80 & 2 & 1356.8226 & 1356.8210 & 679.4178 & 0.0016 & 1.1775 & 1320.227 & 1448.612 & 55.745 & 2255.985 & \text { Yes }\end{array}$ $\begin{array}{lllllllllllllllll}\text { ALLANALTSALR } & 1.00 & 68.62 & 23.73 & 26.01 & 2 & 1356.8228 & 1356.8210 & 679.4178 & 0.0018 & 1.3247 & 2477.505 & 2937.643 & 8.979 & 4068.742 & \text { Yes }\end{array}$ $\begin{array}{lllllllllllllllll}\text { ALLANALTSALR } & 1.00 & 67.43 & 23.73 & 25.72 & 2 & 1356.8220 & 1356.8210 & 679.4178 & 0.0010 & 0.7359 & 2399.969 & 3065.252 & 87.833 & 4319.192 & \text { Yes }\end{array}$ $\begin{array}{llllllllllllllll}\text { ALLANALTSALR } & 1.00 & 69.10 & 23.73 & 25.94 & 2 & 1356.8220 & 1356.8210 & 679.4178 & 0.0010 & 0.7359 & 2868.147 & 3480.801 & 355.624 & 5251.599 & \text { Yes }\end{array}$ $\begin{array}{llllllllllllllll}\text { ALLANALTSALR } & 1.00 & 67.73 & 23.73 & 26.70 & 2 & 1356.8220 & 1356.8210 & 679.4178 & 0.0010 & 0.7359 & 907.963 & 993.084 & 55.834 & 1489.997 & \text { Yes }\end{array}$ $\begin{array}{llllllllllllllll}\text { ALLANALTSALR } & 1.00 & 68.71 & 23.73 & 25.92 & 2 & 1356.8220 & 1356.8210 & 679.4178 & 0.0010 & 0.7359 & 831.305 & 1022.558 & 74.279 & 1461.583 & \text { Yes }\end{array}$ LCLQSIAFISR LCLQSIAFISR ALLANALTSALR LCLQSIAFISR

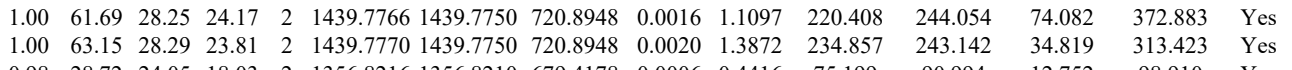

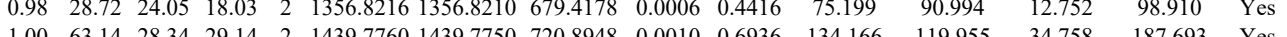

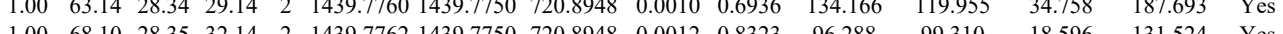

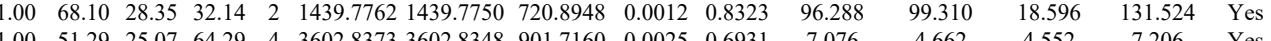

$\begin{array}{lllllllllll}\text { GEMI4_HUMAI } & \text { P57678 } & \text { GEMIN4 } & \text { Component of gen } 119.99 & 1.00 & 3 & 5.5 & -0.2258 & 0.3542 & 0.0524 & 0.7502\end{array}$ LLCGSLTR $\begin{array}{llllllllllll}\text { GLVALVQVMPWCSPQEWQR } & 0.66 & 31.21 & 27.40 & 44.21 & 3 & 2563.2685 & 2563.2660 & 855.4293 & 0.0025 & 0.9742 & 13.109\end{array}$ 7.2991 4.552

$\begin{array}{llllllllllllll} & 25.36 & 3 & 2563.2700 & 2563.2660 & 855.4293 & 0.0040 & 1.5587 & 7.415\end{array}$ $\begin{array}{llll}1864.087 & 6352.602 & \text { Yes }\end{array}$

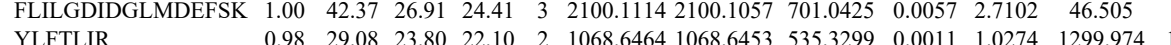
YLFTLIR $\begin{array}{llllllllllllllll}\text { CVPDPDTGLYMLQLAGR } & 1.00 & 85.15 & 27.81 & 22.11 & 2 & 2037.9814 & 2037.9808 & 1019.9977 & 0.0006 & 0.2941 & 1543.565 & 1946.782\end{array}$ $\begin{array}{llllllllllllll}\text { GFFDPNTHENLTYLLLLR } & 0.99 & 30.50 & 27.23 & 19.19 & 3 & 2449.2532 & 2449.2512 & 817.4243 & 0.0020 & 0.8156 & 55.898 & 122.962\end{array}$

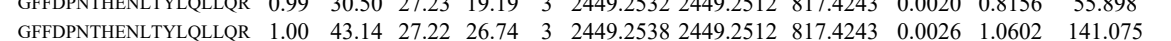
$\begin{array}{lllllllllllll}\text { GFFDPNTHENLTYLOLLOR } & 1.00 & 52.00 & 27.22 & 28.82 & 3 & 2449.2595 & 2449.2512 & 817.4243 & 0.0083 & 3.3846 & 39.422 & 92\end{array}$ $\begin{array}{lllllllllllll}\text { DELLAQHAAGALGLPDLVAVLTR } & 1.00 & 68.38 & 21.90 & 20.93 & 3 & 2486.4010 & 2486.3978 & 829.8065 & 0.0032 & 1.2854 & 77.528\end{array}$ $\begin{array}{lllllllllllll}\text { ALQTVAQLILELIEK } & 1.00 & 35.57 & 16.02 & 20.21 & 3 & 1969.2094 & 1969.2067 & 657.4095 & 0.0027 & 1.3690 & 43.356\end{array}$ $\begin{array}{llllllllllll}\text { ALQTVAQLILELIEK } & 1.00 & 37.09 & 16.02 & 25.30 & 3 & 1969.2097 & 1969.2067 & 657.4095 & 0.0030 & 1.5211 & 53.009\end{array}$ $\begin{array}{lllllllllllll}\text { AVPVWDVLASGYVSR } & 1.00 & 71.31 & 27.87 & 20.63 & 2 & 1761.9554 & 1761.9536 & 881.9841 & 0.0018 & 1.0204 & 1436.569 & 178\end{array}$

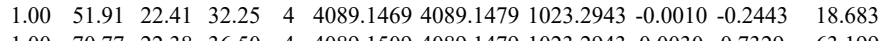

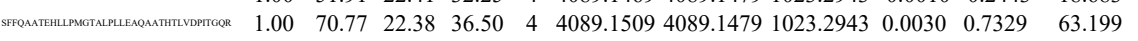

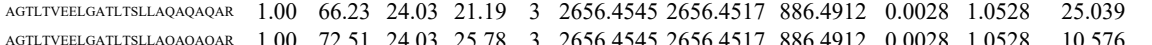

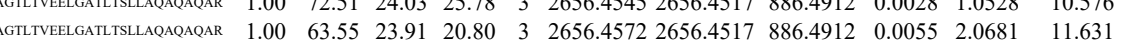

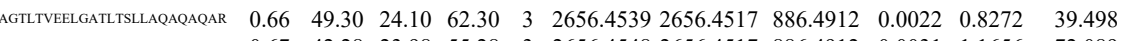

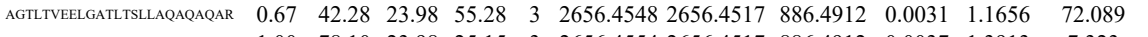
$\begin{array}{lllllllllllll}\text { AGTLTVEELGALTSLLAQAQAQAR } & 1.00 & 78.10 & 23.98 & 25.15 & 3 & 2656.4554 & 2656.4517 & 886.4912 & 0.0037 & 1.3913 & 7.323\end{array}$

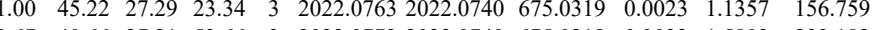
$\begin{array}{llllllllllll}0.67 & 40.66 & 27.31 & 53.66 & 3 & 2022.0772 & 2022.0740 & 675.0319 & 0.0032 & 1.5802 & 232.183\end{array}$ $\begin{array}{llllllllllll}1.00 & 62.15 & 27.31 & 21.32 & 2 & 2022.0774 & 2022.0740 & 1012.0443 & 0.0034 & 1.6798 & 34.378 \\ 1.00 & 40.58 & 27.29 & 17.07 & 3 & 2022.0763 & 2022.0740 & 675.0319 & 0.0023 & 1.1357 & 241.730\end{array}$ $\begin{array}{llllllllllll}1.00 & 40.58 & 27.29 & 17.07 & 3 & 2022.0763 & 2022.0740 & 675.0319 & 0.0023 & 1.1357 & 241.730 \\ 1.00 & 52.04 & 27.29 & 20.19 & 3 & 2022.0763 & 2022.0740 & 675.0319 & 0.0023 & 1.1357 & 282.288 & 2\end{array}$

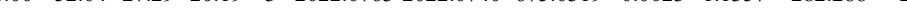
SINSVR $\begin{array}{llllllllllll}1.00 & 65.60 & 25.43 & 36.33 & 2 & 1329.7844 & 1329.7738 & 665.8942 & 0.0106 & 7.9592 & 9327.764\end{array}$ $\begin{array}{lll}2.184 & 0.000 & \text { No }\end{array}$ ATLAALCLENSOQ 
$\begin{array}{lllllllllllll} & \end{array}$

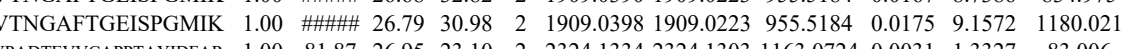

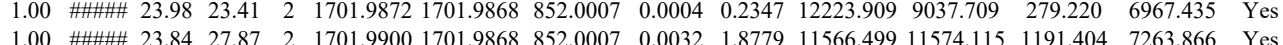
$\begin{array}{llllllllllllllll}\text { QSLGELIGTLNAAK } & 1.00 & 53.10 & 23.75 & 22.11 & 3 & 1701.9910 & 1701.9868 & 568.3362 & 0.0042 & 2.4633 & 519.045 & 305.409 & 6.970 & 433.096 & \text { Yes }\end{array}$ QSLGELIGTLNAAK

IAVAAQNCYK $\begin{array}{llllllllllll}1.00 & 54.72 & 23.75 & 25.46 & 3 & 1701.9913 & 1701.9868 & 568.3362 & 0.0045 & 2.6393 & 564.573 & 397.092\end{array}$

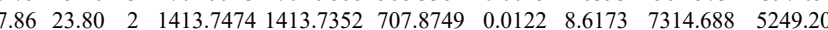
$\begin{array}{lllllllllllllllllll} & 1.00 & 57.26 & 27.71 & 25.93 & 2 & 1413.7490 & 1413.7352 & 707.8749 & 0.0138 & 9.7474 & 2872.768 & 3087.143 & 243.006 & 3378.866 & \text { Yes }\end{array}$

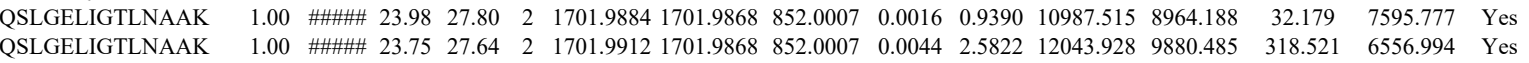
$\begin{array}{llllllllllllll}47.58 & 23.48 & 26.33 & 3 & 1701.9922 & 1701.9868 & 568.3362 & 0.0054 & 2.5822 & 12043.928 & 9880.485 & 318.521 & 6556.994 & \text { Yes }\end{array}$ $\begin{array}{lllllllllllllll} & \end{array}$

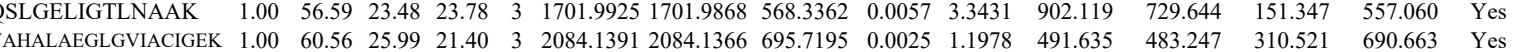

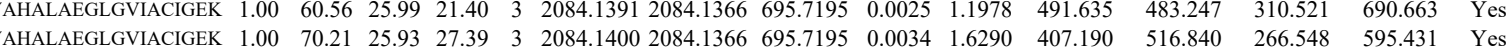
$\begin{array}{lllllllllllllllll}\text { IAVAAQNCYK } & 1.00 & 69.36 & 27.79 & 27.28 & 2 & 1413.7464 & 1413.7352 & 707.8749 & 0.0112 & 7.9109 & 2503.034 & 2362.476 & 359.083 & 2693.304 & \text { Yes }\end{array}$

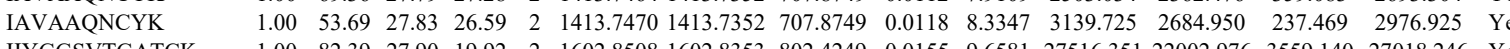

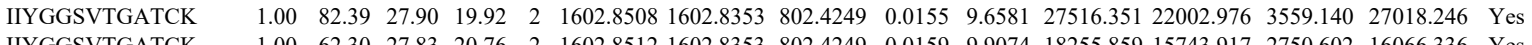

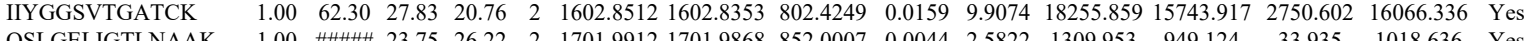

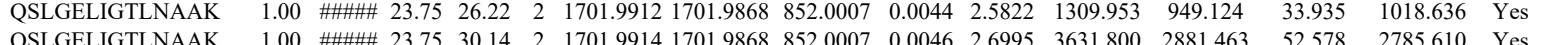

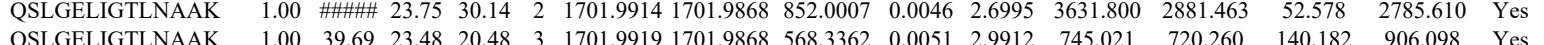
$\begin{array}{llllllllllllll} & \end{array}$ $\begin{array}{lllllllllllllll} & \end{array}$

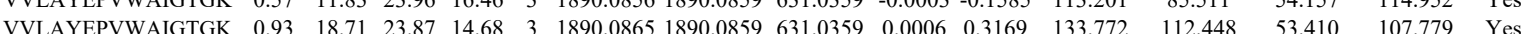

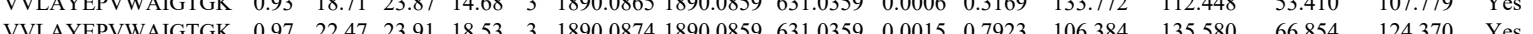

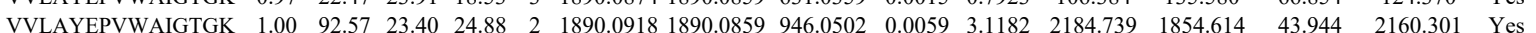
$\begin{array}{llllllllllllllll}\text { VVLAYEPVWAIGTGK } & 1.00 & 88.51 & 23.40 & 24.88 & 2 & 1890.0918 & 1890.0859 & 946.0502 & 0.0059 & 3.1182 & 2184.739 & 1854.614 & 43.944 & 2160.301 & \text { Yes } \\ \text { VVLAYEPW } & 1890.0920 & 1890.0859 & 946.0502 & 0.0061 & 32239 & 11469.065 & 11300.815 & 0.000 & 11034.047 & \text { No }\end{array}$ $\begin{array}{llllllllllllllll}\text { VVLAYEPVWAIGTGK } & 1.00 & 65.17 & 23.01 & 28.27 & 3 & 1890.0943 & 1890.0859 & 631.0359 & 0.0084 & 4.4371 & 712.672 & 552.753 & 88.706 & 665.397 & \text { Yes }\end{array}$ $\begin{array}{lllllllllllllllll}\text { VVLAYEPVWAIGTGK } & 1.00 & 61.63 & 23.01 & 32.43 & 3 & 1890.0943 & 1890.0859 & 631.0359 & 0.0084 & 4.4371 & 2446.912 & 2245.320 & 170.465 & 2337.438 & \text { Yes }\end{array}$ $\begin{array}{llllllllllllllll}\text { VAHALAEGLGVIACIGEK } & 1.00 & 36.61 & 26.01 & 32.04 & 4 & 2084.1393 & 2084.1366 & 522.0414 & 0.0027 & 1.2930 & 109.416 & 73.323 & 22.405 & 114.916 & \text { Yes }\end{array}$ \begin{tabular}{llllllllllllllll} 
VAHALAEGLGVIACIGEK & 1.00 & 66.80 & 25.99 & 27.26 & 3 & 2084.1394 & 2084.1366 & 695.7195 & 0.0028 & 1.3415 & 439.284 & 420.193 & 308.985 & 639.148 & Yes \\
\hline
\end{tabular} $\begin{array}{llllllllllllllll}\text { VAHALAEGLGVIACIGEK } & 1.00 & 69.44 & 25.93 & 20.13 & 3 & 2084.1409 & 2084.1366 & 695.7195 & 0.0043 & 2.0602 & 444.633 & 417.600 & 272.740 & 774.305 & \text { Yes }\end{array}$

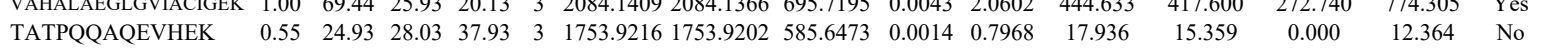
$\begin{array}{llllllllllllllll}\text { VVLAYEPVWAIGTGK } & 1.00 & 84.06 & 23.84 & 24.63 & 2 & 1890.0884 & 1890.0859 & 946.0502 & 0.0025 & 1.3213 & 4216.292 & 3972.465 & 0.000 & 2961.663 & \text { No }\end{array}$ $\begin{array}{llllllllllllllll}\text { VVLAYEPVWAIGTGK } & 1.00 & 81.30 & 23.48 & 24.30 & 2 & 1890.0888 & 1890.0859 & 946.0502 & 0.0029 & 1.5327 & 2477.764 & 3315.697 & 0.000 & 2830.362 & \text { No }\end{array}$ $\begin{array}{lllllllllllllllll}\text { VVLAYEPVWAIGTGK } & 0.99 & 24.82 & 23.38 & 21.57 & 3 & 1890.0904 & 1890.0859 & 631.0359 & 0.0045 & 2.3770 & 406.503 & 519.072 & 96.484 & 633.559 & \text { Yes }\end{array}$ $\begin{array}{llllllllllllllll}\text { TATPQQAQEVHEK } & 1.00 & 34.02 & 27.87 & 18.31 & 3 & 1753.9219 & 1753.9202 & 585.6473 & 0.0017 & 0.9676 & 19.015 & 32.799 & 9.049 & 21.851 & \text { No }\end{array}$ $\begin{array}{llllllllllllllll}\text { VVLAYEPVWAIGTGK } & 1.00 & 82.85 & 23.38 & 25.58 & 2 & 1890.0912 & 1890.0859 & 946.0502 & 0.0053 & 2.8011 & 4318.289 & 3364.745 & 0.000 & 4319.034 & \text { No }\end{array}$ $\begin{array}{llllllllllllllllll}\text { VVLAYEPVWAIGTGK } & 1.00 & 77.47 & 23.42 & 24.63 & 2 & 1890.0916 & 1890.0859 & 946.0502 & 0.0057 & 3.0125 & 3405.539 & 2990.560 & 95.448 & 3520.021 & \text { Yes }\end{array}$ $\begin{array}{llllllllllllllll}\text { VVLAYEPVWAIGTGK } & 0.85 & 21.24 & 23.01 & 17.88 & 3 & 1890.0937 & 1890.0859 & 631.0359 & 0.0078 & 4.1202 & 414.547 & 212.685 & 106.176 & 215.359 & \text { Yes }\end{array}$ $\begin{array}{llllllllllllllll}\text { VVLAYEPVWAIGTGK } & 0.99 & 33.03 & 23.01 & 15.35 & 3 & 1890.0937 & 1890.0859 & 631.0359 & 0.0078 & 4.1202 & 306.469 & 334.926 & 61.222 & 452.142 & \text { Yes }\end{array}$ $\begin{array}{llllllllllllllll}\text { TATPQQAQEVHEK } & 1.00 & 43.42 & 28.02 & 22.72 & 3 & 1753.9204 & 1753.9202 & 585.6473 & 0.0002 & 0.1138 & 62.712 & 69.993 & 19.754 & 65.696 & \text { Yes }\end{array}$ TATPQQAQEVHEK TATPQQAQEVHEK TATPQQAQEVHEK TATPQQAQEVHEK FFVGGNWK FFVGGNWK $\begin{array}{lllllllllll}1.00 & 4.36 & 28.02 & 18.73 & 3 & 1753.9204 & 1753.9202 & 585.6473 & 0.0002 & 0.1138 & 38.648\end{array}$ $\begin{array}{llllllllllll}1.00 & 38.25 & 27.99 & 15.93 & 3 & 1753.9210 & 1753.9202 & 585.6473 & 0.0008 & 0.4553 & 79.032\end{array}$ $\begin{array}{llllllllllll}1.00 & 38.53 & 27.99 & 17.37 & 3 & 1753.9210 & 1753.9202 & 585.6473 & 0.0008 & 0.4553 & 57.503\end{array}$ $\begin{array}{lllllllllllll}1.00 & 44.24 & 27.87 & 18.10 & 3 & 1753.9219 & 1753.9202 & 585.6473 & 0.0017 & 0.9676 & 71.263\end{array}$ $\begin{array}{lllllllllllll}0.81 & 1.58 & 26.56 & 18.01 & 2 & 1241.6816 & 1241.6801 & 621.8473 & 0.0015 & 1.2061 & 188.826\end{array}$ $\begin{array}{llllllllllll}0.75 & 18.04 & 26.56 & 15.56 & 2 & 1241.6822 & 1241.6801 & 621.8473 & 0.0021 & 1.6885 & 180.952\end{array}$ 
TATPQQAQEVHEK TATPQQAQEVHEK TATPQQAQEVHEK TATPQQAQEVHEK TATPQQAQEVHEK SNVSDAVAQSTR SNVDAVAQSR TATPQQAQEVHEK TATPQQAQEVHEK TATPQQAQEVHEK TATPQAQEVHEK HVFGESDELIGQK HVFGESDELIGQK

TATPQQAQEVHEK

TATPQQAQEVHEK

HVFGESDELIGQK

HVFGESDELIGQK

HVFGESDELIGQK

HVFGESDELIGQK

18 MLFDYLADK

LDLLSDTNMVDFAMDV

LDLLSDTNMVDFAMDV

LASELLMQNWDAAMEDL

ASEILMQNWDAAMEDLTR

LASEILMQNWDAAMEDLTR

LASEILMQNWDAAME
YLTTAVITNK

YLTTAVITNK

YLTTAVITNK

HLVFPLLEFLSVK

HLVFPLLEFLSVK

HLVFPLLEFLSVK

HLVFPLLEFLSVK

HLVFPLLEFLSVK

LNMTPEEAER

QLQAETEPIVK

QLQAETEPIVK

PGPTPSGTNVGSS

PGPTPSGTNVGSSGR

FYTEDSPGLK

FYTEDSPGLK
FYTEDSPGLK

2 ALGQNPTNAEVLK

VLGNPK

HVLVTLGEK

HVLVTLGEK

HVLVTLGEK

VLGNPK

VLGNPK

VLGNPK

ILYSQCGDVMR

ILYSQCGDVMR

ILYSQCGDVMR

$\begin{array}{llllllllllllll}\text { VLDFEHFLPMLQTVAK } & 0.72 & 66.21 & 25.29 & 79.21 & 2 & 2175.2034 & 2175.2006 & 1088.6076 & 0.0028 & 1.2860 & 1920.645 & 1189.228 & 24.6\end{array}$

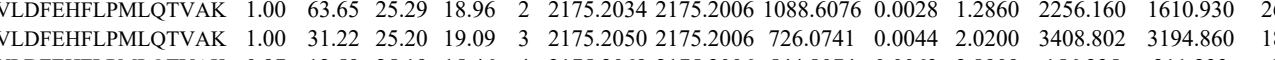

$\begin{array}{llllllllllllll} & \text { VLDFEHFLPMLQTVAK } & 0.97 & 12.59 & 25.19 & 15.46 & 4 & 2175.2069 & 2175.2006 & 544.8074 & 0.0063 & 2.8909 & 156.225 & 211.233\end{array}$

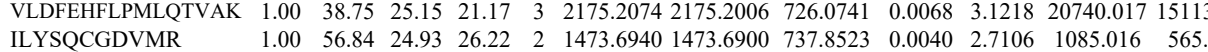

ILYSQCGDVMR

$\begin{array}{lllllllllllll}\text { VLDFEHFLPMLQTVAK } & 1.00 & 73.70 & 25.29 & 17.79 & 2 & 2175.2034 & 2175.2006 & 1088.6076 & 0.0028 & 1.2860 & 487.100 & 314.470 \\ \text { VLDFEHFLPMLQTVAK } & 1.00 & 52.83 & 25.29 & 23.54 & 3 & 2175.2035 & 2175.2006 & 726.0741 & 0.0029 & 13314 & 2140.245 & 1851.566\end{array}$

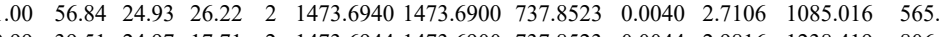

.798 \begin{tabular}{lllllllllllll} 
& 27.96 \\
\hline
\end{tabular} $\begin{array}{llllllllllllll} & \end{array}$ $\begin{array}{llllllllllllllll} & \end{array}$

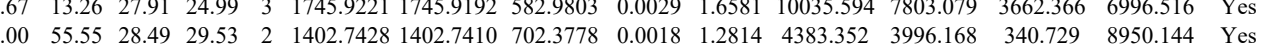
$\begin{array}{llllllllllllll}66.74 & 27.47 & 22.46 & 3 & 2377.1848 & 2377.1789 & 793.4002 & 0.0059 & 2.4788 & 7.184 & 15.031 & 4.328 & 32.352 & \text { Yes } \\ \end{array}$ $\begin{array}{ccccccccccccc}27.01 & 20.20 & 2 & 2350.1434 & 2350.1419 & 1176.0782 & 0.0015 & 0.6377 & 93.112 & 107.794 & 50.443 & 128.446 & \text { Yes } \\ 27.12 & 51.03 & 3 & 2350.1455 & 2350.1419 & 784.3879 & 0.0036 & 1.5299 & 5.833 & 0.000 & 7.169 & 13.93 & \\ \end{array}$

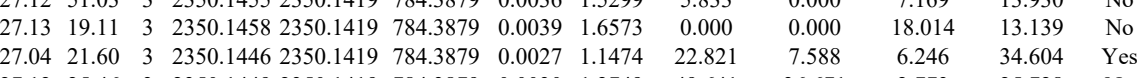
\begin{tabular}{|cccccccccc} 
& 2.75 \\
\end{tabular}

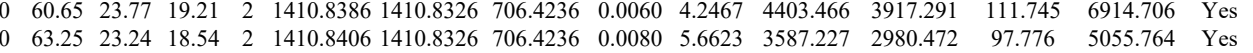
$\begin{array}{llllllllllll} & \end{array}$

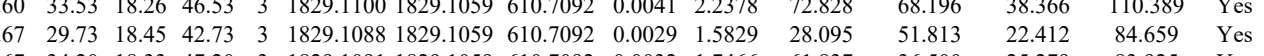
$\begin{array}{lllllllllll} & 84.659 & \text { Yes }\end{array}$ $\begin{array}{lllllllllllll} & 15.85 & 3 & 1829.1103 & 1829.1059 & 610.7092 & 0.0044 & 2.4016 & 92.881 & 102.072 & 57.288 & 112.709 & \text { Yes }\end{array}$ $\begin{array}{llllllllllllll}1 & & \end{array}$ $\begin{array}{lllllllllllllll}0.83 & 24.40 & 23.78 & 30.36 & 2 & 914.5794 & 914.5793 & 458.2969 & 0.0001 & 0.1091 & 42.833 & 29.212 & 12.838 & 53.953 & \text { Yes }\end{array}$ $\begin{array}{llllllllllllllll}1.00 & 46.76 & 22.48 & 20.79 & 2 & 1282.7966 & 1282.7853 & 642.3999 & 0.0113 & 8.7951 & 56.692 & 45.174 & 23.848 & 70.001 & \text { Yes } \\ 0.83 & 2.458 .031 & 5888.470 & 593.720 & 7415.054 & \text { Yes }\end{array}$

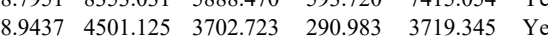

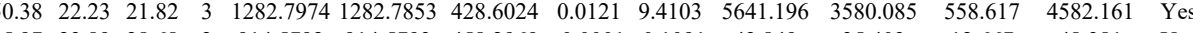

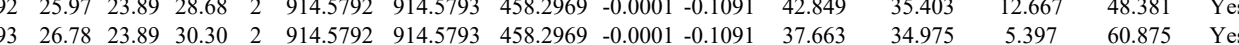

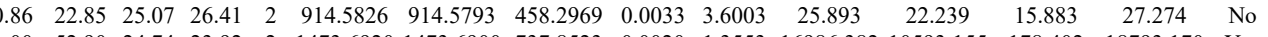

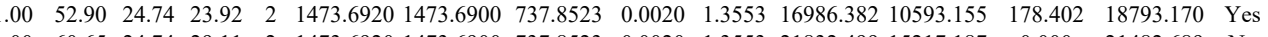
$\begin{array}{lllllllllllll} & 21482.689 & \text { No }\end{array}$ 1631.613 Yes 1504 1554.021 Yes $306 \quad 1172.538$ Y 899.770 Yes 
$\begin{array}{llllllllllllllll}\text { VLDFEHFLPMLQTVAK } & 1.00 & 34.62 & 25.20 & 15.45 & 3 & 2175.2050 & 2175.2006 & 726.0741 & 0.0044 & 2.0200 & 2403.397 & 2166.877 & 653.830 & 2546.372 & \text { Yes }\end{array}$ $\begin{array}{llllllllllllllll}\text { VLDFEHFLPMLQTVAK } & 0.84 & 7.53 & 25.12 & 15.17 & 4 & 2175.2061 & 2175.2006 & 544.8074 & 0.0055 & 2.5238 & 136.033 & 122.920 & 13.420 & 135.399 & \text { Yes }\end{array}$ $\begin{array}{llllllllllllllll}\text { VLDFEHFLPMLQTVAK } & 1.00 & 41.00 & 25.20 & 19.75 & 3 & 2175.2050 & 2175.2006 & 726.0741 & 0.0044 & 2.0200 & 499.824 & 295.752 & 153.393 & 294.813 & \text { Yes }\end{array}$ $\begin{array}{llllllllllllllll}\text { VLDFEHFLPMLQTVAK } & 1.00 & 43.86 & 25.20 & 19.53 & 3 & 2175.2050 & 2175.2006 & 726.0741 & 0.0044 & 2.0200 & 43.188 & 78.806 & 24.432 & 54.526 & \text { No }\end{array}$

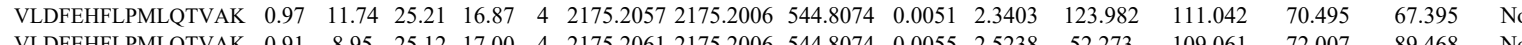

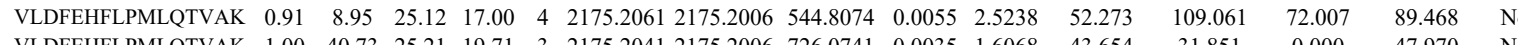
$\begin{array}{llllllllllllllll}\text { VLDFEHFLPMLQTVAK } & 1.00 & 40.73 & 25.21 & 19.71 & 3 & 2175.2041 & 2175.2006 & 726.0741 & 0.0035 & 1.6068 & 43.654 & 31.851 & 0.000 & 47.970 & \text { No } \\ \text { VLDFE }\end{array}$ $\begin{array}{llllllllllllll} & \text { VLDFELA }\end{array}$

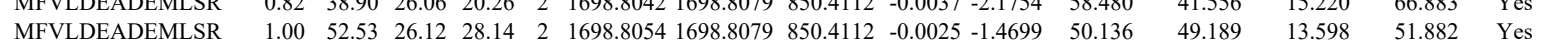

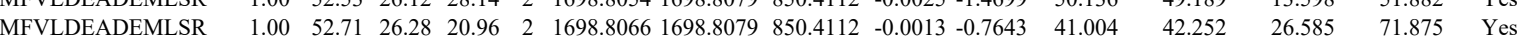

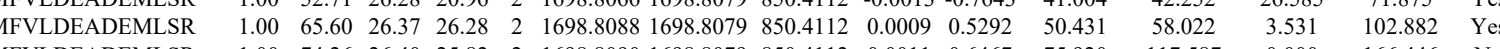

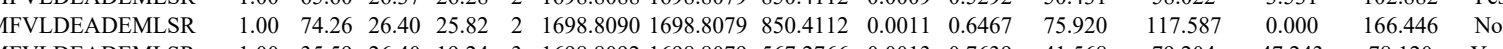

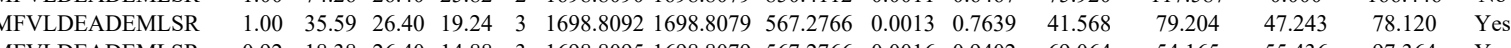
$\begin{array}{llllllllllllllll}\text { MFVLDEADEMLSR } & 0.92 & 18.38 & 26.40 & 14.88 & 3 & 1698.8095 & 1698.8079 & 567.2766 & 0.0016 & 0.9402 & 69.064 & 54.165 & 55.436 & 97.364 & \text { Yes }\end{array}$ $\begin{array}{llllllllllllllll}\text { MFVLDEADEMLSR } & 1.00 & 68.02 & 26.43 & 25.06 & 2 & 1698.8100 & 1698.8079 & 850.4112 & 0.0021 & 1.2347 & 2170.410 & 2702697 & 127.082 & 4660.071 & \text { Yes }\end{array}$ $\begin{array}{llllllllllllllll}\text { MFVLDEADEMLSR } & 1.00 & 74.98 & 26.36 & 26.17 & 2 & 1698.8108 & 1698.8079 & 850.4112 & 0.0029 & 1.7051 & 10827.633 & 11565.890 & 0.000 & 18121.499 & \text { No- }\end{array}$ $\begin{array}{llllllllllllllllll}\text { GVAINMVTEEDKR } & 1.00 & 83.88 & 27.51 & 30.42 & 2 & 1748.9490 & 1748.9334 & 875.4740 & 0.0156 & 8.9094 & 157.312 & 261.880 & 130.943 & 222.627 & \text { Yes }\end{array}$ $\begin{array}{llllllllllllllll}\text { GVAINMVTEEDKR } & 1.00 & 53.29 & 27.47 & 26.88 & 3 & 1748.9494 & 1748.9334 & 583.9851 & 0.0160 & 9.1326 & 6507.424 & 6289.301 & 3871.736 & 6159.339 & \text { Yes }\end{array}$ $\begin{array}{llllllllllllllll}\text { KEELTLEGIR } & 1.00 & 45.70 & 25.53 & 30.08 & 3 & 1474.8739 & 1474.8598 & 492.6272 & 0.0141 & 9.5406 & 9667.506 & 11686.509 & 1588.167 & 14724.369 & \text { Yes } \\ \text { KEELTLEGIR } & 1.00 & 47.93 & 25.53 & 23.32 & 3 & 1474.8742 & 1474.8598 & 492.6272 & 0.0144 & 9.7436 & 8167.493 & 12410.526 & 1320.364 & 12293.888 & \text { Yes }\end{array}$ $\begin{array}{llllllllllllllll}\text { MFVLDEADEMLSR } & 1.00 & 47.93 & 25.53 & 23.32 & 3 & 1474.8742 & 1474.8598 & 492.6272 & 0.0144 & 9.7436 & 8167.493 & 12410.526 & 1320.364 & 12293.888 & \text { Yes }\end{array}$ $\begin{array}{llllllllllllllll}\text { MFVLDEADEMLSR } & 1.00 & 78.51 & 26.43 & 29.86 & 2 & 1698.8100 & 1698.8079 & 850.4112 & 0.0021 & 1.2347 & 1357.012 & 3339.123 & 0.000 & 4763.032 & \text { No }\end{array}$ $\begin{array}{lllllllllllllllll} & \end{array}$ $\begin{array}{llllllllllllllll}\text { MFVLDEADEMLSR } & 1.00 & 72.88 & 26.40 & 28.99 & 2 & 1698.8094 & 1698.8079 & 850.4112 & 0.0015 & 0.8819 & 182.227 & 165.520 & 27.595 & 201.068 & \text { Yes }\end{array}$ $\begin{array}{llllllllllllllll}\text { GYDVIAQAQSGTGK } & 1.00 & 84.75 & 27.30 & 31.50 & 2 & 1681.9008 & 1681.8879 & 841.9512 & 0.0129 & 7.6607 & 557.649 & 621.183 & 620.746 & 634.027 & \text { Yes }\end{array}$ $\begin{array}{llllllllllllllll} & \\ \text { GYDVIAQAQSGTGK } & 1.00 & 84.41 & 27.25 & 33.17 & 2 & 1681.9016 & 1681.8879 & 841.9512 & 0.0137 & 8.1358 & 948.741 & 1005.628 & 1404.537 & 1397.523 & \text { Yes } \\ \text { QFYINVER } & 0.85 & 28.83 & 27.26 & 27.72 & 2 & 1211.6524 & 1211.6420 & 06.8283 & 0.0104 & 8.5691 & 8534.024 & 11369.087 & 1265.820 & 16483.661 & \text { Yes }\end{array}$ $\begin{array}{lllllllllllllllll} & \\ \text { QFYINVER } & 0.85 & 28.83 & 27.26 & 27.72 & 2 & 1211.6524 & 1211.6420 & 606.8283 & 0.0104 & 8.5691 & 8534.024 & 11369.087 & 1265.820 & 16483.661 & \text { Yes } \\ \text { QFYINVER } & 0.81 & 26.90 & 27.13 & 27.33 & 2 & 1211.6538 & 1211.6420 & 606.8283 & 0.0118 & 9.7226 & 13454.357 & 13327.771 & 1111.244 & 26087.989 & \text { Yes }\end{array}$

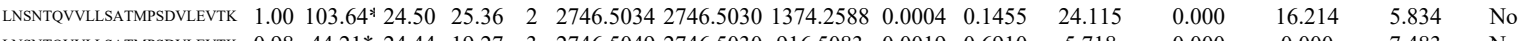

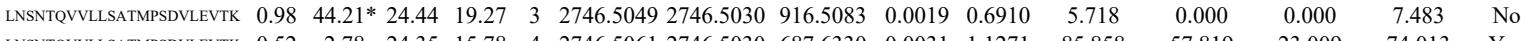

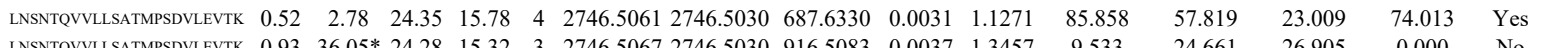

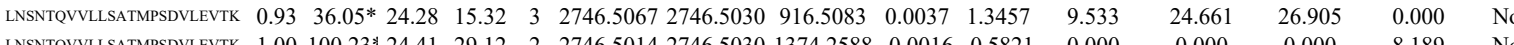

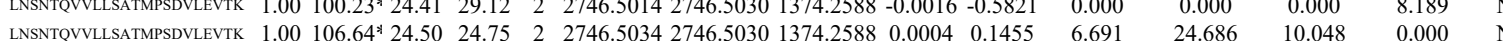

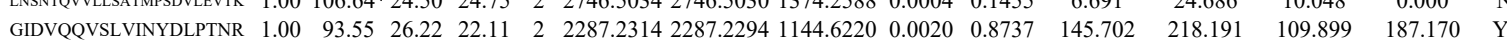

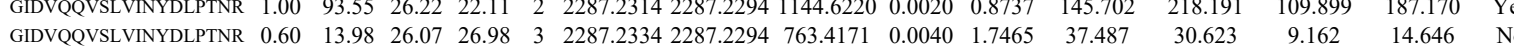

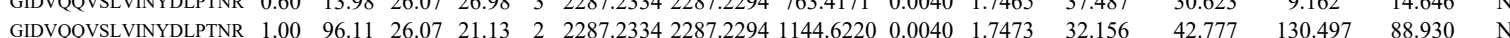

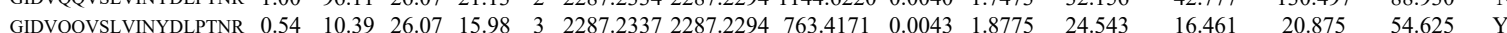
$\begin{array}{lllllllllllllll} & \text { GDV }\end{array}$

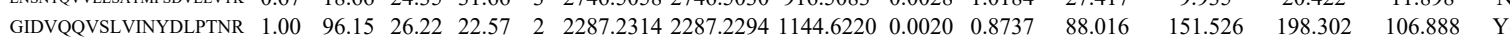
$\begin{array}{llllllllllllllll}\text { GIDVQQVSLVINYDLPTNR } & 0.54 & 9.19 & 26.18 & 16.36 & 3 & 2287.2322 & 2287.2294 & 763.4171 & 0.0028 & 1.2226 & 21.026 & 7.309 & 3.361 & 15.655 & \mathrm{No}\end{array}$ $\begin{array}{lllllllllllllllll}\text { GIDVQQVSLVINYDLPTNR } & 0.60 & 13.11 & 26.11 & 26.11 & 3 & 2287.2331 & 2287.2294 & 763.4171 & 0.0037 & 1.6155 & 31.559 & 22.785 & 32.389 & 40.646 & \text { Y }\end{array}$ $\begin{array}{llllllllllllllll}\text { GIDVQQVSLVINYDLPTNR } & 1.00 & 93.72 & 26.07 & 22.48 & 2 & 2287.2334 & 2287.2294 & 1144.6220 & 0.0040 & 1.7473 & 104.895 & 138.504 & 140.965 & 166.497 & \text { Yes }\end{array}$

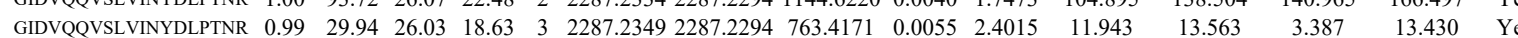
$\begin{array}{llllllllllllllll}\text { GIDVQQVSLVINYDLPTNR } & 1.00 & 43.66 & 25.95 & 17.96 & 3 & 2287.2355 & 2287.2294 & 763.4171 & 0.0061 & 2.6635 & 13.344 & 21.294 & 40.192 & 66.645 & \text { Yes }\end{array}$ $\begin{array}{llllllllllllllll}\text { LNSNTRVVLLSATMPSDVLEVTK } & 0.72 & 25.42 * & 24.44 & 15.63 & 3 & 2746.5043 & 2746.5030 & 916.5083 & 0.0013 & 0.4728 & 31.037 & 20.283 & 13.356 & 86.561 & \text { No }\end{array}$ $\begin{array}{llllllllllllllll}\text { TATFAISILQQIELDLK } & 0.67 & 64.58 & 20.25 & 77.58 & 3 & 2191.2742 & 2191.2707 & 731.4308 & 0.0035 & 1.5950 & 26.253 & 36.124 & 16.972 & 28.749 & \text { Yes }\end{array}$ $\begin{array}{llllllllllllllll}\text { TATFAISILQQIELDLK } & 1.00 & 39.39 & 20.00 & 15.69 & 3 & 2191.2757 & 2191.2707 & 731.4308 & 0.0050 & 2.2786 & 25.196 & 16.349 & 7.440 & 25.303 & \text { Yes }\end{array}$ $\begin{array}{lllllllllllllllll}\text { GIDVQQVSLVINYDLPTNR } & 1.00 & 95.10 & 26.22 & 23.04 & 2 & 2287.2314 & 2287.2294 & 1144.6220 & 0.0020 & 0.8737 & 30.416 & 96.210 & 37.506 & 59.440 & \text { No }\end{array}$ $\begin{array}{llllllllllllllll}\text { GIDVQQVSLVINYDLPTNR } & 0.91 & 18.90 & 26.11 & 21.86 & 3 & 2287.2331 & 2287.2294 & 763.4171 & 0.0037 & 1.6155 & 151.762 & 166.327 & 72.916 & 195.183 & \text { Yes }\end{array}$ $\begin{array}{llllllllllllllll}\text { TATFAISILQQIELDLK } & 1.00 & 40.82 & 20.33 & 19.32 & 3 & 2191.2736 & 2191.2707 & 731.4308 & 0.0029 & 1.3216 & 3.954 & 13.723 & 0.756 & 7.849 & \text { No }\end{array}$

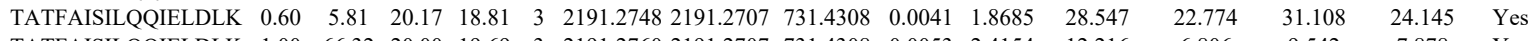

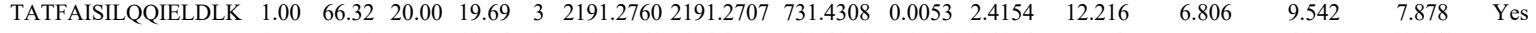

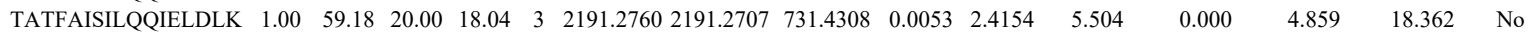
$\begin{array}{llllllllllllllll}\text { VLITTDLLAR } & 0.99 & 51.78 & 23.28 & 51.38 & 2 & 1257.7800 & 1257.7778 & 629.8962 & 0.0022 & 1.7463 & 18508.189 & 19839.881 & 1486.107 & 27998.356 & \text { Yes }\end{array}$ $\begin{array}{llllllllllllllllll}\text { VLITTDLLAR } & 0.99 & 53.93 & 23.03 & 51.66 & 2 & 1257.7812 & 1257.7778 & 629.8962 & 0.0034 & 2.6989 & 15600.213 & 14646.005 & 240.191 & 24866.161 & \text { Yes }\end{array}$ $\begin{array}{lllllllllllllllll}\text { LQMEAPHIIVGTPGR } & 1.00 & 97.43 & 26.73 & 25.85 & 2 & 1761.9826 & 1761.9682 & 881.9914 & 0.0144 & 8.1633 & 3206.658 & 3798.323 & 363.449 & 4562.103 & \text { Yes }\end{array}$ $\begin{array}{lllllllllllllllll}\text { LQMEAPHIIVGTPGR } & 1.00 & 89.38 & 26.51 & 26.19 & 2 & 1761.9834 & 1761.9682 & 881.9914 & 0.0152 & 8.6168 & 5514.764 & 6380.728 & 713.605 & 6795.322 & \text { Yes }\end{array}$ $\begin{array}{llllllllllllllll}\text { LQMEAPHIIVGTPGR } & 1.00 & 75.05 & 26.51 & 20.04 & 3 & 1761.9835 & 1761.9682 & 588.3300 & 0.0153 & 8.6685 & 5056.957 & 6228.051 & 1852.849 & 6504.605 & \text { Yes }\end{array}$

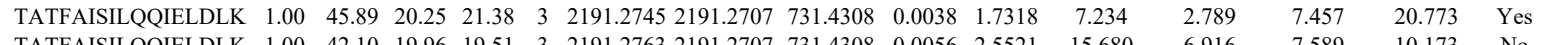

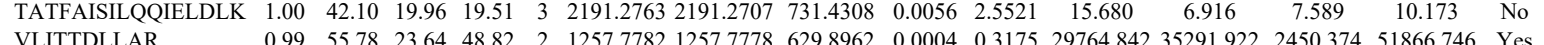
$\begin{array}{lllllllllllllllll}\text { VLITTDLLAR } & 0.99 & 55.78 & 23.64 & 48.82 & 2 & 1257.7782 & 1257.7778 & 629.8962 & 0.0004 & 0.3175 & 29764.842 & 35291.922 & 2450.374 & 51866.746 & \text { Yes }\end{array}$ $\begin{array}{llllllllllllllll}\text { VLITTDLLAR } & 0.98 & 43.87 & 23.26 & 46.71 & 2 & 1257.7792 & 1257.7778 & 29.8962 & 0.0014 & 1.1113 & 87229.691 & 94811.098 & 6622.804 & \text { \#\#\#\#\# Yes } \\ \text { LQMEAPHIIVGTPGR } & 1.00 & 68.49 & 26.64 & 17.39 & 3 & 1761.9832 & 1761.9682 & 588.3300 & 0.0150 & 8.4986 & 5508.456 & 6962.475 & 1473.679 & 8173.697 & \text { Yes }\end{array}$

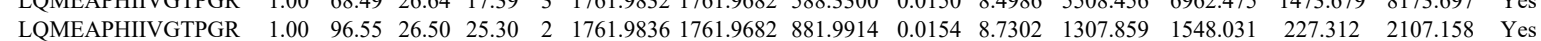
$\begin{array}{llllllllllllllll}\text { TATEAISILQGIELDLK } & 1.00 & 26.25 & 19.96 & 14.83 & 3 & 2191.2751 & 2191.2707 & 731.4308 & 0.0044 & 2.0052 & 7.187 & 3.980 & 1.704 & 11.439 & \text { Yes }\end{array}$

Table S- 4 page 365 of 614 


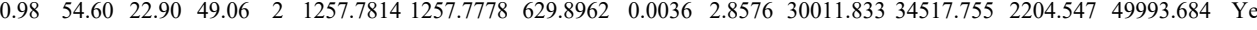
$\begin{array}{lllllllllllllllll}0.99 & 50.67 & 23.26 & 48.67 & 2 & 1257.7792 & 1257.7778 & 629.8962 & 0.0014 & 1.1113 & 11553.370 & 11298.902 & 907.506 & 18551.350 & \text { Yes }\end{array}$ $\begin{array}{lllllllllllllll}0.99 & 51.85 & 23.26 & 48.70 & 2 & 1257.7792 & 1257.7778 & 629.8962 & 0.0014 & 1.1113 & 13451.641 & 14209.293 & 0.000 & 20591.466 & \text { No }\end{array}$ \begin{tabular}{lllllllllllllll}
1.00 & 56.35 & 23.12 & 17.81 & 2 & 1283.7702 & 1283.767833 & 642.8914 & 0.0019 & 1.4777 & 7.471 & 11.903 & 6.907 & 11.846 & Yes \\
\hline & 1283.7683 & 642.8914 & 0.0099 & 7.6995 & 18555.427 & 22406.167 & 22952.218 & 25304.025 & Yes
\end{tabular}

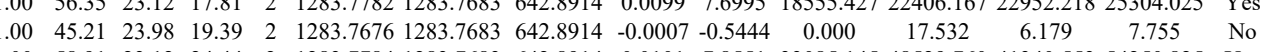
$\begin{array}{lllllllllllllll}1.00 & 58.91 & 23.12 & 24.44 & 2 & 1283.7784 & 1283.7683 & 642.8914 & 0.0101 & 7.8551 & 33085.145 & 48529.760 & 41340.553 & 54250.825 & \text { Yes }\end{array}$ $\begin{array}{llllllllllllllll}0.79 & 20.16 & 23.03 & 22.07 & 3 & 1283.7787 & 1283.7683 & 428.9300 & 0.0104 & 8.0821 & 1203.087 & 1099.783 & 660.498 & 1395.613 & \text { Yes } \\ 1.00 & 59.84 & 23.10 & 19.58 & 2 & 1283.7790 & 1283.7683 & 642.8914 & 0.0107 & 8.3217 & 9655.261 & 12241.033 & 12669.204 & 13627.693 & \text { Yes }\end{array}$

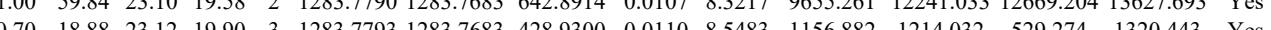

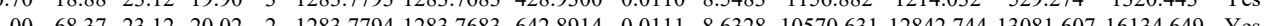

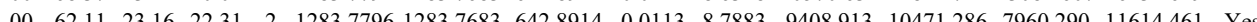
$\begin{array}{llllllllllllllll}1.00 & 63.46 & 23.24 & 20.83 & 2 & 1833.7798 & 1283.7683 & 642.8914 & 0.0115 & 8.9439 & 10494.137 & 13736.957 & 12409.543 & 15274.505 & \text { Yes }\end{array}$ $\begin{array}{llllllllllllllll} & \end{array}$ $\begin{array}{lllllllllllll} & \end{array}$ $\begin{array}{lllllllllllll} & \text { No }\end{array}$

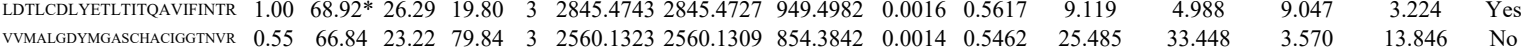

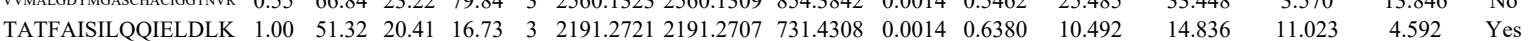
$\begin{array}{llllllllllllllll}\text { TATFAISILQQIELDLK } & 1.00 & 40.12 & 20.25 & 15.83 & 3 & 2191.2745 & 2191.2707 & 731.4308 & 0.0038 & 1.7318 & 5.720 & 2.358 & 12.011 & 7.172 & \text { No }\end{array}$

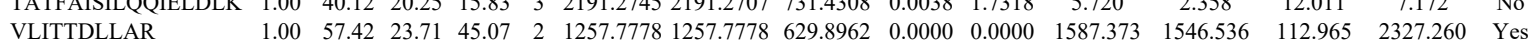

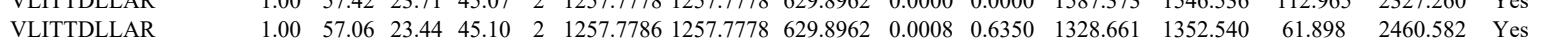
$\begin{array}{llllllllllllllll}\text { ATQALVLAPTR } & 1.00 & 50.78 & 23.98 & 22.09 & 2 & 1283.7676 & 1283.7683 & 642.8914 & -0.0007 & -0.5444 & 210.678 & 198.370 & 327.795 & 158.540 & \text { Yes }\end{array}$ $\begin{array}{lllllllllllllllll}\text { ATQALVLAPTR } & 1.00 & 65.73 & 23.80 & 23.61 & 2 & 1283.7682 & 1283.7683 & 642.8914 & -0.0001 & -0.0778 & 224.109 & 226.998 & 260.524 & 235.805 & \text { Yes }\end{array}$

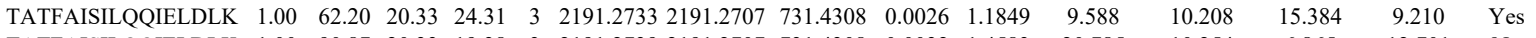
$\begin{array}{llllllllllllllll}\text { TATFAISILQQIELDLK } & 1.00 & 90.87 & 20.33 & 19.38 & 3 & 2191.2739 & 2191.2707 & 731.4308 & 0.0032 & 1.4583 & 20.785 & 10.254 & 6.865 & 12.701 & \text { No }\end{array}$

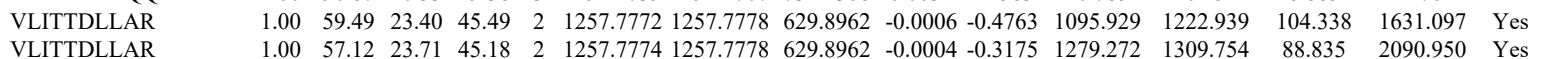
\begin{tabular}{lccccccccccccccc} 
VLITTDLLAR & 1.00 & 57.12 & 23.71 & 45.18 & 2 & 1257.7774 & 1257.7778 & 629.8962 & -0.0004 & -0.3175 & 1279.272 & 1309.754 & 88.835 & 2090.950 & Yes \\
\hline
\end{tabular}

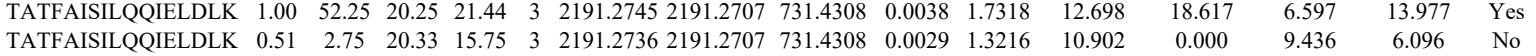

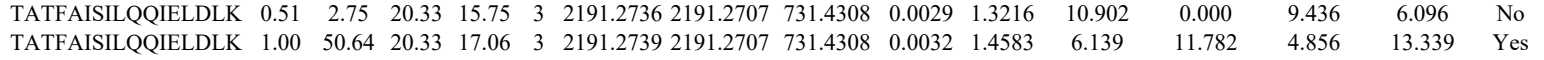

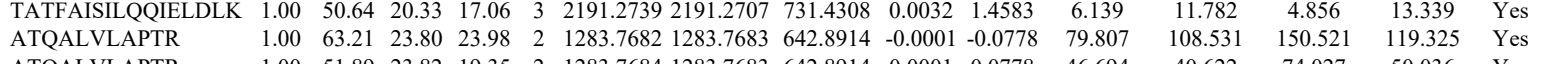
TATFAISILQQIELDLK ATQALVLAPTR ATQALVLAPTR ATQALVLAPT VLITTDLLAR

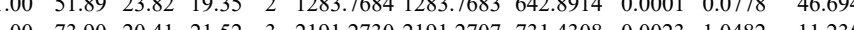
$\begin{array}{lllllllllll}1.00 & 73.90 & 20.41 & 21.52 & 3 & 2191.2730 & 2191.2707 & 731.4308 & 0.0023 & 1.0482 & 11.235 \\ 1.00 & 60.68 & 24.35 & 21.37 & 2 & 1283.7680 & 1283.7683 & 642.8914 & -0.0003 & -0.2333 & 42.550\end{array}$ $\begin{array}{lllllllllll}1.00 & 60.68 & 24.35 & 21.37 & 2 & 1283.7680 & 1283.7683 & 642.8914 & -0.0003 & -0.2333 & 42.550 \\ 1.00 & 57.49 & 23.80 & 23.45 & 2 & 1283.7682 & 1283.7683 & 642.8914 & -0.0001 & -0.0778 & 61.506\end{array}$ $\begin{array}{lllllllllll}1.00 & 58.86 & 23.82 & 19.63 & 2 & 1283.7684 & 1283.7683 & 642.8914 & 0.0001 & 0.0778 & 54.643\end{array}$ $\begin{array}{lllllllllll}1.08 & 58.86 & 23.82 & 19.63 & 2 & 1283.7684 & 1283.7683 & 642.8914 & 0.0001 & 0.0778 & 54.643 \\ 0.88 & 33.42 & 23.44 & 44.21 & 2 & 1257.7788 & 1257.7778 & 629.8962 & 0.0010 & 0.7938 & 53.033\end{array}$ $\begin{array}{llllllllllll}1.00 & 59.66 & 24.08 & 21.61 & 2 & 1283.7686 & 1283.7683 & 642.8914 & 0.0003 & 0.2333 & 100.147\end{array}$ $\begin{array}{lllllllllll}1.00 & 72.25 & 23.44 & 29.35 & 2 & 1257.7788 & 1257.7778 & 629.8962 & 0.0010 & 0.7938 & 36.5\end{array}$

55.754 10.822 41.362 $\begin{array}{lllllllllll}1.00 & 70.07 & 23.80 & 18.13 & 2 & 1283.7682 & 1283.7683 & 642.8914 & -0.0001 & -0.0778 & 84.674\end{array}$

(APLD $\begin{array}{lllllllllll}0.60 & 60.42 & 20.17 & 73.42 & 3 & 2191.2748 & 2191.2707 & 731.4308 & 0.0041 & 1.8685 & 13.708\end{array}$

ATQALVLAPTR $\begin{array}{lllllllllll}1.00 & 47.74 & 23.94 & 20.19 & 2 & 1283.7696 & 1283.7683 & 642.8914 & 0.0013 & 1.0111 & 76.373 \\ 1.00 & 30.40 & 19.96 & 15.97 & 3 & 2191.2763 & 2191.2707 & 731.4308 & 0.0056 & 2.5521 & 14.836\end{array}$ $\begin{array}{lllllllllllll}\text { TATFAISILQQIELDLK } & 1.00 & 32.25 & 20.25 & 20.19 & 3 & 2191.2745 & 2191.2707 & 731.4308 & 0.0038 & 1.7318 & 7.056\end{array}$ $\begin{array}{lllllllllll}1.00 & 53.70 & 23.60 & 24.23 & 2 & 1283.7666 & 1283.7683 & 642.8914 & -0.0017 & -1.3222 & 26.301\end{array}$ EEDKR GVAINMVTEEDKR GVAINMVTEEDKR GVAINMVTEEDKR GVAINMVTEEDKR GVAINMVTEEDKR GVAINMVTEEDKR KEELTLEGIR KEELTLEGIR KEELTLEGIR KEELTLEGIR KEELTLEGIR MFVLDEADEMLSR MFVLDEADEMLSR MFVLDEADEMLSR MFVLDEADEMLSR $\begin{array}{lllllllllll}0.89 & 22.68 & 27.80 & 18.55 & 3 & 1748.9332 & 1748.9334 & 583.9851 & -0.0002 & -0.1142 & 105.247\end{array}$ $\begin{array}{llllllllllll}0.82 & 20.45 & 27.80 & 18.54 & 3 & 1748.9332 & 1748.9334 & 583.9851 & -0.0002 & -0.1142 & 89.543\end{array}$ $\begin{array}{lllllllllll}0.90 & 20.90 & 27.87 & 18.03 & 3 & 1748.9344 & 1748.9334 & 583.9851 & 0.0010 & 0.5708 & 118.01\end{array}$ $\begin{array}{llllllllllll}0.98 & 28.20 & 27.84 & 23.43 & 3 & 1748.9350 & 1748.9334 & 583.9851 & 0.0016 & 0.9133 & 75.032\end{array}$ $\begin{array}{llllllllllll}0.96 & 23.11 & 27.80 & 25.60 & 3 & 1748.9362 & 1748.9334 & 583.9851 & 0.0028 & 1.5982 & 131.067 & 1\end{array}$

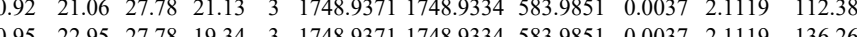
$\begin{array}{lllllll} & \end{array}$ $\begin{array}{lllllllllllllll}1.00 & 55.52 & 25.53 & 31.81 & 3 & 1474.8742 & 1474.8598 & 492.6272 & 0.0144 & 9.7436 & 13266.154 & 18756.584 & 2807.124 & 23580.548 & \text { Yes }\end{array}$ $\begin{array}{lllllllllllllll}1.00 & 44.32 & 25.53 & 23.72 & 2 & 1474.8742 & 4474.8598 & 738.4372 & 0.0144 & 9.7502 & 6226.080 & 7410.959 & 635.484 & 11794.765 & \text { Yes }\end{array}$

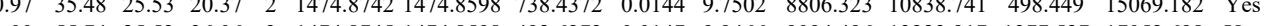
$\begin{array}{lllllllllllllll}1.00 & 55.74 & 25.53 & 36.06 & 3 & 1474.8745 & 1474.8598 & 492.6272 & 0.0147 & 9.9466 & 9094.496 & 13223.917 & 1377.527 & 17052.698 & \text { Yes }\end{array}$ $\begin{array}{lllllllllllllll}1.00 & 74.27 & 26.41 & 25.69 & 2 & 1698.8104 & 1698.8079 & 850.4112 & 0.0025 & 1.4699 & 4762.980 & 5716.877 & 126.928 & 7392.868 & \text { Yes }\end{array}$

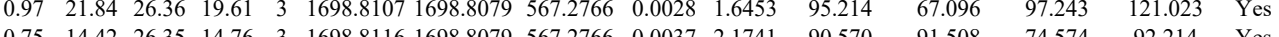

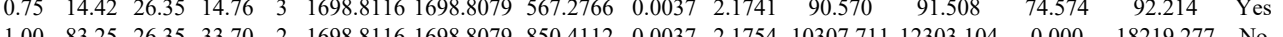
$\begin{array}{lllllllllllllllll}1.00 & 68 & 19 & 27.46 & 32.73 & 3 & 1748.9506 & 1748.9334 & 583.9851 & 0.0172 & 9.8175 & 2966.570 & 3464.186 & 3048099 & 3497.270 & \text { Ye }\end{array}$ $\begin{array}{llllllllllllllll}1.00 & 54.45 & 27.94 & 26.49 & 2 & 1390.7804 & 1390.7690 & 696.3918 & 0.0114 & 8.1850 & 5259.069 & 7047.177 & 12460.260 & 11851.660 & \text { Yes }\end{array}$ $\begin{array}{lllllllllllllllll}1.00 & 51.75 & 27.94 & 27.56 & 2 & 1390.7804 & 1390.7690 & 696.3918 & 0.0114 & 8.1850 & 6122.052 & 6632.709 & 12206.233 & 13287.302 & \text { Yes }\end{array}$ $\begin{array}{llllllllllllllll}1.00 & 42.28 & 27.80 & 17.96 & 3 & 1390.7821 & 1390.7690 & 464.5969 & 0.0131 & 9.3987 & 6376.061 & 10510.978 & 11746.072 & 9691.953 & \text { Yes }\end{array}$

Table S-4 page 366 of 6 


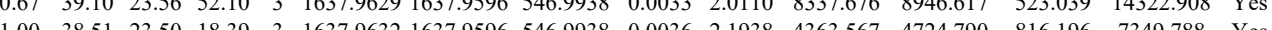
$\begin{array}{llllllllllllllll}1.00 & 38.51 & 23.50 & 18.39 & 3 & 1637.9632 & 1637.9596 & 546.9938 & 0.0036 & 2.1938 & 4363.567 & 4724.790 & 816.196 & 7349.788 & \text { Yes }\end{array}$ $\begin{array}{llllllllllllllll}0.94 & 35.91 & 28.31 & 30.50 & 2 & 978.5202 & 978.5112 & 490.2629 & 0.0090 & 9.1787 & 9981.653 & 11138.875 & 1112.667 & 32891.037 & \text { No }\end{array}$ $\begin{array}{llllllllllllllll}0.91 & 33.59 & 28.29 & 28.88 & 2 & 978.5206 & 978.5112 & 490.2629 & 0.0094 & 9.5866 & 12892.520 & 15715.523 & 817.565 & 37539.193 & \text { Yes }\end{array}$ $\begin{array}{lllllllllllllllll}1.00 & 55.87 & 27.94 & 29.33 & 2 & 139.7806 & 1390.760 & 696.3918 & 0.016 & 8.5286 & 5634.683 & 5706.095 & 7982.061 & 10721.550 & \text { Yes }\end{array}$

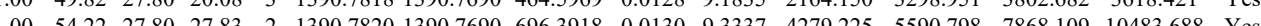

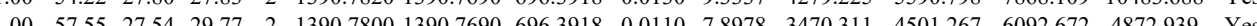

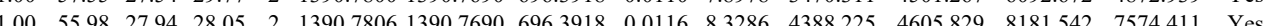

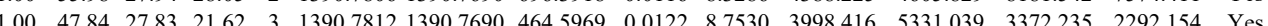
$\begin{array}{llllllllllllllll}1.00 & 69.10 & 27.80 & 23.96 & 3 & 1390.7824 & 1390.7690 & 464.5969 & 0.0134 & 9.6140 & 3904.473 & 5099.195 & 1190.055 & 2193.011 & \text { No }\end{array}$

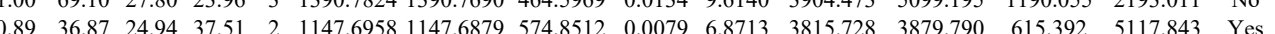
$\begin{array}{lllllllllllllllll}0.94 & 36.75 & 25.22 & 37.55 & 2 & 1147.6982 & 1147.6879 & 574.8512 & 0.0103 & 8.9588 & 6009.564 & 6612.193 & 728.290 & 8111.339 & \text { Yes }\end{array}$ $\begin{array}{llllllllllllllll}0.62 & 25.28 & 25.50 & 35.01 & 2 & 1016.6568 & 1016.6474 & 509.3310 & 0.0094 & 9.2277 & 6580.234 & 5867.026 & 601.717 & 9473.812 & \text { Yes }\end{array}$ $\begin{array}{lllllllllllllll}0.89 & 28.66 & 25.50 & 30.69 & 2 & 1016.6574 & 1016.6474 & 509.3310 & 0.0100 & 9.8167 & 8785.202 & 8134.912 & 260.588 & 11330.624 & \text { Yes }\end{array}$ \begin{tabular}{|lllllllllllllll} 
& & &
\end{tabular} $\begin{array}{lllllllllllllll}\text { VAILVDDMADTCGTICHAADK } & 1.00 & \text { \#\#\#\# } 24.59 & 20.64 & 2 & 2541.1654 & 2541.1649 & 1271.5897 & 0.0005 & 0.1966 & 10.644 & 13.575 & 5.226 & 24.649 & \text { Yes }\end{array}$ $\begin{array}{lllllllllllllllll}\text { VAILVDDMADTCGTICHAADK } & 1.00 & 78.24 & 24.62 & 18.08 & 3 & 2541.1669 & 2541.1649 & 848.0622 & 0.0020 & 0.7861 & 2914.891 & 2138.807 & 1562.218 & 4287.954 & \text { No }\end{array}$

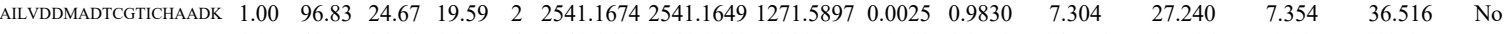
\begin{tabular}{llllllllllllllll} 
VAILVDDMADTCGTICHAADK & 1.00 & 48.60 & 24.71 & 16.57 & 4 & 2541.1681 & 2541.1649 & 636.2985 & 0.0032 & 1.2573 & 94.706 & 87.516 & 50.920 & 113.605 & Yes \\
\hline
\end{tabular}

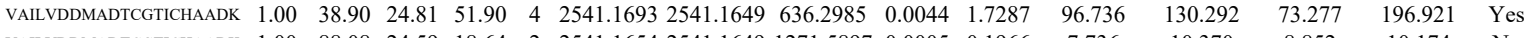
$\begin{array}{llllllllllllllll}\text { NAILVDMADTCGICHAADK } & 1.00 & 88.08 & 24.59 & 18.64 & 2 & 2541.1654 & 2541.1649 & 1271.5897 & 0.0005 & 0.1966 & 7.736 & 10.370 & 8.852 & 10.174 & \text { No }\end{array}$ \begin{tabular}{llllllllllllllll} 
VAILVDDMADTCGTICHAADK & 1.00 & 44.19 & 24.89 & 16.48 & 4 & 2541.1709 & 2541.1649 & 636.2985 & 0.0060 & 2.3574 & 75.746 & 88.864 & 59.059 & 111.528 & Yes \\
\hline
\end{tabular}

LNVDFALIHK

IQVIDISMILAEAIR

IQVIDISMILAEAIR

QQVIDISMILAEAIR

IQVIDISMILAEAIR IQVIDISMILAEAIR IQVIDISMILAEAIR IQVIDISMILAEAIR

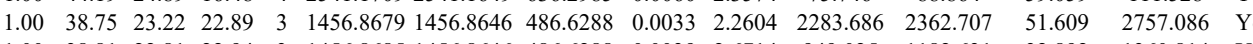
$\begin{array}{llllllllllllllll}1.00 & 38.81 & 22.81 & 22.94 & 3 & 1456.8685 & 1456.8646 & 486.6288 & 0.0039 & 2.6714 & 949.025 & 1182.631 & 32.892 & 1360.814 & \text { Yes }\end{array}$

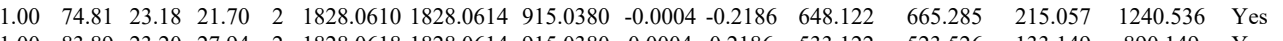
\begin{tabular}{lllllllllllllll}
1.00 & 83.89 & 23.20 & 27.94 & 2 & 1828.0618 & 1828.0614 & 915.0380 & 0.0004 & 0.2186 & 533.122 & 523.526 & 133.149 & 890.149 & Yes \\
\hline
\end{tabular} $\begin{array}{lllllllllllllll}0.55 & 49.37 & 23.20 & 62.37 & 3 & 1828.0621 & 1828.0614 & 610.3611 & 0.0007 & 0.3823 & 37.027 & 67.213 & 26.079 & 56.585 & \text { Yes }\end{array}$ $\begin{array}{lllllllllllllll}1.00 & 68.04 & 23.14 & 24.50 & 3 & 1828.0636 & 1828.0614 & 610.3611 & 0.0022 & 1.2015 & 45.313 & 77.676 & 28.003 & 121.048 & \text { Yes }\end{array}$

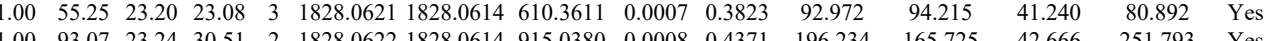

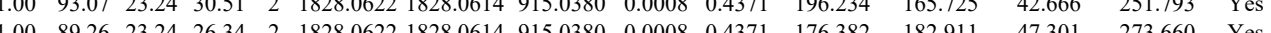

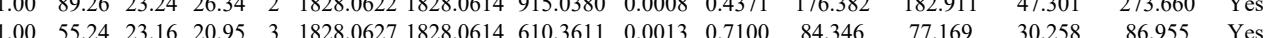

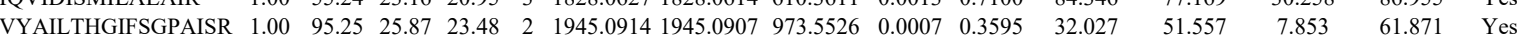

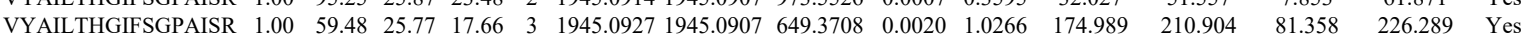

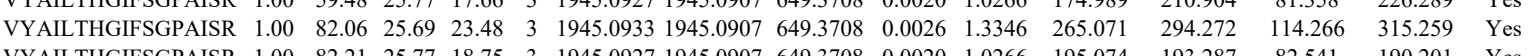

$\begin{array}{lllllllllllllll} & \end{array}$ $\begin{array}{llllllllllllllll}\text { ILTEAEIDAHLVALAER } & 0.96 & 23.17 & 26.04 & 15.68 & 3 & 2007.1132 & 2007.1122 & 670.0447 & 0.0010 & 0.4975 & 14.168 & 26.829 & 7.466 & 25.421 & \text { No }\end{array}$

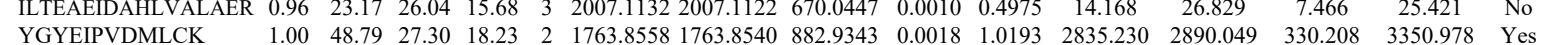
$\begin{array}{llllllllllllllll}\text { YGYEIPVDMLCK } & 0.84 & 50.42 & 27.34 & 63.42 & 2 & 1763.8562 & 1763.8540 & 882.9343 & 0.0022 & 1.2458 & 1939.139 & 1864.553 & 95.275 & 2324.539 & \text { Yes }\end{array}$ $\begin{array}{llllllllllllllll}\text { YGYEIPVDMLCK } & 1.00 & 31.27 & 27.35 & 17.97 & 3 & 1763.8567 & 1763.8540 & 588.9586 & 0.0027 & 1.5281 & 127.447 & 224.796 & 63.250 & 339.405 & \text { No }\end{array}$ $\begin{array}{llllllllllllllll}\text { YGYEIPVDMLCK } & 0.98 & 25.87 & 27.40 & 19.52 & 3 & 1763.8576 & 1763.8540 & 588.9586 & 0.0036 & 2.0375 & 346.677 & 364.574 & 83.556 & 398.841 & \text { Yes }\end{array}$ YYQVEYAK LYQVEYAFK YGYEIPVDMLCK HITIFSPEGR

HITIFSPEGR

CDPAGYYCGFK

CDPAGYYCGFK

LLDSSTVTHLFK

LLDSSTVTHLFK

LLDSSTVTHLFK

LLDSSTVTHLFK

AINQGGLTSVAVR

AINQGGLTSVAVR

AINQGGLTSVAVR

AINQGGLTSVAVR

AINQGGLTSVA

QTESTSFLEK

QTESTSEK

QTESTSFLEK $\begin{array}{llllllllllllllll}0.98 & 25.87 & 27.40 & 19.52 & 3 & 1763.8576 & 1763.8540 & 588.9586 & 0.0036 & 2.0375 & 346.677 & 364.574 & 83.556 & 398.841 & \text { Yes }\end{array}$ $\begin{array}{llllllllllllllll}0.98 & 39.07 & 27.79 & 25.38 & 2 & 1447.8082 & 1447.7955 & 724.9050 & 0.0127 & 8.7597 & 723.770 & 424.753 & 47.483 & 946.456 & \text { Yes } \\ 1.00 & 5236 & 27.60 & 25.55 & 2 & 1447.8086 & 1447.7955 & 72.9050 & 0.0131 & 9.0356 & 54.443 & 356.904 & 179.051 & 522.241 & \text { Yes }\end{array}$ $\begin{array}{lllllllllllllll}1.00 & 41.27 & 27.35 & 18.21 & 2 & 1763.8564 & 1763.8540 & 882.9343 & 0.0024 & 1.3591 & 196.852 & 163.050 & 40.580 & 215.407 & \text { Yes }\end{array}$ $\begin{array}{lllllllllllllll}0.98 & 35.04 & 27.80 & 24.60 & 3 & 1299.7141 & 1299.7057 & 434.2425 & 0.0084 & 6.4480 & 1919.436 & 1729.932 & 559.042 & 1593.175 & \text { Yes }\end{array}$ $\begin{array}{llllllllllllllll}0.94 & 31.77 & 27.77 & 21.88 & 3 & 1299.7147 & 1299.7057 & 434.2425 & 0.0090 & 6.9085 & 2164.278 & 2132.383 & 865.383 & 2027.244 & \text { Yes }\end{array}$ $\begin{array}{lllllllllllllll}1.00 & 55.09 & 18.45 & 19.58 & 2 & 1602.6578 & 1602.6583 & 802.3364 & -0.0005 & -0.3116 & 672.969 & 611.616 & 0.000 & 1065.772 & \text { No }\end{array}$ $\begin{array}{lllllllllllllll}1.00 & 54.34 & 18.39 & 19.13 & 2 & 1602.6588 & 1602.6583 & 802.3364 & 0.0005 & 0.3116 & 811.215 & 645.506 & 208.684 & 1097.891 & \text { Yes }\end{array}$ $\begin{array}{llllllllllllllll}1.00 & 46.92 & 25.68 & 24.04 & 3 & 1647.9469 & 1647.9440 & 550.3219 & 0.0029 & 1.7565 & 10476.468 & 9260.841 & 0.000 & 15480.200 & \text { No }\end{array}$ $\begin{array}{llllllllllllllll}1.00 & 52.63 & 25.63 & 24.02 & 3 & 1647.9481 & 1647.9440 & 550.3219 & 0.0041 & 2.4834 & 12092.625 & 9017.403 & 114.137 & 18072.253 & \text { Yes }\end{array}$

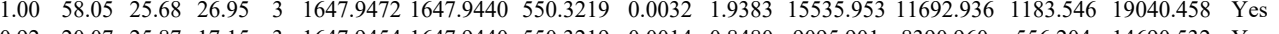
$\begin{array}{llllllllllllllll}0.92 & 20.07 & 25.87 & 17.15 & 3 & 1647.9454 & 1647.9440 & 550.3219 & 0.0014 & 0.8480 & 9095.901 & 8390.960 & 556.204 & 14690.532 & \text { Yes }\end{array}$

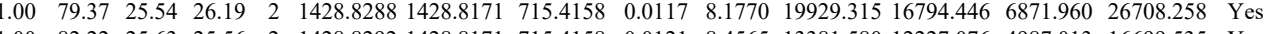
$\begin{array}{lllllllllllllll}1.00 & 82.22 & 25.63 & 25.56 & 2 & 1428.8292 & 1428.8171 & 715.4158 & 0.0121 & 8.4565 & 13381.580 & 12227.076 & 4987.013 & 16699.535 & \text { Yes }\end{array}$

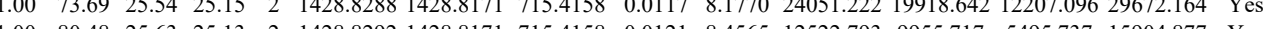
$\begin{array}{lllllllllllllllll}1.00 & 80.48 & 25.63 & 25.13 & 2 & 1428.8292 & 1428.8171 & 715.4158 & 0.0121 & 8.4565 & 12522.793 & 955.717 & 545.737 & 15904.877 & \text { Yes }\end{array}$ $\begin{array}{lllllllllllllll}1.00 & 77.72 & 25.63 & 29.34 & 2 & 1428.8292 & 1428.8171 & 715.4158 & 0.0121 & 8.4565 & 11635.799 & 11072.885 & 4938.789 & 16085.252 & \text { Yes } \\ 0.99 & 45.25 & 28.26 & 30.23 & 2 & 1456.7704 & 1456.7653 & 729.3899 & 0.0051 & 3.4961 & 1748.817 & 162.670 & 893.276 & 1881.253 & \text { Yes }\end{array}$ $\begin{array}{lllllllllllllll}0.99 & 45.25 & 28.26 & 30.23 & 2 & 1456.7704 & 1456.7653 & 729.389 & 0.0051 & 3.4961 & 1748.817 & 1622.670 & 893.276 & 1881.253 & \text { Yes } \\ 0.98 & 43.60 & 28.16 & 33.64 & 2 & 1456.7714 & 14567653 & 729.3899 & 0.0061 & 4.1816 & 1594.680 & 1476.499 & 775.190 & 1998.045 & \text { Yes }\end{array}$

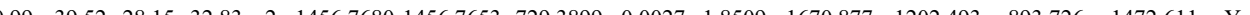
$\begin{array}{llllllllllllllll}0.92 & 32.98 & 28.13 & 26.72 & 2 & 1456.7690 & 1456.7653 & 729.3899 & 0.0037 & 2.5364 & 1444.294 & 957.244 & 660.478 & 1327.197 & \text { Yes }\end{array}$ 


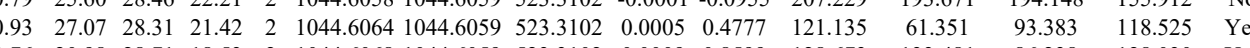
$\begin{array}{llllllllllllllll}0.76 & 20.98 & 28.71 & 18.53 & 2 & 1044.6068 & 1044.6059 & 523.3102 & 0.0009 & 0.8599 & 128.673 & 133.481 & 86.238 & 128.030 & \text { Yes }\end{array}$ $\begin{array}{llllllllllllll}0 & \end{array}$ $\begin{array}{llllllllllllll} & 0.07\end{array}$

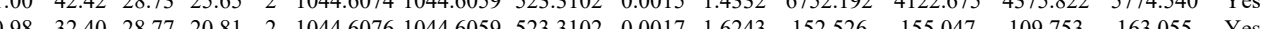

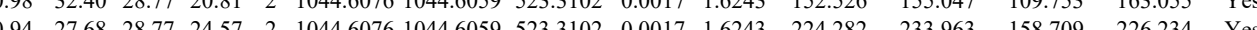

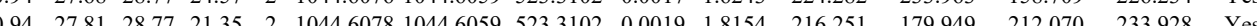

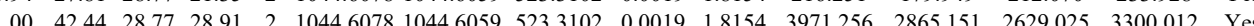

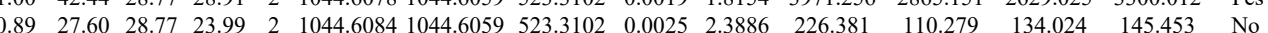

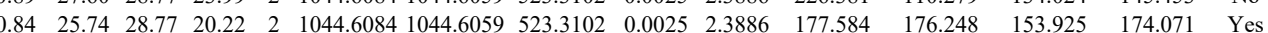
$\begin{array}{lllllllllllllll}0.61 & 20.55 & 28.76 & 22.41 & 2 & 1044.6090 & 1044.6059 & 523.3102 & 0.0031 & 2.9619 & 138.752 & 70.853 & 103.881 & 123.291 & \text { Yes }\end{array}$ $\begin{array}{lllllllllllllll}0.63 & 25.04 & 28.73 & 22.94 & 2 & 1044.6096 & 1044.6059 & 523.3102 & 0.0037 & 3.5352 & 156.413 & 97.737 & 104.388 & 146.447 & \text { Yes }\end{array}$ $\begin{array}{lllllllllllllll}0.61 & 24.81 & 28.98 & 23.84 & 2 & 1044.6102 & 1044.6059 & 523.3102 & 0.0043 & 4.1084 & 176.428 & 115.013 & 105.808 & 112.910 & \text { Yes }\end{array}$ $\begin{array}{lllllllllllllll}0.85 & 34.58 & 27.67 & 32.72 & 2 & 1191.6206 & 1191.6227 & 596.8186 & -0.0021 & -1.7593 & 134.728 & 71.678 & 151.501 & 127.283 & \text { Yes }\end{array}$ $\begin{array}{lllllllllllllll}0.93 & 35.25 & 27.67 & 34.30 & 2 & 1191.6218 & 1191.6227 & 596.8186 & -0.0009 & -0.7540 & 110.048 & 102.234 & 147.261 & 102.921 & \text { Yes }\end{array}$ $\begin{array}{lllllllllllllll}0.96 & 33.79 & 27.73 & 26.49 & 2 & 1191.6228 & 1191.6227 & 596.8186 & 0.0001 & 0.0838 & 301.160 & 291.144 & 222.510 & 293.031 & \text { Yes }\end{array}$ $\begin{array}{lllllllllllllll}1.00 & 54.23 & 24.55 & 19.18 & 3 & 1672.9750 & 1672.9725 & 558.6648 & 0.0025 & 1.4916 & 8938.332 & 6499.017 & 4843.690 & 10166.076 & \text { Yes }\end{array}$

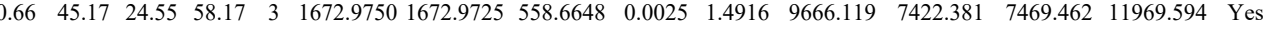

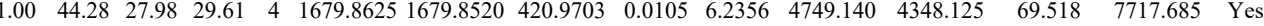
$\begin{array}{lllllllllllllll}1.00 & 36.70 & 28.03 & 24.93 & 4 & 1679.8633 & 1679.8520 & 420.9703 & 0.0113 & 6.7106 & 6002.598 & 4695.229 & 153.992 & 9384.476 & \text { Yes }\end{array}$ $\begin{array}{lllllllllllllll}0.57 & 20.80 & 27.99 & 19.37 & 3 & 1679.8642 & 1679.8520 & 560.9579 & 0.0122 & 7.2495 & 9028.796 & 7469.157 & 1746.824 & 12412.320 & \text { Yes }\end{array}$ $\begin{array}{lllllllllllllll}1.00 & 35.94 & 27.92 & 28.49 & 4 & 1679.8617 & 1679.8520 & 420.9703 & 0.0097 & 5.7605 & 5634.037 & 4361.473 & 0.000 & 9762.776 & \text { No }\end{array}$

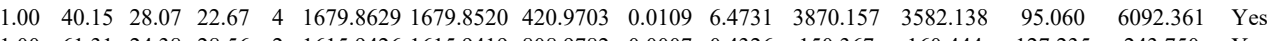

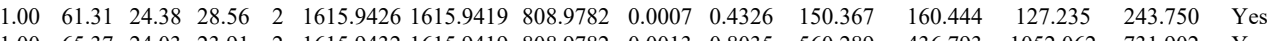

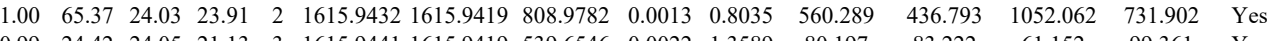

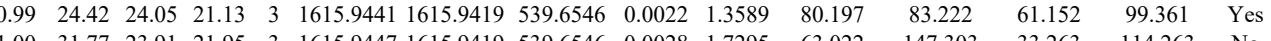

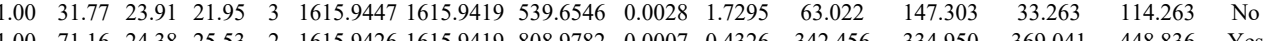
$\begin{array}{lllllllllllllll}1.00 & 11.16 & 24.38 & 25.53 & 2 & 1615.9426 & 1615.9419 & 808.9782 & 0.0007 & 0.4326 & 342.456 & 334.950 & 369.041 & 448.836 & \text { Yes } \\ 1.00 & 6.168 & 24.05 & 22.71 & 2 & 1615.9430 & 1615.9419 & 808.9782 & 0.0011 & 0.6799 & 303.095 & 328981 & 428.814 & 642.096 & \text { Yes }\end{array}$ $\begin{array}{lllllllllllllll}1.00 & 63.68 & 24.05 & 22.71 & 2 & 1615.9430 & 1615.9419 & 808.9782 & 0.0011 & 0.6799 & 303.095 & 328.981 & 428.814 & 642.096 & \text { Yes } \\ 1.00 & 52.76 & 23.91 & 21.11 & 3 & 1615.9447 & 1615.9419 & 539.6546 & 0.0028 & 1.7295 & 62.864 & 16.719 & 35.771 & 88.300 & \text { Yes }\end{array}$

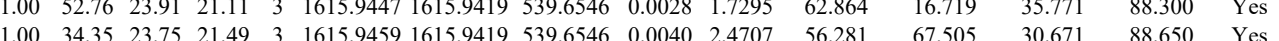

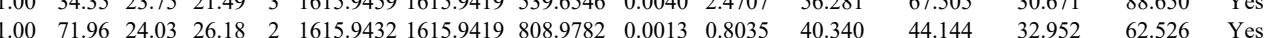

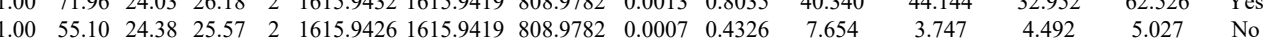

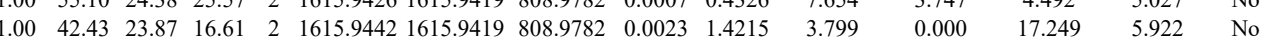

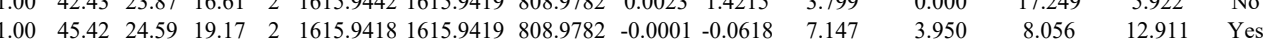

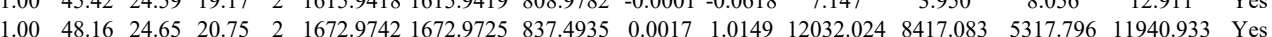
$\begin{array}{llllllllllllllll}1.00 & 48.16 & 24.65 & 20.75 & 2 & 1672.9742 & 1672.9725 & 837.4935 & 0.0017 & 1.0149 & 12032.024 & 8417.083 & 5317.796 & 11940.933 & \text { Yes } \\ 1.00 & 36.92 & 24.55 & 18.83 & 3 & 1672.9750 & 1672.9725 & 558.6648 & 0.0025 & 1.4916 & 19781.987 & 15565.059 & 15462.900 & 27688.960 & \text { Yes }\end{array}$ $\begin{array}{llllllllllllllll}0.60 & 30.99 & 24.49 & 43.99 & 3 & 1672.9765 & 1672.9725 & 558.6648 & 0.0040 & 2.3866 & 63618.908 & 53502.902 & 49187.422 & 87649.524 & \text { Yes }\end{array}$ $\begin{array}{llllllllllllllll}0.60 & 30.99 & 24.49 & 43.99 & 3 & 1672.9765 & 1672.9725 & 558.6648 & 0.0040 & 2.3866 & 63618.908 & 53502.902 & 49187.422 & 87649.524 & \text { Yes } \\ 1.00 & 44.64 & 24.52 & 20.53 & 2 & 1672.9766 & 1672.9725 & 837.4935 & 0.0041 & 2.4478 & 2595.012 & 2166.633 & 1505.268 & 3275.866 & \text { Yes }\end{array}$ $\begin{array}{lllllllllllllll}1.00 & 44.64 & 24.52 & 20.53 & 2 & 1672.9766 & 1672.9725 & 837.4935 & 0.0041 & 2.4478 & 2595.012 & 2166.633 & 1505.268 & 3275.866 & \text { Yes } \\ 1.00 & 54.75 & 28.14 & 21.10 & 2 & 1594.8114 & 1594.8122 & 798.4134 & -0.0008 & -0.5010 & 141.845 & 91.841 & 45.998 & 165.271 & \text { Yes }\end{array}$

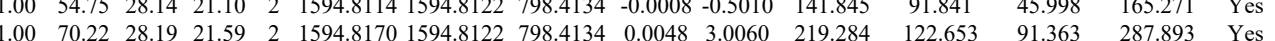
YFVGMLPEK HFVGMLPEK $\begin{array}{lllllllllllllll}0.99 & 40.02 & 26.80 & 22.33 & 2 & 1344.7572 & 1344.7468 & 673.3807 & 0.0104 & 7.7222 & 12379.387 & 8112.953 & 389.104 & 12921.032 & \text { Yes } \\ 0.99 & 41.41 & 27.00 & 23.74 & 2 & 1344.7584 & 1344.746 & 673.3807 & 0.0116 & 8.6132 & 1012.393 & 6699.363 & 0.000 & 12637.992 & \text { No }\end{array}$ $\begin{array}{llllllllllllllll}\text { KEELMFFLWAPELAPLK } & 0.67 & 28.32 & 22.41 & 41.32 & 3 & 2493.4105 & 2493.4071 & 832.1430 & 0.0034 & 1.3619 & 69.602 & 51.956 & 76.174 & 83.395 & \text { Yes }\end{array}$ $\begin{array}{lllllllllllllllll}\text { KEELMFFLWAPELAPLK } & 1.00 & 38.25 & 22.38 & 18.81 & 4 & 2493.4113 & 2493.4071 & 624.3591 & 0.0042 & 1.6817 & 174.582 & 95.974 & 57.769 & 79.390 & \text { No }\end{array}$ $\begin{array}{lllllllllllllllll}\text { KEELMFFLWAPELAPLK } & 1.00 & 55.60 & 22.23 & 24.01 & 4 & 2493.4137 & 2493.4071 & 624.3591 & 0.0066 & 2.6427 & 94.091 & 95.999 & 46.044 & 136.752 & \text { Yes }\end{array}$ $\begin{array}{lllllllllllllllll}\text { HECQANGPEDLNR } & 0.66 & 27.72 & 21.96 & 40.72 & 3 & 1671.7237 & 1671.7215 & 558.2478 & 0.0022 & 1.3136 & 4488.121 & 3829.489 & 4016.539 & 3866.787 & \text { Yes }\end{array}$ $\begin{array}{llllllllllllllll}\text { HECQANGPEDLNR } & 0.67 & 23.34 & 22.12 & 36.34 & 3 & 1671.7246 & 1671.7215 & 558.2478 & 0.0031 & 1.8510 & 7282.160 & 6654.934 & 12752.738 & 5376.226 & \text { No }\end{array}$

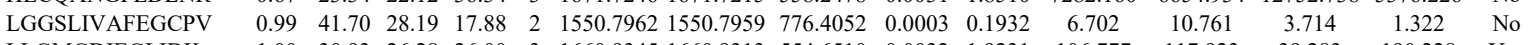

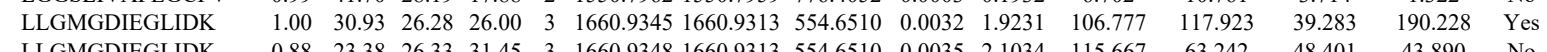
$\begin{array}{llllllllllllllll}\text { LLGMGDIEGLIDK } & 0.88 & 23.38 & 26.33 & 31.45 & 3 & 1660.9348 & 1660.9313 & 554.6510 & 0.0035 & 2.1034 & 115.667 & 63.242 & 48.401 & 43.890 & \text { No }\end{array}$ $\begin{array}{lllllllllllllll} & 1660.9356 & 1660.9313 & 831.4729 & 0.0043 & 2.5858 & 401.870 & 388.514 & 0.000 & 583.858 & \text { No }\end{array}$ $\begin{array}{llllllllllllllll}\text { LLGMGDIEGLIDK } & 1.00 & 79.55 & 26.18 & 37.66 & 2 & 1660.9366 & 1660.9313 & 831.4729 & 0.0053 & 3.1871 & 500.428 & 328.007 & 39.777 & 733.857 & \text { Yes }\end{array}$

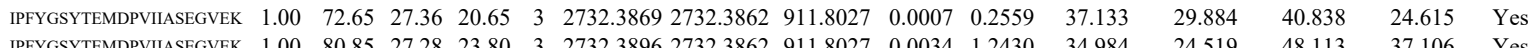

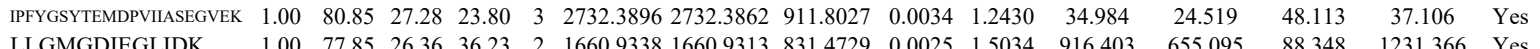

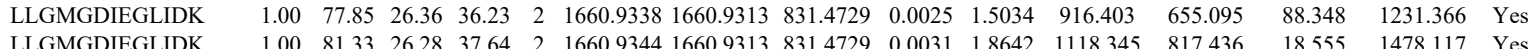
$\begin{array}{llllllllllllllll}\text { LLGMGDIEGLIDK } & 1.00 & 81.33 & 26.28 & 37.64 & 2 & 1660.9344 & 1660.9313 & 831.4729 & 0.0031 & 1.8642 & 1118.345 & 817.436 & 18.555 & 1478.117 & \text { Yes } \\ \text { TASNVEEAFINTAK } & 1.00 & 77.32 & 27.69 & 23.70 & 2 & 1781.9570 & 1781.9403 & 891.9774 & 0.0167 & 9.3611 & 1405.014 & 912.808 & 344.624 & 2320.441 & \text { Yes }\end{array}$

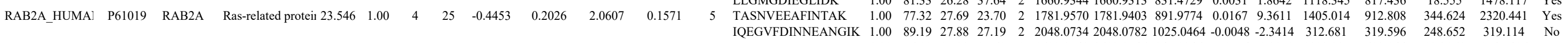

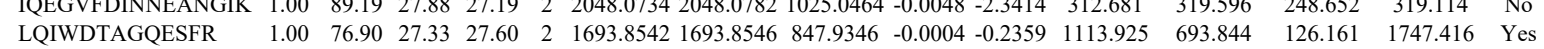
$\begin{array}{llllllllllllllll}\text { LQIWDTAGQESFR } & 1.00 & 68.04 & 27.27 & 26.03 & 2 & 1693.8574 & 1693.8546 & 847.9346 & 0.0028 & 1.6511 & 1936.093 & 1408.794 & 228.567 & 3436.511 & \text { Yes }\end{array}$ 

$\begin{array}{llllllllllll}1.00 & 59.97 & 27.78 & 24.13 & 2 & 1616.8210 & 1616.8186 & 809.4166 & 0.0024 & 1.4825 & 531.680 & 466.483\end{array}$

LVICPDEGFYK

FVFSFK

FVFSFK

FVFSFK

VGQGYPHDPPK $\begin{array}{llllllllllll}1.00 & 56.20 & 27.78 & 20.93 & 2 & 1616.8210 & 1616.8186 & 809.4166 & 0.0024 & 1.4825 & 344.123 & 254.51\end{array}$

GQGYPHDPPK

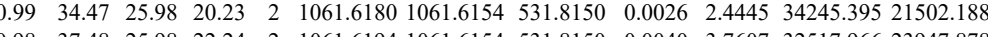

$\begin{array}{llllllllllllllll}0.98 & 37.48 & 25.98 & 22.24 & 2 & 1061.6194 & 1061.6154 & 531.8150 & 0.0040 & 3.7607 & 32517.966 & 23947.878 & 256.147 & 27499.322 & \text { Yss } \\ 0.99 & 37.65 & 25.98 & 19.66 & 2 & 1061.6186 & 1061.6154 & 531.8150 & 0.0032 & 3.0086 & 30420.180 & 19080.991 & 1124.362 & 22502.594 & \text { Yess }\end{array}$

GQGYPHDPPK

MAEPDPPDAVYANQYK

$0.02014779 .85012272 .2228875 .292 \quad 11354.700$ Yes

$\begin{array}{llllllllllllllll} & 0.97 & 25.54 & 28.06 & 22.47 & 3 & 1481.7877 & 1481.7871 & 494.9363 & 0.0006 & 0.4041 & 22090.576 & 19325.681 & 14400.991 & 18865.729 & \text { Yes }\end{array}$

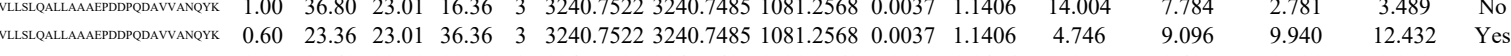

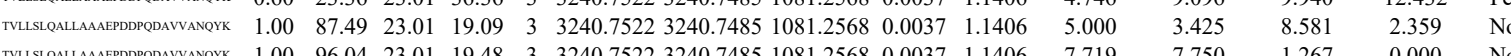

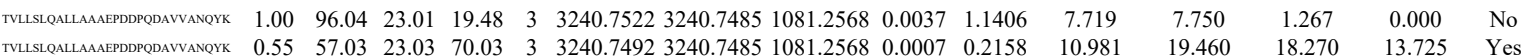

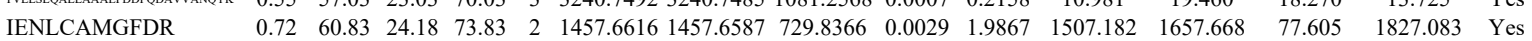
$\begin{array}{llllllllllllllll}\text { IENLCAMGFDR } & 1.00 & 60.95 & 24.42 & 18.60 & 2 & 1457.6638 & 1457.6587 & 729.8366 & 0.0051 & 3.4939 & 1797.599 & 1514.495 & 123.488 & 1669.065 & \text { Yes }\end{array}$ $\begin{array}{llllllllllllllll}\text { NAVIVALSSK } & 1.00 & 61.64 & 23.44 & 19.64 & 2 & 1288.8086 & 1288.7958 & 645.4052 & 0.0128 & 9.9162 & 5559.351 & 6093.497 & 1189.652 & 8868.705 & \text { Yes }\end{array}$ $\begin{array}{lllllllllllllllll}\text { GEIAGPPDTPYEGGR } & 1.00 & 82.33 & 26.88 & 32.91 & 2 & 1658.8032 & 1658.8022 & 830.4084 & 0.0010 & 0.6021 & 705.161 & 719.846 & 237.385 & 1029.351 & \text { Yes }\end{array}$ $\begin{array}{llllllllllllllll}\text { GEIAGPPDTPYEGGR } & 1.00 & 82.75 & 26.93 & 27.91 & 2 & 1658.8034 & 1658.8022 & 830.4084 & 0.0012 & 0.7225 & 594.847 & 559.094 & 206.774 & 488.122 & \text { Yes }\end{array}$ $\begin{array}{llllllllllllllll}\text { VDLVDENFTELR } & 1.00 & 80.18 & 28.16 & 23.66 & 2 & 1592.8178 & 1592.8168 & 797.4157 & 0.0010 & 0.6270 & 4375.262 & 4121.326 & 0.000 & 5453.255 & \text { No }\end{array}$

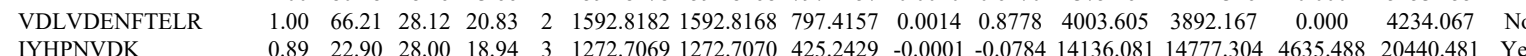

6 IYHPNVDK $\begin{array}{lllllllllllll}\text { LELFLPEEYPMAAPK } & 1.00 & 71.57 & 26.33 & 43.54 & 2 & 2035.0954 & 2035.0943 & 1018.5544 & 0.0011 & 0.5400 & 126.010 & 129.406\end{array}$

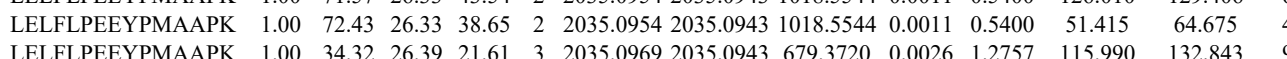
$\begin{array}{llllllllllllll}\text { LELFLPEEYPMAAPK } & 1.00 & 34.32 & 26.39 & 21.61 & 3 & 2035.0969 & 2035.0943 & 679.3720 & 0.0026 & 1.2757 & 115.990 & 132.843 & 9.86 \\ \text { LELFLPEEYPMAAPK } & 1.00 & 70.29 & 26.44 & 25.44 & 3 & 2035.0978 & 2035.0943 & 679.3720 & 0.0035 & 1.7173 & 124.817 & 168.403 & \end{array}$ $\begin{array}{llllllllllllll}\text { LELFLPEEYPMAAPK } & 1.00 & 70.29 & 26.44 & 25.44 & 3 & 2035.0978 & 2035.0943 & 679.3720 & 0.0035 & 1.7173 & 124.817 & 168.403 & 86.33 \\ \text { LELFLPEEYPMAAPK } & 1.00 & 71.18 & 26.33 & 41.54 & 2 & 2035.0954 & 2035.0943 & 1018.5544 & 0.0011 & 0.5400 & 641.429 & 635.561 & \end{array}$ $\begin{array}{llllllllllllll}\text { LELFLPEEYPMAAPK } & 1.00 & 71.18 & 26.33 & 41.54 & 2 & 2035.0954 & 2035.0943 & 1018.5544 & 0.0011 & 0.5400 & 641.429 & 635.561 & 191.8 \\ \text { LELFLPEEYPMAAPK } & 1.00 & 63.69 & 26.33 & 39.57 & 2 & 2035.0954 & 2035.0943 & 1018.5544 & 0.0011 & 0.5400 & 115.228 & 169.854\end{array}$ $\begin{array}{lllllllllllll}\text { LELFLPEEYPMAAPK } & 1.00 & 63.69 & 26.33 & 39.57 & 2 & 2035.0954 & 2035.0943 & 1018.5544 & 0.0011 & 0.5400 & 115.228 & 169.854 \\ \text { LELFLPEEYPMAAPK } & 1.00 & 52.22 & 26.41 & 20.86 & 3 & 2035.0972 & 2035.0943 & 679.3720 & 0.0029 & 1.4229 & 161.081 & 184.976\end{array}$ $\begin{array}{lllllllllllll}\text { LELFLPEEYPMAAPK } & 1.00 & 52.22 & 26.41 & 20.86 & 3 & 2035.0972 & 2035.0943 & 679.3720 & 0.0029 & 1.4229 & 161.081 & 184.976 \\ \text { LELFLPEEYPMAAPK } & 0.99 & 25.60 & 26.41 & 18.39 & 3 & 2035.0972 & 2035.0943 & 679.3720 & 0.0029 & 1.4229 & 101.395 & 74.291\end{array}$ $\begin{array}{lllllllllllll}\text { LELFLPEEYPMAAPK } & 0.99 & 25.60 & 26.41 & 18.39 & 3 & 2035.0972 & 2035.0943 & 679.3720 & 0.0029 & 1.4229 & 101.395 & 74.291 \\ \text { LELFLPEEYPMAAPK } & 1.00 & 65.08 & 26.33 & 37.40 & 2 & 2035.0954 & 2035.0943 & 1018.5544 & 0.0011 & 0.5400 & 276.590 & 277.670\end{array}$

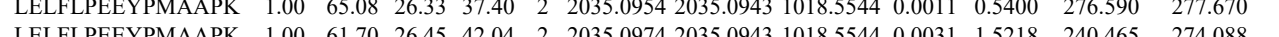
$\begin{array}{lllllllllllll}\text { LELFLPEEYPMAAPK } & 1.00 & 47.02 & 26.50 & 20.24 & 3 & 2035.0984 & 2035.0943 & 679.3720 & 0.0041 & 2.0117 & 223.456 & 89.190\end{array}$

$\begin{array}{lllllllllllll} & \\ \text { LLAEPVPGIK } & 1.00 & 48.00 & 18.92 & 23.64 & 2 & 1323.8490 & 1323.8369 & 662.9257 & 0.0121 & 9.1261 & 16468.175 & 17561.941\end{array}$

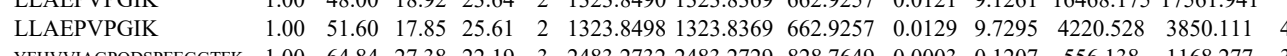
$\begin{array}{llllllllllllll}\text { YFHVVIAGPQDSPFEGGTFK } & 1.00 & 64.84 & 27.38 & 22.19 & 3 & 2483.2732 & 2483.2729 & 828.7649 & 0.0003 & 0.1207 & 556.138 & 1168.277 & 333.1 \\ \text { YFHVVIAGPQDSPFEGGTFK } & 1.00 & 63.75 & 27.35 & 21.48 & 3 & 2483.2753 & 2483.2729 & 828.7649 & 0.0024 & 0.9653 & 608.424 & 444.269 & \\ \text { ICLDILK } & 0.83 & 39.30 & 26.05 & 47.79 & 2 & 1150.6698 & 1150.6697 & 5763421 & 0.0001 & 0.0868 & 11746.470 & 13728.303 & 240.6\end{array}$ ICLDILK

ICLDILK

ICLDILK

ICLDILK

IYHPNVDK

TNEAQAIETAR $\begin{array}{lllllllllllllllll}0.67 & 74.50 & 26.25 & 87.50 & 3 & 2875.4887 & 2875.4857 & 959.5025 & 0.0030 & 1.0422 & 2038.329 & 2096.420 & 3105.383 & 3075.205 & \text { Yes }\end{array}$ $\begin{array}{llllllllllll} & \end{array}$

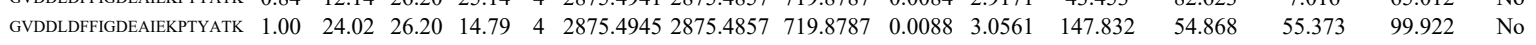

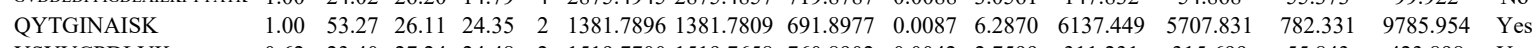

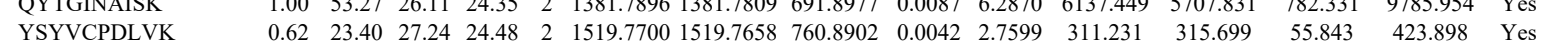

Table S-4 page 369 of 6 
$\begin{array}{lllllllllllll}\text { GVDDDFFIGDEAIEKPTYATK } & 1.00 & 21.17 & 26.24 & 15.75 & 4 & 2875.4896 & 2875.4857 & 959.5025 & 0.0039 & 1.3549 & 976.903 \\ & 0.9 & 1.95 & 24.28 & 24.67 & 2 & 1645.4857 & 719.8787 & 0.0076 & 2.6393 & 106.134\end{array}$

$\begin{array}{lllllllllllll}\text { DQLQTFSEEHPVLLTEAPLNPR } & 0.66 & 60.42 & 26.72 & 73.42 & 3 & 2677.3855 & 2677.3833 & 893.4684 & 0.0022 & 0.8208 & 315.828\end{array}$ $\begin{array}{llllllllllll}\text { DQLQTFSEEHPVLLTEAPLNPR } & 0.60 & 58.39 & 26.66 & 71.39 & 3 & 2677.3870 & 2677.3833 & 893.4684 & 0.0037 & 1.3804 & 441.761 \\ \text { DOLOTFSEHPVLLTEAPLNPR } & 1.00 & 57.91 & 26.84 & 23.57 & 3 & 2677.3849 & 2677.3833 & 893.4684 & 0.0016 & 0.5969 & 476.320\end{array}$ $\begin{array}{lllllllllllll}\text { DQLQTFSEEHPVLLTEAPLNPR } & 1.00 & 57.91 & 26.84 & 23.57 & 3 & 2677.3849 & 2677.3833 & 893.4684 & 0.0016 & 0.5969 & 476.320 \\ \text { DQLOTFSEFHPVLLTEAPLNPR } & 0.66 & 60.42 & 26.84 & 73.42 & 3 & 2677.3849 & 2677.3833 & 893.4684 & 0.0016 & 0.5969 & 216.593\end{array}$ $\begin{array}{llllllllllll}\text { DQLQTFSEEHPVLLTEAPLNPR } & 0.66 & 60.42 & 26.84 & 73.42 & 3 & 2677.3849 & 2677.3833 & 893.4684 & 0.0016 & 0.5969 & 216.593 \\ \text { AQYYLPDGSTIEIGPSR } & 1.00 & 73.78 & 27.25 & 17.98 & 2 & 2010.0174 & 2010.0180 & 1006.0163 & -0.0006 & -0.2982 & 724.569\end{array}$ $\begin{array}{lllllllllllll}\text { AQYYLPDGSTIEIGPSR } & 1.00 & 73.78 & 27.25 & 17.98 & 2 & 2010.0174 & 2010.0180 & 1006.0163 & -0.0006 & -0.2982 & 724.569 \\ \text { AQYYLPDGSTIEIGPSR } & 1.00 & 70.10 & 27.40 & 19.32 & 2 & 2010.0194 & 2010.0180 & 1006.0163 & 0.0014 & 0.6958 & 426.787\end{array}$

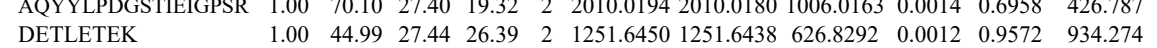
DETLETEK

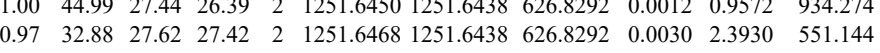

$\begin{array}{llllllllllllll}\text { TLFSNIVLSGGSTLFK } & 1.00 & 32.36 & 23.56 & 15.14 & 3 & 1971.1330 & 1971.1285 & 658.0501 & 0.0045 & 2.2795 & 16.608\end{array}$ $\begin{array}{llllllllllllll}\text { TLFSNIVLSGGSTLFK } & 1.00 & 41.14 & 23.50 & 16.33 & 3 & 1971.1315 & 1971.1285 & 658.0501 & 0.0030 & 1.5196 & 8.710\end{array}$ $\begin{array}{llllllllllllll}\text { TLFSNIVLSGGSTLFK } & 0.95 & 18.26 & 23.34 & 17.02 & 3 & 1971.1321 & 1971.1285 & 658.0501 & 0.0036 & 1.8236 & 12.288\end{array}$ $\begin{array}{lllllllllllll}\text { TLFSNIVLSGGSTLFK } & 0.67 & 42.73 & 23.40 & 55.73 & 3 & 1971.1312 & 1971.1285 & 658.0501 & 0.0027 & 1.3677 & 14.311\end{array}$ $\begin{array}{llllllllllllll}\text { TLFSNIVLSGGSTLFK } & 0.60 & 46.56 & 23.34 & 59.56 & 3 & 1971.1321 & 1971.1285 & 658.0501 & 0.0036 & 1.8236 & 12.111\end{array}$ $\begin{array}{lllllllllllll}\text { TLFSNIVLSGGSTLFK } & 1.00 & 42.34 & 23.34 & 17.66 & 3 & 1971.1321 & 1971.1285 & 658.0501 & 0.0036 & 1.8236 & 4.700\end{array}$ $\begin{array}{llllllllllllll} & \text { TLFSNIVLSGGSTLFK } & 0.99 & 27.82 & 23.28 & 16.85 & 3 & 1971.1297 & 1971.1285 & 658.0501 & 0.0012 & 0.6079 & -16.989\end{array}$ $\begin{array}{lllllllllll} & \end{array}$ $\begin{array}{lllllllllll}1.00 & 36.17 & 27.23 & 21.30 & 3 & 3156.5572 & 3156.5528 & 1053.1915 & 0.0044 & 1.3926 & 0.000\end{array}$ $\begin{array}{llllllllllll} & \end{array}$

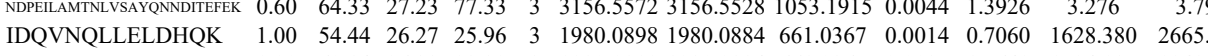



$\begin{array}{lllllllllllllllllll} & & 53.67 & 27.38 & 40.38 & 2 & 1119.5692 & 1119.5716 & 560.7931 & -0.0024 & -2.1398 & 3158.941 & 2971.795 & 438.398 & 5405.725 & \text { Yes } \\ \end{array}$ $\begin{array}{llllllllllllll} & \end{array}$ $\begin{array}{llllllllllllll} & \end{array}$ $\begin{array}{llllllllllllllll}\text { TQAIVCQQLDLTHLK } & 1.00 & 81.62 & 26.80 & 25.78 & 3 & 2044.1092 & 2044.1053 & 682.3757 & 0.0039 & 1.9051 & 6377.528 & 6997.494 & 2284.521 & 6810.069 & \text { Yes }\end{array}$ $\begin{array}{llllllllllllllll}\text { TQAIVCQQLDLTHLK } & 1.00 & 79.42 & 27.02 & 19.09 & 3 & 2044.1062 & 2044.1053 & 682.3757 & 0.0009 & 0.4396 & 2771.288 & 3545.374 & 814.108 & 3883.802 & \text { Yes }\end{array}$ $\begin{array}{llllllllllllllllll}\text { TQAIVCQQLDLTHLK } & 1.00 & 69.81 & 26.71 & 19.45 & 3 & 2044.1086 & 2044.1053 & 682.3757 & 0.0033 & 1.6120 & 3886.899 & 4491.726 & 999.079 & 5360.434 & \text { Yes }\end{array}$ $\begin{array}{lllllllllllllllll}\text { TQAIVCQQLDLTHLK } & 1.00 & 72.14 & 27.02 & 17.73 & 3 & 2044.1068 & 2044.1053 & 682.3757 & 0.0015 & 0.7327 & 1161.491 & 1244.714 & 460.895 & 1483.852 & \text { Yes }\end{array}$ $\begin{array}{llllllllllllllll}\text { CPFGALSIVNLPSNLEK } & 1.00 & 40.07 & 27.80 & 20.60 & 3 & 2135.1388 & 2135.1362 & 712.7193 & 0.0026 & 1.2160 & 27.716 & 74.764 & 8.270 & 80.101 & \text { Yes }\end{array}$

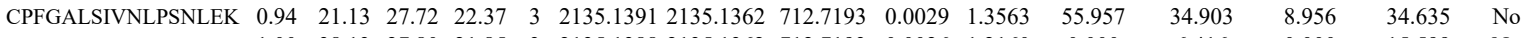

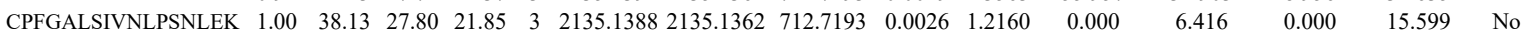
$\begin{array}{llllllllllllllll}\text { FLSQLEITFR } & 1.00 & 62.96 & 26.30 & 26.47 & 2 & 1396.7850 & 1396.7836 & 699.3991 & 0.0014 & 1.0009 & 6698.793 & 7505.488 & 266.819 & 10385.588 & \text { Yes }\end{array}$ $\begin{array}{lllllllllllllllll}\text { FLSQLEITFR } & 1.00 & 62.95 & 26.56 & 30.83 & 2 & 1396.7858 & 1396.7836 & 699.3991 & 0.0022 & 1.5728 & 6852.778 & 6748.969 & 274.063 & 11534.024 & \text { Yes }\end{array}$ $\begin{array}{llllllllllllllll}\text { FLSQLEITFR } & 1.00 & 65.72 & 26.51 & 34.73 & 2 & 1396.7836 & 1396.7836 & 699.3991 & 0.0000 & 0.0000 & 3835.614 & 4113.637 & 94.190 & 5973.818 & \text { Yes }\end{array}$ $\begin{array}{llllllllllllllll}\text { VAETANEEEVKK } & 1.00 & 41.45 & 26.79 & 15.76 & 3 & 1777.9822 & 1777.9787 & 593.6668 & 0.0035 & 1.9652 & 6961.835 & 8896.138 & 4986.164 & 10287.550 & \text { Yes }\end{array}$ $\begin{array}{llllllllllllllll}\text { VAETANEEEVKK } & 1.00 & 47.45 & 26.84 & 18.11 & 3 & 1777.9828 & 1777.9787 & 593.6668 & 0.0041 & 2.3021 & 6819.757 & 7583.205 & 4128.155 & 9547.152 & \text { Yes }\end{array}$ ILEDDLK

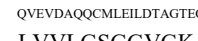
LVVLGSGGVGK INVNEIFYDLVR INVNEIFYDLVR INVNEIFYDLVR INVNETHELR INVIFIFLVR

SALTVQFVQGIFVEK $\begin{array}{llllllllllllllllll}0.50 & 39.65 & 27.74 & 51.53 & 2 & 1132.6670 & 1132.6583 & 567.3364 & 0.0087 & 7.6673 & 2449.377 & 2332.683 & 354.163 & 2640.577 & \text { Yes }\end{array}$

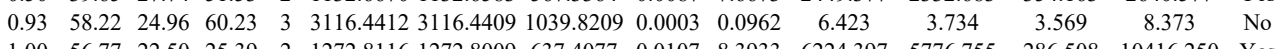
$\begin{array}{lllllllllllllll}1.00 & 56.77 & 22.50 & 25.39 & 2 & 1272.8116 & 1272.8009 & 637.4077 & 0.0107 & 8.3933 & 6224.397 & 5776.755 & 286.508 & 10416.250 & \text { Yes }\end{array}$ $\begin{array}{lllllllllllllll}1.00 & 57.26 & 22.43 & 26.58 & 2 & 1272.8124 & 1272.8009 & 637.4077 & 0.0115 & 9.0208 & 4126.015 & 3963.363 & 215.689 & 6513.992 & \text { Yes } \\ 1.00 & 83.72 & 27.74 & 24.32 & 2 & 1637.8926 & 1637.8899 & 819.9522 & 0.0127 & 1.6464 & 13619.017 & 12083.044 & 0.000 & 2130595 & \text { No }\end{array}$ $\begin{array}{lllllllllllllll}1.00 & 83.72 & 27.84 & 24.32 & 2 & 1637.8926 & 1637.8899 & 819.9522 & 0.0027 & 1.6464 & 13619.017 & 12083.004 & 0.000 & 21306.595 & \text { No }\end{array}$ $\begin{array}{lllllllllllllll}1.00 & 84.04 & 27.87 & 28.44 & 2 & 1637.8932 & 1637.8899 & 819.9522 & 0.0033 & 2.0123 & 12630.626 & 11926.388 & 216.163 & 17727.684 & \text { Yes } \\ 1.00 & 81.49 & 27.75 & 28.02 & 2 & 1637.8916 & 1637.8899 & 819.9522 & 0.0017 & 1.0366 & 9765.309 & 7101.302 & 22.570 & 14735.126 & \text { Yes }\end{array}$

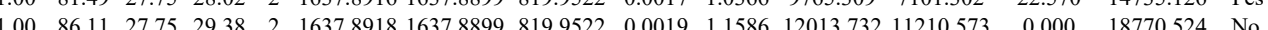
$\begin{array}{llllllllllllllll} & \end{array}$

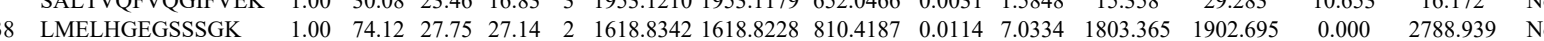
$\begin{array}{llllllllllllllll}\text { LMELHGEGSSSGK } & 1.00 & 59.33 & 27.77 & 20.53 & 3 & 1618.8376 & 16188228 & 540.6149 & 0.0148 & 9.1253 & 18843.616 & 21853625 & 2361.149 & 33837988 & \text { Y }\end{array}$ $\begin{array}{llllllllllllllll}\text { LMELHGEGSSSGK } & 1.00 & 53.25 & 27.77 & 19.62 & 3 & 1618.8376 & 1618.8228 & 540.6149 & 0.0148 & 9.1253 & 12938.508 & 14693.538 & 4485.616 & 23049.794 & \text { Yes }\end{array}$ $\begin{array}{llllllllllllllll}\text { VFEVSLADLQNDEVAFR } & 1.00 & 86.58 & 28.01 & 24.48 & 2 & 2095.0734 & 2095.0708 & 1048.5427 & 0.0026 & 1.2398 & 13.638 & 9.401 & 8.773 & 8.058 & \text { No }\end{array}$

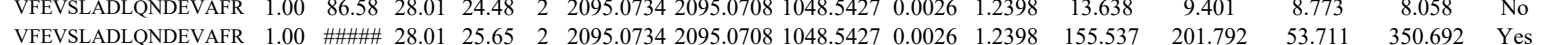

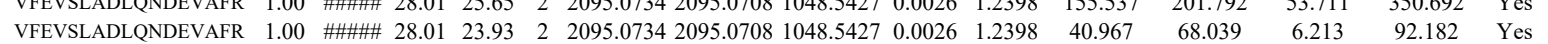

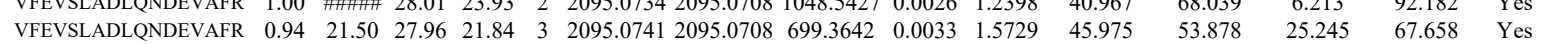

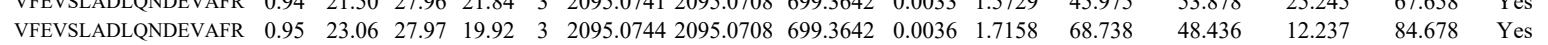
$\begin{array}{llllllllllllllllll}\text { TSYAQHQQVR } & 0.82 & 20.57 & 27.84 & 16.69 & 3 & 1360.6975 & 1360.6969 & 454.5729 & 0.0006 & 0.4400 & 25.374 & 29.881 & 25.090 & 45.970 & \text { Yes }\end{array}$ $\begin{array}{lllllllllllllll}\text { VFEVSLADLQNDEVAFR } & 1.00 & \text { \#\#\#\# } 28.01 & 21.61 & 2 & 2095.0734 & 2095.0708 & 1048.5427 & 0.0026 & 1.2398 & 148.273 & 214.131 & 31.097 & 288.898 & \text { Yes }\end{array}$ $\begin{array}{llllllllllllllll}\text { VFEVSLADLQNDEVAFR } & 1.00 & \text { \#\#\#\# } 28.01 & 21.83 & 2 & 2095.0734 & 2095.0708 & 1048.5427 & 0.0026 & 1.2398 & 90.045 & 86.338 & 8.739 & 180.562 & \text { Yes }\end{array}$ $\begin{array}{lllllllllllllllll}\text { VFEVSLADLQNDEVAFR } & 0.98 & 26.87 & 27.97 & 16.32 & 3 & 2095.0744 & 2095.0708 & 699.3642 & 0.0036 & 1.7158 & 135.689 & 232.183 & 103.651 & 255.489 & \text { Yes }\end{array}$ $\begin{array}{llllllllllllllllll}\text { VFEVSLADLQNDEVAFR } & 0.64 & 20.18 & 27.98 & 15.24 & 3 & 2095.0777 & 2095.0708 & 699.3642 & 0.0069 & 3.2887 & 127.025 & 143.814 & 30.378 & 180.221 & \text { Yes }\end{array}$ $\begin{array}{llllllllllllllll}\text { TSYAQHQQVR } & 0.95 & 25.91 & 27.81 & 15.51 & 3 & 1360.6969 & 1360.6969 & 454.5729 & 0.0000 & 0.0000 & 33.126 & 37.985 & 13.434 & 31.254 & \text { No }\end{array}$

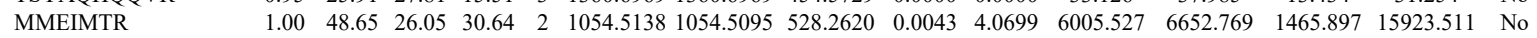
MMEIMTR

ACQSIYPLHDVFVR ACQSIYPLHDVFVR ACQSIYPLHDVFVR ACQSIYPLHDVFVR ACQSIYPLHDVFVR ACQSTYPLHDVFVR ACQSIYPLHDVFVR ACQSTYPLTDR ACQSIYPLHDVFVR $\begin{array}{llllllllllllllll}0.66 & 22.74 & 25.92 & 24.88 & 2 & 1054.5194 & 1054.5095 & 528.2620 & 0.0099 & 9.3703 & 1357.392 & 1613.708 & 266.175 & 2916.384 & \text { Yes }\end{array}$

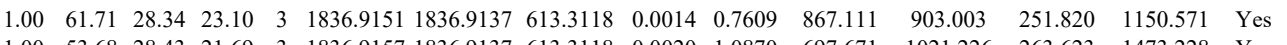

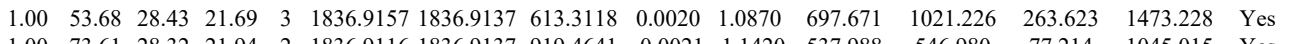

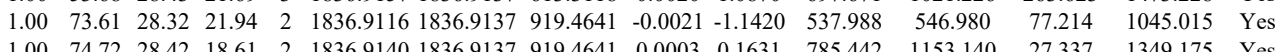
$\begin{array}{lllllllllllllll}1.00 & 74.72 & 28.42 & 18.61 & 2 & 1836.9140 & 1836.9137 & 919.4641 & 0.0003 & 0.1631 & 785.442 & 1153.140 & 27.337 & 1349.175 & \text { Yes } \\ 0.99 & 29.98 & 2.13 & 17.49 & 3 & 1836.9172 & 1836.9137 & 613.3118 & 0.0035 & 1.9022 & 87.313 & 108.494 & 44.14 & 167.167 & \text { Yes }\end{array}$

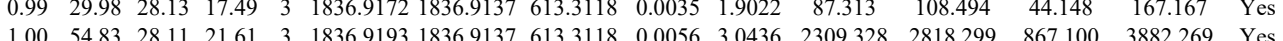
$\begin{array}{lllllllllllllll}1.00 & 54.83 & 28.11 & 21.61 & 3 & 1836.9193 & 1836.9137 & 613.3118 & 0.0056 & 3.0436 & 2309.328 & 2818.299 & 867.100 & 3882.269 & \text { Yes } \\ 0.67 & 51.55 & 28.12 & 64.55 & 3 & 1836.9169 & 1836.9137 & 613.3118 & 0.0032 & 1.7392 & 5157.640 & 5088.022 & 990.084 & 8293.667 & \text { Yes }\end{array}$ $\begin{array}{lllllllllllllll}0.67 & 51.55 & 28.12 & 64.55 & 3 & 1836.9169 & 1836.9137 & 613.3118 & 0.0032 & 1.7392 & 5157.640 & 5088.022 & 990.084 & 8293.667 & \text { Yes } \\ 1.00 & 53.09 & 28.11 & 16.69 & 3 & 1836.9193 & 1836.9137 & 613.3118 & 0.0056 & 3.0436 & 2466.617 & 3426.821 & 563.221 & 3919.272 & \text { Yes }\end{array}$

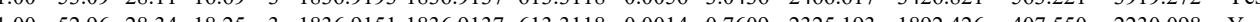
$\begin{array}{lllllllllllllll}0.66 & 50.20 & 28.43 & 63.20 & 3 & 1836.9157 & 1836.9137 & 613.3118 & 0.0020 & 1.0870 & 1744.383 & 2014.203 & 450.542 & 2510.811 & \text { Yes }\end{array}$ 

$\begin{array}{lllllllllllllllll}0.99 & 4.19 & 28.81 & 21.65 & 2 & 1247.6680 & 1247.6650 & 624.8398 & 0.0030 & 2.4006 & 8774.717 & 9444.712 & 1003.000 & 11501.411 & \text { Yes }\end{array}$

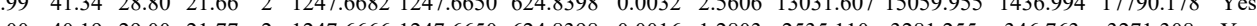

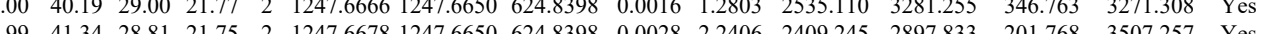

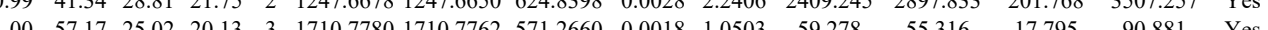

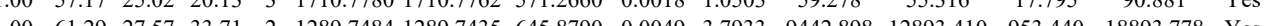

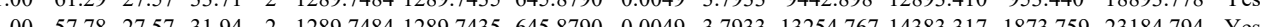

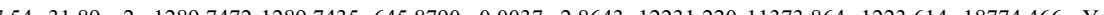

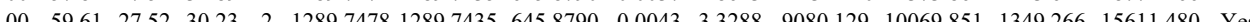

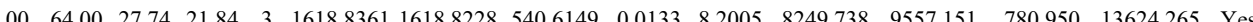
$\begin{array}{lllllllllllllll}1.00 & 74.24 & 27.74 & 27.37 & 2 & 1618.8362 & 1618.8228 & 810.4187 & 0.0134 & 8.2673 & 7703.536 & 9090.358 & 134.033 & 11885.386 & \text { Yes }\end{array}$ $\begin{array}{lllllllllllllll}100 & 65.79 & 27.72 & 31.06 & 2 & 1618.8368 & 1618.8228 & 810.4187 & 0.0140 & 8.6374 & 3214.612 & 3239.037 & 0.000 & 5802.203 & \text { No }\end{array}$ $\begin{array}{lllllllllllllll}1.00 & 54.74 & 27.72 & 23.20 & 3 & 1618.8370 & 1618.8228 & 540.6149 & 0.0142 & 8.7554 & 15411.595 & 16730.535 & 502.559 & 31027.797 & \text { Yes }\end{array}$ $\begin{array}{lllllllllllllll}1.00 & 50.85 & 27.72 & 19.32 & 3 & 1618.8370 & 1618.8228 & 540.6149 & 0.0142 & 8.7554 & 8031.671 & 8469.714 & 3662.225 & 12874.837 & \text { Yes }\end{array}$ $\begin{array}{lllllllllllllll}1.00 & 63.56 & 27.77 & 20.44 & 3 & 1618.8376 & 1618.8228 & 540.6149 & 0.0148 & 9.1253 & 9193.704 & 10189.130 & 3390.922 & 14183.938 & \text { Yes }\end{array}$ $\begin{array}{llllllllllllllll}1.00 & 55.06 & 27.55 & 31.58 & 2 & 1102.5742 & 1102.5741 & 552.2943 & 0.0001 & 0.0905 & 225.353 & 281.013 & 726.129 & 273.625 & \text { No }\end{array}$ $\begin{array}{llllllllllllllll}0.99 & 34.58 & 27.51 & 28.01 & 2 & 1102.5748 & 1102.5741 & 552.2943 & 0.0007 & 0.6337 & 186.913 & 200.002 & 366.780 & 211.040 & \text { Yes }\end{array}$

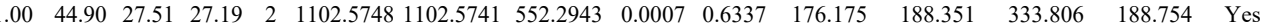
$\begin{array}{llllllllllllll} & & \end{array}$

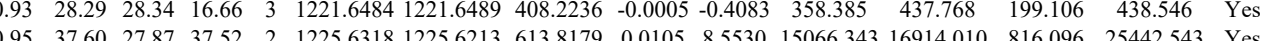
$\begin{array}{lllllllllllllll}0.95 & 37.60 & 27.87 & 37.52 & 2 & 1225.6318 & 1225.6213 & 613.8179 & 0.0105 & 8.5530 & 15066.343 & 16914.010 & 816.096 & 25442.543 & \text { Yes } \\ 0.99 & 41.44 & 27.68 & 34.67 & 2 & 1225.6326 & 1225.6213 & 613.8179 & 0.0113 & 92046 & 13186.822 & 16358.700 & 1616.019 & 25136.389 & \text { Yes }\end{array}$

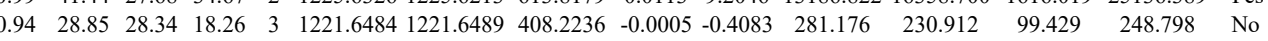

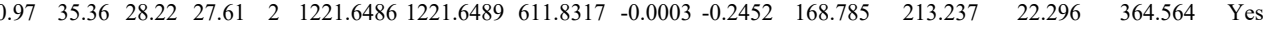

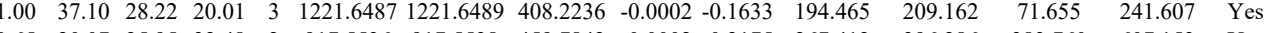
$\begin{array}{lllllllllllllll}0.65 & 20.07 & 25.95 & 32.48 & 2 & 917.5536 & 917.5538 & 459.7842 & -0.0002 & -0.2175 & 267.412 & 396.286 & 383.760 & 607.153 & \text { Yes }\end{array}$

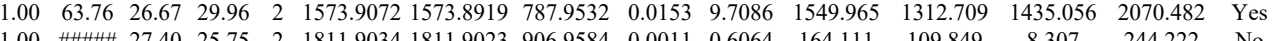

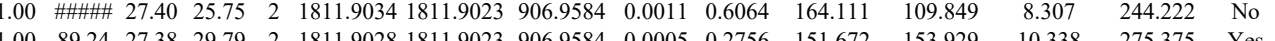

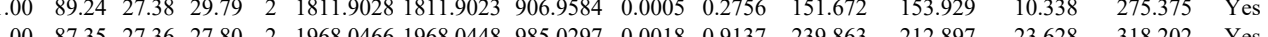

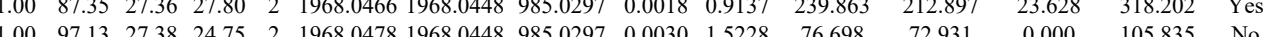
$\begin{array}{lllllllllllllll}1.00 & 37.89 & 27.38 & 24.75 & 2 & 1968.0478 & 1968.0448 & 985.0297 & 0.0030 & 1.5228 & 76.698 & 72.931 & 0.000 & 105.835 & \text { No }\end{array}$ \begin{tabular}{lllllllllllllll}
1.00 & 37.94 & 27.23 & 20.06 & 3 & 1968.0496 & 1968.0448 & 657.0222 & 0.0048 & 2.4352 & 119.084 & 170.534 & 67.356 & 276.821 & Yes \\
\hline
\end{tabular}

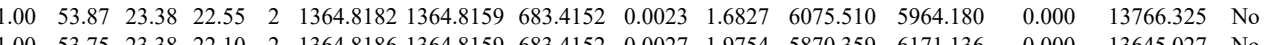
$\begin{array}{lllllllllllllll}1.00 & 32.79 & 27.38 & 18.17 & 3 & 1968.0481 & 1968.0448 & 657.022 & 0.0033 & 1.6742 & 149.051 & 126.318 & 34.718 & 155.375 & N o\end{array}$ $\begin{array}{lllllllllllllll}1.00 & 32.83 & 27.28 & 21.42 & 3 & 1968.0484 & 1968.0448 & 657.0222 & 0.0036 & 1.8264 & 117.491 & 99.980 & 27.539 & 185.700 & \text { Yes }\end{array}$ $\begin{array}{lllllllllllllll}1.00 & 56.11 & 23.44 & 23.58 & 2 & 1364.8164 & 1364.8159 & 683.4152 & 0.0005 & 0.3658 & 4677.538 & 4928.630 & 0.000 & 10271.000 & \text { No } \\ 1.00 & 56.18 & 23.10 & 21.98 & 2 & 1364.876 & 1364.85 & 63.452 & 0.037 & 2.7070 & 3513.111 & 466.450 & 0.000 & 9098.620 & \text { No }\end{array}$

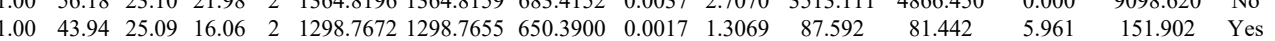
$\begin{array}{lllllllllllllll}1.00 & 48.67 & 26.97 & 27.00 & 2 & 1314.7616 & 13147604 & 658.3875 & 0.0012 & 0.9113 & 242.583 & 240.609 & 35.059 & 524.107 & \text { Yes }\end{array}$

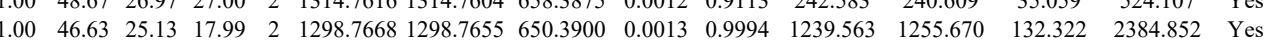
$\begin{array}{llllllllllllllll}1.00 & 47.36 & 25.09 & 17.79 & 2 & 1298.7674 & 1298.7655 & 650.3900 & 0.0019 & 1.4607 & 1958.946 & 2248.010 & 144.548 & 4729.387 & \text { Yes }\end{array}$ $\begin{array}{lllllllllllllll}1.00 & 60.03 & 26.97 & 27.37 & 2 & 1314.7616 & 1314.7604 & 658.3875 & 0.0012 & 0.9113 & 401.299 & 426.031 & 108.591 & 829.745 & \text { Yes }\end{array}$

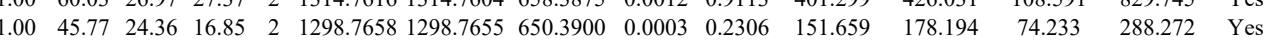
$\begin{array}{lllllllllllllll}1.00 & 46.19 & 24.36 & 19.33 & 2 & 1298.7660 & 1298.7655 & 650.3900 & 0.0005 & 0.3844 & 181.537 & 208.356 & 85.239 & 420.259 & \text { Yes }\end{array}$ $\begin{array}{lllllllllllllll}1.00 & 43.31 & 25.13 & 17.11 & 2 & 1298.7666 & 1298.7655 & 650.3900 & 0.0011 & 0.8456 & 79.699 & 99.286 & 39.525 & 130.956 & \text { Yes }\end{array}$ $\begin{array}{lllllllllllllll}1.00 & 36.40 & 25.13 & 17.68 & 2 & 1298.7666 & 1298.7655 & 650.3900 & 0.0011 & 0.8456 & 73.116 & 96.814 & 0.000 & 185.614 & \text { No }\end{array}$

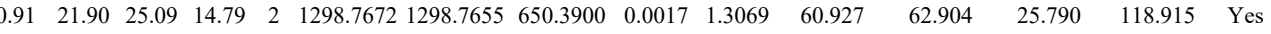

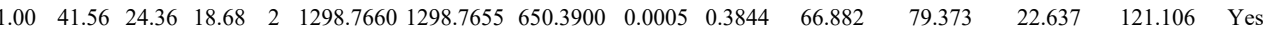

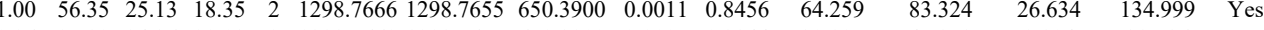

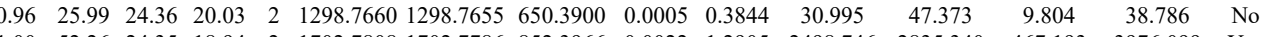

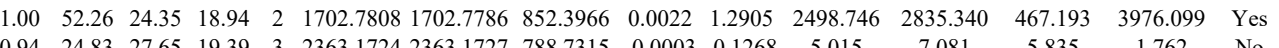

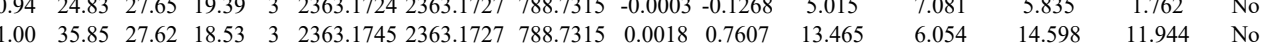

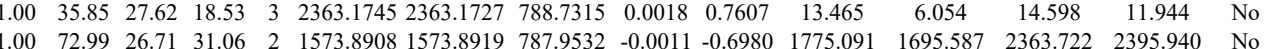

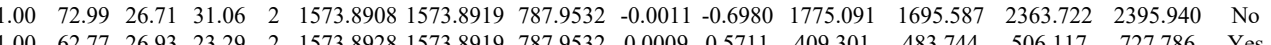
$\begin{array}{lllllllllllllll}1.00 & 48.17 & 28.20 & 19.23 & 2 & 1947.9860 & 1947.9822 & 974.9984 & 0.0038 & 1.9487 & 1362.895 & 1920.918 & 149.039 & 2897.779 & \text { Yes }\end{array}$ $\begin{array}{llllllllllllllll}0.90 & 25.12 & 28.46 & 34.55 & 2 & 804.4582 & 804.4575 & 403.2360 & 0.0007 & 0.8680 & 40.166 & 74.721 & 91.391 & 72.108 & \text { No }\end{array}$ $\begin{array}{llllllllllllllll}1.00 & 24.57 & 21.67 & 37.57 & 4 & 2137.2189 & 2137.2122 & 535.3103 & 0.0067 & 3.1290 & 16775.042 & 20888.122 & 11307.617 & 22960.632 & \text { Yes }\end{array}$

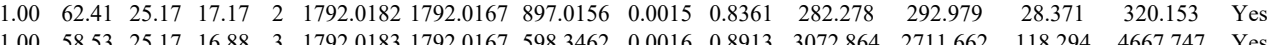

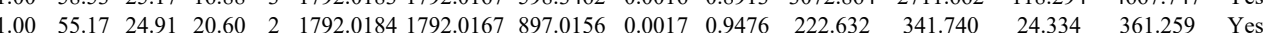

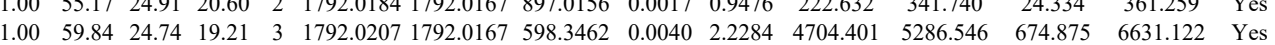


YIQELWR

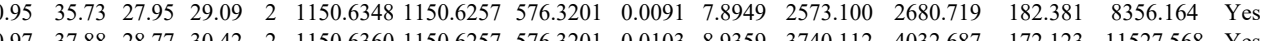

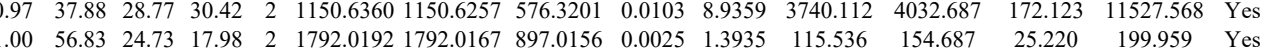
$\begin{array}{llllllllllllllll}1.00 & 55.58 & 24.71 & 16.57 & 3 & 1792.0198 & 1792.0167 & 598.3462 & 0.0031 & 1.7270 & 3341.541 & 3077.125 & 150.945 & 3895.496 & \text { Yes }\end{array}$

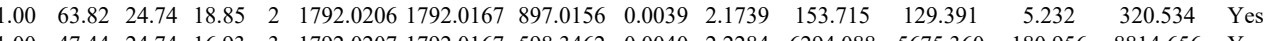
$\begin{array}{lllllllllllllll}1.00 & 47.44 & 24.74 & 16.93 & 3 & 1792.0207 & 1792.0167 & 598.3462 & 0.0040 & 2.2284 & 6294.088 & 5675.360 & 180.956 & 8814.656 & \text { Yes }\end{array}$ $\begin{array}{lllllllllllllll}0.98 & 35.71 & 27.82 & 21.06 & 2 & 1150.6254 & 1150.6257 & 576.3201 & -0.0003 & -0.2603 & 2015.046 & 2394.532 & 341.421 & 7305.025 & \text { Yes }\end{array}$ $\begin{array}{lllllllllllllll}0.98 & 36.47 & 28.01 & 22.27 & 2 & 1150.6260 & 1150.6257 & 576.3201 & 0.0003 & 0.2603 & 2040.308 & 2149.118 & 107.611 & 6730.539 & \text { Yes }\end{array}$

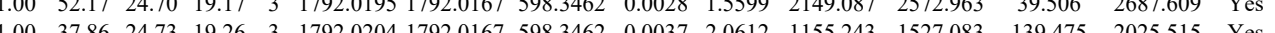

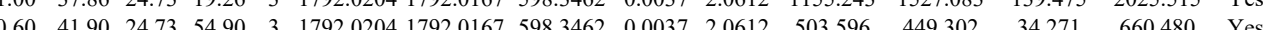

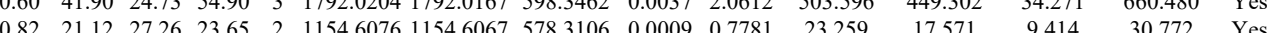

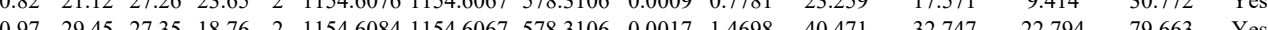

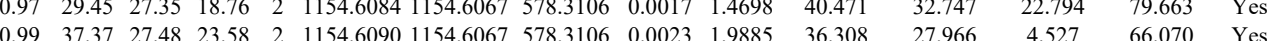

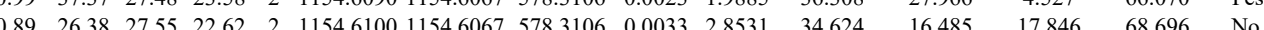

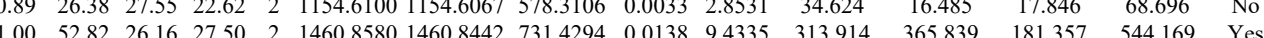

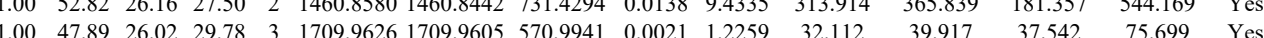

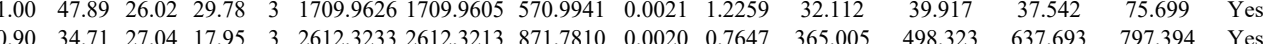
$\begin{array}{llllllllllllllll}0.99 & 43.37 & 27.11 & 18.83 & 3 & 2612.3239 & 2612.3213 & 871.7810 & 0.0026 & 0.9941 & 551.608 & 689.569 & 625.372 & 956.231 & \text { Yes }\end{array}$ \begin{tabular}{lllllllllllllll}
0.87 & 33.28 & 27.04 & 23.96 & 3 & 2612.3233 & 2612.3213 & 871.7810 & 0.0020 & 0.7647 & 152.140 & 241.726 & 229.937 & 297.261 & Yes \\
\hline .98 & 42.60 & 27.06 & 22.86 & 3 & 2612.3236 & 2612.3213 & 871.7810 & 0.0023 & 0.8794 & 178.655 & 116.715 & 224.210 & 294.052 & Yes
\end{tabular} $\begin{array}{llllllllllllllll}1.00 & 46.25 & 26.56 & 18.94 & 2 & 1336.7612 & 1336.7482 & 669.3814 & 0.0130 & 9.7104 & 3807.529 & 3981.155 & 2277.511 & 6705.650 & \text { Yes }\end{array}$ $\begin{array}{lllllllllllllll}1.00 & 50.36 & 27.44 & 30.98 & 2 & 1336.7500 & 1336.7482 & 669.3814 & 0.0018 & 1.3445 & 2259.454 & 2373.506 & 636.469 & 3303.349 & \text { Yes }\end{array}$ $\begin{array}{llllllllllllllll}1.00 & 47.04 & 27.03 & 25.67 & 2 & 1336.7522 & 1336.7482 & 669.3814 & 0.0040 & 2.9878 & 2079.453 & 2580.238 & 293.565 & 3975.762 & \text { Yes }\end{array}$ $\begin{array}{lllllllllllllll}1.00 & 41.56 & 27.44 & 24.10 & 2 & 1336.7500 & 1336.7482 & 669.3814 & 0.0018 & 1.3445 & 1904.671 & 1609.709 & 271.070 & 2380.589 & \text { No } \\ 1.00 & 46.95 & 27.43 & 25.54 & 2 & 1336.7502 & 1336.7482 & 669.3814 & 0.0020 & 1.4939 & 6771.482 & 7763.065 & 938.413 & 13384.762 & \text { Yes }\end{array}$ $\begin{array}{lllllllllllllll}1.00 & 46.95 & 27.43 & 25.54 & 2 & 1336.7502 & 1336.7482 & 669.3814 & 0.0020 & 1.4939 & 6771.482 & 7763.065 & 938.413 & 13384.762 & \text { Yes } \\ 0.79 & 31.40 & 26.22 & 21.03 & 2 & 964.5604 & 964.5619 & 483.2882 & -0.0015 & 1.5519 & 68.381 & 81.810 & 55.236 & 104.024 & \text { No }\end{array}$

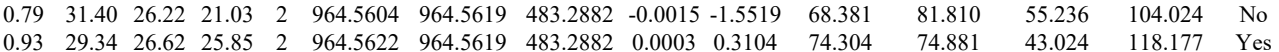
$\begin{array}{llllllllllllllll}0.93 & 29.34 & 26.62 & 25.85 & 2 & 964.5622 & 964.5619 & 483.2882 & 0.0003 & 0.3104 & 74.304 & 74.881 & 43.024 & 118.177 & \text { Yes } \\ 0.76 & 27.17 & 26.20 & 26.82 & 2 & 964.5614 & 964.5619 & 483.282 & -0.0005 & -0.5173 & 45.984 & 57.407 & 28.724 & 91.786 & \text { Yes }\end{array}$ $\begin{array}{llllllllllllllll}0.76 & 27.17 & 26.20 & 26.82 & 2 & 964.5614 & 964.5619 & 483.2882 & -0.0005 & -0.5173 & 45.984 & 57.407 & 28.724 & 91.786 & \text { Yes } \\ 0.58 & 14.88 & 26.50 & 21.26 & 2 & 964.5634 & 964.5619 & 483.2882 & 0.0015 & 1.5519 & 14.368 & 22.270 & 20.210 & 27.776 & \text { No }\end{array}$ $\begin{array}{lllllllllllllllll}0.99 & 38.40 & 28.18 & 15.60 & 3 & 1550.7916 & 1550.7785 & 517.9334 & 0.0131 & 8.4309 & 6091.545 & 8775.143 & 1995.935 & 12588.896 & \text { Yes }\end{array}$ $\begin{array}{llllllllllllllll}0.99 & 37.22 & 28.08 & 17.10 & 3 & 1550.7925 & 1550.7785 & 517.9334 & 0.0140 & 9.0101 & 5355.257 & 8150.667 & 2335.428 & 10127.280 & \text { Yes }\end{array}$ $\begin{array}{llllllllllllllll}1.00 & 50.89 & 28.10 & 28.88 & 2 & 1550.7920 & 1550.7785 & 776.3965 & 0.0135 & 8.6939 & 4607.397 & 6541.290 & 0.000 & 10386.009 & \text { No }\end{array}$ \begin{tabular}{lllllllllllllll}
1.00 & 46.13 & 28.10 & 21.01 & 2 & 1550.7922 & 1550.7785 & 776.3965 & 0.0137 & 8.8227 & 1312.781 & 1680.046 & 33.287 & 3083.995 & Yes \\
\hline
\end{tabular} $\begin{array}{lllllllllllllllllll}0.98 & 36.34 & 28.05 & 17.33 & 3 & 1550.7928 & 1550.7785 & 517.9334 & 0.0143 & 9.2032 & 11561.169 & 15708.940 & 3709.471 & 20164.720 & \text { Yes }\end{array}$ $\begin{array}{llllllllllllllllll}0.71 & 23.09 & 28.10 & 14.62 & 3 & 1550.7922 & 1550.7785 & 517.9334 & 0.0137 & 8.8170 & 12945.907 & 15701.807 & 5191.266 & 28452.922 & \text { Yes } \\ 0.99 & 37.33 & 28.08 & 1.63 & 3 & 150.7925 & 150.7785 & 517.9334 & 0.0140 & 9.0101 & 11461.399 & 11585.917 & 6010.089 & 16080.436 & \text { Yes }\end{array}$ $\begin{array}{llllllllllllllll}0.99 & 37.33 & 28.08 & 19.63 & 3 & 1550.7925 & 1550.7785 & 517.9334 & 0.0140 & 9.0101 & 11461.399 & 11585.917 & 6010.089 & 16080.436 & \text { Yes } \\ 0.93 & 19.39 & 16.72 & 14.64 & 2 & 969.6454 & 969.6457 & 485.8301 & 0.0003 & -0.3087 & 90.364 & 79.567 & 36.088 & 107.837 & \text { No }\end{array}$

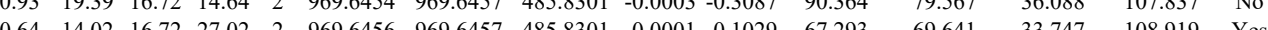

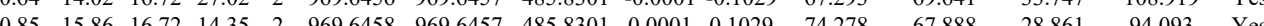

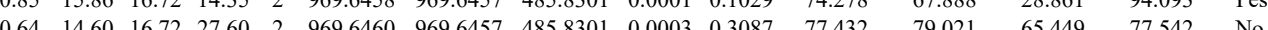

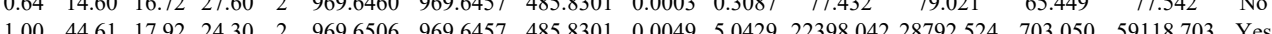
$\begin{array}{lllllllllllllllllll}1.00 & 41.87 & 17.92 & 23.95 & 2 & 969.6508 & 969.6457 & 485.8301 & 0.0051 & 5.2487 & 19414.001 & 21782.863 & 741.741 & 37994.804 & \text { Yes }\end{array}$

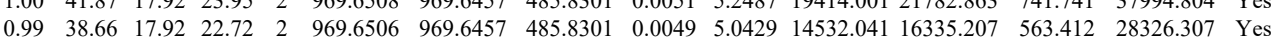

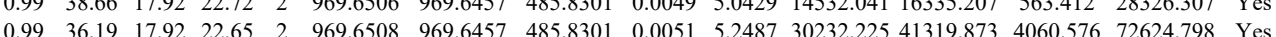
$\begin{array}{lllllllllllllllll}1.00 & 39.00 & 16.72 & 21.46 & 2 & 969.6468 & 969.6457 & 485.8301 & 0.0011 & 1.1321 & 21071.880 & 26358.084 & 1150.774 & 50084.361 & \text { Yes }\end{array}$ $\begin{array}{llllllllllllllll}1.00 & 36.44 & 17.85 & 22.96 & 2 & 969.6476 & 969.6457 & 485.8301 & 0.0019 & 1.9554 & 11813.729 & 16860.918 & 960.995 & 28231.849 & \text { Yes }\end{array}$ $\begin{array}{llllllllllllllllll}1.99 & 35.75 & 16.72 & 20.19 & 2 & 969.6446 & 969.6457 & 485.8301 & -0.0011 & -1.1321 & 8268.452 & 9902.907 & 764.006 & 19947.377 & \text { Yes }\end{array}$ $\begin{array}{llllllllllllllll}0.99 & 36.24 & 16.72 & 20.11 & 2 & 969.6448 & 969.6457 & 485.8301 & -0.0009 & -0.9263 & 4409.061 & 6571.645 & 423.478 & 11969.874 & \text { Yes }\end{array}$ $\begin{array}{llllllllllllllll}0.99 & 31.40 & 27.47 & 22.69 & 3 & 1550.7793 & 1550.7785 & 517.9334 & 0.0008 & 0.5149 & 265.132 & 275.869 & 132.359 & 283.663 & \text { Yes }\end{array}$ $\begin{array}{llllllllllllllll}1.00 & 41.92 & 27.59 & 22.13 & 3 & 1550.7799 & 1550.7785 & 517.9334 & 0.0014 & 0.9010 & 499.046 & 479.572 & 169.509 & 612.921 & \text { Yes }\end{array}$ $\begin{array}{llllllllllllllll}1.00 & 42.74 & 16.72 & 21.65 & 2 & 969.6456 & 969.6457 & 485.8301 & -0.0001 & -0.1029 & 1190.979 & 1391.985 & 159.418 & 2662.160 & \text { Yes }\end{array}$ $\begin{array}{lllllllllllllll}1.00 & 37.51 & 16.72 & 20.98 & 2 & 969.6460 & 969.6457 & 485.8301 & 0.0003 & 0.3087 & 779.766 & 1057.839 & 191.099 & 2004.126 & \text { Yes }\end{array}$ $\begin{array}{lllllllllllllll}1.00 & 31.12 & 16.72 & 18.11 & 2 & 969.6462 & 969.6457 & 485.8301 & 0.0005 & 0.5146 & 2037.565 & 2127.838 & 1161.106 & 3574.802 & \text { Yes }\end{array}$ $\begin{array}{lllllllllllllll}1.00 & 29.25 & 16.72 & 18.98 & 2 & 969.6464 & 969.6457 & 485.8301 & 0.0007 & 0.7204 & 2191.162 & 1751.192 & 868.071 & 3508.242 & \text { No }\end{array}$ $\begin{array}{lllllllllllllll}1.00 & 35.66 & 16.72 & 21.32 & 2 & 969.6456 & 969.6457 & 485.8301 & -0.0001 & -0.1029 & 1088.560 & 1180.719 & 660.870 & 1969.211 & \text { Yes }\end{array}$ $\begin{array}{lllllllllllllll}1.00 & 33.72 & 16.72 & 21.59 & 2 & 969.6458 & 969.6457 & 485.8301 & 0.0001 & 0.1029 & 1360.211 & 1440.034 & 652.606 & 2231.588 & \text { Yes }\end{array}$ $\begin{array}{lllllllllllllll}0.57 & 11.33 & 27.60 & 17.37 & 3 & 1550.7802 & 1550.7785 & 517.9334 & 0.0017 & 1.0941 & 248.324 & 232.946 & 106.473 & 407.969 & \text { Yes }\end{array}$ $\begin{array}{lllllllllllllllll}0.98 & 22.10 & 16.72 & 15.66 & 2 & 969.6462 & 969.6457 & 485.8301 & 0.0005 & 0.5146 & 259.492 & 275.696 & 61.699 & 401.940 & \text { Yes }\end{array}$ $\begin{array}{lllllllllllllll}0.98 & 24.61 & 16.72 & 15.67 & 2 & 969.6458 & 969.6457 & 485.8301 & 0.0001 & 0.1029 & 123.045 & 220.199 & 31.759 & 294.954 & \text { Yes }\end{array}$ $\begin{array}{llllllllllllllll}0.98 & 21.46 & 16.72 & 16.32 & 2 & 969.6464 & 969.6457 & 485.8301 & 0.0007 & 0.7204 & 178.046 & 216.804 & 25.884 & 397.006 & \text { Yes }\end{array}$ $\begin{array}{lllllllllllllll}1.00 & 28.04 & 16.72 & 16.02 & 2 & 969.6470 & 969.6457 & 485.8301 & 0.0013 & 1.3379 & 101.172 & 209.021 & 33.497 & 187.222 & \text { No } \\ 0.99 & 27.58 & 17.85 & 22.42 & 2 & 969.6476 & 969.6457 & 485.8301 & 0.0019 & 1.9554 & 115.502 & 160.542 & 50.482 & 275.231 & \text { Yo }\end{array}$ $\begin{array}{llllllllllllllll}0.99 & 27.58 & 17.85 & 22.42 & 2 & 969.6476 & 969.6457 & 485.8301 & 0.0019 & 1.9554 & 115.502 & 160.542 & 50.482 & 275.231 & \text { Yes } \\ 0.99 & 27.13 & 16.72 & 15.12 & 2 & 969.6462 & 969.6457 & 485.8301 & 0.0005 & 0.5146 & 254.497 & 274.652 & 91.598 & 456.491 & \text { Yes }\end{array}$ $\begin{array}{llllllllllllllll}0.99 & 27.13 & 16.72 & 15.12 & 2 & 969.6462 & 969.6457 & 485.8301 & 0.0005 & 0.5146 & 254.497 & 274.652 & 91.598 & 456.491 & \text { Yes } \\ 1.00 & 37.60 & 16.72 & 18.53 & 2 & 969.6462 & 969.6457 & 485.8301 & 0.0005 & 0.5146 & 297.825 & 433.565 & 49.863 & 612.125 & \text { Yes } \\ 1.00 & 37.17 & 16.72 & 16.11 & 2 & 969.6456 & 969.6457 & 485.830 & -0.001 & -0.102 & 246.999 & 317.067 & 47.664 & 481.412 & \end{array}$ $\begin{array}{lllllllllllllll}1.00 & 37.60 & 16.72 & 18.53 & 2 & 969.6462 & 969.6457 & 485.8301 & 0.0005 & 0.5146 & 297.825 & 433.565 & 49.863 & 612.125 & \text { Yes } \\ 1.00 & 37.17 & 16.72 & 16.11 & 2 & 969.6456 & 969.6457 & 485.8301 & -0.0001 & -0.1029 & 246.999 & 317.067 & 47.664 & 481.412 & \text { Yes }\end{array}$

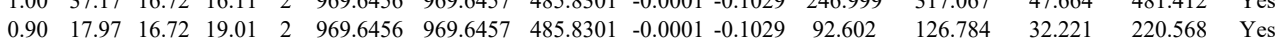
$\begin{array}{cccccccccccccccc}0.90 & 17.97 & 16.72 & 19.01 & 2 & 969.6456 & 969.6457 & 485.8301 & -0.0001 & -0.1029 & 92.602 & 126.784 & 32.221 & 220.568 & \text { Yes } \\ 0.94 & 41.51 & 25.07 & 41.82 & 2 & 1300.7690 & 1300.7594 & 651.3870 & 0.0096 & 7.3688 & 24676.870 & 26076.991 & 9531.617 & 13190.995 & \text { Yes }\end{array}$

Table S-4 page 373 of 614 
GGEIQPVSVK

GGEIQPVSVK

GGEIQPVSVK

GGIMLPEK

VVLDDKDYFLFR

VVLDDKDYFLFR

VVLDDKDYFLFR

VVLDDKDYFLFR

VVLDDKDYFLFR

VVLDDKDYFLFR

VLQATVVAVGSGSK

VLQATVVAVGSGSK

FLPLFDR

FLPLFDR

FLPLFDR

FLPLFDR
FLPLFDR

FLPLFDR

GGEIQPVSVK

GGEIQPVSVK

11 IIEVGDTPK

GQYNTYPIK

GQYNTYPIK

GQYNTYPIK

GQYNTYPIK

AFSPTTVNTGR

AFSPTTVNTGR

AFSPTTVNTG

AFSPTTVNTGR$$
\text { (5) }
$$

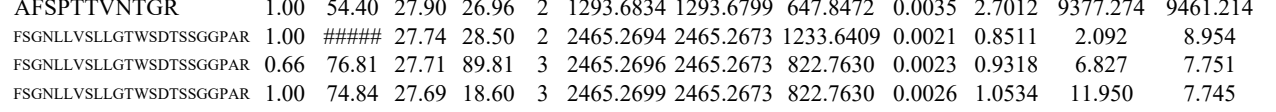

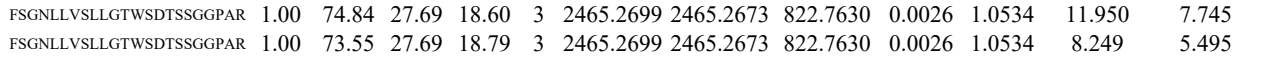
$\begin{array}{llllllllllllll}\text { MLE } & 51.94 & 26.49 & 64.94 & 3 & 2433.2899 & 2433.2858 & 812.1025 & 0.0041 & 1.6829 & 210.396 & 247.653\end{array}$ $\begin{array}{llllllllllllll} & \text { L }\end{array}$ $\begin{array}{llllllllllllll}\text { LHLGIPEANAVDDSTMK } & 1.00 & 38.92 & 26.54 & 16.29 & 4 & 2433.2905 & 2433.2858 & 609.3287 & 0.0047 & 1.9283 & 103.405 & 133.141\end{array}$

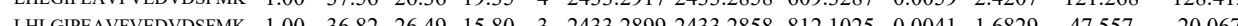
$\begin{array}{llllllllllllll}\text { NLDSLEEDLDFLR } & 1.00 & 72.69 & 27.48 & 40.54 & 2 & 1721.8606 & 1721.8594 & 861.9370 & 0.0012 & 0.6961 & 804.347 & 887.855\end{array}$ $\begin{array}{llllllllllllll}\text { NLDSLEEDLDFLR } & 1.00 & 73.97 & 27.64 & 40.44 & 2 & 1721.8612 & 1721.8594 & 861.9370 & 0.0018 & 1.0442 & 625.043 & 815.894\end{array}$ ADFQGISPER

SASVVSVISR SASVVSVISR SASVVSVISR $\begin{array}{llllllllllll}1.00 & 66.11 & 27.60 & 27.17 & 2 & 1147.6776 & 1147.6683 & 574.8414 & 0.0093 & 8.0891 & 5397.521 & 5073.553 \\ 1.00 & 75.27 & 27.59 & 27.25 & 2 & 1147.6784 & 1147.6683 & 574.8414 & 0.0101 & 8.7850 & 3929.172 & 3055.862\end{array}$ $\begin{array}{lllllllllllllll}0.85 & 22.94 & 28.45 & 32.47 & 2 & 1050.6000 & 1050.5984 & 526.3065 & 0.0016 & 1.5200 & 19284.939 & 21121.954 & 0.000 & 60570.702 & \text { No }\end{array}$ $\begin{array}{lllllllllllllll}0.88 & 24.05 & 28.45 & 32.55 & 2 & 1050.6000 & 1050.5984 & 526.3065 & 0.0016 & 1.5200 & 32667.637 & 33634.542 & 4672.450 & \text { \#\#\#\#\#\# Yes } \\ 0.52 & 22.53 & 28.16 & 32.49 & 2 & 1050.6026 & 1050.5984 & 526.3065 & 0.0042 & 3.9901 & 1346.224 & 13530.781 & 967.393 & 40280.851 & \text { Yes }\end{array}$ $\begin{array}{lllllllllllllll}0.58 & 23.53 & 28.09 & 32.60 & 2 & 1050.6028 & 1050.5984 & 5263065 & 0.0044 & 4.1801 & 13419.680 & 14970.806 & 1237.366 & 44979.281 & \text { Yes }\end{array}$ $\begin{array}{lllllllllllllll}0.96 & 52.15 & 25.53 & 47.93 & 2 & 1300.7674 & 1300.7594 & 651.3870 & 0.0080 & 6.1407 & 18678.634 & 17105.271 & 18716.614 & 18898.128 & \text { No }\end{array}$

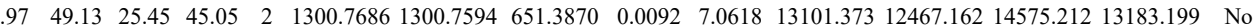
$\begin{array}{llllllllllllllll}1.00 & 63.03 & 25.56 & 29.52 & 2 & 1258.7498 & 1258.7376 & 630.3761 & 0.0122 & 9.6767 & 2678.590 & 2994.198 & 644.801 & 4710.302 & \text { Yes }\end{array}$ $\begin{array}{llllllllllllllll}.99 & 36.71 & 27.40 & 26.27 & 2 & 1370.7472 & 1370.7438 & 686.3792 & 0.0034 & 2.4768 & 8620.792 & 9302.805 & 9990.259 & 14504.188 & \text { Yes }\end{array}$ $\begin{array}{llllllllllllllll}0.98 & 38.86 & 27.35 & 26.44 & 2 & 1370.7480 & 1370.7438 & 686.3792 & 0.0042 & 3.0595 & 8671.552 & 9443.623 & 9635.071 & 13620.978 & \text { Yes }\end{array}$ $\begin{array}{lllllllllllllll}1.00 & 38.86 & 27.46 & 26.49 & 2 & 1370.7460 & 1370.7438 & 686.3792 & 0.0022 & 1.6026 & 8108.022 & 7771.602 & 7998.521 & 11853.463 & \text { Yes }\end{array}$ $\begin{array}{lllllllllllllll}.00 & 55.67 & 27.51 & 28.50 & 2 & 1293.6820 & 1293.6799 & 647.8472 & 0.0021 & 1.6207 & 18612.216 & 19596.288 & 1560.780 & 35667.614 & \text { Yes }\end{array}$ $\begin{array}{lllllllllllllll}1.00 & 55.67 & 27.51 & 28.50 & 2 & 1293.6820 & 1293.6799 & 647.8472 & 0.0021 & 1.6207 & 18612.816 & 19596.288 & 1560.780 & 35667.614 & Y \text { Ses }\end{array}$

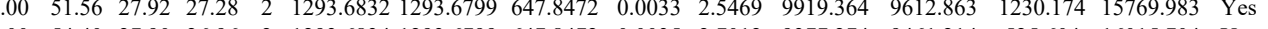
SGINCPIQK SGINCPIQK SGINCPIQK $\begin{array}{llllllllllll}0.55 & 34.48 & 26.30 & 47.48 & 3 & 2455.3102 & 2455.3096 & 819.4438 & 0.0006 & 0.2441 & 2.483 \\ 0.67 & 18.06 & 26.17 & 31.06 & 3 & 2455.3126 & 2455.3096 & 819.4438 & 0.0030 & 1.2203 & 1.102\end{array}$ 1.102 $\begin{array}{ccccccccccccccc}1.00 & 62.36 & 27.85 & 22.87 & 2 & 1262.6476 & 1262.6377 & 632.3261 & 0.0099 & 7.8282 & 8580.103 & 11659.646 & 949.046 & 12679.291 & Y \text { Yes }\end{array}$ $\begin{array}{lllllllllllllllll}0.99 & 46.31 & 27.97 & 29.37 & 2 & 1292.6918 & 1292.6824 & 647.3485 & 0.0094 & 7.2603 & 11435.317 & 10148.767 & 3822.702 & 6940.642 & \text { Yes }\end{array}$ $\begin{array}{lllllllllllllll}1.00 & 47.02 & 27.87 & 27.48 & 2 & 1292.6946 & 1292.6824 & 647.3485 & 0.0122 & 9.4230 & 12269.681 & 8479.169 & 3244.900 & 6810.606 & \text { Yes } \\ 0\end{array}$ $\begin{array}{llllllllllllllll}0.99 & 42.71 & 28.18 & 27.21 & 2 & 1292.6938 & 1292.6824 & 647.3485 & 0.0114 & 8.8051 & 3647.000 & 2933.024 & 1541.325 & 2230.183 & \text { Yes } \\ 1.00 & 45.69 & 25.23 & 18.4 & 2 & 1292.692 & 1292.6824 & 64.3485 & 0.018 & 9.1140 & 8983.673 & 7309.254 & 331.501 & 5682.165 & \text { Yes }\end{array}$

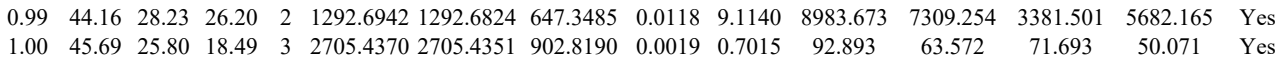

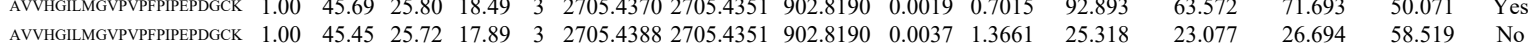

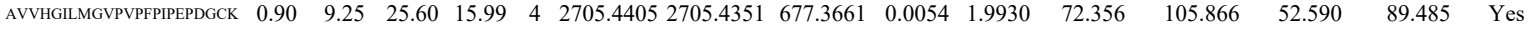
$\begin{array}{lllllllllllllll}\text { GEDVPLTEQTVSQVLQSAK } & 0.84 & \text { \#\#\#\# } 25.97 & \text { \#\#\#\# } 2 & 2316.2434 & 2316.2417 & 1159.1281 & 0.0017 & 0.7333 & 113.542 & 161.017 & 182.883 & 142.708 & \text { Yes }\end{array}$

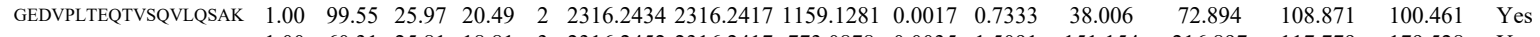
$\begin{array}{llllllllllllllll}\text { GEDVPLTEQTVSQVLQSAK } & 1.00 & 60.31 & 25.81 & 18.81 & 3 & 2316.2452 & 2316.2417 & 773.0878 & 0.0035 & 1.5091 & 151.154 & 216.897 & 117.779 & 179.528 & \text { Yes }\end{array}$

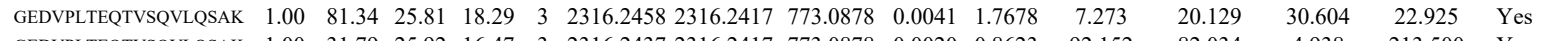
$\begin{array}{llllllllllllllll}\text { GEDVPLTEQTVSQVLQSAK } & 1.00 & 31.79 & 25.92 & 16.47 & 3 & 2316.2437 & 2316.2417 & 773.0878 & 0.0020 & 0.8623 & 92.152 & 82.034 & 4.938 & 213.500 & \text { Yes }\end{array}$

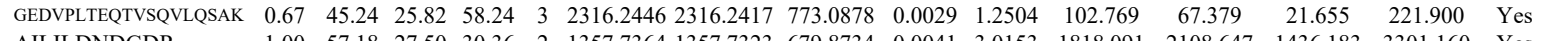
$\begin{array}{lllllllllllllllll}\text { AILILDNDGDR } & 1.00 & 57.18 & 27.50 & 30.36 & 2 & 1357.7364 & 1357.7323 & 679.8734 & 0.0041 & 3.0153 & 1818.091 & 2108.647 & 1436.183 & 3301.160 & \text { Yes }\end{array}$

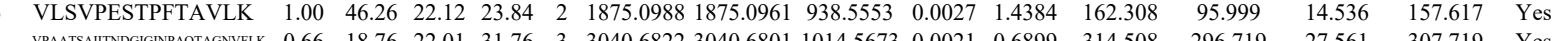
$\begin{array}{llllllllllllllll}\text { VPAASAIISTE } & \end{array}$

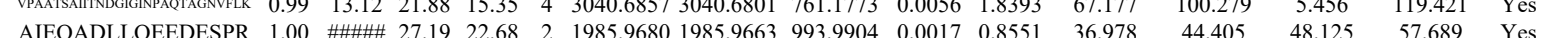

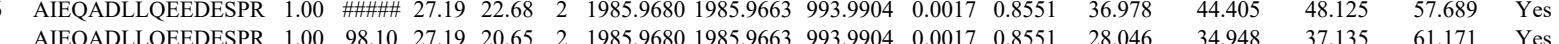

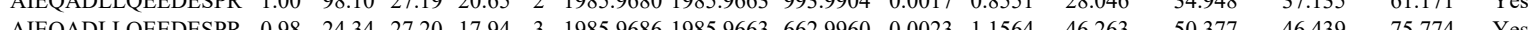
$\begin{array}{llllllllllllllll}\text { AIEQADLLQEEDESPR } & 0.65 & 12.14 & 27.25 & 18.68 & 3 & 1985.9692 & 1985.9663 & 662.9960 & 0.0029 & 1.4580 & 64.739 & 60.202 & 64.154 & 179.535 & \text { Yes }\end{array}$

Table S-4 page 374 of 614 


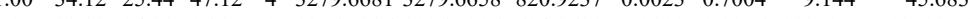

VVECIK

VVECIK

VVECIK

ILSISADIETIGEILK

LSISADIETIGEILK

LSISADIETIGEILK

LSISADIETIGEILK

ILSISADIETIGEILK

LSISADIETIGEILK

$\begin{array}{lllllllllllll}0.98 & 26.62 & 20.90 & 18.86 & 3 & 2002.1794 & 2002.1805 & 668.4008 & -0.0011 & -0.5486 & 125.140\end{array}$

131.241 $\begin{array}{llllllllllll}0.59 & 19.77 & 26.79 & 22.75 & 2 & 1023.5704 & 1023.5700 & 512.7923 & 0.0004 & 0.3900 & 216.378\end{array}$

$\begin{array}{lllllllll} & \end{array}$ $\begin{array}{llllllllllll}1.00 & 76.63 & 20.57 & 21.19 & 2 & 2002.1834 & 2002.1805 & 1002.0975 & 0.0029 & 1.4470 & 1173.027 & 1148.030\end{array}$ LSISADIETIGEILK ILSISADIETIGEILK

ILSISADIETIGEILK

LSISADIETIGEILK

ILSISADIETIGEILK

ILSISADIETIGEILK

ILSISADIETIGEILK

ILSISADIETIGEILK

ILSISADIETIGEILK

IILDLISESPIK

IILDLISESPIK

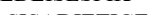

LSISADIETIGEILK

LSADILTHGEILK

LSISADIETIGEILK

LSISADIETIEK

ILSISADIETIGEILK

ILSISADIETIGEILK

ILSISADIETIGEILK

ILSISADIETIGEILK

ILSISADIETIGE

IILDLISESPIK

LDLISESPIK

IILDLISESPIK

LSISADIETIGEILK

$\begin{array}{llllllllll}0 & 202.1836 & 2002.1805 & 668.4008 & 0.0031 & 1.5460 & 171.006\end{array}$

125.087

$\begin{array}{lllllllllll} & \end{array}$

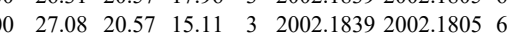

$\begin{array}{lllllllllllll}0.99 & 23.71 & 20.57 & 14.75 & 3 & 2002.1839 & 2002.1805 & 668.4008 & 0.0034 & 1.6956 & 74.603 & 47.506\end{array}$

$\begin{array}{lllllllllllll}1.00 & 38.45 & 20.53 & 15.62 & 3 & 2002.1842 & 2002.1805 & 688.4008 & 0.0037 & 1.8452 & 125.117 & 121.536\end{array}$

$\begin{array}{lllllllllll}1.00 & 38.45 & 20.53 & 15.62 & 3 & 2002.1842002 .1805 & 668.4008 & 0.0037 & 1.8452 & 125.117 & 12\end{array}$

$\begin{array}{llllllllllll}1.00 & 33.47 & 20.53 & 15.41 & 3 & 2002.1842 & 2002.1805 & 668.4008 & 0.0037 & 1.8452 & 1050.307 & 73\end{array}$

$\begin{array}{lllllllllll}1.00 & 27.44 & 2.53 & 15.41 & 3 & 2002.1842 & 2002.1805 & 668.4008 & 0.0037 & 1.8452 & 1050.307\end{array}$ $\begin{array}{lllllllllll}1.00 & 58.64 & 20.57 & 17.46 & 3 & 2002.1851 & 2002.1805 & 668.4008 & 0.0043 & 2.1444 & 116.371 \\ 1.0046 & 2.2940 & 142.53\end{array}$ $\begin{array}{lllllllllll}0.89 & 17.50 & 20.41 & 15.64 & 3 & 2002.1869 & 2002.1805 & 668.4008 & 0.0064 & 3.1917 & 161.513\end{array}$ $\begin{array}{llllllllllll}1.00 & 55.62 & 18.92 & 18.99 & 3 & 1628.0032 & 1628.0004 & 543.6741 & 0.0028 & 1.7167 & 526.135\end{array}$ $\begin{array}{llllllllllll}40.11 & 18.92 & 16.71 & 3 & 1628.0032 & 1628.0004 & 543.6741 & 0.0028 & 1.7167 & 134.763\end{array}$ $\begin{array}{lllllllllllll}1.00 & 94.74 & 18.86 & 32.70 & 2 & 1628.0040 & 1628.0004 & 815.0075 & 0.0036 & 2.2086 & 2468.997 \\ 0.55 & 16.73 & 20.64 & 29.73 & 3 & 2002.1818 & 2002.1805 & 668.4008 & 0.0013 & 0.6483 & 154.629\end{array}$ $\begin{array}{llllllllllll}00 & 26.13 & 20.64 & 15.51 & 3 & 2002.1818 & 2002.1805 & 668.4008 & 0.0013 & 0.6483 & 27.999\end{array}$ $\begin{array}{lllllllllll}.00 & 36.52 & 20.49 & 20.39 & 3 & 2002.1830 & 2002.1805 & 668.4008 & 0.0025 & 1.2468 & 160.998\end{array}$ $\begin{array}{lllllllllllll}1.00 & 83.30 & 20.57 & 22.97 & 2 & 2002.1834 & 2002.1805 & 1002.0975 & 0.025 & 1.440 & 160.998 & 1.514\end{array}$ $\begin{array}{lllllllllll}1.00 & 30.82 & 20.57 & 20.38 & 3 & 2002.1839 & 2002.1805 & 668.4008 & 0.0034 & 1.6956 & 134.111\end{array}$

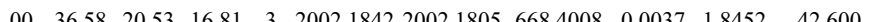
$\begin{array}{llllllllllll}100 & 32.12 & 20.57 & 16.05 & 3 & 20021845 & 2002.1805 & 6688.4008 & 0.0040 & 1.9948 & 316.633\end{array}$ $\begin{array}{llllllllllll}0.99 & 22.86 & 20.57 & 14.64 & 3 & 20021845 & 2002.1805 & 668.4008 & 0.0040 & 1.9948 & 94.192\end{array}$ $\begin{array}{llllllllllll}0.98 & 24.96 & 20.64 & 16.86 & 3 & 20021866 & 2002.1805 & 668.4008 & 0.0061 & 3.0421 & 156.435\end{array}$ $\begin{array}{llllllllllll}1.00 & 30.87 & 18.92 & 18.99 & 3 & 1628.0029 & 1628.0004 & 543.6741 & 0.0025 & 1.5328 & 153.866\end{array}$ $\begin{array}{llllllllllll}0.66 & 32.44 & 18.92 & 45.44 & 3 & 1628.0029 & 1628.0004 & 543.6741 & 0.0025 & 1.5328 & 367.185\end{array}$ $\begin{array}{llllllllllll}1.00 & 30.87 & 18.92 & 18.99 & 3 & 1628.0029 & 1628.0004 & 543.6741 & 0.0025 & 1.5328 & 153.866 & \\ 0.67 .853\end{array}$

ILSISADIETIGEILK

ISISADIETIGEILK $\begin{array}{lllllllllll}1.00 & 75.60 & 18.92 & 30.33 & 2 & 1628.0032 & 1628.0004 & 815.0075 & 0.0028 & 1.7178 & 4009.5\end{array}$

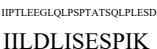

IILDLISESPIK
IILDLISESPIK

IILDLISESPIK
IILDLISESPIK

$\begin{array}{lllllllllll}1.00 & 80.62 & 20.57 & 26.26 & 2 & 2002.1834 & 2002.1805 & 1002.0975 & 0.0029 & 1.4470 & 45.516\end{array}$

$\begin{array}{llllllllll}50.22 & 20.53 & 18.99 & 3 & 2002.1839 & 2002.1805 & 668.4008 & 0.0034 & 1.6956 & 113.949 \\ 1 & 2002.1805 & 668.4008 & 0.0037 & 1.8452 & 112.132\end{array}$

$\begin{array}{llllllllllll}1.00 & 53.79 & 20.57 & 21.98 & 3 & 2002.1848 & 2002.1805 & 668.4008 & 0.0043 & 2.1444 & 98.846\end{array}$

$\begin{array}{llllllllllll}1.00 & 68.97 & 24.74 & 17.99 & 3 & 4331.1922 & 4331.1949 & 1444.7389 & -0.0027 & -0.6230 & 5.754 \\ 1.00 & 31.09 & 24.44 & 18.15 & 3 & 4331.1982 & 4331.1949 & 1444.7389 & 0.0033 & 0.7614 & 2.462\end{array}$

$\begin{array}{cccccccccccc}1.00 & 31.09 & 24.44 & 18.15 & 3 & 4331.1982 & 4331.1949 & 1444.7389 & 0.0033 & 0.7614 & 2.462 \\ 1.00 & 76.21 & 18.92 & 30.53 & 2 & 1628.0032 & 1628.0004 & 815.0075 & 0.0028 & 1.7178 & 567.652 & 10\end{array}$ $\begin{array}{llllllllllll}1.00 & 76.21 & 18.92 & 30.53 & 2 & 1628.0032 & 1628.0004 & 815.0075 & 0.0028 & 1.7178 & 567.652 \\ 1.00 & 26.93 & 18.86 & 17.76 & 3 & 1628.0038 & 1628.0004 & 543.6741 & 0.0034 & 2.0846 & 187.016\end{array}$ $\begin{array}{llllllllllll}1.00 & 26.93 & 18.86 & 17.76 & 3 & 1628.0038 & 1628.0004 & 543.6741 & 0.0034 & 2.0846 & 187.016 \\ 1.00 & 73.83 & 18.86 & 29.20 & 2 & 1628.0040 & 1628.0004 & 815.0075 & 0.0036 & 2.2086 & 849.938\end{array}$ $\begin{array}{lllllllllllll}1.00 & 73.83 & 18.86 & 29.20 & 2 & 1628.0040 & 1628.0004 & 815.0075 & 0.0036 & 2.2086 & 849.938 \\ 1.00 & 30.21 & 18.86 & 15.57 & 3 & 1628.0041 & 1628.0004 & 543.6741 & 0.0037 & 2.2685 & 196.602\end{array}$ $\begin{array}{lllllllllllll}1.00 & 30.21 & 18.86 & 15.57 & 3 & 1628.0041 & 1628.0004 & 543.6741 & 0.0037 & 2.2685 & 196.602 \\ 1.00 & \# \# \# \# & 24.90 & 27.96 & 2 & 2204.2294 & 2204.2296 & 1103.1221 & -0.0002 & -0.0907 & 316.682\end{array}$ $\begin{array}{llllllllllll}\text { GSYGDLGGPIITQVTIPK } & 1.00 & \# \# \# \text { 24.84 } & 27.21 & 2 & 2204.2314 & 2204.2296 & 1103.1221 & 0.0018 & 0.8159 & 581.045\end{array}$ $\begin{array}{llllllllllll}1.00 & 65.01 & 24.64 & 17.82 & 3 & 4331.1952 & 4331.1949 & 1444.7389 & 0.0003 & 0.0692 & 0.000\end{array}$ 


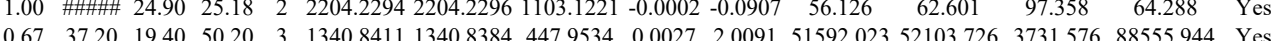
$\begin{array}{lllllllllllllllll}0.67 & 37.20 & 19.40 & 50.20 & 3 & 1340.8411 & 1340.8384 & 447.9534 & 0.0027 & 2.0091 & 51592.023 & 52103.726 & 3731.576 & 88555.944 & \text { Yes }\end{array}$ $\begin{array}{lllllllllllllll}1.00 & 41.00 & 19.49 & 24.28 & 2 & 1340.8416 & 1340.8384 & 671.4265 & 0.0032 & 2.3830 & 14446.678 & 12399.451 & 315.022 & 22173.671 & \text { Yes } \\ 1.00 & 33.31 & 19.49 & 15.28 & 3 & 1340.8417 & 1340.8384 & 447.9534 & 0.0033 & 2.4556 & 69191.205 & 74034.102 & 7092.762 & \text { H\#\#\#\# } & \text { Yes }\end{array}$

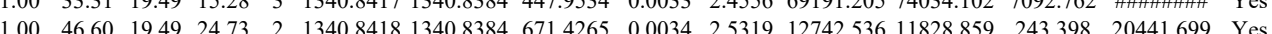

VVLIGGKPDR $\begin{array}{llllllllllllllll}1.00 & 46.60 & 19.49 & 24.73 & 2 & 1340.8418 & 1340.8384 & 671.4265 & 0.0034 & 2.5319 & 12742.536 & 11828.859 & 243.398 & 20441.699 & \text { Yes } \\ 1.00 & 37.56 & 19.29 & 16.35 & 3 & 1340.8408 & 1340.8384 & 447.9534 & 0.0024 & 1.7859 & 35762.346 & 35816511 & 3990.612 & 62610.450 & \text { Yes }\end{array}$

VVLIGGKPDR $\begin{array}{llllllllllllllll}1.00 & 36.50 & 19.40 & 25.56 & 3 & 1340.8408 & 1340.8384 & 447.9534 & 0.0024 & 1.7859 & 35762.346 & 35816.511 & 3930.612 & 62610.450 & \text { Yes } \\ 1.00 & 45.80 & 9.54 & 25.12 & 2 & 140.841 & 1340.8384 & 447.9534 & 0.0027 & 2.0091 & 47444.719 & 46973.891 & 6353.516 & 86139.977 & \text { Yes }\end{array}$ $\begin{array}{lllllllllllllllll}1.00 & 36.90 & 19.40 & 25.56 & 3 & 1340.8411 & 1340.8384 & 447.9534 & 0.0027 & 2.0091 & 47444.719 & 46973.881 & 6353.516 & 86139.977 & \text { Yes } \\ 1.00 & 45.80 & 19.54 & 25.12 & 2 & 1340.8412 & 1340.8384 & 671.4265 & 0.0028 & 2.0851 & 6148.672 & 5187.858 & 999.405 & 9388.191 & \text { Yes }\end{array}$

VVLIGGKPDR $\begin{array}{llllllllllllllll}1.00 & 45.80 & 19.54 & 25.12 & 2 & 1340.8412 & 1340.8384 & 671.4265 & 0.0028 & 2.0851 & 6148.672 & 5187.858 & 999.405 & 9388.191 & \text { Yes } \\ 100 & 45.36 & 19.49 & 26.68 & 2 & 1340.8414 & 1340.8384 & 671.4265 & 0.0030 & 22.2340 & 13605.078 & 11978.412 & 1058.281 & 22343.792 & \text { Yes }\end{array}$

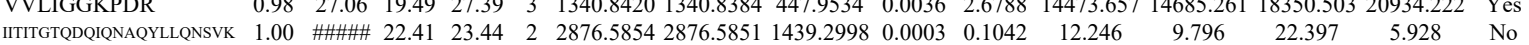

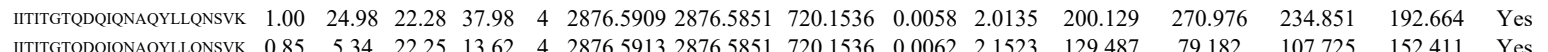

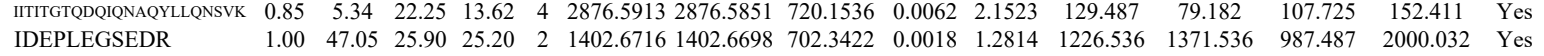
$\begin{array}{llllllllllllllll}\text { IDEPLEGSEDR } & 1.00 & 53.26 & 25.91 & 31.39 & 2 & 1402.6722 & 1402.6698 & 702.3422 & 0.0024 & 1.7086 & 5342.748 & 4603.769 & 4834.169 & 10153.855 & \text { Yes }\end{array}$ $\begin{array}{llllllllllllllll}\text { IITTGTQDQIQNAQYLLQNSVK } & 1.00 & 79.74 & 22.48 & 21.38 & 3 & 2876.5846 & 2876.5851 & 959.8690 & -0.0005 & -0.1736 & 141.787 & 347.548 & 67.061 & 284.356 & \text { No }\end{array}$ (1)

NLPLPPPPPPR $\begin{array}{lllllllllllllll}0.84 & 99.11 & 22.48 & \# \# \# \# 2 & 2876.5874 & 2876.5851 & 1439.2998 & 0.0023 & 0.7990 & 4.157 & 0.000 & 8.004 & 14.743 & \text { No }\end{array}$

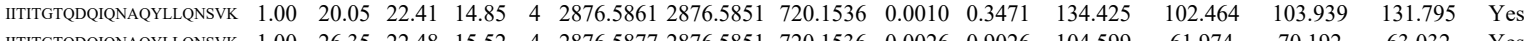

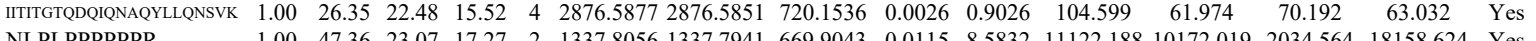
NLPLPPPPPPR NLPLPPPPPPR NLPLPPPPPPR $\begin{array}{llllllllllllllll}1.00 & 47.36 & 23.07 & 17.27 & 2 & 1337.8056 & 1337.7941 & 669.9043 & 0.0115 & 8.5832 & 11122.188 & 10172.019 & 2034.564 & 18158.624 & \text { Yes }\end{array}$ $\begin{array}{lllllllllllllllll}1.00 & 46.80 & 23.05 & 16.22 & 2 & 1337.8058 & 1337.7941 & 669.9043 & 0.0117 & 8.7325 & 13237.232 & 13369.277 & 1270.754 & 18878.568 & \text { Yes }\end{array}$ $\begin{array}{lllllllllllllllll}0.97 & 29.07 & 23.12 & 18.76 & 3 & 1337.8060 & 1337.7941 & 446.9386 & 0.0119 & 8.8751 & 2215.765 & 3009.690 & 914.553 & 3949.473 & \text { Yes } \\ \end{array}$

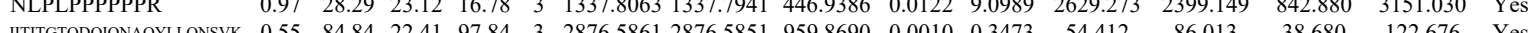

NLPLPPPPPR $\begin{array}{lllllllllllllll}0.55 & 84.84 & 22.41 & 97.84 & 3 & 2876.5861 & 2876.5851 & 959.8690 & 0.0010 & 0.3473 & 54.412 & 86.013 & 38.680 & 122.676 & \text { Yes }\end{array}$

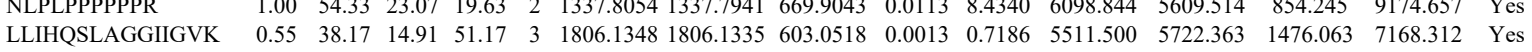
$\begin{array}{lllllllllllllllll} & \text { LLIHOSLAGGIIGVK } & 1.00 & 55.30 & 14.62 & 1.83 & 3 & 18061375 & 18061335 & 603.0518 & 0.0040 & 22110 & 5921.859 & 5647.720 & 1813.963 & 7528.538 & \text { Yes }\end{array}$

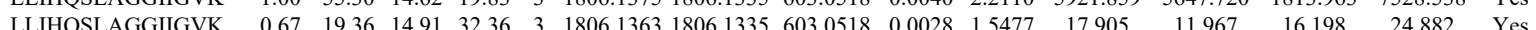
LLIHQSLAGGIIGVK LLIHQSLAGGIIGVK $\begin{array}{llllllllllllllll}1.00 & 59.11 & 14.91 & 19.76 & 3 & 1806.1369 & 1806.1335 & 603.0518 & 0.0034 & 1.8793 & 2109.109 & 1856.596 & 437.048 & 4205.478 & \text { Yes }\end{array}$ $\begin{array}{llllllllllllllll}0.82 & 28.32 & 27.82 & 27.41 & 2 & 1249.6190 & 1249.6094 & 625.8120 & 0.0096 & 7.6700 & 3836.941 & 3911.407 & 1218.958 & 4633.968 & \text { Yes }\end{array}$ $\begin{array}{llllllllllllllll}1.00 & 56.97 & 26.32 & 27.61 & 2 & 1402.6802 & 1402.6698 & 702.3422 & 0.0104 & 7.4037 & 2318.987 & 2781.375 & 2563.218 & 4647.609 & \text { Yes }\end{array}$ $\begin{array}{lllllllllllllll}1.00 & 55.03 & 26.19 & 27.19 & 2 & 1402.6806 & 1402.6698 & 702.3422 & 0.0108 & 7.6885 & 1949.955 & 2407.946 & 2023.496 & 3836.784 & \text { Yes }\end{array}$ $\begin{array}{lllllllllllllll}0.96 & 23.92 & 27.13 & 22.67 & 3 & 1866.9040 & 1866.9025 & 623.3081 & 0.0015 & 0.8022 & 71.239 & 71.567 & 76.524 & 132.215 & \text { Yes }\end{array}$ $\begin{array}{lllllllllll}0.76 & 14.19 & 27.07 & 18.28 & 3 & 1866.9043 & 1866.9025 & 623.3081 & 0.0018 & 0.9626 & 88.228\end{array}$

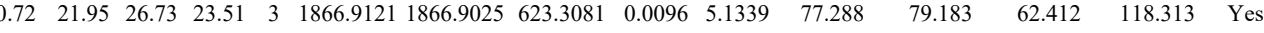
$\begin{array}{llllllllllllllll}0.97 & 32.59 & 26.69 & 22.04 & 3 & 1866.9172 & 1866.9025 & 623.3081 & 0.0147 & 7.8612 & 1972.666 & 1850.967 & 2068.569 & 1899.585 & \text { Yes }\end{array}$

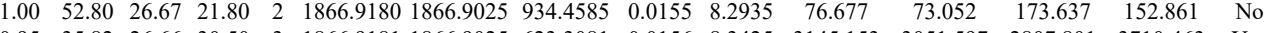
$\begin{array}{lllllllllllllll}0.95 & 35.82 & 26.66 & 30.50 & 3 & 1866.9181 & 1866.9025 & 623.3081 & 0.0156 & 8.3425 & 3145.153 & 3051.597 & 2807.801 & 3710.463 & \text { Yes }\end{array}$

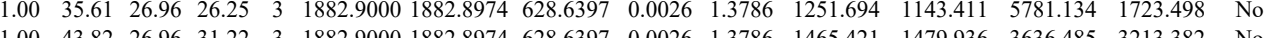
$\begin{array}{lllllllllllllll}1.00 & 43.82 & 26.96 & 31.22 & 3 & 1882.9000 & 1882.8974 & 628.6397 & 0.0026 & 1.3786 & 1465.421 & 1479.936 & 3636.485 & 3213.382 & \text { No }\end{array}$

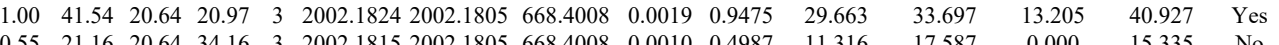

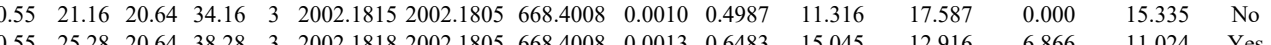

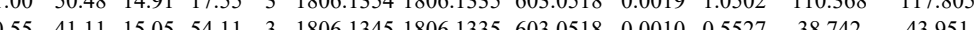
$\begin{array}{lllllllllll}0.66 & 56.40 & 14.91 & 69.40 & 3 & 1806.1354 & 1806.1335 & 603.0518 & 0.0019 & 1.0502 & 59.088\end{array}$

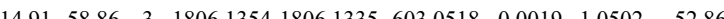
$\begin{array}{lllllllll}14.91 & 66.34 & 3 & 1806.1351 & 1806.1335 & 603.0518 & 0.0016 & 0.8844 & 72.072\end{array}$ 
ILSISADIETIGEILK ILSISADIETIGEILK IILDLISESPIK

ILSISADIETIGEILK

ILSISADIETIGEILK LLIHQSLAGGIIGVK ILSISADIETIGEILK

ILSISADIETIGEILK

LLIHQSLAGGIGVK

LLIHQSLAGGIIGVK

ILSSADIETGEILK

ILSSADIETGEILK

ILSSADIETIGEILK

ILSISADIETIGEILK

ILSISADIETIG

GSDFDCELR

GSDFDCELR

GGDLMAYDR

ILSISADIETIGEILK

ILSISADIETIGEILK

ILSISADIETIGEILK \begin{tabular}{llllllllllll} 
& 3.26 & 20.4 & 14.23 & 3 & 2002.1830 & 2002.1805 & 668.4008 & 0.025 & 1.2468 & 11.655 & 21.908 \\
\hline & 20.4 & 50.67 & 3 & 2002.1830 & 2002.1805 & 668.4008 & 0.0025 & 1.2468 & 18.936 & 23.282
\end{tabular}

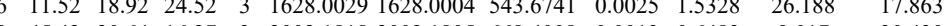
$\begin{array}{llllllllllll}0.66 & 11.52 & 18.92 & 24.52 & 3 & 1628.0029 & 1628.0004 & 543.6741 & 0.0025 & 1.5328 & 26.188 & 17.863 \\ 1.00 & 45.42 & 20.64 & 16.27 & 3 & 2002.1818 & 2002.1805 & 668.4008 & 0.0013 & 0.6483 & 9.017 & 30.430\end{array}$

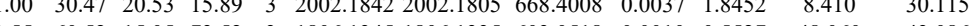
$\begin{array}{lllllllllll}1.00 & 30.47 & 20.53 & 15.89 & 3 & 2002.1842 & 2002.1805 & 668.4008 & 0.0037 & 1.8452 & 8.40\end{array}$ $\begin{array}{lllllllllll}0.55 & 6.52 & 15.05 & 73.52 & 3 & 1806.1345 & 1806.1335 & 603.0518 & 0.0010 & 0.5527 & 48.060\end{array}$

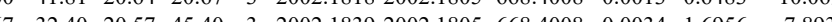

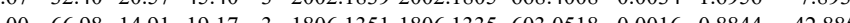
$\begin{array}{llllllllllll}1.00 & 38.03 & 14.91 & 16.83 & 3 & 1806.1360 & 1806.1335 & 603.0518 & 0.0025 & 1.3819 & 28.243\end{array}$ $\begin{array}{lllllllllll}1 & 21.12 & 3 & 2002.1848 & 2002.1805 & 668.4008 & 0.0043 & 2.1444 & 18.945\end{array}$ $\begin{array}{lllllllllll}1.00 & 4.96 & 20.64 & 24.72 & 3 & 2002.1821 & 2002.1805 & 688.4008 & 0.045 & 0.794 & 21.886\end{array}$ $\begin{array}{llllllllllll}1.00 & 81.03 & 20.57 & 18.28 & 2 & 2002 & 1834 & 20021805 & 1002.0975 & 0.0029 & 1.4470 & 9.610\end{array}$ $\begin{array}{llllllllllll}1.00 & 78.87 & 20.79 & 18.03 & 2 & 2002 & 1874 & 2002.1805 & 1002.0975 & 0.0069 & 3.4428 & 11.833\end{array}$ $\begin{array}{llllllllllll}1.00 & 48.38 & 21.04 & 18.93 & 2 & 1230.5142 & 1230.5131 & 616.2638 & 0.0011 & 0.8925 & 2407.595 & 28\end{array}$

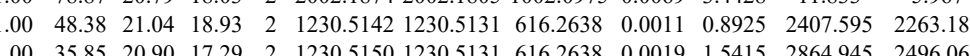
$\begin{array}{lllllllllllll}1.00 & 51.57 & 25.05 & 26.18 & 2 & 1140.5430 & 1140.5355 & 571.2750 & 0.0075 & 6.5642 & 7724.857 & 7172.666 & 54\end{array}$ $\begin{array}{lllllllllllllll}1.00 & 46.48 & 24.96 & 24.05 & 2 & 1140.5438 & 1140.5355 & 571.2750 & 0.0083 & 7.2644 & 6024.330 & 6469.796 & 47\end{array}$ $\begin{array}{lllllllllllll}0.83 & 9.56 & 20.53 & 14.39 & 3 & 2002.1827 & 2002.1805 & 668.4008 & 0.0022 & 1.0971 & 158.687 & 163.622\end{array}$ $\begin{array}{lllllllllllll}0.69 & 8.11 & 20.57 & 19.64 & 3 & 2002.1848 & 2002.1805 & 668.4008 & 0.0043 & 2.1444 & 161.367 & 168.057\end{array}$ $\begin{array}{lllllllllll}0.90 & 11.76 & 20.57 & 14.44 & 3 & 2002.1833 & 2002.1805 & 668.4008 & 0.0028 & 1.3964 & 119.307\end{array}$ $\begin{array}{llllllllllllll} & \text { GEALNSVFYEIONAPEQACHLAK } & 1.00 & 34.84 & 26.26 & 47.84 & 4 & 3288.6593 & 3288.6555 & 823.1712 & 0.0038 & 1.1541 & 9.514\end{array}$ $\begin{array}{lllllllllllll} & \end{array}$ $\begin{array}{llllllllllll} & \end{array}$ $\begin{array}{lllllllllllll} & \end{array}$

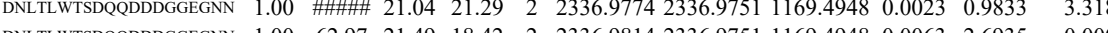
$\begin{array}{llllllllllll}\text { DNLILWTSDQQDDDGGEGNN } & 1.00 & 62.97 & 21.49 & 18.42 & 2 & 2336.9814 & 2336.9751 & 1169.4948 & 0.0063 & 2.6935 & 0.000 \\ \text { NVTELNEPSNERR } & 1.00 & 75.26 & 27.40 & 24.76 & 2 & 1786.8922 & 1786.8819 & 89.4482 & 0.0103 & 5.7577 & 538.18\end{array}$ NVTELNEPLSNEER NVTELNEPLSNEER DNLTLWTSDQODDDGGEG

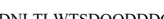
NCSETQYESK NCSETQYESK NCSETQYESK

(1)

NVTELNEPLSNEER

$\begin{array}{lllllllllllll}1.00 & 75.26 & 27.40 & 24.76 & 2 & 1786.8922 & 1786.8819 & 894.4482 & 0.0103 & 5.7577 & 538.189 & 11\end{array}$ $\begin{array}{lllllllllllll}1.00 & 74.58 & 27.36 & 24.64 & 2 & 1786.8934 & 1786.8819 & 894.4482 & 0.0115 & 6.4285 & 455.547 & 57 \\ 0.59 & 20.76 & 27.49 & 14.74 & 3 & 1786.8940 & 1786.8819 & 596.6346 & 0.0121 & 6.7601 & 549.055 & 36\end{array}$ $\begin{array}{ccccccccccc}0.59 & 20.76 & 27.49 & 14.74 & 3 & 1786.8940 & 1786.8819 & 596.6346 & 0.0121 & 6.7601 & 549.055 \\ 1.00 & 78.99 & 21.04 & 26.97 & 2 & 2336.9774 & 2336.9751 & 1169.4948 & 0.0023 & 0.9833 & 7.187\end{array}$ $\begin{array}{lllllllllllll}1.00 & 78.99 & 21.04 & 26.97 & 2 & 2336.9774 & 2336.9751 & 1169.4948 & 0.0023 & 0.9833\end{array}$

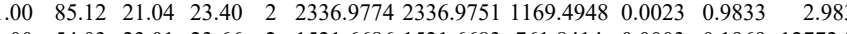
$\begin{array}{llllllllllll} & & & \end{array}$ $\begin{array}{lllllllllllllllll} & \end{array}$

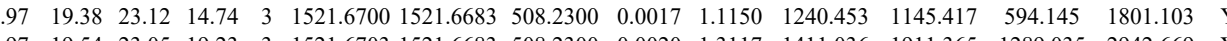

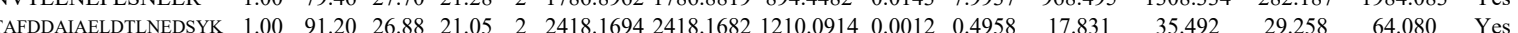
$\begin{array}{llllllllllllllll}\text { TAFDDAIAELDTLNEDSYK } & 1.00 & 85.05 & 26.88 & 18.91 & 2 & 2418.1694 & 2418.1682 & 1210.0914 & 0.0012 & 0.4958 & 31.964 & 56.754 & 49.048 & 65.184 & \text { Yes }\end{array}$ $\begin{array}{llllllllllllllll}\text { TAFDDAIAELDTLNEDSYK } & 0.60 & 81.02 & 26.89 & 94.02 & 3 & 2418.1720 & 2418.1682 & 807.0633 & 0.0038 & 1.5695 & 141.214 & 186.996 & 105.052 & 77.653 & \text { Yes }\end{array}$ $\begin{array}{llllllllllllllllll}\text { YLAEVATGEK } & 1.00 & 59.72 & 27.00 & 26.99 & 2 & 1367.7534 & 1367.7540 & 684.8843 & -0.0006 & -0.4380 & 10059.919 & 13092.533 & 1192.195 & 24847.347 & \text { Yes }\end{array}$ $\begin{array}{llllllllllllllll}\text { YLAEVATGEK } & 1.00 & 54.66 & 26.90 & 26.59 & 2 & 1367.7544 & 1367.7540 & 684.8843 & 0.0004 & 0.2920 & 6640.269 & 10165.352 & 1045.371 & 17037.000 & \text { Yes }\end{array}$ $\begin{array}{llllllllllllllll}\text { TAFDDAIAELDTLNEDSYK } & 0.67 & 47.95 & 26.90 & 60.95 & 3 & 2418.1717 & 2418.1682 & 807.0633 & 0.0035 & 1.4456 & 6.091 & 3.098 & 2.483 & 2.934 & \text { No }\end{array}$ $\begin{array}{llllllllllllllll}\text { YLAEVATGEK } & 1.00 & 57.33 & 26.80 & 33.93 & 2 & 1367.7672 & 1367.7540 & 684.8843 & 0.0132 & 9.6366 & 5699.748 & 7007.330 & 385.400 & 11572.502 & \text { Yes }\end{array}$ $\begin{array}{llllllllllllllll}\text { YLAEVATGEK } & 1.00 & 59.99 & 26.80 & 34.13 & 2 & 1367.7672 & 1367.7540 & 684.8843 & 0.0132 & 9.6366 & 8451.401 & 9677.307 & 647.063 & 16107.926 & \text { Yes }\end{array}$

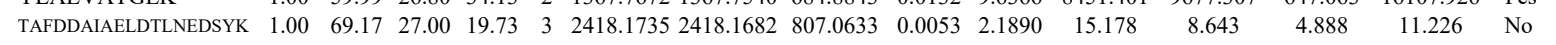

64 ELNITAAK

ELNITAAK

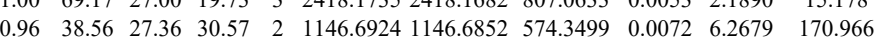
$\begin{array}{llllllllllll}0.98 & 44.55 & 27.34 & 35.84 & 2 & 1146.6932 & 1146.6852 & 574.3499 & 0.0080 & 6.9643 & 518.533 & 594\end{array}$

$\begin{array}{llll}13.861 & 385.351 & 456.185 & \text { Yes }\end{array}$

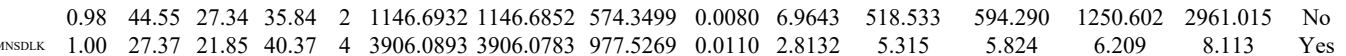

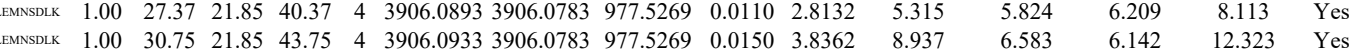
$\begin{array}{lllllllllllllllll}\text { NSSDLK } & 0.75 & 5.40 & 22.04 & 18.40 & 4 & 3906.0857 & 3906.0783 & 977.5269 & 0.0074 & 1.8925 & 46.429 & 31.617 & 5.956 & 20.387 & \text { Yes }\end{array}$ $\begin{array}{lllllllllllll}\text { VETFSGVYK } & 1.00 & 29.93 & 21.96 & 42.93 & 4 & 3906.0865 & 3906.0783 & 977.5269 & 0.0082 & 2.0971 & 34.943 & 51.3\end{array}$

VETSGYK $\begin{array}{lllllllllllllllll}\text { VETFSGVYK } & 1.00 & 57.71 & 28.29 & 39.56 & 2 & 1316.7330 & 1316.7220 & 659.3683 & 0.0110 & 8.3412 & 8907.055 & 8950.400 & 698.729 & 14828.169 & \text { Yes } \\ \text { VETFSGVYK } & 1.00 & 57.82 & 27.99 & 40.81 & 2 & 1316.7346 & 1316.7220 & 659.3683 & 0.0126 & 9.5545 & 7376.535 & 8935.539 & 606.364 & 12421.370 & \text { Yes }\end{array}$

$\begin{array}{lllllllllllllll}1.00 & 57.12 & 28.13 & 38.22 & 2 & 1316.7308 & 1316.7220 & 659.3683 & 0.0088 & 6.6730 & 15400.284 & 14334.469 & 924.599 & 20515.898 & \text { Yes } \\ & 1316.7220 & 659.3683 & 0.0094 & 7.1280 & 15718.645 & 18208.501 & 429.176 & 23955.275 & \text { Yes }\end{array}$

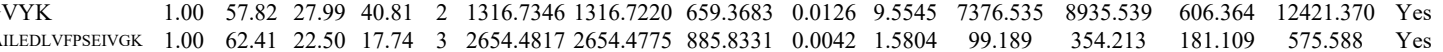
$\begin{array}{llllllllllllllll} & \end{array}$ $\begin{array}{lllllllllllllll} & \end{array}$

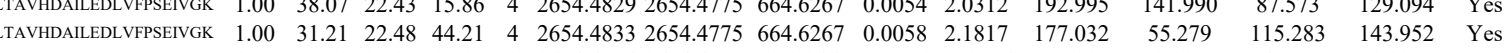

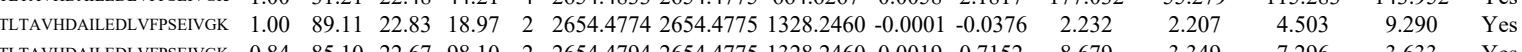
$\begin{array}{llllllllllllll} & 121.613 & 10.193 & \text { Yes }\end{array}$ $\begin{array}{llllllllllllllll}\text { TLTAVHDALEDDLVFPSEIVGK } & 1.00 & 31.35 & 22.48 & 44.35 & 4 & 2654.4833 & 2654.4775 & 664.6267 & 0.0058 & 2.1817 & 37.281 & 84.055 & 89.105 & 92.308 & \text { Yes }\end{array}$

Table S-4 page 377 of 614 

$\begin{array}{lllllllllllllllll}0.51 & 14.98 * 16.53 & 27.36 & 2 & 967.6306 & 967.6300 & 484.8223 & 0.0006 & 0.6188 & 1278.035 & 1518.313 & 1050.597 & 1770.691 & \text { Yes }\end{array}$ $\begin{array}{llllllllllllllll}0.68 & 14.08 * & 16.53 & 22.46 & 2 & 967.6312 & 967.6300 & 484.8223 & 0.0012 & 1.2376 & 1445.337 & 1801.063 & 1135.356 & 1979.490 & \text { Yes } \\ 0.69 & 15.98 & 16.72 & 16.19 & 2 & 111.7312 & 111.7321 & 556.873 & 0.0009 & 0.881 & 621.952 & 6987.171 & 4513.246 & 8872.074 & \text { Yes }\end{array}$

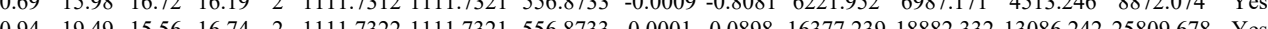
$\begin{array}{lllllllllllllll}0.94 & 19.49 & 15.56 & 16.74 & 2 & 111.7322 & 1111.7321 & 556.8733 & 0.0001 & 0.0898 & 16377.239 & 18882.332 & 13086.242 & 25809.678 & \text { Yes }\end{array}$ $\begin{array}{lllllllllllllll}0.95 & 30.45 & 25.59 & 20.16 & 2 & 1112.6572 & 1112.6577 & 557.3361 & -0.0005 & -0.4486 & 9095.134 & 8752.014 & 2843.354 & 13134.072 & \text { Yes } \\ 0.98 & 30.22 & 25.43 & 20.35 & 2 & 11126584 & 1112.6577 & 557.3361 & 0.0007 & 0.6280 & 12084.915 & 11796.166 & 1784.099 & 19518.015 & \text { Yes }\end{array}$ $\begin{array}{lllllllllllllllll}0.97 & 21.91 & 15.56 & 16.97 & 2 & 111.7322 & 1111.7321 & 556.8733 & 0.0001 & 0.0898 & 6392.949 & 7571.511 & 4306.951 & 9808.889 & \text { Yes }\end{array}$

ILPKPTR

HVVFIAQR

ILPKPTR $\begin{array}{llllllllllllllll}0.95 & 19.76 & 15.56 & 17.04 & 2 & 1111.7324 & 1111.7321 & 556.8733 & 0.0003 & 0.2694 & 10229.135 & 11653.217 & 7387.933 & 14673.749 & \text { Yes }\end{array}$

ILPKPTR

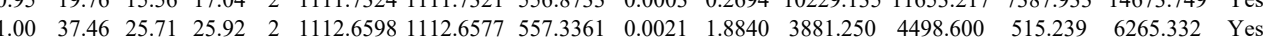

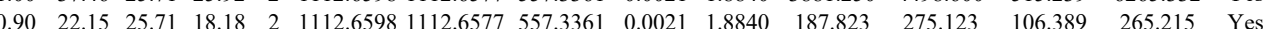
$\begin{array}{lllllllllllllllll}0.88 & 16.88 & 16.72 & 16.38 & 2 & 1111.7318 & 1111.7321 & 556.8733 & -0.0003 & -0.2694 & 4199.107 & 4442.096 & 2568.028 & 5572.491 & \text { Yes }\end{array}$ $\begin{array}{llllllllllllllll}0.94 & 19.06 & 15.56 & 14.64 & 2 & 1111.7324 & 1111.7321 & 556.8733 & 0.0003 & 0.2694 & 3868.943 & 4418.293 & 2693.882 & 5555.316 & \text { Yes }\end{array}$

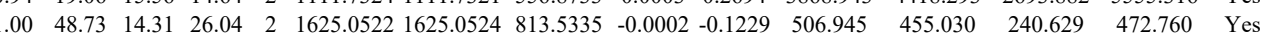
AIIIFVPVPQLK AIIIFVPVPQLK

ILPKPTR

AIIIFVPVPQLK

AIIIFVPVPQLK

AIIIFVPVPQLK

AIIIFVPVPQLK

AIIIFVPVPQLK

AIIIFVPVPQLK

KAIIIFVPVPQLK

AIIIFVPVPQLK

AIIIFVPVPQLK

IIIFVPVPQLK

AIIFVPVPQLK

KAIIFVPYPQLK

KAIITVPYQLKK

AIIFVPVPQLK

AUFVPVYPQLK

AIIIFVPVPOLK

KAIIIFVPVPQLK

HVVFIAQR

AIIIFVPVPOLK

HVVFIAQR

AIIIFVPVPQLK

AIIIFVPVPQLK

HVVFIAQR

HVVFIAQR

HVVFIAQR

AIIIFVPVPQLK

AIIIFVPVPQLK

AIIIFVPVPQLK

AIIIFVPVPQLK

$\begin{array}{lllllllllll}\text { PP1A_HUMAN } & \text { P62136 } & \text { PPP1CA } & \text { Serine/threonine-p } 37.512 & 1.00 & 9 & 37 & -0.1922 & 0.3456 & 1.1301 & 0.5392\end{array}$

AHQVVEDGYEFFAK $\begin{array}{lllllllllll}67.85 & 13.42 & 22.71 & 2 & 1625.0534 & 1625.0524 & 813.5335 & 0.0010 & 0.6146 & 226.308 & 232 .\end{array}$ $\begin{array}{llllllllllll}0.66 & 28.90 & 13.42 & 41.90 & 3 & 1625.0545 & 1625.0524 & 542.6914 & 0.0021 & 1.2899 & 105.931\end{array}$ $\begin{array}{llllllllllll}1.00 & 38.84 & 13.62 & 18.93 & 3 & 1625.0557 & 1625.0524 & 542.6914 & 0.0033 & 2.0269 & 66.081\end{array}$ $\begin{array}{lllllllllll}0.72 & 18.40 & 18.39 & 21.54 & 2 & 1111.7306 & 1111.7321 & 556.8733 & -0.0015 & -1.3468 & 1398.783\end{array}$ $\begin{array}{llllllllllll}0.64 & 40.78 & 14.31 & 53.78 & 2 & 1625.0520 & 1625.0524 & 813.5335 & -0.0004 & -0.2458 & 11.898\end{array}$ $\begin{array}{lllllllllllll}1.00 & 61.22 & 13.42 & 20.61 & 2 & 1625.0536 & 1625.0524 & 813.5335 & 0.0012 & 0.7375 & 694.407 & 61 & \\ 0\end{array}$ $\begin{array}{lllllllllllll}0.55 & 10.27 & 13.42 & 23.27 & 3 & 1625.0539 & 1625.0524 & 542.6914 & 0.0015 & 0.9213 & 54.202 & 55 & \\ 1.00 & 65.96 & 13.42 & 21.20 & 2 & 1625.0544 & 1625.0524 & 813.5335 & 0.0020 & 12292 & 768.837 & 116\end{array}$ $\begin{array}{ccccccccccc}1.00 & 65.96 & 13.42 & 21.20 & 2 & 1625.0544 & 1625.0524 & 813.5335 & 0.0020 & 1.2292 & 768.837 \\ 0.66 & 5.18 & 13.42 & 18.18 & 3 & 1625.0548 & 1625.0524 & 542.6914 & 0.0024 & 1.4741 & 70.047\end{array}$ $\begin{array}{lccccccccccc}0.66 & 5.18 & 13.42 & 18.18 & 3 & 1625.0548 & 1625.0524 & 542.6914 & 0.0024 & 1.4741 & 70.047 \\ 1.00 & 45.30 & 13.62 & 19.29 & 3 & 1625.0557 & 1625.0524 & 542.6914 & 0.0033 & 2.0269 & 55.177\end{array}$ $\begin{array}{lllllllllllll}1.00 & 45.30 & 13.62 & 19.29 & 3 & 1625.0557 & 1625.0524 & 542.6914 & 0.0033 & 2.0269 & 55.177 \\ 1.00 & 36.23 & 13.62 & 19.65 & 3 & 1625.0569 & 1625.0524 & 542.6914 & 0.0045 & 2.7640 & 26.309\end{array}$ $\begin{array}{llllllllllllll}1.00 & 36.23 & 13.62 & 19.65 & 3 & 1625.0569 & 1625.0524 & 542.6914 & 0.0045 & 2.7640 & 26.309 \\ 0.67 & 9.26 & 3.01 & 22.26 & 3 & 1897.2520 & 1897.2494 & 633.4237 & 0.0026 & 1.3682 & 691.197\end{array}$

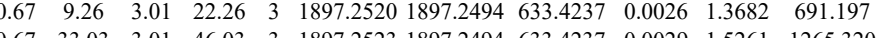
$\begin{array}{llllllllllllll}1.67 & 33.03 & 3.01 & 46.03 & 3 & 1897.2523 & 1897.2494 & 633.4237 & 0.0029 & 1.5261 & 1265.320 & 1299.136\end{array}$ $\begin{array}{llllllllllll}1.00 & 61.63 & 14.31 & 26.27 & 2 & 1625.0522 & 1625.0524 & 813.5335 & -0.0002 & -0.1229 & 130.958\end{array}$ $\begin{array}{lllllllllll}1.00 & 65.86 & 13.62 & 26.57 & 2 & 1625.0530 & 1625.0524 & 813.5355 & 0.0006 & 0.3688 & 236.749\end{array}$ $\begin{array}{lllllllllll}0.67 & 28.40 & 13.42 & 41.40 & 3 & 1625.0551 & 1625.0524 & 542.6914 & 0.0027 & 1.6884 & 12.842\end{array}$

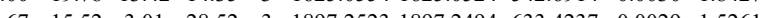
$\begin{array}{lllllllllll}0.67 & 15.52 & 3.01 & 28.52 & 3 & 1825.0554 & 1625.0524 & 542.6914 & 0.0030 & 1.8427 & 14.891\end{array}$ $\begin{array}{lllllllllll}1.00 & 62.59 & 13.62 & 18.68 & 2 & 1625.0532 & 16250524 & 813.5335 & 0.0008 & 0.4917 & 53.363\end{array}$

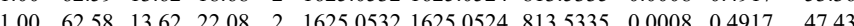
$\begin{array}{lllllllllllll}1.00 & 21.75 & 13.42 & 16.84 & 3 & 1625.0545 & 1625.0524 & 542.6914 & 0.0021 & 1.2899 & 18.252\end{array}$ $\begin{array}{lllllllllll}0.67 & 14.48 & 13.42 & 27.48 & 3 & 1625.0551 & 1625.0524 & 542.6914 & 0.0027 & 1.6584 & 33.576\end{array}$ $\begin{array}{lllllllllllll}0.55 & 12.85 & 3.01 & 25.85 & 3 & 1897.2505 & 1897.2494 & 633.4237 & 0.0011 & 0.5789 & 140.577 & 15\end{array}$ $\begin{array}{llllllllllll}0.91 & 22.95 & 25.43 & 20.04 & 2 & 1112.6582 & 1112.6577 & 557.3361 & 0.0005 & 0.4486 & 443.613\end{array}$ $\begin{array}{llllllllllll}1.00 & 65.67 & 13.42 & 22.20 & 2 & 1625.0544 & 1625.0524 & 813.5335 & 0.0020 & 1.2292 & 28.158\end{array}$ $\begin{array}{lllllllllll}0.96 & 30.92 & 25.59 & 20.83 & 2 & 1112.6572 & 1112.6577 & 557.3361 & -0.0005 & -0.4486 & 425.910\end{array}$ $\begin{array}{llllllllllll}0.66 & 13.24 & 13.42 & 26.24 & 3 & 1625.0545 & 1625.0524 & 542.6914 & 0.0021 & 1.2899 & 43.041\end{array}$ $\begin{array}{lllllllllllll}0.67 & 7.18 & 13.42 & 20.18 & 3 & 1625.0551 & 1625.0524 & 542.6914 & 0.0027 & 1.6584 & 28.562\end{array}$ $\begin{array}{llllllllllll}0.76 & 21.76 & 25.34 & 27.14 & 2 & 1112.6576 & 1112.6577 & 557.3361 & -0.0001 & -0.0897 & 224.725\end{array}$ $\begin{array}{llllllllllll}0.95 & 26.00 & 25.43 & 19.11 & 2 & 1112.6584 & 1112.6577 & 557.3361 & 0.0007 & 0.6280 & 182.381\end{array}$ $\begin{array}{cccccccccccc}0.98 & 29.81 & 25.35 & 19.51 & 2 & 1112.6586 & 1112.6577 & 557.3361 & 0.0009 & 0.8074 & 260.219 & 276 \\ 0.67 & 2.15 & 13.42 & 15.15 & 3 & 1625.0551 & 1625.0524 & 542.6914 & 0.0027 & 1.6584 & 12.557 & 7 .\end{array}$ $\begin{array}{lllllllllllll}0.55 & 4.71 & 13.42 & 17.71 & 3 & 1625.0536 & 1625.0524 & 542.6914 & 0.0012 & 0.7371 & 7.330\end{array}$ $\begin{array}{lllllllllllll}0.97 & 25.80 & 13.62 & 24.66 & 3 & 1625.0575 & 1625.0524 & 542.6914 & 0.0051 & 3.1325 & 13.426 \\ 0.55 & 10.65 & 13.42 & 23.65 & 3 & 1625.0539 & 1625.0524 & 542.6914 & 0.0015 & 0.9213 & 11.632\end{array}$ IYGFYDECK $\begin{array}{lllllllllllll}.55 & 10.65 & 13.42 & 23.65 & 3 & 1625.0539 & 1625.0524 & 542.6914 & 0.0015 & 0.9213 & 11.632 & 9.576\end{array}$ YGFYDECK

$\begin{array}{lllllllllllll}1.00 & 48.49 & 27.70 & 16.97 & 3 & 1926.9754 & 1926.9720 & 643.3313 & 0.0034 & 1.7617 & 1301.452 & 1026.733 \\ 0.96 & 25.64 & 24.97 & 21.63 & 2 & 1470.6782 & 1470.6767 & 736.3456 & 0.0015 & 1.0185 & 893.810 & 867.358 \\ 1.00 & 56.15 & 25.05 & 22.43 & 2 & 440.6701470 .6767 & 736.3456 & 0.003 & 0.037 & 739.004 & 5483\end{array}$ $\begin{array}{llllllllllll}\text { EIFLSQPILLELEAPLK } & 0.84 & 64.36 & 18.39 & 77.36 & 2 & 2240.3294 & 2240.3275 & 1121.1710 & 0.0019 & 0.8473 & 69.126\end{array}$ $\begin{array}{llllllllllll} & \end{array}$ $\begin{array}{lllllllllllll} & \text { EIFLSQPILLELEAPLK } & 1.00 & 42.32 & 18.06 & 17.41 & 3 & 2240.3311 & 2240.3275 & 747.7831 & 0.0036 & 1.6047 & 23.393\end{array}$ $\begin{array}{lllllllllll} & \end{array}$ $\begin{array}{lllllllllllll}\text { TFTDCFNCLPIAAIVDEK } & 1.00 & 85.78 & 26.36 & 21.10 & 2 & 2379.1234 & 2379.1226 & 1190.5686 & 0.0008 & 0.3360 & 55.140\end{array}$ $\begin{array}{llllllll} & \end{array}$

$\begin{array}{lllllllllll}1.00 & 66.50 & 27.23 & 17.63 & 4 & 2379.1265 & 2379.1226 & 595.7879 & 0.0039 & 1.6365 & 90.920\end{array}$

7.65
7
7



\begin{tabular}{llllllllllllllll} 
YPENFFLLR & 1.00 & 50.63 & 27.06 & 27.11 & 2 & 1341.7218 & 1341.7203 & 671.8674 & 0.0015 & 1.1163 & 2266.305 & 1668.342 & 4199.530 & 4568.861 & Yes \\
\hline
\end{tabular} $\begin{array}{llllllllllllllll}\text { IFCCHGGLSPDLQSMEQIR } & 0.66 & 42.17 & 24.20 & 55.17 & 3 & 2369.0602 & 2369.0580 & 790.6933 & 0.0022 & 0.9275 & 234.887 & 238.955 & 36.521 & 322.073 & \text { Yes } \\ \text { LNLDSIIGR } & 0.99 & 43.90 & 26.19 & 26.14 & 2 & 1143.6770 & 1143.6733 & 572.8439 & 0.0037 & 3.2295 & 13390.057 & 15244.570 & 100.850 & 19080.303 & \text { Yes }\end{array}$

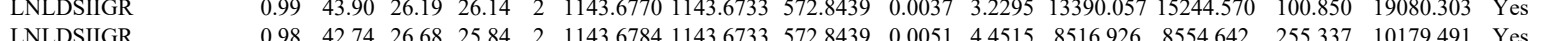

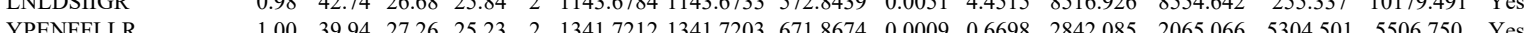

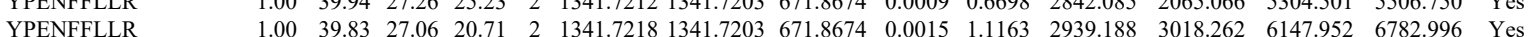

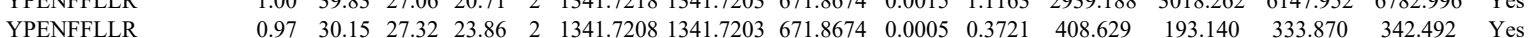

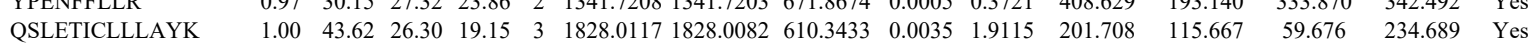
$\begin{array}{lllllllllllllll} & & \end{array}$

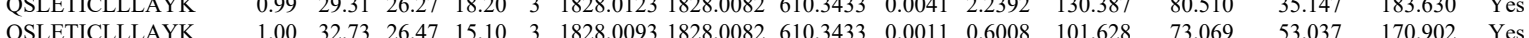

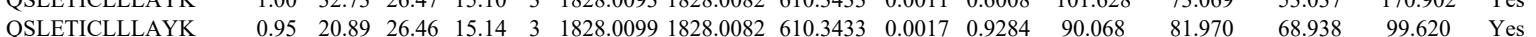

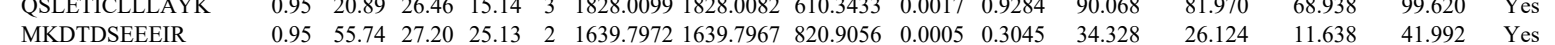
MKDTDSEEEIR

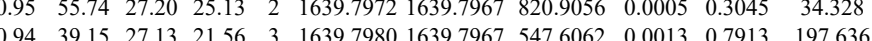

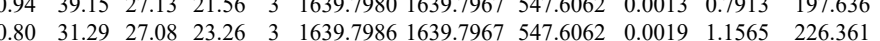

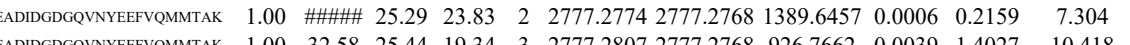
$22.215 \quad 147.129 \quad 253.943$ \begin{tabular}{|lllllllllllllllll} 
NYEEFVQMMTAK & 1.00 & 32.58 & 25.44 & 19.34 & 3 & 2777.2807 & 2777.2768 & 926.7662 & 0.0039 & 1.4027 & 10.418 & 36.610 & 21.102 & 15.980 & No
\end{tabular}

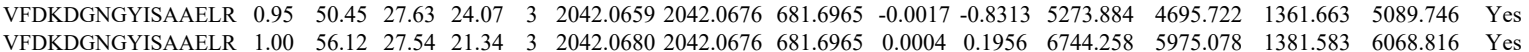
$\begin{array}{lllllllllllllllll}\text { VFDKDGNGYISAAELR } & 1.00 & 76.19 & 27.55 & 29.27 & 2 & 2042.0694 & 2042.0676 & 1022.0411 & 0.0018 & 0.8806 & 222.179 & 190.334 & 46.963 & 177.736 & \text { Yes }\end{array}$ $\begin{array}{llllllllllllllll}\text { VFDKDGNGYISAAELR } & 0.98 & 45.18 & 27.54 & 23.47 & 3 & 2042.0686 & 2042.0676 & 681.6965 & 0.0010 & 0.4890 & 3189.404 & 2894.820 & 560.428 & 3784.678 & \text { Yes }\end{array}$ $\begin{array}{lllllllllllll}\text { DTDSEEEIR } & 1.00 & 57.66 & 23.93 & 24.60 & 2 & 1236.5582 & 1236.5592 & 619.2869 & -0.0010 & -0.8074 & 63.496 & \\ \text { DTDSEEEIR } & 0.61 & 21.57 & 23.93 & 16.13 & 2 & 1236.5582 & 1236.5592 & 619.2869 & -0.0010 & -0.8074 & 45.303\end{array}$

DTDSEEEIR

DTDSEEEIR

DTDSEEEIR

DTDSEEEIR

DTDSEEEIR

DTDSEEEIR

DTDSEEEIR

DTDSEEEIR

DTDSEEEIR

DTDSEEEIR

DTDSEEEIR

DTDSEEEIR

DTDSEEEIR

DTDSEEEIR

DTDSEEEIR

DTDSEEEEIR

MKDTDSEEEIR

MKDTDSEEEIR $\begin{array}{llllllllllll}1.00 & 48.62 & 24.18 & 25.37 & 2 & 1236.5592 & 1236.5592 & 619.2869 & 0.0000 & 0.0000 & 72.254 \\ 1.00 & 42.35 & 24.20 & 20.52 & 2 & 1236.5596 & 1236.5592 & 619.2869 & 0.0004 & 0.3230 & 61.220\end{array}$ $\begin{array}{llllllllllll}1.00 & 52.99 & 24.20 & 23.12 & 2 & 1236.5598 & 1236.5592 & 619.2869 & 0.0006 & 0.4844 & 481.408\end{array}$ $\begin{array}{llllllllllll}1.00 & 55.52 & 24.20 & 25.37 & 2 & 1236.5598 & 1236.5592 & 619.2869 & 0.0006 & 0.4844 & 51.053 \\ 1.00 & 49.04 & 24.20 & 17.71 & 2 & 12365600 & 12365992 & 619.2869 & 0.0008 & 0.6459 & 73.579\end{array}$ $\begin{array}{llllllllllll}1.00 & 49.04 & 24.20 & 17.71 & 2 & 1236.5600 & 1236.5592 & 619.2869 & 0.0008 & 0.6459 & 73.579 \\ 0.95 & 24.12 & 24.20 & 19.55 & 2 & 1236.5600 & 1236.5592 & 619.2869 & 0.0008 & 0.6459 & 58.135\end{array}$ $\begin{array}{lllllllllll}0.95 & 24.12 & 24.20 & 19.55 & 2 & 1236.5600 & 1236.5592 & 619.2869 & 0.0008 & 0.6459 & 58.135 \\ 0.88 & 19.99 & 24.20 & 15.79 & 2 & 1236.5600 & 1236.5592 & 619.2869 & 0.0008 & 0.6459 & 29.077\end{array}$ $\begin{array}{lllllllllll}0.88 & 19.99 & 24.20 & 15.79 & 2 & 1236.5600 & 1236.5592 & 619.2869 & 0.0008 & 0.6459 & 29.077 \\ 1.00 & 43.06 & 23.98 & 21.63 & 2 & 1236.5602 & 1236.5592 & 619.2869 & 0.0010 & 0.8074 & 64.552\end{array}$ $\begin{array}{lllllllllll}1.00 & 43.06 & 23.98 & 21.63 & 2 & 1236.5602 & 1236.5592 & 619.2869 & 0.0010 & 0.8074 & 64.552 \\ 1.00 & 52.55 & 23.98 & 22.66 & 2 & 1236.5602 & 1236.5592 & 619.2869 & 0.0010 & 0.8074 & 59.717\end{array}$ $\begin{array}{lllllllllll}1.00 & 52.55 & 23.98 & 22.66 & 2 & 1236.5602 & 236.5592 & 19.2869 & 0.0010 & 0.8074 & 59.117 \\ 1.00 & 46.13 & 23.91 & 22.25 & 2 & 1236.5604 & 12365592 & 619.2869 & 0.0012 & 0.9689 & 63.203\end{array}$ $\begin{array}{llllllllllll}1.00 & 57.58 & 23.91 & 23.74 & 2 & 1236.5604 & 1236.5592 & 619.2869 & 0.0012 & 0.9689 & 528.559\end{array}$ $\begin{array}{llllllllllll}0.96 & 24.36 & 23.98 & 15.38 & 2 & 1236.5610 & 1236.5592 & 619.2869 & 0.0018 & 1.4533 & 53.140\end{array}$ $\begin{array}{lllllllllllll}1.00 & 44.74 & 24.15 & 28.60 & 2 & 1236.5612 & 1236.5592 & 619.2869 & 0.0020 & 1.6148 & 50.886\end{array}$ $\begin{array}{llllllllllll}16.22 & 24.12 & 29.22 & 2 & 1236.5616 & 1236.5592 & 619.2869 & 0.0024 & 1.9377 & 48.459\end{array}$

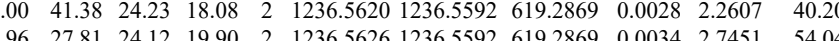
DGDGTITTK

$\begin{array}{lllllllllllll}0.96 & 39.08 & 27.19 & 21.63 & 3 & 1639.7989 & 1639.7967 & 547.6062 & 0.0022 & 1.3392 & 1837.571\end{array}$ $\begin{array}{llllllllllll}0.97 & 39.74 & 27.26 & 20.91 & 3 & 1639.8001 & 1639.7967 & 547.6062 & 0.0034 & 2.0696 & 1969.381\end{array}$ $\begin{array}{llllllllllll}0.97 & 29.86 & 27.56 & 21.40 & 2 & 1194.6346 & 1194.6336 & 598.3241 & 0.0010 & 0.8357 & 603.390\end{array}$ $\begin{array}{llllllllllll}\text { EADIDGDGQVNYEEFVQMMTAK } & 0.82 & 81.29 & 25.29 & 94.29 & 2 & 2777.2774 & 2777.2768 & 1389.6457 & 0.0006 & 0.2159 & 0.000\end{array}$ $\begin{array}{lllllllllllll}\text { EADIDGDGQVNYEEFVQMMTAK } & 0.66 & 50.92 & 25.43 & 63.92 & 3 & 2777.2789 & 2777.2768 & 926.7662 & 0.0021 & 0.7553 & 12.210 \\ \text { EADIDGDGQVNYEFFVMMMTAK } & 1.00 & 84.53 & 25.39 & 20.02 & 2 & 2777.2794 & 2777.2768 & 1389.6457 & 0.0026 & 0.9355 & 10.783\end{array}$ $\begin{array}{lllllllllllll}\text { EADIDGDGQVNYEEFVQMMTAK } & 0.67 & 29.98 & 25.40 & 42.98 & 3 & 2777.2798 & 2777.2768 & 926.7662 & 0.0030 & 1.0790 & 26.073\end{array}$ $\begin{array}{llllllllllll}\text { EADIDGDGQVNYEEFVQMMTAK } & 0.67 & 64.00 & 25.42 & 77.00 & 3 & 2777.2801 & 2777.2768 & 926.7662 & 0.0033 & 1.1869 & 11.905\end{array}$ $\begin{array}{llllllllllllll}\text { EADIDGDGQVNYEEFVQMMTAK } & 1.00 & 63.26 & 25.44 & 19.22 & 3 & 2777.2810 & 2777.2768 & 926.7662 & 0.0042 & 1.5106 & 16.993\end{array}$

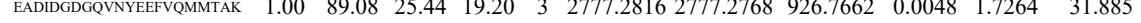
$\begin{array}{lllllllllllll}\text { EADIDGDGQVNYEEFVQMMTAK } & 1.00 & 56.09 & 25.45 & 18.70 & 3 & 2777.2819 & 2777.2768 & 926.7662 & 0.0051 & 1.8343 & 24.102\end{array}$ $\begin{array}{lllllllllllll}\text { EADIDGDGQVNYEEVVMMTAK } & 1.00 & 68.38 & 25.48 & 19.65 & 3 & 2777.2837 & 2777.2768 & 926.7662 & 0.0069 & 2.4817 & 146.150\end{array}$ $\begin{array}{llllllllllll}\text { EADIDGDGQVNYEEFVQMMTAK } & 0.90 & 35.03 * & 24.67 & 15.42 & 3 & 2793.2725 & 2793.2717 & 932.0978 & 0.0008 & 0.2861 & 20.272 \\ \text { DGNGYISAAELR } & 1.00 & 76.84 & 27.99 & 28.40 & 2 & 1408.7204 & 1408.7068 & 705.3607 & 0.0136 & 9.6404 & 221.998\end{array}$ DGNGYISAAELR DGNGYISAAELR $\begin{array}{llllllllllll}1.00 & 69.23 & 27.96 & 21.68 & 2 & 1408.7206 & 1408.7068 & 705.3607 & 0.0138 & 9.7821 & 345.049 & 2\end{array}$

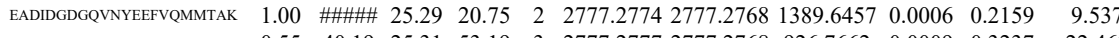

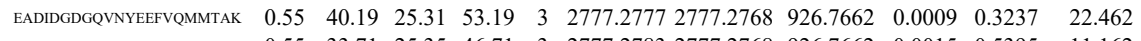
$\begin{array}{lllllllllllll}\text { EADDGDGQUNIEEVQMMTAK } & 0.55 & 33.7 & 25.35 & 46.71 & 3 & 2777.2783 & 2777.2768 & 926.7662 & 0.0015 & 0.5395 & 11.162\end{array}$

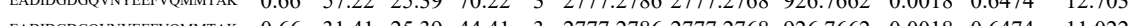

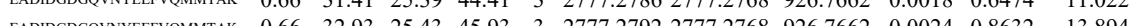

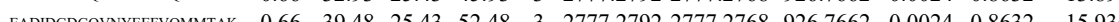
$\begin{array}{lllllllll}0 & 0.036\end{array}$ $\begin{array}{llllllllllll}\text { EADIDGDGOVNYEFFYOMMTAK } & 1.00 & 95.14 & 25.39 & 20.24 & 2 & 2777.2794 & 2777.2768 & 1389.6457 & 0.0026 & 0.9355 & 20.446\end{array}$

$\begin{array}{llll}64.856 & 154.572 & 76.184 & \text { Yes }\end{array}$


$\begin{array}{lllllllllllll} & & 23.80 & 27.84 & 17.53 & 3 & 2052.0769 & 2052.0726 & 685.0315 & 0.0043 & 2.0924 & 13\end{array}$ $\begin{array}{lllllllllllll}\text { TMLELLNQLDGFDSR } & 1.00 & 44.25 & 27.27 & 18.76 & 3 & 1894.9609 & 1894.9580 & 632.6599 & 0.0029 & 1.5279 & 99.351\end{array}$ $\begin{array}{lllllllllllll}\text { HAVIGVLMDDTDPLVTVMK } & 0.67 & 25.32 & 24.81 & 38.32 & 3 & 2440.3345 & 2440.3314 & 814.4511 & 0.0031 & 1.2687 & 477.961 & \\ \text { TMLELLNOLDGFDSR } & 1.00 & 72.15 & 27.23 & 31.12 & 2 & 1894.9602 & 1894.9580 & 948.4863 & 0.0022 & 1.1597 & 69.336\end{array}$ $\begin{array}{llllllllllllll} & \end{array}$

$\begin{array}{lllllllllllll}\text { TMLELLNQDGFDSR } & 1.00 & 43.23 & 27.28 & 28.64 & 3 & 1894.9615 & 1894.9580 & 632.6599 & 0.0035 & 1.8441 & 178.348 & 173.867 \\ \text { GVILYGPPGTGK } & 0.96 & 65.76 & 24.67 & 17.77 & 2 & 1445.804 & 1445.848 & 723.9316 & 0.0118 & 8.1499 & 801.228 & 642.182\end{array}$

IETLDPALIRPGR

IETLDPALIRPGR

AICTEAGLMALR

AICTEAGLMALR

AVANQTSATFLR

AVANQTSATFLR

AVANQTSATFLR

IFQIHTSR

IFQIHTSR

IFQHTSR

Q

$\begin{array}{llllllllllllll}0.96 & 65.76 * 24.67 & 17.77 & 2 & 1445.8604 & 1445.8486 & 723.9316 & 0.0118 & 8.1499 & 801.228 & 642.182\end{array}$

$\begin{array}{lllllllllllll}1.00 & 47.29 & 23.01 & 21.54 & 3 & 1593.9451 & 1593.9324 & 532.3181 & 0.0127 & 7.9526 & 7752.972 & 9418.031 \\ 1.00 & 40.24 & 23.01 & 20.99 & 3 & 1593.9451 & 1593.9324 & 532.3181 & 0.0127 & 7.9526 & 8578.233 & 8559.807 \\ 1.00 & 1.07 & 28.16 & 24.65 & 2 & 1437.7328 & 1437.264 & 719.875 & 0.0064 & 4.4452 & 838.368 & 81.277\end{array}$

$\begin{array}{lllllllllllll}1.00 & 40.24 & 23.01 & 20.99 & 3 & 1593.9451 & 1593.9324 & 532.3181 & 0.0127 & 7.9526 & 8578.233 & 8559.807 & 1900 \\ 1.00 & 61.07 & 28.16 & 24.65 & 2 & 1437.7328 & 1437.7264 & 719.8705 & 0.0064 & 4.4452 & 838.368 & 811.277\end{array}$

$\begin{array}{lllllllllllll}1.00 & 60.46 & 28.16 & 24.00 & 2 & 1437.7328 & 1437.7264 & 719.8705 & 0.0064 & 4.4452 & 621.506 & 997.108\end{array}$

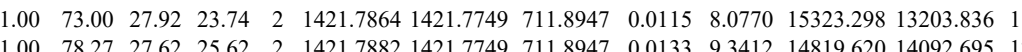
$\begin{array}{lllllllllllll}1.00 & 78.27 & 27.62 & 25.62 & 2 & 1421.7882 & 1421.7749 & 711.8947 & 0.0133 & 9.3412 & 14819.620 & 14092.695 & 1223 .\end{array}$ $\begin{array}{lllllllllll}.00 & 72.28 & 27.50 & 22.12 & 2 & 1421.7856 & 1421.7749 & 711.8947 & 0.0107 & 7.5151 & 3080.054\end{array}$

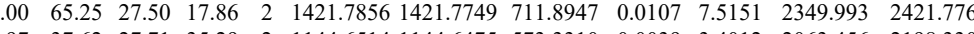

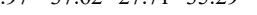

NQEQMKPLEEK $\begin{array}{lllllllllllllll}0.99 & 40.91 & 27.92 & 35.60 & 2 & 1144.6500 & 1144.6475 & 573.3310 & 0.0025 & 2.1802 & 3053.097 & 3554.655 & 848.521 & 6108.368 & Y \text { Ses }\end{array}$ $\begin{array}{lllllllllllllll}0.92 & 22.80 & 27.17 & 25.104 & 3 & 1144.6502 & 1144.6475 & 573.3310 & 0.0027 & 2.3547 & 1086.088 & 1019.114 & 597.311 & 1844.906 & \text { Yes }\end{array}$ $\begin{array}{lllllllllllllllllll} & 0.90 & 24.62 & 27.08 & 19.51 & 3 & 1804.9777 & 1804.9718 & 602.6645 & 0.0059 & 3.2633 & 32952.280 & 32774.224 & 25575.061 & 37772.797 & Y & Y\end{array}$ $\begin{array}{llllllllllllllll} & 21.78 & 2 & 2490.2854 & 2490.2845 & 1246.1495 & 0.0009 & 0.3611 & 12.240 & 14.722 & 11.059 & 21.509 & \text { Yes }\end{array}$ $\begin{array}{llllllllllllllll} & \end{array}$

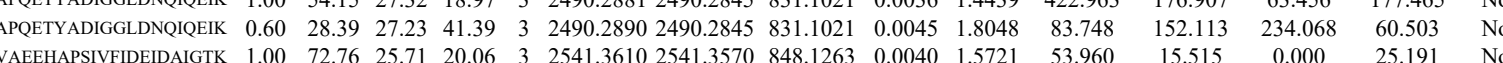

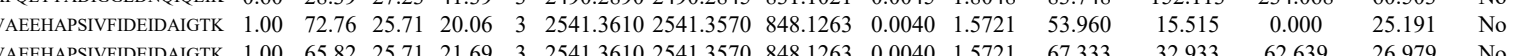
$\begin{array}{lllllllllllllllll}\text { VAEEHAPSIVFIDEIDAIGTK } & 1.00 & 65.82 & 25.71 & 21.69 & 3 & 2541.3610 & 2541.3570 & 848.1263 & 0.0040 & 1.5721 & 67.333 & 32.933 & 62.639 & 26.979 & \text { No } \\ \text { IEELQLIVNDK } & 1.00 & 48.55 & 24.64 & 26.22 & 2 & 1600.9292 & 160.927 & 80.4712 & 0.0013 & 0.8110 & 287.789 & 246.213 & 108.004 & 556.737 & \text { Yes }\end{array}$

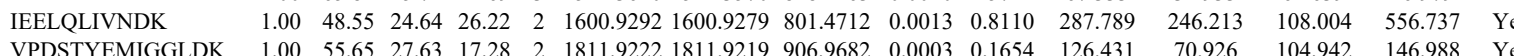
\begin{tabular}{lllllllllllllllll} 
& VPDSTYEMIGGLDK & 1.00 & 55.65 & 27.63 & 17.28 & 2 & 1811.9222 & 1811.9219 & 906.9682 & 0.0003 & 0.1654 & 126.431 & 70.926 & 104.942 & 146.988 & Yes \\
\hline
\end{tabular} $\begin{array}{llllllllllllllllll} & \end{array}$ $\begin{array}{llllllllllllllll}\text { EHAPSIIFMDEIDSIGSSR } & 0.67 & 21.05 & 27.17 & 34.05 & 3 & 2247.0991 & 2247.0963 & 750.0394 & 0.0028 & 1.2444 & 49.001 & 21.993 & 42.142 & 82.279 & \text { Yes }\end{array}$

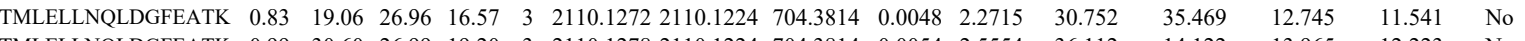
$\begin{array}{llllllllllllllll}\text { TMLELLNQLDGFEATK } & 0.99 & 30.60 & 26.99 & 19.20 & 3 & 2110.1278 & 2110.1224 & 704.3814 & 0.0054 & 2.5554 & 36.112 & 14.122 & 13.965 & 12.223 & \text { No }\end{array}$ $\begin{array}{llllllllllllllll}\text { VDPLVSLMMVEK } & 1.00 & 59.78 & 26.55 & 27.35 & 2 & 1647.9210 & 1647.9183 & 824.9664 & 0.0027 & 1.6364 & 181.366 & 72.803 & 18.853 & 122.945 & \text { No }\end{array}$

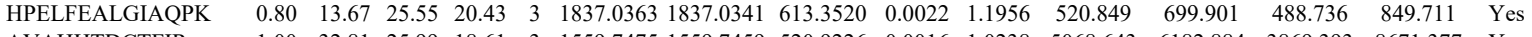

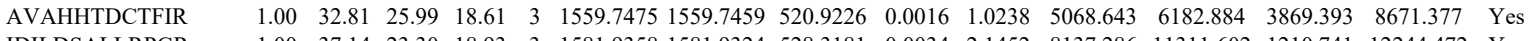
$\begin{array}{llllllllllllllllll}\text { AVILDSALLRPGR } & 1.00 & 37.14 & 23.30 & 18.93 & 3 & 1581.9358 & 1581.9324 & 528.3181 & 0.0034 & 2.1452 & 8137.286 & 11311.602 & 1210.741 & 12244.472 & \text { Yes }\end{array}$ $\begin{array}{llllllllllllllll}\text { IDILDSALLRPGR } & 1.00 & 46.34 & 23.14 & 17.68 & 3 & 1581.9370 & 1581.9324 & 528.3181 & 0.0046 & 2.9023 & 13137.361 & 16186.670 & 1735.974 & 18325.677 & \text { Yes }\end{array}$ $\begin{array}{llllllllllllllll}\text { IDILDSALLRPGR } & 1.00 & 43.69 & 23.34 & 16.27 & 3 & 1581.9355 & 1581.9324 & 528.3181 & 0.0031 & 1.9559 & 7884.806 & 9425.005 & 1523.751 & 10593.876 & \text { Yes }\end{array}$ $\begin{array}{llllllllllllllll}\text { IDILDSALLRPGR } & 0.60 & 36.76 & 23.22 & 49.76 & 3 & 1581.9364 & 1581.9324 & 528.3181 & 0.0040 & 2.5237 & 5552.054 & 6307.139 & 255.780 & 8315.394 & \text { Yes }\end{array}$

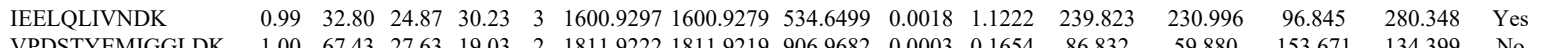

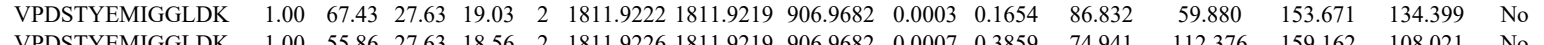
\begin{tabular}{llllllllllllllll} 
VPDSTYEMIGGLDK & 1.00 & 55.86 & 27.63 & 18.56 & 2 & 1811.9226 & 1811.9219 & 906.9682 & 0.0007 & 0.3859 & 74.941 & 112.376 & 159.162 & 108.021 & No \\
\hline ISSLLEQFQQ
\end{tabular} ISSLLEEQFQQGK ISSLLEEQFQQGK ISSLLEQRQQGK $\begin{array}{lllllllllllllll}1.00 & 80.87 & 27.13 & 28.74 & 2 & 1793.9774 & 1793.9767 & 897.9956 & 0.0007 & 0.3898 & 1326.468 & 1497.500 & 240.515 & 1610.022 & \text { Yes } \\ 1.00 & 64.68 & 27.13 & 28.91 & 2 & 1793.9774 & 1793.9767 & 897.9956 & 0.0007 & 0.3898 & 4397.035 & 4256529 & 1218764 & 3068.73 & \text { Yes }\end{array}$

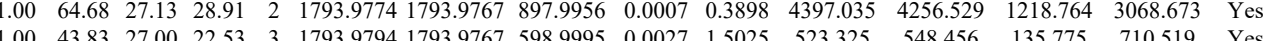

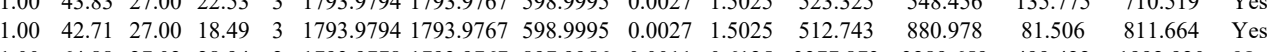

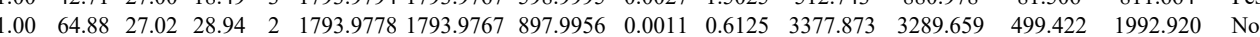
$\begin{array}{lllllllllllllll}1.00 & 68.54 & 27.02 & 28.66 & 2 & 1793.9778 & 1793.9767 & 897.9956 & 0.0011 & 0.6125 & 2660.296 & 2577.033 & 548.107 & 2279.627 & \text { Yes }\end{array}$ 


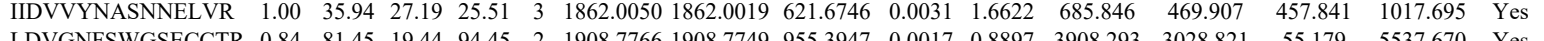

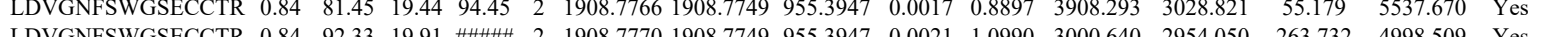
\begin{tabular}{llllllllllllllll} 
& LDVIVLIDSTPYR \\
NCIN & 1.00 & 48.87 & 28.05 & 17.06 & 2 & 1582.7992 & 1582.7969 & 792.4057 & 0.0023 & 1.4513 & 188.235 & 193.511 & 61.468 & 4985.509 & Yes \\
\hline
\end{tabular}

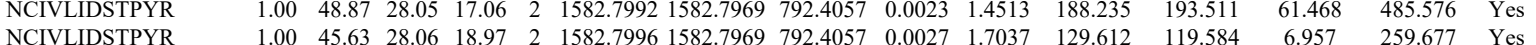
$\begin{array}{lllllllllllllll} & \end{array}$

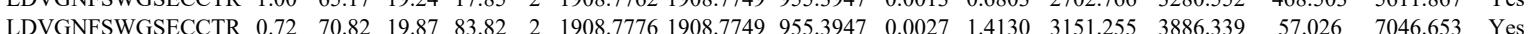
$\begin{array}{llllllllllllllll}\text { NCIVLIDSTPYR } & 0.99 & 47.64 & 27.92 & 19.25 & 2 & 1582.8032 & 1582.7969 & 792.4057 & 0.0063 & 3.9752 & 1077.501 & 1044.841 & 447.786 & 2980.030 & \text { Yes }\end{array}$

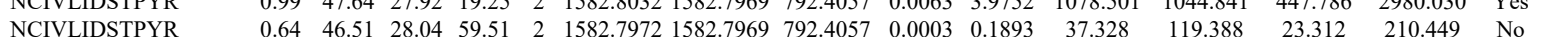

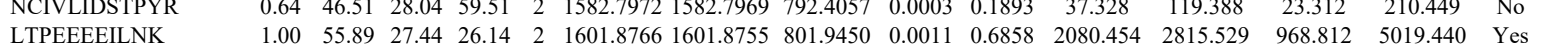
LTPEEEEILNK LTPEEEEILNK LTPEEEEILNK LTPEEEEILNK LTPEEEEILNK LTPEEEEILNK LTPEEEEILNK ADGYVLEGK ADGYVLEGK $\begin{array}{lllllllllllllll}1.00 & 55.89 & 27.44 & 26.14 & 2 & 1601.8766 & 1601.8755 & 801.9450 & 0.0011 & 0.6858 & 2080.454 & 2815.529 & 968.812 & 5019.440 & \text { Yes } \\ 1.00 & 55.53 & 27.32 & 24.80 & 2 & 1601.8770 & 1601.8755 & 801.9450 & 0.0015 & 0.9352 & 5898.439 & 6822.220 & 2962.486 & 11336.228 & \text { Yes }\end{array}$ $\begin{array}{lllllllllllllll}1.00 & 35.98 & 27.57 & 28.49 & 3 & 1601.8774 & 1601.8755 & 534.9658 & 0.0019 & 1.1839 & 114.702 & 63.946 & 90.507 & 81.355 & \text { No }\end{array}$

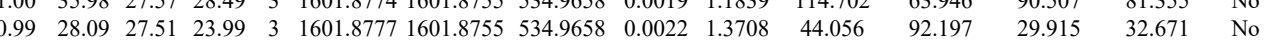
$\begin{array}{lllllllllllllll}1.00 & 54.85 & 27.32 & 24.26 & 2 & 1601.8770 & 1601.8755 & 801.9450 & 0.0015 & 0.9352 & 2371.383 & 2427.979 & 1015.197 & 3750.483 & \text { Yes }\end{array}$ $\begin{array}{lllllllllllllll}1.00 & 57.25 & 27.44 & 24.86 & 2 & 1601.8778 & 1601.8755 & 801.9450 & 0.0023 & 1.4340 & 7917.800 & 8234.848 & 3142.720 & 14221.191 & \text { Yes }\end{array}$ $\begin{array}{lllllllllllllllll}1.00 & 43.28 & 27.47 & 30.46 & 3 & 1601.8780 & 1601.8755 & 534.9658 & 0.0025 & 1.5577 & 306.793 & 233.349 & 94.520 & 345.586 & \text { Yes }\end{array}$ $\begin{array}{lllllllllllllll}1.00 & 35.97 & 27.40 & 26.36 & 3 & 1601.8786 & 1601.8755 & 534.9658 & 0.0031 & 1.9316 & 251.514 & 130.761 & 147.218 & 387.205 & \text { Yes }\end{array}$ $\begin{array}{llllllllllllllll}1.00 & 50.32 & 27.19 & 23.84 & 2 & 1238.6768 & 1238.6750 & 620.3448 & 0.0018 & 1.4508 & 15126.045 & 17175.999 & 1009.251 & 24918.927 & \text { Yes }\end{array}$ $\begin{array}{llllllllllllllll}1.00 & 48.03 & 27.51 & 23.41 & 2 & 1238.6776 & 1238.6750 & 620.3448 & 0.0026 & 2.0956 & 17888.481 & 19107.263 & 2758.939 & 28030.414 & \text { Yes }\end{array}$ $\begin{array}{llllllllllllllllll}0.57 & 21.05 & 25.55 & 32.94 & 2 & 1036.6258 & 1036.6161 & 519.3153 & 0.0097 & 9.3391 & 14765.741 & 14336.889 & 1193.366 & 23403.157 & \text { Yes }\end{array}$

FDVQLK QFGFIVLTTSAGIMDHEE CGVISPR

FLTVMMK

CGVISPR

CGVISPR

CGVISPR

CGVISPR

CGVISPR

CGVISPR

CGVISPR

WQVISPR

WQNNLLPSR
WQNNLLPSR

IVVNLTGR

IVVNLTGR

IVVNLTGR

IVVNLTGR

IVVNLTGR
WQNNLLPSR

WQNNLLPSR
WQNNLLPSR

IVVNLTGR

IVVNLTGR

WQNNLLPSR

WQNNLLPSR

IVVNLTGR

IVVNLTGR

IVVNLTGR

IVVNLTGR

IVVNLTGR

IVVNLTGR

IVVNLTGR

IVVNLTGR

IVVNLTGR

IVVNLTGR

IVVNLTGR

IVVNLTGR

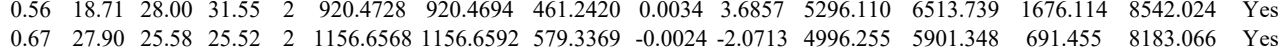
$\begin{array}{llllllllllllllll}0.67 & 27.90 & 25.58 & 25.52 & 2 & 1156.6568 & 1156.6592 & 579.3369 & -0.0024 & -2.0713 & 4996.255 & 5901.348 & 691.455 & 8183.066 & \text { Yes } \\ 0.59 & 24.02 & 28.46 & 31.68 & 2 & 874.4852 & 874.4817 & 4382481 & 0.0035 & 3.9932 & 9044.994 & 9698.708 & 1231.222 & 11689.101 & \text { Yes } \\ 0.52 & 2.86 & 28.58 & 33.83 & 2 & 84.4858 & 844.4817 & 388.2481 & 0.0041 & 4.677 & 12852.570 & 12606.974 & 1945.619 & 15854.961 & \text { Yes }\end{array}$ $\begin{array}{llllllllllllllll}0.59 & 24.02 & 28.46 & 11.68 & 2 & 874.4852 & 874.4817 & 438.2481 & 0.0035 & 3.9932 & 9044.994 & 9698.708 & 1231.222 & 11689.101 & \text { Yes } \\ 0.52 & 2.86 & 28.58 & 33.83 & 2 & 874.458 & 874.417 & 438.481 & 0.0041 & 4.6777 & 10852.570 & 12606.974 & 1945.619 & 15854.961 & \text { Yes }\end{array}$

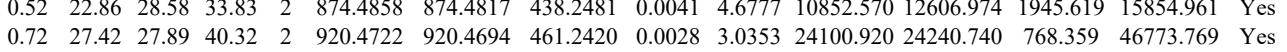

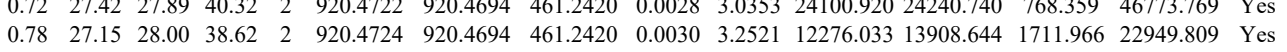
$\begin{array}{lllllllllllllllll}0.78 & 27.15 & 28.00 & 38.62 & 2 & 920.4724 & 920.4694 & 461.2420 & 0.0030 & 3.2521 & 12276.033 & 13908.644 & 1711.966 & 22949.809 & \text { Yes } \\ 0.87 & 27.34 & 28.00 & 36.08 & 2 & 920.4724 & 920.4694 & 461.2420 & 0.0030 & 3.2521 & 16192.159 & 22305.727 & 1346.263 & 31479.980 & \text { Yes }\end{array}$ $\begin{array}{llllllllllllllllll}0.87 & 27.34 & 28.00 & 36.08 & 2 & 920.4724 & 920.4694 & 461.2420 & 0.0030 & 3.2521 & 16192.159 & 22305.727 & 1346.263 & 31479.980 & \text { Yes } \\ 0.88 & 26.68 & 28.00 & 30.00 & 2 & 920.4724 & 920.4694 & 461.2420 & 0.0030 & 3.2521 & 33787.183 & 38835.917 & 2138.753 & 64315.280 & \text { Yes }\end{array}$ $\begin{array}{lllllllllllllll}0.88 & 26.68 & 28.00 & 30.00 & 2 & 920.4724 & 920.4694 & 461.2420 & 0.0030 & 3.2521 & 33787.183 & 38835.917 & 2138.753 & 64315.280 & \text { Yes } \\ 0.87 & 27.45 & 27.89 & 36.15 & 2 & 920.4722 & 920.4694 & 461.2420 & 0.0028 & 3.0353 & 12313.067 & 14076.057 & 1692.088 & 22373.555 & \text { Yes }\end{array}$ $\begin{array}{llllllllllllllll}0.78 & 27.33 & 28.00 & 38.86 & 2 & 920.4726 & 920.4694 & 461.2420 & 0.0032 & 3.4689 & 17314.084 & 18116.633 & 1341.369 & 30889.864 & \text { Yes }\end{array}$ $\begin{array}{lllllllllllllll}0.99 & 41.83 & 26.93 & 29.84 & 2 & 1270.7018 & 1270.6904 & 636.3525 & 0.0114 & 8.9572 & 12446.765 & 12750.323 & 1535.553 & 20671.749 & \text { Yes }\end{array}$

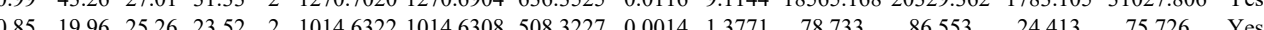
$\begin{array}{lllllllllllllll}0.65 & 14.62 & 2526 & 23.74 & 2 & 1014.6326 & 1014.6308 & 5083227 & 0.0018 & 1.7705 & 70.545 & 88.685 & 32.983 & 112.837 & \text { Yes }\end{array}$ $\begin{array}{lllllllllllllll}0.95 & 38.84 & 26.19 & 34.88 & 2 & 1014.6378 & 1014.6308 & 508.3227 & 0.0070 & 6.8853 & 36846.341 & 47056.637 & 2332.402 & 81147.532 & \text { Yes }\end{array}$ $\begin{array}{llllllllllllllll}0.96 & 38.37 & 26.19 & 32.94 & 2 & 1014.6382 & 1014.6308 & 5083227 & 0.0074 & 7.2788 & 33099.925 & 35867.864 & 1104.119 & 65394.533 & \text { Yes }\end{array}$ $\begin{array}{lllllllllllllllll}0.96 & 35.97 & 27.00 & 30.08 & 2 & 1270.6994 & 1270.6904 & 636.3525 & 0.0090 & 7.0715 & 13200.100 & 13008.522 & 267.293 & 21368.791 & \text { Yes }\end{array}$ $\begin{array}{lllllllllllllllll}0.92 & 33.09 & 27.28 & 27.93 & 2 & 1270.6998 & 1270.6904 & 636.3525 & 0.0094 & 7.3858 & 16062.187 & 16185.071 & 1345.213 & 26400.019 & \text { Yes }\end{array}$ $\begin{array}{lllllllllllllll}0.93 & 35.35 & 26.15 & 31.06 & 2 & 1014.6362 & 1014.6308 & 508.3227 & 0.0054 & 5.3116 & 8454.632 & 8991.287 & 1396.934 & 12418.529 & \text { Yes }\end{array}$ $\begin{array}{llllllllllllllll}0.91 & 33.83 & 26.15 & 29.98 & 2 & 1014.6362 & 1014.6308 & 508.3227 & 0.0054 & 5.3116 & 4344.501 & 5410.477 & 1540.867 & 6528.134 & \text { Yes }\end{array}$ $\begin{array}{lllllllllllllllll}0.97 & 39.64 & 26.71 & 30.56 & 2 & 1270.6986 & 1270.6904 & 636.3525 & 0.0082 & 6.4429 & 4858.374 & 4796.843 & 487.400 & 7232.001 & \text { Yes }\end{array}$ $\begin{array}{llllllllllllllll}0.92 & 32.65 & 26.97 & 25.88 & 2 & 1270.6996 & 1270.6904 & 636.3525 & 0.0092 & 7.2286 & 4762.588 & 4895.675 & 367.624 & 7190.778 & \text { Ye }\end{array}$ $\begin{array}{llllllllllllllll}0.98 & 43.18 & 26.19 & 33.04 & 2 & 1014.6368 & 1014.6308 & 508.3227 & 0.0060 & 5.9017 & 10000.695 & 11415.311 & 1766.936 & 19583.289 & \text { Yes }\end{array}$ $\begin{array}{lllllllllllllll}0.95 & 36.93 & 26.19 & 31.17 & 2 & 1014.6368 & 1014.6308 & 508.3227 & 0.0060 & 5.9017 & 10384.248 & 11826.004 & 1051.535 & 18618.455 & \text { Yes }\end{array}$ $\begin{array}{lllllllllllllll}1.00 & 43.76 & 24.68 & 31.73 & 2 & 1014.6316 & 1014.6308 & 508.3227 & 0.0008 & 0.7869 & 2075.928 & 2183.097 & 595.922 & 3737.579 & \text { Yes }\end{array}$

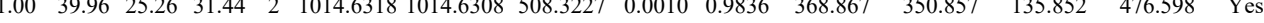
$\begin{array}{lllllllllllllll}0.98 & 29.93 & 25.26 & 23.11 & 2 & 1014.6318 & 1014.6308 & 508.3227 & 0.0010 & 0.9836 & 48.282 & 48.435 & 15.823 & 76.720 & \text { Yes }\end{array}$

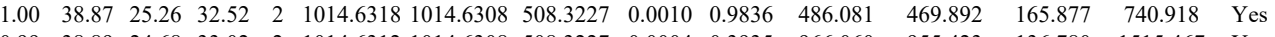

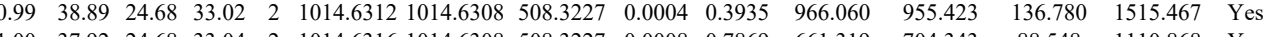
\begin{tabular}{lllllllllllllll}
1.00 & 37.92 & 24.68 & 33.04 & 2 & 1014.6316 & 1014.6308 & 508.3227 & 0.0008 & 0.7869 & 661.319 & 704.343 & 88.548 & 1110.868 & Yes \\
\hline
\end{tabular} $\begin{array}{lllllllllllllll}0.99 & 37.18 & 24.68 & 29.12 & 2 & 1014.6310 & 1014.6308 & 508.3227 & 0.0002 & 0.1967 & 172.741 & 223.621 & 17.565 & 314.767 & \text { Yes }\end{array}$

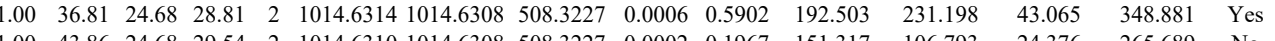

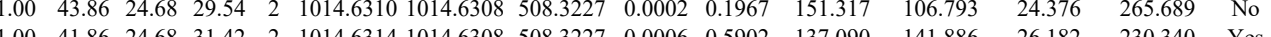

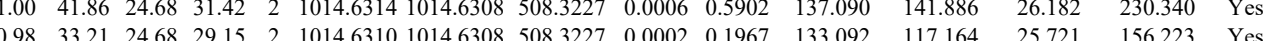

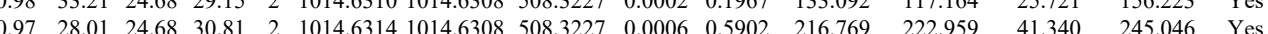

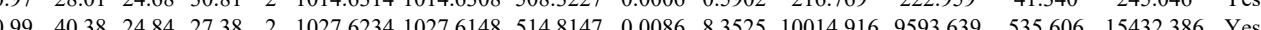

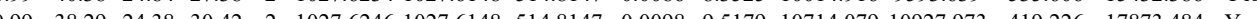

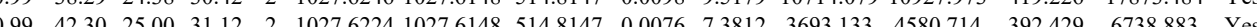



\begin{tabular}{llllllllllllllll}
0.66 & 1.25 & 1.55 & 32.25 & 3 & 1381.9174 & 1381.9152 & 461.6457 & 0.0022 & 1.5885 & 1409.162 & 1539.127 & 95.321 & 2477.506 & Yes \\
\hline
\end{tabular} $\begin{array}{lllllllllllllll}1.00 & 67.41 & 12.55 & 21.62 & 2 & 1381.9176 & 1381.9152 & 691.9649 & 0.022 & 1.7342 & 22743.543 & 25015.607 & 0.000 & 45102.391 & \mathrm{No}\end{array}$

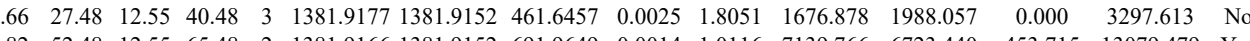

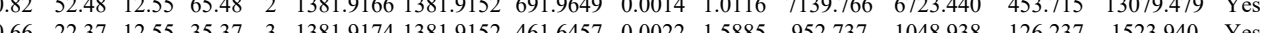

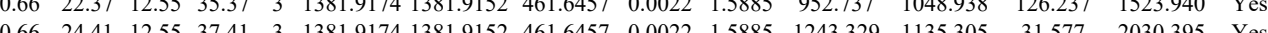

$\begin{array}{lllllllllllllllll}1.00 & 66.19 & 12.55 & 20.85 & 2 & 1881.9166 & 1881.9152 & 691.9649 & 0.0014 & 1.0116 & 5348.136 & 5337.012 & 662.486 & 9057.463 & \text { Yes }\end{array}$

LLEPVLLGK

GGGHVAQIYAIR

GGGHVAQIYAIR

GGGHVAQIYAIR

GGGHVAQIYAIR

GPLQSVQVFGR

GPLQSVQVFGR

GPLQSVQVFGR

GPLQSVQVFGR

GPLQSVQVFGR

GPLQSVQVFGR

GPLQSVQVFGR

$\begin{array}{lllllllllllll}\text { 433E_HUMAN } & \text { P62258 } & \text { YWHAE } & 14-3-3 \text { protein eps } 29.174 & 1.00 & 11 & 64.3 & 0.1850 & 0.5024 & 1.5124 & 0.5763 & 48 & \text { HLIPAANTGESK }\end{array}$

$\begin{array}{lllllllllllll} & \end{array}$

$\begin{array}{llllllllllllllll}1.00 & 75.86 & 26.71 & 27.30 & 2 & 1384.7798 & 1384.7697 & 693.3921 & 0.0101 & 7.2830 & 2429.903 & 2410.506 & 2827.564 & 3315534 & \text { Yes }\end{array}$

$\begin{array}{llllllllllllllll}100 & 76.41 & 26.38 & 22.74 & 2 & 1384.7816 & 1384.7697 & 693.3921 & 0.0119 & 8.5809 & 2834.332 & 3455.689 & 3444.733 & 3559.364 & \text { Yes }\end{array}$ $\begin{array}{lllllllllllllllll}1 & 80 & 8.26 & 26.77 & 27.33 & 2 & 1384.7804 & 1384.7697 & 693.3921 & 0.0107 & 7.7156 & 2927.577 & 3094.246 & 3622.514 & 3583.220 & \text { Yes }\end{array}$ $\begin{array}{lllllllllllllllll}1.00 & 70.51 & 26.56 & 24.60 & 2 & 1384.7808 & 1384.7697 & 693.3921 & 0.0111 & 8.0041 & 2720.784 & 3504.259 & 4088.219 & 3403.703 & \text { Yes }\end{array}$ $\begin{array}{llllllllllllllll}1.00 & 52.02 & 26.57 & 19.54 & 3 & 1384.7806 & 1384.7697 & 462.5972 & 0.0109 & 7.8541 & 5245.417 & 5613.487 & 5370.493 & 6608.585 & \text { Yes }\end{array}$ $\begin{array}{lllllllllllllllll}1.00 & 61.34 & 27.74 & 21.35 & 2 & 1330.7600 & 1330.7479 & 666.3812 & 0.0121 & 9.0788 & 1789.255 & 2083.310 & 5462.528 & 5635.888 & \text { Yes }\end{array}$ $\begin{array}{lllllllllllllllll}1.00 & 63.53 & 27.68 & 25.46 & 2 & 1330.7590 & 1330.7479 & 666.3812 & 0.0111 & 8.3285 & 2755.957 & 3443.679 & 9846.828 & 11040.050 & \text { Yes }\end{array}$ $\begin{array}{llllllllllllllll}1.00 & 58.06 & 27.73 & 21.44 & 2 & 1330.7610 & 1330.7479 & 666.3812 & 0.0131 & 9.8291 & 1809.265 & 1838.012 & 6593.582 & 6068.030 & \text { Yes }\end{array}$ $\begin{array}{llllllllllllllll}1.00 & 68.94 & 27.86 & 28.38 & 2 & 1330.7466 & 1330.7479 & 666.3812 & -0.0013 & -0.9754 & 4253.433 & 4277.426 & 15336.034 & 9968.258 & \text { No }\end{array}$ $\begin{array}{llllllllllllllll}1.00 & 65.21 & 27.86 & 29.62 & 2 & 1330.7466 & 1330.7479 & 666.3812 & -0.0013 & -0.9754 & 4191.801 & 6130.787 & 18603.364 & 15572.124 & \text { Yes }\end{array}$ $\begin{array}{llllllllllllllll}1.00 & 59.53 & 27.85 & 20.37 & 2 & 1330.7472 & 1330.7479 & 666.3812 & -0.0007 & -0.5252 & 3386.224 & 3554.533 & 10491.702 & 9300.026 & \text { Yes }\end{array}$ $\begin{array}{lllllllllllllll}1.00 & 62.09 & 27.88 & 27.70 & 2 & 1330.7478 & 1330.7479 & 666.3812 & -0.0001 & -0.0750 & 4050.964 & 4774.162 & 13597.152 & 12114.344 & \text { Yes }\end{array}$ $\begin{array}{llllllllllllllll}1.00 & 44.55 & 26.36 & 16.73 & 3 & 1524.8545 & 1524.8504 & 509.2907 & 0.0041 & 2.6835 & 1740.989 & 1990.727 & 937.116 & 2151.662 & \text { Yes }\end{array}$ $\begin{array}{lllllllllllllll}0.99 & 42.87 & 25.99 & 36.21 & 2 & 1204.7390 & 1204.7271 & 603.3708 & 0.0119 & 9.8612 & 15701.959 & 20578.262 & 3618.174 & 24925.020 & \text { Yes }\end{array}$ YISSIEQK YLAEFATGNDR

YLAEFATGNDR YLAEFATGNDR

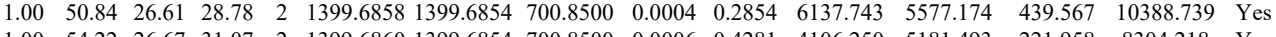
$\begin{array}{llllllllllllllll}1.00 & 54.22 & 26.67 & 31.07 & 2 & 1399.6860 & 1399.6854 & 700.8500 & 0.0006 & 0.4281 & 4106.250 & 5181.493 & 221.958 & 8304.218 & \text { Yes }\end{array}$

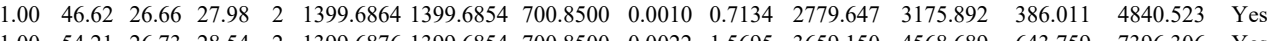
$\begin{array}{llllllllllllllll} & 1.00 & 54.21 & 26.73 & 28.54 & 2 & 1399.6876 & 1399.6854 & 700.8500 & 0.0022 & 1.5695 & 3659.150 & 4568.689 & 643.759 & 7396.306 & \text { Yes }\end{array}$

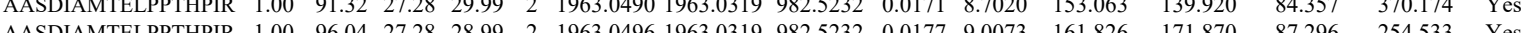
$\begin{array}{llllllllllllll} & \end{array}$

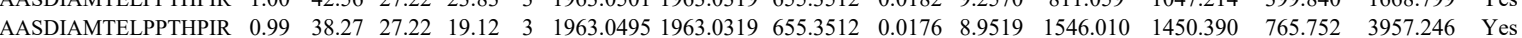
AASDIAMTELPPTHPIR $\begin{array}{lllllllllllllllll}0.76 & 24.55 & 27.22 & 17.61 & 3 & 1963.0501 & 1963.0319 & 655.3512 & 0.0182 & 9.9570 & 1493.782 & 1607.473 & 1590.140 & 3005.606 & \text { Yes }\end{array}$

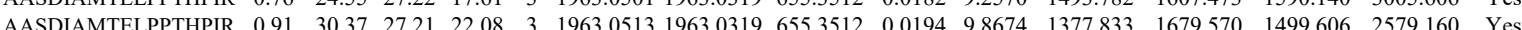
$\begin{array}{llllllllllllllll}\text { LICCDILDVLDK } & 1.00 & 66.45 & 27.24 & 49.96 & 2 & 1741.8752 & 1741.8730 & 871.9438 & 0.0022 & 1.2615 & 8591.791 & 12794.069 & 0.000 & 18370.854 & N\end{array}$

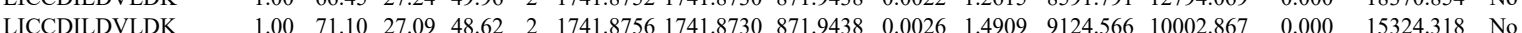

$\begin{array}{llllllllllllllll}\text { LICCDILDVLDK } & 0.83 & 17.05 & 27.06 & 20.11 & 3 & 1741.8766 & 1741.8730 & 581.6316 & 0.0036 & 2.0632 & 96.867 & 107.402 & 17.571 & 139.182 & \text { Yes } \\ \text { LICCDILDVLDK } & 1.00 & 66.72 & 27.08 & 48.28 & 2 & 1741.8754 & 1741.8730 & 871.9438 & 0.0024 & 1.3762 & 9113.698 & 11811.640 & 153.504 & 16870.886 & \text { Yes }\end{array}$ LICCDILDVLDK LICCDILDVLDK LICCDILDVLDK LICCDILDVLDK LICCDILDVLDK LICCDILDVLDK LICCDILDVLDK LICCDILDVLDK LICCDILDVLDK

ICCDILDVLDK

LICCDILDVLDK

ICCDILDVLDK

LICCDILDVLDK

EALQDVEDENQ

EALQDVEDENQ

LICCDILDVLDK DNLTLWTSDMQGDGEEQN DNLTLWTSDMQGDGE HLIPAANTGESK $\begin{array}{llllllllllll}1.00 & 66.72 & 27.08 & 48.28 & 2 & 1741.8754 & 1741.8730 & 871.9438 & 0.0024 & 1.3762 & 9113.698 & 11811.640\end{array}$

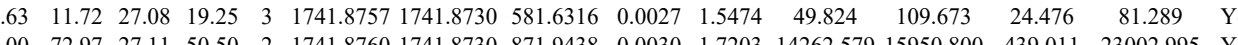
$\begin{array}{lllllllllllllll}1.00 & 32.28 & 27.09 & 24.05 & 3 & 1741.8760 & 1741.8730 & 871.9438 & 0.0030 & 1.7203 & 14262.579 & 109.673 & 24.476 & 81.289 & \text { Yes } \\ 1.00 & 67.80 & 27.24 & 49.97 & 2 & 1741.8752 & 1741.8730 & 581.6316 & 0.0039 & 2.2351 & 138.803 & 98.622 & 6.430 & 141.770 & \text { Yes }\end{array}$ $\begin{array}{llllllllllllllll}1.00 & 67.80 & 27.24 & 49.97 & 2 & 1741.8752 & 1741.8730 & 871.9438 & 0.0022 & 1.2615 & 1219.657 & 1507.944 & 80.255 & 2645.237 & \text { Yes }\end{array}$ $\begin{array}{llllllllllllllll}1.00 & 72.99 & 27.24 & 50.59 & 2 & 1741.8752 & 1741.8730 & 871.9438 & 0.0022 & 1.2615 & 7586.238 & 9683.732 & 192.907 & 14018.624 & \text { Yes }\end{array}$ $\begin{array}{lllllllllllllll}0.62 & 11.45 & 27.08 & 17.64 & 3 & 1741.8757 & 1741.8730 & 581.6316 & 0.0027 & 1.5474 & 51.477 & 45.753 & 39.927 & 56.791 & \text { Yes }\end{array}$ $\begin{array}{llllllllllll}0.62 & 11.45 & 27.08 & 17.64 & 3 & 1741.8757 & 1741.8730 & 581.6316 & 0.0027 & 1.544 & 51.475 & 45.753 \\ 1.63 & 1281 & 27.06 & 22.06 & 3 & 1741.8766 & 1741.8730 & 581.6316 & 0.0036 & 20632 & 62.545 & 32.180\end{array}$ $\begin{array}{lllllllllllll}1.00 & 74.37 & 27.21 & 39.67 & 2 & 1741.8746 & 1741.8730 & 871.9438 & 0.0016 & 0.9175 & 422.090 & 500.712\end{array}$ $\begin{array}{llllllllllll}0.70 & 13.05 & 27.11 & 21.87 & 3 & 1741.8760 & 1741.8730 & 581.6316 & 0.0030 & 1.7193 & 39.209 & 44.484\end{array}$ $\begin{array}{llllllllllll}0.89 & 21.72 & 27.10 & 29.31 & 3 & 1741.8763 & 1741.8730 & 581.6316 & 0.0033 & 1.8912 & 38.709 & 55.375\end{array}$ $\begin{array}{lllllllllllll}1.00 & 83.10 & 27.16 & 39.61 & 2 & 1741.8744 & 1741.8730 & 871.9438 & 0.0014 & 0.8028 & 242.870 & 250.460\end{array}$ $\begin{array}{lllllllllll}0.96 & 25.34 & 24.13 & 19.69 & 2 & 1432.6462 & 1432.6440 & 717.3293 & 0.0022 & 1.5335 & 10.486\end{array}$ $\begin{array}{lllllllllll}0.93 & 25.41 & 24.18 & 22.48 & 2 & 1432.6468 & 1432.6440 & 717.3293 & 0.0028 & 1.9517 & 0.000 \\ 1.00 & 76.54 & 27.20 & 41.69 & 2 & 1741.8740 & 1741.8730 & 871.9438 & 0.0010 & 0.5734 & 43.842\end{array}$ HLPAANTGLSK

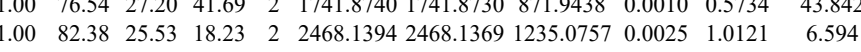
$\begin{array}{lllllllllll}1.00 & 31.57 & 27.03 & 20.59 & 3 & 1524.8530 & 1524.8504 & 509.2907 & 0.0026 & 1.7017 & 91.112 \\ 1.00 & 34.20 & 26.65 & 20.14 & 3 & 1524.8536 & 1524.8504 & 509.2907 & 0.0032 & 2.0944 & 129.388\end{array}$ $\begin{array}{llllllllllll}1.00 & 34.20 & 26.65 & 20.14 & 3 & 1524.8536 & 1524.8504 & 509.2907 & 0.0032 & 2.0944 & 129.388\end{array}$ $\begin{array}{lllllllllll} & \end{array}$ $\begin{array}{lllllllllllll}\text { DNLTLWTSDMQGDGEEQNK } & 1.00 & 70.02 & 25.60 & 17.39 & 2 & 2468.1374 & 2468.1369 & 1235.0757 & 0.0005 & 0.2024 & 12.144\end{array}$ $\begin{array}{llllllllllllll}\text { DNLTLWTSDMOGDGEEONK } & 1.00 & 96.57 & 25.60 & 19.35 & 2 & 2468.1374 & 2468.1369 & 1235.0757 & 0.0005 & 0.2024 & 0.000\end{array}$

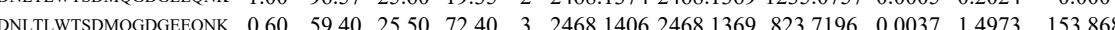




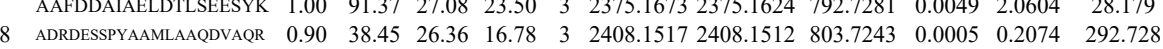

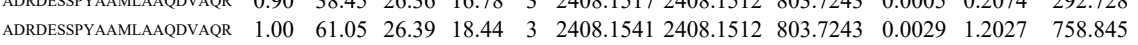
$\begin{array}{lllllllllllllll}\text { ADRDESSPYAAMLAAQDVAQR } & 1.00 & 57.96 & 26.40 & 18.91 & 3 & 2408.1532 & 2408.1512 & 803.7243 & 0.0020 & 0.8295 & 950.027 & 63\end{array}$

TPGPGAQSALR

TPGPGAQSALR

TPGPGAQSALR

ELGITALHIK

ELGITALHIK

TPGPGAQSALR

TPGPGAQSALR

TPGPGAQSALR

TPGPGAQSALR

TPGPGAQSALR

TPGPGAQSALR

IEDVTPIPSDSTR
IEDVTPIPSDSTR

IEDVTPIPSDSTR

IEDVTPIPSDSTR

IEDVTPIPSDSTR

ANPFGGASHAK

ANPFGGASHAK

ANPFGGASHAK

ITAFYPNGGCLNFEENDEVVVVAGFGR

ITAFYPNDGCLNFFENDEVLVAGG

ITAFYPNDGCLNFFENDEVLVAGF

ITAFVNDGGCLNFEENDEVLV

VANVSLLALYK

VANVSLLALYK

VANVSLLALYK

VANVSLLALYK

VANVSLLALYK

$\begin{array}{lllllllllllll}\text { RS18 HUMAN } & \text { P62269 } & \text { RPS18 } & \text { 40S ribosomal pro } 17.719 & 1.00 & 12 & 59.9 & 0.1722 & 0.1801 & 2.2436 & 0.3649 & 48 & \text { KADIDLTK }\end{array}$

KADIDLTK

KADIDLTK

KADIDLTK

TVGVSK

TVGVSK

TVGVSK

YSQVLANGLDNK

YSQVLANGLD

VLNTNIDGR

VLNTNIDGR
YSQVLANGLDNK

YSQVLANGLDNK

AGELTEDEVER

YAHVVLR $\begin{array}{lllllllllll}27.65 & 22.64 & 2 & 1197.6588 & 1197.6588 & 599.8367 & 0.0000 & 0.0000 & 531.711 & 6\end{array}$ $\begin{array}{lllllllllllll}1.00 & 46.91 & 27.76 & 21.09 & 2 & 1197.6594 & 1197.6588 & 599.8367 & 0.0006 & 0.5001 & 566.583 & 49 & \\ 1.00 & 51.28 & 27.77 & 23.02 & 2 & 1197.6590 & 1197.6588 & 599.8367 & 0.0002 & 0.1567 & 396.742 & 37 & \end{array}$ $\begin{array}{lllllllllll}1.00 & 51.28 & 27.77 & 23.02 & 2 & 1197.6590 & 1197.6588 & 599.8367 & 0.0002 & 0.1667 & 396.742\end{array}$ $\left.\begin{array}{llllllllllll}1.00 & 54.52 & 27.77 & 23.13 & 2 & 1197.65921197 .6588 & 599.8367 & 0.0004 & 0.3334 & 328.803 & 296.963\end{array}\right]$

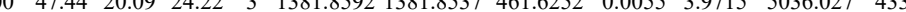
$\begin{array}{llllllllllll}1.00 & 41.65 & 20.09 & 22.22 & 3 & 1381.8592 & 1381.8537 & 461.6252 & 0.0055 & 3.9715 & 6176.474 & 5346.471\end{array}$ $\begin{array}{llllllllllll}0.92 & 25.57 & 27.76 & 22.03 & 2 & 1197.6594 & 1197.6588 & 599.8367 & 0.0006 & 0.5001 & 26.239 & 19.069\end{array}$ $\begin{array}{llllllllllll}0.64 & 58.46 & 26.77 & 71.46 & 2 & 1053.5570 & 1053.5567 & 527.7856 & 0.0003 & 0.2842 & 12.522 & 15.650 \\ 0.82 & 72.67 & 26.90 & 85.67 & 2 & 1053.5574 & 1053.5567 & 527.7856 & 0.0007 & 0.6631 & 6.481 & 10.776\end{array}$

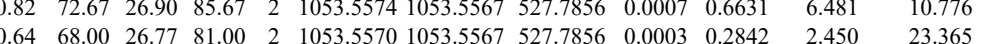

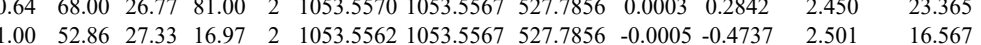

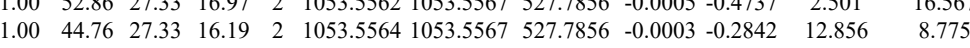
$\begin{array}{lllllllllllll}1.00 & 52.58 & 27.75 & 39.70 & 2 & 1572.8116 & 1572.8117 & 787.4131 & -0.0001 & -0.0635 & 3471.385 & 3737.757 & 85 \\ 1.00 & 50.51 & 27.81 & 37.18 & 2 & 1572.8126 & 1572.8117 & 787.4131 & 0.0009 & 0.5715 & 1097.851 & 895.223 & 50 \\ 1.00 & 63.87 & 27.83 & 21.84 & 2 & 1572.8150 & 1572.8117 & 787.4131 & 0.003 & 2.055 & 489.25 & 4986.199 & 35\end{array}$ $\begin{array}{lllllllllllll}1.00 & 50.51 & 27.81 & 37.18 & 2 & 1572.8126 & 1572.8117 & 787.4131 & 0.0009 & 0.5715 & 1097.851 & 895.223 & 500 \\ 1.00 & 63.87 & 27.83 & 21.84 & 2 & 1572.8150 & 1572.8117 & 787.4131 & 0.0033 & 2.0955 & 4893.251 & 4986.199 & 355 \\ 1.00 & 58.55 & 27.76 & 19.17 & 2 & 572.8156 & 1572.817 & 787.431 & 0.009 & 2.4765 & 717.043 & 541.499\end{array}$

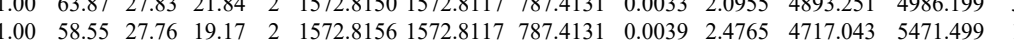

$4.979-84.260$ Y Yes $\begin{array}{llllllllllllllll}00 & 46.20 & 27.57 & 29.41 & 3 & 1343.7205 & 1343.7190 & 448.9136 & 0.0015 & 1.1138 & 3327.086 & 4005.740 & 1421.240 & 5349.847 & \text { Yes }\end{array}$ $\begin{array}{llllllllllllll}0 & 134.7199 & 1343.7190 & 448.9136 & 0.0009 & 0.6683 & 1622.356 & 1529.669 & 882.006 & 2193.692 & \text { Yes }\end{array}$

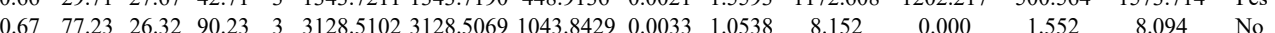

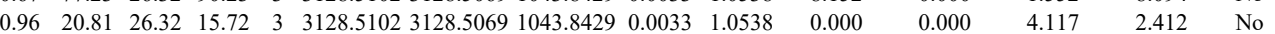

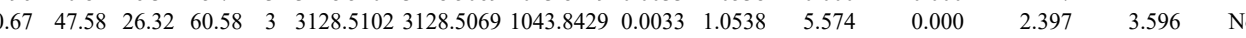

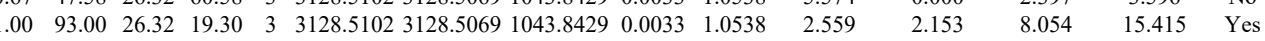

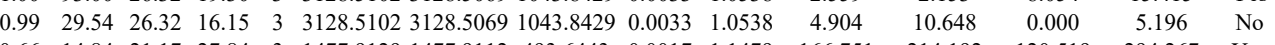
$\begin{array}{lllllllllllllll}0.66 & 14.84 & 21.17 & 27.84 & 3 & 1477.9129 & 1477.9112 & 493.6443 & 0.0017 & 1.1479 & 166.751 & 214.192 & 120.519 & 294.267 & \text { Yes }\end{array}$ $\begin{array}{lllllllllllllll}1.00 & 64.57 & 20.00 & 20.48 & 2 & 1477.9138 & 1477.9112 & 739.9629 & 0.0026 & 1.7568 & 3889.344 & 4119.686 & 0.000 & 8684.955 & \text { No }\end{array}$ $\begin{array}{lllllllllllllll}0.72 & 66.40 & 20.00 & 79.40 & 2 & 1477.9146 & 1477.9112 & 739.9629 & 0.0034 & 2.2974 & 5896.465 & 5151.523 & 981.356 & 10590.249 & \text { Yes }\end{array}$ $\begin{array}{lllllllllllllll}0.60 & 18.11 & 19.96 & 31.11 & 3 & 1477.9150 & 1477.9112 & 493.6443 & 0.0038 & 2.5659 & 258.348 & 272.439 & 144.545 & 401.852 & \text { Yes }\end{array}$

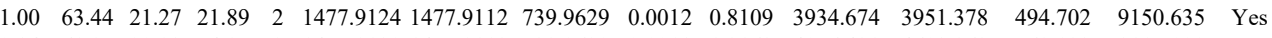
$\begin{array}{llllllllllllllll}0.84 & 61.95 & 20.93 & 74.95 & 2 & 1477.9130 & 1477.9112 & 739.9629 & 0.0018 & 1.2163 & 4076.431 & 4603.962 & 569.123 & 8115.090 & \text { Yes }\end{array}$

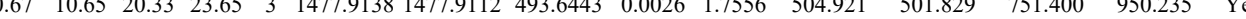
$\begin{array}{lllllllllllllll}0.98 & 34.83 & 21.61 & 25.16 & 2 & 1334.8210 & 1334.8135 & 668.4140 & 0.0075 & 5.6103 & 16126.636 & 16299.258 & 951.958 & 31561.935 & \text { Yes }\end{array}$ $\begin{array}{lllllllllllllll}0.97 & 34.35 & 21.61 & 25.07 & 2 & 1334.8210 & 1334.8135 & 668.4140 & 0.0075 & 5.6103 & 15525.580 & 15580.672 & 1951.763 & 29544.463 & \text { Yes }\end{array}$ $\begin{array}{lllllllllllllll}0.98 & 32.63 & 21.61 & 23.54 & 3 & 1334.8216 & 1334.8135 & 445.9451 & 0.0081 & 6.0545 & 22826.875 & 24127.315 & 1310.924 & 47823.678 & \text { Yes }\end{array}$

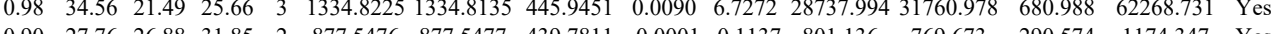
$\begin{array}{llllllllllllllll}0.90 & 27.76 & 26.88 & 31.85 & 2 & 877.5476 & 877.5477 & 439.7811 & -0.0001 & -0.1137 & 801.136 & 769.673 & 290.574 & 1174.347 & \text { Yes }\end{array}$ $\begin{array}{llllllllllllllll}0.93 & 29.68 & 26.88 & 33.55 & 2 & 877.5480 & 877.5477 & 439.7811 & 0.0003 & 0.3411 & 767.427 & 738.547 & 196.010 & 1157.486 & \text { Yes }\end{array}$ $\begin{array}{lllllllllllllll}0.83 & 25.39 & 26.98 & 29.26 & 2 & 877.5472 & 877.5477 & 439.7811 & -0.0005 & -0.5685 & 340.880 & 403.728 & 159.906 & 479.807 & \text { Yes }\end{array}$

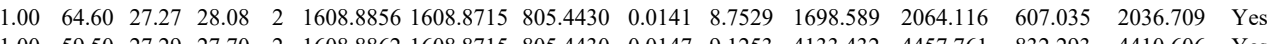

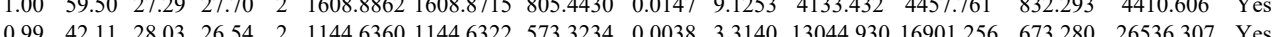
$\begin{array}{llllllllllllllll}0.99 & 42.11 & 28.03 & 26.54 & 2 & 1144.6360 & 1144.6322 & 573.3234 & 0.0038 & 3.3140 & 13044.930 & 16901.256 & 673.280 & 26536.307 & \text { Yes } \\ 0.97 & 37.92 & 28.03 & 26.79 & 2 & 1144.6362 & 1144.6322 & 573.3234 & 0.0040 & 3.4884 & 15216.531 & 16131.400 & 1214.771 & 27431331 & \text { Yes }\end{array}$ $\begin{array}{llllllllllllllllll}0.97 & 37.92 & 28.03 & 26.79 & 2 & 144.6362 & 1144.6322 & 573.3234 & 0.0040 & 3.4884 & 15216.531 & 16131.400 & 1214.771 & 27431.331 & \text { Yes } \\ 1.00 & 64.92 & 27.29 & 27.60 & 2 & 1608.8862 & 1608.8715 & 805.4430 & 0.0147 & 9.1253 & 925.250 & 1102.378 & 259.104 & 1027.762 & \text { Yes }\end{array}$ $\begin{array}{lllllllllllllll}1.00 & 64.92 & 27.29 & 27.60 & 2 & 1608.8862 & 1408.8715 & 805.4430 & 0.0147 & 9.1253 & 925.250 & 1102.378 & 259.104 & 1027.762 & \text { Yes } \\ 1.00 & 62.37 & 25.84 & 35.36 & 2 & 1390.6692 & 1390.6698 & 696.342 & 0.0006 & 0.4308 & 6376.561 & 7915.298 & 5077.963 & 14934.666 & \text { Yes }\end{array}$

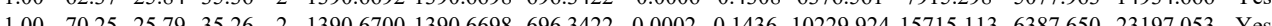
$\begin{array}{lllllllllllllllll}0.99 & 33.85 & 26.66 & 31.71 & 2 & 1000.5950 & 1000.5940 & 501.3043 & 0.0010 & 0.9974 & 4167.334 & 5134.484 & 570.673 & 9396.996 & \text { Yes }\end{array}$

Table S-4 page 383 of 614 

$\begin{array}{llllllllllllllll}1.00 & 45.62 & 28.66 & 26.16 & 2 & 1203.6538 & 1203.6522 & 602.8334 & 0.0016 & 1.3271 & 2304.211 & 2198.875 & 10031.291 & 9901.619 & \text { No }\end{array}$ $\begin{array}{lllllllllllllll}0.99 & 39.01 & 28.66 & 24.03 & 2 & 1203.6540 & 1203.6522 & 602.8334 & 0.0018 & 1.4929 & 3570.333 & 2872.092 & 16879.445 & 13437.772 & \text { No }\end{array}$ $\begin{array}{llllllllllllllllll}1.00 & 54.55 & 19.91 & 27.83 & 2 & 1234.7910 & 1234.7893 & 618.4019 & 0.0017 & 1.3745 & 13063.554 & 12805.510 & 4386.100 & 28749.629 & \text { Yes } \\ 1.00 & 50.66 & 19.91 & 26.88 & 2 & 12347912 & 1234.7893 & 618.4019 & 0.0019 & 1.5362 & 7290.085 & 8541.477 & 3805.932 & 2088.750 & \text { Yes }\end{array}$ $\begin{array}{llllllllllllllll}1.00 & 50.66 & 1.91 & 26.88 & 2 & 1234.7912 & 1234.783 & 618.4019 & 0.0019 & 1.5362 & 7290.085 & 8541.477 & 3805.932 & 20889.750 & \text { Yes } \\ 0.94 & 27.91 & 28.69 & 23.50 & 2 & 1203.6536 & 1203.6522 & 602.8334 & 0.0014 & 1.1612 & 2202.945 & 2274.463 & 8884219 & 9568.463 & \text { No }\end{array}$

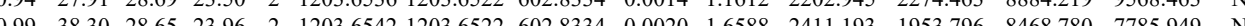

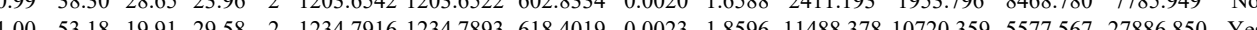
$\begin{array}{llllllllllllllllll}1.00 & 62.92 & 19.64 & 31.49 & 2 & 1324.7922 & 1234.7893 & 618.4019 & 0.0029 & 2.8447 & 19065.143 & 20751.590 & 5974.441 & 57649.102 & \text { No }\end{array}$ $\begin{array}{llllllllllllllll}1.00 & 50.47 & 19.91 & 26.64 & 2 & 1234.7896 & 1234.7893 & 618.4019 & 0.0003 & 0.2426 & 9004.062 & 9474.323 & 2904.599 & 20947.748 & \text { Yes }\end{array}$ $\begin{array}{lllllllllllllll}1.00 & 50.56 & 19.91 & 26.80 & 2 & 1234.7904 & 1234.7893 & 618.4019 & 0.0011 & 0.8894 & 11056.049 & 12178.927 & 4561.516 & 28403.443 & \text { Yes }\end{array}$ $\begin{array}{lllllllllllllllll}0.86 & 24.11 & 26.46 & 24.54 & 2 & 956.5708 & 956.5678 & 4792912 & 0.0030 & 3.1296 & 7646.667 & 8639.760 & 992.080 & 13637.888 & \text { Yes }\end{array}$

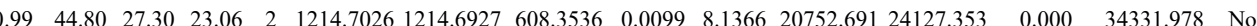

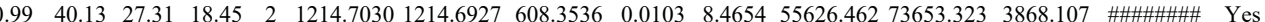
$\begin{array}{lllllllllllllll}1.00 & 42.41 & 28.02 & 20.65 & 2 & 1230.6908 & 1230.6876 & 616.3511 & 0.0032 & 2.5959 & 3138.437 & 3155.907 & 478.022 & 4000.208 & \text { Yes }\end{array}$ $\begin{array}{llllllllllllllll}0.99 & 44.22 & 27.96 & 21.29 & 2 & 1230.6912 & 1230.6876 & 616.3511 & 0.0036 & 2.9204 & 1661.906 & 1999.186 & 372.173 & 2452.464 & \text { Yes }\end{array}$ $\begin{array}{lllllllllllllllll}0.97 & 39.28 & 28.08 & 22.65 & 2 & 1230.6966 & 1230.6876 & 616.3511 & 0.0090 & 7.3010 & 1701.762 & 1680.138 & 180.943 & 2133.610 & \text { Yes }\end{array}$ $\begin{array}{lllllllllllllll}0.96 & 27.22 & 26.45 & 26.76 & 2 & 956.5700 & 956.5678 & 479.2912 & 0.0022 & 2.2951 & 30112.065 & 38596.876 & 3248.540 & 57425.250 & \text { Yes }\end{array}$ $\begin{array}{llllllllllllllll}0.92 & 24.14 & 26.45 & 26.21 & 2 & 956.5702 & 956.5678 & 479.2912 & 0.0024 & 2.5037 & 19533.880 & 24420.136 & 2157.232 & 33747.008 & \text { Yes }\end{array}$ $\begin{array}{lllllllllllllll}1.00 & 49.85 & 27.55 & 24.92 & 2 & 1214.7014 & 1214.6927 & 608.3536 & 0.0087 & 7.1504 & 11723.339 & 12887.559 & 667.009 & 18388.689 & \text { Yes }\end{array}$ $\begin{array}{llllllllllllllll}1.00 & 56.36 & 27.16 & 21.95 & 2 & 1214.7016 & 1214.6927 & 608.3536 & 0.0089 & 7.3148 & 29764.692 & 35594.796 & 1136.584 & 52135.372 & \text { Yes }\end{array}$ $\begin{array}{llllllllllllllll}1.00 & 43.32 & 27.99 & 20.00 & 2 & 1230.6902 & 1230.6876 & 616.3511 & 0.0026 & 2.1092 & 2588.752 & 2845.788 & 402.497 & 3916.685 & \text { Yes }\end{array}$ $\begin{array}{lllllllllllllll}0.99 & 48.58 & 28.39 & 30.87 & 2 & 1230.6954 & 1230.6876 & 616.3511 & 0.0078 & 6.3275 & 2849.278 & 3676.837 & 285.643 & 4107.984 & \text { Yes }\end{array}$ $\begin{array}{llllllllllllllllll}0.99 & 33.04 & 26.45 & 27.69 & 2 & 956.5698 & 956.5678 & 479.2912 & 0.0020 & 2.0864 & 18881.147 & 22917.797 & 2208.723 & 37730.291 & \text { Yes }\end{array}$ $\begin{array}{lllllllllllllllll}0.94 & 25.40 & 26.45 & 30.75 & 2 & 956.5702 & 956.5678 & 479.2912 & 0.0024 & 2.5037 & 15914.965 & 20777.343 & 2598.312 & 30649.322 & \text { Yes }\end{array}$ $\begin{array}{llllllllllllllll}0.98 & 40.93 & 27.48 & 25.26 & 2 & 1214.7004 & 1214.6927 & 608.3536 & 0.0077 & 6.3285 & 10929.723 & 15071.775 & 0.000 & 21656.024 & \text { No }\end{array}$ $\begin{array}{lllllllllllllllll}0.98 & 40.81 & 27.55 & 24.42 & 2 & 1214.7014 & 1214.6927 & 608.3536 & 0.0087 & 7.1504 & 25234.001 & 28999.353 & 245.685 & 44560.812 & \text { Yes }\end{array}$

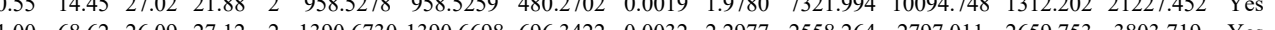
$\begin{array}{llllllllllllllll}0.00 & 68.62 & 26.09 & 27.12 & 2 & 1390.6730 & 1390.6698 & 696.3422 & 0.0032 & 2.2977 & 2558.264 & 2797.011 & 2659.753 & 3803.719 & \text { Yes }\end{array}$ $\begin{array}{llllllllllllllll}1.00 & 6.87 & 26.07 & 31.59 & 2 & 1390.6734 & 1390.6698 & 696.3422 & 0.0036 & 2.5849 & 2897.478 & 2508.717 & 2557.859 & 4102.680 & \text { Yes }\end{array}$

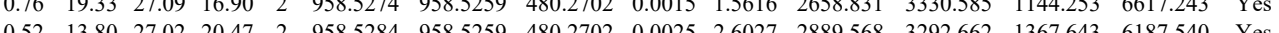

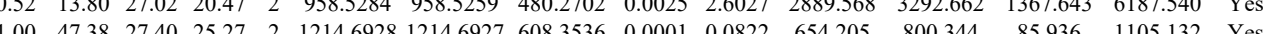

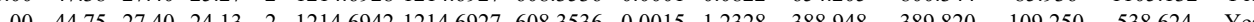

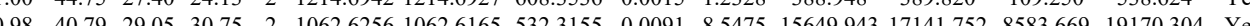
$\begin{array}{lllllllllllllllll}0.98 & 41.21 & 29.05 & 31.29 & 2 & 1062.6258 & 1062.6165 & 532.3155 & 0.0093 & 87353 & 15699.774 & 17840.079 & 7844.594 & 19839.845 & \text { Yes }\end{array}$ $\begin{array}{lllllllllllllllll}0.97 & 3530 & 22.07 & 24.19 & 2 & 1334.8196 & 1334.8135 & 668.4140 & 0.0061 & 45630 & 11102541 & 10529.718 & 840.407 & 19563.339 & \text { Yes }\end{array}$ $\begin{array}{lllllllllllllllll}0.95 & 32.98 & 22.04 & 23.69 & 2 & 1334.8200 & 1334.8135 & 668.4140 & 0.0065 & 4.8622 & 10766.385 & 9021.618 & 525.170 & 18759.191 & \text { Yes }\end{array}$ $\begin{array}{llllllllllllllll}0.99 & 32.56 & 21.61 & 17.74 & 3 & 1334.8210 & 1334.8135 & 445.9451 & 0.0075 & 5.6060 & 14695237 & 17937.750 & 1227.975 & 32431.032 & \text { Yes }\end{array}$

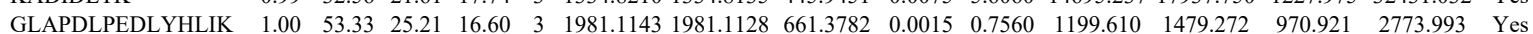
$\begin{array}{llllllllllllllll}\text { GLAPDLPEDLYHLIK } & 1.00 & 71.54 & 25.20 & 23.06 & 3 & 1981.1152 & 1981.1128 & 661.3782 & 0.0024 & 1.2096 & 1039.441 & 1590.587 & 725.956 & 2607.596 & \text { Yes }\end{array}$ $\begin{array}{llllllllllllllll}\text { GLAPDLPEDLYHLIK } & 1.00 & 57.42 & 25.19 & 21.27 & 2 & 1981.1140 & 1981.1128 & 991.5637 & 0.0012 & 0.6051 & 26.796 & 49.266 & 19.863 & 30.233 & \text { No }\end{array}$

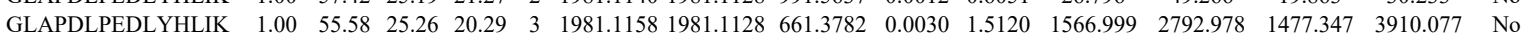
$\begin{array}{llllllllllllllll}\text { GLAPDLPEDLYHLIK } & 1.00 & 64.03 & 25.26 & 17.63 & 3 & 1981.1167 & 1981.1128 & 661.3782 & 0.0039 & 1.9656 & 4238.996 & 5714.366 & 3662.077 & 10221.686 & \text { Yes }\end{array}$ $\begin{array}{llllllllllllllll}\text { FVTGNK } & 0.64 & 23.68 & 25.33 & 26.30 & 2 & 952.5572 & 952.5586 & 477.2866 & -0.0014 & -1.4666 & 53.636 & 80.687 & 27.564 & 100.692 & \text { Yes }\end{array}$ $\begin{array}{llllllllllllllll}\text { GLAPDLPEDLYHLIK } & 1.00 & 55.55 & 25.26 & 19.52 & 3 & 1981.1155 & 1981.1128 & 661.3782 & 0.0027 & 1.3608 & 1867.545 & 2283.236 & 480.347 & 4100.181 & \text { Yes }\end{array}$

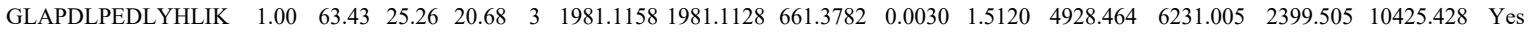
$\begin{array}{lllllllllllllllll}\text { GLAPDLPEDLYHLIK } & 1.00 & 56.88 & 25.21 & 19.25 & 3 & 1981.1143 & 1981.1128 & 661.3782 & 0.0015 & 0.7560 & 3090.022 & 3691.762 & 1540.138 & 6783.405 & \text { Yes }\end{array}$ $\begin{array}{lllllllllllllllll}\text { GLAPDLPEDLYHLIK } & 1.00 & 72.17 & 25.21 & 18.05 & 3 & 1981.1146 & 1981.1128 & 661.3782 & 0.0018 & 0.9072 & 1859.598 & 2157.238 & 536.932 & 3841.958 & \text { Yes }\end{array}$ LILIESR

LILIESR

LILIESR

SVPTWLK

SVPTWLK

SVPTWLK

VLPPNWK

VLPPNWK

VLPPNWK

SVPTWLK

SVPTWLK

VLPPNWK

GLSQSALPYR $\begin{array}{lllllll}0.0054 & 5.4620 & 9059.268 & 9879.263 & 938.665 & 18119.193 & \text { Yes }\end{array}$ $\begin{array}{llllllllllllllll}0.98 & 42.91 & 25.61 & 33.44 & 2 & 986.6304 & 986.6246 & 494.3196 & 0.0058 & 5.8666 & 9308.377 & 11884.503 & 634.096 & 18654.019 & \text { Yes }\end{array}$ $\begin{array}{llllllllllllllll}0.99 & 43.60 & 25.59 & 33.37 & 2 & 986.6332 & 986.6246 & 494.3196 & 0.0086 & 8.6988 & 4981.439 & 6502.641 & 894.202 & 11768.897 & \text { Yes }\end{array}$ $\begin{array}{lllllllllllllll}0.73 & 23.79 & 24.33 & 25.92 & 2 & 1117.6830 & 1117.6739 & 559.8442 & 0.0091 & 8.1272 & 57106.072 & 651982.081 & 3905.885 & 91213.855 & \text { Yes }\end{array}$ $\begin{array}{llllllllllllllll}0.72 & 22.22 & 24.30 & 25.49 & 2 & 1117.6836 & 1117.6739 & 559.8442 & 0.0097 & 8.6630 & 44200.877 & 43339.178 & 2894.916 & 62124.143 & \text { Yes }\end{array}$ $\begin{array}{llllllllllllllll}0.90 & 29.99 & 25.85 & 32.77 & 2 & 1117.6848 & 1117.6739 & 559.8442 & 0.0109 & 9.7348 & 52403.443 & 56162.623 & 3420.159 & 86217.001 & \text { Yes }\end{array}$

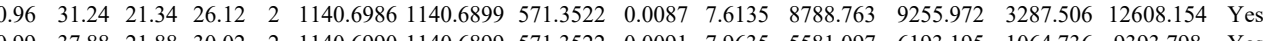
$\begin{array}{lllllllllllllll}0.99 & 37.88 & 21.88 & 30.02 & 2 & 1140.6990 & 1140.6899 & 571.3522 & 0.0091 & 7.9635 & 5581.097 & 6193.195 & 1064.736 & 9393.798 & \text { Yes } \\ 0.97 & 35.04 & 21.88 & 30.72 & 2 & 1140.692 & 1140.6899 & 571.3522 & 0.0093 & 8.1385 & 5498.844 & 6108.962 & 461.035 & 9672.671 & \text { Yes }\end{array}$

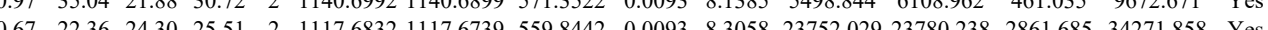

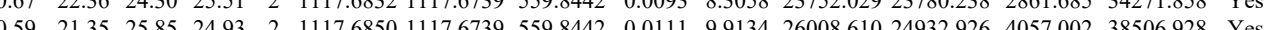
$\begin{array}{lllllllllllllll}0.59 & 21.35 & 25.85 & 24.93 & 2 & 117.6850 & 1117.679 & 559.8442 & 0.0111 & .9134 & 26008.610 & 24932.926 & 4057.002 & 38506.928 & \text { Yes } \\ 0.98 & 37.97 & 22.99 & 28.97 & 2 & 1140.6970 & 1140.6899 & 571.352 & 0.0071 & 62133 & 11906.844 & 11962.304 & 545.547 & 19742.816 & \text { Yes }\end{array}$

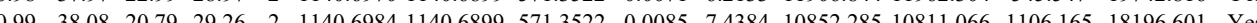
$\begin{array}{llllllllllllllll}1.00 & 49.11 & 28.10 & 28.91 & 2 & 1234.6880 & 1234.6792 & 618.3469 & 0.0088 & 7.1157 & 15078.998 & 15009.443 & 798.263 & 20290.516 & \text { Yes }\end{array}$ 

$\begin{array}{llllllllllllll} & 140.7006 & 1140.6899 & 571.3522 & 0.0107 & 9.3637 & 4823.165 & 4521.373 & 590.292 & 7617.670 & \text { Yes }\end{array}$ $\begin{array}{lllllllllllllll}0.97 .9 & 22.10 & 31.49 & 2 & 1140.7008 & 1140.6899 & 571.3522 & 0.0109 & 9.5387 & 4314.687 & 4474.346 & 444.212 & 7524.709 & \text { Yes }\end{array}$ $\begin{array}{llllllllllllllll}1.00 & 49.19 & 27.84 & 29.25 & 2 & 1234.6888 & 1434.6792 & 618.3469 & 0.0096 & 7.7626 & 25957.152 & 29708.827 & 1605.569 & 41993.619 & \text { Yes }\end{array}$

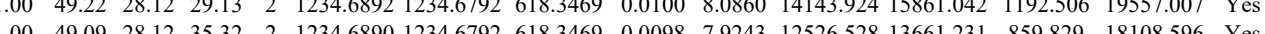
$\begin{array}{lllllllllllllll}1.00 & 49.22 & 28.12 & 29.13 & 2 & 1234.6892 & 1234.6792 & 618.3469 & 0.0100 & 8.0860 & 14143.924 & 15861.042 & 192.506 & 19557.007 & \text { Yes } \\ 1.00 & 47.58 & 28.12 & 35.32 & 2 & 1234.689 & 1234.672 & 618.3469 & 0.0098 & 7.9243 & 12526.528 & 13661.231 & 859.829 & 18108.596 & \text { Yes }\end{array}$ \begin{tabular}{lllllllllllllllll}
1.00 & 47.58 & 28.12 & 34.83 & 2 & 1234.6910 & 1234.6792 & 618.3469 & 0.0118 & 9.5415 & 11711.759 & 12945.667 & 535.969 & 15528.076 & Yes \\
\hline
\end{tabular} $\begin{array}{lllllllllllllll}0.99 & 50.09 & 28.06 & 36.36 & 2 & 1234.6876 & 1234.6792 & 618.3469 & 0.0084 & 6.7923 & 3964.773 & 5065.375 & 415.848 & 5266.729 & \text { No }\end{array}$ $\begin{array}{lllllllllllllll}0.99 & 34.28 & 21.73 & 16.28 & 3 & 1396.8505 & 1396.8524 & 466.6247 & -0.0019 & -1.3573 & 163.511 & 197.036 & 74.540 & 206.593 & \text { Yes } \\ 0.64 & 65.92 & 22.36 & 78.92 & 2 & 1396.8520 & 1396.8524 & 699.4335 & -0.0004 & -0.2859 & 13571.559 & 15563.491 & 5146.614 & 24894772 & \text { Yes }\end{array}$ $\begin{array}{lllllllllllllllll}0.64 & 65.92 & 22.36 & 78.92 & 2 & 1396.8520 & 1396.8524 & 69.4355 & 0.0004 & 0.2859 & 13571.559 & 15563.491 & 5146.614 & 2484.772 & \text { Yes }\end{array}$

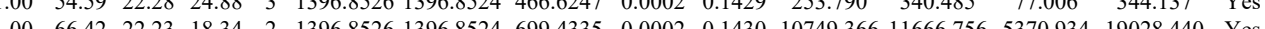

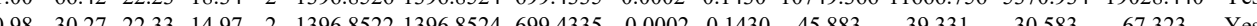

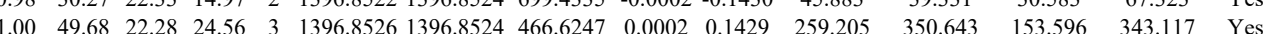
$\begin{array}{lllllllllllllll}1.00 & 50.95 & 22.28 & 23.83 & 3 & 1396.8526 & 1396.8524 & 466.6247 & 0.0002 & 0.1429 & 201.840 & 271.228 & 210.869 & 203.507 & \text { No }\end{array}$ $\begin{array}{lllllllllllllllll}0.82 & 39.71 & 21.70 & 52.71 & 2 & 1396.8534 & 1396.8524 & 699.4335 & 0.0010 & 0.7149 & 68.513 & 75.966 & 29.531 & 89.262 & \text { Yes }\end{array}$ $\begin{array}{lllllllllllllll}0.84 & 49.91 & 21.88 & 62.91 & 2 & 1396.8540 & 1396.8524 & 699.4335 & 0.0016 & 1.1438 & 27464.869 & 31714583 & 14342.151 & 47357.377 & \text { Yes }\end{array}$

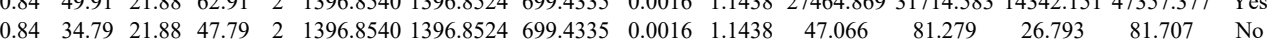
$\begin{array}{llllllllllllllll}0.84 & 57.65 & 21.88 & 70.65 & 2 & 1396.8540 & 1396.8524 & 699.4335 & 0.0016 & 1.1438 & 13963.757 & 18052.161 & 6852.884 & 25793.437 & \text { Yes }\end{array}$

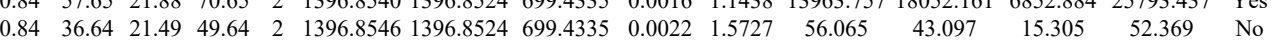
$\begin{array}{lllllllllllllll}1.00 & 65.64 & 22.23 & 20.76 & 2 & 1396.8526 & 1396.8524 & 699.4335 & 0.0002 & 0.1430 & 7880.909 & 10122.143 & 4122.118 & 14426.114 & \text { Yes }\end{array}$ $\begin{array}{lllllllllllllllll}0.82 & 58.58 & 21.70 & 71.58 & 2 & 1396.8534 & 1396.8524 & 699.4335 & 0.0010 & 0.7149 & 15079.559 & 16792.486 & 5547.647 & 27415.122 & \text { Yes }\end{array}$ $\begin{array}{lllllllllllllllll}1.00 & 40.11 & 21.88 & 24.87 & 3 & 1396.8538 & 1396.8524 & 466.6247 & 0.0014 & 1.0001 & 59.847 & 75.175 & 100.783 & 132.419 & \text { No }\end{array}$

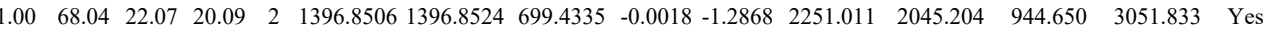

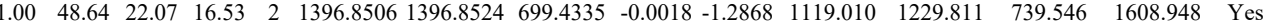
$\begin{array}{llllllllllllllll}0.82 & 62.19 & 21.70 & 75.19 & 2 & 1396.8534 & 1396.8524 & 699.4335 & 0.0010 & 0.7149 & 1437.616 & 1376.904 & 840.885 & 2382.532 & \text { Yes }\end{array}$

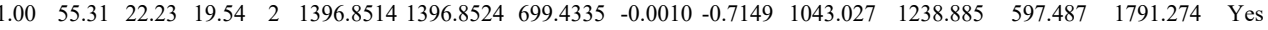

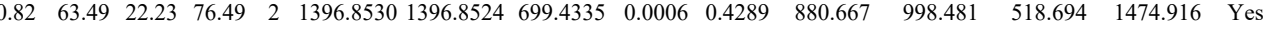
$\begin{array}{lllllllllllllll}1.00 & 66.23 & 21.73 & 18.21 & 2 & 1396.8504 & 1396.8524 & 699.4335 & -0.0020 & -1.4297 & 356.666 & 330.773 & 220.692 & 532.408 & \text { Yes }\end{array}$

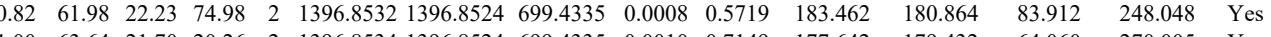
$\begin{array}{lllllllllllllll}1.00 & 63.64 & 21.70 & 20.26 & 2 & 1396.8534 & 1396.8524 & 699.4335 & 0.0010 & 0.7149 & 177.642 & 179.432 & 64.060 & 270.005 & \text { Yes }\end{array}$ $\begin{array}{lllllllllllllll}1.00 & 51.43 & 21.88 & 21.13 & 2 & 1396.8538 & 1396.8524 & 699.4335 & 0.0014 & 1.0008 & 197.738 & 184.129 & 68.109 & 250.770 & \text { Yes }\end{array}$

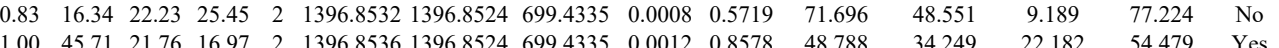

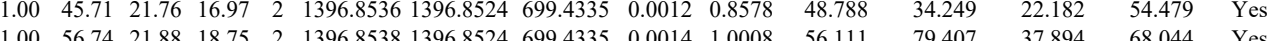
$\begin{array}{llllllllllllllll}1.00 & 56.74 & 21.88 & 18.75 & 2 & 1396.8538 & 1396.8524 & 699.4335 & 0.0014 & 1.0008 & 56.111 & 79.407 & 37.894 & 68.044 & \text { Yes } \\ 0.99 & 40.54 & 26.22 & 32.68 & 2 & 1103.686 & 1103.6794 & 552.8470 & 0.0092 & 8.3205 & 13950.061 & 13323.391 & 1351.866 & 18325.212 & \text { Yes }\end{array}$ $\begin{array}{lllllllllllllllll}0.99 & 40.54 & 26.22 & 32.68 & 2 & 1103.6886 & 1103.6794 & 552.8470 & 0.0092 & 8.3205 & 13950.061 & 13323.391 & 1351.866 & 18325.212 & \text { Yes } \\ 0.99 & 42.30 & 26.14 & 32.93 & 2 & 1103.6898 & 1103.6794 & 552.8470 & 0.0104 & 9.4058 & 17734.953 & 18609.019 & 1521.664 & 29543.848 & \text { Yes }\end{array}$ $\begin{array}{lllllllllllllll}0.99 & 42.30 & 26.14 & 32.93 & 2 & 1103.6898 & 1103.6794 & 552.8470 & 0.0104 & 9.4058 & 17734.953 & 18609.019 & 1521.664 & 29543.848 & \text { Yes } \\ 0.99 & 38.67 & 27.81 & 24.87 & 2 & 1262.7256 & 1262.7227 & 632.3686 & 0.0029 & 2.2930 & 12716.192 & 12687.419 & 32653.914 & 25603.379 & \text { Yes }\end{array}$

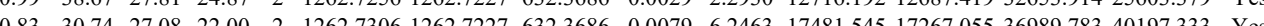

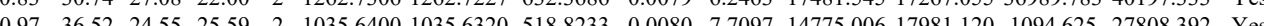

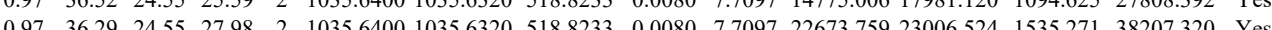
$\begin{array}{llllllllllllllll}0.96 & 38.54 & 25.89 & 28.14 & 2 & 1035.6384 & 1035.6320 & 518.8233 & 0.0064 & 61678 & 13443.908 & 12401.996 & 2754.808 & 21053.682 & \text { Yes }\end{array}$

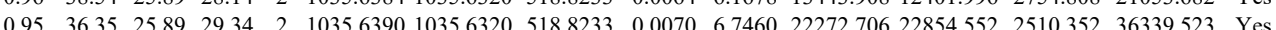

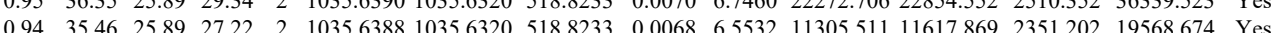
$\begin{array}{lllllllllllllll}0.76 & 24.60 & 24.44 & 27.53 & 2 & 1035.6406 & 1035.6320 & 518.8233 & 0.0086 & 8.2879 & 5387.348 & 5640.391 & 1025.926 & 8455.298 & \text { Yes }\end{array}$ $\begin{array}{llllllllllllllll}0.88 & 46.14 & 21.61 & 46.57 & 2 & 1103.7226 & 1103.7158 & 552.8652 & 0.0068 & 6.1497 & 17497.430 & 20554.850 & 788.256 & 38187.665 & \text { Yes }\end{array}$ $\begin{array}{lllllllllllllll}0.89 & 47.42 & 21.61 & 47.33 & 2 & 1103.7228 & 1103.7158 & 552.8652 & 0.0070 & 6.3306 & 24933.743 & 26261.368 & 2733.666 & 45996.696 & \text { Yes }\end{array}$ $\begin{array}{lllllllllllllll}0.88 & 49.50 & 21.61 & 49.88 & 2 & 1103.7230 & 1103.7158 & 552.8652 & 0.0072 & 6.5115 & 15547.514 & 14412.888 & 721.681 & 27692.420 & \text { Yes }\end{array}$ $\begin{array}{llllllllllllllll}0.87 & 46.61 & 21.61 & 47.33 & 2 & 1103.7230 & 1103.7158 & 552.8652 & 0.0072 & 6.5115 & 17605.480 & 18564.550 & 1401.802 & 32047.380 & \text { Yes }\end{array}$ $\begin{array}{llllllllllllllll}1.00 & 55.90 & 26.42 & 23.89 & 2 & 1282.6300 & 1282.6284 & 642.3215 & 0.0016 & 1.2455 & 4220.958 & 5257.017 & 10523.062 & 9954.634 & \text { Yes }\end{array}$ $\begin{array}{lllllllllllllll}1.00 & 52.15 & 26.51 & 24.49 & 2 & 1282.6310 & 1282.6284 & 642.3215 & 0.0026 & 2.0239 & 1855.720 & 2422.497 & 4497.274 & 3826.457 & \text { Yes }\end{array}$ $\begin{array}{lllllllllllllll}1.00 & 52.03 & 26.78 & 23.71 & 2 & 1282.6338 & 1282.6284 & 642.3215 & 0.0054 & 4.2035 & 2049.970 & 1450.888 & 3557.796 & 3188.319 & \text { Yes }\end{array}$ $\begin{array}{lllllllllllllll}1.00 & 51.70 & 27.09 & 24.24 & 2 & 1282.6380 & 1282.6284 & 642.3215 & 0.0096 & 7.4728 & 1357.286 & 1026.927 & 2168.212 & 2344.022 & \text { Yes }\end{array}$ $\begin{array}{lllllllllllllll}0.95 & 33.80 & 26.97 & 22.99 & 2 & 1282.6382 & 1282.6284 & 642.3215 & 0.0098 & 7.6285 & 456.078 & 350.271 & 620.326 & 622.394 & \text { Yes }\end{array}$ $\begin{array}{llllllllllllllll}0.98 & 34.02 & 27.07 & 15.17 & 3 & 1479.7006 & 1479.6907 & 494.2375 & 0.0099 & 6.6769 & 3045.574 & 3324.379 & 1388.621 & 4550.293 & \text { Yes }\end{array}$ $\begin{array}{lllllllllllllll}1.00 & 52.15 & 26.79 & 23.14 & 2 & 1282.6340 & 1282.6284 & 642.3215 & 0.0056 & 4.3592 & 1185.144 & 1112.610 & 2328.958 & 2110.567 & \text { Yes }\end{array}$

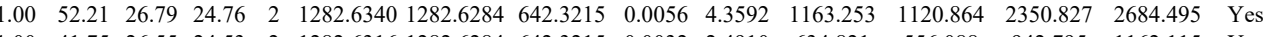

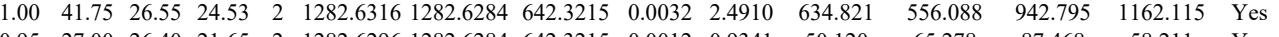
$\begin{array}{lllllllllllllll}0.95 & 27.00 & 26.40 & 21.65 & 2 & 1282.6296 & 1282.6284 & 642.3215 & 0.0012 & 0.9341 & 50.120 & 65.278 & 87.468 & 58.211 & \text { Yes }\end{array}$ $\begin{array}{lllllllllllllll}0.99 & 33.08 & 26.42 & 19.23 & 2 & 1282.6300 & 1282.6284 & 642.3215 & 0.0016 & 1.2455 & 35.886 & 46.099 & 47.138 & 75.320 & \text { Yes }\end{array}$

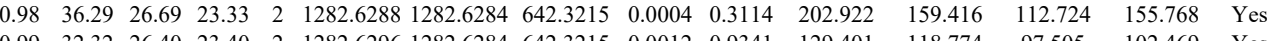
$\begin{array}{llllllllllllllll}0.99 & 32.32 & 26.40 & 23.40 & 2 & 1282.6296 & 1282.6284 & 642.3215 & 0.0012 & 0.9341 & 129.401 & 118.774 & 97.505 & 102.469 & \text { Yes } \\ 0.54 & 11.31 & 28.28 & 16.65 & 3 & 1721.9080 & 1721.9045 & 574.9754 & 0.0035 & 2.0291 & 14.094 & 25.530 & 13.473 & 28.306 & \mathrm{No}\end{array}$ $\begin{array}{lllllllllllllll}0.54 & 11.31 & 28.28 & 16.65 & 3 & 1721.9080 & 1721.9045 & 574.9754 & 0.0035 & 2.0291 & 14.094 & 25.530 & 13.473 & 28.306 & \text { No } \\ 1.00 & 39.74 & 25.82 & 16.35 & 2 & 1488.8620 & 1488.8608 & 745.4377 & 0.0012 & 0.8049 & 222.430 & 188.484 & 30.717 & 316.453 & \text { Yes }\end{array}$ VMVQPINLIFR $\begin{array}{lllllllllll} & \end{array}$ $\begin{array}{lllllllllllll}0.99 & 36.30 & 25.82 & 15.73 & 2 & 1488.8622 & 1488.8608 & 74.4377 & 0.0014 & 0.9390 & 152.089 & 169.401\end{array}$ $\begin{array}{lllllllllllll}0.82 & 20.54 & 27.20 & 17.38 & 2 & 1472.8684 & 1472.8659 & 737.4402 & 0.0025 & 1.6950 & 5.915 & 12.388\end{array}$

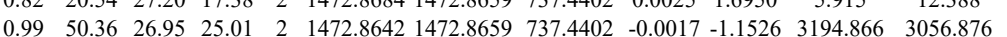



$\begin{array}{llllllllllll}0.98 & 32.13 & 27.20 & 29.07 & 2 & 1472.8684 & 1472.8659 & 737.4402 & 0.0025 & 1.6950 & 37.541 & 52.352\end{array}$

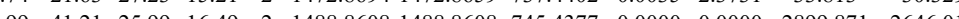

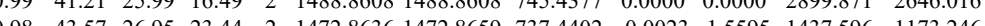
$\begin{array}{llllllllll} & 0.0678 & 5049.320 & 4736.610\end{array}$ $\begin{array}{lllllllllllll}1.82 & 24.04 & 27.20 & 37.04 & 2 & 1472.8668 & 1472.8659 & 737.4402 & 0.0009 & 0.6102 & 21.023 & 25.853\end{array}$ $\begin{array}{llllllllllll}0.82 & 37.68 & 27.20 & 50.68 & 2 & 1472.8670 & 14728659 & 737.4402 & 0.0011 & 0.7458 & 58.825 & 50.885\end{array}$ $\begin{array}{lllllllllllll}0.64 & 12.13 & 27.16 & 25.13 & 3 & 1472.8678 & 1472.8659 & 491.9626 & 0.0019 & 1.74874 & 11.449 & 13.906\end{array}$ $\begin{array}{llllllllllll} & \end{array}$ $\begin{array}{llllllllll} & \end{array}$ \begin{tabular}{llllllllll} 
& 27.20 \\
\hline
\end{tabular} $\begin{array}{llllllllllll}1.00 & 46.05 & 27.20 & 21.67 & 2 & 1472.8668 & 1472.8659 & 737.4402 & 0.0009 & 0.6102 & 306.655 & 270.137\end{array}$ $\begin{array}{llllll}737.4402 & 0.000 & 0.6152 & 0.60170 & 145.264 & 137.815\end{array}$ $\begin{array}{lllllllllllll}0.92 & 27.71 & 27.27 & 23.21 & 2 & 1472.8692 & 1472.8659 & 737.4402 & 0.0033 & 2.2375 & 28.777 & 21.739\end{array}$

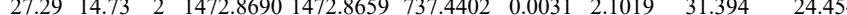
$\begin{array}{llllllllllll}4.69 & 27.23 & 23.28 & 2 & 1472.8664 & 1472.8659 & 737.4402 & 0.0005 & 0.3390 & 27.012 & 15.669\end{array}$

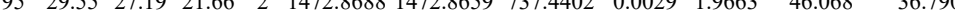

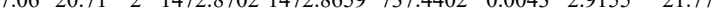

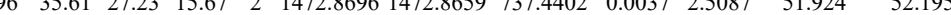
$\begin{array}{llllllllllll}0.87 & 29.76 & 27.25 & 20.25 & 2 & 1472.8700 & 1472.8659 & 737.4402 & 0.0041 & 2.7799 & 56.864 & 56.015\end{array}$ $\begin{array}{llllllllllll}1.00 & 4.75 & 27.23 & 23.85 & 2 & 1472.8694 & 1472.8659 & 737.4402 & 0.0035 & 2.3731 & 33.948 & 29.908\end{array}$

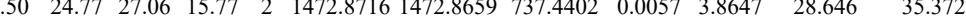

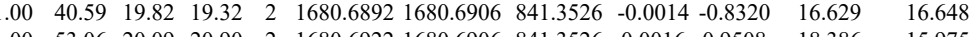
$\begin{array}{lllllllllll}1.00 & 53.06 & 2.09 & 20.90 & 2 & 1680.6922 & 1680.6906 & 841.3526 & 0.0016 & 0.9508 & 18.386\end{array}$ $\begin{array}{llllllllllll}1.00 & 46.51 & 21.46 & 59.51 & 2 & 1680.7040 & 1680.6906 & 841.3526 & 0.0134 & 7.9633 & 16.706\end{array}$

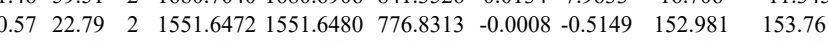
$\begin{array}{llllllllllll}1.00 & 80.84 & 20.93 & 20.68 & 2 & 1551.6492 & 1551.6480 & 776.8313 & 0.0012 & 0.71424 & 77.760 & 67.746\end{array}$ $\begin{array}{llllllllllll}0.99 & 42.62 & 27.44 & 19.45 & 2 & 1183.6080 & 1183.5963 & 592.8054 & 0.0117 & 9.8682 & 5362.490 & 5254.083\end{array}$ $\begin{array}{lllllllllllll}0.99 & 43.53 & 27.16 & 19.80 & 2 & 1183.6050 & 1183.5963 & 592.8054 & 0.0087 & 7.3379 & 1183.825 & 1460.442 & 13\end{array}$ $\begin{array}{llllllllllll}0.66 & 24.95 & 27.00 & 23.73 & 2 & 1183.6058 & 1183.5963 & 592.8054 & 0.0095 & 8.0127 & 436.401 & 461.799\end{array}$ $\begin{array}{lllllllllllll}0.69 & 24.69 & 27.31 & 15.70 & 2 & 1183.6068 & 1183.5963 & 592.8054 & 0.0105 & 8.8561 & 369.940 & 362.072\end{array}$

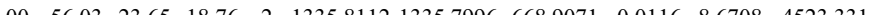

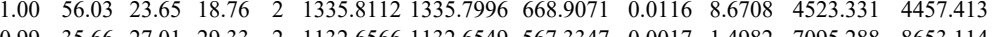
$\begin{array}{lllllllllllll}0.99 & 35.38 & 27.01 & 29.34 & 2 & 112.6568 & 112.6549 & 567.3347 & 0.0019 & 1.6745 & 5047.576 & 5292.843 & 407.8\end{array}$

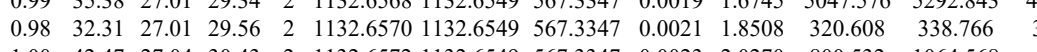
$\begin{array}{llllllllllll}1.00 & 42.47 & 27.04 & 30.43 & 2 & 1132.6572 & 1132.6549 & 567.3347 & 0.0023 & 2.0270 & 800.532 & 1064.568\end{array}$ $\begin{array}{llllllllllll}1.00 & 64.25 & 26.90 & 32.78 & 2 & 1427.8138 & 1427.8106 & 714.9126 & 0.0032 & 2.2380 & 139.157 & 102.376 \\ 1.00 & 66.14 & 26.77 & 33.55 & 2 & 1427.8152 & 1427.8106 & 714.9126 & 0.0046 & 3.2172 & 187.836 & 178.037\end{array}$ $\begin{array}{lllllllllllll}1.00 & 49.35 & 25.85 & 20.95 & 3 & 1697.9590 & 1697.9546 & 566.9921 & 0.0044 & 2.5867 & 3550.058 & 4909.643 & 377\end{array}$ $\begin{array}{llllllllllll}\text { YFILPDSLPLDTLLVDVEPK } & 1.00 & 61.64 & 21.90 & 18.69 & 2 & 2574.4474 & 2574.4440 & 1288.2293 & 0.0034 & 1.3196 & 28.184\end{array}$ $\begin{array}{lllllllllllllll} & 18.00 & 21.85 & 31.15 & 4 & 2574.4481 & 2574.4440 & 644.6183 & 0.0041 & 1.5901 & 71.149 & 61.407\end{array}$ $\begin{array}{lllllllllllllll}\text { YFILPDSLPLDTLLVDVEPK } & 0.82 & 45.16 & 22.04 & 58.16 & 2 & 2574.4454 & 2574.4440 & 1288.2293 & 0.0014 & 0.5434 & 4.802 & 3.024\end{array}$ $\begin{array}{llllllllllllll}\text { YFILPDSLPLDTLLVDVEPK } & 0.67 & 13.99 & 21.93 & 26.99 & 3 & 2574.4474 & 2574.4440 & 859.1553 & 0.0034 & 1.3191 & 6.163 & 12.068\end{array}$ $\begin{array}{llllllllllllll}\text { YFILPDSLPLDTLLVDVEPK } & 0.54 & 6.05 & 21.85 & 17.26 & 3 & 2574.4480 & 2574.4440 & 859.1553 & 0.0040 & 1.5519 & 73.892 & 19.100\end{array}$ $\begin{array}{llllllllllllllll}\text { YFILPDSLPLDTLLVDVEPK } & 1.00 & 31.14 & 21.99 & 15.05 & 3 & 2574.4465 & 2574.4440 & 859.1553 & 0.0025 & 0.9699 & 6.233 & 7.799\end{array}$

$\begin{array}{llllllllllllll}\text { YFILPDSLPLDTLLVDVEPK } & 0.96 & 17.45 & 21.85 & 16.08 & 3 & 2574.4480 & 2574.4440 & 859.1553 & 0.0040 & 1.5519 & 16.696 & 0.000\end{array}$ $\begin{array}{lrlllllllllllll}\text { YFILPDSLPLDTLLVDVEPK } & 0.96 & 17.45 & 21.85 & 16.08 & 3 & 2574.4480 & 2574.4440 & 859.1553 & 0.0040 & 1.5519 & 16.696 & 0.000 & 0.000 & 0.00 \\ \text { REEEEFNTGPLSVLTQSVK } & 1.00 & 43.24 & 26.46 & 17.52 & 3 & 2450.2924 & 2450.2896 & 817.7705 & 0.0028 & 1.1413 & 27.418 & 23.282 & 12.798 & 150.9 \\ \text { REEEEFNTGPLSVLTQSVK } & 1.00 & 61.06 & 26.54 & 20.10 & 3 & 2450.2939 & 2450.2896 & 817.7705 & 0.0043 & 1.7527 & 62.519 & 37.824 & 42.669 & 92.63\end{array}$ $\begin{array}{lllllllllllllll} & \end{array}$ $\begin{array}{llllllllllll}1.00 & 50.14 & 25.95 & 25.32 & 2 & 1100.6712 & 1100.6676 & 551.3411 & 0.0036 & 3.2648 & 2468.869 & 1 \\ 1.00 & 66.14 & 27.39 & 28.43 & 2 & 1363.6932 & 1363.6822 & 682.8484 & 0.0110 & 8.0544 & 5222.405 & 4589\end{array}$ $\begin{array}{llllllllllllllll} & \end{array}$ $\begin{array}{lllllllllllllllll}1.00 & 61.48 & 27.39 & 30.21 & 2 & 1363.6936 & 1363.6822 & 682.8484 & 0.0114 & 8.3473 & 9550.418 & 7326.742 & 2241.024 & 13122.388 & \text { Yes }\end{array}$ $\begin{array}{lllllllllllllllll}1.00 & 56.85 & 27.80 & 26.04 & 2 & 1363.6940 & 1363.6822 & 682.8484 & 0.0118 & 8.6402 & 12643.959 & 10951.373 & 2952.231 & 17817.083 & \text { Yes }\end{array}$

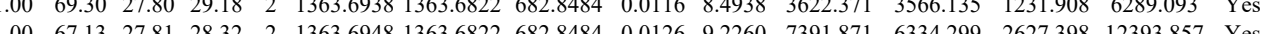




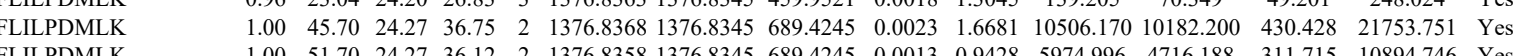
FLILPDMLK

FLILPDMLK

ALQSVGQIVGEVLK ALQSVGQIVGEVLK ALQSVGQIVGEVLK TLMELLNQMDGFDTLH TLMELLNQMDGFDTLHR ALQSVGQIVGEVLK ALQSVGQIVGEVLK ALQSVGQIVGEVLK ALQSVGQIVGEVLK LMELLNQMDGPDLHR VALDMTTLTIMR

VALDMTTLTIMR

VALDMTTLTIMR

VALDMTTLTIMR

VALDMTTLTIMR $\begin{array}{lllllllllllllllllll}\text { MIMATNRPDTLDPALLRPGR } & 0.90 & 20.78 & 25.62 & 14.76 & 3 & 2381.2798 & 2381.2793 & 794.7670 & 0.0005 & 0.2097 & 1960.421 & 2042.346 & 1270.133 & 2359.064 & \text { Yes } \\ \text { MIMATNRPDTLDPALLRPGR } & 0.90 & 16.96 & 25.58 & 16.14 & 3 & 2381.2810 & 2381.2793 & 794.7670 & 0.0017 & 0.7130 & 1479.123 & 1469.969 & 1184.554 & 1998.270 & \text { Yes }\end{array}$ $\begin{array}{llllllllllllllll} & \end{array}$ $\begin{array}{llllllllllllllll} & \text { MIMATNOS }\end{array}$

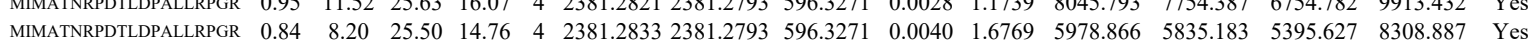

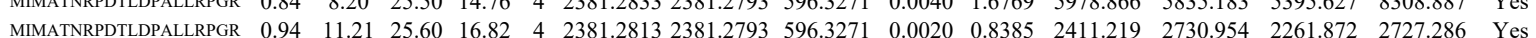
NFGIGQDIQPK NFGIGQDIQPK NFGIGQDIQPK AGVNTVTTLVENK AGVNTVTTLVENK VAPAPAVVK VAPAPAVVK VVNPLFEK VVNPLFEK VVNPLFEK VVNPLFEK KVVNPLFEK KVVNPLFEK

\section{VPPAINQFTQALDR}

VPPAINQFTQALDR

VPPAINQFTQALDR

VPPAINQFTQALDR

VPPAINQFTQALDR

VPPAINQFTQALDR VPPAINQFTQALDR VPPAINQFTQALDR VPPAINQFTQALDR VPPAINQFTQALDR VPPAINQFTQALDR VPPAINQFTQALDR
VPPAINQFTQALDR $\begin{array}{llllllllllllllll}0.97 & 37.33 & 27.90 & 26.59 & 2 & 1503.8430 & 1503.8289 & 752.9217 & 0.0141 & 9.3634 & 19615.601 & 20019.204 & 466.589 & 23916.342 & \text { Yes }\end{array}$ $\begin{array}{lllllllllllllll}0.99 & 44.93 & 28.26 & 24.91 & 2 & 1503.8414 & 1503.8289 & 752.9217 & 0.0125 & 8.3009 & 5140.748 & 5270.556 & 976.501 & 8969.148 & \text { Yes }\end{array}$

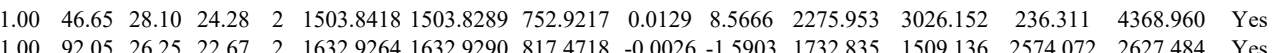

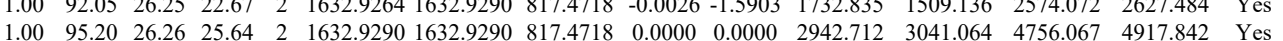
$\begin{array}{lllllllllllllll}0.99 & 25.59 & 26.36 & 15.62 & 3 & 1632.9316 & 1632.9290 & 545.3169 & 0.0026 & 1.5893 & 947.616 & 649.477 & 447.391 & 1351.343 & \text { Yes }\end{array}$

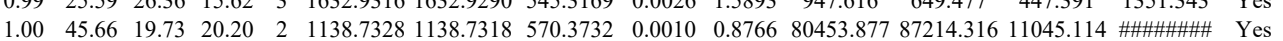
$\begin{array}{lllllllllllllll}1.00 & 47.64 & 20.00 & 16.03 & 2 & 1138.7334 & 1138.7318 & 570.3732 & 0.0016 & 1.4026 & 53829.452 & 64408.807 & 5638.348 & 94481.209 & \text { Yes }\end{array}$ $\begin{array}{llllllllllllllll}1.00 & 47.96 & 24.77 & 17.11 & 2 & 1232.7494 & 1232.7372 & 617.3759 & 0.0122 & 9.8804 & 27324.494 & 32812.095 & 5997.926 & 46083.758 & \text { Yes }\end{array}$ $\begin{array}{lllllllllllllll}100 & 63.48 & 24.77 & 22.40 & 2 & 1232.7494 & 12327372 & 617.3759 & 0.0122 & 9.8804 & 26431.143 & 31835.650 & 4543.086 & 43247.124 & \text { Yes }\end{array}$

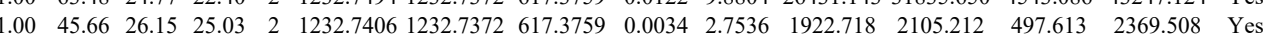
$\begin{array}{llllllllllllllll}1.00 & 48.57 & 25.88 & 27.58 & 2 & 1232.7412 & 1232.7372 & 617.3759 & 0.0040 & 3.2395 & 6346.626 & 6532.364 & 1532.290 & 7910.389 & \text { Yes }\end{array}$ $\begin{array}{lllllllllllllllll}1.00 & 47.46 & 17.40 & 21.51 & 3 & 1504.9444 & 1504.9343 & 502.6520 & 0.0101 & 6.6978 & 5469.247 & 6508.546 & 1230.279 & 13322.508 & \text { Yes }\end{array}$ $\begin{array}{llllllllllllllll}1.00 & 42.41 & 17.40 & 21.96 & 3 & 1504.9450 & 1504.9343 & 502.6520 & 0.0107 & 7.0956 & 6543.954 & 7402.098 & 894.793 & 15960.115 & \text { No }\end{array}$

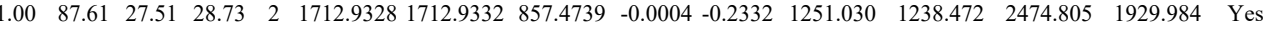
$\begin{array}{lllllllllllllll}1.00 & 74.60 & 27.53 & 24.24 & 2 & 1712.9332 & 1712.9332 & 857.4739 & 0.0000 & 0.0000 & 421.171 & 460.704 & 367.107 & 1028.931 & \text { Yes }\end{array}$ $\begin{array}{lllllllllllllll}0.99 & 31.25 & 27.51 & 20.83 & 3 & 1712.9338 & 1712.9332 & 571.9850 & 0.0006 & 0.3497 & 406.177 & 356.604 & 179.176 & 429.081 & \text { Yes }\end{array}$ $\begin{array}{lllllllllllllll}0.86 & 18.84 & 27.41 & 21.59 & 3 & 1712.9344 & 1712.9332 & 571.9850 & 0.0012 & 0.6993 & 614.662 & 677.317 & 111.140 & 507.816 & \text { Yes }\end{array}$ $\begin{array}{lllllllllllllll}1.00 & 70.17 & 27.47 & 27.32 & 2 & 1712.9322 & 1712.9332 & 857.4739 & -0.0010 & -0.5831 & 604.693 & 1522.747 & 1338.418 & 1362.708 & \text { Yes }\end{array}$ $\begin{array}{lllllllllllllll}1.00 & 72.73 & 27.52 & 28.03 & 2 & 1712.9336 & 1712.9332 & 857.4739 & 0.0004 & 0.2332 & 2174.078 & 1466.898 & 3055.779 & 3476.389 & \text { Yes }\end{array}$ $\begin{array}{lllllllllllllll}1.00 & 34.69 & 27.41 & 21.92 & 3 & 1712.9344 & 1712.9332 & 571.9850 & 0.0012 & 0.6993 & 224.834 & 247.558 & 179.281 & 247.939 & \text { Yes }\end{array}$

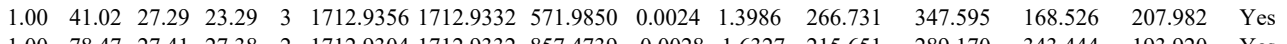

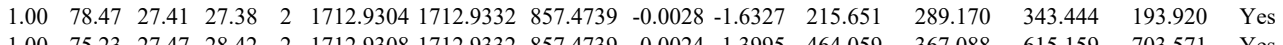

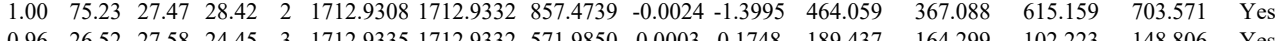
$\begin{array}{lllllllllllllll}0.96 & 26.52 & 27.58 & 24.45 & 3 & 1712.9335 & 1712.9332 & 571.9850 & 0.0003 & 0.1748 & 189.437 & 164.299 & 102.223 & 148.806 & \text { Yes } \\ 0.90 & 18.40 & 27.29 & 20.78 & 3 & 1712.9353 & 1712.9332 & 571.9850 & 0.0021 & 1.2238 & 170.332 & 132.085 & 74.341 & 126.461 & \text { Yes }\end{array}$ $\begin{array}{lllllllllllllll}0.90 & 18.40 & 27.29 & 20.78 & 3 & 1712.9353 & 1712.9332 & 571.9850 & 0.0021 & 1.2238 & 170.332 & 132.085 & 74.341 & 126.461 & \text { Yes } \\ 1.00 & 72.83 & 27.52 & 27.57 & 2 & 1712.9324 & 1712.9332 & 857.4739 & -0.0008 & -0.4665 & 446.684 & 472.725 & 709.273 & 734.816 & \text { Yes }\end{array}$ $\begin{array}{lllllllllll}1.00 & 53.50 & 22.01 & 16.84 & 3 & 2819.5576 & 2819.5564 & 940.8594 & 0.0012 & 0.4251 & 2.341\end{array}$ $\begin{array}{lllllllllll}1.00 & 64.23 & 22.04 & 17.45 & 3 & 2819.5582 & 2819.5564 & 940.8594 & 0.0018 & 0.4251 & 2.341\end{array}$ 


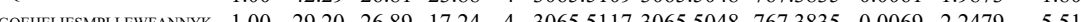
$\begin{array}{lllllllll} & \end{array}$ $\begin{array}{lllllllllll} & 0.3582 & 2.538\end{array}$ $\begin{array}{llllllllllll} & \end{array}$

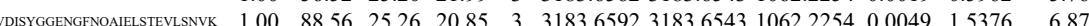

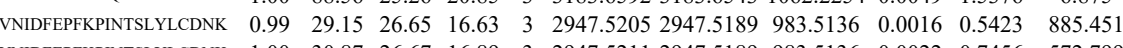

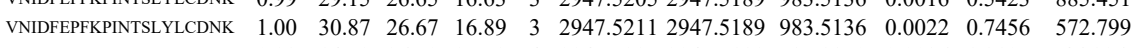
$\begin{array}{lllllllllllll}\text { VNIDFEPFKPINTSLYLCDNK } & 0.98 & 14.52 & 26.59 & 27.52 & 4 & 2947.5225 & 2947.5189 & 737.8870 & 0.0036 & 1.2197 & 46.116 & \end{array}$

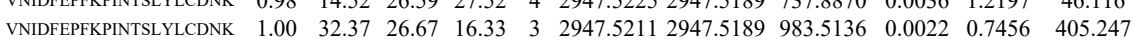
$\begin{array}{llllllllllllll}\text { VNIDFEPFKPINTSLYLCDNK } & 0.80 & 8.64 & 26.67 & 21.64 & 4 & 2947.5221 & 2947.5189 & 737.8870 & 0.0032 & 1.0842 & 34.820 & 3\end{array}$ $\begin{array}{llllllllllllll}\text { VNIDFEPFKPINTSLYLCDNK } & 1.00 & 34.88 & 26.62 & 15.26 & 3 & 2947.5226 & 2947.5189 & 983.5136 & 0.0037 & 1.2540 & 604.723\end{array}$ $\begin{array}{llllllllllll}\text { VNVAGLVLAGSADFK } & 1.00 & 54.11 & 23.94 & 17.20 & 3 & 1748.0161 & 1748.0076 & 583.6765 & 0.0085 & 4.8543 & 205.254\end{array}$

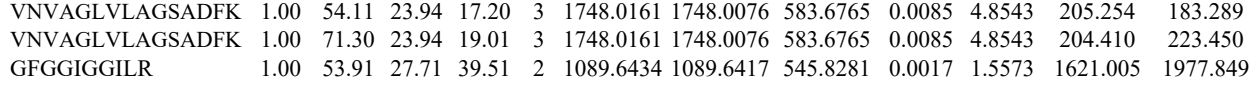

GFGGIGGILR

GFGGIGGILR

GFGGIGGILR

LSVLGAITSVQQR

LSVLGAITSVQQR

LSVLGAITSVQQR

LSVLGAITSVQQR

LSVLGAITSVQQR

LSVLGAITSVQQR

LSVLGAITSVQQR

LSVLGAITSVQQR

LSVLGAITSVQQR

LSVAITSQR

SSVAITVQR

LSVLGAITSVQQR

LSVLGAITSVQQR

LSVLGAITSVQQR

LSVLGAITSVQQR

LSVLGAITSVQQR

LSVLGAITSVQQR

LSVLGAITSVQQR

YFDEISQDTGK

YFDEISQDTGK

$\begin{array}{lllllllllllll}\text { RS4X HUMAN } & \text { P62701 } & \text { RPS4X } & \text { 40S ribosomal pro } 29.598 & 1.00 & 9 & 37.3 & 0.1462 & 0.2379 & 1.0188 & 0.3254 & 80 & \text { VNDTIOIDLETGK }\end{array}$

ITDFIK $\begin{array}{lllllllllllll}1.00 & 53.91 & 27.71 & 39.51 & 2 & 1089.6434 & 1089.6417 & 545.8281 & 0.0017 & 1.5573 & 1621.005 & 19\end{array}$ $\begin{array}{lllllllllllll}70.95 & 27.42 & 46.22 & 2 & 1089.6428 & 1089.6417 & 545.8281 & 0.0011 & 1.0076 & 3138.845 & 3897.743 & 1762.67\end{array}$

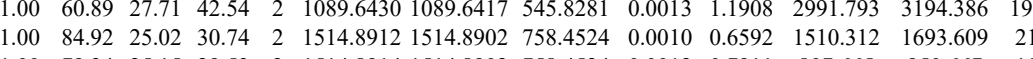

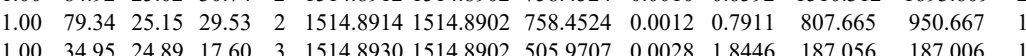
$\begin{array}{lllllllllllll}1.00 & 34.95 & 24.89 & 17.60 & 3 & 1514.8930 & 1514.8902 & 505.9707 & 0.0028 & 1.8446 & 187.056 & 187.006 \\ 0.67 & 35.46 & 24.87 & 48.46 & 3 & 1514.8933 & 1514.8902 & 505.9707 & 0.0031 & 2.0423 & 204.314 & 224.862\end{array}$

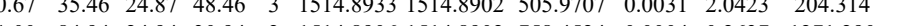
$\begin{array}{llllllllllllll}1 & & \end{array}$ $\begin{array}{llllllllllll}1.00 & 74.96 & 24.93 & 29.97 & 2 & 1514.8908 & 1514.8902 & 758.4524 & 0.0006 & 0.3955 & 1706.482 & 1658.210\end{array}$ $\begin{array}{llllllllllll}1.00 & 31.34 & 24.93 & 17.77 & 3 & 1514.8912 & 1514.8902 & 505.9707 & 0.0010 & 0.6588 & 88.411 & 93.261 \\ 1.00 & 42.80 & 25.04 & 16.97 & 3 & 1514.8924 & 1514.8902 & 505.9707 & 0.0022 & 1.4494 & 150.739 & 117.260\end{array}$

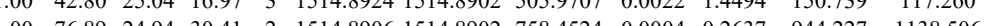
$\begin{array}{llllllllllll}1.00 & 76.89 & 24.94 & 30.41 & 2 & 1514.8906 & 1514.8902 & 758.4524 & 0.0004 & 0.2637 & 944.227 & 1138.506\end{array}$

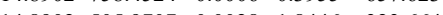
$\begin{array}{lllllllllllll}1.00 & 30.25 & 24.89 & 15.68 & 3 & 1514.8930 & 1514.8902 & 505.9707 & 0.0028 & 1.8446 & 260.230 & 170.520\end{array}$ $\begin{array}{lllllllllllll}1.00 & 86.04 & 24.93 & 31.38 & 2 & 1514.8910 & 1514.8902 & 758.4524 & 0.0008 & 0.5274 & 212.586 & 198.355\end{array}$

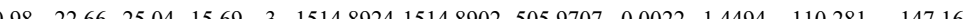

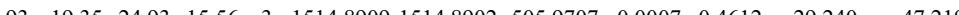
$\begin{array}{lllllllllllll}1.00 & 68.91 & 25.01 & 28.81 & 2 & 15148918 & 15148902 & 758.524 & 0.0016 & 1.0548 & 57.456 & 44.736\end{array}$ $\begin{array}{llllllllllllll}1.00 & 34.23 & 25.04 & 16.84 & 3 & 1514.8921 & 1514.8902 & 505.9707 & 0.0019 & 1.2517 & 30.558 & 44.736\end{array}$ $\begin{array}{lllllllllllll}1.00 & 33.60 & 25.04 & 17.46 & 3 & 1514.8921 & 1514.8902 & 505.9707 & 0.0019 & 1.2517 & 28.899 & 20.416\end{array}$ $\begin{array}{llllllllllll}1.00 & 72.53 & 25.04 & 28.96 & 2 & 1514.8922 & 1514.8902 & 758.4524 & 0.0020 & 1.3185 & 65.757 & 58.4100\end{array}$ $\begin{array}{lllllllllllll}1.00 & 57.34 & 26.85 & 19.99 & 2 & 1589.7822 & 1589.7817 & 795.8981 & 0.0005 & 0.3141 & 1562.223 & 1585.703\end{array}$ $\begin{array}{lllllllllllll}1.00 & 59.09 & 26.95 & 22.90 & 2 & 1589.7828 & 1589.7817 & 795.8981 & 0.0011 & 0.6910 & 1158.894 & 961.789\end{array}$ $\begin{array}{llllllllllllll}1.00 & 70.00 & 27.13 & 24.00 & 2 & 1732.9446 & 1732.9451 & 857.4798 & -0.0005 & -0.2882 & 273.945 & 173.987\end{array}$ $\begin{array}{llllllllllll}0.51 & 16.70 & 25.22 & 22.18 & 2 & 1023.6210 & 1023.6208 & 512.8177 & 0.0002 & 0.1950 & 188.056 & 147.505\end{array}$ $\begin{array}{llllllllllll}0.88 & 20.89 & 25.37 & 25.68 & 2 & 1023.6226 & 1023.6208 & 512.8177 & 0.0018 & 1.7550 & 142.206 & 117.131\end{array}$ $\begin{array}{lllllllllll}0.88 & 20.89 & 25.37 & 25.68 & 2 & 1023.6226 & 1023.6208 & 512.817 & 0.0018 & 1.7550 & 142.206 \\ 1.00 & 84.28 & 27.67 & 24.68 & 2 & 2173.1234 & 2173.1221 & 1087.5683 & 0.0013 & 0.5977 & 1030.114\end{array}$

106.499 $\begin{array}{lllllllllllll}\text { TDITYPAGFMDVISIDK } & 1.00 & 73.58 & 27.76 & 22.55 & 2 & 2173.1254 & 2173.1221 & 1087.5683 & 0.0033 & 1.5171 & 391.080 & 440 .\end{array}$ $\begin{array}{lllllllllllll}\text { TDITYPAGFMDVISIDK } & 0.84 & 17.76 & 27.69 & 23.81 & 3 & 2173.1266 & 2173.1221 & 725.3813 & 0.0045 & 2.0679 & 0.000 & 0.000\end{array}$

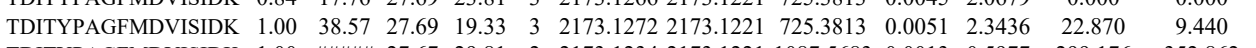

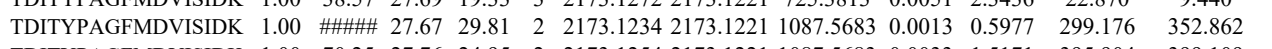
$\begin{array}{lllllllllllll}\text { TDITYPAGFMDVISIDK } & 1.00 & 70.25 & 27.76 & 24.95 & 2 & 2173.1254 & 2173.1221 & 1087.5683 & 0.0033 & 1.5171 & 395.904 & 399.109\end{array}$

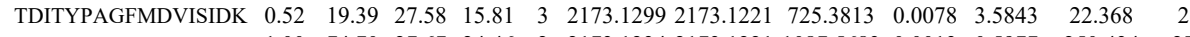
$\begin{array}{lllllllllllllll}\text { TDITYPAGFMDVISIDK } & 1.00 & 74.70 & 27.67 & 24.46 & 2 & 2173.1234 & 2173.1221 & 1087.5683 & 0.0013 & 0.5977 & 250.434 & 279.011 & 106.1\end{array}$ IGVITNR IGVITNR

IGVITNR

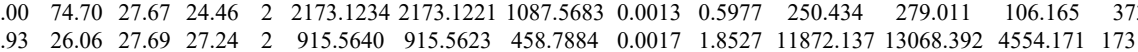

IGVITNR

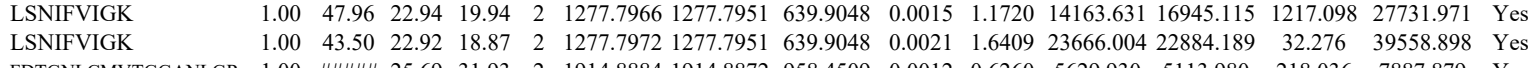
$\begin{array}{lllllllllllllllll}0.95 & 27.60 & 28.26 & 30.79 & 2 & 915.5646 & 915.5623 & 458.7884 & 0.0023 & 2.5066 & 12035.978 & 14316.674 & 5050.934 & 23297.735 & \text { Yes }\end{array}$ $\begin{array}{llllllllllllllllll}0.88 & 23.62 & 28.26 & 28.70 & 2 & 915.5644 & 915.5623 & 458.7884 & 0.0021 & 2.2886 & 18800.127 & 22476.865 & 7393.795 & 29747.632 & \text { Yes }\end{array}$ 


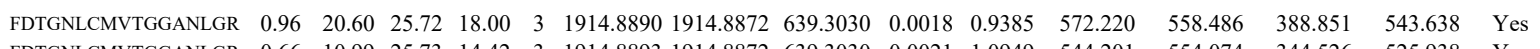
$\begin{array}{llllllllllllllll}\text { FDTGNLCMVTGGANLGR } & 0.66 & 10.99 & 25.73 & 14.42 & 3 & 1914.8893 & 1914.8872 & 639.3030 & 0.0021 & 1.0949 & 544.201 & 554.074 & 344.526 & 525.938 & \text { Yes }\end{array}$ $\begin{array}{lllllllllllllllll}\text { FDTGNLCMVTGGANLGR } & 1.00 & 31.63 & 25.73 & 16.52 & 3 & 1914.8893 & 1914.8872 & 639.3030 & 0.0021 & 1.0949 & 7.364 & 8.137 & 5.820 & 6.116 & \text { Yes }\end{array}$

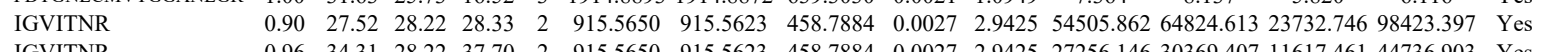

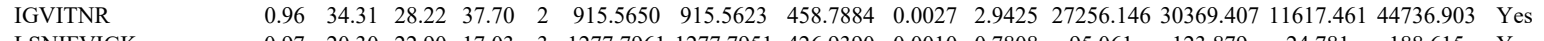

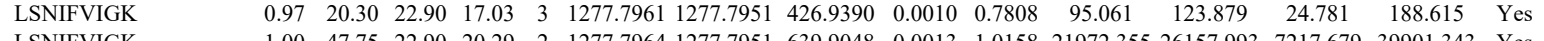

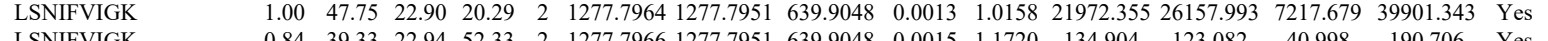
\begin{tabular}{llllllllllllllll} 
LSNIFVIGK & 0.84 & 39.33 & 22.94 & 52.33 & 2 & 1277.7966 & 1277.7951 & 639.9048 & 0.0015 & 1.1720 & 134.904 & 123.082 & 40.998 & 190.706 & Yes \\
\hline
\end{tabular} $\begin{array}{lllllllllllllll}\text { FDTGNLCMVTGGANLGR } & 1.00 & \text { mant } 26.03 & 29.88 & 2 & 1914.8906 & 1914.8872 & 958.4509 & 0.0034 & 1.7737 & 3105.411 & 2377.064 & 467.071 & 3670.469 & \text { No }\end{array}$

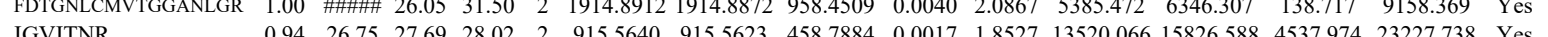
$\begin{array}{lllllllllllllllllll} & \text { IGVITNR } & 0.94 & 26.75 & 27.69 & 28.02 & 2 & 915.5640 & 915.5623 & 458.7884 & 0.017 & 1.8527 & 13520.066 & 15826.588 & 4537.974 & 23227.738 & \text { Yes } \\ \text { IGVITNR } & 0.97 & 32.98 & 27.69 & 37.49 & 2 & 915.540 & 915.5623 & 458.7884 & 0.0017 & 1.8527 & 16495.058 & 22513.139 & 5813.620 & 26789.003 & \text { Yes }\end{array}$ $\begin{array}{llllllllllllllll} & \\ \text { ISNIFVIGK } & 1.00 & 42.84 & 23.48 & 21.00 & 2 & 1277.7954 & 1277.7951 & 639.9048 & 0.0003 & 0.2344 & 27583.999 & 25754.219 & 67.276 & 54546.589 & \text { Yes }\end{array}$

LSNIFVIGK $\begin{array}{llllllllllllllll}1.00 & 42.84 & 23.48 & 21.00 & 2 & 1277.7954 & 1277.7951 & 639.9048 & 0.0003 & 0.2344 & 27583.999 & 29754.219 & 67.276 & 54546.589 & \text { Yes } & \\ 1.00 & 45.39 & 2.90 & 21.72 & 2 & 1277.7958 & 1277.7951 & 639.904 & 0.0007 & 0.570 & 21107.068 & 22309.731 & 745.669 & 3644.620 & \text { Yes }\end{array}$

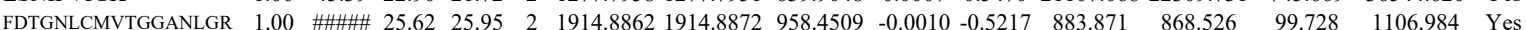

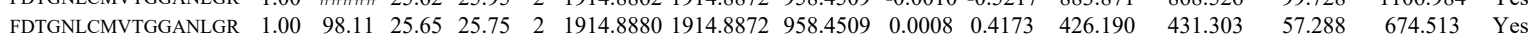
IGVITNR

LSNIFVIGK

LSNIFVIGK

LSNIFVIGK

LSNIFVIGK

GNKPWISLPR

GNKPWISLPR

LSNIFVIGK

GNKPWISLPR

GNKPWISLPR

GNKPWISLPR

GNKPWISLPR

GNKPWISLPR

GNKPWISLPR

LSNIFVIGK

LSNIFVIGK

ECLPLIIFLR

ECLPLIIFLR

GNKPWISLPR

GNKPWISLPR

GNKPWISLPR

GNKPWISLPR

GNRWISLPR

GNKPWISLPR

GNKPWISLPR

GNKPWISLPR

GNKPWISLPR

GNKPWISLPR

ECLPLIIFLR

ECLPLIIFLR

GNKPWISLPR

GNKPWISLPR

ECLPLIIFLR

ECLPLIIFLR

GNKPWISLPR

GNKPWISLPR

GNKPWISLPR

GNKPWISLPR

GNKPWISLPR

GNKPWISLPR

FDTGNLCMVTGGANLGR

FDTGNLCMVTGGANLG FDTGNLCMVTGGANLGR FDTGNLCMVTGG ALTGDEVK YALTGDEVK

YALTGDEVK

VNDTIQIDLETGK

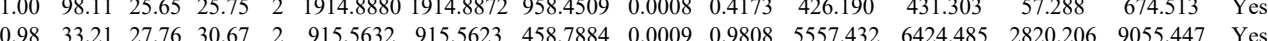
$\begin{array}{llllllllllllllll}0.99 & 34.42 & 27.69 & 33.80 & 2 & 915.563 & 915.5623 & 458.7884 & 0.0013 & 1.4168 & 4179.119 & 4533.360 & 1854.096 & 6144.302 & \text { Yes }\end{array}$ $\begin{array}{llllllllllllllll}1.00 & 44.54 & 23.67 & 19.43 & 2 & 1277.7948 & 1277.7951 & 639.9048 & -0.0003 & -0.2344 & 6632.180 & 6859.502 & 245.734 & 12282.912 & \text { Yes }\end{array}$ $\begin{array}{llllllllllllllll}1.00 & 45.84 & 22.94 & 20.20 & 2 & 12777.7966 & 127777951 & 639.9048 & 0.0015 & 1.1720 & 10033.149 & 11623.826 & 108.931 & 17461.492 & \text { Yes }\end{array}$ $\begin{array}{lllllllllllllllll}0.99 & 33.53 & 22.90 & 16.08 & 2 & 12777.7958 & 1277.7951 & 639.9048 & 0.0007 & 0.5470 & 2056.214 & 2083.165 & 630.885 & 2661.535 & \text { Yes }\end{array}$ $\begin{array}{llllllllllllllll}1.00 & 58.16 & 22.92 & 19.96 & 2 & 1277.7970 & 1277.7951 & 639.9048 & 0.0019 & 1.4846 & 2847.359 & 2859.145 & 157.581 & 4561.345 & \text { Yes }\end{array}$ $\begin{array}{llllllllllllllll}0.71 & 12.12 & 24.18 & 14.95 & 3 & 1454.8609 & 1454.8601 & 485.9606 & 0.0008 & 0.5487 & 44.040 & 45.486 & 22.121 & 39.181 & \text { Yes }\end{array}$

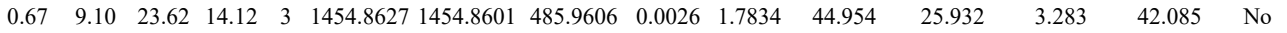
$\begin{array}{lllllllllllllll}1.00 & 57.76 & 22.90 & 18.44 & 2 & 1277.7964 & 1277.7951 & 639.9048 & 0.0013 & 1.0158 & 1247.140 & 1398.731 & 260.277 & 1685.475 & \text { Yes }\end{array}$ $\begin{array}{lllllllllllllll}0.71 & 14.43 & 24.18 & 14.87 & 3 & 1454.8606 & 1454.8601 & 485.9606 & 0.0005 & 0.3430 & 104.155 & 149.797 & 53.139 & 144.946 & \text { Yes }\end{array}$

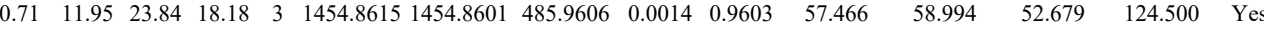
$\begin{array}{llllllllllllllll}0.95 & 32.15 & 23.64 & 23.20 & 2 & 1454.8694 & 1454.8601 & 728.4373 & 0.0093 & 6.3835 & 1702.585 & 1763.417 & 2161.016 & 2503.081 & \text { Yes }\end{array}$ $\begin{array}{lllllllllllllll}0.99 & 38.20 & 23.73 & 22.63 & 2 & 1454.8708 & 1454.8601 & 728.4373 & 0.0107 & 7.3444 & 2786.117 & 2984.321 & 2989.600 & 3547.646 & \text { Yes }\end{array}$

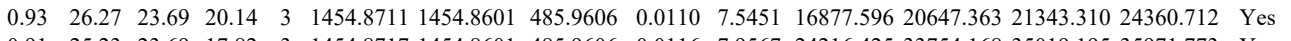

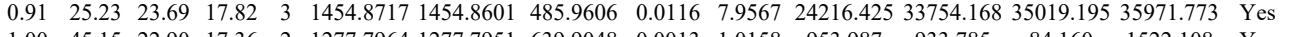
\begin{tabular}{lllllllllllllll}
1.00 & 45.15 & 22.90 & 17.36 & 2 & 1277.7964 & 1277.7951 & 639.9048 & 0.0013 & 1.0158 & 953.987 & 933.785 & 84.160 & 1522.108 & Yes \\
\hline
\end{tabular}

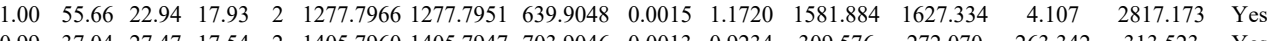

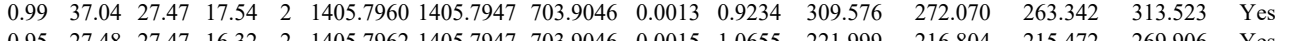
$\begin{array}{lllllllllllllll}0.95 & 27.48 & 27.47 & 16.32 & 2 & 1405.7962 & 1405.7947 & 703.9046 & 0.0015 & 1.0655 & 221.999 & 216.804 & 215.472 & 269.906 & \text { Yes } \\ 0.80 & 16.37 & 4.18 & 22.21 & 3 & 154.8606 & 1454.8601 & 485.960 & 0.0005 & 0.330 & 155.420 & 210.275 & 124.691 & 238.647 & \text { Yes }\end{array}$

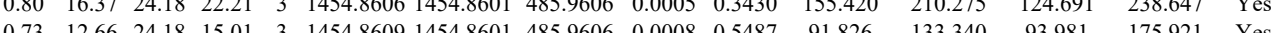

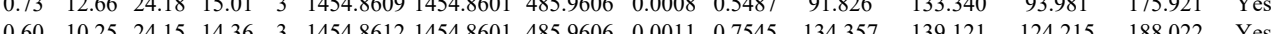

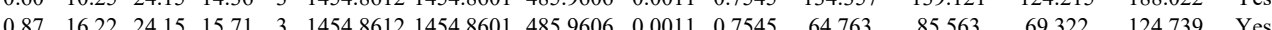

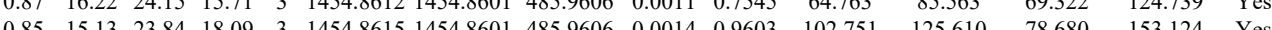

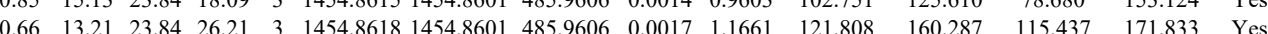

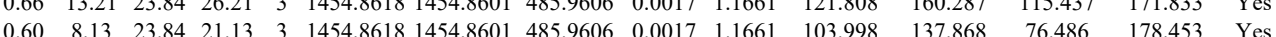
$\begin{array}{lllllllllllllll}0.93 & 16.26 & 23.62 & 16.95 & 3 & 1454.8627 & 1454.8601 & 485.9606 & 0.0026 & 1.7834 & 76.606 & 87.269 & 62317 & 90.645 & \text { Yes }\end{array}$ $\begin{array}{lllllllllllllll}0.99 & 42.41 & 23.64 & 23.41 & 2 & 1454.8694 & 1454.8601 & 728.4373 & 0.0093 & 63835 & 6910.215 & 8885.075 & 8228.846 & 11042.754 & \text { Yes }\end{array}$ $\begin{array}{lllllllllllllll}0.99 & 40.18 & 23.64 & 22.51 & 2 & 1454.8696 & 1454.8601 & 728.4373 & 0.0095 & 6.5208 & 9047.417 & 13260.082 & 12453.039 & 13815.990 & \text { Yes }\end{array}$

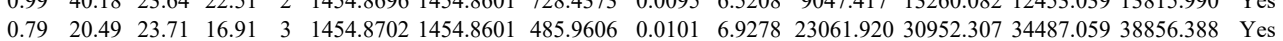
$\begin{array}{lllllllllllllll}0.99 & 36.86 & 27.50 & 23.32 & 2 & 1405.7956 & 1405.7947 & 703.9046 & 0.0009 & 0.6393 & 512.564 & 500.392 & 390.227 & 602.154 & \text { Yes }\end{array}$ $\begin{array}{lllllllllllllll}1.00 & 42.90 & 27.47 & 23.54 & 2 & 1405.7960 & 1405.7947 & 703.9046 & 0.0013 & 0.9234 & 760.044 & 614.905 & 630.284 & 879.565 & \text { Yes }\end{array}$

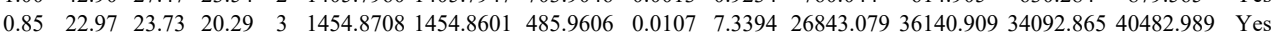
$\begin{array}{llllllllllllllll}0.99 & 38.49 & 23.73 & 22.87 & 2 & 1454.8708 & 1454.8601 & 728.4373 & 0.0107 & 7.3444 & 4548.735 & 6222.872 & 5497.920 & 6242.712 & \text { Yes }\end{array}$ $\begin{array}{lllllllllllllll}1.00 & 40.70 & 27.50 & 23.89 & 2 & 1405.7956 & 1405.7947 & 703.9046 & 0.0009 & 0.6393 & 260.095 & 224.562 & 184.884 & 226.489 & \text { Yes }\end{array}$

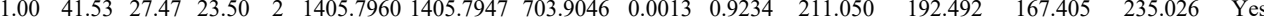
$\begin{array}{llllllllllllllll}0.87 & 24.06 & 23.64 & 19.81 & 3 & 1454.8696 & 454.8601 & 485.9606 & 0.009 & 6.5163 & 91.050 & 192.492 & 167.405 & 235.126 & \text { Yes }\end{array}$ $\begin{array}{llllllllllllllll}0.66 & 20.88 & 23.84 & 33.88 & 3 & 1454.8618 & 1454.8601 & 485.9606 & 0.0017 & 1.1661 & 3297.476 & 3859.853 & 3640.991 & 4872.953 & \text { Yes }\end{array}$ $\begin{array}{llllllllllllllll}0.99 & 23.76 & 23.62 & 17.82 & 3 & 1454.8630 & 1454.8601 & 485.9606 & 0.0029 & 1.9892 & 9595.797 & 11472.446 & 9525.712 & 15492.736 & \text { Yes }\end{array}$ $\begin{array}{lllllllllllllll}0.99 & 23.39 & 23.91 & 18.55 & 3 & 1454.8624 & 1454.8601 & 485.9606 & 0.0023 & 1.5776 & 5738.527 & 7299.027 & 7478.224 & 8872.916 & \text { Yes }\end{array}$ $\begin{array}{lllllllllllllll}0.98 & 22.31 & 23.62 & 16.71 & 3 & 1454.8627 & 1454.8601 & 485.9606 & 0.0026 & 1.7834 & 8102.835 & 11765.368 & 11082.197 & 11112.917 & \text { Yes }\end{array}$ $\begin{array}{llllllllllllllll}0.99 & 26.33 & 23.84 & 17.25 & 3 & 1454.8615 & 1454.8601 & 485.9606 & 0.0014 & 0.9603 & 455.383 & 558.943 & 671.757 & 588.903 & \text { Yes }\end{array}$

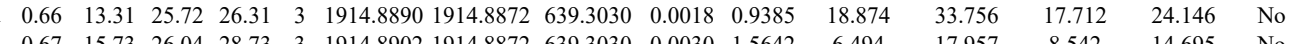

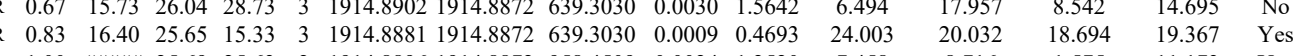

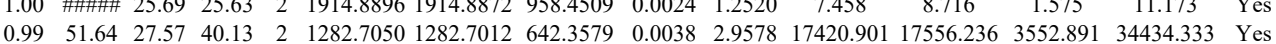
$\begin{array}{llllllllllllllll}1.00 & 54.47 & 27.62 & 42.03 & 2 & 1282.7052 & 1282.7012 & 642.3579 & 0.0048 & 2.9578 & 17420.915 & 17556.236 & 3552.891 & 34434.333 & \text { Yes }\end{array}$

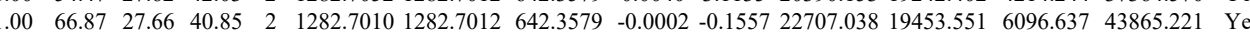

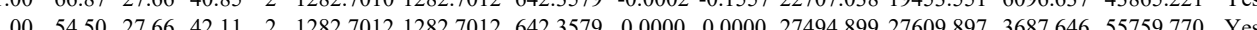

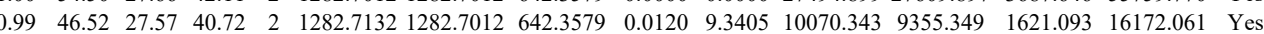
$\begin{array}{lllllllllllllll}1.00 & 90.12 & 27.28 & 26.94 & 2 & 1732.9466 & 1732.9451 & 867.4798 & 0.0015 & 0.8646 & 212.271 & 288.003 & 297.588 & 376.160 & \text { Yes }\end{array}$ 


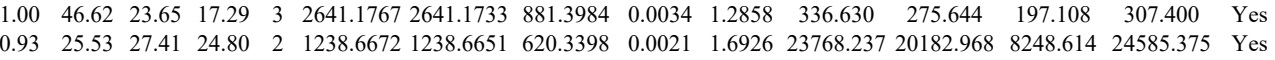

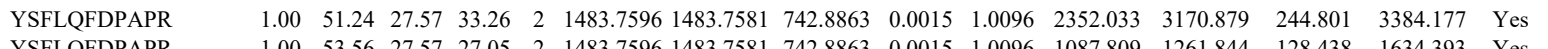
YSFLQFDPAPR GGWGISPR $\begin{array}{lllllllllllllll}1.00 & 53.56 & 27.57 & 27.05 & 2 & 1483.7596 & 1483.7581 & 742.8863 & 0.0015 & 1.0096 & 1087.809 & 1261.844 & 128.438 & 1634.393 & \text { Yes } \\ 0.97 & 1.15 & 27.76 & 27.86 & 2 & 972.5310 & 972.5263 & 487.2704 & 0.0047 & 4.8228 & 15760.412 & 14844.892 & 11098.806 & 20024.896 & \text { Yes }\end{array}$ $\begin{array}{lllllllllllllllll}0.97 & 41.96 & 27.58 & 26.90 & 2 & 972.5320 & 972.5263 & 487.2704 & 0.0057 & 5.8489 & 13927.014 & 14711.409 & 12994.345 & 16240.022 & \text { Yes }\end{array}$ \begin{tabular}{lllllllllllllll}
0.99 & 44.90 & 27.66 & 25.38 & 2 & 1483.7630 & 1483.7581 & 742.8863 & 0.0049 & 3.2979 & 540.683 & 702.473 & 122.241 & 661.445 & Yes \\
\hline
\end{tabular} $\begin{array}{lllllllllllllllll}0.96 & 37.27 & 26.58 & 27.73 & 2 & 972.5346 & 972.5263 & 487.2704 & 0.0083 & 8.5168 & 13389.358 & 16569.660 & 13085.813 & 15238.368 & \text { Yes } \\ 0.98 & 38.47 & 27.69 & 32.71 & 2 & 972.5302 & 972.5263 & 487.2704 & 0.0039 & 4.0019 & 2968.591 & 3828.685 & 3360.065 & 3633.486 & \text { Yes }\end{array}$ $\begin{array}{lllllllllllllllll} & & & \end{array}$

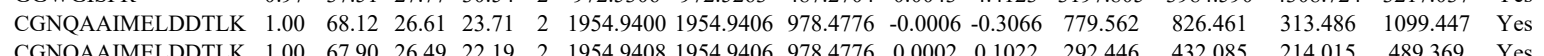
$\begin{array}{lllllllllllllllll} & \end{array}$ $\begin{array}{lllllllllllllllll}\text { CGNOAAIMELDDTLK } & 1.00 & 37.68 & 26.74 & 22.65 & 3 & 1954.9438 & 1954.9406 & 652.6541 & 0.0032 & 1.6343 & 277.278 & 183.019 & 35.857 & 278.944 & \text { No }\end{array}$ \begin{tabular}{lllllllllllllllll} 
LQEVPHEGPMCDLLWSDPDDR & 1.00 & 53.28 & 23.65 & 22.04 & 3 & 2641.1767 & 2641.1733 & 881.3984 & 0.0034 & 1.2858 & 780.118 & 827.667 & 468.539 & 1251.951 & Yes \\
\hline
\end{tabular} $\begin{array}{lllllllllllllllll}\text { LEEVPHEGPMCDLLWSDPDDR } & 1.00 & 41.74 & 23.65 & 19.09 & 3 & 2641.1767 & 2641.1733 & 881.3984 & 0.0034 & 1.2858 & 461.993 & 408.501 & 369.132 & 498.210 & \text { Yes }\end{array}$

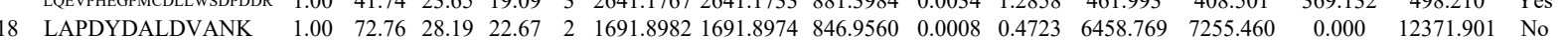
$\begin{array}{llllllllllllllll}\text { LAPDYDALDVANK } & 1.00 & 86.82 & 28.19 & 23.84 & 2 & 1691.8984 & 1691.8974 & 846.9560 & 0.0010 & 0.5903 & 14686.512 & 16336.767 & 0.000 & 28257.708 & \text { No }\end{array}$

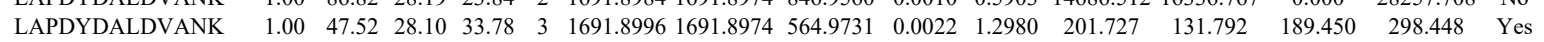
$\begin{array}{lllllllllllllllll}\text { LAPDYDALDVANK } & 1.00 & 57.80 & 28.06 & 30.66 & 3 & 1691.9002 & 1691.8974 & 564.9731 & 0.0028 & 1.6520 & 395.909 & 340.529 & 119.855 & 862.042 & \text { Yes }\end{array}$ $\begin{array}{lllllllllllllllll}\text { IEDNNTLVFIVDVK } & 0.72 & 12.14 & 25.76 & 16.34 & 3 & 1906.0678 & 1906.0655 & 636.3624 & 0.0023 & 1.2048 & 77.110 & 108.211 & 39.851 & 108.742 & \text { No }\end{array}$

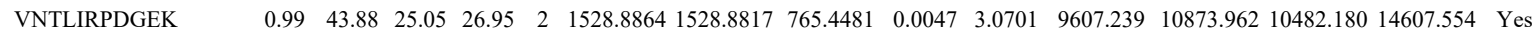

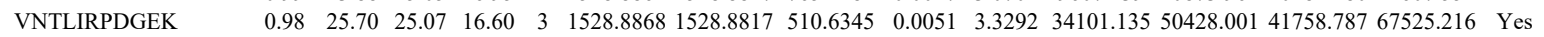
$\begin{array}{lllllllllllllllll}\text { VNTLIRPDGEK } & 1.00 & 50.96 & 25.07 & 28.25 & 2 & 1528.8868 & 1528.8817 & 765.4481 & 0.0051 & 3.3314 & 8347.197 & 10678.714 & 7114.226 & 14973.328 & \text { Yes }\end{array}$

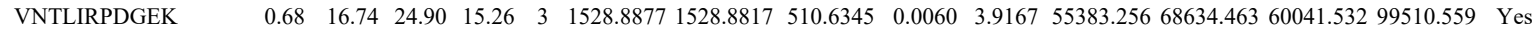
$\begin{array}{llllllllllllllllll}\text { VNTLIRPDGEK } & 0.98 & 36.26 & 24.35 & 28.63 & 2 & 1528.8912 & 1528.8817 & 765.4481 & 0.0095 & 6.2055 & 8686.316 & 8858.078 & 6972.946 & 13381.242 & \text { Yes }\end{array}$ $\begin{array}{lllllllllllllllll}\text { VNTLIRPDGEK } & 0.96 & 32.08 & 24.38 & 29.36 & 2 & 1528.8914 & 1528.8817 & 765.4481 & 0.0097 & 6.3361 & 4588.899 & 5842.643 & 4284.330 & 7198.518 & \text { Yes }\end{array}$

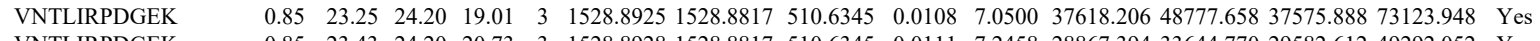

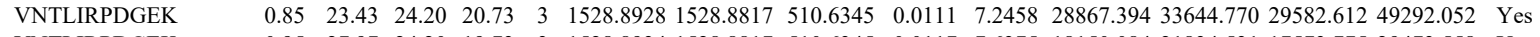
$\begin{array}{lllllllllllllllll}\text { VNTLIRPDGEK } & 0.95 & 27.97 & 24.20 & 19.73 & 3 & 1528.8934 & 1528.8817 & 510.6345 & 0.0117 & 7.6375 & 18150.084 & 21834.531 & 17573.775 & 29473.558 & \text { Yes }\end{array}$ VNTLIRPDGEK LDHYAIIK $\begin{array}{llllllllllllllll}\text { LDHYAIIK } & 0.74 & 35.65 & 25.83 & 37.90 & 3 & 1259.7595 & 1259.7481 & 420.9233 & 0.0114 & 9.0277 & 3567.781 & 3662.322 & 306.869 & 6129.690 & \text { Yes } \\ \text { FPLTTESAMK } & 1.00 & 49.47 & 27.02 & 2.154 & 2 & 1411.7750 & 1411.7625 & 706.8885 & 0.0125 & 8.8415 & 3497.065 & 2984.218 & 7195.922 & 5270.095 & \text { No } \\ \text { LAPDYDALDVANK } & 1.00 & 72.58 & 28.19 & 32.12 & 2 & 1691.8984 & 1691.8974 & 846.9560 & 0.0010 & 0.5903 & 5128.211 & 5877.144 & 231.643 & 9711.650 & \text { Yes }\end{array}$ $\begin{array}{lllllllllllllllllll} & \text { LAPDYDALDVANK } & 1.00 & 72.58 & 28.19 & 32.12 & 2 & 1691.8984 & 1691.8974 & 846.9560 & 0.0010 & 0.5903 & 5128.211 & 5877.144 & 231.643 & 9711.650 & \text { Yes } \\ \text { LAPDYDALDVANK } & 1.0 & 3.64 & 28.06 & 2.82 & & & & \end{array}$

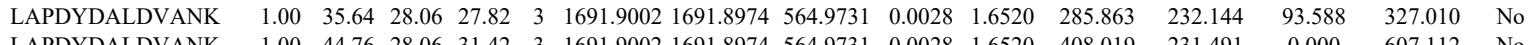

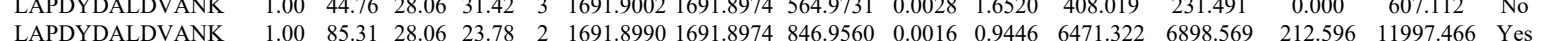
$\begin{array}{lllllllllllllllll}\text { LAPDYDALDVANK } & 1.00 & 35.48 & 28.06 & 30.97 & 3 & 1691.9002 & 1691.8974 & 564.9731 & 0.0028 & 1.6520 & 496.619 & 497.067 & 534.054 & 682.346 & \text { Yes }\end{array}$ $\begin{array}{lllllllllllllllll}\text { LAPDYDALDVANK } & 1.00 & 72.43 & 28.00 & 22.74 & 2 & 1691.9004 & 1691.8974 & 846.9560 & 0.0030 & 1.7710 & 6511.807 & 7569.001 & 303.279 & 1127.275 & \text { Yes } \\ \text { LAPDYDALDVANK } & 0.66 & 31.28 & 28.01 & 43.27 & 3 & 1691.9017 & 1691.8974 & 564.9731 & 0.0043 & 25370 & 512.351 & 420.768 & 492.052 & 845.004 & \text { Yes }\end{array}$ LAPDYDALDVANK $\begin{array}{lllllllllllll}\text { RS6_HUMAN } & \text { P62753 } & \text { RPS6 } & \text { 40S ribosomal pro 28.681 } & 1.00 & 8 & 37.8 & 0.0513 & 0.1868 & 1.6659 & 0.4818 & 27 & \text { LIEVDDE }\end{array}$ LIEVDDER
DIPGLTDTTVPR DIPGLTDTTVPR LFNLSK LNISFPATGCQK LNISFPATGCQK LNISFPATGCQK LNISFPATGCQK LNISFPATGCQK

LNISFPATGCQK

LNISFPATGCQK

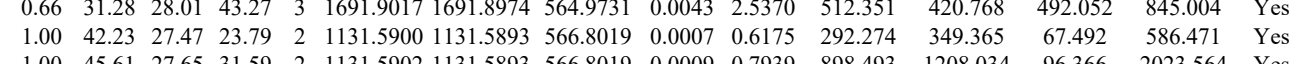
\begin{tabular}{lllllllllllllll}
1.00 & 45.61 & 27.65 & 31.59 & 2 & 1131.5902 & 1131.5893 & 566.8019 & 0.0009 & 0.7939 & 898.493 & 1208.034 & 96.366 & 2023.564 & Yes \\
\hline
\end{tabular}

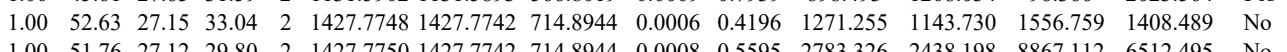

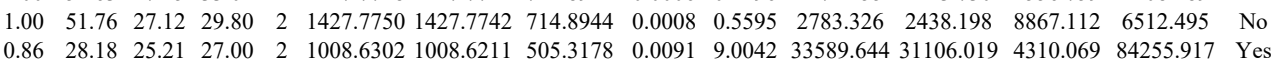

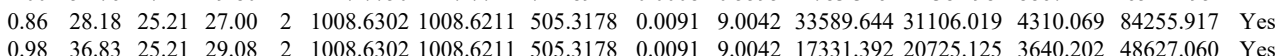
$\begin{array}{lllllllllllllll}0.98 & 36.83 & 25.21 & 29.08 & 2 & 1008.6302 & 1008.6211 & 505.3178 & 0.0091 & 9.0042 & 17331.392 & 20725.125 & 3640.202 & 48627.060 & \text { Yes } \\ 1.00 & 6.59 & 27.87 & 3.84 & 2 & 1611.8358 & 1611.8356 & 806.9251 & 0.0002 & 0.1239 & 5652.905 & 5653.880 & 204.159 & 8746.804 & \text { Yes }\end{array}$ $\begin{array}{cccccccccccccccc}1.00 & 62.59 & 27.87 & 30.84 & 2 & 1611.8358 & 1611.8356 & 806.9251 & 0.0002 & 0.1239 & 5652.905 & 5653.880 & 204.159 & 8746.804 & \text { Yes } \\ 1.00 & 68 & 27.79 & 31.19 & 2 & 1611.8368 & 1611.8356 & 806.9251 & 0.0012 & 0.7436 & 9532.575 & 10766.468 & 0.000 & 15539.053 & \text { No }\end{array}$ $\begin{array}{lllllllllllllll}1.00 & 46.20 & 27.94 & 23.72 & 3 & 1611.8374 & 1611.8356 & 538.2858 & 0.0018 & 1.1146 & 1538.410 & 1487.760 & 427.524 & 1789.934 & \text { Yes }\end{array}$ $\begin{array}{lllllllllllllll}1.00 & 35.91 & 27.94 & 18.65 & 3 & 1611.8377 & 1611.8356 & 538.2858 & 0.0021 & 1.3004 & 1302.642 & 1470.278 & 307.937 & 1779.893 & \text { Yes }\end{array}$

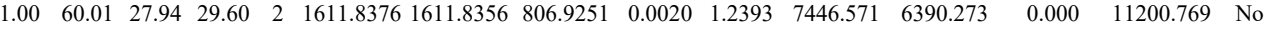

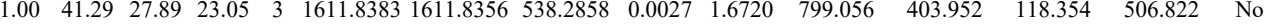
$\begin{array}{llllllllllllllll}\text { GCIVDANLSVLNLVIVK } & 1.00 & 42.88 & 21.79 & 15.84 & 3 & 2103.2077 & 2103.2039 & 702.0752 & 0.0038 & 1.8042 & 89.266 & 84.830 & 51.481 & 73.470 & \text { Yes }\end{array}$

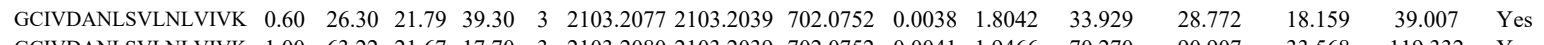

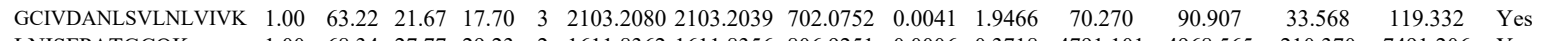

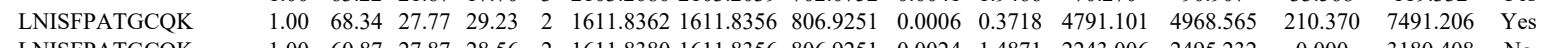

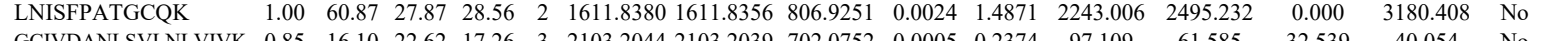

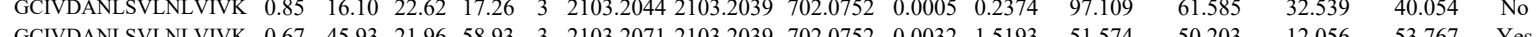

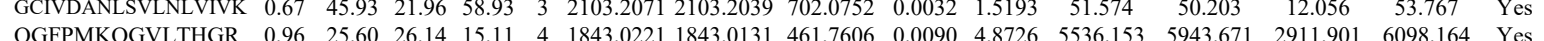
$\begin{array}{llllllllllllllll}\text { QGFPMKQGVLTHGR } & 0.96 & 25.60 & 26.14 & 15.11 & 4 & 1843.0221 & 1843.0131 & 461.7606 & 0.0090 & 4.8726 & 5536.153 & 5943.671 & 2911.901 & 6098.164 & \text { Yes } \\ \text { LIEVDDER } & 0.91 & 35.91 & 28.04 & 28.10 & 2 & 1131.5968 & 1131.5893 & 566.8019 & 0.0075 & 6.6160 & 3522295 & 2967.433 & 625.315 & 4289.276 & \text { Yes }\end{array}$ $\begin{array}{llllllllllllllll}\text { LIEVDDER } & 0.91 & 35.91 & 28.04 & 28.10 & 2 & 1131.598 & 1131.5893 & 566.8019 & 0.0075 & 6.6160 & 3522.295 & 2967.433 & 625.315 & 4289.276 & \text { Yes } \\ \text { LIEVDDER } & 0.93 & 36.23 & 27.94 & 28.53 & 2 & 1131.5974 & 1131.5893 & 566.8019 & 0.0081 & 7.1453 & 3697.008 & 3694.871 & 61.077 & 4687.868 & \text { Yes }\end{array}$ $\begin{array}{llllllllllllllll}\text { NKEEAAEYAK } & 0.80 & 31.25 & 27.29 & 21.04 & 3 & 1583.8549 & 1583.8520 & 528.9579 & 0.0029 & 1.8275 & 3752.381 & 4151.031 & 3365.447 & 6396.788 & \text { Yes }\end{array}$ 


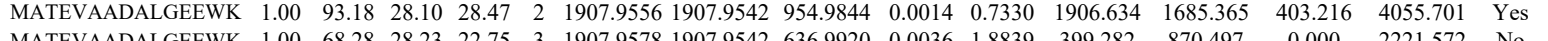

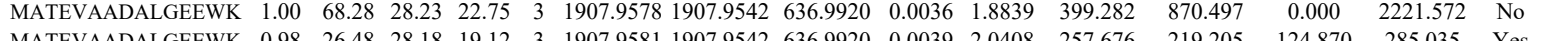

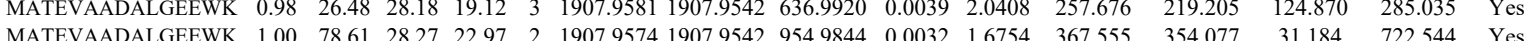

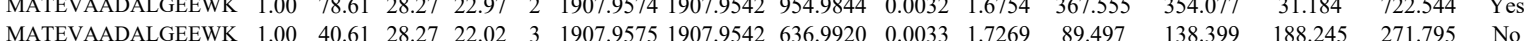

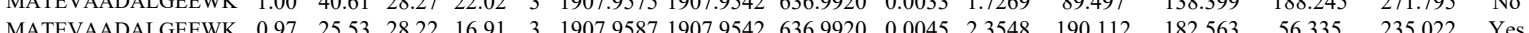

H4 HUMAN P62805 HIST1H4A Histone H4

$\begin{array}{llllllll}11.367 & 1.00 & 7 & 53.4 & 0.1850 & 0.3022 & 2.2667 & 0.3984\end{array}$
87 ISGLIYEETR

ISGLIYEETR

ISGLIYEETR

ISGLIYEETR
ISGLIYEETR

ISGLIYEETR
ISGLIYEETR

ISGLIYEETR

ISGLIYEETR

ISGLIYEETR

ISGLIYEETR
ISGLIYEETR

ISGLIYEETR

ISGLIYEETR

ISGLIYEETR

ISGLIYEETR

ISGLIYEETR
ISGLIYEETR

ISGLIYEETR

ISGLIYEETR

ISGLIYEETR

ISGLIYEETR
ISGLIYEETR

ISGLIYEETR

ISGLIYEETR

ISGLIYEETR

ISGLIYEETR

ISGLIYETR

ISGLIYEETR

ISGLIYEETR

ISGLIYEETR

ISGLIYEETR

ISGLIYEETR

ISGLIYEETR
ISGLIYEETR

ISGLIYEETR
ISGLIYEETR

ISGLIYEETR

ISGLIYEETR

ISGLYYEETR
ISGLIYEETR

ISGLIYEETR

ISGLIYEETR

ISGLIYEETR

ISGLIYEETR

ISGLIYEETR

ISGLIYEETR

ISGLIYEETR

ISGLIYEETR

TVTAMDVVYALK

VFLENVIR

VFLENVIR

ISGLIYEETR

ISGLIYEETR

TVTAMDVVYALK

TVTAMDVVYALK

DNIQGITKPAIR

TVTAMDVVYALK

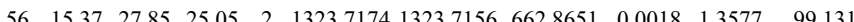
$\begin{array}{lllllllllll}0.92 & 38.12 & 27.99 & 31.79 & 2 & 1323.7140 & 1323.7156 & 662.8651 & -0.0016 & -1.2069 & 139.829\end{array}$ $\begin{array}{lllllllllll}0.99 & 43.32 & 28.08 & 23.31 & 2 & 1323.7148 & 1323.7156 & 662.8651 & -0.0008 & -0.6034 & 148.346\end{array}$ $\begin{array}{lllllllllll}0.98 & 36.61 & 27.91 & 32.18 & 2 & 1323.7152 & 1323.7156 & 662.8651 & -0.0004 & -0.3017 & 163.101\end{array}$ $\begin{array}{lllllllllllll}0.98 & 31.32 & 27.83 & 31.54 & 2 & 1323.7162 & 1323.7156 & 662.8651 & 0.0006 & 0.4526 & 174.995 \\ 0.95 & 27.80 & 29.76 & 2 & 1323.7168 & 1323.7156 & 662.8651 & 0.0012 & 0.9052 & 53.797\end{array}$ $\begin{array}{lllllllllllll}0.97 & 30.81 & 27.85 & 29.68 & 2 & 1323.7170 & 1323.7156 & 662.8651 & 0.0012 & 0.9052 & 53.797 \\ 0.9614 & 0.0014 & 1.0560 & 143.624\end{array}$ $\begin{array}{llllllllllll}0.96 & 28.25 & 27.85 & 23.83 & 2 & 1323.7174 & 1323.7156 & 662.8651 & 0.0018 & 1.3577 & 161.059\end{array}$ $\begin{array}{lllllllllll}0.96 & 29.01 & 27.92 & 25.16 & 2 & 1323.7178 & 1323.7156 & 662.8651 & 0.0022 & 1.6595 & 144.110\end{array}$ $\begin{array}{lllllllllll}0.93 & 43.86 & 27.60 & 26.96 & 2 & 1323.7124 & 1323.7156 & 662.8651 & -0.0032 & -2.4138 & 121.100\end{array}$ $\begin{array}{lllllllllll}1.00 & 55.04 & 27.83 & 27.57 & 2 & 1323.7162 & 1323.7156 & 662.8651 & 0.0006 & 0.4526 & 245.541 \\ 1.00 & 55.51 & 27.83 & 29.89 & 2 & 1323.7164 & 1323.7156 & 662851 & 0.000 & 0.6034 & 81.578\end{array}$ $\begin{array}{llllllllllll}1.00 & 55.51 & 27.83 & 29.89 & 2 & 1323.7164 & 1323.7156 & 662.8651 & 0.0008 & 0.6034 & 81.578\end{array}$ $\begin{array}{llllllllllll}1.00 & 55.87 & 27.82 & 29.11 & 2 & 1323.7166 & 1323.7156 & 662.8651 & 0.0010 & 0.7543 & 261.592\end{array}$ $\begin{array}{llllllllllll}1.00 & 54.63 & 27.80 & 26.38 & 2 & 1323.7168 & 1323.7156 & 662.8651 & 0.0012 & 0.9052 & 264.344 \\ 1.00 & 50.22 & 27.80 & 30.06 & 2 & 1323.7168 & 1323.7156 & 62.8651 & 0.0012 & 0.9052 & 274.903\end{array}$ $\begin{array}{lllllllllllll}1.00 & 50.22 & 27.80 & 30.06 & 2 & 1323.7168 & 1323.7156 & 662.8651 & 0.0012 & 0.9052 & 274.903 & 26\end{array}$ $\begin{array}{llllllllllll}1.00 & 48.07 & 27.80 & 27.24 & 2 & 1323.7168 & 1323.7156 & 662.8651 & 0.0012 & 0.9052 & 63.064 \\ 1.00 & 53.82 & 27.85 & 28.70 & 2 & 1323.7170 & 1323.7156 & 662.8651 & 0.0014 & 1.0560 & 269.966\end{array}$ $\begin{array}{lllllllllllll}1.00 & 53.82 & 27.85 & 28.70 & 2 & 1323.7170 & 1323.7156 & 662.8651 & 0.0014 & 1.0560 & 269.966 \\ 1.00 & 47.66 & 27.85 & 29.76 & 2 & 1323.7170 & 1323.7156 & 662.8651 & 0.0014 & 1.0560 & 252.959 & 23\end{array}$ $\begin{array}{llllllllllll}1.00 & 47.66 & 27.85 & 29.76 & 2 & 1323.7170 & 1323.7156 & 662.8651 & 0.0014 & 1.0560 & 252.959 \\ 1.00 & 44.75 & 27.85 & 29.50 & 2 & 1323.7172 & 1323.7156 & 662.8651 & 0.0016 & 1.2069 & 298.661\end{array}$ $\begin{array}{llllllllllll}1.00 & 44.75 & 27.85 & 29.50 & 2 & 1323.7172 & 1323.7156 & 662.8651 & 0.0016 & 1.2069 & 298.661 \\ 1.00 & 40.35 & 27.85 & 24.70 & 2 & 1323.7174 & 1323.7156 & 662.8651 & 0.0018 & 1.3577 & 148.295\end{array}$ $\begin{array}{lllllllllll}1.00 & 40.35 & 27.85 & 24.70 & 2 & 1323.7174 & 1323.7156 & 662.8651 & 0.0018 & 1.3577 & 148.295 \\ 1.00 & 50.43 & 27.91 & 28.92 & 2 & 1323.7176 & 1323.7156 & 662.8651 & 0.0020 & 1.5086 & 255.238\end{array}$ $\begin{array}{lllllllllllll}1.00 & 50.43 & 27.91 & 28.92 & 2 & 1323.7176 & 1323.7156 & 662.8651 & 0.0020 & 1.5086 & 255.238 \\ 1.00 & 55.83 & 27.91 & 27.71 & 2 & 1323.7176 & 1323.7156 & 662.8651 & 0.0020 & 1.5086 & 263.995\end{array}$ $\begin{array}{lllllllllll}1.00 & 55.83 & 27.91 & 27.71 & 2 & 1323.7176 & 1323.7156 & 662.8651 & 0.0020 & 1.5086 & 263.995 \\ 1.00 & 55.63 & 27.92 & 26.65 & 2 & 1323.7178 & 1323.7156 & 662.8651 & 0.0022 & 1.6595 & 282.335\end{array}$ $\begin{array}{lllllllllll}1.00 & 55.63 & 27.92 & 66.65 & 2 & 1323.7178 & 1323.7156 & 662.8651 & 0.0022 & 1.6595 & 282.335 \\ 1.00 & 54.82 & 27.92 & 26.67 & 2 & 1323.7178 & 1323.7156 & 662.8651 & 0.0022 & 1.6595 & 260.535\end{array}$ $\begin{array}{lllllllllll}1.00 & 54.82 & 27.92 & 26.67 & 2 & 1323.7178 & 1323.7156 & 62.86551 & 0.0022 & 1.6595 & 260.535 \\ 1.00 & 54.02 & 28.08 & 26.80 & 2 & 1323.7180 & 1323.7156 & 662.8651 & 0.0024 & 1.8103 & 267.818\end{array}$

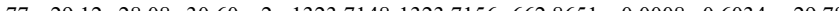

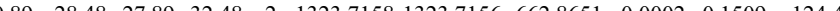
$\begin{array}{lllllllllll}0.97 & 29.74 & 27.83 & 32.97 & 2 & 1323.7162 & 1323.7156 & 6282.8651 & 0.0006 & 0.4526 & 105.651\end{array}$ $\begin{array}{llllllllllll}1.00 & 58.20 & 27.83 & 31.55 & 2 & 1323.7162 & 1323.7156 & 662.8651 & 0.0006 & 0.4526 & 7639.410\end{array}$ $\begin{array}{llllllllllll}1.00 & 45.86 & 27.85 & 28.06 & 2 & 1323.7170 & 1323.7156 & 662.8651 & 0.0014 & 1.0560 & 268.020\end{array}$ $\begin{array}{lllllllllllll}1.00 & 41.78 & 27.85 & 25.91 & 2 & 1323.7170 & 1323.7156 & 662.8651 & 0.0014 & 1.0560 & 300.846\end{array}$ $\begin{array}{llllllllllll}1.00 & 54.76 & 27.85 & 32.29 & 2 & 1323.7170 & 1323.7156 & 662.8651 & 0.0014 & 1.0560 & 285.006 & 23\end{array}$ $\begin{array}{lllllllllll}1.00 & 51.66 & 27.85 & 26.71 & 2 & 1323.7172 & 1323.7156 & 662.8651 & 0.0016 & 1.2069 & 294.682\end{array}$ $\begin{array}{lllllllllll}1.00 & 47.15 & 27.85 & 26.68 & 2 & 1323.7174 & 1323.7156 & 662.8651 & 0.0018 & 1.3577 & 307.164\end{array}$ $\begin{array}{llllllllllll}1.00 & 52.42 & 27.85 & 26.20 & 2 & 1323.7174 & 1323.7156 & 662.8651 & 0.0018 & 1.3577 & 274.095\end{array}$ $\begin{array}{lllllllllll}1.00 & 54.44 & 27.91 & 25.96 & 2 & 1323.7176 & 1323.7156 & 662.8651 & 0.0020 & 1.5086 & 245.933\end{array}$ $\begin{array}{lllllllllll}1.00 & 39.19 & 27.91 & 26.19 & 2 & 1323.7176 & 1323.7156 & 6628651 & 0.0020 & 1.5086 & 218.202\end{array}$ $\begin{array}{lllllllllll}1.00 & 42.95 & 27.91 & 36.27 & 2 & 1323.7176 & 1323.7156 & 662.8651 & 0.0020 & 1.5086 & 221.045\end{array}$

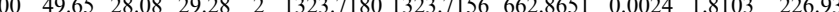
$\begin{array}{llllllllllll}1.00 & 44.63 & 28.08 & 26.83 & 2 & 1323.7184 & 1323.7156 & 662.8651 & 0.0028 & 2.1120 & 244.502 & 210.6\end{array}$ $\begin{array}{llllllllllll}1.00 & 45.96 & 28.07 & 27.14 & 2 & 1323.7186 & 1323.7156 & 662.8651 & 0.0030 & 2.2629 & 261.366 & 333.572\end{array}$ $\begin{array}{lllllllllll}0.63 & 20.00 & 27.90 & 28.98 & 2 & 1323.7190 & 1323.7156 & 662.8651 & 0.0034 & 2.5646 & 40.040\end{array}$ $\begin{array}{lllllllllll}0.83 & 32.88 & 28.02 & 31.84 & 2 & 1323.7214 & 1323.7156 & 662.8651 & 0.0058 & 4.3749 & 177.068\end{array}$ $\begin{array}{lllllllllllll}1.00 & 59.91 & 27.55 & 30.25 & 2 & 1323.7282 & 1323.7156 & 662.8651 & 0.0126 & 9.5041 & 5805.984\end{array}$ $\begin{array}{lllllllllllll}0.64 & 55.34 & 26.70 & 68.34 & 2 & 1613.8940 & 1613.8942 & 807.9544 & -0.0002 & -0.1238 & 469.522 & 59 \\ 0.98 & 31.41 & 27.37 & 21.09 & 2 & 1132.6732 & 1132.6726 & 567.3436 & 0.0006 & 0.5288 & 108680\end{array}$ $\begin{array}{llllllllllll}0.98 & 31.41 & 27.37 & 21.09 & 2 & 1132.6732 & 1132.6726 & 567.3436 & 0.0006 & 0.5288 & 108.680 \\ 0.98 & 32.23 & 27.70 & 21.39 & 2 & 1132.6742 & 1132.6726 & 567.3436 & 0.0016 & 1.4101 & 121.754\end{array}$ $\begin{array}{lllllllllll}0.98 & 32.23 & 27.70 & 21.39 & 2 & 1132.6742 & 1132.6726 & 567.3436 & 0.0016 & 1.4101 & 121.754 \\ 1.00 & 51.68 & 27.91 & 26.52 & 2 & 1323.7156 & 1323.7156 & 662.8651 & 0.0000 & 0.0000 & 94.943\end{array}$ $\begin{array}{lllllllllll}1.00 & 51.68 & 27.91 & 26.52 & 2 & 1323.7156 & 1323.7156 & 662.8651 & 0.0000 & 0.0000 & 94.943 \\ 1.00 & 50.80 & 27.83 & 24.72 & 2 & 1323.7164 & 1323.7156 & 662.8651 & 0.0008 & 0.6034 & 93.748\end{array}$ $\begin{array}{llllllllllll}1.00 & 72.50 & 26.27 & 41.84 & 2 & 1597.8994 & 1597.8993 & 799.9569 & 0.0001 & 0.0625 & 21.640\end{array}$ $\begin{array}{lllllllllllll}1.00 & 70.90 & 26.24 & 37.02 & 2 & 1597.9008 & 1597.8993 & 799.9569 & 0.0015 & 0.9375 & 43.726\end{array}$ $\begin{array}{llllllllllll}1.00 & 40.38 & 22.65 & 15.78 & 3 & 1612.9648 & 1612.9504 & 538.6574 & 0.0144 & 8.9110 & 14122.627 & 10707.468\end{array}$ 
TVTAMDVVYALK

TVTAMDVVYALK

TVTAMDVVYALK

TVTAMDVVYALK

TVTAMDVVYALK

TVTAMDVVYALK

TVTAMDVVYALK

TVTAMDVVYALK

TVTAMDVVYALK

TVTAMDVVYALK

TVTAMDVVYA

TVTAMDVVYALK

KTVTAMDVVYALK

TVTAMDVVYALK

TVTAMDVVYALK

TVTAMDVVYALK

TVTAMDVVYALK

TVTAMDVVYALK

VFLENVIR

TVTAMDVVYALK

TVTAMDVVYALK

TVTAMDVVYALK

VFLENVIR

VFLENVIR
VFLENVIR
VFLENVIR

VFLENVIR

VFLENVIR

VFLENVIR
VFLENVIR
VFLENVIR

VFLENVIR

VFLENVIR

VFLENVIR

VFLENVIR

TVTAMDVVYALK

TVTAMDVVYALK

TVTAMDVVYALK

TVTAMDVVYALK

VFLENVIR

VFLENVIR

VFLENVIR

VFLENVIR

VFLENVIR

VFLENVIR

VFLENVIR

VFLENVIR

VFLENVIR

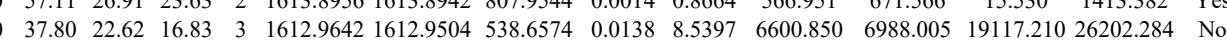

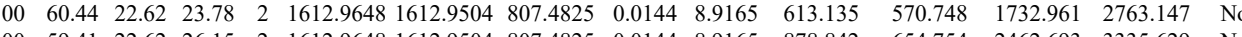
$\begin{array}{lllllllllllllll}1.00 & 59.41 & 22.62 & 26.15 & 2 & 1612.9648 & 1612.9504 & 807.4825 & 0.0144 & 8.9165 & 878.842 & 654.754 & 2462.693 & 3335.629 & \text { No }\end{array}$ $\begin{array}{lllllllllllllll}0.99 & 36.91 & 22.81 & 19.49 & 3 & 1612.9597 & 1612.9504 & 538.6574 & 0.0093 & 5.7550 & 9616.676 & 8805.370 & 18159.338 & 24387.405 & \text { No }\end{array}$

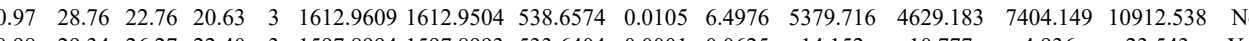

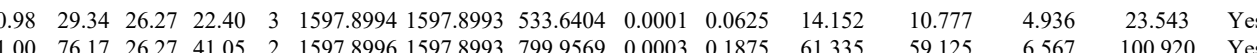
$\begin{array}{lllllllllllll} & 100.920 & \text { Yes } \\ 0\end{array}$ $\begin{array}{lllllllllllllll} & \end{array}$ $\begin{array}{lllllllllllllll}.00 & 74.66 & 26.24 & 43.16 & 2 & 1597.9006 & 1597.8993 & 799.9569 & 0.0013 & 0.8125 & 105.840 & 117.049 & 14.089 & 170.840 & \text { Yes }\end{array}$

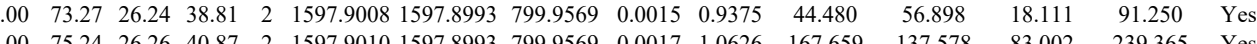

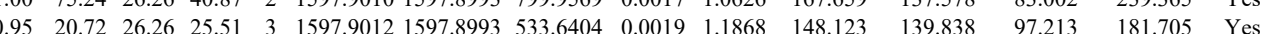

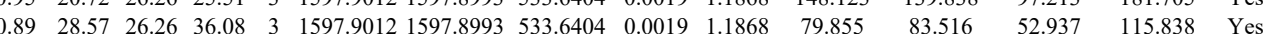
$\begin{array}{lllllllllllllll}0.67 & 12.70 & 26.23 & 25.51 & 3 & 1597.9015 & 1597.8993 & 533.6404 & 0.0022 & 1.3742 & 144.939 & 111.690 & 81.437 & 182.698 & \text { Yes }\end{array}$ $\begin{array}{lllllllllllllll}0.79 & 14.15 & 26.23 & 23.47 & 3 & 1597.9015 & 1597.8993 & 533.6404 & 0.0022 & 1.3742 & 127.414 & 127.493 & 68.894 & 171.449 & \text { Yes }\end{array}$ $\begin{array}{lllllllllllllll}1.00 & 60.72 & 26.24 & 45.09 & 2 & 1597.9016 & 1597.8993 & 799.9569 & 0.0023 & 1.4376 & 149.348 & 181.107 & 177.699 & 212.517 & \text { No }\end{array}$ $\begin{array}{llllllllllllllll}1.00 & 55.73 & 26.19 & 29.11 & 2 & 1597.9020 & 1597.8993 & 799.9569 & 0.0027 & 1.6876 & 14720.077 & 20659.056 & 653.560 & 40129.708 & \text { Yes }\end{array}$

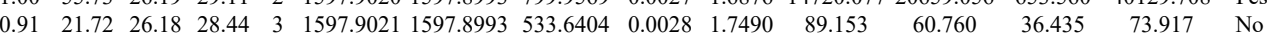
$\begin{array}{llllllllllllllll}0.74 & 14.82 & 26.13 & 26.54 & 3 & 1597.9024 & 1597.8993 & 533.6404 & 0.0031 & 1.9364 & 127.232 & 149.371 & 88.640 & 218.529 & \text { Yes }\end{array}$ $\begin{array}{llllllllllllllll}0.99 & 42.67 & 26.24 & 39.60 & 3 & 1597.9027 & 1597.8993 & 533.6404 & 0.0034 & 2.1238 & 519.061 & 1319.233 & 272.546 & 700.216 & \text { No }\end{array}$

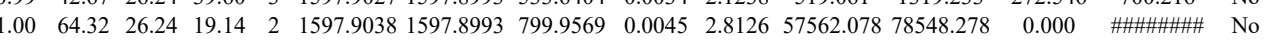
$\begin{array}{llllllllllllllll}0.99 & 37.07 & 26.21 & 32.87 & 3 & 1597.9048 & 1597.8993 & 533.6404 & 0.0055 & 3.4355 & 234.103 & 217.763 & 5.429 & 420.614 & \text { Yes }\end{array}$ $\begin{array}{lllllllllllllll}1.00 & 55.30 & 26.75 & 22.82 & 2 & 1613.8942 & 1613.8942 & 807.9544 & 0.0000 & 0.0000 & 2784.753 & 3075.050 & 151.514 & 6049.402 & \text { Yes }\end{array}$

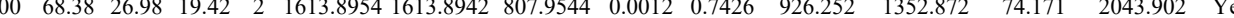

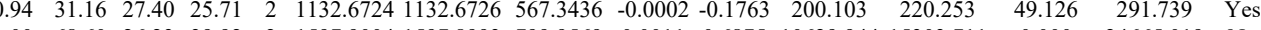

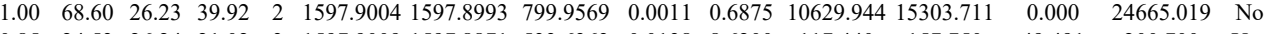

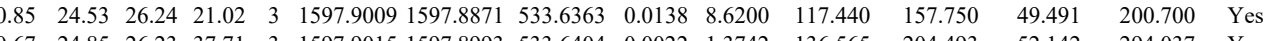
$\begin{array}{lllllllllllllll}0.67 & 24.85 & 26.23 & 37.71 & 3 & 1597.9015 & 1597.8993 & 533.6404 & 0.0022 & 1.3742 & 136.565 & 204.493 & 52.142 & 294.037 & \text { Yes } \\ 1.00 & 57.84 & 2.24 & 29.78 & 2 & 1597.0916 & 1597.8993 & 799.9569 & 0.023 & 1.4376 & 11579.650 & 17856327 & 0.000 & 31815.75 & \end{array}$ $\begin{array}{lllllllllllllll}1.00 & 57.84 & 26.24 & 29.78 & 2 & 1597.9016 & 1597.8993 & 799.9569 & 0.0023 & 1.4376 & 11579.650 & 17856.327 & 0.000 & 31815.765 & \text { No }\end{array}$ $\begin{array}{lllllllllllllll}1.00 & 40.94 & 26.24 & 34.61 & 3 & 1597.9018 & 1597.8993 & 533.6404 & 0.0025 & 1.5616 & 125.070 & 351.463 & 155.544 & 443.150 & \text { No }\end{array}$ $\begin{array}{lllllllllllllll}0.83 & 14.99 & 26.24 & 22.58 & 3 & 1597.9021 & 1597.8993 & 533.6404 & 0.0028 & 1.7490 & 185.217 & 147.634 & 71.594 & 193.499 & \text { Yes } \\ 0.8627 & 1597.8993 & 533.6404 & 0.0034 & 2.1238 & 108.655 & 110.343 & 66.526 & 149.808 & \text { Yes }\end{array}$ $\begin{array}{lllllllllllllll}1.00 & 72.92 & 26.69 & 22.74 & 2 & 1613.8938 & 1613.8942 & 807.9544 & -0.0004 & -0.2475 & 1996.956 & 2498.615 & 956.768 & 3550.835 & \text { Yes }\end{array}$

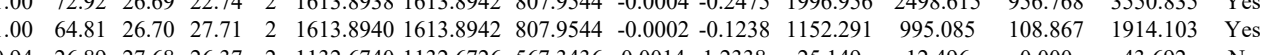

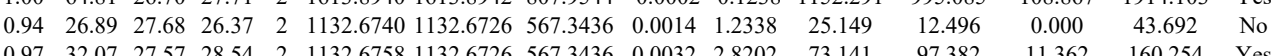

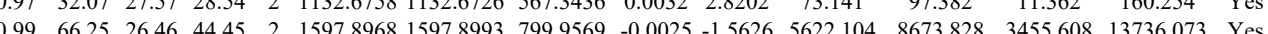

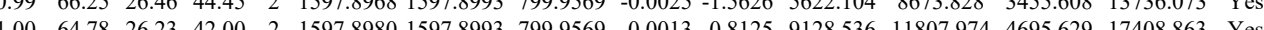

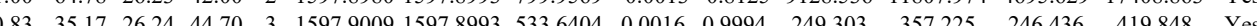

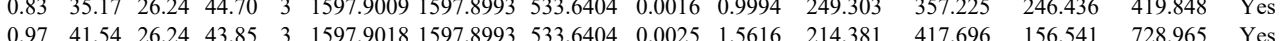

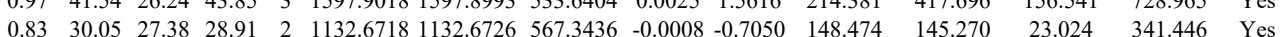

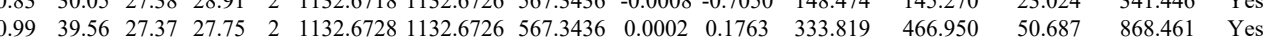
\begin{tabular}{lllllllllllllll}
0.99 & 38.21 & 27.37 & 28.19 & 2 & 1132.6730 & 1132.6726 & 567.3436 & 0.0004 & 0.3525 & 448.215 & 489.653 & 23.535 & 1002.976 & Yes \\
\hline
\end{tabular} $\begin{array}{lllllllllllllll}1.00 & 39.54 & 27.37 & 28.82 & 2 & 1132.6734 & 1132.6726 & 567.3436 & 0.0008 & 0.7050 & 336.872 & 431.862 & 38.321 & 858.344 & \text { Yes }\end{array}$

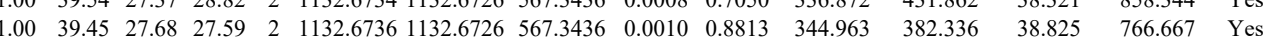

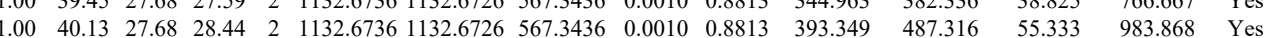
$\begin{array}{llllllllllllllll}1.00 & 41.54 & 27.68 & 35.01 & 2 & 1132.6740 & 1132.6726 & 567.3436 & 0.0014 & 1.2338 & 361.158 & 452.323 & 72.694 & 950.894 & \text { Yes }\end{array}$ $\begin{array}{lllllllllllllll}1.00 & 46.51 & 27.70 & 32.35 & 2 & 1132.6742 & 1132.6726 & 567.3436 & 0.0016 & 1.4101 & 370.662 & 491.075 & 99.904 & 864.095 & \text { Yes }\end{array}$ $\begin{array}{lllllllllllllllll}0.99 & 37.85 & 27.70 & 27.43 & 2 & 1132.6742 & 1132.6726 & 567.3436 & 0.0016 & 1.4101 & 372.656 & 414.435 & 56.565 & 787.281 & \text { Yes }\end{array}$ $\begin{array}{llllllllllllllll}1.00 & 38.09 & 27.60 & 27.24 & 2 & 1132.6750 & 1132.6726 & 567.3436 & 0.0024 & 2.1151 & 330.577 & 431.639 & 46.647 & 841.868 & \text { Yes }\end{array}$

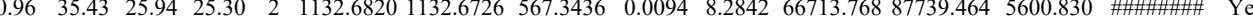
$\begin{array}{lllllllllllllll}1.00 & 65.56 & 26.46 & 38.81 & 2 & 1597.8968 & 1597.8993 & 799.9569 & -0.0025 & -1.5626 & 6057.879 & 6182.843 & 4635.303 & 10735.396 & \text { Yes }\end{array}$ $\begin{array}{lllllllllllllll}1.00 & 71.65 & 26.16 & 48.47 & 2 & 1597.8990 & 1597.8993 & 799.9569 & -0.0003 & -0.1875 & 7040.480 & 9056.192 & 5360.387 & 14393.656 & \text { Yes }\end{array}$ $\begin{array}{lllllllllllllll}0.70 & 24.92 & 26.13 & 37.32 & 3 & 1597.9024 & 1597.8993 & 533.6404 & 0.0031 & 1.9364 & 144.293 & 145.054 & 147.349 & 127.908 & \text { No }\end{array}$

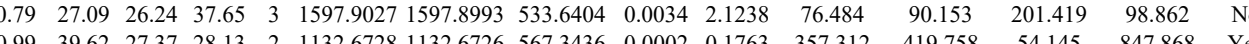
$\begin{array}{lllllllllllllll}0.99 & 39.62 & 27.37 & 28.13 & 2 & 1132.6728 & 1132.6726 & 567.3436 & 0.0002 & 0.1763 & 357.312 & 419.758 & 54.145 & 847.868 & \text { Yes } \\ 0.99 & 38.97 & 27.37 & 31.34 & 2 & 11326730 & 132.6726 & 567.346 & 0.000 & 0.3525 & 136.854 & 141.651 & 13.701 & 355.932 & \text { Yes }\end{array}$ \begin{tabular}{lllllllllllllll}
0.94 .35 & 27.37 & 31.34 & 2 & 1132.6730 & 1132.6726 & 567.3436 & 0.0004 & 0.3525 & 136.854 & 141.651 & 13.701 & 335.932 & Yes \\
\hline
\end{tabular}

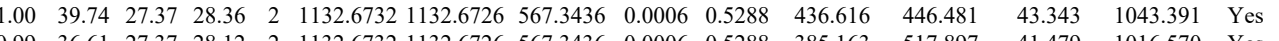

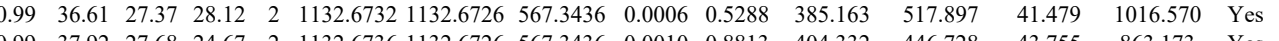
$\begin{array}{lllllllllllllll}0.99 & 37.92 & 27.68 & 24.67 & 2 & 1132.6736 & 1132.6726 & 567.3436 & 0.0010 & 0.8813 & 404.332 & 446.728 & 43.755 & 863.173 & \text { Yes } \\ 1.00 & 40.22 & 27.68 & 26.89 & 2 & 1132.6736 & 11326726 & 567.3436 & 0.0010 & 0.8813 & 355.846 & 439.031 & 26.001 & 906.860 & \text { Yes }\end{array}$

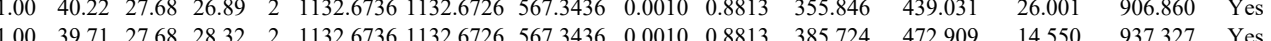

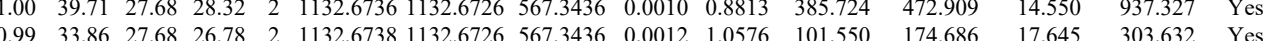
$\begin{array}{lllllllllllllll}0.99 & 33.86 & 27.68 & 26.78 & 2 & 1132.6738 & 1132.6726 & 567.3436 & 0.0012 & 1.0576 & 101.550 & 174.686 & 17.645 & 303.632 & \text { Yes } \\ 1.00 & 50.90 & 27.68 & 28.95 & 2 & 1132.6740 & 1132.6726 & 567.3436 & 0.0014 & 1.2338 & 449.248 & 443.012 & 34.199 & 974.525 & \text { Yes }\end{array}$

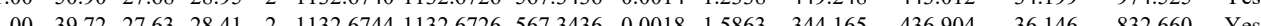

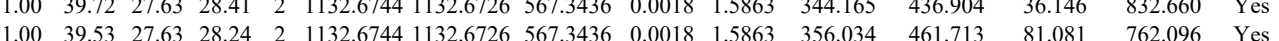

Table S-4 page 392 of 614 

$\begin{array}{llllllllllllllll}1.00 & 37.04 & 26.23 & 23.07 & 3 & 1597.9033 & 1597.8993 & 533.6404 & 0.0040 & 2.4986 & 264.147 & 173.544 & 253.313 & 421.953 & \mathrm{No}\end{array}$

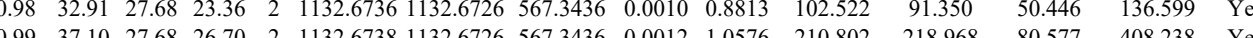

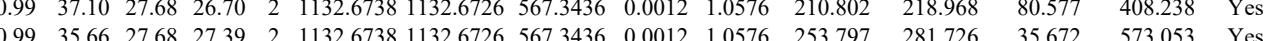

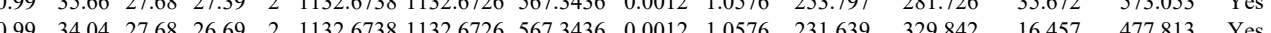

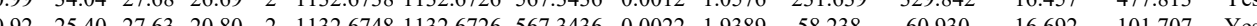

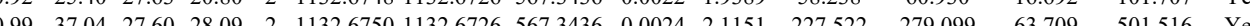

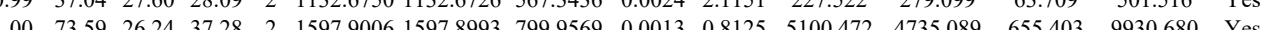
$\begin{array}{llllllllllllllll}1.00 & 77.56 & 26.26 & 4.62 & 2 & 1597.9010 & 1597.8993 & 799.9569 & 0.0017 & 1.0626 & 4840.963 & 6151.283 & 2031.754 & 10908.127 & \text { Yes }\end{array}$ $\begin{array}{llllllllllllllll}0.82 & 2.332 & 26.24 & 39.01 & 3 & 1597.9018 & 1597.8993 & 533.6404 & 0.0025 & 1.5616 & 97.447 & 106.559 & 68.165 & 115.068 & \text { Yes }\end{array}$ $\begin{array}{lllllllllllllll}0.87 & 40.17 & 26.18 & 48.59 & 3 & 1597.9021 & 1597.8993 & 533.6404 & 0.0028 & 1.7490 & 63.201 & 165.867 & 62.404 & 92.298 & \text { No }\end{array}$ $\begin{array}{lllllllllllllll}1.00 & 53.46 & 27.60 & 26.00 & 2 & 1132.6750 & 1132.6726 & 567.3436 & 0.0024 & 2.1151 & 24239.854 & 29930.670 & 0.000 & 71034.976 & \text { No }\end{array}$

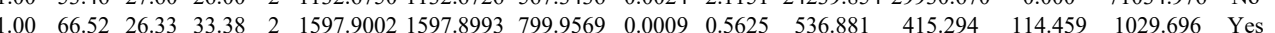
$\begin{array}{lllllllllllllll}1.00 & 63.75 & 26.19 & 40.11 & 2 & 1597.9014 & 1597.8993 & 799.9569 & 0.0021 & 1.3126 & 150.753 & 195.736 & 86.419 & 348.441 & \text { Yes }\end{array}$ $\begin{array}{lllllllllllllll}0.96 & 40.63 & 26.23 & 44.40 & 3 & 1597.9015 & 1597.8993 & 533.6404 & 0.0022 & 1.3742 & 97.208 & 259.330 & 118.986 & 301.192 & \text { Yes }\end{array}$ $\begin{array}{lllllllllllllll}0.75 & 13.13 & 26.24 & 23.83 & 3 & 1597.9027 & 1597.8993 & 533.6404 & 0.0034 & 2.1238 & 108.462 & 128.244 & 127.637 & 172.569 & \text { No }\end{array}$ $\begin{array}{llllllllllllllll}1.00 & 40.38 & 27.63 & 25.20 & 2 & 1132.6748 & 1132.6726 & 567.3436 & 0.0022 & 1.9389 & 17231.419 & 19142.761 & 2042.434 & 39555.823 & \text { Yes } \\ 1.00 & 67.91 & 27.53 & 38.05 & 2 & 1132.6754 & 1132.6726 & 56.3436 & 0.002 & 2.4676 & 1241.065 & 15157149 & 778.652 & 32488.948 & \text { Yes }\end{array}$ \begin{tabular}{lllllllllllllll}
0.99 & 36.43 & 27.58 & 28.05 & 2 & 1132.6754 & 1132.6726 & 567.3436 & 0.0028 & 2.4676 & 12414.065 & 15157.149 & 778.652 & 32488.948 & Yes \\
\hline
\end{tabular} $\begin{array}{lllllllllllllll}1.00 & 67.91 & 26.33 & 38.46 & 2 & 1597.8984 & 1597.8993 & 799.9569 & -0.0009 & -0.5625 & 473.376 & 623.686 & 110.541 & 730.341 & \text { Yes } \\ 1.00 & 72.67 & 2620 & 40.06 & 2 & 1597.8988 & 1597.8993 & 799.9569 & -0.0005 & -0.3125 & 444.027 & 370.052 & 95.635 & 849.590 & \text { Yes }\end{array}$

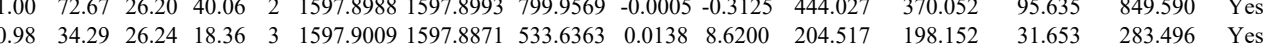
$\begin{array}{lllllllllllllll}1.00 & 34.46 & 26.23 & 21.36 & 3 & 1597.9033 & 1597.8993 & 533.6404 & 0.0040 & 2.4986 & 143.040 & 191.477 & 74.254 & 286.006 & \text { Yes }\end{array}$

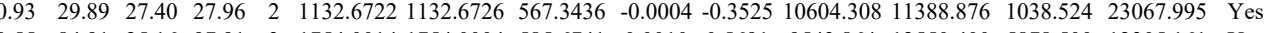
$\begin{array}{lllllllllllllllll}0.55 & 84.91 & 25.16 & 97.91 & 3 & 1754.0014 & 1754.0004 & 585.6741 & 0.0010 & 0.5691 & 9543.864 & 12550.400 & 5878.500 & 12305.161 & \text { Yes }\end{array}$ \begin{tabular}{lllllllllllllll}
0.66 & 88.74 & 25.21 & \#m\#\# & 3 & 1754.0023 & 1754.0004 & 585.6741 & 0.0019 & 1.0814 & 12408.796 & 15274.069 & 9388.030 & 16591.184 & Yes \\
\hline
\end{tabular} $\begin{array}{llllllllllllllll}0.96 & 24.50 & 27.51 & 14.70 & 3 & 1577.8417 & 1577.8405 & 526.9541 & 0.0012 & 0.7591 & 59.776 & 58.857 & 42.765 & 38.519 & \text { No }\end{array}$ $\begin{array}{llllllllllllllll}0.66 & 84.05 & 25.21 & 97.05 & 3 & 1754.0023 & 1754.0004 & 585.6741 & 0.0019 & 1.0814 & 6664.792 & 7718.389 & 4993.024 & 8476.470 & \text { Yes } \\ 0.67 & 84.95 & 25.13 & 97.95 & 3 & 1754.0032 & 1754.0004 & 585.6741 & 0.028 & 1.5936 & 8135.228 & 10204790 & 622.117 & 1657.404 & \text { Yes }\end{array}$

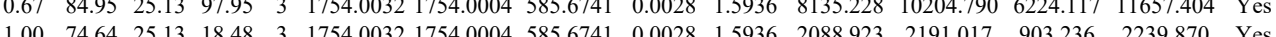

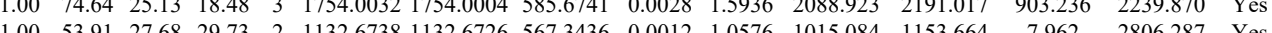

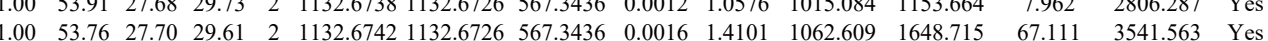

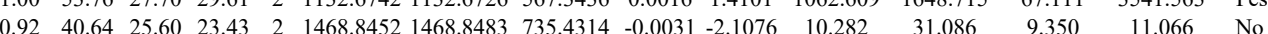

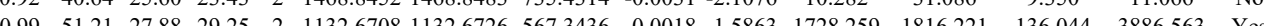

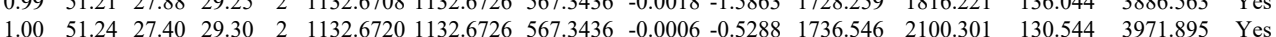

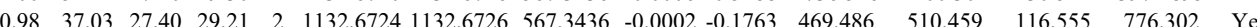

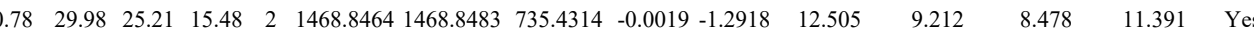

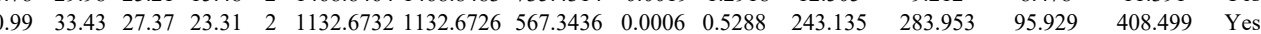
$\begin{array}{lllllllllllllll}0.96 & 29.45 & 27.68 & 23.98 & 2 & 1132.6736 & 1132.6726 & 567.3436 & 0.0010 & 0.8813 & 265.506 & 214.754 & 60.185 & 367.593 & \text { Yes }\end{array}$ $\begin{array}{llllllllllllllll}1.00 & 58.14 & 27.91 & 25.53 & 2 & 1323.7152 & 1323.7156 & 662.8651 & -0.0004 & -0.3017 & 53.983 & 56.816 & 0.025 & 68.247 & \text { No }\end{array}$

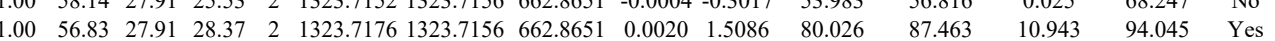

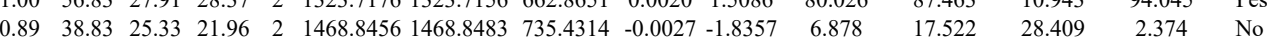
$\begin{array}{lllllllllllllll}1.00 & 50.96 & 27.68 & 32.36 & 2 & 1132.6740 & 1132.6726 & 567.3436 & 0.0014 & 1.2338 & 386.402 & 480.829 & 42.597 & 814.148 & \text { Yes }\end{array}$ $\begin{array}{lllllllllllllllll}1.00 & 39.49 & 27.63 & 23.26 & 2 & 1132.6744 & 1132.6726 & 567.3436 & 0.0018 & 1.5863 & 329.743 & 412.477 & 92.162 & 681.832 & \text { Yes }\end{array}$ $\begin{array}{lllllllllllllll}1.00 & 53.34 & 27.83 & 30.65 & 2 & 1323.7164 & 1323.7156 & 662.8651 & 0.0008 & 0.6034 & 114.650 & 132.821 & 23.505 & 206.734 & \text { Yes }\end{array}$ $\begin{array}{llllllllllllll}0.75 & 33.72 & 26.24 & 45.01 & 3 & 1597.9018 & 1597.8993 & 533.6404 & 0.0025 & 1.5616 & 44.483 & 45.86\end{array}$

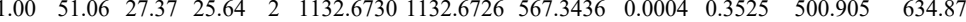
$\begin{array}{llllllllllll}1.00 & 51.01 & 27.37 & 29.01 & 2 & 1132.6732 & 1132.6726 & 567.3436 & 0.0006 & 0.5288 & 565.380 & 674.527\end{array}$ $\begin{array}{lllllllllllll}1.00 & 55.13 & 27.82 & 26.83 & 2 & 1323.7160 & 1323.7156 & 662.8651 & 0.0004 & 0.3017 & 204.895 & 251.397\end{array}$ $\begin{array}{lllllllllllll}1.00 & 56.93 & 27.83 & 30.74 & 2 & 1323.7164 & 1323.7156 & 62.8651 & 0.0008 & 0.6034 & 205.822 & 234.571\end{array}$ $\begin{array}{llllllllllll}1.00 & 70.07 & 26.11 & 38.14 & 2 & 1597.9000 & 1597.8993 & 799.9569 & 0.0007 & 0.4375 & 63.922 & 93.265\end{array}$ $\begin{array}{llllllllllll}1.00 & 50.50 & 27.68 & 28.46 & 2 & 1132.6736 & 1132.6726 & 567.3436 & 0.0010 & 0.8813 & 351.336 & 356.668\end{array}$ $\begin{array}{llllllllllll}1.00 & 39.82 & 27.68 & 30.11 & 2 & 1132.6736 & 1132.6726 & 567.3436 & 0.0010 & 0.8813 & 411.823 & 564.112\end{array}$ $\begin{array}{llllllllllll}1.00 & 63.20 & 27.89 & 31.32 & 2 & 1323.7158 & 1323.7156 & 662.8651 & 0.0002 & 0.1509 & 161.261 & 244.216\end{array}$ $\begin{array}{llllllllllll}1.00 & 54.21 & 27.82 & 32.48 & 2 & 1323.7160 & 1323.7156 & 662.8651 & 0.0004 & 0.3017 & 117.939 & 200.179\end{array}$ $\begin{array}{lllllllllllll}1.00 & 74.79 & 26.24 & 45.51 & 2 & 1597.9006 & 1597.8993 & 799.9569 & 0.0013 & 0.8125 & 83.911 & 91.616\end{array}$ $\begin{array}{cccccccccccc}1.00 & 78.72 & 26.24 & 41.50 & 2 & 1597.9006 & 1597.8993 & 799.9569 & 0.0013 & 0.8125 & 56.939 & 124.152 \\ 1.00 & 50.03 & 27.59 & 24.15 & 2 & 1132.6726 & 1132.6726 & 567.3436 & 0.0000 & 0.0000 & 239.802 & 256.360 \\ 1.00 & 51.01 & 27.37 & 2.16 & 2 & 1132.6730 & 132.6726 & 567.3436 & 0.004 & 0.3525 & 412.762 & 470.671\end{array}$

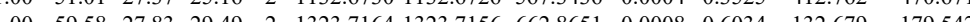
$\begin{array}{llllllllllll}1.00 & 59.58 & 27.83 & 29.49 & 2 & 1323.7164 & 1323.7156 & 6628561 & 0.0008 & 0.6034 & 132.679 & 179.542\end{array}$

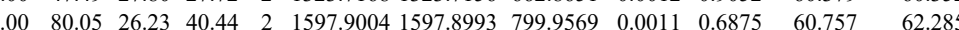
$\begin{array}{lllllllllllll}1.00 & 79.97 & 26.19 & 41.04 & 2 & 1597.9014 & 1597.8993 & 799.9569 & 0.0021 & 1.3126 & 50.090 & 61.479\end{array}$ $\begin{array}{lll}18.347 & 43.160 & \text { Yes }\end{array}$ $41.880 \quad 1370.870 \quad$ Yes $34.957 \quad 639.500 \quad$ Yes

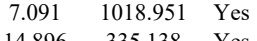
$\begin{array}{lll}14.896 & 335.138 & \text { Yes } \\ 17.609 & 28.25 & \text { Yes }\end{array}$ $\begin{array}{lll}17.609 & 287.257 & \text { Yes }\end{array}$ $\begin{array}{lll}6.527 & 121.810 & \text { Yes } \\ 0.000 & 134.373 & \text { N }\end{array}$ $\begin{array}{lll}6.000 & 134.373 & \text { No } \\ 16.541 & 500.881 & \text { Yes }\end{array}$ $\begin{array}{llll}10.811 & 783.618 & \text { Yes }\end{array}$ $\begin{array}{lll}16.541 & 500.881 & \text { Yes } \\ 16.624 & 24.818 & \text { Yes }\end{array}$ 88.060
8.836 

$\begin{array}{llllllllllll}1.00 & 50.78 & 27.37 & 24.61 & 2 & 1132.6734 & 1132.6726 & 567.3436 & 0.0008 & 0.7050 & 348.582 \\ 1.00 & 51.14 & 27.68 & 29.24 & 2 & 1132.6736 & 1132.6726 & 567.3436 & 0.0010 & 0.8813 & 455.401\end{array}$ $\begin{array}{lllllllllll}1.00 & 51.14 & 27.68 & 29.24 & 2 & 1132.6736 & 1132.6726 & 567.3436 & 0.0010 & 0.8813 & 455.401 \\ 1.00 & 59.22 & 27.85 & 29.63 & 2 & 1323.7170 & 1323.7156 & 662.8651 & 0.0014 & 1.0560 & 158.518\end{array}$

$\begin{array}{llllllllllll}0.77 & 22.56 & 26.23 & 17.52 & 3 & 1597.9015 & 1597.8871 & 533.6363 & 0.0144 & 8.9948 & 6.789 \\ 0.85 & 39.50 & 27.82 & 25.43 & 2 & 1132.6700 & 1132.6726 & 567.3436 & -0.0026 & -2.2914 & 334.856\end{array}$

$\begin{array}{lllllllllll}0.85 & 3.51 & 27.82 & 25.43 & 2 & 1132.6700 & 1132.6726 & 567.3436 & -0.0026 & -2.2914 & 334.856 \\ 1.99 & 48.42 & 27.88 & 30.72 & 2 & 11326704 & 1132.6726 & 567.3436 & -0.0022 & -1.9389 & 412.602\end{array}$

$\begin{array}{lllllllllll}1.00 & 80.18 & 26.16 & 48.45 & 2 & 1597.8990 & 1597.8993 & 799.9569 & -0.0003 & -0.1875 & 46.923\end{array}$

TVTAMDVVYALK

TVTAMDVVYALK

VFLENVIR

$\begin{array}{llllllllllll}1.00 & 73.65 & 26.23 & 40.03 & 2 & 1597.9004 & 1597.8993 & 799.9569 & 0.0011 & 0.6875 & 58.780\end{array}$

$\begin{array}{llllllllllll}0.77 & 21.16 & 26.24 & 32.00 & 3 & 1597.9009 & 1597.8993 & 533.6404 & 0.0016 & 0.9994 & 15.607\end{array}$

$\begin{array}{llllllllllll}0.74 & 23.78 & 26.26 & 35.36 & 3 & 1597.9012 & 1597.8993 & 533.6404 & 0.0019 & 1.1868 & 16.584\end{array}$

$\begin{array}{llllllllllll}0.89 & 32.73 & 27.57 & 24.14 & 2 & 1132.6714 & 1132.6726 & 567.3436 & -0.0012 & -1.0576 & 407.024 & 50 \\ 0.94 & 35.98 & 27.57 & 25.26 & 2 & 1132.6714 & 1132.6726 & 567.3436 & -0.0012 & -1.0576 & 376.946 & \end{array}$

$\begin{array}{lllllllllll}1.00 & 46.88 & 27.85 & 23.58 & 2 & 1323.7174 & 1323.7156 & 662.8651 & 0.0018 & 1.3577 & 125.637\end{array}$

ISGLIYEETR

TVTAMDVVYALK

TVTAMDVVYALK

KTVTAMDVVYALK
TVTAMDVVYALK

TVTAMDVVYALK

VFLENVIR

VFLENVIR

ISGLIYEETR

ISGLTYEETR

TVTAMDVVYALK

TVTAMDVVYALK

$\begin{array}{llllllllllll}.00 & 73.61 & 26.11 & 35.96 & 2 & 1597.9000 & 1597.8993 & 799.9569 & 0.0007 & 0.4375 & 47.067\end{array}$

$\begin{array}{lllllllllll}1.00 & 80.36 & 26.23 & 49.30 & 2 & 1597.9004 & 1597.8993 & 799.9569 & 0.0011 & 0.6875 & 52.442 \\ 0.69 & 20.93 & 26.23 & 17.25 & 3 & 1597.9015 & 1597.8871 & 533.6363 & 0.0144 & 8.9948 & 8.059\end{array}$

$\begin{array}{llllllllllll}0.69 & 32.89 & 26.18 & 45.43 & 3 & 1597.9021 & 1597.8993 & 533.6404 & 0.0028 & 1.7490 & 26.231 \\ 1.00 & 48.80 & 27.59 & 22.30 & 2 & 1132.6726 & 1132.6726 & 567.3436 & 0.0000 & 0.0000 & 461.307\end{array}$

$\begin{array}{lllllllllll}1.00 & 48.80 & 27.59 & 22.30 & 2 & 1132.6726 & 1132.6726 & 567.3436 & 0.0000 & 0.0000 & 461.300 \\ 0.96 & 29.21 & 27.68 & 25.48 & 2 & 1132.6740 & 1132.6726 & 567.3436 & 0.0014 & 1.2338 & 150.775\end{array}$

$\begin{array}{lllllllllll}0.96 & 29.21 & 27.68 & 25.48 & 2 & 132.6740 & 1132.6726 & 567.3436 & 0.0014 & 1.2338 & 150.775 \\ 1.00 & 51.48 & 27.80 & 31.84 & 2 & 1323.7168 & 1323.7156 & 662.8651 & 0.0012 & 0.9052 & 72.516\end{array}$

$\begin{array}{lllllllllll}1.00 & 51.48 & 27.80 & 31.84 & 2 & 1323.7168 & 1323.7156 & 662.8651 & 0.0012 & 0.9052 & 72.516 \\ 1.00 & 40.45 & 28.08 & 25.04 & 2 & 1323.7180 & 1323.7156 & 662.8651 & 0.0024 & 1.8103 & 60.158\end{array}$

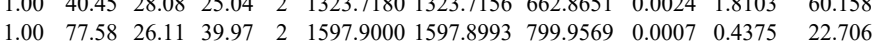

$\begin{array}{lllllllllll}1.00 & 77.58 & 26.1 & 39.97 & 2 & 1597.9000 & 1597.8993 & 799.9569 & 0.0007 & 0.4375 & 22.716 \\ 0.93 & 30.05 & 26.24 & 35.99 & 3 & 1597.9018 & 1597.8993 & 533.6404 & 0.0025 & 1.5616 & 12.164\end{array}$

$\begin{array}{lllllllllll}1.00 & 77.69 & 26.24 & 36.96 & 2 & 1597.9026 & 1597.8993 & 799.9569 & 0.0033 & 2.0626 & 18.562\end{array}$

$\begin{array}{lllllllllllll}0.99 & 29.84 & 27.99 & 23.95 & 3 & 1581.8053 & 1581.8031 & 528.2750 & 0.0022 & 1.3882 & 243.371\end{array}$

FNVWDTAGQEK

$\begin{array}{llllll}1.00 & 36.90 & 27.83 & 24.27 & 3 & 1581.8062 \\ 0.65 & 17.20 & 27.97 & 15.19 & 3 & 1581\end{array}$

LVLVGDGGTGK

$\begin{array}{lllllllllllll} & 0.035\end{array}$

LVLVGDGGTGK

VCENIPIVLCGNK

VCENIPIVLCGNK

VCENIPIVLCGNK

VCENIPIVLCGNK

VCENIPIVLCGNK

VCENIPIVLCGNK

VCENIPIVLCGNK

VCENIPIVLCGNK

VCENIPIVLCGNK

VCENIPIVLCGNK

VCENIPIVLCGNK

VCENIPIVLCGNK

VCENIPIVLCGNK

VCENIPIVLCGNK

$\begin{array}{lllllllllllll}0.99 & 59.54 & 25.54 & 50.44 & 2 & 1302.7854 & 1302.7751 & 652.3948 & 0.0103 & 7.8939 & 26756.618 & 29323.778\end{array}$

$\begin{array}{llllllllllll}1.00 & 69.66 & 28.00 & 20.89 & 2 & 1780.8970 & 1780.8951 & 891.4548 & 0.0019 & 1.0657 & 6914.246 & 6773.994\end{array}$

$\begin{array}{llllllllllllll}1.00 & 74.51 & 28.24 & 23.30 & 2 & 1780.8974 & 1780.8951 & 891.4548 & 0.0023 & 1.2900 & 8797.132 & 9671.534\end{array}$ $\begin{array}{llllllllllll}1.00 & 60.82 & 28.23 & 24.45 & 3 & 1780.8976 & 1780.8951 & 594.6390 & 0.0025 & 1.4014 & 920.698 & 1954.584\end{array}$ $\begin{array}{llllllllllllll}0.99 & 29.89 & 28.25 & 15.93 & 3 & 1780.8988 & 1780.8951 & 594.6390 & 0.0037 & 2.0741 & 1098.470 & 1154.486\end{array}$ $\begin{array}{lllllllllllll}.00 & 75.12 & 28.03 & 21.18 & 2 & 1780.8958 & 1780.8951 & 891.4548 & 0.0007 & 0.3926 & 6509.606 & 5416.839\end{array}$ $\begin{array}{lllllllllllll}100 & 60.05 & 27.99 & 20.97 & 3 & 1780.8970 & 1780.8951 & 594.6390 & 0.0019 & 1.0651 & 1388.902 & 2058.708\end{array}$ $\begin{array}{llllllllllll}1.00 & 66.59 & 28.23 & 21.27 & 2 & 1780.8976 & 1780.8951 & 891.4548 & 0.0025 & 1.4022 & 3646.370 & 3695.493\end{array}$

$\begin{array}{llllllllllll}1.00 & 52.97 & 28.22 & 22.99 & 3 & 1780.8997 & 1780.8951 & 594.6390 & 0.0046 & 2.5786 & 523.242 & 546.330 \\ 1.00 & 56.41 & 28.02 & 19.24 & 2 & 1780.8962 & 1780.8951 & 891.4548 & 0.0011 & 0.6170 & 1070.373 & 1320.408\end{array}$

$\begin{array}{lllllllllllll}1.00 & 56.41 & 28.02 & 19.24 & 2 & 1780.8962 & 1780.8951 & 891.4548 & 0.0011 & 0.6170 & 1070.373 & 1320.408 \\ 1.00 & 53.94 & 27.99 & 18.76 & 2 & 1780.8966 & 1780.8951 & 891.4548 & 0.0015 & 0.8413 & 1517.653 & 2490.277\end{array}$

$\begin{array}{lllllllllllll}1.00 & 38.56 & 28.08 & 19.89 & 3 & 1780.8973 & 1780.8951 & 594.6390 & 0.0022 & 1.2332 & 856.305 & 673.634 \\ 0.99 & 31.33 & 28.23 & 19.80 & 3 & 1780.8976 & 1780.8951 & 594.6390 & 0.0025 & 1.4014 & 248.778 & 462.432\end{array}$

$\begin{array}{llllllllllll}0.99 & 31.33 & 28.23 & 19.80 & 3 & 1780.8976 & 1780.8951 & 594.6390 & 0.0025 & 1.4014 & 248.778 & 462.432\end{array}$

$\begin{array}{lllllllllllll}0.76 & 20.28 & 28.03 & 15.17 & 2 & 1780.8958 & 1780.8951 & 891.4548 & 0.0007 & 0.3926 & 57.811 & 59.237 \\ 0.66 & 24.09 & 28.08 & 37.09 & 3 & 1780.8973 & 1780.8951 & 594.6390 & 0.0022 & 12332 & 278.132 & 279.375 & 8\end{array}$

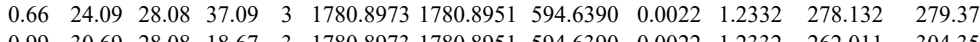

VCENIPIVLCGNK

$\begin{array}{lllllllllllll}0.99 & 30.69 & 28.08 & 18.67 & 3 & 1780.8973 & 1780.8951 & 594.6390 & 0.0022 & 1.2332 & 262.011 & 304.359 \\ 1.00 & 54.15 & 26.12 & 18.80 & 4 & 2195.2001 & 2195.1973 & 549.8066 & 0.0028 & 1.2732 & 316.290 & 4293.473\end{array}$

YVATLGVEVHPLVFHTNR

$\begin{array}{llllllllllllllllll}\text { YVATLGVEVHPLVFHTNR } & 1.00 & 54.15 & 26.12 & 18.80 & 4 & 2195.2001 & 2195.1973 & 549.8066 & 0.0028 & 1.2732 & 3116.290 & 4293.473 & 1789.313 & 4111.365 & \text { Yes } \\ \text { YVATLGVEVHPLVFHTNR } & 1.00 & 58.08 & 26.01 & 32.37 & 4 & 2195.2005 & 2195.1973 & 549.8066 & 0.0032 & 1.4551 & 2566.735 & 4673.082 & 944.820 & 4166.182 & \text { Yes } \\ \text { YVATEVEV }\end{array}$

$\begin{array}{lllllllllllllllll}\text { YVATLGVEVHPLVFHTNR } & 1.00 & 66.62 & 26.04 & 21.09 & 3 & 2195.1964 & 2195.1973 & 732.7397 & -0.0009 & -0.4094 & 3985.901 & 5181.123 & 1202.918 & 4889.590 & \text { Yes } \\ \text { YVATLGVEVHPLVFHTNR } & 1.00 & 77.98 & 26.13 & 18.09 & 3 & 2195.1976 & 2195.1973 & 732.7397 & 0.0003 & 0.1365 & 3474.679 & 3858.045 & 1062.573 & 3546.007 & \text { Yes }\end{array}$ $\begin{array}{lllllllllllllllll} & \end{array}$

$\begin{array}{llllllllllllllll} & & \end{array}$

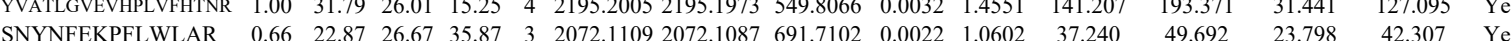




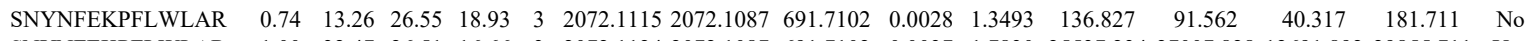

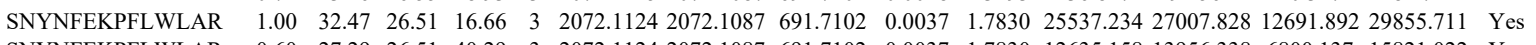
$\begin{array}{llllllllllllllll}\text { SNYNFEKPFLWLAR } & 0.60 & 27.29 & 26.51 & 40.29 & 3 & 2072.1124 & 2072.1087 & 691.7102 & 0.0037 & 1.7830 & 12635.158 & 13956.338 & 6800.137 & 15821.022 & \text { Yes }\end{array}$ $\begin{array}{llllllllllllllll}\text { YVATLGVEVHPLVFHTNR } & 1.00 & 30.04 & 26.12 & 43.04 & 4 & 2195.2001 & 2195.1973 & 549.8066 & 0.0028 & 1.2732 & 21.690 & 25.189 & 21.028 & 25.644 & \text { No }\end{array}$

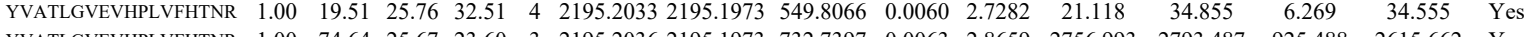

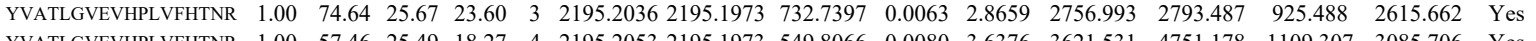

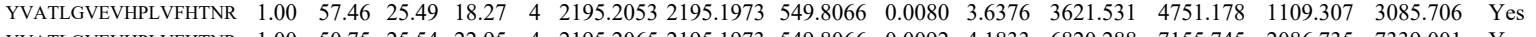
$\begin{array}{llllllllllllllll}\text { YVATLGVEVHPLVFHTNR } & 1.00 & 50.75 & 25.54 & 22.95 & 4 & 2195.2065 & 2195.1973 & 549.8066 & 0.0092 & 4.1833 & 6820.288 & 7155.745 & 2086.735 & 7339.001 & \text { Yes }\end{array}$

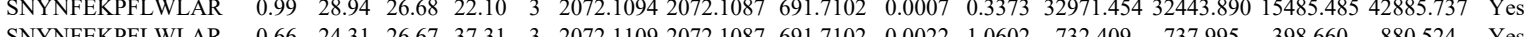
$\begin{array}{llllllllllllllll} & \text { SNYNFER }\end{array}$ $\begin{array}{llllllllllllllll} & \text { Y }\end{array}$

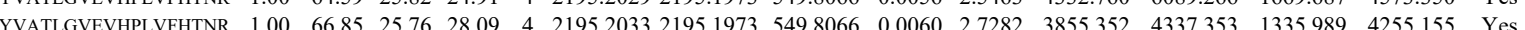

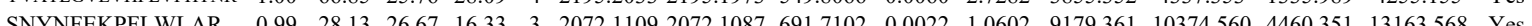

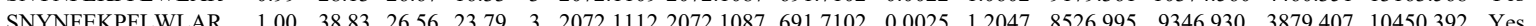
$\begin{array}{lllllllllllllllll} & \text { YVATLVEVHPLVFHTNR } & 1.00 & 59.17 & 25.76 & 19.07 & 4 & 2195.2033 & 2195.1973 & 549.8066 & 0.0060 & 27282 & 1336.043 & 1660.095 & 695.467 & 1843.742 & \text { Yes }\end{array}$ $\begin{array}{lllllllllllllllll}\text { YVATLGVEVHPLVFHTNR } & 1.00 & 49.87 & 26.12 & 17.06 & 4 & 2195.2001 & 2195.1973 & 549.8066 & 0.0028 & 1.2732 & 785.913 & 726.421 & 293.610 & 824.600 & \text { Yes }\end{array}$ $\begin{array}{llllllllllllllll}\text { YVATLGVEVHPLVFHTNR } & 1.00 & 53.88 & 26.16 & 24.12 & 4 & 2195.1985 & 2195.1973 & 549.8066 & 0.0012 & 0.5456 & 137.860 & 151.395 & 31.130 & 144.949 & \text { Yes }\end{array}$ $\begin{array}{llllllllllllllll}\text { YVATLGVEVHPLVFHTNR } & 1.00 & 53.09 & 26.16 & 28.90 & 4 & 2195.1989 & 2195.1973 & 549.8066 & 0.0016 & 0.7275 & 127.507 & 170.221 & 25.984 & 126.821 & \text { Yes }\end{array}$ $\begin{array}{llllllllllllllll}\text { YVATLGVEVHPLVFHTNR } & 1.00 & 51.99 & 26.12 & 20.39 & 4 & 2195.1981 & 2195.1973 & 549.8066 & 0.0008 & 0.3638 & 83.053 & 120.217 & 46.510 & 127.582 & \text { Yes }\end{array}$ $\begin{array}{llllllllllllllll}\text { YVATLGVEVHPLVFHTNR } & 1.00 & 55.00 & 26.16 & 19.47 & 4 & 2195.1985 & 2195.1973 & 549.8066 & 0.0012 & 0.5456 & 80.900 & 108.910 & 40.541 & 117.414 & \text { Yes }\end{array}$ $\begin{array}{llllllllllllllll}\text { YVATLGVEVHPLVFHTNR } & 1.00 & 63.27 & 26.16 & 19.74 & 4 & 2195.1985 & 2195.1973 & 549.8066 & 0.0012 & 0.5456 & 81.655 & 72.448 & 19.753 & 64.005 & \text { Yes }\end{array}$ $\begin{array}{llllllllllllllll}\text { YVATLGVEVHPLVFHTNR } & 1.00 & 61.98 & 26.12 & 26.61 & 4 & 2195.1993 & 2195.1973 & 549.8066 & 0.0020 & 0.9094 & 50.482 & 52.964 & 11.478 & 71.838 & \text { Yes }\end{array}$ $\begin{array}{lllllllllllllllll}\text { YVATLGVEVHPLVFHTNR } & 1.00 & 60.34 & 26.12 & 18.53 & 4 & 2195.1993 & 2195.1973 & 549.8066 & 0.0020 & 0.9094 & 64.631 & 90.752 & 21.627 & 68.062 & \text { Yes }\end{array}$ $\begin{array}{llllllllllllllllll}\text { YVATLGVEVHPLVFHTNR } & 1.00 & 55.28 & 26.12 & 25.02 & 4 & 2195.1993 & 2195.1973 & 549.8066 & 0.0020 & 0.9094 & 80.264 & 88.899 & 18.522 & 89.873 & \text { Yes }\end{array}$ $\begin{array}{llllllllllllllllll}\text { YVATLGVEVHPLVFHTNR } & 1.00 & 56.60 & 26.12 & 21.49 & 4 & 2195.2001 & 2195.1973 & 549.8066 & 0.0028 & 1.2732 & 126.611 & 153.064 & 89.963 & 124.201 & \text { Yes }\end{array}$ $\begin{array}{llllllllllllllll}\text { YVATLGVEVHPLVFHTNR } & 1.00 & 58.40 & 26.01 & 19.15 & 4 & 2195.2005 & 2195.1973 & 549.8066 & 0.0032 & 1.4551 & 86.754 & 131.942 & 60.562 & 96.904 & \text { Yes }\end{array}$ $\begin{array}{llllllllllllllll}\text { YVATLGVEVHPLVFHTNR } & 1.00 & 60.21 & 26.12 & 27.03 & 4 & 2195.1993 & 2195.1973 & 549.8066 & 0.0020 & 0.9094 & 57.056 & 76.796 & 29.973 & 48.124 & \text { Yes }\end{array}$

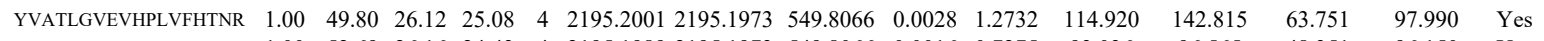
$\begin{array}{llllllllllllllll}\text { YVATLGVEVHPLVFHTNR } & 1.00 & 52.69 & 26.16 & 24.43 & 4 & 2195.1989 & 2195.1973 & 549.8066 & 0.0016 & 0.7275 & 93.036 & 96.565 & 48.351 & 96.150 & \text { Yes }\end{array}$ $\begin{array}{llllllllllllllll}\text { YVATLGVEVHPLVFHTNR } & 1.00 & 51.12 & 26.12 & 19.65 & 4 & 2195.1993 & 2195.1973 & 549.8066 & 0.0020 & 0.9094 & 131.608 & 118.445 & 59.637 & 106.532 & \text { Yes }\end{array}$

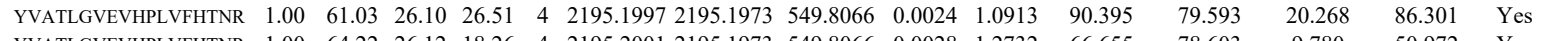

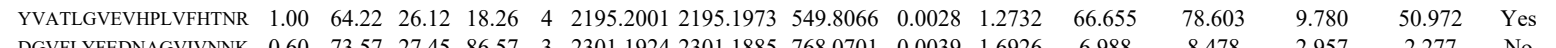

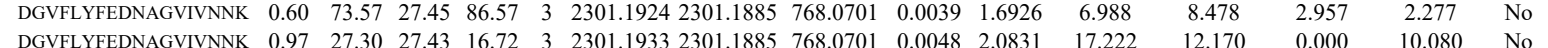

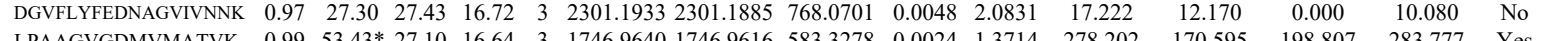

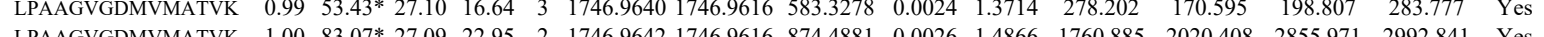
$\begin{array}{lllllllllllllll}\text { LPAAGVGDMVMATVK } & 1.00 & 83.07 * 27.09 & 22.95 & 2 & 1746.9642 & 1746.9616 & 874.4881 & 0.0026 & 1.4866 & 1760.885 & 2020.408 & 2855.971 & 2992.841 & \text { Yes } \\ \text { LPAAGVGDMVMATVK } & 1.00 & 84.92 * 27.05 & 21.93 & 2 & 1746.9646 & 1746.9616 & 874.4881 & 0.0030 & 1.7153 & 2129.636 & 2150.880 & 4542.518 & 3493.065 & \text { Yes }\end{array}$ $\begin{array}{llllllllllll} & \end{array}$

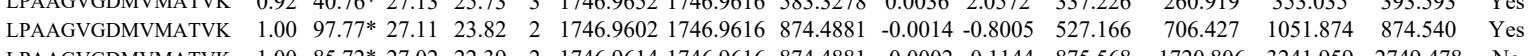

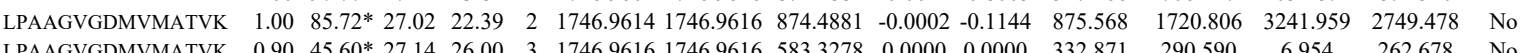

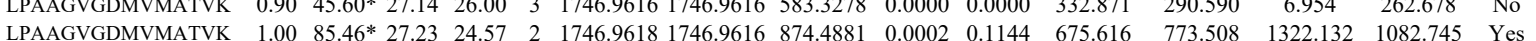

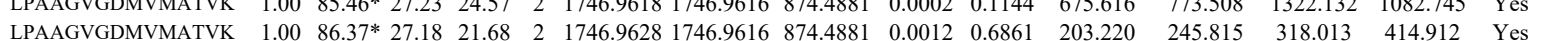
$\begin{array}{llllllllllllllll}\text { LPAAGVGDMVMATVK } & 0.99 & 26.53 & 27.09 & 16.19 & 3 & 1746.9643 & 1746.9616 & 583.3278 & 0.0027 & 1.5429 & 246.383 & 334.468 & 182.830 & 379.779 & \text { Yes }\end{array}$

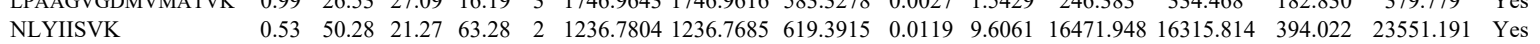
$\begin{array}{llllllllllllllll}\text { NLYIISVK } & 0.53 & 50.38 & 21.27 & 63.38 & 2 & 1236.7804 & 1236.7685 & 619.3915 & 0.0119 & 9.6061 & 16715.636 & 19301.614 & 9.563 & 28019.118 & \text { Yes }\end{array}$

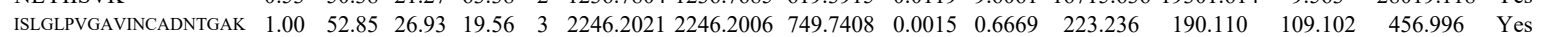

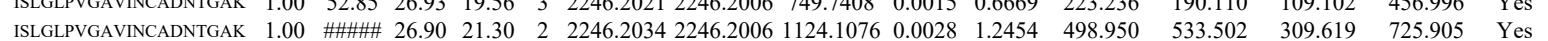

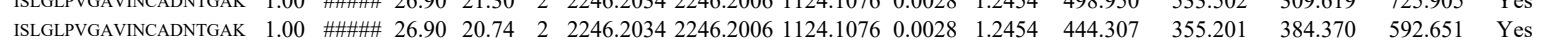

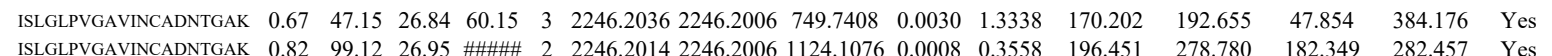
\begin{tabular}{llllllllllllllll} 
ISLGLPVGAVINCADNTGAK & 0.82 & 99.12 & 26.95 & $\# \# \# \#$ & 2 & 2246.2014 & 2246.2006 & 1124.1076 & 0.0008 & 0.3558 & 196.451 & 278.780 & 182.349 & 282.457 & Yes \\
\hline
\end{tabular}

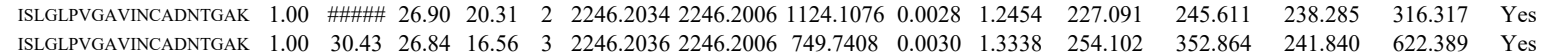

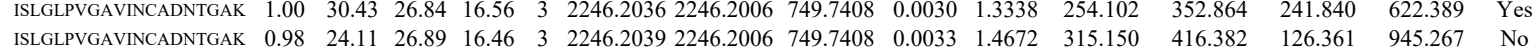
$\begin{array}{llllllllllllllllll}\text { ISLGLPVGAVINCADNTGAK } & 0.55 & 39.92 & 26.95 & 52.92 & 3 & 2246.2015 & 2246.2006 & 749.7408 & 0.0009 & 0.4001 & 160.279 & 69.776 & 70.034 & 338.957 & \text { No }\end{array}$

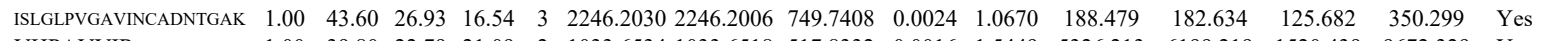

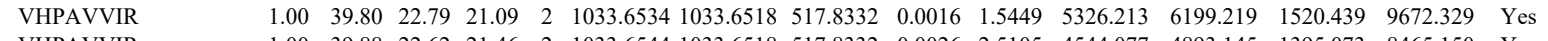
$\begin{array}{lllllllllllllllll}\text { VHPAVVIR } & 1.00 & 39.88 & 22.62 & 21.46 & 2 & 1033.6544 & 1033.6518 & 517.8332 & 0.0026 & 2.5105 & 4544.077 & 4893.145 & 1395.073 & 8465.150 & \text { Yes }\end{array}$ $\begin{array}{llllllllllllllll}\text { VHPAVVIR } & 0.99 & 32.28 & 22.79 & 19.97 & 2 & 1033.6534 & 1033.6518 & 517.8332 & 0.0016 & 1.5449 & 1702.595 & 2032.651 & 1379.264 & 3230.518 & \text { Yes }\end{array}$

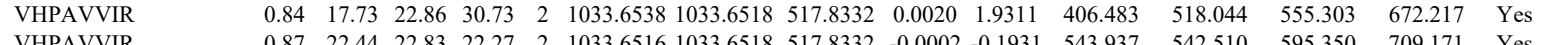

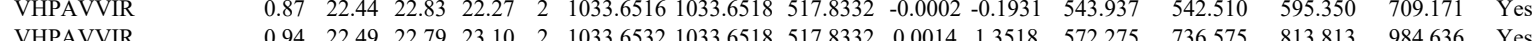

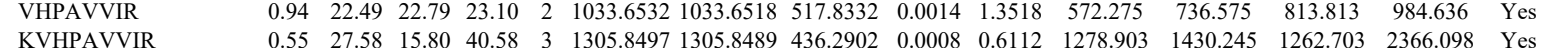

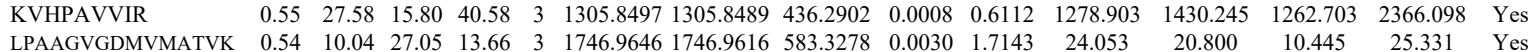
$\begin{array}{llllllllllllllll}\text { LPAAGVGDMVMATVK } & 0.54 & 10.04 & 27.05 & 13.66 & 3 & 1746.9646 & 7746.9616 & 583.3278 & 0.0030 & 1.7143 & 24.053 & 20.800 & 10.445 & 25.331 & \text { Yes } \\ \text { GGSSGAK } & 1.00 & 43.89 & 28.50 & 30.37 & 2 & 850.4750 & 850.4752 & 426.2449 & -0.0002 & -0.2346 & 104.634 & 135.028 & 196.210 & 225.751 & \text { Yes }\end{array}$

$\begin{array}{llllllllllllllll}\text { KEAPPMEKPEVVK } & 1.00 & 25.64 & 20.13 & 18.87 & 4 & 20.457 .2193 & 2057.2042 & 515.3083 & 0.015 & 7.3257 & 12220.701 & 15033.283 & 9949.781 & 21311.553 & \text { Yes }\end{array}$ $\begin{array}{lllllllllllllllll}\text { KEAPPMEKPEVVK } & 1.00 & 28.07 & 19.96 & 21.70 & 4 & 2057.2213 & 2057.2042 & 515.3083 & 0.0171 & 8.2959 & 14121.390 & 16353.972 & 10234.172 & 22977.122 & \text { Yes }\end{array}$ 
\begin{tabular}{llllllllllllllll} 
& \\
TTGFGMIYDSLDYAK & 1.00 & $90.04 *$ & 27.57 & 25.21 & 2 & 1968.9750 & 1968.9747 & 985.4946 & 0.0003 & 0.1522 & 1833.088 & 1954.420 & 186.208 & 2955.422 & Yes \\
TTGFGMIYDSLDYAK & 1.00 & 38.33 & 27.75 & 16.12 & 3 & 1968.9769 & 1968.9747 & 657.3322 & 0.0022 & 1.1156 & 471.690 & 579.237 & 81.924 & 828.394 & Yes \\
\hline
\end{tabular}

QMVIDVLHPGK

QTPDVVLFGR

TTPDVIFVFGFR

TTPDVIFVFGFR

TTPDVIFVFGFR

TTPDVIFVFGFR

TTPDVIFVFGFR

TTPDVIFVFGFR

TTPDVIFVFGFR

QMVIDVLHPGK

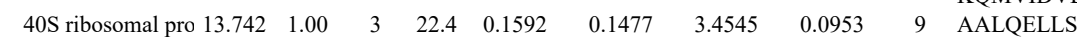

\section{LITPAVVSER}

LITPAVVSER

LITPAVVSER

LITPAVVSER

LITPAVVSER

LNNLVLFDK

LNNLVLFDK

LNNLVLFDK

LNNLVLFDK

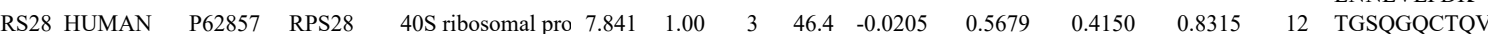

TGSQGQCTQVR

TGSQGQCTQVR

TGSQQTQVR

GSQGQCTQVR

VEFMDDTSR

VEFMDDTSR

EGDVLTLLESER

EGDVLTLLESER

TGSQGQCTQVR

TGSQGQCTQVR

TGSQGQCTQVR

TGSQGQCTQVR

EGDVLTLLESER

EGDVLTLLESER

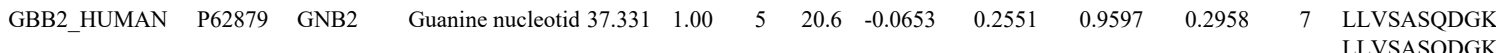

LLVSASQDGK

ACGDSTLTQITAGLDPVG

VSCLGVTDDGMAVATG

VSCLGVTDDGMAVATGSWDSS
VHAIPLR

VHAIPLR

VHAIPL

$\begin{array}{lllllllllll}\text { RL30_HUMAN } & \text { P62888 } & \text { RPL30 } & \text { 60S ribosomal pro } 12.784 & 1.00 & 4 & 37.4 & 0.2956 & 0.3334 & 0.9275 & 0.4023\end{array}$

VCTLAIIDPGDSDIIR

VCTLAIIDPGDSDIIR

VCTLAIIDPGDSDIR

CTLAIDPGSDIIR

VCTLAIIDPGDSDIIR

VCTLAIIDPGDSDIIR $\begin{array}{llllllllllllllll}1.00 & 36.36 & 25.84 & 17.64 & 3 & 1523.8789 & 1523.8738 & 508.9652 & 0.0051 & 3.3401 & 4639.605 & 4900.374 & 13.959 & 7706.769 & \text { Yes }\end{array}$ $\begin{array}{llllllllllllllll}0.92 & 21.23 & 27.46 & 20.93 & 3 & 1541.8375 & 1541.8364 & 514.9527 & 0.0011 & 0.7120 & 46.915 & 77.696 & 10.577 & 74.661 & \text { No }\end{array}$ $\begin{array}{lllllllllllllll}1.00 & 55.00 & 27.44 & 24.78 & 2 & 1541.8380 & 1541.8364 & 771.9255 & 0.0016 & 1.0364 & 4129.957 & 4915.603 & 673.663 & 7960.133 & \text { Yes }\end{array}$

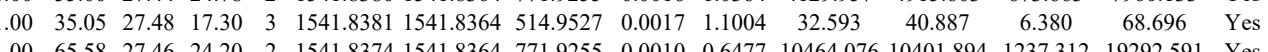
\begin{tabular}{llllllllllllllll}
1.00 & 65.58 & 27.46 & 24.20 & 2 & 1541.8374 & 1541.8364 & 771.9255 & 0.0010 & 0.6477 & 10464.076 & 10401.894 & 1237.312 & 19292.591 & Yes \\
\hline
\end{tabular} $\begin{array}{ccccccccccccccc}1.00 & 51.73 & 27.40 & 22.29 & 2 & 1541.8378 & 1541.8364 & 771.9255 & 0.0014 & 0.9068 & 3211.870 & 3574.835 & 371.980 & 6247.181 & \text { Yes } \\ 0.98 & 26.16 & 27.55 & 2.85 & 3 & 151.8390 & 1541.8364 & 514.9527 & 0.026 & 1.683 & 30.695 & 61.010 & 15.290 & 62.985 & \text { No }\end{array}$

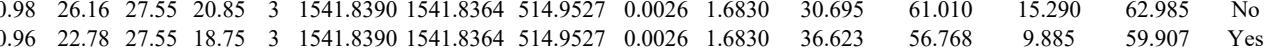
$\begin{array}{lllllllllllllll}1.00 & 55.66 & 27.42 & 22.02 & 2 & 1541.8352 & 1541.8364 & 771.9255 & -0.0012 & -0.7773 & 1623.765 & 1752.937 & 203.203 & 3444.347 & \text { Yes }\end{array}$

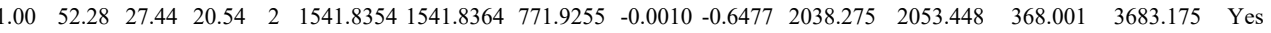

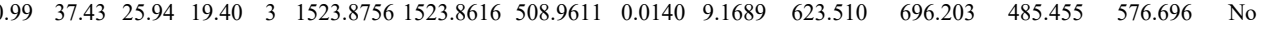

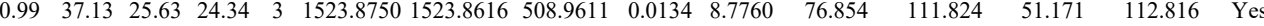

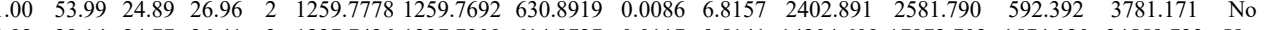
$\begin{array}{lllllllllllllll}0.92 & 29.14 & 24.77 & 26.41 & 2 & 1227.7426 & 1227.7309 & 614.8727 & 0.0117 & 9.5141 & 14204.609 & 17972.702 & 1574.030 & 24559.723 & \text { Yes }\end{array}$ $\begin{array}{llllllllllllllll}0.98 & 38.57 & 24.31 & 30.12 & 2 & 1227.7382 & 1227.7309 & 614.8727 & 0.0073 & 5.9362 & 25072.917 & 25117.134 & 2145.808 & 39630.650 & \text { Yes }\end{array}$ $\begin{array}{lllllllllllllll}0.98 & 39.81 & 24.30 & 32.41 & 2 & 1227.7386 & 1227.7309 & 614.8727 & 0.0077 & 6.2614 & 32829.610 & 36685.240 & 2569.459 & 54625.494 & \text { Yes }\end{array}$ $\begin{array}{llllllllllllllll}0.98 & 38.70 & 24.31 & 24.40 & 2 & 1227.7380 & 1227.7309 & 614.8727 & 0.0071 & 5.7735 & 13327.551 & 12945.085 & 1317.580 & 21361.055 & \text { Yes }\end{array}$ $\begin{array}{llllllllllllllllll}0.98 & 39.59 & 24.30 & 26.84 & 2 & 1227.7386 & 1227.7309 & 614.8727 & 0.0077 & 6.2614 & 9264.354 & 10521.082 & 1237.571 & 16159.376 & \text { Yes }\end{array}$ \begin{tabular}{lllllllllllllllll}
1.00 & 52.12 & 24.50 & 20.63 & 2 & 1362.8152 & 1362.8115 & 682.4130 & 0.0037 & 2.7110 & 13085.097 & 16192.189 & 675.115 & 21598.467 & Yes \\
\hline
\end{tabular} \begin{tabular}{llllllllllllllll}
1.00 & 43.96 & 24.50 & 21.85 & 2 & 1362.8152 & 1362.8115 & 682.4130 & 0.0037 & 2.7110 & 20542.639 & 22985.754 & 1004.232 & 31805.304 & Yes \\
\hline
\end{tabular} $\begin{array}{llllllllllllllll}1.00 & 55.57 & 24.56 & 23.83 & 2 & 1362.8136 & 1362.8115 & 682.4130 & 0.0021 & 1.5387 & 16994.413 & 16683.639 & 1452.905 & 23939.705 & \text { Yes }\end{array}$

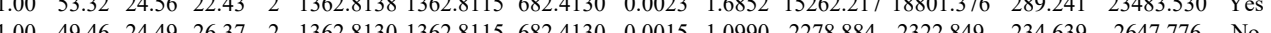
$\begin{array}{lllllllllllllll}1.00 & 49.46 & 24.49 & 26.37 & 2 & 1362.8130 & 1362.8115 & 682.4130 & 0.0015 & 1.0990 & 2278.884 & 2322.849 & 234.639 & 2647.776 & \text { No } \\ 1.00 & 69.40 & 24.93 & 32.47 & 2 & 1353.6256 & 1353.6251 & 677.8198 & 0.0005 & 0.3688 & 220.349 & 269.842 & 248.477 & 312.583 & \text { Yes }\end{array}$

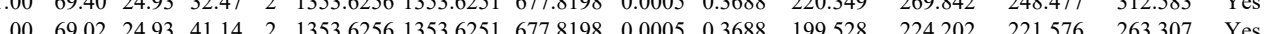

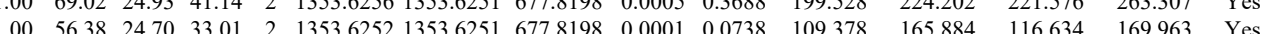

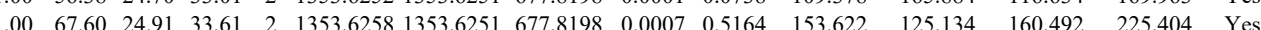
$\begin{array}{lllllllllllllll}0.68 & 14.91 & 24.96 & 24.40 & 2 & 1353.6272 & 1353.6251 & 677.8198 & 0.0021 & 1.5491 & 10.516 & 29.646 & 13.132 & 19.451 & \text { No }\end{array}$

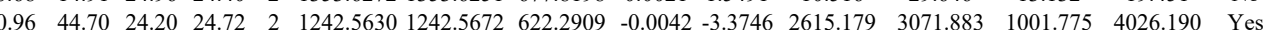
$\begin{array}{lllllllllllllll}0.94 & 43.52 & 24.28 & 27.16 & 2 & 12425636 & 1242.5672 & 6222909 & -0.0036 & -28925 & 2793.573 & 3339.064 & 1039.665 & 4421.788 & \text { Yes }\end{array}$ $\begin{array}{lllllllllllllll}1.00 & 62.32 & 27.79 & 42.71 & 2 & 1503.7916 & 1503.7902 & 752.9024 & 0.0014 & 0.9297 & 529.715 & 444.234 & 618.653 & 3093.718 & \text { Yes }\end{array}$

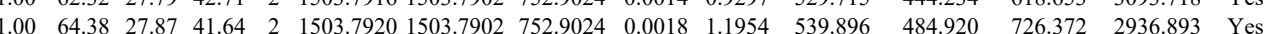

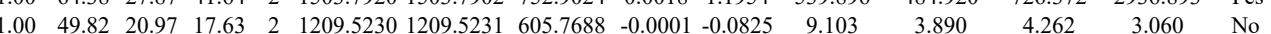
$\begin{array}{lllllllllllllll}0.81 & 14.64 & 21.00 & 18.18 & 2 & 1209.5240 & 1209.5231 & 605.7688 & 0.0009 & 0.7429 & 9.968 & 0.499 & 1.737 & 10.661 & \text { No }\end{array}$

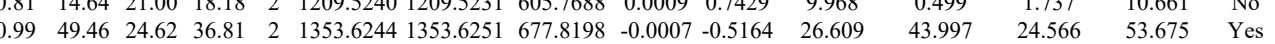
\begin{tabular}{llllllllllllllll}
0.95 & 36.53 & 24.68 & 38.49 & 2 & 1353.6248 & 1353.6251 & 677.8198 & -0.0003 & -0.2213 & 25.880 & 25.737 & 22.206 & 37.644 & Yes \\
\hline
\end{tabular} $\begin{array}{lllllllllllllll}1.00 & 64.09 & 27.79 & 44.67 & 2 & 1503.7916 & 1503.7902 & 752.9024 & 0.0014 & 0.9297 & 76.396 & 52.682 & 31.187 & 355.052 & \text { Yes }\end{array}$

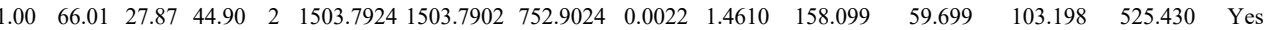
$\begin{array}{llllllllllllllll}1.00 & 47.97 & 26.69 & 23.83 & 2 & 1304.7648 & 1304.7543 & 653.3844 & 0.0105 & 8.0350 & 14165.593 & 14226.558 & 1552.286 & 24432.383 & \text { Yes }\end{array}$ $\begin{array}{lllllllllllllll}1.00 & 57.12 & 26.59 & 26.72 & 2 & 1304.7656 & 1304.7543 & 653.3844 & 0.0113 & 8.6472 & 15055.382 & 14226.362 & 1694.622 & 24680.785 & \text { Yes }\end{array}$

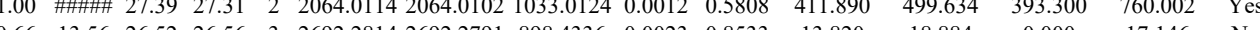

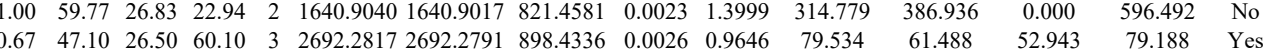
$\begin{array}{lllllllllllllll}0.67 & 16.89 & 26.51 & 29.89 & 3 & 2692.2826 & 2692.2791 & 898.4336 & 0.0035 & 1.2986 & 74.637 & 56.406 & 76.907 & 118.532 & \text { Yes }\end{array}$ $\begin{array}{llllllllllllllll}0.84 & 31.09 & 24.90 & 44.09 & 2 & 948.6010 & 948.5991 & 475.3068 & 0.0019 & 1.9987 & 2532.830 & 2859.788 & 903.340 & 4045.361 & \text { Yes } \\ 1.06 & 70.34 & 2.33 & 26.94 & 2 & 1889.9724 & 1889.9713 & 945.9929 & 0.011 & 0.5814 & 211.981 & 218.022 & 53.434 & 504.683 & \text { Y }\end{array}$

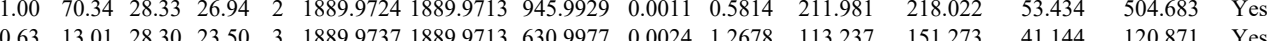

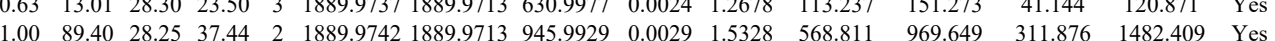

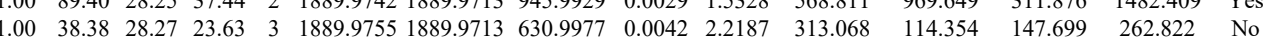
$\begin{array}{llllllllllllll} & \end{array}$ $\begin{array}{llllllllllllllll} & \end{array}$

Table S-4 page 396 of 614 
YVLGYK

YVLGYK

SMPEQTGEK

LVILANNCPALR

LVILANNCPALR

LVILANNCPALR
LVILANNCPALR

LVILANNCPALR

LVILANNCPALR

LVILANNCPALR

LVILANNCPALR

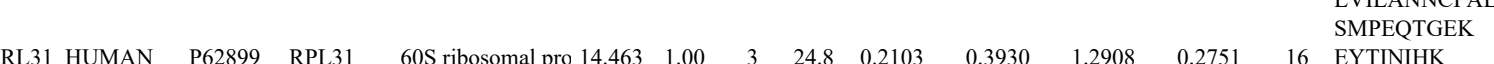

EYTINIHK

LYTLVTYVPVTTFK

LYTLVTYVPVTTFK

LYTLVTYVPVTTFK

LYTLVTYVPVTTFK

LYTLVTYVPVTTFK

LYTLVTYVPVTTFK

LYTLVTYVPVTTFK

LYTLVTYVPVTTFK

LYTLVTYVPVTTFK

LYTLVTYVPVTTFK

LYTLVTYVPVTTFK

LYTLVTYVPVTTFK

LYTLVTYVPVTTFK

LYTLVTYVPVTTFK

LYTLVTYVPVTTFK

$\begin{array}{lllllllllll}\text { RL10A_HUMAr } & \text { P62906 } & \text { RPL10A } & \text { 60S ribosomal pro } 24.831 & 1.00 & 7 & 35 & 0.0927 & 0.2625 & 1.6374 & 0.3858\end{array}$

LYTLTYVPTHK

AVDIPHMDIEALK

AVDIPHMDIEALK

FSVCVLGDQQHCDEAK

AVDIPHMDIEALK

FSVCVLGDQQHCDEA

FSVCVLGDQQHCDEAK 0.6

AVDIPHMDIEALK

YDAFLASESLIK

YDAFLASESLIK

YDAFLASESLIK

YDAFLASESLIK

YDAFLASESLIK

YDAFLASESLIK

KYDAFLASESLIK

FPSLLTHNENMVAK

FPSLLTHNENMVAK

FPSLLTHNENMVAK

ILGPGLNK

LGPGLNK

FPSLLTHNENMVAK

FPSLLTHNENMVAK

ILGPGLNK

ILGPGLNK

ILGPGLNK

ILGPGLNK

LCLAVAVGHVK

VLCLAVAVGHVK

VLCLAVAVGHVK

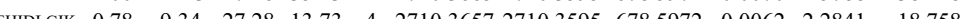

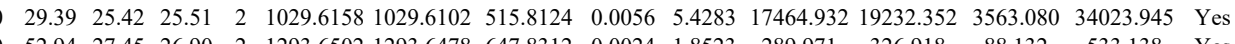

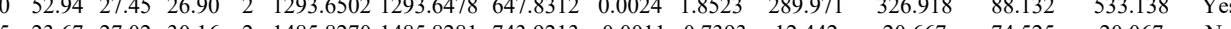

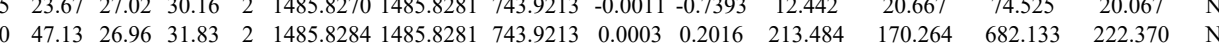

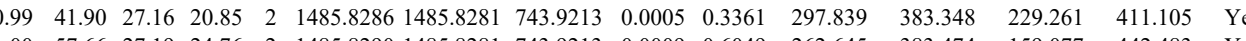

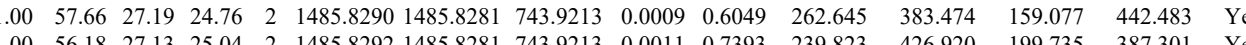
$\begin{array}{lllllllllllllll}1.00 & 56.18 & 27.13 & 25.04 & 2 & 1485.8292 & 1485.8281 & 743.9213 & 0.0011 & 0.7393 & 239.823 & 426.920 & 199.735 & 387.301 & \text { Yes }\end{array}$ $\begin{array}{llllllllllllll} & \end{array}$ $\begin{array}{lllllllllll} & \end{array}$ $\begin{array}{llllllllllll} & \end{array}$

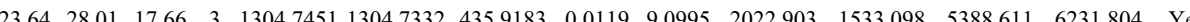

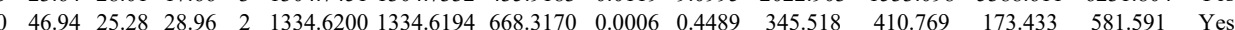

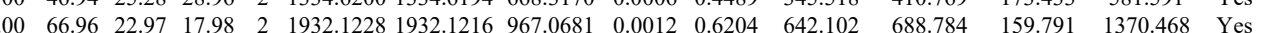
$\begin{array}{llllllllllllllll}0.82 & 68.26 & 22.97 & 81.26 & 2 & 1932.1228 & 1932.1216 & 967.0681 & 0.0012 & 0.6204 & 398.032 & 504.761 & 135.223 & 1031.032 & \text { Yes }\end{array}$

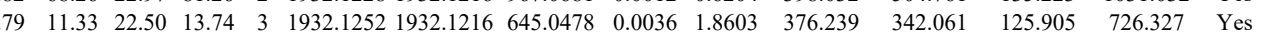
$\begin{array}{lllllllllllllll}1.00 & 45.86 & 22.53 & 16.67 & 3 & 1932.1255 & 1932.1216 & 645.0478 & 0.0039 & 2.0154 & 647.039 & 459.747 & 407.233 & 1197.369 & \text { Yes }\end{array}$ $\begin{array}{lllllllllllllll} & & \end{array}$ $\begin{array}{lllllllllllllll} & \end{array}$

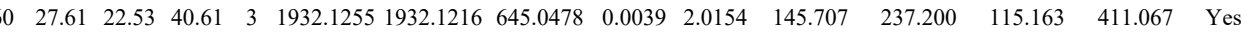

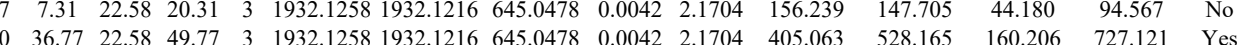
$\begin{array}{lllllllllllllll}0.82 & 69.01 & 22.92 & 82.01 & 2 & 1932.1222 & 1932.1216 & 967.0681 & 0.0006 & 0.3102 & 899.302 & 1104.307 & 180.461 & 1865.801 & \text { Yes }\end{array}$ $\begin{array}{lllllllllllllll} & 1261.112 & 255.158 & 2301.168 & \text { Yes } \\ \end{array}$

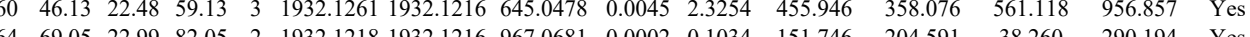

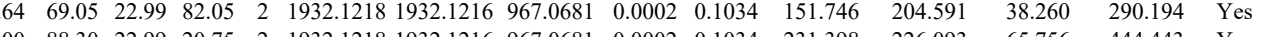
$\begin{array}{llllllllllllll} & \end{array}$ $\begin{array}{llllllllllllll} & \end{array}$

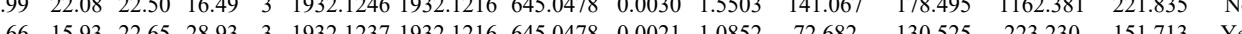

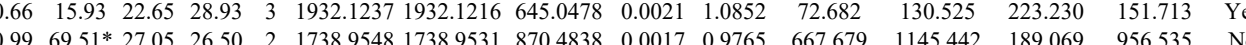

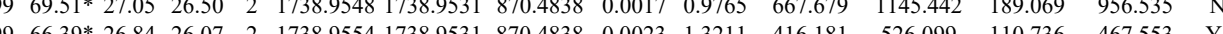

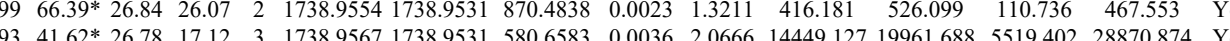
$\begin{array}{lllllllllllllll}0.67 & 54.04 & 24.13 & 67.04 & 3 & 2157.9586 & 2157.9559 & 720.3259 & 0.0027 & 1.2494 & 723.229 & 868.037 & 0.000 & 1104.463 & \text { No }\end{array}$ $\begin{array}{lllllllllllll} & \end{array}$ $\begin{array}{llllllllllllll}65.95 * 26.89 & 21.76 & 2 & 1738.9556 & 1738.9531 & 870.4838 & 0.0025 & 1.4360 & 283.806 & 231.699 & 75.079 & 400.321 & \text { Yes }\end{array}$ $\begin{array}{lllllllllllllll}0.55 & 54.29 & 24.12 & 67.29 & 3 & 2157.9574 & 2157.9559 & 720.3259 & 0.0015 & 0.6941 & 421.216 & 476.773 & 136.819 & 674.311 & \text { Yes }\end{array}$

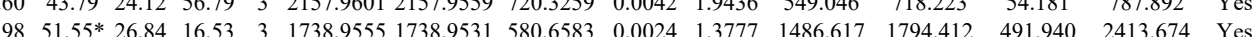
$\begin{array}{lllllllllllllll}1.00 & 70.14 & 27.29 & 24.36 & 2 & 1643.9028 & 1643.9014 & 822.9580 & 0.0014 & 0.8506 & 986.922 & 1183.095 & 0.000 & 822.829 & \mathrm{~N} 0\end{array}$ $\begin{array}{lllllllllllllll}1.00 & 72.31 & 27.10 & 33.94 & 2 & 1643.9032 & 1643.9014 & 822.9580 & 0.0018 & 1.0936 & 320.520 & 271.836 & 9.836 & 212.718 & \text { No }\end{array}$ $\begin{array}{lllllllllllllll}1.00 & 41.59 & 27.15 & 28.22 & 3 & 1643.9038 & 1643.9014 & 548.9744 & 0.0024 & 1.4573 & 124.687 & 158.695 & 33.473 & 135.302 & \text { Y }\end{array}$ $\begin{array}{lllllllllllllll}1.00 & 44.54 & 27.19 & 30.79 & 3 & 1643.9044 & 1643.9014 & 548.9744 & 0.0030 & 1.8216 & 134.679 & 134.914 & 28.310 & 136.098 & \text { Yes }\end{array}$ $\begin{array}{llllllllllllllll}1.00 & 70.33 & 27.29 & 24.98 & 2 & 1643.9026 & 1643.9014 & 822.9580 & 0.0012 & 0.7291 & 181.577 & 184.969 & 11.709 & 158.879 & \text { Yes }\end{array}$ $\begin{array}{lllllllllllllll}1.00 & 38.67 & 27.29 & 29.13 & 3 & 1643.9029 & 1643.9014 & 548.9744 & 0.0015 & 0.9108 & 116.271 & 96.170 & 54.719 & 172.408 & \text { Yes }\end{array}$ $\begin{array}{lllllllllllll} & \end{array}$

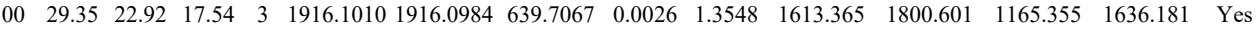

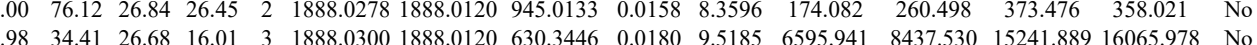

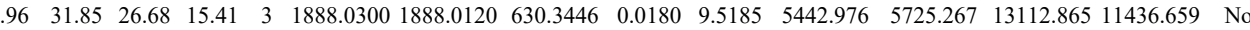

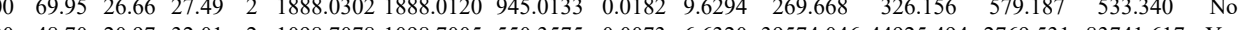
$\begin{array}{llllllllllllllll}1.00 & 48.70 & 20.97 & 32.01 & 2 & 1098.7078 & 1098.7005 & 550.3575 & 0.0073 & 6.6320 & 39574.046 & 44925.494 & 2769.531 & 83741.617 & \text { Yes }\end{array}$ $\begin{array}{lllllllllllllll}1.00 & 50.83 & 20.97 & 32.02 & 2 & 1098.7086 & 1098.7005 & 550.3575 & 0.0081 & 7.3588 & 30312.643 & 34966.699 & 3984.040 & 63261.095 & \text { Yes }\end{array}$ $\begin{array}{lllllllllllllll} & 51.43 & 26.88 & 18.77 & 3 & 1888.0276 & 1888.0120 & 630.3446 & 0.0156 & 8.2494 & 3853.486 & 3986.327 & 5089.156 & 6108.972 & \text { Yes }\end{array}$ $\begin{array}{lllllllllllllll}1.00 & 49.62 & 21.11 & 29.00 & 2 & 1098.7058 & 1098.7005 & 550.3575 & 0.0053 & 4.8150 & 41959.699 & 48782.389 & 3165.744 & 90306.689 & \text { Yes }\end{array}$

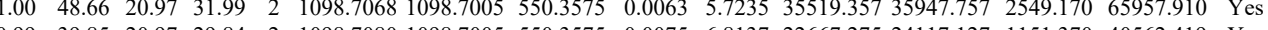
$\begin{array}{llllllllllllllll}0.99 & 39.8 & 20.97 & 29.84 & 2 & 1098.7080 & 1098.7005 & 550.3575 & 0.0075 & 6.8137 & 22667.275 & 24117.127 & 1151.370 & 40562.419 & \text { Yes }\end{array}$ $\begin{array}{lllllllllllllll}0.99 & 41.60 & 20.97 & 30.10 & 2 & 1098.7082 & 1098.7005 & 550.3575 & 0.0077 & 6.9954 & 26062.500 & 27681.522 & 1832.463 & 46405.889 & \text { Yes }\end{array}$

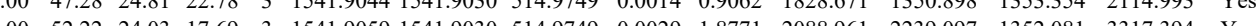
$\begin{array}{lllllllllllllll}1.00 & 52.22 & 24.03 & 17.69 & 3 & 1541.9059 & 1541.9030 & 514.9749 & 0.0029 & 1.8771 & 2088.961 & 2239.097 & 1352.081 & 3317.394 & \text { Yes }\end{array}$ $\begin{array}{lllllllllllll}\text { RL11_HUMAN } & \text { P62913 } & \text { RPL11 } & \text { 60S ribosomal pro 20.252 } & 1.00 & 4 & 28.7 & 0.0230 & 0.2388 & 1.5693 & 0.2125 & 12 & \text { N } N \text { r }\end{array}$

Table S-4 page 397 of 614 
VLEQLTGQTPVFSK VLEQLTGQTPVFSK VLEQLTGQTPVFSK VLEQLTGQTPVFSK VLEQLTGQTPVFSK
VLEQLTGQTPVFSK VLEQLTGQTPVFSK VLEQLTGQ
IAVHCTVR IAVHCTVR IAVHCTVR IAVHCTVR IAVHCTVR AEEILEK

ASGNYATVISHNPET ASGNYATVISHNPET ASGNYATVISHNPETK ASGNYATVISHNPETK IDKPILK

IDKPILK

IDKPILK

IDKPILK

IDKPILK

IDKPILK

IDKPILK

IDKPILK

IDKPILK

IDKPILK

GAGSVFR

GAGSVFR

AVVGVVAGGGR

AVVGVVAGGGR

AVVGVVAGGGR

AVVGVVAGGGR

AVVGVVAGGGR

AVVGVVAGGGR

AVVGVVAGGGR

AVVGVVAGGGR

AVVGVVAGGGR

VGLIAAR

VGLIAAR
VGLIAAR

VGLIAAR

VGLIAAR

AVVGVVAGGGR

AVVGVVAGGGR

AVVGVVAGGGR

ASGNYATVISHNPETK

AVVGVVAGGGR

AVVGVVAGGGR

AVVGVVAGGGR

AVVGVVAGGGR

PPIA_HUMAN P62937 PPIA

Peptidyl-prolyl cis $18.012 \quad 1.00 \quad 13 \quad 86.7 \quad 0.1063$

$0.3234 \quad 1.8683$

0.4395

5 FEDENFILK

ITIADCGQLE

ITIADCGQLE

ITIADCGQLE

ITIADCGQLE

ITIADCGQLE

ITIADCGQLE

ITIADCGQLE

KITIADCGQLE

KITIADCGQLE

VSFELFADK

VSFELFADK

VSFELFADK

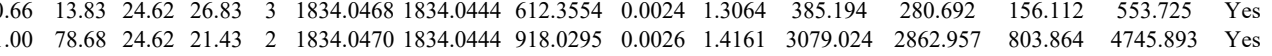
$\begin{array}{lllllllllllllllll}1.00 & 68.97 & 24.67 & 22.34 & 2 & 1834.0456 & 1834.0444 & 918.0295 & 0.0012 & 0.6536 & 3526.471 & 3271.939 & 974.017 & 6083.057 & \text { Yes }\end{array}$ \begin{tabular}{llllllllllllllll}
1.00 & 72.03 & 24.67 & 23.99 & 2 & 1834.0456 & 1834.0444 & 918.0295 & 0.0012 & 0.6536 & 4922.362 & 5288.900 & 1569.046 & 9369.132 & Yes \\
\hline
\end{tabular} $\begin{array}{llllllllllllllll}1.00 & 33.57 & 24.61 & 21.16 & 3 & 1834.0474 & 1834.0444 & 612.3554 & 0.0030 & 1.6330 & 925.596 & 1235.250 & 376.375 & 1489.500 & \text { No }\end{array}$ $\begin{array}{lllllllllllllll}0.99 & 27.74 & 24.64 & 21.56 & 3 & 1834.0483 & 1834.0444 & 612.3554 & 0.0039 & 2.1229 & 685.334 & 588.033 & 382.649 & 1099.819 & \text { Yes } \\ 0.74 & 29.07 & 27.94 & 21.04 & 2 & 1087.5836 & 1087.5752 & 544.7949 & 0.0084 & 7.7093 & 0755.731 & 13031.626 & 2671.383 & 23989.877 & \text { Yes }\end{array}$ \begin{tabular}{llllllllllllllll}
0.74 & 29.07 & 27.94 & 21.04 & 2 & 1087.5836 & 1087.5752 & 544.7949 & 0.0084 & 7.7093 & 10755.731 & 13031.626 & 2671.383 & 23989.877 & Yes \\
\hline
\end{tabular} $\begin{array}{lllllllllllllllll}0.66 & 25.78 & 27.94 & 21.31 & 2 & 1087.5842 & 1087.5752 & 544.7949 & 0.0090 & 8.2599 & 925.439 & 10723.644 & 2150.888 & 20175.287 & \text { Yes } \\ 0.84 & 29.11 & 27.73 & 21.14 & 2 & 1087.5794 & 1087.5752 & 544.7949 & 0.0042 & 3.8546 & 4803.637 & 4954.826 & 1328.802 & 9961.788 & \text { Yes }\end{array}$ $\begin{array}{lllllllllllllll}0.84 & 2.11 & 27.75 & 21.14 & 2 & 1087.5794 & 1087.5752 & 544.7949 & 0.0042 & 3.8546 & 4803.637 & 494.826 & 1328.802 & 961.788 & \text { Yes }\end{array}$

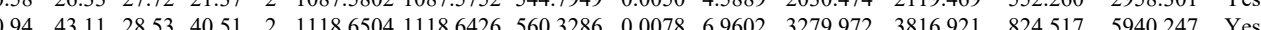

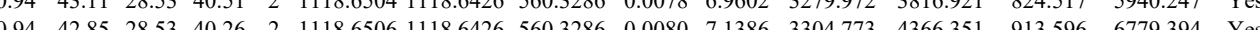

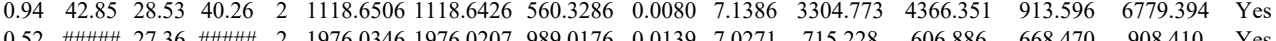
\begin{tabular}{lllllllllllllll}
1.00 & $\# \# \# 27.11$ & 20.51 & 2 & 1976.0358 & 1976.0207 & 989.0176 & 0.0151 & 7.6338 & 555.480 & 672.145 & 507.001 & 871.723 & Yes \\
\hline
\end{tabular} $\begin{array}{lllllllllllllll}1.00 & 59.66 & 27.16 & 17.78 & 3 & 1976.0359 & 1976.0207 & 659.6808 & 0.0152 & 7.6804 & 8671.067 & 11246.010 & 8915.294 & 15927.982 & \text { Yes } \\ 1.00 & 4111 & 27.44 & 24.89 & 2 & 1976.0276 & 1976.0207 & 989.0176 & 0.0069 & 3.4883 & 376.313 & 350.881 & 274.266 & 412.805 & \text { Yes }\end{array}$ $\begin{array}{lllllllllllllll}1.00 & 71.13 & 27.52 & 19.57 & 3 & 1976.0296 & 1976.0207 & 659.6808 & 0.0089 & 4.4871 & 6189.750 & 7967.750 & 5669.865 & 11551.754 & \text { Yes }\end{array}$

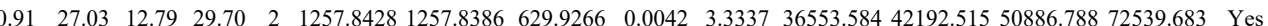

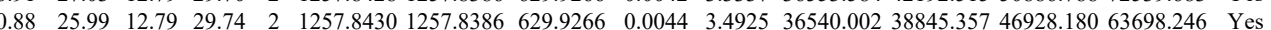

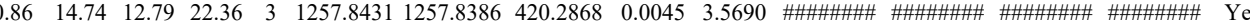

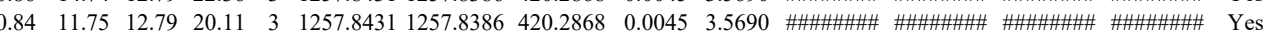

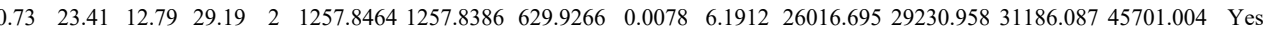

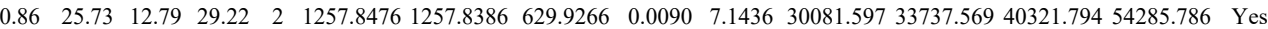
$\begin{array}{lllllllllllllll}0.99 & 35.55 & 13.62 & 35.42 & 2 & 1257.8398 & 1257.8386 & 629.9266 & 0.0012 & 0.9525 & 8107.279 & 8498.628 & 7313.084 & 9033.457 & \text { No }\end{array}$

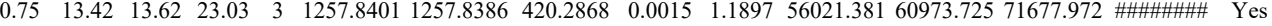
$\begin{array}{llllllllllllllll}0.88 & 18.19 & 13.62 & 26.25 & 3 & 1257.8410 & 1257.8386 & 420.2868 & 0.0024 & 1.9035 & 51264.734 & 53489.711 & 65459.111 & 97436.358 & \text { Yes }\end{array}$ $\begin{array}{llllllllllllllll}0.66 & 15.19 & 17.32 & 24.36 & 3 & 1257.8386 & 1257.8386 & 420.2868 & 0.0000 & 0.0000 & 15800.881 & 17584.999 & 19834.997 & 28401.491 & \text { Yes }\end{array}$ $\begin{array}{llllllllllllllll}0.99 & 40.34 & 27.97 & 30.29 & 2 & 836.4622 & 836.4626 & 419.2386 & -0.0004 & -0.4771 & 661.146 & 709.244 & 644.738 & 940.277 & \text { Yes }\end{array}$ $\begin{array}{llllllllllllllll}0.99 & 40.64 & 27.97 & 30.59 & 2 & 836.4624 & 836.4626 & 419.2386 & -0.0002 & -0.2385 & 590.383 & 781.948 & 697.097 & 1104.208 & \text { Yes }\end{array}$

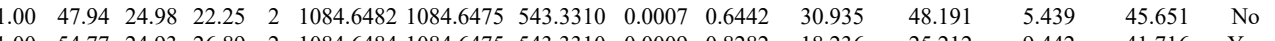
$\begin{array}{lllllllllllllll}1.00 & 54.77 & 24.93 & 26.89 & 2 & 1084.6484 & 084.6475 & 543.3310 & 0.0009 & 0.8282 & 18.236 & 25.212 & 9.442 & 41.716 & \text { Yes }\end{array}$ $\begin{array}{lllllllllllllll}1.00 & 54.70 & 25.19 & 27.78 & 2 & 1084.6488 & 1084.6475 & 543.3310 & 0.0013 & 1.1963 & 31910.138 & 48720.229 & 5464.496 & 64994.213 & \text { Yes }\end{array}$ $\begin{array}{lllllllllllllll}1.00 & 53.56 & 24.91 & 27.52 & 2 & 1084.6494 & 1084.6475 & 543.3310 & 0.0019 & 1.7485 & 15579.628 & 21764.071 & 5425.861 & 28941.287 & \text { Yes }\end{array}$

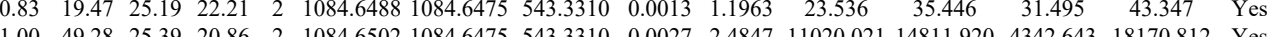
\begin{tabular}{llllllllllllllll}
1.00 & 49.28 & 25.39 & 20.86 & 2 & 1084.6502 & 1084.6475 & 543.3310 & 0.0027 & 2.4847 & 11020.021 & 14811.920 & 4342.643 & 18170.812 & Yes \\
\hline
\end{tabular} $\begin{array}{llllllllllllllll}1.00 & 50.09 & 25.39 & 22.99 & 2 & 1084.6502 & 1084.6475 & 543.3310 & 0.0027 & 2.4847 & 21859.599 & 26994.516 & 4126.170 & 43582.586 & \text { No }\end{array}$

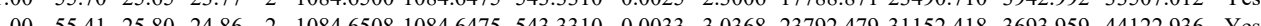

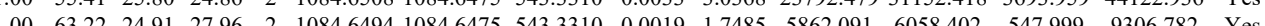

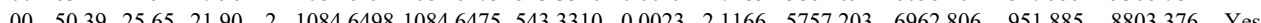
$\begin{array}{lllllllllllllll}0.99 & 41.51 & 21.34 & 35.28 & 2 & 842.5486 & 842.5460 & 422.3803 & 0.0026 & 3.0785 & 39665827 & 46886.658 & 5294.825 & 57034.584 & \text { Yes }\end{array}$ $\begin{array}{lllllllllllllll}1.00 & 39.97 & 22.30 & 31.48 & 2 & 842.5488 & 842.5460 & 4222803 & 0.0028 & 3.3153 & 25167.428 & 33486.753 & 6321.481 & 39983.851 & \text { Yes }\end{array}$

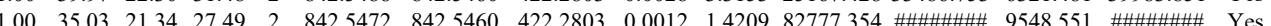
$\begin{array}{llllllllllllllll}0.99 & 36.17 & 21.34 & 34.57 & 2 & 8425476 & 8425460 & 422 & 2803 & 0.0016 & 1.8945 & 57267350 & 67598.632 & 7082.141 & 87786291 & \text { Yes }\end{array}$

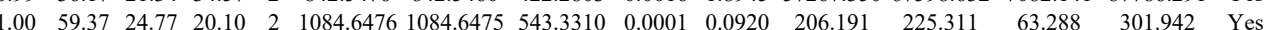

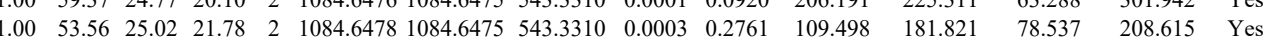
$\begin{array}{lllllllllllllll}0.82 & 31.98 & 26.04 & 17.17 & 2 & 1084.6460 & 1084.6475 & 543.3310 & -0.0015 & -1.3804 & 166.968 & 210.784 & 220.662 & 266.534 & \text { Yes }\end{array}$ $\begin{array}{lllllllllllllll}1.00 & 39.26 & 27.46 & 16.45 & 3 & 1976.0209 & 1976.0207 & 659.6808 & 0.0002 & 0.1011 & 26.789 & 55.946 & 28.606 & 69.209 & \text { No }\end{array}$ $\begin{array}{lllllllllllllll}1.00 & 45.76 & 24.77 & 17.33 & 2 & 1084.6476 & 1084.6475 & 543.3310 & 0.0001 & 0.0920 & 67.890 & 100.356 & 35.610 & 106.057 & \text { Yes }\end{array}$ $\begin{array}{lllllllllllllll}0.99 & 35.31 & 25.01 & 20.00 & 2 & 1084.6480 & 1084.6475 & 543.3310 & 0.0005 & 0.4601 & 42.883 & 54.388 & 9.429 & 67.039 & \text { Yes }\end{array}$ $\begin{array}{lllllllllllllll}1.00 & 48.55 & 25.01 & 26.25 & 2 & 1084.6480 & 1084.6475 & 543.3310 & 0.0005 & 0.4601 & 32.721 & 50.658 & 13.570 & 62.976 & \text { Yes }\end{array}$

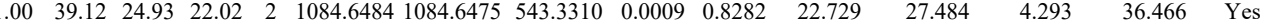

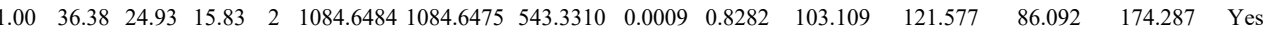

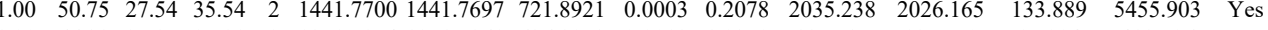
$\begin{array}{lllllllllllllll}1.00 & 66.38 & 25.95 & 25.91 & 2 & 1251.5974 & 1251.5961 & 626.8053 & 0.0013 & 1.0370 & 187.735 & 195.570 & 17.904 & 418.596 & \text { Yes }\end{array}$

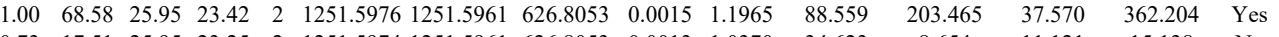

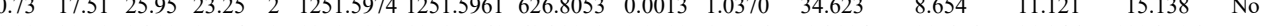
$\begin{array}{llllllllllllllll}0.98 & 30.71 & 26.02 & 27.74 & 2 & 1251.5980 & 1251.5961 & 626.8053 & 0.0019 & 1.5156 & 726.924 & 722.656 & 31.346 & 1896.796 & \text { Yes }\end{array}$

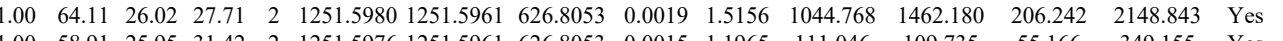

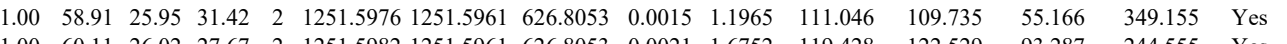
$\begin{array}{lllllllllllllll}1.00 & 60.11 & 26.02 & 27.67 & 2 & 1251.5982 & 1251.5961 & 626.8053 & 0.0021 & 1.6752 & 119.428 & 122.529 & 93.287 & 244.555 & \text { Yes } \\ 0.85 & 23.20 & 28.19 & 19.15 & 2 & 1523.7942 & 1523.7931 & 762.9038 & 0.0011 & 0.7209 & 67.394 & 87.245 & 0.000 & 18.933 & \text { No }\end{array}$

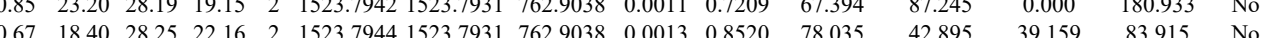

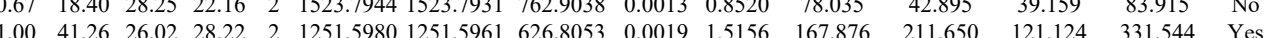

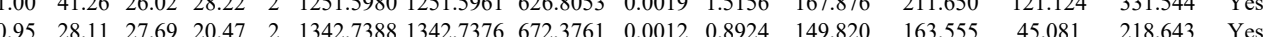

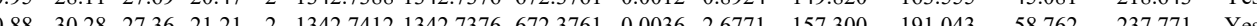
$\begin{array}{lllllllllllllll}0.99 & 46.38 & 27.47 & 26.67 & 2 & 1342.7370 & 1342.7376 & 672.3761 & -0.0006 & -0.4462 & 227.009 & 202.531 & 50.476 & 382.983 & \text { Yes }\end{array}$

Table S-4 page 398 of 614 

$\begin{array}{llllllllllllll}1.00 & 45.41 & 27.50 & 33.26 & 2 & 1342.7394 & 1342.7376 & 672.3761 & 0.0018 & 1.3385 & 255.281 & 244.836\end{array}$ $\begin{array}{llllllllllllll}1.00 & 48.93 & 27.50 & 27.19 & 2 & 1342.7394 & 1342.7376 & 672.3761 & 0.0018 & 1.3385 & 279.247 & 246.679\end{array}$ $\begin{array}{lllllllllllll}1.90 & 47.00 & 27.46 & 25.66 & 2 & 1342.7396 & 1342.7376 & 672.3761 & 0.020 & 1.4873 & 222.448 & 265.993\end{array}$ $\begin{array}{lllllllllllll}1.00 & 48.96 & 27.46 & 27.26 & 2 & 1342.7400 & 1342.7376 & 672.3761 & 0.0024 & 1.7847 & 214.329 & 250.612\end{array}$

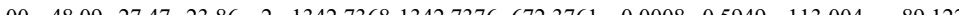

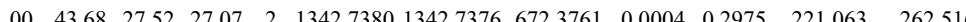
$\begin{array}{llllllllllllll}1.00 & 46.28 & 27.52 & 26.68 & 2 & 13427380 & 1342.7376 & 6723761 & 0.0004 & 02975 & 212.675 & 195.843\end{array}$ $\begin{array}{llllllllllll}1.09 & 41.42 & 27.52 & 23.91 & 2 & 1342.7380 & 1342.7376 & 672.3761 & 0.0004 & 0.2975 & 194.175 & 187.400\end{array}$ $\begin{array}{lllllllllllll}1.00 & 42.59 & 27.52 & 25.46 & 2 & 1342.7384 & 1342.7376 & 672.3761 & 0.0008 & 0.5949 & 232.970 & 195.430\end{array}$ $\begin{array}{llllllllllll}1.00 & 41.05 & 27.51 & 23.08 & 2 & 1342.7390 & 1342.7376 & 672.3761 & 0.0014 & 1.0411 & 187.307 & 223.428\end{array}$ $\begin{array}{lllllllllllll}100 & 45.31 & 27.51 & 27.97 & 2 & 1342.7392 & 1342.7376 & 672.3761 & 0.0016 & 1.1898 & 227.860 & 253.868\end{array}$ $\begin{array}{llllllllllllll}1.00 & 42.44 & 27.50 & 25.62 & 2 & 1342.7394 & 1342.7376 & 672.3761 & 0.0018 & 1.3385 & 190.337 & 177.558 & 6\end{array}$ $\begin{array}{lllllllllllll}1.00 & 48.64 & 27.46 & 26.89 & 2 & 1342.7398 & 1342.7376 & 672.3761 & 0.0022 & 1.6360 & 205.687 & 191.362\end{array}$ $\begin{array}{rlllllllllll}1.00 & 41.75 & 27.46 & 24.32 & 2 & 1342.7400 & 1342.7376 & 672.3761 & 0.0024 & 1.7847 & 109.205 & 89.978\end{array}$ $\begin{array}{llllllllllll}00 & 48.25 & 27.36 & 28.28 & 2 & 1342.7406 & 1342.7376 & 672.3761 & 0.0030 & 2.2309 & 18096.912 & 18106.770\end{array}$ $\begin{array}{lllllllllllll}1.00 & 45.63 & 27.36 & 27.92 & 2 & 1342.7408 & 1342.7376 & 672.3761 & 0.0032 & 2.3796 & 24301.240 & 28874.728\end{array}$ $\begin{array}{lllllllllllll}1.00 & 49.75 & 27.46 & 28.01 & 2 & 1342.7396 & 1342.7376 & 672.3761 & 0.0020 & 1.4873 & 9080.650 & 11911.377\end{array}$ $\begin{array}{llllllllllllll}0.97 & 32.44 & 27.43 & 24.68 & 2 & 1342.7404 & 1342.7376 & 672.3761 & 0.0028 & 2.0822 & 179.654 & 163.198 & 11 \\ 1.00 & 48.33 & 27.43 & 29.15 & 2 & 1342.7404 & 1342.7376 & 672.3761 & 0.0028 & 2.0822 & 13480.266 & 16245.075 & 0 \\ 1.00 & 46.06 & 27.5 & 27.60 & 2 & 1342.7394 & 1342.7376 & 672.3761 & 0.008 & 1.3385 & 9774.584 & 964.961 & 0 .\end{array}$ $\begin{array}{lllllllllllll}1.00 & 48.33 & 27.43 & 29.15 & 2 & 1342.7404 & 1342.7376 & 672.3761 & 0.0028 & 2.0822 & 13480.266 & 16245.075 \\ 1.00 & 46.06 & 27.50 & 27.60 & 2 & 1342.7394 & 1342.7376 & 672.3761 & 0.0018 & 1.3385 & 9774.584 & 9614.961\end{array}$ $\begin{array}{llllllllllllll}1.00 & 47.38 & 27.46 & 27.70 & 2 & 1342.7400 & 1342.7376 & 672.3761 & 0.0024 & 1.7847 & 8857.124 & 8994.956\end{array}$ $\begin{array}{llllllllllll}1.00 & 53.32 & 27.42 & 26.93 & 2 & 1441.7690 & 1441.7697 & 721.8921 & -0.0007 & -0.4848 & 46.048 & 65.532\end{array}$ $\begin{array}{lllllllllllll}0.98 & 40.15 & 27.42 & 23.12 & 2 & 1441.7690 & 1441.7697 & 721.8921 & -0.0007 & -0.4848 & 30.504 & 30.306\end{array}$

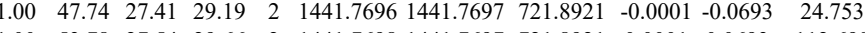
$\begin{array}{llllllllllll}\text { FEDENFILK } & 0.96 & 35.52 & 27.33 & 20.20 & 2 & 1441.7732 & 1441.7697 & 721.8921 & 0.0035 & 2.4242 & 40.486 \\ \text { VNPTVFFDIAVDGEPLGR } & 1.00 & 88.88 & 27.46 & 20.36 & 2 & 2089.0974 & 2089.0966 & 1045.5556 & 0.0008 & 0.3826 & 249.405\end{array}$ $\begin{array}{lllllllllll}1.00 & 53.78 & 27.54 & 29.66 & 2 & 1441.7698 & 1441.7697 & 721.8921 & 0.0001 & 0.0693 & 112.698\end{array}$

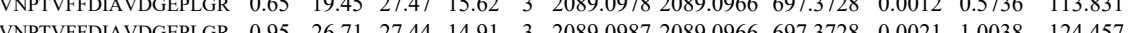
$\begin{array}{lllllllllllll}\text { VNPTVFDIAVDGEPLGR } & 0.95 & 26.71 & 27.44 & 14.91 & 3 & 2089.0987 & 2089.0966 & 697.3728 & 0.0021 & 1.0038 & 124.457\end{array}$

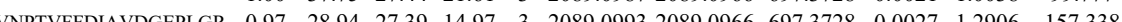

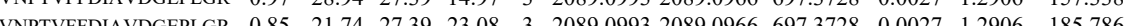

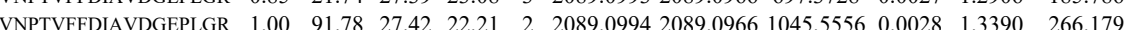
$\begin{array}{lllllllllllllll} & 20.045 .5556 & 0.0028 & 1.3390 & 1140.107 & 2055.814\end{array}$ $\begin{array}{lllllllllllll}\text { NPPTVFPIAVDGEPLGR } & 1.00 & \# \# \# \# 27.42 & 25.09 & 2 & 2089.0994 & 2089.0966 & 1045.5556 & 0.0028 & 1.3390 & 2317.324 & 4290.974 \\ \text { VNPTVFFDIAVDGEPLGR } & 1.00 & 52.73 & 27.41 & 18.14 & 3 & 2089.0996 & 2089.0966 & 697.3728 & 0.0030 & 1.4340 & 139.885 & 107.181\end{array}$ $\begin{array}{lllllllllllll}\text { VNPTVFFDIAVDGEPLGR } & 0.99 & 34.95 & 27.36 & 15.78 & 3 & 2089.1002 & 2089.0966 & 697.3728 & 0.0036 & 1.7207 & 97.611 & 77\end{array}$ $\begin{array}{lllllllllllll}\text { VNPTVFFDIAVDGEPLGR } & 1.00 & 53.86 & 27.36 & 19.01 & 3 & 2089.1002 & 2089.0966 & 697.3728 & 0.0036 & 1.7207 & 97.611 \\ \text { VPTVE } & 0.0036 & 1.7207 & 7.500\end{array}$ $\begin{array}{llllllllllllll}\text { VNPTVFFDIAVDGEPLGR } & 1.00 & 40.31 & 27.42 & 18.66 & 3 & 2089.1017 & 2089.0966 & 697.3728 & 0.0051 & 2.4377 & 96.439\end{array}$ $\begin{array}{lllllllllllll}\text { MVNPTVFFDIAVDGEPLGR } & 0.55 & 24.88 & 27.82 & 37.88 & 3 & 2220.1378 & 2220.1371 & 741.0530 & 0.0007 & 0.3149 & 90.734\end{array}$ $\begin{array}{llllllllllll}\text { MVNPTVFFDIAVDGEPLGR } & 0.55 & 24.05 & 27.83 & 37.05 & 3 & 2220.1381 & 2220.1371 & 741.0530 & 0.0010 & 0.4498 & 94.562\end{array}$ $\begin{array}{lllllllllllll}\text { VNPTVFFDIAVDGEPLGR } & 1.00 & 50.84 & 27.46 & 19.74 & 3 & 2089.0963 & 2089.0966 & 697.3728 & -0.0003 & -0.1434 & 21.916\end{array}$ $\begin{array}{lllllllllllll}\text { VNPTVFFDIAVDGEPLGR } & 1.00 & 98.63 & 27.46 & 21.94 & 2 & 2089.0974 & 2089.0966 & 1045.5556 & 0.0008 & 0.3826 & 870.238 & 1728\end{array}$ $\begin{array}{llllllllllllll}\text { VNPTVFFDIAVDGEPLGR } & 1.00 & 91.98 & 27.46 & 21.93 & 2 & 2089.0974 & 2089.0966 & 1045.5556 & 0.0008 & 0.3826 & 2110.998 & 1288\end{array}$ $\begin{array}{lllllllllllll}\text { VNPTVFFDIAVDGEPLGR } & 0.98 & 33.41 & 27.46 & 21.89 & 3 & 2089.0975 & 2089.0966 & 697.3728 & 0.0009 & 0.4302 & 73.422 \\ \text { VNPTVFFDIAVDGEPLGR } & 0.99 & 31.68 & 27.44 & 16.01 & 3 & 2089.0987 & 2089.0966 & 697.3728 & 0.0021 & 1.0038 & 86.556\end{array}$ $\begin{array}{lllllllllllll}\text { VNPTVFFDIAVDGEPLGR } & 0.66 & 17.64 & 27.39 & 17.35 & 3 & 2089.0993 & 2089.0966 & 697.3728 & 0.0027 & 1.2906 & 157.799 & 22\end{array}$ $\begin{array}{llllllllllllll}\text { VNPTVFFDIAVDGEPLGR } & 0.90 & 24.69 & 27.40 & 15.19 & 3 & 2089.1005 & 2089.0966 & 697.3728 & 0.0039 & 1.8641 & 82.784 & 81 \\ \text { MVNPTVFFDIAVDGEPLGR } & 0.66 & 37.79 & 27.77 & 50.79 & 3 & 2220.1390 & 2220.1371 & 741.0530 & 0.0019 & 0.8546 & 30.147 & 31\end{array}$ $\begin{array}{llllllllllll}\text { MVNPTVFFDIAVDGEPLGR } & 0.66 & 37.79 & 27.77 & 50.79 & 3 & 2220.1390 & 2220.1371 & 741.0530 & 0.0019 & 0.8546 & 30.147 \\ \text { MVNPTVFFDIAVDGEPLGR } & 0.84 & 95.21 & 27.80 & \# \# \# \# & 2 & 2220.1394 & 2220.1371 & 1111.0758 & 0.0023 & 1.0350 & 165.294\end{array}$

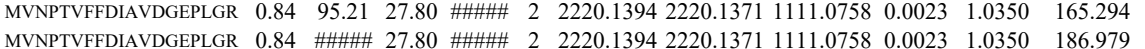
$\begin{array}{llllllllllll}\text { MVNPTVFFDIAVDGEPLGR } & 0.84 & \text { \#\#\#\# } & 27.80 & \text { \#\#\#\# } & 2 & 2220.1394 & 2220.1371 & 1111.0758 & 0.0023 & 1.0350 & 186.979 \\ \text { MVNPTVFFDIAVDGEPLGR } & 0.67 & 44.73 & 27.83 & 57.73 & 3 & 2220.1402 & 2220.1371 & 741.0530 & 0.0031 & 1.3944 & 10.361\end{array}$ $\begin{array}{lllllllllllll}\text { MVNPTVFFDIAVDGEPLGR } & 0.67 & 44.73 & 27.83 & 57.73 & 3 & 2220.1402 & 2220.1371 & 741.0530 & 0.0031 & 1.3944 & 10.361 \\ \text { VNPTVFFDIAVDGEPLGR } & 1.00 & 73.33 & 27.46 & 20.94 & 2 & 2089.0974 & 2089.0966 & 1045.5556 & 0.0008 & 0.3826 & 774.916\end{array}$ $\begin{array}{lllllllllllll}\text { VNPTVFFDIAVDGEPLGR } & 1.00 & 73.33 & 27.46 & 20.94 & 2 & 2089.0974 & 2089.0966 & 1045.5556 & 0.0008 & 0.3826 & 774.916 \\ \text { VNPTVFFDIAVDGEPLGR } & 1.00 & 89.35 & 27.42 & 22.50 & 2 & 2089.0994 & 2089.0966 & 1045.5556 & 0.0028 & 1.3390 & 569.632 & 73\end{array}$

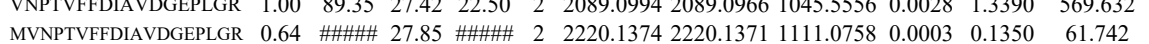

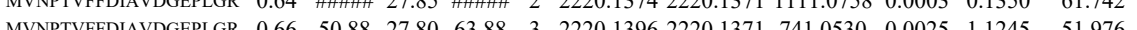
$\begin{array}{llllllllllll}\text { MVNPTVFFDIAVDGEPLGR } & 0.66 & 50.88 & 27.80 & 63.88 & 3 & 2220.1396 & 2220.1371 & 741.0530 & 0.0025 & 1.1245 & 51.976 \\ \text { MVNPTVFFDIAVDGEPLGR } & 1.00 & 53.45 & 27.82 & 23.55 & 3 & 2220.1411 & 2220.1371 & 741.0530 & 0.0040 & 1.7992 & 27.646\end{array}$ $\begin{array}{lllllllllllll}\text { VNPTVFFDIAVDGEPLGR } & 1.00 & 72.76 & 27.46 & 19.34 & 2 & 2089.0974 & 2089.0966 & 1045.5556 & 0.0008 & 0.3826 & 118.535\end{array}$ $\begin{array}{lllllllllllll}\text { GSCFHR } & 0.60 & 14.11 & 20.97 & 22.53 & 2 & 895.3918 & 895.3915 & 448.7030 & 0.0003 & 0.3343 & 127.325\end{array}$ $\begin{array}{lllllllllllllll} & \text { VNPTVFFDIAVDGEPLGR } & 0.75 & 19.19 & 27.39 & 18.02 & 3 & 2089.0993 & 2089.0966 & 697.3728 & 0.0027 & 1.2906 & 1080.341 & 869.906\end{array}$ 

$\begin{array}{llllllllllll}0.90 & 11.46 & 26.48 & 14.95 & 4 & 3067.4933 & 3067.4922 & 767.8803 & 0.0011 & 0.3581 & 44.826\end{array}$

\section{IIPGFMCQGGDFTR}

IIPGFMCQGGDFTR

$\begin{array}{llllllllllll} & 1730.8044 & 1730.8065 & 866.4105 & -0.0021 & -1.2119 & 70.547\end{array}$

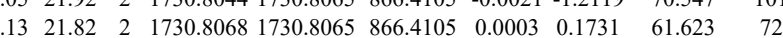

$\begin{array}{lllllllllllll}0.97 & 33.65 & 26.13 & 21.82 & 2 & 173.8068 & 1730.8065 & 86.4105 & 0.003 & 0.1731 & 61.623 & 72.985\end{array}$

$\begin{array}{llllllllllll}65.60 & 26.24 & 20.04 & 2 & 1730.8082 & 1730.8065 & 866.4105 & 0.0017 & 0.9811 & 13875.366 & 15934.802 \\ 33.93 & 26.40 & 15.49 & 3 & 1730.8096 & 1730.8065 & 577.9428 & 0.0031 & 1.7879 & 140.357 & 204.174\end{array}$

$\begin{array}{llllllllllll}0.60 & 46.08 & 26.40 & 59.08 & 3 & 1730.8102 & 1730.8065 & 577.9428 & 0.0037 & 2.1340 & 354.248 & 165.986\end{array}$

$\begin{array}{llllllllllll}1.00 & 88.98 & 26.47 & 19.28 & 3 & 3067.4932 & 3067.4922 & 1023.5047 & 0.0010 & 0.3257 & 365.359 & 276.010 \\ 1.00 & 78.69 & 26.14 & 28.27 & 2 & 1730.8064 & 1730.8065 & 866.4105 & -0.0001 & -0.0577 & 6423.942 & 6002.282\end{array}$

$\begin{array}{lllllllllllll}1.00 & 78.69 & 26.14 & 28.27 & 2 & 1730.8064 & 1730.8065 & 866.4105 & -0.0001 & -0.0577 & 6423.942 & 6002.282 \\ 1.00 & 73.50 & 26.13 & 27.65 & 2 & 1730.8068 & 1730.8065 & 866.4105 & 0.0003 & 0.1731 & 989.980 & 1213.330\end{array}$

$\begin{array}{llllllllllll}1.00 & 65.26 & 26.22 & 22.28 & 2 & 1730.8070 & 1730.8065 & 866.4105 & 0.0005 & 0.2885 & 1444.305 & 1445.546\end{array}$ $\begin{array}{llllllllllll}0.98 & 14.82 & 26.48 & 27.82 & 4 & 3067.4933 & 3067.4922 & 767.8803 & 0.0011 & 0.3581 & 6.595\end{array}$

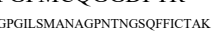

$\begin{array}{llllllllllll}1.00 & 52.65 & 26.15 & 24.94 & 2 & 1730.8066 & 1730.8065 & 866.4105 & 0.0001 & 0.0577 & 92.422\end{array}$

FEDENFILK

$\begin{array}{llll}1.00 & 49.79 & 26.23 & 25.32\end{array}$

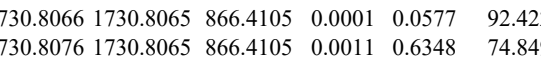

$\begin{array}{lllllllllll}1.00 & 49.79 & 26.23 & 25.32 & 2 & 1730.8076 & 1730.8065 & 866.4105 & 0.0011 & 0.6348 & 74.849\end{array}$

IIPGFMCQGGDFTR

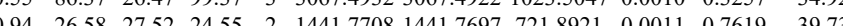

IIPGFMCQGGDFTR

HTGPGLSMANAGPNTNGSQFFICTAK

IIPGFMCQGGDFTR

IIPGFMCQGGDFTR $\begin{array}{lllllllllllll}99 & 32.51 & 26.22 & 24.42 & 2 & 1730.8070 & 1730.8065 & 866.4105 & 0.0005 & 0.2885 & 53.674\end{array}$ $\begin{array}{llllllllllll}1.00 & 58.80 & 26.23 & 26.30 & 2 & 1730.8076 & 1730.8065 & 866.4105 & 0.0011 & 0.6348 & 39.841\end{array}$ $\begin{array}{llllllllllll}1.00 & 86.65 & 26.47 & 22.71 & 3 & 3067.4932 & 3067.4922 & 1023.5047 & 0.0010 & 0.3257 & 15.195\end{array}$ $\begin{array}{lllllllllll}1.00 & 81.85 & 26.47 & 22.38 & 3 & 3067.4932 & 3067.4922 & 1023.5047 & 0.0010 & 0.3257 & 14.219 \\ 1.00 & 48.52 & 26.23 & 23.07 & 2 & 1730.8076 & 1730.8065 & 866.4105 & 0.0011 & 0.6348 & 33.017\end{array}$ $\begin{array}{lllllllllll}1.00 & 48.52 & 26.23 & 23.07 & 2 & 1730.8076 & 1730.8065 & 866.4105 & 0.0011 & 0.6348 & 33.017 \\ 1.00 & 64.52 & 26.24 & 26.23 & 2 & 1730.8082 & 1730.8065 & 866.4105 & 0.0017 & 0.9811 & 54.068\end{array}$ $\begin{array}{lllllllllllll}1.00 & 62.00 & 26.22 & 26.44 & 2 & 1730.8070 & 1730.8065 & 866.4105 & 0.0005 & 0.2885 & 44.800\end{array}$ $\begin{array}{lllllllllllll}1.00 & 62.00 & 26.22 & 26.44 & 2 & 1730.8070 & 1730.8065 & 866.4105 & 0.0005 & 0.2885 & 47.800 \\ 1.00 & 47.37 & 26.15 & 24.73 & 2 & 1730.8066 & 1730.8065 & 866.4105 & 0.0001 & 0.0577 & 47.429\end{array}$ IIPGFMCQGGD
VSFELFADK $\begin{array}{lllllllllllll}1.00 & 76.00 & 26.27 & 27.02 & 2 & 1730.8072 & 1730.8065 & 866.4105 & 0.0007 & 0.4040 & 129.422 \\ 1.00 & 40.00 & 27.69 & 24.68 & 2 & 1342.7388 & 1342.7376 & 672.3761 & 0.0012 & 0.8924 & 65.818\end{array}$

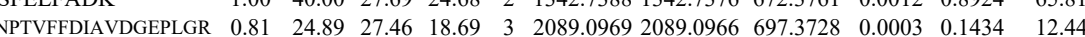
$\begin{array}{lllllllllllll}\text { VNPTVFFDIAVDGEPLGR } & 0.67 & 17.99 & 27.43 & 16.70 & 3 & 2089.0984 & 2089.0966 & 697.3728 & 0.0018 & 0.8604 & 7.880\end{array}$ $\begin{array}{llllllllllllll}\text { VNPTVFFDIAVDGEPLGR } & 0.97 & 30.34 & 27.47 & 16.54 & 3 & 2089.0978 & 2089.0966 & 697.3728 & 0.0012 & 0.5736 & 8.548\end{array}$ $\begin{array}{llllllllllll}\text { VNPTVFDIAVDGEPLGR } & 0.98 & 31.12 & 27.39 & 16.95 & 3 & 2089.0993 & 2089.0966 & 697.3728 & 0.0027 & 1.2906 & 11.788\end{array}$ VNPTVFFDIAVDGEPLGR SIYGEK

SIYGEK

SIYGEK

ALSTGEK

ALSTGEK

TEWLDGK

TEWLDGK

TEWLDGK

TEWLDGK

TEWLAK

TEWLDGK $\begin{array}{llllll}2089.0993 & 2089.0966 & 697.3728 & 0.0027 & 1.2906 & 4.209\end{array}$ $\begin{array}{llllllllllll}0.99 & 39.25 & 26.67 & 28.91 & 2 & 983.5534 & 983.5531 & 492.7838 & 0.0003 & 0.3044 & 48.146 \\ 0.99 & 38.48 & 26.67 & 28.32 & 2 & 983.5534 & 983.5531 & 492.7838 & 0.0003 & 0.3044 & 68.624\end{array}$ $\begin{array}{llllllllllll}0.99 & 38.48 & 26.67 & 28.32 & 2 & 983.5534 & 983.5531 & 492.7838 & 0.0003 & 0.3044 & 68.624 \\ 0.99 & 35.99 & 27.58 & 27.05 & 2 & 983.5544 & 983.5531 & 492.7838 & 0.0013 & 1.3190 & 1547.162\end{array}$ $\begin{array}{lllllllllllll}0.99 & 35.99 & 27.58 & 27.05 & 2 & 983.5544 & 983.5531 & 492.7838 & 0.0013 & 1.3190 & 1547.162 \\ 0.97 & 29.77 & 27.60 & 27.76 & 2 & 992.5752 & 992.5746 & 497.2946 & 0.0006 & 0.6033 & 833.062\end{array}$ $\begin{array}{lllllllllllll}0.97 & 29.77 & 27.60 & 27.76 & 2 & 992.5752 & 992.5746 & 497.2946 & 0.0006 & 0.6033 & 833.062\end{array}$ $\begin{array}{lllllllllllll}0.97 & 30.05 & 27.60 & 28.74 & 2 & 992.5752 & 992.5746 & 497.2946 & 0.0006 & 0.6033 & 823.596\end{array}$ $\begin{array}{llllllllllll}0.63 & 22.33 & 28.67 & 20.57 & 2 & 1135.6116 & 1135.6117 & 568.8131 & -0.0001 & -0.0879 & 171.018 \\ 0.95 & 32.67 & 28.67 & 23.67 & 2 & 1135.6120 & 1135.6117 & 568.8131 & 0.0003 & 0.2637 & 245.960\end{array}$ $\begin{array}{lllllllllll}0.95 & 32.67 & 28.67 & 23.67 & 2 & 1135.6120 & 1135.6117 & 568.8131 & 0.0003 & 0.2637 & 245.960 \\ 0.96 & 30.43 & 28.86 & 23.19 & 2 & 1135.6124 & 1135.6117 & 568.8131 & 0.0007 & 0.6153 & 158.147\end{array}$ $\begin{array}{lllllllllll}0.96 & 30.43 & 28.86 & 33.19 & 2 & 1135.6124 & 135.6177 & 568.8131 & 0.0007 & 0.6153 & 158.147 \\ 0.98 & 33.48 & 28.83 & 26.04 & 2 & 1135.6130 & 1135.6117 & 568.8131 & 0.0013 & 1.1427 & 223.271\end{array}$ $\begin{array}{lllllllllll}0.96 & 29.40 & 28.76 & 23.78 & 2 & 1135.6140 & 1135.6117 & 568.8131 & 0.0023 & 2.0217 & 141.734\end{array}$ $\begin{array}{lllllllllll}0.68 & 21.14 & 28.15 & 22.24 & 2 & 1135.6148 & 1135.6117 & 5688.8131 & 0.0031 & 2.7250 & 187.535\end{array}$ $\begin{array}{lllllllllllll}0.69 & 21.76 & 28.49 & 23.83 & 2 & 1135.6150 & 1135.6117 & 568.8131 & 0.0033 & 2.9008 & 164.477\end{array}$ 


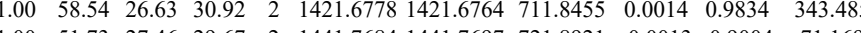
$\begin{array}{lllllllllll}1.00 & 51.73 & 27.46 & 29.67 & 2 & 1441.7684 & 1441.7697 & 721.8921 & -0.0013 & -0.9004 & 71.169 \\ 1.00 & 48.72 & 27.42 & 27.57 & 2 & 1441.7690 & 1441.7697 & 721.8921 & -0.0007 & -0.4848 & 61.031\end{array}$ $\begin{array}{lllllllllll}1.00 & 48.72 & 27.42 & 27.57 & 2 & 1441.7690 & 1441.7697 & 721.8921 & -0.0007 & -0.4848 & 61.031 \\ 1.00 & 52.05 & 27.42 & 26.87 & 2 & 1441.7690 & 1441.7697 & 721.8921 & -0.0007 & -0.4848 & 69.852\end{array}$

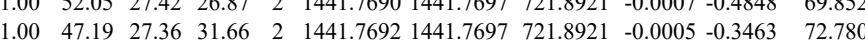
$\begin{array}{lllllllllll}1.00 & 47.48 & 27.54 & 24.70 & 2 & 1441.7698 & 1441.7697 & 721.8921 & 0.0001 & 0.0693 & 64.382\end{array}$ $\begin{array}{lllllllllll}1.00 & 4.382\end{array}$

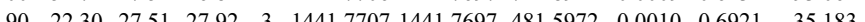
$\begin{array}{lllllllllll}1.00 & 48.14 & 27.52 & 32.21 & 2 & 1441.7708 & 1441.7697 & 721.8921 & 0.0011 & 0.7619 & 48.039\end{array}$ $\begin{array}{lllllllllll}1.00 & 49.81 & 27.36 & 28.11 & 2 & 1441.7710 & 1441.7697 & 721.8921 & 0.0013 & 0.9004 & 76.388\end{array}$ $\begin{array}{lllllllllll}1.00 & 52.24 & 27.36 & 39.31 & 2 & 1441.7712 & 1441.7697 & 721.8921 & 0.0015 & 1.0389 & 1419.069\end{array}$ $\begin{array}{lllllllllll}1.00 & 43.78 & 27.35 & 28.44 & 2 & 1441.7714 & 1441.7697 & 721.8921 & 0.0017 & 1.1775 & 58.200 \\ \end{array}$ $\begin{array}{llllllllllll}1.00 & 38.81 & 27.34 & 31.54 & 2 & 1441.714 & 1441.7697 & 721.8921 & 0.0019 & 1.3160 & 86.475 \\ 0.98 & 32.36 & 27.34 & 29.24 & 2 & 1441.7716 & 1441.7697 & 721.8921 & 0.0019 & 1.3160 & 75.892\end{array}$ $\begin{array}{llllllllllll}1.00 & 38.03 & 27.33 & 26.67 & 2 & 1441.7718 & 1441.7697 & 721.8921 & 0.0021 & 1.4545 & 65.490\end{array}$ $\begin{array}{lllllllllllll}0.84 & 16.50 & 27.32 & 25.75 & 3 & 1441.7719 & 1441.7697 & 481.5972 & 0.0022 & 1.5227 & 36.358\end{array}$ $\begin{array}{llllllllllll}0.99 & 38.22 & 27.23 & 24.38 & 2 & 1441.7722 & 1441.7697 & 721.8921 & 0.0025 & 1.7316 & 94.424\end{array}$ $\begin{array}{llllllllllll}0.99 & 36.17 & 27.23 & 27.36 & 2 & 1441.7722 & 1441.7697 & 721.8921 & 0.0025 & 1.7316 & 66.595\end{array}$ $\begin{array}{lllllllllll}1.00 & 54.68 & 27.23 & 35.36 & 2 & 1441.7722 & 1441.7697 & 721.8921 & 0.0025 & 1.7316 & 7339.104\end{array}$ $\begin{array}{llllllllllll} & 99 & 38.48 & 27.22 & 30.07 & 2 & 1441.7724 & 1441.7697 & 721.8921 & 0.0027 & 1.8701 & 70.786\end{array}$ $\begin{array}{llllllllllll}0.94 & 29.39 & 27.10 & 26.13 & 2 & 1441.7728 & 1441.7697 & 721.8921 & 0.0031 & 2.1471 & 50.279\end{array}$ $\begin{array}{lllllllllllll}0.58 & 14.52 & 25.97 & 15.03 & 2 & 1251.5972 & 1251.5961 & 626.8053 & 0.0011 & 0.8775 & 7.695 \\ 0.83 & 24.99 & 26.67 & 27.55 & 2 & 983.5528 & 983.5531 & 492.7838 & 0.0003 & -0.3044 & 45.953\end{array}$ $\begin{array}{llllllllllll}0.83 & 24.99 & 26.67 & 27.55 & 2 & 983.5528 & 983.5531 & 492.7838 & -0.0003 & -0.3044 & 45.953 \\ 0.93 & 36.9 & 28.63 & 26.80 & 2 & 135.6110 & 1135.6117 & 568.8131 & -0.0007 & -0.6153 & 291.820\end{array}$ $\begin{array}{lllllllllll}0.93 & 36.29 & 28.63 & 26.80 & 2 & 1135.6110 & 1135.6117 & 568.8131 & -0.0007 & -0.6153 & 291.820 \\ 0.91 & 34.88 & 28.63 & 25.54 & 2 & 1135.6112 & 1135.6117 & 568.8131 & -0.0005 & -0.4395 & 156.215\end{array}$ $\begin{array}{llllllllllll}0.91 & 34.88 & 28.63 & 25.54 & 2 & 1135.6112 & 1135.6117 & 568.8131 & -0.0005 & -0.4395 & 156.215 & \\ 0.86 & 27.90 & 28.67 & 28.44 & 2 & 1135.6116 & 1135.6117 & 568.8131 & -0.0001 & -0.0879 & 379.071 & \\ 0.98 & 38.51 & 28.67 & 27.11 & 2 & 135.618 & 135.6117 & 568.813 & 0.000 & 0.0879 & 13.15 & \end{array}$ $\begin{array}{llllllllllll}0.86 & 27.90 & 28.67 & 28.44 & 2 & 1135.6116 & 1135.6117 & 568.8131 & -0.0001 & -0.0879 & 379.071 \\ 0.98 & 38.51 & 28.67 & 27.11 & 2 & 1135.6118 & 1135.6117 & 568.8131 & 0.0001 & 0.0879 & 131.115\end{array}$ $\begin{array}{llllllllllll}0.98 & 38.51 & 28.67 & 27.11 & 2 & 1135.6118 & 1135.6117 & 568.8131 & 0.0001 & 0.0879 & 131.115 & 14 \\ 0.97 & 35.77 & 28.67 & 26.59 & 2 & 1135.6120 & 1135.6117 & 568.8131 & 0.0003 & 0.2637 & 291.992 & 26\end{array}$ $\begin{array}{lllllllllll}0.97 & 35.77 & 28.67 & 26.59 & 2 & 1135.6120 & 1135.6117 & 568.8131 & 0.0003 & 0.2637 & 291.992 \\ 0.98 & 38.56 & 28.67 & 28.79 & 2 & 1135.6120 & 1135.6117 & 568.8131 & 0.0003 & 0.2637 & 438.791\end{array}$

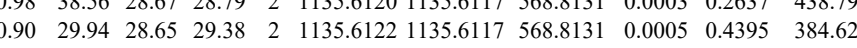
$\begin{array}{llllllllllll}0.88 & 28.70 & 28.65 & 25.28 & 2 & 1135.6122 & 1135.6117 & 568.8131 & 0.0005 & 0.4395 & 331.286 \\ 0.97 & 35.65 & 28.65 & 27.49 & 2 & 1135.6122 & 1135.6117 & 568.8131 & 0.0005 & 0.4395 & 255.184\end{array}$ $\begin{array}{llllllllllll}0.97 & 35.65 & 28.65 & 27.49 & 2 & 1135.6122 & 1135.6117 & 568.8131 & 0.0005 & 0.4395 & 255.184 \\ 0.97 & 35.99 & 28.65 & 26.41 & 2 & 1135.6122 & 1135.6117 & 568.8131 & 0.0005 & 0.4395 & 327.851\end{array}$ $\begin{array}{lllllllllll}0.89 & 25.13 & 28.86 & 25.11 & 2 & 1135.6124 & 1135.6117 & 568.8131 & 0.0007 & 0.6153 & 328.583\end{array}$ $\begin{array}{lllllllllll}0.99 & 37.04 & 28.86 & 28.84 & 2 & 1135.6124 & 1135.6117 & 568.8131 & 0.0007 & 0.6153 & 341.608\end{array}$ $\begin{array}{llllllllllll}0.86 & 24.23 & 28.86 & 23.69 & 2 & 1135.6124 & 1135.6117 & 568.8131 & 0.0007 & 0.6153 & 44.971\end{array}$ $\begin{array}{lllllllllllll}0.99 & 35.89 & 28.84 & 26.45 & 2 & 1135.6126 & 1135.6117 & 568.8131 & 0.0009 & 0.7911 & 384.745\end{array}$ $\begin{array}{llllllllllll}0.99 & 38.31 & 28.84 & 29.40 & 2 & 1135.6126 & 1135.6117 & 568.8131 & 0.0009 & 0.7911 & 337.853\end{array}$ $\begin{array}{lllllllllllll}0.99 & 40.23 & 28.83 & 38.87 & 2 & 1135.6128 & 135.6117 & 588.8131 & 0.009 & 0.7911 & 33.853\end{array}$

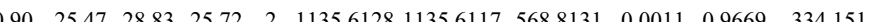

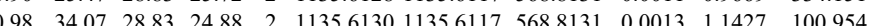
$\begin{array}{lllllllllll}0.89 & 25.16 & 28.84 & 25.41 & 2 & 1135.6132 & 1135.6117 & 568.8131 & 0.0015 & 1.3185 & 307.315\end{array}$ $\begin{array}{lllllllllllll}0.99 & 35.26 & 28.88 & 28.21 & 2 & 1135.6134 & 1135.6117 & 568.8131 & 0.0017 & 1.4943 & 268.354\end{array}$ $\begin{array}{lllllllllll}0.99 & 38.61 & 28.88 & 29.08 & 2 & 1135.6134 & 1135.6117 & 568.8131 & 0.0017 & 1.4943 & 366.163\end{array}$ $\begin{array}{llllllllllllll}0.99 & 37.53 & 28.76 & 25.48 & 2 & 1135.6140 & 1135.6117 & 568.8131 & 0.0023 & 2.0217 & 3472.518 & 4131.214 & 916.771\end{array}$ $\begin{array}{llllllllllll}0.93 & 37.06 & 28.44 & 32.26 & 2 & 1135.6166 & 1135.6117 & 568.8131 & 0.0049 & 4.3072 & 17647.456 & 16339.592\end{array}$ $\begin{array}{llllllllllll}0.91 & 32.55 & 28.06 & 28.97 & 2 & 1135.6224 & 1135.6117 & 568.8131 & 0.0107 & 9.4055 & 4898.446 & 5022.347 \\ 1.00 & 55.90 & 27.36 & 32.51 & 2 & 1441.7692 & 1441.7697 & 721.8921 & -0.0005 & -0.3463 & 87.760 & 98.706\end{array}$

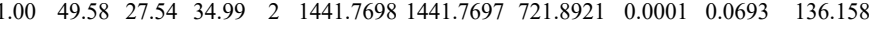
$\begin{array}{llllllllllll}0.99 & 42.04 & 27.54 & 26.80 & 2 & 1441.7700 & 1441.7697 & 721.8921 & 0.0003 & 0.2078 & 37.595\end{array}$ $\begin{array}{llllllllllll}1.00 & 51.82 & 27.50 & 31.99 & 2 & 1441.7702 & 1441.7697 & 721.8921 & 0.0005 & 0.3463 & 56.037\end{array}$ $\begin{array}{llllllllllll}0.58 & 18.64 & 27.50 & 31.23 & 3 & 1441.7704 & 1441.7697 & 481.5972 & 0.0007 & 0.4845 & 91.635\end{array}$ $\begin{array}{lllllllllll}0.83 & 18.33 & 27.50 & 24.93 & 3 & 1441.7704 & 1441.7697 & 481.5972 & 0.0007 & 0.4845 & 104.812\end{array}$ $\begin{array}{llllllllllll}1.00 & 53.86 & 27.50 & 29.83 & 2 & 1441.7704 & 1441.7697 & 721.8921 & 0.0007 & 0.4848 & 84.521\end{array}$ $\begin{array}{lllllllllll}1.00 & 41.64 & 27.51 & 35.61 & 2 & 1441.7706 & 1441.7697 & 721.8921 & 0.0009 & 0.6234 & 133.069 \\ 1.00 & 57.94 & 27.51 & 39.22 & 2 & 1441.7706 & 1441.7697 & 721.8921 & 0.0009 & 0.6234 & 64.905\end{array}$

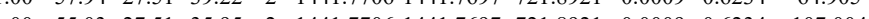
$\begin{array}{lllllllllll}1.00 & 55.03 & 27.51 & 35.95 & 2 & 1441.7706 & 1441.7697 & 721.8921 & 0.0009 & 0.6234 & 107.004 \\ 1.00 & 54.89 & 27.52 & 35.38 & 2 & 1441.7708 & 1441.7697 & 721.8921 & 0.0011 & 0.7619 & 115.620\end{array}$ $\begin{array}{lllllllllll}1.00 & 51.90 & 27.52 & 30.75 & 2 & 1441.7708 & 1441.7697 & 721.8921 & 0.0011 & 0.7619 & 129.359\end{array}$ $\begin{array}{lllllllllll}1.00 & 54.56 & 27.52 & 35.29 & 2 & 1441.7708 & 1441.7697 & 721.8921 & 0.0011 & 0.7619 & 150.405\end{array}$ $\begin{array}{llllllllllll}1.00 & 55.20 & 27.52 & 31.82 & 2 & 1441.7708 & 1441.7697 & 721.8921 & 0.0011 & 0.7619 & 48.612\end{array}$

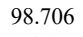

39.358

68.670

87.301

52.011 143.728 119.675 83.789 $\begin{array}{lll}112.884 & 311.036 & \text { Yes } \\ 82.985 & 333.923 & \text { Yes }\end{array}$ $\begin{array}{lll}82.985 & 33.923 & \text { Yes } \\ 90.890 & 307.189 & \text { Yes }\end{array}$ $\begin{array}{lll}537.898 & 393.503 & \text { Yes }\end{array}$ $1162.440-916.177$ No $1162.440 \quad 916.177$ No $\begin{array}{lll}26.180 & 130.109 & \text { Yes } \\ 26.74 & 12535 & \text { Yes }\end{array}$ \begin{tabular}{llll}
923 & 25.050 & 153.449 & Yes \\
\hline & 2.334 & 157.718 & $Y e s$
\end{tabular} \begin{tabular}{llll}
21.334 & 157.718 & Yes \\
\hline & 21.992 & 145.486 & Yes
\end{tabular} \begin{tabular}{llll}
35.992 & 145.486 & Yes \\
\hline & 38.138 & 173.477 & Yes
\end{tabular} $\begin{array}{llll}1.956 & 29.200 & 46.221 & \text { Yes } \\ 4.784 & 40.654 & 126.596 & Y e s\end{array}$ \begin{tabular}{llll}
\hline .784 & 40.654 & 126.596 & Yes
\end{tabular} \begin{tabular}{rrrr}
6.78 & 18.836 & 132.156 & Yes \\
\hline
\end{tabular} $\begin{array}{llll}24.755 & 114.253 & \text { Yes }\end{array}$ $\begin{array}{lll}27.707 & 185.592 & \text { Yes }\end{array}$ $\begin{array}{llll}008 & 44.453 & 154.702 & \text { Yes }\end{array}$ $\begin{array}{llll}369 & 35.791 & 145.587 & \text { Yes }\end{array}$ \begin{tabular}{cccc}
3.442 & 20.301 & 33.733 & No \\
\hline 380 & 31.001 & 167.915 & Yes
\end{tabular} $\begin{array}{llll}27 & 34.634 & 99.490 & \text { Yes } \\ 2.25 & 710.299 & 24180.53 & Y e s\end{array}$ $\begin{array}{llll}710.299 & 24180.530 & \text { Yes }\end{array}$ $\begin{array}{lll}44.007 & 165.083 & \text { Yes } \\ 27.947 & 126.027 & \text { Yes }\end{array}$ \begin{tabular}{cccc}
.786 & 8.979 & 126.027 & Yes \\
\hline 36 & 8.759 & 9.397 &
\end{tabular} $\begin{array}{lll}0.000 & 100.403 & \text { No }\end{array}$ $\begin{array}{lll}66.066 & 715.810 & \text { Yes }\end{array}$

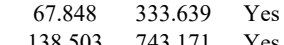
$\begin{array}{lll}138.503 & 743.171 & \text { Yes } \\ 56.714 & 29.562 & \\ \text { Yes }\end{array}$

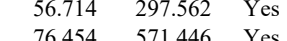

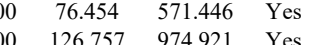
$\begin{array}{llll}108.647 & 801.495 & \text { Yes } \\ 686 & 1084\end{array}$ $\begin{array}{llll}15 & 127.851 & 726.241 & \text { Yes }\end{array}$

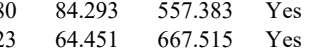
\begin{tabular}{llll}
87.408 & 693.298 & Yes \\
\hline 125.025 & 809.591 & Yes
\end{tabular} $\begin{array}{llll}6.238 & 95.166 & \text { Yes }\end{array}$ $\begin{array}{llll}91.331 & 696.840 & \text { Yes }\end{array}$ $\begin{array}{llll}55.361 & 642.550 & \text { Yes }\end{array}$ $\begin{array}{llll}110.138 & 778.377 & \text { Yes }\end{array}$ $\begin{array}{llll}62.136 & 684.967 & \text { Yes }\end{array}$ $\begin{array}{lll}62.136 & 684.967 & \text { Yes } \\ 23.700 & 229.862 & \text { Yes }\end{array}$ $\begin{array}{llll}84.518 & 660.159 & \text { Yes }\end{array}$ $\begin{array}{lll}66.340 & \text { Yes }\end{array}$ $\begin{array}{lll}6.461 & 279.069 & \text { Yes } \\ 11.675 & 36.60 & Y \text { S }\end{array}$ $\begin{array}{lll}1.675 & 316.460 & \text { Yes } \\ 5.304 & 92.629 & \text { Yes }\end{array}$ $\begin{array}{lll}7.709 & 188.019 & \text { Yes }\end{array}$ $\begin{array}{lll}81.691 & 132.679 & \text { Yes }\end{array}$ $\begin{array}{lll}64.202 & 114.186 & \text { Yes } \\ 0.457 & 35.237 & \mathrm{No}\end{array}$ $\begin{array}{lll}0.457 & 323.237 & \text { No }\end{array}$ \begin{tabular}{lll}
0.757 & 350.248 & Yes \\
\hline & 182.226 & Yes
\end{tabular} $\begin{array}{lll}17.620 & 291.515 & \text { Yes }\end{array}$ $28.684 \quad 399.220$ Yes 

$\begin{array}{llllllllllll}1.00 & 52.14 & 27.36 & 34.85 & 2 & 1441.7710 & 1441.7697 & 721.8921 & 0.0013 & 0.9004 & 128.729 & 107.366\end{array}$ $\begin{array}{llllllllllll}1.00 & 51.53 & 27.36 & 36.18 & 2 & 1441.7710 & 1441.7697 & 721.8921 & 0.0013 & 0.9004 & 54.229 & 62.841 \\ 1.00 & 58.88 & 27.36 & 37.88 & 2 & 1441.7712 & 1441.7697 & 721.8921 & 0.0015 & 1.0389 & 120.164 & 170.376\end{array}$ $\begin{array}{lllllllllllll}1.00 & 58.88 & 27.36 & 37.88 & 2 & 1441.7712 & 1441.7697 & 721.8921 & 0.0015 & 1.0389 & 120.164 & 170.376\end{array}$ $\begin{array}{lllllllllllll}1.00 & 51.27 & 27.36 & 34.29 & 2 & 1441.7712 & 1441.7697 & 721.8921 & 0.0015 & 1.0389 & 16952.199 & 19454.801\end{array}$ $\begin{array}{llllllllll} & \end{array}$

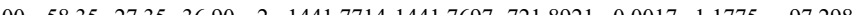
$\begin{array}{lllllllllll}1.00 & 58.35 & 27.35 & 36.90 & 2 & 1441.7714 & 1441.7697 & 721.8921 & 0.0017 & 1.174 & 97.298 \\ 1.85 & 16.84 & 27.35 & 21.59 & 3 & 1441.7716 & 1441.7697 & 481.5972 & 0.0019 & 1.3151 & 30.582\end{array}$ $\begin{array}{llllllllllll}1.00 & 58.69 & 27.34 & 38.88 & 2 & 1441.7716 & 1441.7697 & 721.8921 & 0.0019 & 1.3160 & 85.032\end{array}$

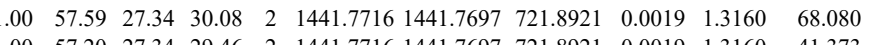
$\begin{array}{lllllllllllll}1.00 & 57.20 & 27.34 & 29.46 & 2 & 1441.7716 & 1441.7697 & 721.8921 & 0.0019 & 1.3160 & 41.373 \\ 0.75 & 16.69 & 27.23 & 28.13 & 3 & 1441.7722 & 1441.7697 & 481.5972 & 0.0025 & 1.7304 & 116.068\end{array}$ $\begin{array}{llllllllllll}0.69 & 13.04 & 27.23 & 23.15 & 3 & 1441.7722 & 1441.7697 & 481.5972 & 0.0025 & 1.7304 & 77.128\end{array}$ $\begin{array}{llllllllllll}1.00 & 47.73 & 27.22 & 28.52 & 2 & 1441.7724 & 1441.7697 & 721.8921 & 0.0027 & 1.8701 & 67719.140 & 80842.466\end{array}$ $\begin{array}{llllllllllll}1.00 & 56.70 & 27.10 & 35.61 & 2 & 1441.7728 & 1441.7697 & 721.8921 & 0.0031 & 2.1471 & 112.416 & 129.625\end{array}$ $\begin{array}{llllllllllll}1.00 & 56.37 & 27.16 & 30.91 & 2 & 1441.7736 & 1441.7697 & 721.8921 & 0.0039 & 2.7012 & 29.005 & 42.046\end{array}$ $\begin{array}{llllllllllll}0.81 & 18.01 & 27.17 & 27.15 & 3 & 1441.7737 & 1441.7697 & 481.5972 & 0.0040 & 2.7686 & 99.376 & 125.171\end{array}$ $\begin{array}{llllllllllll}0.61 & 26.56 & 28.90 & 25.31 & 2 & 1135.6106 & 1135.6117 & 568.8131 & -0.0011 & -0.9669 & 201.206 & 238.840\end{array}$

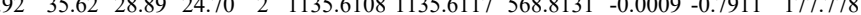
$\begin{array}{lllllllllll}0.72 & 24.23 & 28.62 & 24.97 & 2 & 1135.6114 & 1135.6117 & 568.8131 & -0.0003 & -0.2637 & 186.668\end{array}$ $\begin{array}{lllllllllll}0.91 & 30.17 & 28.62 & 21.68 & 2 & 1135.6114 & 1135.6117 & 568.8131 & -0.0003 & -0.2637 & 74.528 \\ 0.65 & 22.69 & 2.67 & 24.54 & 2 & 1135.6118 & 1135.6117 & 568.8131 & 0.0001 & 0.0879 & 186.969\end{array}$ $\begin{array}{llllllllllll}0.65 & 22.69 & 28.67 & 24.54 & 2 & 1135.6118 & 1135.6117 & 568.8131 & 0.0001 & 0.0879 & 186.969 \\ 0.87 & 28.23 & 28.67 & 22.08 & 2 & 1135.6118 & 1135.6117 & 568.8131 & 0.0001 & 0.0879 & 49.203 & 24\end{array}$ $\begin{array}{lllllllllll}0.87 & 28.23 & 28.67 & 22.08 & 2 & 1135.6118 & 1135.6117 & 568.8131 & 0.0001 & 0.0879 & 49.203 \\ 0.86 & 24.01 & 28.86 & 23.29 & 2 & 1135.6124 & 1135.6117 & 568.8131 & 0.0007 & 0.6153 & 226.705\end{array}$ $\begin{array}{llllllllllll}0.86 & 24.01 & 28.86 & 23.29 & 2 & 1135.6124 & 1135.6117 & 568.8131 & 0.0007 & 0.6153 & 226.705 \\ 0.98 & 33.53 & 28.83 & 24.46 & 2 & 1135.6128 & 1135.6117 & 568.8131 & 0.0011 & 0.9669 & 200.760 & 21\end{array}$ $\begin{array}{llllllllllll}0.98 & 33.53 & 28.83 & 24.46 & 2 & 1135.6128 & 1135.6117 & 568.8131 & 0.0011 & 0.9669 & 200.760 \\ 0.98 & 33.40 & 28.83 & 24.31 & 2 & 1135.6130 & 1135.6117 & 568.8131 & 0.0013 & 1.1427 & 218.592\end{array}$ $\begin{array}{lllllllllllll}0.98 & 33.40 & 28.83 & 24.31 & 2 & 1135.6130 & 1135.6117 & 568.8131 & 0.0013 & 1.1427 & 218.592 & 22 \\ 0.98 & 33.33 & 28.83 & 24.30 & 2 & 1135.6130 & 1135.6117 & 568.8131 & 0.0013 & 1.1427 & 170.592 & 20 \\ 0.85 & 23.35 & 28.88 & 25.33 & 2 & 135.6134 & 135.617 & 568.81 & 0.001 & 1.4943 & 196.122 & 20\end{array}$ $\begin{array}{llllllllllll}0.98 & 33.33 & 28.83 & 24.30 & 2 & 1135.6130 & 1135.6117 & 568.8131 & 0.0013 & 1.1427 & 170.592 & 20 \\ 0.85 & 23.35 & 28.88 & 25.33 & 2 & 1135.6134 & 1135.6117 & 568.8131 & 0.0017 & 1.4943 & 196.124 & 20\end{array}$ $\begin{array}{llllllllllll}0.85 & 23.35 & 28.88 & 25.33 & 2 & 1135.6134 & 1135.6117 & 568.8131 & 0.0017 & 1.4943 & 196.124 & 20 \\ 0.88 & 24.41 & 28.88 & 21.82 & 2 & 1135.6134 & 1135.6117 & 568.8131 & 0.0017 & 1.4943 & 202.215 & 13 \\ 0.97 & 33.71 & 28.13 & 24.64 & 2 & 1135.646 & 1135.617 & 568.8131 & 0.029 & 2.542 & 174.865 & 19\end{array}$ $\begin{array}{llllllllllll}0.88 & 24.41 & 28.88 & 1.82 & 2 & 1135.6134 & 1135.6117 & 568.8131 & 0.0017 & 1.4943 & 202.215 \\ 0.97 & 33.71 & 28.13 & 24.64 & 2 & 1135.6146 & 1135.6117 & 568.8131 & 0.0029 & 2.5492 & 174.865\end{array}$ $\begin{array}{lllllllllll}0.97 & 33.71 & 28.13 & 24.64 & 2 & 1135.6146 & 135.6117 & 568.8131 & 0.0029 & 2.5492 & 174.865 \\ 0.91 & 32.88 & 28.49 & 23.88 & 2 & 1135.6154 & 1135.6117 & 568.8131 & 0.0037 & 3.2524 & 114.484\end{array}$ $\begin{array}{lllllllllll}0.91 & 32.88 & 28.49 & 23.88 & 2 & 1135.6154 & 1135.6117 & 568.8131 & 0.0037 & 3.2524 & 114.484 \\ 0.80 & 28.64 & 28.47 & 21.66 & 2 & 1135.6158 & 1135.6117 & 568.8131 & 0.0041 & 3.6040 & 164.653\end{array}$ $\begin{array}{llllllllllll}1.00 & 54.60 & 27.41 & 32.42 & 2 & 1441.7696 & 1441.7697 & 721.8921 & -0.0001 & -0.0693 & 49.404\end{array}$ $\begin{array}{lllllllllllll}1.00 & 50.69 & 27.54 & 27.32 & 2 & 1441.7700 & 1441.7697 & 721.8921 & 0.0003 & 0.2078 & 65.555\end{array}$ $\left.\begin{array}{lllllllllll}1.00 & 47.73 & 27.50 & 29.05 & 2 & 1441.7704 & 1441.7697 & 721.8921 & 0.0007 & 0.4848 & 44.013\end{array}\right)$ $\begin{array}{llllllllllll}1.00 & 52.65 & 27.36 & 27.22 & 2 & 1441.7710 & 1441.7697 & 721.8921 & 0.0013 & 0.9004 & 52.002\end{array}$

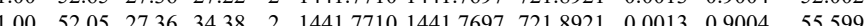
$\begin{array}{lllllllllll}1.00 & 52.12 & 27.36 & 31.92 & 2 & 1441.7710 & 1441.7697 & 721.8921 & 0.0013 & 0.9004 & 4752.954\end{array}$ $\begin{array}{lllllllllllll}1.00 & 52.70 & 27.36 & 27.17 & 2 & 1441.7710 & 1441.7697 & 721.8921 & 0.0013 & 0.9004 & 22.699\end{array}$ $\begin{array}{lllllllllll}1.00 & 50.91 & 27.36 & 27.54 & 2 & 1441.7712 & 1441.7697 & 721.8921 & 0.0015 & 1.0389 & 51.811\end{array}$ $\begin{array}{lllllllllllll}1.00 & 52.18 & 27.36 & 26.61 & 2 & 1441.7712 & 1441.7697 & 721.8921 & 0.0015 & 1.0389 & 58.935\end{array}$ $\begin{array}{llllllllllll}1.00 & 54.29 & 27.36 & 35.24 & 2 & 1441.7712 & 1441.7697 & 721.8921 & 0.0015 & 1.0389 & 52.107\end{array}$ $\begin{array}{llllllllllll}1.00 & 51.66 & 27.36 & 28.12 & 2 & 1441.7712 & 1441.7697 & 721.8921 & 0.0015 & 1.0389 & 32.064\end{array}$ $\begin{array}{llllllllllll}1.00 & 53.12 & 27.34 & 27.62 & 2 & 1441.7716 & 1441.7697 & 721.8921 & 0.0019 & 1.3160 & 80.964\end{array}$ $\begin{array}{llllllllllll}1.00 & 51.87 & 27.34 & 38.85 & 2 & 1441.7716 & 1441.7697 & 721.8921 & 0.0019 & 1.3160 & 14269.816 & 18174.051\end{array}$ $\begin{array}{llllllllllll}1.00 & 53.25 & 27.34 & 30.96 & 2 & 1441.7716 & 1441.7697 & 721.8921 & 0.0019 & 1.3160 & 47.613 & 60.190\end{array}$ $\begin{array}{lllllllllllll}1.00 & 51.90 & 27.34 & 32.01 & 2 & 1441.7716 & 1441.7697 & 721.8921 & 0.0019 & 1.3160 & 67.343 & 60.157\end{array}$ $\begin{array}{lllllllllllll}1.00 & 53.72 & 27.33 & 28.61 & 2 & 1441.7718 & 1441.7697 & 721.8921 & 0.0021 & 1.4545 & 42.292 & 66.325 \\ 1.00 & 52.65 & 27.23 & 27.40 & 2 & 1441.7722 & 1441.7697 & 721.8921 & 0.0025 & 1.7316 & 60.190 & 59.703\end{array}$ $\begin{array}{llllllllllll}1.00 & 52.65 & 27.23 & 27.40 & 2 & 1441.7722 & 1441.7697 & 721.8921 & 0.0025 & 1.7316 & 60.190 & 59.703 \\ 1.00 & 52.18 & 27.10 & 31.10 & 2 & 1441.7728 & 1441.7697 & 721.8921 & 0.0031 & 2.1471 & 49.811 & 67.295\end{array}$ $\begin{array}{lllllllllllll}1.00 & 52.18 & 27.10 & 31.10 & 2 & 1441.7728 & 1441.7697 & 721.8921 & 0.0031 & 2.1471 & 49.811 & 67.295 \\ 1.00 & 53.09 & 27.33 & 3.37 & 2 & 1441.7732 & 1441.7697 & 721.8921 & 0.0035 & 2.4242 & 34.297 & 36.998\end{array}$ $\begin{array}{llllllllllll}1.00 & 53.09 & 27.33 & 30.37 & 2 & 1441.7732 & 1441.7697 & 721.8921 & 0.0035 & 2.4242 & 34.297 & 36.998\end{array}$ $\begin{array}{llllllllllllll}0.52 & 23.09 & 24.12 & 33.09 & 2 & 970.6014 & 970.5933 & 486.3039 & 0.0081 & 8.3281 & 10443.907 & 9114.418 \\ 0.75 & 26.57 & 24.12 & 33.51 & 2 & 970.6018 & 970.5933 & 486.3039 & 0.0085 & 8.7393 & 8774.971 & 6494.802\end{array}$ $\begin{array}{llllllllllllll}0.75 & 26.57 & 24.12 & 33.51 & 2 & 970.6018 & 970.5933 & 486.3039 & 0.0085 & 8.7393 & 8774.971 & 6494 & \\ 0.95 & 21.57 & 27.65 & 16.79 & 3 & 1426.7725 & 1426.7707 & 476.5975 & 0.0018 & 1.2589 & 32.651 & 256 . & \end{array}$ $\begin{array}{llllllllllll}1.00 & 35.41 & 27.90 & 18.36 & 3 & 1472.7592 & 1472.7584 & 491.9267 & 0.0008 & 0.5421 & 732.638 & 298.973\end{array}$ $\begin{array}{llllllllllll}0.99 & 35.06 & 27.84 & 19.09 & 2 & 1472.7596 & 1472.7584 & 737.3865 & 0.0012 & 0.8137 & 300.387 & 126.466\end{array}$ $\begin{array}{lllllllllllll}0.93 & 20.83 & 28.01 & 21.92 & 3 & 1472.7604 & 1472.7584 & 491.9267 & 0.0020 & 1.3552 & 266.518 & 119.58\end{array}$ $\begin{array}{lllllllllllll}1.00 & 50.01 & 28.01 & 26.02 & 2 & 1472.7604 & 1472.7584 & 737.3865 & 0.0020 & 1.3561 & 426.087 & 11 & \\ 0.99 & 31.05 & 27.82 & 21.23 & 3 & 14267716 & 14267707 & 476.5975 & 0.0009 & 0.6295 & 461.816 & 24\end{array}$

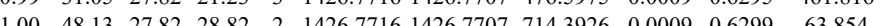

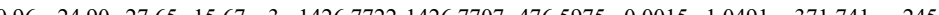


$\begin{array}{llllllllllllllllll} & \text { TITLEVEPSDTIENVK } & 1.00 & 85.17 & 26.66 & 44.43 & 2 & 2075.1274 & 2075.1241 & 1038.5693 & 0.0033 & 1.5887 & 655.028 & 649.297 & 402.365 & 848.224 & \text { Yes }\end{array}$

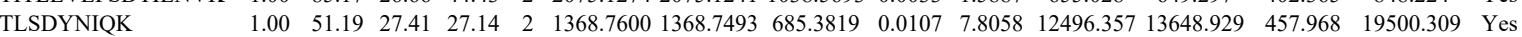

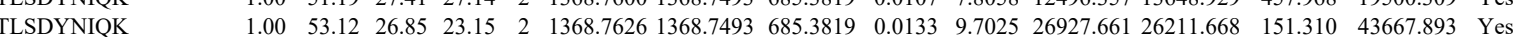

$\begin{array}{llllllllllllllll}\text { TLSDYNIQK } & 0.65 & 16.64 & 27.34 & 17.94 & 2 & 1368.7510 & 1368.7493 & 685.3819 & 0.0017 & 1.2402 & 134.093 & 131.965 & 150.158 & 239.669 & \text { Yes }\end{array}$

TLSDYNIQK

TLSDYNIQK

TLSDYNIQK

TLSDYNIQK

TLSDYNIQK

$\begin{array}{lllllllllllllll}0.65 & 16.64 & 27.34 & 17.94 & 2 & 1368.7510 & 1368.7493 & 685.3819 & 0.0017 & 1.2402 & 134.093 & 131.965 & 150.158 & 239.669 & Y \text { Yes } \\ 1.00 & 51.40 & 26.78 & 23.51 & 2 & 1368.7620 & 1368.7493 & 685.3819 & 0.0127 & 92648 & 14902.178 & 15739.430 & 0.000 & 23289.132 & \text { No }\end{array}$

$\begin{array}{llllllllllllllll}1.00 & 53.55 & 27.28 & 22.94 & 2 & 1368.7612 & 1368.7493 & 685.3819 & 0.0119 & 8.6812 & 11002.968 & 10855.484 & 230.673 & 17058.350 & \text { Yes }\end{array}$ $\begin{array}{lllllllllllllllll}1.00 & 53.35 & 26.78 & 24.82 & 2 & 1368.7620 & 13687493 & 685.3819 & 0.0127 & 9.2648 & 22711.932 & 23248.948 & 253.852 & 34513.164 & \text { Yes }\end{array}$ $\begin{array}{llllllllllllllll}1.00 & 45.50 & 26.88 & 27.69 & 2 & 1368.7628 & 1368.7493 & 685.3819 & 0.0135 & 9.8484 & 10949.683 & 11334.686 & 282.395 & 17256.751 & \text { Yes }\end{array}$ $\begin{array}{llllllllllllllll}1.00 & 54.14 & 27.28 & 24.42 & 2 & 1368.7612 & 1368.7493 & 685.3819 & 0.0119 & 8.6812 & 4952.502 & 4218.490 & 804.011 & 5306.536 & \text { Yes }\end{array}$

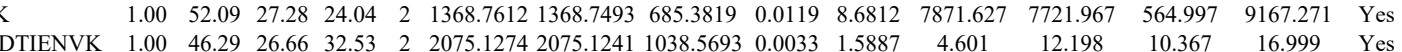
LIFAGKQLEDGR

TLSDYNIQK

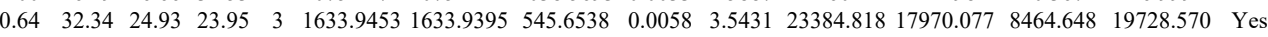

ESTLHLVLR $\begin{array}{lllllllllllllll}1.00 & 52.98 & 27.23 & 21.37 & 2 & 1368.7588 & 1368.7493 & 685.3819 & 0.0095 & 6.9304 & 6314.876 & 6394.922 & 1950.768 & 8354.252 & \text { Yes }\end{array}$

ESTLHLVLR $\begin{array}{lllllllllllllll} & & \end{array}$

TLSDYNIQK $\begin{array}{lllllllllllllll}0.81 & 29.76 & 25.47 & 22.75 & 2 & 1210.7220 & 1210.7155 & 606.3650 & 0.0065 & 5.3598 & 12232.163 & 13877.224 & 9640.428 & 10673.088 & \text { Yes }\end{array}$

TLSDYNIQK $\begin{array}{llllllllllllllll}1.00 & 43.33 & 25.47 & 23.63 & 3 & 1210.7221 & 1210.7155 & 404.5791 & 0.0066 & 5.4377 & 3596.017 & 3561.407 & 6993.429 & 3980.352 & \text { No }\end{array}$

ESTLHLVLR $\begin{array}{llllllllllllllll}1.00 & 50.62 & 27.06 & 25.65 & 2 & 1368.7586 & 1368.7493 & 685.3819 & 0.0093 & 6.7845 & 2876.093 & 2566.494 & 903.498 & 3354.104 & \text { Yes } & \\ 1.00 & 53.74 & 27.23 & 23.71 & 2 & 1368 & \end{array}$

ESTLHLVLR $\begin{array}{llllllllllllllll} & \end{array}$ $\begin{array}{lllllllllllll} & \end{array}$ $\begin{array}{llllllllllllllll}0.71 & 28.17 & 22.88 & 31.68 & 2 & 935.6030 & 935.6048 & 468.8097 & -0.0018 & -1.9198 & 334.277 & 284.884 & 53.587 & 476.330 & \text { Yes }\end{array}$

LIFAGK

LIFAGK

LIFAGK

LIFAGK

LIFAGK

MQIFVK

MQIFVK

MQIFVK

MQIFVK

MQIFVK

MQIFVK

MQIFVK
LIFAGK

LIFAGK

LIFAGK

LIFAGK

LIFAGK

LIFAGK

MQIFVK

MQIFVK

MQIFVK

MQIFVK

MQIFVK

MQIFVK

MQIFVK

MQIFVK

MQIFVK $\begin{array}{rrrrrrrrrrrrrrr}0.84 & 28.53 & 25.00 & 32.13 & 2 & 935.6040 & 935.6048 & 468.8097 & -0.0008 & -0.8532 & 590.261 & 508.265 & 85.290 & 829.386 & \text { Yes } \\ 0.78 & 26.41 & 25.00 & 30.29 & 2 & 935.6042 & 935.6048 & 468.8097 & -0.0006 & -0.6399 & 523.884 & 482549 & 101.457 & 756.369 & \text { Yes }\end{array}$

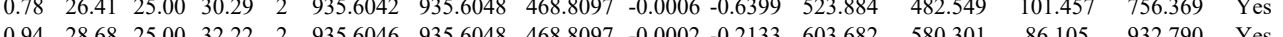

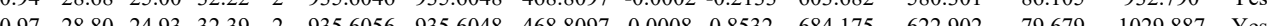

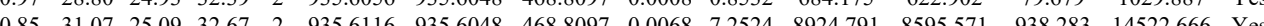

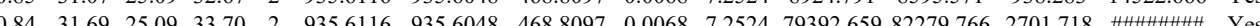
$\begin{array}{llllllllll}0.88 & 31.40 & 25.09 & 31.88 & 2 & 935.6118 & 935.6048 & 468.8097 & 0.0070 & 7.4657\end{array}$

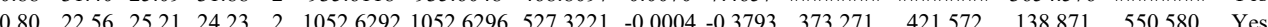

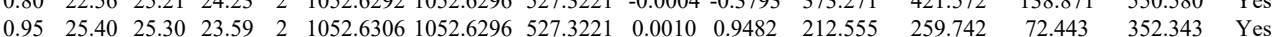
$\begin{array}{lllllllllllllll}0.84 & 19.76 & 25.28 & 24.18 & 2 & 1052.6310 & 1052.6296 & 527.3221 & 0.0014 & 1.3275 & 392.239 & 442.778 & 118.525 & 613.980 & \text { Yes }\end{array}$

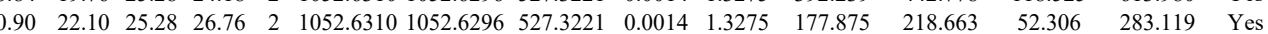
$\begin{array}{lllllllllllllll}0.92 & 37.34 & 24.42 & 36.41 & 2 & 1052.6374 & 1052.6296 & 527.3221 & 0.0078 & 7.3958 & 31829.724 & 33423.042 & 0.000 & 45836.995 & \text { No }\end{array}$ $\begin{array}{lllllllllllllll}0.90 & 29.29 & 24.38 & 31.05 & 2 & 1052.6384 & 1052.6296 & 527.3221 & 0.0088 & 8.3440 & 36507.137 & 35356.971 & 1735.721 & 53525.032 & \text { Yes }\end{array}$ $\begin{array}{llllllllllllllll}0.73 & 26.65 & 22.88 & 29.85 & 2 & 935.6030 & 935.6048 & 468.8097 & -0.0018 & -1.9198 & 563.350 & 551.119 & 89.229 & 877.939 & \text { Yes }\end{array}$ $\begin{array}{lllllllllllllllll}0.85 & 30.57 & 25.00 & 33.97 & 2 & 935.6036 & 935.6048 & 468.8097 & -0.0012 & -1.2798 & 577.754 & 490.094 & 50.283 & 827.321 & \text { Yes }\end{array}$ $\begin{array}{llllllllllllllll}0.85 & 30.60 & 25.00 & 34.01 & 2 & 935.6038 & 935.6048 & 468.8097 & -0.0010 & -1.0665 & 354.249 & 407.215 & 77.099 & 655.652 & \text { Yes }\end{array}$

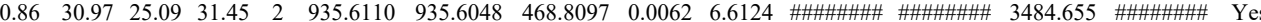

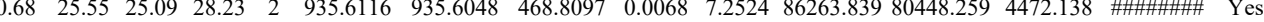
$\begin{array}{lllllllllllllll}0.85 & 27.52 & 24.93 & 31.46 & 2 & 935.6136 & 935.6048 & 468.8097 & 0.0088 & 9.3854 & 21180.779 & 21412.923 & 323.580 & 33677.655 & \text { Yes }\end{array}$

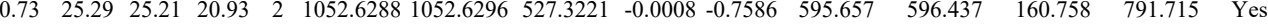
$\begin{array}{lllllllllllllll}0.96 & 30.80 & 25.21 & 26.42 & 2 & 1052.6294 & 052.6296 & 527.3221 & -0.0002 & -0.1896 & 649.577 & 761.070 & 166.176 & 1008.338 & \text { Yes }\end{array}$

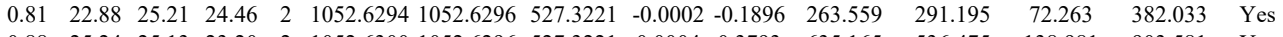

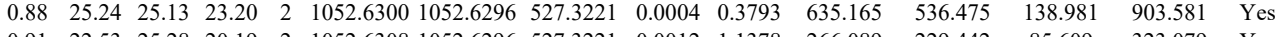
$\begin{array}{lllllllllllllll}0.91 & 22.53 & 25.28 & 20.19 & 2 & 1052.6308 & 1052.6296 & 527.3221 & 0.0012 & 1.1378 & 266.089 & 229.442 & 85.609 & 323.079 & \text { Yes }\end{array}$

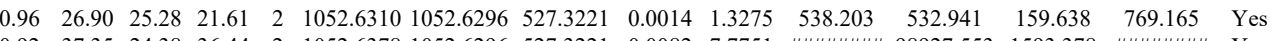

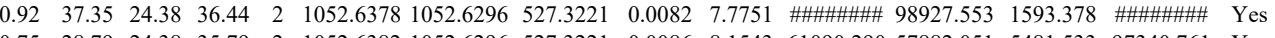
$\begin{array}{lllllllllllllllll}0.75 & 28.7 & 24.38 & 55.79 & 2 & 1052.6382 & 1052.6296 & 527.3221 & 0.0086 & 8.1543 & 61090.290 & 57882.051 & 5481.533 & 97340.761 & \text { Yes }\end{array}$ $\begin{array}{lllllllllllllllll} & \end{array}$ $\begin{array}{lllllllllllllll}0.75 & 28.14 & 25.19 & 33.51 & 2 & 1068.6324 & 068.6245 & 535.3195 & 0.0079 & 7.3787 & 6148.860 & 5994.210 & 1929.384 & 7677.775 & \text { Yes }\end{array}$

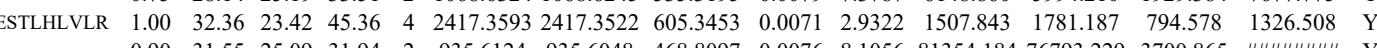




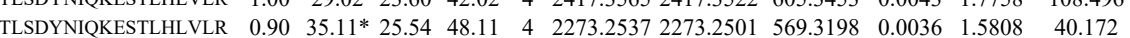
$\begin{array}{lllllllllllll}\text { TLSDYNIQKESTLHLVLR } & 1.00 & 27.85 & 23.60 & 40.85 & 4 & 2417.3569 & 2417.3522 & 605.3453 & 0.0047 & 1.9410 & 105.211\end{array}$ $\begin{array}{llllllllllll}\text { TLSDYNIQKESTLHLVLR } & 0.61 & 28.79 * & 25.62 & 41.79 & 4 & 2273.2509 & 2273.2501 & 569.3198 & 0.0008 & 0.3513 & 46.154\end{array}$ $\begin{array}{llllllllllll}\text { TITLEVEPSDTIENVK } & 0.79 & 42.68 & 27.17 & 25.66 & 2 & 2075.1194 & 2075.1241 & 1038.5693 & -0.0047 & -2.2627 & 11.206\end{array}$ $\begin{array}{lllllllllllll}\text { TITLEVEPSDTIENVK } & 1.00 & 84.44 & 26.79 & 42.61 & 2 & 2075.1254 & 2075.1241 & 1038.5693 & 0.0013 & 0.6259 & 726.145\end{array}$ $\begin{array}{lllllllllllll}\text { TITLEVEPSDTIENVK } & 0.55 & 14.34 & 26.79 & 27.34 & 3 & 2075.1256 & 2075.1241 & 692.7153 & 0.0015 & 0.7218 & 78.467\end{array}$

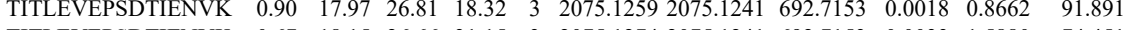

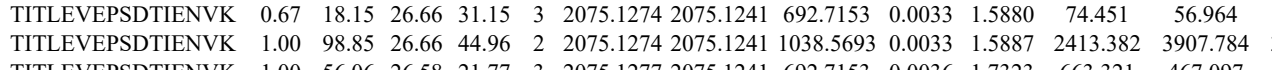
$\begin{array}{lllllllllllllll}\text { TITLEVEPSDTIENVK } & 1.00 & 56.06 & 26.58 & 21.77 & 3 & 2075.1277 & 2075.1241 & 692.7153 & 0.0036 & 1.7323 & 663.321 & 467.097 & 308.8 \\ \text { TITLEVEPSDTIENVK } & 0.87 & 21.03 & 26.88 & 19.39 & 3 & 2075.1241 & 2075.1241 & 692.7153 & 0.0000 & 0.0000 & 85.809 & 108.433 & 57.9\end{array}$ $\begin{array}{lllllllllllllll}\text { TITLEVEPSDTIENVK } & 0.87 & 21.03 & 26.88 & 19.39 & 3 & 2075.1241 & 2075.1241 & 692.7153 & 0.0000 & 0.0000 & 85.809 & 108.433 & 57 & \\ \text { TITLEVEPSDTIENVK } & 0.91 & 22.77 & 26.82 & 14.89 & 3 & 2075.1247 & 2075.1241 & 692.7153 & 0.0006 & 0.2887 & 68.867 & 74.480\end{array}$ $\begin{array}{lllllllllllll}\text { TITLEVEPSDTIENVK } & 0.91 & 22.77 & 26.82 & 14.89 & 3 & 2075.1247 & 2075.1241 & 692.7153 & 0.0006 & 0.2887 & 68.867 & 74.480 \\ \text { TITLEVEPSDIENVK } & 1.00 & 87.83 & 26.79 & 44.17 & 2 & 2075.1254 & 2075.1241 & 1038.5693 & 0.0013 & 0.6259 & 1657.478 & 1456.637\end{array}$ $\begin{array}{llllllllllllll}\text { TITLEVEPSDTIENVKK } & 1.00 & 87.83 & 26.79 & 44.17 & 2 & 2075.1254 & 2075.1241 & 1038.5693 & 0.0013 & 0.6259 & 1657.478 & 1456.637 & 1064.4 \\ \text { TITLEVEPSDTIENVK } & 1.00 & 88.05 & 26.79 & 44.69 & 2 & 2075.1254 & 2075.1241 & 1038.5693 & 0.0013 & 0.6259 & 2008.495 & 1901.677 & 1\end{array}$ $\begin{array}{lllllllllllllll}\text { TITLEVEPSDTIENVK } & 0.66 & 44.68 & 26.71 & 57.68 & 3 & 2075.1262 & 2075.1241 & 692.7153 & 0.0021 & 1.0105 & 1543.575 & 1676.522 & 1415 & \\ \text { TITLEVEPSDTIENVK } & 0.94 & 19.86 & 26.66 & 16.54 & 3 & 2075.1274 & 2075.1241 & 692.153 & 0.0033 & 1.5880 & 11.280 & 99.105 & \end{array}$ $\begin{array}{llllllllllllll}\text { TITLEVEPSDTIENVK } & 0.94 & 19.86 & 26.66 & 16.54 & 3 & 2075.1274 & 2075.1241 & 692.7153 & 0.0033 & 1.5880 & 119.280 & 99.1 & \\ \text { TITLEVEPSDTIENVK } & 0.95 & 20.74 & 26.66 & 14.91 & 3 & 2075.1274 & 2075.1241 & 6927153 & 0.0033 & 1.5880 & 101.709 & 82.1\end{array}$ $\begin{array}{llllllllllll} & \end{array}$ $\begin{array}{llllllllllllll}\text { TITLEVEPSDTIENVK } & 0.83 & 21.77 & 26.55 & 17.52 & 3 & 2075.1301 & 2075.1241 & 692.7153 & 0.0060 & 2.8872 & 106.509 & 148.68\end{array}$

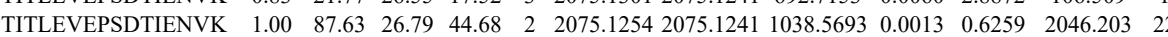
\begin{tabular}{llllllllllllllll} 
& 2075.1268 & 2075.1241 & 692.7153 & 0.0027 & 1.2992 & 845.008 & 1084.771 & 601.586 & 730.576 & Yes \\
\hline
\end{tabular}

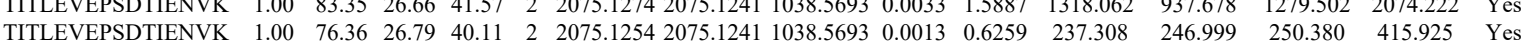
$\begin{array}{lllllllllllllllll}\text { TITLEVEPSDTIENVK } & 1.00 & 72.52 & 26.66 & 45.27 & 2 & 2075.1274 & 2075.1241 & 1038.5693 & 0.0033 & 1.5887 & 16.664 & 35.768 & 19.108 & 56.045 & \text { Yes }\end{array}$

YLECSALTQR

AVLCPPPVK

YLECSALTQR

YLECSALTQR

YLECSALTQR

YLECSALTQR

$\begin{array}{llllllllllll}1.00 & 72.52 & 26.66 & 45.27 & 2 & 2075.1274 & 2075.1241 & 1038.5693 & 0.0033 & 1.5887 & 16.664 & \\ 0.99 & 40.83 & 26.28 & 20.03 & 2 & 1372.6708 & 1372.6601 & 687.3373 & 0.0107 & 7.7836 & 5734.294 & 4268\end{array}$

$\begin{array}{llllllllllllllll}0.99 & 40.83 & 26.28 & 20.03 & 2 & 1372.6708 & 1372.6601 & 687.3373 & 0.0107 & 7.7836 & 5734.294 & 4268.352 & 583.560 & 9946.138 & \text { Yes }\end{array}$ $\begin{array}{lllllllllllllll}1.00 & 47.09 & 26.07 & 18.37 & 2 & 1256.7334 & 1256.7229 & 629.3687 & 0.0105 & 8.3416 & 16137.393 & 16255.270 & 3065.503 & 17811.182 & \text { Yes }\end{array}$ $\begin{array}{lllllllllllllllll}1.00 & 46.82 & 26.07 & 18.05 & 2 & 1256.7334 & 1256.7229 & 629.3687 & 0.0105 & 8.3416 & 17839.012 & 14800.259 & 3966.214 & 20560.195 & \text { Yes }\end{array}$ $\begin{array}{llllllllllllllll}1.00 & 58.23 & 26.66 & 19.91 & 2 & 1372.6736 & 1372.6601 & 687.3373 & 0.0135 & 9.8204 & 8054.662 & 5743.966 & 148.077 & 13215.059 & \text { Yes }\end{array}$ $\begin{array}{llllllllllllllll} & 54.29 & 26.66 & 21.78 & 2 & 1372.6736 & 1372.6601 & 687.3373 & 0.0135 & 9.8204 & 6549.649 & 5036.295 & 74.616 & 10639.869 & \text { Yes }\end{array}$ $\begin{array}{lllllllllllllll} & 13.77 & 25.72 & 25.04 & 2 & 1372.6616 & 1372.6601 & 687.3373 & 0.0015 & 1.0912 & 4085.620 & 2710.330 & 259.530 & 6134.577 & \text { Yes }\end{array}$ $\begin{array}{llllllllllllllll}\text { LTPITYPQGLAMAK } & 1.00 & 74.37 & 24.94 & 23.43 & 2 & 1791.0226 & 1791.0208 & 896.5177 & 0.0018 & 1.0039 & 2860.073 & 2671.252 & 935.582 & 3479.072 & \text { Yes }\end{array}$ $\begin{array}{lllllllllllllllllll}\text { LTPITYPQGLAMAK } & 0.84 & 58.23 & 24.94 & 71.23 & 2 & 1791.0228 & 1791.0208 & 896.5177 & 0.0020 & 1.1154 & 3996.133 & 4060.537 & 1494.041 & 5870.153 & \text { Yes }\end{array}$ $\begin{array}{llllllllllllllllll}\text { LTPTYPQLAMAK } & 0.53 & 8.77 & 24.68 & 16.35 & 3 & 1791.0250 & 1791.0208 & 598.0142 & 0.0042 & 2.3411 & 1218.375 & 1350.013 & 377.834 & 1423.639 & \text { Yes }\end{array}$ $\begin{array}{lllllllllllllll} & & \end{array}$ $\begin{array}{llllllllllllllll} & \end{array}$

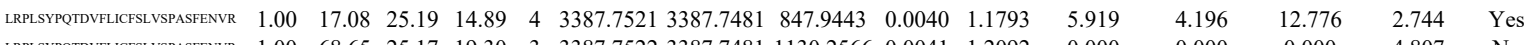
$\begin{array}{lllllllllllllll} & \end{array}$ $\begin{array}{lllllllllllllll} & \end{array}$

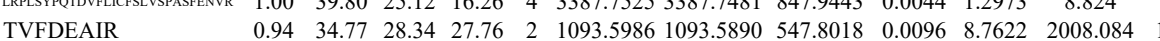
$\begin{array}{lllllllllll} & \end{array}$

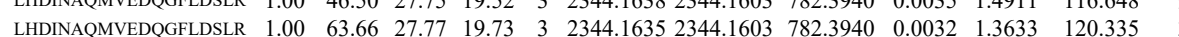
$\begin{array}{llllllllllllll}\text { HDINAQMVEDQGFLDSLR } & 0.60 & 27.90 & 27.75 & 40.90 & 3 & 2344.1644 & 2344.1603 & 782.3940 & 0.0041 & 1.7468 & 47.751 & 37\end{array}$

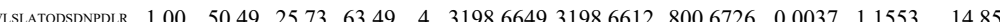
$\begin{array}{llllllllllllll}\text { APEVSOYIYQVYDSILK } & 0.95 & 21.28 & 26.19 & 20.32 & 3 & 2303.2336 & 2303.2293 & 768.7504 & 0.0043 & 1.8645 & 244.503 & 197.375\end{array}$ 
$\begin{array}{lllllllllll}1.00 & 34.73 & 18.51 & 47.73 & 4 & 4186.2829 & 41862778 & 1047.5767 & 0.0051 & 1.2171\end{array}$ $\begin{array}{lllllllllllll}4 & \text { IEDYFPEFAR } & 1.00 & 43.32 & 26.44 & 22.18 & 2 & 1429.7008 & 1429.7000 & 715.8573 & 0.0008 & 0.5588 & 326.067\end{array}$

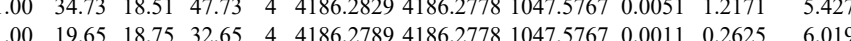

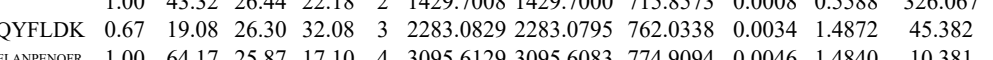
$\begin{array}{lllllllllllll} & \end{array}$

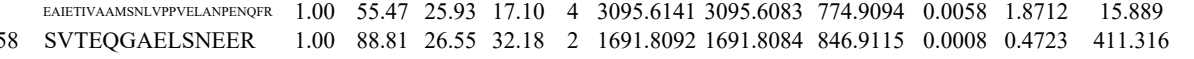

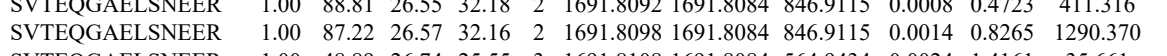
$\begin{array}{lllllllllllll}\text { SVTEQGAELSNEER } & 1.00 & 48.89 & 26.74 & 25.55 & 3 & 1691.8108 & 1691.8084 & 564.9434 & 0.0024 & 1.4161 & 35.661 \\ \text { SVTEQGAELSNEER } & 1.00 & 47.58 & 26.74 & 22.99 & 3 & 1691.8108 & 1691.8084 & 564.9434 & 0.0024 & 1.4161 & 38.128\end{array}$ $\begin{array}{lllllllllllll}\text { SVTEQGAELSNEER } & 1.00 & 48.89 & 26.74 & 25.55 & 3 & 1691.8108 & 1691.8084 & 564.9434 & 0.0024 & 1.4161 & 35.661 \\ \text { SVTEQGAELSNEER } & 1.00 & 47.58 & 26.74 & 22.99 & 3 & 1691.8108 & 1691.8084 & 564.9434 & 0.0024 & 1.4161 & 38.128 \\ \text { TADES }\end{array}$ $\begin{array}{lllllllllllll}\text { TAFDEAIAELDTLSEESYK } & 0.67 & 53.67 & 26.66 & 66.67 & 3 & 2419.1914 & 2419.1886 & 807.4035 & 0.0028 & 1.1560 & 10.233 \\ \text { TAFDEAIAELDTLSEESYK } & 1.00 & 68.92 & 26.60 & 20.56 & 3 & 2419.1965 & 2419.1886 & 807.4035 & 0.0079 & 3.2615 & 0.000\end{array}$ 0.000

VVSSIEQK $\begin{array}{llllllllllll}\text { YDDMAACMK } & 1.00 & 32.99 & 20.45 & 17.90 & 2 & 1380.5796 & 1380.5789 & 691.2967 & 0.0007 & 0.5063 & 110.287 \\ \text { GIVDQSQQAYQEAFEISK } & 0.78 & 17.73 & 28.25 & 15.43 & 3 & 2328.1849 & 2328.1841 & 777.0686 & 0.0008 & 0.3432 & 28.317\end{array}$

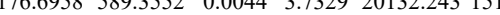
$\begin{array}{lllllllllllll}\text { GIVDQSQQAYQEAFEISK } & 0.82 & 18.59 & 28.25 & 16.47 & 3 & 2328.1849 & 2328.1841 & 777.0686 & 0.0008 & 0.3432 & 18.747\end{array}$ $\begin{array}{llllllllllll}\text { GIVDQSQQAYQEAFEISK } & 1.00 & \text { MI\#\# } & 28.25 & 21.92 & 2 & 2328.1854 & 2328.1841 & 1165.0993 & 0.0013 & 0.5579 & 209.376 \\ \text { GIVDQSQQAYQEAFEISK } & 1.00 & 98.49 & 28.25 & 24.47 & 2 & 2328.1854 & 2328.1841 & 1165.0993 & 0.0013 & 0.5579 & 298.989\end{array}$

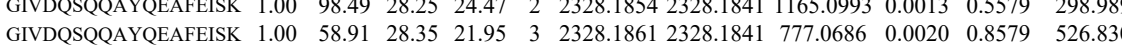
$\begin{array}{lllllllllllll}\text { GIVDQSQQAYQEAFEISK } & 0.66 & 20.87 & 28.35 & 33.87 & 3 & 2328.1861 & 2328.1841 & 777.0686 & 0.0020 & 0.8579 & 18.427 \\ \text { GIVDQSQQAYQEAFEISK } & 1.00 & 53.54 & 28.32 & 17.98 & 3 & 2328.1864 & 2328.1841 & 777.0686 & 0.0023 & 0.9866 & 17.332\end{array}$ $\begin{array}{lllllllllllll}\text { GIVDQSQQAYQEAFEISK } & 1.00 & 53.54 & 28.32 & 17.98 & 3 & 2328.1864 & 2328.1841 & 777.0686 & 0.0023 & 0.9866 & 17.332 \\ \text { GIVDQSQQAYQEAFEISK } & 0.66 & 22.84 & 28.32 & 35.84 & 3 & 2328.1864 & 2328.1841 & 777.0686 & 0.0023 & 0.9866 & 8.255\end{array}$ $\begin{array}{llllllllllll}\text { GIVDQSQQAYQEAFEISK } & 0.66 & 22.84 & 28.32 & 35.84 & 3 & 2328.1864 & 2328.1841 & 777.0686 & 0.0023 & 0.9866 & 8.255 \\ \text { GIVDQSOQAYQEAFEISK } & 1.00 & 58.99 & 28.34 & 19.73 & 3 & 2328.1870 & 2328.1841 & 777.0686 & 0.0029 & 1.2440 & 688.898\end{array}$ $\begin{array}{lllllllllllll}\text { GIVDQSQQAYQEAFEISK } & 1.00 & 58.99 & 28.34 & 19.73 & 3 & 2328.1870 & 2328.1841 & 777.0686 & 0.0029 & 1.2440 & 688.898 \\ \text { GIVDQSQQAYQEAFEISK } & 1.00 & 45.22 & 28.24 & 21.42 & 3 & 2328.1876 & 2328.1841 & 777.0686 & 0.0035 & 1.5014 & 73.856\end{array}$ $\begin{array}{llllllllllll}\text { GIVDQQQAYQEAFEISK } & 1.00 & 45.22 & 28.24 & 21.42 & 3 & 2328.1876 & 2328.184 & 777.0686 & 0.0035 & 1.5014 & 73.856 \\ \text { GIVDQSQQAYQEAFEISK } & 1.00 & 69.39 & 28.24 & 22.01 & 3 & 2328.1882 & 2328.1841 & 777.0686 & 0.0041 & 1.7587 & 9.274\end{array}$

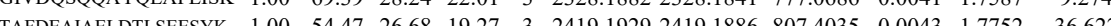
$\begin{array}{llllllllllll}\text { TAFDEAIAELDTLSESYK } & 1.00 & 54.47 & 26.68 & 19.27 & 3 & 2419.1929 & 24190.1886 & 807.4035 & 0.0043 & 1.7752 & 36.622 \\ \text { YDDMAACMK } & 1.00 & 48.69 & 20.64 & 19.51 & 2 & 1380.5814 & 1380.5789 & 691.2967 & 0.0025 & 1.8082 & 8855.285\end{array}$

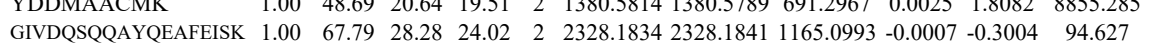
$\begin{array}{llllllllllll}\text { GIVDQSQQAYQEAFEISK } & 1.00 & 72.55 & 28.25 & 24.09 & 2 & 2328.1854 & 2328.1841 & 1165.0993 & 0.0013 & 0.5579 & 225.065\end{array}$ $\begin{array}{lllllllllllll}\text { GIVDQSQQAYQEAFEISK } & 1.00 & 32.45 & 28.35 & 17.40 & 3 & 2328.1861 & 2328.1841 & 777.0686 & 0.0020 & 0.8579 & 13.799\end{array}$ $\begin{array}{llllllllllll}\text { DICNDVLSLLEK } & 1.00 & 65.82 & 28.16 & 24.62 & 2 & 1694.8856 & 1694.8826 & 848.4486 & 0.0030 & 1.7679 & 449.239 \\ \text { DICNDVLSLLEK } & 0.73 & 14.53 & 28.14 & 24.76 & 3 & 1694.8858 & 1694.8826 & 565.9681 & 0.0032 & 1.8847 & 73.103\end{array}$ DICNDVLSLLEK DICNDVLSLLEK DICNDVLSLLEK DICNDVLSLLEK DICNDVLSLLEK $\begin{array}{llllllllllll}0.73 & 14.53 & 28.14 & 24.76 & 3 & 1694.8858 & 1694.8826 & 565.9681 & 0.0032 & 1.8847 & 73.103\end{array}$ $\begin{array}{llllllllllll}1.00 & 76.24 & 28.14 & 25.68 & 2 & 1694.8860 & 1694.8826 & 848.4486 & 0.0034 & 2.0037 & 392.1\end{array}$ $\begin{array}{lllllllllll}1.00 & 65.79 & 28.22 & 23.97 & 2 & 1694.8850 & 1694.8826 & 848.4486 & 0.0024 & 1.4143 & 373.903 \\ 0.69 & 13.86 & 28.14 & 19.01 & 3 & 1694.8855 & 1694.8826 & 565.9681 & 0.0029 & 1.7080 & 43.137\end{array}$ $\begin{array}{llllllllllll}1.00 & 63.76 & 28.16 & 20.36 & 2 & 1694.8856 & 1694.8826 & 848.4486 & 0.0030 & 1.7679 & 655.658\end{array}$ $\begin{array}{llllllllllll}\text { SVTEQGAELSNEER } & 1.00 & 77.71 & 26.55 & 22.22 & 2 & 1691.8064 & 1691.8084 & 846.9115 & -0.0020 & -1.1808 & 17.861\end{array}$

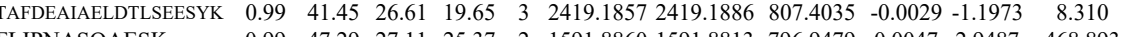
FLIPNASQAESK $\begin{array}{llllllllllll}0.99 & 47.29 & 27.11 & 25.37 & 2 & 1591.8860 & 1591.8813 & 796.9479 & 0.0047 & 2.9487 & 468.893\end{array}$ DICNDVLSLLEK

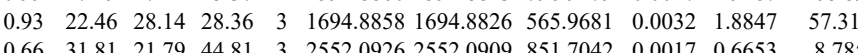

$\begin{array}{lllllllllllll} & \end{array}$ $\begin{array}{lllllllllllll}\text { DNLILADPCEDEAEAGEGGEN } & 0.66 & 36.76 & 21.79 & 49.76 & 3 & 2552.0926 & 2552.0909 & 851.7042 & 0.0017 & 0.6653 & 1.808\end{array}$

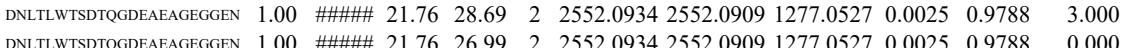

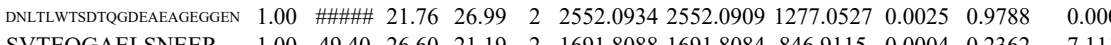

SVTEQGAELSNEER SVTEQGAELSNEER SVTEQGAELSNEER
SVTEQGAELSNEER SVTEQGAELSNEER
SVTEQGAELSNEER SVTEQGAELSNEER YLAEVAAGDDK
YLAEVAAGDDK YLAEVAAGDDK
YLAEVAAGDDK $\begin{array}{lllllllllll}1.00 & 49.40 & 26.60 & 21.19 & 2 & 1691.8088 & 1691.8084 & 846.9115 & 0.0004 & 0.2362\end{array}$ $\begin{array}{lllllllllllll}1.00 & 85.41 & 26.57 & 31.98 & 2 & 1691.8098 & 1691.8084 & 846.9115 & 0.0014 & 0.8265 & 8983.203 & 60\end{array}$

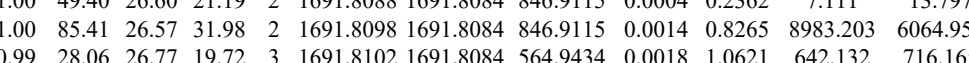
$\begin{array}{llllllllllll}1.00 & 86.91 & 26.74 & 30.56 & 2 & 1691.8108 & 1691.8084 & 846.9115 & 0.0024 & 1.4169 & 11252.647 & 8554.184\end{array}$ $\begin{array}{lllllllllllll}1.00 & 42.32 & 26.91 & 21.56 & 3 & 1691.8126 & 1691.8084 & 564.9434 & 0.0042 & 2.4781 & 441.692 & 488.658\end{array}$ $\begin{array}{lllllllllllll}1.00 & 56.76 & 27.25 & 29.47 & 2 & 1438.7670 & 1438.7547 & 720.3846 & 0.0123 & 8.5370 & 7990.609 & 5960.938\end{array}$ $\begin{array}{llllllllllll}0.77 & 26.04 & 27.28 & 28.15 & 3 & 1438.7680 & 1438.7547 & 480.5922 & 0.0133 & 9.2246 & 157.869 & 108.465\end{array}$

SVTEQGAELSNEER
$1529.434 \quad 4173.920 \quad \mathrm{Y}$

$150.747 \quad 68.954$ Yes

$\begin{array}{llll} & \\ 7.08 & 181.188 & 114.570 & \text { Yes }\end{array}$ $\begin{array}{llll}84.862 & 171.508 & 189.891 & \text { Y }\end{array}$ $\begin{array}{lllll}8.8215 & 3.831 & 16.280 & \text { Yes } & \\ 0 & 22.566 & 23.433 & \text { Yes }\end{array}$ $\begin{array}{llll}8.258 & 14.460 & 9.035 & \text { No }\end{array}$

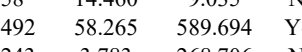
.925 3.440

566.535

1962.036

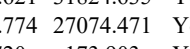
8.745 
YLAEVAAGDDKK YLAEVAAGDDK YLAEVAAGDDKK YLAEVAAGDDKK

YLAEVAAGDDKK

TAFDEAIAELDTLSEESY

TAFDEAIAELDTLSEESY 

$\begin{array}{lllllllllllllllll}1.00 & 41.97 & 27.58 & 23.71 & 2 & 1181.6594 & 1181.6569 & 591.8357 & 0.0025 & 2.1121 & 43284.320 & 49294.823 & 24010.379 & 65893.722 & \text { Yes }\end{array}$

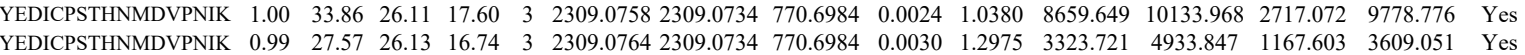
$\begin{array}{lllllllllllllllll} & 19.17 & 3 & 2309.0734 & 2309.0734 & 770.6984 & 0.0000 & 0.0000 & 1853.759 & 2100.161 & 915.110 & 1990.855 & \text { Yes }\end{array}$ $\begin{array}{llllllllllllllll}\text { YEDICPSTHNMDVPNIK } & 1.00 & 40.62 & 26.12 & 19.90 & 3 & 2309.0755 & 2309.0734 & 770.6984 & 0.0021 & 0.9083 & 3288.307 & 3518.825 & 781.357 & 3841.297 & \text { Yes }\end{array}$

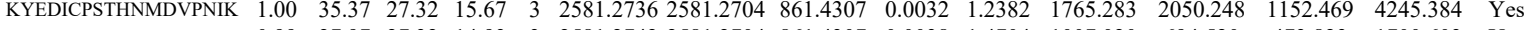
$\begin{array}{lllllllllllllllll}\text { KYEDICPSTHNMDVPNIK } & 0.99 & 27.97 & 27.32 & 14.93 & 3 & 2581.2742 & 2581.2704 & 861.4307 & 0.0038 & 1.4704 & 1007.020 & 694.520 & 473.823 & 1700.603 & \text { Yes }\end{array}$ $\begin{array}{lllllllllllllllll} & \text { KYEDICPSTHNMDVPNIK } & 1.00 & 23.98 & 27.45 & 16.32 & 4 & 2581.2769 & 2581.2704 & 646.3249 & 0.0065 & 2.5142 & 4781.302 & 5509.468 & 2980.301 & 13830.004 & \text { Yes }\end{array}$

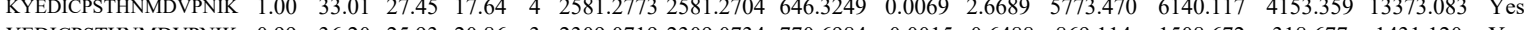

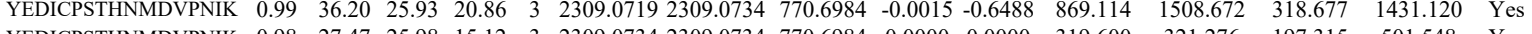

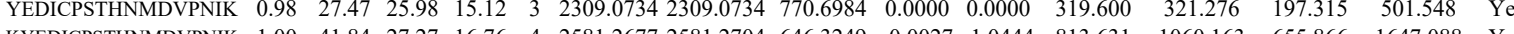

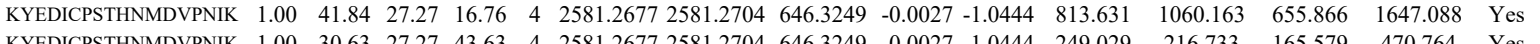
$\begin{array}{lllllllllllllll} & \text { No }\end{array}$

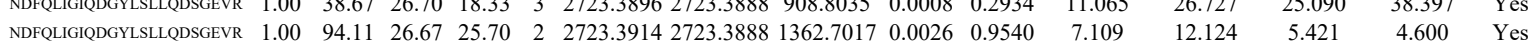

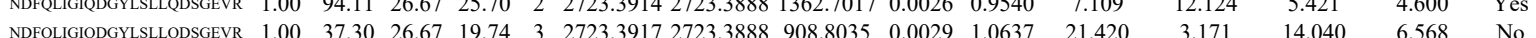

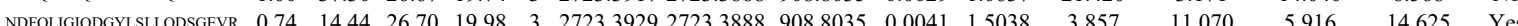

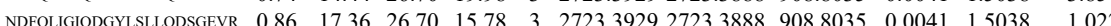

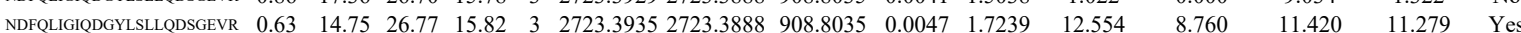

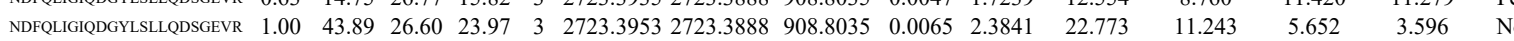
$\begin{array}{llllllllllllllllll}\text { NDFQLIGIQDGYLSLLQDSGEVR } & 0.71 & 20.13 & 26.61 & 18.76 & 3 & 2723.3956 & 2723.3888 & 908.8035 & 0.0068 & 2.4941 & 1.735 & 1.520 & 0.000 & 7.218 & \text { No }\end{array}$ $\begin{array}{lllllllllllllllll}\text { NDFQLIGIQDGYLSLLDDSGEVR } & 0.99 & 40.00 & 26.57 & 18.44 & 3 & 2723.3977 & 2723.3888 & 908.8035 & 0.0089 & 3.2644 & 4.738 & 12.155 & 1.538 & 8.297 & \mathrm{~N}\end{array}$ $\begin{array}{llllllllllllllll}\text { NDFQLIGIQDGYLSLLDSGEVR } & 1.00 & 90.36 & 26.73 & 25.00 & 2 & 2723.3894 & 2723.3888 & 1362.7017 & 0.0006 & 0.2202 & 0.000 & 5.676 & 8.809 & 9.986 & \text { No }\end{array}$ $\begin{array}{llllllllllllllll}\text { NDFQLIGIQDGYLSLLDSGEVR } & 0.91 & 18.24 & 26.66 & 15.27 & 3 & 2723.3914 & 2723.3888 & 908.8035 & 0.0026 & 0.9536 & 5.469 & 7.928 & 9.978 & 13.205 & \text { YeS }\end{array}$ $\begin{array}{llllllllllllllll}\text { NDFQLIGIQDGYLSLLDDSGEVR } & 1.00 & 85.63 & 26.67 & 25.18 & 2 & 2723.3914 & 2723.3888 & 1362.7017 & 0.0026 & 0.9540 & 0.000 & 5.983 & 4.176 & 13.398 & \text { No }\end{array}$ $\begin{array}{lllllllllllllllll}\text { NDFQLIGILDGYLSLLDDSGEVR } & 0.82 & 21.38 & 26.66 & 19.67 & 3 & 2723.3947 & 2723.3888 & 908.8035 & 0.0059 & 2.1640 & 16.408 & 8.770 & 27.406 & 32.682 & \text { YeS }\end{array}$ $\begin{array}{lllllllllllllllll}\text { NDFQLIGILDGYLSLLQDSGEVR } & 0.97 & 29.06 & 26.66 & 20.17 & 3 & 2723.3947 & 2723.3888 & 908.8035 & 0.0059 & 2.1640 & 5.402 & 39.243 & 23.934 & 23.745 & \text { Yes }\end{array}$ $\begin{array}{lllllllllllllllll}\text { NDFQLGILDGYLSLLQDSGEVR } & 0.65 & 20.56 & 26.63 & 15.63 & 3 & 2723.3968 & 2723.3888 & 908.8035 & 0.0080 & 2.9343 & 7.309 & 27.502 & 0.000 & 36.453 & \text { No }\end{array}$ $\begin{array}{llllllllllllllll}\text { NDFQLGIQDGYLSLLQDSGEVR } & 0.89 & 29.77 & 26.52 & 19.40 & 3 & 2723.4094 & 2723.3888 & 908.8035 & 0.0206 & 7.5557 & 4.587 & 0.000 & 10.383 & 25.696 & \text { No }\end{array}$

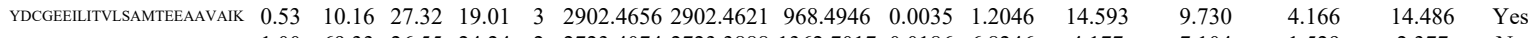
$\begin{array}{llllllllllllllll}\text { NDFQLIGIDDGYLSLLQDSGEVR } & 1.00 & 69.33 & 26.55 & 24.24 & 2 & 2723.4074 & 2723.3888 & 1362.7017 & 0.0186 & 6.8246 & 4.177 & 7.104 & 1.529 & 2.377 & \text { No }\end{array}$

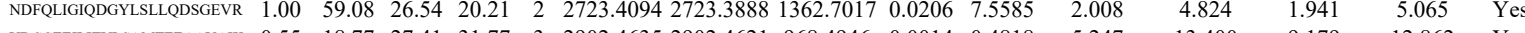
$\begin{array}{lllllllllllll}\text { MDCGEELITVLSAMTEEAAVAIK } & 0.55 & 18.77 & 27.41 & 31.77 & 3 & 2902.4635 & 2902.4621 & 968.4946 & 0.0014 & 0.4818 & 5.247\end{array}$

13.400

NGFVVLK

NGFV LK

NGTVLK

VHLVGIDIFTGK

VHLVGIDIFTGK

VHLVGIDIFTGK

VHLVGIDITGK

VHLVGIDIFTGK
VHLVGIDIFTGK $\begin{array}{lllllllllllllll}0.56 & 25.16 & 26.86 & 28.10 & 2 & 1063.6686 & 033.6634 & 532.8390 & 0.0052 & 4.8795 & 16260.310 & 16913.692 & 3823.144 & 20631.892 & \text { Yes }\end{array}$ $\begin{array}{llllllllllllllll}0.90 & 39.35 & 24.28 & 39.83 & 2 & 1063.6710 & 1063.6634 & 532.8390 & 0.0076 & 7.1316 & 9555.766 & 11401.807 & 3019.382 & 9676.118 & \text { Yes }\end{array}$ $\begin{array}{lllllllllllllll}0.99 & 48.21 & 24.28 & 36.39 & 2 & 1063.6718 & 1063.6634 & 532.8390 & 0.0084 & 7.8822 & 11788.504 & 14948.621 & 4082.386 & 12548.943 & \text { Yes }\end{array}$ $\begin{array}{lllllllllllllll}0.88 & 15.62 & 23.44 & 18.28 & 3 & 1585.9450 & 1585.9436 & 529.6551 & 0.0014 & 0.8811 & 136.712 & 180.809 & 142.111 & 205.673 & \text { Yes }\end{array}$ $\begin{array}{llllllllllllllll}0.96 & 19.10 & 23.34 & 22.41 & 3 & 1585.9456 & 1585.9436 & 529.6551 & 0.0020 & 1.2587 & 160.801 & 160.257 & 130.727 & 253.831 & \text { Yes }\end{array}$ \begin{tabular}{lllllllllllllll}
1.00 & 65.60 & 23.34 & 24.76 & 2 & 1585.9456 & 1585.9436 & 793.9791 & 0.0020 & 1.2595 & 3887.373 & 3827.902 & 588.399 & 6847.146 & Yes \\
\hline
\end{tabular} $\begin{array}{llllllllllllllll}0.97 & 23.85 & 23.22 & 26.24 & 3 & 1585.9465 & 1585.9436 & 529.6551 & 0.0029 & 1.8251 & 7697.499 & 7108.003 & 1039.813 & 9050.464 & \text { Yes } \\ 1.00 & 81.98 & 23.22 & 25.41 & 2 & 1585.9470 & 1585.9436 & 793.9791 & 0.0034 & 2.1411 & 8286.539 & 6438.231 & 430.622 & 12233.606 & \text { Yes }\end{array}$ $\begin{array}{rllllllllllllll}1.00 & 81.98 & 23.22 & 25.41 & 2 & 1585.9470 & 1585.9436 & 793.9791 & 0.0034 & 2.1411 & 8286.539 & 6438.231 & 430.622 & 12233.606 & \text { Yes } \\ 0.82 & 11.89 & 23.24 & 15.24 & 3 & 1585.94711585 .9436 & 529.6551 & 0.0035 & 22027 & 88.194 & 95.065 & 111.098 & 107.101 & Y e s\end{array}$ $\begin{array}{lllllllllllllll}0.82 & 11.89 & 23.24 & 15.24 & 3 & 1585.9471 & 1585.9436 & 529.6551 & 0.0035 & 2.2027 & 88.194 & 95.065 & 111.098 & 107.101 & \text { Yes } \\ 1.00 & 33.92 & 22.92 & 22.88 & 3 & 1585.9483 & 1585.9436 & 529.6551 & 0.0047 & 2.9579 & 29462.642 & 29495.399 & 1451.929 & 48756.953 & \text { Yes }\end{array}$ $\begin{array}{llllllllllllllll}1.00 & 33.92 & 22.92 & 22.88 & 3 & 1585.9483 & 1585.9436 & 529.6551 & 0.0047 & 2.9579 & 29462.642 & 29495.399 & 1451.929 & 48756.953 & \text { Yes } \\ 1.00 & 67.86 & 23.34 & 23.17 & 2 & 1585.9462 & 1585.9436 & 793.9791 & 0.0026 & 1.6373 & 244.567 & 2609.722 & 321.522 & 5337.516 & \text { Yes }\end{array}$

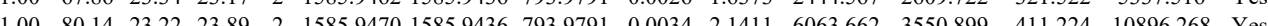
$\begin{array}{lllllllllllllll}1.00 & 80.14 & 23.22 & 23.89 & 2 & 1585.9470 & 1585.9436 & 793.9791 & 0.0034 & 2.1411 & 6063.662 & 3550.899 & 411.224 & 10896.268 & \text { Yes } \\ 1.00 & 36.46 & 23.24 & 22.05 & 3 & 1585.9471 & 1585.9436 & 529.6551 & 0.0035 & 2.2027 & 9573.772 & 10232.886 & 803.009 & 17773.116 & \text { Yes }\end{array}$

Table S-4 page 407 of 614 
VHLVGIDIFTGK $\begin{array}{llllllllll}0.86 & 10.46 & 27.36 & 23.46 & 4 & 2902.4661 & 2902.4621 & 726.6228 & 0.0040 & 1.3762\end{array}$

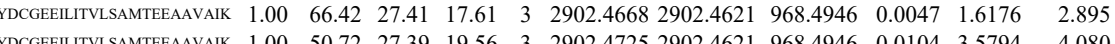

$\begin{array}{llllllllllll}\text { VDCGEELITVLSAMTEEAAVAIK } & 1.00 & 50.72 & 27.39 & 19.56 & 3 & 2902.4725 & 2902.4621 & 968.4946 & 0.0104 & 3.5794 & 4.080\end{array}$

LPEGDLGK

LPEGDLGK

LPEGDLGK

LPEGDLGK

LPEGDLGK

LPEGDLGK

LPEGDLGK

LPEGDLGK

LPEGDLGK

LPEGDLGK

LPEGDLGK

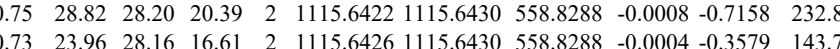
$\begin{array}{lllllllllll}0.74 & 24.14 & 28.14 & 21.53 & 2 & 1115.6428 & 1115.6430 & 558.8288 & -0.0002 & -0.1789 & 156.629\end{array}$ $\begin{array}{llllll}15.6428 & 1115.6430 & 558.8288 & -0.0002 & -0.1789 & 156.629\end{array}$ $\begin{array}{lllllllllllll}0.57 & 2.79 & 28.14 & 20.92 & 2 & 1115.6430 & 1115.6430 & 558.8288 & 0.0000 & 0.0000 & 178.830 & 156 \\ 0.78 & 25.06 & 28.25 & 17.19 & 2 & 1115.6434 & 1115.6430 & 558.8288 & 0.0004 & 0.3579 & 253.553 & 20\end{array}$ $\begin{array}{lllllllllllll}0.78 & 25.06 & 28.25 & 17.19 & 2 & 1115.6434 & 1115.6430 & 558.8288 & 0.0004 & 0.3579 & 253.553 \\ 0.90 & 24.96 & 28.26 & 20.06 & 2 & 1115.6436 & 1115.6430 & 558.8288 & 0.0006 & 0.5368 & 247.717\end{array}$

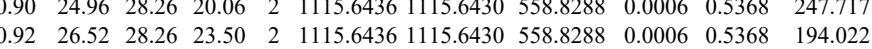

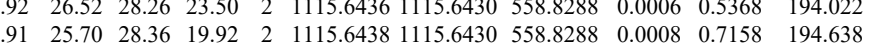
$\begin{array}{lllllllllll}0.90 & 25.77 & 28.36 & 19.92 & 2 & 115.64368 & 115.6430 & 558.8288 & 0.0008 & 0.7158 & 194.638\end{array}$

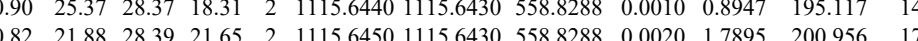

PEGDLGK

LPEGDLGK

PPEGDLGK

LPEGDLGK

LPEGDLGK

LPEGDLGK

LPEGDLGK

LPEGDLGK

LPEGDLGK

$\begin{array}{llllllllllllll}\text { GBLP HUMAN } & \text { P63244 } & \text { GNB2L1 } & \text { Guanine nucleotid 35.077 } & 1.00 & 12 & 46.4 & 0.0513 & 0.2458 & 0.8300 & 0.2503 & 69 & \text { IWDLEGK }\end{array}$

IIVDELK

IWDLEGK

IWDLEGK

IWDLEGK

IWDLEGK

IWDLEGK

IWDLEGK

IWDLEGK

IWDLEGK

IWDLEGK

IWDLEGK

IWDLEGK

IWDLEGK

IWDLEGK

IWDLEGK

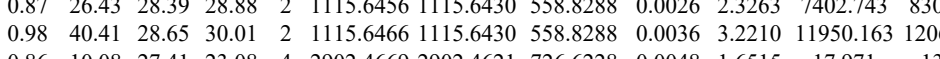

0.000 $\begin{array}{lllllllllllllll}0.56 & 10.08 & 27.41 & 23.08 & 4 & 2902.4669 & 2902.4621 & 726.6228 & 0.0048 & 1.6515 & 17.971 & 13.014 & 10.543 & 5.594 & \text { Yes }\end{array}$

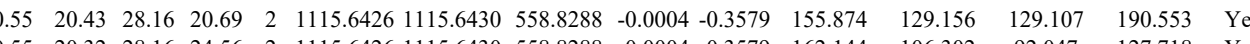
$\begin{array}{lllllllllllllll}0.72 & 23.57 & 28.14 & 19.83 & 2 & 1115.6428 & 1115.6430 & 558.8288 & 0.004 & 0.3789 & 142.609 & 143.134 & 127.454 & 220.813 & \text { Yes }\end{array}$

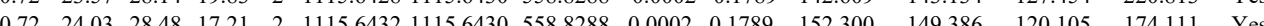
$\begin{array}{lllllllllllllll}0.87 & 28.12 & 28.25 & 26.96 & 2 & 1115.6434 & 1115.6430 & 558.8288 & 0.0004 & 0.3579 & 5854.222 & 8550.834 & 19966.017 & 19758.258 & \text { Yes }\end{array}$

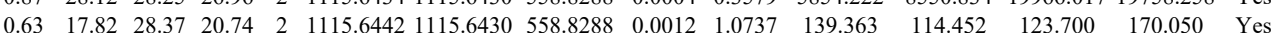
$\begin{array}{lllllllllllllll}0.66 & 18.46 & 28.33 & 22.53 & 2 & 1115.6444 & 11156430 & 558.8288 & 0.0014 & 1.2526 & 165.897 & 141.260 & 125.945 & 185.430 & \text { Yes }\end{array}$ $\begin{array}{lllllllllllllll}0.80 & 21.52 & 28.33 & 16.19 & 2 & 1115.6444 & 1115.6430 & 558.8288 & 0.0014 & 1.2526 & 93.730 & 64.756 & 61.387 & 98.962 & \text { Yes }\end{array}$ $\begin{array}{lllllllllllllll}0.99 & 38.50 & 28.39 & 26.64 & 2 & 1115.6452 & 1115.6430 & 558.8288 & 0.0022 & 1.9684 & 12606.005 & 11458.914 & 37380.201 & 41914.674 & \text { Yes }\end{array}$ $\begin{array}{llllllllllllllll}0.99 & 40.52 & 26.52 & 29.98 & 2 & 1115.6536 & 1115.6430 & 558.8288 & 0.0106 & 9.4840 & 7912.977 & 6322.942 & 15991.465 & 17959.145 & \text { Yes }\end{array}$ $\begin{array}{lllllllllllllll}0.69 & 18.45 & 28.29 & 25.67 & 2 & 1147.6500 & 1147.6481 & 574.8313 & 0.0019 & 1.6527 & 84.562 & 120.030 & 86.045 & 135.660 & \text { Yes }\end{array}$

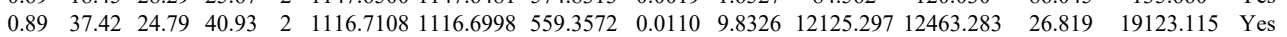
$\begin{array}{llllllllllllllll}0.80 & 25.52 & 28.02 & 29.54 & 2 & 1147.6478 & 1147.6481 & 574.8313 & -0.0003 & -0.2609 & 172.970 & 162.286 & 190.349 & 232.287 & \text { Yes }\end{array}$ $\begin{array}{llllllllllllllll}0.95 & 34.06 & 28.11 & 36.07 & 2 & 1147.6480 & 1147.6481 & 574.8313 & -0.0001 & -0.0870 & 214.128 & 190.138 & 241.581 & 322.551 & \text { Yes }\end{array}$

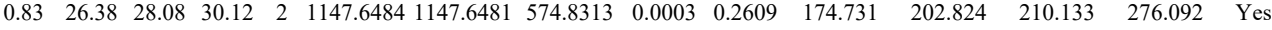

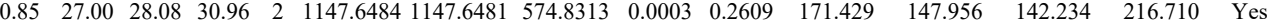

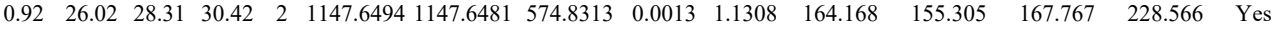
$\begin{array}{llllllllllllllll}0.93 & 26.19 & 28.32 & 29.87 & 2 & 1147.6496 & 1147.6481 & 574.8313 & 0.0015 & 1.3047 & 237.706 & 184.467 & 237.369 & 321.604 & \text { Yes }\end{array}$ $\begin{array}{lllllllllllllll}0.98 & 34.03 & 28.29 & 36.07 & 2 & 1147.6500 & 1147.6481 & 574.8313 & 0.0019 & 1.6527 & 185.751 & 170.420 & 175.267 & 238.382 & \text { Yes }\end{array}$

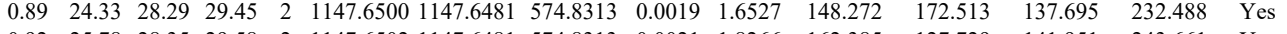
$\begin{array}{lllllllllllllll}0.92 & 25.78 & 28.35 & 29.58 & 2 & 1147.6502 & 1147.6481 & 574.8313 & 0.0021 & 1.8266 & 162.385 & 127.729 & 141.951 & 243.661 & \text { Yes }\end{array}$

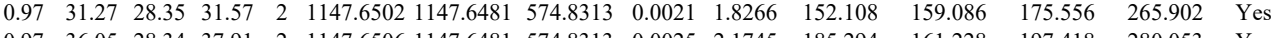
$\begin{array}{lllllllllllllll}0.97 & 36.05 & 28.34 & 37.91 & 2 & 1477.6506 & 1147.6481 & 574.8313 & 0.0025 & 2.1745 & 185.294 & 161.228 & 197.418 & 280.053 & \text { Yes }\end{array}$

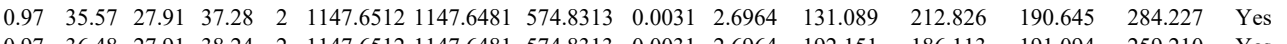
\begin{tabular}{lllllllllllllll}
0.97 & 36.48 & 27.91 & 38.24 & 2 & 147.6512 & 1477.6481 & 574.8313 & 0.0031 & 2.6964 & 192.151 & 186.113 & 191.094 & 259.210 & Yes \\
\hline
\end{tabular} $\begin{array}{lllllllllllllllll}0.98 & 40.92 & 28.31 & 42.54 & 2 & 1147.6494 & 1147.6481 & 574.8313 & 0.0013 & 1.1308 & 5862.894 & 5586.360 & 10778.929 & 12906.822 & \text { Yes } \\ 0.97 & 40.91 & 27.73 & 42.56 & 2 & 1147.6510 & 1147.6481 & 574.8313 & 0.0029 & 2.5225 & 3987.005 & 3991.121 & 6505.128 & 7880278 & \text { Yes }\end{array}$

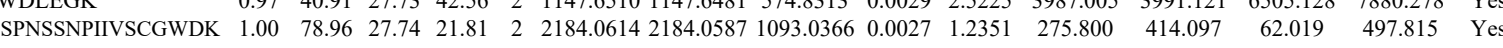
\begin{tabular}{lllllllllllllllll} 
& 27.74 & 21.81 & 2 & 2184.0614 & 2184.0587 & 03.036 & 0.0027 & 1.2351 & 275.805 & 414.097 & 62.019 & 49.815 & Yes \\
\hline
\end{tabular} $\begin{array}{lllllllllllllll}1.00 & 58.73 & 28.44 & 25.63 & 2 & 1407.7610 & 1407.7480 & 704.8813 & 0.0130 & 9.2213 & 067.075 & 816.009 & 223.929 & 1721.230 & \text { Yes }\end{array}$ 
$\begin{array}{llllllllllllllll}\text { LWNTLGVCK } & 1.00 & 53.00 & 28.41 & 27.79 & 2 & 1366.7356 & 1366.7345 & 684.3745 & 0.0011 & 0.8037 & 26989.312 & 28334.784 & 5959.088 & 55929.827 & \text { Yes } \\ \text { LWNTLGVCK } & 1.00 & 49.52 & 28.41 & 22.27 & 2 & 1366.7358 & 1366.7345 & 64.3745 & 0.0013 & 0.9498 & 14403.628 & 15634.811 & 3767.49 & 32123.404 & \text { Yes }\end{array}$

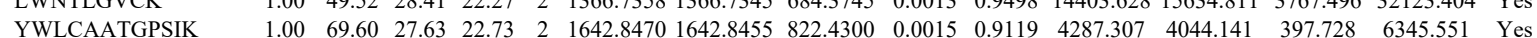

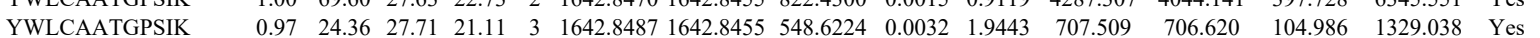
$\begin{array}{llllllllllllllll}\text { YWLCAATGPSIK } & 1.00 & 65.75 & 27.69 & 20.83 & 2 & 1642.8490 & 1642.8455 & 822.4300 & 0.0035 & 21278 & 3554.059 & 4237.918 & 287.199 & 5316.985 & \text { Yes }\end{array}$

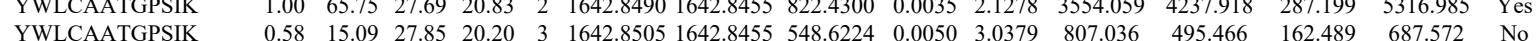
$\begin{array}{llllllllllllllll}\text { GHNGWYTOATTPOFPDMU SASR } & 1.00 & 74.43 & 26.97 & 18.10 & 3 & 2770.3987 & 27703983 & 924.4734 & 0.0004 & 0.1442 & 0.000 & 71.136 & 28.314 & 51.886 & \text { No }\end{array}$

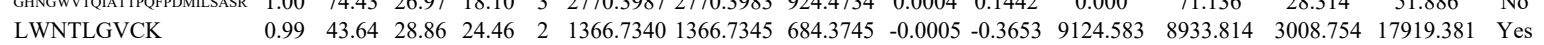
$\begin{array}{llllllllllllllll}\text { LWNTLGVCK } & 1.00 & 49.34 & 28.38 & 21.87 & 2 & 1366.7360 & 1366.7345 & 684.3745 & 0.0015 & 1.0959 & 3256.758 & 2995.732 & 916.157 & 5824.685 & \text { Yes }\end{array}$ $\begin{array}{llllllllllllllll}\text { YWLCAATGPSIK } & 1.00 & 59.19 & 27.74 & 23.06 & 2 & 1642.8476 & 1642.8455 & 822.4300 & 0.0021 & 1.2767 & 258.810 & 220.128 & 66.171 & 570.521 & \text { No }\end{array}$ \begin{tabular}{llllllllllllllll} 
YWLCAATGPSIK & 0.68 & 13.19 & 27.71 & 22.57 & 3 & 1642.8487 & 1642.8455 & 548.6224 & 0.0032 & 1.9443 & 409.726 & 352.613 & 74.946 & 736.282 & Yes \\
\hline
\end{tabular}

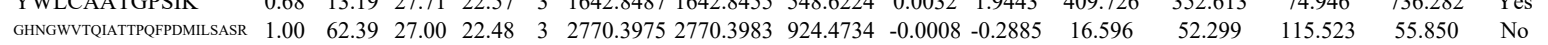
$\begin{array}{lllllllllllllllll}\text { GHNGWVTPIATTPPPDMILSASR } & 1.00 & 51.54 & 26.96 & 18.17 & 3 & 2770.3990 & 2770.3983 & 924.4734 & 0.0007 & 0.2524 & 56.314 & 32.804 & 97.520 & 43.955 & \text { No }\end{array}$ \begin{tabular}{llllllllllllllll} 
VWQVTIGTR & 0.57 & 27.46 & 27.02 & 26.73 & 2 & 1202.6870 & 1202.6894 & 602.3520 & -0.0024 & -1.9922 & 147.297 & 119.789 & 78.121 & 181.903 & Yes \\
\hline
\end{tabular} $\begin{array}{llllllllllllllll}\text { VWQVTIGTR } & 0.59 & 20.28 & 27.28 & 27.28 & 2 & 1202.6894 & 1202.6894 & 602.3520 & 0.0000 & 0.0000 & 142.198 & 130.782 & 75.633 & 211.097 & \text { Yes }\end{array}$

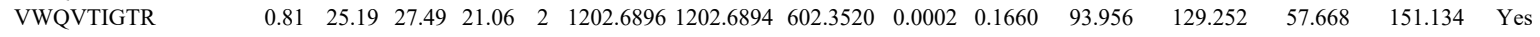
$\begin{array}{llllllllllllllll}\text { VWQVTIGTR } & 0.90 & 28.67 & 27.49 & 16.51 & 2 & 1202.6898 & 1202.6894 & 602.3520 & 0.0004 & 0.3320 & 149.814 & 177.182 & 106.520 & 240.028 & \text { Yes }\end{array}$ $\begin{array}{llllllllllllllll}\text { VWQVTIGTR } & 0.85 & 26.62 & 27.49 & 25.79 & 2 & 1202.6898 & 1202.6894 & 602.3520 & 0.0004 & 0.3320 & 119.466 & 123.095 & 66.836 & 150.248 & \text { Yes }\end{array}$

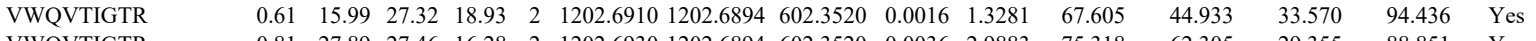

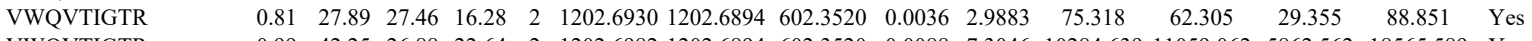

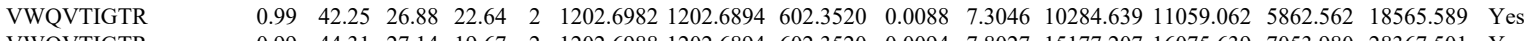
VWQVTIGTR VWQVTIGTR VWQVTIGTR VWQVTIGTR VWQVTIGTR VWQVTIGTR VWQVTGIR

VWQVTIGTR $\begin{array}{lllllllllllllllll}0.99 & 44.31 & 27.14 & 19.67 & 2 & 1202.6988 & 1202.6894 & 602.3520 & 0.0094 & 7.8027 & 15177.207 & 16075.639 & 7053.980 & 28367.501 & \text { Yes }\end{array}$ $\begin{array}{lllllllllllllll}0.98 & 41.91 & 26.88 & 20.98 & 2 & 1202.6976 & 1202.6894 & 602.3520 & 0.0082 & 6.8066 & 8393.490 & 8719.372 & 4559.379 & 15159.910 & \text { Yes }\end{array}$

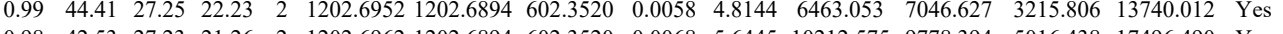
$\begin{array}{lllllllllllllllll}0.98 & 42.53 & 27.23 & 21.26 & 2 & 1202.6962 & 1202.6894 & 602.3520 & 0.0068 & 5.6445 & 0212.575 & 9778.394 & 5016.438 & 17496.490 & \text { Yes }\end{array}$ $\begin{array}{lllllllllllllll}0.98 & 43.50 & 27.20 & 19.84 & 2 & 1202.6958 & 1202.6894 & 602.3520 & 0.0064 & 5.3125 & 1431.701 & 1537.493 & 808.136 & 2834.091 & \text { Yes }\end{array}$

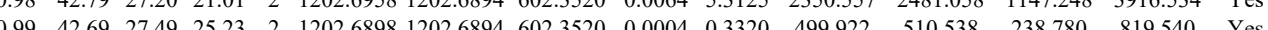
$\begin{array}{lllllllllllllll}0.99 & 41.81 & 27.49 & 21.52 & 2 & 1202.6896 & 1202.6894 & 602.352 & 0.0002 & 0.1260 & 744.509 & 848.421 & 410.413 & 1345.541 & \text { Y }\end{array}$

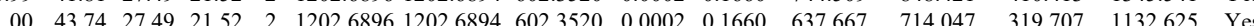
$\begin{array}{llllllllllllllll} & \end{array}$

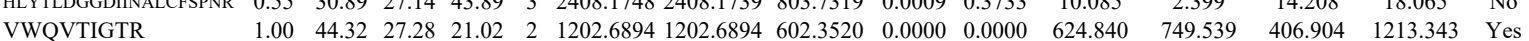

VWQVTIGTR

VWQVTIGTR $\begin{array}{llllllllllll}1.00 & 44.32 & 27.28 & 21.02 & 2 & 1202.6894 & 1202.6894 & 602.3520 & 0.0000 & 0.0000 & 624.840 & 749.5\end{array}$

VWQVTIGTR

VWQVTIGTR

VWQVTIGTR

VWQVTIGTR

VWQVTIGTR

VWQVTIGTR

VWQVTIGTR

VWQVTIGTR

VWQVTIGTR

VWQVTIGTR

DETNYGIPQR

DETNYGIPQR

$\begin{array}{lllllllllllll}1.00 & 43.91 & 27.49 & 22.40 & 2 & 1202.6898 & 1202.6894 & 602.3520 & 0.0004 & 0.3320 & 528.576 & 584.482 \\ 1.00 & 44.72 & 27.33 & 25.37 & 2 & 1202.6904 & 1202.6894 & 602.3520 & 0.0010 & 0.8301 & 190.844 & 168.304\end{array}$

$\begin{array}{lllllllllllll}1.00 & 44.43 & 27.35 & 24.39 & 2 & 1202.6906 & 1202.6894 & 602.3520 & 0.0012 & 0.9961 & 105.672 & 140.495\end{array}$ $\begin{array}{llllllllllll}1.00 & 40.20 & 27.32 & 23.58 & 2 & 1202.6910 & 1202.6894 & 602.3520 & 0.0016 & 1.3281 & 118.810 & 138\end{array}$ $\begin{array}{lllllllllllll}0.99 & 38.88 & 27.31 & 24.57 & 2 & 1202.6920 & 1202.6894 & 602.3520 & 0.0026 & 2.1582 & 101.064\end{array}$ $\begin{array}{llllllllllll}0.98 & 32.21 & 27.16 & 22.05 & 2 & 1202.6902 & 1202.6894 & 602.3520 & 0.0008 & 0.6641 & 133.232 & 13\end{array}$ $\begin{array}{llllllllllll}0.99 & 35.76 & 27.33 & 21.29 & 2 & 1202.6904 & 1202.6894 & 602.3520 & 0.0010 & 0.8301 & 235.591\end{array}$ $\begin{array}{llllllllllll}0.99 & 38.70 & 27.49 & 24.19 & 2 & 1202.6898 & 1202.6894 & 602.3520 & 0.0004 & 0.3320 & 109.969\end{array}$ $\begin{array}{llllllllllllll}100 & 45.80 & 27.49 & 22.53 & 2 & 1202.6898 & 1202.6894 & 602.3520 & 0.0004 & 0.3320 & 167.945 & 186\end{array}$ $\begin{array}{lllllllllllll}1.00 & 43.27 & 27.33 & 20.87 & 2 & 1202.6904 & 1202.6894 & 602.3520 & 0.0010 & 0.8301 & 125.141 & 186 & \\ \end{array}$ $\begin{array}{lllllllllllll}1.00 & 40.98 & 27.35 & 24.20 & 2 & 1202.6906 & 1202.6894 & 62.3520 & 0.0012 & 0.9961 & 142.579 & 177 \\ 0.98 & 32.83 & 27.32 & 22.72 & 2 & 1202.6008 & 1202.6894 & 602.3520 & 0.0014 & 1.1621 & 144.857 & 133\end{array}$ $\begin{array}{llllllllllll}0.98 & 32.83 & 27.32 & 22.72 & 2 & 1202.6908 & 1202.6894 & 602.3520 & 0.0014 & 1.1621 & 144.857 & 13 \\ 0.99 & 35.53 & 27.32 & 24.40 & 2 & 1202.6910 & 1202.6894 & 602.3520 & 0.0016 & 1.3281 & 167.102 & 16 \\ 1.00 & 57.55 & 27.24 & 9.68 & 2 & 1335.6548 & 1335.6541 & 668.8343 & 0.007 & 0.5233 & 5737.909 & 580\end{array}$

$\begin{array}{llllllllllll}1.00 & 50.10 & 27.28 & 23.87 & 2 & 1335.6550 & 1335.6541 & 668.8343 & 0.0009 & 0.6728 & 3396.581 & 3073\end{array}$

DGQAMLWDLNEGK IIVDELK

$\begin{array}{lllllllllllll}0.82 & 68.22 & 27.54 & 81.22 & 2 & 1763.8768 & 1763.8756 & 882.9451 & 0.0012 & 0.6795 & 51.580 & 29.543\end{array}$ IIVDELK

$\begin{array}{llllllllllll}0.99 & 51.96 & 24.79 & 43.26 & 2 & 1116.7104 & 1116.6998 & 559.3572 & 0.0106 & 9.4751 & 11429.074 & 13948.207\end{array}$ $\begin{array}{lllllllllllll}0.99 & 52.03 & 24.79 & 43.33 & 2 & 1116.7108 & 1116.6998 & 559.3572 & 0.0110 & 9.8326 & 18367.183 & 21976.93\end{array}$ \begin{tabular}{lllllllllllll} 
NEGSESAPEGQAQQR & 1.00 & 87.70 & 25.26 & 25.76 & 2 & 1730.7946 & 1730.7941 & 866.4043 & 0.0005 & 0.2885 & 48.783 \\
\hline
\end{tabular} $\begin{array}{lllllllllllll}\text { NEGSESAPEGQAQQR } & 1.00 & 87.70 & 25.26 & 22.20 & 2 & 1730.7946 & 1730.7941 & 866.4043 & 0.0005 & 0.2885 & 21.749\end{array}$ $\begin{array}{llllllllllll}\text { NEGSESAPEQQAQQR } & 1.00 & 57.05 & 25.37 & 18.56 & 3 & 1730.7952 & 1730.7941 & 577.9386 & 0.0011 & 0.6344 & 8.376\end{array}$ $\begin{array}{llllllllllllll}\text { AADPPAENSSAPEAEQGGAE } & 0.64 & 84.91 & 23.84 & 97.91 & 2 & 2040.8994 & 2040.8994 & 1021.4570 & 0.0000 & 0.0000 & 0.000\end{array}$ $\begin{array}{lllllllllllll}\text { EDGMEEDKENOGDETOGOOPPOR } & 1.00 & 35.85 & 22.92 & 48.85 & 4 & 2915.3013 & 2915.3009 & 729.8325 & 0.0004 & 0.1370 & 13.740\end{array}$ $\begin{array}{llllllllllll}\text { EDGNEEDKENOGDETTGOOPPOR } & 1.00 & 59.05 & 22.94 & 17.46 & 3 & 2915.3026 & 2915.3009 & 972.7742 & 0.0017 & 0.5825 & 2.876\end{array}$ 
$\begin{array}{llllllllllll}\text { NYQQNYQNSESGEK } & 1.00 & 77.02 & 25.79 & 25.12 & 2 & 1975.9114 & 1975.9115 & 988.9630 & -0.0001 & -0.0506 & 1754.808\end{array}$

$\begin{array}{llllllllllll}\text { NYQQNYONSESGEK } & 1.00 & 71.26 & 25.75 & 28.99 & 2 & 1975.9118 & 1975.9115 & 988.9630 & 0.0003 & 0.1517 & 1165.088\end{array}$

$\begin{array}{llllllllllllll}\text { NYQQNYQNSESGEK } & 0.55 & 35.88 & 25.74 & 48.88 & 3 & 1975.9126 & 1975.9115 & 659.6444 & 0.0011 & 0.5559 & 354.267\end{array}$ $\begin{array}{llllllllllll}\text { NYQQNYQNSESGEK } & 0.55 & 11.76 & 25.69 & 24.76 & 3 & 1975.9129 & 1975.9115 & 659.6444 & 0.0014 & 0.7075 & 78.485\end{array}$ $\begin{array}{lllllllllll}1.00 & 25.30 & 22.86 & 38.30 & 4 & 2915.3045 & 2915.3009 & 729.8325 & 0.0036 & 1.2332 \\ 0.96 & 15.52 & 2.45 & 28.52 & 4 & 1696.9577 & 1696.9586 & 425.2469 & -0.0009 & -0.5291\end{array}$

$\begin{array}{lllllllllll}0.96 & 15.52 & 25.48 & 28.52 & 4 & 1696.9577 & 1696.9586 & 425.2469 & -0.0009 & -0.5291 & 429.810\end{array}$ $\begin{array}{lllllllllll}0.82 & 6.03 & 26.90 & 28.83 & 3 & 2837.4085 & 2837.4079 & 946.8099 & 0.0006 & 0.2112 & 119.233 \\ 0.99 & 4.03 & 2837.404 & 2837.4079 & 1419.7112 & 0.0015 & 0.5283 & 3.285\end{array}$ $\begin{array}{lllllllllll}0.55 & 15.83 & 26.95 & 28.83 & 3 & 2837.4085 & 2837.4079 & 946.8099 & 0.0006 & 0.2112 & 119.233\end{array}$ $\begin{array}{lllllllllllll}0.82 & 65.03 & 26.90 & 78.03 & 2 & 2837.404 & 2837.4079 & 1419.712 & 0.0015 & 0.5283 & 3.285 & 2.114 & 4 \\ 1.00 & 39.91 & 26.5535 .86 & 3 & 1227.6552 & 1227.6958 & 410.2392 & 0.0006 & 0.4875 & 1079.696 & 1429.528 & 79\end{array}$ $\begin{array}{llllllllllll}1.98 & 3.91 & 26.53 & 32.43 & 3 & 1227.694 & 1227.6958 & 410.2392 & 0.0006 & 0.4875 & 107.513 & 1261.898\end{array}$ $\begin{array}{lllllllllllll}1.00 & 41.92 & 26.61 & 32.76 & 3 & 1227.6967 & 1227.6958 & 410.2392 & 0.0009 & 0.7313 & 1225.598 & 2588.801 & 162\end{array}$ $\begin{array}{llllllllllll}41.47 & 26.53 & 34.90 & 3 & 1227.6961 & 1227.6958 & 410.2392 & 0.0003 & 0.2438 & 1337.844 & 2434.687\end{array}$

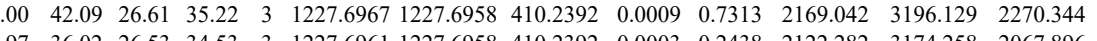

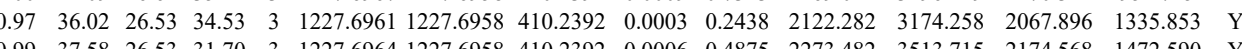
$\begin{array}{llllllllllllllll}0.97 & 36.71 & 26.53 & 34.76 & 3 & 1227.6961 & 1227.6958 & 410.2392 & 0.0003 & 0.2438 & 1276.520 & 1758.630 & 1664.642 & 1134.958 & \text { Yes }\end{array}$ $\begin{array}{llllllllllllllll}1.00 & 43.04 & 26.53 & 35.02 & 3 & 1227.6964 & 1227.6958 & 410.2392 & 0.0006 & 0.4875 & 1277.457 & 1970.760 & 1280.665 & 1033.483 & \text { Yes }\end{array}$ $\begin{array}{llllllllllllllll}0.61 & 28.17 & 26.41 & 35.26 & 3 & 1227.6949 & 1227.6958 & 410.2392 & -0.0009 & -0.7313 & 763.481 & 1065.707 & 1143.795 & 959.393 & \text { Yes } \\ 0.92 & 34.64 & 26.41 & 34.36 & 3 & 1227.6949 & 1227.6958 & 410.2392 & -0.0009 & -0.7313 & 1386.487 & 1762.615 & 1472.291 & 1095.145 & \text { Yes } \\ 1.00 & 42.63 & 66.61 & 29.45 & 3 & 1227.6955 & 1227.6958 & 410.2392 & -0.0003 & -0.2438 & 861.801 & 1616.930 & 1382.515 & 936.326 & \text { Yes }\end{array}$ \begin{tabular}{llllllllllllllll}
1.00 & 42.63 & 26.61 & 29.45 & 3 & 1227.6955 & 1227.6958 & 410.2392 & -0.0003 & -0.2438 & 861.801 & 1616.930 & 1382.515 & 936.326 & Yes \\
\hline
\end{tabular}

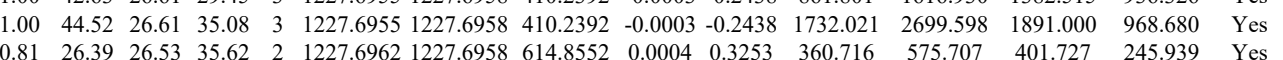
$\begin{array}{lllllllllllllll}0.81 & 26.39 & 26.53 & 35.62 & 2 & 1227.6962 & 1227.6958 & 614.8552 & 0.0004 & 0.3253 & 360.716 & 575.707 & 401.727 & 245.939 & \text { Yes } \\ 1.00 & 45.23 & 66.53 & 32.02 & 3 & 1227.655 & 1227.658 & 410.2392 & 0.0003 & -0.2438 & 594.790 & 994.449 & 880.134 & 527.883 & \text { Yes }\end{array}$ $\begin{array}{lllllllllllllll}0.99 & 35.08 & 26.61 & 27.02 & 3 & 1227.6955 & 1227.6958 & 410.2392 & -0.0003 & -0.2438 & 594.790 & 994.449 & 880.134 & 527.883 & \text { Yes } \\ 1.00 & 47.23 & 26.53 & 32.70 & 3 & 1227.6961 & 1227.6958 & 410.2392 & 0.0003 & 0.2438 & 740.232 & 1415.786 & 1056.089 & 594.380 & \text { Yes }\end{array}$ $\begin{array}{llllllllllllllll}1.00 & 42.84 & 26.61 & 31.82 & 3 & 1227.6955 & 1227.6958 & 410.2392 & -0.0003 & -0.2438 & 475.069 & 869.783 & 669.709 & 413.310 & \text { Yes }\end{array}$

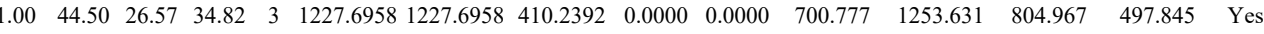

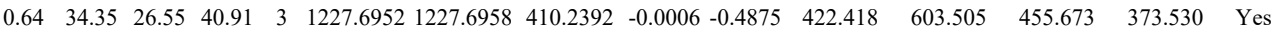

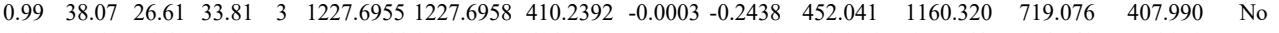

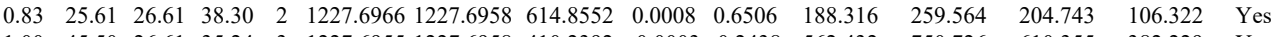
$\begin{array}{llllllllllllllll}1.00 & 45.50 & 26.61 & 35.24 & 3 & 1227.6955 & 1227.6958 & 410.2392 & -0.0003 & -0.2438 & 562.432 & 750.726 & 610.355 & 382.229 & \text { Yes }\end{array}$

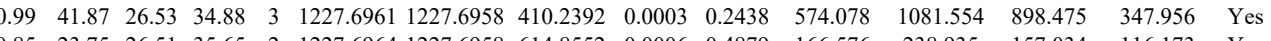
$\begin{array}{llllllllllllllll}0.85 & 23.75 & 26.51 & 35.65 & 2 & 1227.6964 & 1227.6958 & 614.8552 & 0.0006 & 0.4879 & 166.576 & 238.935 & 157.034 & 116.173 & \text { Yes }\end{array}$ $\begin{array}{lllllllllllllll}0.95 & 35.71 & 26.55 & 33.59 & 3 & 1227.6952 & 1227.6958 & 410.2392 & -0.0006 & -0.4875 & 372.500 & 524.976 & 491.480 & 340.794 & \text { Yes }\end{array}$

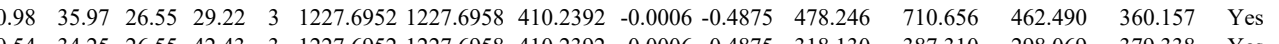

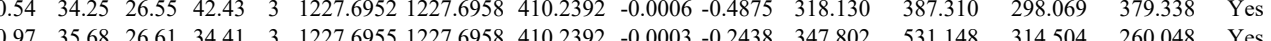
$\begin{array}{ccccccccccccccc}0.97 & 35.68 & 26.61 & 34.41 & 3 & 1227.6955 & 1227.6958 & 410.2392 & -0.0003 & -0.2438 & 347.802 & 531.148 & 314.504 & 260.048 & \text { Yes } \\ 0.83 & 27.23 & 26.61 & 40.06 & 2 & 1227.6966 & 1227.6958 & 614.8552 & 0.0008 & 0.6506 & 113.670 & 143.906 & 94.313 & 102.393 & \text { Yes }\end{array}$

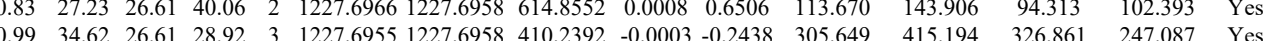
$\begin{array}{lllllllllllllll}0.99 & 34.62 & 26.61 & 28.92 & 3 & 1227.6955 & 1227.6958 & 410.2392 & -0.0003 & -0.2438 & 305.649 & 415.194 & 326.861 & 247.087 & \text { Yes } \\ 0.95 & 32.87 & 26.61 & 33.54 & 3 & 1227.6955 & 1227.6958 & 410.2392 & -0.0003 & -0.2438 & 303.133 & 383.561 & 278.600 & 343.280 & \text { Yes }\end{array}$

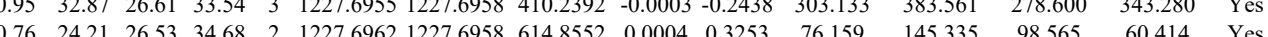

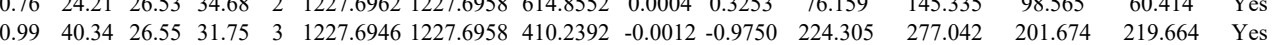



$\begin{array}{lllllllllll}0.96 & 3.23 & 26.53 & 36.67 & 3 & 1227.6961 & 1227.6958 & 410.2392 & 0.0003 & 0.2438 & 224.837\end{array}$ $\begin{array}{lllllllllll}0.99 & 34.16 & 26.61 & 26.79 & 3 & 1227.6955 & 1227.6958 & 410.2392 & -0.0003 & -0.2438 & 44.954\end{array}$

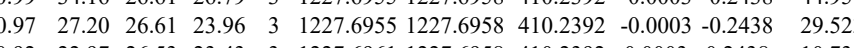
$\begin{array}{lllllllllll}0.92 & 22.97 & 26.53 & 23.43 & 3 & 1227.6961 & 1227.6958 & 410.2392 & 0.0003 & 0.2438 & 10.738\end{array}$ $\begin{array}{lllllllllllll}0.998 & 37.44 & 26.55 & 27.02 & 3 & 1227.6952 & 227.6958 & 40.2392 & 0.003 & 0.4875 & 108.476\end{array}$

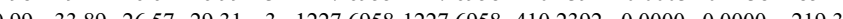

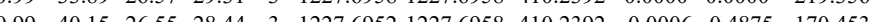
$\begin{array}{llllllllllll}0.99 & 35.58 & 26.57 & 30.47 & 3 & 1227.6958 & 1227.6958 & 4102392 & 0.0000 & 0.0000 & 184.027\end{array}$ $\begin{array}{lllllllllll}0.66 & 29.02 & 26.41 & 35.40 & 3 & 1227.6989 & 1227.6958 & 410.2392 & -0.0009 & -0.7313 & 176.471\end{array}$ $\begin{array}{lllllllllll}1.00 & 44.70 & 26.57 & 27.06 & 3 & 1227.6958 & 1227.6958 & 110.232 & 0.000 & 0.7313 & 17.47\end{array}$ $\begin{array}{llllllllllll}1.00 & 44.7 & 26.57 & 27.06 & 3 & 1227.6958 & 2227.658 & 40.2392 & 0.0009 & 0.7313 & 176.471 \\ 0.95 & 34.18 & 26.55 & 32.02 & 3 & 1227.6952 & 1227.6958 & 410.2392 & 0.0006 & 0.0000 & 128.022\end{array}$ $\begin{array}{llllllllllll}0.88 & 37.73 & 26.61 & 41.95 & 3 & 1227.6955 & 1227.6958 & 410.2392 & -0.0003 & -0.2438 & 132.132\end{array}$ $\begin{array}{lllllllllll}0.94 & 24.26 & 26.57 & 24.26 & 3 & 1227.6958 & 1227.6958 & 410.2392 & 0.0000 & 0.0000 & 118.049\end{array}$ $\begin{array}{lllllllllll}1.00 & 55.30 & 28.60 & 30.78 & 2 & 1249.6644 & 1249.6645 & 625.8395 & -0.0001 & -0.0799 & 711.320\end{array}$

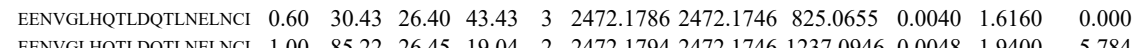
$\begin{array}{lllllllllllll}\text { EENVGLHQTLDQTLNELNCI } & 1.00 & 85.22 & 26.45 & 19.04 & 2 & 2472.1794 & 2472.1746 & 1237.0946 & 0.0048 & 1.9400 & 5.784 \\ \end{array}$ $\begin{array}{llllllllllllll}\text { EENVGLHQTLDQTLNELNCI } & 0.66 & 56.88 & 26.50 & 69.88 & 3 & 2472.1768 & 2472.1746 & 825.0655 & 0.0022 & 0.8888 & 36.683\end{array}$

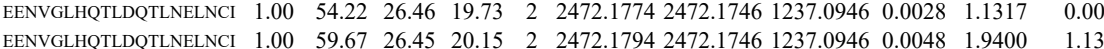

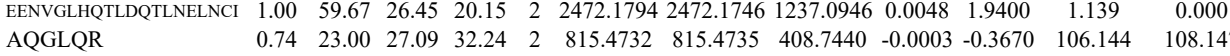

TIDDLEE

TIDDLEEK

IQALQQQADEAEDR

IQALQQQADEAEDR

IQALQQQADEAEDR

IQALQQQADEAEDR

IQALQQQADEAEDR

IQALQQQADEAEDR

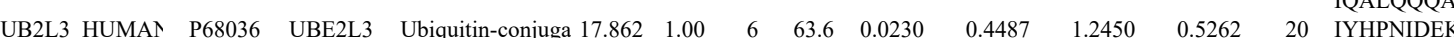

\section{IYHPNIDEK}

$\begin{array}{lllllllllllll}1.00 & 54.74 & 28.34 & 27.94 & 2 & 1249.6742 & 1249.6645 & 625.8395 & 0.0097 & 7.7495 & 6256.413 & 6866.713\end{array}$

$\begin{array}{llllllllllllll}1.00 & 54.41 & 28.52 & 30.08 & 2 & 1249.6746 & 1249.6645 & 625.8395 & 0.0101 & 8.0691 & 5790.319 & 5127.080 & 1120 \\ 1.00 & 41.47 & 27.16 & 18.36 & 3 & 1757.8693 & 1757.8666 & 586.9628 & 0.0027 & 1.5333 & 217.498 & 229.937 & 252 .\end{array}$

$\begin{array}{lllllllllllll}1.00 & 41.47 & 27.16 & 18.36 & 3 & 1757.8693 & 1757.8666 & 586.9628 & 0.0027 & 1.5333 & 217.498 & 229.9 \\ 1.00 & 86.19 & 27.23 & 29.15 & 2 & 1757.8784 & 1757.8666 & 879.9406 & 0.0118 & 6.7050 & 718.707 & 859.0\end{array}$

$\begin{array}{lllllllllllll}1.00 & 86.19 & 27.23 & 29.15 & 2 & 1757.8784 & 1757.8666 & 879.9406 & 0.0118 & 6.7050 & 718.707 & 859.002 & 456.4 \\ 1.00 & 97.50 & 27.23 & 29.74 & 2 & 1757.8784 & 1757.8666 & 879.9406 & 0.0118 & 6.7050 & 2687.736 & 2729.146 & 1202 .\end{array}$

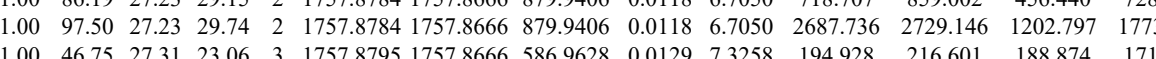
$\begin{array}{lllllllllllllll}1.92 & 46.75 & 27.31 & 23.06 & 3 & 1757.8795 & 1757.8666 & 586.9628 & 0.0129 & 7.3258 & 194.928 & 216.601 & 188.874 & 171.987 & Y e s \\ 0.92 & 28.64 & 27.37 & 14.82 & 3 & 1757.8798 & 1757.8666 & 586.9628 & 0.0132 & 7.4962 & 346.099 & 353.437 & 117.770 & 169.427 & Y \text { Ses }\end{array}$

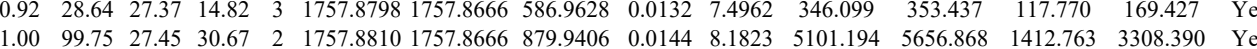

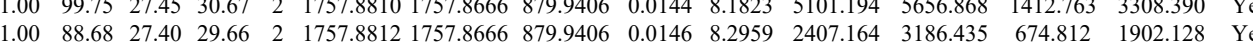
$\begin{array}{lllllllllllllllll}0.95 & 31.44 & 28.00 & 20.55 & 3 & 1415.7754 & 1415.7652 & 472.9290 & 0.0102 & 7.1892 & 26237.706 & 26037.609 & 3012.953 & 49283.544 & \text { Yes } & \\ 0\end{array}$

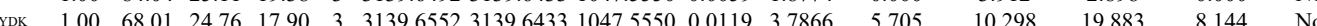

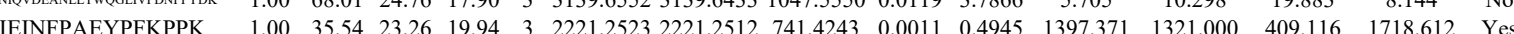

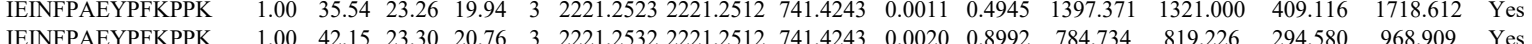
$\begin{array}{llllllllllllllll}\text { IEINPAEYPFKPPK } & 1.00 & 42.15 & 23.30 & 20.76 & 3 & 2221.2532 & 2221.2512 & 741.4243 & 0.0020 & 0.8992 & 784.734 & 819.226 & 294.580 & 968.909 & \text { Yes } \\ \text { IEINFPAEYPFKPPK } & 1.00 & 34.04 & 23.03 & 47.04 & 4 & 2221.2557 & 2221.2512 & 556.3201 & 0.0045 & 2.0222 & 352.997 & 295.524 & 177.245 & 488.727 & \text { Yes }\end{array}$

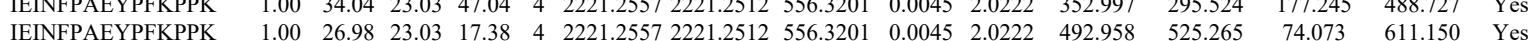
$\begin{array}{llllllllllllllll}\text { IEINFPAEYPFKPPK } & 0.99 & 27.91 & 23.32 & 19.68 & 3 & 2221.2508 & 2221.2512 & 741.4243 & -0.0004 & -0.1798 & 1022.403 & 852.738 & 404.187 & 1371.530 & \text { Yes }\end{array}$

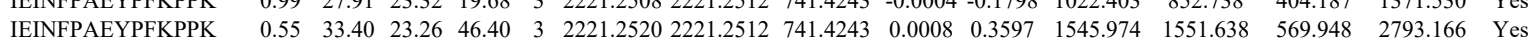

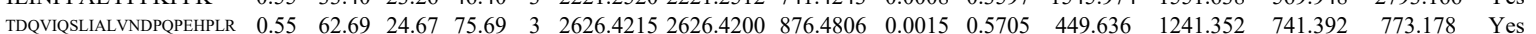

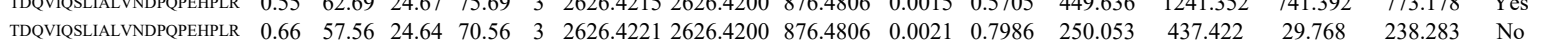
\begin{tabular}{llllllllllllllllll} 
TDQVISLSLALVNDPQPEHPLR & 1.00 & 47.02 & 24.55 & 19.06 & 4 & 2626.4245 & 2626.4200 & 657.6123 & 0.0045 & 1.7107 & 129.340 & 124.602 & 152.773 & 175.539 & Yes \\
\hline
\end{tabular}

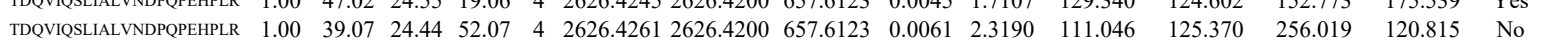

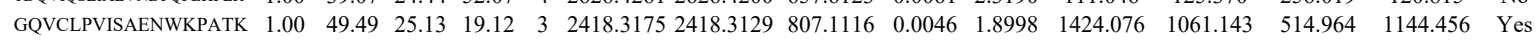
$\begin{array}{llllllllllllllllll}\text { GQVCLPVISAENWKPATK } & 1.00 & 51.35 & 25.15 & 18.03 & 3 & 2418.3205 & 2418.3129 & 807.1116 & 0.0076 & 3.1388 & 1225.326 & 1014.507 & 508.549 & 1176.811 & \text { Yes }\end{array}$ $\begin{array}{llllllllllllllll}\text { TDQVIPSLIALVNDPQPEHPLR } & 0.55 & 66.11 & 24.67 & 79.11 & 3 & 2626.4215 & 2626.4200 & 876.4806 & 0.0015 & 0.5705 & 453.276 & 861.617 & 663.420 & 239.835 & \text { Yes }\end{array}$ $\begin{array}{llllllllllllllll}\text { TDQVISSLIALVNDPQPEHPLR } & 1.00 & 23.50 & 24.59 & 36.50 & 4 & 2626.4237 & 2626.4200 & 657.6123 & 0.0037 & 1.4066 & 82.164 & 108.401 & 72.071 & 196.138 & \text { Yes }\end{array}$ $\begin{array}{llllllllllllllll}\text { TDQVIQSLIALVNDPQPEHPLR } & 0.60 & 66.08 & 24.56 & 79.08 & 3 & 2626.4239 & 2626.4200 & 876.4806 & 0.0039 & 1.4832 & 540.119 & 501.056 & 901.373 & 702.583 & \text { Yes }\end{array}$ $\begin{array}{llllllllllllllllll}\text { TDQVIQSLIALVNDPQPEHPLR } & 0.60 & 61.01 & 24.56 & 74.01 & 3 & 2626.4239 & 2626.4200 & 876.4806 & 0.0039 & 1.4832 & 345.215 & 276.885 & 346.383 & 212.974 & \text { Yes }\end{array}$ $\begin{array}{llllllllllllllll}\text { ADLAEEYSK } & 1.00 & 62.58 & 28.20 & 33.72 & 2 & 1312.6850 & 1312.6754 & 657.3450 & 0.0096 & 7.3020 & 3419.813 & 3165.089 & 680.592 & 4211.762 & \text { Yes }\end{array}$ $\begin{array}{llllllllllllllll}\text { ADLAEEYSK } & 1.00 & 60.31 & 28.08 & 29.86 & 2 & 1312.6852 & 1312.6754 & 657.3450 & 0.0098 & 7.4542 & 3057.835 & 2764.059 & 834.316 & 3907.642 & \text { Yes }\end{array}$

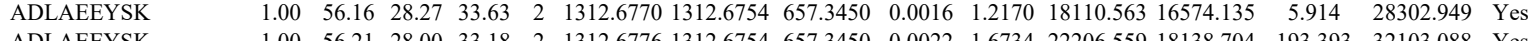
ADLAEEYSK

$\begin{array}{lllllllllllllllll}1.00 & 56.21 & 28.00 & 33.18 & 2 & 1312.6776 & 1312.6754 & 657.3450 & 0.0022 & 1.6734 & 22206.559 & 18138.704 & 193.393 & 32103.088 & \text { Yes }\end{array}$ $\begin{array}{ccccccccccccccc} & & \end{array}$ $\begin{array}{llllllllllllllll} & & & \end{array}$ $\begin{array}{lllllllllllllll} & \end{array}$

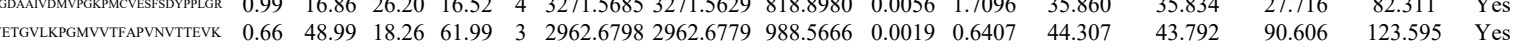

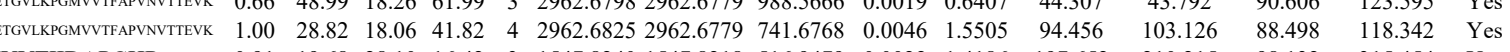
$\begin{array}{lllllllllllllllll}\text { YYVTIIDAPGHR } & 0.91 & 19.68 & 28.10 & 16.42 & 3 & 1547.8240 & 1547.8218 & 516.9479 & 0.0022 & 1.4186 & 197.652 & 210.215 & 98.132 & 315.454 & \text { Yes } \\ \text { YYVTIIDAPGHR } & 0.74 & 15.83 & 28.08 & 17.23 & 3 & 1547.8258 & 1547.8218 & 516.9479 & 0.0040 & 2.5792 & 209.838 & 178.063 & 116.624 & 296.452 & \text { Yes }\end{array}$

Table S-4 page 411 of 6 


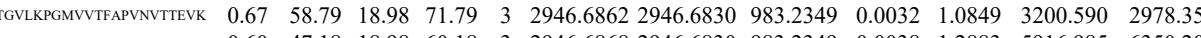
$\begin{array}{lllllllllll}1.00 & 46.14 & 18.81 & 59.14 & 4 & 2946.6873 & 2946.6830 & 737.6780 & 0.0043 & 1.4573 & 187.986 \\ 0.98 & 6.91 & 18.81 & 19.91 & 4 & 2946.6881 & 2946.6830 & 737.6780 & 0.0051 & 1.7284 & 26.918\end{array}$

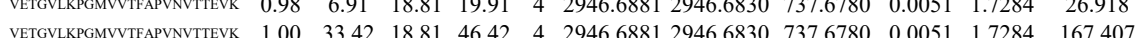

$\begin{array}{lllllllllllll}\text { VETGVLKPGMVVTFAPVNVTTEVK } & 0.92 & 2.95 & 18.81 & 15.95 & 4 & 2946.6881 & 2946.6830 & 737.6780 & 0.0051 & 1.7284 & 22.795\end{array}$

$\begin{array}{lllllllllllll}\text { VETGVLKPGMVVTFAPNNVTTEVK } & 0.60 & 47.21 & 18.20 & 60.21 & 3 & 2962.6816 & 2962.6779 & 988.5666 & 0.0037 & 1.2476 & 264.256\end{array}$

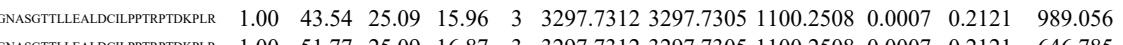

$\begin{array}{llllllllllllll}\text { DGNASGTTLEALDCLPPTRPTDKPLR } & 1.00 & 51.77 & 25.09 & 16.87 & 3 & 3297.7312 & 3297.7305 & 1100.2508 & 0.0007 & 0.2121 & 646.785\end{array}$

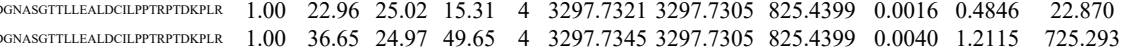

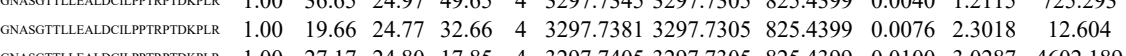




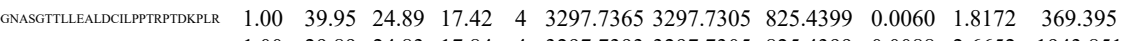
228.317

$\begin{array}{lllllllllllll}\text { DANASGILEALDCLPTRPTDKPLR } & 1.00 & 29.89 & 24.83 & 17.84 & 4 & 3297.7393 & 3297.7305 & 825.4399 & 0.0088 & 2.6652 & 1943.851\end{array}$

204.397 935.692 Yes

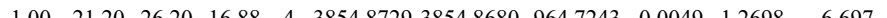

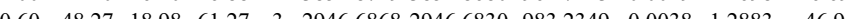

$\begin{array}{llllllllll} & 0.6974\end{array}$

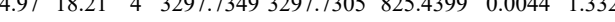
$\begin{array}{lllllllllll}0.91 .36 & 4 & 2946.6881 & 2946.6830 & 737.6780 & 0.0051 & 1.7284 & 26.012 \\ 0.53 & 13.07 & 28.16 & 16.11 & 3 & 1547.8225 & 1547.8218 & 516.9479 & 0.0007 & 0.4514 & 253.507\end{array}$ $\begin{array}{lllllllllllll}1.00 & 41.52 & 28.67 & 24.84 & 2 & 1034.5610 & 1034.5600 & 518.2873 & 0.0010 & 0.9647 & 626.278 & 6\end{array}$ $\begin{array}{llllllllllll}1.00 & 56.93 & 28.06 & 20.04 & 2 & 1547.8230 & 1547.8218 & 774.9182 & 0.0012 & 0.7743 & 97.946\end{array}$

YYVTIDAPGHR $\begin{array}{llllllllll} & \\ 56.93 & 28.06 & 20.04 & 2 & 1547.8230 & 1547.8218 & 774.9182 & 0.0012 & 0.7743 & 97.946\end{array}$ $\begin{array}{lllllllllll}0.90 & 19.30 & 28.10 & 17.18 & 3 & 1547.8240 & 1547.8218 & 516.9479 & 0.0022 & 1.4186 & 198.245\end{array}$

$\begin{array}{llll}76.902 & \text { Yes }\end{array}$ $\begin{array}{llllllllllll}.66 & 46.49 & 19.14 & 59.49 & 3 & 2946.6847 & 2946.6830 & 983.2349 & 0.0017 & 0.5763 & 7.531\end{array}$

$\begin{array}{lccccccccccc}\text { VETGVLKPGMVVTFAPVNVTTEVK } & 0.98 & 9.84 & 18.63 & 22.84 & 4 & 2962.6781 & 2962.6779 & 741.6768 & 0.0002 & 0.0674 & 2.1 .165 \\ \text { YYVTIDAPGHR } & 0.88 & 18.73 & 28.10 & 19.41 & 3 & 1547.8237 & 1547.8218 & 516.9479 & 0.0019 & 1.2251 & 193.238 \\ \text { YYVTIIDAPGHR } & 0.99 & 31.42 & 28.10 & 18.67 & 3 & 1547.8243 & 1547.8218 & 516.9479 & 0.0025 & 1.6120 & 263.217\end{array}$

$\begin{array}{lllllllllllll}\text { YYVTIIDAPGHR } & 0.88 & 18.73 & 28.10 & 19.41 & 3 & 1547.8237 & 1547.8218 & 516.9479 & 0.0019 & 1.2251 & 193.238 \\ \text { YYVTIIDAPGHR } & 0.99 & 31.42 & 28.10 & 18.67 & 3 & 1547.8243 & 1547.8218 & 516.9479 & 0.0025 & 1.6120 & 263.217\end{array}$

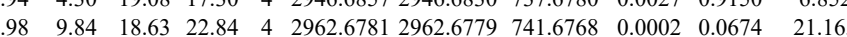
$\begin{array}{lllllllllllll} & \end{array}$ $\begin{array}{llllllllllll}0.66 & 72.59 & 19.08 & 85.59 & 3 & 2946.6853 & 2946.6830 & 983.2349 & 0.0023 & 0.7797 & 12.260\end{array}$ $\begin{array}{llllllllllll}\text { NETGVLKRGMVTFAPVNVTTEVK } & 1.00 & 26.34 & 18.98 & 39.34 & 4 & 2946.6869 & 2946.6830 & 737.6780 & 0.0039 & 1.3217 & 15.205\end{array}$ YYVTIIDAPGHR $\begin{array}{llllllllllll}0.63 & 12.70 & 28.03 & 15.46 & 3 & 1547.8234 & 1547.8218 & 516.9479 & 0.0016 & 1.0317 & 137.641 \\ 0.68 & 13.76 & 28.10 & 17.09 & 3 & 1547.8240 & 1547.8218 & 516.9479 & 0.0022 & 1.4186 & 171.365\end{array}$ $\begin{array}{llllllllllll}0.68 & 13.76 & 28.10 & 17.09 & 3 & 1547.8240 & 1547.8218 & 516.9479 & 0.0022 & 1.4186 & 171.365 \\ 1.00 & 33.60 & 19.08 & 46.60 & 4 & 2946.6857 & 2946.6830 & 737.6780 & 0.0027 & 0.9150 & 16.245\end{array}$

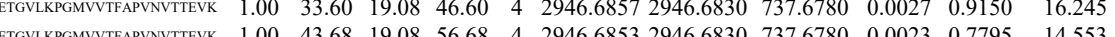
$\begin{array}{lllllllllll}1.00 & 43.68 & 19.08 & 56.68 & 4 & 2946.6853 & 2966.6830 & 737.6780 & 0.0023 & 0.790 & 14.553 \\ 1.00 & 39.31 & 18.98 & 52.31 & 4 & 2946.6865 & 29466830 & 737.6780 & 0.0035 & 1.1862 & 18.180\end{array}$ 年

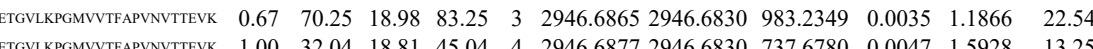

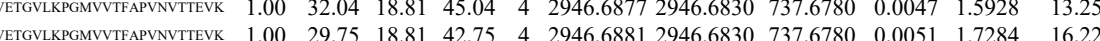
$\begin{array}{lllllllllllll}\text { YYVTIIDAPGHR } & 0.80 & 16.34 & 28.10 & 17.00 & 3 & 1547.8243 & 1547.8218 & 516.9479 & 0.0025 & 1.6120 & 166.570\end{array}$ $\begin{array}{lllllllllllll}\text { VETGVLKPGMVYTFAPVNVTTEVK } & 1.00 & 29.02 & 18.98 & 42.02 & 4 & 2946.6865 & 2946.6830 & 737.6780 & 0.0035 & 1.1862 & 11.179\end{array}$ $\begin{array}{llllllllllllll}\text { VETGVLKPGMVVTFAPVNVTTEVK } & 1.00 & 17.24 & 18.81 & 30.24 & 4 & 2946.6873 & 2946.6830 & 737.6780 & 0.0043 & 1.4573 & 10.937\end{array}$ $\begin{array}{lllllllllllll}\text { VETGVLKPGMVVTFAPVNVTTEVK } & 0.66 & 64.96 & 19.14 & 77.96 & 3 & 2946.6847 & 2946.6830 & 983.2349 & 0.0017 & 0.5763 & 20.292\end{array}$

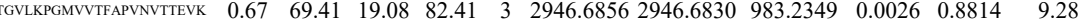

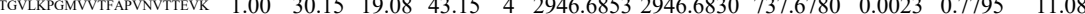
$\begin{array}{lllllllllllll} & \end{array}$

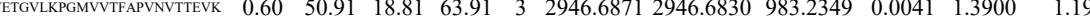
$\begin{array}{lllllllllllll} & 0.55 & 81.59 & 19.29 & 94.59 & 3 & 2946.6838 & 2946.6830 & 983.2349 & 0.0008 & 0.2712 & 44.892\end{array}$ $\begin{array}{llllllllllllll}0.66 & 74.73 & 19.08 & 87.73 & 3 & 2946.6853 & 2946.6830 & 983.2349 & 0.0023 & 0.7797 & 37.29\end{array}$ VETGVLRPG

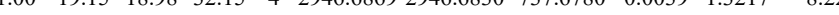
$\begin{array}{llllllllllll}0.97 & 28.66 & 26.49 & 27.54 & 2 & 1067.6122 & 1067.6106 & 534.8126 & 0.0016 & 1.4958 & 387.833 & 474 .\end{array}$ $\begin{array}{llllllllllllllll}0.94 & 38.11 & 25.87 & 35.88 & 2 & 1126.6554 & 1126.6478 & 564.3312 & 0.0076 & 6.7336 & 6222.045 & 3548.591 & 14838.490 & 29434.149 & \text { Yes }\end{array}$ $\begin{array}{llllllllllll}0.94 & 34.51 & 25.82 & 28.35 & 2 & 1126.6556 & 126.6478 & 564.3312 & 0.0078 & 6.9108 & 6279.714 & 4396.929\end{array}$

150.09530435 .021 Yes AVFVDLEPTVIDEIR \begin{tabular}{lllllllllllll}
\hline & 0.94 & 34.51 & 25.82 & 28.35 & 2 & 126.6556 & 126.647 & 564.3312 & 0.078 & 6.9108 & 6279.714 & 4396.929
\end{tabular} $\begin{array}{lll}172.856 & \text { Yes }\end{array}$

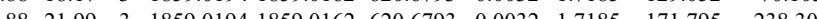
$\begin{array}{lll}23.135 & 225.821 & \text { Yes } \\ 301.130 & 5763.111 & \text { Yes }\end{array}$

$\begin{array}{llllllllllllllll} & \end{array}$ $\begin{array}{llllllllllllllllll}\text { AVFVDLEPTVIDEIR } & 1.00 & 75.18 & 26.97 & 27.71 & 2 & 1859.0170 & 1859.0162 & 930.5154 & 0.0008 & 0.4299 & 1186.596 & 1785.913 & 102.936 & 1507.560 & \text { Yes } \\ & 1.00 & 75.51 & 26.84 & 28.18 & 2 & 1859.0182 & 1859.0162 & 930.5154 & 0.0020 & 1.0747 & 382.610 & 483.081 & 107.664 & 412.453 & \text { Yes }\end{array}$

Table S-4 page 413 of 614 
$\begin{array}{lllllllllllll}1.00 & 58.04 & 24.87 & 17.34 & 3 & 2344.0639 & 2344.0596 & 782.3605 & 0.0043 & 1.8321 & 47.763 & 77.257 \\ 1.00 & 69.43 & 24.79 & 27.87 & 2 & 1272.7758 & 1272.7645 & 637.3895 & 0.0113 & 8.8642 & 5125.556 & 5139.562 & 78\end{array}$

$\begin{array}{llllllllllll}1.00 & 69.34 & 24.70 & 27.80 & 2 & 1272.7764 & 1272.7645 & 637.3895 & 0.0119 & 9.3349 & 4435.074 & 3609.762\end{array}$

$\begin{array}{lllllllllllll}1.00 & 66.33 & 27.12 & 24.93 & 2 & 1860.9146 & 1860.9147 & 931.4646 & -0.0001 & -0.0537 & 10067.153 & 8773.474\end{array}$

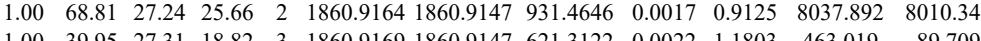

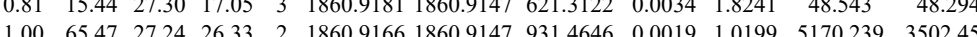

SIQFVDWCPTGFK

$\begin{array}{llllllllllll}1.00 & 65.47 & 27.24 & 26.33 & 2 & 1860.9166 & 1860.9147 & 931.4646 & 0.0019 & 1.0199 & 5170.239 & 3502.456 \\ 1.00 & 65.56 & 27.29 & 25.50 & 2 & 1860.9170 & 1860.9147 & 931.4646 & 0.0023 & 1.2346 & 7522.111 & 6163.707\end{array}$

SIOFVDWCPTGFK

$\begin{array}{llllllllllll}1.00 & 65.56 & 27.29 & 25.50 & 2 & 1860.9170 & 1860.9147 & 931.4646 & 0.0023 & 1.2346 & 7522.111 & 6163.707 \\ 0.81 & 15.72 & 27.30 & 22.49 & 3 & 1860.9172 & 1860.9147 & 621.3122 & 0.0025 & 1.3412 & 35.059 & 29.141\end{array}$

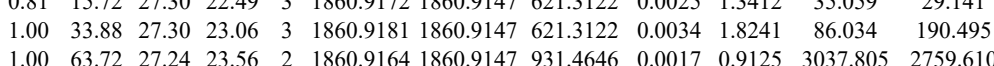

$\begin{array}{llllllllllll}1.00 & 63.72 & 27.24 & 23.56 & 2 & 1860.9164 & 1860.9147 & 931.4646 & 0.0017 & 0.9125 & 3037.805 & 2759.610 \\ 1.00 & 51.27 & 27.24 & 24.35 & 2 & 1860.9164 & 1860.9147 & 931.4646 & 0.0017 & 0.9125 & 790.694 & 624.775\end{array}$

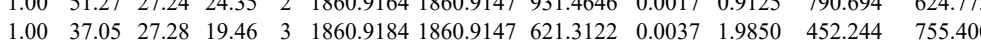

$\begin{array}{llllllllllll}1.00 & 60.29 & 27.11 & 22.20 & 2 & 1860.9158 & 1860.9147 & 931.4646 & 0.0011 & 0.5905 & 247.442 & 172.352\end{array}$

SIQFVDDWCPTGFK

$\begin{array}{lllllllllllll}0.72 & 13.66 & 27.30 & 21.46 & 3 & 1860.9181 & 1860.9147 & 621.3122 & 0.0034 & 1.8241 & 125.054 & 70.424 \\ 0.92 & 0.25 & 27.28 & 17.51 & 3 & 186.9184 & 1860.9147 & 6213122 & 0.0037 & 1.9850 & 103.266 & 76.892\end{array}$

AVFVDLEPTVIDEIR

$\begin{array}{llllllllllll}0.92 & 20.25 & 27.28 & 17.51 & 3 & 1860.9184 & 1860.9147 & 621.3122 & 0.0037 & 1.9850 & 103.266 & 76.892\end{array}$

EPTVIDEIR

$\begin{array}{llllllllllll}1.00 & 83.43 & 26.86 & 28.71 & 2 & 1859.0178 & 1859.0162 & 930.5154 & 0.0016 & 0.8597 & 598.318 & 572.864 \\ 1.00 & 81.10 & 26.88 & 34.77 & 2 & 185.90190 & 1859.0162 & 930.5154 & 0.0028 & 1.5045 & 182515 & 306.828\end{array}$

VLGTEDLYDYIDK

$\begin{array}{llllllllllll}1.00 & 81.10 & 26.88 & 34.77 & 2 & 1859.0190 & 1859.0162 & 930.5154 & 0.0028 & 1.5045 & 182.515 & 306.828 \\ 1.00 & 70.70 & 27.87 & 24.66 & 2 & 1830.9510 & 1830.9495 & 916.4820 & 0.0015 & 0.8183 & 379.673 & 476.426\end{array}$

$\begin{array}{llllllllllll}1.00 & 78.74 & 27.90 & 25.02 & 2 & 1830.9512 & 1830.9495 & 9164820 & 0.0017 & 0.9275 & 381.027 & 308.651\end{array}$

$\begin{array}{llllllllllllll} & \text { VIS }\end{array}$

TPALVFEHVNNTDFK

GGPNIITLADIVK

GGPNIITLADIVK

VYTDVNTHRPR

VYTDVNTHRPR

$\begin{array}{llllllllllll}\text { PA1B2 HUMAN } & \text { P68402 } & \text { PAFAH1B: Platelet-activating 25.569 } & 1.00 & 4 & 14.4 & 0.2352 & 0.2425 & 2.1550 & 0.3047 & 28 & \text { NGELENIKPK }\end{array}$

GEKPNPLR

FVLDCK

FVLDCK

IIVLGLLPR
IIVLGLLPR

IIVLGLLPR
IIVLGLLPR

IIVLGLLPR

IIVLGLLPR

IIVLGLLPR

IIVLGLLPR

IIVLGLLPR

IIVLGLLPR

IIVLGLLPR

IIVLGLLPR

IIVLGLLPR

IIVLGLLPR

IIVLGLLPR

IIVLGLLPR

IIVLGLLPR

IIVLGLLPR

IIVLGLLPR

IIVLGLLPR

IIVLGLLPR

\subsection{0} $\begin{array}{lllllllllllll}1.00 & 76.55 & 22.10 & 24.09 & 2 & 1597.9666 & 1597.9647 & 799.9896 & 0.0019 & 1.1875 & 1575.787 & 1932.954\end{array}$ $\begin{array}{llllllllllllll}1.00 & 34.33 & 27.94 & 23.57 & 3 & 1500.7933 & 1500.7919 & 501.2712 & 0.0014 & 0.9310 & 220.536 & 326.617 \\ 0.98 & 28.05 & 27.94 & 20.69 & 3 & 1500.7933 & 1500.7919 & 501.2712 & 0.0014 & 0.9310 & 309.521 & 366.683\end{array}$ $\begin{array}{llllllllllll}0.98 & 25.50 & 27.78 & 17.55 & 3 & 1500.7936 & 1500.7919 & 501.2712 & 0.0017 & 1.1305 & 189.917 & 208.161\end{array}$ $\begin{array}{lllllllllllll}0.88 & 22.59 & 23.03 & 18.23 & 3 & 1572.9325 & 1572.9200 & 525.3139 & 0.0125 & 7.9317 & 18909.572 & 21094.689 & 14143 \\ 0.92 & 24.76 & 23.14 & 17.60 & 3 & 1572.9334 & 1572.9200 & 525.3139 & 0.0134 & 8.5028 & 20764.566 & 21312.433 & 17270\end{array}$

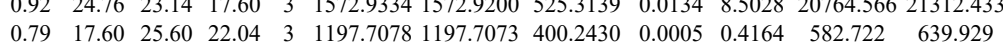
$\begin{array}{llllllllllllll}0.88 & 20.15 & 25.60 & 22.45 & 3 & 1197.7078 & 1197.7073 & 400.2430 & 0.0005 & 0.4164 & 524.969 & 695.481\end{array}$ $\begin{array}{llllllllllll}0.84 & 22.27 & 26.05 & 21.76 & 3 & 1197.7063 & 1197.7073 & 400.2430 & -0.0010 & -0.8328 & 300.194 & 306.189\end{array}$ $\begin{array}{llllllllllll}0.88 & 30.33 & 27.83 & 26.94 & 2 & 1057.5642 & 1057.5544 & 529.7845 & 0.0098 & 9.2490 & 7716.023 & 8118.380\end{array}$ $\begin{array}{lllllllllllll}0.87 & 30.29 & 27.99 & 26.96 & 2 & 1057.5646 & 1057.5544 & 529.7845 & 0.0102 & 9.6265 & 6524.159 & 6892.982 \\ 0.82 & 40.30 & 9.03 & 53.30 & 2 & 1136.7776 & 1136.7767 & 569.3956 & 0.0009 & 0.7903 & 903.604 & 1189.606\end{array}$ $\begin{array}{llllllllllllll}0.82 & 40.30 & 9.03 & 53.30 & 2 & 1136.7776 & 1136.7767 & 569.3956 & 0.0009 & 0.7903 & 903.604 & 1189.606 \\ 1.00 & 36.74 & 9.03 & 15.41 & 2 & 1136.7780 & 11367767 & 569.3956 & 0.0013 & 1.1416 & 596.242 & 691.111\end{array}$ $\begin{array}{cccccccccccc}1.00 & 36.74 & 9.03 & 15.41 & 2 & 1136.7780 & 1136.7767 & 569.3956 & 0.0013 & 1.1416 & 596.242 & 691.111 \\ 0.74 & 16.86 & 16.53 & 16.76 & 2 & 1136.7754 & 1136.7767 & 569.3956 & -0.0013 & -1.1416 & 17.001 & 8.792\end{array}$ $\begin{array}{llllllllllll}0.74 & 16.86 & 16.53 & 16.76 & 2 & 1136.7754 & 1136.7767 & 569.3956 & -0.0013 & -1.1416 & 17.001 & 8.792 \\ 1.00 & 27.40 & 9.03 & 14.92 & 2 & 1136.7776 & 1136.7767 & 569.3956 & 0.0009 & 0.7903 & 11.392 & 12.770\end{array}$

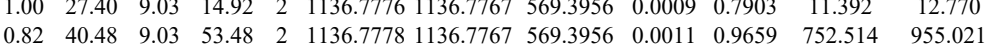
$\begin{array}{llllllllllll}0.98 & 13.58 & 9.03 & 16.46 & 2 & 1136.7778 & 1136.7767 & 569.3956 & 0.0011 & 0.9659 & 17.262 & 10.180\end{array}$

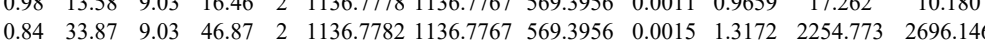
$\begin{array}{llllllllllll}0.66 & 18.73 & 16.53 & 19.84 & 2 & 1136.7748 & 1136.7767 & 569.3956 & -0.0019 & -1.6684 & 16.741 & 14.180\end{array}$ $\begin{array}{llllllllllll}0.64 & 18.83 & 6.99 & 31.83 & 2 & 1136.7764 & 1136.7767 & 569.3956 & -0.0003 & -0.2634 & 31.403 & 33.401\end{array}$ $\begin{array}{lllllllllllll}0.98 & 14.64 & 9.03 & 16.78 & 2 & 1136.7778 & 1136.7767 & 569.3956 & 0.0011 & 0.9659 & 4.840 & 10.127 \\ 0.72 & 29.58 & 9.54 & 42.58 & 2 & 11367792 & 11367767 & 5693956 & 0.0025 & 2.1953 & 17.274 & 31.564\end{array}$ $\begin{array}{lllllllllllll}0.72 & 29.58 & 9.54 & 42.58 & 2 & 1136.7792 & 1136.7767 & 569.3956 & 0.0025 & 2.1953 & 17.274 & 31.564\end{array}$ $\begin{array}{lllllllllllll}1.00 & 40.68 & 9.54 & 15.76 & 2 & 1136.7804 & 1136.7767 & 569.3956 & 0.0037 & 3.2490 & 1019.147 & 1296.884\end{array}$ $\begin{array}{lllllllllllll}1.00 & 40.73 & 9.54 & 15.62 & 2 & 1136.7804 & 1136.7767 & 569.3956 & 0.0037 & 3.2490 & 3197.347 & 3757.325\end{array}$ $\begin{array}{llllllllllll}1.00 & 40.86 & 9.03 & 15.73 & 2 & 1136.7780 & 1136.7767 & 569.3956 & 0.0013 & 1.1416 & 533.683 & 769.223\end{array}$ $\begin{array}{lllllllllllll}0.72 & 38.65 & 9.54 & 51.65 & 2 & 1136.7794 & 1136.7767 & 569.3956 & 0.0027 & 2.3709 & 386.335 & 451.926\end{array}$ $\begin{array}{llllllllllll}1.00 & 40.93 & 9.03 & 15.68 & 2 & 1136.7778 & 1136.7767 & 569.3956 & 0.0011 & 0.9659 & 400.662 & 455.197\end{array}$ $\begin{array}{llllllllllll}0.84 & 34.10 & 9.03 & 47.10 & 2 & 1136.7782 & 1136.7767 & 569.3956 & 0.0015 & 1.3172 & 217.403 & 263.845\end{array}$ $\begin{array}{llllllllllll}0.64 & 33.66 & 8.45 & 46.66 & 2 & 1136.7768 & 1136.7767 & 569.3956 & 0.0001 & 0.0878 & 94.386 & 151.762\end{array}$

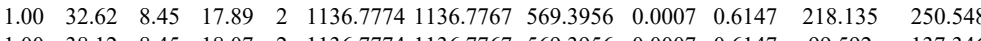
$\begin{array}{llllllllllll}1.00 & 38.12 & 8.45 & 18.07 & 2 & 1136.7774 & 1136.7767 & 569.3956 & 0.0007 & 0.6147 & 99.592 & 137.346 \\ 1.00 & 31.06 & 9.54 & 17.68 & 2 & 1136.7784 & 11367767 & 56.3956 & 0.0017 & 1.4928 & 101.400 & 134.622\end{array}$ $\begin{array}{llllllllllll}1.00 & 31.06 & 9.54 & 17.68 & 2 & 1136.7784 & 1136.7767 & 569.3956 & 0.0017 & 1.4928 & 101.400 & 134.622\end{array}$ $\begin{array}{llllllllllll}1.00 & 31.06 & 9.54 & 17.68 & 2 & 1136.7784 & 1136.7767 & 569.3956 & 0.0017 & 1.4928 & 101.400 & 134.622 \\ 0.84 & 32.53 & .03 & 4.53 & 2 & 1136.7782 & 136.7767 & 569.3956 & 0.0015 & 1.3172 & 86.237 & 81.689\end{array}$

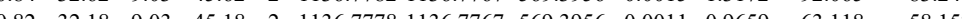
$\begin{array}{llllllllllll}0.82 & 33.94 & 9.03 & 46.94 & 2 & 1136.7778 & 1136.7767 & 569.3956 & 0.0011 & 0.9659 & 72.922 & 74.549\end{array}$ $\begin{array}{lll}6.000 & 18533.906 & \text { No }\end{array}$ \begin{tabular}{llll}
0.000 & 18453.824 & $\mathrm{No}$ & \\
\hline & 0.017 & $\mathrm{No}$
\end{tabular} (89.407 429.191 No $\begin{array}{rrr}5.596 & 84.669 & \text { Yes } \\ & 3519.398 & \text { Yes }\end{array}$ $32.402 \quad 68.687$ Yes $\begin{array}{lll}0.400 & 7049.880 & \text { No }\end{array}$ $\begin{array}{llll}70.952 & 9771.443 & \text { Yes }\end{array}$ $\begin{array}{lll}67.469 & 213.185 & \text { No }\end{array}$ $0.000 \quad 1140.890$ No $\begin{array}{lll}12.733 & 134.994 & \text { Yes }\end{array}$ $\begin{array}{lll}51.002 & 97.055 & \text { Yes } \\ 3.531 & 355.844 & \text { Yes }\end{array}$ $\begin{array}{lll}8.181 & 155.113 & \text { No }\end{array}$ $\begin{array}{lll}3.544 & 646.754 & \text { Yes }\end{array}$ $689.720 \quad 649.858$ Yes $\begin{array}{llll}689.720 & 649.858 & \text { Yes } \\ 3816263 & 3157.621 & \text { Yes }\end{array}$ \begin{tabular}{llll}
4816.263 & 3198.542 & Yes \\
\hline & 134.410 & 130.317 & Yes
\end{tabular} $\begin{array}{lll}964.410 & 1301.317 & \text { Yes }\end{array}$ $64.234 \quad 1796.865$ Yes 143.42118154 .242 Yes

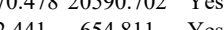
$\begin{array}{lll}691.811 & \text { Yes }\end{array}$ $391.867 \quad$ Yes
0.020 \begin{tabular}{lll}
0.0340 .133 & No \\
\hline & 8326.033 & Yes
\end{tabular} \begin{tabular}{lll}
\hline 6.428 & 1408.422 & Yes
\end{tabular} $\begin{array}{llll}84.021 & 823.841 & \text { Yes }\end{array}$ $\begin{array}{lll}8.638 & 22.411 & \text { No }\end{array}$ $\begin{array}{lll}3.450 & 8.122 & \text { Yes }\end{array}$ $\begin{array}{lll}17.066 & 1205.845 & \text { Yes }\end{array}$ $\begin{array}{ccc}2.025 & 7.395 & \text { No } \\ 0.06414 .952 & \text { Yes }\end{array}$ $\begin{array}{lll}6.310 & 16.596 & \text { Yes }\end{array}$ $\begin{array}{lll}6.295 & 15.801 & \text { No }\end{array}$ $\begin{array}{llll}76.290 & 1551.012 & \text { Yes }\end{array}$ $123.311 \quad 4558.595$ Yes $44.566 \quad 790.156$ Yes $\begin{array}{lll}10.298 & 543.494 & \text { Yes }\end{array}$ $8.066 \quad 292.282$ Yes $36.146 \quad 202.980$ Yes $\begin{array}{lll}1.124 & 202.980 & \text { Yes }\end{array}$ \begin{tabular}{lll}
13.059 & 102.212 & Yes \\
\hline & 147.990 & Yes
\end{tabular} $\begin{array}{lll}5.939 & 96.309 & \text { Yes }\end{array}$

Table S-4 page 414 of 614 


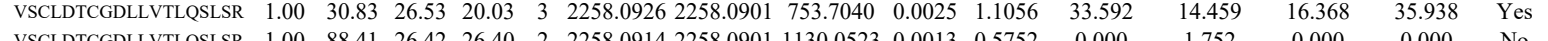

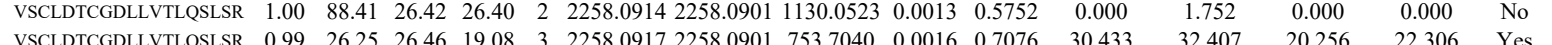

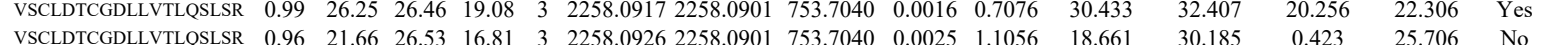

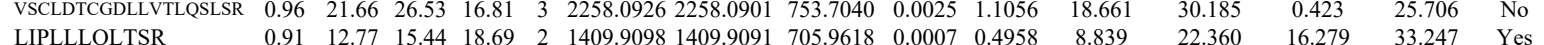

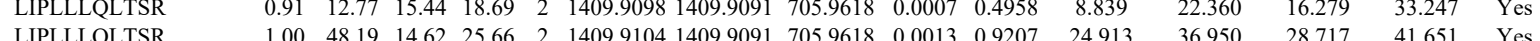

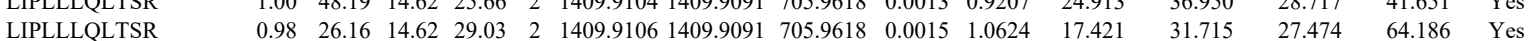
$\begin{array}{lllllllllllllll} & \end{array}$ $\begin{array}{llllllllllllll} & \text { RPELTS }\end{array}$ FGEAIGMGFPVK $\begin{array}{lllllllllllllllllll} & \end{array}$ $\begin{array}{llllllllllllllllll}\text { Gipre } & 0.60 & 46.41 & 25.00 & 59.41 & 3 & 3412.7872 & 3412.7829 & 1138.6016 & 0.0043 & 1.2589 & 12.022 & 19.475 & 50.636 & 87.354 & \text { Yes }\end{array}$

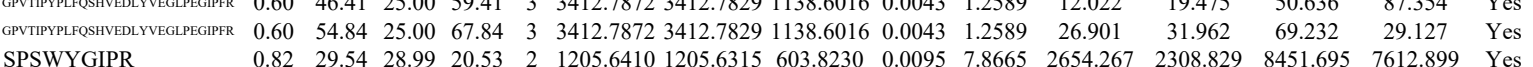

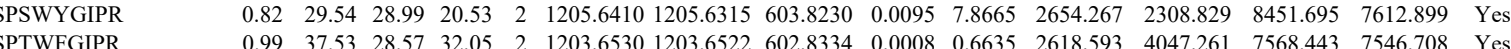

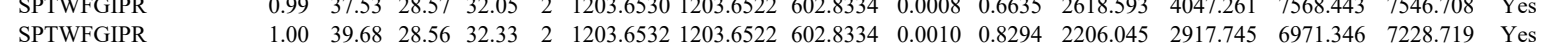

SPTWFGPR

NIGVDNPAAAK NIGVDNPAAK NIGVDNPAAK $\begin{array}{lllllllllllllllll}1.00 & 39.68 & 28.56 & 32.33 & 2 & 1203.6532 & 1203.6522 & 602.8334 & 0.0010 & 0.8294 & 2206.045 & 2917.745 & 6971.346 & 7228.719 & \text { Yes } & \\ 1.00 & 51.12 & 27.47 & 23.34 & 2 & 1285.7270 & 1285.7234 & 643.8690 & 0.0036 & 2.7956 & 11466.484 & 13113.850 & 3418.715 & 13850.188 & \text { Yes } & \\ \end{array}$ $\begin{array}{lllllllllllllllll}1.00 & 1.12 & 27.47 & 23.34 & 2 & 1285.7270 & 1285.7234 & 643.8690 & 0.0036 & 2.7956 & 11466.484 & 13113.850 & 3418.715 & 13850.188 & \text { Yes } \\ 1.00 & 48.13 & 27.15 & 25.81 & 2 & 1285.7322 & 1285.7234 & 643.8690 & 0.0088 & 6.8336 & 22384.176 & 23325.946 & 3994.838 & 31066.389 & \text { Yes }\end{array}$ $\begin{array}{lllllllllllllllll}1.00 & 54.13 & 27.35 & 26.43 & 2 & 1285.7262 & 1285.7234 & 643.8690 & 0.0028 & 2.1744 & 15257.280 & 15145.903 & 1221.450 & 17304.807 & \text { Yes }\end{array}$ $\begin{array}{llllllllllllllllll} & 1.00 & 50.93 & 27.46 & 21.65 & 2 & 1285.7266 & 1285.7234 & 643.8690 & 0.0032 & 2.4850 & 10796.858 & 11406.678 & 708.538 & 13384.317 & \text { Yes }\end{array}$

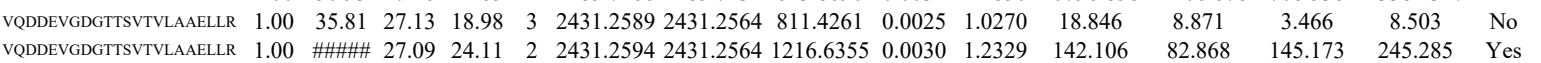

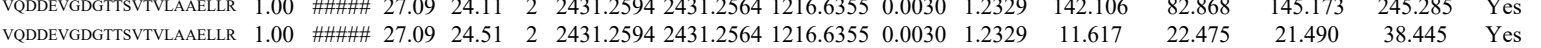

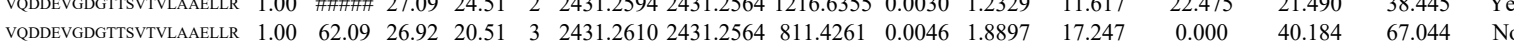
$\begin{array}{llllllllllllllll}\text { ILIANTGMDTDK } & 1.00 & 69.94 & 27.63 & 30.39 & 2 & 1578.8654 & 1578.8531 & 790.4338 & 0.0123 & 7.7805 & 2725.711 & 3650.507 & 0.000 & 4423.886 & \text { No }\end{array}$ $\begin{array}{lllllllllllllllll}\text { ILIANTGMDTDK } & 1.00 & 71.08 & 27.51 & 26.52 & 2 & 1578.8668 & 1578.8531 & 790.4338 & 0.0137 & 8.6661 & 2889.443 & 2343.721 & 118.995 & 3831.456 & \text { Yes }\end{array}$ $\begin{array}{lllllllllllllll}\text { LGGSLADSYLDEGFLLDK } & 1.00 & \text { \#\#\#\# } 27.12 & 30.22 & 2 & 2200.1514 & 2200.1507 & 1101.0826 & 0.0007 & 0.3179 & 578.077 & 647.255 & 175.348 & 931.246 & \text { Yes }\end{array}$ $\begin{array}{llllllllllllllll}\text { LGGSLADSYLDEGFLLDK } & 1.00 & 96.34 & 27.04 & 29.63 & 2 & 2200.1534 & 2200.1507 & 1101.0826 & 0.0027 & 1.2261 & 580.852 & 658.698 & 189.414 & 926.699 & \text { Yes }\end{array}$ $\begin{array}{llllllllllllllll}\text { LGGSLADSYLDEGFLLDK } & 1.00 & 32.75 & 26.85 & 23.27 & 3 & 2200.1542 & 2200.1507 & 734.3908 & 0.0035 & 1.5886 & 17.729 & 27.394 & 20.973 & 0.000 & \text { No }\end{array}$

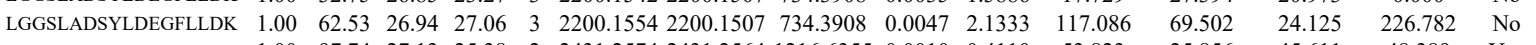
$\begin{array}{llllllllllllllll}\text { VQDDEVGDGTTSVTVLAAELLR } & 1.00 & 97.74 & 27.13 & 25.38 & 2 & 2431.2574 & 2431.2564 & 1216.6355 & 0.0010 & 0.4110 & 53.823 & 25.856 & 45.611 & 48.389 & \text { Yes }\end{array}$

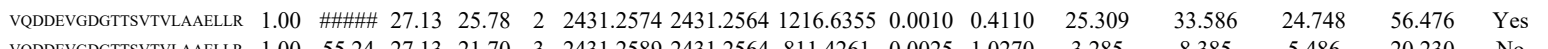

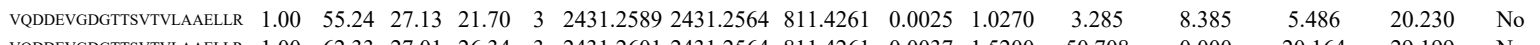
$\begin{array}{llllllllllllllll}\text { VQDDEVGDGTTSVTVLAAELLR } & 1.00 & 62.33 & 27.01 & 26.34 & 3 & 2431.2601 & 2431.2564 & 811.4261 & 0.0037 & 1.5200 & 50.708 & 0.000 & 20.164 & 29.199 & \text { No }\end{array}$

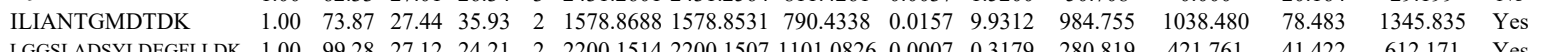

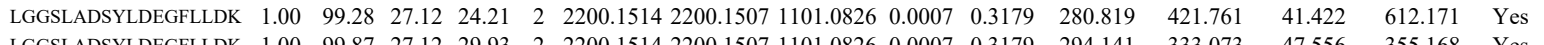

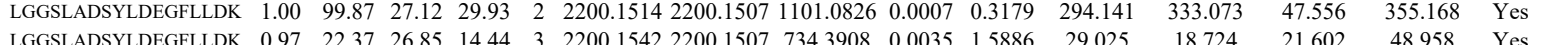

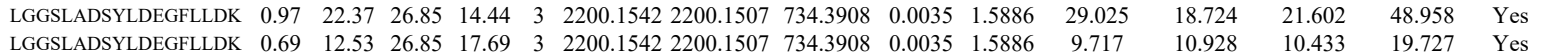

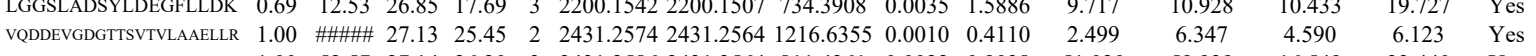

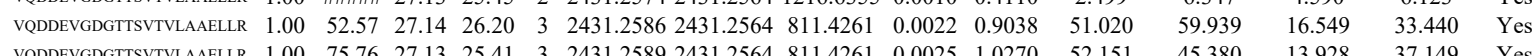



$\begin{array}{lllllllllllllllll} & \text { LALVGASTHPEVK } & 0.55 & 48.05 & 23.84 & 61.05 & 3 & 2384.3209 & 2384.3195 & 795.7804 & 0.0014 & 0.5864 & 995.172 & 1271.166 & 477.538 & 1651.053 & \text { Yes } \\ \text { QDLMNIAGTTLSSK } & 1.00 & 83.76 & 26.65 & 22.01 & 2 & 1765.9640 & 1765.9488 & 883.9817 & 0.0152 & 8.5974 & 2674.764 & 2615.178 & 445.099 & 2944.701 & \text { Yes }\end{array}$ $\begin{array}{llllllllllllllllll} & \end{array}$ \begin{tabular}{lllllllllllllllll} 
QDLMNIAGTILSSK & 1.00 & 86.26 & 26.79 & 26.52 & 2 & 1765.9642 & 1765.9488 & 883.9817 & 0.0154 & 8.7105 & 1433.872 & 1952.453 & 218.045 & 1987.100 & Yes \\
\hline
\end{tabular} $\begin{array}{lllllllllllll} & 46.862 & 76.970 & \text { Yes }\end{array}$

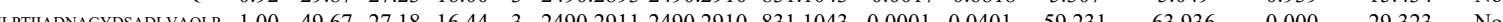
$\begin{array}{llllllllllllll} & \end{array}$ $\begin{array}{lllllllllllll} & \text { MLPTIADNAGYDSA }\end{array}$

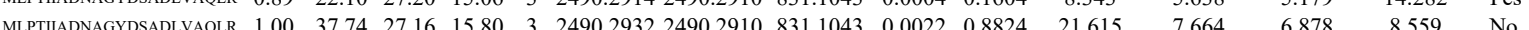

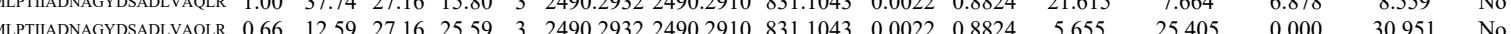
$\begin{array}{lllllllllll} & 0.65 & \end{array}$ $\begin{array}{llllllllllll} & \end{array}$ $\begin{array}{lllllllllllll}\text { QVLLSAAEAAEVILR } & 1.00 & 77.64 & 22.79 & 26.26 & 2 & 1726.0144 & 1726.0110 & 864.0128 & 0.0034 & 1.9676 & 17.667 & 10.114\end{array}$

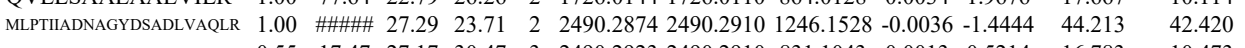
$\begin{array}{llllllllllllll}\text { MLPTIIADNAGYDSADLVAQLR } & 0.55 & 17.47 & 27.17 & 30.47 & 3 & 2490.2923 & 2490.2910 & 831.1043 & 0.0013 & 0.5214 & 16.783 & 10.473\end{array}$

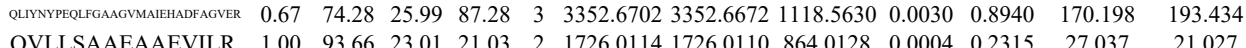
$\begin{array}{lllllllllllll}\text { QVLLSAAEAAEVILR } & 1.00 & 93.19 & 22.88 & 26.37 & 2 & 1726.0118 & 1726.0110 & 864.0128 & 0.0008 & 0.4630 & 7.420 & 13.210\end{array}$

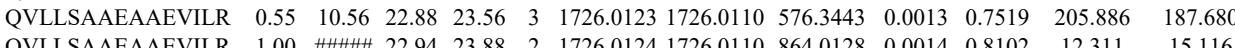
$\begin{array}{lllllllllllll}\text { QVLLSAAEAAEVILR } & 1.00 & \text { \#\#\#\# } 22.94 & 23.88 & 2 & 1726.0124 & 1726.0110 & 864.0128 & 0.0014 & 0.8102 & 12.311 & 15.116\end{array}$ $\begin{array}{lllllllllllll}\text { QVLLSAAEAAEVILR } & 1.00 & 92.86 & 22.97 & 24.91 & 2 & 1726.0126 & 1726.0110 & 864.0128 & 0.0016 & 0.9259 & 174.628 & 254.553\end{array}$ $\begin{array}{llllllllllll}\text { QVLLSAAEAAEVILR } & 1.00 & \text { 22.94 } & 22.72 & 2 & 1726.0130 & 1726.0110 & 864.0128 & 0.0020 & 1.1574 & 219.207 & 332.903\end{array}$

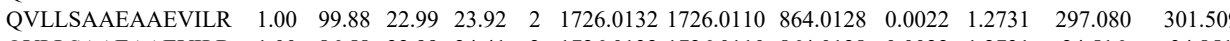
$\begin{array}{lllllllllllll}\text { QVLLSAAEAAEVILR } & 1.00 & 86.58 & 22.99 & 24.41 & 2 & 1726.0132 & 1726.0110 & 864.0128 & 0.0022 & 1.2731 & 24.516 & 34.851\end{array}$ $\begin{array}{lllllllllllll}\text { QVLLSAAEAAEVILR } & 1.00 & \text { \#\#\#\# } 23.03 & 22.41 & 2 & 1726.0134 & 1726.0110 & 864.0128 & 0.0024 & 1.3889 & 354.103 & 352.952\end{array}$ $\begin{array}{llllllllllllll}\text { QVLLSAAEAAEVILR } & 1.00 & \text { \#\#\# } 23.03 & 25.72 & 2 & 1726.0134 & 1726.0110 & 864.0128 & 0.0024 & 1.3889 & 24.461 & 26.164\end{array}$

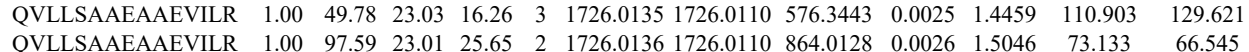
$\begin{array}{lllllllllllll}\text { QVLLSAAEAAEVILR } & 1.00 & 97.59 & 23.01 & 25.65 & 2 & 1726.0136 & 1726.0110 & 864.0128 & 0.0026 & 1.5046 & 73.133 & 66.545 \\ \text { QVLLSAAEAAEVILR } & 1.00 & 84.43 & 23.01 & 22.74 & 2 & 1726.0136 & 1726.0110 & 864.0128 & 0.0026 & 1.5046 & 17.444 & 15.104\end{array}$

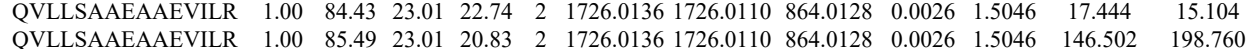

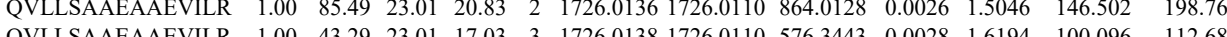

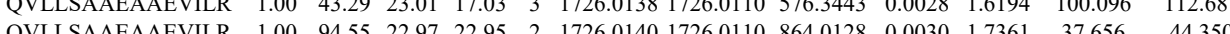

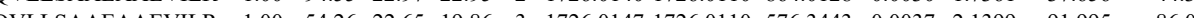

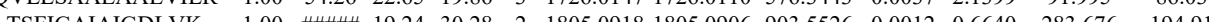

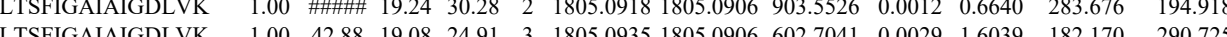
$\begin{array}{lllllllllllll} & 1.00 & 4 & 19.24 & 30.28 & 2 & 1805.0918 & 1805.0906 & 903.5526 & 0.0012 & 0.6640 & 283.676 & 194.918\end{array}$ $\begin{array}{llllllllllllll} & \text { LTSFIGAIAIGDLVK } & 1.00 & 94.48 & 19.24 & 24.30 & 2 & 1805.0920 & 1805.0906 & 903.552 & 0.0014 & 0.7747 & 12.456 & 39.347\end{array}$

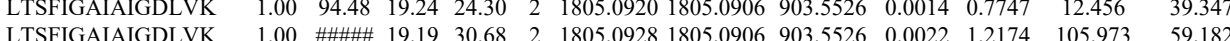
$\begin{array}{lllllllllllll} & \end{array}$ $\begin{array}{llllllllllllll}\text { LTSFIGAIAIGDLVK } & 1.00 & 48.29 & 18.98 & 22.26 & 3 & 1805.0944 & 1805.0906 & 602.7041 & 0.0038 & 2.1016 & 87.273 & 70.140\end{array}$ $\begin{array}{lllllllllllll}\text { SLHDALCVLAQTVK } & 1.00 & 72.84 & 27.14 & 24.39 & 2 & 1830.9908 & 1830.9939 & 916.5042 & -0.0031 & -1.6912 & 751.152 & 876.368\end{array}$ $\begin{array}{llllllllllllll}\text { SLHDALCVLAQTVK } & 0.99 & 39.21 & 27.06 & 24.40 & 3 & 1830.9922 & 1830.9939 & 611.3386 & -0.0017 & -0.9269 & 1079.976 & 727.262\end{array}$ $\begin{array}{lllllllllllll}\text { SLHDALCVLAOTVK } & 0.98 & 28.50 & 26.65 & 19.04 & 3 & 1830.9988 & 1830.9939 & 611.3386 & 0.0049 & 2.6717 & 554.496 & 808.100\end{array}$ $\begin{array}{lllllllllllll}\text { LTSFIGAIAIGDLVK } & 1.00 & 48.20 & 19.19 & 18.92 & 3 & 1805.0932 & 1805.0906 & 602.7041 & 0.0026 & 1.4380 & 57.909 & 72.775\end{array}$ $\begin{array}{llllllllllllll}\text { LTSFIGAIAIGDLVK } & 1.00 & 38.65 & 19.08 & 17.40 & 3 & 1805.0935 & 1805.0906 & 602.7041 & 0.0029 & 1.6039 & 54.675 & 56.463\end{array}$ $\begin{array}{lllllllllllll}\text { SLHDALCVLAQTVK } & 1.00 & 50.39 & 26.81 & 25.16 & 3 & 1830.9961 & 1830.9939 & 611.3386 & 0.0022 & 1.1996 & 353.346 & 356.539\end{array}$ SLHDALCVLAQTVK HGINCFINR

VAEIEHAEK

VAEIEHAEK

GATQQILDEAER

GATQQILDEAER

IHPQTIIAGWR

IHPQTIIAGWR

IHPQTIIAGWR

IHPQTIIAGWR

IHPQTIIAGWR

IHPQTIIAGWR

IHPQTIIAGWR

HPQTHAGWR

THPQTAGW $\begin{array}{lllllllllllll}26.07 & 26.79 & 16.40 & 3 & 1830.9964 & 1830.9939 & 61.3386 & 0.0025 & 1.3631 & 215.315 & 151.509\end{array}$ $\begin{array}{lllllllllllll}1.00 & 37.51 & 27.09 & 15.46 & 3 & 1312.7236 & 1312.7230 & 438.5816 & 0.0006 & 0.4560 & 3731.643 & 4677.684 & 23\end{array}$ $\begin{array}{lllllllllllll}1.00 & 41.80 & 27.09 & 19.31 & 3 & 1312.7236 & 1312.7230 & 438.5816 & 0.0006 & 0.4560 & 3814.615 & 3814.972 & 2 \\ 1.00 & 72.60 & 27.76 & 26.36 & 2 & 1473.7546 & 1473.7545 & 737.8845 & 0.0001 & 0.0678 & 228.141 & 342.003 & 2\end{array}$ $\begin{array}{lllllllllllll}1.00 & 72.60 & 27.76 & 26.36 & 2 & 1473.7546 & 1473.7545 & 737.8845 & 0.0001 & 0.0678 & 228.141 & 342.003 \\ 1.00 & 71.34 & 27.76 & 28.08 & 2 & 1473.7548 & 1473.7545 & 737.8845 & 0.0003 & 0.2033 & 209.453 & 202.227\end{array}$ $\begin{array}{lllllllllllll}0.99 & 47.70 & 26.62 & 23.73 & 2 & 1434.8296 & 1434.8217 & 718.4181 & 0.0079 & 5.4982 & 5261.887 & 6573.198 & 5 \\ 1.00 & 49.40 & 26.57 & 21.44 & 2 & 1434.8304 & 1434.8217 & 718.4181 & 0.0087 & 6.0549 & 3765.861 & 4174.549 & 4\end{array}$ $\begin{array}{llllllllllll}1.00 & 49.40 & 26.57 & 21.44 & 2 & 1434.8304 & 1434.8217 & 718.4181 & 0.0087 & 6.0549 & 3765.861 & 4174.549 \\ 1.00 & 64.05 & 26.26 & 24.98 & 3 & 1434.8329 & 1434.8217 & 479.2812 & 0.0112 & 7.7894 & 4927.107 & 6953.189\end{array}$ $\begin{array}{lllllllllllll}1.00 & 64.05 & 26.26 & 24.98 & 3 & 1434.8329 & 1434.8217 & 479.2812 & 0.0112 & 7.7894 & 4927.107 & 6953.189 \\ 1.00 & 61.96 & 26.26 & 22.02 & 3 & 1434.8329 & 1434.8217 & 479.2812 & 0.0112 & 7.7894 & 2960.529 & 4234.395\end{array}$ $\begin{array}{llllllllllll}1.00 & 61.96 & 26.26 & 22.02 & 3 & 1434.8329 & 1434.8217 & 479.2812 & 0.0112 & 7.7894 & 2960.529 & 4234.395 \\ 1.00 & 6251 & 27.19 & 23.23 & 3 & 1434.8176 & 1434.8217 & 479.2812 & -0.0041 & -2.8515 & 1048.364 & 1391209\end{array}$ $\begin{array}{lllllllllllll}1.00 & 62.51 & 27.19 & 23.23 & 3 & 1434.8176 & 1434.8217 & 479.2812 & -0.0041 & -2.8515 & 1048.364 & 1391.209 \\ 1.00 & 71.05 & 27.19 & 24.11 & 3 & 1434.8176 & 1434.8217 & 479.2812 & -0.0041 & -2.8515 & 1650.923 & 2499.031\end{array}$ $\begin{array}{llllllllllll}1.09 & 11.05 & 27.19 & 24.11 & 3 & 1434.8176 & 434.8217 & 479.2812 & -0.0041 & -2.8515 & 1650.923 & 2499.031 \\ 0.99 & 46.66 & 27.08 & 25.45 & 2 & 1434.8198 & 1434.8217 & 718.4181 & -0.0019 & -1.3224 & 1893.333 & 2110.899\end{array}$ $\begin{array}{llllllllllll}1.00 & 45.59 & 26.89 & 24.54 & 2 & 1434.8220 & 1434.8217 & 718.4181 & 0.0003 & 0.2088 & 1907.055 & 2252.601\end{array}$ $\begin{array}{llllllllllllll}1.00 & 58.69 & 26.97 & 21.60 & 3 & 1434.8203 & 1434.8217 & 479.2812 & -0.0014 & -0.9737 & 429.570 & 570.799\end{array}$ $\begin{array}{llllllllllll}1.00 & 59.09 & 26.81 & 22.05 & 3 & 1434.8209 & 1434.8217 & 4792812 & -0.0008 & -0.5564 & 408.888 & 633.667\end{array}$ 
IHPQTIIAGWR IHPQTIIAGWR GATQQILDEAER GATQQILDEAER LIEEVMIGEDK LIEEVMIGEDK LIEEVMIGEDK

LIEEVMIGEDK

LALVTGGEIASTFDHPEL

LALVTGGEIASTFD

NIGVDNPAAK

VQDDEVGDGTTSVTVLAAE

DEVGDGTTSVTVLAAEL

VQDDEVGDGTTSTYVAN

GSAPPGPVPEGSIR

GSAPPGPVPEGSIR

MILELFSK

MILELFSK

MILELFSK

MILELFSK

MILELFSK

LWMAAMK

VPSLVGSFIR

VPSLVGSFIR

VPSLVGSFIR

VPSLVGSFIR

VPSLVGSFIR

VPSLVGSFIR

LLPDDPYEK

EDPTVSALLTSEK

EDPTVSALLTSEK

EDPTVSALLTSE

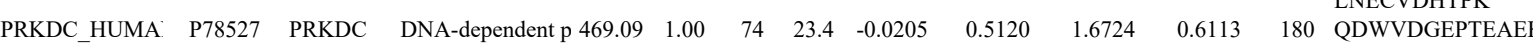

QDWVDGEPTEAEK

IPDTVLEK

NLLTVTSSDEMMK

KIPDTVLEK

YNFPVEVEVPMER

YNFPVEVEVPMER

LACDVDQVTR

NILEESLCELVAK

NILEESLCELVAK

NILEESLCELVAK

NILEESLCELVAK

NILEESLCELVAK

NILEESLCELVAK

NLDLAVLELMQSSVDNTK

NLDLAVLELMQSSVDNTK

NLDLAVLELMQSSVDNTK

NLDLAVLELMQSSVDNTK

\begin{tabular}{llllllllllll}
1.00 & 73.70 & 26.11 & 21.05 & 2 & 2277.67 & 2277.2182 & 2277.2130 & 1139.613 & 0.0044 & 1.9305 & 64.633 \\
\hline
\end{tabular}

$\begin{array}{llllllllllll}\text { LAGANPAVITCDELLLGHEK } & 0.66 & 69.99 & 26.51 & 18.29 & 3 & 2277.2185 & 2277.2130 & 760.0783 & 0.0055 & 2.4120 & 52.853 \\ & 0.69 & 2397.2665 & 2397.2639 & 800.0952 & 0.0026 & 1.0832 & 1259.273\end{array}$

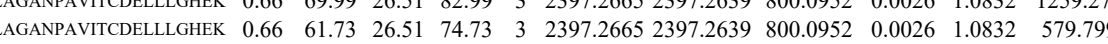

$\begin{array}{llllllllllllll}\text { LAGANPAVITCDELLLGHEK } & 1.00 & 35.93 & 26.59 & 15.34 & 4 & 2397.2689 & 2397.2639 & 600.3233 & 0.0050 & 2.0822 & 64.96\end{array}$

$\begin{array}{lllllllllllll} & \end{array}$

$\begin{array}{lllllllllllll}\text { CLMDQATDPNILGR } & 0.99 & 39.91 & 26.37 & 16.24 & 2 & 1735.8182 & 1735.8177 & 868.9161 & 0.0005 & 0.2877 & 27.024\end{array}$

$\begin{array}{lllllllllllll}\text { CLMDQATDPNILGR } & 0.82 & 68.93 & 26.34 & 81.93 & 2 & 1735.8192 & 1735.8177 & 868.9161 & 0.0015 & 0.8631 & 123.524\end{array}$

$\begin{array}{lllllllllllll}\text { CLMDQATD } & \end{array}$

$\begin{array}{llllllllllll} & \end{array}$
Yes $\begin{array}{lllllllllllll} & \\ 27.78 & 27.13 & 2 & 1473.7658 & 1473.7545 & 737.8845 & 0.0113 & 7.6570 & 6817.567 & 6965.654 & 5567.955 & 8971.375 & \text { Yes } \\ \end{array}$

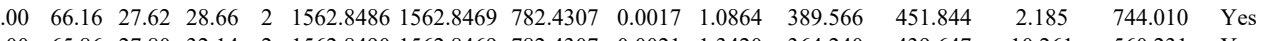
$\begin{array}{llllllllllllll} & 27.81 & 21.17 & 3 & 1562.8492 & 15628469 & 52.9302 & 0.021 & 1.3420 & 384.240 & 439.647 & 10.261 & 560.231 & \text { Yes } \\ & 1.4688 & 20.321 & 26.920 & 23.446 & 36.015 & \text { Yes }\end{array}$

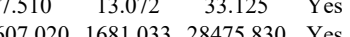

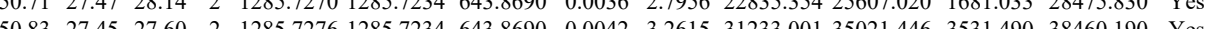
$\begin{array}{lllllllllllll} & 24.85 & 3 & 2431.2604 & 2431.2564 & 811.4261 & 0.0040 & 1.6432 & 19.106 & 17.433 & 18.651 & 17.025 & \text { Yes } \\ \end{array}$ $\begin{array}{lllllllll} & \end{array}$ $\begin{array}{lllllllllllll}31.02 & 2 & 1463.7980 & 1463.7854 & 732.9000 & 0.0126 & 8.5959 & 4822.594 & 5542.192 & 1584.173 & 5811.025 & \text { Yes }\end{array}$ $\begin{array}{llllllllllllll}22.03 & 25.55 & 23.18 & 2 & 1267.7468 & 1267.7453 & 634.8799 & 0.0015 & 1.1813 & 5845.452 & 6650.770 & 43.709 & 9876.627 & \text { Yes }\end{array}$ $\begin{array}{llllllllllllll} & \end{array}$

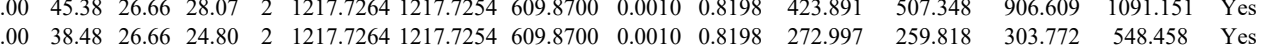

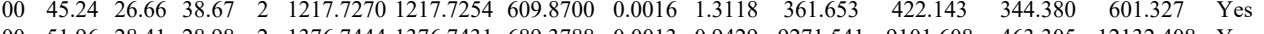

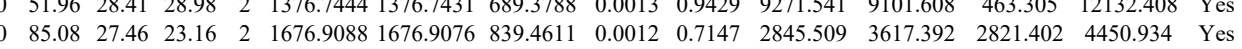
$\begin{array}{ccccccccccccc}27.35 & 15.72 & 3 & 1488.7450 & 1488.7308 & 497.2509 & 0.0142 & 9.5189 & 10108.520 & 12201.067 & 767.976 & 11642.235 & \text { Yes } \\ \end{array}$ $\begin{array}{llllllllll} & \end{array}$

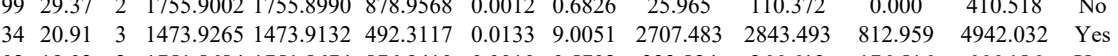

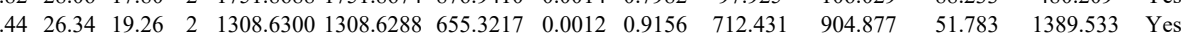
$\begin{array}{lllllllllllll} & \end{array}$ $\begin{array}{lllllllllllll} & \\ 27.66 & 26.53 & 2 & 1793.9542 & 1793.9510 & 897.9828 & 0.0032 & 1.7818 & 546.634 & 361.433 & 181.846 & 1297.777 & \text { Yes }\end{array}$

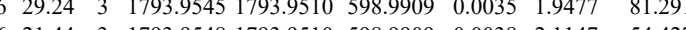




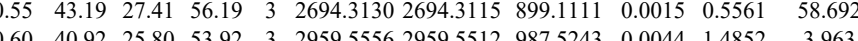

$\begin{array}{lllllllllllll} & 17.5 & \end{array}$

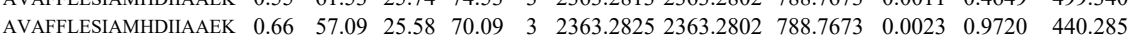

$\begin{array}{lllllllllllll}\text { AVAFFLESIAMHDIIAAEK } & 1.00 & 27.05 & 25.60 & 40.05 & 4 & 2363.2841 & 2363.2802 & 591.8273 & 0.0039 & 1.6474 & 115.472\end{array}$

$\begin{array}{lllllllllllll}\text { AVAFFLESIAMHDIIAAEK } & 1.00 & 35.99 & 25.55 & 19.18 & 4 & 2363.2849 & 2363.2802 & 591.8273 & 0.0047 & 1.9854 & 132.830 \\ \text { NLLIFENLIDLK } & 0.86 & 10.83 & 21.30 & 16.10 & 3 & 1732.0405 & 1732.0378 & 578.3532 & 0.0027 & 1.5561 & 81.275\end{array}$ $\begin{array}{lllllllllll}0.86 & 10.83 & 21.30 & 16.10 & 3 & 1732.0405 & 1732.0378 & 578.3532 & 0.0027 & 1.5561 & 81.275\end{array}$

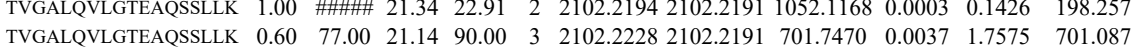
$\begin{array}{llllllllllll}\text { TVGALQVLGTEAQSSLLK } & 0.60 & 77.00 & 21.14 & 90.00 & 3 & 2102.2228 & 2102.2191 & 701.7470 & 0.0037 & 1.7575 & 701.087 \\ \text { TVGALOVLGTEAOSSLLK } & 0.60 & \# \# \# \# & 21.14 & \text { \#\#\#\# } & 3 & 2102.2228 & 2102.2191 & 701.7470 & 0.0037 & 1.7575 & 557.247\end{array}$ $\begin{array}{llllllllllll}\text { DVLIQGLIDENPGLQLIIR } & 1.00 & 70.59 & 21.34 & 22.95 & 3 & 2262.3094 & 2262.3069 & 755.1096 & 0.0025 & 1.1036 & 9.855\end{array}$ $\begin{array}{lllllllllllll}\text { DVLIQGLIDENPGLQLIIR } & 1.00 & 67.03 & 21.40 & 18.85 & 3 & 2262.3097 & 2262.3069 & 755.1096 & 0.0028 & 1.2360 & 12.941\end{array}$ SPNLWLK $\begin{array}{llllllllllll}0.70 & 25.68 & 25.33 & 23.64 & 2 & 1144.6930 & 1144.6848 & 573.3497 & 0.0082 & 7.1509 & 517.948\end{array}$ $\begin{array}{lllllllllll}1.80 & 58.52 & 25.71 & 23.54 & 2 & 1144.6936 & 144.6848 & 573.3497 & 0.0088 & 7.6741 & 972.177\end{array}$

AALSALESFLK $\begin{array}{llllllllllll}1.00 & 58.82 & 24.90 & 34.88 & 2 & 1436.8486 & 1436.8482 & 719.4314 & 0.0004 & 0.2780 & 487.206\end{array}$

AALSALESFLK $\begin{array}{llllllllllll}1.00 & 59.22 & 24.90 & 29.65 & 2 & 1436.8486 & 1436.8482 & 719.4314 & 0.0004 & 0.2780 & 478.947 \\ 0.85 & 15.59 & 26.18 & 20.19 & 3 & 1924.0606 & 1924.0583 & 642.3600 & 0.0023 & 1.1935 & 88.631\end{array}$ $\begin{array}{lllllllllllll}\text { LSDFNDITNMLLLK } & 1.00 & 54.49 & 26.13 & 21.94 & 3 & 1924.0612 & 1924.0583 & 642.3600 & 0.0029 & 1.5049 & 211.747 & 1\end{array}$ $\begin{array}{lllllllllllll}\text { TVGALQVLGTEAQSSLLK } & 0.60 & 18.27 & 21.00 & 31.27 & 3 & 2102.2234 & 2102.2191 & 701.7470 & 0.0043 & 2.0425 & 718.455\end{array}$ $\begin{array}{llllllllllll}\text { LDQGGVIDDFINALDQLSNPELLFK } & 1.00 & 44.57 & 23.28 & 17.49 & 3 & 3074.6602 & 3074.6532 & 1025.8917 & 0.0070 & 2.2744 & 6.054\end{array}$ $\begin{array}{llllllllllll}.98 & 10.94 & 23.30 & 23.94 & 4 & 3074.6585 & 3074.6532 & 769.6706 & 0.0053 & 1.7215 & 7.334 \\ 100 & 61.61 & 23.28 & 20.01 & 3 & 3074.6602 & 3074.6532 & 1025.8917 & 0.0070 & 2.2744 & 11.487\end{array}$

\section{IPALDLLIK}

LGLIEWLENTVTLK

$\begin{array}{lllllllllll}1.00 & 38.95 & 13.01 & 22.68 & 2 & 1282.8488 & 1282.8468 & 642.4307 & 0.0020 & 1.5566 & 1229.029\end{array}$ $\begin{array}{llllllllllll}1.004 & 67.66 & 20.90 & 80.66 & 2 & 1916.1246 & 1916.1226 & 959.0686 & 0.0020 & 1.0427 & 201.801 \\ 0.84 & 62.26 & 20.76 & 75.26 & 2 & 1916.1248 & 1916.1226 & 959.0686 & 0.0022 & 1.1469 & 525.335\end{array}$

LGLIEWLENTVTLK

LGLIEWLENTVTLK

YAVPSAGLR

$\begin{array}{lllllllllll}0.84 & 62.26 & 20.76 & 75.26 & 2 & 1916.1248 & 1916.1226 & 959.0686 & 0.0022 & 1.1469 & 525.335 \\ 0.67 & 41.79 & 20.86 & 54.79 & 3 & 1916.1253 & 1916.1226 & 639.7148 & 0.0027 & 1.4069 & 114.904\end{array}$

YAVPSAGLR

$\begin{array}{llllllllllllll}.67 & 4.79 & 20.86 & 54.79 & 3 & 1916.1253 & 1916.1226 & 639.7148 & 0.0027 & 1.4069 & 114.904\end{array}$

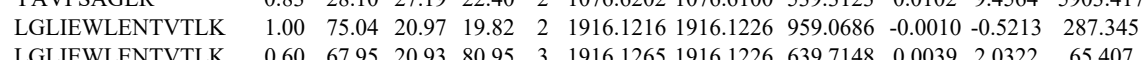

$\begin{array}{rrrrrrrrrrr}1.00 & 66.59 & 20.93 & 20.76 & 3 & 1916.1262 & 1916.1226 & 639.7148 & 0.0036 & 1.8758 & 73.207 \\ 1.00 & 56.74 & 23.52 & 20.28 & 3 & 3074.6572 & 3074.6532 & 1025.8917 & 0.0040 & 1.2997 & 6.289\end{array}$

$\begin{array}{lllllllllllll}0.65 & 25.02 & 27.41 & 22.61 & 2 & 1076.6188 & 1076.6100 & 539.3123 & 0.0088 & 8.1585 & 4221.393\end{array}$ 
$\begin{array}{llllllllllllllll}\text { VYELLGLGEVHPSEMINNAENLFR } & 0.60 & 70.33 & 26.31 & 83.33 & 3 & 3000.5542 & 3000.5500 & 1001.1906 & 0.0042 & 1.3983 & 251.699 & 270.179 & 788.914 & 839.281 & \text { No }\end{array}$ \begin{tabular}{llllllllllllllllll} 
LQSVQALTEIQEFISFISK & 1.00 & 18.05 & 21.88 & 31.05 & 4 & 2468.3805 & 2468.3770 & 618.1015 & 0.0035 & 1.4156 & 66.977 & 80.781 & 49.891 & 89.862 & Yes \\
\hline
\end{tabular}

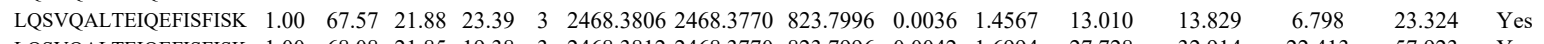
$\begin{array}{llllllllllllllll}\text { LQSVQALTEIQEFISFISK } & 1.00 & 68.08 & 21.85 & 19.38 & 3 & 2468.3812 & 2468.3770 & 823.7996 & 0.0042 & 1.6994 & 27.728 & 32.914 & 22.413 & 57.923 & \text { Yes }\end{array}$ $\begin{array}{llllllllllllllll}\text { LQSVQALTELQEFISFISK } & 0.99 & 13.07 & 21.88 & 26.07 & 4 & 2468.3813 & 2468.3770 & 618.1015 & 0.0043 & 1.7392 & 69.235 & 69.678 & 50.912 & 65.402 & \text { Yes }\end{array}$ $\begin{array}{llllllllllllllll}\text { VYELLGLGEVHPSEMINNAENLFR } & 1.00 & 69.79 & 26.43 & 20.19 & 3 & 3000.5512 & 3000.5500 & 1001.1906 & 0.0012 & 0.3995 & 88.772 & 84.003 & 176.129 & 214.530 & \text { Yes } \\ \text { VYELLGLGEVHPSEMINNAENLFR } & 1.00 & 58.72 & 26.43 & 16.85 & 3 & 3000.5512 & 3000.5500 & 1001.1906 & 0.0012 & 0.3995 & 8.155 & 21.391 & 15.015 & 3.547 & \text { No }\end{array}$ $\begin{array}{llllllllllllllll}\text { LQSVQALTEIQEFISFISK } & 1.00 & 66.74 & 22.04 & 17.92 & 3 & 2468.3794 & 2468.3770 & 823.7996 & 0.0024 & 0.9711 & 10.892 & 6.531 & 1.924 & 10.363 & \text { No }\end{array}$

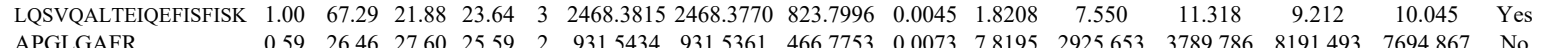

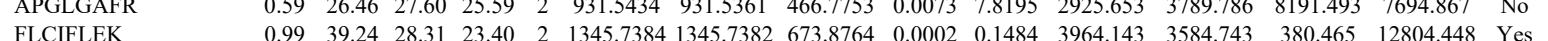

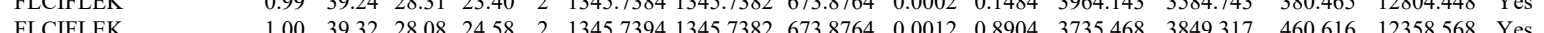
$\begin{array}{lllllllllllll} & \end{array}$

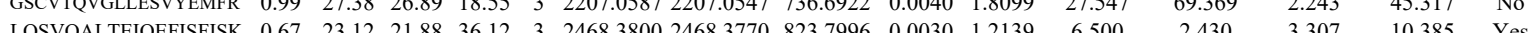

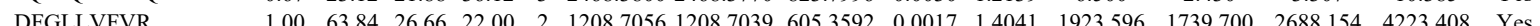
$\begin{array}{llllllllllllllll}\text { DFGLLVFVR } & 1.00 & 63.84 & 26.66 & 22.00 & 2 & 1208.7056 & 1208.7039 & 605.3592 & 0.0017 & 1.4041 & 1923.596 & 1739.700 & 2688.154 & 4223.408 & \text { Yes } \\ \text { DFGLLVFVR } & 1.00 & 54.21 & 26.67 & 22.09 & 2 & 1208.7062 & 1208.7039 & 605.3592 & 0.0023 & 1.8997 & 2048.667 & 1592.497 & 3172.752 & 4030.677 & \text { Yes }\end{array}$

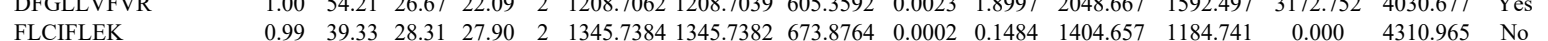
$\begin{array}{lllllllllllllll} & & & \end{array}$ $\begin{array}{llllllllllllllll}\text { LLALNSLYSPK } & 1.00 & 66.11 & 23.67 & 25.85 & 2 & 1505.9066 & 1505.9061 & 753.9603 & 0.0005 & 0.3316 & 1699.189 & 2136.231 & 2304.572 & 7418.892 & \text { Yes }\end{array}$

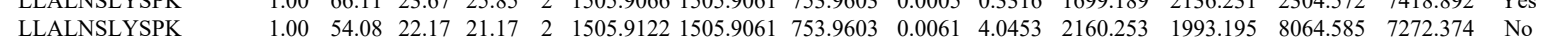

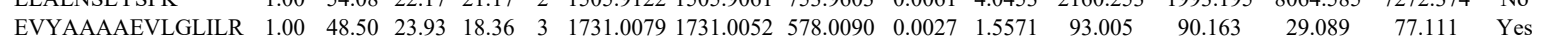
$\begin{array}{llllllllllllllll}\text { EVYAAAAEVLGLILR } & 1.00 & 30.88 & 23.93 & 17.61 & 3 & 1731.0082 & 1731.0052 & 578.0090 & 0.0030 & 1.7301 & 76.363 & 76.389 & 18.431 & 102.195 & \text { Yes }\end{array}$ $\begin{array}{lllllllllllllllll}\text { GSCVTQVGLLESVYEMFR } & 0.60 & 12.37 & 26.89 & 25.37 & 3 & 2207.0587 & 2207.0547 & 736.6922 & 0.0040 & 1.8099 & 5.040 & 6.654 & 3.091 & 2.679 & \text { No }\end{array}$

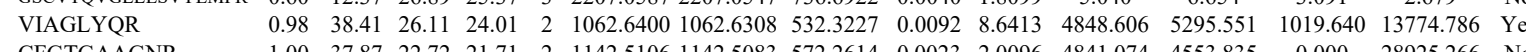
$\begin{array}{lllllllllllllllll}\text { CFGTGAAGNR } & 1.00 & 37.87 & 22.72 & 21.71 & 2 & 1142.5106 & 1142.5083 & 572.2614 & 0.0023 & 2.0096 & 4841.074 & 4553.835 & 0.000 & 28925.266 & \text { No }\end{array}$

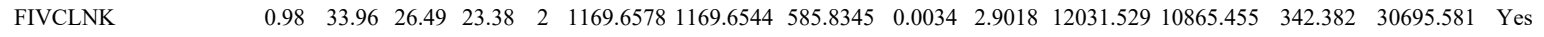
FIVCLNK

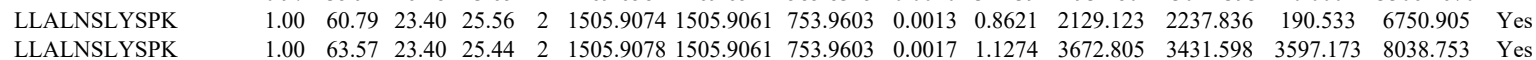
$\begin{array}{lllllllllllllllll}0.97 & 35.91 & 26.48 & 23.65 & 2 & 1169.6584 & 1169.6544 & 585.8345 & 0.0040 & 3.4139 & 12934.802 & 13021.393 & 0.000 & 33062.670 & \text { No }\end{array}$ $\begin{array}{llllllllllllllllll}\text { VVQMLGSLGGQINK } & 1.00 & 63.57 & 23.40 & 25.44 & 2 & 1505.9078 & 1505.9061 & 753.9603 & 0.0017 & 1.1274 & 3672.805 & 3431.598 & 3597.173 & 8038.753 & \text { Yes } \\ \text { V.00 } & 47.09 & 24.64 & 18.51 & 3 & 1730.9983 & 1730.9957 & 578.0058 & 0.0026 & 1.4994 & 926.620 & 1049.715 & 553.464 & 1505.152 & \text { Yes }\end{array}$ $\begin{array}{llllllllllllllll}\text { VVQMLGSLGGQINK } & 1.00 & 46.06 & 24.61 & 20.03 & 3 & 1730.9989 & 1730.9957 & 578.0058 & 0.0032 & 1.8454 & 874.509 & 1032.357 & 665.601 & 1593.673 & \text { Yes }\end{array}$

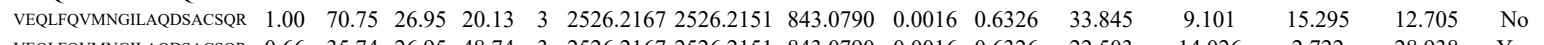

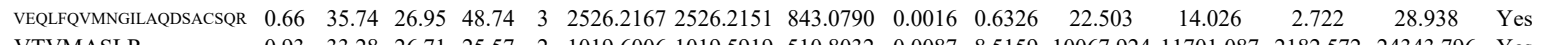

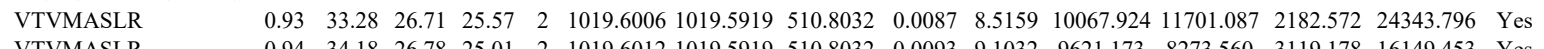

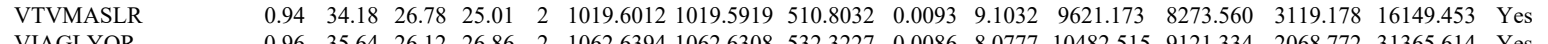
$\begin{array}{llllllllllllllll}\text { VIAGLYQR } & 0.96 & 35.64 & 26.12 & 26.86 & 2 & 1062.6394 & 1062.6308 & 532.3227 & 0.0086 & 8.0777 & 10482.515 & 9121.334 & 2068.772 & 31365.614 & \text { Yes } \\ \text { VIAGLYQR } & 0.97 & 37.20 & 26.11 & 22.70 & 2 & 1062.6400 & 1062.6308 & 532.3227 & 0.0092 & 8.6413 & 10528216 & 9860.003 & 1250.805 & 29080.059 & \text { Yes }\end{array}$ $\begin{array}{llllllllllllllll}\text { VIAGLYQR } & 0.97 & 37.20 & 26.11 & 22.70 & 2 & 1062.6400 & 1062.6308 & 532.3227 & 0.0092 & 8.6413 & 10528.216 & 9860.003 & 1250.805 & 29080.059 & \text { Yes } \\ \text { WPVAGQIR } & 0.88 & 28.75 & 24.87 & 25.65 & 2 & 1069.6240 & 1069.6154 & 535.8150 & 0.0086 & 8.0251 & 6379.090 & 6911352 & 23994.508 & 19405.926 & \text { No }\end{array}$

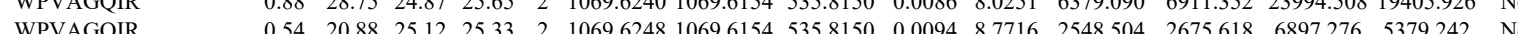

CFFLSK

CFGTGAAGNR

CFGTGAAGNR

FIVCLNK

FIVCLNK

LPLISGFYK

QFINLMLPMK

QFINLMLPMK $\begin{array}{llllllllllllllll}0.54 & 20.88 & 25.12 & 25.33 & 2 & 1069.6248 & 1069.6154 & 535.8150 & 0.0094 & 8.7716 & 2548.504 & 2675.618 & 6897.276 & 5379.242 & N o & \\ \end{array}$

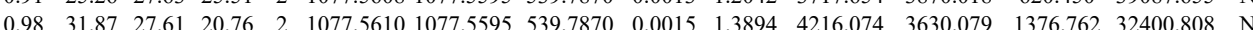
$\begin{array}{lllllllllllllll}1.00 & 44.17 & 22.67 & 22.93 & 2 & 1142.5098 & 1142.5083 & 572.2614 & 0.0015 & 13106 & 2559.421 & 2371.382 & 441.065 & 14732.254 & N 0\end{array}$ $\begin{array}{llllllllllllllll}1.00 & 35.95 & 22.67 & 23.42 & 2 & 11425100 & 1142.5083 & 5722614 & 0.0017 & 1.4853 & 2276.607 & 2202.887 & 175.728 & 13001.461 & N o\end{array}$ $\begin{array}{llllllllllllllll}0.99 & 36.50 & 26.61 & 25.10 & 2 & 1169.6558 & 1169.6544 & 585.8345 & 0.0014 & 1.1949 & 7744.424 & 6324.827 & 537.538 & 18580.248 & \text { Y Se }\end{array}$ $\begin{array}{lllllllllllllll}0.99 & 36.74 & 26.67 & 25.51 & 2 & 1169.6570 & 1169.6544 & 585.8345 & 0.0026 & 2191 & 7049.710 & 5862.240 & 1112724 & 17224.284 & \text { Yes }\end{array}$ $\begin{array}{llllllllllllllllll}1.00 & 44.95 & 23.38 & 22.57 & 2 & 1324.8004 & 1324.7998 & 663.4072 & 0.0006 & 0.4522 & 1665.321 & 2448.341 & 9158.457 & 7841.294 & \mathrm{No}\end{array}$ $\begin{array}{llllllllllllllllll}1.00 & 51.72 & 23.38 & 19.25 & 2 & 1324.8008 & 1324.7998 & 663.4072 & 0.0010 & 0.7537 & 1924.927 & 1312.631 & 7483.081 & 5682.898 & \mathrm{No}\end{array}$

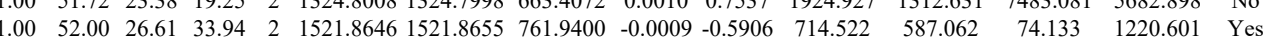
$\begin{array}{llllllllllllllllll}\text { MVSAVLNGMLDQSFR } & 1.00 & 78.91 & 27.74 & 28.68 & 2 & 1810.9194 & 1810.9192 & 906.4669 & 0.0002 & 0.1103 & 513.490 & 468.044 & 28.760 & 1084.695 & \text { Yes }\end{array}$ $\begin{array}{lllllllllllllllll}\text { MVSAVLNGMLDQSFR } & 1.00 & 75.88 & 27.76 & 19.82 & 2 & 1810.9200 & 1810.9192 & 906.4669 & 0.0008 & 0.4413 & 287.750 & 261.522 & 34.276 & 464.310 & \text { Yes }\end{array}$ $\begin{array}{llllllllllllllll}\text { MVSAVLNGMLDQSFR } & 1.00 & 46.65 & 27.80 & 19.63 & 3 & 1810.9216 & 1810.9192 & 604.6470 & 0.0024 & 1.3231 & 189.401 & 238.073 & 78.531 & 217.995 & \text { Yes }\end{array}$ $\begin{array}{llllllllllllllll}\text { SLGTIQQCCDAIDHLCR } & 0.66 & 61.50 & 21.24 & 74.50 & 3 & 2156.9113 & 2156.9089 & 719.9769 & 0.0024 & 1.1111 & 160.199 & 121.697 & 46.829 & 271.066 & \text { Yes }\end{array}$ $\begin{array}{lllllllllllllllll}\text { VEQLFQVMNGILAQDSACSQR } & 0.67 & 73.98 & 26.95 & 86.98 & 3 & 2526.2179 & 2526.2151 & 843.0790 & 0.0028 & 1.1071 & 9.667 & 22.565 & 11.590 & 24.420 & \text { Yes }\end{array}$ $\begin{array}{lllllllllllllllll}\text { VEQLFQVMNGILAQDSACSQR } & 1.00 & 82.25 & 27.05 & 20.83 & 3 & 2526.2185 & 2526.2151 & 843.0790 & 0.0034 & 1.3443 & 34.891 & 8.578 & 5.446 & 44.619 & \text { No }\end{array}$ $\begin{array}{llllllllllllllll}\text { CFGTGAAGNR } & 1.00 & 46.18 & 22.20 & 22.83 & 2 & 1142.5094 & 1142.5083 & 572.2614 & 0.0011 & 0.9611 & 757.517 & 906.446 & 232.501 & 4161.606 & \text { Yes }\end{array}$ $\begin{array}{llllllllllllllll}\text { LPVLAGCLK } & 1.00 & 40.52 & 26.90 & 31.48 & 2 & 1246.7396 & 1246.7385 & 624.3765 & 0.0011 & 0.8809 & 2341.509 & 2686.513 & 3667.946 & 5250.773 & \text { Yes }\end{array}$ $\begin{array}{llllllllllllllll}\text { LPVLAGCLK } & 1.00 & 39.81 & 26.90 & 27.41 & 2 & 1246.7398 & 1246.7385 & 624.3765 & 0.0013 & 1.0410 & 2660.583 & 2471.052 & 6123.492 & 6412.909 & \text { Yes }\end{array}$ $\begin{array}{llllllllllllllll}\text { LPLISGFYK } & 1.00 & 40.45 & 23.40 & 24.12 & 2 & 1324.8000 & 1324.7998 & 663.4072 & 0.0002 & 0.1507 & 768.327 & 631.488 & 2224.579 & 2055.717 & \text { No }\end{array}$

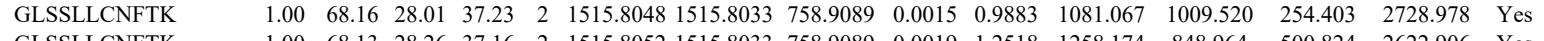
$\begin{array}{lllllllllllllllll} & \text { GLSSLLCNFTK } & 1.00 & 68.13 & 28.26 & 37.16 & 2 & 1515.8052 & 1515.8033 & 758.9089 & 0.0019 & 1.2518 & 1258.174 & 848.964 & 500.824 & 2622.906 & \text { Yes }\end{array}$

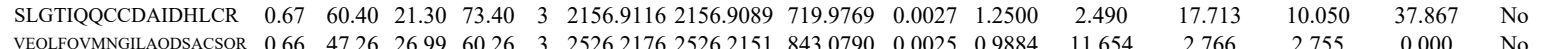

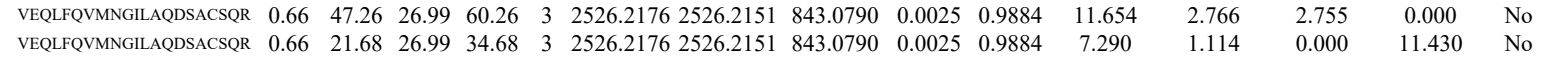

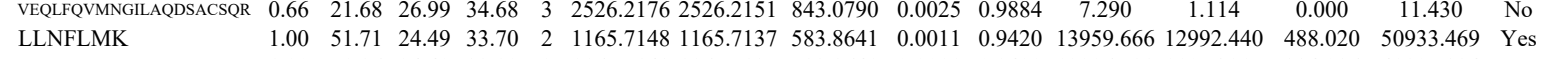
$\begin{array}{llllllllllllll} & & & & \end{array}$ 
$\begin{array}{llllllllllllllll}\text { VLEQLIVAHFPMQSR } & 0.55 & 55.34 & 26.27 & 68.34 & 3 & 1911.0532 & 1911.0522 & 638.0247 & 0.0010 & 0.5224 & 1381.314 & 2655.033 & 621.699 & 5544.421 & \text { Yes } \\ \text { VLEQLIVAHFPMQSR } & 1.00 & 50.41 & 26.10 & 25.07 & 3 & 1911.0568 & 1911.0522 & 638.0247 & 0.0046 & 2.4032 & 2755.596 & 5074.555 & 1833.662 & 11574.346 & \text { Yes }\end{array}$ LSLMYAR $\begin{array}{lllllllllllll} & 0\end{array}$ $\begin{array}{lllllllllllllll}0.99 & 47.99 & 27.80 & 21.38 & 2 & 1160.6490 & 1160.6424 & 581.3285 & 0.0066 & 5.6766 & 4013.204 & 4055.910 & 0.000 & 19125.870 & \text { Yo }\end{array}$ $\begin{array}{llllllllllllll}0.99 & 47.88 & 27.67 & 21.74 & 2 & 1160.6500 & 1160.6424 & 581.3285 & 0.0076 & 6.5367 & 4402203 & 3955.733 & 173.008 & 16865.370\end{array}$ $\begin{array}{lllllllllllllll}1.00 & 44.07 & 24.05 & 33.45 & 2 & 1165.7152 & 1165.7137 & 583.3641 & 0.0015 & 1.2845 & 40455.59 & 3217.006 & 193.517 & 14726.536 & \text { Y }\end{array}$

MAVLALLAK
LPVLAGCLK

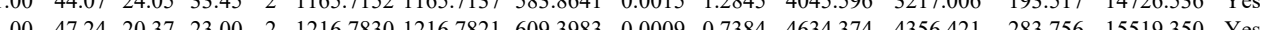

LPVLAGCLK

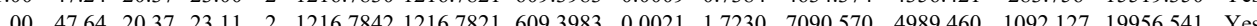

LPVLAGCLK

QLFSSLFSGILK

QLFSSLFSGILK

QLFSSLFSGILK

$\begin{array}{lllllllllllllll}1.00 & 51.71 & 26.73 & 37.26 & 2 & 1246.7380 & 1246.7385 & 624.3765 & -0.0005 & -0.4004 & 1355.393 & 1095.099 & 4277.997 & 3968.988 & \mathrm{No}\end{array}$

$\begin{array}{llllllllllllllll}1.00 & 48.08 & 26.73 & 37.18 & 2 & 1246.7386 & 1246.7385 & 624.3765 & 0.0001 & 0.0801 & 1178.104 & 964.645 & 3137.096 & 3217.714 & \mathrm{No}\end{array}$ $\begin{array}{lllllllllllllllll}1.00 & 74.89 & 23.48 & 28.14 & 2 & 16269600 & 16269589 & 814.4867 & 0.0011 & 0.6753 & 25.745 & 169.204 & 0.000 & 823.388 & \mathrm{No}\end{array}$

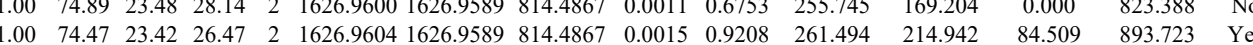
$\begin{array}{lllllllllllllll}1.00 & 56.30 & 23.58 & 33.05 & 3 & 1626.9628 & 1626.9589 & 543.3269 & 0.0039 & 2.3927 & 55.596 & 36.699 & 12.271 & 102.489 & \text { Yes }\end{array}$

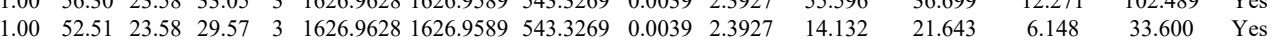
$\begin{array}{lllllllllllllllll}\text { VLEQLIVAHFPMQSR } & 1.00 & 48.17 & 26.23 & 21.04 & 3 & 1911.0544 & 1911.0522 & 638.0247 & 0.0022 & 1.1494 & 2779.450 & 2396.338 & 1177.653 & 5869.129 & \text { Yes }\end{array}$ $\begin{array}{llllllllllllllllll}\text { VLEQLIVAHFPMQSR } & 1.00 & 64.13 & 26.17 & 20.83 & 3 & 1911.0547 & 1911.0522 & 638.0247 & 0.0025 & 1.3061 & 1672.720 & 2001.844 & 1660.553 & 5855.891 & \text { Yes }\end{array}$ TFPVLLR

QLFSSLFSGILK

QLFSSLFSGILK

QLFSSLFSGILK

NCISTVVHQGLIR
NCISTVVHOGLIR

NCISTVVHQGLIR

VLEQLIVAHFPMQSR
VLEQLIVAHFPMQSR VLEQLIVAHFPMQSR

\section{TFPVLLR}

TFPVLLR

LGASLAFNNIYR

LGASLAFNNIYR

QLFSSLFSGILK

QLFSSLFSGILK

NCISTVVHQGLIR

NCISTVVHQGLIR

LGNPIVPLNIR

LGNPIVPLNIR

LGASLAFNNIYR

LGASLAFNNIYR

LSFAVPFR

FVPLLPGNR

FVPLLPGNR

FVPLLPGNR

FVPLLPGNR

FVPLLPGNR

FMNAVFFLLPK

FMNAVFFLLPK

FMNAVFFLLP

LSFAVPFR

LSFAVPFR

FVPLLPGNR

FVPLLPGNR

FVPLLPGNR

FVPLLPGNR
FMNAVFFLLPK

FVPLLPGNR

FVPLLPGNR
FVPLLPGNR

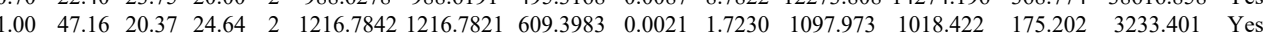

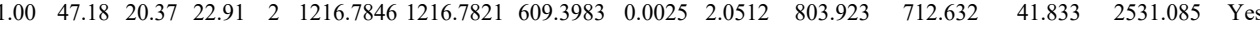
$\begin{array}{llllllllllllllll}1.00 & 47.18 & 20.37 & 22.91 & 2 & 126.7846 & 126.7821 & 609.3983 & 0.0025 & 2.0512 & 803.923 & 712.632 & 41.833 & 2531.085 & \text { Yes } \\ 1.82 & 46.53 & 22.88 & 59.53 & 2 & 1348.8324 & 1348.8312 & 675.4229 & 0.0012 & 0.8883 & 4299.667 & 4768.945 & 3157.915 & 13329.949 & \text { Yes }\end{array}$ $\begin{array}{lllllllllllllll}1.00 & 49.81 & 22.79 & 21.01 & 2 & 1348.8326 & 1348.8312 & 675.4229 & 0.0014 & 1.0364 & 6587.140 & 6181.896 & 4088.180 & 14762.950 & \text { Yes }\end{array}$ $\begin{array}{lllllllllllllll}1.00 & 73.13 & 23.50 & 30.90 & 2 & 1626.9596 & 1626.9589 & 814.4867 & 0.0007 & 0.4297 & 223.751 & 185.496 & 16.668 & 726.022 & \text { Yes }\end{array}$ $\begin{array}{lllllllllllllll}1.00 & 61.68 & 23.34 & 30.10 & 2 & 1626.9608 & 1626.9589 & 814.4867 & 0.0019 & 1.1664 & 256.014 & 246.998 & 0.000 & 905.356 & \text { No }\end{array}$ $\begin{array}{lllllllllllllll}1.00 & 57.46 & 23.58 & 30.78 & 3 & 1626.9628 & 1626.9589 & 543.3269 & 0.0039 & 2.3927 & 19.304 & 37.493 & 8.759 & 40.839 & \text { No }\end{array}$

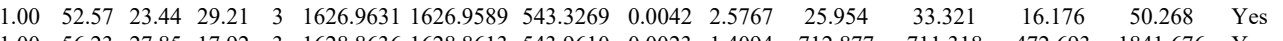

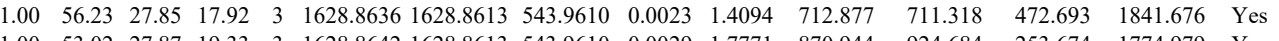
$\begin{array}{lllllllllllllll}1.00 & 53.02 & 27.87 & 19.33 & 3 & 1628.8642 & 1628.8613 & 543.9610 & 0.0029 & 1.7771 & 870.944 & 924.684 & 253.674 & 1774.979 & \text { Yes }\end{array}$

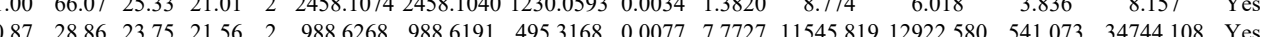

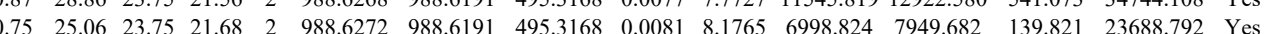

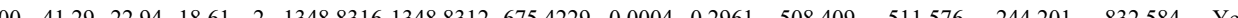

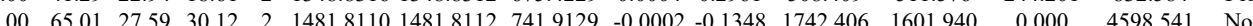

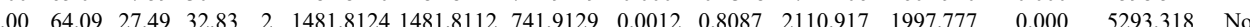

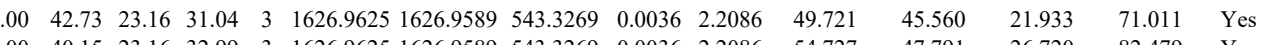
$\begin{array}{lllllllllllllll}1.00 & 40.15 & 23.16 & 32.99 & 3 & 1626.9625 & 1626.9589 & 543.3269 & 0.0036 & 2.2086 & 54.727 & 47.791 & 26.720 & 82.479 & \text { Yes } \\ 1.00 & 54.27 & 27.83 & 17.57 & 3 & 1628.8618 & 1628.863 & 53.9610 & 0.005 & 0.3064 & 652245 & 1914.908 & 689.016 & 955.353 & \text { No }\end{array}$

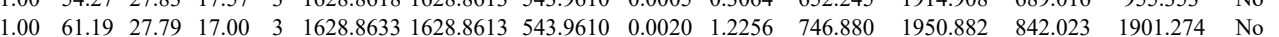
$\begin{array}{lllllllllllllll}0.69 & 25.64 & 23.01 & 16.89 & 2 & 1348.8290 & 1348.8312 & 675.4229 & -0.0022 & -1.6286 & 310.087 & 337.882 & 220.955 & 625.585 & \text { Yes }\end{array}$

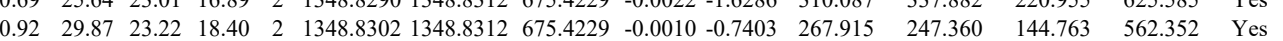

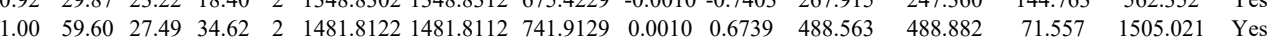
$\begin{array}{llllllllllllllll}1.00 & 65.28 & 27.54 & 35.47 & 2 & 1481.8130 & 1481.8112 & 741.9129 & 0.0018 & 1.2131 & 556.443 & 503.331 & 12.524 & 1382.375 & \text { Yes }\end{array}$ $\begin{array}{lllllllllllllll}1.00 & 39.48 & 27.89 & 26.39 & 2 & 1079.6262 & 1079.6250 & 540.8198 & 0.0012 & 1.1094 & 6709.868 & 7072.921 & 396.928 & 21053.847 & \text { Yes }\end{array}$ $\begin{array}{lllllllllllllll}1.00 & 43.21 & 27.89 & 22.76 & 2 & 1079.6262 & 1079.6250 & 540.8198 & 0.0012 & 1.1094 & 10040.515 & 10880.448 & 119.617 & 32377.217 & \text { Yes }\end{array}$ $\begin{array}{lllllllllllllll}0.75 & 17.51 & 25.85 & 14.12 & 2 & 1155.6902 & 1155.6886 & 578.8516 & 0.0016 & 1.3820 & 35.563 & 39.090 & 15.693 & 65.720 & \text { Yes }\end{array}$ $\begin{array}{lllllllllllllll}0.57 & 13.70 & 25.85 & 20.17 & 2 & 1155.6910 & 1155.6886 & 578.8516 & 0.0024 & 2.0731 & 35.698 & 35.868 & 16.502 & 61.272 & \text { Yes }\end{array}$

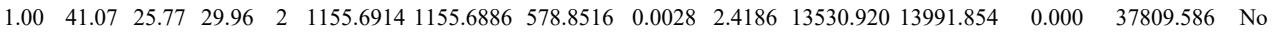
$\begin{array}{lllllllllllllll}0.99 & 36.82 & 25.76 & 26.11 & 2 & 1155.6920 & 1155.6886 & 578.8516 & 0.0034 & 2.9368 & 26109.140 & 22436.813 & 0.000 & 76357.758 & \text { No }\end{array}$

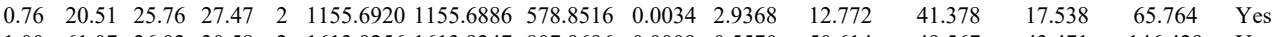

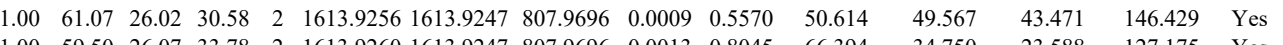

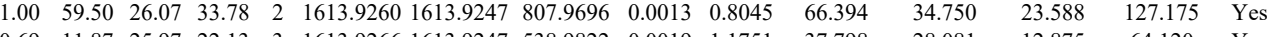

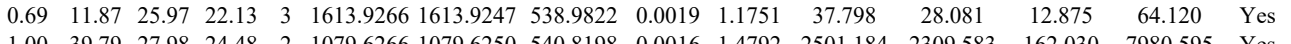

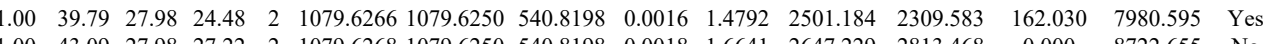

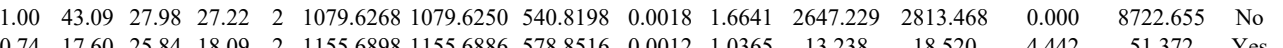
\begin{tabular}{lllllllllllllll}
0.74 & 17.60 & 25.84 & 18.09 & 2 & 1155.6898 & 1155.6886 & 578.8516 & 0.0012 & 1.0365 & 13.238 & 18.520 & 4.442 & 51.372 & Yes \\
\hline .99 & 34.94 & 25.83 & 25.03 & 2 & 1155.6906 & 1155.6886 & 578.8516 & 0.0020 & 1.7276 & 6704.545 & 6251.093 & 345.451 & 18662.29 & Yes
\end{tabular} $\begin{array}{llllllllllllllll}0.99 & 34.94 & 25.83 & 25.03 & 2 & 1155.6906 & 1155.6886 & 578.8516 & 0.0020 & 1.7276 & 6704.545 & 6251.093 & 345.451 & 18662.291 & \text { Yes }\end{array}$ $\begin{array}{lllllllllllllll}0.99 & 55.13 & 25.83 & 25.20 & 2 & 1155.6906 & 155.6886 & 578.8516 & 0.0020 & 1.7276 & 15464.165 & 14429.356 & 643.851 & 41226.300 & \text { Yes } \\ 0.66 & 15.43 & 25.85 & 19.76 & 2 & 1155.6910 & 1155.6886 & 578.8516 & 0.0024 & 2.0731 & 13.994 & 25.209 & 7.604 & 29.245 & \text { Yes }\end{array}$

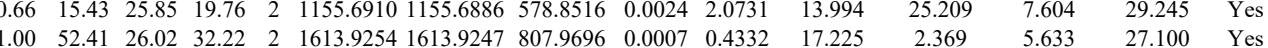

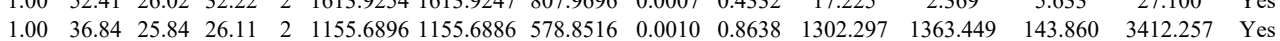

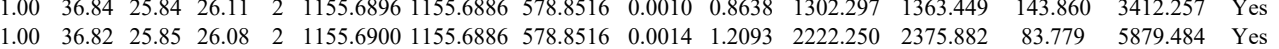




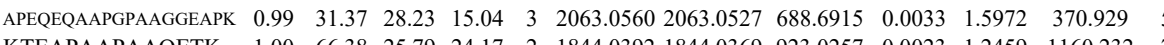

$\begin{array}{llllllllllllll}\text { KTEAPAAPAAQETK } & 1.00 & 66.38 & 25.79 & 24.17 & 2 & 1844.0392 & 1844.0369 & 923.0257 & 0.0023 & 1.2459 & 1160.232 & 729.774\end{array}$

$\begin{array}{llllllllllll}1.00 & 50.93 & 25.69 & 23.07 & 4 & 1844.0401 & 1844.0369 & 462.0165 & 0.0032 & 1.7315 & 458.923 & 742.963\end{array}$

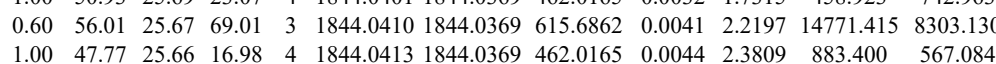

EAPAAPAAQETK

KTEAPAAPAAQETK

$\begin{array}{lllllllllllll}\text { RL24_HUMAN } & \text { P83731 } & \text { RPL24 } & \text { 60S ribosomal pro } 17.779 & 1.00 & 4 & 23.6 & 0.0653 & 0.1017 & 3.0085 & 0.2821 & 16 & \text { TAMAAAK }\end{array}$

AITGASLADIMAK

AITGASLADIMAK

AITGASLADIMAK AITGASLADIMAK AITGASLADIMAK AITGASLADIMAK AITGASLADIMAK ATTASLADIMAK ATTASLADIMAK AITSADAR

VFOFLNAK

VFQFLNAK

VFQFLNAK

VFOFLNAK

QINWTVLYR

QINWTVLYR

QINWTVLYR

QINWTVLYR

$\begin{array}{llllllllllllllll}0.98 & 13.40 & 25.69 & 15.54 & 4 & 1844.0401 & 1844.0369 & 462.0165 & 0.0032 & 1.7315 & 479.130 & 368.990 & 575.435 & 1324.661 & \text { Yes } \\ 0.60 & 2.657 .245 & \text { Yes }\end{array}$

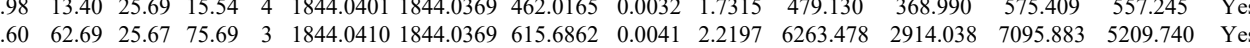
$\begin{array}{llllllllllllllll}1.00 & 37.54 & 25.60 & 16.65 & 4 & 1844.0417 & 1844.0369 & 462.0165 & 0.0048 & 2.5973 & 451.764 & 361.933 & 662.067 & 448.426 & \text { Yes } \\ 0.98 & 39.75 & 26.12 & 28.36 & 2 & 50.5448 & 950.5462 & 47.2804 & 0.0014 & -1697 & 305.63 & 301.228 & 94.49 & 371.648 & \end{array}$ $\begin{array}{lllllllllllllll}.0 & 28.36 & 2 & 950.5448 & 950.5462 & 476.2804 & -0.0014 & -1.4697 & 305.634 & 301.228 & 94.499 & 371.648 & \text { Yes }\end{array}$

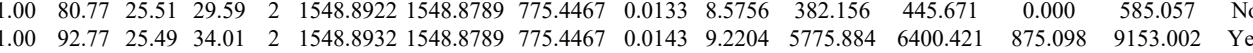

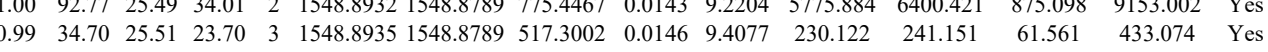
\begin{tabular}{llllllllllllllll}
0.80 & 22.91 & 25.51 & 16.62 & 3 & 1548.8941 & 1548.8789 & 517.3002 & 0.0152 & 9.7943 & 217.849 & 219.227 & 39.375 & 292.973 & Yes \\
\hline
\end{tabular}

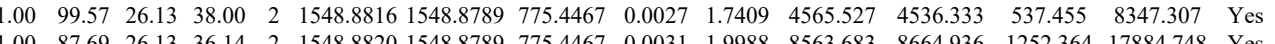
$\begin{array}{lllllllllllllll}1.00 & 87.69 & 26.13 & 36.14 & 2 & 1548.8820 & 1548.8789 & 775.4467 & 0.0031 & 1.9988 & 8563.683 & 8664.936 & 1252.364 & 17884.748 & \text { Yes } \\ 1.00 & 47.33 & 26.13 & 23.53 & 3 & 15488821 & 1548.8789 & 517.3002 & 0.0032 & 2.0620 & 299.979 & 326.539 & 107.801 & 367.702 & \text { Yes }\end{array}$ $\begin{array}{lllllllllllllll}1.00 & 47.33 & 26.13 & 23.53 & 3 & 1548.8821 & 1548.8789 & 517.3002 & 0.0032 & 2.0620 & 299.979 & 326.539 & 107.801 & 367.702 & \text { Yes } \\ 0.91 & 18.99 & 26.14 & 23.58 & 3 & 1548.8830 & 1548.8789 & 517.3002 & 0.0041 & 2.6419 & 259.246 & 157.217 & 86.731 & 298.505 & \text { No }\end{array}$

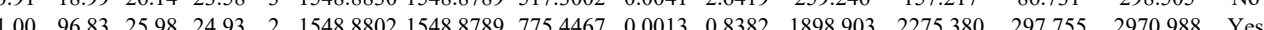

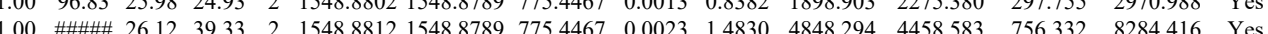
$\begin{array}{lllllllllllllll}0.78 & 13.66 & 6.11 & 16.77 & 3 & 1548.8821 & 1548.8789 & 517.3002 & 0.0032 & 20620 & 178.447 & 159.701 & 107.377 & 284.491 & \text { No }\end{array}$

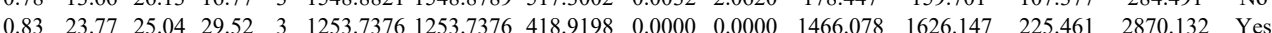
$\begin{array}{lllllllllllllll}1.00 & 47.35 & 25.04 & 24.71 & 2 & 1253.7378 & 1253.7376 & 627.8761 & 0.0002 & 0.1593 & 33555.881 & 33772.487 & 812.192 & 70079.312 & \text { Yes }\end{array}$ $\begin{array}{lllllllllllllll}0.76 & 15.93 & 24.87 & 25.32 & 3 & 12537388 & 1253.7376 & 418.9198 & 0.0012 & 0.9548 & 1369.205 & 1497.335 & 109.460 & 2338.422 & \text { Yes }\end{array}$ $\begin{array}{lllllllllllllll}1.00 & 43.20 & 24.79 & 24.16 & 2 & 1253.7418 & 1253.7376 & 627.8761 & 0.0042 & 3.3446 & 26763.819 & 29391.783 & 0.000 & 57144.702 & \text { No }\end{array}$ $\begin{array}{lllllllllllllll}1.00 & 4.593 & 27.86 & 25.98 & 2 & 1335.7430 & 1335.7421 & 6688.8783 & 0.0009 & 0.6728 & 14471.448 & 13261.509 & 2449.023 & 25285.345 & \text { Yes }\end{array}$ $\begin{array}{llllllllllllllll}1.00 & 47.07 & 27.84 & 25.66 & 2 & 1335.7434 & 1335.7421 & 668.8783 & 0.0013 & 0.9718 & 22878.036 & 24733.356 & 82.687 & 51248.600 & \text { Yes }\end{array}$ $\begin{array}{llllllllllllllll}1.00 & 52.07 & 27.86 & 26.37 & 2 & 1335.7420 & 1335.7421 & 668.8783 & -0.0001 & -0.0748 & 9947.044 & 10670.599 & 729.600 & 20243.193 & \text { Yes }\end{array}$ $\begin{array}{lllllllllllllllll}1.00 & 44.53 & 27.86 & 26.00 & 2 & 1335.7424 & 1335.7421 & 668.8783 & 0.0003 & 0.2243 & 17535.037 & 18042.024 & 686.818 & 38827.383 & \text { Yes }\end{array}$ $\begin{array}{llllllllllllllllll} & \end{array}$ $\begin{array}{llllllllllllllllll}\text { VWLDPNETNEIANANSR } & 1.00 & 97.41 & 27.55 & 25.42 & 2 & 2086.0214 & 2086.0201 & 1044.0173 & 0.0013 & 0.6226 & 2672.774 & 2881.455 & 1371.583 & 3613.330 & \text { Yes }\end{array}$ $\begin{array}{lllllllllllllllll}\text { VWLDPNETNEIANANSR } & 1.00 & 92.92 & 27.55 & 26.66 & 2 & 2086.0214 & 2086.0201 & 1044.0173 & 0.0013 & 0.6226 & 1738.624 & 1761.625 & 634.691 & 3055.976 & \text { Yes }\end{array}$ $\begin{array}{llllllllllllllll}\text { VWLDPNETNEIANANSR } & 1.00 & 96.26 & 27.52 & 25.06 & 2 & 2086.0234 & 2086.0201 & 1044.0173 & 0.0033 & 1.5804 & 4259.836 & 5483.344 & 1447.914 & 6700.845 & \text { Yes }\end{array}$ $\begin{array}{llllllllllllllll}\text { VWLDPNETNEIANANSR } & 1.00 & 87.77 & 27.55 & 25.78 & 2 & 2086.0214 & 2086.0201 & 1044.0173 & 0.0013 & 0.6226 & 916.476 & 1108.156 & 328.314 & 1507.427 & \text { Yes }\end{array}$ $\begin{array}{llllllllllllllll}0.71 & 27.44 & 24.39 & 29.27 & 2 & 851.5090 & 851.5109 & 426.7627 & -0.0019 & -2.2261 & 112.137 & 125.944 & 32.412 & 195.695 & \text { Yes }\end{array}$ GNVFK

GNVFK

ILMEHIHK

ILMEHIHK

ILMEHIHK

VTWMR

VTWMR

VTWMR

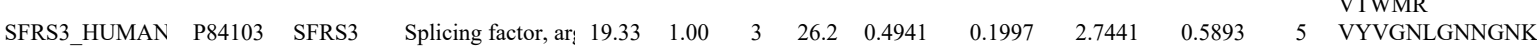
$\begin{array}{lllllllllllllllll}0.83 & 27.33 & 24.39 & 29.25 & 2 & 851.5098 & 851.5109 & 426.7627 & -0.0011 & -1.2888 & 110.606 & 146.740 & 39.875 & 209.477 & \text { Yes }\end{array}$ $\begin{array}{llllllllllllllll}0.68 & 26.82 & 24.39 & 28.48 & 2 & 851.5092 & 851.5109 & 426.7627 & -0.0017 & -1.9917 & 22.456 & 26.091 & 19.404 & 37.016 & \text { No }\end{array}$ $\begin{array}{lllllllllllllll}1.00 & 47.17 & 25.62 & 24.83 & 2 & 1307.7642 & 1307.7627 & 654.8886 & 0.0015 & 1.1452 & 8407.741 & 9120.034 & 767.556 & 16854.660 & \text { Yes }\end{array}$ $\begin{array}{llllllllllllllll}0.99 & 26.30 & 25.85 & 20.83 & 3 & 1307.7646 & 1307.7627 & 436.9282 & 0.0019 & 1.4495 & 34283.305 & 39373.284 & 539.518 & 61924.294 & \text { Yes }\end{array}$ $\begin{array}{lllllllllllllll}0.93 & 19.72 & 25.79 & 17.24 & 3 & 1307.7664 & 1307.7627 & 436.282 & 0.009 & 1.4495 & 34283.305 & 39373.284 & 539.518 & 61924.294 & \text { Yes }\end{array}$ \begin{tabular}{llllllllllllllll}
0.69 & 20.39 & 27.11 & 29.36 & 2 & 835.4526 & 835.4496 & 418.7321 & 0.0030 & 3.5822 & 16510.020 & 20967.187 & 2329.723 & 30750.154 & Yes \\
\hline
\end{tabular} $\begin{array}{lllllllllllllll}0.69 & 20.34 & 27.11 & 29.33 & 2 & 85.4526 & 83.45 .496 & 418.7321 & 0.0030 & 3.5822 & 11054.750 & 14163.156 & 2022.458 & 18997.418 & \text { Yes }\end{array}$ $\begin{array}{llllllllllllllll}0.69 & 20.33 & 27.11 & 29.31 & 2 & 835.4530 & 835.4496 & 418.7321 & 0.0034 & 4.0599 & 1762.259 & 21245.039 & 4126.319 & 32051.360 & \text { Yes } \\ 0.69 & 20.32 & 27.11 & 29.30 & 2 & 835.4526 & 835.4496 & 418.7321 & 0.0030 & 3.5822 & 6639.831 & 7881.457 & 1480.224 & 10746.625 & \text { Yes }\end{array}$ $\begin{array}{llllllllllllllll}0.69 & 20.32 & 27.11 & 29.30 & 2 & 835.4526 & 835.4496 & 418.7321 & 0.0030 & 3.5822 & 6639.831 & 7881.457 & 1480.224 & 10746.625 & \text { Yes } \\ 1.00 & 57.87 & 28.05 & 43.26 & 2 & 1535.8312 & 1535.8300 & 768.9223 & 0.0012 & 0.7803 & 8909.868 & 13987.777 & 33.884 & 5556.481 & \text { Yes }\end{array}$ $\begin{array}{lllllllllllllll}1.00 & 57.87 & 28.05 & 43.26 & 2 & 1535.8312 & 1535.8300 & 768.9223 & 0.0012 & 0.7803 & 8909.868 & 13987.777 & 33.884 & 5556.481 & \text { Yes }\end{array}$ $\begin{array}{llllllllllllllll} & 1.03 .012 & 6362.516 & \text { Yes }\end{array}$ 

$\begin{array}{llllllllllllllll}\text { TGQAPGYSYTAANK } & 1.00 & 66.76 & 27.96 & 21.35 & 2 & 1715.8728 & 1715.8722 & 858.9434 & 0.0006 & 0.3493 & 7362.891 & 9992.800 & 11692.474 & 16861.656 & \text { Yes }\end{array}$ \begin{tabular}{lllllllllllllllll} 
TGQAPGYSYTAANK & 1.00 & 65.55 & 27.85 & 24.34 & 2 & 175.8736 & 1715.8722 & 858.9434 & 0.0014 & 0.8150 & 8830.428 & 10821.901 & 16894.240 & 19222.336 & Yes \\
\hline
\end{tabular} \begin{tabular}{llllllllllllllll} 
TGQAPGYSYTAANK & 0.98 & 28.44 & 27.90 & 18.38 & 3 & 1715.8738 & 1715.8722 & 572.9647 & 0.0016 & 0.9308 & 2418.239 & 3744.497 & 1723.647 & 2262.771 & Yes \\
\hline
\end{tabular} \begin{tabular}{llllllllllllllll} 
TGQAPGYSYTAANK & 1.00 & 40.28 & 27.72 & 20.17 & 3 & 175.8753 & 1715.8722 & 572.9647 & 0.0031 & 1.8035 & 1772.244 & 2339.235 & 2844.256 & 4286.570 & Yes \\
\hline
\end{tabular}

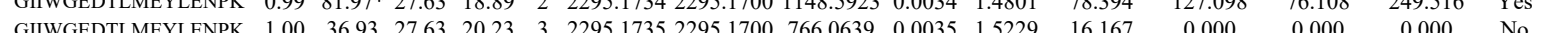

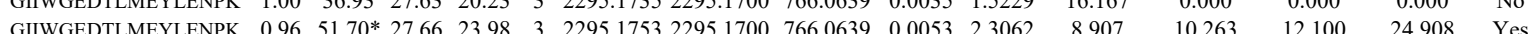

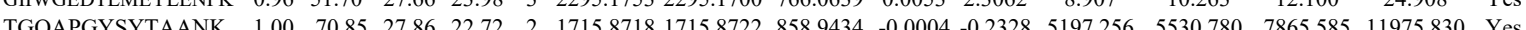

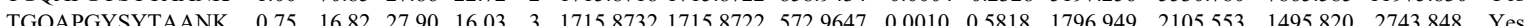
$\begin{array}{lllllllllllllllll}\text { TGQAPGYSYTAANK } & 1.00 & 72.87 & 27.90 & 25.01 & 2 & 1715.8732 & 1715.8722 & 858.9434 & 0.0010 & 0.5821 & 5978.227 & 8441.404 & 8688.803 & 15036.174 & \text { Yes }\end{array}$ $\begin{array}{llllllllllllllll}\text { TGQAPGYSYAANK } & 1.00 & 72.87 & 27.90 & 25.01 & 2 & 1715.8732 & 1715.8722 & 858.9434 & 0.0010 & 0.5821 & 5978.227 & 8441.404 & 8688.803 & 15036.174 & \text { Yes } \\ \text { TGQAPGYSYTAANK } & 0.85 & 17.17 & 27.80 & 23.03 & 3 & 1715.8747 & 1715.8722 & 572.9647 & 0.0025 & 1.4544 & 1869.460 & 1717.031 & 1713.438 & 2741.128 & \text { Yes }\end{array}$

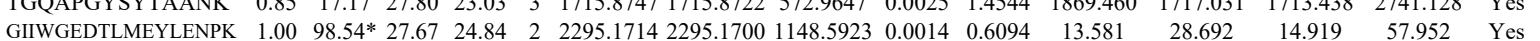

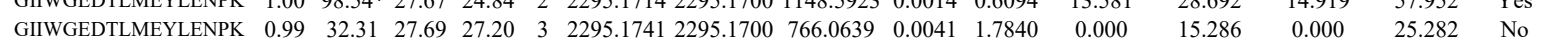

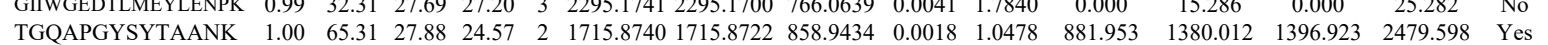
$\begin{array}{llllllllllllllll}\text { TGQAPGYSYTAANK } & 1.00 & 70.71 & 27.88 & 22.67 & 2 & 1715.8740 & 1715.8722 & 858.9434 & 0.0018 & 1.0478 & 3084.384 & 5245.323 & 4694.883 & 7634.229 & \text { Yes }\end{array}$ $\begin{array}{llllllllllllllll}\text { TGQAPGYSYTAANK } & 1.00 & 36.12 & 27.80 & 22.72 & 3 & 1715.8747 & 1715.8722 & 572.9647 & 0.0025 & 1.4544 & 2051.561 & 1732.854 & 1070.699 & 3066.263 & \text { Yes }\end{array}$

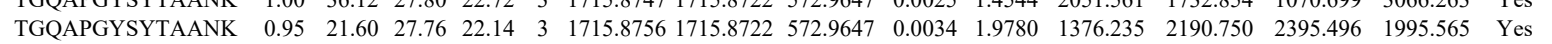

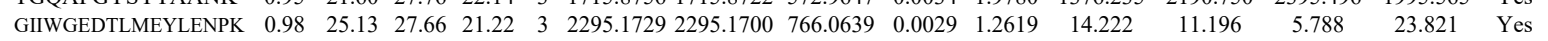

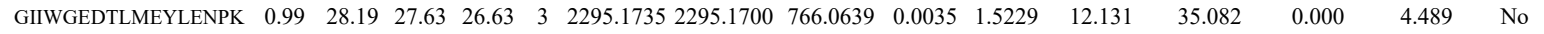

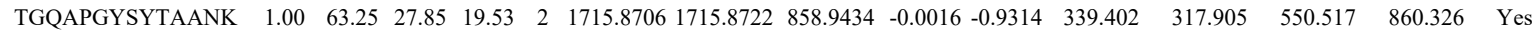
$\begin{array}{llllllllllllllllll}\text { TGQAPGYSYTAANK } & 0.75 & 18.90 & 27.88 & 17.64 & 3 & 1715.8723 & 1715.8722 & 572.9647 & 0.0001 & 0.0582 & 1222.859 & 1233.923 & 2463.919 & 1556.311 & \text { No }\end{array}$ $\begin{array}{lllllllllllllllll}\text { KTGQAPGYSYTAANK } & 0.66 & 66.69 & 26.97 & 79.69 & 3 & 1988.0710 & 1988.0692 & 663.6970 & 0.0018 & 0.9040 & 1321.570 & 2643.284 & 4586.001 & 6769.291 & \text { Yes }\end{array}$ $\begin{array}{llllllllllllllll}\text { KTGQAPGYSYTAANK } & 1.00 & 60.45 & 27.00 & 17.15 & 3 & 1988.0695 & 1988.0692 & 663.6970 & 0.0003 & 0.1507 & 493.781 & 837.655 & 940.816 & 1601.557 & \text { Yes }\end{array}$ $\begin{array}{llllllllllllllll}\text { ADLIAYLK } & 0.92 & 48.20 & 23.82 & 50.09 & 2 & 1193.7362 & 1193.7263 & 597.8704 & 0.0099 & 8.2793 & 1581.288 & 2024.843 & 831.392 & 3295.012 & \text { Yes }\end{array}$ ADLIAYLK

IFIMK

IFIMK

IFIMK

IFIMK

IFIMK

IFIMK

MIFVGIK

TGPNLHGLFGR

TGPNLHGLFGR

TGPNLHGLFGR

TGPNLHGLFGR

TGPNLHGLFGR

TGPNLHGLFGR

TGPNLHGLFGR

TGPNLHGLFGR

TGPNLHGLFGR

TGPNLHGLFGR

TGPNLHGLFGR

TGPNLHGLFGR

TGPNLHGLFGR

TGPNLHGLFG

TGPNLHGLFGR

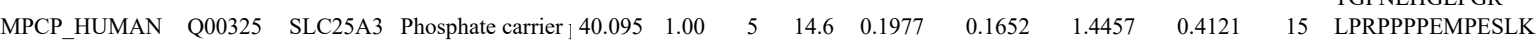

LPRPPPPEMPESLK

LPRPPPPEMPESLK

FGFYEVFK

FGFYEVFK

IQTQPGYANTLR

IQTQPGYANTLR

IQTQPGYANTLR

IQTQPGYANTLR

IQTQPGYANTLR

GIFNGFSVTLK $\begin{array}{llllllllllllllll}1.00 & 50.91 & 24.74 & 36.35 & 2 & 1193.7266 & 1193.7263 & 597.8704 & 0.0003 & 0.2509 & 3827.245 & 5289.587 & 188.391 & 10008.473 & \text { Yes } \\ 0.87 & 31.43 & 21.30 & 32.92 & 2 & 938.526 & 938.5867 & 4703006 & 0.0079 & 8.3988 & 1727.525 & 25987.864 & 0.000 & 56214.356 & \text { No }\end{array}$

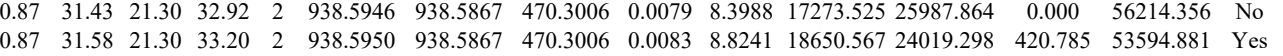
$\begin{array}{lllllllllllllll}0.87 & 31.58 & 21.30 & 33.20 & 2 & 938.5950 & 938.5867 & 470.3006 & 0.0083 & 8.8241 & 18650.567 & 24019.298 & 420.785 & 53594.881 & \text { Yes } \\ 0.82 & 25.71 & 20.76 & 28.57 & 2 & 938.5940 & 938.5867 & 470.3006 & 0.0073 & 7.7609 & 32810.728 & 53047.564 & 0.000 & \# \# \# \# \# & \text { No }\end{array}$ $\begin{array}{lllllllllllllll}0.82 & 25.71 & 20.76 & 28.57 & 2 & 938.5940 & 938.5867 & 470.3006 & 0.0073 & 7.7609 & 32810.728 & 53047.564 & 0.000 & \# \# \text { \#册册 } & \text { No } \\ 0.88 & 31.70 & 21.30 & 32.88 & 2 & 938.5948 & 938.5867 & 470.3006 & 0.0081 & 8.6114 & 28266.196 & 42266.745 & 0.000 & 90959.968 & \text { No }\end{array}$ $\begin{array}{cccccccccccccccc}0.88 & 31.70 & 21.30 & 32.88 & 2 & 938.5948 & 938.5867 & 470.3006 & 0.0081 & 8.6114 & 28266.196 & 42266.745 & 0.000 & 90959.968 & \text { No } \\ 0.75 & 25.01 & 20.76 & 29.60 & 2 & 938.5936 & 938.5867 & 470.3006 & 0.0069 & 7.3357 & 5199.592 & 3965.826 & 703.348 & 20687.718 & \text { No }\end{array}$ $\begin{array}{llllllllllllllll}0.75 & 25.01 & 20.76 & 29.60 & 2 & 938.5936 & 938.5867 & 470.3006 & 0.0069 & 7.3357 & 5199.592 & 3965.826 & 703.348 & 20687.718 & \text { No } \\ 0.84 & 25.69 & 21.30 & 28.56 & 2 & 938.5944 & 938.5867 & 470.3006 & 0.0077 & 8.1862 & 22812.337 & 33157.435 & 0.000 & 73252.054 & \text { No }\end{array}$

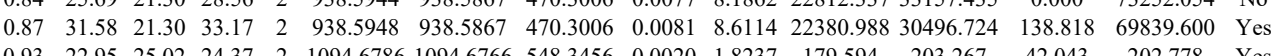
\begin{tabular}{lllllllllllllll}
0.93 & 22.95 & 25.02 & 24.37 & 2 & 1094.6786 & 1094.6766 & 548.3456 & 0.0020 & 1.8237 & 179.594 & 203.267 & 42.043 & 202.778 & Yes \\
\hline
\end{tabular} $\begin{array}{lllllllllllllll}0.98 & 26.03 & 27.23 & 26.04 & 3 & 1311.7195 & 1311.7170 & 438.2463 & 0.0025 & 1.9015 & 70.922 & 106.383 & 29.471 & 113.171 & \text { Yes } \\ \end{array}$

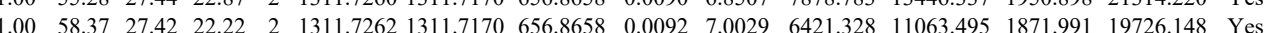

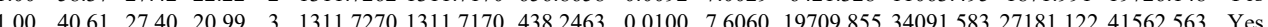
$\begin{array}{lllllllllllllll}1.00 & 45.75 & 27.38 & 18.20 & 3 & 1311.7276 & 1311.7170 & 438.2463 & 0.0106 & 8.0624 & 21536.087 & 45603.108 & 19905.166 & 52840.348 & \text { Yes }\end{array}$

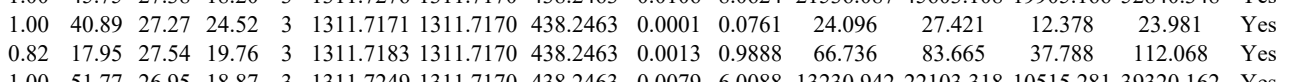
\begin{tabular}{lllllllllllllll}
1.00 & 51.77 & 26.95 & 18.87 & 3 & 1311.7249 & 1311.7170 & 438.2463 & 0.0079 & 6.0088 & 13230.942 & 22103.318 & 10515.281 & 39320.162 & Yes \\
\hline
\end{tabular} $\begin{array}{lllllllllllllll}1.00 & 55.70 & 27.29 & 23.87 & 2 & 1311.7252 & 1311.7170 & 656.8658 & 0.0082 & 6.2417 & 6951.938 & 12696.724 & 1807.299 & 20010.219 & \text { Yes }\end{array}$ $\begin{array}{lllllllllllllllll}1.00 & 59.20 & 27.29 & 22.68 & 2 & 1311.7252 & 1311.7170 & 656.8658 & 0.0082 & 6.2417 & 6061.794 & 12592.222 & 1932.517 & 19480.191 & \text { Yes } \\ 1.00 & 51.69 & 27.42 & 18.31 & 3 & 1311.7264 & 1311.7170 & 438.2463 & 0.0094 & 7.1497 & 27217.350 & 47338.501 & 14845.383 & 72505.221 & \text { Yes }\end{array}$ $\begin{array}{llllllllllllllll}1.00 & 51.69 & 27.42 & 18.31 & 3 & 1311.7264 & 1311.7170 & 438.2463 & 0.0094 & 7.1497 & 27217.350 & 47338.501 & 14845.383 & 72505.221 & \text { Yes } \\ 1.00 & 52.82 & 27.27 & 24.41 & 2 & 1311.7250 & 1311.7170 & 656.8658 & 0.0080 & 6.0895 & 1940.266 & 2955.474 & 506.965 & 5611.469 & \text { Yes }\end{array}$ $\begin{array}{lllllllllllllll}1.00 & 53.65 & 27.29 & 20.62 & 3 & 1311.7252 & 1311.7170 & 438.2463 & 0.0082 & 6.2369 & 7211.171 & 12736.754 & 3032.284 & 15662.483 & \text { Yes }\end{array}$ $\begin{array}{lllllllllllllll}1.00 & 52.92 & 27.29 & 22.77 & 2 & 1311.7252 & 1311.7170 & 656.8658 & 0.0082 & 6.2417 & 2104.004 & 2857.713 & 555.544 & 5137.895 & \text { Yes }\end{array}$

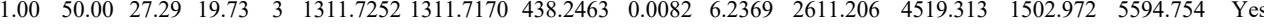

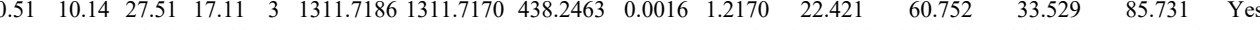

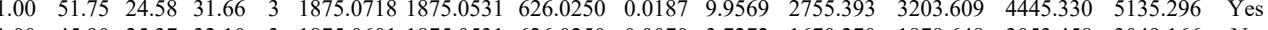
$\begin{array}{lllllllllllllll}1.00 & 45.90 & 25.37 & 32.10 & 3 & 1875.0601 & 1875.0531 & 626.0250 & 0.0070 & 3.7272 & 1670.270 & 1878.648 & 3053.458 & 3049.166 & \text { No }\end{array}$

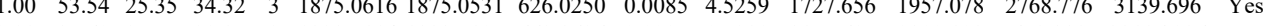
$\begin{array}{lllllllllllllll}0.99 & 35.60 & 27.57 & 20.87 & 2 & 1323.7114 & 1323.7107 & 662.8626 & 0.0007 & 0.5280 & 8157.697 & 9800.102 & 659.389 & 22186.926 & \text { Yes }\end{array}$

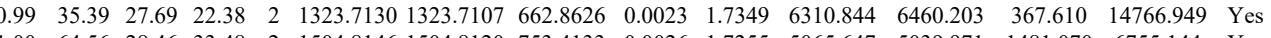
$\begin{array}{lllllllllllllll}1.00 & 64.56 & 28.46 & 33.48 & 2 & 1504.8146 & 1504.8120 & 753.4133 & 0.0026 & 1.7255 & 5065.647 & 5039.971 & 1481.070 & 6755.144 & \text { Yes }\end{array}$ $\begin{array}{llllllllllllllll}1.00 & 63.49 & 27.85 & 34.52 & 2 & 1504.8216 & 1504.8120 & 753.4133 & 0.0096 & 6.3710 & 10322.802 & 14114.986 & 3163.016 & 19984.620 & \text { Yes }\end{array}$ $\begin{array}{lllllllllllllll}1.00 & 51.11 & 27.94 & 32.97 & 2 & 1504.8220 & 1504.8120 & 753.4133 & 0.0100 & 6.6364 & 17154.006 & 20034.063 & 3324.828 & 31733.685 & \text { Yes }\end{array}$ $\begin{array}{llllllllllllllll}1.00 & 57.18 & 28.08 & 34.18 & 2 & 1504.8222 & 1504.8120 & 753.4133 & 0.0102 & 6.7691 & 11490.329 & 11691.543 & 1839.050 & 16592.940 & \text { Yes } \\ 1.00 & 56.57 & 28.06 & 32.80 & 2 & 1504.8224 & 1504.8120 & 753.4133 & 0.0104 & 6.9019 & 7942.356 & 11054.516 & 2711.837 & 16359.862 & \text { Yes }\end{array}$ $\begin{array}{lllllllllllllll}1.00 & 56.57 & 28.06 & 32.80 & 2 & 1504.8224 & 1504.8120 & 753.4133 & 0.0104 & 6.9019 & 7942.356 & 11054.516 & 2711.837 & 16359.862 & \text { Yes } \\ 1.00 & 52.04 & 28.06 & 33.69 & 2 & 15048236 & 15048120 & 753.4133 & 0.0116 & 7.6982 & 1843.776 & 2002.352 & 534.680 & 3469.224 & \text { Yes }\end{array}$

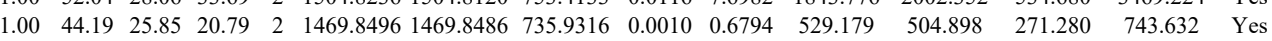
GIFNGFSVTLK

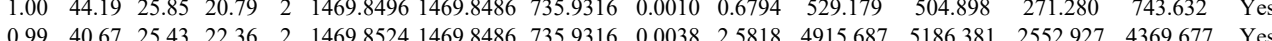




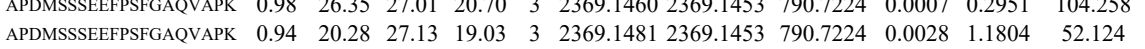
$\begin{array}{llllllllllll}\text { APDMSSSEEFPSFGAQVAPK } & 1.00 & 51.09 & 27.18 & 16.70 & 3 & 2369.1496 & 2369.1453 & 790.7224 & 0.0043 & 1.8127 & 103.892\end{array}$ ELEALLNLDNVVEDSMLVDPK $\begin{array}{lllllllllllll}0.97 & 28.80 & 26.07 & 16.41 & 3 & 2771.4499 & 2771.4506 & 924.8241 & -0.0007 & -0.2523 & 14.502\end{array}$ $\begin{array}{llllllllllll} & 26.00 & 15.24 & 3 & 2771.4517 & 2771.4506 & 924.8241 & 0.0011 & 0.3965 & 15.306\end{array}$

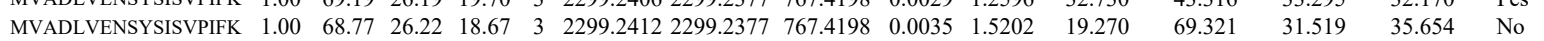
$\begin{array}{llllllllllllllll}\text { KGAVITQIR } & 1.00 & 40.28 & 22.76 & 22.31 & 3 & 1272.8134 & 1272.8121 & 425.2780 & 0.0013 & 1.0189 & 4675.606 & 4652.638 & 1531.426 & 5869.775 & \text { Yes }\end{array}$ $\begin{array}{llllllllllllllll}\text { KGAVITQIR } & 1.00 & 38.80 & 22.76 & 22.18 & 3 & 1272.8134 & 1272.8121 & 425.2780 & 0.0013 & 1.0189 & 3699.185 & 3911.708 & 1993.831 & 5118.324 & \text { Yes }\end{array}$ $\begin{array}{llllllllllllllll}\text { INIPPPSVNR } & 0.92 & 33.29 & 25.71 & 35.59 & 2 & 1249.7382 & 1249.7264 & 625.8705 & 0.0118 & 9.4268 & 4929.541 & 5006.630 & 2287.651 & 7047.244 & \text { Yes }\end{array}$ $\begin{array}{llllllllllllllll}\text { KGAVITQIR } & 1.00 & 31.32 & 20.37 & 19.29 & 3 & 1272.8143 & 1272.8121 & 425.2780 & 0.0022 & 1.7244 & 2773.945 & 3299.142 & 1565.825 & 3813.320 & \text { Yes }\end{array}$ $\begin{array}{llllllllllllllll}\text { KGAVITQIR } & 1.00 & 40.57 & 20.37 & 22.23 & 3 & 1272.8152 & 1272.8121 & 425.2780 & 0.0031 & 2.4298 & 2355.878 & 2743.134 & 1031.786 & 3145.753 & \text { Yes }\end{array}$ $\begin{array}{lllllllllllllllll}\text { INIPPPSVNR } & 0.97 & 35.63 & 25.69 & 30.13 & 2 & 1249.7378 & 1249.7264 & 625.8705 & 0.0114 & 9.1072 & 2463.675 & 2056.759 & 592.269 & 2487.322 & \text { Yes }\end{array}$ $\begin{array}{llllllllllllllllll}\text { INIPPPSVNR } & 0.95 & 38.26 & 25.75 & 37.91 & 2 & 1249.7386 & 1249.7264 & 625.8705 & 0.0122 & 9.7463 & 5539.513 & 5085.867 & 816.443 & 6816.653 & \text { Yes }\end{array}$ $\begin{array}{lllllllllllllllll}\text { ANSFTVSSVAAPSWLHR } & 1.00 & 66.35 & 27.23 & 17.52 & 3 & 1973.0260 & 1973.0241 & 658.6820 & 0.0019 & 0.9615 & 392.745 & 467.744 & 222.433 & 600.378 & \text { Yes }\end{array}$

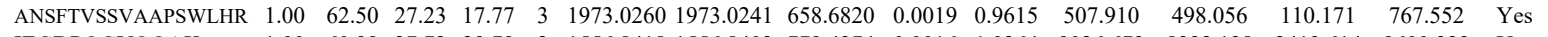
$\begin{array}{llllllllllllllll}\text { IEGDPQGVQQAK } & 1.00 & 60.99 & 27.72 & 29.79 & 2 & 1556.8418 & 1556.8402 & 779.4274 & 0.0016 & 1.0264 & 9026.673 & 8322.128 & 2413.614 & 9600.322 & \text { Yes }\end{array}$ $\begin{array}{lllllllllllllllll}\text { IEGDPQGVQQAK } & 1.00 & 58.57 & 27.76 & 32.26 & 2 & 1556.8424 & 1556.8402 & 779.4274 & 0.0022 & 1.4113 & 4079.502 & 3280.988 & 1142.810 & 4583.557 & \text { Yes }\end{array}$

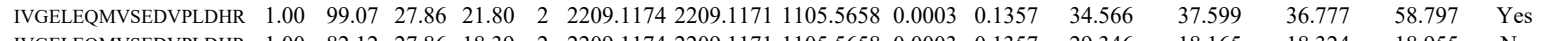

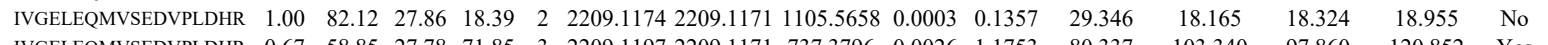

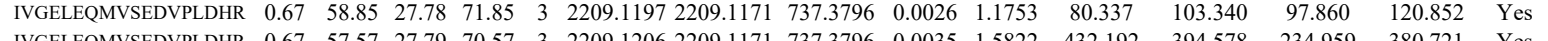

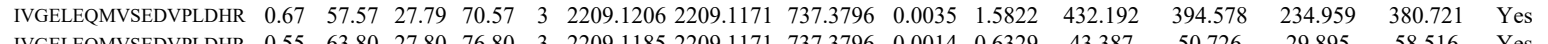

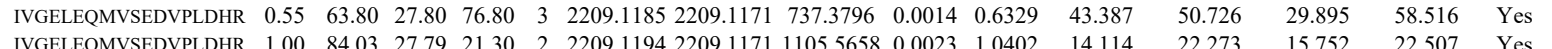

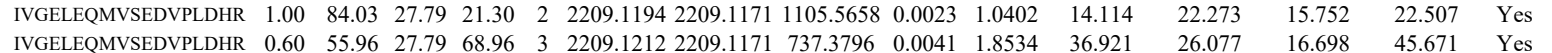

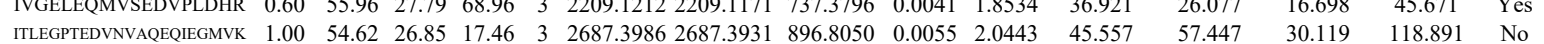

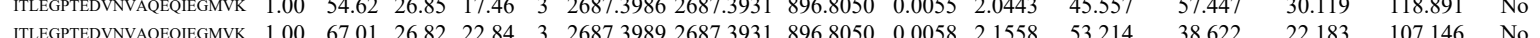

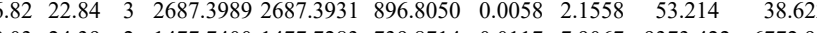

IYIDSNNNPER

IYIDSNNNPER

IHEGCEEPATHNALAK

$\begin{array}{llllllllllll}1.00 & 58.54 & 28.03 & 24.39 & 2 & 1477.7400 & 1477.7283 & 739.8714 & 0.0117 & 7.9067 & 9373.422 & 6772.951 \\ 1.00 & 57.73 & 27.99 & 1.11 & 2 & 1477.7408 & 1477.783 & 799.8714 & 0.025 & 8.4473 & 1186.367 & 8215.817\end{array}$ $\begin{array}{lllllllllllllll}0.52 & 35.43 & 26.95 & 21.33 & 3 & 1519.8574 & 1519.8449 & 507.0222 & 0.0125 & 8 & 8.081 & 21100.871 & 19215.578\end{array}$ $0.180-107.146$ No $\begin{array}{lllllllllllllllll} & & & \end{array}$ DDPSSYMEVVQAANTSGNWEELVK 0.99

ANVPNK

ANVPNK

VAANAPK

VAANAPK

ALEHFTDLYDIK

ALEHFTDLYDIK

ALEHFTDLYDIK

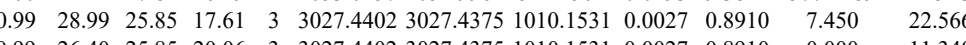
$\begin{array}{llllllllllll}0.99 & 26.40 & 25.85 & 20.06 & 3 & 3027.4402 & 3027.4375 & 1010.1531 & 0.0027 & 0.8910 & 0.000 & 11.340\end{array}$ $\begin{array}{lllllllllllll}0.97 & 29.87 & 26.49 & 21.65 & 2 & 929.5544 & 929.5538 & 465.7842 & 0.0006 & 0.6441 & 599.223 & 461.349\end{array}$ $\begin{array}{lllllllllllll}0.90 & 23.36 & 26.49 & 19.93 & 2 & 929.5546 & 929.5538 & 465.7842 & 0.0008 & 0.8588 & 510.259\end{array}$ $\begin{array}{llllllllllll}0.99 & 31.81 & 24.62 & 23.34 & 2 & 957.5856 & 957.5851 & 479.7998 & 0.0005 & 0.5211 & 305.287\end{array}$ $\begin{array}{llllllllll}2 & 957.5862 & 957.5851 & 479.7998 & 0.0011 & 1.1463 & 520.617 & 358.869\end{array}$

$\begin{array}{llllllllllll}1.00 & 65.90 & 27.72 & 28.59 & 2 & 1751.9364 & 1751.9338 & 876.9742 & 0.0026 & 1.4824 & 1039.141 & 561.928\end{array}$ $\begin{array}{lllllllllllll}1.00 & 42.25 & 27.83 & 18.56 & 3 & 1751.9377 & 1751.9338 & 584.9852 & 0.0039 & 2.2223 & 8161.425 & 5196.684 \\ 1.00 & 53.00 & 27.84 & 22.54 & 2 & 1751.9382 & 1751.9338 & 876.9742 & 0.0044 & 25086 & 180.643 & 189.185\end{array}$ $\begin{array}{lllllllllll} & \end{array}$ $\begin{array}{llllllllllll}1.00 & \text { \#冊 } 27.19 & 26.87 & 2 & 2086.0094 & 2086.0089 & 1044.0117 & 0.0005 & 0.2395 & 2685.178 & 1598.010\end{array}$ \begin{tabular}{|lllllllllllll} 
& & 27.246 .04 & 2420 & 2498.2410 & 833.7543 & 0.0010 & 0.3998 & 16.685 & 19.653
\end{tabular}

\section{(1)}

VAANAPK

VAANAPK

NNLAGAEELFAR

NNLAGAEELFAR

ALEHFTDLYDIK

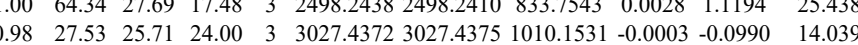
$\begin{array}{lllllllllll} & 25.980\end{array}$ $\begin{array}{llllllllllll}0.85 & 15.19 & 25.85 & 14.76 & 3 & 3027.4402 & 3027.4355 & 1010.1531 & 0.0027 & 0.8910 & 16.287 & 8.730\end{array}$ $\begin{array}{lllllllllllll}0.99 & 31.18 & 24.62 & 26.14 & 2 & 957.5864 & 957.5851 & 479.7998 & 0.0013 & 1.3547 & 150.736 & 107.335\end{array}$ $\begin{array}{llllllllllll}1.00 & 64.46 & 28.39 & 23.50 & 2 & 1447.7574 & 1447.7541 & 724.8843 & 0.0033 & 2.2762 & 1523.707 & 766.273\end{array}$ $\begin{array}{llllllllllll}1.00 & 62.20 & 28.49 & 26.03 & 2 & 1447.7600 & 1447.7541 & 724.8843 & 0.0059 & 4.0696 & 9127.838 & 4055.077\end{array}$ $\begin{array}{lllllllllllll}1.00 & 43.69 & 27.83 & 19.64 & 3 & 1751.9377 & 1751.9338 & 584.9852 & 0.0039 & 2.2223 & 2255.989 & 1700.095\end{array}$ $\begin{array}{llll}3.473 & 0.000 & \text { No }\end{array}$ $\begin{array}{llll}0.000 & 43.471 & \text { No }\end{array}$ $394.970 \quad 559.838$ Yes $81.250 \quad 295.867$ Yes $126.299 \quad 512.809 \quad$ Yes 1218.090 Yes $\begin{array}{lll}8.894 & 5440.585 \quad \text { Yes }\end{array}$ \begin{tabular}{llll}
7.218 & 7340.785 & Yes \\
\hline .148 & 248.981 & Yes
\end{tabular} $0.000 \quad 1635.238$ No 
$\begin{array}{lllllllllll} & \text { TVK } \\ 1.00 & 32.02 & 24.07 & 45.02 & 4 & 3168.7181 & 3168.7122 & 793.1853 & 0.0059 & 1.8596 & 46.977\end{array}$

$\begin{array}{llllllllllll}\text { NNRPSEGPLQTR } & 1.00 & 38.03 & 28.36 & 22.80 & 3 & 1511.7940 & 1511.7926 & 504.9381 & 0.0014 & 0.9242 & 352591\end{array}$ $\begin{array}{lllllllllllll}\text { NNRPSEGPLQTR } & 1.00 & 37.26 & 28.41 & 22.73 & 3 & 1511.7946 & 1511.7926 & 504.9381 & 0.0020 & 1.3203 & 304.712\end{array}$ $\begin{array}{lllllllllllll}\text { AFMTADLPNELIELLEK } & 0.97 & 21.96 & 26.06 & 16.48 & 3 & 2234.2147 & 2234.2112 & 745.7443 & 0.0035 & 1.5644 & 1.565\end{array}$

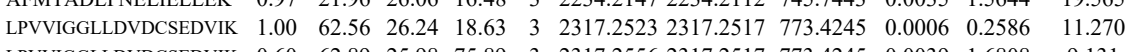
$\begin{array}{llllllllllll}\text { LPVVIGGLLDVDCSEDVIK } & 0.60 & 62.89 & 25.98 & 75.89 & 3 & 2317.2556 & 2317.2517 & 773.4245 & 0.0039 & 1.6808 & 9.131\end{array}$ $\begin{array}{llllllllllll}\text { VGEQAQVVIIDMNDPSNPIR } & 0.99 & 32.02 & 27.32 & 23.20 & 3 & 2338.2082 & 2338.2073 & 780.4097 & 0.0009 & 0.3844 & 98.102\end{array}$ $\begin{array}{llllllllllll}\text { VGEQAQVVIIDMNDPSNPIR } & 1.00 & 76.45 & 27.32 & 26.25 & 3 & 2338.2085 & 2338.2073 & 780.4097 & 0.0012 & 0.5126 & 108.162\end{array}$

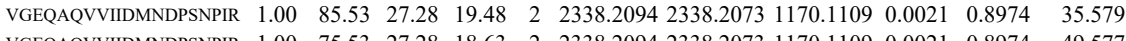
$\begin{array}{llllllllllll}\text { VGEQAQVVIIDMNDPSNPIR } & 1.00 & 75.53 & 27.28 & 18.63 & 2 & 2338.2094 & 2338.2073 & 1170.1109 & 0.0021 & 0.8974 & 49.577\end{array}$ $\begin{array}{llllllllllllll}\text { LAELEEFINGPNNAHIQQVGDR } & 0.67 & 72.42 & 27.21 & 85.42 & 3 & 2607.3190 & 2607.3163 & 870.1127 & 0.0027 & 1.0343 & 3214.714 & 2764.06\end{array}$ $\begin{array}{lllllllllllll}\text { LAELEEFINGPNNAHIQQVGDR } & 0.60 & 62.89 & 27.26 & 75.89 & 3 & 2607.3199 & 2607.3163 & 870.1127 & 0.0036 & 1.3791 & 6294.883 & 4387 .\end{array}$ AVDVFFPEAQNDFPVAMQISEK $0.69 \begin{array}{llllllllllll}0.69 & 12.59 & 26.90 & 13.81 & 3 & 2866.4488 & 2866.4455 & 956.4891 & 0.0033 & 1.1500 & 11.005\end{array}$ $\begin{array}{lllllllllllll}\text { AFMTADLPNELIELLEK } & 0.76 & 13.16 & 26.05 & 22.41 & 3 & 2234.2138 & 2234.2112 & 745.7443 & 0.0026 & 1.1621 & 4.501\end{array}$ $\begin{array}{llllllllllll}\text { AFMTADLPNELIELLEK } & 1.00 & 71.79 & 26.00 & 18.62 & 2 & 2234.2154 & 2234.2112 & 1118.1129 & 0.0042 & 1.8782 & 57.512\end{array}$ $\begin{array}{llllllllllll}\text { AFMTADLPNELIELLEK } & 1.00 & 71.19 & 26.00 & 26.45 & 2 & 2234.2154 & 2234.2112 & 1118.1129 & 0.0042 & 1.8782 & 174.669\end{array}$ $\begin{array}{llllllllllll}\text { LPVVIGGLLDVDCSEDVIK } & 0.55 & 9.42 & 26.15 & 22.42 & 3 & 2317.2547 & 2317.2517 & 773.4245 & 0.0030 & 1.2929 & 18.995\end{array}$ $\begin{array}{llllllllllll}\text { LPVVIGGLLDVDCSEDVIK } & 0.60 & 11.38 & 25.98 & 24.38 & 3 & 2317.2553 & 2317.2517 & 773.4245 & 0.0036 & 1.5515 & 21.078 \\ \text { LAEEEFEIGGPNNAHQQVGGDR } & 0.55 & 80.17 & 27.14 & 93.17 & 3 & 2607.3169 & 26073163 & 870.1127 & 0.0006 & 0.2299 & 2684.963\end{array}$ $\begin{array}{lllllllllllll}\text { LAELEEFINGPNNAHIQQVGDR } & 0.55 & 80.17 & 27.14 & 93.17 & 3 & 2607.3169 & 2607.3163 & 870.1127 & 0.0006 & 0.2299 & 2684.963 & 2397 . \\ \text { LAELEEFNGPNNAHIQQVGDR } & 0.67 & 60.85 & 27.19 & 73.85 & 3 & 2607.3196 & 2607.3163 & 870.1127 & 0.0033 & 1.2642 & 1256.710 & 894 .\end{array}$

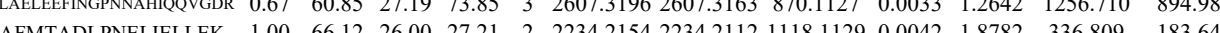
$\begin{array}{llllllllllllll}\text { AFMTADLNELLELLEK } & 1.00 & 66.12 & 26.00 & 27.21 & 2 & 2234.2154 & 2234.2112 & 11118.1129 & 0.0042 & 1.8782 & 336.809 & 183.644\end{array}$

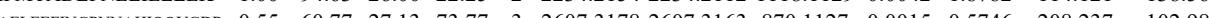

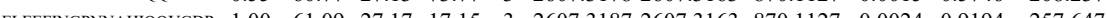

AHIAQLCEK $\begin{array}{llllllllllll}0.99 & 41.27 & 28.80 & 29.90 & 3 & 1345.7194 & 1345.7090 & 449.5769 & 0.0104 & 7.7109 & 7343.423 & 5786.997\end{array}$

AHIAQLCEK

$\begin{array}{llllllllllll}1.00 & 49.65 & 28.80 & 29.82 & 2 & 1345.7196 & 1345.7090 & 673.8618 & 0.0106 & 7.8651 & 6859.3515 & 4383.403\end{array}$

$\begin{array}{llllllllllllll}\text { DPELWGSVLLESNPYR } & 1.00 & 49.33 & 27.97 & 19.24 & 3 & 2018.0260 & 2018.0231 & 673.6816 & 0.0029 & 1.4349 & 111.122 & 168.634\end{array}$ $\begin{array}{llllllllllllll}\text { IVLDNSVFSEHR } & 1.00 & 47.26 & 27.45 & 16.54 & 3 & 1558.8295 & 1558.8225 & 520.6148 & 0.0070 & 4.4819 & 7873.900 & 4307.803 & \end{array}$ $\begin{array}{lllllllllllll}\text { RPISADSAIMNPASK } & 1.00 & 66.23 & 26.47 & 21.03 & 2 & 1845.0178 & 1845.0022 & 923.5084 & 0.0156 & 8.4460 & 1149.188 & 890.774\end{array}$ $\begin{array}{lllllllllllll}\text { RPISADSAIMNPASK } & 0.90 & 28.12 & 26.42 & 19.14 & 3 & 1845.0196 & 1845.0022 & 616.0080 & 0.0174 & 9.4154 & 4001.656 & 4477.001\end{array}$ $\begin{array}{lllllllllllll} & 2234.2147 & 2234.2112 & 745.7443 & 0.0035 & 1.5644 & 42.286 & 29.134\end{array}$ AFMTADL

$\begin{array}{lllllllllllll}\text { CNEPAVWSQLAK } & 1.00 & 68.09 & 28.12 & 24.80 & 2 & 1678.8578 & 1678.8414 & 840.4280 & 0.0164 & 9.7568 & 1615.298 & 1161.837\end{array}$ $\begin{array}{llllllllllll}0.99 & 29.12 & 25.98 & 17.29 & 3 & 2234.2156 & 2234.2112 & 745.7443 & 0.0044 & 1.9667 & 50.073 & 46.103\end{array}$

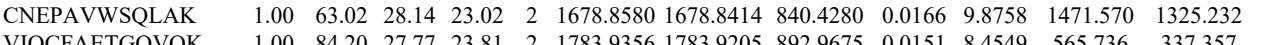

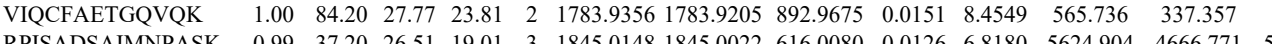
$\begin{array}{llllllllllllll}\text { RPISADSAIMNPASK } & 0.99 & 37.20 & 26.51 & 19.01 & 3 & 1845.0148 & 1845.0022 & 616.0080 & 0.0126 & 6.8180 & 5624.904 & 4666.771 & 5360.9\end{array}$ $\begin{array}{llllllllllllll}\text { RPISADSAIMNPASK } & 0.99 & 37.32 & 26.43 & 17.77 & 3 & 1845.0157 & 1845.0022 & 616.0080 & 0.0135 & 7.3050 & 4110.213 & 3641.876 & 4171.80 \\ \text { KDPELWGSVLLESNPYR } & 1.00 & 46.83 & 26.60 & 19.97 & 3 & 2290.2238 & 2290.2201 & 764.4140 & 0.0037 & 1.6134 & 1476.731 & 1000.737 & 124.39\end{array}$ $\begin{array}{lllllllllllllll} & \\ 6.60 & 19.97 & 3 & 2290.2238 & 2290.2201 & 764.4140 & 0.0037 & 1.6134 & 1476.731 & 1000.737 & 124.392 & 5363.463 & \text { Yes } & \\ \end{array}$ $\begin{array}{llllllllllllllllll} & & \end{array}$

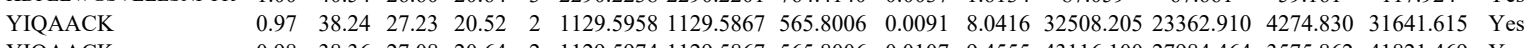

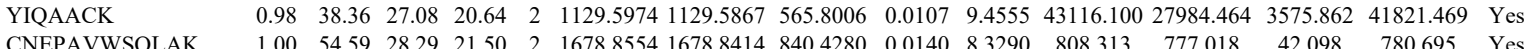

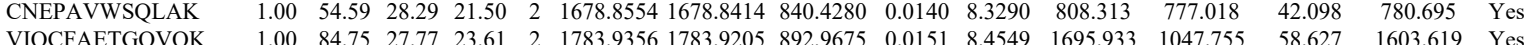

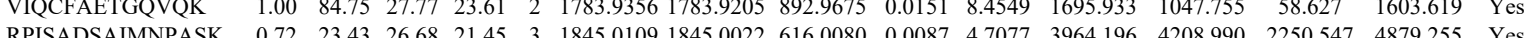
$\begin{array}{llllllllllllllll} & \end{array}$

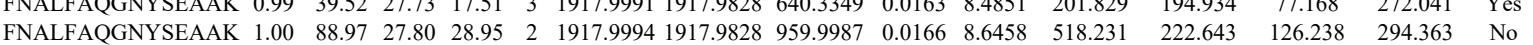


цLЕМNLMAРPР

IAAYLFK

IAAYLFK

SVDPTLALSVYLR

$\begin{array}{llllllllllll}1.00 & 36.75 & 23.05 & 23.70 & 2 & 1112.6848 & 1112.6837 & 557.3491 & 0.0011 & 0.9868 & 18205.825 & 12790.596\end{array}$

SVDPTLALSVYLR
SVDPTLALSVYLR $\begin{array}{lllllllllllll}1.00 & 51.24 & 25.68 & 18.29 & 2 & 1576.8984 & 1576.8946 & 789.4546 & 0.0038 & 2.4067 & 3259.960 & 1700.765\end{array}$

LEMNLMHAPQVADALGNQMFTHY

LLEMNLMARPQVADALGNQMFTHYD

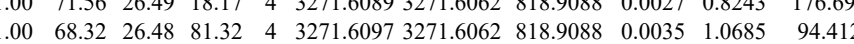

VGYTPDWIFLLR $\begin{array}{llll}1.00 & 54.24 & 26.48 & 16.83\end{array}$ $\begin{array}{lllllllllllll}0.99 & 28.62 & 27.69 & 16.17 & 3 & 2272.1485 & 2272.1450 & 758.3889 & 0.0035 & 1.5383 & 89.390 & 61.564\end{array}$ $\begin{array}{lllllllllllll}1.00 & 34.38 & 27.72 & 22.50 & 3 & 2272.1494 & 2272.1450 & 758.3889 & 0.0044 & 1.9339 & 114.871 & 106.680\end{array}$ $\begin{array}{lllllllllllll}1.00 & 27.72 & 21.40 & 40.72 & 4 & 3474.8805 & 3474.8755 & 869.7262 & 0.0050 & 1.4372 & 12.569 & 0.000\end{array}$ $\begin{array}{lllllllllllll}1.00 & 34.72 & 23.58 & 28.60 & 2 & 1253.7628 & 1253.7617 & 627.8881 & 0.0011 & 0.8760 & 158.531 & 121.971\end{array}$ $\begin{array}{lllllllllllll}0.98 & 31.66 & 23.30 & 34.31 & 2 & 1253.7632 & 1253.7617 & 627.8881 & 0.0015 & 1.1945 & 185.450 & 135.184 \\ 0.84 & 23.78 & 23.28 & 36.68 & 2 & 1253.7638 & 1253.7617 & 627.8881 & 0.0021 & 1.6723 & 142.990 & 104.978\end{array}$ $\begin{array}{llllllllllll}0.99 & 33.00 & 23.28 & 29.05 & 2 & 1253.7644 & 1253.7617 & 627.8881 & 0.0027 & 2.1501 & 34242.999 & 24421.889\end{array}$

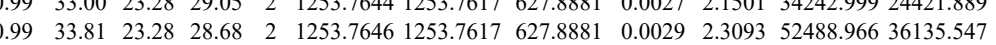
$\begin{array}{llllllllllll}.00 & 63.00 & 27.19 & 24.67 & 2 & 1622.8960 & 1622.8943 & 812.4544 & 0.0017 & 1.0462 & 3613.558 & 2453.846\end{array}$ $\begin{array}{llllllllllll}1.00 & 59.82 & 27.36 & 29.35 & 2 & 1622.8962 & 1622.8943 & 812.4544 & 0.0019 & 1.1693 & 1583.195 & 1189.188\end{array}$ $\begin{array}{llllllllllllll}0.84 & 71.87 & 14.47 & 84.87 & 2 & 1641.0450 & 1641.0432 & 821.5289 & 0.0018 & 1.0955 & 4644.182 & 2957.760\end{array}$ $\begin{array}{llllllllllll}1.00 & 2.82 & 14.31 & 15.713 & 3 & 1641.0460 & 1641.0432 & 548.0217 & 0.0028 & 1.7031 & 141.242\end{array}$ $\begin{array}{lllllllllll}1.00 & 20.82 & 14.31 & 15.13 & 3 & 1641.0466 & 1641.0432 & 548.0217 & 0.0034 & 2.0680 & 50.994\end{array}$ 

$\begin{array}{llllllllllllllll}0.84 & 26.36 & 17.92 & 30.85 & 2 & 969.6544 & 969.6457 & 485.8301 & 0.0087 & 8.9537 & 2798.507 & 1845.800 & 203.947 & 3096.932 & \text { Yes }\end{array}$ $\begin{array}{lllllllllllllll}0.89 & 24.70 & 17.92 & 27.03 & 2 & 969.6550 & 969.6457 & 485.8301 & 0.0093 & 9.5712 & 3129.811 & 2011.822 & 225.318 & 3069.549 & \text { Yes }\end{array}$ $\begin{array}{lllllllllllllllll}0.81 .84 & 23.28 & 30.69 & 2 & 1253.7638 & 1253.7617 & 627.8881 & 0.0021 & 1.6723 & 24440.034 & 16162.929 & 0.000 & 31478.314 & \text { No }\end{array}$ \begin{tabular}{lllllllllllllll}
0.88 & 19.81 & 23.28 & 31.32 & 2 & 1253.7640 & 1253.7617 & 627.8881 & 0.0023 & 1.8315 & 89.546 & 78.845 & 29.560 & 142.333 & Yes \\
\hline
\end{tabular} $\begin{array}{lllllllllllllll}1.00 & 34.08 & 23.28 & 28.95 & 2 & 1253.7640 & 1253.7617 & 627.8881 & 0.0023 & 1.8315 & 32901.115 & 21932.099 & 0.000 & 41062.537 & \text { No }\end{array}$

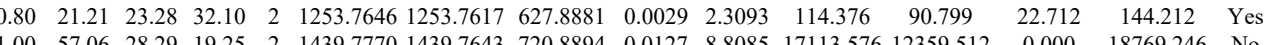
$\begin{array}{llllllllllllllll}1.00 & 57.06 & 28.29 & 19.25 & 2 & 1439.7770 & 1439.7643 & 720.8894 & 0.0127 & 8.8085 & 17113.576 & 12359.512 & 0.000 & 18769.246 & \text { No }\end{array}$ $\begin{array}{llllllllllllllll}1.00 & 55.67 & 28.25 & 22.96 & 2 & 1439.7786 & 1439.7643 & 720.8894 & 0.0143 & 9.9182 & 5880.861 & 4070.557 & 137.149 & 6208.080 & \text { Yes } \\ 1.00 & 63.94 & 27.05 & 26.19 & 2 & 16228958 & 1622.8943 & 812.4544 & 0.0015 & 0.9231 & 1007.251 & 576.272 & 23.968 & 1049.604 & \text { Yes }\end{array}$

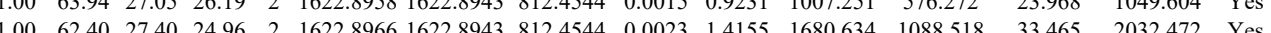

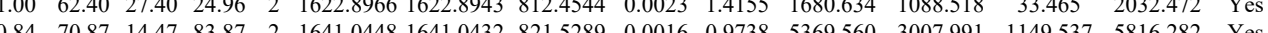

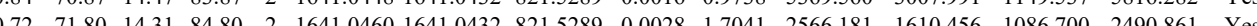

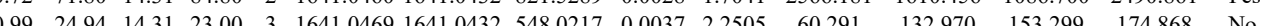
$\begin{array}{lllllllllllllll}0.99 & 23.17 & 13.01 & 18.17 & 3 & 1641.0478 & 1641.0432 & 548.0217 & 0.0046 & 2.7979 & 76.897 & 121.705 & 50.575 & 136.213 & \text { Yes }\end{array}$

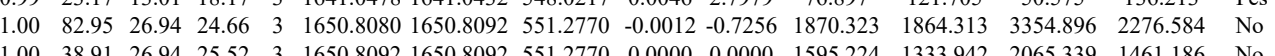

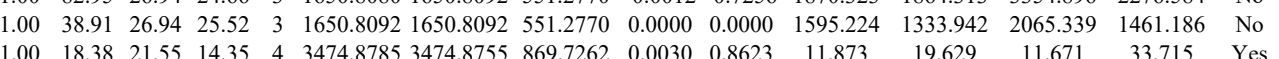

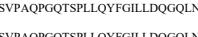

\section{LLLPWLEAR}

LLLPWLEAR

LLYNNVSNFGR

NLQNLLILTAIK

NLQNLLILTAIK

HSSLAGCQIINYR

NLILVVR

NLILVVR

LLYNNVSNFG

LLLPWLEAR

LLLPWLEAR

LLLPWLEAR

LLLPWLEAR

NLQNLLILTAIK

LLLPWLEAR

VGYTPDWIFLLR

WLLLTISAQQNR

LLLTSAR

WLLLTGISAQQNR

WLLTTSISQR

WLLLTGISAQQNR

WLLLTGISAQQNR

WLLLTGISAQQNR

WLLLTGISAQQNR

WLLLTGISAQQNR

WLLLTGISAQQNR

WLLLTGISAQQNR

WLLLTGISAQQNR

WLLLTGISAQQNR

WLLLTGISAQQNR

WLLLTGISAQQNR

WLLLTGISAQQNR

WLLLTGISAQQNR

WLLLTGISAQQNR

WLLLTGISAQQNR

WLLLTGISAQQNR

WLLLTGISAQQNR

NLILVVR

WLLLTGISAQQNR

WLLLTGISAQQNR

WLLLTGISAQQNR

\begin{tabular}{llllllllllll}
1.00 & 10.84 & 21.40 & 23.84 & 4 & 3474.8813 & 3474.8755 & 869.7262 & 0.0058 & 1.6672 & 2.546 & 5.960 \\
\hline
\end{tabular} $\begin{array}{llllllllllll}1 & 34.32 & 23.28 & 29.24 & 2 & 1253.7640 & 1253.7617 & 627.8881 & 0.0023 & 1.8315 & 8230.450 & 5889.973 \\ 0.99 & 34.29 & 23.28 & 29.17 & 2 & 1253.7644 & 1253.7617 & 627.8881 & 0.0027 & 2.1501 & 4389.357 & 3097.335\end{array}$ $\begin{array}{lllllllllllll}1.00 & 54.14 & 28.34 & 21.49 & 2 & 1439.7758 & 1439.7643 & 720.8894 & 0.0115 & 7.9762 & 3522.399 & 1886.246\end{array}$ $\begin{array}{lllllllllllll}1.00 & 54.17 & 28.25 & 19.13 & 2 & 1439.7784 & 1439.7643 & 720.8894 & 0.0141 & 9.7795 & 16351.873 & 12661.112\end{array}$ $\begin{array}{lllllllllllll}0.82 & 70.94 & 14.47 & 83.94 & 2 & 1641.0444 & 1641.0432 & 821.5289 & 0.0012 & 0.7303 & 1947.396 & 1150.375\end{array}$ $\begin{array}{lllllllllllll}0.84 & 72.55 & 14.47 & 85.55 & 2 & 1641.0450 & 1641.0432 & 821.5289 & 0.0018 & 1.0955 & 1668.481 & 1051.275\end{array}$ $\begin{array}{llllllllllll}1.00 & 25.05 & 14.31 & 15.06 & 3 & 1641.0472 & 1641.0432 & 548.0217 & 0.0040 & 2.4330 & 96.206 & 65.063\end{array}$ $\begin{array}{llllllllllll}0.97 & 29.06 & 27.04 & 19.30 & 3 & 1650.8152 & 1650.8092 & 551.2770 & 0.0060 & 3.6279 & 756.013 & 819.932\end{array}$ $\begin{array}{lllllllllllll}0.70 & 18.07 & 17.92 & 24.21 & 2 & 969.6534 & 969.6457 & 485.8301 & 0.0077 & 7.9245 & 4658.356 & 3631.544 \\ 0.80 & 21.40 & 17.92 & 25.41 & 2 & 969.6536 & 969.6457 & 485.8301 & 0.0079 & 8.1303 & 7735.866 & 6637.814\end{array}$ $\begin{array}{llllllllllll}1.00 & 53.57 & 28.25 & 21.93 & 2 & 1439.7766 & 1439.7643 & 720.8894 & 0.0123 & 8.5311 & 3097.369 & 2237.367\end{array}$ $\begin{array}{lllllllllllll}1.00 & 55.89 & 28.24 & 20.46 & 2 & 1439.7776 & 1439.7643 & 720.8894 & 0.0133 & 9.2246 & 5463.226 & 3579.345 \\ 1.00 & 34.40 & 23.30 & 27.51 & 2 & 1253.7636 & 1253.7617 & 627.8881 & 0.0019 & 1.5130 & 990.363 & 726.899\end{array}$ $\begin{array}{lllllllllllll}1.00 & 34.40 & 23.30 & 27.51 & 2 & 1253.7636 & 1253.7617 & 627.8881 & 0.0019 & 1.5130 & 990.363 & 72\end{array}$ $\begin{array}{lllllllllllll}1.00 & 34.51 & 23.30 & 29.42 & 2 & 1253.7636 & 1253.7617 & 627.8881 & 0.0019 & 1.5130 & 964.199 & 66\end{array}$ $\begin{array}{llllllllllllll} & \end{array}$

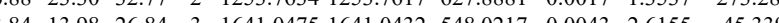
$\begin{array}{lllllllllll} & \end{array}$ $\begin{array}{lllllllllll} & \end{array}$ $\begin{array}{lllllllllllll}00 & 81.12 & 26.00 & 37.44 & 2 & 1642.9290 & 1642.9277 & 822.4711 & 0.0013 & 0.7903 & 514.681 & 2\end{array}$ $\begin{array}{llllllllll} & 46.96 & 3 & 1642.9291 & 1642.9277 & 548.6498 & 0.0014 & 0.8506 & 45.190\end{array}$ $\begin{array}{llllllllllll}0.67 & 46.23 & 25.89 & 59.23 & 3 & 164.29303 & 1642.9277 & 54.6498 & 0.0026 & 1.5796 & 41.739 & 4\end{array}$ $\begin{array}{llllllllllll}1.00 & 77.99 & 26.00 & 31.45 & 2 & 1642.9290 & 1642.9277 & 822.4711 & 0.0013 & 0.7903 & 305.706\end{array}$ $\begin{array}{lllllllllllll}1.00 & 58.80 & 25.98 & 21.59 & 3 & 1642.9297 & 1642.9277 & 548.6498 & 0.0020 & 1.2151 & 42.467 & 170.812\end{array}$ $\begin{array}{llllllllllll}1.00 & 80.66 & 25.89 & 36.50 & 2 & 1642.9300 & 1642.9277 & 822.4711 & 0.0023 & 1.3982 & 540.181 & 33.922\end{array}$ $\begin{array}{llllllllllll}1.00 & 40.80 & 25.81 & 19.32 & 3 & 1642.9306 & 1642.9277 & 548.6498 & 0.0029 & 1.7619 & 77.398 & 84.856\end{array}$ $\begin{array}{lllllllllllll}100 & 77.50 & 25.98 & 35.88 & 2 & 1642.9296 & 1642.9277 & 822.4711 & 0.0019 & 1.1551 & 573.231 & 3\end{array}$ $\begin{array}{lllllllllll}0.66 & 34.31 & 25.89 & 47.31 & 3 & 1642.9300 & 1642.9277 & 548.6498 & 0.0023 & 1.3974 & 92.264\end{array}$ $\begin{array}{lllllllllllll}1.00 & 55.64 & 25.89 & 20.24 & 3 & 1642.9300 & 1642.9277 & 548.6498 & 0.0023 & 1.3974 & 61.235\end{array}$ $\begin{array}{lllllllllllll}1.00 & 77.88 & 25.76 & 32.35 & 2 & 1642.9308 & 1642.9277 & 822.4711 & 0.0031 & 1.8846 & 345.198\end{array}$ $\begin{array}{lllllllllllll}0.67 & 34.63 & 25.76 & 47.63 & 3 & 1642.9309 & 1642.9277 & 548.6498 & 0.0032 & 1.9442 & 19.788\end{array}$ $\begin{array}{lllllllllllll}1.00 & 89.52 & 25.76 & 33.18 & 2 & 1642.9310 & 1642.9277 & 822.4711 & 0.0033 & 2.0061 & 808.280 & 5\end{array}$ $\begin{array}{llllllllllll}0.67 & 38.91 & 25.74 & 51.91 & 3 & 1642.9312 & 1642.9277 & 548.6498 & 0.0035 & 2.1264 & 55.215 \\ 1.00 & 65.51 & 25.55 & 30.21 & 2 & 1642.9320 & 1642.9277 & 822.4711 & 0.0043 & 2.6141 & 718.757\end{array}$ $\begin{array}{lllllllllll}1.00 & 72.15 & 26.06 & 30.61 & 2 & 1642.9288 & 1642.9277 & 822.4711 & 0.0011 & 0.6687 & 133.349\end{array}$ $\begin{array}{lllllllllll}1.00 & 81.24 & 25.99 & 32.72 & 2 & 1642.9292 & 1642.9277 & 822.4711 & 0.0015 & 0.9119 & 200.825\end{array}$ $\begin{array}{llllllllllll}1.00 & 67.02 & 26.06 & 30.13 & 2 & 1642.9288 & 1642.9277 & 822.4711 & 0.0011 & 0.6687 & 77.955\end{array}$ $\begin{array}{llllllllllll}1.00 & 33.86 & 25.99 & 17.66 & 3 & 1642.9294 & 1642.9277 & 548.6498 & 0.0017 & 1.0328 & 103.364\end{array}$ $\begin{array}{llllllllllll}0.98 & 23.88 & 25.99 & 15.26 & 3 & 1642.9294 & 1642.9277 & 548.6498 & 0.0017 & 1.0328 & 52.144\end{array}$ $\begin{array}{llllllllllll}1.00 & 69.16 & 25.98 & 34.28 & 2 & 1642.9294 & 1642.9277 & 822.4711 & 0.0017 & 1.0335 & 119.865\end{array}$ $\begin{array}{llllllllllllll}0.99 & 23.86 & 16.72 & 23.46 & 2 & 969.6466 & 969.6457 & 485.8301 & 0.0009 & 0.9262 & 255.333\end{array}$ $\begin{array}{llllllllllll}1.00 & 6.03 & 26.12 & 30.21 & 2 & 1642.9284 & 1642.9277 & 82.4711 & 0.0007 & 0.4255 & 67.275\end{array}$ $\begin{array}{lllllllllll}1.00 & 63.78 & 25.98 & 29.75 & 2 & 1642.9294 & 1642.9277 & 822.4711 & 0.0017 & 1.0335 & 28.774\end{array}$ $\begin{array}{llllllllllll}1.00 & 36.57 & 25.98 & 19.71 & 3 & 1642.9297 & 1642.9277 & 548.6498 & 0.0020 & 1.2151 & 15.47 \\ 1.00 & 54.75 & 26.06 & 30.55 & 2 & 1642.9288 & 1642.9277 & 822.4711 & 0.0011 & 0.6687 & 34.120\end{array}$ $\begin{array}{lllllllllll}1.00 & 51.76 & 26.06 & 27.85 & 2 & 1642.9288 & 1642.9277 & 822.4711 & 0.0011 & 0.6687 & 26.187\end{array}$ $\begin{array}{llllllllllll}1.00 & 55.10 & 26.00 & 18.34 & 3 & 1642.9291 & 16429277 & 548.6498 & 0.0014 & 0.8506 & 19.221\end{array}$ $\begin{array}{lllllllllll}1.00 & 5.107 & 26.00 & 18.04 & 3 & 1642.9291 & 1624.9277 & 548.6448 & 0.0014 & 0.8506 & 19.221\end{array}$ 
NNRPSEGPLQTR WLLLTGISAQQNR WLLLTGISAQQNR NLILVVR WLLLTGISAQQNR WLLLTGISAQQNR GQFSTDELVAEVEK GQFSTDELVAEVEK GQFSTDELVAEVEK GQFSTDELVAEV LECSEELGDLVK LECSEELGDLVK IYIDSNNNPER IYIDSNNNPER

IHEGCEEPATHNA

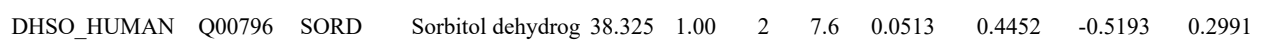
$\begin{array}{lllllllllll}\text { HNRPU HUMA } & \text { Q00839 } & \text { HNRNPU Heterogeneous nu } 90.584 & 1.00 & 14 & 24.2 & 0.0791 & 0.5052 & 0.7462 & 0.5246\end{array}$

AMGAAQVVVTDLSATR SVNVKPLVTHR $\begin{array}{llllllllll} & \end{array}$ $\begin{array}{llllllllllll}1.00 & 52.91 & 25.99 & 18.76 & 3 & 1642.9294 & 1642.9277 & 548.6498 & 0.0017 & 1.0328 & 17.316\end{array}$ $\begin{array}{llllllllllllll}0.97 & 20.02 & 16.72 & 18.06 & 2 & 969.6470 & 969.6457 & 485.8301 & 0.0013 & 1.3379 & 82.629\end{array}$ $\begin{array}{lllllllllll}0.66 & 17.03 & 25.99 & 30.03 & 3 & 1642.9294 & 1642.9277 & 548.6498 & 0.0017 & 1.0328 & 17.315\end{array}$ $\begin{array}{lllllllllll}1.00 & 62.30 & 25.89 & 22.97 & 2 & 1642.9298 & 1642.9277 & 822.4711 & 0.0021 & 1.2766 & 22.766\end{array}$ $\begin{array}{lllllllllll}1.00 & 74.50 & 27.96 & 33.23 & 2 & 1838.9526 & 1838.9505 & 920.4825 & 0.0021 & 1.1407 & 116.600\end{array}$ $\begin{array}{llllllllllll}1.00 & 71.98 & 28.03 & 29.33 & 2 & 1838.9542 & 1838.9505 & 920.4825 & 0.0037 & 2.0098 & 516.399 & 4\end{array}$

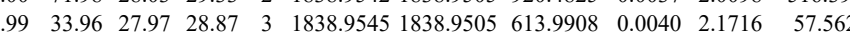

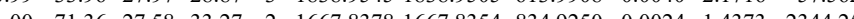

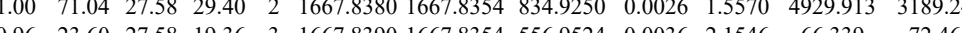
$\begin{array}{lllllllllllll}1.00 & 55.24 & 27.93 & 25.37 & 2 & 1477.7380 & 1477.7283 & 739.8714 & 0.0097 & 6.5552 & 15714.722 & 9321.34\end{array}$ $\begin{array}{llllllllllll}1.00 & 62.81 & 27.94 & 29.32 & 2 & 1477.7382 & 1477.7283 & 739.8714 & 0.0099 & 6.6903 & 16332.729 & 11831.675\end{array}$ $\begin{array}{llllllllllllll}1.00 & 38.84 & 27.61 & 21.11 & 4 & 2053.0133 & 2052.9964 & 514.2564 & 0.0169 & 8.2157 & 3655.045 & 3308.066\end{array}$

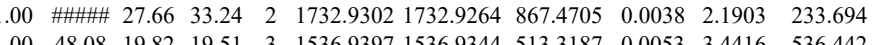
$\begin{array}{lllllllllllll}1.00 & 42.12 & 20.93 & 19.20 & 3 & 1536.93776 & 1536.9344 & 513.3187 & 0.0053 & 3.4416 & 536.442 & 758.838 \\ 1.09344 & 513.3187 & 0.0032 & 2.0780 & 1132.688 & 1132.409\end{array}$ 758.838
1132.409 KAEGGGGGGRPGAPAAC
ASYGVSK $\begin{array}{llllllllllll}1.00 & 42.12 & 20.93 & 19.20 & 3 & 1536.9376 & 1536.9344 & 513.3187 & 0.0032 & 2.0780 & 132.688 \\ 1.00 & 55.81 & 27.02 & 19.79 & 4 & 2098.1265 & 2098.1245 & 525.5384 & 0.0020 & 0.9514 & 154.63\end{array}$ ASYGVSK $\begin{array}{lllllllllllll}0.87 & 25.29 & 25.66 & 19.67 & 2 & 998.5640 & 998.5640 & 500.2893 & 0.0000 & 0.0000 & 669.872 & 706.699\end{array}$ $\begin{array}{lllllllllllllll}0.93 & 24.65 & 26.28 & 19.25 & 2 & 998.5648 & 998.5640 & 500.2893 & 0.0008 & 0.7995 & 505.422 & 614.091\end{array}$ $\begin{array}{lllllllllllll}0.63 & 23.91 & 25.73 & 18.92 & 2 & 998.5630 & 998.5640 & 500.2893 & -0.0010 & -0.9994 & 354.061 & 362.306\end{array}$ ASYGVSK $\begin{array}{llllllllllll}0.84 & 24.46 & 25.66 & 19.18 & 2 & 99.5642 & 99.5640 & 5002893 & 0.0002 & 0.1999 & 450.806\end{array}$

GNFTLPEVAECFDEITYVELOK

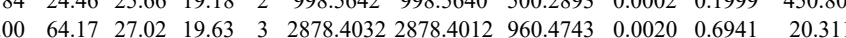
$\begin{array}{llllllllllllll}\text { GFTLPEVAECFDEITYVELQK } & 1.00 & 47.15 & 27.02 & 16.46 & 3 & 2878.4032 & 2878.4012 & 960.4743 & 0.0020 & 0.6941 & 2.272 \\ \text { GNFLPEVAECFDEITYVELQK } & 0.66 & 55.41 & 26.95 & 68.41 & 3 & 2878.4029 & 2878.4012 & 960.4743 & 0.0017 & 0.5900 & 0.000\end{array}$ $\begin{array}{lllllllllllllll}\text { GNTPENAECFEITYVELQK } & 1.00 & 66.96 & 27.02 & 23.89 & 3 & 2878.4032 & 2878.4012 & 960.4743 & 0.0020 & 0.6941 & 0.000\end{array}$

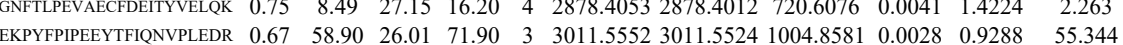

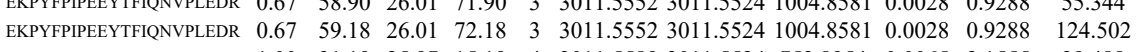

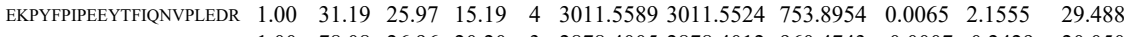
$\begin{array}{llllllllllll}\text { GNFTLPEVAECFDEITYVELQK } & 1.00 & 78.08 & 26.96 & 20.20 & 3 & 2878.4005 & 2878.4012 & 960.4743 & -0.0007 & -0.2429 & 20.050\end{array}$ $\begin{array}{llllllllllll}\text { EKPYFPIPEEYTFIQNVPLEDR } & 0.67 & 50.13 & 26.01 & 63.13 & 3 & 3011.5552 & 3011.5524 & 1004.8581 & 0.0028 & 0.9288 & 16.005\end{array}$

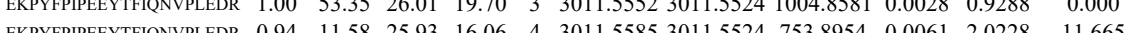

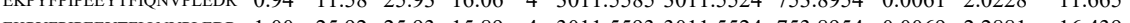

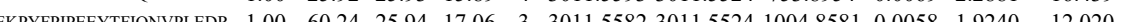

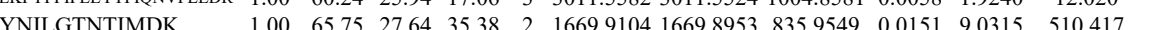

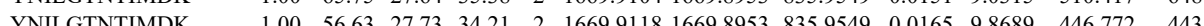

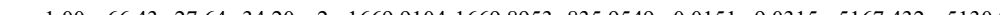
$\begin{array}{llllllllllllllll}\text { YNILGTNTIMDK } & 1.00 & 66.43 & 27.64 & 34.20 & 2 & 1669.9104 & 1669.8953 & 835.9549 & 0.0151 & 9.0315 & 5167.432 & 5130.937 & 1373.069 & 7006.545 & \text { Yes } \\ \text { YNILGTNTIMDK } & 1.00 & 59.41 & 27.63 & 34.64 & 2 & 1669.9110 & 1669.8953 & 835.9549 & 0.0157 & 9.3904 & 2493.786 & 2530.839 & 521.224 & 5118.717 & \text { Yes }\end{array}$ $\begin{array}{llllllllllllllll}\text { NFILDQTNVSAAAQR } & 1.00 & 98.65 & 28.11 & 30.35 & 2 & 1790.9538 & 1790.9397 & 896.4771 & 0.0141 & 7.8641 & 2379.636 & 2503.819 & 0.000 & 4256.374 & \text { No }\end{array}$ $\begin{array}{llllllllllllllll}\text { NFILDQTNVSAAAQR } & 1.00 & 82.79 & 28.14 & 29.25 & 2 & 1790.9548 & 1790.9397 & 896.4771 & 0.0151 & 8.4218 & 1140.785 & 1282.842 & 300.263 & 2088.013 & \text { Yes }\end{array}$ $\begin{array}{llllllllllllllll}\text { FIEIAAR } & 0.87 & 34.05 & 27.78 & 32.90 & 2 & 962.5728 & 962.5671 & 482.2908 & 0.0057 & 5.9093 & 10041.061 & 11791.257 & 1136.011 & 37051.080 & \text { No }\end{array}$ $\begin{array}{llllllllllllllll} & \\ \text { FIEIAAR } & 0.93 & 37.62 & 28.06 & 32.23 & 2 & 962.5732 & 962.5671 & 482.2908 & 0.0061 & 6.3239 & 8631.462 & 7269.971 & 985.236 & 26110.857 & \text { No } \\ \text { AVVVCPK } & 0.99 & 49.42 & 29.37 & 26.45 & 2 & 1048.6100 & 1048.6017 & 525.3081 & 0.0083 & 7.9001 & 25551.186 & 25750.878 & 2818.183 & 47579.927 & \text { Yes }\end{array}$

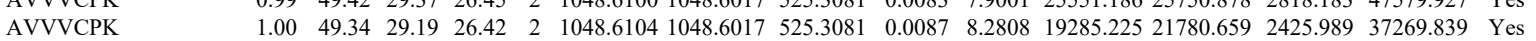

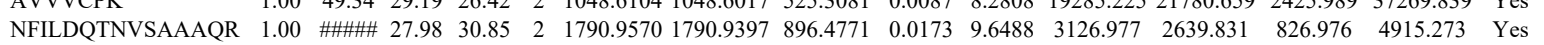
$\begin{array}{llllllllllllllll}\text { LNTLLQR } & 0.78 & 30.05 & 27.25 & 27.54 & 2 & 1000.6220 & 1000.6151 & 501.3148 & 0.0069 & 6.8819 & 1286.960 & 1266.640 & 436.816 & 1719.291 & \text { Yes }\end{array}$

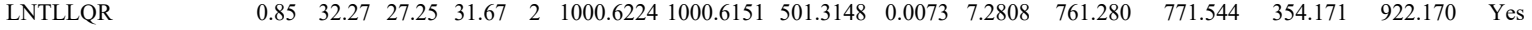
$\begin{array}{llllllllllllllll}\text { LNTLLQR } & 0.94 & 38.24 & 27.25 & 34.65 & 2 & 1000.6214 & 1000.6151 & 501.3148 & 0.0063 & 6.2834 & 19581.445 & 20373.192 & 6670.601 & 38242.219 & \text { Yes }\end{array}$

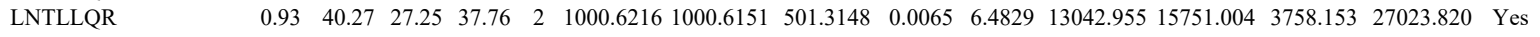
$\begin{array}{llllllllllllllll}\text { LNTLLQR } & 0.82 & 31.82 & 27.23 & 31.60 & 2 & 1000.6210 & 1000.6151 & 501.3148 & 0.0059 & 5.8845 & 17036.589 & 17357.945 & 4434.504 & 31613.763 & \text { Yes }\end{array}$

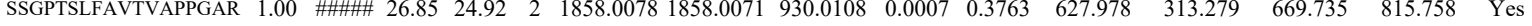

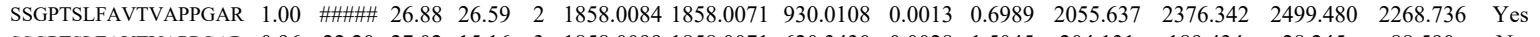
$\begin{array}{llllllllllllllll}\text { SSGPTSLFAVTVAPPGAR } & 0.96 & 22.20 & 27.02 & 15.16 & 3 & 1858.0099 & 1858.0071 & 620.3430 & 0.0028 & 1.5045 & 204.131 & 189.434 & 28.245 & 88.590 & \text { No }\end{array}$ $\begin{array}{llllllllllllllll}\text { SSGPTSLFAVTVAPPGAR } & 1.00 & 30.61 & 26.84 & 19.01 & 3 & 1858.0105 & 1858.0071 & 620.3430 & 0.0034 & 1.8269 & 301.794 & 293.400 & 94.751 & 191.682 & \text { Yes }\end{array}$ $\begin{array}{llllllllllllllll}\text { LNTLLQR } & 0.80 & 34.59 & 27.23 & 37.44 & 2 & 1000.6208 & 1000.6151 & 501.3148 & 0.0057 & 5.6850 & 7021.027 & 7267.660 & 2013.474 & 12126.283 & \text { Yes }\end{array}$

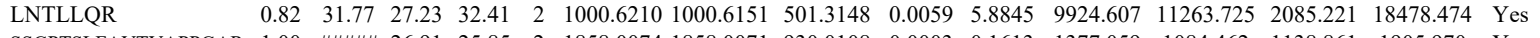
$\begin{array}{lllllllllllllll}\text { SSGPTSLFAVTVAPPGAR } & 1.00 & \ldots \text { m\#冊 } 26.91 & 25.85 & 2 & 1858.0074 & 1858.0071 & 930.0108 & 0.0003 & 0.1613 & 137.059 & 1084.462 & 1138.861 & 1905.970 & \text { Yes }\end{array}$ \begin{tabular}{llllllllllllllll} 
SSGPTSLFAVTVAPPGAR & 1.00 & 26.85 & 20.71 & 2 & 1858.0078 & 1858.007 & 930.0108 & 0.0007 & 0.3763 & 418.247 & 465.007 & 406.877 & 739.932 & Yes \\
\hline
\end{tabular} $\begin{array}{llllllllllllllll}\text { SSGPTSLFAVTVAPPGAR } & 1.00 & 30.30 & 27.02 & 18.69 & 3 & 1858.0102 & 1858.0071 & 620.3430 & 0.0031 & 1.6657 & 314.280 & 405.089 & 270.927 & 196.016 & \text { Yes } \\ \text { LNTLLQR } & 0.97 & 42.49 & 27.23 & 35.35 & 2 & 1000.6210 & 1000.6151 & 501.3148 & 0.0059 & 5.8845 & 4428.708 & 4757.422 & 1080.714 & 7627.789 & \text { Yes }\end{array}$

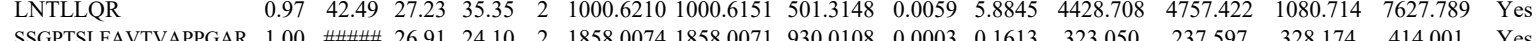

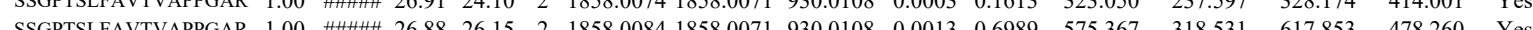
$\begin{array}{lllllllllllllllll}\text { SSGPTSLFAVTVAPPGAR } & 0.67 & 17.09 & 27.02 & 30.09 & 3 & 1858.0099 & 1858.0071 & 620.3430 & 0.0028 & 1.5045 & 176.006 & 217.036 & 129.636 & 158.894 & \text { Yes }\end{array}$

Table S-4 page 427 of 614 
$\begin{array}{lllllllllllll}1.00 & 58.06 & 27.40 & 23.94 & 2 & 1578.7820 & 1578.7809 & 790.3977 & 0.0011 & 0.6959 & 5610.972\end{array}$

GYFEYIEENK

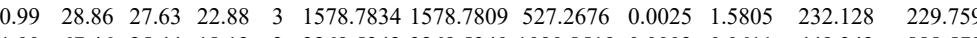

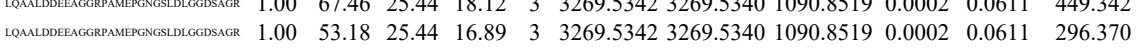

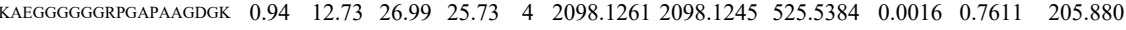

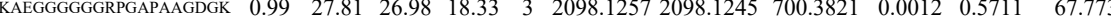

$\begin{array}{llllllllllllll} & \text { KALGGGGGRGGAPAGDGK } & 1.00 & 66.09 & 27.02 & 25.02 & 4 & 2098.1265 & 2098.1245 & 525.5384 & 0.0020 & 0.9514 & 310.665 & 364.325\end{array}$

$\begin{array}{lllllllllllll}\text { KAEGGGGGGRPGAPAAGDGK } & 1.00 & 31.84 & 26.95 & 16.66 & 4 & 2098.1277 & 2098.1245 & 525.5384 & 0.0032 & 1.5222 & 146.488 & 119.244 \\ \text { VDSIDDR } & 0.53 & 14.70 & 27.72 & 23.37 & 2 & 962.408 & 962.4791 & 482.248 & 0.0017 & 1.7626 & 73.976 & 13.910\end{array}$

$\begin{array}{llllllllllllll}\text { VDSIDDR } & 0.53 & 14.70 & 27.72 & 23.37 & 2 & 962.4808 & 962.4791 & 482.2468 & 0.0017 & 1.7626 & 73.976 & 73.910\end{array}$ $\begin{array}{lllllllllllll}\text { LNDGNEYLFQAK } & 0.73 & 21.94 & 27.72 & 19.75 & 2 & 1698.8854 & 1698.8820 & 850.4483 & 0.0034 & 1.9989 & 2104.767 & 1515.176\end{array}$ $\begin{array}{llllllllllll}\text { DDEEMNTWIQAISSAISSDK } & 1.00 & 72.60 & 26.46 & 27.91 & 3 & 2527.2034 & 2527.1992 & 843.4070 & 0.0042 & 1.6599 & 6.793 \\ \text { DDEEMNTWQNSSASSDK } & 1.00 & 99.77 & 26.51 & 26.49 & 3 & 2527.2037 & 2527.1992 & 843.4070 & 0.0045 & 1.7785 & 10.464\end{array}$ $\begin{array}{llllllllllll}\text { DDEEMNWIQALAALSDK } & 1.00 & 99.77 & 26.51 & 26.49 & 3 & 2527.2037 & 2527.1992 & 843.4075 & 0.0045 & 1.7785 & 10.464 \\ \text { DGLNEAWADLLELIDTR } & 0.99 & 30.62 & 27.36 & 20.50 & 3 & 2087.0668 & 2087.0657 & 696.6958 & 0.0011 & 0.5263 & 100.861\end{array}$ $\begin{array}{llllllllllll}\text { VDTVNHLADELNSGHSDAATALEWK K } & 0.66 & 68.61 & 26.34 & 81.61 & 3 & 3093.5632 & 3093.5611 & 1032.1943 & 0.0021 & 0.6782 & 36.736\end{array}$

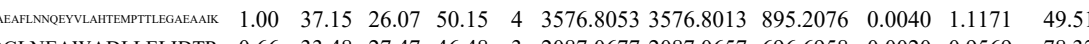

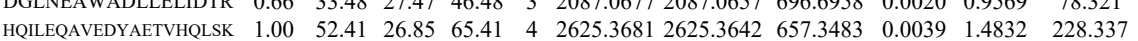
$\begin{array}{lllllllllllll}\text { HQILEQAVEDYAETVHQLSK } & 1.00 & 46.45 & 26.86 & 59.45 & 4 & 2625.3689 & 2625.3642 & 657.3483 & 0.0047 & 1.7875 & 297.376\end{array}$ $\begin{array}{lllllllllllll} & 0.5181 & 80.016\end{array}$ $\begin{array}{llllllllllll}\text { VSODNGFDPAVEATK } & 0.67 & 19.54 & 26.88 & 32.54 & 3 & 2309.2174 & 2309.2147 & 770.7455 & 0.0027 & 1.1677 & 105.641\end{array}$ $\begin{array}{lllllllllllll}\text { LVSQDNFGFDLPAVEAATK } & 0.67 & 59.42 & 26.90 & 72.42 & 3 & 2309.2177 & 2309.2147 & 770.7455 & 0.0030 & 1.2974 & 77.647\end{array}$ $\begin{array}{lllllllllllll}\text { FMELLEPLNER } & 1.00 & 57.01 & 28.12 & 19.84 & 2 & 1533.8000 & 1533.7983 & 767.9064 & 0.0017 & 1.1069 & 827.064\end{array}$ FMELLEPLNER TALPAQSAATLPAR VQAVVAVAR VQAVVAVAR VQAVVAVAR VQAVVAVAR VAVVNQIAR

VAVVNQIAR

VAVVNQIAR

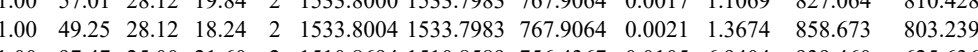
$\begin{array}{lllllllllllll} & \end{array}$ $\begin{array}{llllllllllll}0.98 & 45.09 & 22.97 & 36.87 & 2 & 1055.6654 & 1055.6573 & 528.8359 & 0.0081 & 7.6583 & 21291.677 & 24728.603\end{array}$

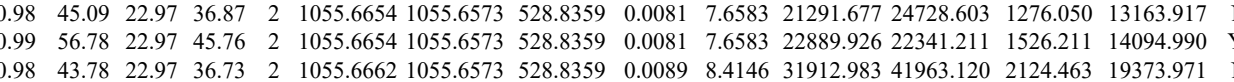

VAVVNQIAR $\begin{array}{lllllllllllllllll}0.99 & 4.58 & 22.97 & 36.07 & 2 & 1055.6664 & 1055.6573 & 528.8359 & 0.0091 & 8.6037 & 26276.004 & 32852.851 & 2882.654 & 18560.316 & \text { Y }\end{array}$ $\begin{array}{llllllllllllllllll}0.99 & 41.27 & 22.88 & 21.04 & 2 & 1112.6882 & 1112.6788 & 557.3467 & 0.0094 & 8.4327 & 26832.128 & 18957.859 & 695.678 & 16541.940 & \text { Yes }\end{array}$ $\begin{array}{llllllllllllllllllll}0.99 & 39.15 & 22.88 & 21.02 & 2 & 1112.6886 & 1112.6788 & 557.3467 & 0.0098 & 8.7916 & 7308.865 & 5871.951 & 436.267 & 5059.621 & \text { Yes }\end{array}$ $\begin{array}{llllllllllllllll} & & & \end{array}$

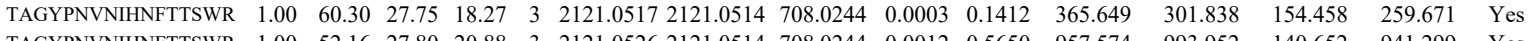
$\begin{array}{llllllllllllllllll} & 1.00 & 52.16 & 27.80 & 20.88 & 3 & 2121.0526 & 2121.0514 & 708.0244 & 0.0012 & 0.5650 & 957.574 & 993.952 & 140.652 & 941.299 & \text { Yes }\end{array}$

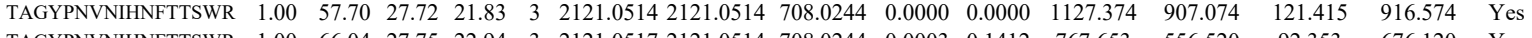
$\begin{array}{llllllllllllllll} & \end{array}$ $\begin{array}{lllllllllllllll} & \end{array}$

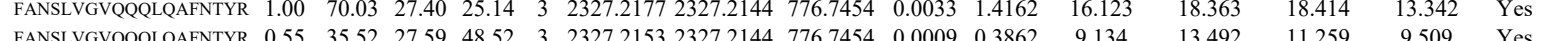

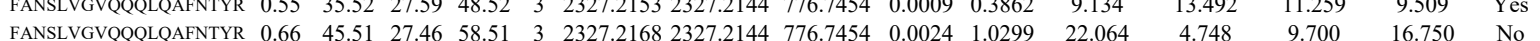

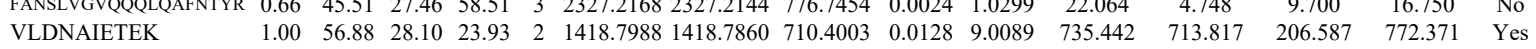
$\begin{array}{llllllllllllllll}\text { LAEISDVWEEMK } & 1.00 & 68.98 & 28.29 & 23.54 & 2 & 1736.8912 & 1736.8898 & 869.4522 & 0.0014 & 0.8051 & 1634.195 & 1325.372 & 42.151 & 1603.151 & \text { Yes }\end{array}$ $\begin{array}{lllllllllllllllll}1.00 & 76.71 & 28.29 & 24.15 & 2 & 1736.8918 & 1736.8898 & 869.4522 & 0.0020 & 1.1501 & 1260.080 & 1020.492 & 0.000 & 1126.168 & \text { No }\end{array}$ 

$\begin{array}{llllllllllllllll} & & & \end{array}$

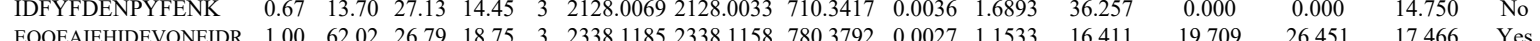
$\begin{array}{llllllllllllllllll} & \\ \text { QPFFQK } & 0.53 & 24.06 & 26.32 & 25.45 & 2 & 1081.6216 & 1081.6164 & 541.8155 & 0.0052 & 47987 & 9501.068 & 8932934 & 37132.153 & 37909.651 & \text { Yes }\end{array}$ QPFFQK $\begin{array}{lllllllllllllll}0.53 & 24.06 & 26.32 & 25.45 & 2 & 1081.6216 & 1081.6164 & 541.8155 & 0.0052 & 4.7987 & 9501.068 & 8932.934 & 37132.153 & 37909.651 & \text { Yes }\end{array}$ $\begin{array}{lllllllllllllll}1.00 & 53.67 & 25.50 & 16.49 & 4 & 38689601 & 3868.9546 & 968.2459 & 0.0055 & 1.4201 & 235.199 & 362082 & 1116.127 & 642.297 & \text { Yes }\end{array}$

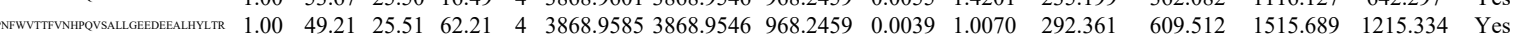
$\begin{array}{llllllllllllllllll} & 1.00 & 48.77 & 25.44 & 61.77 & 4 & 3868.9573 & 3868.9546 & 968.2459 & 0.0027 & 0.6971 & 76.974 & 189.478 & 512.106 & 376.718 & \text { Yes }\end{array}$ $\begin{array}{llllllllllllllll}\text { EDEEALYLIT } & 1.00 & 35.52 & 25.50 & 48.52 & 4 & 3868.9601 & 3868.9546 & 968.2459 & 0.0055 & 1.4201 & 267.591 & 462.639 & 626.749 & 509.789 & \text { Yes }\end{array}$

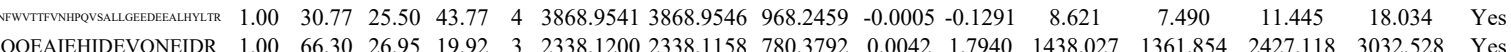
$\begin{array}{lllllllllllllllll}\text { EQQEAEIDHIDEVQNEIDR } & 1.00 & 66.30 & 26.95 & 19.92 & 3 & 2338.1200 & 2338.1158 & 780.3792 & 0.0042 & 1.7940 & 1438.027 & 1361.854 & 2427.118 & 3032.528 & \text { Yes } \\ \text { EQEA } & 1.00 & 66.40 & 26.95 & 28.46 & 3 & 2338.1200 & 2338.1158 & 780.3792 & 0.0042 & 1.7940 & 1150.439 & 1349.102 & 2646.858 & 2425.057 & \text { Yes }\end{array}$

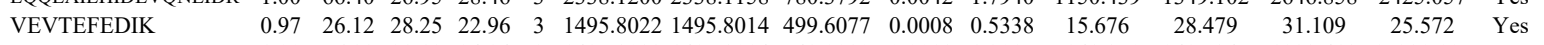

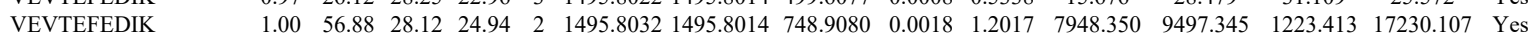
$\begin{array}{llllllllllllllll}\text { VEVTEFEDIK } & 1.00 & 56.84 & 28.07 & 26.78 & 2 & 1495.8038 & 1495.8014 & 748.9080 & 0.0024 & 1.6023 & 13710.302 & 17354.626 & 463.892 & 30938.442 & \text { Yes }\end{array}$ $\begin{array}{lllllllllllllllll}\text { LNEQASEEILK } & 1.00 & 54.63 & 27.51 & 27.73 & 2 & 1560.8602 & 1560.8602 & 781.4374 & 0.0000 & 0.0000 & 6411.262 & 6991.107 & 2658.322 & 12009.066 & \text { Yes }\end{array}$ $\begin{array}{llllllllllllllll}\text { LNEQASEEILK } & 1.00 & 65.82 & 27.52 & 29.21 & 2 & 1560.8608 & 1560.8602 & 781.4374 & 0.0006 & 0.3839 & 11862.056 & 15858.861 & 6101.853 & 23731.302 & \text { Yes }\end{array}$ $\begin{array}{llllllllllllllll}\text { LNEQASEEILK } & 0.99 & 31.48 & 27.44 & 23.63 & 3 & 1560.8617 & 1560.8602 & 521.2940 & 0.0015 & 0.9592 & 540.353 & 224.720 & 128.195 & 285.289 & \text { No }\end{array}$ LNEQASEEILK VEVTEFEDIK VEVTEFEDIK LNEQASEEILK LNEQASEEILK $\begin{array}{llllllllllllllll}0.70 & 18.31 & 23.20 & 23.25 & 2 & 929.4478 & 929.4477 & 465.7311 & 0.0001 & 0.1074 & 97.233 & 111.717 & 55.150 & 166.121 & \text { Yes } \\ 0.61 & 16.44 & 23.20 & 26.38 & 2 & 929.4478 & 929.4477 & 465.7311 & 0.0001 & 0.1074 & 91.228 & 97.667 & 37.993 & 106.598 & Y s\end{array}$

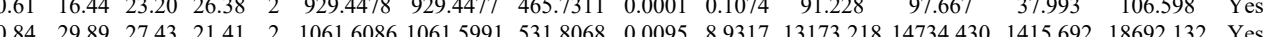
$\begin{array}{llllllllllllllll} & \text { DAEDAMDAMDGAVLDGR } & 1.00 & \text { \#\#\#\# } 22.50 & 24.68 & 2 & 1894.8178 & 1894.8159 & 948.4152 & 0.0019 & 1.0017 & 440.026 & 214.928 & 383.848 & 553.665 & \text { Yes }\end{array}$ $\begin{array}{lllllllllllllllll} & & & \end{array}$ $\begin{array}{lllllllllllll} & \end{array}$

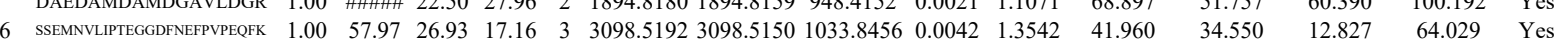
$\begin{array}{llllllllllllllll}\text { SSEMNVLIPTEGGENEFPVPEFFK } & 0.95 & 22.11 & 26.93 & 18.56 & 3 & 3098.5192 & 3098.5150 & 1033.8456 & 0.0042 & 1.3542 & 0.000 & 0.000 & 0.000 & 8.968 & \text { No }\end{array}$ $\begin{array}{lllllllllllllllll}\text { SSEMNVLPTEGGDFNEPYPEQFK } & 1.00 & 47.43 & 26.93 & 17.08 & 3 & 3098.5192 & 3098.5150 & 1033.8456 & 0.0042 & 1.3542 & 0.000 & 0.000 & 11.158 & 16.991 & \text { No }\end{array}$

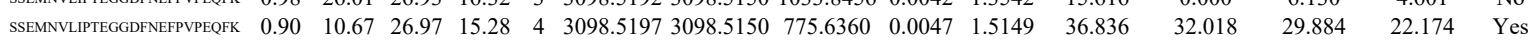
$\begin{array}{llllllllllllllll}\text { SSEMNVLPTEGDFNEPVPEOFK } & 0.77 & 8.22 & 26.93 & 18.67 & 4 & 3098.5201 & 3098.5150 & 775.6360 & 0.0051 & 1.6438 & 9.648 & 28.393 & 28.277 & 19.345 & \text { Yes }\end{array}$ $\begin{array}{llllllllllllllllll} & 3098.5192 & 3098.5150 & 1033.8456 & 0.0042 & 1.3542 & 8.397 & 0.000 & 13.864 & 5.356 & \text { No }\end{array}$ $\begin{array}{llllllllllllllll}\text { SSEMNVLPTEGGDFNEPVPEOFK } & 0.76 & 15.21 & 26.93 & 16.99 & 3 & 3098.5192 & 3098.5150 & 1033.8456 & 0.0042 & 1.3542 & 5.624 & 3.415 & 3.923 & 3.933 & \text { Yes }\end{array}$

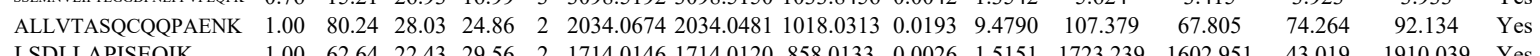
\begin{tabular}{llllllllllllllll} 
LSDLLAPISEQIK & 1.00 & 62.64 & 22.43 & 29.56 & 2 & 1714.0146 & 1714.0120 & 858.0133 & 0.0026 & 1.5151 & 1723.239 & 1602.951 & 43.019 & 1910.039 & Yes \\
\hline LSDLLAPS
\end{tabular}

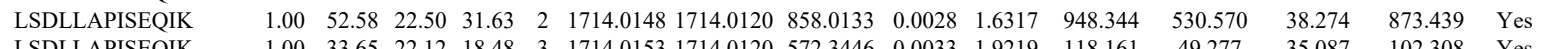

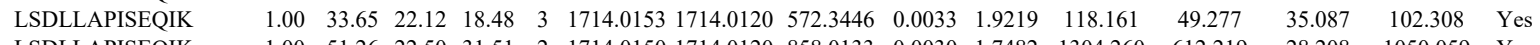

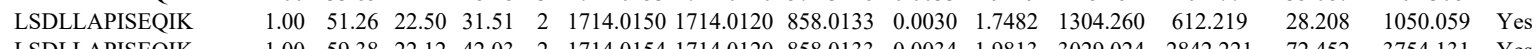

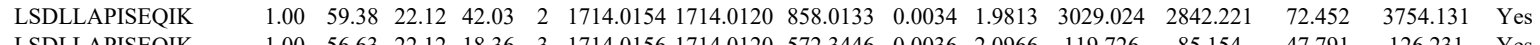

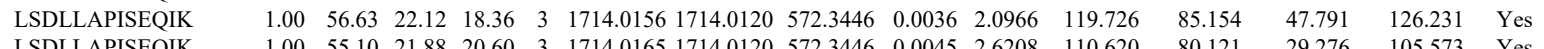

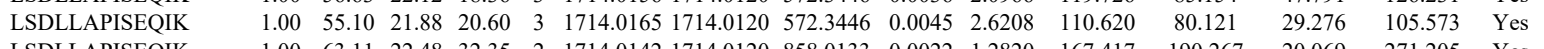

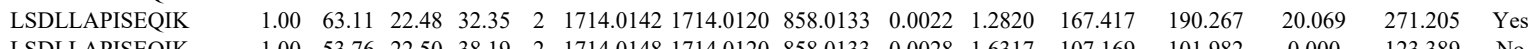

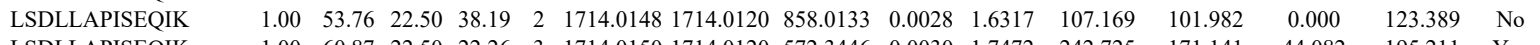
$\begin{array}{llllllllllllllll}\text { LSDLLAPISEQIK } & 1.00 & 60.87 & 22.50 & 22.26 & 3 & 1714.0150 & 1714.0120 & 572.3446 & 0.0030 & 1.7472 & 242.725 & 171.141 & 44.082 & 195.211 & \text { Yes }\end{array}$

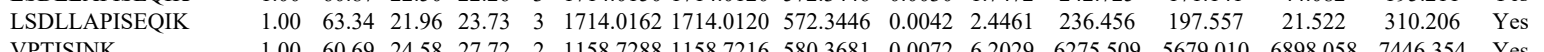

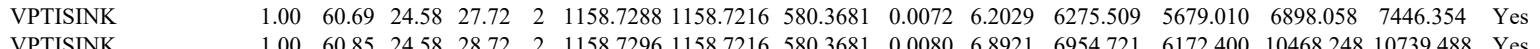
$\begin{array}{llllllllllllllll} & 1.00 & 60.85 & 24.58 & 28.72 & 2 & 1158.7296 & 1158.7216 & 580.3681 & 0.0080 & 6.8921 & 6954.721 & 6172.400 & 10468.248 & 10739.488 & \text { Yes }\end{array}$

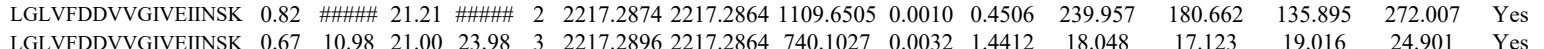

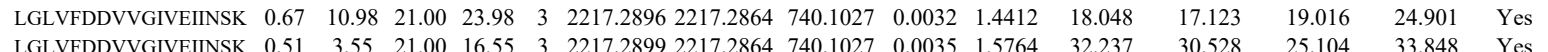

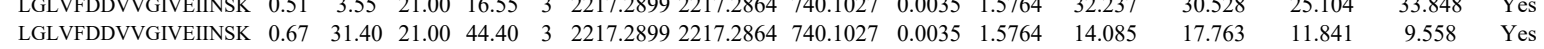

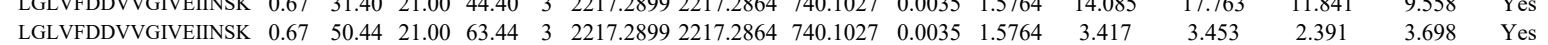




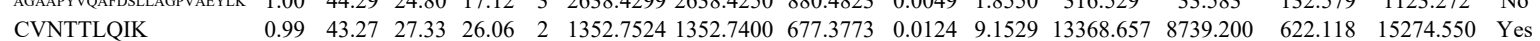

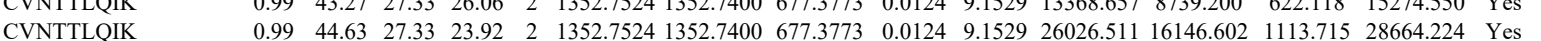

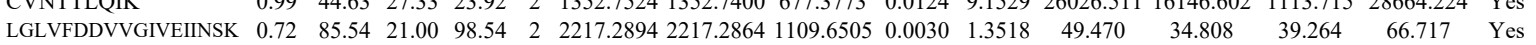

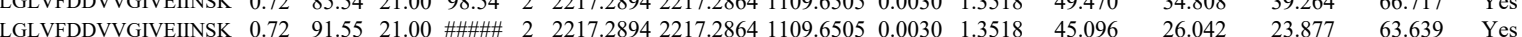

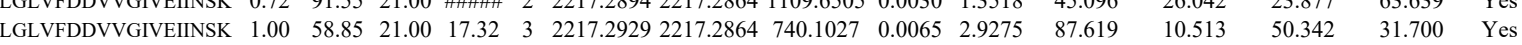

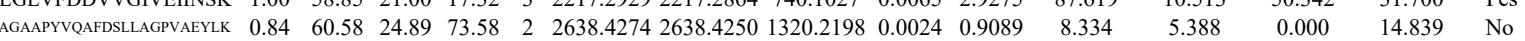

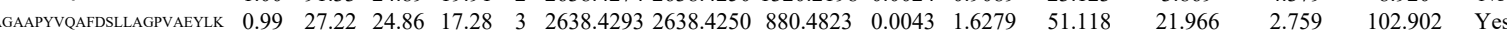

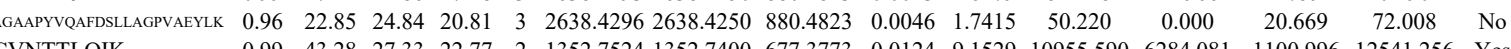

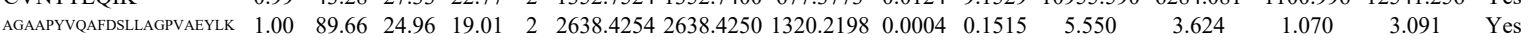
$\begin{array}{llllllllllllllll}\text { AGAAPYVQAFDSLAGPVAEYLK } & 0.97 & 22.15 & 24.80 & 21.70 & 3 & 2638.4287 & 2638.4250 & 880.4823 & 0.0037 & 1.4007 & 5.053 & 10.203 & 0.000 & 35.283 & \text { No }\end{array}$ $\begin{array}{llllllllllllllll}\text { AGAAPYVQAFDSLLAGPVAEYLK } & 0.86 & 15.52 & 24.80 & 19.37 & 3 & 2638.4287 & 2638.4250 & 880.4823 & 0.0037 & 1.4007 & 9.879 & 11.461 & 14.157 & 36.206 & \text { Yes }\end{array}$

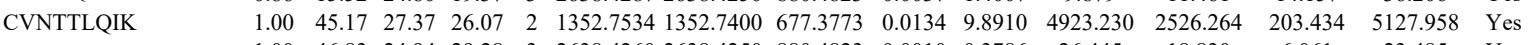
\begin{tabular}{llllllllllllllll} 
AGAAPYVQAFDSLAGPVAEYLK & 1.00 & 46.83 & 24.94 & 29.28 & 3 & 2638.4260 & 2638.4250 & 880.4823 & 0.0010 & 0.3786 & 26.445 & 18.830 & 6.061 & 23.485 & Yes \\
\hline
\end{tabular}

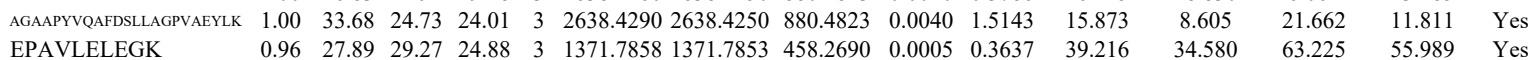
$\begin{array}{llllllllllllllll}\text { EPAVLELEG } & 0.96 & 27.89 & 29.27 & 24.88 & 3 & 1371.7858 & 1371.7853 & 458.2690 & 0.0005 & 0.3637 & 39.216 & 34.580 & 63.225 & 55.989 & \text { Yes } \\ \text { EPALEG } & 0.98 & 29.92 & 29.29 & 26.36 & 3 & 1371.7861 & 1371.7853 & 458.2690 & 0.0008 & 0.5819 & 93.115 & 32.878 & 82.026 & 4.658 & \text { Yes }\end{array}$ $\begin{array}{lllllllllllllllll}\text { EPAVLELEGK } & 1.00 & 59.50 & 29.25 & 30.33 & 2 & 1371.7868 & 1371.7853 & 686.8999 & 0.0015 & 1.0919 & 4250.474 & 2448.138 & 15206.542 & 4803.691 & \text { No }\end{array}$ $\begin{array}{llllllllllllllll}\text { EPAVLELEGK } & 1.00 & 59.66 & 29.20 & 30.49 & 2 & 1371.7872 & 1371.7853 & 686.8999 & 0.0019 & 1.3830 & 2710.938 & 1894.303 & 11136.686 & 2958.538 & \text { No }\end{array}$ \begin{tabular}{llllllllllllllll} 
VENQENVSNLVIEDTELK & 1.00 & 87.43 & 27.23 & 26.97 & 2 & 2360.2314 & 2360.2314 & 1181.1230 & 0.0000 & 0.0000 & 192.513 & 129.369 & 186.747 & 237.996 & Yes \\
\hline
\end{tabular} $\begin{array}{llllllllllllllll}\text { VENQENVSNLVIEDTELK } & 1.00 & 78.83 & 27.27 & 18.98 & 2 & 2360.2334 & 2360.2314 & 1181.1230 & 0.0020 & 0.8467 & 127.760 & 81.276 & 117.430 & 196.544 & \text { Yes }\end{array}$

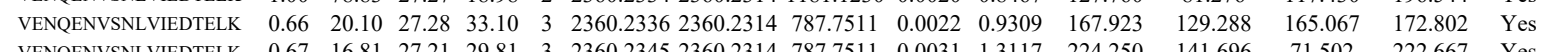
$\begin{array}{llllllllllllllll}\text { VENQENVSNLVIEDTELK } & 0.67 & 16.81 & 27.21 & 29.81 & 3 & 2360.2345 & 2360.2314 & 787.7511 & 0.0031 & 1.3117 & 224.250 & 141.696 & 71.502 & 222.667 & \text { Yes } \\ \text { GYADSPSK } & 0.95 & 26.36 & 26.90 & 20.13 & 2 & & \end{array}$

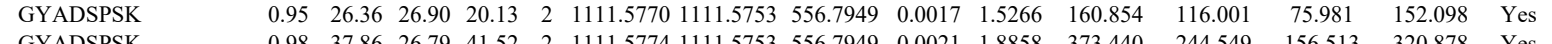

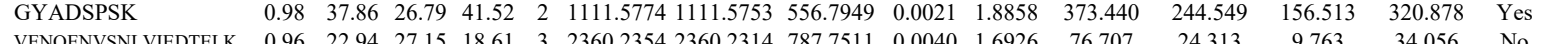

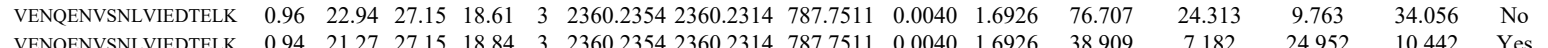

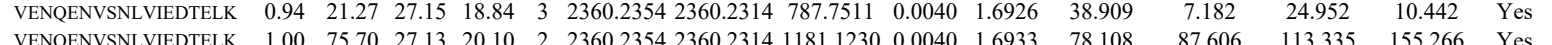

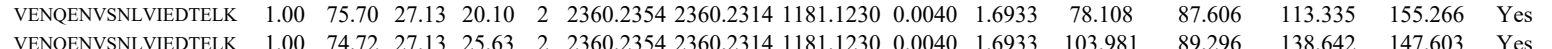

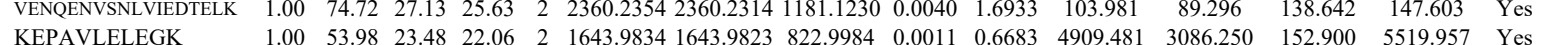

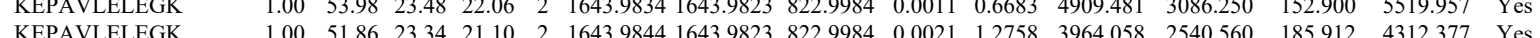

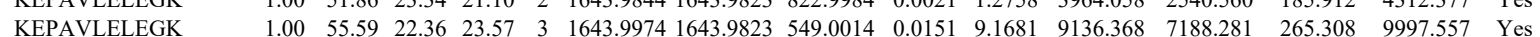

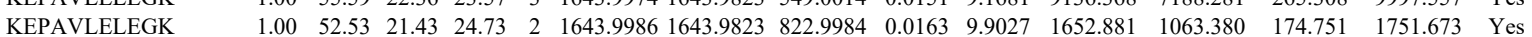

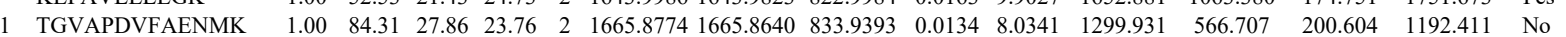

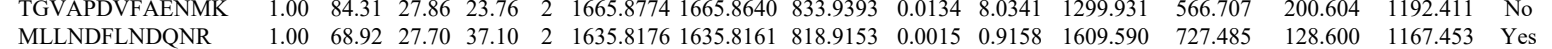
$\begin{array}{llllllllllllllll}\text { MLLNDLNDNR } & 1.00 & 68.92 & 27.76 & 37.10 & 2 & 1635.819 & 135.816 & 81.9153 & 0.0031 & 1.8927 & 4498.121 & 3271.835 & 190.620 & 3723.716 & \text { Yes }\end{array}$

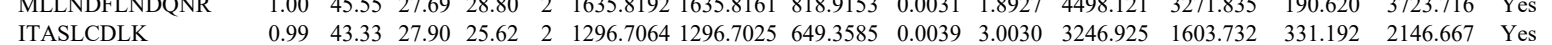

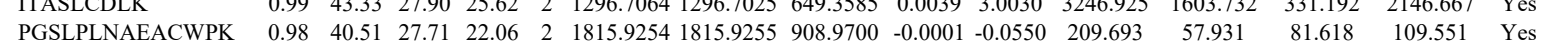

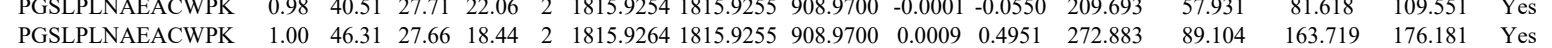

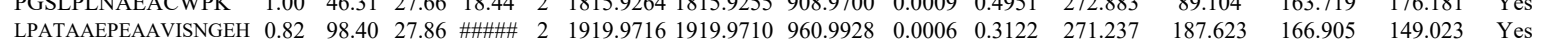
$\begin{array}{llllllllllllllll}\text { LPATAAEPEAAVISNGEH } & 1.00 & 84.49 & 27.80 & 19.55 & 2 & 1919.9730 & 1919.9710 & 960.9928 & 0.0020 & 1.0406 & 30.041 & 38.314 & 36.075 & 28.560 & \text { No }\end{array}$ $\begin{array}{lllllllllllllllll}\text { LEVGTETIIDK } & 1.00 & 59.99 & 26.34 & 24.54 & 2 & 1504.8612 & 1504.8592 & 753.4369 & 0.0020 & 1.3272 & 651.706 & 389.662 & 179.657 & 525.638 & \text { Yes }\end{array}$

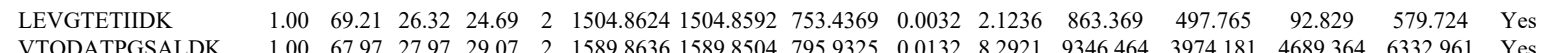
$\begin{array}{llllllllllllllll}\text { VTQDATPGSALDK } & 1.00 & 67.97 & 27.97 & 29.07 & 2 & 1589.8636 & 1589.8504 & 795.9325 & 0.0132 & 8.2921 & 9346.464 & 3974.181 & 4689.364 & 6332.961 & \text { Yes } \\ \text { VTQDATPGSALDK } & 1.00 & 63.47 & 27.87 & 26.20 & 2 & 1589.8640 & 1589.8504 & 795.9325 & 0.0136 & 85434 & 9451.627 & 4619312 & 5145.812 & 6585.139 & \text { Yes }\end{array}$

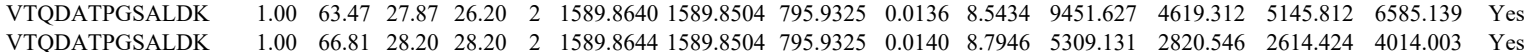
$\begin{array}{llllllllllllllll}\text { VTQDATPGSALDK } & 1.00 & 66.81 & 28.20 & 28.20 & 2 & 1589.8644 & 1589.8504 & 795.9325 & 0.0140 & 8.7946 & 5309.131 & 2820.546 & 2614.424 & 4014.003 & \text { Yes } \\ \text { GDVSNDPNFSFEGTK } & 1.00 & 80.16 & 27.48 & 25.00 & 2 & 2013.9894 & 2013.9887 & 1008.0016 & 0.0007 & 0.3472 & 376.719 & 434.692 & 577.081 & 842.495 & \text { Yes }\end{array}$ $\begin{array}{llllllllllllllllll}\text { GDVSNDDPNFSFEGTK } & 1.00 & 80.16 & 27.48 & 25.00 & 2 & 2013.9894 & 2013.9887 & 1008.0016 & 0.0007 & 0.3472 & 37.713 & 434.692 & 577.081 & 842.495 & \text { Yes } \\ \text { GDVSNDPNFSFEGTK } & 1.00 & 97.04 & 27.48 & 25.54 & 2 & 2013.9894 & 2013.9887 & 1008.0016 & 0.0007 & 0.3472 & 334.746 & 354.199 & 586.964 & 789.514 & \text { Yes }\end{array}$ $\begin{array}{llllllllllllllll}\text { GDVSNLDPNFSFEGTK } & 0.66 & 21.16 & 27.74 & 34.16 & 3 & 2013.9913 & 2013.9887 & 672.3368 & 0.0026 & 1.2890 & 543.767 & 503.922 & 146.049 & 557.628 & \text { No }\end{array}$ $\begin{array}{llllllllllllllll}\text { GDVSNLDPNFSFEGTK } & 0.54 & 10.86 & 27.75 & 18.12 & 3 & 2013.9916 & 2013.9887 & 672.3368 & 0.0029 & 1.4378 & 228.964 & 233.555 & 141.741 & 263.215 & \text { Yes }\end{array}$

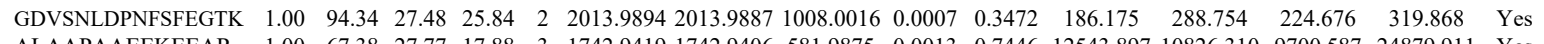

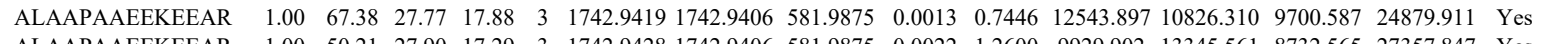
$\begin{array}{lllllllllllllllll}\text { ALAAPAAEEKEEAR } & 1.00 & 50.21 & 27.90 & 17.29 & 3 & 1742.9428 & 1742.9406 & 581.9875 & 0.0022 & 1.2600 & 9929.902 & 13345.561 & 8732.565 & 27357.847 & \text { Yes }\end{array}$

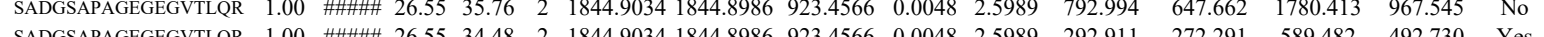

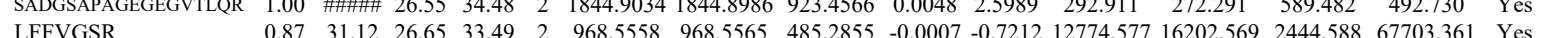

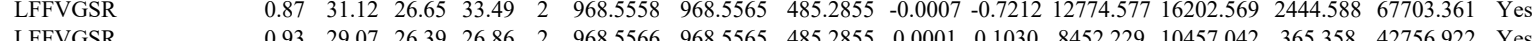

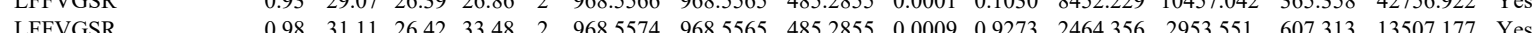

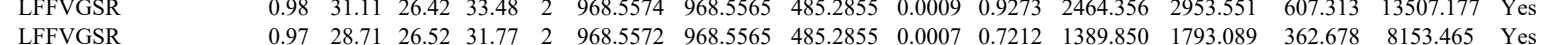



$\begin{array}{llllllllllllllll}\text { ALAAPAAEEKEEAR } & 1.00 & 62.61 & 27.77 & 20.56 & 3 & 1742.9419 & 1742.9406 & 581.9875 & 0.0013 & 0.7446 & 8038.895 & 11501.659 & 8656.364 & 23671.030 & \text { Yes }\end{array}$

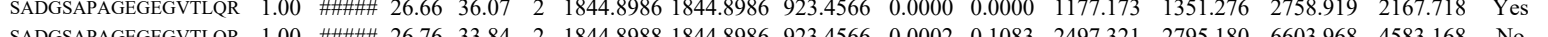

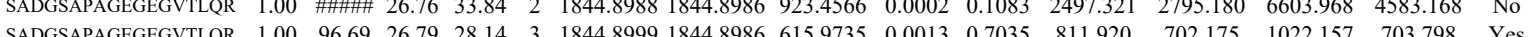

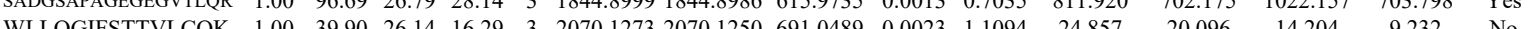

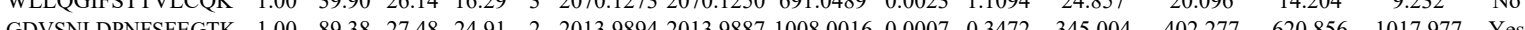

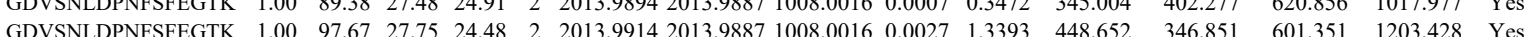

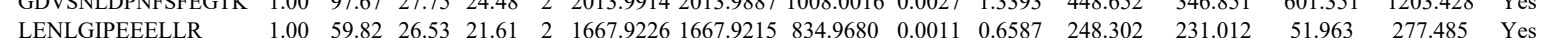
$\begin{array}{llllllllllllll}\text { TISPPHVP } & 27.485 & \text { Yes }\end{array}$

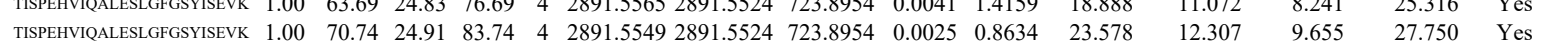

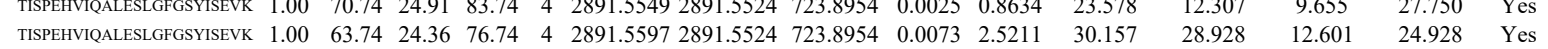

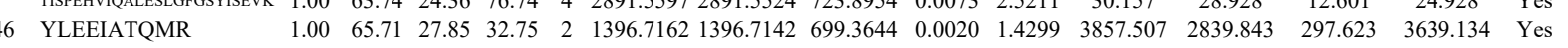

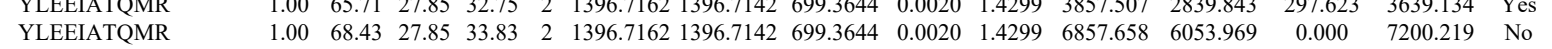
$\begin{array}{llllllllllllllllll}\text { YLEEIATQMR } & 1.00 & 65.89 & 27.83 & 32.26 & 2 & 1396.7170 & 1396.7142 & 699.3644 & 0.0028 & 2.0018 & 7613.579 & 5918.806 & 199.766 & 8649.080 & \text { Yes }\end{array}$ $\begin{array}{lllllllllllllllll}\text { YLEEIATQMR } & 1.00 & 51.17 & 27.69 & 27.49 & 2 & 1396.7142 & 1396.7142 & 699.3644 & 0.0000 & 0.0000 & 2869.513 & 2020.934 & 372.067 & 3281.862 & \text { Yes }\end{array}$ $\begin{array}{lllllllllllllllll}\text { NVIFQPVAELK } & 1.00 & 57.39 & 23.46 & 26.38 & 2 & 1544.9196 & 1544.9170 & 773.4658 & 0.0026 & 1.6807 & 1325.732 & 1144.544 & 0.000 & 1463.796 & \text { No }\end{array}$ $\begin{array}{llllllllllllllll}\text { NVIFQPVAELK } & 1.00 & 49.51 & 23.46 & 24.02 & 2 & 1544.9198 & 1544.9170 & 773.4658 & 0.0028 & 1.8100 & 3839.940 & 3132.613 & 102.189 & 3603.077 & \text { Yes }\end{array}$ $\begin{array}{lllllllllllllllll}\text { FLEHLSGAGK } & 0.93 & 31.91 & 29.37 & 22.96 & 3 & 1345.7704 & 1345.7598 & 449.5939 & 0.0106 & 7.8589 & 9915.678 & 8831.173 & 515.783 & 12471.465 & \text { Yes }\end{array}$ $\begin{array}{llllllllllllllll}\text { FLEHLSGAGK } & 1.00 & 53.91 & 29.30 & 32.38 & 2 & 1345.7716 & 1345.7598 & 673.8872 & 0.0118 & 8.7551 & 7683.001 & 6118.971 & 1035.824 & 7476.605 & \text { Yes }\end{array}$

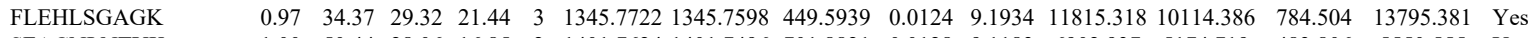
$\begin{array}{llllllllllllllll}\text { SFAGNLNTYK } & 1.00 & 50.44 & 28.06 & 16.85 & 2 & 1401.7624 & 1401.7496 & 701.8821 & 0.0128 & 9.1183 & 6902.937 & 5174.719 & 483.806 & 5550.555 & \text { Yes }\end{array}$

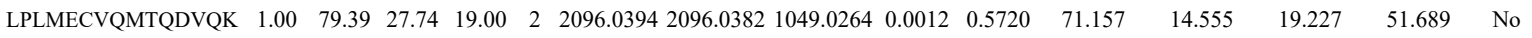
$\begin{array}{lllllllllllllllll}\text { LPLMECVQMTQDVQK } & 1.00 & 32.58 & 27.72 & 22.80 & 3 & 2096.0404 & 2096.0382 & 699.6867 & 0.0022 & 1.0481 & 191.228 & 223.777 & 220.084 & 261.659 & \text { Yes }\end{array}$

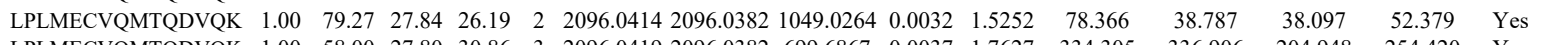
$\begin{array}{llllllllllllllll}\text { LPLMECVQMTQDVQK } & 1.00 & 58.00 & 27.80 & 30.86 & 3 & 2096.0419 & 2096.0382 & 699.6867 & 0.0037 & 1.7627 & 334.305 & 336.906 & 204.948 & 254.420 & \text { Yes }\end{array}$

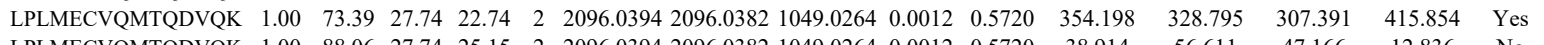

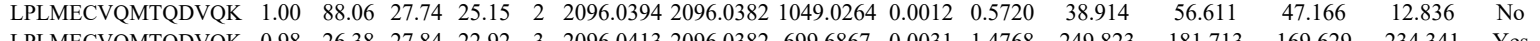

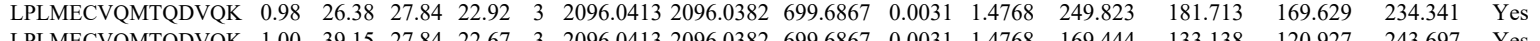

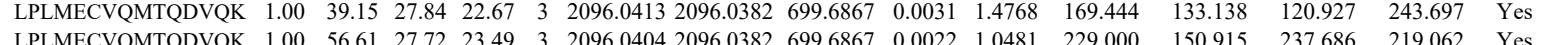

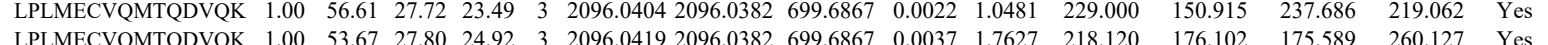
$\begin{array}{lllllllllllll} & 175.589 & 260.127 & \text { Yes }\end{array}$ $\begin{array}{lllllllllllllll} & \text { HEV }\end{array}$

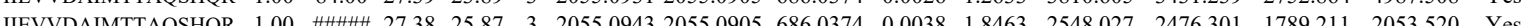

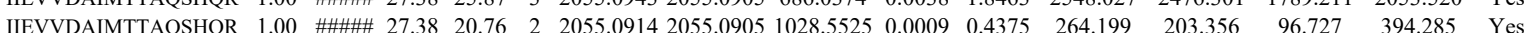
$\begin{array}{llllllllllllllll}\text { IIEVVDAIMTTAQSHQR } & 1.00 & 76.64 & 27.39 & 21.84 & 3 & 2055.0931 & 2055.0905 & 686.0374 & 0.0026 & 1.263 & 2205.458 & 1915.242 & 1195.070 & 2595.264 & \text { Yes }\end{array}$

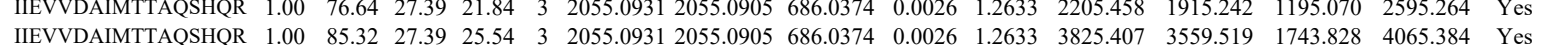
$\begin{array}{llllllllllllllllll} & \text { IIEVVVDAIMTTAQSHOR } & 1.00 & \# \# \# \# 27.39 & 26.79 & 3 & 2055.0931 & 2055.0905 & 686.0374 & 0.0026 & 1.2633 & 961.151 & 835.103 & 509.987 & 907.505 & \text { Yes }\end{array}$

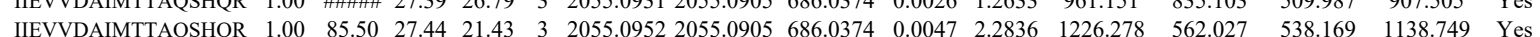
$\begin{array}{lllllllllllllllll}\text { AACNLLQR } & 0.93 & 33.49 & 28.31 & 19.80 & 2 & 1077.5642 & 1077.5545 & 539.7845 & 0.0097 & 8.9850 & 14896.166 & 10435.527 & 2848.645 & 16655.850 & \text { Yes }\end{array}$

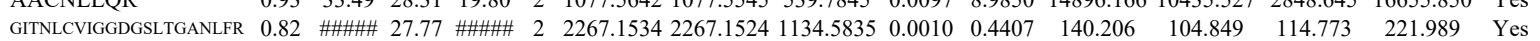

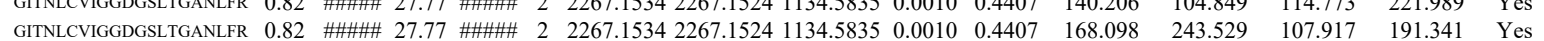
$\begin{array}{lllllllllllllllll}\text { GITNLCVIGGDGSLTGANLFR } & 0.59 & 11.73 & 27.72 & 24.73 & 3 & 2267.1547 & 2267.1524 & 756.7247 & 0.0023 & 1.0131 & 194.778 & 283.951 & 105.767 & 397.670 & \text { Yes }\end{array}$ $\begin{array}{lllllllllllllllll}\text { GITNLCVIGGDGSLTGANLFR } & 0.67 & 26.67 & 27.78 & 39.67 & 3 & 2267.1553 & 2267.1524 & 756.7247 & 0.0029 & 1.2774 & 127.845 & 173.052 & 59.477 & 133.940 & \text { Yes }\end{array}$

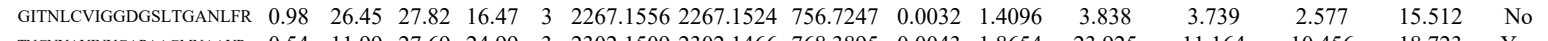

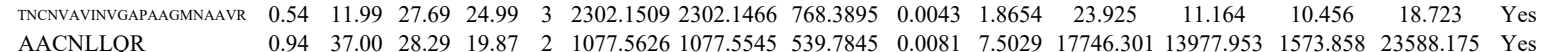

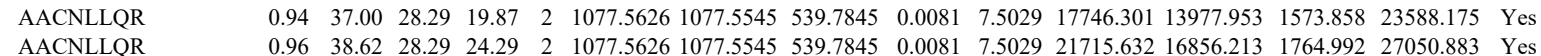
$\begin{array}{lllllllllllllllll}\text { AACNLLQR } & 0.96 & 38.62 & 28.29 & 24.29 & 2 & 1077.5626 & 1077.5545 & 539.7845 & 0.0081 & 7.5029 & 21715.632 & 16856.213 & 1764.992 & 27050.883 & \text { Yes } \\ \text { VTILGHVQR } & 0.84 & 49.18 & 24.01 & 54.51 & 2 & 1165.7092 & 1165.7053 & 583.8599 & 0.0039 & 3.3398 & 4432.498 & 4077.202 & 347.276 & 3802.756 & \text { Yes }\end{array}$ $\begin{array}{lllllllllllllllll} & \\ \text { GITNLCVIGGDGSLTGANLFR } & 0.84 & 1.00 & \text { \#\#\#\# } 27.77 & 21.66 & 2 & 2267.1534 & 2267.1524 & 1134.5835 & 0.0010 & 0.4407 & 148.943 & 148.967 & 86.571 & 128.574 & \text { Yes }\end{array}$ $\begin{array}{lllllllllllllll}\text { GITNLCVIGGDGSLTGANLFR } & 1.00 & \text { \#\#.77 } & 21.43 & 2 & 2267.1534 & 2267.1524 & 1134.5835 & 0.0010 & 0.4407 & 125.078 & 116.054 & 74.045 & 142.273 & \text { Yes }\end{array}$

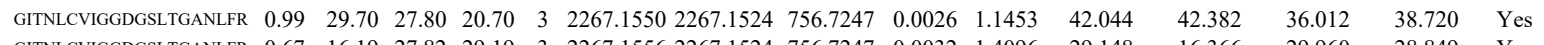

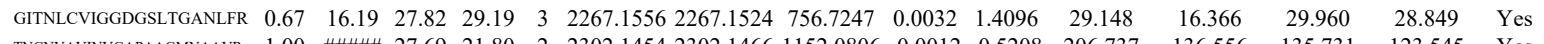

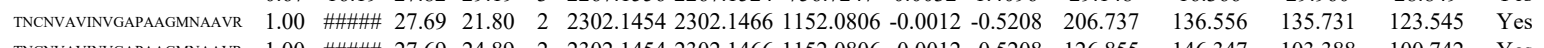

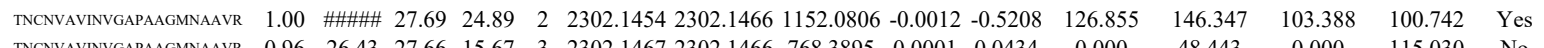

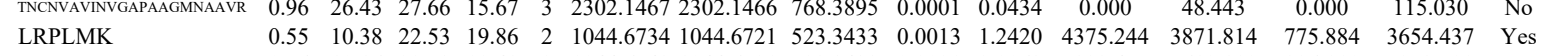
$\begin{array}{llllllllllllllll}\text { LRPLMK } & 0.55 & 10.38 & 22.53 & 19.86 & 2 & 1044.6734 & 1044.6721 & 523.3433 & 0.0013 & 1.2420 & 4375.244 & 3871.814 & 775.884 & 3654.437 & \text { Yes } \\ \text { LRPLMK } & 0.56 & 10.16 & 22.53 & 19.48 & 2 & 1044.6742 & 1044.6721 & 523.3433 & 0.0021 & 2.0063 & 5822.475 & 5619.110 & 896.110 & 5252.799 & \text { Yes }\end{array}$

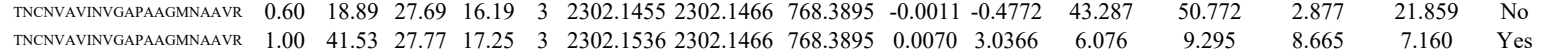

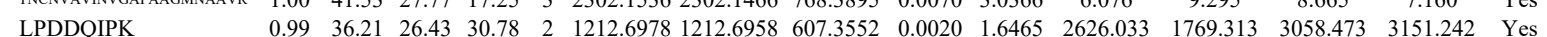



$\begin{array}{llllllllllllll}\text { DDLIASILSEVAPTPLDELR } & 1.00 & 98.34 & 26.17 & 33.74 & 2 & 2310.2454 & 2310.2440 & 1156.1293 & 0.0014 & 0.6055 & 17.68\end{array}$

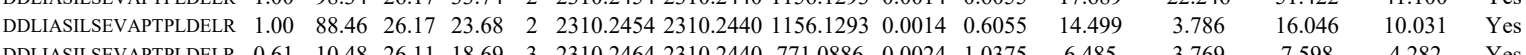

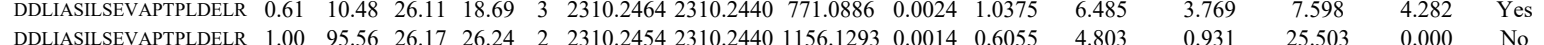

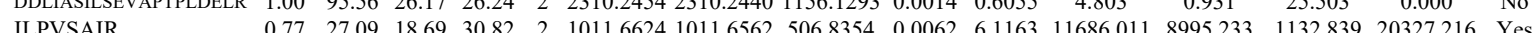
$\begin{array}{llllllllllllll} & \end{array}$ $\begin{array}{llllllllllllllll} & 0.87 & 40.72 & 19.08 & 53.72 & 2 & 1211.7744 & 1211.7723 & 66.8934 & 0.0021 & 1.7301 & 2686.045 & 2179.749 & 25.502 & 3633.088 & \text { Yes } \\ \text { VVLPTLASLR } & 0.72 & 37.23 & 19.14 & 50.23 & 2 & 121.7750 & 12117723 & 606.8934 & 0.0027 & 22244 & 4527.481 & 3467.219 & 208.860 & 6302.077 & \text { Yes }\end{array}$

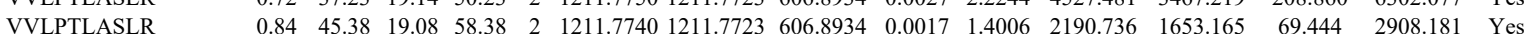
$\begin{array}{llllllllllllllll}\text { VVLPLASLR } & 0.84 & 45.38 & 19.08 & 58.38 & 2 & 1211.7740 & 1211.7723 & 66.894 & 0.0017 & 1.4006 & 2190.736 & 1653.159 & 69.444 & 2908.181 & \text { Yes } \\ \text { VVLPTLASLR } & 0.84 & 43.03 & 19.08 & 56.03 & 2 & 1211.7740 & 1211.7723 & 606.8934 & 0.0017 & 1.4006 & 1877.966 & 1365.590 & 44.014 & 2024.640 & \text { Yes }\end{array}$

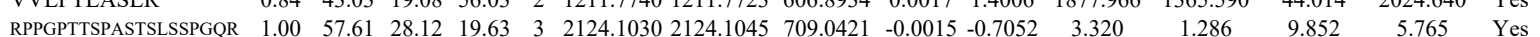

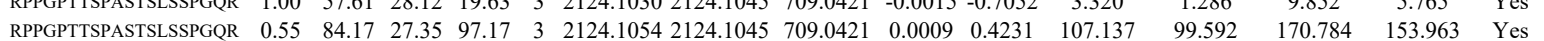
$\begin{array}{llllllllllllllll}\text { RPPGPTTSPASTSLSSPGQR } & 0.66 & 73.30 & 27.38 & 86.30 & 3 & 2124.1066 & 2124.1045 & 709.0421 & 0.0021 & 0.9872 & 129.842 & 167.536 & 188.255 & 142.908 & \text { Yes }\end{array}$ $\begin{array}{lllllllllllllllll}\text { RPPGPTTSPASTSLSSPGQR } & 0.55 & 67.35 & 27.38 & 80.35 & 3 & 2124.1057 & 2124.1045 & 709.0421 & 0.0012 & 0.5641 & 13.604 & 25.751 & 15.247 & 15.255 & \text { No }\end{array}$ $\begin{array}{llllllllllllllllll}\text { LVAGQQQVLQQLAEEEPK } & 1.00 & 38.93 & 24.61 & 21.68 & 3 & 2295.2695 & 2295.2678 & 766.0965 & 0.0017 & 0.7397 & 277.092 & 338.603 & 92.273 & 390.814 & \text { Yes }\end{array}$ $\begin{array}{llllllllllllllll}\text { LVAGQQQVLQQLAEEEPK } & 1.00 & 63.59 & 24.58 & 22.39 & 3 & 2295.2710 & 2295.2678 & 766.0965 & 0.0032 & 1.3923 & 160.921 & 121.539 & 122.503 & 214.184 & \text { Yes }\end{array}$

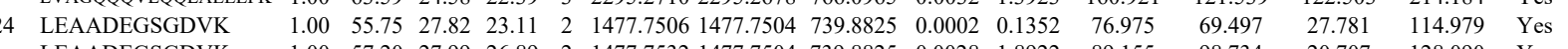
$\begin{array}{llllllllllllllll}\text { LEAADEGSGDVK } & 1.00 & 57.20 & 27.99 & 26.89 & 2 & 1477.7532 & 1477.7504 & 739.8825 & 0.0028 & 1.8922 & 89.155 & 98.734 & 20.707 & 128.090 & \text { Yes }\end{array}$ $\begin{array}{llllllllllllllll}\text { FLQMCNDDPDVLPDLK } & 0.59 & 10.67 & 26.76 & 17.25 & 3 & 2196.0535 & 2196.0509 & 733.0242 & 0.0026 & 1.1823 & 52.070 & 12.868 & 37.987 & 32.038 & \text { No }\end{array}$ $\begin{array}{lllllllllllllllll}\text { FLQMCNDDPDVLPDLK } & 0.96 & 22.85 & 26.76 & 17.34 & 3 & 2196.0547 & 2196.0509 & 733.0242 & 0.0038 & 1.7280 & 28.110 & 23.591 & 20.472 & 19.917 & \text { Yes }\end{array}$ $\begin{array}{llllllllllllllll} & \text { Fes }\end{array}$ $\begin{array}{llllllllllllllll}\text { FLQMCNDDPDVLPDLK } & 1.00 & 38.90 & 26.76 & 20.75 & 3 & 2196.0547 & 2196.0509 & 733.0242 & 0.0038 & 1.7280 & 46.523 & 70.000 & 15.055 & 42.102 & \text { No }\end{array}$ $\begin{array}{llllllllllllllll} & & & \end{array}$ $\begin{array}{llllllllllllllll} & & & \end{array}$ $\begin{array}{llllllllllllllll} & \\ \text { FGLEGCEVLIPALK } & 1.00 & 69.75 & 26.62 & 29.65 & 2 & 1822.0006 & 1821.9976 & 912.0061 & 0.0030 & 1.6447 & 275.932 & 232.180 & 0.000 & 390.932 & \text { No }\end{array}$ IEQLSPFPLLLK IEQLSPFPFDLLK TEQLSPFPFDLLLK QLSPFIL IEQLSPFPFDLLLK

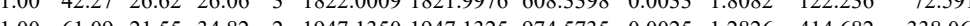
$\begin{array}{llllllllllll}1.00 & 61.09 & 21.55 & 34.82 & 2 & 1947.1350 & 1947.1325 & 974.5735 & 0.0025 & 1.2826 & 414.682 & 338.064\end{array}$ $\begin{array}{lllllllllllll}1.00 & 4.08 & 21.55 & 24.83 & 3 & 1947.1354 & 1947.1325 & 650.0514 & 0.0029 & 1.4871 & 99.512 & 155.025\end{array}$ $\begin{array}{lllllllllllll}1.00 & 62.68 & 21.55 & 26.60 & 2 & 1947.1360 & 1947.1325 & 974.5735 & 0.0035 & 1.7957 & 461.563 & 513.926\end{array}$

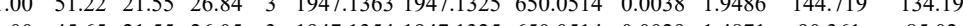
$\begin{array}{llllllllllllll}1.00 & 45.65 & 21.55 & 26.05 & 3 & 1947.1354 & 1947.1325 & 650.0514 & 0.0029 & 1.4871 & 90.361 & 85.024\end{array}$

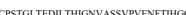

AKPVWYAGR AKPVWYAGR $\begin{array}{lllllllll} & \end{array}$

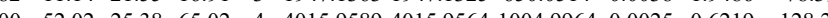

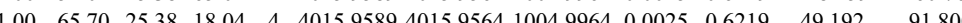
\begin{tabular}{lll}
1.087 & 129.418 & Yes \\
\hline 452 & 524.196 & Yes
\end{tabular} $\begin{array}{lll}41.452 & 524.196 & \text { Yes } \\ 27.993 & 183.417 & \text { Yes } \\ 62.400 & 802.813 & \text { Yes }\end{array}$

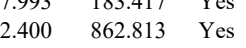
\begin{tabular}{lll}
862.813 & Yes \\
211.785 & Yes \\
\hline 7.019 & -100 \\
\hline
\end{tabular} \begin{tabular}{lll}
71.148 & 125.314 & Yes \\
\hline & 121.134 &
\end{tabular} $\begin{array}{lll}8.105 & 141.134 & \text { No }\end{array}$ $\begin{array}{llll} & -1 \\ 193.114 & 235.078 & \text { Yes }\end{array}$ $\begin{array}{llllllllllllll} & 1334.7742 & 1334.7703 & 445.9307 & 0.0039 & 2.9152 & 3965.290 & 3454.602 & 1759.662 & 3820.528 & \text { Yes } \\ \end{array}$ $\begin{array}{lllllllllllllll}1.00 & 71.48 & 25.54 & 33.93 & 3 & 1334.7745 & 1334.7703 & 445.9307 & 0.0042 & 3.1395 & 5907.569 & 6362.083 & 1831.639 & 7383.150 & \text { Yes }\end{array}$

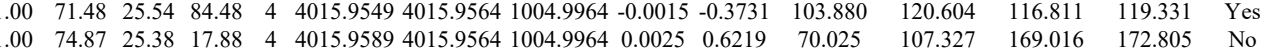

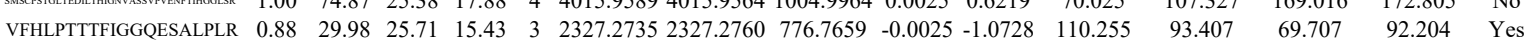
$\begin{array}{llllllllllllllll}\text { VFHLPTTTFIGGQESALPLR } & 1.00 & 28.99 & 25.33 & 16.84 & 3 & 2327.2786 & 2327.2760 & 776.7659 & 0.0026 & 1.1157 & 83.645 & 166.144 & 138.821 & 84.786 & \text { No }\end{array}$

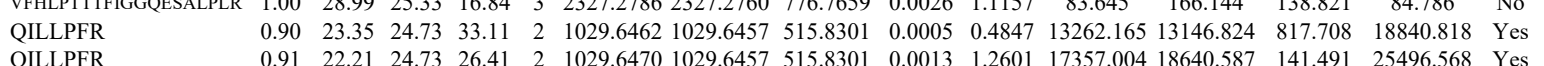

LNVLANVIR

LNVLANVIR

LNVLANVIR

LNVLANVIR

VIPEDGPAAQNPENYK LGFYGLDESDLDK

ASSVETKPGASK ASSVETKPGASK GGVSLAALK GGVSLAALK ASSVETKPGASK ASSVETKPGASK DLTTAGAVTQCYR IFAPNHVVAK IFAPNHVVAK IFAPNHVAK IFAPNHVVAK $\begin{array}{llllllllllllllll}0.91 & 22.21 & 24.73 & 26.41 & 2 & 1029.6470 & 1029.6457 & 515.8301 & 0.0013 & 1.2601 & 17357.004 & 18640.587 & 141.491 & 25496.568 & \text { Yes } \\ 1.00 & 39.94 & 21.21 & 21.91 & 2 & 1154.7264 & 1154.7257 & 578.3701 & 0.0007 & 0.6051 & 2803.174 & 2797.182 & 330.027 & 3682.182 & \text { Yes }\end{array}$ $\begin{array}{lllllllllllllll}1.00 & 51.10 & 21.21 & 21.56 & 2 & 1154.7264 & 1154.7257 & 578.3701 & 0.0007 & 0.6051 & 1897.112 & 1776.694 & 183.533 & 2428.270 & \text { Yes }\end{array}$

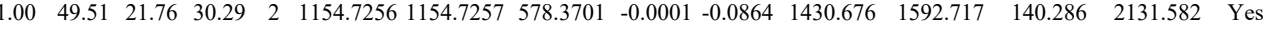
$\begin{array}{lllllllllllllll}1.00 & 48.42 & 21.21 & 25.59 & 2 & 1154.7264 & 1154.7257 & 578.3701 & 0.0007 & 0.6051 & 1017.201 & 1149.846 & 148.992 & 1387.711 & \text { Yes }\end{array}$ $\begin{array}{lllllllllllllll}1.00 & 76.92 & 27.54 & 26.35 & 2 & 1965.0488 & 1965.0411 & 983.5278 & 0.0077 & 3.9145 & 561.043 & 497.561 & 363.880 & 666.804 & \text { Yes }\end{array}$ $\begin{array}{lllllllllllllll}1.00 & 56.19 & 27.51 & 22.59 & 2 & 1758.8920 & 1758.8920 & 880.4533 & 0.0000 & 0.0000 & 1037.427 & 702.411 & 59.432 & 1081.280 & \text { Yes }\end{array}$

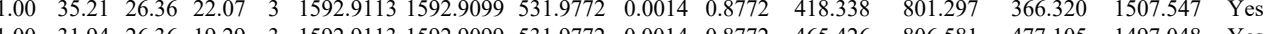
$\begin{array}{lllllllllllllll}1.00 & 31.94 & 26.36 & 19.29 & 3 & 1592.9113 & 1592.9099 & 531.9772 & 0.0014 & 0.8772 & 465.426 & 806.581 & 477.105 & 1497.048 & \text { Yes }\end{array}$ $\begin{array}{llllllllllllllll}1.00 & 56.42 & 25.09 & 31.47 & 2 & 1102.7014 & 1102.6954 & 552.3550 & 0.0060 & 5.4313 & 3554.243 & 5322.342 & 3492.752 & 6652.764 & \text { Yes }\end{array}$

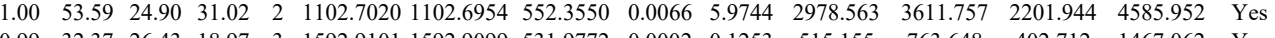
$\begin{array}{lllllllllllllll}0.99 & 32.37 & 26.43 & 18.97 & 3 & 1592.9101 & 1592.9099 & 531.9772 & 0.0002 & 0.1253 & 515.155 & 763.648 & 402.712 & 1467.062 & \text { Yes }\end{array}$

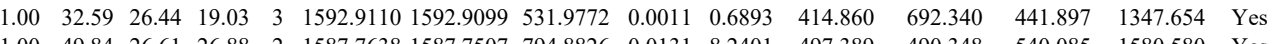

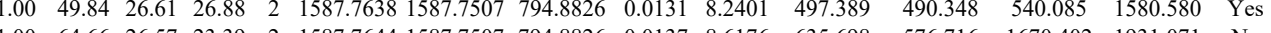

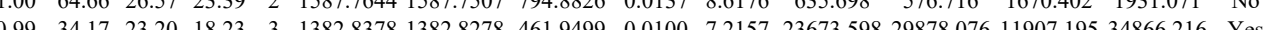

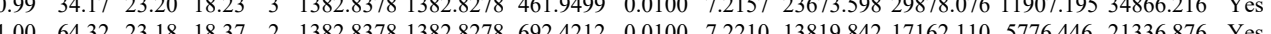

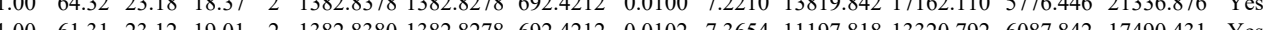
$\begin{array}{lllllllllllllll}0.65 & 17.10 & 23.12 & 18.94 & 3 & 1382.8381 & 1382.8278 & 461.949 & 0.0103 & 7.4322 & 51193.322 & 60059.875 & 27570383 & 79886.445 & \text { Yes }\end{array}$ $\begin{array}{lllllllllllllll}1.00 & 49.05 & 23.48 & 16.75 & 2 & 1382.8374 & 1382.8278 & 692.4212 & 0.0096 & 6.9321 & 5338.226 & 5226.515 & 2136.493 & 7922.777 & \text { Yes }\end{array}$ 

$\begin{array}{lllllllllllllllll}0.53 & 14.92 & 22.62 & 14.28 & 3 & 1382.8402 & 1382.8278 & 461.9499 & 0.0124 & 8.9475 & 8745.661 & 9366.511 & 4460.611 & 10976.176 & \text { Yes }\end{array}$ $\begin{array}{llllllllllllllll}0.68 & 23.55 & 26.42 & 19.90 & 2 & 1175.5804 & 1175.5701 & 588.7923 & 0.0103 & 8.7466 & 4409.024 & 2228.052 & 1688.594 & 8057.212 & \text { Yes } & \\ \end{array}$

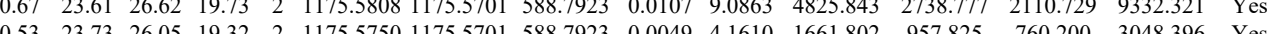

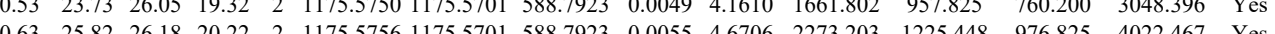

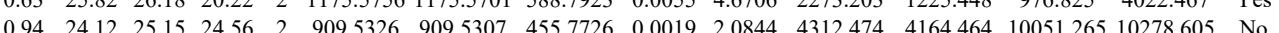

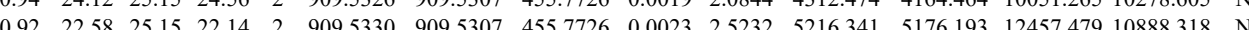

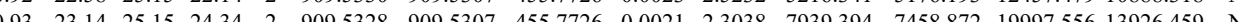

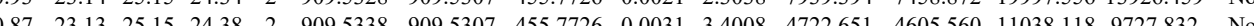
$\begin{array}{llllllllllllllll}0.81 & 21.19 & 25.15 & 20.98 & 2 & 909.5332 & 909.5307 & 455.7726 & 0.0025 & 2.7426 & 5127.073 & 6032.152 & 12951.983 & 11159.771 & N 0 & 0\end{array}$ $\begin{array}{llllllllllllllll}0.87 & 23.36 & 25.15 & 25.38 & 2 & 909.5334 & 909.5307 & 455.7726 & 0.0027 & 2.9620 & 3395.323 & 3627.750 & 7880.951 & 7245.420 & \mathrm{No}\end{array}$ $\begin{array}{lllllllllllllll}0.82 & 18.49 & 25.15 & 23.82 & 2 & 909.5326 & 909.5307 & 455.7726 & 0.0019 & 2.0844 & 3456.457 & 3237.019 & 5405.612 & 5431.293 & \text { Yes }\end{array}$

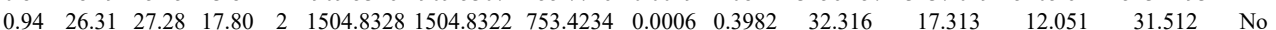
$\begin{array}{llllllllllllllll}1.00 & 56.40 & 27.47 & 25.12 & 2 & 1504.8338 & 1504.8322 & 753.4234 & 0.0016 & 1.0618 & 8086.510 & 7038.686 & 4606.436 & 17069.881 & \text { Yes }\end{array}$ \begin{tabular}{lllllllllllllllll}
1.00 & 42.08 & 27.47 & 24.68 & 2 & 15048340 & 15048322 & 753.4234 & 0.0018 & 1.1945 & 2881.717 & 3427.694 & 2466.079 & 6841.717 & Yes \\
\hline
\end{tabular}

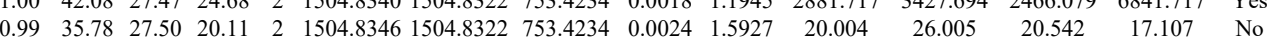
$\begin{array}{lllllllllllllll}0.93 & 20.24 & 27.51 & 19.43 & 3 & 1504.8352 & 1504.8322 & 502.6180 & 0.0030 & 1.9896 & 144.349 & 145.158 & 165.339 & 269.906 & \text { Yes }\end{array}$ $\begin{array}{lllllllllllllll}0.85 & 16.73 & 27.44 & 22.66 & 3 & 1504.8355 & 1504.8322 & 502.6180 & 0.0033 & 2.1885 & 122.978 & 61.199 & 20.859 & 103.505 & \text { No }\end{array}$ $\begin{array}{llllllllllllllll}0.88 & 33.73 & 27.56 & 18.36 & 2 & 1504.8368 & 1504.8322 & 753.4234 & 0.0046 & 3.0527 & 19.417 & 18.552 & 5.730 & 58.564 & \text { Yes }\end{array}$ $\begin{array}{lllllllllllllll}0.99 & 37.75 & 27.72 & 23.78 & 2 & 1048.5952 & 1048.5940 & 525.3043 & 0.0012 & 1.1422 & 944.480 & 957.454 & 168.812 & 2470.506 & \text { Yes }\end{array}$

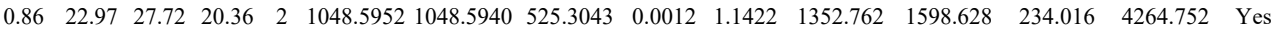
$\begin{array}{lllllllllllllll}0.60 & 16.63 & 27.72 & 19.83 & 2 & 1048.5952 & 1048.5940 & 525.3043 & 0.0012 & 1.1422 & 63.476 & 85.644 & 36.048 & 106.086 & \text { Yes }\end{array}$

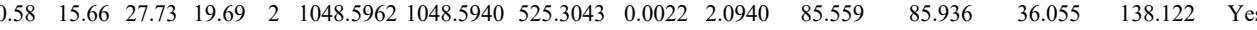

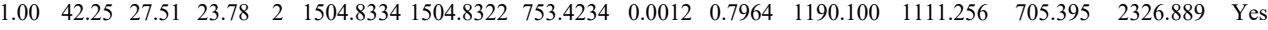

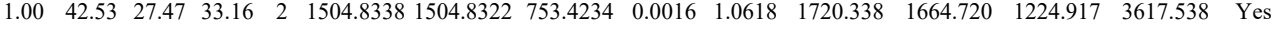

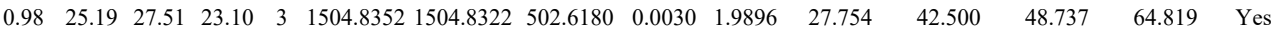

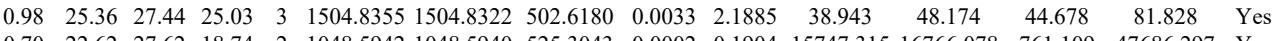
$\begin{array}{lllllllllllllll}0.70 & 22.62 & 27.62 & 18.74 & 2 & 1048.5942 & 1048.5940 & 525.3043 & 0.0002 & 0.1904 & 15747.315 & 16766.078 & 761.109 & 47686.297 & \text { Yes }\end{array}$

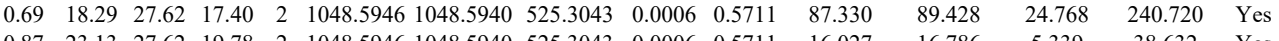

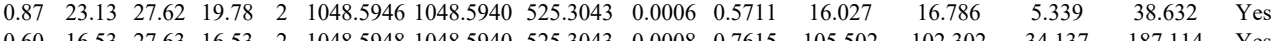

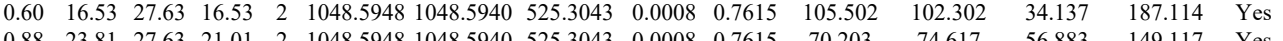
$\begin{array}{lllllllllllllll}0.88 & 23.81 & 27.63 & 21.01 & 2 & 1048.5948 & 1048.5940 & 525.3043 & 0.0008 & 0.7615 & 70.203 & 74.617 & 56.883 & 149.117 & \text { Yes } \\ 0.85 & 22.71 & 27.72 & 18.89 & 2 & 1048.5950 & 1048.5940 & 525.3043 & 0.0010 & 0.9518 & 30056.880 & 30787.691 & 1.155 & 92198.074 & \text { Ne }\end{array}$

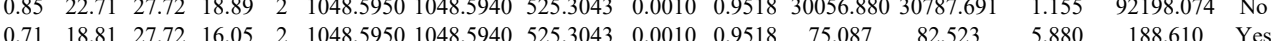

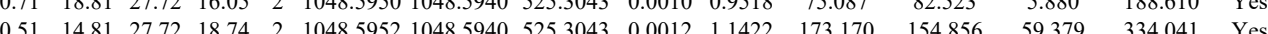

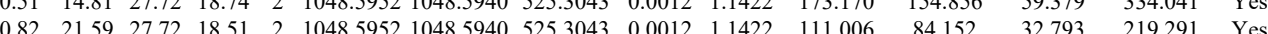

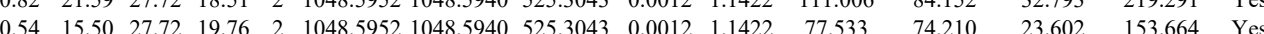

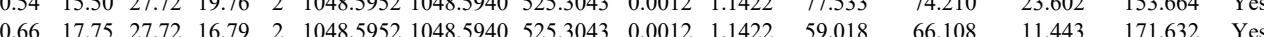
$\begin{array}{lllllllllllllll}1.00 & 56.41 & 27.28 & 25.39 & 2 & 1504.8326 & 1504.8322 & 753.4234 & 0.0004 & 0.2655 & 58.032 & 57.881 & 21.101 & 127.863 & \text { Yes }\end{array}$ $\begin{array}{lllllllllllllll}1.00 & 56.41 & 27.28 & 25.39 & 2 & 1504.8326 & 1504.8322 & 753.423 & 0.0004 & 0.2655 & 58.032 & 57.881 & 21.101 & 127.863 & \text { Yes } \\ 1.00 & 43.53 & 27.27 & 24.31 & 2 & 1504.8330 & 1504.8322 & 753.4234 & 0.0008 & 0.5309 & 103.431 & 159.804 & 56.163 & 220.867 & \text { Yes }\end{array}$

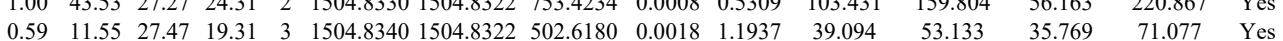

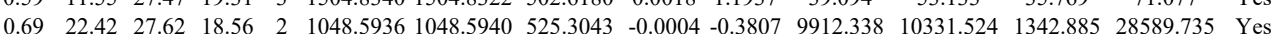
$\begin{array}{llllllllllllllll}0.73 & 23.46 & 27.62 & 21.61 & 2 & 1048.5944 & 1048.5940 & 525.3043 & 0.0004 & 0.3807 & 13349.469 & 15457.981 & 1815.750 & 37283.720 & \text { Yes }\end{array}$

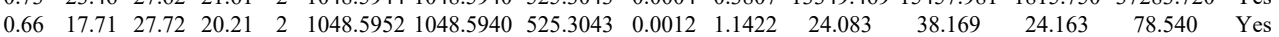
$\begin{array}{lllllllllllllll}0.61 & 16.68 & 27.72 & 17.53 & 2 & 1048.5954 & 1048.5940 & 525.3043 & 0.0014 & 1.3326 & 34.501 & 43.826 & 27.803 & 92.786 & \text { Yes }\end{array}$ $\begin{array}{llllllllllllllll}0.65 & 17.07 & 27.73 & 15.77 & 2 & 1048.5958 & 1048.5940 & 525.3043 & 0.0018 & 1.7133 & 70.278 & 65.360 & 28.377 & 145.760 & \text { Yes }\end{array}$ $\begin{array}{lllllllllllllll}0.56 & 20.98 & 19.24 & 18.42 & 3 & 1294.8130 & 1294.8117 & 432.6112 & 0.0013 & 1.0017 & 7012.740 & 7206.953 & 5565.047 & 9453.045 & \text { Yes }\end{array}$ $\begin{array}{lllllllllllllll}0.53 & 23.74 & 27.45 & 20.59 & 2 & 1048.5930 & 1048.5940 & 525.3043 & -0.0010 & -0.9518 & 1458.459 & 1509.912 & 188.698 & 4091.570 & \text { Yes }\end{array}$

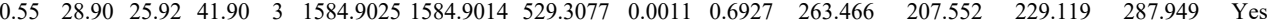
VSHKPSGLVMA VSHKPSGLVMAR

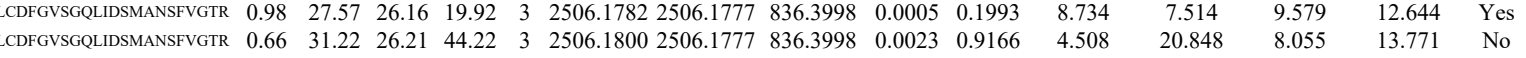
$\begin{array}{lllllllllllllll}0.94 & 19.80 & 24.84 & 19.52 & 3 & 1568.9080 & 1568.9064 & 523.9761 & 0.0016 & 1.0179 & 4180.723 & 3637.366 & 2181.714 & 4348.569 & \text { Yes }\end{array}$ $\begin{array}{llllllllllllllll} & 0.66 & 14.81 & 24.84 & 27.81 & 3 & 1568.9083 & 1568.9064 & 523.9761 & 0.0019 & 1.2087 & 3600.890 & 3259.590 & 1958.118 & 4651.761 & \text { Yes } \\ \end{array}$ $\begin{array}{llllllllllllllll} & \end{array}$

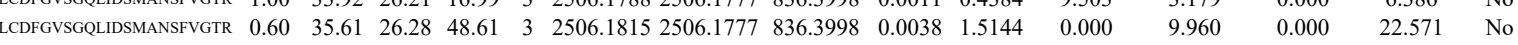

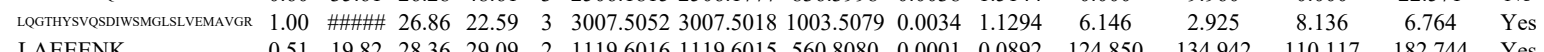

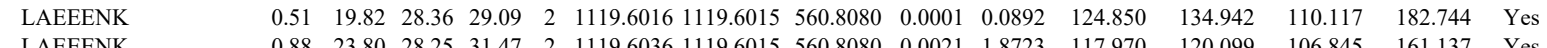

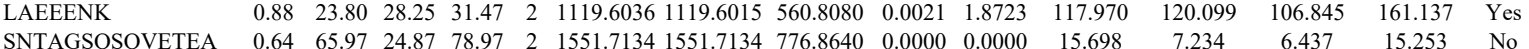
$\begin{array}{llllllllllllllll}\text { SNTAGSQSQVETEA } & 0.64 & 65.97 & 24.87 & 78.97 & 2 & 1551.7134 & 1551.7134 & 776.8640 & 0.0000 & 0.0000 & 15.698 & 7.234 & 6.437 & 15.253 & \text { No } \\ \text { SNTAGSQSQVETEA } & 0.64 & 69.96 & 24.90 & 82.96 & 2 & 1551.71361551 .7134 & 776.8640 & 0.0002 & 0.1287 & 9.826 & 15.872 & 8.995 & 23.160 & \text { Yes }\end{array}$

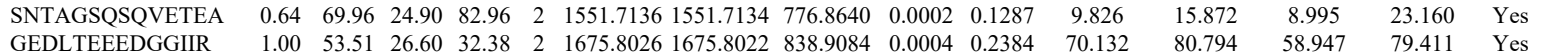
$\begin{array}{llllllllllllllll}\text { GEDLTEEEDGGIIR } & 1.00 & 53.51 & 26.60 & 32.38 & 2 & 1675.8026 & 1675.8022 & 838.9084 & 0.0004 & 0.2384 & 70.132 & 80.794 & 58.947 & 79.411 & \text { Yes } \\ \text { GEDLTEEEDGGIIR } & 1.00 & 74.64 & 26.69 & 32.39 & 2 & 1675.8032 & 1675.8022 & 838.9084 & 0.0010 & 0.5960 & 71.695 & 79.900 & 65.227 & 67.291 & \text { Yes }\end{array}$ $\begin{array}{lllllllllllllll}51.55 & 27.85 & 19.54 & 3 & 1684.8685 & 1684.8654 & 562.6291 & 0.0031 & 1.8366 & 1438.824 & 1258.030 & 1211.236 & 1253.082 & \text { Yos } & \\ \end{array}$ $\begin{array}{lllllllllllllllll}\text { GEAHLAVNDFELAR } & 1.00 & 48.38 & 27.87 & 19.04 & 3 & 1684.8700 & 1684.8654 & 562.6291 & 0.0046 & 2.7253 & 1216.349 & 1507.183 & 684.894 & 869.253 & \text { No }\end{array}$

Table S- 4 page 433 of 614 


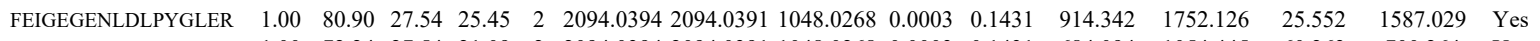
$\begin{array}{lllllllllllllllll}\text { FEIGEGENLDLPYGLER } & 1.00 & 72.24 & 27.54 & 21.09 & 2 & 2094.0394 & 2094.0391 & 1048.0268 & 0.0003 & 0.1431 & 684.094 & 1054.445 & 60.263 & 700.264 & \text { Yes }\end{array}$ $\begin{array}{llllllllllllllll}\text { AWDIAIATMK } & 0.99 & 46.65 & 28.00 & 21.66 & 2 & 1406.7818 & 1406.7835 & 704.3990 & -0.0017 & -1.2067 & 1517.821 & 1747.605 & 369.019 & 1529.806 & \text { Yes }\end{array}$ $\begin{array}{llllllllllllllll}\text { AWDIAIATMK } & 1.00 & 57.65 & 27.50 & 25.67 & 2 & 1406.7828 & 1406.7835 & 704.3990 & -0.0007 & -0.4969 & 1621.271 & 1504.048 & 407.427 & 1725.648 & \text { Yes }\end{array}$ $\begin{array}{llllllllllllllll}\text { VFVHYTGWLLDGTK } & 1.00 & 50.39 & 26.93 & 17.62 & 3 & 1923.0517 & 1923.0498 & 642.0239 & 0.0019 & 0.9865 & 6300.766 & 6611.135 & 3168.206 & 7054.894 & \text { Yes }\end{array}$

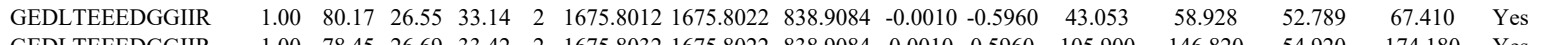

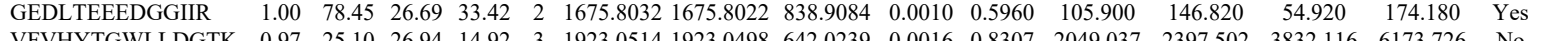
$\begin{array}{llllllllllllllll}\text { VFVHYTGWLLDGTK } & 0.97 & 25.10 & 26.94 & 14.92 & 3 & 1923.0514 & 1923.0498 & 642.0239 & 0.0016 & 0.8307 & 2049.037 & 2397.502 & 3832.116 & 6173.726 & \text { No }\end{array}$ \begin{tabular}{llllllllllllllll} 
VFVHYTGLLDGGK & 1.00 & 34.00 & 26.84 & 19.79 & 3 & 1923.0532 & 1923.0498 & 642.0239 & 0.0034 & 1.7652 & 2997.315 & 3060.557 & 2753.565 & 4403.539 & Yes \\
\hline
\end{tabular}

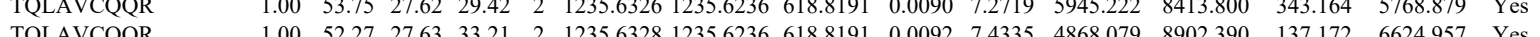

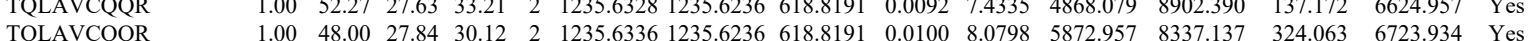

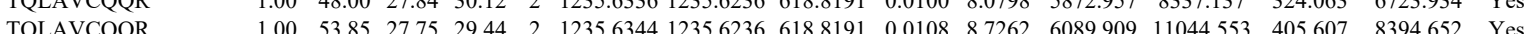

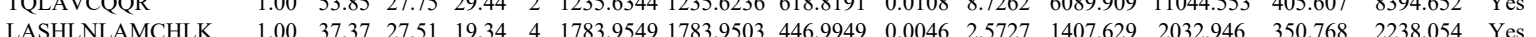

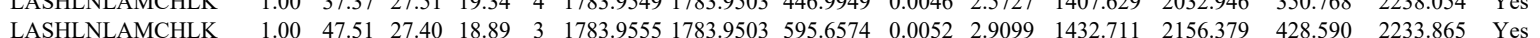
$\begin{array}{lllllllllllllllll}\text { LASHLNLAMCHLK } & 1.00 & 43.05 & 27.40 & 18.15 & 3 & 1783.9555 & 1783.9503 & 595.6574 & 0.0052 & 2.9099 & 1014.186 & 1449.307 & 438.590 & 1572.600 & \text { Yes }\end{array}$

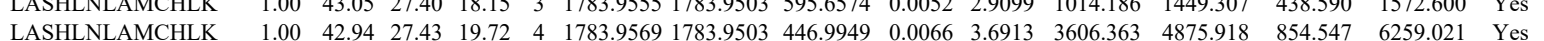
$\begin{array}{llllllllllllllll}\text { LASHLNLAMCHLK } & 1.00 & 38.77 & 27.42 & 18.54 & 4 & 1783.9585 & 1783.9503 & 446.9949 & 0.0082 & 4.5862 & 2353.446 & 2649.933 & 580.652 & 3769.648 & \text { Yes }\end{array}$ $\begin{array}{lllllllllllllllll}\text { LASHLNLAMCHLK } & 1.00 & 33.60 & 27.72 & 21.19 & 4 & 1783.9509 & 1783.9503 & 446.9949 & 0.0006 & 0.3356 & 1289.069 & 1715.897 & 315.868 & 1766.193 & \text { Yes }\end{array}$ $\begin{array}{lllllllllllllllll}\text { LASHLNLAMCHLK } & 1.00 & 44.38 & 27.72 & 19.89 & 3 & 1783.9510 & 1783.9503 & 595.6574 & 0.0007 & 0.3917 & 666.309 & 985.163 & 258.574 & 1050.750 & \text { Yes }\end{array}$ $\begin{array}{lllllllllllllllll}\text { AEASSGDHPTDTEMK } & 0.55 & 38.76 & 25.51 & 51.76 & 3 & 1862.8570 & 1862.8560 & 621.9593 & 0.0010 & 0.5359 & 253.368 & 323.594 & 163.587 & 236.543 & \text { Yes }\end{array}$ $\begin{array}{llllllllllllllllll}\text { AEASSGDHPTDTEMKEEQK } & 1.00 & 27.44 & 26.77 & 18.38 & 4 & 2521.1989 & 2521.1968 & 631.3065 & 0.0021 & 0.8316 & 4914.999 & 9001.176 & 6032.995 & 7617.002 & \text { Yes }\end{array}$ $\begin{array}{lllllllllllllllll}\text { AEASSGDHPTDTEMKEEQK } & 0.83 & 17.55 & 26.68 & 21.08 & 4 & 2521.1993 & 2521.1968 & 631.3065 & 0.0025 & 0.9900 & 4371.089 & 8084.965 & 5719.246 & 6641.088 & \text { Yes }\end{array}$ $\begin{array}{lllllllllllllllll}\text { FEIGEGENLDLPYGLER } & 1.00 & 81.17 & 27.54 & 26.94 & 2 & 2094.0394 & 2094.0391 & 1048.0268 & 0.0003 & 0.1431 & 224.859 & 458.416 & 37.518 & 334.773 & \text { Yes }\end{array}$ $\begin{array}{llllllllllllllll}\text { FEIGEGENLDLPYGLER } & 1.00 & 85.85 & 27.54 & 24.33 & 2 & 2094.0394 & 2094.0391 & 1048.0268 & 0.0003 & 0.1431 & 41.374 & 31.996 & 4.431 & 36.992 & \text { No }\end{array}$

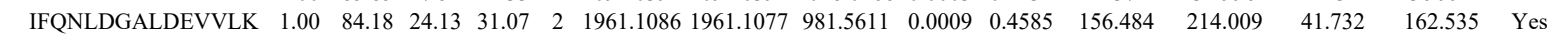

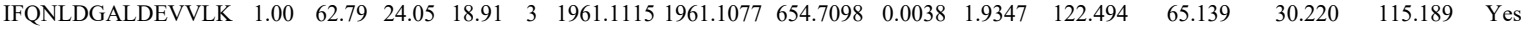

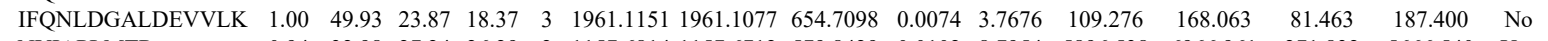
$\begin{array}{llllllllllllllll}\text { NVIAPLMTR } & 0.94 & 32.98 & 27.24 & 26.29 & 2 & 1157.6814 & 1157.6712 & 579.8429 & 0.0102 & 8.7954 & 5896.538 & 6966.961 & 271.832 & 5666.540 & \text { Yes }\end{array}$ $\begin{array}{llllllllllllllll}\text { LQLNYLGNYIPR } & 1.00 & 59.35 & 27.22 & 19.53 & 2 & 1606.8968 & 1606.8953 & 804.4549 & 0.0015 & 0.9323 & 616.263 & 775.182 & 0.000 & 420.897 & \text { No }\end{array}$ $\begin{array}{llllllllllllllll}\text { LQLNYLGNYIPR } & 1.00 & 60.59 & 26.99 & 22.44 & 2 & 1606.8984 & 1606.8953 & 804.4549 & 0.0031 & 1.9268 & 616.590 & 624.728 & 8.932 & 316.606 & \text { Yes }\end{array}$ \begin{tabular}{llllllllllllllll} 
LQLNYLGNYIPR & 1.00 & 68.23 & 27.21 & 24.18 & 2 & 1606.8964 & 1606.8953 & 804.4549 & 0.0011 & 0.6837 & 167.054 & 149.959 & 5.397 & 122.202 & Yes \\
\hline
\end{tabular}

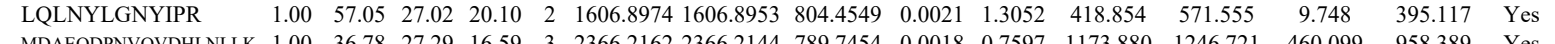

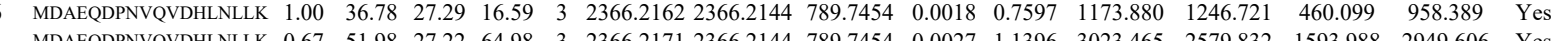
\begin{tabular}{lllllllllllllllll} 
MDAEQDPNVQVDHLNLLK & 0.67 & 51.98 & 27.22 & 64.98 & 3 & 2366.2171 & 2366.2144 & 789.7454 & 0.0027 & 1.1396 & 3023.465 & 2579.832 & 1593.988 & 2949.606 & Yes \\
\hline YLQEVIDVLETDGHFR & 1.00 & 93.31 & 28.22 & 31.76 & 3 & 2077.0582 & 2077.0602 & 693.3607 & -0.0020 & -0.9615 & 363.541 & 357.008 & 67.13 & 399.877 & Yes
\end{tabular}

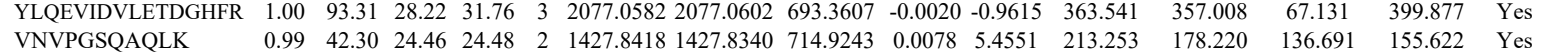

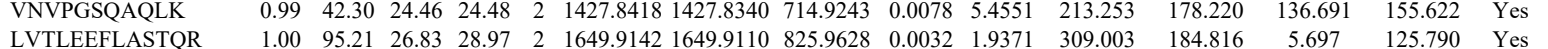
$\begin{array}{lrllllllllllll} & & \end{array}$

AVDSQILPK AVDSQILPK IDISNVK IDISNVK IDISNVK

VLATVTKPVGGDK VLATVTKPVGGDK VLATVTKPVGGDK VLATVTKPVGGDK VLATVTKPVGGDK VLATVTKPVGGDK NPVLVR

FVIATSTK

FVIATSTK

FVIATSTK

FVIATSTK

FVIATSTK

KPFSQHVR

KPFSQHVR

KPFSQHVR

KPFSQHVR

KPFSQHVR

SVFALTNR $\begin{array}{llllllllllllllll}1.00 & 59.22 & 28.15 & 37.44 & 2 & 1359.7606 & 1359.7601 & 680.8873 & 0.0005 & 0.3672 & 6684.770 & 4988.246 & 1752.833 & 4603.576 & \text { Yes }\end{array}$

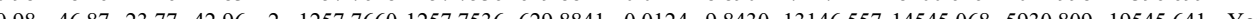
$\begin{array}{llllllllllllllllll}0.89 & 40.37 & 23.87 & 44.49 & 2 & 1257.7652 & 1257.7536 & 629.8841 & 0.0116 & 9.2080 & 3047.472 & 3734.308 & 1735.739 & 4377.887 & \text { Yes }\end{array}$

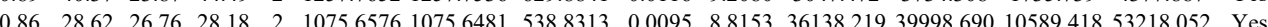
$\begin{array}{lllllllllllllll}0.54 & 28.27 & 26.76 & 40.67 & 2 & 1075.6578 & 1075.6481 & 538.8313 & 0.0097 & 9.0009 & 23086.107 & 26928.644 & 7281.221 & 37057.776 & \text { Yes }\end{array}$

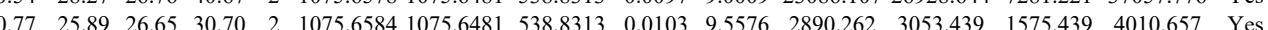
$\begin{array}{llllllllllllllll}1.00 & 68.37 & 17.78 & 18.03 & 2 & 1716.0628 & 1716.0511 & 859.0328 & 0.0117 & 6.8099 & 6699.958 & 6371.962 & 2320.375 & 10214.961 & \text { Yes }\end{array}$ $\begin{array}{llllllllllllllll}0.53 & 65.46 & 17.78 & 78.46 & 2 & 1716.0630 & 1716.0511 & 859.0328 & 0.0119 & 6.9263 & 537.882 & 517.632 & 257.472 & 717.506 & \text { Yes }\end{array}$ $\begin{array}{lllllllllllllll}1.00 & 35.97 & 17.78 & 15.51 & 3 & 1716.0634 & 1716.0511 & 573.0243 & 0.0123 & 7.1550 & 31030.274 & 36269.073 & 20199.154 & 53338.226 & \text { Yes }\end{array}$ $\begin{array}{llllllllllllllll}1.00 & 67.80 & 17.71 & 17.27 & 2 & 1716.0654 & 1716.0511 & 859.0328 & 0.0143 & 8.3232 & 7374.350 & 7742.815 & 3740.731 & 9888.130 & \text { Yes }\end{array}$ $\begin{array}{lllllllllllllll}0.99 & 33.86 & 17.71 & 20.59 & 3 & 1716.0658 & 1716.0511 & 573.0243 & 0.0147 & 8.5510 & 31843.035 & 38961.405 & 17772.865 & 56117.873 & \text { Yes }\end{array}$

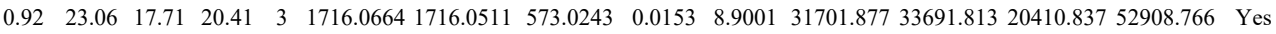
$\begin{array}{lllllllllllllll}0.50 & 68.41 & 17.71 & 81.41 & 2 & 1716.0664 & 1716.0511 & 859.0328 & 0.0153 & 8.9053 & 1943.790 & 2022.017 & 1004.142 & 2819.252 & \text { Yes }\end{array}$ $\begin{array}{llllllllllllllll}0.64 & 20.57 & 20.25 & 33.57 & 2 & 840.5302 & 840.5303 & 421.2724 & -0.0001 & -0.1187 & 1966.581 & 1870.203 & 2465.281 & 2595.866 & \text { Yes }\end{array}$ $\begin{array}{lllllllllllllll}0.04 & 49.22 & 23.03 & 16.19 & 2 & 1153.6974 & 1153.6951 & 577.8548 & 0.0023 & 1.9901 & 34494.011 & 42683.192 & 1918.125 & 72042.837 & \text { Yes }\end{array}$ $\begin{array}{lllllllllllllll}1.00 & 47.12 & 23.36 & 19.61 & 2 & 1153.7024 & 1153.6951 & 577.8548 & 0.0073 & 6.3164 & 37244.361 & 37818.463 & 3363.685 & 57245.995 & \text { Yes }\end{array}$ $\begin{array}{lllllllllllllll}1.00 & 47.06 & 23.30 & 19.50 & 2 & 1153.7030 & 1153.6951 & 577.8548 & 0.0079 & 6.8356 & 36498.283 & 42076.996 & 152.162 & 71288.427 & \text { Yes }\end{array}$ $\begin{array}{llllllllllllllll}0.98 & 37.40 & 23.30 & 21.30 & 2 & 1153.7032 & 1153.6951 & 577.8548 & 0.0081 & 7.0086 & 11167.492 & 12895.054 & 572.446 & 21508.866 & \text { Yes }\end{array}$ $\begin{array}{llllllllllllllll}1.00 & 51.53 & 23.30 & 19.64 & 2 & 1153.7032 & 1153.6951 & 577.8548 & 0.0081 & 7.0086 & 16384.867 & 17759.405 & 2072.956 & 28810.727 & \text { Yes }\end{array}$ $\begin{array}{lllllllllllllll}0.90 & 22.00 & 26.82 & 21.32 & 3 & 1285.7500 & 1285.7499 & 429.5906 & 0.0001 & 0.0776 & 99.846 & 123.229 & 426.892 & 416.321 & \text { No }\end{array}$ $\begin{array}{lllllllllllllll}0.60 & 19.94 & 26.86 & 22.77 & 2 & 1285.7500 & 1285.7499 & 643.8822 & 0.0001 & 0.0777 & 33.672 & 44.618 & 106.851 & 95.148 & \text { No }\end{array}$ $\begin{array}{lllllllllllllll}0.94 & 24.31 & 26.86 & 22.00 & 3 & 1285.7503 & 1285.7499 & 429.5906 & 0.0004 & 0.3104 & 124.704 & 118.456 & 394.459 & 443.684 & \text { No } \\ 0.68 & 17.34 & 2.86 & 24.50 & 2 & 1285.7504 & 1285.7499 & 643.8822 & 0.0005 & 0.3883 & 21.616 & 34.496 & 96.845 & 10.508 & \text { No }\end{array}$

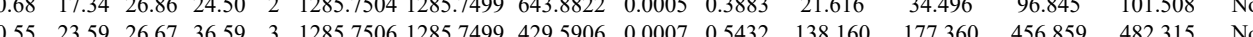

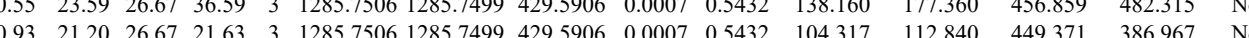
$\begin{array}{lllllllllllllll}0.93 & 21.20 & 26.67 & 21.63 & 3 & 1285.7506 & 1285.7499 & 429.5906 & 0.0007 & 0.5432 & 104.317 & 112.840 & 449.371 & 386.967 & \mathrm{No} \\ 1.00 & 44.36 & 26.69 & 19.91 & 3 & 1733.9719 & 1733.9708 & 578.9975 & 0.0011 & 0.6333 & 3052560 & 3219.336 & 1100.175 & 4429.609 & \text { Yes }\end{array}$ $\begin{array}{lllllllllllllll}1.00 & 4.36 & 26.69 & 19.91 & 3 & 1733.9719 & 1733.9708 & 578.9975 & 0.0011 & 0.6333 & 3052.560 & 3219.336 & 1100.175 & 4429.609 & \text { Yes } \\ 1.00 & 47.30 & 26.60 & 24.26 & 3 & 1733.9725 & 1733.9708 & 578.9975 & 0.0017 & 0.9787 & 3872.113 & 2916.306 & 912.788 & 6677.353 & \text { Yes }\end{array}$

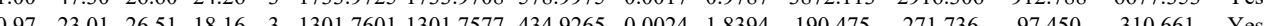
$\begin{array}{lllllllllllllll}1.00 & 49.33 & 26.53 & 29.21 & 2 & 1301.7606 & 1301.7577 & 651.8861 & 0.0029 & 2.2243 & 18499.749 & 21877.183 & 655.089 & 33834.988 & \text { Yes }\end{array}$ 


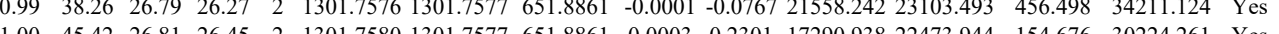
$\begin{array}{lllllllllllllllll}0.93 & 25.36 & 26.81 & 28.71 & 2 & 1301.7584 & 1301.7577 & 651.8861 & 0.0007 & 0.5369 & 1787.909 & 2391.550 & 222.475 & 2886.966 & \text { Yes }\end{array}$

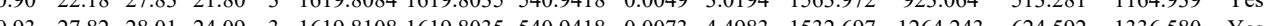

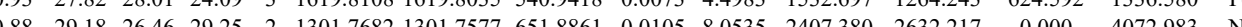
$\begin{array}{lllllllllllllllll}0.85 & 28.14 & 26.49 & 29.05 & 2 & 1301.7690 & 1301.7577 & 651.8861 & 0.0113 & 8.6671 & 1845.944 & 1750.474 & 159.600 & 2467.926 & \text { Yes }\end{array}$

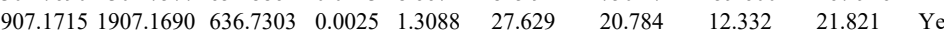

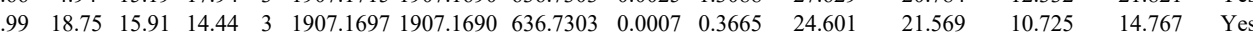
$\begin{array}{llllllllllllllll}\text { QLASGLLLVTGPLVLNR } & 1.00 & 20.13 & 15.80 & 15.04 & 3 & 1907.1706 & 1907.1690 & 636.7303 & 0.0016 & 0.8376 & 20.778 & 36.849 & 2.120 & 19.518 & \text { Yes }\end{array}$

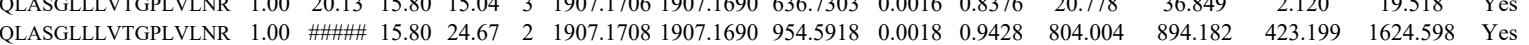
$\begin{array}{llllllllllllllll}\text { QLASGLLVVTGPLVLNR } & 0.99 & 17.50 & 15.80 & 14.40 & 3 & 1907.1712 & 1907.1690 & 636.7303 & 0.0022 & 1.1517 & 18.619 & 26.332 & 14.816 & 16.338 & \text { Yes }\end{array}$ $\begin{array}{llllllllllllllll}\text { QLASGLLVVTGPIVLNR } & 0.66 & 44.51 & 15.19 & 57.51 & 3 & 1907.1715 & 1907.1690 & 636.7303 & 0.0025 & 1.3088 & 25.404 & 23.764 & 10.211 & 28.404 & \text { Yes }\end{array}$

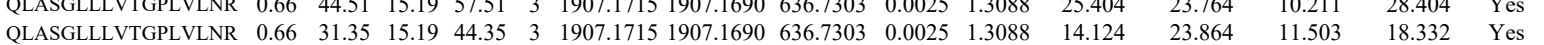

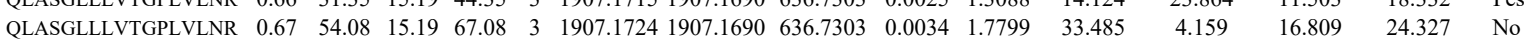
$\begin{array}{llllllllllllllll}\text { QLASGLLLVTGPLVLNR } & 0.67 & 39.81 & 15.19 & 52.81 & 3 & 1907.1724 & 1907.1690 & 636.7303 & 0.0034 & 1.7799 & 24.062 & 66.951 & 10.627 & 30.173 & \text { No }\end{array}$ $\begin{array}{lllllllllllllllll}\text { ASITPGTILIILTGR } & 1.00 & 63.33 & 20.29 & 22.41 & 2 & 1524.9264 & 1524.9239 & 763.4692 & 0.0025 & 1.6373 & 5.285 & 10.454 & 13.006 & 2.326 & \text { No }\end{array}$ $\begin{array}{llllllllllllllll}\text { ASITPGTILIILTGR } & 0.72 & 41.45 & 20.41 & 54.45 & 2 & 1524.9266 & 1524.9239 & 763.4692 & 0.0027 & 1.7682 & 2.272 & 9.988 & 0.000 & 3.931 & \text { No }\end{array}$ $\begin{array}{llllllllllllllll}\text { ASITPGTILIILTGR } & 0.99 & 40.15 & 17.78 & 22.63 & 3 & 1669.0234 & 1669.0260 & 557.3493 & -0.0026 & -1.5550 & 4.905 & 18.111 & 8.722 & 4.166 & \text { No }\end{array}$ $\begin{array}{lllllllllllll}\text { ASITPGTILILTGR } & 1.00 & 31.34 & 17.92 & 20.95 & 3 & 1669.0261 & 1669.0260 & 557.3493 & 0.0001 & 0.0598 & 5.947\end{array}$ $\begin{array}{lllllllllllll}\text { QLASGLLLVTGPLVLNR } & 0.55 & 18.96 & 15.91 & 31.96 & 3 & 1907.1697 & 1907.1690 & 636.7303 & 0.0007 & 0.3665 & 6.659\end{array}$ $\begin{array}{lllllllllllll}\text { QLASGLLLVTGPLVLNR } & 1.00 & 98.55 & 15.80 & 22.83 & 2 & 1907.1702 & 1907.1690 & 954.5918 & 0.0012 & 0.6285 & 405.055\end{array}$

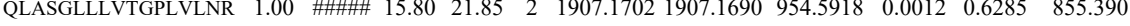
$\begin{array}{lllllllllllll}\text { QLASGLLLVTGPLVLNR } & 0.67 & 44.79 & 15.19 & 57.79 & 3 & 1907.1721 & 1907.1690 & 636.7303 & 0.0031 & 1.6229 & 8.178\end{array}$ $\begin{array}{llllllllllll}\text { QLASGLLLVTGPLVLNR } & 0.60 & 9.74 & 15.19 & 22.74 & 3 & 1907.1727 & 1907.1690 & 636.7303 & 0.0037 & 1.9370 & 19.156\end{array}$ $\begin{array}{lllllllllll}\text { ASITPGTILIILTGR } & 0.84 & 95.54 & 17.92 & 2 & 1669.0284 & 1669.0260 & 835.5203 & 0.0024 & 1.4362 & 18.372\end{array}$

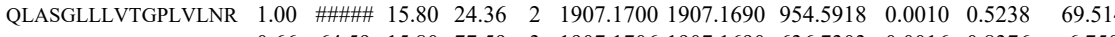
$\begin{array}{llllllllllll}\text { QLASGLLLVTGPLVLNR } & 0.66 & 64.59 & 15.80 & 77.59 & 3 & 1907.1706 & 1907.1690 & 636.7303 & 0.0016 & 0.8376 & 6.750\end{array}$

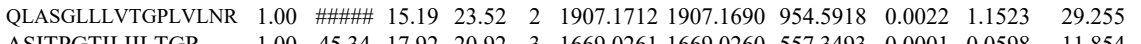
$\begin{array}{llllllllllll}\text { ASITPGTILILTGR } & 1.00 & 45.34 & 17.92 & 20.92 & 3 & 1669.0261 & 1669.0260 & 557.3493 & 0.0001 & 0.0598 & 11.854\end{array}$

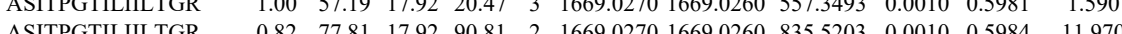

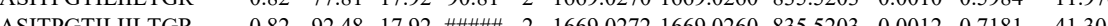
$\begin{array}{llllllllllll}0.82 & 77.81 & 17.92 & 90.81 & 2 & 1669.0270 & 1669.0260 & 835.5203 & 0.0010 & 0.5984 & 11.970\end{array}$

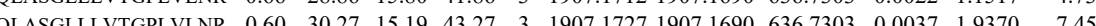
$\begin{array}{llllllllllllll} & \text { QLEGEIFDTEK } & 0.84 & 61.38 & 27.85 & 74.38 & 2 & 1619.8056 & 1619.8035 & 810.9090 & 0.0021 & 1.2948 & 274.741\end{array}$ ASITPGTILIILTGR ASITPGTILILTTGR ASITPGTILIILTGR ASITPGTILIILTGR ASITPGTILIILTGR ASITPGTILILILTGR ASITPGTILILTGR ASITPGTILILLTGR

$\begin{array}{lllllllllll}0.84 & 61.38 & 27.85 & 74.38 & 2 & 1619.8056 & 1619.8035 & 810.9090 & 0.0021 & 1.2948 & 274.741 \\ 0.64 & 88.39 & 17.92 & 3 & & \\ 0.82 & 80.07 & 17.92 & 93.07 & 2 & 1669.0264 & 1669.0260 & 835.5203 & 0.0004 & 0.2394 & 139.764\end{array}$ $\begin{array}{lllllllllllll}0.64 & 88.39 & 17.92 & \ldots & 2 & 1669.0264 & 1669.0260 & 835.5203 & 0.0004 & 0.2394 & 139.764 \\ 0.82 & 80.07 & 17.92 & 93.07 & 2 & 1669.0270 & 1669.0260 & 835.5203 & 0.0010 & 0.5984 & 16.184\end{array}$ $\begin{array}{lllllllllll}0.74 & 9.75 & 17.92 & 2.75 & 2 & 1669.0274 & 1669.0260 & 835.5203 & 0.0014 & 0.8378 & 15.775\end{array}$ $\begin{array}{lllllllllllll}1.00 & 32.20 & 17.92 & 21.89 & 3 & 1669.0282 & 1669.0260 & 557.3493 & 0.0022 & 1.3158 & 7.644\end{array}$ $\begin{array}{llllllllllll}0.84 & 96.77 & 17.92 & \text { \#\#\#\# } & 2 & 16699.0282 & 1669.0260 & 835.5203 & 0.0022 & 1.3165 & 930.160 & 8\end{array}$ $\begin{array}{llllllllllll}0.72 & 79.57 & 17.63 & 92.57 & 2 & 16690288 & 16690260 & 835.5203 & 0.0028 & 1.6756 & 19.459\end{array}$ $\begin{array}{llllllllllll}1.00 & 43.71 & 17.63 & 17.83 & 3 & 1669.0291 & 1669.0260 & 557.3493 & 0.0031 & 1.8540 & 6.674\end{array}$ $\begin{array}{llllllllllll}\text { QLASGLLLVTGPLVLNR } & 0.66 & 12.14 & 15.19 & 25.14 & 3 & 1907.1715 & 1907.1690 & 636.7303 & 0.0025 & 1.3088 & 22.712\end{array}$ $\begin{array}{llllllllllll}\text { AIPQLQGYLR } & 0.87 & 21.96 & 26.75 & 25.56 & 2 & 1301.7594 & 1301.7577 & 651.8861 & 0.0017 & 1.3039 & 123.578\end{array}$

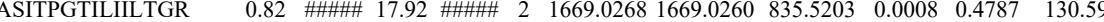
$\begin{array}{lllllllllllll}\text { ASITPGTILILTTGR } & 0.82 & 85.67 & 17.92 & 98.67 & 2 & 1669.0268 & 1669.0260 & 835.5203 & 0.0008 & 0.4787 & 74.366\end{array}$ $\begin{array}{lllllllllllll}\text { ASITPGTILIILTGR } & 1.00 & 60.42 & 17.92 & 24.70 & 3 & 1669.0279 & 1669.0260 & 557.3493 & 0.0019 & 1.1363 & 8.822\end{array}$ $\begin{array}{lllllllllllll}\text { ASITPGTILIILTGR } & 1.00 & 46.96 & 17.92 & 24.36 & 3 & 1669.0282 & 1669.0260 & 557.3493 & 0.0022 & 1.3158 & 13.916\end{array}$ $\begin{array}{llllllllllll}\text { QLASGLLLVTGPLVLNR } & 0.55 & 38.85 & 15.91 & 51.85 & 3 & 1907.1700 & 1907.1690 & 636.7303 & 0.0010 & 0.5235 & 28.343\end{array}$ $\begin{array}{llllllllllll}\text { QLASGLLLVTGPLVLNR } & 0.66 & 23.01 & 15.80 & 36.01 & 3 & 1907.1706 & 1907.1690 & 636.7303 & 0.0016 & 0.8376 & 22.894\end{array}$ $\begin{array}{lllllllllllll}\text { ASITPGTILIILTGR } & 0.82 & 86.65 & 17.92 & 99.65 & 2 & 1669.0270 & 1669.0260 & 835.5203 & 0.0010 & 0.5984 & 90.520\end{array}$ $\begin{array}{llllllllllll}\text { ASITPGTILILTTGR } & 0.82 & 79.38 & 17.92 & 92.38 & 2 & 1669.0274 & 1669.0260 & 835.5203 & 0.0014 & 0.8378 & 33.672\end{array}$ $\begin{array}{lllllllllllll}\text { ASITPGTILIILTGR } & 1.00 & 47.33 & 17.92 & 23.26 & 3 & 1669.0279 & 1669.0260 & 557.3493 & 0.0019 & 1.1363 & 8.54 \\ \text { ASITPGTILIILTGR } & 1.00 & 43.08 & 17.92 & 24.45 & 3 & 1669.0279 & 1669.0260 & 557.3493 & 0.0019 & 1.1363 & 5.086\end{array}$

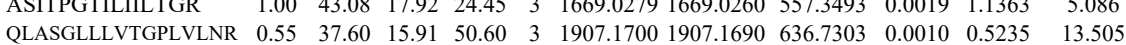
$\begin{array}{llllllllllll}\text { QLASGLLLVTGPLVLNR } & 0.55 & 37.60 & 15.91 & 50.60 & 3 & 1907.1700 & 1907.1690 & 636.7303 & 0.0010 & 0.5235 & 13.505 \\ \text { QLASGLLLVTGPLVLNR } & 0.66 & 56.57 & 15.80 & 69.57 & 3 & 1907.1706 & 1907.1690 & 636.7303 & 0.0016 & 0.8376 & 15.711\end{array}$ $\begin{array}{llllllllllll}\text { QLASGLLLVTGPLVLNR } & 1.00 & \# \# \# \# 15.19 & 24.22 & 2 & 1907.1714 & 1907.1690 & 954.5918 & 0.0024 & 1.2571 & 7.084\end{array}$ $\begin{array}{lllllllllllll}\text { QLASGLLLVTGPLVLNR } & 1.00 & \# \# \# & 15.19 & 22.60 & 2 & 1907.1722 & 1907.1690 & 954.5918 & 0.0032 & 1.6761 & 13.112\end{array}$ $\begin{array}{llllllllllllll}\text { ASITPGTILILLTGR } & 1.00 & 50.62 & 17.92 & 16.83 & 3 & 1669.0261 & 1669.0260 & 557.3493 & 0.0001 & 0.0598 & 1.554\end{array}$ 

\begin{tabular}{lllllllllllll} 
QLASGLLLVTGPLVLNR & 1.00 & 96.79 & 15.80 & 24.44 & 2 & 1907.1704 & 1907.1690 & 954.5918 & 0.0014 & 0.7333 & 9.551 \\
\hline
\end{tabular} $\begin{array}{llllllllllllll}\text { QLASGLLLVTGPLVLNR } & 0.66 & 35.05 & 15.80 & 48.05 & 3 & 1907.1706 & 1907.1690 & 636.7303 & 0.0016 & 0.8336 & 16.918 \\ \text { QLASGLLVTGPLVLNR } & 1.00 & 86.33 & 15.19 & 21.94 & 2 & 1907.1716 & 1907.1690 & 954.5918 & 0.0026 & 1.3618 & 6.213\end{array}$ $\begin{array}{llllllllllll}\text { ASITPGTILIILTGR } & 0.82 & 82.96 & 17.92 & 95.96 & 2 & 1669.0266 & 1669.0260 & 835.5203 & 0.0006 & 0.3591 & 37.223\end{array}$ $\begin{array}{llllllllllll}\text { ASITPGTILIILTGR } & 1.00 & 44.10 & 17.92 & 19.58 & 3 & 1669.0267 & 1669.0260 & 557.3493 & 0.0007 & 0.4186 & 36.659\end{array}$ $\begin{array}{llllllllllll}\text { ASITPGTILIILTGR } & 0.55 & 35.31 & 17.92 & 48.31 & 3 & 1669.0270 & 1669.0260 & 557.3493 & 0.0010 & 0.5981 & 11.675\end{array}$

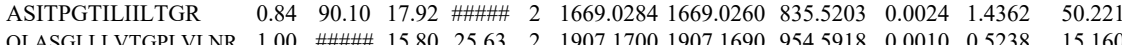
QLASGLLLVTGPLVLNR $1.00 \quad$ \#\#\#\# $15.80 \begin{array}{llllllllll}25.63 & 2 & 1907.1700 & 1907.1690 & 954.5918 & 0.0010 & 0.5238 & 15.160\end{array}$ $\begin{array}{llllllllllll}\text { QLASGLLLVTGPLVLNR } & 1.00 & 92.23 & 15.80 & 21.08 & 2 & 1907.1708 & 1907.1690 & 954.5918 & 0.0018 & 0.9428 & 13.908\end{array}$ $\begin{array}{lllllllllllll}\text { QLASGLLLVTGPLVLNR } & 0.66 & 33.83 & 15.80 & 46.83 & 3 & 1907.1712 & 1907.1690 & 636.7303 & 0.0022 & 1.1517 & 5.861\end{array}$ $\begin{array}{lllllllllllll}\text { QLASGLLLVTGPLVLNR } & 0.67 & 19.62 & 15.19 & 32.62 & 3 & 1907.1721 & 1907.1690 & 636.7303 & 0.0031 & 1.6229 & 10.718 \\ \text { ASITPGTILULTGR } & 1.00 & 37.78 & 17.92 & 17.35 & 3 & 1669.0279 & 1669.0260 & 557.3493 & 0.0019 & 1.1363 & 23.277\end{array}$ $\begin{array}{llllllllllll}\text { ASITPGTILIILTGR } & 1.00 & 37.78 & 17.92 & 17.35 & 3 & 1669.0279 & 1669.0260 & 557.3493 & 0.0019 & 1.1363 & 23.277 \\ \text { QLASGLLLVTGPLVLNR } & 0.82 & 92.48 & 15.80 & \# \# \# & 2 & 1907.1700 & 1907.1690 & 954.5918 & 0.0010 & 0.5238 & 21.925\end{array}$ $\begin{array}{llllllllllll}\text { QLASGLLLVTGPLVLNR } & 0.82 & 92.48 & 15.80 & \# \# \# \text { \# } & 2 & 1907.1700 & 1907.1690 & 954.5918 & 0.0010 & 0.5238 & 21.925\end{array}$ $\begin{array}{lllllllllllll}\text { QLASGLLLVTGPLVLNR } & 0.55 & 37.21 & 15.80 & 50.21 & 3 & 1907.1703 & 1907.1690 & 636.7303 & 0.0013 & 0.6806 & 13.953\end{array}$ $\begin{array}{lllllllllllll}\text { QLASGLLLVTGPLVLNR } & 0.55 & 35.49 & 15.80 & 48.49 & 3 & 1907.1703 & 1907.1690 & 636.7303 & 0.0013 & 0.6806 & 16.245\end{array}$

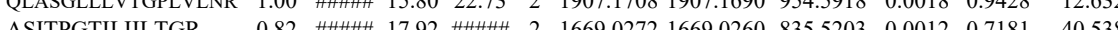

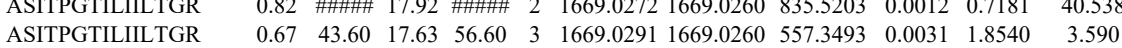

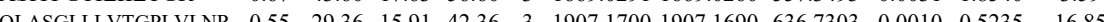

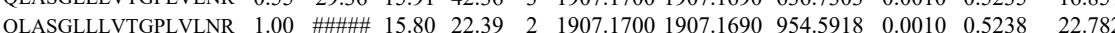
$\begin{array}{llllllllllll} & \end{array}$ ASITPGTILIILTGR

\section{QLASGLLLVTGPLVLN}

QLAVSGLGVIGR

YIFTMLSTLAR

$\begin{array}{lllllllllll}0.99 & 23.66 & 16.23 & 15.79 & 3 & 1907.1679 & 1907.1690 & 636.7303 & -0.0011 & -0.5759 & 2.526\end{array}$

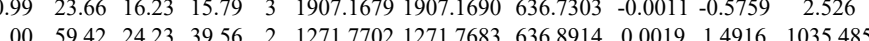
$\begin{array}{llllllllllll} & \\ & 1.00 & 60.32 & 28.14 & 21.96 & 2 & 1458.8022 & 1458.8026 & 730.4086 & -0.0004 & -0.2738 & 81.287 \\ \text { Y } & 1.00 & 58.33 & 28.23 & 25.88 & 2 & 1458.8040 & 1458.8026 & 730.4086 & 0.0014 & 0.9584 & 107.010\end{array}$ $\begin{array}{lllllllllll}1.00 & 36.55 & 23.67 & 15.97 & 4 & 3120.6825 & 3120.6798 & 781.1772 & 0.0027 & 0.8641 & 10.648\end{array}$ $\begin{array}{lllllllllllll}\text { VLGETANILTGETLPAGAHLVLEEK } & 1.00 & 40.77 & 23.52 & 20.61 & 4 & 3120.6829 & 3120.6798 & 781.1772 & 0.0031 & 0.9921 & 6.019\end{array}$

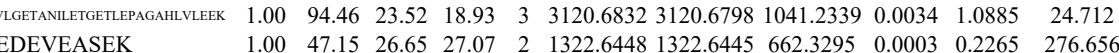

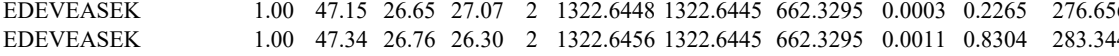
$\begin{array}{llllllllllll}\text { LVQNIIQTAVDQFVR } & 1.00 & \text { \#\#\#\# } 24.98 & 26.95 & 2 & 1887.0706 & 1887.0700 & 944.5423 & 0.0006 & 0.3176 & 367.230\end{array}$ $\begin{array}{lllllllllllll}\text { LVQNIIQTAVDQFVR } & 1.00 & 37.39 & 25.05 & 21.14 & 3 & 1887.0715 & 1887.0700 & 630.0306 & 0.0015 & 0.7936 & 29.990\end{array}$ $\begin{array}{lllllllllllll}\text { LVQNIIQTAVDQFVR } & 0.84 & 87.51 & 24.98 & \# \# \# \text { 2 } & 1887.0720 & 1887.0700 & 944.5423 & 0.0020 & 1.0587 & 303.463\end{array}$

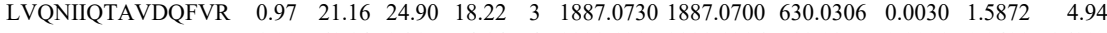
$\begin{array}{llllllllllllll} & \text { LTASEQAHPQEPAESAHEPR } & 1.00 & 61.14 & 26.95 & 74.14 & 4 & 2328.1217 & 2328.1216 & 583.0377 & 0.0001 & 0.0429 & 2680.569 & 3388.053\end{array}$ $\begin{array}{lllllllllllllll}\text { LTASEQAHPQEPAESAHEPR } & 1.00 & 56.32 & 26.91 & 69.32 & 4 & 2328.1229 & 2328.1216 & 583.0377 & 0.0013 & 0.5574 & 1319.436 & 1829.813\end{array}$ $\begin{array}{lllllllllllll}\text { LVQNIIQTAVDQFVR } & 1.00 & 96.17 & 25.01 & 21.55 & 2 & 1887.0694 & 1887.0700 & 944.5423 & -0.0006 & -0.3176 & 171.622 & 195.596\end{array}$ $\begin{array}{lllllllllllll}\text { LVQNIIQTAVDQFVR } & 1.00 & 44.31 & 25.00 & 21.60 & 3 & 1887.0697 & 1887.0700 & 630.0306 & -0.0003 & -0.1587 & 29.350\end{array}$ $\begin{array}{llllllllllll}\text { LVQNIIQTAVDQFVR } & 1.00 & \text { 25 \#\#\# } & 25.02 & 22.45 & 2 & 1887.0702 & 1887.0700 & 944.5423 & 0.0002 & 0.1059 & 257.663\end{array}$ $\begin{array}{lllllllllllll}\text { LVQNIIQTAVDQFVR } & 1.00 & 44.83 & 25.05 & 16.12 & 3 & 1887.0715 & 1887.0700 & 630.0306 & 0.0015 & 0.7936 & 15.593\end{array}$ $\begin{array}{lllllllllllllll} & \text { TASEQAHPQEPAESAHEPR } & 1.00 & 38.19 & 27.04 & 17.98 & 4 & 2328.1233 & 2328.1216 & 583.0377 & 0.0017 & 0.7289 & 6013.747 & 7771.203 & 26\end{array}$

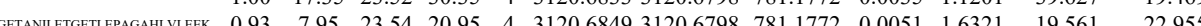
$\begin{array}{llllllllllll}\text { AVVVNAAQLASYSQSK } & 1.00 & \text { \#\#\# } 24.55 & 21.59 & 2 & 1923.0854 & 1923.0669 & 962.5407 & 0.0185 & 9.6099 & 133.118 & 143.986\end{array}$

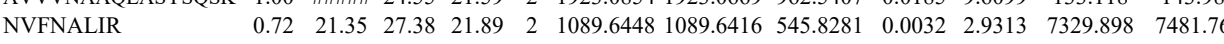


GIYTGLSAGLLR GIYTGLSAGLLR NVFNALIR

GIYTGLSAGLLR

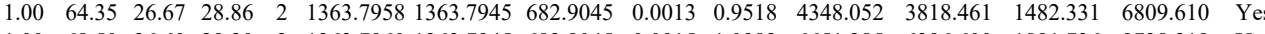
GIYTGLSAGLLR

$\begin{array}{llllllllllllllll}1.00 & 68.50 & 26.60 & 29.20 & 2 & 1363.7960 & 1363.7945 & 682.9045 & 0.0015 & 1.0982 & 6651.285 & 6396.600 & 1891.736 & 9738.219 & \text { Yes } & \\ \end{array}$

$\begin{array}{lllllllllllllll}0.99 & 34.21 & 27.71 & 23.26 & 2 & 1089.6434 & 1089.6416 & 545.8281 & 0.0018 & 1.6489 & 3948.180 & 4509.676 & 488.655 & 6435.815 & \text { Yes }\end{array}$

$\begin{array}{lllllllllllllll}1.00 & 63.34 & 26.67 & 28.06 & 2 & 1363.7954 & 1363.7945 & 682.9045 & 0.0009 & 0.6589 & 2349.577 & 2920.260 & 713.509 & 3803.292 & \text { Yes }\end{array}$

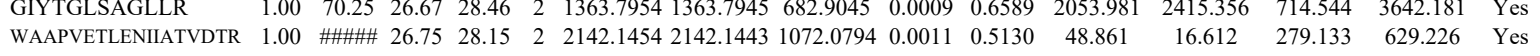
$\begin{array}{llllllllllllllll} & \end{array}$

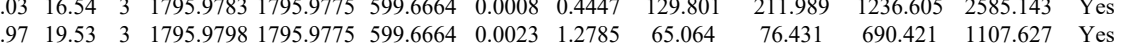
$\begin{array}{llllllllllllllll}\text { DVMQQQLAEYQELLDVK } & 1.00 & 52.78 & 27.00 & 21.75 & 3 & 2337.2158 & 2337.2130 & 780.0783 & 0.0028 & 1.1965 & 47.913 & 33.809 & 40.374 & 99.687 & \text { Yes }\end{array}$ $\begin{array}{llllllllllllllll} & \\ \text { DVMQQQLAEYQELLDVK } & 1.00 & 67.73 & 26.99 & 27.26 & 3 & 2337.2161 & 2337.2130 & 780.0783 & 0.0031 & 1.3247 & 56.342 & 34.707 & 40.191 & 77.895 & \text { No } \\ \text { ATSSSSGSLSATGR } & 1.00 & 88.97 & 27.11 & 26.44 & 2 & 1411.032 & 1411.7025 & 706.8585 & 0.0007 & 0.495 & 46.629 & 55.069 & 9.466 & 124.100 & \text { Yes }\end{array}$ $\begin{array}{llllllllllllll} & \end{array}$

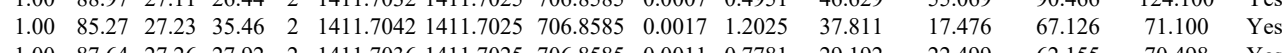
$\begin{array}{llllllllllllll}1.00 & \text { m\#\# } 27.16 & 29.31 & 2 & 1411.7028 & 1411.7025 & 7068585 & 0.0003 & 0.2122 & 9.227 & 6.591 & 23.625 & 27.906 & \text { Yes }\end{array}$

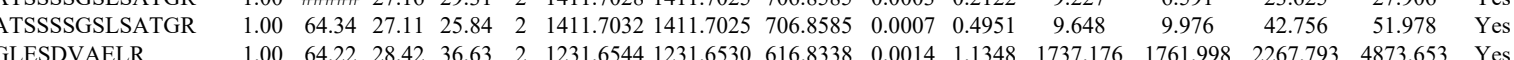
GLESDVAELR

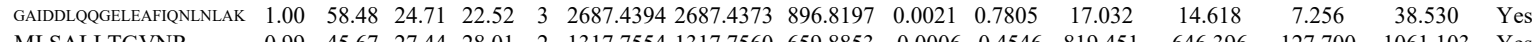
$\begin{array}{llllllllllllllll}1.00 & 64.22 & 28.42 & 36.63 & 2 & 1231.6544 & 1231.6530 & 616.8338 & 0.0014 & 1.1348 & 1767.176 & 1761.998 & 2265.793 & 4873.653 & \text { Yes } \\ 1.00 & 63.43 & 28.37 & 38.98 & 2 & 1231.6546 & 1231.6530 & 616.8338 & 0.0016 & 1.2969 & 1613.468 & 1616.894 & 1854.955 & 3906.519 & \text { Yes }\end{array}$

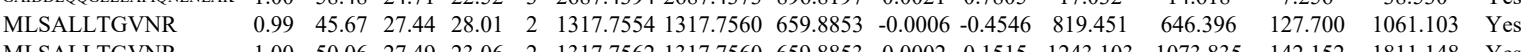

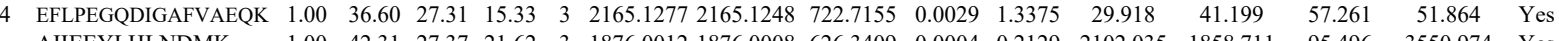
$\begin{array}{llllllllllllllll}\text { AIIEEYLHLNDMK } & 1.00 & 42.31 & 27.37 & 21.62 & 3 & 1876.0012 & 1876.0008 & 626.3409 & 0.0004 & 0.2129 & 2102.035 & 1858.711 & 95.496 & 3550.974 & \text { Yes }\end{array}$ $\begin{array}{llllllllllllllll}\text { AIIEEYLHLNDMK } & 1.00 & 42.12 & 27.39 & 21.40 & 3 & 1876.0030 & 1876.0008 & 626.3409 & 0.0022 & 1.1708 & 1113.069 & 1622.861 & 58.750 & 2075.688 & \text { Yes }\end{array}$ \begin{tabular}{llllllllllllllll} 
GVIDLIFEK & 1.00 & 63.68 & 24.77 & 27.71 & 2 & 1320.7914 & 1320.7897 & 661.4021 & 0.0017 & 1.2851 & 3746.416 & 4423.514 & 214.326 & 6353.730 & Yes \\
\hline
\end{tabular} $\begin{array}{lllllllllllllllll}1.00 & 56.46 & 24.77 & 27.09 & 2 & 1320.7914 & 1320.7897 & 661.4021 & 0.0017 & 1.2851 & 5295.669 & 7096.992 & 266.236 & 9400.169 & \text { Yes }\end{array}$ $\begin{array}{llllllllllllllll}\text { FSALQQAVPTESTDNR } & 1.00 & 90.05 & 28.06 & 20.47 & 2 & 1906.9692 & 1906.9507 & 954.4826 & 0.0185 & 9.6910 & 232.594 & 229.827 & 136.938 & 287.837 & \text { Yes }\end{array}$ $\begin{array}{lllllllllllllllll}\text { FSALQQAVPTESTDNR } & 1.00 & 75.13 & 28.06 & 21.40 & 2 & 1906.9692 & 1906.9507 & 954.4826 & 0.0185 & 9.6910 & 22.866 & 28.986 & 22.862 & 49.733 & \text { Yes }\end{array}$

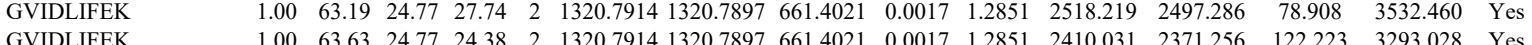
$\begin{array}{llllllllllllllllll} & 1.00 & 63.63 & 24.77 & 24.38 & 2 & 1320.7914 & 1320.7897 & 661.4021 & 0.0017 & 1.2851 & 2410.031 & 2371.256 & 122.223 & 3293.028 & \text { Yes }\end{array}$

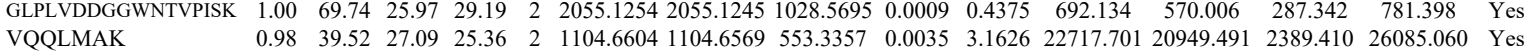

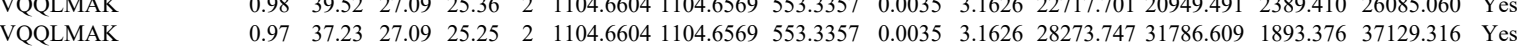

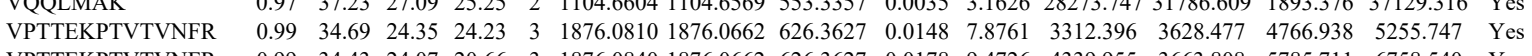

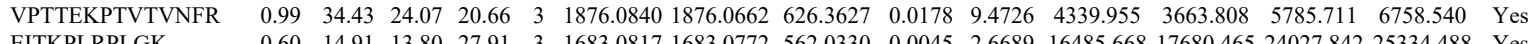

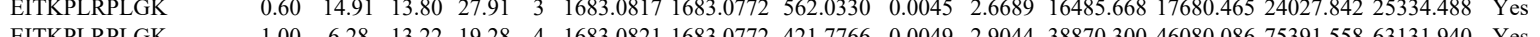
$\begin{array}{lllllllllllllll} & & & & \end{array}$

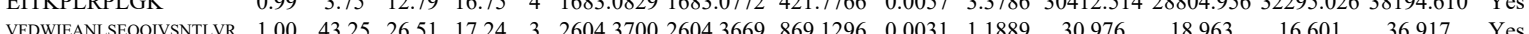
\begin{tabular}{lllllllllllllll}
\hline & YTKEALSES
\end{tabular}

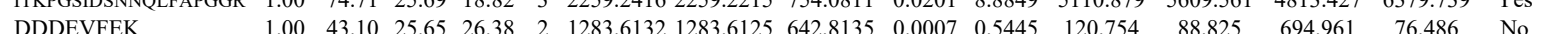

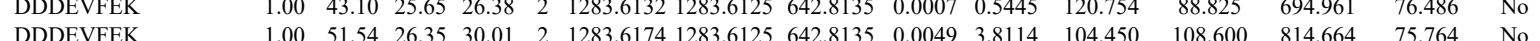
$\begin{array}{llllllllllllllllll} & \text { DDDEVFK } & 1.00 & 33.42 & 26.84 & 25.92 & 2 & 1011.5600 & 1011.5523 & 506.7834 & 0.0077 & 7.5969 & 16297.489 & 13288.861 & 866.097 & 30080.957 & \text { Yes }\end{array}$ $\begin{array}{lllllllllllllllll}\text { LTPQMFOQLMK } & 100 & 49.33 & 27.50 & 23.08 & 2 & 1651.9034 & 1651.9033 & 826.9589 & 0.0001 & 0.0605 & 1151.845 & 1516.064 & 182.231 & 1737.411 & \text { Yes }\end{array}$

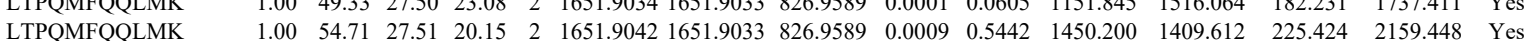
$\begin{array}{llllllllllllllll}\text { LTPQMFQQLMK } & 0.66 & 17.96 & 27.33 & 30.96 & 3 & 1651.9054 & 1651.9033 & 551.6417 & 0.0021 & 1.2689 & 763.136 & 348.331 & 166.596 & 486.913 & \text { No }\end{array}$

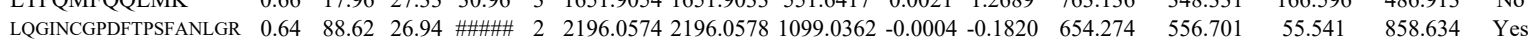
$\begin{array}{llllllllllllllll}\text { LQGINCGPDFTPSFANLGR } & 0.55 & 28.43 & 27.07 & 41.43 & 3 & 2196.0586 & 2196.0578 & 733.0265 & 0.0008 & 0.3638 & 218.365 & 154.814 & 68.672 & 240.121 & \text { Yes }\end{array}$ $\begin{array}{llllllllllllllll}\text { LQGINCGPDFTPSFANLGR } & 1.00 & 36.03 & 27.08 & 17.35 & 3 & 2196.0592 & 2196.0578 & 733.0265 & 0.0014 & 0.6366 & 24.079 & 61.744 & 10.125 & 74.517 & \text { Yes }\end{array}$

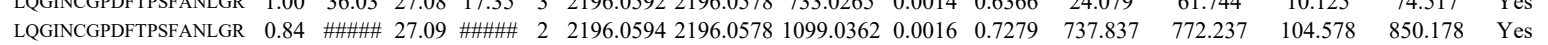
$\begin{array}{llllllllllllllllll}\text { LTPQMFQQLMK } & 0.75 & 16.28 & 27.51 & 22.29 & 3 & 1651.9042 & 1651.9033 & 551.6417 & 0.0009 & 0.5438 & 1343.264 & 1416.586 & 154.137 & 1733.749 & \text { Yes }\end{array}$ $\begin{array}{lllllllllllllllll}\text { LQGINCGPDFTPSFANLGR } & 1.00 & 96.02 & 27.09 & 20.11 & 2 & 2196.0594 & 2196.0578 & 1099.0362 & 0.0016 & 0.7279 & 520.549 & 531.942 & 29.336 & 669.285 & \text { Yes }\end{array}$ $\begin{array}{llllllllllllllll}\text { EAVQCVQELASPSLLFIFVR } & 0.82 & 68.78 & 26.77 & 81.78 & 2 & 2438.2834 & 2438.2823 & 1220.1484 & 0.0011 & 0.4508 & 2.198 & 2.098 & 0.000 & 1.568 & \text { No }\end{array}$ $\begin{array}{llllllllllllllll}\text { EAVQCVQELASPSLLFIFVR } & 0.67 & 19.44 & 26.69 & 32.44 & 3 & 2438.2855 & 2438.2823 & 813.7680 & 0.0032 & 1.3108 & 5.804 & 18.067 & 4.758 & 12.154 & \text { No }\end{array}$ $\begin{array}{llllllllllllllll}\text { ELQALYALQALVVTLEQPPNLLR } & 1.00 & 66.19 & 18.20 & 17.32 & 3 & 2735.5729 & 2735.5707 & 912.8642 & 0.0022 & 0.8033 & 2.011 & 3.033 & 2.164 & 8.238 & \text { No }\end{array}$ $\begin{array}{llllllllllllllll}\text { ELQALYALQALVVTLEQPPNLLR } & 0.66 & 62.12 & 18.20 & 75.12 & 3 & 2735.5729 & 2735.5707 & 912.8642 & 0.0022 & 0.8033 & 0.000 & 8.087 & 1.547 & 3.036 & \text { No }\end{array}$ $\begin{array}{llllllllllllllll}\text { EAVQCVQELASPSLLFIFVR } & 0.55 & 10.02 & 26.74 & 16.40 & 3 & 2438.2849 & 2438.2823 & 813.7680 & 0.0026 & 1.0650 & 7.626 & 9.903 & 8.545 & 12.750 & \text { Yes }\end{array}$ \begin{tabular}{llllllllllllllll} 
EAVQCVQELASPSLLFIFVR & 0.67 & 18.31 & 26.67 & 31.31 & 3 & 2438.2858 & 2438.2823 & 813.7680 & 0.0035 & 1.4337 & 14.253 & 6.812 & 3.011 & 21.437 & Yes \\
\hline
\end{tabular}

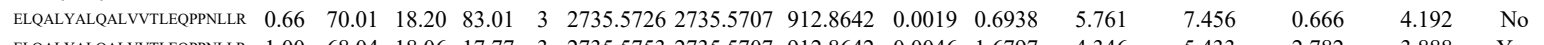

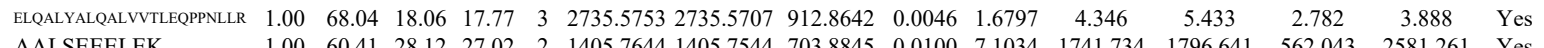

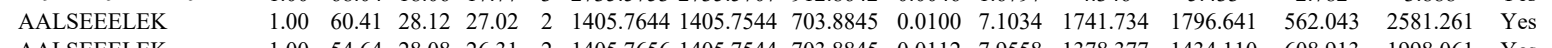
$\begin{array}{llllllllllllllll}\text { AALSEEELEK } & 1.00 & 54.64 & 28.08 & 26.31 & 2 & 1405.7656 & 1405.7544 & 703.8845 & 0.0112 & 7.9558 & 1378.377 & 1434.110 & 608.913 & 1998.061 & \text { Yes } \\ \text { VEYTLGESSER } & 1.00 & 9.11 & 27.49 & 23.64 & 2 & 1807.8846 & 1807.8710 & 904.9428 & 0.0136 & 7.5142 & 347.248 & 441.399 & 56.59 & 490.719 & \text { Yes }\end{array}$

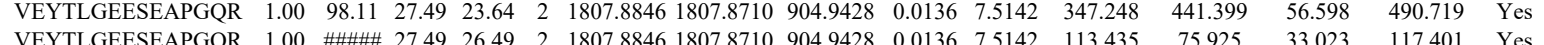

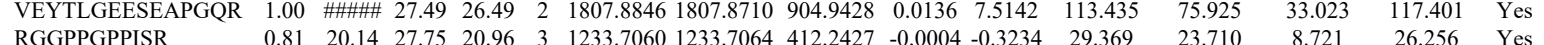

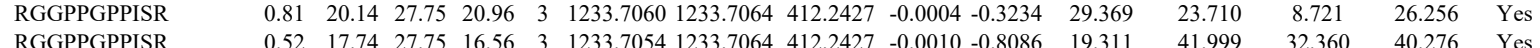

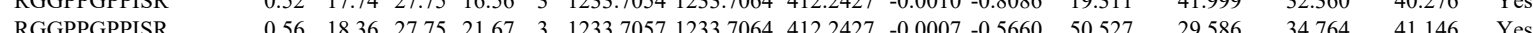

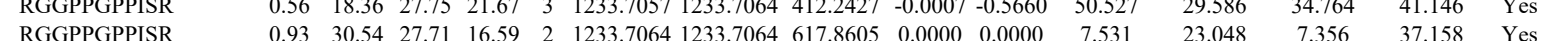


RGGPPGPPISR QVTQLAIDTEER QVTQLAIDTEER ALPSEELNR

ALPSEELNR

IHNAENIQPGEQK

IHNAENIQPGEQK

IHNAENIQPGEQK

IHNAENIQPGEQK

INAENIQPGEQK

MFEILYEQ

MFFDALYDEDVVK

MFFDALYDEDVVK

MFFDALYDEDVVK

100 ADLEMQIENLK

ADLEMQIENLK

ADLEMQIENLK

LLEGEDAHLTQYK

LLEGEDAHLTQYK GQVGGEINVEMDAAPGVDLSR 0.0

ATMQNLNDR

LLEGEDAHLTQYK

ATMQNLNDR

ATMQNLNDR

GSSGLGGGSSR

GSSGLGGGSSR

ATMQNLNDR

LSVEADINGLR
LSVEADINGLR

MQALEIELQSQLSMK TMQALEIELQSQLSMK

TMQALEIELQSQLSMK

TMQALEIELQSQLSMK

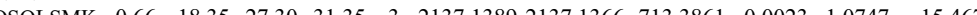

$\begin{array}{lllllllllllll} & 1.00 & 53.29 & 28.31 & 21.16 & 2 & 1632.8794 & 16328814 & 817.4480 & 0.0020 & -1.2233 & 50.268 & 73.329\end{array}$

$\begin{array}{llllllllllllll}\text { TMQALEIELQSQLSMK } & 0.98 & 28.82 & 27.36 & 16.57 & 3 & 2137.1368 & 2137.1366 & 713.3861 & 0.0002 & 0.0935 & 13.786 & 35.995\end{array}$

$\begin{array}{lllllllllllll}\text { TMQALEIELQSQLSMK } & 1.00 & \text { \#\#\#\# } 27.33 & 23.56 & 2 & 2137.1374 & 2137.1366 & 1069.5756 & 0.0008 & 0.3740 & 85.299 & 199.916\end{array}$

$\begin{array}{lllllllllllll}\text { TMQALEIELQSQLSMK } & 1.00 & \# \# \# \text { 27.33 } & 26.48 & 2 & 2137.1374 & 2137.1366 & 1069.5756 & 0.0008 & 0.3740 & 80.315 & 27.689\end{array}$

$\begin{array}{lllllllllllllll} & & \end{array}$

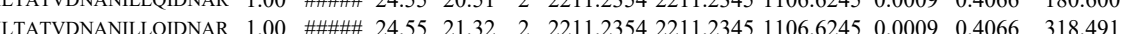

$\begin{array}{lllllllllllll}\text { ILTATVDNANILLOIDNAR } & 0.67 & 17.31 & 24.30 & 30.31 & 3 & 2211.2377 & 2211.2345 & 738.0854 & 0.0032 & 1.4452 & 29.727\end{array}$ $\begin{array}{llllllllllllll}\text { LTATVDNANILLOIDNAR } & 0.60 & 11.02 & 24.30 & 24.02 & 3 & 2211.2383 & 2211.2345 & 738.0854 & 0.0038 & 1.7161 & 80.735\end{array}$ $\begin{array}{lllllllllllllll} & \end{array}$ LSGGLGAGSCR $\begin{array}{lllll}0.00 & 69.15 & 26.34 & 24.08\end{array}$

$\begin{array}{lllllllll} & \end{array}$

LSGGLGASCR

LSGGGAGSR

$\begin{array}{lllllllll}2 & 1166.5748 & 1166.5658 & 584.2902 & 0.0090 & 7.5016 & 525.5444 & 1679.426\end{array}$

LSGGLGAGSCR

$\begin{array}{lllllllllllll}1.00 & 65.52 & 26.35 & 17.63 & 2 & 1166.5748 & 1166.5658 & 584.2902 & 0.0090 & 7.7016 & 6689.966 & 22756.3\end{array}$

LSGGLGAGSCR $\begin{array}{llllllllllll}1.00 & 70.51 & 26.35 & 25.83 & 2 & 1166.5748 & 1166.5658 & 584.2902 & 0.0090 & 7.7016 & 11430.082 & 40522.682\end{array}$

YCVQLSOIQGLIGSVEELLAQLR

YCVQLSQIQGLIGSVE TIVEVQDGK TIVEEVQDGK

TIVEEVDGK

ALEEANTELEVK

ALEEANTELEVK

ALEEANTELEVK

ALEEANTELEVK $\begin{array}{llllllllllll}1.00 & 61.80 & 26.35 & 21.84 & 3 & 2764.4389 & 2764.4373 & 922.4864 & 0.00016 & 0.57451 & 1.421 \\ 0.000\end{array}$ $\begin{array}{lllllllllllll}.60 & 15.47 & 27.93 & 16.66 & 3 & 1404.7756 & 1404.7704 & 469.2641 & 0.0052 & 3.6937 & 306.722 & 4.769\end{array}$ $\begin{array}{lllllllllllll}1.60 & & \end{array}$ $\begin{array}{llllllllllll}1.00 & 7.67 & 27.92 & 28.14 & 2 & 1404.7768 & 1404.7104 & 703.5925 & 0.0564 & 4.5494 & 2495.555 & 8910.490\end{array}$ $\begin{array}{llllllllllll}0.99 & 55.43 & 28.31 & 23.44 & 2 & 1632.8772 & 1632.8814 & 817.4480 & -0.0042 & -2.5690 & 6.204 & 22.072 \\ 0.98 & 51.92 & 2.28 & 2.26 & 2 & 1632.8780 & 16328814 & 817.4480 & -0.034 & -2.0796 & 70.084 & 192.52\end{array}$

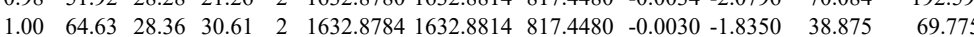

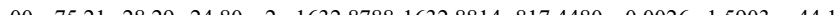

$\begin{array}{llllllllllll}1.00 & 67.14 & 28.07 & 27.97 & 2 & 1632.8790 & 1632.8814 & 817.4480 & -0.0024 & -1.4680 & 73.271\end{array}$

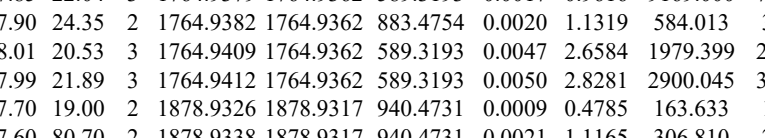
$\begin{array}{llllllllllll}0.98 & 30.80 & 28.31 & 25.89 & 3 & 1590.8530 & 1590.8530 & 531.2916 & 0.0000 & 0.0000 & 189.802 & 43\end{array}$
Yes \begin{tabular}{rrrr}
0.1882 & 200.546 & 439.787 \\
\hline & 54.3024 & 130.808
\end{tabular} $\begin{array}{lll}.252 & 1944.460 & 4517 \\ 1.797 & 44.671 & 45.1\end{array}$ $\begin{array}{lll}44.671 & 45.180 \\ 50.472 & 31.453\end{array}$ $\begin{array}{llll} & \\ 4.387 & 1.065 & 0.984 & \text { No }\end{array}$ \begin{tabular}{cccc}
9.86 & 9.879 & 45.113 & Yes \\
\hline .866 & 575.740 & 2052.982 & Yes
\end{tabular} \begin{tabular}{ccc}
57.740 & 2052.982 & Yes \\
\hline 534 & 38.101 & No
\end{tabular} $852 \quad 21.662$ Yes $\begin{array}{lll}50.899 & \text { Yes }\end{array}$

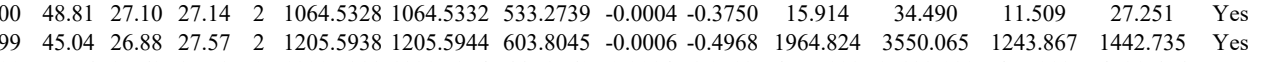

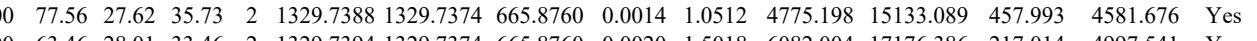

Table S-4 page 438 of 614 
ALEEANTELEVK ALEEANTELEVK

ALEEANTELEVK

ALEEANTELEVK

ALEEANTELEVK

ALEEANTELEVK

ALEEANTELEVK

ALEEANTELEVK

ALEEANTELEVK

LEEANTELEVK

ELEVK

LEEANTELEVK

LEEANTELEVK

ALEEANTELEVK

ALEEANTELEVK

DYSQYYR

DYSQYYR

DYSQYYR

DYSQYYR

ATMQNLNDR

ATMQNLNDR

DYSQYYR

DYSQYYR

DYSQYYR

DYSQYYR

DYSQYYR

DYSQYYR

TIVEEVQDGK

TIVEEVQDGK

TIVEEVQDGK

ASLEGNLAETENR

ASLEGNLAETENR

ALEEANTELEVK

DYSQYYR

DYSQYYR

DYSQYYR

LSVEADINGLRR

LSVEADINGLRR

DYSQYYR

LSVEADINGLRR

DYSQYYR

DYSQYYR

TMQALEIEL
DYSQYYR

DYSQYYR

DYSQYYR

DYSQYYR

DYSQYYR

ASLEGNLAETENR

ASLEGNLAETENR

TIEELQNK

TIEELQNK

ADLEMQIENLK

ADLEMQIENLK

ADLEMQIENLK

LLEGEDAHLTQYK

LLEGEDAHLTQYK

LLEGEDAHLIQYK

LLEGEDAHLTQYK

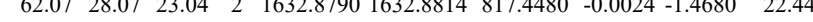

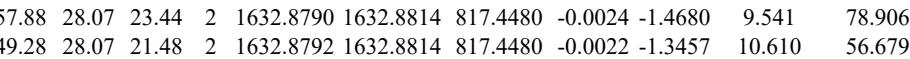
$\begin{array}{llllllll} & \end{array}$

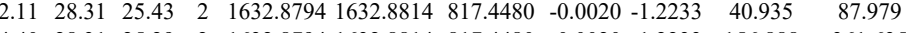

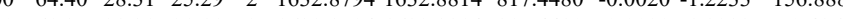
$\begin{array}{lllllllll} & \end{array}$

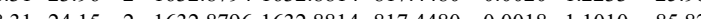

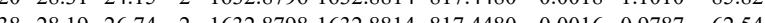

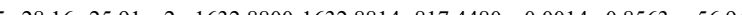
$\begin{array}{llllllllll}50.87 & 28.16 & 23.16 & 2 & 1632.8800 & 1632.8814 & 817.4480 & -0.0014 & -0.8563 & 15.370\end{array}$ $\begin{array}{lllllllllllll}100 & 78.31 & 28.18 & 26.09 & 2 & 1632.8802 & 1632.8814 & 817.4480 & -0.0012 & -0.7340 & 99.460\end{array}$ $\begin{array}{lllllllllll}1.07 .48 & 28.18 & 25.20 & 2 & 1632.8802 & 1632.8814 & 817.4480 & -0.0012 & -0.7340 & 61.158\end{array}$ $\begin{array}{lllllllllll}1.00 & 73.73 & 28.18 & 26.79 & 2 & 1632.8802 & 1632.8814 & 817.4480 & -0.0012 & -0.7340 & 22.362\end{array}$ $\begin{array}{lllllllllll}1.00 & 88.90 & 28.14 & 29.62 & 2 & 1632.8806 & 1632.8814 & 817.4480 & -0.0008 & -0.4893 & 14.924\end{array}$ $\begin{array}{llllllllllll}1.00 & 73.16 & 28.10 & 24.76 & 2 & 1632.8818 & 1632.8814 & 817.4480 & 0.0004 & 0.2447 & 28.318\end{array}$ $\begin{array}{llllllllllll}0.87 & 28.37 & 24.22 & 18.15 & 2 & 1137.5204 & 1137.5213 & 569.7679 & -0.0009 & -0.7898 & 273.947\end{array}$ $\begin{array}{lllllllllllll}0.98 & 28.52 & 23.78 & 21.58 & 2 & 1137.5222 & 1137.5213 & 569.7679 & 0.0009 & 0.7898 & 258.931\end{array}$ $\begin{array}{lllllllllllll}0.98 & 28.36 & 23.91 & 17.94 & 2 & 1137.5226 & 1137.5213 & 569.7679 & 0.0013 & 1.1408 & 232.412 & 64 & \\ 0\end{array}$

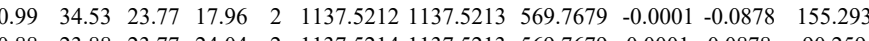
$\begin{array}{lllllllllll}0.88 & 23.88 & 23.77 & 24.04 & 2 & 1137.5214 & 1137.5213 & 569.7679 & 0.0001 & 0.0878 & 90.259\end{array}$ $\begin{array}{llllllllllll}0.69 & 26.16 & 26.81 & 22.24 & 2 & 1205.5934 & 1205.5944 & 603.8045 & -0.0010 & -0.8281 & 29.666\end{array}$ $\begin{array}{lllllllllllll}0.90 & 27.98 & 26.88 & 25.79 & 2 & 1205.5942 & 1205.5944 & 603.8045 & -0.0002 & -0.1656 & 22.334\end{array}$ $\begin{array}{llllllllllll}0.53 & 15.56 & 23.77 & 28.56 & 2 & 1137.5214 & 1137.5213 & 569.7679 & 0.0001 & 0.0878 & 133.249 & 450\end{array}$ $\begin{array}{llllllllllll}0.87 & 23.59 & 23.77 & 17.99 & 2 & 1137.5214 & 1137.5213 & 569.7679 & 0.0001 & 0.0878 & 83.433 \\ 0.84 & 21.45 & 24.00 & 34.45 & 2 & 1137.5230 & 1137.5213 & 569.7679 & 0.0017 & 1.4918 & 36.778\end{array}$ $\begin{array}{lllllllllllll}0.84 & 21.45 & 24.00 & 34.45 & 2 & 1137.5230 & 1137.5213 & 569.7679 & 0.0017 & 1.4918 & 36.778 & \\ 0.96 & 24.52 & 23.78 & 16.44 & 2 & 1137.5222 & 1137.5213 & 569.7679 & 0.0009 & 0.7898 & 38.262 & \end{array}$ $\begin{array}{llllllllllll}0.96 & 24.52 & 23.78 & 16.44 & 2 & 1137.5222 & 1137.5213 & 569.7679 & 0.0009 & 0.7898 & 38.262 \\ 0.93 & 2670 & 23.71 & 16.64 & 2 & 1137.5210 & 1137.5213 & 569.7679 & -0.0003 & -0.2633 & 105.958\end{array}$ $\begin{array}{llllllllllll}0.93 & 26.70 & 23.71 & 16.64 & 2 & 1137.5210 & 1137.5213 & 569.7679 & -0.0003 & -0.2633 & 105.958 \\ 0.93 & 26.57 & 23.77 & 18.64 & 2 & 1137.5212 & 1137.5213 & 569.7679 & -0.0001 & -0.0878 & 120.945\end{array}$ $\begin{array}{llllllllllll}0.93 & 26.57 & 23.77 & 18.64 & 2 & 1137.5212 & 1137.5213 & 569.7679 & -0.0001 & -0.0878 & 120.945 & 40 \\ 0.87 & 26.52 & 27.67 & 18.59 & 3 & 1404.7786 & 1404.7704 & 469.2641 & 0.0082 & 5.8247 & 109.364 & 32\end{array}$ $\begin{array}{lllllllllllll}0.87 & 26.52 & 27.67 & 18.59 & 3 & 1404.7786 & 1404.7704 & 469.2641 & 0.0082 & 5.8247 & 109.364 & 325 \\ 1.00 & 58.09 & 27.69 & 27.12 & 2 & 1404.7792 & 1404.7704 & 703.3925 & 0.0088 & 6.2554 & 5857.764\end{array}$ $\begin{array}{lllllllllllll}1.00 & 58.09 & 27.69 & 27.12 & 2 & 1404.7792 & 1404.7704 & 703.3925 & 0.0088 & 6.2554 & 5857.764 & 142.10 \\ 0.82 & 26.62 & 27.69 & 16.84 & 3 & 1404.7798 & 1404.7704 & 469.2641 & 0.0094 & 6.6771 & 105.859 & 276 .\end{array}$

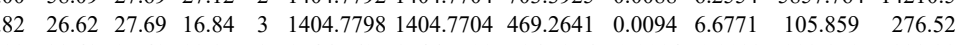
$\begin{array}{llllllllllllll}0.98 & 33.43 & 27.42 & 23.85 & 3 & 1546.7695 & 1546.7704 & 516.5976 & -0.0014 & -0.9033 & 222.151 & 333.388\end{array}$ $\begin{array}{llllllllllll}1.00 & 80.38 & 27.43 & 22.31 & 2 & 1546.7698 & 1546.7709 & 774.3927 & 0.0011 & 0.7102 & 8252.902 & 30093.823\end{array}$

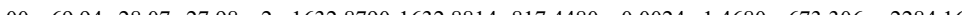

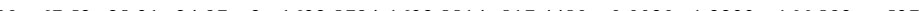
$\begin{array}{llllllllllll}0.87 & 28.55 & 24.20 & 22.86 & 2 & 1137.5206 & 1137.5213 & 569.7679 & -0.0007 & -0.6143 & 289.908 & 1001.913\end{array}$ $\begin{array}{lllllllllllll}0.95 & 28.62 & 23.71 & 18.61 & 2 & 1137.5208 & 1137.5213 & 569.7679 & -0.0005 & -0.4388 & 346.444 & 10.52\end{array}$ $\begin{array}{llllllllllll}0.95 & 28.47 & 23.71 & 21.47 & 2 & 1137.5208 & 1137.5213 & 569.7679 & -0.0005 & -0.4388 & 330.574 & 1134\end{array}$

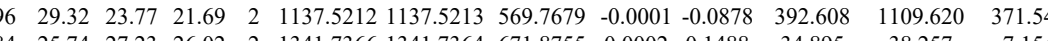
$\begin{array}{lllllllllllll}0.91 & 22.43 & 27.42 & 27.73 & 3 & 1341.7372 & 1341.7364 & 448.2527 & 0.0008 & 0.5949 & 60.078 & 80.6\end{array}$ $\begin{array}{llllllllllll}0.96 & 29.69 & 23.65 & 19.33 & 2 & 1137.5216 & 1137.5213 & 569.7679 & 0.0003 & 0.2633 & 306.240 & 972\end{array}$ $\begin{array}{llllllllllll}0.98 & 27.95 & 23.62 & 20.07 & 2 & 1137.5218 & 1137.5213 & 569.7679 & 0.0005 & 0.4388 & 261.563 & 947 .\end{array}$ $\begin{array}{llllllllllllllll}0.73 & 15.83 & 27.42 & 19.52 & 3 & 1341.7372 & 1341.7364 & 448.2527 & 0.0008 & 0.5949 & 58.408 & 71.224\end{array}$ $\begin{array}{llllllllllllll}0.98 & 27.35 & 24.13 & 17.76 & 2 & 1137.5232 & 1137.5213 & 569.7679 & 0.0019 & 1.6673 & 160.095 & 466.065\end{array}$

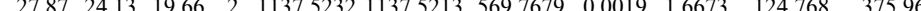
$\begin{array}{llllllllllllll}0.90 & 18.63 & 27.30 & 14.40 & 3 & 2137.1389 & 2137.1366 & 713.3861 & 0.0023 & 1.0747 & 47.077\end{array}$ $\begin{array}{lllllllllllll}0.94 & 22.51 & 23.93 & 15.09 & 2 & 1137.5228 & 1137.5213 & 569.7679 & 0.0015 & 1.3163 & 167.003 & 4\end{array}$ $\begin{array}{lllllllllllll}0.97 & 26.53 & 24.13 & 19.09 & 2 & 1137.5232 & 1137.5213 & 569.7679 & 0.0019 & 1.6673 & 137.094 & 374 .\end{array}$

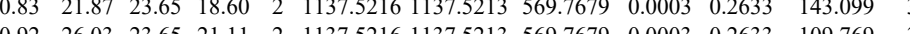
$\begin{array}{llllllllllll}0.92 & 26.03 & 23.65 & 21.11 & 2 & 1137.5216 & 1137.5213 & 569.7679 & 0.0003 & 0.2633 & 109.769 & 362 .\end{array}$ $\begin{array}{llllllllllllll}1.00 & 68.17 & 27.55 & 22.28 & 2 & 1546.7724 & 1546.7709 & 774.3927 & 0.0015 & 0.9685 & 2661.276 & 5828.665 & 74.5 .0\end{array}$ $\begin{array}{lllllllllllll}0.17 & \end{array}$

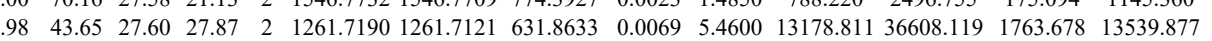
$\begin{array}{llllllllllllllll}0.99 & 44.24 & 27.57 & 31.55 & 2 & 1261.7192 & 1261.7121 & 631.8633 & 0.0071 & 5.6183 & 14012.828 & 41313.653 & 1038.781 & 14998.694 & \text { Yes }\end{array}$

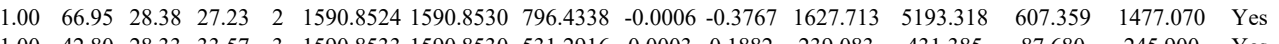
$\begin{array}{lllllllllllllll}1.00 & 42.80 & 28.33 & 33.57 & 3 & 1590.8533 & 1590.8530 & 531.2916 & 0.0003 & 0.1882 & 239.083 & 431.385 & 87.680 & 245.900 & \text { Yes } \\ 1.00 & 5.28 & 28.15 & 31.13 & 3 & 1590.8539 & 1590.8530 & 53.2916 & 0.000 & 0.5647 & 151.990 & 461.644 & 125.799 & 198.710 & \text { Yes }\end{array}$

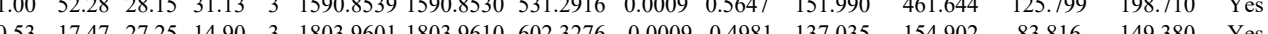

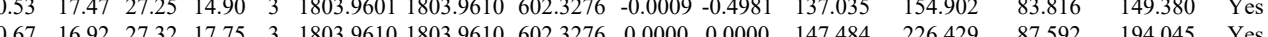

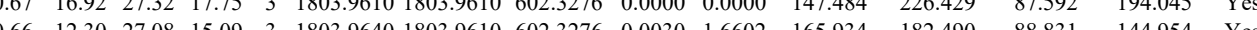

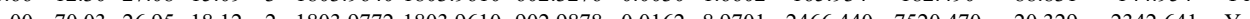
$\begin{array}{llllllllllllllll}100 & 50.28 & 26.95 & 16.68 & 3 & 1803.9778 & 1803.9610 & 602.3276 & 0.0168 & 9.2972 & 5493.371 & 20383.796 & 2055.560 & 5482.038 & \text { Yes }\end{array}$

Table S-4 page 439 of 614 

$\begin{array}{lllllllllllllll} & \end{array}$

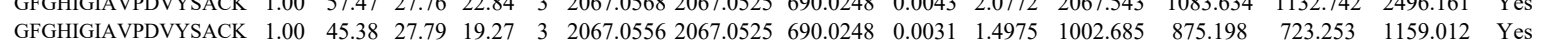

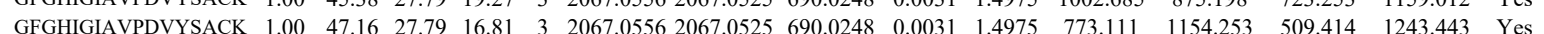
$\begin{array}{lllllllllllllllllll} & \text { VLGMTLIQK } & 0.99 & 37.95 & 21.52 & 24.48 & 2 & 1289.8082 & 1289.7985 & 645.9065 & 0.0097 & 7.5088 & 20632.128 & 20989.455 & 1545.460 & 32617.723 & Y^{2}\end{array}$

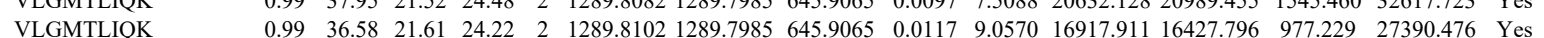

IAWALSR

IAWALSR

IAWALSR

$\begin{array}{llllllllllllllllll}0.99 & 36.58 & 21.61 & 24.22 & 2 & 1289.8102 & 1289.7985 & 645.9065 & 0.0117 & 9.0570 & 16917.911 & 16427.796 & 977.229 & 27390.476 & \text { Yes } & & \\ 0.85 & 35.31 & 27.56 & 36.68 & 2 & 959.5732 & 959.5674 & 480.7910 & 0.0058 & 6.0317 & 13368.660 & 14022.957 & 2817.489 & 28793.604 & \text { Yes }\end{array}$ $\begin{array}{llllllllllllllllll}0.96 & 38.72 & 27.32 & 32.81 & 2 & 959.5744 & 959.5674 & 480.7910 & 0.0070 & 7.2796 & 18854.151 & 20890.111 & 4191.657 & 40813.235 & \text { Yes }\end{array}$ $\begin{array}{lllllllllllllllll}0.95 & 38.48 & 27.56 & 33.03 & 2 & 959.5732 & 959.5674 & 480.7910 & 0.0058 & 6.0317 & 7764.360 & 8469.062 & 1305.02 & 18963.045 & \text { Yes }\end{array}$ $\begin{array}{lllllllllllllllll}0.96 & 38.73 & 27.50 & 29.37 & 2 & 959.5748 & 959.5674 & 480.7910 & 0.0074 & 7.6956 & 12054.592 & 12428.453 & 3346.882 & 26636.161 & \text { Yes }\end{array}$ $\begin{array}{llllllllllllllllll}0.99 & 35.20 & 27.85 & 33.04 & 2 & 959.5692 & 959.5674 & 480.7910 & 0.0018 & 1.8719 & 4065.067 & 4617.171 & 813.791 & 9642.764 & \text { Yes }\end{array}$ $\begin{array}{llllllllllllllllll}0.98 & 32.83 & 27.85 & 33.12 & 2 & 959.5694 & 959.5674 & 480.7910 & 0.0020 & 20799 & 6110.628 & 7086.201 & 927.923 & 13047.967 & \text { Yes }\end{array}$ $\begin{array}{llllllllllllllll}0.98 & 32.83 & 27.85 & 33.12 & 2 & 959.5694 & 95.5674 & 480.7910 & 0.0020 & 2.0799 & 6110.628 & 7086.201 & 927.923 & 13047.967 & \text { Yes } \\ 0.94 & 34.18 & 26.33 & 32.39 & 2 & 959.5668 & 959.5674 & 480.7910 & -0.0006 & -0.6240 & 369.998 & 363.291 & 107.854 & 634.293 & \text { Yes }\end{array}$

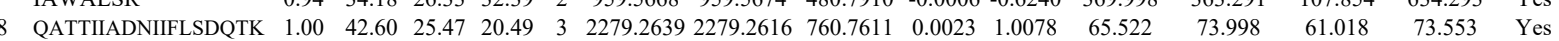
\begin{tabular}{llllllllllllllll} 
QATTIIADNIIFLSDQTK & 1.00 & 34.70 & 25.37 & 17.10 & 3 & 2279.2657 & 2279.2616 & 760.7611 & 0.0041 & 1.7964 & 43.686 & 67.880 & 45.117 & 93.611 & Yes \\
\hline
\end{tabular}

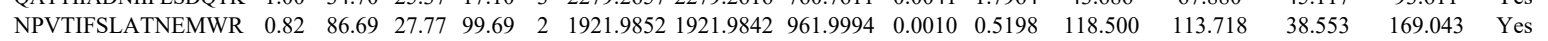
$\begin{array}{llllllllllllllll}\text { NPVTIFSLATNEMWR } & 0.67 & 44.11 & 27.92 & 57.11 & 3 & 1921.9873 & 1921.9842 & 641.6687 & 0.0031 & 1.6104 & 140.808 & 92.249 & 47.390 & 64.921 & \text { Yes }\end{array}$

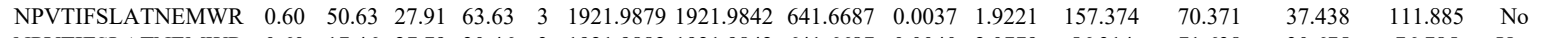
$\begin{array}{lllllllllllllllll}\text { NPVTIFSLATNEMWR } & 0.60 & 17.46 & 27.79 & 30.46 & 3 & 1921.9882 & 1921.9842 & 641.6687 & 0.0040 & 2.0779 & 56.314 & 71.638 & 30.675 & 76.785 & \text { Yes }\end{array}$ $\begin{array}{lllllllllllllllll}\text { VGQDPVLR } & 0.98 & 37.95 & 25.25 & 18.36 & 2 & 882.4918 & 882.4923 & 442.2534 & -0.0005 & -0.5653 & 29.560 & 48.292 & 32.861 & 40.401 & \text { Yes }\end{array}$

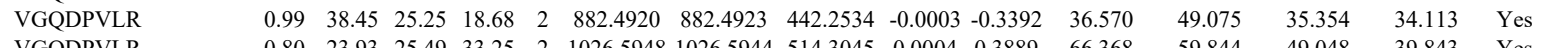
VGQDPVLR VGQDPVLR VGQDPVLR VGQDPVLR VGQDPVLR VGQDPVLR VGQDPVLR VGQDPVLR VGQDPVLR
VGQDPVLR VGQDPVLR VGQDPVLR VGQDPVLR VGQDPVLR VGQDPVLR VGQDPVLR ISVFRPGLR
ISVFRPGLR ISVFRPGLR
ISVFRPGLR ISVFRPGLR
ISVFRPGLR ISVFRPGLR
ISVFRPGLR ISVFRPGLR ISVFRPGLR $\begin{array}{lllllllllllll}0.80 & 23.93 & 25.49 & 33.25 & 2 & 1026.5948 & 1026.5944 & 514.3045 & 0.0004 & 0.3889 & 66.368 \\ 0.69 & 24.50 & 25.24 & 17.77 & 2 & 882.4914 & 882.4923 & 442.2534 & -0.0009 & -1.0175 & 61.573\end{array}$ $\begin{array}{lllllllllll}0.89 & 25.66 & 25.25 & 18.08 & 2 & 882.4914 & 882.4923 & 442.2534 & -0.0009 & -1.0175 & 61.573 \\ 0.920 & 882.4923 & 442.2534 & -0.0003 & -0.3392 & 92.940\end{array}$

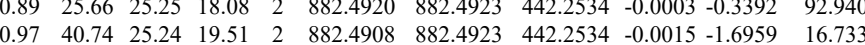

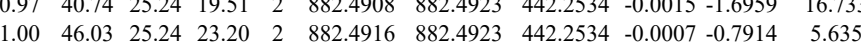

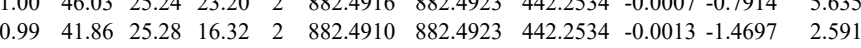

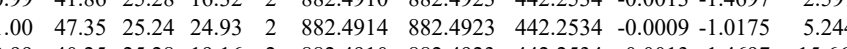
$\begin{array}{lllllllllll}0.99 & 40.25 & 25.28 & 19.16 & 2 & 882.4910 & 882.4923 & 442.2534 & -0.0013 & -1.4697 & 15.665\end{array}$ $\begin{array}{llllllllllll}0.96 & 35.94 & 25.25 & 21.90 & 2 & 882.4912 & 882.4923 & 442.2534 & -0.0011 & -1.2436 & 1.652\end{array}$

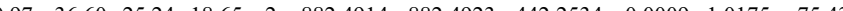

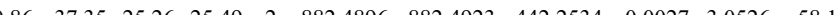

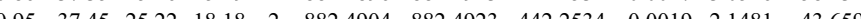
$\begin{array}{llllllllllll}0.97 & 36.94 & 25.25 & 21.87 & 2 & 882.4918 & 882.4923 & 442.2534 & -0.0005 & 0.5653 & 29.324\end{array}$ $\begin{array}{llllllllllll}0.97 & 36.54 & 25.25 & 21.28 & 2 & 882.4918 & 882.4923 & 442.2534 & -0.0005 & 0.5653 & 53.418\end{array}$ $\begin{array}{lllllllllll}0.58 & 17.39 & 24.64 & 14.11 & 2 & 1187.7264 & 1187.7261 & 594.8703 & 0.0003 & 0.2522 & 312.476\end{array}$ $\begin{array}{llllllllllll}0.79 & 17.21 & 24.20 & 16.54 & 2 & 1187.7270 & 1187.7261 & 594.8703 & 0.0009 & 0.7565 & 1541.608 & 1444\end{array}$

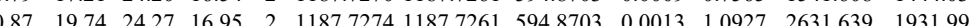
$\begin{array}{llllllllllll}0.90 & 20.68 & 24.23 & 16.56 & 2 & 1187.7282 & 1187.7261 & 594.8703 & 0.0021 & 1.7651 & 1153.837 & 919.172\end{array}$ $\begin{array}{lllllllllllll}0.51 & 18.26 & 24.15 & 15.48 & 2 & 1187.7296 & 1187.7261 & 594.8703 & 0.0035 & 2.9418 & 922.866 & 669.874\end{array}$ $\begin{array}{llllllllllll}0.80 & 17.15 & 24.23 & 15.64 & 2 & 1187.7276 & 1187.7261 & 594.8703 & 0.0015 & 1.2608 & 714.171 & 515.007 \\ 0.84 & 18.44 & 24.22 & 17.66 & 2 & 1187.7284 & 1187.7261 & 594.8703 & 0.0023 & 1.9332 & 446.182 & 391.056\end{array}$

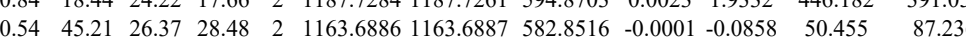

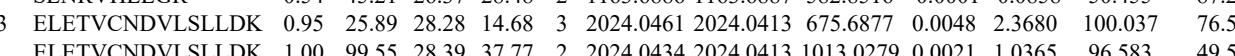
$\begin{array}{lllllllllllll}\text { ELETVCNDVLSLLDK } & 1.00 & 99.55 & 28.39 & 37.77 & 2 & 2024.0434 & 2024.0413 & 1013.0279 & 0.0021 & 1.0365 & 96.583 & 49.524\end{array}$ \begin{tabular}{lllllllllllll} 
ELETVCNDVLSLLDK & 1.00 & 84.50 & 28.39 & 38.09 & 2 & 2024.0434 & 2024.0413 & 1013.0279 & 0.0021 & 1.0365 & 65.621 & 29.537 \\
\hline
\end{tabular} $\begin{array}{lllllllllllll}\text { ELETVCNDVLSLLDK } & 1.00 & 32.58 & 28.42 & 19.14 & 3 & 2024.0443 & 2024.0413 & 675.6877 & 0.0030 & 1.4800 & 125.590 & 111.78\end{array}$ $\begin{array}{lllllllllllll}\text { ELETVCNDVLSLLDK } & 1.00 & 38.48 & 28.33 & 20.66 & 3 & 2024.0458 & 2024.0413 & 675.6877 & 0.0045 & 2.2200 & 149.121 & 74.917\end{array}$ $\begin{array}{lllllllllllll}\text { ELETVCNDVLSLLDK } & 1.00 & \text { \#\#\#\# } 28.39 & 29.13 & 2 & 2024.0434 & 2024.0413 & 1013.0279 & 0.0021 & 1.0365 & 44.210 & 22.843\end{array}$ $\begin{array}{llllllllllllll}\text { ELETVCNDVLSLLDK } & 0.98 & 26.34 & 28.27 & 17.18 & 3 & 2024.0452 & 2024.0413 & 675.6877 & 0.0039 & 1.9240 & 76.651 & 96.168\end{array}$ $\begin{array}{llllllllllllll}\text { ELETVCNDVLSLLDK } & 0.94 & 22.53 & 28.27 & 14.75 & 3 & 2024.0455 & 2024.0413 & 675.6877 & 0.0042 & 2.0720 & 66.546 & 66.333 \\ \text { ELETVCNDVLSLLDK } & 1.00 & 41.38 & 28.27 & 19.21 & 3 & 2024.0452 & 2024.0413 & 675.6877 & 0.0039 & 1.9240 & 120.573 & 81.599\end{array}$ $\begin{array}{lllllllllllll}\text { ELETVCNDVLSLLDK } & 1.00 & 41.38 & 28.27 & 19.21 & 3 & 2024.0452 & 2024.0413 & 675.6877 & 0.0039 & 1.9240 & 120.573 & 81.599 \\ \text { AVTELNEPLSNEDR } & 1.00 & 68.85 & 27.44 & 26.77 & 2 & 1729.8622 & 1729.8604 & 865.9375 & 0.0018 & 1.0393 & 72.195 & 109.746\end{array}$

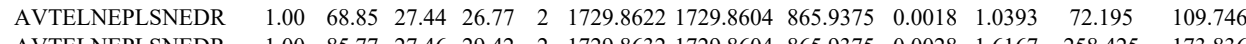

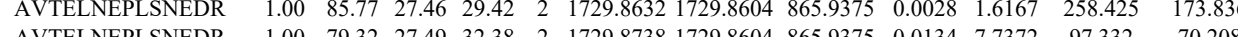
$\begin{array}{lllllllllllll}\text { AVTELNEPLSNEDR } & 1.00 & 79.32 & 27.49 & 32.38 & 2 & 1729.8738 & 1729.8604 & 865.9375 & 0.0134 & 7.7372 & 97.332 & 70.208\end{array}$ $\begin{array}{lllllllllllll}\text { QAFDDAIAELDTLNEDSYK } & 0.97 & 24.32 & 27.19 & 15.41 & 3 & 2445.1834 & 2445.1791 & 816.0670 & 0.0043 & 1.7564 & 7.645 & 11.108 \\ \text { QAFDDAIAELDTLNEDSYK } & 1.00 & 80.09 & 27.30 & 21.55 & 2 & 2445.1854 & 2445.1791 & 1223.5968 & 0.0063 & 2.5744 & 2.890 & 5.009\end{array}$

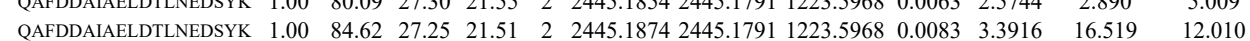

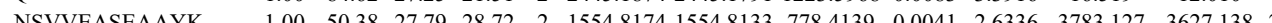
$\begin{array}{llllllllllllll}\text { NSVVEASEAAYK } & 1.00 & 50.38 & 27.79 & 28.72 & 2 & 1554.8174 & 1554.8133 & 778.4139 & 0.0041 & 2.6336 & 3783.127 & 3627.138 & 22.132 .4 \\ \text { NSVVEASEAAYK } & 1.00 & 72.13 & 27.56 & 41.63 & 2 & 1554.8178 & 1554.8133 & 778.4139 & 0.0045 & 2.8905 & 4191.849 & 2919.066 & 7982.7\end{array}$ 


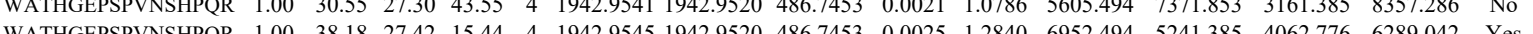

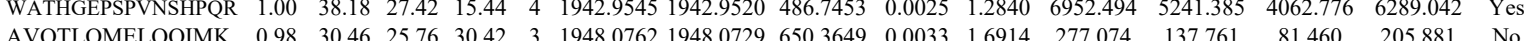
$\begin{array}{llllllllllllll} & \end{array}$ $\begin{array}{llllllllllllllll} & 102.655 & \text { No }\end{array}$ $\begin{array}{lllllllllllllll} & \end{array}$

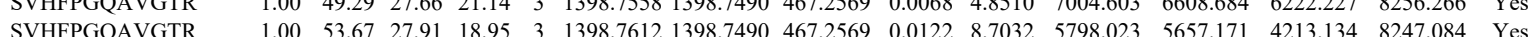

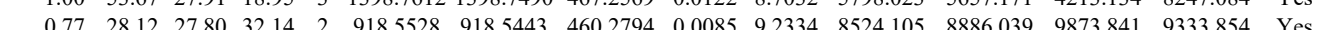

SVLIMGR

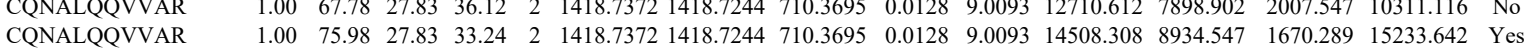
$\begin{array}{lllllllllllllllll}0.77 & 28.12 & 27.80 & 32.14 & 2 & 918.5528 & 918.5443 & 460.2794 & 0.0085 & 9.2334 & 8524.105 & 8886.039 & 9873.841 & 9333.854 & Y e s & \\ 1.00 & 67.78 & 27.83 & 36.12 & 2 & 1418.7372 & 1418.7244 & 710.365 & 0.0128 & 9.0093 & 12710.612 & 7898.902 & 2007.547 & 10311.116 & N o\end{array}$ $\begin{array}{lllllllllllllll}\text { GALTVGITNTVGSSISR } & 1.00 & \text { \#\#\#\# } 26.20 & 46.68 & 2 & 1775.9878 & 1775.9863 & 889.0004 & 0.0015 & 0.8436 & 416.191 & 392.694 & 397.395 & 544.005 & \text { Yes }\end{array}$

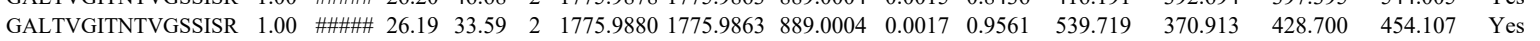
$\begin{array}{llllllllllllllll}\text { CQNALQQVVAR } & 1.00 & 69.07 & 27.60 & 26.52 & 2 & 1418.7352 & 1418.7244 & 710.3695 & 0.0108 & 7.6016 & 209.261 & 159.076 & 28.055 & 212.091 & \text { Yes }\end{array}$ $\begin{array}{llllllllllllllll}\text { GALTVGITNTVGSSISR } & 1.00 & 85.48 & 26.32 & 45.05 & 2 & 1775.9884 & 1775.9863 & 889.0004 & 0.0021 & 1.1811 & 160.785 & 136.100 & 192.142 & 170.497 & \text { Yes }\end{array}$ $\begin{array}{llllllllllllllll}\text { GALTVGITNTVGSSISR } & 1.00 & 99.46 & 26.20 & 26.78 & 2 & 1775.9872 & 1775.9863 & 889.0004 & 0.0009 & 0.5062 & 35.696 & 27.227 & 25.735 & 17.800 & \text { No }\end{array}$

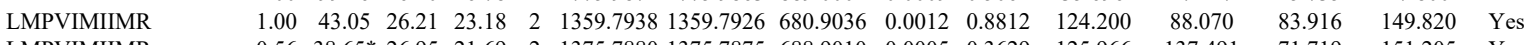

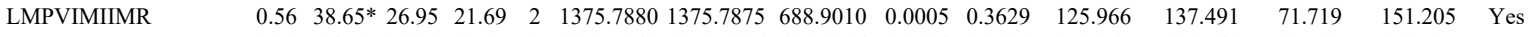
$\begin{array}{llllllllllllllll}\text { LMPVIMIIMR } & 0.99 & 34.53 & 26.21 & 22.65 & 2 & 1359.7940 & 1359.7926 & 680.9036 & 0.0014 & 1.0280 & 152.965 & 102.740 & 80.723 & 168.785 & \text { Yes }\end{array}$ $\begin{array}{llllllllllllllll}\text { LMPVIMIIMR } & 0.98 & 30.94 & 26.64 & 21.18 & 2 & 1359.7944 & 1359.7926 & 680.9036 & 0.0018 & 1.3218 & 64.928 & 32.564 & 41.721 & 64.018 & \text { Yes }\end{array}$ $\begin{array}{lllllllllllllllll} & 0.61 & 31.82 * & 26.95 & 22.72 & 2 & 1375.7886 & 1375.7875 & 688.9010 & 0.0011 & 0.7984 & 169.839 & 97.140 & 106.273 & 183.429 & \text { Yes }\end{array}$ $\begin{array}{lllllllllllllllll}\text { LMPVIMIIMR } & 0.59 & 31.15 * 26.95 & 20.40 & 2 & 1375.7886 & 1375.7875 & 688.9010 & 0.0011 & 0.7984 & 138.796 & 96.493 & 69.720 & 133.967 & \text { Yes }\end{array}$

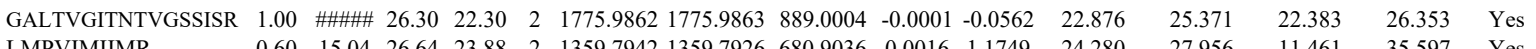
LMPVIMIIMR VIFLEDDDVAAVVDG $\begin{array}{lllllllllllll}\text { PSME1_HUMAI Q06323 } & \text { PSME1 } & \text { Proteasome activa 28.723 } & 1.00 & 10 & 47.4 & -0.3314 & 0.3006 & 1.8105 & 0.3015 & 43 & \text { EPALNEANLSNLK }\end{array}$ APLDIPVPDPVK APLDIPVPDPVK APLDIPVPDP ISELDAFLK

ISELDAFLK

APLDIPVPDPVK

ISELDAFLK

ISELDAFLK

ISELDAFLK

LEGFHTOISK

LEGFHTQISK

TENLLGSYFPK

NAYAVLYDIILK

VFELMTSLHTK

VFELMTSLHTK

NAYAVLYDIILK

NAYAVLYDIILK $\begin{array}{llllllllllllllll}\text { VFELMTSLHTK } & 0.66 & 39.55 & 26.78 & 52.55 & 3 & 1592.8864 & 1592.8840 & 531.9686 & 0.0024 & 1.5038 & 3295.212 & 3204.029 & 190.662 & 3790.074 & \text { Yes } \\ \text { VFELMTSLHTK } & 1.00 & 47.73 & 26.75 & 18.74 & 3 & 1592.8873 & 1592.8840 & 531.9686 & 0.0033 & 2.0678 & 4287.344 & 3562.742 & 572.809 & 4728.836 & \text { Yes }\end{array}$

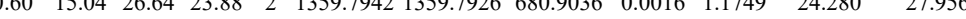
$\begin{array}{lllllllllllll}0.63 & 15.64 & 26.64 & 16.52 & 2 & 1359.7946 & 1359.7926 & 680.9036 & 0.0020 & 1.4686 & 38.191 & 28.272\end{array}$ $\begin{array}{lllllllllll}1.00 & 27.97 & 26.90 & 2 & 1875.9718 & 1875.9700 & 938.9923 & 0.0018 & 0.9585 & 230.391 & \end{array}$

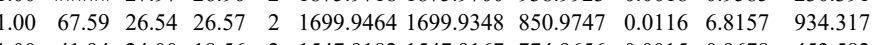
$\begin{array}{lllllllllll}1.00 & 41.94 & 24.00 & 18.56 & 2 & 1547.9182 & 1547.9167 & 774.9656 & 0.0015 & 0.9678 & 453.582\end{array}$ $\begin{array}{llllllllllll}0.71 & 10.23 & 24.00 & 19.84 & 3 & 1547.9185 & 1547.9167 & 516.9795 & 0.0018 & 1.1606 & 101.514 \\ 1.00 & 55.97 & 23.32 & 19.55 & 2 & 1547.9202 & 1547.9167 & 774.9656 & 0.0035 & 2.2582 & 98.134\end{array}$

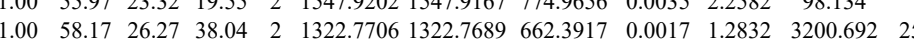
$\begin{array}{lllllllllll} & \end{array}$ $\begin{array}{lllllllllllllll}.00 & 44.97 & 26.27 & 31.05 & 2 & 1322.7708 & 1322.7689 & 662.3917 & 0.0019 & 1.4342 & 7289.512 & 5811.677 & 316.753 & 8443.140 & \text { Ycs } \\ .99 & 31.66 & 24.01 & 15.32 & 2 & 1547.9190 & 1547.9167 & 774.9656 & 0.0022 & 1.4839 & 34.737 & 24.410 & 11.899 & 34.079 & \text { Ycs } \\ .72 & 40.46 & 23.87 & 53.46 & 2 & 1547.9194 & 1547.9167 & 774.9656 & 0.0027 & 1.7420 & 27.980 & 0.000 & 10.411 & 11.863 & \text { No } \\ .00 & 45.04 & 26.27 & 31.28 & 2 & 1322.7706 & 1322.7689 & 662.3917 & 0.0017 & 1.2832 & 9905.174 & 7371.490 & 525.587 & 11055.041 & Y c 5\end{array}$

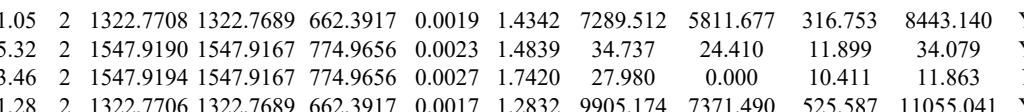
$\begin{array}{lllllllllllllll}0.99 & 42.30 & 27.69 & 28.10 & 2 & 1446.8178 & 1446.8074 & 724.4110 & 0.0104 & 7.1782 & 341.988 & 181.771 & 95.033 & 174.375 & \text { No }\end{array}$ $\begin{array}{llllllllllllllll}0.55 & 20.02 & 27.42 & 17.89 & 3 & 1446.8197 & 1446.8074 & 483.2764 & 0.0123 & 8.4837 & 17852.153 & 13829.611 & 495.621 & 19581.453 & \text { Yes }\end{array}$ \begin{tabular}{llllllllllllllll}
0.99 & 43.32 & 26.59 & 26.48 & 2 & 1555.8640 & 1555.8490 & 778.9318 & 0.0150 & 9.6285 & 1692.772 & 1296.800 & 186.984 & 1447.081 & Yes \\
\hline
\end{tabular} $\begin{array}{lllllllllllllll}1.00 & 41.11 & 26.82 & 29.29 & 2 & 1555.8514 & 1555.8490 & 778.9318 & 0.0024 & 1.5406 & 731.415 & 396.179 & 93.529 & 556.230 & \text { Yes } \\ 0.88 & 14.63 & 23.10 & 17.14 & 3 & 1682.9887 & 1682.9850 & 562.0023 & 0.0037 & 2.1945 & 47.367 & 54.732 & 15.068 & 45.916 & \text { No }\end{array}$

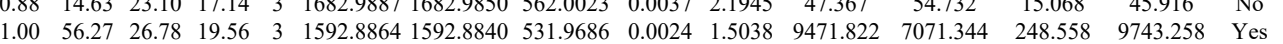
$\begin{array}{lllllllllllllll}1.00 & 47.98 & 26.64 & 19.41 & 3 & 1592.8882 & 1592.8840 & 531.9686 & 0.0042 & 2.6317 & 9789.009 & 9629.648 & 2.429 & 11877.972 & \text { Yes }\end{array}$ $\begin{array}{lllllllllllllll}0.99 & 25.80 & 23.16 & 20.03 & 3 & 1682.9878 & 1682.9850 & 562.0023 & 0.0028 & 1.6607 & 29.281 & 76.408 & 45.586 & 72.035 & \text { No }\end{array}$ $\begin{array}{llllllllllllllll}0.58 & 7.99 & 23.10 & 16.00 & 3 & 1682.9887 & 1682.9850 & 562.0023 & 0.0037 & 2.1945 & 119.522 & 169.464 & 79.142 & 349.876 & \text { No }\end{array}$ $\begin{array}{llllllllllllllll}\text { DVIEQLNLVTTWLQLQIPR } & 1.00 & 41.12 & 21.96 & 17.33 & 3 & 2422.3732 & 2422.3706 & 808.4641 & 0.0026 & 1.0720 & 22.083 & 14.443 & 3.396 & 16.549 & \text { Yes }\end{array}$ $\begin{array}{lllllllllllllllll}\text { IVVLLQR } & 0.86 & 30.70 & 18.45 & 31.69 & 2 & 983.6672 & 983.6613 & 492.8379 & 0.0059 & 5.9857 & 18604.084 & 15162.295 & 1238.252 & 21931.417 & \text { Yes }\end{array}$ IVVLLQR IVVLLQR IVVLLQR IVVLLQR $\begin{array}{llllllllllllllllllll}0.86 & 30.62 & 18.45 & 31.31 & 2 & 983.6674 & 983.6613 & 492.8379 & 0.0061 & 6.1886 & 16640.904 & 12893.059 & 1514.294 & 21025.229 & \text { Yes }\end{array}$ $\begin{array}{lllllllllllllll}0.72 & 12.14 & 14.91 & 23.57 & 2 & 983.6616 & 983.6613 & 492.8379 & 0.0003 & 0.3044 & 48.120 & 49.399 & 10.371 & 61.452 & \text { Yes }\end{array}$ $\begin{array}{llllllllllllllll}0.89 & 13.32 & 14.91 & 23.55 & 2 & 983.6620 & 983.6613 & 492.8379 & 0.0007 & 0.7102 & 62.472 & 34.829 & 24.383 & 72.940 & \text { Yes }\end{array}$ $\begin{array}{llllllllllllllll}0.98 & 21.31 & 14.91 & 23.43 & 2 & 983.6620 & 983.6613 & 492.8379 & 0.0007 & 0.7102 & 40.210 & 26.952 & 26.933 & 42.236 & \text { Yes }\end{array}$ $\begin{array}{lllllllllllllll}0.92 & 13.56 & 14.91 & 22.12 & 2 & 983.6622 & 983.6613 & 492.8379 & 0.0009 & 0.9131 & 39.650 & 35.458 & 24.545 & 60.363 & \text { Yes } \\ 0.95 & 15.11 & 14.91 & 21.36 & 2 & 983.6626 & 983.6613 & 4928379 & 0.0013 & 1.3189 & 55.826 & 43.452 & 24.716 & 56.279 & \text { Yes }\end{array}$ $\begin{array}{lllllllllllllll}0.95 & 15.11 & 14.91 & 21.36 & 2 & 983.6626 & 983.6613 & 492.8379 & 0.0013 & 1.3189 & 55.826 & 43.452 & 24.716 & 56.279 & \text { Yes } \\ 0.90 & 14.91 & 17.85 & 21.76 & 2 & 983.6628 & 983.6613 & 4928379 & 0.0015 & 1.5218 & 39.145 & 31.226 & 31.930 & 73.998 & \text { Yes }\end{array}$ $\begin{array}{lllllllllllllll}0.90 & 14.91 & 17.85 & 21.76 & 2 & 983.6628 & 983.6613 & 492.8379 & 0.0015 & 1.5218 & 39.145 & 31.226 & 31.930 & 73.998 & \text { Yes } \\ 0.93 & 17.24 & 17.85 & 25.56 & 2 & 983.6628 & 983.6613 & 4928379 & 0.0015 & 1.5218 & 40.021 & 52.212 & 20.420 & 49.990 & \text { Yes }\end{array}$

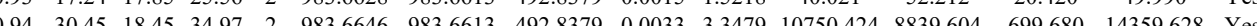
$\begin{array}{lllllllllllllll}0.93 & 30.60 & 18.45 & 31.51 & 2 & 983.6654 & 983.6613 & 492.8379 & 0.0041 & 4.1596 & 17414.423 & 13450.311 & 850.863 & 26263.773 & \text { Yes }\end{array}$

Table S-4 page 441 of 614 

$\begin{array}{llllllllllllllll}0.97 & 32.15 & 14.91 & 32.66 & 2 & 983.6614 & 983.6613 & 492.8379 & 0.000 & 0.1015 & 3499.495 & 2457.713 & 22.499 & 4257.750 & \text { Yes }\end{array}$ $\begin{array}{lllllllllllllll}0.97 & 30.36 & 4.91 & 30.37 & 2 & 983.6614 & 983.6613 & 492.8379 & 0.0001 & 0.1015 & 531.294 & 348.434 & 72.038 & 548.510 & \text { Yes }\end{array}$ $\begin{array}{llllllllllllllll}0.94 & 21.31 & 14.91 & 24.82 & 2 & 983.6616 & 983.6613 & 492.8379 & 0.0003 & 0.3044 & 2045.619 & 1571.052 & 467.349 & 2620.434 & \text { Yes }\end{array}$ $\begin{array}{lllllllllllllll}0.99 & 29.74 & 14.91 & 29.86 & 2 & 983.6620 & 983.6613 & 492.8379 & 0.0007 & 0.7102 & 191.136 & 164.306 & 48.680 & 223.125 & \text { Yes } \\ 0.99 & 29.90 & 14.91 & 30.25 & 2 & 983.6624 & 983.6613 & 492.8379 & 0.0011 & 1.1160 & 189.601 & 160.319 & 56.301 & 229.137 & \text { Yes }\end{array}$ \begin{tabular}{lllllllllllllll}
1.99 & 7.90 & 14.91 & 30.25 & 2 & 983.6624 & 983.6613 & 492.8379 & 0.0011 & 1.1160 & 189.601 & 160.319 & 56.301 & 229.137 & Yes \\
\hline
\end{tabular} $\begin{array}{lllllllllllllll}1.00 & 52.87 & 27.65 & 23.39 & 2 & 1806.9404 & 1806.9356 & 904.4751 & 0.0048 & 2.6535 & 547.018 & 374.364 & 114.721 & 575.363 & \text { Yes }\end{array}$ $\begin{array}{lllllllllllllll}1.00 & 77.15 & 26.68 & 29.90 & 2 & 1699.9452 & 1699.9348 & 850.9747 & 0.0104 & 6.1106 & 1600.152 & 1487.781 & 2120.078 & 2001.699 & N 0\end{array}$

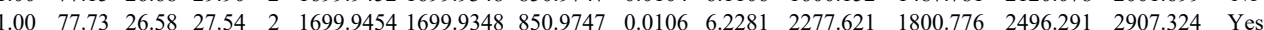
$\begin{array}{lllllllllllllll}0.97 & 31.96 & 26.54 & 23.67 & 3 & 1699.9465 & 1699.9348 & 567.6522 & 0.0117 & 6.8704 & 757.688 & 593.302 & 381.678 & 778.011 & \text { Yes }\end{array}$

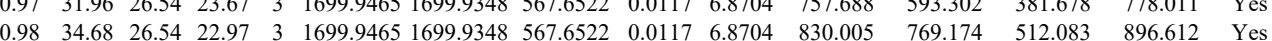
$\begin{array}{lllllllllllllll}0.66 & 42.35 & 27.25 & 55.35 & 3 & 2572.3162 & 2572.3142 & 858.4453 & 0.0020 & 0.7766 & 28.625 & 30.709 & 14.112 & 31.062 & \text { Yes }\end{array}$ $\begin{array}{lllllllllllllll}0.67 & 33.96 & 27.16 & 46.96 & 3 & 1768.8472 & 1768.8446 & 590.6221 & 0.0026 & 1.4674 & 3369.148 & 3472.332 & 1567.950 & 4538.057 & \text { Yes }\end{array}$

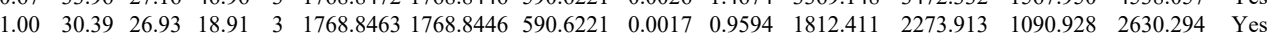

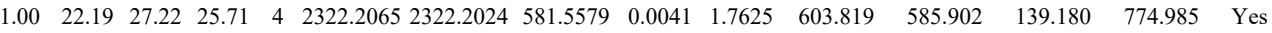
$\begin{array}{lllllllllllllll}0.97 & 32.61 & 26.32 & 23.86 & 2 & 1207.7058 & 1207.7056 & 604.8601 & 0.0002 & 0.1653 & 169.932 & 175.747 & 85.357 & 217.147 & \text { Yes }\end{array}$

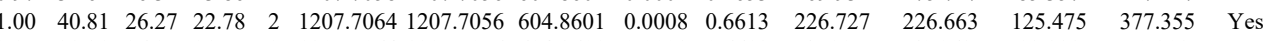
$\begin{array}{lllllllllllllll}0.97 & 28.31 & 26.27 & 21.55 & 2 & 1207.7064 & 1207.7056 & 604.8601 & 0.0008 & 0.6613 & 65.295 & 60.063 & 18.888 & 70.208 & \text { Yes } \\ 0.99 & 3.68 & 26.23 & 25.78 & 2 & 1207.7070 & 1207.756 & 604001 & 0.004 & 1.1573 & 23.545 & 239.445 & 127.843 & 281.097 & \text { Yes }\end{array}$

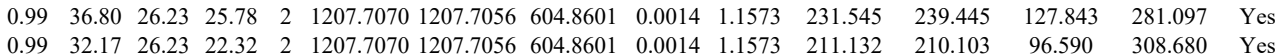
$\begin{array}{lllllllllllllll}0.99 & 32.17 & 26.23 & 22.32 & 2 & 1207.7070 & 1207.7056 & 604.8601 & 0.0014 & 1.1573 & 211.132 & 210.103 & 96.590 & 308.680 & \text { Yes } \\ 1.00 & 37.43 & 26.23 & 24.10 & 2 & 1207.7070 & 1207.7056 & 604.8601 & 0.0014 & 1.1573 & 189.427 & 186.377 & 85.354 & 327.478 & \text { Yes }\end{array}$ $\begin{array}{llllllllllllllll}1.00 & 51.96 & 26.23 & 29.20 & 2 & 1207.7070 & 1207.7056 & 604.8601 & 0.0014 & 1.1573 & 9316.299 & 7361.282 & 0.000 & 14874.795 & \text { No }\end{array}$

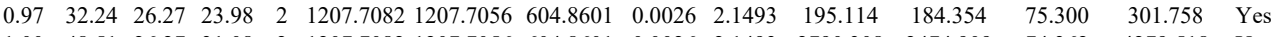
$\begin{array}{lllllllllllllll}1.00 & 48.51 & 26.27 & 31.08 & 2 & 1207.7082 & 1207.7056 & 604.8601 & 0.0026 & 2.1493 & 2790.308 & 2474.909 & 74.362 & 4279.518 & \text { Yes }\end{array}$ $\begin{array}{lllllllllllllll}1.00 & 48.11 & 26.27 & 28.04 & 2 & 1207.7082 & 1207.7056 & 604.8601 & 0.0026 & 2.1493 & 23998.093 & 21553.196 & 0.000 & 34374.541 & \text { No }\end{array}$

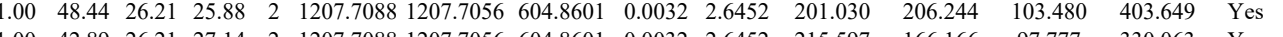
$\begin{array}{llllllllllllllll}1.00 & 42.89 & 26.21 & 27.14 & 2 & 1207.7088 & 1207.7056 & 604.8601 & 0.0032 & 2.6452 & 215.597 & 166.166 & 97.777 & 330.063 & \text { Yes }\end{array}$ \begin{tabular}{lllllllllllllll}
0.95 & 28.56 & 26.21 & 16.55 & 2 & 1207.7090 & 1207.7056 & 604.8601 & 0.0034 & 2.8106 & 41.575 & 26.228 & 13.729 & 49.952 & Yes \\
\hline
\end{tabular}

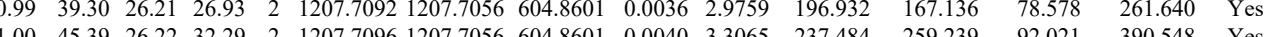
$\begin{array}{llllllllllllllll}1.00 & 45.39 & 26.22 & 32.29 & 2 & 1207.7096 & 1207.7056 & 604.8601 & 0.0040 & 3.3065 & 237.484 & 259.239 & 92.021 & 390.548 & \text { Yes } \\ 1.00 & 46.53 & 26.23 & 27.92 & 2 & 1207.7070 & 1207.7056 & 604.8601 & 0.0014 & 1.1573 & 9320.129 & 7167.071 & 0.000 & 13574.017 & \text { No }\end{array}$ $\begin{array}{lllllllllllllll}1.00 & 46.53 & 26.23 & 27.92 & 2 & 1207.7070 & 1207.7056 & 604.8601 & 0.0014 & 1.1573 & 9320.129 & 7167.071 & 0.000 & 13574.017 & \text { No } \\ 1.00 & 47.95 & 26.23 & 27.89 & 2 & 1207.7070 & 1207.7056 & 604.8601 & 0.0014 & 1.1573 & 17642.084 & 15340.043 & 92.773 & 25943.718 & \text { Yes }\end{array}$

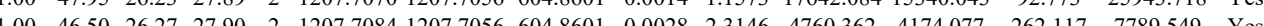

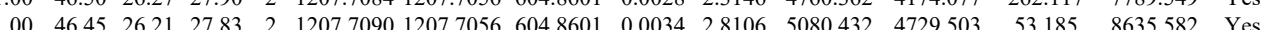

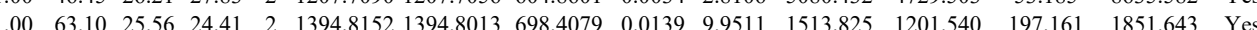
$\begin{array}{lllllllllllllll}1.00 & 69.81 & 24.87 & 20.75 & 2 & 1910.0722 & 1910.0539 & 956.0342 & 0.0183 & 9.5707 & 1451.598 & 1553.830 & 826.019 & 1517.559 & \text { Yes }\end{array}$

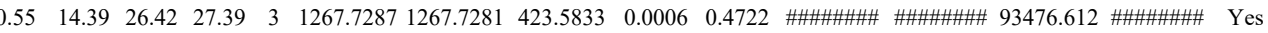
$\begin{array}{lllllllllllllll}1.00 & 63.33 & 26.37 & 22.78 & 2 & 1267.7292 & 1267.7281 & 634.8713 & 0.0011 & 0.8663 & 30900.794 & 25072.080 & 21726.098 & 38750.961 & \text { Yes }\end{array}$ $\begin{array}{lllllllllllllll}1.00 & 63.20 & 25.95 & 22.73 & 2 & 1267.7304 & 1267.7281 & 634.8713 & 0.0023 & 1.8114 & 40546.934 & 33867.418 & 27297.332 & 49135.522 & \text { Yes }\end{array}$

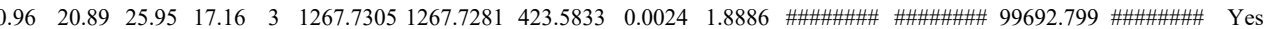
$\begin{array}{llllllllllllllll}1.00 & 50.56 & 26.15 & 22.10 & 2 & 1483.8414 & 1483.8279 & 742.9212 & 0.0135 & 9.0857 & 4191.879 & 2286.280 & 0.000 & 3887.928 & \text { No }\end{array}$

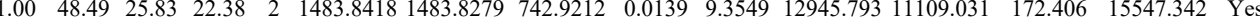

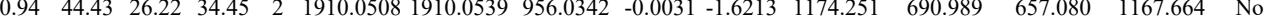

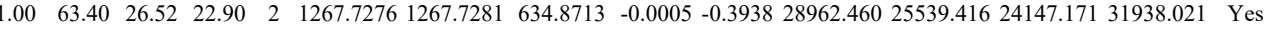
$\begin{array}{lllllllllllllll}1.00 & 68.00 & 26.52 & 23.19 & 2 & 1267.7280 & 1267.7281 & 634.8713 & -0.0001 & -0.0788 & 20838.760 & 18934.284 & 14078.609 & 28517.763 & \text { Yes }\end{array}$

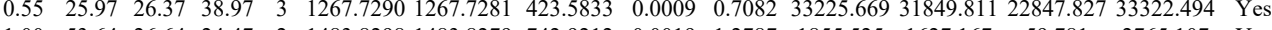
\begin{tabular}{lllllllllllllll}
1.00 & 53.64 & 26.64 & 24.47 & 2 & 1483.8298 & 1483.8279 & 742.9212 & 0.0019 & 1.2787 & 1855.525 & 1627.167 & 59.781 & 2765.107 & Yes \\
\hline
\end{tabular} $\begin{array}{lllllllllllllll}0.55 & 24.43 & 26.21 & 37.43 & 3 & 1267.7296 & 1267.7281 & 423.5833 & 0.0015 & 1.1804 & 9721.459 & 9803.986 & 6644.366 & 11863.905 & \text { Yes }\end{array}$ $\begin{array}{lllllllllllllll}0.55 & 16.81 & 26.37 & 29.81 & 3 & 126.7290 & 1267.7281 & 423.5833 & 0.0009 & 0.7082 & 5023.441 & 4332.735 & 2707.196 & 4606.420 & \text { Yes }\end{array}$ $\begin{array}{lllllllllllllll}0.93 & 20.53 & 26.21 & 15.19 & 3 & 1267.7296 & 1267.7281 & 423.5833 & 0.0015 & 1.1804 & 8448.790 & 7304.483 & 5232.311 & 8829.531 & \text { Yes }\end{array}$

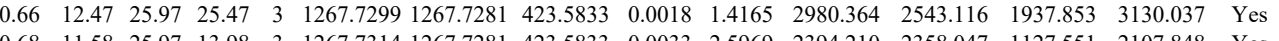
$\begin{array}{lllllllllllllll}0.68 & 11.58 & 25.97 & 13.98 & 3 & 1267.7314 & 1267.7281 & 423.5833 & 0.0033 & 2.5969 & 2394.210 & 2358.047 & 1127.551 & 2107.848 & \text { Yes } \\ 1.00 & 39.07 & 26.38 & 15.53 & 4 & 3018.4617 & 3018.4580 & 755.6218 & 0.0037 & 1.2242 & 85.149 & 89.454 & 78.025 & 89.930 & \text { Yes }\end{array}$ $\begin{array}{lllllllllllllll}1.00 & 39.07 & 26.38 & 15.53 & 4 & 3018.4617 & 3018.4580 & 755.6218 & 0.0037 & 1.2242 & 85.149 & 89.454 & 78.025 & 89.930 & \text { Yes } \\ 1.00 & 22.82 & 6.36 & 35.82 & 4 & 3018.4625 & 3018.4580 & 755.6218 & 0.0045 & 1.4888 & 39.678 & 40.774 & 59.387 & 5.324 & \text { No }\end{array}$

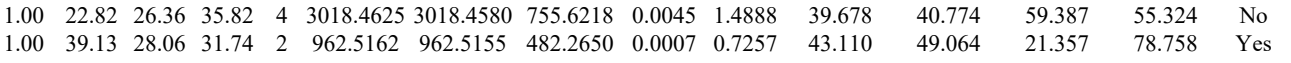
$\begin{array}{lllllllllllllll}0.55 & 23.63 & 26.37 & 36.63 & 3 & 1267.7290 & 1267.7281 & 423.5833 & 0.0009 & 0.7082 & 265.688 & 241.286 & 224.423 & 303.595 & \text { Yes }\end{array}$ 


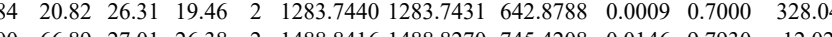
$\begin{array}{llllllllllllll}1.00 & 72.09 & 27.75 & 36.55 & 2 & 1488.8416 & 1488.8270 & 745.4208 & 0.0146 & 9.7930 & 12.022 & 62.085 & 0.000 & 55.47 \\ 1 & 75.8286 & 1488.8270 & 745.4208 & 0.0016 & 1.0732 & 1120.170 & 1223.520 & 275.686 & 193.0\end{array}$ $\begin{array}{lllllllllllll} & \end{array}$

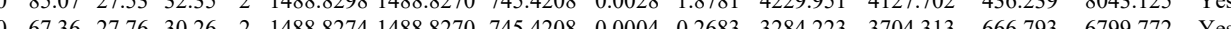
$\begin{array}{lllllllllllllll}1.00 & 73.14 & 27.76 & 30.71 & 2 & 1488.8276 & 1488.8270 & 745.4208 & 0.0006 & 0.4025 & 3351.469 & 3567.574 & 616.705 & 5667.941 & \text { Yes }\end{array}$

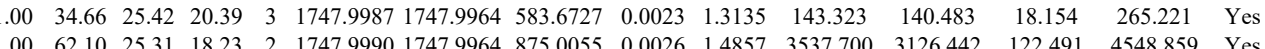
$\begin{array}{lllllllllllllll}0.60 & 40.12 & 25.12 & 53.12 & 3 & 1748.0005 & 1747.9964 & 583.6727 & 0.0041 & 2.3415 & 103.612 & 203.530 & 44.569 & 241.534 & \text { Yes }\end{array}$ $\begin{array}{lllllllllllllll}0.88 & 18.70 & 26.34 & 1828 & 3 & 1283.7439 & 1283.7431 & 428.9216 & 0.0008 & 0.6217 & 747.305 & 735.122 & 128.323 & 56.207 & \text { Yes }\end{array}$ $\begin{array}{llllllllllllllll}0.73 & 14.83 & 26.34 & 16.93 & 3 & 1283.7439 & 1283.7431 & 428.9216 & 0.0008 & 0.6217 & 475.293 & 471.333 & 134.931 & 47.056 & \text { Yes }\end{array}$ $\begin{array}{llllllllllllllll}0.98 & 31.10 & 26.31 & 28.65 & 2 & 1283.7440 & 1283.7431 & 642.8788 & 0.0009 & 0.7000 & 159.458 & 156.289 & 23.940 & 14.694 & \text { Yes }\end{array}$ $\begin{array}{lllllllllllllll}0.97 & 28.54 & 26.50 & 28.03 & 2 & 1283.7446 & 1283.7431 & 642.8788 & 0.0015 & 1.1666 & 170.452 & 170.197 & 38.239 & 19.814 & \text { Yes }\end{array}$

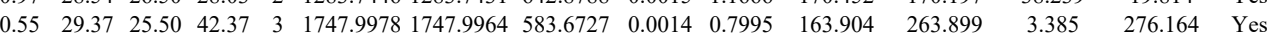

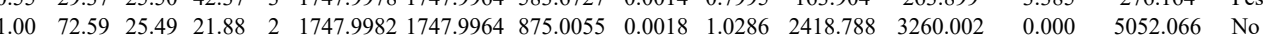
$\begin{array}{llllllllllllllll}1.00 & 74.82 & 25.31 & 21.57 & 2 & 1747.9992 & 1747.9964 & 875.0055 & 0.0028 & 1.6000 & 4080.664 & 5797.328 & 47.479 & 8249.220 & \text { Yes }\end{array}$ $\begin{array}{lllllllllllllll}0.99 & 26.75 & 25.29 & 18.18 & 3 & 1747.9996 & 1747.9964 & 583.6727 & 0.0032 & 1.8275 & 214.604 & 283.910 & 42.846 & 336.825 & \text { Yes }\end{array}$ $\begin{array}{lllllllllllllll}1.00 & 55.46 & 26.02 & 40.20 & 2 & 1537.8840 & 1537.8708 & 769.9427 & 0.0132 & 8.5720 & 10789.099 & 10275.890 & 3512.982 & 15282.044 & \text { Yes }\end{array}$ $\begin{array}{lllllllllllllll}1.00 & 57.29 & 26.02 & 38.44 & 2 & 1537.8840 & 1537.8708 & 769.9427 & 0.0132 & 8.5720 & 10569.982 & 10808.333 & 4155.353 & 14660.457 & \text { Yes }\end{array}$

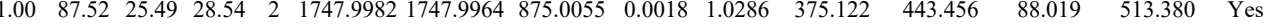
$\begin{array}{lllllllllllllll}0.94 & 19.81 & 25.09 & 19.01 & 3 & 1748.0002 & 1747.9964 & 583.6727 & 0.0038 & 2.1702 & 133.043 & 138.017 & 38.351 & 286.539 & \text { Yes }\end{array}$ $\begin{array}{lllllllllllllll}1.00 & 53.45 & 26.02 & 29.67 & 2 & 1537.8818 & 1537.8708 & 769.9427 & 0.0110 & 7.1433 & 3667.979 & 3604.334 & 1040.508 & 5495.919 & \text { Yes }\end{array}$

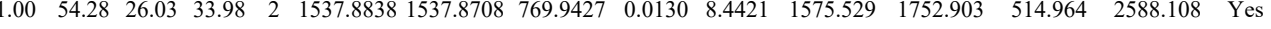
$\begin{array}{lllllllllllllll}1.00 & 52.90 & 26.05 & 26.14 & 2 & 1537.8790 & 1537.8708 & 769.9427 & 0.0082 & 5.3250 & 1671.167 & 1858.864 & 582.091 & 2733.287 & \text { Yes }\end{array}$ $\begin{array}{llllllllllllllll}1.00 & 55.67 & 26.00 & 28.28 & 2 & 1537.8792 & 1537.8708 & 769.9427 & 0.0084 & 5.4549 & 3064.096 & 3519.716 & 1087.415 & 4404.765 & \text { Yes }\end{array}$ $\begin{array}{lllllllllllllll}0.80 & 9.60 & 26.66 & 17.73 & 4 & 1835.0057 & 1835.0046 & 459.7584 & 0.0011 & 0.5981 & 22.936 & 43.150 & 6.465 & 68.172 & \text { Yes } \\ 0.99 & 18.62 & 26.6 & 20.66 & 4 & 185.0053 & 1355.0046 & 45.7584 & 0.0007 & 0.3806 & 8.490 & 32.138 & 10.186 & 27.249 & \mathrm{No}\end{array}$ $\begin{array}{lllllllllllllll}0.99 & 18.62 & 26.66 & 20.66 & 4 & 1835.0053 & 1835.0046 & 459.7584 & 0.0007 & 0.3806 & 8.490 & 32.138 & 10.186 & 27.249 & \text { No } \\ 0.92 & 12.212 & 26.70 & 25.12 & 4 & 1835.0061 & 1835.0046 & 45.7584 & 0.0015 & 0.8156 & 11.012 & 13.234 & 1.702 & 35.55 & \text { No }\end{array}$

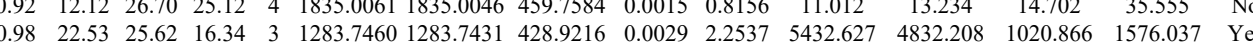
$\begin{array}{lllllllllllllll}0.98 & 22.53 & 25.62 & 16.34 & 3 & 1283.7460 & 1283.7431 & 428.9216 & 0.0029 & 2.2537 & 5432.627 & 4832.208 & 1020.866 & 1576.037 & \text { Yes } \\ 0.98 & 16.89 & 26.66 & 29.89 & 4 & 1835.0049 & 1835.0046 & 459.7584 & 0.0003 & 0.1631 & 37.950 & 21.184 & 21.760 & 61.463 & \text { No }\end{array}$

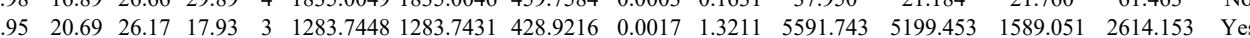
$\begin{array}{lllllllllllllll}0.81 & 15.02 & 25.58 & 14.31 & 3 & 1283.7469 & 1283.7431 & 428.9216 & 0.0038 & 2.9531 & 4407.793 & 3612.458 & 1451.800 & 1765.244 & \text { Y }\end{array}$ $\begin{array}{llllllllllllllll}0.00 & 64.46 & 28.45 & 2.17 & 2 & 1248.6556 & 1248.6441 & 625.3293 & 0.0115 & 9.1951 & 3233.193 & 2826.987 & 927.007 & 4939.352 & \text { Y }\end{array}$

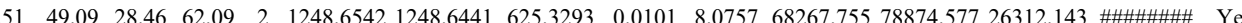
$\begin{array}{llllllllllllllll}1.00 & 63.79 & 28.48 & 19.86 & 2 & 1248.6548 & 1248.6441 & 625.3293 & 0.0107 & 8.5554 & 1917.636 & 2145.640 & 638.847 & 2895.189 & \text { Yes }\end{array}$ $\begin{array}{llllllllllllllll}0.55 & 20.44 & 26.49 & 33.44 & 3 & 1283.7445 & 1283.7431 & 428.9216 & 0.0014 & 1.0880 & 4437.610 & 4329.575 & 1570.701 & 2508.588 & \text { Yes }\end{array}$ $\begin{array}{lllllllllllllllll}0.98 & 23.71 & 26.17 & 18.91 & 3 & 1283.7448 & 1283.7431 & 428.9216 & 0.0017 & 1.3211 & 4939.867 & 5066.548 & 2143.831 & 1822.259 & \text { No }\end{array}$ $\begin{array}{llllllllllllllll}1.00 & 60.12 & 28.61 & 19.02 & 2 & 1248.6520 & 1248.6441 & 625.3293 & 0.0079 & 63166 & 14927.325 & 17171.959 & 4870.723 & 22678.806 & \text { Yes }\end{array}$ $\begin{array}{llllllllllllllll}0.99 & 25.59 & 26.17 & 18.03 & 3 & 1283.7448 & 1283.7431 & 428.9216 & 0.0017 & 1.3211 & 3677.122 & 3485.800 & 960.254 & 990.908 & \text { Yes }\end{array}$ $\begin{array}{llllllllllllllll}0.97 & 22.05 & 26.02 & 21.64 & 3 & 1283.7457 & 1283.7431 & 428.9216 & 0.0026 & 2.0206 & 3924.309 & 3827.164 & 985.889 & 861.854 & \text { Yes }\end{array}$ $\begin{array}{lllllllllllllllll}1.00 & 64.00 & 28.56 & 19.41 & 2 & 1248.6526 & 1248.6441 & 625.3293 & 0.0085 & 6.7964 & 9242.013 & 10535.565 & 2552.747 & 13472.262 & \text { Yes }\end{array}$ $\begin{array}{lllllllllllllll}0.97 & 21.43 & 25.56 & 18.08 & 3 & 1283.7463 & 1283.7431 & 428.9216 & 0.0032 & 2.4869 & 1998.782 & 2280.121 & 417.471 & 1502.571 & \text { Yes }\end{array}$ $\begin{array}{lllllllllllllll}.97 & 24.20 & 25.58 & 25.64 & 3 & 1283.7469 & 1283.7431 & 428.9216 & 0.0038 & 2.9531 & 2283.561 & 2271.467 & 420.540 & 1491.350 & \text { Yes }\end{array}$ $\begin{array}{llllllllllllllll}1.00 & 61.56 & 28.42 & 18.51 & 2 & 1248.6534 & 1248.6441 & 625.3293 & 0.0093 & 7.4360 & 3263.562 & 4017.140 & 1218.035 & 5626.130 & \text { Yes }\end{array}$ $\begin{array}{llllllllllllllll}0.98 & 25.11 & 26.34 & 20.63 & 3 & 1283.7439 & 1283.7431 & 428.9216 & 0.0008 & 0.6217 & 2320.561 & 2361.851 & 610.215 & 1162.394 & \text { Yes }\end{array}$ $\begin{array}{lllllllllllllll}.92 & 20.14 & 26.31 & 22.23 & 3 & 1283.7442 & 1283.7431 & 428.9216 & 0.0011 & 0.8549 & 2089.138 & 2032.573 & 396.259 & 1578.257 & \text { Yes }\end{array}$ $\begin{array}{llllllllllllllll}1.00 & 61.46 & 28.36 & 19.46 & 2 & 1248.6472 & 1248.6441 & 625.3293 & 0.0031 & 2.4787 & 2184.431 & 2434.342 & 985.836 & 3065.076 & \text { Yes }\end{array}$ $\begin{array}{llllllllllllllll}0.83 & 22.14 & 26.27 & 21.87 & 3 & 1283.7424 & 1283.7431 & 428.9216 & -0.0007 & -0.5440 & 1722.314 & 1845.978 & 449.759 & 548.657 & \text { Yes }\end{array}$ $\begin{array}{llllllllllllllll}.78 .47 & 26.61 & 20.63 & 3 & 1283.7430 & 1283.7431 & 428.9216 & -0.0001 & -0.0777 & 1886.047 & 2058.717 & 425.866 & 556.079 & \text { Yes }\end{array}$ $\begin{array}{lllllllllllllll}0.93 & 23.46 & 26.46 & 20.48 & 3 & 1283.7436 & 1283.7431 & 428.9216 & 0.0005 & 0.3886 & 1134.069 & 1205.367 & 305.655 & 211.448 & \text { Yes }\end{array}$ $\begin{array}{lllllllllllllll}0.93 & 21.09 & 26.34 & 22.07 & 3 & 1283.7439 & 1283.7431 & 428.9216 & 0.0008 & 0.6217 & 738.205 & 765.690 & 180.196 & 206.422 & \text { Yes }\end{array}$ $\begin{array}{lllllllllllllll}1.00 & 57.87 & 28.38 & 20.79 & 2 & 1248.6462 & 1248.6441 & 625.3293 & 0.0021 & 1.6791 & 295.790 & 299.002 & 180.839 & 388.693 & \text { No }\end{array}$

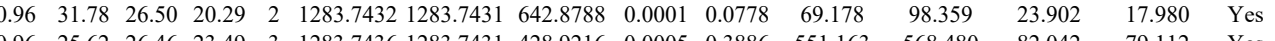
$\begin{array}{lllllllllllllll}0.96 & 25.62 & 26.46 & 23.49 & 3 & 1283.7436 & 1283.7431 & 428.9216 & 0.0005 & 0.3886 & 551.163 & 568.480 & 82.042 & 79.112 & \text { Yes } \\ 0.98 & 25.94 & 26.34 & 23.11 & 3 & 1283.7439 & 1283.7431 & 428.9216 & 0.0008 & 0.6217 & 402.012 & 428.216 & 54.474 & 65.344 & \text { Yes }\end{array}$

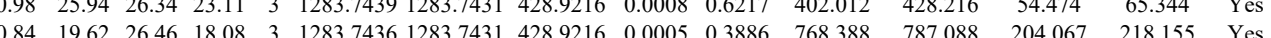

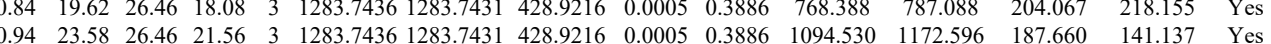

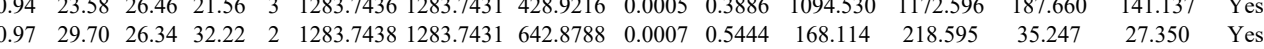

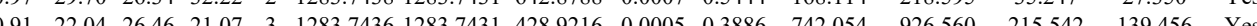

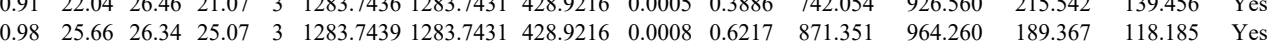




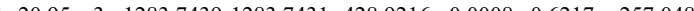

FVDFL SDEIKEER

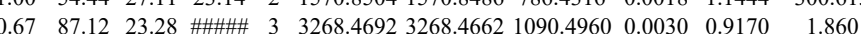

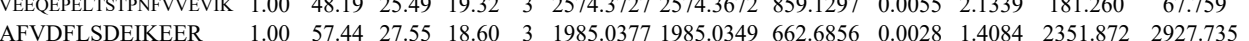

$\begin{array}{llllllllllllll}\text { AFVDFLSDEIKEER } & 1.00 & 57.44 & 27.55 & 18.60 & 3 & 1985.0377 & 1985.0349 & 662.6856 & 0.0028 & 1.4084 & 2351.872 & 2927.735 & 253.6 \\ \text { AFVDFLSDEIKEER } & 0.99 & 47.53 & 27.54 & 21.11 & 3 & 1985.0380 & 1985.0349 & 662.6856 & 0.0031 & 1.5593 & 2298.470 & 2927.672 & 1957\end{array}$

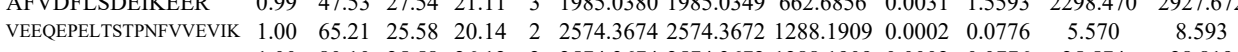
$\begin{array}{llllllllllllll}\text { VEEQEPELTSTPNFVVEVIK } & 1.00 & 65.21 & 25.58 & 20.14 & 2 & 2574.3674 & 2574.3672 & 1288.1909 & 0.0002 & 0.0776 & 5.570 & 8.593 \\ \text { VEEQEPELTSTPNFVVEVIK } & 1.00 & 80.10 & 25.58 & 26.12 & 2 & 2574.3674 & 2574.3672 & 1288.1909 & 0.0002 & 0.0776 & 25.574 & 28.819\end{array}$ $\begin{array}{lllllllllllll}\text { VEEQEPELTSTPNFVVEVIK } & 1.00 & 46.48 & 25.38 & 16.11 & 3 & 2574.3703 & 2574.3672 & 859.1297 & 0.0031 & 1.2028 & 66.800 & 20.917 \\ \text { VEFEFPELTSTPNFVVEVIK } & 1.00 & 45.50 & 25.45 & 17.65 & 3 & 2574.3709 & 2574.3672 & 859.1297 & 0.0037 & 1.4356 & 58.610 & 39.837\end{array}$

$\begin{array}{lllllllllll}.00 & 45.50 & 25.45 & 17.65 & 3 & 2574.3709 & 2574.3672 & 859.1297 & 0.0037 & 1.4356 & 58.610\end{array}$

39.837

$\begin{array}{lllllllllllll} & \\ \text { QTESLESLLSK } & 1.00 & 74.19 & 27.75 & 28.09 & 2 & 1521.8494 & 1521.8494 & 761.9320 & 0.0000 & 0.0000 & 158.108 & 183.149\end{array}$ $\begin{array}{llllllllllllll} & & & \end{array}$ \begin{tabular}{lllllllllllllll} 
& \\
SLGETQLVLYGDVEELKR & 1.00 & 86.04 & 26.43 & 28.61 & 2 & 1760.9800 & 1760.9764 & 881.4955 & 0.0036 & 2.0420 & 619.869 & 810.853 & 243.9 \\
\hline
\end{tabular} $\begin{array}{llllllllllllll} & \text { SLGETQLVLYGDVEELKR } & 1.00 & 64.08 & 24.41 & 18.16 & 3 & 2336.2855 & 2336.2831 & 779.7683 & 0.0024 & 1.0259 & 431.125 & 603\end{array}$

822.829
603.106

ISEVLQK

LALQALTEK $\begin{array}{llllllllllllll}0.71 & 23.80 & 26.14 & 29.53 & 2 & 1103.6896 & 1103.6794 & 552.8470 & 0.0102 & 9.2249 & 11562.633 & 14894.901 & 3297 . \\ 0.98 & 47.03 & 24.15 & 42.28 & 2 & 1273.7972 & 1273.7849 & 637.8997 & 0.0123 & 9.6409 & 4882.618 & 5491.154 & 548.6\end{array}$

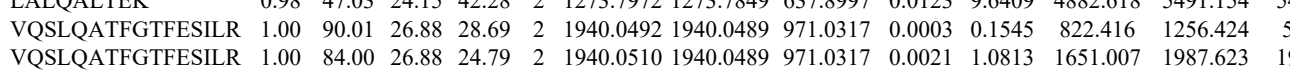
$\begin{array}{llllllllllllll}\text { VQSLQATFGTFESILR } & 1.00 & 84.00 & 26.88 & 24.79 & 2 & 1940.0510 & 1940.0489 & 971.0317 & 0.0021 & 1.0813 & 1651.007 & 1987.623 & 197.4 \\ \text { VQSLQATFGTFESILR } & 0.79 & 15.86 & 27.05 & 14.55 & 3 & 1940.0527 & 1940.0489 & 647.6902 & 0.0038 & 1.9557 & 2562.652 & 2326.949 & 1567.5\end{array}$ $\begin{array}{llllllllllllll}\text { VQSLQATFGTFESILR } & 0.79 & 15.86 & 27.05 & 14.55 & 3 & 1940.0527 & 1940.0489 & 647.6902 & 0.0038 & 1.9557 & 2562.652 & 2326.949 \\ \text { VQSLQATFGTFESILR } & 1.00 & 92.80 & 26.89 & 26.71 & 2 & 1940.0494 & 1940.0489 & 971.0317 & 0.0005 & 0.2575 & 293.027 & 351.110\end{array}$ $\begin{array}{lllllllllllll}\text { VQSLQATFGTFESILR } & 1.00 & 92.80 & 26.89 & 26.71 & 2 & 1940.0494 & 1940.0489 & 971.0317 & 0.0005 & 0.2575 & 293.027 & 351.110 \\ \text { VQSLQATFGTFESILR } & 0.55 & 16.92 & 26.88 & 29.92 & 3 & 1940.0503 & 1940.0489 & 647.6902 & 0.0014 & 0.7205 & 523.666 & 465.411\end{array}$ $\begin{array}{llllllllllllll}\text { VQSLQATFGTFESILR } & 0.55 & 16.92 & 26.88 & 29.92 & 3 & 1940.0503 & 1940.0489 & 647.6902 & 0.0014 & 0.7205 & 523.666 & 465.411 \\ \text { VQSLQATFGTFESILR } & 0.77 & 16.12 & 26.88 & 16.15 & 3 & 1940.0503 & 1940.0489 & 647.6902 & 0.0014 & 0.7205 & 880.283 & 561.107\end{array}$ $\begin{array}{llllllllllllll}\text { VQSLQATFGTFESILR } & 1.00 & 99.49 & 26.91 & 27.16 & 2 & 1940.0508 & 1940.0489 & 971.0317 & 0.0019 & 0.9783 & 744.610 & 873.311\end{array}$

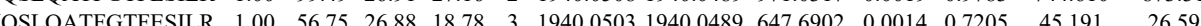


$\begin{array}{lllllllllllll}1.00 & 66.79 & 27.28 & 18.47 & 2 & 1915.9328 & 1915.9319 & 958.9732 & 0.0009 & 0.4693 & 1336.259 & 18 & \\ 1.00 & 81.49 & 27.28 & 21.36 & 2 & 1915.9330 & 1915.9319 & 958.9732 & 0.0011 & 0.5735 & 409.287 & 6\end{array}$

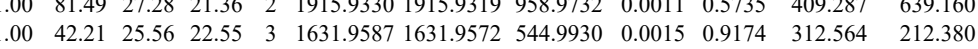

SVASSQPAKPTK

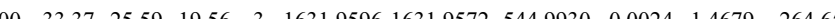

10 SGSMDPSGAHPS YLPELMAEK
YLPELMAEK

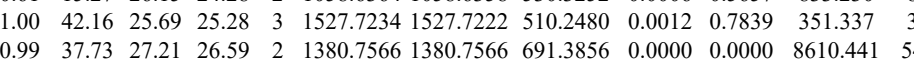
$\begin{array}{llllllllllll}1.00 & 38.74 & 27.31 & 27.51 & 2 & 1380.7572 & 1380.7566 & 691.3856 & 0.0006 & 0.4339 & 8629.408 & 6314\end{array}$ $\begin{array}{lllllllllllllllll} & 1.00 & 38.74 & 27.31 & 27.51 & 2 & 1380.7572 & 1380.7566 & 691.3856 & 0.0006 & 0.4339 & 8629.408 & 6314.944 & 12509.802 & 13428.707 & \text { Yes } \\ \text { DSLDPSFTHAMQLLTAEIEK } & 1.00 & 33.79 & 26.88 & 19.01 & 4 & 2533.3025 & 25332978 & 634.3317 & 0.0047 & 1.8523 & 66.701 & 64.551 & 41.802 & 57.864 & \text { ( }\end{array}$ $\begin{array}{llllllllllllllll}\text { DSLDPSFTHAMQLLTAEIEK } & 1.00 & 29.78 & 26.83 & 24.37 & 4 & 2533.3037 & 2533.2978 & 634.3317 & 0.0059 & 2.3253 & 60.949 & 49.997 & 41.154 & 103.196 & \text { Yos }\end{array}$ $\begin{array}{llllllllllllllll}\text { FNFVGK } & 0.89 & 28.62 & 24.42 & 30.50 & 2 & 998.5880 & 998.5793 & 500.2969 & 0.0087 & 8.6948 & 28409.203 & 17311.206 & 5137.856 & 39922.583 & \text { Yes }\end{array}$ $\begin{array}{llllllllllllllll}\text { FNFVGK } & 0.90 & 30.27 & 24.42 & 32.04 & 2 & 998.5882 & 998.5793 & 500.2969 & 0.0089 & 8.8946 & 35357.687 & 22333.894 & 8583.262 & 43578.755 & \text { Yes }\end{array}$ $\begin{array}{llllllllllllllll}\text { FNFVGK } & 0.88 & 28.88 & 24.07 & 31.60 & 2 & 998.5884 & 998.5793 & 500.2969 & 0.0091 & 9.0945 & 31548.604 & 17883.891 & 7416.630 & 38706.618 & \text { Yes }\end{array}$

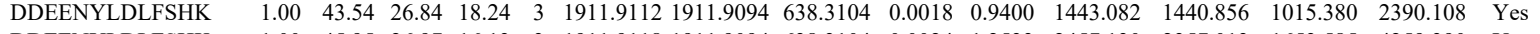
$\begin{array}{lllllllllllllllll}\text { DDEENYLDLFSHK } & 1.00 & 45.95 & 26.97 & 16.13 & 3 & 1911.9118 & 1911.9094 & 638.3104 & 0.0024 & 1.2533 & 2457.130 & 2357.013 & 1653.585 & 4259.390 & \text { Yes }\end{array}$ $\begin{array}{llllllllllllllll}\text { KDDEENYLDLFSHK } & 1.00 & 45.41 & 27.81 & 22.45 & 4 & 2184.1101 & 2184.1064 & 547.0339 & 0.0037 & 1.6909 & 1024.701 & 685.965 & 125.530 & 1386.441 & \text { Yes }\end{array}$

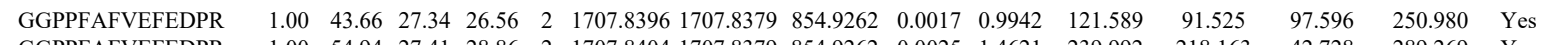

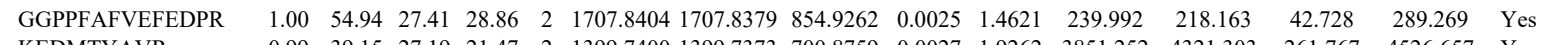
$\begin{array}{llllllllllllllll}\text { KEDMTYAVR } & 0.99 & 39.15 & 27.19 & 21.47 & 2 & 1399.7400 & 1399.7373 & 700.8759 & 0.0027 & 1.9262 & 3851.252 & 4321.303 & 261.767 & 4526.657 & \text { Yes } \\ \text { KEDMTYAVR } & 1.00 & 40.39 & 27.34 & 21.65 & 3 & 1399.7407 & 1399.733 & 47.5864 & 0.034 & 2.423 & 12917.308 & 16283.844 & 2279.58 & 1844.494 & \text { Yes }\end{array}$ $\begin{array}{llllllllllllllll}\text { KEDMTYAVR } & 1.00 & 40.39 & 27.34 & 21.65 & 3 & 1399.7407 & 1399.7373 & 467.5864 & 0.0034 & 2.4238 & 12917.308 & 16283.844 & 2279.508 & 18044.494 & \text { Yes }\end{array}$ \begin{tabular}{lllllllllllllllll} 
KEDMTYAVR & 1.00 & 33.95 & 27.34 & 17.99 & 3 & 1399.7407 & 1399.7373 & 467.5864 & 0.0034 & 2.4238 & 13782.968 & 16275.220 & 2857.154 & 16238.901 & Yes \\
\hline SSSPELVTHLK & 1.00 & 4.08 & 25.42 & 26.57 & 3 & 1484.8588 & 1484.8442 & 495.9553 & 0.0146 & 9.8126 & 3241.913 & 2567.674 & 2020.982 & 3998.077 & Yes
\end{tabular}

SSSPELVTHLK $\begin{array}{lllllllllllllllll}1.00 & 41.08 & 25.42 & 26.57 & 3 & 1484.8588 & 1484.8442 & 495.9553 & 0.0146 & 9.8126 & 3241.913 & 2567.674 & 2020.982 & 3998.077 & \text { Yes }\end{array}$ $\begin{array}{lllllllllllllll} & & & \end{array}$ $\begin{array}{lccccccccccccccc} & & \end{array}$

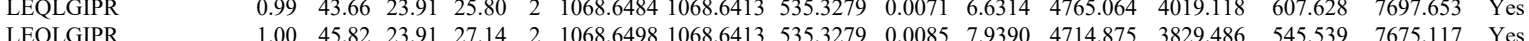

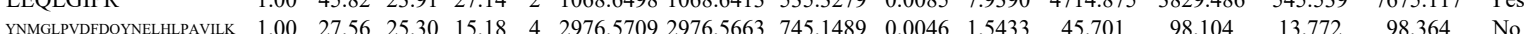
$\begin{array}{lllllllllllllllll}\text { AINPINTFTK } & 0.53 & 51.24 & 25.08 & 64.24 & 2 & 1405.8292 & 1405.8173 & 703.9159 & 0.0119 & 8.4526 & 909.686 & 700.974 & 395.645 & 1095.287 & \text { Yes }\end{array}$

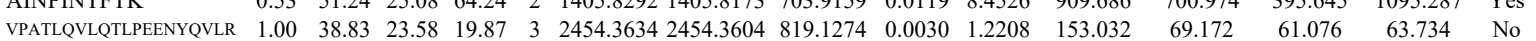

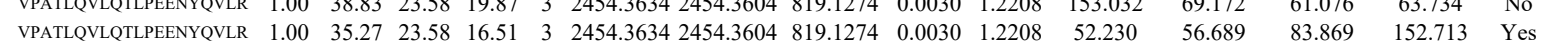

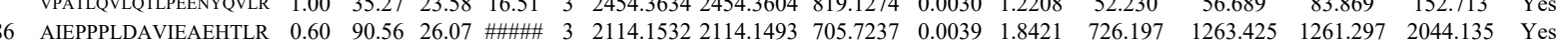

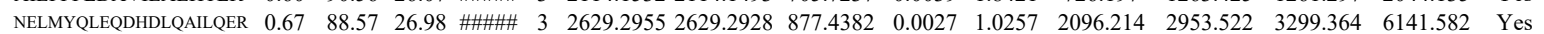
$\begin{array}{llllllllllllllll}\text { NELMYOLEODHDLOAILERR } & 0.60 & 84.49 & 27.10 & 97.49 & 3 & 26292964 & 26292928 & 877.4382 & 0.0036 & 1.3676 & 1766.076 & 2511.715 & 3619644 & 3888.581 & \text { Yes }\end{array}$ $\begin{array}{lllllllllllllllll}\text { AIEPPPLDAVIEAEHTLR } & 0.67 & 78.20 & 26.23 & 91.20 & 3 & 2114.1523 & 2114.1493 & 705.7237 & 0.0030 & 1.4170 & 1330.643 & 1805.140 & 2425.820 & 2474.218 & \text { Yes }\end{array}$

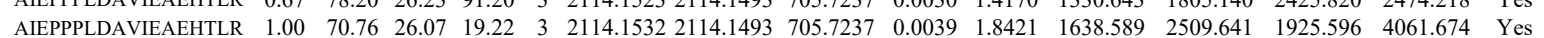
$\begin{array}{lllllllllllllllll}\text { AAMEALVVEVTK } & 0.98 & 26.55 & 26.63 & 18.66 & 3 & 1547.8849 & 1547.8836 & 516.9685 & 0.0013 & 0.8382 & 133.546 & 106.146 & 65.404 & 167.520 & \text { Yes }\end{array}$ $\begin{array}{lllllllllllllllll}\text { AAMEALVVEVTK } & 0.96 & 21.05 & 26.39 & 23.67 & 3 & 1547.8858 & 1547.8836 & 516.9685 & 0.0022 & 1.4185 & 124.729 & 110.940 & 79.300 & 150.700 & \text { Yes }\end{array}$ $\begin{array}{llllllllllllllll}\text { AAMEALVVEVTK } & 1.00 & 83.25 & 26.41 & 35.60 & 2 & 1547.8858 & 1547.8836 & 774.9491 & 0.0022 & 1.4194 & 139.006 & 166.296 & 59.906 & 331.081 & \text { Yes }\end{array}$ $\begin{array}{lllllllllllllllll}\text { AAMEALVVEVTK } & 1.00 & 89.94 & 26.39 & 38.41 & 2 & 1547.8864 & 1547.8836 & 774.9491 & 0.0028 & 1.8066 & 149.087 & 111.150 & 21.747 & 235.673 & \text { Yes }\end{array}$ $\begin{array}{llllllllllllllll}\text { AIEPPPLDAVIEAEHTLR } & 0.66 & 65.04 & 26.30 & 78.04 & 3 & 2114.1517 & 2114.1493 & 705.7237 & 0.0024 & 1.1336 & 686.559 & 825.470 & 1018.586 & 1253.489 & \text { Yes }\end{array}$

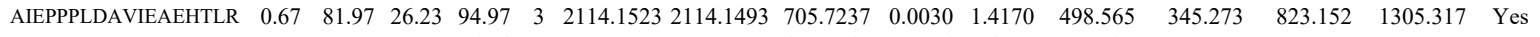
$\begin{array}{lllllllllllllllll}\text { YGDGPRPPK } & 0.82 & 18.52 & 28.08 & 16.34 & 3 & 1273.7029 & 1273.7023 & 425.5747 & 0.0006 & 0.4700 & 1003.603 & 990.081 & 927.780 & 1500.080 & \text { Yes }\end{array}$ $\begin{array}{llllllllllllllll}\text { YGDGPRPPK } & 0.85 & 19.36 & 28.03 & 16.18 & 3 & 1273.7038 & 1273.7023 & 425.5747 & 0.0015 & 1.1749 & 973.415 & 938.987 & 906.571 & 1380.258 & \text { Yes }\end{array}$

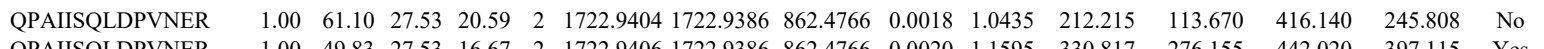
$\begin{array}{llllllllllllllll}\text { QPAIISQLDPVNER } & 1.00 & 49.83 & 27.53 & 16.67 & 2 & 1722.9406 & 1722.9386 & 862.4766 & 0.0020 & 1.1595 & 330.817 & 276.155 & 442.020 & 397.115 & \text { Yes }\end{array}$

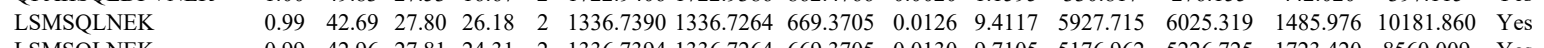
$\begin{array}{llllllllllllllll}\text { LSMSQLNEK } & 0.99 & 42.96 & 27.81 & 24.31 & 2 & 1336.7394 & 1336.7264 & 669.3705 & 0.0130 & 9.7105 & 5176.962 & 5226.725 & 1723.420 & 8560.009 & \text { Yes }\end{array}$

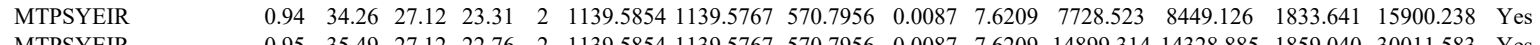
$\begin{array}{llllllllllllllll}\text { MTPSYEIR } & 0.95 & 35.49 & 27.12 & 22.76 & 2 & 1139.5854 & 1139.5767 & 570.7956 & 0.0087 & 7.6209 & 14899.314 & 14328.885 & 1859.040 & 30011.583 & \text { Yes } \\ \text { ETPFELIEALLK } & 1.00 & 5.76 & 23.87 & 23.81 & 2 & 1689.9818 & 1689.9796 & 845.9971 & 0.0022 & 1.3002 & 46.594 & 49.273 & 88.574 & 154.479 & \text { Yes }\end{array}$

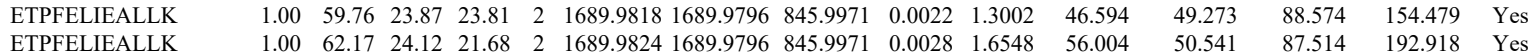
$\begin{array}{llllllllllllllll}\text { ETPFELIEALLK } & 1.00 & 62.17 & 24.12 & 21.68 & 2 & 1689.9824 & 1689.9796 & 845.9971 & 0.0028 & 1.6548 & 56.004 & 50.541 & 87.514 & 192.918 & \text { Yes } \\ \text { ETPFELIEALLK } & 0.98 & 23.45 & 24.12 & 24.56 & 3 & 1689.9826 & 1689.9796 & 564.3338 & 0.0030 & 1.7720 & 84.899 & 91.414 & 42.168 & 73.656 & \text { Yes }\end{array}$ $\begin{array}{llllllllllllll} & & \end{array}$

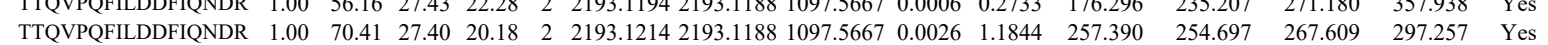


LNMATLR

LFTAHNNMTNYATVWASK

NFLYAWCGK

YQILPLHSQIPR

YQILPLHSQIPR

LAAQSCALSLVR

SK 0.55

GMTLVTPLQLLLFASK $\begin{array}{lllllllllll}0.55 & 73.17 & 28.06 & 86.17 & 3 & 1771.9210 & 1771.9195 & 591.6471 & 0.0015 & 0.8451 & 775.885 \\ 0.55 & 40.29 & 27.02 & 53.29 & 3 & 2356.1893 & 2356.1878 & 786.4032 & 0.0015 & 0.6358 & 204.250 \\ 0.82 & 31.21 & 27.43 & 44.21 & 2 & 1434.7042 & 1434.7032 & 718.3589 & 0.0010 & 0.6960 & 452.061 \\ 1.00 & 58.53 & 25.28 & 19.98 & 2 & 1607.9280 & 1607.9269 & 804.9707 & 0.0011 & 0.6833 & 719.347\end{array}$ $\begin{array}{llllllllllll}1.00 & 57.94 & 24.03 & 16.72 & 2 & 1607.9394 & 1607.9269 & 804.9707 & 0.0125 & 7.7642 & 993.597 \\ 1.00 & 66.90 & 27.47 & 21.75 & 2 & 1420.7652 & 1420.7652 & 711.3899 & 0.0000 & 0.0000 & 1234.605 & 13\end{array}$ $\begin{array}{llllllllllll}1.00 & 66.90 & 27.47 & 21.75 & 2 & 1420.7652 & 1420.7652 & 711.3899 & 0.0000 & 0.0000 & 1234.605 \\ 1.00 & 71.26 & 27.90 & 21.79 & 2 & 1420.7656 & 1420.7652 & 711.3899 & 0.0004 & 0.2811 & 1264.984\end{array}$ $\begin{array}{llllllllllll} & 5.01 & 20.03 .2013 & 2035.1995 & 679.4071 & 0.0018 & 0.8831 & 31.035\end{array}$

LAAQSCALSLVR $\begin{array}{lllllllllll}0.66 & 40.51 & 20.00 & 53.51 & 3 & 2035.2016 & 2035.1995 & 679.4071 & 0.0021 & 1.0303 \\ 1.00 & 62.69 & 27.49 & 26.92 & 2 & 1420.7648 & 1420.7652 & 711.3899 & -0.0004 & -0.2811 & \end{array}$

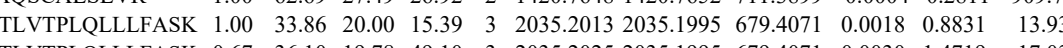

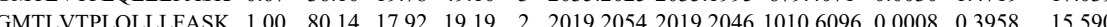

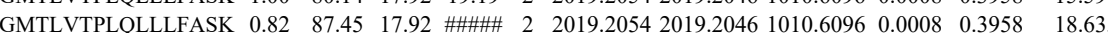
$\begin{array}{llllllllllll}\text { GMTLVTPLQLLLFASK } & 0.66 & 54.05 & 17.92 & 67.05 & 3 & 2019.2065 & 2019.2046 & 674.0755 & 0.0019 & 0.9396 & 49.386\end{array}$ $\begin{array}{llllllllllll}\text { GMTLVTPLOLLLFASK } & 0.66 & 44.66 & 17.63 & 59.66 & 3 & 2019.2065 & 2019.2046 & 674.0755 & 0.0019 & 0.9396 & 49.386 \\ \text { GMT } & 2019.2046 & 674.0755 & 0.0025 & 1.2363 & 13.088\end{array}$ $\begin{array}{llllllllllll}\text { GMTLVTPLQLLLFASK } & 0.66 & 45.34 & 20.00 & 58.34 & 3 & 2035.2013 & 2035.1995 & 679.4071 & 0.0018 & 0.8831 & 15.478\end{array}$ $\begin{array}{lllllllllllll}\text { GMTLVTPLQLLLFASK } & 0.66 & 55.36 & 20.00 & 68.36 & 3 & 2035.2013 & 2035.1995 & 679.4071 & 0.0018 & 0.8831 & 14.589\end{array}$

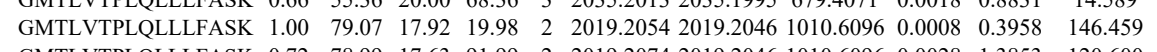

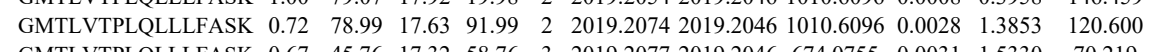
$\begin{array}{llllllllllll}\text { GMTLVTPLQLLLFASK } & 0.67 & 45.76 & 17.32 & 58.76 & 3 & 2019.2077 & 2019.2046 & 674.0755 & 0.0031 & 1.5330 & 70.219\end{array}$ $\begin{array}{llllllllllll}\text { GMTLVTPLQLLLFASK } & 1.00 & 42.01 & 17.08 & 18.55 & 3 & 2019.2095 & 2019.2046 & 674.0755 & 0.0049 & 2.4231 & 246.443\end{array}$ $\begin{array}{llllllllllll}\text { GMTLVTPLQLLLFASK } & 0.66 & 41.43 & 19.96 & 54.43 & 3 & 2035.2019 & 2035.1995 & 679.4071 & 0.0024 & 1.1775 & 19.774\end{array}$ \begin{tabular}{llllllllllll} 
GMTLVTPLQLLLFASK & 0.66 & 32.94 & 19.96 & 45.94 & 3 & 2035.2019 & 2035.1995 & 679.4071 & 0.0024 & 1.1775 & 11.185 \\
\hline
\end{tabular}

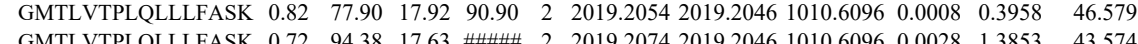
$\begin{array}{lllllllllllll}\text { GMTLVTPLQLLLFASK } & 0.72 & 94.38 & 17.63 & \# \# \# \# & 2 & 2019.2074 & 2019.2046 & 1010.6096 & 0.0028 & 1.3853 & 43.574 \\ \text { GMTLVTPLQLLLFASK } & 0.60 & 42.43 & 17.24 & 55.43 & 3 & 20192086 & 20192046 & 674.0755 & 0.0040 & 1.9780 & 22.695\end{array}$ $\begin{array}{llllllllllll}\text { GMTLVTPLQLLLFASK } & 0.60 & 42.43 & 17.24 & 55.43 & 3 & 2019.2086 & 2019.2046 & 674.0755 & 0.0040 & 1.9780 & 22.695 \\ \text { GMTLVTPLQLLLFASK } & 0.60 & 40.82 & 17.24 & 53.82 & 3 & 2019.2089 & 2019.2046 & 674.0755 & 0.0043 & 2.1264 & 95.996\end{array}$ $\begin{array}{lllllllllllll}\text { GMTLVTPLQLLLASK } & 0.60 & 40.82 & 17.24 & 53.82 & 3 & 2019.2089 & 2019.2046 & 674.0755 & 0.0043 & 2.1264 & 95.996 \\ \text { GMTLVTPLQLLLFASK } & 0.67 & 42.14 & 19.78 & 55.14 & 3 & 2035.2022 & 2035.1995 & 679.4071 & 0.0027 & 1.3247 & 13.233\end{array}$ $\begin{array}{lllllllllllll}\text { GMTLVTPLQLLLFASK } & 0.67 & 42.14 & 19.78 & 55.14 & 3 & 2035.2022 & 2035.1995 & 679.4071 & 0.0027 & 1.3247 & 13.233 \\ \text { GMTLVTPLQLLLFASK } & 0.67 & 44.73 & 19.78 & 57.73 & 3 & 2035.2025 & 2035.1995 & 679.4071 & 0.0030 & 1.4719 & 19.748\end{array}$ $\begin{array}{lllllllllllll}\text { GMTLVTPLQLLFASK } & 0.67 & 44.73 & 19.78 & 57.73 & 3 & 2035.2025 & 2035.1995 & 679.4071 & 0.0030 & 1.4719 & 19.748 \\ \text { GMTLVTPLQLLLFASK } & 1.00 & 43.00 & 17.32 & 19.18 & 3 & 2019.2077 & 2019.2046 & 674.0755 & 0.0031 & 1.5330 & 17.322\end{array}$ $\begin{array}{llllllllllll}\text { GMTLVTPLQLLLFASK } & 1.00 & 43.00 & 17.32 & 19.18 & 3 & 2019.2077 & 2019.2046 & 674.0755 & 0.0031 & 1.5330 & 17.322 \\ \text { GMTLVTPLOLLLFASK } & 0.60 & 30.76 & 19.59 & 43.76 & 3 & 2035.2037 & 2035.1995 & 679.4071 & 0.0042 & 2.0606 & 2.069\end{array}$

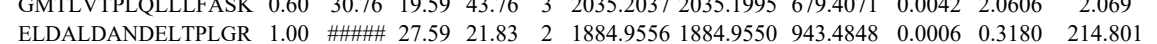

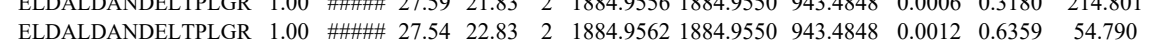

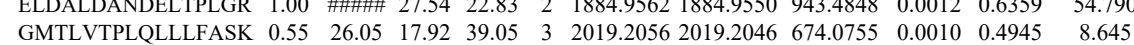
$\begin{array}{llllllllllll}\text { GMTLVTPLQLLFASK } & 0.55 & 26.05 & 17.92 & 39.05 & 3 & 2019.2056 & 2049.2046 & 674.0755 & 0.0010 & .44945 & 8.645 \\ \text { LQISHEAAACITGLR } & 0.99 & 44.58 & 27.92 & 18.77 & 2 & 1771.9188 & 1771.9195 & 886.9670 & -0.0007 & -0.3946 & 10.942\end{array}$

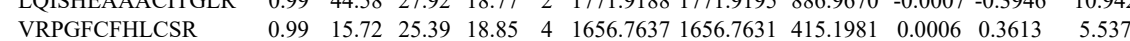
$\begin{array}{lllllllllllllll}\text { VRPGFCFHLCSR } & 0.99 & 15.72 & 25.39 & 18.85 & 4 & 1656.7637 & 1656.7631 & 415.1981 & 0.0006 & 0.3613 & 5.537 \\ \text { VRPGFCFHLCSR } & 1.00 & 19.20 & 25.35 & 18.52 & 4 & 1656.7641 & 1656.7631 & 415.1981 & 0.0010 & 0.6021 & 13.155\end{array}$ 
$\begin{array}{llllllllllllll} & \end{array}$

$\begin{array}{lllllllllll} & \end{array}$

$\begin{array}{lllllllllllllllll} & \end{array}$ $\begin{array}{llllllllllllllll} & \end{array}$

$\begin{array}{lllllllllllll} & & \end{array}$

$\begin{array}{llllllllllllll}\text { QGAAIGIPYFTAYR } & 1.00 & 59.36 & 27.82 & 31.12 & 2 & 1670.8926 & 1670.8902 & 836.4524 & 0.0024 & 1.4346 & 244.823 & 140.770\end{array}$ $\begin{array}{lllllllllllll} & \end{array}$

$\begin{array}{llllllllllllll} & 0.63 & 40.69 & 26.83 & 53.69 & 3 & 2937.5023 & 2937.5004 & 980.1741 & 0.0019 & 0.6461 & 10.331\end{array}$

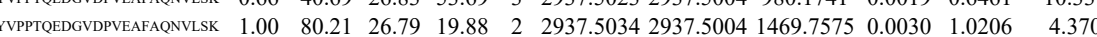

$\begin{array}{lllllllllllllll} & \text { FVPPTOEDGVDPVEAFAQNVLSK } & 0.60 & 14.47 & 26.67 & 27.47 & 3 & 2937.5047 & 2937.5004 & 980.1741 & 0.0043 & 1.4623 & 0.000\end{array}$

$\begin{array}{llllllllllllll} & \\ \text { YYVPPTEEDGVDPVEAFAQNVLSK } & 0.60 & 36.10 & 26.67 & 49.10 & 3 & 2937.5044 & 2937.5004 & 980.1741 & 0.0040 & 1.3603 & 3.061\end{array}$

$\begin{array}{llllllllllll} & \\ \text { FDEISFVNFAR } & 1.00 & 61.49 & 27.33 & 28.28 & 2 & 1487.7544 & 1487.7531 & 744.8838 & 0.0013 & 0.8726 & 230.150 \\ & 1.00 & 67.37 & 27.33 & 27.85 & 2 & 1487.7544 & 1487.7531 & 744.8838 & 0.0013 & 0.8726 & 172.263\end{array}$

GWNWGTVK

IPYTTVLR

PYTTVLR

GFIYVHKPPVHIR

GFIYVHKPPVHIR

GFIYVHKPPVHIR

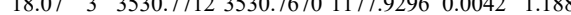

6.791

2956.95

$\begin{array}{llllllllllll}\text { GFIYVHKPPVHIR } & 1.00 & 22.15 & 22.17 & 35.15 & 4 & 1850.0917 & 1850.0923 & 463.5304 & -0.0006 & -0.3236 & 3058.912 \\ \text { NEVTLFHHQNDDAEVSLMEVR } & 1.00 & 48.22 & 26.28 & 16.63 & 3 & 2618.2375 & 2618.2404 & 873.7541 & -0.0029 & -1.1063 & 20.490 \\ \text { NEVTLEFHQNDDAEVSLMEVR } & 1.00 & 78.78 & 26.42 & 21.72 & 3 & 2618.2435 & 2618.2404 & 873.7541 & 0.0031 & 1.1826 & 28.780\end{array}$

$\begin{array}{llllllllllllll} & \end{array}$

$67.688 \quad 4835.80$
$\begin{array}{llllllllllllll} & \end{array}$ $\begin{array}{llllllllllll}\text { NEVTLEFHQNDDAEVSLMEVR } & 1.00 & 60.26 & 26.52 & 18.09 & 3 & 2618.2453 & 2618.2404 & 873.7541 & 0.0049 & 1.8693 & 30.911 \\ \text { ELEDLEVDGQK } & 1.00 & 63.79 & 28.38 & 28.24 & 2 & 1561.8092 & 1561.079 & 781.9112 & 0.0013 & 0.8313 & 84.356\end{array}$ $\begin{array}{llllllllllll}1.00 & 63.79 & 28.38 & 28.24 & 2 & 1561.8092 & 1561.8079 & 781.9112 & 0.0013 & 0.8313 & 84.356\end{array}$

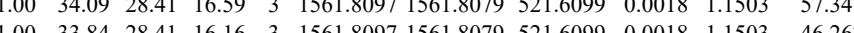
$\begin{array}{ccc}1.368 & \text { No } \\ 5757.669 & \text { Y } \\ & 2964.246 & \text { Yes }\end{array}$

$\begin{array}{llllllllll}\text { NSUN2 HUMAl Q08J23 NSUN2 } & \text { tRNA (cytosine-5. 86.471 } & 1.00 & 10 & 19 & -0.2429 & 0.3812 & 1.3968 & 0.8859\end{array}$

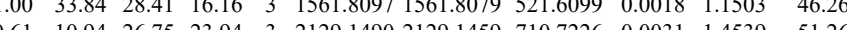

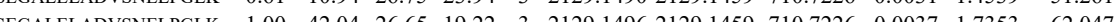

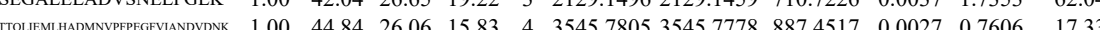

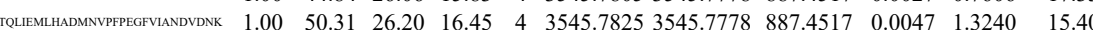
$\begin{array}{lllllllllll}1.00 & 50.31 & 26.20 & 16.45 & 4 & 3545.7825 & 3545.7778 & 887.4517 & 0.0047 & 1.3240 & 15.405 \\ 1.00 & 53.79 & 26.14 & 18.79 & 4 & 3545.7821 & 3545.7778 & 887.4517 & 0.0043 & 1.2113 & 64.213\end{array}$

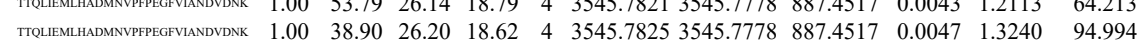
$\begin{array}{llllllllllllll}\text { IVPEGEWGQFMDALR } & 1.00 & 61.57 & 27.74 & 25.51 & 2 & 1890.9432 & 1890.9420 & 946.4783 & 0.0012 & 0.6339 & 237.113 & 180 & \\ \end{array}$

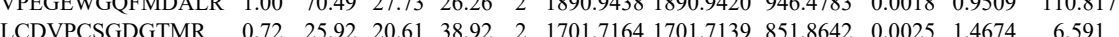
$\begin{array}{llllllllllll}\text { IVPEGEWGQFMDALR } & 1.00 & 52.38 & 27.77 & 23.90 & 2 & 1890.9424 & 1890.9420 & 946.4783 & 0.0004 & 0.2113 & 188.160\end{array}$ $\begin{array}{llllllllllllll}\text { VPEGEWGQFMDALR } & 1.00 & 50.60 & 27.87 & 24.63 & 2 & 1890.9442 & 1890.9420 & 946.4783 & 0.0022 & 1.1622 & 214.404 & 131.166\end{array}$ $\begin{array}{lllllllllllll}\text { DVDNKR } & 1.00 & 81.68 & 24.61 & 94.68 & 4 & 3701.8869 & 3701.8789 & 926.4770 & 0.0080 & 2.1587 & 25.385 & 50.551\end{array}$ WMPGITQWK

(1) $\begin{array}{lllllllllllll}.00 & 47.98 & 28.49 & 18.93 & 2 & 1433.7734 & 1433.7733 & 717.8939 & 0.0001 & 0.0696 & 1587.612 & 1192.183\end{array}$

LLTQENPFFR $\begin{array}{lllllllll} & \end{array}$

$\begin{array}{llllllllllllllllll} & \\ \text { LQQQQRPEDAEDGAEGGGK } & 1.00 & 48.36 & 27.72 & 24.09 & 3 & 2300.1241 & 2300.1236 & 767.7151 & 0.0005 & 0.2171 & 3723.713 & 2758.076 & 11141.862 & 11531.598 & \text { Yes } \\ \text { QQQQQRPEDAEDGAEGGGK } & 1.00 & 40.35 & 27.57 & 19.81 & 3 & 2300.1274 & 2300.1236 & 767.7151 & 0.0038 & 1.6499 & 4710.158 & 5563.337 & 17983.445 & 21947.871 & \text { Yes }\end{array}$ $\begin{array}{lllllllllll}54.94 & 27.20 & 20.18 & 2 & 1520.8490 & 1520.8473 & 76.4309 & 0.0017 & 1.1163 & 323.127 & 265.992\end{array}$ $\begin{array}{lllllllllllllll} & & & \end{array}$ $\begin{array}{llllllllllllllll} & \end{array}$ $\begin{array}{lllllllllllllll} & \end{array}$ $\begin{array}{llllllllllllll} & \end{array}$

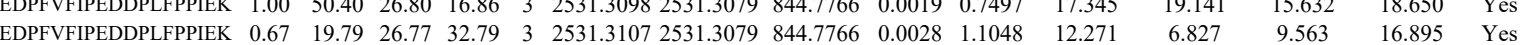

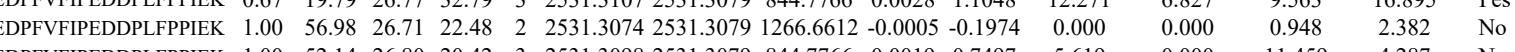

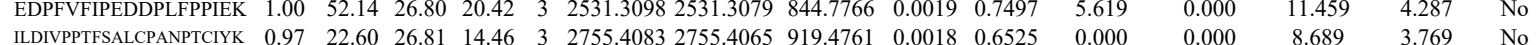

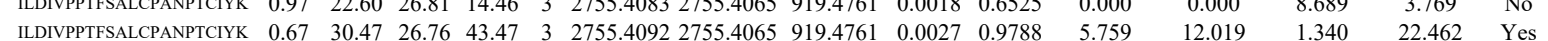


DVPNPNQDDDDDEGFSFNPLK
IEVFVQTLLHLAAK
LQPGSLPQVLAQATEMLYMR

LLCTVAR

LLCTVAR
LFVWEILHSTIR

LFVWEILHSTIR
LFVWEILHSTIR

LQPGSLPQVLAQATEMLYMR

LQPGSLPQVLAQA
LLCTVAR

TSDANETEDHLESLICK

NLFLVIFQR

NLFLVIFQR

NLFLVIFQR

LTIYTTLVGLLNAR

LTIYTTLVGLLNAR
LTIYTTLVGLLNAR

LTIYTTLVGLLNAR

LTIYTTLVGLLNAR
LTIYTTLVGLLNAR

LTIYTTLVGLLNAR
LTIYTTLVGLLNAR

LTIYTTLVGLLN

NLFLVIFQR
LTIYTTLVGLLNAR

LTIYTTLVGLLNAR
LTIYTTLVGLLNAR

LTIYTTLVGLLNAR

LTIYTTLVGLLNAR

LTIYTTLVGLLNAR

NLFLVIFQR

NLFLVIFQR
NLFLVIFQR

NLFLVIFQR

LTIYTTLVGLLNAR
LTIYTTLVGLLNAR

LTIYTTLVGLLNAR

LTIYTTLVGLLNAR

LTIYTTLVGLLNAR

LTIYTTLVGLLNAR

LTIYTTLVGLLNAR

LTIYTTLVGLLNAR

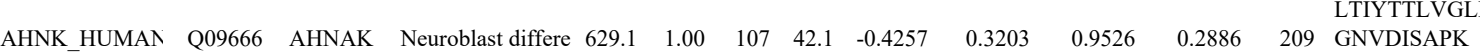

GNVDISAPK

GPQVSGELK

VDINAPDVDVR

VKGDADVSVPK

$\begin{array}{lllllllllllllllll}\text { VKGDADVSVPK } & 0.91 & 48.95 & 24.03 & 30.19 & 3 & 1545.9193 & 1545.9092 & 516.3103 & 0.010 & 6.5206 & 9394.851 & 9473.638 & 3194.871 & 11420.948 & \text { Yes } \\ \text { VKGDADVSVPK } & 0.59 & 46.25 & 24.17 & 26.50 & 2 & 1545.9218 & 1545.9092 & 773.9619 & 0.0126 & 8.1399 & 1379.429 & 902.037 & 591.371 & 1495.125 & \text { Yes } \\ \text { APDVDVNIAGPDAALK } & 1.00 & 93.45 & 27.46 & 19.41 & 2 & 1853.0146 & 1853.0138 & 927.5142 & 0.0008 & 0.4313 & 151.841 & 93.747 & 161.410 & 152.988 & \text { No }\end{array}$ $\begin{array}{llllllllllllllll}\text { VDIDAPDVDVHGPDWHLK } & 1.00 & 46.97 & 27.32 & 17.81 & 2 & 1853.0146 & 1853.0138 & 927.5142 & 0.0008 & 0.4313 & 151.841 & 93.747 & 161.410 & 152.988 & \text { No } \\ \text { Ves } & 2315.1811 & 2315.1790 & 772.7336 & 0.0021 & 0.9059 & 3316.277 & 2531.321 & 1224.417 & 3260.233 & \text { Yes }\end{array}$

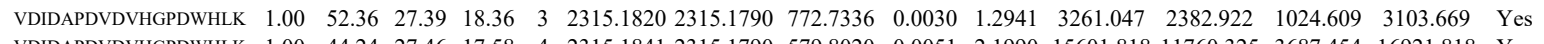

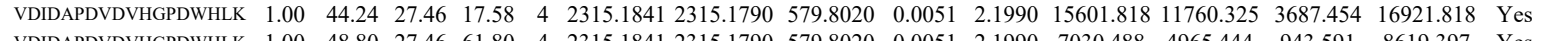
\begin{tabular}{llllllllllllllllll} 
VDIDAPDVDVHGPDWHLK & 1.00 & 48.80 & 27.46 & 61.80 & 4 & 2315.1841 & 2315.1790 & 579.8020 & 0.0051 & 2.1990 & 7030.488 & 4965.444 & 943.591 & 8619.397 & Yes \\
\hline
\end{tabular}

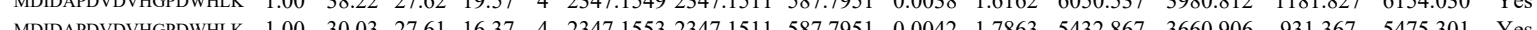
$\begin{array}{lllllllllllllllll}\text { MDIDAPDVDVHGPDWHLK } & 1.00 & 30.03 & 27.61 & 16.37 & 4 & 2347.1553 & 2347.1511 & 587.7951 & 0.0042 & 1.7863 & 5432.867 & 3660.906 & 931.367 & 5475.301 & \text { Yes } \\ \text { MDIDAPDVEVQGPDWHLK } & 1.00 & 51.09 & 26.90 & 17.93 & 3 & 2352.1714 & 2352.1664 & 785.0627 & 0.0050 & 2.1230 & 770.624 & 755.797 & 616.305 & 1467.419 & \text { Yes }\end{array}$

Table S-4 page 448 of 614 


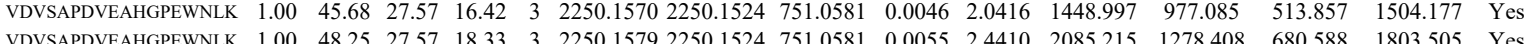
\begin{tabular}{llllllllllllllll} 
VDIDAPDVDVHGPDWHIK & 1.00 & 48.25 & 27.57 & 18.33 & 3 & 2250.1579 & 2250.1524 & 751.0581 & 0.0055 & 2.4410 & 2085.215 & 1278.408 & 680.588 & 1803.505 & Yes \\
\hline
\end{tabular} $\begin{array}{llllllllllllllll} & \end{array}$

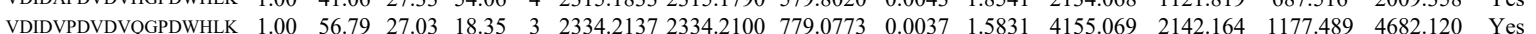

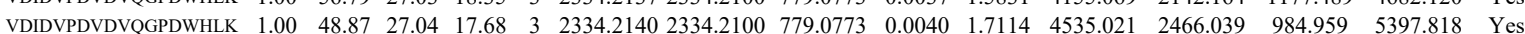

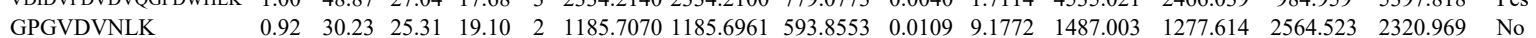

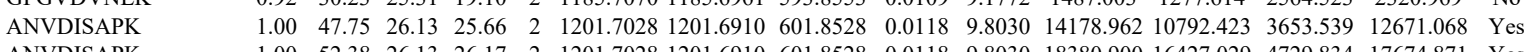
$\begin{array}{llllllllllllllll}\text { ANVDISAPK } & 1.00 & 52.38 & 26.13 & 26.17 & 2 & 1201.7028 & 1201.6910 & 601.8528 & 0.0118 & 9.8030 & 18380.900 & 16427.029 & 4729.834 & 17674.871 & \text { Yes } \\ \text { ISMQDVDLSLGSPK } & 0.67 & 18.11 & 28.25 & 27.43 & 2 & 1648.8480 & 1648.8464 & 825.4305 & 0.0016 & 0.9692 & 1806.188 & 1764.247 & 118.928 & 2509.001 & \text { Yes }\end{array}$

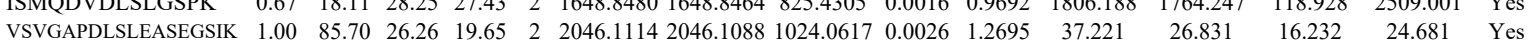

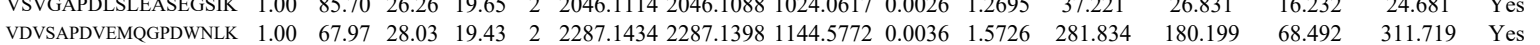

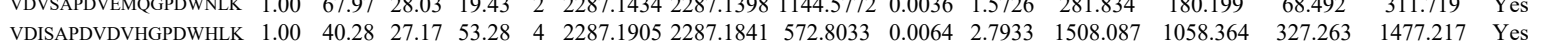
$\begin{array}{lllllllllllllllll}\text { VDINAPDVDVOGPDWHLK } & 0.60 & 56.60 & 27.20 & 69.60 & 3 & 2305.1986 & 2305.1947 & 769.4055 & 0.0039 & 1.6896 & 1959.542 & 1185.017 & 633.812 & 2402.060 & \text { Yes }\end{array}$ $\begin{array}{llllllllllllllll}\text { VDINAPDVDVQGPDWHLK } & 1.00 & 50.39 & 27.15 & 17.93 & 3 & 2305.2013 & 2305.1947 & 769.4055 & 0.0066 & 2.8593 & 2089.774 & 1413.795 & 883.495 & 2809.100 & \text { Yes }\end{array}$ $\begin{array}{lllllllllllllllll}\text { VDINAPDVDVHGPDWHLK } & 1.00 & 48.35 & 26.89 & 61.35 & 4 & 2314.1981 & 2314.1950 & 579.5560 & 0.0031 & 1.3372 & 1898.752 & 1619.242 & 646.547 & 2117.813 & \text { Yes }\end{array}$ $\begin{array}{lllllllllllllllll}\text { VDIDAPDVDVHGPDWHLK } & 1.00 & 38.26 & 27.34 & 23.62 & 4 & 2315.1825 & 2315.1790 & 579.8020 & 0.0035 & 1.5091 & 1173.887 & 1017.270 & 268.512 & 1018.641 & \text { Yes }\end{array}$ VDIDVPDVDVQGPDWHLK $\begin{array}{lllllllllllllllll}0.67 & 57.34 & 27.04 & 70.34 & 3 & 2334.2128 & 2334.2100 & 779.0773 & 0.0028 & 1.1980 & 3425.630 & 2584.731 & 1017.569 & 4260.331 & \text { Yes }\end{array}$ $\begin{array}{llllllllllllllllll}\text { VDIDVPDVDVQGPDWHLK } & 1.00 & 62.86 & 27.04 & 17.97 & 3 & 2334.2131 & 2334.2100 & 779.0773 & 0.0031 & 1.3264 & 3885.798 & 2854.875 & 776.659 & 3619.802 & \text { Yes }\end{array}$

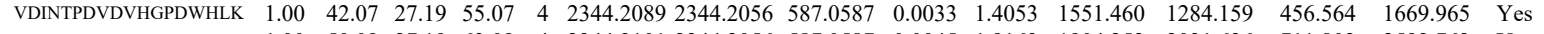

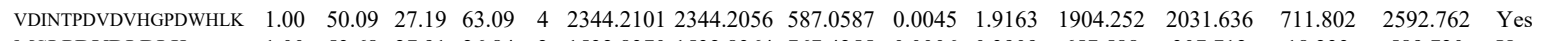
$\begin{array}{llllllllllllllll}\text { MSLPDVDLDLK } & 1.00 & 53.68 & 27.91 & 26.84 & 2 & 1532.8370 & 1532.8364 & 767.4255 & 0.0006 & 0.3909 & 657.588 & 307.712 & 18.233 & 589.720 & \text { Yes }\end{array}$ $\begin{array}{llllllllllllllll}\text { MSLPDVDLDLK } & 1.00 & 62.02 & 27.99 & 30.71 & 2 & 1532.8388 & 1532.8364 & 767.4255 & 0.0024 & 1.5637 & 328.441 & 163.599 & 0.000 & 503.302 & \text { No }\end{array}$ $\begin{array}{lllllllllllllllll}\text { ISMQDVDLSLGSPK } & 0.65 & 17.62 & 28.22 & 26.31 & 2 & 1648.8484 & 1648.8464 & 825.4305 & 0.0020 & 1.2115 & 2735.395 & 3143.170 & 448.480 & 4310.507 & \text { Yes } \\ \text { ISMQDVDLSLGSPK } & 0.86 & 22.87 & 28.25 & 30.65 & 2 & 1648.8488 & 1648.8464 & 825.4305 & 0.0024 & 1.4538 & 1345.655 & 1630.412 & 111.883 & 1926.935 & \text { Yes }\end{array}$ $\begin{array}{llllllllllllllll}\text { ISMQDVDLSLGSPK } & 0.86 & 22.87 & 28.25 & 30.65 & 2 & 1648.8488 & 1648.8464 & 825.4305 & 0.0024 & 1.4538 & 1345.655 & 1630.412 & 111.883 & 1926.935 & \text { Yes } \\ \text { VNVEAPDVNLEGLGGK } & 1.00 & 87.24 & 26.63 & 24.21 & 2 & 1898.0380 & 1898.0353 & 950.0249 & 0.0027 & 1.4210 & 429.279 & 347.302 & 148.919 & 406.710 & \text { Yes } \\ \text { VNVEAPDVNLEGLGGK } & 0.99 & 28.24 & 26.63 & 16.44 & 3 & 1898.0392 & 1898.0353 & 633.6857 & 0.0039 & 2.0515 & 919.348 & 788.162 & 229.385 & 1070.900 & \text { Yes }\end{array}$ $\begin{array}{llllllllllllllll}\text { VNVEAPDVNLEGLGGK } & 0.99 & 28.24 & 26.63 & 16.44 & 3 & 1898.0392 & 1898.0353 & 633.6857 & 0.0039 & 2.0515 & 919.348 & 788.162 & 229.385 & 1070.900 & \text { Yes } \\ \text { VNVEAPDVNLEGLGGK } & 1.00 & 93.61 & 26.64 & 26.33 & 2 & 1898.0392 & 1898.0353 & 950.0249 & 0.0039 & 2.0526 & 809.173 & 439.732 & 138.833 & 811.342 & \text { Yes }\end{array}$ $\begin{array}{llllllllllllllll}\text { VNVEAPDVNLEGLGGK } & 1.00 & 93.61 & 26.64 & 26.33 & 2 & 1898.0392 & 1898.0353 & 950.0249 & 0.0039 & 2.0526 & 809.173 & 439.732 & 138.833 & 811.342 & \text { Yes } \\ \text { AGAISASGPELOGAGHSK } & 1.00 & 84.64 & 27.08 & 19.26 & 3 & 1925.0251 & 1925.0210 & 642.6809 & 0.0041 & 2.1265 & 5028.585 & 3498.274 & 3063.365 & 5180.091 & \text { Yes }\end{array}$

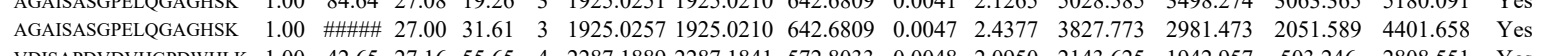
$\begin{array}{lllllllllllllllll}\text { VDISAPDVDVHGPDWHLK } & 1.00 & 42.65 & 27.16 & 55.65 & 4 & 2287.1889 & 2287.1841 & 572.8033 & 0.0048 & 2.0950 & 2143.625 & 1942.957 & 503.246 & 2808.551 & \text { Yes } \\ \text { VDINPDVDVQGPWHEK } & 0.60 & 49.01 & 27.22 & 62.01 & 3 & 2305.1992 & 2305.1947 & 769.4055 & 0.045 & 1.9496 & 1639.583 & 1260.570 & 508.935 & 1383.444 & \text { Yes }\end{array}$

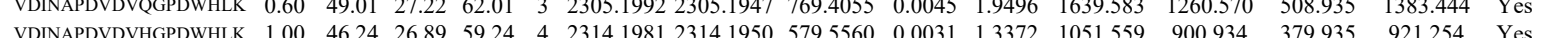
$\begin{array}{llllllllllllllll}\text { VDNAPDVDVGDWHL } & 1.00 & 46.24 & 26.89 & 5.24 & 4 & 2314.1981 & 2314.1950 & 579.5560 & 0.0031 & 1.3372 & 1051.559 & 90.934 & 39.935 & 921.254 & \text { Yes }\end{array}$ $\begin{array}{llllllllllllllll}\text { VDINAPDVEVHGPWHLK } & 1.00 & 42.71 & 27.44 & 16.14 & 4 & 2328.2129 & 2328.2106 & 583.0599 & 0.0023 & 0.9862 & 1129.684 & 678.908 & 540.908 & 1118.171 & \text { Yes } \\ \text { VDINAPDVEVHGPDWL } & 1.00 & 43.37 & 27.36 & 19.93 & 4 & 2328.2181 & 2328.2106 & 583.0599 & 0.0075 & 3.2158 & 89.360 & 53.602 & 8.133 & 47.579 & \mathrm{No}\end{array}$

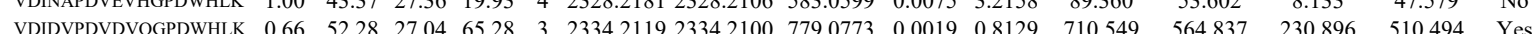

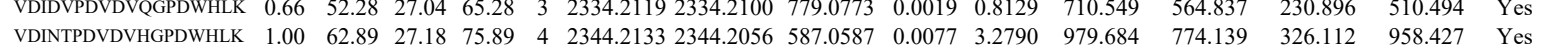

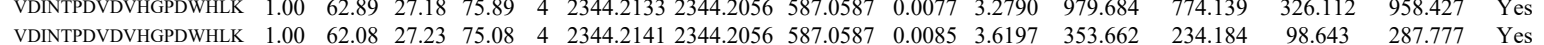

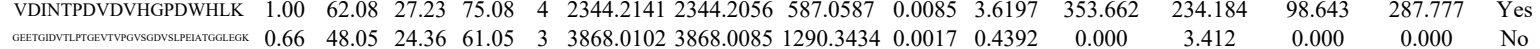

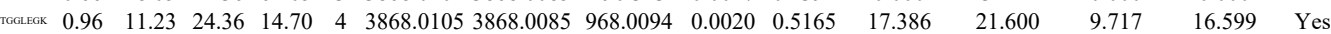
$\begin{array}{llllllllllllllllll}\text { VSAPEVSVGHK } & 1.00 & 49.98 & 26.12 & 19.31 & 3 & 1396.7965 & 1396.7918 & 466.6045 & 0.0047 & 3.3576 & 18013.925 & 12935.340 & 1036.348 & 18052.013 & \text { Yes }\end{array}$ $\begin{array}{lllllllllllllllll}\text { ISIPDVDLDLK } & 1.00 & 67.61 & 25.39 & 21.47 & 2 & 1514.8832 & 1514.8799 & 758.4472 & 0.0033 & 2.1755 & 2025.802 & 1396.878 & 63.607 & 2452.901 & \text { Yes }\end{array}$

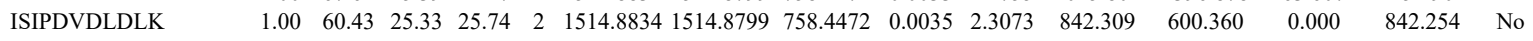
$\begin{array}{lllllllllllllllll}\text { VDVNAPDVQAPDWHLK } & 0.60 & 58.24 & 27.48 & 71.24 & 3 & 2091.1033 & 2091.0993 & 698.0404 & 0.0040 & 1.9101 & 2702.373 & 3057.570 & 4530.463 & 2332.206 & \text { No }\end{array}$ $\begin{array}{lllllllllllllllll}\text { VDVNAPDVQAPDWHLK } & 1.00 & 64.04 & 27.48 & 19.87 & 3 & 2091.1033 & 2091.0993 & 698.0404 & 0.0040 & 1.9101 & 3905.319 & 2553.544 & 2902.522 & 3930.931 & \text { Yes }\end{array}$ $\begin{array}{lllllllllllllllll}\text { VSAPEVSVGHK } & 1.00 & 57.30 & 25.84 & 17.48 & 3 & 1396.7986 & 1396.7918 & 466.6045 & 0.0068 & 4.8578 & 11915.718 & 7576.335 & 1387.013 & 10496.914 & \text { Yes } \\ \text { VSAPEVSVGHK } & 0.99 & 35.39 & 25.80 & 17.73 & 3 & 1396.7992 & 1396.7918 & 466.6045 & 0.0074 & 5.2864 & 8756.066 & 6148.532 & 1768.037 & 8433.106 & \text { Yes }\end{array}$ $\begin{array}{lllllllllllllllll}\text { VDIETPNLEGTLTGPR } & 1.00 & 87.83 & 27.20 & 23.59 & 2 & 1854.9816 & 1854.9809 & 928.4977 & 0.0007 & 0.3770 & 518.153 & 270.600 & 181.481 & 505.222 & \text { Yes }\end{array}$ $\begin{array}{llllllllllllllllll}\text { VDIETPNLEGTLTGPR } & 1.00 & 91.43 & 27.21 & 24.06 & 2 & 1854.9822 & 1854.9809 & 928.4977 & 0.0013 & 0.7001 & 548.148 & 308.797 & 150.688 & 552.584 & \text { Yes }\end{array}$

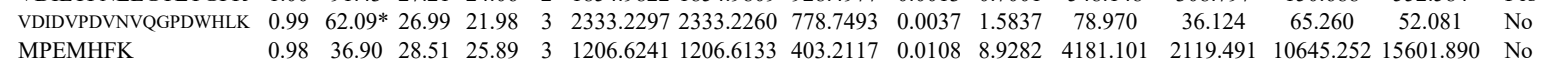

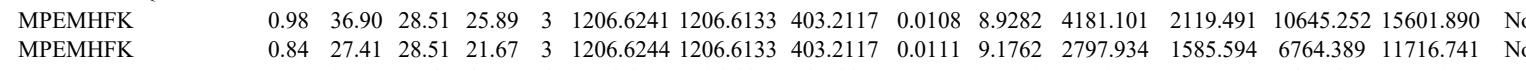
$\begin{array}{lllllllllllllll}0.84 & 27.41 & 28.51 & 21.67 & 3 & 1206.6244 & 1206.6133 & 403.2117 & 0.0111 & 9.1762 & 2797.934 & 1585.594 & 6764.389 & 11716.741 & \text { No } \\ 1.00 & 32.25 & 22.62 & 45.25 & 4 & 2986.6529 & 2986.6470 & 747.6690 & 0.0059 & 1.9728 & 15.377 & 39.717 & 43.761 & 51.937 & \text { No }\end{array}$

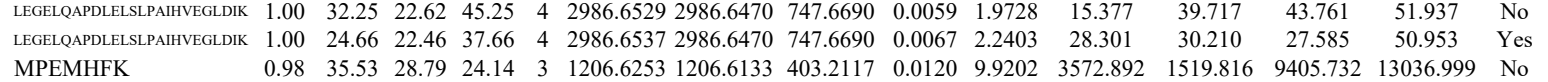
MPEMHFK

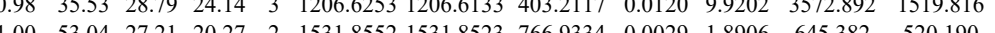

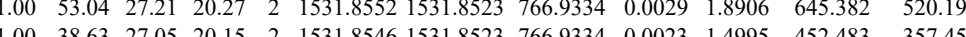
$\begin{array}{ccc}59.344 & 710.838 & \text { Yes }\end{array}$ $\begin{array}{llllllllllllll}1.00 & 52.60 & 27.00 & 26.43 & 2 & 1531.8556 & 1531.8523 & 766.9334 & 0.0033 & 2.1514 & 256.678 & 172.929\end{array}$ 

$\begin{array}{llllllllllll} & \end{array}$ $\begin{array}{lllllllllllllll}0.99 & 35.45 & 27.97 & 28.47 & 3 & 1554.8722 & 1554.8683 & 519.2967 & 0.0039 & 2.5034 & 16138.381 & 10130.138 & 169.918 & 19236.950 & \text { Yes } \\ 0.98 & 5.62 & 26.79 & 25.62 & 2 & 1565.8378 & 1565.8367 & 783.9256 & 0.0011 & 0.7016 & 1013.688 & 767.383 & 257.661 & 1024.236 & \text { Yes }\end{array}$

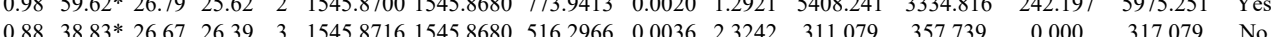

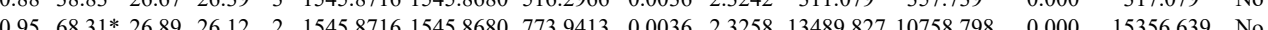
$\begin{array}{lllllllllllllll}0.75 & 38.1 & * 2.899 & 29.42 & 3 & 1545.8719 & 1545.8680 & 5162966 & 0.0039 & 2.5179 & 359.826 & 378.724 & 2.942 & 289.122 & N\end{array}$

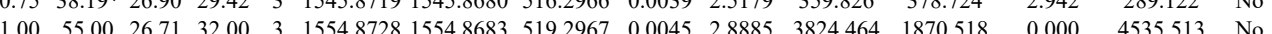
$\begin{array}{lllllllllllllll}1.00 & 55.44 & 26.77 & 27.52 & 3 & 1554.8731 & 1554.8683 & 5192967 & 0.0048 & 3.0811 & 4968.710 & 3127.469 & 0.000 & 5625.106 & \mathrm{No}\end{array}$ $\begin{array}{lllllllllllllll}1.00 & 52.90 & 26.49 & 25.63 & 2 & 1559.8862 & 1559.8836 & 780.9491 & 0.0026 & 1.6646 & 1001.495 & 547.873 & 0.000 & 848.585 & \mathrm{No}\end{array}$ $\begin{array}{llllllllllllllll}1.00 & 59.59 & 26.49 & 27.15 & 2 & 1559.8866 & 1559.8836 & 780.9491 & 0.0030 & 1.9207 & 1126.139 & 755.394 & 76.461 & 1141.515 & \text { Yes }\end{array}$ $\begin{array}{lllllllllllllll}1.00 & 47.75 & 26.24 & 21.37 & 3 & 15688873 & 15688840 & 523.9686 & 0.0033 & 2.0994 & 1942.893 & 1252.928 & 0.000 & 2325.762 & \text { No }\end{array}$ $\begin{array}{lllllllllllllll}1.00 & 39.80 & 26.26 & 23.14 & 3 & 1568.8879 & 1568.8840 & 523.9686 & 0.0039 & 2.4811 & 5529.217 & 4267.939 & 0.000 & 6174.654 & \text { No }\end{array}$ $\begin{array}{lllllllllllllll}1.00 & 46.94 & 27.93 & 25.82 & 3 & 1602.8710 & 1602.8683 & 535.2967 & 0.0027 & 1.6813 & 3396.682 & 2895.660 & 0.000 & 5251.365 & \text { No }\end{array}$ $\begin{array}{llllllllllllllll}1.00 & 47.43 & 28.14 & 27.05 & 3 & 1602.8725 & 1602.8683 & 535.2967 & 0.0042 & 2.6154 & 3573.992 & 2817.810 & 48.214 & 5618.737 & \text { No }\end{array}$ $\begin{array}{llllllllllllllll}1.00 & 71.78 & 26.77 & 34.88 & 2 & 1333.7838 & 1333.7809 & 667.8977 & 0.0029 & 2.1710 & 14629.416 & 11298.284 & 1920.924 & 15809.057 & \text { Yes }\end{array}$ $\begin{array}{llllllllllllll}0.98 & 68.06 * 26.67 & 24.64 & 2 & 1545.8714 & 1545.8680 & 773.9413 & 0.0034 & 2.1965 & 3048.782 & 2116.567 & 0.000 & 2811.985 & \text { No }\end{array}$ $\begin{array}{lllllllllllllll}0.92 & 63.20 * & 26.90 & 31.02 & 2 & 1545.8722 & 1545.8680 & 773.9413 & 0.0042 & 2.7134 & 1435.952 & 956.758 & 0.000 & 1522.330 & \text { No }\end{array}$ $\begin{array}{lllllllllllllll}1.00 & 49.61 & 27.87 & 31.89 & 2 & 1602.8696 & 1602.8683 & 802.4414 & 0.0013 & 0.8100 & 1537.471 & 930.515 & 15.781 & 1925.684 & \text { Yes }\end{array}$ $\begin{array}{llllllllllllllll}1.00 & 39.78 & 27.91 & 25.62 & 3 & 1602.8704 & 1602.8683 & 535.2967 & 0.0021 & 1.3077 & 14700.778 & 10427.721 & 86.984 & 19946.027 & \text { Yes }\end{array}$ $\begin{array}{lllllllllllllll}1.00 & 47.78 & 27.91 & 35.23 & 3 & 1602.8719 & 1602.8683 & 535.2967 & 0.0036 & 2.2417 & 12333.055 & 6481.182 & 0.000 & 16205.077 & \text { No }\end{array}$

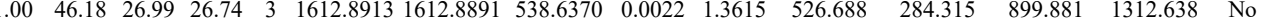
$\begin{array}{lllllllllllllll}1.00 & 45.38 & 27.12 & 25.54 & 3 & 1612.8934 & 1612.8891 & 538.6370 & 0.0043 & 2.6610 & 335.413 & 202.684 & 753.688 & 1050.152 & \text { No }\end{array}$

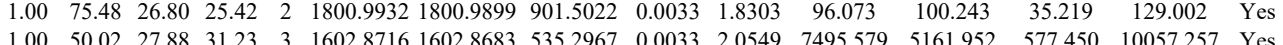
$\begin{array}{lllllllllllllll}1.00 & 5.02 & 27.88 & 31.23 & 3 & 1602.8716 & 1602.8683 & 535.2967 & 0.0033 & 2.0549 & 7495.579 & 5161.952 & 577.450 & 10057.257 & \text { Yes }\end{array}$ $\begin{array}{lllllllllllllll}1.00 & 52.39 & 27.90 & 30.57 & 3 & 1602.8719 & 1602.8683 & 535.2967 & 0.0036 & 2.2417 & 9713.230 & 5207.923 & 157.490 & 10862.885 & \text { Yes }\end{array}$

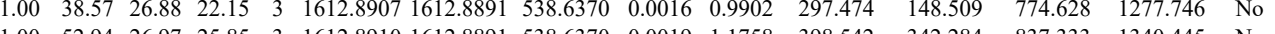

ISMPDVGLNLK

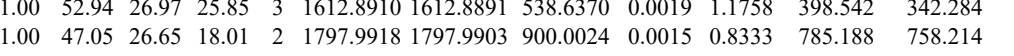
$\begin{array}{lllllllllllll}1.00 & 47.05 & 26.65 & 18.01 & 2 & 1797.9918 & 1797.9903 & 900.0024 & 0.0015 & 0.8333 & 785.188 & 758.214 & 594.7 \\ 1.00 & 48.72 & 25.93 & 25.89 & 2 & 1297.7600 & 1297.7476 & 649.8811 & 0.0124 & 9.5401 & 6672.850 & 4674.213 & 776.3\end{array}$ ISMPDVGLNLK 1.00

ISMPDVNLNLK
ISMPDVNLNLK

FSVSGLK

ISMPDVGLNLK

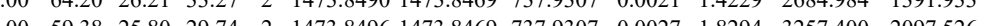
$\begin{array}{llllllllllll}1.00 & 51.19 & 26.49 & 22.89 & 2 & 1530.8714 & 1530.8683 & 766.4414 & 0.0031 & 2.0223 & 478.626 & 353.511\end{array}$ $\begin{array}{lllllllllllll}1.00 & 55.45 & 26.45 & 32.64 & 2 & 1530.8718 & 1530.8683 & 766.4414 & 0.0035 & 2.2833 & 766.691 & 688.359 \\ 0.97 & 38.41 & 25.94 & 26.54 & 2 & 1024.6234 & 1024.6161 & 513.3153 & 0.0073 & 7.1106 & 5163.612 & 3264.525\end{array}$ $\begin{array}{lllllllllllllll}0.97 & 38.41 & 25.94 & 26.54 & 2 & 1024.6234 & 1024.6161 & 513.3153 & 0.0073 & 7.1106 & 5163.612 & 3264.525 & 973.258 & 4965.646 & \text { Yes } \\ 1.00 & 57.41 & 26.18 & 22.80 & 2 & 1473.8474 & 1473.8469 & 737.9307 & 0.0005 & 0.3388 & 951.685 & 564.514 & 114.465 & 989.714 & \text { Yes } \\ 1.00 & 59.68 & 26.06 & 25.53 & 2 & 1473.8748 & 1473.8469 & 737.9307 & 0.0009 & 0.6098 & 940.324 & 769.237 & 24.303 & 1104.659 & \text { Yes } \\ 1.00 & 86.45 & 26.89 & 23.60 & 2 & 1741.9606 & 1741.9445 & 871.9795 & 0.0161 & 9.2318 & 631.132 & 362.870 & 439.691 & 529.627 & \text { Yes } \\ 1.00 & 64.79 & 26.88 & 23.83 & 2 & 1741.9618 & 1741.9445 & 871.9795 & 0.0173 & 9.9199 & 48.008 & 97.591 & 29.961 & 140.749 & \text { No } \\ 0.87 & 31.23 & 22.36 & 32.79 & 2 & 970.6496 & 970.6419 & 486.3282 & 0.0077 & 7.9164 & 4641.321 & 3192.928 & 2078.719 & 4426.576 & \text { Yes } \\ 0.87 & 31.25 & 22.36 & 32.90 & 2 & 970.6502 & 970.6419 & 486.3282 & 0.0083 & 8.5333 & 6861.222 & 5755.955 & 3248.803 & 7641.472 & \text { Yes } \\ 1.00 & 50.58 & 19.34 & 17.84 & 3 & 1478.9104 & 1478.9064 & 493.9761 & 0.0040 & 2.6992 & 2186.044 & 1617.303 & 106.951 & 2230.093 & \text { Yes } \\ 0.66 & 11.18 & 22.65 & 24.18 & 3 & 2733.5110 & 2733.5091 & 912.1770 & 0.0019 & 0.6943 & 91.209 & 63.657 & 37.388 & 96.511 & \text { Yes } \\ 1.00 & 61.19 & 27.29 & 23.12 & 2 & 1257.7070 & 1257.6961 & 629.8553 & 0.0109 & 8.6527 & 16966.905 & 12078.612 & 2641.005 & 17732.820 & \text { Yes } \\ 1.00 & 53.93 & 27.54 & 21.16 & 2 & 1257.7086 & 1257.6961 & 629.8553 & 0.0125 & 9.9228 & 17241.605 & 12336.796 & 2075.750 & 16684.393 & \text { Yes } \\ 0.93 & 15.69 & 22.65 & 14.58 & 3 & 2733.5113 & 2733.5091 & 912.1770 & 0.0022 & 0.8039 & 53.732 & 36.752 & 29.082 & 86.584 & \text { Yes }\end{array}$

ISMPDVGLNLK

GGVQVPAVDISSSLGGR

IGIPGVK

ISIPDVGLHLK

$$
\begin{array}{ll} 
& 1.00 \\
& 0.87 \\
& 0.87 \\
& 1.00 \\
& 0.66
\end{array}
$$

FGTFGGLGSK
FGTFGGLGSK

GPTVGGGLPGIGVQ

ISMPGFK

FSMPGFK
FSMPGFK

FSMPGFK

FSMPGFK

FSMPGFK

FSMPGFK

LQVTMPGIK

FSMPGFK

FSMPGFK

FSMPGFK

FSMPGFK
FSMPGFK

GGQIGLQAPGL

FTFSGR

$$
\begin{array}{ll} 
& 1 \\
1.00 \\
1.00
\end{array}
$$
$\begin{array}{ccccccccccccccc}1 & 15.93 & 27.54 & 21.16 & 2 & 1257.7086 & 1257.6961 & 629.8553 & 0.0125 & 9.9228 & 17241.605 & 12336.796 & 2075.750 & 16684.393 & \text { Yes } \\ 0.93 & 15.69 & 22.65 & 14.58 & 3 & 2733.5113 & 2733.5091 & 912.1770 & 0.0022 & 0.8039 & 53.732 & 36.752 & 29.082 & 86.584 & \text { Yes }\end{array}$ $\begin{array}{lllllllllllllll}0.89 & 30.74 & 27.42 & 30.57 & 2 & 1066.6194 & 1066.6089 & 534.3117 & 0.0105 & 9.8256 & 28240.538 & 17967.259 & 1577.804 & 28499.407 & \text { Yes }\end{array}$ $\begin{array}{lllllllllllllll}0.90 & 23.29 & 26.67 & 18.91 & 2 & 1100.5948 & 1100.5932 & 551.3039 & 0.0016 & 1.4511 & 418.454 & 275.802 & 56.898 & 425.632 & \text { Yes }\end{array}$

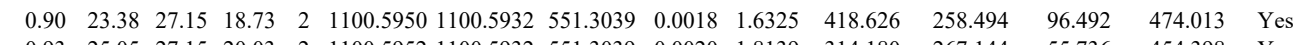
$\begin{array}{llllllllllllllll}0.93 & 25.05 & 27.15 & 20.03 & 2 & 1100.5952 & 1100.5932 & 551.3039 & 0.0020 & 1.8139 & 314.180 & 267.144 & 55.736 & 454.398 & \text { Yes }\end{array}$ $\begin{array}{lllllllllllllll}0.89 & 22.92 & 27.10 & 18.25 & 2 & 1100.5956 & 1100.5932 & 551.3039 & 0.0024 & 2.1767 & 241.080 & 147.850 & 38.278 & 218.490 & \text { Yes }\end{array}$ $\begin{array}{lllllllllllllll}0.79 & 22.72 & 27.11 & 18.25 & 2 & 1100.5958 & 1100.5932 & 551.3039 & 0.0026 & 2.3580 & 201.613 & 198.415 & 53.884 & 242.003 & \text { Yes }\end{array}$ $\begin{array}{lllllllllllllll}0.62 & 23.39 & 27.25 & 19.03 & 2 & 1100.5968 & 1100.5932 & 551.3039 & 0.0036 & 3.2650 & 419.257 & 255.199 & 71.117 & 437.459 & \text { Yes }\end{array}$ $\begin{array}{llllllllllllllll}1.00 & 45.22 & 24.62 & 32.29 & 2 & 1273.7778 & 1273.7672 & 637.8909 & 0.0106 & 8.3086 & 8949.652 & 6851.978 & 3787.155 & 7716.244 & \text { Yes }\end{array}$

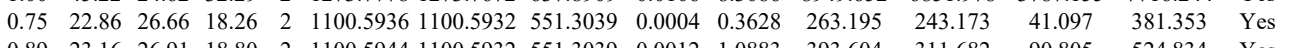

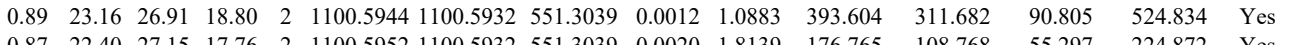
$\begin{array}{lllllllllllllll}0.87 & 22.40 & 27.15 & 17.76 & 2 & 1100.5952 & 1100.5932 & 551.3039 & 0.0020 & 1.8139 & 176.765 & 108.768 & 55.297 & 224.872 & \text { Yes } \\ 0.77 & 26.41 & 27.25 & 19.92 & 2 & 1100.5974 & 1100.5932 & 5513039 & 0.0042 & 3.8091 & 491.687 & 312.459 & 84.681 & 505.467 & \text { Yes }\end{array}$

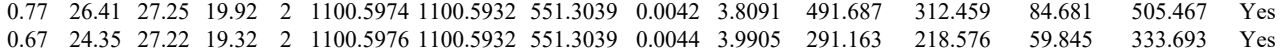
$\begin{array}{llllllllllll}0.53 & 4.62 & 25.60 & 16.79 & 4 & 2705.4405 & 2705.4341 & 677.3658 & 0.0064 & 2.3621 & 98.787 & 110 .\end{array}$

$\begin{array}{lllllllllllllll}0.77 & 20.95 & 25.95 & 26.30 & 2 & 857.4548 & 857.4518 & 429.7332 & 0.0030 & 3.4905 & 16780.845 & 12210.241 & 4307.046 & 156.278 & \text { Yes }\end{array}$ $\begin{array}{llllllllllllllll}0.78 & 21.26 & 25.95 & 26.31 & 2 & 857.4550 & 857.4518 & 429.7332 & 0.0032 & 3.7232 & 16915.265 & 13298.133 & 4409.156 & 19500.940 & Y e s\end{array}$

Table S-4 page 450 of 614 
$\begin{array}{lllllllll}0 & 0\end{array}$

$\begin{array}{llllllllllll}\text { GEVDVSLANVEGDLK } & 1.00 & 42.01 & 27.73 & 21.62 & 3 & 1831.9798 & 1831.9771 & 611.6663 & 0.0027 & 1.4714 & 130.555 \\ \text { GEVDVSLANVEGDLK } & 1.00 & 36.98 & 27.73 & 23.14 & 3 & 1831.9798 & 1831.9771 & 611.6663 & 0.0027 & 1.4714 & 73.471\end{array}$

$\begin{array}{lll}1.00 & 74.26 \\ 1.00 & 42.01 \\ 1.00 & 36.98 \\ 1.00 & 87.91 \\ 1.00 & 82.49\end{array}$

$\begin{array}{llllllllllllll}\text { GEVDVSLANVEGDLK } & 1.00 & 87.91 & 27.72 & 21.40 & 2 & 1831.9802 & 1831.9771 & 916.9958 & 0.0031 & 1.6903 & 99.906 & 66.0 \\ \text { VDIDAPDVSIEGPDAK } & 1.00 & 82.49 & 27.62 & 31.65 & 2 & 1928.0004 & 1927.9982 & 965.0064 & 0.0022 & 1.139 & 656.616 & 553.2\end{array}$

$\begin{array}{lllllllllllll}\text { VDIDAPDVSIEGPDAK } & 1.00 & 82.49 & 27.62 & 31.65 & 2 & 1928.0004 & 1927.9982 & 965.0064 & 0.0022 & 1.1399 & 656.616 & 553.2 \\ \text { VIDAPD.05 } & 27.63 & 27.34 & 2 & 1928.0012 & 1927.9982 & 965.0064 & 0.0030 & 1.5544 & 1133.331 & 750.7\end{array}$

$\begin{array}{llllllllllllll}\text { VDTNAPDLSLEGPEGK } & 1.00 & 84.83 & 27.86 & 26.93 & 2 & 1928.9950 & 1928.9935 & 965.004 & 0.0030 & 1.5544 & 1133.331 & 750.782\end{array}$

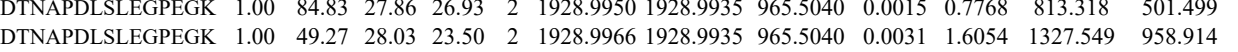

$\begin{array}{lllllllllllllll}\text { VDIEGPDVNIEGPEGK } & 1.00 & 86.10 & 27.59 & 22.79 & 2 & 1955.0114 & 1955.0091 & 978.5118 & 0.0023 & 1.1753 & 249.390 & 147.125\end{array}$

$\begin{array}{lllllllllllll}\text { VDVEVPDVSLEGPEGK } & 1.00 & 92.59 & 27.04 & 28.18 & 2 & 1956.0320 & 1956.0295 & 979.0220 & 0.0025 & 1.2768 & 2121.515 & 1816.219\end{array}$

$\begin{array}{llllllllllllll}\text { VDVEVPDVSLEGPEGK } & 1.00 & 61.10 & 27.03 & 20.83 & 3 & 1956.0328 & 1956.0295 & 653.0171 & 0.0033 & 1.6845 & 285.931 & 204.531 \\ \text { VDVEVPDVSLEGPEGK } & 1.00 & 66.85 & 27.03 & 27.82 & 2 & 1956.0328 & 1956.0295 & 979.0220 & 0.0033 & 1.6854 & 1007.943 & 471.171 & 3\end{array}$

$\begin{array}{lllllllllllll}\text { VDVDVPDVNIEGPDAK } & 1.00 & \text { \#\#\#\# } 27.62 & 27.19 & 2 & 1969.0272 & 1969.0248 & 985.5197 & 0.0024 & 1.2176 & 608.216 & 328.590 & 2\end{array}$

$\begin{array}{llllllllllll}\text { VDVDVPDVNIEGPDAK } & 1.00 & \# \# \# \# \text { 27.66 } & 30.41 & 2 & 1969.0278 & 1969.0248 & 985.5197 & 0.0030 & 1.5220 & 1706.414 & 1152.065\end{array}$

$\begin{array}{llllllllllllll}\text { VDVDVPDVNIEGPDAK } & 1.00 & 38.01 & 27.71 & 16.79 & 3 & 1969.0288 & 1969.0248 & 657.3489 & 0.0040 & 2.0283 & 138.644 & 116.551 \\ \text { VDVDVPDVNIEGPDAK } & 1.00 & 40.45 & 27.71 & 17.86 & 3 & 1969.0288 & 1969.0248 & 657.3489 & 0.0040 & 2.0283 & 151.169 & 165.528 & 103 .\end{array}$

$\begin{array}{lllllllllllll}\text { MDVNVGDIDIEGPEGK } & 1.00 & 61.89 & 27.32 & 20.76 & 2 & 1974.9792 & 1974.9812 & 988.4979 & -0.0020 & -1.0116 & 816.552 & 551.840\end{array}$

$\begin{array}{lllllllllllllll}\text { MDVNVGDIDIEGPEGK } & 1.00 & 78.19 & 27.36 & 24.08 & 2 & 1974.9834 & 1974.9812 & 988.4979 & 0.0022 & 1.1128 & 717.751 & 840.466 \\ \text { IDVDAPDIDIHGPDAK } & 0.66 & 43.24 & 27.77 & 56.24 & 3 & 1978.0276 & 1978.0251 & 660.3490 & 0.0025 & 1.2620 & 1462.130 & 1308.101\end{array}$

$\begin{array}{lllllllllllll}\text { IDVAPDDIHGPAK } & 0.66 & 43.24 & 27.77 & 56.24 & 3 & 1978.0276 & 1978.0251 & 660.3490 & 0.0025 & 1.2620 & 1462.130 & 1308.101\end{array}$

$\begin{array}{llllllllllllll}\text { VDIDVPDVNIEGPDAK } & 0.99 & 67.94 * 27.29 & 19.19 & 2 & 1983.0428 & 1983.0404 & 992.5275 & 0.0024 & 1.2090 & 282.250 & 292.688\end{array}$

$\begin{array}{lllllllllllll}\text { VDIDVPDVNIEGPDAK } & 0.99 & 78.25 * & 27.36 & 25.43 & 2 & 1983.0430 & 1983.0404 & 992.5275 & 0.0026 & 1.3098 & 148.599 & 86.920\end{array}$

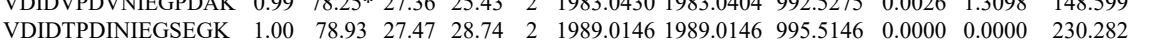

$\begin{array}{lllllllllllllll}\text { VDIDTPDINIEGSEGK } & 1.00 & 89.87 & 27.47 & 22.41 & 2 & 1989.0146 & 1989.0146 & 995.5146 & 0.0000 & 0.0000 & 101.937 & 85.480\end{array}$

$\begin{array}{lllllllllllllll}\text { VDIDTPDIDIHGPEGK } & 1.00 & 61.29 & 27.75 & 19.73 & 3 & 2008.0390 & 2008.0357 & 670.3525 & 0.0033 & 1.6409 & 4695.734 & 3408.768 & 1557 .\end{array}$ $\begin{array}{lllllllllllllll}\text { GPSLDIDTPDVNIEGPEGK } & 1.00 & 65.90 & 27.63 & 20.74 & 2 & 2240.1434 & 2240.1416 & 1121.0781 & 0.0018 & 0.8028 & 72.335 & 108.168\end{array}$

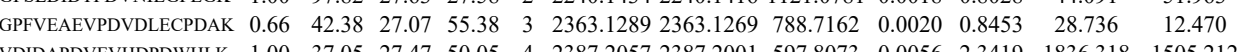

VPDVDIK

ADIEISGPK

GDVDVSLPK

GDVDVSLPK

GDMDVSLPK

AEGPEVDVNLPK

$\begin{array}{lllllllllllll}0.87 & 42.07 & 24.70 & 46.49 & 2 & 1072.6472 & 1072.6372 & 537.3259 & 0.0100 & 9.3053 & 2968.738 & 2187.418 & 5706\end{array}$

\begin{tabular}{llllllllllllllll}
1.00 & 53.73 & 27.97 & 35.83 & 2 & 1216.7018 & 1216.6907 & 609.3526 & 0.0007 & 0.5744 & 14919.647 & 12079.283 & 1906.966 & 11931.295 & Yes \\
\hline
\end{tabular}

$\begin{array}{lllllllllllllllll}0.87 & 52.52 * & 27.98 & 29.85 & 2 & 1248.6658 & 1248.6628 & 625.3387 & 0.0030 & 2.3987 & 3743.911 & 2743.603 & 2270.939 & 3003.966 & \text { Yes } \\ 1.00 & 74.65 & 27.10 & 27.56 & 2 & 1554.8542 & 1554.8497 & 778.4321 & 0.0045 & 2.8904 & 10402.296 & 6271.115 & 1928.822 & 9559.060 & \text { Yes }\end{array}$ $\begin{array}{llllllllllllllllll} & \\ \text { G }\end{array}$ $\begin{array}{lllllllllllllllllll} & \end{array}$ $\begin{array}{lllllllllllllll} & \end{array}$

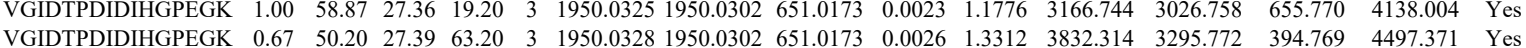

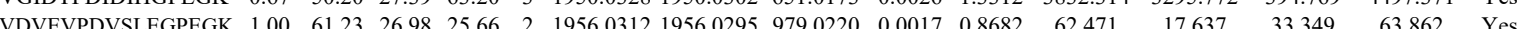
$\begin{array}{llllllllllllllll}\text { VDVEVPDVSLEGPEGK } & 1.00 & 61.23 & 26.98 & 25.66 & 2 & 1956.0312 & 1956.0295 & 979.0220 & 0.0017 & 0.8682 & 62.471 & 17.637 & 33.349 & 63.862 & \text { Yes } \\ \text { VDVEVPDVSLEGPEGK } & 1.00 & 84.61 & 27.08 & 33.16 & 2 & 1956.0332 & 1956.0295 & 979.0220 & 0.0037 & 1.8896 & 171.931 & 120.939 & 126.273 & 289.193 & \text { Yes }\end{array}$ 


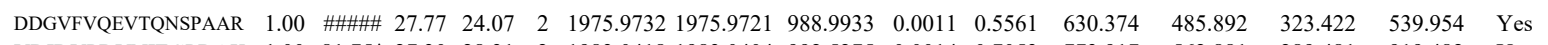
$\begin{array}{lllllllllllllll}\text { VDIDVPDVNIEGPDAK } & 1.00 & 81.75 * 27.30 & 28.31 & 2 & 1983.0418 & 1983.0404 & 992.5275 & 0.0014 & 0.7053 & 773.917 & 562.881 & 289.481 & 919.482 & \text { Yes }\end{array}$

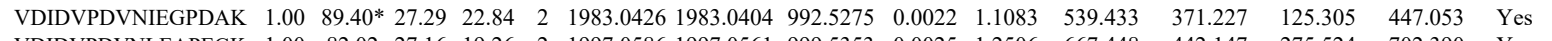
$\begin{array}{lllllllllllllllll}\text { VDIDVPDVNLEAPEGK } & 1.00 & 82.02 & 27.16 & 19.26 & 2 & 1997.0586 & 1997.0561 & 999.5353 & 0.0025 & 1.2506 & 667.448 & 442.147 & 275.524 & 702.390 & \text { Yes } \\ \text { VDIDVPDVNLEAPEGK } & 1.00 & 73.37 & 27.10 & 18.36 & 2 & 1997.0592 & 1997.0561 & 999.5353 & 0.0031 & 1.5507 & 944.237 & 789.488 & 540.123 & 1459.794 & \text { Yes }\end{array}$ $\begin{array}{llllllllllllllll}\text { VDIDVPDVNLEAPEGK } & 1.00 & 73.37 & 27.10 & 18.36 & 2 & 1997.0592 & 1997.0561 & 999.5353 & 0.0031 & 1.5507 & 944.237 & 789.488 & 540.123 & 1459.794 & \text { Yes } \\ \text { VDVECPDVNIEGPEGK } & 0.97 & 24.57 & 26.75 & 19.02 & 3 & 2032.9729 & 2032.9689 & 678.6636 & 0.0040 & 1.9646 & 228.236 & 246.370 & 96.853 & 178.650 & \text { Yes } \\ \text { VDVECPDV }\end{array}$ $\begin{array}{llllllllllllllll}\text { VDVECPDVNIEGPEGK } & 0.97 & 24.57 & 26.75 & 19.02 & 3 & 2032.9729 & 2032.9689 & 678.6636 & 0.0040 & 1.9646 & 228.236 & 246.370 & 96.853 & 178.650 & \text { Yes } \\ \text { VDVECPDVNIEGPEGK } & 1.00 & 68.29 & 26.79 & 24.52 & 2 & 2032.9734 & 2032.9689 & 1017.4917 & 0.0045 & 2.2113 & 85.022 & 54.385 & 19.782 & 78.373 & \text { Yes }\end{array}$

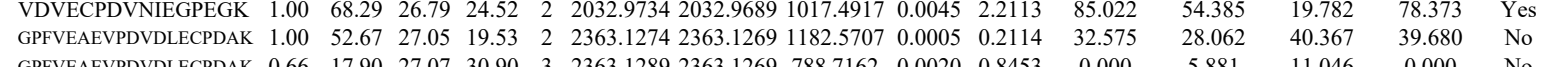
$\begin{array}{llllllllllllllll}\text { GPFVEAEVPDVDLECPDAK } & 0.66 & 17.90 & 27.07 & 30.90 & 3 & 2363.1289 & 2363.1269 & 788.7162 & 0.0020 & 0.8453 & 0.000 & 5.881 & 11.046 & 0.000 & \text { No }\end{array}$

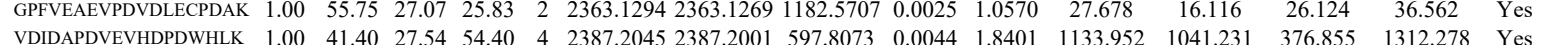
$\begin{array}{llllllllllllllll}\text { VDIDAPDVEVHDPWHLK } & 1.00 & 41.40 & 27.54 & 54.40 & 4 & 2387.2045 & 2387.200 & 597.8073 & 0.0044 & 1.8401 & 133.952 & 1041.231 & 376.855 & 1312.278 & \text { Yes }\end{array}$ $\begin{array}{lllllllllllllllll} & \text { GDLDASVPSMK } & 100 & 54.58 & 28.34 & 28.52 & 2 & 14067446 & 14067319 & 704.3732 & 0.0127 & 9.0150 & 507.872 & 377.268 & 224.740 & 498.281 & \text { Yese }\end{array}$

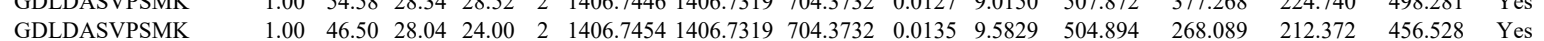

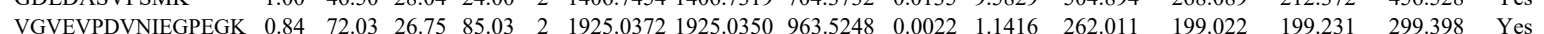
$\begin{array}{llllllllllllllll}\text { VGVEVPDVNIEGPEGK } & 1.00 & 77.06 & 26.88 & 20.29 & 2 & 1925.0378 & 1925.0350 & 963.5248 & 0.0228 & 1.4530 & 377.316 & 288.692 & 126.221 & 219.541 & \text { Yes }\end{array}$

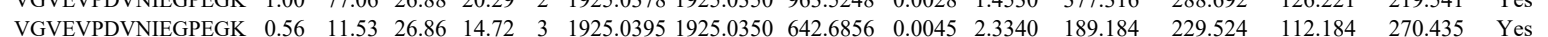
$\begin{array}{lllllllllllllllll}\text { VGIDTPDIDIHGPEGK } & 1.00 & 55.89 & 27.45 & 19.21 & 3 & 1950.0349 & 1950.0302 & 651.0173 & 0.0047 & 2.4065 & 3359.772 & 2717.621 & 834.756 & 3196.272 & \text { Yes }\end{array}$

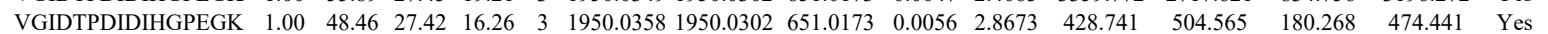
$\begin{array}{llllllllllllllll}\text { VDIDVPDVNIEGPEGK } & 0.52 & 53.75 * & 27.43 & 22.78 & 2 & 1983.0388 & 1983.0404 & 992.5275 & -0.0016 & -0.8060 & 685.117 & 455.235 & 895.880 & 864.103 & \text { No }\end{array}$ $\begin{array}{lllllllllllllllll}\text { VDIDVPDVNIEGPDAK } & 0.93 & 60.89 * & 27.44 & 22.12 & 2 & 1983.0408 & 1983.0404 & 992.5275 & 0.0004 & 0.2015 & 628.585 & 383.314 & 508.875 & 680.475 & \text { Yes }\end{array}$ $\begin{array}{llllllllllllllllll}\text { VDIDVPDVNLEAPEGK } & 1.00 & 41.60 & 27.15 & 16.80 & 3 & 1997.0596 & 1997.0561 & 666.6926 & 0.0035 & 1.7499 & 241.674 & 234.367 & 379.505 & 270.862 & \text { No }\end{array}$ $\begin{array}{llllllllllllllll}\text { LEGDLTGPVGVEVPDVELECPAK } & 1.00 & 65.15 & 26.89 & 17.86 & 3 & 2901.4285 & 2901.4231 & 968.1483 & 0.0054 & 1.8592 & 22.148 & 11.716 & 15.396 & 21.565 & \text { Yes }\end{array}$

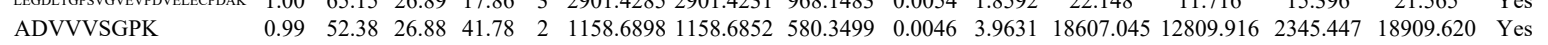
$\begin{array}{lllllllllllllllll}\text { ADVVVSGPK } & 0.98 & 50.86 & 26.82 & 41.70 & 2 & 1158.6902 & 1158.6852 & 580.3499 & 0.0050 & 4.3077 & 15525.470 & 9050.051 & 1924.447 & 12541.524 & \text { Yes }\end{array}$

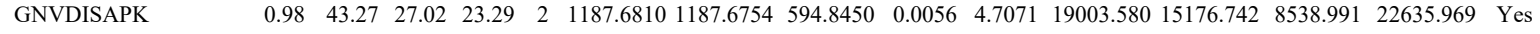
$\begin{array}{llllllllllllllll}\text { GNVDISAPK } & 0.98 & 43.06 & 27.11 & 24.03 & 2 & 1187.6814 & 1187.6754 & 594.8450 & 0.0060 & 5.0433 & 16604.384 & 11937.473 & 5934.510 & 17933.428 & \text { Yes }\end{array}$ $\begin{array}{llllllllllllllll}\text { VKGDADVSVPK } & 0.75 & 36.90 & 24.25 & 22.51 & 3 & 1545.9229 & 1545.9092 & 516.3103 & 0.0137 & 8.8447 & 8285.269 & 8053.253 & 4068.401 & 8811.328 & \text { Yes }\end{array}$ $\begin{array}{lllllllllllllllll}\text { GEGPDVHMTLPK } & 0.98 & 35.40 & 27.58 & 16.81 & 3 & 1567.8421 & 1567.8272 & 523.6163 & 0.0149 & 9.4852 & 1533.938 & 1424.027 & 994.718 & 1667.792 & \text { Yes }\end{array}$ $\begin{array}{lllllllllllllll}\text { GGVTGSPEASISGSK } & 1.00 & \text { 28.06 } & 32.66 & 2 & 1620.8694 & 1620.8563 & 811.4354 & 0.0131 & 8.0720 & 997.401 & 943.202 & 542.605 & 865.196 & \text { Yes }\end{array}$

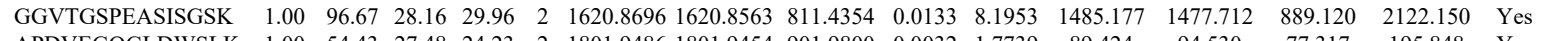
$\begin{array}{llllllllllllllll}\text { APDVEGQGLDWSLK } & 1.00 & 54.43 & 27.48 & 24.23 & 2 & 1801.9486 & 1801.9454 & 901.9800 & 0.0032 & 1.7739 & 89.424 & 94.530 & 77.317 & 195.848 & \text { Yes }\end{array}$

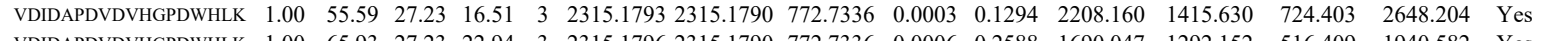
$\begin{array}{llllllllllllllll}\text { VDIDAPDVDVHGPDWHLK } & 1.00 & 65.93 & 27.23 & 22.94 & 3 & 2315.1796 & 2315.1790 & 772.7336 & 0.0006 & 0.2588 & 1690.047 & 1292.152 & 516.409 & 1940.582 & \text { Yes }\end{array}$

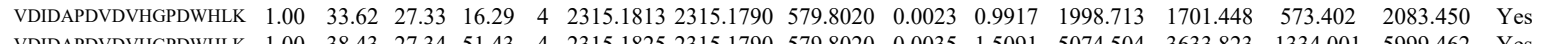
\begin{tabular}{llllllllllllllll} 
VDIDAPDVDVHGPDWHLK & 1.00 & 38.43 & 27.34 & 51.43 & 4 & 2315.1825 & 2315.1790 & 579.8020 & 0.0035 & 1.5091 & 5074.504 & 3633.823 & 1334.001 & 5999.462 & Yes \\
\hline
\end{tabular}

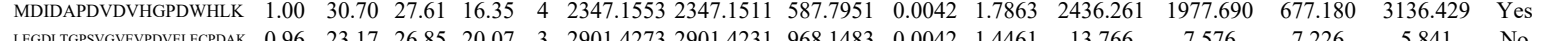
$\begin{array}{lllllllllllllll} & \end{array}$ $\begin{array}{llllllllllllll} & 25.525 & 25.73 & 16.60 & 2 & 2556.1834 & 2556.1845 & 1279.0995 & -0.0011 & -0.4300 & 0.000\end{array}$ $\begin{array}{lllllllllll}\text { KPTEtTeELVeVULSLATQDSDNPLLR } & 1.00 & \text { \#\#\#\# } 25.24 & 23.20 & 3 & 3212.6752 & 3212.6768 & 1071.8995 & -0.0016 & -0.4976 & 10.477\end{array}$

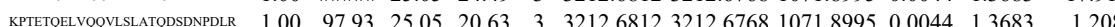
$\begin{array}{lllllllllllll}\text { APEVSQHVYQAYETILK } & 1.00 & 46.77 & 26.56 & 24.73 & 3 & 2263.2100 & 2263.2092 & 755.4103 & 0.0008 & 0.3530 & 254.204\end{array}$ $\begin{array}{lllllllllll} & \end{array}$ $\begin{array}{llllllllllllll}\text { LAPPLVTLLSAEPELQYVALR } & 0.84 & 75.69 & 17.99 & 88.69 & 2 & 2436.4134 & 2436.4113 & 1219.2129 & 0.0021 & 0.8612 & 32.523\end{array}$ $\begin{array}{llllllllllllll}\text { LAPPLVTLLSAEPELQYVALR } & 0.84 & 87.50 & 17.99 & \# \# \# \text { 2 } & 2436.4134 & 2436.4113 & 1219.2129 & 0.0021 & 0.8612 & 25.803\end{array}$ $\begin{array}{llllllllllllll}\text { LAPPLVTLLSAEPELQYVALR } & 0.80 & 5.83 & 17.85 & 14.92 & 3 & 2436.4144 & 2436.4113 & 813.1444 & 0.0031 & 1.2708 & 15.802\end{array}$ $\begin{array}{llllllllllll}\text { LAPPLVTLLSAEPELQYVALR } & 0.84 & 77.16 & 17.99 & 90.16 & 2 & 2436.4134 & 2436.4113 & 1219.2129 & 0.0021 & 0.8612 & 29.294\end{array}$ $\begin{array}{llllllllllllll}\text { LAPPLVTLLSAEPELQYVALR } & 0.84 & 56.34 & 17.99 & 69.34 & 2 & 2436.4134 & 2436.4113 & 1219.2129 & 0.0021 & 0.8612 & 14.494\end{array}$ $\begin{array}{lllllllllllll}\text { LAPPLVTLLSAEPELQYVALR } & 0.67 & 33.72 & 17.85 & 46.72 & 3 & 2436.4144 & 2436.4113 & 813.1444 & 0.0031 & 1.2708 & 11.912\end{array}$ $\begin{array}{llllllllllll}\text { LAPPLVTLLSAEPELQYVALR } & 0.67 & 6.05 & 17.85 & 19.05 & 3 & 2436.4144 & 2436.4113 & 813.1444 & 0.0031 & 1.2708 & 5.270\end{array}$ $\begin{array}{llllllllllll}\text { LAPPLVTLLSAEPELQYVALR } & 0.60 & 10.12 & 17.40 & 23.12 & 3 & 2436.4156 & 2436.4113 & 813.1444 & 0.0043 & 1.7627 & 5.122\end{array}$ $\begin{array}{llllllllllllll} & \end{array}$ $\begin{array}{lllllllllllll}\text { LAPPLVTLLSAEPELQYVALR } & 0.67 & 9.84 & 17.85 & 22.84 & 3 & 2436.4144 & 2436.4113 & 813.1444 & 0.0031 & 1.2708 & 9.503 \\ \text { EPAAEIEALLGMDLVR } & 0.97 & 23.98 & 27.15 & 16.96 & 3 & 1870.0009 & 1869.9991 & 624.3403 & 0.0018 & 0.9610 & 76.992\end{array}$ $\begin{array}{llllllllllllll}\text { EPAAEIEALLGMDLVR } & 0.98 & 24.29 & 27.10 & 21.27 & 3 & 1870.0024 & 1869.9991 & 624.3403 & 0.0033 & 1.7619 & 97.309\end{array}$

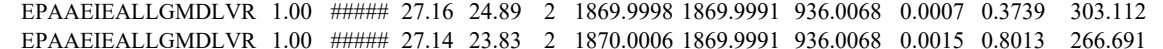
$\begin{array}{lllllllllllll}\text { EPAAEIEALLGMDLVR } & 1.00 & \text { \#\#\#\# } & 27.14 & 23.83 & 2 & 1870.0006 & 1869.9991 & 936.0068 & 0.0015 & 0.8013 & 266.691 \\ \text { EPAAEIEALLGMDLVR } & 1.00 & 36.00 & 27.15 & 31.47 & 3 & 1870.0009 & 1869.9991 & 624.3403 & 0.0018 & 0.9610 & 80.446\end{array}$ $\begin{array}{llllllllllll}\text { EPAAEIEALLGMDLVR } & 1.00 & 36.00 & 27.15 & 31.47 & 3 & 1870.0009 & 1869.9991 & 624.3403 & 0.0018 & 0.9610 & 80.446 \\ \text { EPAAEIEALLGMDLVR } & 1.00 & 38.63 & 27.22 & 26.50 & 3 & 1870.0015 & 1869.9991 & 624.3403 & 0.0024 & 1.2814 & 110.597\end{array}$ $\begin{array}{llllllllllll}\text { EPAAEIEALLGMDLVR } & 1.00 & 38.63 & 27.22 & 26.50 & 3 & 1870.0015 & 1869.9991 & 624.3403 & 0.0024 & 1.2814 & 110.597 \\ \text { EPAAEIEALLGMDLVR } & 1.00 & 50.53 & 27.12 & 26.64 & 3 & 1870.0018 & 1869.9991 & 624.3403 & 0.0027 & 1.4415 & 87.725\end{array}$

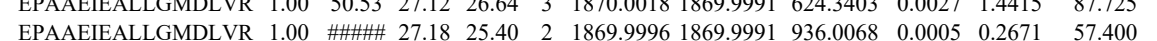
$\begin{array}{lllllllllll}\text { EPAAEIEALLGMDLVR } & 1.00 & \# \# \# \text { 27.18 } & 25.40 & 2 & 1869.9996 & 1869.9991 & 936.0068 & 0.0005 & 0.2671 & 57.400 \\ \text { EPAAEIEALLGMDLVR } & 1.00 & \text { \#\#\#\# } 27.12 & 20.63 & 2 & 1870.0004 & 1869.9991 & 936.0068 & 0.0013 & 0.6944 & 31.994\end{array}$ $\begin{array}{llllllllllll}\text { EPAAEIEALLGMDLVR } & 1.00 & 47.28 & 27.12 & 20.63 & 2 & 1870.0004 & 1869.9991 & 936.0068 & 0.0013 & 0.6944 & 31.994 \\ \text { EPAAEIEALLGMDLVR } & 1.00 & 47.28 & 27.12 & 25.73 & 3 & 1870.0018 & 1869.9991 & 624.3403 & 0.0027 & 1.4415 & 79.065\end{array}$ $\begin{array}{llllllllllll} & \end{array}$ $\begin{array}{lllllllllllll}\text { KPTDPVDWPPLVLGLLTLLK } & 1.00 & 41.58 & 11.76 & 54.58 & 4 & 2646.6105 & 2646.6090 & 662.6595 & 0.0015 & 0.5659 & 64.419\end{array}$

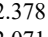

8.474

17.004

12.743 248.353 5.885 
VPINESFISMVIGR IVSCGNAIIAELL

8 LPLTPVFEGLAFK LGDAVIWGTGQLFQAQQDLLHR

GFNPAQPLNIR

GFNPAQPLNIR

FVSSPQTIVELFFQEVAR 1,00

FVSSPQTIVELFFQEVAR

FVSSPQTIVELFFQEVAR
LLTGWMPTAIR
LLTGWMPTAIR

LLTGWMPTAIR

NPIHAIGLLIR

NPIHAIGLLIR
NPIHAIGLLIR

NPIHAIGLLIR

VIILMLTNQTVHR

VIILMLTNQTVHR

VIILMLTNQTVHR

VIILMLTNQTVHR

VIILMLTNQTVHR

VIILMLTNQTVHR

18 YLLSQSSPAPLTAAEEE

HQTLQGVAFPISR

HQTLQGVAFPISR

HQTLQGVAFPISR

HQTLQGVAFPISR

HQTLQGVAFPISR

HQTLQGVAFPISR
HQTLQGVAFPISR

HQTLQGVAFPISR

HQTLQGVAFPISR

HQTLQGVAFPISR

HQTLQGVAFPISR

HQTLQGVAFPIS

TQTLQGVAFISR

HQTLQGVAFPISR

HQTLQGVAFPISR

HQTLQGVAFPISR

INEVQTDVGVDTK

INEVOTDVGVDTK

8 VLLGLK

VLLGLK

GSLLTLQR

GHFASVWQR

LGIYDADGDGDFDVDDAK LGIYDADGDGDFDVDDAK LGIYDADGDGDFDVDDAK

GAEADQIIEYLK

GAEADQIIEYLK

$\begin{array}{llllllllllllllllllllll}\text { QQSIAGSADSKPIDVSR } & 1.00 & 60.69 & 26.30 & 18.78 & 3 & 2046.1090 & 2046.0949 & 683.0389 & 0.0141 & 6.8810 & 9406.944 & 10814.293 & 7873.560 & 14495.411 & \text { Yes } \\ \text { QQSIAGSADSKPIDVSR } & 1.00 & 50.86 & 26.36 & 18.80 & 3 & 2046.1105 & 2046.0949 & 683.0389 & 0.0156 & 7.6130 & 7520.799 & 7819.794 & 7642.212 & 10536.391 & \text { Yes }\end{array}$ $\begin{array}{llllllllllllllll}\text { IWEQIQPDLHTNDECVATYK } & 1.00 & 38.89 & 27.02 & 19.17 & 3 & 2736.3163 & 2736.3131 & 913.1116 & 0.0032 & 1.1682 & 244.795 & 281.745 & 126.528 & 401.017 & \text { Yes } \\ \text { TVVSGLVNHVPLEQMQNR } & 0.98 & 29.09 & 27.26 & 18.17 & 3 & 2164.1542 & 2164.1545 & 722.3921 & -0.0003 & -0.1384 & 2100.423 & 2126.346 & 641.970 & 2308.124 & \text { Yes }\end{array}$

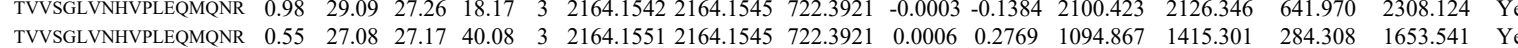
AILQATLR AILQATLR IGCITAR IGCIITAR

MVILLCNLKPAK

IGCITAR

$\begin{array}{llllllllll}57.30 & 27.51 & 18.20 & 2 & 1704.9376 & 1704.9355 & 853.4750 & 0.0021 & 1.2303 & 17.008 \\ 95.98 & 27.08 & 23.81 & 2 & 1660.9138 & 1660.9126 & 831.4636 & 0.0012 & 0.7216 & 117.767\end{array}$

$\begin{array}{lllllllllllll} & 17.13 & 22.07 & 17.44 & 3 & 1719.0247 & 1719.0215 & 574.0144 & 0.0032 & 1.8583 & 93.246\end{array}$ $\begin{array}{lllllllllll}64.65 & 26.12 & 21.33 & 3 & 2609.3848 & 2609.3836 & 870.8018 & 0.0012 & 0.4593 & 40.974 \\ 1 & 2609.3836 & 870.8018 & 0.0018 & 0.6890 & 94.366\end{array}$

$\begin{array}{lllllllll} & \end{array}$

$\begin{array}{lllllllllll} & \end{array}$

$\begin{array}{cc}45.968 & 1 \\ 3833.821 & 4771 . \\ 4587.505 & 6414.7\end{array}$

$\begin{array}{lllllllllll}5.22 & 26.36 & 25.27 & 2 & 2240.1974 & 2240.1963 & 1121.1054 & 0.0011 & 0.4906 & 47.896\end{array}$

3.857

91.306 $\begin{array}{lllllllllllll}1.00 & 35.37 & 21.30 & 23.56 & 3 & 1359.8482 & 1359.8472 & 454.2897 & 0.0010 & 0.7337 & 91.589\end{array}$ $\begin{array}{llllllllllll}0.99 & 29.76 & 21.30 & 17.51 & 2 & 1359.8482 & 1359.8472 & 680.9309 & 0.0010 & 0.7343 & 188.258\end{array}$ $\begin{array}{lllllllllllll}0.82 & 34.43 & 21.24 & 47.43 & 2 & 1359.8486 & 1359.8472 & 680.9309 & 0.0014 & 1.0280 & 171.396\end{array}$ $\begin{array}{lllllllllllll}1.00 & 82.27 & 22.83 & 22.78 & 2 & 1680.9842 & 1680.9831 & 841.4988 & 0.0011 & 0.6536 & 37.334\end{array}$ $\begin{array}{llllllllllll}0.67 & 1.13 & 22.70 & 64.13 & 3 & 1680.9856 & 1680.9831 & 561.3350 & 0.0025 & 1.4846 & 302.044 \\ 0.67 & 57.18 & 22.70 & 7.18 & 3 & 1680.959 & 1680.9831 & 561.3350 & 0.0028 & 1.6627 & 191.475\end{array}$ $\begin{array}{llllllllllll}1.00 & 74.88 & 22.55 & 21.95 & 2 & 1680.9862 & 1680.9831 & 841.4988 & 0.0031 & 1.8419 & 38.810\end{array}$ $\begin{array}{lllllllllll}77.42 & 22.86 & 70.42 & 3 & 1680.9850 & 1680.9831 & 561.3350 & 0.0019 & 1.1283 & 103.396\end{array}$ \begin{tabular}{lllllllllllll}
0.83 & 24.30 & 26.29 & 17.56 & 3 & 1596.8989 & 1596.8858 & 533.3025 & 0.0131 & 8.1879 & 1981.169 & 1649.048 \\
\hline & 39.00 & 26.14 & 16.12 & 3 & 1596.9010 & 1596.8858 & 533.3025 & 0.0152 & 9.5005 & 1938.914 & 1668.208
\end{tabular} $\begin{array}{llllllllllll}0.00 & 32.03 & 26.14 & 16.128 & 3 & 1596.9010 & 1596.8858 & 533.3025 & 0.0152 & 9.5005 & 1938.914 & 1668.208\end{array}$

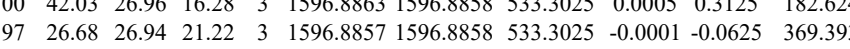
$\begin{array}{llllllllllll}1.00 & 34.79 & 26.69 & 18.31 & 3 & 1596.8881 & 1596.8858 & 533.3025 & 0.0023 & 1.4376 & 286.405\end{array}$ $\begin{array}{lllllllllll}1.00 & 66.87 & 26.95 & 20.78 & 2 & 1596.8856 & 1596.8858 & 799.4502 & -0.0002 & -0.1251 & 186.907\end{array}$ $\begin{array}{lllllllllllll}1.00 & 37.02 & 26.79 & 23.41 & 3 & 1596.8866 & 1596.8858 & 533.3025 & 0.0008 & 0.5000 & 167.412 \\ 0 & 32.05 & 26.69 & 19.45 & 3 & 1596.8878 & 1596.8858 & 533.3025 & 0.0020 & 1.2501 & 116.192\end{array}$ $\begin{array}{lllllllllll} & & \end{array}$ $\begin{array}{llllllllllll}0.99 & 29.44 & 26.69 & 21.73 & 3 & 1596.8878 & 1596.8858 & 533.3025 & 0.0020 & 1.2501 & 33.698 & 3\end{array}$ $\begin{array}{lllllllllll}1.00 & 70.42 & 26.69 & 26.95 & 3 & 1596.8878 & 1596.8858 & 533.3025 & 0.0020 & 1.2501 & 33.993\end{array}$ $\begin{array}{llllllllllll}39.55 & 26.69 & 19.12 & 3 & 1596.8881 & 1596.8858 & 533.3025 & 0.0023 & 1.4376 & 28.8\end{array}$

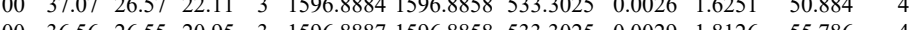
$\begin{array}{lllllllllllll} & 1.00 & 36.56 & 26.55 & 20.95 & 3 & 156.8887 & 1596888 & 533.3025 & 0.0029 & 1.8126 & 55.786 & 44.519 \\ 0.81 & 17.03 & 26.75 & 20.41 & 3 & 1596.8869 & 1596.8858 & 5333.3025 & 0.0011 & 0.6875 & 49.142 & 62.128\end{array}$ $\begin{array}{llllllllllllll}0.94 & 22.28 & 26.82 & 21.48 & 3 & 1596.8872 & 1596.8858 & 533.3025 & 0.0014 & 0.8750 & 41.663 & 48.181\end{array}$ $\begin{array}{lllllllllllll}1.00 & 55.42 & 27.77 & 23.42 & 2 & 1704.9202 & 1704.9138 & 853.4642 & 0.0064 & 3.7494 & 46.249 & 24.557\end{array}$ $\begin{array}{llllllllllll}1.00 & 69.88 & 27.75 & 20.39 & 2 & 1704.9216 & 1704.9138 & 853.4642 & 0.0078 & 4.5696 & 144.597\end{array}$ $\begin{array}{lllllllllllllll}0.91 & 31.30 & 21.34 & 32.53 & 2 & 929.6606 & 929.6517 & 465.8331 & 0.0089 & 9.5527 & 30564.267 & 22311.491 & 711.008 & 41263.150 & \text { Yes }\end{array}$ $\begin{array}{llllllllllllllll}0.59 & 18.57 & 25.60 & 23.95 & 2 & 886.5232 & 886.5236 & 444.2691 & -0.0004 & -0.4502 & 1965.671 & 1811.086 & 2461.418 & 3155.919 & \text { Yes }\end{array}$

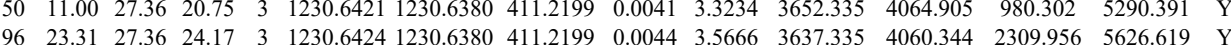
$\begin{array}{lllllllllllllll}1.00 & 77.65 & 26.21 & 28.25 & 2 & 2188.0074 & 2188.0052 & 1095.0099 & 0.0022 & 1.0046 & 25.224 & 21.614 & 12.594 & 48.678 & \text { Yes }\end{array}$

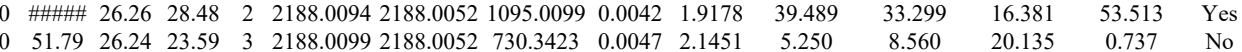

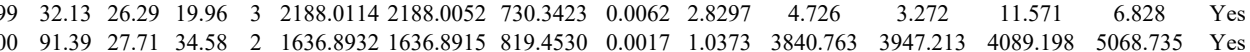

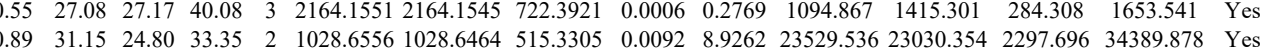
$\begin{array}{lllllllllllllllll}0.90 & 30.55 & 24.80 & 32.42 & 2 & 1028.6556 & 1028.6464 & 515.3305 & 0.0092 & 8.9262 & 14403.837 & 14981.505 & 699.715 & 20331.418 & \text { Yes }\end{array}$ $\begin{array}{llllllllllllllllll}0.67 & 29.18 & 28.76 & 27.17 & 2 & 1035.5736 & 1035.5691 & 518.7918 & 0.0045 & 4.3370 & 19590.897 & 20729.055 & 1656.907 & 32323.693 & \text { Yes }\end{array}$ $\begin{array}{lllllllllllllllll}0.80 & 32.09 & 28.76 & 31.95 & 2 & 1035.5736 & 1035.5691 & 518.7918 & 0.0045 & 4.3370 & 18393.790 & 20171.401 & 1667.499 & 35103.147 & \text { Yes } \\ 1.00 & 36.36 & 20.64 & 18.20 & 3 & 1820.0827 & 1820.0815 & 607.7011 & 0.0012 & 0.6582 & 384.95 & 317.440 & 347.707 & 417.857 & \text { Yes }\end{array}$ $\begin{array}{llllllllllllllll}1.00 & 36.18 & 20.86 & 16.13 & 3 & 1820.0833 & 1820.0815 & 607.7011 & 0.0018 & 0.9873 & 320.787 & 378.954 & 300.604 & 444.996 & \text { Yes }\end{array}$ $\begin{array}{lllllllllllllll}0.68 & 29.32 & 28.72 & 30.90 & 2 & 1035.5742 & 1035.5691 & 518.7918 & 0.0051 & 4.9152 & 14636.708 & 17381.405 & 1256.115 & 29967.537 & \text { Yes }\end{array}$

Table S-4 page 453 of 614 
$\begin{array}{lllllllllllll} & & & \end{array}$ $\begin{array}{llllllllllll}\text { NQDLAPNSAEQASILSLVTK } & 1.00 & 35.50 & 25.05 & 19.24 & 3 & 2386.2967 & 2386.2947 & 796.4388 & 0.0020 & 0.8371 & 134.009\end{array}$

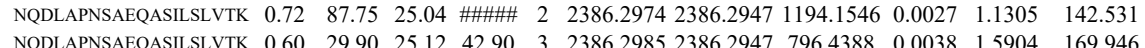
$\begin{array}{llllllllllll}\text { NQDLAPNSAEQASLLSLVTK } & 0.73 & 11.51 & 25.12 & 14.18 & 3 & 2386.2979 & 2386.2947 & 796.4388 & 0.0032 & 1.3393 & 157.209\end{array}$ $\begin{array}{lllllllllllll}\text { INNVIDNLIVAPGTEEVIEEVR } & 0.99 & 27.55 & 24.53 & 19.71 & 3 & 2725.4785 & 2725.4772 & 909.4997 & 0.0013 & 0.4765 & 34.442\end{array}$ $\begin{array}{llllllllllllll}\text { INNVIDNLIVAPGTFEVQIEEVR } & 1.00 & 53.84 & 24.44 & 24.12 & 3 & 2725.4797 & 2725.4772 & 909.4997 & 0.0025 & 0.9163 & 21.483\end{array}$

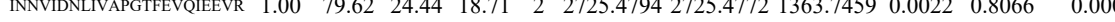
$\begin{array}{llllllllllllll}\text { INNVIDNLIVAPGTFEVQIEEVR } & 1.00 & 81.37 & 24.31 & 18.59 & 2 & 2725.4814 & 2725.4772 & 1363.7459 & 0.0042 & 1.5399 & 1.527\end{array}$

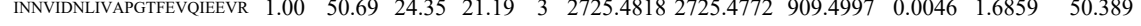
$\begin{array}{llllllllllll}\text { INNVIDNLIVAPGTEEVQIEEVR } & 1.00 & 59.77 & 24.35 & 31.18 & 3 & 2725.4818 & 2725.4772 & 909.4997 & 0.0046 & 1.6859 & 21.528\end{array}$ $\begin{array}{lllllllllllll}\text { INNVIDNLIVAPGTFEVQIEEVR } & 1.00 & 41.31 & 24.39 & 19.67 & 3 & 2725.4803 & 2725.4772 & 909.4997 & 0.0031 & 1.1362 & 42.596 \\ \text { INNYIDNLIVAPGTEEYOIEVYR } & 0.67 & 13.47 & 24.39 & 26.47 & 3 & 2725.4806 & 2725.4772 & 909.4997 & 0.0034 & 1.2461 & 27.049\end{array}$ $\begin{array}{lllllllllllll}\text { INNVIDNLIVAPGTFEVQIEEVR } & 0.67 & 13.47 & 24.39 & 26.47 & 3 & 2725.4806 & 2725.4772 & 909.4997 & 0.0034 & 1.2461 & 27.049\end{array}$ $\begin{array}{lllllllllllll}\text { GTMTTGHNVADLVVILK } & 1.00 & 45.49 & 24.03 & 22.52 & 3 & 2056.1614 & 2056.1595 & 686.3938 & 0.0019 & 0.9227 & 2478.048 & 2076.914\end{array}$ $\begin{array}{lllllllllllll}\text { GTMTTGHNVADLVVILK } & 1.00 & 38.16 & 23.87 & 19.80 & 3 & 2056.1644 & 2056.1595 & 686.3938 & 0.0049 & 2.3796 & 2828.226 & 3105.256\end{array}$ $\begin{array}{llllllllllllll}\text { GTMTTGHNVADLVVILK } & 0.75 & 47.36 & 24.15 & 54.80 & 3 & 2056.1593 & 2056.1595 & 686.3938 & -0.0002 & -0.0971 & 1464.423 & 1188.711 & 315.8 \\ \text { GTMTTGHNVADLVVILK } & 1.00 & 52.91 & 23.94 & 24.11 & 3 & 2056.1623 & 2056.1595 & 686.3938 & 0.0028 & 1.3598 & 1763.419 & 1939.466 & \end{array}$ $\begin{array}{lllllllllllll}\text { GTMTTGHNVADLVVILK } & 1.00 & 52.91 & 23.94 & 24.11 & 3 & 2056.1623 & 2056.1595 & 686.3938 & 0.0028 & 1.3598 & 1763.419 & 1939.466 \\ \text { ILPTLEAVAALGNK } & 1.00 & 83.28 & 19.19 & 26.68 & 2 & 1697.0338 & 1697.0331 & 849.5238 & 0.0007 & 0.4120 & 416.649 & 690.617\end{array}$ $\begin{array}{llllllllllllll}\text { ILPTLEAVAALGNK } & 1.00 & 83.28 & 19.19 & 26.68 & 2 & 1697.0338 & 1697.0331 & 849.5238 & 0.0007 & 0.4120 & 416.649 & 690.617 \\ \text { ILPTLEAVAALGNK } & 0.55 & 31.31 & 19.19 & 44.31 & 3 & 1697.0344 & 1697.0331 & 566.6850 & 0.0013 & 0.7647 & 185.467 & 135.055\end{array}$

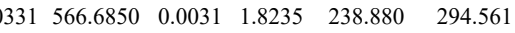
$\begin{array}{lllllllllllll}1.72 & 39.13 & 26.97 & 25.53 & 2 & 1287.7534 & 1287.7421 & 644.8783 & 0.0113 & 8.7613 & 1511.382 & 1472.38\end{array}$ $\begin{array}{llllllllllll}0 & & \end{array}$ $\begin{array}{llllllllllllllll}0.99 & 42.21 & 26.88 & 24.82 & 2 & 1287.7528 & 1287.7421 & 644.8783 & 0.0107 & 8.2961 & 2120.926 & 2750.746 & 5358.718 & 4071.321 & \text { No } \\ 0 & 49.78 & 27.10 & 26.95 & 2 & 1287.7546 & 1287.7421 & 644.8783 & 0.0125 & 9.6917 & 3933.136 & 3775.518 & 9004.989 & 6499.693 & \text { No }\end{array}$ $\begin{array}{lllllllllllllllll}0.96 & 35.38 & 27.72 & 36.70 & 2 & 1029.5846 & 1029.5842 & 515.7994 & 0.0004 & 0.3877 & 2756.484 & 3340.316 & 905.688 & 7737.720 & \text { No }\end{array}$ $\begin{array}{llllllllllllllll}0.98 & 35.28 & 27.71 & 36.96 & 2 & 1029.5850 & 1029.5842 & 515.7994 & 0.0008 & 0.7755 & 4300.879 & 4977.214 & 626.927 & 11211.584 & \text { No }\end{array}$ \begin{tabular}{lllllllllllllll}
1.00 & 55.40 & 23.64 & 26.58 & 2 & 1184.7380 & 1184.7363 & 593.3754 & 0.0017 & 1.4325 & 8495.342 & 8534.347 & 492.681 & 12491.298 & Yes \\
\hline
\end{tabular} $\begin{array}{lllllllllllllll}1.00 & 59.09 & 23.64 & 28.56 & 2 & 1184.7380 & 1184.7363 & 593.3754 & 0.0017 & 1.4325 & 14014.308 & 18847.443 & 57.745 & 23477.786 & \text { Yes }\end{array}$ $\begin{array}{lllllllllllllll}1.00 & 45.06 & 20.21 & 27.22 & 2 & 1379.8614 & 1379.8622 & 690.9384 & -0.0008 & -0.5789 & 3529.741 & 3996.159 & 109.625 & 5029.238 & \text { Yes }\end{array}$ $\begin{array}{lllllllllllllll}1.00 & 52.58 & 20.21 & 28.37 & 2 & 1379.8618 & 1379.8622 & 690.9384 & -0.0004 & -0.2895 & 1382.456 & 1647.853 & 148.456 & 2094.997 & \text { Yes }\end{array}$

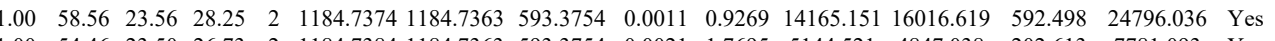
$\begin{array}{lllllllllllllll}1.00 & 54.46 & 23.50 & 26.73 & 2 & 1184.7384 & 1184.7363 & 593.3754 & 0.0021 & 1.7695 & 5144.521 & 4847.038 & 202.613 & 7781.093 & \text { Yes }\end{array}$ $\begin{array}{lllllllllllllll}0.96 & 29.81 & 20.21 & 26.02 & 2 & 1379.8612 & 1379.8622 & 690.9384 & -0.0010 & -0.7237 & 757.983 & 701.867 & 44.442 & 951.451 & \text { Yes } \\ 1.00 & 45.98 & 19.96 & 28.39 & 2 & 1379.8622 & 1379.8622 & 690.9384 & 0.0000 & 0.0000 & 3315.943 & 3544.949 & 174.410 & 4509.964 & \text { Yes }\end{array}$ $\begin{array}{lllllllllllllll}1.00 & 45.98 & 19.96 & 28.39 & 2 & 1379.8622 & 1379.8622 & 690.9384 & 0.0000 & 0.0000 & 3315.943 & 3544.949 & 174.410 & 4509.964 & \text { Yes } \\ 1.00 & 47.27 & 19.96 & 30.79 & 2 & 1379.8624 & 1379.8622 & 690.9384 & 0.0002 & 0.1447 & 34.954 & 34.193 & 16.846 & 48.575 & Y e s\end{array}$

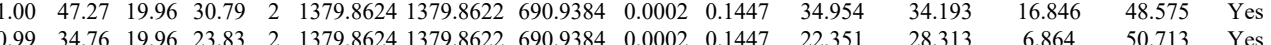

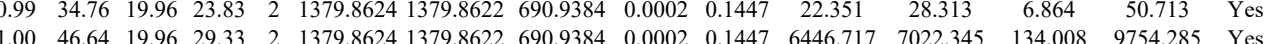




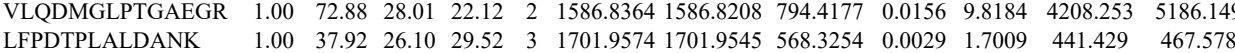

$\begin{array}{llllllllllllll}\text { LFPDTPLALDANK } & 1.00 & 57.52 & 26.07 & 21.59 & 2 & 1701.9590 & 1701.9545 & 851.9845 & 0.0045 & 2.6409 & 1642.408 & 1280.413 \\ \text { LFPDTPLALDANK } & 1.00 & 33.05 & 26.07 & 22.27 & 3 & 1701.9592 & 1701.9545 & 568.3254 & 0.0047 & 2.7566 & 224.058 & 248.747\end{array}$

$\begin{array}{llllllllllll}1.00 & 73.58 & 25.88 & 24.26 & 2 & 1701.9596 & 1701.9545 & 851.9845 & 0.0051 & 2.9930 & 2205.679 & 2121.441\end{array}$

$\begin{array}{lllllllllllll}\text { VLQDMGLPTGAEGR } & 1.00 & 66.56 & 27.80 & 21.79 & 2 & 1586.8212 & 1586.8208 & 794.4177 & 0.0004 & 0.2518 & 220.007 & 268.546\end{array}$

$\begin{array}{lllllllllllll}\text { VLQDMGLPTGAEGR } & 1.00 & 53.32 & 27.66 & 21.37 & 2 & 1586.8224 & 1586.8208 & 794.4177 & 0.0016 & 1.0070 & 248.897 & 290.921 \\ \text { LFPDTPLALDANK } & 1.00 & 58.24 & 26.07 & 25.14 & 2 & 1701.9576 & 1701.9545 & 851.9845 & 0.0031 & 1.8193 & 149.322 & 108.501\end{array}$

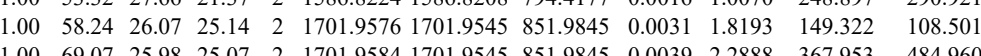

LFPDTPLALDANK

$\begin{array}{lllllllllllll}1.00 & 69.07 & 25.98 & 25.07 & 2 & 1701.9584 & 1701.9545 & 851.9845 & 0.0039 & 2.2888 & 367.953 & 484.960 \\ 0.87 & 17.22 & 26.01 & 17.94 & 3 & 1701.9586 & 1701.9545 & 568.3254 & 0.0041 & 2.4047 & 105.548 & 86.433\end{array}$

DANK

$\begin{array}{llllllllllll}0.87 & 17.22 & 26.01 & 17.94 & 3 & 1701.9586 & 1701.9545 & 568.3254 & 0.0041 & 2.4047 & 105.548 & 86.433 \\ 1.00 & 51.59 & 25.44 & 22.39 & 3 & 2775.2938 & 2775.2905 & 926.1041 & 0.0033 & 1.1878 & 11.327 & 25.903\end{array}$

$\begin{array}{lllllllllllllll} & 25.375 .2938 & 2775.2905 & 926.1041 & 0.0033 & 1.1878 & 11.327 & 25.903 & 15 .\end{array}$

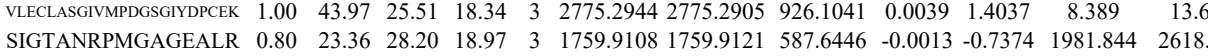
$\begin{array}{lllllllllllll} & \end{array}$

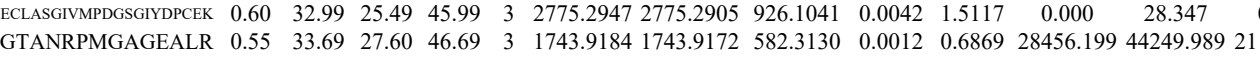
$\begin{array}{llllll} & \\ 0\end{array}$ $\begin{array}{lllllllllllllllll} & \end{array}$ $\begin{array}{llllllllllllllllll} & & \end{array}$

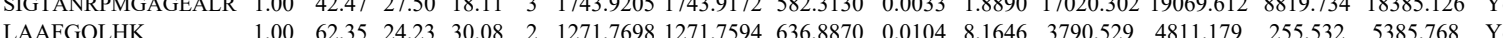

LAAFGQLHK

LAAFGQLHK

LNQLKPGLQYK

LNQLKPGLQYK
LAAFGQLHK

LAAFGQLHK

RPMEEDGEEK

RPMEEDGEEK

$\begin{array}{llllllllllllllll}1.00 & 41.00 & 24.23 & 23.59 & 3 & 1271.7700 & 1271.7594 & 424.9271 & 0.0106 & 8.3151 & 31582.902 & 37927.340 & 1858.897 & 51102.856 & \text { Yes }\end{array}$

$\begin{array}{llllllllllllllll}0.99 & 42.05 & 24.23 & 29.88 & 3 & 1271.7706 & 1271.7594 & 424.9271 & 0.0112 & 8.7857 & 32654.608 & 37885227 & 2381.795 & 51693.114 & \text { Yes }\end{array}$ $\begin{array}{llllllllllllllll}100 & 39.22 & 18.06 & 22.75 & 2 & 1733.0704 & 1733.0565 & 867.5355 & 0.0139 & 8.0111 & 2375.338 & 2507.835 & 1626.952 & 2331.333 & \text { Yes }\end{array}$

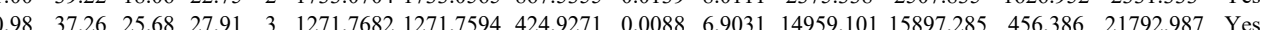
$\begin{array}{lllllllllllllllll}0.95 & 31.84 & 25.54 & 27.74 & 3 & 1271.7697 & 1271.7594 & 424.9271 & 0.0103 & 8.0798 & 13076.919 & 14536.384 & 622.525 & 20456.329 & \text { Yes }\end{array}$ $\begin{array}{llllllllllllllll}1.00 & 31.46 & 26.13 & 22.08 & 3 & 1506.7246 & 1506.7228 & 503.2482 & 0.0018 & 1.1923 & 904.563 & 752.532 & 1074.146 & 931.238 & \text { No }\end{array}$ $\begin{array}{lllllllllllllll}1.00 & 43.26 & 26.05 & 22.03 & 3 & 1506.7252 & 1506.7228 & 503.2482 & 0.0024 & 1.5897 & 654.749 & 637.886 & 925.342 & 889.128 & \text { No }\end{array}$ $\begin{array}{llllllllllllllll}\text { EPPLSLTIHLTSPVVR } & 0.67 & 70.03 & 22.72 & 83.03 & 3 & 1902.1096 & 1902.1060 & 635.0426 & 0.0036 & 1.8896 & 963.627 & 1265.567 & 628.419 & 1432.971 & \text { Yes }\end{array}$ $\begin{array}{lllllllllllllllll}\text { EPPLSLTIHLTSPVVR } & 0.55 & 65.75 & 22.76 & 78.75 & 3 & 1902.1072 & 1902.1060 & 635.0426 & 0.0012 & 0.6299 & 2192.609 & 2221.082 & 926.597 & 2723.162 & \text { Yes }\end{array}$ $\begin{array}{llllllllllllllll}\text { EPPLSLTIHLTSPVVR } & 0.55 & 85.63 & 22.76 & 98.63 & 3 & 1902.1072 & 1902.1060 & 635.0426 & 0.0012 & 0.6299 & 2068.587 & 2138.786 & 1283.567 & 3242.193 & \text { Yes }\end{array}$ $\begin{array}{lllllllllllllll}-0.67 & 22.89 & 25.82 & 23.36 & 2 & 1068.6242 & 068.6202 & 535.3174 & 0.0040 & 3.7361 & 54.116 & 28.534 & 42.402 & 53.971 & \text { Yes }\end{array}$ $\begin{array}{llllllllllllllll}\text { CLAALASLR } & 0.97 & 31.16 & 28.33 & 20.15 & 2 & 1106.6070 & 1106.6062 & 554.3104 & 0.0008 & 0.7216 & 24.155 & 28.115 & 8.788 & 42.032 & \text { Yes }\end{array}$

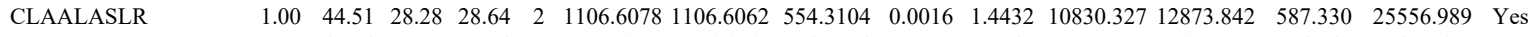

CLAALASLR

CLAALASLR CLAALASLR CLAALASLR CLAALASLR CLAALASLR

$\begin{array}{lllllllllllllll}1.00 & 42.54 & 28.09 & 28.24 & 2 & 1106.6082 & 1106.6062 & 554.3104 & 0.0020 & 1.8040 & 15811.739 & 17610.779 & 224.245 & 33475.618 & \text { Yes }\end{array}$ $\begin{array}{lllllllllllllll}1.00 & 43.74 & 28.09 & 37.06 & 2 & 1106.6082 & 1106.6062 & 554.3104 & 0.0020 & 1.8040 & 10133.306 & 12567.024 & 0.000 & 27730.753 & \text { No }\end{array}$

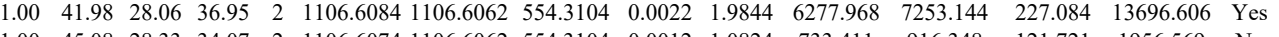
$\begin{array}{lllllllllllllll}1.00 & 45.08 & 28.33 & 34.07 & 2 & 1106.6074 & 1106.6062 & 554.3104 & 0.0012 & 1.0824 & 733.411 & 916.348 & 121.721 & 1956.569 & \text { No }\end{array}$ $\begin{array}{lllllllllllllll}1.00 & 41.77 & 28.28 & 34.73 & 2 & 1106.6078 & 1106.6062 & 554.3104 & 0.0016 & 1.4432 & 638.620 & 853.659 & 61.168 & 1610.211 & \text { Yes }\end{array}$

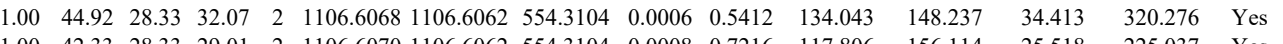

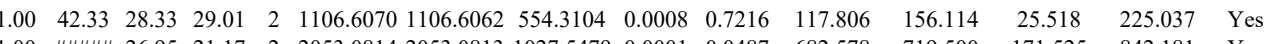
$\begin{array}{llllllllllllll} & \end{array}$

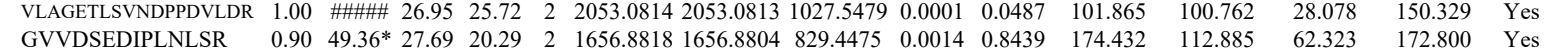

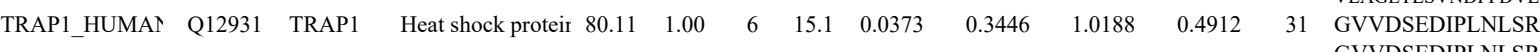
$\begin{array}{llllllllllll}0.99 & 69.21 * 27.69 & 22.40 & 2 & 1656.8820 & 1656.8804 & 829.4475 & 0.0016 & 0.9645 & 120.828 & 88.848\end{array}$ $\begin{array}{lll}62.323 & 172.800 & \text { Yes } \\ 29.617 & 89.023 & \text { Yes }\end{array}$ 
$\begin{array}{lllllllllllllll} & \end{array}$

$\begin{array}{rrrrrrrrrrrr}1.00 & 36.37 & 22.12 & 49.37 & 4 & 2749.5365 & 2749.5301 & 688.3898 & 0.0064 & 2.3243 & 110.353 & 146.580 \\ 1.00 & 22.27 & 22.43 & 18.47 & 4 & 1742.0333 & 1742.0307 & 436.5150 & 0.0026 & 1.4891 & 7509.935 & 8012.141\end{array}$

16 LDDLSVLDLSHNQLTECPR 1.0 EGEEATAEAEEK

EGEEATAEAEEK

EGEEATAEAEEK

EGEEATAEAEEK

EGEEATAEAEEK

EGEEATAEAEEK

ADLTALFLPR

ADLTALFLPR

ACSAIHAVNLR
ACSAIHAVNLR

ACSAIHAVNLR
ACSAIHAVNLR

ACSAIHAVNLR

$\begin{array}{llllllllllll}1.00 & 67.94 & 27.13 & 18.30 & 3 & 2357.1508 & 2357.1477 & 786.7232 & 0.0031 & 1.3135 & 345.459\end{array}$

$\begin{array}{llllllllllll}1.00 & 65.49 & 27.15 & 18.24 & 3 & 2357.1526 & 2357.1477 & 786.7232 & 0.0049 & 2.0761 & 261.017 & 307.274\end{array}$

QLPAMTALQTLHLR $\begin{array}{lllllllllll}1.00 & 61.91 & 26.32 & 28.06 & 2 & 1579.7456 & 1579.7457 & 790.8801 & -0.0001 & -0.0632 & 93.316\end{array}$ $\begin{array}{lllllllllllll}0.93 & 23.17 & 26.32 & 14.87 & 3 & 1579.7458 & 1579.7457 & 527.5892 & 0.0001 & 0.0632 & 33.36\end{array}$ $\begin{array}{lllllllllllll}1.00 & 72.40 & 26.33 & 27.37 & 2 & 1579.7464 & 1579.7457 & 790.8801 & 0.0007 & 0.4425 & 106.460 & 53.633\end{array}$ $\begin{array}{llllllllllll}1.00 & 36.59 & 26.33 & 19.76 & 3 & 1579.7467 & 1579.7457 & 527.5892 & 0.0010 & 0.6318 & 33.966 & 23.641\end{array}$ $\begin{array}{lllllllllllll}1.00 & 45.79 & 26.27 & 22.63 & 3 & 1579.7470 & 1579.7457 & 527.5892 & 0.0013 & 0.8213 & 25.177 & 35.237\end{array}$ $\begin{array}{lllllllllllll}0.66 & 18.99 & 26.33 & 31.99 & 3 & 1579.7473 & 1579.7457 & 527.5892 & 0.0016 & 1.0109 & 27.881 & 26.673 \\ 1.00 & 61.52 & 27.02 & 27.27 & 2 & 1259.7384 & 1259.7359 & 630.8752 & 0.0025 & 1.9814 & 5106.624 & 6353.976\end{array}$ $\begin{array}{lllllllllllll}1.00 & 61.52 & 27.02 & 27.27 & 2 & 1259.7384 & 1259.7359 & 630.8752 & 0.0025 & 1.9814 & 5106.624 & 6353.976\end{array}$ $\begin{array}{llllllllllll}1.00 & 56.26 & 27.02 & 26.49 & 2 & 1259.7388 & 1259.7359 & 630.8752 & 0.0029 & 2.2984 & 6231.529 & 7490.334\end{array}$ $\begin{array}{lllllllllllll}0.84 & 26.85 & 27.63 & 27.38 & 3 & 1343.7046 & 1343.6924 & 448.9047 & 0.0122 & 9.0590 & 633.772 & 666.789 \\ 0.95 & 31.08 & 27.67 & 19.99 & 3 & 1343.705 & 3343.6924 & 48.9047 & 0.0131 & 9.7273 & 531.309 & 749.418\end{array}$

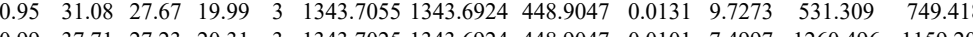

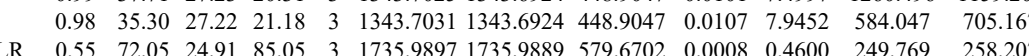



$\begin{array}{lllllllllllll} & \end{array}$ $\begin{array}{llllllllllllll}\text { SGLLVLTTPLASLAPR } & 1.00 & 85.87 & 17.32 & 33.59 & 2 & 1752.0640 & 1752.0631 & 877.0388 & 0.0009 & 0.5131 & 4.895\end{array}$ $\begin{array}{lllllllllllll}\text { SGLLVLTTPLASLAPR } & 0.66 & 19.13 & 17.40 & 32.13 & 3 & 1752.0649 & 1752.0631 & 585.0283 & 0.0018 & 1.0256 & 2.309 \\ \text { SGLLVLTTPLASLAPR } & 0.67 & 52.64 & 17.32 & 5.64 & 3 & 1752.0664 & 17520631 & 585.0283 & 0.0033 & 1.8802 & 6.823\end{array}$ $\begin{array}{llllllllllllll}\text { SGLLVLTTPLASLAPR } & 0.67 & 52.64 & 17.32 & 65.64 & 3 & 1752.0664 & 1752.0631 & 585.0283 & 0.0033 & 1.8802 & 6.823\end{array}$ $\begin{array}{lllllllllllll}\text { SGLLVLTTPLASLAPR } & 0.55 & 8.80 & 17.40 & 21.80 & 3 & 1752.0646 & 1752.0631 & 585.0283 & 0.0015 & 0.8547 & 23.904\end{array}$ $\begin{array}{llllllllllll}\text { SGLLVLTTPLASLAPR } & 1.00 & 77.74 & 17.24 & 30.74 & 2 & 1752.0664 & 1752.0631 & 877.0388 & 0.0033 & 1.8813 & 1.796\end{array}$

$\begin{array}{lllllllllll}\text { RM28_HUMAN } & \text { Q13084 } & \text { MRPL28 } & \text { 39S ribosomal pro 30.157 } & 1.00 & 3 & 22.7 & 0.7136 & 0.5806 & 1.0853 & 0.8448\end{array}$ $\begin{array}{lllllllllll}\text { ACACA_HUMA } & \text { Q13085 } & \text { ACACA } & \text { Acetyl-CoA carbo } 265.55 & 1.00 & 10 & 7 & 0.3190 & 0.5376 & -0.3254 & 0.5686\end{array}$ $\begin{array}{llllllllllllll} & 174.9753 & 1747.9726 & 438.0004 & 0.0027 & 1.5411 & 97.253 & 89.910\end{array}$ $\begin{array}{lllllllllllllll} & \end{array}$

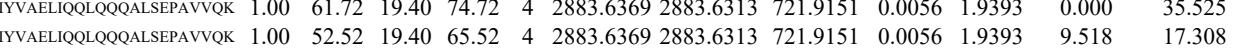

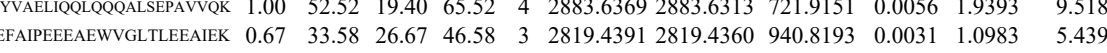
$\begin{array}{llllllllllll}\text { GVISDILDWK } & 1.00 & 52.31 & 27.09 & 22.92 & 2 & 1432.8188 & 1432.8170 & 717.4158 & 0.0018 & 1.2545 & 114.127 \\ \text { LLLEAMDELEVAFNNTNVR } & 1.00 & 53.88 & 26.95 & 20.75 & 3 & 2334.2044 & 2334.2011 & 779.0743 & 0.0033 & 1.4119 & 31.686\end{array}$

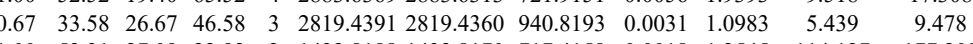
$\begin{array}{lllllllllllll}\text { LLLEAMDELEVAFNNTNVR } & 0.60 & 31.54 & 26.89 & 44.54 & 3 & 2334.2050 & 2334.2011 & 779.0743 & 0.0039 & 1.6686 & 13.061\end{array}$ $\begin{array}{lllllllllllll}\text { LLLEAMDELEVAFNNTNVR } & 1.00 & 37.86 & 26.89 & 18.13 & 3 & 2334.2050 & 2334.2011 & 779.0743 & 0.0039 & 1.6686 & 0.000\end{array}$ $\begin{array}{lllllllllllll}\text { LLLEAMDELEVAFNNTNVR } & 1.00 & 42.24 & 26.89 & 16.74 & 3 & 2334.2050 & 2334.2011 & 779.0743 & 0.0039 & 1.6686 & 6.776\end{array}$ $\begin{array}{lllllllllll} & \text { LLLEAMELLVANANG }\end{array}$

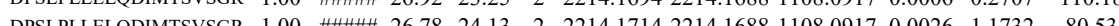
$\begin{array}{lllllllllllll}\text { IGSFGPQEDLLFLR } & 1.00 & 69.06 & 27.60 & 28.55 & 2 & 1734.9444 & 1734.9427 & 868.4786 & 0.0017 & 0.9787 & 489.385\end{array}$ $\begin{array}{llllllllllllll}\text { DPSLPLLELQDIMTSVSGR } & 1.00 & 99.12 & 26.78 & 21.82 & 2 & 2214.1714 & 2214.1688 & 1108.0917 & 0.0026 & 1.1732 & 66.914\end{array}$ $\begin{array}{lllllllllll}\text { DPSLPLLELQDIMTSVSGR } & 1.00 & \text { \#\#\#\# } 26.78 & 24.80 & 2 & 2214.1714 & 2214.1688 & 1108.0917 & 0.0026 & 1.1732 & 129.302\end{array}$ $\begin{array}{lllllllllllll}\text { TDCNHIFLNFVPTVIMDPSK } & 0.61 & 7.30 & 27.63 & 20.30 & 4 & 2624.3089 & 2624.3045 & 657.0834 & 0.0044 & 1.6741 & 101.103\end{array}$ $\begin{array}{lllllllllllll}\text { TDCNHIFLNFVPTVIMDPSK } & 1.00 & 40.71 & 27.67 & 18.86 & 3 & 2624.3101 & 2624.3045 & 875.7754 & 0.0056 & 2.1314 & 18.442\end{array}$ $\begin{array}{lllllllllllll}\text { TLRDPSLPLLELQDIMTSVSGR } & 1.00 & 48.51 & 25.69 & 17.58 & 3 & 2584.4032 & 2584.4016 & 862.4745 & 0.0016 & 0.6184 & 8.118\end{array}$ $\begin{array}{llllllllllll}\text { VQARRPTMLGVVCGALHVADSLLR } & 1.00 & 56.12 & 26.72 & 17.27 & 4 & 2825.4505 & 2825.4472 & 707.3691 & 0.0033 & 1.1663 & 318.913\end{array}$ $\begin{array}{llllllllllll}\text { VQAERPTMLGVVCGALHVAVSLR } & 1.00 & 55.87 & 26.73 & 68.87 & 4 & 2825.4517 & 2825.4472 & 707.3691 & 0.0045 & 1.5904 & 457.991 \\ \text { SDMNTVLNYIFSAQVTKK } & 1.00 & 64.74 & 27.40 & 21.03 & 3 & 2355.2149 & 2355.2137 & 786.0785 & 0.0012 & 0.5089 & 137.521\end{array}$ $\begin{array}{lllllllllllll}\text { SDMNTVLYIFSHAQVTK } & 1.00 & 47.75 & 27.40 & 19.51 & 3 & 2355.2149 & 2355.2137 & 786.0785 & 0.0012 & 0.5089 & 75.794\end{array}$ $\begin{array}{llllllllllll}\text { IASSIVAQTAGIPTLPWSGSGLR } & 1.00 & \text { \#\#\#\# } 23.67 & 19.80 & 2 & 2425.3454 & 2425.3451 & 1213.6798 & 0.0003 & 0.1236 & 2.992\end{array}$ $\begin{array}{lllllllllllll}\text { NLLVTMLIDQLCGR } & 1.00 & 86.14 & 28.03 & 39.41 & 2 & 1777.9384 & 1777.9374 & 889.9760 & 0.0010 & 0.5618 & 29.259\end{array}$

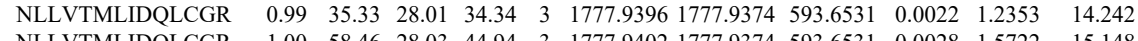
$\begin{array}{llllllllllll}\text { NLLVTMLIDQLCGR } & 1.00 & 58.46 & 28.03 & 44.94 & 3 & 1777.9402 & 1777.9374 & 593.6531 & 0.0028 & 1.5722 & 15.148\end{array}$

LFLELEPQVR $\begin{array}{llllllllllll}1.00 & 66.57 & 25.82 & 26.97 & 2 & 1386.8014 & 1386.7993 & 694.4069 & 0.0021 & 1.5121 & 2592.981 & 2250.120\end{array}$ LFLELEPQVR LQFIADHCPTLR $\begin{array}{llllllllllll}1.00 & 53.18 & 25.82 & 26.05 & 2 & 1386.8018 & 1386.7993 & 694.4069 & 0.0025 & 1.8001 & 1522.452\end{array}$ LQFIADHCPTLR

$\begin{array}{llllllllllllll}1.00 & 43.25 & 28.01 & 21.05 & 3 & 1602.8149 & 1602.8132 & 535.2783 & 0.0017 & 1.0586 & 4472.070 & 4147.331\end{array}$

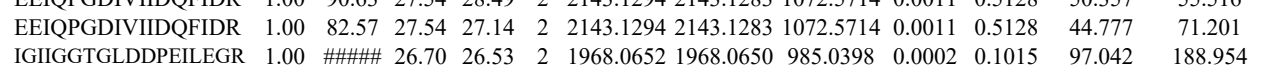
$\begin{array}{llllllllllllllll}\text { IGIIGGTGLDDPEILEGR } & 1.00 & 91.44 & 26.63 & 19.37 & 2 & 1968.0660 & 1968.0650 & 985.0398 & 0.0010 & 0.5076 & 814.815 & 1344.553 & 725.45 & \end{array}$ $\begin{array}{llllllllllll}\text { IGIIGGTGLDDPEILEGR } & 1.00 & 48.81 & 26.48 & 24.10 & 3 & 1968.0676 & 1968.0650 & 657.0289 & 0.0026 & 1.3191 & 115.726\end{array}$ $\begin{array}{lllllllllllll} & \end{array}$ $\begin{array}{llllllllllllll}\text { IGIIGGTGLDDPEILEGR } & 1.00 & 91.12 & 26.48 & 24.17 & 2 & 1968.0670 & 1968.0650 & 985.0398 & 0.0020 & 1.0152 & 348.443 & 591.346 & 457.061 \\ \text { GTMVTIEGPR } & 0.98 & 40.93 & 28.60 & 28.75 & 2 & 1203.6500 & 1203.6403 & 602.8274 & 0.0097 & 8.0454 & 8042.545 & 8312.553 & 3844.948\end{array}$ \begin{tabular}{llllllllllllllll} 
GTMVTIEGPR & 0.98 & 40.93 & 28.60 & 28.75 & 2 & 1203.6500 & 1203.6403 & 602.8274 & 0.0097 & 8.0454 & 8042.545 & 8312.553 & 3844.948 & 10091.159 & Yes \\
GTMVTIEGPR & 1.00 & 48.43 & 28.77 & 28.45 & 2 & 1203.6508 & 1203.6403 & 602.8274 & 0.0105 & 8.7089 & 12834.442 & 16280.676 & 6289.782 & 19510.554 & Y \\
\hline
\end{tabular}

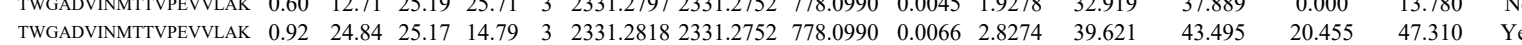


$\begin{array}{llllllllllll}\text { TWGADVINMTTVPEVVLAK } & 0.99 & 29.25 & 25.33 & 16.36 & 3 & 2331.2788 & 2331.2752 & 778.0990 & 0.0036 & 1.5422 & 28.942\end{array}$ $\begin{array}{lllllllllllll}\text { SLLLTIPQIGSTEWSETLHNLK } & 1.00 & 74.81 & 21.85 & 19.43 & 3 & 2868.5866 & 2868.5840 & 957.2019 & 0.0026 & 0.9054 & 612.842\end{array}$ $\begin{array}{llllllllllllll} & \end{array}$ $\begin{array}{llllllllllll}\text { SLLLTTIPIIGSTEWSETLHNLK } & 1.00 & 67.32 & 22.50 & 17.26 & 3 & 2868.5830 & 2868.5840 & 957.2019 & -0.0010 & -0.3482 & 736.938\end{array}$ $\begin{array}{lccccccccccc}\text { SLLLTTPPIGSTEWSETLHNLK } & 0.67 & 74.24 & 21.76 & 87.24 & 3 & 2868.5872 & 2868.5840 & 957.2019 & 0.0032 & 1.1144 & 1092.788 \\ \text { SLLTTPOIGSTEWSETLHNKK } & 0.89 & 5.24 & 21.43 & 18.24 & 4 & 2868.5877 & 2868.5840 & 718.1533 & 0.0037 & 1.2880 & 10.492\end{array}$ $\begin{array}{lllllllllllll}\text { SLLLTTPPIGSTEWSETLHNLK } & 0.89 & 5.24 & 21.43 & 18.24 & 4 & 2868.5877 & 2868.5840 & 718.1533 & 0.0037 & 1.2880 & 10.492 \\ \text { SLLLTTPOIGSTEWSETLHNLK } & 0.54 & 0.49 & 21.40 & 13.49 & 4 & 2868.5897 & 2868.5840 & 718.1533 & 0.0057 & 1.9843 & 8.794\end{array}$ $\begin{array}{lllllllllllll}\text { SLLLTTPQIGSTEWSETLHNLK } & 0.54 & 0.49 & 21.40 & 13.49 & 4 & 2868.5897 & 2868.5840 & 718.1533 & 0.0057 & 1.9843 & 8.794 \\ \text { SULTTPQIGSTEWSETLHNLK } & 1.00 & 65.91 & 21.85 & 19.51 & 3 & 2868.5866 & 2868.5840 & 957.2019 & 0.0026 & 0.9054 & 145.434\end{array}$ $\begin{array}{llllllllllll}\text { SLLLTTIPQIGSTEWSETLHNLK } & 1.00 & 65.91 & 21.85 & 19.51 & 3 & 2868.5866 & 2868.5840 & 957.2019 & 0.0026 & 0.9054 & 145.434 \\ \text { TTMRPQSFYDGSHSCAR } & 1.00 & 23.34 & 23.69 & 36.34 & 4 & 2132.9497 & 2132.9312 & 534.2401 & 0.0185 & 8.6571 & 1667.295\end{array}$ $\begin{array}{llllllllllll}\text { EEIQPGDIVIIDQFIDR } & 1.00 & 71.14 & 27.54 & 25.86 & 2 & 2143.1294 & 2143.1283 & 1072.5714 & 0.0011 & 0.5128 & 98.151\end{array}$

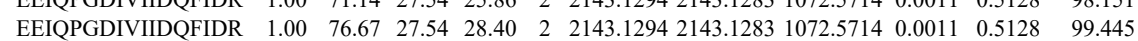
$\begin{array}{lllllllllllll}\text { EEIQPGDIVIIDQFIDR } & 0.62 & 12.05 & 27.53 & 15.63 & 3 & 2143.1314 & 2143.1283 & 715.3834 & 0.0031 & 1.4444 & 152.680\end{array}$ CTEDM

TSDLIVLGLPWK

TSDLIVLGLPWK

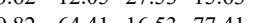
$\begin{array}{lllllllllll}0.82 & 64.41 & 16.53 & 77.41 & 2 & 1530.6136 & 1530.6122 & 766.3134 & 0.0014 & 0.9135 & 138.540 \\ 1.00 & 67.07 & 228 & 29.30 & 2 & 1688.9760 & 1628.9745 & 815.5945 & 0.015 & 0.919 & 176.454\end{array}$

TSDLIVLGLPWK $\begin{array}{lllllllllllll}1.00 & 58.66 & 22.88 & 29.79 & 2 & 1628.9762 & 1628.9745 & 815.4945 & 0.0017 & 1.0423 & 43.124 & \end{array}$

TSDLIVLGLPWK

NPVSQCMR

$\begin{array}{llllllllllll}0.96 & 25.15 & 22.90 & 28.42 & 3 & 1628.9767 & 1628.9745 & 543.9988 & 0.0022 & 1.3480 & 154.556\end{array}$

$\begin{array}{llllllllllll}1.00 & 45.37 & 24.08 & 20.48 & 2 & 1123.5148 & 1123.5058 & 562.7602 & 0.0090 & 7.9962 & 2313.870\end{array}$ $\begin{array}{llllllllllll}\text { FGGNPGGFGNQGGFGNSR } & 1.00 & 45.25 & 24.07 & 23.84 & 2 & 1123.5152 & 1123.5058 & 562.7602 & 0.0094 & 8.3516 & 1811.826 \\ & 1.06 .44 & 23.20 & 2 & 1869.8804 & 1869.8629 & 935.9387 & 0.0175 & 9.3488 & 423.110\end{array}$ FGGNPGGFGNQGGFGNSR $1.00 \quad 43.90 \begin{array}{llllllllllll}26.43 & 16.01 & 3 & 1869.8809 & 1869.8629 & 624.2949 & 0.0180 & 9.6108 & 889.739 & 84\end{array}$ $\begin{array}{lllllllllllll}\text { FGGNPGGFGNOGGFGNSR } & 0.99 & 39.56 & 26.42 & 15.58 & 3 & 1869.8815 & 1869.8629 & 624.2949 & 0.0186 & 9.9311 & 803.111\end{array}$ $\begin{array}{lllllllllll}\text { FGGNPGGFGNQGGFGNSR } & 1.00 & \text { \#\#\# } 26.45 & 22.54 & 2 & 1869.8782 & 1869.8629 & 935.9387 & 0.0153 & 8.1735 & 384.558\end{array}$ $\begin{array}{llllllllllllll} & \end{array}$

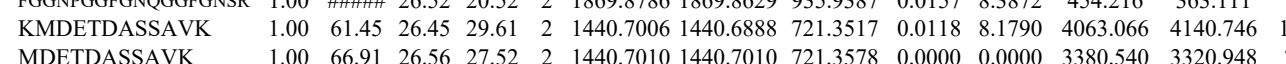
CTEDMTEDELR $\begin{array}{lllllllllllll}1.00 & 66.91 & 26.56 & 27.52 & 2 & 1440.7010 & 1440.7010 & 721.3578 & 0.0000 & 0.0000 & 3380.540 & 33\end{array}$ MDETDASSAVK $\begin{array}{lllllllllllll}0.84 & 35.31 & 16.53 & 48.31 & 2 & 1530.6138 & 1530.6122 & 766.3134 & 0.0016 & 1.0440 & 89.834\end{array}$ $\begin{array}{llllllllllllll}\text { GDVAEGDLIEHFSQFGTVEK } & 0.55 & 60.89 & 26.88 & 73.89 & 3 & 2465.2330 & 2465.2318 & 822.7512 & 0.0012 & 0.4862 & 1606.901 & 2\end{array}$ $\begin{array}{lllllllllllll}\text { GDVAEGDLIEHFSQFGTVEK } & 0.66 & 51.90 & 26.87 & 64.90 & 3 & 2465.2342 & 2465.2318 & 822.7512 & 0.0024 & 0.9723 & 2442.451\end{array}$ $\begin{array}{llllllllllllll}\text { GDVAEGDLIEHFSQFGTVEK } & 1.00 & 39.96 & 26.94 & 19.00 & 4 & 2465.2353 & 2465.2318 & 617.3152 & 0.0035 & 1.4174 & 53.519 & 10\end{array}$

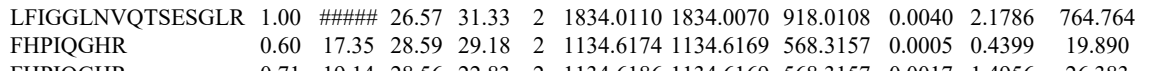
FHPIQG

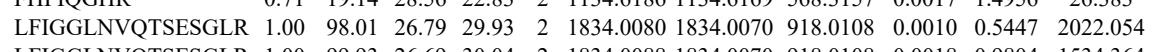
$\begin{array}{llllllllllll}\text { LFIGGLNVQTSESGLR } & 1.00 & 99.93 & 26.69 & 30.04 & 2 & 1834.0088 & 1834.0070 & 918.0108 & 0.0018 & 0.9804 & 1534.364 \\ \text { FHPIQGHR } & 0.89 & 25.20 & 28.59 & 30.22 & 2 & 1134.6174 & 1134.6169 & 568.3157 & 0.0005 & 0.4399 & 41.349 \\ \text { FHPIQGHR } & 0.81 & 21.97 & 28.49 & 28.15 & 2 & 1134.6180 & 1134.6169 & 568.3157 & 0.0011 & 0.9678 & 25.785\end{array}$ FHPIQGHR

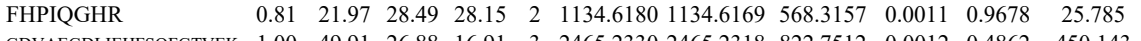

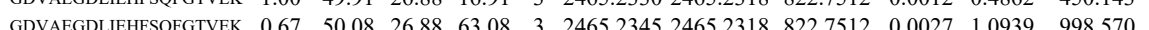
\begin{tabular}{llllllllllll}
\hline GDVAEGDLIEHSOFGTUEK & 0.67 & 50.08 & 26.88 & 63.08 & 3 & 2465.2345 & 2465.2318 & 822.7512 & 0.0027 & 1.0939 & 998.570
\end{tabular} $\begin{array}{lllllllllllll}\text { GDVAEGDLIEHFSPFGTVEK } & 0.99 & 21.99 & 27.08 & 14.73 & 4 & 2465.2409 & 2465.2318 & 617.3152 & 0.0091 & 3.6853 & 80.166\end{array}$

SCENLAPFNTALK

FLFSLFGQK

FLFSLFGQK

FLFSLFGQK

FLFSLFGQK

FLFSLFGQK

FLFSLFGQK

FLFSLFGQK

TIVSIGDPK

ALYLIATNGTPELQN

KNPQAVLDVLK

KNPQAVLDVLK

SVIDPVPAPVGDSHVDGAAK

SVIDPVPAPVGDSHVDGAAK
VEEAEPEEFVVEK

VEEAEPEEFVVEK DSDEADLVLAK DSDEADLVLAK VEEAEPEEFVVEK VEAEPEEFVEK VEAEEETVKK

KVEALPETVK

KVEEAEPEEFVVEK

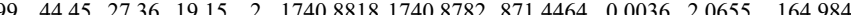

$\begin{array}{lllllllllllll}1.00 & 43.34 & 25.66 & 21.77 & 2 & 1373.7978 & 1373.7951 & 687.9048 & 0.0027 & 1.9625 & 4230.849 & 4549.138\end{array}$ $\begin{array}{llllllllllllll}1.00 & 4429 & 26.33 & 21.77 & 2 & 1373.7986 & 1373.7951 & 687.9048 & 0.0035 & 25440 & 4878.376 & 4427.214\end{array}$ $\begin{array}{lllllllllllll}0.55 & 19.73 & 26.20 & 32.73 & 3 & 1373.7958 & 1373.7951 & 458.9390 & 0.0007 & 0.5084 & 105.781 & 102.949\end{array}$ $\begin{array}{llllllllllllll}0.99 & 25.70 & 25.62 & 14.70 & 3 & 1373.7967 & 1373.7951 & 458.9390 & 0.0016 & 1.1621 & 91.634 & 128.936\end{array}$ $\begin{array}{llllllllllllll}1.00 & 42.29 & 25.63 & 20.06 & 2 & 1373.7970 & 1373.7951 & 687.9048 & 0.0019 & 1.3810 & 2734.073 & 3045.888\end{array}$ $\begin{array}{llllllllllllll}1.00 & 48.69 & 25.63 & 22.24 & 2 & 1373.7970 & 1373.7951 & 687.9048 & 0.0019 & 1.3810 & 4140.549 & 3988.840\end{array}$ $\begin{array}{llllllllllllll}1.00 & 43.17 & 26.28 & 20.72 & 2 & 1373.7954 & 1373.7951 & 687.9048 & 0.0003 & 0.2181 & 228.867 & 217.478\end{array}$ $\begin{array}{lllllllllllll}1.00 & 47.43 & 25.65 & 22.70 & 2 & 1373.7964 & 1373.7951 & 687.9048 & 0.0013 & 0.9449 & 421.335 & 496.408\end{array}$ $\begin{array}{llllllllllllll}0.95 & 31.70 & 25.33 & 24.52 & 2 & 1216.7388 & 1216.7271 & 609.3708 & 0.0117 & 9.6000 & 366.760 & 336.043\end{array}$ $\begin{array}{llllllllllllll}0.66 & 21.54 & 25.33 & 16.39 & 2 & 1216.7390 & 1216.7271 & 609.3708 & 0.0119 & 9.7641 & 289.827 & 397.276\end{array}$ $\begin{array}{llllllllllllll}0.99 & 27.90 & 25.81 & 15.03 & 3 & 2259.2365 & 2259.2354 & 754.0857 & 0.0011 & 0.4862 & 64.679 & 98.502\end{array}$ $\begin{array}{llllllllllllll}1.00 & 43.48 & 14.47 & 20.16 & 3 & 1656.0448 & 1656.0300 & 553.0173 & 0.0148 & 8.9207 & 4802.447 & 5539.266\end{array}$ $\begin{array}{llllllllllll}1.00 & 39.16 & 14.47 & 17.09 & 3 & 1656.0448 & 1656.0300 & 553.0173 & 0.0148 & 8.9207 & 3282.047 & 33\end{array}$ $\begin{array}{lllllllllllll}1.00 & 78.04 & 26.55 & 21.75 & 3 & 2218.1905 & 2218.1838 & 740.4019 & 0.0067 & 3.0164 & 1554.814 & \\ 1.00 & 69.88 & 26.50 & 21.11 & 3 & 2218.1908 & 2218.1838 & 740.4019 & 0.0070 & 3.1514 & 1767.046 & 234 .\end{array}$ $\begin{array}{llllllllllll}1.00 & 50.07 & 26.17 & 18.11 & 3 & 2218.1008 & 2218.1838 & 740.4019 & 0.0070 & 3.1514 & 1567.044 \\ & 221838 & 740.4019 & 0.0217 & 9.7694 & 43.817\end{array}$ $\begin{array}{llllllllllll}1.00 & 86.66 & 28.11 & 39.90 & 2 & 1820.9294 & 1820.9287 & 911.4716 & 0.0007 & 0.3840 & 74.049 \\ 1.00 & 71.07 & 28.20 & 33.73 & 2 & 1820.9298 & 1820.9287 & 911.4716 & 0.0011 & 0.6034 & 58.336\end{array}$ $\begin{array}{llllllllllll}1.00 & 71.07 & 28.20 & 33.73 & 2 & 1820.9298 & 1820.9287 & 911.4716 & 0.0011 & 0.6034 & 58.336 \\ 1.00 & 61.94 & 28.49 & 33.24 & 2 & 1462.7770 & 1462.7759 & 732.3952 & 0.0011 & 0.7510 & 53.372\end{array}$ $\begin{array}{lllllllllll}1.00 & 61.94 & 28.49 & 33.24 & 2 & 1462.7770 & 1462.7759 & 732.3952 & 0.0011 & 0.7510 & 53.372 \\ 1.00 & 66.11 & 28.46 & 26.27 & 2 & 1462.7778 & 1462.7759 & 732.3952 & 0.0019 & 1.2971 & 122.722\end{array}$ $\begin{array}{llllllllllll}1.00 & 66.11 & 28.46 & 26.27 & 2 & 1462.7778 & 1462.7759 & 732.3952 & 0.0019 & 1.2971 & 12.372 \\ 1.00 & 74.02 & 28.20 & 32.77 & 2 & 1820.9298 & 1820.9287 & 911.4716 & 0.0011 & 0.6034 & 222.327\end{array}$ $\begin{array}{lllllllllll}1.00 & 75.13 & 28.20 & 33.87 & 2 & 1820.9298 & 1820.9287 & 911.4716 & 0.0011 & 0.6034 & 158.345\end{array}$ $\begin{array}{rrrrrrrrrrrr}0.95 & 22.48 & 28.16 & 20.24 & 3 & 1820.9308 & 1820.9287 & 607.9835 & 0.0021 & 1.1513 & 89.719 \\ 1.00 & 55.59 & 26.85 & 23.37 & 3 & 2093.1259 & 2093.1257 & 698.7158 & 0.0002 & 0.0954 & 539.965\end{array}$ $\begin{array}{llllllllllll}1.00 & 55.59 & 26.85 & 23.37 & 3 & 2093.1259 & 2093.1257 & 698.7158 & 0.0002 & 0.0954 & 539.965 \\ 1.00 & 62.34 & 26.75 & 25.66 & 3 & 2093.1280 & 2093.1257 & 698.7158 & 0.0023 & 1.0972 & 516.245\end{array}$ $\begin{array}{llllllllllll}1.00 & 54.94 & 26.84 & 22.02 & 3 & 2093.1283 & 2093.1257 & 698.7158 & 0.0026 & 1.0404 & 574.978 & 676.6\end{array}$
$24.073 \quad 14.469 \quad$ Yes $1027.774 \quad 1346.371 \quad$ Yes $1510.126 \quad 1979.066$ Yes 1506.595 1090.168 Yes \begin{tabular}{lll}
26.877 & 2331.813 & Yes \\
\hline & 13.639 & -1
\end{tabular} $9.615-13.639$ Yes

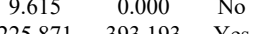
$\begin{array}{lll}286.793 & 1873.206 & \text { Yes }\end{array}$ $156.999 \quad 350.154 \quad$ Yes $80.846-174.843$ Yes $51.265 \quad 258.354$ Yes $38.742 \quad 253.248$ Yes $0.000 \quad 206.093 \quad$ No $104.861 \quad 189.857$ Yes $3355.248 \quad 4052.357$ No $\begin{array}{llll}2682.549 & 2911.252 & \mathrm{No}\end{array}$ $\begin{array}{llll}199.964 & 539.455 & \text { Yes }\end{array}$ $245.981 \quad 357.304 \quad$ Yes $\begin{array}{lll}77.033 & 485.854 & \text { Yes }\end{array}$ $\begin{array}{lll}5.021 & 460.404 & \text { Yes }\end{array}$

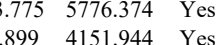
$\begin{array}{llll}24.459 & 159.863 & \text { Yes }\end{array}$ $\begin{array}{lll}1465.535 & 8303.552 & \text { Yes }\end{array}$ $2725.338 \quad 4147.052$ Yes \begin{tabular}{lllll}
02.554 & 2725.338 & 4147.052 & Yes \\
0.491 & 3925.057 & 5604.479 & Yes \\
\hline
\end{tabular} \begin{tabular}{llll}
7.491 & 39.341 & 118.156 & No \\
\hline & 21.239 & 2071.462 & No
\end{tabular} $\begin{array}{ccc}21.239 & 2071.462 & \text { No } \\ 14.730 & 39.390 & \text { Yes } \\ 14.185 & 45.071 & \text { Yes }\end{array}$ $\begin{array}{lll}14.185 & 45.071 & \text { Yes }\end{array}$ $200.548 \quad 3997.743$ Yes $131.873 \quad 3730.877$ Yes $2.553-48.651$ Yes $583.479 \quad 909.616$ Yes $\begin{array}{lll}101.306 & 2591.844 & \text { Yes } \\ 158.426 & \text { Yes }\end{array}$ $\begin{array}{lll}105.883 & 144.253 & \text { Yes }\end{array}$ $\begin{array}{lll}79.080 & 199.281 \quad \text { Yes }\end{array}$ $\begin{array}{llll}0.48 .472 & 10819.268 \quad \text { Yes }\end{array}$ $\begin{array}{llll}95.919 & 189.394 & \text { Yes }\end{array}$ $94.370 \quad 175.216 \quad$ Yes $\begin{array}{lll}66.416 & 6234.019 & \text { Yes }\end{array}$ $56.358 \quad 417.465 \quad$ Yes $\begin{array}{llll}19.449 & 1012.777 & \text { Yes }\end{array}$ $121.444 \quad 546.930 \quad$ Yes $\begin{array}{lll}9.631 & 449.645 & \text { Yes }\end{array}$ $\begin{array}{lll}9.148 & 90.796 & \text { Yes } \\ & \end{array}$ $\begin{array}{llll}61.104 & 108.510 & 7861.588 & \text { Yes } \\ 82.198 & 112.856 & 101.104 & \text { Yes }\end{array}$ $\begin{array}{llll}62.198 & 112.856 & 78.961 & \text { Yes } \\ 95.656 & 100.563 & 96.976 & Y e s\end{array}$ $\begin{array}{llll}65.656 & 100.563 & 101.104 & \text { Yes } \\ 71.467 & 188.21 & 129.188 & \text { Yes }\end{array}$ $\begin{array}{llll}1.414 & 188.211 & 129.188 & \text { No } \\ 1.03 & 251.289 & 24.085 & Y c 5\end{array}$ $\begin{array}{llll}71.44 & 188.211 & 129.108 & \\ & 251.289 & 249.085 & \text { Y }\end{array}$ \begin{tabular}{lllll}
10.0154 & 251.289 & 249.085 & Yes \\
\hline
\end{tabular} $\begin{array}{llll}87.922 & 155.323 & 282.161 & \text { Yes } \\ & 110.882 & 142.570 & \text { Yes }\end{array}$ \begin{tabular}{llll}
87.922 & 155.323 & 282.161 & Yes \\
\hline & 142.570 & Yes
\end{tabular} 

$\begin{array}{llllllllllllllll} & 1.00 & 4.48 & 18.92 & 2.56 & 2 & 1199.7764 & 1199.7733 & 600.8939 & 0.0031 & 2.5795 & 4694.896 & 4066.946 & 4759.374 & 5078.658 & \text { Yes } \\ \text { VGQAVDVGQAGKPK } & 1.00 & 60.47 & 19.19 & 17.55 & 3 & 1884.1312 & 1884.1158 & 629.0459 & 0.0154 & 8.1604 & 14880.848 & 13363.868 & 13971.142 & 14241.40 & \text { Y }\end{array}$

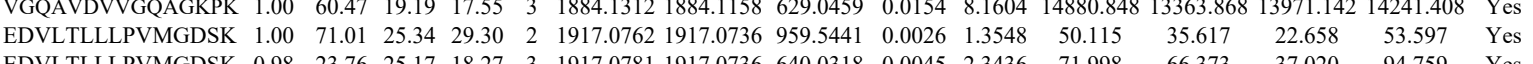
$\begin{array}{lllllllllllllllll} & \end{array}$ $\begin{array}{llllllllllllllll} & 36.55 \\ 25.17 & 18.10 & 3 & 1917.0781 & 1917.0736 & 640.0318 & 0.0045 & 2.3436 & 34.520 & 42.937 & 24.927 & 86.546 & \text { Y S }\end{array}$ $\begin{array}{llllllllllllllll}0.99 & 41.66 & 28.56 & 27.41 & 2 & 1248.6526 & 1248.6407 & 625.3276 & 0.0119 & 9.5149 & 6637.744 & 5563.808 & 6073.447 & 5896.107 & \text { Y }\end{array}$ $\begin{array}{lllllllllllllll} & & & \end{array}$

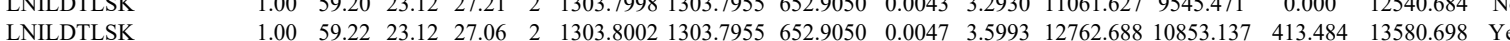

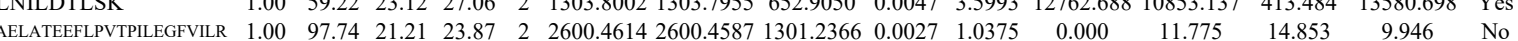

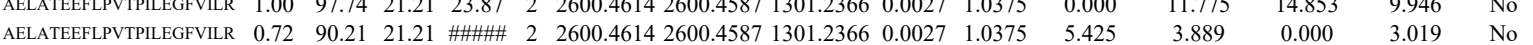
$\begin{array}{llllllllllllllll}\text { AELATEEFLPVTPILEGFVILR } & 0.60 & 15.47 & 21.14 & 28.47 & 3 & 2600.4628 & 2600.4587 & 867.8268 & 0.0041 & 1.5748 & 24.466 & 5.778 & 0.000 & 22.796 & \text { No }\end{array}$

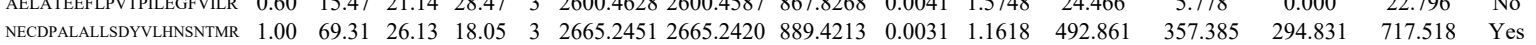
$\begin{array}{lllllllllllllllll}\text { NECDPALALLSDYVLHNSNTMR } & 0.60 & 67.32 & 26.10 & 80.32 & 3 & 2665.2463 & 2665.2420 & 889.4213 & 0.0043 & 1.6115 & 517.063 & 319.472 & 309.976 & 636.698 & \text { Yes }\end{array}$ $\begin{array}{llllllllllllllll} & 6.045 & \text { Yes }\end{array}$

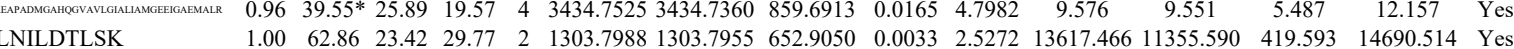

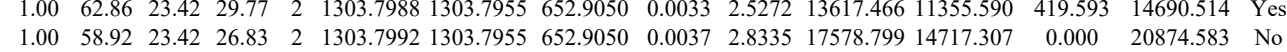

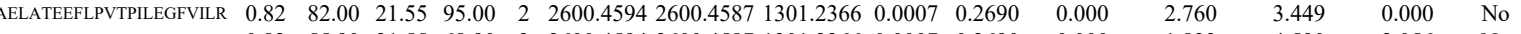

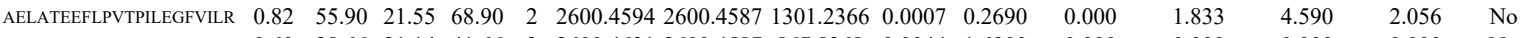

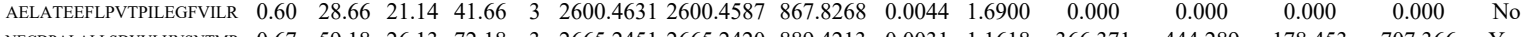
$\begin{array}{llllllllllllllll}\text { NECDPALALLSDYVLHNSNTMR } & 0.67 & 59.18 & 26.13 & 72.18 & 3 & 2665.2451 & 2665.2420 & 889.4213 & 0.0031 & 1.1618 & 366.371 & 444.289 & 178.453 & 707.366 & \text { Yes }\end{array}$ $\begin{array}{llllllllllllllll}\text { NECDPALALLSDYVLHNSNTMR } & 0.60 & 74.98 & 26.12 & 87.98 & 3 & 2665.2457 & 2665.2420 & 889.4213 & 0.0037 & 1.3867 & 446.167 & 387.754 & 212.444 & 484.798 & \text { Yes }\end{array}$

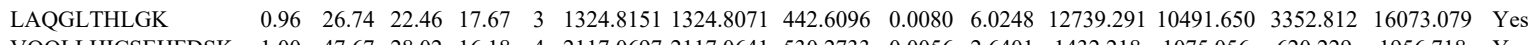
\begin{tabular}{lllllllllllllllllll} 
VQQLLHICSEHFDSK & 1.00 & 47.67 & 28.02 & 16.18 & 4 & 2117.0697 & 2117.0641 & 530.2733 & 0.0056 & 2.6401 & 1432.218 & 1075.056 & 620.229 & 1956.718 & Yes \\
\hline
\end{tabular} \begin{tabular}{llllllllllllllll} 
MLVTFDEELRPLPVSVR & 0.66 & 23.16 & 25.93 & 36.16 & 3 & 2144.1811 & 2144.1785 & 715.7334 & 0.0026 & 1.2109 & 4046.976 & 4979.151 & 1727.122 & 4581.123 & Yes \\
\hline
\end{tabular} $\begin{array}{llllllllllllllll}\text { MLVTFDEELRPLPVSVR } & 0.67 & 28.17 & 25.90 & 41.17 & 3 & 2144.1820 & 2144.1785 & 715.7334 & 0.0035 & 1.6300 & 8422.764 & 8236.481 & 3185.481 & 9013.568 & \text { Yes }\end{array}$

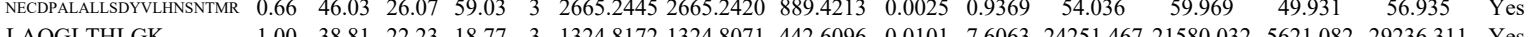
$\begin{array}{lllllllllllllllllll} & & \end{array}$

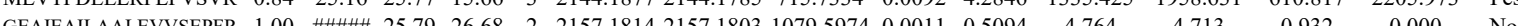
$\begin{array}{llllllllllllll} & 5.000 & \text { No }\end{array}$ $\begin{array}{lllllllllllll} & \text { GEATE }\end{array}$

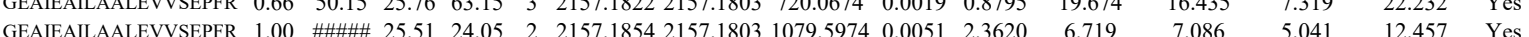
$\begin{array}{llllllllllllllll}\text { GEALALTHLGK } & 0.88 & 21.53 & 2228 & 17.74 & 3 & 1324.8175 & 1324.8071 & 442.6096 & 0.0104 & 7.8323 & 12708.250 & 9874.998 & 3818.354 & 14591.996 & \text { Yes }\end{array}$

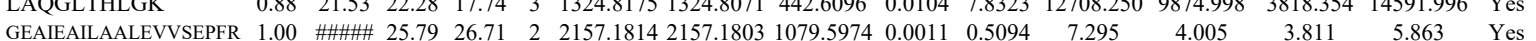

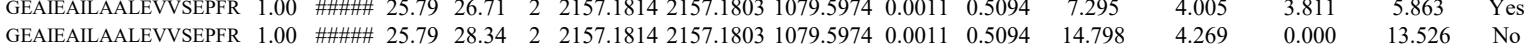

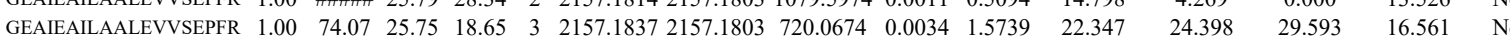
$\begin{array}{llllllllllllllll}\text { GEAIEAILAALEVVSEPFR } & 1.00 & 83.53 & 25.51 & 21.42 & 3 & 2157.1867 & 2157.1803 & 720.0674 & 0.0064 & 2.9627 & 36.248 & 19.576 & 5.889 & 44.124 & \text { Yes }\end{array}$ $\begin{array}{llllllllllllllll}\text { GEAIEAILAALEVVSEPFR } & 1.00 & 70.91 & 25.76 & 19.96 & 3 & 2157.1822 & 2157.1803 & 720.0674 & 0.0019 & 0.8795 & 8.720 & 9.230 & 6.607 & 15.770 & \text { Yes }\end{array}$ $\begin{array}{lllllllllllllll}\text { GEAIEAILAALEVVSEPFR } & 1.00 & \text { \#\#\# } 25.74 & 24.96 & 2 & 2157.1834 & 2157.1803 & 1079.5974 & 0.0031 & 1.4357 & 16.997 & 18.155 & 4.960 & 15.703 & \text { Yes }\end{array}$ $\begin{array}{lllllllllllllll}\text { GEAIEAILAALEVVSEPFR } & 1.00 & \text { \#\#\#\# } 25.74 & 23.97 & 2 & 2157.1834 & 2157.1803 & 1079.5974 & 0.0031 & 1.4357 & 12.103 & 10.542 & 4.967 & 32.657 & \text { No }\end{array}$ $\begin{array}{llllllllllllllll}\text { GEAIEAILAALEVVSEPFR } & 1.00 & 68.16 & 25.54 & 18.11 & 3 & 2157.1843 & 2157.1803 & 720.0674 & 0.0040 & 1.8517 & 13.610 & 3.317 & 20.297 & 17.366 & \text { No }\end{array}$

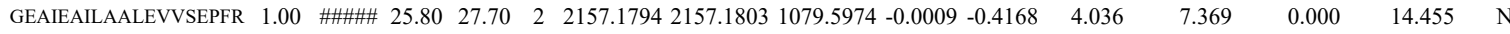
$\begin{array}{llllllllllllllll}\text { GEAIEAILAALEVVSEPFR } & 1.00 & 49.56 & 25.90 & 16.52 & 3 & 2157.1801 & 2157.1803 & 720.0674 & -0.0002 & -0.0926 & 13.272 & 9.005 & 5.690 & 9.858 & \text { Yes }\end{array}$ $\begin{array}{llllllllllllllll}\text { GEAIEAILAALEVVSEPFR } & 1.00 & \text { \#\#\#\# } 25.79 & 27.37 & 2 & 2157.1814 & 2157.1803 & 1079.5974 & 0.0011 & 0.5094 & 9.164 & 12.804 & 4.762 & 6.158 & \text { Yes }\end{array}$

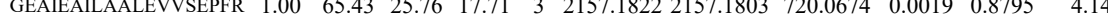
$\begin{array}{llllllllllllll}\text { EQELSEEDK } & 0.75 & 31.71 & 27.58 & 33.42 & 2 & 1393.6798 & 1393.6816 & 697.8481 & -0.0018 & -1.2897 & 708.407 & 6\end{array}$ $\begin{array}{lllllllllll}0.91 & 36.58 & 27.53 & 37.10 & 2 & 1393.6806 & 1393.6816 & 697.8481 & -0.0010 & -0.7165 & 621.485\end{array}$ $\begin{array}{lllllllllllll}\text { EWQELDDAEK } & 1.00 & 49.15 & 26.77 & 24.81 & 2 & 1549.7514 & 1549.7504 & 775.8825 & 0.0010 & 0.6444 & 70.431 \\ \text { EWQELDDAEK } & 1.00 & 53.21 & 26.88 & 25.01 & 2 & 1549.7534 & 1549.7504 & 775.8825 & 0.0030 & 1.9333 & 68.719\end{array}$

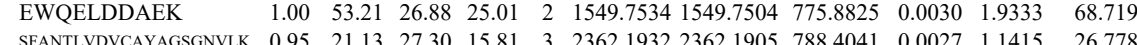
$\begin{array}{llllllllllllll}\text { SFANTLVDVCAYAGSGNVLK } & 0.95 & 21.13 & 27.30 & 15.81 & 3 & 2362.1932 & 2362.1905 & 788.4041 & 0.0027 & 1.1415 & 26.778 \\ \text { GEAIEAILAALEVVSEPFR } & 0.66 & 14.05 & 25.76 & 27.05 & 3 & 2157.1822 & 2157.1803 & 720.0674 & 0.0019 & 0.8795 & 17.533\end{array}$ $\begin{array}{llllllllllllll}\text { GEAIEAILAALEVVSEPFR } & 0.66 & 14.05 & 25.76 & 27.05 & 3 & 2157.1822 & 2157.1803 & 720.0674 & 0.0019 & 0.8795 & 17.533 \\ \text { GEIEA } & 0.60 & 30.33 & 25.56 & 43.33 & 3 & 2157.1846 & 2157.1803 & 720.0674 & 0.0043 & 1.9906 & 10.004\end{array}$

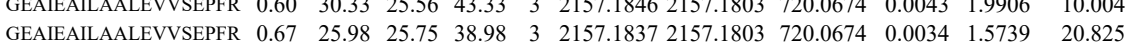
$\begin{array}{lllllllllllll}\text { GCAIEALCAALENYPEPNSALLR } & 0.94 & 22.06 & 27.09 & 14.53 & 3 & 2718.3022 & 2718.3011 & 907.1076 & 0.0011 & 0.4042 & 16.498\end{array}$ $\begin{array}{lllllllllllll}\text { VCLYLISCVNYVPEPENSALLR } & .94 & 22.06 & 27.09 & 4.53 & 3 & 2718.3022 & 2718.3011 & 907.1076 & 0.0011 & 0.4042 & 16.498 \\ \text { VCLYLTSCVNYVPEPENSALLR } & 0.67 & 14.31 & 27.04 & 14.59 & 3 & 2718.3025 & 2718.3011 & 907.1076 & 0.0014 & 0.5145 & 6.927\end{array}$ $\begin{array}{lllllllllllll}\text { MNLASSFVNGFVNAAFGQDK } & 1.00 & 66.38 & 27.77 & 24.26 & 3 & 2404.2109 & 2404.2089 & 802.4102 & 0.0020 & 0.8308 & 43.797\end{array}$ $\begin{array}{lllllllllllll} & \end{array}$

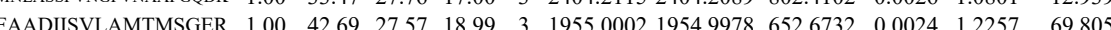



$\begin{array}{lllllllllllll}0.60 & 6.74 & 19.91 & 73.74 & 3 & 1705.0327 & 1705.0283 & 569.3500 & 0.0044 & 2.5760 & 4111.654 & 4536.242 & 0.03 \\ 0.66 & 56.38 & 19.91 & 69.38 & 3 & 1705.0303 & 1705.0283 & 569.3500 & 0.0020 & 1.1709 & 2303.556 & 2014230 & 0.0\end{array}$

CALGVFR $\begin{array}{llllllllllllll}0.65 & 21.85 & 29.38 & 29.71 & 2 & 954.4932 & 954.4901 & 478.2523 & 0.0031 & 3.2410 & 8151.820 & 7987.557 & 927.4 \\ 0.73 & 23.41 & 29.38 & 30.02 & 2 & 954.934 & 954.401 & 478.2523 & 0.0033 & 3.450 & 7898.82 & & \\ 1\end{array}$

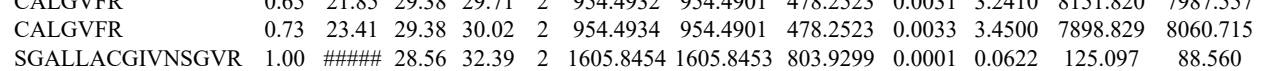
$\begin{array}{lllllllllllll}\text { SGALLACGIVNSGVR } & 1.00 & \text { \#\#\# } & 28.56 & 32.39 & 2 & 1605.8454 & 1605.8453 & 803.9299 & 0.0001 & 0.0622 & 125.097 & 88.560 \\ \text { SGALLACGIVNSGVR } & 0.61 & 12.76 & 28.45 & 23.39 & 3 & 1605.8473 & 1605.8453 & 536.2890 & 0.0020 & 1.2431 & 171.103 & 170.327\end{array}$

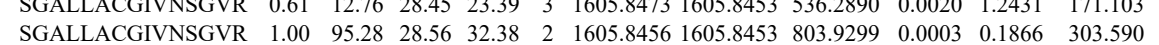

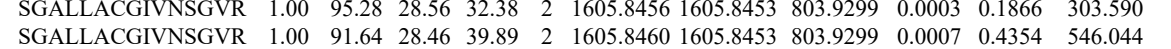
$\begin{array}{llllllllllllll}\text { SGALLACGIVNSGVR } & 1.00 & 91.64 & 28.46 & 39.89 & 2 & 1605.8460 & 1605.8453 & 803.9299 & 0.0007 & 0.4354 & 546.044 & 417 \\ \text { SGALLACGIVNSGVR } & 0.99 & 31.07 & 28.45 & 22.54 & 3 & 1605.8473 & 1605.8453 & 536.2890 & 0.0020 & 1.2431 & 37.570 & \\ \text { SGALE. }\end{array}$

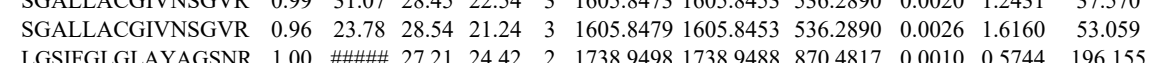

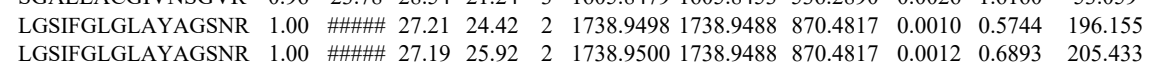
$\begin{array}{lllllllllll}\text { LGSIFGLGLAYAGSNR } & 1.00 & \# \# \# \# \text { 27.19 } & 25.92 & 2 & 1738.9500 & 1738.9488 & 870.4817 & 0.0012 & 0.6893 & 205.433\end{array}$ $\begin{array}{llllllllllll}\text { LGSIFGLGLAYAGSNR } & 1.00 & 66.67 & 27.08 & 17.51 & 3 & 1738.9513 & 1738.9488 & 580.6569 & 0.0025 & 1.4352 & 6.823 \\ \text { LGSIFGLGLAYAGSNR } & 0.67 & 46.86 & 26.78 & 59.86 & 3 & 1738.9522 & 1738.9488 & 580.6569 & 0.0034 & 1.9518 & 5.936\end{array}$ $\begin{array}{llllllllllll}\text { LGSIFGLGLAYAGSNR } & 0.67 & 46.86 & 26.78 & 59.86 & 3 & 1738.9522 & 1738.9488 & 580.6569 & 0.0034 & 1.9518 & 5.936 \\ \text { LGSIFGLGLAYAGSNR } & 0.66 & 28.22 & 27.08 & 41.22 & 3 & 1738.9513 & 1738.9488 & 580.6569 & 0.0025 & 1.4352 & 17.149\end{array}$ $\begin{array}{llllllllllll}\text { LGSIFGLGLAYAGSNR } & 0.66 & 28.22 & 27.08 & 41.22 & 3 & 1738.9513 & 1738.9488 & 580.6569 & 0.0025 & 1.4352 & 17.149 \\ \text { LGSIFGLGLAYAGSNR } & 1.00 & 37.33 & 26.93 & 20.62 & 3 & 1738.9519 & 1738.9488 & 580.6569 & 0.0031 & 1.7796 & 10.379\end{array}$ $\begin{array}{llllllllllll}\text { LGSIFGLGLAYAGSNR } & 1.00 & 37.33 & 26.93 & 20.62 & 3 & 1738.950 & 173.948 & 58.6969 & 0.0031 & 1.7352 & 17.149 \\ \text { AVPLALALSVSNPR } & 0.64 & 23.60 & 23.58 & 36.60 & 2 & 1519.9088 & 1519.9086 & 760.9616 & 0.0002 & 0.1314 & 2.897\end{array}$ $\begin{array}{llllllllllll}\text { AVPLALALISVSNPR } & 0.64 & 23.60 & 23.58 & 36.60 & 2 & 1519.9108 & 1519.9086 & 76.9616 & 0.0002 & 0.1314 & 2.897 \\ \text { AVPLALALISVSNPR } & 0.82 & 28.12 & 23.93 & 41.12 & 2 & 1519.9100 & 1519.9086 & 760.9616 & 0.0014 & 0.9199 & 3.738\end{array}$ $\begin{array}{lllllllllllll}\text { AVPLALALISVSNPR } & 0.99 & 19.16 & 20.29 & 16.21 & 3 & 1664.0134 & 1664.0107 & 555.6775 & 0.0027 & 1.6196 & 18.768\end{array}$ $\begin{array}{llllllllllll}\text { AVPLALALISVSNPR } & 0.82 & 23.22 & 23.93 & 36.22 & 2 & 1519.9100 & 1519.9086 & 760.9616 & 0.0014 & 0.9199 & 14.727 \\ \text { AVPLALALISVSNPR } & 0.55 & 30.18 & 20.13 & 43.18 & 3 & 1664.0113 & 1664.0107 & 555.6775 & 0.0006 & 0.3599 & 3.167\end{array}$ $\begin{array}{llllllllllll}\text { AVPLALALISVSNPR } & 0.55 & 30.18 & 20.13 & 43.18 & 3 & 1664.0113 & 1664.0107 & 555.6775 & 0.0006 & 0.3599 & 3.167 \\ \text { AVPLALALISVSNPR } & 0.66 & 24.20 & 20.29 & 37.20 & 3 & 1664.0131 & 1664.0107 & 555.6775 & 0.0024 & 1.4397 & 19.001\end{array}$

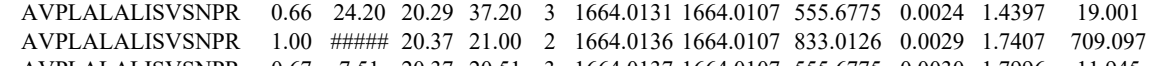
$\begin{array}{lllllllllllll}\text { AVPLALALISVSNPR } & 0.67 & 7.51 & 20.37 & 20.51 & 3 & 1664.0137 & 1664.0107 & 555.6775 & 0.0030 & 1.7996 & 11.945\end{array}$

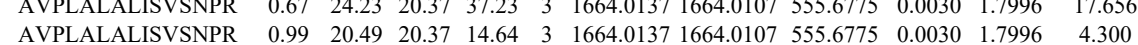
$\begin{array}{llllllllllll}\text { AVPLALALISVSNPR } & 1.00 & 90.51 & 20.37 & 20.69 & 2 & 1664.0138 & 1664.0107 & 833.0126 & 0.0031 & 1.8607 & 325.314\end{array}$

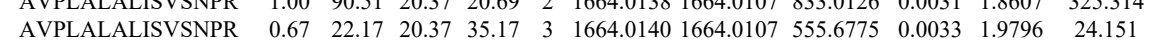
$\begin{array}{llllllllllll}\text { AVPLALALISVSNPR } & 1.00 & 52.30 & 20.37 & 17.77 & 3 & 1664.0140 & 1664.0107 & 555.6775 & 0.0033 & 1.9796 & 13.134\end{array}$ $\begin{array}{llllllllllll}\text { AVPLALALISVSNPR } & 0.63 & 5.78 & 20.04 & 15.41 & 3 & 1664.0149 & 1664.0107 & 555.6775 & 0.0042 & 2.5194 & 14.044\end{array}$ $\begin{array}{llllllllllll}\text { AVPLALALISVSNPR } & 0.60 & 50.36 & 19.82 & 63.36 & 3 & 1664.0152 & 1664.0107 & 555.6775 & 0.0045 & 2.6994 & 23.664\end{array}$ $\begin{array}{llllllllllll}\text { AVPLALALLVAAMQPR } & 1.00 & 50.94 & 27.62 & 23.49 & 3 & 1847.9860 & 1847.9838 & 617.0019 & 0.0022 & 1.1885 & 70.111\end{array}$ $\begin{array}{llllllllllllll}\text { SHYVLYGLVAAMQPR } & 1.00 & 44.15 & 27.65 & 18.06 & 3 & 1847.9872 & 1847.9838 & 617.0019 & 0.0034 & 1.8368 & 52.767\end{array}$ $\begin{array}{lllllllllllllll}\text { SGALLACGIVNSGVR } & 0.99 & 38.40 & 28.45 & 21.67 & 2 & 1605.8464 & 1605.8453 & 803.9299 & 0.0011 & 0.6841 & 52.951\end{array}$ $\begin{array}{lllllllllllll}\text { SGALLACGIVNSGVR } & 1.00 & 84.61 & 28.45 & 28.73 & 2 & 1605.8466 & 1605.8453 & 803.9299 & 0.0013 & 0.8085 & 71.302\end{array}$

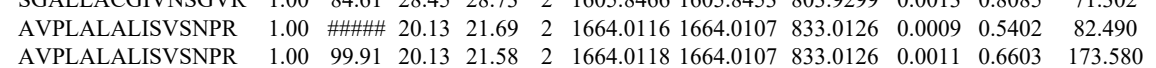
$\begin{array}{llllllllllll}\text { AVPLALALISVSNPR } & 0.55 & 16.56 & 20.13 & 29.56 & 3 & 1664.0119 & 1664.0107 & 555.6775 & 0.0012 & 0.7198 & 11.264\end{array}$ $\begin{array}{lllllllllllll}\text { AVPLALALISVSNPR } & 0.66 & 19.81 & 20.29 & 32.81 & 3 & 1664.0128 & 1664.0107 & 555.6775 & 0.0021 & 1.2597 & 10.157\end{array}$ $\begin{array}{llllllllllll}\text { AVPLALALISVSNPR } & 0.66 & 8.61 & 20.29 & 21.61 & 3 & 1664.0131 & 1664.0107 & 555.6775 & 0.0024 & 1.4397 & 31.812 \\ \text { AVPLALALIVSNPR } & 0.92 & 12.8 & 20.29 & 1429 & 3 & 164.0131 & 164.0107 & 555.6775 & 0.0024 & 1.4397 & 14111\end{array}$ $\begin{array}{llllllllllll}\text { AVPLALALISVSNPR } & 0.92 & 12.28 & 20.29 & 14.29 & 3 & 1664.0131 & 1664.0107 & 555.6775 & 0.0024 & 1.4397 & 14.111\end{array}$ $\begin{array}{lllllllllllll}\text { AVPLALALISVSNPR } & 1.00 & 56.31 & 20.29 & 20.63 & 3 & 1664.0134 & 1664.0107 & 555.6775 & 0.0027 & 1.6196 & 18.273\end{array}$ $\begin{array}{llllllllllllll}\text { SHYVLYGLVAAMQPR } & 1.00 & 51.93 & 27.66 & 28.39 & 3 & 1847.9854 & 1847.9838 & 617.0019 & 0.0016 & 0.8644 & 31.682\end{array}$ $\begin{array}{lllllllllllll}\text { SGALLACGIVNSGGVR } & 1.00 & 71.54 & 28.46 & 27.12 & 2 & 1605.8458 & 1605.8453 & 803.9299 & 0.0005 & 0.3110 & 49.909\end{array}$ $\begin{array}{llllllllllll}\text { SGALLACGIVNSGVR } & 1.00 & 83.26 & 28.45 & 30.91 & 2 & 1605.8472 & 1605.8453 & 803.9299 & 0.0019 & 1.1817 & 56.521\end{array}$

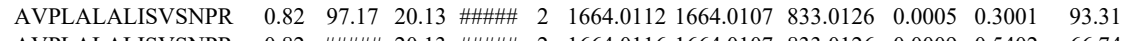
$\begin{array}{llllllllllll}\text { AVPLALALISVSNPR } & 0.82 & \text { \#\#\#\# } 20.13 & \text { \#\#\#\# } 2 & 2 & 1664.0116 & 1664.0107 & 833.0126 & 0.0009 & 0.5402 & 66.74\end{array}$ $\begin{array}{llllllllllll}\text { AVPLALALISVSNPR } & 1.00 & 49.61 & 20.29 & 16.92 & 3 & 1664.0128 & 1664.0107 & 555.6775 & 0.0021 & 1.2597 & 13.216\end{array}$ $\begin{array}{lllllllllllll}\text { SGALLACGIVNSGVR } & 1.00 & 61.45 & 28.46 & 29.14 & 2 & 1605.8460 & 1605.8453 & 803.9299 & 0.0007 & 0.4354 & 23.703\end{array}$

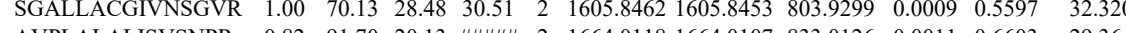
$\begin{array}{llllllllllll}\text { AVPLALALISVSNPR } & 0.82 & 91.70 & 20.13 & \ldots \# \# & 2 & 1664.0118 & 1664.0107 & 833.0126 & 0.0011 & 0.6603 & 29.364\end{array}$ $\begin{array}{llllllllllll}\text { AVPLALALISVSNPR } & 0.66 & 19.73 & 20.13 & 32.73 & 3 & 1664.0125 & 1664.0107 & 555.6775 & 0.0018 & 1.0798 & 8.142\end{array}$ $\begin{array}{llllllllllll}\text { AVPLALALISVSNPR } & 0.66 & 27.14 & 20.13 & 40.14 & 3 & 1664.0125 & 1664.0107 & 555.6775 & 0.0018 & 1.0798 & 9.432 \\ \text { AVPLALALISVSNPR } & 0.72 & 66.58 & 20.21 & 79.58 & 2 & 1664.0134 & 1664.0107 & 833.0126 & 0.0027 & 1.6206 & 17.911\end{array}$ $\begin{array}{llllllllllll}\text { SGALLACGIVNSGVR } & 1.00 & 70.70 & 28.45 & 27.25 & 2 & 1605.8466 & 1605.8453 & 803.9299 & 0.0013 & 0.8085 & 27.708\end{array}$ $\begin{array}{lllllllllllll}\text { SGALLACGIVNSGVR } & 1.00 & 83.85 & 28.46 & 28.41 & 2 & 1605.8470 & 1605.8453 & 803.9299 & 0.0017 & 1.0573 & 32.361\end{array}$

14658.051 Yes 10186.344 Yes $50.613-5253.086$ Yes $0.000 \quad 2502.094$ No 927.413 14270.358 Yes \begin{tabular}{lll}
2.463 & 95.963 & Yes \\
\hline & 146.927 & Yes
\end{tabular} $\begin{array}{llll}0.460 & 319.278 \text { Yes }\end{array}$

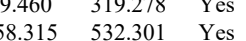
$9.536 \quad 45.394 \quad$ Yes $19.571 \quad 83.379$ Yes 189.903 Yes $\begin{array}{lll}16.435 & 190.020 & \text { Yes }\end{array}$ $\begin{array}{lll}8.327 & 14.057 & \text { Yes }\end{array}$ 


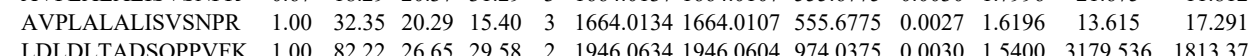
$\begin{array}{llllllllllll}\text { LDLDLTADSQPPVFK } & 1.00 & \# \# \# 26.54 & 32.38 & 2 & 1946.0642 & 1946.0604 & 974.0375 & 0.0038 & 1.9506 & 906.143 & 591.304\end{array}$ $\begin{array}{lllllllllllllll}\text { LDLDLTADSQPPVFK } & 1.00 & 64.83 & 26.47 & 29.42 & 3 & 1946.0650 & 1946.0604 & 649.6941 & 0.0046 & 2.3601 & 632.146 & 376.392\end{array}$ $\begin{array}{llllllllllllll}\text { LDLDLTADSQPPVFK } & 1.00 & 46.00 & 26.43 & 21.26 & 3 & 1946.0653 & 1946.0604 & 649.6941 & 0.0049 & 2.5140 & 538.156 & 435.639\end{array}$ $\begin{array}{lllllllllllllll}\text { LDLDLTADSQPPVFK } & 0.76 & 16.88 & 26.43 & 16.95 & 3 & 1946.0653 & 1946.0604 & 649.6941 & 0.0049 & 2.5140 & 121.889 & 180.085\end{array}$ $\begin{array}{llllllllllllll}\text { LDLDLTADSQPPVFK } & 1.00 & 42.02 & 26.41 & 20.92 & 3 & 1946.0659 & 1946.0604 & 649.6941 & 0.0055 & 2.8218 & 191.653 & 213.140\end{array}$ $\begin{array}{lllllllllllll}\text { VFPGSTTEDYNLIVIER } & 1.00 & 99.27 & 27.56 & 23.39 & 2 & 2096.0934 & 2096.0912 & 1049.0529 & 0.0022 & 1.0486 & 3432.285 & 2496.592\end{array}$ $\begin{array}{lllllllllllll}\text { LSPPYSSPQEFAQDVGR } & 1.00 & 84.59 & 27.47 & 22.29 & 2 & 2020.9974 & 2020.9976 & 1011.5061 & -0.0002 & -0.0989 & 1479.019 & 912.058\end{array}$ $\begin{array}{lllllllllllll}\text { LSPPYSSPQEFAQDVGR } & 1.00 & 77.96 & 27.72 & 20.99 & 2 & 2020.9994 & 2020.9976 & 1011.5061 & 0.0018 & 0.8898 & 2572.664 & 1527.741\end{array}$ \begin{tabular}{llllllllllllllll} 
LSPPYSSPQEFAQDVGR & 1.00 & 80.09 & 27.72 & 20.58 & 2 & 2020.9994 & 2020.9976 & 1011.5061 & 0.0018 & 0.8898 & 296.742 & 213.165 & 36.6 \\
\hline
\end{tabular} $\begin{array}{lllllllllllll}\text { LSPPYSSPQEFAQDVGR } & 1.00 & 88.63 & 27.63 & 21.18 & 2 & 2021.0014 & 2020.9976 & 1011.5061 & 0.0038 & 1.8784 & 509.518 & 392.009\end{array}$

TVYCNEVPVHK

ADVQSIIGLQR

ADVQSIIGLQR

ADVQSIIGLQR

FQWDLNAWTK

FQWDLNAWTK

FQWDLNAWTK

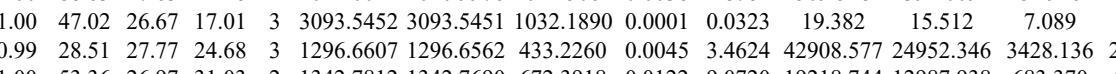

$\begin{array}{llllllllllll}1.00 & 53.26 & 26.94 & 37.26 & 2 & 1342.7818 & 1342.7690 & 672.3918 & 0.0128 & 9.5182 & 16354.650 & 12330.208\end{array}$

$\begin{array}{llllllllllll}1.00 & 59.04 & 26.94 & 37.26 & 2 & 1342.7820 & 1342.7690 & 672.3918 & 0.0130 & 9.6669 & 23744.053 & 15617.54\end{array}$ $\begin{array}{llllllllllll}1.00 & 55.35 & 27.80 & 26.40 & 2 & 1595.8420 & 1595.8340 & 798.9243 & 0.0080 & 5.0067 & 1209.879 & 714.919 \\ 1.00 & 50.81 & 27.82 & 26.02 & 2 & 1595.8422 & 1595.8340 & 798.9243 & 0.0082 & 5.1319 & 2277.777 & 1730.699\end{array}$

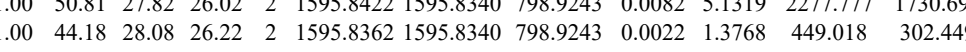

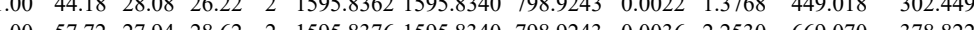
$\begin{array}{ll}45.381 \\ 378.822 & 29.997\end{array}$

AERPGTNSTGPAPMAPR

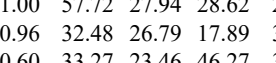

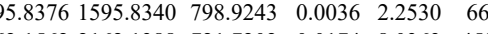
$3712.929 \quad 1893.0$

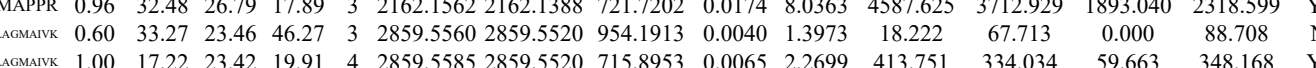

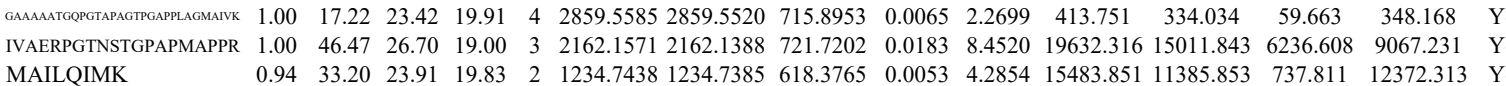
MAILQIMK MAILQIMK MAILQIMK
MAILQIMK MAILQIMK MAILQIMK
LIYFQLHR LIYFQLHR LIYFQLHR LIYFQLHR LIYFQLHR $\begin{array}{llllllllllllllllll}0.94 & 33.20 & 23.91 & 19.83 & 2 & 1234.7438 & 1234.7385 & 618.3765 & 0.0053 & 4.2854 & 15483.851 & 11385.853 & 737.811 & 12372.313 & \text { Y S } & \\ 0.91 & 32.18 & 24.41 & 20.92 & 2 & 12347450 & 12347385 & 618.3765 & 0.0065 & 5.2557 & 21473.985 & 13338513 & 150.349 & 14133.404 & \text { Y }\end{array}$ $\begin{array}{lllllllllllllllll}0.99 & 41.29 & 24.65 & 25.53 & 2 & 1234.7422 & 1234.7385 & 618.3765 & 0.0037 & 2.9917 & 15004.067 & 10387.203 & 0.000 & 8889.750 & \mathrm{No}\end{array}$ $\begin{array}{llllllllllllllll}0.87 & 3020 & 24.67 & 20.51 & 2 & 1234.7430 & 1234.7385 & 618.3765 & 0.0045 & 3.6385 & 16947.147 & 11634.141 & 448.723 & 10748.963 & \text { Yes }\end{array}$ $\begin{array}{lllllllllllllllll}0.99 & 37.71 & 24.73 & 24.65 & 2 & 1234.7412 & 1234.7385 & 618.3765 & 0.0027 & 2.1831 & 6376.169 & 4933.344 & 390.550 & 4128.678 & \text { Yes }\end{array}$ $\begin{array}{llllllllllllllll}0.99 & 32.32 & 27.84 & 23.74 & 3 & 1232.7154 & 1232.7151 & 411.9123 & 0.0003 & 0.2428 & 1492.613 & 1153.852 & 227.288 & 1091.593 & \text { Yes }\end{array}$ $\begin{array}{llllllllllllllll}1.00 & 41.30 & 27.32 & 25.26 & 3 & 1232.7157 & 1232.7151 & 411.9123 & 0.0006 & 0.4855 & 714.737 & 468.399 & 70.398 & 515.936 & \text { Yes }\end{array}$ $\begin{array}{llllllllllllllll}1.00 & 38.66 & 27.42 & 23.25 & 3 & 1232.7163 & 1232.7151 & 411.9123 & 0.0012 & 0.9711 & 2814.205 & 1852.511 & 275.230 & 1874.716 & \text { Yes }\end{array}$ $\begin{array}{lllllllllllllllll}1.00 & 38.14 & 27.42 & 23.74 & 3 & 1232.7163 & 1232.7151 & 411.9123 & 0.0012 & 0.9711 & 3730.611 & 2555.906 & 320.300 & 2602.495 & \text { Yes }\end{array}$ $\begin{array}{lllllllllllllllll} & 1.00 & 37.44 & 27.32 & 23.97 & 3 & 1232.7157 & 1232.7151 & 411.9123 & 0.0006 & 0.4855 & 990.696 & 743.748 & 147.209 & 657.003 & \text { Yes }\end{array}$ $\begin{array}{lllllllllllllllll} & 53.38 & 27.81 & 66.38 & 3 & 1768.9120 & 1768.9095 & 590.6438 & 0.0025 & 1.4109 & 530.837 & 669.871 & 182.727 & 552.696 & \text { Yes } \\ \end{array}$

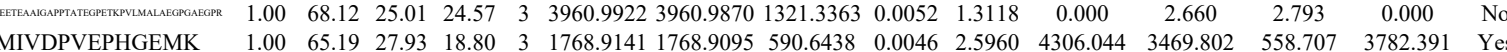
$\begin{array}{llllllllllllllllll} & \end{array}$

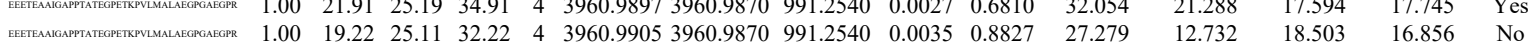

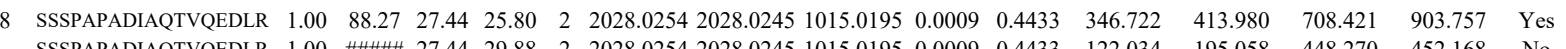

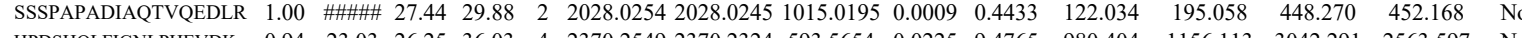
$\begin{array}{llllllllllllllll}\text { HPDSHQLFIGNLPHEVDK } & 0.94 & 23.03 & 26.25 & 36.03 & 4 & 2370.2549 & 2370.2324 & 593.5654 & 0.0225 & 9.4765 & 980.404 & 1156.113 & 3042.291 & 2563.597 & \text { No }\end{array}$ $\begin{array}{llllllllllllllll}\text { LPNFGFVVFDDSEPVQK } & 0.64 & 83.70 & 27.28 & 96.70 & 2 & 2225.1614 & 2225.1612 & 1113.5879 & 0.0002 & 0.0898 & 190.014 & 143.803 & 399.076 & 405.413 & \text { No }\end{array}$

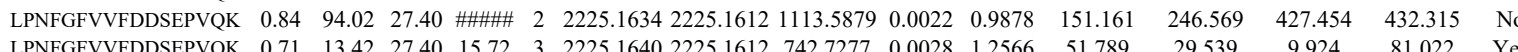

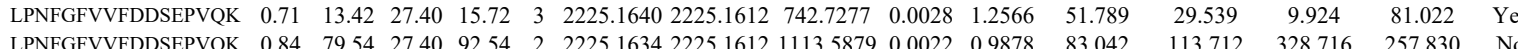

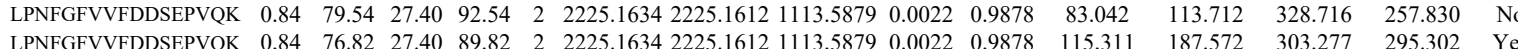

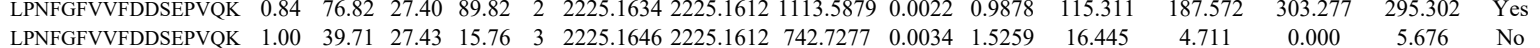

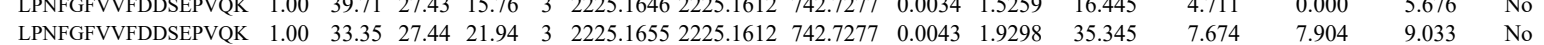

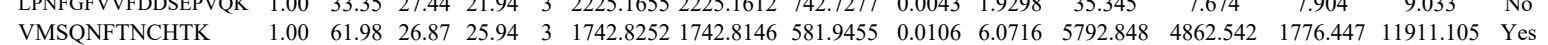

Table S-4 page 461 of 614 

$\begin{array}{llllllllllllllll}0.98 & 34.95 & 28.33 & 15.86 & 3 & 1353.7054 & 1353.6952 & 452.2390 & 0.0102 & 7.5181 & 3314.134 & 3482.728 & 1291.255 & 8682.581 & \text { Yes }\end{array}$

$\begin{array}{lllllllllllllllll} & \end{array}$

VLSNRPIMFR

VLSNRPIMFR

VLSNPPIMFR

VISNRPIMFR

VLSNRPIMFR

VLSNRPIMFR

VLSNRPIMFR

VLSNRPIMFR

VLSNRPIMFR

VLSNRPIMFR

VLSNRPIMFR

VLSNRPIMFR

VLSNRPIMFR

VLSNRPIMFR

VLSNRPIMFR

VLSNRPIMFR

VLSNRPIMFR

VLSNRPIMFR

VLSNRPIMFR

VLSNRPIMFR

VLSNRPIMFR

VLSNRPIMFR

VLSNRPIMFR

VLSNRPIMFR

VLSNRPIMFR

LSNRPIMFR $\begin{array}{llllllllllll}0.82 & 17.70 & 27.29 & 15.45 & 3 & 1375.7890 & 1375.7880 & 459.6033 & 0.0010 & 0.7253 & 817.763 & 987.330\end{array}$ $\begin{array}{lllllllllllll}0.69 & 1.32 & 27.36 & 18.14 & 3 & 137.7905 & 1375.7880 & 459.6033 & 0.0025 & 1.8132 & 614.665 & 772.932 & 56.246\end{array}$

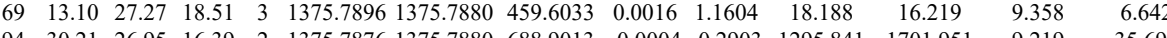
$\begin{array}{lllllllllllll}0.51 & 9.93 & 27.27 & 22.93 & 3 & 1375.7896 & 1375.7880 & 459.6033 & 0.0016 & 1.1604 & 24.155 & 22.455 & 9.12\end{array}$ $\begin{array}{lllllllllllll}0.70 & 13.05 & 27.20 & 21.41 & 3 & 1375.7908 & 1375.7880 & 459.6033 & 0.0028 & 2.0307 & 20477.232 & 25942.444 & 198\end{array}$ $\begin{array}{llllllllllllll}0.86 & 26.98 & 27.51 & 18.55 & 2 & 1391.7828 & 1391.7829 & 696.8987 & -0.0001 & -0.0717 & 907.404 & 1037.503 & 0.00\end{array}$ $\begin{array}{llllllllllllll}0.55 & 12.80 & 27.58 & 15.33 & 3 & 1391.7835 & 1391.7829 & 464.9349 & 0.0006 & 0.4302 & 4950.948 & 6009.663 & 449.67\end{array}$ $\begin{array}{llllllllllllll}0.57 & 27.70 & 27.36 & 20.32 & 2 & 1375.7858 & 1375.7880 & 688.9013 & -0.0022 & -1.5967 & 1781.574 & 2060.356 & 11.37\end{array}$ $\begin{array}{lllllllllllll}0.88 & 26.98 & 26.95 & 18.15 & 2 & 1375.7876 & 1375.7880 & 688.9013 & -0.0004 & -0.2903 & 1069.869 & 1272.877\end{array}$ $\begin{array}{lllllllllllll}0.83 & 30.02 & 27.21 & 16.87 & 2 & 1375.7866 & 1375.7880 & 688.9013 & -0.0014 & -1.0161 & 624.558 & 723.732\end{array}$ $\begin{array}{lllllllllllll}0.61 & 16.08 & 27.51 & 15.15 & 3 & 1391.7829 & 1391.7829 & 464.9349 & 0.0000 & 0.0000 & 860.193 & 1086.236 & 1\end{array}$ $\begin{array}{lllllllllllll}0.69 & 17.45 & 27.61 & 17.92 & 3 & 1391.7832 & 1391.7829 & 464.9349 & 0.0003 & 0.2151 & 857.271 & 985.335 & 57\end{array}$ $\begin{array}{llllllllllll}0.62 & 20.53 & 26.95 & 15.56 & 2 & 1375.7876 & 1375.7880 & 688.9013 & -0.0004 & -0.2903 & 533.478 & 586.329\end{array}$ $\begin{array}{llllllllllll}0.89 & 27.58 & 26.95 & 18.78 & 2 & 1375.7876 & 1375.7880 & 688.9013 & -0.0004 & -0.2903 & 415.452 & 485.280\end{array}$ $\begin{array}{lllllllllllll}0.95 & 31.43 & 26.95 & 22.31 & 2 & 1375.7884 & 1375.7880 & 688.9013 & 0.0004 & 0.2903 & 481.679 & 527.830\end{array}$ $\begin{array}{lllllllllllll}0.80 & 17.14 & 27.28 & 15.28 & 3 & 1375.7893 & 1375.7880 & 459.6033 & 0.0013 & 0.9428 & 635.743 & 807.170\end{array}$ $\begin{array}{llllllllllllll}0.88 & 21.46 & 26.95 & 22.16 & 3 & 1375.7884 & 1375.7880 & 459.6033 & 0.0004 & 0.2901 & 985.772 & 1127.049 & 92 .\end{array}$ $\begin{array}{lllllllllllll}0.77 & 19.47 & 26.95 & 21.02 & 2 & 1375.7886 & 1375.7880 & 688.9013 & 0.0006 & 0.4355 & 241.023 & 280.408 & 9.41\end{array}$ $\begin{array}{lllllllllllllll}0.74 & 17.84 & 26.95 & 21.40 & 3 & 1375.7881 & 1375.7880 & 459.6033 & 0.0001 & 0.0725 & 995.902 & 1183.304 & 70.03\end{array}$ $\begin{array}{llllllllllllll}0.75 & 15.72 & 26.95 & 22.15 & 3 & 1375.7887 & 1375.7880 & 459.6033 & 0.0007 & 0.5077 & 812.623 & 1038.514 & 49.80 \\ 0.55 & 14.93 & 26.95 & 17.16 & 2 & 1375.7888 & 1357.7880 & 688.9013 & 0.0008 & 0.0806 & 212.732 & 29.910 & \end{array}$ $\begin{array}{lllllllllllll}0.55 & 14.93 & 26.95 & 17.16 & 2 & 1375.7888 & 1375.7880 & 688.9013 & 0.0008 & 0.5806 & 212.732 & 297.910 & 19.79\end{array}$

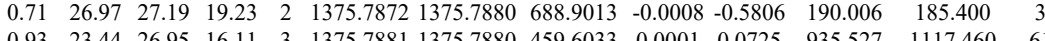

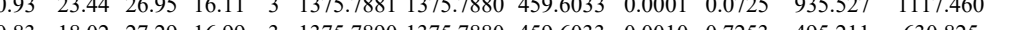
$\begin{array}{llllllllllllll}0.83 & 18.02 & 27.29 & 16.99 & 3 & 1375.7890 & 1375.7880 & 459.6033 & 0.0010 & 0.7253 & 495.211 & 630.825 & 31 \\ 0.64 & 13.76 & 26.95 & 15.10 & 3 & 1375.7887 & 1375.7880 & 459.6033 & 0.0007 & 0.5077 & 1182.085 & 1447.348 & 72\end{array}$ $\begin{array}{llllllllllllll}0.64 & 13.76 & 26.95 & 15.10 & 3 & 1375.7887 & 1375.7880 & 459.6033 & 0.0007 & 0.5077 & 1182.085 & 1447.348 & 72 . & \\ 0.85 & 18.18 & 6.95 & 15.07 & 3 & 1375.7887 & 1375.7880 & 459.6033 & 0.0007 & 0.5077 & 742.397 & 910.752 & 39 .\end{array}$ $\begin{array}{lllllllllllll}0.85 & 18.18 & 26.95 & 15.07 & 3 & 1375.7887 & 1375.7880 & 459.6033 & 0.0007 & 0.5077 & 742.397 & 910.752 & \\ 1.00 & 89.60 & 27.45 & 2.96 & 2 & 2028.0234 & 2028.0245 & 1015.0195 & 0.0011 & -0.5419 & 28.49 & 410.719 & 620\end{array}$

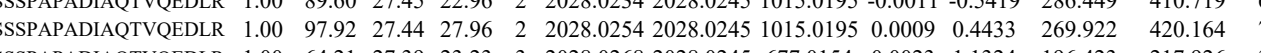

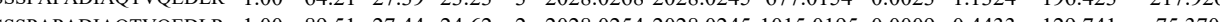
NFGEEVDDESLK

NLDDTIDDEK

NLDDTIDDEK

FSPAGPVISIR

FSPAGPVLSIR

IIFVGR

IIFVGR

IIFVGR

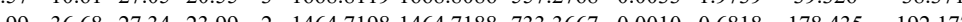

GVVNGTGAPGQSPGAGR AGVVNGTGAPGQSPGAG AISALVPQGGPVLCR AISALVPQGGPVLC

SGEVLVNVK

SGEVLVNVK

LFDSTTLEHQK

LFDSTTLEHQK

MKPILLQGHER

MKPILLQGHER

MKPILLQGHER

MKPILLQGHER

MKPILLQGHER

YPEAPPFVR

YPEAPPFVR

INMNGVNSSNGVVDPR

AISVLAK

AISVLAK $\begin{array}{llllllllllllllll}1 & 1.00 \\ 0.00 & 46.66 & 25.69 & 23.07 & 2 & 12867578 & 1286.7469 & 644.3807 & 0.0109 & 8.4577 & 6541.575 & 7244.588 & 996.579 & 9486.931 & \text { Yes }\end{array}$ $\begin{array}{lllllllllllllll}0.56 & 23.40 & 24.64 & 25.01 & 2 & 847.5458 & 847.5402 & 424.7774 & 0.0056 & 6.5916 & 28572.533 & 29252.007 & 2785.332 & 38530.303 & \text { Yes }\end{array}$ $\begin{array}{llllllllllllllllll}0.64 & 21.77 & 27.86 & 26.27 & 2 & 847.5406 & 847.5402 & 424.7774 & 0.0004 & 0.4708 & 9564.770 & 11918.281 & 1984.761 & 15206.887 & \text { Yes } \\ 0\end{array}$ $\begin{array}{llllllllllllllllll}0.72 & 18.92 & 27.64 & 19.45 & 2 & 847.5414 & 847.5402 & 424.7774 & 0.0012 & 1.4125 & 4715.841 & 5875.371 & 1509.932 & 10492.862 & \text { No } \\ \end{array}$ 


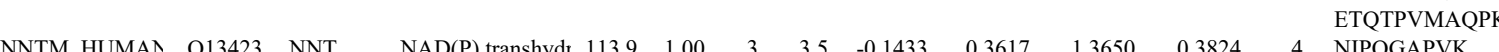

4 NIPQGAPVK NIPQGAPVK SAPLLLPGR

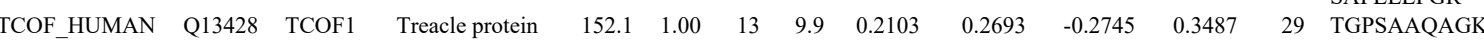
AGAVASQTK

AGAVASQTK

VGDVTPQVK

KGAAPAPPGK

KGAAPAPPGK

TGPAAAQVQVGK

TGPAAAQVQVGK

TGPAAAQVQVGK

TGPAAAQVQVGK

GPASVPSVGK

TGPAAAQVQVGK

TGPAAAQVQVGK

GPASVPSVGK

VGPATPSAQVGK

VGPATPSAQVGK

VGPATPSAQVGK

VGPATPSAQVGK

VGPATPSAQVGK

VGPATPSAQVGK

SPAGPAATPAQAQAASTR

SPAGPAATPAQAQAAS

TNVVTMPTAHPR

TNVTMPTAHPR

TNVTMPTAHPR

TNVVTMPTAHPR

DEPEEELQK

DEPEEELQK

KAEEDAALQAK

GMGTVEGGDQSN

TGPSAAQAGK

\section{GPAPELQGVE}

GPAPELGVEVALAPEELELDPMAMT

\section{KGPAPELLGVVYLLAPELLLDPMAM}

GIEKPPFELPDFIK

GIEKPPFELPDFIK

GIEKPPFELPDFIK

LAEIGAPIOGNR

ISLGMPVGPNAHK

MGTPVPRPPQDMGQIGV
VGEPVALSEEER

QTGIVLNRPVLR

QTGIVLNRPVLR

QTGIVLNRPVLR

QTGIVLNRPVLR

QTGIVLNRPVLR

QTGIVLNPPLR

KPGDLSDELR

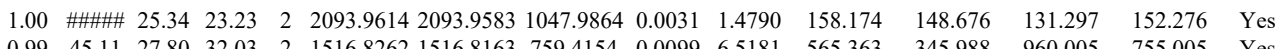
$\begin{array}{llllllllllllllll}0.99 & 45.11 & 27.80 & 32.03 & 2 & 1516.8262 & 1516.8163 & 759.4154 & 0.0099 & 6.5181 & 565.363 & 345.988 & 960.005 & 755.005 & \text { Yes } \\ 0.96 & 24.98 & 24.56 & 20.02 & 2 & 1210.7302 & 1210.7277 & 60.3711 & 0.0025 & 2.0614 & 5337.331 & 4499.387 & 923.292 & 5922.867 & \text { Yes }\end{array}$ $\begin{array}{lllllllllllllll}0.96 & 24.98 & 24.56 & 20.02 & 2 & 1210.7302 & 1210.7277 & 606.3711 & 0.0025 & 2.0614 & 5337.331 & 4499.387 & 923.292 & 5922.867 & \text { Yes } \\ 1.00 & 43.28 & 23.89 & 23.57 & 2 & 1210.7320 & 1210.7277 & 606.3711 & 0.0043 & 3.5457 & 1369.812 & 10109.971 & 1549.879 & 13352.469 & \text { Yes }\end{array}$ $\begin{array}{llllllllllllllll}1.00 & 43.28 & 23.89 & 23.57 & 2 & 1210.7320 & 1210.7277 & 606.371 & 0.0043 & 3.5457 & 13699.812 & 10109.971 & 1549.879 & 13352.469 & \text { Yes } \\ 0.67 & 64.95 & 27.26 & 77.95 & 3 & 2360.2321 & 23602289 & 787.7502 & 0.0032 & 1.3541 & 45.085 & 58.773 & 27.872 & 73.219 & \text { Yes }\end{array}$ $\begin{array}{lllllllllllllll}1.00 & 48.82 & 23.54 & 23.39 & 2 & 1066.6708 & 1066.6620 & 534.3383 & 0.0088 & 8.2344 & 1979.528 & 1630.678 & 302.532 & 1759.781 & \text { Yes }\end{array}$ $\begin{array}{lllllllllllllll}0.99 & 42.38 & 27.62 & 22.40 & 2 & 1174.6554 & 1174.6550 & 588.3348 & 0.0004 & 0.3399 & 44.219 & 50.470 & 31.478 & 45.351 & \text { Yes } \\ 0.99 & 35.01 & 27.89 & 30.48 & 2 & 1119.6498 & 1119.6492 & 560.8319 & 0.0006 & 0.5349 & 46.825 & 45.587 & 31.693 & 58.961 & \text { Yes }\end{array}$

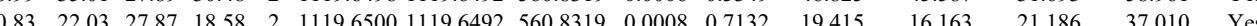
$\begin{array}{lllllllllllllll}0.93 & 31.40 & 25.85 & 29.43 & 2 & 1229.7324 & 1229.7224 & 615.8685 & 0.0100 & 8.1186 & 9392.363 & 13571.603 & 3484.831 & 15288.324 & \text { Yes }\end{array}$ $\begin{array}{lllllllllllllll}0.94 & 31.76 & 25.85 & 29.74 & 2 & 1229.7324 & 1229.7224 & 615.8685 & 0.0100 & 8.1186 & 9620.488 & 13126.432 & 4288.014 & 16330.350 & \text { Yes }\end{array}$

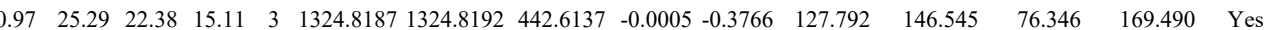
$\begin{array}{lllllllllllllll}0.84 & 15.61 & 22.55 & 15.05 & 3 & 1324.8190 & 1324.8192 & 442.6137 & -0.0002 & -0.1506 & 120.871 & 168.333 & 119.426 & 183.831 & \text { Yes }\end{array}$ $\begin{array}{lllllllllllllll}1.00 & 71.87 & 25.66 & 18.40 & 2 & 1413.8204 & 1413.8184 & 707.9165 & 0.0020 & 1.4126 & 5024.896 & 5855.092 & 5652.717 & 7175.501 & \text { Yes }\end{array}$ $\begin{array}{lllllllllllllll}1.00 & 85.86 & 25.66 & 21.15 & 2 & 1413.8208 & 1413.8184 & 707.9165 & 0.0024 & 1.6951 & 7787.490 & 8664.046 & 10006.675 & 12687.101 & \text { Yes }\end{array}$ $\begin{array}{lllllllllllllllll}0.92 & 17.58 & 25.53 & 14.80 & 3 & 1413.8215 & 1413.8184 & 472.2801 & 0.0031 & 2.1880 & 3199.548 & 2987.542 & 1700.396 & 2952.384 & \text { No }\end{array}$ $\begin{array}{llllllllllllllllll}0.60 & 21.34 & 25.53 & 34.34 & 3 & 1413.8221 & 1413.8184 & 472.2801 & 0.0037 & 2.6114 & 3326.962 & 3883.519 & 2954.725 & 3168.531 & \text { No }\end{array}$

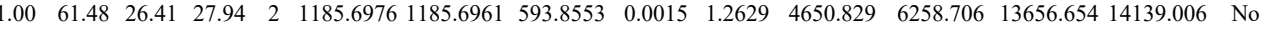
$\begin{array}{lllllllllllllll}1.00 & 55.18 & 26.41 & 29.75 & 2 & 1185.6976 & 1185.6961 & 593.8553 & 0.0015 & 1.2629 & 7442.731 & 8486.206 & 18537.991 & 19905.445 & \text { Yes }\end{array}$ $\begin{array}{lllllllllllllll}1.00 & 70.83 & 26.23 & 20.64 & 2 & 1413.8198 & 1413.8184 & 707.9165 & 0.0014 & 0.9888 & 2744.440 & 3634.921 & 2902.187 & 5840.313 & \text { Yes }\end{array}$ $\begin{array}{lllllllllllllll}1.00 & 10.83 & 26.23 & 20.64 & 2 & 1413.8198 & 1413.8184 & 707.9165 & 0.0014 & 0.988 & 2744.440 & 3634.921 & 2902.187 & 5840.313 & \text { Yes } \\ 1.92 .26 & 26.05 & 17.78 & 3 & 1413.8203 & 1413.8184 & 472.2801 & 0.0019 & 1.3410 & 2764.611 & 2895.406 & 1646.124 & 3247.605 & \text { Yes }\end{array}$ $\begin{array}{llllllllllllllll}1.00 & 50.70 & 26.15 & 28.28 & 2 & 1185.6968 & 1185.6961 & 593.8553 & 0.0007 & 0.5894 & 5759.639 & 6087.281 & 14920.448 & 11079.687 & \text { No }\end{array}$ $\begin{array}{llllllllllllllll}1.00 & 65.28 & 26.41 & 27.69 & 2 & 1398.8082 & 1398.8075 & 700.4110 & 0.0007 & 0.4997 & 10352.425 & 14722.887 & 13088.712 & 21088.109 & \text { Yes }\end{array}$ $\begin{array}{llllllllllllllllll}1.00 & 65.28 & 26.41 & 27.69 & 2 & 13988082 & 1398.8075 & 700.4110 & 0.0007 & 0.4997 & 0352.425 & 14722.887 & 13088.712 & 21088.109 & \text { Yes }\end{array}$ $\begin{array}{lllllllllllllll}1.00 & 7.55 & 26.30 & 27.44 & 2 & 1398.8086 & 1398.8075 & 700.4110 & 0.0011 & 0.7853 & 13811.175 & 21453.116 & 17668.515 & 27528.423 & \text { Yes }\end{array}$ \begin{tabular}{lllllllllllllll}
1.00 & 7.55 & 26.30 & 27.44 & 2 & 1398.8086 & 1398.8075 & 700.410 & 0.0011 & 0.7853 & 13811.175 & 21453.116 & 17668.515 & 27528.423 & Yes \\
\hline
\end{tabular}

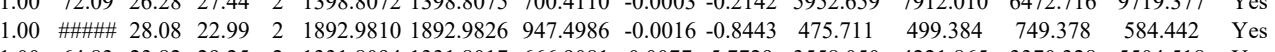

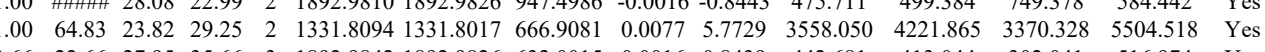
$\begin{array}{lllllllllllllll}1.06 & 22.66 & 27.95 & 35.66 & 3 & 1892.9842 & 1892.9826 & 632.0015 & 0.0016 & 0.8439 & 442.681 & 413.044 & 302.041 & 516.974 & \text { Yes }\end{array}$ $\begin{array}{llllllllllllllll} & \end{array}$ $\begin{array}{lllllllllllllll}99 & 30.87 & 27.99 & 15.85 & 3 & 1482.7753 & 1482.7735 & 495.2651 & 0.0018 & 1.2115 & 63.234 & 46.100 & 43.558 & 88.852 & \text { Yes }\end{array}$ $\begin{array}{llllllllllllllll}1.00 & 41.51 & 28.04 & 20.00 & 3 & 1466.7832 & 1466.7786 & 489.9335 & 0.0046 & 3.1297 & 3824.942 & 4763.793 & 2495.364 & 6028.174 & \text { Yes } \\ 1.00 & 43.00 & 27.13 & 23.00 & 2 & 1403 & 14022 & 1403.723 & 72.8584 & 0.000 & -0.711 & 200.519 & 1599.411 & 1983.776 & 2821.354 & \text { Yes }\end{array}$ $\begin{array}{lllllllllllllll}0.99 & 38.30 & 27.08 & 24.58 & 2 & 14037024 & 14037023 & 702.8584 & 0.0001 & 0.0711 & 1140.329 & 1433.028 & 1612.956 & 2401.038 & \text { Yes }\end{array}$ $\begin{array}{lllllllllllllll}1.00 & 38.41 & 26.47 & 29.79 & 3 & 1604.9116 & 1604.9099 & 535.9772 & 0.0017 & 1.0573 & 3872.145 & 5081.745 & 1267.153 & 7455.055 & \text { No }\end{array}$ $\begin{array}{lllllllllllllll}1.00 & 79.87 & 27.02 & 35.11 & 2 & 1663.8066 & 1663.8079 & 832.9112 & -0.0013 & -0.7804 & 644.029 & 813.814 & 1127.189 & 1047.026 & \text { Yes }\end{array}$

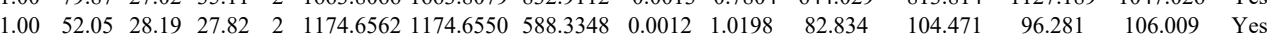
$\begin{array}{lllllllllllllll}1.00 & 20.67 & 26.31 & 33.67 & 4 & 3250.6721 & 3250.6709 & 813.6750 & 0.0012 & 0.3687 & 38.661 & 16.327 & 24.980 & 27.846 & \text { Yes } \\ 1.06\end{array}$

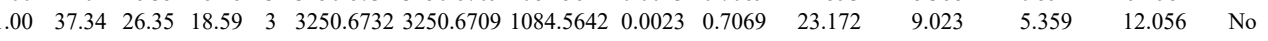
$\begin{array}{lllllllllllllll}1.00 & 47.29 & 23.20 & 60.29 & 4 & 3522.8689 & 3522.8679 & 881.7243 & 0.0010 & 0.2835 & 43.287 & 64.104 & 52.412 & 63.466 & \text { Yes } \\ 1.00 & 77.74 & 23.14 & 20.69 & 4 & 3522.8713 & 3522.8679 & 881.7243 & 0.0034 & 0.9640 & 45.650 & 85.007 & 25.575 & 79.262 & \text { Yes }\end{array}$ $\begin{array}{lllllllllllllll}1.00 & 77.74 & 23.14 & 20.69 & 4 & 3522.8713 & 3522.8679 & 881.7243 & 0.0034 & 0.9640 & 45.650 & 85.007 & 25.575 & 79.262 & \text { Yes } \\ 1.00 & 38.54 & 21.96 & 24.99 & 3 & 2061.1909 & 2061.1876 & 688.0698 & 0.0033 & 1.5987 & 4144.918 & 3659.840 & 4745.764 & 5094.550 & \text { Yes }\end{array}$ $\begin{array}{lllllllllllllll}1.00 & 37.07 & 21.82 & 25.17 & 3 & 2061.1918 & 2061.1876 & 688.0698 & 0.0042 & 2.0347 & 3714.789 & 3891.125 & 4334.991 & 6061.178 & \text { Yes }\end{array}$ $\begin{array}{lllllllllllllll}1.00 & 38.16 & 22.28 & 20.77 & 3 & 2061.1882 & 2061.1876 & 688.0698 & 0.0006 & 0.2907 & 3461.626 & 2937.413 & 4306.964 & 4344.529 & \text { Yes }\end{array}$ $\begin{array}{lllllllllllllll}1.00 & 36.78 & 22.10 & 16.81 & 3 & 2061.1900 & 2061.1876 & 688.0698 & 0.0024 & 1.1627 & 3039.395 & 2657.933 & 3200.672 & 3737.515 & \text { Yes }\end{array}$ $\begin{array}{lllllllllllllll}0.99 & 41.51 & 26.20 & 21.08 & 2 & 1381.7912 & 1381.7799 & 691.8972 & 0.0113 & 8.1659 & 2134.188 & 1958.649 & 1183.381 & 2988.359 & \text { Yes }\end{array}$ $\begin{array}{lllllllllllllll}1.00 & 54.51 & 25.60 & 19.99 & 3 & 1607.9206 & 1607.9061 & 536.9760 & 0.0145 & 9.0009 & 17815.529 & 18694.628 & 5618.481 & 22561.569 & \text { Yes }\end{array}$

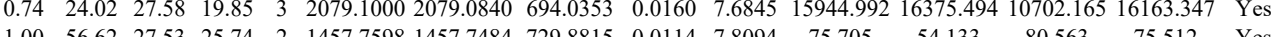

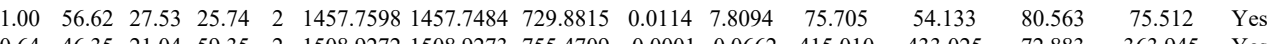

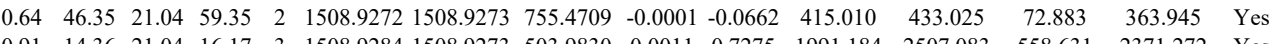
$\begin{array}{llllllllllllllll}0.91 & 14.36 & 21.04 & 16.17 & 3 & 1508.9284 & 1508.9273 & 503.9830 & 0.0011 & 0.7275 & 1991.184 & 2507.083 & 558.631 & 2371.272 & \text { Yes } \\ 0.55 & 12.67 & 21.11 & 25.67 & 3 & 1508.9287 & 1508.9273 & 503.9830 & 0.0014 & 0.9260 & 734.684 & 780.148 & 221.116 & 850.866 & \text { Yes }\end{array}$

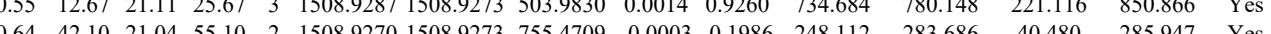

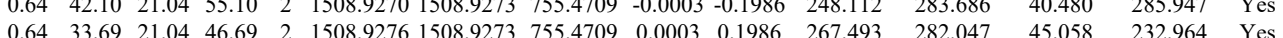

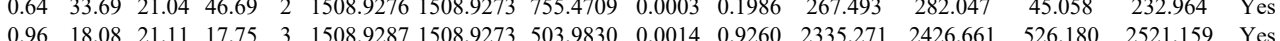
$\begin{array}{lllllllllllllllll}0.97 & 1.84 & 21.11 & 16.39 & 3 & 1508.9287 & 1508.9273 & 503.9830 & 0.0014 & 0.9260 & 1024.574 & 1204.445 & 246.741 & 977.445 & \text { Yes }\end{array}$ $\begin{array}{lllllllllllllll}1.00 & 44.62 & 27.25 & 25.05 & 3 & 1416.7846 & 1416.7816 & 473.2678 & 0.0030 & 2.1130 & 3863.331 & 3351.691 & 9508.655 & 11002.137 & \text { No }\end{array}$ 


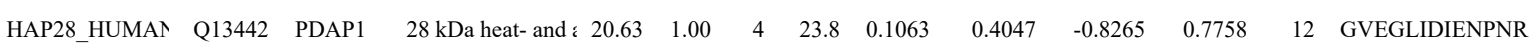

$\begin{array}{lllllllllll}\text { FKBP5_HUMAP } & \text { Q13451 } & \text { FKBP5 } & \text { Peptidyl-prolyl cis 51.212 } & 1.00 & 4 & 8.1 & 0.3982 & 0.2820 & 0.3783 & 1.0187\end{array}$

MYO9B HUMA Q13459 MYO9B Myosin-IXb

$\begin{array}{llllllll}243.56 & 1.00 & 2 & 1.3 & -0.4064 & 0.5372 & 0.0390 & 0.4088\end{array}$

$\begin{array}{llllllllll}\text { PICAL HUMAN Q13492 } & \text { PICALM } & \text { Phosphatidylinosil } 70.755 & 1.00 & 5 & 12 & -0.0960 & 0.1735 & -0.2253 & 0.3538\end{array}$

$\begin{array}{lllllllllll}\text { TBB3_HUMAN } & \text { Q13509 } & \text { TUBB3 } & \text { Tubulin beta-3 ch` } 50.433 & 1.00 & 2 & 38.4 & -0.5059 & 0.4882 & 0.0188 & 0.5675\end{array}$

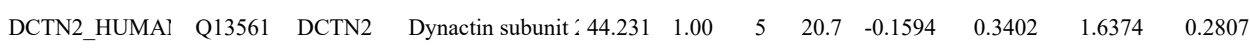
GVEGLIDIENPNR GVEGLIDIENPNR GVEGLIDIENPNR VAQTTK MQSLSLNK MQSLSLNK $\begin{array}{lllllllllllll} & 0.86 & 34.32 & 27.05 & 35.09 & 2 & 1207.6902 & 1207.6838 & 604.8492 & 0.0064 & 5.2905 & 7059.574 & 7280 \\ \text { QYTSPEEIDAQLQAEK } & 1.00 & 86.73 & 27.90 & 25.59 & 2 & 2137.0774 & 2137.0782 & 1069.5464 & -0.0008 & -0.3740 & 295.068 & 43 . \\ \text { QYTSPEEIDAQLQAEK } & 1.00 & 92.37 & 27.90 & 28.16 & 2 & 2137.0794 & 2137.0782 & 1069.5464 & 0.0012 & 0.5610 & 220.186 & \\ \end{array}$

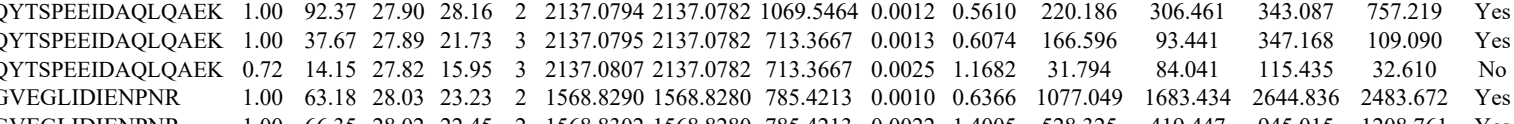
GVEGLDIENPNR GVGLIDIENPNR

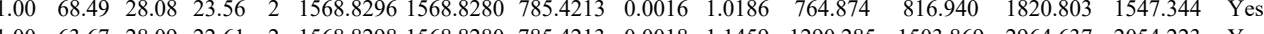
$\begin{array}{lllllllllllllll}1.00 & 63.67 & 28.09 & 22.61 & 2 & 1568.8298 & 1568.8280 & 785.4213 & 0.0018 & 1.1459 & 1290.285 & 1503.869 & 2964.637 & 2054.223 & \text { Yes } \\ 1.00 & 73.87 & 27.91 & 19.68 & 2 & 1568.8280 & 1568.8280 & 785.4213 & 0.0000 & 0.0000 & 42.555 & 41.634 & 64.901 & 28.717 & \text { Yes }\end{array}$

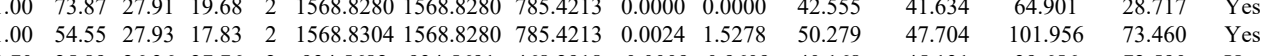

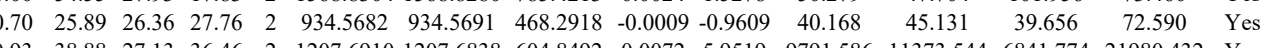

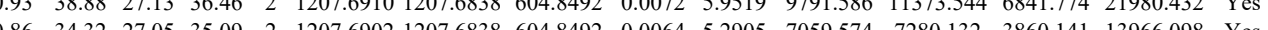
$\begin{array}{llllllllllllllll}0.86 & 34.32 & 27.05 & 35.09 & 2 & 1207.6902 & 1207.6838 & 604.8492 & 0.0064 & 5.2905 & 7059.574 & 7280.132 & 3860.141 & 13966.098 & \text { Yes }\end{array}$ $\begin{array}{llllllllllllllll} & \\ \text { ENPNR } & 1.00 & 63.18 & 28.03 & 23.23 & 2 & 1568.8290 & 1568.8280 & 785.4213 & 0.0010 & 0.6366 & 1077.049 & 1683.434 & 2644.836 & 2483.672 & \text { Yes } \\ \text { ENPNR } & 1.00 & 66.35 & 28.02 & 22.45 & 2 & 1568.8302 & 1568.8280 & 785.4213 & 0.0022 & 1.4005 & 528.325 & 419.447 & 945.015 & 1208.761 & \text { Yes } \\ \text { MNEFESAK } & 1.00 & 50.71 & 27.47 & 22.29 & 3 & 2010.0466 & 2010.0448 & 671.0222 & 0.0018 & 0.8942 & 754.264 & 743.895 & 154.755 & 985.584 & \text { Yes }\end{array}$ $\begin{array}{llllllllllllllllllll} & & \end{array}$ $\begin{array}{llllllllllllllll} & 0.99 & 30.66 & 26.58 & 16.23 & 3 & 1484.8366 & 1484.8353 & 495.9524 & 0.0013 & 0.8737 & 34717.828 & 48681.610 & 8861.773 & 10215.118 & \text { Yes }\end{array}$

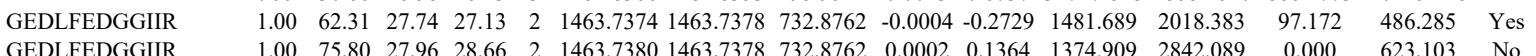

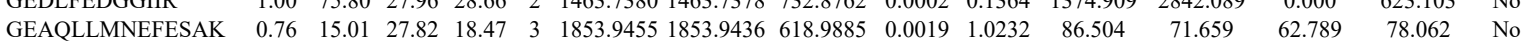
$\begin{array}{llllllllllllllll}\text { EEGLEVGPPEVLDTLSQLLK } & 1.00 & 81.62 & 23.67 & 21.63 & 3 & 2453.3557 & 2453.3508 & 818.7909 & 0.0049 & 1.9948 & 29.504 & 15.332 & 20.976 & 21.393 & \text { Yes }\end{array}$ $\begin{array}{llllllllllllllll}\text { EEGLEVGPPEVLDTLSQLLK } & 1.00 & 55.44 & 23.62 & 21.96 & 3 & 2453.3560 & 2453.3508 & 818.7909 & 0.0052 & 2.1169 & 17.315 & 13.013 & 11.866 & 18.718 & \text { Yes }\end{array}$

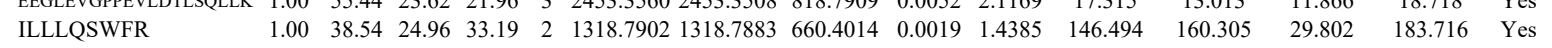
$\begin{array}{llllllllllllllll}\text { QAALEEEQAR } & 0.99 & 40.35 & 27.08 & 22.00 & 2 & 1287.6538 & 1287.6540 & 644.8343 & -0.0002 & -0.1551 & 73.154 & 58.367 & 7.468 & 92.158 & \text { Yes }\end{array}$

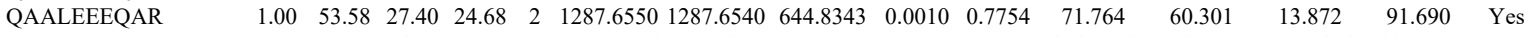

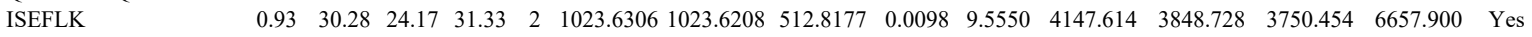
$\begin{array}{lllllllllllllllll}\text { ITAAQHSVTGSAVSK } & 1.00 & 60.53 & 26.60 & 18.62 & 3 & 1743.9733 & 1743.9723 & 582.3314 & 0.0010 & 0.5724 & 7010.371 & 5791.954 & 7655.028 & 7809.519 & \text { Yes }\end{array}$ $\begin{array}{lllllllllllllllll}\text { ITAAQHSVTGSAVSK } & 0.55 & 62.27 & 26.60 & 75.27 & 3 & 1743.9733 & 1743.9723 & 582.3314 & 0.0010 & 0.5724 & 8289.944 & 8054.942 & 7089.778 & 7954.072 & \text { Yes }\end{array}$

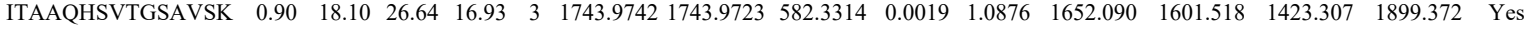
$\begin{array}{llllllllllllllllll}0.67 & 69.60 & 25.65 & 82.60 & 3 & 3091.6312 & 3091.6281 & 1031.5500 & 0.0031 & 1.0017 & 178.877 & 205.934 & 385.155 & 322.957 & \text { Yes }\end{array}$ $\begin{array}{llllllllllllllll}\text { GDPDLSQAPSSLDALEOHLASLEGK } & 0.67 & 69.75 & 25.65 & 82.75 & 3 & 3091.6312 & 3091.6281 & 1031.5500 & 0.0031 & 1.0017 & 198.121 & 210.648 & 212.992 & 279.311 & \text { Yes }\end{array}$

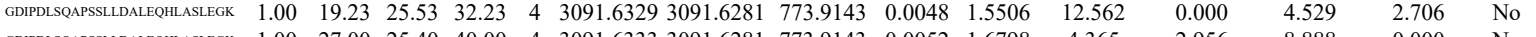
$\begin{array}{llllllllllllllll}\text { GDPPLSAAPSSLDALEOHLASLEGK } & 1.00 & 27.00 & 25.40 & 40.00 & 4 & 3091.6333 & 3091.6281 & 773.9143 & 0.0052 & 1.6798 & 4.365 & 2.956 & 8.888 & 0.000 & \text { No }\end{array}$ $\begin{array}{llllllllllllllll} & \end{array}$ $\begin{array}{lllllllllllllll} & & & \end{array}$

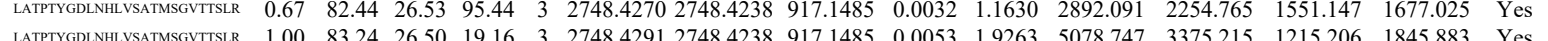

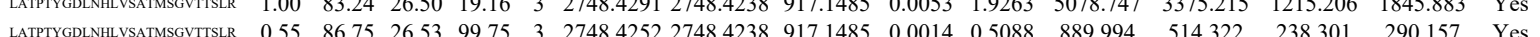
$\begin{array}{llllllllllllllll} & \end{array}$

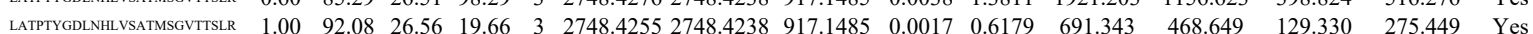

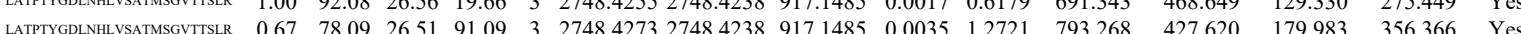

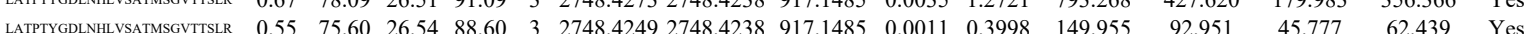
$\begin{array}{lllllllllllllll} & \end{array}$

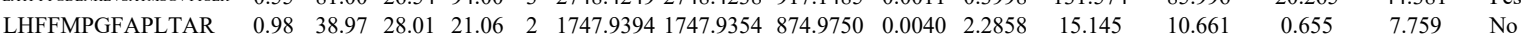
$\begin{array}{llllllllllllllll}\text { LHFFMPGFAPLTAR } & 0.95 & 23.21 & 28.08 & 16.08 & 3 & 1763.9344 & 1763.9303 & 588.9840 & 0.0041 & 2.3204 & 278.717 & 265.958 & 75.710 & 122.337 & \text { Yes }\end{array}$

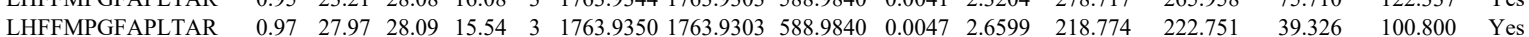

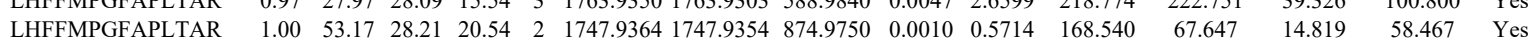
$\begin{array}{llllllllllllllll}\text { LHFFMPGFAPLTAR } & 1.00 & 55.27 & 28.14 & 20.43 & 2 & 1747.9372 & 1747.9354 & 874.9750 & 0.0018 & 1.0286 & 252.094 & 105.660 & 19.131 & 99.701 & \text { Yes }\end{array}$

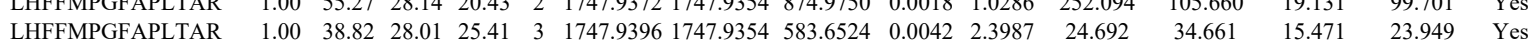
$\begin{array}{llllllllllllllll}\text { LHFFMPGFAPLTAR } & 0.97 & 31.30 & 27.95 & 25.66 & 3 & 1747.9420 & 1747.9354 & 583.6524 & 0.0066 & 3.7694 & 46.196 & 22.519 & 7.728 & 27.967 & \text { Yes }\end{array}$

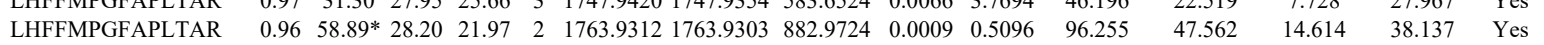

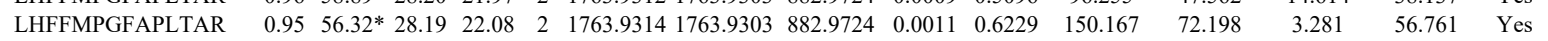
$\begin{array}{lllllllllllllllllll}\text { LHFFMPGFAPLTAR } & 1.00 & 45.08 & 28.05 & 22.73 & 3 & 1763.9332 & 1763.9303 & 588.9840 & 0.0029 & 1.6412 & 137.681 & 95.733 & 70.752 & 90.999 & \text { Yes }\end{array}$ $\begin{array}{llllllllllllllll}\text { LHFFMPGFAPLTAR } & 1.00 & 36.80 & 28.05 & 25.42 & 3 & 1763.9332 & 1763.9303 & 588.9840 & 0.0029 & 1.6412 & 100.303 & 104.064 & 56.714 & 81.704 & \text { Yes }\end{array}$ $\begin{array}{llllllllllllllll}\text { LHFFMPGFAPLTAR } & 0.67 & 35.20 & 27.99 & 48.20 & 3 & 1747.9381 & 1747.9354 & 583.6524 & 0.0027 & 1.5420 & 30.125 & 37.165 & 22.253 & 61.575 & \text { No }\end{array}$ $\begin{array}{llllllllllllllll}\text { LHFFMPGFAPLTAR } & 0.99 & 28.15 & 28.06 & 15.64 & 3 & 1747.9387 & 1747.9354 & 583.6524 & 0.0033 & 1.8847 & 52.934 & 57.287 & 26.730 & 56.179 & \text { Yes }\end{array}$ $\begin{array}{lllllllllllllllll}\text { LHFFMPGFAPLTAR } & 0.99 & 30.89 & 28.01 & 21.82 & 3 & 1747.9384 & 1747.9354 & 583.6524 & 0.0030 & 1.7133 & 22.331 & 48.290 & 9.792 & 27.747 & \text { No }\end{array}$ $\begin{array}{llllllllllllllll}\text { LHFFMPGFAPLTAR } & 0.99 & 29.57 & 28.01 & 22.40 & 3 & 1747.9396 & 1747.9354 & 583.6524 & 0.0042 & 2.3987 & 58.151 & 41.362 & 12.046 & 29.353 & \text { Yes }\end{array}$

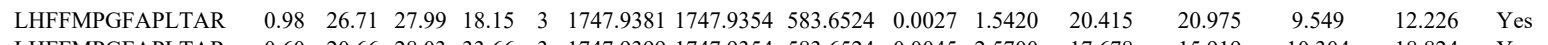
$\begin{array}{llllllllllllllll}\text { LHFFMPGFAPLTAR } & 0.60 & 20.66 & 28.03 & 33.66 & 3 & 1747.9399 & 1747.9354 & 583.6524 & 0.0045 & 2.5700 & 17.678 & 15.919 & 10.304 & 18.824 & \text { Yes }\end{array}$ $\begin{array}{llllllllllllllll}\text { LHFFMPGFAPLTAR } & 0.66 & 25.60 & 28.14 & 38.60 & 3 & 1747.9375 & 1747.9354 & 583.6524 & 0.0021 & 1.1993 & 14.243 & 30.775 & 20.381 & 15.268 & \text { No }\end{array}$ $\begin{array}{llllllllllllllll}\text { LHFFMPGFAPLTAR } & 0.80 & 17.13 & 27.99 & 17.28 & 3 & 1747.9390 & 1747.9354 & 583.6524 & 0.0036 & 2.0560 & 25.209 & 17.913 & 17.638 & 7.352 & \text { No }\end{array}$

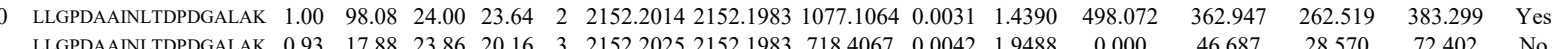
$\begin{array}{llllllllllllllll}\text { LLGPDAAINLTDPDGALAK } & 0.93 & 17.88 & 23.86 & 20.16 & 3 & 2152.2025 & 2152.1983 & 718.4067 & 0.0042 & 1.9488 & 0.000 & 46.687 & 28.570 & 72.402 & \text { No }\end{array}$

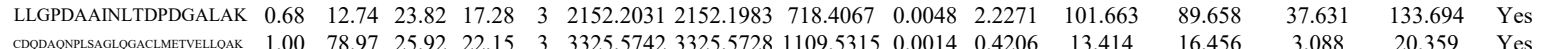
$\begin{array}{llllllllllllll} & & & \end{array}$

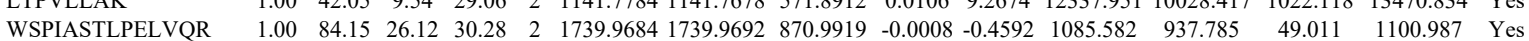
$\begin{array}{llllllllllllllll}\text { WSPIASTLPELVR } & 1.00 & 84.15 & 26.12 & 30.28 & 2 & 1739.9684 & 1739.9692 & 870.9919 & -0.0008 & -0.4592 & 1085.582 & 937.785 & 49.011 & 1100.987 & \text { Yes } \\ \text { WSPIASTLPELVQR } & 1.00 & 88.62 & 25.97 & 28.98 & 2 & 1739.9694 & 1739.9692 & 870.9919 & 0.0002 & 0.1148 & 395.983 & 226.166 & 13.901 & 403.156 & \text { Yes }\end{array}$

Table S-4 page 464 of 614 


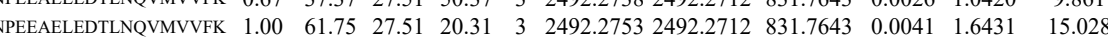
QIGLDQIWDDLR

2 LGPLLDILADSR $\begin{array}{rrrrrrrrrrr}1.00 & 70.89 & 24.77 & 25.15 & 2 & 1425.8340 & 1425.8313 & 713.9229 & 0.0027 & 1.8910 & 276.989\end{array}$ $\begin{array}{lllllllllllll}\text { LAGSLLTQALESHAEGFR } & 0.60 & 79.15 & 27.30 & 92.15 & 3 & 2043.0913 & 2043.0871 & 682.0363 & 0.0042 & 2.0527 & 813.481\end{array}$ $\begin{array}{llllllllllllll}\text { LAGSLLTQALESHAEGFR } & 1.00 & 90.53 & 27.30 & 21.05 & 3 & 2043.0913 & 2043.0871 & 682.0363 & 0.0042 & 2.0527 & 696.281 & & \\ \text { LGPLLDILADSR } & 1.00 & 5.97 & 24.77 & 19.11 & 2 & 142.8340 & 142.8313 & 713.922 & 0.0027 & 1.8910 & 213.266\end{array}$

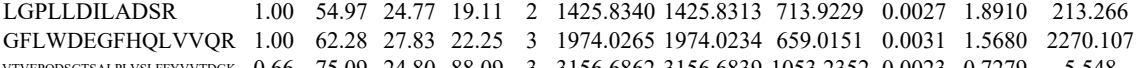
$\begin{array}{llllllllllll}\text { VTVEPQDGGTSAPLVSLFFYVTDGK } & 0.66 & 75.09 & 24.80 & 88.09 & 3 & 3156.6862 & 3156.6839 & 1053.2352 & 0.0023 & 0.7279 & 5.548\end{array}$

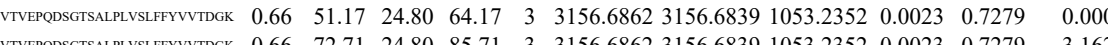
$\begin{array}{lllllllllllll}\text { VIVEPRSGGISALPVSLFFYVVTDGK } & 0.66 & 72.71 & 24.80 & 85.71 & 3 & 3156.6862 & 3156.6839 & 1053.2352 & 0.0023 & 0.7279 & 3.162\end{array}$ $\begin{array}{lllllllllllll} & \end{array}$ $\begin{array}{lllllllllllll} & \end{array}$ $\begin{array}{llllllllllllll}\text { VDPALFPPVPLFTAVPSR } & 1.00 & 70.89 & 23.77 & 19.62 & 2 & 2066.1694 & 2066.1687 & 1034.0916 & 0.0007 & 0.3385 & 392.649 & \\ \text { VDPALFPPVPLFTAVPSR } & 0.82 & 54.35 & 23.77 & 67.35 & 2 & 2066.1694 & 2066.1687 & 1034.0916 & 0.0007 & 0.3385 & 798.309 & 63\end{array}$ $\begin{array}{lllllllllllll}\text { DDPALFPPVPLFTAVPSR } & 0.82 & 54.35 & 23.77 & 67.35 & 2 & 2066.1694 & 2066.1687 & 1034.0916 & 0.0007 & 0.3385 & 798.309 \\ \text { VDPALFPPVPLFTAVPS } & 1.00 & 49.16 & 23.60 & 16.59 & 3 & 2066.1715 & 2066.1687 & 689.7302 & 0.0028 & 1.3532 & 72.502\end{array}$ $\begin{array}{llllllllllllll} & \text { VDPALFPPVPLFTAVPSR } & 1.00 & 49.16 & 23.60 & 16.59 & 3 & 2066.1715 & 2066.1687 & 689.7302 & 0.0028 & 1.3532 & 72.502\end{array}$ $\begin{array}{lllllllllllllll}\text { NDPALFPPVPLFTAVPSR } & 0.60 & 35.16 & 23.54 & 48.16 & 3 & 2066.1730 & 2066.1687 & 689.7302 & 0.0043 & 2.0781 & 107.704 \\ \text { VDPALFPPVPLFTAVPSR } & 0.60 & 18.46 & 23.54 & 31.46 & 3 & 2066.1730 & 2066.1687 & 689.7302 & 0.0043 & 2.0781 & 77.784\end{array}$ CWVALGAR CWVALGAR CWVALGAR

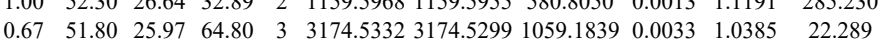
$\begin{array}{lllllllllllll} & \end{array}$

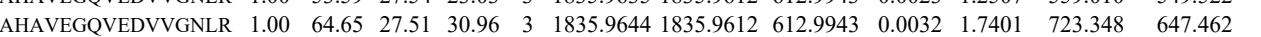

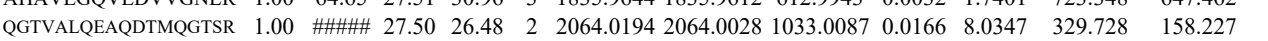

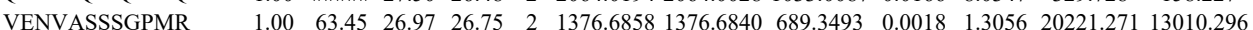
VENVASSSGPMR

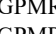
IQEVGEITNLR

$\begin{array}{lllllllllllll}1.00 & 63.45 & 26.97 & 26.75 & 2 & 1376.6858 & 1376.6840 & 689.3493 & 0.0018 & 1.3056 & 20221.271 & 13010.296\end{array}$ $\begin{array}{llllllllllll}1.00 & 66.91 & 27.14 & 36.98 & 2 & 1414.7912 & 1414.7902 & 708.4024 & 0.0010 & 0.7058 & 1524.188 & 879.935 \\ 1.00 & 72.81 & 24.07 & 22.35 & 2 & 2408.3294 & 2408.3284 & 1205.1715 & 0.0010 & 0.4149 & 167.658 & 120.417\end{array}$ $\begin{array}{lrlllllllllllll}\text { TLQGLQLDLPLEEETLSLPR } & 1.00 & 72.81 & 24.07 & 22.35 & 2 & 2408.3294 & 2408.3284 & 1205.1715 & 0.0010 & 0.4149 & 167.658 & 120.417\end{array}$ $\begin{array}{llllllllllllll}\text { TLQGLQLDLPLEEETLSLPR } & 1.00 & 67.01 & 24.07 & 26.11 & 2 & 2408.3294 & 2408.3284 & 1205.1715 & 0.0010 & 0.4149 & 170.456 & 96.277\end{array}$

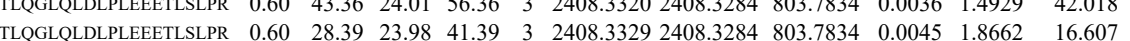
$\begin{array}{lllllllllllll}\text { LGQSSMLGEQGAR } & 1.00 & 67.81 & 28.38 & 35.70 & 2 & 1476.7600 & 1476.7477 & 739.3811 & 0.0123 & 8.3177 & 9220.930 & 5789.475\end{array}$ $\begin{array}{llllllllllllll}\text { TLQGLQLDLPLEEETLSLPR } & 0.67 & 21.94 & 24.12 & 34.94 & 3 & 2408.3314 & 2408.3284 & 803.7834 & 0.0030 & 1.2441 & 160.484 & 164.945\end{array}$

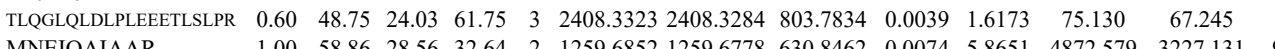
$\begin{array}{lllllllllllllll} & \text { MNEIQAIAAR } & 1.00 & 58.86 & 28.56 & 32.64 & 2 & 1259.6852 & 1259.6778 & 630.8462 & 0.0074 & 5.8651 & 4872.579 & 3227.131 & 992.1\end{array}$ $\begin{array}{lllllllllllll}\text { MNEIQAIAAR } & 1.00 & 59.38 & 28.41 & 26.67 & 2 & 1259.6864 & 1259.6778 & 630.8462 & 0.0086 & 6.8162 & 2316.185 & \end{array}$ $\begin{array}{llllllllllllll}\text { WQSQNDVNPVSLQLDLDR } & 0.72 & 96.19 & 27.42 & \text { \#\#\# } & 2 & 2456.2234 & 2456.2206 & 1229.1176 & 0.0028 & 1.1390 & 38.002 & 18.874 \\ \text { VLLNLMDLVSGIPATQSQK } & 1.00 & 53.31 & 24.28 & 19.11 & 3 & 2329.2955 & 2329.2919 & 777.4379 & 0.0036 & 1.5435 & 140.219 & 66.097\end{array}$ $\begin{array}{lllllllllllll}\text { VQLNLMDLVSGIPATQSQK } & 1.00 & 53.31 & 24.28 & 19.11 & 3 & 2329.2955 & 2329.2919 & 777.4379 & 0.0036 & 1.5435 & 140.219 & 66.097 \\ \text { VQLNLMDLVSGIPATQSQK } & 0.99 & 28.00 & 24.20 & 15.39 & 3 & 2329.2964 & 2329.2919 & 777.4379 & 0.0045 & 1.9294 & 104.092 & 94.413\end{array}$ $\begin{array}{lllllllllllll} & & \end{array}$ $\begin{array}{llllllllllll} & 22.67 & 32.64 & 2 & 2582.4414 & 2582.4401 & 1292.2273 & 0.0013 & 0.5030 & 10.445\end{array}$ $\begin{array}{lllllllllllll}\text { AVLSSPAVTEQEVAQVASAALSLR } & 1.00 & 45.90 & 22.60 & 18.24 & 3 & 2582.4439 & 2582.4401 & 861.8206 & 0.0038 & 1.4698 & 6.692\end{array}$

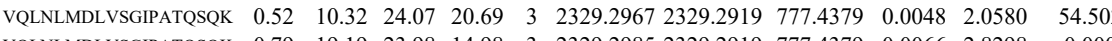

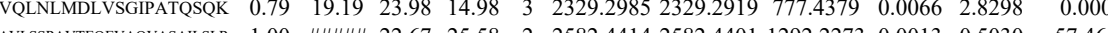

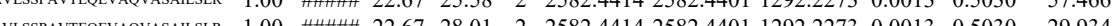
$\begin{array}{lllllllllllll} & \text { Avs }\end{array}$ $\begin{array}{lllllllllllllll}\text { AVLSSPAVTFEEVAQVASAIISLR } & 1.00 & 37.45 & 22.55 & 20.36 & 4 & 2582.4441 & 2582.4401 & 646.6173 & 0.0040 & 1.5465 & 88.830\end{array}$ $\begin{array}{llllllllllllll}\text { AVLSPAVTEEEVAQVASALSLLR } & 1.00 & 25.33 & 22.41 & 38.33 & 4 & 2582.4449 & 2582.4401 & 646.6173 & 0.0048 & 1.8558 & 85.629\end{array}$ 


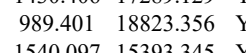

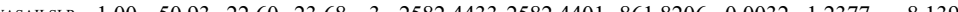
$\begin{array}{llllllllllllll} & 33.652 & \text { Yes }\end{array}$ $\begin{array}{llllllllllllllll} & \end{array}$ $\begin{array}{lllllllllllllllll}\text { TEAEELFGETMEMMDR } & 1.00 & 39.92 & 22.07 & 19.14 & 3 & 2061.8848 & 2061.8815 & 688.3011 & 0.0033 & 1.5981 & 60.147 & 25.997 & 66.735 & 42.246 & \text { No }\end{array}$

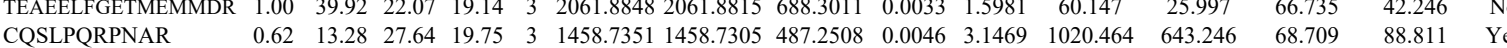
$\begin{array}{llllllllllllllll}\text { CQSLPQRPNAR } & 0.56 & 14.53 & 27.66 & 16.88 & 3 & 1458.7354 & 1458.7305 & 487.2508 & 0.0049 & 3.3521 & 1331.721 & 778.479 & 71.862 & 75.304 & \text { No }\end{array}$ $\begin{array}{lllllllllllllll}\text { AAEESASOIQSSAQR } & 1.00 & \text { \#\#\#\# } 27.22 & 32.19 & 2 & 1705.8368 & 1705.8353 & 853.9249 & 0.0015 & 0.8783 & 5279.832 & 2514.661 & 1122.994 & 2705.918 & \text { Yes }\end{array}$

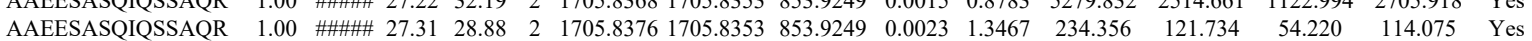

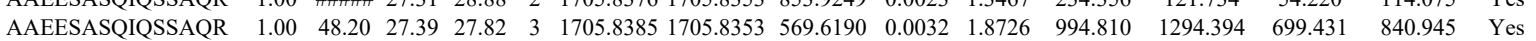
$\begin{array}{lllllllllllllllll}\text { AAEESASQIQSSAQR } & 0.81 & 16.81 & 27.42 & 15.48 & 3 & 1705.8394 & 1705.8353 & 569.6190 & 0.0041 & 2.3993 & 739.032 & 680.633 & 478.175 & 535.779 & \text { Yes }\end{array}$ $\begin{array}{lllllllllllllll}\text { AAEESASQIQSSAQR } & 1.00 & \text { \#\#\#\# } 27.36 & 28.50 & 2 & 1705.8384 & 1705.8353 & 853.9249 & 0.0031 & 1.8151 & 2918.866 & 1483.147 & 766.664 & 1397.412 & \text { Yes }\end{array}$ $\begin{array}{llllllllllllllll}\text { AAEESASQIQSSAQR } & 1.00 & 42.25 & 27.38 & 23.42 & 3 & 1705.8391 & 1705.8353 & 569.6190 & 0.0038 & 2.2237 & 1221.954 & 1346.200 & 1078.226 & 1731.227 & \text { Yes }\end{array}$ $\begin{array}{lllllllllllllllll}\text { AAEESASQIQSSAQR } & 0.60 & 21.05 & 27.46 & 34.05 & 3 & 1705.8397 & 1705.8353 & 569.6190 & 0.0044 & 2.5748 & 1235.106 & 1038.300 & 943.454 & 1128.998 & \text { Yes }\end{array}$

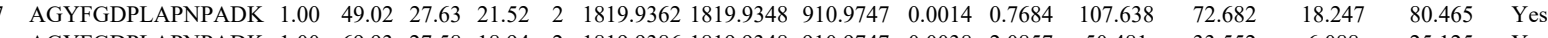

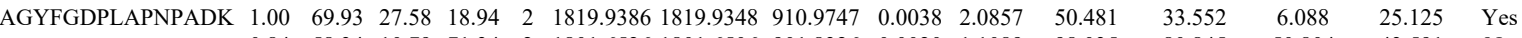

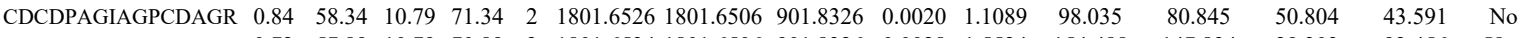

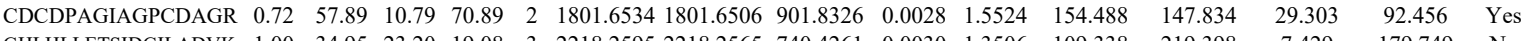

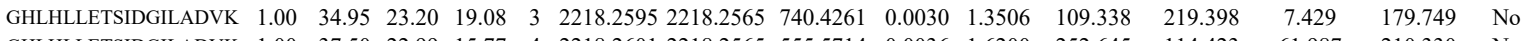

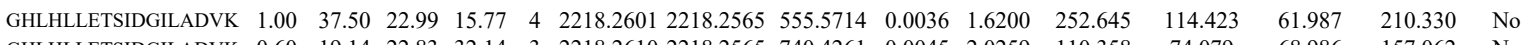
$\begin{array}{llllllllllllllll}\text { GHLHLLETSIDGILADVK } & 0.60 & 19.14 & 22.83 & 32.14 & 3 & 2218.2610 & 2218.2565 & 740.4261 & 0.0045 & 2.0259 & 110.358 & 74.079 & 68.986 & 157.062 & \text { No }\end{array}$

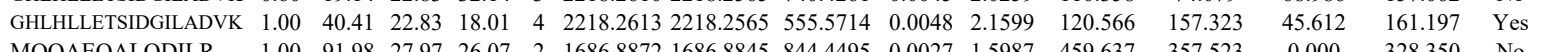

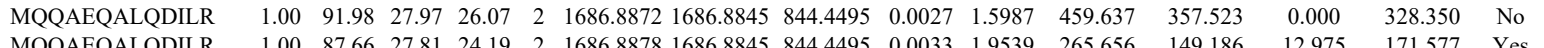

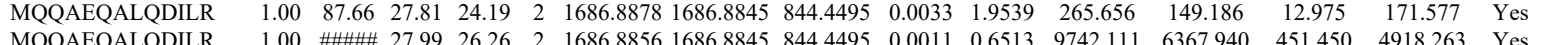

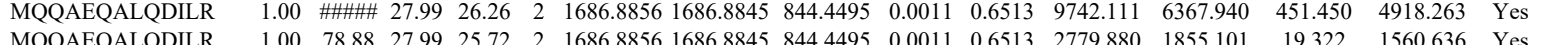

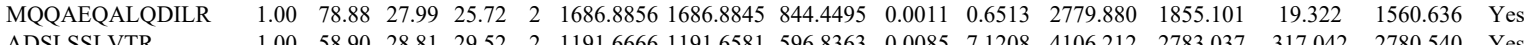

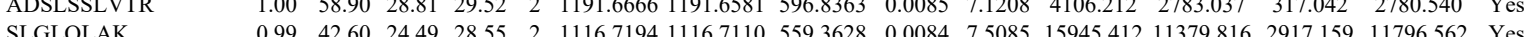

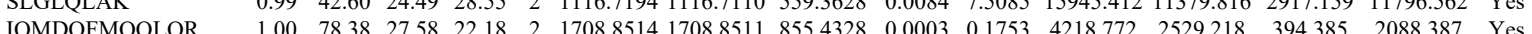

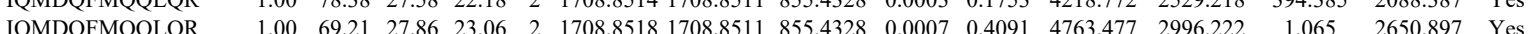

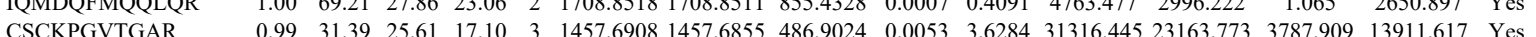
$\begin{array}{llllllllllllllllll} & \text { CSCKPGVTGAR } & 1.00 & 31.13 & 25.44 & 19.24 & 3 & 145.6899 & 1457.6855 & 486.9024 & 0.0044 & 3.0122 & 24736.351 & 18479.586 & 3006.552 & 12414.872 & \text { Yes }\end{array}$ $\begin{array}{lllllllllllllllll} & \text { CSCKPGVAR } & 1.00 & 31.13 & 25.44 & 19.24 & 3 & 1457.6899 & 1457.6855 & 486.924 & 0.0044 & 3.0122 & 24736.351 & 18479.586 & 3006.552 & 12414.872 & \text { Yes } \\ \text { CSCKPGVTGAR } & 0.93 & 21.56 & 25.61 & 14.61 & 3 & 1457.6908 & 1457.6855 & 486.9024 & 0.0053 & 3.6284 & 6187.636 & 4460.020 & 1246.817 & 3501689 & \text { Yes }\end{array}$

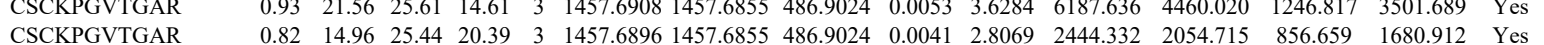

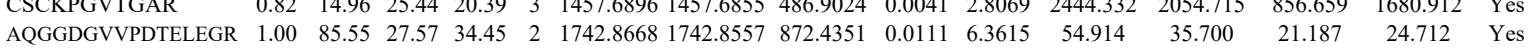
$\begin{array}{llllllllllllllll}\text { AQGGDGVVPDTLEGR } & 1.00 & 85.55 & 27.57 & 34.45 & 2 & 1742.8668 & 1742.8557 & 872.4351 & 0.0111 & 6.3615 & 54.914 & 35.700 & 21.187 & 24.712 & \text { Yes } \\ \text { AQGGDGVVPDTELEGR } & 1.00 & 79.71 & 27.66 & 27.34 & 2 & 1742.8678 & 1742.8557 & 872.4351 & 0.0121 & 6.9346 & 72.793 & 59.264 & 39.876 & 34.243 & \text { No }\end{array}$

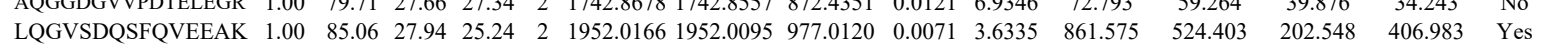

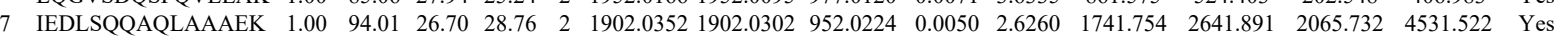
$\begin{array}{llllllllllllllll}\text { IEDLSQQAQLAAAEK } & 1.00 & 91.23 & 26.68 & 27.53 & 2 & 1902.0356 & 1902.0302 & 952.0224 & 0.0054 & 2.8361 & 1648.865 & 1900.467 & 1307.825 & 4193.328 & \text { Yes }\end{array}$ $\begin{array}{lllllllllllllllll}\text { IEDLSQQAQLAAAEK } & 1.00 & 45.60 & 26.78 & 22.98 & 3 & 1902.0370 & 1902.0302 & 635.0173 & 0.0068 & 3.5694 & 3205.970 & 3419.446 & 1656.904 & 4625.813 & \text { Yes }\end{array}$ $\begin{array}{lllllllllllllllll}\text { IEDLSQQAQLAAAEK } & 1.00 & 49.17 & 26.78 & 29.56 & 3 & 1902.0370 & 1902.0302 & 635.0173 & 0.0068 & 3.5694 & 2887.148 & 3097.095 & 833.861 & 4067.996 & \text { Yes }\end{array}$ $\begin{array}{lllllllllllllllll}\text { SPASDTYIVFGEAK } & 1.00 & 78.54 & 27.97 & 25.13 & 2 & 1771.9242 & 1771.9236 & 886.9691 & 0.0006 & 0.3382 & 227.420 & 196.882 & 1103.162 & 809.115 & \text { No }\end{array}$ $\begin{array}{llllllllllllllll}\text { SPASDTYIVFGEAK } & 1.00 & 79.30 & 27.99 & 22.92 & 2 & 1771.9250 & 1771.9236 & 886.9691 & 0.0014 & 0.7892 & 801.944 & 916.521 & 2214.402 & 2575.886 & \text { Yes }\end{array}$

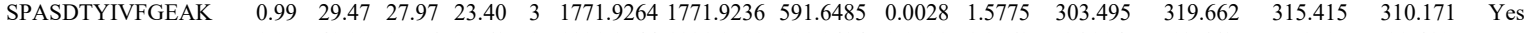

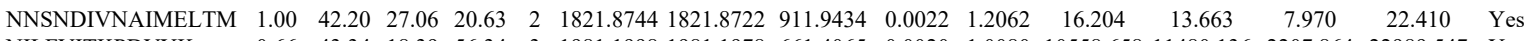

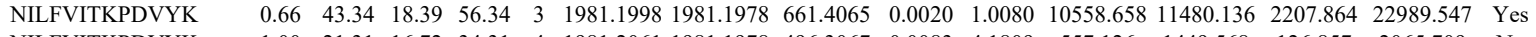
$\begin{array}{llllllllllllllll}\text { NILFVITKPDVYK } & 1.00 & 21.31 & 16.72 & 34.31 & 4 & 1981.2061 & 1981.1978 & 496.3067 & 0.0083 & 4.1809 & 557.126 & 1449.568 & 126.857 & 2065.709 & \text { No }\end{array}$

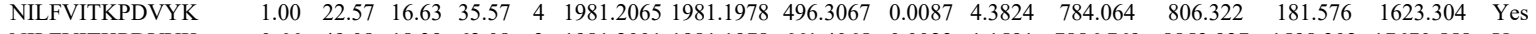
$\begin{array}{llllllllllllllll}\text { NILFVITKPDVYK } & 0.66 & 49.08 & 18.39 & 62.08 & 3 & 1981.2001 & 1981.1978 & 661.4065 & 0.0023 & 1.1591 & 7886.769 & 8853.927 & 1598.302 & 17670.558 & \text { Yes }\end{array}$ $\begin{array}{llllllllllllllll}\text { NILFVITKPDVYK } & 0.66 & 56.61 & 18.39 & 69.61 & 3 & 1981.2001 & 1981.1978 & 661.4065 & 0.0023 & 1.1591 & 12905.396 & 15118.521 & 3722.863 & 31931.448 & \text { Yes }\end{array}$

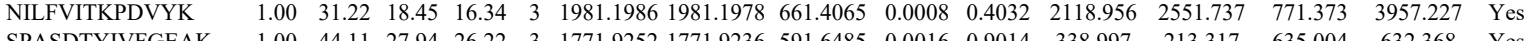
\begin{tabular}{lllllllllllllllll} 
& SPASDTYIVFGEAK & 1.00 & 44.11 & 27.94 & 26.22 & 3 & 1771.9252 & 1771.9236 & 591.6485 & 0.0016 & 0.9014 & 338.997 & 213.317 & 635.004 & 632.368 & Yes \\
\hline
\end{tabular}

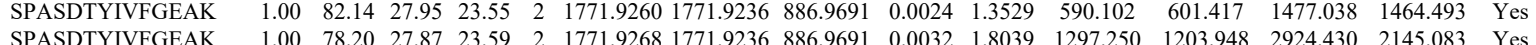
$\begin{array}{lllllllllllllllll}\text { SPASDTYIVFEAK } & 1.00 & 78.20 & 27.87 & 23.59 & 2 & 1771.9268 & 1771.9236 & 886.9691 & 0.0032 & 1.8039 & 1297.250 & 1203.948 & 2924.430 & 2145.083 & \text { Yes } \\ \text { SPASDTYIVFGEAK } & 0.99 & 31.15 & 27.90 & 16.24 & 3 & 1771.9276 & 1771.9236 & 591.6485 & 0.0040 & 2.2536 & 268.641 & 168.576 & 529.499 & 364.960 & \text { Yes }\end{array}$ $\begin{array}{lllllllllllllllll}\text { IEDLSQQAQLAAAEK } & 1.00 & 90.42 & 26.91 & 29.48 & 2 & 1902.0318 & 1902.0302 & 952.0224 & 0.0016 & 0.8403 & 406.679 & 538.242 & 590.498 & 765.190 & \text { Yes }\end{array}$

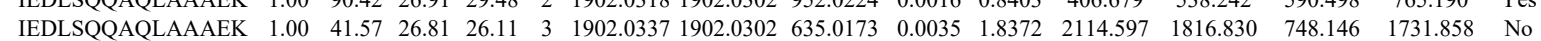

Table S-4 page 466 of 614 

$\begin{array}{llllllllllll}\text { ALINADELASDVAGAEALLDR } & 1.00 & 49.34 & 27.20 & 20.24 & 3 & 2270.1919 & 2270.1875 & 757.7364 & 0.0044 & 1.9356 & 8.678\end{array}$ $\begin{array}{lllllllllllll} & \text { NADELASDVAGAEALLDR } & 1.00 & 57.66 & 27.20 & 22.20 & 3 & 2270.1919 & 2270.1875 & 757.7364 & 0.0044 & 1.9356 & 6.856\end{array}$ DLMSWINGIR

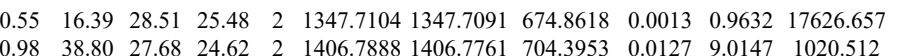
$\begin{array}{lllllllllllll}\text { MTLVASEDYGDTLAAIRGLLK } & 1.00 & 69.52 & 25.56 & 18.83 & 3 & 2496.3421 & 2496.3389 & 833.1202 & 0.0032 & 1.2803 & 33.575 \\ \end{array}$ $\begin{array}{lllllllllllll} & \end{array}$

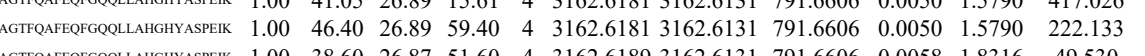
$\begin{array}{lllllllllllll} & \end{array}$ $\begin{array}{lllllllllllll}\text { LAALADQWQFLVQK } & 0.67 & 27.85 & 24.23 & 40.85 & 3 & 1918.0951 & 1918.0920 & 640.3713 & 0.0031 & 1.6136 & 133.375 & 110\end{array}$ $\begin{array}{llllllllllllll}\text { LAALADQWQFLVQK } & 0.81 & 12.40 & 24.25 & 13.91 & 3 & 1918.0954 & 1918.0920 & 640.3713 & 0.0034 & 1.7698 & 209.246 & 178.0\end{array}$ $\begin{array}{llllllllllllll}\text { AQLADSFHLQQFFR } & 1.00 & 71.72 & 28.09 & 22.90 & 3 & 1850.9569 & 1850.9550 & 617.9923 & 0.0019 & 1.0248 & 3236.348 & 2691.083\end{array}$ $\begin{array}{lllllllllllll}\text { AQLADSFHLQQFFR } & 1.00 & 53.85 & 28.34 & 24.46 & 3 & 1850.9533 & 1850.9550 & 617.9923 & -0.0017 & -0.9169 & 1628.620 & 1522 .\end{array}$ $\begin{array}{llllllllllllllll}\text { AQLADSFHLQQFFR } & 1.00 & 71.79 & 28.27 & 31.94 & 3 & 1850.9539 & 1850.9550 & 617.9923 & -0.0011 & -0.5933 & 1530.658 & 1244.721 & 1357\end{array}$

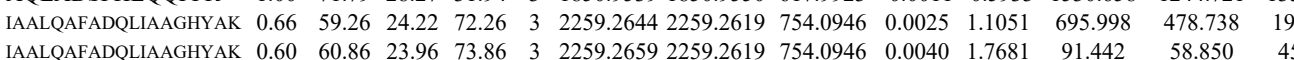
$\begin{array}{llllllllllllll}\text { IAALQAFADQLIAAGHYAK } & 0.60 & 60.86 & 23.96 & 73.86 & 3 & 2259.2659 & 2259.2619 & 754.0946 & 0.0040 & 1.7681 & 91.442 & 58.850 & \\ \text { FMLFR } & 0.56 & 18.80 & 26.41 & 24.96 & 2 & 856.4756 & 856.4751 & 429.2448 & 0.0005 & 0.5824 & 1909.469 & 1619.769 & 138 .\end{array}$ $\begin{array}{lllllllllllll}0.56 & 18.80 & 26.41 & 24.96 & 2 & 856.4756 & 856.4751 & 429.2448 & 0.0005 & 0.5824 & 1909.469 & 1619.769 \\ 0.77 & 18.91 & 26.41 & 25.01 & 2 & 856.4758 & 856.4751 & 429.2448 & 0.0007 & 0.8154 & 1910.080 & 1310.324 \\ 1.00 & 32.43 & 26.22 & 23.85 & 3 & 893.0484 & 1893.0451 & 632.0223 & 0.03 & 1.7404 & 6865.966 & 8336.086 & 43\end{array}$ $\begin{array}{lllllllllllllll}\text { LIQEQHPEEELIK } & 1.00 & 32.43 & 26.22 & 23.85 & 3 & 1893.0484 & 1893.0451 & 632.0223 & 0.00033 & 1.7404 & 6865.966 & 8336.086 & \end{array}$

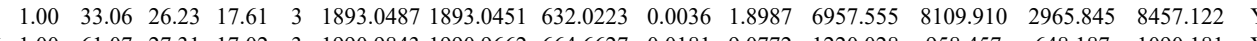

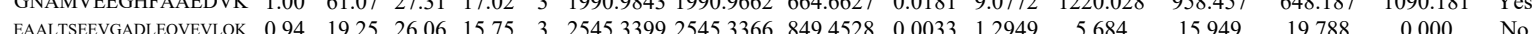
$\begin{array}{lllllllllllllll} & 15.78 & 0.000 & \text { No }\end{array}$

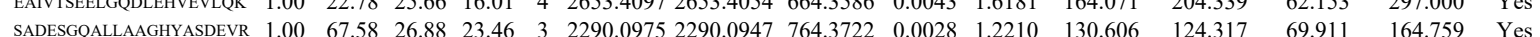

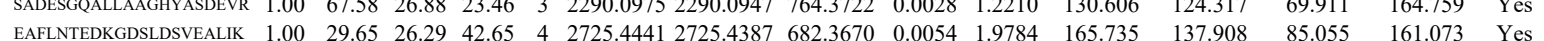
$\begin{array}{llllllllllllllll}\text { ADVVESWIGEK } & 1.00 & 63.02 & 28.40 & 28.26 & 2 & 1519.8146 & 1519.8126 & 760.9136 & 0.0020 & 1.3142 & 420.161 & 422.411 & 221.172 & 419.462 & \text { Yes }\end{array}$ $\begin{array}{llllllllllllllll}\text { ADVVESWIGEK } & 1.00 & 63.02 & 28.40 & 28.26 & 2 & 1519.8146 & 159.8126 & 70.9136 & .0020 & 1.3142 & 420.161 & 422.411 & 221.172 & 419.462 & \text { Yes } \\ \text { ADVE } & 1.00 & 59.64 & 28.45 & 24.33 & 2 & 1519.8158 & 1519.8126 & 760.9136 & 0.0032 & 2.1027 & 519.590 & 367.599 & 283.498 & 372.113 & \text { Yes }\end{array}$ $\begin{array}{llllllllllllllll}\text { HALLEADVAAHQDR } & 1.00 & 65.33 & 28.09 & 20.38 & 4 & 1688.8865 & 1688.8716 & 423.2252 & 0.0149 & 8.8014 & 790.792 & 845.684 & 435.151 & 903.930 & \text { Yes }\end{array}$

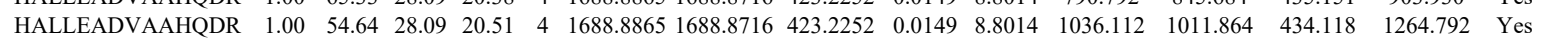
$\begin{array}{lllllllllllllllll}\text { LLEATELK } & 0.98 & 44.97 & 24.10 & 39.07 & 2 & 1203.7422 & 1203.7318 & 602.8732 & 0.0104 & 8.6253 & 3205.651 & 2324.395 & 1232.048 & 2427.283 & \text { Yes }\end{array}$

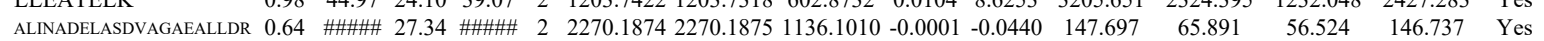

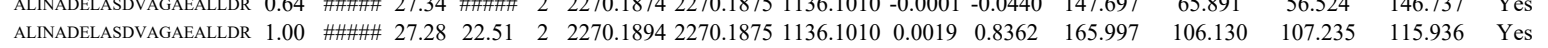

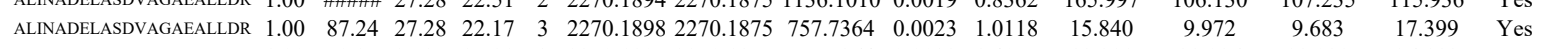

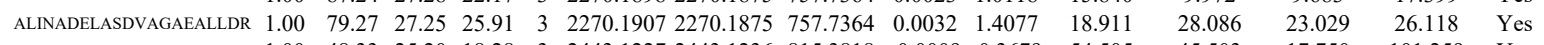
$\begin{array}{lllllllllllllllll} & \end{array}$ $\begin{array}{llllllllllllllll}\text { FEVNISELPDEIDISSYIEQTR } & 1.00 & 63.46 & 27.27 & 20.61 & 3 & 2740.3549 & 2740.3565 & 914.4594 & -0.0016 & -0.5832 & 38.239 & 28.923 & 21.952 & 52.069 & \text { Yes }\end{array}$ $\begin{array}{llllllllllllllll} & \\ \text { PENISELPDEIDISSYIEQTR } & 1.00 & 58.23 & 27.32 & 19.99 & 3 & 2740.3561 & 2740.3565 & 914.4594 & -0.0004 & -0.1458 & 46.936 & 43.192 & 11.180 & 54.799 & \text { Yes }\end{array}$

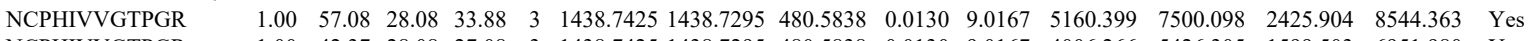
$\begin{array}{lllllllllllllllll}\text { NCPHIVVGTPGR } & 1.00 & 42.37 & 28.08 & 27.08 & 3 & 1438.7425 & 1438.7295 & 480.5838 & 0.0130 & 9.0167 & 4006.266 & 5426.305 & 1599.503 & 6951.980 & \text { Yes }\end{array}$ $\begin{array}{llllllllllllllll}\text { NCPHIVVGTPGR } & 0.93 & 30.18 & 28.02 & 16.61 & 3 & 1438.7422 & 1438.7295 & 480.5838 & 0.0127 & 8.8087 & 11400.954 & 14135.924 & 1449.133 & 16064.929 & \text { Yes }\end{array}$

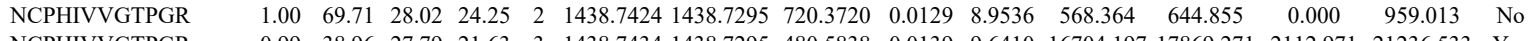

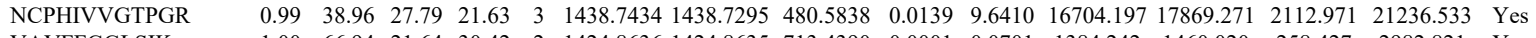

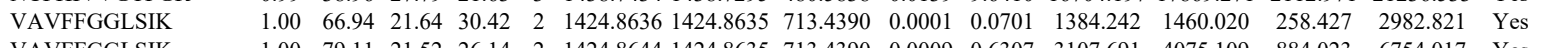

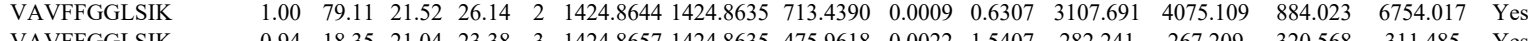

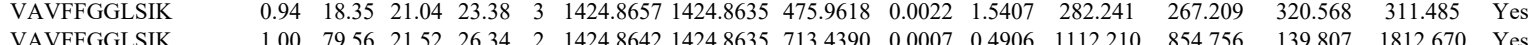
$\begin{array}{llllllllllllllll}\text { VAVFFGGLSIK } & 1.00 & 79.56 & 21.52 & 26.34 & 2 & 1424.8642 & 1424.8635 & 713.4390 & 0.0007 & 0.4906 & 1112.210 & 854.756 & 139.807 & 1812.670 & \text { Yes } \\ \text { VAVFFGGLSIK } & 1.00 & 63.65 & 21.37 & 25.10 & 2 & 1424.8650 & 1424.8635 & 713.4390 & 0.0015 & 1.0512 & 563.297 & 617.103 & 128.985 & 1364.848 & \text { Yes }\end{array}$ $\begin{array}{llllllllllllllll}\text { VAVFFGGLSIK } & 1.00 & 63.65 & 21.37 & 25.10 & 2 & 1424.8650 & 1424.8635 & 713.4390 & 0.0015 & 1.0512 & 563.297 & 617.103 & 128.985 & 1364.848 & \text { Yes } \\ \text { ILALAR } & 0.89 & 22.55 & 14.91 & 30.25 & 2 & 799.5428 & 799.5401 & 400.7773 & 0.0027 & 3.3684 & 7489.265 & 7696.470 & 1098.437 & 24692.956 & \text { No }\end{array}$ $\begin{array}{llllllllllllllll}\text { ILALAR } & 0.89 & 22.55 & 14.91 & 30.25 & 2 & 799.5428 & 799.5401 & 400.7773 & 0.0027 & 3.3684 & 7489.265 & 7696.470 & 1098.437 & 24692.956 & \text { No } \\ \text { CIALAQLLVEONFPAIAIHR } & 0.67 & 71.21 & 25.00 & 84.21 & 3 & 2409.3172 & 2409.3146 & 804.1121 & 0.0026 & 1.0778 & 38.327 & 32.897 & 39.050 & 37.934 & \text { Yes }\end{array}$

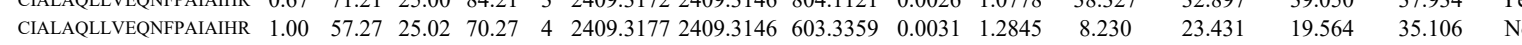

Table S-4 page 467 of 614 

$\begin{array}{lllllllllllll}\text { MFFEDERPALLSQIDAEFEK } & 0.67 & 48.25 & 26.49 & 61.25 & 3 & 2818.4494 & 2818.4464 & 940.4894 & 0.0030 & 1.0633 & 96.218 \\ \text { MFFEDEKPALLSOIDAEFEK } & 0.60 & 47.49 & 26.47 & 60.49 & 3 & 2818.4509 & 2818.4464 & 940.4894 & 0.0045 & 1.5949 & 62.919\end{array}$ $\begin{array}{lllllllllllll}\text { GKPAAPGGAGNTGTK } & 0.55 & 78.14 & 25.99 & 91.14 & 3 & 1714.9699 & 1714.9692 & 572.6637 & 0.0007 & 0.4075 & 121.964\end{array}$ $\begin{array}{llllllllllll}\text { GKPAAPGGAGNTGTK } & 1.00 & 93.24 & 25.87 & 19.11 & 3 & 1714.9711 & 1714.9692 & 572.6637 & 0.0019 & 1.1059 & 111.228\end{array}$ $\begin{array}{llllllllllll}\text { GKPAAPGGAGNTGTK } & 0.55 & 76.98 & 25.99 & 89.98 & 3 & 1714.9699 & 1714.9692 & 572.6637 & 0.0007 & 0.4075 & 34.369\end{array}$ $\begin{array}{lllllllllllll}\text { GKPAAPGGAGNTGTK } & 0.55 & 66.50 & 25.99 & 79.50 & 3 & 1714.9699 & 1714.9692 & 572.6637 & 0.0007 & 0.4075 & 37.87\end{array}$ $\begin{array}{lllllllllllll}\text { GKPAAPGGAGNTGTK } & 1.00 & 37.78 & 25.92 & 20.29 & 3 & 1714.9708 & 1714.9692 & 572.6637 & 0.0016 & 0.9313 & 19.403\end{array}$

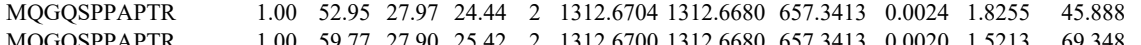
$\begin{array}{lllllllllllll}\text { MQGQSPPAPTR } & 1.00 & 59.77 & 27.90 & 25.42 & 2 & 1312.6700 & 1312.6680 & 657.3413 & 0.0020 & 1.5213 & 69.348 \\ \text { GEA } & 1.00 & 78.25 & 25.44 & 21.91 & 3 & 2028.1255 & 2028.1247 & 677.0488 & 0.0008 & 0.3939 & 499.22\end{array}$

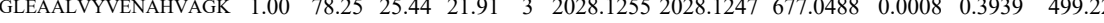
$\begin{array}{llllllllllllll}\text { GLEAALVYVENAHVAGK } & 0.66 & 74.78 & 25.45 & 87.78 & 3 & 2028.1270 & 2028.1247 & 677.0488 & 0.0023 & 1.1324 & 464.624\end{array}$

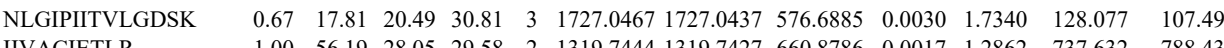
IIVACIETLR WNFTTPR IILLKPIIK ILLKPIIK

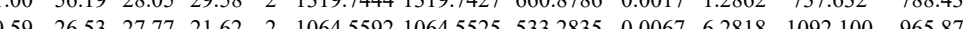

ILLKPIIK $\begin{array}{lllllllllllll} & \end{array}$

IILLKPIIK $\begin{array}{lllllllllllll} & 0.00 & 35.22 & 3 & 1482.0673 & 1482.0638 & 495.0285 & 0.0035 & 2.3568 & 11659.988 & 12081.373\end{array}$

FTTGDAMSK $\begin{array}{lllllllllllllll}1.55 & 25.34 & 0.00 & 38.34 & 3 & 1482.0652 & 482.0638 & 495.0285 & 0.0014 & 0.9427 & 1025.142 & 1029.988 & 557.021 & 1745.191 & \text { Yes } \\ 1.00 & 50.60 & 28.81 & 29.03 & 2 & 1191.6596 & 1191.6590 & 596.8368 & 0.0006 & 0.5026 & 431.937 & 537.330 & 126.915 & 999.201 & \text { Yes }\end{array}$ $\begin{array}{llllllllllllllll}1.00 & 49.03 & 28.83 & 29.04 & 2 & 1191.6600 & 1191.6590 & 596.8368 & 0.0010 & 0.8377 & 1206.764 & 1256.116 & 217.194 & 2945.597 & \text { Yes } \\ \end{array}$

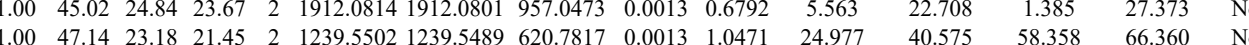

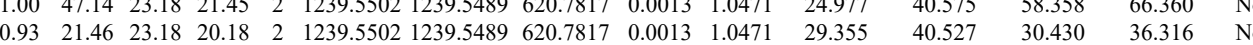
$\begin{array}{lllllllllllllll}0.99 & 44.15 & 27.83 & 26.93 & 2 & 1244.6428 & 1244.6315 & 623.3230 & 0.0113 & 9.0642 & 30887.651 & 18248.675 & 14772.268 & 37952.093 & \text { No }\end{array}$ $\begin{array}{lllllllllllllll}0.00 & 51.19 & 26.88 & 31.14 & 2 & 1244.6330 & 1244.6315 & 623.3230 & 0.0015 & 1.2032 & 30291.764 & 19977393 & 14264.113 & 40528.692 & \text { Yes }\end{array}$ $\begin{array}{llllllllllllll}1.00 & 54.26 & 27.01 & 28.94 & 2 & 1244.6340 & 1244.6315 & 623.3230 & 0.0025 & 2.0054 & 47438.734 & 28256.225 & 21489.71259510 .953 & \text { Yes }\end{array}$ $\begin{array}{lllllllllllllllll}1.00 & 51.17 & 27.46 & 31.46 & 2 & 1244.6358 & 1244.6315 & 623.3230 & 0.0043 & 3.4492 & 13055.040 & 8505.974 & 5668.646 & 14095.478 & \text { Yes }\end{array}$ $\begin{array}{lllllllllllllllll}\text { HFœectDDVR } & 0.66 & 53.55 & 23.36 & 66.55 & 3 & 3245.4532 & 3245.4516 & 1082.8245 & 0.0016 & 0.4925 & 607.727 & 309.316 & 1026.529 & 863.227 & \text { No }\end{array}$ $\begin{array}{lllllllllllllllll} & 3245.4532 & 3245.4516 & 1082.8245 & 0.0016 & 0.4925 & 322.306 & 210.490 & 587.265 & 557.129 & \text { No }\end{array}$ $\begin{array}{lllllllllllllll} & \end{array}$ $\begin{array}{lllllllllllllllll} & \text { FALITWIGENVSGLQR } & 1.00 & 81.04 & 26.36 & 31.69 & 2 & 1947.0706 & 1947.0700 & 974.5423 & 0.0006 & 0.3078 & 370.871 & 266.635 & 0.000 & 562.741 & \text { No }\end{array}$

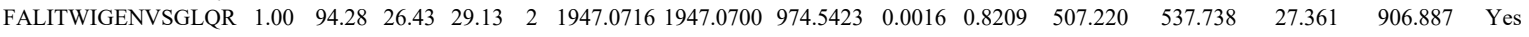
$\begin{array}{llllllllllllllll}\text { FALITWIGENVSGLQR } & 1.00 & 43.52 & 26.27 & 23.69 & 3 & 1947.0736 & 1947.0700 & 650.0306 & 0.0036 & 1.8461 & 107.569 & 63.466 & 31.045 & 142.332 & \text { Yes }\end{array}$ $\begin{array}{llllllllllllllll}\text { FALITWIGENVSGLQR } & 1.00 & 41.80 & 26.12 & 24.82 & 3 & 1947.0751 & 1947.0700 & 650.0306 & 0.0051 & 2.6153 & 243.459 & 264.187 & 118.930 & 418.744 & \text { Yes }\end{array}$ $\begin{array}{llllllllllllllll}\text { FALITWIGENVSGLQR } & 1.00 & 91.31 & 26.35 & 32.50 & 2 & 1947.0704 & 1947.0700 & 974.5423 & 0.0004 & 0.2052 & 278.910 & 173.940 & 58.465 & 438.574 & \text { Yes }\end{array}$

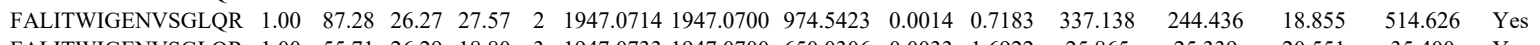

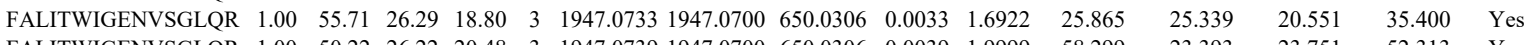

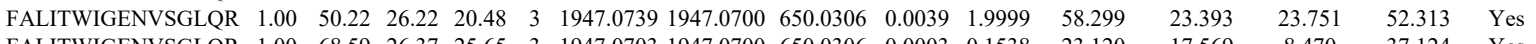

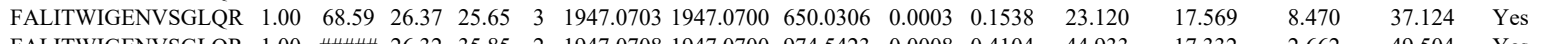

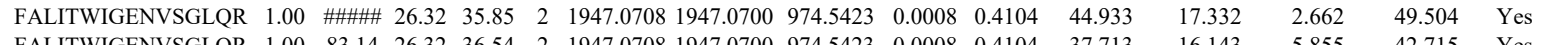

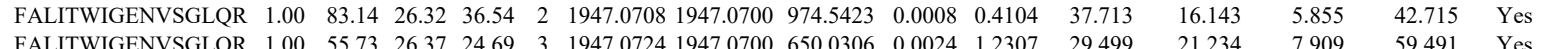

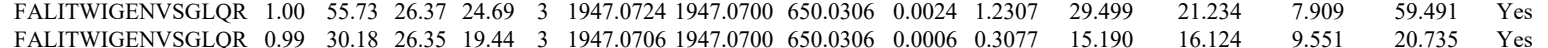

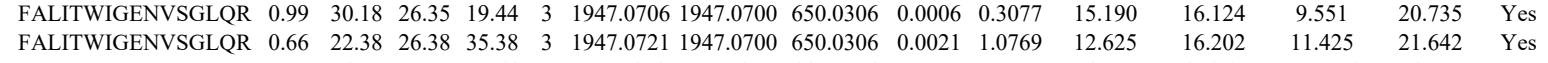

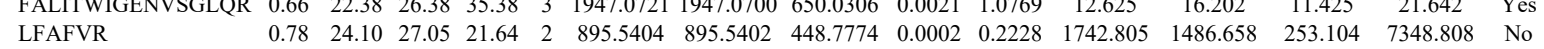
$\begin{array}{llllllllllllllll}\text { LFAFVR } & 0.78 & 24.10 & 27.05 & 21.64 & 2 & 895.5404 & 895.5402 & 448.7774 & 0.0002 & 0.2228 & 1742.805 & 1486.658 & 253.104 & 7348.808 & \text { No } \\ \text { LFAFVR } & 0.95 & 27.39 & 27.05 & 22.30 & 2 & 895.5408 & 895.5402 & 448.7774 & 0.0006 & 0.6685 & 1323.627 & 875.753 & 204.663 & 4709.754 & \text { Yes }\end{array}$ 

$\begin{array}{lllllllllllllllll}0.95 & 27.32 & 27.05 & 21.41 & 2 & 895.5410 & 895.5402 & 448.7774 & 0.0008 & 0.8913 & 2725.354 & 2041.883 & 578.309 & 10384.476 & \text { Yes } \\ 1.00 & 87.11 & 27.43 & 32.93 & 2 & 1775.9564 & 1775.9549 & 88.9847 & 0.0015 & 0.8437 & 946.898 & 7980.906 & 661.648 & 8190.917 & \text { Yes }\end{array}$ $\begin{array}{lllllllllllllll}1.00 & 67.91 & 27.44 & 28.59 & 2 & 1775.9568 & 1775.9549 & 888.9847 & 0.0019 & 1.0686 & 3080.362 & 3785.962 & 153.222 & 3954.050 & \text { Yes } \\ 1.00 & 46.32 & 27.39 & 18.54 & 3 & 1775.9587 & 1775.9549 & 592.9922 & 0.0038 & 2.1361 & 329.452 & 416540 & 109.870 & 377.566 & \text { Yes }\end{array}$ $\begin{array}{lllllllllllllllllll} & \end{array}$ $\begin{array}{llllllllllllll} & \end{array}$

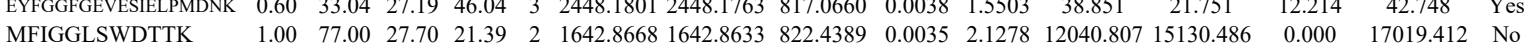

GFCFITFK

GFCFITFK

GFCFITFK

GFCFITFK

GFCFITFK

GFCFITFK

GFCFITFK

GFCFITFK

GFCFITFK

GFCFITFK

GFCFITFK

GFCFITFK

GFCFITFK

GFCFITFK

GFCFITFK

GFCFITFK

IFVGGLSPDTPEEK

FVGLSPDPEEK

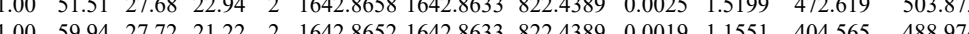

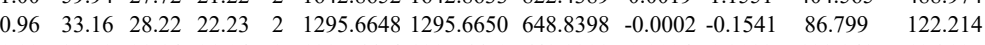
$\begin{array}{llllllllllll}0.92 & 30.52 & 28.14 & 21.04 & 2 & 1295.6654 & 1295.6650 & 6488398 & 0.0004 & 0.3082 & 128.948 & 126.925\end{array}$ $\begin{array}{llllllllllll}0.98 & 3237 & 28.14 & 21.42 & 2 & 1295.6664 & 129556650 & 648.8398 & 0.0014 & 1.0788 & 202.133 & 238.018\end{array}$ $\begin{array}{llllllllllll}0.93 & 26.42 & 28.18 & 21.16 & 2 & 1295.6666 & 1295.6650 & 648.8398 & 0.0016 & 1.2330 & 205.445 & 186.796\end{array}$ $\begin{array}{llllllllllll}0.84 & 22.31 & 28.18 & 16.54 & 2 & 1295.6668 & 1295.6650 & 648.8398 & 0.0018 & 1.3871 & 120.343 & 122.515\end{array}$ $\begin{array}{llllllllllll}1.00 & 39.23 & 28.18 & 23.29 & 2 & 1295.6668 & 1295.6650 & 648.8398 & 0.0018 & 1.3871 & 26725.849 & 34317.617 \\ 10\end{array}$

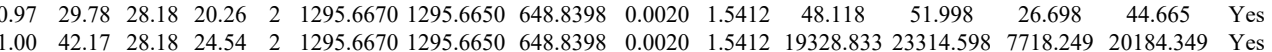

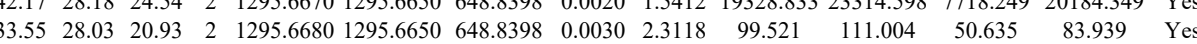

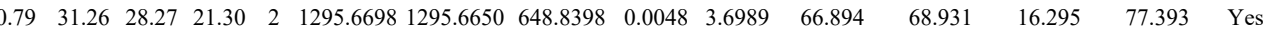

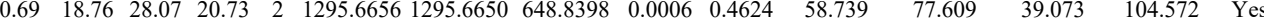

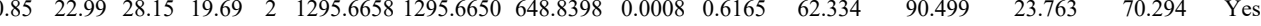

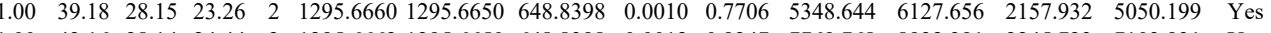

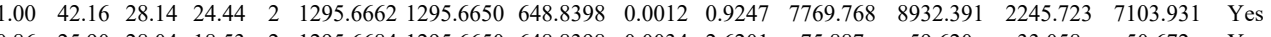

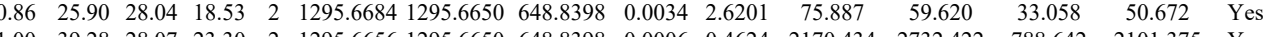
$\begin{array}{llllllllllllllll}1.00 & 39.28 & 28.07 & 23.30 & 2 & 1295.6656 & 1295.6650 & 648.8398 & 0.0006 & 0.4624 & 2170.434 & 2732.422 & 788.642 & 2101.375 & \text { Yes }\end{array}$ $\begin{array}{lllllllllllllll}1.00 & 39.19 & 28.15 & 24.11 & 2 & 1295.6660 & 1295.6650 & 648.8398 & 0.0010 & 0.7706 & 3955.391 & 4273.282 & 1353.315 & 3641.867 & \text { Yes }\end{array}$ $\begin{array}{lllllllllllllllll}1.00 & 44.17 & 28.14 & 23.57 & 2 & 1295.6664 & 1295.6650 & 648.8398 & 0.0014 & 1.0788 & 523.815 & 631.080 & 189.987 & 437.379 & \text { Yes }\end{array}$ $\begin{array}{lllllllllllllll}1.00 & 39.11 & 28.14 & 23.58 & 2 & 1295.6664 & 1295.6650 & 648.8398 & 0.0014 & 1.0788 & 624.470 & 743.994 & 258.309 & 615.522 & \text { Yes }\end{array}$

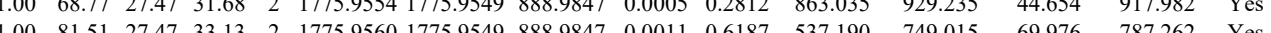
\begin{tabular}{llllllllllllllll}
\hline K & 1.00 & 31.17 & 27.23 & 19.92 & 3 & 1775.9581 & 1775.9549 & 592.9922 & 0.0032 & 1.7988 & 186.059 & 134.278 & 111.432 & 146.383 & $Y=5$
\end{tabular} $\begin{array}{lllllllllllllllll} & 24.9172 & 2448.1763 & 817.0660 & 0.0029 & 1.1831 & 38.111 & 29.649 & 42.057 & 84.371 & \text { Yes }\end{array}$

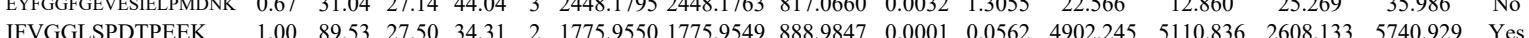

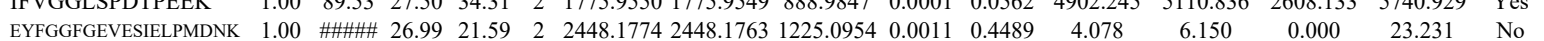

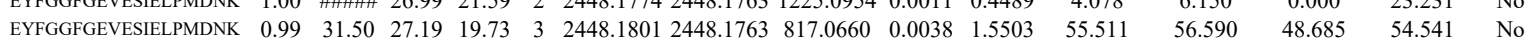

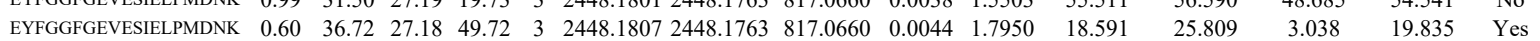
$\begin{array}{llllllllllllllll}\text { GGGASGGGYASSGAGGOPPPOPR } & 1.00 & 72.78 & 27.34 & 22.00 & 3 & 2279.1151 & 2279.1125 & 760.7114 & 0.0026 & 1.1393 & 20.086 & 16.492 & 23.603 & 20.617 & \text { Yes }\end{array}$

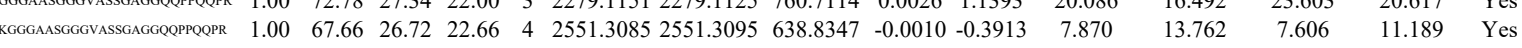

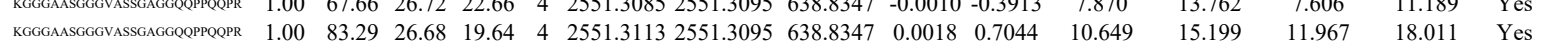
20 GNNVEKPLELR $\quad \begin{array}{lllllllllllllll}0.95 & 30.07 & 25.68 & 22.12 & 3 & 1555.9039 & 1555.8925 & 519.6381 & 0.0114 & 7.3127 & 4559.365 & 5831.196 & 18512.676 & 22455.280 & \text { Yes }\end{array}$ $\begin{array}{llllllllllllllll}\text { GNNVEKPLELR } & 0.97 & 31.33 & 25.53 & 20.46 & 3 & 1555.9051 & 1555.8925 & 519.6381 & 0.0126 & 8.0825 & 4164.370 & 5782.732 & 20679.850 & 27427.737 & \text { Yes }\end{array}$ $\begin{array}{lllllllllllllllll}\text { GFTPIPGIEMLHPWNNEGAPPEDK } & 1.00 & 50.84 & 27.11 & 17.13 & 3 & 3034.5112 & 3034.5102 & 1012.5107 & 0.0010 & 0.3292 & 93.087 & 83.367 & 338.260 & 427.653 & \text { Yes }\end{array}$ $\begin{array}{llllllllllllllll}\text { GFTPPGTIEMLHPWNNEGAPPEDK } & 0.55 & 50.95 & 27.11 & 63.95 & 3 & 3034.5112 & 3034.5102 & 1012.5107 & 0.0010 & 0.3292 & 133.006 & 128.710 & 320.535 & 381.003 & \text { Yes }\end{array}$

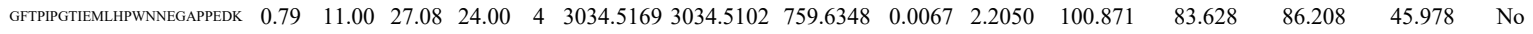

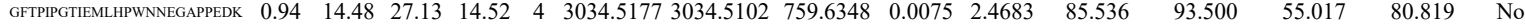

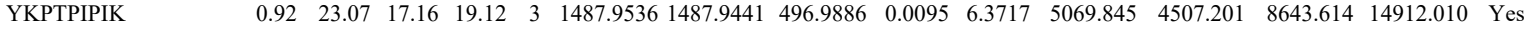
$\begin{array}{lllllllllllllllll}\text { YKPTPIPIK } & 0.97 & 22.00 & 17.16 & 16.17 & 3 & 1487.9539 & 1487.9441 & 496.9886 & 0.0098 & 6.5729 & 4971.853 & 3474.127 & 12944.137 & 24122.762 & \text { Yes }\end{array}$ \begin{tabular}{|lllllllllllllllll} 
&
\end{tabular} $\begin{array}{llllllllllllllll} & \end{array}$ $\begin{array}{llllllllllllllll}\text { YKPTPIPIK } & 0.91 & 19.22 & 17.32 & 15.93 & 3 & 1487.9527 & 1487.9441 & 496.9886 & 0.0086 & 5.7680 & 4568.366 & 3602.848 & 8769.410 & 15539.636 & \text { Yes } \\ \text { YKPTPIPIK } & 0.96 & 21.73 & 17.24 & 15.58 & 3 & 1487.9542 & 1487.941 & 496.988 & 0.001 & 6.7741 & 4788.037 & 368.080 & 10633.378 & 1822.064 & \text { Yes }\end{array}$ $\begin{array}{llllllllllllllllll} & 0.96 & 21.73 & 17.24 & 15.58 & 3 & 1487.9542 & 1487.9441 & 496.9886 & 0.0101 & 6.7741 & 4798.037 & 3680.080 & 10633.378 & 18122.064 & \text { Yes }\end{array}$ $\begin{array}{llllllllllllllll}\text { VVPSFLPVDQGGSLVGR } & 1.00 & 82.58 & 25.13 & 20.42 & 2 & 1870.0420 & 1870.0435 & 936.0290 & -0.0015 & -0.8013 & 1700.491 & 1399.607 & 1450.134 & 10790.160 & \text { Yes }\end{array}$

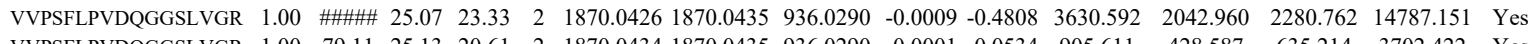
$\begin{array}{llllllllllllllll}\text { VVPSFLPVDQGGSLVGR } & 1.00 & 79.11 & 25.13 & 20.61 & 2 & 1870.0434 & 1870.0435 & 936.0290 & -0.0001 & -0.0534 & 905.611 & 428.587 & 635.214 & 3702.422 & \text { Yes }\end{array}$

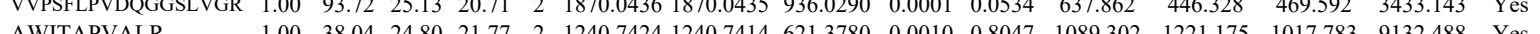
AWITAPVALR

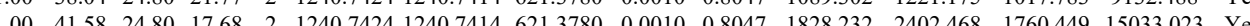




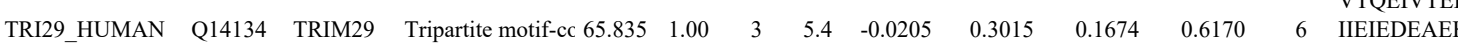

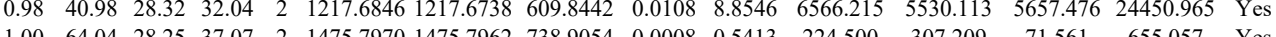
$\begin{array}{llllllllllllllll}1.00 & 64.04 & 28.25 & 37.07 & 2 & 1475.7970 & 1475.7962 & 738.9054 & 0.0008 & 0.5413 & 224.500 & 307.209 & 71.561 & 655.057 & \text { Yes } \\ 1.00 & 66.31 & 28.22 & 35.38 & 2 & 1475.7974 & 1475.7962 & 738.9054 & 0.0012 & 0.8120 & 227.736 & 265.608 & 54.517 & 509.339 & \text { Yes }\end{array}$ $\begin{array}{ccccccccccccccc}0.69 & 15.41 & 28.12 & 27.95 & 3 & 1475.7982 & 1475.7962 & 492.9393 & 0.0020 & 1.3524 & 64.600 & 61.554 & 43.697 & 60.238 & \text { Yes }\end{array}$ $\begin{array}{llllllllllllllll}0.78 & 15.92 & 28.18 & 17.75 & 3 & 1475.7985 & 1475.7962 & 492.9393 & 0.0023 & 1.5553 & 49.146 & 40.834 & 99.614 & 79.379 & \text { Yes } & \\ \end{array}$

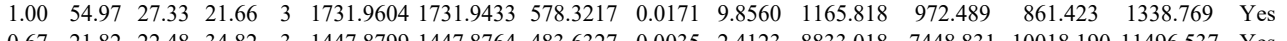
$\begin{array}{lllllllllllllll}0.67 & 21.82 & 22.48 & 34.82 & 3 & 1447.8799 & 1447.8764 & 483.6327 & 0.0035 & 2.4123 & 8833.018 & 7448.831 & 10018.190 & 11496.537 & \text { Yes }\end{array}$

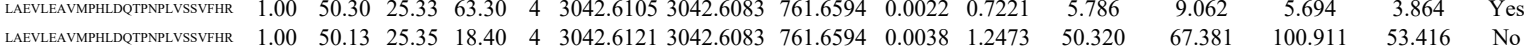
$\begin{array}{llllllllllllllllll} & \end{array}$ $\begin{array}{lllllllllllllllll}\text { TFPEVMIPVFDILLGR } & 1.00 & 69.41 & 25.65 & 22.90 & 2 & 1990.1096 & 1990.1084 & 996.0615 & 0.0012 & 0.6024 & 258.819 & 196.622 & 51.067 & 345.828 & \text { Yes }\end{array}$ $\begin{array}{lllllllllllllll} & \end{array}$ $\begin{array}{llllllllllllll} & \end{array}$

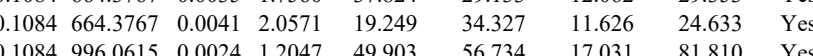
$\begin{array}{llllllllll}1990.1108 & 1990.1084 & 996.0615 & 0.0024 & 1.2047 & 49.903 & 56.734 & 17.031 & 81.810 & \text { Yes }\end{array}$

$\begin{array}{llllllllllll} & \end{array}$ QPALDVLYDVMK QPALDVLYDVMK QPALDVLYDVMK QPALDVLYDVMK QPALDVLYDVMK QPALDVLYDVMK QPALDVLYDVMK

\section{VPPPALSR}

DMDLWEQQEEER

LTSLVPFVDAFQLER $\begin{array}{llllllllllll}\text { LTSLVPFVDAFQLER } & 1.00 & 71.39 & 26.62 & 28.73 & 2 & 1878.0390 & 1878.0373 & 940.0259 & 0.0017 & 0.9042 & 325.331 \\ \text { LTSLVPFVDAFQLER } & 1.00 & 42.35 & 26.53 & 24.56 & 3 & 1878.0406 & 1878.0373 & 627.0197 & 0.0033 & 1.7543 & 241.468\end{array}$ $\begin{array}{llllllllllll}.089 & 17.41 & 26.85 & 19.34 & 3 & 1678.9237 & 1678.9208 & 560.6475 & 0.0029 & 1.7242 & 57.419 & 58.909\end{array}$ $\begin{array}{llllllllllll}0.99 & 29.38 & 26.91 & 18.71 & 3 & 1678.9243 & 1678.9208 & 560.6475 & 0.0035 & 2.0809 & 62.453\end{array}$ $\begin{array}{llllllllllllll}1.00 & 50.00 & 26.74 & 21.05 & 2 & 1678.9262 & 1678.9208 & 840.4677 & 0.0054 & 3.2125 & 251.314 & 36\end{array}$ $\begin{array}{llllllllllll}0.99 & 47.28 & 26.78 & 24.41 & 2 & 1678.9264 & 1678.9208 & 840.4677 & 0.0056 & 3.3315 & 242.308\end{array}$ $\begin{array}{llllllllllll}1.00 & 31.63 & 26.95 & 21.80 & 3 & 1678.9234 & 1678.9208 & 560.6475 & 0.0026 & 1.5458 & 64.927\end{array}$ $\begin{array}{llllllllllll}1.00 & 50.08 & 26.95 & 16.78 & 2 & 1678.9234 & 1678.9208 & 840.4677 & 0.0026 & 1.5468 & 229.367 & 24 \\ 1.00 & 51.87 & 26.85 & 22.01 & 2 & 1678.9236 & 1678.9208 & 840.677 & 0.0028 & 1.6657 & 185.955 & 13\end{array}$ $\begin{array}{llllllllllll}1.00 & 51.87 & 26.85 & 22.01 & 2 & 1678.9236 & 1678.9208 & 840.4677 & 0.0028 & 1.6657 & 185.955\end{array}$ $\begin{array}{llllllllllll}1.00 & 42.29 & 26.88 & 26.31 & 3 & 1678.9240 & 1678.9208 & 560.6475 & 0.0032 & 1.9026 & 92.092\end{array}$

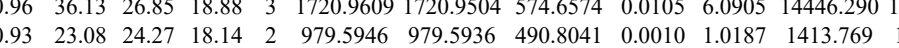
$\begin{array}{llllllllllll}1.00 & 56.33 & 23.12 & 23.80 & 2 & 1750.7604 & 1750.7590 & 876.3868 & 0.0014 & 0.7987 & 14.557\end{array}$ $\begin{array}{llllllllllll}1.00 & 36.72 & 23.30 & 20.90 & 2 & 1750.7612 & 1750.7590 & 876.3868 & 0.0022 & 1.2552 & 6.612 \\ 1.00 & 75.38 & 26.62 & 27.04 & 2 & 1878.0390 & 1878.0373 & 940.0259 & 0.0017 & 0.9042 & 810.102\end{array}$ $\begin{array}{llllllllllll}\text { LTSLVPFDAFQLER } & 1.00 & 42.35 & 26.53 & 24.56 & 3 & 1878.0406 & 1878.0373 & 627.0197 & 0.0033 & 1.7543 & 241.468 \\ \text { LTSLVPFVDAFQLER } & 0.60 & 38.09 & 26.39 & 51.09 & 3 & 1878.0409 & 1878.0373 & 627.0197 & 0.0036 & 1.9138 & 174.420\end{array}$ $\begin{array}{llllllllllll}\text { LTSLVPFVDAFQLER } & 1.00 & 82.11 & 26.63 & 24.94 & 2 & 1878.0378 & 1878.0373 & 940.0259 & 0.0005 & 0.2660 & 869.103\end{array}$ $\begin{array}{llllllllllll}\text { LTSLVPFVDAFQLER } & 1.00 & 73.24 & 26.51 & 30.76 & 2 & 1878.0394 & 1878.0373 & 940.0259 & 0.0021 & 1.1170 & 205.384\end{array}$ $\begin{array}{llllllllllll}\text { LTSLVPFVDAFQLER } & 1.00 & 52.44 & 26.55 & 20.11 & 3 & 1878.0397 & 1878.0373 & 627.0197 & 0.0024 & 1.2759 & 218.018\end{array}$ $\begin{array}{llllllllllll}\text { LTSLVPFVDAFQLER } & 0.67 & 56.59 & 26.50 & 69.59 & 3 & 1878.0403 & 1878.0373 & 627.0197 & 0.0030 & 1.5948 & 181.444\end{array}$

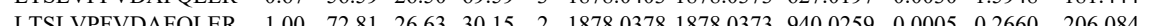
\begin{tabular}{llllllllllll}
\hline LTSLVPFVDAFQLER & 1.00 & 44.40 & 26.56 & 27.96 & 2 & 1878.0384 & 1878.0373 & 940.0259 & 0.0011 & 0.5851 & 17.410
\end{tabular}

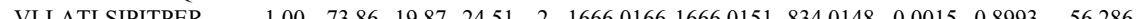
$\begin{array}{llllllllllll}\text { VLLATLSIPITPER } & 0.84 & 76.49 & 19.87 & 89.49 & 2 & 1666.0166 & 1666.0151 & 834.0148 & 0.0015 & 0.8993 & 73.966\end{array}$ $\begin{array}{llllllllllll}\text { VLLATLSIPITPER } & 0.62 & 4.02 & 19.64 & 17.02 & 3 & 1666.0183 & 1666.0151 & 556.3456 & 0.0032 & 1.9173 & 16.001\end{array}$ $\begin{array}{lllllllllllll}\text { VLLATLSIPITPER } & 0.72 & 87.26 & 19.64 & \# \# \# & 2 & 1666.0184 & 1666.0151 & 834.0148 & 0.0033 & 1.9784 & 14.057\end{array}$ $\begin{array}{llllllllllll}\text { LLQQVSQIYQSIEFSR } & 1.00 & \text { \#\#\# } 26.74 & 22.60 & 2 & 2082.1234 & 2082.1231 & 1042.0688 & 0.0003 & 0.1439 & 607.331\end{array}$

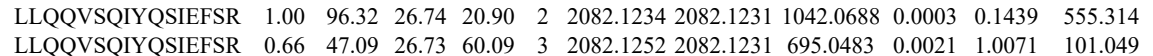
LLQQVSQIYQSIEFSR VLNWVR VLNWVR VLNWVR

LATLLGLQAPPTR

LATLLGLQAPPTR

LATLLGLQAPPTR

LATLLGLQAPPT

LATLLGLQAPPTR

LATLLGLQAPPTR

LATLLGLQAPPTR

LATLLGLQAPPTR

LATLLGLQAPPTR

LATLLGLQAPPTR

LATLLGLQAPPTR DIDIEDLEELDPDFIMAK

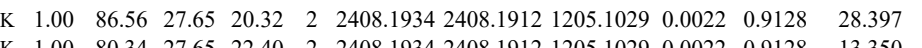
$\begin{array}{lllllllllllll}\text { DIDIEDLEELDPDFIMAK } & 1.00 & 71.25 & 27.69 & 21.85 & 3 & 2408.1946 & 2408.1912 & 803.7377 & 0.0034 & 1.4101 & 20.633\end{array}$

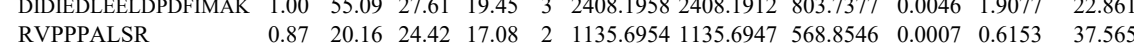
RVPPPALSR $\begin{array}{lllllllllll}0.86 & 19.03 & 23.80 & 21.53 & 2 & 1135.6958 & 1135.6947 & 568.8546 & 0.0011 & 0.9669 & 37.153\end{array}$ $\begin{array}{lllllllllllll}\text { DIDIEDLEELDPDFIMAK } & 1.00 & 58.55 & 27.66 & 18.79 & 3 & 2408.1952 & 2408.1912 & 803.7377 & 0.0040 & 1.6589 & 5.315\end{array}$

$\begin{array}{lllllllllllll} & \end{array}$ $\begin{array}{lllllllllllll}0.56 & 25.23 & 26.56 & 27.48 & 2 & 929.5624 & 929.5569 & 465.7857 & 0.0055 & 5.9040 & 9024.119 & 9264.589\end{array}$ $\begin{array}{llllllllllllll}0.68 & 26.70 & 26.11 & 27.46 & 2 & 929.5636 & 929.5569 & 465.7857 & 0.0067 & 7.1921 & 8778.955 & 8952.724 & \\ 0 & 0.86 & 3.95 & 27.64 & 33.21 & 2 & 929.5620 & 929.5569 & 465.785 & 0.0051 & 7.746 & 7170.593 & 6552.873 & 1\end{array}$ $\begin{array}{lllllllllllll}0.64 & 83.68 & 22.81 & 96.68 & 2 & 1493.9052 & 1493.9051 & 747.9598 & 0.0001 & 0.0668 & 963.768 & 932.876\end{array}$ $\begin{array}{lllllllllllll}0.64 & 85.95 & 22.81 & 98.95 & 2 & 1493.9052 & 1493.9051 & 747.9598 & 0.0001 & 0.0668 & 3655.607 & 4201.395\end{array}$ $\begin{array}{llllllllllll}0.99 & 25.45 & 22.79 & 19.31 & 3 & 1493.9071 & 1493.9051 & 498.9756 & 0.0020 & 1.3361 & 33.967 & 96.310\end{array}$ $\begin{array}{lllllllllllll}0.96 & 17.94 & 22.60 & 15.43 & 3 & 1493.9074 & 1493.9051 & 498.9756 & 0.0023 & 1.5365 & 84.914 & 204.843\end{array}$ $\begin{array}{llllllllllllll}0.82 & 61.54 & 22.81 & 74.54 & 2 & 1493.9060 & 1493.9051 & 747.9598 & 0.0009 & 0.6016 & 2000.722 & 1559.141 \\ 0.82 & 84.86 & 22.81 & 97.86 & 2 & 1493.9060 & 1493.9051 & 747.9598 & 0.0009 & 0.6016 & 2133.128 & 2337.717\end{array}$ $\begin{array}{llllllllllll}0.82 & 84.86 & 22.81 & 97.86 & 2 & 1493.9060 & 1493.9051 & 747.9598 & 0.0009 & 0.6016 & 2133.128 & 2.04\end{array}$ $\begin{array}{llllllllllllll}0.50 & 5.08 & 22.60 & 16.02 & 3 & 1493.9077 & 1493.9051 & 498.9756 & 0.0026 & 1.7369 & 106.023\end{array}$ $\begin{array}{lllllllllll}0.50 & 5.08 & 22.60 & 16.02 & 3 & 1493.9077 & 1493.9051 & 48.9756 & 0.026 & 1.7369 & 106.023\end{array}$

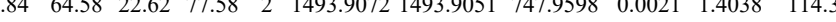




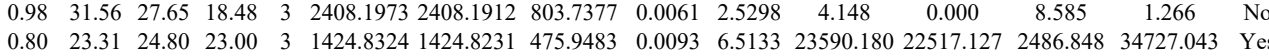

$\begin{array}{lllllllllllllll}0.88 & 20.02 & 27.70 & 17.13 & 3 & 1440.7927 & 1440.7919 & 481.2712 & 0.0008 & 0.5541 & 103.259 & 134.247 & 91.753 & 137.931 & \text { Yes }\end{array}$ $\begin{array}{llllllllllllllll} & \end{array}$

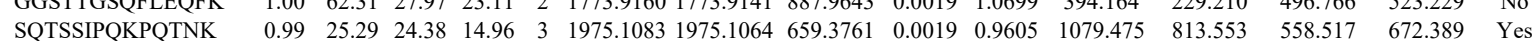

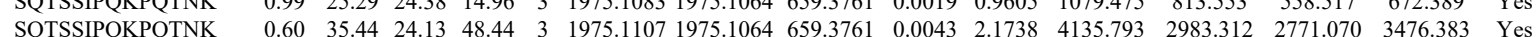
IDLAVLLGK

IDLAVLLGK $\begin{array}{lllllllllllllll}0.60 & 35.44 & 24.13 & 48.44 & 3 & 1975.1107 & 1975.1064 & 659.3761 & 0.0043 & 2.1738 & 4135.793 & 2983.312 & 2771.070 & 3476.383 & \text { Yes } \\ 1\end{array}$

IDLAVLLGK
IDLAVLLGK

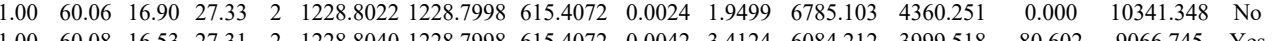
$\begin{array}{llllllllllllllll}\text { GNWEQPQNQNQTQHK } & 0.66 & 38.37 & 27.60 & 51.37 & 3 & 2124.0358 & 2124.0340 & 709.0186 & 0.0018 & 0.8462 & 4462.162 & 5907.763 & 5192225 & 6594.880 & \text { Yes }\end{array}$ $\begin{array}{llllllllllllllll}\text { GNWEQPQNQNQTQHK } & 1.00 & 57.72 & 27.60 & 21.51 & 3 & 2124.0358 & 2124.0340 & 709.0186 & 0.0018 & 0.8462 & 4526.469 & 5153.580 & 8643.866 & 5615.616 & \text { Yes }\end{array}$ $\begin{array}{llllllllllllllll}\text { GNWEOPQNONOTQHK } & 0.55 & 51.98 & 27.64 & 64.98 & 3 & 2124.0352 & 2124.0340 & 709.0186 & 0.0012 & 0.5642 & 1193.189 & 1332.608 & 1458.047 & 2014.561 & \text { Yes }\end{array}$

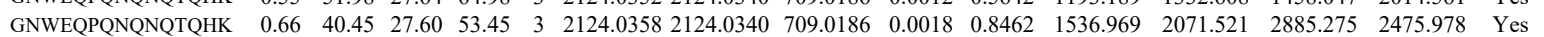

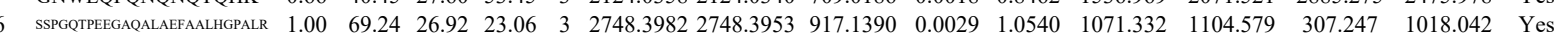
$\begin{array}{llllllllllllllll}\text { QYPEFPWTDVQAEIFR } & 1.00 & 80.95 & 28.12 & 23.08 & 2 & 2169.0654 & 2169.0653 & 1085.5399 & 0.0001 & 0.0461 & 555.036 & 430.081 & 36.013 & 523.591 & \text { Yes }\end{array}$ $\begin{array}{llllllllllllllll}\text { FTLTQSEADADILFNFSHFK } & 0.60 & 61.20 & 27.23 & 74.20 & 3 & 2618.3299 & 2618.3261 & 873.7826 & 0.0038 & 1.4496 & 108.628 & 109.140 & 141.661 & 221.885 & \text { No }\end{array}$ $\begin{array}{llllllllllllllll}\text { TELPQFVSYFQQR } & 1.00 & 67.68 & 27.76 & 31.89 & 2 & 1785.9192 & 1785.9172 & 893.9659 & 0.0020 & 1.1186 & 1582.673 & 1334.802 & 206.970 & 1589.306 & \text { Yes }\end{array}$ $\begin{array}{llllllllllllllll}\text { TELPQFVSYFQQR } & 1.00 & 73.29 & 27.72 & 27.02 & 2 & 1785.9198 & 1785.9172 & 893.9659 & 0.0026 & 1.4542 & 1075.879 & 963.539 & 122.067 & 1268.460 & \text { Yes }\end{array}$ $\begin{array}{lllllllllllllllll}\text { QQLQQVPGLLHR } & 0.96 & 40.11 & 25.15 & 34.53 & 3 & 1559.9158 & 1559.9018 & 520.9745 & 0.0140 & 8.9575 & 1660.068 & 1398.510 & 774.986 & 1852.354 & \text { Yes }\end{array}$

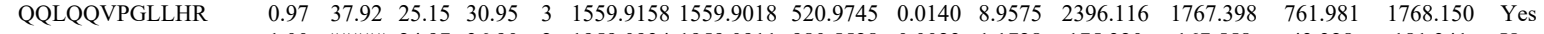

AFLQGGQEATDIALL

SLDFLIELLHK

SLDFLIELLHK

SLDFLIELLHK

$\begin{array}{lllllllllllll}\text { TSQLLETLNQLSTHTHVVDITR } & 1.00 & 63.36 & 24.83 & 76.36 & 4 & 2649.4229 & 2649.4208 & 663.3625 & 0.0021 & 0.7914 & 809.489 \\ \text { TSOLLETLNQLSTHTHVVDITR } & 1.00 & 65.58 & 24.86 & 78.58 & 4 & 2649.4249 & 2649.4208 & 663.3625 & 0.0041 & 1.5452 & 817.502\end{array}$

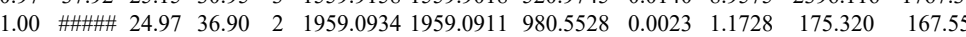

$\begin{array}{lllllllllllll}1.00 & 43.75 & 22.43 & 24.69 & 3 & 1614.9619 & 1614.9588 & 539.3269 & 0.0031 & 1.9160 & 2722.491 & 2745.567\end{array}$

$\begin{array}{llllllllllllll}1.00 & 49.80 & 22.46 & 23.56 & 3 & 1614.9622 & 1614.9588 & 539.3269 & 0.0034 & 2.1014 & 1394.325 & 1293.316 & 0\end{array}$

$\begin{array}{lllllllllll}1.00 & 47.80 & 22.43 & 26.03 & 3 & 1614.9619 & 1614.9588 & 539.3269 & 0.0031 & 1.9160 & 688.428\end{array}$

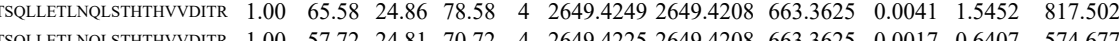
$\begin{array}{lllllllllllll} & 1.00 & 57.72 & 24.81 & 70.72 & 4 & 2649.4225 & 2649.4208 & 663.3625 & 0.0017 & 0.6407 & 574.677\end{array}$ $\begin{array}{llllllllllll}1.06 & 57.72 & 24.81 & 70.72 & 4 & 2649.4225 & 2649.4208 & 663.3625 & 0.0017 & 0.6407 & 574.677\end{array}$ $\begin{array}{lllllllllllll} & 0.92 & 22.86 & 26.45 & 22.51 & 3 & 2250.0631 & 2250.0630 & 751.0283 & 0.0001 & 0.0444 & 15.323\end{array}$ VDELTTDLEILK

$\begin{array}{lllllllllll}1.00 & 74.37 & 25.74 & 41.53 & 2 & 1675.9514 & 1675.9487 & 838.9816 & 0.0027 & 1.6091 & 226.145\end{array}$ $\begin{array}{lllllllllll}1 & 1675.9520 & 1675.9487 & 838.9816 & 0.0033 & 1.9667 & 195.345\end{array}$

\section{YTGEDFDEDLR}

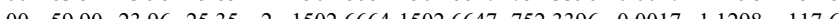
$\begin{array}{llllllllll} & 1.04\end{array}$ $\begin{array}{lllllllllll} & 0.126\end{array}$

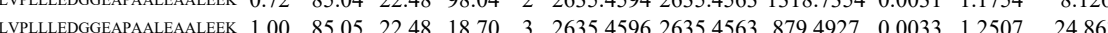
$\begin{array}{llllllllllllll}\text { LVPLLEDGGFAPANEALEFK } & 1.00 & 37.13 & 22.38 & 17.29 & 4 & 2635.4613 & 2635.4563 & 659.8714 & 0.0050 & 1.8943 & 66.502\end{array}$ $\begin{array}{llllllllllllll}\text { LVPLLLEDGGFAPAALEAALEEK } & 1.00 & 19.67 & 22.48 & 19.25 & 4 & 2635.4617 & 2635.4563 & 659.8714 & 0.0054 & 2.0458 & 66.401\end{array}$ TPVSITEHPK

TPVSITEHPK

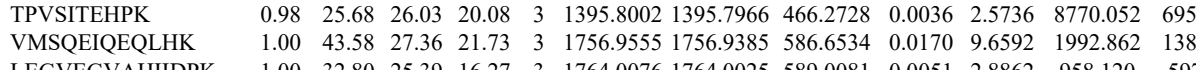

$\begin{array}{llllllllllllllll}0.99 & 28.14 & 26.24 & 19.31 & 3 & 1395.7993 & 1395.7966 & 466.2728 & 0.0027 & 1.9302 & 7699.220 & 50\end{array}$

$\begin{array}{lllllllllllllll}\text { LEGVEGVAHIIDPK } & 1.00 & 32.80 & 25.39 & 16.27 & 3 & 1764.0076 & 1764.0025 & 589.0081 & 0.0051 & 2.8862 & 958.120 & 597.425\end{array}$

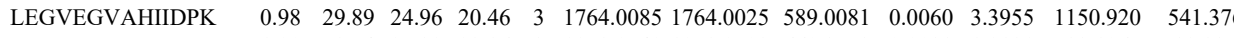

$\begin{array}{lllllllllllll}\text { DFPLNDLLSATELDK } & 1.00 & 58.74 & 27.32 & 22.86 & 3 & 1978.0540 & 1978.0502 & 660.3573 & 0.0038 & 1.9181 & 83.106 & 82.236\end{array}$

\section{VQVALEELQDLK}

VQVALEELQDLK

VQVALEELQDLK

VQVALEELQDLK

DFPLNDLLSATELDK

DFPLNDLLSATELDK

ILDDDTIITTLENLK

ILDDDTIITTLENL

LNTQEIFDDWAR

LNTQEIFDDWAR

ILDDDTIITTLENLK

$\begin{array}{lllllllllll}0.99 & 30.35 & 27.31 & 22.57 & 3 & 1978.0546 & 1978.0502 & 660.3573 & 0.0044 & 2.2210 & 120.863\end{array}$

$\begin{array}{llllllllllllll}1.00 & 59.60 & 24.93 & 23.12 & 2 & 1671.9674 & 1671.9651 & 836.9898 & 0.0023 & 1.3740 & 181.010 & 184.345\end{array}$

$\begin{array}{lllllllllllll}1.00 & 39.33 & 24.93 & 22.31 & 3 & 1671.9676 & 1671.9651 & 558.3290 & 0.0025 & 1.4925 & 97.078 & 77.574\end{array}$

$\begin{array}{lllllllllllll}1.00 & 63.06 & 24.93 & 24.38 & 2 & 1671.9676 & 1671.9651 & 836.9898 & 0.0025 & 1.4934 & 198.946 & 152.744\end{array}$

$\begin{array}{llllllllllll}1.00 & 33.85 & 24.67 & 22.18 & 3 & 1671.9688 & 1671.9651 & 558.3290 & 0.0037 & 2.2090 & 52.368 & 55.935\end{array}$

$\begin{array}{llllllllllll}1.00 & 57.83 & 27.31 & 23.29 & 3 & 1978.0546 & 1978.0502 & 660.3573 & 0.0044 & 2.2210 & 112.012 & 128.568 \\ 0.98 & 27.54 & 27.32 & 24.22 & 3 & 1978.0549 & 1978.0502 & 660.3573 & 0.0047 & 2.3724 & 90.091 & 72.709\end{array}$

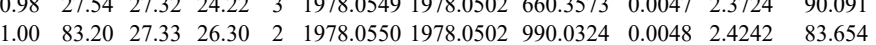

$\begin{array}{lllllllllll}0.99 & 34.19 & 24.22 & 29.03 & 3 & 2004.1273 & 2004.1234 & 669.0484 & 0.0039 & 1.42431 & 83.654 \\ 0 & 27.043 .598 & 24.22 & 27.32 & 3 & 004.1273 & 2004.1234 & 669.048 & 0.0039 & 1.943 & 13.586\end{array}$ $\begin{array}{lllllllllllll}0.98 & 27.53 & 24.22 & 27.32 & 3 & 2004.1273 & 2004.1234 & 669.0484 & 0.0039 & 1.9431 & 146.88\end{array}$ $\begin{array}{lllllllllllll}1.00 & 56.34 & 27.06 & 23.82 & 2 & 1650.8148 & 1650.8124 & 826.4135 & 0.0024 & 1.4521 & 896.766 \\ 1.00 & 67.75 & 27.03 & 31.59 & 2 & 1650.8162 & 1650.8124 & 826.4135 & 0.0038 & 2.2991 & 1151.463\end{array}$ $\begin{array}{llllllllllll}1.00 & 67.75 & 27.03 & 31.59 & 2 & 1650.8162 & 1650.8124 & 826.4135 & 0.0038 & 2.2991 & 1151.463 \\ 1.00 & 99.45 & 24.30 & 31.66 & 2 & 2004.1254 & 2004.1234 & 1003.0690 & 0.0020 & 0.9969 & 241.246\end{array}$ $\begin{array}{lllllllllll}1.00 & 45.14 & 24.22 & 23.60 & 3 & 2004.1273 & 2004.1234 & 669.0484 & 0.0039 & 1.9431 & 285.076\end{array}$

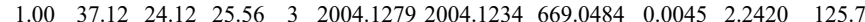

$\begin{array}{llllllllllll}\text { GTVGEPTYDAEFOHFLR } & 1.00 & 54.55 & 27.74 & 18.49 & 3 & 2110.0282 & 2110.0242 & 704.3487 & 0.0040 & 1.8930 & 155.858\end{array}$
686.237

789.476
577.839
456.892

9.822

97.306

(1.71

83.170
12.363

1.815

-8.894
108.639

-1
91.673

$\begin{array}{lll}4.328 & 181.341 & \text { Yes }\end{array}$

$\begin{array}{lll}176.636 & 3734.036 & \text { Yes }\end{array}$

$\begin{array}{lll}17.000 & 3734.036 & \text { No } \\ 41.303 & 92.677 & \text { No }\end{array}$

$\begin{array}{lll}0.31 .303 & 929.777 & \text { Yes } \\ 5 & \end{array}$

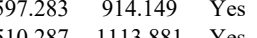
$\begin{array}{lll} & \end{array}$ $\begin{array}{llll}7.960 & 16.883 & \text { Yes } & \\ 0 & 13.416 & \text { No }\end{array}$ $\begin{array}{lll}223.208 & \text { Yes }\end{array}$ $\begin{array}{lll}3.9632 & 204.482 & \text { Yes } \\ & \end{array}$

$\begin{array}{lll}6.032 & 186.100 & \text { Yos } \\ & \end{array}$

$\begin{array}{lll}6.980 & 19.430 & \text { Yes }\end{array}$

$\begin{array}{lll}2.548 & 20.076 \quad \mathrm{Yes}\end{array}$

$\begin{array}{lll}0.432 & 5.042 & \text { No }\end{array}$

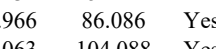
$\begin{array}{lll}10756.855 & 9902.879 & \text { Yes }\end{array}$ $805.359 \quad 2030.730 \quad$ Yes $\begin{array}{lll}257.461 & 1196.269 & \text { Yes }\end{array}$ $\begin{array}{llll}93.300 & 1175.296 & \text { Yes } \\ 12981 & \text { Yes }\end{array}$ $\begin{array}{lll}79.449 & 110.723 & \text { Yes }\end{array}$ $38.912 \quad 224.873 \quad$ Yes

$\begin{array}{lll}14.982 & 256.024 & \text { Yes }\end{array}$

$\begin{array}{lll}26.198 & 75.051 & \text { Yes }\end{array}$

$\begin{array}{llll}72.709 & 78.225 & 99.440 & \text { Yes }\end{array}$ \begin{tabular}{llll}
57.9756 & 40.465 & 102.376 & Yes \\
\hline 14.765 & 76.297 & 1074.911 & Yes
\end{tabular} \begin{tabular}{lllll}
1.74 .756 & 59.465 & 102.376 & Yes \\
\hline & 53.297 & 174.911 & Yes
\end{tabular} $\begin{array}{llll}114.765 & 76.297 & 174.911 & \text { Yes } \\ 910.410 & 556.747 & 1156.537 & \text { Yes }\end{array}$ $\begin{array}{llll}65.163 & 217.603 & \text { Yes }\end{array}$ $\begin{array}{lll}63.163 & 217.603 & \text { Yes } \\ 151.370 & 308.859 & \text { Yes }\end{array}$ 

$\begin{array}{lllllllllllllll} & \text { UDEKPNYIVPDYMPVVYDK } & 0.64 & 14.49 & 26.29 & 16.72 & 3 & 2860.4803 & 2860.4756 & 954.4991 & 0.0047 & 1.6413 & 32.201 & 24.647\end{array}$ $\begin{array}{llllllllllll} & \end{array}$ $\begin{array}{lllllllllllll} & \text { (1) }\end{array}$

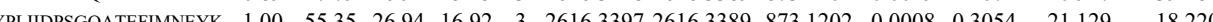
$\begin{array}{lllllllllllll}\text { YPLIDPSCA ATFIMNEYK } & 1.00 & 79.82 & 26.90 & 23.30 & 3 & 2616.3439 & 2616.338 & 873.1202 & 0.0050 & 1.9089 & 34.394 & 51.796\end{array}$

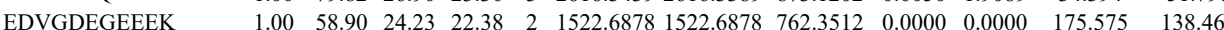

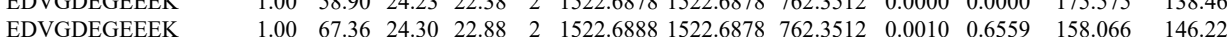

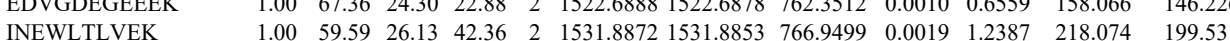
INEWLTLVEK $\begin{array}{lllllllllll}1.00 & 59.59 & 26.13 & 42.36 & 2 & 1531.8872 & 1531.8853 & 766.9499 & 0.0019 & 1.2387 & 218.074 \\ 1.00 & 56.22 & 26.05 & 34.66 & 2 & 1531.8882 & 1531.8853 & 766.9499 & 0.0029 & 1.8906 & 118.435\end{array}$ $\begin{array}{llllllllllll} & \end{array}$

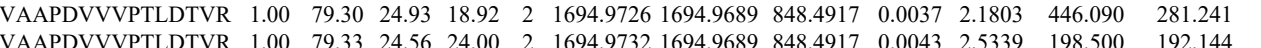

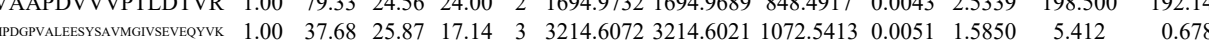
SLLQALNEVK

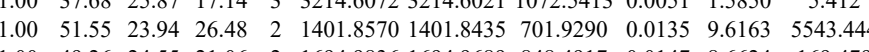

$\begin{array}{llllllllllllll}\text { VAAPDVVVPTLDTVR } & 1.00 & 49.26 & 24.55 & 21.06 & 2 & 1694.9836 & 1694.9689 & 848.4917 & 0.0147 & 8.6624 & 169.479 & 143.614\end{array}$ $\begin{array}{llllllllllllll} & \text { VAAPDVVPTLDSVR }\end{array}$ $\begin{array}{lllllllllllll} & \end{array}$ $\begin{array}{lllllllllllll}\text { TYAEPLTAAMVEFYTMSQER } & 1.00 & \text { \#\#\#\#\# } 26.07 & 26.12 & 2 & 2481.1694 & 2481.1678 & 1241.5912 & 0.0016 & 0.6443 & 24.356 & 29.976\end{array}$ $\begin{array}{lllllllllllllll}\text { YYAPLTAAMVEFYTMSQER } & 1.00 & 46.61 & 26.09 & 22.19 & 3 & 2481.1702 & 2481.1678 & 828.0632 & 0.0024 & 0.9661 & 30.237 & 24.893\end{array}$ $\begin{array}{llllllllllllll}\text { ALPDMEVVGLNFSSATTPELLLK } & 1.00 & 77.45 & 23.80 & 21.92 & 3 & 2732.4931 & 2732.4914 & 911.8377 & 0.0017 & 0.6215 & 52.707 & 66.338\end{array}$ $\begin{array}{lllllllllllll}\text { ALPDMEVVGLNFSSATPPELLK } & 1.00 & 90.64 & 23.77 & 21.06 & 3 & 2732.4946 & 2732.4914 & 911.8377 & 0.0032 & 1.1698 & 98.906 & 105.534\end{array}$ $\begin{array}{lllllllllllllll}\text { FGNPLVQDVESYDPVLNPVLNR } & 1.00 & 84.72 & 26.47 & 26.90 & 2 & 2741.4474 & 2741.4510 & 1371.7328 & -0.0036 & -1.3122 & 7.908 & 0.000\end{array}$ $\begin{array}{lllllllllllllll}\text { FGNPLLVDDVESYDPVLNPVLNR } & 1.00 & 81.31 & 26.47 & 20.04 & 2 & 2741.4494 & 2741.4510 & 1371.7328 & -0.0016 & -0.5832 & 0.000 & 10.737\end{array}$ $\begin{array}{llllllllllllll}\text { FGNPLLVDVESYDPVLNPVLNR } & 1.00 & 35.01 & 26.32 & 21.03 & 3 & 2741.4541 & 2741.4510 & 914.8243 & 0.0031 & 1.1295 & 11.419 & 20.626 \\ \text { FGNPLVVDVVESYDPVLNPVLNR } & 1.00 & 78.30 & 26.26 & 17.92 & 3 & 2741.4544 & 2741.4510 & 914.8243 & 0.0034 & 1.2389 & 0.000 & 14.013\end{array}$ $\begin{array}{lllllllllllll}\text { FGNPLLVQDVESYDPVLNPVLNRR } & 1.00 & 78.30 & 26.26 & 17.92 & 3 & 2741.4544 & 2741.4510 & 914.8243 & 0.0034 & 1.2389 & 0.000 & 14.013 \\ \text { MPDGPVAEESYAVMGIVSEVEOYVK } & 0.99 & 29.10 & 25.83 & 18.74 & 3 & 3214.6042 & 3214.6021 & 1072.5413 & 0.0021 & 0.6527 & 3.406 & 3.560\end{array}$

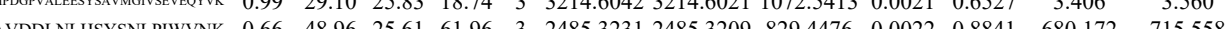

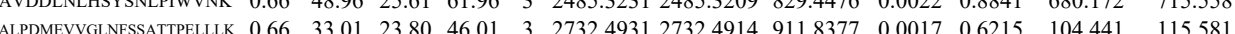

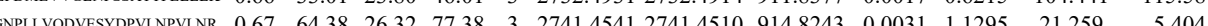

\begin{tabular}{lllllllllllll}
\hline LGGSPFGPAGTGK & 1.00 & 80.73 & 27.55 & 27.07 & 2 & 1432.8024 & 1432.7918 & 717.4032 & 0.0106 & 7.3877 & 1482.767 & 1062.698
\end{tabular} $\begin{array}{llllllllllllll}\text { IFVFEPPPGVK } & 1.00 & 38.54 & 25.26 & 16.86 & 2 & 1516.8918 & 1516.8897 & 759.4521 & 0.0021 & 1.3826 & 230.574 & 172.391 & 1\end{array}$ $\begin{array}{llllllllllllll} & 1.00 & 38.54 & 25.26 & 16.86 & 2 & 15 & 6.8918 & 1516.8897 & 759.4521 & 0.021 & 1.3826 & 230.574 & 172.391\end{array}$ $\begin{array}{lllllllllllllll}\text { LALESICLLUGESTDDWK } & 0.99 & 2836 & 27.02 & 15.76 & 3 & 23252248 & 23252204 & 776.0807 & 0.0044 & 1.8898 & 15.968 & 1.8585\end{array}$ $\begin{array}{llllllllllllll} & \text { LALESICLLLGESTTDWK } & 1.00 & 44.48 & 27.12 & 19.11 & 3 & 2325.2263 & 2325.2204 & 776.0807 & 0.0059 & 25341 & 14.040 & 15.585\end{array}$ $\begin{array}{llllllllllllll}\text { NVHLAPGWLMQLEK } & 0.62 & 10.81 & 26.46 & 21.55 & 3 & 1923.0673 & 1923.0644 & 642.0287 & 0.0029 & 1.5056 & 373.891 & 356.143\end{array}$ $\begin{array}{llllllllllllll}\text { NVHLAPGWLMQLEK } & 0.92 & 48.65 * & 26.12 & 27.32 & 3 & 1923.0694 & 1923.0644 & 62.0287 & 0.0050 & 2.5959 & 1737.469 & 1370.136\end{array}$ VPLAIVNK YATLATVSR VNFLPEITLSK LLNTFLER LLNTFLER SFEWLSQMR FQSISTEFLALMK FQSISTEFLALMK FQSISTEFLALMK SIPLDEGEDEAQR SIPLDEGEDEAQR TFSSIPVSR TFSSIPVSR $\begin{array}{llllllllllllll}1.00 & 48.23 & 18.98 & 25.67 & 2 & 1140.7576 & 1140.7474 & 571.3810 & 0.0102 & 8.9257 & 5057.235 & 4311.262 & 403\end{array}$ $\begin{array}{lllllllllllll}1.00 & 50.51 & 26.81 & 25.29 & 2 & 1124.6416 & 1124.6311 & 563.3228 & 0.0105 & 9.3196 & 7065.173 & 5455.61\end{array}$ $\begin{array}{lllllllllllll}0.98 & 19.75 & 20.90 & 17.77 & 3 & 1661.0044 & 1661.0007 & 554.6742 & 0.0037 & 2.2235 & 134.483 & 69.915\end{array}$ $\begin{array}{lllllllllllll}1.00 & 40.93 & 28.18 & 28.24 & 2 & 1148.6692 & 1148.6675 & 575.3410 & 0.0017 & 1.4774 & 4980.624 & 4176.608\end{array}$ $\begin{array}{llllllllllll}1.00 & 48.25 & 27.83 & 29.48 & 2 & 1148.6698 & 1148.6675 & 575.3410 & 0.0023 & 1.9988 & 10096.070 & 8000.994\end{array}$ $\begin{array}{lllllllllllll}0.98 & 35.34 & 26.74 & 23.18 & 2 & 1326.6510 & 1326.6512 & 664.3329 & -0.0002 & -0.1505 & 8894.832 & 6277.585 & 692 .\end{array}$ $\begin{array}{llllllllllll}0.53 & 18.70 * 26.43 & 14.55 & 3 & 1801.9921 & 1801.9892 & 601.6703 & 0.0029 & 1.6066 & 189.829 & 169.172 & 101.4 \\ 0.66 & 23.05 * 2.43 & 21.47 & 3 & 1801.9921 & 1801.9892 & 601.6703 & 0.0029 & 1.6066 & 256.525 & 251.487 & 94.4\end{array}$ $\begin{array}{lllllllllll}0.66 & 23.05 * 26.43 & 21.47 & 3 & 1801.9921 & 1801.9892 & 601.6703 & 0.0029 & 1.6066 & 256.525 & 251.487 \\ 0.96 & 75.94 * 26.38 & 22.65 & 2 & 1801.9938 & 1801.9892 & 902.0019 & 0.0046 & 2.5499 & 224.876 & 106.462\end{array}$ $\begin{array}{llllllllllll}0.96 & 75.94 * & 26.38 & 22.65 & 2 & 1801.9938 & 1801.9892 & 902.0019 & 0.0046 & 2.5499 & 224.876 & 106.462 \\ 1.00 & 70.76 & 26.58 & 18.62 & 2 & 1601.7666 & 1601.7655 & 801.8900 & 0.0011 & 0.6859 & 104.743 & 90.215\end{array}$ $\begin{array}{llllllllllll}1.00 & 54.76 & 26.49 & 18.55 & 2 & 1601.7668 & 1601.7655 & 801.8900 & 0.0013 & 0.8106 & 24.102 & 28.463\end{array}$ $\begin{array}{llllllllllll}0.97 & 38.16 & 27.99 & 24.90 & 2 & 1136.6406 & 1136.6312 & 569.3229 & 0.0094 & 8.2554 & 5167.301 & 3961.081\end{array}$ $\begin{array}{llllllllllllll}\text { FQSISTEFLALMK } & 0.92 & 38.85 & 26.37 & 23.21 & 3 & 1801.9933 & 1801.9892 & 601.6703 & 0.0041 & 2.2714 & 342.645 & 317.729 \\ \text { GIFEALRPLETLPVEGLIR } & 0.60 & 37.25 & 19.73 & 50.25 & 3 & 2266.3210 & 2266.3171 & 756.4463 & 0.0039 & 1.7186 & 1320.930 & 1199.214\end{array}$ $\left.\begin{array}{llllllllllllll}0.97 & 38.14 & 27.87 & 24.86 & 2 & 1136.6418 & 1136.6312 & 569.3229 & 0.0106 & 9.3092 & 6475.729 & 4322.868 & 3\end{array}\right]$ $\begin{array}{lllllllllllllllll} & \end{array}$ $\begin{array}{lllllllllllllllll} & \end{array}$

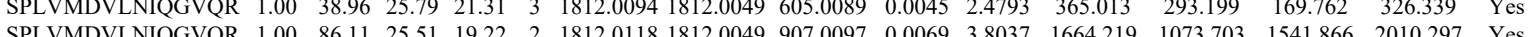

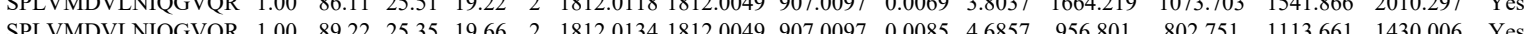
$\begin{array}{lllllllllllllll} & \end{array}$ $\begin{array}{lllllllllllllllll}\text { GIFEALRPLETLPVEGLIR } & 0.66 & 41.44 & 19.78 & 54.44 & 3 & 2266.3195 & 2266.3171 & 756.4463 & 0.0024 & 1.0576 & 2295.137 & 2879.115 & 2448.678 & 3154.994 & \text { Yes }\end{array}$ 


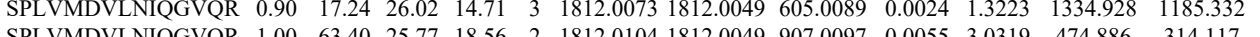
LSCLPAFK

$\begin{array}{llllll} & 0.03\end{array}$

$\begin{array}{lllllllllllll}0.91 & 27.22 & 27.42 & 22.93 & 2 & 1211.6682 & 1211.6650 & 606.8398 & 0.0032 & 2.6366 & 15347.901 & 1 & 0216.037\end{array}$ $\begin{array}{llllllllllll}0.96 & 25.35 & 20.53 & 29.35 & 3 & 1415.8972 & 1415.8955 & 472.9724 & 0.0017 & 1.1981 & 314.210 & 255.100\end{array}$

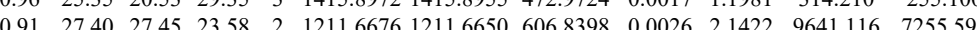

$\begin{array}{lllllllllllllll}0.91 & 32.77 & 27.61 & 27.01 & 2 & 1179.6616 & 1179.6522 & 590.8334 & 0.0094 & 7.9548 & 6715.110 & 4323.179 & 632.942 & 13313.340 & \text { No }\end{array}$ $\begin{array}{llllllllllllllll} & 1.00 & 46.08 & 26.84 & 20.20 & 2 & 1326.7450 & 1326.7418 & 664.3782 & 0.0032 & 2.4083 & 10891.465 & 10826.484 & 413.004 & 10521.566 & \text { Yes } \\ & 0.99 & 37.66 & 26.84 & 25.90 & 2 & 1326.7450 & 1326.7418 & 664.3782 & 0.0032 & 2.4083 & 10691.045 & 11795.011 & 601.279 & 10171.333 & \text { Yes }\end{array}$ $\begin{array}{lllllllllllllll} & & & \end{array}$ $\begin{array}{lllllllllllllllll} & & & \end{array}$ ASVVTLPVYLNFTR

WQALLVQIR

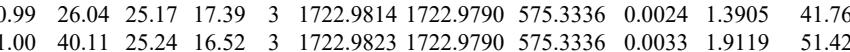

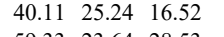

$\begin{array}{rrrrrrrr} & \end{array}$

ASVVTLPVYLNFTR WQALLVQIR $\begin{array}{llllllllllll}1.00 & 47.19 & 23.30 & 22.91 & 2 & 1269.7698 & 1269.7679 & 635.8912 & 0.0019 & 1.4940 & 2786.366 & \end{array}$ $\begin{array}{llllllllllll} & \end{array}$ $\begin{array}{llllllllllllll} & \end{array}$ QALVAIFTHLR $\begin{array}{llllllll} & \end{array}$ QALVAIFTHLR $\begin{array}{lllllllllllll}1.00 & 57.70 & 23.77 & 23.92 & 3 & 1411.8442 & 1411.8421 & 471.6213 & 0.0021 & 1.4842 & 1921.890 & 16\end{array}$ $\begin{array}{lllllllllllll}\text { QLIAQVMLYSQGFR } & 1.00 & 37.05 & 26.88 & 17.48 & 3 & 1796.9767 & 1796.9729 & 599.9982 & 0.0038 & 2.1111 & 41.747\end{array}$ $\begin{array}{lllllllllllllll}\text { QLIAQVMLYSOGFR } & 1.00 & 56.32 & 26.92 & 26.52 & 3 & 1796.9770 & 1796.9729 & 599.9982 & 0.0041 & 2.2778 & 23.650\end{array}$ $\begin{array}{lllllllllllll}\text { YLIAQVMLYSQGFR } & 1.00 & 56.32 & 26.92 & 26.52 & 3 & 1796.9770 & 1796.9729 & 599.9982 & 0.0041 & 2.2778 & 23.650 \\ \text { YLVYAILWSLSGDSR } & 0.67 & 17.73 & 27.09 & 30.73 & 3 & 1886.0095 & 1886.0060 & 629.6759 & 0.0035 & 1.8528 & 36.539\end{array}$ $\begin{array}{lllllllllllll}\text { LSLSNAISTALPLTQLR } & 1.00 & 44.08 & 22.46 & 18.98 & 3 & 1941.1363 & 1941.1380 & 648.0533 & -0.0017 & -0.8744 & 14.360\end{array}$ $\begin{array}{llllllllllll}\text { LSLSNAISTALPLTQLR } & 1.00 & \text { \#\#\#\# } 22.01 & 27.18 & 2 & 1941.1374 & 1941.1380 & 971.5763 & -0.0006 & -0.3088 & 429.598\end{array}$

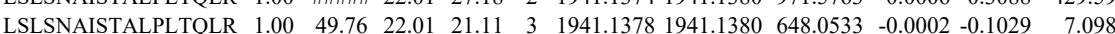
$\begin{array}{llllllllllll}\text { LSLSNAISTALPLTOLR } & 1.00 & \text { \#\#\# } 22.04 & 23.89 & 2 & 1941.1386 & 1941.1380 & 971.5763 & 0.0006 & 0.3088 & 896.713\end{array}$ $\begin{array}{llllllllllll}\text { QALVAIFTHLR } & 1.00 & 59.08 & 23.86 & 22.46 & 3 & 1411.8439 & 1411.8421 & 471.6213 & 0.0018 & 1.2722 & 277.153\end{array}$

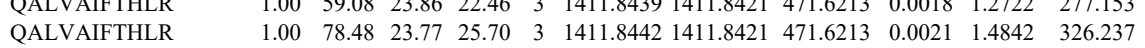
$\begin{array}{lllllllllllll}\text { LLLIQAFRPDR } & 0.55 & 6.24 & 22.99 & 18.74 & 3 & 1484.8981 & 1484.8949 & 495.9722 & 0.0032 & 2.1507 & 807.801\end{array}$ $\begin{array}{llllllllllllll}\text { LSLSNAISTALPLTQLR } & 1.00 & 42.78 & 22.25 & 20.40 & 3 & 1941.1366 & 1941.1380 & 648.0533 & -0.0014 & -0.7201 & 9.106\end{array}$ $\begin{array}{lllllllllll}\text { LSLSNAISTALPLTQLR } & 1.00 & \text { \#\#\#\# } 22.01 & 24.52 & 2 & 1941.1376 & 1941.1380 & 971.5763 & -0.0004 & -0.2059 & 68.675\end{array}$ $\begin{array}{lllllllllllll}\text { LSLSNAISTALPLTQLR } & 1.00 & 58.34 & 22.04 & 25.02 & 3 & 1941.1384 & 1941.1380 & 648.0533 & 0.0004 & 0.2057 & 24.444\end{array}$ $\begin{array}{lllllllllllll}\text { LSLSNAISTALPLTQLR } & 1.00 & \text { 22.04 } & 25.23 & 2 & 1941.1384 & 1941.1380 & 971.5763 & 0.0004 & 0.2059 & 89.638\end{array}$ $\begin{array}{llllllllllll}\text { LLLIQAFRPDR } & 0.70 & 9.13 & 23.03 & 20.26 & 3 & 1484.8972 & 1484.8949 & 495.9722 & 0.0023 & 1.5458 & 269.972\end{array}$

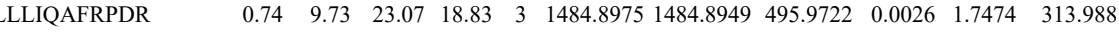
$\begin{array}{llllllllllll}\text { LSLSNAISTALPLTLR } & 1.00 & 82.14 & 22.50 & 20.65 & 2 & 1941.1332 & 1941.1380 & 971.5763 & -0.0048 & -2.4702 & 8.537\end{array}$ $\begin{array}{llllllllllllll}\text { LSLSNAISTALPLTQLR } & 1.00 & 34.95 & 21.90 & 17.58 & 3 & 1941.1402 & 1941.1380 & 648.0533 & 0.0022 & 1.1316 & 6.305\end{array}$ $\begin{array}{lllllllllllll}\text { LSLSNAISTALPLTQLR } & 1.00 & 39.08 & 21.64 & 23.80 & 3 & 1941.1414 & 1941.1380 & 648.0533 & 0.0034 & 1.7488 & 9.947\end{array}$ QALVAIFTHLR QALVAIFTHLR QALVAIFTHLR QALVAIFTHLR QALVAIFTHLR 1.00 $\begin{array}{llllllllll}1.00 & 51.77 & 23.77 & 23.33 & 3 & 1411.8445 & 1411.8421 & 471.6213 & 0.0012 & 0.8481\end{array}$ $\begin{array}{llllllllllll}1.00 & 51.77 & 23.77 & 23.33 & 3 & 1411.8445 & 1411.8421 & 41.6213 & 0.0024 & 1.6963 & 31.640\end{array}$

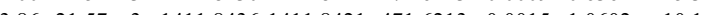
$\begin{array}{lllllllllll}1.00 & 45.93 & 23.86 & 21.57 & 3 & 1411.8436 & 1411.8421 & 41.6213 & 0.000 & 0.6361 & 25.305\end{array}$ $\begin{array}{llllllllllll}1.00 & 32.85 & 24.00 & 23.74 & 3 & 1411.8433 & 1411.8421 & 41.6213 & 0.0012 & 0.8481 & 27.862 & \end{array}$ $\begin{array}{lllllllllll}1.00 & 29.01 & 23.86 & 15.71 & 3 & 1411.8439 & 1411.8421 & 471.6213 & 0.0018 & 1.2722 & 22.008\end{array}$ 

$\begin{array}{llllllllllllllll}\text { SAVGFEYQGK } & 1.00 & 53.74 & 28.27 & 24.60 & 2 & 1372.7364 & 1372.7231 & 687.3688 & 0.0133 & 9.6745 & 10028.644 & 6884.687 & 2895.303 & 17612.272 & \text { Yes }\end{array}$ $\begin{array}{llllllllllllllll}\text { ANFENLAK } & 0.98 & 39.13 & 27.15 & 26.27 & 2 & 1193.6758 & 1193.6648 & 597.8397 & 0.0110 & 9.1997 & 10354.687 & 9414.776 & 3452.851 & 14770.433 & \text { Yes }\end{array}$ $\begin{array}{llllllllllllllll}\text { GPVSGTEPEPVYSMEAADYR } & 0.64 & 79.52 & 25.63 & 92.52 & 2 & 2298.0594 & 2298.0596 & 1150.0371 & -0.0002 & -0.0870 & 142.892 & 110.074 & 202.393 & 210.051 & \text { Yes }\end{array}$ $\begin{array}{lllllllllllllllll}\text { GPVSGTEPEPVYSMEAADYR } & 1.00 & 71.85 & 25.71 & 20.17 & 2 & 2298.0614 & 2298.0596 & 1150.0371 & 0.0018 & 0.7826 & 233.027 & 166.344 & 151.851 & 296.633 & \text { Yes }\end{array}$ $\begin{array}{llllllllllllllll}\text { TQTPPVSPAPQPTEER } & 1.00 & 73.64 & 27.98 & 23.71 & 2 & 1877.9702 & 1877.9605 & 939.9875 & 0.0097 & 5.1596 & 1865.274 & 1469.810 & 2952.733 & 3311.759 & \text { Yes }\end{array}$ $\begin{array}{lllllllllllllllll}\text { TQTPPVSPAPQPTEER } & 1.00 & 73.53 & 28.01 & 23.65 & 2 & 1877.9712 & 1877.9605 & 939.9875 & 0.0107 & 5.6915 & 1465.511 & 1373.081 & 2061.303 & 2599.878 & \text { Yes }\end{array}$ $\begin{array}{llllllllllllllll}\text { TQTPPVSPAPQPTEER } & 1.00 & 67.91 & 28.02 & 22.60 & 2 & 1877.9740 & 1877.9605 & 939.9875 & 0.0135 & 7.1809 & 297.996 & 234.714 & 397.929 & 453.766 & \text { Yes }\end{array}$

$\begin{array}{llllllllllllll}\text { RCN2_HUMAN } & \text { Q14257 } & \text { RCN2 } & \text { Reticulocalbin-2 } & 36.876 & 1.00 & 4 & 23.3 & 0.2717 & 1.6695 & -0.2253 & 1.1270 & 8\end{array}$ $\begin{array}{lllllllllll}\text { TRI25_HUMAN } & \text { Q14258 } & \text { TRIM25 } & \text { E3 ubiquitin/ISG1 } 70.989 & 1.00 & 7 & 16.3 & -0.0806 & 0.5135 & 0.6832 & 0.4670\end{array}$ $\begin{array}{lllllllllll}0.67 & 26.48 & 24.59 & 39.48 & 3 & 2358.0649 & 2358.0621 & 787.0280 & 0.0028 & 1.1859 & 1.194\end{array}$ $\begin{array}{llllllllllll}\text { NGDGFVSLEEFLGDYR } & 1.00 & 66.73 & 26.26 & 17.42 & 2 & 1960.9316 & 1960.9289 & 981.4717 & 0.0027 & 1.3755 & 54.278\end{array}$ $\begin{array}{lllllllllllll}\text { LSEEELENPDLFLTSEATDYGR } & 1.00 & \text { \#\#\#\# } 27.08 & 21.93 & 2 & 2784.3474 & 2784.3463 & 1393.1804 & 0.0011 & 0.3948 & 1.801\end{array}$

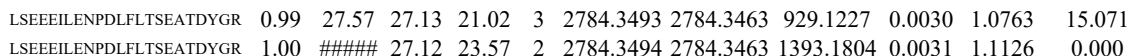

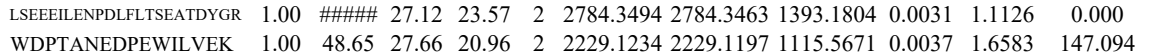
$\begin{array}{llllllllllll}\text { WDPTANEDPEWILVEK } & 1.00 & 48.65 & 27.66 & 20.96 & 2 & 2229.1234 & 2229.1197 & 1115.5671 & 0.0037 & 1.6583 & 147.094 \\ \text { WDPTANEDPEWILVEK } & 0.97 & 40.64 & 27.72 & 17.05 & 2 & 2229.1254 & 2229.1197 & 1115.5671 & 0.0057 & 2.5547 & 239.205\end{array}$ $\begin{array}{llllllllllll}\text { WDPTANEDPEWILVEK } & 0.97 & 40.64 & 27.72 & 17.05 & 2 & 2229.1254 & 2229.1197 & 1115.5671 & 0.0057 & 2.5547 & 239.205 \\ \text { WDPTANEDPEWILVEK } & 0.99 & 36.78 & 27.65 & 28.56 & 3 & 2229.1270 & 2229.1197 & 744.0472 & 0.0073 & 3.2704 & 18.049\end{array}$ $\begin{array}{llllllllllll}\text { WDPTANEDPEWILVEK } & 0.91 & 28.57 & 27.70 & 19.93 & 3 & 2229.1300 & 2229.1197 & 744.0472 & 0.0103 & 4.6144 & 12.898\end{array}$

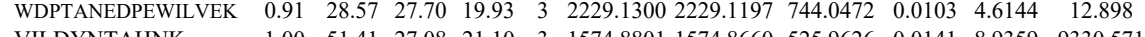

\section{LPTFGAPEQLVDLK}

$\begin{array}{lllllllllllll}1.00 & 51.41 & 27.08 & 21.10 & 3 & 1574.8801 & 1574.8660 & 525.9626 & 0.0141 & 8.9359 & 9330.571 & \\ 1.00 & 60.33 & 24.55 & 25.30 & 2 & 1815.0406 & 1815.0386 & 908.5266 & 0.0020 & 1.1007 & 269.029\end{array}$ LPTFGAPEQLVDLK
LPTFGAPEQLVDLK

FDTIYQILLK

FDTIYQILLK

FDTIYQILLK

FDTIYQILLK $\begin{array}{llllllllllll}1.00 & 42.11 & 24.50 & 33.17 & 3 & 1815.0415 & 1815.0386 & 606.0201 & 0.0029 & 1.5951 & 232.325\end{array}$ $\begin{array}{lllllllllll}1.00 & 52.44 & 22.48 & 31.05 & 3 & 1815.0427 & 1815.0386 & 606.0201 & 0.0041 & 2.2551 & 287.745\end{array}$ $\begin{array}{lllllllllllll}1.00 & 53.39 & 23.18 & 26.43 & 2 & 1540.9140 & 1540.9108 & 771.4627 & 0.0032 & 2.0740 & 849.206 & 1\end{array}$ $\begin{array}{llllllllllll}0.99 & 24.31 & 23.18 & 23.68 & 3 & 1540.9141 & 1540.9108 & 514.6442 & 0.0033 & 2.1374 & 73.486\end{array}$ $\begin{array}{lllllllllll}0.99 & 24.31 & 23.18 & 23.68 & 3 & 540.9141540 .9108 & 514.6442 & 0.0033 & 2.1374 & 73.486\end{array}$ $\begin{array}{lllllllllllll}1.65 & 6.68 & 26.61 & 15.82 & 4 & 30354581 & 3035.4537 & 759.8707 & 0.0044 & 1.4476 & 0.000\end{array}$

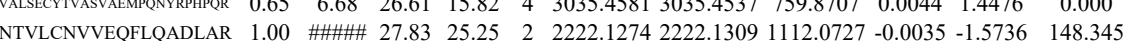
$\begin{array}{lllllllllllll}\text { NTVLCNVVEOFLADLLAR } & 0.99 & 41.03 & 27.82 & 19.36 & 3 & 2222.1289 & 2222.1309 & 741.7176 & -0.0020 & -0.8988 & 55.222\end{array}$ $\begin{array}{lllllllllllllllll}\text { NTVLCNVVEQFLQADLAR } & 1.00 & \text { \#\#\#\# } 27.77 & 24.88 & 2 & 2222.1294 & 2222.1309 & 1112.0727 & -0.0015 & -0.6744 & 65.763\end{array}$

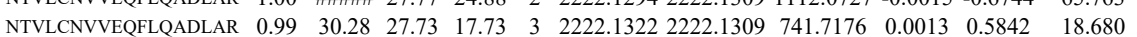
$\begin{array}{llllllllllll}\text { NTVLCNVVEQFLQADLAR } & 1.00 & \text { \#\#\# } & 27.83 & 27.92 & 2 & 2222.1274 & 2222.1309 & 1112.0727 & -0.0035 & -1.5736 & 281.543\end{array}$ $\begin{array}{lllllllllllllll}\text { NTVLCNVVEQFLQADLAR } & 1.00 & 35.81 & 27.71 & 17.28 & 3 & 2222.1313 & 2222.1309 & 741.7176 & 0.0004 & 0.1798 & 104.047\end{array}$ NTVLCNVVEQFLQADLAR $1.00 \quad \begin{array}{lllllllllll}27.72 & 24.90 & 2 & 2222.1314 & 2222.1309 & 1112.0727 & 0.0005 & 0.2248 & 357.617\end{array}$ $\begin{array}{lllllllllllll}\text { NTVLCNVVEQFLQADLAR } & 1.00 & 45.09 & 27.71 & 17.18 & 3 & 2222.1355 & 2222.1309 & 741.7176 & 0.0046 & 2.0673 & 108.727\end{array}$

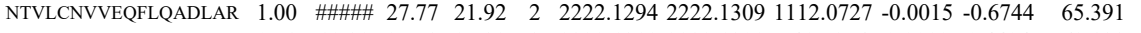

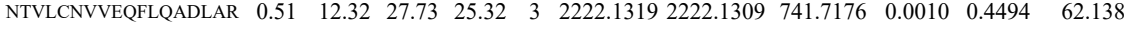
$\begin{array}{llllllllllll}\text { NTVLCNVVEQFLQADLAR } & 0.55 & 25.15 & 27.73 & 38.15 & 3 & 2222.1325 & 2222.1309 & 741.7176 & 0.0016 & 0.7191 & 43.510\end{array}$ LTVMYSQINGASR LTVMYSQINGAS LTVMYSQINGASR LTVMYSQINGASR ALLDASETTSTR $\begin{array}{llllllllll}291.02 & 1.00 & 5 & 5.1 & -0.0058 & 0.4821 & 0.4201 & 1.0216 & 6 & \text { VPQLLPITNFNR } \\ & & & & & & & & & \text { VPQLPTNNF }\end{array}$

FLNC HUMAN Q14315 FLNC Filnit-C VPQLPITNFNR VPQLPITNFNR SLTHGGNRTAR
1.00 $\begin{array}{lllllllllll}1.00 & 75.75 & 28.19 & 29.03 & 2 & 1582.8398 & 1582.8259 & 792.4202 & 0.0139 & 8.7705 & 335.126\end{array}$ $\begin{array}{llllllllllll}1.00 & 75.75 & 28.19 & 29.03 & 2 & 1582.8398 & 1582.8259 & 792.4202 & 0.0139 & 8.7705 & 335.126\end{array}$ $\begin{array}{lllllllllll}1.00 & 73.99 & 8.22 & 27.72 & 2 & 1582.8354 & 1582.8259 & 792.4202 & 0.005 & 5.9943 & 392.783\end{array}$ $\begin{array}{lllllllllll}0.99 & 45.15 & 27.80 & 26.43 & 2 & 1407.7314 & 1407.7327 & 704.8736 & -0.0013 & -0.9222 & 601.081\end{array}$ $\begin{array}{llllllllllll}1.00 & 50.53 & 26.59 & 33.34 & 2 & 1441.8174 & 1441.8163 & 721.9154 & 0.0011 & 0.7619 & 957.259\end{array}$

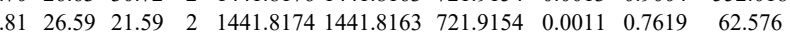
$\begin{array}{lllllllllll} & 24.816 & 2 & 1441.8180 & 1441.8163 & 721.9154 & 0.0017 & 1.1774 & 51.591\end{array}$ $\begin{array}{lllllllllll}1.00 & 55.11 & 27.75 & 17.11 & 2 & 1283.6574 & 1283.6582 & 642.8364 & -0.0008 & -0.6222 & 2.719\end{array}$ $\begin{array}{lllllllllllll}0.98 & 31.70 & 26.63 & 30.72 & 2 & 1441.8176 & 1441.8163 & 721.9154 & 0.0013 & 0.9004 & 552.018\end{array}$
1.124

37.587

3.585

0.000

153.015

35.419

1079.444

1079.444

95.627

9.966

99.400

109.400
27.636
85.642
3.876

-1
-35.876

0.114

15.869

-1.869
75.769

35.66

105.780

320.554

258.945

247.419

335.887 602.74 50.446 $\begin{array}{lll}21.419 & 14.731 & \text { Yes }\end{array}$

$\begin{array}{lll}14.795 & 11.267 & \text { Yes }\end{array}$ $\begin{array}{lll}14.964 & 44.656 & \text { Yes }\end{array}$ \begin{tabular}{lll}
13.964 & 44.656 & Yes \\
\hline &
\end{tabular} $\begin{array}{lll}10.141 & 4.501 & Y e s \\ 3 & 468 & \end{array}$ $\begin{array}{lll}38.163 & \text { Yes }\end{array}$ \begin{tabular}{lll}
12.694 & 307.647 & Yes \\
\hline 38.238 & 312.378 & No
\end{tabular}

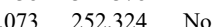
$\begin{array}{lll}1.875 & 77.880 & \text { Yes }\end{array}$ $\begin{array}{lll}0.000 & 13.169 & \text { No }\end{array}$ \begin{tabular}{l}
$43.975 \quad 4936$ Yes \\
\hline 35.252
\end{tabular} $\begin{array}{lll}35.279 & 92.192 & \text { Yes } \\ & \end{array}$ \begin{tabular}{lll}
\hline .508 & 337.968 & Yes \\
\hline 9223 & 108.109 & Yes
\end{tabular} $\begin{array}{lll}116.961 \quad 335.175 & \text { Yes }\end{array}$ $\begin{array}{lll}47.527 & 51.227 & \text { No }\end{array}$ $\begin{array}{lll}.016 & 52.743 & \text { Yes } \\ .379 & 89.847 & \text { Yes }\end{array}$ $\begin{array}{lll}7.395 & 156.915 & \text { No }\end{array}$ $\begin{array}{lll}0.040 & \text { Yes }\end{array}$

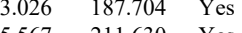
\begin{tabular}{lll} 
& 38.704 & Yes \\
\hline 171.254 & 211.630 & Yes
\end{tabular} $\begin{array}{lll}124.454 & 489.327 & \text { Yes }\end{array}$ $139.539 \quad 250.538$ Yes $\begin{array}{lll}8.589 & 362.339 & \text { Yes } \\ 81.769 & \text { Yes }\end{array}$ $\begin{array}{lll}7.401 & 31.334 & \text { Ye }\end{array}$ 
AWGPGLETGQVGK AWVGEGSHPER

LEPGGGAEAQAVR

$\begin{array}{lllllllllll}\text { GALE_HUMAN } & \text { Q14376 } & \text { GALE } & \text { UDP-glucose 4-ep 38.282 } & 1.00 & 3 & 13.2 & 0.0087 & 0.5501 & -0.3604 & 0.2192\end{array}$

CAPR1_HUMAI Q14444 CAPRIN1 Caprin-1

SVEFEEMDILDQGALQR

$\begin{array}{llllllllll}78.366 & 1.00 & 7 & 11.6 & -0.3684 & 0.4293 & 2.1442 & 0.3594 & 15 & \text { LGDDEVR } \\ \text { LGDDEVR }\end{array}$

LGDDEVR
LNQDQLDAVSK

YQEVTNNLEFAK

YQEVTNNLEFAK

YQEVTNNLEFAK

QGLNGVPILSEEELSLLDEF

QGLNGVPLSEEELSLLDEFYK

QGLNGVPILSEE

TVLELQYVLDK

TVLELQYVLDK

TVLELQYVLDK

SFMALSQDIQK

SFMALSQDIQK

LNQDQLDAVSK

VLGVPIIVQASQAEK

GIAYVEFVDVSSVPLAIGLTGQR

$\begin{array}{llllllllllll}1.00 & 46.38 & 24.46 & 18.97 & 3 & 2534.3878 & 2534.3866 & 845.8028 & 0.0012 & 0.4729 & 50.645 & 41.070\end{array}$

\begin{tabular}{lllllllllllll} 
GIAYVEFVDVSSVPLAIGLTGQR & 0.67 & 21.64 & 24.33 & 34.64 & 3 & 2534.3896 & 2534.3866 & 845.8028 & 0.0030 & 1.1823 & 89.133 & 92.910 \\
\hline
\end{tabular}

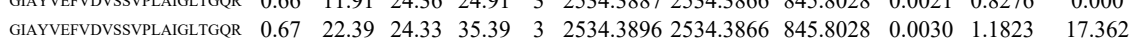

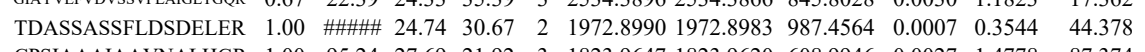
$\begin{array}{lllllllllllll}\text { CPSIAAAIAAVNALHGR } & 1.00 & 95.24 & 27.69 & 21.92 & 3 & 1823.9647 & 1823.9620 & 608.9946 & 0.0027 & 1.4778 & 87.374 & \\ \text { CPSIAAAIAAVNALHGR } & 1.00 & 79.83 & 27.69 & 23.80 & 3 & 1823.9647 & 1823.9620 & 608.9946 & 0.0027 & 1.4778 & 59.303 & \end{array}$

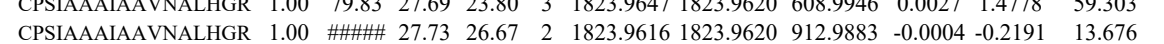

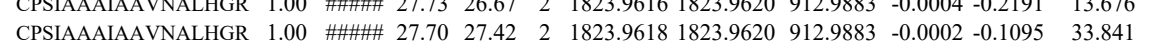

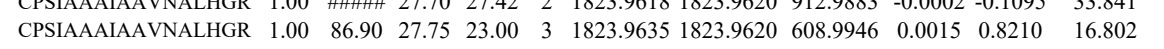
$\begin{array}{lllllllllllll}\text { CPSIAAAIAAVNALHGR } & 1.00 & \text { \#\#\#\# } 27.75 & 27.60 & 3 & 1823.9635 & 1823.9620 & 608.9946 & 0.0015 & 0.8210 & 26.199 & 4.6\end{array}$ $\begin{array}{lllllllllll}\text { CPSIAAAIAAVNALHGR } & 0.82 & \# \# \# \# \text { 27.75 \#\#\#\# } & 2 & 1823.9630 & 1823.9620 & 912.9883 & 0.0010 & 0.5477 & 8.124 & 5.788\end{array}$

1 EIESEIDSEEELINK

EIESEIDSEEELINK

YLQLAEELIRPER

YLQLAEELIRPER

YLQLAEELIRPER

ASSAAGLTAAVVR QNINLSAPIMSR

IGLLTR
IGLLTR

GVLLMLFGGVPK

GVLLMLFGGVPK

GVLLMLFGGVPK

YLLFAR

GVLLMLFGGVPK

GVLLMLFGGVPK

GVLLMLFGGVPK

GVLLMLFGGVPK

GVLLMLFGGVPK

GVLLMLFGGVPK

GVLLMLFGGVPK

GVLLMLFGGV

ISNLIVLHLR

ISNLIVLHLR

ISNLIVLHLR

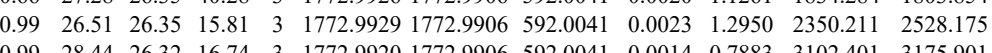
$\begin{array}{lllllllllllll}0.66 & 26.83 & 21.64 & 39.83 & 3 & 1517.9272 & 1517.9247 & 506.9822 & 0.0025 & 1.6437 & 26.159 & 28.105\end{array}$

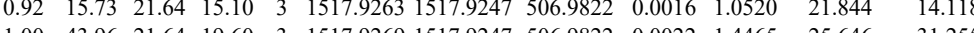

$\begin{array}{llllllllllll}1.00 & 72.86 & 27.67 & 26.37 & 3 & 2064.0373 & 2064.0353 & 689.0190 & 0.0020 & 0.9676 & 16.888 & 17.429\end{array}$

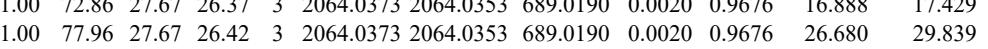
$\begin{array}{lllllllllllll}0.66 & 27.28 & 26.35 & 40.28 & 3 & 1772.9926 & 1772.9906 & 592.0041 & 0.0020 & 1.1261 & 1834.284 & 1803.854 & 21\end{array}$ $\begin{array}{lllllllllllllll}0.99 & 28.44 & 26.32 & 16.74 & 3 & 1772.9920 & 1772.9906 & 592.0041 & 0.0014 & 0.7883 & 3102.401 & 3175.901 & 20\end{array}$ $\begin{array}{lllllllllllll}0.99 & 28.88 & 26.33 & 16.24 & 3 & 1772.9923 & 1772.9906 & 592.0041 & 0.0017 & 0.9572 & 2960.515 & 3214.731 & 2\end{array}$ $\begin{array}{llllllllllllll}1.00 & 78.31 & 26.68 & 24.75 & 2 & 1316.7644 & 1316.7534 & 659.3840 & 0.0110 & 8.3410 & 9083.865 & 9516.066 & 26\end{array}$ $\begin{array}{llllllllllllllll}1.00 & 78.31 & 26.68 & 24.75 & 2 & 1316.7644 & 1316.7534 & 659.3840 & 0.0110 & 8.3410 & 9083.865 & 9516.066 & 2655.989 & 12258.609 & \text { Yes } \\ 1.00 & 66.02 & 27.66 & 34.75 & 2 & 1486.8156 & 1486.8047 & 744.4096 & 0.0109 & 7.3212 & 3239.857 & 4106.381 & 522.230 & 6025.679 & \text { Yes } \\ 0.92 & 24.40 & 23.71 & 29.02 & 2 & 815.5378 & 815.5351 & 408.7748 & 0.0027 & 3.3025 & 13694.273 & 16456.610 & 3199.623 & 23842.556 & \text { Yes }\end{array}$ $\begin{array}{llllllllllllllllll} & & \end{array}$

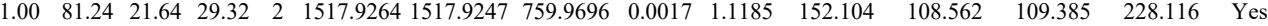
$\begin{array}{llllllllllll}0.99 & 21.00 & 21.64 & 20.55 & 3 & 1517.9272 & 1517.9247 & 506.9822 & 0.0025 & 1.6437 & 13.001 & 20.308\end{array}$ $\begin{array}{llllllllllll}0.99 & 22.49 & 21.70 & 19.04 & 3 & 1517.9278 & 1517.9247 & 506.9822 & 0.0031 & 2.0382 & 22.130 & 16.078\end{array}$ $\begin{array}{llllllllllll}0.84 & 21.08 & 27.10 & 26.06 & 2 & 925.5532 & 925.5507 & 463.7826 & 0.0025 & 2.6952 & 1210.746 & 1405.373\end{array}$ $\begin{array}{llllllllllll}1.00 & 66.42 & 21.64 & 27.31 & 2 & 1517.9260 & 1517.9247 & 759.9696 & 0.0013 & 0.8553 & 58.478 & 55.732\end{array}$

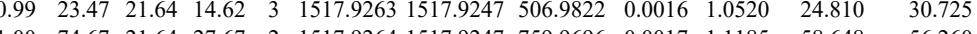

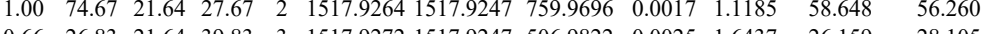
$\begin{array}{llllllllllll}1.00 & 62.45 & 21.67 & 27.85 & 2 & 1517.9250 & 1517.9247 & 759.9696 & 0.0003 & 0.1974 & 26.889 & 11.652\end{array}$

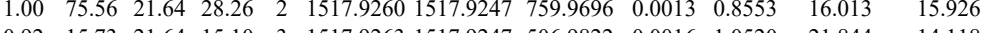

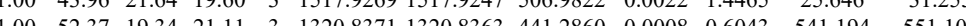

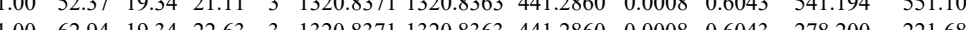
$\begin{array}{llllllllllll}1.00 & 54.38 & 19.34 & 29.45 & 3 & 13208371 & 1320.8363 & 441.2860 & 0.0008 & 0.6043 & 273.630 & 2\end{array}$ $\begin{array}{lllllllllll}1.00 & 28.03 & 19.34 & 21.20 & 3 & 1320.8371 & 1320.8363 & 441.2860 & 0.0008 & 0.6043 & 56.389\end{array}$

$27.406 \quad 22.747 \quad$ Yes

$204.658 \quad 3445.342 \quad$ Yes $290.494 \quad 4885.007$ Yes 5622098 Yes $\begin{array}{lll}548 & 34.446 & \text { Yes }\end{array}$ $\begin{array}{lll}61.197 \quad 4097.320 & \text { No }\end{array}$ $\begin{array}{lll}41.221 & 82.792 \quad \text { Yes } \\ 13.180 & 54.779 & \text { Yes }\end{array}$

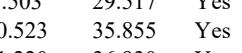
$87.500 \quad 551.135$ Yes $\begin{array}{lll} & \\ 0.890 & 418.126 & \text { Yes }\end{array}$
Yes No Yes Yes Yes $\begin{array}{llllllllllllllll}0.98 & 26.07 & 27.39 & 14.95 & 3 & 2123.0353 & 2123.0327 & 708.6848 & 0.0026 & 1.2229 & 0.000 & 30.599 & 25.141 & 21.890 & \text { No } \\ 1.00 & 63.61 & 27.43 & 20.23 & 3 & 2123.0365 & 2123.0327 & 708.6848 & 0.0038 & 1.7873 & 15.305 & 22.249 & 18.225 & 14.419 & \text { Yes }\end{array}$ $\begin{array}{rrr}55.767 & 86.904 & \text { Yes } \\ 44.093 & 99.027 & \text { Yes }\end{array}$ \begin{tabular}{lll}
5870.036 & Yes \\
\hline & .261 & -1 \\
338.422 & Yes
\end{tabular} $\begin{array}{llll}87.085 & 954.787 & \text { Yes }\end{array}$ $\begin{array}{ccc}76.409 & 2173.316 & \text { Yes } \\ 8.452 & 2.803 & \text { No }\end{array}$ $\begin{array}{lll}8.130 & 4.427 & \text { No }\end{array}$ $\begin{array}{lll}8.902 & 21.536 & \text { No }\end{array}$ $\begin{array}{ccc}7.920 & 0.000 & \text { No } \\ 315.048 & 10262.066 & \text { Yes }\end{array}$ $\begin{array}{llll}31.559 & 435.582 & \text { Yes }\end{array}$ $\begin{array}{lll}112.367 & 189.589 & \text { Yes }\end{array}$ $135.661 \quad 611.950 \quad$ Yes $\begin{array}{llll}36.997 & 452.848 & \text { Yes } \\ 31.502 & 1363.843 & \text { Yes }\end{array}$ $\begin{array}{lll}51.895 & 540.500 \quad \text { Yes }\end{array}$ $\begin{array}{ccc}266.784 & 3392.897 & \text { Yes } \\ 73.335 & 164.068 & \text { Yes }\end{array}$ $\begin{array}{lll}73.572 & 52.767 \text { Yes }\end{array}$ $\begin{array}{lll}19.572 & 52.7672 & \text { Yes } \\ 30.585 & 18.600 & \text { Yes }\end{array}$ $\begin{array}{lll}23.115 & 25.888 & \mathrm{No}\end{array}$ $6.658 \quad 44.741 \quad$ Yes $\begin{array}{lll}106.931 & 146.457 & \text { Yes } \\ 100.727 & 69.827 & \text { Yes }\end{array}$ \begin{tabular}{lll}
24.893 & 39.827 & Yes \\
\hline & 38.742 & Y
\end{tabular} $\begin{array}{lll}38.683 & 25.138 & \text { Yes }\end{array}$ $\begin{array}{lll}37.780 & 41.758 & \text { Yes } \\ 21.818 & 36.020 & \text { Yes }\end{array}$

$\begin{array}{lll}2.330 & 4.671 & \text { Yes }\end{array}$ $\begin{array}{lll}47.805 & 95.337 & \text { Yes }\end{array}$ $\begin{array}{lll}12.662 & 48.729 & \text { Yes } \\ 41.221 & 82.792 & \text { Yes }\end{array}$ $\begin{array}{lll}13.180 & 54.779 & \text { Yes }\end{array}$ \begin{tabular}{lll}
13.180 & 54.779 & Yes \\
7.326 & 34.329 & Yes \\
\hline & 29.517 & Yes
\end{tabular} \begin{tabular}{lll}
1.220 & 36.930 & Yes \\
\hline 86.811 & 951.988 & Yes
\end{tabular} 

$\begin{array}{lllllllllllll} & 0.58 .03159 & 2308.3124 & 770.4447 & 0.0035 & 1.5143 & 22.396\end{array}$ $\begin{array}{lllllllllllll} & 31.55 & 22.48 & 44.55 & 3 & 2308.3165 & 2308.3124 & 770.4447 & 0.0041 & 1.7739 & 0.000\end{array}$ $\begin{array}{llllllllllll} & 0.8739 & 0.000\end{array}$

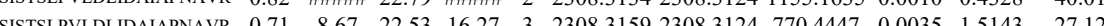

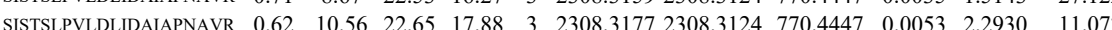
$\begin{array}{llllllllllllll}\text { SISTSLPVIDLIDAIAPNAVR } & 0.67 & 26.14 & 22.55 & 39.14 & 3 & 2308.3153 & 2308.3124 & 770.4447 & 0.0029 & 1.2547 & 11.880\end{array}$ $\begin{array}{lllllllllllll}\text { AGLMLOEADK } & 0.99 & 44.34 & 28.10 & 26.06 & 2 & 1362.7538 & 1362.7421 & 682.3783 & 0.0117 & 8.5729 & 997.941\end{array}$ $\begin{array}{llllllllllll}\text { NEALIALLNEGEELFELMK } & 0.66 & 22.65 & 26.56 & 35.65 & 3 & 2445.2935 & 2445.2915 & 816.1044 & 0.0020 & 0.8169 & 21.162\end{array}$ $\begin{array}{llllllllllllll} & \end{array}$ $\begin{array}{llllllllllllll}\text { NEALIALLNEGEELEELMK } & 0.92 & 20.73 & 26.61 & 16.03 & 3 & 2445.2929 & 2445.2915 & 816.1044 & 0.0014 & 0.5718 & 24.699\end{array}$ $\begin{array}{llllllllllllll}\text { NEALIALLNEGEELEELMK } & 0.66 & 15.14 & 26.53 & 28.14 & 3 & 2445.2941 & 2445.2915 & 816.1044 & 0.0026 & 1.0620 & 16.515\end{array}$

$\begin{array}{llllllllllllll}\text { ASPDQNASTHTPQSSVK } & 1.00 & 90.30 & 27.56 & 21.16 & 2 & 2042.0274 & 2042.0272 & 1022.0209 & 0.0002 & 0.0978 & 29.156\end{array}$ $\begin{array}{llllllllllll}\text { ASPDQNASTHTPQSSVK } & 1.00 & 49.54 & 27.57 & 22.12 & 3 & 2042.0305 & 2042.0272 & 681.6830 & 0.0033 & 1.6137 & 1975.228\end{array}$ $\begin{array}{llllllllllll}\text { ASPDQNASTHTPQSSVK } & 1.00 & 58.04 & 27.57 & 20.36 & 3 & 2042.0326 & 2042.0272 & 681.6830 & 0.0054 & 2.6405 & 4881.550 \\ \text { ASPDONASTHTPOSSVK } & 1.00 & 51.59 & 27.60 & 20.57 & 3 & 2042.0287 & 2042.0272 & 681.6830 & 0.0015 & 0.7335 & 278.379\end{array}$ $\begin{array}{llllllllllllll}\text { ASPDQNASTHTPQSSVK } & 1.00 & 43.93 & 27.57 & 18.09 & 3 & 2042.0290 & 2042.0272 & 681.6830 & 0.0018 & 0.8802 & 528.060 & 52\end{array}$

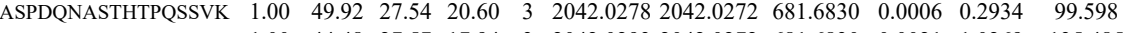

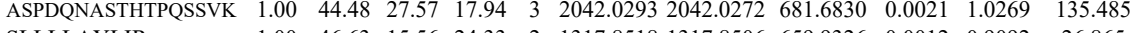
SLLLLAYLIR SLLLLAYLIR SLLLLAYLIR SLLLLAYLIR SLLLLAYLIR $\begin{array}{lllllllllll}1.00 & 46.63 & 15.56 & 24.33 & 2 & 1317.8518 & 1317.8506 & 659.9326 & 0.0012 & 0.9092 & 26.865 \\ 1.00 & 39.09 & 15.80 & 27.79 & 2 & 1317.8538 & 1317.8506 & 659.9326 & 0.0032 & 2.4245 & 39.962\end{array}$ SLLLLAYLI $\begin{array}{llllllllll} & \end{array}$ $\begin{array}{lllllllllllll}1.00 & 63.54 & 15.56 & 35.62 & 2 & 1317.8518 & 1317.8506 & 659.9326 & 0.0012 & 0.9092 & 71.612 \\ 1.00 & 38.73 & 15.80 & 28.49 & 2 & 1317.8536 & 1317.8506 & 659.9326 & 0.0030 & 22730 & 44.759\end{array}$ $\begin{array}{lllllllllll}0.80 & 11.69 & 15.80 & 17.36 & 2 & 1317.8536 & 1317.8506 & 659.9326 & 0.0030 & 2.2730 & 5.982\end{array}$

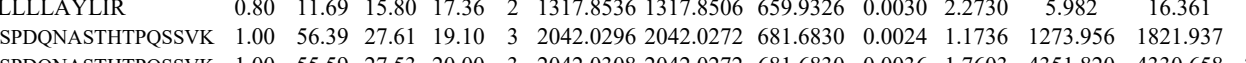
$\begin{array}{lllllllllll} & 1.1736 & 1273.956 & 1821.965\end{array}$

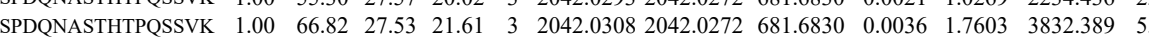
$\begin{array}{llllllllllllll}\text { AEIMESIKR } & 0.62 & 23.75 & 27.71 & 29.77 & 2 & 1235.6772 & 1235.6665 & 618.8405 & 0.0107 & 8.6451 & 4112.657 & 4934 \\ \text { SNLMDAISFVLGEK } & 1.00 & 54.08 & 27.02 & 22.75 & 3 & 1810.9768 & 1810.9742 & 604.6653 & 0.0026 & 1.4333 & 150294 & 143\end{array}$ SNTMDASPVI $\begin{array}{llllllllllllll}\text { GEPETFLPLDYLEVKPTDEK } & 0.66 & 37.46 & 25.80 & 50.46 & 3 & 2751.4600 & 2751.4584 & 918.1601 & 0.0016 & 0.5809 & 167.585\end{array}$ $\begin{array}{lllllllllllll}\text { GEPETFLPLDYLEVKPTDEK } & 0.84 & 8.32 & 25.71 & 21.32 & 4 & 2751.4617 & 2751.4584 & 688.8719 & 0.0033 & 1.1976 & 536.735\end{array}$ $\begin{array}{lllllllllllll}\text { GEPETFLPLDYLEVKPTDEK } & 0.98 & 13.86 & 25.66 & 26.86 & 4 & 2751.4637 & 2751.4584 & 688.8719 & 0.0053 & 1.9234 & 355.905\end{array}$

2 IPLLLTSLSFK IPLLLTSLSFK IPLLLTSLSFK IPLLLTSLSFK IPLLLTSLSFK IPLLLTSLSFK IPLLLTSLSFK ACILCVHPR ACILCVHPR ACILCVHPR ACILCVHPR KVVILNVDLLK

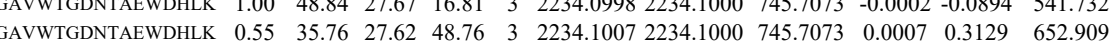
$\begin{array}{llllllllllll}1.00 & 70.87 & 16.90 & 21.29 & 2 & 1518.9640 & 1518.9629 & 760.4887 & 0.0011 & 0.7232 & 51.894\end{array}$ $\begin{array}{lllllllllllll}1.00 & 74.01 & 16.90 & 21.56 & 2 & 1518.9640 & 1518.9629 & 760.4887 & 0.0011 & 0.7232 & 82.956\end{array}$ $\begin{array}{llllllllllll}0.67 & 1.85 & 14.77 & 14.85 & 3 & 1518.9658 & 1518.9629 & 507.3282 & 0.0029 & 1.9054 & 30.706 \\ 1.0629 & 507.3282 & 0.0032 & 2.1025 & 44.604\end{array}$ $\begin{array}{llllllllllll}1.00 & 61.77 & 16.90 & 20.08 & 2 & 1518.9636 & 1518.9629 & 760.4887 & 0.0007 & 0.4602 & 38.692\end{array}$ $\begin{array}{lllllllllll}1.00 & 72.22 & 16.90 & 21.60 & 2 & 1518.9638 & 1518.9629 & 760.4887 & 0.0009 & 0.5917 & 64.072\end{array}$ $\begin{array}{llllllllllll}0.99 & 15.49 & 15.80 & 14.33 & 3 & 1518.9646 & 1518.9629 & 507.3282 & 0.0017 & 1.1170 & 70.231\end{array}$ $\begin{array}{llllllllllll}0.99 & 39.68 & 25.48 & 19.29 & 2 & 1246.5926 & 1246.5929 & 624.3037 & -0.0003 & -0.2403 & 543.611 \\ 1.00 & 52.89 & 25.53 & 18.60 & 3 & 1246.5931 & 1246.5929 & 416.5382 & 0.0002 & 0.1600 & 941.973\end{array}$ $\begin{array}{llllllllllll}1.00 & 48.88 & 25.33 & 22.33 & 3 & 1246.5934 & 1246.5929 & 416.5382 & 0.0005 & 0.4001 & 1146.096 & 9\end{array}$ $\begin{array}{lllllllllllll}1.00 & 42.09 & 25.33 & 18.91 & 2 & 1246.5936 & 1246.5929 & 624.3037 & 0.0007 & 0.5606 & 722.438 & 6\end{array}$ $\begin{array}{llllllllllllll}0.65 & 5.35 & 12.79 & 16.83 & 3 & 1541.0173 & 1541.0160 & 514.6793 & 0.0013 & 0.8419 & 26.082\end{array}$ $\begin{array}{lllllllllllll}0.91 & 29.99 & 28.59 & 22.89 & 2 & 1634.8480 & 1634.8477 & 818.4311 & 0.0003 & 0.1833 & 9.104\end{array}$

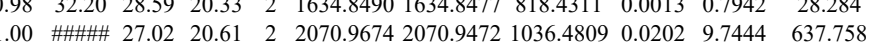
$\begin{array}{llllllllllll}1.00 & 4.60 & 27.77 & 19.00 & 3 & 2234.1031 & 234.10000 & 745.7073 & 0.0007 & 0.3129 & 652.909 & \end{array}$ $\begin{array}{llllllllllll}1.00 & 50.06 & 25.72 & 17.97 & 2 & 1504.8748 & 1504.8735 & 753.4440 & 0.0013 & 0.8627 & 329.925\end{array}$ \begin{tabular}{lllllllll}
\hline .84 & 17.77 & 2 & 1504.8744 & 1504.8735 & 753.4440 & 0.0009 & 0.5973 & 300.886
\end{tabular}

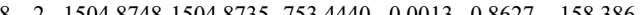
$\begin{array}{lllllllllllll}1.00 & 54.63 & 27.29 & 25.00 & 3 & 1861.0150 & 1860.9968 & 621.3395 & 0.0182 & 9.7638 & 8486.529 & 8715.242 & 3348.73\end{array}$ $\begin{array}{llll}40.659 & 1060.762 & 7649.700 & \text { Yes }\end{array}$ $\begin{array}{lllll}158.531 & 298.058 & 319.022 & \text { Yes }\end{array}$ $\begin{array}{llll}637.374 & 330.425 & 1097.630 & \text { Yes }\end{array}$ $\begin{array}{llll}420.426 & 205.184 & 561.091 & \text { Yes }\end{array}$ $\begin{array}{llll}57.906 & 74.018 & 71.390 & \text { Yes }\end{array}$ $\begin{array}{lllll}62.569 & 61.360 & 100.473 & \text { Yes }\end{array}$ $\begin{array}{llll}28.718 & 12.374 & 27.720 & \text { Yes }\end{array}$ $\begin{array}{llll}21.730 & 21.816 & 45.857 & \text { Yes }\end{array}$ $\begin{array}{llll}34.926 & 32.946 & 30.629 & \text { Yes }\end{array}$ $\begin{array}{llll}34.826 & 32.946 & 30.629 & \text { Yes } \\ 63.010 & 27.256 & 85.373 & \text { Yes } \\ & 17.873 & 73.175 & \text { Yes }\end{array}$

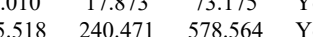
$\begin{array}{llll}778.631 & 242.131 & 769.148 & \text { Yes }\end{array}$ $\begin{array}{llll}913.693 & 193.683 & 1101.135 & \text { Yes }\end{array}$ $\begin{array}{llll}652.498 & 199.766 & 578.811 & \text { Yes }\end{array}$ 

$\begin{array}{llllllllllllllll}0.92 & 26.64 & 24.33 & 21.41 & 2 & 842.5096 & 842.5096 & 422.2621 & 0.0000 & 0.0000 & 189.217 & 218.279 & 187.239 & 276.856 & \text { Yes }\end{array}$ $\begin{array}{lllllllllllllll}0.96 & 29.28 & 24.33 & 27.71 & 2 & 842.5096 & 842.5096 & 422.2621 & 0.0000 & 0.0000 & 13.166 & 39.476 & 17.089 & 20.850 & \text { Yes }\end{array}$ $\begin{array}{llllllllllllllll}0.98 & 33.97 & 24.17 & 24.93 & 2 & 842.5100 & 842.5096 & 422.2621 & 0.0004 & 0.4736 & 19.396 & 27.130 & 18.385 & 26.581 & \text { Yes }\end{array}$

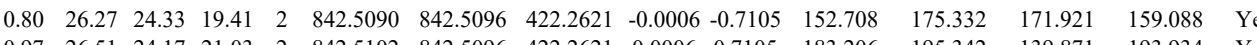

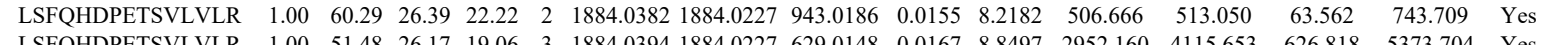
$\begin{array}{llllllllllllllll}\text { LSFQHDPETSVLVLR } & 1.00 & 51.48 & 26.17 & 19.06 & 3 & 1884.0394 & 1884.0227 & 629.0148 & 0.0167 & 8.8497 & 2952.160 & 4115.653 & 626.818 & 5373.704 & \text { Yes } \\ \text { LSFQHDPETSVLVLR } & 1.00 & 52.64 & 26.19 & 21.44 & 3 & 1884.0400 & 1884.0227 & 629.0148 & 0.0173 & 9.1677 & 2654.270 & 2749.955 & 368.901 & 4018367 & \text { Yes }\end{array}$ \begin{tabular}{llllllllllllllll} 
& \\
LSFQHDPETSVLVR & 1.00 & 52.64 & 26.19 & 21.44 & 3 & 1884.0400 & 1884.0227 & 629.0148 & 0.0173 & 9.1677 & 2654.270 & 2749.955 & 368.901 & 4018.367 & Yes \\
\hline LSFQHDPETSVLVLR & 1.00 & 51.63 & 6.81 & 19.08 & 3 & 1884.0283 & 1884.027 & 629.0148 & 0.0056 & 2.9676 & 3079.146 & 4708.887 & 629.207 & 4726.978 & Yes
\end{tabular}

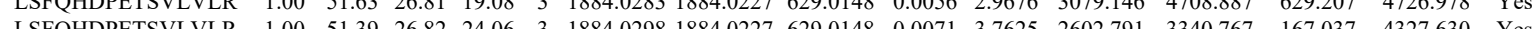

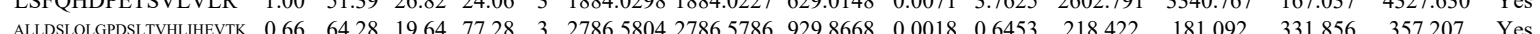
\begin{tabular}{llllllllllllllll} 
ALLDSLQLADSTHLHEVTK & 0.66 & 64.28 & 19.64 & 77.28 & 3 & 2786.5804 & 2786.5786 & 929.8668 & 0.0018 & 0.6453 & 218.422 & 181.092 & 331.856 & 357.207 & Yes \\
\hline
\end{tabular}

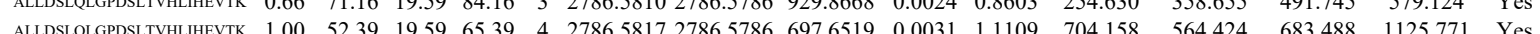

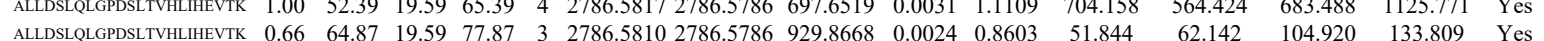
$\begin{array}{lllllllllllllllll}\text { ALLDSLLESSLAL } & 0.66 & 64.87 & 19.59 & 77.87 & 3 & 2786.5810 & 2786.5786 & 929.8668 & 0.0024 & 0.8603 & 51.844 & 62.142 & 104.920 & 133.809 & \text { Yes } \\ \text { VLLVLELQGLQK } & 0.84 & 62.70 & 14.15 & 75.70 & 2 & 1640.0498 & 1640.0480 & 821.0313 & 0.0018 & 1.0962 & 53.331 & 72.239 & 67.779 & 108.046 & \text { Yes }\end{array}$ $\begin{array}{llllllllllllllll}\text { VLLVLELQGLQK } & 0.84 & 62.73 & 13.15 & 75.70 & 2 & 1640.0498 & 1640.0480 & 821.0113 & 0.018 & 1.0962 & 53.331 & 72.239 & 67.779 & 108.046 & \text { Yes } \\ \text { VLLVLELQGLQK } & 0.67 & 64.53 & 13.98 & 77.53 & 3 & 1640.0509 & 1640.0480 & 547.6899 & 0.0029 & 1.7650 & 177.982 & 283.525 & 87.134 & 359.727 & \text { Yes }\end{array}$ $\begin{array}{llllllllllllllll}\text { VLLVLELQGLQK } & 0.67 & 57.01 & 13.98 & 70.01 & 3 & 1640.0509 & 1640.0480 & 547.6899 & 0.0029 & 1.7650 & 240.361 & 232.162 & 123.421 & 334.457 & \text { Yes }\end{array}$ $\begin{array}{llllllllllllllllll}\text { VLLVLELQGLQK } & 0.66 & 50.79 & 14.15 & 63.79 & 3 & 1640.0500 & 1640.0480 & 547.6899 & 0.0020 & 1.2172 & 140.527 & 113.334 & 108.547 & 135.444 & \text { Yes }\end{array}$ $\begin{array}{lllllllllllllllll}\text { DPAEGDGAQPEETPR } & 1.00 & 68.17 & 25.33 & 21.75 & 2 & 1711.7764 & 1711.7771 & 856.8958 & -0.0007 & -0.4085 & 332.122 & 246.716 & 329.554 & 258.332 & \text { Yes }\end{array}$ $\begin{array}{llllllllllllllll}\text { DPAEGDGAQPEETPR } & 1.00 & 71.32 & 25.28 & 21.52 & 2 & 1711.7770 & 1711.7771 & 856.8958 & -0.0001 & -0.0584 & 448.392 & 603.114 & 623.851 & 567.796 & \text { Yes }\end{array}$ $\begin{array}{lllllllllllllllll}\text { KPGINVASDWSIHLR } & 1.00 & 51.29 & 24.98 & 64.29 & 4 & 1980.1165 & 1980.1149 & 496.0360 & 0.0016 & 0.8064 & 37.484 & 24.424 & 36.667 & 49.470 & \text { Yes }\end{array}$ $\begin{array}{llllllllllllllll}\text { KPGINVASDWSIHLR } & 1.00 & 38.21 & 25.12 & 51.21 & 4 & 1980.1185 & 1980.1149 & 496.0360 & 0.0036 & 1.8144 & 15.566 & 25.477 & 19.324 & 33.372 & \text { Yes }\end{array}$

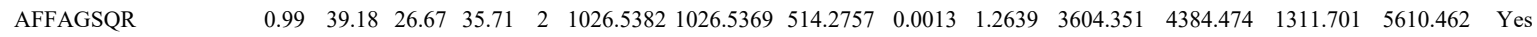
$\begin{array}{lllllllllllllllll}\text { AFFAGSQR } & 0.97 & 31.00 & 26.15 & 21.35 & 2 & 1026.5396 & 1026.5369 & 514.2757 & 0.0027 & 2.6250 & 3228.851 & 3584.030 & 422.324 & 5130.710 & \text { Yes }\end{array}$ $\begin{array}{llllllllllllllll}\text { SLLLSVNAR } & 0.79 & 32.53 & 25.91 & 36.95 & 2 & 1115.6866 & 1115.6784 & 558.8465 & 0.0082 & 7.3365 & 26605.741 & 31729.273 & 857.729 & 30170.728 & \text { Yes }\end{array}$ $\begin{array}{llllllllllllllll}\text { SLLLSVNAR } & 0.97 & 43.96 & 25.76 & 37.66 & 2 & 1115.6852 & 1115.6784 & 558.8465 & 0.0068 & 6.0839 & 8125.169 & 9196.649 & 626.718 & 10852.177 & \text { Yes }\end{array}$

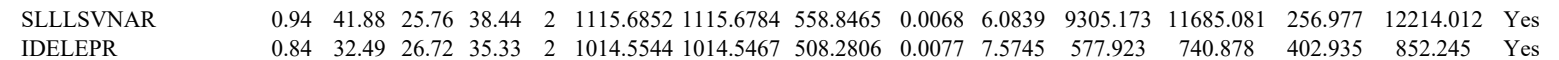

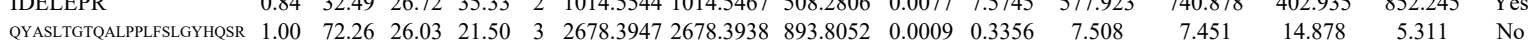
$\begin{array}{llllllllllllllll}\text { QYASLTGTQALPPLFLLYYHQSR } & 1.00 & 67.66 & 26.02 & 21.52 & 3 & 2678.3953 & 2678.3938 & 893.8052 & 0.0015 & 0.5594 & 19.715 & 34.982 & 51.864 & 56.173 & \text { Yes }\end{array}$

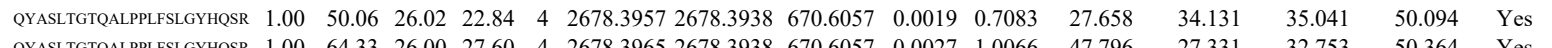

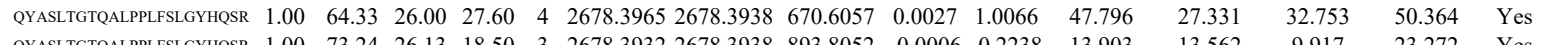

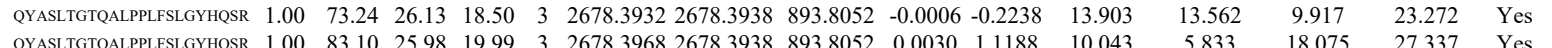

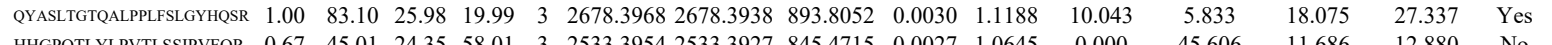

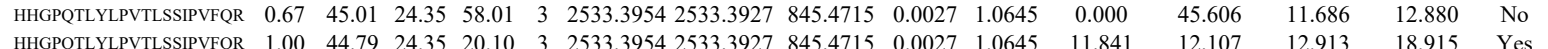

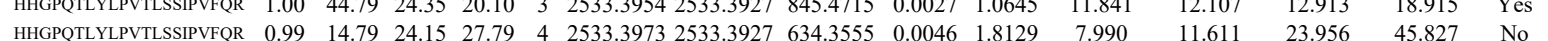

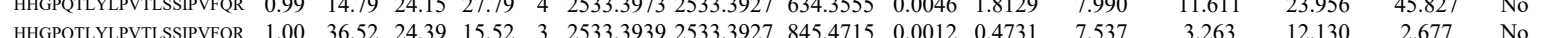

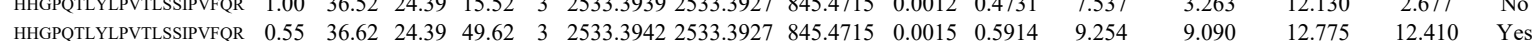

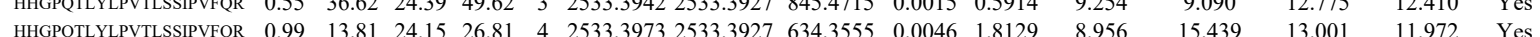

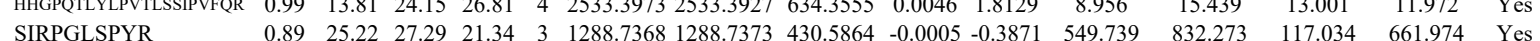
SIRPGLSPYR HHGPQTLYLPVTLSSIPVFO SIRPGLSPYR SIRPGLSPYR SIRPGLSPYR SIRPGLSPYR SIRPGLSPYR SIRPGLSPYR SIRPGLSPYR SIRPGLSPYR SIRPGLSPYR SIRPGLSPYR

LDLLEDR

LDLLEDR

NPEPELLVR NPEPELLVR

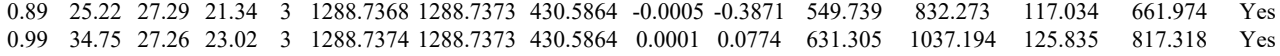
$\begin{array}{lllllllllllllll}0.99 & 34.75 & 27.26 & 23.02 & 3 & 1288.7374 & 1288.7373 & 430.5864 & 0.0001 & 0.0774 & 631.305 & 1037.194 & 125.835 & 817.318 & \text { Yes } \\ 0.74 & 5.44 & 24.18 & 18.44 & 4 & 2533.3969 & 2533.3927 & 634.3555 & 0.0042 & 1.655 & 2.383 & 5.560 & 7.648 & 9.787 & \text { Yes } \\ 0.90 & 32.5 & 27.37 & 21.28 & 3 & 1288.7341 & \end{array}$

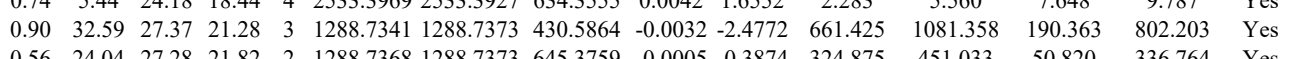

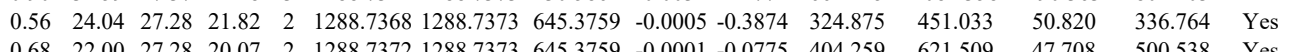
$\begin{array}{lllllllllllllll}0.68 & 22.00 & 27.28 & 20.07 & 2 & 1288.7372 & 1288.7373 & 645.3759 & -0.0001 & -0.0775 & 404.259 & 621.509 & 47.708 & 500.538 & \text { Yes }\end{array}$

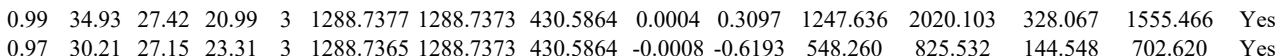
$\begin{array}{llllllllllllllll}0.97 & 30.21 & 27.15 & 23.31 & 3 & 1288.7365 & 1288.7373 & 430.5864 & -0.0008 & -0.6193 & 548.260 & 825.532 & 144.548 & 702.620 & \text { Yes } \\ 0.74 & 26.20 & 27.2 & 24.17 & 2 & 1288.7372 & 1288.7373 & 645.3759 & -0.00 & 0.0775 & 406.684 & 580.064 & 31.137 & 475.664 & \text { Yes }\end{array}$ $\begin{array}{lllllllllllllll}0.85 & 26.20 & 27.28 & 24.17 & 2 & 1288.7372 & 1288.7373 & 645.3759 & -0.0001 & -0.0775 & 406.684 & 580.064 & 31.137 & 475.664 & \text { Yes } \\ 0.74 & 23.39 & 27.42 & 18.98 & 2 & 1288.7378 & 1288.7373 & 645.3759 & 0.0005 & 0.3874 & 377.241 & 545.296 & 52.729 & 450.790 & \text { Yes }\end{array}$ $\begin{array}{llllllllllllllll}0.99 & 31.28 & 27.47 & 21.10 & 3 & 1288.7386 & 1288.7373 & 430.5864 & 0.0013 & 1.0064 & 1808.476 & 3217.993 & 369.784 & 2568.947 & \text { Yes }\end{array}$ $\begin{array}{lllllllllllllll}0.98 & 32.51 & 27.19 & 22.03 & 3 & 1288.7362 & 1288.7373 & 430.5864 & -0.0011 & -0.8516 & 675.603 & 1184.745 & 172.160 & 984.466 & \text { Yes }\end{array}$

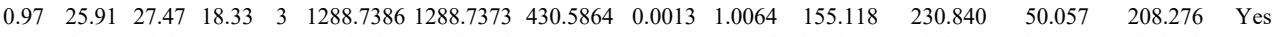

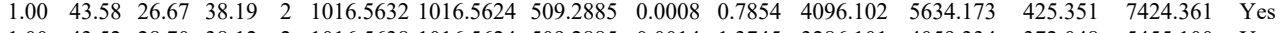
$\begin{array}{llllllllllllllll}1.00 & 43.52 & 28.70 & 38.12 & 2 & 1016.5638 & 1016.5624 & 509.2885 & 0.0014 & 1.3745 & 3286.101 & 4059.334 & 372.048 & 5455.100 & \text { Yes }\end{array}$ $\begin{array}{lllllllllllllll}0.81 & 25.07 & 27.44 & 21.97 & 2 & 1209.6844 & 1209.6839 & 605.8492 & 0.0005 & 0.4126 & 5787.145 & 6510.260 & 13413.477 & 8917.491 & \text { Yes }\end{array}$

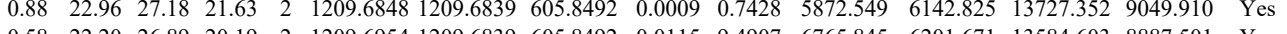
$\begin{array}{lllllllllllllllll}\text { NVLALLR } & 0.58 & 22.20 & 26.89 & 20.19 & 2 & 1209.6954 & 1209.6839 & 605.8492 & 0.0115 & 9.4907 & 6765.845 & 6201.671 & 13584.603 & 8887.501 & \text { Yes }\end{array}$

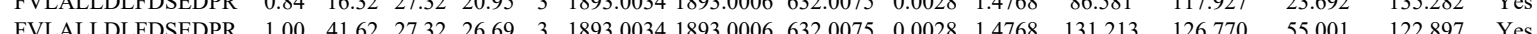
$\begin{array}{llllllllllllllll}\text { FVLALLDLFDSEDPR } & 1.00 & 41.62 & 27.32 & 26.69 & 3 & 1893.0034 & 1893.0006 & 632.0075 & 0.0028 & 1.4768 & 131.213 & 126.770 & 55.001 & 122.897 & \text { Yes } \\ \text { RPSNSTPPPTQLSK } & 0.55 & 42.91 & 26.16 & 55.91 & 3 & 1797.0001 & 1796.998 & 600.0069 & 0.0013 & 0.7222 & 1617.552 & 1569.908 & 1470.810 & 1284.477 & \text { Yes }\end{array}$ $\begin{array}{llllllllllllllll}\text { RPSNSTPPTQLSK } & 0.55 & 42.91 & 26.16 & 55.91 & 3 & 1797.0001 & 1796.9988 & 600.0069 & 0.0013 & 0.7222 & 1617.552 & 1569.908 & 1470.810 & 1284.477 & \text { Yes } \\ \text { RPSNSTPPPTQLSK } & 0.66 & 39.24 & 26.26 & 52.24 & 3 & 1797.0010 & 1796.9988 & 600.0069 & 0.0022 & 1.2222 & 1540.063 & 1681.608 & 1297.240 & 1484.889 & \text { Yes }\end{array}$ $\begin{array}{llllllllllllllll}\text { RPSNSTPPTELK } & 0.66 & 3.24 & 26.26 & 52.24 & 3 & 1797.010 & 1796.998 & 60.006 & 0.0022 & 1.2222 & 1540.063 & 1681.608 & 1297.240 & 1484.889 & \text { Yes } \\ \text { RPSNSTPPPTQLSK } & 0.55 & 30.86 & 26.16 & 43.86 & 3 & 1797.0001 & 1796.9988 & 600.0069 & 0.0013 & 0.7222 & 491.980 & 470.769 & 446.207 & 455.880 & \text { Yes }\end{array}$

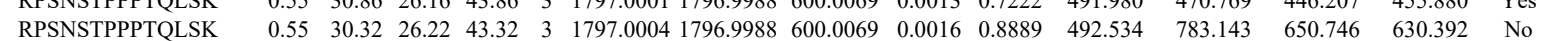
VLPIMFPALYR $\begin{array}{llllll}0.7222 & 491.980 & 470.769 & 446.207 & 455.880 & \text { Yes }\end{array}$

Table S-4 page 477 of 614 
VLPIMFPALYR VLPIMFPALYR

VLPIMFPALYR

ELLELEALSMAVESTG

LAQDPFPLYPGEVLEK
LFSVPDFVGDACK

LFSVPDFVGDACK

LFSVPDFVGDACK

LFSVPDFVGDACK

LLPGEQLERGipDVYVLSERQGLLLR

VviseQgelLr

SLQPLAP

DITPLQVVLPNTALHLK

SLQPLAPR

ALQPLEEGEDEEK

ALQPLEEGEDEEK

ALQPLEEGEDEEK

VLFAPMR

VLFAPMR

VLFAPMR

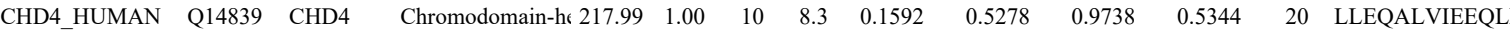

TIEQLR

LLEQALVIEEQLR

LLEQALVIEEQLR

FHNLEGFLEEFADIAK

FHNLEGFLEEFADIAK
EEEMGEEEEVER

EEEMGEEEEVER

EEEMGEEEEVER $\begin{array}{llllllllllll}\text { GGGNQVSLLNVVMDLK } & 1.00 & 71.77 * 25.53 & 28.84 & 3 & 1931.0782 & 1931.0754 & 644.60991 & 0.0028 & 1.4477 & 196.759 \\ \text { GGGNQVSLLNVVMDLK } & 0.99 & 60.71 * 25.53 & 27.41 & 3 & 1931.0782 & 1931.0754 & 644.6991 & 0.0028 & 1.4477 & 145.587\end{array}$ $\begin{array}{llllllllllllll} & \end{array}$ $\begin{array}{lllllllllll}0.95 & 8.02 & 22.43 & 21.02 & 4 & 3770.0081 & 3770.0046 & 943.5084 & 0.0035 & 0.9274 & 1.834\end{array}$

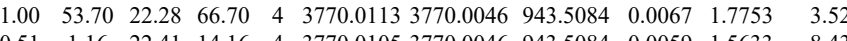

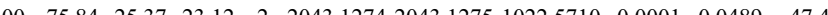

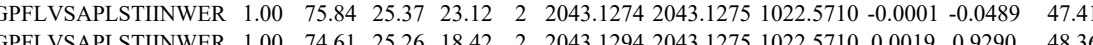

GPFLVSAPLSTIINWER

AFLNAIMR

AFLNAIMR
IGVMSLIR

IGVMSLIR

QELDDILK

QELDDILK

15 TQDQISNIK

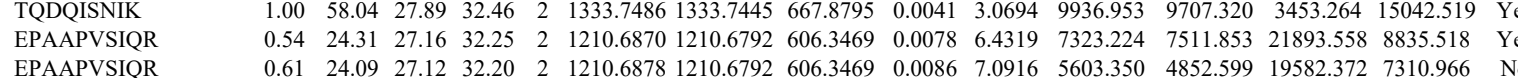

$\begin{array}{llllllllllllllll}\text { TQDQISNIK } & 1.00 & 58.04 & 27.89 & 32.46 & 2 & 1333.7486 & 1333.7445 & 667.8795 & 0.0041 & 3.0694 & 9936.953 & 9707.320 & 3453.264 & 15042.519 & \text { Yes } \\ \text { EPAAPVSIQR } & 0.54 & 24.31 & 27.16 & 32.25 & 2 & 1210.6870 & 1210.6792 & 606.3469 & 0.0078 & 6.4319 & 7323.224 & 7511.853 & 21893.558 & 8835.518 & \text { Yes } \\ \text { EPAAPVSIQR } & 0.61 & 24.09 & 27.12 & 32.20 & 2 & 1210.6878 & 1210.6792 & 606.3469 & 0.0086 & 7.0916 & 5603.350 & 4852.599 & 19582.372 & 7310.966 & \text { No }\end{array}$

$\begin{array}{lllllllllllll}1.99 & 44.50 & 28.13 & 37.08 & 2 & 1078.6086 & 1078.6079 & 540.3112 & 0.0007 & 0.6478 & 5781.707 & 7839.922 & 33.60\end{array}$

$\begin{array}{lllllllllllll}0.99 & 35.58 & 28.13 & 30.61 & 2 & 1031.6284 & 1031.6283 & 516.8214 & 0.0001 & 0.0967 & 1200.968 & 1432.323 & 319.2 \\ 0.92931 .6283 & 516.8214 & 0.0007 & 0.6772 & 1701.184 & 2068.492 & 460 .\end{array}$

$\begin{array}{llllllllllll}0.99 & 50.16 & 27.93 & 39.59 & 2 & 1260.7162 & 1260.7169 & 631.3657 & -0.0007 & -0.5544 & 2374.643 & 2679.273 \\ 1.00 & 4.04 & 27.75 & 33.57 & 2 & 1260.7178 & 1260.7169 & 631.3657 & 0.009 & 0.7127 & 2869.919 & 3735.898\end{array}$

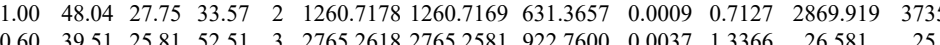

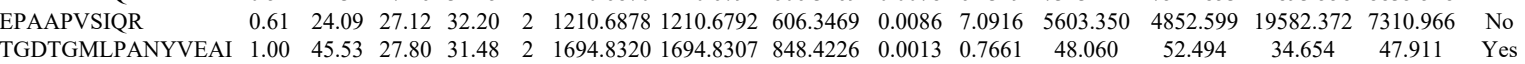

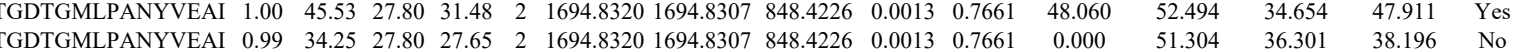
EPAAPVSIQR

EPAAPVSIQR

EPAAPVSIQR

EPAAPVSIQR

GFSVVADTPELQR

KPYCNAHYPK

MGPSGGEGMEPER

MGPSGGEGMEPER

MGPSGGEGM

SAPGGGGK

TQDQISNIK

TGDTGMLPANY

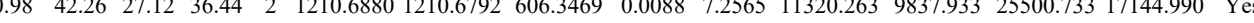
$\begin{array}{lllllllllllllll}0.99 & 45.03 & 27.11 & 36.78 & 2 & 1210.6886 & 1210.6792 & 606.3469 & 0.0094 & 7.7513 & 9705.761 & 8081.167 & 18282.580 & 13456.013 & \text { Yes }\end{array}$ $\begin{array}{lllllllllllllll}0.96 & 34.82 & 27.09 & 33.19 & 2 & 1210.6890 & 1210.6792 & 606.3469 & 0.0098 & 8.0811 & 7440.629 & 5117.498 & 8514.116 & 10625.054 & \text { Yes } \\ 0.91 & 35.20 & 27.02 & 37.72 & 2 & 120.6894 & 1210.6792 & 606349 & 0.002 & 8.4110 & 749.795 & 6376.960 & 9431372 & 178 & \text { Yes }\end{array}$ $\begin{array}{lllllllllllllll}0.91 & 35.20 & 27.02 & 37.72 & 2 & 1210.6894 & 1210.6792 & 606.3469 & 0.0102 & 8.4110 & 7449.795 & 6376.960 & 9431.372 & 9059.178 & \text { Yes }\end{array}$ $\begin{array}{llllllllllllllll}0.64 & 62.92 & 28.55 & 75.92 & 2 & 1561.8224 & 1561.8222 & 781.9184 & 0.0002 & 0.1279 & 209.739 & 212.467 & 56.142 & 314.462 & \text { Yes }\end{array}$

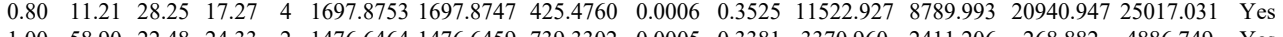
$\begin{array}{lllllllllllllll}1.00 & 58.90 & 22.48 & 24.33 & 2 & 1476.6464 & 1476.6459 & 739.3302 & 0.0005 & 0.3381 & 3370.960 & 2411.206 & 268.882 & 4886.749 & \text { Yes }\end{array}$ $\begin{array}{lllllllllllllll}1.00 & 5.16 & 22.48 & 23.17 & 2 & 1476.6470 & 1476.6459 & 739.3302 & 0.0011 & 0.7439 & 3657.047 & 3128.128 & 306.243 & 6984.700 & \text { Yes }\end{array}$ $\begin{array}{lllllllllllllll}1.00 & 60.37 & 22.30 & 23.76 & 2 & 1476.6478 & 1476.6459 & 739.3302 & 0.0019 & 1.2849 & 7559.431 & 5064.252 & 543.485 & 9347.454 & \text { Yes } \\ 0.67 & 20.65 & 26.24 & 26.65 & 2 & 917.5174 & 917.5174 & 459.760 & 0.0000 & 0.0000 & 62.805 & 87.891 & 72.830 & 76.381 & \text { Yes }\end{array}$ $\begin{array}{ccccccccccccccc}0.67 & 20.65 & 26.24 & 26.65 & 2 & 917.5174 & 917.5174 & 459.7660 & 0.0000 & 0.0000 & 62.805 & 87.891 & 72.830 & 76.381 & \text { Yes } \\ 1.00 & 58.04 & 27.72 & 33.36 & 2 & 1333.7494 & 1333.7445 & 667.8795 & 0.0049 & 3.663 & 13928.889 & 11835.042 & 3246.043 & 18728.781 & \text { Yes }\end{array}$ $\begin{array}{lllllllllllllllll}1.00 & 58.13 & 27.72 & 33.36 & 2 & 1333.7494 & 1333.7445 & 667.8795 & 0.0049 & 3.6683 & 13928.889 & 11835.042 & 3246.043 & 18728.781 & \text { Yes } \\ \end{array}$

\begin{tabular}{|lllllllllllllllll} 
& PAVAI & 0.95 & 28.12 & 27.75 & 15.65 & 2 & 1694.8318 & 1694.8307 & 848.4226 & 0.0011 & 0.6483 & 41.276 & 8.883 & 7.671 & 12.084 & No
\end{tabular}

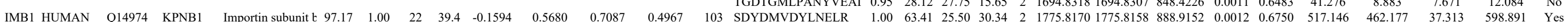

Table S-4 page 478 of 614 

\begin{tabular}{lllllllllllllllll}
\hline &
\end{tabular} $\begin{array}{llllllllllllllllllll}\text { LLETTDRPDGHQNNLR } & 0.98 & 22.49 & 27.74 & 19.93 & 4 & 2022.0541 & 2022.0364 & 506.5164 & 0.0177 & 8.7361 & 22601.815 & 20621.684 & 8749.710 & 26085.305 & \text { Yes }\end{array}$

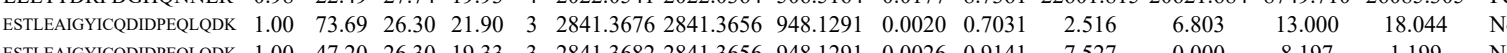
$\begin{array}{lllllllllllllll} & 0.049 & & \end{array}$

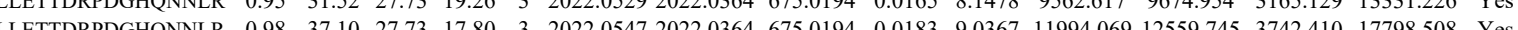
$\begin{array}{lllllllllllllllll} & \end{array}$

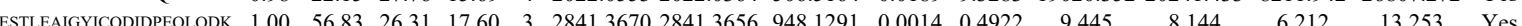

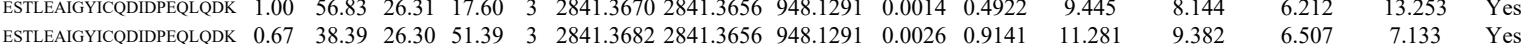
$\begin{array}{llllllllllllllll}\text { LLETTDRPDGHONNLR } & 0.96 & 14.45 & 27.51 & 18.73 & 4 & 20220389 & 20220364 & 506.5164 & 0.0025 & 1.2339 & 10523.963 & 10447.418 & 6923.111 & 16538.061 & \text { Yes }\end{array}$ $\begin{array}{llllllllllllllll}\text { SSAYESLMEIVK } & 1.00 & 72.13 & 28.17 & 29.16 & 2 & 1643.8708 & 1643.8684 & 822.9415 & 0.0024 & 1.4582 & 461.165 & 403.280 & 0.000 & 723.869 & \text { No }\end{array}$

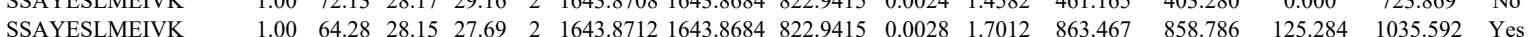
$\begin{array}{lllllllllllllllll}\text { SSAYESLMEIVK } & 1.00 & 33.75 & 28.08 & 23.49 & 3 & 1643.8723 & 1643.8684 & 548.9634 & 0.0039 & 2.3681 & 113.068 & 115.844 & 19.913 & 148.983 & \text { Yes }\end{array}$ $\begin{array}{llllllllllllllll}\text { SSAYESLMEIVK } & 1.00 & 46.78 & 28.06 & 25.86 & 3 & 1643.8735 & 1643.8684 & 548.9634 & 0.0051 & 3.0967 & 121.677 & 146.395 & 67.205 & 215.100 & \text { Yes }\end{array}$

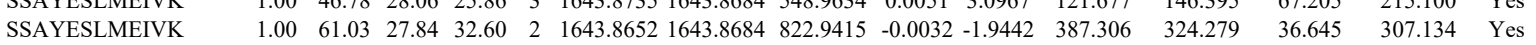

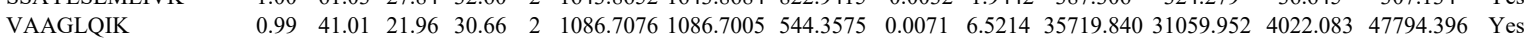
$\begin{array}{llllllllllllllll}\text { VAAGLQIK } & 0.99 & 41.14 & 21.96 & 30.75 & 2 & 1086.7076 & 1086.7005 & 544.3575 & 0.0071 & 6.5214 & 33113.574 & 26753.303 & 4572.026 & 44934.685 & \text { Yes }\end{array}$ $\begin{array}{llllllllllllllll}\text { TLATWATK } & 1.00 & 48.58 & 26.61 & 23.45 & 2 & 1178.7004 & 1178.6903 & 590.3524 & 0.0101 & 8.5541 & 10405.636 & 9345.238 & 1545.543 & 17528.098 & \text { Yes }\end{array}$ $\begin{array}{llllllllllllllll}\text { TLATWATK } & 1.00 & 47.20 & 26.31 & 26.53 & 2 & 1178.7014 & 1178.6903 & 590.3524 & 0.0111 & 9.4011 & 3428.490 & 2881.036 & 285.138 & 5352.586 & \text { Yes }\end{array}$

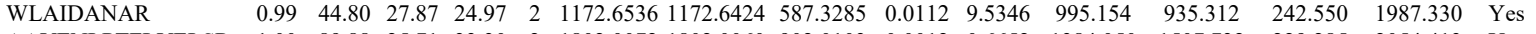

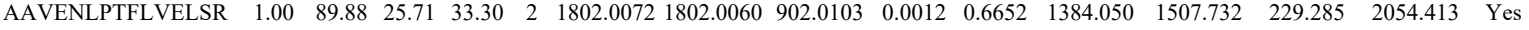
$\begin{array}{lllllllllllllllll}\text { AAVENLPTFLVELSR } & 1.00 & 92.57 & 25.82 & 33.41 & 2 & 1802.0076 & 1802.0060 & 902.0103 & 0.0016 & 0.8869 & 3434.650 & 2209.275 & 329.707 & 4179.461 & \text { Yes }\end{array}$

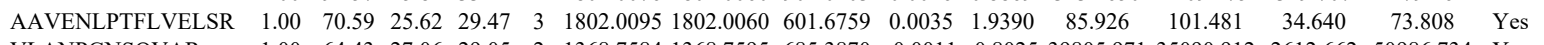
$\begin{array}{llllllllllllllll}\text { VLANPGNSQVAR } & 1.00 & 64.43 & 27.06 & 29.05 & 2 & 1368.7584 & 1368.7595 & 685.3870 & -0.0011 & -0.8025 & 39805.971 & 35090.912 & 2612.662 & 50986.734 & \text { Yes }\end{array}$

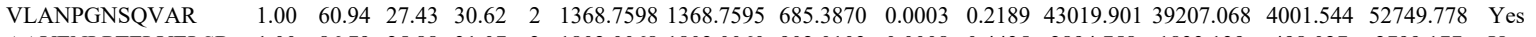

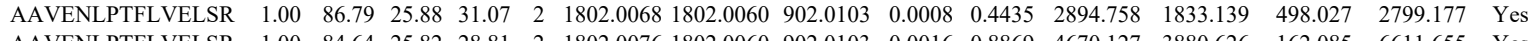

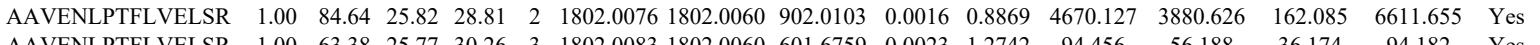

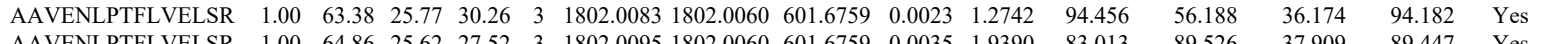

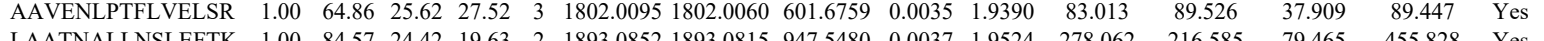

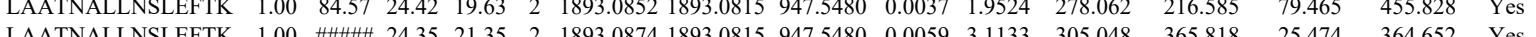
$\begin{array}{lllllllllllll} & \end{array}$ $\begin{array}{llllllllllllll} & \end{array}$

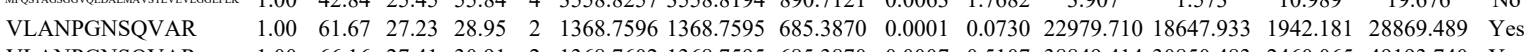
$\begin{array}{lllllllllllllllll} & \end{array}$ $\begin{array}{lllllllllllllll} & \end{array}$

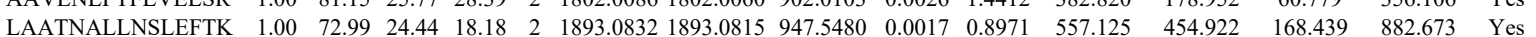

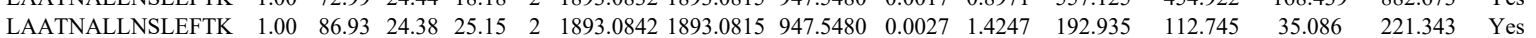

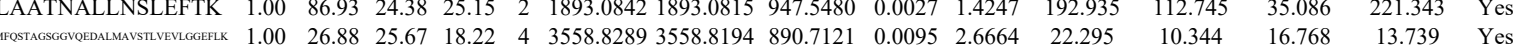
$\begin{array}{llllllllllllllll}\text { VLGGFIK } & 0.99 & 65.59 * & 25.55 & 21.60 & 3 & 3574.8142 & 3574.8143 & 1192.6120 & -0.0001 & -0.0279 & 5.133 & 1.823 & 0.000 & 1.983 & \text { No }\end{array}$ $\begin{array}{llllllllllllllll}\text { VLANPGNSQVAR } & 1.00 & 60.26 & 27.23 & 28.96 & 2 & 1368.7596 & 1368.7595 & 685.3870 & 0.0001 & 0.0730 & 9357.988 & 8443.959 & 705.490 & 13006.276 & \text { Yes } \\ \text { VLANPGNSQVAR } & 1.00 & 60.21 & 27.43 & 28.52 & 2 & 1368.7598 & 1368.7595 & 685.3870 & 0.0003 & 0.2189 & 13288.723 & 11700.064 & 485.061 & 18256.646 & \text { Yes }\end{array}$

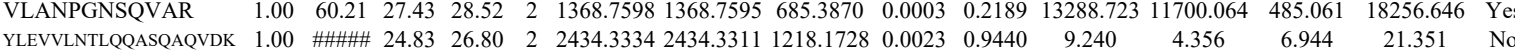

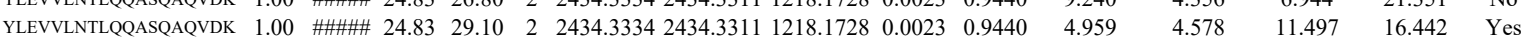
$\begin{array}{lllllllllllllllll}\text { YLEVVLNTLQQASQAQVDK } & 0.74 & 11.43 & 24.77 & 16.77 & 3 & 2434.3342 & 2434.3311 & 812.4510 & 0.0031 & 1.2719 & 22.355 & 38.809 & 0.000 & 54.074 & \text { No }\end{array}$ $\begin{array}{llllllllllllllll}\text { YLEVVLNTLQQASQAQVDK } & 1.00 & 65.51 & 24.68 & 21.56 & 4 & 2434.3365 & 2434.3311 & 609.5901 & 0.0054 & 2.2146 & 53.144 & 64.998 & 48.401 & 67.441 & \text { Yes }\end{array}$ $\begin{array}{lllllllllllllll} & & \end{array}$ \begin{tabular}{llllllllllllllll} 
VOHQDALQISDVVMASLLR & 1.00 & 74.27 & 26.01 & 17.96 & 3 & 2266.2223 & 2266.2225 & 756.4148 & -0.0002 & -0.0881 & 14.221 & 12.094 & 7.188 & 20.655 & Yes \\
\hline
\end{tabular} $\begin{array}{llllllllllllllll}\text { VQHQDALQISDVVMASLLR } & 1.00 & 59.56 & 25.89 & 21.90 & 3 & 2266.2253 & 2266.2225 & 756.4148 & 0.0028 & 1.2339 & 721.802 & 511.865 & 344.067 & 1220.906 & \text { Yes }\end{array}$

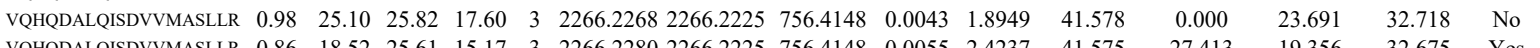

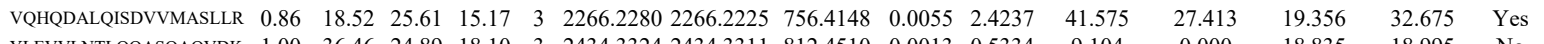

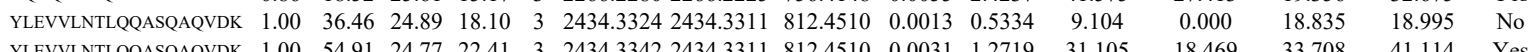

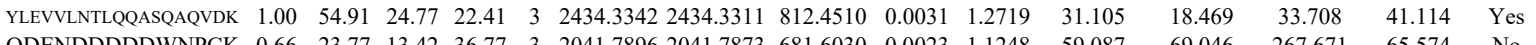
$\begin{array}{llllllllllllll} & \end{array}$ $\begin{array}{lllllllllllllll} & \end{array}$ $\begin{array}{llllllllllllll} & \end{array}$ \begin{tabular}{llllllllllll}
\hline &
\end{tabular}

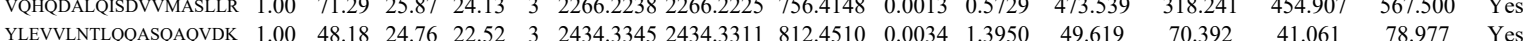

Table S-4 page 479 of 614 
\begin{tabular}{lllllllllllll} 
SVRPOILSVFGDIALAIGGEFK & 1.00 & 38.80 & 15.91 & 51.80 & 4 & 2720.5881 & 2720.5842 & 681.1533 & 0.0039 & 1.4314 & 119.199 \\
\hline
\end{tabular}

$\begin{array}{lllllllllll}1.00 & 52.16 & 16.02 & 65.16 & 4 & 2720.5897 & 2720.5842 & 681.1533 & 0.0055 & 2.0186 & 162.800 \\ 1.00 & 83.27 & 27.89 & 34.06 & 2 & 1588.8752 & 1588.8728 & 795.4437 & 0.0024 & 1.5086 & 5092.990\end{array}$

SNEITAIIQGMR

$\begin{array}{llllllllllll}1.00 & 70.21 & 27.90 & 28.74 & 2 & 1588.8754 & 1588.8728 & 795.4437 & 0.0026 & 1.6343 & 8419.549 & 71\end{array}$

$\begin{array}{lllllllllll}1.00 & 75.03 & 27.80 & 21.73 & 3 & 1588.8760 & 1588.8728 & 530.6315 & 0.0032 & 2.0102 & 27.078\end{array}$

$\begin{array}{lllllllllllll} & & & \end{array}$

VKPQILSVFGDIALAIGG

11.378

SNEILTAIIQGMR

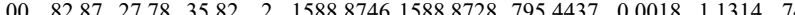

SNEILTAIIQGMR

$\begin{array}{lllllllllll}1.00 & 66.85 & 27.97 & 29.49 & 3 & 1588.8748 & 1588.8728 & 530.6315 & 0.0020 & 1.2564 & 165.387\end{array}$

SNEILTAIIQGMR

$\begin{array}{lllllllllllll}1.00 & 80.37 & 27.89 & 34.01 & 2 & 1588.8752 & 1588.8728 & 795.4437 & 0.0024 & 1.5086 & 8717.659 & & \\ 1.00 & 60.37 & 27.90 & 26.96 & 3 & 1588.8754 & 1588.8728 & 530.6315 & 0.0026 & 1.6333 & 90.323 & \end{array}$

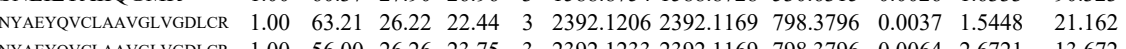

$\begin{array}{lllllllllllll}\text { NYAEYQVCLAAVGLVGDLCR } & 1.00 & 56.00 & 26.26 & 23.75 & 3 & 2392.1233 & 2392.1169 & 798.3796 & 0.0064 & 2.6721 & 13.672 \\ \text { SNEILTAIIQGMR } & 1.00 & 8.9 & 27.85 & 3.41 & 2 & 1588.8756 & 1588.8728 & 795.4437 & 0.0028 & 1.7600 & 6342.278\end{array}$

SNEILTAIIQGMR

$\begin{array}{lllllllllll}1.00 & 80.97 & 27.85 & 32.41 & 2 & 1588.8756 & 1588.8728 & 795.4437 & 0.0028 & 1.7600 & 6342.278 \\ 1.00 & 49.91 & 27.77 & 25.39 & 3 & 1588.8769 & 1588.8728 & 530.6315 & 0.0041 & 2.5755 & 89.201\end{array}$

$\begin{array}{lllllllllllll} & & & 23.812 & 238.8169 & 798.3796 & 0.0043 & 1.7953 & 18.975\end{array}$

$\begin{array}{lllllllllllll}\text { GALOYLVPILTQTLTK } & 0.84 & 76.72 & 15.44 & 89.72 & 2 & 2046.2354 & 2046.2332 & 1024.1239 & 0.0022 & 1.0741 & 40.747\end{array}$

$\begin{array}{llllllllllll}\text { GALQYLVPILTQTLTK } & 0.97 & 15.18 & 15.68 & 14.24 & 3 & 2046.2380 & 2046.2332 & 683.0850 & 0.0048 & 2.3423 & 613.153\end{array}$

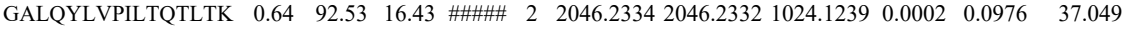

$\begin{array}{llllllllllllll}\text { GALQYLVPILTQTLTK } & 0.84 & 84.90 & 15.44 & 97.90 & 2 & 2046.2354 & 2046.2332 & 1024.1239 & 0.0022 & 1.0741 & 72.820\end{array}$

$\begin{array}{lllllllllllll}\text { GALQYLVPILTQTLTK } & 0.67 & 24.82 & 15.19 & 37.82 & 3 & 2046.2359 & 2046.2332 & 683.0850 & 0.0027 & 1.3176 & 80.126\end{array}$

$\begin{array}{llllllllllllll}\text { GALQYLVPILTQTLTK } & 0.60 & 45.43 & 15.68 & 58.43 & 3 & 2046.2374 & 2046.2332 & 683.0850 & 0.0042 & 2.0495 & 141.537\end{array}$

$\begin{array}{llllllllllll}\text { SNEILTAIIQGMR } & 1.00 & 70.26 & 27.91 & 28.08 & 2 & 1588.8740 & 1588.8728 & 795.4437 & 0.0012 & 0.7543 & 106.972\end{array}$

$\begin{array}{lllllllllllll}\text { GALQYLVPILTQTLTK } & 0.66 & 51.64 & 16.33 & 64.64 & 3 & 2046.2350 & 2046.2332 & 683.0850 & 0.0018 & 0.8784 & 12.910\end{array}$

$\begin{array}{llllllllllll}\text { GALQYLVPILTQTLTK } & 0.84 & 76.05 & 15.44 & 89.05 & 2 & 2046.2354 & 2046.2332 & 1024.1239 & 0.0022 & 1.0741 & 29.664\end{array}$

$\begin{array}{lllllllllllll}\text { GALQYLVPLTQTLTK } & 0.84 & 79.22 & 15.44 & 92.22 & 2 & 2046.2354 & 2046.2332 & 1024.1239 & 0.0022 & 1.0741 & 18.736\end{array}$

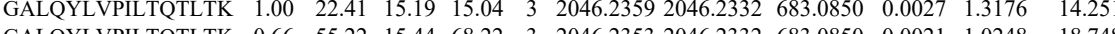

$\begin{array}{llllllllllll}\text { GALQYLVILTQTLTK } & 0.66 & 55.22 & 15.44 & 68.22 & 3 & 2046.2353 & 2046.2332 & 683.0850 & 0.0021 & 1.0248 & 18.748\end{array}$

$\begin{array}{lllllllllllll}\text { GALQYLVPILTQTLTK } & 0.67 & 45.25 & 15.19 & 58.25 & 3 & 2046.2359 & 2046.2332 & 683.0850 & 0.0027 & 1.3176 & 12.934\end{array}$

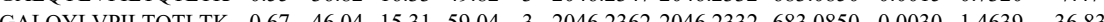

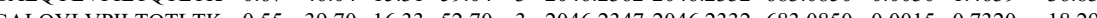

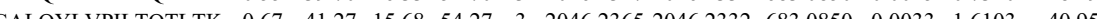

$\begin{array}{llllllllll} & 0.98\end{array}$

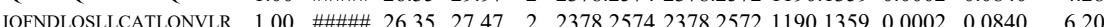

$\begin{array}{llllllllllll}\text { IOFNDLQSLLCATLONVLR } & 1.00 & 82.99 & 26.29 & 19.78 & 3 & 2378.2603 & 2378.2572 & 793.7597 & 0.0031 & 1.3018 & 7.251\end{array}$

$\begin{array}{llllllllllll}\text { IOFNDLOSLLCATLONVLR } & 1.00 & 66.96 & 26.34 & 23.04 & 3 & 2378.2609 & 2378.2572 & 793.7597 & 0.0037 & 1.5538 & 9.213\end{array}$

LELEAAQK

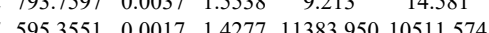

$\begin{array}{llllllllllllllll}1.00 & 4329 & 27.55 & 36.58 & 2 & 1188.6980 & 1188.6957 & 595.3551 & 0.0023 & 1.9316 & 8929.870 & 7166.828 & 1670.684 & 8897.56 & \end{array}$

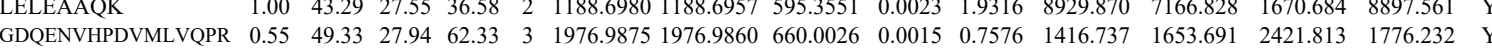
$\begin{array}{lllllllllllllllll} & \text { GDQENVHPDVMLVQPR } & 0.67 & 46.13 & 28.00 & 59.13 & 3 & 1976.9893 & 1976.9860 & 660.0026 & 0.0033 & 1.6667 & 1335.307 & 1482.828 & 2169.764 & 1760.080 & \text { Yes }\end{array}$ $\begin{array}{llllllllllllllll}\text { SDYDMVDYLNELR } & 1.00 & 81.57 & 25.50 & 28.85 & 2 & 1775.8170 & 1775.8158 & 888.9152 & 0.0012 & 0.6750 & 1481.955 & 1195.821 & 100.070 & 1986.472 & \text { Yes }\end{array}$ $\begin{array}{lllllllllllllllll}\text { SDYDMVDYLNELR } & 1.00 & 70.81 & 25.54 & 29.62 & 2 & 1775.8174 & 1775.8158 & 888.9152 & 0.0016 & 0.9000 & 3379.293 & 3136.195 & 41.433 & 4641.617 & \text { Yes }\end{array}$ $\begin{array}{llllllllllllllll} & 197.8174 & 1976.986 & 6600.0026 & 0.0186 & 9.3938 & 1918.538 & 2390.491 & 5128.874 & 2755.174 & \text { No }\end{array}$ $\begin{array}{llllllllllllllll}\text { SDYDMVDYLNELR } & 1.00 & 69.21 & 25.54 & 24.35 & 2 & 1775.8174 & 1775.8158 & 888.9152 & 0.0016 & 0.9000 & 357.902 & 318.392 & 84.349 & 514.021 & \text { Yes }\end{array}$

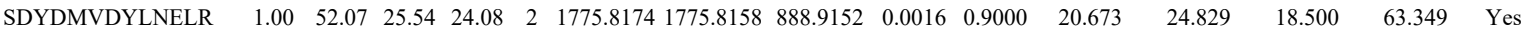

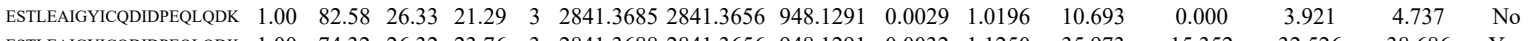
$\begin{array}{llllllllllllllll}\text { ESTLEAIGYICQDIDPEQLQDK } & 1.00 & 74.32 & 26.32 & 23.76 & 3 & 2841.3688 & 2841.3656 & 948.1291 & 0.0032 & 1.1250 & 35.973 & 15.352 & 32.526 & 38.686 & \text { Yes }\end{array}$ $\begin{array}{llllllllllllllll}\text { ESTLEAIGYICQDIDPEQLODK } & 1.00 & 20.75 & 26.30 & 33.75 & 4 & 2841.3721 & 2841.3656 & 711.3487 & 0.0065 & 2.2844 & 4.929 & 22.887 & 2.055 & 14.992 & \text { No }\end{array}$ $\begin{array}{llllllllllllllll}\text { NSSNKPAVTTK } & 0.99 & 28.94 & 25.25 & 19.94 & 3 & 1577.9113 & 1577.9102 & 526.9773 & 0.0011 & 0.6958 & 86.445 & 90.045 & 99.385 & 118.656 & \text { Yes }\end{array}$ $\begin{array}{lllllllllllllllll}\text { NSSNKPAVTTK } & 0.55 & 11.06 & 25.26 & 24.06 & 3 & 1577.9116 & 1577.9102 & 526.9773 & 0.0014 & 0.8856 & 75.601 & 95.934 & 72.499 & 102.740 & \text { Yes }\end{array}$

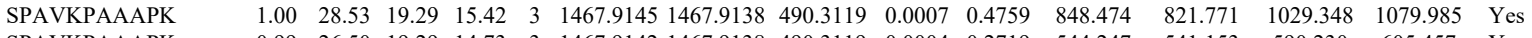

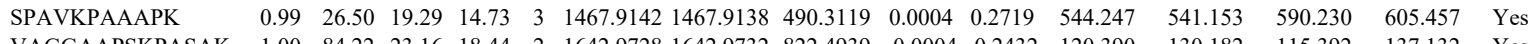
$\begin{array}{llllllllllllllll}\text { VAGGAAPSKPASAK } & 1.00 & 84.22 & 23.16 & 18.44 & 2 & 1642.9728 & 1642.9732 & 822.4939 & -0.0004 & -0.2432 & 120.390 & 130.182 & 115.392 & 137.132 & \text { Yes }\end{array}$ $\begin{array}{llllllllllllllll}\text { VAGGAAPSKPASAK } & 0.64 & 75.98 & 23.16 & 88.98 & 2 & 1642.9732 & 1642.9732 & 822.4939 & 0.0000 & 0.0000 & 122.216 & 102.373 & 87.431 & 92.948 & \text { Yes } \\ \text { VAGGAPSKASAK } & 0.66 & 59.86 & 23.20 & 72.86 & 3 & 1642.9756 & 1642.9732 & 548.6650 & 0.0024 & 1.4581 & 1262.591 & 1202.619 & 1359.335 & 1647.728 & \text { Yes }\end{array}$ \begin{tabular}{llllllllllllllll} 
VAGGAAPSKPASAK & 0.66 & 59.86 & 23.20 & 72.86 & 3 & 1642.9756 & 1642.9732 & 548.6650 & 0.0024 & 1.4581 & 1262.591 & 1202.619 & 1359.335 & 1647.728 & Yes \\
\hline VAGGAAPSKPASAK & 0.67 & 47.30 & 23.20 & 60.30 & 3 & 1642.9765 & 1642.9732 & 548.6650 & 0.0033 & 2.0049 & 2731.794 & 2807.264 & 2650.249 & 3454.097 & Yes
\end{tabular}

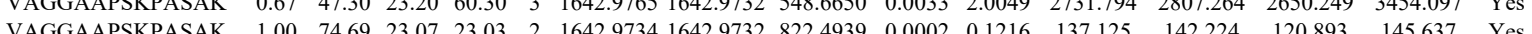

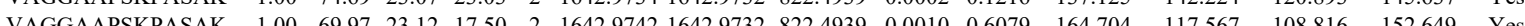
$\begin{array}{llllllllllllllll}\text { VAGGAAPSKPASAK } & 0.67 & 38.97 & 23.20 & 51.97 & 3 & 1642.9765 & 1642.9732 & 548.6650 & 0.0033 & 2.0049 & 2227.050 & 2172.628 & 2199.678 & 3209.017 & \text { Yes }\end{array}$

Table S- 4 page 480 of 614 
$\begin{array}{llllllllllll}\text { VAGGAAPSKPASAK } & 0.60 & 57.52 & 23.20 & 70.52 & 3 & 1642.9771 & 1642.9732 & 548.6650 & 0.0039 & 2.3694 & 683.177\end{array}$ $\begin{array}{lllllllllllll}\text { VAGGAAPSKPASAK } & 0.55 & 35.90 & 23.12 & 48.90 & 3 & 1642.9747 & 1642.9732 & 548.6650 & 0.0015 & 0.9113 & 350.883\end{array}$ $\begin{array}{lllllllllllll}\text { VAGGAAPSKPASAK } & 0.55 & 51.71 & 23.12 & 64.71 & 3 & 1642.9747 & 1642.9732 & 548.6650 & 0.0015 & 0.9113 & 500.993\end{array}$ $\begin{array}{llllllllllll}\text { VAGGAAPSKPASAK } & 0.66 & 30.49 & 23.12 & 43.49 & 3 & 1642.9750 & 1642.9732 & 548.6650 & 0.0018 & 1.0936 & 214.271 \\ \text { VAGGAAPSKPASAK } & 0.67 & 38.68 & 23.20 & 51.68 & 3 & 1642.9762 & 1642.9732 & 548.6650 & 0.0030 & 1.8226 & 253.489\end{array}$ $\begin{array}{llllllllllll}\text { VAGGAAPSKPASAK } & 0.67 & 38.68 & 23.20 & 51.68 & 3 & 1642.9762 & 1642.9732 & 548.6650 & 0.0030 & 1.8226 & 253.489\end{array}$ AALSLPAK $\begin{array}{llllllllllll}0.99 & 44.30 & 24.22 & 26.80 & 2 & 1057.6800 & 1057.6739 & 529.8442 & 0.0061 & 5.7564 & 15548.056 & 152 \\ 1.00 & 70.87 & 22.94 & 18.80 & 2 & 1831.0740 & 1831.0730 & 916.5438 & 0.0010 & 0.5455 & 381.733\end{array}$ $\begin{array}{llllllllllll}\text { VVPSDLYPLVLGFLR } & 1.00 & 70.87 & 22.94 & 18.80 & 2 & 1831.0740 & 1831.0730 & 916.5438 & 0.0010 & 0.5455 & 381.733 \\ \text { VI.46 } & 22.79 & 24.32 & 2 & 1831.0746 & 1831.0730 & 916.5438 & 0.0016 & 0.8728 & 292.838\end{array}$ $\begin{array}{llllllllllll}\text { VVPSDLYPLVLGFLR } & 1.00 & 51.46 & 22.79 & 24.32 & 2 & 1831.0746 & 1831.0730 & 916.5438 & 0.0016 & 0.8728 & 292.838 \\ \text { VVPSDLYPLVLGFLR } & 1.00 & 65.55 & 22.79 & 26.01 & 2 & 1831.0746 & 1831.0730 & 916.5438 & 0.0016 & 0.8728 & 462.299\end{array}$

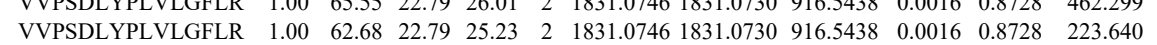
$\begin{array}{lllllllllllll}\text { VVPSDLYPLVLGFLR } & 0.66 & 29.47 & 22.79 & 42.47 & 3 & 1831.0747 & 1831.0730 & 611.3649 & 0.0017 & 0.9269 & 41.704\end{array}$ $\begin{array}{lllllllllllll}\text { VVSDLYPLVLGFLR } & 0.66 & 51.04 & 22.76 & 64.04 & 3 & 1831.0753 & 1831.0730 & 611.3649 & 0.0023 & 1.2540 & 26.719\end{array}$ $\begin{array}{lllllllllllll}\text { VVPSDLYPLVLGLLR } & 1.00 & 60.65 & 22.94 & 19.47 & 2 & 1831.0740 & 1831.0730 & 916.5438 & 0.0010 & 0.5455 & 61.180\end{array}$ $\begin{array}{lllllllllllll} & \text { FVIDECI }\end{array}$ $\begin{array}{llllllllllllll}\text { FVLDHEDGLNLNEDLENFLOK } & 1.00 & 26.81 & 26.99 & 39.81 & 4 & 2789.4145 & 2789.4115 & 698.3602 & 0.0030 & 1.0739 & 79.502\end{array}$ $\begin{array}{llllllllllll}\text { GEVLGDVLQLETLK } & 1.00 & 76.85 & 23.65 & 23.36 & 2 & 1801.0464 & 1801.0441 & 901.5293 & 0.0023 & 1.2756 & 130.019\end{array}$ $\begin{array}{lllllllllllll}\text { GEVLGDVLQLETLK } & 0.67 & 41.73 & 23.58 & 54.73 & 3 & 1801.0474 & 1801.0441 & 601.3553 & 0.0033 & 1.8292 & 199.818\end{array}$ $\begin{array}{lllllllllllll}\text { AQELGHSQSALASAQR } & 1.00 & 60.39 & 28.34 & 17.52 & 3 & 1796.9263 & 1796.9251 & 599.9823 & 0.0012 & 0.6667 & 1144.030 & 1117.2\end{array}$ $\begin{array}{lllllllllllll}\text { AQELGHSQSALASAQR } & 0.55 & 60.31 & 28.32 & 73.31 & 3 & 1796.9266 & 1796.9251 & 599.9823 & 0.0015 & 0.8334 & 4150.763 & 4626\end{array}$ $\begin{array}{lllllllllllll}\text { AQELGHSQSALASAQR } & 0.66 & 73.52 & 28.30 & 86.52 & 3 & 1796.9272 & 1796.9251 & 599.9823 & 0.0021 & 1.1667 & 4769.087 & 4667 .\end{array}$ $\begin{array}{llllllllllll}\text { VEFATLQEALAHALTEK } & 0.55 & 64.09 & 25.22 & 77.09 & 3 & 2158.1887 & 2158.1877 & 720.4032 & 0.0010 & 0.4627 & 190.720\end{array}$ $\begin{array}{lllllllllllll}\text { QQLSSLITDLQSSISNLSQAK } & 1.00 & 32.35 & 24.30 & 24.58 & 3 & 2548.3978 & 2548.3952 & 850.4723 & 0.0026 & 1.0190 & 58.679\end{array}$ $\begin{array}{lllllllllllll}\text { QQLSSLITDLQSSISNLSQAK } & 0.66 & 57.80 & 24.31 & 70.80 & 3 & 2548.3975 & 2548.3952 & 850.4723 & 0.0023 & 0.9015 & 9.702\end{array}$ LDFVCSFLQK $\begin{array}{lllllllllll}1.00 & 51.57 & 27.98 & 27.10 & 2 & 1532.7980 & 1532.7975 & 767.4060 & 0.0005 & 0.3258 & 333.024 \\ 0.58 & 11.85 & 27.99 & 17.21 & 3 & 1532.7991 & 1532.7975 & 511.9398 & 0.0016 & 1.0418 & 78.970\end{array}$ LDFVCSFLQK $\begin{array}{lllllllllllll}0.58 & 11.85 & 27.99 & 17.21 & 3 & 1532.7991 & 1532.7975 & 511.9398 & 0.0016 & 1.0418 & 78.970\end{array}$ $\begin{array}{lllllllllllll}\text { IATTTASAATAAAIGATPR } & 0.52 & 11.83 & 27.11 & 14.90 & 3 & 1859.0242 & 1859.0234 & 620.6817 & 0.0008 & 0.4296 & 13.581 \\ \text { IATTASATAAAGATR } & 0.97 & 22.61 & 27.06 & 15.85 & 3 & 1859.0266 & 1859.0234 & 620.6817 & 0.0032 & 1.7185 & 12.450\end{array}$ $\begin{array}{lllllllllllll}\text { IATTTASAATAAAIGATPR } & 0.97 & 22.61 & 27.06 & 15.85 & 3 & 1859.0266 & 1859.0234 & 620.6817 & 0.0032 & 1.7185 & 12.450 \\ \text { IATTTASAATAAAIGATPR } & 1.00 & 31.99 & 27.02 & 16.10 & 3 & 1859.0269 & 1859.0234 & 620.6817 & 0.0035 & 1.8797 & 14.768\end{array}$ $\begin{array}{llllllllllll}\text { IATTTASAATAAAIGATPR } & 1.00 & 31.99 & 27.02 & 16.10 & 3 & 1859.0269 & 1859.0234 & 620.6817 & 0.0035 & 1.8797 & 14.768 \\ \text { ELAEAMAOHTAESECELVK } & 0.99 & 17.34 & 26.64 & 17.65 & 4 & 2621.2401 & 26212378 & 656.3167 & 0.0023 & 0.8761 & 116.632\end{array}$ $\begin{array}{lllllllllllll}\text { ELAEAMAAQHTAESECEQLVK } & 0.99 & 17.34 & 26.64 & 17.65 & 4 & 2621.2401 & 2621.2378 & 656.3167 & 0.0023 & 0.8761 & 116.632 \\ \text { LQQLGEAHQAETEVLR } & 0.85 & 41.59 & 28.34 & 17.65 & 3 & 1965.0205 & 1965.0401 & 656.0206 & -0.0196 & -9.9591 & 2687.201\end{array}$ $\begin{array}{lllllllllllll}\text { LQQLGEAHQAETEVLR } & 0.85 & 41.59 & 28.34 & 17.65 & 3 & 1965.0205 & 1965.0401 & 656.0206 & -0.0196 & -9.9591 & 2687.201 \\ \text { DPTGMDPDDIWQLSSSLK } & 0.99 & 81.93 & 27.22 & 79.55 & 2 & 2292.1194 & 2292.1188 & 1147.0667 & 0.0006 & 0.2615 & 55.949\end{array}$ $\begin{array}{llllllllllll}\text { DPTGMDPDDIWQLSSSLK } & 0.99 & 81.93 & 27.22 & 79.55 & 2 & 2292.1194 & 2292.1188 & 1147.0667 & 0.0006 & 0.2615 & 55.949 \\ \text { SGGSGGCSGAGGASNCGTGSGR } & 1.00 & \# \# \# \# \text { 12.30 } & 29.40 & 2 & 1978.7472 & 1978.7472 & 990.3809 & 0.0000 & 0.0000 & 201.442\end{array}$ $\begin{array}{llllllllllll}\text { SGGGGGCSGAGGASNCGTGSGR } & 1.00 & \# \# \# 12.30 & 29.40 & 2 & 1978.7472 & 1978.7472 & 990.3809 & 0.0000 & 0.0000 & 201.442 & \\ \text { SGGSGGCSGAGGASNCGTGSGR } & 1.00 & \# \# \# \# 12.30 & 26.87 & 2 & 1978.7482 & 1978.7472 & 990.3809 & 0.0010 & 0.5049 & 212.344\end{array}$

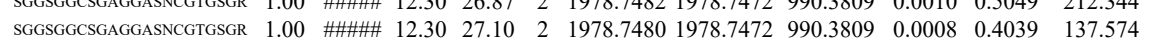
$\begin{array}{lllllllllll}\text { SGGSGGCSGAGGASNCGTGSGR } & 1.00 & \text { \#\#\#\# } 12.30 & 28.87 & 2 & 1978.7484 & 1978.7472 & 990.3809 & 0.0012 & 0.6058 & 163.626\end{array}$ $\begin{array}{lllllllllll}1.00 & 52.65 & 26.11 & 25.79 & 2 & 1085.6510 & 1085.6467 & 543.8306 & 0.0043 & 3.9534 & 4287.677 \\ 0\end{array}$

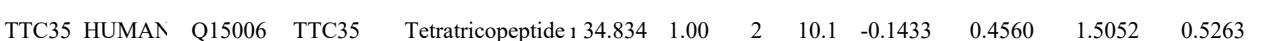

NSEQIVEVGEEL

NSEQIVEVGEEINEYASK 1.0

$\begin{array}{lllllllllllll}0.67 & 31.51 & 27.23 & 44.51 & 3 & 2438.2453 & 2438.2420 & 813.7546 & 0.0033 & 1.3518 & 0.000\end{array}$

YASWAASQINR

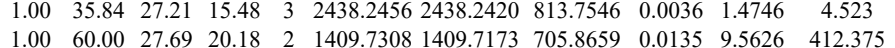

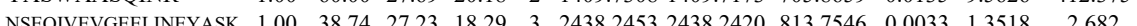

$\begin{array}{llllllllllll}\text { NSEQIVEVGEELINEYASK } & 0.60 & 30.83 & 27.21 & 43.83 & 3 & 2438.2456 & 2438.2420 & 813.7546 & 0.0036 & 1.4746 & 14.516\end{array}$

$\begin{array}{llllllllllll}\text { NSEQIVEVGEELINEYASK } & 1.00 & 45.35 & 27.31 & 16.15 & 3 & 2438.2447 & 2438.2420 & 813.7546 & 0.0027 & 1.4060 & 18.672\end{array}$

$\begin{array}{lllllllllllllll}13 & \text { NWQYQETIK } & 0.91 & 32.14 & 28.01 & 21.41 & 2 & 1496.8004 & 1496.7867 & 749.4006 & 0.0137 & 9.1406 & 234.030 & 16\end{array}$ $\begin{array}{lllllllllllll}\text { QAAELFLDTVSTFTSYLLMVYK } & 1.00 & 49.79 & 26.85 & 17.17 & 3 & 2859.4144 & 2859.4132 & 954.1450 & 0.0012 & 0.4192 & 14.394 & 21\end{array}$

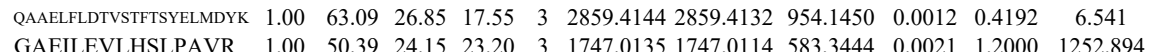

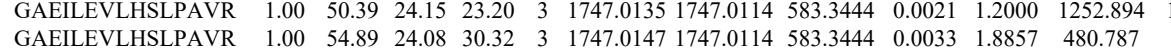
$\begin{array}{llllllllllllll}\text { GAEILEVLHSLPAVR } & 1.00 & 54.89 & 24.08 & 30.32 & 3 & 1747.0147 & 1747.0114 & 583.3444 & 0.0033 & 1.8857 & 480.787 & 8 \\ \text { GAEILEVLHSLPAVR } & 1.00 & 54.86 & 24.17 & 21.95 & 3 & 1747.0132 & 1747.0114 & 583.3444 & 0.0018 & 1.0286 & 1158.218 & 1655.3\end{array}$ $\begin{array}{lllllllllllll}\text { GAEILEVLHSLPAVR } & 1.00 & 54.31 & 24.30 & 19.22 & 3 & 1747.0144 & 1747.0114 & 583.3444 & 0.0030 & 1.7143 & 666.136 & 817.0\end{array}$ LDEELEDAEK

LDEELEDAEK

FLLSLPEHR

FLLSLPEHR

LDIVFYLLR

LDIVFYLLR

PLENLEEEGLPK

SEPT2_HUMAN Q15019 SEPT2 Septin-2

$\begin{array}{llllllllll}41.487 & 1.00 & 6 & 26.9 & -0.3498 & 0.2368 & 1.2880 & 0.2437 & 12 & \text { TIISYIDEQFER } \\ & & & & & & & & & \end{array}$ $\begin{array}{llllllllllllll}0.99 & 40.03 & 27.87 & 23.04 & 2 & 1477.7394 & 1477.7391 & 739.8768 & 0.0003 & 0.2027 & 60.269 & 62.077\end{array}$ $\begin{array}{lllllllllll}0.96 & 0.03 & 27.87 & 23.04 & 2 & 1477.7394 & 1477.7391 & 739.8768 & 0.0003 & 0.2027 & 6.269\end{array}$ $\begin{array}{llllllllllllll}1.00 & 39.86 & 25.54 & 21.26 & 3 & 1254.7309 & 1254.7206 & 419.2475 & 0.0103 & 8.1892 & 4108.416 & 3328.435 & 27 \\ 0.99 & 35.88 & 25.45 & 16.36 & 3 & 1254.7321 & 1254.7206 & 419.2475 & 0.0115 & 9.1433 & 3383.414 & 3037.465 & 52.2\end{array}$ $\begin{array}{lllllllllllll}0.99 & 35.88 & 25.45 & 16.36 & 3 & 1254.7321 & 1254.7206 & 419.2475 & 0.0115 & 9.1433 & 3383.414 & 3037.465 & 5 \\ 1.00 & 43.31 & 22.92 & 27.16 & 2 & 1294.7784 & 1294.7771 & 648.3958 & 0.0013 & 1.0025 & 424.213 & 565.873 & 5\end{array}$ $\begin{array}{lllllllllllll}1.00 & 41.47 & 22.92 & 29.06 & 2 & 1294.7786 & 1294.7771 & 648.3958 & 0.0015 & 1.1567 & 800.581\end{array}$ $\begin{array}{llllllllllll}1.00 & 56.90 & 27.63 & 23.67 & 2 & 1654.9028 & 1654.9021 & 828.4583 & 0.0007 & 0.4225 & 231.273\end{array}$ $\begin{array}{llllllllllll}\text { LYPWGVVEVENPEHNDFLK } & 0.66 & 41.12 & 27.25 & 54.12 & 3 & 2572.3228 & 2572.3206 & 858.4475 & 0.0022 & 0.8543 & 1645.858 \\ \text { LYPWGVEEVENPEHNDFL } & 1.00 & 57.13 & 27.18 & 18.46 & 3 & 2572.3264 & 2572.3206 & 858.4475 & 0.0058 & 2.2521 & 403.552\end{array}$ $\begin{array}{llllllllllll}\text { LYPWGVVEVENPEHNDFLK } & 1.00 & 57.13 & 27.18 & 18.46 & 3 & 2572.3264 & 2572.3206 & 858.4475 & 0.0058 & 2.2521 & 403.552 \\ \text { LTVVDTPGYGDAINCR } & 1.00 & 68.51 & 27.20 & 27.57 & 2 & 1882.9034 & 1882.9039 & 942.4592 & -0.0005 & -0.2653 & 83.877\end{array}$ $\begin{array}{lllllllllllll}\text { TMLTHMODLOEVTODL HYENFR } & 1.00 & 49.15 & 26.26 & 23.07 & 4 & 3005.4541 & 3005.4497 & 752.3697 & 0.0044 & 1.4620 & 420.483 & 5\end{array}$ $\begin{array}{llllllllllllll}\text { TMLITHMQDLDEVTQDLHYENFR } & 1.00 & 56.40 & 26.26 & 69.40 & 4 & 3005.4541 & 3005.4497 & 752.3697 & 0.0044 & 1.4620 & 345.887\end{array}$ $\begin{array}{llllllllllll}\text { LTVVDTPGYGDAINCR } & 1.00 & 48.63 & 27.19 & 23.37 & 2 & 1882.9048 & 1882.9039 & 942.4592 & 0.0009 & 0.4775 & 114.756\end{array}$ $\begin{array}{llllllllllll}\text { TMLTHMODLOEVTODLHYENFR } & 1.00 & 42.96 & 26.23 & 55.96 & 4 & 3005.4533 & 3005.4497 & 752.3697 & 0.0036 & 1.1962 & 87.683\end{array}$ 
$\begin{array}{llllllllllll} & \end{array}$

$\begin{array}{lllllllllllll} & & & \end{array}$

FFDDPMLLELAK

FFDDPMLLELAK

FFDDPMLLELAK

FFDDPMLLELAK

$\begin{array}{lllllllllll}1.00 & 61.67 & 27.11 & 21.64 & 2 & 1725.9270 & 1725.9255 & 863.9700 & 0.0015 & 0.8681 & 175.269\end{array}$

FFDDPMLLELAK

$\begin{array}{llllllllllll}1.00 & 55.14 & 27.11 & 19.94 & 2 & 1725.9270 & 1725.9255 & 863.9700 & 0.0015 & 0.8681 & 296.395\end{array}$ $\begin{array}{lllllllllllll}18.92 & 27.925 .9262 & 1725.9255 & 863.9700 & 0.0007 & 0.4051 & 1252.671 & 1205.948\end{array}$

LDAVVAQEPLHR

$\begin{array}{llllllllll} & \end{array}$

$\begin{array}{lllllllllllll}1.00 & 49.03 & 25.49 & 21.52 & 3 & 1603.9318 & 1603.9168 & 535.6462 & 0.0150 & 9.3344 & 1094.551 & 1475.274\end{array}$ $\begin{array}{lllllllllllllll} & \end{array}$

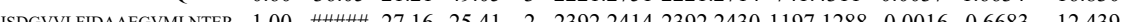
$\begin{array}{llllllllll} & 0.0039 & 12.49\end{array}$ $\begin{array}{lllllllllllll}\text { SDGVVLFIDAAEGVMLNTER } & 1.00 & 93.64 & 27.14 & 21.91 & 3 & 2392.2481 & 2392.2430 & 798.4216 & 0.0051 & 2.1292 & 2.768\end{array}$ $\begin{array}{lllllllllllll}\text { TCFVDCLIEQTHPEIR } & 1.00 & 65.80 & 25.13 & 24.05 & 3 & 2138.9767 & 2138.9743 & 713.9987 & 0.0024 & 1.1204 & 72.609\end{array}$ $\begin{array}{lllllllllllll}\text { TCFVDCLIEQTHPEIR } & 1.00 & 55.63 & 25.07 & 18.32 & 3 & 2138.9773 & 2138.9743 & 713.9987 & 0.0030 & 1.4006 & 15.382\end{array}$ $\begin{array}{lllllllllllll}\text { VADPVVTFCETVVETSSLK } & 1.00 & 73.63 & 27.11 & 25.82 & 2 & 2357.2114 & 2357.2102 & 1179.6124 & 0.0012 & 0.5086 & 62.269 \\ \text { VADPVVTFCETVVETSSLK } & 1.00 & 79.24 & 27.14 & 18.16 & 2 & 2357.2134 & 2357.2102 & 1179.6124 & 0.0032 & 1.3564 & 56.074\end{array}$ $\begin{array}{lllllllllllll}\text { VADPVVVTFCETVVETSSLK } & 1.00 & 55.71 & 27.15 & 16.63 & 3 & 2357.2144 & 2357.2102 & 786.7440 & 0.0042 & 1.7564 & 56.074 & 47.622\end{array}$ $\begin{array}{lllllllllllll}\text { VADPVVTFCETVVETSSLK } & 0.99 & 33.21 & 27.19 & 16.37 & 3 & 2357.2153 & 2357.2102 & 786.7440 & 0.0051 & 2.1608 & 59.890\end{array}$ $\begin{array}{lllllllllllll}\text { FNTTSVIK } & 0.95 & 36.16 & 25.87 & 25.91 & 2 & 1196.7074 & 1196.7009 & 599.3577 & 0.0065 & 5.4224 & 2307.750\end{array}$ $\begin{array}{lllllllllllll}\text { VADPVVTFCETVVETSSLK } & 1.00 & 61.59 & 27.15 & 17.70 & 3 & 2357.2141 & 2357.2102 & 786.7440 & 0.0039 & 1.6524 & 8.697\end{array}$ $\begin{array}{lllllllllllll}\text { VADPVVTFCETVVETSSLK } & 0.60 & 55.86 & 27.21 & 68.86 & 3 & 2357.2147 & 2357.2102 & 786.7440 & 0.0045 & 1.9066 & 21.648\end{array}$ LWISVAR $\begin{array}{lllllllllllll}0.66 & 24.33 & 24.97 & 27.99 & 2 & 843.5048 & 843.4967 & 422.7556 & 0.0081 & 9.5799 & 87.162 & 93.9\end{array}$ $\begin{array}{lcccccccccccc}\text { VLSGTIHAGQPVK } & 0.56 & 6.02 & 22.60 & 19.02 & 3 & 1593.9478 & 1593.9446 & 532.3221 & 0.0032 & 2.0038 & 9239.434 & 11548\end{array}$ $\begin{array}{lllllllllllll}\text { VADPVVTFCETVVETSSLK } & 1.00 & 89.48 & 27.15 & 19.27 & 3 & 2357.2141 & 2357.2102 & 786.7440 & 0.0039 & 1.6524 & 5.787 \\ \text { VADPVVTFCETVVETSSLK } & 1.00 & 58.93 & 27.21 & 17.85 & 3 & 2357.2147 & 2357.2102 & 786.7440 & 0.0045 & 1.9066 & 28.289\end{array}$ $\begin{array}{lllllllllllllllllll} & \end{array}$

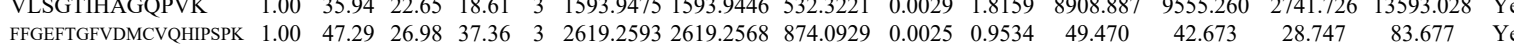
LWISVA

LWISVAR

LNIRPLLR $\begin{array}{lllllllllll}1.00 & 47.29 & 26.98 & 37.36 & 3 & 2619.2593 & 2619.2568 & 874.0929 & 0.0025 & 0.9534 & 49.470 \\ 0.69 & 27.61 & 26.87 & 28.22 & 2 & 987.6036 & 987.5987 & 494.8066 & 0.0049 & 4.9514 & 4476.023\end{array}$

LNIRPLLR $\begin{array}{llllllllllll}0.59 & 25.68 & 26.87 & 28.22 & 2 & 987.6036 & 987.5987 & 494.8066 & 0.0049 & 4.9514 & 44.6 .023 & 360\end{array}$ 
IGCPLTPLPPVSIAIR

GDIIGVQGNPGK

ILDDICVAK

ILDDICVAK

LDDICVAK

RGDIIGVQGNPGK

RGDIIGVQGNP

MLVVGGIDR

YLDVGIDR

YLDLILNDFVR

YLDLILNDFVR

YLDLILNDFVR

LPETNLFETEETR

LPETNLFETEETR

INMVEELEK

INMVEELEK

MPLHTIIPLLQELTK

MPLHTIIPLLQELTK MPLHTIIPLLQELTK

LLNVWQVR

LLNVWQVR
LLNVWQVR IGCPLTPLPPVSIAIR

$\begin{array}{lllllllllll}0.84 & 60.01 & 24.22 & 73.01 & 2 & 1836.0508 & 1836.0487 & 919.0316 & 0.0021 & 1.1425 & 99.845\end{array}$ $\begin{array}{llllllllll} & \end{array}$ $\begin{array}{llllllllllll}.00 & 66.86 & 26.95 & 28.28 & 2 & 1441.8266 & 1441.8133 & 721.9139 & 0.0133 & 9.2115 & 2389.151\end{array}$ $\begin{array}{lllllllllllll}0.71 & 15.44 & 26.07 & 15.98 & 3 & 2651.2462 & 2651.2415 & 884.7544 & 0.0047 & 1.7707 & 286.809 & 173.667\end{array}$ $\begin{array}{lllllllllllll}1.00 & 52.68 & 27.55 & 32.44 & 2 & 1322.7254 & 1322.7182 & 662.3664 & 0.0072 & 5.4350 & 4120.399 & 3507.892\end{array}$ $\begin{array}{llllllllllll}0.99 & 43.12 & 27.44 & 23.11 & 2 & 1322.7284 & 1322.7182 & 662.3664 & 0.0102 & 7.6996 & 7960.562 & 7844.269\end{array}$ $\begin{array}{llllllllllllll}0.98 & 41.88 & 27.64 & 31.48 & 2 & 1322.7260 & 1322.7182 & 662.3664 & 0.0078 & 5.8879 & 4987.567 & 4120.947 & 82\end{array}$ $\begin{array}{llllllllllllll}0.55 & 35.63 & 25.66 & 48.63 & 3 & 1597.9159 & 1597.9144 & 533.6454 & 0.0015 & 0.9370 & 5072.976 & 3603.308 & 154\end{array}$ $\begin{array}{llllllllllllll}0.74 & 25.23 & 25.89 & 16.04 & 3 & 1597.9168 & 1597.9144 & 533.6454 & 0.0024 & 1.4991 & 1526.638 & 161.202 & 120\end{array}$ $\begin{array}{llllllllllll}0.79 & 27.57 & 27.84 & 28.42 & 2 & 1102.6390 & 1102.6291 & 552.3218 & 0.0099 & 8.9621 & 5417.704 & 6291.395\end{array}$ $\begin{array}{llllllllllllll}1.00 & 64.98 & 26.51 & 28.47 & 2 & 1523.8500 & 1523.8470 & 762.9308 & 0.0030 & 1.9661 & 221.709 & 207.596\end{array}$ $\begin{array}{llllllllllll} & \end{array}$ $\begin{array}{llllllll}15 & 0\end{array}$

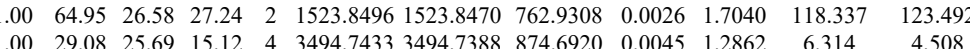

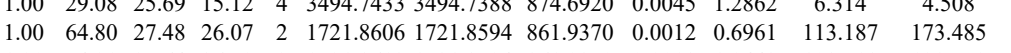
$\begin{array}{llllllllllll}1.00 & 74.21 & 27.64 & 36.59 & 2 & 1721.8612 & 1721.8594 & 861.9370 & 0.0018 & 1.0442 & 108.718 & 128.752\end{array}$ $\begin{array}{llllllllllll}1.00 & 56.57 & 28.36 & 26.82 & 2 & 1391.7588 & 1391.7574 & 696.8860 & 0.0014 & 1.0045 & 4424.073 & 5328.166\end{array}$ $\begin{array}{lllllllllllll}1.00 & 54.61 & 28.36 & 30.07 & 2 & 1391.7590 & 1391.7574 & 696.8860 & 0.0016 & 1.1480 & 3286.005 & 3771.616\end{array}$ $\begin{array}{llllllllllll}1.00 & 49.33 & 18.06 & 16.13 & 3 & 2034.2158 & 2034.2155 & 679.0791 & 0.0003 & 0.1473 & 189.505 & 167.705\end{array}$ $\begin{array}{lllllllllllll}1.00 & 43.03 & 17.99 & 17.07 & 3 & 2034.2167 & 2034.2155 & 679.0791 & 0.0012 & 0.5890 & 181.602 & 191.637 & 262\end{array}$ $\begin{array}{lllllllllllll}1.00 & 43.47 & 17.99 & 17.62 & 3 & 2034.2167 & 2034.2155 & 679.0791 & 0.0012 & 0.5890 & 318.773 & 338.790\end{array}$ $\begin{array}{lllllllllllll}.00 & 65.67 & 17.99 & 27.68 & 3 & 2034.2167 & 2034.2155 & 679.0791 & 0.0012 & 0.5890 & 199.970 & 222.249 & 29\end{array}$ $\begin{array}{lllllllllllll}1.00 & 48.16 & 25.75 & 26.40 & 2 & 1170.6998 & 1170.6995 & 586.3570 & 0.0003 & 0.2558 & 1250.571 & 1144.515 & 10 \\ 1.00 & 42.84 & 25.75 & 22.52 & 2 & 1170.6998 & 1170.6995 & 586.3570 & 0.0003 & 0.2558 & 975.590 & 1056.328 & 19\end{array}$

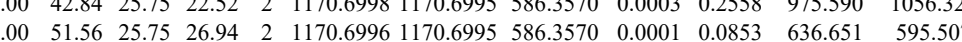
$\begin{array}{lllllllllllll}1.00 & 45.29 & 24.41 & 19.20 & 3 & 2924.5669 & 2924.5626 & 975.8615 & 0.0043 & 1.4688 & 16.975 & 8.605 \\ 0.55 & 43.03 & 24.50 & 56.03 & 3 & 2924.5636 & 2924.5626 & 975.8615 & 0.0010 & 0.3416 & 6.340 & 5.828\end{array}$ $\begin{array}{llllllllllllll} & \text { N }\end{array}$

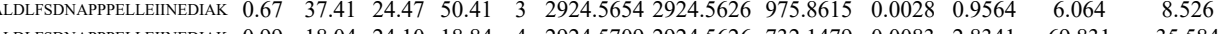
$\begin{array}{llllllllllllll} & \end{array}$ $\begin{array}{llllllllllllll}\text { ALDLFSDNAPPPELEIINEDIAK } & 1.00 & 31.81 & 23.93 & 16.37 & 4 & 2924.5725 & 2924.5626 & 732.1479 & 0.0099 & 3.3805 & 72.305 & 23.785 & 0.0 \\ \text { ILDLFSDNAPPPELLEINEDIAK } & 0.67 & 57.15 & 24.47 & 70.15 & 3 & 2924.5654 & 2924.5626 & 975.8615 & 0.0028 & 0.9564 & 2.783 & 10.527 & 2.4\end{array}$

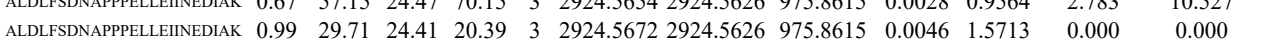

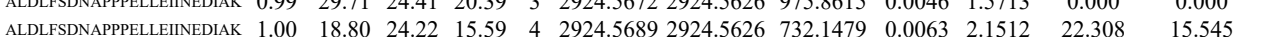

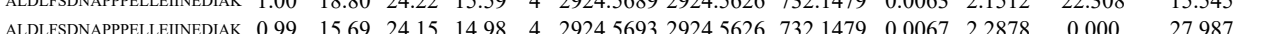

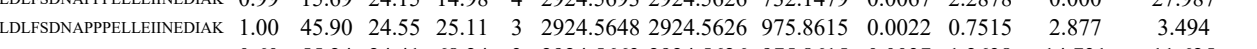
$\begin{array}{llllllllllllll} & \end{array}$

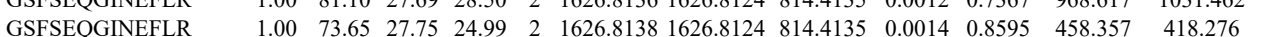
GSTSEQTNEFR

GSFSEQGINEFLR

GSFSQGINEFLR

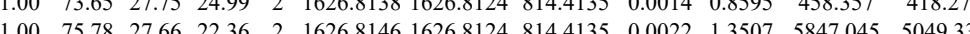

$\begin{array}{lllllllllllll}1.00 & 81.19 & 27.71 & 28.70 & 2 & 1626.8142 & 1626.8124 & 814.4135 & 0.0018 & 1.1051 & 442.157 & 445.989\end{array}$

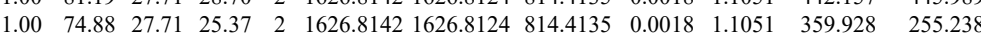
$\begin{array}{lllllllllllll}\text { GSFSEQGINEFLR } & 1.00 & 74.88 & 27.71 & 25.37 & 2 & 1626.8142 & 1626.8124 & 814.4135 & 0.0018 & 1.1051 & 359.928 & 25.238\end{array}$ GSTAPVGGGAFPTIVER GFPTIK

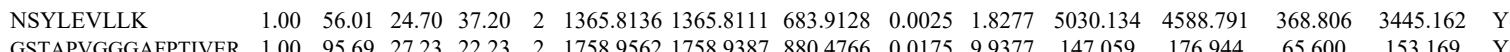

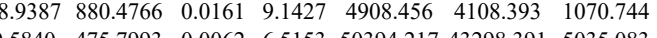
$\begin{array}{lllllllllllllllll}\text { GSTAPVGGGAFPTIVER } & 1.00 & 88.48 & 27.23 & 26.08 & 2 & 1758.9562 & 1758.9387 & 880.4766 & 0.0175 & 9.9377 & 556.614 & 521.701 & 215.254 & 304.132 & \text { Yes }\end{array}$

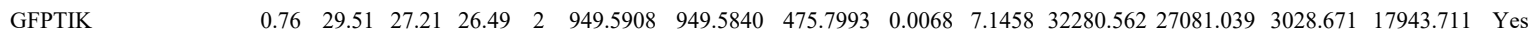
GFPTIK $\begin{array}{llllllllllllllll}\text { TGEAIVDAALSALR } & 1.00 & 93.43 & 27.72 & 39.97 & 2 & 1529.8552 & 1529.8535 & 765.9340 & 0.0017 & 1.1098 & 4897.634 & 4620.689 & 796.735 & 3469.753 & \text { Yes }\end{array}$

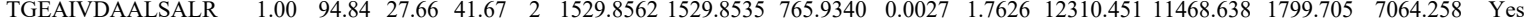
$\begin{array}{lllllllllllllllll}\text { TGEAIVDAALSALR } & 1.00 & 52.38 & 27.66 & 23.14 & 3 & 1529.8564 & 1529.8535 & 510.9584 & 0.0029 & 1.8919 & 77.243 & 88.495 & 15.561 & 100.110 & \text { Yes }\end{array}$ $\begin{array}{llllllllllllllll}\text { TGEAIVDAALSALR } & 1.00 & 47.40 & 27.64 & 21.95 & 3 & 1529.8567 & 1529.8535 & 510.9584 & 0.0032 & 2.0876 & 90.152 & 220.054 & 21.128 & 106.258 & \text { No }\end{array}$ $\begin{array}{llllllllllllllll}\text { TGEAIVDAALSALR } & 1.00 & 94.40 & 27.72 & 40.28 & 2 & 1529.8550 & 1529.8535 & 765.9340 & 0.0015 & 0.9792 & 6575.961 & 5919.562 & 1296.758 & 4929.107 & \text { Yes }\end{array}$ $\begin{array}{lllllllllllllll}\text { TGEAIVDAALSALR } & 1.00 & \text { \#\#\# } 27.72 & 43.36 & 2 & 1529.8552 & 1529.8535 & 765.9340 & 0.0017 & 1.1098 & 5994.758 & 5305.283 & 924.983 & 3825.318 & \text { Yes }\end{array}$

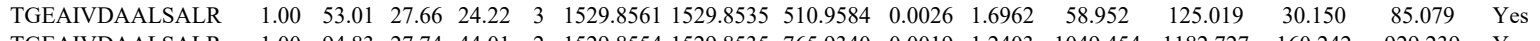

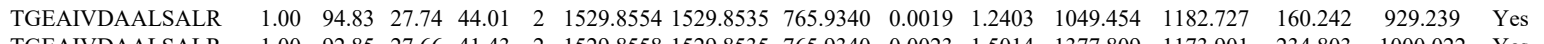

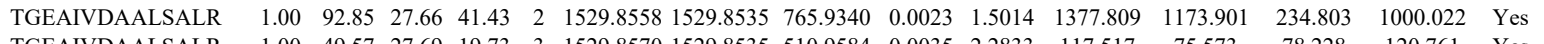

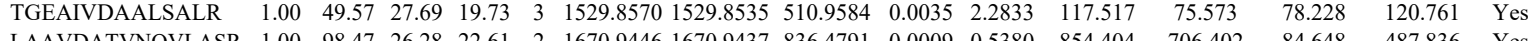

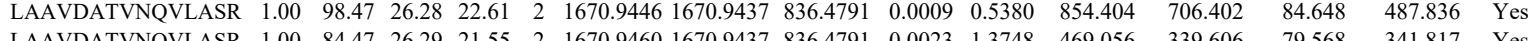

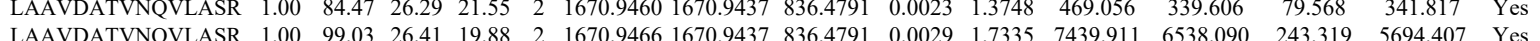

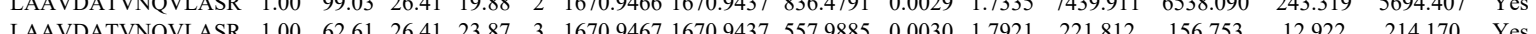

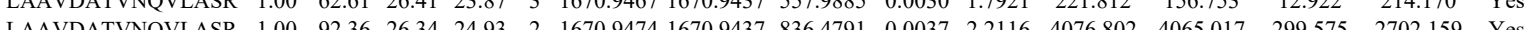

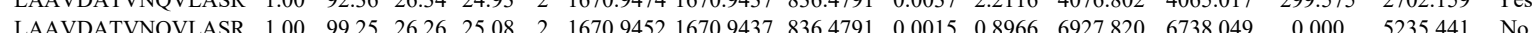

Table S-4 page 483 of 614 
$\begin{array}{llllllllllllllll}\text { LAAVDATVNQVLASR } & 1.00 & 97.80 & 26.26 & 24.65 & 2 & 1670.9452 & 1670.9437 & 836.4791 & 0.0015 & 0.8966 & 8778.536 & 7210.164 & 464.480 & 5789.925 & \text { Yes }\end{array}$ $\begin{array}{lllllllllllllllllll}\text { LAAVDATVNQVLASR } & 1.00 & 59.08 & 26.36 & 23.92 & 3 & 1670.9470 & 1670.9437 & 557.9885 & 0.0033 & 1.9714 & 589.324 & 420.767 & 123.220 & 615.646 & \text { Yes }\end{array}$ $\begin{array}{llllllllllllllll}\text { LAAVDATVNQVLASR } & 0.67 & 30.45 & 26.36 & 43.45 & 3 & 1670.9470 & 1670.9437 & 557.9885 & 0.0033 & 1.9714 & 224.977 & 442.523 & 0.000 & 518.681 & \text { No }\end{array}$

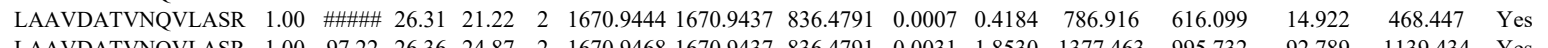
$\begin{array}{llllllllllllllll}\text { LAAVDATVNQVLASR } & 1.00 & 97.22 & 26.36 & 24.87 & 2 & 1670.9468 & 1670.9437 & 836.4791 & 0.0031 & 1.8530 & 1377.463 & 995.732 & 92.789 & 1139.434 & \text { Yes }\end{array}$

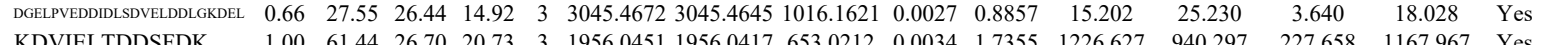
$\begin{array}{llllllllllllllll}\text { KDDIELTDDSFDK } & 1.00 & 61.44 & 26.70 & 20.73 & 3 & 1956.0451 & 1956.0417 & 653.0212 & 0.0034 & 1.7355 & 1226.627 & 940.297 & 227.658 & 1167.967 & \text { Yes }\end{array}$

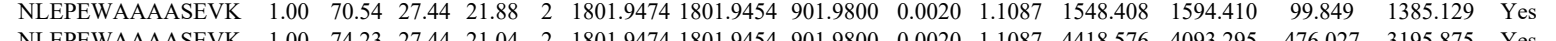
$\begin{array}{llllllllllllllll}\text { NLEPEWAAAASEVK } & 1.00 & 74.23 & 27.44 & 21.04 & 2 & 1801.9474 & 1801.9454 & 901.9800 & 0.0020 & 1.1087 & 4418.576 & 4093.295 & 476.027 & 3195.875 & \text { Yes } \\ \text { NLEPEWAAAASEVK } & 1.00 & 52.39 & 27.54 & 32.61 & 3 & 1801.9480 & 1801.9454 & 601.6557 & 0.0026 & 1.4405 & 156.524 & 136.438 & 85.747 & 146.355 & \text { Yes }\end{array}$

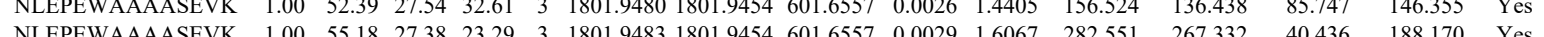

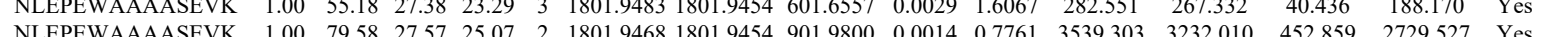

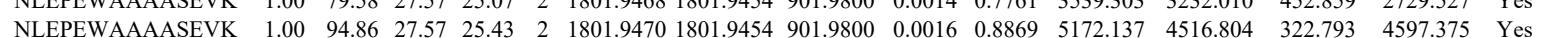

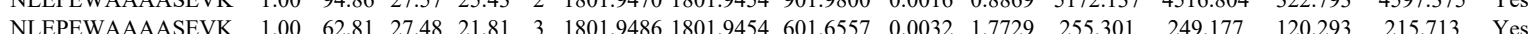

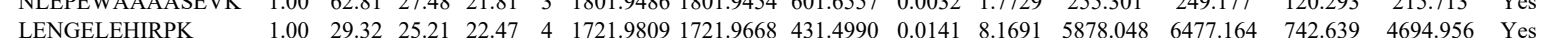

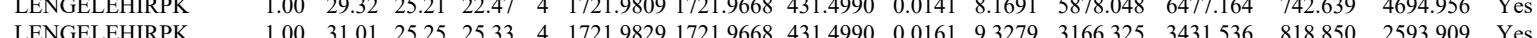

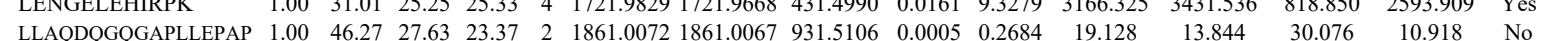

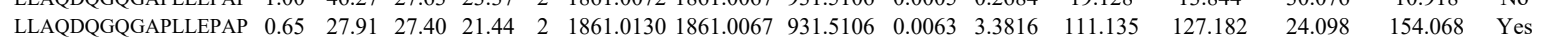
$\begin{array}{llllllllllllllll}\text { LLAQDOGQGAPLLEPAP } & 0.66 & 25.08 & 27.19 & 20.66 & 2 & 1861.0156 & 1861.0067 & 931.5106 & 0.0089 & 4.7772 & 105.956 & 112.046 & 40.358 & 148.304 & \text { Yes }\end{array}$ $\begin{array}{llllllllllllllll} & & & \end{array}$ $\begin{array}{llllllllllllllll}\text { ALHSLLLR } & 1.00 & 43.94 & 18.86 & 19.26 & 2 & 1065.6784 & 1065.6780 & 533.8463 & 0.0004 & 0.3746 & 6142.303 & 5892.590 & 683.725 & 7227.508 & \text { Yes }\end{array}$ $\begin{array}{llllllllllllllll}\text { VVVLGLLPR } & 0.82 & 36.55 & 7.78 & 49.55 & 2 & 1108.7466 & 1108.7454 & 555.3800 & 0.0012 & 1.0803 & 31.647 & 27.386 & 18.174 & 47.459 & \text { Yes }\end{array}$ $\begin{array}{llllllllllllllll}\text { VVVLGLLPR } & 0.82 & 32.80 & 7.78 & 45.80 & 2 & 1108.7468 & 1108.7454 & 555.3800 & 0.0014 & 1.2604 & 5584.880 & 6631.507 & 127.974 & 5916.385 & \text { Yes }\end{array}$ $\begin{array}{lllllllllllllllll}\text { VVVLGLLPR } & 0.84 & 33.06 & 7.78 & 46.06 & 2 & 1108.7470 & 1108.7454 & 555.3800 & 0.0016 & 1.4405 & 3467.775 & 3635.550 & 20.939 & 3969.238 & \text { Yes }\end{array}$

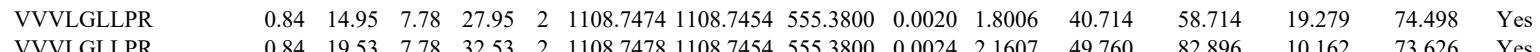
VVVLGLLPR VVVLGLLPR VVVLGLLPR VVVLGLLPR VVVLGLLPR VVVLGLLPR $\begin{array}{lllllllllllll}\text { PEA15_HUMAN Q15121 } & \text { PEA15 } & \text { Astrocytic phosph } & 15.04 & 1.00 & 2 & 23.8 & 0.1462 & 0.1996 & 0.0457 & 0.5209 & 5 & \text { ISEEDELDTK } \\ \text { RPDLLTMVVDYR }\end{array}$ RPDLLTMVVDYR ISEEDELDTK ISEEDELDTK

$\begin{array}{lllllllllllll}\text { PMVK_HUMAN Q15126 } & \text { PMVK } & \text { Phosphomevalona 21.995 } & 1.00 & 2 & 10.9 & -0.4854 & 0.3384 & 1.6218 & 0.3099 & 3 & \text { LEEQLENLIEFIR } \\ & & & & & & & & & & & & \end{array}$ LEEQLENLIEFIR

LEEQLENLIE
LVLLFSGK
LQAEEAER

LQAEEAER
LQAEEAER

LQAEEAER

LQAEEAER
LQAFEAER

SLAAEEEAAR

SLAAEEEAAR

QAEEIGEK

QAEEIGEK

QQEELLAEENQR

QQEELLAEENQR

GLVGPELHDR

GLVGPELHDR

GLVGPELHDR

VQMEELSK

VQMEELSK

SELELTLGK

SELELTLGK

AGLVGPEFHEK

AGLVGPEFHEK

AGLVGPEFHEK

AGLVGPEFHEK

AGLVGPEFHEK

19.279

$\begin{array}{llllllllllll}0.82 & 34.23 & 7.78 & 47.23 & 2 & 1108.7468 & 1108.7454 & 555.3800 & 0.0014 & 1.2604 & 5108.194 & 5038.443\end{array}$

$\begin{array}{lllllllllllll}0.84 & 30.76 & 7.78 & 43.76 & 2 & 1108.7472 & 1108.7454 & 555.3800 & 0.0018 & 1.6205 & 3767.561 & 3981.330\end{array}$

$\begin{array}{llllllllllll}0.82 & 22.05 & 6.99 & 35.05 & 2 & 1108.7462 & 1108.7454 & 555.3800 & 0.0008 & 0.7202 & 243.525 & 267.277\end{array}$

$\begin{array}{llllllllllll}0.82 & 26.99 & 6.99 & 39.99 & 2 & 1108.7464 & 1108.7454 & 555.3800 & 0.0010 & 0.9003 & 278.093 & 261.405\end{array}$

$\begin{array}{llllllllllll}0.64 & 21.15 & 6.99 & 34.15 & 2 & 1108.7456 & 1108.7454 & 555.3800 & 0.0002 & 0.1801 & 87.286 & 114.86\end{array}$

$\begin{array}{llllllllllll}0.99 & 42.71 & 28.40 & 31.86 & 2 & 1465.7392 & 1465.7391 & 733.8768 & 0.0001 & 0.0681 & 120.367 & 139.830 \\ 1.00 & 50.06 & 28.01 & 19.00 & 3 & 1620.8815 & 1620.8779 & 541.2999 & 0.0036 & 2.2169 & 175.478 & 226.921\end{array}$

$\begin{array}{llllllllllll}1.00 & 50.06 & 28.01 & 19.00 & 3 & 1620.8815 & 1620.8779 & 541.2999 & 0.0036 & 2.2169 & 175.478 & 226.921 \\ 1.00 & 53.40 & 27.94 & 17.84 & 3 & 1620.8830 & 1620.8779 & 541.2999 & 0.0051 & 3.1406 & 591.395 & 745.748\end{array}$

$\begin{array}{llllllllllll}1.00 & 53.40 & 27.94 & 17.84 & 3 & 1620.8830 & 1620.8779 & 541.2999 & 0.0051 & 3.1406 & 591.395 & 745.748 \\ 1.00 & 55.38 & 28.41 & 28.24 & 2 & 1465.7390 & 1465.7391 & 733.8768 & -0.0001 & -0.0681 & 734.099 & 770.619\end{array}$

$\begin{array}{llllllllllll}1.00 & 55.38 & 28.41 & 28.24 & 2 & 1465.7390 & 465.7391 & 733.8768 & -0.0001 & -0.0681 & 734.099 & 770.619 \\ 1.00 & 60.92 & 28.40 & 27.92 & 2 & 1465.7392 & 1465.7391 & 733.8768 & 0.0001 & 0.0681 & 698.564 & 786.686\end{array}$

$\begin{array}{llllllllllll}1.00 & 53.73 & 28.62 & 29.89 & 2 & 1465.7500 & 1465.7391 & 733.8768 & 0.0109 & 7.4263 & 232.911 & 207.353 \\ 1\end{array}$

$\begin{array}{llllllllllll}1.00 & 81.78 & 26.91 & 30.72 & 2 & 1788.9764 & 1788.9743 & 895.4944 & 0.0021 & 1.1725 & 356.508 & 322.486\end{array}$

$\begin{array}{llllllllllll}1.00 & 64.40 & 26.88 & 29.64 & 2 & 1788.9768 & 1788.9743 & 895.4944 & 0.0025 & 1.3959 & 62.057 & 35.160\end{array}$

$\begin{array}{lllllllllllll}1.00 & 53.12 & 19.24 & 22.60 & 2 & 1163.7546 & 1163.7522 & 582.8834 & 0.0024 & 2.0587 & 4309.620 & 3471.603\end{array}$

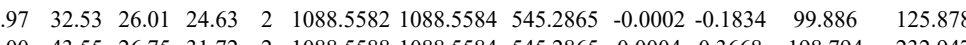

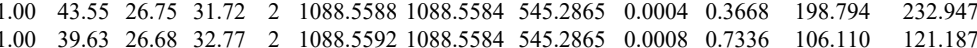

$\begin{array}{lllllllllll}1.00 & 45.56 & 26.68 & 29.08 & 2 & 1088.5592 & 1088.5584 & 545.2865 & 0.0008 & 0.7336 & 120.711\end{array}$

$\begin{array}{lllllllllllll}1.00 & 63.71 & 27.48 & 30.81 & 2 & 1189.6064 & 1189.6060 & 595.8103 & 0.0004 & 0.3357 & 706.466 & 69 & \\ 0\end{array}$ $\begin{array}{llllllllllll}0.98 & 33.12 & 27.82 & 34.15 & 2 & 1190.6392 & 1190.6386 & 59.8103 & 0.0004 & 0.3357 & 931.454 & 9 \\ 0.95 & 33.98 & 27.82 & 40.11 & 2 & 1190.6394 & 1190.6386 & 596.3266 & 0.0006 & 0.5031 & 470.318 & 4\end{array}$ $\begin{array}{lll}0.6708 & 432.769 & 410.000\end{array}$ $\begin{array}{llllllllllll}1.00 & 82.78 & 27.67 & 34.29 & 2 & 1629.8072 & 1629.8080 & 815.9113 & -0.0008 & -0.4902 & 167.432 & 175.534\end{array}$ $\begin{array}{llllllllllllll}0.96 & 24.72 & 27.53 & 22.25 & 3 & 1629.8092 & 1629.8080 & 544.2766 & 0.0012 & 0.7349 & 95.039\end{array}$ $\begin{array}{lllllllllll} & 27.53 & 22.25 & 3 & 1629.8092 & 1629.8080 & 544.2766 & 0.012 & 0.7349 & 95.039 & 87.830\end{array}$

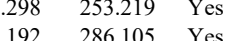

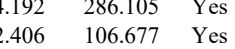
$810-106.677$ Yes $\begin{array}{lll}0.810 & 174.495 & \text { Yes } \\ 1.2801 & 158.596 & \text { Yes }\end{array}$ $\begin{array}{lll}11.401 & 158.596 & \text { Yes } \\ 1467.553 & 659.288 & \text { No }\end{array}$ $598.518 \quad 1732.088$ Yes
50859 $1353.135 \quad$ Yes \begin{tabular}{llll}
0.864 & 369.204 & Yes \\
\hline & 239.355 & Yes
\end{tabular} LEQLFQDEVAK

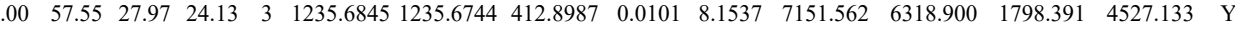
$\begin{array}{lllllllllllllllll}0.94 & 38.14 & 28.30 & 38.44 & 2 & 1250.6884 & 1250.6784 & 626.3465 & 0.0100 & 7.9827 & 18905.772 & 19685.569 & 14159.051 & 21420.026 & \text { Yes }\end{array}$ $\begin{array}{lllllllllllllllll}.97 .82 & 28.30 & 27.05 & 2 & 1250.6898 & 1250.6784 & 626.3465 & 0.0114 & 9.1003 & 18751.775 & 16823.707 & 4138.797 & 17426.147 & \text { Yes } \\ 1.00 & 58.81 & 26.42 & 35.80 & 2 & 1276.7492 & 1276.7482 & 639.3814 & 0.0010 & 0.7820 & 9427.223 & 8805.351 & 824.966 & 8559.701 & \text { Yes }\end{array}$ $\begin{array}{lllllllllllllll}1.00 & 58.81 & 26.42 & 35.80 & 2 & 1276.7492 & 1276.7482 & 639.3814 & 0.0010 & 0.7820 & 9427.223 & 8805.351 & 824.966 & 8559.701 & \text { Yes } \\ 1.00 & 58.87 & 26.42 & 31.06 & 2 & 1276.7494 & 1276.7482 & 639.3814 & 0.0012 & 0.9384 & 10006.849 & 9322.691 & 802.059 & 8810.528 & \text { Yes }\end{array}$ $\begin{array}{llllllllllllllll}0.81 & 19.39 & 27.12 & 15.34 & 3 & 1470.8080 & 1470.8074 & 491.2764 & 0.0006 & 0.4071 & 119.986 & 135.632 & 99.784 & 179.310 & \text { Yes }\end{array}$ $\begin{array}{llllllllllllllll}0.53 & 10.10 & 27.13 & 16.40 & 3 & 1470.8098 & 1470.8074 & 491.2764 & 0.0024 & 1.6284 & 108.239 & 115.645 & 81.917 & 118.829 & \text { Yes } \\ \end{array}$

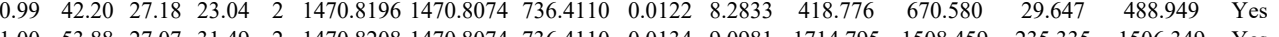

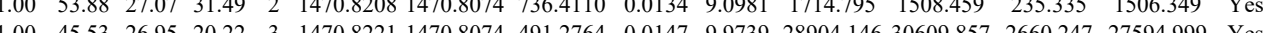

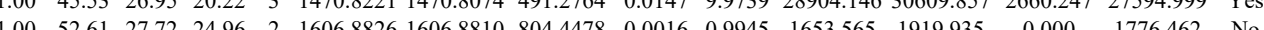

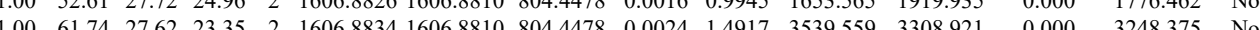
$\begin{array}{llllllllllllllll} & & & \end{array}$ $\begin{array}{llllllllllllllll} & 97.78 & 27.68 & 27.79 & 2 & 1713.9038 & 1713.9019 & 857.9582 & 0.0019 & 1.1073 & 2583.506 & 3429.439 & 2035.902 & 1297.354 & \text { Yes }\end{array}$ $\begin{array}{llllllllllllll} & 0.000 & \text { No }\end{array}$

Table S-4 page 484 of 614 

$\begin{array}{lllll}1.00 & 49.36 & 26.21 & 17.82 & 3 \\ 1.00 & 47.99 & 26.39 & 31.83 & 2\end{array}$ $\begin{array}{lllllllllll}.00 & 47.99 & 26.39 & 31.83 & 2 & 1185.6938 & 1185.6839 & 593.8492 & 0.0099 & 83354\end{array}$ $\begin{array}{lllll}1.00 & 59.14 & 26.72 & 33.40 & 2\end{array}$

$\begin{array}{lllllll} & \end{array}$

LLEAQIATGGIIDPEESHR

EQELQQTLQQEQSVLDQLR 1.00

EQELQQTLQQEQSVLDQLR
EQELQQTLQQEQSVLDQLR
1.00

LQEDKEQMAQQ

AQFEQLK

AQFEQLK

LTVNEAVK

LTVNEAVK

LTAEDLFAR

GLHQSIEEFR

GLHQSIEEFR

AEMEVLLASK

AEMEVLLASK

AQLEPVASPAK

AQLEPVASPAK

QLQLAQEAAQK

QLQLAQEAAQK

LAQGHTTVDELAR

LAQGHTTVDELAR

LAQGHTTVDELAR

SLQEEHVAVAQLR

VPPGYHPLDVEK

VPPGYHPLDVEK

$\begin{array}{lllll}1514.8778 & 1514.8660 & 758.4403 & 0.0118 & 7.7791 \\ 1553.848 & 1553.828 & 58.9501 & 0.024 & 7.9647\end{array}$

$\begin{array}{llllllll}15 & \end{array}$

$\begin{array}{llllllll}553.8420 & 1553.8284 & 518.9501 & 0.0136 & 8.7355 & 6370.951 & 5625.812\end{array}$

$\begin{array}{rr}6.778 & 7719 \\ 5.812 & 7457 \\ 1.065 & 149.045\end{array}$

QEQIQAMPLADSQAVR

QEQIQAMPLADSQAVR

QTNLENLDQAFSVAER

QTNLENLDQAFSVAER

AGVVGPELHEQLLSAEK

CVEDPETGLCLLPLLTDK
SEEMQTVQQEqLLETQALQQSFLSEK

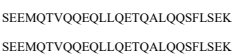

\begin{tabular}{llll} 
& 28.60 & 36.06 \\
\hline & 69.78 & 27.02 & 17.57
\end{tabular}

1699.92501699 .9226
$1699.9267 \quad 1699.9226$

$\begin{array}{llll}59.55 & 26.98 & 20.55 & 3 \\ 57.73 & 27.81 & 21.72 & 3\end{array}$

1977.98861977 .9877990 .001

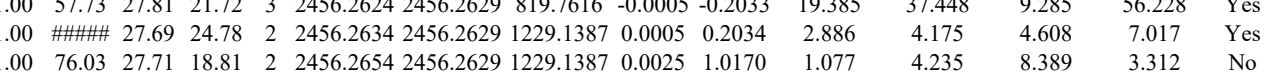

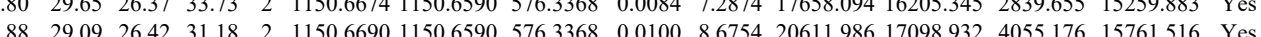

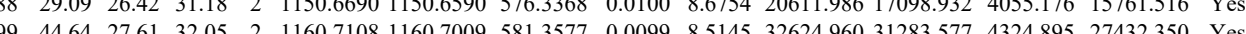

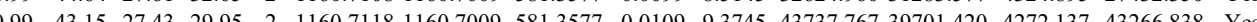

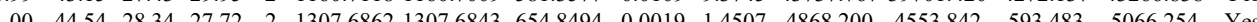
$\begin{array}{llllllllllllllll}1.00 & 42.28 & 28.34 & 22.41 & 2 & 1307.6864 & 1307.6843 & 654.8494 & 0.0021 & 1.6034 & 5391.751 & 5153.804 & 548.926 & 6524.362 & \text { Yes }\end{array}$

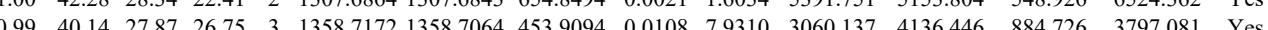
$\begin{array}{llllllllllllllll}1.00 & 47.53 & 27.80 & 28.36 & 3 & 1358.7196 & 1358.7064 & 453.9094 & 0.0132 & 9.6935 & 3121.185 & 3632859 & 763.846 & 3564.343 & \text { Yes }\end{array}$ $\begin{array}{llllllllllllllll}1.00 & 69.97 & 26.97 & 25.46 & 2 & 1377.7800 & 1377.7781 & 689.8963 & 0.0019 & 1.3770 & 3063.044 & 3375.762 & 524.740 & 2213.369 & \text { Yes }\end{array}$ $\begin{array}{lllllllllllllll}1.00 & 69.26 & 26.96 & 25.27 & 2 & 1377.7810 & 1377.7781 & 689.8963 & 0.0029 & 2.1018 & 2500.170 & 2390.753 & 429.077 & 1727.959 & \text { Yes }\end{array}$ $\begin{array}{llllllllllllllll}1.00 & 56.22 & 25.02 & 22.24 & 2 & 1397.8230 & 1397.8122 & 699.9134 & 0.0108 & 7.7152 & 18591.329 & 16913.011 & 2291.911 & 18816.820 & \text { Yes }\end{array}$ $\begin{array}{lllllllllllllll}100 & 48.12 & 25.00 & 19.93 & 2 & 1397.8240 & 1397.8122 & 699.9134 & 0.0118 & 8.4295 & 17800.633 & 16461.378 & 1545.645 & 16819.539 & \text { Yes }\end{array}$ $\begin{array}{llllllllllllllll}1.00 & 60.04 & 25.94 & 34.69 & 2 & 1514.8788 & 1514.8660 & 758.4403 & 0.0128 & 8.4383 & 11056.070 & 10518.410 & 804.129 & 9631.103 & \text { Yes }\end{array}$ $\begin{array}{lllllllllllllllll}1.00 & 68.42 & 25.99 & 35.59 & 2 & 1514.8806 & 1514.8660 & 758.4403 & 0.0146 & 9.6249 & 4095.512 & 4304.540 & 402.969 & 4120.284 & \text { Yes }\end{array}$ $\begin{array}{lllllllllllllll}1.00 & 83.28 & 27.22 & 31.59 & 2 & 1553.8410 & 1553.8284 & 777.9215 & 0.0126 & 8.0984 & 5279.449 & 5886.424 & 605.682 & 6774.655 & \text { Yes }\end{array}$ $\begin{array}{lllllllllllllll}1.00 & 47.95 & 27.19 & 20.12 & 3 & 1553.8426 & 1553.8284 & 518.9501 & 0.0142 & 9.1209 & 10050.659 & 9189.066 & 3955.302 & 10205.238 & \text { Yes }\end{array}$ $\begin{array}{llllllllllllllll}1.00 & 79.89 & 27.13 & 31.06 & 2 & 1553.8430 & 1553.8284 & 777.9215 & 0.0146 & 9.3839 & 7092.597 & 5964.265 & 733.852 & 7246.990 & \text { Yes }\end{array}$

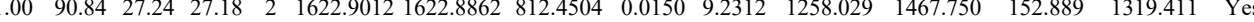
$\begin{array}{llllllllllllll} & \end{array}$

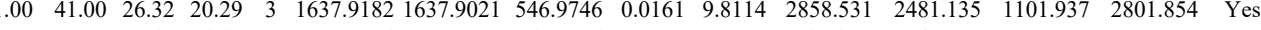
$\begin{array}{llllllllllllll}1.00 & \text { \#\#\#\# 27.39 } & 26.93 & 2 & 1928.0078 & 1927.9907 & 965.0026 & 0.0171 & 8.8600 & 798.997 & 697.455 & 237.169 & 419.649 & \text { Yes } \\ & 28 & 1977.9886 & 1977.9877 & 990.0011 & 0.0009 & 0.4545 & 432.418 & 444.733 & 154.161 & 337.497 & \text { Yes }\end{array}$ $\begin{array}{llllllllllllll} & 1005.441 & \text { Yes } \\ \end{array}$

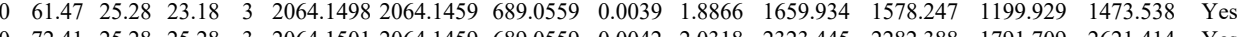
$\begin{array}{lllllllllllll} & 232.423 .445 & 2282.388 & 1791.709 & 2621.414 & \text { Yes } \\ \end{array}$

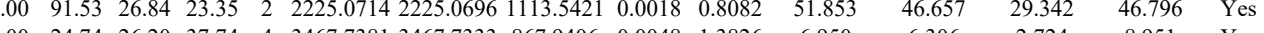

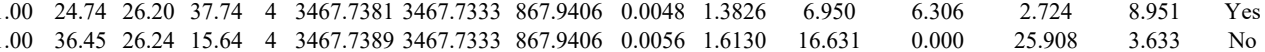
\begin{tabular}{llllllllllllll}
1.00 & $\# \# \# \# 26.28$ & 20.75 & 3 & 3467.7412 & 3467.7333 & 1156.9184 & 0.0079 & 2.2762 & 9.972 & 15.144 & 6.470 & 13.743 & Yes \\
\hline
\end{tabular}

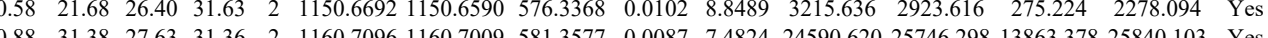



$\begin{array}{lllllllllllllll}1.00 & 50.17 & 28.02 & 30.62 & 2 & 1261.6842 & 1261.6822 & 631.8484 & 0.0020 & 1.5827 & 14375.017 & 14056.818 & 169.640 & 12133.647 & \text { Yes }\end{array}$

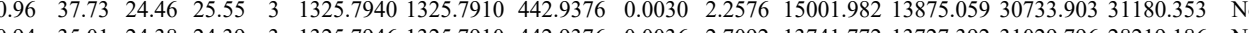
$\begin{array}{llllllllllllll}0.94 & 35.01 & 24.38 & 24.39 & 3 & 1325.7946 & 1325.7910 & 442.9376 & 0.0036 & 2.7092 & 13741.772 & 13727.392 & 31029.796 & 28219.186\end{array}$

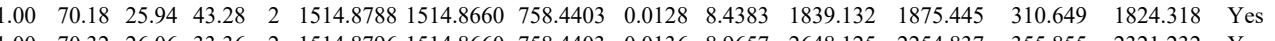

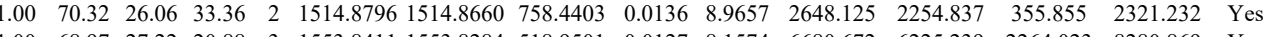

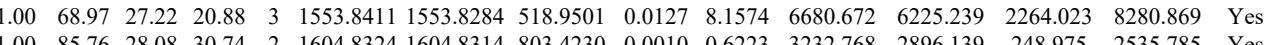
$\begin{array}{lllllllllllllll} & \end{array}$

ALQALEELR

ALQALEELR

LPLDKEPAR

SQVMDEATALQLR

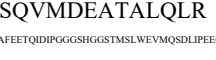

ALQALEELR

LLEAAAQSTK

LLEAAAQSTK

QVQVALETAQR

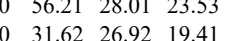

$1952.00081951 .9973 \quad 977.0059 \quad 0.0035 \quad 1.7912$

$\begin{array}{llllllllll}31.41 & 26.85 & 18.09 & 3 & 2225.0740 & 2225.0696 & 742.6971 & 0.0044 & 1.9748 & 6.0383\end{array}$

62.536

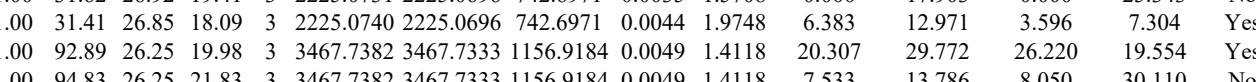

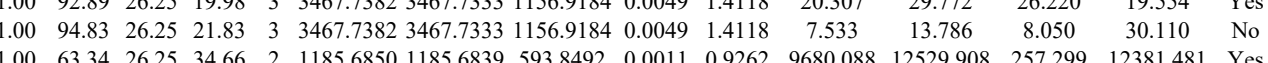
$\begin{array}{lllllllllllllll}1 & & \end{array}$ $\begin{array}{lllllllllllllll}0.99 & 39.74 & 26.31 & 26.85 & 2 & 1318.7828 & 1318.7700 & 660.3923 & 0.0128 & 9.6911 & 7495.026 & 7313.120 & 1481.567 & 5035.257 & \text { Yes }\end{array}$ $\begin{array}{lllllllllllllll}0.80 & 36.60 & 24.46 & 31.46 & 3 & 1325.7943 & 1325.7910 & 442.9376 & 0.0033 & 2.4834 & 7165.638 & 8383.468 & 17371.661 & 17587.046 & \text { No }\end{array}$ \begin{tabular}{lllllllllllllll}
1.00 & 70.62 & 28.08 & 25.14 & 2 & 1604.8324 & 1604.8314 & 803.4230 & 0.0010 & 0.6223 & 3249.265 & 3264.631 & 403.580 & 2704.494 & Yes \\
\hline
\end{tabular} $\begin{array}{lllllllllllllll}1.00 & 88.25 & 27.92 & 25.97 & 2 & 1604.8328 & 1604.8314 & 803.4230 & 0.0014 & 0.8713 & 4679.703 & 5127.683 & 368.955 & 3951.043 & \text { Yes } \\ 1\end{array}$

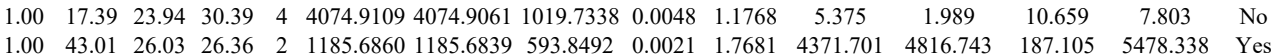
$\begin{array}{lllllllllllllll}1.00 & 62.00 & 26.31 & 38.92 & 2 & 1318.7810 & 1318.7700 & 660.3923 & 0.0110 & 8.3283 & 29918.980 & 29441.719 & 4194.034 & 25651.932 & \text { Yes }\end{array}$ $\begin{array}{lllllllllllllllll}1.00 & 64.50 & 26.31 & 39.25 & 2 & 1318.7812 & 1318.7700 & 660.3923 & 0.0112 & 8.4797 & 36504.333 & 40456.221 & 3404.955 & 32884.813 & \text { Yes }\end{array}$

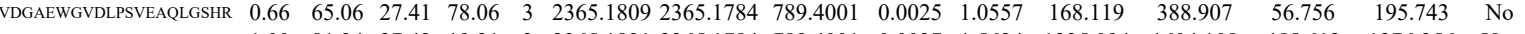
$\begin{array}{llllllllllllllllll}\text { VDGAEWGVDLPSVEAQLGSHR } & 1.00 & 81.34 & 27.42 & 19.21 & 3 & 2365.1821 & 2365.1784 & 789.4001 & 0.0037 & 1.5624 & 1335.094 & 1604.108 & 455.612 & 1276.256 & \text { Yes }\end{array}$ $\begin{array}{llllllllllllllll} & 0.98 & 25.78 & 26.93 & 14.69 & 3 & 2460.1798 & 2460.1753 & 821.0657 & 0.0045 & 1.8269 & 50.530 & 12.916 & 31.828 & 30.145 & \text { Yes }\end{array}$ $\begin{array}{llllllllllllll} & \end{array}$

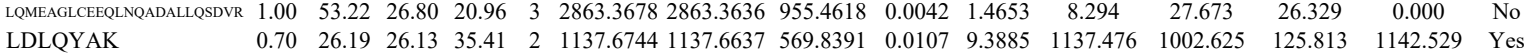

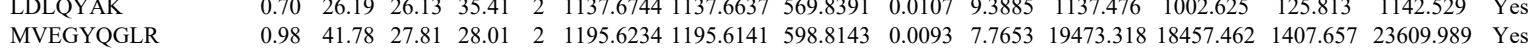
$\begin{array}{llllllllllllllllll}\text { MVEGYQGLR } & 0.98 & 38.70 & 28.12 & 27.39 & 2 & 1195.6242 & 1195.6141 & 598.8143 & 0.0101 & 8.4333 & 20826.649 & 20574.925 & 1912.704 & 28152.717 & \text { Yes }\end{array}$ LLEAAAQSTK $\begin{array}{llllllllllllllll}\text { QVQVALETAQR } & 1.00 & 65.94 & 26.10 & 27.01 & 2 & 1385.7848 & 1385.7749 & 693.8947 & 0.0099 & 7.1336 & 26691.093 & 27624.000 & 1239.119 & 26881.872 & \text { Yes } \\ \text { QVQVALETAQR } & 1.00 & 65.82 & 26.03 & 26.54 & 2 & 1385.7860 & 1385.7749 & 693.8947 & 0.0111 & 7.9983 & 28434.913 & 30100.804 & 1231.028 & 27857.460 & \text { Yes } \\ \text { SLVPAAELASR } & 1100 & 50.28 & 27.08 & 19.33 & 2 & 1427.122 & 1427.05 & 714.9125 & 0.0017 & 1.1890 & 99.191 & 170.673 & 7.605 & 183.107 & \text { Yes }\end{array}$ $\begin{array}{llllllllllllllll}0.98 & 38.70 & 28.12 & 27.39 & 2 & 1195.6242 & 1195.6141 & 598.8143 & 0.0101 & 8.4333 & 20826.649 & 20574.925 & 1912.704 & 28152.717 & \text { Yes } \\ 0.97 & 37.18 & 26.10 & 26.70 & 2 & 1318.7788 & 1318.7700 & 660.3923 & 0.0088 & 6.6627 & 20486.409 & 21849.377 & 5849.910 & 21693.434 & \text { Yes }\end{array}$ $\begin{array}{llllllllllllllll} & 1.00 & 50.28 & 27.08 & 19.33 & 2 & 1427.8122 & 1427.8105 & 714.9125 & 0.0017 & 1.1890 & 99.181 & 170.673 & 7.605 & 183.107 & \text { Y }\end{array}$ $\begin{array}{lllllllllll} & \end{array}$

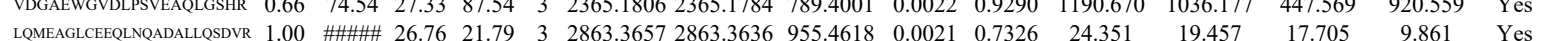

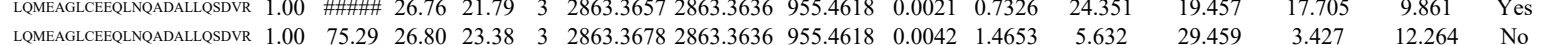
$\begin{array}{llllllllllllllll}\text { MVEGYQGLR } & 0.73 & 28.65 & 27.85 & 30.59 & 2 & 1195.6224 & 1195.6141 & 598.8143 & 0.0083 & 6.9303 & 7372.224 & 7298.296 & 940.199 & 9148.758 & \text { Yes }\end{array}$

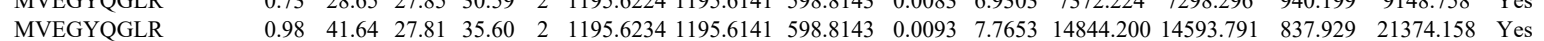

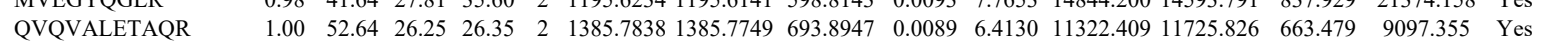
$\begin{array}{llllllllllllllll}\text { QVQVALETAQR } & 1.00 & 46.27 & 26.05 & 24.69 & 2 & 1385.7842 & 1385.7749 & 693.8947 & 0.0093 & 6.7013 & 6341.340 & 5968.074 & 406.106 & 5409.859 & \text { Yes }\end{array}$ $\begin{array}{llllllllllllllllll}\text { TPVEVPVGGFK } & 0.52 & 54.44 & 25.38 & 67.44 & 2 & 1416.8360 & 1416.8221 & 709.4183 & 0.0139 & 9.7967 & 4807293 & 4331.710 & 4174.455 & 4018.863 & \text { Yes }\end{array}$ $\begin{array}{llllllllllllllll}\text { SLVPAAELLESR } & 1.00 & 51.68 & 27.08 & 21.60 & 2 & 1427.8122 & 1427.8105 & 714.9125 & 0.0017 & 1.1890 & 3885.436 & 3797.268 & 355.121 & 4182.579 & \text { Yes }\end{array}$

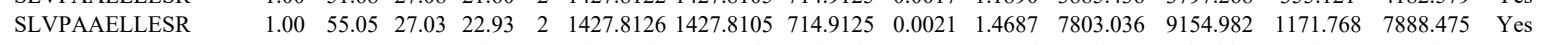
$\begin{array}{lllllllllllllllll}\text { ILITIVEEVETLR } & 1.00 & 71.90 & 22.92 & 26.31 & 2 & 1670.9960 & 1670.9940 & 836.5043 & 0.0020 & 1.1954 & 596.890 & 749.443 & 176.131 & 705.423 & \text { Yes }\end{array}$ $\begin{array}{llllllllllllllllll}\text { ILITIVEEVETLR } & 0.67 & 11.09 & 22.88 & 24.09 & 3 & 1670.9968 & 1670.9940 & 558.0053 & 0.0028 & 1.6726 & 107.480 & 108.957 & 43.514 & 155.162 & \text { Yes }\end{array}$ $\begin{array}{lllllllllllllllll}\text { LLEAQACTGGIDPSTGER } & 1.00 & 90.62 & 27.45 & 25.37 & 2 & 2120.0374 & 2120.0364 & 1061.0255 & 0.0010 & 0.4712 & 276.121 & 301.532 & 103.743 & 203.450 & \text { Yes }\end{array}$

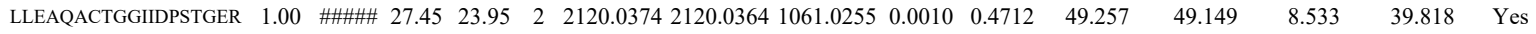
$\begin{array}{llllllllllllllll}\text { LLEAQACTGGIIDPSTGER } & 0.98 & 26.20 & 27.54 & 20.69 & 3 & 2120.0398 & 2120.0364 & 707.6861 & 0.0034 & 1.6015 & 227.636 & 165.407 & 101.323 & 312.718 & \text { Yes }\end{array}$ $\begin{array}{llllllllllllllll}\text { VDGAEWGVDLPSVEAQLGSHR } & 1.00 & 92.76 & 27.33 & 22.95 & 3 & 2365.1800 & 2365.1784 & 789.4001 & 0.0016 & 0.6756 & 118.779 & 78.265 & 39.836 & 116.450 & \text { Yes }\end{array}$

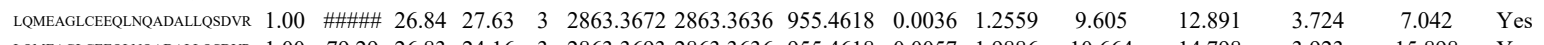

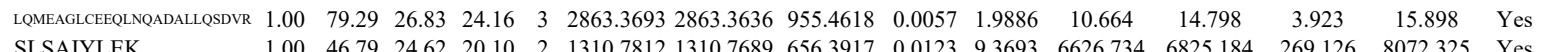
SLSAIYLEK TPVEVPVGGFK SLVPAAELLESR SLVPAAELLESR ILITIVEEVETLR ILITIVEEVETLR

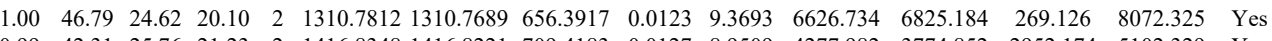
$\begin{array}{lllllllllllllll}0.99 & 42.31 & 25.76 & 21.23 & 2 & 1416.8348 & 1416.8221 & 709.4183 & 0.0127 & 8.9509 & 4277.982 & 3774.852 & 2952.174 & 5102.329 & \text { Yes }\end{array}$ $\begin{array}{lllllllllllllll}1.00 & 55.29 & 26.97 & 23.30 & 2 & 1427.8114 & 1427.8105 & 714.9125 & 0.0009 & 0.6294 & 1275.346 & 1347.406 & 28.705 & 1113.908 & \text { Yes } \\ 1 & 62.52 & 27.28 & 24.92 & 2 & 1427.8118 & 1427.8105 & 71.9125 & 0.0013 & 0.9092 & 837.589 & 718.384 & 41.58 & 781.710 & \text { Yes }\end{array}$ $\begin{array}{llllllllllllllll}1.00 & 62.52 & 27.28 & 24.92 & 2 & 1427.8118 & 1427.8105 & 714.9125 & 0.0013 & 0.9092 & 837.589 & 718.384 & 41.508 & 781.710 & \text { Yes } \\ 1.00 & 27.68 & 22.90 & 18.03 & 3 & 1670.9962 & 1670.9940 & 558.0053 & 0.0022 & 1.3142 & 201.620 & 115.047 & 37.432 & 169.785 & \text { Yes }\end{array}$ $\begin{array}{lllllllllllllll}1.00 & 27.68 & 22.90 & 18.03 & 3 & 1670.9962 & 1670.9940 & 558.0053 & 0.0022 & 1.3142 & 201.620 & 115.047 & 37.432 & 169.785 & \text { Yes } \\ 0 & 14.07 & 22.88 & 27.09 & 3 & 1670.9968 & 1670.9940 & 558.0053 & 0.0028 & 1.6726 & 131.924 & 97.809 & 21.099 & 152.491 & \text { Yes }\end{array}$

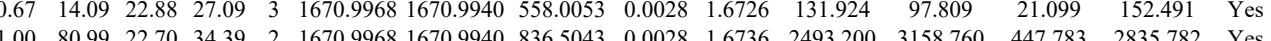


AAEEAEEAR

KDLLPDMAVALEAC

VSIYEAMR

VSIYEAMR

AQLMADFQAG
LLFNDVTLK
LLFNDVQTLK

$\begin{array}{llllllllllll}0.93 & 39.90 * & 27.27 & 20.00 & 3 & 2059.0567 & 2059.0540 & 687.3586 & 0.0027 & 1.3094 & 373.3 \\ 0.99 & 99.74 & 26.24 & 98.72 & 3 & 3076.6012 & 3076.5985 & 1026.5401 & 0.0027 & 0.8767 & 773.1\end{array}$

$\begin{array}{llll}1035.296 & 908\end{array}$

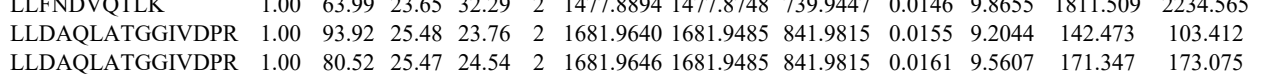

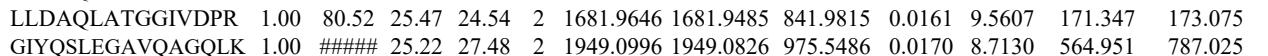
$\begin{array}{lllllllllllll}\text { GIYQSLEGAVQAGQLK } & 0.51 & 28.21 & 25.16 & 32.75 & 3 & 1949.1016 & 1949.0826 & 650.7015 & 0.0190 & 9.7330 & 1253.205 & 865.069\end{array}$ $\begin{array}{lllllllllllll}\text { DPYTEQTISLFQAMK } & 0.97 & 51.79 * 27.32 & 17.23 & 3 & 2059.0552 & 2059.0540 & 687.3586 & 0.0012 & 0.5819 & 270.648 & 270.437 & 180\end{array}$ $\begin{array}{llllllllllll}\text { DPYTEQTISLFQAMK } & 0.98 & 65.71 * 27.32 & 20.44 & 2 & 2059.0554 & 2059.0540 & 1030.5343 & 0.0014 & 0.6793 & 583.605 & 475.037\end{array}$

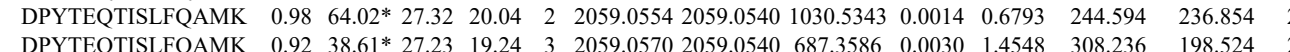
$\begin{array}{llllllllllllll}\text { DPYTEQTISLFQAMK } & 0.92 & 38.61 * & 27.23 & 19.24 & 3 & 2059.0570 & 2059.0540 & 687.3586 & 0.0030 & 1.4548 & 308.236 & 198.524 & 218\end{array}$

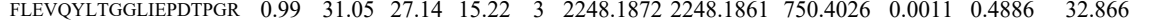

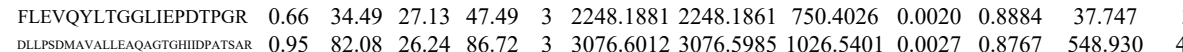

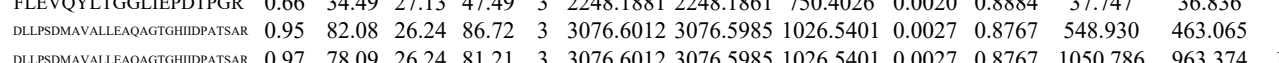

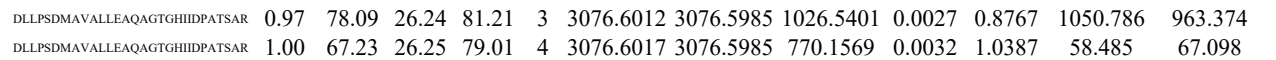

KDLLPSDAVALEAQ

VSIYEAMR

VSIYEAMR

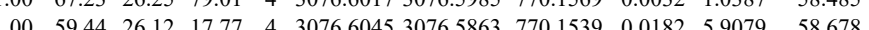

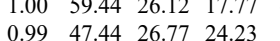

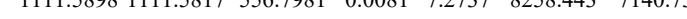
AQLMADFQAGR $\begin{array}{llllllllllll}.00 & 62.40 & 27.81 & 36.87 & 2 & 1350.6926 & 1350.6836 & 676.3491 & 0.0090 & 6.6533 & 3514.240 & 3381.862\end{array}$ LLFNDVQTLK $\begin{array}{llllllllllllll}1.00 & 61.44 & 24.39 & 30.40 & 2 & 1477.8794 & 1477.8748 & 739.9447 & 0.0046 & 3.1083 & 1817.348 & 1439.395\end{array}$ $\begin{array}{llllll}1.00 & 96.18 & 26.14 & 26.21 & 2 & 1\end{array}$

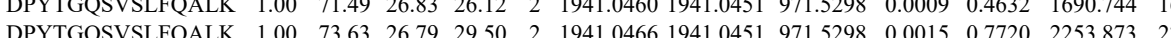

$\begin{array}{llllllllllllll}\text { DPYTGQSVSLFQALK } & 0.99 & 30.13 & 26.81 & 29.44 & 3 & 1941.0475 & 1941.0451 & 648.0223 & 0.0024 & 1.2345 & 381.577 & 458.3\end{array}$

$\begin{array}{llllllllllllll}\text { FLEVQYLTGGLLEPDTPGR } & 1.00 & \ldots & 27.20 & 19.66 & 2 & 2248.1894 & 2248.1861 & 1125.1003 & 0.0033 & 1.4665 & 139.077 & 156.3 \\ \text { FLEVQYLTGGLIEPDTPGR } & 1.00 & 90.10 & 27.06 & 23.01 & 2 & 2248.1914 & 2248.1861 & 1125.1003 & 0.0053 & 2.3553 & 198.238 & 174.4\end{array}$

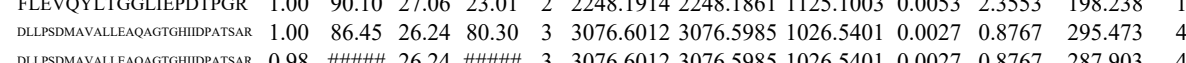
$\begin{array}{llllllllllllll}\text { DLLPSDMAVALEARAGGGHIIDPATSAR } & 0.98 & \text { \#\#\#\# } & 26.24 & \text { \#\#\#\# } & 3 & 3076.6012 & 3076.5985 & 1026.5401 & 0.0027 & 0.8767 & 287.903 & 4 \\ \text { DPYSGSTISLFQAMQK } & 0.61 & 12.04 & 27.69 & 17.79 & 3 & 2060.0509 & 2060.0492 & 687.6903 & 0.0017 & 0.8240 & 1096.717 & 1132 .\end{array}$ $\begin{array}{lllllllllllll}\text { LLLEAQAATGFLLDPVK } & 0.55 & 51.73 & 19.34 & 64.73 & 3 & 2086.2289 & 2086.2281 & 696.4166 & 0.0008 & 0.3829 & 70.402\end{array}$ $\begin{array}{llllllllllllll}\text { LLLEAQAATGFLLDPVK } & 1.00 & 66.84 & 19.44 & 19.99 & 3 & 2086.2298 & 2086.2281 & 696.4166 & 0.0017 & 0.8137 & 29.078 & 23.98\end{array}$ $\begin{array}{lllllllllllllll}\text { LLLEAQAATGFLLDPVK } & 1.00 & 54.02 & 19.44 & 18.50 & 3 & 2086.2301 & 2086.2281 & 696.4166 & 0.0020 & 0.9573 & 66.184 & 26.714\end{array}$ $\begin{array}{llllllllllllll}\text { LLLEAQAATGFLLDPVK } & 0.67 & 35.50 & 19.24 & 48.50 & 3 & 2086.2310 & 2086.2281 & 696.4166 & 0.0029 & 1.3881 & 72.490 & 107.252\end{array}$ $\begin{array}{llllllllllllll}\text { LLLEAQAATGFLLDPVK } & 0.60 & 54.59 & 18.98 & 67.59 & 3 & 2086.2322 & 2086.2281 & 696.4166 & 0.0041 & 1.9624 & 186.489 & 199.4\end{array}$ $\begin{array}{lllllllllllllll}\text { FLEVQYLTGGLIEPDTPGR } & 1.00 & 86.41 & 27.15 & 18.94 & 2 & 2248.1854 & 2248.1861 & 1125.1003 & -0.0007 & -0.3111 & 130.728\end{array}$ $\begin{array}{lllllllllllllll} & 1.00 & 33.43 & 27.13 & 18.49 & 3 & 2248.1881 & 2248.1861 & 750.4026 & 0.0020 & 0.8884 & 60.698 & 108.287\end{array}$ $\begin{array}{lllllllllllllll}\text { FLEVQYLTGGLIEPDTPGR } & 1.00 & 64.34 & 27.20 & 17.18 & 2 & 2248.1894 & 2248.1861 & 1125.1003 & 0.0033 & 1.4665 & 98.014 & 84.469\end{array}$ $\begin{array}{llllllllllllll}\text { TVIVWELISSEYFTAEQR } & 1.00 & 34.75 & 27.58 & 22.23 & 3 & 2302.1638 & 2302.1603 & 768.3940 & 0.0035 & 1.5183 & 50.293 & 67.015\end{array}$ $\begin{array}{lllllllllllll}\text { TVTVWELISSEYFTAEQR } & 1.00 & 36.59 & 27.55 & 21.98 & 3 & 2302.1641 & 2302.1603 & 768.3940 & 0.0038 & 1.6485 & 89.834 & 74.286 \\ \text { VPLDVACAR } & 0.92 & 32.14 & 27.21 & 16.56 & 2 & 1132.5960 & 1132.5855 & 567.3000 & 0.0105 & 9.2543 & 2889.080 & 3314.867\end{array}$ VPLDVACAR LSVYQAM

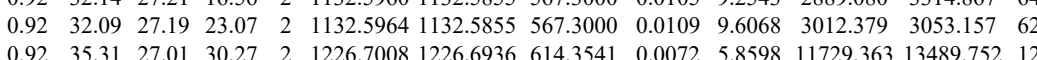
$\begin{array}{llllllllllllllll}\text { YLQDLLAWVEENQHR } & 1.00 & 59.60 & 26.99 & 17.05 & 3 & 2057.0500 & 2057.0452 & 686.6890 & 0.0048 & 2.3300 & 1995.124 & 2839.866 & 0.000 & 2344.791 & \text { Nos }\end{array}$ $\begin{array}{llllllllllllllll}\text { FLEGTSCIAGVFVDATK } & 1.00 & 32.93 & 27.56 & 16.58 & 3 & 2091.0643 & 2091.0624 & 698.0281 & 0.0019 & 0.9073 & 95.831 & 116.741 & 35.575 & 130.403 & \text { Yes }\end{array}$

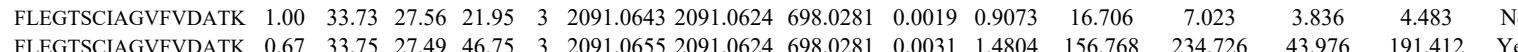

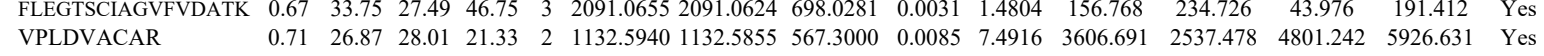
$\begin{array}{llllllllllllllll}\text { VPLDVACAR } & 0.71 & 26.87 & 28.01 & 21.33 & 2 & 1132.5940 & 1132.5855 & 567.3000 & 0.0085 & 7.4916 & 3606.691 & 2537.478 & 4801.242 & 5926.631 & \text { Yes } \\ \text { VPLDVACAR } & 0.91 & 32.07 & 27.97 & 22.74 & 2 & 1132.5956 & 1132.5855 & 567.3000 & 0.0101 & 8.9017 & 3882.224 & 3006.254 & 4442.675 & 6155.429 & \text { Yes }\end{array}$ 


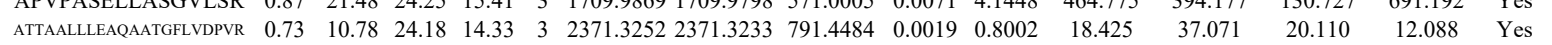

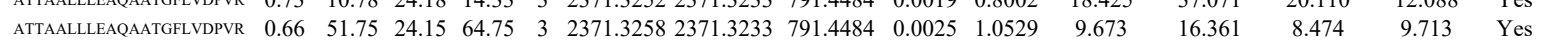
\begin{tabular}{llllllllllllllll} 
ATTAALLEAQAATGFLVDPVR & 0.66 & 16.26 & 24.15 & 29.26 & 3 & 2371.3258 & 2371.3233 & 791.4484 & 0.0025 & 1.0529 & 8.351 & 12.039 & 6.635 & 13.541 & Yes \\
\hline
\end{tabular} \begin{tabular}{llllllllllllllll} 
ATTAALLLEAQAATGFLVDPVR & 0.68 & 9.52 & 24.05 & 15.32 & 3 & 2371.3261 & 2371.3233 & 791.4484 & 0.0028 & 1.1793 & 4.371 & 9.286 & 3.242 & 14.738 & Yes \\
\hline
\end{tabular} $\begin{array}{llllllllllllllll}\text { ATTAALLLEAQAATGFLVDPVR } & 0.67 & 10.57 & 24.01 & 23.57 & 3 & 2371.3264 & 2371.3233 & 791.4484 & 0.0031 & 1.3056 & 16.490 & 6.220 & 4.621 & 36.680 & \text { No }\end{array}$

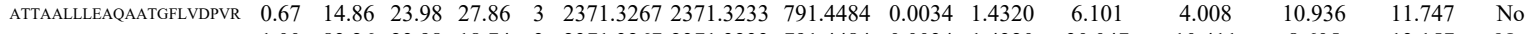

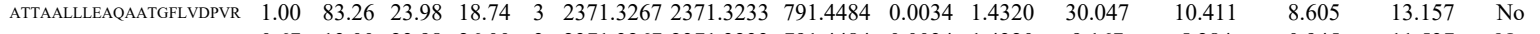
$\begin{array}{llllllllllllllll}\text { ATTAALLLEAQAATGFLVDPVR } & 0.67 & 13.00 & 23.98 & 26.00 & 3 & 2371.3267 & 2371.3233 & 791.4484 & 0.0034 & 1.4320 & 9.167 & 5.284 & 0.945 & 11.537 & \text { No }\end{array}$

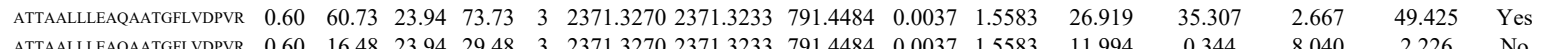

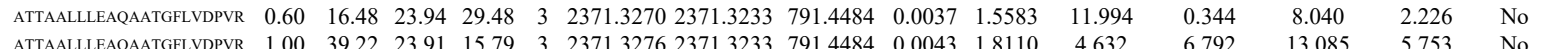
$\begin{array}{llllllllllllllll}\text { ATTAALLLEAQAATGFLVDPVR } & 1.00 & 39.22 & 23.91 & 15.79 & 3 & 2371.3276 & 2371.3233 & 791.4484 & 0.0043 & 1.8110 & 4.632 & 6.792 & 13.085 & 5.753 & \text { No }\end{array}$

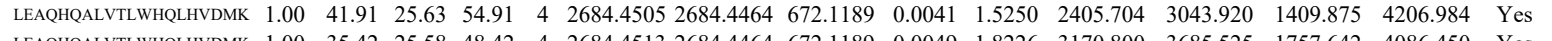

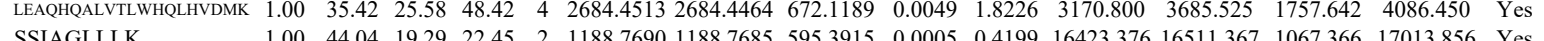
$\begin{array}{llllllllllllllll}\text { SSIAGLLLK } & 1.00 & 44.04 & 19.29 & 22.45 & 2 & 1188.7690 & 1188.7685 & 595.3915 & 0.0005 & 0.4199 & 16423.376 & 16511.367 & 1067.366 & 17013.856 & \text { Yes } \\ \text { SSIAGLLLK } & 1.00 & 55.58 & 18.57 & 27.18 & 2 & 1188.7718 & 1188.7685 & 595.3915 & 0.0033 & 27713 & 26812679 & 29549.302 & 1808.810 & 29583.546 & \text { Yes }\end{array}$

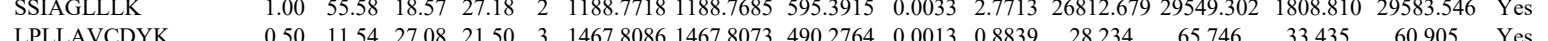

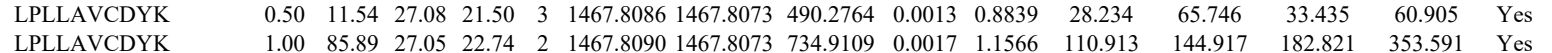

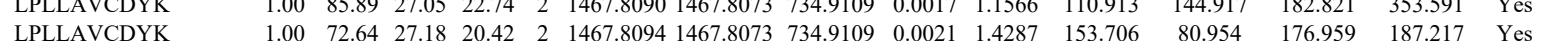

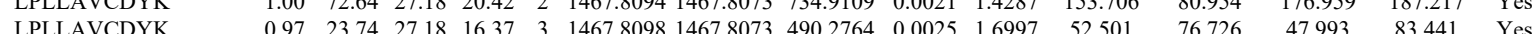

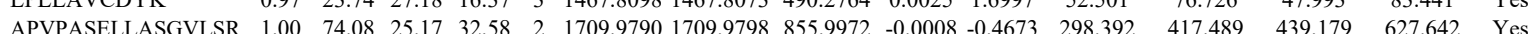

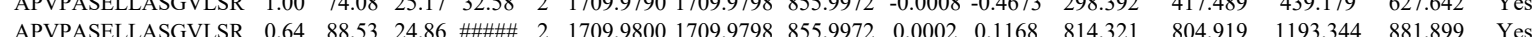
$\begin{array}{lllllllllllllllll}\text { APVASESLLASGVLSR } & 1.00 & 36.94 & 24.80 & 17.07 & 3 & 1709.9815 & 1709.9798 & 571.0005 & 0.0017 & 0.9924 & 209.947 & 146.341 & 121.064 & 246.974 & \text { Yes }\end{array}$

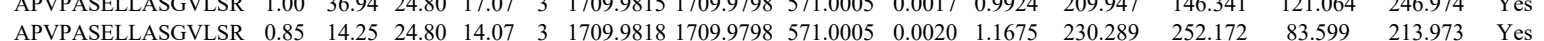
$\begin{array}{llllllllllllllllll}\text { ATPPPTGLCLLPLK } & 1.00 & 92.08 & 28.19 & 26.76 & 2 & 1994.0330 & 1994.0316 & 998.0231 & 0.0014 & 0.7014 & 462.386 & 510.464 & 48.706 & 452.676 & \text { Yes }\end{array}$ $\begin{array}{llllllllllllllll}\text { CITDPQTGLCLLPLK } & 1.00 & 71.14 & 28.19 & 23.20 & 2 & 1994.0332 & 1994.0316 & 998.0231 & 0.0016 & 0.8016 & 608.720 & 663.364 & 8.215 & 661.798 & \text { Yes }\end{array}$

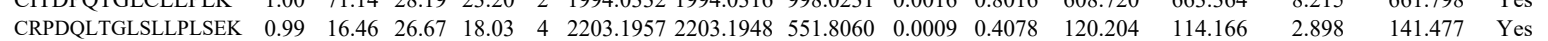

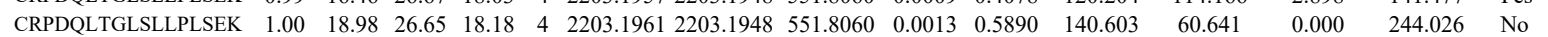
$\begin{array}{llllllllllllllll}\text { CRPDQLTGLSLLPLSEK } & 1.00 & 48.32 & 26.54 & 16.34 & 3 & 2203.1974 & 2203.1948 & 735.4055 & 0.0026 & 1.1785 & 2892.192 & 3410.326 & 1478.782 & 4258.507 & \text { Yes }\end{array}$ $\begin{array}{lllllllllllllllll}\text { CRPDQLTGLSLLPLSEK } & 1.00 & 45.40 & 26.44 & 21.02 & 3 & 2203.1980 & 2203.1948 & 735.4055 & 0.0032 & 1.4504 & 2312.192 & 2693.865 & 998.731 & 2827.440 & \text { Yes }\end{array}$ $\begin{array}{lllllllllllllllll}\text { AGTLSTTEFADMLSGNAGGFR } & 1.00 & 98.03 & 27.31 & 19.94 & 2 & 2258.1134 & 2258.1123 & 1130.0634 & 0.0011 & 0.4867 & 179.249 & 238.507 & 64.180 & 281.448 & \text { Yes }\end{array}$

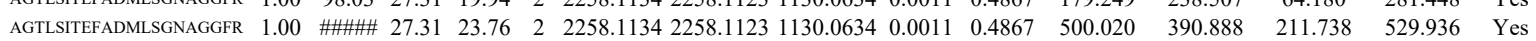
$\begin{array}{llllllllllllllll}\text { AGTLSITEFADMLSGNAGGFR } & 0.66 & 21.69 & 27.29 & 34.69 & 3 & 2258.1142 & 2258.1123 & 753.7114 & 0.0019 & 0.8403 & 62.285 & 20.182 & 22.142 & 18.137 & \text { No }\end{array}$

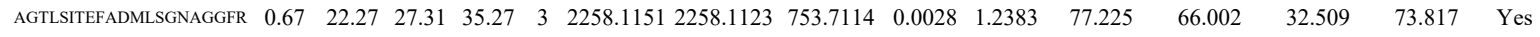

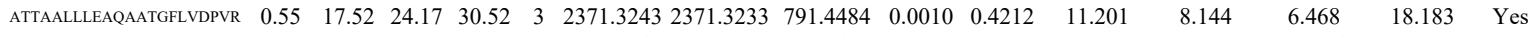
$\begin{array}{lllllllllllllllll}\text { ATTAALLEAQAATGFLVDPVR } & 0.66 & 25.35 & 24.18 & 38.35 & 3 & 2371.3249 & 2371.3233 & 791.4484 & 0.0016 & 0.6739 & 15.505 & 8.092 & 17.394 & 19.871 & \text { Yes }\end{array}$ $\begin{array}{llllllllllllllll}\text { ATTAALLEAQQATGFLVDPVR } & 1.00 & 62.01 & 24.05 & 17.56 & 3 & 2371.3261 & 2371.3233 & 791.4484 & 0.0028 & 1.1793 & 7.619 & 11.931 & 6.654 & 13.417 & \text { Yes }\end{array}$ \begin{tabular}{llllllllllllllll} 
ATTAALLLEAQAATGFLVDPVR & 0.67 & 34.19 & 24.05 & 47.19 & 3 & 2371.3261 & 2371.3233 & 791.4484 & 0.0028 & 1.1793 & 16.067 & 17.133 & 7.833 & 21.791 & Yes \\
\hline
\end{tabular} \begin{tabular}{llllllllllllllll} 
ATTAALLEAQAATGFLVDPVR & 0.67 & 14.64 & 24.01 & 27.64 & 3 & 2371.3264 & 2371.3233 & 791.4484 & 0.0031 & 1.3056 & 7.090 & 8.300 & 3.463 & 10.757 & Yes \\
\hline
\end{tabular}

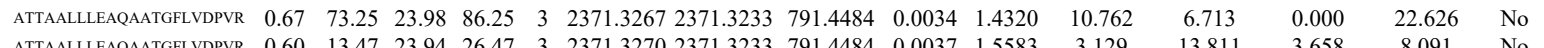

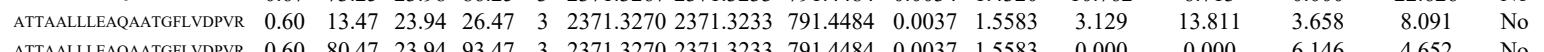

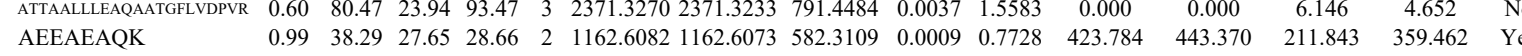
$\begin{array}{lllllllllllllll}1.00 & 51.90 & 19.34 & 24.98 & 2 & 1188.7704 & 1188.7685 & 595.3915 & 0.0019 & 1.5956 & 18699.284 & 17814.841 & 0.000 & 20088.884 & \text { No }\end{array}$

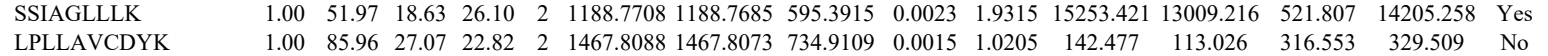
$\begin{array}{llllllllllllllll} & \\ \text { LPLLAVCDYK } & 1.00 & 85.96 & 27.07 & 22.82 & 2 & 1467.8088 & 1467.8073 & 734.9109 & 0.0015 & 1.0205 & 142.477 & 113.026 & 316.553 & 329.509 & \text { No } \\ \text { LPLAVCDYK } & 0.85 & 16.74 & 27.18 & 15.17 & 3 & 1467.8095 & 1467.8073 & 490.2764 & 0.0022 & 1.4958 & 66.416 & 59.843 & 65.668 & 55.820 & \text { Yes }\end{array}$ 

$\begin{array}{lllllllllllllll} & \text { C }\end{array}$

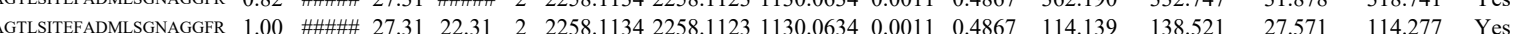

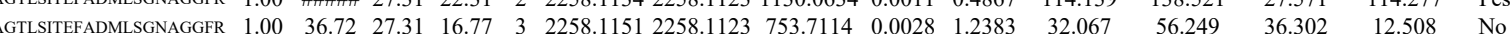

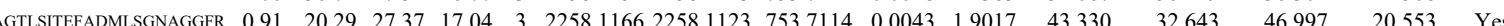
$\begin{array}{lllllllllllllll} & & \end{array}$ $\begin{array}{lllllllllllllllll} & \text { NTALLEAQAATGELVPVYR } & 0.55 & 19.62 & 24.17 & 32.62 & 3 & 2371.3243 & 2371.3233 & 791.4484 & 0.0010 & 0.4212 & 0.000 & 7.632 & 5.507 & 3.824 & \text { No }\end{array}$

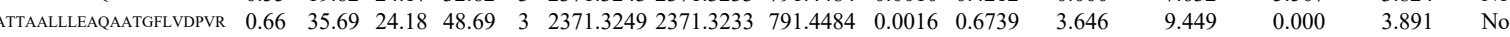
$\begin{array}{lllllllllllllllll}\text { ATAALLLEAQAATGFLVDPVR } & 0.66 & 34.78 & 24.15 & 47.78 & 3 & 2371.3258 & 2371.3233 & 791.4484 & 0.0025 & 1.0529 & 0.955 & 6.048 & 0.000 & 2.757 & \text { No }\end{array}$ $\begin{array}{llllllllllllllll}\text { CRPDQLTGLSLLPLSEK } & 1.00 & 39.06 & 26.65 & 23.09 & 3 & 2203.1959 & 2203.1948 & 735.4055 & 0.0011 & 0.4986 & 2908.887 & 2976.286 & 523.559 & 3766.641 & \text { Yes }\end{array}$

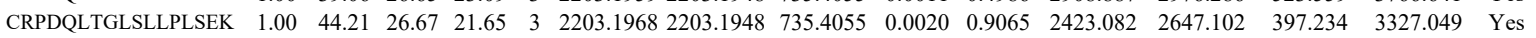

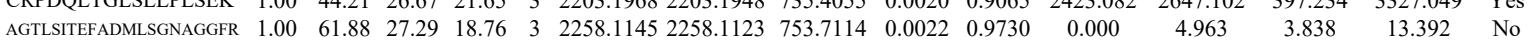

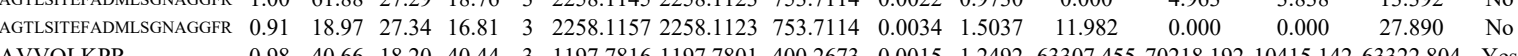

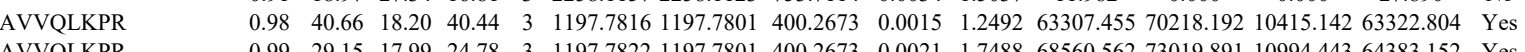

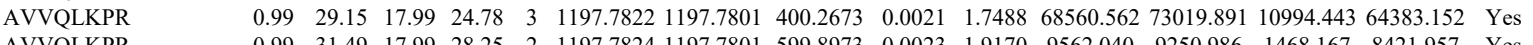

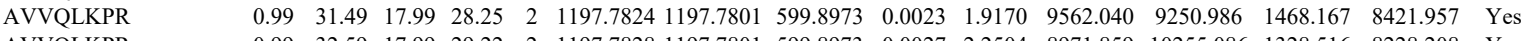

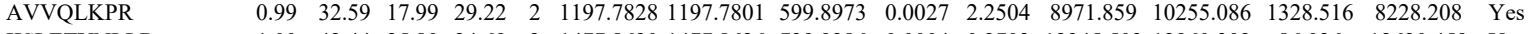
$\begin{array}{lllllllllllllllll}\text { AISLETYNLLR } & 1.00 & 42.44 & 25.80 & 24.69 & 2 & 1477.8630 & 1477.8626 & 739.9386 & 0.0004 & 0.2703 & 12345.503 & 12960.302 & 86.026 & 12630.459 & \text { Yes }\end{array}$ $\begin{array}{llllllllllllllll} & 1.00 & 44.72 & 25.56 & 32.78 & 2 & 1477.8658 & 1477.8626 & 739.9386 & 0.0032 & 2.1623 & 8050.911 & 7764.287 & 0.000 & 8833.964 & \text { No }\end{array}$ \begin{tabular}{lllllllllllllllll} 
LQNVQIALDYLR & 0.99 & 27.76 & 26.29 & 16.80 & 3 & 1588.9066 & 1588.9059 & 530.6426 & 0.0007 & 0.4397 & 226.850 & 140.104 & 84.057 & 181.561 & Yes \\
\hline
\end{tabular} $\begin{array}{llllllllllllllll}\text { LQNVQIALDYLR } & 1.00 & 78.64 & 26.28 & 22.35 & 2 & 1588.9066 & 1588.9059 & 795.4602 & 0.0007 & 0.4400 & 12385.865 & 14922.565 & 0.000 & 17060.029 & \text { No }\end{array}$

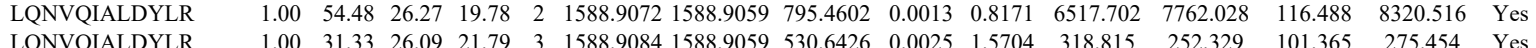

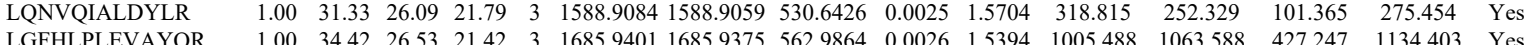
AVVQLKPR AVVQLKPR IISLETYNLLR IISLETYNLLR $\begin{array}{llllllllllllllll}1.00 & 34.42 & 26.53 & 21.42 & 3 & 1685.9401 & 1685.9375 & 562.9864 & 0.0026 & 1.5394 & 1005.488 & 1063.588 & 427.247 & 1134.403 & \text { Yes } & \end{array}$ $\begin{array}{lllllllllllllllll}0.95 & 25.63 & 17.78 & 22.98 & 3 & 1197.7789 & 1197.7801 & 400.2673 & -0.0012 & -0.9993 & 41581.350 & 50553.328 & 11552.304 & 49356.937 & \text { Yes } & \end{array}$ $\begin{array}{lllllllllllllllllll}0.98 & 26.77 & 17.99 & 23.38 & 3 & 1197.7798 & 1197.7801 & 400.2673 & -0.0003 & -0.2498 & 31223.652 & 34414.156 & 13243.793 & 44762.451 & \text { Yes }\end{array}$ $\begin{array}{lllllllllllllllll}0.99 & 37.46 & 1.985 & 28.95 & 2 & 1197.7804 & 1197.7801 & 599.8973 & 0.0003 & 0.2500 & 4502.636 & 4092.845 & 994.713 & 3700.489 & \text { Yes } & \\ \end{array}$ $\begin{array}{lllllllllllllllll} & \end{array}$ $\begin{array}{llllllllllllllll}1.00 & 54.48 & 25.61 & 34.88 & 2 & 1477.8644 & 1477.8626 & 739.9386 & 0.0018 & 1.2163 & 3158.996 & 5189.744 & 7.898 & 5686.922 & \text { Yes } & \\ 1.00 & 66.47 & 26.28 & 19.14 & 2 & 1588.9070 & 1588.9059 & 795.4602 & 0.0011 & 0.6914 & 7716.019 & 8032.101 & 658.421 & 8435.107 & \text { Yes }\end{array}$

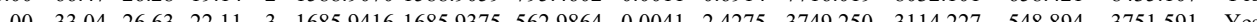

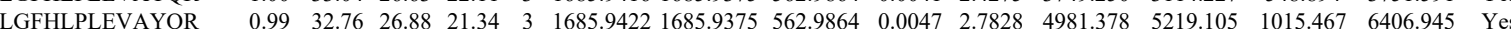

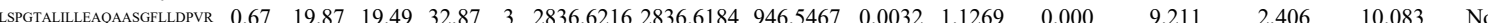

AVVQLKPR

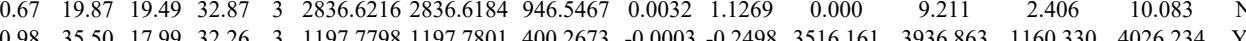
AVVQLKPR

AVVQLKPR

IISLETYNLLR

LQNVQIALDYLR $\begin{array}{llllllllllllllll}1.00 & 35.37 & 18.13 & 28.61 & 2 & 1197.7808 & 1197.7801 & 599.8973 & 0.0007 & 0.5834 & 937.772 & 1037.680 & 237.786 & 1031.859 & \text { Yes } \\ \end{array}$ $\begin{array}{llllllllllllllll}1.00 & 38.26 & 17.63 & 33.92 & 2 & 1197.7810 & 1197.7801 & 599.8973 & 0.0009 & 0.7501 & 1001.419 & 1129.857 & 275.176 & 1097.755 & \text { Yes }\end{array}$ $\begin{array}{llllllllllllllll}1.00 & 66.10 & 26.51 & 18.74 & 2 & 1588.9060 & 1588.9059 & 795.4602 & 0.0001 & 0.0629 & 2725.410 & 2677.687 & 193.453 & 2972.381 & \text { Yes }\end{array}$ \begin{tabular}{lllllllllllllllll} 
& \\
LGFHLPLEVAYQR & 1.00 & 72.20 & 26.28 & 20.42 & 2 & 1588.9070 & 1588.9059 & 795.4602 & 0.0011 & 0.6914 & 2173.774 & 1951.161 & 109.268 & 2180.561 & Yes \\
& 1.00 & 42.32 & 26.86 & 24.94 & 3 & 1685.9431 & 1685.9375 & 562.9864 & 0.0056 & 3.3156 & 2764547 & 2639.730 & 402.881 & 2389.613 & Yes \\
\hline
\end{tabular} $\begin{array}{lllllllllllllllll}\text { LGFHLPLEVAYQR } & 1.00 & 44.47 & 26.77 & 23.66 & 3 & 1685.9446 & 1685.9375 & 562.9864 & 0.0071 & 4.2038 & 1872.586 & 1632.836 & 331.057 & 1712964 & \text { Yes }\end{array}$

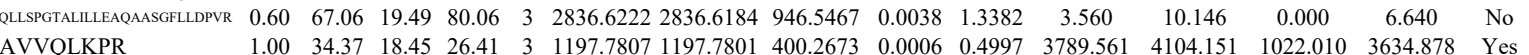

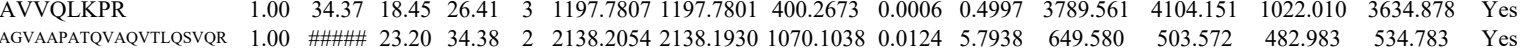
$\begin{array}{llllllllllllllll}\text { AGVAAPATQVAQVTLQSVQR } & 1.00 & \text { \#\#\#\# } 23.20 & 30.30 & 2 & 2138.2054 & 2138.1930 & 1070.1038 & 0.0124 & 5.7938 & 670.013 & 586.999 & 685.325 & 414.456 & \text { Yes }\end{array}$ $\begin{array}{lllllllllllllllll}\text { AGVAAPATQVAQVTLQSVQR } & 1.00 & 65.51 & 23.03 & 35.06 & 3 & 2138.2072 & 2138.1930 & 713.7383 & 0.0142 & 6.6317 & 309.262 & 542.018 & 90.441 & 251.495 & \text { No }\end{array}$ $\begin{array}{llllllllllllllll}\text { AGVAAPATQVAQVTLQSVQR } & 1.00 & 53.38 & 22.90 & 20.24 & 3 & 2138.2087 & 2138.1930 & 713.7383 & 0.0157 & 7.3322 & 395.916 & 269.668 & 274.754 & 269.500 & \text { Yes }\end{array}$ $\begin{array}{llllllllllll} & \end{array}$ $\begin{array}{llllllllllllll} & \end{array}$

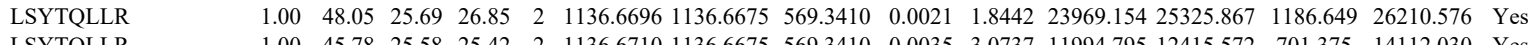

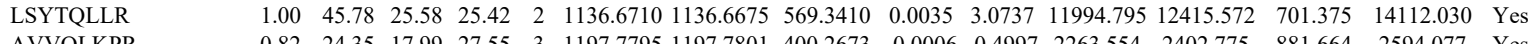
$\begin{array}{llllllllllllllll}\text { AVVQLKPR } & 0.82 & 24.35 & 17.99 & 27.55 & 3 & 1197.7795 & 1197.7801 & 400.2673 & -0.0006 & -0.4997 & 2263.554 & 2402.775 & 881.664 & 2594.077 & \text { Yes }\end{array}$

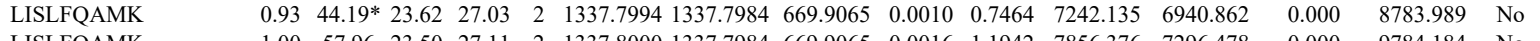

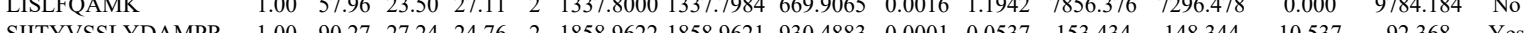
$\begin{array}{llllllllllllllll} & \end{array}$

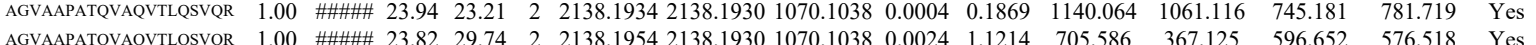
$\begin{array}{lllllllllllllllll}\text { AGVAAPATQVAQVTLQSVQR } & 0.67 & 52.03 & 23.77 & 65.03 & 3 & 2138.1964 & 2138.1930 & 713.7383 & 0.0034 & 1.5879 & 483.671 & 190.468 & 336.370 & 262.340 & \text { Yes }\end{array}$ $\begin{array}{llllllllllllllll}\text { LSFSGLR } & 0.82 & 37.18 & 27.65 & 40.03 & 2 & 922.5430 & 922.5358 & 462.2752 & 0.0072 & 7.7875 & 32283.850 & 34567.554 & 3030.761 & 51803.415 & \text { Yes }\end{array}$ 

$\begin{array}{lllllllllllllllll}1.00 & 51.59 & 26.41 & 31.12 & 2 & 1163.6882 & 1163.6784 & 582.8465 & 0.0098 & 8.4069 & 3646.377 & 3004.353 & 378.840 & 3840.955 & \text { Yes }\end{array}$ $\begin{array}{lllllllllllllllll}0.55 & 6.89 & 18.20 & 19.89 & 3 & 1197.7816 & 1197.7801 & 400.2673 & 0.0015 & 1.2492 & 2026.008 & 2042.752 & 1923.601 & 2247.833 & \text { Yes }\end{array}$ $\begin{array}{llllllllllllllll}0.94 & 45.56 * & 23.64 & 26.68 & 2 & 1337.7992 & 1337.7984 & 669.9065 & 0.0008 & 0.5971 & 15694.556 & 16189.783 & 0.000 & 20725.873 & \text { No } \\ 1.00 & 53.64 & 23.50 & 27.66 & 2 & 1337.7996 & 1337.7984 & 669.9065 & 0.0012 & 0.8956 & 7106.842 & 9293.463 & 0.000 & 11309.139 & \text { No }\end{array}$

SIITYVSSLYDA

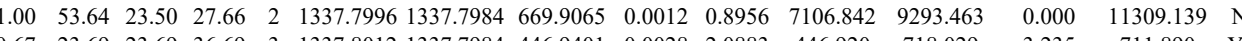

SWSLATFR

QLAEAHAQAK

QLAEAHAQAK

LAEDEAFQR

LAEDEAFQR

FLQEEAEK

GLQEEAEK

GGELVYTDSEAR

QLAEEDLAQQR

QLAEEDLAQQR

QEQALLEEIER

QEQALLEEIER

QQEELLAEENQR

QQEELLAEENQR

LEDLLQDAQDEK

LEDLLQDAQDEK

LLDPEDVDVPQPDEK

DALDGPAAEAEPEHSFDGLR

DALDGPAAEAEPEHSFDGLR
GLFDEEMNEILTDPSDDTK

GLFDEEMNEILTD

SLLAWQSLR

LFNAIIHR

SLLAWQSLR

SLLAWQSLR

LFNAIIHR

LFNAIIHR

ELVLLLLQWMR

LLLWSQR

LLLWSQR

LLLWSQR

ELVLLLLQWMR

LLLWSQR

LLLWSQR
ELVLLLLOWMR

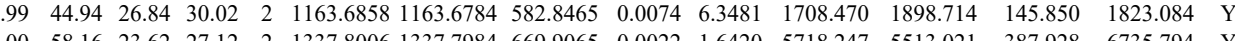
$\begin{array}{lllllllllllllll}1.00 & 58.16 & 23.62 & 27.12 & 2 & 1337.8006 & 1337.7984 & 669.9065 & 0.0022 & 1.6420 & 5718.247 & 5513.021 & 387.928 & 6735.794 & \text { Yes } \\ 1.00 & 53.52 & 23.67 & 25.76 & 2 & 1337.8010 & 1337.7984 & 669.9065 & 0.0026 & 1.9406 & 9438.501 & 9974.462 & 493.157 & 13149.735 & \text { Yes }\end{array}$

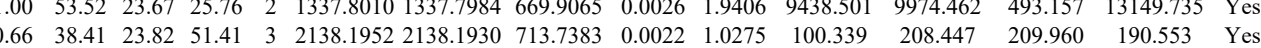

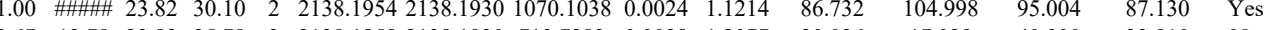

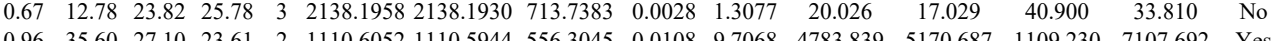
$\begin{array}{lllllllllllllll}0.96 & 35.60 & 27.10 & 23.61 & 2 & 1110.6052 & 1110.5944 & 556.3045 & 0.0108 & 9.7068 & 4783.839 & 5170.687 & 1109.230 & 7107.692 & \text { Yes } \\ 0.85 & 16.24 & 26.80 & 6.64 & 3 & 1353.7624 & 1353.7608 & 452.269 & 0.0016 & 1.1793 & 58.994 & 68.688 & 97.145 & 5436 & \text { No }\end{array}$

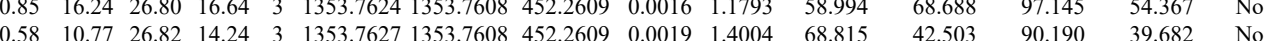
$\begin{array}{llllllllllllllll}0.58 & 10.77 & 26.82 & 14.24 & 3 & 1353.7627 & 1353.7608 & 452.2609 & 0.0019 & 1.4004 & 68.815 & 42.503 & 90.190 & 39.682 & \text { No }\end{array}$ $\begin{array}{lllllllllllllll}0.99 & 43.74 & 27.80 & 26.00 & 2 & 1221.6194 & 1221.6111 & 611.8128 & 0.0083 & 6.7831 & 629.278 & 626.524 & 219.001 & 768.812 & \text { Yes }\end{array}$ $\begin{array}{lllllllllllllll}0.96 & 37.21 & 27.83 & 20.37 & 2 & 1221.6206 & 1221.6111 & 611.8128 & 0.0095 & 7.7638 & 540.153 & 670.831 & 284.504 & 644.008 & \text { Yes }\end{array}$

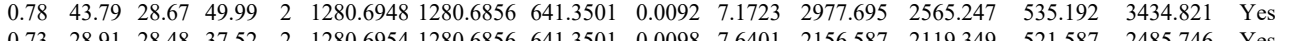

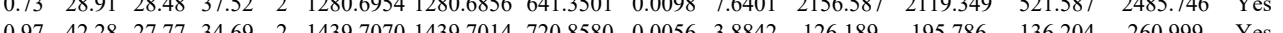

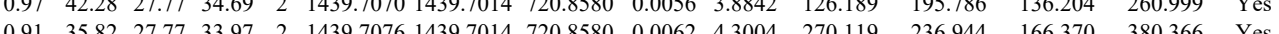

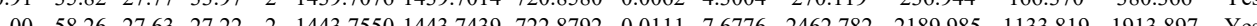

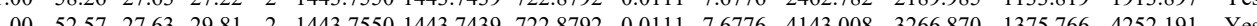
$\begin{array}{lllllllllllllll}1.00 & 59.35 & 27.96 & 34.66 & 2 & 1500.7914 & 1500.7905 & 751.4025 & 0.0009 & 0.5989 & 704.037 & 770.464 & 46.281 & 914.040 & \text { Yes }\end{array}$

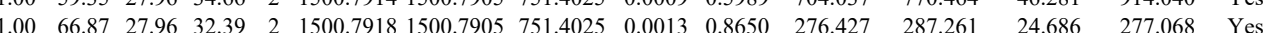

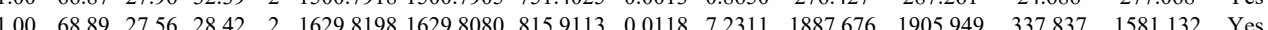

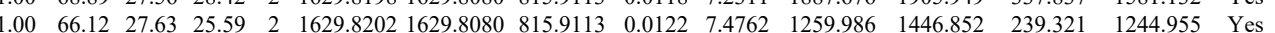

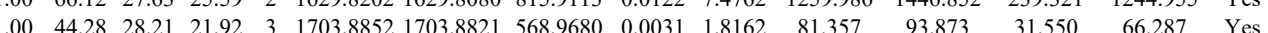
$\begin{array}{lllllllllllllll}1.00 & 33.93 & 28.20 & 20.63 & 3 & 1703.8858 & 1703.8821 & 568.9680 & 0.0037 & 2.1677 & 72.861 & 74.368 & 57.626 & 102.414 & \text { Yes }\end{array}$ $\begin{array}{lllllllllllllll}0.00 & 63.24 & 27.65 & 24.14 & 2 & 1996.0288 & 1996.0244 & 999.0195 & 0.0044 & 2.2022 & 187.138 & 283.545 & 85.555 & 317.963 & \text { Yes }\end{array}$ $\begin{array}{lllllllllllllll}0.99 & 46.49 & 27.55 & 22.63 & 2 & 1996.0298 & 1996.0244 & 999.0195 & 0.0054 & 2.7026 & 291.025 & 317.016 & 70.288 & 244.026 & \text { Yes }\end{array}$ $\begin{array}{lllllllllllllll} & 77.03 & 2620 & 26.30 & 3 & 2240.0494 & 2240.0467 & 747.6895 & 0.0027 & 1.2037 & 526.673 & 725.768 & 664.278 & 702.836 & \text { Yes }\end{array}$

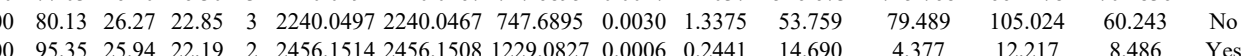
$\begin{array}{lllllllllllllll}0 & 95.35 & 25.94 & 22.19 & 2 & 2456.1514 & 2456.1508 & 1229.0827 & 0.0006 & 0.2441 & 14.690 & 4.377 & 12.217 & 8.486 & \text { Yes } \\ 1.00 & 80.26 & 25.99 & 18.53 & 2 & 2456.1534 & 2456.1508 & 1229.0827 & 0.0026 & 1.0577 & 11.348 & 15.026 & 2.265 & 5.867 & \text { Yes }\end{array}$ $\begin{array}{lllllllllllllll}1.00 & 45.35 & 27.00 & 30.85 & 2 & 1216.7064 & 1216.7050 & 609.3598 & 0.0014 & 1.1487 & 9628.638 & 11339.808 & 0.000 & 5.867 & \text { Yes }\end{array}$ $\begin{array}{lllllllllllllll}0.62 & 18.68 & 27.06 & 19.01 & 3 & 1353.7603 & 1353.7608 & 452.2609 & -0.0005 & -0.3685 & 69.599 & 70.630 & 133.751 & 37.818 & \text { No }\end{array}$

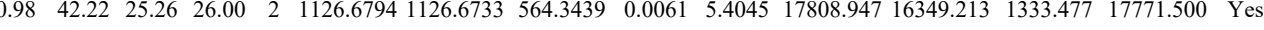
$\begin{array}{lllllllllllllll}1.00 & 43.02 & 27.00 & 31.17 & 2 & 1216.7062 & 1216.7050 & 609.3598 & 0.0012 & 0.9846 & 16532.880 & 17283.959 & 204.608 & 18923.184 & \text { Yes }\end{array}$

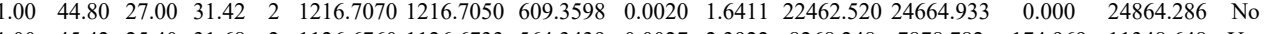
$\begin{array}{lllllllllllllll}1.00 & 45.42 & 25.40 & 31.68 & 2 & 1126.6760 & 1126.6733 & 564.3439 & 0.0027 & 2.3922 & 8268.248 & 7878.782 & 174.969 & 11348.648 & \text { Yes }\end{array}$ $\begin{array}{lllllllllllllll}1.00 & 44.83 & 25.40 & 25.06 & 2 & 1126.6766 & 1126.6733 & 564.3439 & 0.0033 & 2.9237 & 10814.142 & 9925.685 & 250.365 & 12718.699 & \text { Yes }\end{array}$ $\begin{array}{lllllllllllllll}1.00 & 54.05 & 23.62 & 36.27 & 2 & 1556.9242 & 1556.9234 & 779.4690 & 0.0008 & 0.5132 & 17.844 & 10.087 & 4.141 & 7.696 & \text { No }\end{array}$ $\begin{array}{lllllllllllllll}0.97 & 28.74 & 26.24 & 22.75 & 2 & 1058.6374 & 1058.6358 & 530.3252 & 0.0016 & 1.5085 & 2702.976 & 2771.480 & 238.596 & 5226.411 & \text { No } \\ 1.00 & 41.07 & 2624 & 24.96 & 2 & 10586374 & 1058.358 & 530.3252 & 0.016 & 1.5085 & 6159798 & 7199.464 & 123.252 & 1496.671 & \text { No }\end{array}$ $\begin{array}{llllllllllllllll}1.00 & 41.07 & 26.24 & 24.96 & 2 & 1058.6374 & 1058.6358 & 530.3252 & 0.0016 & 1.5085 & 6159.798 & 7199.464 & 123.252 & 14961.671 & \text { No }\end{array}$

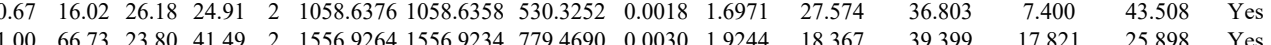

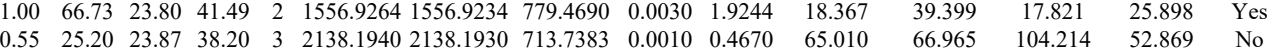

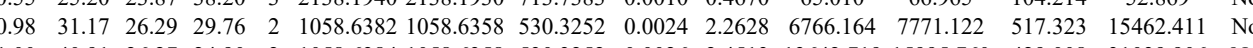

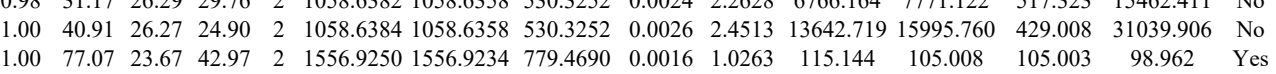

Table S-4 page 490 of 614 
$\begin{array}{llllllllllll}0.99 & 34.87 & 26.06 & 23.74 & 2 & 1058.6372 & 1058.6358 & 530.3252 & 0.0014 & 1.3199 & 3425.487 & 4228.175\end{array}$

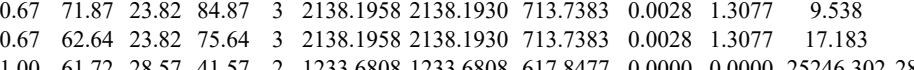
$\begin{array}{lllllllllllll}28.51 & 39.85 & 2 & 1233.6828 & 1233.6808 & 617.8477 & 0.0020 & 1.6185 & 47966.853 & 40443.962\end{array}$ $\begin{array}{llllllllllllll}1.00 & 47.52 & 27.12 & 30.01 & 2 & 1243.6920 & 1243.6894 & 622.8520 & 0.0026 & 2.0872 & 11286.400 & 11979.893\end{array}$ $\begin{array}{lllllllllllll}1.00 & 46.54 & 27.47 & 28.08 & 2 & 1243.6922 & 1243.6894 & 622.8520 & 0.0028 & 2.2477 & 8379.520 & 8191.656 \\ 1.00 & 55.71 & 27.36 & 32.91 & 2 & 1272.6802 & 1272.6795 & 637.3470 & 0.0007 & 0.5492 & 5557.372 & 4396.222\end{array}$ $\begin{array}{lllllllllllll}1.00 & 47.86 & 27.40 & 35.43 & 2 & 1272.6808 & 1272.6795 & 637.3470 & 0.0013 & 1.0199 & 7003.388 & 6331.051 & 3\end{array}$ $\begin{array}{lllllllllllll}1.00 & 52.84 & 25.28 & 21.77 & 2 & 1307.6078 & 1307.5972 & 654.8059 & 0.0106 & 8.0939 & 3682.906 & 3473.832 \\ 1.00 & 56.49 & 25.47 & 24.74 & 2 & 1307.6088 & 1307.5972 & 654.8059 & 0.0116 & 8.8575 & 3331.193 & 3634.644\end{array}$ $\begin{array}{lllllllllllll}1.00 & 56.49 & 25.47 & 24.74 & 2 & 1307.6088 & 1307.5972 & 654.8059 & 0.0116 & 8.8575 & 3331.193 & 3634.644 & 316.77 \\ 0.77 & 50.26 & 28.64 & 35.44 & 2 & 1317.7300 & 1317.7383 & 659.8764 & -0.0083 & -6.2891 & 2597.804 & 2615.353 & 3\end{array}$ $\begin{array}{llllllllllllll}1.00 & 57.75 & 27.93 & 34.39 & 2 & 1500.7920 & 1500.7905 & 751.4025 & 0.0015 & 0.9981 & 1934.330 & 1884.290 & 12600\end{array}$

1.00
0.07
1.00
1.00

1.00
1.00
1.00 1.00

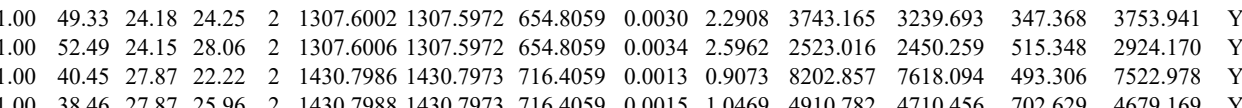
$\begin{array}{llllllllllllllllll}1.00 & 38.46 & 27.87 & 25.96 & 2 & 1430.7988 & 1430.7973 & 716.4059 & 0.0015 & 1.0469 & 4910.782 & 4710.456 & 702.629 & 4679.169 & \text { Yes } \\ 1.00 & 5.05 & 37.4 & 3.74 & 2 & 438.7582 & 448.7547 & 72.384 & 0.035 & 2.493 & 17.025 & 89.175 & 34.06 & 10339 & \end{array}$

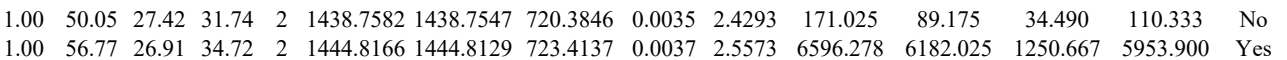
$\begin{array}{llllllllllllllll}1.00 & 57.99 & 26.91 & 38.51 & 2 & 1444.8168 & 1444.8129 & 723.4137 & 0.0039 & 2.6955 & 7911.185 & 8142.099 & 798.426 & 7470.481 & \text { Yes }\end{array}$ $\begin{array}{lllllllllllllll}1.00 & 60.72 & 26.06 & 27.80 & 2 & 1458.8562 & 1458.8537 & 730.4341 & 0.0025 & 1.7113 & 6542.398 & 2953.289 & 990.493 & 12661.972 & \text { No }\end{array}$ $\begin{array}{lllllllllllllll}1.00 & 67.32 & 26.06 & 32.06 & 2 & 1458.8564 & 1458.8537 & 730.4341 & 0.0027 & 1.8482 & 4755.138 & 2791.686 & 1078.553 & 9806.836 & \text { No }\end{array}$

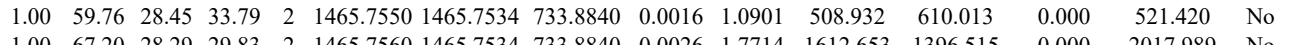

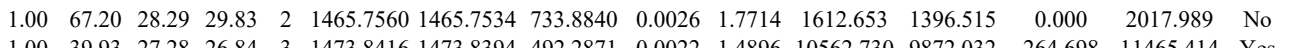

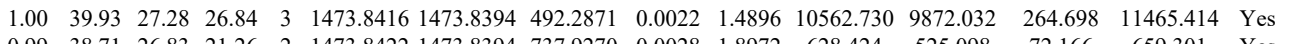
$\begin{array}{lllllllllllllll}0.99 & 38.71 & 26.83 & 21.26 & 2 & 1473.8422 & 1473.8394 & 737.9270 & 0.0028 & 1.8972 & 628.424 & 525.098 & 72.166 & 659.301 & \text { Yes }\end{array}$

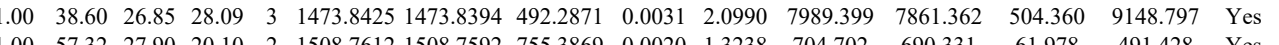
$\begin{array}{lllllllllllllll}1.00 & 57.32 & 27.90 & 20.10 & 2 & 1508.7612 & 1508.7592 & 755.3869 & 0.0020 & 1.3238 & 704.702 & 690.331 & 61.978 & 491.428 & \text { Yes } \\ 1.00 & 63.25 & 28.09 & 22.14 & 2 & 1508.7632 & 1508.7592 & 755.3869 & 0.0040 & 2.6476 & 1334.257 & 1686.920 & 311.944 & 1318.540 & \text { Yes }\end{array}$

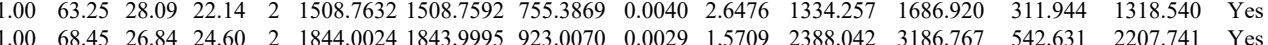
$\begin{array}{ccccccccccccccc}1.00 & 68.45 & 26.84 & 24.60 & 2 & 1844.0024 & 1844.9995 & 923.0070 & 0.0029 & 1.5709 & 2388.042 & 3186.767 & 542.631 & 2207.741 & \text { Yes } \\ 1.00 & 59.04 & 26.83 & 31.09 & 3 & 1844.0032 & 1843.9995 & 615.6738 & 0.0037 & 20032 & 9752.900 & 10758.026 & 4818.001 & 9759.618 & \text { Yes }\end{array}$

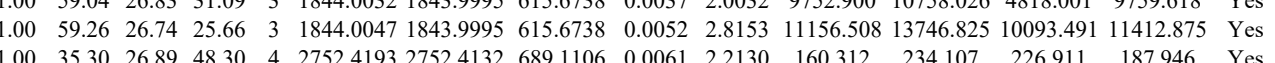

187.946 Yes

Table S-4 page 491 of 614 

$\begin{array}{lllllllllllllll}1.00 & 72.03 & 31.11 & 34.61 & 2 & 1359.7874 & 1359.7853 & 680.8999 & 0.0021 & 1.5421 & 6308.791 & 6987.578 & 308.819 & 8437.465 & \text { Yes }\end{array}$ $\begin{array}{lllllllllllllllll}1.00 & 67.36 & 31.09 & 34.54 & 2 & 1359.7876 & 1359.7853 & 680.8999 & 0.0023 & 1.6889 & 15459.381 & 14750.112 & 0.000 & 17573.834 & \text { No }\end{array}$

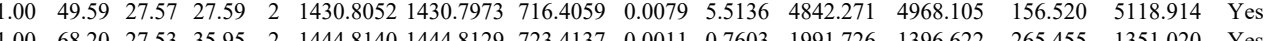
$\begin{array}{lllllllllllllllll}1.00 & 44.58 & 24.44 & 26.24 & 2 & 1343.8032 & 1343.7904 & 672.9025 & 0.0128 & 9.5109 & 14382.876 & 13987.447 & 3942.083 & 14212.269 & \text { Yes }\end{array}$ $\begin{array}{llllllllllllllll}1.00 & 69.76 & 31.11 & 35.31 & 2 & 1359.7872 & 1359.7853 & 680.8999 & 0.0019 & 1.3952 & 5662.771 & 5786.883 & 161.793 & 6747.421 & \text { Yes }\end{array}$ $\begin{array}{lllllllllllllll}1.00 & 69.66 & 31.11 & 34.58 & 2 & 1359.7872 & 1359.7853 & 680.8999 & 0.0019 & 1.3952 & 6171.346 & 7303.242 & 0.000 & 7854.180 & \mathrm{~N} \\ 1.00 & 41.77 & 26.94 & 19.45 & 3 & 1470.8215 & 1470.8074 & 491.2764 & 0.0141 & 9.5668 & 12052.721 & 12825.174 & 805.296 & 10971.417 & \mathrm{Y}\end{array}$ $\begin{array}{llllllllllllll} & & & \end{array}$

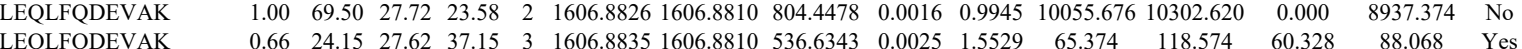
\begin{tabular}{llllllllllllllll} 
& \\
LEQLFQDEVAK & 0.66 & 24.15 & 27.62 & 37.15 & 3 & 1606.8835 & 1606.8810 & 536.6343 & 0.0025 & 1.5529 & 65.374 & 118.574 & 60.328 & 88.068 & Yes \\
\hline
\end{tabular} $\begin{array}{llllllllllllllll} & 0.67 & 14.70 & 27.70 & 27.70 & 3 & 1606.8838 & 1606.8810 & 536.6343 & 0.0028 & 1.7392 & 56.139 & 35.483 & 43.471 & 67.976 & \text { Yes }\end{array}$ $\begin{array}{lllllllllllllllll} & \end{array}$

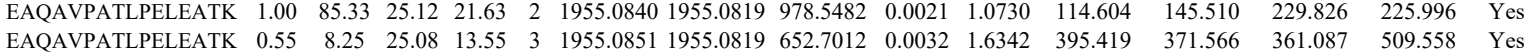

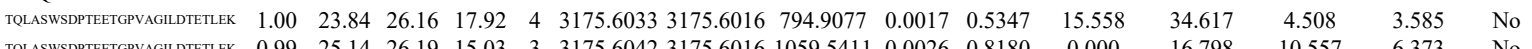

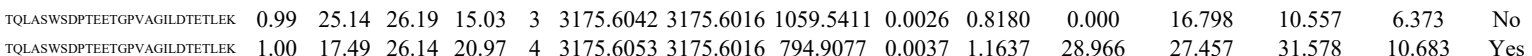

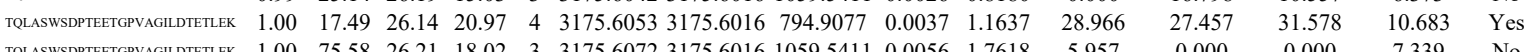

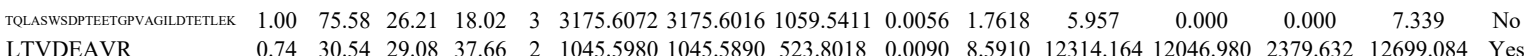

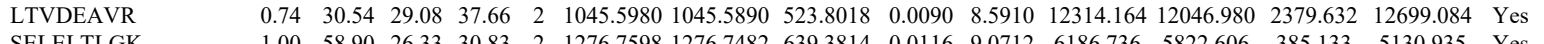

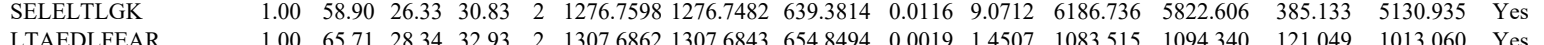

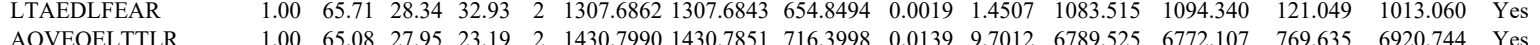

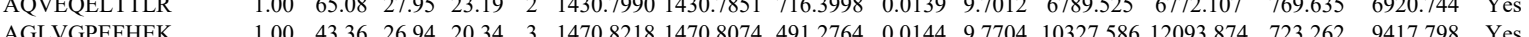

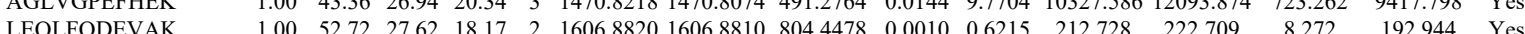

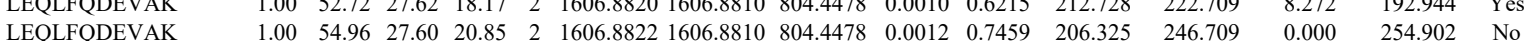

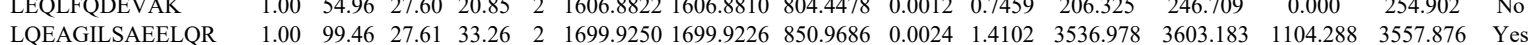
$\begin{array}{llllllllllllll}\text { LQEAGILSAEELQR } & 1.00 & \# \# \# \# \frac{27.61}{30.98} & 2 & 1699.9258 & 1699.9226 & 850.9686 & 0.0032 & 1.8802 & 929.232 & 758.819 & 368.689 & 873.399 & \text { Yes }\end{array}$ $\begin{array}{lllllllllllllll} & \end{array}$ $\begin{array}{llllllllllllllll}\text { DDGTGQLLPLSDAR } & 1.00 & 97.59 & 27.57 & 24.42 & 2 & 1713.9032 & 1713.9019 & 857.9582 & 0.0013 & 0.7576 & 818.803 & 822.534 & 854.105 & 652.662 & \text { Yes }\end{array}$

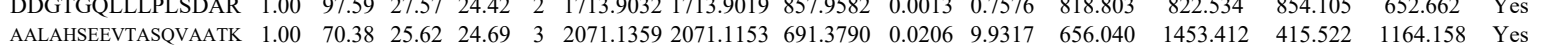

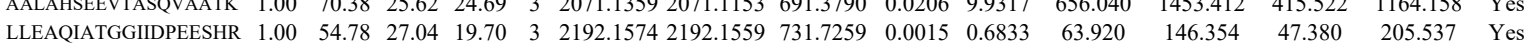
$\begin{array}{lllllllllllllllll} & \text { LLEAQIATGGIIDPEESHR } & 1.00 & 46.73 & 26.99 & 21.40 & 3 & 2192.1580 & 2192.1559 & 731.7259 & 0.0021 & 0.9566 & 54.725 & 47.218 & 69.164 & 0.000 & \text { No }\end{array}$ $\begin{array}{llllllllllllllll}\text { EQELQQTLQQEQSVLDQLR } & 1.00 & 49.16 & 27.69 & 16.11 & 2 & 2456.2634 & 2456.2629 & 1229.1387 & 0.0005 & 0.2034 & 6.341 & 9.156 & 6.750 & 7.877 & \text { Yes }\end{array}$

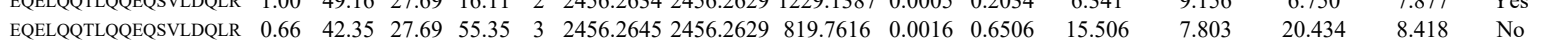

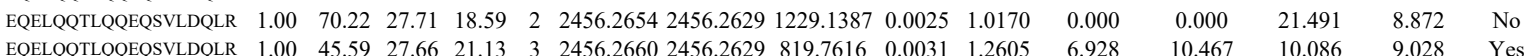
$\begin{array}{llllllllllllllll}\text { EQELQQTLQQEQSVLDQLR } & 1.00 & 45.59 & 27.66 & 21.13 & 3 & 2456.2660 & 2456.2629 & 819.7616 & 0.0031 & 1.2605 & 6.928 & 10.467 & 10.086 & 9.028 & \text { Yes } \\ & 1.96 & 21.87 & 26.17 & 16.56 & 4 & 3175.605 & 3175.6016 & 794.9077 & 0.0049 & 1.5411 & 30.663 & 34.836 & 43.217 & 45.124 & \text { Yes }\end{array}$ 


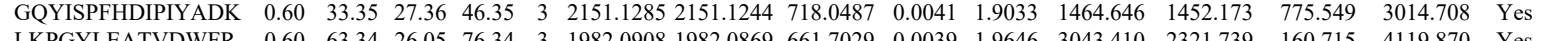
$\begin{array}{llllllllllllllll}\text { LKPGYLEATVDWFR } & 0.60 & 63.34 & 26.05 & 76.34 & 3 & 1982.0908 & 1982.0869 & 661.7029 & 0.0039 & 1.9646 & 3043.410 & 2321.739 & 160.715 & 4119.870 & \text { Yes }\end{array}$ \begin{tabular}{llllllllllllllll} 
LKPGYLEATVDWFR & 0.60 & 61.99 & 26.05 & 74.99 & 3 & 1982.0908 & 1982.0869 & 661.7029 & 0.0039 & 1.9646 & 4999.016 & 3757.922 & 443.773 & 7429.183 & Yes \\
\hline LKPGYLEATVDWFR & 1.00 & 64.61 & 26.18 & 17.85 & 3 & 1982.0893 & 1982.0869 & 661.7029 & 0.0024 & 1.2090 & 4126.740 & 3883.959 & 743.168 & 6524.666 & Yes
\end{tabular} \begin{tabular}{lllllllllllllllll} 
& LKPGYEATVDFR & 1.00 & 64.61 & 26.18 & 17.85 & 3 & 1982.0893 & 1982.0869 & 661.7029 & 0.0024 & 1.2090 & 4126.740 & 3883.959 & 743.168 & 6524.666 & Yes \\
\hline
\end{tabular} $\begin{array}{llllllllllllllll}\text { LKPGYLEATVDWR } & 0.60 & 60.44 & 26.05 & 73.44 & 3 & 1982.0914 & 1982.086 & 661.7029 & 0.025 & 2.2669 & 425.508 & 4356.933 & 183.046 & 9710.021 & \text { Yes }\end{array}$

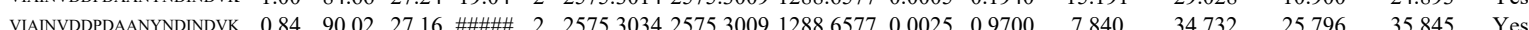
$\begin{array}{lllllllllllllllll}\text { DPLNPIK } & 0.97 & 34.37 & 24.58 & 28.81 & 2 & 1083.6628 & 1083.6532 & 542.8339 & 0.0096 & 8.8424 & 10871.098 & 9761.776 & 13436.337 & 15003.182 & \text { Yes }\end{array}$

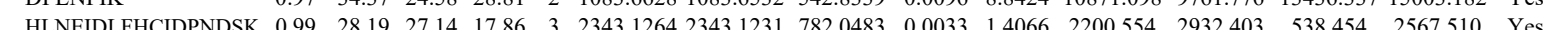
$\begin{array}{llllllllllllllll}\text { HLNEIDLFHCIDPNDSK } & 1.00 & 31.51 & 27.14 & 16.67 & 3 & 2343.1264 & 2343.1231 & 782.0483 & 0.0033 & 1.4066 & 1434.294 & 2039.686 & 602.166 & 3094.924 & \text { Yes }\end{array}$ $\begin{array}{llllllllllllllll}\text { HLNEIDLFHCIDPNDSK } & 1.00 & 23.40 & 27.13 & 36.40 & 4 & 2343.1269 & 2343.1231 & 5867881 & 0.0038 & 1.6190 & 1912.454 & 2055.816 & 330.132 & 2748.681 & \text { Yes }\end{array}$ $\begin{array}{lllllllllllllllll}\text { HLNEIDLFHCIDPNDSK } & 1.00 & 29.61 & 27.20 & 42.61 & 4 & 2343.1273 & 2343.1231 & 586.7881 & 0.0042 & 1.7894 & 1209.758 & 2630.898 & 530.107 & 2262.533 & \text { Yes }\end{array}$ $\begin{array}{llllllllllllllll}\text { HLNEIDLFHCIDPNDSK } & 0.99 & 27.62 & 27.08 & 15.62 & 3 & 2343.1252 & 2343.1231 & 782.0483 & 0.0021 & 0.8951 & 295.135 & 198.601 & 25.884 & 189.620 & \text { No }\end{array}$ $\begin{array}{llllllllllllllll}\text { HLNEIDLFHCIDPNDSK } & 0.99 & 28.52 & 27.14 & 17.47 & 3 & 2343.1264 & 2343.1231 & 782.0483 & 0.0033 & 1.4066 & 634.585 & 796.657 & 172.057 & 997.438 & \text { Yes }\end{array}$ $\begin{array}{llllllllllllllll}\text { HLNEIDLFHCIDPNDSK } & 1.00 & 27.07 & 27.15 & 18.29 & 4 & 2343.1265 & 2343.1231 & 586.7881 & 0.0034 & 1.4486 & 832.683 & 1050.980 & 338.933 & 1346.183 & \text { Yes }\end{array}$ $\begin{array}{llllllllllllllll}\text { HLNEIDLFHCIDPNDSK } & 1.00 & 26.29 & 27.19 & 15.01 & 4 & 2343.1277 & 2343.1231 & 586.7881 & 0.0046 & 1.9598 & 971.973 & 1004.552 & 140.685 & 1336.182 & \text { Yes }\end{array}$ $\begin{array}{llllllllllllllll}\text { KGESGQSWPR } & 0.99 & 31.44 & 28.16 & 19.23 & 3 & 1418.7511 & 1418.7510 & 473.9243 & 0.0001 & 0.0703 & 605.361 & 708.089 & 284.846 & 846.234 & \text { Yes }\end{array}$ $\begin{array}{lllllllllllllllll}\text { KGESGQSWPR } & 0.80 & 20.32 & 28.16 & 20.80 & 3 & 1418.7511 & 1418.7510 & 473.9243 & 0.0001 & 0.0703 & 520.513 & 523.148 & 295.971 & 659.458 & \text { Yes }\end{array}$ $\begin{array}{lllllllllllllllll}\text { HLNEIDLFHCIDPNDSK } & 0.97 & 14.61 & 27.20 & 26.36 & 4 & 2343.1273 & 2343.1231 & 586.7881 & 0.0042 & 1.7894 & 223.006 & 123.961 & 119.799 & 281.144 & \text { No }\end{array}$ $\begin{array}{llllllllllllllll}\text { KGESGQSWPR } & 1.00 & 38.56 & 28.18 & 19.52 & 3 & 1418.7514 & 1418.7510 & 473.9243 & 0.0004 & 0.2813 & 727.866 & 1120.068 & 120.867 & 1034.642 & \text { Yes }\end{array}$ $\begin{array}{llllllllllllllll}\text { KGESGQSWPR } & 1.00 & 46.88 & 28.18 & 20.36 & 3 & 1418.7514 & 1418.7510 & 473.9243 & 0.0004 & 0.2813 & 583.248 & 879.852 & 131.264 & 780.062 & \text { Yes }\end{array}$ $\begin{array}{llllllllllllllll}\text { KGESGQSWPR } & 1.00 & 40.22 & 28.02 & 22.98 & 3 & 1418.7517 & 1418.7510 & 473.9243 & 0.0007 & 0.4923 & 300.183 & 436.211 & 122.031 & 483.785 & \text { Yes }\end{array}$ $\begin{array}{llllllllllllllll}\text { LTFSCLGGSDNFK } & 1.00 & 64.23 & 26.93 & 20.27 & 2 & 1721.8370 & 1721.8361 & 861.9253 & 0.0009 & 0.5221 & 1156.690 & 1256.864 & 1.789 & 2219.097 & \text { Yes }\end{array}$ $\begin{array}{llllllllllllllll}\text { LTFSCLGGSDNFK } & 1.00 & 64.32 & 27.07 & 17.18 & 2 & 1721.8426 & 1721.8361 & 861.9253 & 0.0065 & 3.7706 & 1153.852 & 1405.268 & 41.165 & 2223.174 & \text { Yes }\end{array}$ $\begin{array}{llllllllllllllll}\text { LTFSCLGGSDNFK } & 1.00 & 57.63 & 27.03 & 19.64 & 2 & 1721.8368 & 1721.8361 & 861.9253 & 0.0007 & 0.4061 & 222.518 & 322.704 & 79.131 & 502.307 & \text { Yes } \\ \text { LNWLSVDFNNWK } & 1.00 & 57.92 & 28.07 & 21.96 & 2 & 1822.9635 & 122.9610 & 912.8878 & 0.022 & 1.205 & 165.074 & 144.986 & 0.00 & 336.53 & \text { Ne }\end{array}$

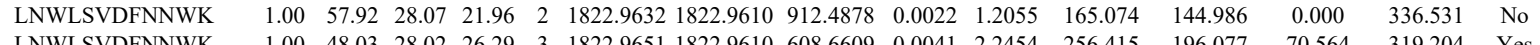
$\begin{array}{llllllllllllllll}\text { LNWLSVDFNNWK } & 1.00 & 48.03 & 28.02 & 26.29 & 3 & 1822.9651 & 1822.9610 & 608.6609 & 0.0041 & 2.2454 & 256.415 & 196.077 & 70.564 & 319.204 & \text { Yes } \\ \text { LNWLSVDFNNWK } & 1.00 & 50.02 & 28.03 & 25.63 & 3 & 1822.9657 & 1822.9610 & 608.6609 & 0.0047 & 2.5739 & 1188.874 & 770.411 & 0.000 & 1114.023 & \text { No }\end{array}$ LNWLSVDFNNWK LNWLSVDFNNWK LNWLSVDFNNWK LNWLSVDFNNWK LNWLSVPNNKK LNWLSDPNNK LNWLSVDFNNW

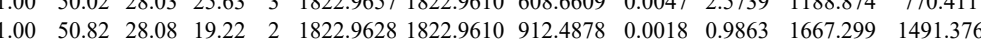
$\begin{array}{llllllllllll}0.99 & 30.17 & 28.11 & 22.97 & 3 & 1822.9642 & 1822.9610 & 608.6609 & 0.0032 & 1.7525 & 392.292 & 406.31\end{array}$ $\begin{array}{llllllllllll}1.00 & 46.22 & 28.02 & 25.40 & 3 & 1822.9651 & 1822.9610 & 608.6609 & 0.0041 & 2.2454 & 551.686 & 603.471\end{array}$

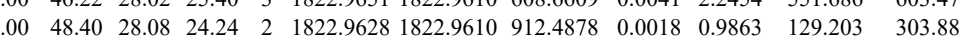
$\begin{array}{lllllll} & \\ 0\end{array}$ $\begin{array}{llllllllllll}0.67 & 21.90 & 28.06 & 34.90 & 3 & 1822.9639 & 1822.9610 & 608.6609 & 0.0029 & 1.5882 & 484.936 & 662.549\end{array}$

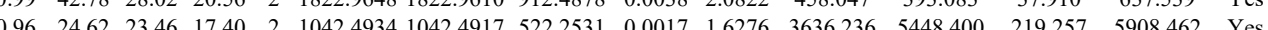
$\begin{array}{lllllllllllllll}0.84 & 26.29 & 23.30 & 39.29 & 2 & 1042.4936 & 1042.4917 & 522.2531 & 0.0019 & 1.8190 & 31853.652 & 46049.709 & 1625.829 & 44321.733 & \text { Yes }\end{array}$ $\begin{array}{llllllllllllllll}0.89 & 22.97 & 23.84 & 18.00 & 2 & 1042.4948 & 1042.4917 & 522.2531 & 0.0031 & 29679 & 35.621 & 40.828 & 13.697 & 73.866 & \text { Yes }\end{array}$ $\begin{array}{llllllllllllllll}0.82 & 28.81 & 23.52 & 41.81 & 2 & 1042.4926 & 1042.4917 & 522.2531 & 0.0009 & 0.8617 & 14824.745 & 20610.507 & 858.848 & 23271.692 & \text { Yes }\end{array}$ $\begin{array}{lllllllllllllllll}0.82 & 28.81 & 23.52 & 41.81 & 2 & 1042.4926 & 142.4917 & 522.2531 & 0.0009 & 0.8617 & 14824.745 & 20610.507 & 858.848 & 23271.692 & \text { Yes } \\ 0.82 & 26.77 & 23.67 & 39.77 & 2 & 1042.4928 & 1042.4917 & 522.2531 & 0.0011 & 1.0531 & 3545.688 & 4981.661 & 47.424 & 5153.839 & \text { Yes }\end{array}$

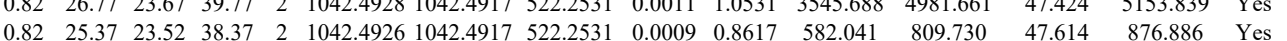

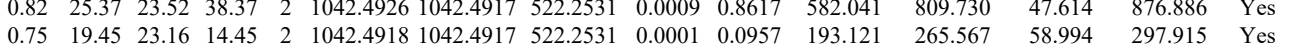

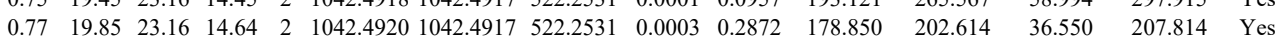
$\begin{array}{lllllllllllllll}0.78 & 16.20 & 23.36 & 17.61 & 2 & 1042.4924 & 1042.4917 & 522.2531 & 0.0007 & 0.6702 & 135.633 & 175.370 & 91.607 & 189.676 & \text { No }\end{array}$

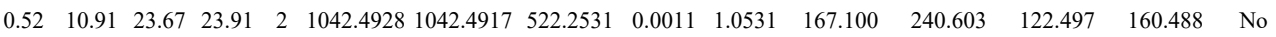
$\begin{array}{lllllllllllllll}0.96 & 24.24 & 23.36 & 15.11 & 2 & 1042.4924 & 1042.4917 & 522.2531 & 0.0007 & 0.6702 & 130.015 & 233.499 & 22.614 & 183.813 & \text { Yes }\end{array}$ $\begin{array}{lllllllllllllll}0.85 & 18.52 & 23.69 & 21.03 & 2 & 1042.4930 & 1042.4917 & 522.2531 & 0.0013 & 1.2446 & 122.206 & 129.411 & 31.331 & 154.137 & \text { Yes }\end{array}$ $\begin{array}{lllllllllllllll}0.82 & 17.14 & 23.36 & 19.85 & 2 & 1042.4924 & 1042.4917 & 522.2531 & 0.0007 & 0.6702 & 105.163 & 126.985 & 70.727 & 129.622 & \text { No }\end{array}$

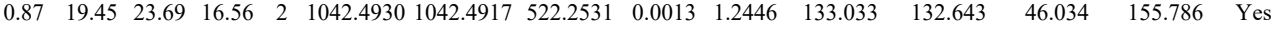

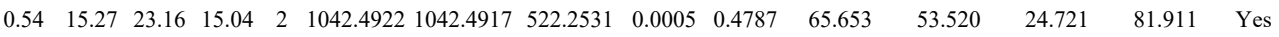
$\begin{array}{lllllllllllllll}0.95 & 23.67 & 23.69 & 17.27 & 2 & 1042.4930 & 1042.4917 & 522.2531 & 0.0013 & 1.2446 & 60.035 & 100.843 & 21.980 & 96.715 & \text { Yes }\end{array}$

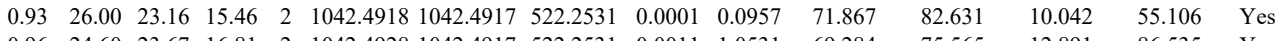

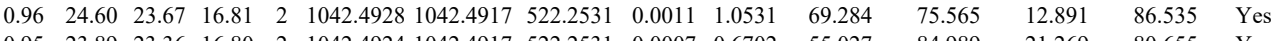

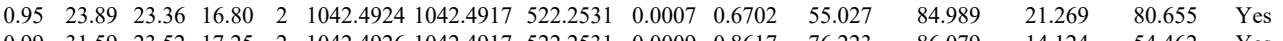

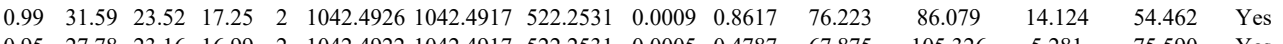

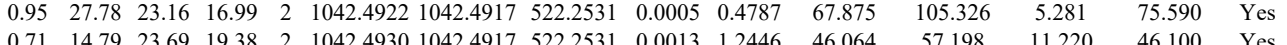

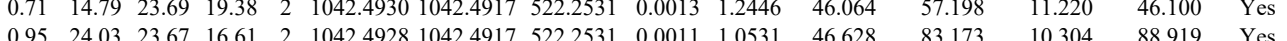

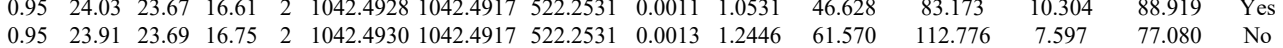

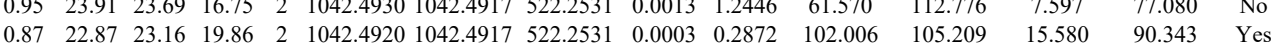

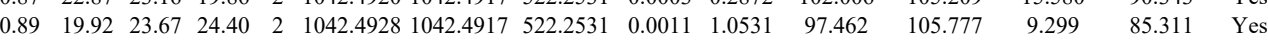



$\begin{array}{llllllllllllllll}\text { AAPGAEFAPNKR } & 0.52 & 12.26 & 27.45 & 25.26 & 3 & 1515.8407 & 1515.8401 & 506.2873 & 0.0006 & 0.3950 & 702.971 & 879.759 & 477.768 & 1081.064 & \text { Yes }\end{array}$

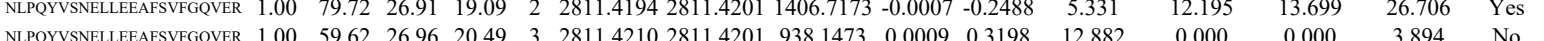
$\begin{array}{lllllllllllll} & \end{array}$ $\begin{array}{lllllllllllll} & \text { NLPYSNEL }\end{array}$

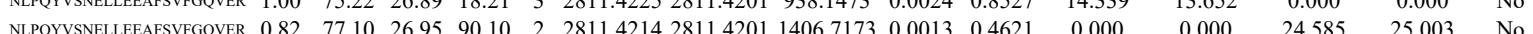

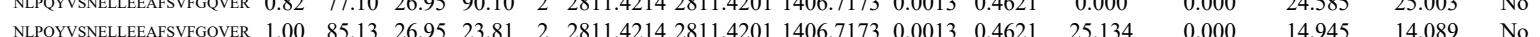

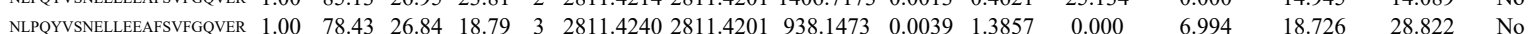

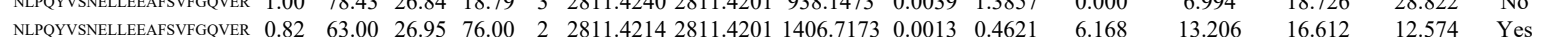

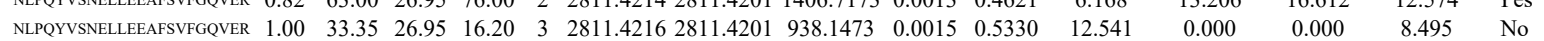

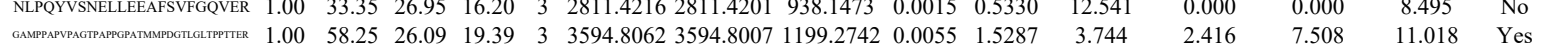

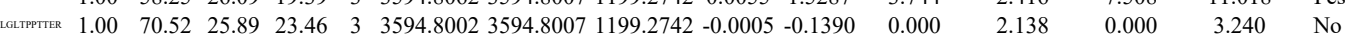
$\begin{array}{llllllllllllllll}\text { FGQAATMEGIGAIGGTPAFNR } & 1.00 & 99.60 & 27.63 & 20.63 & 2 & 2306.1594 & 2306.1599 & 1154.0872 & -0.0005 & -0.2166 & 165.084 & 73.861 & 197.628 & 262.230 & \text { Yes }\end{array}$

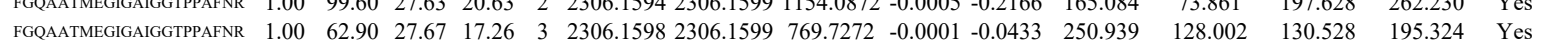
\begin{tabular}{llllllllllllllll} 
FGQAATMEGIGAIGGTPAPNR & 1.00 & \#\#\#\# 27.63 & 24.19 & 2 & 2306.1614 & 2306.1599 & 1154.0872 & 0.0015 & 0.6499 & 92.275 & 30.304 & 113.843 & 101.004 & Yes \\
\hline
\end{tabular} \begin{tabular}{lllllllllllllllll} 
FGQAATMEGIGAIGGTPAFNR & 0.66 & 12.95 & 27.63 & 17.60 & 3 & 2306.1616 & 2306.1599 & 769.7272 & 0.0017 & 0.7362 & 291.974 & 275.700 & 145.772 & 427.033 & Yes \\
\hline
\end{tabular} $\begin{array}{lllllllllllllll}\text { FGQAATMEGIGAIGGTPAFNR } & 1.00 & \text { \#\#\#\# } 27.60 & 22.10 & 2 & 2306.1634 & 2306.1599 & 1154.0872 & 0.0035 & 1.5163 & 173.433 & 167.339 & 156.361 & 347.051 & \text { Yes }\end{array}$

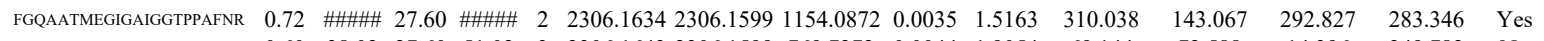
$\begin{array}{llllllllllllllll}\text { FGQAATMEGIGAIGGTPAAFNR } & 0.60 & 38.02 & 27.60 & 51.02 & 3 & 2306.1643 & 2306.1599 & 769.7272 & 0.0044 & 1.9054 & 69.144 & 72.588 & 14.396 & 249.782 & \text { No }\end{array}$

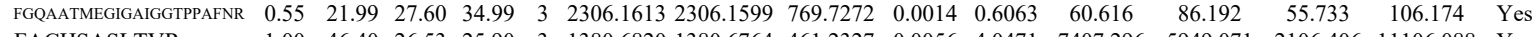

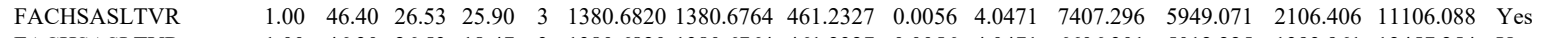
$\begin{array}{lllllllllllllllll}\text { FACHSASLTVR } & 1.00 & 46.30 & 26.53 & 18.47 & 3 & 1380.6820 & 1380.6764 & 461.2327 & 0.0056 & 4.0471 & 6606.301 & 5012.225 & 1393.961 & 12457.254 & \text { Yes }\end{array}$

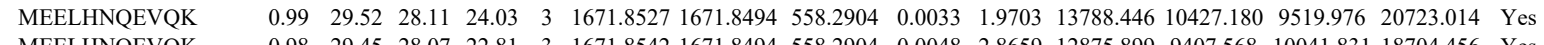
$\begin{array}{llllllllllllllll}\text { MEELHNQEVQK } & 0.98 & 29.45 & 28.07 & 22.81 & 3 & 1671.8542 & 1671.8494 & 558.2904 & 0.0048 & 2.8659 & 12875.899 & 9407.568 & 10041.831 & 18704.456 & \text { Yes }\end{array}$ $\begin{array}{lllllllllllllllll}\text { MEELHNQEVQK } & 1.00 & 36.80 & 28.11 & 25.83 & 3 & 1671.8527 & 1671.8494 & 558.2904 & 0.0033 & 1.9703 & 6190.110 & 4920.669 & 1431.328 & 10351.291 & \text { Yes }\end{array}$ $\begin{array}{llllllllllllllll}\text { RMEELHNQEVQK } & 1.00 & 19.86 & 27.88 & 15.81 & 4 & 1827.9525 & 1827.9505 & 457.9949 & 0.0020 & 1.0917 & 2515.339 & 1975.388 & 702.058 & 4813.490 & \text { Yes }\end{array}$

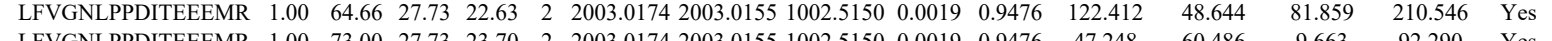

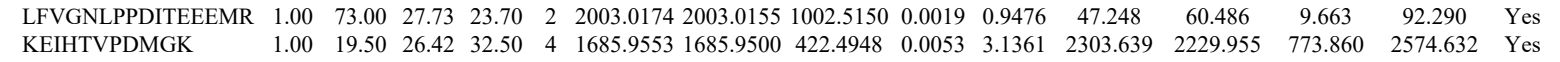
4 KEIHTVPDMGK

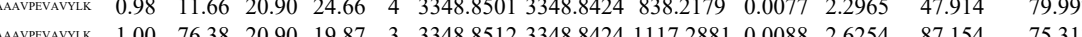
$\begin{array}{llllllllll} & 0\end{array}$ $\begin{array}{llllllllll} & \end{array}$ $\begin{array}{cccc}773.860 & 2574.632 & \text { Yes } \\ 67.592 & 38.663 & \text { Yes }\end{array}$

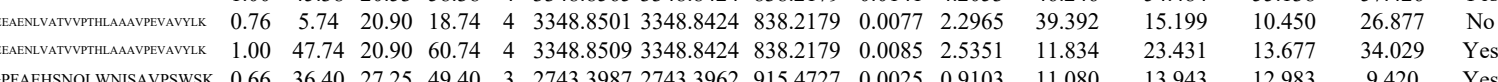
$\begin{array}{llllllllllllllll}\text { FPVIQHFK } & 1.00 & 42.43 & 25.75 & 19.73 & 3 & 1302.7795 & 1302.7692 & 435.2637 & 0.0103 & 7.8879 & 8854.567 & 7579.429 & 15043.724 & 16254.793 & \text { Yes }\end{array}$

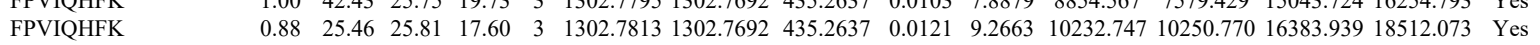
$\begin{array}{llllllllllllllll}\text { LVALLNTLDR } & 1.00 & 51.49 & 24.31 & 31.68 & 2 & 1270.7746 & 1270.7731 & 636.3938 & 0.0015 & 1.1785 & 6435.709 & 6422.029 & 557.626 & 9509.881 & \text { Yes }\end{array}$

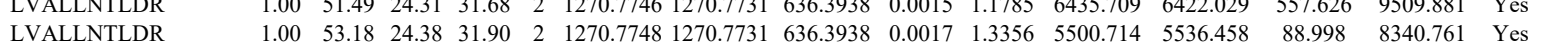
FPVIOHFK FGSLLPIHPVTSG FGSLLPIHPVTSG FGSLLPIHPVTS $\begin{array}{llllllllllllllll}1.00 & 53.18 & 24.38 & 31.90 & 2 & 1270.7748 & 1270.7731 & 636.3938 & 0.0017 & 1.3356 & 5500.714 & 5536.458 & 88.998 & 8340.761 & \text { Yes } \\ 0.99 & 37.69 & 25.81 & 17.59 & 3 & 1302.7801302 .7692 & 435.2637 & 0.0118 & 9.0366 & 8574.256 & 8924.659 & 14494.462 & 15973.422 & \text { Yes }\end{array}$ $\begin{array}{lllllllllllllllll}0.99 & 37.69 & 25.81 & 17.59 & 3 & 1302.7810 & 1302.7692 & 435.2637 & 0.0118 & 9.0366 & 8574.256 & 8924.659 & 14494.462 & 15973.422 & \text { Yes } \\ 1.00 & 50.90 & 26.79 & 16.76 & 2 & 1467.8214 & 1467.8208 & 734.9177 & 0.0006 & 0.4082 & 1275.754 & 620.478 & 327.059 & 1716.084 & \text { Yes }\end{array}$ $\begin{array}{llllllllllllllll} & \end{array}$ $\begin{array}{lllllllllllllllll} & 0.96 & 35.67 & 27.57 & 21.00 & 2 & 1241.6642 & 1241.6535 & 621.8340 & 0.0107 & 8.6035 & 2863.671 & 3793.894 & 507.800 & 7577.319 & \text { Yes } \\ \text { IDNDGDGFVTTEELK } & 1.00 & 79.77 & 28.08 & 22.71 & 2 & 1939.9616 & 1939.9619 & 970.9882 & -0.0003 & -0.1545 & 129.892 & 197.329 & 88.914 & 378.002 & \text { Yes }\end{array}$ $\begin{array}{lllllllllllllll}1.00 & 74.22 & 27.98 & 33.63 & 2 & 1567.8096 & 1567.7973 & 784.9059 & 0.0123 & 7.8353 & 473.303 & 718.970 & 82.901 & 1423.589 & \text { Yes }\end{array}$ $\begin{array}{llllllllllllllll} & \end{array}$ $\begin{array}{llllllllllllll} & \end{array}$

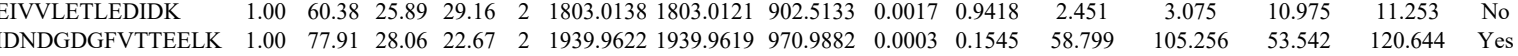
$\begin{array}{lllllllllllllll} & \end{array}$ $\begin{array}{llllllllllllllllllll} & \end{array}$ $\begin{array}{llllllllllllllll}\text { LEEMNELAVAMTAVK } & 1.00 & 88.05 & 27.08 & 28.06 & 2 & 2049.1114 & 2049.1093 & 1025.5619 & 0.0021 & 1.0238 & 558.639 & 622.067 & 349.781 & 697.812 & \text { Yes }\end{array}$

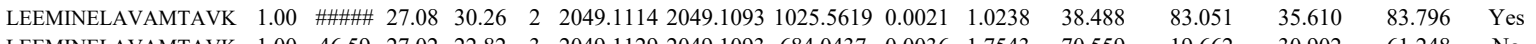

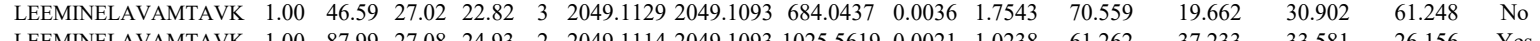

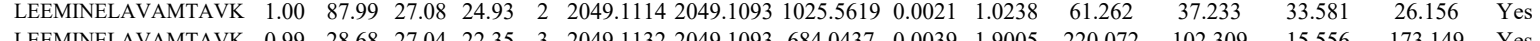

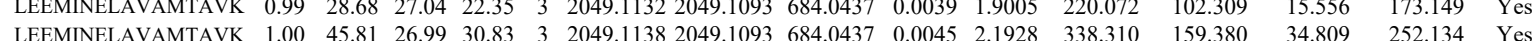

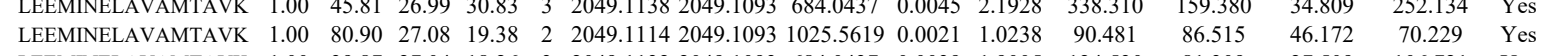
$\begin{array}{llllllllllllllll}\text { LEEMINELAVAMTAVK } & 1.00 & 39.87 & 27.04 & 18.26 & 3 & 2049.1132 & 2049.1093 & 684.0437 & 0.0039 & 1.9005 & 124.530 & 81.309 & 27.509 & 106.721 & \text { Yes }\end{array}$ $\begin{array}{lllllllllllll}\text { LEEMINELAVAMTAVK } & 0.99 & 31.57 & 26.98 & 19.28 & 3 & 2049.1141 & 2049.1093 & 684.0437 & 0.0048 & 2.3390 & 63.574 & 100.199\end{array}$

Table S-4 page 494 of 614 


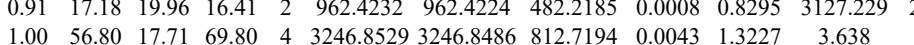

$\begin{array}{lllllllllll}1.00 & 59.97 & 17.32 & 72.97 & 4 & 3246.8553 & 3246.8486 & 812.7194 & 0.0067 & 2.0610 & 1.838\end{array}$ $\begin{array}{lllllllllllll}\text { AITIAGVPQSVTECVK } & 1.00 & 95.64 & 27.02 & 28.57 & 2 & 1949.0570 & 1949.0569 & 975.5357 & 0.0001 & 0.0513 & 1132.891 & 926.686 \\ \text { AITIAGVPSVTECVK } & 1.00 & 80.90 & 26.88 & 28.23 & 2 & 1949.0580 & 1949.0569 & 975.5357 & 0.0011 & 0.5638 & 1861.378 & 1511.407\end{array}$

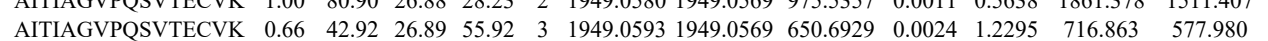
$\begin{array}{llllllllllllll}\text { AITIAGVPQSVTECVK } & 0.99 & 28.08 & 26.89 & 15.49 & 3 & 1949.0596 & 1949.0569 & 650.6929 & 0.0027 & 1.3831 & 667.621 & 517.3\end{array}$ $\begin{array}{llllllll} & \end{array}$

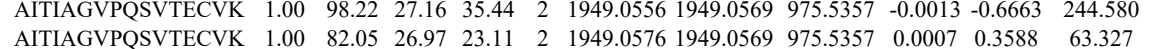
$\begin{array}{lllllllllllll}\text { AITIAGVPQSVTECVK } & 0.55 & 44.86 & 26.89 & 57.86 & 3 & 1949.0578 & 1949.0569 & 650.6929 & 0.0009 & 0.4610 & 738.038 & 624.364\end{array}$ $\begin{array}{llllllllllllll}\text { AITIAGVPQSVTECVK } & 0.66 & 56.64 & 26.91 & 69.64 & 3 & 1949.0587 & 1949.0569 & 650.6929 & 0.0018 & 0.9221 & 441.677 & 329.161\end{array}$ $\begin{array}{lllllllllllll}\text { AITIAGVPQSVTECVK } & 1.00 & 84.21 & 26.91 & 27.03 & 2 & 1949.0588 & 1949.0569 & 975.5357 & 0.0019 & 0.9738 & 263.926 & 232 . \\ \text { AITIAGVPOSVTECVK } & 1.00 & 59.45 & 26.69 & 20.80 & 3 & 1949.0617 & 1949.0569 & 650.6929 & 0.0048 & 2.4589 & 772770 & 60 .\end{array}$ 232.028
690.253

VAFAMIIIIP $\begin{array}{llllllllllllll} & \text { MTIPYQPMPASSPASAPVTLR } & 0.97 & 19.86 & 24.87 & 32.86 & 4 & 3665.9049 & 3665.9000 & 917.4823 & 0.0049 & 1.3352 & 285.364 & 319.730\end{array}$

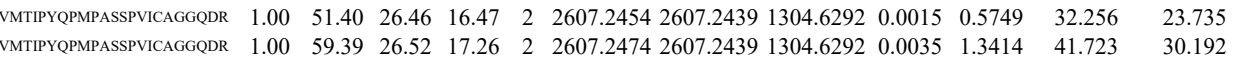
$\begin{array}{llllllllllllll}\text { VMTIPYOMASSHCAGGQDR } & 1.00 & 59.39 & 26.52 & 17.26 & 2 & 2607.2474 & 2607.2439 & 1304.6292 & 0.0035 & 1.3414 & 41.723 & 30.192\end{array}$

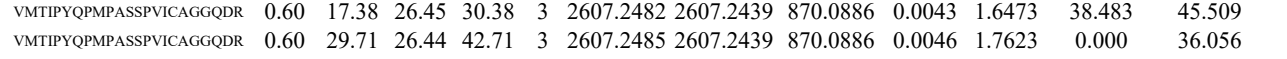
$\begin{array}{llllllllllllll}\text { IITLTGPTNAIFK } & 1.00 & 58.63 & 20.86 & 20.24 & 2 & 1676.0148 & 1676.0116 & 839.0131 & 0.0032 & 1.9070 & 4201.732 & 3194.089\end{array}$ $\begin{array}{lllllllllllll}\text { IITLTGPTNAIFK } & 1.00 & 72.99 & 20.37 & 21.19 & 2 & 1676.0164 & 1676.0116 & 839.0131 & 0.0048 & 2.8605 & 4335.150 & 3994.807\end{array}$

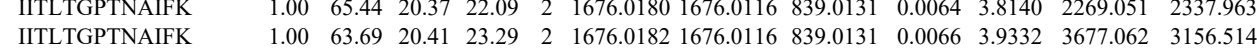
$\begin{array}{lllllllllllll}\text { IITLTGPNAAIFK } & 1.00 & 63.69 & 20.41 & 23.29 & 2 & 1676.0182 & 1676.0116 & 839.0131 & 0.0066 & 3.9332 & 3677.062 & 3156.514 \\ \text { IITLTGPTNAIFK } & 0.99 & 32.24 & 19.64 & 17.13 & 3 & 1676.0197 & 1676.0116 & 559.6778 & 0.0081 & 4.8242 & 1364.208 & 1124.072\end{array}$ $\begin{array}{lllllllllllll}\text { LVVPATQCGSLIGK } & 0.77 & 81.33 * & 26.25 & 55.12 & 2 & 1718.9680 & 1718.9667 & 860.4906 & 0.0013 & 0.7554 & 5739.510 & 5349.052\end{array}$

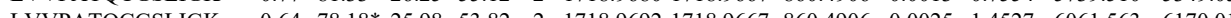
$\begin{array}{llllllllllll}\text { LVVPATQCGSLIGK } & 0.76 & 77.82 * 26.25 & 54.05 & 2 & 1718.9682 & 1718.9667 & 860.4906 & 0.0015 & 0.8716 & 3834.485 & 4154.359\end{array}$ $\begin{array}{lllllllllllllll}\text { LVVPATQCGSLIGK } & 0.81 & 76.24 * & 26.25 & 52.05 & 2 & 1718.9682 & 1718.9667 & 860.4906 & 0.0015 & 0.8716 & 2395.742 & 2449.951 & 278.3\end{array}$ $\begin{array}{lllllllllllll}\text { QICLVMLETLSQSPQGR } & 1.00 & \text { \#\#\#\# } & 27.87 & 27.13 & 2 & 2092.0614 & 2092.0601 & 1047.0373 & 0.0013 & 0.6208 & 128.454 & 186.863 \\ \text { QICLVMLETLSQSPQGR } & 1.00 & 96.86 & 27.87 & 21.47 & 2 & 2092.0614 & 2092.0601 & 1047.0373 & 0.0013 & 0.6208 & 157.329 & 195.726\end{array}$ $\begin{array}{lllllllllllll}\text { QICLVMLETLSQSPQGR } & 1.00 & 96.86 & 27.87 & 21.47 & 2 & 2092.0614 & 2092.0601 & 1047.0373 & 0.0013 & 0.6208 & 157.329 & 195.726 \\ \text { LVVPATQCGSLIGK } & 0.79 & 37.12 * & 26.05 & 27.65 & 2 & 1718.9686 & 1718.9667 & 860.4906 & 0.0019 & 1.1040 & 55.957 & 56.682\end{array}$ $\begin{array}{llllllllllll}\text { QICLVMLETLSQSPQGR } & 1.00 & \# \# \# \# 27.87 & 27.43 & 2 & 20920614 & 2092.0601 & 1047.0373 & 0.0013 & 0.6208 & 206.456 & 146.480\end{array}$ $\begin{array}{llllllllllllll}\text { QICLVMLETLSQSPQGR } & 1.00 & \text { \#\#\#\# } 27.87 & 22.26 & 2 & 2092.0614 & 2092.0601 & 1047.0373 & 0.0013 & 0.6208 & 127.357 & 164.633\end{array}$ $\begin{array}{lllllllllllll}\text { QICLVMLELSQSPGR } & 1.00 & & 27.87 & 22.26 & 2 & 202.0614 & 2092.061 & 047.033 & 0.0013 & 0.6208 & 206.456 & 146.480\end{array}$ $\begin{array}{llllllllllllll}\text { QICLVMLETLSOSPQGR } & 1.00 & 96.34 & 27.83 & 27.03 & 2 & 2092.0594 & 2092.0601 & 1047.0373 & -0.0007 & -0.3343 & 30.851 & 46.918\end{array}$ $\begin{array}{llllllllllll}\text { QICLVMLETLSOSPOGR } & 1.00 & \text { \#\#\#\# } 27.87 & 25.64 & 2 & 2092.0614 & 2092.0601 & 1047.0373 & 0.0013 & 0.6208 & 50.845 & 46.990\end{array}$ $\begin{array}{llllllllllllll}\text { QICLVMLETLSQSPQGR } & 0.67 & 64.90 & 27.79 & 77.90 & 3 & 2092.0627 & 2092.0601 & 698.3606 & 0.0026 & 1.2410 & 24.849 & 19.947\end{array}$ $\begin{array}{lllllllllllll}\text { QICLVMLETLSQSPQGR } & 1.00 & 43.22 & 27.79 & 17.70 & 3 & 2092.0630 & 2092.0601 & 698.3606 & 0.0029 & 1.3842 & 25.691\end{array}$

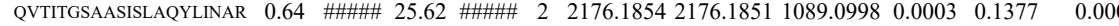

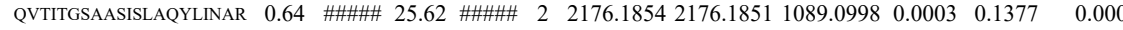
$\begin{array}{llllllllllllll}\text { QICLVMLETLSQSPQGR } & 0.66 & 71.39 & 27.76 & 84.39 & 3 & 2092.0624 & 2092.0601 & 698.3606 & 0.0023 & 1.0978 & 14.183\end{array}$ $\begin{array}{lllllllllllll}\text { QICLVMLETLSQSPQGR } & 0.67 & 47.96 & 27.79 & 60.96 & 3 & 2092.0627 & 2092.0601 & 698.3606 & 0.0026 & 1.2410 & 6.976\end{array}$ $\begin{array}{lllllllllllll}\text { QVTITGSAASISLAQYLINAR } & 1.00 & 51.24 & 23.96 & 17.73 & 3 & 2320.2889 & 2320.2872 & 774.4363 & 0.0017 & 0.7317 & 7.796\end{array}$ $\begin{array}{lllllllllllll}\text { QICLVMLETLSQSPQGR } & 0.66 & 48.84 & 27.76 & 61.84 & 3 & 2092.0624 & 2092.0601 & 698.3606 & 0.0023 & 1.0978 & 14.075\end{array}$ $\begin{array}{llllllllllll}\text { QICLVMLETLSQSPQGR } & 1.00 & 35.48 & 27.79 & 15.59 & 3 & 2092.0627 & 2092.0601 & 698.3606 & 0.0026 & 1.2410 & 9.926\end{array}$ $\begin{array}{llllllllllll}\text { QVTITGSAASISLAQYLINAR } & 0.66 & 94.21 & 23.73 & \text { \#\#\#\# } & 3 & 2320.2895 & 2320.2872 & 774.4363 & 0.0023 & 0.9900 & 11.452\end{array}$ $\begin{array}{llllllllllll}\text { QVTITGSAASISLAQYLINAR } & 1.00 & 60.12 & 23.71 & 19.78 & 3 & 2320.2904 & 2320.2872 & 774.4363 & 0.0032 & 1.3773 & 14.273\end{array}$ $\begin{array}{llllllllllll}\text { QICLVMLETLSQSPQGR } & 0.66 & 15.17 & 27.76 & 28.17 & 3 & 2092.0624 & 2092.0601 & 698.3606 & 0.0023 & 1.0978 & 1.9892\end{array}$ $\begin{array}{llllllllllll}\text { QVTITGSAASISLAQYLINAR } & 1.00 & 49.51 & 23.65 & 16.47 & 3 & 2320.2901 & 2320.2872 & 774.4363 & 0.0029 & 1.2482 & 9.353\end{array}$ $\begin{array}{lllllllllllll}\text { QVIITGSAASISLAQYLNARR } & 1.00 & 66.35 & 23.71 & 19.95 & 3 & 2320.2904 & 2320.2872 & 744.4363 & 0.0032 & 1.3773 & 11.283\end{array}$ $\begin{array}{llllllllllll}\text { QVTITGSAASISLAQYLINAR } & 0.66 & 26.38 & 23.73 & 39.38 & 3 & 2320.2895 & 2320.2872 & 774.4363 & 0.0023 & 0.9900 & 4.872\end{array}$ $\begin{array}{llllllllllll}\text { QVTITGSAASISLAOYLINAR } & 0.55 & 43.80 & 23.94 & 56.80 & 3 & 23202883 & 2320.2872 & 774.4363 & 0.0011 & 0.4735 & 13.849\end{array}$ $\begin{array}{llllllllllll}\text { QVTITGSAASISLAQYLINAR } & 0.67 & 40.34 & 23.65 & 53.34 & 3 & 2320.2901 & 2320.2872 & 774.4363 & 0.0029 & 1.2482 & 12.451\end{array}$ $\begin{array}{lrl}4.462 & 6.936 \\ 0.148 & 2555.7\end{array}$ .09934144 .880 Yes

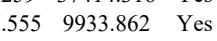

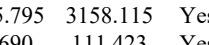
$431.895 \quad 1020.397$ Yes $\begin{array}{lll}754.741 \quad 1645.666 & \text { Yes }\end{array}$ $243.805 \quad 1252.349$ Yes $\begin{array}{lll}412.699 & 566.982 & \text { Yes }\end{array}$ $86.097 \quad 239.526 \quad$ Yes $53.676 \quad 58.772 \quad$ Yes $\begin{array}{lll}457.921 & 1144.418 & \text { Yes }\end{array}$ \begin{tabular}{lll}
150 & 823.365 & Yes \\
\hline 76.56 & 157.543 & Yes
\end{tabular} $\begin{array}{lll}18.963 & 1995.448 & \text { Yes } \\ 0.387 .137 & \text { Yes }\end{array}$ $\begin{array}{lll}0.000 & 74.615 & \text { No }\end{array}$ $\begin{array}{lll}8.005 & 56.602 & \text { No }\end{array}$ $83.411-51.02 .417$
No $\begin{array}{lll}6410.132 & \text { No }\end{array}$ \begin{tabular}{lll}
5841.945 & Yes \\
\hline 537 & 5590.834 & Yes
\end{tabular} $\begin{array}{lll}73.024 & 222.149 & \text { Yes }\end{array}$ $\begin{array}{lll}37.214 & 178.223 & \text { Yes }\end{array}$ $\begin{array}{ccc}14.649 & 44.608 & \text { Yes } \\ 61.851 & 204.983 & \text { Yes }\end{array}$ $\begin{array}{lll}61.851 & 204.983 & \text { Yes } \\ 35.587 & 243.467 & \text { Yes }\end{array}$ $37.482 \quad 33.166$ Yes $12.914 \quad 34.678$ Yes $\begin{array}{lll}18.879 & 59.172 & \text { Yes }\end{array}$ $5.623 \quad 15.368$ Yes $13.114 \quad 26.645$ Yes 0.000

16.489

8.642

2.753

18.291 


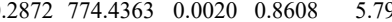

$\begin{array}{lllllllllll} & \end{array}$

$\begin{array}{llllllllllllll}\text { QVTITGSAASISLAQYLINAR } & 0.55 & 48.17 & 23.94 & 61.17 & 3 & 2320.2883 & 2320.2872 & 774.4363 & 0.0011 & 0.4735 & 9.688\end{array}$

$\begin{array}{llllllllllll}\text { QVIITGSAASISLAQYLINAR } & 1.00 & 77.12 & 23.65 & 19.46 & 3 & 2320.2898 & 2320.2872 & 774.4363 & 0.0026 & 1.1191 & 19.429 \\ \text { QVTITGSAASISLAQYLINAR } & 0.66 & 80.48 & 23.96 & 93.48 & 3 & 2320.2889 & 2320.2872 & 774.4363 & 0.0017 & 0.7317 & 11.435\end{array}$

$\begin{array}{llllllllllll}\text { QVTITGSAASISLAQYLINAR } & 0.66 & 80.48 & 23.96 & 93.48 & 3 & 2320.2889 & 2320.2872 & 774.4363 & 0.0017 & 0.7317 & 11.435 \\ \text { QVTITGSAASISLAOYLINAR } & 1.00 & 51.80 & 23.58 & 19.48 & 3 & 2320.2913 & 2320.2872 & 774.4363 & 0.0041 & 1.7647 & 27.193\end{array}$ $\begin{array}{llllllllllll}\text { QVTITGSAASISLAQYLINAR } & 1.00 & 51.80 & 23.58 & 19.48 & 3 & 2320.2913 & 2320.2872 & 774.4363 & 0.0041 & 1.7647 & 27.193 \\ \text { QVTITGSAASISLAOYLINAR } & 1.00 & 72.98 & 23.96 & 18.53 & 3 & 2320.2892 & 2320.2872 & 774.4363 & 0.0020 & 0.8608 & 11.647\end{array}$ $\begin{array}{llllllllllll}\text { QVTITGSAASISLAQYLINAR R } & 1.00 & 72.98 & 23.96 & 18.53 & 3 & 2320.2892 & 2320.2872 & 774.4363 & 0.0020 & 0.8608 & 11.647 \\ \text { QVTITGSAASILLAQYIINAR } & 1.00 & 67.29 & 23.96 & 19.98 & 3 & 2320.2892 & 2320.2872 & 774.4363 & 0.0020 & 0.8608 & 6.846\end{array}$

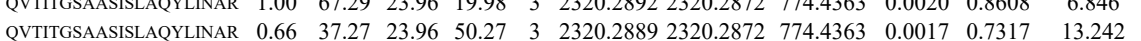

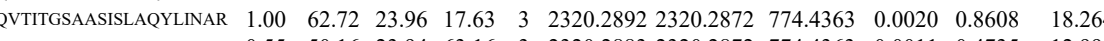
$\begin{array}{lllllllllllll} & \end{array}$

IANPVEGSTDR

14736.77013830 .972

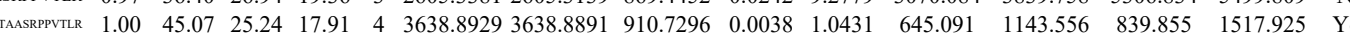

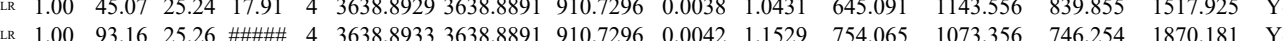

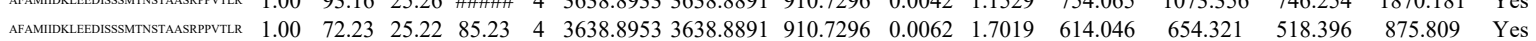
$\begin{array}{lllllllllllllll}\text { AITIAGIPQSIIECVK } & 1.00 & \text { \#\#\#\# } 24.20 & 39.81 & 2 & 1989.1252 & 1989.1246 & 995.5696 & 0.0006 & 0.3013 & 233.778 & 310.169 & 291.055 & 473.100 & \text { Yes }\end{array}$

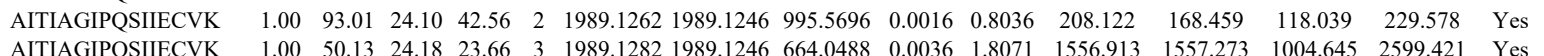
$\begin{array}{lllllllllllllllll}\text { AITIAGIPQSIIECVK } & 1.00 & 50.13 & 24.18 & 23.66 & 3 & 1989.1282 & 1989.1246 & 664.0488 & 0.0036 & 1.8071 & 1556.913 & 1557.273 & 1004.645 & 2599.421 & \text { Yes } \\ \text { A }\end{array}$ $\begin{array}{llllllllllllllll}\text { AITIAGIPQSIIECVK } & 1.00 & 87.61 & 24.17 & 38.03 & 2 & 1989.1258 & 1989.1246 & 995.5696 & 0.0012 & 0.6027 & 1000.819 & 886.075 & 1078.085 & 1776.707 & \text { Yes } \\ \text { AITIAGIPQSIIECVK } & 1.00 & 71.58 & 24.13 & 29.80 & 2 & 1989.1268 & 1989.1246 & 995.5696 & 0.0022 & 1.1049 & 411.517 & 674.226 & 546.738 & 989.400 & \text { Yes }\end{array}$ $\begin{array}{llllllllllllllllll}\text { AITIAGIPQSIIECVK } & 1.00 & 52.77 & 24.12 & 21.57 & 3 & 1989.1270 & 1989.1246 & 664.0488 & 0.0024 & 1.2047 & 231.328 & 473.874 & 171.839 & 570.546 & \text { Yes }\end{array}$ $\begin{array}{llllllllllllllll}\text { AITIAGIPQSIIECVK } & 1.00 & 63.16 & 24.17 & 24.49 & 3 & 1989.1288 & 1989.1246 & 664.0488 & 0.0042 & 2.1083 & 1233.272 & 1465.507 & 995.652 & 2554.883 & \text { Yes }\end{array}$ $\begin{array}{llllllllllllllll}\text { AITIAGIPQSIIECVK } & 1.00 & 84.32 & 24.20 & 35.24 & 2 & 1989.1250 & 1989.1246 & 995.5696 & 0.0004 & 0.2009 & 252.345 & 206.511 & 159.425 & 442.081 & \text { Yes }\end{array}$

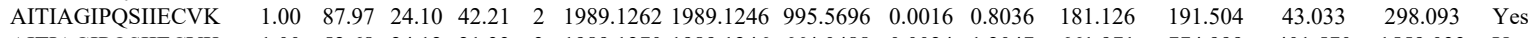
$\begin{array}{llllllllllllllll}\text { AITIAGIPQSIIECVK } & 1.00 & 52.68 & 24.12 & 21.33 & 3 & 1989.1270 & 1989.1246 & 664.0488 & 0.0024 & 1.2047 & 661.971 & 774.999 & 401.570 & 1559.033 & \text { Yes }\end{array}$ $\begin{array}{lllllllllllllllll}\text { AITIAGIPQSIIECVK } & 1.00 & 56.01 & 24.22 & 25.04 & 3 & 1989.1279 & 1989.1246 & 664.0488 & 0.0033 & 1.6565 & 153.994 & 178.107 & 165.628 & 281.696 & \text { Yes }\end{array}$ $\begin{array}{llllllllllllllll}\text { QICVVMLETLSQSPPK } & 1.00 & 40.82 & 27.60 & 16.27 & 3 & 2106.1165 & 2106.1131 & 703.0450 & 0.0034 & 1.6120 & 114.582 & 112.789 & 83.402 & 201.362 & \text { Yes }\end{array}$

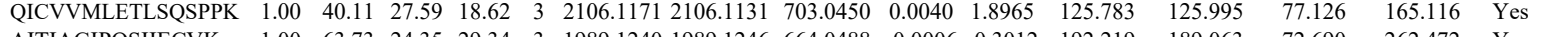

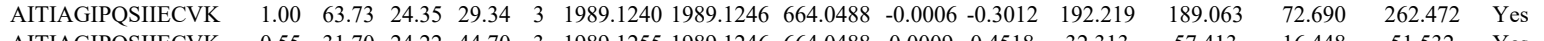

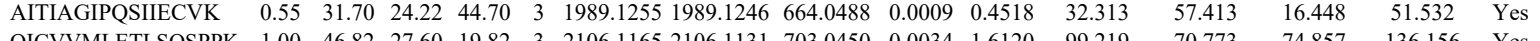

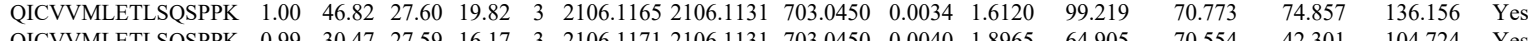
$\begin{array}{llllllllllllllll} & \\ \text { QICVNMLETLSQSPPK } & 0.99 & 30.47 & 27.59 & 16.17 & 3 & 2106.1171 & 2106.1131 & 703.0450 & 0.0040 & 1.8965 & 64.905 & 70.554 & 42.301 & 104.724 & \text { Yes } \\ \text { ITLAGPTNAIFK } & 1.00 & 74.61 & 21.21 & 31.75 & 2 & 1646.0048 & 1646.0011 & 824.0078 & 0.0037 & 2.2451 & 1159.296 & 1529.091 & 92.982 & 2595.113 & \text { Yes }\end{array}$

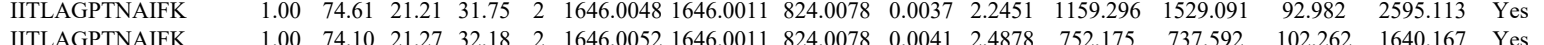
$\begin{array}{lllllllllllllll} & 1.02 .262 & 1640.167 & \text { Yes }\end{array}$

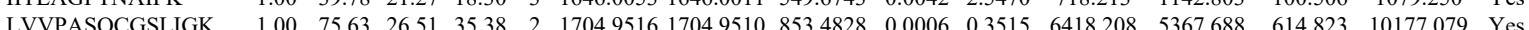

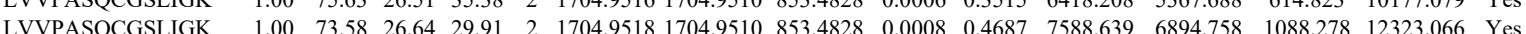
$\begin{array}{llllllllllllllll}\text { LVVPASQCGSLIGK } & 1.00 & 42.04 & 26.43 & 26.06 & 3 & 1704.9532 & 1704.9510 & 569.3243 & 0.0022 & 1.2881 & 877.711 & 549.044 & 0.000 & 1235.344 & \text { No }\end{array}$ $\begin{array}{llllllllllllllll}\text { LVVPASOCGSLIGK } & 1.00 & 40.11 & 26.38 & 19.15 & 3 & 1704.9535 & 1704.9510 & 569.3243 & 0.0025 & 1.4637 & 722.107 & 706.138 & 132.185 & 882.782 & \text { Yes }\end{array}$

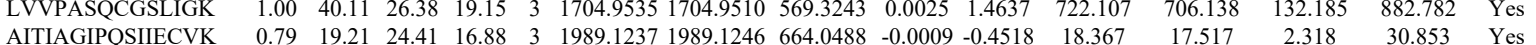

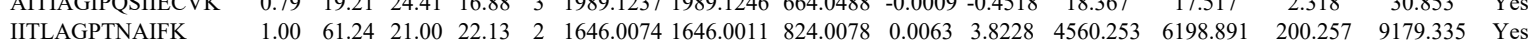
$\begin{array}{llllllllllllllll}\text { IITLAGPTNAIFK } & 1.00 & 65.10 & 21.04 & 22.13 & 2 & 1646.0090 & 1646.0011 & 824.0078 & 0.0079 & 4.7936 & 6363.881 & 6697.563 & 1466.818 & 10713.510 & \text { Yes }\end{array}$ $\begin{array}{llllllllllllllll}\text { LVVPASOCGSLIGK } & 1.00 & 75.65 & 26.22 & 33.96 & 2 & 1704.9566 & 1704.9510 & 853.4828 & 0.0056 & 3.2807 & 7802.075 & 6493.890 & 893.952 & 10275.409 & \text { Yes }\end{array}$ $\begin{array}{llllllllllllllll}\text { LVVPASQCGSLIGK } & 1.00 & 68.74 & 26.22 & 29.79 & 2 & 1704.9568 & 1704.9510 & 853.4828 & 0.0058 & 3.3978 & 6810.172 & 7690.519 & 475.127 & 11109.202 & \text { Yes }\end{array}$

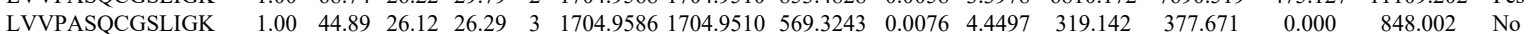
$\begin{array}{llllllllllllllll}\text { LVVPASQCGSLIGK } & 1.00 & 74.39 & 26.47 & 33.34 & 2 & 1704.9508 & 1704.9510 & 853.4828 & -0.0002 & -0.1172 & 2535.224 & 2709.203 & 424.209 & 3904.934 & \text { Yes }\end{array}$ $\begin{array}{lllllllllllllllll}\text { LVVPASQCGSLIGK } & 1.00 & 88.28 & 26.55 & 28.08 & 2 & 1704.9514 & 1704.9510 & 853.4828 & 0.0004 & 0.2343 & 2696.268 & 2486.176 & 161.848 & 3963.394 & \text { Yes }\end{array}$ $\begin{array}{lllllllllllllllll}\text { LVVPASQCGSLIGK } & 1.00 & 38.61 & 26.42 & 21.83 & 3 & 1704.9529 & 1704.9510 & 569.3243 & 0.0019 & 1.1124 & 340.717 & 414.139 & 188.624 & 505.709 & \text { Yes }\end{array}$ $\begin{array}{lllllllllllllllll}\text { LVVPASQCGSLIGK } & 0.99 & 27.84 & 26.38 & 21.20 & 3 & 1704.9538 & 1704.9510 & 569.3243 & 0.0028 & 1.6394 & 158.944 & 139.677 & 90.416 & 246.407 & \text { Yes }\end{array}$ $\begin{array}{lllllllllllllllll}\text { IITLAGPTNAIFK } & 0.63 & 6.18 & 21.52 & 14.25 & 3 & 1646.0038 & 1646.0011 & 549.6743 & 0.0027 & 1.6373 & 158.441 & 179.790 & 69.136 & 174.848 & \text { Yes }\end{array}$ $\begin{array}{lllllllllllllllllll}\text { IITLAGPTNAIFK } & 0.84 & 20.49 & 21.85 & 26.98 & 2 & 1646.0006 & 1646.0011 & 824.0078 & -0.0005 & -0.3034 & 90.478 & 84.896 & 45.346 & 107.632 & \text { Yes }\end{array}$ $\begin{array}{lllllllllllllllll}\text { IITLAGPTNAIFK } & 0.66 & 25.82 & 21.55 & 38.82 & 3 & 1646.0029 & 1646.0011 & 549.6743 & 0.0018 & 1.0916 & 128.519 & 145.678 & 50.643 & 165.874 & \text { Yes }\end{array}$ $\begin{array}{llllllllllllllllll}\text { IITLAGPTNAIFK } & 0.66 & 34.76 & 21.58 & 47.76 & 3 & 1646.0035 & 1646.0011 & 549.6743 & 0.0024 & 1.4554 & 148.824 & 196.253 & 47.237 & 277.100 & \text { Yes }\end{array}$ $\begin{array}{llllllllllllllll}\text { LVVPASQCGSLIGK } & 0.87 & 17.52 & 26.40 & 19.22 & 3 & 1704.9547 & 1704.9510 & 569.3243 & 0.0037 & 2.1663 & 27.691 & 40.576 & 16.000 & 40.935 & \text { Yes }\end{array}$ $\begin{array}{llllllllllllllll}\text { LVVPASQCGSLIGK } & 0.55 & 12.99 & 26.22 & 14.02 & 3 & 1704.9565 & 1704.9510 & 569.3243 & 0.0055 & 3.2202 & 19.250 & 24.334 & 6.617 & 19.762 & \text { Yes }\end{array}$

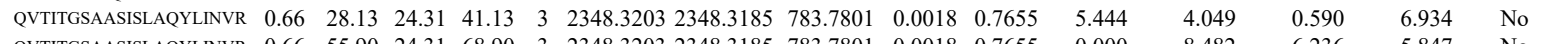

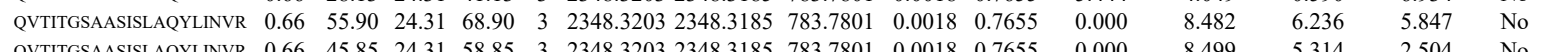

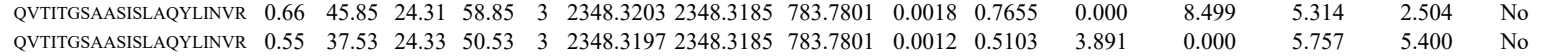
$\begin{array}{llllllllllllllll}\text { QVTITGSAASISLAQYLINVR } & 0.55 & 62.39 & 24.33 & 75.39 & 3 & 2348.3200 & 2348.3185 & 783.7801 & 0.0015 & 0.6379 & 9.530 & 3.170 & 5.208 & 1.702 & \text { No }\end{array}$

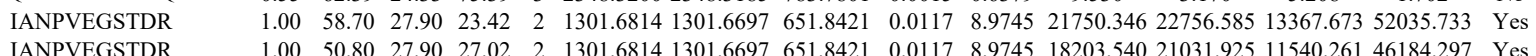

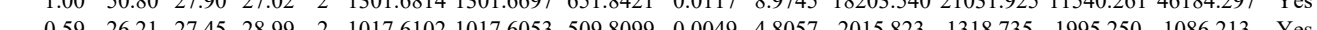



$\begin{array}{lllllllllllll}\text { LGAVFNQVAFPLQYTPR } & 0.99 & 27.92 & 26.59 & 20.93 & 3 & 2064.1303 & 2064.1278 & 689.0499 & 0.0025 & 1.2094 & 111.763 & 87.054\end{array}$ MFLYNLTLQR $\begin{array}{llllllllllll}1.00 & 43.92 & 27.55 & 24.02 & 2 & 1441.7882 & 1441.7873 & 721.9009 & 0.0009 & 0.6234 & 154.944 & 171.863\end{array}$

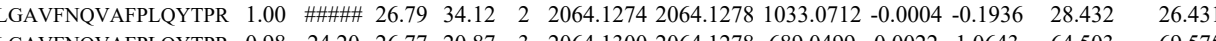

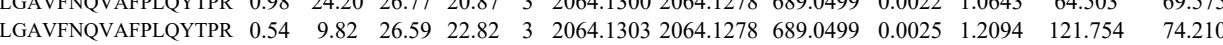
$\begin{array}{lllllllllllllll} & \text { TVLDPVTGDLSDTR } & 1.00 & 79.30 & 27.90 & 36.09 & 2 & 1631.8486 & 1631.8488 & 816.9317 & 0.0002 & 0.1224 & 753.384 & 843.103\end{array}$ $\begin{array}{llllllllllllllll}\text { TVLDPVTGDLSDTR } & 1.00 & 65.15 & 7.88 & 30.29 & 2 & 1631.8500 & 1631.8488 & 816.9317 & 0.0012 & 0.7345 & 1017.659 & 893.196\end{array}$

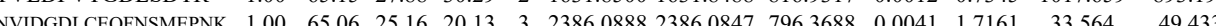

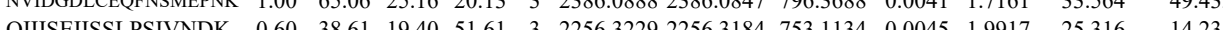
$\begin{array}{lllllllllllllll} & 14.238\end{array}$ $\begin{array}{lllllllllllll}\text { QUISEISSLPSIVNDK } & 0.60 & 35.08 & 19.40 & 48.08 & 3 & 2256.3226 & 2256.3184 & 753.1134 & 0.0042 & 1.8589 & 58.757 & 37.866\end{array}$

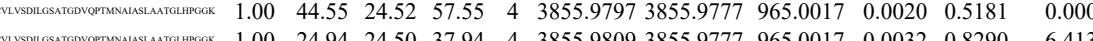

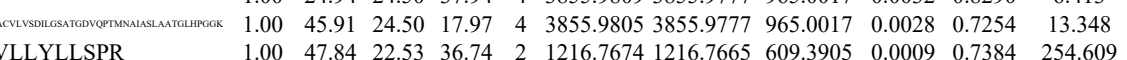
\begin{tabular}{lllllllllllll} 
& QAFEELRDDLVELSK & 0.74 & 43.84 & 22.53 & 36.74 & 2 & 1216.7674 & 216.7665 & 609.3905 & 0.0009 & 0.7384 & 254.609 \\
\hline & 0.73 .70 & 3 & 2079.1141 & 2079.1091 & 694.0436 & 0.0050 & 2.4014 & 2664.356
\end{tabular}

$\begin{array}{lllllllllllll}\text { ALYLSDNDFEILPPDIGK } & 1.00 & 36.03 & 26.61 & 17.09 & 3 & 2307.2245 & 2307.2242 & 770.0820 & 0.0003 & 0.1299 & 90.384\end{array}$ 286.059 $\begin{array}{lllllllllllll}\text { ALYLSDNDFEILPPDIGK } & 1.00 & 38.53 & 26.61 & 17.07 & 3 & 2307.2275 & 2307.2242 & 770.0820 & 0.0033 & 1.4284 & 68.329\end{array}$

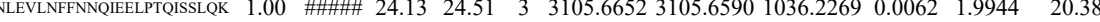

LQILSLR

LQILSLR

LQILSLR

KPLAAK

KPLAAK

LQILSLR

KPLAAK

KPLAAK

CNN3 HUMAN Q15417 CNN3 - Calpo

$\begin{array}{lllllllllllllll}36.414 & 1.00 & 3 & 14.9 & -1.0806 & 1.6242 & -0.0297 & 0.6502 & 7 & \text { YDHQAEEDLR }\end{array}$

YDHQAEEDLR

YDHQAEDDLR

$\begin{array}{llllllllll}19.08 & 26.25 & 32.08 & 3 & 2489.3191 & 2489.3158 & 830.7792 & 0.0033 & 1.3241 & 21.128\end{array}$

$\begin{array}{llllllllllll} & 1.00 & 74.42 & 26.27 & 23.49 & 2 & 2489.3194 & 2489.3158 & 1245.6652 & 0.0036 & 1.4450 & 29.565\end{array}$ $\begin{array}{lllllllllll}93.57 & 26.14 & 19.45 & 3 & 3173.6062 & 3173.6056 & 1058.8758 & 0.0006 & 0.1889 & 37.847 & 44.640\end{array}$ $\begin{array}{llllllllllllll}0.99 & 31.25 & 23.38 & 30.89 & 2 & 985.6422 & 985.6406 & 493.8276 & 0.0016 & 1.6200 & 6207.208 & 5899.219 & 2\end{array}$ $\begin{array}{llllllllllllll}0.99 & 33.64 & 23.20 & 30.73 & 2 & 985.6416 & 985.6406 & 493.8276 & 0.0010 & 1.0125 & 8566.443 & 7007.180 & 15 . \\ 0.99 & 33.32 & 23.20 & 32.19 & 2 & 985.6418 & 985.6406 & 493.8276 & 0.0012 & 1.2150 & 8512.868 & 8090.024 & 38.4\end{array}$ $\begin{array}{llllllllllllll}0.9 & 33.12 & 23.20 & 32.19 & 2 & 985.6418 & 985.6406 & 493.8276 & 0.0012 & 1.2150 & 8512.868 & 8\end{array}$ $\begin{array}{lllllllllllll}0.64 & 6.12 & 11.76 & 19.12 & 2 & 1058.7178 & 1058.7177 & 530.3661 & 0.0001 & 0.0943 & 176.464 & \\ 0.75 & 7.88 & 11.76 & 14.20 & 2 & 1058.7178 & 1058.7177 & 530.3661 & 0.0001 & 0.0943 & 117.992 & & \\ 0.98 & 30.36 & 23.20 & 32.04 & 2 & 985.6618 & 985.6406 & 493.826 & 0.0012 & 1.250 & 176.779 & \end{array}$

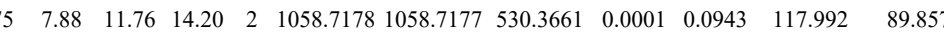

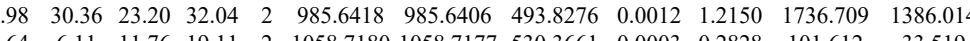
$\begin{array}{llllllllllllll}0.64 & 6.11 & 11.76 & 19.11 & 2 & 1058.7180 & 1058.7177 & 530.3661 & 0.0003 & 0.2828 & 101.612 & 33.519 & 4\end{array}$ $\begin{array}{lllllllllll}1.00 & 41.69 & 24.27 & 23.23 & 2 & 1418.6552 & 1418.6548 & 710.3347 & 0.0004 & 0.2816 & 14.532\end{array}$

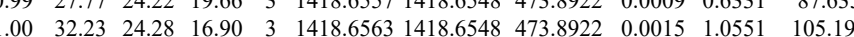
9.462 9.462 


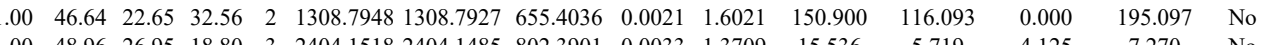
$\begin{array}{llllllllllllllll}\text { AIEDEGGNPDEIEITSEGNK } & 1.00 & 48.96 & 26.95 & 18.80 & 3 & 2404.1518 & 2404.1485 & 802.3901 & 0.0033 & 1.3709 & 15.536 & 5.719 & 4.125 & 7.270 & \text { No } \\ \text { ILDILGETCK } & 1.00 & 65.67 & 27.75 & 49.92 & 2 & 1437.7828 & 1437.7815 & 719.8980 & 0.0013 & 0.9029 & 162.211 & 136.453 & 0.000 & 683.032 & \text { No }\end{array}$

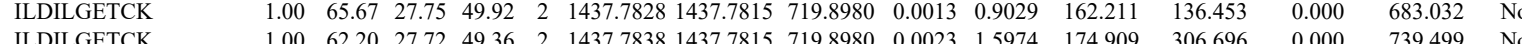

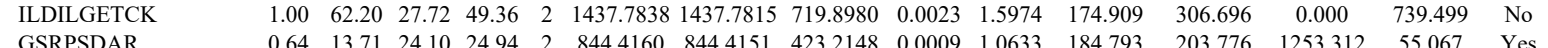

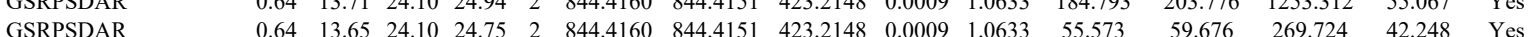

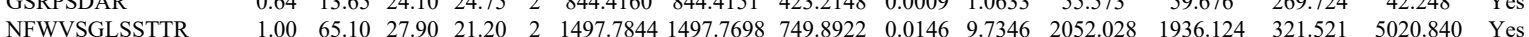
$\begin{array}{llllllllllllllll} & & \end{array}$

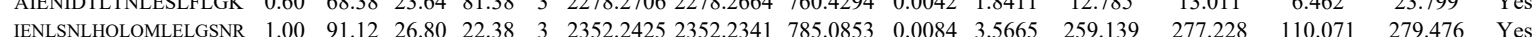

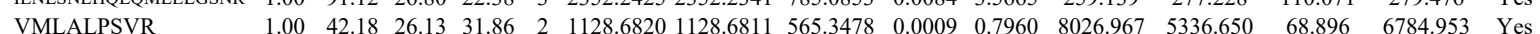
VMLALPSVR

GPQVQQPPPSR

GPQVQQPPPSNR

$\begin{array}{llllllllllll}1.00 & 42.18 & 26.13 & 31.86 & 2 & 1128.6820 & 1128.6811 & 565.3478 & 0.0009 & 0.7960 & 8026.967 & 5336.65\end{array}$ $68.896 \quad 6784.953$ Yes GPQVQQPPPSNR MVVPVAALFTPLK MVVPVAALFTPLK MVVPVAALFTPLK MVVPVAALFTPLK MVVPVAALFTPLK MVVPVAALFTPLK $\begin{array}{llllllllllll}1.00 & 40.42 & 26.13 & 32.00 & 2 & 1128.6824 & 1128.6811 & 565.3478 & 0.0013 & 1.1497 & 7342.920 & 5071.643\end{array}$ $\begin{array}{llllllllllll}0.96 & 29.85 & 28.69 & 21.67 & 2 & 1447.7660 & 1447.7654 & 724.8900 & 0.0006 & 0.4139 & 25.133 & 20.037 \\ 0.94 & 30.24 & 28.48 & 17.74 & 2 & 1447.7680 & 1447.7654 & 724.8900 & 0.0026 & 1.7934 & 15.583 & 19.651\end{array}$ $\begin{array}{llllllllllll}1.00 & 48.04 & 28.44 & 18.10 & 2 & 1447.7678 & 1447.7654 & 724.8900 & 0.0024 & 1.6554 & 9.696 & 11.466\end{array}$ $\begin{array}{lllllllllllll}0.60 & 17.51 & 19.54 & 30.51 & 3 & 1673.0230 & 1673.0194 & 558.6804 & 0.0036 & 2.1479 & 65.993 & 74.186\end{array}$ $\begin{array}{lllllllllllll}0.60 & 29.19 & 19.54 & 42.19 & 3 & 1673.0236 & 1673.0194 & 558.6804 & 0.0042 & 2.5059 & 160.774 & 164.092\end{array}$ $\begin{array}{lllllllllllll}1.00 & 65.01 & 19.49 & 26.98 & 2 & 1673.0212 & 1673.0194 & 837.5170 & 0.0018 & 1.0746 & 340.900 & 337.099\end{array}$ $\begin{array}{llllllllllll}1.00 & 62.54 & 19.49 & 20.97 & 2 & 1673.0216 & 1673.0194 & 837.5170 & 0.0022 & 1.3134 & 343.748\end{array}$ $\begin{array}{lllllllllllll}0.97 & 16.64 & 19.54 & 18.10 & 3 & 1673.0233 & 1673.0194 & 558.6804 & 0.0039 & 2.3269 & 34.551 & 72.147\end{array}$ MVVPVAALFTPLK MVVPVAALFTPLK

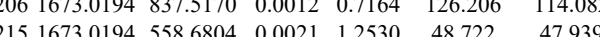
THETK

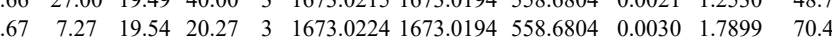

$\begin{array}{lllllllllllll} & \end{array}$

$\begin{array}{llllllllllllll} & & 65.45 & \end{array}$

$\begin{array}{lllllllllllll}\text { ICGLPPSTLGIYFEVVNNHNTPPPQGGR } & 1.00 & 67.63 & 25.92 & 80.63 & 4 & 3315.6537 & 3315.6502 & 829.9198 & 0.0035 & 1.0543 & 14.424 & 20.591 \\ \text { STGVALSIAVGLEGTPPNGAR } & 1.00 & 62.19 & 25.31 & 21.11 & 3 & 2374.3000 & 23742978 & 792.4399 & 0.0022 & 0.9254 & 2.069 & 6.522\end{array}$

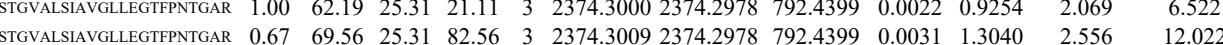

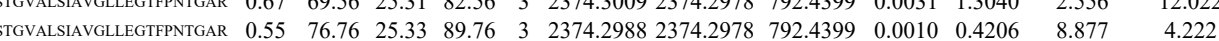

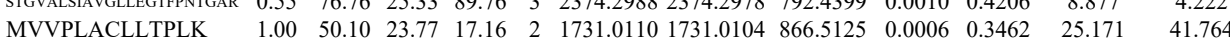
$\begin{array}{lllllllllllll} & & & \end{array}$ MVVLACLLTPLK MVVPLACLLTPLK

MVVPLACLLTPLK

MVTPLACLITLK

MVVPLACLLTPLK

MVVPLACLLTPLK

MVVPLACLLTPLK

AQEPSAAIPK EPPPEFEFIADPPS LTAQFVAR

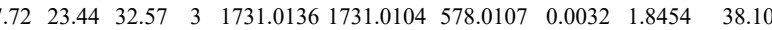
$\begin{array}{lllllllllll}42 & 23.89 & 18.34 & 3 & 1731.0118 & 1731.0104 & 578.0107 & 0.0014 & 0.8074 & 22.277\end{array}$ $\begin{array}{llllllllllll} & 0.03 & 17.82 & 16.42 & 2 & 1731.0122 & 1731.0104 & 866.5125 & 0.0018 & 1.0386 & 8.908 & 23.132\end{array}$

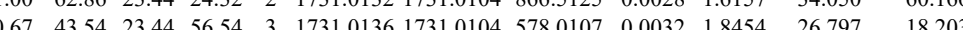

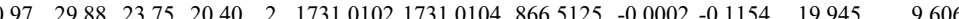

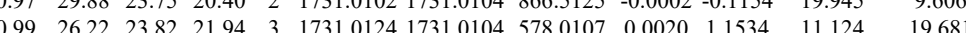
$\begin{array}{lllllllllllll}0.99 & 26.14 & 23.82 & 21.28 & 3 & 1731.0127 & 1731.0104 & 578.0107 & 0.0023 & 1.3264 & 13.061 & 11.882\end{array}$

ILGDPEALR TLFELAAESDVSTAIDLFR

TLFELAAESDVSTAIDLFR

GCPALPLSNLYYELLGVGSTTTQLYTDR

GCPALPLSNLYETLGVGSTTTQLYTDR
GCPALPLSNLYETLGVGSTTTLYYTDR

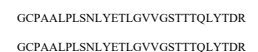

LTLLAPLNSVFK

LTLLAPLNSVFK $\begin{array}{llllllllllll}0.00 & 43.08 & 26.42 & 18.43 & 3 & 2946.5185 & 2946.5146 & 983.1788 & 0.0039 & 1.3222 & 7.634 & 0.001\end{array}$

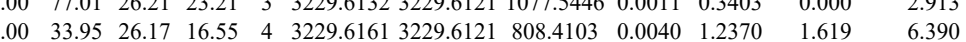
$\begin{array}{llllllllllll}00 & 37.02 & 26.23 & 15.53 & 4 & 3229.6197 & 3229.6121 & 808.4103 & 0.0076 & 2.3503 & 13.042 & 2.834\end{array}$ $\begin{array}{llllllllllll}1.00 & 49.81 & 26.21 & 17.90 & 3 & 3229.6132 & 3229.6121 & 1077.5446 & 0.0011 & 0.3403 & 0.000 & 0.000\end{array}$ $\begin{array}{lllllllllllll}0.64 & 67.61 & 19.24 & 80.61 & 2 & 1602.9950 & 1602.9952 & 802.5049 & -0.0002 & -0.1246 & 1272.809 & 2318.884\end{array}$

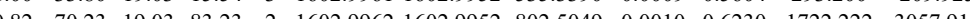


LTLLAPLNSVFK LTLLAPLNSVFK LTLLAPLNSVFK LTLLAPLNSVFK LTLLAPLNSVFK LTLLAPLNSVFK LTLLAPLNSVFK FSMLVAAIQSAGLTETL FSMLVAAIQSAGLTETLN FSMLVAAIQSAGLIETL FSMLVAAIQSAGLTETLNR FSMLVAAIQSAGLTETL GDELADSALEIFK GDELADSALEIFK GDELADSALEIFK GDELADSALEIFK GDELADSALEIFK

6 FQRPGDPQSAQDK FQRPGDPQSAQDK VMIPQDEYPEINFVGLLIGPR VMIPQDEYPEINFVGLLIGPR VMIPQDEYPEINFVGLLIGPR
VMIPQDEYPEINFVGLLIGPR ILRPWQSSETR

ILRPWQSSETR

ILRPWQSSETR

ILRPWQSSETR

TVIPGMPTVIPPGLTR

$\begin{array}{lllllllllllll}\text { TVIPGMPTVIPPGLTR } & 1.00 & 74.87 & 23.18 & 28.62 & 2 & 1792.0418 & 1792.0403 & 897.0274 & 0.0015 & 0.8361 & 527.784 & 360 . \\ \text { TVIPGMPTVIPPGLTR } & 0.67 & 37.75 & 23.26 & 50.75 & 3 & 1792.0435 & 1792.0403 & 598.3540 & 0.0032 & 1.7827 & 19.249 & \end{array}$

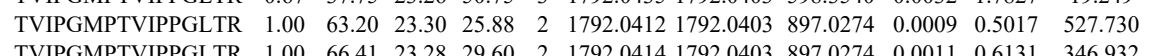

$\begin{array}{llllllllllllll}\text { TVIPGMPTVIPPGLTR } & 1.00 & 26.56 & 23.28 & 29.60 & 2 & 1792.0414 & 1792.0403 & 897.0274 & 0.0011 & 0.6131 & 346.932 & 437.25 \\ \text { TVIPMPTI } & 1792.0432 & 1792.0403 & 598.3540 & 0.0029 & 1.6155 & 33.344 & 31.5\end{array}$

$\begin{array}{lllllllllllll}\text { TVIPGMPTVIPPGLTR } & 1.00 & 62.32 & 23.30 & 29.32 & 2 & 1792.0412 & 1792.0403 & 897.0274 & 0.0009 & 0.5017 & 67.25 & \end{array}$

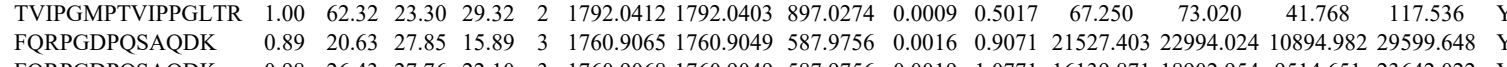

$\begin{array}{llllllllllllllll}\text { FQRPGDPQSAQDK } & 0.98 & 26.43 & 27.76 & 22.10 & 3 & 1760.9068 & 1760.9049 & 587.9756 & 0.0019 & 1.0771 & 16139.871 & 18902.954 & 9514.651 & 23642.022 & \text { Yes }\end{array}$

$\begin{array}{lllllllllll}\text { TRP13_HUMAN } & \text { Q15645 } & \text { TRIP13 } & \text { Thyroid receptor-i } 48.551 & 1.00 & 4 & 12.7 & -0.1757 & 0.3127 & 2.3717 & 0.3914\end{array}$

MIGFIENNVSK

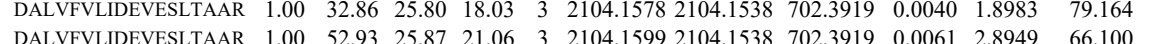

$\begin{array}{llllllllllllll}\text { DALVFULDEISLIA } & 1.00 & 52.93 & 25.87 & 21.06 & 3 & 2104.1599 & 2104.1538 & 72.3919 & 0.061 & 2.8949 & 66.100\end{array}$

VVNAVLTQIDQIX
LSLLLNDISR

LSLLLNDISR
LSLLLNDISR

LSLLLNDISR

LSLLLNDISR

$\begin{array}{lllllllllll}1.00 & 51.42 & 25.09 & 37.12 & 2 & 12867706 & 12867680 & 644.3913 & 0.0026 & 2.0174 & 415.763\end{array}$

$\begin{array}{lllllllllllll}1.00 & 63.77 & 24.77 & 42.92 & 2 & 1286.7710 & 1286.7680 & 644.3913 & 0.0030 & 2.3278 & 943.843\end{array}$

$\begin{array}{llllllllllll}1.00 & 65.98 & 25.09 & 39.69 & 2 & 1286.7706 & 1286.7680 & 644.3913 & 0.0026 & 2.0174 & 2216.946 & 2343.99\end{array}$

$\begin{array}{lllllllllll}1.00 & 67.61 & 25.09 & 41.13 & 2 & 1286.7706 & 1286.7680 & 644.3913 & 0.0026 & 2.0174 & 2293.589\end{array}$ $\begin{array}{lllllllllllll}\text { AETLADTPALSLIAETVEDMVK } & 0.84 & 30.62 * & 26.06 & 19.39 & 3 & 2732.4418 & 2732.4397 & 911.8205 & 0.0021 & 0.7677 & 6.678\end{array}$

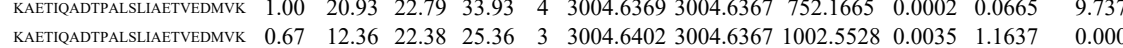
VPLILNLIR

VPLILNLIR $0.64 \quad 16.88$

VPLILNLIR

$\begin{array}{lllllllllllll}1.00 & 30.06 & 9.54 & 14.90 & 2 & 1193.7996 & 1193.7981 & 597.9063 & 0.0015 & 1.2544 & 82.190\end{array}$

$\begin{array}{llllllllllllll}0.64 & 24.02 & 10.00 & 37.02 & 2 & 1193.7986 & 1193.7981 & 597.9063 & 0.0005 & 0.4181 & 24.789\end{array}$

$\begin{array}{llllllllllllll} & 0.82 & 31.03 & 9.54 & 44.03 & 2 & 1193.7992 & 1193.7981 & 597.9063 & 0.0011 & 0.9199 & 35.410 & 42 \\ & 0.55 & 74.89 & 27.54 & 87.89 & 3 & 1901.0152 & 1901.0142 & 6346787 & 0.0010 & 0.5252 & 359.205 & 298\end{array}$

$\begin{array}{llllllllllllll} & \end{array}$

$\begin{array}{llllllllllllll}\text { GTPGPPPAHGAALQPHPR } & 0.55 & 61.08 & 27.54 & 74.08 & 3 & 1901.0152 & 1901.0142 & 634.6787 & 0.0010 & 0.5252 & 1179.367 & 983.256 & 1402\end{array}$

$\begin{array}{lllllllllllll}\text { GTPGPPAHGALQPPHPR } & 1.00 & 88.29 & 27.36 & 4 & 4 & 1901.0177 & 1901.0142 & 476.2608 & 0.0035 & 1.8372 & 3411.129 & 5147.811 \\ \text { GTPPPAHGALQPHPR } & 1.00 & 68.72 & 27.36 & 81.72 & 4 & 1901.0177 & 1901.0142 & 476.2608 & 0.0035 & 1.8372 & 2468.220 & 2392.285\end{array}$

$\begin{array}{llllllllllllll}\text { GTPGPPPAHGAALQPHPR } & 0.96 & 29.27 & 27.44 & 26.03 & 3 & 1901.0131 & 1901.0142 & 634.6787 & -0.0011 & -0.5777 & 224.378 & 181.861 \\ \text { GTPGPPAHGAALPHPR } & 1.00 & 71.02 & 27.52 & 84.02 & 4 & 1901.0149 & 1901.0142 & 476.2608 & 0.0007 & 0.3674 & 683.742 & 930.010\end{array}$ $\begin{array}{llllllllllllll}\text { GTPGPPPAHGAALQPHPR } & 1.00 & 71.02 & 27.52 & 84.02 & 4 & 1901.0149 & 1901.0142 & 476.2608 & 0.0007 & 0.3674 & 683.742 & 930\end{array}$ $\begin{array}{lllllllllllll}\text { GTPGPPPAHGAALQPHPR } & 1.00 & 64.16 & 27.53 & 17.52 & 4 & 1901.0157 & 1901.0142 & 476.2608 & 0.0015 & 0.7874 & 1942.021 & 29.4 \\ \text { GTPGPPPAHGAALQPHPR } & 1.00 & 78.58 & 27.52 & 22.35 & 4 & 1901.0149 & 1901.0142 & 476.2608 & 0.0007 & 0.3674 & 3193.736 & 29.4 .\end{array}$ $\begin{array}{llllllllllllll}\text { GTPGPPPAHGAALQPHPR } & 1.00 & 66.04 & 27.57 & 17.15 & 4 & 1901.0161 & 1901.0142 & 476.2608 & 0.0019 & 0.9974 & 986.397 & 963\end{array}$

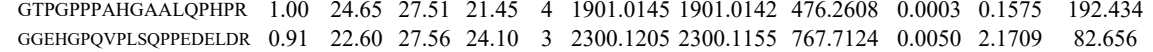

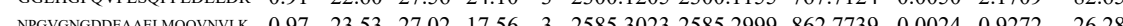

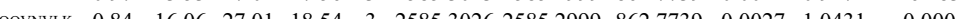

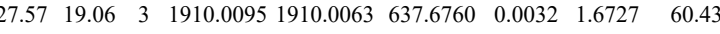
$\begin{array}{llll}8.974 & 0.000 & 14.472 & \text { No }\end{array}$ $\begin{array}{cccc}8.955 & 44.136 & \mathrm{Y} & \\ 15 & 23.000 & 25.807 & \end{array}$ $\begin{array}{llll}18975.674 & \text { Yes } \\ 710.368 & 4341.454 & \text { Yes }\end{array}$ $\begin{array}{lll}242.288 & 632.475 & \text { Yes }\end{array}$ $\begin{array}{llll}9.688 & 242.288 & 632.475 & \text { Yes }\end{array}$ $\begin{array}{lll}33.230 & 36.008 & \text { Yes }\end{array}$ \begin{tabular}{lll}
39.685 & 94.739 & Yes \\
\hline 4.030 & 87.153 & Yes
\end{tabular} $\begin{array}{lll}54.403 & 78.026 & \text { Yes }\end{array}$ $\begin{array}{ccc}14.706 & 39.558 & \text { Yes } \\ 3.732 & 276.605 & \text { Yes }\end{array}$ $\begin{array}{llll}5.284 & 1212.793 & \text { Yes }\end{array}$ $220.801 \quad 2457.311$ Yes $\begin{array}{llll}44.030 & 2411.658 & \text { Yes }\end{array}$ $\begin{array}{llll}7.913 & 5.815 & \text { Yes }\end{array}$ $\begin{array}{llll}4.463 & 8.647 & 16.567 & \text { Yes }\end{array}$ $\begin{array}{llll}3.632 & 6.457 & 7.162 & \text { No } \\ 6.369 & 2.830 & 4.882 & \text { Yes }\end{array}$ $\begin{array}{llll}7.789 & 7.606 & 13.626 & \text { Yes }\end{array}$ $\begin{array}{lll}150.452 & 179.729 & \text { Yes }\end{array}$ $36.033 \quad 33.849$ Yes $\begin{array}{lll}1491.754 & 1829.017 & \text { Yes } \\ 3 & 2736.900 & \text { Yes }\end{array}$ $\begin{array}{lll} & \\ 324.920 & 2847.541 & \text { Yes }\end{array}$ 104.659
2303.180
3500.654 \begin{tabular}{llll}
\hline .722 & 2903.522 & 4043.811 & Yes
\end{tabular}

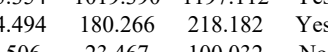


$\begin{array}{llllllllllllllllll}0.59 & 30.49 & 26.79 & 38.52 & 2 & 1063.6700 & 1063.6633 & 532.8389 & 0.0067 & 6.2870 & 15979.736 & 23171.276 & 2713.722 & 49430.360 & \text { Yes }\end{array}$ $\begin{array}{lllllllllllllll} & 0.73 & & \end{array}$ $\begin{array}{llllllllllllllllll}\text { KPLISSSAPPISTQR } & 1.00 & 33.57 & 23.12 & 46.57 & 4 & 2212.2545 & 2212.2531 & 554.0706 & 0.0014 & 0.6317 & 117.163 & 178.601 & 224.050 & 133.736 & \text { Yes }\end{array}$

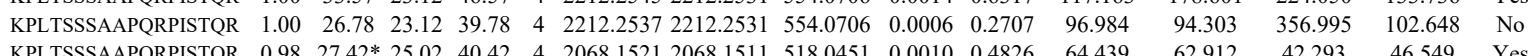

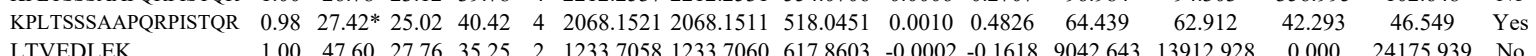

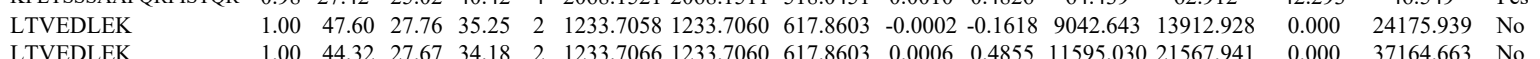
$\begin{array}{llllllllllllllll} & 1.00 & 44.32 & 27.67 & 34.18 & 2 & 1233.7066 & 1233.7060 & 617.8603 & 0.0006 & 0.4855 & 11595.030 & 21567.941 & 0.000 & 37164.663 & \text { No }\end{array}$ \begin{tabular}{llllllllllllllll} 
NIELICQENEGENDPVLQR & 1.00 & 65.03 & 26.89 & 24.25 & 2 & 2402.1334 & 2402.1328 & 1202.0737 & 0.0006 & 0.2496 & 29.898 & 56.502 & 48.962 & 60.372 & Yes \\
\hline
\end{tabular}

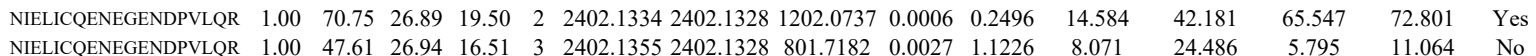
\begin{tabular}{llllllllllllllll} 
NPGVGNGDDEAAELMQQVNVLK & 1.00 & 41.07 & 26.91 & 21.44 & 3 & 2402.1358 & 2402.1328 & 801.7182 & 0.0030 & 1.2473 & 10.046 & 42.691 & 45.260 & 15.770 & Yes \\
\hline
\end{tabular}

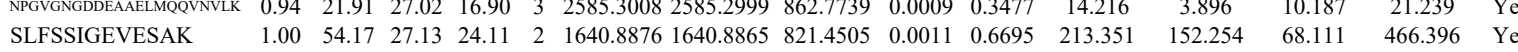

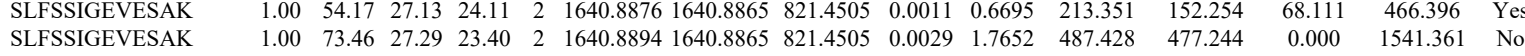

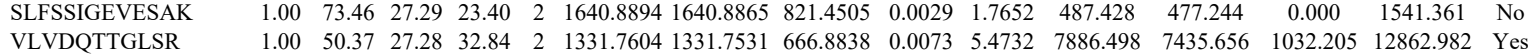
$\begin{array}{llllllllllllllll}\text { TNLIVNYLPQNMTQDELR } & 1.00 & 75.86 & 27.79 & 25.37 & 2 & 2305.1854 & 2305.1858 & 1153.6002 & -0.0004 & -0.1734 & 85.104 & 62.616 & 38.590 & 149.529 & \text { Yes }\end{array}$

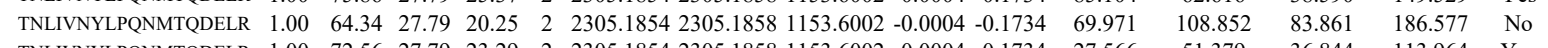

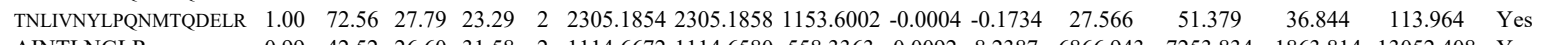

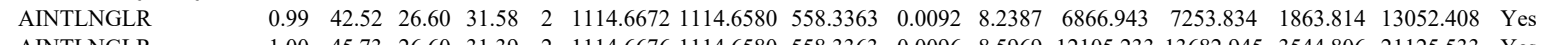

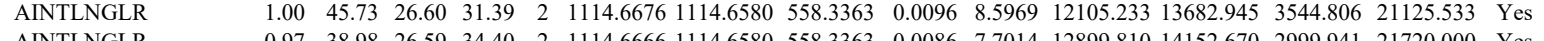
$\begin{array}{llllllllllllllll}\text { AINTLNGLR } & 0.97 & 38.98 & 26.59 & 34.40 & 2 & 1114.6666 & 1114.6580 & 558.3363 & 0.0086 & 7.7014 & 12899.810 & 14152.670 & 2999.941 & 21720.000 & \text { Yes }\end{array}$

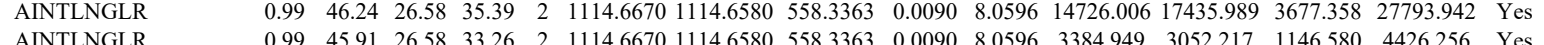
AINTLNGLR

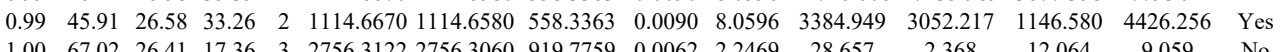

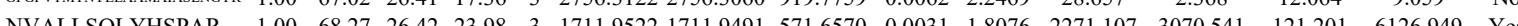
$\begin{array}{llllllllllllllll}\text { NVALLSQLYHSPAR } & 1.00 & 68.27 & 26.42 & 23.98 & 3 & 1711.9522 & 1711.9491 & 571.6570 .0031 & 1.8076 & 2271.107 & 3070.541 & 121.201 & 6126.949 & \text { Yes }\end{array}$

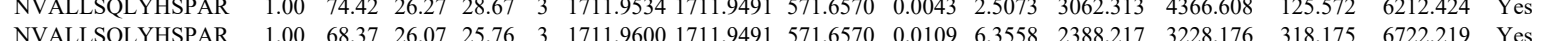
$\begin{array}{llllllllllllllll}\text { NVALLSQLYHSAR } & 1.00 & 68.37 & 26.07 & 25.76 & 3 & 171.960 & 171.9491 & 51.6570 & 0.011 & 6.358 & 2388.217 & 3228.176 & 318.175 & 6722.219 & \text { Yes } \\ \text { NVALLSQLYHSPAR } & 1.00 & 70.84 & 26.17 & 28.14 & 3 & 1711.9609 & 1711.9491 & 571.6570 & 0.0118 & 6.8805 & 4148837 & 3766344 & 289.860 & 6537.716 & \text { Yes }\end{array}$ \begin{tabular}{llllllllllllllll} 
NVALLSQLYHSPAR & 1.00 & 70.17 & 26.31 & 29.70 & 3 & 1711.9555 & 1711.9491 & 571.6570 & 0.0064 & 3.7318 & 1292.317 & 1180.708 & 203.790 & 2041.027 & Yes \\
\hline
\end{tabular} $\begin{array}{llllllllllllllll}\text { NVALLSLCSHSPR } & 1.00 & 64.33 & 26.34 & 21.60 & 3 & 1711.9567 & 1711.9491 & 571.6570 & 0.0076 & 4.4315 & 2001.064 & 2322.519 & 421.496 & 2947.341 & \text { Yes } \\ \text { NVALLSQLYHSAR }\end{array}$ $\begin{array}{lllllllllllllllll}\text { NVALLSQLYHSPAR } & 1.00 & 64.33 & 26.34 & 21.60 & 3 & 1711.9567 & 1711.9491 & 571.6570 & 0.0076 & 4.4315 & 2001.064 & 2322.519 & 421.496 & 2947.341 & \text { Yes } \\ \text { NVALLSQLYHSPAR } & 1.00 & 38.15 & 26.27 & 20.55 & 3 & 1711.9534 & 1711.9491 & 571.6570 & 0.0043 & 2.5073 & 384.233 & 544.086 & 23.472 & 397.473 & \text { No }\end{array}$

5 SELPLDPLPYPTEEGNPLIK NIFPSNLVSAAFR NIFPSNLVSAAFR NIFPSNLVSAAFR NIFPSNLVSAAFR NIFPSNLVSAAFR

\section{STEPELIQVK}

STEPELIQVK

EEGNELVK

EEGNELVK

WNSLPSENHK

TVLQIDDNVTSAVEGINR

SSFADISNLLQIEPR SSFADISNLLQIEPR SSFADISNLLQIEPR LPSIPLVPVSAQK LPSIPLVPVSAQK LPSIPLVPVSAQK LPSIPLVPVVAQK LPDSVEELR

FPDSVEELR $\begin{array}{llllllllllll}0.64 & 64.67 & 23.32 & 77.67 & 2 & 2445.3614 & 2445.3610 & 1223.6878 & 0.0004 & 0.1634 & 27.430 & 13.576 \\ 1.00 & 71.17 & 27.64 & 23.68 & 2 & 1578.8650 & 1578.8640 & 790.4393 & 0.0010 & 0.6326 & 492.654 & 521.559\end{array}$

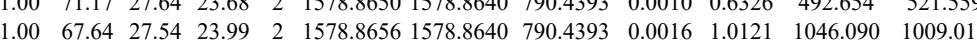
$\begin{array}{llllllllllll}1.00 & 72.21 & 27.64 & 25.68 & 2 & 1578.8650 & 1578.8640 & 790.4393 & 0.0010 & 0.6326 & 511.699 & 409.601\end{array}$ $\begin{array}{llllllllllll}1.00 & 60.99 & 27.64 & 23.56 & 2 & 1578.8650 & 1578.8640 & 790.4393 & 0.0010 & 0.6326 & 150.879 & 150.706\end{array}$ $\begin{array}{lllllllllllllll}1.00 & 60.99 & 27.64 & 23.56 & 2 & 1578.8650 & 1578.8640 & 790.4393 & 0.0010 & 0.6326 & 150.879 & 150.706 & 0.000 & 125.304 & \mathrm{~N} \\ 1.00 & 62.84 & 27.66 & 33.67 & 2 & 1578.8652 & 1578.8640 & 790.4393 & 0.0012 & 0.7591 & 106.319 & 93.620 & 0.000 & 98.259 & \mathrm{~N} \\ 0.67 & 76.99 & 23.73 & 89.99 & 3 & 3114.6772 & 3114.6741 & 1039.2320 & 0.0031 & 0.9943 & 4.113 & 1.472 & 2.898 & 6.916 & \mathrm{Y}\end{array}$

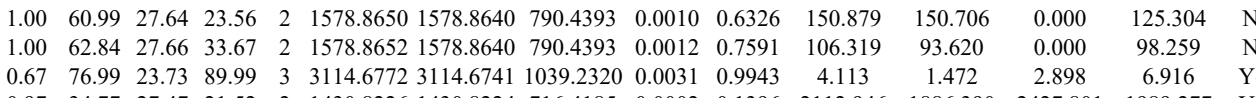
$\begin{array}{lllllllllllll} & \end{array}$ $\begin{array}{llllllllllllllll}1.00 & 43.79 & 27.25 & 23.38 & 2 & 1430.8232 & 1430.8224 & 716.4185 & 0.0008 & 0.5583 & 1842.257 & 1412.527 & 1974.946 & 1659.016 & \text { Yes }\end{array}$ $\begin{array}{llllllllllllllll}0.51 & 24.87 & 28.86 & 27.54 & 2 & 1204.6536 & 1204.6543 & 603.3344 & -0.0007 & -0.5801 & 87.644 & 121.311 & 140.752 & 238.555 & \text { Yes }\end{array}$

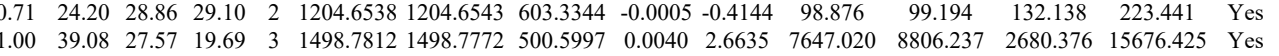
$\begin{array}{llllllllllllllll}0.66 & 62.83 & 27.50 & 75.83 & 3 & 2087.1001 & 2087.0981 & 696.7066 & 0.0020 & 0.9569 & 264.860 & 333.452 & 394.251 & 300.268 & \text { Yes }\end{array}$

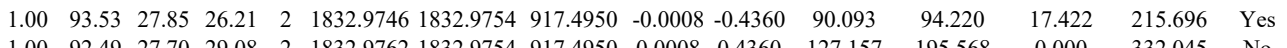

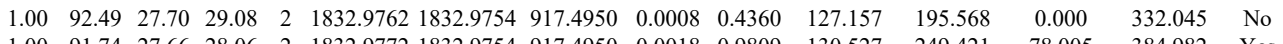

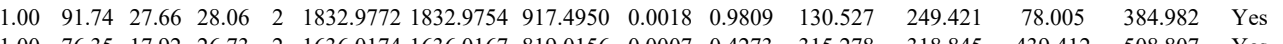
$\begin{array}{lllllllllllllll}1.00 & 76.35 & 17.92 & 26.73 & 2 & 1636.0174 & 1636.0167 & 819.0156 & 0.0007 & 0.4273 & 315.278 & 318.845 & 439.412 & 508.807 & \text { Yes } \\ 1.00 & 84.49 & 17.92 & 25.17 & 2 & 1636.0184 & 1636.0167 & 819.0156 & 0.0017 & 1.0378 & 48.856 & 478.486 & 994.812 & 988.99 & \text { Yes }\end{array}$ $\begin{array}{lllllllllllllll}1.00 & 84.49 & 17.92 & 25.17 & 2 & 1636.0184 & 1636.0167 & 819.0156 & 0.0017 & 1.0378 & 484.856 & 478.486 & 994.812 & 988.990 & \text { Yes } \\ 0.66 & 1426 & 17.48 & 27.26 & 3 & 1636.0192 & 1636.0167 & 5463462 & 0.0025 & 1.5253 & 394.243 & 350.397 & 147.412 & 172.209 & \text { No }\end{array}$ $\begin{array}{lllllllllllllll}0.66 & 14.26 & 17.48 & 27.26 & 3 & 1636.0192 & 1636.0167 & 546.3462 & 0.0025 & 1.5253 & 394.243 & 350.397 & 147.412 & 172.209 & \text { No } \\ 0.67 & 15.05 & 17.63 & 28.05 & 3 & 16360198 & 16360167 & 546.3462 & 0.0031 & 1.8913 & 455.449 & 420.893 & 99.243 & 207.661 & \text { No }\end{array}$ $\begin{array}{lllllllllllllll}0.67 & 15.05 & 17.63 & 28.05 & 3 & 1636.0198 & 1636.0167 & 546.3462 & 0.0031 & 1.8913 & 455.449 & 420.893 & 99.243 & 207.661 & \text { No } \\ 1.00 & 71.74 & 17.92 & 25.68 & 2 & 16360168 & 16360167 & 8190156 & 0.0001 & 0.0610 & 127.087 & 105.412 & 85.188 & 195.775 & \text { Yes }\end{array}$

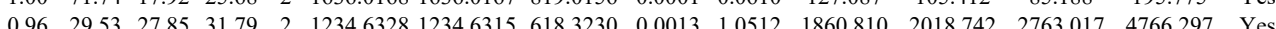

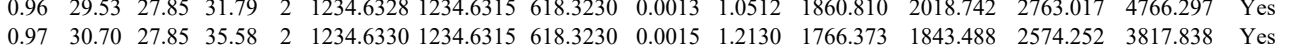



$\begin{array}{lllllllllllllllll}0.90 & 32.07 & 27.47 & 24.73 & 2 & 1158.6248 & 1158.6155 & 580.3150 & 0.0093 & 8.0128 & 8458.691 & 6983.743 & 8879.610 & 9876.071 & \text { Yes } \\ \end{array}$ $\begin{array}{llllllllllllllll}0.91 & 31.92 & 28.02 & 22.69 & 2 & 1158.6250 & 1158.6155 & 580.3150 & 0.0095 & 8.1851 & 6372.780 & 4931.292 & 6977.248 & 8947.396 & \text { Yes }\end{array}$

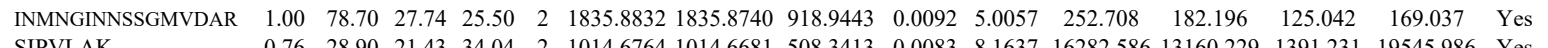
$\begin{array}{lllllllllllllllll}\text { SIPVLAK } & 0.76 & 28.90 & 21.43 & 34.04 & 2 & 1014.6764 & 1014.6681 & 508.3413 & 0.0083 & 8.1637 & 16282.586 & 13160.229 & 1391.231 & 19545.986 & \text { Yes } \\ \text { SIPVLAK } & 1.00 & 43.15 & 19.59 & 27.41 & 2 & 1014.6774 & 1014.6681 & 508.3413 & 0.0093 & 9.1473 & 15417.968 & 11411.848 & 1329.726 & 18003.231 & \text { Yes }\end{array}$ $\begin{array}{llllllllllllllllll} & \end{array}$

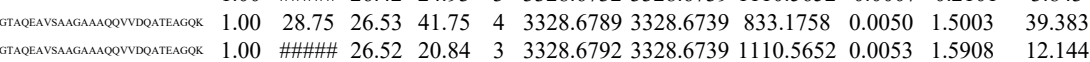

$\begin{array}{llllllllllll}\text { VSSIDLEIDSLSSLLDDMTK } & 0.60 & 42.37 & 27.62 & 55.37 & 3 & 2468.2849 & 2468.2811 & 823.7676 & 0.0038 & 1.5376 & 5.904\end{array}$

$\begin{array}{lllllllllllllll} & \text { FSPGAPGGSGSQPNQK } & 1.00 & 89.55 & 28.10 & 22.67 & 2 & 1802.9152 & 1802.9155 & 902.4650 & -0.0003 & -0.1662 & 769.469 & 668.350\end{array}$ $\begin{array}{llllllllllll} & \end{array}$

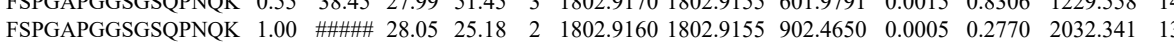
\begin{tabular}{llllllllllllll}
\hline & Q
\end{tabular} $\begin{array}{lllllllllllll} & \end{array}$ $\begin{array}{llllllllll} & \text { Q }\end{array}$ $\begin{array}{llllllllllll}\text { QHPVPPPAQNQNQVR } & 1.00 & 34.48 & 27.57 & 18.63 & 3 & 1852.9804 & 1852.9778 & 618.6665 & 0.0026 & 1.4009 & 15.457\end{array}$ $\begin{array}{llllllllllll}\text { QHPVPPPAQNQNQVR } & 1.00 & 38.01 & 27.60 & 22.03 & 3 & 1852.9783 & 1852.9778 & 618.6665 & 0.0005 & 0.2694 & 24.681\end{array}$ $\begin{array}{lllllllllllll}\text { QHPVPPPAQNQNQVR } & 1.00 & 43.95 & 27.60 & 25.10 & 3 & 1852.9792 & 1852.9778 & 618.6665 & 0.0014 & 0.7543 & 23.155\end{array}$ $\begin{array}{llllllllllllll} & \text { QPGAPGPLTLK } & 0.99 & 40.19 & 22.86 & 22.41 & 2 & 1324.8056 & 1324.7958 & 663.4052 & 0098 & 7.3861 & 2742.353 & 2012.038\end{array}$ $\begin{array}{llllllllllllll}\text { SPGAPGPLTLK } & 0.96 & 30.62 & 23.05 & 20.97 & 2 & 1324.8062 & 1324.7958 & 663.4052 & 0.0104 & 7.8383 & 1932.854 & 142 .\end{array}$ $\begin{array}{lllllllllllll}\text { QHPVPPAQNQNQQVR } & 1.00 & 36.55 & 27.60 & 23.89 & 3 & 1852.9819 & 1852.9778 & 618.6665 & 0.0041 & 2.2090 & 10.919 & 6.89 \\ \text { VNPFRPGDSEPPPAPGAQR } & 0.96 & 31.95 & 27.61 & 21.48 & 3 & 2132.1025 & 2132.0885 & 711.7034 & 0.0140 & 6.5570 & 1972.373 & 169\end{array}$ $\begin{array}{lllllllllllll}\text { LGHPEALAGGGSPPPSETYAQQR } & 1.00 & 71.09 & 27.26 & 19.13 & 3 & 2740.3945 & 2740.3691 & 914.4636 & 0.0254 & 9.2585 & 32.952\end{array}$ $\begin{array}{llllllllllll}\text { QHPVPPPAQNQNQVR } & 0.86 & 17.47 & 27.61 & 14.97 & 3 & 1852.9795 & 1852.9778 & 618.6665 & 0.0017 & 0.9159 & 21.016\end{array}$

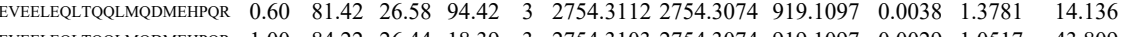
$\begin{array}{llllllllllll}\text { EVEELEQLTQQLMQDMEHPQR } & 1.00 & 84.22 & 26.44 & 18.39 & 3 & 2754.3103 & 2754.3074 & 919.1097 & 0.0029 & 1.0517 & 43.809\end{array}$ $\begin{array}{llllllllllll}\text { ADTLTPEECQQFK } & 0.97 & 65.34 * 26.43 & 37.60 & 2 & 1842.8752 & 1842.8736 & 922.4441 & 0.0016 & 0.8673 & 313.241 & 287\end{array}$ $\begin{array}{lllllllllllll}\text { NLEGYVGFANLPNQVYR } & 1.00 & \text { \#\#\#\# } 27.56 & 21.34 & 2 & 2097.0814 & 2097.0765 & 1049.5455 & 0.0049 & 2.3343 & 266.953 & 323\end{array}$ $\begin{array}{lllllllllllll}\text { NLEGYVGFANLPNQVYR } & 0.99 & 34.84 & 27.54 & 19.91 & 3 & 2097.0823 & 2097.0765 & 700.0328 & 0.0058 & 2.7618 & 238.615 & 25 \\ \text { STLNSLELTLYSPEYPGPSR } & 1.00 & 89.83 & 27.34 & 20.89 & 3 & 2750.4067 & 2750.4037 & 917.8085 & 0.0030 & 1.0896 & 129.819 & 51\end{array}$ $\begin{array}{llllllllllll}\text { STLINSLFLTDLYSPEYPGPSHR } & 1.00 & 89.83 & 27.34 & 20.89 & 3 & 2750.4067 & 2750.4037 & 917.8085 & 0.0030 & 1.0896 & 129.819\end{array}$ $\begin{array}{lllllllllllll}\text { STLINSLFLTDLYSPEYPGPSHR } & 0.67 & 80.49 & 27.33 & 93.49 & 3 & 2750.4070 & 2750.4037 & 917.8085 & 0.0033 & 1.1985 & 114.762\end{array}$ $\begin{array}{lllllllllllll}\text { IYEFPETDDEEENK } & 1.00 & 35.27 & 25.94 & 19.14 & 3 & 2044.9381 & 2044.9357 & 682.6525 & 0.0024 & 1.1719 & 335.531 \\ \text { IYEFPETDDEEENK } & 0.89 & 16.52 & 25.94 & 17.07 & 3 & 2044.9390 & 2044.9357 & 682.6525 & 0.0033 & 1.6114 & 169.826\end{array}$ $\begin{array}{llllllllllll}\text { IYEFPETDDEEENK } & 0.89 & 16.52 & 25.94 & 17.07 & 3 & 2044.9390 & 2044.9357 & 682.6525 & 0.0033 & 1.6114 & 169.826 \\ \text { IYEFPETDDEEENK } & 1.00 & 81.22 & 25.98 & 18.91 & 2 & 2044.9394 & 2044.9357 & 1023.4751 & 0.0037 & 1.8076 & 22.302\end{array}$ TYEFPETDDEEENK TYEFPETDDEE SPLAQMEEER IYEFPETDDEEENK $\begin{array}{lllllllllll}1.00 & 81.22 & 25.98 & 18.91 & 2 & 2044.9394 & 2044.9357 & 1023.4751 & 0.0037 & 1.8076 & 22.302 \\ 1.00 & 71.44 & 26.01 & 23.08 & 2 & 2044.9414 & 2044.9357 & 1023.4751 & 0.0057 & 2.7846 & 15.628\end{array}$ $\begin{array}{lllllllllll}1.00 & 71.44 & 26.01 & 23.08 & 2 & 2044.9414 & 2044.9357 & 1023.4751 & 0.0057 & 2.7846 & 15.628 \\ 1.00 & 36.93 & 26.30 & 24.97 & 2 & 1332.6488 & 1332.6465 & 667.3305 & 0.0023 & 1.7233 & 663.523\end{array}$

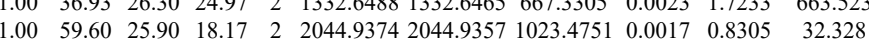

$\begin{array}{llllllllll} & \end{array}$ $\begin{array}{llllllllllll}\text { SQSAAVSSTTSTR } & 1.00 & 56.63 & 27.73 & 22.75 & 2 & 1710.8518 & 1710.8506 & 856.4326 & 0.0012 & 0.7006 & 19.068 \\ \text { SOSAAVTPSTTSSTR } & 1.00 & 68.73 & 27.71 & 24.69 & 2 & 1710.8522 & 1710.8506 & 856.4326 & 0.0016 & 0.9341 & 16.513\end{array}$ $\begin{array}{ccc}378.320 & 5.063 & \text { Yes } \\ 1402.365 & 1842.053 & \text { Yes }\end{array}$ $\begin{array}{llll}1051.611 & 1170.323 & \text { Yes }\end{array}$ 
$\begin{array}{llll}0.034 & 1.9850 & 4.560\end{array}$

VPQCPSGR $\begin{array}{llllllllllll}1.00 & 79.05 & 23.38 & 25.13 & 2 & 1397.8480 & 1397.8476 & 699.9311 & 0.0004 & 0.2857 & 1488.063 & 744.835\end{array}$

AVLLLAGGQGTR

VAVLLLAGGQGTR

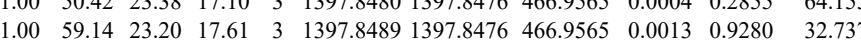

VAVLLLAGQGTR $\begin{array}{lllllllllll}1.00 & 88.04 & 23.26 & 27.01 & 2 & 1397.8489 & 1397.8476 & 466.9565 & 0.0013 & 0.9280 & 32.737\end{array}$

VAVLLLAGGGQGTR

VAVLLLAGGQGTR

$\begin{array}{llllllllllll}1.00 & 78.30 & 23.36 & 25.44 & 2 & 13978492 & 1397.8476 & 699.9311 & 0.0016 & 1.1430 & 307.470\end{array}$

140.130

AAVLLLAGGQGT $\begin{array}{lllllllllll}1.00 & 52.50 & 23.20 & 19.95 & 2 & 1397.8488 & 1397.8476 & 699.9311 & 0.0012 & 0.8572 & 34.219\end{array}$ CIIPWYIMTSGR $\begin{array}{llllllllllll}1.00 & 77.55 & 23.30 & 24.75 & 2 & 1397.8502 & 1397.8476 & 699.9311 & 0.0026 & 1.8573 & 47.591\end{array}$

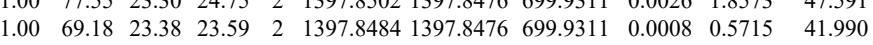
CIIPWYIMTSGR $\begin{array}{llllllllllll}1.00 & 44.63 & 27.04 & 17.01 & 2 & 1628.8008 & 1628.7999 & 815.4072 & 0.0009 & 0.5519 & 132.428\end{array}$ CIIPWYIMTSGR $\begin{array}{lllllllllll}.05 & 27.00 & 53.05 & 2 & 1628.8010 & 1628.7999 & 815.4072 & 0.0011 & 0.6745 & 69.429\end{array}$ (ISGR $\begin{array}{lllllllllll}0.84 & 28.52 & 27.07 & 18.95 & 2 & 1644.7960 & 1644.7948 & 823.4047 & 0.0012 & 0.7287 & 58.551\end{array}$ $\begin{array}{lllllllllll}1.00 & 81.55 & 27.31 & 24.97 & 2 & 1730.8750 & 1730.8743 & 866.4444 & 0.0007 & 0.4039 & 414.029\end{array}$

DQDQLQAWESEGLFOISQNK

IVENSDAVTEILNNAELLK

DPLELFR

DPLELF $\begin{array}{lllllllllllll}.66 & 21.31 & 26.34 & 34.31 & 3 & 2651.3089 & 2651.3071 & 884.7763 & 0.0018 & 0.6781 & 20.074\end{array}$

EMIISODPTMGGVAVDVGGLGSNEGKK GISSQPFPELHCAAL
TTLCVSILER LGPLFSLLNENHR LGPLFSLLNENHR LGPLFSLLNENHR

\section{ILTLSQIGR}

ILTLSQIGR
ILTLSQIGR
ILTLSQIGR

ILTLSQIGR
LEAPLEELR

LEAPLEELR

GLIHPDDSVK

GLIHPDDSVK

\section{TVPTYIGESPR}

TVPLYESPR

$\begin{array}{lllllllllll}1.00 & 34.95 & 24.50 & 22.04 & 3 & 2372.3065 & 2372.3042 & 791.7753 & 0.0023 & 0.9683 & 26.819\end{array}$

$\begin{array}{llllllllllll}0.74 & 24.69 & 28.63 & 31.23 & 2 & 1032.5730 & 1032.5726 & 517.2936 & 0.0004 & 0.3866 & 807.062\end{array}$ $\begin{array}{ccccccccccccc}0.95 & 29.28 & 28.91 & 31.31 & 2 & 1032.5736 & 1032.5726 & 517.2936 & 0.0010 & 0.9666 & 1262.549 & 1 \\ 0.67 & 80.22 & 25.37 & 93.22 & 3 & 3422.7592 & 3422.7557 & 1141.9258 & 0.0035 & 1.0217 & 0.958\end{array}$

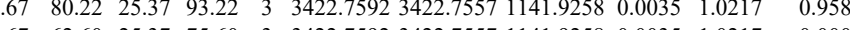

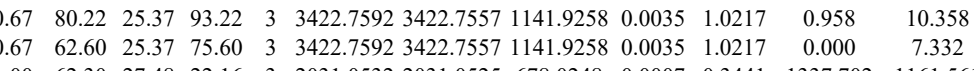
$\begin{array}{llllllllll} & \end{array}$

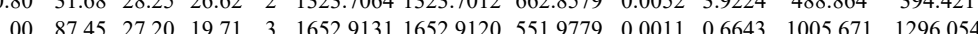

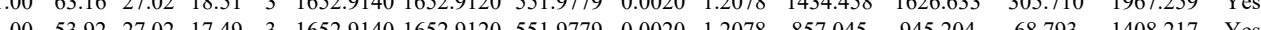
$\begin{array}{llllllllllllllll}1.00 & 63.54 & 26.81 & 18.54 & 3 & 1652.9149 & 1652.9120 & 551.9779 & 0.0029 & 1.7513 & 2038.349 & 1948.864 & 691.414 & 1821.317 & \text { Yes }\end{array}$

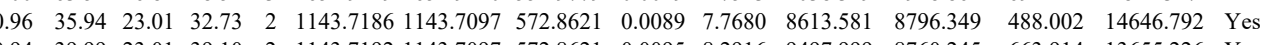

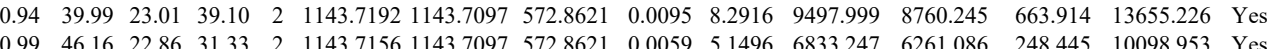
$\begin{array}{lllllllllllllll}0.99 & 46.12 & 22.96 & 33.07 & 2 & 1143.7174 & 1143.7097 & 572.8621 & 0.0077 & 5.796 & 6833.247 & 6261.086 & 248.445 & 10098.953 & \text { Yes } \\ 0.1181 .194 & 10366.973 & 159.143 & 17461.511 & \text { Yes }\end{array}$ $\begin{array}{lllllllllllllllll}1.00 & 49.87 & 27.18 & 28.74 & 2 & 1212.6848 & 1212.6835 & 607.3490 & 0.0013 & 1.0702 & 3325.694 & 3289.999 & 196.624 & 5162.764 & \text { Yes }\end{array}$ $\begin{array}{lllllllllllllll}1.00 & 53.25 & 27.14 & 33.32 & 2 & 1212.6856 & 1212.6835 & 607.3490 & 0.0021 & 1.7288 & 3328.790 & 3198.510 & 26.431 & 5296.071 & \text { Yes }\end{array}$ $\begin{array}{llllllllllllllll}0.68 & 19.11 & 26.16 & 15.86 & 3 & 1367.7727 & 1367.7653 & 456.9290 & 0.0074 & 5.3983 & 2681.145 & 2741.087 & 3552.316 & 3549.292 & \text { No }\end{array}$ $\begin{array}{llllllllllllllll}0.96 & 30.67 & 26.16 & 20.74 & 3 & 1367.7730 & 1367.7653 & 456.9290 & 0.0077 & 5.6172 & 3680.419 & 3080.464 & 1748.576 & 4540.874 & \text { Yes }\end{array}$

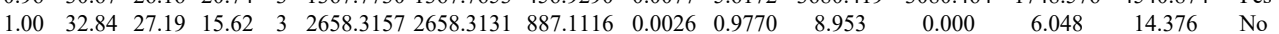
$\begin{array}{llllllllllllllll}0.58 & 26.30 & 28.35 & 27.58 & 2 & 1204.6656 & 1204.6574 & 603.3360 & 0.0082 & 6.7955 & 17016.367 & 20224.455 & 3913.212 & 29305.486 & \text { Yes }\end{array}$ $\begin{array}{lllllllllllllll}0.94 & 34.39 & 28.11 & 20.68 & 2 & 1204.6672 & 1204.6574 & 603.3360 & 0.0098 & 8.1214 & 14249.454 & 19258.419 & 2800.537 & 30218.299 & \text { Yes }\end{array}$

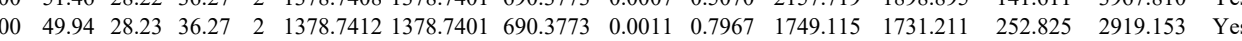

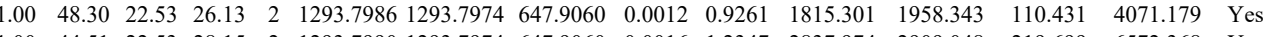

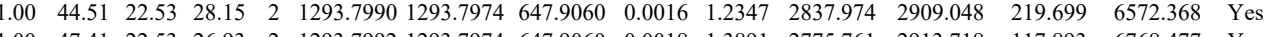

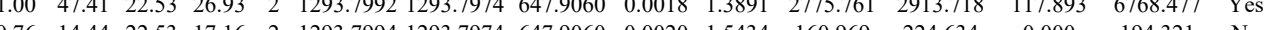

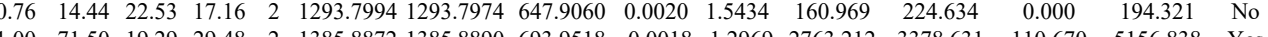
$\begin{array}{lllllllllllllll}1.00 & 71.50 & 19.29 & 29.48 & 2 & 1385.8872 & 1385.8890 & 693.9518 & -0.0018 & -1.2969 & 2763.212 & 3378.631 & 110.670 & 5156.838 & \text { Yes }\end{array}$ $\begin{array}{cccccccccccccc}1.08 & \end{array}$ $\begin{array}{llllllllllllllll}1.00 & 55.08 & 24.22 & 29.80 & 2 & 1327.8064 & 1327.7946 & 664.9046 & 0.0118 & 8.8734 & 5012.170 & 6441.615 & 3260.617 & 9644.629 & \text { Yes }\end{array}$ $\begin{array}{lllllllllllllll}1.00 & 57.88 & 24.17 & 30.14 & 2 & 1327.8068 & 1327.7946 & 664.9046 & 0.0122 & 9.1742 & 4707.730 & 4572.556 & 2558.825 & 7871.656 & \text { Yes }\end{array}$ $\begin{array}{lllllllllllllllll}0.98 & 51.54 & 25.75 & 42.33 & 2 & 1216.7344 & 1216.7261 & 609.3703 & 0.0083 & 6.8103 & 10131.989 & 12296.454 & 488.647 & 23908.589 & \text { Yes }\end{array}$

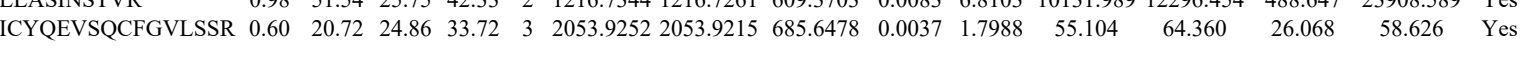



$\begin{array}{llllllllllll}\text { LGPGGLDPVEVYESLPEELQK } & 1.00 & 39.89 & 25.92 & 17.52 & 3 & 2556.3595 & 2556.3567 & 853.1262 & 0.0028 & 1.0940 & 10.958\end{array}$ LGPGGLDPVEVYES
LQAEAQQLR

$\begin{array}{llllllllllll}1.00 & 49.45 & 27.75 & 28.00 & 2 & 1199.6786 & 1199.6744 & 600.8445 & 0.0042 & 3.4951 & 28719.370 & 23441.318\end{array}$ $\begin{array}{lllllllllllll}\text { EGEEAGPGDPLLEAVPK } & 0.99 & 36.25 & 27.47 & 18.12 & 2 & 1995.0432 & 1995.0404 & 998.5275 & 0.0028 & 1.4021 & 103.822 & 116.922\end{array}$

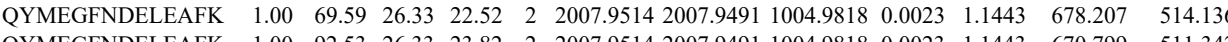

514.136
511.342

MVIPGGIDVHTR

$\begin{array}{llllllllllll}1.00 & 61.84 & 27.36 & 18.38 & 3 & 2712.3634 & 2712.3639 & 905.1286 & -0.0005 & -0.1841 & 74.659 & 49.966\end{array}$

MVIPGGIDVHTR

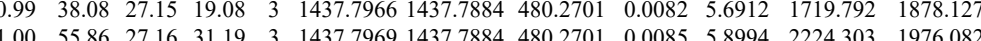

$\begin{array}{lllllllllllllll}1.00 & 55.86 & 27.16 & 31.19 & 3 & 1437.7969 & 1437.7884 & 480.2701 & 0.0085 & 5.8994 & 2224.303 & 1976.082 & 6 \\ \end{array}$

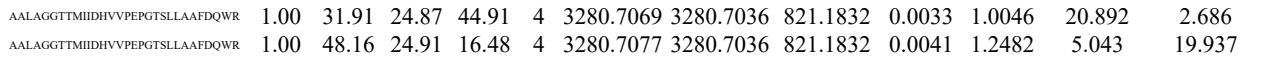

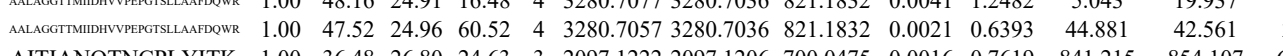

$\begin{array}{lllllllllllll}\text { AITIANQTNCPLYITK } & 1.00 & 36.48 & 26.80 & 24.63 & 3 & 2097.1222 & 2097.1206 & 700.0475 & 0.0016 & 0.7619 & 841.215 & 854.107\end{array}$

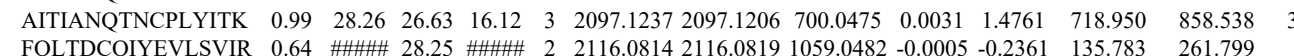

$\begin{array}{lllllllllllll}\text { FQLTDCQIYEVLSVIR } & 0.64 & \# \# \# \# & 28.25 & \# \# \# \# & 2 & 2116.0814 & 2116.0819 & 1059.0482 & -0.0005 & -0.2361 & 135.783 & 261.799 \\ \text { VFNLYPR } & 0.81 & 30.12 & 26.35 & 21.42 & 2 & 1051.6006 & 1051.5936 & 526.8041 & 0.0070 & 6.6438 & 4224.319 & 5405.913\end{array}$ VFNLYPR

GIQEEMEALVK

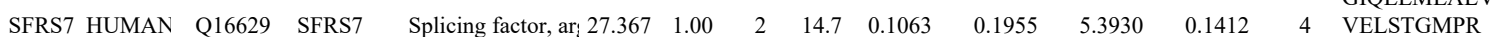

VELSTGMPR

$\begin{array}{lllllllllllll}0 & 1025.772 & 1286.355 & 401.003\end{array}$

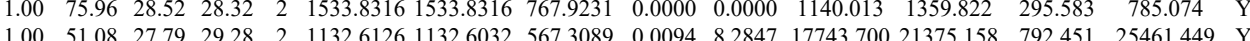

$\begin{array}{llllllllllllllllll}\text { VYVGNLGTGAGK } & 1.00 & 82.06 & 26.27 & 26.56 & 2 & 1422.8140 & 1422.8075 & 712.4110 & 0.0065 & 4.5620 & 13582.202 & 15180.049 & 13.809 & 19806.079 & \text { Yes }\end{array}$

$\begin{array}{llllllllllllllll}1.00 & 79.56 & 26.21 & 24.57 & 2 & 1422.8176 & 1422.8075 & 712.4110 & 0.0101 & 7.0886 & 11733.318 & 12858.685 & 246.364 & 18120.004 & \text { Yes }\end{array}$

VYVGNLGTGAGK

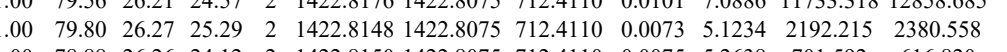

$0.000 \quad 3042.013$ No

VUISLQDCLHGIESK

$\begin{array}{llllllllllll}1.00 & 78.88 & 26.26 & 24.12 & 2 & 1422.8150 & 1422.8075 & 712.4110 & 0.0075 & 5.2638 & 701.592 & 616.820\end{array}$

$\begin{array}{ccc}0.000 & 3042.013 & \text { No } \\ 48.862 & 861.780 & \text { Yes }\end{array}$ $\begin{array}{lllllllllllllllll}\text { VLISSLQDCLHGIESK } & 1.00 & 11.42 & 28.13 & 19.28 & 3 & 2075.1028 & 2075.0999 & 692.7072 & 0.0029 & 1.3955 & 2035.383 & 2250.187 & 315.266 & 4412.864 & \text { Yes } \\ \text { VLISSLQDCLHGIESK } & 1.00 & 58.71 & 28.14 & 20.86 & 3 & 2075.1034 & 075.0999 & 692.7072 & 0.0035 & 1.6842 & 2520.337 & 2435.292 & 445.615 & 5085.813 & \text { Yes }\end{array}$

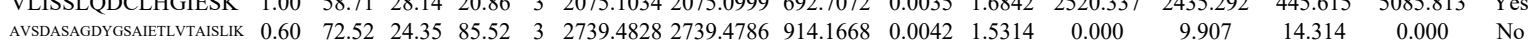

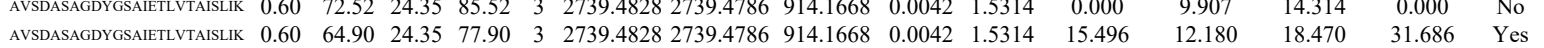

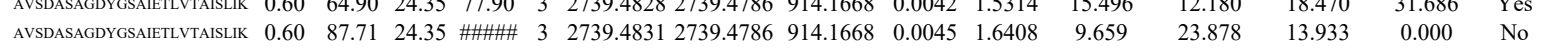
$\begin{array}{llllllllllllllll}\text { AVSDASAGDYGSAIETLVTAISLIK } & 0.66 & 27.71 & 24.53 & 40.71 & 3 & 2739.4804 & 2739.4786 & 914.1668 & 0.0018 & 0.6563 & 4.783 & 6.699 & 2.672 & 6.956 & \text { Yes }\end{array}$

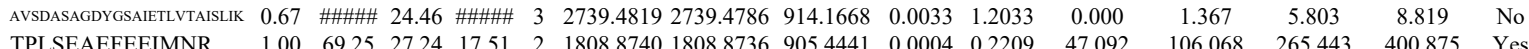
$\begin{array}{llllllllllllllll}\text { TPLSEAEFEEIMNR } & 1.00 & 69.25 & 27.24 & 17.51 & 2 & 1808.8740 & 1808.8736 & 905.4441 & 0.0004 & 0.2209 & 47.092 & 106.068 & 265.443 & 400.875 & \text { Yes } \\ \text { TPSEAEFEEIMNR } & 1.00 & 77.23 & 27.36 & 19.06 & & \end{array}$ \begin{tabular}{llllllllllllllll} 
TPLSEAEFEEIMNR & 1.00 & 77.23 & 27.36 & 19.29 & 2 & 1808.8744 & 1808.8736 & 905.4441 & 0.0008 & 0.4418 & 42.329 & 44.582 & 56.442 & 163.713 & Yes \\
\hline
\end{tabular}

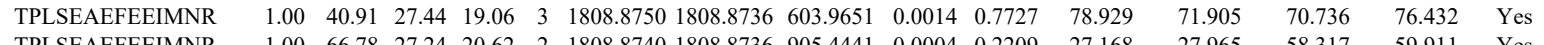
$\begin{array}{llllllllllllllll}\text { TPLSEAEFEEIMNR } & 1.00 & 66.78 & 27.24 & 20.62 & 2 & 1808.8740 & 1808.8736 & 905.4441 & 0.0004 & 0.2209 & 27.168 & 27.965 & 58.317 & 59.911 & \text { Yes } \\ \text { TPLSEAEFEEIMNR } & 1.5 & 83.6 & 27.3 & 22.73 & 2 & 188.8746 & 18.938 & \end{array}$

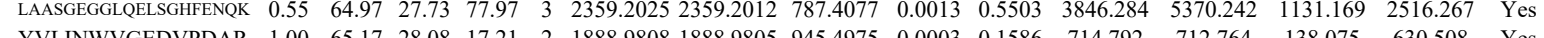
$\begin{array}{llllllllllllllll}\text { YVLINWVGEDVPDAR } & 1.00 & 65.17 & 28.08 & 17.21 & 2 & 1888.9808 & 1888.9805 & 945.4975 & 0.0003 & 0.1586 & 714.792 & 712.764 & 138.075 & 630.508 & \text { Yes } \\ \text { YVLINWVGEDVPDAR } & 1.0 & 79.02 & 28.03 & 20.58 & 2 & 188.8916 & 188.9805 & 945.4975 & 0.0011 & 0.5817 & 344.84 & 463.822 & 118.071 & 389.693 & \text { Yes }\end{array}$

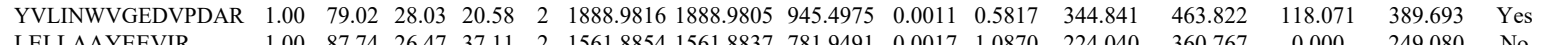

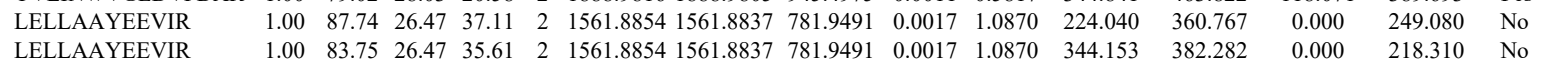

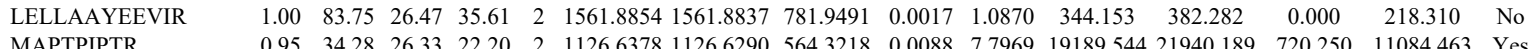

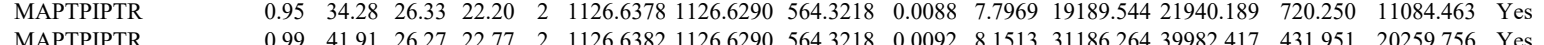

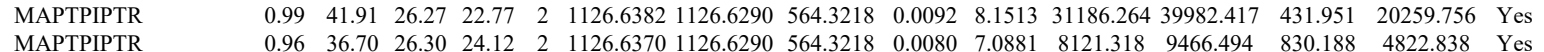
$\begin{array}{lllllllllllllllll}\text { MAPTPIPTR } & 0.96 & 36.70 & 26.30 & 24.12 & 2 & 1126.6370 & 1126.6290 & 564.3218 & 0.0080 & 7.0881 & 8121.318 & 9466.494 & 830.188 & 4822.838 & \text { Yes } \\ \text { MAPTPIPTR } & 0.97 & 36.44 & 26.27 & 23.74 & 2 & 1126.6382 & 1126.6290 & 564.3218 & 0.0092 & 8.1513 & 17809.158 & 22034.153 & 1481.638 & 10866093 & \text { Yes }\end{array}$ $\begin{array}{lllllllllllllllll}\text { SESEVEFAAAIIAQRPDNPR } & 0.66 & 37.07 & 27.57 & 50.07 & 3 & 2325.1699 & 2325.1682 & 776.6033 & 0.0017 & 0.7302 & 2462.375 & 2892.797 & 1010.449 & 1378.702 & \text { Yes }\end{array}$ $\begin{array}{llllllllllllllll}\text { SESEVEEAAAIIAQRPDNPR } & 0.66 & 37.89 & 27.57 & 50.89 & 3 & 2325.1699 & 2325.1682 & 776.0633 & 0.0017 & 0.7302 & 105.573 & 164.762 & 26.374 & 56.767 & \text { Yes }\end{array}$

Table S-4 page 503 of 6 


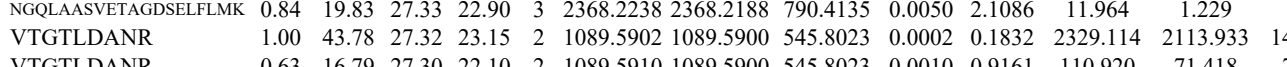
VTGTLDANR

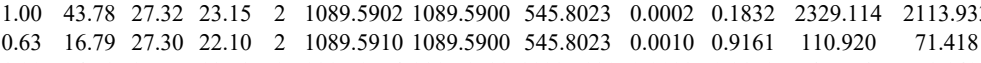

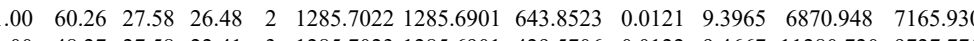

KVTGTLDANR

$\begin{array}{lllllllllllll}0.98 & 26.82 & 27.34 & 18.68 & 3 & 13617886 & 13617870 & 454.9363 & 0.0016 & 1.1723 & 527.951 & 498.506\end{array}$

FLIVAHDDGR

$\begin{array}{lllllllllllll}1.00 & 60.37 & 27.58 & 23.96 & 3 & 1285.7023 & 1285.6901 & 429.5706 & 0.0122 & 9.4667 & 10598.701 & 10564.390\end{array}$

QIWTLEQPPDEAGSAAVC

$\begin{array}{llllllllllllllll} & \\ \text { GR } & 1.00 & 60.11 & 27.98 & 26.36 & 2 & 1285.7024 & 1285.6901 & 643.8523 & 0.0123 & 9.5518 & 10417.812 & 9389.490 & 587.021 & 13987.357 & \text { Yes } \\ \text { AGSAAVCLR } & 1.00 & 90.18 & 27.94 & 25.17 & 2 & 2373.1574 & 2373.1579 & 1187.5862 & -0.0005 & -0.2105 & 375.972 & 352.539 & 61.079 & 464.308 & \text { Yes }\end{array}$

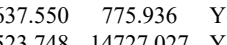

$\begin{array}{llllllllllllllll} & & & \end{array}$

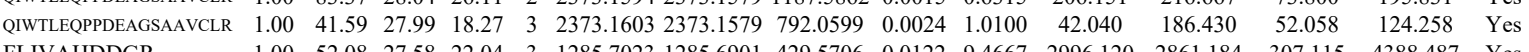

FLIVAHDDGR

$\begin{array}{llllllllllll}1.00 & 41.59 & 27.99 & 18.27 & 3 & 2373.1603 & 2373.1579 & 792.0599 & 0.0024 & 1.0100 & 42.040 & 186.430 \\ 1.00 & 52.08 & 27.58 & 22.04 & 3 & 1285.7023 & 1285.6901 & 429.5706 & 0.0122 & 9.4667 & 2996.120 & 2861.184 \\ 1.00 & 63.06 & 27.58 & 23.97 & 3 & 1285.7023 & 1285.6901 & 429.5706 & 0.0122 & 9.4667 & 5235.143 & 5166.399\end{array}$ $\begin{array}{lllllllllllll} & & & \end{array}$

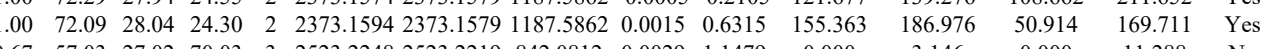

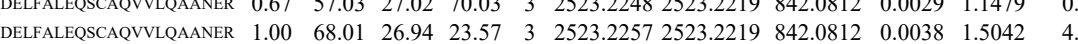

0.000

WSLQSEAHR

$\begin{array}{lllllllllllll}1.00 & 48.15 & 27.12 & 25.24 & 2 & 1256.6388 & 1256.6384 & 629.3265 & 0.0004 & 0.3178 & 12158.626 & 12399.039\end{array}$

0.000

11.288

WSLQSEAHR

$\begin{array}{llllllllllllll}1.00 & 40.30 & 27.08 & 22.17 & 2 & 1256.6394 & 12566.6384 & 629.3265 & 0.0010 & 0.7945 & 5352.281 & 4657.666\end{array}$

WSLQSAHR

$\begin{array}{llllllllllllll} & \\ \text { HR } & 0.55 & 37.08 & 27.08 & 50.08 & 3 & 1256.6395 & 1256.6384 & 419.8867 & 0.0011 & 0.8733 & 12957.443 & 10619.318 \\ \text { QVVLQAANER } & 0.95 & 24.74 & 26.90 & 16.50 & 3 & 2523.2218 & 2523.2219 & 842.0812 & -0.0001 & -0.0396 & 16.804 & 19.897\end{array}$

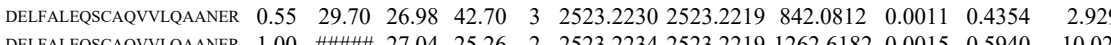

$\begin{array}{lllllllllllll}\text { DELFALEQSCAQVVLQAANER } & 1.00 & \text { 27.04 } & 25.26 & 2 & 2523.2234 & 2523.2219 & 1262.6182 & 0.0015 & 0.5940 & 10.028\end{array}$

$\begin{array}{llllllllllll} & \text { DELALESCAQVVLQAANER } & 1.00 & 27.04 & 20.00 & 2 & 2523.2234 & 2523.2219 & 1262.6182 & 0.0015 & 0.5940 & 7.967\end{array}$

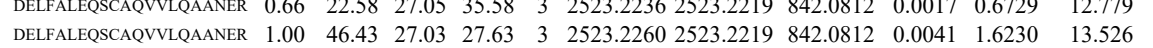

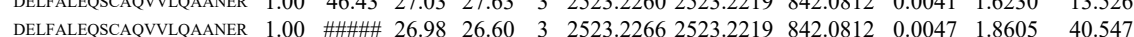
$\begin{array}{llllllllllll}\text { DELFALEOSCAQVVLQAANER } & 1.00 & 79.70 & 26.93 & 18.99 & 3 & 2523.2275 & 2523.2219 & 842.0812 & 0.0056 & 2.2167 & 0.000\end{array}$ $\begin{array}{lllllllllllll}\text { DELFALEQSCAQVVLQAANER } & 1.00 & 73.25 & 27.01 & 18.12 & 3 & 2523.2251 & 2523.2219 & 842.0812 & 0.0032 & 1.2667 & 0.000\end{array}$

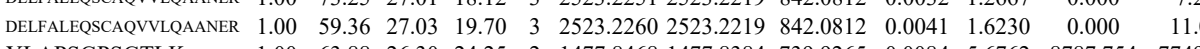

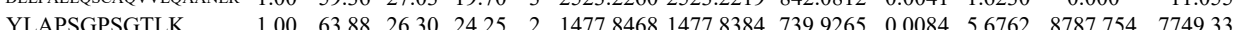
$\begin{array}{lllllllllllllllll}\text { YLAPSGPSGTLK } & 1.00 & 60.39 & 26.49 & 21.80 & 2 & 1477.8482 & 1477.8384 & 739.9265 & 0.0098 & 6.6222 & 14353.919 & 15174.183\end{array}$ $\begin{array}{lllllllllllll}\text { DELFALEOSCAQVVLOANER } & 0.67 & 37.47 & 27.01 & 50.47 & 3 & 2523.2251 & 2523.2219 & 842.0812 & 0.0032 & 1.62667 & 3.520 & 6.667\end{array}$

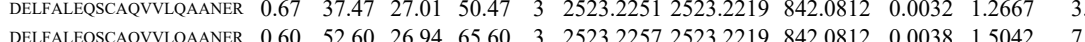
$\begin{array}{llllllllllll}1.00 & 68.69 & 27.64 & 20.53 & 2 & 1713.8826 & 1713.8673 & 857.9409 & 0.0153 & 8.9166 & 3740.940 & 3218.278\end{array}$ $\begin{array}{llllllllllll}1.00 & 73.10 & 27.62 & 19.25 & 2 & 1713.8828 & 1713.8673 & 857.9409 & 0.0155 & 9.0332 & 5931.576 & 6944.665\end{array}$ $\begin{array}{lllllllllllll}1.00 & 58.65 & 28.03 & 30.66 & 2 & 1433.7830 & 1433.7798 & 717.8972 & 0.0032 & 2.2287 & 596.127 & 638.770\end{array}$ YLAPSGPSGTLK

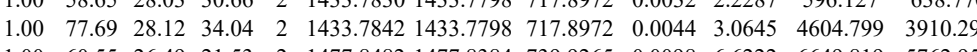
YLAPSGPSGTLK $\begin{array}{llllllllllll}1.00 & 60.55 & 26.49 & 21.53 & 2 & 1477.8482 & 1477.8384 & 739.9265 & 0.0098 & 6.6222 & 6649.819 & 5762.957\end{array}$ LSCFAQTVSPAEK $\begin{array}{lllllllllllll}.00 & 57.55 & 26.42 & 21.98 & 2 & 1477.8492 & 1477.8384 & 739.9265 & 0.0108 & 7.2980 & 3780.413 & 3218.993\end{array}$ LSCFAQTVSPAEK $\begin{array}{lllllllllllll}1.00 & 64.72 & 27.81 & 25.03 & 2 & 1713.8674 & 1713.8673 & 857.9409 & 0.0001 & 0.0583 & 1046.173 & 761.686\end{array}$ $\begin{array}{llllllllllllll} & \\ \text { S } & 1.00 & 63.55 & 27.93 & 21.16 & 2 & 1713.8684 & 1713.8673 & 857.9409 & 0.0011 & 0.6411 & 2254.736 & 1591.780\end{array}$ $\begin{array}{lllllllllllll} & \end{array}$ $\begin{array}{lllllllllllllll}\text { VGKDELFLERSCAQVVLQAANER } & 1.00 & 63.94 & 26.59 & 31.06 & 4 & 2951.5137 & 2951.5088 & 738.8845 & 0.0049 & 1.6579 & 23.385 & 56.404\end{array}$ $\begin{array}{llllllllllllll}\text { VGRDELFALEQSCAQVVLQAANER } & 1.00 & 93.29 & 26.60 & 38.78 & 3 & 2951.5141 & 2951.5088 & 984.8435 & 0.0053 & 1.7939 & 24.130 & 23.836\end{array}$

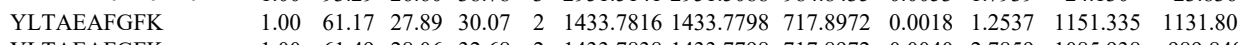
$\begin{array}{llllllllllllll}\text { YLTAEAFGFK } & 1.00 & 61.49 & 28.06 & 32.68 & 2 & 1433.7838 & 1433.7798 & 717.8972 & 0.0040 & 2.7859 & 1085.938 & 989.840\end{array}$ $\begin{array}{llllllllllllll}\text { DVPWGVDSLITLAFQDQR } & 0.99 & 27.66 & 27.63 & 16.52 & 3 & 2203.1416 & 2203.1395 & 735.3871 & 0.0021 & 0.9519 & 23.547 & 1.758 \\ \text { DVPWGVDSLITLAFODQR } & 0.83 & 17.56 & 27.75 & 21.09 & 3 & 2203.1434 & 2203.1395 & 735.3871 & 0.0039 & 1.7678 & 0.000 & 0.000\end{array}$

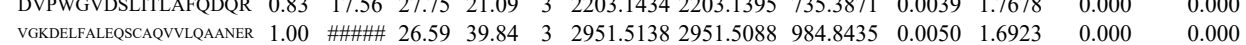

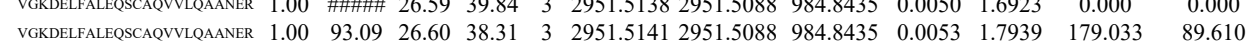
$\begin{array}{lllllllllllll}\text { VGKDELFALEQSCAQVVLQAANER } & 1.00 & 33.56 & 26.60 & 19.28 & 4 & 2951.5141 & 2951.5088 & 738.8845 & 0.0053 & 1.7932 & 0.000 & 41.040\end{array}$

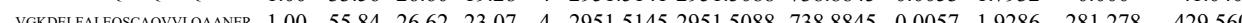

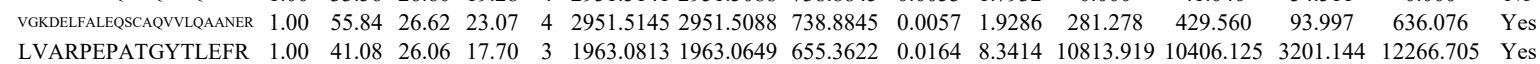

$\begin{array}{ccc}4498.723 & 17696.268 & \text { Yes } \\ 17.492 & 19.036 & \text { Yes } \\ 1.563 & 15.288 & \text { Yes } \\ 6.080 & 7.576 & \text { No } \\ 8.786 & 8.339 & \text { Yes } \\ 20.680 & 16.853 & \text { Yes } \\ 0.000 & 10.470 & \text { No } \\ 22.359 & 33.368 & \text { Yes } \\ 15.913 & 41.388 & \text { No } \\ 0.000 & 3.430 & \text { No } \\ 5.106 & 0.000 & \text { No } \\ 0.000 & 9644.619 & \text { No } \\ 0.000 & 16741.724 & \text { No } \\ 2.950 & 17.029 & \text { Yes } \\ 0.000 & 0.000 & \text { No } \\ 566.881 & 2395.382 & \text { Ye } \\ 49.776 & 1085.396 & \text { Yes } \\ 47.378 & 10800.050 & \text { Yes } \\ 0.000 & 20496.927 & \text { No } \\ 72.073 & 3093.409 & \text { Yes } \\ 105.074 & 6627.170 & \text { Yes } \\ 86.626 & 1010.161 & \text { Yes } \\ 504.837 & 7550.964 & \text { Ye } \\ 0.000 & 7590.343 & \text { No } \\ 0.000 & 4420.272 & \text { No } \\ 0.768 & 897.971 & \text { No } \\ 14.103 & 2441.074 & \text { Yes } \\ 0.000 & 6.464 & \text { No } \\ 42.924 & 0.000 & \text { No } \\ 7.292 & 56.951 & \text { Ye } \\ 58.055 & 84.186 & \text { Yes } \\ 171.052 & 1674.422 & \text { Yes } \\ 140.502 & 1493.452 & \text { Yes } \\ 0.000 & 12.180 & \text { No } \\ 8.856 & 7.338 & \text { No } \\ 0.000 & 0.000 & \text { No } \\ 137.953 & 447.529 & \text { Yes } \\ 54.511 & 0.000 & \text { No } \\ 93.997 & 636.076 & \text { Yos }\end{array}$


$\begin{array}{lllllllllllll}\text { YWTLTATGGVQSTASSK } & 1.00 & 48.13 & 27.47 & 23.45 & 3 & 2045.0692 & 2045.0673 & 682.6964 & 0.0019 & 0.9277 & 35.129\end{array}$

$\begin{array}{llllllllllll}\text { LINRPIIVFR } & 0.98 & 22.43 & 20.61 & 16.16 & 3 & 1239.7813 & 1239.7815 & 414.2678 & -0.0002 & -0.1609 & 32.384 \\ \text { LINRPIIVFR } & 0.64 & 26.52 & 20.76 & 39.52 & 2 & 1239.7820 & 1239.7815 & 620.8980 & 0.0005 & 0.4026 & 35.399\end{array}$

$\begin{array}{lllllllllllll}\text { LINRPIIVFR } & 0.64 & 26.52 & 20.76 & 39.52 & 2 & 1239.7820 & 1239.7815 & 620.8980 & 0.0005 & 0.4026 & 35.399 \\ \text { YWTLTATGGVQSTASSK } & 0.66 & 37.01 & 27.45 & 50.01 & 3 & 2045.0695 & 2045.0673 & 682.6964 & 0.0022 & 1.0742 & 33.954\end{array}$

$\begin{array}{llllllllllll}\text { YWTLTATGGVQSTASSK } & 0.66 & 37.01 & 27.45 & 50.01 & 3 & 2045.0695 & 2045.0673 & 682.6964 & 0.0022 & 1.0742 & 33.954 \\ \text { LINRPIIVFR } & 0.96 & 19.97 & 20.76 & 17.96 & 3 & 1239.7816 & 1239.7815 & 414.2678 & 0.0001 & 0.0805 & 20.148\end{array}$

$\begin{array}{lllllllllllll} & \text { LINRPIIVFR } & 0.98 & 23.14 & 20.76 & 16.98 & 3 & 1239.7816 & 1239.7815 & 414.2678 & 0.0001 & 0.0805 & 34.424\end{array}$

$\begin{array}{lllllllllllll} & 23.045\end{array}$ $\begin{array}{llllllllllll}0.59 & 11.44 & 27.47 & 15.77 & 3 & 2045.0692 & 2045.0673 & 682.6964 & 0.0019 & 0.9277 & 26.395 \\ 0.93 & 17.46 & 20.61 & 15.90 & 3 & 1239.7813 & 1239.7815 & 414.2678 & -0.0002 & -0.1609 & 40.760\end{array}$

$\begin{array}{lllllllllllll} & \text { LINRPIIVFR } & 0.93 & 17.46 & 20.61 & 15.90 & 3 & 1239.7813 & 1239.7815 & 414.2678 & -0.0002 & -0.1609 & 40.760\end{array}$

$\begin{array}{llllllllllll} & 0.99 & 28.24 & 20.76 & 16.86 & 3 & 1239.781 & 239.7815 & 14.2678 & 0.0004 & 0.32169 & 28.367\end{array}$

$\begin{array}{lllllllllllll}\text { LINRPIIVFR } & 0.95 & 22.34 & 20.76 & 15.57 & 3 & 1239.7810 & 1239.7815 & 414.2678 & -0.0005 & -0.4023 & 34.209\end{array}$

LINRPIIVFR $\begin{array}{lllllllllll}0.90 & 15.74 & 20.76 & 16.11 & 3 & 12399.7810 & 1239.785 & 44.2678 & 0.0005 & 0.4023 & 34.209\end{array}$

LINRPIIVFR

LINRPIIVFR $\begin{array}{lllllllllll}0.64 & 24.00 & 20.76 & 37.00 & 2 & 1239.7814 & 1239.7815 & 620.8980 & 0.0001 & 0.0805 & 33.275\end{array}$

LINRPIIVFR

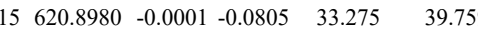

LINRPIIVFR $\begin{array}{llllllllllll}0 & 0.0012 & 0.8652 & 6304.877 & 8995.624\end{array}$

LINRPIIVFR $\begin{array}{llllllllllllll}0 & & \end{array}$

LINRPIIVFR $\begin{array}{llllllllllllll}0.67 & 14.13 & 16.53 & 27.13 & 3 & 1383.8869 & 1383.8836 & 462.3018 & 0.0033 & 2.3794 & 18208.696 & 25003.774 & 2207.238\end{array}$ $\begin{array}{llllllllllllll}0.60 & 15.79 & 16.33 & 28.79 & 3 & 1383.8875 & 1383.8836 & 462.3018 & 0.0039 & 2.8120 & 15950.612 & 23973.429 & 2164.083\end{array}$

LINRPIIVFR

LINRPIIVFR

LINRPIIVFR

LINRPIIVFR

LINRPIIVFR $\begin{array}{llllllllllllll}0.97 & 24.20 & 27.47 & 15.72 & 3 & 2045.0692 & 2045.0673 & 682.6964 & 0.0019 & 0.9277 & 25.449 & 22.518\end{array}$

LINRPIIVFR $\begin{array}{lllllllllllll}0.99 & 28.10 & 20.76 & 17.27 & 3 & 1239.7816 & 1239.7815 & 414.2678 & 0.0001 & 0.0805 & 14.830 & 56.053 & 31.636\end{array}$

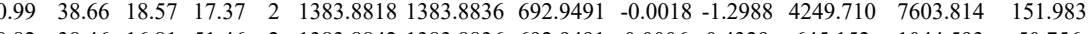
$\begin{array}{llllllllllllll}0.82 & 38.46 & 16.81 & 51.46 & 2 & 1383.8842 & 1383.8836 & 692.9491 & 0.0006 & 0.4329 & 645.152 & 1044.593 & 50.756 \\ 0.67 & 19.38 & 16.53 & 32.38 & 3 & 1383.8869 & 1383.8836 & 462.3018 & 0.0033 & 2.3794 & 22659.456 & 41348.555 & 3727.128\end{array}$ YWTLTATGGVQSTASSK LINRPIIVFR

LINRPIIVFR

LINRPIIVFR

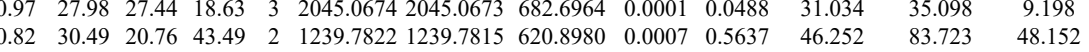

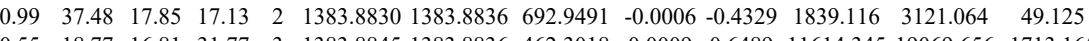




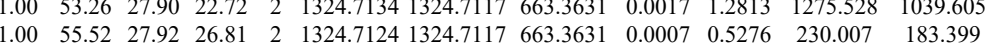

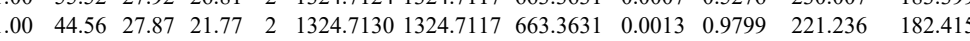
$\begin{array}{llllllllllllll}.94 & 26.52 & 26.86 & 20.92 & 2 & 1115.5754 & 1115.5742 & 558.7944 & 0.0012 & 1.0737 & 140.812 & 137.46\end{array}$

\begin{tabular}{lllllllllllll}
\hline FTNLLTSILDSAETK & 0.95 & 19.58 & 25.83 & 18.68 & 3 & 1940.0740 & 1940.0710 & 647.6976 & 0.0030 & 1.5439 & 161.198
\end{tabular} \begin{tabular}{lllllllllllll} 
FTNLLTSILDSAETK & 1.00 & 37.98 & 25.89 & 16.29 & 3 & 1940.0734 & 1940.0710 & 647.6976 & 0.0024 & 1.2351 & 80.359 & 84.3 \\
\hline
\end{tabular} $\begin{array}{llllllllllll}\text { FTNLLTSILDSAETK } & 1.00 & 66.16 & 25.89 & 22.49 & 3 & 1940.0743 & 1940.0710 & 647.6976 & 0.0033 & 1.6983 & 225.737\end{array}$ LQLIPGVCGFR LQLIPGVCGFR $\begin{array}{llllllllllll}0.96 & 29.43 & 28.41 & 26.54 & 2 & 1391.7556 & 1391.7539 & 696.8842 & 0.0017 & 1.2197 & 81.442\end{array}$ $\begin{array}{llllllllllll}0.96 & 29.01 & 28.31 & 25.42 & 2 & 1391.7560 & 1391.7539 & 696.8842 & 0.0021 & 1.5067\end{array}$ LQLIPGVCGFR

LQLIPGVCGFR IEDILEVIEK
IEDILEVIEK $\begin{array}{lllllllllll}0.96 & 29.50 & 28.38 & 25.41 & 2 & 1391.7550 & 1391.7539 & 696.8842 & 0.0011 & 0.7892 & 59.42\end{array}$

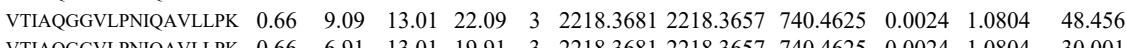
$\begin{array}{lllllllllllll}\text { VTIAQGGVLPNIQAVLLPK } & 0.66 & 6.91 & 13.01 & 19.91 & 3 & 2218.3681 & 2218.3657 & 740.4625 & 0.0024 & 1.0804 & 30.001 \\ \text { VTARG }\end{array}$ $\begin{array}{lllllllllllll}\text { VTIAQGGVLPNIQAVLLPK } & 0.55 & 52.60 & 13.22 & 34.60 & 3 & 2218.3663 & 2218.3657 & 740.4625 & 0.020 & 0.2704 & 57.200 \\ \text { VIA.66 } & 3 & 2218.3666 & 2218.3657 & 740.4625 & 0.0009 & 0.4052 & 50.068\end{array}$ $\begin{array}{llllllllllllll}\text { VTIAQGGVLPNIQAVLLPK } & 0.55 & 19.93 & 13.22 & 32.93 & 3 & 2218.3672 & 2218.3657 & 740.4625 & 0.0015 & 0.6753 & 28.253\end{array}$

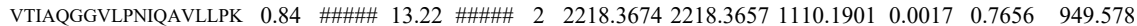
$\begin{array}{lllllllllllllllll}\text { VTIAQGGVLPNIQAVLLPK } & 0.84 & 88.27 & 13.22 & \text { \#\#\#\# } & 2 & 2218.3674 & 2218.3657 & 1110.1901 & 0.0017 & 0.7656 & 1096.259\end{array}$ $\begin{array}{llllllllllllll}\text { VTIAQGGVLPNIQAVLLPK } & 0.66 & 48.14 & 13.01 & 61.14 & 3 & 2218.3675 & 2218.3657 & 740.4625 & 0.0018 & 0.8103 & 32.773\end{array}$ $\begin{array}{llllllllllllll}\text { VTIAQGGVLPNIQAVLLPK } & 0.66 & 45.44 & 13.01 & 58.44 & 3 & 2218.3675 & 2218.3657 & 740.4625 & 0.0018 & 0.8103 & 14.641\end{array}$ $\begin{array}{lllllllllllll}\text { VTIAQGGVLPNIQAVLLPK } & 0.66 & 35.33 & 13.01 & 48.33 & 3 & 2218.3681 & 2218.3657 & 740.4625 & 0.0024 & 1.0804 & 38.935 \\ \text { VTIAQGGVLPNIQAVLLPK } & 0.66 & 6.50 & 13.01 & 19.50 & 3 & 2218.3681 & 2218.3657 & 740.4625 & 0.0024 & 1.0804 & 57.082\end{array}$ $\begin{array}{lllllllllllll}\text { VTIAQGGVLPNIQAVLLPK } & 0.66 & 6.50 & 13.01 & 19.50 & 3 & 2218.3681 & 2218.3657 & 740.4625 & 0.0024 & 1.0804 & 57.082 \\ \text { VTIAQGGVLPNIQAVLLPK } & 0.66 & 31.37 & 13.01 & 44.37 & 3 & 2218.3681 & 2218.3657 & 740.4625 & 0.0024 & 1.0804 & 37.428\end{array}$ $\begin{array}{llllllllllll}\text { VTIAQGGVLPNIQAVLLPK } & 0.66 & 31.37 & 13.01 & 44.37 & 3 & 2218.3681 & 2218.3657 & 740.4625 & 0.0024 & 1.0804 & 37.428 \\ \text { VTIAQGGVLPNIQAVLLPK } & 0.67 & 49.06 & 13.01 & 62.06 & 3 & 2218.3684 & 2218.3657 & 740.4625 & 0.0027 & 1.2155 & 11.709\end{array}$ $\begin{array}{llllllllllll}\text { VTIAQGGVLPNIQAVLLPK } & 0.67 & 49.06 & 13.01 & 62.06 & 3 & 2218.3684 & 2218.3657 & 740.4625 & 0.0027 & 1.2155 & 11.709 \\ \text { VTIAQGGVLPNIQAVLLPK } & 0.67 & 26.69 & 13.01 & 39.69 & 3 & 2218.3687 & 2218.3657 & 740.4625 & 0.0030 & 1.3505 & 70.742\end{array}$ $\begin{array}{lllllllllllll}\text { VTIAQGGVLPNIQAVLLPK } & 0.67 & 26.69 & 13.01 & 39.69 & 3 & 2218.3687 & 2218.3657 & 740.4625 & 0.0030 & 1.3505 & 70.742 \\ \text { VTIAQGGVLPNIQAVLLPK } & 0.67 & 4.59 & 13.01 & 17.59 & 3 & 2218.3690 & 2218.3657 & 740.4625 & 0.0033 & 1.4856 & 48.968\end{array}$ $\begin{array}{lllllllllllll}\text { VTIAQGGVLPNIQAVLLPK } & 0.67 & 4.59 & 13.01 & 17.59 & 3 & 2218.3690 & 2218.3657 & 740.4625 & 0.0033 & 1.4856 & 48.968 \\ \text { VTIAQGGVLPNIQAVLLPK } & 1.00 & 33.60 & 13.01 & 46.60 & 4 & 2218.3697 & 2218.3657 & 555.5987 & 0.0040 & 1.7999 & 10.886\end{array}$

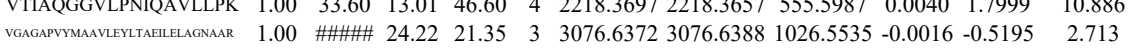
$\begin{array}{ccccccccccc}1.00 & \ldots 4.10 & 24.22 & 21.35 & 3 & 3076.6372 & 3076.6388 & 1026.5535 & -0.0016 & -0.5195 & 2.713 \\ 1.00 & 94.12 & 23.96 & 22.34 & 3 & 3076.6402 & 3076.6388 & 1026.5535 & 0.0014 & 0.4546 & 1.639\end{array}$

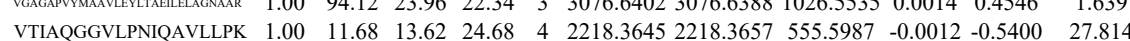




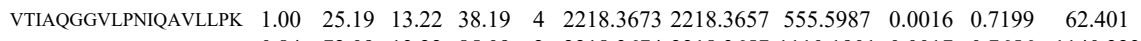
$\begin{array}{llllllllllllllll}\text { VTIAQGGVLPNIQAVLLPK } & 0.84 & 72.09 & 13.22 & 85.09 & 2 & 2218.3674 & 2218.3657 & 1110.1901 & 0.0017 & 0.7656 & 1140.223\end{array}$ $\begin{array}{llllllllllllll}\text { VTIAQGGVLPNIQAVLLPK } & 0.84 & 94.33 & 13.22 & \text { \#\#\# } 2 & 2218.3674 & 2218.3657 & 1110.1901 & 0.0017 & 0.7656 & 518.338\end{array}$ $\begin{array}{lllllllllllll}\text { VTIAQGGVLPNIQAVLLPK } & 0.84 & \text { \#\#\#\# } & 13.22 & \text { \#\#\#\# } & 2 & 2218.3674 & 2218.3657 & 1110.1901 & 0.0017 & 0.7656 & 1101.015 \\ \text { VTIAQGGVLPNIQAVLLPK } & 0.66 & 47.40 & 13.01 & 60.40 & 3 & 2218.3675 & 2218.3657 & 740.4625 & 0.0018 & 0.8103 & 52.852\end{array}$ $\begin{array}{llllllllllll}\text { VTIAQGGVLPNIQAVLLPK } & 0.66 & 47.40 & 13.01 & 60.40 & 3 & 2218.3675 & 2218.3657 & 740.4625 & 0.0018 & 0.8103 & 52.852 \\ \text { VTIAQGGVLPNIQAVLLPK } & 0.66 & 48.87 & 13.01 & 61.87 & 3 & 2218.3678 & 2218.3657 & 740.4625 & 0.0021 & 0.9454 & 55.172\end{array}$ $\begin{array}{lllllllllllll}\text { VTIAQGGVLPNIQAVLLPK } & 0.66 & 48.87 & 13.01 & 61.87 & 3 & 2218.3678 & 2218.3657 & 740.4625 & 0.0021 & 0.9454 & 55.172 \\ \text { VTIAQGGVLPNIQAVLLPK } & 0.66 & 43.78 & 13.01 & 56.78 & 3 & 2218.3678 & 2218.3657 & 740.4625 & 0.0021 & 0.9454 & 60.726\end{array}$ $\begin{array}{lllllllllllll}\text { VTIAQGGVLPNIQAVLLPK } & 0.66 & 43.78 & 13.01 & 56.78 & 3 & 2218.3678 & 2218.3657 & 740.4625 & 0.0021 & 0.9454 & 60.726 \\ \text { VTIAQGGVLPNIQAVLLPK } & 0.66 & 11.01 & 13.01 & 24.01 & 3 & 2218.3678 & 2218.3657 & 740.4625 & 0.0021 & 0.9454 & 31.932\end{array}$ $\begin{array}{llllllllllll}\text { VITAQGGVLPNIQAVLLPK } & 0.66 & 11.01 & 13.01 & 24.01 & 3 & 2218.3678 & 2218.3657 & 740.4625 & 0.0021 & 0.9454 & 31.932 \\ \text { VTIAQGGVLPNIQAVLLPK } & 0.66 & 74.04 & 13.01 & 87.04 & 3 & 2218.3681 & 2218.3657 & 740.4625 & 0.0024 & 1.0804 & 49.525\end{array}$ $\begin{array}{llllllllllll}\text { VITAQGGLVPNQAVLLPK } & 0.66 & 74.04 & 13.01 & 87.04 & 3 & 2218.3681 & 2218.3657 & 740.4625 & 0.0024 & 1.0804 & 49.525 \\ \text { VTIAQGGVLPNIQAVLLPK } & 0.66 & 40.75 & 13.01 & 53.75 & 3 & 2218.3681 & 2218.3657 & 740.4625 & 0.0024 & 1.0804 & 58.185\end{array}$ $\begin{array}{llllllllllllll}\text { VTIAQGGVLPNIQAVLLPK } & 0.66 & 70.10 & 13.01 & 83.10 & 3 & 2218.3681 & 2218.3657 & 740.4625 & 0.0024 & 1.0804 & 44.841\end{array}$ $\begin{array}{llllllllllllll} & \end{array}$ $\begin{array}{lllllllllllll} & \text { VTIAQGGVIPNQAVLIPK } & 0.66 & 51.68 & 13.01 & 64.68 & 3 & 22183681 & 22183657 & 740.4625 & 0.0024 & 1.0804 & 50.058\end{array}$ $\begin{array}{lllllllllllll} & \text { VTIAQGGVLPNDAVILPK } & 0.67 & 59.76 & 13.01 & 72.76 & 3 & 22183684 & 22183657 & 740.4625 & 0.0027 & 1.2155 & 43.598\end{array}$ $\begin{array}{llllllllllllll} & \text { VTIAQGGVLPNIQAVLIPK } & 1.00 & 39.26 & 13.01 & 5226 & 4 & 22183689 & 22183657 & 555.5987 & 0.0032 & 1.4399 & 42.398\end{array}$ $\begin{array}{lllllllllllll} & \text { VTIAQGGVLPNIOAVLLPK } & 1.00 & 20.98 & 13.01 & 33.98 & 4 & 2218.3689 & 22183657 & 555.5987 & 0.0032 & 1.4399 & 22.59\end{array}$ $\begin{array}{llllllllllllll}\text { VTIAQGGVLPNIPAVLIPK } & 0.67 & 44.61 & 13.01 & 57.61 & 3 & 22183690 & 2218.3657 & 740.4625 & 0.0033 & 1.4856 & 29.626\end{array}$ $\begin{array}{lllllllllllll}\text { VTIAQGGVLPNIQAVLLPK } & 0.60 & 9.35 & 13.01 & 22.35 & 3 & 2218.3693 & 2218.3657 & 740.4625 & 0.0036 & 1.6206 & 13.829\end{array}$ $\begin{array}{lllllllllllll}\text { VTIAQGGVLPNIOAVLLPK } & 1.00 & 29.95 & 13.01 & 42.95 & 4 & 2218.3693 & 2218.3657 & 555.5987 & 0.0036 & 1.6199 & 55.445\end{array}$

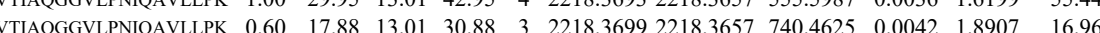
$\begin{array}{lllllllllllllll} & \text { VIA Q }\end{array}$ VTIAQGGVLPNIQAVLLPK 0.64 \#\#\#\# 13.22 \#\#\#\# 2 2 $2218.36542218 .36571110 .1901-0.0003-0.1351 \quad 585.359$ $\begin{array}{lllllllllllllllll}\text { VTIAQGGVLPNIQAVLLPK } & 0.84 & 93.18 & 13.22 & \text { \# } & 2218.3674 & 2218.3657 & 1110.1901 & 0.0017 & 0.7656 & 623.007\end{array}$ $\begin{array}{lllllllllllll}\text { VTIAQGGVLPNIQAVLLPK } & 0.66 & 84.43 & 13.01 & 97.43 & 3 & 2218.3675 & 2218.3657 & 740.4625 & 0.0018 & 0.8103 & 101.320\end{array}$

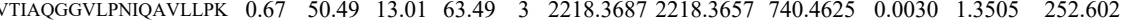

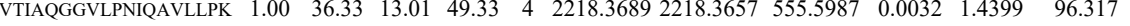

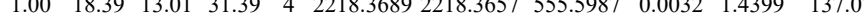
$\begin{array}{lllllllllllll}\text { VGAGAPYYMANVEEYTAEILELAGNAAR } & 1.00 & 73.20 & 24.22 & 18.44 & 3 & 3076.6372 & 3076.6388 & 1026.5535 & -0.0016 & -0.5195 & 0.000\end{array}$ $\begin{array}{llllllllllll}\text { VTIAQGGVLPNIQAVLLPK } & 0.64 & 82.65 & 13.22 & 95.65 & 2 & 2218.3654 & 2218.3657 & 1110.1901 & -0.0003 & -0.1351 & 171.189\end{array}$ $\begin{array}{llllllllllll}\text { VTIAQGGVLPNIQAVLLPK } & 0.84 & 83.09 & 13.22 & 96.09 & 2 & 2218.3674 & 2218.3657 & 1110.1901 & 0.0017 & 0.7656 & 115.99\end{array}$ $\begin{array}{llllllllllll}\text { VTIAQGGVLPNIQAVLLPK } & 1.00 & 27.26 & 13.01 & 40.26 & 4 & 2218.3677 & 2218.3657 & 555.5987 & 0.0020 & 0.8999 & 37.134\end{array}$ $\begin{array}{llllllllllll}\text { VIIAQGGVLPNIQAVLLPK } & 0.67 & 62.10 & 13.01 & 75.10 & 3 & 2218.3690 & 2218.3657 & 740.4625 & 0.0033 & 1.4856 & 304.86\end{array}$ $\begin{array}{llllllllllllll} & \end{array}$ $\begin{array}{llllllllllll}\text { VIAQGGVLPNQAVLPK } & 0.64 & 83.39 & 13.22 & 96.39 & 2 & 2218.3654 & 2218.3657 & 110.1901 & -0.0003 & -0.1351 & 79.641 \\ \text { VTIAQGGVLPNIQAVLLPK } & 0.66 & 37.45 & 13.01 & 50.45 & 3 & 2218.3675 & 2218.3657 & 740.4625 & 0.0018 & 0.8103 & 26.951\end{array}$

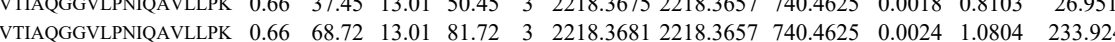
$\begin{array}{llllllllllllll}\text { VTIAQGGVLPNIQAVLLPK } & 1.00 & 14.80 & 13.01 & 27.80 & 4 & 2218.3693 & 2218.3657 & 555.5987 & 0.0036 & 1.6199 & 46.411\end{array}$

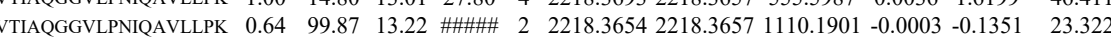

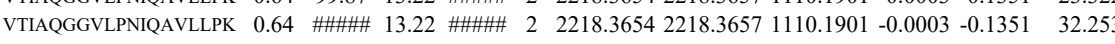
$\begin{array}{llllllllllll}\text { VTIAQGGVLPNIQAVLLPK } & 0.66 & 59.98 & 13.01 & 72.98 & 3 & 2218.3681 & 2218.3657 & 740.4625 & 0.0024 & 1.0804 & 13.995\end{array}$ $\begin{array}{lllllllllllll}\text { VTIAQGGVLPNIQAVLLPK } & 0.60 & 81.38 & 13.01 & 94.38 & 3 & 2218.3693 & 2218.3657 & 740.4625 & 0.0036 & 1.6206 & 94.044\end{array}$

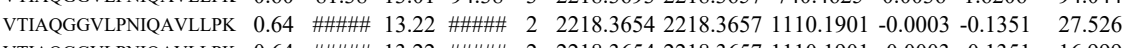

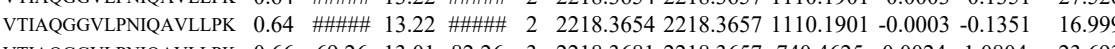
$\begin{array}{lllllllllllll}\text { VTIAQGGVLPNIQAVLLPK } & 0.66 & 69.26 & 13.01 & 82.26 & 3 & 2218.3681 & 2218.3657 & 740.4625 & 0.0024 & 1.0804 & 23.693\end{array}$ $\begin{array}{lllllllllllll}\text { VTIAQGGVLPNIQAVLLPK } & 0.67 & 32.30 & 13.01 & 45.30 & 3 & 2218.3684 & 2218.3657 & 740.4625 & 0.0027 & 1.2155 & 19.556\end{array}$ $\begin{array}{lllllllllllll}\text { VTIAQGGVLPNIQAVLLPK } & 0.64 & 87.36 & 19.78 & \# \# \# \# \quad 2 & 1930.1612 & 1930.1615 & 966.0880 & -0.0003 & -0.1553 & 1.532\end{array}$ $\begin{array}{llllllllllll}\text { VTIAQGGVLPNIQAVLLPK } & 0.64 & 63.37 & 19.78 & 76.37 & 2 & 1930.1612 & 1930.1615 & 966.0880 & -0.0003 & -0.1553 & 3.964\end{array}$ $\begin{array}{llllllllllll}\text { VTIAQGGVLPNIQAVLLPK } & 0.87 & 8.83 & 16.90 & 15.11 & 3 & 2074.2649 & 2074.2636 & 692.4285 & 0.0013 & 0.6258 & 15.049\end{array}$ VTIAQGGVLPNIQAVLLPKK 0.64 \#\#\#\# 13.22 \#\#\#\# 2 2 $2218.36542218 .36571110 .1901-0.0003-0.1351 \quad 12.006$ $\begin{array}{llllllllllll}\text { VTIAQGGVLPNIQAVLLPK } & 0.84 & 96.73 & 13.22 & \text { \#\#\#\# } 2 & 2218.3674 & 2218.3657 & 1110.1901 & 0.0017 & 0.7656 & 4.977\end{array}$

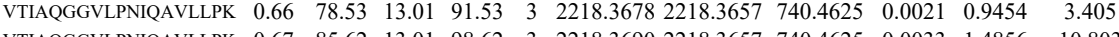

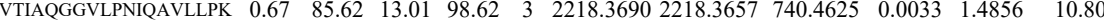

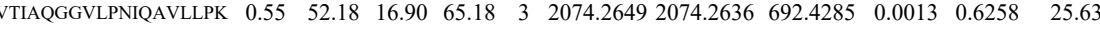
$\begin{array}{lllllllllllll}\text { VTIAQGGVLPNIQAVLLPK } & 0.66 & 91.25 & 13.01 & \ldots \text { m\#\#\# } & 3 & 2218.3678 & 2218.3657 & 740.4625 & 0.0021 & 0.9454 & 5.890\end{array}$ $\begin{array}{lllllllllllll}\text { VTIAQGGVLPNIQAVLLPK } & 0.60 & 74.99 & 13.01 & 87.99 & 3 & 2218.3693 & 2218.3657 & 740.4625 & 0.0036 & 1.6206 & 2.672\end{array}$

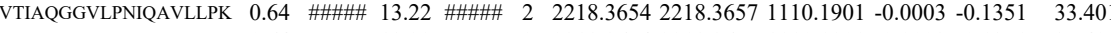

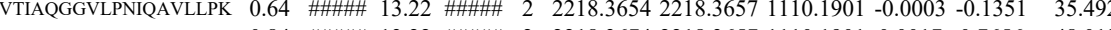
$\begin{array}{lllllllllllllll}\text { VTIAQGGVLPNIQAVLLPK } & 0.84 & \text { \#\#\#\# } 13.22 & \text { \#\#\#\# } 2 & 2218.3674 & 2218.3657 & 1110.1901 & 0.0017 & 0.7656 & 48.012\end{array}$ $\begin{array}{lllllllllll}\text { VTIAQGGVLPNIQAVLLPK } & 0.84 & \text { \#\#\#\# } 13.22 & \text { \#\#\#\# } 2 & 2 & 2218.3674 & 2218.3657 & 1110.1901 & 0.0017 & 0.7656 & 39.63\end{array}$ $\begin{array}{llllllllllll}\text { VTIAQGGVLPNIQAVLLPK } & 0.60 & 41.94 & 13.01 & 54.94 & 3 & 2218.3693 & 2218.3657 & 740.4625 & 0.0036 & 1.6206 & 32.22\end{array}$ $\begin{array}{llllllllllll}\text { VIAQGVLPNQAVLLK } & 0.55 & 78.04 & 13.22 & 91.04 & 3 & 2218.3666 & 2218.3657 & 740.4625 & 0.0009 & 0.4052 & 5.131\end{array}$ $\begin{array}{llllllllllll} & \text { M }\end{array}$

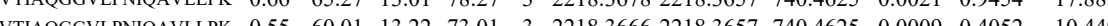
$\begin{array}{llllllllllllll}\text { VTIAQGGVLPNIOAVLLPK } & 0.66 & 96.52 & 13.01 & \text { \#\#\#\# } & 3 & 2218.3675 & 22183657 & 740.4625 & 0.0018 & 0.8103 & 22.771\end{array}$ $\begin{array}{lllllllllllll}\text { VTIAQGGVLPNIQAVLLPK } & 0.66 & 66.78 & 13.01 & 79.78 & 3 & 2218.3675 & 2218.3657 & 740.4625 & 0.0018 & 0.8103 & 6.039\end{array}$

$\begin{array}{llll}64.409 & 125.992 & 61.904 & \end{array}$ \begin{tabular}{lllll}
64.409 & 125.992 & 61.904 & $\mathrm{Ne}$ \\
1.691 & 987.083 & 3344.041 & Yes \\
\hline
\end{tabular} 31.292 37.890
51.553 23.095

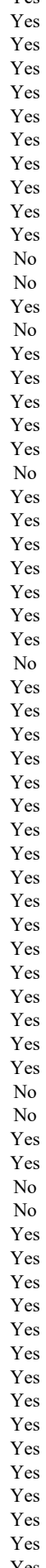

Table S-4 page 507 of 614 


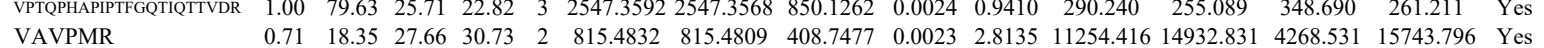
$\begin{array}{llllllllllllllll} & \\ \text { VAVPMR } & 0.71 & 18.35 & 27.66 & 30.73 & 2 & 815.4832 & 815.4809 & 408.7477 & 0.0023 & 2.8135 & 11254.416 & 14932.831 & 4268.531 & 15743.796 & \text { Yes } \\ \text { VAVPMR } & 0.67 & 17.79 & 27.53 & 26.18 & 2 & 815.4820 & 815.4809 & 4087477 & 0.0011 & 13456 & 5466.115 & 6580.757 & 3586.832 & 9388.546 & \text { Yes }\end{array}$

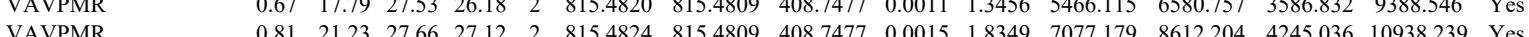

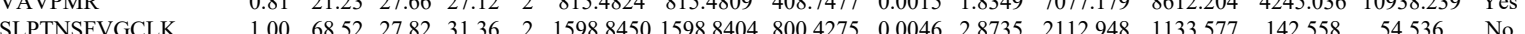
$\begin{array}{lllllllllllllll} & & & \end{array}$ $\begin{array}{llllllllllllll} & \end{array}$ $\begin{array}{llllllllllllllll}\text { LGGSNFEGCISNVFVQR } & 0.67 & 43.47 & 26.95 & 56.47 & 3 & 2015.9707 & 2015.9679 & 672.9966 & 0.0028 & 1.3868 & 194.521 & 190.744 & 152.507 & 176.336 & \text { Yes }\end{array}$

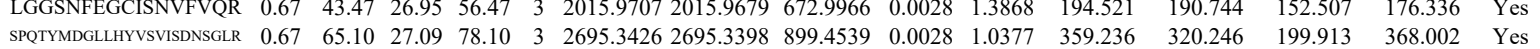
$\begin{array}{llllllllllllllll}\text { SPOTYMDGLLHYVSVISDNSGLR } & 1.00 & 68.01 & 27.12 & 17.33 & 3 & 2695.3426 & 2695.3398 & 899.4539 & 0.0028 & 1.0377 & 359.236 & 320.246 & 199.913 & 368.002 & \text { Yes } \\ \end{array}$ $\begin{array}{lllllllllllllll} & \end{array}$ $\begin{array}{llllllllllllllll}\text { LGGSNFEGCISNVFVQR } & 0.89 & 18.95 & 27.02 & 18.80 & 3 & 2015.9719 & 2015.9679 & 672.9966 & 0.0040 & 1.9812 & 183.549 & 150.500 & 152.500 & 179.672 & \text { Yes }\end{array}$

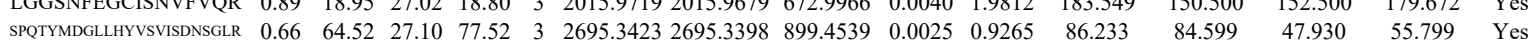

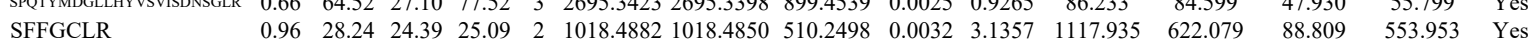
$\begin{array}{llllllllllllllll}\text { SFFGCLR } & 0.96 & 24.65 & 24.30 & 19.76 & 2 & 1018.4872 & 1018.4850 & 510.2498 & 0.0022 & 2.1558 & 3618.623 & 1938.997 & 43.895 & 1583.754 & \text { Yes }\end{array}$ $\begin{array}{llllllllllllllllll}\text { SFFGCLR } & 0.98 & 31.78 & 24.41 & 16.20 & 2 & 1018.4876 & 1018.4850 & 510.2498 & 0.0026 & 2.5478 & 4436.441 & 2406.708 & 76.222 & 1606.453 & \text { Yes }\end{array}$ $\begin{array}{llllllllllllllll}\text { ELTDLNQEFETLQEK } & 1.00 & 79.10 & 28.23 & 33.08 & 2 & 2124.0854 & 2124.0830 & 1063.0488 & 0.0024 & 1.1288 & 56.904 & 32.143 & 39.985 & 66.193 & \text { Yes }\end{array}$ $\begin{array}{llllllllllllllll}\text { ELTDLNQEFETLQEK } & 1.00 & 76.46 & 28.23 & 28.14 & 2 & 2124.0854 & 2124.0830 & 1063.0488 & 0.0024 & 1.1288 & 44.725 & 32.315 & 13.891 & 56.105 & \text { Yes }\end{array}$ $\begin{array}{llllllllllllllll}\text { ANDITDEVLDGLNPIQTDVER } & 0.80 & 22.59 & 27.62 & 21.05 & 3 & 2470.2298 & 2470.2309 & 824.4176 & -0.0011 & -0.4448 & 200.813 & 189.657 & 44.583 & 202.267 & \text { Yes }\end{array}$

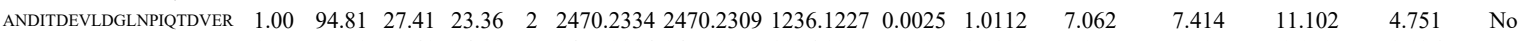

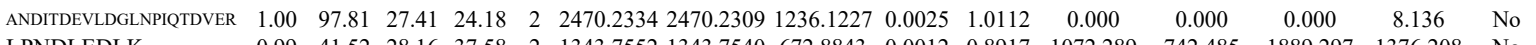

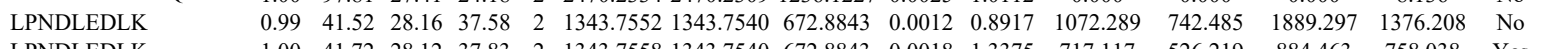

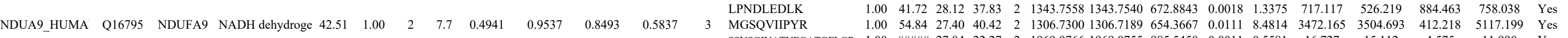

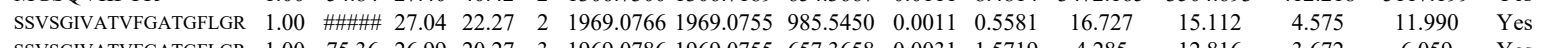

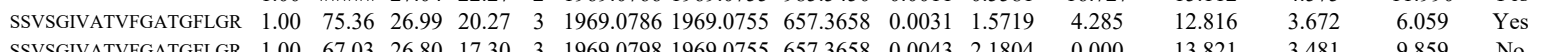

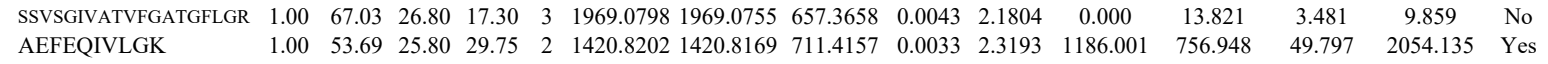
AEFEQIVLGK

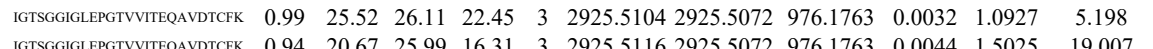
$\begin{array}{llll}13.782 & 32.440 & \text { Yes }\end{array}$ $\begin{array}{llllllllllllll} & \end{array}$ $\begin{array}{llllllllllllllll}\text { NVLSEYQQRPQR } & 0.83 & 16.53 & 27.83 & 20.75 & 3 & 1660.8802 & 1660.8767 & 554.6328 & 0.0035 & 2.1035 & 9022.934 & 5841.629 & 2599.527 & 11118.878 & \text { Yes }\end{array}$ 

$\begin{array}{lllllllllllllllll}0.99 & 48.09 & 26.70 & 23.58 & 2 & 1197.5830 & 1197.5757 & 599.7951 & 0.0073 & 6.0854 & 3969.372 & 2192.788 & 430.777 & 7191.552 & \text { Yes }\end{array}$ $\begin{array}{ccccccccccccccccc} & \end{array}$ $\begin{array}{lllllllllllllllllll} & \end{array}$

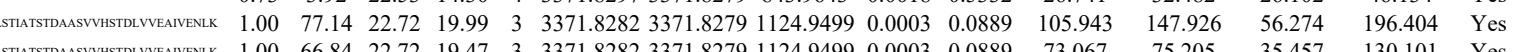

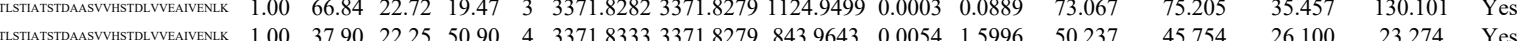

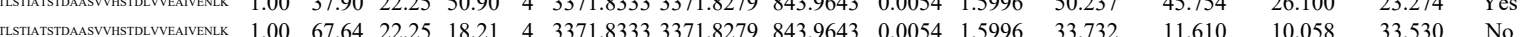
\begin{tabular}{llllllllllllll}
\hline & 13.921 & No
\end{tabular}

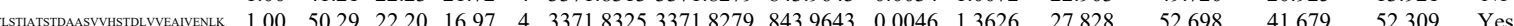

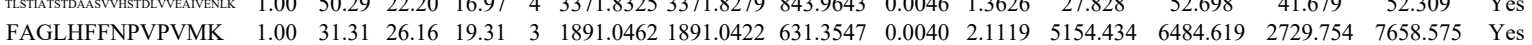
$\begin{array}{llllllllllllllll}\text { FAGLHFFNPVPVMK } & 1.00 & 31.26 & 26.06 & 25.22 & 3 & 1891.0459 & 1891.0422 & 631.3547 & 0.0037 & 1.9535 & 831.786 & 980.678 & 463.420 & 1142.824 & \text { Yes }\end{array}$ $\begin{array}{llllllllllllllll}\text { FAGLHFFNPVPVMK } & 1.00 & 31.48 & 26.11 & 16.96 & 3 & 1891.0465 & 1891.0422 & 631.3547 & 0.0043 & 2.2702 & 987.619 & 1071.726 & 493.429 & 1337.415 & \text { Yes }\end{array}$ $\begin{array}{llllllllllllllll}\text { FAGLLTLLDATYK } & 0.99 & 28.20 & 25.93 & 16.57 & 3 & 1909.0690 & 1909.0652 & 637.3623 & 0.0038 & 1.9874 & 79.254 & 114.127 & 57.308 & 131.727 & \text { Yes }\end{array}$

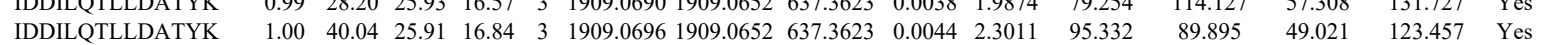
$\begin{array}{llllllllllllllll}\text { IDDILQTLLDATYK } & 0.76 & 14.27 & 25.93 & 15.47 & 3 & 1909.0693 & 1909.0652 & 637.3623 & 0.0041 & 2.1442 & 75.565 & 47.340 & 39.369 & 88.359 & \text { Yes }\end{array}$ $\begin{array}{lllllllllllllllll}\text { TFTYLLGSDAAALLFNSK } & 1.00 & 32.17 & 26.69 & 15.94 & 3 & 2219.2105 & 2219.2081 & 740.7433 & 0.0024 & 1.0800 & 8.351 & 5.257 & 5.165 & 18.996 & \text { Yes }\end{array}$ $\begin{array}{llllllllllllllll}\text { TFTYLLGSDAAALLFNSK } & 0.67 & 19.39 & 26.67 & 32.39 & 3 & 2219.2108 & 2219.2081 & 740.7433 & 0.0027 & 1.2150 & 9.934 & 8.649 & 6.143 & 5.291 & \text { Yes }\end{array}$

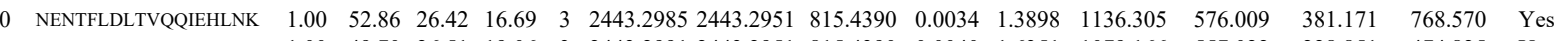
$\begin{array}{lllllllllllllllll}\text { NENTFLDLTVQQIEHLNK } & 1.00 & 49.70 & 26.51 & 19.06 & 3 & 2443.2991 & 2443.2951 & 815.4390 & 0.0040 & 1.6351 & 1079.166 & 557.022 & 228.851 & 474.825 & \text { Yes }\end{array}$ $\begin{array}{llllllllllllllll}\text { TLDGGLNVIQLETAVGAAIK } & 0.98 & 19.05 & 19.64 & 15.41 & 3 & 2270.3134 & 2270.3089 & 757.7769 & 0.0045 & 1.9795 & 0.000 & 7.815 & 0.000 & 8.489 & \text { No }\end{array}$

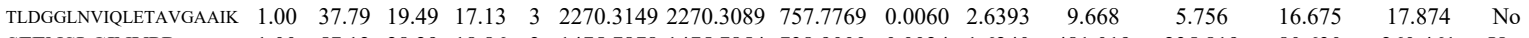

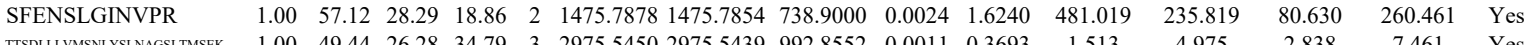

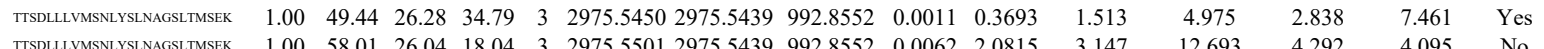

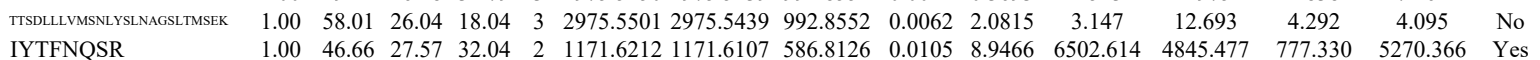

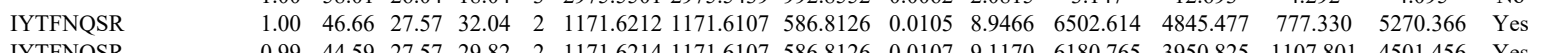

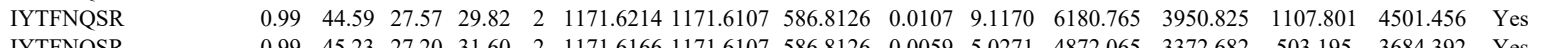

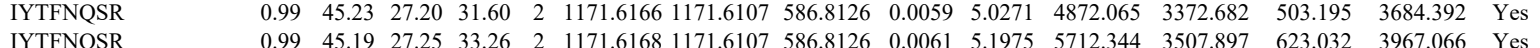
$\begin{array}{llllllllllllllll} & 0.99 & 45.19 & 27.25 & 33.26 & 2 & 1171.6168 & 1171.6107 & 586.8126 & 0.0061 & 5.1975 & 5712.344 & 3507.897 & 623.032 & 3967.066 & \text { Yes } \\ \text { IYGTNQSR } & 1.00 & 55.30 & 27.37 & 21.72 & 2 & 1340.7270 & 1340.7180 & 671.3663 & 0.0090 & 6.7027 & 11461.764 & 8137.519 & 6864.881 & 7726.499 & \text { Yes }\end{array}$ $\begin{array}{llllllllllllllll}\text { GGTLTQYEGK } & 1.00 & 55.30 & 27.37 & 21.72 & 2 & 1340.7270 & 1340.7180 & 671.3663 & 0.0090 & 6.7027 & 11461.764 & 8137.519 & 6864.881 & 7726.499 & \text { Yes } \\ \text { GGTLTQYEGK } & 1.00 & 55.26 & 27.51 & 25.24 & 2 & 1340.7280 & 1340.7180 & 671.3663 & 0.0100 & 7.4474 & 11705.825 & 7913.622 & 6125.027 & 7320.369 & \text { Yes }\end{array}$

$\begin{array}{lllllllllll}\text { TRXR1_HUMAI } & \text { Q16881 } & \text { TXNRD1 } & \text { Thioredoxin reduc } 70.906 & 1.00 & 7 & 16.8 & 0.3982 & 0.2120 & 1.6418 & 0.4594\end{array}$

$\begin{array}{lllllllllll}\text { IMMT_HUMAN } & \text { Q16891 } & \text { IMMT } & \text { Mitochondrial inn } 83.678 & 1.00 & 3 & 5.4 & -0.4652 & 0.5753 & 0.4355 & 0.3962\end{array}$

$\begin{array}{llllllllll}\text { HNRL2_HUMAl Q1KMD3 } & \text { HNRNPUL Heterogeneous nu } 85.105 & 1.00 & 8 & 14.3 & 0.0373 & 0.2453 & 0.2908 & 0.2693\end{array}$

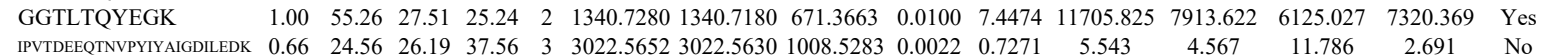

VVupsTsere $\begin{array}{llllllllllllllll}\text { KK } & 1.00 & 59.70 & 23.16 & 17.31 & 3 & 2569.4275 & 2569.4261 & 857.4826 & 0.0014 & 0.5442 & 172.864 & 173.332 & 299.234 & 156.646 & \text { Yes }\end{array}$ $\begin{array}{llllllllllllllll} & & & \end{array}$

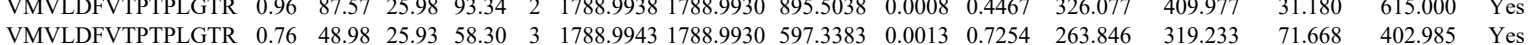

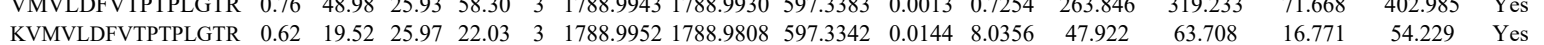

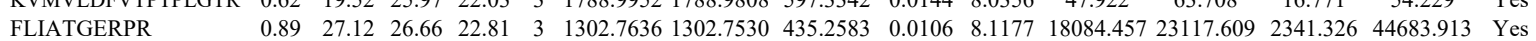

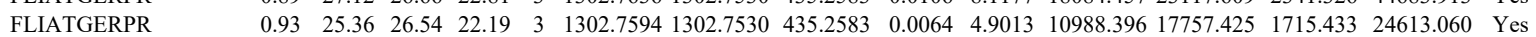
$\begin{array}{llllllllllllllll}\text { FLIATGERPR } & 0.90 & 25.24 & 26.53 & 21.38 & 3 & 1302.7603 & 1302.7530 & 435.2583 & 0.0073 & 5.5905 & 7579.362 & 9628.579 & 1636.620 & 15883.438 & \text { Yes }\end{array}$ $\begin{array}{llllllllllllllll}\text { VEQIEAGTPGR } & 1.00 & 63.35 & 27.47 & 18.31 & 2 & 1299.6988 & 1299.6905 & 650.8525 & 0.0083 & 6.3762 & 4392.296 & 6721.590 & 1021.762 & 9246.979 & \text { Yes }\end{array}$ $\begin{array}{lllllllllllllllll}\text { VEQIEAGTPGR } & 1.00 & 63.48 & 27.54 & 22.44 & 2 & 1299.7008 & 1299.6905 & 650.8525 & 0.0103 & 7.9126 & 3419.580 & 5120.430 & 856.878 & 6904.251 & \text { Yes }\end{array}$ $\begin{array}{lllllllllllllllll}4 & \text { YSTSGSSGLTTGK } & 1.00 & 79.15 & 27.77 & 21.50 & 2 & 1532.7942 & 1532.7926 & 767.4036 & 0.0016 & 1.0425 & 2847.719 & 2805.388 & 1586.980 & 4089.811 & \text { Yes }\end{array}$

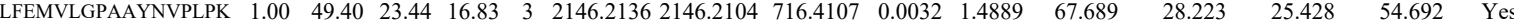

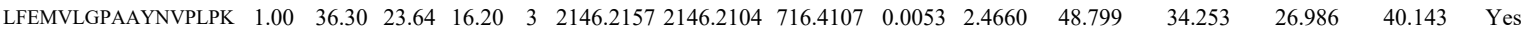
$\begin{array}{lllllllllllllllll}\text { AVDEAADALLK } & 1.00 & 89.15 & 27.00 & 32.87 & 2 & 1402.7918 & 1402.7911 & 702.4028 & 0.0007 & 0.4983 & 3839.969 & 3666.867 & 426.907 & 3326.261 & \text { Yes }\end{array}$

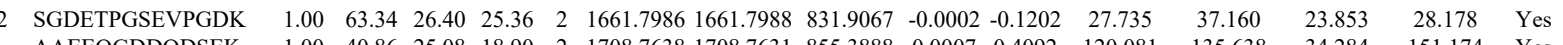

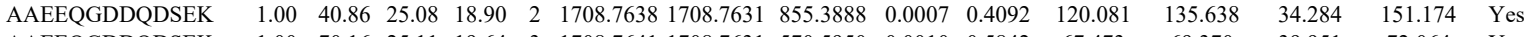

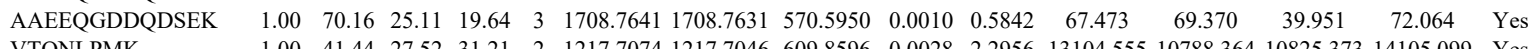
$\begin{array}{llllllllllllllll}\text { VTQNLPMK } & 1.00 & 41.44 & 27.52 & 31.21 & 2 & 1217.7074 & 1217.7046 & 609.8596 & 0.0028 & 2.2956 & 13104.555 & 10788.364 & 10825.373 & 14105.099 & \text { Yes }\end{array}$

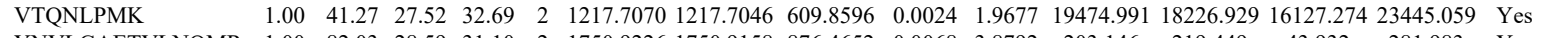

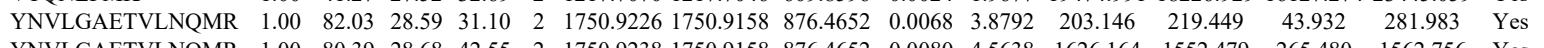
$\begin{array}{llllllllllllllll}\text { YNVLGAETVLNQMR } & 1.00 & 80.39 & 28.68 & 42.55 & 2 & 1750.9238 & 1750.9158 & 876.4652 & 0.0080 & 4.5638 & 1626.164 & 1552.479 & 265.480 & 1562.756 & \text { Yes } \\ \text { YNVVGGAETVLNQ } & 1.00 & 52.70 & 28.59 & 22.44 & 3 & 1750.261 & 1750.158 & 584.645 & 0.0103 & 5.8725 & 322.192 & 319.429 & 148.825 & 309.427 & \text { Yes }\end{array}$ $\begin{array}{llllllllllllllll}\text { YNVLGAETVLNQMR } & 1.00 & 52.70 & 28.59 & 22.44 & 3 & 1750.9261 & 1750.9158 & 584.6459 & 0.0103 & 5.8725 & 322.192 & 319.429 & 148.825 & 309.427 & \text { Yes } \\ \text { YNVLGAETVLNQMR } & 1.00 & 9.66 & 28.51 & 33.37 & 2 & 1750.9168 & 1750.9158 & 876.4652 & 0.0010 & 0.5705 & 312.943 & 236.155 & 70.233 & 310.384 & \text { Yes }\end{array}$ $\begin{array}{llllllllllllllll}\text { YNVLGAETVLNQMR } & 1.00 & 90.66 & 28.51 & 33.37 & 2 & 1750.9168 & 1750.9158 & 876.4652 & 0.0010 & 0.5705 & 312.943 & 236.155 & 70.233 & 310.384 & \text { Yes } \\ \text { LVQIASR } & 0.98 & 33.30 & 27.00 & 27.42 & 2 & 929.5806 & 929.5780 & 465.7963 & 0.0026 & 27009 & 8125.140 & 8095.955 & 1913.480 & 13325.060 & \text { Yes }\end{array}$ $\begin{array}{llllllllllllllll}\text { LVQIASR } & 0.98 & 33.30 & 27.00 & 27.42 & 2 & 929.5806 & 929.5780 & 465.7963 & 0.0026 & 2.7909 & 8125.140 & 8095.955 & 1913.480 & 13325.060 & \text { Yes } \\ \text { EVEGDDVPESIMLEMK } & 1.00 & 37.47 & 27.92 & 15.59 & 3 & 2108.0284 & 2108.0261 & 703.6826 & 0.0023 & 1.0895 & 75.514 & 102.162 & 104.671 & 109.521 & \text { Yes }\end{array}$

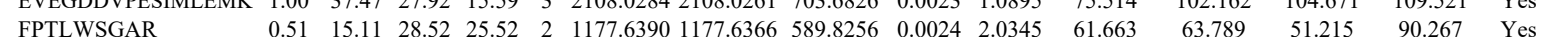

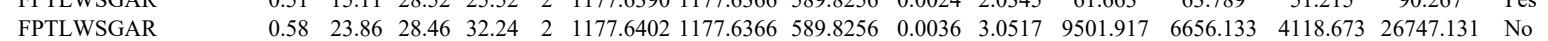



$\begin{array}{llllllllllll} & & \end{array}$

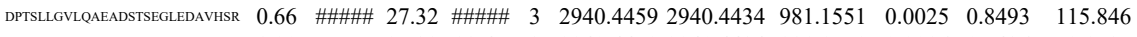

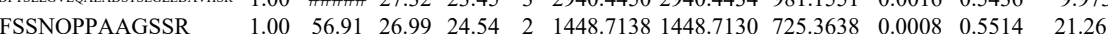
$\begin{array}{lllllllllllll}\text { NEFIGLQLLDVLAR } & 1.00 & 96.38 & 24.86 & 22.40 & 2 & 1744.0032 & 1744.0005 & 873.0075 & 0.0027 & 1.5464 & 267.442\end{array}$

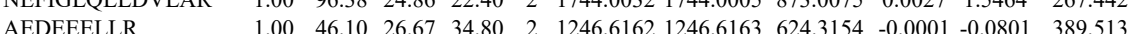
$\begin{array}{lllllllllllll}\text { SSQLLWEALESLVNR } & 1.00 & 49.76 & 26.96 & 27.77 & 3 & 1888.0213 & 1888.0176 & 630.3465 & 0.0037 & 1.9566 & 101.843\end{array}$ $\begin{array}{lllllllllllll}\text { SSQLLWEALESLVNR } & 1.00 & 47.33 & 26.97 & 21.69 & 3 & 1888.0216 & 1888.0176 & 630.3465 & 0.0040 & 21152 & 68.633\end{array}$ $\begin{array}{lllllllllllll}\text { AQLVLAACESLLTSR } & 1.00 & \# \# \# \# \quad 27.80 & 21.37 & 2 & 1763.9398 & 1763.9395 & 882.9770 & 0.0003 & 0.1699 & 40.338\end{array}$ $\begin{array}{lllllllllllll}\text { AQLVLAACESLLTSR } & 1.00 & 56.06 & 27.82 & 17.24 & 3 & 1763.9413 & 1763.9395 & 588.9871 & 0.0018 & 1.0187 & 48.790\end{array}$ $\begin{array}{lllllllllllll}\text { LLQMPSVVNYSGLR } & 1.00 & 66.77 & 27.46 & 28.31 & 2 & 1719.9464 & 1719.9463 & 860.9804 & 0.0001 & 0.0581 & 145.606\end{array}$ $\begin{array}{lllllllllllll}\text { LLQMPSVVNYSGLR } & 1.00 & 70.78 & 27.61 & 27.78 & 2 & 1719.9480 & 1719.9463 & 860.9804 & 0.0017 & 0.9872 & 199.783\end{array}$ $\begin{array}{lllllllllllll}\text { AQLVLAACESLLTSR } & 1.00 & 95.13 & 27.80 & 26.81 & 2 & 1763.9398 & 1763.9395 & 882.9770 & 0.0003 & 0.1699 & 28.510\end{array}$ $\begin{array}{lllllllllllll}\text { AQLVLAACESLLTSR } & 1.00 & 89.67 & 27.82 & 21.80 & 2 & 1763.9410 & 1763.9395 & 882.9770 & 0.0015 & 0.8494 & 36.986\end{array}$ $\begin{array}{llllllllllll}\text { AQLVLAACESLLTSR } & 1.00 & 53.40 & 27.80 & 21.06 & 3 & 1763.9419 & 1763.9395 & 588.9871 & 0.0024 & 1.3583 & 24.426\end{array}$ $\begin{array}{lllllllllllll}\text { AQLVLAACESLLTSR } & 1.00 & 39.27 & 27.87 & 17.24 & 3 & 1763.9422 & 1763.9395 & 588.9871 & 0.0027 & 1.5280 & 20.54\end{array}$ $\begin{array}{lllllllllllll}\text { AQLVLAACESLLTSR } & 1.00 & 59.31 & 27.94 & 29.84 & 2 & 1763.9390 & 1763.9395 & 882.9770 & -0.0005 & -0.2831 & 6.919\end{array}$ $\begin{array}{llllllllllll}\text { AQLVLAACESLLTSR } & 0.66 & 17.14 & 27.82 & 25.05 & 3 & 1763.9395 & 1763.9395 & 588.9871 & 0.0000 & 0.0000 & 18.041\end{array}$ $\begin{array}{lllllllllllll}\text { AQLVLAACESLLTSR } & 0.74 & 19.47 & 27.82 & 29.21 & 3 & 1763.9404 & 1763.9395 & 588.9871 & 0.0009 & 0.5093 & 11.499\end{array}$

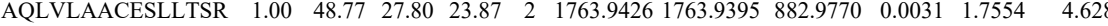
$\begin{array}{llllllllllll}\text { AQLVLAACESLLTSR } & 0.54 & 15.38 & 27.91 & 23.30 & 3 & 1763.9392 & 1763.9395 & 588.9871 & -0.0003 & -0.1698 & 11.983 \\ \text { AQLVLAACESLLTSR } & 0.77 & 19.27 & 27.91 & 24.11 & 3 & 1763.9392 & 1763.9395 & 588.9871 & -0.0003 & -0.1698 & 13.420\end{array}$ $\begin{array}{lllllllllllll}\text { AQLVLAACESLLTSR } & 0.77 & 19.27 & 27.91 & 24.11 & 3 & 1763.9392 & 1763.9395 & 588.9871 & -0.0003 & -0.1698 & 13.420 \\ \text { QLPIFCQLILR } & 0.92 & 25.09 & 26.91 & 19.93 & 2 & 1532.8706 & 1532.8693 & 767.4419 & 0.0013 & 0.8470 & 30.513\end{array}$ VDESGPPAPSKPR $\begin{array}{lllllllllll}0.66 & 43.34 & 27.74 & 56.34 & 3 & 1623.8848 & 1623.8824 & 542.3014 & 0.0024 & 1.4752 & 4018.063\end{array}$ TVQTIEACIANFFN $\begin{array}{lllllllllll}1.00 & 40.25 & 26.46 & 15.81 & 3 & 2525.3275 & 2525.3256 & 842.7825 & 0.0019 & 0.7515 & 3.533\end{array}$ NDDLNKPINK VDESGPPAPSKPR

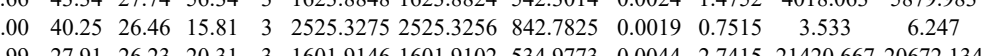
VDESGPPAPSK

$\begin{array}{llllllllllll}\text { TSR1_HUMAN Q2NL82 TSR1 } & \text { Pre-rRNA-process } 91.81 & 1.00 & 4 & 6.8 & 0.4309 & 0.1922 & 0.4406 & 0.2942 & 5 & \text { MSVLNMVVR }\end{array}$ MSVLNMVVR IFQFQNFTNTR

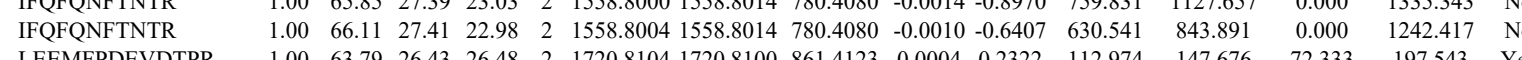
LEEMFPDEVDTPR $\begin{array}{llllllllllllll} & \end{array}$ $\begin{array}{lllllllllllllll}1.00 & 56.02 & 27.74 & 23.25 & 3 & 1623.8848 & 1623.8824 & 542.3014 & 0.0024 & 0.7376 & 5510.010 & 5452.519 & 8652.170 & 6831.483 & \text { Yes }\end{array}$ $\begin{array}{llllllllllllllll}0.99 & 36.47 & 28.80 & 36.13 & 2 & 1191.6598 & 1191.6590 & 596.8368 & 0.0008 & 0.6702 & 1655.892 & 2387.750 & 438.763 & 2288.725 & \text { Yes }\end{array}$ $\begin{array}{llllllllllllllll}0.99 & 37.50 & 28.71 & 36.43 & 2 & 1191.6606 & 1191.6590 & 596.8368 & 0.0016 & 1.3404 & 1494.958 & 1841.450 & 401.391 & 2133.317 & \text { Yes }\end{array}$ $\begin{array}{lllllllllllllll}1.00 & 65.85 & 27.39 & 28.31 & 2 & 1191.6600 & 1191.6590 & 596.8368 & 0.0010 & 0.8377 & 1360.422 & 1576.659 & 0.2068 & 1886.280 & \text { Yes }\end{array}$ \begin{tabular}{|lllllllllllllllll}
197.543 & Yes
\end{tabular} $\begin{array}{llllllllllllllll}\text { DPDMAMEICATDAVDDMEEGLK } & 0.66 & 33.28 & 20.37 & 46.28 & 3 & 2732.1625 & 2732.1603 & 911.7274 & 0.0022 & 0.8043 & 16.787 & 8.140 & 11.850 & 8.312 & \text { No }\end{array}$

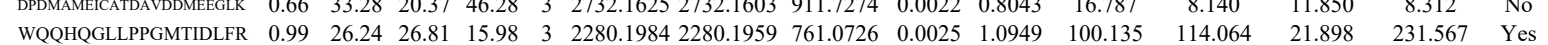
$\begin{array}{llllllllllllllll}\text { LMALLGQALK } & 0.99 & 28.20 & 21.21 & 26.14 & 3 & 1344.8416 & 1344.8406 & 449.2875 & 0.0010 & 0.7419 & 88.128 & 109.169 & 48.730 & 261.963 & \text { Yes }\end{array}$ $\begin{array}{llllllllllllllll}\text { LMALLGQALK } & 1.00 & 56.47 & 21.07 & 26.54 & 2 & 1344.8420 & 1344.8406 & 673.4276 & 0.0014 & 1.0395 & 1464.813 & 1557.719 & 98.693 & 2666.196 & \text { Yes }\end{array}$ LMALLGQALK

AGGEELDEGVAK $\begin{array}{lllllllllllll}1.00 & 56.47 & 21.07 & 26.54 & 2 & 1344.8420 & 1344.8406 & 673.4276 & 0.0014 & 1.0395 & 1464.813 & 1557.719\end{array}$ $\begin{array}{llllllllllll}1.00 & 52.12 & 21.07 & 25.63 & 2 & 1344.8424 & 1344.8406 & 673.4276 & 0.0018 & 1.3364 & 1547.437 & 1660.030\end{array}$ AGGEELDEGVAK $\begin{array}{llllllllllll}1.00 & 49.20 & 28.31 & 19.34 & 2 & 1461.7566 & 1461.7555 & 731.8850 & 0.001 & 0.7515 & 126.459 & 126.650 \\ 1461.7555 & 731.8850 & 0.0017 & 1.1614 & 94.264 & 91.852\end{array}$

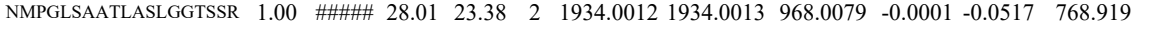
$\begin{array}{lllllllllllllll}\text { NMPGLSAATLASLGGTSSR } & 0.87 & 19.54 & 28.25 & 16.61 & 3 & 1934.0050 & 1934.0013 & 645.6744 & 0.0037 & 1.9101 & 318.830 & 39\end{array}$ $\begin{array}{lllllllllllllll}\text { NMPGLSAATLASLGGTSSR } & 0.92 & 21.34 & 28.25 & 16.32 & 3 & 1934.0050 & 1934.0013 & 645.6744 & 0.0037 & 1.9101 & 309.145 & 366 & & \\ \text { AGGEELDEGVAK } & 1.00 & 66.17 & 28.17 & 21.40 & 2 & 1461758 & 14617555 & 731.8850 & 0.0003 & 0.2050 & 259.593 & 227 & \end{array}$ $\begin{array}{llllllllllll}\text { AGGEELDEGVAK } & 1.00 & 66.17 & 28.17 & 21.40 & 2 & 1461.7558 & 1461.7555 & 731.8850 & 0.0003 & 0.2050 & 259.593 \\ \text { AGGEELDEGVAK } & 1.00 & 53.08 & 28.31 & 22.54 & 2 & 14617572 & 14617555 & 731.8850 & 0.0017 & 1.1614 & 304320\end{array}$ $\begin{array}{lllllllllllll}\text { AGGEELDEGVAK } & 1.00 & 53.08 & 28.31 & 22.54 & 2 & 1461.7572 & 1461.7555 & 731.8850 & 0.0017 & 1.1614 & 304.320 \\ \text { DMLLELEEQLAESR } & 1.00 & 75.83 & 27.66 & 23.89 & 2 & 1818.9170 & 1818.9155 & 910.4650 & 0.0015 & 0.8238 & 11.533\end{array}$ $\begin{array}{llllllllllll}\text { DMLLELEEQLAESR } & 1.00 & 75.83 & 27.66 & 23.89 & 2 & 1818.9170 & 1818.9155 & 910.4650 & 0.0015 & 0.8238 & 11.533 \\ \text { DMLLELEEQLAESR } & 1.00 & 89.12 & 27.66 & 22.76 & 2 & 1818.9172 & 1818.9155 & 910.4650 & 0.0017 & 0.9336 & 25.831\end{array}$ $\begin{array}{lllllllllllll}\text { DMLLELEEQLAESR } & 1.00 & 89.12 & 27.66 & 22.76 & 2 & 1818.9172 & 1818.9155 & 910.4650 & 0.0017 & 0.9336 & 25.831 \\ \text { ALDSNSLENDDLSAPGR } & 1.00 & 98.77 & 27.08 & 27.84 & 2 & 1916.9244 & 1916.9197 & 959.4671 & 0.0047 & 2.4493 & 81.512\end{array}$ $\begin{array}{llllllllllll}\text { ALDSNSLENDDLSAPGR } & 1.00 & 98.77 & 27.08 & 27.84 & 2 & 1916.9244 & 1916.9197 & 959.4671 & 0.0047 & 2.4493 & 81.512 \\ \text { TPETLLPFAEAEAFLK } & 1.00 & 71.73 & 25.81 & 22.37 & 3 & 2064.1441 & 2064.1387 & 689.0535 & 0.0054 & 2.6123 & 140.327\end{array}$ $\begin{array}{llllllllllll}\text { TPETLLPFAEAEAFLK } & 1.00 & 70.11 & 25.81 & 17.93 & 3 & 2064.1444 & 2064.1387 & 689.0535 & 0.0057 & 2.7574 & 210.044\end{array}$ $\begin{array}{llllllllllll}\text { TPETLLPFAEAEAFLK } & 1.00 & 43.50 & 25.80 & 26.49 & 3 & 2064.1435 & 2064.1387 & 689.0535 & 0.0048 & 2.3220 & 98.234 \\ \text { TPETLLPFAEAEAFLK } & 1.00 & 65.00 & 25.81 & 20.60 & 3 & 2064.1444 & 2064.1387 & 689.0535 & 0.0057 & 2.7574 & 192.168\end{array}$ $\begin{array}{llllllllllllll}\text { TPETLLPFAEAEAFLK } & 1.00 & 65.00 & 25.81 & 20.60 & 3 & 2064.1444 & 2064.1387 & 689.0535 & 0.0057 & 2.7574 & 192.168\end{array}$ KPNAGGSPAPV KPNAGGSPAPVR $\begin{array}{llllllllllll}0.66 & 44.53 & 25.65 & 57.53 & 3 & 1437.8320 & 1437.8296 & 480.2838 & 0.0024 & 1.6657 & 22.309\end{array}$ 
$\begin{array}{lllllllllllll} & \text { TFVDFFSQCLHEEYR } & 0.66 & 53.26 & 24.65 & 66.26 & 3 & 2109.9433 & 2109.9410 & 704.3209 & 0.0023 & 1.0885 & 76.702\end{array}$ $\begin{array}{llllllllllll}\text { TFVDFFSQCLHEEYR } & 1.00 & 59.01 & 24.71 & 18.19 & 3 & 2109.9436 & 2109.9410 & 704.3209 & 0.0026 & 1.2305 & 85.434 \\ \text { TFV }\end{array}$ $\begin{array}{llllllllllll}\text { TFVDFFSQCLHEEYR } & 1.00 & 53.03 & 24.65 & 20.24 & 3 & 2109.9433 & 2109.9410 & 704.3209 & 0.0023 & 1.0885 & 90.770\end{array}$ $\begin{array}{llllllllllll}\text { TFVDFFSQCLHEEYR } & 0.67 & 40.85 & 24.56 & 53.85 & 3 & 2109.9442 & 2109.9410 & 704.3209 & 0.0032 & 1.5145 & 146.356\end{array}$ $\begin{array}{lllllllllllll}\text { TFVDFFSQCLHEEYR } & 0.67 & 28.65 & 24.56 & 41.65 & 3 & 2109.9442 & 2109.9410 & 704.3209 & 0.0032 & 1.5145 & 36.325 & 6\end{array}$

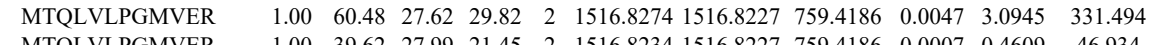

MTQLVLPGMVER

MTQLVLPGMVER

VVLISR

GALLNISSGSGMLPVPLLI

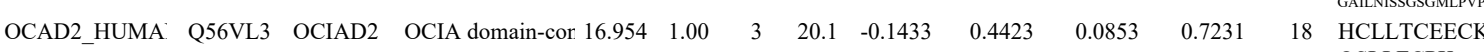

QSLLFCPK

QSLLFCPK

QSLLFCPK

QSLLFCPK

VALAGLLGFGLGK

VALAGLLGFGLGK

VALAGLLGGLK

VALAGGLGGLK

VALAGLLGFGLGK

VALAGLLGFGLGKK

VALAGLLGFGLGK

VALAGLLGFGLGK

VALAGLLGFGLGK

VALAGLLGFGLGK

VALAGLLGFGLGK

VALAGLLGFGLGK

VALAGLLGFGLGK

VALAGLLGFGLGK

VALAGLLGFGLGK

VALAGLLGFGLGK

VALAGLLGFGLGK

VALAGLLGFGLGK

VALAGLLGFGLGK

VALAGLLGFGLGK

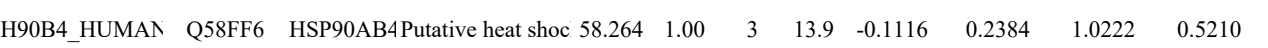

GFEVIYMSEPIDEY
SLINTFYSNK

SLIINTFYSNK
SLIINTFYSNK
SLIINTFYSNK

SLIINTFYSNK
SLIINTFYSNK

SLIINTFYSNK
SLIINTFYSNK

SLIINTFYSNK
SLIINTFYSNK

$\begin{array}{llllllllllll}1.00 & 39.62 & 27.99 & 21.45 & 2 & 1516.8234 & 1516.8227 & 759.4186 & 0.0007 & 0.4609 & 46.934\end{array}$

$\begin{array}{llllllllllll}1.00 & 55.51 & 27.86 & 26.79 & 2 & 1516.8252 & 1516.8227 & 759.4186 & 0.0025 & 1.6460 & 320.475 & 290.870\end{array}$

$\begin{array}{llllllllllll}0.86 & 21.83 & 22.76 & 31.05 & 2 & 829.5536 & 829.5507 & 415.7826 & 0.0029 & 3.4874 & 25696.793 & 26402.201\end{array}$

$\begin{array}{lllllllllllll}0.92 & 24.43 & 22.76 & 30.90 & 2 & 829.5540 & 829.5507 & 415.7826 & 0.0033 & 3.9684 & 23684.195 & 27748.451 \\ 0.55 & 21.69 & 2.09 & 34.69 & 3 & 2790.5815 & 2790.5809 & 931.2009 & 0.0006 & 0.2148 & 9.158 & 10.11\end{array}$ $\begin{array}{cccccccccccc}0.55 & 21.69 & 20.09 & 34.69 & 3 & 2790.5815 & 2790.5809 & 931.2009 & 0.0006 & 0.2148 & 9.158 & 10.211 \\ 1.00 & 40.32 & 19.78 & 15.70 & 3 & 1603.6618 & 1603.6602 & 535.5607 & 0.0016 & 0.9958 & 601.719 & 626.108 \\ 1.00 & 45.78\end{array}$ $\begin{array}{lllllllllllll}1.00 & 40.32 & 19.78 & 15.70 & 3 & 1603.6618 & 1603.6602 & 535.5607 & 0.0016 & 0.9958 & 601.719 & 626.108 \\ 1.00 & 45.78 & 27.78 & 32.00 & 2 & 1268.6892 & 1268.6865 & 635.3505 & 0.0027 & 2.1248 & 22294.987 & 21179.610\end{array}$ $\begin{array}{lllllllllllll}1.00 & 45.78 & 27.78 & 32.00 & 2 & 1268.6892 & 1268.6865 & 635.3505 & 0.0027 & 2.1248 & 22294.987 & 21179.610 \\ 1.00 & 46.20 & 27.78 & 31.06 & 2 & 1268.6894 & 1268.6865 & 635.3505 & 0.0029 & 2.2822 & 18112.166 & 14369.230\end{array}$ $\begin{array}{lllllllllllll}1.00 & 46.20 & 27.78 & 31.06 & 2 & 1268.6894 & 1268.6865 & 635.3505 & 0.0029 & 2.2822 & 18112.166 & 14369.230 \\ 1.00 & 47.89 & 27.78 & 35.01 & 2 & 1268.6892 & 1268.6865 & 635.3505 & 0.0027 & 2.1248 & 12675.937 & 10226.619\end{array}$ $\begin{array}{lllllllllllll}1.00 & 47.89 & 27.78 & 35.01 & 2 & 1268.6892 & 1268.6865 & 635.3505 & 0.0027 & 2.1248 & 12675.937 & 10226.619 & 0\end{array}$ $\begin{array}{llllllllllll}0.99 & 50.25 & 27.80 & 38.38 & 2 & 1268.6904 & 1268.6865 & 635.3505 & 0.0039 & 3.0692 & 9227.299 & 8648.797 \\ 0.84 & 89.60 & 19.40 & \# \# \# \# & 2 & 1502.9446 & 1502.9428 & 752.4787 & 0.0018 & 1.1960 & 246.265 & 196.541\end{array}$ $\begin{array}{llllllllllll}0.84 & 89.60 & 19.40 & \# \# \# & 2 & 1502.9446 & 1502.9428 & 752.4787 & 0.0018 & 1.1960 & 246.265 & 196.541 \\ 0.66 & 23.40 & 18.13 & 36.40 & 3 & 1502.9452 & 1502.9428 & 501.9882 & 0.0024 & 1.5937 & 60.351 & 61.167\end{array}$ $\begin{array}{lllllllllllll}0.66 & 23.40 & 18.13 & 36.40 & 3 & 1502.9452 & 1502.9428 & 501.9882 & 0.0024 & 1.5937 & 60.351 & 61.167 \\ 0.67 & 13.89 & 18.13 & 26.89 & 3 & 1502.9455 & 1502.9428 & 501.9882 & 0.0027 & 1.7929 & 61.681 & 56.821\end{array}$

$\begin{array}{ccccccccccc}0.82 & 89.94 & 19.40 & \# \# \# \# \quad 2 & 1502.9442 & 1502.9428 & 752.4787 & 0.0014 & 0.9303 & 1181.668 & 1054.640\end{array}$ $\begin{array}{llllllllllll}0.82 & 90.62 & 19.40 & \# \# \# \# \quad 2 & 1502.9442 & 1502.9428 & 752.4787 & 0.0014 & 0.9303 & 620.190 & 588.556\end{array}$ $\begin{array}{llllllllllll}0.67 & 15.9428 & 1502.9428 & 501.9882 & 0.0027 & 1.7929 & 70.133 & 62.112\end{array}$ $\begin{array}{llllllllllll}0.82 & 77.51 & 19.40 & 90.51 & 2 & 1502.9461 & 1502.9428 & 501.9882 & 0.0033 & 2.1913 & 80.073 & 71.435 \\ 0.52 & 0.89 & 18.13 & 13.77 & 3 & 1502.942 & 1502.9428 & 752.4787 & 0.0014 & 0.9303 & 311.395 & 273.551\end{array}$ $\begin{array}{lllllllllllll}0.82 & 0.89 & 18.13 & 13.77 & 3 & 1502.9455 & 1502.9428 & 501.9882 & 0.0027 & 1.7929 & 46.432 & 27.973\end{array}$ $\begin{array}{llllllllllllll}0.56 & 0.96 & 17.56 & 13.30 & 3 & 1502.9458 & 1502.9428 & 501.9882 & 0.0270 & 1.9921 & 21.589 & 21.137\end{array}$ $\begin{array}{llllllllllllll}0.84 & 81.73 & 18.13 & 94.73 & 2 & 1502.9452 & 1502.9428 & 752.4787 & 0.0024 & 1.5947 & 65.554 & 79.440\end{array}$ $\begin{array}{llllllllllllll}0.67 & 28.76 & 17.56 & 41.76 & 3 & 1502.9458 & 1502.9428 & 501.9882 & 0.0030 & 1.9921 & 21.720 & 38.426\end{array}$ $\begin{array}{llllllllllll}1.00 & 28.16 & 17.56 & 15.16 & 3 & 1502.9470 & 1502.9428 & 501.9882 & 0.0042 & 2.7889 & 42.683 & 60.087\end{array}$ $\begin{array}{lllllllllllll}0.55 & 21.44 & 9.44 & 34.44 & 3 & 15029437 & 1502.9428 & 501.9882 & 0.0009 & 0.5976 & 6.256 & 20.087\end{array}$ $\begin{array}{lllllllllllll}0.99 & 19.77 & 18.13 & 15.88 & 3 & 1502.9452 & 1502.9428 & 501.9882 & 0.0024 & 1.5937 & 6.339 & 10.801\end{array}$ $\begin{array}{llllllllllllll}0.66 & 16.27 & 19.40 & 29.27 & 3 & 1502.9446 & 1502.9428 & 501.9882 & 0.0018 & 1.1952 & 19.253 & 9.694\end{array}$ $\begin{array}{lllllllllllll}1.00 & 24.42 & 19.34 & 16.03 & 3 & 1502.9449 & 1502.9428 & 501.9882 & 0.0021 & 1.3945 & 10.407 & 13.686\end{array}$ $\begin{array}{llllllllllll}1.00 & 24.42 & 19.34 & 16.03 & 3 & 1502.9449 & 1502.9428 & 501.9882 & 0.0021 & 1.3945 & 10.407 & 13.686 \\ 0.84 & 61.04 & 9.40 & 74.04 & 2 & 1502.9446 & 1502.9428 & 752.4787 & 0.0018 & 1.1960 & 11.408 & 7.669\end{array}$ $\begin{array}{lllllllllllll}0.66 & 21.76 & 18.13 & 34.76 & 3 & 1502.9452 & 1502.9428 & 501.9882 & 0.0024 & 1.5937 & 28.376 & 13.418\end{array}$ $\begin{array}{llllllllllll}1.00 & 39.80 & 18.13 & 20.82 & 3 & 1502.9455 & 1502.9428 & 501.9882 & 0.0027 & 1.7929 & 13.974 & 12.687\end{array}$

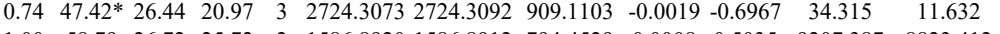
$\begin{array}{llllllllllll}1.00 & 58.79 & 26.72 & 25.72 & 2 & 1586.8920 & 1586.8912 & 794.4529 & 0.0008 & 0.5035 & 9207.387 & 8823.412\end{array}$ $\begin{array}{llllllllllll}1.00 & 59.16 & 26.67 & 27.38 & 2 & 1586.8926 & 1586.8912 & 794.4529 & 0.0014 & 0.8811 & 7387.303 & 7411.894 \\ 0.95 & 26.02 & 26.60 & 23.68 & 3 & 1586.8939 & 1586.8912 & 529.9710 & 0.0027 & 1.6982 & 1666.873 & 1195.758\end{array}$ $\begin{array}{llllllllllllll}0.95 & 26.02 & 26.60 & 23.68 & 3 & 1586.8939 & 1586.8912 & 529.9710 & 0.0027 & 1.6982 & 1666.873 & 1195.758 \\ 0.90 & 22.53 & 26.60 & 17.64 & 3 & 1586.8945 & 1586.8912 & 529.9710 & 0.0033 & 2.0756 & 1386.309 & 1019.622\end{array}$ $\begin{array}{lllllllllllll}0.90 & 22.53 & 26.60 & 17.64 & 3 & 1586.8945 & 1586.8912 & 529.9710 & 0.0033 & 2.0756 & 1386.309 & 1019.622 \\ 0.99 & 51.56 & 27.02 & 27.82 & 2 & 15868888 & 15868912 & 794.5529 & -0.0024 & -1.5105 & 1485.989 & 1410.978\end{array}$

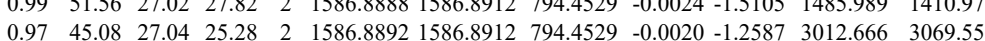

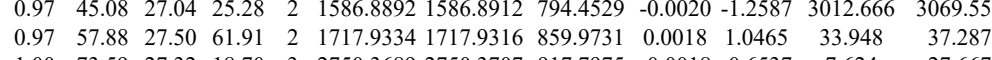
$\begin{array}{llllllllllllll}\text { NVAELTVMDVYDIASLVGHEFER } & 1.00 & 73.59 & 27.32 & 18.70 & 3 & 2750.3689 & 2750.3707 & 917.7975 & -0.0018 & -0.6537 & 7.624 & 27.667 \\ \text { NVAELTVMDVYDIALLVGHEFER } & 0.55 & 85.01 & 27.11 & 98.01 & 3 & 2750.3722 & 2750.3707 & 917.7975 & 0.0015 & 0.5448 & 30.987 & 36.075\end{array}$ $\begin{array}{lllllllllllll}\text { NVAELTYMDVYDISLLGHEFER } & 0.60 & 82.77 & 27.02 & 95.77 & 3 & 2750.3752 & 2750.3707 & 917.7975 & 0.0045 & 1.6343 & 210.768 & 209.617\end{array}$

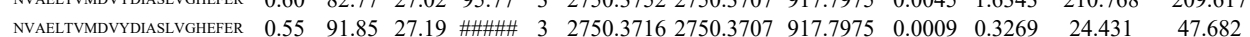
$\begin{array}{lllllllllllll}0.99 & 21.01 & 19.40 & 16.22 & 3 & 1502.9443 & 1502.9428 & 501.9882 & 0.0015 & 0.9960 & 12.966 & 8.073\end{array}$ MSLIINTFYSNK

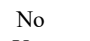


CAAPRPPSSSPEQR

CAAPRPPSSSPEQR

CAAPRPPSSSPEQR

CAAPRPPSSSPEQR QEIIEQLLSNIFHK QEIIEQLLSNIFHK QEIIEQLLSNIFHK QEIIEQLLSNIFHK QEIEQLLSNIFH

VLSILISR

VLSILISR

VLSILISR

IFSOHLQN

IFSQHLQNR
IFSQHLQNR

THFLMPFPVNYVGECIR

THFLMPFPVNYVGECIR 1.00

LSVLDLVVALAPCADEAAIS

LSVLDLVVALAPCADEAAISK LSVLDLVVALAPCADEAAISK
LSVLDLVVALAPCADEAAISK

LQWDLGLGHLPR

SWLLPVIR

SWLLPVIR

AAELLMSCFR

AAELLMSCFR

CQTVIVQSFLR
CQTVIVQSFLR

LDFSLQPET
FSLFVR

ITIPITPAFLGQLR

ITIPITPAFLGQLR

ITIPITPAFLGQLR

ITIPITPAFLGQLR

GGGPAGAGGEAPAAL

LYPVLQQSLVR

LYPVLQQSLVR

LYPVLQQSLVR

LYPVLQQSLVR

TRPSSTVIK

ALPPLIVGAQLIHADK

ALPLIVGAQLIHADK

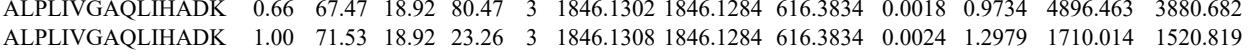
$\begin{array}{llllllllllll}\text { TIPSWATLSASQLAR } & 1.00 & \text { \#\#\#\# } 27.19 & 27.70 & 2 & 1744.9598 & 1744.9594 & 873.4870 & 0.0004 & 0.2290 & 1182.826 & 716.407\end{array}$ $\begin{array}{lllllllllllll}\text { TIPSWATLSASQLAR } & 1.00 & \text { \#\#\#\# } 27.19 & 27.62 & 2 & 1744.9598 & 1744.9594 & 873.4870 & 0.0004 & 0.2290 & 962.169\end{array}$ $\begin{array}{lllllllllllllll} & \text { TPSWATLSASQLAR } & 0.67 & 12.23 & 26.96 & 25.23 & 3 & 1744.9621 & 1744.9594 & 582.6604 & 0.0027 & 1.5446 & 156.546\end{array}$ $\begin{array}{lllllllllllll}\text { TIPSWATLSASQLAR } & 1.00 & \text { \#\#\#\# } 27.31 & 26.11 & 2 & 1744.9584 & 1744.9594 & 873.4870 & -0.0010 & -0.5724 & 733.768 & 3 \\ \text { TIPSWATLSASQLAR } & 1.00 & \text { m\#\#\# } & 27.19 & 27.17 & 2 & 1744.9596 & 1744.9594 & 873.4870 & 0.0002 & 0.1145 & 661.454 & 3\end{array}$ TIPSWATLSASQLAR 1.00 \#\#\#\# $27.19 \begin{array}{lllllllll}27.17 & 2 & 1744.9596 & 1744.9594 & 873.4870 & 0.0002 & 0.1145 & 661.454\end{array}$ $\begin{array}{llllllllllllll}\text { RPSQEQSASASSGQPQAPLNR } & 1.00 & 66.59 & 27.77 & 18.29 & 3 & 2339.1706 & 2339.1700 & 780.7306 & 0.0006 & 0.2562 & 14.714\end{array}$

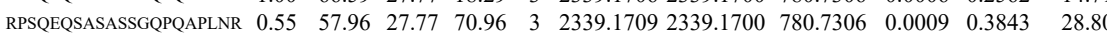
$\begin{array}{lllllllllllll}\text { RPSQEQSASASSGQPQAPLNR } & 0.55 & 58.54 & 27.77 & 71.54 & 3 & 2339.1706 & 2339.1700 & 780.7306 & 0.0006 & 0.2562 & 36.239 \\ \text { TAPATMSTPTIVYATAVHAYR } & 1.00 & 74.22 & 26.12 & 25.79 & 3 & 2315.2444 & 23152429 & 772.7549 & 0.0015 & 0.6470 & 104.796\end{array}$ \begin{tabular}{llllllllllll} 
TAPATMSTPTILVATAVHAYR & 1.00 & 74.22 & 26.12 & 25.79 & 3 & 2315.2444 & 2315.2429 & 772.7549 & 0.0015 & 0.6470 & 104.796 \\
TAPATMSTPTIVATAVHAYR & 1.00 & 76.14 & 26.11 & 22.56 & 3 & 2315.2453 & 2315.2429 & 772.7549 & 0.0024 & 1.0353 & 145.533 \\
\hline
\end{tabular} $\begin{array}{lllllllllllll}\text { TAPATMSTPTILVATAVHAYR } & 1.00 & 76.14 & 26.11 & 22.56 & 3 & 2315.2453 & 2315.2429 & 772.7549 & 0.0024 & 1.0353 & 145.533\end{array}$ $\begin{array}{llllllllllll}\text { ELPQLVASVIESESEILHHEK } & 1.00 & 44.09 & 24.68 & 57.09 & 4 & 2674.4449 & 2674.4421 & 669.6178 & 0.0028 & 1.0454 & 110.206\end{array}$ $\begin{array}{lllllllllllll}\text { ELPQLVASUESESELLHHEK } & 1.00 & 49.83 & 24.73 & 20.02 & 4 & 2674.4461 & 2674.4421 & 669.6178 & 0.0040 & 1.4934 & 159.886\end{array}$ $\begin{array}{lllllllllllll}\text { LEQVSSDEGIGTLAENLLEALR } & 0.95 & 23.77 & 26.36 & 18.07 & 3 & 2500.3189 & 2500.3142 & 834.4453 & 0.0047 & 1.8775 & 9.580\end{array}$

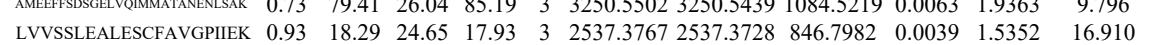
$\begin{array}{lllllllllllll}\text { GVVSSLEALESCFAVGPIIEK } & 0.93 & 18.29 & 24.65 & 17.93 & 3 & 2537.3767 & 2537.3728 & 846.7982 & 0.0039 & 1.5352 & 16.91 \\ \text { GHAADVFEAYTQLTEMVLR } & 0.60 & 22.13 & 27.40 & 35.13 & 3 & 2407.2364 & 2407.2328 & 803.4182 & 0.0036 & 1.4936 & 1.723\end{array}$ $\begin{array}{lllllllllllll}\text { TTLEVLQLFPINIK } & 0.98 & 15.34 & 18.33 & 14.07 & 3 & 1916.1622 & 1916.1590 & 639.7269 & 0.0032 & 1.6674 & 99.608\end{array}$ $\begin{array}{lllllllllllll}\text { TTLEVLQLFPINIK } & 0.99 & 28.00 & 18.39 & 22.61 & 3 & 1916.1634 & 1916.1590 & 639.7269 & 0.0044 & 2.2926 & 223.050\end{array}$ $\begin{array}{llllllllllllllll}1.00 & 47.34 & 27.83 & 25.09 & 3 & 1285.7038 & 1285.7013 & 429.5744 & 0.0025 & 1.9399 & 5396.547 & 5718.515 & 4971.032 & 8820.915 & \text { Yes }\end{array}$ 9.835 9.135 2.689 10.959

1294.438
931.743
831.128 799.150 805.117 94.942 145.770
292.957 292.957
881.306 60.408 20.516 21.390
7.987 13.763

2515.637 338.082 $\begin{array}{lllllllllllllll}35.08 & 26.05 & 17.82 & 3 & 1671.7954 & 1671.7943 & 558.2720 & 0.0011 & 0.6568 & 6483.498 & 6923.988 & 3351.917 & 10381.167 & \text { Yes } \\ 36.02 & 26.04 & 15.49 & 3 & 1671.7957 & 1671.7943 & 558.2720 & 0.0014 & 0.8359 & 5656.408 & 7327.122 & 3822.674 & 10410.362 & \text { Yes }\end{array}$ $\begin{array}{lllllllllllllll}6.06 & 15.90 & 3 & 1671.7948 & 1671.7943 & 558.2720 & 0.0005 & 0.2985 & 13797.697 & 13775.910 & 7125.109 & 19653.243 & \text { Yes } \\ \end{array}$

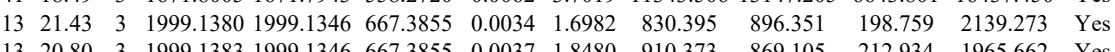

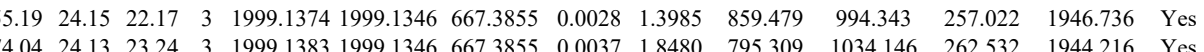
$\begin{array}{llllllllllllllll}40.79 & 19.96 & 20.07 & 2 & 1043.6840 & 1043.6824 & 522.8485 & 0.0016 & 1.5301 & 2218.171 & 2257.615 & 892.716 & 7989.923 & \text { Yes }\end{array}$ $\begin{array}{lllllllllllllll}1.00 & 45.17 & 20.17 & 21.23 & 2 & 1043.6830 & 1043.6824 & 522.8485 & 0.0006 & 0.5738 & 931.127 & 920.255 & 567.798 & 2967.227 & \text { Yes }\end{array}$ $\begin{array}{lllllllllllllllll}.99 & 35.39 & 27.83 & 32.90 & 3 & 1285.7041 & 1285.7013 & 429.5744 & 0.0028 & 2.1727 & 4636.522 & 6350.115 & 4856.816 & 7609.252 & \text { Yes }\end{array}$ $\begin{array}{llll}8.104 & 20.071 & 29.338 & \text { Yes }\end{array}$ $\begin{array}{llll}56.306 & 82.139 & 78.574 & \text { Yes }\end{array}$ 


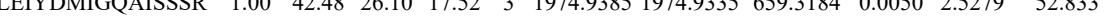
$\begin{array}{lllllllllllll} & \text { CLEV }\end{array}$ $\begin{array}{llllllllllll}\text { CLEIYDMIGQAAISSSR } & 0.98 & 23.54 & 20.83 & 37.46 & 3 & 2765.5567 & 2765.5530 & 922.8583 & 0.0037 & 1.3364 & 32.123 \\ \text { C. } & 3 & 1974.9370 & 1974.9335 & 659.3184 & 0.0035 & 1.7695 & 55.465\end{array}$

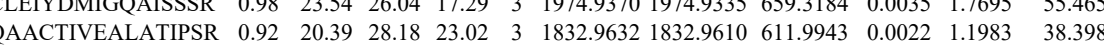
SNPSVLQGLLR

$\begin{array}{lllllllllllll}0.92 & 20.39 & 28.18 & 23.02 & 3 & 1832.9632 & 1832.9610 & 611.9943 & 0.0022 & 1.1983 & 38.398 & 41.383\end{array}$ $\begin{array}{lllllllllllll}\text { GHQGFGVLSVILANHAIK } & 1.00 & 50.18 & 21.76 & 17.68 & 4 & 2148.2441 & 2148.2411 & 538.0676 & 0.0030 & 1.3939 & 267.150\end{array}$ $\begin{array}{llllllllllllll}\text { IIQLLGTTPR } & 1.00 & 52.40 & 22.30 & 27.65 & 2 & 1254.7782 & 1254.7782 & 628.3964 & 0.0000 & 0.0000 & 940.739\end{array}$ $\begin{array}{lllllllllllll} & \end{array}$ $\begin{array}{llllllllllll}\text { GNALLALSSLAVVVSR } & 1.00 & 45.60 & 20.76 & 26.88 & 3 & 1713.0298 & 1713.0270 & 572.0163 & 0.0028 & 1.6317 & 12.649\end{array}$ $\begin{array}{llllllllllllll}\text { GNALLALSSLAVVVSR } & 1.00 & 64.27 & 20.76 & 23.65 & 3 & 1713.0304 & 1713.0270 & 572.0163 & 0.0034 & 1.9813 & 4.68\end{array}$ $\begin{array}{llllllllllllll}\text { FIEAEQVPELEAVLHLVIASSDTR } & 1.00 & 79.71 & 24.79 & 18.72 & 3 & 2809.5016 & 2809.4983 & 937.5067 & 0.0033 & 1.1733 & 63.003\end{array}$ $\begin{array}{lllllllllllll}\text { FIEAEQVPELEAVLHLVISSDTR } & 1.00 & 70.61 & 24.70 & 17.48 & 3 & 2809.5028 & 2809.4983 & 937.5067 & 0.0045 & 1.6000 & 25.533\end{array}$ $\begin{array}{lllllllllllll}\text { GLGLVYELCNEDDOEELVSTLVETLMTGK } & 1.00 & 53.30 & 25.43 & 66.30 & 4 & 3451.8041 & 3451.8000 & 863.9573 & 0.0041 & 1.1864 & 20.089\end{array}$ $\begin{array}{lllllllllllll}\text { TEALSVIELLLK } & 1.00 & 51.27 & 20.13 & 23.45 & 3 & 1616.0020 & 1616.0004 & 539.6741 & 0.0016 & 0.9882 & 53.445\end{array}$ $\begin{array}{lllllllllllll}\text { TEALSVIELLLK } & 1.00 & 29.57 & 19.78 & 19.54 & 3 & 1616.0029 & 1616.0004 & 539.6741 & 0.0025 & 1.5441 & 71.798 \\ \text { TEALSVIELLLK } & 1.00 & 38.33 & 19.78 & 23.77 & 3 & 1616032 & 161.0004 & 539.6741 & 0.0028 & 1.7294 & 87.570\end{array}$ LPEIWETLFR LPEIWETLFR $\begin{array}{lllllllllll}1.00 & 41.80 & 27.77 & 23.70 & 2 & 1446.8010 & 1446.7993 & 724.4069 & 0.0017 & 1.1734 & 33.338\end{array}$ $\begin{array}{lllllllllllll} & & & \end{array}$ $\begin{array}{llllllllllll}\text { VNDVVPWVLDVILNK } & 1.00 & 45.66 & 21.21 & 20.48 & 3 & 2010.1792 & 2010.1758 & 671.0659 & 0.0034 & 1.6889 & 94.704\end{array}$ $\begin{array}{lllllllllllll}\text { VNDVVPWVLDVILNK } & 1.00 & 40.10 & 21.21 & 20.14 & 3 & 2010.1792 & 2010.1758 & 671.0659 & 0.0034 & 1.6889 & 57.764\end{array}$ $\begin{array}{llllllllllll}\text { VNDVVPWVLDVILNK } & 1.00 & 25.67 & 21.21 & 18.25 & 3 & 2010.1792 & 2010.1758 & 671.0659 & 0.0034 & 1.6889 & 111.483\end{array}$ $\begin{array}{llllllllllllll}\text { ELAALFYSVVVSTVSGNELK } & 1.00 & 32.01 & 24.08 & 21.23 & 3 & 2413.3366 & 2413.3348 & 805.4522 & 0.0018 & 0.7449 & 6.377\end{array}$

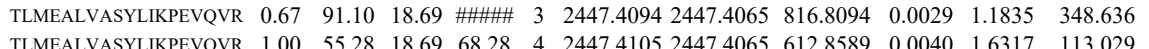
$\begin{array}{lllllllllllll}\text { TLMEALVASYLIKPEVQVR } & 1.00 & 55.28 & 18.69 & 68.28 & 4 & 2447.4105 & 2447.4065 & 612.8589 & 0.0040 & 1.6317 & 113.029 & \\ \text { TLEALVASYLKPEVQVR } & 1.00 & 45.78 & 18.63 & 58.78 & 4 & 2447.4113 & 2447.4065 & 612.8589 & 0.0048 & 1.9580 & 91.048 & 12\end{array}$ $\begin{array}{lllllllllllll}\text { TLMEALVASYLIKPEVQVR } & 1.00 & 45.78 & 18.63 & 58.78 & 4 & 2447.4113 & 2447.4065 & 612.8589 & 0.0048 & 1.9580 & 91.048\end{array}$ LHLVESLLSR LHLVESLLSR

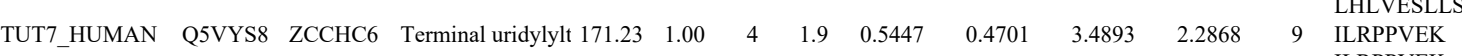
ILRPPY

VPIVK

CPIVK

CFICGR

CFICGR

CFICGR

CFICGR

LVPLVIAFR

LVPLVIAFR

LVPLVIAFR

$\begin{array}{llllllllllll}0.98 & 44.26 & 24.22 & 39.37 & 2 & 1309.7878 & 1309.7840 & 655.8993 & 0.0038 & 2.8968 & 3865.921 \\ 0.97 & 44.12 & 23.96 & 41.21 & 2 & 1309.7882 & 3209.7840 & 655.8993 & 0.0042 & 3.2017 & 2850.495 & 18\end{array}$ $\begin{array}{llllllllllll}0.97 & 44.12 & 23.96 & 41.21 & 2 & 1309.7882 & 1309.7840 & 655.8993 & 0.0042 & 3.2017 & 2850.495 & 1 \\ 1.00 & 48.48 & 23.75 & 30.38 & 3 & 1309.7896 & 1309.7840 & 437.6019 & 0.0056 & 4.2657 & 769.869 & \end{array}$

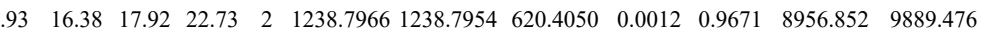
$\begin{array}{llllllllllll}0.93 & 16.42 & 17.92 & 22.36 & 2 & 1238.7978 & 1238.7954 & 620.4050 & 0.0024 & 1.9342 & 10916.373 & 9847 \\ 0.56 & 18.91 & 22.17 & 22.24 & 2 & 842.5826 & 842.5833 & 422.2989 & -0.0007 & -0.8288 & 870.127 & 939\end{array}$ $\begin{array}{lllllllllllll}0.78 & 19.09 & 22.17 & 22.28 & 2 & 842.5830 & 842.5833 & 422.2989 & -0.0003 & -0.3552 & 824.121 & \end{array}$ $\begin{array}{lllllllllllll}0.88 & 13.98 & 17.71 & 24.68 & 2 & 933.3820 & 933.3815 & 467.6980 & 0.0005 & 0.5345 & 342.201\end{array}$ $\begin{array}{llllllllllll}0.88 & 13.85 & 17.56 & 24.56 & 2 & 933.3822 & 933.3815 & 467.6980 & 0.0007 & 0.7483 & 654.869 \\ 0.52 & 13.92 & 17.56 & 24.61 & 2 & 933.3804 & 933.3815 & 467.6980 & -0.0011 & -1.1760 & 750.148\end{array}$ $\begin{array}{llllllllllll}0.75 & 13.95 & 17.71 & 24.68 & 2 & 933.3816 & 933.3815 & 467.6980 & 0.0001 & 0.1069 & 676.864 & \end{array}$ $\begin{array}{lllllllllllll}0.52 & 13.86 & 17.56 & 24.64 & 2 & 933.3800 & 933.3815 & 467.6980 & -0.0015 & -1.6036 & 275.750\end{array}$

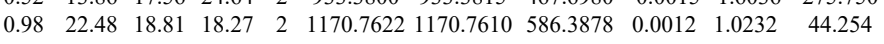
$\begin{array}{lllllllllllll}0.98 & 26.52 & 18.69 & 22.69 & 2 & 1170.7612 & 1170.7610 & 586.3878 & 0.0002 & 0.1705 & 19.907\end{array}$ $\begin{array}{lllllllllllll}0.99 & 24.61 & 18.81 & 19.63 & 2 & 1170.7622 & 1170.7610 & 586.3878 & 0.0012 & 1.0232 & 35.139\end{array}$ $\begin{array}{lllllllllllll}\text { VQEAVNYGLQVLDSAFEQLDIK } & 1.00 & 55.88 & 25.19 & 28.32 & 3 & 2766.4723 & 2766.4683 & 923.1634 & 0.0040 & 1.4443 & 18.837\end{array}$ $\begin{array}{llllllllllllll}\text { VEEAVNYGLQVLDSAFEQLDIK } & 1.00 & 30.76 & 25.22 & 15.59 & 4 & 2766.4725 & 2766.4683 & 692.6244 & 0.0042 & 1.5160 & 98.693 \\ \text { VOEAVNYGLOVLDSAFELLDIK } & 1.00 & 86.22 & 25.17 & 21.97 & 3 & 2766.4732 & 2766.4683 & 923.1634 & 0.0049 & 1.7693 & 21.078\end{array}$

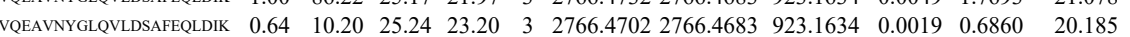
EPQKPEQPTPR EPQKPEQPTPR $\begin{array}{lllllllllllll}0.66 & 15.33 & 27.61 & 28.33 & 3 & 1593.8740 & 1593.8718 & 532.2979 & 0.0022 & 1.3777 & 4462.654 & 39\end{array}$

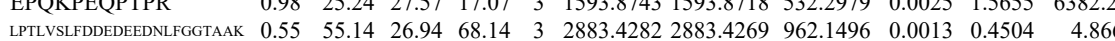
$\begin{array}{llllllllllll}0.55 & 55.14 & 26.94 & 68.14 & 3 & 2883.4282 & 2883.4269 & 962.1496 & 0.0013 & 0.4504 & 4.866 \\ 1.00 & 63.12 & 26.95 & 18.25 & 3 & 2883.4297 & 2883.4269 & 962.1496 & 0.0028 & 0.9700 & 10.640\end{array}$ $\begin{array}{llllllllllll}0.98 & 27.04 & 27.15 & 19.89 & 3 & 2096.0236 & 2096.0229 & 699.6816 & 0.0007 & 0.3335 & 392.963\end{array}$ $\begin{array}{llllllllllll}0.66 & 34.03 & 27.16 & 47.03 & 3 & 2096.0251 & 2096.0229 & 699.6816 & 0.0022 & 1.0481 & 235.069\end{array}$

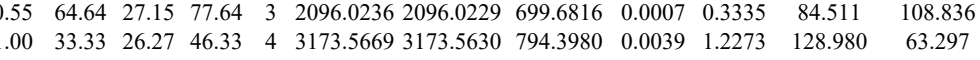




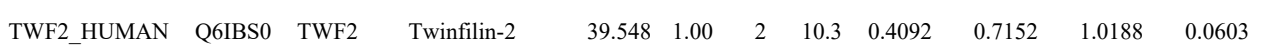

$\begin{array}{lllllllll}\text { SCMC1_HUMAl Q6NUK1 } & \text { SLC25A24 Calcium-binding r } 53.354 & 1.00 & 3 & 7.8 & -0.3872 & 0.2456 & 1.9491 & 0.6547\end{array}$

$\begin{array}{llllllllll}\text { ESRP1_HUMAN Q6NXG1 } & \text { ESRP1 } & \text { Epithelial splicing } 75.585 & 1.00 & 2 & 7.9 & -0.5266 & 0.8502 & -0.2253 & 0.6721\end{array}$ $\begin{array}{llllllllllll} & \end{array}$ $\begin{array}{llllllllllllll}\text { LYGQGIPTLIMLDPQGEVITR } & 0.67 & 43.10 & 23.52 & 56.10 & 3 & 2570.4295 & 2570.4264 & 857.8161 & 0.0031 & 1.2046 & 17.384\end{array}$ $\begin{array}{lllllllllllll} & 2570.4298 & 2570.4264 & 857.8161 & 0.0034 & 1.3212 & 35.051\end{array}$ $\begin{array}{lllllllllllll}\text { LLDSVQDFHLEIAK } & 0.87 & 26.13 & 26.09 & 21.94 & 3 & 2044.1248 & 2044.1084 & 682.3767 & 0.0164 & 8.0112 & 919.661 \\ \text { LLDSVQDFHLEIAK } & 0.99 & 35.00 & 26.43 & 18.89 & 3 & 2044.1146 & 2044.1084 & 682.3767 & 0.0062 & 3.0286 & 671.209\end{array}$ $\begin{array}{lllllllllllll}\text { IEIGDGAELTAEFLYDEVHPK } & 1.00 & 64.02 & 26.81 & 18.42 & 3 & 2633.3587 & 2633.3468 & 878.7895 & 0.0119 & 4.5138 & 76.778\end{array}$ $\begin{array}{llllllllllll}\text { DYLFNPVIEEIIR } & 1.00 & 72.24 & 27.60 & 20.14 & 2 & 2127.1034 & 2127.1010 & 1064.5578 & 0.0024 & 1.1272 & 18.961\end{array}$

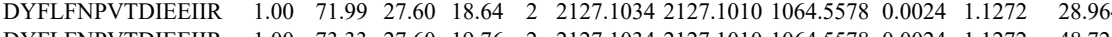
$\begin{array}{llllllllllll}\text { DYFLFNPVIDIELIR } & 1.00 & 73.33 & 27.60 & 19.76 & 2 & 2127.1034 & 2127.1010 & 1064.5578 & 0.0024 & 1.1272 & 48.726\end{array}$

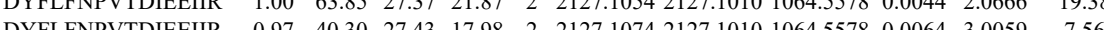

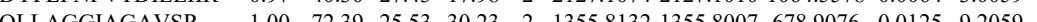
MNIFGGFR

MNIFGGFR $\begin{array}{llllllllllll}1.00 & 72.39 & 25.53 & 30.23 & 2 & 1355.8132 & 1355.8007 & 678.9076 & 0.0125 & 9.2059 & 7986.741 & 5072.989 \\ 0.88 & 27.35 & 27.21 & 21.43 & 2 & 1084.5606 & 1084.5610 & 543.2878 & -0.0004 & -0.3681 & 9314.229 & 6540.125 \\ 0.95 & 27.57 & 27.0 & 2.04 & 2 & & \end{array}$ $\begin{array}{lllllllllllll}0.95 & 27.57 & 27.01 & 22.00 & 2 & 1084.5616 & 1084.5610 & 543.2878 & 0.0006 & 0.5522 & 7843.440 & 7060.058\end{array}$

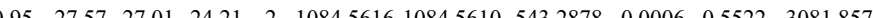
$\begin{array}{lllllllllllll}0.66 & 86.52 & 26.76 & 99.52 & 3 & 2910.4669 & 2910.4652 & 971.1623 & 0.0017 & 0.5835 & 125.701\end{array}$ $\begin{array}{llllllllllllll} & \end{array}$ $\begin{array}{llllllllllllll}\text { OLPFATAEVVAFFGOHCPTGGK } & 1.00 & 40.17 & 26.76 & 15.70 & 4 & 2910.4681 & 2910.4652 & 728.6236 & 0.0029 & 0.9950 & 5.718\end{array}$ $\begin{array}{llllllllllll}\text { GLPTATAEEVVAFFGHCPITGKK } & 1.00 & 44.18 & 26.79 & 57.18 & 4 & 2910.4701 & 2910.4652 & 728.6236 & 0.0049 & 1.6812 & 3.631\end{array}$ $\begin{array}{llllllllllll}\text { GLPTATAEEVYAFGOHCPITGKK } & 0.55 & 71.59 & 26.88 & 84.59 & 3 & 2910.4666 & 2910.4652 & 971.1623 & 0.0014 & 0.4805 & 57.522\end{array}$ \begin{tabular}{llllllllllll} 
GLPFTATAEEVVAFFG & \\
\hline
\end{tabular}

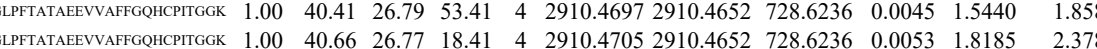

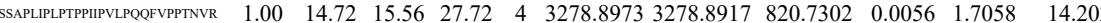

$\begin{array}{lllllllllllll}\text { QAEMEGAVQSIQGELSK } & 1.00 & 72.10 & 27.84 & 19.69 & 3 & 2092.0729 & 2092.0714 & 698.3644 & 0.0015 & 0.7160 & 286.381\end{array}$ $\begin{array}{lllllllllllll}\text { QAEMEGAVQSIQGELSK } & 0.90 & 20.97 & 27.84 & 21.29 & 3 & 2092.0729 & 2092.0714 & 698.3644 & 0.0015 & 0.7160 & 123.862\end{array}$

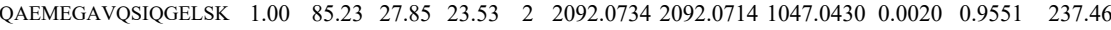

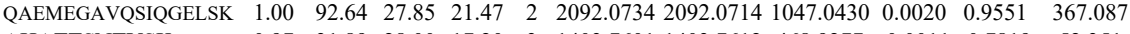
AHATTSNTVSK $\begin{array}{llllllllllll}\text { AHATTSNTVSK } & 0.98 & 33.05 & 28.14 & 18.65 & 3 & 1403.7607 & 1403.7612 & 468.9277 & -0.0005 & -0.3554 & 54.329 \\ \text { QAEMEGAVQSIQGELSK } & 0.71 & 20.87 & 27.74 & 17.22 & 3 & 2092.0708 & 2092.0714 & 698.3644 & -0.0006 & -0.2864 & 345.979\end{array}$ $\begin{array}{llllllllllll}0.97 & 31.89 & 28.00 & 17.20 & 3 & 1403.7601 & 1403.7612 & 468.9277 & -0.0011 & -0.7819 & 52.351\end{array}$ $\begin{array}{llllllllllllll}\text { AHATTSNTVSK } & 0.86 & 21.85 & 28.16 & 17.45 & 3 & 1403.7616 & 1403.7612 & 468.9277 & 0.0004 & 0.2843 & 20.489 \\ \text { IGGAVDQIQLTQAQLEER } & 1.00 & 91.75 & 25.48 & 19.29 & 2 & 2168.1934 & 2168.1923 & 1085.1034 & 0.0011 & 0.5069 & 641.968\end{array}$

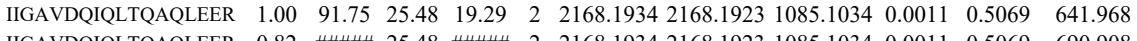
$\begin{array}{lllllllllll}\text { IIGAVDQIQLTQAQLEER } & 0.82 & \text { \#\#\#\# } 25.48 & \text { \#\#\#\# } & 2 & 2168.1934 & 2168.1923 & 1085.1034 & 0.0011 & 0.5069 & 690.908\end{array}$ $\begin{array}{llllllllllll}\text { IIGAVDQIQLTQAQLEER } & 1.00 & 37.41 & 25.51 & 15.40 & 3 & 2168.1952 & 2168.1923 & 723.7380 & 0.0029 & 1.3357 & 112.631 \\ \text { IIGAVDOIQLTQAQLEER } & 0.67 & 26.00 & 25.51 & 39.00 & 3 & 2168.1952 & 2168.1923 & 723.7380 & 0.0029 & 1.3357 & 457.518\end{array}$

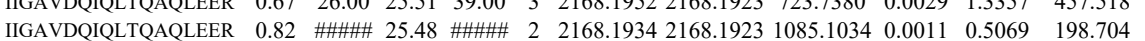

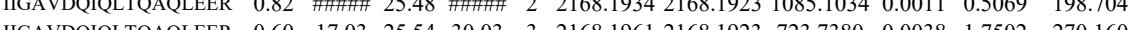

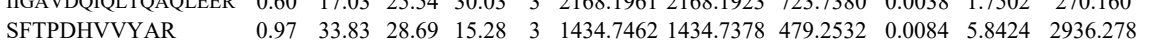

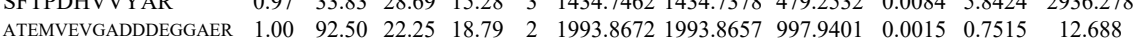

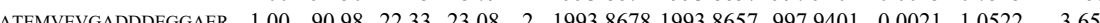

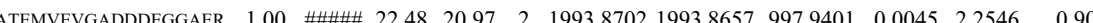

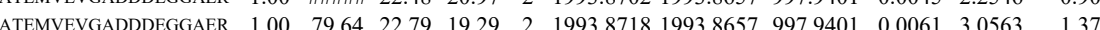
$\begin{array}{lllllllllllll}\text { ATEMNEGADLR } & 1.00 & 74.42 & 26.82 & 34.90 & 2 & 1328.7434 & 1328.7421 & 665.3783 & 0.0013 & 0.9769 & 1.372\end{array}$

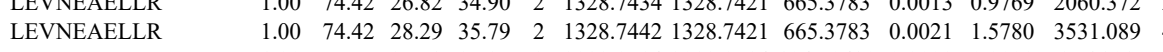
$\begin{array}{llllllllllll}\text { QAEMEGAVQSIQGELSK } & 1.00 & \text { \#\#\#\# } 27.73 & 25.27 & 2 & 2092.0714 & 2092.0714 & 1047.0430 & 0.0000 & 0.0000 & 256.308\end{array}$ $\begin{array}{lllllllllllll}\text { QAEMEGAVQSIQGELSK } & 0.55 & 50.78 & 27.84 & 63.78 & 3 & 2092.0729 & 2092.0714 & 698.3644 & 0.0015 & 0.7160 & 297.176\end{array}$ $\begin{array}{llllllllllllll}\text { QAEMEGAVQSIQGELSK } & 1.00 & 99.10 & 27.85 & 24.16 & 2 & 2092.0734 & 2092.0714 & 1047.0430 & 0.0020 & 0.9551 & 560.263\end{array}$ $\begin{array}{llllllllllllll}\text { QAEMEGAVQSIQGELSK } & 1.00 & 54.71 & 27.72 & 25.33 & 3 & 2092.0753 & 2092.0714 & 698.3644 & 0.0039 & 1.8615 & 809.764\end{array}$ NIFAILQSVK NIFAILQSVK

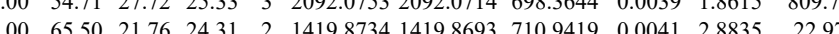
NIFAILQSVK $\begin{array}{lllllllllll}1.00 & 58.15 & 21.79 & 18.37 & 2 & 1419.8738 & 1419.8693 & 710.9419 & 0.0045 & 3.8648\end{array}$ $\begin{array}{llllll}1.00 & 62.67 & 21.46 & 23.81 & 2 & 1419.8\end{array}$ $\begin{array}{llllllllllll}\text { TPIIIIPAATTSLITMLNAK } & 0.67 & 6.27 & 14.47 & 74.27 & 3 & 2369.4238 & 2369.4211 & 790.8143 & 0.0027 & 1.1381 & 21.874\end{array}$ $\begin{array}{lllllllllllll}\text { TPIIIIPAATTSLITMLNAK } & 0.67 & 73.50 & 14.47 & 86.50 & 3 & 2369.4241 & 2369.4211 & 790.8143 & 0.0030 & 1.2645 & 9.578\end{array}$ $\begin{array}{lllllllllllll}\text { TPIIIIPAATTSLITMLNAK } & 1.00 & 49.72 & 16.63 & 16.13 & 3 & 2385.4189 & 2385.4160 & 796.1459 & 0.0029 & 1.2142 & 3.312\end{array}$ $\begin{array}{lllllllllllll}\text { TPIIIIPAATTSLITMLNAK } & 0.67 & 60.29 & 16.63 & 73.29 & 3 & 2385.4189 & 2385.4160 & 796.1459 & 0.0029 & 1.2142 & 2.786\end{array}$ $\begin{array}{lllllllllll}\text { TPIIIIPAATTSLITMLNAK } & 0.84 & \text { \#\#\# } 14.47 \text { \#\#\#\# } 2 & 2369.4234 & 2369.4211 & 1185.7178 & 0.0023 & 0.9699 & 4.715\end{array}$ $\begin{array}{lllllllllllll}\text { TPIIIIPAATTSLITMLNAK } & 0.67 & 64.07 & 14.47 & 77.07 & 3 & 2369.4241 & 2369.4211 & 790.8143 & 0.0030 & 1.2645 & 4.749\end{array}$ $\begin{array}{lllllllllllll}\text { TPIIIIPAATTSLITMLNAK } & 0.60 & 63.34 & 14.31 & 76.34 & 3 & 2369.4253 & 2369.4211 & 790.8143 & 0.0042 & 1.7703 & 15.224\end{array}$ $\begin{array}{llllllllllll}\text { IPIIIIPAATITLITMLNAK } & 0.67 & 60.61 & 14.47 & 73.61 & 3 & 2369.4238 & 2369.4211 & 790.8143 & 0.0027 & 1.1381 & 13.52\end{array}$ $\begin{array}{lllllllllllll}\text { TPIIIIPAATTSLITMLNAK } & 0.60 & 58.04 & 14.31 & 71.04 & 3 & 2369.4250 & 2369.4211 & 790.8143 & 0.0039 & 1.6439 & 18.06\end{array}$ $\begin{array}{lllllllllllll}\text { NEPCHILILEIMSAVR } & 1.00 & 57.94 & 27.88 & 25.93 & 3 & 2155.1101 & 2155.1073 & 719.3764 & 0.0028 & 1.2974 & 7.640\end{array}$

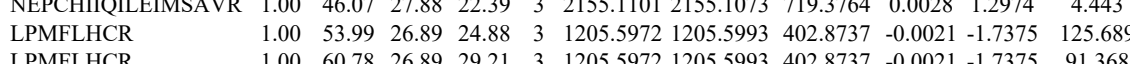
$\begin{array}{llllllllllll}1.00 & 53.99 & 26.89 & 24.88 & 3 & 1205.5972 & 1205.5993 & 402.8737 & -0.0021 & -1.7375 & 125.689 \\ 1.00 & 60.78 & 26.89 & 29.21 & 3 & 1205.5972 & 1205.5993 & 402.8737 & -0.0021 & -1.7375 & 91.368\end{array}$

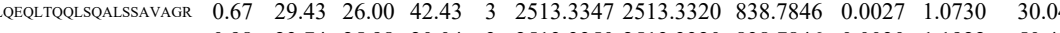
$\begin{array}{llllllllllll}\text { GiLSTLQSATEOMASTVAGSVR } & 1.00 & 87.20 & 27.04 & 22.03 & 3 & 2320.2181 & 2320.2179 & 774.4132 & 0.0002 & 0.0861 & 2.185\end{array}$ 

$\begin{array}{llllllllllll}\text { IEDPDLPAFYFDPLINPISHR } & 1.00 & 78.25 & 27.02 & 19.35 & 3 & 2600.3062 & 2600.3033 & 867.7750 & 0.0029 & 1.1140 & 100.376\end{array}$ $\begin{array}{llllllllllllll}\text { AAVMHDILDMMPEGIK } & 1.00 & 46.30 & 27.68 & 24.32 & 3 & 2058.0592 & 2058.0555 & 687.0258 & 0.0037 & 1.7952 & 737.612\end{array}$ $\begin{array}{llllllllll} & 1.75\end{array}$

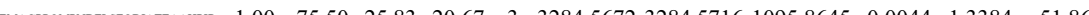
$\begin{array}{llllllll} & \end{array}$

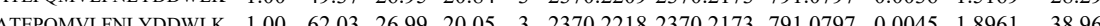

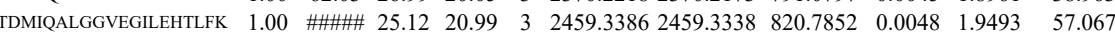
$\begin{array}{llllllllllllll}\text { TDMIQALGGVEGILEHTLFK } & 1.00 & 80.74 & 24.98 & 18.81 & 3 & 2459.3389 & 2459.3338 & 820.7852 & 0.0051 & 2.0712 & 201.909\end{array}$ $\begin{array}{llllllllllllll}\text { GMLDPLEVHLLDFPNIVIK } & 0.82 & 43.23 & 21.99 & 53.17 & 3 & 2450.3878 & 2450.3851 & 817.8023 & 0.0027 & 1.1005 & 472.437 & 57\end{array}$

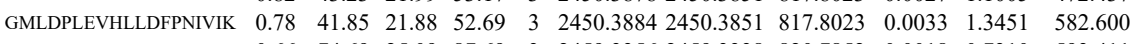
$\begin{array}{lllllllllllll}\text { TDMIQALGGVEGLEHTLFK } & 0.66 & 74.69 & 25.09 & 87.69 & 3 & 2459.3356 & 2459.3338 & 820.7852 & 0.0018 & 0.7310 & 593.411\end{array}$ $\begin{array}{lllllllllllllll}\text { TDMIQALGGVEGLEHTLFK } & 1.00 & 21.97 & 25.04 & 18.82 & 4 & 2459.3365 & 2459.3338 & 615.8407 & 0.0027 & 1.0961 & 85.439 & 6\end{array}$ $\begin{array}{lllllllllllll}\text { TDMIQALGGVEGLLEHTLFK } & 0.99 & 15.54 & 25.07 & 21.75 & 4 & 2459.3381 & 2459.3338 & 615.8407 & 0.0043 & 1.7456 & 44.285\end{array}$ $\begin{array}{llllllllllll}\text { TDMIQALGGVEGILEHTLFK } & 1.00 & 86.79 & 25.12 & 20.23 & 3 & 2459.3386 & 2459.3338 & 820.7852 & 0.0048 & 1.9493 & 5749.674\end{array}$ $\begin{array}{lllllllllllll}\text { GMLDPLEVHLLDFPNIVIK } & 0.88 & 47.53 & 21.90 & 54.69 & 3 & 2450.3890 & 2450.3851 & 817.8023 & 0.0039 & 1.5896 & 50.055\end{array}$

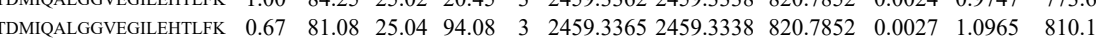
$\begin{array}{llllllllllll}\text { TDMIOALGGVEGILEHTLFK } & 1.00 & 76.64 & 25.12 & 24.53 & 3 & 2459.3386 & 2459.3338 & 820.7852 & 0.0048 & 1.9493 & 54.999\end{array}$
FICISDLR

LLILALER

AISAANLHLR

AISAANLHLR

VPGLPTPIENMILR

VPGLPTPIENMILR

VPGLPTPIENMILR

VPGLPTPIENMILR TILQHLSEAWR

TILQHLSEAWR

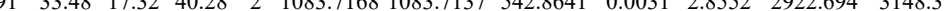
$\begin{array}{llllllllllll}1.00 & 45.24 & 25.09 & 22.42 & 3 & 1208.7214 & 1208.7111 & 403.9110 & 0.0103 & 8.5002 & 6029.294\end{array}$ $\begin{array}{llllllllllll}0.98 & 39.59 & 24.83 & 15.90 & 2 & 1692.9706 & 1692.9718 & 847.4932 & -0.0012 & -0.7080 & 46.681\end{array}$ $\begin{array}{llllllllllll}0.64 & 24.82 & 24.71 & 37.82 & 2 & 1692.9714 & 1692.9718 & 847.4932 & -0.0004 & -0.2360 & 92.944\end{array}$ $\begin{array}{lllllllllll}0.82 & 63.16 & 24.53 & 76.16 & 2 & 1692.9724 & 1692.9718 & 847.4932 & 0.0006 & 0.3540 & 387.875\end{array}$ $\begin{array}{lllllllllllll}1.00 & 58.96 & 24.65 & 16.92 & 2 & 1692.9728 & 1692.9718 & 847.4932 & 0.0010 & 0.5900 & 515.281\end{array}$

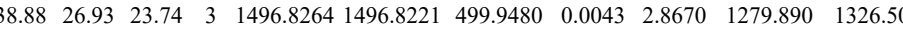
$\begin{array}{lllllllllllll}1.00 & 38.88 & 26.93 & 23.74 & 3 & 1496.8264 & 1496.822 & 499.948 & 0.0043 & 2.8670 & 1279.890 & 1326.504\end{array}$

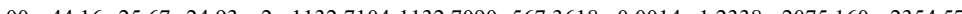
$\begin{array}{llllllllllll}1.00 & 42.51 & 25.29 & 27.88 & 2 & 1132.7108 & 1132.7090 & 567.3618 & 0.0018 & 1.5863 & 1462.724 & 1495.511\end{array}$ $\begin{array}{llllllllllll}1.00 & 42.68 & 25.68 & 25.33 & 2 & 1132.7102 & 1132.7090 & 567.3618 & 0.0012 & 1.0575 & 540.709 & 526.169\end{array}$

ISLIQIFR

ISLIQIFR

ISLIQIFR

DINLQDEDWNEFNDINK 526.169
731.545

VWLFFMR

LTLEDLEDSWDR

LTLEDLEDSWDR

TSYEEFTHK

TSYEEFTHK

$\begin{array}{llllllllll}\text { PDXD1_HUMAl Q6P996 } & \text { PDXDC1 } & \text { Pyridoxal-depends 86.707 } & 1.00 & 3 & 5.8 & -0.3684 & 0.2520 & 1.4150 & 0.4200\end{array}$

LPLLLVANAGTAAVGHT

FSPLMTAAVLGTR

SSPMTAAVLGTR

GEDVDQLVACIESK

4.647

$\begin{array}{llllllllllll}1.00 & 37.92 & 27.35 & 17.19 & 3 & 3036.4762 & 3036.4735 & 1013.1651 & 0.0027 & 0.8883 & 4.660\end{array}$

$\begin{array}{lllllllllll}0.84 & 25.82 & 27.03 & 24.23 & 2 & 1141.6228 & 1141.6228 & 571.8187 & 0.0000 & 0.0000 & 24.609\end{array}$

$\begin{array}{lllllllllllll}1.00 & 64.00 & 26.54 & 27.47 & 2 & 1634.7926 & 1634.7910 & 818.4028 & 0.0016 & 0.9775 & 234.192 \\ 1.00 & 26.47 & 24.06 & 2 & 1634.7930 & 1634.7910 & 818.4028 & 0.0020 & 1.2219 & 132.885\end{array}$

$\begin{array}{lllllllllllll}100 & 40.78 & 26.91 & 25.88 & 3 & 1428.7201 & 1428.7129 & 477.2449 & 0.0072 & 5.0288 & 5257.322 & 4955.832\end{array}$ $\begin{array}{llllllllllll}1.00 & 41.74 & 27.18 & 25.83 & 3 & 1428.7237 & 1428.7129 & 477.2449 & 0.0108 & 7.5432 & 6348.837 & 5258.014\end{array}$ $\begin{array}{llllllllllll}0.67 & 98.75 & 20.86 & \# \# \# \quad 3 & 2148.2545 & 2148.2510 & 717.0909 & 0.0035 & 1.6269 & 154.004\end{array}$ 126.601 $\begin{array}{llllllllllll}0.60 & 96.14 & 27.24 & 26.07 & 2 & 1506.8348 & 1506.8350 & 754.4248 & -0.0002 & -0.1326 & 420.308\end{array}$ 347.720 VQELPQLLDAR

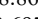
$\begin{array}{lllllllllllll}1.00 & 63.50 & 24.41 & 28.27 & 2 & 1537.8974 & 1537.8950 & 769.9548 & 0.0024 & 1.5585 & 913.051\end{array}$

66.936

(DERTQDASIK

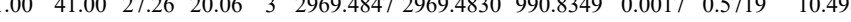

698.212
6.289

NYKPVVQTTGNAR $\begin{array}{llllllll}1.52 & 3 & 2969.4865 & 2969.4830 & 990.8349 & 0.0035 & 1.1775 & 5.965\end{array}$

$\begin{array}{llllllllllllll}\text { SAPIADQAVLQLLPK } & 1.00 & 38.72 & 16.90 & 17.43 & 3 & 1964.1955 & 1964.1914 & 655.7377 & 0.0041 & 2.0842 & 136.547 & 102.897\end{array}$ $\begin{array}{lllllllllllll}\text { SAPLIADQAVLQLLPK } & 1.00 & 40.88 & 16.90 & 18.05 & 3 & 1964.1955 & 1964.1914 & 655.7377 & 0.0041 & 2.0842 & 77.841 & 103.4 \\ \text { NYKPVVQTTGNAR } & 1.00 & 52.08 & 26.41 & 17.60 & 3 & 1734.9628 & 1734.9621 & 579.3280 & 0.0007 & 0.4028 & 1628.673 & 1219 .\end{array}$ 102.897 NYKPVVQTTGNAR
NYKPVVQTTGNAR NYKPVVQTTGNAI LMLLDATFR LMLLDATFR $\begin{array}{cccccccccccc}0.53 & 9.19 & 26.17 & 20.33 & 3 & 1734.9637 & 1734.9621 & 579.3280 & 0.0016 & 0.9206 & 689.779 & 681.030 \\ 0.94 & 27.36 & 27.63 & 29.95 & 2 & 1222.6880 & 1222.6866 & 612.3506 & 0.0014 & 1.1431 & 10201.034 & 5683.940\end{array}$ $\begin{array}{llllllllllll}0.94 & 27.36 & 27.63 & 29.95 & 2 & 1222.6880 & 1222.6866 & 612.3506 & 0.0014 & 1.1431 & 10201.034 & 5683.940 \\ 1.00 & 47.81 & 27.50 & 29.55 & 2 & 1222.6886 & 1222.6866 & 612.3506 & 0.0020 & 1.6330 & 4739.420 & 2852.791\end{array}$ VTDTDFDGVEVR $\begin{array}{llllllllllll}1.00 & 58.86 & 27.60 & 21.89 & 2 & 1495.7324 & 1495.7277 & 748.8711 & 0.0047 & 3.1380 & 521.447 & 343.843\end{array}$ $\begin{array}{lllllllllll}.00 & 65.19 & 27.60 & 23.91 & 2 & 1495.7324 & 1495.7277 & 748.8711 & 0.0047 & 3.1380 & 451.716\end{array}$ 7.293 $\begin{array}{llllllllllll}\text { AQGLELALVFLGQTLGPPR } & 0.67 & 21.49 & 21.76 & 34.49 & 3 & 2123.2255 & 2123.2225 & 708.7481 & 0.0030 & 1.4109 & 1.417\end{array}$

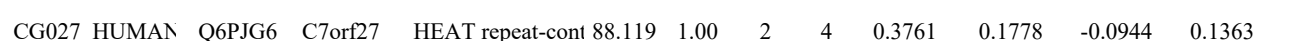
$\begin{array}{llllllllllll}.00 & 56.46 & 25.09 & 27.19 & 3 & 1208.7214 & 1208.7111 & 403.9110 & 0.0103 & 8.5002 & 5133.873 & 5279.036\end{array}$ $\begin{array}{lllllllllll}1.00 & 34.79 & 27.76 & 16.92 & 3 & 1838.9023 & 1838.8998 & 613.9739 & 0.0025 & 1.3573 & 72.244 \\ 1.00 & 50.52 & 27.72 & 18.09 & 3 & 18389032 & 1838.8998 & 613.9739 & 0.0034 & 1.8459 & 83.305\end{array}$ $\begin{array}{lllllllllllll}1.00 & 52.08 & 26.41 & 17.60 & 3 & 1734.9628 & 1734.9621 & 579.3280 & 0.0007 & 0.4028 & 1628.673 & 1219.572 \\ 0.53 & 9.19 & 26.17 & 20.33 & 3 & 1734.9637 & 1734.9621 & 579.3280 & 0.0016 & 0.9206 & 689.779 & 681.030\end{array}$

0.000

$4.367 \quad 37.494-2000$

$2.640 \quad 3.545$

$42.664 \quad 101.5$

$\begin{array}{rr}260.499 & 481.746 \\ 135.692 & 186.911\end{array}$

135.692

369.436

26.476

$\begin{array}{ll}16.238 & 19.369 \\ 145.775 & 166.790\end{array}$

$\begin{array}{ccc}48.885 & 160.933 & \text { Yes } \\ 218.642 & 358.611 & \text { Yes }\end{array}$

$\begin{array}{lll}218.642 & 358.611 & \text { Yes } \\ 722.195 & 925.366 & \text { Yes }\end{array}$

$296.213 \quad 1019.342$ Yes

$527.687 \quad 1679.634$ Yes

$\begin{array}{lll}41.422 & 108.977 & \text { Yes }\end{array}$

$\begin{array}{lll}60.260 & 70.702 & \text { Yes }\end{array}$

$\begin{array}{lll}55.583 & 84.040 \quad \text { Yes } \\ 808.389 & 1592.921 & \text { Yes }\end{array}$

$\begin{array}{lll}808.389 & 1592.921 & \text { Yes } \\ 860.223 & 1687.932 & \text { Yes } \\ 38.265 & 83.443 & \text { Yes }\end{array}$

$\begin{array}{lll}38.265 & 83.443 & \text { Yes }\end{array}$

$\begin{array}{lll}335.260 & 7736.346 & \text { Yes } \\ 177.902 & \text { Yes }\end{array}$

$\begin{array}{lll}1771.129 & 7811.211 & \text { Yes }\end{array}$

$\begin{array}{lll}1652.368 & 8703.831 & \text { Yes }\end{array}$

$\begin{array}{lll}152.181 & 217.521 & \text { No } \\ 165.437 & 201.171 & \text { Yos }\end{array}$

$\begin{array}{lll}155.437 & 201.171 & \text { Yes } \\ 705.822 & 516.924 & \text { Yes }\end{array}$

$\begin{array}{lll}165.437 & 201.171 & \text { Yes } \\ 425.878 & 316824 & \text { Yes }\end{array}$

$\begin{array}{ccc}212.321 & 2493.303 & \text { Yes }\end{array}$

$\begin{array}{lll}19.344 & 2401.312 & \text { Yes }\end{array}$

$\begin{array}{lll}101.569 & 114.555 & \text { Yes } \\ 671.845 & 2654.210 & \text { Yes }\end{array}$

$\begin{array}{lll}131.889 & 4221.040 & \text { Yes }\end{array}$

$\begin{array}{lll}135.654 & 2746.077 & \text { Yes } \\ 66.460 & 919.989 & \text { Yes }\end{array}$

$\begin{array}{llll}46.544 & 1159.625 & \text { Yes }\end{array}$

$\begin{array}{lll}23.113 & 32.267 & \text { No }\end{array}$

$\begin{array}{lll}2.842 & 2.866 \quad \mathrm{No}\end{array}$

$\begin{array}{lll}34.660 & 85.671 & \text { Yes }\end{array}$

$\begin{array}{lll}0.000 & 600.779 & \text { No }\end{array}$

$28.153 \quad 442.931$ Yes

$\begin{array}{lll}153.345 & 7896.483 & \text { Yes } \\ 1309.632 & 8363.997 & \text { Yes }\end{array}$

$\begin{array}{llll}184.266 & 349.090 & \text { Yes }\end{array}$

$\begin{array}{lll}29.382 & 897.206 & \text { Yes }\end{array}$

$\begin{array}{lll}60.357 & 1819.687 & \text { Yes }\end{array}$

$66.745 \quad 115.549 \quad$ Yes

$\begin{array}{ccc}59.074 & 106.050 & \text { Yes } \\ 207.296 & 1486.159 & \text { Yes }\end{array}$

$\begin{array}{lll}1486.159 & \text { Yes } \\ 0.000 & \text { No }\end{array}$

12071.339 15354.982 Yes

$\begin{array}{lll}12.167 & 153.914 & \text { No }\end{array}$

$\begin{array}{lll}12.280 & 132.179 & \text { Yes } \\ 567.710 & 2075.904 & \text { Yes }\end{array}$

$\begin{array}{lll}60.11 .174 & \text { Yes }\end{array}$

$80.956 \quad 8475.366$ Yes

\begin{tabular}{lll}
\hline & 84756.366 & Yes \\
\hline 05.304 & 803.822 & Yes
\end{tabular}

\begin{tabular}{lll}
106 & 785.010 & Yes \\
\hline
\end{tabular} 

$\begin{array}{llllllllllll}\text { SPVTLTAYIVTSLLGYR } & 1.00 & \text { \#\#\#\# } 24.46 & 20.24 & 2 & 1997.1350 & 1997.1319 & 999.5732 & 0.0031 & 1.5507 & 3.384\end{array}$ $\begin{array}{lllllllllll}\text { SPVTLTAYIVTSLLGYR } & 1.00 & \text { \#\#\# } 24.39 & 21.26 & 2 & 1997.1356 & 1997.1319 & 999.5732 & 0.0037 & 1.8508 & 13.009\end{array}$ $\begin{array}{llllllllllll}\text { SPILTAYIVISLLYR } & 0.99 & 28.49 & 24.13 & 16.56 & 3 & 1997.1364 & 1997.1319 & 666.7179 & 0.0045 & 2.2498 & 2.240\end{array}$

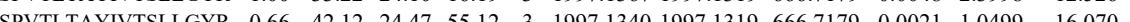
$\begin{array}{lllllllllll} & \end{array}$

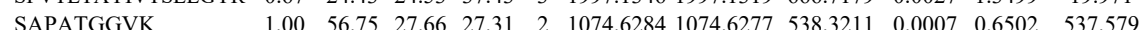



\begin{tabular}{llllllllllllllll} 
ALLLPDYYLVTVMLSGIK & 0.99 & 25.27 & 19.87 & 14.97 & 3 & 2296.3363 & 2296.3360 & 766.4526 & 0.0003 & 0.1305 & 12.938 & 12.101 & 5.479 & 19.985 & Yes \\
\hline
\end{tabular}

$\begin{array}{llllllllllllllll}\text { LGTLSPAFSTR } & 1.00 & 55.83 & 27.43 & 24.72 & 2 & 1292.7290 & 1292.7210 & 647.3678 & 0.0080 & 6.1788 & 10678.741 & 11219.580 & 333.669 & 14338.113 & \text { Yes }\end{array}$

$\begin{array}{llllllllllllllll}\text { LGTLSPAFSTR } & 1.00 & 50.28 & 27.40 & 24.33 & 2 & 1292.7302 & 1292.7210 & 647.3678 & 0.0092 & 7.1056 & 13246.277 & 14208.896 & 251.493 & 14657.672 & \text { Yes }\end{array}$

$\begin{array}{llllllllllllllll}\text { LGTLSPAFSTR } & 1.00 & 50.09 & 27.44 & 23.93 & 2 & 1292.7284 & 1292.7210 & 647.3678 & 0.0074 & 5.7154 & 2757.269 & 3096.338 & 209.306 & 3389.785 & \text { Yes }\end{array}$

QFLPFLR

QFLPFLQR $\begin{array}{lllllllllllllll}0.87 & 31.26 & 26.87 & 29.01 & 2 & 1191.6874 & 1191.6886 & 596.8516 & -0.0012 & -1.0053 & 2582.441 & 2957.400 & 809.797 & 2373.591 & \text { Yes }\end{array}$

QFLPFLQR

LSECEEQAK

MVLSGCAIIVR $\begin{array}{lllllllllllllll}0.87 & 26.59 & 26.99 & 28.62 & 2 & 1191.6884 & 1191.6886 & 596.8516 & -0.0002 & -0.1675 & 3190.243 & 3076.396 & 591.061 & 2678.157 & \text { Yes }\end{array}$

$\begin{array}{lllllllllllllll}0.90 & 27.73 & 26.61 & 29.43 & 2 & 1191.6890 & 1191.6886 & 596.8516 & 0.0004 & 0.3351 & 1462.464 & 1591.830 & 244.387 & 1399.797 & \text { Yes } \\ 0.95 & 26.55 & 26.56 & 28.98 & 2 & 1191.6898 & 1191.6886 & 596.8516 & 0.0012 & 1.0053 & 1714.073 & 1905.056 & 166.419 & 1655.528 & \text { Yes }\end{array}$

MVLSGCAIIVR

MVLSGCAIIVR

THLSSRPPR

$\begin{array}{llllllllllllll}0.95 & 26.55 & 26.56 & 28.98 & 2 & 1191.6898 & 1191.6886 & 596.8516 & 0.0012 & 1.0053 & 1714.073 & 1905.056 & 166.2 \\ 1.00 & 46.90 & 24.94 & 32.06 & 2 & 1369.6494 & 1369.6461 & 685.8303 & 0.0033 & 2.4058 & 3287.978 & 2853.853\end{array}$

$\begin{array}{llllllllllll}1.00 & 46.90 & 24.94 & 32.06 & 2 & 1369.6494 & 1369.6461 & 685.8303 & 0.0033 & 2.4058 & 3287.978 & 2853.853 \\ 0.85 & 27.93 & 28.80 & 35.54 & 2 & 1350.7308 & 1350.7307 & 676.3726 & 0.0001 & 0.0739 & 80.567 & 88.354\end{array}$ $\begin{array}{llllllllllll}0.98 & 33.60 & 28.77 & 36.23 & 2 & 1350.7314 & 1350.7307 & 676.3726 & 0.0007 & 0.5175 & 81.462\end{array}$ $\begin{array}{llllllllllll}0.97 & 31.03 & 28.65 & 33.97 & 2 & 1350.7330 & 1350.7307 & 676.3726 & 0.0023 & 1.7002 & 42.348\end{array}$ $\begin{array}{lllllllllll} & \end{array}$ $\begin{array}{llllllllllll}1.00 & 42.43 & 28.66 & 37.77 & 2 & 1350.7326 & 1350.7307 & 676.3726 & 0.0019 & 1.4045 & 41.539 & 68.763\end{array}$

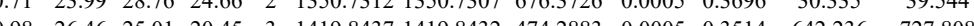
$\begin{array}{llllllllllll}0.98 & 26.46 & 25.01 & 20.45 & 3 & 1419.8437 & 4119.8432 & 474.2883 & 0.0005 & 0.3514 & 642.236 & 727.808 \\ 0.98 & 24.60 & 24.53 & 23.07 & 3 & 1419.8443 & 1419.8432 & 474.2883 & 0.0011 & 0.7731 & 431.357 & 518.690\end{array}$

SLLSAFEAAK

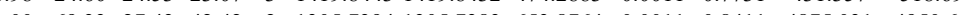

$\begin{array}{lllllllllllll}1.00 & 69.33 & 27.43 & 42.42 & 2 & 1305.7394 & 1305.7383 & 653.8764 & 0.0011 & 0.8411 & 4875.031 & 4950.691 \\ 1.00 & 57.68 & 27.75 & 38.66 & 2 & 1305.7400 & 1305.7383 & 653.8764 & 0.0017 & 1.2999 & 10232.544 & 9703.072\end{array}$

$\begin{array}{llllllllllll} & \text { VWATVM }\end{array}$

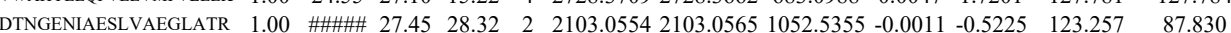

$\begin{array}{rrr}769.063 & 4037.792 & \text { Yes }\end{array}$

$\begin{array}{lllllllllll}\text { DDX46_HUMAI } & \text { Q7L014 } & \text { DDX46 } & \text { Probable ATP-der } 117.36 & 1.00 & 3 & 4 & 0.3073 & 0.1222 & 3.0128 & 0.3469\end{array}$

EGNEMEGEELDPLD

LLVATSVAAR

LLVATSVAAR
TIAFLLPMFR

TIAFLLPMFR

TIAFLLPMFR

TIAFLLPMFR

TIAFLLPMFR

TIAFLLPMFR

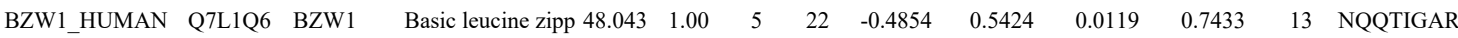

:DPTPFPDCIRGLLETGTDLEAV

DPTPFQDCLQLLLTETGTDLEAVAK

FDPPPFQDCLILGLTETGTDLEAVA

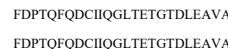

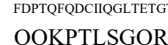

QQKPTLSGQR $\begin{array}{lllllllllllll}1.00 & 54.19 & 26.39 & 26.35 & 2 & 1351.7828 & 1351.7808 & 676.8977 & 0.0020 & 1.4773 & 265.241 & 340.880\end{array}$ $\begin{array}{llllllllllllll}1.00 & 54.35 & 26.03 & 25.66 & 2 & 1351.7834 & 1351.7808 & 676.8977 & 0.0026 & 1.9205 & 275.532 & 335.872\end{array}$ $\begin{array}{lllllllllll}.00 & 59.46 & 25.85 & 26.95 & 2 & 1351.7816 & 1351.7808 & 676.8977 & 0.0008 & 0.5909 & 272.613\end{array}$ $\begin{array}{llllllllllllll}1.00 & 50.29 & 26.38 & 24.82 & 2 & 1351.7820 & 1351.7808 & 676.8977 & 0.0012 & 0.8864 & 303.683 & 4\end{array}$

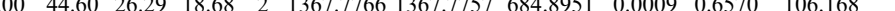
$\begin{array}{llllllllllll}1.00 & 49.27 & 26.29 & 20.48 & 2 & 1367.7766 & 1367.7757 & 684.8951 & 0.0009 & 0.6570 & 101.550 & 132.984\end{array}$ $\begin{array}{llllllllllll}1.00 & 43.20 & 27.12 & 30.43 & 2 & 1030.5656 & 1030.5641 & 516.2893 & 0.0015 & 1.4527 & 48.275\end{array}$ $\begin{array}{lllllllllll}1.00 & 38.32 & 26.36 & 51.32 & 4 & 3173.5581 & 3173.5505 & 794.3949 & 0.0076 & 2.3918 & 6.072\end{array}$ $\begin{array}{rrrrrrrrrrr}0.99 & 29.63 & 26.48 & 15.14 & 3 & 3173.5552 & 3173.5505 & 1058.8574 & 0.0047 & 1.4796 & 0.000 \\ 1.00 & 73.13 & 26.51 & 86.13 & 4 & 3173.5565 & 3173.5505 & 794.3949 & 0.0060 & 1.8882 & 15.523\end{array}$ $\begin{array}{llllllllllll}1.00 & 73.13 & 26.51 & 86.13 & 4 & 3173.5565 & 3173.5505 & 794.3949 & 0.0060 & 1.8882 & 15.523 \\ 1.00 & 59.40 & 26.35 & 17.75 & 4 & 3173.5593 & 3173.5505 & 794.3949 & 0.0088 & 2.7694 & 19.620\end{array}$ $\begin{array}{llllllllllll}1.00 & 59.40 & 26.35 & 17.75 & 4 & 3173.5593 & 3173.5505 & 794.3949 & 0.0088 & 2.7694 & 19.620\end{array}$ $\begin{array}{llllllllllll}1.00 & 66.71 & 26.48 & 17.26 & 3 & 3173.5552 & 3173.5505 & 1058.8574 & 0.0047 & 1.4796 & 0.000 \\ 1.00 & 62.02 & 26.49 & 75.02 & 4 & 3173.5561 & 3173.5505 & 794.3949 & 0.0056 & 1.7623 & 6.239\end{array}$ $\begin{array}{llllllllllll}1.00 & 62.02 & 26.49 & 75.02 & 4 & 3173.5561 & 3173.5505 & 794.3949 & 0.0056 & 1.7623 & 6.239 \\ 1.00 & 35.80 & 26.44 & 48.80 & 4 & 3173.5569 & 3173.5505 & 794.3949 & 0.0064 & 2.0141 & 8.935\end{array}$ $\begin{array}{llllllllllll}1.00 & 35.80 & 26.44 & 48.80 & 4 & 3173.5569 & 3173.5505 & 794.3949 & 0.0064 & 2.0141 & 8.935 \\ 0.82 & 17.24 & 26.88 & 19.32 & 3 & 1429.8259 & 1429.8245 & 477.6154 & 0.0014 & 0.9771 & 211.537\end{array}$ $\begin{array}{llllllllllll}0.85 & 16.46 & 26.87 & 17.12 & 3 & 1429.8265 & 1429.8245 & 477.6154 & 0.0020 & 1.3958 & 357.884\end{array}$ $\begin{array}{lllllllllll}0.85 & 16.46 & 26.87 & 17.12 & 3 & 1429.8265 & 1429.8245 & 477.6154 & 0.0020 & 1.3958 & 357.884 \\ 0.67 & 19.92 & 27.01 & 27.72 & 2 & 1429.8272 & 1429.8245 & 715.9195 & 0.0027 & 1.8857 & 50.177\end{array}$ $\begin{array}{lllllllllll}0.67 & 1.92 & 13.01 & 27.72 & 2 & 1429.8272 & 1429.8245 & 15.9154 & 0.0027 & 1.8857 & 50.177\end{array}$ $\begin{array}{llllllllllll}0.65 & 13.84 & 26.88 & 21.70 & 3 & 1429.8259 & 1429.8245 & 477.6154 & 0.0014 & 0.9771 & 169.944\end{array}$ $\begin{array}{lllllllllllll}0.97 & 33.04 & 27.01 & 27.99 & 2 & 1429.8274 & 1429.8245 & 715.9195 & 0.0029 & 2.0254 & 35.628\end{array}$ 


1.00



$\begin{array}{lllllllllll}1.00 & 83.55 & 27.42 & 20.49 & 2 & 1718.9476 & 1718.9471 & 860.4808 & 0.0005 & 0.2905 & 856.760\end{array}$ TDISEDISELQK

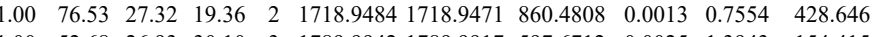
LDISEDISELQK

$\begin{array}{lllllllllllll} & 7 & & \end{array}$

\section{VFPSHFTQQR}

\section{VFPSHFTQQR}

IPIPLMDYILNVMK

IPIPLMDYILNVMK

IPIPLMDYILNVMK

$\begin{array}{lllllllllllll}0.98 & 28.28 & 28.39 & 20.03 & 3 & 1389.7321 & 1389.7275 & 464.2498 & 0.0046 & 3.3028 & 3078.448 & 2818 \\ 0.77 & 19.12 & 28.44 & 17.04 & 3 & 1389.7327 & 1389.7275 & 464.2498 & 0.0052 & 3.7336 & 1840.234 & 200\end{array}$

IPIPLMDYILNVMK

LPGGVQNFPQFSALR

SLLSILQR

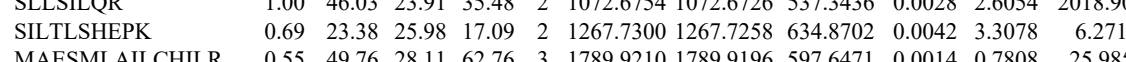

$\begin{array}{lllllllllll}1.00 & 27.85 & 23.07 & 19.81 & 3 & 1947.1207 & 1947.1181 & 650.0466 & 0.0026 & 1.3332 & 61.347 \\ 0.98 & 1.15 & 23.07 & 18.25 & 3 & 1974.1207 & 1947.1181 & 650.046 & 0.002 & 1.3332 & 91.680\end{array}$

$\begin{array}{lllllllllll}0.98 & 21.15 & 23.07 & 18.25 & 3 & 1947.1207 & 1947.1181 & 650.0466 & 0.0026 & 1.3332 & 91.680 \\ 1.00 & 35.63 & 23.07 & 23.19 & 3 & 1947.1207 & 1947.1181 & 650.0466 & 0.0026 & 1.3332 & 45.950\end{array}$

$\begin{array}{llllllllllll}1.00 & 35.63 & 23.07 & 23.19 & 3 & 1947.1207 & 1947.1181 & 650.0466 & 0.0026 & 1.3332 & 45.951 \\ 1.00 & 43.28 & 23.07 & 17.45 & 3 & 1947.1216 & 1947.1181 & 650.0466 & 0.0035 & 1.7947 & 51.510\end{array}$ \begin{tabular}{llllllllllllll} 
& 0.55 & 49.76 & 28.11 & 62.76 & 3 & 1789.9210 & 1789.9196 & 597.6471 & 0.0014 & 0.7808 & 25.985 \\
\hline MAESMLAILCHILR & 1.00 & 58.68 & 28.04 & 27.66 & 3 & 1789.9216 & 1789.9196 & 597.6471 & 0.0020 & 1.1155 & 34.818
\end{tabular}

$\begin{array}{lllllllllllll}6 & \text { QGEDNSTAQDTEELEK } & 0.55 & 33.68 & 25.69 & 46.68 & 3 & 2080.9654 & 2080.9640 & 694.6619 & 0.0014 & 0.6718 & 245.478\end{array}$

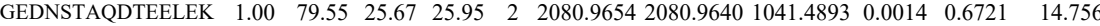
$\begin{array}{lllllllllllll}\text { Q } & \text { QGEDSTAQDTEELE K } & 1.00 & 79.55 & 25.67 & 25.95 & 2 & 208.9654 & 2080.9640 & 104.4893 & 0.0014 & 0.6721 & 14.756\end{array}$ $\begin{array}{lllllllllllll} & \text { SWQDELAQQAEEGSAR } & 1.00 & 70.96 & 25.11 & 20.07 & 2 & 1947.8886 & 1947.9044 & 974.9595 & -0.0158 & -8.1030 & 181.982\end{array}$ $\begin{array}{llllllllllll}\text { SWQDELAQQAEEGSAR } & 1.00 & 75.17 & 25.15 & 20.98 & 2 & 1947.8956 & 1947.9044 & 974.9595 & -0.0088 & -4.5130 & 183.774\end{array}$ $\begin{array}{lllllllllllll} & \text { EEAAAVPAAAPDDLALLK } & 1.00 & 33.53 & 25.79 & 18.83 & 3 & 2052.1360 & 2052.1346 & 685.0521 & 0.0014 & 0.6812 & 187.671\end{array}$ $\begin{array}{lllllllllllll}\text { EEAAAVPAAAPDDLALLK } & 0.95 & 19.83 & 25.75 & 18.54 & 3 & 2052.1369 & 2052.1346 & 685.0521 & 0.0023 & 1.1191 & 225.952\end{array}$

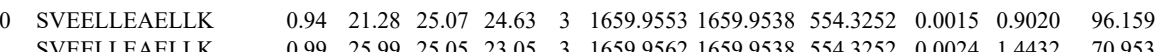
$\begin{array}{llllllllllll}\text { SVEELLEAELLK } & 0.99 & 25.99 & 25.05 & 23.05 & 3 & 1659.9562 & 1659.9538 & 554.3252 & 0.0024 & 1.4432 & 70.953 \\ \text { Q }\end{array}$ $\begin{array}{lllllllllllll}\text { LQALANEQAAAAHELEK } & 1.00 & 64.28 & 26.45 & 22.35 & 3 & 2094.1345 & 2094.1312 & 699.0510 & 0.0033 & 1.5736 & 1285.502 & 1753 \\ \text { LQALANEQAAAHELEK } & 1.00 & 65.17 & 6.45 & 21.65 & 3 & 2094.1345 & 2094.1312 & 699.0510 & 0.0033 & 1.5736 & 3127.434 & 270\end{array}$ $\begin{array}{cccccccccccc}\text { LQALANEQAAAAHELEK } & 1.00 & 65.17 & 26.45 & 21.65 & 3 & 2094.1345 & 2094.1312 & 699.0510 & 0.0033 & 1.5736 & 3127.434 \\ \text { QNDQVSFASLVEELK } & 1.00 & 87.35 & 27.44 & 38.23 & 2 & 1994.0582 & 1994.0564 & 998.0355 & 0.0018 & 0.9018 & 46.867\end{array}$ $\begin{array}{llllllllllll}\text { QNDQVSFASLVEELK } & 1.00 & 87.35 & 27.44 & 38.23 & 2 & 1994.0582 & 1994.0564 & 998.0355 & 0.0018 & 0.9018 & 46.867 \\ \text { QNDQVSFASLVEELK } & 1.00 & 78.69 & 27.25 & 32.97 & 2 & 1994.0588 & 1994.0564 & 998.0355 & 0.0024 & 1.2024 & 90.957\end{array}$ $\begin{array}{llllllllllll}\text { QNDQVSFASLVEELK } & 1.00 & 78.69 & 27.25 & 32.97 & 2 & 1994.0588 & 1994.0564 & 998.0355 & 0.0024 & 1.2024 & 90.957 \\ \text { QNDQVSFASLVEELK } & 1.00 & 43.19 & 27.23 & 18.81 & 3 & 1994.0608 & 1994.0564 & 665.6927 & 0.0044 & 2.2032 & 115.648\end{array}$ $\begin{array}{llllllllllll}\text { QNDQVSFASLVEELK } & 1.00 & 43.19 & 27.23 & 18.81 & 3 & 1994.0608 & 1994.0564 & 665.6927 & 0.0044 & 2.2032 & 115.648 \\ \text { LSDALAVEDDQYAVPLINVEETSSYR } & 0.56 & 10.54 & 25.87 & 15.85 & 3 & 2953.5406 & 2953.5366 & 985.5195 & 0.0040 & 1.3529 & 16.053\end{array}$ $\begin{array}{llllllllllll}\text { QNDQVSFASLVEELK } & 1.00 & 35.96 & 27.28 & 25.13 & 3 & 1994.0599 & 1994.0564 & 665.6927 & 0.0035 & 1.7526 & 74.294\end{array}$ $\begin{array}{lllllllllllll} & & \end{array}$ $\begin{array}{lllllllllllll}\text { TVEELLETGLIQVATK } & 1.00 & 57.96 & 22.88 & 23.60 & 3 & 2031.1753 & 2031.1707 & 678.0642 & 0.0046 & 2.2613 & 167.463\end{array}$ 
$\begin{array}{lllllllllll}1.00 & 30.33 & 24.81 & 21.69 & 3 & 1659.9562 & 1659.9538 & 554.3252 & 0.0024 & 1.4432 & 102.851\end{array}$

SVELAEABLK

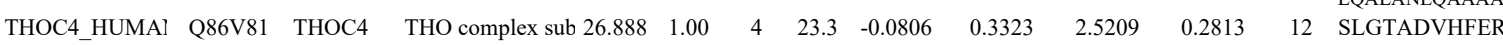

$\begin{array}{lllllllllll}1.00 & 85.94 & 28.04 & 32.46 & 2 & 1374.7134 & 1374.7014 & 688.3580 & 0.0120 & 8.7163 & 4045.919\end{array}$

SLGTADVHFER

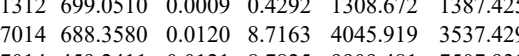

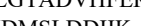

$\begin{array}{llllllllllll} & \end{array}$

$\begin{array}{llllllllllll}1.00 & 53.55 & 27.75 & 24.18 & 2 & 1467.7574 & 1467.7557 & 734.8851 & 0.0017 & 1.1566 & 608.921 & 561.236\end{array}$

MDMSLDDIIK

$\begin{array}{llllllllllll}1.00 & 55.61 & 27.72 & 23.34 & 2 & 1467.7590 & 1467.7557 & 734.8851 & 0.0033 & 2.2452 & 872.354 & 992.953\end{array}$

$\begin{array}{llllllllllllll}\text { VOHDLFDSGFGGGAGVETGGK } & 0.67 & 59.19 & 26.80 & 72.19 & 3 & 2409.1627 & 2409.1594 & 804.0604 & 0.0033 & 1.3681 & 1204.694 & 1584.135\end{array}$

$\begin{array}{llllllllllllll}\text { QQLSAFEDAOLDAYNAR } & 0.64 & 83.04 & 27.60 & 96.04 & 2 & 2178.0674 & 2178.0674 & 1090.0410 & 0.0000 & 0.0000 & 241.434\end{array}$

$\begin{array}{lllllllllllll}\text { QQLSAEELDAQLDAYNAR } & 1.00 & 74.84 & 27.65 & 21.93 & 2 & 2178.0694 & 2178.0674 & 1090.0410 & 0.0020 & 0.9174 & 324.426\end{array}$

$\begin{array}{llllllllllll}\text { QQLSAEELDAQLDAYNAR } & 0.97 & 23.31 & 27.66 & 19.39 & 3 & 2178.0700 & 2178.0674 & 727.0297 & 0.0026 & 1.1921 & 251.363\end{array}$

$\begin{array}{llllllllllllll}\text { QQLSAEELDAQLDAYNAR } & 1.00 & 46.87 & 27.66 & 18.95 & 3 & 2178.0700 & 2178.0674 & 727.0297 & 0.0026 & 1.1921 & 251.363\end{array}$

263.884

$\begin{array}{llllllllll} & \end{array}$

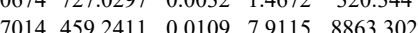

356.976

SLGTADVHFER

$\begin{array}{lllllllllllll}1.00 & 60.91 & 28.03 & 36.88 & 3 & 1374.7132 & 1374.7014 & 459.2411 & 0.0118 & 8.5648 & 5946.853 & 6811.448\end{array}$

MDMSLDDIIK

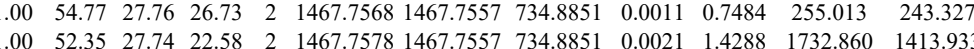

QEDVSVQLEALDIMADMLSR

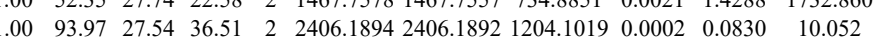
$\begin{array}{llllllllllll} & \end{array}$ $\begin{array}{lllllllllllll}\text { QEDVSVQLEALDIMADMLSR } & 1.00 & 41.12 & 27.57 & 15.70 & 3 & 2406.1924 & 2406.1892 & 803.0703 & 0.0032 & 1.3282 & 14.368 & 15.323\end{array}$ $\begin{array}{llllllllllllll}\text { QEDVSVQLEALDIMADMLSR } & 1.00 & 43.35 & 27.57 & 22.73 & 3 & 2406.1924 & 2406.1892 & 803.0703 & 0.0032 & 1.3282 & 14.914 & 14.943\end{array}$ $\begin{array}{llllllllllllll}\text { AVAALLTIPEAEK } & 1.00 & 86.78 & 22.55 & 31.16 & 2 & 1612.9656 & 1612.9643 & 807.4894 & 0.0013 & 0.8050 & 137.646 & 164.787\end{array}$ $\begin{array}{lllllllllllll}\text { AVAALLTIPEAEK } & 0.66 & 13.16 & 22.60 & 26.16 & 3 & 1612.9660 & 1612.9643 & 538.6620 & 0.0017 & 1.0520 & 84.878 & 70.155\end{array}$ $\begin{array}{llllllllllllll}\text { FMATNDLMTELQK } & 1.00 & 69.50 & 27.39 & 23.12 & 2 & 1828.9338 & 1828.9307 & 915.4726 & 0.0031 & 1.6931 & 260.678 & 398.286\end{array}$ MATNDLMTELQK FMATNDLMTELQK $\begin{array}{llllllllllll}0.63 & 11.95 & 27.40 & 16.35 & 3 & 1828.9339 & 1828.9307 & 610.6508 & 0.0032 & 1.7468 & 205.978 & 158.02\end{array}$ TISDHPQPIDPLLK

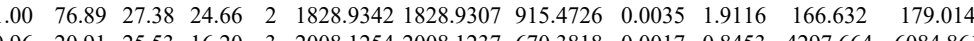

$\begin{array}{lllllllllllll}1.00 & 31.21 & 25.54 & 18.22 & 3 & 2008.1257 & 2008.1237 & 670.3818 & 0.0020 & 0.9945 & 5945.258 & 14286.239 & 33\end{array}$ \begin{tabular}{|lllllllllllll} 
& \\
\hline
\end{tabular}

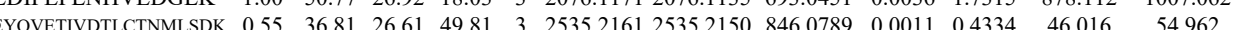

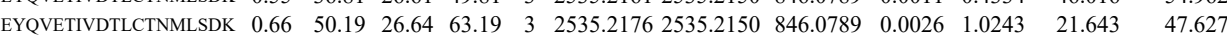

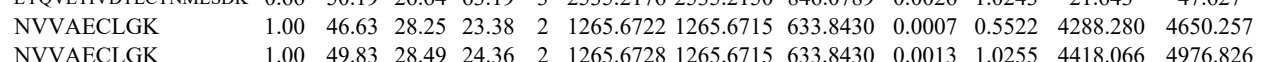

LDIFEFLNHVEDGLK

ITSEALLVTQQLVK

ITSEALLVTOQLVK

ITSEALLVTQQLVK

$\begin{array}{llllllllllll}0.67 & 42.63 & 26.95 & 55.63 & 3 & 2076.1162 & 2076.1135 & 693.0451 & 0.0027 & 1.2986 & 926.135\end{array}$

LTLIDPETLLPR

$\begin{array}{lllllllllllll}1.00 & 51.40 & 26.92 & 19.07 & 3 & 2076.1171 & 2076.1135 & 693.0451 & 0.0036 & 1.7315 & 737.368 \\ 1.00 & 78.69 & 19.44 & 26.35 & 2 & 1830.1082 & 1830.1070 & 9160608 & 0.0012 & 0.6550 & 126.124\end{array}$

$\begin{array}{llllllllllllll}0.66 & 53.77 & 19.49 & 66.77 & 3 & 1830.1087 & 1830.1070 & 611.0429 & 0.0017 & 0.9274 & 262.495\end{array}$

$\begin{array}{llllllllllllll}0.99 & 18.44 & 19.49 & 14.33 & 3 & 1830.1096 & 1830.1070 & 611.0429 & 0.0026 & 1.4183 & 247.967\end{array}$ $\begin{array}{lllllllllll}1.00 & 98.51 & 19.54 & 31.93 & 2 & 1830.1108 & 1830.1070 & 916.0608 & 0.0038 & 2.0741 & 144.505\end{array}$

ITSEALLVTQQLVK $\begin{array}{lllllllllllll}1.00 & 60.23 & 23.84 & 29.05 & 2 & 1523.9066 & 1523.9045 & 762.9595 & 0.0021 & 1.3762 & 73.472 \\ 0.67 & 6.16 & 19.44 & 19.16 & 3 & 1830.1099 & 1830.1070 & 61.0429 & 0.0029 & 1.5820 & 367.769\end{array}$

ITSEALLVTQQLVK \begin{tabular}{lllllllllllll}
0.67 & 20.79 & 19.44 & 33.79 & 3 & 1830.1099 & 1830.1070 & 611.0429 & 0.0029 & 1.5820 & 367.769 & 274.265 \\
\hline
\end{tabular} $\begin{array}{llllllllllll} & 0.1892\end{array}$ $\begin{array}{lllllllllllll}\text { SPLMSEFQSOISSNPELAAIFESIQK } & 1.00 & 19.89 & 26.04 & 32.89 & 4 & 3168.6293 & 3168.6256 & 793.1637 & 0.0037 & 1.1662 & 0.000\end{array}$

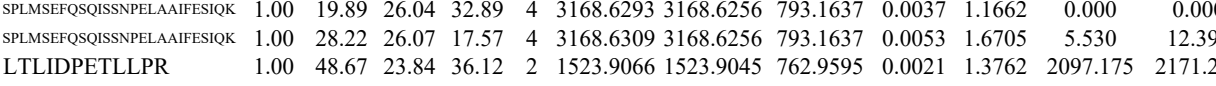

SPLMSEFQSQISSNPELAAI

LTLIDPETLLPR

LGTLSALDILIK

LGTLSALDILIK

LGTLSALDILIK

MLTGPVYSQSTALTHK

MLTGPVYSQSTA
TVSPALISR
TVSPALISR

LGTLSALDILIK

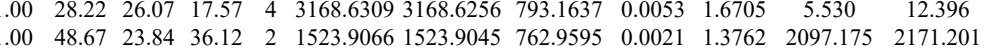

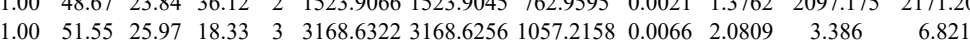
$\begin{array}{lllllllllllll}1.00 & 49.74 & 23.80 & 30.55 & 2 & 1523.9060 & 1523.9045 & 762.9595 & 0.0015 & 0.9830 & 408.660 & 358.271 \\ 1.00 & 60.20 & 17.71 & 28.98 & 2 & 1543.9810 & 1543.9792 & 772.9969 & 0.0018 & 1.1643 & 909.374 & 780.981\end{array}$ $\begin{array}{llllllllllll}1.00 & 60.20 & 17.71 & 28.98 & 2 & 1543.9810 & 1543.9792 & 772.9969 & 0.0018 & 1.1643 & 909.374 & 780.981 \\ 1.00 & 70.89 & 17.71 & 28.56 & 2 & 1543.9814 & 1543.9792 & 772.9969 & 0.0022 & 1.4230 & 603.984 & 654.784\end{array}$ $\begin{array}{lllllllllllll}1.00 & 70.89 & 17.71 & 28.56 & 2 & 1543.9814 & 1543.9792 & 772.9969 & 0.0022 & 1.4230 & 603.984 & 654.784 \\ 0.99 & 22.08 & 17.71 & 20.52 & 3 & 1543.9816 & 1543.9792 & 515.6670 & 0.0024 & 1.5514 & 124.951 & 80.338\end{array}$ $\begin{array}{llllllllllll}0.99 & 22.08 & 17.71 & 20.52 & 3 & 1543.9816 & 1543.9792 & 515.6670 & 0.0024 & 1.5514 & 124.951 & 80.338 \\ 0.99 & 29.52 & 16.72 & 26.76 & 3 & 1543.9822 & 1543.9792 & 515.6670 & 0.0030 & 1.9392 & 122.920 & 125.323\end{array}$

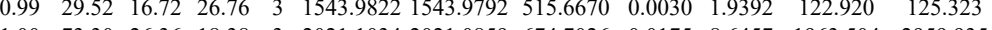
$\begin{array}{lllllllllllll}0.97 & 36.90 & 26.66 & 29.13 & 2 & 1086.6604 & 1086.6519 & 544.3332 & 0.0085 & 7.8077 & 15841.148 & 17876.050 & 21.935\end{array}$ $\begin{array}{lllllllllllllll}0.92 & 31.01 & 26.37 & 25.34 & 2 & 1086.6624 & 1086.6519 & 544.3332 & 0.0105 & 9.6447 & 18129.451 & 22434.860\end{array}$ $\begin{array}{llllllllllll}1.00 & 68.05 & 17.92 & 31.82 & 2 & 1543.9806 & 1543.9792 & 772.9969 & 0.0014 & 0.9056 & 3169.800 & 2764.852\end{array}$ 
LGTLSALDILIK LGTLSALDILIK

ADVFHAYLSLLK

ADVFHAYLSLLK

ISGSILNELIGLVR

ISGSILNELIGLVR

ISGSILNELIGLVR

ISGSILNELIGLVR

ISGSILNELIGLVR

ISGSILNELIGLVR

\section{ISGSILNELIGL}

TYIQCIAAISR

TYIDCIAAISR

LSTLCPSAVLQR
LSTLCPSAVLQR

IDLRPVLGEGVPILASFLR
IDLRPVLGEGVILASFLR

TYIQCIAAISR

TYIQCIAAISR
LSTLCPSAVLQR

LSTLCPSAVLQR
LSTLCPSAVLQR

LSTLCPSAVLQR
LSTLCPSAVLQR

LSTLCPSAVLQR

IDLRPVLGEGVPILASFLR
IDLRPVLGEGVPILASFLR

LSTLCPSAVLQR

HTVDDGLDIR

HTVDDGLDIR

HTVDDGLDIR
TLEDPDLNVR

FCNVDDDELR

MLTFLMLVR

MLTFLMLVR

MLTFLMLVR

MLTFLMLVR
MLTFLMLVR

MLTFMLVR

MLTFLMLVR

MLTFLMLVR

MLTFLMLVR

MLTFLMLVR

MLTFLMLVR

MLTFLMLVR

TYIQCIAAISR

MLTFLMLVR

TYIQCIAAISR

MLTFLMLVR

MLTFLMLVR

TYIQCIAAISR

TYIQCIAAISR

MLTFLMLVR

MLTFLMLVR

MLTTMLVR

MLTFLMLVR
MLTFLMLVR

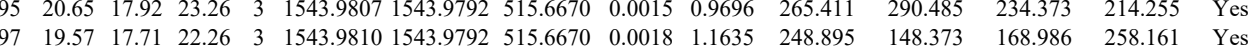

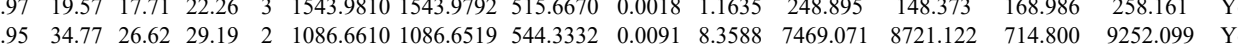
$\begin{array}{llllllllllllllll}0.96 & 34.27 & 26.37 & 32.77 & 2 & 1086.6624 & 1086.6519 & 544.3332 & 0.0105 & 9.6447 & 14929.981 & 19471.659 & 1579.355 & 18170.612 & \text { Yes }\end{array}$ $\begin{array}{lllllllllllllllll}0.82 & 31.64 & 28.49 & 25.11 & 2 & 1149.6576 & 1149.6494 & 575.8320 & 0.0082 & 7.1201 & 10513.820 & 10231.409 & 1215.915 & 14244.093 & \text { Yes }\end{array}$ $\begin{array}{lllllllllllllllll}0.97 & 38.39 & 28.50 & 25.50 & 2 & 1149.6592 & 1149.6494 & 575.8320 & 0.0098 & 8.5094 & 15709.128 & 17437.341 & 370.663 & 25821.895 & \text { Yes }\end{array}$ $\begin{array}{lllllllllllllll}1.00 & 75.16 & 19.08 & 23.42 & 2 & 1370.8762 & 1370.8741 & 686.4443 & 0.0021 & 1.5296 & 4023.179 & 4042.555 & 236.160 & 4648.406 & \text { Yes }\end{array}$

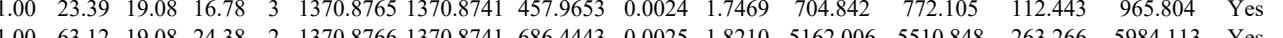
$\begin{array}{lllllllllllllll}1.00 & 63.12 & 19.08 & 24.38 & 2 & 1370.8766 & 1370.8741 & 686.4443 & 0.0025 & 1.8210 & 5162.006 & 5510.848 & 263.266 & 5984.113 & \text { Yes } \\ 1.00 & 26.01 & 19.08 & 16.68 & 3 & 1370.8768 & 1370.8741 & 457.9653 & 0.0027 & 1.9652 & 631.664 & 511.970 & 224296 & 658.032 & \text { Yes }\end{array}$

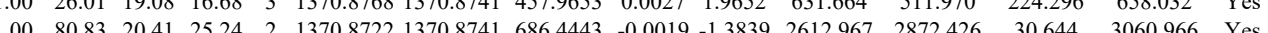

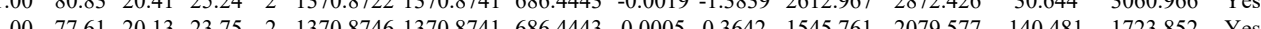

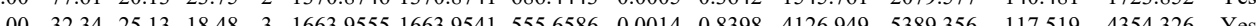

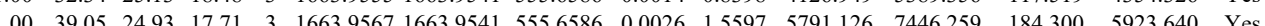
$\begin{array}{lllllllllllllllll}0.93 & 15.90 & 6.99 & 16.12 & 2 & 1068 & 7606 & 1068.7514 & 535.3830 & 0.0092 & 8.5919 & 38796105 & 39612.728 & 505.560 & 27993.434 & \text { Yes }\end{array}$ $\begin{array}{lllllllllllllllll}1.00 & 38.31 & 25.37 & 17.50 & 3 & 1663.9540 & 1663.9541 & 555.6586 & -0.0001 & -0.0600 & 1561.777 & 1430.522 & 95.918 & 1510.636 & \text { Yes }\end{array}$

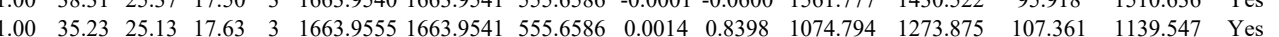
$\begin{array}{llllllllllllllll}1.00 & 87.20 & 22.36 & 34.83 & 2 & 16269810 & 1626.9790 & 814.4968 & 0.0020 & 1.8278 & 345.627 & 374.100 & 47.200 & 564.124 & \text { Yes }\end{array}$

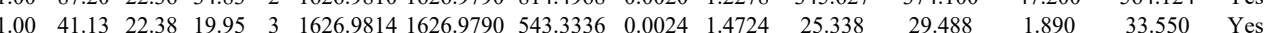
$\begin{array}{lllllllllllllll}1.00 & 47.44 & 22.38 & 24.94 & 3 & 1626.9817 & 1626.9790 & 543.3336 & 0.0027 & 1.6564 & 12.471 & 22.445 & 4.503 & 23.087 & \text { Yes }\end{array}$ $\begin{array}{llllllllllllllll}1.00 & 92.64 & 22.36 & 38.16 & 2 & 1626.9806 & 1626.9790 & 814.4968 & 0.0016 & 0.9822 & 786.771 & 836.777 & 53.399 & 12.16 .433 & \text { Yes }\end{array}$

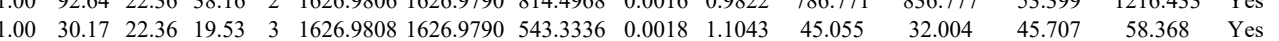
$\begin{array}{llllllllllllllll}1.00 & 89.32 & 22.36 & 29.56 & 2 & 1626.9810 & 1626.9790 & 814.4968 & 0.0020 & 1.2278 & 1445.269 & 1765.580 & 194.424 & 2048.577 & \text { Yes }\end{array}$

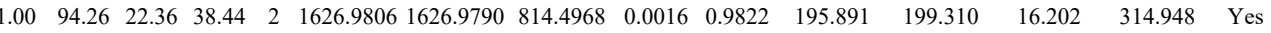

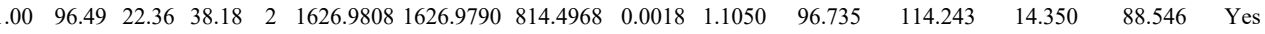
$\begin{array}{lllllllllllllll}1.00 & 59.57 & 27.73 & 24.43 & 2 & 1427.7390 & 1427.7386 & 714.8766 & 0.0004 & 0.2798 & 257.896 & 205.267 & 37.731 & 236.312 & \text { Yes }\end{array}$

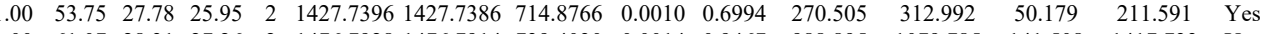

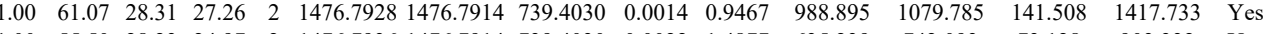

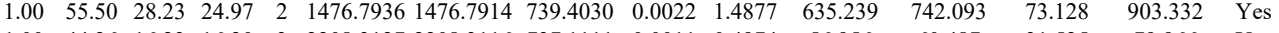
$\begin{array}{llllllllllll}1.00 & 44.26 & 16.23 & 16.20 & 3 & 2208.3127 & 2208.3116 & 737.1111 & 0.0011 & 0.4974 & 56.256 & 6\end{array}$ $\begin{array}{lllllllllllll}1.00 & 50.26 & 16.23 & 17.48 & 3 & 2208.3127 & 2208.3116 & 737.1111 & 0.0011 & 0.4974 & 36.006 & 59 . & \\ 1.00 & 54.48 & 27.63 & 22.91 & 2 & 1427.7380 & 1427.7386 & 714.8766 & 0.0006 & -0.197 & 373.069 & 362 & \end{array}$

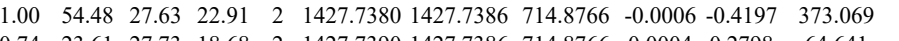

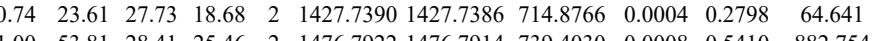

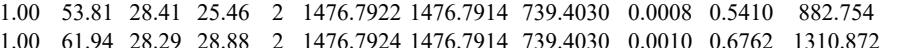
$\begin{array}{llllllllllll}1.00 & 61.94 & 28.29 & 28.88 & 2 & 1467.7924 & 1467.7914 & 739.4030 & 0.0010 & 0.6762 & 1310.872 & 151 \\ 1.00 & 57.73 & 28.29 & 28.19 & 2 & 1476.7926 & 1476.7914 & 739.4030 & 0.0012 & 0.8115 & 639.372 & \end{array}$ $\begin{array}{lllllllllll}1.00 & 57.73 & 28.29 & 28.19 & 2 & 1476.7926 & 1476.7914 & 739.4030 & 0.0012 & 0.8115 & 639.372 \\ 1.00 & 56.98 & 28.31 & 25.16 & 2 & 1476.7928 & 1476.7914 & 739.4030 & 0.0014 & 0.9467 & 468.094\end{array}$ $\begin{array}{lllllllll} & \end{array}$ $\begin{array}{llllllll} & 0.008 & 32.069\end{array}$

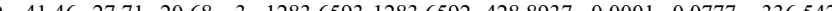
$\begin{array}{llllllllllll}1.00 & 42.76 & 27.81 & 21.90 & 3 & 1283.6596 & 1283.6592 & 428.8937 & 0.0004 & 0.3109 & 357.900 & 5.5\end{array}$ $\begin{array}{llllllllllllll}1.00 & 51.10 & 28.10 & 32.62 & 2 & 1314.7016 & 1314.6901 & 658.3523 & 0.0115 & 8.7338 & 5384.822 & 5093\end{array}$ $\begin{array}{llllllllllll}1.00 & 43.43 & 20.68 & 20.97 & 2 & 1414.5998 & 1414.5979 & 708.3062 & 0.0019 & 1.3412 & 695.059 & 792\end{array}$ $\begin{array}{lllllllllllll}1.00 & 53.60 & 26.11 & 29.54 & 2 & 1266.7318 & 1266.7314 & 634.3730 & 0.0004 & 0.3153 & 293.758\end{array}$ $\begin{array}{lllllllllll}1.00 & 46.37 & 26.15 & 28.27 & 2 & 1266.7326 & 1266.7314 & 634.3730 & 0.0012 & 0.9458 & 132.476\end{array}$ $\begin{array}{llllllllllll}0.96 & 36.49 & 26.76 & 23.84 & 2 & 1282.7256 & 1282.7263 & 642.3704 & -0.0007 & -0.5449 & 130.140\end{array}$ $\begin{array}{lllllllllll}0.93 & 29.34 & 26.70 & 24.09 & 2 & 1282.7260 & 1282.7263 & 642.3704 & -0.0003 & -0.2335 & 175.172\end{array}$ $\begin{array}{llllllllllll}0.99 & 37.08 & 26.68 & 25.61 & 2 & 1282.7264 & 1282.7263 & 642.3704 & 0.0001 & 0.0778 & 145.208\end{array}$ $\begin{array}{lllllllllll}0.99 & 33.57 & 26.77 & 21.54 & 2 & 1282.7270 & 1282.7263 & 642.3704 & 0.0007 & 0.5449 & 163.414\end{array}$ $\begin{array}{lllllllllll}1.00 & 47.26 & 26.11 & 30.59 & 2 & 1266.7316 & 1266.7314 & 634.3730 & 0.0002 & 0.1576 & 140.816\end{array}$ $\begin{array}{llllllllllll}.00 & 48.31 & 26.11 & 28.78 & 2 & 1266.7320 & 1266.7314 & 634.3730 & 0.0006 & 0.4729 & 215.813\end{array}$

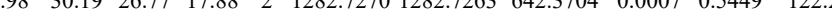
$\begin{array}{lllllllllllll}0.99 & 36.39 & 26.79 & 19.73 & 2 & 1282.7272 & 1282.7263 & 642.3704 & 0.0009 & 0.7005 & 139.153 \\ 1.00 & 42.84 & 26.74 & 25.28 & 2 & 12827274 & 1282.7263 & 642.3704 & 0.0011 & 0.8562 & 149.123\end{array}$ $\begin{array}{llllllllllllll}1.00 & 42.84 & 26.74 & 25.28 & 2 & 1282.7274 & 1282.7263 & 642.3704 & 0.0011 & 0.8562 & 149.123 \\ 1.00 & 42.12 & 26.74 & 26.28 & 2 & 1282.7274 & 1282.7263 & 642.3704 & 0.0011 & 0.8562 & 188.839\end{array}$ $\begin{array}{lllllllllllll}1.00 & 42.12 & 26.74 & 26.28 & 2 & 1282.7274 & 1282.7263 & 642.3704 & 0.0011 & 0.8562 & 188.839\end{array}$ $\begin{array}{llllllllllll}1.00 & 61.29 & 27.44 & 23.98 & 2 & 1427.7386 & 1427.7386 & 714.8766 & 0.0000 & 0.0000 & 39.047\end{array}$ $\begin{array}{lllllllllll}0.96 & 32.21 & 26.11 & 28.79 & 2 & 1266.7316 & 1266.7314 & 634.3730 & 0.0002 & 0.1576 & 29.702\end{array}$ $\begin{array}{llllllllllll}1.00 & 50.25 & 27.82 & 30.53 & 2 & 1427.7398 & 1427.7386 & 714.8766 & 0.0012 & 0.8393 & 28.967\end{array}$ $\begin{array}{llllllllllll}0.81 & 23.91 & 26.11 & 27.15 & 2 & 1266.7312 & 1266.7314 & 634.3730 & -0.0002 & -0.1576 & 45.021\end{array}$ $\begin{array}{llllllllllll}.93 & 29.26 & 26.12 & 31.82 & 2 & 1266.7314 & 1266.7314 & 634.3730 & 0.0000 & 0.0000 & 36.338\end{array}$ $\begin{array}{lllllllllllll}1.00 & 60.55 & 27.44 & 27.31 & 2 & 1427.7386 & 1427.7386 & 714.8766 & 0.0000 & 0.0000 & 61.002\end{array}$ $\begin{array}{lllllllllll}1.00 & 60.55 & 27.44 & 27.31 & 2 & 1427.7386 & 1427.7386 & 714.8766 & 0.0000 & 0.0000 & 61.002\end{array}$ $\begin{array}{lllllllllll}1.00 & 60.36 & 27.75 & 8.87 & 2 & 1427.7400 & 1427.7386 & 714.8766 & 0.074 & 0.9792 & 53.322\end{array}$

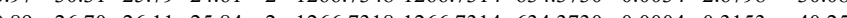
$\begin{array}{lllllllllll}1.00 & 37.31 & 26.11 & 32.20 & 2 & 1266.7330 & 126677314 & 634.3730 & 0.0016 & 1.2611 & 34.769\end{array}$ $\begin{array}{lllllllllll}0.83 & 20.31 & 26.15 & 24.10 & 2 & 1266.7326 & 1266.7314 & 634.3730 & 0.0012 & 0.9458 & 25.746\end{array}$
362.496 58.757 13.43 794.284 (5) 92.137 152.526 141.83 166.70

Table S-4 page 521 of 614 


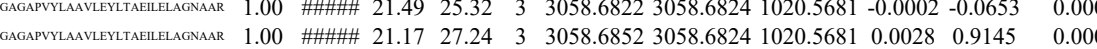
$\begin{array}{llllllllllll}\text { LLGGVTIAQGGVLPNIQAVLLPK } & 1.00 & 28.04 & 8.45 & 19.43 & 3 & 2558.5810 & 2558.5767 & 853.8662 & 0.0043 & 1.6786 & 51.750 \\ \text { LLGGVTIAQGGVLPNIQAVLLPK } & 1.00 & 20.37 & 8.45 & 33.37 & 4 & 2558.5829 & 2558.5767 & 640.6515 & 0.0062 & 2.4194 & 189.168\end{array}$ $\begin{array}{lllllllllllll} & & \end{array}$ HLQLAVR $\begin{array}{llllllllllll}1.00 & 4.86 & 8.45 & 17.86 & 4 & 2558.5829 & 2558.5767 & 640.6515 & 0.0062 & 2.4194 & 278.936 \\ 0.85 & 23.72 & 24.08 & 36.37 & 2 & 979.6066 & 979.6049 & 490.8097 & 0.0017 & 1.7318 & 426.054 & 22\end{array}$ $\begin{array}{lllllllllllll} & 0.85 & 2.72 & 24 & 17.86 & 4 & 2558.5829 & 2558.5767 & 60.6515 & 0.062 & 2.4194 & 278.936\end{array}$ $\begin{array}{lllllllllllll}\text { LLGGVTIAQGGVLPNIQAVLLPK } & 1.00 & 87.08 & 10.41 & 19.92 & 2 & 2558.5774 & 2558.5767 & 1280.2956 & 0.0007 & 0.2734 & 1.782\end{array}$ \begin{tabular}{lllllllllllll} 
LLGGVTIAQGGVLPNIQAVLLPK & 0.93 & 11.13 & 10.41 & 15.46 & 3 & 2558.5780 & 2558.5767 & 853.8662 & 0.0013 & 0.5075 & 34.468 \\
\hline LGGVTIAQGGLPNIOAVLLPK & 1.00 & 22.93 & 8.45 & 35.93 & 4 & 2558.5841 & 2558.5767 & 640.6515 & 0.0074 & 2.8877 & 41.489
\end{tabular} $\begin{array}{lllllllllllll}\text { LLGGVTIAQGGVLPNIQAVLLPK } & 1.00 & 22.93 & 8.45 & 35.93 & 4 & 2558.5841 & 2558.5767 & 640.6515 & 0.0074 & 2.8877 & 41.489 \\ \text { LLGVTIAQGGVLPNIQAVLPPK } & 1.00 & 23.56 & 8.45 & 36.56 & 4 & 2558.5885 & 2558.5767 & 640.6515 & 0.0118 & 4.6047 & 198.277\end{array}$ $\begin{array}{llllllllllll}\text { LLGGVTIAQGGVLPNIQAVLLPK } & 1.00 & 23.56 & 8.45 & 36.56 & 4 & 2558.5885 & 2558.5767 & 640.6515 & 0.0118 & 4.6047 & 198.277 \\ \text { HLQLAVR } & 0.83 & 22.22 & 23.96 & 29.07 & 2 & 979.6044 & 979.6049 & 490.8097 & -0.0005 & -0.5094 & 435.177\end{array}$ $\begin{array}{lllllllllllll}\text { LLGGVTIAQGGVLPNIQAVLLPK } & 0.55 & 6.22 & 10.41 & 19.22 & 3 & 2558.5777 & 2558.5767 & 853.8662 & 0.0010 & 0.3904 & 10.382 \\ \text { LLGGVTIAQGGVLPNIQAVLLPKK } & 0.60 & 21.63 & 8.45 & 34.63 & 3 & 2558.5804 & 2558.5767 & 853.8662 & 0.0037 & 1.4444 & 7.763\end{array}$ $\begin{array}{llllllllllll}\text { LLGGVTIAQGGLPPNIQAVLLPK } & 1.00 & 21.74 & 8.45 & 34.74 & 4 & 2558.58517 & 2558.5767 & 640.6515 & 0.0050 & 1.9511 & 21.396\end{array}$ $\begin{array}{lllllllllllll}\text { HLQLAVR } & 0.92 & 22.12 & 23.96 & 29.42 & 2 & 979.6058 & 979.6049 & 490.8097 & 0.0009 & 0.9169 & 451.398\end{array}$ $\begin{array}{llllllllllllll}0.88 & 26.50 & 23.96 & 37.41 & 2 & 979.6058 & 979.6049 & 490.8097 & 0.0009 & 0.9169 & 527.589\end{array}$

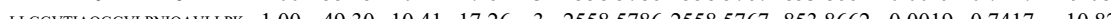
\begin{tabular}{lllllllllllll}
\hline & L
\end{tabular}

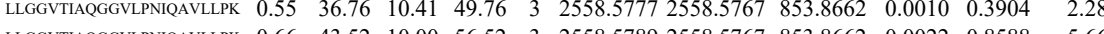
$\begin{array}{llllllllllll}\text { LLGGVTIRGGVLPNQAVLPK } & 0.66 & 69.25 & 10.00 & 82.25 & 3 & 2558.5792 & 2558.5767 & 853.8662 & 0.0025 & 0.9760 & 10.671\end{array}$ $\begin{array}{llllllllllll}\text { LLGGVTIAGGVPNIAVILPK } & 0.67 & 14.55 & 10.00 & 27.55 & 3 & 25858.5795 & 2558.5767 & 853.8662 & 0.0028 & 1.0931 & 3.641\end{array}$ $\begin{array}{llllllllllllll}\text { LLGGVTLOGVPNIOAVLPK } & 0.55 & 17.89 & 10.41 & 30.89 & 3 & 2585.5777 & 2558.5767 & 853.8662 & 0.0010 & 0.3904 & 6.84\end{array}$ $\begin{array}{llllllllllllll}\text { LLGGVTIRGGVLPNQAVLPK } & 0.98 & 21.81 & 8.45 & 20.79 & 3 & 2558.5804 & 2558.5767 & 853.8662 & 0.0037 & 1.4444 & 9.909\end{array}$ $\begin{array}{llllllllllll}\text { LLGGVTLQGGVLPNIQAVLPRK } & 0.67 & 32.59 & 10.00 & 45.59 & 3 & 2585.5795 & 2558.5767 & 853.8662 & 0.0028 & 1.0931 & 9.947\end{array}$ $\begin{array}{llllllllllllll}\text { LLGGVTIAOGGVLPNIOAVLLPK } & 0.60 & 43.23 & 8.45 & 56.23 & 3 & 2558.5810 & 2558.5767 & 853.8662 & 0.0043 & 1.6786 & 8.336\end{array}$ $\begin{array}{llllllllllllll}\text { SMATVDEEEQAVLDR } & 1.00 & 87.24 & 27.22 & 36.20 & 2 & 1835.8702 & 1835.8693 & 918.9419 & 0.0009 & 0.4897 & 20.915\end{array}$ $\begin{array}{lllllllllllll}\text { SMATVDEEEQAVLDR } & 1.00 & 99.11 & 27.22 & 36.71 & 2 & 1835.8702 & 1835.8693 & 918.9419 & 0.0009 & 0.4897 & 45.089\end{array}$ $\begin{array}{lllllllllllll}\text { MGFPPGAAQALVLQVFK } & 1.00 & 29.38 & 23.80 & 23.56 & 3 & 2061.1720 & 2061.1689 & 688.0636 & 0.0031 & 1.5018 & 89.291\end{array}$

$\begin{array}{llllllllllll}\text { GTPAGTTPGASQAPK } & 1.00 & 68.20 & 27.57 & 27.10 & 2 & 1627.8768 & 1627.8773 & 814.9459 & -0.0005 & -0.3068 & 41.693\end{array}$ $\begin{array}{llllllllllll}\text { GTPAGTTPGASQAPK } & 1.00 & 62.76 & 27.57 & 29.40 & 2 & 1627.8776 & 1627.8773 & 814.9459 & 0.0003 & 0.1841 & 69.229\end{array}$ $\begin{array}{llllllllllllll}\text { GTPAGTTPGASQAPK } & 0.67 & 38.53 & 27.72 & 51.53 & 3 & 1627.8805 & 1627.8773 & 543.6330 & 0.0032 & 1.9621 & 62.876\end{array}$ $\begin{array}{llllllllllllll}\text { GTPAGTTPGASQAPK } & 1.00 & 49.83 & 27.60 & 20.49 & 3 & 1627.8787 & 1627.8773 & 533.6330 & 0.0014 & 0.8584 & 66.796\end{array}$ $\begin{array}{llllllllllll}\text { GTPAGTTPGASQAPK } & 1.00 & 32.76 & 27.61 & 17.69 & 3 & 1627.8793 & 1627.8773 & 543.6330 & 0.0020 & 1.2263 & 92.910 \\ \text { WAVIQGQAVR } & 1.00 & 54.65 & 25.74 & 32.29 & 2 & 1270.7374 & 1270.7268 & 636.3707 & 0.0106 & 8.3284 & 420.622\end{array}$ 


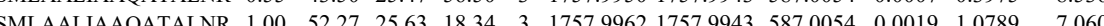
$\begin{array}{lllllllllllll}\text { SMLAALIAAQATALNR } & 1.00 & 42.54 & 26.50 & 15.95 & 3 & 1773.9910 & 1773.9892 & 592.3370 & 0.0018 & 1.0129 & 35.594\end{array}$ $\begin{array}{lllllllllll}\text { SMLAALIAAQATALNR } & 1.00 & \text { \#\#\#\#\# } 25.60 & 28.40 & 2 & 1757.9966 & 1757.9943 & 880.0044 & 0.0023 & 1.3068 & 52.708\end{array}$

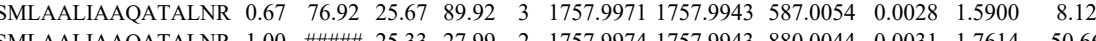
$\begin{array}{llllllllllll} & \end{array}$ $\begin{array}{lllllllllllll}\text { SMLAALIAAQATALNR } & 1.00 & 41.95 & 25.66 & 22.15 & 3 & 1757.9959 & 1757.9943 & 587.0054 & 0.0016 & 0.9086 & 16.311\end{array}$ $\begin{array}{lllllllllllll}\text { SMLAALIAAQATALNR } & 1.00 & 38.81 & 25.44 & 20.94 & 3 & 1757.9953 & 1757.9943 & 587.0054 & 0.0010 & 0.5679 & 22.946\end{array}$ $\begin{array}{lllllllllllll}\text { SMLAALIAAQATALNR } & 1.00 & 32.90 & 25.63 & 16.51 & 3 & 1757.9962 & 1757.9943 & 587.0054 & 0.0019 & 1.0789 & 21.949\end{array}$ $\begin{array}{llllllllllll}\text { SMLAALIAAQATALNR } & 0.96 & 22.20 & 25.44 & 19.18 & 3 & 1757.9953 & 1757.9943 & 587.0054 & 0.0010 & 0.5679 & 10.120\end{array}$ $\begin{array}{llllllllllllll}\text { SMLAALIAAQATALNR } & 1.00 & 30.33 & 25.63 & 19.52 & 3 & 1757.9962 & 1757.9943 & 587.0054 & 0.0019 & 1.0789 & 12.066\end{array}$ $\begin{array}{lllllllllllll}\text { SMLAALIAAQATALNR } & 0.92 & 19.88 & 25.66 & 15.87 & 3 & 1757.9959 & 1757.9943 & 587.0054 & 0.0016 & 0.9086 & 15.750\end{array}$

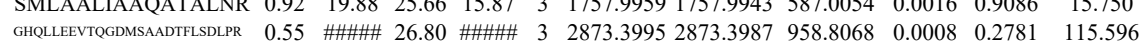

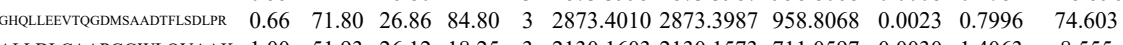
$\begin{array}{llllllllllll}\text { ALLDLCAAPGGWLQVAAK } & 1.00 & 51.93 & 26.12 & 18.25 & 3 & 2130.1603 & 2130.1573 & 711.0597 & 0.0030 & 1.4063 & 8.555 \\ & 1.00 & 57.59 & 25.92 & 23.67 & 3 & 2130.1618 & 2130.1573 & 711.0597 & 0.0045 & 2.1095 & 19.452\end{array}$ $\begin{array}{lllllllllllll} & \\ \text { ALLDLCAAPGGWLQVAAK } & 1.00 & 57.59 & 25.92 & 23.67 & 3 & 2130.1618 & 2130.1573 & 711.0597 & 0.0045 & 2.1095 & 19.452 \\ \text { EINARPIK } & 0.66 & 9.23 & 22.10 & 19.80 & 3 & 1227.7549 & 1227.7543 & 410.2587 & 0.0006 & 0.4875 & 317.242 & 4\end{array}$

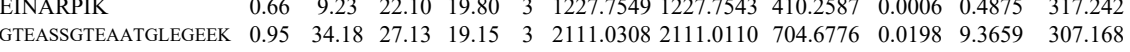
$\begin{array}{llllllllllll}\text { DYQPLLWIFQQLFR } & 1.00 & 50.36 & 26.42 & 18.18 & 2 & 2010.0874 & 2010.0849 & 1006.0497 & 0.0025 & 1.2425 & 9.314\end{array}$ $\begin{array}{llllllllllll}\text { DYQPLLWIFQQLFR } & 1.00 & 74.47 & 26.42 & 23.26 & 2 & 2010.0874 & 2010.0849 & 1006.0497 & 0.0025 & 1.2425 & 21.16\end{array}$ $\begin{array}{lllllllllllll}\text { DYQPLLWIFQQLFR } & 0.67 & 22.19 & 26.37 & 35.19 & 3 & 2010.0880 & 2010.0849 & 671.0356 & 0.0031 & 1.5399 & 13.439 \\ \text { DYQPLLWIFQQLFR } & 0.67 & 18.90 & 26.37 & 31.90 & 3 & 2010.0880 & 2010.0849 & 671.0356 & 0.0031 & 1.5399 & 12.823\end{array}$ $\begin{array}{llllllllllll}\text { DYQPLLWIFQQLFR } & 0.67 & 18.90 & 26.37 & 31.90 & 3 & 2010.0880 & 2010.0849 & 671.0356 & 0.0031 & 1.5399 & 12.823 \\ \text { GSFAGIEDADEALESOAQLLFER } & 0.55 & 23.99 & 26.61 & 36.99 & 3 & 2981.4391 & 2981.4376 & 994.8198 & 0.0015 & 0.5026 & 5.639\end{array}$

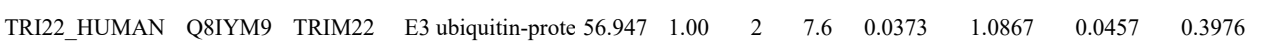
$\begin{array}{llllllllll}\text { A16A1_HUMAR } & \text { Q81Z83 } & \text { ALDH16A Aldehyde dehydro } 85.127 & 1.00 & 3 & 6.9 & -0.2601 & 0.1460 & 2.0306 & 0.1901\end{array}$ PELP1_HUMAN Q8IZL8 PELP1
Proline-, glutamic $\quad 119.7 \quad 1.00 \quad 7 \quad 11.5 \quad 0.2837 \quad 0.4877$
GSEAGIEDADEALELSSAQLLFEN

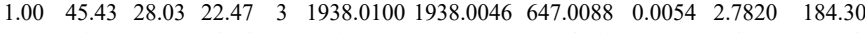

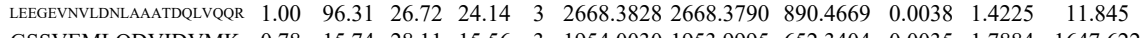
$\begin{array}{llllllllllll}\text { GSSVEMLQDVIDVMK } & 0.78 & 15.74 & 28.11 & 15.56 & 3 & 1954.0030 & 1953.9995 & 652.3404 & 0.0035 & 1.7884 & 1647.622\end{array}$ GWSAHPGVVR

LLWTLESLVTGR

LLWTESLITGR

LLWTLESLVTGR

\section{DISMNHLPGLLTSLLGLRPECESALEGMK}

HDLVIPLLMGVQQGEVLLGSPPTSSR

YAAQLPALFR

YAAQLPALFR

YAAQLPALFR

YAAQLPALFR

LLLLESVSGLLQPR

LLLLESVSGLLQPR

LLLLESVSGLLQPR
YAAQLPALFR

YAAQLPALFR

LLLLESVSGLLQPR

LLLLESVSGLLQPR

LLLLESVSGLLQPR

LLLLESVSGLLQPR

LLLLESVSGLLQPR

LLLLESVSGLLQPR

LLLLESVSGLLQPR

LLLLESVSGLLQPR

LLLESSGLLQR

LLPQVLNSWSIGR

LLPQVLNSWSIGR $\begin{array}{llllllllllll}0.91 & 20.23 & 28.44 & 14.29 & 3 & 1208.6563 & 1208.6536 & 403.8918 & 0.0027 & 2.2283 & 3806.163\end{array}$ $\begin{array}{lllllllllll}.82 & 16.96 & 28.37 & 17.13 & 3 & 1208.6566 & 208.6536 & 403.8918 & 0.0030 & 2.4759 & 1933.003 \\ 1.00 & 65.73 & 25.15 & 24.62 & 2 & 1530.8908 & 1530.8892 & 766.4519 & 0.0016 & 1.0438 & 671.248\end{array}$ $\begin{array}{llllllllllll}1.00 & 73.10 & 25.12 & 33.93 & 2 & 1530.8910 & 1530.8892 & 766.4519 & 0.0018 & 1.1742 & 1200.652\end{array}$ $\begin{array}{llllllllllll}1.00 & 83.69 & 25.12 & 29.87 & 2 & 1530.8912 & 1530.8892 & 766.4519 & 0.0020 & 1.3047 & 416.800\end{array}$ $\begin{array}{lllllllllllll}1.00 & 61.84 & 24.76 & 22.21 & 2 & 1530.8918 & 1530.8892 & 766.4519 & 0.0026 & 1.6961 & 210.635\end{array}$ $\begin{array}{lllllllllll}1.00 & 73.12 & 26.23 & 22.51 & 3 & 3099.4642 & 3099.4685 & 1034.1634 & -0.0043 & -1.3860 & 10.242\end{array}$

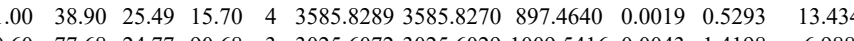

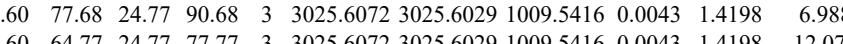

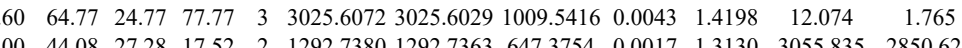

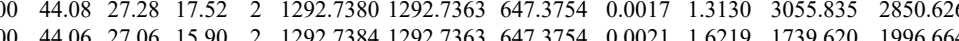
$\begin{array}{llllllllllll}1.00 & 44.07 & 27.45 & 17.70 & 2 & 1292.7372 & 1292.7363 & 647.3754 & 0.0009 & 0.6951 & 3533.671 & 3764.214\end{array}$ $\begin{array}{llllllllllllll}1.00 & 43.91 & 27.30 & 15.90 & 2 & 1292.7374 & 1292.7363 & 647.3754 & 0.0011 & 0.8496 & 2289.833 & 2666.474\end{array}$ $\begin{array}{lllllllllllll}0.82 & 58.25 & 18.98 & 71.25 & 2 & 1681.0270 & 1681.0260 & 841.5203 & 0.0010 & 0.5942 & 23.032 & 12.684\end{array}$ $\begin{array}{lllllllllllll}1.00 & 36.06 & 18.98 & 17.02 & 3 & 1681.0279 & 1681.0260 & 561.3493 & 0.0019 & 1.1282 & 106.303\end{array}$ $\begin{array}{lllllllllll}1.00 & 37.46 & 18.98 & 17.19 & 3 & 1681.0282 & 1681.0260 & 561.3493 & 0.0022 & 1.3064 & 101.474\end{array}$ $\begin{array}{llllllllllll}0.86 & 31.20 & 27.32 & 25.29 & 2 & 1292.7356 & 1292.7363 & 647.3754 & -0.0007 & -0.5406 & 472.199 & 5\end{array}$ $\begin{array}{llllllllllll}0.92 & 29.65 & 27.33 & 18.05 & 2 & 1292.7362 & 1292.7363 & 647.3754 & -0.0001 & -0.0772 & 565.307 & 6\end{array}$ $\begin{array}{llllllllllll}0.64 & 86.74 & 18.98 & 99.74 & 2 & 1681.0262 & 1681.0260 & 841.5203 & 0.0002 & 0.1188 & 86.116\end{array}$ $\begin{array}{lllllllllllll}0.82 & 84.30 & 18.98 & 97.30 & 2 & 1681.0270 & 1681.0260 & 841.5203 & 0.0010 & 0.5942 & 79.633 \\ 0.66 & 56.46 & 18.98 & 69.46 & 3 & 1681.0282 & 1681.0260 & 561.3493 & 0.0022 & 1.3064 & 61.653\end{array}$ $\begin{array}{llllllllllll}0.66 & 56.46 & 18.98 & 69.46 & 3 & 1681.0282 & 1681.0260 & 561.3493 & 0.0022 & 1.3064 & 61.653 \\ 0.67 & 41.89 & 18.86 & 54.89 & 3 & 1681.0291 & 1681.0260 & 561.3493 & 0.0031 & 1.8408 & 24.370\end{array}$ $\begin{array}{llllllllllll}0.67 & 41.89 & 18.86 & 54.89 & 3 & 1681.0291 & 1681.0260 & 561.3493 & 0.0031 & 1.8408 & 24.370 \\ 0.82 & \# \# \# \# & 18.98 & \# \# \# \# & 2 & 1681.0270 & 1681.0260 & 841.5203 & 0.0010 & 0.5942 & 56.001\end{array}$ $\begin{array}{lllllllll}0.82 & \# \# \# 18.98 \text { \#\#\#\# } & 2 & 1681.0270 & 1681.0260 & 841.5203 & 0.0010 & 0.5942 & 56.001 \\ 0.82 & \# \# \# 18.98 \text { \#\#\#\# } & 2 & 1681.0270 & 1681.0260 & 841.5203 & 0.0010 & 0.5942 & 42.648\end{array}$

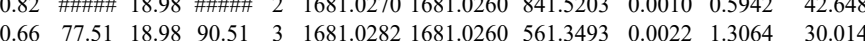
$\begin{array}{lllllllllll}0.66 & 65.40 & 18.98 & 78.40 & 3 & 1681.0282 & 1681.0260 & 561.3493 & 0.0022 & 1.3064 & 32.153\end{array}$ $\begin{array}{lllllllllllll}0.66 & 41.24 & 18.98 & 54.24 & 3 & 1681.0276 & 1681.0260 & 561.3493 & 0.0016 & 0.9501 & 8.779\end{array}$

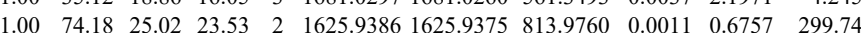
$\begin{array}{llllllllllll}1.00 & 71.62 & 25.02 & 24.12 & 2 & 1625.9386 & 1625.9375 & 813.9760 & 0.0011 & 0.6757 & 158.314 & 164.223\end{array}$ 
491.031

$\begin{array}{llllllllllllllll}0.79 & 21.76 & 26.09 & 23.61 & 2 & 966.5764 & 966.5732 & 484 & 2939 & 0.0032 & 3.83038 & 20600.196 & 19515.231 & 3265.803 & 14584.461 & Y\end{array}$

$\begin{array}{lllllllllllllllll}\text { QGILGAQPQLIFQPHR } & 0.67 & 50.84 & 24.59 & 63.84 & 3 & 1946.1007 & 1946.0972 & 649.7063 & 0.0035 & 1.7957 & 1517.128 & 1599.263 & 329.957 & 1839.403 & \text { Yes }\end{array}$

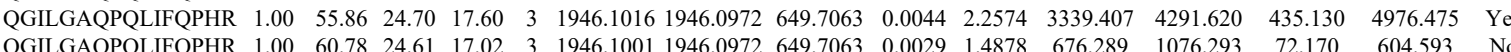

$\begin{array}{llllllllllllllll} & \end{array}$

$\begin{array}{lllllllllllllllll}\text { ALVSHGSUNGGSLOR } & 1.00 & 52.73 & 23.73 & 19.36 & 3 & 2021.1499 & 2021.1503 & 674.7240 & -0.0004 & -0.1976 & 294.830 & 359.236 & 161.878 & 303.990 & \text { Y }\end{array}$

$\begin{array}{lllllllllllllllll}\text { ALVSHNGSLINVGSLLQR } & 1.00 & 62.50 & 23.69 & 18.72 & 3 & 2021.1520 & 2021.1503 & 674.7240 & 0.0017 & 0.8398 & 251.809 & 205.824 & 197.745 & 275.951 & \text { Yes }\end{array}$ \begin{tabular}{llllllllllllllll} 
ALVSHNGSLINVGSLLQR & 1.00 & 56.81 & 23.30 & 17.29 & 3 & 2021.1538 & 2021.1503 & 674.7240 & 0.0035 & 1.7291 & 203.582 & 175.183 & 141.584 & 216.447 & Yes \\
\hline
\end{tabular} \begin{tabular}{llllllllllllllll} 
ALVSHNGSLINVGSLLQR & 1.00 & 51.19 & 23.34 & 16.36 & 3 & 2021.1547 & 2021.1503 & 674.7240 & 0.0044 & 2.1737 & 177.246 & 156.705 & 144.810 & 214.433 & Yes \\
\hline
\end{tabular} $\begin{array}{llllllllllllllll}\text { MLLSLPEK } & 0.92 & 24.55 & 26.42 & 23.30 & 2 & 1217.7304 & 1217.7297 & 609.8721 & 0.0007 & 0.5739 & 1787.649 & 1000.495 & 179.426 & 3442.326 & \text { No }\end{array}$ $\begin{array}{llllllllllllllll}\text { MLLSLPEK } & 0.93 & 25.04 & 26.42 & 23.63 & 2 & 1217.7306 & 1217.7297 & 609.8721 & 0.0009 & 0.7379 & 1220.229 & 692.114 & 30.983 & 2174.562 & \text { Yes }\end{array}$ $\begin{array}{lllllllllllllllll}\text { ILLTLGIR } & 1.00 & 37.48 & 13.22 & 15.79 & 2 & 1041.7040 & 1041.7032 & 521.8589 & 0.0008 & 0.7665 & 128.599 & 177.295 & 8.530 & 282.254 & \text { Yes }\end{array}$

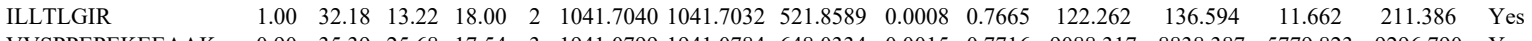
$\begin{array}{llllllllllllllll}\text { VVSPPEPEKEEAAK } & 0.90 & 35.39 & 25.68 & 17.54 & 3 & 1941.0799 & 1941.0784 & 648.0334 & 0.0015 & 0.7716 & 9088.317 & 8838.387 & 5779.823 & 9296.790 & \text { Yes }\end{array}$ $\begin{array}{lllllllllllllll}\text { GEASEDLCEMALDPELLLLR } & 1.00 & \text { \#\#\#\# } 27.16 & 22.54 & 2 & 2406.1614 & 2406.1602 & 1204.0874 & 0.0012 & 0.4983 & 0.000 & 6.280 & 1.114 & 10.608 & \text { No }\end{array}$

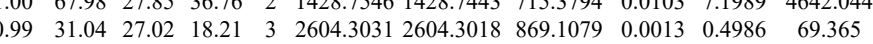
$\begin{array}{llllllllllllll}\text { APGPGLAQGLPQLHSLVLR } & 0.55 & 63.58 & 19.96 & 76.58 & 3 & 2067.2083 & 2067.2075 & 690.0764 & 0.0008 & 0.3864 & 164.529 & 27\end{array}$ $\begin{array}{llllllllllll} & 24.10 & 22.64 & 3 & 2723.4874 & 2723.4836 & 908.8351 & 0.0038 & 1.3937 & 18.939\end{array}$

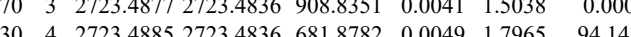
$\begin{array}{lllllllllll}3.30 & 24.03 & 26.30 & 4 & 2723.4885 & 2723.4836 & 681.8782 & 0.0049 & 1.7965 & 94.143\end{array}$ $\begin{array}{llllllllllll}1.00 & 28.11 & 23.89 & 6.97 & 4 & 2723.4889 & 2723.4836 & 681.8782 & 0.0053 & 1.9432 & 86.135 \\ 1.67 & 53.61 & 24.25 & 66.61 & 3 & 2723.4865 & 2723.4836 & 908.8351 & 0.0029 & 1.0636 & 4.842\end{array}$ $\begin{array}{lllllllllllllll} & \end{array}$

TPAILYTYSGLR TPAILYTYSGLR

$\begin{array}{llllllllll}\text { K0090_HUMAN } & \text { Q8N766 } & \text { KIAA0090 Uncharacterized p } 111.76 & 1.00 & 3 & 4.1 & -0.0353 & 0.1803 & 1.1488 & 0.4726\end{array}$

ALPTEDHLLLFLQQLA

VTAFPATR

VTAFPATR

VTAFPATR

TFIGIFLIDGVTGR

TFIGIFLIDGVTGR

$\begin{array}{lllllllllll} & & \end{array}$

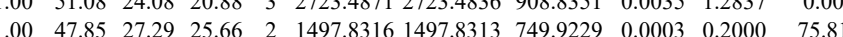
$\begin{array}{lllllllllll}1.00 & 48.88 & 27.32 & 24.76 & 2 & 1497.8326 & 1497.8313 & 749.9229 & 0.0013 & 0.8668 & 64.376\end{array}$ $\begin{array}{lllllllllll}1.00 & 41.16 & 20.90 & 16.11 & 4 & 2424.4029 & 2424.3984 & 607.1069 & 0.0045 & 1.8530 & 49.093\end{array}$ $\begin{array}{lllllllllllll}0.92 & 26.40 & 28.70 & 23.52 & 2 & 1005.5754 & 1005.5729 & 503.7937 & 0.0025 & 2.4812 & 1811.223 & 2135.901\end{array}$ $\begin{array}{lllllllllllll}0.86 & 26.81 & 28.93 & 24.40 & 2 & 1005.5762 & 1005.5729 & 503.7937 & 0.0033 & 3.2751 & 3486.897 & 3488.208 & 11\end{array}$ (27.0707 Yes $\begin{array}{lll}39.969 & 390.443 & \text { Yes } \\ 26.654 & 21.619 & \text { Yes }\end{array}$

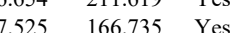
$65.851 \quad 155.199$ Yes $\begin{array}{cccc}19.929 & 19.267 & 162.182 & \text { Yes } \\ & 9.363 & 51.651 & \text { Yes }\end{array}$ $33.813 \quad 18.653 \quad 35.905$ Yes $\begin{array}{llll}31.776 & -27.832 & 35.344 & \text { Yes } \\ 15.061 & 5.719 & 11.204 & \text { No }\end{array}$

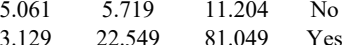
$\begin{array}{rrrr}7.129 & 22.549 & 81.049 & \text { Yes } \\ 76.257 & 10.839 & 138.625 & \text { Yes }\end{array}$ $\begin{array}{llll}7.507 & 8.808 & 5.529 & \text { Yes }\end{array}$ $\begin{array}{llll}7.507 & 8.808 & 5.629 & \text { Yes } \\ 12.172 & 9.629 & \text { No }\end{array}$ $\begin{array}{llll}70.924 & 161.371 & \text { Yes } \\ 0.08 & & 0 \\ 74.314 & 90.249 & 178.796 & \text { Yes }\end{array}$ $11.380 \quad 38.918$ Yes

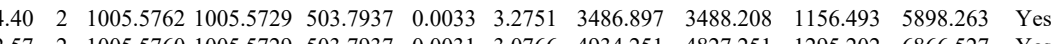

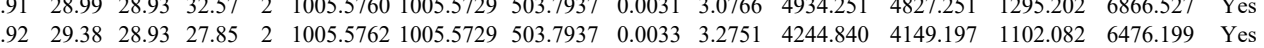
$\begin{array}{llllllllllllllll}.00 & 77.62 & 25.48 & 24.63 & 2 & 1651.9438 & 1651.9420 & 826.9783 & 0.0018 & 1.0883 & 106.279 & 94.347 & 30.582 & 104.523 & \text { Yes }\end{array}$ $\begin{array}{llllllllllllllll}1.00 & 86.00 & 25.53 & 20.75 & 2 & 1651.9440 & 1651.9420 & 826.9783 & 0.0020 & 1.2092 & 73.296 & 64.676 & 38.466 & 98.128 & \text { Ye } \\ 0\end{array}$

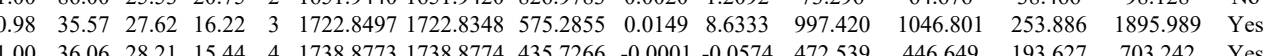

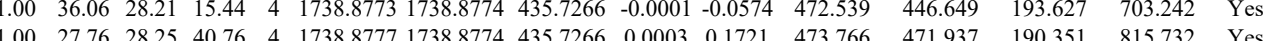

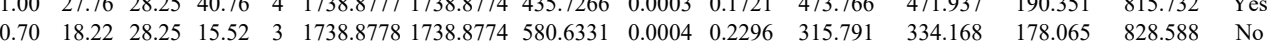


VHIYHHTGNNTFR VHIYHHTGNNTFR VHIYHHTGNNTFR VHIYHHTGNNTFR VHIYHHTGNNTFR VHIYHHTGNNTFR VHIYHTGNNTR VHTHHTNNTR VHIYHHTGNNTFR MIYHTANR

$\begin{array}{lllllllll}\text { GT251 HUMAN Q8NBJ5 } & \text { GLT25D1 Procollagen galac1 71.636 } & 1.00 & 8 & 13 & 0.3306 & 0.2829 & 1.6440 & 0.2021\end{array}$

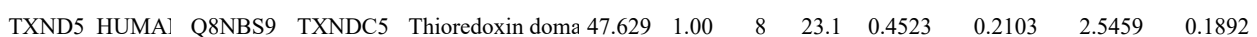

$\begin{array}{lllllllllll}\text { PAIRB_HUMAI } & \text { Q8NC51 } & \text { SERBP1 } & \text { Plasminogen activ } 44.965 & 1.00 & 11 & 32.1 & -0.3684 & 0.4059 & -0.1778 & 0.8647\end{array}$

作 MLPVDEFLPVMFDK FISAPTK

KLLAAEPLSK

KLLAAEPLSK FISAPTK TPAYIPIR

TPAYIPIR

VLIALLAR

VLIALLAR

VLIALLAR

VLIALLAR

VLIALLAR

VLIALLAR

VLIALLAR

VLIALLAR

VLIALLAR

VLIALLAR

VLIALLAR

VLIALLAR

VLIALLAR

VLIALLAR

VLIALLAR

VLIALLAR

LQPTWNDLGDK

TLAPTWEELSK

GYPTLLLFR

GYPTLLLFR

GYPTLLLFR

GYPTLLWFR

GYPTLLWFR

GYPTLLLFR

GYPTLLLFR

GYPTLLWFR

GYPTLLWFR

GYPTLLWFR

4 RFEKPLEEK
1.00

$\begin{array}{llllllllllll}1.00 & 26.46 & 28.22 & 40.46 & 4 & 1738.8781 & 1738.8774 & 435.7266 & 0.0007 & 0.4016 & 273.247 & 245.394\end{array}$

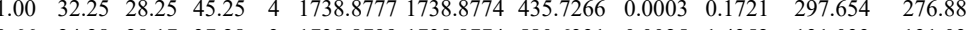

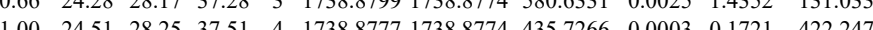
$\begin{array}{lllllllllll}1.00 & 24.51 & 28.25 & 37.51 & 4 & 1738.8777 & 1738.8774 & 435.7266 & 0.0003 & 0.1721 & 422.247\end{array}$

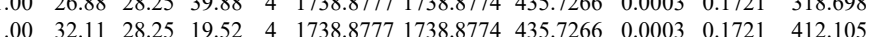
$\begin{array}{lllllllllll}1.00 & \end{array}$

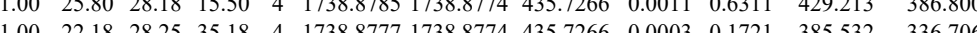

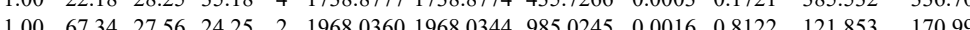
$\begin{array}{llllllllllll}1.00 & 50.37 & 27.52 & 17.77 & 2 & 1968.0362 & 1968.0344 & 985.0245 & 0.0018 & 0.9137 & 1104.480 \\ 1.00 & 62.00 & 27.57 & 23.37 & 2 & 1968.0338 & 1968.0344 & 985.0245 & -0.0006 & -0.3046 & 407.755\end{array}$

$\begin{array}{lllllllllllll}1.00 & 38.89 & 27.12 & 34.43 & 2 & 1050.6338 & 1050.6317 & 526.3231 & 0.0021 & 1.9950 & 34363.601 & 38015.668\end{array}$ $\begin{array}{lllllllllll} & 35.433 .903\end{array}$

$\begin{array}{lllllllllllllll} & 26.81 & 27.40 & 17.37 & 3 & 1677.9403 & 1677.9284 & 560.3167 & 0.0119 & 7.0793 & 2381.046 & 2065.980 & 787.102 & 2679.698 & \text { Yes }\end{array}$ $\begin{array}{lllllllllllllllll}0.93 & 25.50 & 27.15 & 23.31 & 2 & 1050.6328 & 1050.6317 & 526.3231 & 0.0011 & 1.0450 & 19062.793 & 23331.433 & 2242.669 & 18486.768 & \text { Y }\end{array}$ $\begin{array}{lllllllllllllllll}0.57 & 21.60 & 25.44 & 18.48 & 2 & 1073.6448 & 1073.6355 & 537.8250 & 0.0093 & 8.6459 & 7231.095 & 9631.608 & 4567.831 & 12203.350 & \mathrm{Nos} & \\ 0.99 & 20.73 & 3.01 & 17.09 & 2 & 867.5906 & 867.5905 & 434.8025 & 0.000 & 0.1150 & 10.693 & 16.735 & 28.045 & 20.023 & \mathrm{No}\end{array}$ $\begin{array}{llllllllllllllll}1.00 & 29.17 & 6.02 & 17.48 & 2 & 1011.6930 & 1011.6926 & 506.8536 & 0.0004 & 0.3946 & 396.138 & 514.463 & 41.476 & 325.092 & \text { Yes } & \end{array}$ $\begin{array}{lllllllllllllll}1.00 & 31.54 & 6.02 & 18.45 & 2 & 1011.6934 & 1011.6926 & 506.8536 & 0.0008 & 0.7892 & 798.134 & 1174.727 & 48.124 & 701.686 & \text { Yes }\end{array}$ $\begin{array}{lllllllllllllll}1.00 & 30.32 & 6.02 & 19.76 & 2 & 1011.6932 & 1011.6926 & 506.8536 & 0.0006 & 0.5919 & 235.138 & 342.910 & 41.854 & 186.280 & \text { Yes }\end{array}$ $\begin{array}{lllllllllllllll}1.00 & 32.71 & 6.02 & 18.54 & 2 & 1011.6934 & 1011.6926 & 506.8536 & 0.0008 & 0.7892 & 839.733 & 1070.995 & 24.535 & 700.027 & \text { Yes }\end{array}$ $\begin{array}{lllllllllllllll}1.00 & 37.12 & 6.02 & 20.83 & 2 & 1011.6932 & 1011.6926 & 506.8536 & 0.0006 & 0.5919 & 1415.225 & 1655.574 & 150.618 & 1160.694 & \text { Yes }\end{array}$ $\begin{array}{lllllllllllllll}1.00 & 32.49 & 6.02 & 17.34 & 2 & 1011.6936 & 1011.6926 & 506.8536 & 0.0010 & 0.9865 & 1961.864 & 2184.048 & 116.383 & 1655.669 & \text { Yes }\end{array}$ $\begin{array}{lllllllllllllll}0.82 & 24.47 & 6.02 & 37.47 & 2 & 1011.6932 & 1011.6926 & 506.8536 & 0.0006 & 0.5919 & 336.814 & 404.902 & 36.760 & 297.575 & \text { Yes }\end{array}$ $\begin{array}{lllllllllllllll}0.82 & 25.14 & 6.02 & 38.14 & 2 & 1011.6932 & 1011.6926 & 506.8536 & 0.0006 & 0.5919 & 407.498 & 563.216 & 61.092 & 383.736 & \text { Yes }\end{array}$ $\begin{array}{lllllllllllllll}1.00 & 24.56 & 6.02 & 18.80 & 2 & 1011.6934 & 1011.6926 & 506.8536 & 0.0008 & 0.7892 & 234.852 & 233.121 & 33.745 & 200.196 & \text { Yes }\end{array}$ $\begin{array}{lllllllllllllll}1.00 & 25.55 & 6.02 & 15.13 & 2 & 1011.6936 & 1011.6926 & 506.8536 & 0.0010 & 0.9865 & 250.728 & 204.200 & 33.842 & 190.172 & \text { Yes }\end{array}$ $\begin{array}{lllllllllllllll}1.00 & 19.14 & 6.02 & 14.77 & 2 & 1011.6932 & 1011.6926 & 506.8536 & 0.0006 & 0.5919 & 65.994 & 92.804 & 10.660 & 73.905 & \text { Yes }\end{array}$ \begin{tabular}{llllllllllllllll}
0.84 & 15.63 & 6.02 & 28.63 & 2 & 1011.6948 & 1011.6926 & 506.8536 & 0.0022 & 2.1702 & 40.635 & 59.452 & 11.377 & 42.564 & Yes \\
\hline
\end{tabular}

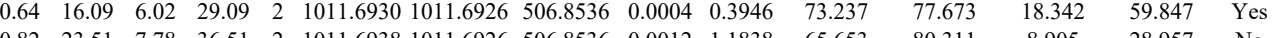
$\begin{array}{lllllllllllllll}0.82 & 23.51 & 7.78 & 36.51 & 2 & 1011.6938 & 1011.6926 & 506.8536 & 0.0012 & 1.1838 & 65.653 & 80.311 & 8.905 & 28.957 & \text { No } \\ \end{array}$

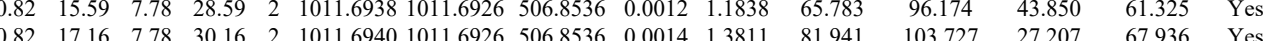
$\begin{array}{lllllllllllllll}0.82 & 17.16 & 7.78 & 30.16 & 2 & 1011.6940 & 1011.6926 & 506.8536 & 0.0014 & 1.3811 & 81.941 & 103.727 & 27.207 & 67.936 & \text { Yes } \\ 1.00 & 47.74 & 28.06 & 21.75 & 2 & 1236.6476 & 1236.6472 & 619.3309 & 0.0004 & 0.3229 & 2066.541 & 2875.956 & 134.811 & 2090.372 & \text { Yes }\end{array}$ $\begin{array}{llllllllllllllll}1.00 & 47.74 & 28.06 & 21.75 & 2 & 1236.6476 & 1236.6472 & 619.3309 & 0.0004 & 0.3229 & 2066.541 & 2875.956 & 134.811 & 2090.372 & \text { Yes } \\ 1.00 & 56.58 & 26.95 & 20.51 & 2 & 1349.6674 & 1349.6553 & 675.8349 & 0.0121 & 8.9518 & 1980.666 & 2956.932 & 564.445 & 1849.984 & \text { Yes }\end{array}$ $\begin{array}{llllllllllllllll}1.00 & 43.75 & 27.81 & 32.56 & 2 & 1573.8362 & 1573.8344 & 787.9245 & 0.0018 & 1.1422 & 1126.745 & 1950.117 & 0.000 & 1605.222 & N o\end{array}$ $\begin{array}{lllllllllllllll}1.00 & 70.92 & 27.80 & 25.90 & 2 & 1561.8594 & 1561.8595 & 781.9370 & -0.0001 & -0.0639 & 889.192 & 1250.939 & 0.000 & 1214.076 & \text { No }\end{array}$ $\begin{array}{llllllllllllllll} & \end{array}$

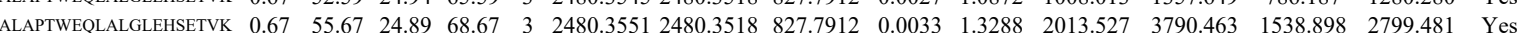

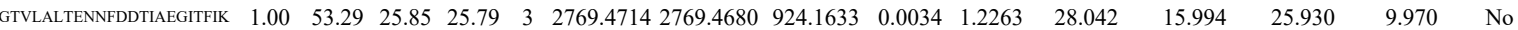
$\begin{array}{llllllllllllllll}\text { GTVLALTENNFDDTIAEGTFIK } & 1.00 & 55.14 & 25.85 & 18.18 & 3 & 2769.4714 & 2769.4680 & 924.1633 & 0.0034 & 1.2263 & 0.000 & 14.068 & 32.492 & 9.331 & \text { No }\end{array}$

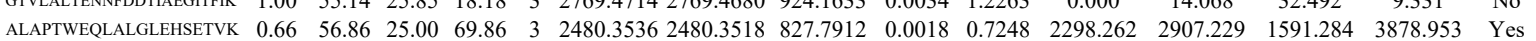
$\begin{array}{llllllllllllllll}\text { GTVLALTENNFDDTIAEGITFIK } & 1.00 & 43.60 & 25.90 & 17.71 & 3 & 2769.4702 & 2769.4680 & 924.1633 & 0.0022 & 0.7935 & 15.994 & 16.863 & 10.271 & 31.585 & \text { Yes }\end{array}$

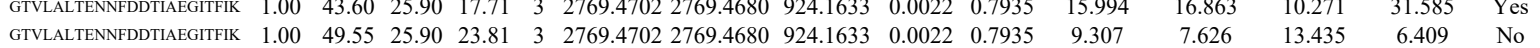

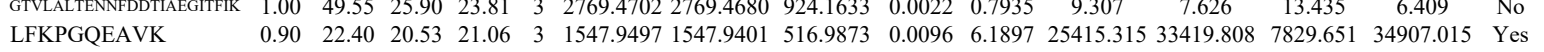

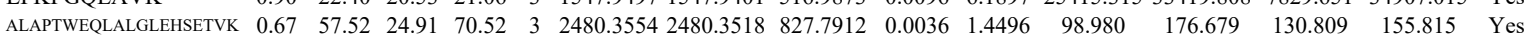
$\begin{array}{llllllllllllllll}\text { FVLSQAK } & 0.99 & 31.72 & 25.42 & 24.11 & 2 & 1079.6604 & 1079.6583 & 540.8364 & 0.0021 & 1.9414 & 29923.321 & 31468.435 & 2685.790 & 33475.976 & \text { Yes }\end{array}$

RFEKPLEEK

KPNEGADGQWK

$\begin{array}{llllllllllllllll}1.00 & 50.55 & 26.34 & 23.98 & 2 & 1222.7206 & 1222.7196 & 612.3671 & 0.0010 & 0.8165 & 1769.663 & 2700.044 & 135.286 & 2902.736 & \text { Yes }\end{array}$ $\begin{array}{lllllllllllllllll}1.00 & 43.39 & 26.34 & 27.70 & 2 & 1222.7208 & 1222.7196 & 612.3671 & 0.0012 & 0.9798 & 2969.799 & 4250.157 & 83.931 & 4903.508 & \text { Yes }\end{array}$ $\begin{array}{llllllllllllllll}1.00 & 41.53 & 26.34 & 23.38 & 2 & 1222.7206 & 1222.7196 & 612.3671 & 0.0010 & 0.8165 & 2400.199 & 3298.198 & 98.427 & 4334.292 & \text { Yes }\end{array}$ $\begin{array}{llllllllllllllll}1.00 & 38.88 & 26.35 & 27.53 & 2 & 1222.7210 & 1222.7196 & 612.3671 & 0.0014 & 1.1431 & 2770.836 & 3732.690 & 88.784 & 4611.123 & \text { Yes }\end{array}$ $\begin{array}{lllllllllllllll}0.99 & 37.36 & 27.33 & 18.38 & 2 & 1295.7156 & 1295.7148 & 648.8647 & 0.0008 & 0.6165 & 306.043 & 418.677 & 12.158 & 479.556 & \text { Yes }\end{array}$

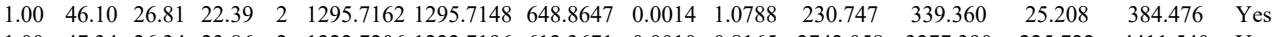
$\begin{array}{lllllllllllllll}1.00 & 47.34 & 26.34 & 23.86 & 2 & 1222.7206 & 1222.7196 & 612.3671 & 0.0010 & 0.8165 & 2742.058 & 3277.390 & 225.722 & 4411.540 & \text { Yes }\end{array}$ $\begin{array}{lllllllllllllll}1.00 & 42.85 & 26.34 & 27.94 & 2 & 1222.7206 & 1222.7196 & 612.3671 & 0.0010 & 0.8165 & 3025.442 & 3869.064 & 359.377 & 5004.361 & \text { Yes }\end{array}$ $\begin{array}{lllllllllllllll}1.00 & 49.11 & 27.33 & 22.92 & 2 & 1295.7156 & 1295.7148 & 648.8647 & 0.0008 & 0.6165 & 2849.697 & 3808.871 & 0.000 & 5064.102 & \text { No }\end{array}$

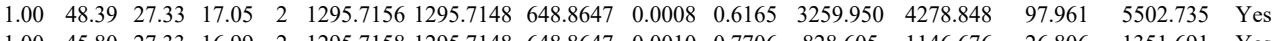

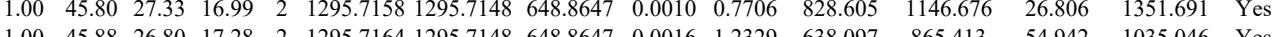

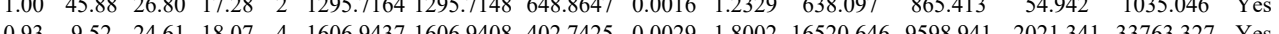
$\begin{array}{lllllllllllllllll}0.93 & 9.52 & 24.61 & 18.07 & 4 & 1606.9437 & 1606.9408 & 402.7425 & 0.0029 & 1.8002 & 16320.646 & 9598.941 & 2021.341 & 33763.327 & \text { Yes } \\ 0.99 & 12.87 & 23.62 & 18.76 & 4 & 16069465 & 1606.9408 & 402.7425 & 0.0057 & 3.5382 & 27419.427 & 17469.983 & 2890314 & 57817.638 & \text { Yes }\end{array}$ $\begin{array}{lllllllllllllll}0.99 & 12.87 & 23.62 & 18.76 & 4 & 1606.9465 & 1606.9408 & 402.7425 & 0.0057 & 3.5382 & 27419.427 & 17469.983 & 2890.314 & 57817.638 & \text { Yes } \\ 1.00 & 43.81 & 27.66 & 30.21 & 3 & 1660.8907 & 16608898 & 554.6372 & 0.0009 & 0.5409 & 2946347 & 2202.002 & 16598.197 & 16466.965 & \text { Yes }\end{array}$

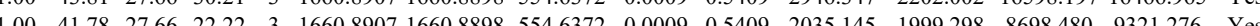

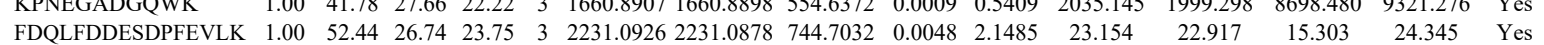

Table S-4 page 525 of 614 
RFEKPLEEK

$\begin{array}{llllllllllll}1.00 & 20.03 & 23.60 & 18.44 & 4 & 1606.9457 & 1606.9408 & 402.7425 & 0.0049 & 3.0416 & 18274.062 & 1373\end{array}$

\section{RFEKPLEEK}

DDDESDDTLEENR IFLLVQSR IFLLVQSR IFLLVQSR IFLLVQSR IFLLVQSR

$\begin{array}{lllllllllllll}1.00 & 17.35 & 23.62 & 30.35 & 4 & 1606.9465 & 1606.9408 & 402.7425 & 0.0057 & 3.5382 & 18724.373\end{array}$ $\begin{array}{llllllllllll}1.00 & 77.93 & 19.24 & 20.08 & 2 & 1695.6858 & 1695.6829 & 848.8487 & 0.0029 & 1.7082 & 15.032 \\ 1.00 & 57.92 & 19.64 & 17.41 & 2 & 1695.6866 & 1695.6829 & 848.8487 & 0.0037 & 2.1794 & 15.727 & \\ 1.00 & 51.21 & 25.93 & 39.88 & 2 & 1118.6936 & 118.6934 & 560.3540 & 0.0002 & 0.1785 & 919.197 & 800\end{array}$ $\begin{array}{lllllllllll}1.00 & 51.21 & 25.93 & 39.88 & 2 & 1118.6936 & 1118.6934 & 560.3540 & 0.0002 & 0.1785 & 919.197 \\ 1.00 & 48.44 & 25.93 & 39.41 & 2 & 1118.6940 & 1118.6934 & 5603540 & 0.0006 & 0.5354 & 708.484\end{array}$ $\begin{array}{llllllllllll}1.00 & 48.44 & 25.93 & 39.41 & 2 & 1118.6940 & 1118.6934 & 560.3540 & 0.0006 & 0.5354 & 708.484 & 56 \\ 0.99 & 42.61 & 26.00 & 39.10 & 2 & 1118.6948 & 1118.6934 & 5603540 & 0.0014 & 1.2492 & 560.455 & 45\end{array}$ $\begin{array}{llllllllllll}0.99 & 42.61 & 26.00 & 39.10 & 2 & 1118.6948 & 1118.6934 & 560.3540 & 0.0014 & 1.2492 & 560.455 & 45 \\ 1.00 & 51.10 & 26.00 & 35.26 & 2 & 1118.6948 & 1118.6934 & 560.3540 & 0.0014 & 1.2492 & 752.763 & 61\end{array}$ $\begin{array}{lllllllllll}1.00 & 51.10 & 26.00 & 35.26 & 2 & 1118.6948 & 1118.6934 & 560.3540 & 0.0014 & 1.2492 & 752.763 \\ 0.99 & 34.86 & 26.00 & 28.76 & 2 & 1118.6946 & 1118.6934 & 560.3540 & 0.0012 & 1.0708 & 169.240\end{array}$

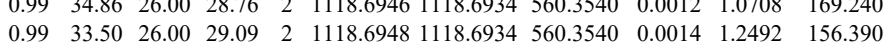
GLTVPIASIDIPSGWDVEK

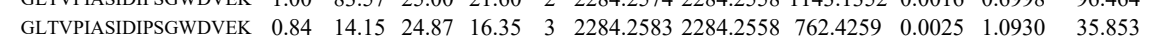

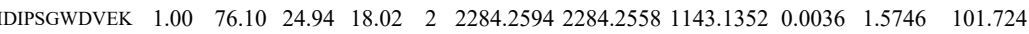
$\begin{array}{lllllllllllllll}\text { GNAGGIOPDLLISLTAPK } & 1.00 & 82.19 & 22.41 & 21.52 & 2 & 2052.1834 & 2052.1823 & 1027.0984 & 0.0011 & 0.5355 & 123.127\end{array}$

Table S-4 page 526 of 614 
FGIDDQDYLVSLTR

FGIDDQDYLVSLTR

IMDYSLLLGIHDIIR

IMDYSLLLGIHD
LVFPQDLLEK

LVFPQDLLEK

LVFPQDLLEK

LVFPQDLLEK

LVFPQDLLEK

LVFPQDLLEK

FFPASFPNR

FFPASFPNR

FFPASFPNR

FFPASFPNR

FFPASFPNR

DFPASFPNR

DPAAVTESK

DPAAVTESK

NASDMPETITSR

AYITTLCPSIR

AYITTLCPSIR

AYITTLCPSIR

AYITTLCPSIR

LLETELLQEISEIEK

LLETELLQEISEIEK

$\begin{array}{lllllllllllll}1.00 & 70.06 & 27.51 & 35.66 & 2 & 1331.7662 & 1331.7540 & 666.8843 & 0.0122 & 9.1469 & 2774.611 & 2227.907\end{array}$

$\begin{array}{llllllllllll}1.00 & 65.43 & 27.71 & 23.01 & 2 & 1784.9066 & 1784.9067 & 893.4606 & -0.0001 & -0.0560 & 326.082 & 201.318\end{array}$

$\begin{array}{lllllllllllll}1.00 & 74.28 & 27.76 & 23.18 & 2 & 1784.9078 & 1784.9067 & 893.4606 & 0.0011 & 0.6156 & 357.030 & 214.146 \\ 1.00 & 65.42 & 27.72 & 21.03 & 2 & 1784.9076 & 1784.9067 & 893.4606 & 0.0009 & 0.5037 & 202.499 & 97.757\end{array}$

$\begin{array}{llllllllllll}1.00 & 65.90 & 27.68 & 25.34 & 2 & 1784.9086 & 1784.9067 & 893.4606 & 0.0019 & 1.0633 & 297.183 & 223.565\end{array}$

$\begin{array}{llllllllllllll}1.00 & 73.52 & 25.61 & 18.73 & 3 & 1915.0747 & 1915.0723 & 639.3647 & 0.0024 & 1.2512 & 1221.478 & 842.384 \\ 1.00 & 68.27 & 25.72 & 18.27 & 3 & 1915.0756 & 1915.0723 & 639.3647 & 0.0033 & 1.7205 & 633.689 & 711.006\end{array}$

$\begin{array}{ccccccccccccc}1.00 & 68.27 & 25.72 & 18.27 & 3 & 1915.0756 & 1915.0723 & 639.3647 & 0.0033 & 1.7205 & 633.689 & 711.006 \\ 1.00 & 50.30 & 24.39 & 20.77 & 2 & 1488.8806 & 1488.8795 & 745.4470 & 0.0011 & 0.7378 & 1066.222 & 1320.321\end{array}$

$\begin{array}{llllllllllll}1.00 & 38.15 & 24.39 & 18.03 & 2 & 1488.8812 & 1488.8795 & 745.4470 & 0.0017 & 1.1403 & 3097.709 & 3920.504\end{array}$

$\begin{array}{llllllllllll}1.00 & 42.97 & 24.73 & 19.59 & 2 & 1488.8792 & 1488.8795 & 745.4470 & -0.0003 & -0.2012 & 1584.133 & 2624.859 \\ 1.00 & 48.74 & 24.71 & 21.12 & 2 & 1488.8796 & 1488.8795 & 745.4470 & 0.0001 & 0.0671 & 2826.626 & 3580.716\end{array}$

$\begin{array}{lllllllllllll}1.00 & 48.74 & 24.71 & 21.12 & 2 & 1488.8796 & 1488.8795 & 745.4470 & 0.0001 & 0.0671 & 2826.626 & 3580.716 \\ 0.99 & 38.48 & 24.71 & 18.88 & 2 & 1488.8796 & 1488.8795 & 745.4470 & 0.0001 & 0.0671 & 244.386 & 244.948\end{array}$

$\begin{array}{lllllllllllll}0.99 & 38.48 & 24.71 & 18.88 & 2 & 1488.8796 & 1488.8795 & 745.4470 & 0.0001 & 0.0671 & 244.386 & 244.948 \\ 1.00 & 48.66 & 24.71 & 20.02 & 2 & 1488.8800 & 1488.8795 & 7454470 & 0.005 & 0.3354 & 151.756 & 243.422\end{array}$

$\begin{array}{llllllllllll}1.00 & 40.66 & 24.71 & 20.02 & 2 & 1488.8800 & 1488.8795 & 745.4470 & 0.0005 & 0.3354 & 151.756 & 243.422 \\ 0.96 & 39.50 & 27.38 & 25.79 & 2 & 1225.6438 & 1225.6366 & 613.8256 & 0.0072 & 5.8648 & 7108.868 & 8101.699\end{array}$ $\begin{array}{llllllllllll}0.96 & 39.50 & 27.38 & 25.79 & 2 & 1225.6438 & 1225.6366 & 613.8256 & 0.0072 & 5.8648 & 7108.868 & 8101.699 \\ 0.98 & 40.79 & 27.32 & 27.33 & 2 & 1225.6448 & 1225.6366 & 613.8256 & 0.0082 & 6.6794 & 4757.484 & 5597.683\end{array}$

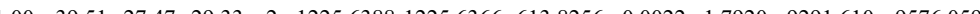
$\begin{array}{lllllllllllll}0.99 & 40.90 & 27.58 & 29.44 & 2 & 1225.6396 & 1225.6366 & 613.8256 & 0.0030 & 2.4437 & 4635.385 & 5120.461\end{array}$ $\begin{array}{llllllllllll}0.98 & 41.05 & 27.84 & 29.67 & 2 & 1225.6356 & 1225.6366 & 613.8256 & -0.0010 & -0.8146 & 2092.876 & 2463.363\end{array}$ $\begin{array}{llllllllllll}0.99 & 40.58 & 27.75 & 29.44 & 2 & 1225.6364 & 1225.6366 & 613.8256 & -0.0002 & -0.1629 & 2234.412 & 2579.838\end{array}$ $\begin{array}{lllllllllllll}0.97 & 39.89 & 28.46 & 26.79 & 2 & 1204.6534 & 1204.6543 & 603.3344 & -0.0009 & -0.7459 & 38.334 & 27.705 \\ 1.00 & 51.74 & 28.52 & 31.32 & 2 & 1204.6548 & 1204.6543 & 603.3344 & 0.0005 & 0.4144 & 45.428 & 24.229\end{array}$

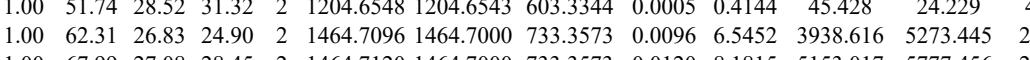

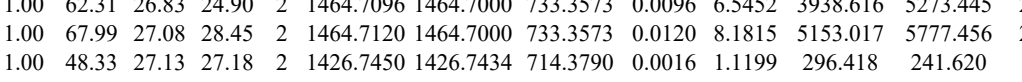
$\begin{array}{lllllllllllll}1.00 & 48.33 & 27.13 & 27.18 & 2 & 1426.7450 & 1426.7434 & 714.3790 & 0.0016 & 1.1199 & 296.418 & 241.620 \\ 1.00 & 42.02 & 27.15 & 23.75 & 2 & 1426.7454 & 1426.7434 & 714.3790 & 0.0020 & 1.3998 & 538.123 & 461.711\end{array}$ $\begin{array}{lllllllllllll}1.00 & 65.80 & 27.15 & 26.64 & 2 & 1426.7452 & 1426.7434 & 714.3790 & 0.0018 & 1.2598 & 21.914 & 23.460 \\ 1.00 & 53.29 & 27.05 & 26.57 & 2 & 1426.7456 & 1426.7434 & 7143790 & 0.0022 & 1.5398 & 107.619 & 83.962\end{array}$ $\begin{array}{llllllllllll}1.00 & 53.29 & 27.05 & 26.57 & 2 & 1426.7456 & 1426.7434 & 714.3790 & 0.0022 & 1.5398 & 107.619 & 83.962\end{array}$ $\begin{array}{llllllllllll}1.00 & 30.92 & 23.98 & 17.66 & 3 & 2074.1692 & 2074.1652 & 692.3957 & 0.0040 & 1.9257 & 150.199 & 160.076\end{array}$ $\begin{array}{llllllllllll}0.98 & 22.04 & 23.86 & 16.74 & 3 & 2074.1698 & 2074.1652 & 692.3957 & 0.0046 & 2.2145 & 139.010 & 130.921\end{array}$ $\begin{array}{llllllllllll}1.00 & 55.26 & 23.98 & 24.16 & 3 & 2074.1692 & 2074.1652 & 692.3957 & 0.0040 & 1.9257 & 110.839 & 94.180\end{array}$ $\begin{array}{llllllllllll}0.55 & 29.23 & 25.31 & 42.23 & 3 & 1571.7199 & 1571.7185 & 524.9134 & 0.0014 & 0.8890 & 289.005 & 347.147\end{array}$ $\begin{array}{lllllllllllll}0.94 & 20.50 & 25.31 & 15.65 & 3 & 1571.7199 & 1571.7185 & 524.9134 & 0.0014 & 0.8890 & 339.149 & 397.802 & 5\end{array}$ $\begin{array}{llllllllllll}0.97 & 29.41 & 20.45 & 27.01 & 2 & 1133.7452 & 1133.7416 & 567.8781 & 0.0036 & 3.1697 & 5509.724 & 4284.455\end{array}$ $\begin{array}{lllllllllllll}0.99 & 39.02 & 20.45 & 30.48 & 2 & 1133.7454 & 1133.7416 & 567.8781 & 0.0038 & 3.3458 & 13356.516 & 10867.179 & 105.6 .6\end{array}$

FVLNLIK

FVLNLIK

ILIFSSR

ILIFSSR

ILIFSSR

ILIFSSR

$\begin{array}{lllllllllllll}0.84 & 28.97 & 25.82 & 23.75 & 2 & 978.5972 & 978.5984 & 490.3065 & -0.0012 & -1.2237 & 1697.249 & 1564.472\end{array}$

$\begin{array}{llllllllllllll}0.84 & 28.93 & 25.81 & 24.00 & 2 & 978.5976 & 978.5984 & 490.3065 & -0.0008 & -0.8158 & 1509.489 & 1405.250 & 281.6 \\ 0.99 & 35.50 & 24.42 & 23.30 & 2 & 978.5986 & 978.5984 & 490.3065 & 0.0002 & 0.2040 & 1166.095 & 1030.922 & 78.5\end{array}$

$\begin{array}{llllllllllllll}0.99 & 36.24 & 24.42 & 23.64 & 2 & 978.5988 & 978.5984 & 490.3065 & 0.0004 & 0.4079 & 1043.930 & 927.937 \\ 0.97 & 26.44 & 24.44 & 23.76 & 2 & 978.5990 & 978.5984 & 490.3065 & 0.0006 & 0.6119 & 920.877 & 787.833\end{array}$

AGLLVLAVLSDGAGDH

\begin{tabular}{llllllllllll}
\hline LCPQLMPMLEEALR & 1.00 & 52.62 & 24.25 & 22.25 & 3 & 1920.0916 & 1920.0914 & 641.0377 & 0.0002 & 0.1040 & 27.278
\end{tabular}

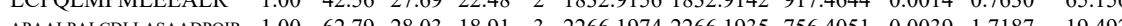

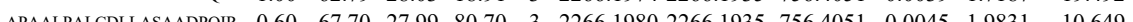

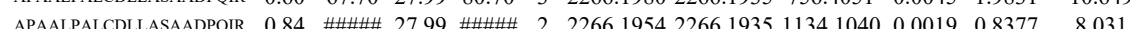
$\begin{array}{llllllllllll}\text { APAALPALCDLLASAADPOIR } & 1.00 & 69.06 & 28.03 & 19.93 & 3 & 2266.1974 & 2266.1935 & 756.4051 & 0.0039 & 1.7187 & 16.654\end{array}$ 
$\begin{array}{llllllllllll}0.66 & 19.35 & 25.88 & 32.35 & 3 & 2524.3432 & 2524.3407 & 842.4542 & 0.0025 & 0.9892 & 50.281 \\ 0.87 & 35.93 & 22.90 & 42.95 & 2 & 1157.7256 & 1157.7254 & 579.8700 & 0.0002 & 0.1725 & 4561.011 & 38 \\ 0.94 & 35.96 & 22.67 & 43.31 & 2 & 1157.7260 & 1157.7254 & 579.8700 & 0.0006 & 0.5174 & 4274.177 & 41\end{array}$

LLPPLLQIVCK $\begin{array}{llllllllllll}0.87 & 35.93 & 22.90 & 42.95 & 2 & 1157.7256 & 1157.7254 & 579.8700 & 0.0002 & 0.1725 & 4561.011 & 38 \\ 0.94 & 35.96 & 22.67 & 43.31 & 2 & 1157.7260 & 1157.7254 & 579.8700 & 0.0006 & 0.5174 & 4274.177 & 41\end{array}$

LLPLLQIVCK

$\begin{array}{lllllllllll}1.00 & 53.21 & 21.46 & 25.67 & 2 & 1569.9590 & 1569.9594 & 785.9870 & -0.0004 & -0.2545 & 14.936\end{array}$

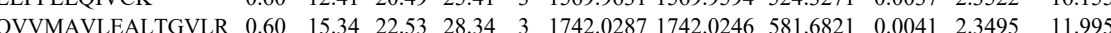
$\begin{array}{lllllllllllll}\text { QVVMAVLEALTGVLR } & 1.00 & \text { \#\#\#\# } 22.50 & 33.76 & 2 & 1742.0260 & 1742.0246 & 872.0196 & 0.0014 & 0.8027 & 109.938\end{array}$ $\begin{array}{llllllllllll}\text { QVVMAVLEALTGVLR } & 1.00 & 99.33 & 22.50 & 32.69 & 2 & 1742.0260 & 1742.0246 & 872.0196 & 0.0014 & 0.8027 & 59.604\end{array}$ $\begin{array}{llllllllllll}\text { QVVMAVLEALTGVLR } & 1.00 & 54.55 & 22.43 & 22.80 & 3 & 1742.0269 & 1742.0246 & 581.6821 & 0.0023 & 1.3180 & 37.790 \\ \text { QVVMAVLEALTGVLR } & 0.82 & 86.18 & 24.49 & 99.18 & 2 & 1758.0202 & 1758.0195 & 880.0170 & 0.0007 & 0.3977 & 5.273\end{array}$ $\begin{array}{llllllllllllll}\text { QVVMAVLEALTGVLR } & 0.82 & 86.18 & 24.49 & 99.18 & 2 & 1758.0202 & 1758.0195 & 880.0170 & 0.0007 & 0.3977 & 56.273\end{array}$ $\begin{array}{lllllllllllll}\text { QVVMAVLEALTGVLR } & 1.00 & 40.98 & 24.39 & 22.18 & 3 & 1758.0220 & 1758.0195 & 587.0138 & 0.0025 & 1.4196 & 18.86\end{array}$ $\begin{array}{lllllllllllllll} & \end{array}$ $\begin{array}{lllllllllllll} & \text { APALPALCDLLASAADPIIR } & 0.99 & 31.11 & 28.07 & 18.32 & 3 & 2266.1950 & 2266.1935 & 756.4051 & 0.0015 & 0.6610 & 17.534 \\ \text { APAALPALCDLLASAADPOIR } & 0.66 & 31.84 & 27.99 & 44.84 & 3 & 2266.1959 & 2266.1935 & 756.4051 & 0.0024 & 1.0576 & 15.743\end{array}$ \begin{tabular}{llllllllllll} 
QVVMAVLEALTGVLR & 1.00 & \#\#\#\# 22.60 & 34.91 & 2 & 1742.0264 & 1742.0246 & 872.0196 & 0.0018 & 1.0321 & 63.479 \\
\hline QVVMAVLEALTGVLR & 1.00 & 47.70 & 22.43 & 24.64 & 3 & 1742.0269 & 1742.0246 & 581.6821 & 0.0023 & 1.3180 & 27.710
\end{tabular} $\begin{array}{llllllllllll}\text { QVVMAVLEALTGVLR } & 1.00 & 47.70 & 22.43 & 24.64 & 3 & 1742.0269 & 1742.0246 & 581.6821 & 0.0023 & 1.3180 & 27.710 \\ \text { QVVMAVLEALTGVLR } & 1.00 & 52.01 & 22.43 & 27.39 & 3 & 1742.0269 & 1742.0246 & 581.6821 & 0.0023 & 1.3180 & 33.537\end{array}$ $\begin{array}{llllllllllll}\text { QVVMAVLEALTGVLR } & 1.00 & 52.01 & 22.43 & 27.39 & 3 & 1742.0269 & 1742.0246 & 581.6821 & 0.0023 & 1.3180 & 33.537 \\ \text { QVVMAVLEALTGVLR } & 1.00 & 33.15 & 24.53 & 22.32 & 3 & 1758.0238 & 1758.0195 & 587.0138 & 0.0043 & 2.4417 & 34.484\end{array}$ $\begin{array}{llllllllllll}\text { QVVMAVLEALTGVLR } & 1.00 & 33.15 & 24.53 & 22.32 & 3 & 1758.0238 & 1758.0195 & 587.0138 & 0.0043 & 2.4417 & 34.484 \\ \text { QVVMAVLEALTGVLR } & 0.99 & 46.88 & 23.40 & 22.58 & 2 & 1742.0224 & 1742.0246 & 872.0196 & -0.0022 & -1.2614 & 8.784\end{array}$ $\begin{array}{llllllllllll}\text { QVVMAVLEALTGVLR } & 0.99 & 46.88 & 23.40 & 22.58 & 2 & 1742.0224 & 1742.0246 & 872.0196 & -0.0022 & -1.2614 & 8.784 \\ \text { QVVMAVLEALTGVLR } & 1.00 & 39.97 & 22.55 & 24.73 & 3 & 1742.0266 & 1742.0246 & 581.6821 & 0.0020 & 1.1461 & 11.325\end{array}$ $\begin{array}{llllllllllllll}\text { QVVMAVLEALTGVLR } & 1.00 & 39.97 & 22.55 & 24.73 & 3 & 1742.0266 & 1742.0246 & 581.6821 & 0.0020 & 1.1461 & 11.325 \\ \text { QVVMAVLEALTGVLR } & 1.00 & 44.21 & 22.43 & 30.41 & 3 & 1742.0272 & 1742.0246 & 581.6821 & 0.0026 & 1.4899 & 8.759\end{array}$ $\begin{array}{llllllllllll}\text { QVVMAVLEALTGVLR } & 1.00 & 44.21 & 22.43 & 30.41 & 3 & 1742.0272 & 1742.0246 & 581.6821 & 0.0026 & 1.4899 & 8.759 \\ \text { QVVMAVLEALTGVLR } & 1.00 & 93.59 & 22.48 & 34.27 & 2 & 1742.0278 & 1742.0246 & 872.0196 & 0.0032 & 1.8348 & 13.027\end{array}$ $\begin{array}{llllllllllll}\text { QVVMAVLEALTGVLR } & 1.00 & 93.59 & 22.48 & 34.27 & 2 & 1742.0278 & 1742.0246 & 872.0196 & 0.0032 & 1.8348 & 13.027 \\ \text { OVVMAVLEALTGVLR } & 1.00 & 57.75 & 24.27 & 19.04 & 2 & 1758.0254 & 1758.0195 & 880.0170 & 0.0059 & 3.3522 & 10.883\end{array}$ $\begin{array}{llllllllllll}\text { QVVMAVLEALTGVLR } & 1.00 & 57.75 & 24.27 & 19.04 & 2 & 1758.0254 & 1758.0195 & 880.0170 & 0.0059 & 3.3522 & 10.883 \\ \text { LLGLLFPLLAR } & 0.64 & 34.70 & 15.91 & 47.70 & 2 & 1224.7962 & 1224.7958 & 613.4052 & 0.0004 & 0.3260 & 14.385\end{array}$ $\begin{array}{llllllllllll}\text { LLGLLFPLLAR } & 0.64 & 34.70 & 15.91 & 47.70 & 2 & 1224.7962 & 1224.7958 & 613.4052 & 0.0004 & 0.3260 & 14.385 \\ \text { LLGLLFPLAR } & 1.00 & 50.43 & 14.15 & 23.04 & 2 & 1368.8982 & 1368.8979 & 685.4562 & 0.0003 & 0.2188 & 205.519\end{array}$ $\begin{array}{llllllllllll}\text { LLGLLFPLLAR } & 1.00 & 50.43 & 14.15 & 23.04 & 2 & 1368.8982 & 1368.8979 & 685.4562 & 0.0003 & 0.2188 & 205.519 \\ \text { LLGLLFPLLAR } & 0.64 & 23.05 & 16.13 & 36.05 & 2 & 1224.7960 & 1224.7958 & 613.4052 & 0.0002 & 0.1630 & 21.673\end{array}$ $\begin{array}{llllllllllll}\text { VCPVLIELTAPDSNDDVK } & 0.80 & 17.45 & 27.57 & 15.78 & 3 & 2261.1541 & 226.1527 & 754.7248 & 0.0014 & 0.6183 & 2.483 \\ \text { LHAATPTFGVDLNELVENFG } & 1.00 & 63.87 & 25.69 & 17.02 & 3 & 2653.4026 & 2653.3986 & 885.4735 & 0.0040 & 1.5058 & 25.084\end{array}$ $\begin{array}{llllllllllll}\text { LHAATPPTFGVDLNELVENFGR } & 0.66 & 33.77 & 25.79 & 46.77 & 3 & 2653.4011 & 2653.3986 & 885.4735 & 0.0025 & 0.9411 & 15.356\end{array}$ LHAATPTIFGVDLINELVENFGR $\begin{array}{lllllllllllll}0.66 & 23.00 & 25.79 & 36.00 & 3 & 2633.4011 & 2653.3986 & 885.4735 & 0.0025 & 0.9411 & 14.178\end{array}$ FLLPIVVR FLLPIVVR FLLPIVVR $\begin{array}{lllllllllllll}1.00 & 34.86 & 19.49 & 21.18 & 2 & 1099.7250 & 1099.7239 & 550.8692 & 0.0011 & 0.9984 & 986.055\end{array}$ $\begin{array}{lllllllllllll}\text { AQICSLVELLATTLK } & 0.93 & 16.89 & 23.89 & 18.70 & 3 & 1936.1005 & 1936.0981 & 646.3733 & 0.0024 & 1.2377 & 59.723\end{array}$ $\begin{array}{llllllllllll}\text { AQICSLVELLATTLK } & 1.00 & 30.23 & 23.73 & 20.11 & 3 & 1936.1017 & 1936.0981 & 646.3733 & 0.0036 & 1.8565 & 54.177\end{array}$ $\begin{array}{llllllllllll}\text { AQICSLVELLATTLK } & 0.91 & 16.46 & 23.73 & 17.50 & 3 & 1936.1017 & 1936.0981 & 646.3733 & 0.0036 & 1.8565 & 79.288\end{array}$ $\begin{array}{llllllllllll}\text { AQICSLVELLATTLK } & 0.64 & 9.67 & 23.73 & 19.41 & 3 & 1936.1017 & 1936.0981 & 646.3733 & 0.0036 & 1.8565 & 75.453\end{array}$ $\begin{array}{lllllllllllll}\text { AQICSLVELLATTLK } & 1.00 & 36.40 & 23.91 & 22.32 & 3 & 1936.1002 & 1936.0981 & 646.3733 & 0.0021 & 1.0830 & 31.193\end{array}$ QAGSAAPRPP QAGSAAPRPP $\begin{array}{lllllllllllll}1.00 & 38.93 & 27.54 & 19.59 & 3 & 1250.6965 & 1250.6965 & 417.9061 & 0.0000 & 0.0000 & 119.451\end{array}$ $\begin{array}{llllllllllll}\text { QAGSAAPRPPR } & 0.97 & 29.75 & 27.43 & 17.18 & 2 & 1250.6976 & 1250.6965 & 626.3555 & 0.0011 & 0.8781 & 82.527 \\ \text { QAGSAAPRPPR } & 0.99 & 36.07 & 27.72 & 16.74 & 2 & 1250.6980 & 1250.6965 & 626.3555 & 0.0015 & 1.1974 & 82.140\end{array}$ QAGSAAPRPR QAGSAAPRPPR $\begin{array}{llllllllllll}0.96 & 26.49 & 27.66 & 19.53 & 3 & 1250.6971 & 1250.6965 & 417.9061 & 0.0006 & 0.4786 & 31.752\end{array}$ QAGSAAPRPPR $\begin{array}{lllllllllll}0.93 & 25.97 & 27.43 & 15.52 & 2 & 1250.6974 & 1250.6965 & 626.3555 & 0.0009 & 0.7184 & 18.623\end{array}$

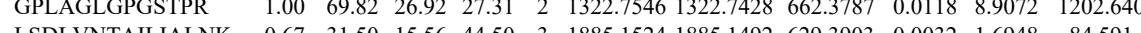

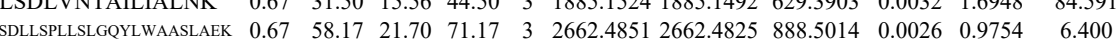
$\begin{array}{llllllllllll}\text { LSDLVNTAILIALNK } & 0.67 & 38.63 & 15.56 & 51.63 & 3 & 1885.1521 & 1885.1492 & 629.3903 & 0.0029 & 1.5359 & 84.346\end{array}$

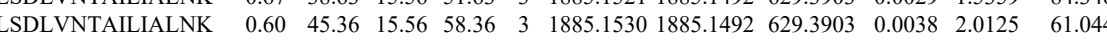

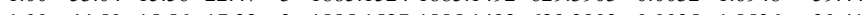

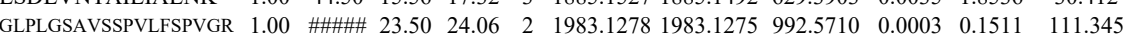



$\begin{array}{lllllllllllll}\text { NLATAYDNFVELVANLK } & 1.00 & 64.23 & 25.90 & 28.66 & 3 & 2182.1920 & 2182.1877 & 728.4032 & 0.0043 & 1.9678 & 46.324\end{array}$ $\begin{array}{llllllllllll}\text { NLATAYDNFVELVANLK } & 1.00 & 49.06 & 25.92 & 23.66 & 3 & 2182.1926 & 2182.1877 & 728.4032 & 0.0049 & 2.2423 & 132.504 \\ 3\end{array}$ $\begin{array}{lllllllllllll}\text { NLATAYDNFVELVANLK } & 1.00 & 30.03 & 25.81 & 23.68 & 3 & 2182.1905 & 2182.1877 & 728.4032 & 0.0028 & 1.2813 & 23.238 \\ \text { LDDEEEATDNDLR } & 1.00 & 70.56 & 26.57 & 45.69 & 2 & 1675.8010 & 1675.8022 & 838.9084 & -0.0012 & -0.7152 & 66.804\end{array}$ $\begin{array}{lllllllllllll}\text { LLDEEEATDNDLR } & 1.00 & 70.56 & 26.57 & 45.69 & 2 & 1675.8010 & 1675.8022 & 838.9084 & -0.0012 & -0.7152 & 66.804 \\ \text { LLDEEEATDNDLR } & 1.00 & 70.88 & 26.72 & 48.18 & 2 & 1675.8044 & 1675.8022 & 838.9084 & 0.0022 & 1.3112 & 80.008\end{array}$ $\begin{array}{llllllllllll}\text { MVPVSVQQSLAAYNQR } & 1.00 & \# \# \# \# & 27.93 & 26.97 & 2 & 1934.0164 & 1934.0166 & 968.0156 & -0.0002 & -0.1033 & 332.129 \\ \text { MVPVSVQQSAAYNQR } & 0.55 & 41.82 & 27.78 & 54.82 & 3 & 1934.0173 & 1934.0166 & 645.6795 & 0.0007 & 0.3614 & 602.943\end{array}$ $\begin{array}{llllllllllll}\text { MVPVSVQQSLAAYNQR } & 0.55 & 41.82 & 27.87 & 54.82 & 3 & 1934.0173 & 1934.0166 & 645.6795 & 0.0007 & 0.3614 & 602.943\end{array}$ $\begin{array}{llllllllllll}\text { MVPVSVQQSLAAYNQR } & 1.00 & \text { \#\#\#\# } 27.88 & 27.97 & 2 & 1934.0168 & 1934.0166 & 968.0156 & 0.0002 & 0.1033 & 760.298\end{array}$ $\begin{array}{llllllllllll}\text { MVPVSVQQSLAAYNQR } & 0.55 & 42.33 & 27.84 & 55.33 & 3 & 1934.0179 & 1934.0166 & 645.6795 & 0.0013 & 0.6711 & 627.654 \\ \text { MVPVSVQQSLAAYNQR } & 1.00 & & 27.77 & 30.72 & 2 & 1934.0184 & 1934.0166 & 968.0156 & 0.0018 & 0.9297 & 493.162\end{array}$ $\begin{array}{lllllllllllll}\text { MVPVSVQQSLAAYNQR } & 1.00 & \text { \#\#\#\# } & 27.77 & 30.72 & 2 & 1934.0184 & 1934.0166 & 968.0156 & 0.0018 & 0.9297 & 493.162 \\ \text { MVPVSVQQSLAAYNQR } & 0.69 & 15.61 & 27.87 & 19.40 & 3 & 1934.0173 & 1934.0166 & 645.6795 & 0.0007 & 0.3614 & 1123.182\end{array}$

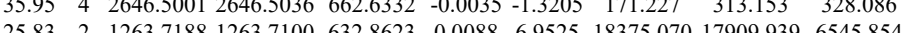
$\begin{array}{llllllllllllllllll} & \end{array}$ $\begin{array}{lllllllllllll} & \end{array}$

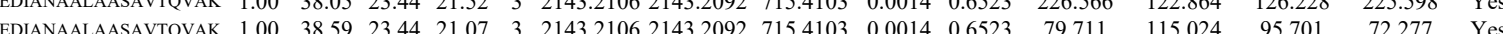
$\begin{array}{llllllllllllllll}\text { AGAAGGPEEEAEKPVK } & 1.00 & 47.86 & 26.55 & 18.57 & 3 & 1971.0655 & 1971.0638 & 658.0285 & 0.0017 & 0.8612 & 10931.276 & 13256.964 & 14709.067 & 20079.976 & \text { Yes }\end{array}$

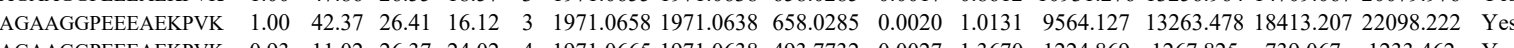

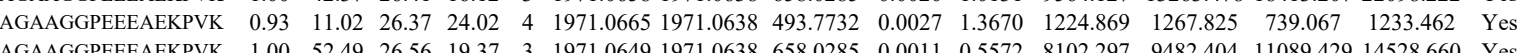
\begin{tabular}{lllllllllllllllll} 
AGAAGGPEEEAEKPVK & 1.00 & 52.49 & 26.56 & 19.37 & 3 & 1971.0649 & 1971.0638 & 658.0285 & 0.0011 & 0.5572 & 8102.297 & 9482.404 & 11089.429 & 14528.660 & Yes \\
\hline
\end{tabular} $\begin{array}{llllllllllllllll}\text { AGAAGGPEEEAEKPVK } & 1.00 & 48.85 & 26.55 & 17.07 & 3 & 1971.0655 & 1971.0638 & 658.0285 & 0.0017 & 0.8612 & 6738.831 & 9462.469 & 10125.756 & 12934.940 & \text { Yes } \\ \text { SAEEEAADLPTKPTK } & 1.00 & 44.83 & 26.99 & 17.39 & 3 & 2018.0953 & 2018.0897 & 673.7038 & 0.0056 & 2.7707 & 4328.800 & 4445.343 & 4454.880 & 5755.057 & \text { Yes }\end{array}$

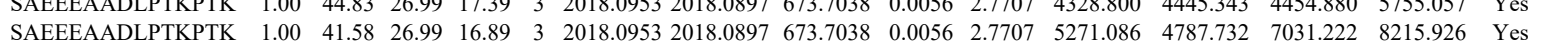

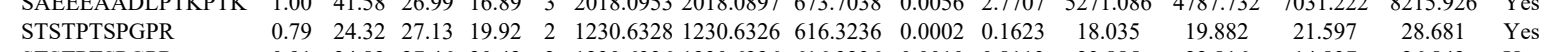

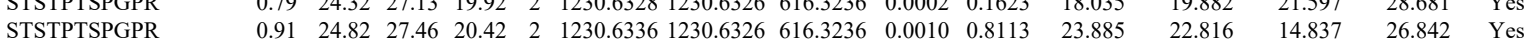

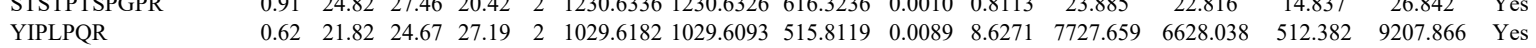
$\begin{array}{llllllllllllllll}\text { GEDKDEGPVAEQVK } & 1.00 & 55.76 & 27.34 & 29.12 & 3 & 1932.0199 & 1932.0166 & 645.0128 & 0.0033 & 1.7054 & 4204.529 & 3710.336 & 4509.920 & 4803.357 & \text { Yes }\end{array}$

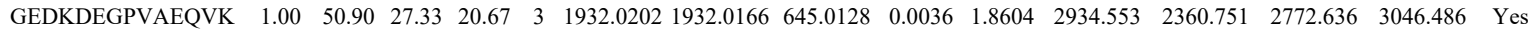
$\begin{array}{lllllllllllllll} & 0.000 & \text { No }\end{array}$

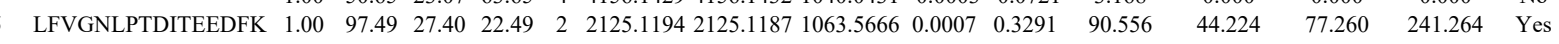

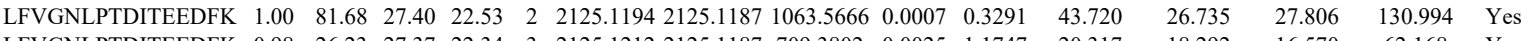

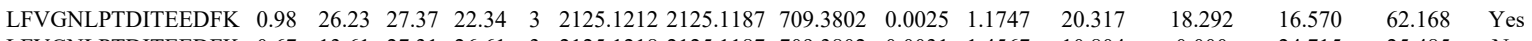
$\begin{array}{llllllllllllllll}\text { LFVGNLPTDITEEDFK } & 0.67 & 13.61 & 27.31 & 26.61 & 3 & 2125.1218 & 2125.1187 & 709.3802 & 0.0031 & 1.4567 & 10.804 & 0.000 & 24.715 & 25.485 & \text { No }\end{array}$ $\begin{array}{llllllllllllllll}\text { NLSPVVSNELLEQAFSQFGPVEK } & 0.67 & 36.97 & 25.08 & 49.97 & 3 & 2819.4982 & 2819.4949 & 940.8389 & 0.0033 & 1.1692 & 36.012 & 13.192 & 0.000 & 12.223 & \text { No }\end{array}$ \begin{tabular}{llllllllllllllll} 
NLSPVVSNELLEQAFSOFGPVEK & 0.67 & 29.11 & 25.08 & 42.11 & 3 & 2819.4982 & 2819.4949 & 940.8389 & 0.0033 & 1.1692 & 86.315 & 45.179 & 36.823 & 125.954 & Yes \\
\hline
\end{tabular} $\begin{array}{lllllllllllllllll}\text { FATHGAALTVK } & 1.00 & 31.33 & 25.77 & 22.14 & 3 & 1402.8208 & 1402.8176 & 468.6131 & 0.0032 & 2.2762 & 2924.607 & 3517.587 & 2137.817 & 6778.684 & \text { Yes }\end{array}$

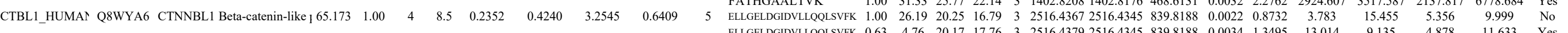

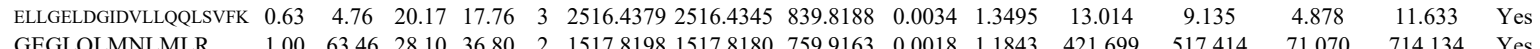

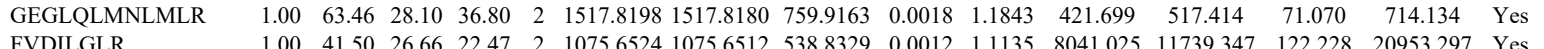

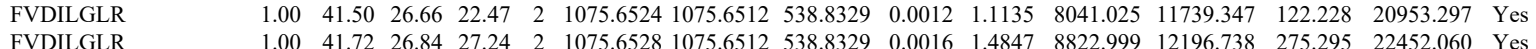

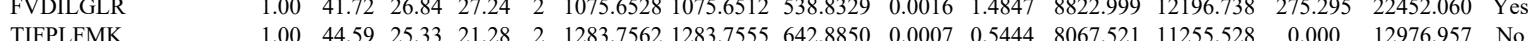

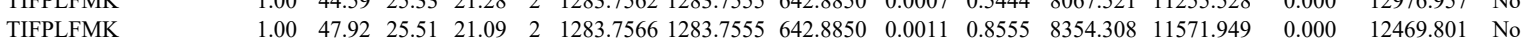

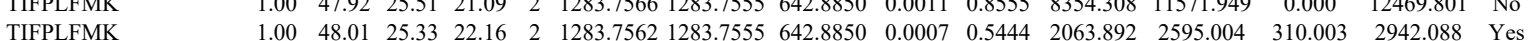



$\begin{array}{lllllllllllllll}\text { GIDHGVPYVINYTLPDEK } & 1.00 & 32.52 & 23.34 & 17.96 & 3 & 2366.3128 & 2366.3089 & 789.7769 & 0.0039 & 1.6460 & 652.438 & 576.520\end{array}$

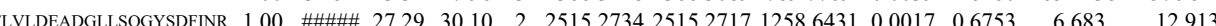

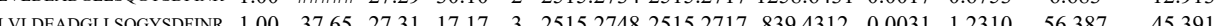
$\begin{array}{llllllllllllll}\text { FLVLDEADGLLSQGYSDFINR } & 1.00 & 45.78 & 27.28 & 23.58 & 3 & 2515.2754 & 2515.2717 & 839.4312 & 0.0037 & 1.4692 & 33.159 & 83.728\end{array}$ $\begin{array}{llllllllllllll}\text { IMHFPTWVDLK } & 1.00 & 47.25 & 26.90 & 26.63 & 3 & 1673.9233 & 1673.9207 & 558.9808 & 0.0026 & 1.5504 & 2697.083 & 2056.726\end{array}$ $\begin{array}{lllllllllllll}\text { IMHFPTWVDLK } & 1.00 & 69.07 & 26.65 & 20.36 & 3 & 1673.9251 & 1673.9207 & 558.9808 & 0.0044 & 2.6238 & 2879.311 & 1971.462\end{array}$ $\begin{array}{llllllllllllll}\text { IMHFPWVDK } & 1.00 & 50.00 & 26.90 & 26.73 & 3 & 1673.9233 & 1673.9207 & 558.9808 & 0.0026 & 1.5504 & 1256.682 & 854.886 \\ \text { IMHFPTWVDLK } & 1.00 & 46.08 & 26.73 & 18.16 & 3 & 1673.9245 & 1673.9207 & 558.9808 & 0.0038 & 2.660 & 357.677 & 210.720\end{array}$ FLICTDVAAR FLICTDVAAR

$\begin{array}{lllllllllllll}1.00 & 38.14 & 27.28 & 25.59 & 2 & 1297.6668 & 1297.6644 & 649.8395 & 0.0024 & 1.8466 & 11564.192 & 10182.289 & 6\end{array}$ $\begin{array}{llllllllllllll} & 0.99 & 40.61 & 27.36 & 25.93 & 2 & 1297.6672 & 1297.6644 & 649.8395 & 0.0028 & 2.1544 & 9749.035 & 7849.148 & 3 \\ \text { ICTDVAAR } & 1.00 & 84.49 & 20.49 & 18.90 & 2 & 21662574 & 21662544 & 1084.1345 & 0.0030 & 1.3836 & 36.396 & 20.105\end{array}$ $\begin{array}{lllllllllllllll} & \text { TGAFSIPVIQIVYETLK } & 0.60 & 17.55 & 20.49 & 30.55 & 3 & 2166.2584 & 2166.2544 & 723.0921 & 0.0040 & 1.8439 & 8.581 & 7.644\end{array}$

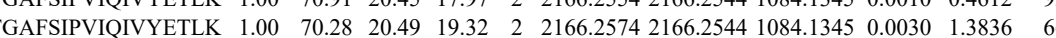
VPVDEFDGK

$\begin{array}{llllllllllll}\text { FAM3C_HUMA } & \text { Q92520 } & \text { FAM3C } & \text { Protein FAM3C } & 24.68 & 1.00 & 2 & 12.8 & -0.1433 & 0.5788 & 2.0407 & 0.3365\end{array}$

$\begin{array}{llllllllllll} & \end{array}$ $\begin{array}{lllllllllllll}1.00 & 53.92 & 28.25 & 25.32 & 2 & 1292.6974 & 1292.6856 & 647.3501 & 0.0118 & 9.1140 & 1375.505 & 1097.146 \\ 1.00 & 79.72 & 28.15 & 26.28 & 2 & 1753.9034 & 1753.9020 & 877.9583 & 0.014 & 0.7973 & 271.028 & 201.10\end{array}$

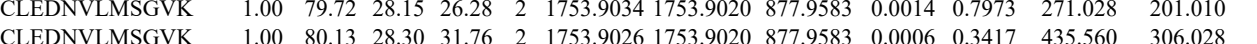

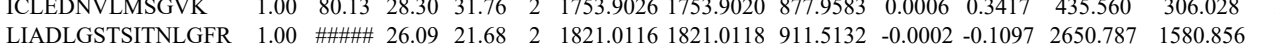

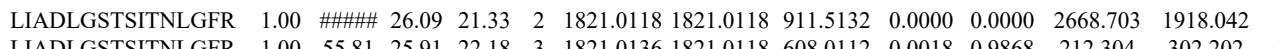
$\begin{array}{lllllllllllll}\text { LIADLGSTSITNLGFR } & 1.00 & 55.81 & 25.91 & 22.18 & 3 & 1821.0136 & 1821.0118 & 608.0112 & 0.0018 & 0.9868 & 212.304 & 302.202\end{array}$ $\begin{array}{llllllllllllll}\text { LIADLGSTSITNLGFR } & 1.00 & 56.13 & 25.91 & 16.77 & 3 & 1821.0139 & 1821.0118 & 608.0112 & 0.0021 & 1.1513 & 219.810 & 242.807\end{array}$ $\begin{array}{llllllllllll} & \end{array}$

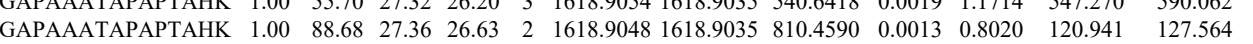
$\begin{array}{lllllllllllll}\text { GAPAAATAPAPTAHK } & 1.00 & 51.79 & 27.35 & 18.33 & 3 & 1618.9051 & 1618.9035 & 540.6418 & 0.0016 & 0.9865 & 1801.257 & 1892.512\end{array}$ $\begin{array}{lllllllllllllll}\text { SAPAAATAPAPAAHK } & 1.00 & 74.89 & 27.16 & 17.88 & 3 & 1618.9066 & 1618.9035 & 540.6418 & 0.0031 & 1.9113 & 2826.519 & 3429.193 & 11\end{array}$ $\begin{array}{llllllllllllll}\text { GAPAAATAPAPTAHK } & 1.00 & 56.61 & 27.32 & 18.49 & 3 & 1618.9060 & 1618.9035 & 540.6418 & 0.0025 & 1.5414 & 365.296 & 339.399 & 2303\end{array}$ $\begin{array}{lllllllllllll}\text { YAPALVVETIR } & 0.79 & 26.26 & 26.57 & 23.51 & 2 & 1350.7726 & 1350.7629 & 676.3887 & 0.0097 & 7.1704 & 3197.315 & 3238.325\end{array}$ $\begin{array}{lllllllllllll}\text { AASSSSPGSPVASSPSR } & 1.00 & 94.23 & 26.86 & 22.93 & 2 & 1674.8304 & 1674.8295 & 838.4220 & 0.0009 & 0.5367 & 14.878 & 18.055\end{array}$ $\begin{array}{lllllllllllll}\text { AASSSSPGSPVASSPSR } & 1.00 & 90.24 & 26.87 & 19.43 & 2 & 1674.8300 & 1674.8295 & 838.4220 & 0.0013 & 0.7753 & 30.543 & 30.219\end{array}$ $\begin{array}{llllllllllllll}\text { SAEHTLVDMVQLLFTR } & 1.00 & 65.37 & 26.80 & 26.05 & 3 & 2003.0698 & 2003.0632 & 668.6950 & 0.0066 & 3.2900 & 53.629 & 54.732 \\ \text { SAEHTLVDMVOLLFTR } & 1.00 & 54.97 & 26.85 & 22.57 & 3 & 2003.0710 & 2003.0632 & 668.6950 & 0.0078 & 3.8882 & 42.934 & 46.897\end{array}$

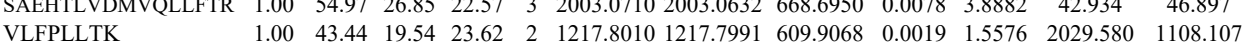
VLFPLLTK $\begin{array}{llllllllllll}.00 & 43.44 & 19.54 & 23.62 & 2 & 1217.8010 & 1217.7991 & 609.9068 & 0.0019 & 1.5576 & 2029.580 & 1108.107\end{array}$ NIMEAMLQLFR

$\begin{array}{llllllllllll}\text { TM9S4_HUMAI } & \text { Q92544 } & \text { TM9SF4 } & \text { Transmembrane } 9 & 74.519 & 1.00 & 3 & 6.5 & 0.4629 & 0.2987 & 0.4355 & 0.4258\end{array}$ NIMEAMLQ FEVIPQSIR

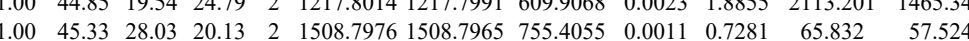
$\begin{array}{llllllllllll}1.00 & 53.70 & 27.22 & 21.71 & 3 & 2346.2359 & 2346.2341 & 783.0853 & 0.0018 & 0.7662 & 111.785 & 183.935 \\ 0.97 & 36.46 & 27.63 & 20.77 & 2 & 1231.7146 & 1231.7047 & 616.8596 & 0.0099 & 8.0245 & 3554.413 & 5116.328\end{array}$ $\begin{array}{lllllllllllllll} & 0.67 & 17.90 & 23.50 & 30.90 & 3 & 1970.8675 & 1970.8659 & 657.9626 & 0.0016 & 0.8106 & 32.909 & 36.067\end{array}$

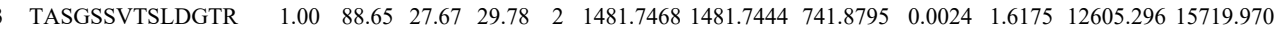

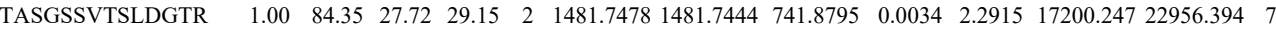
$\begin{array}{llllllllllllll}\text { TASGSSVTSLDGTR } & 1.00 & 95.69 & 27.78 & 30.24 & 2 & 1481.7450 & 1481.7444 & 741.8795 & 0.0006 & 0.4044 & 9842.081 & 10165.447 & 618.73 \\ \text { TASGSSVTSLDGTR } & 1.00 & 85.62 & 27.55 & 29.54 & 2 & 1481.7456 & 1481.7444 & 741.8795 & 0.0012 & 0.8088 & 9711.365 & 11565.372 & 49\end{array}$ $\begin{array}{lllllllllllll}\text { MADCGGLPQISQPAK } & 1.00 & 52.06 & 28.11 & 25.11 & 2 & 1848.9292 & 1848.9140 & 925.4643 & 0.0152 & 8.2120 & 535.995 & 530.869\end{array}$ $\begin{array}{lllllllllllll}\text { MADCGGLPQISQPAK } & 1.00 & 62.10 & 28.31 & 19.45 & 2 & 1848.9278 & 1848.9140 & 925.4643 & 0.0138 & 7.4557 & 562.650 & 955.867 \\ \text { MADPCGGLPISQPAK } & 1.00 & 77.29 & 28.14 & 27.24 & 2 & 1848.9294 & 1848.9140 & 925.4643 & 0.0154 & 8.3201 & 350.022 & 509.591\end{array}$ $\begin{array}{lllllllllllll}\text { MADCGGLPQISQPAK } & 1.00 & 77.29 & 28.14 & 27.24 & 2 & 1848.9294 & 1848.9140 & 925.4643 & 0.0154 & 8.3201 & 350.022 & 509.591 \\ \text { ISGWTQALPDMVVSHLFGK } & 1.00 & 49.35 & 26.04 & 17.39 & 3 & 2373.2782 & 2373.2759 & 792.0992 & 0.0023 & 0.9679 & 1121.343 & 2043.547\end{array}$ $\begin{array}{lllllllllllllll}\text { ISGWTQALPDMVVSHLFGK } & 1.00 & 49.35 & 26.04 & 17.39 & 3 & 2373.2782 & 2373.2759 & 792.0992 & 0.0023 & 0.9679 & 1121.343 & 2043.547 & 172.9 \\ \text { ISGWTQALPDMVVSHLFGK } & 0.67 & 52.69 & 25.99 & 65.69 & 3 & 2373.2788 & 2373.2759 & 792.0992 & 0.0029 & 1.2204 & 3836.842 & 6337.349 & \end{array}$ $\begin{array}{llllllllllllll}\text { ISGWTQALPDMVVSHLFGK } & 0.67 & 52.69 & 25.99 & 65.69 & 3 & 2373.2788 & 2373.2759 & 792.0992 & 0.0029 & 1.2204 & 3836.842 & 6337.349 & 463.5 \\ \text { ISGWTQALPDMVVSHLFGK } & 1.00 & 28.43 & 26.12 & 16.55 & 4 & 2373.2789 & 2373.2759 & 594.3263 & 0.0030 & 1.2619 & 109.722 & 140.759 & 0.49\end{array}$ $\begin{array}{llllllllllllll}\text { ISGWTQALPDMVVSHLFGK } & 1.00 & 28.43 & 26.12 & 16.55 & 4 & 2373.2789 & 2373.2759 & 594.3263 & 0.0030 & 1.2619 & 109.722 & 140.759 \\ \text { ISGWTQALPDMVVSHLFGK } & 0.55 & 54.03 & 26.09 & 67.03 & 3 & 2373.2773 & 2373.2759 & 792.0992 & 0.0014 & 0.5892 & 468.127 & 908.845\end{array}$

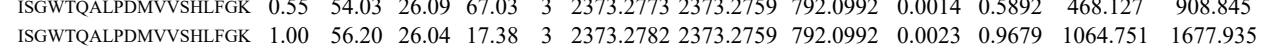
$\begin{array}{lllllllllllllll}\text { ISGWTQALPDMVVSHLFGK } & 0.55 & 61.72 & 26.09 & 74.72 & 3 & 2373.2773 & 2373.2759 & 792.0992 & 0.0014 & 0.5892 & 415.190 & 569.439\end{array}$ $\begin{array}{llllllllllllll}\text { ISGWTQALPDMVVSHLFGK } & 0.67 & 47.58 & 26.10 & 60.58 & 3 & 2373.2791 & 2373.2759 & 792.0992 & 0.0032 & 1.3466 & 383.654 & 646.626\end{array}$

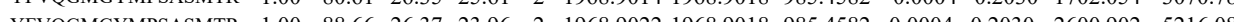
\begin{tabular}{llllllllllllll}
\hline SIGGGTGAGAYILTR & 1.00 & 85.98 & 26.92 & 40.02 & 2 & 1723.9410 & 1723.9413 & 862.9779 & 0.0003 & -0.1738 & 110.003 & 234.412
\end{tabular} 


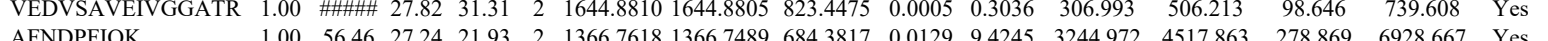

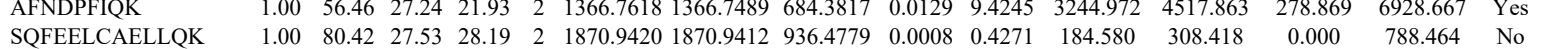

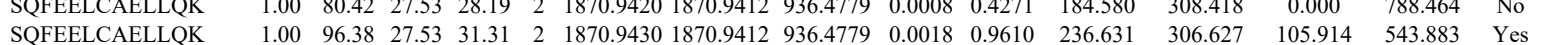

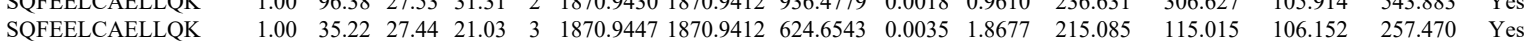

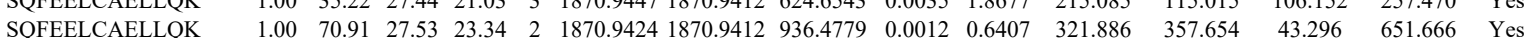

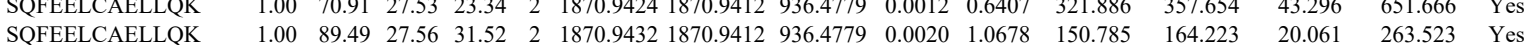
$\begin{array}{llllllllllllllll}\text { SQFEELCAELLQK } & 1.00 & 45.03 & 27.48 & 25.80 & 3 & 1870.9444 & 1870.9412 & 624.6543 & 0.0032 & 1.7076 & 125.634 & 158.332 & 34.616 & 107.621 & \text { No }\end{array}$

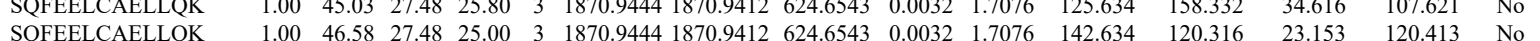

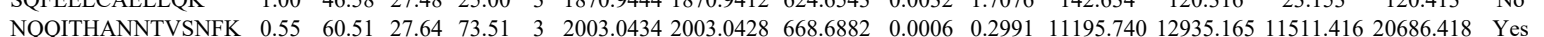
$\begin{array}{lllllllllllllllll}\text { NQQITHANNTVSNFK } & 1.00 & 61.41 & 27.54 & 19.51 & 3 & 2003.0446 & 2003.0428 & 668.6882 & 0.0018 & 0.8973 & 8779.747 & 12269.206 & 9260.435 & 17443.675 & \text { Yes }\end{array}$

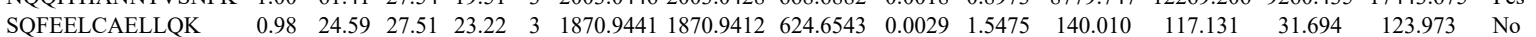

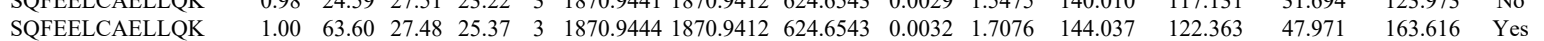
$\begin{array}{lllllllllllllllll}\text { NQQITHANNTVSNFK } & 0.55 & 59.15 & 27.64 & 72.15 & 3 & 2003.0434 & 2003.0428 & 668.6882 & 0.0006 & 0.2991 & 6924.967 & 10567.397 & 8231.022 & 17654.527 & \text { Yes }\end{array}$ $\begin{array}{llllllllllllllll}\text { NQQITHANNTVSNFK } & 1.00 & 62.71 & 27.64 & 18.94 & 3 & 2003.0434 & 2003.0428 & 668.6882 & 0.0006 & 0.2991 & 7252.604 & 8661.521 & 5897.631 & 14366.150 & \text { Yes }\end{array}$ $\begin{array}{llllllllllllllll}\text { FVVQNVSAQK } & 1.00 & 55.86 & 25.50 & 20.95 & 2 & 1406.8198 & 1406.8125 & 704.4135 & 0.0073 & 5.1816 & 9209.379 & 12573.296 & 4356.410 & 19934.322 & \text { Yes }\end{array}$ $\begin{array}{lllllllllllllllll}\text { FVVQNVSAQK } & 1.00 & 48.46 & 25.49 & 23.89 & 2 & 1406.8202 & 1406.8125 & 704.4135 & 0.0077 & 5.4655 & 11247.875 & 16814.152 & 4556.831 & 28037.949 & \text { Yes }\end{array}$

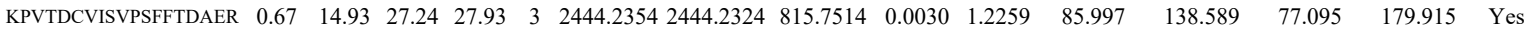
$\begin{array}{llllllllllllllll}\text { FVVQNVSAQK } & 1.00 & 53.59 & 25.79 & 23.51 & 2 & 1406.8210 & 1406.8125 & 704.4135 & 0.0085 & 6.0334 & 1428.968 & 1878.361 & 657.889 & 3562.774 & \text { Yes }\end{array}$

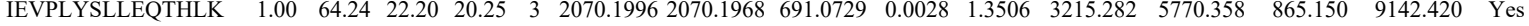

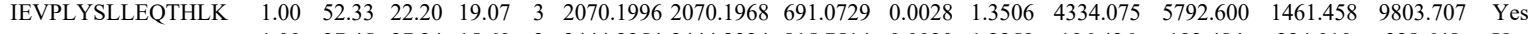
$\begin{array}{lllllllllllllllll}\text { KPVTDCVISVPSFFTDAER } & 1.00 & 37.45 & 27.24 & 15.60 & 3 & 2444.2354 & 2444.2324 & 815.7514 & 0.0030 & 1.2259 & 196.436 & 192.484 & 324.010 & 328.648 & \text { Yes }\end{array}$ $\begin{array}{llllllllllllllll}\text { KPVTDCVISVPSFFTDAER } & 0.60 & 35.79 & 27.23 & 48.79 & 3 & 2444.2363 & 2444.2324 & 815.7514 & 0.0039 & 1.5936 & 128.108 & 109.081 & 481.172 & 297.387 & \text { No }\end{array}$

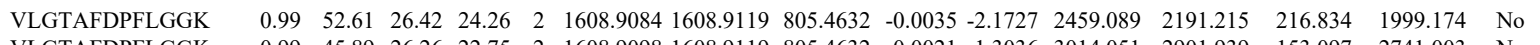
$\begin{array}{llllllllllllllll}\text { VLGTAFDPFLGGK } & 0.99 & 45.89 & 26.26 & 22.75 & 2 & 1608.9098 & 1608.9119 & 805.4632 & -0.0021 & -1.3036 & 3014.051 & 2901.939 & 153.097 & 2741.003 & \text { No }\end{array}$

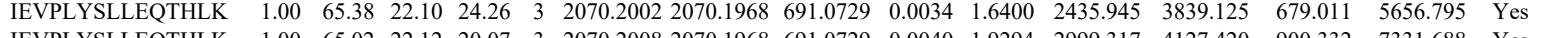
$\begin{array}{llllllllllllllllll}\text { IEVPLYSLLEQTHLK } & 1.00 & 65.02 & 22.12 & 20.07 & 3 & 2070.2008 & 2070.1968 & 691.0729 & 0.0040 & 1.9294 & 2999.317 & 4127.420 & 900.332 & 7331.688 & \text { Yes }\end{array}$

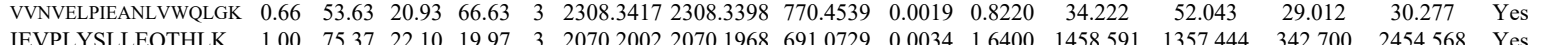

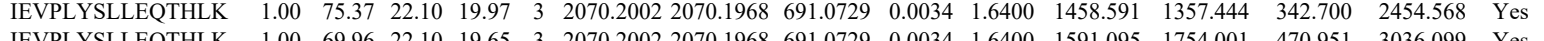
\begin{tabular}{llllllllllllllll} 
IEVPLYSLLEQTHLK & 1.00 & 69.96 & 22.10 & 19.65 & 3 & 2070.2002 & 2070.1968 & 691.0729 & 0.0034 & 1.6400 & 1591.095 & 1754.001 & 470.951 & 3036.099 & Yes \\
\hline
\end{tabular} $\begin{array}{llllllllllllll} & \end{array}$

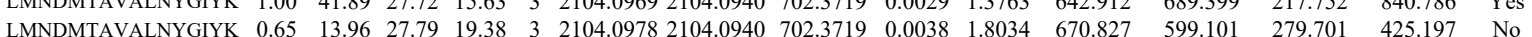

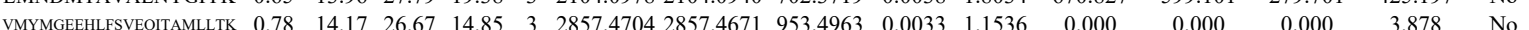

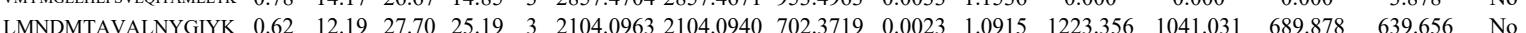

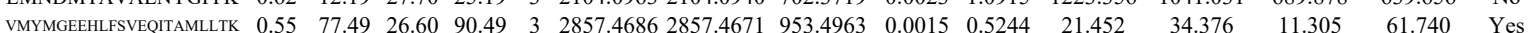

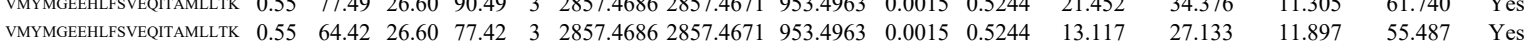
$\begin{array}{llllllllllllllll}\text { VMYMGEEHLFSVEOITAMLLTK } & 1.00 & 19.58 & 26.66 & 32.58 & 4 & 2857.4709 & 2857.4671 & 715.3741 & 0.0038 & 1.3280 & 20.144 & 24.148 & 25.423 & 43.970 & \text { Yes }\end{array}$

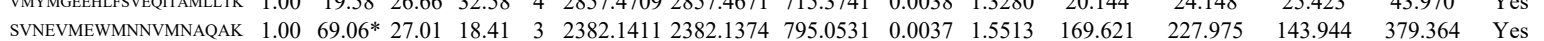
$\begin{array}{llllllllllllllll}\text { EEDLEDK } & 0.72 & 27.88 & 26.57 & 32.79 & 2 & 1164.5808 & 1164.5754 & 583.2950 & 0.0054 & 4.6289 & 1427.161 & 1423.733 & 2848.794 & 2387.174 & \text { No }\end{array}$

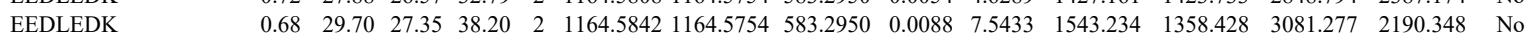

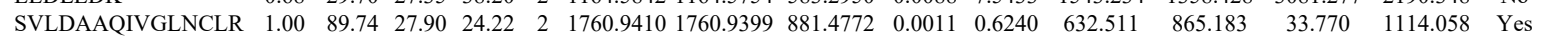
$\begin{array}{lllllllllllllll}\text { SVLDAAQIVGLNCLR } & 1.00 & \# \# \# \# \frac{27.90}{27.63} & 2 & 1760.9414 & 1760.9399 & 881.4772 & 0.0015 & 0.8508 & 231.260 & 310.775 & 29.213 & 573.739 & \text { Yes }\end{array}$ \begin{tabular}{llllllllllllllllll} 
SVLDAAQIVGLNCLR & 1.00 & 74.22 & 27.81 & 23.40 & 3 & 1760.9422 & 1760.9399 & 587.9872 & 0.0023 & 1.3039 & 36.912 & 32.757 & 23.681 & 74.428 & Yes \\
\hline
\end{tabular} $\begin{array}{llllllllllllllll}\text { SVLDAAQIVGLNCLR } & 1.00 & 63.42 & 27.80 & 23.13 & 3 & 1760.9428 & 1760.9399 & 587.9872 & 0.0029 & 1.6440 & 34.887 & 50.166 & 26.197 & 70.247 & \text { Yes }\end{array}$ $\begin{array}{llllllllllllllll}\text { SVLDAAQIVGLNCLR } & 1.00 & 82.84 & 27.82 & 23.08 & 2 & 1760.9396 & 1760.9399 & 881.4772 & -0.0003 & -0.1702 & 231.951 & 297.457 & 19.309 & 320.665 & \text { Yes }\end{array}$ $\begin{array}{llllllllllllllll}\text { TPNGPNIDK } & 0.91 & 27.78 & 27.66 & 20.26 & 2 & 1242.6842 & 1242.6812 & 622.3479 & 0.0030 & 2.4102 & 3870.774 & 5233.682 & 11342.978 & 7065.001 & \text { No }\end{array}$ $\begin{array}{llllllllllllllll}\text { TPNGPNIDK } & 0.97 & 33.26 & 27.69 & 22.45 & 2 & 1242.6844 & 1242.6812 & 622.3479 & 0.0032 & 2.5709 & 4688.999 & 6611.505 & 10976.893 & 7668.158 & \text { No }\end{array}$

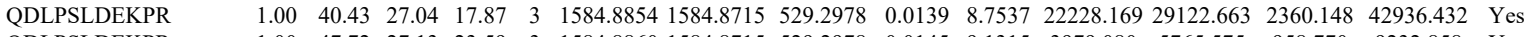
$\begin{array}{llllllllllllllll}\text { QDLPSLDEKPR } & 1.00 & 47.72 & 27.13 & 23.59 & 3 & 1584.8860 & 1584.8715 & 529.2978 & 0.0145 & 9.1315 & 3979.080 & 5765.575 & 958.770 & 9232.858 & \text { Yes }\end{array}$

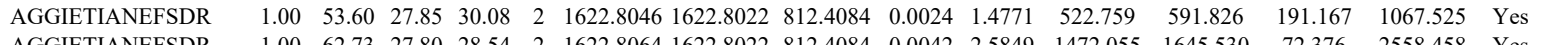
$\begin{array}{llllllllllllllll}\text { AGGIETIANEFSDR } & 1.00 & 62.73 & 27.80 & 28.54 & 2 & 1622.8064 & 1622.8022 & 812.4084 & 0.0042 & 2.5849 & 1472.055 & 1645.530 & 72.376 & 2558.458 & \text { Yes }\end{array}$

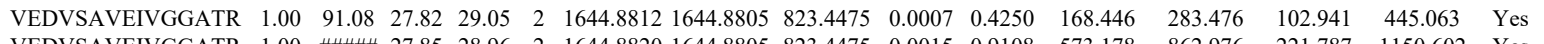
$\begin{array}{lllllllllllllll}\text { VEDVSAVEIVGGATR } & 1.00 & \text { \#\#\# } 27.85 & 28.96 & 2 & 1644.8820 & 1644.8805 & 823.4475 & 0.0015 & 0.9108 & 573.178 & 862.976 & 221.787 & 1150.602 & \text { Yes }\end{array}$

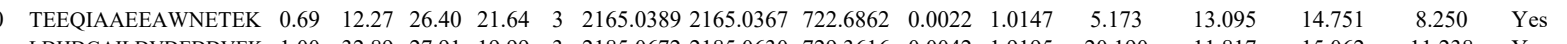

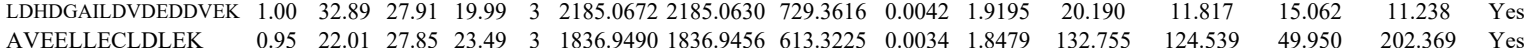

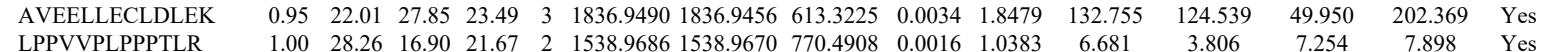

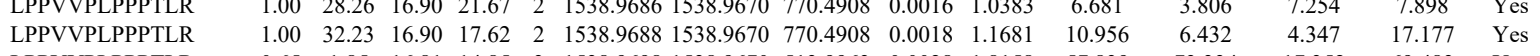

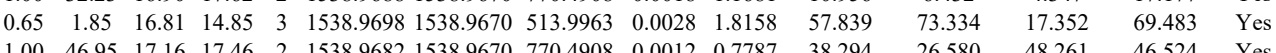




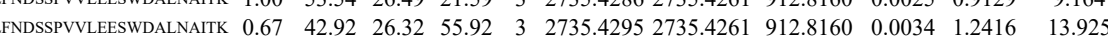
$\begin{array}{llllllllllll}\text { LFNDSSPVVLEESWDALNATTK } & 1.00 & 39.03 & 26.49 & 17.70 & 3 & 2735.4286 & 2735.4261 & 912.8160 & 0.0025 & 0.9129 & 33.29\end{array}$ $\begin{array}{llllllllllll}\text { LFNDSSPVVLEESWDALNAITK } & 0.60 & 66.14 & 26.26 & 79.14 & 3 & 2735.4301 & 2735.4261 & 912.8160 & 0.0040 & 1.4607 & 47.077 \\ \text { ILPEIPILEGLR } & 1.00 & 43.76 & 20.37 & 15.84 & 3 & 1748.0596 & 1748.0569 & 583.6929 & 0.0027 & 1.5419 & 94.086\end{array}$ ILPEIIPILEEGLR $\begin{array}{lllllllllll}.00 & 43.76 & 20.37 & 15.84 & 3 & 1748.0596 & 1748.0569 & 583.6929 & 0.0027 & 1.5419 & 94.086\end{array}$ EIIPILEEGLR $\begin{array}{llllllllllll}1.00 & 75.73 & 20.41 & 26.41 & 2 & 1748.0600 & 1748.0569 & 875.0357 & 0.0031 & 1.7714 & 580.252\end{array}$ LPETILEEGLR $\begin{array}{llllllllllllll}0.74 & 19.48 & 27.70 & 21.32 & 2 & 1367.7408 & 1367.7396 & 684.8771 & 0.0012 & 0.8761 & 3529.912 & 29\end{array}$ $\begin{array}{llllllllllll}\text { NPEILAIAPVLLDALTDPSR } & 1.00 & 82.67 & 22.10 & 24.19 & 3 & 2261.2819 & 2261.2753 & 754.7657 & 0.0066 & 2.9148 & 4.220\end{array}$ $\begin{array}{llllllllllll}0.86 & 24.07 & 26.14 & 18.80 & 2 & 1141.6610 & 1141.6577 & 571.8361 & 0.0033 & 2.8854 & 7309.670 & \\ 1.00 & 68.26 & 22.23 & 18.65 & 3 & 2261.2810 & 2261.2753 & 754.7657 & 0.0057 & 25173 & 22.380 & \end{array}$

$\begin{array}{llllllllllll}0.00 & 65.22 & 27.31 & 18.01 & 3 & 2337.1678 & 2337.1653 & 780.0624 & 0.0025 & 1.0683 & 115.497 & 112.169 \\ 89 & 25.30 & 26.14 & 19.79 & 2 & 1141.6610 & 1141.6577 & 571.8361 & 0.0033 & 2.8854 & 3931.410 & 3813.704\end{array}$

LTTPPVNTR

$\begin{array}{llllll}41.6610 & 1141.6577 & 571.8361 & 0.0033 & 2.8854 & 3931.410 \\ 41.6610 & 1141.6577 & 571.8361 & 0.0033 & 2.8854 & 2940.619\end{array}$ $\begin{array}{llllllllllll}\text { CMLDAALATLNTHGK } & 0.99 & 39.90 & 27.77 & 17.58 & 3 & 1891.9546 & 1891.9562 & 631.6593 & -0.0016 & -0.8443 & 1510.001\end{array}$ $\begin{array}{llllllllllllll} & \end{array}$ DTLLQALDLLPLLIQTVEK $\begin{array}{lllllllllll}0.67 & 35.17 & 15.91 & 48.17 & 3 & 2480.4742 & 2480.4709 & 827.8309 & 0.0033 & 1.3288 & 1.748\end{array}$ $\begin{array}{llllllllllll} & \end{array}$ $\begin{array}{llllllllllllll}\text { GDTLLQALDLLPLLIQTVEK } & 0.67 & 31.45 & 16.13 & 44.45 & 3 & 2480.4736 & 2480.4709 & 827.8309 & 0.0027 & 1.0872 & 14.206\end{array}$ $\begin{array}{lllllllllllll}\text { GDTLLQALDLLPLLIQTVEK } & 0.60 & 45.52 & 16.02 & 58.52 & 3 & 2480.4748 & 2480.4709 & 827.8309 & 0.0039 & 1.5704 & 3.719\end{array}$ $\begin{array}{lllllllllllll}\text { GDTLLQALDLLPLLIQTVEK } & 0.60 & 18.28 & 16.02 & 31.28 & 3 & 2480.4748 & 2480.4709 & 827.8309 & 0.0039 & 1.5704 & 4.260\end{array}$ $\begin{array}{llllllllllll}\text { VLQEALCVISGVPGLK } & 0.60 & 51.45 & 24.01 & 64.45 & 3 & 1959.1177 & 1959.1141 & 654.0453 & 0.0036 & 1.8347 & 56.862\end{array}$

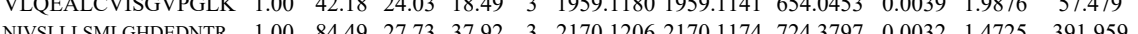
$\begin{array}{llllllllllll} & \text { G }\end{array}$

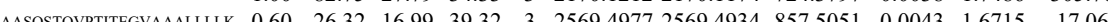

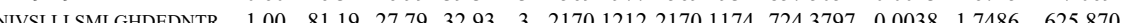

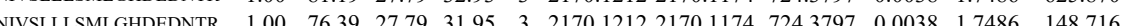

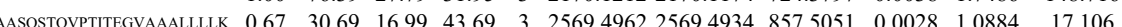

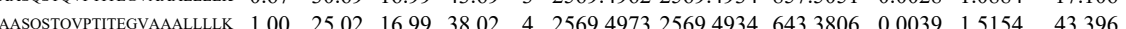
$\begin{array}{llllllllllllll} & \text { ASSOSTOVPTITEGVAAALLLLK } & 1.00 & 19.03 & 16.99 & 32.03 & 4 & 2569.4989 & 2569.4934 & 643.3806 & 0.0055 & 2.1371 & 47.226\end{array}$ $\begin{array}{llllllllllll}\text { YLLDSCAPLLR } & 0.82 & 34.05 & 28.04 & 29.01 & 2 & 1452.7572 & 1452.7590 & 727.3868 & -0.0018 & -1.2373 & 160.553\end{array}$ $\begin{array}{lllllllllllll}\text { YLLDSCAPLLR } & 0.99 & 53.52 & 28.01 & 37.89 & 2 & 1452.7574 & 1452.7590 & 727.3868 & -0.0016 & -1.0998 & 1042.943\end{array}$

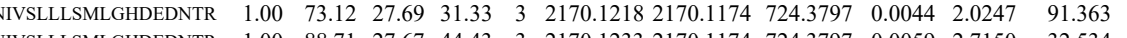
$\begin{array}{lllllllllllll} & \text { NVSLLLSSMGHEDNR } & 100 & 88.71 & 27.67 & 44.43 & 3 & 2170.1233 & 2170.1174 & 724.3797 & 0.0059 & 2.7150 & 32.334\end{array}$ $\begin{array}{llllllllllll} & & & \end{array}$ SLVSGLIR $\begin{array}{llllllllllllll}0.60 & 26.98 & 13.98 & 39.98 & 3 & 1643.0518 & 1643.0476 & 548.6898 & 0.0042 & 2.5515 & 42.898 & 5\end{array}$ $\begin{array}{lllllllllllll}0.89 & 41.57 & 26.67 & 43.95 & 2 & 987.6290 & 987.6199 & 494.8172 & 0.0091 & 9.1952 & 6677.980\end{array}$ $\begin{array}{llllllllllll}0.84 & 78.59 & 16.13 & 91.59 & 2 & 1643.0492 & 1643.0476 & 822.5311 & 0.0016 & 0.9726 & 84.967\end{array}$

ALLETLSLLLAK $\begin{array}{lllllllllll}0.84 & 79.14 & 16.02 & 92.14 & 2 & 1643.0498 & 1643.0476 & 822.5311 & 0.0022 & 1.3373 & 130.996\end{array}$ AALLETLSLLLAK $\begin{array}{llllllllllll}0.60 & 48.02 & 13.98 & 61.02 & 3 & 1643.0515 & 1643.0476 & 548.6898 & 0.0039 & 2.3693\end{array}$ $\begin{array}{llllllllllll}0.60 & 53.28 & 13.98 & 66.28 & 3 & 1643.0518 & 1643.0476 & 548.6898 & 0.0042 & 2.5515 & 60.945\end{array}$ $\begin{array}{lllllllllllll} & \end{array}$ $\begin{array}{lllllllllllll}\text { NPSGLTQYIPVLVDSFLPLLK } & 1.00 & 26.00 & 16.72 & 15.16 & 3 & 2601.5053 & 2601.5025 & 868.1748 & 0.0028 & 1.0751 & 26.914\end{array}$ $\begin{array}{lllllllllllll}\text { HAALSTPSQQVVEESVASCPPLVPAIK } & 0.66 & 41.01 & 21.82 & 54.01 & 3 & 3193.7722 & 3193.7698 & 1065.5972 & 0.0024 & 0.7508 & 0.000\end{array}$ $\begin{array}{lllllllllllll}\text { AALLETLSLLLAK } & 0.84 & 81.67 & 16.02 & 94.67 & 2 & 1643.0494 & 1643.0476 & 822.5311 & 0.0018 & 1.0942 & 33.289 \\ \text { AALLETLSLLLAK } & 0.67 & 58.60 & 15.80 & 71.60 & 3 & 1643.0503 & 1643.0476 & 548.6898 & 0.0027 & 1.6403 & 50.21\end{array}$ AALLETLSLLLAK AALLETLSLLLAK $\begin{array}{llllllllllll}0.67 & 42.00 & 15.80 & 55.00 & 3 & 1643.0503 & 1643.0476 & 548.6898 & 0.0027 & 1.6403 & 47.403\end{array}$ AALLETLSLLLAK $\begin{array}{lllllllllll}0.72 & 96.46 & 15.80 & 2 & 1643.0504 & 1643.0476 & 822.5311 & 0.0028 & 1.7021 & 15.069\end{array}$ $\begin{array}{lllllllllllll}\text { NPSGLTQYIPVLVDSFLPLLK } & 0.66 & 41.32 & 16.72 & 54.32 & 3 & 2601.5044 & 2601.5025 & 868.1748 & 0.0019 & 0.7295 & 34.916\end{array}$

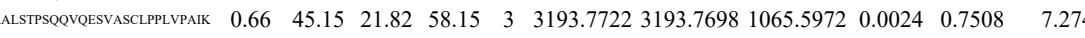
$\begin{array}{lllllllllll} & 0.7508\end{array}$

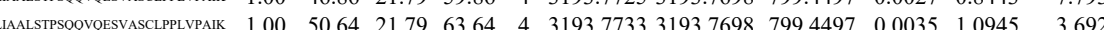

266.173

\section{$170 \quad 54.00$}

170 
$\begin{array}{llllllllllllllll}\text { ALGTLVSHVTLR } & 1.00 & 80.28 & 22.23 & 22.90 & 3 & 149.8506 & 1409.8476 & 470.9565 & 0.0130 & 92010 & 2102.897 & 2557.877 & 247.204 & 3267820 & \text { Yes }\end{array}$

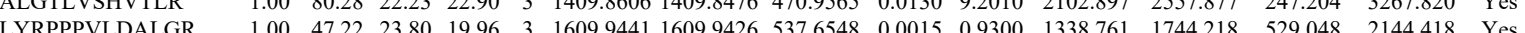
$\begin{array}{llllllllllllll} & \end{array}$ $\begin{array}{llllllllllllllll}\text { LTSADALRPSVYSITGPLIR } & 0.66 & 40.00 & 18.69 & 53.00 & 3 & 2209.2934 & 2209.2916 & 737.4378 & 0.0018 & 0.8136 & 609.454 & 1073.825 & 759.075 & 982.217 & \text { Yes }\end{array}$ $\begin{array}{llllllllllllllll}\text { VGIALKPFLPQLOTTFTK } & 0.67 & 43.42 & 13.01 & 56.42 & 3 & 2433.4753 & 2433.4725 & 812.1648 & 0.0028 & 1.1492 & 72.380 & 86.918 & 72.892 & 125.703 & \text { Yes }\end{array}$

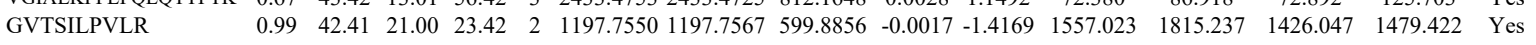

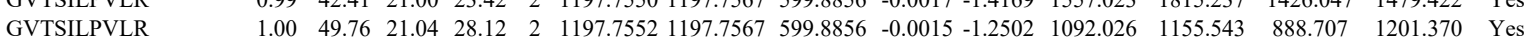
$\begin{array}{lllllllllllllllll}\text { ALGTLVSHVTLR } & 1.00 & 81.05 & 22.55 & 22.62 & 3 & 1409.8543 & 1409.8476 & 470.9565 & 0.0067 & 4.7421 & 2747.905 & 3169.659 & 407.227 & 3586.907 & \text { Yes }\end{array}$ $\begin{array}{llllllllllllllll}\text { ALGTLVSHVTLR } & 1.00 & 80.66 & 22.36 & 23.82 & 3 & 1409.8546 & 1409.8476 & 470.9565 & 0.0070 & 4.9544 & 2436.318 & 3191.633 & 520.146 & 3990.258 & \text { Yes }\end{array}$ $\begin{array}{lllllllllllllllll}\text { AVMLLHTHTITSR } & 1.00 & 55.29 & 26.79 & 16.83 & 3 & 1622.9065 & 1622.9048 & 541.9755 & 0.0017 & 1.0456 & 933.970 & 1377.209 & 513.772 & 1031.747 & \text { Yes }\end{array}$ $\begin{array}{llllllllllllllll}\text { LTSADALRPSVVSITGPLIR } & 0.55 & 33.07 & 18.69 & 46.07 & 3 & 2209.2928 & 2209.2916 & 737.4378 & 0.0012 & 0.5424 & 913.596 & 1167.066 & 894.168 & 1233.548 & \text { Yes }\end{array}$ $\begin{array}{llllllllllllllll}\text { LTSADALRPSVVSITGPLIR } & 0.66 & 29.62 & 18.57 & 42.62 & 3 & 2209.2937 & 2209.2916 & 737.4378 & 0.0021 & 0.9492 & 2281.002 & 2831.893 & 1844.491 & 2886.680 & \text { Yes }\end{array}$

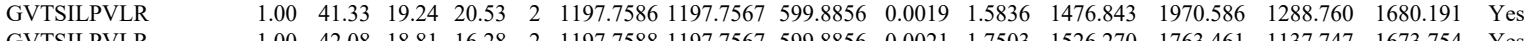
$\begin{array}{lllllllllllllllll}\text { GVTSILPVLR } & 1.00 & 42.08 & 18.81 & 16.28 & 2 & 1197.7588 & 1197.7567 & 599.8856 & 0.0021 & 1.7503 & 1526.270 & 1763.461 & 1137.747 & 1673.754 & \text { Yes }\end{array}$ $\begin{array}{lllllllllllllllll}\text { ALGTLVSHVTLR } & 1.00 & 64.94 & 22.86 & 24.08 & 3 & 1409.8510 & 1409.8476 & 470.9565 & 0.0034 & 2.4064 & 598.823 & 963.509 & 4097.364 & 560.240 & \text { No }\end{array}$ $\begin{array}{llllllllllllllll}\text { HLGVILPAVMLALK } & 0.66 & 50.58 & 11.46 & 63.58 & 3 & 1762.1164 & 1762.1146 & 588.3788 & 0.0018 & 1.0198 & 44.110 & 72.219 & 35.525 & 97.759 & \text { Yes }\end{array}$

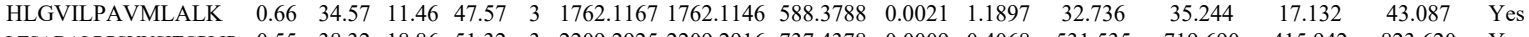
$\begin{array}{lllllllllllllllll} & \end{array}$ $\begin{array}{llllllllllllllll}\text { ALVAVLLSR } & 1.00 & 52.73 & 19.34 & 29.12 & 2 & 1084.7100 & 1084.7090 & 543.3618 & 0.0010 & 0.9202 & 2606.324 & 2993.858 & 188.185 & 3773.444 & \text { Yes } \\ \text { ALVAVLLSR } & 1.00 & 52.84 & 19.34 & 29.39 & 2 & 1084.7100 & 1084.7090 & 543.3618 & 0.0010 & 0.9202 & 2643.240 & 3196.534 & 390.616 & 3755.136 & \text { Yes }\end{array}$ ALVAVLLS ALVAVLLSR ALVAVLLSR ALVAVLLSR ALVAVLLSR LLTWVIGTGSPR LLTWVIGTGSP LFLTLHR $\begin{array}{llllllllllll}1.00 & 54.64 & 19.34 & 29.69 & 2 & 1084.7098 & 1084.7090 & 543.3618 & 0.0008 & 0.7362 & 617.694 & \end{array}$ $\begin{array}{lllllllllllll}1.00 & 54.43 & 19.34 & 29.51 & 2 & 1084.7102 & 1084.7090 & 543.3618 & 0.0012 & 1.1042 & 811.441 & 861.56\end{array}$ $\begin{array}{llllllllllll}1.00 & 30.80 & 19.34 & 21.22 & 2 & 1084.7096 & 1084.7090 & 543.3618 & 0.0006 & 0.5521 & 113.749\end{array}$

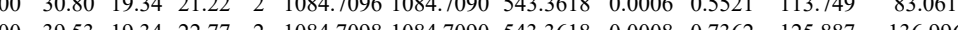

\section{LLTWVIGTGSP}

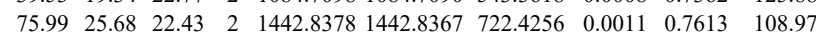

$\begin{array}{lllllllllll}1.00 & 70.89 & 25.60 & 21.21 & 2 & 1442.8382 & 1442.8367 & 722.4256 & 0.0015 & 1.0382 & 130.379\end{array}$ $\begin{array}{llllllllllllll} & \end{array}$ $\begin{array}{llllllllllllll}\text { NPFLSLAACVMPSR } & 0.71 & 14.38 & 28.14 & 15.05 & 3 & 1694.8444 & 1694.8428 & 565.9549 & 0.0016 & 0.9424 & 5.425\end{array}$ $\begin{array}{lllllllllllllll}\text { NPFLSLAACVMPSR } & 1.00 & 74.74 & 28.11 & 19.62 & 2 & 1694.8458 & 1694.8428 & 848.4287 & 0.0030 & 1.7680 & 27.657\end{array}$ $\begin{array}{llllllllllllll}\text { VLPQLISTITASVQNPALR } & 0.55 & 60.29 & 20.21 & 73.29 & 3 & 2164.2712 & 2164.2701 & 722.4306 & 0.0011 & 0.5075 & 3.834\end{array}$ $\begin{array}{lllllllllllll}\text { VLPQLISTITASVQNPALR } & 0.82 & \text { \#\#\# } 20.21 & \text { \#\#\#\# } 2 & 2164.2714 & 2164.2701 & 1083.1423 & 0.0013 & 0.6001 & 37.901\end{array}$ $\begin{array}{lllllllllllll}\text { VLPQLISTITASVQNPALR } & 0.55 & 68.45 & 20.21 & 81.45 & 3 & 2164.2715 & 2164.2701 & 722.4306 & 0.0014 & 0.6460 & 4.574\end{array}$ $\begin{array}{llllllllllll}\text { NPFLSLAACVMPSR } & 0.64 & 40.46 & 28.06 & 53.46 & 2 & 1694.8424 & 1694.8428 & 848.4287 & -0.0004 & -0.2357 & 8.733\end{array}$ $\begin{array}{lllllllllllll}\text { VLPQLISTITASVQNPALR } & 1.00 & 45.05 & 20.13 & 16.36 & 3 & 2164.2718 & 2164.2701 & 722.4306 & 0.0017 & 0.7844 & 7.062 \\ \text { VLPQLISTITASVQNPALR } & 0.66 & 45.35 & 19.91 & 58.35 & 3 & 2164.2721 & 2164.2701 & 722.4306 & 0.0020 & 0.9228 & 11.551\end{array}$ $\begin{array}{llllllllllllll}\text { VLPQLISTITASVQNPALR } & 0.66 & 24.90 & 20.13 & 37.90 & 3 & 2164.2718 & 2164.2701 & 722.4306 & 0.0017 & 0.7844 & 18.826\end{array}$ $\begin{array}{lllllllllllll}\text { VLPQLISTITASVQNPALR } & 0.67 & 18.73 & 19.82 & 31.73 & 3 & 2164.2730 & 2164.2701 & 722.4306 & 0.0029 & 1.3381 & 31.255\end{array}$ $\begin{array}{llllllllllllll}\text { VLPQLISTITASVQNPALR } & 0.55 & 24.62 & 20.21 & 37.62 & 3 & 2164.2712 & 2164.2701 & 722.4306 & 0.0011 & 0.5075 & 14.944\end{array}$ $\begin{array}{lllllllllllll}\text { VLPQLISTITASVQNPALR } & 1.00 & 31.48 & 19.87 & 16.54 & 3 & 2164.2727 & 2164.2701 & 722.4306 & 0.0026 & 1.1997 & 9.965\end{array}$ $\begin{array}{lllllllllllll}\text { VLPQLISTITASVQNPALR } & 0.55 & 16.64 & 20.21 & 29.64 & 3 & 2164.2715 & 2164.2701 & 722.4306 & 0.0014 & 0.6460 & 16.249\end{array}$ $\begin{array}{lllllllllllll}\text { VLPQLISTITASVQNPALR } & 0.87 & 11.97 & 20.21 & 14.77 & 3 & 2164.2715 & 2164.2701 & 722.4306 & 0.0014 & 0.6460 & 24.994\end{array}$ $\begin{array}{lllllllllllll} & \text { VLPLEALVTDAGEVTEAGK } & 1.00 & 90.38 & 24.20 & 19.27 & 3 & 2199.2302 & 2199.2242 & 734.0820 & 0.0060 & 2.7245 & 0.000\end{array}$ $\begin{array}{lllllllllllll}\text { ASTEGVAIQGQQGTR } & 1.00 & 91.68 & 28.06 & 34.84 & 2 & 1645.8522 & 1645.8506 & 823.9326 & 0.0016 & 0.9710 & 948.124\end{array}$ $\begin{array}{llllllllllll}\text { QLVEILTACPQDLIQAEDR } & 0.67 & 65.99 & 27.23 & 78.99 & 3 & 2457.2758 & 2457.2729 & 820.0982 & 0.0029 & 1.1787 & 25.334\end{array}$ $\begin{array}{lllllllllllll}\text { QLVEIILTACPQDLIQAEDR } & 1.00 & 75.09 & 27.23 & 23.05 & 3 & 2457.2758 & 2457.2729 & 820.0982 & 0.0029 & 1.1787 & 15.807\end{array}$ $\begin{array}{llllllllllll}\text { CQDVSAGSLQELALLTGIISK } & 1.00 & 65.26 & 25.92 & 19.86 & 3 & 2479.3306 & 2479.3270 & 827.4496 & 0.0036 & 1.4502 & 32.313\end{array}$ $\begin{array}{lllllllllllll}\text { CQDVSAGSLQELALLTGISK } & 1.00 & 58.13 & 25.89 & 20.06 & 3 & 2479.3315 & 2479.3270 & 827.4496 & 0.0045 & 1.8128 & 8.543\end{array}$ $\begin{array}{lllllllllllll}\text { CQDVSAGSLQELALLTGIISK } & 1.00 & 59.47 & 25.94 & 20.25 & 3 & 2479.3300 & 2479.3270 & 827.4496 & 0.0030 & 1.2085 & 73.56\end{array}$ $\begin{array}{llllllllllll}\text { CQDVSAGSLQLLALLGGISK } & 1.00 & 63.18 & 25.94 & 20.37 & 3 & 2479.3300 & 2479.3270 & 827.4496 & 0.0030 & 1.2085 & 40.058\end{array}$

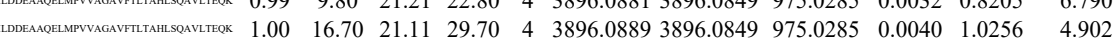
$\begin{array}{llllllllll}1.00 & 37.70 & 21.04 & 50.70 & 4 & 3896.08973896 .0849 & 975.0285 & 0.0048 & 1.2307 & 13.069\end{array}$ $\begin{array}{lllllllllll}1.00 & 23.48 & 20.83 & 36.48 & 4 & 3896.0913 & 3896.0849 & 975.0285 & 0.0064 & 1.6410 & 5.843\end{array}$ $\begin{array}{llllllllllll}1.00 & 35.29 & 21.21 & 48.29 & 4 & 3896.088138960849 & 975.0285 & 0.0032 & 0.8205 & 1.745\end{array}$ 
$\begin{array}{lllllllllllll}\text { IPIHNEDITYDELVLMMQR } & 1.00 & 44.78 & 26.78 & 19.52 & 3 & 2473.2481 & 2473.2467 & 825.4228 & 0.0014 & 0.5654 & 77.267 \\ \text { IPHNNEDTYPDELVLMMQR } & 0.99 & 28.64 & 26.84 & 21.61 & 3 & 2473.2496 & 2473.2467 & 825.4228 & 0.0029 & 1.1711 & 33.645\end{array}$ $\begin{array}{llllllllllll}\text { QSTQVMAASMSAFDPLK } & 0.80 & 15.94 & 27.90 & 14.83 & 3 & 2099.0668 & 2099.0635 & 700.6951 & 0.0033 & 1.5699 & 1106.241\end{array}$ $\begin{array}{llllllllllll}\text { NRPPFGQGYTQPGPGYR } & 1.00 & 48.72 & 27.05 & 16.72 & 3 & 2035.0108 & 2035.0146 & 679.3455 & -0.0038 & -1.8645 & 168.915 \\ 9 & 9 & \end{array}$ $\begin{array}{llllllllllll}\text { DPTLLDNFLDEIIAFQADK } & 0.67 & 16.96 & 27.04 & 29.96 & 3 & 2465.2960 & 2465.2933 & 822.7717 & 0.0027 & 1.0939 & 12.968\end{array}$ $\begin{array}{lllllllllllll}\text { TVIQSLTMYPR } & 1.00 & 48.05 & 27.71 & 18.13 & 2 & 1451.7926 & 1451.7928 & 726.9037 & -0.0002 & -0.1376 & 93.554 \\ \text { TVIQSLTMYPR } & 1.00 & 49.39 & 27.52 & 21.87 & 2 & 1451.7938 & 1451.7928 & 726.9037 & 0.0010 & 0.6878 & 137.315\end{array}$ TVIQSLTMYPR $\begin{array}{llllllllllll}1.00 & 49.39 & 27.52 & 21.87 & 2 & 1451.7938 & 1451.7928 & 726.9037 & 0.0010 & 0.6878 & 137.315\end{array}$

LIDFLESGK

\section{LIDFLESGK}

\section{MEEIMAEK}

LIQLMEEIMAEK

LIQLMEEIMAEK

LIQLMEEIMAEK

LIQLMEEIMAEK

LIQLMEEIMAEK

LIQLMEEIMAEK $\begin{array}{llllllllllllll}\text { TLAYLLPAIVHINHQPYLER } & 1.00 & 15.01 & 22.48 & 28.01 & 4 & 2504.4041 & 2504.4025 & 627.1079 & 0.0016 & 0.6378 & 836.867 & 10\end{array}$ $\begin{array}{llllllllllll}\text { TLAYLLPAIVHINHQPYLER } & 1.00 & 15.01 & 22.48 & 28.01 & 4 & 2504.404 & 2504.4025 & 627.1079 & 0.0016 & 0.6378 & 836.867 \\ \text { TLAYLLPAIVHINHQPYLER } & 1.00 & 31.22 & 22.50 & 15.44 & 4 & 2504.4053 & 2504.4025 & 627.1079 & 0.0028 & 1.1162 & 1070.691\end{array}$

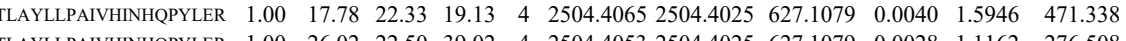

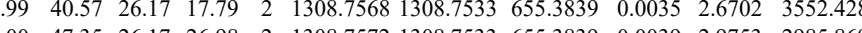
$\begin{array}{llllllllllll}1.00 & 80.26 & 27.34 & 23.23 & 2 & 1734.9520 & 1734.9503 & 868.4824 & 0.0017 & 0.9787 & 360.479 & \end{array}$ $\begin{array}{lllllllllll}1 & 1.32 & 27.32 & 24.05 & 3 & 1734.9528 & 1734.9503 & 868.4824 & 0.0025 & 1.4393 & 336.967\end{array}$ $\begin{array}{llllllllllll} & 0\end{array}$

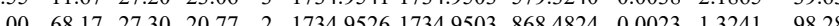

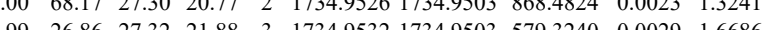
$\begin{array}{lllllllllll}1.00 & 26.02 & 22.50 & 39.02 & 4 & 2504.4053 & 2504.4025 & 627.1079 & 0.0028 & 1.1162 & 276.508\end{array}$ \begin{tabular}{llllllllllllll} 
VFOTEAELOEVISDLOSK & 0.99 & 41.71 & 26.02 & 27.93 & 2 & 1612.9182 & 1612.9028 & 807.4587 & 0.0154 & 9.5360 & 31.360 \\
\hline
\end{tabular} $\begin{array}{llllllllllllll} & \text { VFOTEAELOEVISDLQSK } & 1.00 & 60.17 & 26.63 & 25.81 & 3 & 2351.2501 & 2351.2464 & 784.7561 & 0.0037 & 1.5716 & 12.008\end{array}$ $\begin{array}{lllllllllllll}\text { VFQTEAELQEVISDLQSK } & 1.00 & 80.23 & 26.65 & 27.42 & 3 & 2351.2504 & 2351.2464 & 784.7561 & 0.0040 & 1.6990 & 21.912\end{array}$ $\begin{array}{llllllllllllll}\text { VFQTEAELQEVISDLQSK } & 1.00 & 45.56 & 26.63 & 25.94 & 3 & 2351.2498 & 2351.2464 & 784.7561 & 0.0034 & 1.4442 & 7.80\end{array}$ $\begin{array}{lllllllllllll}\text { VFQTEAELQEVISDLQSK } & 1.00 & 63.23 & 26.63 & 33.85 & 3 & 2351.2501 & 2351.2464 & 784.7561 & 0.0037 & 1.5716 & 32.710\end{array}$

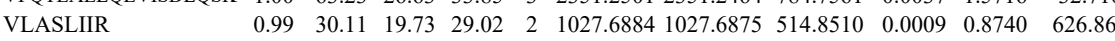
$\begin{array}{llllllllllll}\text { VLASLIIR } & 0.99 & 30.35 & 19.82 & 28.91 & 2 & 1027.6886 & 1027.6875 & 514.8510 & 0.0011 & 1.0683 & 578.693\end{array}$ $\begin{array}{lllllllllllll}\text { ILELDQELIK } & 0.99 & 38.76 & 24.07 & 28.48 & 2 & 1500.9006 & 1500.9007 & 751.4576 & -0.0001 & -0.0665 & 233.347 & 25 \\ & 1.00 & 50.32 & 24.13 & 34.83 & 2 & 1500.9010 & 1500.9007 & 751.4576 & 0.0003 & 0.1996 & 125.782 & 17\end{array}$ $\begin{array}{lllllllllllll}\text { ILELDQELIK } & 1.00 & 50.32 & 24.13 & 34.83 & 2 & 1500.9010 & 1500.9007 & 751.4576 & 0.0003 & 0.1996 & 125.782\end{array}$ $\begin{array}{lllllllllll}\text { ARHG1_HUMA } & \text { Q92888 } & \text { ARHGEF1 Rho guanine nucle } 102.44 & 1.00 & 5 & 8.6 & 0.4941 & 0.7573 & 0.6702 & 1.0274 & 6\end{array}$

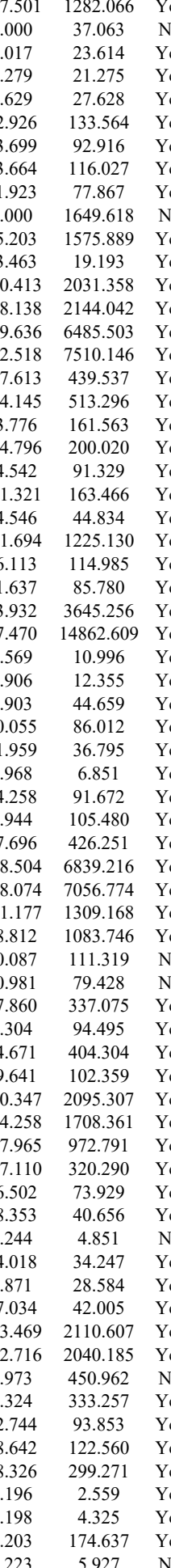


IINDLLQSLR

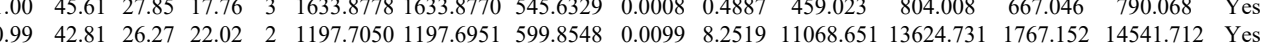
$\begin{array}{lllllllllllllllllll}1.00 & 45.11 & 26.27 & 22.40 & 2 & 1197.7050 & 1197.6951 & 599.8548 & 0.0099 & 8.2519 & 10284.606 & 12577.908 & 1827.705 & 12529.597 & \text { Yes }\end{array}$ \begin{tabular}{lllllllllllllll}
1.00 & 64.10 & 28.34 & 34.01 & 2 & 1263.6814 & 1263.6801 & 632.8473 & 0.0013 & 1.0271 & 2763.701 & 2695.219 & 211.547 & 4322.203 & Yes \\
\hline
\end{tabular} $\begin{array}{llllllllllllllll}0.96 & 17.95 & 27.90 & 16.44 & 4 & 1633.8765 & 1633.8770 & 409.4765 & -0.0005 & -0.3053 & 3442.643 & 4338.478 & 4726.830 & 5105.351 & \text { Yes }\end{array}$

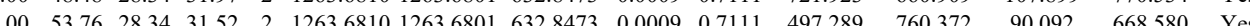
$\begin{array}{lllllllllllllll}0.61 & 22.82 & 27.51 & 23.89 & 2 & 1430.8012 & 1430.7882 & 716.4014 & 0.0130 & 9.0730 & 620.717 & 0.000 & 11671.565 & 142.277 & \text { No }\end{array}$

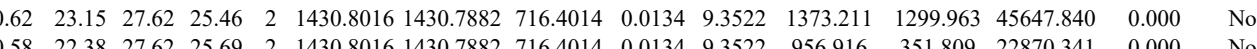
$\begin{array}{lllllllllllllll}1.00 & 37.81 & 27.13 & 16.18 & 3 & 1876.0264 & 1876.0239 & 626.3486 & 0.0025 & 1.3305 & 2988.016 & 3364.339 & 5998.798 & 4114.085 & \text { Yes } \\ 0.5 & 44.94 & 27.42 & 24.88 & 2 & 1328.7242 & 1328.7229 & 665.3687 & 0.0013 & 0.9769 & 61.0374 & 777.695 & 25.576 & 1191.042 & \text { Yes }\end{array}$

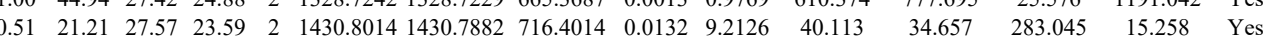

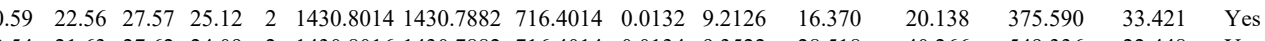
$\begin{array}{lllllllllllllll}1.00 & 54.05 & 28.04 & 31.18 & 2 & 1497.8046 & 1497.7909 & 749.9027 & 0.0137 & 9.1344 & 367.507 & 447.241 & 0.000 & 1156.997 & \text { No }\end{array}$ $\begin{array}{lllllllllllllll}0.96 & 35.77 & 28.04 & 24.49 & 2 & 1497.8048 & 1497.7909 & 749.9027 & 0.0139 & 9.2678 & 191.364 & 317.155 & 45.032 & 632.266 & \text { Yes } \\ 1.00 & 73.58 & 26.87 & 28.03 & 2 & 1589.9002 & 1589.8868 & 795.9507 & 0.0134 & 8.4175 & 646.796 & 817.012 & 439.586 & 1970.169 & \text { Yes }\end{array}$

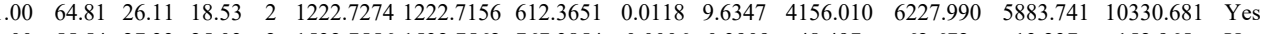

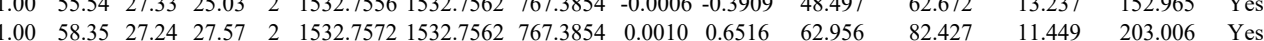

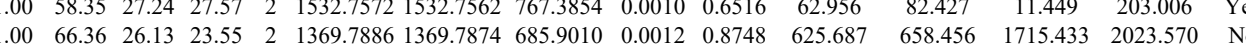

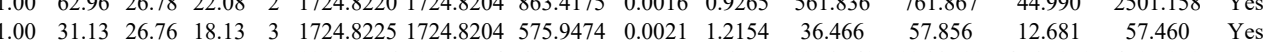

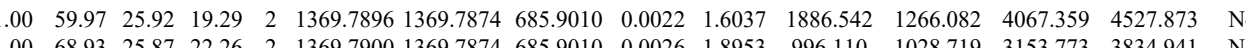

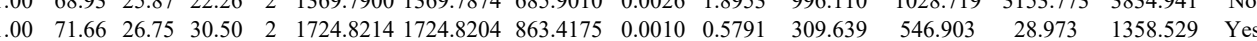
$\begin{array}{lllllllllllllll}1.00 & 34.49 & 26.76 & 17.19 & 3 & 1724.8225 & 1724.8204 & 575.9474 & 0.0021 & 1.2154 & 28.906 & 60.249 & 10.541 & 71.708 & \text { YeS }\end{array}$ $\begin{array}{lllllllllllllll}1.00 & 40.52 & 26.71 & 16.24 & 3 & 1724.8228 & 1724.8204 & 575.9474 & 0.0024 & 1.3890 & 59.514 & 86.150 & 22.288 & 60.265 & \mathrm{No}\end{array}$

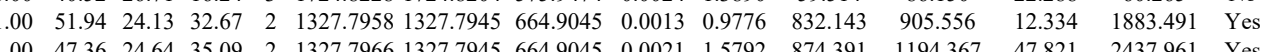
$\begin{array}{lllllllllllllll}1.00 & 55.27 & 24.13 & 32.70 & 2 & 1327.7960 & 1327.7945 & 664.9045 & 0.0015 & 1.1280 & 2008.416 & 2780.820 & 77.212 & 6624.659 & \text { Yes }\end{array}$ $\begin{array}{lllllllllllllll}1.00 & 52.97 & 24.25 & 28.85 & 2 & 1479.8798 & 1479.8792 & 740.9469 & 0.0006 & 0.4049 & 397.488 & 441.026 & 42.895 & 991.759 & \text { Yes }\end{array}$ $\begin{array}{rllllllllllllll}1.00 & 41.50 & 24.25 & 26.49 & 2 & 1479.8800 & 1479.8792 & 740.9469 & 0.0008 & 0.5398 & 238.067 & 227.143 & 0.000 & 596.106 & \text { No }\end{array}$ $\begin{array}{llllllllllllllll}1.00 & 34.03 & 26.75 & 17.84 & 3 & 3032.5492 & 3032.5476 & 1011.8565 & 0.0016 & 0.5271 & 280.813 & 256.241 & 439.064 & 537.871 & \text { No } \\ 10.14 & 30.32 & 2 & 1444.8472 & 1444.8371 & 723.4258 & 0.0101 & 6.9806 & 1698.632 & 1564.865 & 25.915 & 2651.687 & \text { Y }\end{array}$ $\begin{array}{llllllllllllll} & \end{array}$ $\begin{array}{rllllllllllll} & 24020.9741 & 2020.9698 & 674.6639 & 0.0043 & 2.1245 & 167.940 & 202.047 & 47.566 & 243.664 & \text { Yes } \\ \end{array}$

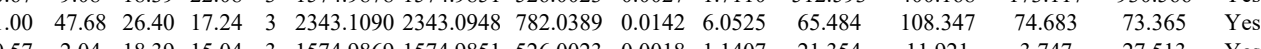
$\begin{array}{llllllllllll}0.57 & 2.04 & 18.39 & 15.04 & 3 & 1574.9869 & 1574.9851 & 526.0023 & 0.0018 & 1.1407 & 21.354 & 11.921\end{array}$ $\begin{array}{lllllllllllll}0.60 & 25.97 & 17.16 & 38.97 & 3 & 1574.9896 & 1574.9851 & 526.0023 & 0.0045 & 2.8517 & 7.265 & 19.680\end{array}$ 


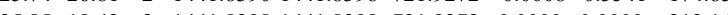

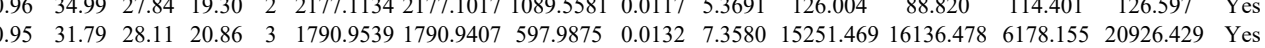

\section{LLDQIVEK}

GTPQQIDYAR

GTPQQIDYAR

GTPQQIDYAR

SVQAGNPGGPGPG

IGGNEGIDVPIPR IGGNEGIDVPIPR SVQAGNPGGPGPGG IGGNEGIDVPIP IAQITGPPDR
IAQITGPPDR IAQITGPPDR CQHAAEIITDLLR CQHAAEIITDLLR CQHAAEIITDLLR CQHAAEIITDLLR CQHAAEITDLLR CQHAAEIITDLLR CQHAAEIITDLLR NPPPNADPNMK NPPPNADPNMK NPPPNADPNMK IQFKPDDGTTPER IQFKPDDGTTPER

$\begin{array}{llllllllllll}\text { LRC59_HUMAN Q96AG4 } & \text { LRRC59 } & \text { Leucine-rich reper } 34.93 & 1.00 & 8 & 29.6 & -0.2429 & 0.3255 & 1.7002 & 0.2802 & 26 & \text { DNPLDPVLAK } \\ \text { DNPLDPVLK }\end{array}$

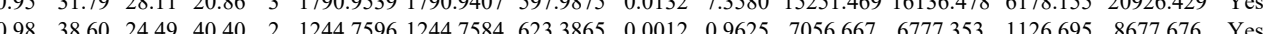
$\begin{array}{llllllllllllllllll}1.00 & 41.69 & 28.02 & 26.06 & 2 & 1291.6656 & 1291.6642 & 646.8394 & 0.0014 & 1.0822 & 14008.938 & 14039.783 & 5488383 & 16686.567 & \text { Yes }\end{array}$

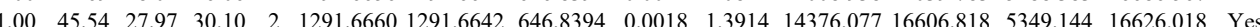

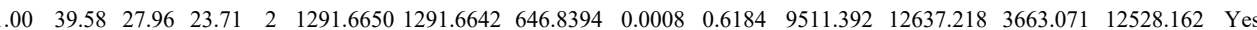
$\begin{array}{lllllllllllllll}1.00 & 41.94 & 27.98 & 25.03 & 2 & 1291.6654 & 1291.6642 & 646.8394 & 0.0012 & 0.9276 & 6956.350 & 6446.635 & 2954.755 & 7715.189 & \text { Yes }\end{array}$ $\begin{array}{lllllllllllllll}0.80 & 18.32 & 28.38 & 18.75 & 3 & 1450.7410 & 1450.7399 & 484.5872 & 0.0011 & 0.7567 & 48.925 & 54.920 & 17.371 & 51.203 & \text { Yes }\end{array}$ $\begin{array}{lllllllllllllll}1.00 & 67.82 & 26.99 & 21.29 & 2 & 1479.8226 & 1479.8167 & 740.9156 & 0.0059 & 3.9815 & 435.694 & 546.409 & 224.742 & 736.661 & \text { Yes } \\ 0.89 & 34.03 & 26.99 & 22.72 & 2 & 1479.8228 & 1479.8167 & 740.9156 & 0.0061 & 4.1165 & 2755.368 & 3977.340 & 1716.954 & 3142.047 & \text { Yes }\end{array}$

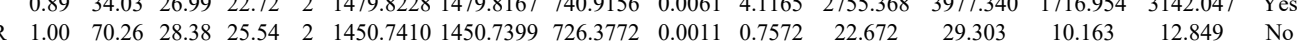

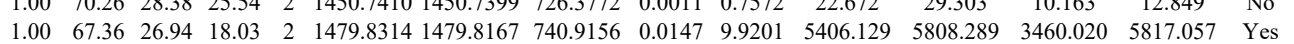
$\begin{array}{lllllllllllllll}0.98 & 39.81 & 27.12 & 26.95 & 2 & 1210.6882 & 1210.6792 & 606.3469 & 0.0090 & 7.4214 & 14574.217 & 14831.722 & 3661.679 & 20528.287 & \text { Yes }\end{array}$ $\begin{array}{lllllllllllllll}0.98 & 41.06 & 27.11 & 27.09 & 2 & 1210.6886 & 1210.6792 & 606.3469 & 0.0094 & 7.7513 & 12953.655 & 12216.660 & 2790.782 & 16644.179 & \text { Yes }\end{array}$ $\begin{array}{lllllllllllllll}0.99 & 41.08 & 27.16 & 27.77 & 2 & 1210.6836 & 1210.6792 & 606.3469 & 0.0044 & 3.6283 & 4885.927 & 4745.908 & 8486.934 & 5475.382 & \text { No }\end{array}$ $\begin{array}{lllllllllllllll}1.00 & 60.83 & 28.03 & 22.31 & 2 & 1671.8574 & 1671.8558 & 836.9352 & 0.0016 & 0.9559 & 1370.327 & 953.599 & 254.541 & 1100.431 & \text { No }\end{array}$ $\begin{array}{lllllllllllllll}1.00 & 65.15 & 28.03 & 29.79 & 2 & 1671.8574 & 1671.8558 & 836.9352 & 0.0016 & 0.9559 & 653.863 & 722.345 & 82.041 & 917.452 & \text { Yes }\end{array}$

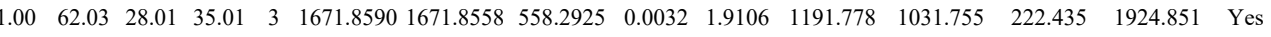

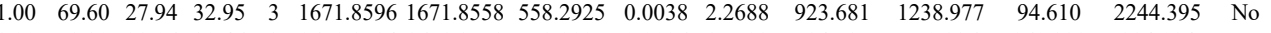

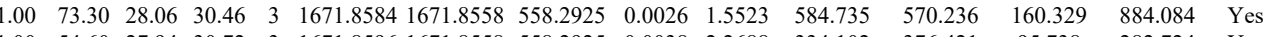
$\begin{array}{lllllllllllllll}1.00 & 54.60 & 27.94 & 30.72 & 3 & 1671.8596 & 1671.8558 & 558.2925 & 0.0038 & 2.2688 & 334.102 & 376.421 & 95.738 & 282.724 & \text { Yes }\end{array}$ $\begin{array}{lllllllllllllll}0.99 & 28.85 & 27.89 & 23.67 & 3 & 1671.8599 & 1671.8558 & 558.2925 & 0.0041 & 2.4479 & 96.951 & 87.391 & 34.111 & 187.449 & \text { Yes }\end{array}$

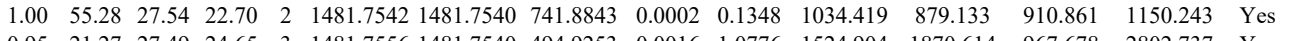
$\begin{array}{lllllllllllllll}0.95 & 21.27 & 27.49 & 24.65 & 3 & 1481.7556 & 1481.7540 & 494.9253 & 0.0016 & 1.0776 & 1524.904 & 1870.614 & 967.678 & 2802.737 & \text { Yes }\end{array}$ $\begin{array}{lllllllllllllll}1.00 & 51.33 & 27.49 & 22.33 & 2 & 1481.7556 & 1481.7540 & 741.8843 & 0.0016 & 1.0783 & 1465.669 & 1595.972 & 1467.187 & 1616.999 & \text { Yes }\end{array}$ $\begin{array}{lllllllllllllll}0.99 & 40.93 & 28.23 & 21.15 & 2 & 1790.9526 & 1790.9407 & 896.4776 & 0.0119 & 6.6370 & 1584.220 & 1860.716 & 498.157 & 1975.010 & \text { Yes } \\ 0.65 & 22.42 & 28.18 & 20.59 & 3 & 1790.9530 & 1790.9407 & 597.9875 & 0.0123 & 6.8563 & 26234.752 & 25824.877 & 10846.028 & 34107.877 & \text { Yes }\end{array}$ $\begin{array}{lllllllllllllll}0.65 & 22.42 & 28.18 & 20.59 & 3 & 1790.9530 & 1790.9407 & 597.9875 & 0.0123 & 6.8563 & 26234.752 & 25824.877 & 10846.028 & 34107.877 & \text { Yes } \\ 0.85 & 26.69 & 28.11 & 20.98 & 3 & 1790.9539 & 1790.9407 & 597.9875 & 0.0132 & 7.3580 & 28230.531 & 29197.570 & 12185281 & 41292777 & \text { Yes }\end{array}$ $\begin{array}{llllllllllllllll}0.85 & 26.69 & 28.11 & 20.98 & 3 & 1790.9539 & 1790.9407 & 597.9875 & 0.0132 & 7.3580 & 28230.531 & 29197.570 & 12185.281 & 41292.777 & \text { Yes } \\ 1.00 & 52.83 & 25.67 & 23.56 & 2 & 1368.7892 & 1368.7856 & 685.4001 & 0.0036 & 2.6262 & 5068.426 & 2777.254 & 7901.365 & 5093.814 & \text { No }\end{array}$ $\begin{array}{llllllllllllllll}1.00 & 52.83 & 25.67 & 23.56 & 2 & 1368.7892 & 1368.7856 & 685.4001 & 0.0036 & 2.6262 & 5068.426 & 2777.254 & 7901.365 & 5093.814 & \text { No } \\ 1.00 & 53.59 & 25.67 & 22.42 & 2 & 1368.7892 & 13687856 & 685.4001 & 0.0036 & 2.6262 & 4695.542 & 3088.571 & 5770.239 & 5118.401 & \text { Yes }\end{array}$ $\begin{array}{lllllllllllllll} & \end{array}$ 
LDGNELDLSLSDLNEVPVK LQQLPADFGR LQQLPADFGR

LQQLPADFGR

LVNLQHLDLLNNK

LVNLQHLDLLNNK

LVNLQHLDLLNNK

LVNLQHLDLLNNK

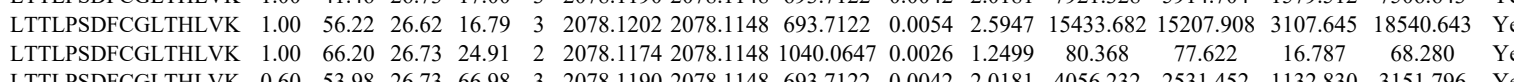

$\begin{array}{llllllllllllllll}\text { LTTLPSDFCGTTLEK } & 0.60 & 53.98 & 26.73 & 66.98 & 3 & 2078.1190 & 2078.1148 & 693.7122 & 0.0042 & 2.0181 & 4056.232 & 2531.452 & 1132.830 & 3151.796 & \text { Yes }\end{array}$

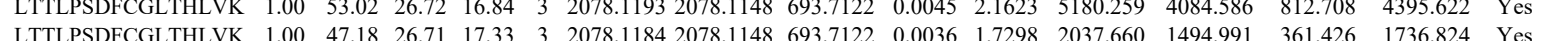

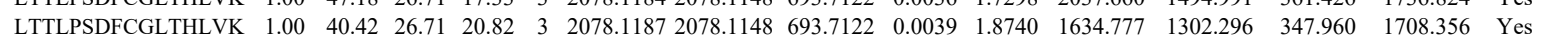

$\begin{array}{llllllllllllllll}\text { LVTLPVSFAQLK } & 0.55 & 32.96 & 19.03 & 45.96 & 3 & 1602.9964 & 1602.9953 & 535.3390 & 0.0011 & 0.6849 & 111.525 & 130.407 & 46.507 & 56.264 & \text { Yes }\end{array}$

$\begin{array}{lllllllllllllllll}\text { LVTLPVSFAQLK } & 0.60 & 33.30 & 17.56 & 4630 & 3 & 1602.9991 & 16029953 & 535.3390 & 0.0038 & 2.3661 & 154.737 & 259.608 & 33.553 & 195.631 & \text { Yes }\end{array}$

$\begin{array}{llllllllllllllllll}\text { LVTLPVSFAQLK } & 1.00 & 59.91 & 18.92 & 18.44 & 2 & 1602.9970 & 1602.9953 & 802.5049 & 0.0017 & 1.0592 & 7645.254 & 5686.452 & 9.742 & 5982.621 & \text { Yes }\end{array}$

$\begin{array}{lllllllllllllllll}\text { LVTLPVSFAQLK } & 1.00 & 56.49 & 18.69 & 20.75 & 2 & 1602.9974 & 1602.9953 & 802.5049 & 0.0021 & 1.3084 & 3408.000 & 2972.717 & 75.511 & 3216.733 & \text { Yes }\end{array}$

$\begin{array}{lllllllllllllllll}\text { LVTLPVSFAQLK } & 0.67 & 54.40 & 18.69 & 67.40 & 3 & 1602.9979 & 1602.9953 & 535.3390 & 0.0026 & 1.6189 & 306.821 & 155.394 & 63.161 & 325.329 & \text { Yes }\end{array}$

$\begin{array}{llllllllllllllll}\text { LVTLPVSFAQLK } & 1.00 & 56.14 & 19.14 & 19.19 & 2 & 1602.9946 & 1602.9953 & 802.5049 & -0.0007 & -0.4361 & 2189.427 & 2056.109 & 98.754 & 2018.069 & \text { Yes }\end{array}$

$\begin{array}{llllllllllllllll}\text { LVTLPVSFAQLK } & 0.55 & 55.14 & 19.03 & 68.14 & 3 & 1602.9964 & 1602.9953 & 535.3390 & 0.0011 & 0.6849 & 321.383 & 238.974 & 99.436 & 341.332 & \text { Yes }\end{array}$

$\begin{array}{lllllllllllllllll}\text { LVTLPVSFAQLK } & 1.00 & 56.44 & 18.92 & 20.16 & 2 & 1602.9970 & 1602.9953 & 802.5049 & 0.0017 & 1.0592 & 1929.417 & 1751.790 & 244.827 & 1857.621 & \text { Yes }\end{array}$ $\begin{array}{llllllllllllllll}\text { LVTLPVSFAQLK } & 0.66 & 38.04 & 18.69 & 51.04 & 3 & 1602.9976 & 1602.9953 & 535.3390 & 0.0023 & 1.4321 & 367.002 & 113.534 & 62.330 & 177.202 & \text { No }\end{array}$ $\begin{array}{llllllllllllllll}\text { VAGDCLDEK } & 0.99 & 39.45 & 26.70 & 30.64 & 2 & 1282.6258 & 1282.6141 & 642.3143 & 0.0117 & 9.1076 & 5384.804 & 4600.879 & 400.131 & 5900.783 & \text { Yes }\end{array}$ $\begin{array}{llllllllllllllll}\text { DKLDGNELDLSLSDLNEVPVK } & 1.00 & 57.31 & 25.04 & 16.70 & 3 & 2744.4841 & 2744.4809 & 915.8342 & 0.0032 & 1.1647 & 18.641 & 20.010 & 60.816 & 77.145 & \text { No }\end{array}$ $\begin{array}{llllllllllllllll}\text { DLLDGNLDSLSDLNEVPVK } & 1.00 & 25.67 & 25.09 & 15.62 & 4 & 2744.4865 & 2744.4809 & 687.1275 & 0.0056 & 2.0375 & 60.220 & 66.168 & 50.776 & 40.107 & \text { Yes }\end{array}$

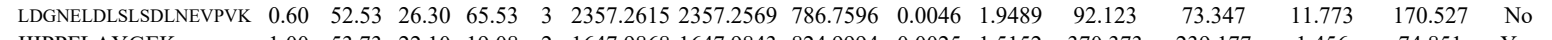

16 KPPPPSAPVIK

$\begin{array}{lllllllllllll}\text { EFHD2_HUMAI } & \text { Q96C19 } & \text { EFHD2 } & \text { EF-hand domain-c 26.697 } & 1.00 & 4 & 18.3 & -0.4652 & 0.1774 & 1.6484 & 0.3972 & 9 & \text { ADLNQGIGEPQS } \\ & & & & & & & & & & & & \end{array}$

$\begin{array}{lllllllllll}\text { FAF2_HUMAN } & \text { Q96CS3 } & \text { FAF2 } & \text { FAS-associated fa } 52.623 & 1.00 & 3 & 11.2 & 0.2103 & 0.3394 & 0.4954 & 0.4157\end{array}$ IIIPPFLAYGEK NTLVAIVVGVGR NTLVAIVVGVGR NTLVAIVVGVGR KPPPPSAPVIK KPPPPSAPVIK RPERPVGPL KPRPPK

RPERPVGPLTHTR

RPEPVGTTHR

RPERPVGPLTHTR

RPERPVGPLTHTR

RPERPVGPLTHTR

RPERPVGPLTHTR

RPERPVGPLTHTR

RPERPVGPLTHTR

RPERPVGPLTHTR

RPERPVGPLTHTR

RPERPVGPLTHTR

RPERPVGPLTHTR

RPERPVGPLTHTR

RPERPVGPLTHTR

LGAPQTHLGLK

LGAPQTHLGLK

LGAPQTHLGLK
VQAINVSSR

VQAINVSSR

VQAINVSSR

VQAINVSSR

EVDEDFDSK

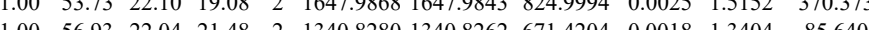

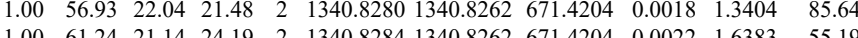

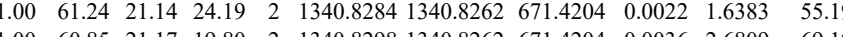

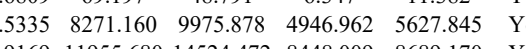
$\begin{array}{llllllllllllll} & \end{array}$ $\begin{array}{lllllllllllllll}0.52 & 9.08 & 26.05 & 22.08 & 4 & 1658.9445 & 1658.9451 & 415.7436 & -0.0006 & -0.3608 & 46.462 & 53.746 & 99.000 & 56.538 & \text { Yes } \\ 0.61 & 17.92 & 16.81 & 21.68 & 1153.7642 & 1153.7661 & 577.8903 & 0.0019 & -1.6439 & 37.905 & 31.724 & 28.223 & 35.915 & \text { Yes }\end{array}$

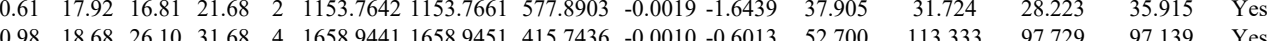

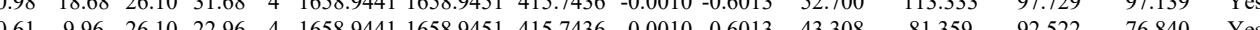

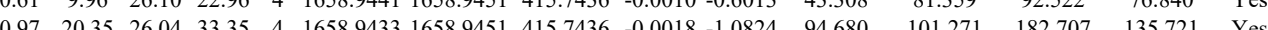

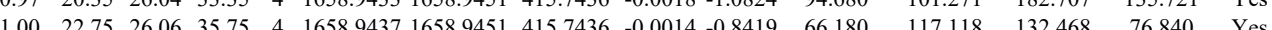

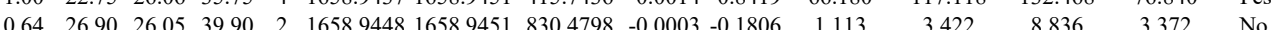

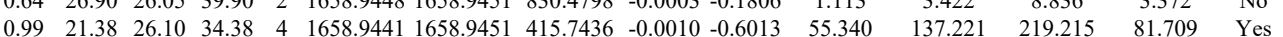

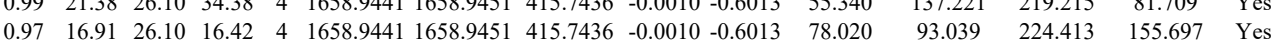

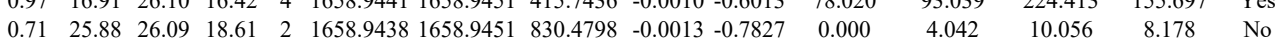
$\begin{array}{lllllllllllllll}0.92 & 14.61 & 26.10 & 27.61 & 4 & 1658.9441 & 1658.9451 & 415.7436 & -0.0010 & -0.6013 & 72.578 & 153.395 & 197.440 & 136.054 & \text { Yes }\end{array}$ $\begin{array}{lllllllllllllll}1.00 & 22.30 & 26.10 & 35.30 & 4 & 1658.9441 & 1658.9451 & 415.7436 & -0.0010 & -0.6013 & 84.111 & 136.599 & 212.318 & 144.292 & \text { Yes }\end{array}$ $\begin{array}{lllllllllllllll}0.57 & 16.84 & 26.05 & 14.77 & 3 & 1658.9446 & 1658.9451 & 553.9890 & -0.0005 & -0.3008 & 45.398 & 127.483 & 108.788 & 87.335 & \text { Yes }\end{array}$ $\begin{array}{llllllllllllllll}0.74 & 14.13 & 26.04 & 27.13 & 4 & 1658.9433 & 1658.9451 & 415.7436 & -0.0018 & -1.0824 & 55.977 & 71.214 & 125.881 & 95.094 & \text { Yes }\end{array}$

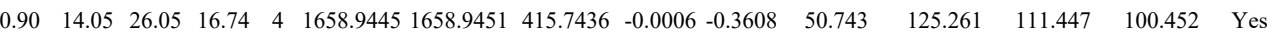

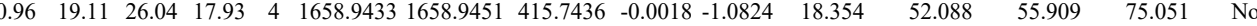

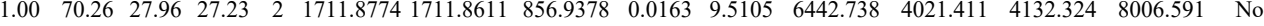
$\begin{array}{lllllllllllllll}1.00 & 37.27 & 21.43 & 16.05 & 3 & 1421.8699 & 1421.8598 & 474.9605 & 0.0101 & 7.0883 & 16695.558 & 10940.907 & 6479.575 & 24753.771 & \text { Yes }\end{array}$ $\begin{array}{lllllllllllllll}0.97 & 27.61 & 21.37 & 15.03 & 3 & 1421.8705 & 1421.8598 & 474.9605 & 0.0107 & 7.5093 & 16416.588 & 12539.400 & 5651.357 & 25104.935 & \text { Yes }\end{array}$ $\begin{array}{lllllllllllllll}1.00 & 36.12 & 21.96 & 17.02 & 3 & 1421.8711 & 1421.8598 & 474.9605 & 0.0113 & 7.9304 & 15161.213 & 9201.417 & 6983.144 & 19160.053 & \text { Yes }\end{array}$

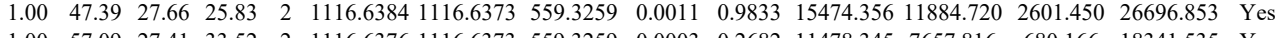
$\begin{array}{llllllllllllllll}1.00 & 57.09 & 27.41 & 33.52 & 2 & 1116.6376 & 1116.6373 & 559.3259 & 0.0003 & 0.2682 & 11478.345 & 7657.816 & 680.166 & 18341.535 & \text { Yes }\end{array}$

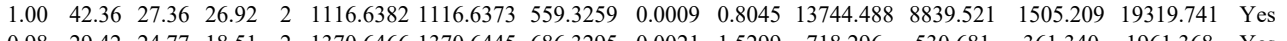

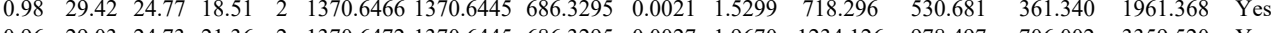
$\begin{array}{lllllllllllllll}0.96 & 29.03 & 24.73 & 21.36 & 2 & 1370.6472 & 1370.6445 & 686.3295 & 0.0027 & 1.9670 & 1234.126 & 978.497 & 706.002 & 3359.520 & \text { Yes } \\ 1.00 & 48.30 & 27.69 & 17.60 & 3 & 2324.1616 & 2324.1602 & 775.7273 & 0.0014 & 0.6016 & 49.815 & 6.156 & 36.216 & 90.799 & \text { Yes }\end{array}$ VTDPVGDIVSFMHSFEEK VTDPVG VTDPVGDIVSFMHSFEE

LIDPVGIVSFMHSFEEK $\begin{array}{lll}90.799 & \text { Yes }\end{array}$

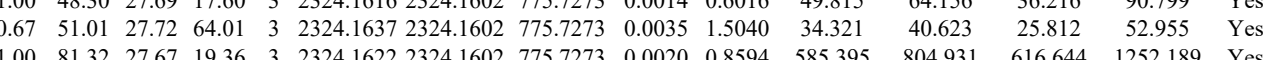

$\begin{array}{lllllllllll} & \end{array}$

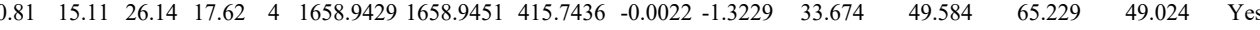
$\begin{array}{llllllllllllllll}0.98 & 32.78 & 27.41 & 23.56 & 2 & 1116.6380 & 1116.6373 & 559.3259 & 0.0007 & 0.6258 & 11285.686 & 10087.991 & 3454.604 & 18085.324 & \text { Yes }\end{array}$ 


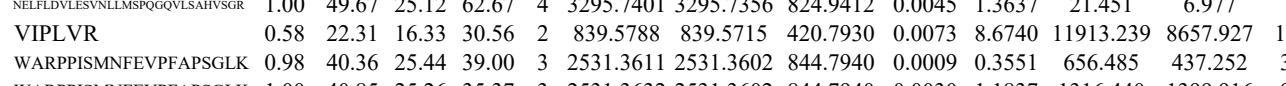

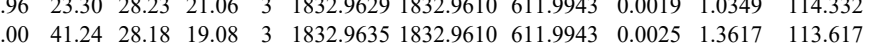

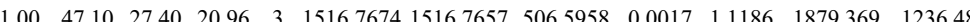
$\begin{array}{llllllllllll}\text { ISFDEYWTLIGGITGPIAK } & 0.72 & 64.14 & 25.33 & 77.14 & 2 & 2368.2954 & 2368.2922 & 1185.1534 & 0.0032 & 1.3500 & 64.717\end{array}$ $\begin{array}{llllllllllll}\text { ISFDEYWTLIGGITGPIAK } & 1.00 & 72.15 & 25.33 & 17.89 & 2 & 2368.2954 & 2368.2922 & 1185.1534 & 0.0032 & 1.3500 & 46.648\end{array}$

$\begin{array}{llllllllllllllll} & \end{array}$ $\begin{array}{lllllllllllll}\text { AFGFSHLEALLDDSK } & 1.00 & 47.79 & 27.80 & 28.85 & 3 & 1937.0179 & 1937.0138 & 646.6785 & 0.0041 & 2.1134 & 1791.307 & 1352.198\end{array}$ $\begin{array}{llllllllllllll}\text { AFGFSHLEALLDDSK } & 1.00 & 56.88 & 27.79 & 25.67 & 3 & 1937.0170 & 1937.0138 & 646.6785 & 0.0032 & 1.6495 & 1846.180 & 1958.031\end{array}$ $\begin{array}{lllllllllllll}\text { AFGFSHLEALLDDSK } & 1.00 & 42.20 & 27.74 & 27.25 & 3 & 1937.0185 & 1937.0138 & 646.6785 & 0.0047 & 2.4226 & 1548.479 & 2054.006 \\ \text { IQQEIAVQNPLVSER } & 1.00 & 98.68 & 26.71 & 26.22 & 2 & 1867.0320 & 1867.0285 & 934.5215 & 0.0035 & 1.8726 & 884.798 & 590.658\end{array}$

\section{IQQEIAVQNPLVSER}

TRPDGNCFYR

TRPDGNCFYR

TRPDGNCFYR

\begin{tabular}{llllllllllll}
1.00 & 93.29 & 26.71 & 27.46 & 2 & 1867.0320 & 1867.0285 & 934.5215 & 0.0035 & 1.8726 & 559.518 & 502.237 \\
\hline
\end{tabular}

$\begin{array}{llllllllllllll}0.67 & 48.87 & 23.73 & 61.87 & 3 & 1417.6387 & 1417.6353 & 473.5524 & 0.0034 & 2.3933 & 6841.032 & 7737.467 & 279 \\ 1.00 & 46.68 & 23.77 & 17.95 & 3 & 1417.6393 & 1417.6353 & 473.5524 & 0.0040 & 2.8156 & 5642.699 & 7329.995 & 141 .\end{array}$

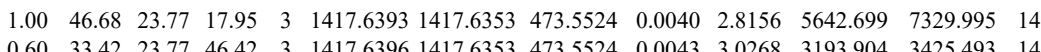

$\begin{array}{llllllllll}\text { PGM2_HUMAN Q96G03 } & \text { PGM2 } & \text { Phosphoglucomut 68.283 } & 1.00 & 3 & 6.9 & -0.2258 & 0.5177 & 0.0917 & 1.0602\end{array}$
LLTSGYLQR

LLTSGYQR $\begin{array}{lllllllllllllll}0.95 & 32.75 & 26.21 & 29.29 & 2 & 1193.6990 & 1193.6890 & 597.8518 & 0.0100 & 8.3632 & 18409.840 & 14131.251 & 3274.4 \\ 0.98 & 37.12 & 26.15 & 29.17 & 2 & 1193.6992 & 1193.6890 & 597.8518 & 0.0102 & 8.5305 & 11903.931 & 10912.862 & 3461.6\end{array}$ $\begin{array}{lllllllllllll} & \end{array}$

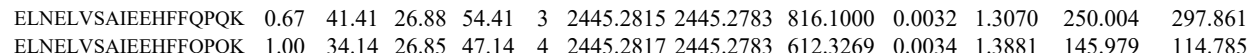
$\begin{array}{llllllllllll} & \end{array}$ $\begin{array}{lllllllllll} & 0\end{array}$

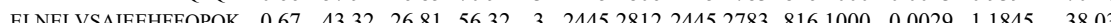




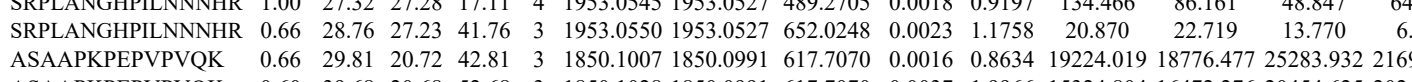
$\begin{array}{llllllllllllllll} & \end{array}$ $\begin{array}{lllllllllllllllll} & \end{array}$ $\begin{array}{lllllllllllllll} & \end{array}$ $\begin{array}{lllllllllllll} & \end{array}$ $\begin{array}{llllllllllllllll} & \text { SPSWQRPNQGVPSTGR } \\ 0.98 & 25.66 & 27.87 & 23.44 & 3 & 1896.9685 & 1896.9677 & 633.3298 & 0.0008 & 0.4211 & 2286.704 & 401.455 & 518.146 & 455.359 & \text { Yes }\end{array}$ $\begin{array}{lllllllllllllll} & \text { SPSWQRPNOGVPSTGR } \\ 0.98 & 29.95 & 27.91 & 20.35 & 3 & 1896.9676 & 1896.9677 & 633.3298 & -0.0001 & -0.0526 & 122.771 & 125.718 & 180.861 & 154.934 & \text { Yes }\end{array}$

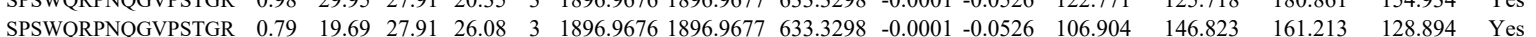
\begin{tabular}{llllllllllllllll} 
SPSWQRPNQGVPSTGR & 0.78 & 15.45 & 27.83 & 19.33 & 3 & 1896.9694 & 1896.9677 & 633.3298 & 0.0017 & 0.8947 & 40.739 & 53.050 & 48.200 & 68.213 & Yes \\
\hline
\end{tabular} $\begin{array}{llllllllllllllll}\text { OPTVTSVCSETSOELAEGOR } & 1.00 & 60.58 & 26.36 & 20.75 & 3 & 2339.0872 & 2339.0855 & 780.7024 & 0.0017 & 0.7258 & 131.172 & 178.445 & 72.695 & 81.523 & \text { No }\end{array}$ $\begin{array}{llllllllllllllll}\text { SFPLHFDENSFFAGDK } & 0.67 & 33.41 & 27.41 & 46.41 & 3 & 2145.0445 & 2145.0411 & 716.0210 & 0.0034 & 1.5828 & 1178.776 & 1153.197 & 153.454 & 1186.034 & \text { Yes }\end{array}$

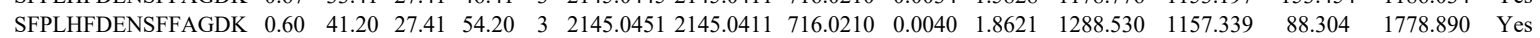
$\begin{array}{llllllllllllllll}\text { MLLLEILHEIK } & 1.00 & 73.00 & 19.19 & 21.56 & 2 & 1639.0010 & 1638.9986 & 820.5066 & 0.0024 & 1.4625 & 562.221 & 381.936 & 26.131 & 561.960 & \text { Yes }\end{array}$ $\begin{array}{llllllllllllllll}\text { MLLLEILHEIK } & 1.00 & 73.03 & 18.86 & 18.07 & 2 & 1639.0012 & 1638.9986 & 820.5066 & 0.0026 & 1.5844 & 586.241 & 417.098 & 31.740 & 550.354 & \text { Yes }\end{array}$ $\begin{array}{llllllllllllllll}\text { MLLLEILHEIK } & 1.00 & 49.06 & 18.92 & 16.97 & 3 & 1639.0024 & 1638.9986 & 547.3401 & 0.0038 & 2.3142 & 3183.863 & 2303.845 & 103.252 & 2765.714 & \text { Yes }\end{array}$ $\begin{array}{lllllllllllllllll}\text { MLLLEILHEIK } & 0.60 & 46.25 & 18.92 & 59.25 & 3 & 1639.0027 & 1638.9986 & 547.3401 & 0.0041 & 2.4969 & 5036.725 & 4119.299 & 45.094 & 5015.742 & \text { Yes }\end{array}$

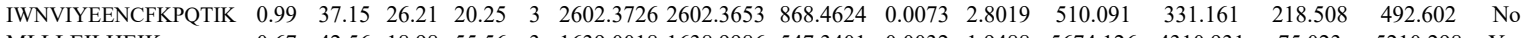
$\begin{array}{llllllllllllllll}\text { MLLLEILHEIK } & 0.67 & 42.56 & 18.98 & 55.56 & 3 & 1639.0018 & 1638.9986 & 547.3401 & 0.0032 & 1.9488 & 5674.126 & 4310.931 & 75.023 & 5210.298 & \text { Yes }\end{array}$ $\begin{array}{lllllllllllllllll}\text { MLLLEILHEIK } & 0.67 & 64.72 & 18.81 & 77.72 & 3 & 1639.0021 & 1638.9986 & 547.3401 & 0.0035 & 2.1315 & 3290.989 & 2252.343 & 0.000 & 3524.977 & \text { No }\end{array}$ $\begin{array}{llllllllllllllll}\text { MLLLEILHEIK } & 0.67 & 48.56 & 19.03 & 61.56 & 3 & 1639.0015 & 1638.9986 & 547.3401 & 0.0029 & 1.7661 & 738.615 & 446.453 & 65.580 & 639.404 & \text { Yes }\end{array}$

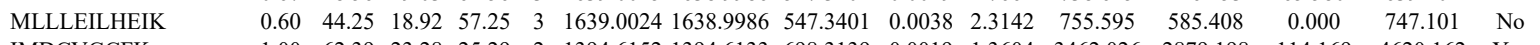
IMDCVGCFK

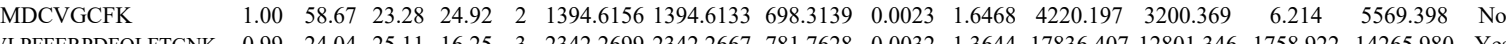
$\begin{array}{lllllllllllllll}1.00 & 62.39 & 23.28 & 25.29 & 2 & 1394.6152 & 1394.6133 & 698.3139 & 0.0019 & 1.3604 & 3462.026 & 2879.198 & 114.169 & 4620.162 & \text { Yes }\end{array}$ $\begin{array}{llllllllllllllllllll} & & \end{array}$ \begin{tabular}{llllllllllllllll} 
VLPFERPDFLLFTGNK & 0.70 & 12.04 & 25.04 & 14.42 & 3 & 2342.2711 & 2342.2667 & 781.7628 & 0.0044 & 1.8761 & 1431.676 & 1286.046 & 125.854 & 1106.433 & Yes \\
\hline
\end{tabular} $\begin{array}{llllllllllllllll}\text { QEIVSLFNAFGR } & 0.91 & 23.15 & 25.01 & 20.97 & 3 & 2342.2723 & 2342.2667 & 781.7628 & 0.0056 & 2.3878 & 1546.919 & 1382.161 & 173.548 & 1238.926 & \text { Yes } \\ \text { LEAVI } & 59.80 & 27.61 & 34.53 & 2 & 1523.8234 & 1523.8218 & 762.9182 & 0.0016 & 1.0486 & 3996.111 & 3108.256 & 72.982 & 2325.467 & \text { No }\end{array}$ $\begin{array}{lllllllllllllll} & \end{array}$

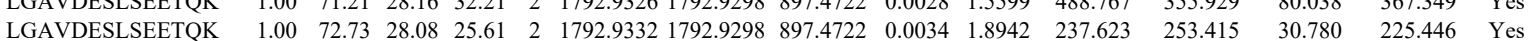

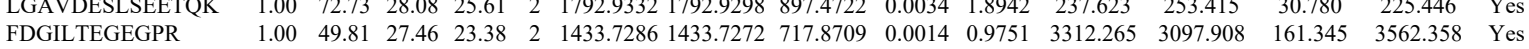
$\begin{array}{llllllllllllllll}\text { FDGILTEGEGPR } & 1.00 & 55.99 & 27.46 & 22.51 & 2 & 1433.7290 & 1433.7272 & 717.8709 & 0.0018 & 1.2537 & 4937.162 & 3651.169 & 97.592 & 3981.544 & \text { Yes }\end{array}$

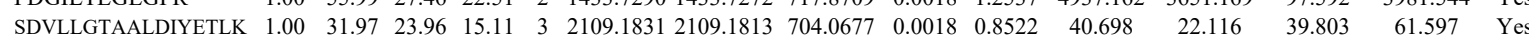
$\begin{array}{lllllllllllllllll}\text { SDVLLGTAALDIYETLK } & 1.00 & 37.46 & 24.03 & 18.40 & 3 & 2109.1837 & 2109.1813 & 704.0677 & 0.0024 & 1.1363 & 33.774 & 75.502 & 31.894 & 83.341 & \text { Yes }\end{array}$ $\begin{array}{llllllllllllllll}\text { SQLQGAMQQFNQR } & 1.00 & 81.99 & 28.09 & 28.81 & 2 & 1678.8470 & 1678.8331 & 840.4238 & 0.0139 & 8.2696 & 568.407 & 690.462 & 131.925 & 954.146 & \text { Yes }\end{array}$ $\begin{array}{llllllllllllllll}\text { SQLQGAMQQFNQR } & 0.65 & 22.19 & 28.14 & 17.29 & 3 & 1678.8472 & 1678.8331 & 560.6183 & 0.0141 & 8.3835 & 157.519 & 88.224 & 143.821 & 114.430 & \text { No }\end{array}$

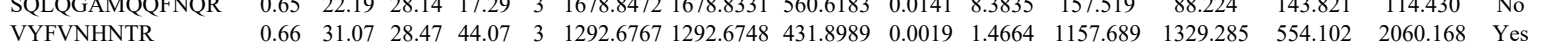
$\begin{array}{llllllllllllllll}\text { FIAMALFHGK } & 1.00 & 32.56 & 27.02 & 17.12 & 3 & 1421.8117 & 1421.8097 & 474.9438 & 0.0020 & 1.4037 & 1350.539 & 1299.639 & 342.671 & 2686.710 & \text { Yes }\end{array}$ $\begin{array}{llllllllllllllll}\text { FIAMALFHGK } & 1.00 & 4228 & 26.90 & 19.80 & 3 & 1421.8123 & 1421.8097 & 474.9438 & 0.0026 & 1.8248 & 1376.280 & 1220.472 & 308.930 & 2279.905 & \text { Yes }\end{array}$

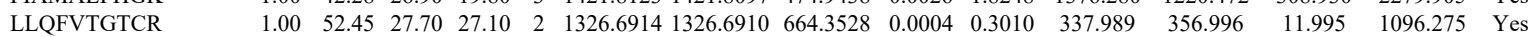

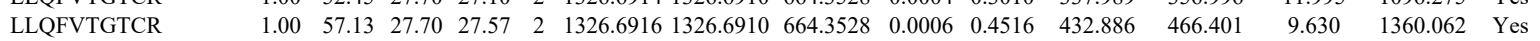
$\begin{array}{llllllllllllllll}\text { LLQFVTGTCR } & 1.00 & 55.52 & 27.69 & 28.19 & 2 & 1326.6910 & 1326.6910 & 664.3528 & 0.0000 & 0.0000 & 85.256 & 65.782 & 22.477 & 178.675 & \text { Yes }\end{array}$ $\begin{array}{lllllllllllllllll}\text { LLQFVTGTCR } & 1.00 & 48.86 & 28.01 & 26.24 & 2 & 1326.6924 & 1326.6910 & 664.3528 & 0.0014 & 1.0537 & 96.914 & 140.296 & 29.667 & 274.212 & \text { Yes }\end{array}$ $\begin{array}{lllllllllllll} & \end{array}$ $\begin{array}{lllllllllllll} & \end{array}$

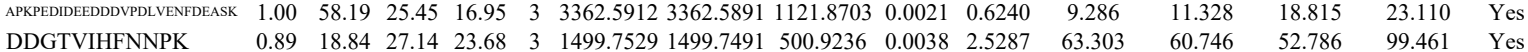

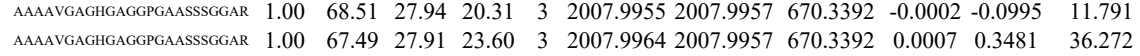
ATMPIWVVLLSR TMPIWVVLLSR $\begin{array}{lllllllllll}23.60 & 3 & 2007.99642007 .9957 & 670.3392 & 0.0007 & 0.3481 & 36.272 & 13.457 & 28.537 & 51.440 & \text { Yes }\end{array}$ $\begin{array}{lllllllllll}\text { S35E1_HUMAN } & \text { Q96K37 } & \text { SLC35E1 } & \text { Solute carrier fam: } 44.773 & 1.00 & 2 & 8.8 & 0.0230 & 0.9588 & -0.4330 & 0.7417\end{array}$ $\begin{array}{llllllllllll}1.00 & 60.37 & 24.28 & 26.28 & 2 & 1528.8944 & 1528.8921 & 765.4533 & 0.0023 & 1.5024 & 163.831 & 143.499\end{array}$ $\begin{array}{rlllllllllll}1.00 & 33.80 & 24.33 & 23.73 & 3 & 1528.8952 & 1528.8921 & 510.6380 & 0.0031 & 2.0236 & 5.298 & 7.265\end{array}$ $\begin{array}{llllllllllll} & \end{array}$ $\begin{array}{lllllllllll}39.57 & 25.01 & 19.35 & 3 & 2491.3576 & 2491.3526 & 831.4581 & 0.0050 & 2.0045 & 59.737 & 0.0\end{array}$ $\begin{array}{llllllllllllll} & & & & \end{array}$

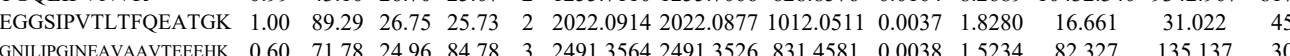



$\begin{array}{llllllllllllll}\text { GLLRPHVPPAAITTLAR } & 0.55 & 46.69 & 18.57 & 59.69 & 3 & 1926.1657 & 1926.1649 & 643.0622 & 0.0008 & 0.4147 & 42.117\end{array}$ $\begin{array}{llllllllllllll}\text { GLLRPHVPPAAITTLAR } & 0.94 & 4.45 & 18.33 & 17.45 & 4 & 1926.1661 & 1926.1649 & 482.5485 & 0.0012 & 0.6217 & 38.943\end{array}$ $\begin{array}{llllllllllllll}\text { GLLRPHVPPAAITTLAR } & 0.99 & 7.52 & 18.33 & 20.52 & 4 & 1926.1665 & 1926.1649 & 482.5485 & 0.0016 & 0.8289 & 90.826\end{array}$ $\begin{array}{llllllllllllll}\text { GLLRPHVPPAAITTLAR } & 0.97 & 8.38 & 18.57 & 21.38 & 4 & 1926.1653 & 1926.1649 & 482.5485 & 0.0004 & 0.2072 & 57.142\end{array}$ $\begin{array}{llllllllllllll}\text { GLLRPHVPPAAITTLAR } & 1.00 & 39.58 & 18.57 & 16.37 & 3 & 1926.1657 & 1926.1649 & 643.0622 & 0.0008 & 0.4147 & 29.877\end{array}$ $\begin{array}{llllllllllllllll}\text { GLLRPHVPPAAITTLAR } & 1.00 & 12.81 & 18.33 & 25.81 & 4 & 1926.1661 & 1926.1649 & 482.5485 & 0.0012 & 0.6217 & 47.139\end{array}$ $\begin{array}{llllllllllllll}\text { GLLRPHVPPAAITTLAR } & 0.97 & 5.60 & 18.33 & 18.60 & 4 & 1926.1665 & 1926.1649 & 482.5485 & 0.0016 & 0.8289 & 64.593\end{array}$ $\begin{array}{llllllllllllll}\text { SAVRPASLNLNR } & 1.00 & 42.34 & 25.92 & 29.13 & 3 & 1440.8284 & 1440.8283 & 481.2834 & 0.0001 & 0.0693 & 425.984 \\ \text { SAVRPASLNLNR } & 1.00 & 40.62 & 25.92 & 26.11 & 3 & 1440.8284 & 1440.8283 & 481.2834 & 0.0001 & 0.0693 & 416.676 & 4\end{array}$ $\begin{array}{llllllllllllll}\text { SAVRPASLNLNR } & 1.00 & 40.62 & 25.92 & 26.11 & 3 & 1440.8284 & 1440.8283 & 481.2834 & 0.0001 & 0.0693 & 416.676 & 41\end{array}$ $\begin{array}{llllllllllll}\text { SAVRPASLNLNR } & 1.00 & 45.59 & 25.67 & 26.18 & 3 & 1440.8278 & 1440.8283 & 481.2834 & -0.0005 & -0.3463 & 568.348 \\ \text { SAVRPASLNLNR } & 1.00 & 39.00 & 25.92 & 24.91 & 3 & 1440.8281 & 1440.8283 & 481.2834 & -0.0002 & -0.1385 & 622.193\end{array}$ $\begin{array}{lllllllllllll}\text { SAVRPASLNLNR } & 0.99 & 29.64 & 25.92 & 21.75 & 3 & 1440.8281 & 1440.8283 & 481.2834 & -0.0002 & -0.1385 & 558.31\end{array}$ $\begin{array}{llllllllllll}\text { SAVRPASLNLNR } & 0.99 & 30.33 & 25.92 & 24.86 & 3 & 1440.8281 & 1440.8283 & 481.2834 & -0.0002 & -0.1385 & 602.800\end{array}$ $\begin{array}{llllllllllll}\text { SAVRPASLNLNR } & 1.00 & 39.17 & 25.80 & 25.20 & 3 & 1440.8272 & 1440.8283 & 481.2834 & -0.0011 & -0.7619 & 201.017 \\ \text { EEIILTPIEVAIEDMQK } & 0.98 & 62.67 * & 25.72 & 23.63 & 2 & 2258.2334 & 2258.2323 & 1130.1234 & 0.0011 & 0.4867 & 4.155\end{array}$

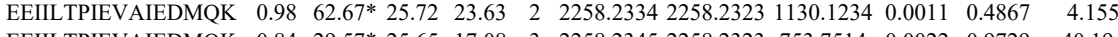
$\begin{array}{llllllllllll}\text { EEIILTPIEVAIEDMQK } & 0.84 & 29.57 * & 25.65 & 17.08 & 3 & 2258.2345 & 2258.2323 & 753.7514 & 0.0022 & 0.9729 & 40.194\end{array}$

$\begin{array}{llllllllllll}0.65 & 25.49 & 26.16 & 29.64 & 2 & 1189.7058 & 1189.6974 & 595.8560 & 0.0084 & 7.0486 & 845.108\end{array}$ LASMATLLAR $\begin{array}{lllllllllll}0.61 & 21.80 & 26.00 & 27.65 & 2 & 1189.7076 & 1189.6974 & 595.8560 & 0.0102 & 8.5590 & 963.119 \\ 0.99 & 28.55 & 26.72 & 17.70 & 3 & 1283.7259 & 1283.7220 & 428.9146 & 0.0039 & 3.0309 & 1858.870\end{array}$ LHALAGFQQR $\begin{array}{lllllllllll}1.00 & 36.95 & 26.75 & 22.48 & 3 & 1283.7265 & 1283.7220 & 428.9146 & 0.0045 & 3.4972 & 1930.760\end{array}$ $\begin{array}{lllllllllllll}\text { YSAVLDAVIASAGLLR } & 1.00 & \text { 24.62 } & 24.47 & 2 & 1762.0122 & 1762.0110 & 882.0128 & 0.0012 & 0.6803 & 96.652\end{array}$ $\begin{array}{llllllllllll}\text { YSAVLDAVIASAGLLR } & 1.00 & 44.56 & 24.59 & 29.71 & 3 & 1762.0138 & 1762.0110 & 588.3443 & 0.0028 & 1.5864 & 80.924 \\ & 1.00 & 3.28 & 26.88 & 25.36 & 3 & 1283.7244 & 1282.0110 & 588.3443 & 0.0028 & 1.5864 & 68.226\end{array}$ $\begin{array}{lllllllllllll}\text { LHALAGFQQR } & 1.00 & 39.28 & 26.88 & 25.36 & 3 & 1283.7244 & 1283.7220 & 428.9146 & 0.0024 & 1.8652 & 1629.370 & 1818.948 \\ \text { LHALAGFQQR } & 1.00 & 42.08 & 26.71 & 27.67 & 3 & 1283.7250 & 1283.7220 & 428.9146 & 0.0030 & 2.3315 & 1462.233 & 2121.165\end{array}$ $\begin{array}{lllllllllllll} & \end{array}$ $\begin{array}{lllllllllllll}\text { YSAVLDAVIASAGLLR } & 0.95 & 18.70 & 24.65 & 20.75 & 3 & 1762.0141 & 1762.0110 & 588.3443 & 0.0031 & 1.7563 & 71.360 & \end{array}$ LASMATLLAR $\begin{array}{llllllllllll} & \end{array}$ $\begin{array}{llllllllllll}\text { WAQDLLANATDENESAAALAAAATR } & 1.00 & 57.52 & 24.71 & 70.52 & 4 & 2929.5713 & 2929.5630 & 733.3980 & 0.0083 & 2.8293 & 7.685\end{array}$ $\begin{array}{llllllllll} & \end{array}$

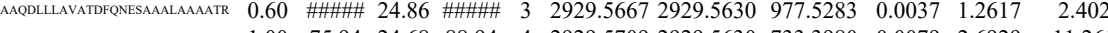

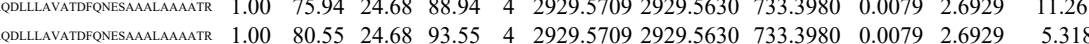
$\begin{array}{llllllllllll}\text { LIPTLVSIMQAPADK } & 1.00 & 49.21 & 20.97 & 16.45 & 3 & 1884.1030 & 1884.0998 & 629.0405 & 0.0032 & 1.6957 & 220.900\end{array}$ $\begin{array}{lllllllllllll}\text { LIPTLVSIMQAPADK } & 1.00 & 55.46 & 20.86 & 16.55 & 3 & 1884.1033 & 1884.0998 & 629.0405 & 0.0035 & 1.8547 & 328.928\end{array}$ $\begin{array}{llllllllllll} & \end{array}$ $\begin{array}{llllllllllll}\text { IFTMAEVYGIR } & 1.00 & 61.59 & 28.10 & 23.46 & 2 & 1442.7728 & 1442.7713 & 722.3929 & 0.0015 & 1.0382 & 341.805 \\ \text { LIPTLVSIMQAPADK } & 1.00 & 49.25 & 20.90 & 18.11 & 3 & 1884.1039 & 1884.0998 & 629.0405 & 0.0041 & 2.1726 & 215.501\end{array}$

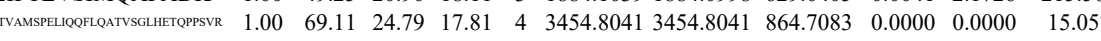
$\begin{array}{llllllllllllll}\text { HVAMSPELLOFLLATVSCLETTPPSVR } & 1.00 & \text { \#\#\#\# } 24.79 & 22.84 & 3 & 3454.8052 & 3454.8041 & 1152.6086 & 0.0011 & 0.3181 & 21.628\end{array}$

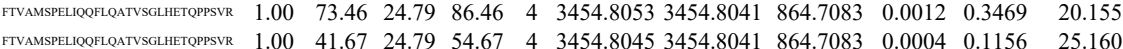
$\begin{array}{lllllllllllll} & 0.00\end{array}$

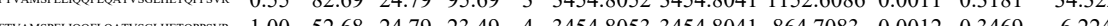

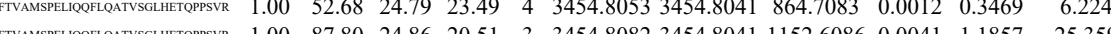



$\begin{array}{llllllllllll}\text { IPAGLCATAIDILTTVVR } & 1.00 & \text { \#\#\#\# } & 25.11 & 23.37 & 2 & 2016.1254 & 2016.1233 & 1009.0689 & 0.0021 & 1.0406 & 2.328 \\ \text { IPAGLCATAIDILTTVVR } & 1.00 & 44.55 & 25.22 & 18.59 & 3 & 2016.1264 & 2016.1233 & 673.0484 & 0.0031 & 1.5353 & 28.498\end{array}$ $\begin{array}{llllllllllll}\text { IPAGLCATAIDILTTTVR } & 1.00 & 44.55 & 25.22 & 18.59 & 3 & 2016.1264 & 2016.1233 & 673.0484 & 0.0031 & 1.5353 & 28.498 \\ \text { IPAGLCATAIDILTTVVR } & 1.00 & 63.42 & 25.31 & 32.76 & 3 & 2016.1270 & 2016.1233 & 673.0484 & 0.0037 & 1.8325 & 10.660\end{array}$ $\begin{array}{llllllllllll}\text { IPAGLCATAIDILTTVVR } & 1.00 & 43.12 & 25.15 & 25.29 & 3 & 2016.1246 & 2016.1233 & 673.0484 & 0.0013 & 0.6438 & 10.195\end{array}$ $\begin{array}{llllllllllll}\text { IPAGLCATAIDILTTVVR } & 1.00 & 78.93 & 25.11 & 26.80 & 2 & 2016.1254 & 2016.1233 & 1009.0689 & 0.0021 & 1.0406 & 3.000\end{array}$ $\begin{array}{lllllllllllll}\text { IPAGLCATAIDILTTVVR } & 1.00 & 54.82 & 25.22 & 19.19 & 3 & 2016.1264 & 2016.1233 & 673.0484 & 0.0031 & 1.5353 & 8.936\end{array}$

$\begin{array}{lllllllllll}\text { MACF4_HUMA } & \text { Q96PK2 } & \text { MACF1 } & \text { Microtubule-actin 670.14 } & 1.00 & 3 & 1.1 & 0.0653 & 0.7592 & -1.9812 & 0.7468\end{array}$

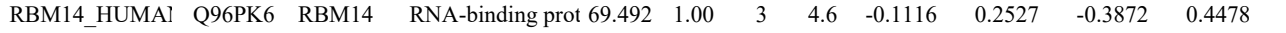
$\begin{array}{llllllllllll}\text { SLLELLNSAADLINSSEADEDGIRDEK } & 0.99 & 25.86 & 25.63 & 16.57 & 4 & 3317.7093 & 3317.7081 & 830.4343 & 0.0012 & 0.3613 & 19.768\end{array}$

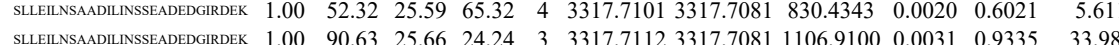

\section{DAVTVGLLDK}

DAVTVGLLDK

GALPDDTEALQSLIDTH

TQPMTAQAASY QPTPPFFGR
QPTPFFR QPTPPFFGR LPDAHSDYAR LPDAHSDYAR

38 LLDEAIQAVK LLDEAIQAVK LNLEHIATSSAVSK IPVDTYNNILTVLK IPVDTYNNILTVLK IPVDTYNNILTVLK IPVDTYNNILTVLK NIIIALIDR IPVDTYNNILTVLK IPVDTYNNILTVLK NIIIALIDR NIIALIDR

NIHALIDR $\begin{array}{lllllllllllll}0.63 & 21.51 & 25.82 & 26.44 & 2 & 1317.7866 & 1317.7748 & 659.8947 & 0.0118 & 8.9407 & 762.582\end{array}$ $\begin{array}{llllllllllll}0.62 & 21.29 & 25.82 & 25.98 & 2 & 13177.7868 & 131777748 & 659.8947 & 0.0120 & 9.0923 & 691.352\end{array}$ $\begin{array}{lllllllllll}0.62 & 21.29 & 25.82 & 25.98 & 2 & 1317.7868 & 1317.7748 & 659.8947 & 0.0120 & 9.0923 & 691.352 \\ 1.00 & 50.09 & 27.18 & 17.84 & 3 & 2211.1648 & 2211.1627 & 738.0615 & 0.0021 & 0.9484 & 29.320\end{array}$ $\begin{array}{llllllllllll}1.00 & 71.97 & 27.31 & 32.30 & 2 & 1467.7236 & 1467.7262 & 738.0615 & 0.0021 & 0.9484 & 29.320 & 78.289 \\ 1.00 & 60.00 & 27.36 & 27.97 & 2 & 1467.7252 & 1467.262 & -0.0026 & -1.7690 & 3565242 & 2640.754\end{array}$

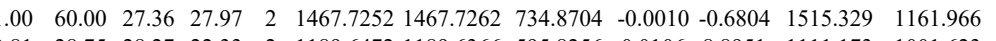
$\begin{array}{lllllllllllll}0.81 & 28.75 & 28.27 & 22.33 & 2 & 1189.6472 & 1189.6366 & 595.8256 & 0.0106 & 8.8951 & 1111.173 & 1001.623\end{array}$ $\begin{array}{lllllllllllll}0.89 & 30.83 & 28.02 & 23.54 & 2 & 1189.6482 & 1189.6366 & 595.8256 & 0.0116 & 9.7343 & 1646.024 & 1917.383\end{array}$ $\begin{array}{lllllllllllll}1.00 & 41.06 & 26.49 & 18.40 & 3 & 1287.6370 & 1287.6329 & 430.2182 & 0.0041 & 3.1767 & 931.452 & 959.680\end{array}$

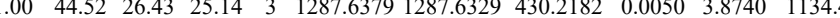
$\begin{array}{lllllllllllll}1.00 & 73.32 & 23.32 & 39.51 & 2 & 1386.8358 & 1386.8326 & 694.4236 & 0.0032 & 2.3041 & 2772.152 & 2439.945\end{array}$ $\begin{array}{llllllllllllll}1.00 & 54.26 & 25.05 & 17.09 & 3 & 1757.0098 & 1756.9927 & 586.6715 & 0.0171 & 9.7157 & 2832.593 & 2796 . \\ 1.00 & 55.97 & 21.14 & 19.24 & 2 & 1890.1068 & 1890.1070 & 946.0608 & -0.0002 & -0.1057 & 1188.050 & 797.8\end{array}$ $\begin{array}{lllllllllllll}1.00 & 55.97 & 21.14 & 19.24 & 2 & 1890.1068 & 1890.1070 & 946.0608 & -0.0002 & -0.1057 & 1188.050 & 797.8 \\ 0.82 & 64.10 & 21.00 & 77.10 & 2 & 1890.1080 & 1890.1070 & 946.0608 & 0.0010 & 0.5285 & 1866.995 & 123 .\end{array}$ $\begin{array}{lllllllllllll}0.82 & 64.10 & 21.00 & 77.10 & 2 & 1890.1080 & 1890.1070 & 946.0608 & 0.0010 & 0.5285 & 1866.995 & 1923 . \\ 1.00 & 45.54 & 21.04 & 21.28 & 3 & 1890.1099 & 1890.1070 & 631.0429 & 0.0029 & 1.5319 & 672.317 & 5 \\ 0 & 26.6 & 1.2 & 22.82 & 3 & 18.9\end{array}$ $\begin{array}{llllllllllll}0.99 & 26.66 & 21.21 & 22.82 & 3 & 1890.1120 & 1890.1070 & 631.0429 & 0.0050 & 2.6411 & 698.428 & 725.6 \\ 1.00 & 38.00 & 21.07 & 24.87 & 2 & 1183.7428 & 1183.7410 & 592.8778 & 0.0018 & 1.5180 & 1822.757 & 135 .\end{array}$ $\begin{array}{llllllllllll}1.00 & 38.00 & 21.07 & 24.87 & 2 & 1183.7428 & 1183.7410 & 592.8778 & 0.0018 & 1.5180 & 1822.757 & 1355.120\end{array}$ $\begin{array}{lllllllllllll}1.00 & 59.81 & 21.00 & 21.07 & 2 & 1890.1064 & 1890.1070 & 946.0608 & -0.0006 & -0.3171 & 156.681 & 161.814 \\ 1.00 & 64.40 & 21.11 & 20.95 & 2 & 1890.1070 & 1890.1070 & 946.0608 & 0.0000 & 0.0000 & 767.722 & 448.300\end{array}$ $\begin{array}{lllllllllllll} & \end{array}$ $\begin{array}{llllllllllll} & \end{array}$ $\begin{array}{lccccccccccccccc}\text { NIIIALIDR } & 1.00 & 36.12 & 20.86 & 18.08 & 2 & 1183.7444 & 1183.7410 & 592.8778 & 0.0034 & 2.8674 & 3059.437 & 2547.617 & 628.892 & 4423.370 & \text { Yes } \\ \text { VADLYELVQYAGNIIPR } & 0.54 & 10.03 & 26.79 & 23.03 & 3 & 2077.1353 & 2077.1330 & 693.3849 & 0.0023 & 1.1057 & 59.241 & 72.730 & 39.738 & 82.271 & \text { Yes } \\ \text { QIVLTGIEQVVNCR } & 0.60 & 39.80 & 27.12 & 52.80 & 3 & 1874.0278 & 1874.0240 & 625.6819 & 0.0038 & 2.0245 & 54.311 & 59.153 & 47.891 & 80.222 & \text { Yes }\end{array}$

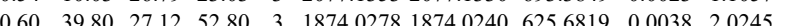
$\begin{array}{lllllllllllllllll}\text { QIVLTGILEQVVNCR } & 0.60 & 56.64 & 27.11 & 69.64 & 3 & 1874.0281 & 1874.0240 & 625.6819 & 0.0041 & 2.1843 & 72.508 & 82.906 & 51.263 & 69.410 & \text { Yes }\end{array}$ $\begin{array}{lllllllllllllllll}\text { AQLAAITLIIGTFER } & 0.82 & 74.50 & 22.43 & 87.50 & 2 & 1760.0330 & 1760.0318 & 881.0232 & 0.0012 & 0.6810 & 34.214 & 15.114 & 20.768 & 14.739 & \text { No }\end{array}$ $\begin{array}{llllllllllllllllll}\text { AQLAAITLIIGTFER } & 0.84 & 86.37 & 22.28 & 99.37 & 2 & 1760.0338 & 1760.0318 & 881.0232 & 0.0020 & 1.1350 & 112.865 & 90.157 & 84.141 & 136.438 & \text { Yes }\end{array}$

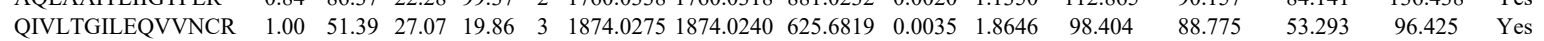
$\begin{array}{llllllllllllllll}\text { QIVLTGILEQVVNCR } & 1.00 & 51.66 & 27.12 & 23.03 & 3 & 1874.0278 & 1874.0240 & 625.6819 & 0.0038 & 2.0245 & 93.991 & 121.057 & 23.105 & 89.605 & \text { No }\end{array}$

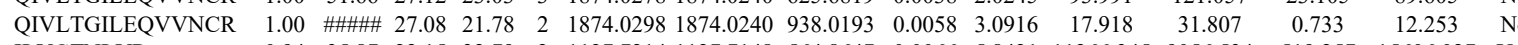
$\begin{array}{llllllllllllllll}\text { ILVGTNLVR } & 0.94 & 35.87 & 22.15 & 32.79 & 2 & 1127.7214 & 1127.7148 & 564.8647 & 0.0066 & 5.8421 & 11266.345 & 9056.534 & 519.257 & 15606.027 & \text { Y }\end{array}$ $\begin{array}{llllllllllllllll}\text { ILVGTNLVR } & 0.97 & 39.88 & 22.15 & 32.56 & 2 & 1127.7216 & 1127.7148 & 564.8647 & 0.0068 & 6.0191 & 11945.224 & 9928.843 & 520.058 & 18390.116 & \text { Yes }\end{array}$

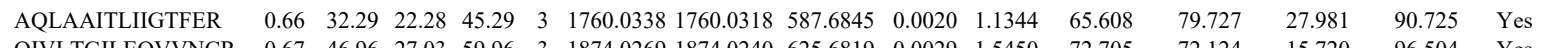

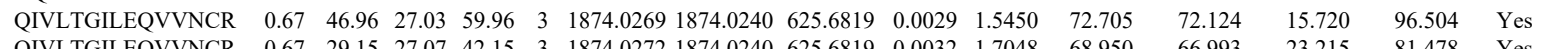

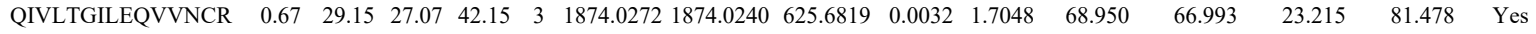
$\begin{array}{lllllllllllllllll}\text { LFDIFSQQVATVIQSR } & 1.00 & 89.20 & 26.17 & 21.56 & 2 & 1995.0922 & 1995.0911 & 998.5528 & 0.0011 & 0.5508 & 243.945 & 263.467 & 21.073 & 463.396 & \text { Yes }\end{array}$

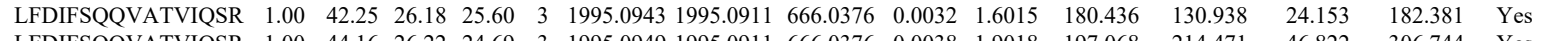

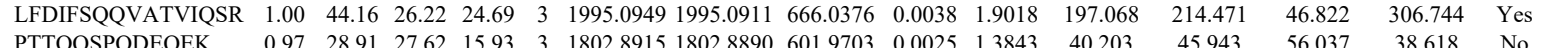
$\begin{array}{llllllllllllllll}\text { PTTQQSPQDEQEK } & 0.97 & 28.91 & 27.62 & 15.93 & 3 & 1802.8915 & 1802.8890 & 601.9703 & 0.0025 & 1.3843 & 40.203 & 45.943 & 56.037 & 38.618 & \text { No }\end{array}$

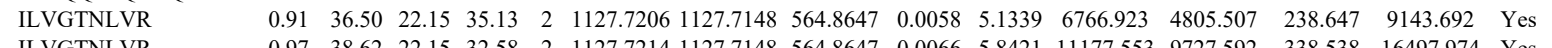
$\begin{array}{llllllllllllllll}\text { ILVGTNLVR } & 0.97 & 38.62 & 22.15 & 32.58 & 2 & 1127.7214 & 1127.7148 & 564.8647 & 0.0066 & 5.8421 & 11177.553 & 9727.592 & 338.538 & 16497.974 & \text { Yes }\end{array}$

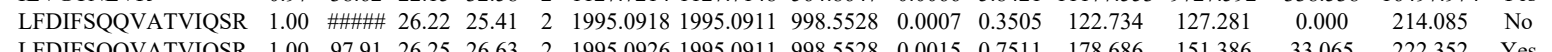
$\begin{array}{llllllllllllllll}\text { LFDIFSQQVATVIQSR } & 1.00 & 97.91 & 26.25 & 26.63 & 2 & 1995.0926 & 995.0911 & 998.5528 & 0.0015 & 0.7511 & 178.686 & 151.386 & 33.065 & 222.352 & \text { Yes }\end{array}$

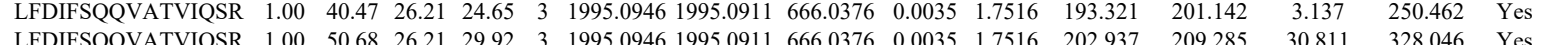

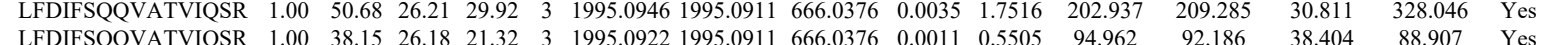
$\begin{array}{llllllllllllllll}\text { LFDIFSQQVATVIQSR } & 1.00 & 38.15 & 26.18 & 21.32 & 3 & 1995.0922 & 1995.0911 & 666.0376 & 0.0011 & 0.5505 & 94.962 & 92.186 & 38.404 & 88.907 & \text { Yes } \\ \text { LFDIFSQQVATVIQSR } & 1.00 & 34.28 & 26.25 & 19.31 & 3 & 1995.0928 & 1995.0911 & 666.0376 & 0.0017 & 0.8508 & 93.740 & 83.092 & 27.565 & 136.317 & \text { Yes }\end{array}$

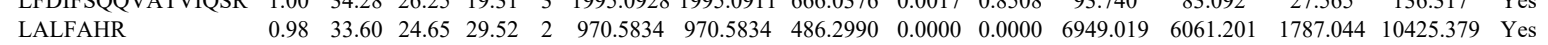
$\begin{array}{llllllllllllllll}\text { LALFAR } & 0.98 & 33.60 & 24.65 & 29.52 & 2 & 970.5834 & 970.5834 & 486.2990 & 0.0000 & 0.0000 & 6949.019 & 6061.201 & 1787.044 & 10425.379 & \text { Yes } \\ \text { FIHLLR } & 0.60 & 29.29 * & 25.85 & 28.11 & 2 & 941.5938 & 941.5932 & 471.8039 & 0.0006 & 0.6359 & 1807.312 & 1484.580 & 332.975 & 3446.983 & \text { Yes }\end{array}$ 

$\begin{array}{lllllllllllll}\text { LSVDQYLELIGNSLPGTTAK } & 1.00 & 59.65 & 21.67 & 19.33 & 3 & 2620.4596 & 2620.4567 & 874.4928 & 0.0029 & 1.1054 & 10.645\end{array}$

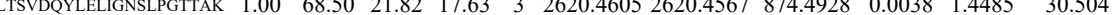


$\begin{array}{lllllllllllll}\text { PSB7_HUMAN } & \text { Q99436 } & \text { PSMB7 } & \text { Proteasome subun 29.965 } & 1.00 & 3 & 14.1 & -0.2601 & 0.1029 & -0.2173 & 0.1285 & 4 & \text { GTTAVLTEK }\end{array}$ GTTAVLTEK FRPDMEEEEAK FRPDMEEEEAK ITPLEIEVLEETVQTM ITPLEIEVLEETVQT
GLQSGVDIGVK WIEGLTGLSIGPDFQK TWIEGLTCLSIPDFK 

$\begin{array}{llllllllllllllll}1.00 & 44.65 & 28.01 & 34.70 & 2 & 1277.7118 & 1277.7101 & 639.8623 & 0.0017 & 1.3284 & 7060.001 & 6562.035 & 244.855 & 11346.953 & \text { Yes } \\ 1.00\end{array}$

EELTNLIR

FEELTNLIR

LNEILQAR

LNEILQAR

GCILTLVER

GCILTLVER

GCILTLVER

TMVQLGICAFR

TMVQLGICAFR

KLNEILQAR

KLNEILQAR
QLTPPEGSSK

$\begin{array}{lllllllllll}\text { DNJC7_HUMAI } & \text { Q99615 } & \text { DNAJC7 } & \text { DnaJ homolog sut } 56.441 & 1.00 & 3 & 8.5 & 0.2837 & 0.2161 & 1.4856 & 0.1010\end{array}$

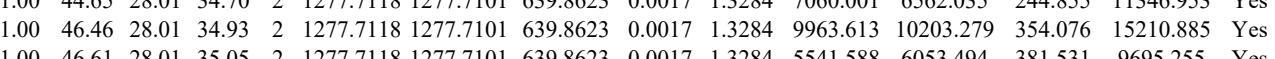
\begin{tabular}{lllllllllllllll}
1.00 & 46.61 & 28.01 & 35.05 & 2 & 1277.7118 & 1277.7101 & 639.8623 & 0.0017 & 1.3284 & 5541.588 & 6053.494 & 381.531 & 9695.255 & Yes \\
\hline
\end{tabular}

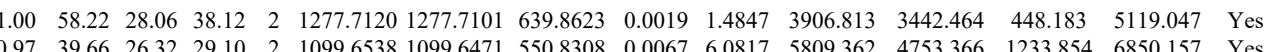
$\begin{array}{lllllllllllllll}0.97 & 39.66 & 26.32 & 29.10 & 2 & 1099.6538 & 1099.6471 & 550.8308 & 0.0067 & 6.0817 & 5809.362 & 4753.366 & 1233.854 & 6850.157 & \text { Yes } \\ 0.97 & 3.6 & 26.31 & 2.49 & 2 & 1099.6542 & 1099.6471 & 550.8308 & 0.0071 & 6.448 & 6200.864 & 5636.618 & 907.785 & 7269.099 & \text { Yes }\end{array}$ $\begin{array}{lllllllllllllllll}0.97 & 39.69 & 26.31 & 29.49 & 2 & 1099.6542 & 1099.6471 & 550.8308 & 0.0071 & 6.4448 & 6200.864 & 5636.618 & 907.785 & 7269.099 & \text { Yes } \\ 0.98 & 43.33 & 28.05 & 24.72 & 2 & 1192.6488 & 1192.6430 & 597.3288 & 0.0058 & 4.8549 & 7277.088 & 8688.777 & 896.513 & 14453.712 & \text { Yes }\end{array}$ $\begin{array}{lllllllllllllllll}1.00 & 40.17 & 27.76 & 22.31 & 2 & 1192.6442 & 1192.6430 & 597.3288 & 0.0012 & 1.0045 & 3903.976 & 3794.976 & 815.805 & 6429.143 & \text { Yes }\end{array}$ $\begin{array}{llllllllllllllll}1.00 & 47.99 & 27.89 & 26.53 & 2 & 1192.6450 & 1192.6430 & 597.3288 & 0.0020 & 1.6741 & 2047.919 & 2491.998 & 507.837 & 3716.016 & \text { Yes }\end{array}$

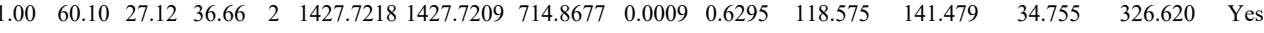

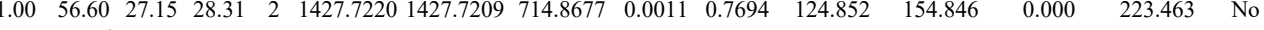
$\begin{array}{llllllllllllll}0.59 & 25.36 * 23.98 & 27.24 & 2 & 1227.7434 & 1227.7421 & 614.8783 & 0.0013 & 1.0571 & 225.393 & 261.367 & 130.912 & 239.769 & \text { Yes }\end{array}$

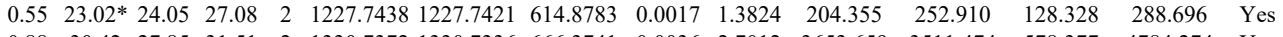
$\begin{array}{lllllllllllllllll} & & 0.878 & 30.42 & 27.85 & 31.51 & 2 & 1330.7372 & 1330.7336 & 666.3741 & 0.0036 & 2.7012 & 3653.659 & 3511.474 & 578.377 & 4784.274 & \text { Yes } \\ \text { KLDDAIEDCTNAVK } & 1.00 & 59.57 & 27.64 & 20.42 & 3 & 2012.0302 & 2012.0284 & 671.6834 & 0.0018 & 0.8933 & 269.671 & 294.617 & 160.271 & 475.261 & \text { Yes }\end{array}$

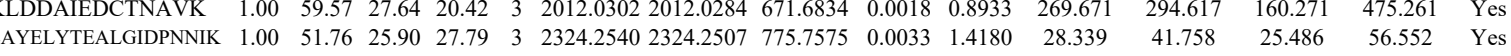
\begin{tabular}{lllllllllllllllll} 
AVQFFVQALR & 1.00 & 43.66 & 27.00 & 18.09 & 2 & 1321.7640 & 1321.7628 & 661.8887 & 0.0012 & 0.9065 & 403.138 & 500.925 & 68.710 & 76.552 & Yes \\
\hline
\end{tabular}

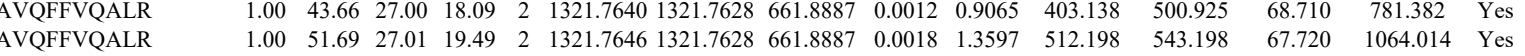
$\begin{array}{llllllllllllllllll}\text { IGGVQQDTILAEGLHFR } & 1.00 & 73.93 & 26.45 & 27.56 & 3 & 1997.1013 & 1997.0816 & 666.7011 & 0.0197 & 9.8494 & 961.524 & 876.519 & 395.527 & 894.501 & \text { Yes }\end{array}$ \begin{tabular}{lllllllllllllllll} 
& \\
IGGVQQDTILAEGLHFR & 1.00 & 76.88 & 26.69 & 30.83 & 3 & 1997.0827 & 1997.0816 & 666.7011 & 0.0011 & 0.5500 & 1064.693 & 1208.176 & 596.367 & 1467.289 & Yes \\
\hline IGGVQQDTILAEGLHFR & 1.00 & 78.53 & 26.78 & 33.14 & 3 & 1997.0833 & 1997.0816 & 666.7011 & 0.0017 & 0.8500 & 1238.736 & 1073.543 & 741.605 & 1499.116 & Yes
\end{tabular} $\begin{array}{lllllllllllllllll}\text { IGGVQQDTLAEGLFR } & 1.00 & 78.53 & 26.78 & 33.14 & 3 & 1997.0833 & 1997.0816 & 666.7011 & 0.0017 & 0.8500 & 1238.736 & 1073.543 & 741.605 & 1499.116 & \text { Yes } \\ \text { VLPSIVNEVLK } & 1.00 & 60.46 & 19.19 & 31.18 & 2 & 1497.9392 & 1497.9374 & 749.9760 & 0.0018 & 12000 & 837.475 & 893.138 & 43.164 & 994.178 & \text { Yes }\end{array}$

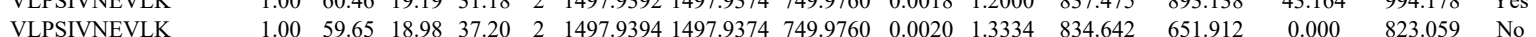

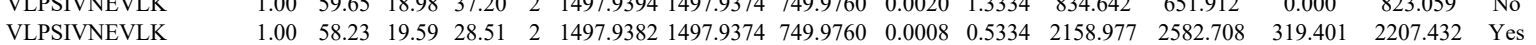



$\begin{array}{llllllllllllll} & 1042.6712 & 1042.6620 & 522.3383 & 0.0092 & 8.8065 & 7865.147 & 7549.525 & 1396.155 & 7939.119 & \text { Yes }\end{array}$

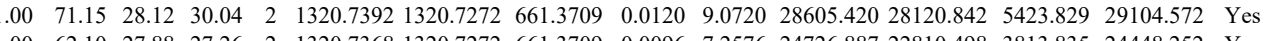
$\begin{array}{lllllllllllllll}1.00 & 62.10 & 27.88 & 27.26 & 2 & 1320.7368 & 1320.7272 & 661.3709 & 0.0096 & 7.2576 & 24726.887 & 22810.498 & 3813.835 & 24448.252 & \text { Yes }\end{array}$

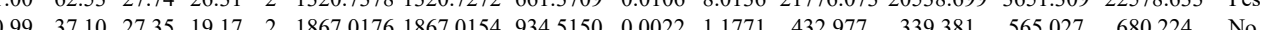
$\begin{array}{llllllllllllll} & 0\end{array}$

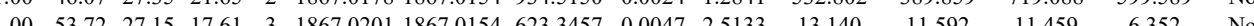

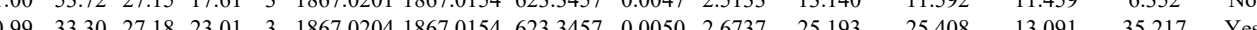
$\begin{array}{lllllllllllllll}1.00 & 68.42 & 27.80 & 27.83 & 2 & 1320.7348 & 1320.7272 & 661.3709 & 0.0076 & 5.7456 & 5702.122 & 6469.657 & 870.733 & 6282.136 & \text { Yes }\end{array}$ $\begin{array}{lllllllllllllll}1.00 & 68.42 & 27.80 & 27.83 & 2 & 1320.7348 & 132.7272 & 61.37 & 0.0076 & 5.7456 & 5702.122 & 6469.657 & 870.733 & 6282.136 & \text { Yes } \\ 1.00 & 73.89 & 27.99 & 27.76 & 2 & 1320.7362 & 1320.7272 & 661.3709 & 0.0090 & 6.8040 & 10041.584 & 8906.525 & 1502.006 & 9145.453 & \text { Yes }\end{array}$ $\begin{array}{lllllllllllllll}1.09 & 39.72 & 27.23 & 20.15 & 2 & 1867.0158 & 1867.0154 & 934.5150 & 0.0004 & 0.2140 & 151.460 & 159.106 & 213.919 & 274.251 & \text { No }\end{array}$ $\begin{array}{lllllllllllllll}0.99 & 35.58 & 27.26 & 20.13 & 2 & 1867.0162 & 1867.0154 & 934.5150 & 0.0008 & 0.4280 & 200.948 & 240.411 & 270.028 & 322.729 & \text { No }\end{array}$

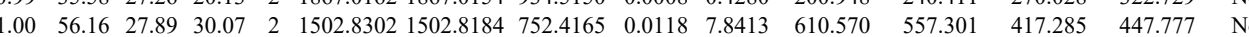

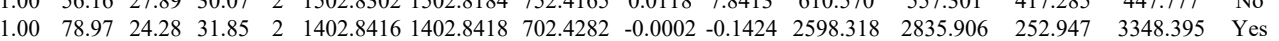
$\begin{array}{llllllllllllllll}1.00 & 73.25 & 24.23 & 29.19 & 2 & 1402.8420 & 1402.8418 & 702.4282 & 0.0002 & 0.1424 & 4870.226 & 4493.641 & 154.620 & 5683.467 & \text { Yes }\end{array}$ $\begin{array}{llllllllllllllll}1.00 & 76.11 & 24.28 & 29.33 & 2 & 1402.8418 & 1402.8418 & 702.4282 & 0.0000 & 0.0000 & 1659.807 & 1579.339 & 38.705 & 1831.466 & \text { Yes }\end{array}$ $\begin{array}{llllllllllllllll}0.96 & 27.75 & 22.76 & 20.91 & 2 & 1042.6622 & 1042.6620 & 522.3383 & 0.0002 & 0.1914 & 370.015 & 312.320 & 155.272 & 375.073 & \text { Yes }\end{array}$ $\begin{array}{lllllllllllllll}0.82 & 22.33 & 22.74 & 35.33 & 2 & 1042.6626 & 1042.6620 & 522.3383 & 0.0006 & 0.5743 & 179.606 & 204.777 & 64.246 & 243.085 & \text { Yes }\end{array}$

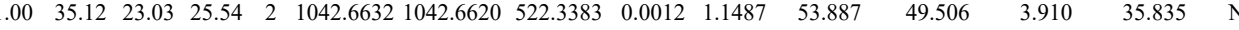
$\begin{array}{lllllllllllll}1.00 & 43.14 & 24.00 & 24.55 & 2 & 1042.6644 & 1042.6620 & 522.3383 & 0.0024 & 2.2974 & 124.700 & 129.777 & 7.600\end{array}$ $\begin{array}{lllllllllllllll}1.00 & 67.45 & 27.92 & 28.40 & 2 & 1502.8202 & 1502.8184 & 752.4165 & 0.0018 & 1.1961 & 6098.468 & 6750.194 & 3471.192 & 6474.752 & \text { Yes }\end{array}$ $\begin{array}{lllllllllllllll}1.00 & 62.34 & 27.87 & 29.71 & 2 & 1502.8204 & 1502.8184 & 752.4165 & 0.0020 & 1.3290 & 4335.133 & 4415.578 & 1440.695 & 5074.654 & \text { Yes }\end{array}$

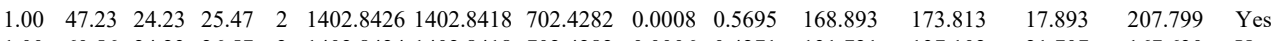
$\begin{array}{lllllllllllllll}1.00 & 60.56 & 24.23 & 26.57 & 2 & 1402.8424 & 1402.8418 & 702.4282 & 0.0006 & 0.4271 & 131.721 & 137.102 & 21.707 & 167.630 & \text { Yes }\end{array}$ $\begin{array}{lllllllllllllll}1.00 & 40.55 & 24.23 & 26.18 & 2 & 1402.8420 & 1402.8418 & 702.4282 & 0.0002 & 0.1424 & 57.960 & 63.973 & 8.487 & 73.271 & \text { Yes }\end{array}$

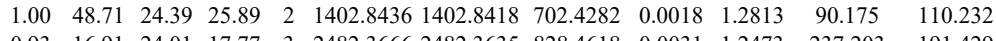
$\begin{array}{lllllllllllllll} & \text { LULGAGAVAYGVR } & 1.00 & 48.71 & 24.39 & 25.89 & 2 & 1402.8436 & 1402.8418 & 702.4282 & 0.0018 & 1.2813 & 90.175 & 11 \\ \end{array}$

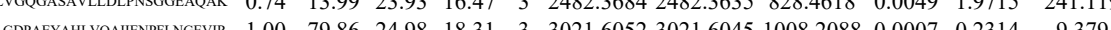

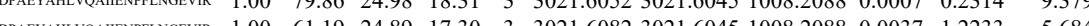

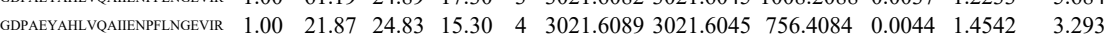
$\begin{array}{lllllllllll} & 0.35\end{array}$ $\begin{array}{lllllllllll} & 0\end{array}$

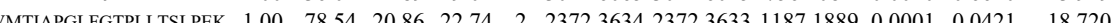

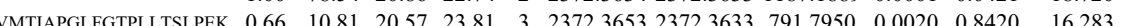
$\begin{array}{llllllllllll}\text { VMTIAPGLFGTPLLTSLPEK } & 0.64 & 70.69 & 20.86 & 83.69 & 2 & 232.3634 & 2372.3633 & 1187.1889 & 0.0001 & 0.0421 & 18.719\end{array}$ $\begin{array}{lllllllllllll}\text { VMTIAPGLFGTPLLTSLPEK } & 1.00 & 68.46 & 20.57 & 17.71 & 2 & 2372.3654 & 2372.3633 & 1187.1889 & 0.0021 & 0.8844 & 25.679\end{array}$

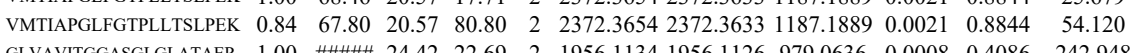
$\begin{array}{lllllllllll}\text { GLVAVITGGaAGLGLATAER } & 1.00 & \text { \#\#\#\# } 24.42 & 22.69 & 2 & 1956.1134 & 1956.1126 & 979.0636 & 0.0008 & 0.4086 & 242.948 \\ \end{array}$ $\begin{array}{llllllllllll}\text { GLVAVITGGASGLGLATAER } & 1.00 & 59.37 & 23.91 & 18.03 & 3 & 1956.1156 & 1956.1126 & 653.0448 & 0.0030 & 1.5313 & 121.860 \\ \text { GLVAVITGGASGLGLATAER } & 0.82 & \# \# \# \# & 24.42 & \# \# \# \# & 2 & 1956.1136 & 1956.1126 & 979.0636 & 0.0010 & 0.5107 & 144.706\end{array}$ $\begin{array}{lllllllllll}\text { GLVAVITGGASGLGLATAER } & 1.00 & \text { \#\#\#\# } 24.42 & 27.71 & 2 & 1956.1140 & 1956.1126 & 979.0636 & 0.0014 & 0.7150 & 86.334\end{array}$ $\begin{array}{llllllllllll}\text { GLVAVITGGASGLGLATAER } & 1.00 & 53.01 & 24.10 & 18.69 & 3 & 1956.1153 & 1956.1126 & 653.0448 & 0.0027 & 1.3782 & 255.429\end{array}$

$\begin{array}{lllllllllllll}\text { GLVAVITGGASGLGLATAER } & 1.00 & 73.69 & 24.10 & 20.94 & 3 & 1956.1153 & 1956.1126 & 653.0448 & 0.0027 & 1.3782 & 195.481 & 226.432 \\ \text { GGIVGMTLPIAR } & 1.00 & 58.71 & 25.37 & 27.78 & 2 & 1327.7782 & 1327.7768 & 664.8957 & 0.0014 & 1.0528 & 2909.177 & 2394.473\end{array}$ GIVGMTPIAR

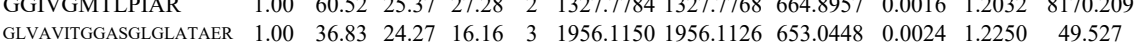
$\begin{array}{lllllllllllll}\text { GLVAVITGGASGLGLATAER } & 0.67 & 65.55 & 23.91 & 78.55 & 3 & 1956.1156 & 1956.1126 & 653.0448 & 0.0030 & 1.5313 & 50.027\end{array}$ $\begin{array}{llllllllllllll}\text { VCNFLASQVPFPSR } & 1.00 & 80.02 & 27.95 & 20.61 & 2 & 1753.8770 & 1753.8766 & 877.9456 & 0.0004 & 0.2278 & 108.790\end{array}$ $\begin{array}{lllllllllllll}\text { VCNFLASQVPFPSR } & 0.98 & 25.14 & 27.92 & 17.76 & 3 & 1753.8796 & 1753.8766 & 585.6328 & 0.0030 & 1.7076 & 46.171\end{array}$ VCNFLASQVPFPSR VCNFLASQVPFPSR VCNFLASQVPFPSR VCNFLASQVPFPSR
VCNFLASQVPFPSR $\begin{array}{llllllllllll}1.00 & 82.15 & 27.91 & 27.12 & 2 & 1753.8782 & 1753.8766 & 877.9456 & 0.0016 & 0.9112 & 347.455\end{array}$ $\begin{array}{lllllllllll}1.00 & 43.88 & 27.92 & 25.65 & 3 & 1753.8796 & 1753.8766 & 585.6328 & 0.0030 & 1.7076 & 58.807\end{array}$

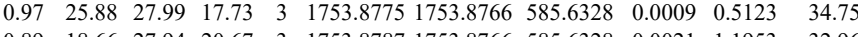
$\begin{array}{lllllllllll} & \end{array}$

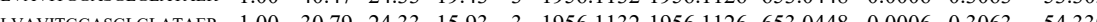

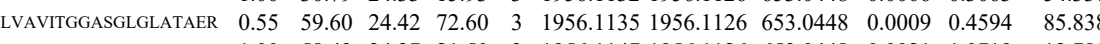




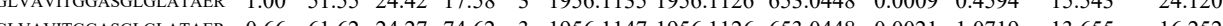

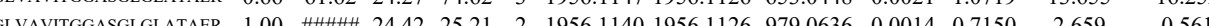
$\begin{array}{llllllllllllll}\text { GLVAVITGGASGLGLATAER } & 0.84 & 79.24 & 24.27 & 92.24 & 2 & 1956.1144 & 1956.1126 & 979.0636 & 0.0018 & 0.9192 & 6.309 & 5.411\end{array}$ $\begin{array}{llllllllllllll} & & 1.00 & 54.30 & 23.87 & 18.28 & 3 & 1956.1162 & 1956.1126 & 653.0448 & 0.0036 & 1.8375 & 15.650 & 13.221\end{array}$

$\begin{array}{lllllllllll}0.89 & 27.70 & 26.93 & 25.67 & 2 & 1049.5234 & 1049.5233 & 525.7689 & 0.0001 & 0.0951 & 54.704\end{array}$

MFVGGLSWDTSK

MFVGGLSWDTSK

MFVGGLSWDTSK

GFVFITFK

GFVFITFK

GFGFILFK

GFVFITFK

GFGFILFK

GFGFILFK

GFVFITFK

GFGFILFK

$\begin{array}{lllllllllll}\text { NP1L4_HUMAN } & \text { Q99733 } & \text { NAP1L4 } & \text { Nucleosome assen } 42.823 & 1.00 & 6 & 24.5 & -0.1433 & 0.5807 & 1.1488 & 0.4057\end{array}$

AAATAEEPDPK

AAATAEEPDK

NVDMLSELVQEYDEPILK

NVDMLSELVQEYD

LTDQVMQNPR

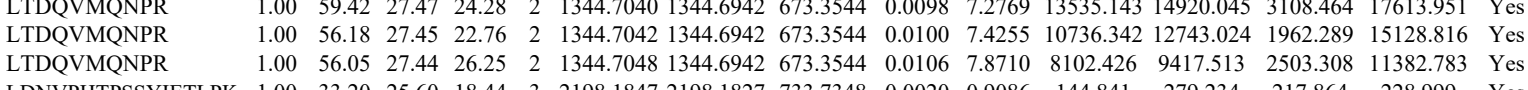

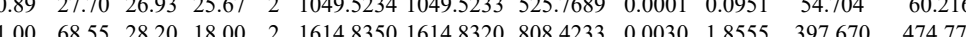

$\begin{array}{lllllllllllll}1.00 & 54.03 & 28.20 & 19.75 & 2 & 1614.8354 & 1614.8320 & 808.4233 & 0.0034 & 2.1029 & 159.380 & 162.402\end{array}$

$\begin{array}{lllllllllllll}1.00 & 66.33 & 28.08 & 19.27 & 2 & 1614.8334 & 16148320 & 808.4233 & 0.0014 & 0.8659 & 1657.269 & 19746.670\end{array}$

$\begin{array}{lllllllllllllll}1.00 & 70.09 & 28.12 & 25.27 & 2 & 1614.8338 & 1614.8320 & 808.4233 & 0.0018 & 1.1133 & 2442.334 & 2649.722 & 0\end{array}$

$\begin{array}{llllllllllllll}1.00 & 44.53 & 25.79 & 24.78 & 2 & 1245.7364 & 1245.7365 & 623.8755 & -0.0001 & -0.0801 & 7242.784 & 10922.737 & 21\end{array}$ $\begin{array}{llll} & 0.4830 .483 & 6003.249 & 27130.312 \quad \text { Yes }\end{array}$ $\begin{array}{llllllllllllllllll}1.00 & 47.77 & 25.34 & 23.03 & 2 & 1215.7274 & 1215.7260 & 608.8703 & 0.0014 & 1.1497 & 15943.612 & 21858.513 & 7128.480 & 27112.012 & \text { Yes }\end{array}$ $\begin{array}{lllllllllllllll}1.00 & 44.55 & 25.73 & 25.33 & 2 & 1245.7374 & 1245.7365 & 623.8755 & 0.0009 & 0.7213 & 13574.503 & 17399.667 & 5021.951 & 23234.210 & \text { Yes }\end{array}$ $\begin{array}{lllllllllllllll}1.00 & 41.30 & 25.35 & 24.01 & 2 & 1215.7268 & 1215.7260 & 608.8703 & 0.0008 & 0.6570 & 19333.326 & 24897.861 & 8653.976 & 29088.380 & \text { Yes }\end{array}$ $\begin{array}{llllllllllllllll}1.00 & 39.39 & 25.33 & 20.89 & 2 & 1215.7284 & 1215.7260 & 608.8703 & 0.0024 & 1.9709 & 11371.226 & 15434.008 & 5502.444 & 18980.806 & \text { Yes }\end{array}$ $\begin{array}{llllllllllllllll}1.00 & 44.28 & 25.73 & 25.03 & 2 & 1245.7374 & 1245.7365 & 623.8755 & 0.0009 & 0.7213 & 4529.883 & 5326.755 & 1676.317 & 8021.342 & \text { Yes }\end{array}$ $\begin{array}{lllllllllllllll}1.00 & 48.03 & 25.34 & 24.24 & 2 & 1215.7270 & 1215.7260 & 608.8703 & 0.0010 & 0.8212 & 3564.128 & 4591.649 & 1628.243 & 5838.744 & \text { Yes }\end{array}$ $\begin{array}{lllllllllllllll}1.00 & 39.13 & 25.34 & 20.74 & 2 & 1215.7270 & 1215.7260 & 608.8703 & 0.0010 & 0.8212 & 5824.079 & 6979.490 & 2086.695 & 7920.925 & \text { Yes }\end{array}$

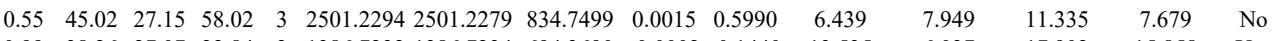

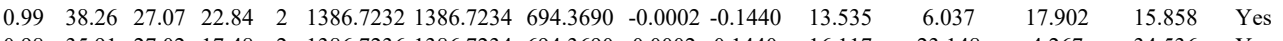
$\begin{array}{lllllllllllllll}0.98 & 35.91 & 27.02 & 17.48 & 2 & 1386.7236 & 1386.7234 & 694.3690 & 0.0002 & 0.1440 & 16.117 & 23.148 & 4.267 & 34.536 & \text { Yes }\end{array}$

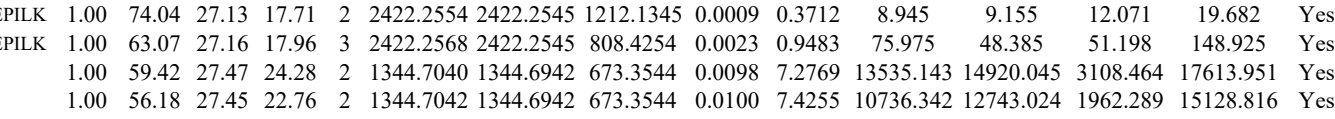
$\begin{array}{llllllllllllllll} & \end{array}$ $\begin{array}{lllllllllllllllll} & 27.62 & 21.08 & 3 & 2115.1078 & 2115.1033 & 706.0417 & 0.0045 & 2.1245 & 108.519 & 163.512 & 0.000 & 101.927 & \text { No }\end{array}$ $\begin{array}{llllllllllllll} & \end{array}$ $\begin{array}{lllllllllllllllll}\text { QVPNESFFNFFNPLK } & 1.00 & 50.21 & 27.63 & 20.18 & 2 & 2115.1074 & 2115.1033 & 1058.5589 & 0.0041 & 1.9366 & 714.726 & 788.357 & 0.000 & 903.673 & \text { No }\end{array}$ $\begin{array}{lllllllllllllllll} & \text { QVPNESFFNFFNPLK } & 1.00 & 46.39 & 27.61 & 18.64 & 3 & 2115.1081 & 2115.1033 & 706.0417 & 0.0048 & 2.2661 & 195.141 & 187.924 & 12.898 & 174.721 & \text { Yes }\end{array}$ $\begin{array}{llllllllllllllll}\text { QVPNESFFNFFNPLK } & 1.00 & 52.71 & 27.49 & 23.82 & 3 & 2115.1054 & 2115.1033 & 706.0417 & 0.0021 & 0.9914 & 179.891 & 243.976 & 49.013 & 144.728 & \text { Yes }\end{array}$ $\begin{array}{llllllllllllll}\text { QVPNESFFNFFNPLK } & 0.99 & 27.79 & 27.68 & 23.37 & 3 & 2115.1069 & 2115.1033 & 706.0417 & 0.0036 & 1.6996 & 237.920 & 157.232 & 6.5 \\ \text { GIPEFWFTIFR } & 1.00 & 57.47 & 27.72 & 20.33 & 2 & 1555.8328 & 1555.8309 & 778.9227 & 0.019 & 1.2196 & 35.860 & 26.937 & 2.77\end{array}$

NVDMLSELVEEY
LQLLEPFDK

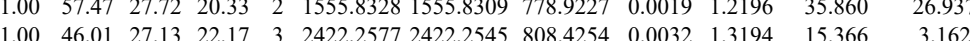
$\begin{array}{llllllll} & \end{array}$ $\begin{array}{lllllllllllll} & & \end{array}$ $\begin{array}{lllllllllllllll} & \end{array}$ $\begin{array}{llllllllllllll} & \text { VAMQDATAQMAMLLFISSGLSK } & 0.58 & 11.11 & 27.19 & 15.43 & 3 & 2615.3389 & 2615.3365 & 872.7861 & 0.0024 & 0.9166 & 4.695 & 5.693 \\ \end{array}$ $\begin{array}{lllllllllllll}\text { VAMDATAQMAMLOFISSGLSK } & 0.60 & 33.49 & 27.16 & 46.49 & 3 & 2615.3407 & 2615.3365 & 872.7861 & 0.0042 & 1.6041 & 10.481 & 19.718 \\ \text { LEAPDADELPK } & 1.00 & 59.55 & 28.07 & 25.72 & 2 & 1484.7994 & 14847966 & 743.4056 & 0.0028 & 1.8832 & 417.894 & 252.276\end{array}$ LEAPDADELPK

VVTMEVEAR NCSSPEFSK NCSSPEFSK GTITVSAQELK SDPFLEFFR SDPFLEFFR SDPFLEFFR SDPFLEFFR $\begin{array}{llllllllllll}1.00 & 59.55 & 28.07 & 25.72 & 2 & 1484.7994 & 1484.7966 & 743.4056 & 0.0028 & 1.8832 & 417.894 & 252.276 \\ 1.00 & 79.74 & 27.99 & 26.60 & 2 & 1484.7998 & 1484.7966 & 743.4056 & 0.0032 & 2.1523 & 772.315 & 468.405\end{array}$ $\begin{array}{llllllllllll}1.00 & 79.74 & 27.99 & 26.60 & 2 & 1484.7998 & 1484.7966 & 743.4056 & 0.0032 & 2.1523 & 772.315 & 468.405 \\ 0.99 & 45.50 & 28.36 & 31.22 & 2 & 1176.6406 & 1176.6294 & 589.3220 & 0.0112 & 9.5024 & 6993.999 & 9478.573\end{array}$ $\begin{array}{lllllllllllllll}0.99 & 42.48 & 25.25 & 21.37 & 2 & 1331.6198 & 1331.6093 & 666.8119 & 0.0105 & 7.8732 & 11274.545 & 17398.680 & 3194.793 & 18519.117 & \text { Yes }\end{array}$ $\begin{array}{lllllllllllllll}1.00 & 50.78 & 25.38 & 21.72 & 2 & 1331.6206 & 1331.6093 & 666.8119 & 0.0113 & 8.4731 & 8259.156 & 12754.284 & 1962.702 & 14137.029 & \text { Yes }\end{array}$ $\begin{array}{lllllllllllllllll}1.00 & 59.23 & 25.63 & 29.49 & 2 & 1433.8470 & 1433.8333 & 717.9239 & 0.0137 & 9.5413 & 755.142 & 1385.221 & 797.885 & 1114.050 & \text { Yes }\end{array}$

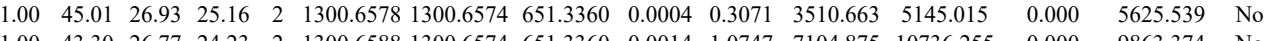
$\begin{array}{lllllllllllllll}1.00 & 43.30 & 26.77 & 24.23 & 2 & 1300.6588 & 1300.6574 & 651.3360 & 0.0014 & 1.0747 & 7104.875 & 10736.255 & 0.000 & 9863.374 & \text { No }\end{array}$

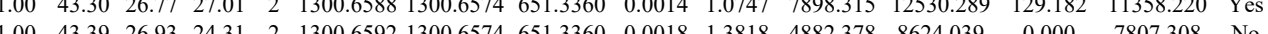
$\begin{array}{lllllllllllllll}1.07 & 43.39 & 26.93 & 24.31 & 2 & 1300.6592 & 1300.6574 & 651.3360 & 0.0018 & 1.3818 & 4882.378 & 8624.039 & 0.000 & 7807.308 & \text { No }\end{array}$ $\begin{array}{llllllllllll}79.07 & 27.87 & 20.24 & 2 & 2361.1594 & 2361.1579 & 1181.5862 & 0.0015 & 0.6347 & 51.925 & & \\ 10\end{array}$ $\begin{array}{llllllllllllllll}\text { SDPLCVLLDVGGGSWAELGR } & 1.00 & 87.94 & 27.77 & 21.30 & 3 & 2361.1609 & 2361.1579 & 788.0599 & 0.0030 & 1.2689 & 7.120 & 10.992 & 16.860 & 22.871 & \text { Yes }\end{array}$

Table S-4 page 546 of 614 
$\begin{array}{llllllllllll} & \\ 0\end{array}$

$\begin{array}{lllllllllllll} & \end{array}$

$\begin{array}{lllllllllllllll} & \\ 0\end{array}$

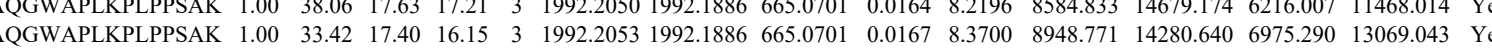

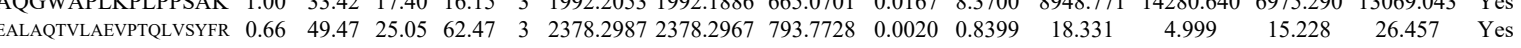
$\begin{array}{llllllllll} & 0\end{array}$ $\begin{array}{lllllllllll} & \end{array}$ $\begin{array}{llllllllllllll} & \text { YYGPTNFAPINHVAR } & 0.64 & 96.23 & 26.61 & \text { \#\#\#\# } & 2 & 19260598 & 1926.0597 & 964.0371 & 0.0001 & 0.0519 & 359.184\end{array}$

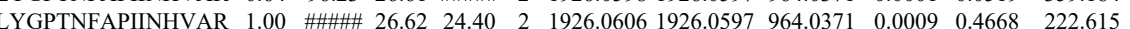

$\begin{array}{lllllllllllll}\text { LYGPTNFAPIINHVAR } & 1.00 & 42.98 & 26.55 & 25.43 & 3 & 1926.0610 & 1926.0597 & 643.0272 & 0.0013 & 0.6739 & 487.450\end{array}$ $\begin{array}{lllllllllllll}\text { LYGPTNFAPIINHVAR } & 0.93 & 19.12 & 26.58 & 14.22 & 3 & 1926.0625 & 1926.0597 & 643.0272 & 0.0028 & 1.4515 & 38.394 \\ \text { LYGPTNFAPINHVAR } & 0.53 & 9.48 & 26.47 & 18.82 & 3 & 1926.0616 & 1926.0597 & 643.0272 & 0.0019 & 0.9849 & 44.868\end{array}$ \begin{tabular}{llllllllllll} 
LYGPTNFAPIINHVAR & 0.53 & 9.48 & 26.47 & 18.82 & 3 & 1926.0616 & 1926.0597 & 643.0272 & 0.001 & 0.4515 & 38.394 \\
\hline
\end{tabular}

$\begin{array}{llllllllllllll}\text { LYGPTNFAPIINHVAR } & 0.99 & 30.75 & 26.58 & 18.55 & 3 & 1926.0607 & 1926.0597 & 643.0272 & 0.0010 & 0.5184 & 25.638\end{array}$

LYGPTNFAPIINHVAR $1.00 \quad 32.1226 .4720 .71 \quad 3 \quad 1926.06161926 .0597 \quad 643.0272 \quad 0.0019 \quad 0.9849 \quad 29.286$

LYGPTNFAPIINHVAR $0.99 \begin{array}{llllllllllllll}24.11 & 26.61 & 20.31 & 3 & 1926.0598 & 1926.0597 & 643.0272 & 0.0001 & 0.0518 & 25.74\end{array}$

$\begin{array}{lllllllllllll}\text { LYGPTNFAPIINHVAR } & 1.00 & 45.23 & 26.61 & 23.80 & 3 & 1926.0598 & 1926.0597 & 643.0272 & 0.0001 & 0.0518 & 31.318\end{array}$

$\begin{array}{lllllllllllll}\text { LYGPTNFAPIINHVAR } & 0.53 & 18.69 & 26.57 & 29.88 & 3 & 1926.0601 & 1926.0597 & 643.0272 & 0.0004 & 0.2074 & 16.605\end{array}$

$\begin{array}{llllllllllllll}\text { LYGPTNFAPIINHVAR } & 0.92 & 20.69 & 26.55 & 21.97 & 3 & 1926.0610 & 1926.0597 & 643.0272 & 0.0013 & 0.6739 & 21.825 \\ \text { LYGPTNFAPIINHVAR } & 0.99 & 28.64 & 26.58 & 26.25 & 3 & 1926.0625 & 1926.0597 & 643.0272 & 0.0028 & 1.4515 & 18.955\end{array}$

$\begin{array}{lllllllllllll}\text { LYGPTNFAPIINHVAR } & 0.99 & 28.64 & 26.58 & 26.25 & 3 & 1926.0625 & 1926.0597 & 643.0272 & 0.0028 & 1.4515 & 18.955\end{array}$

CQVFEETQIGGER $\begin{array}{llllllllllll}1.00 & 67.41 & 24.93 & 23.80 & 2 & 1684.7684 & 1684.7671 & 843.3908 & 0.0013 & 0.7707 & 275.147\end{array}$ $\begin{array}{lllllllllllllll} & \end{array}$ $\begin{array}{llllllllllll}\text { SQDAEVGDGTTVVTLLAAEFLK } & 1.00 & 92.89 & 26.61 & 29.12 & 2 & 2539.3274 & 2539.3261 & 1270.6703 & 0.0013 & 0.5115 & 4.053 \\ \text { SQDAEVGGGTTSUTLAAFFLK } & 0.97 & 13.31 & 26.67 & 23.03 & 4 & 2539.3309 & 2539.3261 & 635.8388 & 0.0048 & 1.8873 & 106.913\end{array}$

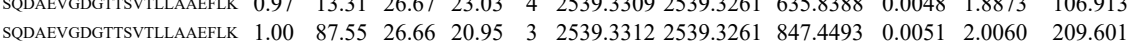

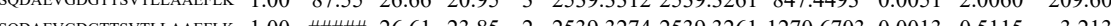
$\begin{array}{llllllllllll}1.00 & 87.02 & 26.64 & 22.79 & 3 & 2539.3300 & 2539.3261 & 847.4493 & 0.0039 & 1.5340 & 47.119\end{array}$

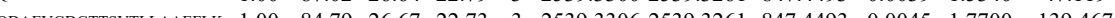

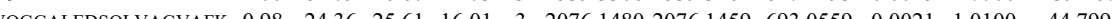
$\begin{array}{llllllllll} & 0.74 .790\end{array}$

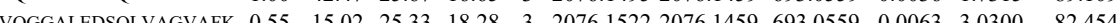
$\begin{array}{llllllllllll}\text { VQGGALEDSQLVAGVAFK } & 0.99 & 31.09 & 25.33 & 19.42 & 3 & 2076.1522 & 2076.1459 & 6930559 & 0.0063 & 3.0300 & 57.632\end{array}$ $\begin{array}{cc}82.454 & 54.063 \\ 57.632 & 37.750 \\ 1.886 & 4858.000\end{array}$ LLDVVHPAAK LLDVVHPAAK LLDVVHPAAK $\begin{array}{llllllllllll}1.00 & 41.42 & 21.43 & 20.54 & 3 & 1349.8393 & 1349.8275 & 450.9498 & 0.0118 & 8.7223 & 4401.886 & 4858.000 \\ 1.00 & 70.56 & 21.21 & 35.18 & 2 & 1349.8402 & 1349.8275 & 675.9210 & 0.0127 & 9.3945 & 2855.222 & 3195.237\end{array}$ $\begin{array}{lllllllllllll} & 1.00 & 70.53 & 21.21 & 35.72 & 2 & 1349.8406 & 1349.8275 & 675.9210 & 0.0131 & 9.6904 & 3108.444 & 3128.313\end{array}$ $\begin{array}{llllllllll} & (3.650 & 7517.569\end{array}$ $\begin{array}{llllllllllllll}\text { TFSYAGFEMQPK } & 1.00 & 63.64 & 28.12 & 29.62 & 2 & 1692.8582 & 1692.8425 & 847.4285 & 0.0157 & 9.2632 & 384.589 & 666.369\end{array}$ $\begin{array}{lllllllllllll}\text { QLCDNAGFDATNILNK } & 1.00 & 92.24 & 27.60 & 23.43 & 2 & 2070.0114 & 2070.0118 & 1036.0132 & -0.0004 & -0.1930 & 1972.150 & 2311.54\end{array}$ $\begin{array}{llllllllllll} & 27.62 & 23.29 & 2 & 2070.0134 & 2070.0118 & 1036.0132 & 0.0016 & 0.7722 & 1575.197 & 1811.927\end{array}$

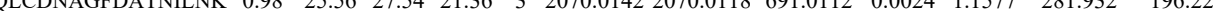
$\begin{array}{llllllllllllll} & \text { QLCDNAGFDATNILNK } & 0.99 & 31.32 & 27.61 & 27.19 & 3 & 2070.0160 & 2070.0118 & 61.0112 & 0.0042 & 2.0260 & 281.008 & 258.132\end{array}$ INALTAASEAACLIVSVD $\begin{array}{lllllllllll}0.66 & 13.51 & 26.02 & 26.51 & 3 & 2565.3658 & 2565.3637 & 856.1285 & 0.0021 & 0.8176 & 8.919\end{array}$ $\begin{array}{lllllllllllllll} & 0.99 & 31.44 & 21.43 & 18.32 & 3 & 1349.8396 & 1349.8275 & 450.9498 & 0.0121 & 8.9440 & 1412.032 & 157\end{array}$

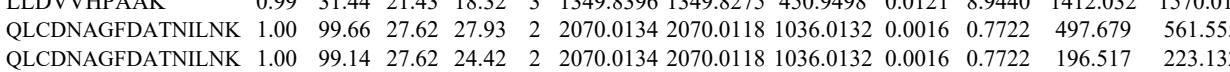
$\begin{array}{lllllllllllll} & 0.07\end{array}$ $\begin{array}{llllllllllllll} & \text { ALTAASEAACLIVSVDETIK } & 0.99 & 30.18 & 26.01 & 16.78 & 3 & 2565.3643 & 2565.3637 & 856.1285 & 0.0006 & 0.2336 & 19.749 & 3.450\end{array}$

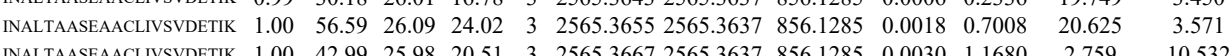

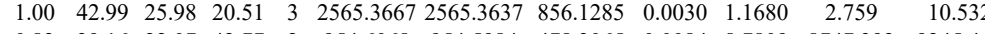
ALEIIPR $\begin{array}{lllllllllllll}0.82 & 39.16 & 22.07 & 42.77 & 2 & 954.6068 & 954.5984 & 478.3065 & 0.0084 & 8.7809 & 8747.392 & 9245.442 & 92\end{array}$ $\begin{array}{lllllllllllll}\text { ALEIIPR } & 0.89 & 35.59 & 21.27 & 38.12 & 2 & 954.6072 & 954.5984 & 478.3065 & 0.0088 & 9.1990 & 9407.126 & 11893.893 \\ \text { INALTAASEAACLIVSVDETIK } & 0.55 & 12.32 & 26.13 & 25.32 & 3 & 2565.3646 & 2565.3637 & 856.1285 & 0.0009 & 0.3504 & 7.786 & 12.892\end{array}$

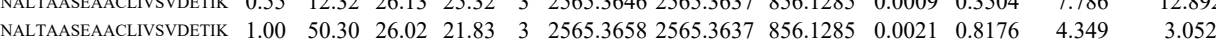

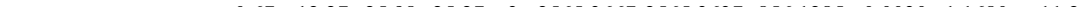

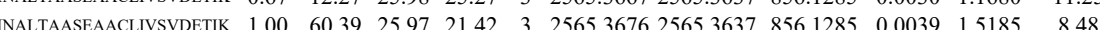

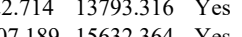


$\begin{array}{lllllllllllllllll} & \text { ALEIIPR } & 0.54 & 33.67 & 23.46 & 42.58 & 2 & 954.6052 & 954.5984 & 478.3065 & 0.0068 & 7.1084 & 6470.045 & 8248.053 & 229.828 & 11087.947 & \text { Y }\end{array}$ $\begin{array}{llllllllllllllllll}\text { LPIGDVATQYFADR } & 1.00 & 48.63 & 28.08 & 25.53 & 2 & 1708.8916 & 1708.8906 & 855.4526 & 0.0010 & 0.5845 & 982.594 & 1046.286 & 9310.666 & 1338.459 & \text { Yce }\end{array}$ $\begin{array}{llllllllllllllllllll}\text { LPIGDVATQYFADR } & 0.94 & 27.34 & 28.08 & 27.33 & 2 & 1708.8916 & 1708.8906 & 855.4526 & 0.0010 & 0.5845 & 680.838 & 654.131 & 3988.190 & 954.946 & \text { No }\end{array}$ $\begin{array}{lllllllllllllll} & \end{array}$ $\begin{array}{lllllllllllll} & \end{array}$ $\begin{array}{lll}2.066 & 49.631 & 37.004\end{array}$

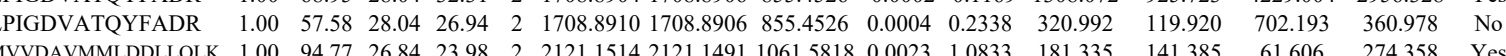
$\begin{array}{lllllllllllll} & \end{array}$ $\begin{array}{llllllllllllllll} & \end{array}$

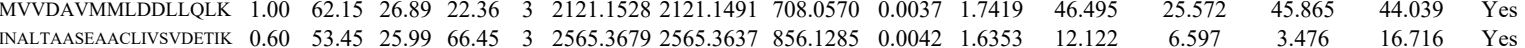
$\begin{array}{llllllllllllllll}\text { NALTAASEAACLIVSYDETIK } & 1.00 & 63.83 & 25.98 & 20.86 & 3 & 2565.3685 & 2565.3637 & 856.1285 & 0.0048 & 1.8689 & 5.461 & 8.130 & 19.947 & 0.000 & \text { No }\end{array}$ $\begin{array}{lllllllllllllllll}\text { QQLLIGAYAK } & 1.00 & 57.59 & 23.80 & 25.30 & 2 & 1391.8464 & 1391.8380 & 696.9263 & 0.0084 & 6.0264 & 8726.967 & 9117.258 & 469.546 & 9531.246 & \text { Yes }\end{array}$

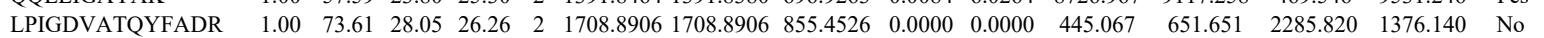
$\begin{array}{lllllllllllllllll}\text { LPIGDVATQYFADR } & 1.00 & 75.10 & 28.08 & 28.18 & 2 & 1708.8924 & 1708.8906 & 855.4526 & 0.0018 & 1.0521 & 198.484 & 138.871 & 520.392 & 451.799 & \text { Yes }\end{array}$ \begin{tabular}{lllllllllllllllll} 
MVVDAVMMLDDLLQLK & 1.00 & 82.48 & 26.84 & 23.37 & 2 & 2121.1514 & 2121.1491 & 1061.5818 & 0.0023 & 1.0833 & 31.656 & 71.298 & 23.320 & 96.086 & Yes \\
\hline
\end{tabular}

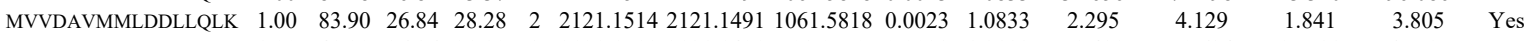

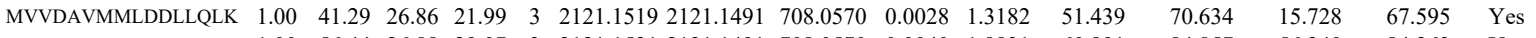
$\begin{array}{lllllllllllllllll}\text { MVVDAVMMLDDLLQLK } & 1.00 & 56.44 & 26.88 & 29.07 & 3 & 2121.1531 & 2121.1491 & 708.0570 & 0.0040 & 1.8831 & 60.991 & 84.857 & 56.340 & 84.263 & \text { Yes }\end{array}$

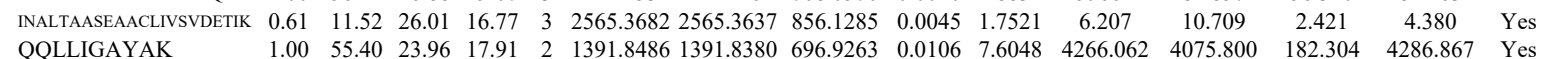
\begin{tabular}{llllllllllllllll} 
MVVDAVMMLDDLLQLK & 1.00 & 55.40 & 23.96 & 17.91 & 2 & 1391.8486 & 1391.8380 & 696.9263 & 0.0106 & 7.6048 & 4266.062 & 4075.800 & 182.304 & 4286.867 & Yes \\
\hline
\end{tabular}

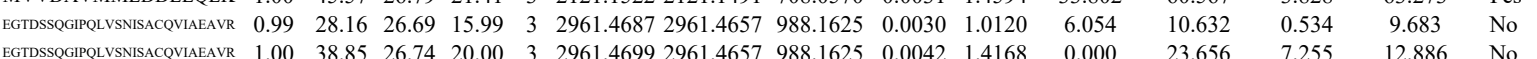

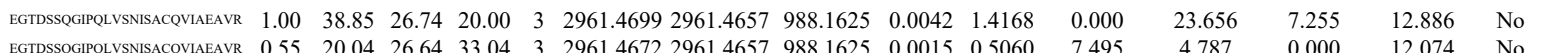

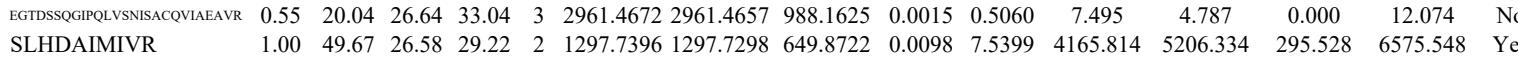
$\begin{array}{lllllllllllllll} & & & \end{array}$ $\begin{array}{llllllllllllllllll} & \text { SLHDAIMIVR } & 1.00 & 59.07 & 26.43 & 29.52 & 3 & 1297.7416 & 1297.7298 & 433.5839 & 0.0118 & 9.0716 & 4051.691 & 3087.415 & 4526.195 & 10036.840 & \text { Yes }\end{array}$

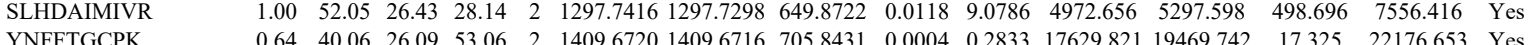
$\begin{array}{llllllllllllllllll} & \text { YNFFTGCPK } & 0.64 & 40.06 & 26.09 & 53.06 & 2 & 1409.6720 & 1409.6716 & 705.8431 & 0.0004 & 0.2833 & 17629.821 & 19469.742 & 17.325 & 22176.653 & \text { Yes } \\ \text { YNFFTGCPK } & 0.82 & 45.94 & 26.03 & 58.94 & 2 & 1409.6726 & 1409.6716 & 705.8431 & 0.0010 & 0.7084 & 11379.731 & 13540294 & 1026.038 & 13988.188 & \text { Yes }\end{array}$

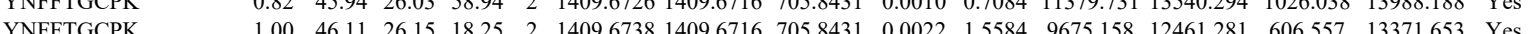
$\begin{array}{llllllllllllllll}\text { YNFFTGCPK } & 0.72 & 43.49 & 26.16 & 56.49 & 2 & 1409.6744 & 1409.6716 & 705.8431 & 0.0028 & 1.9834 & 4837.493 & 5524.097 & 158.554 & 6352.032 & \text { Yes }\end{array}$

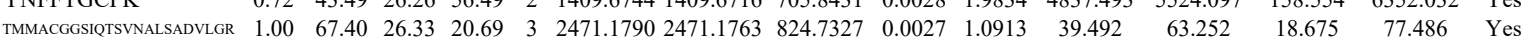
$\begin{array}{llllllllllllllll}\text { MMACGGSITSYNALSADVLGR } & 1.00 & 69.93 & 26.35 & 20.53 & 3 & 2471.1793 & 2471.1763 & 824.7327 & 0.0030 & 1.2125 & 76.454 & 52.263 & 11.257 & 68.486 & \text { YeS }\end{array}$ $\begin{array}{lllllllllllllllll}\text { TMMACGGSITSVNALSADVLGR } & 1.00 & 55.01 & 26.32 & 16.59 & 3 & 2471.1781 & 2471.1763 & 824.7327 & 0.0018 & 0.7275 & 22.934 & 42.973 & 90.961 & 16.420 & \text { No }\end{array}$

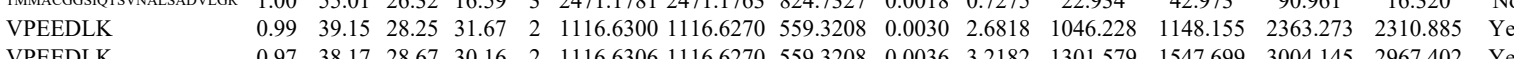
$\begin{array}{lllllllllllllllll}\text { VPEEDLK } & 0.97 & 38.17 & 28.67 & 30.16 & 2 & 1116.6306 & 1116.6270 & 559.3208 & 0.0036 & 3.2182 & 1301.579 & 1547.699 & 3004.145 & 2967.402 & \text { Yes }\end{array}$ $\begin{array}{llllllllllllllll}\text { GGAEQFMEETER } & 1.00 & 64.41 & 24.17 & 28.70 & 2 & 1526.6886 & 1526.6793 & 764.3469 & 0.0093 & 6.0836 & 265.024 & 302.801 & 360.959 & 380.804 & \text { Yes }\end{array}$ TCTFILR TCTFILR TCTFILR $\begin{array}{lllllllllllllll}1.00 & 63.94 & 24.39 & 25.79 & 2 & 1526.6898 & 1526.6793 & 764.3469 & 0.0105 & 6.8686 & 172.672 & 289.732 & 360.959 & 380.804 & \text { Yes } \\ & & \\ 0 & 28.435 & \text { Yes }\end{array}$

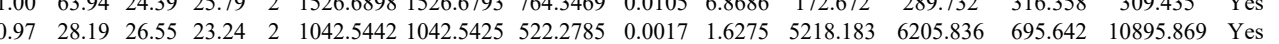
$\begin{array}{lllllllllllllllll}0.97 & 28.13 & 26.46 & 25.85 & 2 & 1042.5448 & 1042.5425 & 522.2785 & 0.0023 & 2.2019 & 7202.461 & 8637.549 & 780.948 & 14745.442 & \text { Yes }\end{array}$ $\begin{array}{llllllllllllllll}0.95 & 26.22 & 26.45 & 26.42 & 2 & 1042.5446 & 1042.5425 & 522.2785 & 0.0021 & 2.0104 & 7178.314 & 9030.309 & 678.604 & 14335.065 & \text { Yes } \\ 0.95 & 26.53 & 26.46 & 23.33 & 2 & 10425448 & 10425425 & 522.2785 & 0.0023 & 22019 & 6049.115 & 6349.707 & 418.573 & 11087.181 & \text { Ys }\end{array}$

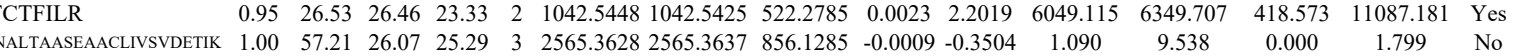
$\begin{array}{llllllllllllllll}\text { TMMACGGSIPSVNALSADVLGR } & 1.00 & 32.73 & 26.32 & 16.72 & 3 & 2471.1781 & 2471.1763 & 824.7327 & 0.0018 & 0.7275 & 3.948 & 3.848 & 0.000 & 1.799 & \text { No }\end{array}$

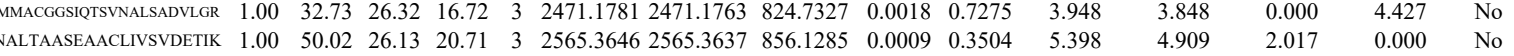
$\begin{array}{llllllllllllllll} & & & \end{array}$

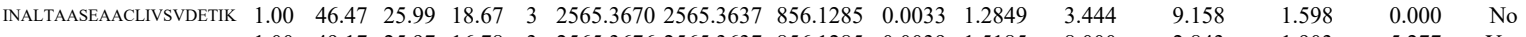

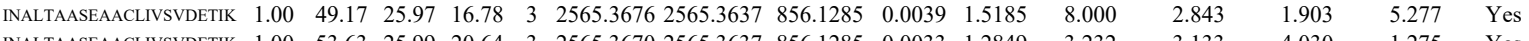
\begin{tabular}{llllllllllllll} 
& 1.275 & Yes \\
\hline
\end{tabular}

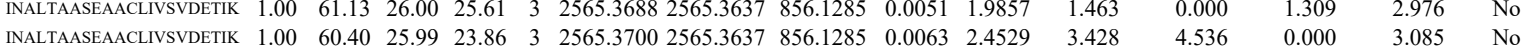

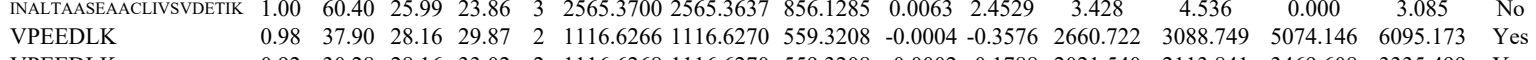

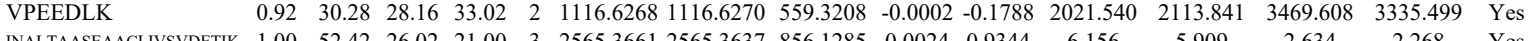
$\begin{array}{lllllllllllllll} & & & \end{array}$ $\begin{array}{lllllllllllllll} & \text { NALIAASEAACLIVVDETIK } \\ 1.00 & 41.94 & 26.02 & 16.02 & 3 & 2565.3661 & 2565.3637 & 856.1285 & 0.0024 & 0.9344 & 1.517 & 1.909 & 3.832 & 0.000 & \text { No }\end{array}$

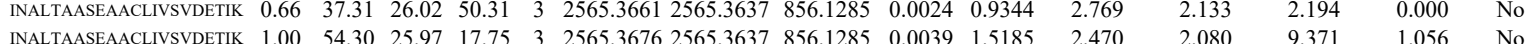

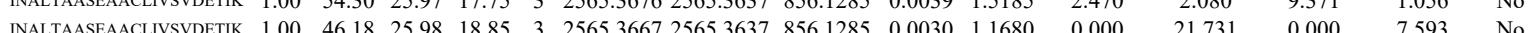

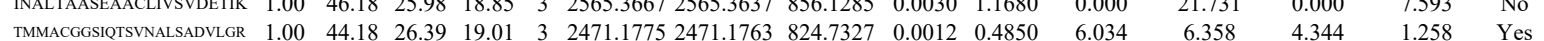

Table S-4 page 548 of 614 
$\begin{array}{llllllllll}\text { EBP2 HUMAN } & \text { Q99848 } & \text { EBNA1BP: Probable rRNA-pr 34.852 } & 1.00 & 5 & 21.9 & -0.2429 & 0.2639 & 0.7867 & 0.3202\end{array}$

$\begin{array}{lllllllllll}\text { ANM1_HUMAN } & \text { Q99873 } & \text { PRMT1 } & \text { Protein arginine N } 41.516 & 1.00 & 4 & 11.4 & -0.4064 & 0.2189 & 2.3849 & 0.2778\end{array}$

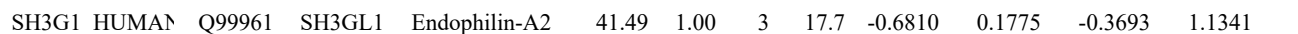

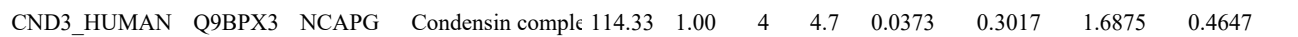

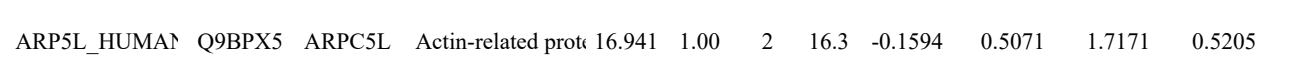

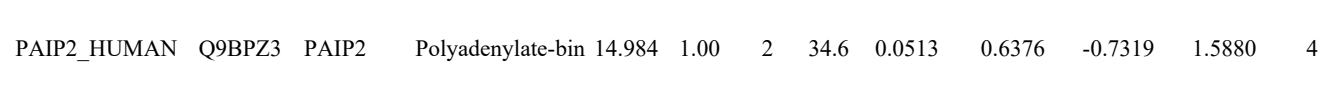

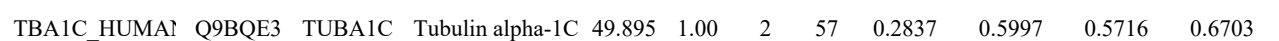

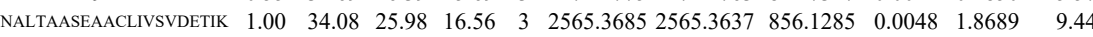
$\begin{array}{lllllllllllll} & 0.99 & 33.29 & 26.36 & 19.87 & 3 & 2471.1766 & 2471.1763 & 824.7327 & 0.0003 & 0.1213 & 6.158\end{array}$

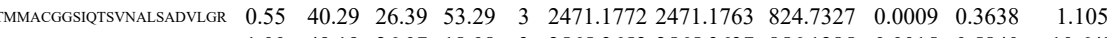
$\begin{array}{llllllllllll}\text { INALTAASEAACLIVSVDETIK } & 1.00 & 49.19 & 26.07 & 18.08 & 3 & 2565.3652 & 2565.3637 & 856.1285 & 0.0015 & 0.5840 & 10.647\end{array}$

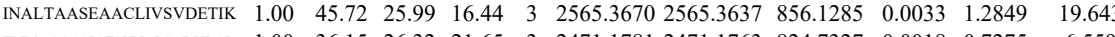

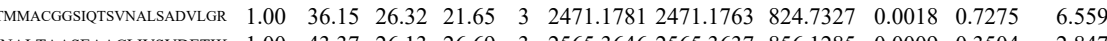
$\begin{array}{lllllllllllll}\text { NALTAASEAACLNSVDETIK } & 1.00 & 43.37 & 26.13 & 26.69 & 3 & 2565.3646 & 2565.3637 & 856.1285 & 0.0009 & 0.3504 & 2.847\end{array}$

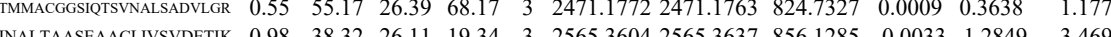

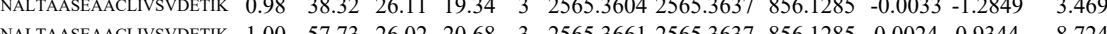

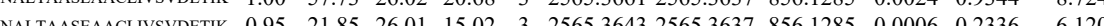

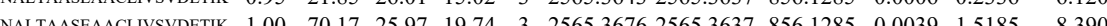

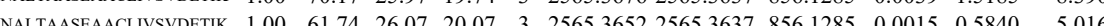
$\begin{array}{llllllllllll} & \text { NDSVVAGGG }\end{array}$

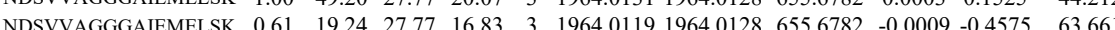
$\begin{array}{lllllllllllll}\text { NDSVVAGGGAIEMELSK } & 0.71 & 13.93 & 27.75 & 15.26 & 3 & 1964.0158 & 1964.0128 & 655.6782 & 0.0030 & 1.5251 & 113.453\end{array}$ $\begin{array}{lllllllllllll}\text { NDSVVAGGGAIEMELSK } & 0.94 & 21.76 & 27.66 & 16.94 & 3 & 1964.0173 & 1964.0128 & 655.6782 & 0.0045 & 2.2877 & 26.416\end{array}$ $\begin{array}{lllllllllllll}\text { CQVFEETQIGGER } & 1.00 & 62.48 & 25.02 & 21.36 & 2 & 1684.7692 & 1684.7671 & 8543.3908 & 0.0021 & 1.2450 & 1002.478\end{array}$
10 AVDPEDDFQR AVDPEDDFQR

LDVTLGPVPEIGGSEAPAO

LDFLEGDQKPLAQR

$\begin{array}{llllllllllll}1.00 & 40.10 & 25.13 & 20.62 & 2 & 1334.6234 & 1334.6225 & 668.3185 & 0.0009 & 0.6733 & 209.692\end{array}$ $\begin{array}{lllllllllllll}1.00 & 40.36 & 25.13 & 20.01 & 2 & 1334.6234 & 1334.6225 & 668.3185 & 0.0009 & 0.6733 & 257.884\end{array}$

QAQAAVLAVLPR

QAQAAVLAVLPR

QAQAAVLAVLPR

QAQAAVLAVLPR

AVDPEDDFQR

AVNDVNGLK

LDHVVTIIK
LDHVVTIIK

WLAPDGLIFPDR

WLAPDGLIFPDR

WLAPDGLIFPDR

WLAPDGLIFPDR

WLAPDGLIFPDR

WLAPDGLIFPDR

EPLVDVVDPK

VEEVELPVEK

VEEVELPVEK
VEEVELPVEK

OVSELLALVDALLDYHR

ELGESIILDELAEK

QAVQILDELAEK

LLSDFLDSEVSELR DLLVLLNEILEQVK DLLVLLNEILEQVK IQAVLALSR LMFSGLLVSSR

SSEIEQAVQSLDR

SSEIEQAVQSLDR ALAVGGLGSIIR

ALAVGGLGSIIR

ALAVGGLGSIIR

ALAVGGLGSIIR

ALAVGGLGSIIR

QIEEELWEEEFIER

QIEEELWEEEFIER $\begin{array}{lllllllllll}1.00 & 71.30 & 25.56 & 22.24 & 4 & 3897.9213 & 3897.9176 & 975.4867 & 0.0037 & 0.9482 & 5.1\end{array}$ $\begin{array}{lllllllllll}1.00 & 73.61 & 27.77 & 23.80 & 2 & 1604.8136 & 1604.8127 & 803.4136 & 0.0009 & 0.5601 & 1944.429\end{array}$ $\begin{array}{llllllllllll}1.00 & 89.32 & 27.08 & 31.60 & 2 & 2021.9694 & 2021.9703 & 1011.9924 & -0.0009 & -0.4447 & 33.18\end{array}$ $\begin{array}{llllllllllll}0.90 & 20.36 & 27.20 & 19.48 & 3 & 2021.9719 & 2021.9703 & 674.9974 & 0.0016 & 0.7901 & 8.712\end{array}$ \begin{tabular}{llllllllll}
9 & 0.26 \\
\hline & 2476.3441 & 24763417 & 826.4545 & 0.0024 & 0.9680 & 157.237 & 83.620
\end{tabular} $\begin{array}{llllllllllll}1.00 & 43.16 & 26.22 & 20.20 & 3 & 1917.0616 & 1917.0563 & 640.0260 & 0.0053 & 2.7603 & 3859.384 & 3097.256\end{array}$ $\begin{array}{llllllllllllll}0.55 & 27.61 & 23.12 & 40.61 & 3 & 1379.8384 & 1379.8371 & 460.9530 & 0.0013 & 0.9401 & 357.188 & 420.24\end{array}$ $\begin{array}{llllllllllll}0.82 & 73.16 & 23.12 & 86.16 & 2 & 1379.8384 & 1379.8371 & 690.9258 & 0.0013 & 0.9408 & 2941.749 & 3154.492 \\ 0.72 & 73.44 & 22.50 & 86.44 & 2 & 1379.8396 & 1379.8371 & 690.9258 & 0.0025 & 1.8092 & 2705.312 & 2213.599\end{array}$

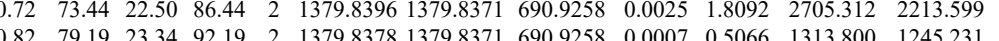
$\begin{array}{lllllllllllll}0.82 & 79.19 & 23.34 & 92.19 & 2 & 1379.8378 & 1379.8371 & 690.9258 & 0.0007 & 0.5066 & 1313.800 & 1245.231 \\ 0.73 & 23.23 & 25.05 & 22.00 & 2 & 1334.6328 & 1334.6225 & 668.3185 & 0.0103 & 7.7058 & 1620.026 & 1356.595 & 69 .\end{array}$

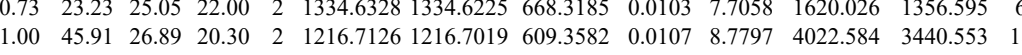
$\begin{array}{llllllllllllll}1.00 & 60.01 & 17.85 & 23.94 & 2 & 1324.8436 & 1324.8322 & 663.4234 & 0.0114 & 8.5917 & 3193.864 & 1988.819 & 606.8\end{array}$ $\begin{array}{lllllllllllll}1.00 & 62.46 & 17.40 & 25.47 & 2 & 1324.8450 & 1324.8322 & 663.4234 & 0.0128 & 9.6468 & 13998.005 & 9103.472 & 160 \\ 1.00 & 55.78 & 27.15 & 26.20 & 2 & 1542.8320 & 1542.8317 & 772.4231 & 0.0003 & 0.1942 & 204.967 & 201.444\end{array}$ $\begin{array}{llllllllllll}1.00 & 55.78 & 27.15 & 26.20 & 2 & 1542.8320 & 1542.8317 & 772.4231 & 0.0003 & 0.1942 & 204.967 & 201.444 \\ 1.00 & 60.88 & 27.04 & 23.85 & 2 & 1542.8330 & 1542.8317 & 772.4231 & 0.0013 & 0.8415 & 576.624 & 412.392\end{array}$ $\begin{array}{lllllllllllll}.00 & 47.72 & 27.04 & 20.93 & 2 & 1542.8330 & 1542.8317 & 772.4231 & 0.0013 & 0.8415 & 9666.384 & 7306.726\end{array}$ $\begin{array}{llllllllllll}1.00 & 48.72 & 27.01 & 24.66 & 2 & 1542.8332 & 1542.8317 & 772.4231 & 0.0015 & 0.9710 & 8424.420 & 8084.970 \\ 1.00 & 65.35 & 27.40 & 26.64 & 2 & 1542.8336 & 1542.8317 & 772.4231 & 0.0019 & 1.2299 & 1201.686 & 888.002\end{array}$ $\begin{array}{llllllllllll}1.00 & 65.35 & 27.40 & 26.64 & 2 & 1542.8336 & 1542.8317 & 772.4231 & 0.0019 & 1.2299 & 1201.686 & 888.002 \\ 1.00 & 45.89 & 27.43 & 22.31 & 2 & 1542.8348 & 1542.8317 & 772.4231 & 0.0031 & 2.0067 & 644.366 & 674.741\end{array}$

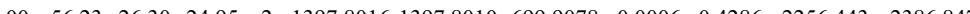

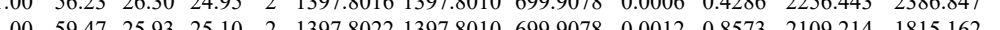
$\begin{array}{lllllllllllll}1.00 & 68.68 & 27.38 & 36.87 & 2 & 1457.8224 & 1457.8221 & 729.9183 & 0.0003 & 0.2055 & 602.722 & 437.494\end{array}$ $\begin{array}{llllllllllll}1.00 & 45.98 & 27.23 & 30.27 & 2 & 1457.8230 & 1457.8221 & 729.9183 & 0.0009 & 0.6165 & 2485.491 & 2047.066\end{array}$ $\begin{array}{lllllllllllll}0.97 & 25.52 & 26.05 & 26.64 & 3 & 2327.1232 & 2327.1195 & 776.7138 & 0.0037 & 1.587 & 60.180 & 32.486 \\ 1.00 & 87.19 & 28.26 & 25.98 & 2 & 1643.9359 & 1643.9337 & 548.9852 & 0.0022 & 1.3358 & 54.783 & 37.640\end{array}$ $\begin{array}{llllllllllll}1.00 & 87.19 & 28.26 & 25.98 & 2 & 1765.9244 & 1765.9220 & 883.9683 & 0.0024 & 1.3575 & 209.541 & 334.481\end{array}$ $\begin{array}{lllllllllllll}1.00 & 81.85 & 28.15 & 20.97 & 2 & 1765.9256 & 1765.9220 & 883.9683 & 0.0036 & 2.0363 & 101.079 & 142.906\end{array}$ $\begin{array}{lllllllllllll}1.00 & 48.59 & 18.33 & 16.16 & 3 & 1926.1669 & 1926.1645 & 643.0621 & 0.0024 & 1.2440 & 120.429 & 122.049\end{array}$ $\begin{array}{lllllllllllll}1.00 & 55.78 & 18.33 & 19.59 & 3 & 1926.1669 & 1926.1645 & 643.0621 & 0.0024 & 1.2440 & 128.316 & 107.745\end{array}$ $\begin{array}{rrrrrrrrrrrr}1.00 & 21.87 & 18.33 & 15.63 & 3 & 1926.1672 & 1926.1645 & 643.0621 & 0.0027 & 1.3996 & 91.549 & 81.855\end{array}$ $\begin{array}{lllllllllllll}0.97 & 32.81 & 23.14 & 25.47 & 2 & 1113.7032 & 1113.6992 & 557.8569 & 0.0040 & 3.5851 & 1483.474 & 1302.294\end{array}$ $\begin{array}{lllllllllllll}1.00 & 58.43 & 26.88 & 27.90 & 2 & 1352.7628 & 1352.7608 & 677.3877 & 0.0020 & 1.4763 & 268.119 & 329.222\end{array}$ $\begin{array}{lllllllllllll}1.00 & 67.11 & 27.77 & 22.55 & 2 & 1604.8136 & 1604.8127 & 803.4136 & 0.0009 & 0.5601 & 403.746 & 327.104\end{array}$ $\begin{array}{lllllllllllll}1.00 & 70.72 & 22.10 & 26.34 & 2 & 1269.7888 & 1269.7890 & 635.9018 & -0.0002 & -0.1573 & 1952.515 & 2364.475 \\ 1.00 & 64.81 & 22.10 & 29.77 & 2 & 1269.7894 & 1269.7890 & 635.9018 & 0.0004 & 0.3145 & 2993.205 & 3013.227 & 3\end{array}$ $\begin{array}{lllllllllllll}1.00 & 64.81 & 22.10 & 29.77 & 2 & 1269.7894 & 1269.7890 & 635.9018 & 0.0004 & 0.3145 & 2993.205 & 3013.227 & \\ 1.00 & 74.63 & 22.04 & 25.74 & 2 & 1269.7900 & 1269.7890 & 635.9018 & 0.0010 & 0.7863 & 1697.149 & 2083.990 & 5\end{array}$ $\begin{array}{llllllllllll}0.98 & 35.20 & 21.00 & 25.86 & 2 & 1269.7901269 .7890 & 635.9018 & 0.0010 & 0.7863 & 1697.149 & 2083.990 \\ 0.7269 .7890 & 635.9018 & 0.0046 & 3.6169 & 65.588 & 31.18\end{array}$

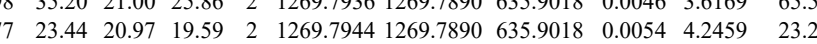
$\begin{array}{llllllllllllll}1.00 & 33.67 & 27.13 & 17.36 & 3 & 2021.9722 & 2021.9703 & 674.9974 & 0.0019 & 0.9383 & 10.582 \\ 1.00 & 72.18 & 25.15 & 22.83 & 4 & 3649.8285 & 3649.8277 & 913.4642 & 0.0008 & 0.2189 & 7.171\end{array}$ $\begin{array}{llllllllllll}1.00 & 72.18 & 25.15 & 22.83 & 4 & 3649.8285 & 3649.8277 & 913.4642 & 0.0008 & 0.2189 & 7.171 \\ 1.00 & 85.60 & 25.11 & 21.25 & 4 & 3649.8297 & 3649.8277 & 913.4642 & 0.0020 & 0.5474 & 2.975\end{array}$

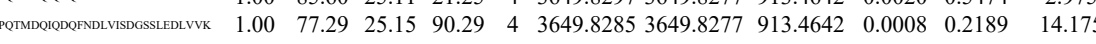

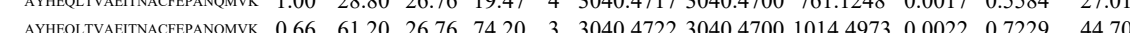
$\begin{array}{llllllllllll}\text { AYHEQLTVAEITNACFEPANOMVK } & 1.00 & 21.76 & 26.79 & 34.76 & 4 & 3040.4741 & 3040.4700 & 761.1248 & 0.0041 & 1.3467 & 10.857\end{array}$ 


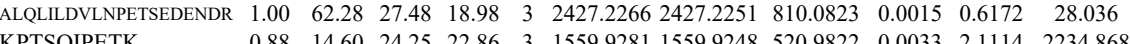
\begin{tabular}{lllllllllllll} 
ALQLILDVLNPETSEDENDR & 0.88 & 14.64 & 88.75 & 24.25 & 22.86 & 3 & 1559.9281 & 1559.9248 & 522.9822 & 0.0033 & 2.1114 & 2234.868 \\
\hline
\end{tabular}

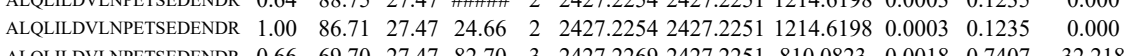
$\begin{array}{llllllllllll}\text { ALQLILDVLNPETSEDENDR } & 0.66 & 69.70 & 27.47 & 82.70 & 3 & 2427.2269 & 2427.2251 & 810.0823 & 0.0018 & 0.7407 & 32.218\end{array}$ $\begin{array}{llllllllllll}\text { ALQLILDVLNPETSEDENDR } & 0.67 & 50.89 & 27.42 & 63.89 & 3 & 2427.2284 & 2427.2251 & 810.0823 & 0.0033 & 1.3579 & 38.220\end{array}$

ALVDILSEVSK

ALVDILSEVSK LVSIVDSLHLEMEEALTE

ATLQEILPEVLK

ATLQEILPEVLK $\begin{array}{ccccccccccc}7.04 .84 & 26.46 & 24.77 & 3 & 2625.3850 & 2625.3805 & 876.1341 & 0.0045 & 1.7121 & 3.900 & 7 .\end{array}$ $\begin{array}{lllllllllllll}\text { AMFLPDLDSLVDFSTNNQK } & 1.00 & 60.64 & 27.24 & 26.80 & 3 & 2570.2957 & 2570.2930 & 857.7716 & 0.0027 & 1.0492 & 16.560\end{array}$

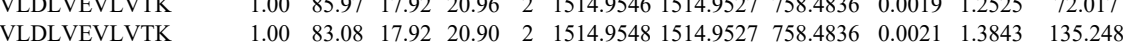

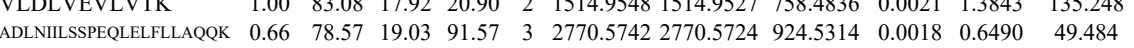

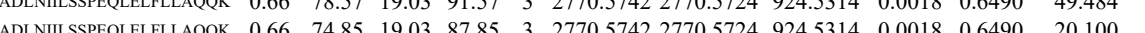

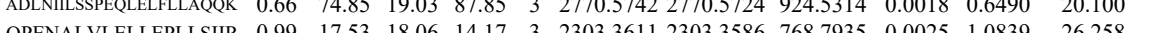
$\begin{array}{llllllllllllll}\text { QPENALVLELLEPLLSIIR } & 1.00 & 33.35 & 17.92 & 17.70 & 3 & 2303.3611 & 2303.3586 & 768.7935 & 0.0025 & 1.0839 & 26.258 & 13 \\ & 2303.3586 & 768.7935 & 0.0034 & 1.4742 & 22.160 & 13\end{array}$ $\begin{array}{llllllllllllll}\text { RPNALVLELLE } & 1.00 & 47.31 & 1.78 & 26.17 & 2 & 2303.3674 & 2303.3586 & 1152.6866 & 0.0088 & 3.8172 & 0.000\end{array}$

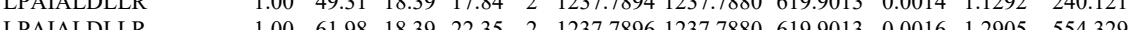

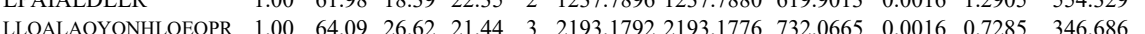

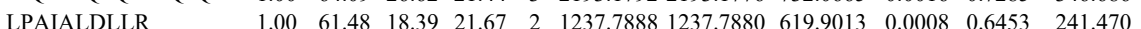
LPAIALDLLR

NPAIALDLLR $\begin{array}{llllllllllll}\text { NSPLTVPMFLSLFSR } & 0.60 & 38.58 & 27.11 & 51.58 & 3 & 1852.0081 & 1852.0039 & 618.3419 & 0.0042 & 2.2641 & 17.235 \\ \text { NSPLTVPMFLSLFSR } & 1.00 & 70.73 & 27.11 & 24.55 & 2 & 1852.0082 & 1852.0039 & 927.0092 & 0.0043 & 2.3193 & 89.350\end{array}$ ALOLILDVLNPETSEDEND

LEEVMQELR

LEEVMQELR VGIIAWHPTAR VGIIAWHPTAR VGIIAWHPTAR VGIIAWHPTAR VGIIAWHPTAR VGIIAWHPTAR VGIIAWHPTAR VGIIAWHPTAR VGIIAWHPTAR LEEVMQELR

LEEVMQEL

$\begin{array}{llllllllllll}\text { TXD17 HUMAP Q9BRA2 } & \text { TXNDC17 Thioredoxin doma 13.941 } & 1.00 & 3 & 20.3 & -0.1433 & 0.1106 & 1.8144 & 0.3118 & 7 & \text { YGTPQK }\end{array}$ YGTPQK

VTAVPTLLK

TIFAYFTGSK

TIFAYFTGSK

TIFAYTCSK

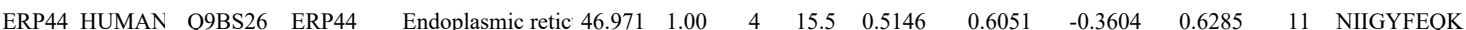
$\begin{array}{lllllllllll}1.00 & 59.06 & 24.71 & 22.58 & 2 & 1460.8700 & 1460.8694 & 731.4420 & 0.0006 & 0.410\end{array}$ $\begin{array}{lllllllllll}17.22 & 24.47 & 23.96 & 2 & 1460.8702 & 1460.8694 & 731.4420 & 0.0008 & 0.5469 & 97.736\end{array}$ $\begin{array}{llllllllllll}1.00 & 61.48 & 18.39 & 21.67 & 2 & 1237.7888 & 1237.7880 & 619.9013 & 0.0008 & 0.6453 & 241.470 & \\ 1.00 & 53.35 & 18.39 & 18.76 & 2 & 1237.7890 & 1237.7880 & 619.9013 & 0.0010 & 0.8066 & 237.414 & 3\end{array}$ $\begin{array}{lllllllllll}.00 & 53.35 & 18.39 & 18.76 & 2 & 1237.7890 & 1237.7880 & 619.9013 & 0.0010 & 0.8066 & 237.4\end{array}$ $\begin{array}{llllllllllll}0.60 & 38.58 & 27.11 & 51.58 & 3 & 1852.0081 & 1852.0039 & 618.3419 & 0.0042 & 2.2641 & 17.235\end{array}$ $\begin{array}{llllllllllll}1.00 & 70.73 & 27.11 & 24.55 & 2 & 1852.0082 & 1852.0039 & 927.0092 & 0.0043 & 2.3193 & 89.350 & 76.724 \\ 0.67 & 46.05 & 27.40 & 59.05 & 3 & 2427.2278 & 2427.2251 & 810.0823 & 0.0027 & 1.1110 & 30.763 & 22.380\end{array}$ $\begin{array}{llllllllllll}1.00 & 54.61 & 28.14 & 34.85 & 2 & 1289.6780 & 1289.6771 & 645.8458 & 0.0009 & 0.6968 & 12540.815 & 10696.245\end{array}$ $\begin{array}{llllllllllll}1.00 & 55.15 & 28.12 & 35.88 & 2 & 1289.6792 & 1289.6771 & 645.8458 & 0.0021 & 1.6258 & 7712.610 & 7135.669\end{array}$ $\begin{array}{llllllllllllll}0.99 & 33.97 & 26.53 & 18.86 & 3 & 1363.7914 & 1363.7846 & 455.6021 & 0.0068 & 4.9751 & 3067.571 & 3348.959\end{array}$

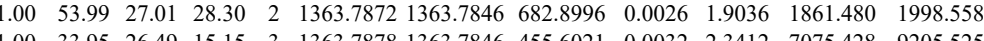
$\begin{array}{llllllllllll}1.00 & 33.95 & 26.49 & 15.15 & 3 & 1363.7878 & 1363.7846 & 455.6021 & 0.0032 & 2.3412 & 7075.428 & 9205.52\end{array}$ $\begin{array}{llllllllllllllll}1.00 & 45.28 & 26.51 & 21.09 & 3 & 1363.7887 & 1363.7846 & 455.6021 & 0.0041 & 2.9997 & 13735.540 & 13436.708 & 1980.645 & 24151.284 & \text { Yes }\end{array}$ $\begin{array}{llllllllllllllll}1.00 & 41.96 & 27.01 & 20.89 & 3 & 1363.7872 & 1363.7846 & 455.6021 & 0.0026 & 1.9022 & 6942.433 & 7880.643 & 1621.608 & 14181.675 & \text { Yes } \\ 1.00 & 39.63 & 27.01 & 20.59 & 3 & 1363.7872 & 1363.7846 & 455.6021 & 0.0026 & 1.9022 & 5309.899 & 6072.681 & 1972.234 & 12474.462 & \text { Yes } \\ 1.00 & 53.54 & 27.22 & 21.77 & 3 & 1363.7857 & 1363.7846 & 455.6021 & 0.001 & 0.8048 & 985.605 & 1185.500 & 672.855 & 1681.073 & \text { No }\end{array}$ $\begin{array}{lllllllllllllll}1.00 & 53.54 & 27.22 & 21.77 & 3 & 1363.7857 & 1363.7846 & 455.6021 & 0.0026 & 1.9022 & 5309.899 & 6072.681 & 1972.234 & 12474.462 & \text { Yes } \\ 1.0048 & 985.605 & 1185.500 & 672.855 & 1681.073 & \text { No }\end{array}$ $\begin{array}{llllllllllllllll}1.00 & 43.40 & 27.22 & 19.87 & 3 & 1363.7857 & 1363.7846 & 455.6021 & 0.0011 & 0.8048 & 1014.496 & 1271.340 & 421.174 & 1909.817 & \text { No }\end{array}$ $\begin{array}{lllllllllllllll}1.00 & 53.78 & 28.18 & 35.86 & 2 & 1289.6786 & 1289.6771 & 645.8458 & 0.0015 & 1.1613 & 4518.374 & 4181.404 & 370.613 & 8803.919 & \text { Yes }\end{array}$ $\begin{array}{llllllllllllllll}1.00 & 55.88 & 28.18 & 36.00 & 2 & 1289.6786 & 1289.6771 & 645.8458 & 0.0015 & 1.1613 & 4373.402 & 4068.234 & 189.075 & 8935.821 & \text { Yes }\end{array}$

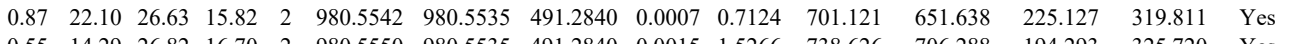
$\begin{array}{lllllllllllllll}0.55 & 14.29 & 26.82 & 16.70 & 2 & 980.5550 & 980.5535 & 491.2840 & 0.0015 & 1.5266 & 738.626 & 706.288 & 194.293 & 325.720 & \text { Yes } \\ 1.00 & 48.28 & 17.85 & 31.67 & 2 & 1228.8118 & 1228.7999 & 615.4072 & 0.0119 & 9.6683 & 4043.844 & 3096.066 & 374.906 & 2070.123 & \text { Yes }\end{array}$ $\begin{array}{lllllllllllllll}1.00 & 48.28 & 17.85 & 31.67 & 2 & 1228.8118 & 1228.7999 & 615.4072 & 0.0119 & 9.6683 & 4043.844 & 3096.066 & 374.906 & 2070.123 & \text { Yes } \\ 1.00 & 58.20 & 27.77 & 24.53 & 2 & 1421.7820 & 1421.7798 & 711.8972 & 0.0022 & 1.5452 & 389.818 & 346.307 & 68.767 & 108.801 & \text { Yes }\end{array}$ $\begin{array}{lllllllllllllll}1.00 & 58.20 & 27.77 & 24.53 & 2 & 1421.7820 & 1421.7798 & 711.8972 & 0.0022 & 1.5452 & 389.818 & 346.307 & 68.767 & 108.801 & \text { Yes } \\ 1.00 & 63.67 & 27.60 & 29.85 & 2 & 1421.7822 & 1421.7798 & 711.8972 & 0.0024 & 1.6856 & 856721 & 773.600 & 8.664 & 416.868 & \text { Yes }\end{array}$

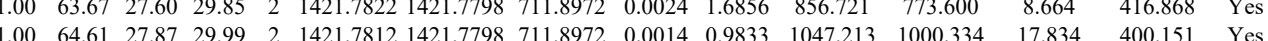
$\begin{array}{llllllllllllll}1.00 & 64.61 & 27.87 & 29.85 & 2 & 1421.7822 & 1421.7798 & 711.8972 & 0.0024 & 1.686 & 856.721 & 773.600 & 8.64 & 416.868\end{array}$ $\begin{array}{lllllllllllllll}1.00 & 43.71 & 27.59 & 25.97 & 2 & 1398.7766 & 1398.7751 & 700.3948 & 0.0015 & 1.0708 & 2974.209 & 3588.777 & 132.656 & 5642.173 & \text { Yes }\end{array}$

Table S-4 page 550 of 614 


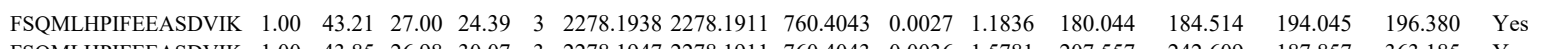
$\begin{array}{llllllllllllllll}\text { FSQMLHPIFEEASDVIK } & 1.00 & 43.85 & 26.98 & 30.07 & 3 & 2278.1947 & 2278.1911 & 760.4043 & 0.0036 & 1.5781 & 207.557 & 242.609 & 187.857 & 363.185 & \text { Yes }\end{array}$

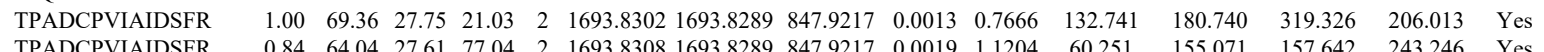
$\begin{array}{llllllllllllllll}\text { TPADCPVIAIDSFR } & 0.84 & 64.04 & 27.61 & 77.04 & 2 & 1693.8308 & 1693.8289 & 847.9217 & 0.0019 & 1.1204 & 60.251 & 155.071 & 157.642 & 243.246 & \text { Yes }\end{array}$

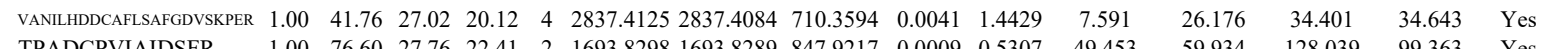
$\begin{array}{llllllllllllllll}\text { TPADCPVIAIDSFR } & 1.00 & 76.60 & 27.76 & 22.41 & 2 & 1693.8298 & 1693.8289 & 847.9217 & 0.0009 & 0.5307 & 49.453 & 59.934 & 128.039 & 99.363 & \text { Yes } \\ \text { TPADCPVIADSFR } & 0.84 & 60.98 & 27.61 & 73.98 & 2 & 1693.8306 & 1693.8289 & 847.9217 & 0.0017 & 1.0025 & 651.534 & 565.938 & 702.611 & 1302.54 & \text { Yes }\end{array}$ $\begin{array}{lllllllllllllllll}\text { TPADCPVIAIDSFR } & 0.84 & 60.98 & 27.61 & 73.98 & 2 & 1693.8306 & 1693.8289 & 847.9217 & 0.0017 & 1.0025 & 651.534 & 565.938 & 702.611 & 1302.454 & \text { Yes } \\ \text { VANT. }\end{array}$

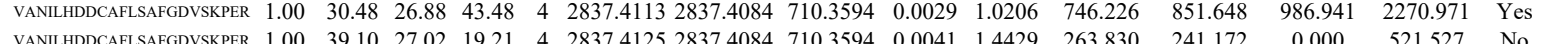
$\begin{array}{llllllllllllllll}\text { VANLHDDCAFLSAFGDVSKPER } & 1.00 & 39.10 & 27.02 & 19.21 & 4 & 2837.4125 & 2837.4084 & 710.3594 & 0.0041 & 1.4429 & 263.830 & 241.172 & 0.000 & 521.527 & \text { No } \\ \text { TPADCPVIAIDSFR } & 1.00 & 56.16 & 27.77 & 18.42 & 2 & 1693.8300 & 1693.8289 & 847.9217 & 0.0011 & 0.6486 & 37.368 & 42.991 & 124.670 & 130.069 & \text { Yes }\end{array}$

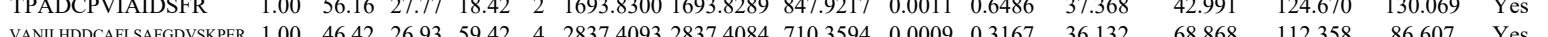

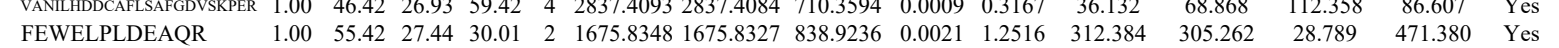

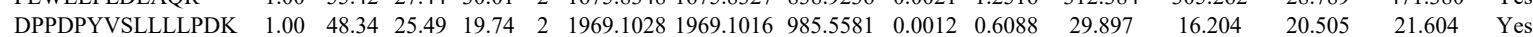

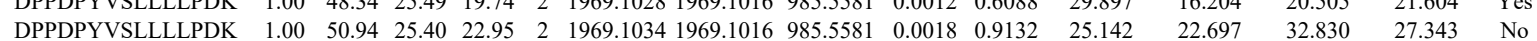

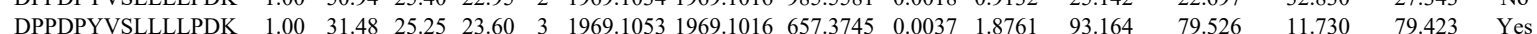

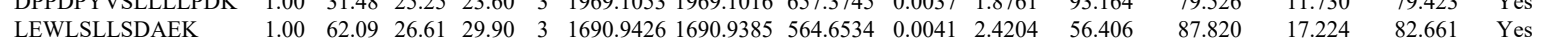

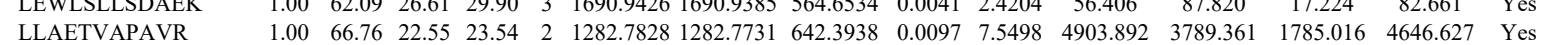

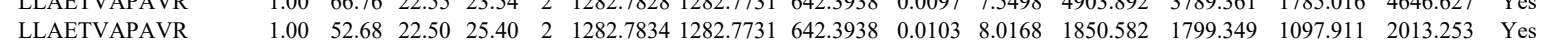

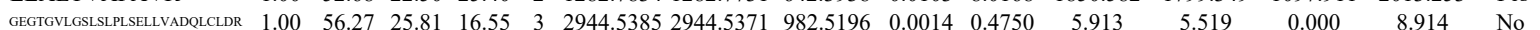

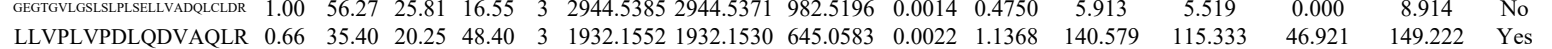
\begin{tabular}{llllllllllllllll} 
LLVPLVPDLODVAQLR & 0.98 & 16.95 & 20.13 & 14.76 & 3 & 1932.1561 & 1932.1530 & 645.0583 & 0.0031 & 1.6019 & 100.604 & 114.621 & 56.710 & 79.603 & Yes \\
\hline
\end{tabular}

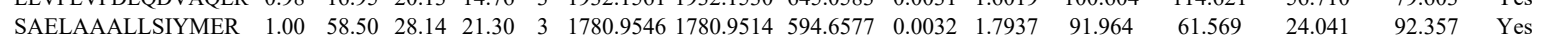
\begin{tabular}{llllllllllllllll} 
LLVPLVPDLQDVAQLR & 1.00 & 57.31 & 20.04 & 21.80 & 3 & 1932.1564 & 1932.1530 & 645.0583 & 0.0034 & 1.7569 & 232.376 & 408.316 & 117.745 & 260.088 & Yes \\
\hline
\end{tabular} $\begin{array}{lllllllllllllllll}\text { LLVPLVPDLQDVAQLR } & 1.00 & 49.89 & 20.04 & 19.95 & 3 & 1932.1570 & 1932.1530 & 645.0583 & 0.0040 & 2.0670 & 285.730 & 286.659 & 135.316 & 339.263 & \text { Yes }\end{array}$ $\begin{array}{llllllllllllllll}\text { VLQASVLDDWFPLGGGGQVHLR } & 1.00 & 88.08 & 25.48 & 23.07 & 3 & 2706.4393 & 2706.4364 & 903.1527 & 0.0029 & 1.0703 & 23.118 & 5.982 & 30.230 & 33.155 & \text { No } \\ \text { VLOASVIDDWFLOGGQGQVHRR } & 0.67 & 78.67 & 25.48 & 91.67 & 3 & 2706.4393 & 2706.4364 & 903.1527 & 0.0029 & 1.0703 & 30.907 & 22.445 & 9.847 & 40.515 & \text { Yes }\end{array}$ $\begin{array}{lllllllllllllllll}\text { LLVPLVPDLQDVAQLR } & 1.00 & 51.92 & 20.04 & 22.59 & 3 & 1932.1570 & 1932.1530 & 645.0583 & 0.0040 & 2.0670 & 112.006 & 154.430 & 31.217 & 130.381 & \text { Yes }\end{array}$ $\begin{array}{llllllllllllllll}\text { LLTAPELILDQWFQLSSSGPNSR } & 1.00 & 50.50 & 25.16 & 21.52 & 3 & 2715.4384 & 2715.4353 & 906.1524 & 0.0031 & 1.1404 & 8.395 & 0.811 & 6.338 & 1.639 & \text { No }\end{array}$

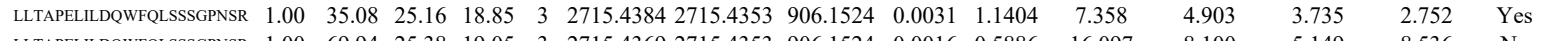

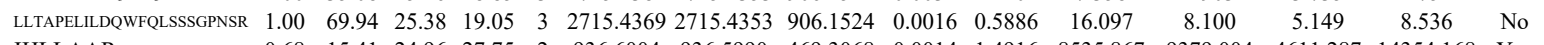
$\begin{array}{llllllllllllllll}\text { IHLLAAR } & 0.68 & 15.41 & 24.96 & 27.75 & 2 & 936.6004 & 936.5990 & 469.3068 & 0.0014 & 1.4916 & 8535.867 & 9379.004 & 4611.287 & 14354.168 & \text { Yes }\end{array}$

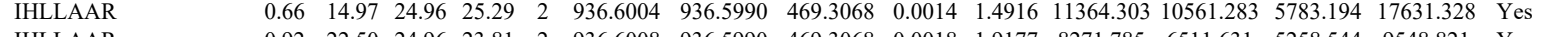
$\begin{array}{lllllllllllllllll}\text { IHLLAAR } & 0.92 & 22.50 & 24.96 & 23.81 & 2 & 936.6008 & 936.5990 & 469.3068 & 0.0018 & 1.9177 & 8271.785 & 6511.631 & 5258.544 & 9548.821 & \text { Yes }\end{array}$

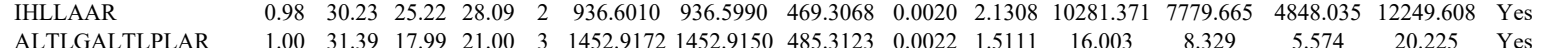

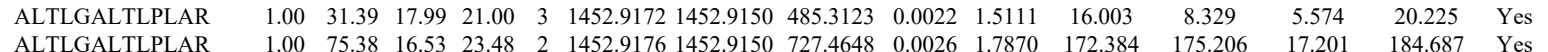

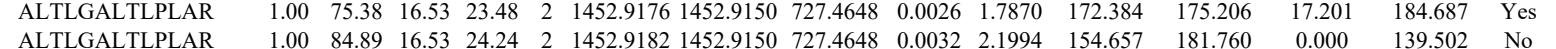

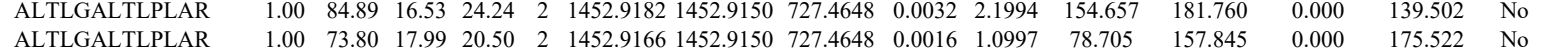

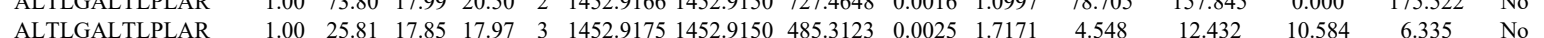

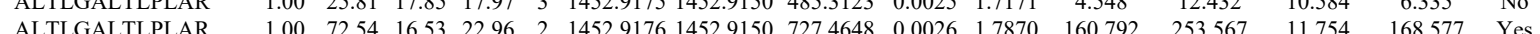

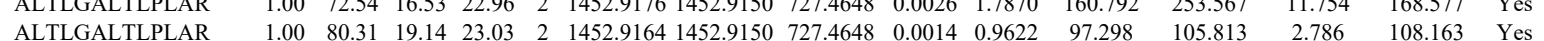

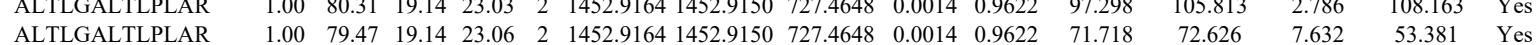

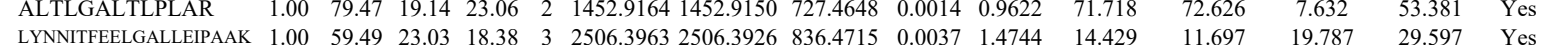

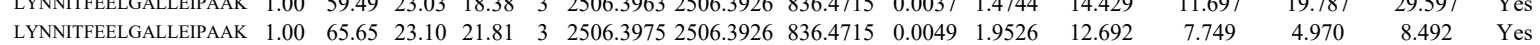

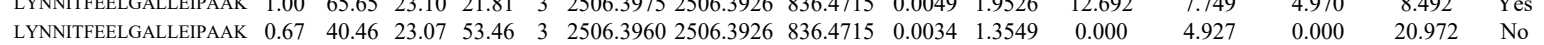

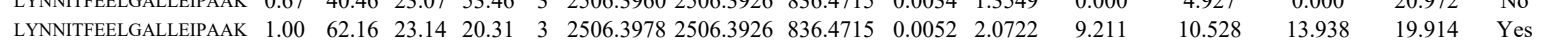

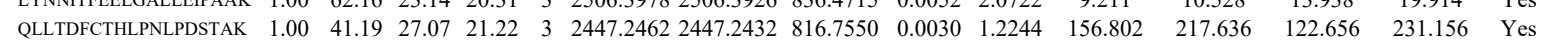

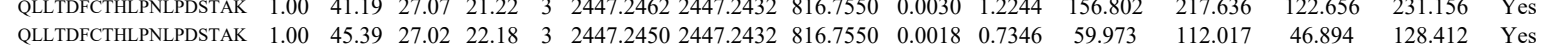

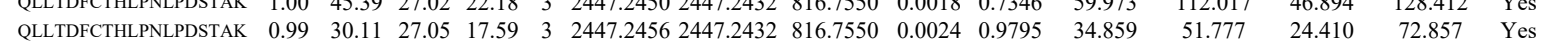
$\begin{array}{lllllllllllllllll}2 & \text { VSPSTSYTPSR } & 1.00 & 59.52 & 27.51 & 21.66 & 2 & 1324.6752 & 1324.6745 & 663.3445 & 0.0007 & 0.5276 & 3205.497 & 3306.866 & 23.591 & 3368.810 & \text { Yes }\end{array}$ $\begin{array}{lllllllllllllllll}\text { VSPSTSYTPSR } & 1.00 & 57.73 & 27.48 & 23.20 & 2 & 1324.6750 & 1324.6745 & 663.3445 & 0.0005 & 0.3769 & 9293.521 & 8470.948 & 285.850 & 9193.663 & \text { Yes }\end{array}$ $\begin{array}{llllllllllllllll}\text { VSPSTSYTPSR } & 1.00 & 55.48 & 27.44 & 18.73 & 2 & 1324.6742 & 1324.6745 & 663.3445 & -0.0003 & -0.2261 & 3005.231 & 3406.265 & 180.610 & 3517.504 & \text { Yes }\end{array}$ $\begin{array}{lllllllllllllllll}\text { VSPSTSYTPSR } & 0.82 & 29.69 & 27.51 & 42.69 & 2 & 1324.6752 & 1324.6745 & 663.3445 & 0.0007 & 0.5276 & 645.324 & 679.331 & 139.773 & 709.594 & \text { Yes }\end{array}$ $\begin{array}{llllllllllllllll}\text { IHVILAQK } & 0.82 & 15.43 & 16.63 & 16.66 & 3 & 1208.7952 & 1208.7849 & 403.9356 & 0.0103 & 8.4996 & 4357.330 & 3635.967 & 1536.403 & 5495.053 & \text { Yes }\end{array}$ $\begin{array}{llllllllllllllll}\text { IHVILAQK } & 0.94 & 22.08 & 16.63 & 17.62 & 3 & 1208.7955 & 1208.7849 & 403.9356 & 0.0106 & 8.7472 & 4091.107 & 4119.156 & 2232.018 & 5082.253 & \text { Yes }\end{array}$ $\begin{array}{lllllllllllllllll}\text { LQHINPLLPACLNK } & 0.91 & 18.59 & 25.16 & 18.34 & 3 & 1907.0743 & 1907.0728 & 636.6982 & 0.0015 & 0.7853 & 3552.919 & 5374.510 & 1047.460 & 7683.728 & \text { Yes }\end{array}$ $\begin{array}{lllllllllllllllll}\text { LQHINPLLPACLNK } & 0.66 & 11.75 & 25.20 & 24.75 & 3 & 1907.0746 & 1907.0728 & 636.6982 & 0.0018 & 0.9424 & 4438.565 & 5069.645 & 769.974 & 9563.347 & \text { No }\end{array}$ $\begin{array}{llllllllllllllll}\text { LQHINPLLPACLNK } & 0.75 & 13.26 & 25.25 & 20.08 & 3 & 1907.0767 & 1907.0728 & 636.6982 & 0.0039 & 2.0418 & 1703.867 & 2240.595 & 868.957 & 3501.113 & \text { Yes }\end{array}$ $\begin{array}{llllllllllllllll}\text { LQHINPLLPACLNK } & 0.93 & 26.54 & 25.17 & 23.18 & 3 & 1907.0809 & 1907.0728 & 636.6982 & 0.0081 & 4.2406 & 1532.772 & 1693.463 & 1127.791 & 2365.340 & \text { No }\end{array}$ $\begin{array}{llllllllllllllll}\text { CLSLSAGQTTLSR } & 1.00 & 90.17 & 28.25 & 27.80 & 2 & 1525.7846 & 1525.7714 & 763.8930 & 0.0132 & 8.6399 & 397.117 & 383.414 & 20.710 & 504.977 & \text { Yes }\end{array}$ $\begin{array}{llllllllllllllll}\text { IIQHLVPASFR } & 0.67 & 10.17 & 24.30 & 23.17 & 3 & 1423.8451 & 1423.8421 & 475.6213 & 0.0030 & 2.1025 & 472.714 & 372.915 & 141.956 & 464.825 & \text { Yes } \\ \text { IYLTLLR } & 1 & & & & & \end{array}$

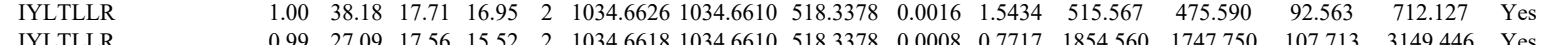
$\begin{array}{lccccccccccccccc}\text { IYLTLLR } & 0.99 & 27.09 & 17.56 & 15.52 & 2 & 1034.6618 & 1034.6610 & 518.3378 & 0.0008 & 0.7717 & 1854.560 & 1747.750 & 107.713 & 3149.446 & \text { Yes }\end{array}$

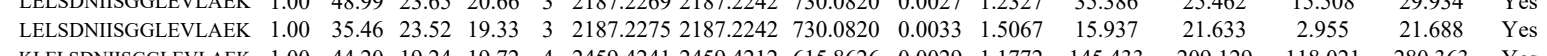

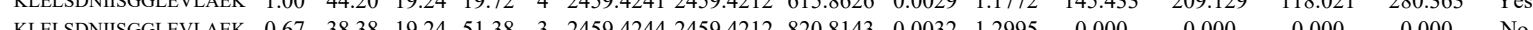
$\begin{array}{lllllllllllllllll}\text { KLELSDNIISGGLEVLAEK } & 1.00 & 57.36 & 19.24 & 19.43 & 4 & 2459.4245 & 2459.4212 & 615.8626 & 0.0033 & 1.3396 & 207.069 & 121.969 & 166.383 & 289.711 & \text { Yes }\end{array}$ 

$\begin{array}{lllllllllllll}\text { AALVDLEPGTMDSVR } & 1.00 & 76.62 & 28.14 & 22.39 & 2 & 1716.8856 & 1716.8838 & 859.4492 & 0.0018 & 1.0472 & 353.336\end{array}$

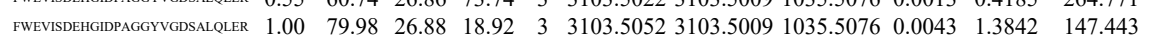
$\begin{array}{llllllllllll}\text { GHYTEGAELVDAVALLLR } & 0.55 & 52.16 & 26.86 & 65.16 & 3 & 3103.5022 & 3103.5009 & 1035.5076 & 0.0013 & 0.4185 & 43.684\end{array}$ $\begin{array}{llllllllllll}\text { GHYTEGAELVDAVLDVVR } & 1.00 & 56.81 & 27.58 & 25.74 & 3 & 2086.0855 & 2086.0817 & 696.3678 & 0.0038 & 1.8190 & 101.288\end{array}$ $\begin{array}{lllllllllllll}\text { GHYTEGAELVDAVLDVVR } & 1.00 & 72.00 & 27.58 & 31.18 & 3 & 2086.0855 & 2086.0817 & 696.3678 & 0.0038 & 1.8190 & 182.538\end{array}$ $\begin{array}{lllllllllllll}\text { GHYTEGAELVDAVLDVVR } & 1.00 & 55.23 & 27.58 & 23.55 & 3 & 2086.0855 & 2086.0817 & 696.3678 & 0.0038 & 1.8190 & 126.458\end{array}$ $\begin{array}{llllllllllllll}\text { ALTVPELTQQMFDAR } & 1.00 & 70.78 & 27.60 & 20.14 & 2 & 1862.9708 & 1862.9682 & 932.4914 & 0.0026 & 1.3941 & 226.966\end{array}$ $\begin{array}{llllllllllllll}\text { ALTVPELTQQMFDAR } & 1.00 & 71.67 & 27.66 & 19.23 & 2 & 1862.9718 & 1862.9682 & 932.4914 & 0.0036 & 1.9303 & 869.199\end{array}$ $\begin{array}{lllllllllllll}\text { ALTVPELTQQMFDAR } & 1.00 & 36.61 & 27.61 & 21.85 & 3 & 1862.9725 & 1862.9682 & 621.9967 & 0.0043 & 2.3044 & 164.713\end{array}$ $\begin{array}{lllllllllllll}\text { ALTVPELTQQMFDAR } & 1.00 & 72.21 & 27.57 & 29.56 & 2 & 1862.9698 & 1862.9682 & 932.4914 & 0.0016 & 0.8579 & 208.935\end{array}$ $\begin{array}{lllllllllll}\text { MASTFIGNSTAIQELFK } & 0.95 & 42.74 * 27.36 & 19.83 & 3 & 2161.1368 & 2161.1333 & 721.3850 & 0.0035 & 1.6173 & 141.920\end{array}$

ISEQFSAMFR

ISEQFSAMFR

ISEQFSAMFR $\begin{array}{lllllllllllll}0.64 & 3.46^{*} & 22.15 & 14.70 & 4 & 3340.4701 & 3340.4655 & 836.1237 & 0.0046 & 1.3754 & 18.640\end{array}$ $\begin{array}{llllllllllll}0.94 & 58.24 * 27.09 & 25.75 & 2 & 1358.6806 & 1358.6774 & 680.3460 & 0.0032 & 2.3517 & 19695.721 & 10109.838\end{array}$ ISEQFSAMFR $\begin{array}{llllllllllll}54.44 * 27.24 & 24.23 & 2 & 1358.6812 & 1358.6774 & 680.3460 & 0.0038 & 2.7927 & 17356.220 & 9652.922\end{array}$ $\begin{array}{lllllllllllllllll} & \end{array}$ $\begin{array}{lllllllllllllllll} & 2778.4369 & 2778.4344 & 927.1521 & 0.0025 & 0.8988 & 1837.242 & 1031.712 & 715.595 & 1272.311 & \text { Yes } \\ \end{array}$ $\begin{array}{lllllllllllllll} & \end{array}$ $\begin{array}{llllllllllllllll} & \\ \text { LTTPTYGDLNHLVSATMSGVTTSLR } & 0.66 & 81.23 & 26.75 & 94.23 & 3 & 27778.4366 & 2778.4344 & 927.1521 & 0.0022 & 0.7910 & 1604.454 & 712.556 & 538.896 & 732.833 & \text { Yes }\end{array}$

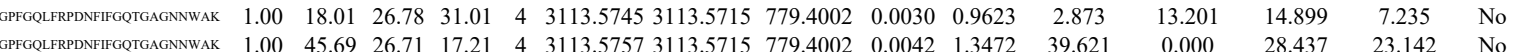
$\begin{array}{llllllllllllll} & \end{array}$

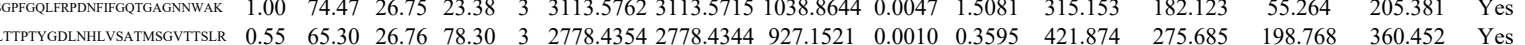

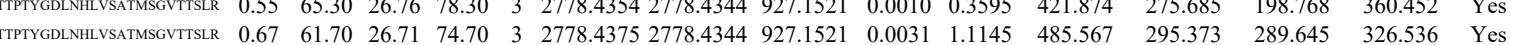

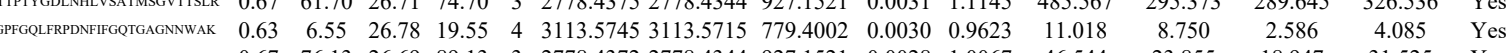

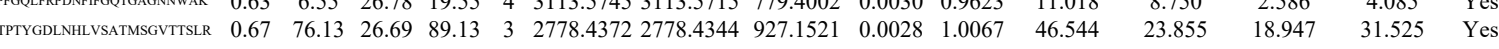
$\begin{array}{llllllllllllllllll}\text { AALVDLEPGTMDSVR } & 1.00 & 88.31 & 28.03 & 25.79 & 2 & 1716.8842 & 1716.8838 & 859.4492 & 0.0004 & 0.2327 & 958.033 & 350.831 & 92.160 & 686.258 & \text { Yes }\end{array}$

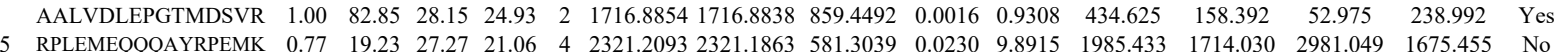
$\begin{array}{lllllllllllllllll}\text { MRPFEGFQR } & 0.68 & 21.94 & 27.37 & 17.90 & 3 & 1310.6779 & 1310.6676 & 437.8965 & 0.0103 & 7.8405 & 12654.997 & 18394005 & 5833.072 & 20889.831 & \text { Yes }\end{array}$

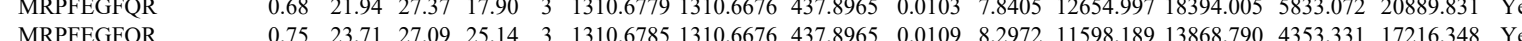

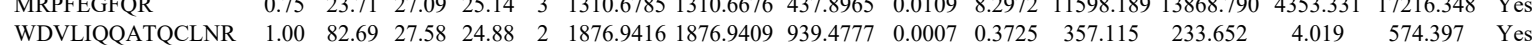

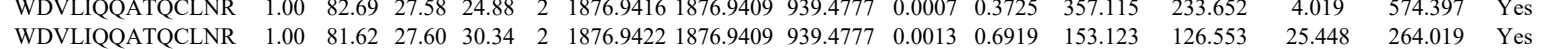

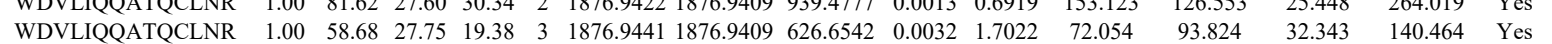

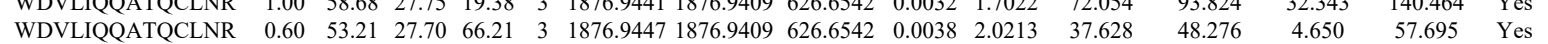

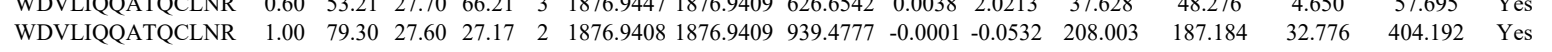

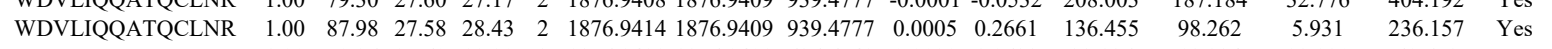
$\begin{array}{llllllllllllllll}\text { WDVLIQQATQCLNR } & 1.00 & 59.26 & 27.60 & 19.20 & 3 & 1876.9429 & 1876.9409 & 626.6542 & 0.0020 & 1.0638 & 33.186 & 18.234 & 23.220 & 61.658 & \text { Yes }\end{array}$ $\begin{array}{lllllllllllllllll}\text { WDVLIQQATQCLNR } & 1.00 & 49.57 & 27.71 & 18.12 & 3 & 1876.9438 & 1876.9409 & 626.6542 & 0.0029 & 1.5426 & 29.397 & 43.111 & 16.713 & 61.853 & \text { Yes }\end{array}$ $\begin{array}{lllllllllllllllll}\text { WDVLIQQATQCLNR } & 1.00 & 87.62 & 27.57 & 23.42 & 2 & 1876.9412 & 1876.9409 & 939.4777 & 0.0003 & 0.1597 & 17.572 & 8.417 & 2.366 & 32.777 & \text { Yes }\end{array}$

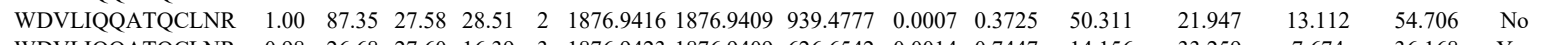
$\begin{array}{lllllllllllllllll}\text { WDVLIQQATQCLNR } & 0.98 & 26.68 & 27.60 & 16.39 & 3 & 1876.9423 & 1876.9409 & 626.6542 & 0.0014 & 0.7447 & 14.156 & 33.259 & 7.674 & 36.168 & \text { Yes }\end{array}$ $\begin{array}{llllllllllllllll}\text { WDVLIQQATQCLNR } & 1.00 & 43.45 & 27.60 & 16.56 & 3 & 1876.9429 & 1876.9409 & 626.6542 & 0.0020 & 1.0638 & 38.026 & 26.637 & 8.706 & 39.650 & \text { Yes }\end{array}$

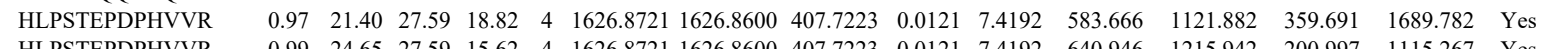

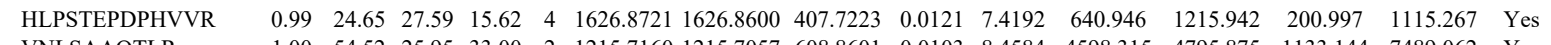
VNLSAAQTLR VNLSAAQTLR VNLSAAQTLR VNLSAAQTLR VNLSAAQTLR VNLSAAQTLR

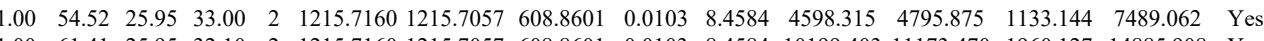

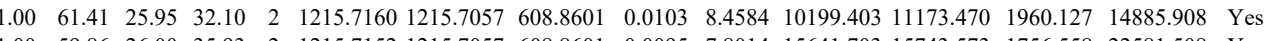
$\begin{array}{llllllllllllllllll}1.00 & 59.86 & 26.00 & 35.93 & 2 & 1215.7152 & 1215.7057 & 608.8601 & 0.0095 & 7.8014 & 15641.703 & 15743.573 & 1756.558 & 22581.508 & \text { Yes }\end{array}$ $\begin{array}{llllllllllllllllll}1.00 & 55.19 & 25.95 & 32.83 & 2 & 1215.7158 & 1215.7057 & 608.8601 & 0.0101 & 8.2941 & 10464.123 & 9203.495 & 1648.325 & 12707.731 & \text { Yes } \\ 0.98 & 45.89 & 25.87 & 39.82 & 2 & 1215.7164 & 1215.7057 & 608.8601 & 0.0107 & 8.7868 & 10265.126 & 14095.511 & 1770.728 & 18205.357 & \text { Yes }\end{array}$

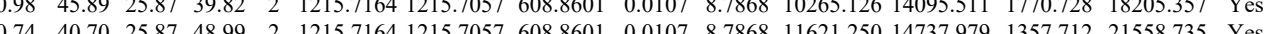
$\begin{array}{lllllllllllllll}0.74 & 40.70 & 25.87 & 48.99 & 2 & 1215.7164 & 1215.7057 & 608.8601 & 0.0107 & 8.7868 & 11621.250 & 14737.979 & 1357.712 & 21558.735 & \text { Yes } \\ 0.67 & 37.81 & 20.00 & 50.81 & 3 & 1856.1157 & 185.1127 & 619.7115 & 0.0030 & 1.6137 & 148.803 & 2374.635 & 1173.987 & 3232.088 & \text { Yes }\end{array}$ $\begin{array}{llllllllllllllll}0.60 & 37.08 & 19.64 & 50.08 & 3 & 18561166 & 18561127 & 619.7115 & 0.0039 & 2.0977 & 1901.624 & 2720.057 & 1185.456 & 3896.522 & \text { Y }\end{array}$ $\begin{array}{llllllllllllllll}1.60 & 35.38 & 19.87 & 15.46 & 3 & 1856.1142 & 1856.1127 & 619.7115 & 0.0015 & 0.8068 & 864.276 & 825.930 & 290.517 & 1154.923 & \text { Yes }\end{array}$ 


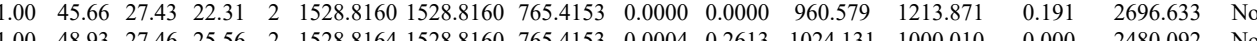
$\begin{array}{lllllllllllllll}1.00 & 48.93 & 27.46 & 25.56 & 2 & 1528.8164 & 1528.8160 & 765.4153 & 0.0004 & 0.2613 & 1024.131 & 1000.010 & 0.000 & 2480.092 & \text { No }\end{array}$

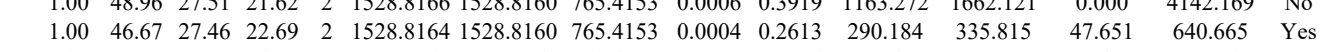
$\begin{array}{llllllllllllllll} & 1.00 & 52.11 & 27.53 & 24.73 & 2 & 1528.8168 & 1528.8160 & 765.4153 & 0.0008 & 0.5226 & 211.608 & 231.578 & 29.431 & 510.765 & \text { Yes } \\ \end{array}$ $\begin{array}{lllllllllllll} & \end{array}$ $\begin{array}{llllllllllll} & \end{array}$ $\begin{array}{lllllllllllll} & \end{array}$ $\begin{array}{lllllllllllllll}1.00 & 40.95 & 27.57 & 25.79 & 2 & 1241.6730 & 1241.6712 & 621.8429 & 0.0018 & 1.4473 & 4711.841 & 3747.632 & 154.527 & 5409.964 & \text { Yes }\end{array}$ $\begin{array}{llllllllllllllll}1.00 & 41.92 & 27.49 & 25.74 & 2 & 1241.6732 & 1241.6712 & 621.8429 & 0.0020 & 1.6081 & 4733.950 & 3563.595 & 58.895 & 5721.991 & \text { Yes }\end{array}$

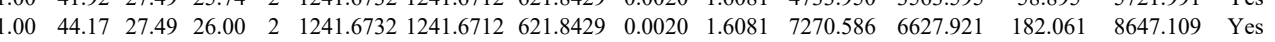
$\begin{array}{llllllllllllllll}1.00 & 43.69 & 27.49 & 27.28 & 2 & 1241.6732 & 1241.6712 & 621.8429 & 0.0020 & 1.6081 & 9978.564 & 9066.133 & 342.145 & 10976.955 & \text { Yes }\end{array}$ $\begin{array}{llllllllllllllll}1.00 & 50.80 & 27.58 & 24.07 & 2 & 1257.6672 & 1257.6662 & 629.8404 & 0.0010 & 0.7939 & 2476.075 & 2092.974 & 140.378 & 2844.642 & \text { Yes }\end{array}$

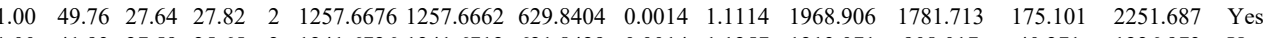
$\begin{array}{llllllllllllllll}1.00 & 41.93 & 27.59 & 25.65 & 2 & 1241.6726 & 1241.6712 & 621.8429 & 0.0014 & 1.1257 & 1213.071 & 908.017 & 40.271 & 1226.973 & \text { Yes }\end{array}$

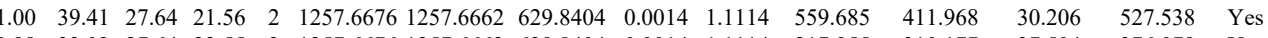

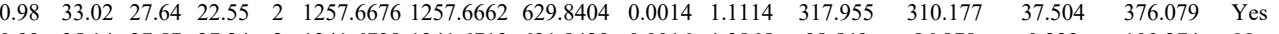

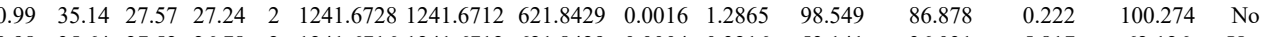

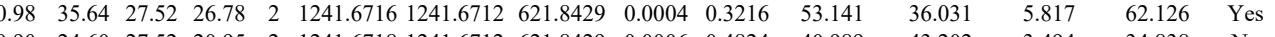

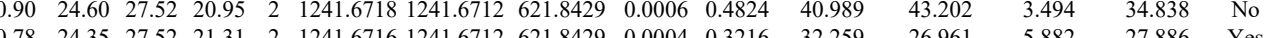

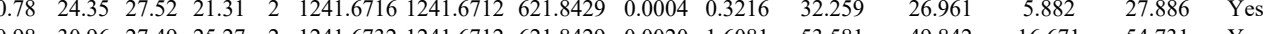

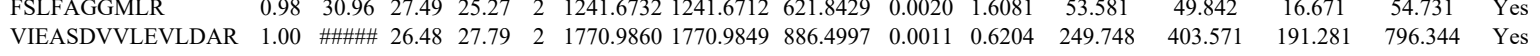
$\begin{array}{lllllllllllllllll} & \end{array}$ $\begin{array}{lllllllllllllllll} & \end{array}$

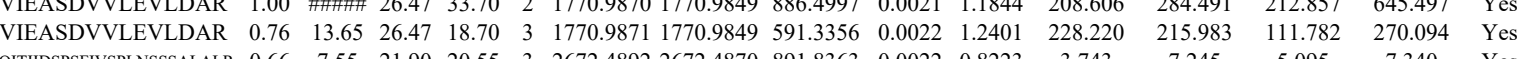
$\begin{array}{llllllllllllll} & 0.54 & 7.55 & 21.90 & 2.55 & 3 & 2672.4892 & 2672.4870 & 891.8363 & 0.0022 & 0.8223 & 3.743 & & 7.245 \\ \end{array}$

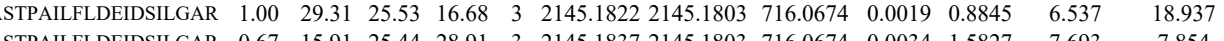

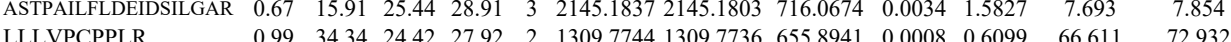
LLLVPCPPLR $\begin{array}{llllllllllll}0.99 & 34.34 & 24.42 & 27.92 & 2 & 1309.7744 & 1309.7736 & 655.8941 & 0.0008 & 0.6099 & 66.611 & 72.932 \\ 0.99 & 31.57 & 24.59 & 25.47 & 2 & 1309.7754 & 1309.7736 & 655.8941 & 0.0018 & 1.3722 & 107.382 & 67.674\end{array}$ \begin{tabular}{lllllllllllll} 
LLLVPCPPLR & 0.99 & 31.57 & 24.59 & 25.47 & 2 & 1309.7754 & 1309.7736 & 655.8941 & 0.0018 & 1.3722 & 107.382 & 67.674 \\
\hline
\end{tabular} $\begin{array}{llllllllllllll}\text { SFWMTLLTDALPLLEQK } & 0.73 & 11.13 & 24.61 & 15.92 & 3 & 2293.2667 & 2293.2636 & 765.4285 & 0.0031 & 1.3500 & 24.649 & 16.286\end{array}$ $\begin{array}{lllllllllllll}\text { SFWMTLLTDALPLLEQK } & 0.98 & 23.19 & 24.47 & 15.54 & 3 & 2293.2670 & 2293.2636 & 765.4285 & 0.0034 & 1.4806 & 19.095 & 22.889 \\ \text { FADAASLLLSLMTSR } & 1.00 & 90.24 & 27.35 & 23.22 & 2 & 1738.9408 & 1738.9409 & 870.4777 & -0.0001 & -0.0574 & 37.349 & 28.386\end{array}$ $\begin{array}{llllllllllllll}\text { FADAASLLLSLMTSR } & 1.00 & 85.89 & 27.32 & 24.52 & 2 & 1738.9422 & 1738.9409 & 870.4777 & 0.0013 & 0.7467 & 35.176 & 19.218\end{array}$ $\begin{array}{llllllllllllll}\text { FADAASLLLSLMTSR } & 0.99 & 27.61 & 27.28 & 15.98 & 3 & 1738.9426 & 1738.9409 & 580.6542 & 0.0017 & 0.9759 & 10.568 & 9.742\end{array}$ $\begin{array}{lllllllllllll}\text { FADAASLLLSLMTSR } & 1.00 & 43.05 & 27.41 & 18.43 & 3 & 1738.9429 & 1738.9409 & 580.6542 & 0.0020 & 1.1481 & 16.861 & 19.887\end{array}$ $\begin{array}{lllllllllllll}\text { FADAASLLLSLMTSR } & 1.00 & \text { \#\#\#\# } 27.28 & 24.15 & 2 & 1738.9424 & 1738.9409 & 870.4777 & 0.0015 & 0.8616 & 86.441 & 55.161\end{array}$ $\begin{array}{llllllllllll}\text { FADAASLLLSLMTSR } & 1.00 & \text { \#\#\# } 27.28 & 27.23 & 2 & 1738.9424 & 1738.9409 & 870.4777 & 0.0015 & 0.8616 & 53.339 & 40.683\end{array}$ $\begin{array}{lllllllllllllll}\text { FADAASLLLSLMTSR } & 1.00 & 50.16 & 27.41 & 18.25 & 3 & 1738.9429 & 1738.9409 & 580.6542 & 0.0020 & 1.1481 & 19.949 & 24.138\end{array}$ $\begin{array}{llllllllllllll}\text { FADAASLLLSLMTSR } & 1.00 & \text { \#册册 } 27.28 & 27.57 & 2 & 1738.9420 & 1738.9409 & 870.4777 & 0.0011 & 0.6318 & 81.364 & 48.913\end{array}$ $\begin{array}{llllllllllllll}\text { FADAASLLLSLMTSR } & 1.00 & 49.25 & 27.32 & 19.02 & 3 & 1738.9423 & 1738.9409 & 580.6542 & 0.0014 & 0.8037 & 29.831 & 28.892 & 9.5\end{array}$ $\begin{array}{lllllllllllll}\text { ATVAPEDVEVVIFGHVLAACCGQNPVR } & 1.00 & 80.95 & 26.68 & 25.31 & 3 & 2925.4615 & 2925.4599 & 976.1606 & 0.0016 & 0.5464 & 138.863 & 78.640\end{array}$ $\begin{array}{llllllllllllll}\text { ATVAPEDVEVVIGGHVAAGCGQNPVR } & 1.00 & 82.43 & 26.68 & 24.92 & 3 & 2925.4636 & 2925.4599 & 976.1606 & 0.0037 & 1.2635 & 665.999 & 674.370 & 6 \\ \text { ATVAPEDSEVIFGHVLAAGCGNPVR } & 1.00 & 89.79 & 26.67 & 24.70 & 3 & 2925.4621 & 2925.4599 & 976.1606 & 0.0022 & 0.7512 & 2244.429 & 1265.811 & 15\end{array}$

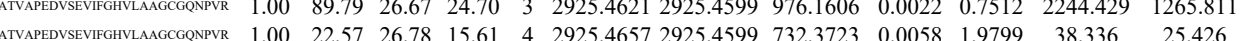
$\begin{array}{llllllllllllll}\text { ATVAPEDSEVIFGHVLAGCGQNPVR } & 1.00 & 80.22 & 26.68 & 19.31 & 3 & 2925.4615 & 2925.4599 & 976.1606 & 0.0016 & 0.5464 & 874.107 & 898.195 & \text { (69. }\end{array}$ $\begin{array}{llllllllllllll}\text { VAVLSQNR } & 0.99 & 36.82 & 26.79 & 34.89 & 2 & 1029.6068 & 1029.6053 & 515.8099 & 0.0015 & 1.4540 & 4112.515 & 3340.931 & 44 . \\ \text { VAVLSQNR } & 1.00 & 47.26 & 27.05 & 35.54 & 2 & 1029.6074 & 1029.6053 & 515.8099 & 0.0021 & 2.0356 & 6051.649 & 5220.723 & 288 .\end{array}$

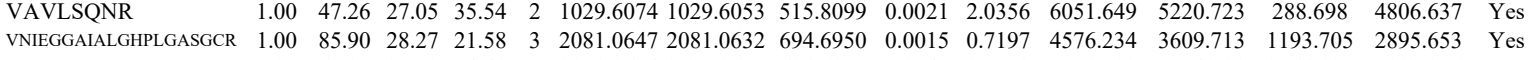

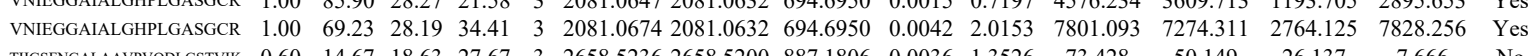

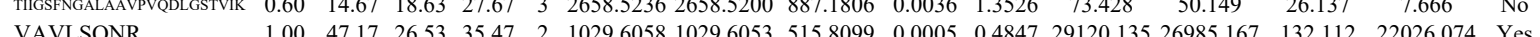

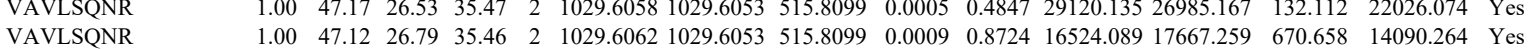



$\begin{array}{lllllllllllllllll} & \text { Mes }\end{array}$

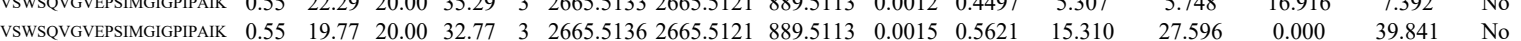

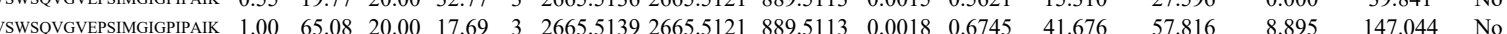
$\begin{array}{llllllllllllllll} & 0.55 & 33.10 & 20.00 & 46.10 & 3 & 265.55136 & 2655.5121 & 889.5113 & 0.0015 & 0.5621 & 63.202 & 86.054 & 29.736 & 89.126 & \text { Y }\end{array}$

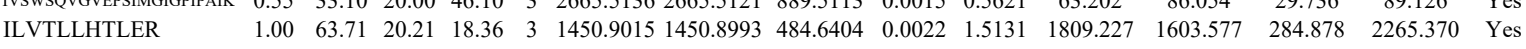
$\begin{array}{lllllllllllllllll} & \text { ILVTLLHTLER } & 1.00 & 47.63 & 20.49 & 16.17 & 3 & 1450.9003 & 1450.8993 & 484.6404 & 0.0010 & 0.6878 & 535.904 & 577.708 & 100.240 & 783.674 & \text { Yes }\end{array}$

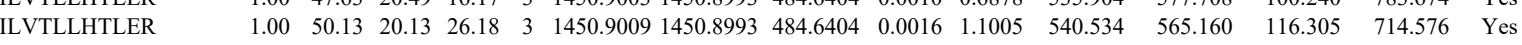
$\begin{array}{llllllllllllllll}\text { ILVTLLHTLER } & 1.00 & 60.39 & 18.69 & 22.57 & 2 & 1450.9056 & 1450.8993 & 726.4569 & 0.0063 & 4.3361 & 49.629 & 82.356 & 10.561 & 105.783 & \text { Yes }\end{array}$

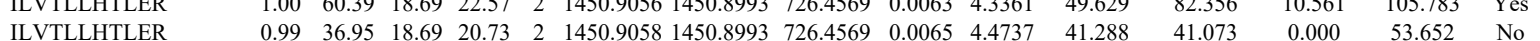

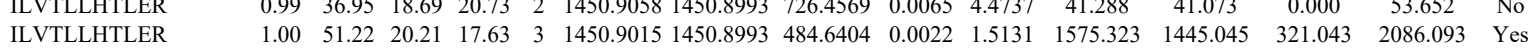
$\begin{array}{llllllllllllllll}\text { ILVTLLHTLER } & 0.66 & 60.22 & 20.09 & 73.22 & 3 & 1450.9018 & 1450.8993 & 484.6404 & 0.0025 & 1.7195 & 1241.154 & 1144.735 & 202.565 & 1881.326 & \text { Yes }\end{array}$

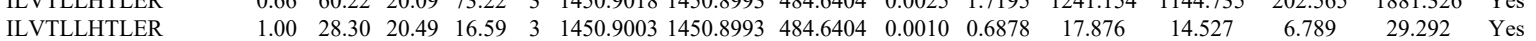
$\begin{array}{llllllllllllllllll} & \text { AIELATTLDESLTNR } & 0.99 & 32.42 & 27.57 & 28.54 & 3 & 1789.9570 & 1789.9543 & 597.6587 & 0.0027 & 1.5059 & 196.421 & 206.254 & 66.846 & 175.276 & \text { Yes }\end{array}$ $\begin{array}{llllllllllllllll}\text { VAIIEELVVGYETSLK } & 0.91 & 15.86 & 22.20 & 15.29 & 3 & 2050.1818 & 2050.1805 & 684.4008 & 0.0013 & 0.6332 & 98.589 & 134.175 & 54.166 & 126.510 & \text { Yes }\end{array}$ $\begin{array}{llllllllllllllll}\text { VAIIEELVVGYETSLK } & 0.67 & 37.14 & 22.72 & 50.14 & 3 & 2050.1833 & 2050.1805 & 684.4008 & 0.0028 & 1.3637 & 113.164 & 81.885 & 55.749 & 169.136 & \text { Yes }\end{array}$

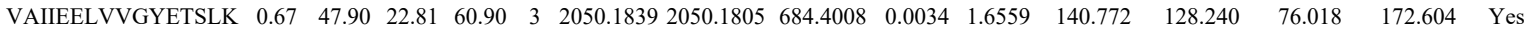

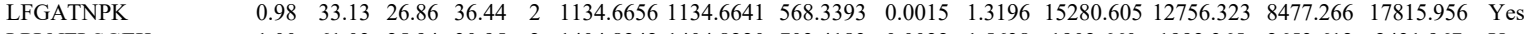
$\begin{array}{llllllllllllllll}\text { LPLNFLSGEK } & 1.00 & 61.03 & 25.94 & 30.95 & 2 & 1404.8242 & 1404.8220 & 703.4183 & 0.0022 & 1.5638 & 1902.660 & 1992.365 & 2653.612 & 2431.967 & \text { Yes }\end{array}$ $\begin{array}{llllllllllllllll}\text { DDDDEEIGGPK } & 1.00 & 59.82 & 25.11 & 29.12 & 2 & 1476.6822 & 1476.6824 & 739.3485 & -0.0002 & -0.1353 & 30.416 & 38.632 & 73.410 & 31.566 & \text { No }\end{array}$

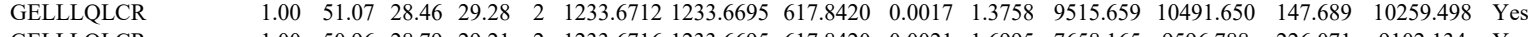
$\begin{array}{llllllllllllllll}\text { GELLLQLCR } & 1.00 & 50.96 & 28.79 & 29.21 & 2 & 1233.6716 & 1233.6695 & 617.8420 & 0.0021 & 1.6995 & 7658.165 & 9596.788 & 226.071 & 9102.134 & \text { Yes }\end{array}$ $\begin{array}{llllllllllllllll}\text { GELLLQLCR } & 1.00 & 51.21 & 28.60 & 29.36 & 2 & 1233.6698 & 1233.6695 & 617.8420 & 0.0003 & 0.2428 & 1701.535 & 2049.878 & 74.051 & 1799.133 & \text { Yes }\end{array}$

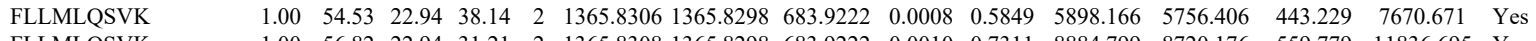
$\begin{array}{lllllllllllllllll}\text { FLLMLQSVK } & 1.00 & 56.82 & 22.94 & 31.21 & 2 & 1365.8308 & 1365.8298 & 683.9222 & 0.0010 & 0.7311 & 8884.799 & 8720.176 & 559.779 & 11836.695 & \text { Yes }\end{array}$ $\begin{array}{lllllllllllllllll}\text { GCPPVFNTLR } & 0.82 & 38.69 & 27.72 & 51.69 & 2 & 1292.6502 & 1292.6491 & 647.3318 & 0.0011 & 0.8496 & 4248.056 & 3964.885 & 442.926 & 3791.934 & \text { Yes }\end{array}$ $\begin{array}{llllllllllllllll} & & \end{array}$

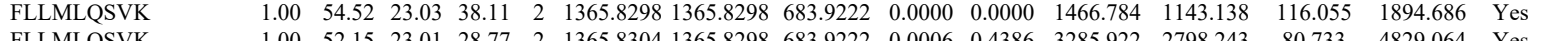

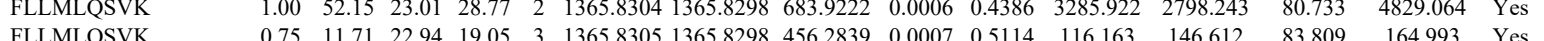

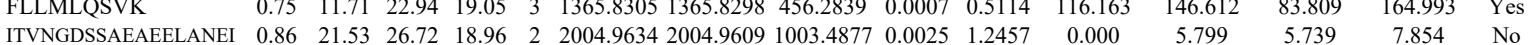

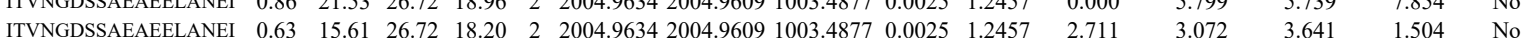

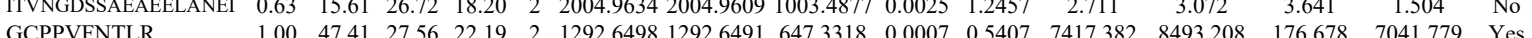

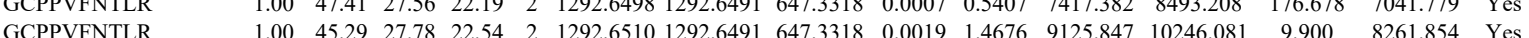

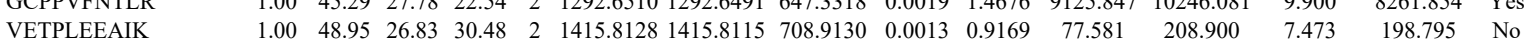

$\begin{array}{llllllllll}\text { ITPA HUMAN Q9BY32 } & \text { ITPA } & \text { Inosine triphospha } 21.446 & 1.00 & 3 & 30.9 & -0.7772 & 0.4759 & -0.7319 & 0.7086\end{array}$

$\begin{array}{lllllllllll}\text { EIF2A HUMAN Q9BY44 EIF2A } & \text { Eukaryotic transla } 64.99 & 1.00 & 4 & 6.8 & 0.4941 & 0.2286 & 1.7129 & 0.2416\end{array}$ IDLPEYQGEPDEISIQK IDLPEYQGEPDEISIQK IDLPEYQGEPDEISI

GLLHSFDLLK VNIISVTNK APSTPLLTVR APSTPLLTVR

VATAYRPPALR

VATAYRPPALR

VATAYRPPALR

VATAYRPPAL

QQTTVPQKP QQTTVPQKPR KQQTTVPQKPR KQQTTVPQKPR KQQTTVPQKPR KQQTTVPQKPR KQQTTPQKPR KQQTTVPQKPR VGIQQGLISQSTR

UGLQLLSQST

GIQQLLSQS

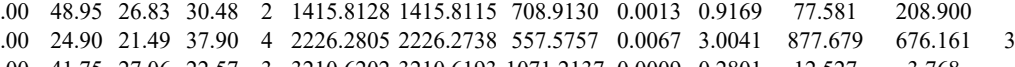

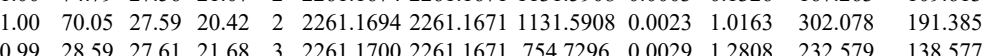

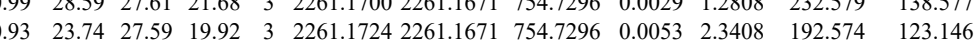
$\begin{array}{lllllllllllll}1.00 & 35.26 & 24.15 & 18.56 & 3 & 1429.8553 & 1429.8537 & 477.6252 & 0.0016 & 1.1166 & 1187.267 & 1777.597\end{array}$ $\begin{array}{llllllllllllll}1.00 & 47.15 & 23.54 & 21.36 & 2 & 1274.7892 & 1274.7802 & 638.3974 & 0.0090 & 7.0489 & 3224.232 & 4224.356 & 128\end{array}$

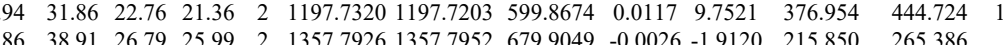
$\begin{array}{llllllllllll}0.98 & 30.20 & 26.36 & 24.58 & 2 & 1357.7960 & 1357.7952 & 679.9049 & 0.0008 & 0.5883 & 175.558 & 263.409\end{array}$ $\begin{array}{lllllllllllll}0.97 & 33.01 & 26.23 & 24.93 & 2 & 1357.7954 & 1357.7952 & 679.9049 & 0.0002 & 0.1471 & 162.104 & 209.499 & 63\end{array}$ $\begin{array}{llllllllllllll}1.00 & 39.79 & 26.28 & 24.45 & 2 & 1357.7964 & 1357.7952 & 679.9049 & 0.0012 & 0.8825 & 70.677 & 132.326 & 16\end{array}$ $\begin{array}{llllllllllll}0.99 & 30.50 & 25.94 & 19.83 & 3 & 1469.8564 & 1469.8558 & 490.9592 & 0.0006 & 0.4074 & 25.047 & 26.121\end{array}$ $\begin{array}{llllllllllll}0.99 & 30.25 & 25.89 & 19.87 & 3 & 1469.8558 & 1469.8558 & 490.9592 & 0.0000 & 0.0000 & 92.167 & 88.597\end{array}$ $\begin{array}{llllllllllll}0.55 & 29.36 & 20.68 & 42.36 & 3 & 1742.0536 & 1742.0528 & 581.6915 & 0.0008 & 0.4584 & 10.013\end{array}$ $\begin{array}{lllllllllll}1.00 & 19.21 & 20.68 & 32.21 & 4 & 1742.0537 & 1742.0528 & 436.5205 & 0.0009 & 0.5154 & 40.72\end{array}$ $\begin{array}{lllllllllll}1.00 & 18.34 & 20.68 & 31.34 & 4 & 1742.0537 & 1742.0528 & 436.5205 & 0.0009 & 0.5154 & 37.142\end{array}$ $\begin{array}{llllllllllll}0.55 & 38.54 & 2.68 & 51.54 & 3 & 1742.0542 & 1742.0528 & 581.6915 & 0.0014 & 0.8023 & 23.938 & 30.753\end{array}$ $\begin{array}{llllllllllll}0.55 & 16.66 & 20.68 & 29.66 & 3 & 1742.0536 & 1742.0528 & 581.6915 & 0.0008 & 0.4584 & 12.693 & 17.726\end{array}$ $\begin{array}{llllllllllllll}1.00 & 25.83 & 20.68 & 38.83 & 4 & 1742.0541 & 1742.0528 & 436.5205 & 0.0013 & 0.7445 & 217.796 & 284.688\end{array}$

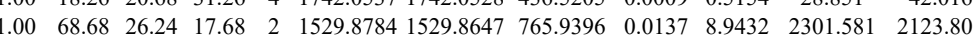

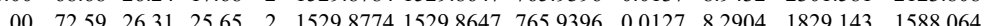
$\begin{array}{lllllllllllll}1.00 & 72.59 & 26.31 & 25.65 & 2 & 1529.8774 & 1529.8647 & 765.9396 & 0.0127 & 8.2904 & 1829.143 & 1588.064 & 546.275 \\ 1.00 & 56.10 & 23.01 & 25.38 & 2 & 1242.7792 & 1242.7782 & 622.3964 & 0.0010 & 0.8033 & 7123.508 & 7523.174 & 260.502\end{array}$ 

$\begin{array}{llllllllllll}.88 & 24.41 & 28.49 & 23.51 & 2 & 990.5588 & 990.5580 & 496.2863 & 0.0008 & 0.8060 & 37.841\end{array}$

$\begin{array}{llllllllll} & 01.335\end{array}$

$\begin{array}{lllllllllllll} & \end{array}$ $\begin{array}{lllllllllllll} & \end{array}$

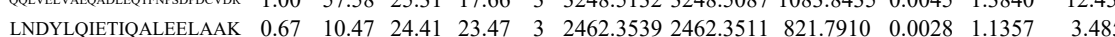
$\begin{array}{llllllllllll}\text { LNDYLQIETIQALEELAAK } & 0.60 & 49.09 & 24.35 & 62.09 & 3 & 2462.3548 & 2462.3511 & 821.7910 & 0.0037 & 1.5008 & 12.015\end{array}$ $\begin{array}{llllllllllll}\text { LNDYLQIETIQALEELAAK } & 0.60 & 32.95 & 24.31 & 45.95 & 3 & 2462.3557 & 2462.3511 & 821.7910 & 0.0046 & 1.8658 & 6.605\end{array}$ $\begin{array}{lllllllllllll}\text { NEILTAILASLTAR } & 1.00 & 91.75 & 23.73 & 33.19 & 2 & 1628.9594 & 1628.9583 & 815.4864 & 0.0011 & 0.6744 & 63.501\end{array}$ $\begin{array}{llllllllllll}\text { NEILTAILASLTAR } & 1.00 & 44.16 & 23.80 & 28.03 & 3 & 1628.9602 & 1628.9583 & 543.9934 & 0.0019 & 1.1642 & 59.648\end{array}$ $\begin{array}{lllllllllllll}\text { NEILTAILASLTAR } & 1.00 & 32.51 & 23.80 & 26.41 & 3 & 1628.9602 & 1628.9583 & 543.9934 & 0.0019 & 1.1642 & 34.261\end{array}$ NEILTAILASLTAR NEILTAILASLTAR NEILTAILASLTAR NEILTAILASLTAR NEILTAILASLTAR NEILTAILASLTAR NEILTAILASLTAR $\begin{array}{lllllllllll}1.00 & 23.73 & 35.47 & 2 & 1628.9592 & 1628.9583 & 815.4864 & 0.0009 & 0.5518 & 114.139\end{array}$ $\begin{array}{lllllllllll}0.99 & 25.96 & 23.73 & 22.38 & 3 & 1628.9593 & 1628.9583 & 543.9934 & 0.0010 & 0.6128 & 57.715 \\ 1.00 & 4 \# \# & 23.73 & 30.96 & 2 & 1628.9594 & 1628.953 & 815.4864 & 0.0011 & 0.6744 & 98.049\end{array}$ $\begin{array}{llllllllllll}1.00 & \text { \#\#\#\# } 23.73 & 30.96 & 2 & 1628.9594 & 1628.9583 & 815.4864 & 0.0011 & 0.6744 & 98.049 \\ 1.00 & 43.40 & 23.80 & 27.43 & 3 & 1628.9599 & 1628.9583 & 543.9934 & 0.0016 & 0.9804 & 50.397\end{array}$ $\begin{array}{llllllllllll}1.00 & 43.40 & 23.80 & 27.43 & 3 & 1628.9599 & 1628.9583 & 543.9934 & 0.0016 & 0.9804 & 50.397 \\ 0.95 & 23.19 & 23.73 & 25.64 & 3 & 1628.9593 & 1628.9583 & 543.9934 & 0.0010 & 0.6128 & 33.890\end{array}$ $\begin{array}{lllllllllllll}0.95 & 23.19 & 23.73 & 25.64 & 3 & 1628.9593 & 1628.9583 & 543.9934 & 0.0010 & 0.6128 & 33.890\end{array}$ $\begin{array}{lllllllllllll}1.00 & 82.77 & 23.73 & 26.14 & 2 & 1628.9594 & 1628.9583 & 815.4864 & 0.0011 & 0.6744 & 17.527\end{array}$ $\begin{array}{lllllllllllll}0.88 & 15.27 & 23.80 & 23.28 & 3 & 1628.9605 & 1628.9583 & 543.9934 & 0.0022 & 1.3481 & 26.571\end{array}$ $\begin{array}{llllllllllll}1.00 & 65.46 & 23.80 & 27.70 & 2 & 1628.9602 & 1628.9583 & 815.4864 & 0.0019 & 1.1649 & 12.024 \\ 1.00 & 46.44 & 25.49 & 17.83 & 3 & 3728.8732 & 3728.8655 & 1243.9624 & 0.0077 & 2.0633 & 0.000 \\ 1.00 & 43.99 & 25.60 & 19.97 & 3 & 3728.8642 & 3728.8655 & 1243.9624 & 0.0013 & -0.3483 & 0.000\end{array}$

GVGQADWTPDLGLR 1.0 $\begin{array}{ccccccccccccc}0.84 & 15.16 & 26.04 & 14.07 & 3 & 1613.9263 & 1613.9245 & 538.9821 & 0.0018 & 1.1132 & 1588.368 & 1633.705 \\ 0.58 & 8.30 & 26.17 & 21.30 & 4 & 1613.9241 & 1613.9245 & 404.4884 & -0.0004 & -0.2472 & 1597.953 & 1886.675\end{array}$ $\begin{array}{llllllllllllll}0.75 & 10.14 & 26.15 & 13.97 & 4 & 1613.9249 & 1613.9245 & 404.4884 & 0.0004 & 0.2472 & 1795.040 & 1815.692 & 32\end{array}$ $\begin{array}{llllllllllllll}0.55 & 8.03 & 26.15 & 21.03 & 4 & 1613.9249 & 1613.9245 & 404.4884 & 0.0004 & 0.2472 & 773.162 & 762.341 & 3\end{array}$ $\begin{array}{llllllllllll}1.00 & 48.88 & 23.30 & 18.21 & 2 & 1629.9712 & 1629.9698 & 815.9922 & 0.0014 & 0.8579 & 106.097 & 120.481\end{array}$ $\begin{array}{lllllllllllll}0.67 & 18.23 & 23.26 & 31.23 & 3 & 1629.9724 & 1629.9698 & 544.3305 & 0.0026 & 1.5922 & 564.234 & 766.069 & 145.086\end{array}$ $\begin{array}{llllllllllll} & \end{array}$ $\begin{array}{lllllllllllllll}1.00 & 56.03 & 26.95 & 32.17 & 2 & 1824.0038 & 1824.0025 & 913.0085 & 0.0013 & 0.7119 & 407.989 & 563.020 & 174.525 & 521.163 & \text { Yes }\end{array}$

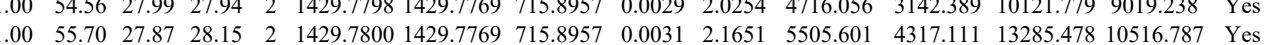

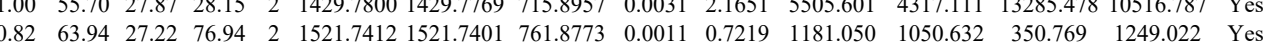
\begin{tabular}{lllllllllllllll}
1.00 & 52.21 & 27.33 & 20.94 & 3 & 2553.2920 & 2553.2884 & 852.1034 & 0.0036 & 1.4083 & 40.410 & 26.888 & 31.403 & 41.625 & Yes \\
\hline
\end{tabular} $\begin{array}{lllllllllllllll}1.00 & 41.36 & 26.18 & 31.52 & 2 & 1335.7794 & 1335.7785 & 668.8965 & 0.0009 & 0.6727 & 504.902 & 454.799 & 1078.051 & 1263.742 & \text { Yes }\end{array}$

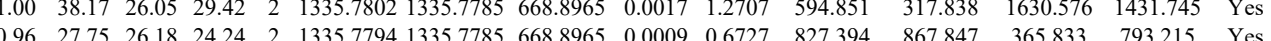
MDDDLR $\begin{array}{lllllllllllllllll}1.00 & 38.69 & 26.05 & 25.12 & 2 & 1335.7800 & 1335.7785 & 668.8965 & 0.0015 & 1.1212 & 714.259 & 767.620 & 444.685 & 773.226 & \text { Yes }\end{array}$

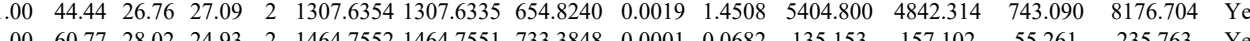
$\begin{array}{llllllllllllllll} & \end{array}$ 
VHLDQAAFR

KYPLPPPSGR

DPQFAEDYIFK

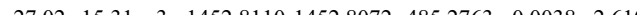

735.430

57.832

5.277

21.255
7.019
34.587

KPHIIIATPGR

$\begin{array}{llllllllll} & 0\end{array}$

$\begin{array}{lllllllllllllll}0.83 & 30.10 & 25.34 & 24.80 & 2 & 957.5608 & 957.5551 & 479.7848 & 0.0057 & 5.9401 & 10021.755 & 8874.888\end{array}$

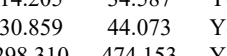

$\begin{array}{llllllllll}58.57 & 27.51 & 23.05 & 2 & 1659.8390 & 1659.8388 & 830.9267 & 0.0002 & 0.1203 & 221.240\end{array}$

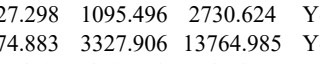

$\begin{array}{lllllllllll}\text { DDX47_HUMAI } & \text { Q9H0S4 } & \text { DDX47 } & \text { Probable ATP-der 50.647 } & 1.00 & 3 & 8.6 & 0.2596 & 0.3073 & 1.3915 & 0.4408\end{array}$

GAFALPILNALLETPQR

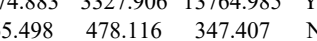
$\begin{array}{lllllllllllllllll} & 1.00 & 38.83 & 15.91 & 15.58 & 3 & 1489.9384 & 1489.9336 & 497.6518 & 0.0048 & 3.2151 & 903.463 & 1035.393 & 1024.388 & 1385.600 & \text { Yes } \\ \end{array}$

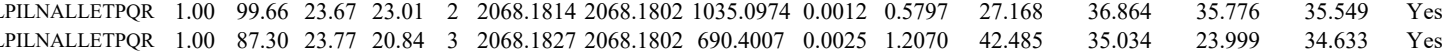
$\begin{array}{llllllllllllllll}\text { TGAFALPILNALLETPQR } & 1.00 & \text { \#\#\#\# } 23.67 & 22.31 & 2 & 2068.1814 & 2068.1802 & 1035.0974 & 0.0012 & 0.5797 & 22.788 & 39.842 & 24.144 & 51.194 & \text { Yes }\end{array}$ $\begin{array}{lllllllllllllllll}\text { TGAFALPILNALLETPQR } & 0.66 & 67.32 & 23.77 & 80.32 & 3 & 2068.1824 & 2068.1802 & 690.4007 & 0.0022 & 1.0622 & 37.202 & 16.603 & 20.550 & 43.573 & \text { No }\end{array}$

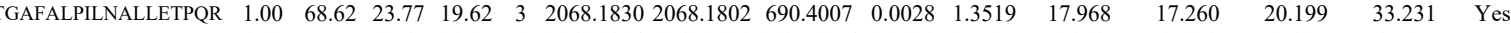

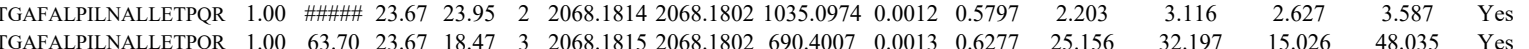
$\begin{array}{llllllllllllllll}\text { GAFALPILNALLETPQR } & 1.00 & 63.70 & 23.67 & 18.47 & 3 & 2068.1815 & 2068.1802 & 690.4007 & 0.0013 & 0.6277 & 25.156 & 32.197 & 15.026 & 48.035 & \text { Yes } \\ \end{array}$

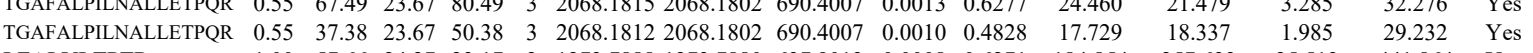

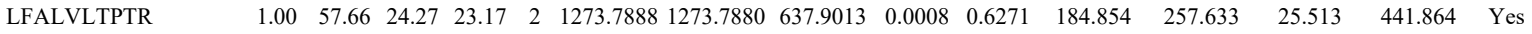
LFALVLTPTR LFALVLTPTR LFALVLTPTR LFALVLTPTR LFALVLTPTR LFALVLTPTR LFALVLTPTR LFALVLTPTR $\begin{array}{lllllllllllll}1.00 & 59.57 & 24.27 & 26.78 & 2 & 1273.7894 & 1273.7880 & 637.9013 & 0.0014 & 1.0973 & 357.643 & 371.995\end{array}$ $\begin{array}{lllllllllllllll}1.00 & 57.83 & 24.27 & 25.44 & 2 & 1273.7892 & 1273.7880 & 637.9013 & 0.0012 & 0.9406 & 204.680 & 227.220\end{array}$ $\begin{array}{llllllllllll}1.00 & 61.91 & 24.27 & 27.89 & 2 & 1273.7894 & 1273.7880 & 637.9013 & 0.0014 & 1.0973 & 407.021 & 396.64\end{array}$ $\begin{array}{llllllllllll}.00 & 58.26 & 24.27 & 25.93 & 2 & 1273.7894 & 1273.7880 & 637.9013 & 0.0014 & 1.0973 & 583.609\end{array}$ $\begin{array}{lllllllllll}1.00 & 59.40 & 24.25 & 26.40 & 2 & 1273.7898 & 1273.7880 & 637.9013 & 0.0018 & 1.4109 & 415.961\end{array}$

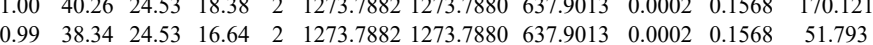
$\begin{array}{lllllllllll}1.00 & 41.40 & 24.42 & 22.21 & 2 & 1273.7886 & 1273.7880 & 637.9013 & 0.0006 & 0.4703 & 31.209\end{array}$

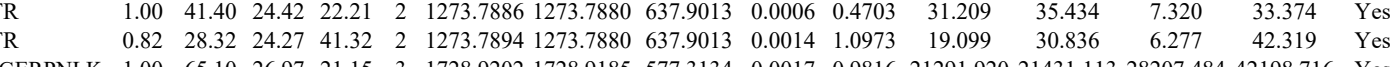

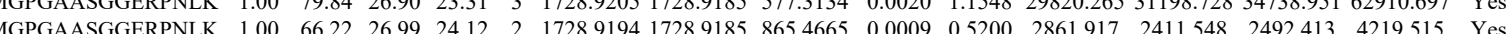

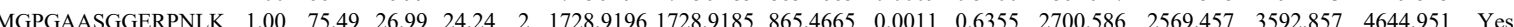

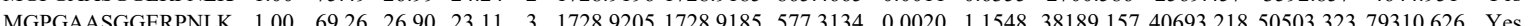

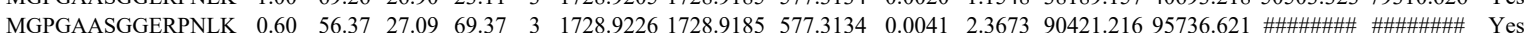

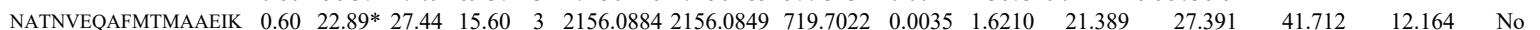

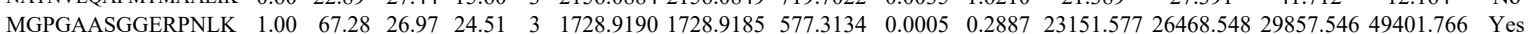

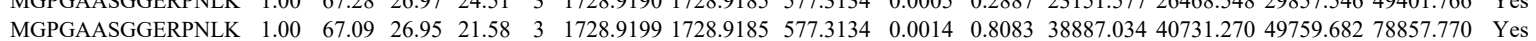
$\begin{array}{llllllllllllllll}\text { NATNVEQAFMTMAAEIK } & 0.99 & 55.59 * & 27.44 & 24.99 & 3 & 2156.0881 & 21560849 & 719.7022 & 0.0032 & 1.4821 & 32.332 & 16.013 & 10.773 & 24.476 & \text { No }\end{array}$

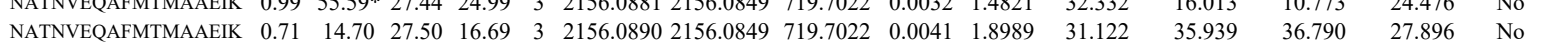

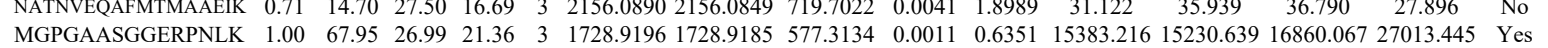
$\begin{array}{llllllllllllllll}\text { VLQTLGVLLTTCR } & 1.00 & 67.34 & 26.68 & 28.16 & 2 & 1605.9090 & 1605.9068 & 803.9607 & 0.0022 & 1.3682 & 32.863 & 43.380 & 1.900 & 46.011 & \text { Yes }\end{array}$ VLFALCSLLR VLFALCSLLR

$\begin{array}{lllllllllll}\text { SIL1_HUMAN } & \text { Q9H173 } & \text { SIL1 } & \text { Nucleotide exchar 52.085 } & 1.00 & 2 & 5 & 0.4838 & 0.1593 & 1.2037 & 0.2670\end{array}$ $\begin{array}{lllllllllll}1.00 & 67.95 & 26.68 & 28.16 & 2 & 1605.9090 & 1605.9068 & 803.9607 & 0.0022 & 1.3682 & 32.863\end{array}$ RPFTIPQVLR RPFTIPQVLR RPFTIPQVLR RPFTIPQVLR EGADEEEW $\begin{array}{lllllllllllll}1.00 & 42.38 & 26.21 & 28.30 & 2 & 1323.7542 & 1323.7529 & 62.8837 & 0.0013 & 0.9806 & 145.827 & 230.48\end{array}$ $\begin{array}{llllllllllll}1.00 & 54.57 & 27.33 & 21.19 & 3 & 3038.5222 & 3038.5206 & 1013.8475 & 0.0016 & 0.5260 & 1.06\end{array}$ $\begin{array}{llll}30.487 & 74.088 & 147.511 & \text { Yes } \\ 1.66 & 5.666 & 3.135 & \text { Yes }\end{array}$ $\begin{array}{lllllllllll}\text { ASCC2_HUMAI } & \text { Q9H1I8 } & \text { ASCC2 } & \text { Activating signal ( 86.36 } & 1.00 & 2 & 4.8 & 1.9832 & 0.7794 & -1.8023 & 0.8284\end{array}$ $\begin{array}{lllllllllll}\text { EHD4_HUMAN } & \text { Q9H223 } & \text { EHD4 } & \text { EH domain-contai } 61.175 & 1.00 & 6 & 13.5 & -0.3872 & 0.3895 & 0.0323 & 0.4681\end{array}$ DIQSLPQK

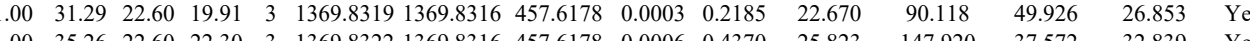

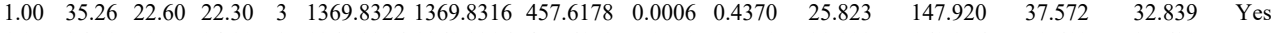
$\begin{array}{lllllllllllllll}1.00 & 36.98 & 22.70 & 24.90 & 3 & 1369.8316 & 1369.8316 & 457.6178 & 0.0000 & 0.0000 & 38.922 & 169.376 & 59.612 & 30.632 & \text { Yes }\end{array}$

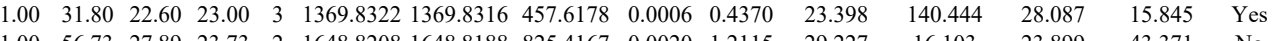

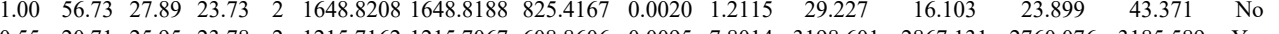
$\begin{array}{llllllllllllllll} & 0.55 & 20.71 & 25.95 & 23.78 & 2 & 1215.7162 & 1215.7067 & 608.8606 & 0.0095 & 7.8014 & 3198.601 & 2867.131 & 2760.076 & 3185.589 & \text { Yes }\end{array}$ $\begin{array}{lllllllllllllll} & & & \end{array}$

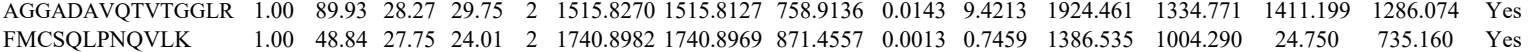
$\begin{array}{llllllllllllll} & \end{array}$ FGNAFLNR FGNAFLNR $\begin{array}{lllllllllllllll}0.56 & 11.10 & 27.77 & 24.10 & 3 & 1740.9001 & 1740.8969 & 581.3062 & 0.0032 & 1.8349 & 387.825 & 450.818 & 306.604 & 636.334 & \text { Yes } \\ \end{array}$ $\begin{array}{lllllllllllllll}0.82 & 28.87 & 27.22 & 24.84 & 2 & 1081.5876 & 1081.5791 & 541.7968 & 0.0085 & 7.8442 & 6158.130 & 5587.116 & 3223.071 & 5258.864 & \text { Yes } \\ 0.75 & 29.31 & 27.26 & 18.78 & 2 & 1081.5864 & 1081.5791 & 541.7968 & 0.0073 & 6.7368 & 9771.527 & 8269.429 & 6762218 & 7552.750 & \text { Yes }\end{array}$ $\begin{array}{lllllllllllllll}0.75 & 29.31 & 27.26 & 18.78 & 2 & 1081.5864 & 1081.5791 & 541.798 & 0.0073 & 6.7368 & 1581.527 & 8269.429 & 6762.218 & 7552.750 & Y\end{array}$ $\begin{array}{lllllllllllllll}1.00 & 49.48 & 28.92 & 28.73 & 2 & 1447.7332 & 1447.7211 & 724.8678 & 0.0121 & 8.3463 & 604.108 & 442.879 & 88.224 & 386.393 & \text { Yes }\end{array}$ $\begin{array}{lllllllllllllllll}0.97 & 27.30 & 24.62 & 21.62 & 2 & 957.5862 & 957.5851 & 479.7998 & 0.0011 & 1.1463 & 267.083 & 191.961 & 85.258 & 228.786 & \text { Yes }\end{array}$ 
$\begin{array}{llllllllllllllll}\text { IQYQLVDISQDNALRDEMR } & 0.66 & 30.74 & 27.69 & 17.04 & 3 & 2450.2360 & 2450.2345 & 817.7521 & 0.0015 & 0.6114 & 958.238 & 721.403 & 212.332 & 645.928 & \text { Yes }\end{array}$ $\begin{array}{lllllllllllllllll}\text { QQYQLVDISQDNALRDEMR } & 0.50 & 26.37 & 27.76 & 14.94 & 3 & 2450.2363 & 2450.2345 & 817.7521 & 0.0018 & 0.7337 & 541.704 & 545.183 & 258.658 & 513.840 & \text { Yes }\end{array}$

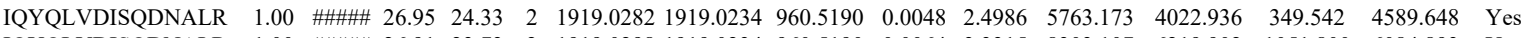

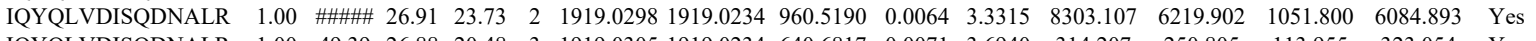

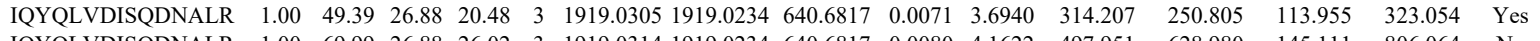
$\begin{array}{llllllllllllllll}\text { IQYQLVDISQDNALR } & 1.00 & 69.99 & 26.88 & 26.02 & 3 & 1919.0314 & 1919.0234 & 640.6817 & 0.0080 & 4.1622 & 497.951 & 628.980 & 145.111 & 806.064 & \text { No }\end{array}$

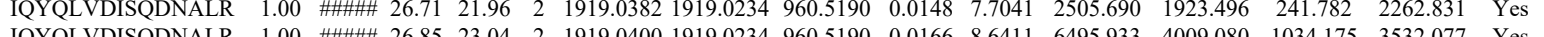

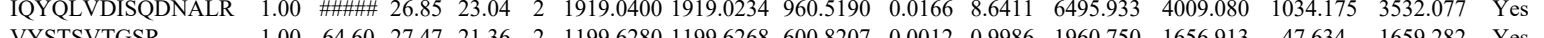

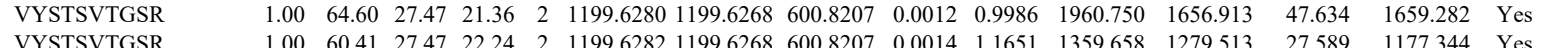
VYSTSVTGR YSTSVTGSR YSTSVTGSR VYSTSVTGSR VYSTSVTGSR VYSTSVTGSR VYSTSVTGSR VYSTSVTGSR VYSTSVTGSR VYSTSVTGSR

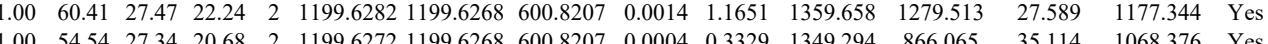

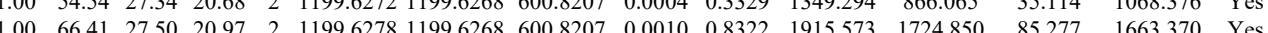

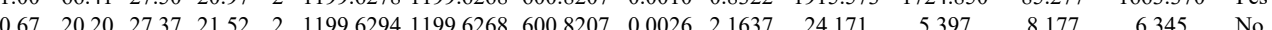

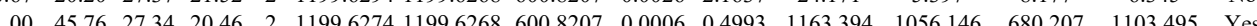

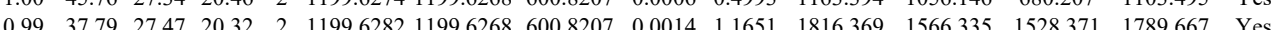
$\begin{array}{llllllllllllllll}0.98 & 31.19 & 27.26 & 21.85 & 2 & 1199.6284 & 1199.6268 & 600.8207 & 0.0016 & 1.3315 & 1196.440 & 1048.114 & 1586.620 & 1154.448 & \text { No }\end{array}$ $\begin{array}{llllllllllllllll}0.99 & 37.59 & 27.47 & 18.70 & 2 & 1199.6280 & 1199.6268 & 600.8207 & 0.0012 & 0.9986 & 556.021 & 472.486 & 384.337 & 526.817 & \text { Yes }\end{array}$

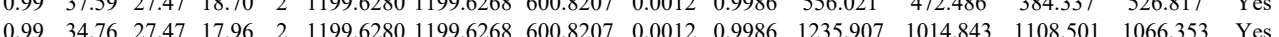
$\begin{array}{lllllllllllllll}0.93 & 26.01 & 27.50 & 19.04 & 2 & 1199.6278 & 1199.6268 & 600.8207 & 0.0010 & 0.8322 & 336.160 & 342.190 & 209.622 & 321.484 & \text { Yes }\end{array}$

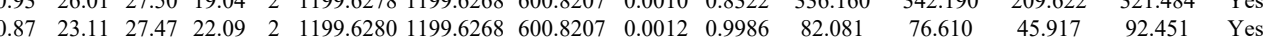
$\begin{array}{llllllllllllllll}\text { ILGILALIDEGETDWK } & 1.00 & 81.25 & 24.59 & 21.42 & 2 & 2073.1634 & 2073.1601 & 1037.5873 & 0.0033 & 1.5902 & 11.768 & 8.423 & 0.358 & 6.509 & \text { No }\end{array}$ $\begin{array}{llllllllllllllll}\text { ILGILALIDEGETDWK } & 0.99 & 37.51 & 24.49 & 17.14 & 3 & 2073.1699 & 2073.1601 & 692.0606 & 0.0098 & 4.7202 & 43.036 & 36.938 & 12.570 & 36.815 & \text { No }\end{array}$

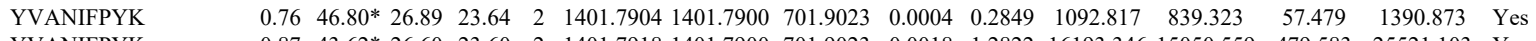

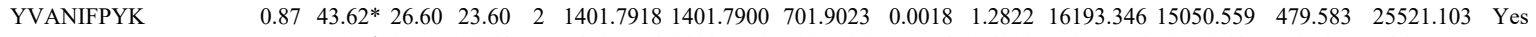
YVANIFPYK $\quad \begin{array}{llllllllllllllll} & 0.88 & 51.25 * 27.20 & 22.64 & 2 & 1401.7934 & 1401.7900 & 701.9023 & 0.0034 & 2.4220 & 15973.826 & 13118.649 & 51.733 & 24697.503 & \text { Yes }\end{array}$

$\begin{array}{lllllllllllll} & & & \end{array}$ GFSDSGGGPPAK MEEETEVR IFGLLMGTLQK IFGLLMGTLQK IFGLLMGTLQK IFGLLMGTLQK IFGLLMGTLQK

GFSDSGGGPPAK

DLEAEHVEVEDTTLNR

DLEAEHVEVEDTTLNR 1.0

VDVTEQPGLSGR

VDVTEQPGLSGR VDVTEQPGLSGR RPQPYPYPSK RPQPYPYPSK RPQPYPYPSK FIITALPTIYHCK FIITALPTIYHCK FIITALPTIYHCK

GATDELWAPSSIASLLTAAVIDNIR LLLGTLHLPR LLLGTLHLPR LLLGTLHLPR LLLGTLHLPR $\begin{array}{llllllllll}\text { UN45A_HUMAI Q9H3U1 } & \text { UNC45A } & \text { Protein unc-45 ho1 } 103.08 & 1.00 & 3 & 4.6 & 0.0373 & 0.3259 & 2.1628 & 0.3934\end{array}$

VLISNLLDLLTEVGVSGQGi VLISNLLDLLTEVGVSGQGR TVATLSILGTR FFLALVEEVEDR $\begin{array}{llllllllllll}\text { AMPB_HUMAN Q9H4A4 } & \text { RNPEP } & \text { Aminopeptidase B } 72.596 & 1.00 & 5 & 10 & -0.1594 & 0.5227 & 1.2653 & 1.1179 & 13 & \text { AEFGPPGPGAGSR } \\ & & & & & & & & & & & \end{array}$ VDIIPGFEFDR KPFVYTQGQAVLN

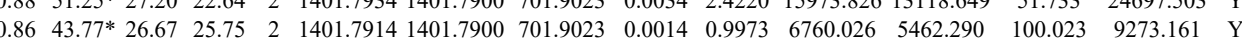

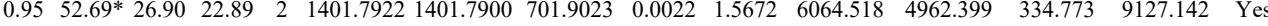
$\begin{array}{lllllllllllllll}1.00 & 68.81 & 27.77 & 21.84 & 2 & 1363.6976 & 1363.6976 & 682.8561 & 0.0000 & 0.0000 & 4358.133 & 4413.750 & 2197.328 & 5639.967 & \text { Yes }\end{array}$ $\begin{array}{lllllllllllllll}1.00 & 59.01 & 27.85 & 26.18 & 2 & 1363.6978 & 1363.6976 & 682.8561 & 0.0002 & 0.1464 & 2713.766 & 2381.478 & 1271.740 & 3073.651 & \text { Yes }\end{array}$

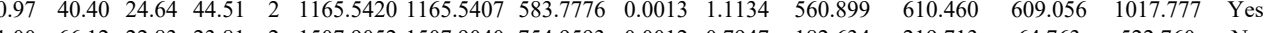
$\begin{array}{lllllllllllllll}1.00 & 66.12 & 22.83 & 23.81 & 2 & 1507.9052 & 1507.9040 & 754.9593 & 0.0012 & 0.7947 & 182.634 & 219.713 & 64.763 & 522.760 & \text { No }\end{array}$ $\begin{array}{lllllllllllllll}0.98 & 19.96 & 22.83 & 16.92 & 3 & 1507.9057 & 1507.9040 & 503.6419 & 0.0017 & 1.1251 & 50.775 & 48.206 & 20.437 & 61.825 & \text { Yes }\end{array}$ $\begin{array}{lllllllllllllll}1.00 & 41.15 & 22.83 & 19.42 & 3 & 1507.9057 & 1507.9040 & 503.6419 & 0.0017 & 1.1251 & 49.588 & 54.298 & 24.706 & 88.833 & \text { Yes }\end{array}$ \begin{tabular}{lllllllllllllll}
1.00 & 66.83 & 22.83 & 22.55 & 2 & 1507.9050 & 1507.9040 & 754.9593 & 0.0010 & 0.6623 & 56.609 & 84.450 & 36.854 & 119.049 & Yes \\
\hline
\end{tabular}

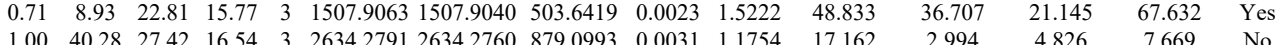
$\begin{array}{lllllllllllllll}1.00 & 71.23 & 27.44 & 21.18 & 3 & 2634.2797 & 2634.2760 & 879.0993 & 0.0037 & 1.4029 & 3.796 & 34.271 & 18.940 & 11.186 & \text { No }\end{array}$ $\begin{array}{lllllllllllllll}1.00 & 82.93 & 28.28 & 22.10 & 2 & 1363.7004 & 1363.6976 & 682.8561 & 0.0028 & 2.0502 & 7153.780 & 6671.785 & 3237.333 & 9733.262 & \text { Yes }\end{array}$

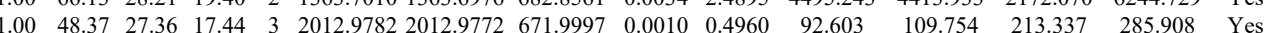

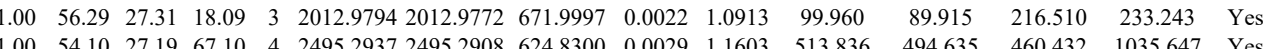
$\begin{array}{lllllllllllllll}1.00 & 55.58 & 27.68 & 35.19 & 2 & 1400.7496 & 1400.7382 & 701.3764 & 0.0114 & 8.1268 & 4297.271 & 3295.551 & 1886.199 & 4842.272 & \text { Yes }\end{array}$ $\begin{array}{lllllllllllllllll}1.00 & 57.15 & 27.64 & 35.05 & 2 & 1400.7500 & 1400.7382 & 701.3764 & 0.0118 & 8.4120 & 6462.543 & 4962.780 & 1886.624 & 7482.394 & \text { Yes }\end{array}$ $\begin{array}{llllllllllllllll}0.95 & 34.72 & 27.75 & 29.50 & 2 & 1400.7512 & 1400.7382 & 701.3764 & 0.0130 & 9.2674 & 1858.901 & 1562.090 & 1073.773 & 2163.361 & \text { Yes }\end{array}$ $\begin{array}{lllllllllllllll}0.90 & 19.09 & 27.72 & 16.65 & 3 & 1519.8409 & 1519.8391 & 507.6203 & 0.0018 & 1.1820 & 3753.930 & 2673.186 & 5017.101 & 4738.115 & \text { Yes }\end{array}$ $\begin{array}{lllllllllllllll}0.84 & 20.94 & 27.72 & 17.25 & 3 & 1519.8394 & 1519.8391 & 507.6203 & 0.0003 & 0.1970 & 4428.979 & 3415.758 & 7144.034 & 5374.194 & \text { Yes }\end{array}$ $\begin{array}{lllllllllllllll}0.77 & 19.06 & 27.72 & 16.59 & 3 & 1519.8394 & 1519.8391 & 507.6203 & 0.0003 & 0.1970 & 1816.533 & 1396.536 & 3044.160 & 1726.383 & \text { Yes }\end{array}$ $\begin{array}{llllllllllllllll}1.00 & 48.11 & 26.91 & 16.99 & 3 & 1853.0218 & 1853.0187 & 618.6802 & 0.0031 & 1.6702 & 1743.773 & 1623.368 & 190.305 & 2521.534 & \text { Yes }\end{array}$ $\begin{array}{lllllllllllllll}1.00 & 64.51 & 26.93 & 21.37 & 3 & 1853.0215 & 1853.0187 & 618.6802 & 0.0028 & 1.5086 & 1257.816 & 863.389 & 189.570 & 1418.741 & \text { Yes }\end{array}$ $\begin{array}{lllllllllllllll}1.00 & 57.00 & 26.93 & 17.84 & 3 & 1853.0212 & 1853.0187 & 618.6802 & 0.0025 & 1.3470 & 286.833 & 242.517 & 68.276 & 351.732 & \text { Yes }\end{array}$

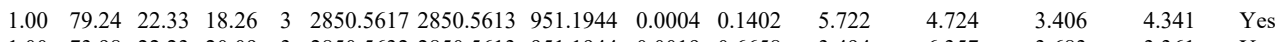

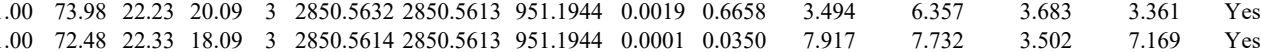
$\begin{array}{lllllllllllllll}1.00 & 50.15 & 21.11 & 22.50 & 3 & 1275.8155 & 1275.8149 & 426.2789 & 0.0006 & 0.4692 & 1300.943 & 1841.830 & 121.811 & 2486.035 & \text { Yes }\end{array}$ $\begin{array}{lllllllllllllll}1.00 & 59.74 & 21.11 & 26.83 & 3 & 1275.8155 & 1275.8149 & 426.2789 & 0.0006 & 0.4692 & 1607.990 & 1898.434 & 115.495 & 2719.192 & \text { Yes }\end{array}$ $\begin{array}{lllllllllllllll}1.00 & 51.31 & 21.00 & 25.92 & 3 & 1275.8158 & 1275.8149 & 426.2789 & 0.0009 & 0.7038 & 647.121 & 931.634 & 109.236 & 1177.048 & \text { Yes }\end{array}$

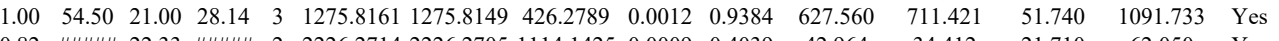

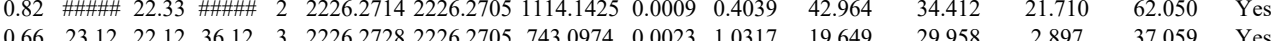
$\begin{array}{lllllllllllllll}0.66 & 60.45 & 22.07 & 73.45 & 3 & 2226.2731 & 2226.2705 & 743.0974 & 0.0026 & 1.1663 & 45.320 & 46.970 & 4.961 & 81.741 & \text { Yes }\end{array}$

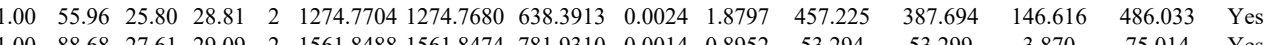

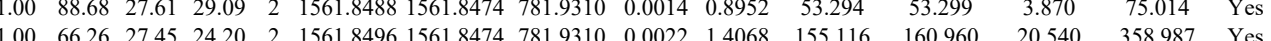

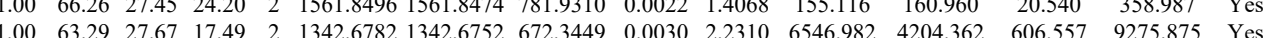

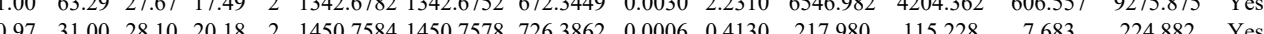

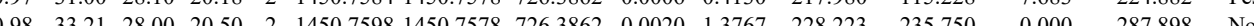
$\begin{array}{lllllllllllllllll}1.00 & 63.77 & 23.71 & 18.42 & 3 & 1908.0973 & 1908.0825 & 637.0348 & 0.0148 & 7.7442 & 987.790 & 669.136 & 718.437 & 819.180 & \text { Yes }\end{array}$ 
$\begin{array}{lllllllllllll}\text { LLDTVDDMLANDIAR } & 1.00 & 90.74 & 28.08 & 26.63 & 2 & 1817.9346 & 1817.9315 & 909.9730 & 0.0031 & 1.7033 & 555.945\end{array}$ $\begin{array}{lllllllllllll} & \end{array}$ $\begin{array}{lllllllllllllll}\text { LLDTVDDMLANDIAR } & 1.00 & 86.32 & 28.07 & 28.75 & 2 & 1817.9350 & 1817.9315 & 909.9730 & 0.0035 & 1.9231 & 1043.432 & 609.256\end{array}$ $\begin{array}{llllllllllllll}\text { LLDTVDDMLANDIAR } & 0.59 & 13.16 & 28.09 & 14.48 & 3 & 1817.9356 & 1817.9315 & 606.9844 & 0.0041 & 2.2516 & 87.842 & 100.987\end{array}$ $\begin{array}{llllllllllllll}\text { LLDTVDDMLANDIAR } & 1.00 & 90.82 & 28.08 & 24.47 & 2 & 1817.9352 & 1817.9315 & 909.9730 & 0.0037 & 2.0330 & 672.487 & 245.783\end{array}$ $\begin{array}{lllllllllllllll}\text { LLDTVDDMLANDIAR } & 0.74 & 15.95 & 28.09 & 18.13 & 3 & 1817.9356 & 1817.9315 & 606.9844 & 0.0041 & 2.2516 & 140.991 & 118.394\end{array}$ $\begin{array}{lllllllllllllll}\text { LLDTVDDMLANDIAR } & 1.00 & 90.87 & 28.09 & 24.20 & 2 & 1817.9358 & 1817.9315 & 909.9730 & 0.0043 & 2.3627 & 293.115 & 166.354\end{array}$ $\begin{array}{lllllllllllll}\text { EPELFQTVAEGLR } & 1.00 & 72.58 & 27.63 & 33.71 & 2 & 1631.8658 & 1631.8641 & 816.9393 & 0.0017 & 1.0405 & 457.586 & 317.037\end{array}$ $\begin{array}{lllllllllllll}\text { EPELFQTVAEGLR } & 1.00 & 62.07 & 27.72 & 27.68 & 2 & 1631.8664 & 1631.8641 & 816.9393 & 0.0023 & 1.4077 & 244.005 & 197.346 \\ \text { IINTPEVVR } & 0.96 & 35.26 & 23.28 & 33.12 & 2 & 1183.7158 & 1183.7047 & 592.8596 & 0.0111 & 9.3613 & 3846.661 & 2595.073\end{array}$ $\begin{array}{llllllllllll}0.96 & 35.26 & 23.28 & 33.12 & 2 & 1183.7158 & 1183.7047 & 592.8596 & 0.0111 & 9.3613 & 3846.661 & 2595.073 \\ 0.99 & 29.95 & 25.56 & 15.41 & 3 & 34157572 & 3415.7568 & 11395929 & 0.0004 & 0.1170 & 102.279 & 97.864\end{array}$

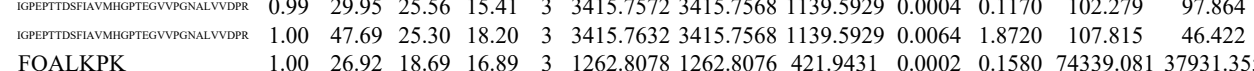

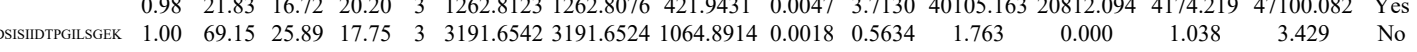
$\begin{array}{llllllllllllll} & \text { M. }\end{array}$

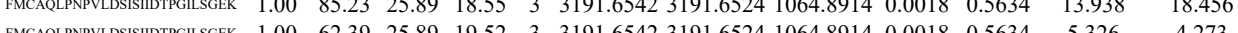
$\begin{array}{lllllllllllll}\text { FMCAQLPNPVLDSISIDTPGISGGK } & 1.00 & 35.62 & 25.89 & 15.90 & 3 & 3191.6542 & 3191.6524 & 1064.8914 & 0.0018 & 0.5634 & 18.124 & 8.385\end{array}$

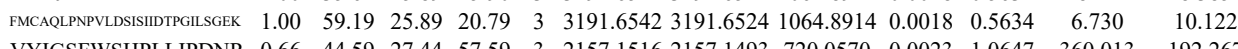
$\begin{array}{lllllllllllll}\text { VYIGSFWSHPLLIPDNR } & 0.60 & 40.54 & 27.38 & 53.54 & 3 & 2157.1531 & 157.1493 & 720.0570 & 0.0038 & 1.7591 & 485.774 & 305.288\end{array}$ $\begin{array}{lllllllllllll}\text { VYIGSFWSHPLLIPDNR } & 0.67 & 39.88 & 27.36 & 52.88 & 3 & 2157.1528 & 2157.1493 & 720.0570 & 0.0035 & 1.6202 & 20.557 & 24.268\end{array}$ $\begin{array}{llllllllllllll}\text { VYIGSFWSHPLLIPDNR } & 1.00 & 55.13 & 27.38 & 16.64 & 3 & 2157.1531 & 2157.1493 & 720.0570 & 0.0038 & 1.7591 & 84.129 & 147.777\end{array}$ $\begin{array}{llllllllllllll}\text { LNAFGNAFLNR } & 0.92 & 34.73 & 28.06 & 23.06 & 2 & 1379.7418 & 1379.7431 & 690.8788 & -0.0013 & -0.9408 & 8075.595 & 5500.886\end{array}$ LNAFGNAFLNR LNAFGNAFLNR LNAFGNAFLNR LNAFGNAFLNR LFEAEEQDLFK
LFEAEEQDLFK $\begin{array}{llllllllllll}0.92 & 34.73 & 28.06 & 23.06 & 2 & 1379.7418 & 1379.7431 & 690.8788 & -0.0013 & -0.9408 & 8075.595 & 5500.886 \\ 0.97 & 35.10 & 28.06 & 22.99 & 2 & 1379.7434 & 1379.7431 & 690.8788 & 0.0003 & 0.2171 & 8194.239 & 6327.583\end{array}$ $\begin{array}{lllllllllllll}0.75 & 17.03 & 28.22 & 14.56 & 3 & 1379.7445 & 1379.7431 & 460.9216 & 0.0014 & 1.0125 & 154.882 & 172.505\end{array}$ $\begin{array}{llllllllllll}0.68 & 30.83 & 28.27 & 18.44 & 2 & 1379.7410 & 1379.7431 & 690.8788 & -0.0021 & -1.5198 & 3681.242 & 2661.46\end{array}$ $\begin{array}{llllllllllll}1.00 & 72.63 & 27.69 & 26.75 & 2 & 1655.8666 & 1655.8650 & 828.9398 & 0.0016 & 0.9651 & 1184.199 & 641.898\end{array}$ $\begin{array}{lllllllllllll} & 1.00 & 59.84 & 27.69 & 22.18 & 2 & 1655.8666 & 1655.8650 & 828.9398 & 0.0016 & 0.9651 & 448.688 & 431.045\end{array}$ $\begin{array}{lllllllllllllll} & \end{array}$ $\begin{array}{llllllllllllll}\text { DGLLDDEEFALANHLIK } & 1.00 & 71.16 & 26.78 & 20.99 & 3 & 2200.1665 & 2200.1619 & 734.3946 & 0.0046 & 2.0879 & 1308.466 & 579.628 \\ \text { DGLLDDEFFALANHLIK } & 0.67 & 57.23 & 26.84 & 70.23 & 3 & 2200.1650 & 2200.1619 & 734.3946 & 0.0031 & 1.4071 & 269.131 & 170.931\end{array}$ $\begin{array}{llllllllllll} & \end{array}$ $\begin{array}{lllllllllllllll} & \end{array}$ $\begin{array}{lllllllllllll} & \end{array}$ $\begin{array}{llllllllllllll} & \end{array}$

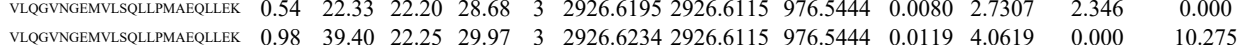

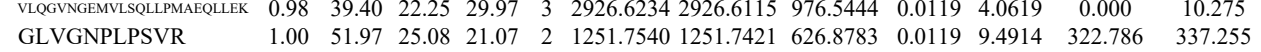
VTLILELLQHK

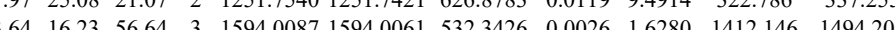
$\begin{array}{llllllllllll}0.55 & 60.94 & 16.23 & 73.94 & 3 & 15940069 & 1594.0061 & 532.3426 & 0.0008 & 0.5009 & 376.297 & 348.813\end{array}$ $\begin{array}{llllllllllll}0.67 & 37.08 & 18.06 & 50.08 & 3 & 1647.0244 & 1647.0214 & 550.0144 & 0.0030 & 1.8181 & 66.633 & 64.64\end{array}$ $\begin{array}{llllllllllll}0.67 & 32.65 & 18.06 & 45.65 & 3 & 1647.0247 & 1647.0214 & 550.0144 & 0.0033 & 1.9999 & 65.228 & 100.396\end{array}$

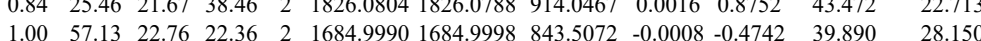
velN 
VSLLNEQFLPLIR WFWLLPVK SPQILVPTLFNLLSR

DEVLEVLEDGR DEVLEVLEDGR

GYQPTPAMAK

APAEGVLTLR

APAEGVLTLR

YWGPASPTHK

SQTVLNQLR

SQTVNQR

SQTVLNQLR

LAINLLAK

SVSCPLLSR

SVSCPLLSR
SVSCPLLSR

SVDCPLLSR

LLDIESQEELEDFPLPTVQR

NANELSVLKDEVLEVL

VDLPLAVLSK

AALQEELSDVLIYLVALAAR

6 NISHDTFGTTYGR

SLLIDFFR

SLLIDFFR

RPNNLVIGR

RPNNLVIGR

RPNNLVIGR

RPNNLVIGR

EVPFPFEVSQDELNEINOFLGPVEK

EINQFLGPVY

IPVENILGEVGDGFK
FSMGSVVAGLLK

FSMGSVVAGL

QAITQVVVSR

QAITQVVVSR

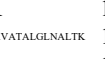

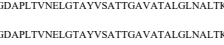

ILMAAPGMAIPPFIMNTL

VGIPVTDENG
DPLLLAIIPK

DPLLLAIIPK
DPLLLAIIPK

$\begin{array}{llllllll}136.31 & 1.00 & 8 & 11.5 & 0.3761 & 0.3857 & 0.6307 & 0.4603\end{array}$

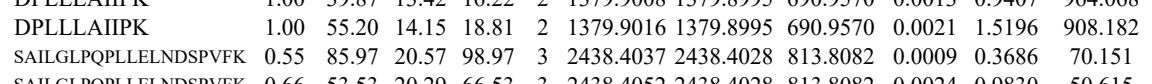
$\begin{array}{lllllllllllll}\text { SAILGLPQPLLELNDSPVFK } & 0.66 & 53.53 & 20.29 & 66.53 & 3 & 2438.4052 & 2438.4028 & 813.8082 & 0.0024 & 0.9830 & 50.615\end{array}$ $\begin{array}{lllllllllllll}\text { VFLEELMAPVASIWLSODMHR } & 1.00 & 94.45 & 27.30 & 22.00 & 3 & 2615.3371 & 2615.3362 & 872.7860 & 0.0009 & 0.3437 & 262.710\end{array}$ $\begin{array}{lllllllllll}\text { VFLEELMAPVASIWLSQDMHR } & 1.00 & \text { \#\#\#\# } 27.43 & 24.67 & 3 & 2615.3323 & 2615.3362 & 872.7860 & -0.0039 & -1.4895 & 163.615\end{array}$ $\begin{array}{llllllllllll}\text { VFLEELMAPVASIWLSODMHR } & 1.00 & 94.27 & 27.40 & 21.16 & 3 & 2615.3332 & 2615.3362 & 872.7860 & -0.0030 & -1.1458 & 148.243\end{array}$ $\begin{array}{llllllllllll}\text { IFSFLLNTLQENVNK } & 1.00 & 64.04 & 24.61 & 22.52 & 3 & 2067.1642 & 2067.1608 & 690.0609 & 0.0034 & 1.6424 & 226.525\end{array}$ $\begin{array}{lrllllllllll}\text { ISFLLNTLQENVNK } & 1.00 & 51.93 & 24.62 & 19.62 & 3 & 2067.1651 & 2067.1608 & 690.0609 & 0.0043 & 2.0771 & 149.801\end{array}$ $\begin{array}{llllllllllll}\text { CALMEALVLISNQFK } & 1.00 & 40.66 & 27.31 & 21.89 & 3 & 2013.0736 & 2013.0704 & 672.0307 & 0.0032 & 1.5872 & 14.803\end{array}$ $\begin{array}{llllllllllllll}\text { CALMEALVLISNQFK } & 1.00 & 42.02 & 27.35 & 18.27 & 3 & 2013.0742 & 2013.0704 & 672.0307 & 0.0038 & 1.8848 & 35.253\end{array}$ $\begin{array}{lllllllllllll}\text { CALMEALVLISNQFK } & 1.00 & 91.47 & 27.40 & 21.04 & 2 & 2013.0714 & 2013.0704 & 1007.5425 & 0.0010 & 0.4963 & 1.492\end{array}$ $\begin{array}{llllllllllll}\text { CALMEALVLISNQFK } & 1.00 & 41.17 & 27.33 & 19.04 & 3 & 2013.0724 & 2013.0704 & 672.0307 & 0.0020 & 0.9920 & 28.944 \\ \text { CALMEALVLISNQFK } & 1.00 & 36.20 & 27.31 & 19.85 & 3 & 2013.0736 & 2013.0704 & 672.0307 & 0.0032 & 1.5872 & 27.838\end{array}$ \begin{tabular}{llllllllllll} 
CALMEALVLISNQFK & 1.00 & 36.20 & 27.31 & 19.85 & 3 & 2013.0736 & 2013.0704 & 672.0307 & 0.0032 & 1.5872 & 27.838 \\
LLDNLLALIR & 1.00 & 74.17 & 16.90 & 35.51 & 2 & 1296.8262 & 1296.8251 & 649.4198 & 0.0011 & 0.8469 & 515.195 \\
\hline LLDNLLALR & 1.00 & 72.04 & 16.90 & 34.56 & 2 & 1296.8262 & 296.825 & 649.498 & 0.001 & 0.8469 & 479.84
\end{tabular} $\begin{array}{llllllllllll}\text { LLDNLLALIR } & 1.00 & 72.04 & 16.90 & 34.56 & 2 & 1296.8262 & 1296.8251 & 649.4198 & 0.0011 & 0.8469 & 479.284 \\ \text { SSTQMTWGALFR } & 1.00 & 71.83 & 27.47 & 23.69 & 2 & 1527.7628 & 1527.7626 & 764.8886 & 0.0002 & 0.1307 & 235.575 \\ & 1.00 & 63.98 & 27.54 & 22.75 & 2 & 1527.7630 & 1527.7626 & 764.8886 & 0.0004 & 0.2615 & 411.465\end{array}$

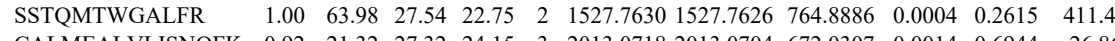
$\begin{array}{llllllllllllll}\text { CALMEALVLISNQFK } & 0.92 & 21.32 & 27.32 & 24.15 & 3 & 2013.0718 & 2013.0704 & 67.0307 & 0.0014 & 0.6944 & 26.869\end{array}$ $\begin{array}{llllllllllll}\text { EKPSYDTETDPSEGLMNVLK } & 1.00 & 63.93 * & 27.40 & 20.93 & 3 & 2684.3599 & 2684.3580 & 895.7933 & 0.0019 & 0.7070 & 445.467\end{array}$ EKPSYDTETDP. $\begin{array}{llllllllllllll}.067 .67 & 25.31 & 26.59 & 2 & 1375.8270 & 1375.8260 & 688.9203 & 0.0010 & 0.7258 & 170.469 & 168.692 & 26.719 & 263.493 & \text { Yes } \\ 0.67 & 21.79 & 42.29 & 3 & 1841.0926 & 1841.0896 & 614.7038 & 0.0030 & 1.6268 & 1.905 & 13.136 & 2.836 & 3.841 & \text { No }\end{array}$

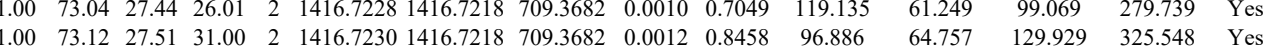
$\begin{array}{lllllllllllllll}1.00 & 43.07 & 24.28 & 25.19 & 2 & 1169.6998 & 1169.6890 & 585.8518 & 0.0108 & 9.2173 & 949.216 & 1089.945 & 2291.295 & 1662.994 & \text { Yes } \\ \end{array}$ $\begin{array}{lllllllllllllll}1.00 & 43.09 & 27.66 & 19.32 & 3 & 1430.7574 & 1430.7550 & 477.9256 & 0.0024 & 1.6739 & 3897.426 & 3678.959 & 3597.206 & 61.06354 & \text { Yes }\end{array}$ $\begin{array}{llllllllllllll}48.88 & 26.90 & 37.28 & 2 & 1201.7004 & 1201.6901 & 601.8523 & 0.0103 & 8.5568 & 4850.680 & 3882.162 & 943.525 & 10657.398 & \text { Yes }\end{array}$ $\begin{array}{lllllllllllllll}1.00 & 1142.7646 & 1142.7630 & 572.3888 & 0.0016 & 1.3976 & 6091.469 & 4933.094 & 728.734 & 14019.475 & \text { Yes } \\ 1.00 & 42.24 & 27.86 & 24.77 & 2 & 1150.5982 & 1150.5900 & 576.3053 & 0.0022 & 1.9087 & 2435.311 & 1783.933 & 132.174 & 5183.893 & \text { Yes }\end{array}$ $\begin{array}{lllllllllllllll}0.99 & 39.11 & 28.40 & 25.69 & 2 & 1150.592 & 1150.5960 & 5763053 & 0.0032 & 2.7763 & 2261.629 & 1971.672 & 249.113 & 5605.676 & \text { Yes }\end{array}$

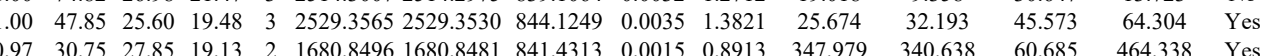

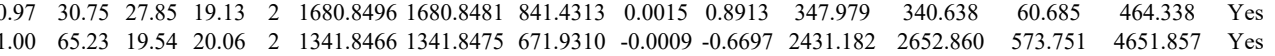

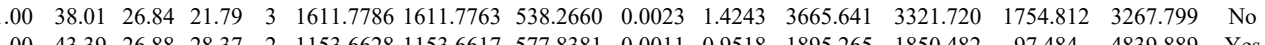

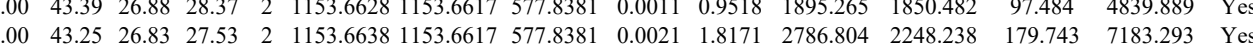
$\begin{array}{lllllllllllllll}0.99 & 33.28 & 24.00 & 26.26 & 2 & 1181.7126 & 1181.7115 & 591.8630 & 0.0011 & 0.9293 & 475.667 & 777.064 & 559.003 & 394.622 & \text { Yes } \\ 0.99 & 36.20 & 24.30 & 6.22 & 2 & 1181.7114 & 1817115 & 59.8630 & 0.000 & -0945 & 35.852 & 454.272 & 414.987 & 27937 & \text { Yes }\end{array}$

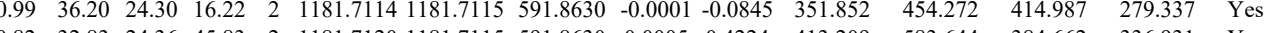

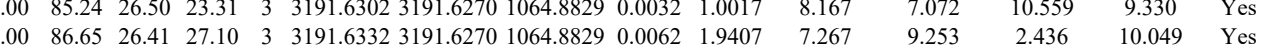

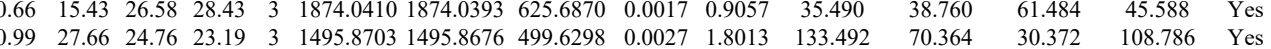
$\begin{array}{llllllllllllllll}1.00 & 63.33 & 25.71 & 27.88 & 2 & 1243.7464 & 1243.7370 & 622.8758 & 0.0094 & 7.5456 & 9140.350 & 8725.980 & 969.260 & 9848.558 & \text { Yes }\end{array}$ \begin{tabular}{lllllllllllllllll}
1.00 & 64.86 & 25.75 & 27.80 & 2 & 1243.7468 & 1243.7370 & 622.8758 & 0.0098 & 7.8667 & 15832.338 & 84997.446 & 1441.863 & 17094.884 & Yes \\
\hline
\end{tabular} $\begin{array}{llllllllllll}1.00 & 78.78 & 22.94 & 18.15 & 3 & 3534.9052 & 3534.9025 & 1179.3081 & 0.0027 & 0.7632 & 3.401\end{array}$

6.908

4.739

1.808

1341.154

1216.213 52.903 52.903
98.558
412.485 412.485 191.224 203.18 205.037

21.576

28.949

45.189

7.866

28.760

36.776

676.910

671.705

362.275

547.193

33.254
13.079

820.110 150.146 $\begin{array}{ccc}0.000 & 16337.491 & \text { Yes } \\ 0.199 & \text { No }\end{array}$

$\begin{array}{lll}6.362 & 4.732 & \text { Yes } \\ 3 & 3.524 & \text { No }\end{array}$ \begin{tabular}{ccc}
.959 & 14.371 & No \\
\hline & 1398.853 & Ye
\end{tabular} $\begin{array}{llll}1.9598 & 14.371 & & \text { No } \\ 648.863 & 1798.223 & \text { Yes }\end{array}$ $\begin{array}{lll}49.685 & 1420.599 & \text { Yes }\end{array}$ $\begin{array}{llll}41.012 & 65.794 & \text { Yes }\end{array}$ $\begin{array}{llll}35.285 & 84.211 & \text { Yes }\end{array}$ $\begin{array}{lll}231.104 & 501.343 & \text { Yes }\end{array}$ \begin{tabular}{lll}
1.006 & 258.048 & No \\
\hline 5.890 & 303.817 & Yes
\end{tabular} \begin{tabular}{lll}
\hline .937 & 308.822 & Yes
\end{tabular} \begin{tabular}{lll}
\hline .497 & 20.982 & No
\end{tabular}

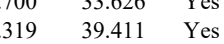
$\begin{array}{lll}3.004 & 1491.059 & \text { No }\end{array}$ $\begin{array}{lll}0.989 & 1437.240 & \text { No }\end{array}$ $\begin{array}{lll}6.989 & 1437.240 & \text { No } \\ & 373.680 & \text { Yes }\end{array}$ $\begin{array}{lll}0.997 & 14.879 & \text { No }\end{array}$ $\begin{array}{lll}6.987 & 14.879 & \text { No } \\ 6 & 1214.835 & \text { Yes }\end{array}$

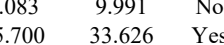



$\begin{array}{llllllllllllllll} & \\ \text { SYSMIVNNLLKPISVEGSSK } & 0.88 & 5.50 & 22.25 & 15.73 & 4 & 2597.4517 & 2597.4464 & 650.3689 & 0.0053 & 2.0373 & 2348.351 & 2245.841 & 837.021 & 10133.874 & \text { No } \\ \text { TDTVLILCR } & 1.00 & 5236 & 28.25 & 42.37 & 2 & 1222.6554 & 1222.6535 & 6123340 & 0.0019 & 1.5514 & 5475.176 & 5832.715 & 275.140 & 9854.078 & \text { Yos }\end{array}$

TDTVLILCR
TDTVLILCR

TDTVLILCR
IVQPSRPVK $\begin{array}{lllllllllllllll}1.00 & 52.24 & 28.25 & 44.54 & 2 & 1222.6554 & 1222.6535 & 612.3340 & 0.0019 & 1.5514 & 5144.276 & 5487.091 & 130.809 & 9261.777 & \text { Yes } \\ 0.89 & 19.52 & 19.40 & 25.29 & 3 & 130.8291 & 130.8278 & 437.949 & 0.0013 & 0.9895 & 3167.089 & 3538.634 & 2289.959 & 3861.325 & \text { Yes }\end{array}$

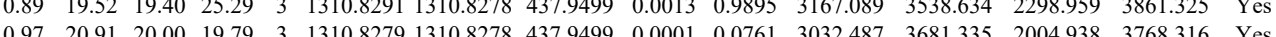

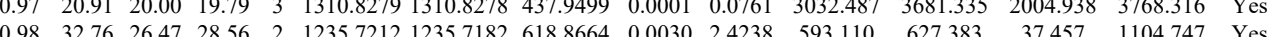
$\begin{array}{llllllllll} & \\ 0\end{array}$ $37.457 \quad 1104.747 \quad$ Yes

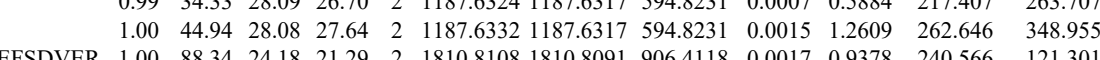

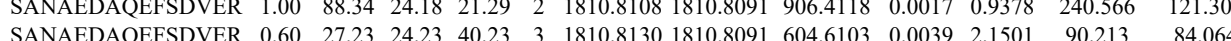
$\begin{array}{llllllllllllll}\text { SANAEDAQEFSDVER } & 1.00 & 37.93 & 24.23 & 17.03 & 3 & 1810.8133 & 1810.8091 & 604.6103 & 0.0042 & 2.3155 & 84.392 & 70.566\end{array}$ $\begin{array}{lllllllllllll}\text { SFWELIGEAAK } & 1.00 & 64.39 & 27.41 & 25.08 & 2 & 1537.8424 & 1537.8384 & 769.9265 & 0.0040 & 2.5976 & 12011.465 & 4950.313 \\ \text { SFWELIGEAAK } & 0.99 & 32.70 & 27.36 & 22.40 & 3 & 1537.8430 & 1537.8384 & 513.6201 & 0.0046 & 2.9853 & 37.771 & 66.928\end{array}$ SFWELIGEAAK SFWELIGEAAK SFWELIGEAAK SFWELIGEAAK SFWELIGEAAK SFWELIGEAAK SFWELIGEAAK

SFWELIGEAAK

SANAEDAQEFSDVER

SANAEDAQEFSDV

GLFEVNPWK $\begin{array}{lllllllllllll}1.00 & 43.51 & 27.36 & 26.14 & 3 & 1537.8430 & 1537.8384 & 513.6201 & 0.0046 & 2.9853 & 73.017 & 50.357\end{array}$ $\begin{array}{llllllllllll}1.00 & 69.12 & 27.57 & 24.78 & 2 & 1537.8434 & 1537.8384 & 769.9265 & 0.0050 & 3.2471 & 8171.887 & 2654.544\end{array}$ $\begin{array}{llllllllllll}0.99 & 30.17 & 27.41 & 23.49 & 3 & 1537.8427 & 1537.8384 & 513.6201 & 0.0043 & 2.7906 & 90.406 & 45.875\end{array}$ $\begin{array}{llllllllllll}1.00 & 65.35 & 27.57 & 23.69 & 2 & 1537.8432 & 1537.8384 & 769.9265 & 0.0048 & 3.1172 & 5174.103 & 2502.062\end{array}$ $\begin{array}{llllllllllll}1.00 & 44.25 & 27.57 & 27.05 & 3 & 1537.8436 & 1537.8384 & 513.6201 & 0.0052 & 3.3747 & 72.732 & 36.283\end{array}$

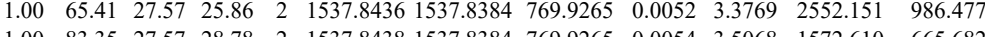
$\begin{array}{llllllllllllll}1.00 & 83.35 & 27.57 & 28.78 & 2 & 1537.8438 & 1537.8384 & 769.9265 & 0.0054 & 3.5068 & 1572.610 & 665.682\end{array}$ $145.418 \quad 307.622$ Yes $\begin{array}{llll}145.418 & 307.622 & \text { Yes } \\ 204.899 & 415.326 & \text { Yes }\end{array}$ $32.384 \quad 117.767 \quad$ Yes $0.000 \quad 6141.125 \quad$ No $36.239 \quad 34.741 \quad$ No $\begin{array}{lll}27.925 & 15.247 \quad \text { No }\end{array}$ $0.000 \quad 3619.682$ No $\begin{array}{lll}0.217 & 95.814 \quad \text { Yes }\end{array}$ .000 $3298.447 \quad$ No \begin{tabular}{ccc}
9.817 & 52.953 & Yes \\
\hline 9.161 & 1477.380 & Yes
\end{tabular} GLEVWNWT $\begin{array}{lllllllllll}1.00 & 24.61 & 25.77 & 2 & 1810.8212 & 1810.8091 & 906.4118 & 0.0121 & 6.6746 & 1197.701 & 561.767\end{array}$ \begin{tabular}{|lllllllllllll} 
& 1.00 & 49.42 & 25.15 & 23.27 & 2 & 1573.9228 & 1573.9170 & 787.9658 & 0.0058 & 3.6803 & 346.717 & 257.088 \\
& 1.00 & 49.66 & 27.50 & 31.21 & 2 & 1376.7712 & 1376.7696 & 689.3921 & 0.0016 & 1.1604 & 4331.196 & 2754.235
\end{tabular} $\begin{array}{llllllllllllll} & \end{array}$ $\begin{array}{lllllllllllllll} & \end{array}$ $\begin{array}{llllllllllllll} & \end{array}$

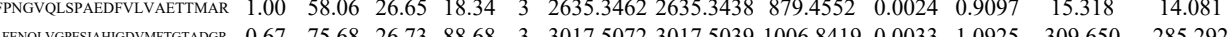
$\begin{array}{lllllllllll} & \end{array}$

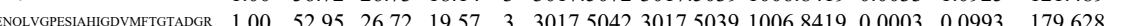

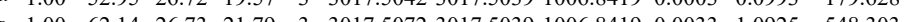

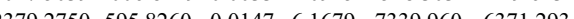
$\begin{array}{lllllllllllll}\text { RPLRPQVVTDDDGQAPEAK } & 0.78 & 13.80 & 25.04 & 26.80 & 4 & 2379.2933 & 2379.2750 & 595.8260 & 0.0183 & 7.6784 & 5300.044 & 6643.113\end{array}$

$\begin{array}{llllllllllllll}\text { RPLRPQVVTDDDGQAPEAK } & 0.88 & 27.46 & 24.84 & 17.30 & 3 & 2379.2959 & 2379.2750 & 794.0989 & 0.0209 & 8.7730 & 1670.105 & 1288.087\end{array}$

SVLVDFLIGSGLK SVLVDFLIGSGLK $\begin{array}{llllllllllll}1.00 & 52.10 & 20.37 & 26.70 & 3 & 1634.9884 & 1634.9851 & 546.0023 & 0.0033 & 2.0146 & 87.760\end{array}$ $\begin{array}{llllllllllll}1.00 & 42.64 & 20.37 & 21.64 & 3 & 1634.9884 & 1634.9851 & 546.0023 & 0.0033 & 2.0146 & 101.616 \\ 1.00 & 29.38 & 19.96 & 15.42 & 3 & 1634.9896 & 1634.9851 & 546.0023 & 0.0045 & 2.7472 & 89.567\end{array}$ $\begin{array}{llllllllllllll}\text { SVLVDFLIGSGLK } & 1.00 & 29.38 & 19.96 & 15.42 & 3 & 1634.9896 & 1634.9851 & 546.0023 & 0.0045 & 2.7472 & 89.567 & 92.041 \\ \text { APLVPGSPVVNALFR } & 1.00 & 53.42 & 23.54 & 23.26 & 2 & 1777.0378 & 1777.0372 & 889.5259 & 0.0006 & 0.3373 & 40.478 & 20.935 \\ \text { APLVPGGSPVVNALFR } & 1.00 & 45.57 & 23.52 & 20.67 & 2 & 1777.0382 & 1777.0372 & 889.5259 & 0.0010 & 0.5621 & 17.869 & 15.998\end{array}$ TRPEVGEMLR

ASINPVTGR GEVDEEDAALYR $\begin{array}{llllllllllllll}0.77 & 18.53 & 27.97 & 19.31 & 3 & 1330.7203 & 1330.7149 & 444.5789 & 0.0054 & 4.0488 & 13941.104 & 15 & \\ 0 & & \end{array}$ $\begin{array}{llllllllllll}0.70 & 21.04 & 26.01 & 25.31 & 2 & 1057.6004 & 1057.6002 & 529.8074 & 0.0002 & 0.1887 & 29.958\end{array}$ GEVDEEDAALYR

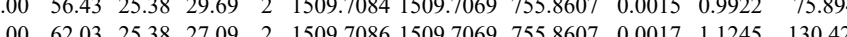
$\begin{array}{lllllllllll} & \end{array}$ $\begin{array}{llllllllllllll} & 0.99 & 41.38 & 23.60 & 19.94 & 2 & 1036.6604 & 1036.6515 & 519.3330 & 0.0089 & 8.5686 & 10153.865 & 7977.481 \\ \text { LPPSHR } & 1.00 & 58.51 & 22.81 & 19.05 & 3 & 2101.2049 & 2101.2017 & 701.4078 & 0.0032 & 1.5207 & 150.689 & 79.318\end{array}$ $\begin{array}{lllllllllllll}\text { LAELLVSVLEQGLPPSHR } & 0.60 & 56.70 & 22.67 & 69.70 & 3 & 2101.2055 & 2101.2017 & 701.4078 & 0.0038 & 1.8059 & 163.221 & 128.096 \\ \text { LAELLVSVLEQGLPPSHR } & 0.66 & 68.88 & 22.83 & 81.88 & 3 & 2101.2040 & 2101.2017 & 701.4078 & 0.0023 & 1.0930 & 174.476 & 194.144\end{array}$ $\begin{array}{lllllllllllll}\text { LAELLVSLLQGLPPSHR } & 0.66 & 68.88 & 22.83 & 81.88 & 3 & 2101.2040 & 2101.2017 & 701.4078 & 0.0023 & 1.0930 & 174.476 & 194.144 \\ \text { LAELLVSVLEQGLPPSHR } & 0.67 & 71.78 & 22.81 & 84.78 & 3 & 2101.2046 & 2101.2017 & 701.4078 & 0.0029 & 1.3782 & 311.477 & 167.314\end{array}$

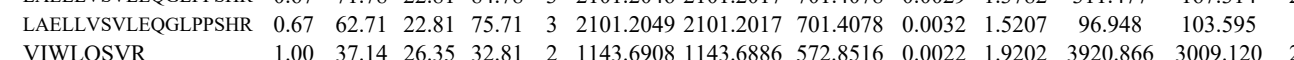
$\begin{array}{llllllllllllll}\text { VIWLQSVR } & 1.00 & 37.14 & 26.35 & 32.81 & 2 & 1143.6908 & 1143.6886 & 572.8516 & 0.0022 & 1.9202 & 3920.866 & 3009.120 & 2820.0 \\ \text { VIWLQSVR } & 0.98 & 37.15 & 26.25 & 36.87 & 2 & 1143.6916 & 1143.6886 & 572.8516 & 0.0030 & 2.6185 & 3696.440 & 3358.052 & \end{array}$ VIWLQSVR $\begin{array}{llllllllllllll}0.98 & 37.15 & 26.25 & 36.87 & 2 & 1143.6916 & 1143.6886 & 572.8516 & 0.0030 & 2.6185 & 3696.440 & 3358.052 \\ 0.99 & 41.09 & 26.40 & 28.77 & 2 & 1143.6884 & 1143.6886 & 572.8516 & -0.0002 & -0.1746 & 2526.820 & 2386.022\end{array}$ $\begin{array}{llllllllllll}0.99 & 41.09 & 26.40 & 28.77 & 2 & 1143.6884 & 1143.6886 & 572.8516 & -0.0002 & -0.1746 & 2526.820 & 2386.022 \\ 1.00 & 46.59 & 26.25 & 30.02 & 2 & 1143.6892 & 1143.6886 & 572.8516 & 0.0006 & 0.5237 & 2374.381 & 2083.980\end{array}$ $\begin{array}{llllllllllllll} & \text { CLCNIVISPVAOMLAAEAR } & 1.00 & 32.74 & 26.97 & 18.40 & 3 & 2324.1331 & 2324.1304 & 775.7174 & 0.0027 & 1.1602 & 8.482 & 17.750\end{array}$ $\begin{array}{llllllllllll}\text { CICNISSPMMLAAEAR } & 1.00 & 32.74 & 26.97 & 18.40 & 3 & 2324.1331 & 2324.1304 & 775.7174 & 0.0027 & 1.1602 & 8.482\end{array}$ $\begin{array}{lllllllllllll}\text { AVAEAVETGEEDVIMEALR } & 1.00 & 99.13 & 27.64 & 34.56 & 2 & 2175.0874 & 2175.0851 & 1088.5498 & 0.0023 & 1.0565 & 38.262\end{array}$ $\begin{array}{llllllllll}27.64 & 36.83 & 2 & 2175.0874 & 2175.0851 & 1088.5498 & 0.0023 & 1.0565 & 48.482\end{array}$ 


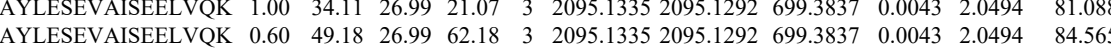
$\begin{array}{llllllllllll}\text { AYLESEVAISEELVQK } & 0.60 & 42.93 & 26.99 & 55.93 & 3 & 2095.1335 & 2095.1292 & 699.3837 & 0.0043 & 2.0494 & 80.035\end{array}$ $\begin{array}{lllllllllllll}\text { AYLESEVAISEELVQK } & 0.60 & 17.62 & 27.04 & 20.94 & 3 & 2095.1350 & 2095.1292 & 699.3837 & 0.0058 & 2.7643 & 36.262\end{array}$ $\begin{array}{lllllllllllll}\text { AYLESEVAISEELVQK } & 0.87 & 24.33 & 26.95 & 16.37 & 3 & 2095.1359 & 2095.1292 & 699.3837 & 0.0067 & 3.1933 & 88.782\end{array}$ AYLESEVAISEELVQK $0.99 \begin{array}{lllllllllll}0.99 .79 & 27.19 & 17.83 & 3 & 2095.1275 & 2095.1292 & 699.3837 & -0.0017 & -0.8102 & 10.139\end{array}$

$\begin{array}{llllllllllllll}\text { IASLPQEVQDVSLLEK } & 1.00 & 60.78 & 23.36 & 18.49 & 3 & 2056.1674 & 2056.1659 & 686.3959 & 0.0015 & 0.7284 & 272.793\end{array}$

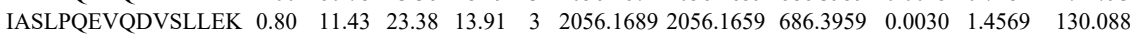

$\begin{array}{llllllllllll}\text { IASLPQEVQDVSLLEK } & 1.00 & 48.04 & 23.44 & 17.08 & 3 & 2056.1701 & 2056.1659 & 686.3959 & 0.0042 & 2.0396 & 371.672 \\ \text { LLNIWOER } & 0.99 & 39.89 & 27.44 & 37.03 & 2 & 1214.6904 & 1214.6893 & 608.3519 & 0.0011 & 0.9041 & 7001.567\end{array}$

LLNIWQER

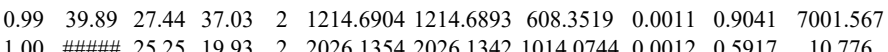

$\begin{array}{llllllllllll}\text { LTFLYLANDVIQNSK } & 1.00 & \# \# \# \frac{25.25}{19.93} & 2 & 2026.1354 & 2026.1342 & 1014.0744 & 0.0012 & 0.5917 & 10.776 \\ \text { LTFLYLANDVIQNSK } & 1.00 & 59.79 & 25.21 & 17.81 & 3 & 2026.1362 & 2026.1342 & 676.3853 & 0.0020 & 0.9856 & 439.937\end{array}$ $\begin{array}{lllllllllllll}\text { LTFLYLANDVIQNSK } & 1.00 & 59.79 & 25.21 & 17.81 & 3 & 2026.1362 & 2026.1342 & 676.3853 & 0.0020 & 0.9856 & 439.937 \\ \text { LTFLYLANDVIQNSK } & 1.00 & 32.41 & 25.21 & 19.29 & 3 & 2026.1362 & 2026.1342 & 676.3853 & 0.0020 & 0.9856 & 185.559\end{array}$ $\begin{array}{lllllllllllll}\text { LTFLYLANDVIQNSK } & 1.00 & 32.41 & 25.21 & 19.29 & 3 & 2026.1362 & 2026.1342 & 676.3853 & 0.0020 & 0.9856 & 185.559 \\ \text { LTFLYLANDVIQNSK } & 0.67 & 21.87 & 25.11 & 34.87 & 3 & 2026.1374 & 2026.1342 & 676.3853 & 0.0032 & 1.5770 & 101.730\end{array}$ $\begin{array}{llllllllllll}\text { LTFLYLANDVIQNSK } & 0.67 & 21.87 & 25.11 & 34.87 & 3 & 2026.1374 & 2026.1342 & 676.3853 & 0.0032 & 1.5770 & 101.730 \\ \text { LSELSNSQQSVQTLSLWLIHHR } & 1.00 & 56.26 & 25.55 & 69.26 & 4 & 2719.4513 & 2719.4527 & 680.8705 & -0.0014 & -0.5140 & 215.409\end{array}$

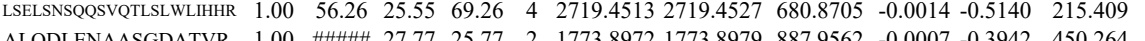

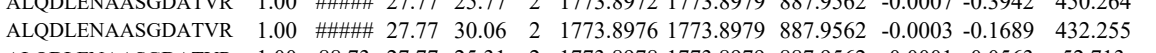

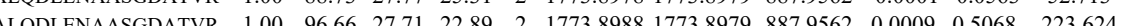

$\begin{array}{llllllllllll}\text { LVNILVQLPLSGNR } & 0.97 & 20.11 & 18.92 & 20.33 & 3 & 1679.0227 & 1679.0216 & 560.6811 & 0.0011 & 0.6540 & 8.584\end{array}$

AVSATPPRPPSR AVSATPPRPPSR AVSATPPRPPSR AVSATPPRPPSR AVSATPPRPPSR AVSATPPRPPSR AVSATPPRPPSR VFMLLSCIGQR VFMLLSCIGQR VFMLLSCIGQR

2 TEEIAEEEETVFPK $\begin{array}{llllllllllll}0.97 & 20.11 & 18.92 & 20.33 & 3 & 1679.0227 & 1679.0216 & 560.6811 & 0.0011 & 0.6540 & 8.584 \\ 0.79 & 29.31 & 27.80 & 20.27 & 2 & 1378.7794 & 1378.7803 & 690.3974 & -0.0009 & -0.6518 & 115.311\end{array}$ $\begin{array}{lllllllllll}0.79 & 29.31 & 27.80 & 20.27 & 2 & 1378.7794 & 1378.7803 & 690.3974 & -0.0009 & -0.6518 & 115.311 \\ 0.75 & 23.95 & 27.75 & 19.55 & 2 & 1378.7798 & 1378.7803 & 690.3974 & -0.0005 & -0.3621 & 71.848\end{array}$ $\begin{array}{llllllllllllll}0.93 & 22.34 & 27.86 & 23.36 & 3 & 1378.7809 & 1378.7803 & 460.6007 & 0.0006 & 0.4342 & 269.343\end{array}$ $\begin{array}{lllllllllllll}0.93 & 22.51 & 27.80 & 20.63 & 3 & 1378.7812 & 1378.7803 & 460.6007 & 0.0009 & 0.6513 & 423.852\end{array}$ $\begin{array}{lllllllllll}0.73 & 28.03 & 27.80 & 18.11 & 2 & 1378.7794 & 1378.7803 & 690.3974 & -0.0009 & -0.6518 & 61.478\end{array}$ $\begin{array}{lllllllllllll}0.91 & 23.77 & 28.08 & 21.01 & 3 & 1378.7806 & 1378.7803 & 460.6007 & 0.0003 & 0.2171 & 360.516 & 37\end{array}$ $\begin{array}{lllllllllll}0.93 & 24.57 & 28.08 & 21.57 & 3 & 1378.7806 & 1378.7803 & 460.6007 & 0.0003 & 0.2171 & 243.329\end{array}$ $\begin{array}{llllllllllll}0.98 & 41.68 & 27.29 & 22.71 & 2 & 1455.7512 & 1455.7522 & 728.8834 & -0.0010 & -0.6860 & 19.644\end{array}$ $\begin{array}{llllllllllll}1.00 & 45.09 & 27.21 & 18.06 & 2 & 1455.7522 & 1455.7522 & 728.8834 & 0.0000 & 0.0000 & 30.906\end{array}$ $\begin{array}{lllllllllllll}1.00 & 63.35 & 27.40 & 22.38 & 2 & 1455.7528 & 1455.7522 & 728.8834 & 0.0006 & 0.4116 & 20.046\end{array}$ TVFPK $\begin{array}{lllllllllll}1.00 & 74.59 & 28.50 & 24.31 & 3 & 1937.9746 & 1937.9713 & 646.9977 & 0.0033 & 1.7002\end{array}$ $\begin{array}{lllllllllllll} & \text { SDKIEEIAEEEETVFPK } & 1.00 & 48.07 & 27.53 & 18.75 & 4 & 2412.2293 & 2412.2273 & 604.0641 & 0.0020 & 0.8277 & 21.364\end{array}$

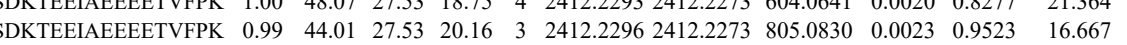

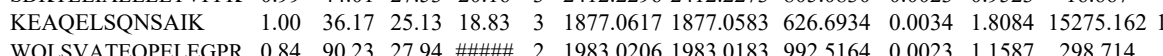
$\begin{array}{lllllllllllll}\text { WQLSVATEQPELEGPR } & 0.84 & 90.23 & 27.94 & \# \# \# & 2 & 1983.0206 & 1983.0183 & 992.5164 & 0.0023 & 1.1587 & 298.714 \\ \text { LGVCFDVPTASVTEIQEK } & 1.00 & 99.02 & 27.36 & 22.39 & 2 & 2269.1594 & 2269.1578 & 1135.5862 & 0.0016 & 0.7045 & 61.190\end{array}$ $\begin{array}{llllllllllll}\text { LGVCFDVPTASVTEIQEK } & 1.00 & 99.02 & 27.36 & 22.39 & 2 & 2269.1594 & 2269.1578 & 1135.5862 & 0.0016 & 0.7045 & 61.190 \\ \text { LGVFDVPTASVTEIQEK } & 1.00 & 42.04 & 27.30 & 16.29 & 3 & 2269.16142269 .1578 & 757.3932 & 0.0036 & 1.5844 & 57.134\end{array}$ $\begin{array}{llllllllllll}\text { LGVCFDVPTASVTEIQEK } & 1.00 & 42.04 & 27.30 & 16.29 & 3 & 2269.1614 & 2269.1578 & 757.3932 & 0.0036 & 1.5844 & 57.134 \\ \text { LGVCFDPTASVTEIOEK } & 1.00 & 78.19 & 27.30 & 18.75 & 2 & 2269.1614 & 2269.1578 & 1135.5862 & 0.0036 & 1.5851 & 109.384\end{array}$ $\begin{array}{llllllllllll}\text { LGVCFDVPTASVTEIQEK } & 1.00 & 78.19 & 27.30 & 18.75 & 2 & 2269.1614 & 2269.1578 & 1135.5862 & 0.0036 & 1.5851 & 109.384 \\ \text { LGVCFDVPTASVTEIQEK } & 1.00 & 67.41 & 27.30 & 19.84 & 3 & 2269.1617 & 2269.1578 & 757.3932 & 0.0039 & 1.7164 & 90.339\end{array}$ LGVCFDVPTAS TAVFAPLIEK TFSFAIPLIEK GVTFLFPIQAK $\begin{array}{lllllllllll} & 103.962\end{array}$ $\begin{array}{llllllllllll}1.00 & 45.85 & 23.38 & 25.57 & 2 & 1056.6418 & 1056.6413 & 529.3279 & 0.0005 & 0.4723 & 1523.969 & 1265.142\end{array}$ $\begin{array}{llllllllllll}1.00 & 55.51 & 23.01 & 22.07 & 2 & 1552.9124 & 1552.9108 & 777.4627 & 0.0016 & 1.0290 & 418.482 & 341.274\end{array}$ $\begin{array}{lllllllllll} & \end{array}$ $\begin{array}{llllllllllllll} & 1.025\end{array}$

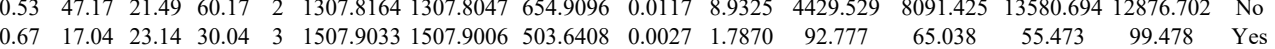


GVTFLFPIQAK NEEPSEEEIDAPK SDAGLESDTAMK AEPSEVDMNSPK AEPSEVDMNSPK KAEPSEVDMNSPK KAEPSEVDMNSPK QDAQSLHGDIPQK QDAQSLHGDIPQK

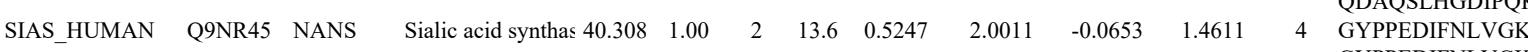
VIPTVEDD VLVTVEEDDTIMEELVDNH

TAICNLILGNPPSK IFTPIVEHLGLQIR TAICNLILGNPPSK TAICNLILGNPPSK TAICNLILGNPPSK

2 MLQIPNR NLLTGLVR GNCLPPLPLPR GNCLPPLPLPR GNCLPPLPLPR GNCLPPLPLPR GNCLPPLPLPR GNCLPPLPLPR

LFQVLAPR LFQVLAPR LFQVLAPR LFQVLAPR LQMEQQQQLQQR LWGLTEMFPER LWGLTEMFPER LWGLTEMFPER QILLGPNTGLSGGMPGALPSLP OILLGPNTGLSGGMPGALPSLPRX

IILLGPNTGLSGG

LFEISDIVIK

ADIHACDIVEDAAIAYGYNNIO

YDLLCLEGLVR
NPGFEIIHGLLDR NPGFEIIHGLLDR

TTLLPGLLK
TTLLPGLLK

SCQTALVEILDVIVR

SCQTALVEILDVIVR

SCQTALVEILDVIVR

FPLLKPSPK

SCQTALVEILDVIVR SCQTALVEILDVIVR
SCQTALVEILDVIVR SCQTALVEILDVIVR
SCQTALVEILDVIVR SCQTALVEILDVIK
VWGVPIPVFHHK VWGVPIPVFHHK SYKPVFWSPSSR

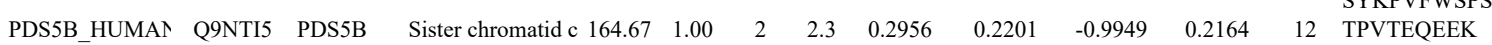

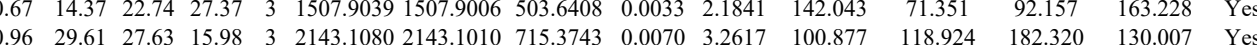

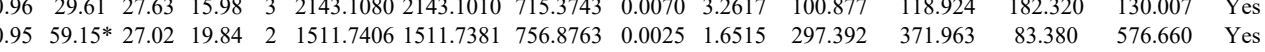
$\begin{array}{lllllllllllllll}1.00 & 63.14 & 27.15 & 28.82 & 2 & 1590.7808 & 1590.7803 & 796.3974 & 0.0005 & 0.3139 & 1780.998 & 1638.385 & 396.763 & 2912.365 & \text { Yes }\end{array}$ \begin{tabular}{lllllllllllllllll}
1.00 & 73.33 & 27.26 & 33.28 & 2 & 1590.7812 & 1590.7803 & 796.3974 & 0.0009 & 0.5650 & 1916.974 & 1863.960 & 853.632 & 3148.451 & Yes \\
\hline
\end{tabular} $\begin{array}{lllllllllllllllll}1.00 & 5.25 & 27.75 & 30.43 & 3 & 1862.9803 & 1862.9773 & 621.9997 & 0.0030 & 1.6077 & 3203.572 & 3146.458 & 1896.253 & 5254.919 & \text { Yes }\end{array}$ \begin{tabular}{lllllllllllllllll}
1.00 & 49.50 & 27.75 & 35.48 & 3 & 1862.9803 & 1862.9773 & 621.9997 & 0.0030 & 1.6077 & 6370.904 & 6093.972 & 2401.029 & 10337.940 & Yes \\
\hline
\end{tabular} \begin{tabular}{lllllllllllllll}
0.99 & 40.43 & 27.90 & 16.16 & 3 & 1723.9219 & 1723.9097 & 575.6438 & 0.0122 & 7.0645 & 8633.028 & 10812.292 & 1927.299 & 18308.365 & Yes \\
\hline
\end{tabular} $\begin{array}{lllllllllllllll}0.99 & 38.27 & 27.75 & 16.57 & 3 & 1723.9237 & 1723.9097 & 575.6438 & 0.0140 & 8.1068 & 9823.268 & 9890.289 & 1793.642 & 16243.161 & \text { Yes } \\ 0.98 & 35.45 & 27.89 & 17.37 & 3 & 1723.9258 & 1723.9097 & 575.6438 & 0.0161 & 9.3228 & 6568.900 & 7146.955 & 2278.017 & 11361366 & \text { Yes }\end{array}$

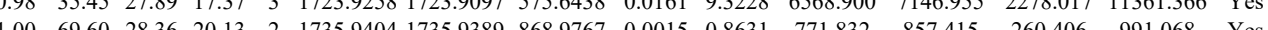

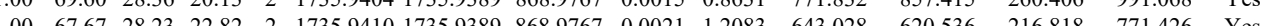

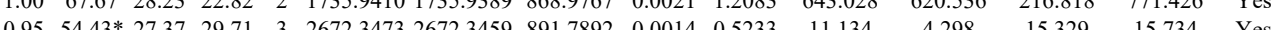

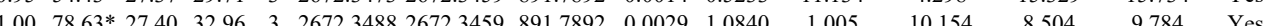
$\begin{array}{lllllllllllllll}0.91 & 18.81 & 27.10 & 17.97 & 3 & 1773.9760 & 1773.9725 & 592.3314 & 0.0035 & 1.9696 & 356.917 & 484.205 & 100.705 & 618.058 & \text { Yes }\end{array}$ $\begin{array}{llllllllllllllll}1.00 & 54.14 & 22.58 & 20.45 & 3 & 1779.0532 & 17790529 & 594.0249 & 0.0003 & 0.1683 & 1188.724 & 1534.213 & 690.986 & 1797.893 & \text { Yes }\end{array}$ $\begin{array}{llllllllllllllll}1.00 & 30.61 & 27.10 & 21.96 & 3 & 1773.9742 & 1773.9725 & 592.3314 & 0.0017 & 0.9567 & 234.258 & 224.840 & 79.844 & 588.999 & \text { Yes }\end{array}$ $\begin{array}{llllllllllllllll}1.00 & 31.10 & 27.04 & 19.62 & 3 & 1773.9754 & 1773.9725 & 592.3314 & 0.0029 & 1.6320 & 254.064 & 262.855 & 45.524 & 561.382 & \text { Yes }\end{array}$ $\begin{array}{lllllllllllllll}1.00 & 35.99 & 27.17 & 20.20 & 3 & 1773.9727 & 1773.9725 & 592.3314 & 0.0002 & 0.1125 & 110.154 & 108.385 & 33.026 & 234.861 & \text { Yes }\end{array}$

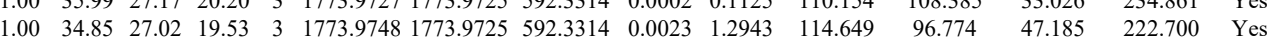

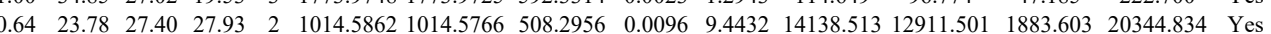
$\begin{array}{llllllllllllllll}0.95 & 38.51 & 25.13 & 42.79 & 2 & 1028.6492 & 1028.6464 & 515.3305 & 0.0028 & 2.7167 & 3102.108 & 2861.682 & 106.592 & 3289.923 & \text { Yes }\end{array}$ $\begin{array}{llllllllllllllll}0.98 & 28.81 & 28.43 & 16.08 & 3 & 1365.7393 & 1365.7383 & 456.2534 & 0.0010 & 0.7306 & 69.835 & 102.642 & 52.406 & 140.028 & \text { Yes }\end{array}$ $\begin{array}{lllllllllllllll}0.99 & 27.82 & 28.33 & 17.03 & 3 & 1365.7399 & 1365.7383 & 456.2534 & 0.0016 & 1.1689 & 140.465 & 175.087 & 39.266 & 279.758 & \text { Yes }\end{array}$ $\begin{array}{lllllllllllllll}0.84 & 54.75 & 28.31 & 67.75 & 2 & 1365.7402 & 1365.7383 & 683.8764 & 0.0019 & 1.3891 & 976.320 & 1148.289 & 427.463 & 1008.345 & \text { Yes }\end{array}$ $\begin{array}{lllllllllllllll}1.00 & 55.62 & 28.33 & 16.68 & 2 & 1365.7406 & 1365.7383 & 683.8764 & 0.0023 & 1.6816 & 1453.306 & 1305.129 & 481.033 & 1280.171 & \text { Yes }\end{array}$ $\begin{array}{lllllllllllllll}1.00 & 46.97 & 28.64 & 16.09 & 2 & 1365.7394 & 1365.7383 & 683.8764 & 0.0011 & 0.8042 & 860.591 & 952.125 & 246.722 & 1085.706 & \text { Yes }\end{array}$ $\begin{array}{llllllllllllllll}1.00 & 45.71 & 28.33 & 16.36 & 2 & 1365.7406 & 1365.7383 & 683.8764 & 0.0023 & 1.6816 & 382.572 & 467.895 & 128.525 & 515.698 & \text { Yes }\end{array}$ $\begin{array}{lllllllllllllll}0.99 & 38.10 & 24.90 & 22.78 & 2 & 1086.6676 & 1086.6671 & 544.3408 & 0.0005 & 0.4593 & 2849.352 & 2985.077 & 86.510 & 4802.150 & \text { Yes }\end{array}$ $\begin{array}{llllllllllllllll}1.00 & 44.25 & 24.90 & 26.98 & 2 & 1086.6682 & 1086.6671 & 544.3408 & 0.0011 & 1.0104 & 4089.914 & 3989.316 & 54.663 & 6963.987 & \text { Yes }\end{array}$ $\begin{array}{llllllllllllllll}0.96 & 38.04 & 24.35 & 22.96 & 2 & 1086.6654 & 1086.6671 & 544.3408 & -0.0017 & -1.5615 & 1253.580 & 1320.249 & 445.420 & 2130.188 & \text { Yes }\end{array}$ \begin{tabular}{llllllllllllllll}
0.98 & 38.01 & 24.22 & 22.85 & 2 & 1086.6660 & 1086.6671 & 544.3408 & -0.0011 & -1.0104 & 1722.308 & 1789.464 & 353.413 & 2725.192 & Yes \\
\hline
\end{tabular} $\begin{array}{lllllllllllllll}1.00 & 83.63 & 28.01 & 24.19 & 2 & 1700.8884 & 1700.8750 & 851.4448 & 0.0134 & 7.8689 & 4875.024 & 4376.561 & 353.137 & 6622.078 & \text { Yes }\end{array}$

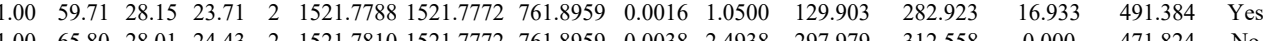

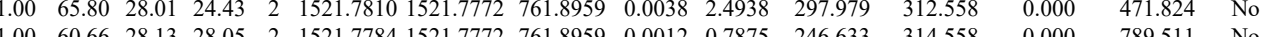

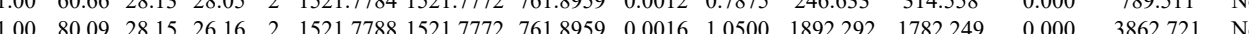

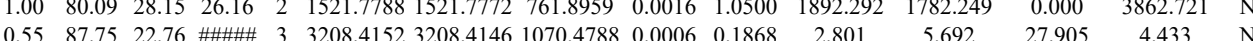
$\begin{array}{lllllllllllllll}1.00 & 48.24 & 1.30 & 17.53 & 3 & 2562.4465 & 2562.4447 & 855.1555 & 0.0018 & 0.7016 & 170.159 & 186.636 & 58.749 & 251.652 & \text { Yes }\end{array}$ $\begin{array}{lllllllllllllll}1.00 & 49.03 & 21.30 & 21.13 & 3 & 2562.4465 & 2562.4447 & 855.1555 & 0.0018 & 0.7016 & 53.269 & 53.072 & 41.804 & 43.580 & \text { Yes }\end{array}$ $\begin{array}{lllllllllllllll}1.00 & 44.65 & 21.43 & 27.67 & 2 & 1463.8866 & 1463.8843 & 732.9494 & 0.0023 & 1.5690 & 173.279 & 91.249 & 36.140 & 209.141 & \text { Yes } \\ \end{array}$

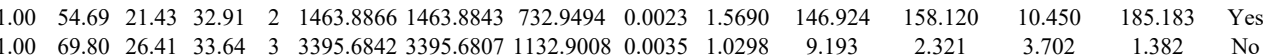
$\begin{array}{lllllllllllllll}0.73 & 12.70 & 26.63 & 14.49 & 4 & 3395.6893 & 3395.6807 & 849.9275 & 0.0086 & 2.5296 & 29.918 & 59.155 & 37.148 & 103.377 & \text { Yes }\end{array}$ $\begin{array}{llllllllllllllll}1.00 & 63.28 & 28.08 & 35.07 & 2 & 1482.7718 & 1482.7696 & 742.3921 & 0.0022 & 1.4817 & 368.989 & 471.743 & 0.000 & 821.273 & \text { No }\end{array}$ $\begin{array}{lllllllllllllll}1.00 & 77.52 & 27.63 & 19.66 & 3 & 1623.8866 & 1623.8855 & 542.3024 & 0.0011 & 0.6761 & 587.913 & 639.587 & 1078.450 & 1071.285 & \text { Yes }\end{array}$ $\begin{array}{lllllllllllllllll}1.00 & 57.34 & 27.36 & 26.12 & 3 & 1623.8881 & 1623.8855 & 542.3024 & 0.0026 & 1.5981 & 472.159 & 353.700 & 698.503 & 925.849 & \text { Yes }\end{array}$ $\begin{array}{lllllllllllllll}1.00 & 51.40 & 17.16 & 24.79 & 2 & 1242.8176 & 1242.8155 & 622.4150 & 0.0021 & 1.6870 & 6990.011 & 4701.504 & 243.772 & 8487.121 & \text { Yes }\end{array}$ $\begin{array}{lllllllllllllll}1.00 & 45.01 & 17.16 & 23.92 & 2 & 1242.8178 & 1242.8155 & 622.4150 & 0.0023 & 1.8476 & 9434.754 & 6539.311 & 597.174 & 12085.117 & \text { Yes }\end{array}$

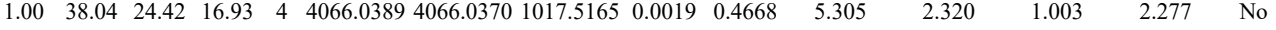

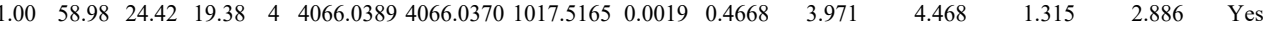

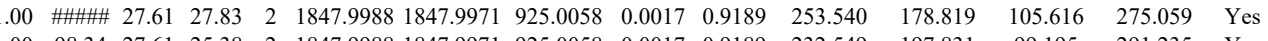

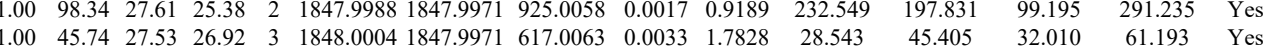
$\begin{array}{lllllllllllllll}1.00 & 54.77 & 27.53 & 31.66 & 3 & 1848.0004 & 1847.9971 & 617.0063 & 0.0033 & 1.7828 & 18.780 & 29.481 & 5.367 & 33.821 & \text { Yes }\end{array}$

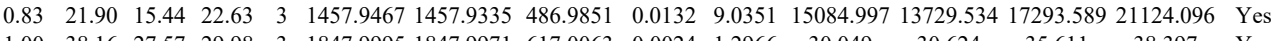

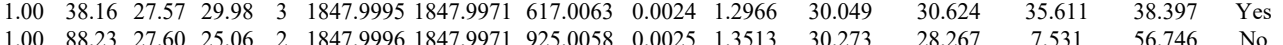

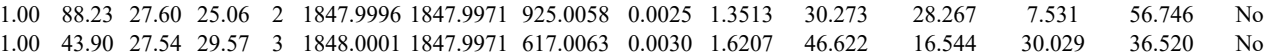

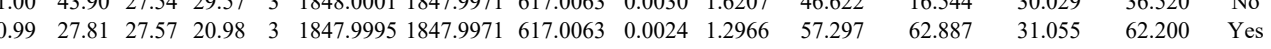
$\begin{array}{lllllllllllllll}1.00 & 19.42 & 23.22 & 16.39 & 4 & 1702.9949 & 1702.9915 & 426.7552 & 0.0034 & 1.9918 & 184.227 & 209.235 & 84.399 & 238.015 & \text { Yes } \\ 1.00 & 21.65 & 32.36 & 15.10 & 4 & 1702.9961 & 1702.9915 & 426.752 & 0.0046 & 2.647 & 1151.255 & 993.423 & 162.158 & 162.63 & \text { Yes }\end{array}$ $\begin{array}{llllllllllllllll}1.00 & 21.65 & 23.36 & 15.10 & 4 & 1702.9961 & 1702.9915 & 426.7552 & 0.0046 & 2.6947 & 1151.255 & 993.423 & 162.158 & 1622.863 & \text { Yes } \\ 0.82 & 24.95 & 27.17 & 19.22 & 3 & 1727.9389 & 1727.9239 & 576.9819 & 0.0150 & 8.6657 & 2762.487 & 2620.077 & 1281.062 & 3269.936 & \text { Yes }\end{array}$

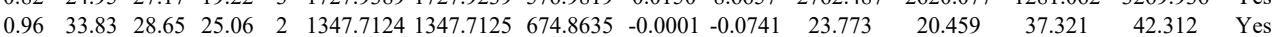
$\begin{array}{lllllllllllllll}1.00 & 13.11 & 18.75 & 26.11 & 4 & 1693.0361 & 1693.0365 & 424.2664 & -0.0004 & -0.2357 & 440.245 & 604.708 & 695.931 & 810.900 & \text { Yes }\end{array}$

Table S- 4 page 562 of 614 

$\begin{array}{lllllllllllll}0.55 & 24.38 & 18.92 & 37.38 & 3 & 1693.0375 & 1693.0365 & 565.3528 & 0.0010 & 0.5896 & 407.585 \\ 0.97 & 18.32 & 18.63 & 15.47 & 3 & 1693.0369 & 1693.0365 & 565.3528 & 0.0004 & 0.2358 & 236.498\end{array}$

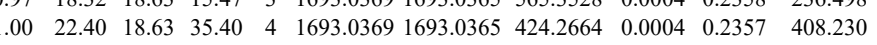
$\begin{array}{lllllllllllll}.00 & 21.73 & 18.92 & 34.73 & 4 & 1693.0373 & 1693.0365 & 424.2664 & 0.0008 & 0.4714 & 825.731\end{array}$ $\begin{array}{cccccccccccc}1.00 & 16.32 & 18.63 & 29.32 & 4 & 1693.0365 & 1693.0365 & 424.2664 & 0.0000 & 0.0000 & 262.119 \\ 0.97 & 9.37 & 18.75 & 22.37 & 4 & 1693.0353 & 1693.0365 & 424.2664 & -0.0012 & -0.7071 & 140.315\end{array}$ $\begin{array}{lllllllllll}1.00 & 14.65 & 18.75 & 16.76 & 4 & 1693.0361 & 1693.0365 & 424.2664 & -0.0004 & -0.2357 & 105.943\end{array}$ $\begin{array}{llllllllllll}0.68 & 21.16 & 26.49 & 16.74 & 2 & 929.5542 & 929.5538 & 465.7842 & 0.0004 & 0.4294 & 108.816\end{array}$ $\begin{array}{llllllllllll}0.89 & 24.35 & 28.02 & 23.61 & 2 & 1246.6920 & 1246.6914 & 624.3530 & 0.0006 & 0.4805 & 7673.729 & 653\end{array}$ $\begin{array}{lllllllllllll}0.90 & 25.00 & 28.02 & 23.65 & 2 & 1246.6924 & 1246.6914 & 624.3530 & 0.0010 & 0.8008 & 4793.998\end{array}$

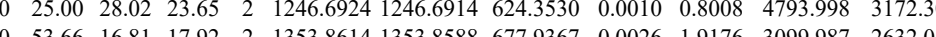
$\begin{array}{llllllllllllll}1.00 & 52.61 & 16.81 & 17.70 & 2 & 1353.8616 & 1353.8588 & 677.9367 & 0.0028 & 2.0651 & 4637.366 & 3843.376\end{array}$ $\begin{array}{lllllllllllll}1.00 & 65.16 & 17.92 & 18.53 & 2 & 1353.8574 & 1353.8588 & 677.9367 & -0.0014 & -1.0325 & 7208.991 & 6447 & \end{array}$ $\begin{array}{lllllllllllll}1.00 & 54.65 & 17.92 & 17.85 & 2 & 1353.8578 & 1353.8588 & 677.9367 & -0.0010 & -0.7375 & 8758.900\end{array}$ $\begin{array}{llllllllllllll} & \end{array}$ IPAFLNVVDIAGLVK $\begin{array}{lllllllllllll} & \text { PAFNDIAGLK } & 0.84 & 74.76 & 17.63 & 87.76 & 2 & 1856.1396 & 1856.1379 & 929.0762 & 0.0017 & 0.9149 & 67.145\end{array}$

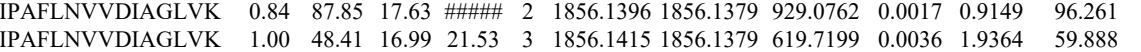
$\begin{array}{lllllllllllll}\text { IPAFLNVVDIAGLVK } & 1.00 & 67.11 & 16.99 & 25.18 & 3 & 1856.1415 & 1856.1379 & 619.7199 & 0.0036 & 1.9364 & 170.317\end{array}$ $\begin{array}{llllllllllllll}\text { IPAFLNVVDIAGLVK } & 0.81 & 10.33 & 17.78 & 18.74 & 3 & 1856.1391 & 1856.1379 & 619.7199 & 0.0012 & 0.6455 & 241.933\end{array}$ PAFLNVVDIAGLVK DEEMIGPIIDK $\begin{array}{lllllllllll}1.00 & 43.14 & 17.63 & 25.11 & 3 & 1856.1400 & 1856.1379 & 619.7199 & 0.0021 & 1.1295 & 51.0058\end{array}$ FEDDDITHVEGSVDP $\begin{array}{lllllllllll}1.06 & 67.20 & 27.93 & 27.70 & 2 & 1546.8180 & 1546.8156 & 774.4151 & 0.0024 & 1.5496 & 99.467\end{array}$ $\begin{array}{llllllllllllll} & \end{array}$ IPAFLNVVDIAGLVK IPAFLNVVDIAGLVK IPAFLNVVDIAGLVK $\begin{array}{lllllllllll}1.00 & 91.96 & 17.63 & 21.96 & 2 & 1856.1396 & 1856.1379 & 929.0762 & 0.0017 & 0.9149 & 19.532 \\ 1.061379 & 929.0762 & 0.0019 & 1.0225 & 10.914\end{array}$ $\begin{array}{lllllllllllll} & \end{array}$

$\begin{array}{llllllllllllll} & \text { IPAFLNVVDIAGLVK } & 1.00 & 43.51 & 17.63 & 21.17 & 3 & 1856.1406 & 1856.1379 & 619.7199 & 0.0027 & 1.4523 & 4.073\end{array}$

$\begin{array}{llllllllllllll} & \text { Q }\end{array}$

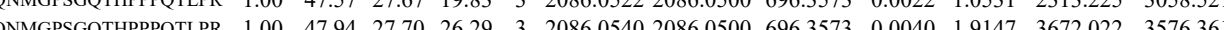
QNMGSGQTH

$\begin{array}{lllllllllll} & \end{array}$ $\begin{array}{llllllllllll}1.00 & 58.74 & 26.10 & 24.12 & 2 & 1626.9264 & 1626.9249 & 814.4697 & 0.0015 & 0.9208 & 465.769 & 572.104\end{array}$

VITTDPOOQP

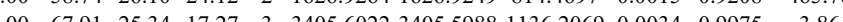
$\begin{array}{lllllllllllll}\text { QPтESEK } & 1.00 & 62.28 & 25.34 & 17.95 & 3 & 3405.6022 & 3405.5988 & 1136.2069 & 0.0034 & 0.9975 & 0.000\end{array}$ $\begin{array}{llllllllllll} & \end{array}$

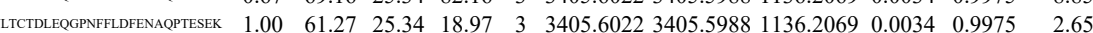
$\begin{array}{llllllllllll}\text { MLTTDLEGCPNFFLFENAAPTESEK } & 1.00 & 49.54 & 25.47 & 21.43 & 3 & 3405.6052 & 3405.5988 & 1136.2069 & 0.0064 & 1.8776 & 3.588\end{array}$ $\begin{array}{lllllllllllll} & \end{array}$ $\begin{array}{llllllllllll}\text { NLPIENTTDCLSTMASVCR } & 1.00 & \text { \#\#\#\# } 23.84 & 23.05 & 2 & 2303.0234 & 2303.0210 & 1152.5178 & 0.0024 & 1.0412 & 742.457\end{array}$

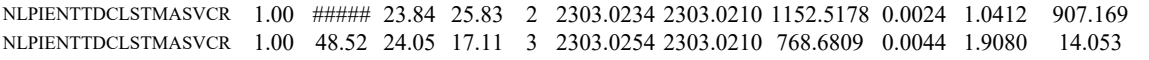
AWGAVVPLVGK AWGAVVPLVGK

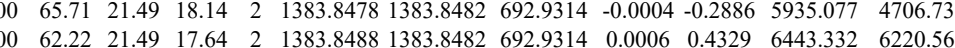
$\begin{array}{llllllllllllll} & 2183.184 .1661 & 729.0626 & 0.0005 & 0.2286 & 315.852 & 238.740\end{array}$

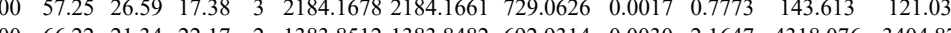
21.033 GLLGALTSTPYSPTQHL

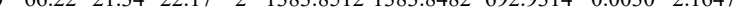
40.135 GLLGALTSTPYSPTQH

QFAEILHFTLR $\begin{array}{llllllllllll}1.00 & 50.17 & 26.54 & 17.03 & 3 & 2184.1675 & 2184.1661 & 729.0626 & 0.0014 & 0.6401 & 282.794 & 156.451 \\ 1.00 & 61.93 & 27.37 & 26.81 & 3 & 1517.8507 & 1517.8476 & 506.9565 & 0.0031 & 2.0383 & 1889.391 & 212759\end{array}$ $\begin{array}{lllllllllllll}\text { QFAEILHFTLR } & 1.00 & 80.08 & 27.37 & 29.15 & 3 & 1517.8507 & 1517.8476 & 506.9565 & 0.0031 & 2.0383 & 2735.702 & 3185 \\ \text { INNVPAEGENEVNNELANR } & 1.00 & 97.49 & 26.83 & 25.97 & 2 & 2239.0974 & 2239.0950 & 1120.5548 & 0.0024 & 1.0709 & 91.496\end{array}$ $\begin{array}{llllllllllllll}1.00 & 61.93 & 27.37 & 26.81 & 3 & 1517.8507 & 1517.8476 & 506.9565 & 0.0031 & 2.0383 & 1889.391 & 2212.759 & 252.8 \\ 1.00 & 80.08 & 27.37 & 29.15 & 3 & 1517.8507 & 1517.8476 & 506.9565 & 0.0031 & 2.0383 & 2735.702 & 3188.471 & 425.6\end{array}$

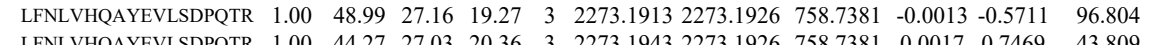
$\begin{array}{llllllllllll}\text { LFNLVHQAYEVLSDPQTR } & 1.00 & 44.27 & 27.03 & 20.36 & 3 & 2273.1943 & 2273.1926 & 758.7381 & 0.0017 & 0.7469 & 43.809\end{array}$

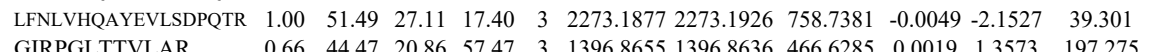
GIRPGLTTVLAR GIRPGLTTVLAR GIRPGLTTVLAR $\begin{array}{lllllllllll}0.66 & 44.47 & 20.86 & 57.47 & 3 & 1396.8655 & 1396.8636 & 466.6285 & 0.0019 & 1.3573 & 197.275\end{array}$ $\begin{array}{llllllllllll}0.64 & 32.85 & 20.76 & 45.85 & 2 & 1396.8636 & 1396.8636 & 699.4391 & 0.0000 & 0.0000 & 178.823 & 198 \\ 0.55 & 48.74 & 20.76 & 61.74 & 3 & 1396.8643 & 1396.8636 & 466.6285 & 0.0007 & 0.5000 & 1301.305 & 102\end{array}$ $\begin{array}{llllllllllllll}1.00 & 37.26 & 20.76 & 16.62 & 2 & 1396.8644 & 1396.8636 & 699.4391 & 0.0008 & 0.5719 & 316.056 & 241.786\end{array}$ $\begin{array}{lllllllllllll}0.55 & 48.87 & 20.76 & 61.87 & 3 & 1396.8646 & 1396.8636 & 466.6285 & 0.0010 & 0.7143 & 1197.343 & 1009.124\end{array}$ $\begin{array}{llllllllllll}1.00 & 40.55 & 20.76 & 16.31 & 2 & 1396.8644 & 1396.8636 & 699.4391 & 0.0008 & 0.5719 & 147.985 & 110.803\end{array}$
GIRPGL 
GIRPGLTTVLAR GIRPGLTTVLAR GIRPGLTTVLAR

SLELLPIILTALATK SLELLPIILTALATK SLELLPIILTALATK SLELLPIILTALATK SLELLPILTALATK MNLQEIPPLVYQLLVLS MNLQEIPPLVYQLLV SS SLELLPIILTALATK $\begin{array}{llllllllllll} & \end{array}$ $\begin{array}{llllllllllllll} & 21.52 .51 & 2162.1973 & 721.7397 & 0.0018 & 0.8313 & 10.013\end{array}$

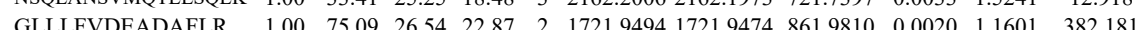
GLLLFVDEADAFLR GLLLFVDEADAFLR GLLLFVDEADAFLR VQDAVQQHQQK

TLAFLIPAVELIVK TLAFLIPAVELIVK TLAFLIPAVELIVK TLAFLIPAVELIVK $\begin{array}{lllllllllll}0.67 & 7.52 & 12.04 & 20.52 & 3 & 1814.1553 & 1814.1525 & 605.7248 & 0.0028 & 1.5409 & 172.561\end{array}$ \begin{tabular}{llllllllllllllll} 
& \\
\hline
\end{tabular} $\begin{array}{llllllllllll} & \end{array}$ $\begin{array}{llllllllllll}\text { LGNGINIIVATPGR } & 1.00 & 95.11 & 23.30 & 31.66 & 2 & 1537.9078 & 1537.9062 & 769.9604 & 0.0016 & 1.0390 & 353.593\end{array}$ $\begin{array}{llllllllllll}\text { LGNGINIIVATPGR } & 1.00 & 87.64 & 23.24 & 23.49 & 2 & 1537.9056 & 1537.9062 & 769.9604 & -0.0006 & -0.3896 & 837.433\end{array}$ LGNGINIIVATPGR FLLLFTFLK

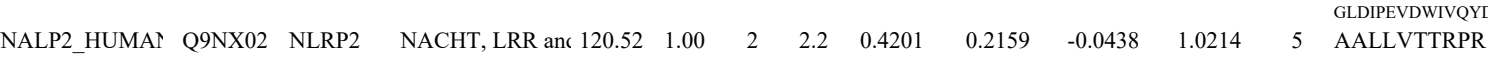
AALLVTTRPR KALLVTTRPR $\begin{array}{lllllllllllll}1.00 & 86.80 & 23.22 & 26.40 & 2 & 1537.9070 & 1537.9062 & 769.9604 & 0.0008 & 0.5195 & 720.915\end{array}$ $\begin{array}{lllllllllll}1.00 & 49.96 & 19.78 & 28.92 & 2 & 1428.9020 & 1428.8988 & 715.4567 & 0.0032 & 2.2363 & 12.78\end{array}$ $\begin{array}{lllllllllll}0.67 & 16.98 & 27.19 & 29.98 & 3 & 2598.3127 & 2598.3097 & 867.1105 & 0.0030 & 1.1533 & 7.701\end{array}$

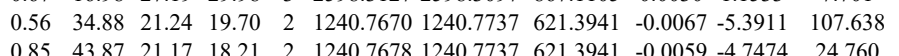
$\begin{array}{lllllllllll}0.85 & 43.87 & 21.17 & 18.21 & 2 & 1240.7678 & 1240.7737 & 621.3941 & -0.0059 & -4.7474 & 24.760\end{array}$ $\begin{array}{lllllllllll}0.99 & 39.99 & 21.27 & 20.68 & 3 & 1240.7692 & 1240.7737 & 414.5985 & -0.0045 & -3.6180 & 514.01\end{array}$ $\begin{array}{llllllllll}\text { TEX10_HUMAN } & \text { Q9NXF1 TEX10 } & \text { Testis-expressed s } 105.67 & 1.00 & 3 & 5.1 & -0.1594 & 0.7383 & -0.1317 & 0.4596\end{array}$ $\begin{array}{ccccccccccc}1.00 & 55.25 & 11.14 & 20.93 & 3 & 1693.0897 & 1693.0858 & 565.3692 & 0.0039 & 2.2994 & 62.807 \\ 1.00 & 56.29 & 11.14 & 20.99 & 3 & 1693.0903 & 1693.0858 & 565.3692 & 0.0045 & 2.6531 & 107.939 \\ 1.00 & 77.77 & 26.11 & 27.83 & 3 & 2106.1561 & 2106.1555 & 703.0591 & 0.0006 & 0.2845 & 1037.646\end{array}$ KPVPVLLGS

$\begin{array}{lllllllllllll}\text { NPELSTQLIDIIHTAAAR } & 1.00 & 77.77 & 26.11 & 27.83 & 3 & 2106.1561 & 2106.1555 & 703.0591 & 0.0006 & 0.2845 & 1037.646 \\ \text { NPELSTQLIDIIHTAAAR } & 1.00 & 98.09 & 26.05 & 22.07 & 3 & 2106.1573 & 2106.1555 & 703.0591 & 0.0018 & 0.8534 & 656.617\end{array}$ \begin{tabular}{lllllllllllll}
\hline LAAVQLLOFLAPK & 1.00 & 84.69 & 15.91 & 22.19 & 2 & 1699.0644 & 1699.0640 & 850.5393 & 0.0004 & 0.8351 & 23.770
\end{tabular} \begin{tabular}{llllllllllll}
\hline LAAVQLLPLAPK & 0.99 & 17.92 & 14.31 & 15.35 & 3 & 1699.0663 & 1699.0640 & 567.3619 & 0.0023 & 1.2513 & 43.478
\end{tabular} \begin{tabular}{lllllllllllll}
\hline LAAVQLLPFAPK & 1.00 & 35.57 & 14.62 & 21.70 & 3 & 1699.0669 & 1699.0640 & 567.3619 & 0.0029 & 1.7038 & 65.211
\end{tabular} $\begin{array}{llllllllllllll}\text { LAAVOLLOFLAPK } & 1.00 & 29.80 & 14.31 & 14.89 & 3 & 1699.0660 & 16990640 & 567.3619 & 0.0020 & 1.1750 & 31.630\end{array}$ $\begin{array}{lllllllllllll}\text { LAAVQLLQFLAPK } & 0.66 & 33.95 & 14.31 & 46.95 & 3 & 1699.0663 & 1699.0640 & 567.3619 & 0.0023 & 1.3513 & 46.191\end{array}$ $\begin{array}{llllllllllllll}\text { LSSSLAAMLIGILHMR } & 1.00 & 51.49 & 24.91 & 21.61 & 3 & 1856.0491 & 1856.0497 & 619.6905 & -0.0006 & -0.3227 & 8.013\end{array}$ $\begin{array}{lllllllllllll}\text { LSSSLAAMLIGILHMR } & 1.00 & 54.73 & 24.65 & 20.29 & 3 & 1856.0521 & 1856.0497 & 619.6905 & 0.0024 & 1.2910 & 16.359\end{array}$ $\begin{array}{lllllllllllll}\text { LSSSLAAMLIGILHMR } & 1.00 & 33.66 & 24.93 & 17.57 & 3 & 1856.0503 & 1856.0497 & 619.6905 & 0.0006 & 0.3227 & 25.489\end{array}$ $\begin{array}{llllllllllllll}\text { LSSSLAAMLIGILHMR } & 1.00 & 49.33 & 24.71 & 17.91 & 3 & 1856.0515 & 1856.0497 & 619.6905 & 0.0018 & 0.9682 & 20.043 \\ \text { FPEDGPELEELTOLATADAR } & 0.64 & 67.97 & 27.47 & 80.97 & 2 & 2458.2354 & 2458.2349 & 1230.1247 & 0.0005 & 0.2032 & 11.052\end{array}$ $\begin{array}{lllllllllllll}\text { FPEDGPELEELLTLLATADAR } & 1.00 & 63.20 & 27.52 & 25.01 & 3 & 2458.2370 & 2458.2349 & 820.4189 & 0.0021 & 0.8532 & 1.783\end{array}$ $\begin{array}{llllllllllllll}\text { FPEDGPELEELLTQLATADAR } & 0.84 & 84.08 & 27.54 & 97.08 & 2 & 2458.2374 & 2458.2349 & 1230.1247 & 0.0025 & 1.0162 & 6.504\end{array}$ $\begin{array}{lllllllllllll}\text { FPEDGPELEELLTLLATADAR } & 1.00 & 59.81 & 27.58 & 24.15 & 3 & 2458.2382 & 2458.2349 & 820.4189 & 0.0033 & 1.3408 & 3.634\end{array}$ $\begin{array}{llllllllllll}\text { FPEDGPELEELTLLATADAR } & 1.00 & 47.57 & 27.58 & 24.46 & 3 & 2458.2382 & 2458.2349 & 820.4189 & 0.0033 & 1.3408 & 3.045\end{array}$

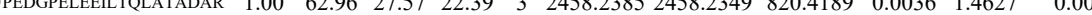
$\begin{array}{lllllllllllll}\text { FPEDGPELEELTLLATADAR } & 1.00 & 54.32 & 27.58 & 28.06 & 3 & 2458.2391 & 2458.2349 & 820.4189 & 0.0042 & 1.7064 & 8.564\end{array}$ $\begin{array}{llllllllllllll}\text { NVSLGNVLAVAYATQR } & 1.00 & 95.71 & 26.64 & 19.50 & 2 & 1819.0076 & 1819.0074 & 910.5110 & 0.0002 & 0.1098 & 173.560\end{array}$

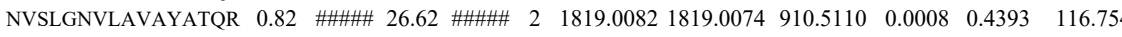
$\begin{array}{lllllllllllll}\text { NVSLGNVLAVAYATQR } & 1.00 & 33.59 & 26.62 & 15.76 & 3 & 1819.0084 & 1819.0074 & 607.3431 & 0.0010 & 0.5488 & 114.068\end{array}$ $\begin{array}{lllllllllllll}\text { NVSLGNVLAVAYATQR } & 1.00 & 57.04 & 26.41 & 20.00 & 3 & 1819.0090 & 1819.0074 & 607.3431 & 0.0016 & 0.8781 & 109.50\end{array}$ $\begin{array}{lllllllllllll}\text { NVSLGNVLAVAYATQR } & 1.00 & 48.82 & 26.41 & 21.22 & 3 & 1819.0090 & 1819.0074 & 607.3431 & 0.0016 & 0.8781 & 83.231 \\ \text { NVSLGNVLAVAYATQR } & 1.00 & 45.66 & 26.36 & 23.11 & 3 & 1819.0096 & 1819.0074 & 607.3431 & 0.0022 & 1.2074 & 106.838\end{array}$ $\begin{array}{llllllllllll}\text { NVSLGNVLAVAYATQR } & 1.00 & 45.66 & 26.36 & 23.11 & 3 & 1819.0096 & 1819.0074 & 607.3431 & 0.0022 & 1.2074 & 106.838\end{array}$ $\begin{array}{lllllllllllll} & \end{array}$ $\begin{array}{llllllllllllll} & \text { VILGSEAAQQHPEEVR } & 1.00 & 94.94 & 27.26 & 25.12 & 3 & 1906.0057 & 1906.0030 & 636.3416 & 0.0027 & 1.4143 & 3204.341 & 3682.886\end{array}$

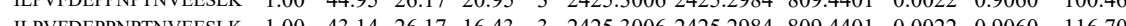

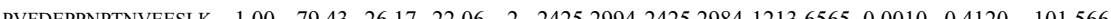
$\begin{array}{llllllllll} & 1.425\end{array}$ $\begin{array}{llllllllllllll}\text { IIPVFDEPPNPTNVEESLK } & 1.00 & 56.19 & 26.17 & 20.57 & 3 & 2425.3006 & 2425.2984 & 809.4401 & 0.0022 & 0.9060 & 193.210\end{array}$ 
$\begin{array}{llllllllll}\text { UGGG1_HUMA Q9NYU2 } & \text { UGGT1 } & \text { UDP-glucose:glyc } 177.19 & 1.00 & 3 & 3.2 & -0.1433 & 0.4923 & 1.0787 & 0.3305\end{array}$

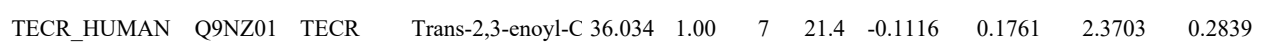

ILASPVELALVVMK

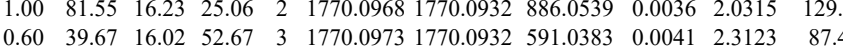

VEPHATIAEIK

LCFLDK

\section{THPQWYPA}

THPQWYPAR

THPQWYPAR

FSHGTMPLR

FSHGTMPLR

LLETLFVHR

LLETLFVHR

LLETLFVHR

LLETLFVHR

LLETLFVHR

LPVGTTATLYFR

LPVGTTATLYFR

LPVGTTATLY

\section{LKDEDVLQK}

SLKDEDVLQK

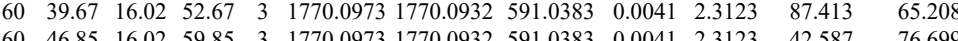
$\begin{array}{llllllllllll}1.00 & 75.96 & 16.43 & 18.76 & 2 & 1918.1804 & 1918.1787 & 960.0966 & 0.0017 & 0.3853 & 93.304 & 77.984\end{array}$ $\begin{array}{lllllllllllll}0.72 & 65.12 & 16.02 & 78.12 & 2 & 1918.1814 & 1918.1787 & 960.0966 & 0.0027 & 1.4061 & 214.779 & 157.675\end{array}$ $\begin{array}{llllllllllllll}1.00 & 31.53 & 16.02 & 15.44 & 3 & 1918.1815 & 1918.1787 & 640.4002 & 0.0028 & 1.4574 & 72.789 & 63.813\end{array}$ $\begin{array}{lllllllllllll}0.67 & 24.66 & 15.56 & 37.66 & 3 & 1918.1818 & 1918.1787 & 640.4002 & 0.0031 & 1.6136 & 63.084 & 81.294\end{array}$ $\begin{array}{lllllllll} & \end{array}$ $\begin{array}{lllllllllllll}0.60 & 20.15 & 15.68 & 33.15 & 3 & 1918.1824 & 1918.1787 & 640.4002 & 0.0037 & 1.9259 & 72.692 & 84.686\end{array}$ $\begin{array}{llllllllllllll}0.60 & 30.67 & 15.68 & 43.67 & 3 & 1918.1830 & 1918.1787 & 640.4002 & 0.0043 & 2.2382 & 75.888 & 47.865\end{array}$ $\begin{array}{llllllllllll}1.00 & 44.88 & 24.59 & 23.38 & 2 & 1494.8786 & 1494.8649 & 748.4397 & 0.0137 & 9.1523 & 1226.037 & 1192.252\end{array}$ $\begin{array}{llllllllllllll} & 9.63 .6 & 27.34 & 17.17 & 3 & 1298.6653 & 1298.6642 & 433.8953 & 0.0011 & 0.8451 & 5981.447 & 8828.374 & 1079.105 & 57\end{array}$ $\begin{array}{lllllllllllllll}1.00 & 45.56 & 27.47 & 21.90 & 2 & 1298.6654 & 1298.6642 & 650.3394 & 0.0012 & 0.9226 & 1340.470 & 1223.864 & 218.888\end{array}$ $\begin{array}{llllllllllllll}0.99 & 27.81 & 27.56 & 19.18 & 3 & 1298.6686 & 1298.6642 & 433.8953 & 0.0044 & 3.3802 & 3186.430 & 3341.972 & 588\end{array}$ $\begin{array}{llllllllllllll}0.99 & 45.21 & 28.10 & 26.17 & 2 & 1188.6256 & 1188.6196 & 595.3171 & 0.0060 & 5.0393 & 3035.390 & 2733.912 & 293.8 \\ 0.99 & 45.46 & 27.69 & 22.81 & 2 & 1188.6238 & 1188.6196 & 595.3171 & 0.0042 & 3.5275 & 7227.133 & 5928.778 & 787.7 \\ 1.06 & 2.92 & 25.38 & 22.12 & & \end{array}$ $\begin{array}{llllllllllllll} & \end{array}$ $\begin{array}{llllllllllllll}1.00 & 42.92 & 25.38 & 22.12 & 3 & 1270.7530 & 1270.7519 & 424.5912 & 0.0011 & 0.8636 & 5991.837 & 5552.666 & 150 & \\ 1.00 & 42.75 & 25.38 & 23.86 & 3 & 1270.7533 & 1270.7519 & 424.5912 & 0.0014 & 1.0991 & 5551.154 & 4594.336 & 169\end{array}$ $\begin{array}{lllllllllllll} & \end{array}$ $\begin{array}{lllllllllllll} & \end{array}$

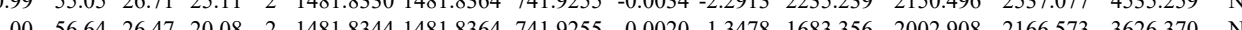

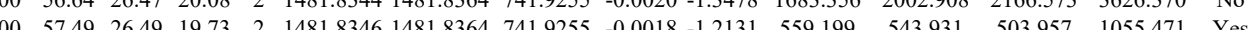
$\begin{array}{lllllllllllllll}0.85 & 21.96 & 25.42 & 16.29 & 3 & 1270.7512 & 1270.7519 & 424.5912 & -0.0007 & -0.5495 & 19.339 & 20.304 & 8.324 & 20.567 & \text { Yes }\end{array}$ $\begin{array}{lllllllllllllll}0.58 & 31.13 & 24.70 & 22.06 & 3 & 1605.9364 & 1605.9303 & 536.3174 & 0.0061 & 3.7913 & 20558.610 & 20206.761 & 2129.660 & 21193.187 & \text { Yes }\end{array}$ $\begin{array}{lllllllllllllll}0.78 & 35.71 & 24.05 & 23.27 & 3 & 1605.9376 & 1605.9303 & 536.3174 & 0.0073 & 4.5371 & 31397.160 & 24666.574 & 2325.103 & 29146.540 & \text { Yes }\end{array}$

TDVILPEEVEWIK $\begin{array}{llllllllllll} & \end{array}$

CVQQTIETIEENIGWMD CVQQTIETIEENIGWMDK TQEFPQILTLIGR GFPLITITVR NPVGYPLAWQFLR
NPVGYPLAWQFLR GFPLITITVR GFPLITITVR

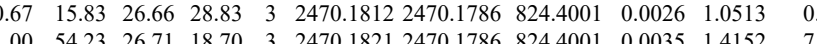
$\begin{array}{lllllllllll}1.00 & 76.60 & 26.20 & 26.12 & 2 & 1658.9478 & 1658.9477 & 830.4811 & 0.0001 & 0.0602 & 942.971\end{array}$ $\begin{array}{lllllllllll}1.00 & 71.62 & 25.94 & 29.13 & 2 & 1658.9494 & 1658.9477 & 830.4811 & 0.0017 & 1.0235 & 1207.401\end{array}$ $\begin{array}{lllllllllll}1.00 & 56.61 & 25.17 & 39.82 & 2 & 1259.7736 & 1259.7724 & 630.8935 & 0.0012 & 0.9510 & 344.000\end{array}$ 3.616

\begin{tabular}{lll}
118.832 & Yes \\
\hline 8.188 & 193.427 & Yes \\
0.000 & 4.499 &
\end{tabular} VVIIESVLCPSHFR $\begin{array}{llllllllllll}0.88 & 23.27 & 27.52 & 17.95 & 2 & 1703.9280 & 1703.9269 & 852.9707 & 0.0011 & 0.6448 & 54.834 \\ 0 & 23.02 & 27.44 & 17.08 & 2 & 1703.9286 & 1703.9269 & 852.9707 & 0.0017 & 0.9965 & 68.393\end{array}$ $\begin{array}{llllllllllll}1.00 & 56.72 & 25.29 & 39.93 & 2 & 1259.7728 & 1259.7724 & 630.8935 & 0.0004 & 0.3170 & 553.722\end{array}$ $\begin{array}{llllllllllll}1.00 & 56.61 & 25.17 & 39.88 & 2 & 1259.7736 & 1259.7724 & 630.8935 & 0.0012 & 0.9510 & 630.020\end{array}$ $\begin{array}{llllllllllll}1.00 & 65.39 & 27.78 & 21.55 & 3 & 1787.9557 & 1787.9548 & 596.9922 & 0.0009 & 0.5025 & 78.127\end{array}$ $\begin{array}{llllllllllll}0.67 & 20.00 & 27.63 & 33.00 & 3 & 1787.9575 & 1787.9548 & 596.9922 & 0.0027 & 1.5076 & 61.949\end{array}$ $\begin{array}{lllllllllllllll} & \end{array}$ $\begin{array}{lllllllllllll}\text { QLAENLVVIGGTSMLPGFLHR } & 1.00 & 64.74 & 24.52 & 22.95 & 3 & 2395.3183 & 2395.3168 & 799.4462 & 0.0015 & 0.6254 & 19.025\end{array}$ $\begin{array}{lllllllllllll}\text { QLAENLVVIGGTSMLPGFLHR } & 1.00 & 48.40 & 24.52 & 27.53 & 3 & 2395.3183 & 2395.3168 & 799.4462 & 0.0015 & 0.6254 & 15.308\end{array}$ ILHILGSIR ILHILGSIR

QTAQQIVSHVQNK $\begin{array}{lllllllllll}1.00 & 41.02 & 17.32 & 22.90 & 2 & 1164.7472 & 1164.7464 & 583.3805 & 0.0008 & 0.6857 & 622.486\end{array}$ $\begin{array}{llllllllllll}1.00 & 33.59 & 17.32 & 23.57 & 2 & 1164.7474 & 1164.7464 & 583.3805 & 0.0010 & 0.8571 & 496.770\end{array}$ $\begin{array}{llllllllllll}0.66 & 30.70 & 26.41 & 43.70 & 3 & 1767.9859 & 1767.9835 & 590.3351 & 0.0024 & 1.3552 & 11117.623 & 734 . \\ 0.68 & 21.28 & 22.94 & 25.11 & 2 & 1084.6816 & 1084.6726 & 543.3436 & 0.0090 & 8.2820 & 656.924 & 831\end{array}$ $\begin{array}{llllllllllll}0.68 & 21.28 & 22.94 & 25.11 & 2 & 1084.6816 & 1084.6726 & 543.3436 & 0.0090 & 8.2820 & 656.924 & 831 \\ 0.99 & 37.64 & 22.76 & 28.47 & 2 & 1084.6830 & 1084.6726 & 543.3436 & 0.0104 & 9.5703 & 9155.564 & \end{array}$

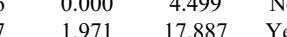
GVISTPVIR $\begin{array}{llllllllllll}0.99 & 37.64 & 22.76 & 28.47 & 2 & 1084.6830 & 1084.6726 & 543.3436 & 0.0104 & 9.5703 & 9155.564 & 0 \\ 1.00 & 51.16 & 26.32 & 18.87 & 3 & 2694.4093 & 2694.4080 & 899.1433 & 0.0013 & 0.4819 & 10.230\end{array}$ $\begin{array}{lllllllllllll}\text { QSHTLPPPPPALPFYPASAYPR } & 1.00 & 51.16 & 26.32 & 18.87 & 3 & 2694.4093 & 2694.4080 & 899.1433 & 0.0013 & 0.4819 & 10.230 \\ \text { QSHTLPFPPPALPFYPASAYPR } & 0.66 & 48.80 & 26.28 & 61.80 & 3 & 2694.4099 & 2694.4080 & 899.1433 & 0.0019 & 0.7044 & 24.376\end{array}$ $\begin{array}{llllllllllll}\text { QSHTLPPPPPALPFYPASAYPR } & 0.66 & 48.80 & 26.28 & 61.80 & 3 & 2694.4099 & 2694.4080 & 899.1433 & 0.0019 & 0.7044 & 24.376 \\ \text { QSHTLPPPPPALPFYPASAYPR } & 0.55 & 52.03 & 26.29 & 65.03 & 3 & 2694.4087 & 2694.4080 & 899.1433 & 0.0007 & 0.2595 & 5.443\end{array}$ $\begin{array}{llllllllllllll}\text { QSHTLPFPPPALPFYPASAYYR } & 1.00 & 46.53 & 26.26 & 17.48 & 3 & 2694.4108 & 2694.4080 & 899.1433 & 0.0028 & 1.0380 & 10.216\end{array}$ $\begin{array}{lllllllllllll}\text { QRPPQTPLR } & 0.73 & 20.08 & 26.53 & 17.84 & 3 & 1235.7214 & 1235.7220 & 412.9146 & -0.0006 & -0.4844 & 82.795\end{array}$ QRPPQTPR

$\begin{array}{lllllllllllll}0.88 & 20.88 & 26.56 & 15.46 & 3 & 1235.7220 & 1235.7220 & 412.9146 & 0.0000 & 0.0000 & 66.011\end{array}$ 


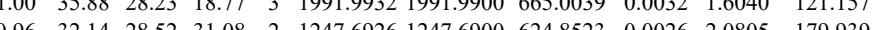

ALFAISCLVR $\begin{array}{lllllllllll}0.96 & 32.14 & 28.52 & 31.08 & 2 & 1247.6926 & 1247.6900 & 624.8523 & 0.0026 & 2.0805 & 179.939 \\ 1.00 & 91.25 & 25.16 & 22.00 & 3 & 2813.5033 & 2813.5013 & 938.8410 & 0.0020 & 0.7101 & 6.145 \\ 0.95 & 27.91 & 27.51 & 31.12 & 2 & 1281.7072 & 1281.7059 & 641.8602 & 0.0013 & 1.0127 & 15.949\end{array}$ $\begin{array}{llllllllllll} & \end{array}$

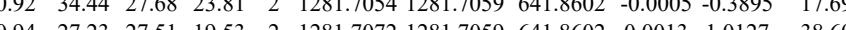

ALFAISCLVR

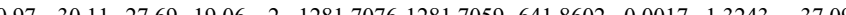
$\begin{array}{lllllllllll}1.00 & 39.73 & 25.76 & 15.85 & 4 & 3253.5445 & 3253.5439 & 814.3933 & 0.0006 & 0.1842 & 6.927\end{array}$ $\begin{array}{llllllllllll}1.00 & 39.73 & 25.76 & 15.85 & 4 & 3253.5445 & 3253.5439 & 814.3933 & 0.0006 & 0.1842 & 6.927\end{array}$ $\begin{array}{lllllllllll}1.00 & 25.34 & 25.82 & 15.13 & 4 & 3253.5449 & 3253.5439 & 814.3933 & 0.0010 & 0.3070 & 4.135 \\ 0.99 & 17.67 & 25.74 & 16.90 & 4 & 3253.5441 & 3253.5439 & 814.3933 & 0.0002 & 0.0614 & 3.547\end{array}$

(S) SSAGGSGNS $\begin{array}{lllllllllll}0 & 17.67 & 25.74 & 16.90 & 4 & 3253.5441 & 3253.5439 & 814.3933 & 0.0002 & 0.0614 & 3.547 \\ 100 & 37.52 & 25.81 & 50.52 & 4 & 3253.5465 & 3253.5439 & 814.3933 & 0.0026 & 0.7981 & 6.125\end{array}$ GTLCSMGMVQLVVALVR $\begin{array}{lllllllllll}1.00 & 79.18 & 27.54 & 21.27 & 2 & 1995.0356 & 1995.0260 & 998.5203 & 0.0096 & 4.8071 & 2.860\end{array}$ EPELGLEELLLR $\begin{array}{lllllllllll}0.90 & 49.08 * 27.57 & 33.14 & 2 & 1440.7958 & 1440.7946 & 721.4046 & 0.0012 & 0.8317 & 69.528\end{array}$ $\begin{array}{llllllllll}0.91 & 48.99 * 27.31 & 34.38 & 2 & 1440.7970 & 1440.7946 & 721.4046 & 0.0024 & 1.6634 & 69.139\end{array}$ EPELGLEELLR EPELGLEELLR

2 TQGLVPEHVETR

TQGLVPEHVETR

LDMIPDLK

GPVGTVSEAQLAR

IDVGFVYDEPGHA

KPVVGQCTIER

KPVVGQCTIER

ILVELATFLEK

ILVELATFLEK

ILVELATFLEK

ILVELATFLEK

LDAVNTLLAMAER $\begin{array}{lllllllllll}0.91 & 48.61 * 27.40 & 31.27 & 2 & 1440.7964 & 1440.7946 & 721.4046 & 0.0018 & 1.2476 & 81.005\end{array}$ $\begin{array}{lllllllllll}0.77 & 45.10 * 27.34 & 34.47 & 2 & 1440.7972 & 1440.7946 & 721.4046 & 0.0026 & 1.8020 & 124.403\end{array}$ $\begin{array}{llllllllllll}1.00 & 45.33 & 27.92 & 16.56 & 3 & 1508.8210 & 1508.8069 & 503.9429 & 0.0141 & 9.3264 & 4028.088 & 327 .\end{array}$ $\begin{array}{llllllllllll}27.92 & 16.56 & 3 & 1508.8210 & 1508.8069 & 503.9429 & 0.0141 & 9.3264 & 428.088 & 3273.824 & 235\end{array}$ $\begin{array}{lllllllllllll}0.99 & 33.50 & 27.90 & 30.14 & 2 & 1231.7112 & 1231.7090 & 616.8618 & 0.0022 & 1.7832 & 6094.589 & 3663.210 & \end{array}$ $\begin{array}{llllllllllllll}0.93 & 28.93 & 28.01 & 29.21 & 2 & 1231.7120 & 1231.7090 & 616.8618 & 0.0030 & 2.4317 & 5535.993 & 3494.074\end{array}$

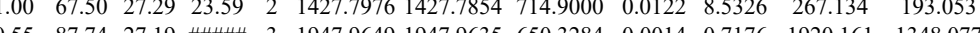

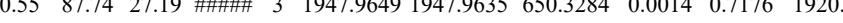
$\begin{array}{lllllllllllll}0.98 & 34.64 & 27.19 & 19.51 & 3 & 1562.8618 & 1562.8516 & 521.9578 & 0.0102 & 6.5139 & 4826.540 & 4067 . \\ 0.97 & 32.56 & 27.21 & 17.02 & 3 & 1562.8621 & 1562.8516 & 521.9578 & 0.0105 & 6.7055 & 2959.401 & 2616 .\end{array}$ $\begin{array}{lllllllllll}0.67 & 27.23 & 20.17 & 40.23 & 3 & 1562.9554 & 1562.9527 & 521.9915 & 0.0027 & 1.7242 & 89.952\end{array}$ $\begin{array}{llllllllllll}0.67 & 27.23 & 20.17 & 40.23 & 3 & 1562.9554 & 1562.9527 & 521.9915 & 0.0027 & 1.7242 & 89.952 \\ 1.00 & 50.00 & 20.13 & 20.48 & 3 & 1562.95571562 .9527 & 521.9915 & 0.0030 & 1.9157 & 70.276\end{array}$ $\begin{array}{lllllllllll}1.00 & 50.00 & 20.13 & 20.48 & 3 & 1562.9557 & 1562.9527 & 521.9915 & 0.0030 & 1.9157 & 70.276 \\ 0.66 & 29.53 & 20.25 & 42.53 & 3 & 1562.9551 & 1562.9527 & 521.9915 & 0.0024 & 1.5326 & 114.183\end{array}$ $\begin{array}{lllllllllll}0.66 & 29.53 & 20.25 & 42.53 & 3 & 1562.9551 & 1562.9527 & 521.9915 & 0.0024 & 1.5326 & 114.183 \\ 0.60 & 26.29 & 20.04 & 39.29 & 3 & 1562.9563 & 1562.9527 & 521.9915 & 0.0036 & 2.2989 & 82.784\end{array}$ $\begin{array}{lllllllllll}0.60 & 26.29 & 20.04 & 39.29 & 3 & 1562.9563 & 562.9527 & 521.9915 & 0.0036 & 2.2989 & 82.784 \\ 1.00 & 74.53 & 27.66 & 25.49 & 2 & 1559.8488 & 1559.8463 & 780.9304 & 0.0025 & 1.6007 & 533.309\end{array}$ $\begin{array}{llllllllllll}1.00 & 74.53 & 27.66 & 25.49 & 2 & 1559.8488 & 1559.8463 & 780.9304 & 0.0025 & 1.6007 & 533.309 & 309 \\ 1.00 & 78.40 & 27.58 & 29.19 & 2 & 1559.8490 & 1559.8463 & 780.9304 & 0.0027 & 1.7287 & 647.337 & 497\end{array}$

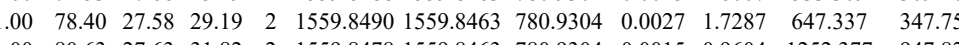
$\begin{array}{llllllllllllll}1.00 & 8.63 & 27.63 & 31.82 & 2 & 1559.8478 & 1559.8463 & 780.9304 & 0.0075 & 0.9604 & 1252.377 & 947.823\end{array}$

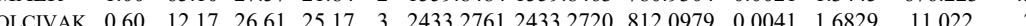
$\begin{array}{llllllllllll}\text { DQLRPTQLLQNVAR } & 0.91 & 25.03 & 24.17 & 19.28 & 3 & 1795.0336 & 1795.0186 & 599.3468 & 0.0150 & 8.3423 & 2382.748 \\ \text { DLPNRPETSFLWFTNPCK } & 1.00 & 22.30 & 27.13 & 14.93 & 4 & 2611.3209 & 2611.3171 & 653.8366 & 0.0038 & 1.4530 & 226.295\end{array}$

LDLPNRPETSFLWFTNPCK

DQLRPTQLLQNVAR

WGTSGLVGR

DQLRPTQLLQNVAR

ASLLSAPPCR $\begin{array}{lllllllllllll}1.00 & 39.42 & 23.94 & 19.45 & 3 & 1795.0363 & 1795.0186 & 599.3468 & 0.0177 & 9.8440 & 4356.474 & 3488 . \\ 0.89 & 32.21 & 27.99 & 23.33 & 2 & 1075.5988 & 1075.5896 & 538.8021 & 0.0092 & 8.5374 & 1545.744 & 1067 .\end{array}$

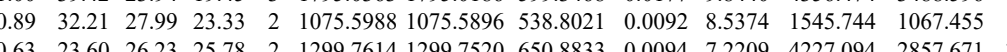
ASLLSAPPCR SLGPPGPPFNITPR SLGPPGPPFNITPR LGPPGPPFNITPR LEPISNDDLLVVEK

STLAEIEDWLDK

LFELEEQDLFR $\begin{array}{llllllllllll}0.99 & 36.71 & 23.94 & 24.02 & 3 & 1795.0363 & 1795.0186 & 599.3468 & 0.0177 & 9.8440 & 2166.935 & 1461 .\end{array}$ $\begin{array}{llllllllllll}1.00 & 52.07 & 28.06 & 29.87 & 2 & 1203.6240 & 1203.6226 & 602.8186 & 0.0014 & 1.1612 & 292.828\end{array}$ $\begin{array}{llllllllllll}1.00 & 47.14 & 29.21 & 30.37 & 2 & 1203.6250 & 1203.6226 & 602.8186 & 0.0024 & 1.9906 & 1471.753 & 876.92\end{array}$ $\begin{array}{llllllllllll}1.00 & 76.95 & 27.28 & 29.09 & 2 & 1592.8794 & 1592.8797 & 797.4471 & -0.0003 & -0.1881 & 2349.721 & 1347.839\end{array}$ $\begin{array}{lllllllllllll}1.00 & 78.34 & 27.04 & 26.11 & 2 & 1592.8806 & 1592.8797 & 797.4471 & 0.0009 & 0.5643 & 3155.164 & 1868.232\end{array}$ $\begin{array}{lllllllllllll}1.00 & 49.40 & 26.87 & 17.48 & 3 & 1592.8822 & 1592.8797 & 531.9672 & 0.0025 & 1.5665 & 310.039 & 320.862\end{array}$ $\begin{array}{llllllllllll}1.00 & 75.80 & 25.62 & 25.61 & 2 & 1871.0508 & 1871.0495 & 936.5320 & 0.0013 & 0.6940 & 716.869\end{array}$ $\begin{array}{llllllllllll}1.00 & 80.30 & 25.63 & 23.07 & 2 & 1871.0516 & 1871.0495 & 936.5320 & 0.0021 & 1.1212 & 608.873\end{array}$ $\begin{array}{lllllllllll}1.00 & 67.85 & 27.99 & 23.45 & 2 & 1706.8998 & 1706.8970 & 854.4558 & 0.0028 & 1.6385 & 45.533\end{array}$ LLEALDEMLTHDIAK $\begin{array}{lllllllllll}.00 & 52.84 & 28.00 & 30.83 & 2 & 1581.8192 & 1581.8160 & 791.9153 & 0.0032 & 2.0204 & 195.757\end{array}$ $\begin{array}{llllllllllllll} & \end{array}$ $\begin{array}{llllllllllllll} & \text { L }\end{array}$ $\begin{array}{lllllllllllll} & \text { LLEALDEMLTHDIAK } & 1.00 & 47.50 & 25.83 & 17.16 & 3 & 1999.0927 & 1999.0903 & 667.3707 & 0.0024 & 1.1987 & 1355.780\end{array}$ $\begin{array}{lllllllllllll}\text { LLEALDEMLTHDIAK } & 1.00 & 44.09 & 25.89 & 16.98 & 3 & 1999.0933 & 1999.0903 & 667.3707 & 0.0030 & 1.4984 & 2020.925 & 2319 . \\ \text { LLEALDEMLTHDIAK } & 1.00 & 64.04 & 25.92 & 19.69 & 3 & 1999.0930 & 1999.0903 & 667.3707 & 0.0027 & 1.3486 & 634.668 & 74.3\end{array}$ $\begin{array}{llllllllllllll} & \end{array}$ $\begin{array}{llllllllllllll} & \text { LLEALDEMLTHDIAK } & 1.00 & 54.09 & 25.94 & 17.28 & 3 & 1999.0915 & 1999.0903 & 667.3707 & 0.0012 & 0.5994 & 388.436 & 341 .\end{array}$ LLEALDEMLTHDIAK MQELLMAR

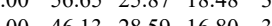
$\begin{array}{llllll}999.0921 & 1999.0903 & 667.3707 & 0.0018 & 0.8990 & 374.563\end{array}$

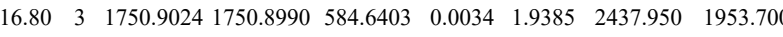
$\begin{array}{llllllllllllll}0.81 & 27.65 & 26.30 & 26.42 & 2 & 998.6082 & 998.5995 & 500.3070 & 0.0087 & 8.6946 & 2156.166 & 2864.76\end{array}$

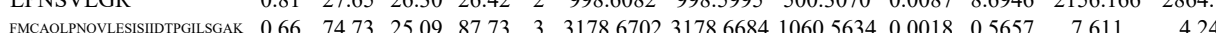


$\begin{array}{lllllllllllllllll} & \text { DGMLDEALASHLEK } \\ 0.66 & 66.10 & 27.02 & 79.10 & 3 & 2391.1894 & 2391.1871 & 798.0696 & 0.0023 & 0.9607 & 757.447 & 1171.121 & 3293.659 & 3439.877 & \text { Yes }\end{array}$

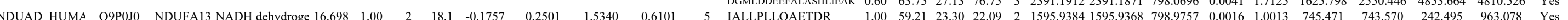
$\begin{array}{llllllllllllllll}\text { IALLPLLQAETDR } & 1.00 & 59.21 & 23.30 & 22.09 & 2 & 1595.9384 & 595.9368 & 788.9757 & 0.016 & 1.0013 & 745.471 & 743.570 & 242.495 & 963.078 & \text { Yes } \\ \text { IALLPLLQAETDR } & 1.00 & 50.59 & 22.99 & 21.31 & 2 & 1595.9402 & 1595.9368 & 798.9757 & 0.0034 & 2.1277 & 900.012 & 809.739 & 121.950 & 1299.535 & \text { Yes }\end{array}$

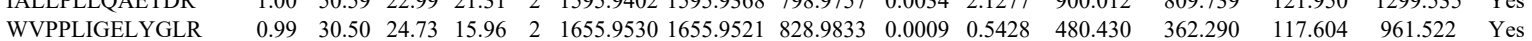

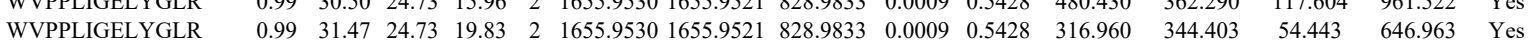

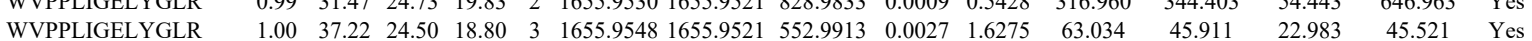

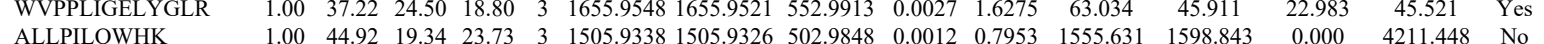
ALLPILQWHK LLGLLMPFR LLGLLMPFR LLGLLMPFR LLGLLMPFR LLGLLMPFR

$\begin{array}{llllllllllll}1.00 & 44.92 & 19.34 & 23.73 & 3 & 1505.9338 & 1505.9326 & 502.9848 & 0.0012 & 0.7953 & 1555.631 & 1598.843 \\ 1.00 & 49.13 & 19.29 & 28.15 & 3 & 1505.9347 & 1505.9326 & 502.9848 & 0.0021 & 1.3917 & 1899.814 & 1775.934\end{array}$ $\begin{array}{lllllllllllll}1.00 & 49.13 & 19.29 & 28.15 & 3 & 1505.9347 & 1505.9326 & 502.9848 & 0.0021 & 1.3917 & 1899.814 & 1775.934 \\ 1.00 & 34.03 & 19.34 & 24.82 & 3 & 1505.9335 & 1505.9326 & 502.9848 & 0.0009 & 0.5964 & 1411.096 & 1233.794\end{array}$ $\begin{array}{llllllllllllll}1.00 & 43.38 & 25.42 & 24.78 & 2 & 1202.7332 & 1202.7331 & 602.3738 & 0.0001 & 0.0830 & 189.720 & 152.708\end{array}$ $\begin{array}{lllllllllllll}1.00 & 44.78 & 25.42 & 19.79 & 2 & 1202.7332 & 1202.7331 & 602.3738 & 0.0001 & 0.0830 & 245.623 & 253.556\end{array}$ $\begin{array}{lllllllllllll}1.00 & 42.77 & 25.44 & 21.70 & 2 & 1202.7330 & 1202.7331 & 602.3738 & -0.0001 & -0.0830 & 294.402 & 257.153\end{array}$ $\begin{array}{llllllllllllll}0.99 & 37.13 & 25.42 & 20.47 & 2 & 1202.7332 & 1202.7331 & 602.3738 & 0.0001 & 0.0830 & 173.847 & 169.050\end{array}$ $\begin{array}{llllllllllllll}0.83 & 23.96 & 25.47 & 20.07 & 2 & 1202.7334 & 1202.7331 & 602.3738 & 0.0003 & 0.2490 & 25.553 & 18.886\end{array}$

HEQILVLDPPTDLK

$\begin{array}{llllllllllll}0.58 & 9.18 & 24.28 & 19.43 & 3 & 1905.0856 & 1905.0815 & 636.0344 & 0.0041 & 2.2487 & 1757.182 & 1300.035\end{array}$

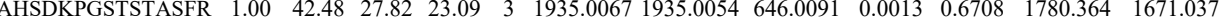
$\begin{array}{llllllllllllll}\text { VAHSDKPGSTSTASFR } & 1.00 & 45.29 & 27.77 & 24.88 & 3 & 1935.0070 & 1935.0054 & 646.0091 & 0.0016 & 0.8256 & 2330.694 & 1847.716\end{array}$ $\begin{array}{lllllllllllllll}\text { VAHSDKPGSTSTASFR } & 1.00 & 48.52 & 27.77 & 61.52 & 4 & 1935.0077 & 1935.0054 & 484.7586 & 0.0023 & 1.1862 & 2474.427 & 2276.303 & 82\end{array}$ $\begin{array}{lllllllllllll}\text { VAHSDKPGSTSTASFR } & 1.00 & 51.15 & 27.77 & 17.39 & 4 & 1935.0077 & 1935.0054 & 484.7586 & 0.0023 & 1.1862 & 3971.987 & 3255.235 \\ \text { VAHSDKPGSTSTASFR } & 1.00 & 54.72 & 27.82 & 23.62 & 3 & 1935.0067 & 1935.0054 & 646.0091 & 0.0013 & 0.6708 & 2664.470 & 2188.411\end{array}$ $\begin{array}{lllllllllllllll}\text { VAHSDKPGSTSTASFR } & 1.00 & 54.72 & 27.82 & 23.62 & 3 & 1935.0067 & 1935.0054 & 646.0091 & 0.0013 & 0.6708 & 2664.470 & 2188.411 & 679.7 & \\ \text { VAHSDKPGSTSTASFR } & 1.00 & 47.90 & 27.77 & 24.68 & 4 & 1935.0073 & 1935.0054 & 484.7586 & 0.0019 & 0.9799 & 7655.197 & 6133.568 & 2531 . \\ \text { VAHSDKPGSTSTASFR } & 1.00 & 44.89 & 27.77 & 21.75 & 3 & 1935.0076 & 1935.0054 & 646.0091 & 0.0022 & 1.1352 & 2364.975 & 2175.752 & 636.2\end{array}$ $\begin{array}{llllllllllllllll}\text { VAHSDKPGSTSTASFR } & 1.00 & 44.89 & 27.77 & 21.75 & 3 & 1935.0076 & 1935.0054 & 646.0091 & 0.0022 & 1.1352 & 2364.975 & 2175.752 & 636.2\end{array}$ $\begin{array}{llllllllllllllll}\text { VAHSDKPGSTSTASFR } & 1.00 & 43.64 & 27.77 & 56.64 & 4 & 1935.0077 & 1935.0054 & 484.7586 & 0.0023 & 1.1862 & 951.409 & 1009.056 & 405.20 \\ \text { VAHSDKPGSTSTASFR } & 1.00 & 38.46 & 27.81 & 51.46 & 4 & 1935.0069 & 1935.0054 & 484.7586 & 0.0015 & 0.7736 & 5373.414 & 6214.261 & 1326.89\end{array}$

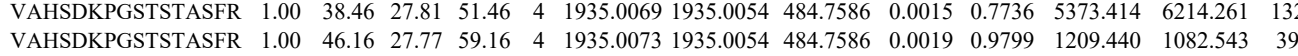
$\begin{array}{lllllllllllll}\text { VAHSDKPGSTSTASFR } & 1.00 & 32.29 & 27.81 & 45.29 & 4 & 1935.0069 & 1935.0054 & 484.7586 & 0.0015 & 0.7736 & 258.999 & 236.476 \\ \text { CVFEMPNENDK } & 1.00 & 55.40 & 23.48 & 19.85 & 2 & 1658.7374 & 1658.7346 & 830.3746 & 0.0028 & 1.6860 & 395.686 & 306.289\end{array}$ CVFEMPNENDK

$\begin{array}{llllllllllll}\text { CF115_HUMAN Q9P1F3 } & \text { C6orf115 } & \text { UPF0727 protein } 19.0565 & 1.00 & 2 & 23.5 & -0.2089 & 0.3679 & 2.2710 & 0.2781 & 18 & \text { CANLFEALVGTLK }\end{array}$ $\begin{array}{llllllllllll}1.00 & 55.40 & 23.48 & 19.85 & 2 & 1658.7374 & 1658.7346 & 830.3746 & 0.0028 & 1.6860 & 395.686 & 306.289 \\ 1.00 & 46.07 & 23.60 & 25.37 & 2 & 1658.7380 & 1658.7346 & 830.3746 & 0.0034 & 2.0473 & 299.994 & 309.755\end{array}$ CANLFEALVGTLK CANLFEALVGTLK CANLFEALVGTLK CANLFEALVGTLK CANLFEALVGTLK CANLFEALVGTLK CANLFEALVGTLK CANLFEALVGTLK CANLFEALVGTLK CANLFEALVGTLK CANLFEALVGTLK FGVLFR FGVLFR FGVLFR FGVLFR

FGVLFR

FGVLFR

FGVLFR CANLFEALVGTLK FGVLFR FGVLFR CANLFEALI FGVLFR

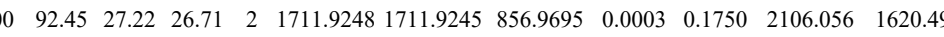
$\begin{array}{lllllllllllll}1.00 & 84.69 & 27.31 & 26.64 & 2 & 1711.9254 & 1711.9245 & 856.9695 & 0.0009 & 0.5251 & 3044.054 & 3398.4\end{array}$ $\begin{array}{lllllllllllll}0.99 & 30.64 & 26.95 & 21.57 & 3 & 1711.9285 & 1711.9245 & 571.6488 & 0.0040 & 2.3324 & 156.315 & 379.886\end{array}$ $\begin{array}{lllllllllllll}1.00 & 70.94 & 26.98 & 24.11 & 2 & 1711.9274 & 1711.9245 & 856.9695 & 0.0029 & 1.6920 & 6583.891 & 4822.85\end{array}$ $\begin{array}{lllllllllllll}1.00 & 80.04 & 26.94 & 24.60 & 2 & 1711.9280 & 1711.9245 & 856.9695 & 0.0035 & 2.0421 & 2683.904 & 1957.203\end{array}$ $\begin{array}{lllllllllllll}0.95 & 22.19 & 26.92 & 23.91 & 3 & 1711.9288 & 1711.9245 & 571.6488 & 0.0043 & 2.5074 & 64.534 & 25.120\end{array}$ $\begin{array}{lllllllllllll}0.94 & 23.89 & 26.99 & 18.61 & 3 & 1711.9291 & 1711.9245 & 571.6488 & 0.0046 & 2.6823 & 385.965 & 71.182\end{array}$ $\begin{array}{llllllllllll}1.00 & 76.46 & 27.23 & 24.51 & 2 & 1711.9250 & 1711.9245 & 856.9695 & 0.0005 & 0.2917 & 1120.828 & 1112.639\end{array}$ $\begin{array}{lllllllllllll}1.00 & 59.92 & 27.15 & 22.39 & 2 & 1711.9264 & 1711.9245 & 856.9695 & 0.0019 & 1.1086 & 1346.846 & 1318.940\end{array}$ $\begin{array}{llllllllllllll}0.96 & 22.34 & 27.00 & 24.27 & 3 & 1711.9273 & 1711.9245 & 571.6488 & 0.0028 & 1.6327 & 25.419 & 19.090\end{array}$ $\begin{array}{lllllllllllll}0.92 & 22.24 & 26.99 & 24.26 & 3 & 1711.9291 & 1711.9245 & 571.6488 & 0.0046 & 2.6823 & 69.279 & 36.729\end{array}$ $\begin{array}{lllllllllllll}1.00 & 34.06 & 26.95 & 22.13 & 3 & 1711.9276 & 1711.9245 & 571.6488 & 0.0031 & 1.8076 & 79.784 & 54.344 \\ 0\end{array}$ $\begin{array}{llllllllllll}1.00 & 31.57 & 26.95 & 19.39 & 3 & 1711.9282 & 1711.9245 & 571.6488 & 0.0037 & 2.1575 & 41.517 & 35.548 \\ 0.59 & 15.44 & 26.70 & 25.89 & 2 & 881.5256 & 881.5245 & 441.7695 & 0.0011 & 1.2450 & 63.767 & 41.216\end{array}$

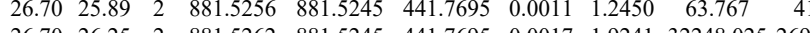
$\begin{array}{lllllllllllllllll} & & & \end{array}$

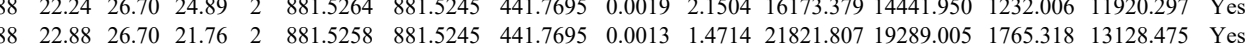
$\begin{array}{lllllllllllll} & \end{array}$ $\begin{array}{llllllllllllllll}0.81 & 20.33 & 26.87 & 24.11 & 2 & 881.5254 & 881.5245 & 441.7695 & 0.0009 & 1.0186 & 7755.900 & 8361.465 & 426.313 & 5767.023 & \text { Yes }\end{array}$ $\begin{array}{lllllllllllllllll}0.89 & 22.79 & 26.70 & 21.90 & 2 & 881.5262 & 881.5245 & 441.7695 & 0.0017 & 1.9241 & 19418.522 & 19682.034 & 1050.927 & 14875.788 & \text { Yes }\end{array}$ $\begin{array}{lllllllllllllll}0.96 & 21.65 & 26.84 & 16.60 & 3 & 1711.9279 & 1711.9245 & 571.6488 & 0.0034 & 1.9826 & 28.172 & 21.198 & 6.970 & 30.028 & \text { Yes }\end{array}$ $\begin{array}{lllllllllllllllll}0.77 & 19.49 & 26.87 & 16.13 & 2 & 881.5254 & 881.5245 & 441.7695 & 0.0009 & 1.0186 & 3456.972 & 3333.418 & 234.264 & 2792.237 & \text { Yes }\end{array}$ $\begin{array}{lllllllllllllll}0.84 & 21.07 & 26.70 & 20.96 & 2 & 881.5256 & 881.5245 & 441.7695 & 0.0011 & 1.2450 & 4999.691 & 4741.967 & 461.426 & 3671.870 & \text { Yes } \\ 0.99 & 27.73 & 26.95 & 24.25 & 3 & 171.9276 & 171.9245 & 571.6488 & 0.0031 & 1.8076 & 33.008 & 22.434 & 14.07 & 18.68 & \text { No }\end{array}$ $\begin{array}{lllllllllllllll}0.99 & 27.73 & 26.95 & 24.25 & 3 & 1711.9276 & 1711.9245 & 571.6488 & 0.0031 & 1.8076 & 33.008 & 22.434 & 14.707 & 18.658 & \text { No } \\ 0.73 & 2.75 & 26.92 & 26.67 & 2 & 881.5248 & 881.5245 & 441.7695 & 0.0003 & 0.3395 & 395.825 & 383.362 & 33.308 & 272.828 & \text { Yos }\end{array}$ $\begin{array}{lllllllllllllll}0.73 & 22.75 & 26.92 & 26.67 & 2 & 881.5248 & 881.5245 & 441.7695 & 0.0003 & 0.3395 & 395.825 & 383.362 & 33.308 & 272.828 & \text { Yes } \\ 0.74 & 18.50 & 26.70 & 21.77 & 2 & 881.5256 & 881.5245 & 441.7695 & 0.0011 & 1.2450 & 291.085 & 333.813 & 30.538 & 218.377 & \text { Yes }\end{array}$

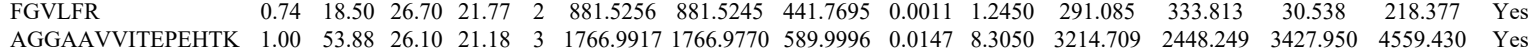




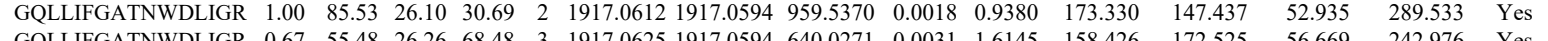

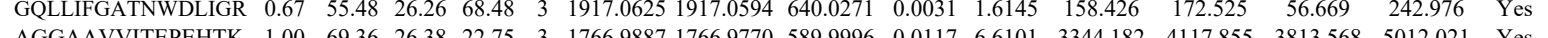
$\begin{array}{llllllllllllllll}\text { AGGAAVVITEPEHTK } & 1.00 & 69.36 & 26.38 & 22.75 & 3 & 1766.9887 & 1766.9770 & 589.9996 & 0.0117 & 6.6101 & 3344.182 & 4117.855 & 3813.568 & 5012.021 & \text { Yes } \\ \text { AGGAAVVITEPEHTK } & 1.00 & 87.89 & 26.09 & 26.82 & 2 & 1766.9902 & 1766.9770 & 884.4958 & 0.0132 & 7.4618 & 364.966 & 296.198 & 358.218 & 467.335 & \text { Yes }\end{array}$

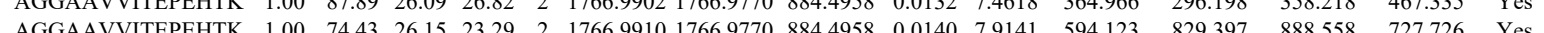

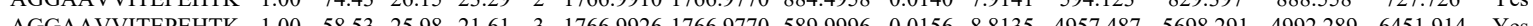

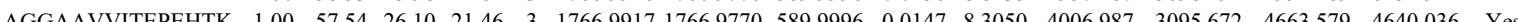

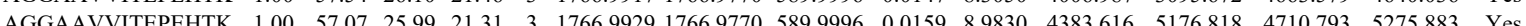
$\begin{array}{llllllllllllllll}\text { NQTPAPSAATSAPSK } & 0.99 & 28.60 & 27.61 & 15.15 & 3 & 1842.9688 & 1842.9679 & 615.3299 & 0.0009 & 0.4875 & 472.673 & 673.189 & 362.928 & 582.198 & \text { Yes }\end{array}$ $\begin{array}{llllllllllllllll}\text { NQTPAPSAAQTSAPSK } & 0.85 & 18.82 & 27.69 & 14.98 & 3 & 1842.9685 & 1842.9679 & 615.3299 & 0.0006 & 0.3250 & 126.663 & 112.223 & 131.251 & 163.735 & \text { Yes }\end{array}$

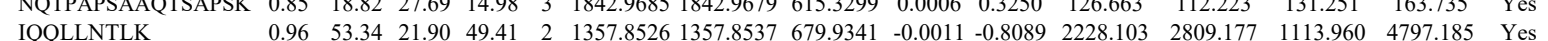

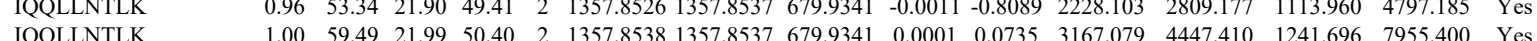

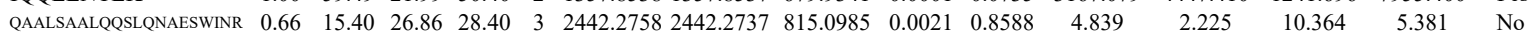

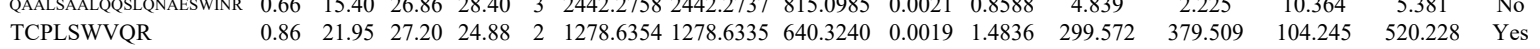
$\begin{array}{lllllllllllllllll}\text { RPGVPGAPLPGR } & 0.86 & 22.61 & 25.84 & 14.68 & 3 & 1316.7793 & 1316.7799 & 439.9339 & -0.0006 & -0.4546 & 53.147 & 94.666 & 54.408 & 84.737 & \text { Yes }\end{array}$ $\begin{array}{lllllllllllllllll}\text { RPGVPGAPLPGR } & 1.00 & 47.44 & 25.76 & 23.85 & 2 & 1316.7798 & 1316.7799 & 659.3972 & -0.0001 & -0.0758 & 53.845 & 138.465 & 101.762 & 142.754 & \text { Yes }\end{array}$ $\begin{array}{llllllllllllllllll}\text { RPGVPGAPLPGR } & 1.00 & 41.71 & 25.76 & 23.62 & 2 & 1316.7798 & 1316.7799 & 659.3972 & -0.0001 & -0.0758 & 42.140 & 123.461 & 78.302 & 105.388 & \text { Yes }\end{array}$ $\begin{array}{llllllllllllllll}\text { RPGVPGAPLPGR } & 0.99 & 45.21 & 25.84 & 22.56 & 2 & 1316.7790 & 1316.7799 & 659.3972 & -0.0009 & -0.6824 & 65.955 & 141.933 & 152.669 & 104.435 & \text { Yes }\end{array}$ $\begin{array}{lllllllllllllllll}\text { RPGVPGAPLPGR } & 1.00 & 64.37 & 25.82 & 21.34 & 3 & 1316.7796 & 1316.7799 & 439.9339 & -0.0003 & -0.2273 & 98.862 & 218.545 & 111.720 & 94.724 & \text { Yes }\end{array}$ $\begin{array}{llllllllllllllllll}\text { RPGVPGAPLPGR } & 1.00 & 41.35 & 25.81 & 23.50 & 2 & 1316.7802 & 1316.7799 & 659.3972 & 0.0003 & 0.2275 & 44.301 & 142.485 & 123.257 & 92.530 & \text { Yes }\end{array}$

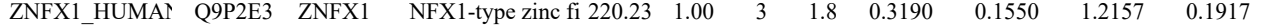

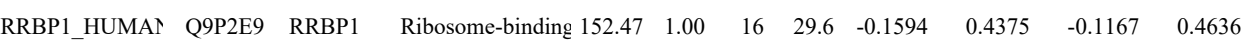

PPQKPTEQPQQAK

VCPICQVPIR

VCPICQVPIR

DAQDVQASQAEADQQQTR DAQDVQASQAEADQQQ
GNTPATGTTQGK GNTPATGTTOGK SILAETEGMLR SILAETEGMLR SILAETEGMLR

TLVSTVGSMVFNEGEAQ

QVLQLQASHR

QVLQLQASHR

QVLQLQASHR $\begin{array}{llllllllllllll}9.11 & 27.01 & 27.22 & 3 & 1322.7562 & 1322.7541 & 441.9253 & 0.0021 & 1.5840 & 1901.409 & 2149.093 & 778.8\end{array}$ \begin{tabular}{llllllllllllll} 
VEPAVSSVVNSIQVLTSK & 0.67 & 14.51 & 21.72 & 22.73 & 3 & 2144.2318 & 2144.2296 & 715.7505 & 0.0022 & 1.0246 & 57.047 & 31.116 \\
\hline
\end{tabular} $\begin{array}{lllllllllllll}\text { VEPAVSSVVNSIQVLTSK } & 0.67 & 14.51 & 21.79 & 27.51 & 3 & 2144.2330 & 2144.2296 & 715.7505 & 0.0034 & 1.5834 & 12.917 & 7.553 \\ \text { VEPAVSSVVNSIQVLTSK } & 0.67 & 20.14 & 21.79 & 33.14 & 3 & 2144.2330 & 2144.2296 & 715.7505 & 0.0034 & 1.5834 & 36.335 & 31.595\end{array}$ VEPAVSSVVNSIQVLTSK 0.67 VGAAEEELQK VGAAEEELQK

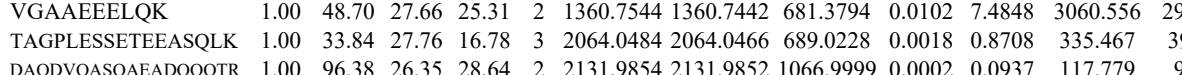
$\begin{array}{lllllllllllll}\text { DAQDVQASOAEADQQOTR } & 1.00 & 96.38 & 26.35 & 28.64 & 2 & 2131.9854 & 2131.9852 & 1066.9999 & 0.0002 & 0.0937 & 117.77 & \end{array}$ DAQDVQASQAEADQQQTR

HLEEIVEK $\begin{array}{lllllllllll}1.00 & 61.57 & 26.40 & 17.72 & 3 & 2131.9870 & 2131.9852 & 711.6690 & 0.0018 & 0.8431 & 56.566\end{array}$ $\begin{array}{lllllllllllll}.99 & 16.43 & 25.95 & 29.43 & 4 & 2049.1369 & 2049.1333 & 513.2906 & 0.0036 & 1.7534 & 67.284\end{array}$ $\begin{array}{llllllllllll}1.00 & 43.87 & 26.91 & 25.59 & 2 & 1362.6780 & 1362.6766 & 682.3456 & 0.0014 & 1.0259 & 843.104\end{array}$ $\begin{array}{llllllllllll}1.00 & 45.09 & 26.91 & 20.65 & 2 & 1362.6780 & 1362.6766 & 682.3456 & 0.0014 & 1.0259 & 442.786 \\ 1.00 & 47.02 & 23.30 & 20.13 & 2 & 1348.8218 & 1348.8200 & 675.4173 & 0.0018 & 1.3325 & 103.005\end{array}$ 97.079 90.225 876.441 $\begin{array}{lllllllllll}.00 & 47.80 & 26.36 & 16.96 & 3 & 2131.9861 & 2131.9852 & 711.6690 & 0.0009 & 0.4215 & 8.523\end{array}$ $\begin{array}{lllllllllll}0.98 & 24.55 & 26.40 & 15.12 & 3 & 2131.9870 & 2131.9852 & 111.6690 & 0.0018 & 0.8431 & 15.325\end{array}$ $\begin{array}{lllllllllll}1.00 & 56.25 & 28.69 & 22.71 & 2 & 1419.7582 & 1419.7562 & 710.8854 & 0.0020 & 1.4067 & 25.202\end{array}$ $\begin{array}{llllllllllll}1.00 & 50.77 & 28.14 & 28.22 & 2 & 1462.7334 & 1362.7299 & 682.3722 & 0.0035 & 2.5646 & 1112.448 & 988.893\end{array}$

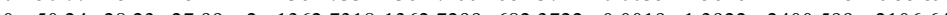

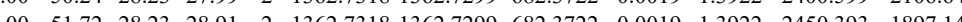
36.943 (29.5.455 397.558 16.917 25.862

TQLEWTEAILEDEQTQR TQLEWTEAILEDEQTQR KAEGAQNQGK KAEGTPNQGK KAEGTPNQGK KVEGAQNQGK

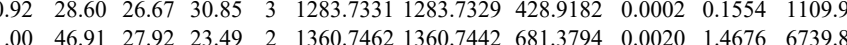
$625.824 \quad$ Yes KVEGAQNQG $\begin{array}{llllllllllllll} & \end{array}$ $\begin{array}{lllllllllllllllllll}\text { AQEQQQQMAELHSK } & 1.00 & 56.13 & 27.63 & 22.39 & 3 & 1942.9804 & 1942.9774 & 648.6664 & 0.0030 & 1.5416 & 5366.474 & 5795.169 & 2771.549 & 5531.093 & \text { Yes }\end{array}$

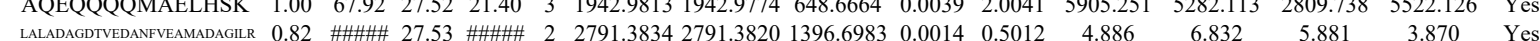

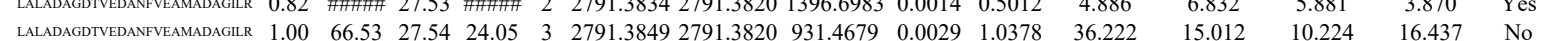




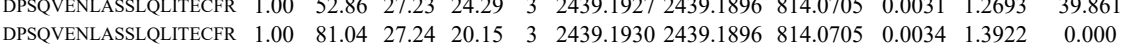
$\begin{array}{llllllllllllll}\text { DPSOVENLASSLQLITECFR } & 1.00 & 80.66 & 27.23 & 22.67 & 3 & 2439.1927 & 2439.1896 & 814.0705 & 0.0031 & 1.2693 & 12.951\end{array}$

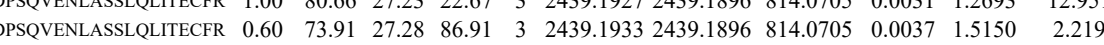

IPILSTFLTAR

$\begin{array}{lllllllllll}1.00 & 42.03 & 24.08 & 23.79 & 2 & 1374.8364 & 1374.8357 & 688.4251 & 0.0007 & 0.5084 & 122.7\end{array}$

IPILSTFLTAR $\begin{array}{lllllllllll}1.00 & 51.48 & 24.08 & 20.35 & 2 & 1374.8364 & 1374.8357 & 688.4251 & 0.0007 & 0.5084 & 38.194\end{array}$ $\begin{array}{lllllllllllllll} & 1.00\end{array}$ $\begin{array}{llllllllllllll}\text { LLLAANVATLGLLMAR } & 1.00 & \text { \#\#\#\# } & 18.20 & 22.13 & 2 & 1783.0890 & 1783.0875 & 892.5510 & 0.0015 & 0.8403 & 17.169\end{array}$ $\begin{array}{lllllllllllllll}\text { LLLAANVATLGLLMAR } & 1.00 & 90.74 & 18.26 & 24.55 & 2 & 1783.0898 & 1783.0875 & 892.5510 & 0.0023 & 1.2884 & 17.150\end{array}$ $\begin{array}{llllllllllll}\text { LLLAANVATLGLLMAR } & 1.00 & 23.59 & 18.26 & 14.66 & 3 & 1783.0900 & 1783.0875 & 595.3698 & 0.0025 & 1.3997 & 7.803 \\ \text { GFFAAAILFLSOSHVAR } & 0.67 & 15.46 & 26.40 & 28.46 & 3 & 1978.0942 & 1978.0910 & 660.3709 & 0.0032 & 1.6153 & 4.271\end{array}$

$\begin{array}{llllllllllll}\text { GDTEDIEK } & 1.00 & 46.81 & 28.08 & 30.54 & 2 & 1235.6498 & 1235.6489 & 6618.8317 & 0.0032 & 1.6153 & 4.271 \\ \text { VDTEO } & 0.7272 & 389.721\end{array}$ $\begin{array}{llllllllllllll}\text { NDVLDSLGISPDLLPEDFVR } & 0.84 & 81.82 & 27.30 & 94.82 & 2 & 2357.2254 & 2357.2236 & 1179.6191 & 0.0018 & 0.7630 & 35.122\end{array}$

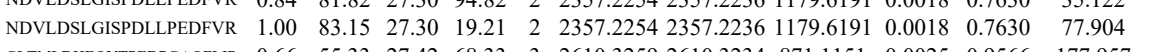
$\begin{array}{llllllllllll}\text { GLTMLDHEQVTPEDPGAQFLIR } & 0.66 & 55.33 & 27.42 & 68.33 & 3 & 2610.3259 & 2610.3234 & 871.1151 & 0.0025 & 0.9566 & 177.957\end{array}$ $\begin{array}{lllllllllllll}\text { GLTMLDHEQVTPEDPGAQFLIR } & 1.00 & 34.07 & 27.45 & 15.96 & 3 & 2610.3277 & 2610.3234 & 871.1151 & 0.0043 & 1.6454 & 42.256 & 21.959\end{array}$ VLLVGLK $\begin{array}{llllllllllll}0.99 & 38.85 & 15.05 & 28.50 & 2 & 1028.7284 & 1028.7201 & 515.3673 & 0.0083 & 8.0524 & 9448.532 & 9657.078 \\ 0.99 & 36.98 & 15.05 & 27.07 & 2 & 1028.7286 & 1028.7201 & 515.3673 & 0.0085 & 8.2465 & 14001.228 & 15927.359\end{array}$ VLLVGLK

GIPTSENPFK SDPLLIGIPTSENPFK TASTNNIAQAR

TASQGQWGR LSDIWAK

YTAAVPYR

YTAAVPYR

YTAAVPYR
YTAAVPYR

\section{FLPGYVGGIQEGAV}

GYFFPTSAR

LLVSGFWGVAR

LLVSGFWGVAR $\begin{array}{lllllllllllll} & \end{array}$

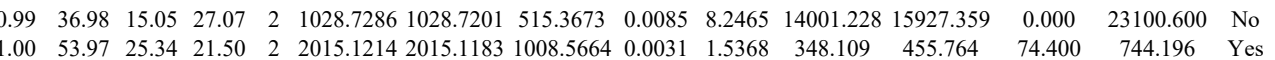

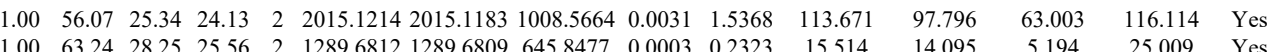

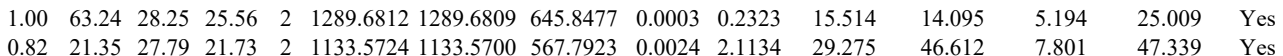

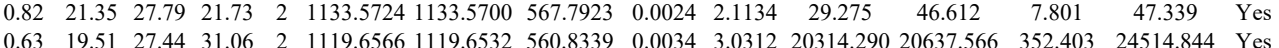
$\begin{array}{lllllllllllllll}0.63 & 1.51 & 27.44 & 31.06 & 2 & 1119.6566 & 1119.6532 & 560.8339 & 0.0034 & 3.0312 & 20314.290 & 20637.566 & 352.403 & 24514.844 & \text { Yes } \\ 0.98 & 36.02 & 27.4 & 22.38 & 2 & 1183.5836 & 1083.5835 & 542.7990 & 0.000 & 0.021 & 1842.953 & 2145.960 & 254684 & 1864.482 & \text { Yes }\end{array}$ $\begin{array}{lllllllllllllll}0.98 & 36.02 & 27.40 & 22.38 & 2 & 1083.5836 & 1083.5835 & 542.7990 & 0.0001 & 0.0921 & 18422.953 & 21451.960 & 2546.684 & 18646.482 & \text { Yes }\end{array}$

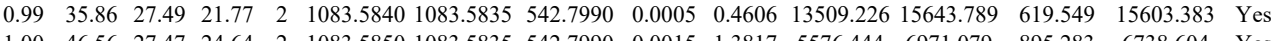
$\begin{array}{llllllllllllllll}1.00 & 46.56 & 27.47 & 24.64 & 2 & 1083.5850 & 1083.5835 & 542.7990 & 0.0015 & 1.3817 & 5576.444 & 6971.079 & 895.283 & 6738.604 & \text { Yes } \\ 0\end{array}$ $\begin{array}{lllllllllllllll}0.99 & 36.43 & 27.54 & 23.55 & 2 & 1083.5852 & 1083.5835 & 542.7990 & 0.0017 & 1.5660 & 7312.131 & 9102.337 & 569.774 & 7234.891 & \text { Yes } \\ 0.67 & 26.87 & 23.20 & 39.87 & 3 & 2460.3652 & 2460.3621 & 821.1280 & 0.0031 & 1.2584 & 589.208 & 484.971 & 54.703 & 534.929 & \text { No }\end{array}$

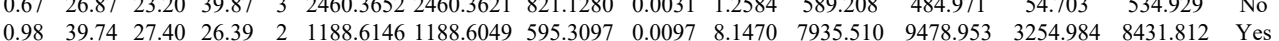
$\begin{array}{lllllllllllllll}0.98 & 39.74 & 27.40 & 26.39 & 2 & 1188.6146 & 1188.6049 & 595.3097 & 0.0097 & 8.1470 & 7935.510 & 9478.953 & 3254.984 & 8431.812 & \text { Yes } \\ 1.00 & 46.89 & 27.40 & 26.51 & 2 & 1188.6148 & 1188.6049 & 595.3097 & 0.0099 & 83149 & 3919.295 & 4799.231 & 1921.170 & 3999.306 & \text { No }\end{array}$

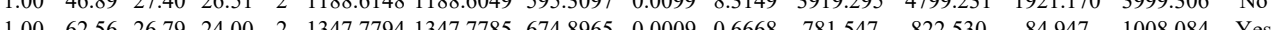
$\begin{array}{lllllllllllllll}1.00 & 64.95 & 26.79 & 23.16 & 2 & 1347.7794 & 1347.7785 & 674.8965 & 0.0009 & 0.6668 & 944.155 & 1000.097 & 70.806 & 1201.121 & \text { Yes }\end{array}$ 

$\begin{array}{llllllllllllll} & 0.66 & 65.12 & 26.78 & 72.13 & 3 & 2841.4651 & 2841.4626 & 948.1615 & 0.0025 & 0.8789 & 6.083\end{array}$ $\begin{array}{llllllllllll} & \text { G }\end{array}$

LKPFGVQR

6.567
3.124
3.662

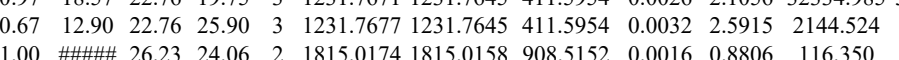

$\begin{array}{lllllllllll}\text { NTMSLLAANNLLAGLR } & 1.00 & \text { \#\#\#\# } 26.23 & 24.06 & 2 & 1815.0174 & 1815.0158 & 908.5152 & 0.0016 & 0.8806 & 116.350 \\ \text { NTMSLLAANNLLAGLR } & 1.00 & \text { \#\#\# } 26.22 & 26.72 & 2 & 1815.0176 & 1815.0158 & 908.5152 & 0.0018 & 0.9906 & 160.983\end{array}$

$\begin{array}{llllllllllll}\text { NTMSLLAANNLLAGLR } & 1.00 & 26.22 & 26.72 & 2 & 1815.0176 & 1815.0158 & 908.5152 & 0.0018 & 0.9906 & 160.983 \\ \text { NTMSLLAANNLLAGLR } & 1.00 & 70.06 & 26.19 & 20.53 & 3 & 1815.0193 & 1815.0158 & 606.0125 & 0.0035 & 1.9251 & 20.798 \\ \text { NMSLLANN }\end{array}$

$\begin{array}{lllllllllll}\text { NTMSLLAANNLLAGLR } & 1.00 & \text { \#\#\#\# } 26.28 & 23.49 & 2 & 1815.0166 & 1815.0158 & 908.5152 & 0.0008 & 0.4403 & 204.011\end{array}$ $\begin{array}{llllllllllll}\text { NTMSLLAANNLLAGLR } & 1.00 & \# \# \# \# \quad 26.22 & 23.22 & 2 & 1815.0176 & 1815.0158 & 908.5152 & 0.0018 & 0.9906 & 170.376\end{array}$ $\begin{array}{lllllllllllll}\text { NTMSLLAANNLLAGLR } & 1.00 & 47.95 & 26.18 & 20.79 & 3 & 1815.0187 & 1815.0158 & 606.0125 & 0.0029 & 1.5951 & 11.499\end{array}$ \begin{tabular}{lllllllllllll} 
NTMSLLAANNLLAGLR & 1.00 & 53.55 & 26.11 & 21.75 & 3 & 1815.0199 & 1815.0158 & 606.0125 & 0.0041 & 2.2552 & 10.604 \\
\hline
\end{tabular}

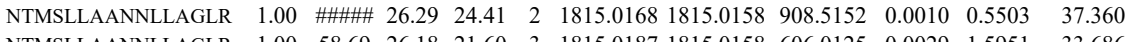
$\begin{array}{llllllllllll}\text { NTMSLLAANNLLAGLR } & 1.00 & 58.69 & 26.18 & 21.60 & 3 & 1815.0187 & 1815.0158 & 606.0125 & 0.0029 & 1.5951 & 33.686\end{array}$ $\begin{array}{lllllllllllll}\text { NTMSLLAANNLLAGLR } & 1.00 & 63.68 & 26.11 & 22.01 & 3 & 1815.0199 & 1815.0158 & 606.0125 & 0.0041 & 2.2552 & 24.637 \\ & 0.58 & 19.50 & 26.82 & 23.46 & 2 & 1428.792 & 1428.7088 & 7155317 & 0.0004 & 0.2796 & 1.9497\end{array}$

$\begin{array}{llllllllllll}0.58 & 19.50 & 26.82 & 23.46 & 2 & 1428.7092 & 1428.7088 & 715.3617 & 0.0004 & 0.2796 & 19.497\end{array}$ $\begin{array}{llllllllllll}\text { NPDDPQAQEK } & 1.00 & 43.09 & 26.80 & 25.33 & 2 & 1428.7094 & 1428.7088 & 715.3617 & 0.0006 & 0.4194 & 26.084 \\ \text { NQDLGAY } & 1.00 & 76.01 & 27.87 & 23.67 & 2 & 2059.0374 & 2059.0353 & 1030.5249 & 0.0021 & 1.0189 & 169.002\end{array}$

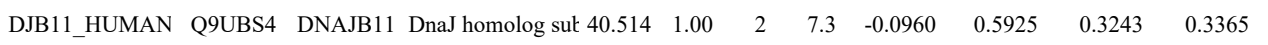
$\begin{array}{lllllllllll}\text { SAE2_HUMAN } & \text { Q9UBT2 } & \text { UBA2 } & \text { SUMO-activating } 71.224 & 1.00 & 7 & 22.7 & 0.1977 & 0.5589 & -0.2014 & 0.8802\end{array}$

$\begin{array}{llllllllllllll} & \end{array}$ $\begin{array}{lllllllllllll} & \text { LADDLCDILLINLHEDLGK } & 0.60 & 75.14 & 25.01 & 88.14 & 3 & 3061.6252 & 3061.6215 & 1021.5478 & 0.0037 & 1.2073 & 338.164\end{array}$

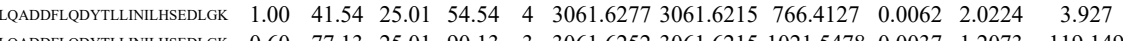

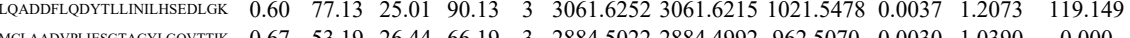
$\begin{array}{lllllllllllll} & 0.67 & 53.19 & 26.44 & 66.19 & 3 & 2884.5022 & 2884.4992 & 962.5070 & 0.0030 & 1.0390 & 0.000\end{array}$ $\begin{array}{lllllllllllll} & \text { MCAADVLIESGTAGYLGQVTTIK } & 1.00 & 32.24 & 26.50 & 21.88 & 3 & 2884.5016 & 2884.4992 & 962.5070 & 0.0024 & 0.8312 & 31.745\end{array}$ $\begin{array}{llllllllllll} & \end{array}$ TFPGCTIR $\begin{array}{lllllllllll}0.73 & 25.97 & 26.53 & 29.99 & 2 & 1083.5422 & 1083.5327 & 542.7736 & 0.0095 & 8.7513 & 2497.664 \\ 0.55 & 72.11 & 14.77 & 85.11 & 3 & 2937.7189 & 2937.7180 & 980.2466 & 0.0009 & 0.3060 & 3.378\end{array}$

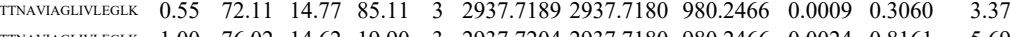

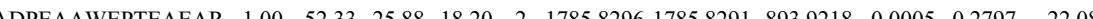

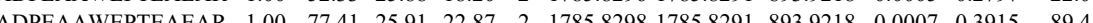
$\begin{array}{lllllllllllllll}\text { YLFNOLFGEEDADOEVSPDR } & 1.00 & 81.31 & 25.59 & 20.86 & 2 & 2515.1614 & 2515.1625 & 1258.5885 & -0.0011 & -0.4370 & 8.776\end{array}$ $\begin{array}{llllllllllll}\text { YLFNOLFGEEDADOEVSPDR } & 1.00 & 65.84 & 25.66 & 17.22 & 2 & 2515.1634 & 2515.1625 & 1258.5885 & 0.0009 & 0.3575 & 2.476\end{array}$ \begin{tabular}{lllllllllllll|} 
& 45.530 .8677 & 3630.8621 & 908.7228 & 0.0056 & 1.5406 & 2.778
\end{tabular} $\begin{array}{lllllllllllll}\text { WVMVNGTPMEDVLHSFAVQLLR } & 0.55 & 58.32 & 26.32 & 71.32 & 3 & 2613.3544 & 2613.3529 & 872.1249 & 0.0015 & 0.5733 & 28.048\end{array}$ $\begin{array}{llllllllllll}\text { VMVNGTPMEDVLHSFAVQQLR } & 1.00 & 82.78 & 26.43 & 20.76 & 3 & 2613.3559 & 2613.3529 & 872.1249 & 0.0030 & 1.1466 & 251.871\end{array}$ GFGIAVSGGR GFGIAVSGGR GFGIAVSGGR LQLVVLR LQLVVLR

GRPGPIGVLLMK

GRPGPIGVLLMK

GRPGPIGVLLMK

AFEVMDEFDGR SNPSAVAGNETPGASTK

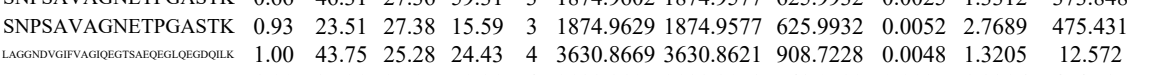

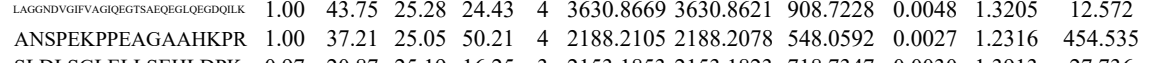
$\begin{array}{lllllllllllll} & \end{array}$

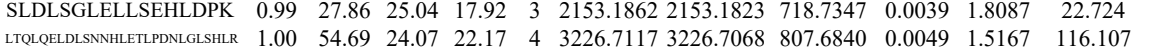
$\begin{array}{lllllllllllll}0.99 & 46.08 & 28.03 & 27.93 & 2 & 1063.5990 & 1063.5896 & 532.8021 & 0.0094 & 8.8212 & 4482.108 & 4614.082 & 3\end{array}$ $\begin{array}{llllllllllllll}0.97 & 38.01 & 28.03 & 22.34 & 2 & 1063.5992 & 1063.5896 & 532.8021 & 0.0096 & 9.0089 & 4558.787 & 4571.227\end{array}$ $\begin{array}{llllllllllllll}.98 & 40.77 & 28.03 & 30.53 & 2 & 1063.5990 & 1063.5896 & 532.8021 & 0.0094 & 8.8212 & 3563.829 & 3160.628 & 3 \\ 1.00 & 50.56 & 28.03 & 28.58 & 2 & 1063.5992 & 1063.5896 & 532.8021 & 0.0096 & 9.0089 & 3734.473 & 2794.183\end{array}$ $\begin{array}{lllllllllllllll}0.98 & 40.38 & 14.91 & 37.94 & 2 & 983.6616 & 983.6613 & 492.8379 & 0.0003 & 0.3044 & 2814.707 & 2102.588 & 6\end{array}$ $\begin{array}{llllllllllllll}1.00 & 38.99 & 14.91 & 30.37 & 2 & 983.6626 & 983.6613 & 492.8379 & 0.0013 & 1.3189 & 4226.137 & 3243.896 & 1569\end{array}$ $\begin{array}{llllllllllllll}0.66 & 31.81 & 18.26 & 44.81 & 3 & 1524.9442 & 1524.9418 & 509.3212 & 0.0024 & 1.5707 & 1983.165 & 1595.741 & 331 \\ 1.00 & 37.72 & 18.69 & 19.86 & 3 & 1524.9451 & 1524.9418 & 509.3212 & 0.0033 & 2.1597 & 525.396 & 488.874 & 954\end{array}$ $\begin{array}{lllllllllllll}1.00 & 37.72 & 18.69 & 19.86 & 3 & 1524.9451 & 1524.9418 & 509.3212 & 0.0033 & 2.1597 & 525.396 & 488.874 & 954\end{array}$ $\begin{array}{lllllllllllll}0.60 & 26.90 & 18.69 & 39.90 & 3 & 1524.9454 & 1524.9418 & 509.3212 & 0.0036 & 2.3561 & 358.690 & 399.049\end{array}$ $\begin{array}{lllllllllllll}0.62 .84 & 16.04 & 2 & 1458.6578 & 1458.6571 & 730.3358 & 0.0007 & 0.4792 & 50.740 & 39.123\end{array}$ \begin{tabular}{lllllllllllll} 
LIRLEEDLSNNHLETLPNLGLLSHLR & 1.00 & 54.69 & 24.07 & 22.17 & 4 & 3226.7117 & 3226.7068 & 807.6840 & 0.0049 & 1.5167 & 116.107 \\
\hline
\end{tabular} RWSVLAAAGLR $\begin{array}{lll}417.617 & 2355.149 & \text { Yes } \\ 47.786 & 151.816 & \text { Yes }\end{array}$ $\begin{array}{lll}25.759 & 27.035 & \text { Yes }\end{array}$ $\begin{array}{lll}80.966 \quad 257.386 & \text { Yes }\end{array}$ $\begin{array}{lll}136.474 & 226.701 & \text { Yes }\end{array}$ $22.927 \quad 21.714 \quad$ No $\begin{array}{lll}13.252 & 29.532 & \text { Yes }\end{array}$ $\begin{array}{lll}25.021 & 47.600 & \text { Yes } \\ 28.426 & 35.648 & \text { Yes }\end{array}$ $\begin{array}{lll}28.426 & 35.648 & \text { Yes } \\ 26.007 & 31.473 & \text { Yes }\end{array}$ $\begin{array}{llll}7624.291 & \text { Yes }\end{array}$ $\begin{array}{lll}14.005 \quad 6076.119 & \text { Yes }\end{array}$ \begin{tabular}{lll} 
& 1190.018 & Yes \\
\hline 93.9667 & 160.987 & Yes
\end{tabular} \begin{tabular}{lll} 
& 676.987 & Yes \\
\hline
\end{tabular} 
$\begin{array}{lllllllllllllll}1.00 & 37.63 & 23.36 & 24.45 & 2 & 1188.7358 & 1188.7352 & 595.3749 & 0.0006 & 0.5039 & 1100.211 & 1450.560 & 77.577 & 1853.710 & \text { Yes }\end{array}$ $\begin{array}{llllllllllllllll}1.00 & 37.20 & 23.28 & 23.02 & 2 & 1188.7360 & 1188.7352 & 595.3749 & 0.0008 & 0.6718 & 1218.243 & 1496.183 & 89.739 & 1931.288 & \text { Yes }\end{array}$ \begin{tabular}{llllllllllllllll} 
IAWPPPTELGSSGSALEEGIK & 1.00 & 74.32 & 26.30 & 20.84 & 2 & 2426.2954 & 2426.2937 & 1214.1541 & 0.0017 & 0.7001 & 63.681 & 27.619 & 116.328 & 129.595 & Yes \\
\hline
\end{tabular}

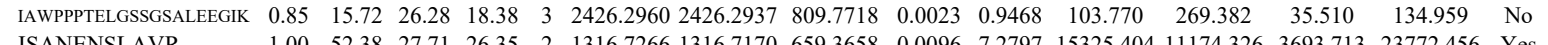
$\begin{array}{llllllllllllllll}\text { ISANENSLAVR } & 1.00 & 52.38 & 27.71 & 26.35 & 2 & 1316.7266 & 1316.7170 & 659.3658 & 0.0096 & 7.2797 & 15325.404 & 11174.326 & 3693.713 & 23772.456 & \text { Yes }\end{array}$

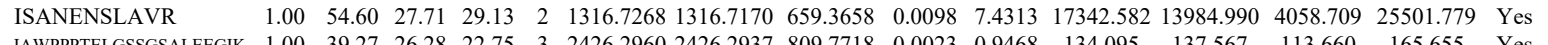

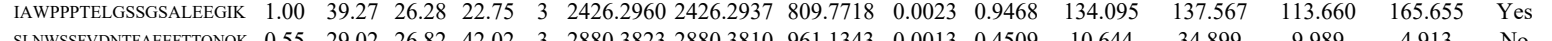

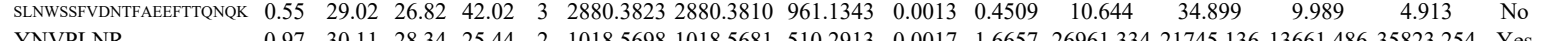
$\begin{array}{llllllllllllllll}\text { YNVPLNR } & 0.97 & 30.11 & 28.34 & 25.44 & 2 & 1018.5698 & 1018.5681 & 510.2913 & 0.0017 & 1.6657 & 26961.334 & 21745.136 & 13661.486 & 35823.254 & \text { Yes } \\ \text { YNVPLNR } & 0.97 & 30.01 & 28.34 & 28.16 & 2 & 1018.5700 & 10185681 & 510.2913 & 0.0019 & 1.8617 & 11260.181 & 7604.992 & 6834.976 & 13425.751 & \text { Yes }\end{array}$

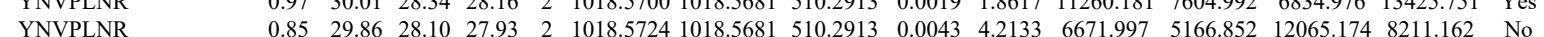

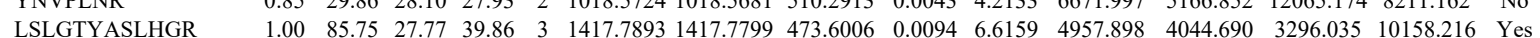
$\begin{array}{lllllllllllllllll}\text { LSLGTYASLHGR } & 1.00 & 85.75 & 27.77 & 39.86 & 3 & 1417.7893 & 1417.7799 & 473.6006 & 0.094 & 6.6159 & 4957.898 & 4044.690 & 3296.035 & 10158.216 & \text { Yes } \\ \text { LSLGTYASLHGR } & 1.00 & 63.35 & 27.77 & 35.24 & 3 & 1417.7902 & 1417.7799 & 473.6006 & 0.0103 & 72494 & 6543.129 & 5422.953 & 3895.371 & 10957.834 & \text { Yes }\end{array}$ $\begin{array}{llllllllllllllll}\text { LLANQQVFHISCFR } & 1.00 & 60.64 & 27.91 & 19.33 & 3 & 1864.9489 & 1864.9562 & 62.6593 & -0.0073 & -3.9080 & 35.191 & 29.820 & 8.458 & 38.562 & \text { Yes }\end{array}$

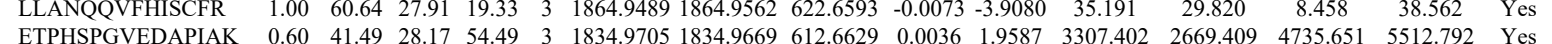
$\begin{array}{llllllllllllllll}\text { ADHPPAEVTSHAASGAK } & 1.00 & 70.72 & 27.80 & 83.72 & 4 & 1932.9913 & 1932.9897 & 484.2547 & 0.0016 & 0.8260 & 4223.915 & 2529.390 & 5916.890 & 13030.508 & \text { Yes }\end{array}$ $\begin{array}{llllllllllllllll}\text { ADHPPAEVTSHAASGAK } & 0.66 & 72.18 & 27.82 & 85.18 & 3 & 1932.9922 & 1932.9897 & 645.3372 & 0.0025 & 1.2913 & 1547.223 & 786.156 & 2364.595 & 4411.637 & \text { Yes }\end{array}$ $\begin{array}{llllllllllllllll}\text { ADHPPAEVTSHAASGAK } & 1.00 & 53.69 & 27.91 & 66.69 & 4 & 1932.9933 & 1932.9897 & 484.2547 & 0.0036 & 1.8585 & 4785.872 & 2588.318 & 10132.489 & 14848.255 & \text { Yes }\end{array}$

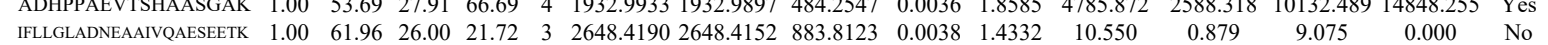

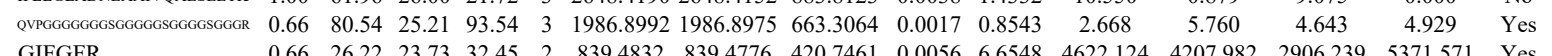

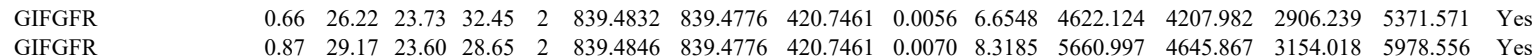
$\begin{array}{llllllllllllllll}\text { FHLLSR } & 0.87 & 29.17 & 23.60 & 28.65 & 2 & 839.4846 & 839.4776 & 420.7461 & 0.0070 & 8.3185 & 5660.997 & 4645.867 & 3154.018 & 5978.556 & \text { Yes } \\ \text { FHLL } & 0.79 & 20.17 & 27.48 & 20.02 & 2 & 915.5432 & 915.5412 & 458.7779 & 0.0020 & 2.1797 & 7697.778 & 4249.217 & 3514.101 & 11154.743 & \text { Yes }\end{array}$ $\begin{array}{lllllllllllllllll}\text { FHLLSR } & 0.80 & 20.38 & 27.48 & 19.62 & 2 & 915.5432 & 915.5412 & 458.7779 & 0.0020 & 2.1797 & 6490.156 & 3887.227 & 2751.115 & 8596.916 & \text { Yes }\end{array}$ $\begin{array}{llllllllllllllll}\text { IFLLGLADNEAAIVQAESEETK } & 1.00 & 34.15 & 25.94 & 16.75 & 3 & 2648.4166 & 2648.4152 & 883.8123 & 0.0014 & 0.5280 & 2.946 & 1.334 & 8.292 & 4.791 & \text { Yes }\end{array}$

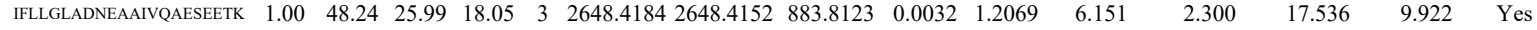

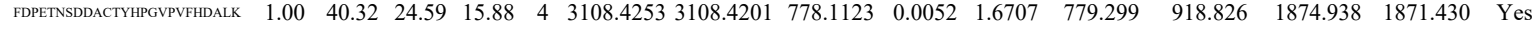
$\begin{array}{llllllllllllllllll}\text { RDPETNDDACTYHPGVVFFDALK } & 1.00 & 40.84 & 24.73 & 53.84 & 4 & 3108.4269 & 3108.4201 & 778.1123 & 0.0068 & 2.1848 & 775.705 & 935.730 & 1027.041 & 2100.825 & \text { Yes }\end{array}$ $\begin{array}{lllllllllllllllll}\text { SYVTMTATK } & 1.00 & 41.99 & 27.75 & 22.87 & 2 & 1288.6968 & 1288.6941 & 645.3543 & 0.0027 & 2.0919 & 4387.216 & 3936.717 & 5987.878 & 10518.857 & \text { Yes }\end{array}$

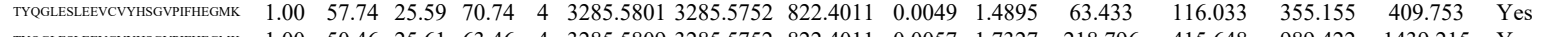
$\begin{array}{llllllllllllllll}\text { TYQGLESLEVCCYHSGVPFHEGMK } & 1.00 & 50.46 & 25.61 & 63.46 & 4 & 3285.5809 & 3285.5752 & 822.4011 & 0.0057 & 1.7327 & 218.796 & 415.648 & 989.422 & 1439.215 & \text { Yes } \\ \text { LWGVIDVK } & 0.99 & 35.40 & 25.04 & 30.68 & 2 & 126.7422 & 125.7423 & 609.3784 & 0.0001 & 0.021 & 1329.022 & 1404.148 & 14.449 & 5831.126 & \text { No }\end{array}$ $\begin{array}{llllllllllllllll}\text { LWGVIDVK } & 0.99 & 35.40 & 25.04 & 30.68 & 2 & 1216.7422 & 1216.7423 & 609.3784 & -0.0001 & -0.0821 & 1329.022 & 1404.148 & 147.449 & 5831.126 & \text { No }\end{array}$ \begin{tabular}{llllllllllllllll} 
TTDFSDFLSIVGCTK & 1.00 & 82.78 & 27.64 & 26.71 & 2 & 1966.9630 & 1966.9624 & 984.4885 & 0.0006 & 0.3047 & 141.287 & 172.722 & 104.204 & 265.977 & Yes \\
\hline TTDFSDFLSIVCTKK & 1.00 & 5.12 & 27.75 & 21.81 & 3 & 1966.948 & 1966.9624 & 96.661 & 0.0024 & 1.2183 & 129.627 & 149.769 & 53.176 & 308.037 & Yes
\end{tabular} \begin{tabular}{llllllllllllllll} 
TTDFSDFLSIVGCTK & 1.00 & 53.12 & 27.75 & 21.81 & 3 & 1966.9648 & 1966.9624 & 656.6614 & 0.0024 & 1.2183 & 129.627 & 149.769 & 53.176 & 308.037 & Yes \\
\hline TTDFSDFLSIVGCTK & 1.00 & 80.73 & 27.79 & 19.98 & 2 & 196.9648 & 196.9624 & 984.4885 & 0.0024 & 1.2189 & 160.007 & 149.888 & 63.118 & 326.104 & Yes
\end{tabular} $\begin{array}{llllllllllllllll}\text { TTDFSDFLSIVGCTK } & 1.00 & 80.73 & 27.79 & 19.98 & 2 & 1966.9648 & 1966.9624 & 984.4885 & 0.0024 & 1.2189 & 160.007 & 149.888 & 63.118 & 326.104 & \text { Yes } \\ \text { TTDFSDFLSIVGCTK } & 1.00 & 48.41 & 27.97 & 22.48 & 3 & 1966.9666 & 1966.9624 & 656.6614 & 0.0042 & 2.1320 & 53.154 & 97.418 & 7.916 & 88.909 & \text { No }\end{array}$ $\begin{array}{llllllllllllllll}\text { TTDFSDFLSIVGCTK } & 1.00 & 48.41 & 27.97 & 22.48 & 3 & 1966.9666 & 1966.9624 & 656.6614 & 0.0042 & 2.1320 & 53.154 & 97.418 & 7.916 & 88.909 & \text { No } \\ \text { TTDFSDFLSIVGCTK } & 1.00 & 54.09 & 27.61 & 24.69 & 2 & 1966.9628 & 1966.9624 & 984.4885 & 0.0004 & 0.2032 & 83.545 & 52.121 & 3.645 & 187.507 & \text { Yes }\end{array}$

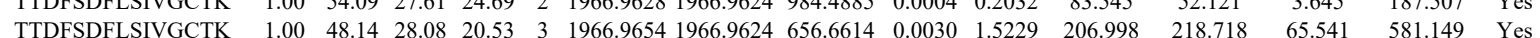

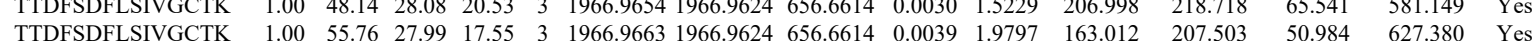

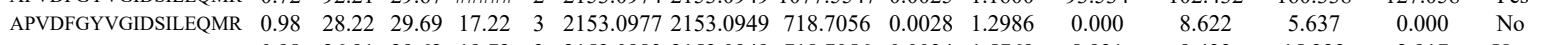
$\begin{array}{llllllllllllllll}\text { APVDFGYVGIDSILEQMR } & 0.98 & 26.91 & 29.62 & 19.72 & 3 & 2153.0983 & 2153.0949 & 718.7056 & 0.0034 & 1.5769 & 8.931 & 9.433 & 15.323 & 2.917 & \text { Yes }\end{array}$ $\begin{array}{llllllllllllllll}\text { APVDFGYVGIDSILEQMR } & 1.00 & 78.95 & 29.74 & 20.75 & 2 & 2153.0934 & 2153.0949 & 1077.5547 & -0.0015 & -0.6960 & 155.422 & 136.193 & 276.451 & 310.880 & \text { Yes }\end{array}$

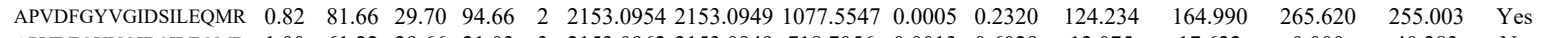

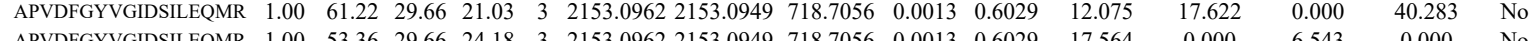

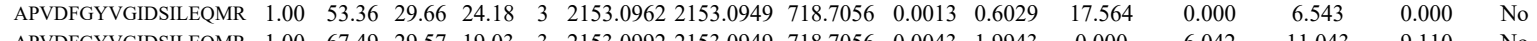
$\begin{array}{llll}6.042 & 11.043 & 9.110 & \text { No }\end{array}$ $\begin{array}{lllllllllllll}\text { APVDFGYVGIDSILEQMR } & 1.00 & 67.49 & 29.57 & 19.03 & 3 & 2153.0992 & 2153.0949 & 718.7056 & 0.0043 & 1.9943 & 0.000\end{array}$

VVNIVPVIAK

STLINTLFK

STLINTLFK

VVNIVPVIAK

VQTPLLR

STLINTLFK

SOEATEAAPSC $\begin{array}{llllllllllllllll}0.72 & 50.16 & 11.46 & 63.16 & 2 & 1338.8868 & 1338.8842 & 670.4494 & 0.0026 & 1.9390 & 15980.060 & 11734.828 & 5184.812 & 15417.148 & \text { Yes } \\ 0.99 & 48.73 & 23.22 & 38.95 & 2 & 1323.7998 & 1323.8006 & 662.9076 & 0.0008 & -0.6034 & 17495.521 & 14807.519 & 5193.415 & 20442.723 & \text { Yes }\end{array}$ $\begin{array}{llllllllllllllll}0.99 & 48.73 & 23.22 & 38.95 & 2 & 1323.7998 & 1323.8006 & 662.9076 & -0.0008 & -0.6034 & 17495.521 & 14807.519 & 5193.415 & 20442.723 & \text { Yes } \\ 1.00 & 58.71 & 23.10 & 40.98 & 2 & 1323.8000 & 1323.8006 & 662.9076 & -0.0006 & -0.4526 & 18420.225 & 12036.970 & 5067.231 & 17758.121 & \text { Yes }\end{array}$ $\begin{array}{lllllllllllllllll}1.00 & 58.71 & 23.10 & 40.98 & 2 & 1323.8000 & 1323.8006 & 662.9076 & -0.0006 & -0.4526 & 18420.225 & 12036.970 & 5067.231 & 17758.121 & \text { Yes } \\ 0.64 & 49.55 & 12.79 & 62.55 & 2 & 1338.8840 & 1338.8842 & 670.4494 & -0.0002 & -0.1492 & 12138.993 & 9873.640 & 7401.311 & 12759.280 & \text { Yes }\end{array}$ $\begin{array}{llllllllllllllll}0.64 & 49.55 & 12.79 & 62.55 & 2 & 1338.8840 & 1338.8842 & 670.4494 & -0.0002 & -0.1492 & 12138.993 & 9873.640 & 7401.311 & 12759.280 & \text { Yes } \\ 0.79 & 22.88 & 21.93 & 19.09 & 2 & 969.6188 & 969.6093 & 485.8119 & 0.0095 & 9.7774 & 395.070 & 416.269 & 112.558 & 578.247 & \text { Yes } \\ 1.00 & 46.15 & 3.1 & 32.09 & 2 & 1323.8002 & 1323.8006 & 662.906 & -0.004 & -0.307 & 3329.439 & 2477.600 & 113.820 & 2764.39 & \text { Yes }\end{array}$ $\begin{array}{lllllllllllllll}0.79 & 22.88 & 21.93 & 19.09 & 2 & 969.6188 & 969.6093 & 485.8119 & 0.0095 & 9.7774 & 395.070 & 416.269 & 112.558 & 578.247 & \text { Yes } \\ 1.00 & 46.15 & 23.10 & 32.09 & 2 & 1323.8002 & 1323.8006 & 6629076 & -0.0004 & -0.3017 & 3329.439 & 2477.600 & 1133.820 & 2764.394 & \text { Yes } \\ 1.00 & 5.8 & 22.55 & 0.4 & 2 & 323 & \end{array}$ $\begin{array}{lllllllllllllll}1.00 & 46.15 & 23.10 & 32.09 & 2 & 1323.8002 & 1323.8006 & 662.9076 & -0.0004 & -0.3017 & 3329.439 & 2477.600 & 1133.820 & 2764.394 & \text { Yes } \\ 1.00 & 59.80 & 22.55 & 40.49 & 2 & 1323.8018 & 1323.8006 & 662.9076 & 0.0012 & 0.9051 & 7881.945 & 5532.832 & 2207.806 & 8335.350 & \text { Yes }\end{array}$

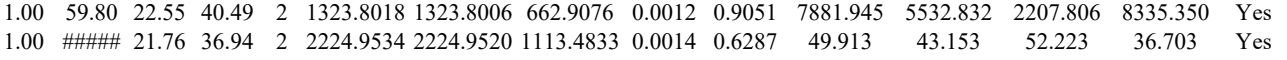
$\begin{array}{llllllllllllllll}\text { TLLSFAQGDVITLLIPEEK } & 0.60 & 36.05 & 20.93 & 49.05 & 3 & 2374.3642 & 2374.3603 & 792.4607 & 0.0039 & 1.6405 & 39.484 & 40.662 & 15.956 & 57.870 & \text { Yes }\end{array}$

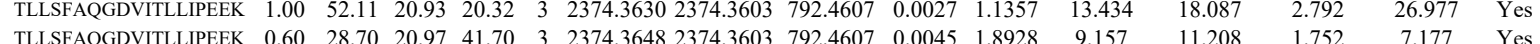
$\begin{array}{llllllllllllll} & \text { ILSFes }\end{array}$

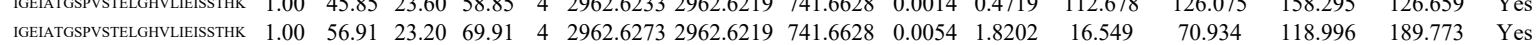

Table S-4 page 571 of 614 

$\begin{array}{llllllllllllll}\text { VLLQNTSFFSSLLNEMAHK } & 1.00 & 63.55 & 25.81 & 17.16 & 3 & 2466.3205 & 2466.3184 & 823.1134 & 0.0021 & 0.8504 & 98.783 & 9\end{array}$ $\begin{array}{llllllllllllll}\text { AGLTNFNEPINPIATPIAVLIAK } & 1.00 & 70.23 & 18.75 & 21.09 & 3 & 2839.6435 & 2839.6415 & 947.5544 & 0.0020 & 0.7036 & 7.707\end{array}$ $\begin{array}{lllllllllllll} & \text { GLITNFNEPNQIATRIAVLIAK } & 1.00 & 64.38 & 18.81 & 24.11 & 3 & 2839.6447 & 2839.6415 & 947.5544 & 0.0032 & 1.1257 & 11.921\end{array}$ $\begin{array}{llllllllll} & 0\end{array}$ (1.00 $\begin{array}{lllllllll} & 0.373\end{array}$

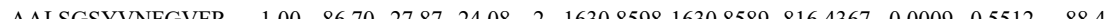
\begin{tabular}{llllllllllll}
\hline LATFVTQALIPLYAR & 1.00 & \#\#\#\# & 22.74 & 27.37 & 2 & 1851.0744 & 1851.0740 & 9265443 & 0.0004 & 0.2159 & 8.487
\end{tabular}

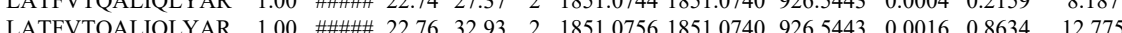
$\begin{array}{llllllllllll}\text { LATFVTQALIQLYAR } & 0.79 & 18.82 & 22.79 & 29.54 & 3 & 1851.0772 & 1851.0740 & 618.0319 & 0.0032 & 1.7259 & 31.718\end{array}$ $\begin{array}{llllllllllll}\text { LATFVTQALIQLYAR } & 1.00 & \# \# \# \# \text { 22.79 } & 31.19 & 2 & 1851.0752 & 1851.0740 & 926.5443 & 0.0012 & 0.6476 & 47.253\end{array}$ $\begin{array}{llllllllllll}\text { LATFVTQALIQLYAR } & 1.00 & \text { \#\#\#\# } 22.81 & 25.72 & 2 & 1851.0754 & 1851.0740 & 926.5443 & 0.0014 & 0.7555 & 14.111\end{array}$ $\begin{array}{llllllllllll}\text { LATFVTQALIQLYAR } & 1.00 & 30.48 & 22.76 & 22.59 & 3 & 1851.0757 & 1851.0740 & 618.0319 & 0.0017 & 0.9169 & 18.217\end{array}$ $\begin{array}{llllllllllll}\text { LATFVTQALIQLYAR } & 0.94 & 15.72 & 22.65 & 17.09 & 3 & 1851.0775 & 1851.0740 & 618.0319 & 0.0035 & 1.8877 & 16.522\end{array}$ $\begin{array}{lllllllllllll}\text { DGLEDPLEDTGLVQQQLDQLSTIGR } & 1.00 & 40.43 & 26.86 & 16.02 & 3 & 2883.4603 & 2883.4584 & 962.1601 & 0.0019 & 0.6582 & 4.957 \\ \end{array}$ $\begin{array}{lllllllllllll}\text { GILNGQK } & 0.80 & 22.18 & 24.61 & 24.17 & 2 & 1016.6224 & 1016.6222 & 509.3184 & 0.0002 & 0.1963 & 325.641\end{array}$ $\left.\begin{array}{llllllllllll}0.73 & 20.42 & 24.61 & 21.88 & 2 & 1016.6220 & 1016.6222 & 509.3184 & -0.0002 & -0.1963 & 1\end{array}\right)$

LQILTALCH

LQILTALCHR

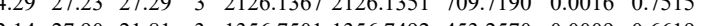
$\begin{array}{llllllllllll}1.00 & 42.14 & 27.90 & 21.81 & 3 & 1356.7501 & 1356.7492 & 453.2570 & 0.0009 & 0.6619 & 74.292\end{array}$ $\begin{array}{lllllllllllll}\text { LQILTALCHR } & 1.00 & 35.30 & 27.71 & 19.21 & 3 & 1356.7507 & 1356.7492 & 453.2570 & 0.0015 & 1.1031 & 75.255 \\ \text { AGTGENAPWVVEDELVK } & 0.98 & 25.96 & 27.36 & 17.77 & 3 & 2101.0969 & 2101.0935 & 701.3718 & 0.0034 & 1.6159 & 114.775\end{array}$ $\begin{array}{llllllllllll}\text { ANLINNIFELAGLGK } & 1.00 & 98.04 & 23.14 & 31.32 & 2 & 1874.0886 & 1874.0869 & 938.0507 & 0.0017 & 0.9061 & 97.85 \\ \text { ANLINNIFELAGLGK } & 1.00 & 99.96 & 23.03 & 26.59 & 2 & 1874.0888 & 1874.0869 & 938.0507 & 0.0019 & 1.0127 & 86.23\end{array}$ $\begin{array}{lllllllllllllll}\text { ANLINNIFELAGLGK } & 1.00 & 47.49 & 22.99 & 22.74 & 3 & 1874.0890 & 1874.0869 & 625.7029 & 0.0021 & 1.1187 & 94.590\end{array}$ $\begin{array}{llllllllllll}\text { ANLINNIFELAGLGK } & 1.00 & 52.50 & 22.86 & 24.71 & 3 & 1874.0908 & 1874.0869 & 625.7029 & 0.0039 & 2.0777 & 199.373\end{array}$ ANLINNIFELAGLGK ANLINNIFELAGLG LPTAVVPLR $\begin{array}{lllllllllll}1.00 & 96.28 & 23.12 & 30.37 & 2 & 1874.0882 & 1874.0869 & 938.0507 & 0.0013 & 0.6929 & 145.898\end{array}$ $\begin{array}{lllllllllll}1.00 & 31.50 & 23.05 & 19.50 & 3 & 1874.0893 & 1874.0869 & 625.7029 & 0.0024 & 1.2786 & 111.865 \\ 0.67 & 17.77 & 23.07 & 30.77 & 3 & 1874.0902 & 1874.0869 & 625.7029 & 0.0033 & 1.7580 & 110.841\end{array}$ $\begin{array}{llllllllllll}0.82 & 39.08 & 19.29 & 52.08 & 2 & 1108.7102 & 1108.7090 & 555.3618 & 0.0012 & 1.0804 & 2475.941 & 2183.541 \\ 0.83 & 25.32 & 27.08 & 21.35 & 2 & 1173.6784 & 1173.6780 & 587.8463 & 0.0004 & 0.3402 & 1782513 & 1610.008\end{array}$ $\begin{array}{lllllllllllll}0.83 & 25.32 & 27.08 & 21.35 & 2 & 1173.6784 & 1173.6780 & 587.8463 & 0.0004 & 0.3402 & 1782.513 & 1610.008 & 65.177 \\ 0.90 & 28.18 & 27.08 & 21.74 & 2 & 1173.6784 & 1173.6780 & 587.8463 & 0.0004 & 0.3402 & 2359.104 & 2653.486 & 200.588\end{array}$ 


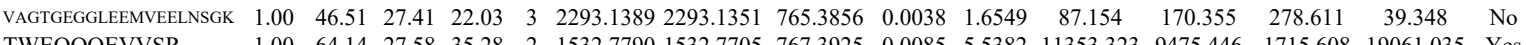
$\begin{array}{llllllllllllllll}\text { TWEQQQEVVSR } & 1.00 & 64.14 & 27.58 & 35.28 & 2 & 1532.7790 & 1532.7705 & 767.3925 & 0.0085 & 5.5382 & 11353.323 & 9475.446 & 1715.608 & 19061.035 & \text { Yes }\end{array}$

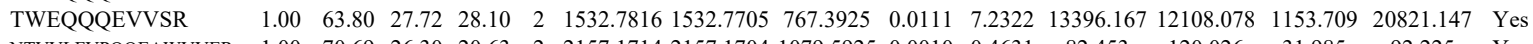

$\begin{array}{lllllllllll} & \end{array}$ $\begin{array}{llllllllllll} & \text { VIALA }\end{array}$ $\begin{array}{llllllllllll} & \end{array}$ $\begin{array}{llllllllllll} & \end{array}$ $\begin{array}{llllllllllll} & \end{array}$ $\begin{array}{llllllllllllll}\text { GFDPLLNLVLDGTIEYMR } & 1.00 & 92.25 & 26.64 & 19.76 & 2 & 2209.1594 & 2209.1575 & 1105.5860 & 0.0019 & 0.8593 & 37.360 & 47.357\end{array}$ $\begin{array}{llllllllllllll}\text { GFDPLLNLVLDGTIEYMR } & 1.00 & 75.11 & 26.64 & 18.28 & 2 & 2209.1594 & 2209.1575 & 1105.5860 & 0.0019 & 0.8593 & 36.428 & 46.616 & 67.0\end{array}$ $\begin{array}{llllllllllllll}\text { GFDPLLNLVLDGTIEYMR } & 0.67 & 32.49 & 26.73 & 45.49 & 3 & 2209.1608 & 2209.1575 & 737.3931 & 0.0033 & 1.4917 & 20.959 & 39.955 & 1.40\end{array}$

QLGLVVCR

$\begin{array}{llllllllllll}0.98 & 34.88 & 28.58 & 24.71 & 2 & 1076.5982 & 1076.5956 & 539.3051 & 0.0026 & 2.4105 & 3994.869 & 4052.389\end{array}$ $\begin{array}{lllllllllllllll}\text { MASNIFGTPEENQASWAK } & 1.00 & 68.67 & 27.61 & 20.27 & 2 & 2268.1114 & 2268.1088 & 1135.0617 & 0.0026 & 1.1453 & 235.110 & 130.602\end{array}$ $\begin{array}{lllllllllllllll}\text { VLRPGGGGSNFLGFPEPTEPPVR } & 1.00 & 47.37 & 26.93 & 19.91 & 3 & 2699.3812 & 2699.3789 & 900.8002 & 0.0023 & 0.8511 & 1606.670 & 877.683 & 40.6\end{array}$ $\begin{array}{llllllllllllll}\text { GVVTLLSDYEVCK } & 1.00 & 50.51 & 27.07 & 16.19 & 3 & 2699.3788 & 2699.3789 & 900.8002 & -0.0001 & -0.0370 & 812.558 & 725.663 \\ \end{array}$ GVVTLLSDYEVCK YLFIFSVANMR YLFIFSVANMR YLFIFSVANMR

TTYMDPTGK

TTYMDPTGK QYIISEELISEGK QYIISEELISEGK LDALVAEEHLTVDAR LDALVAEEHLT TTYMDPTGK LDALVAEEHLTVDAR $\begin{array}{lllllllllllll} & \end{array}$ $\begin{array}{lllllllllll}0.97 & 24.72 & 28.12 & 15.81 & 3 & 1758.9169 & 1758.9140 & 587.3119 & 0.0029 & 1.6459 & 101.763\end{array}$ $\begin{array}{llllllllllll} & \end{array}$ $\begin{array}{cccccccccccc}1.00 & 63.65 & 28.34 & 22.36 & 2 & 1503.8050 & 1503.8030 & 752.9088 & 0.0020 & 1.3282 & 232.520 & 240.892 \\ 0.82 & 34.26 & 28.11 & 47.26 & 2 & 1503.8040 & 1503.8030 & 752.9088 & 0.0010 & 0.6641 & 7.813 & 22.094\end{array}$ $\begin{array}{llllllll}-1.28 & 2 & 1503.8040 & 1503.8030 & 752.9088 & 0.0010 & 0.6641\end{array}$ $\begin{array}{lll}40.519 & \text { Yes }\end{array}$ $\begin{array}{lll}14.328 & \text { No }\end{array}$

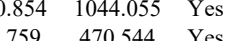

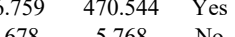
$0.342-1728.521$ Y $\begin{array}{lll}64.774 & 406.235 & \text { Yes }\end{array}$ $\begin{array}{lll}6.7781 & 63.274 & \text { Yes } \\ 13.169 & 43.382 & \text { Yes }\end{array}$ . 407.967 - 56.625 Yes \begin{tabular}{lll}
56.625 & Yes \\
\hline & 32.541 & Yes
\end{tabular} $\begin{array}{lll}0.061 & \text { Yes }\end{array}$ $\begin{array}{lll}7.011 & 76.561 & \text { Yes }\end{array}$ $\begin{array}{lll}67.019 & 80.817 & \text { Yes } \\ 14.027 & 52.493 & \text { Yes } \\ & 1171.080 & \text { Yes }\end{array}$ $\begin{array}{lll}11711.080 & \text { Yes }\end{array}$ $\begin{array}{lll}4.142 & 10878.333 & \text { Yes }\end{array}$ \begin{tabular}{lll}
.409 & 208.819 & Yes \\
\hline &
\end{tabular} STAVTTSSAK $\begin{array}{lllllllllllllll}0.90 & 19.07 & 26.88 & 22.05 & 3 & 1795.9852 & 1795.9811 & 599.6676 & 0.0041 & 2.2790 & 186.316 & 167.504 & 171.656 & 255.612 & \text { No } \\ 0.99 & 29.18 & 27.77 & 16.09 & 3 & 1794.9610 & 1794.9597 & 599.3272 & 0.0013 & 0.7230 & 33.660 & 52.562 & 23.949 & 50.05 & \text { Yes }\end{array}$

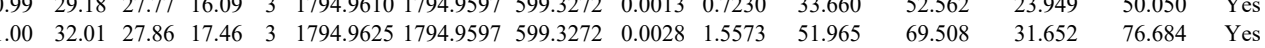

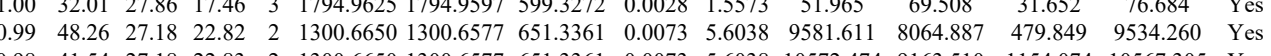

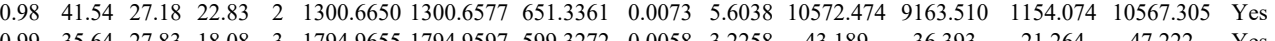

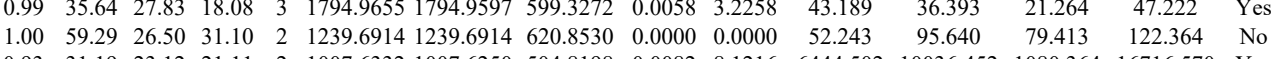
$\begin{array}{lllllllllllllll}0.93 & 31.19 & 23.12 & 21.11 & 2 & 1007.6332 & 1007.6250 & 504.8198 & 0.0082 & 8.1216 & 6444.502 & 10036.452 & 1080.364 & 16716.570 & \text { Yes } \\ 0.97 & 33.59 & 23.12 & 21.17 & 2 & 1007.6336 & 1007.6250 & 504.8198 & 0.0086 & 8.5178 & 13704.431 & 21315565 & 1866.978 & 29318.934 & \text { Yes }\end{array}$ \begin{tabular}{lllllllllllllll}
0.99 & 38.70 & 23.12 & 21.40 & 2 & 1007.6336 & 1007.6250 & 504.8198 & 0.0086 & 8.5178 & 137.54 .431 & 21315.265 & 1866.978 & 29318.934 & Yes \\
\hline
\end{tabular} $\begin{array}{llllllllllllllll}0.98 & 36.12 & 23.12 & 25.15 & 2 & 1007.6340 & 1007.6250 & 504.8198 & 0.0090 & 8.9140 & 10951.060 & 19490.317 & 1595.164 & 24722.425 & \text { Yes }\end{array}$ 

$\begin{array}{lllllllllllllllll}1.00 & 57.56 & 27.31 & 39.53 & 2 & 1316.7576 & 1316.7543 & 659.3844 & 0.0033 & 2.5023 & 10272.628 & 14830.391 & 2319.048 & 20427.668 & \text { Yes }\end{array}$ $\begin{array}{lllllllllllllllllll}0.99 & 53.11 & 27.89 & 41.69 & 2 & 1316.7538 & 1316.7543 & 659.3844 & -0.0005 & -0.3791 & 16387.483 & 27199.378 & 1393.119 & 32381.659 & \text { Yes }\end{array}$ $\begin{array}{lllllllllllllll}1.00 & 52.47 & 27.89 & 41.26 & 2 & 1316.7540 & 1316.7543 & 659.3844 & -0.0003 & -0.2275 & 16398.231 & 31504.473 & 706.136 & 42902.157 & \text { Yes }\end{array}$ $\begin{array}{llllllllllllllll}1.00 & 62.16 & 26.83 & 38.23 & 2 & 1316.7646 & 1316.7543 & 659.3844 & 0.0103 & 7.8103 & 4612.870 & 6980.857 & 772.217 & 8877.685 & \text { Yes } \\ 1.00 & 57.78 & 27.12 & 39.78 & 2 & 1316.7658 & 1316.7543 & 659.3844 & 0.0115 & 8.7202 & 5231.512 & 8115348 & 192.739 & 11493.920 & \text { Yes }\end{array}$ $\begin{array}{llllllllllllllll}1.00 & 57.78 & 27.12 & 39.78 & 2 & 1316.7658 & 1316.7543 & 659.3844 & 0.015 & 8.7202 & 5231.512 & 8115.348 & 192.739 & 11493.920 & \text { Yes }\end{array}$

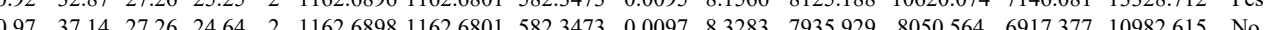

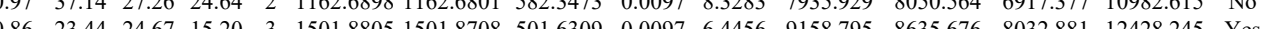
GLLVDRPSETK

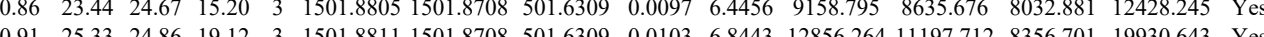

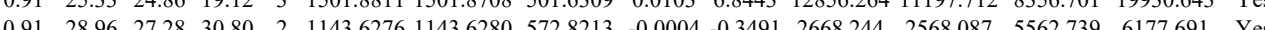

TEEEEEEEEEEEDEEEEGDDEGOQ

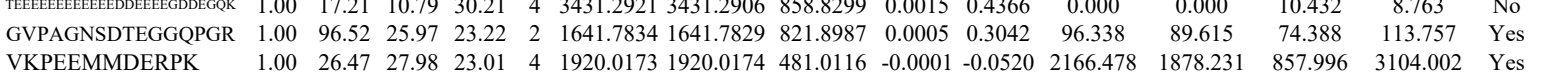

$\begin{array}{lllllllllllllll}0.91 & 28.96 & 27.28 & 30.80 & 2 & 1143.6276 & 1143.6280 & 572.8213 & -0.0004 & -0.3491 & 2668.244 & 2568.087 & 5562.739 & 6177.691 & \text { Yes }\end{array}$

$\begin{array}{llllllllllll}\text { NUP50_HUMAז Q9UKX7 NUP50 } & \text { Nuclear pore com] } 50.144 & 1.00 & 3 & 9.6 & -0.8023 & 0.6053 & 0.3461 & 0.6191 & 4 & \text { GGDEEENDEPPK } \\ \text { GGDEEENDEPPK }\end{array}$

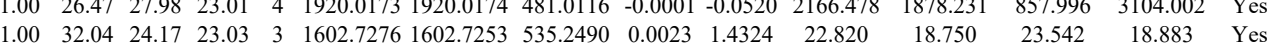

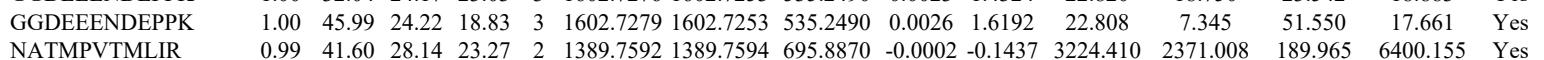

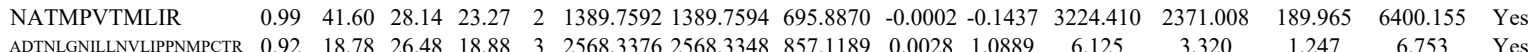

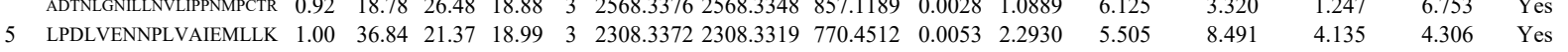
$\begin{array}{lllllllllllllllll}\text { LPDLVENNPLVAIEMLLK } & 1.00 & 44.02 & 21.27 & 16.60 & 3 & 2308.3375 & 2308.3319 & 770.4512 & 0.0056 & 2.4228 & 5.521 & 7.964 & 4.332 & 13.250 & \text { Yes }\end{array}$ $\begin{array}{llllllllllllllll}\text { FFLSQLMLAPPR } & 1.00 & 61.61 & 27.10 & 20.35 & 2 & 1562.8786 & 1562.8765 & 782.4455 & 0.0021 & 1.3419 & 199.595 & 181.216 & 80.533 & 310.026 & \text { Yes }\end{array}$

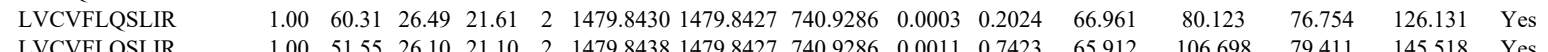
LVCVFLQSLIR

20 QNLFQEAEEFLYR QNLFQEAEEFLYR QNLFQEAEEFLYR

QNLFQEAEEFLYR

QNLFQEAEEFLYR

QNLFQEAEEFLYR

QNLFQEAEEFLYR

QNLFQEAEEFLYR

QNLFQEAEEFLYR

QNLFQEAEEFLYR

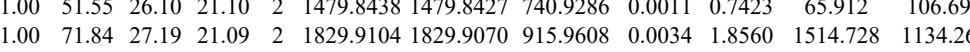
$\begin{array}{lllllllllllll}1.00 & 83.29 & 27.19 & 24.15 & 2 & 1829.9104 & 1829.9070 & 915.9608 & 0.0034 & 1.8560 & 652.889 & 672.367\end{array}$ $\begin{array}{llllllllllll}1.00 & 39.27 & 27.19 & 20.85 & 3 & 1829.9107 & 1829.9070 & 610.9763 & 0.0037 & 2.0186 & 90.018 & 53.126 \\ 1.00 & 49.01 & 27.21 & 34.50 & 3 & 1829.9110 & 1829.9070 & 610.9763 & 0.0040 & 2.1823 & 128.853 & 165.528\end{array}$ $\begin{array}{lllllllllllll}1.00 & 49.01 & 27.21 & 34.50 & 3 & 1829.9110 & 1829.9070 & 610.9763 & 0.0040 & 2.1823 & 128.853 & 165.528 \\ 1.00 & 86.98 & 27.19 & 21.65 & 2 & 1829.9092 & 1829.9070 & 915.9608 & 0.0022 & 1.2009 & 1611.852 & 1351.032\end{array}$ $\begin{array}{lllllllllllll}1.00 & 86.98 & 27.19 & 21.65 & 2 & 1829.9092 & 1829.9070 & 915.9608 & 0.0022 & 1.2009 & 1611.852 & 1351.032 \\ 1.00 & 76.70 & 27.19 & 24.26 & 2 & 1829.9094 & 1829.9070 & 915.9608 & 0.0024 & 1.3101 & 2949.507 & 2128.817\end{array}$ $\begin{array}{cccccccccccc}1.00 & 76.70 & 27.19 & 24.26 & 2 & 1829.9094 & 1829.9070 & 915.9608 & 0.0024 & 1.3101 & 2949.507 & 2128.817 \\ 1.00 & 31.65 & 27.19 & 17.00 & 3 & 1829.9101 & 1829.9070 & 610.9763 & 0.0031 & 1.6913 & 97.721 & 171.749\end{array}$ $\begin{array}{llllllllllll}1.00 & 31.65 & 27.19 & 17.00 & 3 & 1829.9101 & 1829.9070 & 610.9763 & 0.0031 & 1.6913 & 97.721 & 171.749\end{array}$ $\begin{array}{llllllllllll}1.00 & 34.08 & 27.19 & 21.66 & 3 & 1829.9104 & 1829.9070 & 610.9763 & 0.0034 & 1.8550 & 54.848 & 40.669\end{array}$

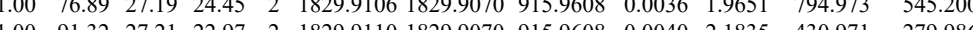

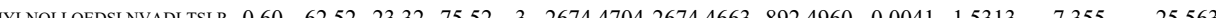

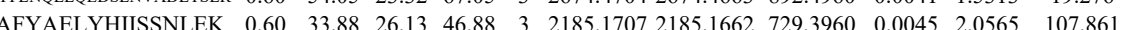

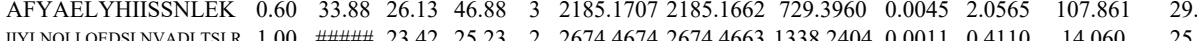
$\begin{array}{lllllllllllll} & \text { IVINOLOE }\end{array}$ \begin{tabular}{llllllllllllll}
\hline IYLNOLLOEDSNYADLTSR & 1.00 & 57.13 & 23.32 & 21.34 & 3 & 2674.4704 & 2674.4663 & 892.4960 & 0.0041 & 1.5313 & 27.918 & 26.83
\end{tabular}

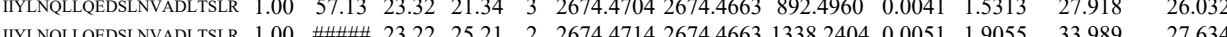
$\begin{array}{llllllllll} & \end{array}$ $\begin{array}{lllllllllllll}\text { IIYNOLLOEDSLNYALTSLR } & 0.67 & 67.60 & 23.34 & 80.60 & 3 & 2674.4689 & 2674.4663 & 892.4960 & 0.0026 & 0.9711 & 18.18\end{array}$ $\begin{array}{llllllllllll}\text { IIYLNOLLOEDSLNVADLTSLR } & 1.00 & 62.71 & 23.36 & 18.00 & 3 & 2674.4698 & 2674.4663 & 892.4960 & 0.0035 & 1.3072 & 12.893\end{array}$ $\begin{array}{lllllllllllll}\text { IIYLNOLLOEDSLNVADLTSLR } & 0.66 & 98.75 & 23.38 & \text { \#\#\#\# } & 3 & 2674.4686 & 2674.4663 & 892.4960 & 0.0023 & 0.8590 & 19.065\end{array}$ $\begin{array}{lllllllllllll}\text { VLSLLALVKPEVWTLK } & 1.00 & 20.07 & 6.99 & 33.07 & 4 & 2240.4269 & 2240.4237 & 561.1132 & 0.0032 & 1.4257 & 75.825\end{array}$

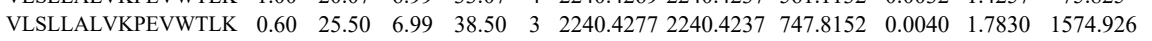
$\begin{array}{llllllllllll}\text { VLSLLALVKPEVWTLK } & 1.00 & 3.46 & 6.99 & 16.46 & 4 & 2240.4297 & 2240.4237 & 561.1132 & 0.0060 & 2.6733 & 59.939\end{array}$ $\begin{array}{llllllllllll}\text { VLSLLALVKPEVWTLK } & 0.66 & 32.42 & 6.99 & 45.42 & 3 & 2240.4259 & 2240.4237 & 747.8152 & 0.0022 & 0.9806 & 198.496\end{array}$ $\begin{array}{llllllllllll}\text { VLSLLALVKPEVWTLK } & 0.60 & 32.84 & 6.99 & 45.84 & 3 & 2240.4280 & 2240.4237 & 747.8152 & 0.0043 & 1.9167 & 247.435\end{array}$

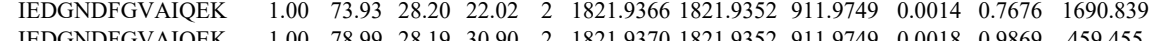
$\begin{array}{llllllllllll}\text { IEDGNDFGVAIQEK } & 1.00 & 78.99 & 28.19 & 30.90 & 2 & 1821.9370 & 1821.9352 & 911.9749 & 0.0018 & 0.9869 & 459.455 \\ \text { LYPAAVDTIVAIMAEGK } & 1.00 & \text { m\#\# } & 25.55 & 31.03 & 2 & 2049.1434 & 2049.1424 & 1025.5785 & 0.0010 & 0.4875 & 250.453\end{array}$ $\begin{array}{lllllllllllll}\text { LYPAAVDTIVAIMAEGK } & 1.00 & \text { \#\#\#\# } & 25.55 & 31.03 & 2 & 2049.1434 & 2049.1424 & 1025.5785 & 0.0010 & 0.4875 & 250.453 \\ \text { LYPAAVDTIVAIMAEGK } & 1.00 & 57.60 & 25.58 & 21.81 & 3 & 2049.1438 & 2049.1424 & 684.0547 & 0.0014 & 0.6822 & 164.816\end{array}$ $\begin{array}{llllllllllll}\text { LYPAAVDTIVAIMAEGK } & 1.00 & 57.60 & 25.58 & 21.81 & 3 & 2049.1438 & 2049.1424 & 684.0547 & 0.0014 & 0.6822 & 164.816 \\ \text { LYPAAVDTIVAIMAEGK } & 1.00 & 34.69 & 25.58 & 22.11 & 3 & 2049.1441 & 2049.1424 & 684.0547 & 0.0017 & 0.8284 & 41.576\end{array}$ $\begin{array}{llllllllllll}\text { LYPAAVDTIVAIMAEGK } & 1.00 & 34.69 & 25.58 & 22.11 & 3 & 2049.1441 & 2049.1424 & 684.0547 & 0.0017 & 0.8284 & 41.576 \\ \text { LYPAAVDTIVAIMAEGK } & 1.00 & \# \# \# \# \frac{25.42}{25.93} & 2 & 2049.1454 & 2049.1424 & 1025.5785 & 0.0030 & 1.4626 & 256.088\end{array}$

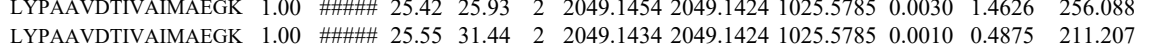

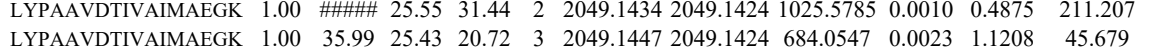

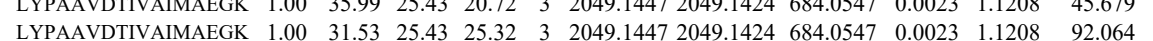

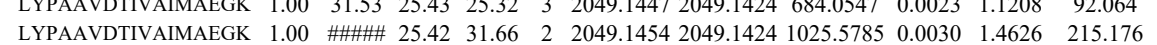
$\begin{array}{llllllllllll}\text { LYPAAVDTIIAIMAEGK } & 1.00 & \ldots \text { mal } & 25.42 & 31.66 & 2 & 2049.1454 & 2049.1424 & 025.5785 & 0.0030 & 1.4626 & 215.176 \\ \text { LYPAAVDTIVAIMAEGK } & 1.00 & 61.63 & 25.40 & 22.89 & 3 & 2049.1456 & 2049.1424 & 684.0547 & 0.0032 & 1.5593 & 134.269\end{array}$

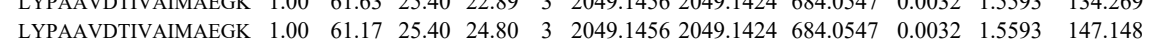
\begin{tabular}{lllllllllllll}
\hline FVISGANIMCPGLTSPGAK & 1.00 & 61.89 & 27.60 & 32.08 & 3 & 2196.1387 & 2196.1349 & 733.0522 & 0.0038 & 1.7279 & 80.453
\end{tabular} $\begin{array}{llllllllllll}\text { FVLSGANIMCPGLTSPGAK } & 1.00 & 61.80 & 27.58 & 25.27 & 3 & 2196.1399 & 2196.1349 & 733.0522 & 0.0050 & 2.2736 & 53.125\end{array}$ 


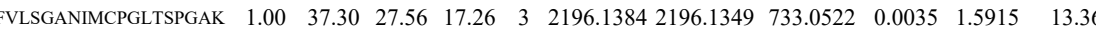

MSAEDIEK

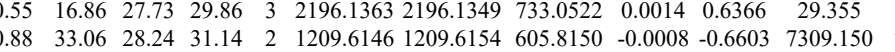

8.453

CDLISIPK

CDLISIPK

CDLISIPK

CEPIIMTVPR

CEPIIMTVPR

CEPIIMTVPR

VTWDSSFCAVNPR

VTWDSSFCAVNPR

VTWDSSFCAVNPR

AIFLADGNVFTTGISR
VGIVAWHPTAR

VGIVAWHPTAR

VGIVAWHPTAR

GIVAWHPTAR

VGIVAWHPTAR

VGIVAWHPTAR

VGIVAWHPTAR

VGIVAWTAR

VGIVAWHPTAR

VGIVAWHPTAR

VGIVAWHPTAR

VGIVAWHPTAR

VGIVAWHPTAR

VGIVAWHPTAR

LDEILK $\begin{array}{llllllll} & \end{array}$ $\begin{array}{lllllllllllllll}1.00 & 49.23 & 28.51 & 24.99 & 2 & 1221.6722 & 1221.6705 & 611.8425 & 0.0017 & 1.3892 & 3524.263 & 3024.614 & 204.561 & 5395.031 & \text { Yes }\end{array}$ $\begin{array}{lllllllllllll}28.51 & 24.99 & 2 & 121.6722 & 1221.6705 & 611.8425 & 0.0017 & 1.3892 & 3524.263 & 3024.614 & 204.561 & 5395.031 & \text { Yes }\end{array}$ $\begin{array}{llllllllllllllll} & \end{array}$ $\begin{array}{lllllllllllllll}1.00 & 41.83 & 27.76 & 24.61 & 2 & 1347.6844 & 1347.6835 & 674.8490 & 0.0009 & 0.6668 & 6958.174 & 9003.467 & 515.809 & 10749.294 & \text { Yes }\end{array}$

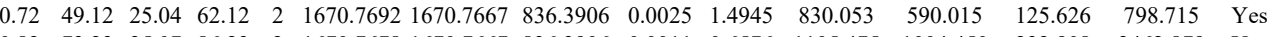
$\begin{array}{lllllllllllllll}0.82 & 73.23 & 25.07 & 86.23 & 2 & 1670.7678 & 1670.7667 & 836.3906 & 0.0011 & 0.6576 & 1105.475 & 1004.450 & 232.908 & 2462.879 & \text { Yes }\end{array}$

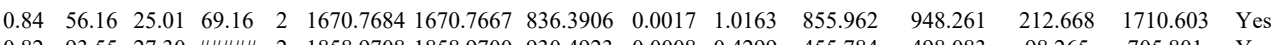

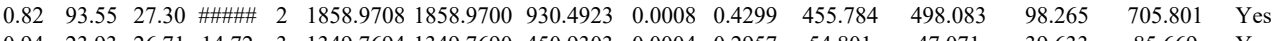
$\begin{array}{lllllllllllllll}0.94 & 23.93 & 26.71 & 14.72 & 3 & 1349.7694 & 1349.7690 & 450.9303 & 0.0004 & 0.2957 & 54.801 & 47.071 & 39.633 & 85.669 & \text { Yes } \\ \end{array}$

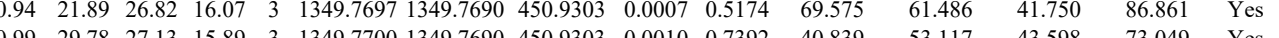

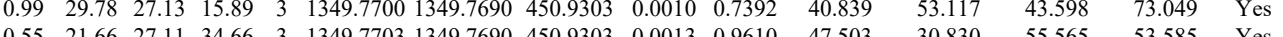

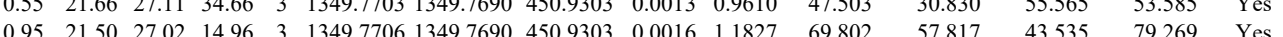
$\begin{array}{lllllllllllllll}0.95 & 21.50 & 27.02 & 14.96 & 3 & 1349.7706 & 1349.7690 & 450.9303 & 0.0016 & 1.1827 & 69.802 & 57.817 & 43.535 & 79.269 & \text { Yes } \\ 0.86 & 16.69 & 27.02 & 16.80 & 3 & 1349.7712 & 1349.7690 & 450.9303 & 0.0022 & 1.6263 & 40.294 & 36.990 & 35.325 & 49.081 & \text { Yes }\end{array}$

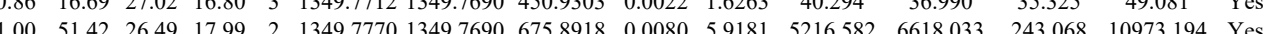

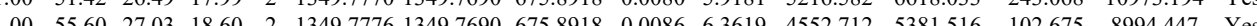
$\begin{array}{llllllllllllllll}1.00 & 55.49 & 27.03 & 19.41 & 3 & 1349.7778 & 1349.7690 & 450.9303 & 0.0088 & 65050 & 8591.263 & 11451.746 & 3931.602 & 14087.957 & \text { Yes }\end{array}$ $\begin{array}{lllllllllllllllll}0.99 & 36.84 & 26.89 & 17.99 & 3 & 1349.7781 & 1349.7690 & 450.9303 & 0.0091 & 6.7268 & 15334.093 & 25041.009 & 2921.650 & 28861.901 & \text { Yes }\end{array}$ $\begin{array}{llllllllllllllllll}1.00 & 64.93 & 26.30 & 18.86 & 2 & 1349.7762 & 1349.7690 & 675.8918 & 0.0072 & 5.3263 & 1269.857 & 1247.392 & 109.394 & 1869.060 & \text { Yes }\end{array}$ $\begin{array}{lllllllllllllllll}1.00 & 45.44 & 26.30 & 18.93 & 3 & 1349.7763 & 1349.7690 & 450.9303 & 0.0073 & 5.3962 & 11283.236 & 16086292 & 2142.447 & 17795.320 & \text { Yes }\end{array}$ $\begin{array}{llllllllllllllllll}100 & 40.46 & 26.25 & 18.49 & 3 & 1349.7766 & 1349.7690 & 450.9303 & 0.0076 & 5.6180 & 7335.607 & 10137209 & 1893.866 & 11570.332 & \text { Yes }\end{array}$ $\begin{array}{llllllllllllllll}1.00 & 40.46 & 26.25 & 8.49 & 3 & 1349.766 & 349.7690 & 450.9303 & 0.0076 & 5.6180 & 7335.607 & 10167.209 & 1893.866 & 1157.332 & \text { Yes } \\ 1.00 & 77.79 & 26.78 & 17.04 & 3 & 1349.7688 & 1349.7690 & 450.9303 & -0.0002 & -0.1478 & 4809.634 & 5720.070 & 1320.656 & 7615.293 & \text { Yes }\end{array}$ $\begin{array}{lllllllllllllllll}1.00 & 44.29 & 26.71 & 16.32 & 3 & 1349.7694 & 1349.7690 & 450.9303 & 0.0004 & 0.2957 & 4695.345 & 5858.984 & 1571.807 & 6519.346 & \text { Yes }\end{array}$

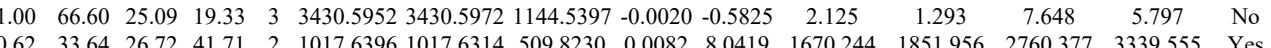

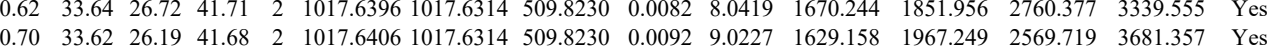

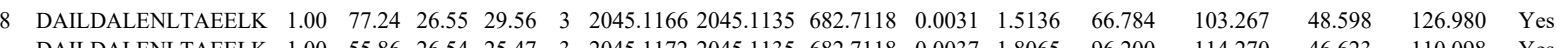
$\begin{array}{llllllllllllllll}\text { DAILDALENLTAEELK } & 1.00 & 55.86 & 26.54 & 25.47 & 3 & 2045.1172 & 2045.1135 & 682.7118 & 0.0037 & 1.8065 & 96.200 & 114.270 & 46.623 & 110.098 & \text { Yes }\end{array}$ $\begin{array}{lllllllllllllllll}\text { GALLSMDALDLTDK } & 1.00 & 88.46 & 27.90 & 25.87 & 2 & 1749.9438 & 1749.9426 & 875.9786 & 0.0012 & 0.6849 & 337.647 & 434.822 & 108.376 & 340.915 & \text { Yes }\end{array}$ $\begin{array}{llllllllllllllllll}\text { GALLSMDALDLTDK } & 1.00 & 92.05 & 27.90 & 30.78 & 2 & 1749.9440 & 1749.9426 & 875.9786 & 0.0014 & 0.7991 & 774.237 & 808.576 & 104.228 & 639.752 & \text { Yes }\end{array}$ $\begin{array}{llllllllllllllll}\text { VTNVEWLLDALYGK } & 1.00 & 39.27 & 25.99 & 22.62 & 3 & 1908.0631 & 1908.0600 & 637.0273 & 0.0031 & 1.6221 & 302.758 & 263.084 & 43.652 & 554.646 & \text { No }\end{array}$

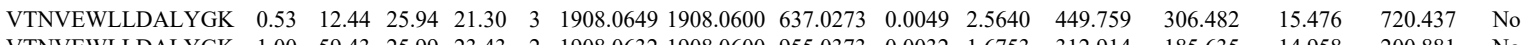

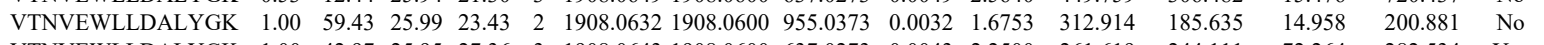
$\begin{array}{llllllllllllllll}\text { VTNVEWLLDALYGK } & 1.00 & 42.97 & 25.95 & 27.36 & 3 & 1908.0643 & 1908.0600 & 637.0273 & 0.0043 & 2.2500 & 261.619 & 244.111 & 72.264 & 282.534 & \text { Yes }\end{array}$

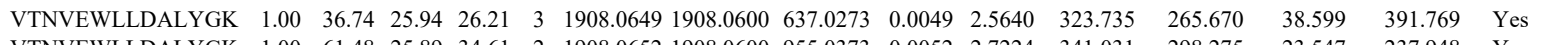
$\begin{array}{llllllllllllllll}\text { VTNVEWLLDALYGK } & 1.00 & 61.48 & 25.89 & 34.61 & 2 & 1908.0652 & 1908.0600 & 955.0373 & 0.0052 & 2.7224 & 341.031 & 298.275 & 23.547 & 237.948 & \text { Yes }\end{array}$

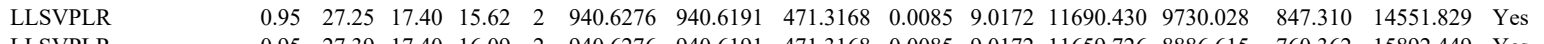

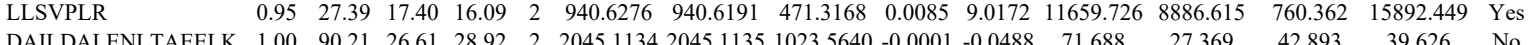

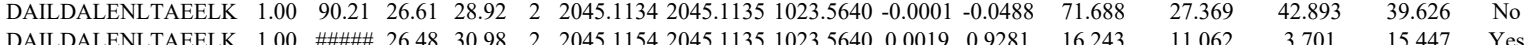
$\begin{array}{lllllllllllll} & \end{array}$ $\begin{array}{llllllllllllll} & \end{array}$ $\begin{array}{lllllllllllll} & \end{array}$ $\begin{array}{llllllllllllllll}\text { DAILDALENLTAEELK } & 1.00 & \text { \#\#\#\# } 26.48 & 29.43 & 2 & 2045.1154 & 2045.1135 & 1023.5640 & 0.0019 & 0.9281 & 29.652 & 50.940 & 19.923 & 43.697 & \text { Yes } \\ \text { DAILDALENLTAEELK } & 1.00 & 90.90 & 26.48 & 27.67 & 2 & 2045.1154 & 2045.1135 & 1023.5640 & 0.0019 & 0.9281 & 46.675 & 44.001 & 53.936 & 62.501 & \text { No }\end{array}$

Table S-4 page 575 of 614 
$\begin{array}{llllllllllllllll} & 0\end{array}$ $\begin{array}{llllllllllllllll}1.00 & 38.86 & 25.80 & 19.90 & 3 & 1751.9794 & 1751.9774 & 584.9997 & 0.0020 & 1.1396 & 12837.889 & 12396.627 & 9097.714 & 15658.411 & \text { Yes }\end{array}$ $\begin{array}{lllllllllllllll}0.96 & 22.44 & 26.05 & 19.92 & 3 & 1760.9899 & 1760.9885 & 588.0034 & 0.0014 & 0.7936 & 6359.224 & 6671.993 & 5356.466 & 9334.943 & \text { Yes }\end{array}$

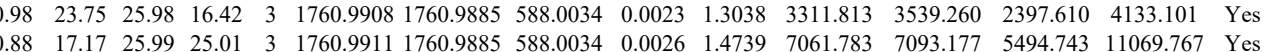
\begin{tabular}{llllllllllllllllllll} 
& 0.91 \\
\hline
\end{tabular} $\begin{array}{llllllllllllllll}0.96 & 27.70 & 25.38 & 25.31 & 3 & 1751.9830 & 1751.9774 & 584.9997 & 0.0056 & 3.1909 & 18259.464 & 18376.454 & 13733.585 & 21932.893 & \text { Yes } \\ & \end{array}$ $\begin{array}{lllllllllllllllll} & & & \end{array}$ $\begin{array}{llllllllllllllll}\text { LYENFISEFEHR } & 1.00 & 59.78 & 27.03 & 34.93 & 3 & 1726.8460 & 1726.8436 & 576.6218 & 0.0024 & 1.3874 & 1156.193 & 1276.176 & 0.000 & 1952.526 & \text { No }\end{array}$

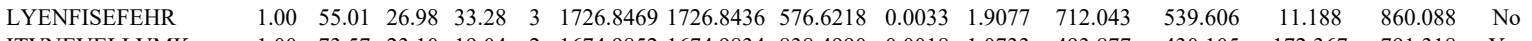

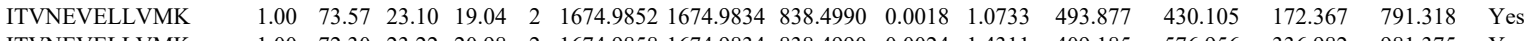
$\begin{array}{lllllllllllllllll}\text { ITVNEVELLVMK } & 1.00 & 72.30 & 23.22 & 20.98 & 2 & 1674.9858 & 1674.9834 & 838.4990 & 0.0024 & 1.4311 & 409.185 & 576.956 & 336.982 & 981.375 & \text { Yes }\end{array}$ $\begin{array}{lllllllllllllllll}\text { ITVNEVELLVMK } & 1.00 & 32.64 & 23.10 & 16.08 & 3 & 1674.9862 & 1674.9834 & 559.3351 & 0.0028 & 1.6686 & 163.822 & 122.080 & 76.804 & 329.574 & \text { Yes }\end{array}$ $\begin{array}{llllllllllllllll}\text { ITVNEVELLVMK } & 1.00 & 27.26 & 22.99 & 17.87 & 3 & 1674.9865 & 1674.9834 & 559.3351 & 0.0031 & 1.8474 & 164.155 & 177.107 & 45.158 & 324.386 & \text { Yes }\end{array}$

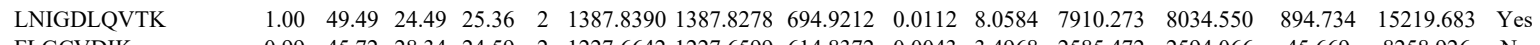
FLGCVDIK

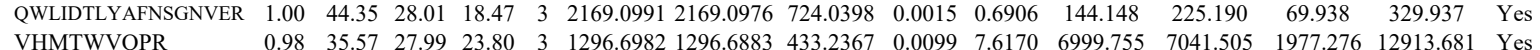
$\begin{array}{llllllllllllllll}0.98 & 35.57 & 27.99 & 23.80 & 3 & 1296.6982 & 1296.6883 & 433.2367 & 0.0099 & 7.6170 & 6999.755 & 7041.505 & 1977.276 & 12913.681 & \text { Yes } \\ 0.98 & 36.33 & 27.85 & 21.09 & 3 & 1296.6994 & 1296.6883 & 433.2367 & 0.0111 & 8.5403 & 9741.889 & 10655.781 & 2585.574 & 14393.446 & \text { Yes }\end{array}$ $\begin{array}{llllllllllllllll}0.98 & 36.35 & 27.85 & 21.09 & 3 & 1296.6994 & 1296.6883 & 433.2367 & 0.0111 & 8.5403 & 9741.889 & 10655.781 & 2585.574 & 14393.446 & \text { Yes } \\ 0.97 & 37.65 & 27.85 & 17.21 & 2 & 1296.6996 & 1296.6883 & 649.3514 & 0.0113 & 8.7009 & 1176.211 & 960.743 & 518.879 & 2038.320 & \text { Yes }\end{array}$ $\begin{array}{lllllllllllllll}0.97 & 30.66 & 28.06 & 19.10 & 3 & 1296.6943 & 1296.6883 & 443.2367 & 0.0060 & 4.6164 & 1176.211 & 960.743 & 518.879 & 2038.320 & \text { Yes }\end{array}$

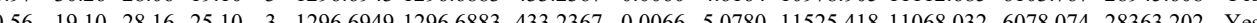
$\begin{array}{lllllllllllllll}0.98 & 40.76 & 27.96 & 19.59 & 2 & 1296.6978 & 1296.6883 & 649.3514 & 0.0095 & 7.3149 & 1841.929 & 1416.526 & 405.781 & 3317.560 & \text { Yes }\end{array}$ 


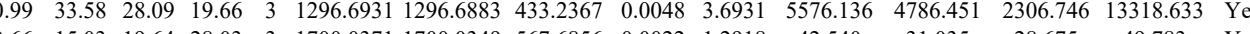

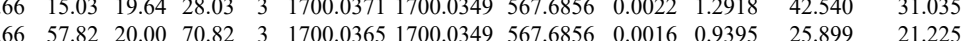
$\begin{array}{lllllllllll}0.84 & 94.00 & 20.00 & \# \# \# \# \quad 2 & 1700.0366 & 1700.0349 & 851.0247 & 0.0017 & 0.9988 & 6.505 & 11.769\end{array}$ $\begin{array}{llllllllll}0.66 & 92.76 & 17.32 & \# \# \# \# \quad 3 & 1844.1391 & 1844.1369 & 615.7196 & 0.0022 & 1.1910 & 39.614\end{array}$ $\begin{array}{llllllllll}0.72 & \# \# \# 17.08 \ldots \# \# 2 & 2 & 1844.1400 & 1844.1369 & 923.0757 & 0.0031 & 1.6792 & 14.283\end{array}$ $\begin{array}{lllllllllll}0.55 & 50.44 & 17.48 & 85.08 & 3 & 1844.1385 & 1844.1369 & 615.7196 & 0.0016 & 0.8662 & 16.271\end{array}$

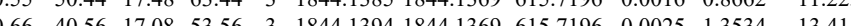
$\begin{array}{lllllllllllll}0.84 & 90.92 & 17.08 & \text { m\#\#\# } & 2 & 1844.1394 & 1844.1369 & 923.0757 & 0.0025 & 1.3542 & 6.076\end{array}$ $\begin{array}{llllllllllll}0.67 & 4630 & 17.08 & 59.30 & 3 & 1844.1400 & 1844.1369 & 615.7196 & 0.0031 & 1.6783 & 2.902\end{array}$

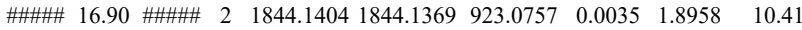
$\begin{array}{lllllllllllll}1.00 & 61.38 & 28.08 & 25.64 & 2 & 1397.7276 & 1397.7138 & 699.8642 & 0.0138 & 9.8590 & 1981.521\end{array}$ $\begin{array}{llllllllllll}34.36 & 26.68 & 15.55 & 3 & 1896.9217 & 1896.9195 & 633.3138 & 0.0022 & 1.1579 & 595.101\end{array}$ $\begin{array}{llllllllllll}1.00 & 77.82 & 28.26 & 31.99 & 2 & 1563.8410 & 1563.8388 & 782.9267 & 0.0022 & 1.4050 & 473.917\end{array}$ $\begin{array}{lllllllllll}1.00 & 62.96 & 28.23 & 31.15 & 2 & 1563.8416 & 1563.8388 & 782.9267 & 0.0028 & 1.7882 & 876.775\end{array}$ $\begin{array}{lllllllllll}0.93 & 21.75 & 28.14 & 15.30 & 3 & 1563.8425 & 1563.8388 & 522.2869 & 0.0037 & 2.3614 & 73.162 \\ 1.00 & 85.77 & 28.11 & 24.64 & 2 & 1907.9856 & 1907.9720 & 954.9933 & 0.0136 & 7.1204 & 142.45\end{array}$ $\begin{array}{lllllllllll}1.00 & 61.52 & 28.10 & 27.04 & 2 & 1563.8406 & 1563.8388 & 782.9267 & 0.0018 & 1.1495 & 396.530\end{array}$ $\begin{array}{llllllllllll} & 20.75 & 3 & 2799.4189 & 2799.4170 & 934.1463 & 0.0019 & 0.6780 & 38.659\end{array}$ $\begin{array}{llllllllllll}\text { EDSALCPELLDEGELLATFHGIR } & 1.00 & 74.79 & 26.53 & 19.62 & 3 & 2799.4210 & 2799.4170 & 934.1463 & 0.0040 & 1.4273 & 32.644 \\ \text { EDVLECK } & 1.00 & 71.92 & 27.15 & 20.81 & 3 & 2550.2350 & 2550.2324 & 851.0847 & 0.0026 & 1.0183 & 3.938\end{array}$ $\begin{array}{llllllllllll}\text { EDLSLPELLDEEDVLQECK } & 0.67 & 52.81 & 27.19 & 65.81 & 3 & 2550.2359 & 2550.2324 & 851.0847 & 0.0035 & 1.3708 & 5.475\end{array}$

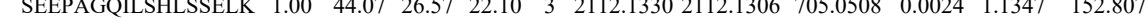
$\begin{array}{llllllllllll}\text { TPTAPAVNLAGAR } & 1.00 & 59.54 & 26.33 & 23.65 & 2 & 1381.7916 & 1381.7799 & 691.8972 & 0.0117 & 8.4549 & 1704.027\end{array}$ $\begin{array}{llllllllllll}\text { TPAAAAAMNLASPR } & 1.00 & 84.97 & 27.60 & 31.87 & 2 & 1484.8024 & 1484.7891 & 743.4018 & 0.0133 & 8.9453 & 177.661 \\ \text { TPAAAAAMNLASPR } & 1.00 & 83.28 & 27.60 & 32.75 & 2 & 1484.8030 & 1484.7891 & 743.4018 & 0.0139 & 9.3488 & 245.132\end{array}$ $\begin{array}{llllllllllll}\text { TPAAAAAMNLASPR } & 1.00 & 91.27 & 27.78 & 29.86 & 2 & 1484.8016 & 1484.7891 & 743.4018 & 0.0125 & 8.4072 & 234.958 \\ \text { TPAAAAAMNLASPR } & 1.00 & 87.84 & 27.78 & 30.51 & 2 & 1484.8016 & 1484.7891 & 743.4018 & 0.0125 & 8.4072 & 209.350\end{array}$ $\begin{array}{lllllllllllll}\text { TPAALAALSASGPPAANTPSSR } & 0.55 & 15.33 & 26.79 & 28.33 & 3 & 2702.4004 & 2702.3997 & 901.8072 & 0.0007 & 0.2587 & 0.000\end{array}$

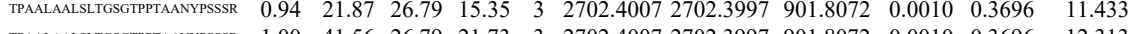
$\begin{array}{llllllllllll}\text { IALALTAIILGTARPPSMSAAGLAAR } & 0.66 & 42.58 & 21.67 & 55.58 & 3 & 2576.4493 & 2576.4472 & 859.8230 & 0.0021 & 0.8141 & 6.874\end{array}$

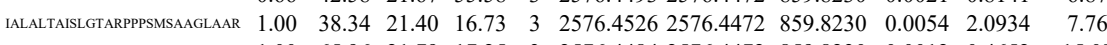
$\begin{array}{llllllllllllll} & \text { MLALTAIILGTARPPSMSAAGLAAR } & 1.00 & 65.96 & 21.79 & 17.25 & 3 & 2576.4484 & 2576.4472 & 859.8230 & 0.0012 & 0.4652 & 15.072\end{array}$ $\begin{array}{llllllllllll}\text { IALALTAILLGTARPPSMSAAGLAAR } & 0.98 & 22.14 & 21.88 & 15.20 & 3 & 2576.4481 & 2576.4472 & 859.8230 & 0.0009 & 0.3489 & 13.994 \\ \text { AEFEVHEVYAVDVLVSSGEGK } & 1.00 & 28.16 & 26.79 & 17.07 & 4 & 2551.3065 & 2551.3050 & 638.8335 & 0.0015 & 0.5870 & 21.212\end{array}$

TIIQNPTDQQK TIIQNPTDQQK TIIQNPTDQQK

TTIYK

TTIYK

ITSGPFEPDLYK

ITSGPFEPDLYK ITSGPFEPDLYK ITSGPFEPDLYK MGVVECAK $\begin{array}{llllllllllll}1.00 & 67.36 & 27.08 & 31.73 & 2 & 1572.8828 & 1572.8715 & 787.4430 & 0.0113 & 7.1751 & 9947.056 & 9554.769\end{array}$ $\begin{array}{llllllllllll}1.00 & 66.21 & 27.27 & 30.20 & 2 & 1572.8846 & 1572.8715 & 787.4430 & 0.0131 & 8.3180 & 4837.930 & 5240.942\end{array}$ $\begin{array}{llllllllllllll}1.00 & 67.00 & 27.13 & 31.69 & 2 & 1572.8850 & 1572.8715 & 787.4430 & 0.0135 & 8.5720 & 7884.803 & 7111.790 & 366.0\end{array}$ $\begin{array}{lllllllllllll}0.59 & 24.33 & 23.52 & 25.71 & 2 & 912.5504 & 912.5524 & 457.2835 & -0.0020 & -2.1868 & 79.511 & 77.237\end{array}$ $\begin{array}{llllllllllll}0.85 & 30.33 & 23.52 & 26.25 & 2 & 912.5504 & 912.5524 & 457.2835 & -0.0020 & -2.1868 & 65.159 & 71.424\end{array}$ $\begin{array}{lllllllllllll}1.00 & 79.73 & 27.66 & 34.91 & 2 & 1653.8872 & 1653.8858 & 827.9502 & 0.0014 & 0.8455 & 7597.928 & 9373.588 & 915.7\end{array}$ $\begin{array}{llllllllllllll}1.00 & 83.85 & 27.66 & 33.98 & 2 & 1653.8880 & 1653.8858 & 827.9502 & 0.0022 & 1.3286 & 8161.975 & 9075.974 & 275 & 1.98\end{array}$ $\begin{array}{llllllllllll}1.00 & 48.88 & 27.76 & 32.95 & 2 & 1653.8844 & 1653.8858 & 827.9502 & -0.0014 & -0.8455 & 420.887 & 387.068\end{array}$ $\begin{array}{llllllllllll}1.00 & 62.85 & 27.77 & 30.66 & 2 & 1653.8846 & 1653.8858 & 827.9502 & -0.0012 & -0.7247 & 3919.932 & 3763.654\end{array}$ $\begin{array}{llllllllllll}0.97 & 36.01 & 26.88 & 24.11 & 2 & 1169.5946 & 1169.5850 & 585.7998 & 0.0096 & 8.1939 & 6910.252 & 6923.645\end{array}$ $\begin{array}{llllllllllll}0.95 & 34.26 & 26.75 & 26.10 & 2 & 1169.5958 & 1169.5850 & 585.7998 & 0.0108 & 9.2181 & 10327.946 & 1\end{array}$ $\begin{array}{llllllllllllll}\text { SLVEASSSGVSVLSLCEK } & 0.98 & 28.22 & 27.57 & 15.53 & 3 & 2128.1053 & 2128.0999 & 710.3739 & 0.0054 & 2.5339 & 10.117 & 7.761\end{array}$ $\begin{array}{llllllllllllll}\text { SLVEASSSGVSVLSLCEK } & 0.67 & 12.91 & 27.57 & 14.33 & 3 & 2128.1029 & 2128.0999 & 710.3739 & 0.0030 & 1.4077 & 12.911 & 8.193\end{array}$ $\begin{array}{llllllllllllll}\text { VAHSFNCTPIEGMLSHQLK } & 1.00 & 45.22 & 27.23 & 58.22 & 4 & 2445.2353 & 2445.2211 & 612.3126 & 0.0142 & 5.7977 & 1148.992 & 1305.313\end{array}$ $\begin{array}{lllllllllllll}\text { VAHSFNCTPIEGMLSHQLK } & 1.00 & 38.99 & 27.45 & 51.99 & 4 & 2445.2245 & 2445.2211 & 612.3126 & 0.0034 & 1.3882 & 745.677 & 836.941\end{array}$ $\begin{array}{lllllllllllllll}\text { VASFNCTLGMLSQLK } & 1.00 & 45.36 & 27.27 & 15.85 & 4 & 2445.2313 & 2445.2211 & 612.3126 & 0.0102 & 4.1645 & 987.804 & 1 .\end{array}$ $\begin{array}{lllllllllllll}\text { TAENATSGETLEENEAGD } & 1.00 & 89.87 & 21.67 & 21.80 & 2 & 1980.8492 & 1980.8518 & 991.4332 & -0.0026 & -1.3112 & 2.213\end{array}$ $\begin{array}{llllllllllll}\text { TAENATSGETLEENEAGD } & 1.00 & 87.28 & 21.70 & 19.40 & 2 & 1980.8506 & 1980.8518 & 991.4332 & -0.0012 & -0.6052 & 3.618\end{array}$ $\begin{array}{llllllllllllll}0.98 & 19.65 & 24.62 & 32.65 & 4 & 3378.7781 & 3378.7807 & 845.7025 & -0.0026 & -0.7686 & 0.807\end{array}$

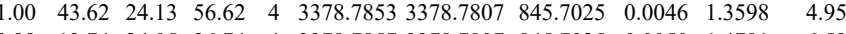

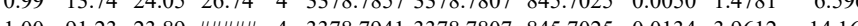

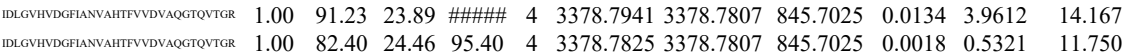
$\begin{array}{llllllllllll}1.00 & 48.83 & 24.05 & 61.83 & 4 & 3378.7857 & 3378.7807 & 845.7025 & 0.0050 & 1.4781 & 9.488\end{array}$ $\begin{array}{lllllllllllll}0.99 & 20.02 & 23.93 & 33.02 & 4 & 3378.7933 & 3378.7807 & 845.7025 & 0.0126 & 3.7247 & 2.705\end{array}$
$28.675 \quad 49.783$ Yes $\begin{array}{lll}31.168 & 38.605 & \text { No } \\ 2.063 & 11.309 & \text { Yes }\end{array}$ $\begin{array}{lll}2.063 & 11.309 & \text { Yes } \\ 28.411 & 34.948 & \text { Yes }\end{array}$ $1.384-8.735$ Yes $\begin{array}{llll}1.384 & 8.735 & \text { No }\end{array}$

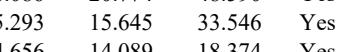
$\begin{array}{llll}12.861 & 12.430 & \mathrm{No}\end{array}$ $\begin{array}{lll}2.900 & 8.034 & \mathrm{No}\end{array}$ 6.360
-4.85 0.460
.822

\begin{tabular}{ll}
0.728 \\
.421 \\
\hline 569
\end{tabular}

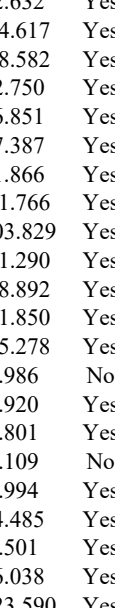
$\begin{array}{lll}17.148 & \text { Yes }\end{array}$ $\begin{array}{lll}1065.391 & \text { Yes }\end{array}$ $\begin{array}{lll}1295.136 & \text { Yes }\end{array}$ $\begin{array}{lll}427.352 & 437.091 & \text { Yes }\end{array}$ $\begin{array}{lll}10.396 & 1065.792 & \text { Yes }\end{array}$ $\begin{array}{lll}301 & 62.632 & \text { Yes } \\ 4.515 & 174.617 & \text { Y }\end{array}$ $\begin{array}{lll}4.641 & 368.582 & \text { Yes }\end{array}$ -10.8
-042 $\begin{array}{lll}11.866 & Y \mathrm{es} \\ 74.876 & 121.766 & \text { Yes } \\ & 2503.829 & \text { Yes }\end{array}$ $\begin{array}{lll}103.152 & 151.290 & \text { Yes }\end{array}$ $\begin{array}{ll}629 & 6.920\end{array}$ 6.629
0.000 
GDAMIMEETGK SEMEVQDAELK SEMEVQDAELK FTVLLMPNGPMR FTVLLMPNGPMR FTVLLMPNGPMR FTVLLMPNGPMR FTVLLMPNGPMR FTVLLMPNGPMR FTLLMPNGMR TTLMP TTLMN TILAP FTVLLMPNGPMR FTVLLMPNGPMR FTVLLMPNGPMR FTVLLMPNGPMR FTVLLMPNGPMR FTVLLMPNGPMR FTVLLMPNGPMR FTVLLMPNGPMR GDAMIMEETGK $\begin{array}{lllllllllllll}1.00 & 58.36 & 28.21 & 23.99 & 2 & 1565.7958 & 1565.7850 & 783.8998 & 0.0108 & 6.8886 & 358.053\end{array}$ $\begin{array}{lllllllllll}1.00 & 69.65 & 28.21 & 26.98 & 2 & 1565.7958 & 1565.7850 & 783.8998 & 0.0108 & 6.8886 & 334.599\end{array}$ $\begin{array}{lllllllllll}1.00 & 56.29 & 28.19 & 29.54 & 2 & 1518.8172 & 1518.8173 & 760.4159 & -0.0001 & -0.0658 & 535.616\end{array}$ $\begin{array}{llllllllllll}1.00 & 56.84 & 28.22 & 24.15 & 2 & 1518.8174 & 1518.8173 & 760.4159 & 0.0001 & 0.0658 & 685.465\end{array}$ $\begin{array}{llllllllllll}1.00 & 64.92 & 28.22 & 28.95 & 2 & 1518.8176 & 1518.8173 & 760.4159 & 0.0003 & 0.1973 & 867.212\end{array}$ $\begin{array}{lllllllllllll}1.00 & 56.55 & 28.22 & 25.45 & 2 & 1518.8176 & 1518.8173 & 760.4159 & 0.0003 & 0.1973 & 1792.367 \\ 0.99 & 28.70 & 28.06 & 18.82 & 3 & 15188206 & 15188173 & 507.2797 & 0.0033 & 2.1684 & 28.453\end{array}$ $\begin{array}{llllllllllll}0.99 & 28.70 & 28.06 & 18.82 & 3 & 1518.8206 & 1518.8173 & 507.2797 & 0.0033 & 2.1684 & 28.453 \\ 0.62 & 43.62 * & 28.29 & 29.07 & 2 & 1534.8124 & 1534.8122 & 768.4134 & 0.0002 & 0.1301 & 432.064 \\ 1.00 & 57.23 & 28.09 & 27.99 & 2 & 1518.8182 & 1518.8173 & 760.459 & 0.0009 & 0.5918 & 215.489\end{array}$ $\begin{array}{lllllllllll}1.00 & 57.23 & 28.09 & 27.99 & 2 & 1518.8182 & 1518.8173 & 760.4159 & 0.0009 & 0.5918 & 215.489\end{array}$ $\begin{array}{lllllllllll}1.00 & 57.23 & 28.09 & 27.99 & 2 & 1534.8182 & 1518.8173 & 760.4159 & 0.0009 & 0.5918 & 215.489\end{array}$

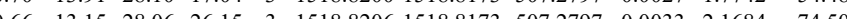
$\begin{array}{llllllllllllll}0.66 & 45.78 * 28.29 & 29.69 & 2 & 1534.8126 & 1534.8122 & 768.4134 & 0.0004 & 0.2603 & 133.507\end{array}$ $\begin{array}{llllllllllll}0.67 & 36.97 * & 28.24 & 29.60 & 2 & 1534.8128 & 1534.8122 & 768.4134 & 0.0006 & 0.3904 & 152.451 & 16\end{array}$ $\begin{array}{lllllllllllll}0.74 & 16.92 & 28.22 & 14.81 & 3 & 1534.8136 & 1534.8122 & 512.6113 & 0.0014 & 0.9104 & 72.118\end{array}$ $\begin{array}{lllllllllllll}0.83 & 17.39 & 28.42 & 18.16 & 3 & 1550.8096 & 1550.8071 & 517.9430 & 0.0025 & 1.6089 & 85.789\end{array}$ $\begin{array}{lllllllllllll}1.00 & 57.63 & 28.08 & 25.71 & 2 & 1518.8180 & 1518.8173 & 760.4159 & 0.0007 & 0.4603 & 119.095\end{array}$ $\begin{array}{lllllllllllll}1.00 & 54.37 & 28.08 & 24.73 & 2 & 1518.8180 & 1518.8173 & 760.4159 & 0.0007 & 0.4603 & 95.954\end{array}$ $\begin{array}{llllllllllllll}0.97 & 23.62 & 28.04 & 15.42 & 3 & 1518.8191 & 1518.8173 & 507.2797 & 0.0018 & 1.1828 & 41.026\end{array}$ $\begin{array}{llllllllllll}0.99 & 27.71 & 28.10 & 15.51 & 3 & 1518.8200 & 1518.8173 & 507.2797 & 0.0027 & 1.7742 & 36.091\end{array}$ $\begin{array}{llllllllllll}0.71 & 14.32 & 28.19 & 18.17 & 3 & 1534.8139 & 1534.8122 & 512.6113 & 0.0017 & 1.1054 & 28.580 & 3\end{array}$ $\begin{array}{lllllllllll}1.00 & 56.52 & 28.03 & 26.52 & 2 & 1518.8210 & 1518.8173 & 760.4159 & 0.0037 & 2.4329 & 32.572\end{array}$ $\begin{array}{lllllllllll}1.00 & 67.93 & 26.24 & 25.66 & 2 & 1468.7072 & 1468.7145 & 735.3645 & -0.0073 & -4.9635 & 752.930\end{array}$ $\begin{array}{llllllllllll}\text { AEFEHEVYAVDVLVSSGEGK } & 1.00 & 39.46 & 26.86 & 17.53 & 3 & 2551.3060 & 2551.3050 & 851.4423 & 0.0010 & 0.3915 & 12.128\end{array}$ $\begin{array}{llllllllllll} & \end{array}$ $\begin{array}{llllllllllllll}\text { AEFEVHEVYAVDVLVSSGEGK } & 1.00 & 54.93 & 26.63 & 17.00 & 3 & 2551.3096 & 2551.3050 & 851.4423 & 0.0046 & 1.8009 & 20.924\end{array}$ $\begin{array}{lllllllllllll}\text { AEFEVHEVYAVDVLVSSGEGK } & 1.00 & 30.45 & 26.64 & 16.37 & 4 & 2551.3097 & 2551.3050 & 638.8335 & 0.0047 & 1.8393 & 15.069\end{array}$ AEFEVHEVYAVDVLVSSGEGK TIIQNPTDQQK TIIQNPTDQQK TIIQNPTDQQK

TIIQNPTDQQK

$\begin{array}{llllllllllll}\text { SMC3_HUMAN Q9UQE7 } & \text { SMC3 } & \text { Structural mainten } 141.54 & 1.00 & 2 & 2.7 & 0.3306 & 0.3019 & 0.7787 & 0.2763 & 4 & \text { INQMATAPDSQR }\end{array}$ NQMATAPDSQR LDQVEQELNELR

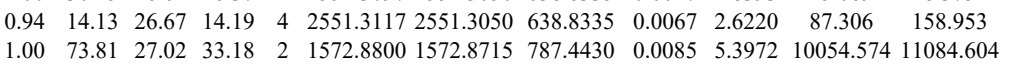
$\begin{array}{lllllllllllllll}0.51 & 20.22 & 27.02 & 19.14 & 3 & 1572.8803 & 1572.8715 & 525.2978 & 0.0088 & 5.5841 & 2705.271 & 3073.236 & 195\end{array}$ $\begin{array}{lllllllllllll}1.00 & 67.49 & 26.95 & 30.13 & 2 & 1572.8806 & 1572.8715 & 787.4430 & 0.0091 & 5.7782 & 5523.875 & 6869 . \\ 0.86 & 25.95 & 27.14 & 18.47 & 3 & 1572.8815 & 1572.8715 & 525.2978 & 0.0100 & 6.3456 & 2141.448 & 2801\end{array}$ $\begin{array}{lllllllllllll}1.00 & 63.57 & 26.85 & 24.08 & 2 & 1474.7322 & 1474.7320 & 738.3733 & 0.0002 & 0.1354 & 2039.752 & 2713.133 & 2603\end{array}$. $\begin{array}{llllllllllll}1.00 & 63.95 & 26.80 & 24.84 & 2 & 1474.7334 & 1474.7320 & 738.3733 & 0.0014 & 0.9480 & 2221.574 & 2132 \\ 1.00 & 58.85 & 27.63 & 30.62 & 2 & 1628.8500 & 1628.8491 & 815.4318 & 0.0009 & 0.5519 & 243.401 & 372\end{array}$ $\begin{array}{llllllllllll}1.00 & 68.21 & 27.65 & 35.07 & 2 & 1628.8502 & 1628.8491 & 815.4318 & 0.0011 & 0.6745 & 317.8\end{array}$ $\begin{array}{llllllllllllll}1.00 & 91.56 & 27.07 & 25.78 & 2 & 2100.1094 & 2100.1095 & 1051.0620 & -0.0001 & -0.0476 & 230.207\end{array}$ (1)

ILGFDTGDAVLNEAAQII

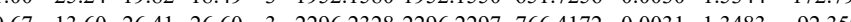

INEAIVAVQAIIADP $\begin{array}{lllllllllllll}1 & 13.60 & 26.41 & 26.60 & 3 & 2296.2328 & 2296.2297 & 766.4172 & 0.0031 & 1.3483 & 92.350\end{array}$ $\begin{array}{llllllllllll}1.00 & 76.40 & 20.41 & 21.51 & 2 & 19521562 & 1952.1550 & 977.0848 & 0.0012 & 0.6141 & 16.033\end{array}$ INEAIVAVQAIIADPK $\begin{array}{lllllllllllll} & 1.052 .1571 & 1952.1550 & 651.7256 & 0.0021 & 1.0741 & 174.911\end{array}$ $\begin{array}{lllllllllllll}\text { HILGFDTGDAVLNEAAQILR } & 0.55 & 28.33 & 26.54 & 41.33 & 3 & 2296.2307 & 2296.2297 & 766.4172 & 0.0010 & 0.4349 & 31.552 \\ \text { HILGEDTGDAVLNEAAILR } & 1.00 & 47.40 & 26.47 & 18.12 & 3 & 2296.2331 & 2296.2297 & 766.4172 & 0.0034 & 1.4787 & 28.553\end{array}$ HILGFDTGDAVLNEAAQILR QEAIDWLLGLAVR QEAIDWLLGLAVR QEAIDWLLGLAVR AGVMALANLLQIQR AGVMALANLLQIQR AGVMALANLLQIQR AGVMALANLLQIQR AGVMALANLLQIQR AGVMALANLLQIQR AGVMALANLLQIQR AGVMALANLLQIQ AGVMALANLLQIQR AGVMALANLLQIQR AGVMALANLLQIQR

RUVB2 HUMA1 Q9Y230 RUVBL2 RuvB-like 2 $\begin{array}{llllllllll}51.157 & 1.00 & 14 & 37.6 & 0.0373 & 0.2208 & 1.2681 & 0.2560 & 28 & \text { TTEMETIYDLGTK }\end{array}$ VQAGDVITIDK

Q $\begin{array}{llllllllllll}1 & 47.40 & 26.47 & 18.12 & 3 & 2296.2331 & 2296.2297 & 766.4172 & 0.0034 & 1.4787 & 28.553 & 10.900\end{array}$ $\begin{array}{llllllllllll}1.00 & 68.94 & 26.10 & 25.23 & 2 & 1626.9216 & 1626.9215 & 814.4680 & 0.0001 & 0.0614 & 3600.928 & 2870.432 \\ 1626.9215 & 814.4680 & 0.0013 & 0.7981 & 2518.565 & 1961.041\end{array}$ $\begin{array}{llllllllllll}0.95 & 32.49 & 25.89 & 36.90 & 3 & 1626.92471626 .9215 & 543.3144 & 0.0032 & 1.9633 & 60.267 & 88.865\end{array}$ $\begin{array}{lllllllllll}0.95 & 32.49 & 25.89 & 36.90 & 3 & 1626.9247 & 1626.9215 & 543.3144 & 0.0032 & 1.9633 & 60.26 \\ 0.94 & 25.92 & 25.79 & 29.92 & 3 & 1626.9253 & 1626.9215 & 543.3144 & 0.0038 & 2.3314 & 71.544\end{array}$ $\begin{array}{lllllllllll}1.00 & 88.27 & 24.22 & 23.83 & 2 & 1640.9524 & 1640.9518 & 821.4832 & 0.0006 & 0.3652 & 15.852 \\ 1.00 & 88.71 & 24.38 & 23.98 & 2 & 1640.9544 & 1640.9518 & 821.4832 & 0.0026 & 1.5825 & 24.307\end{array}$ $\begin{array}{lllllllllll}1.00 & 88.71 & 24.38 & 23.98 & 2 & 1640.9544 & 1640.9518 & 821.4832 & 0.0026 & 1.5825 & 24.307\end{array}$ $\begin{array}{llllllllllll}1.00 & 82.15 & 24.15 & 23.55 & 2 & 1640.9540 & 1640.9518 & 821.4832 & 0.0022 & 1.3390 & 71.824 \\ 1.00 & 75.68 & 24.22 & 25.56 & 2 & 1640.9546 & 1640.9518 & 821.4832 & 0.0028 & 1.7042 & 45.909\end{array}$

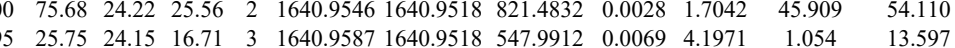
$\begin{array}{lllllllllllll}.99 & 32.34 & 24.10 & 16.41 & 3 & 1640.9593 & 1640.9518 & 547.9912 & 0.0075 & 4.5621 & 3.844 & 7.210\end{array}$

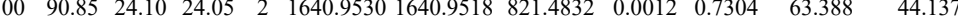
$\begin{array}{lllllllllll}1.00 & 8.85 & 24.10 & 24.05 & 2 & 1640.9530 & 1640.9518 & 821.4832 & 0.0012 & 0.7304 & 63.388\end{array}$ $\begin{array}{lllllllllll}1.00 & 75.45 & 24.25 & 23.30 & 2 & 1640.9548 & 1640.9518 & 821.4832 & 0.0030 & 1.8260 & 10.215\end{array}$ $\begin{array}{llllllllllll}1.00 & 54.21 & 24.10 & 21.33 & 2 & 1640.9530 & 1640.9518 & 821.4832 & 0.0012 & 0.7304 & 7.406 \\ 1.00 & 67.63 & 24.03 & 23.53 & 2 & 1640.9536 & 1640.9518 & 821.4832 & 0.0018 & 1.0956 & 9.839\end{array}$ $\begin{array}{lllllllllll}1.00 & 61.99 & 24.25 & 20.11 & 2 & 1640.9552 & 1640.9518 & 821.4832 & 0.0034 & 2.0694 & 9.233\end{array}$ $\begin{array}{lllllllllll}1.00 & 74.80 & 28.03 & 23.35 & 2 & 1788.9052 & 1788.9059 & 895.4602 & -0.0007 & -0.3909 & 509.720\end{array}$

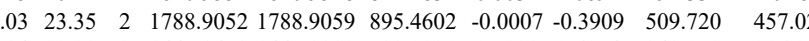

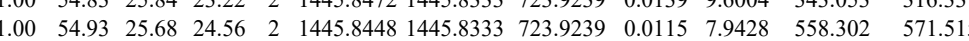
$\begin{array}{lllllllllllll}100 & 73.32 & 25.98 & 27.17 & 2 & 1445.8466 & 14458333 & 723.9239 & 0.0133 & 9.1860 & 1708.425 & 2061.611\end{array}$ $\begin{array}{lllllllllllll}1.09 & 36.12 & 27.36 & 22.02 & 2 & 1596.7890 & 1596.7884 & 799.4015 & 0.0006 & 0.3753 & 1643.199 & 1529.284 & 215.764\end{array}$ $\begin{array}{lllllllllll}1.00 & 88.08 & 24.10 & 24.23 & 2 & 1640.9528 & 1640.9518 & 821.4832 & 0.0010 & 0.6087 & 31.003\end{array}$ $93.214 \quad 921.780$ Yes $91.214 \quad 1073.546 \quad$ Yes $7.657 \quad 41.373$ Yes $59.853 \quad 516.506 \quad$ Yes $45.286 \quad 280.305$ Yes $4.253 \quad 147.634$ Yo $37.420-178.837$ Yes $\begin{array}{lll}15.475 & 78.584 & \text { Yes }\end{array}$ $\begin{array}{llll}83.976 & 119.167 & \text { Yes }\end{array}$ $\begin{array}{lll}11.390 & 144.289 & \text { Yes }\end{array}$ $\begin{array}{lll}9.077 & 89.762 & \text { Yes }\end{array}$ $\begin{array}{llll}167.962 & 1293.962 & \text { Yes }\end{array}$ \begin{tabular}{lll}
18.803 & 18.935 & Yes \\
\hline .017 & 11.672 & Yes
\end{tabular} $\begin{array}{rrr}9.017 & 11.672 & \text { Yes } \\ 190.463 & \text { Yes }\end{array}$ $23.814 \quad 28.256$ No $\begin{array}{lll}8.604 & 27.947 \quad \text { Yes }\end{array}$ $\begin{array}{lll}9.968 & 6.860 & \text { No }\end{array}$ $\begin{array}{lll}6.546 & 164.473 & \text { Yes } \\ 65.560 & 13625.523 & \text { Yes }\end{array}$ 164.806
3133.440 Yes \begin{tabular}{llll}
164.8003 & 3064.317 & Yes \\
\hline & $144.877 \quad 3212.431$ & Yes
\end{tabular} $\begin{array}{lll}0.892 & 514.659 & \text { Yes }\end{array}$ $\begin{array}{llll}139.759 & 128.151 & \text { Y } & 100\end{array}$ $\begin{array}{lll}13.7597 & 128.151 & \text { Yes } \\ 1387 & \text { Yes }\end{array}$ $41.957 \quad 29.754 \quad \mathrm{No}$

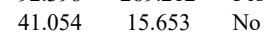
$\begin{array}{lll}209.069 & 289.449 & \text { Yes }\end{array}$ $\begin{array}{lll}2.874 & 20.850 & \text { Yes }\end{array}$ $\begin{array}{lll}130.442 & 4230.120 & \text { Yes }\end{array}$ $\begin{array}{llll}285.041 & 3097.644 & \text { Yes }\end{array}$ $\begin{array}{lll}31.119 & 67.682 & \text { Yes }\end{array}$ $\begin{array}{lll}17.148 & 153.875 & \text { No } \\ 5.861 & 27.557 & \text { Yes } \\ 4.941 & 25.50 & Y e s\end{array}$ $\begin{array}{lll}4.941 & 25.500 & \text { Yes }\end{array}$ $\begin{array}{ccc}19.154 & 106.894 & \text { Yes } \\ 34.265 & 41.401 & \text { Yes }\end{array}$ $\begin{array}{ccc}34.265 & 41.401 & \text { Yes } \\ 2.394 & 9.271 & \text { No }\end{array}$ $\begin{array}{lll}9.823 & 6.177 & \text { No }\end{array}$ $\begin{array}{lll}15.356 & 42.835 & \text { Yes }\end{array}$ $\begin{array}{lll}15.196 & 42.835 & \text { Yes } \\ 11.381 & 37.450 & \text { Yes } \\ 3 & 1.328 & \text { Yes }\end{array}$ $\begin{array}{lll}11.381 & 37.103 & \text { Yes } \\ 3.320 & 14.286 & \text { Yes }\end{array}$ $\begin{array}{lll}3.320 & 14.286 & \text { Yes } \\ 5.939 & 9.977 & \text { Yes }\end{array}$ $\begin{array}{ccc}5.939 & 9.977 & \text { Yes } \\ 12.456 & 10.489 & \text { Yes }\end{array}$ $0.000 \quad 9.343 \quad \mathrm{~N}$ $236.837-677.885 \quad \mathrm{Ycs}$ $\begin{array}{lll}648.386 & \text { Yes }\end{array}$ 


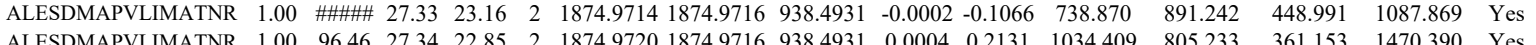

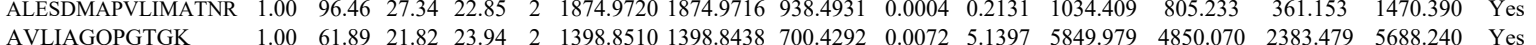

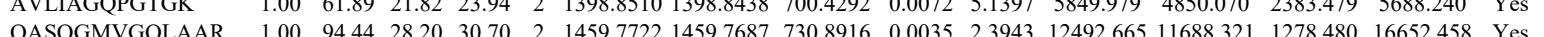
$\begin{array}{llllllllllllllll} & \end{array}$ $\begin{array}{llllllllllllllllll} & \end{array}$ $\begin{array}{llllllllllllllllllllll} & 1.04540 .786 & \text { Yes }\end{array}$

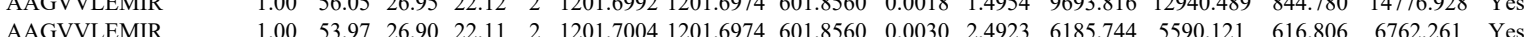

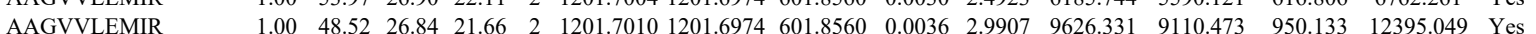
$\begin{array}{llllllllllllllll}\text { GTEVQVDDIK } & 1.00 & 66.69 & 27.99 & 29.92 & 2 & 1390.7542 & 1390.7548 & 696.3847 & -0.0006 & -0.4308 & 2712.963 & 2882.492 & 4289.290 & 3598.124 & \text { No }\end{array}$

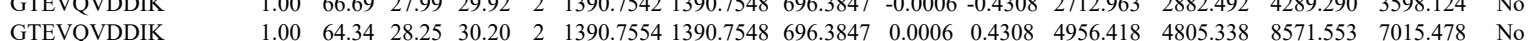
$\begin{array}{lllllllllllllllll}\text { CEFEDVEMSDAYTVLTR } & 0.89 & 17.66 & 21.14 & 17.27 & 2 & 2307.9674 & 2307.9667 & 1154.9906 & 0.0007 & 0.3030 & 6.823 & 4.151 & 5.712 & 6.949 & \text { No }\end{array}$

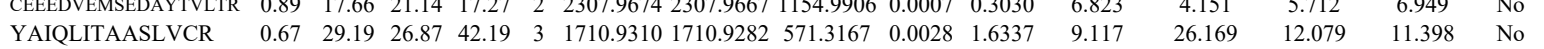
\begin{tabular}{llllllllllllllll} 
YAIQLITAASLVCR & 1.00 & 81.82 & 27.17 & 30.57 & 2 & 1710.9262 & 1710.9282 & 856.4714 & -0.0020 & -1.1676 & 16.942 & 20.793 & 11.072 & 33.258 & Yes \\
\hline
\end{tabular}

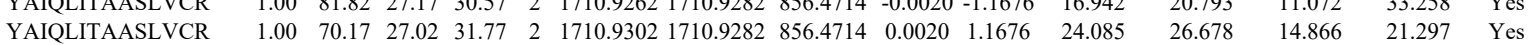

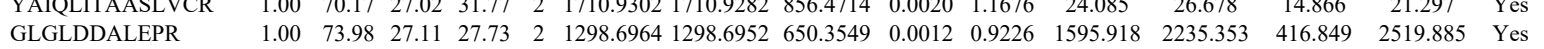
$\begin{array}{llllllllllllllll}\text { GLGLDDALEPR } & 1.00 & 72.56 & 27.12 & 32.14 & 2 & 1298.6970 & 1298.6952 & 650.3549 & 0.0018 & 1.3839 & 1461.532 & 1544.419 & 318.816 & 2152.096 & \text { Yes }\end{array}$ $\begin{array}{llllllllllllllll}\text { GLGLDDALEPR } & 1.00 & 77.64 & 27.25 & 25.28 & 2 & 1298.6968 & 1298.6952 & 650.3549 & 0.0016 & 1.2301 & 2009.116 & 2426.977 & 329.153 & 2619.826 & \text { Yes }\end{array}$ $\begin{array}{llllllllllllllll}\text { TTEMETIYDLGTK } & 1.00 & 73.63 & 28.08 & 23.90 & 2 & 1788.9062 & 1788.9059 & 895.4602 & 0.0003 & 0.1675 & 1083.470 & 1045.347 & 490.160 & 1587.552 & \text { Yes }\end{array}$ $\begin{array}{llllllllllllllll}\text { TTEMETIYDLGTK } & 1.00 & 73.28 & 28.10 & 23.57 & 2 & 1788.9072 & 1788.9059 & 895.4602 & 0.0013 & 0.7259 & 1375.738 & 1203.496 & 507.872 & 1450.515 & \text { Yes }\end{array}$

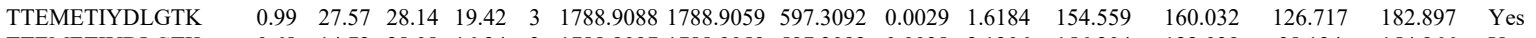
$\begin{array}{llllllllllllllll}\text { TTEMETIYDLGTK } & 0.68 & 14.72 & 28.08 & 16.24 & 3 & 1788.9097 & 1788.9059 & 597.3092 & 0.0038 & 2.1206 & 156.204 & 122.039 & 38.124 & 154.966 & \text { Yes }\end{array}$

VYEIQDIYENSWTK LAGFLDLTEQEFR LAGFLDLTEQEFR LAGFLDLTEQEFR LAGFLDLTEQEFR YGDFFIR YGDFFIR LYTTMPVAK LHSLLGDYYQAIK IQLLVFK

IWNVHSVLNVLHSLVDK MLGYFSLVGLLR

MLGYFSLVGLLF

VSSDVIDQK
VSSDVIDQK

VSSDVIDQK

TVSDLIDQK $\begin{array}{lllllllllllll}0.78 & 18.46 & 27.70 & 14.21 & 3 & 2075.0509 & 2075.0455 & 692.6891 & 0.0054 & 2.5986 & 185.869 & 168.969\end{array}$ $\begin{array}{lllllllllllll}1.00 & 97.42 & 27.51 & 32.36 & 2 & 1681.8830 & 1681.8797 & 841.9471 & 0.0033 & 1.9597 & 545.102 & 437.316\end{array}$ $\begin{array}{llllllllllll}1.00 & 80.25 & 27.56 & 30.89 & 2 & 1681.8832 & 1681.8797 & 841.9471 & 0.0035 & 2.0785 & 509.463 & 469.72\end{array}$ $\begin{array}{lllllllllllll}1.00 & 62.36 & 27.60 & 25.24 & 2 & 1681.8820 & 1681.8797 & 841.9471 & 0.0023 & 1.3659 & 212.022 & 223.032 \\ 1.00 & 59.51 & 27.51 & 28.68 & 2 & 1681.8822 & 1681.8797 & 841.9471 & 0.0025 & 1.4847 & 154.534 & 167.839\end{array}$ $\begin{array}{llllllllllll}1.00 & 59.51 & 27.51 & 28.68 & 2 & 1681.8822 & 1681.8797 & 841.9471 & 0.0025 & 1.4847 & 154.534 & 167.839 \\ 0.92 & 39.46 & 28.25 & 41.33 & 2 & 1060.5560 & 1060.5464 & 531.2805 & 0.0096 & 9.0347 & 3632.562 & 4228.605\end{array}$ $\begin{array}{llllllllllll}0.92 & 39.46 & 28.25 & 41.33 & 2 & 1060.5560 & 1060.5464 & 531.2805 & 0.0096 & 9.0347 & 3632.562 & 4228.605 \\ 0.88 & 30.60 & 28.03 & 34.85 & 2 & 1060.5564 & 1060.5464 & 531.2805 & 0.0100 & 9.4111 & 5110.867 & 5420.442\end{array}$ $\begin{array}{llllllllllllll}0.88 & 30.60 & 28.03 & 34.85 & 2 & 1060.5564 & 1060.5464 & 531.2805 & 0.0100 & 9.4111 & 5110.867 & 5420.442 & 58\end{array}$ $\begin{array}{llllllllllllll}1.00 & 55.80 & 26.05 & 30.60 & 2 & 1310.7588 & 1310.7512 & 656.3829 & 0.0076 & 5.7893 & 7227.748 & 7326.366 & 1078\end{array}$ $\begin{array}{llllllllllllll}1.04 & \end{array}$ $\begin{array}{llllllllllllllll}1.00 & 41.16 & 21.07 & 30.62 & 2 & 1477.7590 & 1477.7572 & 574.8859 & 0.0018 & 1.5655 & 10215.443 & 8774.749 & 1601.735 & 16146.227 & \text { Yes } \\ 1.00 & 45.21 & 21.70 & 16.88 & 3 & 2260.2955 & 2260.2936 & 754.4385 & 0.0019 & 0.8395 & 10.560 & 13.652 & 14.805 & 14.001 & \text { No }\end{array}$

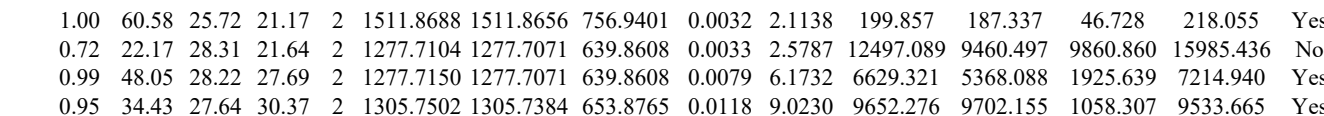

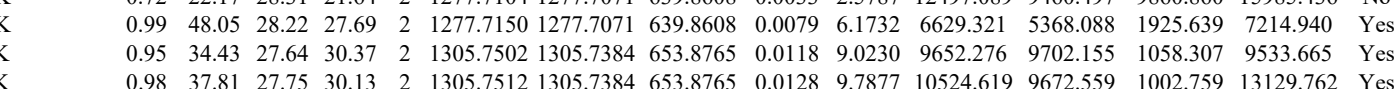
$\begin{array}{lllllllllllllllllll}0.98 & 37.81 & 27.75 & 30.13 & 2 & 1305.7512 & 1305.7384 & 653.8765 & 0.0128 & 9.7877 & 10524.619 & 9672.559 & 1002.759 & 13129.762 & \text { Yes }\end{array}$ $\begin{array}{lllllllllllllllll} & & & \end{array}$ $\begin{array}{llllllllllllllll}\text { AINCPEDIVFPALDILR } & 1.00 & 32.79 & 27.01 & 20.02 & 3 & 2088.0907 & 2088.0869 & 697.0362 & 0.0038 & 1.8172 & 99.526 & 104.308 & 31.337 & 89.253 & \text { Yes }\end{array}$ $\begin{array}{llllllllllllllll}\text { AINCPEDIVFPALDILR } & 1.00 & 94.65 & 27.00 & 21.41 & 2 & 2088.0874 & 2088.0869 & 1045.0507 & 0.0005 & 0.2392 & 93.719 & 69.310\end{array}$ $\begin{array}{lllllllllllll}\text { LTEDDLILLEK } & 1.00 & 77.60 & 25.84 & 44.67 & 2 & 1588.9178 & 1588.9167 & 795.4656 & 0.0011 & 0.6914 & 417.762 & 474.801\end{array}$

$\begin{array}{llllllllllllll}\text { GLGLDESGLAK } & 1.00 & 77.6077 & 27.23 & 33.38 & 2 & 1346.7766 & 1346.7649 & 674.3897 & 0.0117 & 8.6744 & 41706212 & 37464.368\end{array}$ GLGLDESGLAK $\begin{array}{lllllllllllllllll}1.00 & 70.77 & 27.30 & 27.48 & 2 & 1346.7782 & 1346.7649 & 674.3897 & 0.0133 & 9.8607 & 6417.028 & 7737.640 & 759.955 & 10222.926 & \text { Yes }\end{array}$ $\begin{array}{lllllllllllllllll}\text { GTEDITSPHGIPLDLLDR } & 1.00 & 58.29 & 27.78 & 17.99 & 3 & 2092.0942 & 2092.0922 & 698.3713 & 0.0020 & 0.9546 & 441.677 & 372.548 & 586.477 & 511.916 & \text { Yes }\end{array}$ $\begin{array}{lllllllllllllllll} & & & \end{array}$ $\begin{array}{lllllllllllllllll}\text { GTEDITSPHGIPLDLLDR } & 1.00 & 59.83 & 27.81 & 16.96 & 3 & 2092.0936 & 2092.0922 & 698.3713 & 0.0014 & 0.6682 & 300.308 & 436.955 & 386.451 & 416.620 & \text { Yes }\end{array}$ \begin{tabular}{lllllllllllllllll} 
GTEDITSPHGIPLDLLDR & 0.67 & 48.53 & 27.85 & 61.53 & 3 & 2092.0951 & 2092.0922 & 698.3713 & 0.0029 & 1.3842 & 540.741 & 920.279 & 698.116 & 858.729 & Yes \\
\hline
\end{tabular}

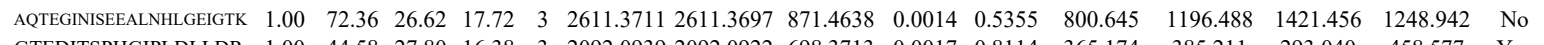
$\begin{array}{llllllllllllllll}\text { GTEDITSPHGIPLDLLDR } & 1.00 & 44.58 & 27.80 & 16.38 & 3 & 2092.0939 & 2092.0922 & 698.3713 & 0.0017 & 0.8114 & 365.174 & 385.211 & 293.040 & 458.577 & \text { Yes }\end{array}$

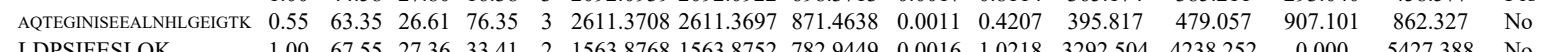

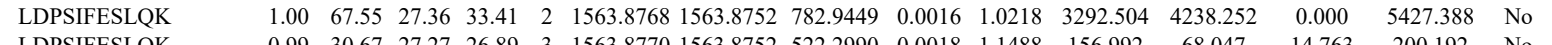

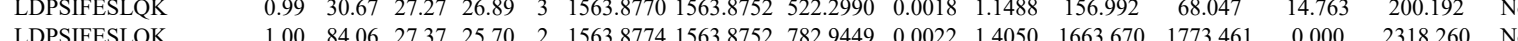

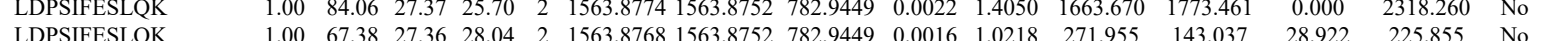

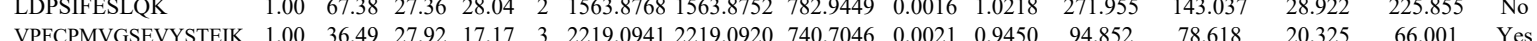

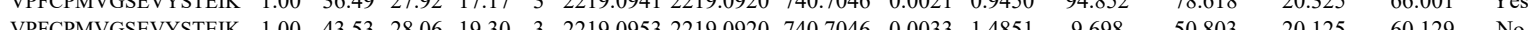

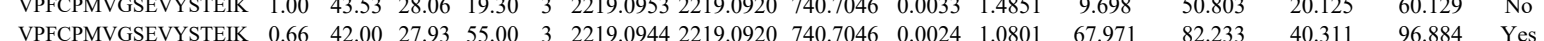

Table S-4 page 579 of 614 
AVLLAGPPGTGK TALALAIAQELGSK TALALAIAQELGSK TALALAIAQELGSK TALALAIAQELGSK TALALAIAQELGSK TALALAIAQELG TISHVIIGLK

TISHVIGLK

ISHVITLK

TISHVIIGLK

ALESSIAPIVIFASN

YLEQLLTPANLLAK

YSVQLLTPANLLAK

YSVQLLTPANLLAK

YSVQLLTPANLLAK

YSVQLLTPANLLAK EVYEGEVTELTPCETENPMG

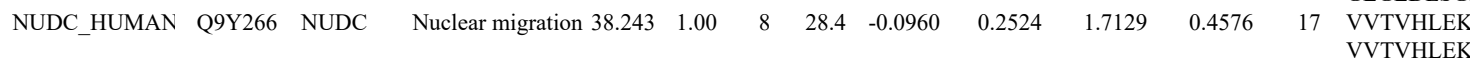

QDTEEDEEEDEKDK

QDTEEDEEEDEKDK

ITQTFSHHNQLAQK

LITQTFSHHNQLAQK

LITQTFSHHNQLAQK
VEESSWLIEDGK

VEESSWLIEDGK
VEESSWLIEDGK

VEESSWLIEDGK
SMGLPTSDEQK

SMGLPTSDEQK
SMGLPTSDEQK

SMGLPTSDEQK

LVSSDPEINTK

GQPAIIDGELYNEVK GQPAIIDGELYNEVK GQPAIIDGELYNEVK LQLEIDQK

LTLEIDQK
LTLALGK

LTLSALIDGK

LTLSALIDGK

LTLSALIDGK
LTLSALIDGK

LTLSALIDGK

LTLSALIDGK

LTLSALIDGK

LTLSALIDGK

VNNASLIGLGYTQTLRPGVK

VNNASLIGLGYTQTLRPGVK

DPAEALQLPMDYVQR

SLQALGEVIEAELR

SLQALGEVIEAELR

SLQALGEVIEAELR

SLQALGEVIEAELR

LGITQLR

LGITQLR

LDAEPRPPPTQEAA

LDAEPRPPPTQEAA

$\begin{array}{llllllllllll}\text { NCKP1_HUMA1 Q9Y2A7 } & \text { NCKAP1 } & \text { Nck-associated pr } 128.79 & 1.00 & 3 & 3.4 & -0.3132 & 0.3324 & 0.7907 & 0.2886 & 9 & \text { AINQIAAALFTIHK }\end{array}$

AINQIAAALFTIHK

AINQIAAALFTIHK

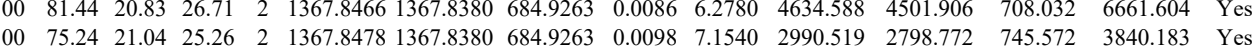

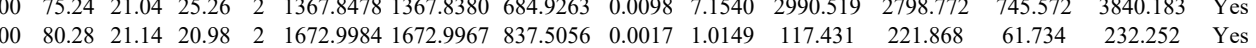
$\begin{array}{lllllllllllllll}1.00 & 79.20 & 21.21 & 20.67 & 2 & 1672.9988 & 1672.9967 & 837.5056 & 0.0021 & 1.2537 & 91.256 & 99.625 & 88.161 & 143.387 & \text { Yes }\end{array}$ $\begin{array}{lllllllllllllll}1.00 & 50.04 & 20.86 & 18.08 & 3 & 1673.0011 & 1672.9967 & 558.6728 & 0.0044 & 2.6253 & 84.328 & 301.031 & 0.000 & 466.901 & \text { No }\end{array}$

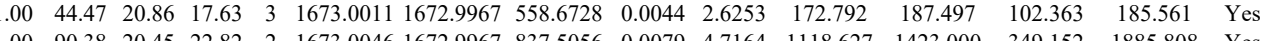
$\begin{array}{llllllllllllllll}1.00 & 90.38 & 20.45 & 22.82 & 2 & 1673.0046 & 1672.9967 & 837.5056 & 0.0079 & 4.7164 & 1118.627 & 1423.000 & 349.152 & 1885.808 & \text { Yes }\end{array}$ $\begin{array}{lllllllllllllll}1.00 & 86.46 & 20.45 & 22.31 & 2 & 1673.0050 & 1672.9967 & 837.5056 & 0.0083 & 4.9552 & 346.899 & 362.973 & 110.193 & 632.728 & \text { Yes } \\ \end{array}$

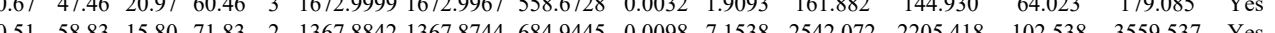

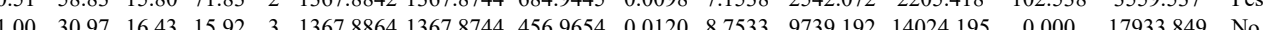

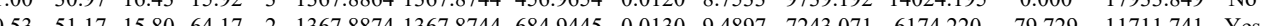

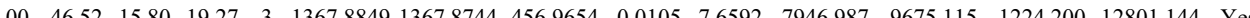

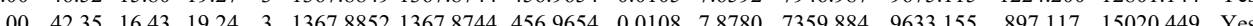

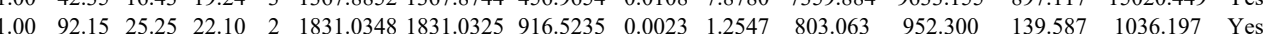
$\begin{array}{lllllllllllllll}1.00 & 65.73 & 21.21 & 18.89 & 2 & 18180852 & 18180858 & 910.0502 & -0.0006 & -0.3297 & 1006.384 & 847.018 & 218.517 & 1114.070 & \text { Yes }\end{array}$ $\begin{array}{lllllllllllllll}1.00 & 79.11 & 21.21 & 20.06 & 2 & 1818.0852 & 1818.0858 & 910.0502 & -0.0006 & -0.3297 & 664.471 & 742.895 & 261.294 & 906.520 & \text { Yes }\end{array}$ $\begin{array}{llllllllllllllll}0.55 & 15.31 & 20.64 & 28.31 & 3 & 1818.0871 & 1818.0858 & 607.0359 & 0.0013 & 0.7139 & 1193.887 & 712.185 & 278.268 & 724.563 & \text { No }\end{array}$ $\begin{array}{lllllllllllllll}0.66 & 21.26 & 20.64 & 34.26 & 3 & 1818.0880 & 1818.0858 & 607.0359 & 0.0022 & 1.2081 & 1620.585 & 818.920 & 385.647 & 1198.249 & \text { No }\end{array}$ $\begin{array}{lllllllllllllll}1.00 & 42.42 & 21.21 & 17.56 & 3 & 1818.0850 & 1818.0858 & 607.0359 & -0.0008 & -0.4393 & 552.773 & 493.066 & 278.093 & 593.586 & \text { Yes }\end{array}$

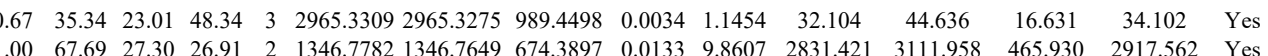
$\begin{array}{llllllllllllllll}0.93 & 28.00 & 21.88 & 25.10 & 3 & 1211.7583 & 1211.7482 & 404.9233 & 0.0101 & 8.3143 & 15756.137 & 14908.149 & 1124.110 & 24736.058 & \text { Yes }\end{array}$ $\begin{array}{lllllllllllllll}0.89 & 26.77 & 21.88 & 25.07 & 3 & 1211.7589 & 1211.7482 & 404.9233 & 0.0107 & 8.8082 & 17864.330 & 14581.403 & 681.540 & 26565.214 & \text { Yes }\end{array}$

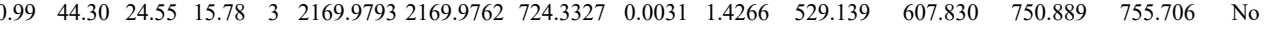

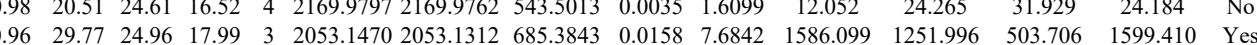
$\begin{array}{llllllllllllllll}.99 & 38.21 & 24.87 & 16.45 & 3 & 2053.1473 & 2053.1312 & 685.3843 & 0.0161 & 7.8301 & 6956.747 & 6691.912 & 2393.078 & 9885.351 & \text { Yes }\end{array}$ $\begin{array}{llllllllllllllll}0.98 & 19.70 & 24.84 & 32.70 & 4 & 2053.1481 & 2053.1312 & 514.2901 & 0.0169 & 8.2151 & 7510.902 & 7044.940 & 1856.059 & 6999.681 & \text { Yes }\end{array}$

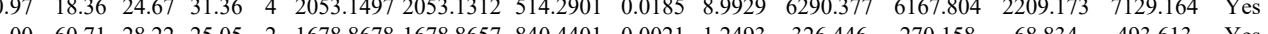
$\begin{array}{lllllllllllllll}1.00 & 60.71 & 28.22 & 25.05 & 2 & 1678.8678 & 1678.8657 & 840.4401 & 0.0021 & 1.2493 & 326.446 & 270.158 & 68.834 & 493.613 & \text { Yes }\end{array}$

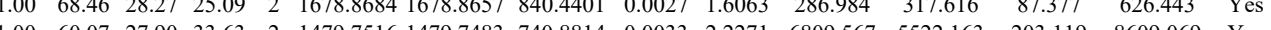

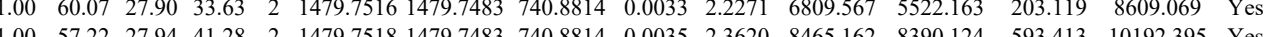

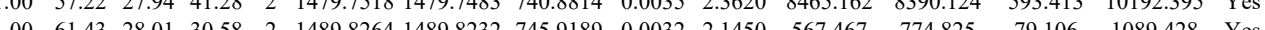

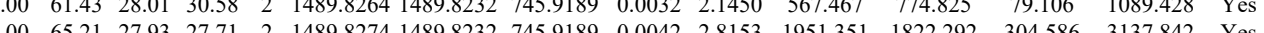

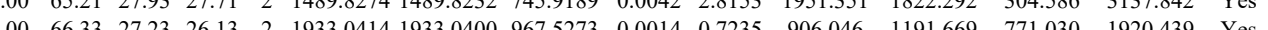

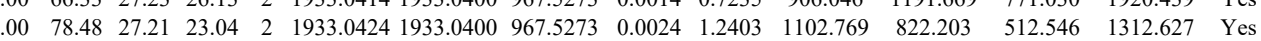
$\begin{array}{llllllllllllllll}1.00 & 31.44 & 27.17 & 21.44 & 3 & 1933.0432 & 1933.0400 & 645.3539 & 0.0032 & 1.6528 & 1568.539 & 1183.642 & 583.813 & 1124.145 & \text { Yes }\end{array}$ $\begin{array}{lllllllllllllll}0.96 & 23.55 & 27.14 & 18.98 & 3 & 1933.0438 & 1933.0400 & 645.3539 & 0.0038 & 1.9627 & 1240.738 & 1051.794 & 453.658 & 976.976 & \text { Yes }\end{array}$ $\begin{array}{llllllllllllll}0.85 & 28.37^{*} 2.92 & 36.52 & 2 & 1273.7610 & 1273.7485 & 637.8815 & 0.0125 & 9.7980 & 6114.661 & 5248.131 & 854.127 & 735.935 & \text { Yes }\end{array}$ $\begin{array}{lllllllllllllll}0.99 & 60.23 * 22.99 & 23.51 & 2 & 1317.8126 & 1317.8111 & 659.9128 & 0.0015 & 1.1365 & 16128.510 & 16104.140 & 365.141 & 22824.257 & \text { Yes }\end{array}$

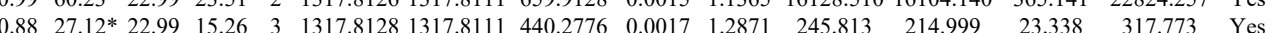
$\begin{array}{lllllllllllllll}0.99 & 61.79 * 23.03 & 26.07 & 2 & 1317.8132 & 1317.8111 & 659.9128 & 0.0021 & 1.5911 & 23207.579 & 24457.484 & 35.934 & 34180.613 & \text { Yes }\end{array}$

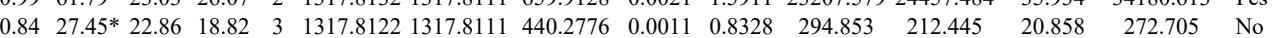
$\begin{array}{llllllllllllllll}0.98 & 56.98 * 22.99 & 24.28 & 2 & 1317.8126 & 1317.8111 & 659.9128 & 0.0015 & 1.1365 & 22065.130 & 24806.089 & 0.000 & 34555.202 & \text { No }\end{array}$ $\begin{array}{lllllllllllllll}0.99 & 56.86 * 22.99 & 22.38 & 2 & 1317.8128 & 1317.8111 & 659.9128 & 0.0017 & 1.2880 & 13289.560 & 13177.674 & 289.490 & 15553.879 & \text { Yes }\end{array}$ $\begin{array}{lllllllllllllllll}0.96 & 52.78 * 22.79 & 21.67 & 2 & 1317.8138 & 1317.8111 & 659.9128 & 0.0027 & 2.0457 & 10966.012 & 11071.421 & 140.570 & 15469.652 & \text { Yes }\end{array}$ $\begin{array}{lllllllllllllll}0.96 & 52.70 * 22.28 & 24.49 & 2 & 1317.8144 & 1317.8111 & 659.9128 & 0.0033 & 2.5003 & 10536.852 & 10576.732 & 0.000 & 14616.774 & \text { No }\end{array}$ $\begin{array}{llllllllllllllll}0.55 & 83.22 & 21.64 & 96.22 & 3 & 2388.3745 & 2388.3733 & 797.1317 & 0.0012 & 0.5018 & 4431.351 & 3605.634 & 3559.440 & 4449.139 & \text { No }\end{array}$ $\begin{array}{lllllllllllllll}0 & 75.37 & 21.64 & 88.37 & 3 & 2388.3742 & 2388.3733 & 797.1317 & 0.0009 & 0.3763 & 2247.193 & 2119.349 & 1694.248 & 2514.972 & \text { Yes } \\ 100 & 70.24 & 21.58 & 18.63 & 3 & 2388.3748 & 2388.3733 & 797.1317 & 0.0015 & 0.6272 & 4682.266 & 3467.108 & 2699.218 & 5043.657 & \text { Yes }\end{array}$

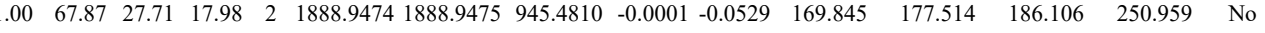

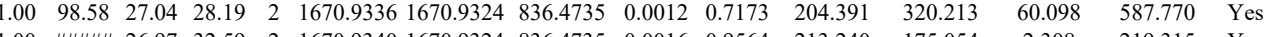

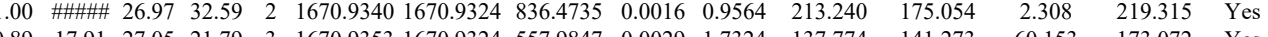
$\begin{array}{lllllllllllllll}0.89 & 17.91 & 27.05 & 21.79 & 3 & 1670.9353 & 1670.9324 & 557.9847 & 0.0029 & 1.7324 & 137.774 & 141.273 & 60.153 & 173.072 & \text { Yes } \\ 1.00 & 87.81 & 26.97 & 28.24 & 2 & 1670.938 & 1670.932 & 83.4735 & 0.014 & 0.836 & 27.010 & 16.854 & 38.067 & 30495 & \text { Yes }\end{array}$

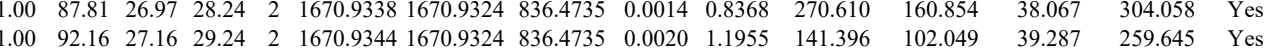

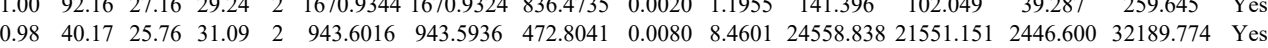

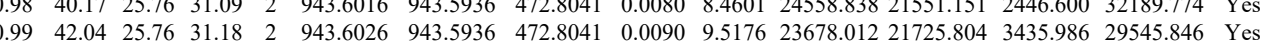

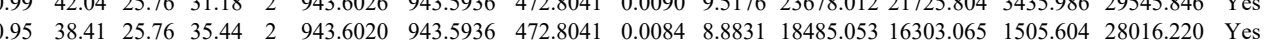
\begin{tabular}{lllllllllllllllll}
0.97 & 38.02 & 28.31 & 16.01 & 2 & 1634.8430 & 1634.8386 & 818.4266 & 0.0044 & 2.6881 & 1663.005 & 1711.570 & 1027.410 & 1996.872 & Yes \\
\hline
\end{tabular}

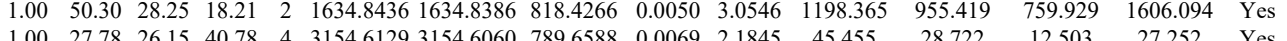

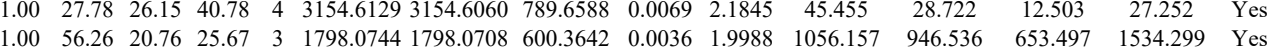
$\begin{array}{lllllllllllllll}.00 & 64.63 & 20.76 & 24.20 & 3 & 1798.0744 & 1798.0708 & 600.3642 & 0.0036 & 1.9988 & 1419.453 & 1115.039 & 694.069 & 1412.156 & \text { Yes }\end{array}$ $\begin{array}{lllllllllllllll}1.00 & 62.93 & 20.76 & 24.08 & 3 & 1798.0744 & 1798.0708 & 600.3642 & 0.0036 & 1.9988 & 745.505 & 716.107 & 535.638 & 1112.198 & \text { Yes }\end{array}$

Table S-4 page 580 of 614 
AINQIAAALFTIHK AINQIAAALFTIHK AINQIAAALFTIHK LALQSSSCLSLFR LALQSSSCLSLFR

MTIIGVILSFR

$\begin{array}{llllllllllll}\text { MTIIGVILSFR } & 1.00 & 40.66 & 24.56 & 19.47 & 2 & 1392.8288 & 1392.8285 & 697.4215 & 0.0003 & 0.2151 & 11.441 \\ \text { INPDGSQSVVEVPYAR } & 1.00 & \# \# \# \# \text { 27.92 } & 25.32 & 2 & 1873.9824 & 1873.9656 & 937.9901 & 0.0168 & 8.9552 & 374.104\end{array}$ $\begin{array}{llllllllllll} & 28.11 & 24.51 & 2 & 1873.9842 & 1873.9656 & 937.9901 & 0.0186 & 9.9147 & 466.650\end{array}$ $\begin{array}{llllllllllllll}\text { ALVDELEWEIAQVDPK } & 0.98 & 24.01 & 26.69 & 18.96 & 3 & 2142.1486 & 2142.1452 & 715.0557 & 0.0034 & 1.5850 & 98.754\end{array}$

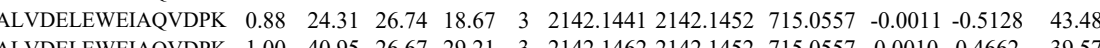

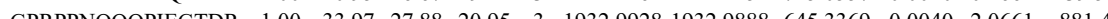

$\begin{array}{llllllllllll}\text { QPRAPGPQAPGP } & 1.00 & 43.97 & 27.88 & 20.95 & 3 & 1432.9928 & 1932.988 & 645.3369 & 0.040 & 2.062 & 881.439\end{array}$ $\begin{array}{llllllllllll}\text { QQAPGPQQAPGPR } & 0.98 & 37.27 & 28.56 & 22.01 & 2 & 1474.7766 & 1474.7763 & 738.3954 & 0.0003 & 0.2031 & 89.347\end{array}$

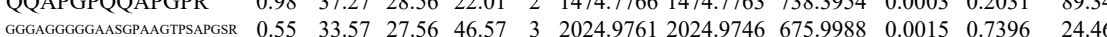

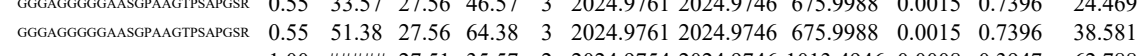
$\begin{array}{llllllllllll}\text { GGGAGGGGGASGPAAGTSAPGSR } & 1.00 & \text { \#\#\#\#\# } 27.5135 .57 & 2 & 2024.9754 & 2024.9746 & 1013.4946 & 0.0008 & 0.3947 & 62.788\end{array}$ $\begin{array}{llllllllllll}\text { GGGAGGGGGASGPAAGTPAPGSSR } & 1.00 & \text { \#\#\#\# } & 27.51 & 31.26 & 2 & 2024.9754 & 2024.9746 & 1013.4946 & 0.0008 & 0.3947 & 40.022 \\ \text { GGGAGGGGAASGPAAGPSAPGS } & 0.99 & 29.01 & 27.56 & 21.79 & 3 & 2024.9761 & 2024.9746 & 675.9988 & 0.0015 & 0.7396 & 21.542\end{array}$

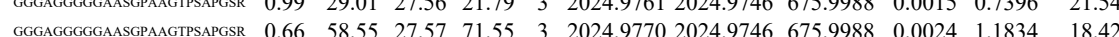
$\begin{array}{lllllllllll}\text { GGGAGGGGGAAGPAAGTSAPGSR } & 1.00 & \text { \#\#\#\# } 27.51 & 31.18 & 2 & 2024.9754 & 2024.9746 & 1013.4946 & 0.0008 & 0.3947 & 19.379\end{array}$ $\begin{array}{llllllllllll}\text { GGGAGGGGGAASGPAGGPSAPGSR } & 1.00 & \text { \#\#\#\# } & 27.51 & 27.02 & 2 & 2024.9754 & 2024.9746 & 1013.4946 & 0.0008 & 0.3947 & 11.374\end{array}$

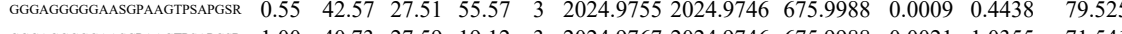

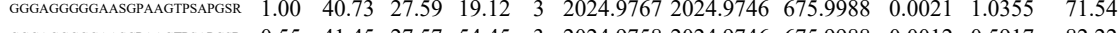
$\begin{array}{lllllllllllll} & \end{array}$ GGGAGGGGGASGPAAGTPAPGSR $\quad 0.76 \quad 14.76 \quad 27.59$ SPPSTGSTYGSSQK SPPSTGSTYGSSQK SPPSTGSTYGSSQK SPPSTGSTYGSSQK SPPSTGSTYGSSQK SPLQSVVVR SPLQSVVVR SPLQSVVVR SIFQHIQSAQSQR SIFQHIQSAQSQR SIFQHIQSAQSQR $\begin{array}{lllllllllllll}0.66 & 22.54 & 27.85 & 35.54 & 3 & 1670.8375 & 1670.8355 & 557.9524 & 0.0020 & 1.1948 & 66.238\end{array}$ $\begin{array}{lllllllllllll}0.66 & 37.70 & 27.77 & 50.70 & 3 & 1670.8378 & 1670.8355 & 557.9524 & 0.0023 & 1.3741 & 66.937\end{array}$ $\begin{array}{llllllllllll}0.55 & 40.48 & 27.77 & 53.48 & 3 & 1670.8369 & 1670.8355 & 557.9524 & 0.0014 & 0.8364 & 60.753\end{array}$ $\begin{array}{llllllllllll}0.55 & 32.90 & 27.77 & 45.90 & 3 & 1670.8369 & 1670.8355 & 557.9524 & 0.0014 & 0.8364 & 77.651\end{array}$ $\begin{array}{llllllllllll}0.55 & 16.08 & 27.77 & 29.08 & 3 & 1670.8369 & 1670.8355 & 557.9524 & 0.0014 & 0.8364 & 71.377\end{array}$ $\begin{array}{lllllllllllllllll}0.96 & 33.63 & 24.73 & 24.88 & 2 & 1127.6874 & 1127.6785 & 564.8465 & 0.008 & 7.8782 & 4408.640 & 4120.580 & 7680.184 & 8145.440 & Y 0 & & \end{array}$

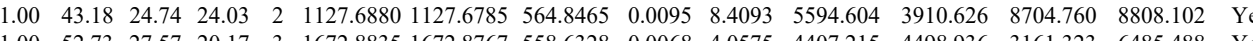
$\begin{array}{llllllllllllllllll}1.00 & 49.38 & 27.66 & 20.06 & 3 & 1672.8838 & 1672.8767 & 558.6328 & 0.0071 & 4.2365 & 4567.792 & 3803.355 & 3949.456 & 5203.213 & \text { Yes } & \\ \end{array}$

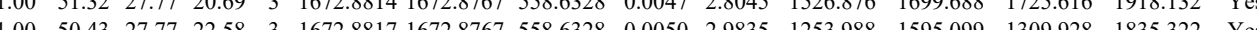
$\begin{array}{llllllllllllll} & \end{array}$

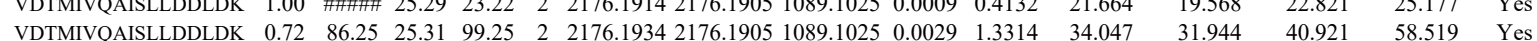
$\begin{array}{llllllllll} & \end{array}$ VEEEEEEK $\begin{array}{lllllllllll}1.00 & 49.09 & 26.74 & 33.33 & 2 & 1307.6340 & 1307.6336 & 654.8241 & 0.0004 & 0.3054 & 354.923 \\ 1.00 & 46.82 & 26.61 & 28.08 & 2 & 1307.6346 & 1307.6336 & 654.8241 & 0.0010 & 0.7636 & 402.857\end{array}$

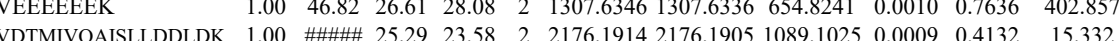
$\begin{array}{lllllllllllll} & \end{array}$ $\begin{array}{llllllllllllll}\text { VDTMIVQASLLDDLDK } & 1.00 & 48.02 & 25.28 & 21.77 & 3 & 2176.1947 & 2176.1905 & 726.4041 & 0.0042 & 1.9273 & 7.554\end{array}$ $\begin{array}{llllllllllll}\text { VDTMIVQAISLLDDLDK } & 1.00 & 52.61 & 25.29 & 19.52 & 3 & 2176.1938 & 2176.1905 & 726.4041 & 0.0033 & 1.5143 & 5.987\end{array}$ $\begin{array}{lllllllllllll}\text { VDTMIVQAISLLDDLDK } & 1.00 & 67.02 & 25.28 & 21.77 & 3 & 2176.1947 & 2176.1905 & 726.4041 & 0.0042 & 1.9273 & 9.082\end{array}$ $\begin{array}{lllllllllllll}\text { FODTAEALAAFTALMEGK } & 1.00 & 48.72 & 27.16 & 20.00 & 3 & 2201.1322 & 2201.1282 & 734.7167 & 0.0040 & 1.8148 & 89.082\end{array}$ $\begin{array}{llllllllllll}\text { FQDTAEALAAFTALMEGK } & 1.00 & 53.38 & 27.15 & 25.26 & 3 & 2201.1325 & 2201.1282 & 734.7167 & 0.0043 & 1.9509 & 33.078\end{array}$ $\begin{array}{llllllllllllll}\text { FQDTAEALAAFTALMEGK } & 1.00 & 40.02 & 27.08 & 16.71 & 3 & 2201.1316 & 2201.1282 & 734.7167 & 0.0034 & 1.5425 & 25.027\end{array}$ $\begin{array}{lllllllllllll}\text { FQDTAEALAAFTALMEGK } & 1.00 & 65.55 & 27.16 & 23.05 & 3 & 2201.1322 & 2201.1282 & 734.7167 & 0.0040 & 1.8148 & 138.088\end{array}$ $\begin{array}{llllllllllll}\text { FQDTAEALAAFTALMEGK } & 0.67 & 22.73 & 27.15 & 35.73 & 3 & 2201.1313 & 2201.1282 & 734.7167 & 0.0031 & 1.4064 & 8.772\end{array}$ $\begin{array}{llllllllllllll}\text { FQDTAEALAAFTALMEGK } & 0.60 & 30.10 & 27.16 & 43.10 & 3 & 2201.1322 & 2201.1282 & 734.7167 & 0.0040 & 1.8148 & 14.757\end{array}$ $\begin{array}{llllllllllllll}\text { LIAHAGSLLNLAK } & 1.00 & 49.77 & 15.44 & 18.12 & 3 & 1608.0058 & 1607.9966 & 537.0061 & 0.0092 & 5.7106 & 3819.670 & 3294.426 & \\ \text { LNLSCIHSPVVNELMR } & 1.00 & 71.41 & 28.05 & 17.72 & 3 & 2014.0291 & 2014.0284 & 672.3501 & 0.0007 & 0.3470 & 536.384 & 761.250\end{array}$ $\begin{array}{lllllllllllllll}\text { LNLSCIHSPVVNELMR } & 1.00 & 43.55 & 28.16 & 16.44 & 3 & 2014.0297 & 2014.0284 & 672.3501 & 0.0013 & 0.6445 & 644.658 & 762.957\end{array}$ $\begin{array}{lllllllllllll}\text { LIAHAGSLLNLAK } & 0.55 & 32.61 & 15.68 & 45.61 & 3 & 1607.9980 & 1607.9966 & 537.0061 & 0.0014 & 0.8690 & 9499.229\end{array}$ $\begin{array}{lllllllllllllllll}\text { LIAHAGSLLNLAK } & 0.65 & 32.61 & 15.68 & 45.61 & 3 & 1607.9980 & 1607.9966 & 537.0061 & 0.0014 & 0.8690 & 9499.229 & 8008.424 & 1038.967 & 13239.075 \\ \text { LIAHAGSLLNLAK } & 0.66 & 27.76 & 15.31 & 40.76 & 3 & 1607.9989 & 1607.9966 & 537.0061 & 0.0023 & 1.4277 & 10961.752 & 8796.515 & 1324.813 & 14516.0 \\ \text { LNLSCIHSPVVNELMR } & 1.00 & 51.99 & 28.09 & 16.73 & 3 & 2014.0288 & 2014.0284 & 672.3501 & 0.0004 & 0.1983 & 1170.839 & 1452.505 & 257.075 & 1952.801\end{array}$ $\begin{array}{lllllllllllllllllll} & \end{array}$

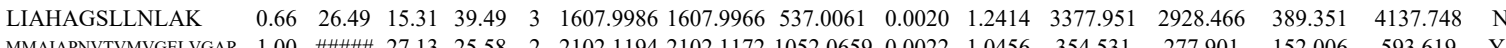
\begin{tabular}{lllllllllllll} 
& 152.006 & 593.619 & Yes \\
\hline
\end{tabular}

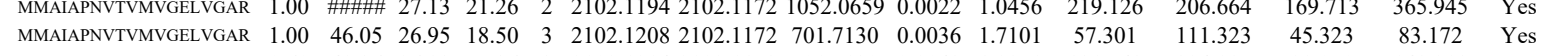

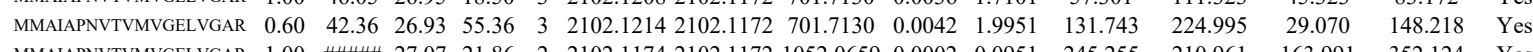

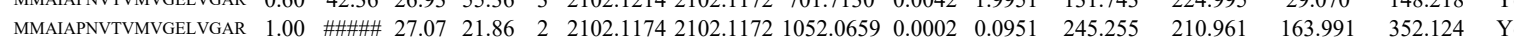



$\begin{array}{llllllllllll}.75 & 17.26 & 26.97 & 21.50 & 3 & 1876.0081 & 1876.0033 & 626.3417 & 0.0048 & 2.5545 & 80.060 \\ 1.00 & 71.45 & 27.29 & 31.22 & 3 & 2490.2284 & 2490.2347 & 831.0855 & -0.0063 & -2.5268 & 74.383\end{array}$ $\begin{array}{lllllllllllllll}0.99 & 40.66 & 24.22 & 29.20 & 2 & 1215.7524 & 1215.7430 & 608.8788 & 0.0094 & 7.7190 & 4266.419 & 5220.532 & 1350.910 & 8995.262 & \text { Y } \\ 0.99 & 39.13 & 24.28 & 28.19 & 2 & 1215.7538 & 1215.7430 & 608.8788 & 0.0108 & 8.8687 & 5595.109 & 6181.117 & 1163.906 & 12885.349 & \text { Yes }\end{array}$ $\begin{array}{llllllllllllllll}1.00 & 45.41 & 24.44 & 28.59 & 2 & 1303.7870 & 1303.7744 & 652.8945 & 0.0126 & 9.6492 & 3342.697 & 3651.064 & 556.609 & 9255.794 & \text { Yes }\end{array}$ $\begin{array}{llllllllllllllll}0.85 & 36.59 & 26.19 & 39.00 & 2 & 1014.6386 & 1014.6308 & 508.3227 & 0.0078 & 7.6722 & 12311.885 & 14797.871 & 5157.403 & 36963.084 & \text { Yes } \\ 0.88 & 37.91 & 26.19 & 39.11 & 2 & 1014.6386 & 1014.6308 & 508.3227 & 0.0078 & 7.6722 & 10956.407 & 4306.552 & 4405.739 & 31750.357 & \text { Yes }\end{array}$ $\begin{array}{llllllllllllllll}0.88 & 37.91 & 26.19 & 39.11 & 2 & 1014.6386 & 1014.6308 & 508.3227 & 0.0078 & 7.6722 & 10956.407 & 14306.552 & 4405.739 & 31750.357 & \text { Yes } \\ 0.99 & 36.57 & 23.01 & 23.46 & 3 & 1402.8532 & 1402.8418 & 468.6212 & 0.0114 & 8.1088 & 1523.428 & 3110.192 & 3120.338 & 2223.387 & \text { Yes }\end{array}$ $\begin{array}{llllllllllllllll}0.99 & 36.57 & 23.01 & 23.46 & 3 & 1402.8532 & 1402.8418 & 468.6212 & 0.0114 & 8.1088 & 1523.428 & 3110.192 & 3120.338 & 2223.387 & \text { Yes } \\ 1.00 & 37.26 & 23.01 & 22.40 & 3 & 1402.8535 & 1402.8418 & 468.6212 & 0.0117 & 8.3222 & 1107.951 & 1854.312 & 3236.638 & 1062.056 & \text { Yes }\end{array}$ $\begin{array}{lllllllllllllll}1.00 & 37.26 & 23.01 & 22.40 & 3 & 1402.8535 & 1402.8418 & 468.6212 & 0.0117 & 8.3222 & 1107.951 & 1854.312 & 3236.638 & 1062.056 & \text { Yes } \\ 0.99 & 35.65 & 22.92 & 22.21 & 3 & 1402.8547 & 1402.8418 & 468.6212 & 0.0129 & 9.1758 & 1023.840 & 1443.687 & 2844.325 & 934.947 & \text { Yes } \\ 1.00 & 67.74 & 27.40 & 24.5 & 3 & 2490.216 & 2490.234 & 831.035 & 0.0231 & -9.265 & & \end{array}$ $\begin{array}{ccccccccccccccc}0.84 & 79.19 & 27.16 & 27.94 & 3 & 2490.2245 & 2490.2347 & 831.0855 & -0.0102 & -4.0911 & 275.304 & 336.488 & 190.606 & 368.243 & \text { Yes } \\ 1.00 & 57.68 & 26.27 & 62.09 & 2 & 1735.8172 & 22.8735 .8153 & 868.9149 & 0.0019 & 1.0933 & 43.575 & 26.190 & 7.796 & 84.682 & \text { No } \\ 1.00 & 53.54 & 28.73 & 25.74 & 3 & 1408.7338 & 1408.7221 & 470.5813 & 0.0117 & 8.2876 & 2972.703 & 3153.795 & 1112.261 & 3784.22 & Y e s\end{array}$ $\begin{array}{llllllllllllllllll} & 1.00 & 53.54 & 28.73 & 25.74 & 3 & 1408.7356 & 1408.7221 & 470.5813 & 0.0135 & 9.5625 & 2008.966 & 1882.306 & 893.408 & 2703.011 & \text { Yes } \\ & 0.66 & 67.01 & 27.25 & 80.01 & 3 & 2350.1959 & 2350.1938 & 784.4052 & 0.0021 & 0.8924 & 1434.350 & 1274.661 & 778.050 & 195.519 & Y=5\end{array}$ $\begin{array}{lllllllllllllllll} & \end{array}$ $\begin{array}{llllllllllllll} & \end{array}$ 


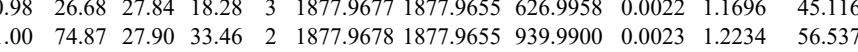
$\begin{array}{llllllllllll}1.00 & 68.76 & 16.81 & 27.67 & 2 & 1510.9584 & 1510.9578 & 756.4862 & 0.0006 & 0.3966 & 0.000\end{array}$ $\begin{array}{lcccccccccc}0.66 & 4.16 & 15.80 & 17.16 & 3 & 1510.9594 & 1510.9578 & 504.6599 & 0.0016 & 1.0568 & 52.109 \\ 1.00 & 49.04 & 15.19 & 27.17 & 2 & 1510.9602 & 1510.9578 & 756.4862 & 0.0024 & 1.5863 & 0.000\end{array}$ $\begin{array}{lllllllllllll}0.97 & 13.99 & 15.19 & 16.72 & 3 & 1510.9603 & 1510.9578 & 504.6599 & 0.0025 & 1.6513 & 94.964\end{array}$

GLLQTEPQNNQAK $\begin{array}{lllllllllllll}0.99 & 19.73 & 17.85 & 16.54 & 3 & 1590.9961 & 1590.9943 & 531.3387 & 0.0018 & 1.1292 & 10.052\end{array}$ $\begin{array}{llllllllllll}0.66 & 24.51 & 17.85 & 37.51 & 3 & 1590.9964 & 1590.9943 & 531.3387 & 0.0021 & 1.3174 & 13.684\end{array}$ $\begin{array}{lllllllllllll}1.00 & 30.28 & 17.85 & 20.36 & 3 & 1590.9955 & 1590.9943 & 531.3387 & 0.00012 & 0.7528 & 11.651\end{array}$ $\begin{array}{lllllllllll}1.00 & 68.23 & 17.71 & 28.17 & 2 & 1590.9934 & 1590.9943 & 796.5044 & -0.0009 & -0.5650 & 4.804\end{array}$ $\begin{array}{lllllllllll}1.00 & 62.36 & 17.85 & 27.63 & 2 & 1590.9940 & 1590.9943 & 796.5044 & -0.0003 & -0.1883 & 10.118\end{array}$ $\begin{array}{lllllllllllll}1.00 & 70.14 & 17.85 & 26.85 & 2 & 1590.9956 & 1590.9943 & 796.5044 & 0.0013 & 0.8161 & 6.758 \\ 1.00 & 46.04 & 14.15 & 16.75 & 3 & 1747.0966 & 1747.0954 & 583.3724 & 0.0012 & 0.6857 & 26.550\end{array}$ $\begin{array}{llllllllllllll}1.00 & 40.54 & 13.98 & 21.29 & 3 & 1747.0972 & 1747.0954 & 583.3724 & 0.0018 & 1.0285 & 21.271 \\ 1.00 & 51.50 & 17.85 & 26.39 & 2 & 1590.9936 & 1590.9943 & 796.5044 & -0.0007 & 0.4394 & 12.514\end{array}$ $\begin{array}{llllllllllll}1.00 & 51.50 & 17.85 & 26.39 & 2 & 1590.9936 & 1590.9943 & 796.5044 & -0.0007 & -0.4394 & 12.514 \\ 0.55 & 40.75 & 14.15 & 53.75 & 3 & 1747.0966 & 1747.0954 & 583.3724 & 0.0012 & 0.6857 & 10.378\end{array}$ $\begin{array}{llllllllllll}0.55 & 40.75 & 14.15 & 53.75 & 3 & 1747.0966 & 1747.0954 & 583.3724 & 0.0012 & 0.6857 & 10.378 \\ 0.66 & 33.96 & 13.98 & 46.96 & 3 & 1747.0972 & 1747.0954 & 583.3724 & 0.0018 & 1.0285 & 23.733 \\ 0.87 & 18.61 & 14.47 & 14.72 & 2 & 1747.0948 & 1747.055 & 874.5550 & -0.0006 & -0.3430 & 4.526\end{array}$ $\begin{array}{lllllllllll}0.87 & 18.61 & 14.47 & 14.72 & 2 & 1747.0948 & 1747.0954 & 874.5550 & -0.0006 & -0.3430 & 4.526\end{array}$ $\begin{array}{llllllllllll}1.00 & 34.10 & 14.47 & 15.56 & 2 & 1747.0958 & 1747.0954 & 874.5550 & 0.0004 & 0.2287 & 5.978\end{array}$ $\begin{array}{lllllllllllll}0.55 & 47.61 & 14.15 & 60.61 & 3 & 1747.0966 & 1747.0954 & 583.3724 & 0.0012 & 0.6857 & 10.713 \\ 1.00 & 33.23 & 13.98 & 17.26 & 3 & 1747.0972 & 1747.0954 & 583.3724 & 0.0018 & 1.0285 & 16.284\end{array}$ $\begin{array}{llllllllllll}1.00 & 33.23 & 13.98 & 17.26 & 3 & 1747.0972 & 1747.0954 & 533.3724 & 0.0018 & 1.0285 & 16.284 \\ 1.00 & 50.13 & 17.85 & 26.56 & 2 & 1590.9942 & 1590.9943 & 796.5044 & -0.0001 & -0.0628 & 4.130\end{array}$ $\begin{array}{lllllllllll}1.00 & 50.13 & 17.85 & 26.56 & 2 & 1590.9942 & 1590.9943 & 796.5044 & -0.0001 & -0.0628 & 4.130 \\ 1.00 & 55.46 & 17.85 & 20.72 & 2 & 1590.9956 & 1590.9943 & 796.5044 & 0.0013 & 0.8161 & 8.780\end{array}$ $\begin{array}{llllllllllll}1.00 & 55.46 & 17.85 & 20.72 & 2 & 1590.9956 & 1590.9943 & 796.5044 & 0.0013 & 0.8161 & 8.780 \\ 0.55 & 47.51 & 14.15 & 60.51 & 3 & 1747.0963 & 1747.0954 & 583.3724 & 0.0009 & 0.5143 & 15.151 \\ 0.55 & 47.90 & 14.15 & 60.90 & 3 & 1747.0969 & 1747.0954 & 583.3724 & 0.0015 & 0.8571 & 17.873\end{array}$

VPVLGSLLNLPGIR $\begin{array}{lllllllllllll}0.99 & 34.62 & 14.47 & 17.72 & 2 & 1747.0948 & 1747.0954 & 874.5550 & -0.0006 & -0.3430 & 7.792\end{array}$

RVPVLGSLLNLPGIR $\begin{array}{llllllllllll}1.00 & 30.63 & 14.47 & 15.41 & 2 & 1747.0954 & 1747.0954 & 874.5550 & 0.0000 & 0.0000 & 3.640\end{array}$

RVPVLGSLLNLPGIR $\begin{array}{llllllllllll}1.00 & 30.63 & 4.47 & 15.41 & 2 & 1747.0954 & 1747.0954 & 874.5550 & 0.0000 & 0.0000 & 3.640 \\ 1.00 & 38.76 & 14.47 & 21.32 & 3 & 1747.0960 & 1747.0954 & 583.3724 & 0.0006 & 0.3428 & 29.488\end{array}$

RVPVLGSLLNLP $\begin{array}{lllllllllllll}0.55 & 45.07 & 14.15 & 58.07 & 3 & 1747.0969 & 1747.0954 & 583.3724 & 0.0015 & 0.8571 & 19.447 \\ 0.55 & 44.07 & 14.47 & 57.07 & 3 & 1747.0960 & 1747.0954 & 583.3724 & 0.0006 & 0.3428 & 23.268\end{array}$

AATAAADFTAK $\begin{array}{llllllllllll}0.55 & 44.07 & 14.47 & 57.07 & 3 & 1747.0960 & 1747.0954 & 583.3724 & 0.0006 & 0.3428 & 23.268 & 29.551 \\ 1.00 & 71.82 & 27.33 & 24.56 & 2 & 1324.7314 & 1324.7230 & 663.3688 & 0.0084 & 6.3313 & 10963.218 & 12525.023\end{array}$ VWDAVSGDELMTLAHK QGDTGDWIGTFLGHK $\begin{array}{llllllllllllll}1 & \end{array}$ $\begin{array}{lllllllllllllllll} & \end{array}$ $\begin{array}{llllllllllllllllll}\text { NHYAEQVVDERNEYAAK } & 0.62 & 11.13 & 25.21 & 24.13 & 4 & 3504.8229 & 3504.8132 & 877.2106 & 0.0097 & 2.7644 & 24.564 & 19.745 & 56.676 & 27.579 & \text { No }\end{array}$

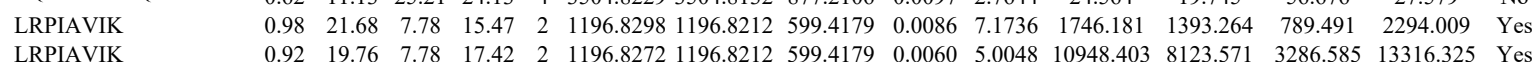


TNLDESDVQPVK TNLDESDVQPVK LVMEEAPESYK NLDFQDVLDK NLDFQDVLDK SYNDELQFLEK NLDFQDVLDK NLDFQDVLDK

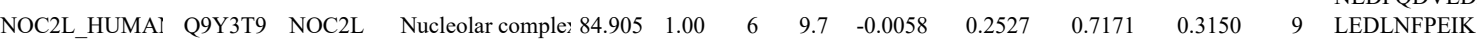
QEDQNFIGK QVQQLLGK

\section{VLAFLVLSR}

VLAFLVLSR
VLAFLVLSR

GILRPLSTR

VLAFLVLSR

VLAFLVLSR

VLAFLVLSR

SPDKPGGSPSASR

SPDKPGGSPSASR

LTDNIFLEILYSTDPK

$\begin{array}{llllllllllll}1.00 & 34.45 & 25.74 & 26.58 & 3 & 2169.1852 & 2169.1813 & 724.0677 & 0.0039 & 1.7954 & 16.064\end{array}$

$\begin{array}{llllllllllllll} & \end{array}$

$\begin{array}{lllllllllllll}\text { LTDNIFLEILYSTDPK } & 1.00 & 38.96 & 25.74 & 22.62 & 3 & 2169.1852 & 2169.1813 & 724.0677 & 0.0039 & 1.7954 & 8.352\end{array}$

$\begin{array}{lllllllllllll}\text { VGNIIDTMITDAFLK } & 1.00 & 75.80 & 25.38 & 27.09 & 2 & 1938.0764 & 1938.0740 & 970.0443 & 0.0024 & 1.2371 & 154.676 & 139 \\ \text { VGNIIDTMMTDAFLK } & 1.0 & 55.29 & 25.40 & 24.64 & 3 & 1938.0772 & 1938.070 & 647.0319 & 0.032 & 1.646 & 7.153 & 116\end{array}$ $\begin{array}{llllllllllllll}\text { VGNIIDTMITDAFLK } & 1.00 & 55.29 & 25.40 & 24.64 & 3 & 1938.0772 & 1938.0740 & 647.0319 & 0.0032 & 1.6486 & 79.153 & 16 \\ \text { VGNIIDTMITDAFLK } & 1.00 & 57.25 & 25.44 & 24.02 & 3 & 1938.0778 & 1938.0740 & 647.0319 & 0.0038 & 1.9577 & 82.032 & 68\end{array}$ $\begin{array}{lllllllllllll}\text { VGNIIDTMITDAFLK } & 1.00 & 68.93 & 25.43 & 23.23 & 3 & 1938.0763 & 1938.0740 & 647.0319 & 0.0023 & 1.1849 & 181.458 & 27\end{array}$ $\begin{array}{llllllllllll}\text { VGNIIDTMITDAFLK } & 1.00 & 45.12 & 25.40 & 24.08 & 3 & 1938.0775 & 1938.0740 & 647.0319 & 0.0035 & 1.8031 & 68.067\end{array}$ $\begin{array}{llllllllllll}\text { VGNIIDTMITDAFLK } & 0.65 & 19.63 & 25.16 & 24.38 & 3 & 1938.0817 & 1938.0740 & 647.0319 & 0.0077 & 3.9668 & 171.108\end{array}$

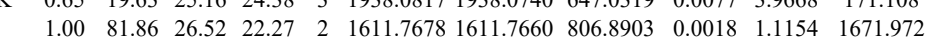

$6 \begin{array}{llllllllllll}\text { ELPLAADALTFAEVSK } & 0.60 & 47.96 & 25.44 & 60.96 & 3 & 1962.0955 & 1962.0917 & 655.0378 & 0.0038 & 1.9337 & 126.937\end{array}$ $\begin{array}{llllllllllll}\text { ELPLAADALTFAEVSK } & 0.55 & 56.42 & 25.35 & 69.42 & 3 & 1962.0928 & 1962.0917 & 655.0378 & 0.0011 & 0.5598 & 50.316 \\ \text { ELPLAADALTEAEVSK } & 1.00 & 55.34 & 25.47 & 22.42 & 3 & 1962.0958 & 1962.0917 & 655.0378 & 0.0041 & 2.0864 & 26.960\end{array}$ $\begin{array}{lllllllllllll}\text { ELPLAADALTFAEVSK } & 1.00 & 55.34 & 25.47 & 22.42 & 3 & 1962.0958 & 1962.0917 & 655.0378 & 0.0041 & 2.0864 & 26.960\end{array}$ NLSSASQATR ILNPLLDR LLQLGQQPR $\begin{array}{llllllllllll}0.94 & 27.22 & 28.04 & 27.00 & 2 & 1177.6190 & 1177.6173 & 589.8159 & 0.0017 & 1.4411 & 28.435 \\ 0.55 & 50.03 & 26.68 & 6.03 & 3 & 24962716 & 24962708 & 833.0975 & 0.0008 & 0.3201 & 44.373\end{array}$ 1.00 $\begin{array}{llllllll} & \end{array}$ $\begin{array}{llllllllllllll}0.99 & 40.30 & 24.17 & 25.14 & 2 & 1195.7252 & 1195.7159 & 598.8652 & 0.0093 & 7.7646 & 18258.574 & 14958.951 & 53.45\end{array}$ $\begin{array}{lllllllllllll}0.99 & 39.16 & 24.17 & 23.94 & 2 & 1195.7256 & 1195.7159 & 598.8652 & 0.0097 & 8.0986 & 9565.191 & 7896.979\end{array}$ $\begin{array}{llllllll}269.77 & 1.00 & 32 & 23.2 & -0.3872 & 0.6420 & 0.1917 & 0.4817\end{array}$
GAAAHPDSEEQQQR

GAAAHPDSEEQQQR

$\begin{array}{llllllllllll}1.00 & 38.96 & 25.49 & 18.85 & 3 & 1666.780 & 1666.7781 & 556.600 & 0.0016 & 0.9582 \\ 0.70 & 18.78 & 28.41 & 24.01 & 2 & 1019.5876 & 1019.5855 & 510.8000 & 0.0021 & 2.0556\end{array}$ $\begin{array}{lllllllllllll}\text { GAAAIEAAK } & 1.00 & 78.89 & 26.31 & 19.85 & 3 & 3338.7172 & 3338.7125 & 1113.9114 & 0.0047 & 1.4065 & 1.065\end{array}$

$\begin{array}{lllllllllllll} & & & \end{array}$ $\begin{array}{llllllllllll}\text { IPAPAGPPSDFGLFLSDDDPK } & 1.00 & 60.72 & 27.43 & 22.85 & 3 & 2572.2979 & 2572.2941 & 858.4386 & 0.0038 & 1.4755 & 18.81 \\ \text { IPAPAGPSDFGLFLSDDDPK } & 0.60 & 53.82 & 27.37 & 66.82 & 3 & 2572.2985 & 2572.2941 & 858.4386 & 0.0044 & 1.7085 & 36.676\end{array}$

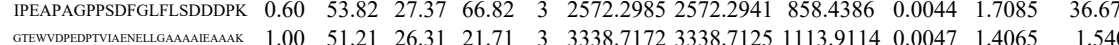

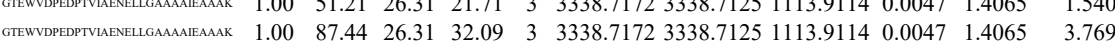

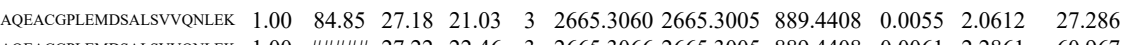

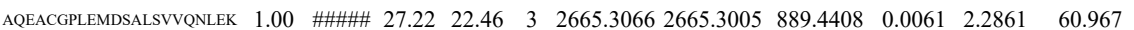
$\begin{array}{lllllllllllll}\text { LGAASLGAEDPETQVVLINAVK } & 0.67 & 16.77 & 22.83 & 29.77 & 3 & 2482.3921 & 2482.3886 & 828.4701 & 0.0035 & 1.4082 & 186.072\end{array}$ $\begin{array}{llllllllllll}\text { LGAASLGAEDPETQVVLINAVK } & 0.60 & 8.58 & 22.50 & 21.58 & 3 & 2482.3930 & 2482.3886 & 828.4701 & 0.0044 & 1.7703 & 220.937\end{array}$ $\begin{array}{llllllllllll}\text { GVAALISDPAVQAIVLDTASDVLDK } & 0.60 & 72.55 & 23.93 & 85.55 & 3 & 2756.5096 & 2756.5051 & 919.8423 & 0.0045 & 1.6307 & 31.356\end{array}$ $\begin{array}{llllllllllll}\text { GVAALTSDPAVQAIVLDTASDVLDK } & 1.00 & 82.28 & 23.84 & 20.36 & 3 & 2756.5114 & 2756.5051 & 919.8423 & 0.0063 & 2.2830 & 8.183\end{array}$ $\begin{array}{lllllllllllll}\text { LGAASLGAEDPETQVVLINAVK } & 1.00 & 55.87 & 22.76 & 16.82 & 3 & 2482.3900 & 2482.3886 & 828.4701 & 0.0014 & 0.5633 & 110.628\end{array}$ $\begin{array}{lllllllllllll}\text { GVAALTSDPAVQAVLDTASDVLDK } & 1.00 & 77.37 & 23.69 & 21.37 & 3 & 2756.5129 & 2756.5051 & 919.8423 & 0.0078 & 2.8266 & 0.000\end{array}$ $\begin{array}{lllllllllll}\text { GVAALTSDPAVQAIVLDTASDVLDK } & 1.00 & \text { \#\#\#\# } 23.75 & 20.06 & 3 & 2756.5135 & 2756.5051 & 919.8423 & 0.0084 & 3.0440 & 3.802\end{array}$

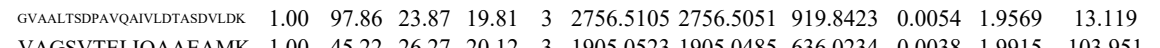
$\begin{array}{llllllllllll}\text { VAGSVTELIQAAEAMK } & 1.00 & 45.22 & 26.27 & 20.12 & 3 & 1905.0523 & 1905.0485 & 636.0234 & 0.0038 & 1.9915 & 103.951 \\ \text { NLGTALAELR } & 1.00 & 46.67 & 26.70 & 28.00 & 2 & 1200.7066 & 1200.6948 & 601.3547 & 0.0118 & 9.8111 & 1901.535\end{array}$

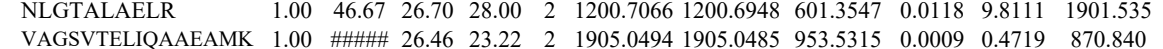
$\begin{array}{llllllllllll}\text { VAGSVTELIQAAEAMK } & 1.00 & \# \# \# \# 26.46 & 23.22 & 2 & 1905.0494 & 1905.0485 & 953.5315 & 0.0009 & 0.4719 & 870.840 \\ \text { VAGSVTELIQAAEAMK } & 1.00 & \# \# \# \# \text { 26.44 } & 26.22 & 2 & 1905.0508 & 1905.0485 & 953.5315 & 0.0023 & 12060 & 847.940\end{array}$ $\begin{array}{llllllllllll}\text { VAGSVTELIQAAEAMK } & 1.00 & \# \# \# \# \text { 26.44 } & 26.22 & 2 & 1905.0508 & 1905.0485 & 953.5315 & 0.0023 & 1.2060 & 847.940 \\ \text { VAGSVTELIQAAEAMK } & 0.60 & 44.76 & 26.31 & 57.76 & 3 & 1905.0529 & 1905.0485 & 636.0234 & 0.0044 & 2.3060 & 94.974\end{array}$ $\begin{array}{lllllllllllll}\text { VAGSVTELIQAAEAMK } & 0.60 & 44.76 & 26.31 & 57.76 & 3 & 1905.0529 & 1905.0485 & 636.0234 & 0.0044 & 2.3060 & 94.974 \\ \text { VVAPTISPVCQEQLVEAGR } & 0.84 & 97.63 & 27.41 & \# \# \# \# & 2 & 2272.1694 & 2272.1677 & 1137.0911 & 0.0017 & 0.7475 & 356.450\end{array}$

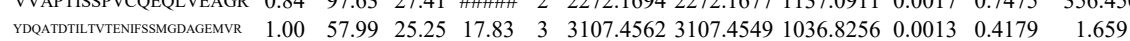
$\begin{array}{llllllllllllll}\text { YDDATDTLTVTENIFSSMGDAGEMVR } & 0.55 & 46.05 & 25.25 & 59.05 & 3 & 3107.4562 & 3107.4549 & 1036.8256 & 0.0013 & 0.4179 & 0.000\end{array}$

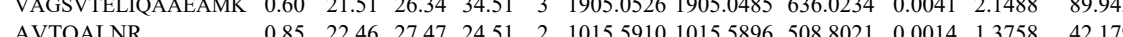


$\begin{array}{lllllllllllll}0.77 & 6.83 & 25.25 & 17.12 & 4 & 3613.8417 & 3613.8385 & 904.4669 & 0.0032 & 0.8845 & 62.268 \\ 1.00 & 62.12 & 22.97 & 43.81 & 2 & 1318.8160 & 1318.8064 & 660.4105 & 0.0096 & 7.2682 & 4957.504 & 30\end{array}$ $\begin{array}{llllllllllll}00 & 81.16 & 26.23 & 23.09 & 3 & 2716.4305 & 2716.4265 & 906.4828 & 0.0040 & 1.4709 & 0.000\end{array}$ $\begin{array}{lllllllllll}1.00 & 74.17 & 24.50 & 87.17 & 4 & 3513.8433 & 3513.8371 & 879.4666 & 0.0062 & 1.7624 & 867.363\end{array}$ $\begin{array}{lllllllllll}1.00 & 82.69 & 23.24 & 30.54 & 2 & 1535.6822 & 1535.6821 & 768.8483 & 0.0001 & 0.0650 & 544.592\end{array}$ $\begin{array}{lllllllllllll}1.00 & 50.78 & 23.32 & 16.74 & 3 & 1809.0535 & 1809.0491 & 604.0236 & 0.0044 & 2.4282 & 330.280 & \end{array}$ $\begin{array}{llllllllllll}\text { ASK } & 0.89 & 18.32 & 25.80 & 19.04 & 3 & 2469.3190 & 2469.3181 & 824.1133 & 0.0009 & 0.3640 & 766.198 \\ \text { GiAAR } & 1.00 & 34.73 & 26.23 & 15.82 & 3 & 2716.4305 & 2716.4265 & 906.4828 & 0.0040 & 1.4709 & 0.000\end{array}$

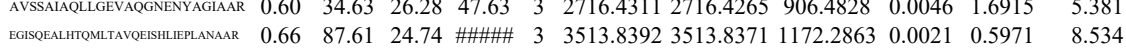

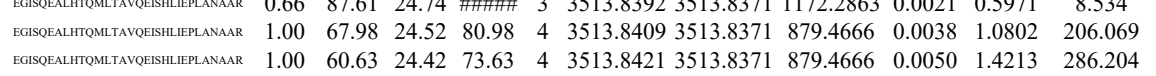

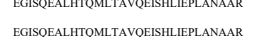

EGISEEALHTMLITVQEISHLLPP
VMVTNVTSLLK $\begin{array}{lllllllllll} & \end{array}$ $1.00 \quad 50.85 \quad 24.46 \quad 63.85$

LAQAAQSSVATITR

$\begin{array}{llllllllll} & \end{array}$ $\begin{array}{lllllllllll}1.00 & 26.17 & 26.52 & 33.32 & 2 & 1559.8872 & 1559.8753 & 780.9449 & 0.0119 & 7.6189 & 12535.715 \\ 1.00 & 38.10 & 26.17 & 31.94 & 3 & 2195.0362 & 2195.0328 & 732.6849 & 0.0034 & 1.5468 & 2.404\end{array}$ $\begin{array}{llllllllllll}\text { APGQLECETAIAALNSCLR } & 1.00 & 83.27 & 26.19 & 28.66 & 3 & 2195.0377 & 2195.0328 & 732.6849 & 0.0049 & 2.2292 & 6.513\end{array}$

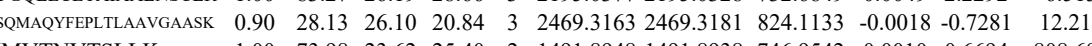
VMVTNVTSLLK $\begin{array}{lllllllllllll} & & \end{array}$

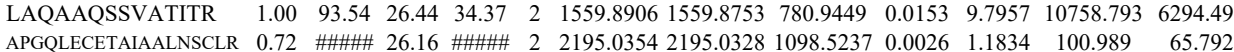

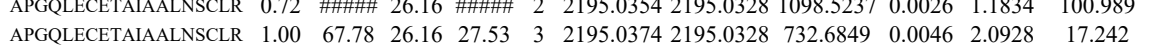

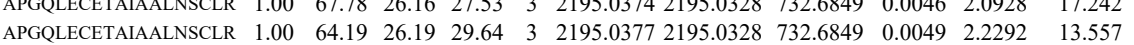
$\begin{array}{llllllllllllll}\text { AEDSGLTOVIMAATOCALSTSOLVACTK } & 0.74 & 8.56 & 26.43 & 18.34 & 4 & 3317.6229 & 3317.6219 & 830.4128 & 0.0010 & 0.3011 & 31.438\end{array}$

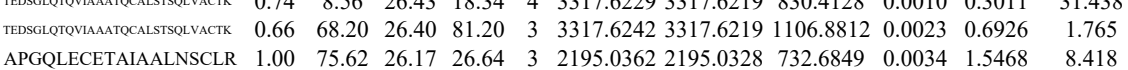
$\begin{array}{lllllllllllll}\text { APGQLECETAIAALNSCLR } & 1.00 & 41.84 & 26.17 & 25.54 & 3 & 2195.0362 & 2195.0328 & 732.6849 & 0.0034 & 1.5468 & 4.809\end{array}$ $\begin{array}{lllllllllllll}\text { AVTDSINQLITMCTQQAPGQK } & 0.70 & 14.26 & 27.23 & 15.45 & 3 & 2580.2995 & 2580.2953 & 861.1057 & 0.0042 & 1.6258 & 58.291\end{array}$

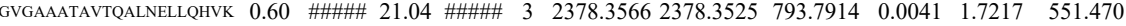

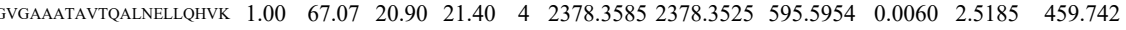

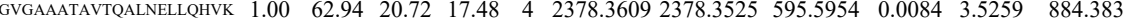

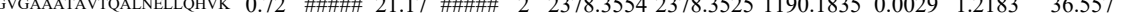
$\begin{array}{llllllllllllll}\text { GVGAAATAVTQALNELLQHVK } & 1.00 & 65.72 & 20.72 & 78.72 & 4 & 2378.3597 & 2378.3525 & 595.5954 & 0.0072 & 3.0222 & 1117.862\end{array}$

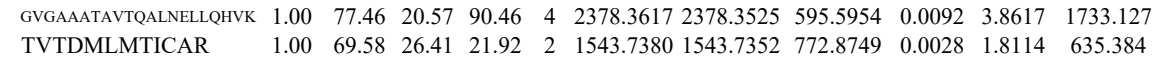
\begin{tabular}{lllllllllllll} 
& \\
TVTDMLMTICAR & 1.00 & 69.58 & 26.41 & 21.92 & 2 & 1543.7380 & 1543.7352 & 772.8749 & 0.0028 & 1.8114 & 635.384 \\
\hline
\end{tabular}

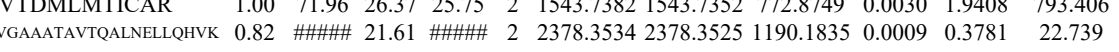
$\begin{array}{lllllllllllll}\text { GVGAAATAVTQALNELLQHVK } & 0.67 & 95.19 & 21.17 & \text { \#\#\#\# } & 3 & 2378.3554 & 2378.3525 & 793.7914 & 0.0029 & 1.2178 & 61.758\end{array}$

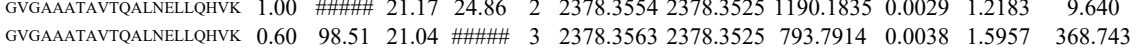
$\begin{array}{llllllllllll}\text { GVGAAATAVTQALNELLQHVK } & 0.60 & 98.51 & 21.04 & \ldots & 3 & 2378.3563 & 2378.3525 & 793.7914 & 0.0038 & 1.5957 & 368.743 \\ \text { GVGAAATAVTQALNELLQHVK } & 1.00 & 57.35 & 20.90 & 70.35 & 4 & 2378.3573 & 2378.3525 & 595.5954 & 0.0048 & 2.0148 & 277.144\end{array}$

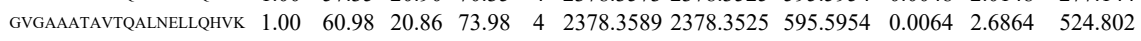
$\begin{array}{lllllllllllll}\text { TVTDMLMTICAR } & 1.00 & 56.36 & 26.41 & 33.11 & 2 & 1543.7380 & 1543.7352 & 772.8749 & 0.0028 & 1.8114 & 1020.758 & 626.869\end{array}$ 


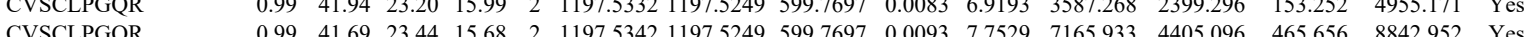

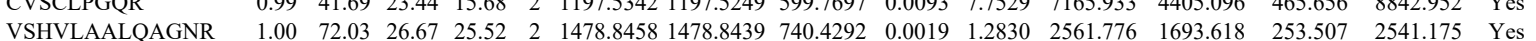

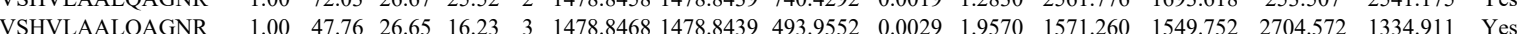

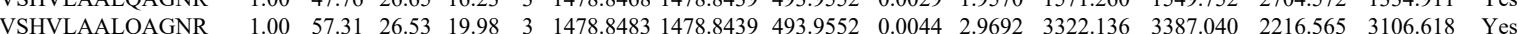

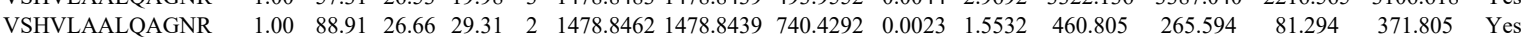

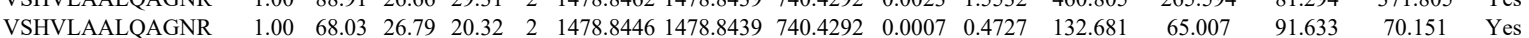
$\begin{array}{lllllllllllllllll}\text { VSHVLAALQAGNR } & 1.00 & 81.08 & 26.79 & 28.57 & 2 & 1478.8446 & 1478.8439 & 740.4292 & 0.0007 & 0.4727 & 229.775 & 149.907 & 67.513 & 230.827 & \text { Yes }\end{array}$

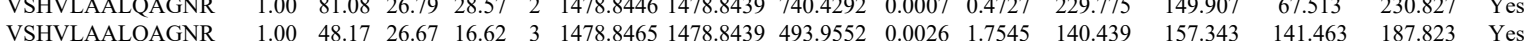
$\begin{array}{llllllllllllllll}\text { VSHVLAALQAGNR } & 1.00 & 46.65 & 26.68 & 21.74 & 3 & 1478.8471 & 1478.8439 & 493.9552 & 0.0032 & 2.1594 & 211.953 & 149.405 & 215.631 & 147.680 & \text { Yes }\end{array}$ $\begin{array}{llllllllllllllllll}\text { VSHVLAALQAGNR } & 0.66 & 31.65 & 26.66 & 44.65 & 3 & 1478.8456 & 1478.8439 & 493.9552 & 0.0017 & 1.1472 & 211.349 & 243.207 & 267.950 & 226.053 & \text { Yes }\end{array}$ $\begin{array}{lllllllllllllllll}\text { VSHVLAALQAGNR } & 0.70 & 12.71 & 26.66 & 16.54 & 3 & 1478.8456 & 1478.8439 & 493.9552 & 0.0017 & 1.1472 & 91.438 & 86.948 & 144.682 & 87.154 & \text { Yes }\end{array}$ $\begin{array}{lllllllllllllllll}\text { VSHVLAALQAGNR } & 0.99 & 31.97 & 26.77 & 16.33 & 3 & 1478.8444 & 1478.8439 & 493.9552 & 0.0005 & 0.3374 & 48.411 & 69.542 & 60.603 & 82.895 & \text { Yes }\end{array}$ $\begin{array}{llllllllllllllll}\text { IPEAPAGPSDFGLFLSDDDPK } & 1.00 & 48.57 & 27.37 & 21.89 & 3 & 2572.2985 & 2572.2941 & 858.4386 & 0.0044 & 1.7085 & 38.536 & 23.024 & 52.008 & 53.467 & \text { Yes }\end{array}$ $\begin{array}{lllllllllllllllll}\text { IPEAPAGPPDFGLFLSDDDPK } & 1.00 & 56.64 & 27.37 & 21.86 & 3 & 2572.2985 & 2572.2941 & 858.4386 & 0.0044 & 1.7085 & 39.405 & 40.494 & 82.470 & 60.227 & \text { Yes }\end{array}$

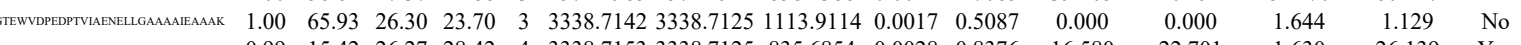

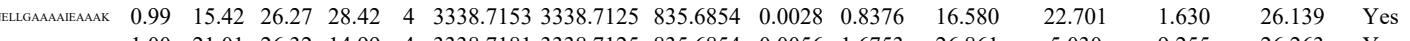
$\begin{array}{lllllllllllll}\text { NFIQAILTSLIEK } & 1.00 & 21.01 & 26.32 & 14.99 & 4 & 3338.7181 & 3338.7125 & 835.6854 & 0.0056 & 1.6753 & 26.861 & 5.030 \\ \text { NFI } & 1.608 & 16.66 & 3 & 1777.0627 & 1777.0593 & 593.3604 & 0.0034 & 1.9100 & 93.945 & 84.957\end{array}$ $\begin{array}{llllllllllllllll}\text { NFIQAILTSLIEK } & 0.80 & 9.91 & 20.68 & 15.00 & 3 & 1777.0630 & 1777.0593 & 593.3604 & 0.0037 & 2.0786 & 162.217 & 109.620\end{array}$ $\begin{array}{llllllllllllllll}\text { HTLLPGCAQTAVRPGSPSTSTMR } & 1.00 & 27.50 & 24.08 & 19.53 & 3 & 2701.4728 & 2701.4707 & 901.4975 & 0.0021 & 0.7765 & 10.206 & 38.748\end{array}$ $\begin{array}{lllllllllllllll}\text { FITLLLPGGAQTAVRPGSPSTTMR } & 1.00 & 29.01 & 24.08 & 16.55 & 3 & 2701.4728 & 2701.4707 & 901.4975 & 0.0021 & 0.7765 & 28.186 & 23.584\end{array}$

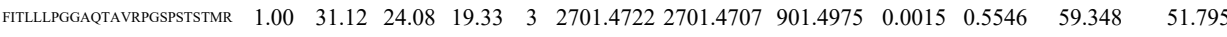

$\begin{array}{llllllllllllll}\text { NDSIIVDIFHGLFK } & 0.67 & 52.32 & 25.28 & 65.32 & 3 & 1905.0637 & 1905.0604 & 636.0274 & 0.0033 & 1.7295 & 1390.949 & 1113.395\end{array}$ $\begin{array}{lllllllllllll}\text { NDSIIVDIFHGLFK } & 1.00 & 40.13 & 25.33 & 16.77 & 3 & 1905.0640 & 1905.0604 & 636.0274 & 0.0036 & 1.8867 & 1320.283 & 1033.587\end{array}$ $\begin{array}{llllllllllllll}\text { IGNILDLCTALSALSGIPADK } & 0.67 & 24.52 & 25.21 & 37.52 & 3 & 2418.3139 & 2418.3106 & 807.1108 & 0.0033 & 1.3629 & 16.222 & 8.891\end{array}$ $\begin{array}{lllllllllllll}\text { IGNILDLCTALSALSGIPADK } & 0.60 & 30.60 & 25.25 & 43.60 & 3 & 2418.3148 & 2418.3106 & 807.1108 & 0.0042 & 1.7346 & 9.561 & 9.729\end{array}$ $\begin{array}{lllllllllllll}\text { IGNILDLCTALSALSGIPADK } & 1.00 & 51.16 & 25.28 & 16.31 & 3 & 2418.3112 & 2418.3106 & 807.1108 & 0.0006 & 0.2478 & 6.477 & 22.940 \\ \text { IGNILDLCTALSALSGIPADK } & 1.00 & 39.12 & 25.30 & 16.64 & 3 & 2418.3121 & 24183106 & 807.1108 & 0.0015 & 0.6195 & 4.482 & 6.332\end{array}$

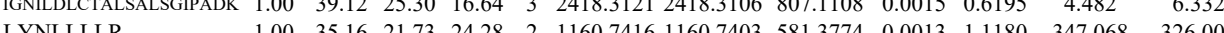

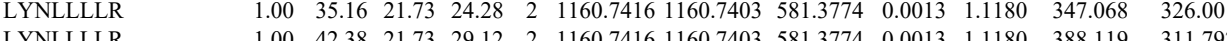
$\begin{array}{llllllllllll} & 1.00 & 42.38 & 21.73 & 29.12 & 2 & 1160.7416 & 1160.7403 & 581.3774 & 0.0013 & 1.1180 & 347.068\end{array}$

$\begin{array}{lllllllllllll} & \end{array}$ $\begin{array}{lllllllllllll}\text { VEFEELCADLFER } & 1.00 & 83.07 & 25.31 & 23.44 & 2 & 1788.8186 & 1788.8184 & 895.4165 & 0.0002 & 0.1117 & 165.349 & 21\end{array}$ $\begin{array}{lllllllllllll}\text { VEFEELCADLFER } & 1.00 & 85.45 & 25.34 & 20.10 & 2 & 1788.8190 & 1788.8184 & 895.4165 & 0.0006 & 0.3350 & 93.118\end{array}$ $\begin{array}{lllllllllllll}\text { TVLSANADHMAOIFLMDDVDFK } & 1.00 & 58.39 & 27.47 & 16.91 & 3 & 2807.3734 & 2807.3714 & 936.7977 & 0.0020 & 0.7116 & 37.275\end{array}$

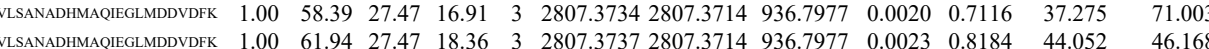
$\begin{array}{lllllllllllll}\text { TVLSANADHMAOIFGLMDDVDFK } & 1.00 & 19.57 & 27.47 & 32.57 & 4 & 2807.3773 & 2807.3714 & 702.8501 & 0.0059 & 2.0986 & 168.553 & 85.399\end{array}$ $\begin{array}{lllllllllllll}\text { VEFEELCADLFER } & 1.00 & 84.53 & 25.30 & 24.50 & 2 & 1788.8188 & 1788.8184 & 895.4165 & 0.0004 & 0.2234 & 286.615 & 395.326\end{array}$ $\begin{array}{lllllllllllll}\text { VEFEELCADLFER } & 1.00 & 88.31 & 25.34 & 24.94 & 2 & 1788.8194 & 1788.8184 & 895.4165 & 0.0010 & 0.5584 & 491.699 & 586.294\end{array}$ $\begin{array}{lllllllllll}1.00 & 88.31 & 25.34 & 24.94 & 2 & 1788.8194 & 1788.8184 & 895.4165 & 0.0010 & 0.5584 & 491.699\end{array}$ $\begin{array}{llllllllllll} & \end{array}$ $\begin{array}{lllllllllllll}\text { VEFEELCADLFER } & 1.00 & 94.23 & 25.49 & 24.16 & 2 & 1788.8214 & 1788.8184 & 895.4165 & 0.0030 & 1.6752 & 48.087 & 109.917\end{array}$ $\begin{array}{llllllllllllll}\text { NINADEAAAMGAVYQAAALSK } & 0.59 & 14.61 & 27.25 & 22.12 & 3 & 2238.1126 & 2238.1072 & 747.0430 & 0.0054 & 2.4095 & 3.044 & 5.302\end{array}$ $\begin{array}{lllllllllllll}\text { QADNPHVALYQAR } & 1.00 & 47.53 & 27.97 & 19.90 & 3 & 1625.8426 & 1625.8396 & 542.9538 & 0.0030 & 1.8418 & 5388.539 & 6548.412\end{array}$ $\begin{array}{lllllllllllll}\text { QADNPHVALYQAR } & 1.00 & 50.40 & 27.97 & 17.39 & 3 & 1625.8432 & 1625.8396 & 542.9538 & 0.0036 & 2.2101 & 5618.147 & 5678.822\end{array}$ $\begin{array}{lllllllllllll}\text { LSAASTWLEDEGVGATTVMLK } & 0.66 & 19.29 & 25.97 & 32.29 & 3 & 2466.2944 & 2466.2920 & 823.1046 & 0.0024 & 0.9719 & 24.167 & 71.426\end{array}$ $\begin{array}{lllllllllllll}\text { LSAASTWLEDEGVGATTVMLK } & 0.60 & 22.52 & 25.93 & 35.52 & 3 & 2466.2956 & 2466.2920 & 823.1046 & 0.0036 & 1.4579 & 37.298 & 17.962\end{array}$ $\begin{array}{lllllllllllll}\text { NINADEAAAMGAVYQAAALSK } & 1.00 & \text { \#\#\# } & 27.25 & 23.51 & 2 & 2366.2154 & 2366.2143 & 1184.1144 & 0.0011 & 0.4645 & 38.809 & 74.968 \\ \text { NINADEAAAMGAVYQAAALSK } & 0.67 & 13.07 & 27.19 & 26.07 & 3 & 2366.2177 & 2366.2143 & 789.7454 & 0.0034 & 1.4351 & 31.562 & 72.394\end{array}$ $\begin{array}{lllllllllllll}\text { NINADEAAAMGAVYQAAALSK } & 0.67 & 13.07 & 27.19 & 26.07 & 3 & 2366.2177 & 2366.2143 & 789.7454 & 0.0034 & 1.4351 & 31.562 & 72.394\end{array}$ $\begin{array}{lllllllllllll}\text { INADEAAAMGAVYQAAALSK } & 0.55 & 10.36 & 27.19 & 14.45 & 3 & 2366.2177 & 2366.2143 & 789.7454 & 0.0034 & 1.4351 & 1.1 .778 & 13.905 \\ \text { ISAASTWLEDEGVGATVMLK } & 1.00 & 63.62 & 25.94 & 18.24 & 3 & 2466.2950 & 2466.2920 & 823.1046 & 0.0030 & 1.2149 & 52.899 & 84.972\end{array}$ $\begin{array}{lllllllllllll}\text { VESVFETLVEDSAEEESTLTK } & 0.66 & 29.34 & 26.96 & 42.34 & 3 & 2629.3120 & 2629.3102 & 877.4440 & 0.0018 & 0.6838 & 2.791 & 1.590\end{array}$

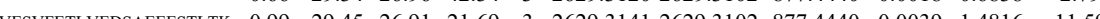




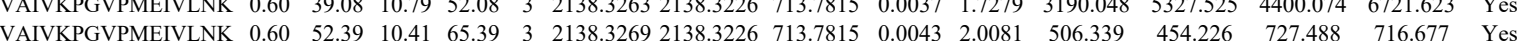

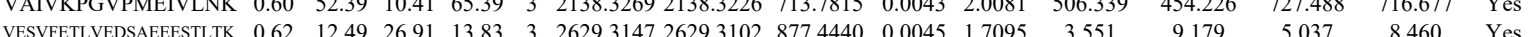

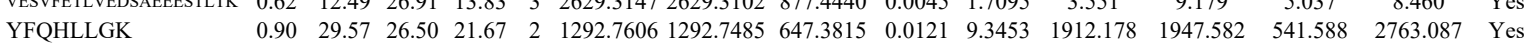

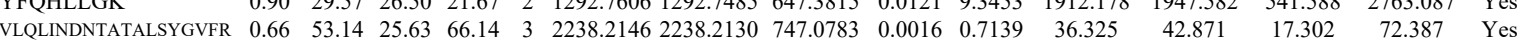

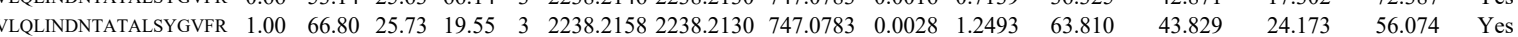

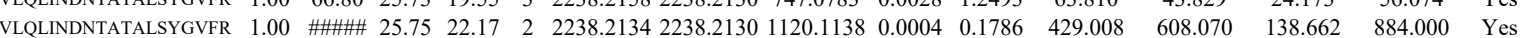

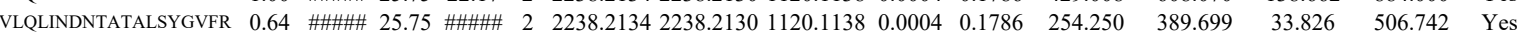
$\begin{array}{llllllllllllllll}\text { VLQLINDNTATALSYGVFR } & 1.00 & 55.73 & 25.65 & 17.80 & 3 & 2238.2152 & 2238.2130 & 747.0783 & 0.0022 & 0.9816 & 204.053 & 106.844 & 15.695 & 245.743 & \text { Yes }\end{array}$ $\begin{array}{lllllllllllllllll}\text { VLQLINDNTATALSYGVFR } & 0.66 & 31.68 & 25.65 & 44.68 & 3 & 2238.2152 & 2238.2130 & 747.0783 & 0.0022 & 0.9816 & 147.421 & 135.028 & 33.119 & 150.153 & \text { Yes }\end{array}$ $\begin{array}{llllllllllllllll}\text { VKPFVVR } & 0.84 & 18.40 & 20.41 & 31.40 & 2 & 1131.7390 & 1131.7372 & 566.8759 & 0.0018 & 1.5876 & 5588.615 & 8855.731 & 1112.440 & 8516.609 & \text { Yes }\end{array}$ $\begin{array}{llllllllllllllll}\text { VKPFVVR } & 0.72 & 17.36 & 20.13 & 30.36 & 2 & 1131.7406 & 1131.7372 & 566.8759 & 0.0034 & 2.9989 & 6965.801 & 11019.466 & 869.973 & 9589.086 & \text { Yes }\end{array}$ $\begin{array}{llllllllllllllllll}\text { VLQLINDNTATALSYGVFR } & 1.00 & 44.74 & 25.80 & 18.49 & 3 & 2238.2113 & 2238.2130 & 747.0783 & -0.0017 & -0.7585 & 272.335 & 215.718 & 84.700 & 349.381 & \text { Yes }\end{array}$

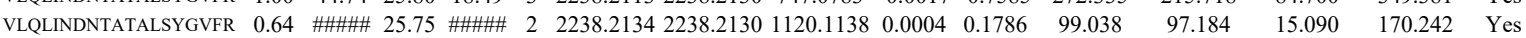

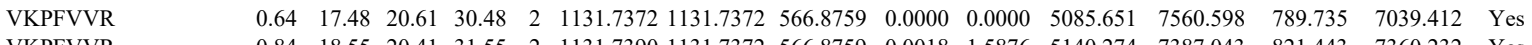

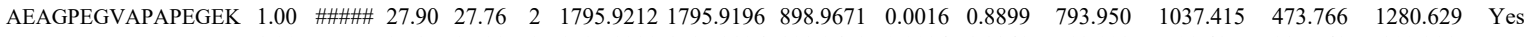

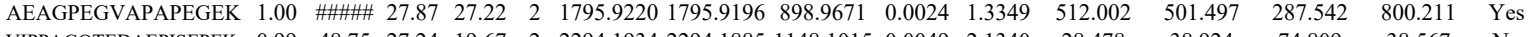

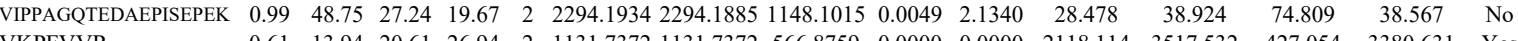
$\begin{array}{llllllllllllllll}\text { VKPFVVR } & 0.61 & 13.94 & 20.61 & 26.94 & 2 & 1131.7372 & 1131.7372 & 566.8759 & 0.0000 & 0.0000 & 2118.114 & 3517.532 & 427.054 & 3380.631 & \text { Yes }\end{array}$

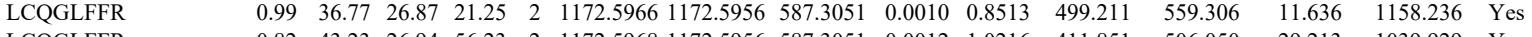
$\begin{array}{lllllllllllllll} & & 0 & \end{array}$ \begin{tabular}{llllllllllllllll} 
& 0.98 & 35.37 & 26.79 & 16.11 & 2 & 1172.5960 & 1172.5956 & 587.3051 & 0.0004 & 0.3405 & 162.224 & 202.029 & 10.529 & 355.777 & Yes \\
\hline
\end{tabular}

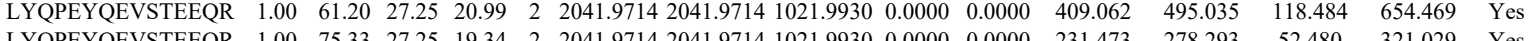

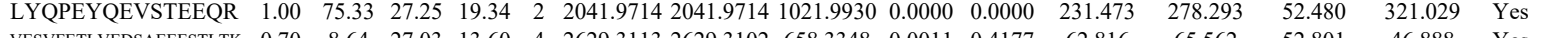

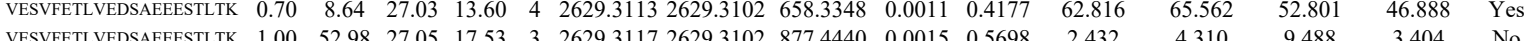

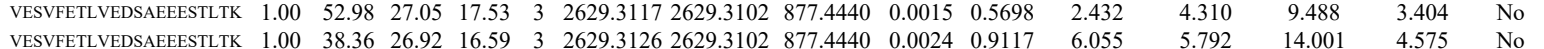

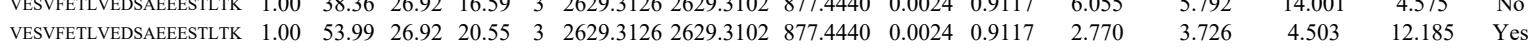

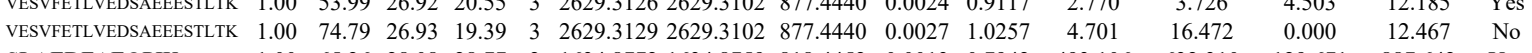

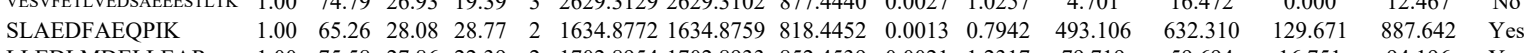
$\begin{array}{lllllllllllllllll}\text { LLEDLMDELLEAR } & 1.00 & 75.58 & 27.86 & 22.39 & 2 & 1702.8954 & 1702.8933 & 852.4539 & 0.0021 & 1.2317 & 79.719 & 59.694 & 16.751 & 94.196 & \text { Yes }\end{array}$ $\begin{array}{lllllllllllll} & \end{array}$ $\begin{array}{lllllllllllllllll}\text { AMEAVLTGLVEAALGPEVISR } & 0.67 & 58.19 & 25.16 & 71.19 & 3 & 2269.2502 & 2269.2473 & 757.4230 & 0.0029 & 1.2763 & 11.271 & 49.150 & 7.487 & 8.827 & \text { No }\end{array}$

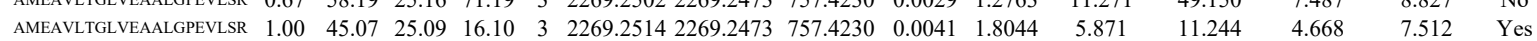

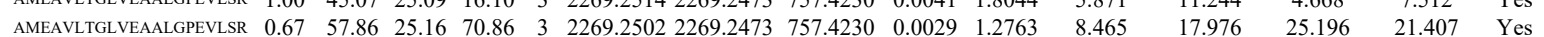

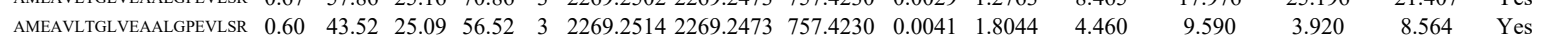
$\begin{array}{llllllllllllllll}\text { VLQAVVDLLGGLDSSVSFVSSVLGGK } & 1.00 & 91.55 & 21.34 & 21.74 & 3 & 2919.6163 & 2919.6161 & 974.2126 & 0.0002 & 0.0684 & 9.390 & 0.997 & 1.662 & 10.555 & \text { No }\end{array}$

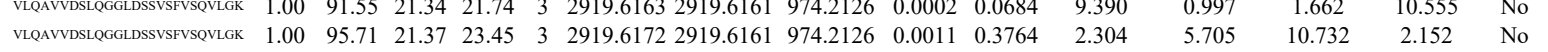
$\begin{array}{lllllllllllllllll}\text { LLFLQSR } & 0.97 & 34.45 & 27.80 & 28.70 & 2 & 1019.6250 & 1019.6249 & 510.8197 & 0.0001 & 0.0979 & 897.889 & 997.393 & 335.231 & 2681.377 & \text { No }\end{array}$ $\begin{array}{llllllllllllllll}\text { FNSVAGHFFFPLLQR } & 1.00 & 48.64 & 27.19 & 16.86 & 3 & 1923.0289 & 1923.0277 & 642.0165 & 0.0012 & 0.6230 & 165.719 & 153.085 & 72.755 & 213.582 & \text { Yes }\end{array}$ $\begin{array}{llllllllllllllllll}\text { FNSVAGHFFFPLLQR } & 1.00 & 45.72 & 27.20 & 17.48 & 3 & 1923.0298 & 1923.0277 & 642.0165 & 0.0021 & 1.0903 & 338.715 & 272.134 & 133.456 & 289.302 & \text { Yes }\end{array}$ $\begin{array}{llllllllllllllll}\text { QGLLSAVSSVLLSLPAAR } & 0.66 & 35.53 & 19.19 & 48.53 & 3 & 1925.1448 & 1925.1431 & 642.7216 & 0.0017 & 0.8817 & 9.729 & 11.709 & 10.667 & 7.552 & \text { Yes }\end{array}$ $\begin{array}{llllllllllllllll}\text { QGLLSAVSSVLLSLPAAR } & 0.66 & 48.37 & 19.19 & 61.37 & 3 & 1925.1451 & 1925.1431 & 642.7216 & 0.0020 & 1.0373 & 9.836 & 12.679 & 5.204 & 10.924 & \text { Yes }\end{array}$ $\begin{array}{lllllllllllllllll}\text { QGLLSAVSSVLLSLPAAR } & 1.00 & 40.28 & 19.40 & 16.62 & 3 & 1925.1445 & 1925.1431 & 642.7216 & 0.0014 & 0.7261 & 20.332 & 12.788 & 22.783 & 8.260 & \text { Yes }\end{array}$ $\begin{array}{llllllllllllllll}\text { QGLLSAVSSVLLSLPAAR } & 0.84 & 94.82 & 19.19 & \text { \#\#\# } & 2 & 1925.1448 & 1925.1431 & 963.5788 & 0.0017 & 0.8821 & 6.025 & 13.363 & 6.804 & 6.793 & \text { Yes }\end{array}$ $\begin{array}{llllllllllllllll}\text { QGLLSAVSSVLLSLPAAR } & 0.66 & 36.29 & 19.19 & 49.29 & 3 & 1925.1454 & 1925.1431 & 642.7216 & 0.0023 & 1.1928 & 8.222 & 9.445 & 13.030 & 5.631 & \text { Yes }\end{array}$

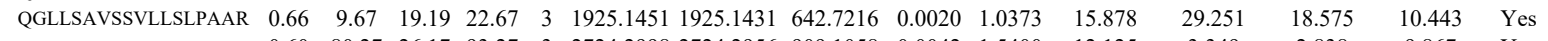

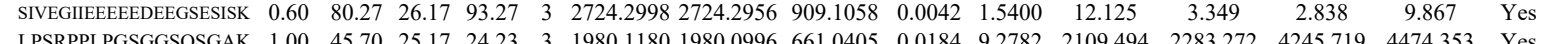
$\begin{array}{lllllllllllllllll}\text { LPSRPPLPGSGGSQSGAK } & 1.00 & 45.70 & 25.17 & 24.23 & 3 & 1980.1180 & 1980.0996 & 661.0405 & 0.0184 & 9.2782 & 2109.494 & 2283.272 & 4245.719 & 4474.353 & \text { Yes }\end{array}$ $\begin{array}{lllllllllllllllll}\text { LPSRPPLPGSGGSQSGAK } & 1.00 & 44.37 & 25.17 & 17.73 & 3 & 1980.1180 & 1980.0996 & 661.0405 & 0.0184 & 9.2782 & 1684.646 & 1775.302 & 2972.780 & 3813.977 & \text { Yes }\end{array}$

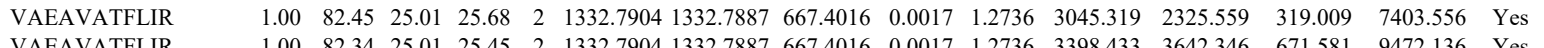

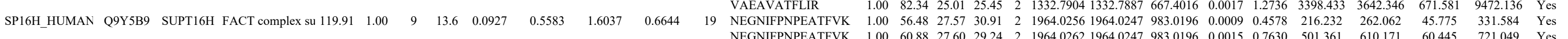

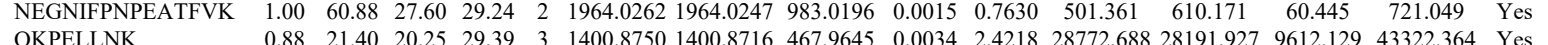

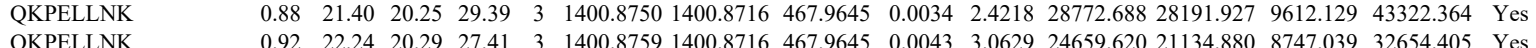
$\begin{array}{lllllllllllll} & \end{array}$ 

$\begin{array}{lllllllllllllll}\text { AGAGPGGPPQKPAPSSQR } & 1.00 & 31.79 & 26.73 & 18.63 & 4 & 1947.0553 & 1947.0530 & 487.7705 & 0.0023 & 1.1788 & 70.835 \\ \end{array}$ $\begin{array}{lllllllllllll}\text { AGAGPGGPPQKPAPSSQR } & 0.97 & 13.62 & 26.70 & 15.08 & 4 & 1947.0569 & 1947.0530 & 487.7705 & 0.0039 & 1.9989 & 57.103 \\ \text { AGAGPGGPPQKPAPSSQR } & 1.00 & 60.49 & 26.82 & 17.11 & 3 & 1947.0541 & 1947.0530 & 650.0249 & 0.0011 & 0.5641 & 440.541\end{array}$ $\begin{array}{lllllllllllll}\text { AGAGPGGPQKPAPSSQR } & 1.00 & 53.54 & 26.75 & 17.79 & 3 & 1947.0550 & 1947.0530 & 650.0249 & 0.0020 & 1.0256 & 858.864\end{array}$ $\begin{array}{lllllllllllll}\text { AGAGPGGPPQKPAPSSQR } & 1.00 & 19.27 & 26.75 & 14.79 & 4 & 1947.0557 & 1947.0530 & 487.7705 & 0.0027 & 1.3838 & 97.321 \\ & & \end{array}$ $\begin{array}{lllllllllllll}\text { AGAGPGGPPQKPAPSSQR } & 1.00 & 41.09 & 26.79 & 22.05 & 4 & 1947.0537 & 1947.0530 & 487.7705 & 0.0007 & 0.3588 & 56.973 \\ \text { (n) }\end{array}$ $\begin{array}{llllllllllllll}\text { AGAGPGGPPQKPAPSSQR } & 1.00 & 25.55 & 26.79 & 16.07 & 4 & 1947.0537 & 1947.0530 & 487.7705 & 0.0007 & 0.3588 & 39.977 & 35\end{array}$

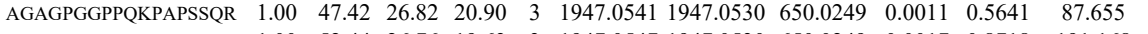
$\begin{array}{llllllllllllll}\text { AGAGPGGPPQKPAPSSQR } & 1.00 & 52.44 & 26.76 & 19.63 & 3 & 1947.0547 & 1947.0530 & 650.0249 & 0.0017 & 0.8718 & 191.168\end{array}$

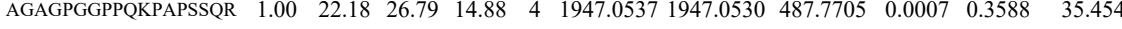
$\begin{array}{lllllllllllll}\text { AGAGPGGPPQKPAPSSQR } & 0.55 & 55.23 & 26.79 & 68.23 & 3 & 1947.0544 & 1947.0530 & 650.0249 & 0.0014 & 0.7179 & 120.741 \\ \text { AGAGPGGPPOKPAPSSQR } & 0.66 & 47.12 & 26.76 & 60.12 & 3 & 1947.0547 & 1947.0530 & 650.0249 & 0.0017 & 0.8718 & 122.042\end{array}$ $\begin{array}{lllllllllllll}\text { AGAGPGGPPQKPAPSSQR } & 0.66 & 47.12 & 26.76 & 60.12 & 3 & 1947.0547 & 1947.0530 & 650.0249 & 0.0017 & 0.8718 & 122.042 \\ \text { AGAGPGGPQKPAPSSOR } & 1.00 & 19.78 & 26.76 & 32.78 & 4 & 1947.0549 & 1947.0530 & 487.7705 & 0.0019 & 0.9738 & 43.488\end{array}$ $\begin{array}{llllllllllll}\text { AGAGPGGPPQKPAPSSQR } & 1.00 & 19.78 & 26.76 & 32.78 & 4 & 1947.0549 & 1947.0530 & 487.7705 & 0.0019 & 0.9738 & 43.488 \\ \text { AGAGPGGPQKPAPSSOR } & 0.92 & 12.28 & 26.79 & 18.58 & 4 & 1947.0537 & 1947.0530 & 487.7705 & 0.0007 & 0.3588 & 32.002\end{array}$ $\begin{array}{llllllllllll}\text { AGAGPGGPPQKPAPSSQR } & 0.92 & 12.28 & 26.79 & 18.58 & 4 & 1947.0537 & 1947.0530 & 487.7705 & 0.0007 & 0.3588 & 32.002 \\ \text { AGAGPGGPQKPAPSSQR } & 0.98 & 26.29 & 26.82 & 18.03 & 3 & 1947.0541 & 1947.0530 & 650.0249 & 0.0011 & 0.5641 & 23.667\end{array}$ $\begin{array}{lllllllllllll}\text { AGAGPGGPPKPAPSSQR } & 0.98 & 26.29 & 26.82 & 18.03 & 3 & 1947.0541 & 1947.0530 & 650.0249 & 0.0011 & 0.5641 & 23.667 \\ \text { AGAGPGGPPKPAPSSQR } & 0.55 & 56.07 & 26.79 & 69.07 & 3 & 1947.0544 & 1947.0530 & 650.0249 & 0.0014 & 0.7179 & 66.664\end{array}$

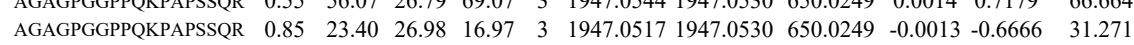
$\begin{array}{llllllllllllll} & & 16.34 & 3 & 1947.0532 & 1947.0530 & 650.0249 & 0.0002 & 0.1026 & 49.357\end{array}$

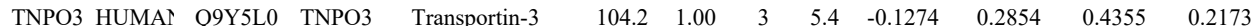

$\begin{array}{lllllllllll}\text { NCOR2_HUMAl Q9Y618 } & \text { NCOR2 } & \text { Nuclear receptor c } 274.8 & 1.00 & 2 & 1.5 & -0.7283 & 1.2163 & -0.4803 & 1.1968\end{array}$

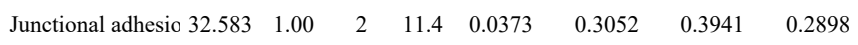

COPG_HUMAN Q9Y678 COPG

atomer subunit $97.718 \quad 1.00$ $\begin{array}{lllllllllllllll}\text { TGNFISTSTSLPR } & 1 & 1.00 & 66.28 & 27.90 & 27.37 & 2 & 1523.8198 & 1523.8066 & 762.9106 & 0.0132 & 8.6510 & 64.506\end{array}$

$\begin{array}{lrllllllllll}\text { TGNFISTSTSLPR } & 1.00 & 66.28 & 27.90 & 27.37 & 2 & 1523.8198 & 1523.8066 & 762.9106 & 0.0132 & 8.6510 & 649.506 \\ \text { AMMNVTGVTSLTFNPTTELAAASEK } & 1.00 & 79.61 & 21.79 & 24.13 & 3 & 3121.7182 & 3121.7188 & 1041.5802 & -0.0006 & -0.1920 & 3.478\end{array}$

$\begin{array}{lllllllllllll}\text { SLDSFLLSPEAAVGLLK } & 1.00 & 59.24 & 21.76 & 23.03 & 3 & 2047.1851 & 2047.1809 & 683.4009 & 0.0042 & 2.0486 & 209.089\end{array}$ $\begin{array}{lllllllllllll}\text { SLDSFLLSPEAAVGLK } & 0.67 & 33.36 & 21.76 & 46.36 & 3 & 2047.1839 & 2047.1809 & 683.4009 & 0.0030 & 1.4633 & 75.832\end{array}$ $\begin{array}{llllllllllllll}\text { LLALLFEVLQQDK } & 0.60 & 16.43 & 18.63 & 29.43 & 3 & 1817.0950 & 1817.0906 & 606.7041 & 0.0044 & 2.4174 & 85.408\end{array}$ $\begin{array}{lllllllllllll}\text { LLALLFEVLQQDK } & 0.99 & 21.37 & 18.75 & 18.32 & 3 & 1817.0938 & 1817.0906 & 606.7041 & 0.0032 & 1.7581 & 177.934\end{array}$ $\begin{array}{llllllllllllll}\text { SQVVIPLQWAIASTTLDHR } & 0.66 & 50.93 & 22.65 & 63.93 & 3 & 2391.3412 & 2391.3396 & 798.1205 & 0.0016 & 0.6682 & 8.022\end{array}$ $\begin{array}{lllllllllllll}\text { SQVVIPILQWAIASTTLDHR } & 0.66 & 49.67 & 22.58 & 62.67 & 3 & 2391.3418 & 2391.3396 & 798.1205 & 0.0022 & 0.9188 & 4.406\end{array}$ $\begin{array}{llllllllllll}\text { SQQQQQQQQQQQQQQQQQQPMPR } & 1.00 & 81.95 & 26.48 & 19.69 & 3 & 2907.3895 & 2907.3876 & 970.1365 & 0.0019 & 0.6528 & 0.000\end{array}$ $\begin{array}{llllllllllllll}\text { SQQQQQQQQQQQQQQQQQPMPR } & 1.00 & 86.11 & 26.50 & 19.32 & 3 & 2907.3904 & 2907.3876 & 970.1365 & 0.0028 & 0.9621 & 0.000 \\ \text { SRPGTASSSGGSIAR } & 0.98 & 32.10 & 28.14 & 23.04 & 2 & 1533.7988 & 1533.7981 & 767.9063 & 0.0007 & 0.4558 & 24.601\end{array}$ $\begin{array}{lllllllllllll}\text { SRPGTASSSGGSIAR } & 0.95 & 28.21 & 28.14 & 18.59 & 2 & 1533.7988 & 1533.7981 & 767.9063 & 0.0007 & 0.4558 & 14.107\end{array}$ $\begin{array}{lllllllllllll}\text { SRPGTASSSGGSIAR } & 1.00 & 78.18 & 28.13 & 25.17 & 3 & 1533.7999 & 1533.7981 & 512.2733 & 0.0018 & 1.1712 & 39.906\end{array}$ $\begin{array}{llllllllllllll}\text { SRPGTASSSGGSIAR } & 1.00 & 62.88 & 28.13 & 28.45 & 3 & 1533.7999 & 1533.7981 & 512.2733 & 0.0018 & 1.1712 & 27.942\end{array}$ $\begin{array}{llllllllllllll}\text { SRPGTASSSGGSIAR } & 0.99 & 38.70 & 28.14 & 27.27 & 2 & 1533.7988 & 1533.7981 & 767.9063 & 0.0007 & 0.4558 & 11.381\end{array}$ $\begin{array}{lllllllllllll}\text { SRPGTASSSGGSIAR } & 1.00 & 41.71 & 28.17 & 23.62 & 3 & 1533.7996 & 1533.7981 & 512.2733 & 0.0015 & 0.9760 & 17.471\end{array}$ $\begin{array}{lllllllllllll}\text { SRPGTASSSGGSIAR } & 1.00 & 47.98 & 28.13 & 22.37 & 3 & 1533.7999 & 1533.7981 & 512.2733 & 0.0018 & 1.1712 & 12.070\end{array}$ $\begin{array}{lllllllllllll}\text { SRPGTASSSGGSIAR } & 0.99 & 36.30 & 28.12 & 24.87 & 2 & 1533.8000 & 1533.7981 & 767.9063 & 0.0019 & 1.2371 & 0.000\end{array}$

VTFLPTGITFK

VTFLPTGITFK

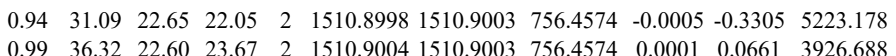
$\begin{array}{llllllllllll}0.99 & 36.32 & 22.60 & 23.67 & 2 & 1510.9004 & 1510.9003 & 756.4574 & 0.0001 & 0.0661 & 3926.688 & 41 \\ 0.99 & 29.50 & 22.55 & 22.12 & 2 & 1510.9014 & 1510.9003 & 756.4574 & 0.0011 & 0.7271 & 805.662 & 98\end{array}$

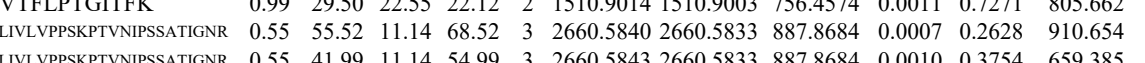
$\begin{array}{lllllllllllll}\text { LIVLVPPSKPTVNIPSSATIGNR } & 0.55 & 41.99 & 11.14 & 54.99 & 3 & 2660.5843 & 2660.5833 & 887.8684 & 0.0010 & 0.3754 & 659.385 \\ \text { LIVLVPSSPTVNIPSSATIGNR } & 1.00 & 4.40 & 10.79 & 17.40 & 4 & 2660.5857 & 2660.5833 & 666.1531 & 0.0024 & 0.9007 & 1052.574\end{array}$ $\begin{array}{llllllllllllll}\text { LIVLVPPSKPTVNIPSATIGNR } & 0.66 & 53.00 & 10.79 & 66.00 & 3 & 2660.5852 & 2660.5833 & 887.8684 & 0.0019 & 0.7133 & 237.326\end{array}$ $\begin{array}{llllllllllll}\text { LVVLVPSKPTVNIPSSATIGNR } & 0.66 & 48.04 & 10.79 & 61.04 & 3 & 2660.5855 & 2660.5833 & 887.8684 & 0.0022 & 0.8259 & 239.150 \\ \text { CVMDDDDNEVR } & 0.82 & 53.32 & 17.16 & 6.32 & 2 & 1384.5552 & 1384.5543 & 693.2844 & 0.0009 & 0.6491 & 292.836 \\ \text { CVMDDDNER } & 0.84 & 62.29 & 17.40 & 75.29 & 2 & 13845564 & 13845543 & 93.2844 & 0.0021 & 1.5145 & 251.489\end{array}$ 

$\begin{array}{llllllllllllll}\text { QEIFQEQLAAVPEFR } & 1.00 & 88.65 & 27.66 & 23.48 & 2 & 1948.0186 & 1948.0176 & 975.0161 & 0.0010 & 0.5128 & 284.809 & 192.931 & 34.4\end{array}$ $\begin{array}{lllllllllllll}\text { QEIFQEQLAAVPEFR } & 1.00 & 61.94 & 27.59 & 27.39 & 3 & 1948.0198 & 1948.0176 & 650.3465 & 0.0022 & 1.1276 & 173.934 & 194.153\end{array}$ $\begin{array}{lllllllllllll}\text { AIVDCIISIIEENSESK } & 0.98 & 25.98 & 27.75 & 20.39 & 3 & 2196.1297 & 2196.1261 & 733.0493 & 0.0036 & 1.6370 & 17.389 & 9.124\end{array}$ $\begin{array}{llllllllllll}\text { EMSCIAEDVIIVTSSLTK } & 0.99 & 26.77 & 27.29 & 15.80 & 3 & 2272.1629 & 2272.1608 & 758.3942 & 0.0021 & 0.9230 & 16.922\end{array}$ $\begin{array}{lllllllllllll}\text { AIVDCIISIIEENSESK } & 0.99 & 27.98 & 27.80 & 19.62 & 3 & 2196.1282 & 2196.1261 & 733.0493 & 0.0021 & 0.9549 & 57.340\end{array}$ $\begin{array}{lllllllllllll}\text { AIVDCIISIIEENSESK } & 0.98 & 26.70 & 27.75 & 17.73 & 3 & 2196.1297 & 2196.1261 & 733.0493 & 0.0036 & 1.6370 & 45.921\end{array}$

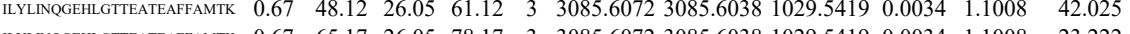
$\begin{array}{lllllllllllll} & \text { MYLNQGEHLGTIEATEAFFAMTK } & 0.67 & 65.17 & 26.05 & 78.17 & 3 & 3085.6072 & 3085.6038 & 1029.5419 & 0.0034 & 1.1008 & 23.222\end{array}$ $\begin{array}{llllllllllll} & \end{array}$

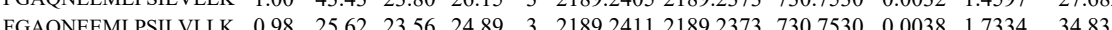

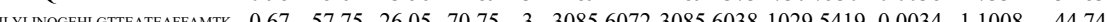
$\begin{array}{lllllllllllllll} & 0.745\end{array}$ FGAQNEEMLPSILVLLK $\begin{array}{lllllllllllll}0.98 & 22.18 & 23.89 & 19.82 & 3 & 2189.2396 & 2189.2373 & 730.7530 & 0.0023 & 1.0491 & 74.365\end{array}$

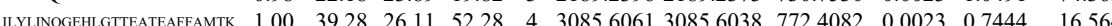

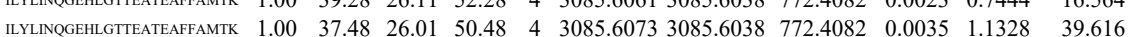
$\begin{array}{llllllllllllll}\text { VPSVSSSALVSSLHLLK } & 1.00 & 86.99 & 18.51 & 24.40 & 3 & 2011.1983 & 2011.1921 & 671.4046 & 0.0062 & 3.0781 & 877.953 & 1127 . & \end{array}$ $\begin{array}{lllllllllllllll} & \end{array}$ $\begin{array}{llllllllllllllllll}\text { VPSVSSSALVSSLHLLK } & 1.00 & 87.92 & 18.57 & 22.89 & 3 & 2011.1959 & 2011.1921 & 671.4046 & 0.0038 & 1.8866 & 1063.116 & 1505.404 & 2252.177 & 2111.736 & \text { Y }\end{array}$ $\begin{array}{llllllllllllllll}\text { VPSSSALVSSLHLLK } & 1.00 & \text { \#\#\#\# } & 18.57 & 25.13 & 3 & 2011.1965 & 2011.1921 & 671.4046 & 0.0044 & 2.1845 & 1627.675 & 1427.243 & 1744.756 & 1762.581 & \text { Yes } \\ \text { VPSVSSALVSSLHLLK } & 1.00 & 88.96 & 18.39 & 21.00 & 3 & 2011.1944 & 2011.1921 & 671.4046 & 0.0023 & 1.1419 & 961.253 & 1031.965 & 1267.099 & 1434.262 & \text { Yes }\end{array}$ \begin{tabular}{lllllllllllllllll} 
VPSVSSSALVSSLHLLK & 1.00 & 85.39 & 18.39 & 18.57 & 3 & 2011.1944 & 2011.1921 & 671.4046 & 0.0023 & 1.1419 & 1467.897 & 1125.741 & 1724.021 & 1942.282 & Yes \\
\hline
\end{tabular} $\begin{array}{llllllllllllllll}\text { ALNAGYILNGLTVSIPGLER } & 0.60 & 7.69 & 23.64 & 20.69 & 3 & 2214.2524 & 2214.2494 & 739.0904 & 0.0030 & 1.3530 & 14.726 & 20.872 & 5.017 & 21.206 & \text { Yes } \\ \end{array}$

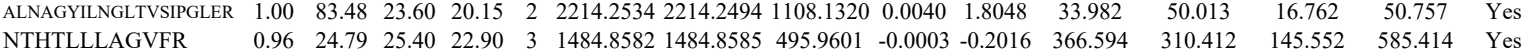

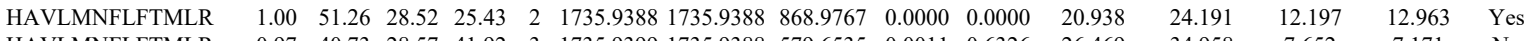
$\begin{array}{lllllllllllllllll}\text { HAVLMNFLFTMLR } & 0.97 & 40.73 & 28.57 & 41.92 & 3 & 1735.9399 & 1735.9388 & 579.6535 & 0.0011 & 0.6326 & 26.469 & 34.958 & 7.652 & 7.171 & \text { No }\end{array}$ \begin{tabular}{llllllllllllllll} 
HAVLMNFLFTMLR & 1.00 & 52.62 & 28.38 & 24.94 & 2 & 1735.9408 & 1735.9388 & 868.9767 & 0.0020 & 1.1508 & 40.882 & 23.089 & 11.813 & 25.455 & Yes \\
\hline
\end{tabular}

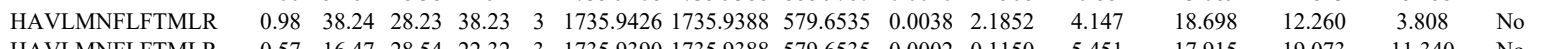

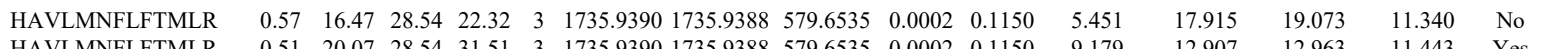

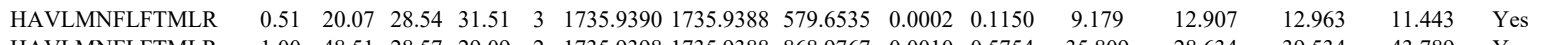

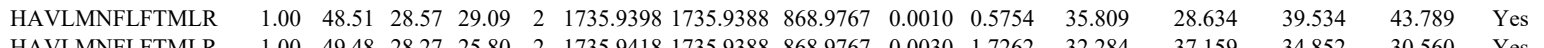

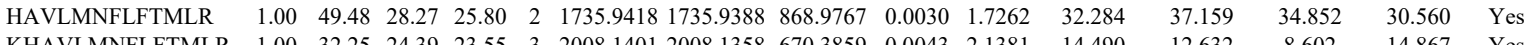

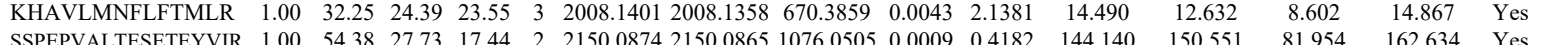

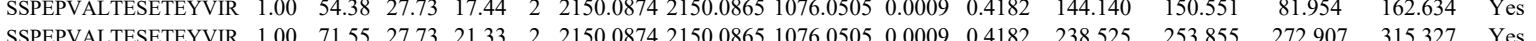

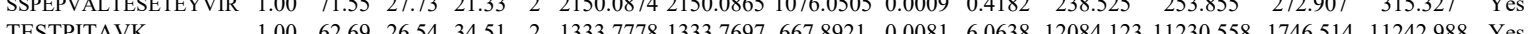
$\begin{array}{llllllllllllllllllll} & \text { IESTPITAVK } & 1.00 & 62.69 & 26.54 & 34.51 & 2 & 133.08748 & 1333.7697 & 667.8921 & 0.0081 & 6.0638 & 12084.123 & 11230.558 & 1746.514 & 11242.988 & \text { Yes }\end{array}$ $\begin{array}{lllllllllllllll}1.00 & 61.66 & 26.62 & 30.64 & 2 & 1333.7784 & 1333.7697 & 667.821 & 0.0087 & 6.5130 & 17189.187 & 15362.238 & 2243.738 & 18155.447 & \text { Yes } \\ 1.00 & 61.38 & 28.03 & 25.77 & 2 & 1878.9730 & 1878.9715 & 940.4930 & 0.0015 & 0.7975 & 8.322 & 11.719 & 11.575 & 15.309 & \text { Yes }\end{array}$

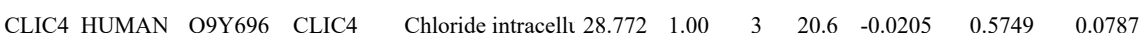

$\begin{array}{lllllllllll}\text { SAR1B_HUMAI } & \text { Q9Y6B6 } & \text { SAR1B } & \text { GTP-binding prot } 22.41 & 1.00 & 3 & 36.9 & 0.0927 & 0.6170 & 0.2508 & 0.7890\end{array}$

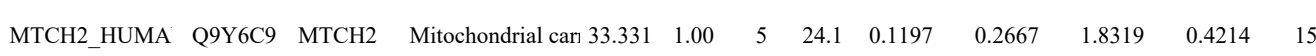

EEFLEEVLCPPK

IEEFLEEVLCPPK

IEEFLEEVVLCPPK

IEEFLEEVLCPPK

IEEFLEEVLCPPK

IEEFLEEVLCPPK

IEEFLEEVLCPPK

FLDGNEMTLADCNLLP

LDEYLNSPLPDEIDENSMEDIK

LDEYLNSPLPDEIDENSMEDIK

EELDSLMTDETIANVPLILLG

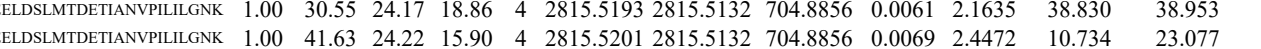
$\begin{array}{llllllllllllll}\text { EELDSLMTDETIANVPILILGNK } & 1.00 & 67.60 & 24.44 & 18.26 & 3 & 2815.5139 & 2815.5132 & 939.5117 & 0.0007 & 0.2484 & 18.652 & 16.325\end{array}$ $\begin{array}{lllllllllllll}\text { NYLPAINGIVFLVDCADHER } & 1.00 & 58.17 & 27.66 & 18.10 & 3 & 2448.2086 & 2448.2052 & 817.0757 & 0.0034 & 1.3871 & 6.632 & 7.437\end{array}$ IDRPEAISEER

EEGILGFFAGLVPR EEGILGFFAGLVPR LCSGVLGTVVHGK LCSGVLGTVVHGK LCSGVGTVHK LCSGVLGTVVHGK LCSGVLGTVVHGK $\begin{array}{lllllllllll} & \end{array}$ $\begin{array}{lllllllllllll}1.00 & 63.34 & 28.12 & 27.91 & 2 & 1878.9742 & 18789715 & 940.4930 & 0.0027 & 1.4354 & 10.603 & 19.259\end{array}$ $\begin{array}{lllllllllllll}1.00 & 46.39 & 28.18 & 24.28 & 3 & 1878.9745 & 1878.9715 & 627.3311 & 0.0030 & 1.5941 & 45.396 & 56.128\end{array}$ $\begin{array}{llllllllllll}1.00 & 31.57 & 28.18 & 22.50 & 3 & 1878.9745 & 1878.9715 & 627.3311 & 0.0030 & 1.5941 & 56.125 & 70.167\end{array}$ $\begin{array}{llllllllllll}1.00 & 56.48 & 28.10 & 24.82 & 2 & 1878.9746 & 1878.9715 & 940.4930 & 0.0031 & 1.6481 & 8.653 & 4.688\end{array}$ $\begin{array}{llllllllllllll}0.81 & 16.48 & 28.12 & 20.28 & 3 & 1878.9736 & 1878.9715 & 627.3311 & 0.0021 & 1.1158 & 100.946 & 83.266 \\ 1.00 & 32.59 & 28.10 & 20.51 & 3 & 1878.9748 & 187.9715 & 27.3311 & 0.0033 & 1.7535 & 124.848 & 126.355\end{array}$ $\begin{array}{llllllllllll}0 & 2.59 & 28.10 & 20.51 & 3 & 1878.9748 & 1878.9715 & 627.3311 & 0.0033 & 1.7535 & 124.848 \\ 0 & 69.48 & 27.97 & 63.35 & 3 & 2227.0963 & 2227.0930 & 743.3716 & 0.0033 & 1.4797 & 47.444\end{array}$ $\begin{array}{lllllllllll} & \end{array}$ $\begin{array}{llllllllllllll}1.00 & 37.35 & 27.64 & 23.14 & 3 & 1457.7619 & 1457.7596 & 486.9271 & 0.0023 & 1.5745 & 2070.464 & 2421.905\end{array}$ $\begin{array}{llllllllllll}1.00 & 39.08 & 27.06 & 19.51 & 3 & 1647.9130 & 1647.9106 & 550.3108 & 0.0024 & 1.4537 & 61.538 & 100.439 \\ 1.00 & 51.26 & 27.05 & 20.08 & 3 & 1647.9136 & 1647.9106 & 550.3108 & 0.0030 & 1.8172 & 96.022 & 70.809\end{array}$ $\begin{array}{rrrrrrrrrrrr}1.00 & 51.26 & 27.05 & 20.08 & 3 & 1647.9136 & 1647.9106 & 550.3108 & 0.0030 & 1.8172 & 96.022 & 70.809 \\ 1.00 & 43.04 & 27.98 & 18.86 & 3 & 1602.8848 & 1602.8830 & 535.3016 & 0.0018 & 1.1209 & 3988.571 & 3845.668\end{array}$ $\begin{array}{llllllllllll}1.00 & 43.04 & 27.98 & 18.86 & 3 & 1602.8848 & 1602.8830 & 535.3016 & 0.0018 & 1.1209 & 3988.571 & 3845.668 \\ 1.00 & 44.56 & 27.86 & 16.87 & 3 & 1602.8860 & 1602.8830 & 535.3016 & 0.0030 & 1.8681 & 2790.883 & 3686.409\end{array}$ $\begin{array}{lllllllllllll}0.67 & 45.11 & 27.86 & 58.11 & 3 & 1602.8860 & 1602.8830 & 535.3016 & 0.0030 & 1.8681 & 4493.340 & 5090.620\end{array}$ $\begin{array}{llllllllllllll}1.00 & 48.64 & 27.81 & 18.86 & 3 & 1602.8872 & 1602.8830 & 535.3016 & 0.0042 & 2.6153 & 6946.229 & 6876.025\end{array}$ $\begin{array}{lllllllllllll}1.00 & 40.02 & 27.75 & 20.22 & 3 & 1602.8875 & 1602.8830 & 535.3016 & 0.0045 & 2.8022 & 2356.982 & 2078.769 \\ 0.66 & 73.53 & 27.51 & 86.53 & 3 & 2492.2444 & 24922426 & 831.7548 & 0.0018 & 0.7214 & 111.494 & 103.331\end{array}$

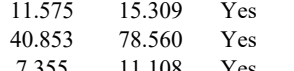

$\begin{array}{llll}7.355 & 11.108 & \text { Yes } \\ 7.677 & 22.884 & \text { Yes }\end{array}$

\begin{tabular}{lll}
78.676 & 72.884 & Yes \\
\hline & 76.353 & Yes
\end{tabular}

$2.651 \quad 17.170 \quad$ No $\begin{array}{lll}37.398 & 144.370 & \text { Yes }\end{array}$ $19.516 \quad 28.191 \quad$ No $\begin{array}{lll}19.160 & 27.153 & \text { Yes } \\ 19.487 & 38.292 & \text { Yes }\end{array}$ $\begin{array}{lll}4.328 & 19.422 & \text { Yes }\end{array}$ $\begin{array}{lll} & 0.000 & \text { No }\end{array}$ $\begin{array}{lll}3.996 & 49.672 & \text { Yes }\end{array}$ $\begin{array}{lll}113.189 & \text { Yes } \\ 1.395 & 133.163 & \text { Yes }\end{array}$ $\begin{array}{lll}1086.603 & \text { Ye }\end{array}$ $\begin{array}{llll}228.919 & 7232.208 & \mathrm{Yes} \\ & & \end{array}$ $\begin{array}{llll}288.536 & 7369.168 & \text { Yes }\end{array}$ 4284.589 Y 

$\begin{array}{lllllllllllllllll} & \end{array}$ $\begin{array}{lllllllllllllll} & \text { SAATCE }\end{array}$ \begin{tabular}{llllllllllllllll} 
& SAATLITAVR \\
\hline
\end{tabular}

$\begin{array}{llllllllll}\text { BIG2_HUMAN } & \text { Q9Y6D5 } & \text { ARFGEF2 Brefeldin A-inhibi 202.04 } & 1.00 & 4 & 2.2 & 0.2228 & 0.4353 & 0.7171 & 0.3760\end{array}$

$\begin{array}{llllllllll}\text { STK24_HUMAN Q9Y6E0 } & \text { STK24 } & \text { Serine/threonine-p } 49.308 & 1.00 & 3 & 12.4 & -0.0653 & 0.5924 & 1.6702 & 0.4169\end{array}$

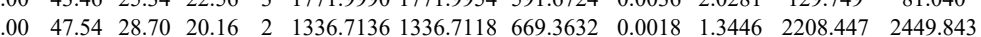
$\begin{array}{lllllllllllll}0.96 & 34.72 & 27.54 & 35.97 & 2 & 1031.5846 & 1031.5845 & 516.7995 & 0.0001 & 0.0967 & 92.335 & 154.643\end{array}$

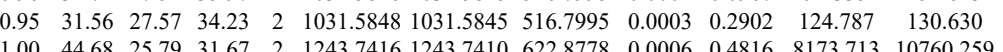
$\begin{array}{llllllllllll}1.00 & 44.68 & 25.79 & 31.67 & 2 & 1243.7416 & 1243.7410 & 622.8778 & 0.0006 & 0.4816 & 8173.713 & 10760.259\end{array}$

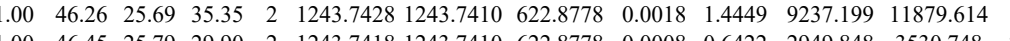
DTLVQGLNEAGDDLEAVAK $\begin{array}{lllllllllllll}0.82 & 24.78 & 24.38 & 37.78 & 2 & 1450.8618 & 1450.8612 & 726.4379 & 0.0006 & 0.4130 & 13.733 & 47.757 & 8.8 .2 \\ 0.82 & 26.83 & 24.38 & 39.83 & 2 & 1450.8618 & 1450.8612 & 726.4379 & 0.0006 & 0.4130 & 18.539 & 20.292 & 14.1\end{array}$

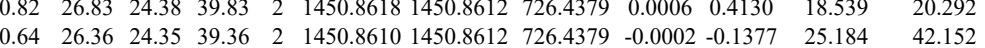
$\begin{array}{llllllllllll}0.82 & 24.57 & 24.35 & 37.57 & 2 & 1450.8622 & 1450.8612 & 726.4379 & 0.0010 & 0.6883 & 8.353 & 36.850\end{array}$ $\begin{array}{lllllllllllll}0.64 & 24.40 & 24.35 & 37.40 & 2 & 1450.8610 & 1450.8612 & 726.4379 & -0.0002 & -0.1377 & 16.515 & 22.632\end{array}$ $\begin{array}{lllllllllll}0.64 & 27.54 & 24.38 & 40.54 & 2 & 1450.8616 & 1450.8612 & 726.4379 & 0.0004 & 0.2753 & 29.565\end{array}$ $\begin{array}{llllllllllll}0.56 & 16.73 & 24.35 & 29.73 & 2 & 1450.8608 & 1450.8612 & 726.4379 & -0.0004 & -0.2753 & 7.026\end{array}$ $\begin{array}{lllllllllllll} & 2.87 & 15.05 & 15.87 & 4 & 3246.8829 & 3246.8757 & 812.7262 & 0.0072 & 2.2148 & 9.204 \\ & 0.65 & 12.65 & 27.61 & 25.65 & 3 & 2245.1704 & 2245.1681 & 749.3966 & 0.0023 & 1.0230 & 51.105\end{array}$ $\begin{array}{llllllllllll} & \end{array}$ $\begin{array}{lllllllllll} & 0.0006 & 0.4063 & 203.660\end{array}$ $\begin{array}{lllllllllllll}\text { QPPTAAGRPVDASPR } & 0.80 & 17.78 & 27.92 & 17.39 & 3 & 1662.8935 & 16628923 & 555.3047 & 0.0012 & 0.7203 & 192.042\end{array}$ $\begin{array}{llllllllllllllll}\text { AGATSEGVLANFFNSLISK } & 1.00 & 45.27 & 25.67 & 19.44 & 3 & 2213.1979 & 22131 & 1936 & 738.7385 & 0.0043 & 1.9402 & 255.344 & 36\end{array}$

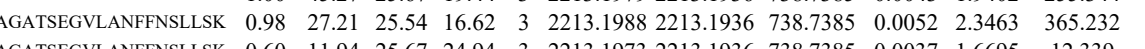
$\begin{array}{llllllllllll}\text { GATSEGVLANFFNSLLSK } & 0.60 & 11.94 & 25.67 & 24.94 & 3 & 2213.1973 & 2213.1936 & 738.7385 & 0.0037 & 1.6695 & 12.339 \\ \text { AEDNFEDITKKPPVR } & 0.96 & 22.38 & 27.07 & 16.76 & 3 & 2031.0901 & 2031.0880 & 678.0366 & 0.0021 & 1.0324 & 884.449\end{array}$

LGAAAPR TVLELVTQYR FISEFLQPNR

LTFPEQSVPGALQFR $\begin{array}{lllllllllll}0.96 & 22.38 & 27.07 & 16.76 & 3 & 2031.0901 & 2031.0880 & 678.0366 & 0.0021 & 1.0324 & 884.449 \\ 1.00 & 39.37 & 27.05 & 15.59 & 3 & 3004.5142 & 3004.5096 & 1002.5105 & 0.0046 & 1.5295 & 9.311\end{array}$ $\begin{array}{lllllllllll}0.66 & 20.75 & 22.04 & 27.58 & 2 & 798.4822 & 798.4834 & 400.2490 & -0.0012 & -1.4991 & 62.243\end{array}$ $\begin{array}{lllllllllll}0.65 & 20.50 & 22.04 & 28.72 & 2 & 798.4824 & 798.4834 & 400.2490 & -0.0010 & -1.2492 & 45.152\end{array}$ $\begin{array}{lllllllllllll}0.97 & 39.00 & 28.66 & 23.96 & 2 & 10625984 & 10625944 & 532.3045 & 0.0040 & 3.7572 & 9592.450 & 99.776\end{array}$ $\begin{array}{lllllllllllll}1.00 & 67.44 & 26.96 & 39.01 & 2 & 1364.7804 & 1364.7785 & 683.3965 & 0.0019 & 1.3901 & 3922.752 & 4722.174 \\ 1.00 & 62.50 & 28.22 & 29.36 & 2 & 1393.7490 & 1393.7476 & 697.8811 & 0.0014 & 1.0030 & 2240.850 & 2580.355\end{array}$ $\begin{array}{llllll}1.00 & 78.62 & 27.02 & 23.90 & 2 & 1832.9\end{array}$ $\begin{array}{llllllllllllllll}1.00 & 54.64 & 21.27 & 31.75 & 2 & 1069.6738 & 1069.6729 & 535.8437 & 0.0009 & 0.8398 & 1681.668 & 2132.164 & 81.486 & 1958.397 & \text { Yes }\end{array}$

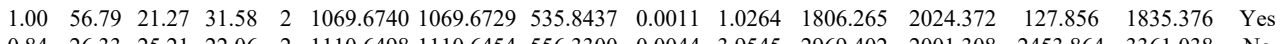

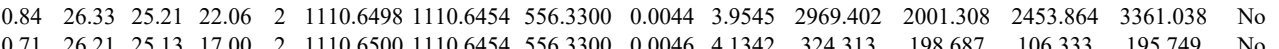
$\begin{array}{lllllllllllllll}0.71 & 26.21 & 25.13 & 17.00 & 2 & 1110.6500 & 1110.6454 & 556.3300 & 0.0046 & 4.1342 & 324.313 & 198.687 & 106.333 & 195.749 & \text { No } \\ 1.00 & 51.94 & 21.27 & 30.08 & 2 & 1069.6742 & 1069.6729 & 535.8437 & 0.0013 & 1.2130 & 2072.845 & 2335.577 & 93.671 & 2150.644 & \text { Yes }\end{array}$ $\begin{array}{llllllllllllllll}1.00 & 51.94 & 21.27 & 30.08 & 2 & 1069.6742 & 1069.6729 & 535.8437 & 0.0013 & 1.2130 & 2072.845 & 2335.577 & 93.671 & 2150.644 & \text { Yes } \\ 1.00 & 51.80 & 23.38 & 29.85 & 2 & 1069.6760 & 1069.6729 & 535.8437 & 0.0031 & 2.8926 & 3229.965 & 3482.533 & 232.251 & 3421.228 & \text { Yes }\end{array}$ $\begin{array}{llllllllllllllll}1.00 & 51.80 & 23.38 & 29.85 & 2 & 1069.6760 & 1069.6729 & 535.8437 & 0.0031 & 2.8926 & 3229.965 & 3482.533 & 232.251 & 3421.228 & \text { Yes } \\ 1.00 & 42.06 & 25.66 & 25.81 & 2 & 1110.6460 & 1110.6454 & 556.3300 & 0.0006 & 0.5392 & 2900.929 & 1869.082 & 1397.965 & 2740.108 & \text { Yes }\end{array}$ $\begin{array}{lllllllllllllll}1.00 & 42.06 & 25.66 & 25.81 & 2 & 1110.6460 & 1110.6454 & 556.3300 & 0.0006 & 0.5392 & 2900.929 & 1869.082 & 1397.965 & 2740.108 & \text { Yes } \\ 1.00 & 49.11 & 22.30 & 30.75 & 2 & 1069.6744 & 1069.6729 & 535.8437 & 0.0015 & 1.3997 & 894.201 & 944.568 & 55.042 & 917.371 & \text { Yes }\end{array}$

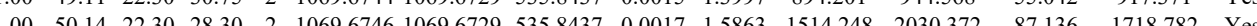
$\begin{array}{lllllllllllllll}1.00 & 42.31 & 24.31 & 28.78 & 2 & 1199.7394 & 1199.7369 & 600.8757 & 0.0025 & 2.0803 & 6609.453 & 7161.787 & 930.076 & 7220.430 & \text { Yes }\end{array}$ 

$\begin{array}{lllllllllllllll} & \end{array}$ $\begin{array}{llllllllllll} & \end{array}$ \begin{tabular}{llllllllllllllll}
\hline LAPAVLLTGLTEVPVPTR & 0.55 & 22.94 & 16.72 & 35.94 & 3 & 1990.1956 & 1990.1949 & 644.4056 & 0.0007 & 0.3512 & 110.668 & 65.867 & 41.360 & 74.821 & No
\end{tabular} $\begin{array}{lllllllllllllllll}\text { FLFLLLGPAGK } & 0.55 & 17.04 & 17.78 & 3.04 & 3 & 1462.9168 & 1462.9155 & 488.6458 & 0.0013 & 0.8868 & 59.383 & 53.703 & 20.409 & 109.961 & \text { Yes }\end{array}$

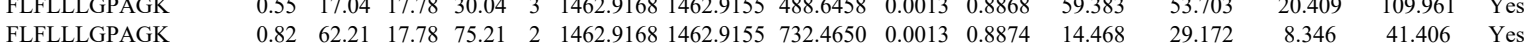
$\begin{array}{llllllllllllllll}\text { FLFLLLGPAGK } & 0.66 & 22.10 & 17.78 & 35.10 & 3 & 1462.9177 & 1462.9155 & 488.6458 & 0.0022 & 1.5007 & 29.357 & 58.882 & 5.551 & 89.281 & \text { Yes }\end{array}$

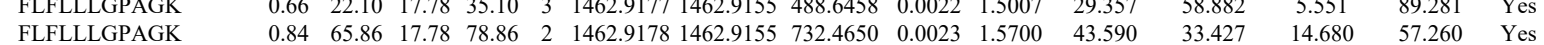

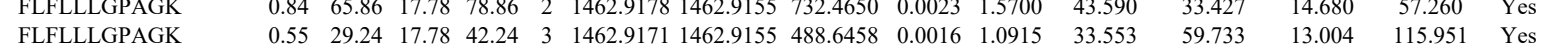

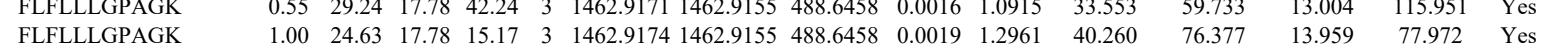
$\begin{array}{llllllllllllllll}\text { FLFLLLGPAGK } & 0.84 & 68.46 & 17.78 & 81.46 & 2 & 1462.9176 & 1462.9155 & 732.4650 & 0.0021 & 1.4335 & 16.040 & 24.335 & 11.498 & 29.253 & \text { Yes }\end{array}$

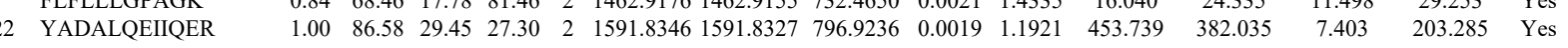
$\begin{array}{lllllllllllllllll}\text { YADALQEIIQER } & 1.00 & 75.99 & 29.38 & 26.25 & 2 & 1591.8348 & 1591.8327 & 796.9236 & 0.0021 & 1.3176 & 370.622 & 316.205 & 8.670 & 123.645 & \text { Yes }\end{array}$ $\begin{array}{llllllllllllllll}\text { TSPVADAAGWVDVDKETLOHR } & 1.00 & 57.08 & 26.70 & 23.95 & 4 & 2582.3333 & 2582.3333 & 646.5906 & 0.0000 & 0.0000 & 1605.979 & 1315.060 & 472.360 & 1134.165 & \text { Yes }\end{array}$ $\begin{array}{llllllllllllllll}\text { GLPEGFAHPK } & 0.96 & 30.84 & 26.51 & 20.26 & 3 & 1339.7593 & 1339.7492 & 447.5903 & 0.0101 & 7.5217 & 32925.895 & 25491.906 & 4023.600 & 13070.609 & \text { Yes }\end{array}$ $\begin{array}{llllllllllllllll}\text { GLPEGFAHPK } & 0.98 & 32.95 & 26.18 & 16.44 & 3 & 1339.7608 & 1339.7492 & 447.5903 & 0.0116 & 8.6388 & 31130.352 & 24270.083 & 3383.156 & 12900.395 & \text { Yes }\end{array}$ $\begin{array}{lllllllllllllllll}\text { GLPEGFAHPK } & 0.98 & 34.51 & 26.18 & 21.12 & 3 & 1339.7608 & 1339.7492 & 447.5903 & 0.0116 & 8.6388 & 23975.780 & 19445.351 & 1943.688 & 7998.742 & \text { Yes }\end{array}$ GLPEGFAHPK $\begin{array}{lllllllllllllllll}\text { TAAAVAAQSGILDR } & 1.90 & 36.02 & 26.27 & 21.51 & 3 & 1339.7611 & 1339.7492 & 447.5903 & 0.0119 & 8.8622 & 29430.167 & 23883.955 & 2464.640 & 12024.846 & \text { Yes }\end{array}$ $\begin{array}{lllllllllllllllll} & \end{array}$ $\begin{array}{llllllllllllllll} & \\ \text { TAAANAAQSGILDR } & 1.00 & 63.30 & 26.99 & 32.41 & 2 & 1486.8262 & 1486.8225 & 744.4185 & 0.0037 & 2.4852 & 548.026 & 428.637 & 78.140 & 344.576 & \text { Yes }\end{array}$

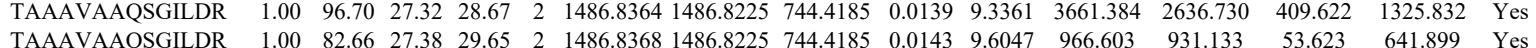

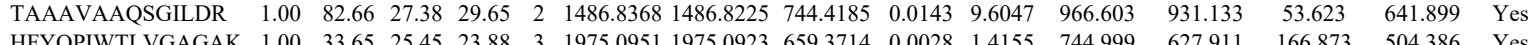
$\begin{array}{lllllllllllllllll}\text { HFYQPWTLVGAGAK } & 1.00 & 33.65 & 25.45 & 23.88 & 3 & 1975.0951 & 1975.0923 & 659.3714 & 0.0028 & 1.4155 & 744.999 & 627.911 & 166.873 & 504.386 & \text { Yes }\end{array}$

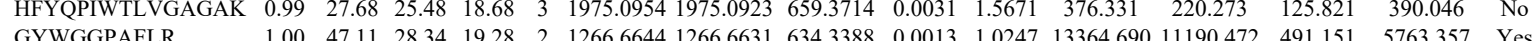
\begin{tabular}{lllllllllllllllll} 
GYWGGPAFLR & 1.00 & 47.11 & 28.34 & 19.28 & 2 & 1266.6644 & 1266.6631 & 634.3388 & 0.0013 & 1.0247 & 13364.690 & 11190.472 & 491.151 & 5763.357 & Yes \\
\hline GYWGGPAFL & 0.99 & 37.74 & 28.12 & 17.86 & 2 & 1266.6650 & 1266.631 & 6343388 & 0.0019 & 1.4976 & 9408.824 & 7429.300 & 218.734 & 358.225 & Yes
\end{tabular} $\begin{array}{llllllllllllllll}\text { GYWQPIWTLRGAGAK } & 0.99 & 37.74 & 28.12 & 17.86 & 2 & 1266.6650 & 1266.6631 & 634.3388 & 0.0019 & 1.4976 & 9408.824 & 7429.300 & 218.734 & 3588.225 & \text { Yes }\end{array}$ \begin{tabular}{llllllllllllllll} 
HFYPWLVGAGAK & 1.00 & 48.30 & 25.48 & 29.58 & 3 & 1975.0939 & 1975.0923 & 659.3714 & 0.0016 & 0.8089 & 467.519 & 357.556 & 104.456 & 290.636 & Yes \\
\hline
\end{tabular}

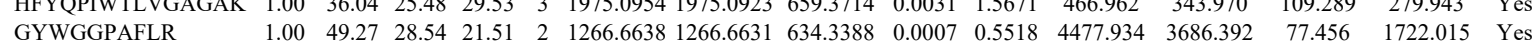

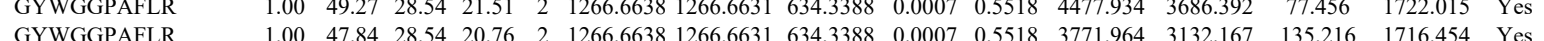

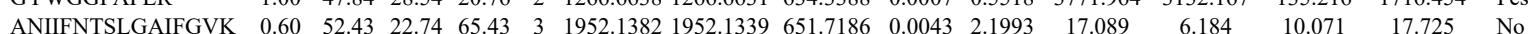

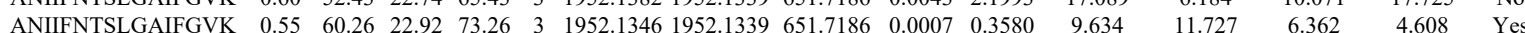
$\begin{array}{llllllllllllllll}\text { ANIIFNTSLGAIFGVK } & 0.66 & 32.87 & 22.81 & 45.87 & 3 & 1952.1361 & 1952.1339 & 651.7186 & 0.0022 & 1.1252 & 15.544 & 29.155 & 2.515 & 7.386 & \text { No }\end{array}$ $\begin{array}{llllllllllllllll}\text { ANIIFNTSLGAIFGVK } & 0.67 & 41.87 & 22.90 & 54.87 & 3 & 1952.1370 & 19521339 & 651.7186 & 0.0031 & 1.5855 & 10.343 & 10.491 & 6.905 & 8674 & \text { Yes }\end{array}$ $\begin{array}{llllllllllllllll}\text { ANIIFNTSLGAIFGVK } & 1.00 & 57.42 & 22.81 & 16.84 & 3 & 1952.1364 & 1952.1339 & 651.7186 & 0.0025 & 1.2787 & 14.146 & 23.392 & 10.685 & 7.505 & \text { Yes }\end{array}$ $\begin{array}{lllllllllllllllll}\text { ANIIFNTSLGAIFGVK } & 1.00 & 41.74 & 22.60 & 25.17 & 3 & 1952.1400 & 1952.1339 & 651.7186 & 0.0061 & 3.1199 & 18.296 & 21.418 & 6.902 & 8.848 & \text { Yes }\end{array}$ $\begin{array}{lllllllllllllllll}\text { VGAENVAIVEPSER } & 1.00 & 75.40 & 27.77 & 23.87 & 2 & 1612.8548 & 1612.8542 & 807.4344 & 0.0006 & 0.3715 & 724.050 & 594.235 & 564.660 & 428.376 & \text { No }\end{array}$

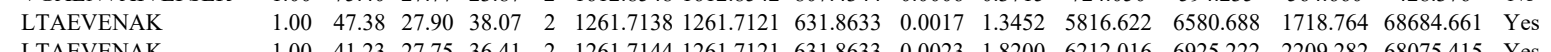
\begin{tabular}{llllllllllllllll}
1.00 & 41.23 & 27.75 & 36.41 & 2 & 1261.7144 & 1261.7121 & 631.8633 & 0.0023 & 1.8200 & 6212.016 & 6925.222 & 2209.282 & 68075.415 & Yes \\
\hline
\end{tabular}

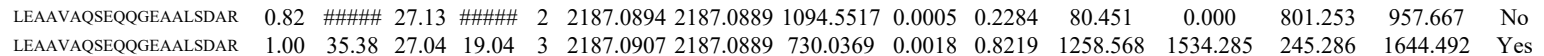

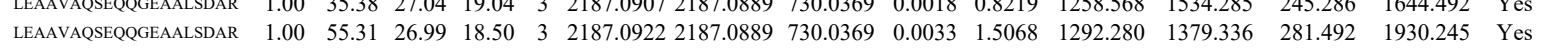
$\begin{array}{llllllllllllllll}\text { TKEEINELNR } & 1.00 & 73.88 & 28.13 & 35.85 & 2 & 1532.8418 & 1532.8402 & 767.4274 & 0.0016 & 1.0424 & 282.119 & 355.544 & 1224.110 & 3335.467 & \text { Yes }\end{array}$ $\begin{array}{llllllllllllllll}\text { TKEEINELNR } & 0.79 & 33.67 & 28.16 & 28.84 & 3 & 1532.8426 & 1532.8402 & 511.9540 & 0.0024 & 1.5626 & 867.694 & 1629.060 & 10718.691 & 27055.991 & \text { Yes }\end{array}$

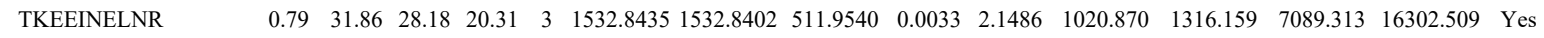
$\begin{array}{llllllllllllllll}0.68 & 14.02 & 19.44 & 18.14 & 2 & 920.3832 & 920.3832 & 461.1989 & 0.0000 & 0.0000 & 8004.324 & 7852.243 & 1467.832 & 6533.706 & \text { Yes }\end{array}$

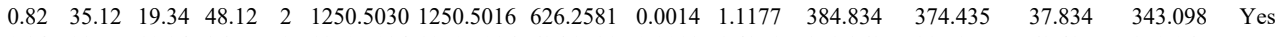
$\begin{array}{lllllllllllllll}0.84 & 23.75 & 19.24 & 36.75 & 2 & 1250.5034 & 1250.5016 & 626.2581 & 0.0018 & 1.4371 & 373.363 & 397.975 & 62.427 & 279.065 & \text { Yes }\end{array}$ $\begin{array}{lllllllllllllll}0.53 & 42.83 & 19.59 & 55.83 & 2 & 1250.5140 & 1250.5016 & 626.2581 & 0.0124 & 9.9000 & 20279.494 & 20929.852 & 1079.046 & 13920.765 & \text { Yes }\end{array}$ $\begin{array}{lllllllllllllll}0.99 & 32.89 & 19.24 & 19.74 & 2 & 1250.5018 & 1250.5016 & 626.2581 & 0.0002 & 0.1597 & 241.892 & 316.610 & 25.127 & 215.549 & \text { Yes }\end{array}$ $\begin{array}{lllllllllllllll}0.64 & 33.86 & 19.24 & 46.86 & 2 & 1250.5018 & 1250.5016 & 626.2581 & 0.0002 & 0.1597 & 626.692 & 638.917 & 9.049 & 422.171 & \text { Yes }\end{array}$ $\begin{array}{llllllllllllllll}0.82 & 38.53 & 19.34 & 51.53 & 2 & 1250.5026 & 1250.5016 & 626.2581 & 0.0010 & 0.7984 & 700.541 & 795.519 & 12.774 & 563.225 & \text { Yes }\end{array}$

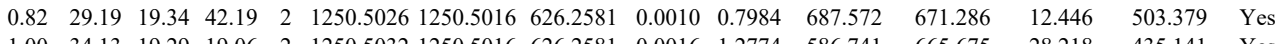

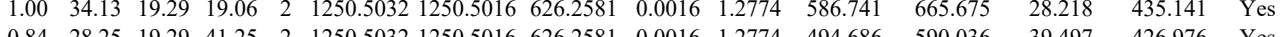

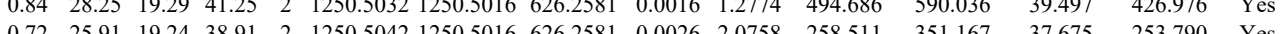

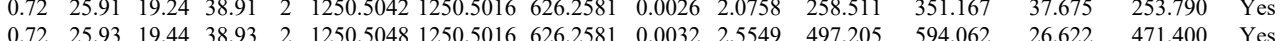

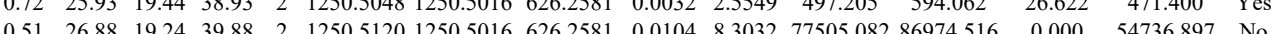

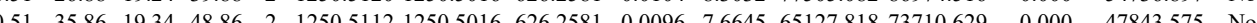
$\begin{array}{llllllllllllllll}0.98 & 31.74 & 19.34 & 22.41 & 2 & 1250.5118 & 1250.5016 & 626.2581 & 0.0102 & 8.1435 & 25007.285 & 32095.675 & 1382.371 & 19963.690 & \text { Yes }\end{array}$ 


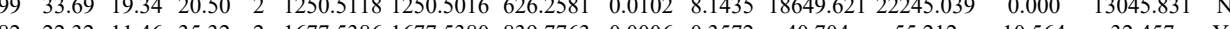
$\begin{array}{lllllllllllllll}.82 & 22.32 & 11.46 & 35.32 & 2 & 1677.5386 & 1677.5380 & 839.7763 & 0.0006 & 0.3572 & 40.704 & 55.212 & 10.564 & 32.457 & \text { Yes }\end{array}$ $\begin{array}{lllllllllllllll}0.77 & 4.74 & 11.46 & 15.77 & 3 & 1677.5398 & 1677.5380 & 560.1866 & 0.0018 & 1.0711 & 98.865 & 87.033 & 23.676 & 113.935 & \text { Yes }\end{array}$ $\begin{array}{llllllllllllll} & \end{array}$ $\begin{array}{llllllllllllllll}0.82 & 59.01 & 11.46 & 72.01 & 2 & 1677.5386 & 1677.5380 & 839.7763 & 0.0006 & 0.3572 & 72.552 & 79.520 & 4.583 & 46.553 & \text { Yes }\end{array}$ $\begin{array}{lllllllllllllll}0.82 & 48.94 & 11.46 & 61.94 & 2 & 1677.5388 & 1677.5380 & 839.7763 & 0.0008 & 0.4763 & 28.010 & 37.004 & 1.162 & 20.702 & \text { Yes } \\ 0.55 & 2.73 & 11.46 & 15.73 & 3 & 1677.5389 & 1677.5380 & 560.1866 & 0.0009 & 0.5355 & 118.333 & 111.108 & 63.525 & 180.684 & \text { No }\end{array}$

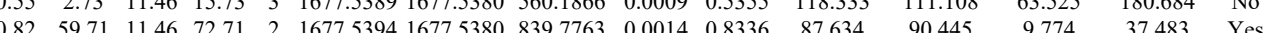
$\begin{array}{lllllllllllllll}0.82 & 65.98 & 1.46 & 78.98 & 2 & 1677.5394 & 1677.5380 & 839.7763 & 0.0014 & 0.8336 & 95.48 .488 & 13238.474 & 215.212 & 4389.431 & \text { Yes }\end{array}$

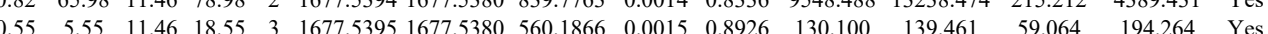
$\begin{array}{llllllllllllllll}0.84 & 65.36 & 11.46 & 78.36 & 2 & 1677.5398 & 1677.5380 & 839.7763 & 0.0018 & 1.0717 & 15443.590 & 19404.743 & 0.000 & 5990.038 & \text { No- }\end{array}$ $\begin{array}{llllllllllllllll}0.84 & 61.01 & 11.46 & 74.01 & 2 & 1677.5400 & 1677.5380 & 839.7763 & 0.0020 & 1.1908 & 113.043 & 168.502 & 0.000 & 77.235 & \text { No }\end{array}$

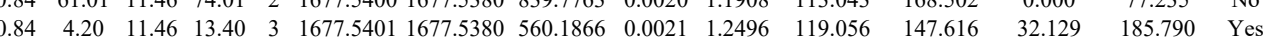
$\begin{array}{llllllllllllllll}0.87 & 7.41 & 11.46 & 15.70 & 3 & 1677.5404 & 1677.5380 & 560.1866 & 0.0024 & 1.4281 & 164.223 & 134.848 & 43.882 & 178.429 & \text { Yes }\end{array}$ $\begin{array}{lllllllllllllll}1.00 & 22.49 & 11.14 & 15.60 & 3 & 1677.5419 & 1677.5380 & 560.1866 & 0.0039 & 2.3206 & 197.056 & 386.364 & 0.000 & 153.033 & \text { No }\end{array}$ $\begin{array}{lllllllllllllll}0.64 & 57.97 & 11.46 & 70.97 & 2 & 1677.5378 & 1677.5380 & 839.7763 & -0.0002 & -0.1191 & 69.397 & 87.641 & 1.082 & 22.524 & \text { Yes }\end{array}$

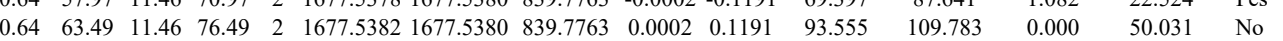
$\begin{array}{llllllllllllllll}0.55 & 7.95 & 11.46 & 20.95 & 3 & 1677.5386 & 1677.5380 & 560.1866 & 0.0006 & 0.3570 & 129.381 & 136.092 & 46.433 & 162.516 & \text { Yes }\end{array}$

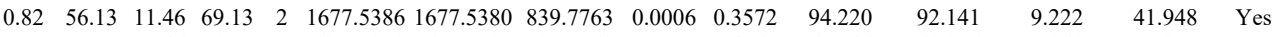

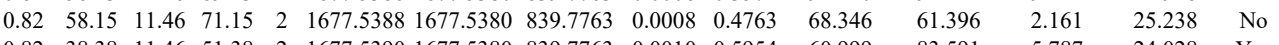

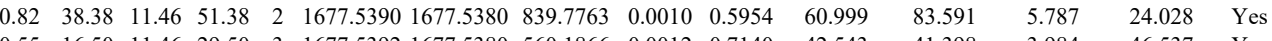

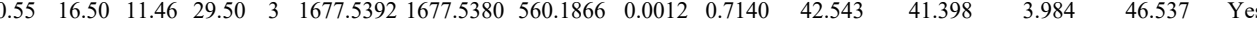
$\begin{array}{lllllllllllllll}0.55 & 1.08 & 11.46 & 14.08 & 3 & 1677.5395 & 1677.5380 & 560.1866 & 0.0015 & 0.8926 & 113.887 & 150.971 & 26.777 & 166.720 & \text { Yes }\end{array}$ $\begin{array}{llllllllllllllll}0.66 & 7.99 & 11.46 & 20.99 & 3 & 1677.5398 & 1677.5380 & 560.1866 & 0.0018 & 1.0711 & 132.600 & 118.519 & 31.281 & 178.593 & \text { Yes }\end{array}$ $\begin{array}{lllllllllllllll}0.84 & 63.99 & 11.46 & 76.99 & 2 & 1677.5398 & 1677.5380 & 839.7763 & 0.0018 & 1.0717 & 20980.355 & 26226.742 & 524.635 & 8599.236 & \text { Yes }\end{array}$ $\begin{array}{lllllllllllllll}0.66 & 3.99 & 11.46 & 16.99 & 3 & 1677.5401 & 1677.5380 & 560.1866 & 0.0021 & 1.2496 & 154.580 & 161.129 & 46.320 & 221.390 & \text { Yes }\end{array}$ $\begin{array}{lllllllllllllll}0.84 & 45.85 & 11.46 & 58.85 & 2 & 1677.5404 & 1677.5380 & 839.7763 & 0.0024 & 1.4289 & 66.800 & 79.418 & 11.720 & 30.714 & \text { Yes } \\ 0\end{array}$

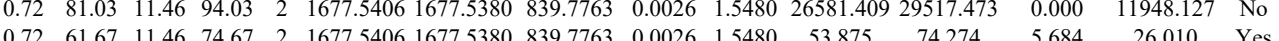

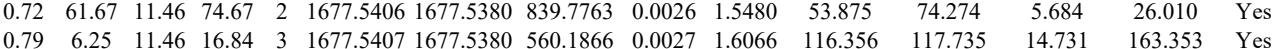

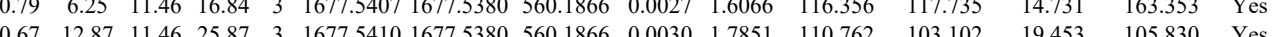
\begin{tabular}{lllllllllllllll}
0.67 & 12.87 & 11.46 & 25.87 & 3 & 1677.5410 & 1677.5380 & 560.1866 & 0.0030 & 1.7851 & 110.762 & 103.102 & 19.453 & 105.830 & Yes \\
\hline
\end{tabular}

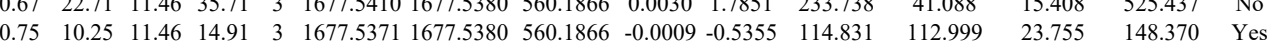

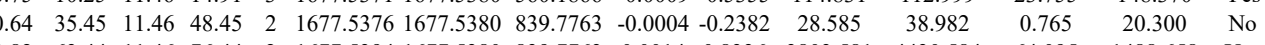
$\begin{array}{lllllllllllllll}0.82 & 63.44 & 11.46 & 76.44 & 2 & 1677.5394 & 1677.5380 & 839.7763 & 0.0014 & 0.8336 & 3803.581 & 4430.584 & 64.095 & 1488.658 & \text { Yes }\end{array}$

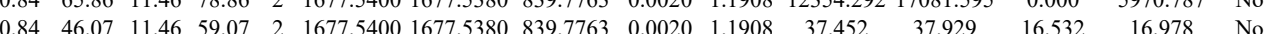

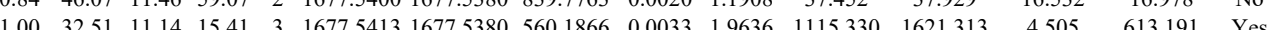

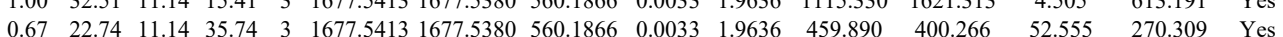

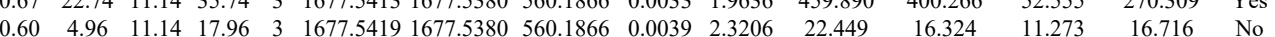

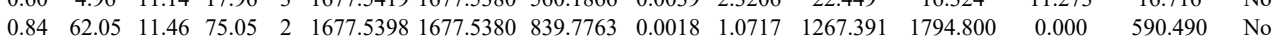

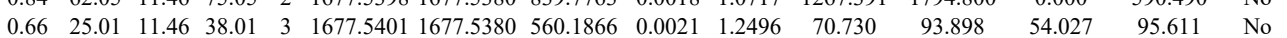
$\begin{array}{llllllllllllllll}0.98 & 16.09 & 11.46 & 16.96 & 3 & 1677.5404 & 1677.5380 & 560.1866 & 0.0024 & 1.4281 & 125.349 & 90.247 & 0.000 & 127.128 & \text { No }\end{array}$ $\begin{array}{lllllllllllllll}0.84 & 62.28 & 11.46 & 75.28 & 2 & 1677.5404 & 1677.5380 & 839.7763 & 0.0024 & 1.4289 & 2429.562 & 3061.058 & 4.309 & 957.580 & \text { Yes } \\ 0.82 & 72.47 & 1.6 & 85.47 & 2 & 167.5394 & 167.5380 & 839.773 & 0.004 & 0.336 & 564.233 & 674.325 & 0.000 & 228.117 & \text { No }\end{array}$ $\begin{array}{lllllllllllllll}0.82 & 72.47 & 11.46 & 85.47 & 2 & 1677.5394 & 1677.5380 & 839.7763 & 0.0014 & 0.8336 & 564.233 & 674.325 & 0.000 & 228.117 & \text { No }\end{array}$ $\begin{array}{lllllllllllllll}0.84 & 62.02 & 11.46 & 75.02 & 2 & 1677.5400 & 1677.5380 & 839.7763 & 0.0020 & 1.1908 & 584.258 & 732.010 & 0.000 & 317.827 & \text { No }\end{array}$

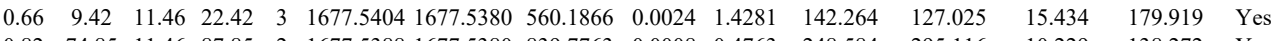

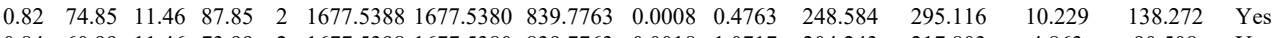

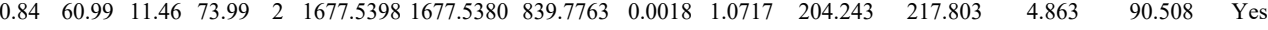

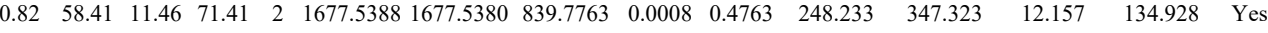
$\begin{array}{lllllllllllllll}0.84 & 48.98 & 11.46 & 61.98 & 2 & 1677.5400 & 1677.5380 & 839.7763 & 0.0020 & 1.1908 & 184.054 & 212.016 & 0.019 & 75.341 & \text { No }\end{array}$ $\begin{array}{lllllllllllllll}0.66 & 10.21 & 11.46 & 23.21 & 3 & 1677.5404 & 1677.5380 & 560.1866 & 0.0024 & 1.4281 & 47.218 & 57.808 & 14.625 & 66.698 & \text { Yes }\end{array}$

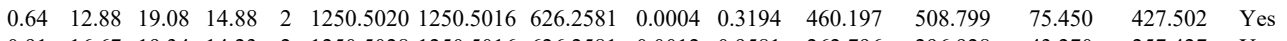
\begin{tabular}{llllllllllllllll}
0.91 & 16.67 & 19.34 & 14.23 & 2 & 1250.5028 & 1250.5016 & 626.2581 & 0.0012 & 0.9581 & 262.796 & 296.928 & 43.270 & 257.427 & Yes \\
\hline
\end{tabular}

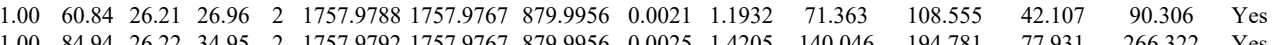

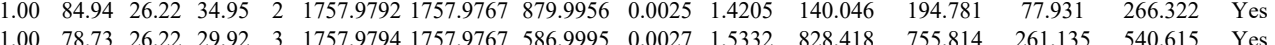

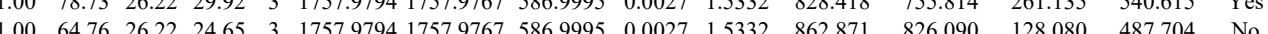

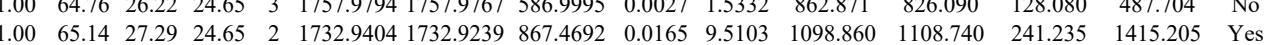

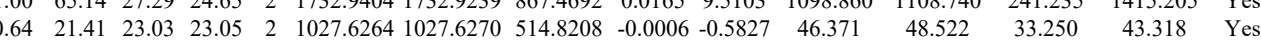

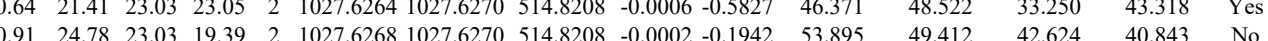

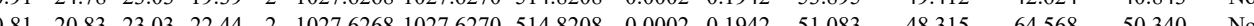

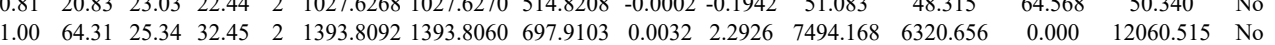

Table S-4 page 592 of 614 
$\begin{array}{llllllllllll}\text { YPIEHGIITNWDDMEK } & 0.91 & 29.02 & 27.51 & 25.18 & 2 & 2248.1074 & 2248.1078 & 1125.0612 & -0.0004 & -0.1778 & 493.030\end{array}$ $\begin{array}{llllllllllll}\text { YPIEHGIITNWDDMEK } & 0.87 & 27.15 & 27.51 & 20.57 & 2 & 2248.1074 & 2248.1078 & 1125.0612 & -0.0004 & -0.1778 & 5.604\end{array}$ $\begin{array}{lllllllllllll}\text { YPIEHGIITNWDDMEK } & 0.81 & 17.44 & 27.36 & 19.50 & 3 & 2248.1086 & 2248.1078 & 750.3765 & 0.0008 & 0.3554 & 44.823\end{array}$ $\begin{array}{llllllllllll}\text { YPIEHGIITNWDDMEK } & 0.90 & 20.44 & 27.40 & 18.20 & 3 & 2248.1089 & 2248.1078 & 750.3765 & 0.0011 & 0.4886 & 264.823\end{array}$ $\begin{array}{llllllllllll}\text { YPIEHGIITNWDDMEK } & 0.50 & 11.89 & 27.42 & 16.85 & 3 & 2248.1092 & 2248.1078 & 750.3765 & 0.0014 & 0.6219 & 4064.843\end{array}$ $\begin{array}{lllllllllllll}\text { YPIEHGIITNWDDMEK } & 0.93 & 25.34 & 27.41 & 23.87 & 2 & 2248.1094 & 2248.1078 & 1125.0612 & 0.0016 & 0.7111 & 716.399\end{array}$ $\begin{array}{lllllllllllll}\text { YPIEHGIITNWDDMEK } & 1.00 & 40.98 & 27.41 & 27.89 & 2 & 2248.1094 & 2248.1078 & 1125.0612 & 0.0016 & 0.7111 & 2.119\end{array}$ $\begin{array}{lllllllllllll}\text { YPIEHGIITNWDDMEK } & 0.59 & 15.63 & 27.41 & 25.30 & 2 & 2248.1094 & 2248.1078 & 1125.0612 & 0.0016 & 0.7111 & 5.505\end{array}$ $\begin{array}{llllllllllll}\text { YPIEHGIITNWDDMEK } & 0.52 & 10.25 & 27.42 & 13.67 & 3 & 2248.1095 & 2248.1078 & 750.3765 & 0.0017 & 0.7552 & 148.010\end{array}$ $\begin{array}{llllllllllll}\text { YPIEHGIITNWDDMEK } & 0.64 & 12.38 & 27.42 & 18.56 & 3 & 2248.1095 & 2248.1078 & 750.3765 & 0.0017 & 0.7552 & 133.387\end{array}$ $\begin{array}{llllllllllll}\text { YPIEHGIITNWDDMEK } & 0.77 & 14.96 & 27.42 & 18.85 & 3 & 2248.1095 & 2248.1078 & 750.3765 & 0.0017 & 0.7552 & 107.074\end{array}$ $\begin{array}{llllllllllll}\text { YPIEHGIITNWDDMEK } & 0.97 & 23.26 & 27.42 & 21.21 & 3 & 2248.1095 & 2248.1078 & 750.3765 & 0.0017 & 0.7552 & 61.059\end{array}$ $\begin{array}{llllllllllll}\text { YPIEHGIITNWDDMEK } & 0.90 & 18.79 & 27.42 & 14.90 & 3 & 2248.1095 & 2248.1078 & 750.3765 & 0.0017 & 0.7552 & 53.710 \\ \text { YPIEHGIITNWDDMEK } & 0.83 & 16.43 & 27.42 & 18.49 & 3 & 2248.1095 & 2248.1078 & 750.3765 & 0.0017 & 0.7552 & 68.412\end{array}$ $\begin{array}{llllllllllll}\text { YPIEHGIITNWDDMEK } & 0.83 & 16.43 & 27.42 & 18.49 & 3 & 2248.1095 & 2248.1078 & 750.3765 & 0.0017 & 0.7552 & 68.412 \\ \text { YPIEHGIITNWDDMEK } & 0.99 & 28.94 & 27.44 & 25.25 & 3 & 2248.1101 & 2248.1078 & 750.3765 & 0.0023 & 1.0217 & 135.306\end{array}$ $\begin{array}{llllllllllll}\text { YPIEHGIITNWDDMEK } & 0.99 & 28.94 & 27.44 & 25.25 & 3 & 2248.1101 & 2248.1078 & 750.3765 & 0.0023 & 1.0217 & 135.306 \\ \text { YPIEHGIITNWDDMEK } & 0.98 & 16.33 & 27.44 & 17.08 & 4 & 2248.1101 & 2248.1078 & 563.0342 & 0.0023 & 1.0213 & 60.149\end{array}$

$\begin{array}{llllllllllll}\text { YPIEHGITNWDDMEK } & 0.61 & 11.58 & 27.40 & 21.51 & 3 & 2248.1104 & 2248.1078 & 750.3765 & 0.0026 & 1.1550 & 226.525\end{array}$

$\begin{array}{lllllllllllll}\text { YPIEHGIINWDDMEK } & 0.66 & 1.56 & 27.40 & 18.47 & 3 & 2248.1104 & 2248.1078 & 750.3765 & 0.0026 & 1.1550 & 144.337\end{array}$ 

$\begin{array}{llllllllllll}\text { YPIEHGIITNWDDMEK } & 0.88 & 17.80 & 27.43 & 19.48 & 3 & 2248.1110 & 2248.1078 & 750.3765 & 0.0032 & 1.4215 & 123.315\end{array}$ $\begin{array}{llllllllllll}\text { YPIEHGIITNWDDMEK } & 0.94 & 20.43 & 27.43 & 21.45 & 3 & 2248.1110 & 2248.1078 & 750.3765 & 0.0032 & 1.4215 & 131.113 \\ \text { YPIEHGITNWDDMEK } & 0.95 & 21.28 & 27.43 & 18.55 & 3 & 2248.110 & 2248.178 & 7503765 & 0.032 & 1.4215 & 135.378\end{array}$ $\begin{array}{llllllllllll}\text { YPIEHGIITNWDDMEK } & 0.95 & 21.28 & 27.43 & 18.55 & 3 & 2248.1110 & 2248.1078 & 750.3765 & 0.0032 & 1.4215 & 135.378 \\ \text { YPI.02 } & 27.43 & 18.26 & 3 & 2248.1110 & 2248.1078 & 750.3765 & 0.0032 & 1.4215 & 123.905\end{array}$ $\begin{array}{llllllllllll}\text { YPIEHGIITNWDDMEK } & 0.80 & 15.55 & 27.43 & 15.53 & 3 & 2248.1110 & 2248.1078 & 750.3765 & 0.0032 & 1.4215 & 59.655\end{array}$ $\begin{array}{llllllllllll}\text { YPIEHGIITNWDDMEK } & 0.95 & 21.83 & 27.53 & 19.44 & 3 & 2248.1113 & 2248.1078 & 750.3765 & 0.0035 & 1.5548 & 151.013 \\ \text { YPIEHGITNWDDMEK } & 0.92 & 19.44 & 27.53 & 2.26 & 3 & 22.1113 & 22.1078 & 7503765 & 0.0035 & 1.5548 & 109.038\end{array}$ $\begin{array}{llllllllllll}\text { YPIEHGIITNWDDMEK } & 0.92 & 19.44 & 27.53 & 20.26 & 3 & 2248.1113 & 2248.1078 & 750.3765 & 0.0035 & 1.5548 & 109.038\end{array}$ $\begin{array}{llllllllllll}\text { YPIEHGIITNWDDMEK } & 0.93 & 19.96 & 27.53 & 17.54 & 3 & 2248.1113 & 2248.1078 & 750.3765 & 0.0035 & 1.5548 & 100.338\end{array}$ $\begin{array}{lllllllllllll}\text { YPIEHGIITNWDDMEK } & 0.87 & 18.69 & 27.51 & 20.16 & 3 & 2248.1116 & 2248.1078 & 750.3765 & 0.0038 & 1.6880 & 120.193 \\ \text { YPIEHGITNWDDMEK } & 0.74 & 15.33 & 27.51 & 20.28 & 3 & 2248.1116 & 2248.1078 & 750.3765 & 0.0038 & 1.6880 & 72.409\end{array}$ $\begin{array}{lllllllllllll}\text { YPIEHGIITNWDDMEK } & 0.74 & 15.33 & 27.51 & 20.28 & 3 & 2248.1116 & 2248.1078 & 750.3765 & 0.0038 & 1.6880 & 72.409\end{array}$ $\begin{array}{lllllllllllll}\text { YPIEHGIITNWDDMEK } & 0.85 & 20.14 & 27.51 & 24.43 & 3 & 2248.1128 & 2248.1078 & 750.3765 & 0.0050 & 2.2211 & 11339.789 \\ \text { YPIEHGITNWDDMEK } & 0.84 & 19.78 & 27.51 & 19.52 & 3 & 2248.1128 & 2248.1078 & 750.3765 & 0.0050 & 22211 & 56.987\end{array}$ $\begin{array}{llllllllllll}\text { YPIEHGIITNWDDMEK } & 0.84 & 19.78 & 27.51 & 19.52 & 3 & 2248.1128 & 2248.1078 & 750.3765 & 0.0050 & 2.2211 & 56.987 \\ \text { YPIEHGIITNWDDMEK } & 0.63 & 15.59 & 27.56 & 20.13 & 3 & 2248.1131 & 2248.1078 & 750.3765 & 0.0053 & 2.3544 & 3969.455\end{array}$ $\begin{array}{lllllllllllll}\text { YPIEHGIITNWDDMEK } & 0.63 & 15.59 & 27.56 & 20.13 & 3 & 2248.1131 & 2248.1078 & 750.3765 & 0.0053 & 2.3544 & 3969.455 \\ \text { LCYVALDFENEMATAASSSLEK } & 1.00 & 46.27 & 26.97 & 22.70 & 3 & 2812.3411 & 2812.3212 & 938.4477 & 0.0199 & 7.0684 & 23.900\end{array}$ $\begin{array}{llllllllllll}\text { LCYVALDEENEMATAASSSSLEK } & 1.00 & 46.27 & 26.97 & 22.70 & 3 & 2812.3411 & 2812.3212 & 938.4477 & 0.0199 & 7.0684 & 23.900 \\ \text { LCYVALDFENEMATAASSSLEK } & 0.89 & 30.02 & 26.97 & 15.77 & 3 & 2812.3411 & 2812.3212 & 938.4477 & 0.0199 & 7.0684 & 1.946\end{array}$ $\begin{array}{llllllllllll}\text { LCYVALDFENEMATAASSSSLEK } & 0.89 & 30.02 & 26.97 & 15.77 & 3 & 2812.3411 & 2812.3212 & 938.4477 & 0.0199 & 7.0684 & 1.946 \\ \text { YPIEHGIITNWDDMEK } & 0.99 & 35.43 & 27.41 & 24.17 & 2 & 2248.1094 & 2248.1078 & 1125.0612 & 0.0016 & 0.7111 & 442.307\end{array}$ $\begin{array}{llllllllllll}\text { YPIEHGITNNDDDMEK } & 0.69 & 13.15 & 27.40 & 18.92 & 3 & 2248.1104 & 2248.1078 & 750.3765 & 0.0026 & 1.1550 & 6537.982\end{array}$ $\begin{array}{llllllllllll}\text { YPIEHGIITNWDDMEK } & 0.85 & 16.92 & 27.43 & 18.73 & 3 & 2248.1110 & 2248.1078 & 750.3765 & 0.0032 & 1.4215 & 2890.497\end{array}$

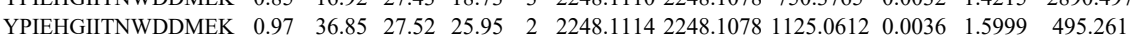
$\begin{array}{lllllllllllll}\text { YPIEHGIITNWDDMEK } & 0.64 & 19.79 & 27.57 & 18.62 & 3 & 2248.1146 & 2248.1078 & 750.3765 & 0.0068 & 3.0207 & 62.229\end{array}$ $\begin{array}{lllllllllll}34.75 & 26.95 & 16.18 & 3 & 2812.3411 & 2812.3212 & 938.4477 & 0.0205 & 7.2815 & 4.508\end{array}$

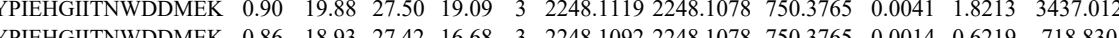

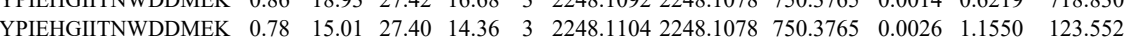
$\begin{array}{llllllllllllll}\text { YPIEHGIITNWDDMEK } & 0.61 & 13.57 & 27.36 & 16.33 & 3 & 2248.1086 & 2248 & 1078 & 750.3765 & 0.0008 & 0.3554 & 6.565\end{array}$

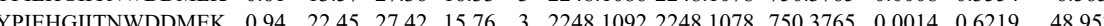

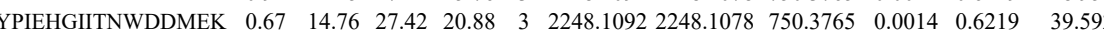
$\begin{array}{llllllllllllll}\text { YPIEHGIITNWDDMEK } & 0.54 & 10.53 & 27.42 & 15.05 & 3 & 2248.1095 & 2248.1078 & 750.3765 & 0.0017 & 0.7552 & 44.151\end{array}$ $\begin{array}{llllllllllllll}\text { YPIEHGIITNWDDMEK } & 0.91 & 19.18 & 27.40 & 21.75 & 3 & 2248.1104 & 2248.1078 & 750.3765 & 0.0026 & 1.1550 & 34.030\end{array}$ $\begin{array}{lllllllllllll}\text { YPIEHGIITNWDDMEK } & 0.52 & 10.10 & 27.41 & 20.17 & 3 & 2248.1107 & 2248.1078 & 750.3765 & 0.0029 & 1.2882 & 37.166\end{array}$ $\begin{array}{llllllllllllll}\text { YPIEHGIITNWDDMEK } & 0.82 & 15.85 & 27.41 & 23.05 & 3 & 2248.1107 & 2248.1078 & 750.3765 & 0.0029 & 1.2882 & 61.572\end{array}$ $\begin{array}{llllllllllll}\text { YPIEHGIITNWDDMEK } & 0.98 & 24.72 & 27.43 & 20.58 & 3 & 2248.1110 & 2248.1078 & 750.3765 & 0.0032 & 1.4215 & 51.269\end{array}$

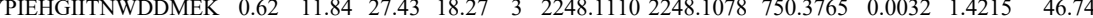
$\begin{array}{llllllllllll}\text { YPIEHGIITNWDDMEK } & 0.94 & 20.79 & 27.43 & 19.12 & 3 & 2248.1110 & 2248.1078 & 750.3765 & 0.0032 & 1.4215 & 40.820\end{array}$ $\begin{array}{lllllllllllll}\text { YPIEHGIITNWDDMEK } & 0.83 & 16.19 & 27.53 & 14.16 & 3 & 2248.1113 & 2248.1078 & 750.3765 & 0.0035 & 1.5548 & 46.348\end{array}$ \begin{tabular}{lllllllllllll} 
& YPIEHGIITNWDDMEK & 0.68 & 14.22 & 27.51 & 15.61 & 3 & 2248.1116 & 2248.1078 & 750.3765 & 0.0038 & 1.6880 & 46.861 \\
\hline
\end{tabular} $\begin{array}{lllllllllllllll}\text { YPIEHGIITNWDDMEK } & 0.87 & 18.66 & 27.50 & 17.55 & 3 & 2248.1119 & 2248.1078 & 750.3765 & 0.0041 & 1.8213 & 50.119\end{array}$ $\begin{array}{llllllllllllll}\text { YPIEHGIITNWDDMEK } & 0.89 & 19.29 & 27.50 & 18.56 & 3 & 2248.1122 & 2248.1078 & 750.3765 & 0.0044 & 1.9546 & 35.747\end{array}$ $\begin{array}{lllllllllllll}\text { YPIEHGIITNWDDMEK } & 0.64 & 14.14 & 27.40 & 20.91 & 3 & 2248.1089 & 2248.1078 & 750.3765 & 0.0011 & 0.4886 & 40.130\end{array}$ $\begin{array}{llllllllllll}\text { YPIEHGIITNWDDMEK } & 0.67 & 12.94 & 27.42 & 19.07 & 3 & 2248.1095 & 2248.1078 & 750.3765 & 0.0017 & 0.7552 & 35.728\end{array}$ $\begin{array}{llllllllllll}\text { YPIEHGIITNWDDMEK } & 0.63 & 12.10 & 27.41 & 14.66 & 3 & 2248.1107 & 2248.1078 & 750.3765 & 0.0029 & 1.2882 & 49.977\end{array}$ $\begin{array}{lllllllllllll}\text { YPIEHGIITNWDDMEK } & 0.77 & 14.86 & 27.43 & 2.48 & 3 & 2248.1110 & 2248.1078 & 750.3765 & 0.0032 & 1.4215 & 54.166\end{array}$ $\begin{array}{llllllllllll}\text { YPIEHGIITNWDDMEK } & 0.66 & 12.56 & 27.43 & 23.72 & 3 & 2248.1110 & 2248.1078 & 750.3765 & 0.0032 & 1.4215 & 58.226\end{array}$ $\begin{array}{llllllllllllll}\text { YFIEMANADMEK } & 0.81 & 15.76 & 27.53 & 22.49 & 3 & 2248.1113 & 2248.1078 & 750.3765 & 0.0035 & 1.5548 & 31.462\end{array}$

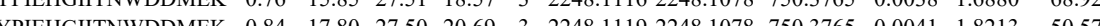
$\begin{array}{lllllllllllll}\text { YPIEHGIITNWDDMEK } & 0.59 & 12.53 & 27.50 & 16.70 & 3 & 2248.1119 & 2248.1078 & 750.3765 & 0.0041 & 1.8213 & 61.882\end{array}$ $\begin{array}{lllllllllllll}\text { YPIEHGITNWDDMEK } & 0.64 & 13.38 & 27.50 & 15.93 & 3 & 2248.1122 & 2248.1078 & 750.3765 & 0.0044 & 1.9546 & 55.631\end{array}$ 


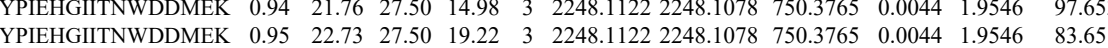
$\begin{array}{llllllllllllll}\text { YPIEHGIITNWDDMEK } & 0.68 & 19.41 & 27.57 & 21.21 & 3 & 2248.1137 & 2248.1078 & 750.3765 & 0.0059 & 2.6209 & 48.950\end{array}$ $\begin{array}{llllllllllllll}\text { YPIEHGIITNWDDMEK } & 0.94 & 24.79 & 27.42 & 15.77 & 3 & 2248.1080 & 2248.1078 & 750.3765 & 0.0002 & 0.0888 & 4.511\end{array}$ $\begin{array}{lllllllllllll}\text { YPIEHGIITNWDDMEK } & 0.57 & 12.32 & 27.50 & 15.72 & 3 & 2248.1119 & 2248.1078 & 750.3765 & 0.0041 & 1.8213 & 6.333\end{array}$ $\begin{array}{lllllllllllll}\text { YPIEHGIITNWDDMMEK } & 0.53 & 10.46 & 27.53 & 23.46 & 3 & 2248.1113 & 2248.1078 & 750.3765 & 0.0035 & 1.5548 & 1.289\end{array}$ $\begin{array}{llllllllllllll}\text { YPIEHGIITNWDDMEK } & 0.63 & 12.16 & 27.42 & 14.75 & 3 & 2248.1095 & 2248.1078 & 750.3765 & 0.0017 & 0.7552 & 9.715\end{array}$ $\begin{array}{lllllllllllllll}\text { YPIEHGIITNWDDMEK } & 0.99 & 29.10 & 27.51 & 17.75 & 3 & 2248.1116 & 2248.1078 & 750.3765 & 0.0038 & 1.6880 & 20.76\end{array}$ $\begin{array}{llllllllllll}\text { YPIEHGIITNWDDMEK } & 0.55 & 15.89 & 27.40 & 28.89 & 3 & 2248.1089 & 2248.1078 & 750.3765 & 0.0011 & 0.4886 & 7.993\end{array}$ $\begin{array}{llllllllllllll}\text { YPIEHGIITNWDDMEK } & 0.87 & 17.58 & 27.43 & 17.54 & 3 & 2248.1110 & 2248.1078 & 750.3765 & 0.0032 & 1.4215 & 17.879\end{array}$ $\begin{array}{lllllllllllll}\text { YPIEHGIITNWDDMEK } & 0.67 & 14.27 & 27.43 & 27.27 & 3 & 2248.1110 & 2248.1078 & 750.3765 & 0.0032 & 1.4215 & 6.678\end{array}$ $\begin{array}{llllllllllllll}\text { YPIEHGIITNWDDMEK } & 0.93 & 24.13 & 27.42 & 15.15 & 3 & 2248.1080 & 2248.1078 & 750.3765 & 0.0002 & 0.0888 & 7.007\end{array}$

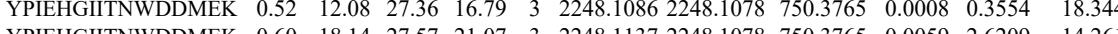

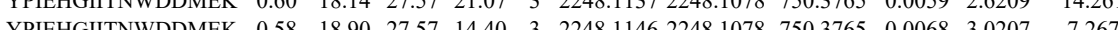
$\begin{array}{llllllllllll}\text { YPIEHGIITNWDDMEK } & 0.58 & 18.90 & 27.57 & 14.40 & 3 & 2248.1146 & 2248.1078 & 750.3765 & 0.0068 & 3.0207 & 7.267 \\ \text { YPIEHGIITNWDDMEK } & 0.84 & 20.54 & 27.43 & 14.99 & 3 & 2248.1077 & 2248.1078 & 750.3765 & -0.0001 & -0.0444 & 13.797\end{array}$ $\begin{array}{llllllllllllll}\text { YPIEHGIITNWDDMEK } & 0.76 & 16.43 & 27.40 & 14.37 & 3 & 2248.1089 & 2248.1078 & 750.3765 & 0.0011 & 0.4886 & 10.596\end{array}$ $\begin{array}{llllllllllllll}\text { YPIEHGIITNWDDMEK } & 0.79 & 19.30 & 27.43 & 17.21 & 3 & 2248.1077 & 2248.1078 & 750.3765 & -0.0001 & -0.0444 & 107.309\end{array}$ $\begin{array}{llllllllllll}\text { YPIEHGIITNWDDMEK } & 0.89 & 18.08 & 27.42 & 19.94 & 3 & 2248.1095 & 2248.1078 & 750.3765 & 0.0017 & 0.7552 & 96.969\end{array}$ $\begin{array}{llllllllllllll}\text { YPIEHGIITNWDDMEK } & 0.92 & 19.34 & 27.41 & 14.53 & 3 & 2248.1107 & 2248.1078 & 750.3765 & 0.0029 & 1.2882 & 85.275\end{array}$ $\begin{array}{lllllllllllll}\text { YPIEHGIITNWDDMEK } & 0.86 & 17.30 & 27.53 & 18.08 & 3 & 2248.1113 & 2248.1078 & 750.3765 & 0.0035 & 1.5548 & 81.340\end{array}$ $\begin{array}{lllllllllllll}\text { YPIEHGIITNWDDMEK } & 0.84 & 16.48 & 27.53 & 18.56 & 3 & 2248.1113 & 2248.1078 & 750.3765 & 0.0035 & 1.5548 & 96.039\end{array}$ $\begin{array}{lllllllllllll}\text { YPIEHGIITNWDDMEK } & 0.67 & 14.07 & 27.51 & 22.19 & 3 & 2248.1116 & 2248.1078 & 750.3765 & 0.0038 & 1.6880 & 104.629\end{array}$ $\begin{array}{lllllllllllll}\text { YPIEHGIITNWDDMEK } & 0.85 & 17.89 & 27.50 & 22.49 & 3 & 2248.1119 & 2248.1078 & 750.3765 & 0.0041 & 1.8213 & 83.637\end{array}$ $\begin{array}{llllllllllllll}\text { YPIEHGIITNWDDMEK } & 0.70 & 14.56 & 27.50 & 16.57 & 3 & 2248.1119 & 2248.1078 & 750.3765 & 0.0041 & 1.8213 & 79.778\end{array}$ $\begin{array}{lllllllllllll}\text { YPIEHGIITNWDDMEK } & 0.71 & 14.64 & 27.50 & 22.29 & 3 & 2248.1122 & 2248.1078 & 750.3765 & 0.0044 & 1.9546 & 66.878\end{array}$ $\begin{array}{llllllllllll}\text { YPIEHGIITNWDDMEK } & 0.93 & 20.99 & 27.50 & 24.27 & 3 & 2248.1122 & 2248.1078 & 750.3765 & 0.0044 & 1.9546 & 63.545 \\ \text { YPIEGT }\end{array}$ $\begin{array}{llllllllllll}\text { YPIEHGIITNWDDMEK } & 0.59 & 14.80 & 27.49 & 18.22 & 3 & 2248.1125 & 2248.1078 & 750.3765 & 0.0047 & 2.0878 & 91.159\end{array}$ $\begin{array}{llllllllllll}\text { YPIEHGIITNWDDMEK } & 0.88 & 21.20 & 27.49 & 14.35 & 3 & 2248.1125 & 2248.1078 & 750.3765 & 0.0047 & 2.0878 & 105.715\end{array}$ $\begin{array}{lllllllllllll}\text { YPIEHGIITNWDDMEK } & 0.64 & 22.20 & 27.60 & 21.40 & 3 & 2248.1191 & 2248.1078 & 750.3765 & 0.0113 & 5.0197 & 96.986\end{array}$

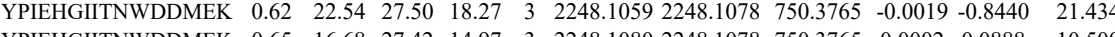
$\begin{array}{lllllllllllll}\text { YPIEHGIITNWDDMEK } & 0.65 & 16.68 & 27.42 & 14.97 & 3 & 2248.1080 & 2248.1078 & 750.3765 & 0.0002 & 0.0888 & 10.500\end{array}$ $\begin{array}{lllllllllllll}\text { YPIEHGIITNWDDMEK } & 0.75 & 16.16 & 27.40 & 15.27 & 3 & 2248.1089 & 2248.1078 & 750.3765 & 0.0011 & 0.4886 & 18.105 \\ \text { YPIEHGITNWDDMEK } & 0.70 & 15.20 & 27.42 & 19.23 & 3 & 2248.1092 & 2248.1078 & 750.3765 & 0.0014 & 0.6219 & 19.872\end{array}$ $\begin{array}{lllllllllllll}\text { YPIEHGIITNWDDMEK } & 0.70 & 15.20 & 27.42 & 19.23 & 3 & 2248.1092 & 2248.1078 & 750.3765 & 0.0014 & 0.6219 & 19.872 \\ \text { YPIEHGITNWDDMEK } & 0.53 & 10.45 & 27.44 & 17.23 & 3 & 2248.1101 & 2248.1078 & 750.3765 & 0.0023 & 1.0217 & 7.850\end{array}$ $\begin{array}{lllllllllllll}\text { YPIEHGIITNWDDMEK } & 0.53 & 10.45 & 27.44 & 17.23 & 3 & 2248.1101 & 2248.1078 & 750.3765 & 0.0023 & 1.0217 & 7.850 \\ \text { YPIEHGIITNWDDMEK } & 0.95 & 21.10 & 27.41 & 19.81 & 3 & 2248.1107 & 2248.1078 & 750.3765 & 0.0029 & 1.2882 & 21.594\end{array}$ $\begin{array}{llllllllllll}\text { YPIEHGIITNWDDMEK } & 0.95 & 21.10 & 27.41 & 19.81 & 3 & 2248.1107 & 2248.1078 & 750.3765 & 0.0029 & 1.2882 & 21.594 \\ \text { YPIEHGIITNWDDMEK } & 0.82 & 15.91 & 27.41 & 14.40 & 3 & 2248.1107 & 2248.1078 & 750.3765 & 0.0029 & 1.2882 & 11.728\end{array}$ $\begin{array}{lllllllllllll}\text { YPIEHGIITNWDDMEK } & 0.82 & 15.91 & 27.41 & 14.40 & 3 & 2248.1107 & 2248.1078 & 750.3765 & 0.0029 & 1.2882 & 11.728 \\ \text { YPIEHGIITNWDDMEK } & 0.60 & 21.12 & 27.50 & 34.12 & 3 & 2248.1119 & 2248.1078 & 750.3765 & 0.0041 & 1.8213 & 15.989\end{array}$ $\begin{array}{lllllllllllll}\text { YPIEHGIITNWDDMEK } & 0.60 & 21.12 & 27.50 & 34.12 & 3 & 2248.1119 & 2248.1078 & 750.3765 & 0.0041 & 1.8213 & 15.989 \\ \text { YPIEHGIITNWDDMEK } & 0.54 & 17.18 & 27.55 & 14.48 & 3 & 2248.1134 & 2248.1078 & 750.3765 & 0.0056 & 2.4876 & 11.117\end{array}$ $\begin{array}{llllllllllll}\text { YPIEHGIITNWDDMEK } & 0.54 & 17.18 & 27.55 & 14.48 & 3 & 2248.1134 & 2248.1078 & 750.3765 & 0.056 & 2.4876 & 1 . .117 \\ \text { YPIEHGIITNWDDMEK } & 0.68 & 19.40 & 27.55 & 18.11 & 3 & 2248.1134 & 2248.1078 & 750.3765 & 0.0056 & 2.4876 & 11.10\end{array}$ $\begin{array}{lllllllllllll}\text { YPIEHGIITNWDDMEK } & 0.64 & 14.19 & 27.40 & 20.76 & 3 & 2248.1089 & 2248.1078 & 750.3765 & 0.0011 & 0.4886 & 143.305 \\ \text { YPIEHGITNWDDMEK } & 0.58 & 13.16 & 27.42 & 16.40 & 3 & 2248.1092 & 2248.1078 & 750.3765 & 0.0014 & 0.6219 & 131.523\end{array}$ $\begin{array}{llllllllllll}\text { YPIEHGIITNWDDMEK } & 0.58 & 13.16 & 27.42 & 16.40 & 3 & 2248.1092 & 2248.1078 & 750.3765 & 0.0014 & 0.6219 & 131.523 \\ \text { YPIEHGIITNWDDMEK } & 0.78 & 15.16 & 27.42 & 14.23 & 3 & 2248.1095 & 2248.1078 & 750.3765 & 0.0017 & 0.7552 & 146.114\end{array}$ $\begin{array}{llllllllllll}\text { YPIEHGIITNWDDMEK } & 0.68 & 13.03 & 27.42 & 17.23 & 3 & 2248.1095 & 2248.1078 & 750.3765 & 0.0017 & 0.7552 & 142.623\end{array}$ $\begin{array}{llllllllllll}\text { YPIEHGIITNWDDMEK } & 0.83 & 16.44 & 27.42 & 19.56 & 3 & 2248.1095 & 2248.1078 & 750.3765 & 0.0017 & 0.7552 & 74.100\end{array}$ $\begin{array}{llllllllllllll}\text { YPIEHGIITNWDDMEK } & 0.52 & 10.19 & 27.42 & 13.79 & 3 & 2248.1095 & 2248.1078 & 750.3765 & 0.0017 & 0.7552 & 91.190\end{array}$ 
$\begin{array}{lllllllllllll}\text { YPIEHGIITNWDDMEK } & 0.87 & 17.73 & 27.44 & 20.09 & 3 & 2248.1101 & 2248.1078 & 750.3765 & 0.0023 & 1.0217 & 43.040\end{array}$ $\begin{array}{lllllllllllll}\text { YPIEHGIITNWDDMEK } & 0.78 & 14.99 & 27.40 & 16.43 & 3 & 2248.1104 & 2248.1078 & 750.3765 & 0.0026 & 1.1550 & 113.239\end{array}$ $\begin{array}{lllllllllllll}\text { YPIEHGIITNWDDMEK } & 0.65 & 12.36 & 27.40 & 19.69 & 3 & 2248.1104 & 2248.1078 & 750.3765 & 0.0026 & 1.1550 & 97.945\end{array}$ $\begin{array}{lllllllllllll}\text { YPIEHGIITNWDDMEK } & 0.99 & 27.44 & 27.40 & 19.69 & 3 & 2248.1104 & 2248.1078 & 750.3765 & 0.0026 & 1.1550 & 82.679\end{array}$ $\begin{array}{lllllllllllll}\text { YPIEHGIITNWDDMEK } & 0.70 & 13.37 & 27.41 & 18.94 & 3 & 2248.1107 & 2248.1078 & 750.3765 & 0.0029 & 1.2882 & 102.619\end{array}$ $\begin{array}{llllllllllllll}\text { YPIEHGIITNWDDMEK } & 0.79 & 9.16 & 27.43 & 17.47 & 4 & 2248.1109 & 2248.1078 & 563.0342 & 0.0031 & 1.3765 & 61.480\end{array}$

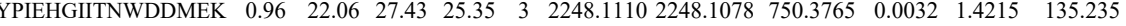
$\begin{array}{lllllllllllll}\text { YPIEHGIITNWDDMEK } & 0.84 & 16.61 & 27.43 & 17.85 & 3 & 2248.1110 & 2248.1078 & 750.3765 & 0.0032 & 1.4215 & 83.281\end{array}$

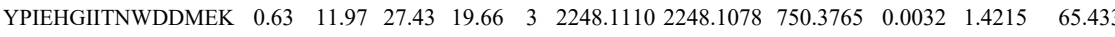
$\begin{array}{llllllllllll}\text { YPIEHGIITNWDDMEK } & 0.92 & 19.28 & 27.43 & 19.63 & 3 & 2248.1110 & 2248.1078 & 750.3765 & 0.0032 & 1.4215 & 31.663\end{array}$ $\begin{array}{llllllllllll}\text { YPIEHGIITNWDDMEK } & 0.81 & 15.77 & 27.43 & 18.29 & 3 & 2248.1110 & 2248.1078 & 750.3765 & 0.0032 & 1.4215 & 172.928\end{array}$ $\begin{array}{llllllllllll}\text { YPIEHGIITNWDDMEK } & 0.60 & 16.28 & 27.51 & 29.28 & 3 & 2248.1116 & 2248.1078 & 750.3765 & 0.0038 & 1.6880 & 12.203\end{array}$ $\begin{array}{llllllllllll}\text { YPIEHGIITNWDDMMEK } & 0.80 & 16.69 & 27.50 & 22.99 & 3 & 2248.1122 & 2248.1078 & 750.3765 & 0.0044 & 1.9846 & 47.912\end{array}$ $\begin{array}{lllllllllllll}\text { YPIEHGIITNWDDMEK } & 0.75 & 14.56 & 27.63 & 19.89 & 3 & 2264.1043 & 2264.1027 & 755.7082 & 0.0016 & 0.7057 & 2409.638 \\ \text { YPIEHGIITNWDDMEK } & 0.66 & 17.50 & 27.60 & 30.50 & 3 & 2264.1046 & 2264.1027 & 755.7082 & 0.0019 & 0.8381 & 2628.666\end{array}$ $\begin{array}{llllllllllll}\text { YPIEHGIITNWDDMEK } & 0.66 & 17.50 & 27.60 & 30.50 & 3 & 2264.1046 & 264.1027 & 755.7082 & 0.0019 & 0.8381 & 2628.666 \\ \text { YPIEHGIITNWDDMEK } & 0.65 & 26.06 & 27.35 & 19.41 & 3 & 2248.1044 & 2248.1078 & 750.3765 & -0.0034 & -1.5104 & 188.742\end{array}$

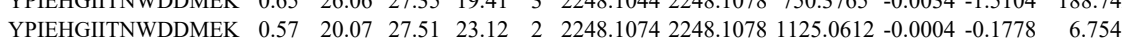
$\begin{array}{llllllllllll}\text { YPIEHGIITNWDDMEK } & 0.94 & 31.24 & 27.51 & 26.39 & 2 & 2248.1074 & 2248.1078 & 1125.0612 & -0.0004 & -0.1778 & 3.679\end{array}$

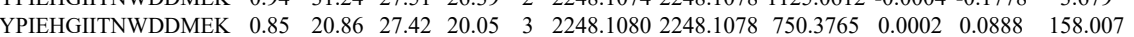

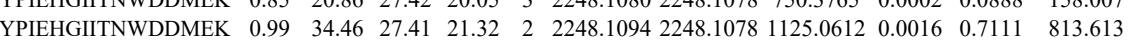

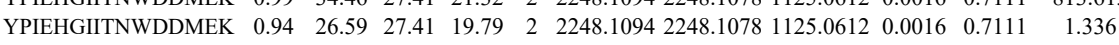
$\begin{array}{lllllllllllll}\text { YPIEHGIITNWDDMEK } & 0.78 & 19.65 & 27.41 & 24.43 & 2 & 2248.1094 & 2248.1078 & 1125.0612 & 0.0016 & 0.7111 & 6.385\end{array}$ $\begin{array}{llllllllllll}\text { YPIEHGIITNWDDMEK } & 0.87 & 22.43 & 27.41 & 22.96 & 2 & 2248.1094 & 2248.1078 & 1125.0612 & 0.0016 & 0.7111 & 4.518\end{array}$ $\begin{array}{lllllllllllll}\text { YPIEHGIITNWDDMEK } & 0.87 & 22.74 & 27.41 & 26.81 & 2 & 2248.1094 & 2248.1078 & 1125.0612 & 0.0016 & 0.7111 & 2.750\end{array}$ $\begin{array}{lllllllllllll}\text { YPIEHGIITNWDDMEK } & 0.96 & 27.86 & 27.41 & 27.46 & 2 & 2248.1094 & 2248.1078 & 1125.0612 & 0.0016 & 0.7111 & 0.000\end{array}$ $\begin{array}{lllllllllllll}\text { YPIEHGIITNWDDMEK } & 0.96 & 22.98 & 27.42 & 18.64 & 3 & 2248.1095 & 2248.1078 & 750.3765 & 0.0017 & 0.7552 & 94.992\end{array}$ $\begin{array}{llllllllllll}\text { YPIEHGIITNWDDMEK } & 0.96 & 22.80 & 27.42 & 19.99 & 3 & 2248.1095 & 2248.1078 & 750.3765 & 0.0017 & 0.7552 & 35.548\end{array}$ $\begin{array}{lllllllllllll}\text { YPIEHGIITNWDDMEK } & 0.92 & 19.67 & 27.44 & 19.33 & 3 & 2248.1101 & 2248.1078 & 750.3765 & 0.0023 & 1.0217 & 167.400\end{array}$ $\begin{array}{llllllllllll}\text { YPIEHGIITNWDDMEK } & 0.82 & 15.95 & 27.44 & 21.12 & 3 & 2248.1101 & 2248.1078 & 750.3765 & 0.0023 & 1.0217 & 199.370\end{array}$ $\begin{array}{llllllllllll}\text { YPIEHGIITNWDDMEK } & 0.73 & 14.02 & 27.44 & 22.25 & 3 & 2248.1101 & 2248.1078 & 750.3765 & 0.0023 & 1.0217 & 168.558\end{array}$ $\begin{array}{llllllllllll}\text { YPIEHGIITNWDDMEK } & 0.66 & 12.77 & 27.44 & 25.77 & 3 & 2248.1101 & 2248.1078 & 750.3765 & 0.0023 & 1.0217 & 170.335\end{array}$ $\begin{array}{llllllllllll}\text { YPIEHGIITNWDDMEK } & 0.94 & 20.52 & 27.44 & 21.03 & 3 & 2248.1101 & 2248.1078 & 750.3765 & 0.0023 & 1.0217 & 35.635 \\ \text { YPEEHGITNWDDMEK } & 0.87 & 17.52 & 27.44 & 20.42 & 3 & 2241101 & 2248.1078 & 750.3765 & 0.023 & 1.0217 & 23.958\end{array}$ $\begin{array}{llllllllllll}\text { YPIEHGIITNWDDMEK } & 0.87 & 17.52 & 27.44 & 20.42 & 3 & 2248.1101 & 2248.1078 & 750.3765 & 0.0023 & 1.0217 & 23.958 \\ \text { YPIEHGITNWDDMEK } & 0.99 & 17.24 & 27.44 & 20.51 & 4 & 22481101 & 2248.1078 & 563.0342 & 0.0023 & 1.0213 & 51.032\end{array}$ $\begin{array}{llllllllllll}\text { YPIEHGIITNWDDMEK } & 0.99 & 17.24 & 27.44 & 20.51 & 4 & 2248.1101 & 2248.1078 & 563.0342 & 0.0023 & 1.0213 & 51.032\end{array}$ $\begin{array}{lllllllllllll}\text { YPIEHGIITNWDDMEK } & 0.84 & 16.42 & 27.40 & 18.75 & 3 & 2248.1104 & 2248.1078 & 750.3765 & 0.0026 & 1.1550 & 142.158 \\ \text { YPIEHGITNWDDMEK } & 0.88 & 17.70 & 27.40 & 18.60 & 3 & 2248.1104 & 2248.1078 & 750.3765 & 0.0026 & 1.1550 & 205.618\end{array}$ $\begin{array}{llllllllllll}\text { YPIEHGIITNWDDMEK } & 0.88 & 17.70 & 27.40 & 18.60 & 3 & 2248.1104 & 2248.1078 & 750.3765 & 0.0026 & 1.1550 & 205.618 \\ \text { YPIEHGIITNWDDMEK } & 0.83 & 16.10 & 27.40 & 21.49 & 3 & 2248.1104 & 2248.1078 & 750.3765 & 0.0026 & 1.1550 & 135.499\end{array}$ $\begin{array}{lllllllllllll}\text { YPIEHGIITNWDDMEK } & 0.83 & 16.10 & 27.40 & 21.49 & 3 & 2248.1104 & 2248.1078 & 750.3765 & 0.0026 & 1.1550 & 135.499 \\ \text { YPIEHGITNWDDMEK } & 0.85 & 16.62 & 27.40 & 19.95 & 3 & 2248.1104 & 2248.1078 & 750.3765 & 0.0026 & 1.1550 & 37.349\end{array}$ $\begin{array}{lllllllllllll}\text { YPIEHGIITNWDDMEK } & 0.85 & 16.62 & 27.40 & 19.95 & 3 & 2248.1104 & 2248.1078 & 750.3765 & 0.0026 & 1.1550 & 37.349 \\ \text { YPIEHGITNWDDMEK } & 0.94 & 20.39 & 27.41 & 20.76 & 3 & 2248.1107 & 2248.1078 & 750.3765 & 0.0029 & 1.2882 & 156.824\end{array}$ $\begin{array}{llllllllllll}\text { YPIEHGIITNWDDMEK } & 0.94 & 20.39 & 27.41 & 20.76 & 3 & 2248.1107 & 2248.1078 & 750.3765 & 0.0029 & 1.2882 & 156.824 \\ \text { YPIEHGIITNWDDMEK } & 0.61 & 11.64 & 27.41 & 14.90 & 3 & 2248.1107 & 2248.1078 & 750.3765 & 0.0029 & 1.2882 & 107.041\end{array}$ $\begin{array}{lllllllllllll}\text { YPIEHGIITNWDDMEK } & 0.61 & 11.64 & 27.41 & 14.90 & 3 & 2248.1107 & 2248.1078 & 750.3765 & 0.0029 & 1.2882 & 107.041 \\ \text { YPIEHGIITNWDDMEK } & 0.96 & 22.37 & 27.41 & 23.29 & 3 & 2248.1107 & 2248.1078 & 750.3765 & 0.0029 & 1.2882 & 62.672\end{array}$ $\begin{array}{llllllllllll}\text { YPIEHGIITNWDDMEK } & 0.96 & 22.37 & 27.41 & 23.29 & 3 & 2248.1107 & 2248.1078 & 750.3765 & 0.0029 & 1.2882 & 62.672 \\ \text { YPIEHGIITNWDDMEK } & 0.92 & 11.80 & 27.43 & 17.41 & 4 & 2248.1109 & 2248.1078 & 563.0342 & 0.0031 & 1.3765 & 63.992\end{array}$

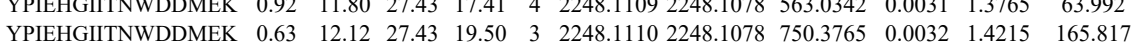
$\begin{array}{llllllllllll}\text { YPIEHGIITNWDDMEK } & 0.63 & 12.12 & 27.43 & 19.50 & 3 & 2248.1110 & 2248.1078 & 750.3765 & 0.0032 & 1.4215 & 165.817 \\ \text { YPIEHGITNWDDDMEK } & 0.87 & 17.36 & 27.43 & 17.99 & 3 & 2248.1110 & 2248.1078 & 750.3765 & 0.0032 & 1.4215 & 187.182\end{array}$ $\begin{array}{llllllllllll}\text { YPIEHGIITNWDDMEK } & 0.67 & 17.89 & 27.43 & 30.89 & 3 & 2248.1110 & 2248.1078 & 750.3765 & 0.0032 & 1.4215 & 193.834\end{array}$ $\begin{array}{llllllllllll}\text { YPIEHGIITNWDDMEK } & 0.81 & 22.05 & 27.43 & 32.18 & 3 & 2248.1110 & 2248.1078 & 750.3765 & 0.0032 & 1.4215 & 113.632\end{array}$

$\begin{array}{llllllllllll}\text { YPIEHGITNWDDDMEK } & 0.91 & 18.99 & 27.43 & 20.04 & 3 & 2248.1110 & 2248.1078 & 750.3765 & 0.0032 & 1.4215 & 160.110\end{array}$

(1)




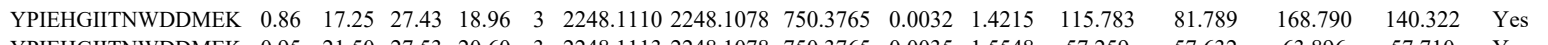
$\begin{array}{llllllllllllllll}\text { YPIEHGIITNWDDMEK } & 0.95 & 21.50 & 27.53 & 20.60 & 3 & 2248.1113 & 2248.1078 & 750.3765 & 0.0035 & 1.5548 & 57.259 & 57.632 & 63.896 & 57.710 & \text { Yes }\end{array}$

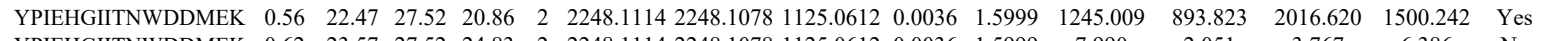

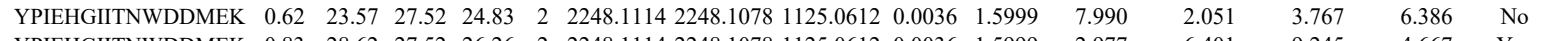

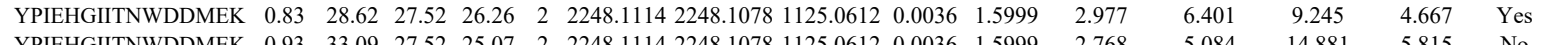

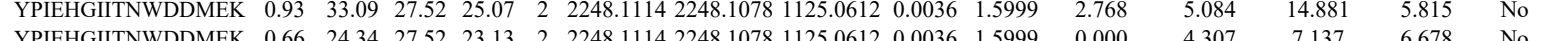

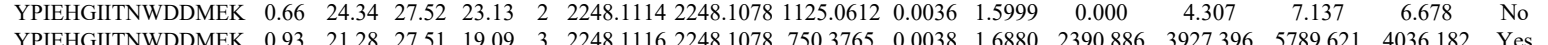
$\begin{array}{llllllllllllllll}\text { YPIEHGIITNWDDMEK } & 0.93 & 21.28 & 27.51 & 19.09 & 3 & 2248.1116 & 2248.1078 & 750.3765 & 0.0038 & 1.6880 & 2390.886 & 3927.396 & 5789.621 & 4036.182 & \text { Yes } \\ \text { YPIEHINWD }\end{array}$

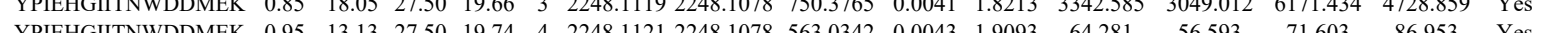

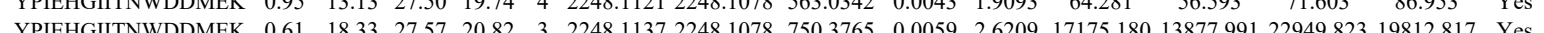

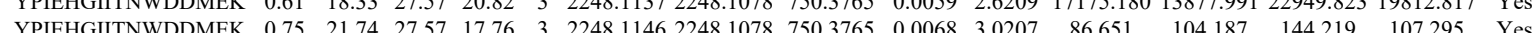

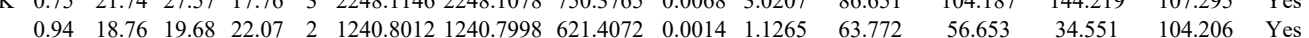
LLLPGELAK LLLPGELAK SAPAPK SAPAPK SAPAPK EIQTAVR
EIQTAVR EIQTAVR
EIQTAVR LLLPGELAK QVHPDTGISSK QVHPDTGISSK QVHPDTGISSK QVHPDTGISSK QVHPDTGISSK QVHPDTGISSK QVHPDTGISSK QVHPDTGISSK QVHPDTGISSK QVHPDTGISSK QVHPDTGISSK QVHPDTGISSK QVHPDTGISSK QVHPDTGISSK QVHPDTGISSK QVHPDTGISSK

SAPAPK

QVTSK

QVHPDTGISSK

QVHPDTGISSK

QVHPDTGISSK

LLLPGELAK

LLLPGELAK

LLLPGELAK

LLLPGELAK

LLLPGELAK

LAHYNK

LLLPGELAK

LLLPGELAK

LLLPGELAK

LLLPGELAK

QVHPDTGISSK

QVHPDTGISSK

KESYSVYVYK

KESYSVYVYK

KESYSVYVYK

LLLPGELAK

LLLPGELAK

LLLPGELAK

LLLPGELAK

QVHPDTGISSK

KESYSVYVYK

$\begin{array}{lll}34.551 & 104.206 & \text { Yes } \\ 15.401 & 36.850 & \text { Yes }\end{array}$

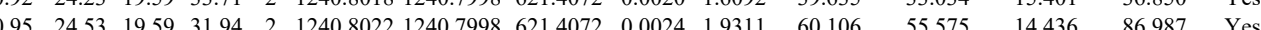
$\begin{array}{lllllllllllllll}0.93 & 28.23 & 25.40 & 21.48 & 2 & 857.5214 & 857.5214 & 429.7680 & 0.0000 & 0.0000 & 1002.345 & 1161.683 & 23.430 & 2028.701 & \text { Yes }\end{array}$ $\begin{array}{llllllllllllllll}0.97 & 28.00 & 25.17 & 22.69 & 2 & 857.5226 & 857.5214 & 429.7680 & 0.0012 & 13961 & 4499.994 & 5990.563 & 126.100 & 9525.524 & \text { Yes }\end{array}$ $\begin{array}{llllllllllllllll}0.94 & 41.72 & 27.52 & 44.89 & 2 & 959.5520 & 959.5522 & 480.7834 & -0.0002 & -0.2080 & 2714.888 & 3066.798 & 5919.467 & 9456.617 & \text { No }\end{array}$

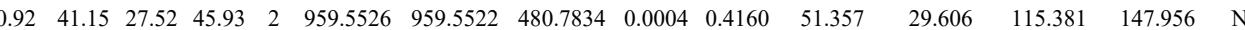
$\begin{array}{llllllllllllllll}0.89 & 38.20 & 27.52 & 44.19 & 2 & 959.5526 & 959.5522 & 480.7834 & 0.0004 & 0.4160 & 20.842 & 35.861 & 72.655 & 79.713 & \text { No }\end{array}$ $\begin{array}{llllllllllllllll}0.98 & 44.02 & 27.45 & 46.92 & 2 & 959.5532 & 959.5522 & 480.7834 & 0.0010 & 1.0400 & 2660.746 & 2569.285 & 5590.192 & 8603.978 & \text { No }\end{array}$ $\begin{array}{lllllllllllllllll}0.67 & 14.07 & 19.68 & 26.12 & 2 & 1240.8002 & 1240.7998 & 621.4072 & 0.0004 & 0.3219 & 193.447 & 171.143 & 100.247 & 245.877 & \text { Yes }\end{array}$ $\begin{array}{lllllllllllllll}0.96 & 37.48 & 28.06 & 21.11 & 3 & 1455.7897 & 1455.7925 & 486.2714 & -0.0028 & -1.9194 & 80.800 & 56.160 & 33.303 & 102.405 & \text { Yes }\end{array}$ $\begin{array}{lllllllllllllll}0.93 & 35.02 & 28.20 & 18.73 & 3 & 1455.7900 & 1455.7925 & 486.2714 & -0.0025 & -1.7137 & 203.848 & 187.663 & 83.405 & 251.598 & \text { Yes }\end{array}$

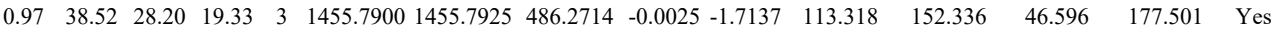
$\begin{array}{llllllllllllllll}0.98 & 34.09 & 28.22 & 19.82 & 3 & 1455.7918 & 1455.7925 & 486.2714 & -0.0007 & -0.4798 & 124.160 & 121.070 & 66.664 & 158.687 & \text { Yes }\end{array}$ $\begin{array}{llllllllllllllll}1.00 & 66.58 & 28.21 & 37.77 & 2 & 1455.7926 & 1455.7925 & 728.9035 & 0.0001 & 0.0686 & 3423.404 & 5345.145 & 0.000 & 7926.075 & \text { No }\end{array}$ $\begin{array}{lllllllllllllll}1.00 & 63.46 & 28.21 & 43.79 & 2 & 1455.7926 & 1455.7925 & 728.9035 & 0.0001 & 0.0686 & 7025.677 & 9265.747 & 0.000 & 15401.817 & \text { No }\end{array}$

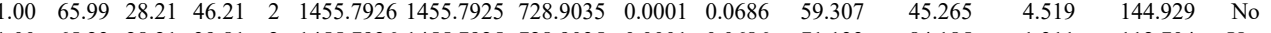

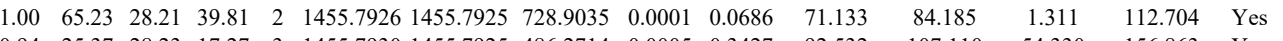
$\begin{array}{lllllllllllllll}0.94 & 25.37 & 28.23 & 17.27 & 3 & 1455.7930 & 1455.7925 & 486.2714 & 0.0005 & 0.3427 & 92.532 & 107.110 & 54.330 & 156.863 & \text { Yes }\end{array}$ $\begin{array}{lllllllllllllllll}1.00 & 45.71 & 28.31 & 21.73 & 3 & 1455.7933 & 1455.7925 & 486.2714 & 0.0008 & 0.5484 & 255.714 & 313.845 & 9.627 & 538.505 & \text { Yes }\end{array}$ $\begin{array}{lllllllllllllll}1.00 & 43.37 & 28.31 & 20.94 & 3 & 1455.7933 & 1455.7925 & 486.2714 & 0.0008 & 0.5484 & 237.801 & 299.711 & 10.553 & 470.806 & \text { Yes }\end{array}$ $\begin{array}{lllllllllllllllll}1.00 & 36.34 & 28.27 & 19.93 & 3 & 1455.7936 & 1455.7925 & 486.2714 & 0.0011 & 0.7540 & 139.155 & 177.391 & 67.245 & 240.612 & \text { Yes } \\ 0.55 & 32.31 & 28.22 & 45.31 & 3 & 1455.7939 & 1455.7925 & 486.2714 & 0.0014 & 0.9597 & 116.912 & 131316 & 78.847 & 165.557 & \text { Yes }\end{array}$ $\begin{array}{lllllllllllllll}0.55 & 32.31 & 28.22 & 45.31 & 3 & 1455.7939 & 1455.7925 & 486.2714 & 0.0014 & 0.9597 & 116.912 & 131.316 & 78.847 & 165.557 & \text { Yes } \\ 0.99 & 30.07 & 2.22 & 16.90 & 3 & 1455.7939 & 1455.7925 & 486.2714 & 0.0014 & 0.9597 & 108.780 & 92.623 & 49.547 & 144.110 & \text { Yes }\end{array}$ $\begin{array}{lllllllllllllll}0.99 & 30.07 & 28.22 & 16.90 & 3 & 1455.7939 & 1455.7925 & 486.2714 & 0.0014 & 0.9597 & 108.780 & 92.623 & 49.547 & 144.110 & \text { Yes }\end{array}$

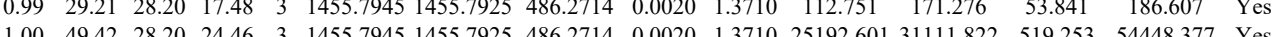

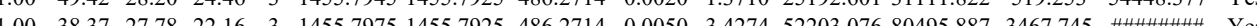
$\begin{array}{lllllllllllllll}0.54 & 17.38 & 25.40 & 26.64 & 2 & 857.5210 & 857.5214 & 429.7680 & -0.0004 & 0.4654 & 484.507 & 533.474 & 24.156 & 899.766 & \text { Yes }\end{array}$

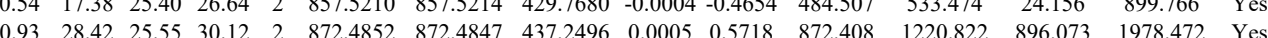

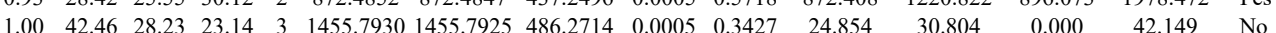
$\begin{array}{lllllllllllllll}1.00 & 36.64 & 28.31 & 23.65 & 3 & 1455.7933 & 1455.7925 & 486.2714 & 0.0008 & 0.5484 & 19.370 & 7.711 & 4.224 & 40.590 & \text { No- }\end{array}$

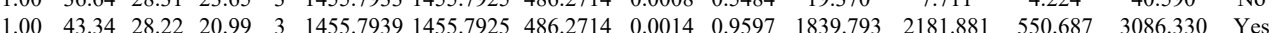

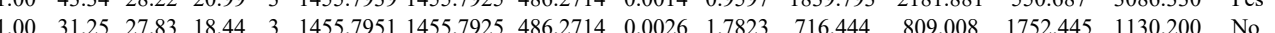
$\begin{array}{lllllllllllllll}0.80 & 26.91 & 20.21 & 31.79 & 2 & 1240.7990 & 1240.7998 & 621.4072 & -0.0008 & -0.6437 & 211.030 & 219.412 & 96.001 & 321.902 & \text { Yes }\end{array}$ $\begin{array}{lllllllllllllll}0.94 & 25.01 & 20.13 & 28.46 & 2 & 1240.7994 & 1240.7998 & 621.4072 & -0.0004 & -0.3219 & 187.169 & 184.380 & 74.851 & 263.283 & \text { Yes }\end{array}$ $\begin{array}{lllllllllllllll}0.78 & 26.78 & 19.78 & 28.69 & 2 & 1240.7976 & 1240.7998 & 621.4072 & -0.0022 & -1.7702 & 157.646 & 213.518 & 57.323 & 249.833 & \text { Yes }\end{array}$ $\begin{array}{llllllllllllllll}0.97 & 29.19 & 19.87 & 29.09 & 2 & 1240.8000 & 1240.7998 & 621.4072 & 0.0002 & 0.1609 & 203.571 & 246.949 & 58.289 & 341.217 & \text { Yes }\end{array}$ $\begin{array}{lllllllllllllll}0.97 & 36.56 & 19.68 & 36.10 & 2 & 1240.8002 & 1240.7998 & 621.4072 & 0.0004 & 0.3219 & 271.594 & 248.333 & 88.683 & 374.434 & \text { Yes }\end{array}$ $\begin{array}{lllllllllllllll}0.98 & 27.83 & 19.68 & 29.55 & 2 & 1240.8010 & 1240.7998 & 621.4072 & 0.0012 & 0.9655 & 252.968 & 253.217 & 69.089 & 363.744 & \text { Yes }\end{array}$

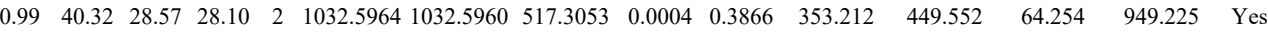

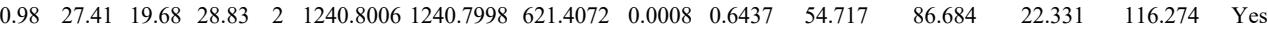

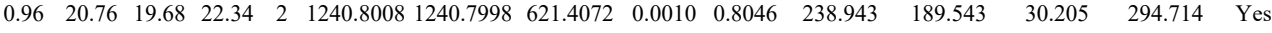

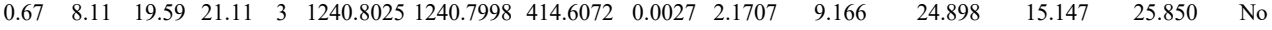
$\begin{array}{lllllllllllllll}0.78 & 22.41 & 19.59 & 25.73 & 2 & 1240.8052 & 1240.7998 & 621.4072 & 0.0054 & 4.3450 & 173.604 & 193.695 & 37.000 & 273.705 & \text { Yes }\end{array}$ $\begin{array}{lllllllllllllll}0.99 & 34.59 & 28.22 & 20.13 & 3 & 1455.7918 & 1455.7925 & 486.2714 & -0.0007 & -0.4798 & 132.819 & 206.078 & 82.631 & 208.709 & \text { Yes }\end{array}$ $\begin{array}{lllllllllllllll}1.00 & 39.95 & 28.21 & 23.66 & 3 & 1455.7927 & 4555.7925 & 486.2714 & 0.0002 & 0.1371 & 219.079 & 273.247 & 72.516 & 335.529 & \text { Yes }\end{array}$ $\begin{array}{lllllllllllllll}0.99 & 38.85 & 25.77 & 18.71 & 2 & 1696.9524 & 1696.9401 & 849.4773 & 0.0123 & 7.2397 & 10974.294 & 17927.203 & 0.000 & 23501.309 & \text { No }\end{array}$ $\begin{array}{lllllllllllllllll}0.98 & 36.50 & 25.59 & 21.24 & 2 & 1696.9532 & 1696.9401 & 849.4773 & 0.0131 & 7.7106 & 13108.242 & 21452.740 & 1282.226 & 31191.988 & \text { Yes }\end{array}$ $\begin{array}{llllllllllllllll}0.99 & 38.59 & 25.59 & 20.14 & 3 & 1696.9534 & 1696.9401 & 566.6540 & 0.0133 & 7.8236 & 14110.176 & 23788.919 & 1918.845 & 36440.828 & \text { Yes }\end{array}$

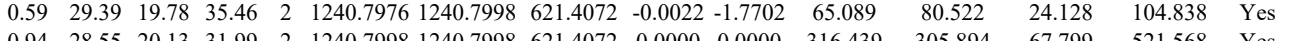
$\begin{array}{lllllllllllllll}0.94 & 28.55 & 20.13 & 31.99 & 2 & 1240.7998 & 1240.7998 & 621.4072 & 0.0000 & 0.0000 & 316.439 & 305.894 & 67.799 & 521.568 & \text { Yes } \\ 0.97 & 18.04 & 19.68 & 19.19 & 3 & 1240.8004 & 1240.7998 & 414.6072 & 0.0006 & 0.4824 & 28.777 & 31.343 & 17.703 & 34.949 & \text { Yes }\end{array}$

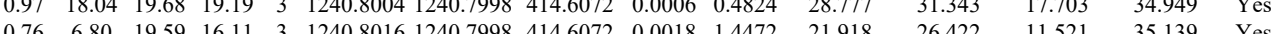

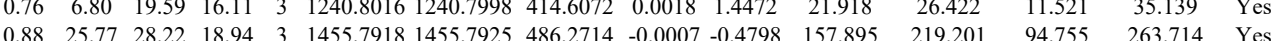

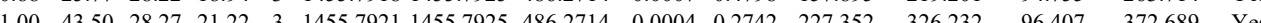
$\begin{array}{lllllllllllllll}1.09 & 39.55 & 28.27 & 21.22 & 3 & 1455.7921 & 1455.7925 & 486.2714 & -0.0004 & -0.2742 & 227.352 & 326.232 & 96.407 & 372.689 & \text { Yes } \\ 0.99 & 39.75 & 2 & 1696.9520 & 1696.9401 & 849.4773 & 0.0119 & 7.0043 & 8659.451 & 14918.802 & 0.000 & 21011.267 & \text { No }\end{array}$

Table S-4 page 597 of 614 

$\begin{array}{lllllllllllll}0.98 & 43.22 & 19.87 & 40.28 & 2 & 1240.8000 & 1240.7998 & 621.4072 & 0.0002 & 0.1609 & 406.903 & 494.313\end{array}$ $\begin{array}{lllllllllllllll}0.97 & 39.29 & 19.87 & 39.04 & 2 & 1240.8000 & 1240.7998 & 621.4072 & 0.0002 & 0.1609 & 171.928 & 275.732\end{array}$ $\begin{array}{llllllllllll}0.99 & 44.36 & 19.68 & 42.46 & 2 & 1240.8004 & 1240.7998 & 621.4072 & 0.0006 & 0.4828 & 480.366 & 5\end{array}$ $\begin{array}{llllllllllll}1.00 & 44.73 & 19.68 & 40.22 & 2 & 1240.8008 & 1240.7998 & 621.4072 & 0.0010 & 0.8046 & 434.956 & \end{array}$ $\begin{array}{lllllllllllll}0.99 & 42.46 & 19.68 & 40.25 & 2 & 1240.8010 & 1240.7998 & 621.4072 & 0.0012 & 0.9655 & 533.675 & 6\end{array}$ $\begin{array}{llllllllllll}0.99 & 44.35 & 19.68 & 40.15 & 2 & 1240.8010 & 1240.7998 & 621.4072 & 0.0012 & 0.9655 & 489.455 & 5\end{array}$ $\begin{array}{llllllllllll}0.99 & 40.27 & 19.68 & 40.00 & 2 & 1240.8010 & 1240.7998 & 621.4072 & 0.0012 & 0.9655 & 484.959 & 5\end{array}$ $\begin{array}{llllllllllll}0.99 & 44.50 & 19.68 & 40.37 & 2 & 1240.8010 & 1240.7998 & 621.4072 & 0.0012 & 0.9655 & 469.221 & \end{array}$ $\begin{array}{llllllllllllll}0.99 & 40.95 & 19.59 & 39.91 & 2 & 1240.8016 & 1240.7998 & 621.4072 & 0.0018 & 1.4483 & 477.002 & 5 & \end{array}$ $\begin{array}{lllllllllllll}0.99 & 42.28 & 19.59 & 40.03 & 2 & 1240.8018 & 1240.7998 & 621.4072 & 0.0020 & 1.6092 & 475.790 & 531\end{array}$ $\begin{array}{lllllllllllllll}0.99 & 40.51 & 19.59 & 39.08 & 2 & 1240.8022 & 1240.7998 & 621.4072 & 0.0024 & 1.9311 & 152.900 & 201.952\end{array}$ $\begin{array}{lllllllllllll}1.00 & 29.66 & 19.59 & 16.29 & 3 & 1240.8031 & 1240.7998 & 414.6072 & 0.0033 & 2.6531 & 30.563 & 40.072\end{array}$ $\begin{array}{lllllllllllll}0.98 & 29.82 & 19.14 & 20.49 & 3 & 1240.8109 & 1240.7998 & 414.6072 & 0.0111 & 8.9240 & 78.192 & 72.806\end{array}$ $\begin{array}{lllllllllllll}0.96 & 23.88 & 19.14 & 17.92 & 3 & 1240.8109 & 1240.7998 & 414.6072 & 0.0111 & 8.9240 & 58.961 & 64.142\end{array}$ $\begin{array}{lllllllllllll}1.00 & 46.12 & 28.23 & 20.58 & 3 & 1455.7930 & 4455.7925 & 486.2714 & 0.0005 & 0.3427 & 130.788 & 146.167\end{array}$

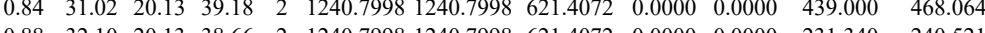
$\begin{array}{llllllllllll}0.88 & 32.10 & 0.13 & 38.66 & 2 & 1240.7998 & 1240.7998 & 621.4072 & 0.0000 & 0.0000 & 231.340 & 240.521 \\ 0.98 & 40.63 & 20.13 & 39.27 & 2 & 1240.7998 & 1240.7998 & 621.4072 & 0.000 & 0.0000 & 229.840 & 244.606\end{array}$

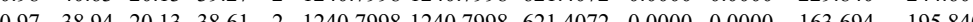

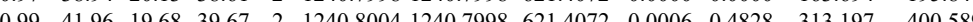

\section{LLLPGELAK}

LLLPGELAK

LLLPGELAK

LLLPGELAK

LLLPPGELAK

LLLPGELAK
LLLPGELAK

LLLPGELAK

LLLPGELAK

LLLPGELAK

LLLPGELAK

LLLPGELAK

LLLPGELAK

LLLPGELAK

LLLPGELAK

LLLPGELAK

LLLPGELAK

LLLPGELAK

LLLPGELAK

LLLPGELAK

LLLPGELAK

LLLPGELAK

LLLPGELAK

LLLPGELAK

LLLPGELAK

LLLPGELAK

$\begin{array}{lllllllllllll}.99 & 41.96 & 19.68 & 39.67 & 2 & 1240.8004 & 1240.7998 & 621.4072 & 0.0006 & 0.4828 & 313.197 & 400.589\end{array}$ $\begin{array}{lllllllllllllll}0.95 & 22.11 & 19.68 & 25.13 & 3 & 1240.8007 & 1240.7998 & 414.6072 & 0.0009 & 0.7236 & 47.628 & 29.131\end{array}$ $\begin{array}{llllllllllllll}0.93 & 41.46 & 19.68 & 49.63 & 2 & 1240.8008 & 1240.7998 & 621.4072 & 0.0010 & 0.8046 & 488.405 & 480.282\end{array}$ $\begin{array}{llllllllllllllll}0.98 & 37.18 & 19.68 & 39.76 & 2 & 1240.8008 & 1240.7998 & 621.4072 & 0.0010 & 0.8046 & 394.553 & 449.210\end{array}$ $\begin{array}{llllllllllllll}0.99 & 43.98 & 19.68 & 39.82 & 2 & 1240.8010 & 1240.7998 & 621.4072 & 0.0012 & 0.9655 & 328.014 & 377.564\end{array}$ $\begin{array}{llllllllllllll}0.93 & 15.00 & 19.68 & 19.18 & 3 & 1240.8013 & 1240.7998 & 414.6072 & 0.0015 & 1.2060 & 42.006 & 32.772\end{array}$ $\begin{array}{lllllllllllll}0.99 & 42.31 & 19.59 & 40.12 & 2 & 1240.8014 & 1240.7998 & 621.4072 & 0.0016 & 1.2874 & 466.663 & 513.102\end{array}$ $\begin{array}{lllllllllllll}0.99 & 42.03 & 19.59 & 39.83 & 2 & 1240.8016 & 1240.7998 & 621.4072 & 0.0018 & 1.4483 & 375.436 & 450.438\end{array}$ $\begin{array}{ccccccccccccc}1.00 & 44.69 & 19.59 & 40.22 & 2 & 1240.8018 & 1240.7998 & 621.4072 & 0.0020 & 1.6092 & 412.473 & 494.018 \\ 0.60 & 5.08 & 19.59 & 18.08 & 3 & 1240.8037 & 1240.7998 & 414.6072 & 0.0039 & 3.1355 & 50.574 & 44.354\end{array}$ $\begin{array}{llllllllllll}0.98 & 29.74 & 19.49 & 21.67 & 3 & 1240.8076 & 1240.7998 & 414.6072 & 0.0078 & 6.2710 & 74.265 & 76.035\end{array}$ $\begin{array}{lllllllllllll}0.95 & 28.59 & 19.49 & 23.21 & 3 & 1240.8091 & 1240.7998 & 414.6072 & 0.0093 & 7.4769 & 67.471 & 73.454\end{array}$ $\begin{array}{llllllllllll}0.69 & 46.73 & 19.14 & 56.01 & 2 & 1240.8110 & 1240.7998 & 621.4072 & 0.0112 & 9.0117 & 4047.332 & 4771.769\end{array}$

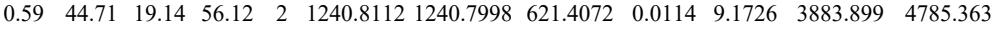
$\begin{array}{lllllllllllll}0.80 & 27.55 & 19.87 & 37.07 & 2 & 1240.8000 & 1240.7998 & 621.4072 & 0.0002 & 0.1609 & 198.854 & 214.477\end{array}$ $\begin{array}{llllllllllll}0.79 & 26.41 & 19.87 & 36.02 & 2 & 1240.8000 & 1240.7998 & 621.4072 & 0.0002 & 0.1609 & 127.311 & 124.315\end{array}$ $\begin{array}{lllllllllllll}0.95 & 26.53 & 19.68 & 33.57 & 2 & 1240.8004 & 1240.7998 & 621.4072 & 0.0006 & 0.4828 & 98.429 & 130.631\end{array}$ $\begin{array}{lllllllllllll}0.99 & 42.54 & 19.68 & 40.66 & 2 & 1240.8010 & 1240.7998 & 621.4072 & 0.0012 & 0.9655 & 231.731 & 275.913\end{array}$ $\begin{array}{llllllllllll}0.97 & 33.00 & 19.59 & 37.69 & 2 & 1240.8014 & 1240.7998 & 621.4072 & 0.0016 & 1.2874 & 229.498 & 223.713\end{array}$ $\begin{array}{llllllllllllll}0.99 & 40.28 & 19.59 & 37.95 & 2 & 1240.8018 & 1240.7998 & 621.4072 & 0.0020 & 1.6092 & 211.152 & 222.231\end{array}$ $\begin{array}{lllllllllllll}0.77 & 38.30 & 19.59 & 50.12 & 2 & 1240.8026 & 1240.7998 & 621.4072 & 0.0028 & 2.2529 & 202.280 & 215.579\end{array}$ $\begin{array}{lllllllllllll}0.73 & 30.80 & 19.14 & 39.30 & 2 & 1240.8108 & 1240.7998 & 621.4072 & 0.0110 & 8.8508 & 10201.449 & 17012.439\end{array}$

LLLPGELAK $\begin{array}{lllllllllllll}0.94 & 48.33 & 19.59 & 56.28 & 2 & 1240.8014 & 1240.7998 & 621.4072 & 0.0016 & 1.2874 & 20206.266 & 26655.274\end{array}$ $\begin{array}{lllllllllllll}0.99 & 59.72 & 19.59 & 56.69 & 2 & 1240.8024 & 1240.7998 & 621.4072 & 0.0026 & 2.0920 & 32022.058 & 41612.422\end{array}$ $\begin{array}{llllllllllll}0.88 & 45.10 & 19.68 & 56.03 & 2 & 1240.8006 & 1240.7998 & 621.4072 & 0.0008 & 0.6437 & 10783.302 & 1261.634\end{array}$ 
$\begin{array}{lllllllllllll}\text { AMGMNFFNIFER } & 1.00 & 87.13 & 27.24 & 31.96 & 2 & 1886.9150 & 1886.9141 & 944.4643 & 0.0009 & 0.4765 & 1135.549 & 1702.200 \\ \text { AMGIMNSFVNDIFER } & 1.00 & 72.48 & 27.16 & 21.37 & 2 & 1886.9152 & 1886.9141 & 944.4643 & 0.0011 & 0.5823 & 1228.884 & 1420.103\end{array}$

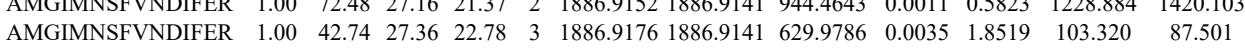
QVHPDTGISSK $\begin{array}{llllllllllll}0.96 & 27.69 & 28.21 & 22.40 & 3 & 1455.7927 & 1455.7925 & 486.2714 & 0.0002 & 0.1371 & 252.666 & 226.431\end{array}$

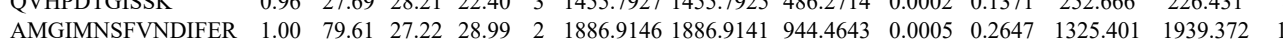
$\begin{array}{llllllllllllll}\text { AMGIMNSFVNDIFER } & 1.00 & 93.86 & 27.24 & 31.94 & 2 & 1886.9150 & 1886.9141 & 944.4643 & 0.0009 & 0.4765 & 1457.607 & 2246.2\end{array}$

QVHPDTGISSK $\begin{array}{lllllllllllll}0.97 & 28.60 & 28.23 & 15.35 & 3 & 1455.7930 & 1455.7925 & 486.2714 & 0.0005 & 0.3427 & 226.171\end{array}$

QVHPDTGISSK $\begin{array}{llllllllllllll}1.00 & 34.75 & 28.31 & 22.59 & 3 & 1455.7933 & 1455.7925 & 486.2714 & 0.0008 & 0.5484 & 189.771 \\ 0.89 & 20.90 & 28.22 & 14.54 & 3 & 1455.7939 & 1455.7925 & 486.2714 & 0.0014 & 0.9597 & 98.290\end{array}$

AMGIMNSFVND 1.00

QVHPDTGISSK $\begin{array}{lllllllllll}1.00 & \# \# \# \text { \#\#\# 27.17 } & 30.51 & 2 & 1886.9144 & 1886.9141 & 944.4643 & 0.0003 & 0.1588 & 25.299\end{array}$

QVHPDTGISSK $\begin{array}{llllllllllll}0.99 & 33.09 & 28.21 & 15.85 & 3 & 1455.7927 & 1455.7925 & 486.2714 & 0.0002 & 0.1371 & 211.144 \\ 0.55 & 4.44 & 28.31 & 54.44 & 3 & 1455.7933 & 1455.7925 & 4862714 & 0.0008 & 0.5484 & 286.607\end{array}$ $\begin{array}{lllllllllllll}1.00 & 38.79 & 28.31 & 19.38 & 3 & 1455.7933 & 1455.7925 & 486.2714 & 0.0008 & 0.5484 & 380.951\end{array}$ $\begin{array}{llllllllllll}1.00 & 49.01 & 28.31 & 22.72 & 3 & 1455.7933 & 1455.7925 & 486.2714 & 0.0008 & 0.5484 & 260.457\end{array}$ $\begin{array}{lllllllllll}1.00 & 50.67 & 28.21 & 36.66 & 2 & 1455.7924 & 1455.7925 & 728.9035 & -0.0001 & -0.0686 & 84.063 \\ 1.00 & 61.91 & 28.21 & 28.32 & 2 & 1455.7926 & 1455.7925 & 728.9035 & 0.0001 & 0.0686 & 76.53\end{array}$ $\begin{array}{llllllllllll}1.00 & 61.91 & 28.21 & 28.32 & 2 & 1455.7926 & 1455.7925 & 728.9035 & 0.0001 & 0.0686 & 76.253\end{array}$ $\begin{array}{cccccccccccc}1.00 & 50.01 & 28.21 & 37.08 & 2 & 1455.7926 & 1455.7925 & 728.9035 & 0.0001 & 0.0686 & 50.779\end{array}$ $\begin{array}{lllllllllllll}1.00 & 43.41 & 28.31 & 19.16 & 3 & 1455.7933 & 1455.7925 & 486.2714 & 0.0008 & 0.5484 & 282.921\end{array}$ $\begin{array}{llllllllllll}0.55 & 36.46 & 28.27 & 49.46 & 3 & 1455.7936 & 1455.7925 & 486.2714 & 0.0011 & 0.7540 & 241.464 \\ 1.00 & 42.02 & 28.27 & 20.30 & 3 & 1455.7936 & 1455.7925 & 486.2714 & 0.0011 & 0.7540 & 194.197\end{array}$ $\begin{array}{llllllllllll}1.00 & 42.02 & 28.27 & 20.30 & 3 & 1455.7936 & 1455.7925 & 486.2714 & 0.001 & 0.7540 & 194.197 \\ 1.00 & 70.88 & 28.22 & 43.15 & 2 & 1455.7910 & 1455.7925 & 728.9035 & -0.0015 & -1.0289 & 20.588\end{array}$ $\begin{array}{rrrrrrrrrrr}1.00 & 70.88 & 28.22 & 43.15 & 2 & 455.7910 & 1455.7925 & 728.9035 & -0.0015 & -1.0289 & 20.588 \\ 0.55 & 30.23 & 28.22 & 43.23 & 3 & 1455.7939 & 1455.7925 & 486.2714 & 0.0014 & 0.9597 & 43.569\end{array}$ $\begin{array}{lllllllllll}0.99 & 35.70 & 28.20 & 30.22 & 2 & 1455.7944 & 1455.7925 & 728.9035 & 0.0019 & 1.3033 & 13.200\end{array}$ 
$\begin{array}{llllllllllll}1.00 & 67.53 & 27.38 & 19.65 & 2 & 18869170 & 1886.9141 & 944.4643 & 0.0029 & 1.5353 & 27.308\end{array}$ $\begin{array}{lllllllllllll}0.74 & 23.40 & 27.52 & 33.46 & 2 & 959.5520 & 959.5522 & 480.7834 & -0.0002 & -0.2080 & 14.283 \\ 0.73 & 23.32 & 27.52 & 32.91 & 2 & 959.5520 & 959.5522 & 480.7834 & -0.0002 & 0.2080 & 15.241\end{array}$ QVHPDTGISSK $\begin{array}{lllllllllllll}0.68 & 15.85 & 28.31 & 22.77 & 3 & 1455.7933 & 1455.7925 & 486.2714 & 0.0008 & 0.5484 & 20.542\end{array}$ $\begin{array}{lllllllllllll}0.97 & 29.02 & 28.19 & 32.00 & 3 & 1455.7942 & 1455.7925 & 486.2714 & 0.0017 & 1.1653 & 13.542\end{array}$ $\begin{array}{lllllllllllll}0.70 & 22.57 & 27.52 & 32.61 & 2 & 959.5522 & 959.5522 & 480.7834 & 0.0000 & 0.0000 & 17.774 \\ 0.68 & 22.11 & 7.52 & 33.56 & 2 & 959.5524 & 959.5522 & 480.7834 & 0.0002 & 0.2080 & 11.082\end{array}$ LLLPGELAK

EIQTAVR $\begin{array}{rrrrrrrrrrrr}0.68 & 22.11 & 27.52 & 33.56 & 2 & 959.5524 & 959.5522 & 480.7834 & 0.0002 & 0.2080 & 11.082 \\ 1.00 & 42.78 & 19.59 & 38.13 & 2 & 1240.8022 & 1240.7998 & 621.4072 & 0.0024 & 1.9311 & 147.731\end{array}$

EIQTAVR $\begin{array}{lllllllllllll}1.00 & 23.32 & 27.52 & 32.44 & 2 & 959.5524 & 959.5522 & 480.7834 & 0.0002 & 0.2080 & 12.002\end{array}$

LLLPGELAK

QVHPDTGISSK $\begin{array}{lllllllllllll}0.74 & 23.53 & 27.52 & 33.01 & 2 & 959.5526 & 959.5522 & 480.7834 & 0.0004 & 0.4160 & 33.648\end{array}$

LLLPGELAK

LLLPGELAK

QVHPDTGISSK

LLLPGELAK

LLLPGELAK

LLLPGELAK

LLLPGELAK

LLLPGELAK

$\begin{array}{llllllllllll}1.00 & 54.37 & 19.68 & 49.83 & 2 & 1240.8008 & 1240.7998 & 621.4072 & 0.0010 & 0.8046 & 260.085\end{array}$ $\begin{array}{llllllllllllll}1.00 & 45.57 & 19.68 & 39.45 & 2 & 1240.8010 & 1240.7998 & 621.4072 & 0.0012 & 0.9655 & 224.590 \\ 0.88 & 20.64 & 28.31 & 18.78 & 3 & 1455.7933 & 1455.7925 & 486.2714 & 0.0008 & 0.5484 & 30.794\end{array}$ $\begin{array}{llllllllllll}0.88 & 20.64 & 28.31 & 18.78 & 3 & 1455.7933 & 1455.7925 & 486.2714 & 0.0008 & 0.5484 & 30.794 \\ 0.95 & 22.18 & 27.83 & 17.81 & 3 & 1455.7954 & 1455.7925 & 486.2714 & 0.0029 & 1.9879 & 16.115\end{array}$ $\begin{array}{llllllllllll}0.93 & 44.59 & 19.68 & 52.62 & 2 & 1240.8004 & 1240.7998 & 621.4072 & 0.0006 & 0.4828 & 403.833\end{array}$ $\begin{array}{llllllllllll}0.99 & 44.53 & 19.68 & 42.68 & 2 & 1240.8004 & 1240.7998 & 621.4072 & 0.0006 & 0.4828 & 512.908\end{array}$ $\begin{array}{lllllllllll}0.88 & 25.64 & 28.27 & 16.16 & 3 & 1455.7921 & 1455.7925 & 486.2714 & -0.0004 & -0.2742 & 63.567\end{array}$ $\begin{array}{llllllllllll}0.95 & 39.81 & 23.12 & 46.21 & 2 & 1096.6986 & 1096.6978 & 549.3562 & 0.0008 & 0.7281 & 38.010\end{array}$ $\begin{array}{llllllllllll}0.99 & 34.38 & 23.12 & 27.72 & 2 & 1096.6982 & 1096.6978 & 549.3562 & 0.0004 & 0.3641 & 55.467\end{array}$ $\begin{array}{llllllllllll}0.98 & 32.48 & 23.12 & 34.52 & 2 & 1096.6986 & 1096.6978 & 549.3562 & 0.0008 & 0.7281 & 27.823 \\ 0.84 & 22.11 & 23.48 & 23.79 & 2 & 952.5958 & 952.5957 & 477.3051 & 0.0001 & 0.1048 & 42.327 \\ 0.99 & 45.3 & 23.12 & 42.81 & 2 & 106.698 & & \end{array}$

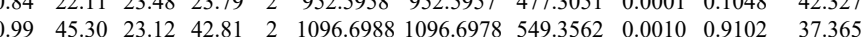
$\begin{array}{llllllllllll}0.98 & 33.39 & 23.14 & 34.63 & 2 & 1096.6990 & 1096.6978 & 549.3562 & 0.0012 & 1.0922 & 37.365 \\ 0\end{array}$

AMGIMNSFVNDIFER

AMGIMNSFVNDIFER

LLLPGELAK

QVEPPDGISSK

QVHPDTGISSK

AMGIMNSFVNDI

LLLPGELAK

LLLPGELAK

QVHPDTGISSK

QVHPDTGISSK (1) $\begin{array}{llllllllllll}1.00 & 49.52 & 23.14 & 35.82 & 2 & 10966990 & 1096.6978 & 549.3562 & 0.0012 & 1.0922 & 37.2017\end{array}$ $\begin{array}{lllllllllll} & 0\end{array}$ $\begin{array}{lllllllllllll}0.99 & 27.96 & 28.19 & 15.46 & 3 & 1455.7942 & 1455.7925 & 486.2714 & 0.0017 & 1.1653 & 48.308\end{array}$ $\begin{array}{lllllllllllll}1.00 & 89.48 & 27.16 & 25.60 & 2 & 1886.9152 & 1886.9141 & 944.4643 & 0.0011 & 0.5823 & 21.304\end{array}$ $\begin{array}{llllllllllll}0.97 & 36.43 & 23.12 & 41.24 & 2 & 1096.6986 & 1096.6978 & 549.3562 & 0.0008 & 0.7281 & 45.778\end{array}$ $\begin{array}{llllllllllll}0.87 & 37.11 & 19.59 & 48.91 & 2 & 1240.8014 & 1240.7998 & 621.4072 & 0.0016 & 1.2874 & 429.549\end{array}$ $\begin{array}{lllllllllll}0.93 & 25.64 & 22.53 & 27.87 & 2 & 1096.6976 & 1096.6978 & 549.3562 & -0.0002 & -0.1820 & 51.108\end{array}$ $\begin{array}{llllllllllll}0.88 & 25.76 & 28.22 & 20.13 & 3 & 1455.7918 & 1455.7925 & 486.2714 & -0.0007 & -0.4798 & 64.481\end{array}$ $\begin{array}{llllllllllllll}\text { QVHPDTGISSK } & 0.62 & 14.58 & 28.22 & 15.47 & 3 & 1455.7939 & 1455.7925 & 486.2714 & 0.0014 & 0.9597 & 44.964 \\ \text { AMGIMNSFVNDIFER } & 1.00 & 81.06 & 27.23 & 22.88 & 2 & 1886.9154 & 1886.9141 & 944.4643 & 0.0013 & 0.6882 & 11.465\end{array}$ $\begin{array}{llllllllllllll}\text { AMGIMNSFVNDIFER } & 0.56 & 10.74 & 27.27 & 16.90 & 3 & 1886.9164 & 1886.9141 & 629.9786 & 0.0023 & 1.2170 & 11.723\end{array}$

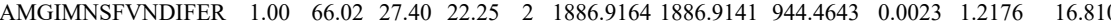

HAVSEGTK

AMGIMNSFVNDIFER

IASEASR

SAPAPK

SAPAPK

QVHPDTGISSK

QVHPDTGISSK

QVHPDTGISSK

QVHPDTGISSK

QVHPDTGISSK

QVHPDTGISSK

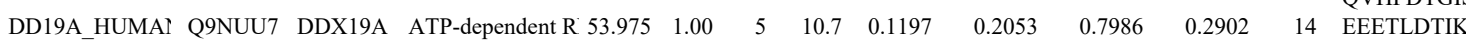
$\begin{array}{lllllllllll}0.64 & 36.92 & 27.09 & 49.92 & 2 & 1115.6180 & 1115.6179 & 558.8162 & 0.0001 & 0.0895 & 129.841\end{array}$ $\begin{array}{llllllllllll}1.00 & 86.68 & 27.40 & 26.64 & 2 & 1886.9176 & 1886.9141 & 944.4643 & 0.0035 & 1.8529 & 13.723\end{array}$ $\begin{array}{lllllllllllll}0.83 & 22.84 & 28.77 & 23.42 & 2 & 876.4792 & 876.4787 & 439.2466 & 0.0005 & 0.5692 & 201.011 & 232.971\end{array}$ $\begin{array}{lllllllllllllll}0.94 & 29.03 & 25.17 & 22.92 & 2 & 857.5218 & 857.5214 & 429.7680 & 0.0004 & 0.4654 & 1946.380 & 2670.640 & 25 \\ 0.98 & 29.03 & 25.17 & 25.26 & 2 & 857.5220 & 857.5214 & 429.7680 & 0.0006 & 0.6981 & 1356.825 & 1718.580 & 0.0\end{array}$ $\begin{array}{lllllllllllllll}0.98 & 29.03 & 25.17 & 25.26 & 2 & 857.5220 & 857.5214 & 429.7680 & 0.0006 & 0.6981 & 1356.825 & 1718.580 & 0\end{array}$ $\begin{array}{llllllllllllll}0.62 & 19.00 & 25.55 & 24.02 & 2 & 872.4852 & 872.4847 & 437.2496 & 0.0005 & 0.5718 & 1806.632 & 2236.989 & 16\end{array}$ $\begin{array}{lllllllllllllll}1.00 & 66.65 & 28.16 & 40.01 & 2 & 1455.7906 & 1455.7925 & 728.9035 & -0.0019 & -1.3033 & 1462.848 & 1904.253 & 47.221 & 3437.231 & Y \text { Ys } \\ 1.00 & 68.69 & 28.21 & 46.58 & 2 & 1455.7916 & 1455.7925 & 728.9035 & -0.0009 & -0.6174 & 1025.924 & 1501.037 & 149.896 & 2639.344 & Y \text { ses }\end{array}$ $\begin{array}{llllllllllllllllllll}1.00 & 60.28 & 28.22 & 25.18 & 3 & 1455.7918 & 1455.7925 & 486.2714 & -0.0007 & -0.4798 & 17601.509 & 22502.210 & 2068.015 & 35291.269 & \text { Yes }\end{array}$ $\begin{array}{llllllllllllllll}1.00 & 4.12 & 28.21 & 16.08 & 3 & 1455.7927 & 1455.7925 & 486.2714 & 0.0002 & 0.1371 & 10766.097 & 15089.369 & 674.708 & 22455.518 & \text { Yes } \\ 0.97 & 26.72 & 28.31 & 18.36 & 3 & 14557933 & 14557925 & 486.2714 & 0.0008 & 0.5484 & 55.576 & 71.192 & 15.259 & 67.127 & \text { Yes }\end{array}$ $\begin{array}{llllllllllll}1.00 & 4.12 & 8.21 & 16.08 & 3 & 1455.7927 & 1455.7925 & 486.2714 & 0.0002 & 0.1371 & 10766.097 & 15089.369\end{array}$

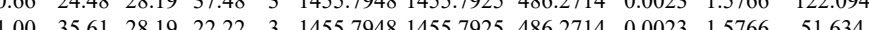

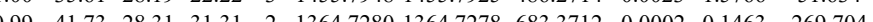




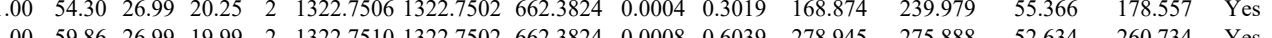
$\begin{array}{lllllllllllllll}1.00 & 59.86 & 26.99 & 19.99 & 2 & 1322.7510 & 1322.7502 & 662.3824 & 0.0008 & 0.6039 & 278.945 & 275.888 & 52.634 & 260.734 & \text { Yes }\end{array}$ $\begin{array}{lllllllllllllll}1.05 & 65.51 & 26.98 & 24.03 & 2 & 1322.7512 & 1322.7502 & 662.3824 & 0.0010 & 0.7549 & 81.080 & 102.504 & 18.073 & 101.297 & \text { Yes } \\ 1.00 & 60.07 & 26.95 & 25.93 & 2 & 1322.7524 & 1322.7502 & 662.3824 & 0.0022 & 1.6607 & 94.657 & 119.806 & 30.476 & 131.095 & \text { Yes }\end{array}$

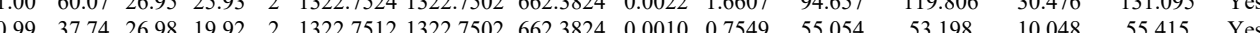

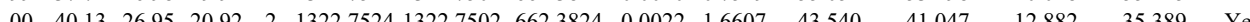
$\begin{array}{lllllllllllll}1.00 & 45.66 & 27.23 & 18.44 & 2 & 1194.6896 & 1194.6883 & 598.3514 & 0.0013 & 1.0863 & 1692.738 & 1491.298\end{array}$

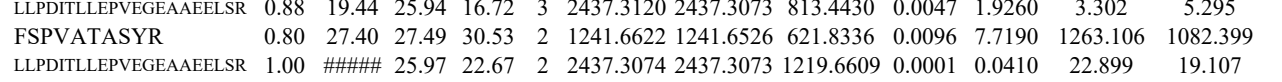
$\begin{array}{llllllllllll}0.82 & 21.45 & 26.54 & 34.45 & 2 & 1125.6382 & 1125.6376 & 563.8261 & 0.000 & 0.5321 & 9.560 & 1 . .254 \\ 0.75 & 18.61 & 6.54 & 18.30 & 2 & 125.638 & 125 & 0.5321 & 18.636 & 27.690\end{array}$ $\begin{array}{llllllllllll}0.75 & 18.61 & 26.54 & 18.30 & 2 & 1125.6382 & 1125.6376 & 563.8261 & 0.0006 & 0.5321 & 18.505 & 21.460\end{array}$ $\begin{array}{lllllllllllll}0.87 & 21.39 & 25.99 & 14.53 & 2 & 1125.6386 & 1125.6376 & 563.8261 & 0.0010 & 0.8868 & 12.276\end{array}$ \begin{tabular}{lllllllllllll} 
& 25.97 & 22.67 & 2 & 2437.3074 & 2437.3073 & 1219.6609 & 0.0001 & 0.041 & 22.899 & 19.107 & \\
\hline
\end{tabular}

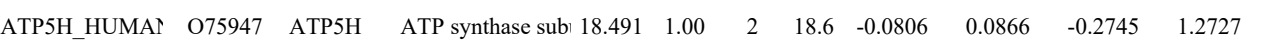
促

AGLVDDFEK AGLVDDFEK AGLVDDFEK

$\begin{array}{lllllllllllll}\text { UROK_HUMAN } & \text { P00749 } & \text { PLAU } & \text { Urokinase-type pl: } 48.507 & 1.00 & 2 & 4.4 & -1.0205 & 0.0528 & 0.4905 & 0.3000 & 3 & \begin{array}{l}\text { VSHFLPWIR } \\ \text { VSHFLPWIR }\end{array}\end{array}$ KPSSPPEELK

$\begin{array}{llllllllllll} & & \end{array}$ EGNNPAENGDAK

EGNNPAENGDAK

TDQAQK

TDQAQK

$\begin{array}{lllllllllllll}\text { LAMP1_hUMA] P11279 } & \text { LAMP1 } & \text { Lysosome-associa 44.882 } & 1.00 & 2 & 4.8 & -0.4854 & 0.1621 & 1.3461 & 0.1679 & 5 & \text { ALQATVGNSYK }\end{array}$

ALQATVGNSYK

ALQATVGNSYK

TVESITDIR

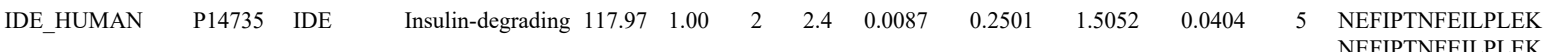
AFIPQLLSR AFIPQLLSR AFIPQLLSR \begin{tabular}{llllllllllllllll}
0.96 & 21.19 & 26.41 & 21.99 & 3 & 1297.7437 & 1297.7417 & 433.5878 & 0.0020 & 1.5376 & 182.815 & 86.990 & 29.877 & 169.842 & Yes \\
\hline
\end{tabular} $\begin{array}{llllllllllllllll}0.99 & 27.94 & 26.00 & 23.61 & 3 & 1297.7443 & 1297.7417 & 433.5878 & 0.0026 & 1.9988 & 149.329 & 72.277 & 38.575 & 154.894 & \text { Yes } \\ 1.00 & 40.67 & 24.64 & 20.70 & 3 & 1542.9034 & 1542.8983 & 515.3067 & 0.0051 & 3.2990 & 4693.720 & 2395.847 & 5833.584 & 6520.578 & \text { Yes }\end{array}$

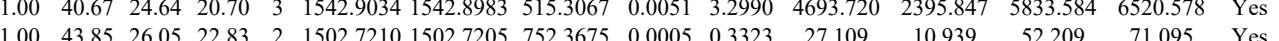

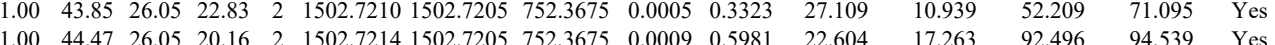
$\begin{array}{lllllllllllllll}1.09 & 13.77 & 26.14 & 18.84 & 3 & 1502.7217 & 1502.7205 & 501.9141 & 0.0012 & 0.7969 & 15.148 & 15.981 & 20.543 & 30.152 & \text { Yes }\end{array}$

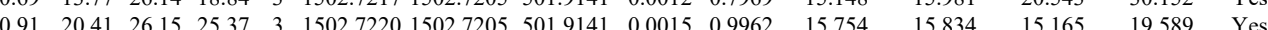
$\begin{array}{lllllllllllllll}0.88 & 24.75 & 28.87 & 28.11 & 2 & 977.5392 & 977.5385 & 489.7765 & 0.0007 & 0.7146 & 299.967 & 271.950 & 148.529 & 492.409 & \text { Yes }\end{array}$ $\begin{array}{lllllllllllllll}0.74 & 24.90 & 29.05 & 30.56 & 2 & 977.5390 & 977.5385 & 489.7765 & 0.0005 & 0.5104 & 212.955 & 219.417 & 148.984 & 492.4322 & \text { Yes }\end{array}$ $\begin{array}{llllllllllllllll}1.00 & 69.27 & 27.07 & 26.29 & 2 & 1438.8076 & 1438.8024 & 720.4085 & 0.0052 & 3.6091 & 11733.149 & 7055.894 & 946.657 & 8221.569 & \text { Yes }\end{array}$ $\begin{array}{lllllllllllllll}1.00 & 67.03 & 27.05 & 26.37 & 2 & 1438.8078 & 1438.8024 & 720.4085 & 0.0054 & 3.7479 & 1287.710 & 1002.462 & 366.192 & 1215.428 & \text { Yes }\end{array}$ $\begin{array}{lllllllllllllll}1.00 & 70.16 & 27.31 & 27.05 & 2 & 1438.8052 & 1438.8024 & 720.4085 & 0.0028 & 1.9433 & 14723.955 & 11632.950 & 2218.774 & 11877.159 & \text { Yes }\end{array}$ $\begin{array}{lllllllllllllll}1.00 & 70.30 & 27.15 & 25.68 & 2 & 1438.8058 & 1438.8024 & 720.4085 & 0.0034 & 2.3598 & 13114.839 & 8833.425 & 2086.391 & 9687.376 & \text { Yes }\end{array}$ $\begin{array}{lllllllllllllll}0.99 & 42.65 & 28.16 & 33.41 & 2 & 1176.6584 & 1176.6472 & 589.3309 & 0.0112 & 9.5022 & 5534.005 & 3989.747 & 694.352 & 4114.760 & \text { Yes }\end{array}$

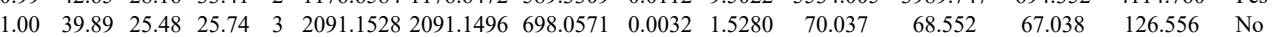
$\begin{array}{lllllllllllllll}1.00 & 34.97 & 25.45 & 21.70 & 3 & 2091.1537 & 2091.1496 & 698.0571 & 0.0041 & 1.9578 & 83.155 & 111.457 & 44.771 & 137.635 & \text { Yes }\end{array}$ $\begin{array}{lllllllllllllll}0.96 & 31.07 & 25.24 & 36.18 & 2 & 1187.7158 & 1187.7148 & 594.8647 & 0.0010 & 0.8405 & 3727.555 & 3679.818 & 1185.095 & 6594.370 & \text { Yes }\end{array}$ $\begin{array}{llllllllllllllll}0.99 & 33.64 & 25.26 & 29.49 & 2 & 1187.7162 & 1187.7148 & 594.8647 & 0.0014 & 1.1767 & 3793.925 & 3499.675 & 716.791 & 6527.212 & \text { Yes }\end{array}$

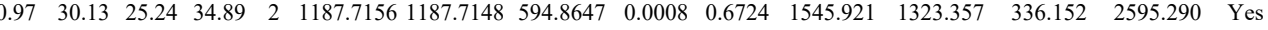
$\begin{array}{lllllllllllllll}0.97 & 32.02 & 25.26 & 35.40 & 2 & 1187.7160 & 1187.7148 & 594.8647 & 0.0012 & 1.0086 & 1073.716 & 1011.268 & 290.977 & 1782.570 & \text { Yes }\end{array}$

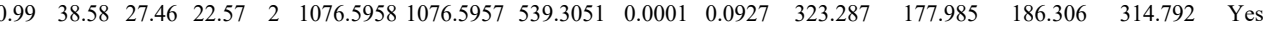
$\begin{array}{llllllllllllllll}1.00 & 40.77 & 28.76 & 29.90 & 2 & 1076.5964 & 1076.5957 & 539.3051 & 0.0007 & 0.6490 & 318.452 & 203.337 & 118.947 & 310.182 & \text { Yes }\end{array}$ $\begin{array}{lllllllllllllll}0.99 & 36.97 & 28.73 & 26.36 & 2 & 1076.5966 & 1076.5957 & 539.3051 & 0.0009 & 0.8344 & 592.725 & 357.569 & 263.826 & 527.136 & \text { Yes }\end{array}$

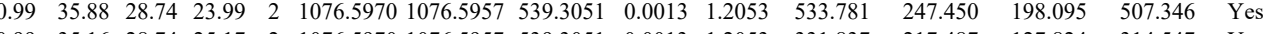
$\begin{array}{lllllllllllllll}0.99 & 35.16 & 28.74 & 25.17 & 2 & 1076.5970 & 1076.5957 & 539.3051 & 0.0013 & 1.2053 & 331.837 & 217.487 & 127.824 & 314.547 & \text { Yes }\end{array}$ $\begin{array}{lllllllllllllll}0.99 & 36.85 & 28.58 & 24.41 & 2 & 1076.5980 & 1076.5957 & 539.3051 & 0.0023 & 2.1324 & 520.096 & 334.622 & 215.519 & 558.941 & \text { Yes }\end{array}$ $\begin{array}{lllllllllllllll}1.00 & 40.40 & 28.58 & 25.13 & 2 & 1076.5982 & 1076.5957 & 539.3051 & 0.0025 & 2.3178 & 372.108 & 261.190 & 185.900 & 352.957 & \text { Yes }\end{array}$

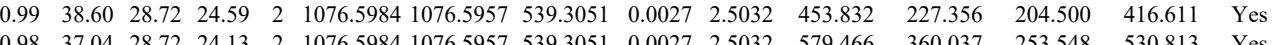

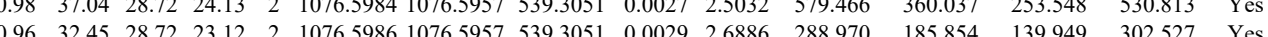

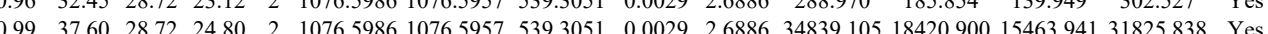
$\begin{array}{llllllllllllllll}0.99 & 37.60 & 28.72 & 24.80 & 2 & 1076.5986 & 1076.5957 & 539.3051 & 0.0029 & 2.6886 & 34839.105 & 18420.900 & 15463.941 & 31825.838 & \text { Yes }\end{array}$ $\begin{array}{lllllllllllllll}0.99 & 39.49 & 28.72 & 28.02 & 2 & 1067.5886 & 106.557 & 539.301 & 0.0029 & 2.6886 & 47555.880 & 21159.005 & 17638.775 & 38016.618 & \text { Yes }\end{array}$

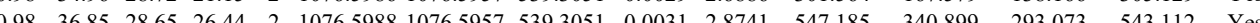
$\begin{array}{lllllllllllllll}0.98 & 36.68 & 28.38 & 25.44 & 2 & 1076.5990 & 1076.5957 & 539.3051 & 0.0033 & 3.0595 & 437.231 & 268.543 & 199.775 & 414.721 & \text { Yes }\end{array}$ 

$\begin{array}{lllllllllllllll}0.65 & 12.24 & 22.30 & 18.86 & 2 & 1262.5520 & 1262.5515 & 632.2830 & 0.0005 & 0.3954 & 172.477 & 152.770 & 88.999 & 202.498 & Y(5)\end{array}$ $\begin{array}{lllllllllllllll}1.00 & 35.20 & 22.28 & 19.87 & 2 & 1262.5536 & 1262.5515 & 632.2830 & 0.0021 & 1.6606 & 26998.206 & 12246.996 & 582.573 & 24599.926 & \text { No }\end{array}$ $\begin{array}{llllllllllllllll}0.99 & 31.16 & 22.30 & 19.76 & 2 & 1262.5540 & 1262.5515 & 632.2830 & 0.0025 & 1.9770 & 14576.013 & 8203.901 & 727.205 & 13308.045 & \mathrm{No}\end{array}$

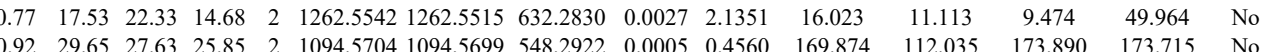

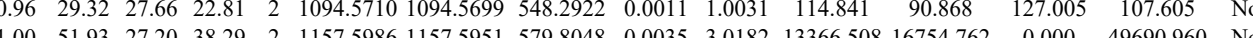
$\begin{array}{lllllllllllllll}1.00 & 51.93 & 27.20 & 38.29 & 2 & 1157.5986 & 1157.5951 & 579.8048 & 0.0035 & 3.0182 & 13366.508 & 16754.762 & 0.000 & 49690.960 & \text { No }\end{array}$ $\begin{array}{lllllllllllllll}1.00 & 53.73 & 27.11 & 36.12 & 2 & 157.5990 & 157.5951 & 579.8048 & 0.0059 & 3.3632 & 22314.466 & 22552.408 & 937.674 & 75305.065 & \text { Yes }\end{array}$

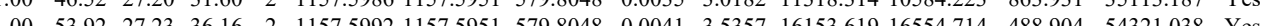

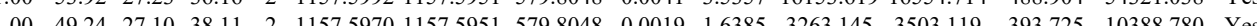

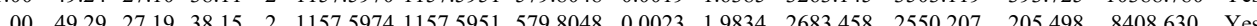

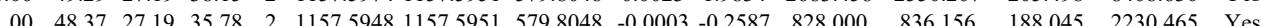
$\begin{array}{lllllllllllllll}1.00 & 5221 & 27.19 & 38.02 & 2 & 1157.5952 & 1157.5951 & 5798.8048 & 0.0001 & 0.0862 & 875.088 & 901.762 & 216.936 & 2734.905 & \text { Yes }\end{array}$ $\begin{array}{lllllllllllllll}1.00 & 44.32 & 23.78 & 31.04 & 2 & 1197.7208 & 1197.7203 & 599.8674 & 0.0005 & 0.4168 & 4137.077 & 2333.982 & 2036.597 & 3894697 & \text { Yes }\end{array}$ $\begin{array}{lllllllllllllll}1.00 & 41.88 & 23.60 & 30.21 & 2 & 1197.7210 & 1197.7203 & 599.8674 & 0.0007 & 0.5835 & 4975.908 & 3200.573 & 2452.045 & 3981.255 & \text { Yes }\end{array}$ $\begin{array}{llllllllllllllllll}0.99 & 38.80 & 22.88 & 23.20 & 2 & 996.6294 & 996.6202 & 499.3174 & 0.0092 & 9.2125 & 42764.587 & 30690.474 & 1970.053 & 31702.653 & \text { Yes }\end{array}$ $\begin{array}{llllllllllllllll}0.98 & 35.62 & 22.88 & 2280 & 2 & 996.6296 & 996.6202 & 499.3174 & 0.0094 & 9.4128 & 51788.976 & 35821.107 & 2051.205 & 37040.297 & \text { Yes }\end{array}$ $\begin{array}{llllllllllllllll}0.99 & 39.65 & 22.88 & 24.03 & 2 & 996.6292 & 996.6202 & 499.3174 & 0.0090 & 9.0122 & 17970.253 & 11556.953 & 673.647 & 11753.295 & \text { Yes }\end{array}$ $\begin{array}{lllllllllllllll}1.00 & 50.48 & 27.73 & 20.66 & 2 & 1393.6932 & 1393.6929 & 697.8537 & 0.0003 & 0.2149 & 71.037 & 56.915 & 61.687 & 53.414 & \text { Yes }\end{array}$ $\begin{array}{lllllllllllllll}1.00 & 54.71 & 27.73 & 18.87 & 2 & 1393.6936 & 1393.6929 & 697.8537 & 0.0007 & 0.5015 & 105.868 & 65.262 & 73.951 & 58.005 & \text { Yes }\end{array}$ $\begin{array}{lllllllllllllllll}\text { MEEDPDDVPHGHITSLAVK } & 0.99 & 17.11 & 27.52 & 30.11 & 4 & 2377.1861 & 2377.1828 & 595.3030 & 0.0033 & 1.3858 & 830.739 & 648.937 & 537.883 & 758.936 & \text { Yes }\end{array}$

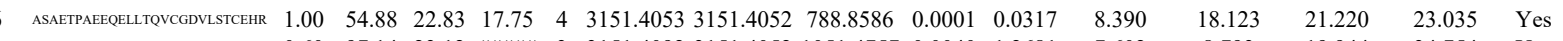
$\begin{array}{llllllllllll} & \end{array}$ $\begin{array}{llllllllllllllll}\text { ASAEPAEEEELLPVCGDVLSTCHR } & 1.00 & 33.95 & 23.20 & 46.95 & 4 & 3151.4085 & 3151.4052 & 788.8586 & 0.0033 & 1.0458 & 7.764 & 4.923 & 4.274 & 20.511 & \text { Yes }\end{array}$

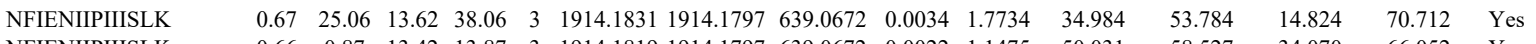

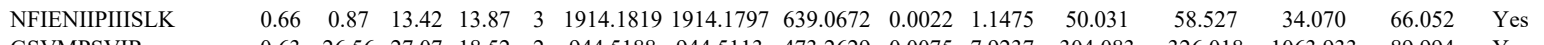
$\begin{array}{llllllllllllllll}\text { GSVMPSVIR } & 0.63 & 26.56 & 27.07 & 18.52 & 2 & 944.5188 & 944.5113 & 473.2629 & 0.0075 & 7.9237 & 304.083 & 326.018 & 1063.933 & 89.994 & \text { Yes }\end{array}$

QQLILAR $\begin{array}{llllllllllllllll}0.93 & 32.64 & 23.91 & 24.35 & 2 & 984.6252 & 984.6202 & 493.3174 & 0.0050 & 5.0677 & 6587.508 & 5358.578 & 1241.474 & 8618.782 & \text { Y }\end{array}$ $\begin{array}{lllllllllllllllll}0.90 & 27.91 & 23.12 & 23.12 & 2 & 984.6292 & 984.6202 & 493.3174 & 0.0090 & 9.1218 & 5242.517 & 4800.556 & 1285.229 & 7036.212 & \text { Yes } \\ \end{array}$

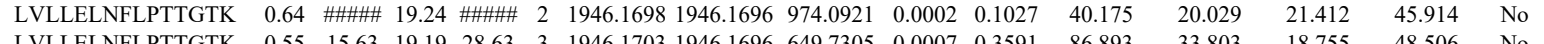

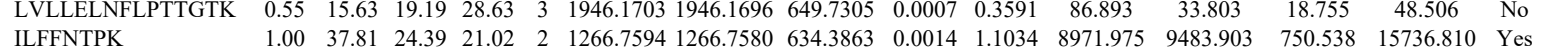

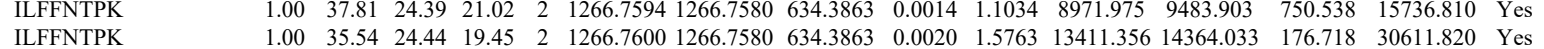

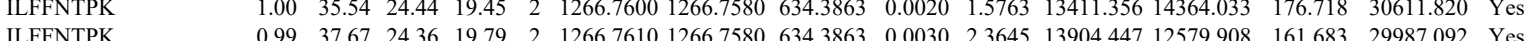

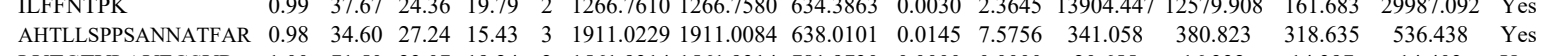

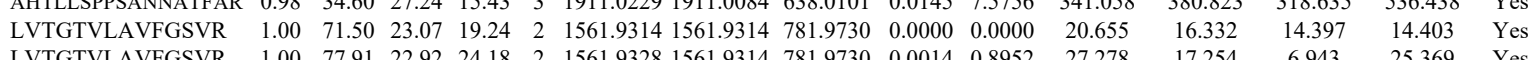
$\begin{array}{lllllllllllllll} & \end{array}$

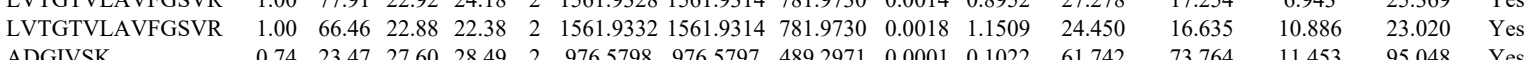
ADGIVSK TYAICGAIR TYAICGAIR TYAICGAIR TYAICGAIR TYAICGAIR MGESDDSILR MGESDDSILR TYAICGAIR TYAICGAIR TYAICGAIR TYAICGAIR TYAICGAIR TYAICGAIR $\begin{array}{lllllllllllllll}1.00 & 39.00 & 26.45 & 21.49 & 2 & 1156.5866 & 1156.5854 & 579.3000 & 0.0012 & 1.0357 & 21 . .742 & 73.764 & 11.453 & 95.048 & \text { Yes }\end{array}$

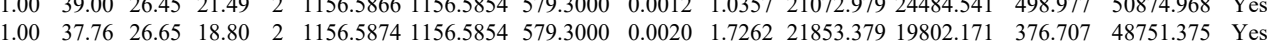

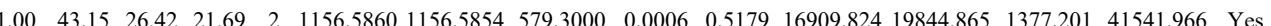
$\begin{array}{llllllllllllllllll}1.00 & 43.15 & 26.42 & 21.69 & 2 & 1156.5860 & 1156.5854 & 57.3000 & 0.0006 & 0.5179 & 16909.824 & 19844.865 & 1377.201 & 41541.966 & \text { Yes } \\ 1.00 & 38.27 & 26.49 & 21.58 & 2 & 1156.5862 & 1156.5854 & 579.3000 & 0.0008 & 0.6905 & 15769.773 & 18007.865 & 2077.239 & 36334.208 & \text { Yes }\end{array}$

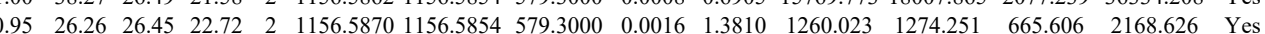

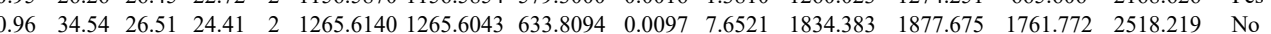
$\begin{array}{llllllllllllllll}0.92 & 31.38 & 26.43 & 24.65 & 2 & 1265.6152 & 1265.6043 & 633.8094 & 0.0109 & 8.5987 & 2291.457 & 1812.183 & 1627.199 & 2744.137 & \text { No }\end{array}$ $\begin{array}{llllllllllllllll}0.55 & 43.09 & 25.74 & 22.20 & 2 & 1265.5936 & 1265.6043 & 633.8094 & -0.0107 & -8.4411 & 7188.939 & 7735.787 & 3641.221 & 10913.222 & \text { Yes }\end{array}$

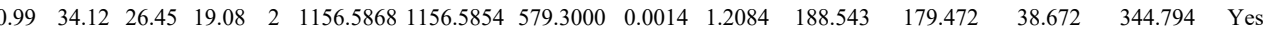
$\begin{array}{llllllllllllllll}0.99 & 37.67 & 26.36 & 19.87 & 2 & 1156.5858 & 1156.5854 & 579.3000 & 0.0004 & 0.3452 & 156.718 & 142.152 & 40.293 & 278.928 & \text { Yes }\end{array}$

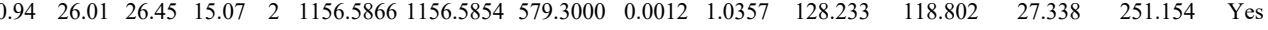

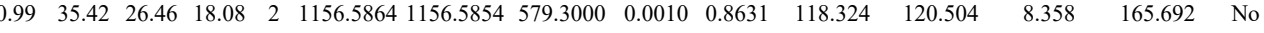
$\begin{array}{lllllllllllllll}0.99 & 36.98 & 26.49 & 19.31 & 2 & 1156.5862 & 1156.5854 & 579.3000 & 0.0008 & 0.6905 & 98.480 & 107.527 & 10.711 & 178.753 & \text { Yes }\end{array}$ $\begin{array}{lllllllllllllll}0.91 & 23.96 & 26.46 & 17.32 & 2 & 1156.5864 & 1156.5854 & 579.3000 & 0.0010 & 0.8631 & 70.851 & 91.189 & 17.203 & 138.443 & \text { Yes }\end{array}$

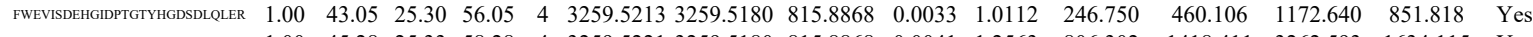

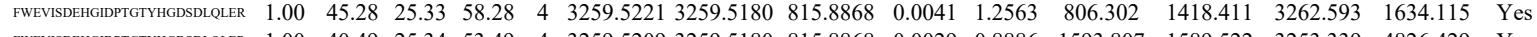

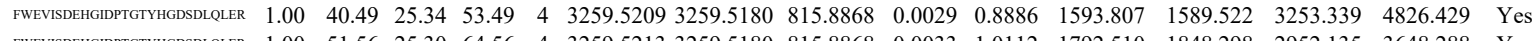
$\begin{array}{lllllllllllllllll}\text { FWEVISDEHGIDPGTYYGDSDLLLER } & 1.00 & 51.56 & 25.30 & 64.56 & 4 & 3259.5213 & 3259.5180 & 815.8868 & 0.0033 & 1.0112 & 1792.510 & 1848.298 & 2952.135 & 3648.288 & \text { Yes }\end{array}$

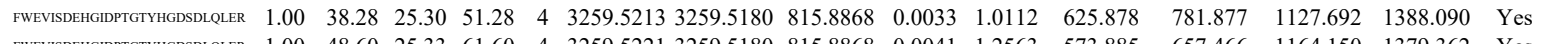

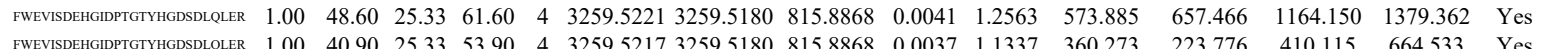

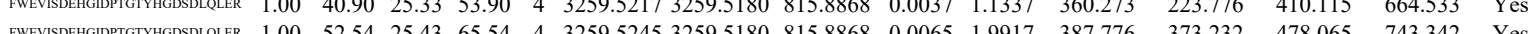

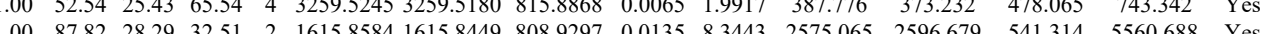
$\begin{array}{lllllllllllllll}1.00 & 87.82 & 28.29 & 32.51 & 2 & 1615.8584 & 1615.8449 & 808.9297 & 0.0135 & 8.3443 & 2575.065 & 2596.679 & 541.314 & 5560.688 & \text { Yes }\end{array}$

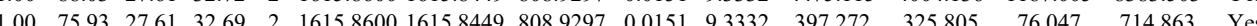
$\begin{array}{llllllllllllllll}\text { FWEVISDEHGIPTGTYHGDSDLLLER } & 1.00 & 38.49 & 25.33 & 51.49 & 4 & 3259.5193 & 3259.5180 & 815.8868 & 0.0013 & 0.3983 & 756.175 & 944.098 & 1865.453 & 1722.488 & \text { Yes }\end{array}$ 

$\begin{array}{lllllllllllll}\text { RPP30_HUMAN } & \text { P78346 } & \text { RPP30 } & \text { Ribonuclease P pr } 29.321 & 1.00 & 2 & 9.3 & 0.0927 & 0.1473 & -0.3083 & 0.2045 & 4 & \text { RPPINVINATIDR }\end{array}$ RPPINVAIDR RPPINVAIDR LTIIVSDPSHCNVLR FGISSVPTK FGISSVPTK FGLNVSSISR FGLNVSSISR FGLNVSSISR

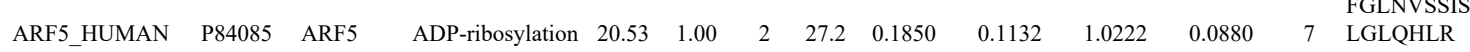

LGLQHLR

LGLQHLR
LGLQHLR

VGLESADELOK

VQESADELQK

VQESADELQK
VQESADELQK

ERH HUMAN P84090 ERH

$\begin{array}{llllllllll}\text { Enhancer of rudir } 12.259 & 1.00 & 3 & 28.8 & 0.0927 & 0.1080 & 1.9092 & 0.1435 & 9 & \text { IYVLLR }\end{array}$

IYVLLR

IYVLLR

IYVLLR

IYVLLR

IYVLLR

IYVLLR

IYVLLR
IYVLLR

QAQQAGK

TYADYESVNECMEGVCK

LGSLWVPGGQGGSGNPV
IFSLLVPTALPLLR

IFSLLVPTALPLLR

IFSLLVPTALPLL

$\begin{array}{llllllllll}\text { Fragile X mental r } 71.174 & 1.00 & 2 & 3.5 & 0.2352 & 0.6715 & 1.0755 & 0.2632 & 10 & \begin{array}{l}\text { SVNPNKPATK } \\ \text { SVNPNKPATK }\end{array}\end{array}$

SVNPNKPATK
SVNPNKPATK

QIGASSRPPPNR

QIGASSRPPPNR

QIGASSRPPPNR

QIGASSRPPPNR

QIGASSRPPPNR

QIGASSRPPPNR

QIGASSRPPPNR

QIGASSRPPPNR

QIGASSRPPPNR

GSIGPTVLEVFNTLLK

GSIGPTVLEVFNTLLK AGIIQVLLEAVAIAAK

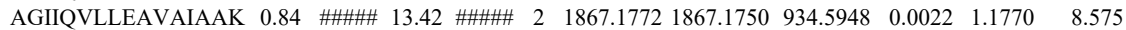
$\begin{array}{llllllllllll}\text { AGIIQVLLEAVAIAAK } & 0.67 & 63.62 & 13.42 & 76.62 & 3 & 1867.1776 & 1867.1750 & 623.3989 & 0.0026 & 1.3902 & 54.307\end{array}$ $\begin{array}{llllllllllll}\text { AGIIQVLLEAVAIAAK } & 0.66 & 57.57 & 13.62 & 70.57 & 3 & 1867.1767 & 1867.1750 & 623.3989 & 0.0017 & 0.9090 & 30.948\end{array}$ $\begin{array}{lllllllllllll}\text { AGIIQVLLEAVAIAAK } & 0.66 & 49.67 & 13.42 & 62.67 & 3 & 1867.1773 & 1867.1750 & 623.3989 & 0.0023 & 1.2298 & 27.408\end{array}$

IADVVLLQK

IADVVLLQK LWTEIPTAITIK

INLFMQFR
TGPPMGSR

EPTEEER

EPTEEER

$\begin{array}{llllllllllllll}0.83 & 13.69 & 19.64 & 25.44 & 2 & 1285.8226 & 1285.8213 & 643.9179 & 0.0013 & 1.0094 & 1434.133 & 1457.916\end{array}$

$\begin{array}{lllllllllllll}0.95 & 19.78 & 19.64 & 21.45 & 2 & 1285.8228 & 1285.8213 & 643.9179 & 0.0015 & 1.1647 & 1616.551 & 1878.084 & 0\end{array}$

$\begin{array}{lllllllllllll}0.58 & 4.22 & 20.29 & 16.39 & 3 & 1673.0032 & 1673.0007 & 558.6742 & 0.0025 & 1.4916 & 85.776 & 120.214\end{array}$

$\begin{array}{lllllllllllll}1.00 & 42.15 & 26.71 & 23.65 & 2 & 1211.6622 & 1211.6607 & 606.8376 & 0.0015 & 1.2359 & 1517.774 & 1318.505\end{array}$ $\begin{array}{lllllllllllll}0.85 & 21.00 & 26.16 & 21.36 & 2 & 945.4836 & 945.4824 & 473.7485 & 0.0012 & 1.2665 & 48.149 & 38 .\end{array}$ $\begin{array}{llllllllllll}0.69 & 18.14 & 23.36 & 29.66 & 2 & 1032.4850 & 1032.4845 & 517.2495 & 0.0005 & 0.4833 & 98.987\end{array}$ $\begin{array}{lllllllllll}0.82 & 28.09 & 23.36 & 36.80 & 2 & 1032.4850 & 1032.4845 & 517.2495 & 0.0005 & 0.4833 & 104.053\end{array}$ $\begin{array}{lllllllllllll}\text { TVATPLNQVANPNSAIFGARPR } & 1.00 & 46.13 & 25.76 & 20.79 & 3 & 2494.3513 & 2494.3526 & 832.4581 & -0.0013 & -0.5205 & 24.824 & \\ \text { TVATPINOVANPNSAFGGARPR } & 1.00 & 43.21 & 25.75 & 16.22 & 3 & 2494.3528 & 2494.3526 & 832.4581 & 0.0002 & 0.0801 & 26.767 & 40\end{array}$ $\begin{array}{lllllllllllll}\text { VATPLNQVANPNSAIFGGARPR } & 1.00 & 39.37 & 25.79 & 16.33 & 3 & 2494.3525 & 2494.3526 & 832.4581 & -0.0001 & -0.0400 & 89.364\end{array}$

$\begin{array}{llllllllllllll}\text { HPAKPDPSGECNPDLR } & 0.93 & 19.92 & 27.57 & 14.61 & 4 & 2066.0053 & 2065.9917 & 517.5052 & 0.0136 & 6.5699 & 5234.005 & 4 \\ \text { GEFGGFGSVTGK } & 1.00 & 77.35 & 28.03 & 25.53 & 2 & 1429.7564 & 1429.7446 & 715.8796 & 0.0118 & 8.2415 & 704.702 & 701.8\end{array}$

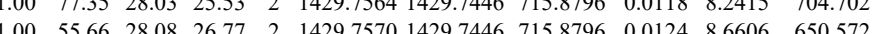

701.844 GDPVNYILQY 35.708

71.679
4578.907
701844

Yes $\begin{array}{llllllllllll} & \end{array}$ \begin{tabular}{llllllllllllll}
32.98 & 24.64 & 28.12 & 3 & 1293.7747 & 1293.7639 & 432.2619 & 0.0108 & 8.3282 & 2127.551 & 2326.397 & 2437.068 & 2555.835 & Yes \\
\hline
\end{tabular} $\begin{array}{llllllllll} & \end{array}$ $\begin{array}{lllllllllll} & 1796.290 & \text { Yes } \\ \end{array}$ $\begin{array}{llllllllllllll}23.69 & 2 & 1222.6886 & 1222.6792 & 612.3469 & 0.0094 & 7.6753 & 2537.862 & 2624.461 & 72.021 & 2720.557 & \text { Yes }\end{array}$ $\begin{array}{lllllllllllllll} & 97.51 & 25.54 & 2 & 979.6076 & 979.6049 & 490.8097 & 0.0027 & 2.7505 & 5861.167 & 7424.927 & 2859.585 & 5951.526 & \text { Yes }\end{array}$ $\begin{array}{llllllllllllll}24 & 30.78 & 2 & 919.6020 & 919.5977 & 460.8061 & 0.0043 & 4.6657 & 17808.463 & 19284.576 & 10250.294 & 41339.062 & \text { Yes }\end{array}$ $\begin{array}{lllllllllllllll}19.03 & 24.80 & 2 & 919.5976 & 919.5977 & 460.8061 & -0.0001 & -0.1085 & 13949.207 & 15358.953 & 1574.031 & 32363.386 & \text { Yes }\end{array}$ $\begin{array}{lllllllllllllll}10.08329 .029 & 1083.708 & 32809.599 & \text { Yes }\end{array}$ $\begin{array}{lllllllllllll} & \end{array}$ $\begin{array}{llllllllllllll}25.06 & 19.08 & 31.29 & 2 & 919.5988 & 919.5977 & 460.8061 & 0.0011 & 1.1936 & 983.539 & 951.001 & 202.408 & 1688.514 & \text { Yes }\end{array}$ $\begin{array}{llllllllllllll}0.67 & 21.08 & 12.04 & 34.08 & 3 & 1696.0807 & 1696.0773 & 566.3664 & 0.0034 & 2.0011 & 11.851 & 17.782\end{array}$ $\begin{array}{lllllllllll} & \end{array}$ 44.143 0.809
395.902

319.423
57.864

63.408

31.516

5.157
20.450

68.522
51.132

52.076 5.993

30.976

21.138

$\begin{array}{lll}111.183 & \text { Yes } \\ 60.447 & 11.047 & \end{array}$

$19.383 \quad 34.047$ Yes

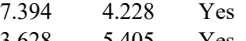
(12.03 $\begin{array}{lll}8.012 & 67.997 & \text { Yes }\end{array}$ $\begin{array}{lll}38.783 & 388.878 & \text { Yes }\end{array}$ $\begin{array}{lll}29.699 & \text { No }\end{array}$

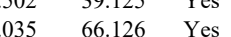
$\begin{array}{lll}6.385 & 22.068 & \text { Yes }\end{array}$ $235 \quad 57.346$ Yes \begin{tabular}{l}
6.34676 Yes \\
\hline
\end{tabular} 10.938 Yes 81.535 Yes \begin{tabular}{ll}
5.678 & Yes \\
\hline & Yes
\end{tabular} \begin{tabular}{ll}
0.773 & Yes \\
\hline 8.138 & Yes
\end{tabular} \begin{tabular}{lll}
2812.367 & Yes \\
\hline & 377.535 & No
\end{tabular} $\begin{array}{lll}0.0003 & 115.523 & \text { Yes } \\ 17.259 & \text { Yes }\end{array}$ $\begin{array}{lll}.121 & 172.259 & \text { Yes } \\ 4.441 & 344.355 & \text { Yes }\end{array}$

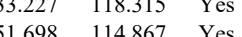
\begin{tabular}{llll}
1 & 18.315 & Yes \\
\hline
\end{tabular} $\begin{array}{lll}6.453 & 5819.133 & \text { Yes }\end{array}$ 

$\begin{array}{llllllllllll}0.75 & 5.39 & 24.03 & 16.69 & 4 & 3226.7017 & 3226.6974 & 807.6816 & 0.0043 & 1.3310 & 12.306 & 14.019\end{array}$ $\begin{array}{llllllllllll} & 3 & 3226.7002 & 3226.6974 & 1076.5731 & 0.0028 & 0.8669 & 16.241 & 13.113\end{array}$ $\begin{array}{lllllllllllll} & 3226.7005 & 3226.6974 & 807.6816 & 0.0031 & 0.9595 & 13.112 & 17.734\end{array}$ $\begin{array}{lllllllllllll} & & & \end{array}$ $\begin{array}{lllllllllllllll} & 1.00 & 46.03 & 24.30 & 16.80 & 4 & 3226.6993 & 3226.6974 & 807.6816 & 0.0019 & 0.5881 & 14.010 & 14.066\end{array}$ $\begin{array}{lllllllllllll} & \end{array}$

\section{LPWAVAGR}

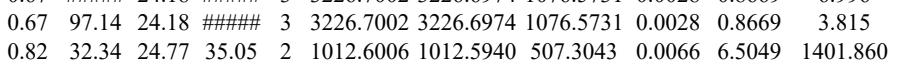

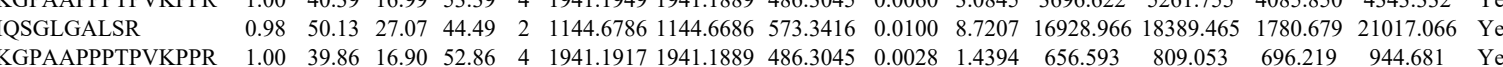

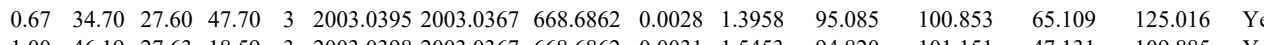
$\begin{array}{llllllllllllllllll} & & & \end{array}$ $\begin{array}{llllllllllllllll} & & \end{array}$ $\begin{array}{llllllllllllllll}\text { AGLLKPQTGGR } & 0.78 & 24.71 & 22.86 & 28.80 & 3 & 1384.8388 & 1384.8394 & 462.6204 & -0.0006 & -0.4323 & 6335.330 & 7757.131 & 4576.982 & 7543.061 & \text { Yes }\end{array}$ $\begin{array}{lllllllllllllllll}\text { AGLLKPQTGGR } & 0.99 & 27.68 & 23.18 & 23.56 & 3 & 1384.8403 & 1384.8394 & 462.6204 & 0.0009 & 0.6485 & 6419.596 & 8808.653 & 4964.423 & 7412.827 & \text { Yes }\end{array}$ $\begin{array}{llllllllllllllll}\text { AGLLKPQTGGR } & 0.93 & 30.57 & 22.41 & 26.04 & 3 & 1384.8379 & 1384.8394 & 462.6204 & -0.0015 & -1.0808 & 4155.700 & 4704.863 & 2691.612 & 4343.465 & \text { Yes }\end{array}$ $\begin{array}{llllllllllllllll}\text { AGLLKPQTGGR } & 0.83 & 15.84 & 22.86 & 20.43 & 3 & 1384.8391 & 1384.8394 & 462.6204 & -0.0003 & -0.2162 & 1753.723 & 2334.001 & 1532.755 & 2156.278 & \text { Yes }\end{array}$ IPILLIQQPGK $\begin{array}{llllllllllllllll}0.60 & 9.51 & 12.04 & 22.51 & 3 & 1506.9781 & 1506.9741 & 503.3320 & 0.0040 & 2.6490 & 142.805 & 186.661 & 65.496 & 353.278 & \text { No }\end{array}$

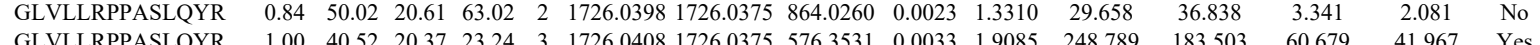
$\begin{array}{llllllllllllllll}\text { GLVLLRPPASLQYR } & 1.00 & 40.52 & 20.37 & 23.24 & 3 & 1726.0408 & 1726.0375 & 576.3531 & 0.0033 & 1.9085 & 248.789 & 183.503 & 60.679 & 41.967 & \text { Yes } \\ \text { GLVLLPPPASLQYR } & 1.00 & 39.07 & 20.61 & 20.74 & 3 & 1726.0396 & 1726.0375 & 576.3531 & 0.0021 & 1.2145 & 298.911 & 238542 & 64.928 & 38.565 & \text { Yes }\end{array}$

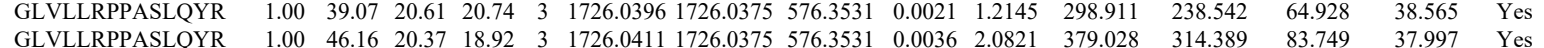

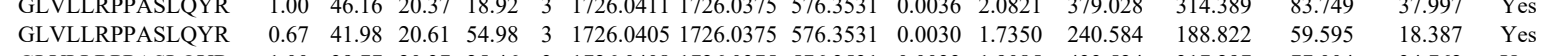
$\begin{array}{llllllllllllllllll} & \text { GLVLLRPPASLQYR } & 1.00 & 39.77 & 20.37 & 25.46 & 3 & 1726.0408 & 1726.0375 & 576.3531 & 0.0033 & 1.9085 & 433.524 & 317.297 & 77.004 & 34.762 & \text { Yes }\end{array}$

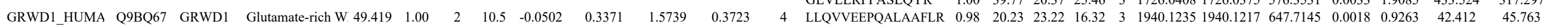




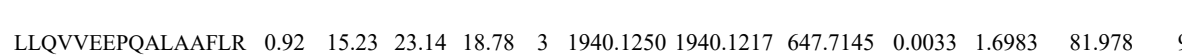
$\begin{array}{llllllllllllll}\text { LLQVVEEPQALAAFLR } & 0.82 & 13.65 & 23.24 & 18.08 & 3 & 1940.1229 & 1940.1217 & 647.7145 & 0.0012 & 0.6176 & 64.041 \\ \text { LLQVVEEPQALAAFLR } & 0.67 & 17.38 & 23.07 & 30.38 & 3 & 1940.1247 & 1940.1217 & 647.7145 & 0.0030 & 1.5439 & 45.068\end{array}$ $\begin{array}{lllllllllllll}\text { LLQVVEEPQALAAFLR } & 0.67 & 17.38 & 23.07 & 30.38 & 3 & 1940.1247 & 1940.1217 & 647.7145 & 0.0030 & 1.5439 & 45.068 \\ \end{array}$ $\begin{array}{llllllllllllll}\text { DPEGCDEADPCLADLPOLLFH HOGETLLK } & 1.00 & 35.89 & 25.31 & 17.99 & 4 & 3618.8333 & 3618.8297 & 905.7147 & 0.0036 & 0.9937 & 8.478\end{array}$ $\begin{array}{llllllllllll}\text { VGTQVEEAAEGVLR } & 1.00 & 66.82 & 27.95 & 25.31 & 2 & 1600.8574 & 1600.8542 & 801.4344 & 0.0032 & 1.9964 & 144.761 \\ \text { VGTQVEEAAEGVLR } & 1.00 & 51.86 & 27.70 & 23.11 & 2 & 1600.8594 & 1600.8542 & 801.4344 & 0.0052 & 3.2442 & 152.679\end{array}$ $\begin{array}{llllllllllllll}\text { VGTQVEEAAEGVLR } & 1.00 & 51.86 & 27.70 & 23.11 & 2 & 1600.8594 & 1600.8542 & 801.4344 & 0.0052 & 3.2442 & 152.679 & & \\ \text { V }\end{array}$ $\begin{array}{llllllllllllllll}\text { KQEFLEK } & 0.98 & 22.27 & 23.69 & 23.23 & 3 & 1352.8060 & 1352.8029 & 451.9416 & 0.0031 & 2.2864 & 20309.639 & 28898.024 & 738.829 & 34490.304 & \text { Yes } \\ \text { GGPTPQEAIQR } & 1.00 & 57.45 & 28.23 & 23.68 & 2 & 1296.6922 & 1296.6908 & 649.3527 & 0.0014 & 1.0780 & 5854.091 & 7624.444 & 6142.908 & 6391.820 & \text { Yes }\end{array}$ $\begin{array}{lllllllllllllllll}\text { KQEFLEK } & 0.98 & 22.27 & 23.69 & 23.23 & 3 & 1352.8060 & 1352.8029 & 451.9416 & 0.0031 & 2.2864 & 20309.639 & 28898.024 & 738.829 & 34490.304 & \text { Yes } \\ \text { GGPTPQEAIQR } & 1.00 & 57.45 & 28.23 & 23.68 & 2 & 1296.6922 & 1296.6908 & 649.3527 & 0.0014 & 1.0780 & 5854.091 & 7624.444 & 6142.908 & 6391.820 & \text { Yes } \\ \end{array}$ $\begin{array}{llllllllllllll} & \end{array}$

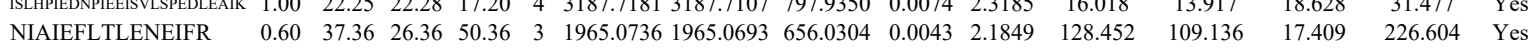

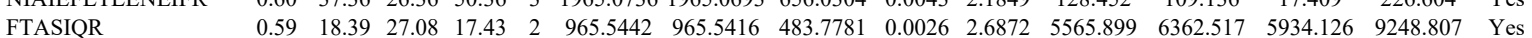
$\begin{array}{lllllllllllllllllllll} & \text { FTASIQR } & 0.85 & 24.65 & 27.11 & 23.43 & 2 & 965.5450 & 965.5416 & 483.7781 & 0.0034 & 3.5140 & 8826.436 & 12505.437 & 7460.341 & 17622.141 & \text { Yes }\end{array}$

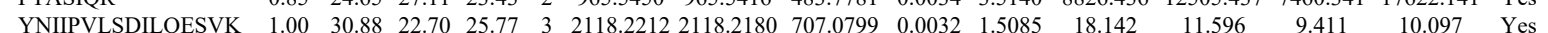

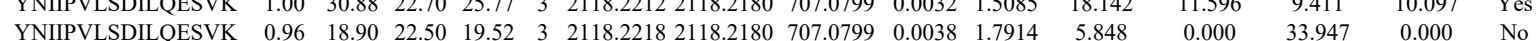

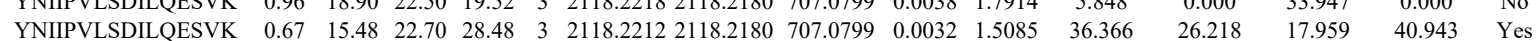
$\begin{array}{llllllllllllllll}\text { YNIIPVLSDILOESVK } & 0.82 & 17.28 & 22.58 & 19.31 & 3 & 2118.2242 & 2118.2180 & 707.0799 & 0.0062 & 2.9228 & 8.583 & 1.107 & 8.197 & 22.279 & \text { Yes }\end{array}$

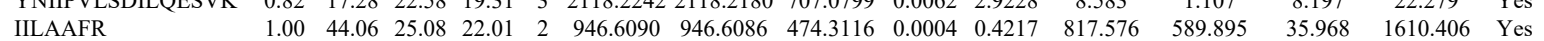
$\begin{array}{llllllllllllllll}\text { IILAAFR } & 1.00 & 43.68 & 25.08 & 20.36 & 2 & 946.6098 & 946.6086 & 474.3116 & 0.0012 & 1.2650 & 889.763 & 757.388 & 115.048 & 1472.552 & \text { Yes }\end{array}$ $\begin{array}{lllllllllllll}\text { IILAAFR } & 1.00 & 40.98 & 25.08 & 20.27 & 2 & 946.6086 & 946.6086 & 474.3116 & 0.0000 & 0.0000 & 873.424\end{array}$ $\begin{array}{llllllllllll}1.00 & 40.98 & 25.08 & 20.27 & 2 & 946.6086 & 946.6086 & 474.3116 & 0.0000 & 0.0000 & 873.424 & 8\end{array}$ $\begin{array}{lllllllllllll}\text { FGLGSVAGAVGATAVYPIDLVK } & 0.66 & 61.78 & 21.37 & 74.78 & 3 & 2392.3630 & 2392.3610 & 798.4609 & 0.0020 & 0.8349 & 18.626 \\ \text { MGGSG } & 0.66 & 72.26 & 21.27 & 85.26 & 3 & 2392.3633 & 23923610 & 798.4609 & 0.0023 & 0.9602 & 26.894\end{array}$

YSTLAGTR

VSALSVVR

VSALSVVR

IYSTLAGTR

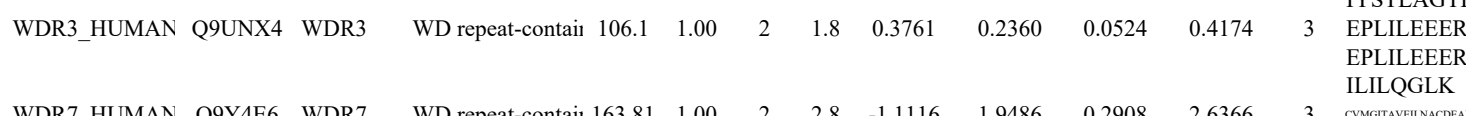

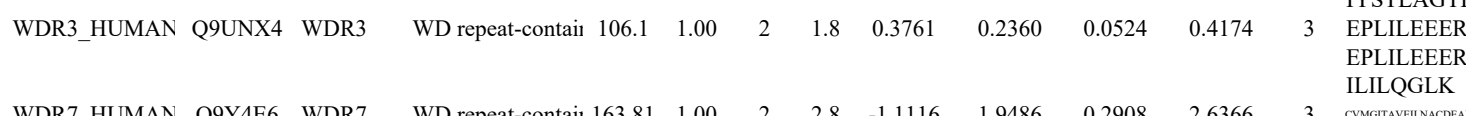

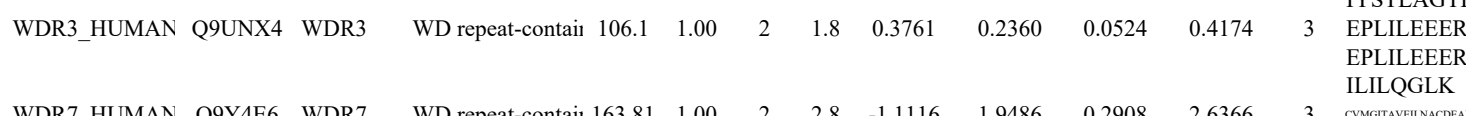

$\begin{array}{llllllllllll}\text { MRCKB_HUMA Q9Y5S2 } & \text { CDC42BPI Serine/threonine-p 194.32 } & 1.00 & 2 & 1.3 & -0.2601 & 0.1981 & 1.5529 & 0.2093 & 4 & \begin{array}{l}\text { RTAIDLIGR } \\ \text { WVGLEGLSILHK } \\ \text { WVGILEGLQSILHK }\end{array}\end{array}$

$\begin{array}{llllllllllll}\text { MRCKB_HUMA Q9Y5S2 } & \text { CDC42BPI Serine/threonine-p 194.32 } & 1.00 & 2 & 1.3 & -0.2601 & 0.1981 & 1.5529 & 0.2093 & 4 & \begin{array}{l}\text { RTAIDLIGR } \\ \text { WVGILEGLQSILHK } \\ \text { WVGILGLQSILHK }\end{array}\end{array}$ WVGILEGLQSIL
IVILLCGR IVILLCGR

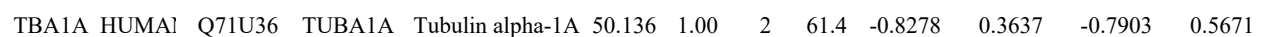
DYEVGVDSVEGEGEEEGE

LIGQIVSSITASLR LIGQIVSSITASLR LIGQIVSSITASLR LIGQIVSSITASLR LIGQIVSSITASLR LIGQIVSSITASLR LIGQIVSSITASLR LIGQIVSSITASLR LIGQIVSSITASLR LIGQIVSSITASLR LIGQIVSSITASLR LIGQIVSSITASLR LIGQIVSSITASLR LIGQIVSSITASLR

$\begin{array}{lllllllllll}\text { ARVC_HUMAN } & \text { O00192 } & \text { ARVCF } & \text { Armadillo repeat } 1104.64 & 1.00 & 3 & 6.8 & -0.3314 & 0.5663 & 1.2186 & 0.6793\end{array}$

GLPLLVALLDHP GLPLLVALLDHPR GVPALVALVASSQSVI
TQQMLHGLQR LFSLPAQPLWNNR LFSLPAQPLWNNR LFSPAQPLWNNR

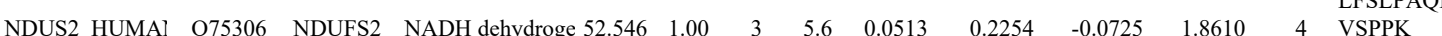

\section{LLNIRPPPR}

LDELEELLTNNR

LDELEELLTNNR $\begin{array}{lllllllllllllllll}1.00 & 48.76 & 27.02 & 28.07 & 2 & 1124.6410 & 1124.6311 & 563.3228 & 0.0099 & 8.7871 & 1886.669 & 1390.816 & 2972.536 & 7922.237 & \text { Yes } \\ \end{array}$

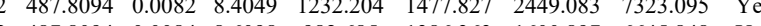

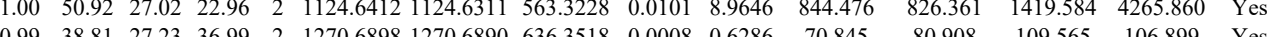

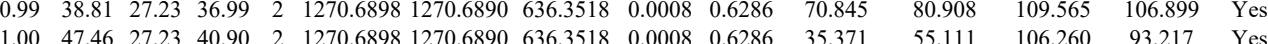

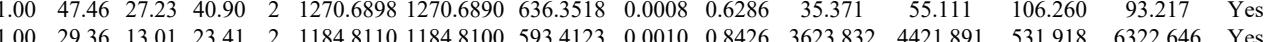
$\begin{array}{lllllllllllllll}1.00 & 29.36 & 13.01 & 23.41 & 2 & 1184.8110 & 1184.8100 & 593.4123 & 0.0010 & 0.8426 & 3623.832 & 4421.891 & 531.918 & 6322.646 & \text { Yes }\end{array}$ $\begin{array}{lllllllllllllll}1.00 & 34.72 & 25.75 & 47.72 & 4 & 3729.8557 & 3729.8516 & 933.4702 & 0.0041 & 1.0981 & 3.535 & 7.609 & 8.024 & 14.807 & \text { Yes } \\ 0.97 & 26.9 & 23.62 & 30.25 & 2 & 1157.7010 & 1157.7002 & 579.8574 & 0.0008 & 0.6898 & 5774.865 & 1602.296 & 438.424 & 130.411 & \text { Yes }\end{array}$

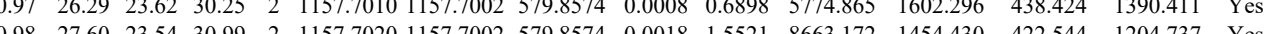

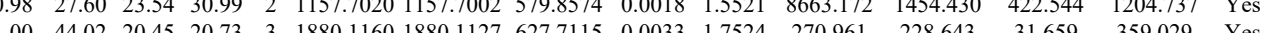

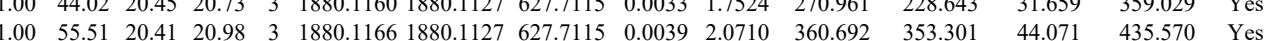

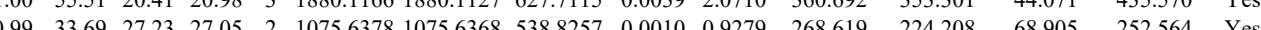

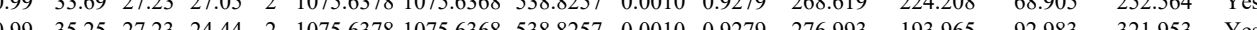
$\begin{array}{llllllll}0.5 & 0.000\end{array}$ $\begin{array}{lllllllllllll}1.00 & 68.77 & 22.62 & 22.58 & 2 & 1600.9658 & 1600.9634 & 801.4890 & 0.0024 & 1.4972 & 48.230 & 23.016\end{array}$

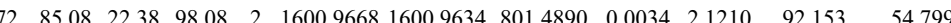
$\begin{array}{llllllllllll}1.00 & 75.09 & 22.70 & 22.87 & 2 & 1600.9652 & 1600.9634 & 801.4890 & 0.0018 & 1.1229 & 67.506 & 26.217\end{array}$ $\begin{array}{llllllllllll}1.00 & 67.47 & 22.62 & 17.28 & 2 & 1600.9658 & 1600.9634 & 801.4890 & 0.0024 & 1.4972 & 95.655 & 58.285\end{array}$ $\begin{array}{llllllllllll}0.84 & 75.19 & 22.62 & 88.19 & 2 & 1600.9658 & 1600.9634 & 801.4890 & 0.0024 & 1.4972 & 100.183 & 66.495\end{array}$ $\begin{array}{llllllllllll}100 & 77.94 & 22.70 & 17.89 & 2 & 1600.9662 & 1600.9634 & 801.4890 & 0.0028 & 1.7467 & 87.175\end{array}$ $\begin{array}{lllllllllllll}0.82 & 80.92 & 22.70 & 93.92 & 2 & 1600.9648 & 1600.9634 & 801.4890 & 0.0014 & 0.8734 & 140.067\end{array}$ $\begin{array}{lllllllllllll}1.00 & 65.89 & 22.70 & 19.91 & 2 & 1600.9652 & 1600.9634 & 801.4890 & 0.0018 & 1.1229 & 65.313\end{array}$ $\begin{array}{llllllllllll}0.72 & 81.22 & 22.38 & 94.22 & 2 & 1600.9664 & 1600.9634 & 801.4890 & 0.0030 & 1.8715 & 113.568\end{array}$ $\begin{array}{lllllllllll}1.00 & 78.28 & 22.70 & 19.60 & 2 & 1600.9652 & 1600.9634 & 801.4890 & 0.0018 & 1.1229 & 76.076\end{array}$ $\begin{array}{llllllllllll}0.64 & 80.59 & 22.70 & 93.59 & 2 & 1600.9636 & 1600.9634 & 801.4890 & 0.0002 & 0.1248 & 83.969\end{array}$ $\begin{array}{llllllllllll}1.00 & 82.96 & 22.38 & 23.58 & 2 & 1600.9666 & 1600.9634 & 801.4890 & 0.0032 & 1.9963 & 129.608 & 59\end{array}$ $\begin{array}{lllllllllllll}0.82 & 73.02 & 22.67 & 86.02 & 2 & 1600.9642 & 1600.9634 & 801.4890 & 0.0008 & 0.4991 & 119.913 \\ \end{array}$ $\begin{array}{llllllllllll}0.82 & 78.92 & 22.70 & 91.92 & 2 & 1600.9648 & 1600.9634 & 801.4890 & 0.0014 & 0.8734 & 177.861\end{array}$ $\begin{array}{llllllllllll}1.00 & 66.80 & 25.11 & 79.80 & 4 & 4003.9829 & 4003.9853 & 1002.0036 & -0.0024 & -0.5988 & 15.736 \\ 0.66 & 76.96 & 20.04 & 89.96 & 3 & 1556.9548 & 1556.9524 & 519.9914 & 0.0024 & 1.5385 & 82.824\end{array}$ $\begin{array}{lllllllllllll}0.66 & 76.96 & 20.04 & 89.96 & 3 & 1556.9548 & 1556.9524 & 519.9914 & 0.0024 & 1.5385 & 82.824 \\ 0.66 & 61.75 & 20.04 & 74.75 & 3 & 1556.9548 & 1556.9524 & 519.9914 & 0.0024 & 1.5385 & 74.419\end{array}$ $\begin{array}{llllllllllll}0.66 & 22.72 & 23.24 & 35.72 & 3 & 1696.9975 & 1696.9958 & 566.6725 & 0.0017 & 1.0000 & 17.619\end{array}$ $\begin{array}{lllllllllll}0.97 & 26.59 & 27.54 & 15.68 & 3 & 1354.7308 & 1354.7261 & 452.5826 & 0.0047 & 3.4616 & 5331.914 \\ 1.00 & 69.86 & 26.30 & 29.30 & 2 & 1698.9322 & 1698.9327 & 850.4736 & -0.0005 & -0.2940 & 49.003\end{array}$ $\begin{array}{lllllllllll}1.00 & 69.86 & 26.30 & 29.30 & 2 & 1698.9322 & 1698.9327 & 850.4736 & -0.0005 & -0.2940 & 49.003 \\ 1.00 & 55.20 & 26.31 & 29.99 & 2 & 1698.9330 & 1698.9327 & 850.4736 & 0.0003 & 0.1764 & 36.170\end{array}$ $\begin{array}{lllllllllll}1.00 & 55.20 & 26.31 & 29.99 & 2 & 1698.9330 & 1698.9327 & 850.4736 & 0.0003 & 0.1764 & 36.170 \\ 1.00 & 56.86 & 26.19 & 31.69 & 2 & 1698.9336 & 1698.9327 & 850.4736 & 0.0009 & 0.5291 & 20.589\end{array}$ $\begin{array}{llllllllllll}1.00 & 72.17 & 26.29 & 35.35 & 2 & 1698.9350 & 1698.9327 & 850.4736 & 0.0023 & 1.3522 & 31.058\end{array}$ $\begin{array}{lllllllllll}0.66 & 17.47 & 23.30 & 25.05 & 2 & 814.5152 & 814.5156 & 408.2651 & -0.0004 & -0.4899 & 114.243\end{array}$

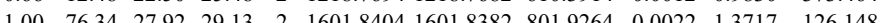

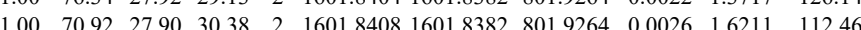



\begin{tabular}{llllllllllllllll} 
LPNGLVIASLENYSPVSR & 1.00 & 51.56 & 25.66 & 18.82 & 3 & 2072.1394 & 2072.1388 & 691.7202 & 0.0006 & 0.2891 & 257.424 & 211.254 & 95.211 & 312.523 & Yes \\
\hline
\end{tabular} $\begin{array}{lllllllllllllllll} & \\ \text { LPNGLVIASLENYSPVSR } & 0.55 & 26.90 & 25.58 & 39.90 & 3 & 2072.1400 & 2072.1388 & 691.7202 & 0.0012 & 0.5783 & 189.473 & 298.151 & 133.435 & 384.984 & \text { Yes } \\ \text { MALIGLGVSHPVLK } & 0.60 & 61.84 & 18.45 & 74.84 & 3 & 1722.0508 & 1722.0470 & 575.0229 & 0.0038 & 2.2028 & 8157.904 & 9107.850 & 1008.718 & 12315.649 & \text { Yes }\end{array}$ $\begin{array}{lllllllllllllllll}\text { MALIGLGVSHPVLK } & 0.60 & 61.84 & 18.45 & 74.84 & 3 & 1722.0508 & 1722.0470 & 575.0229 & 0.0038 & 2.2028 & 8157.904 & 9107.850 & 1008.718 & 12315.649 & \text { Yes } \\ \text { LAGVTLGQR } & 0.97 & 36.36 & 26.30 & 31.79 & 2 & 1057.6466 & 1057.6366 & 529.8256 & 0.0100 & 9.4370 & 3290265 & 3171.924 & 4745.806 & 4506.501 & \text { Yes }\end{array}$

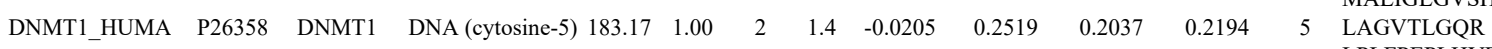

\section{LPLFPEPLHEAPR}

LPLFPEPLHVFAPR

LPLFPEPLHVFAPR

VQEGETIEDGAR

VQEGETIEDGAR

LYTLVLVLQPQR

LYTLVLVLQPQR

LYTLVLVLQPQR

LYTLVLVLQPQR

LYTLVLVLQPQR

LYTLVLVLQPQR

LYTLVLVLQPQR

LYTLVLVLQPQR

LYTLVLVLQPQR

LYTLVLVLQPQR

LYTLVLVLQPQR

LYTLVLVLQPQR

LYTLVLVLQPQR

CHQGPIKPYQQGR
CHQGPIKPYQQGR

CHQGPIKPYQQGR

NIVPGWLQR

VPGWLQR

$\begin{array}{lllllllllllllllll}0.97 & 36.36 & 26.30 & 31.79 & 2 & 1057.6466 & 1057.6366 & 529.8256 & 0.0100 & 9.4370 & 3290.265 & 3171.924 & 4745.806 & 4506.501 & \text { Yes } & \\ 1.00 & 54.06 & 4.33 & 26.02 & 3 & 1776.0226 & 1776.0208 & 593.0142 & 0.0018 & 1.0118 & 2570.828 & 2221.735 & 1129.151 & 2853.023 & \text { Yes }\end{array}$

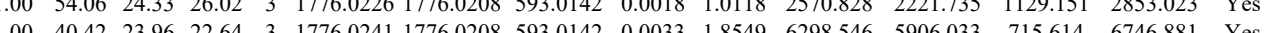

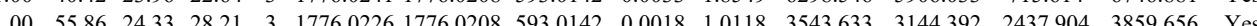
$\begin{array}{lllllllllllllll}100 & 48.85 & 23.96 & 25.21 & 3 & 1776.0238 & 1776.020 & 593.0142 & 0.0030 & 1.6863 & 2067.361 & 2753.572 & 1365.008 & 3083.932 & \text { Yes }\end{array}$ $\begin{array}{lllllllllllllll}1.00 & 56.92 & 26.85 & 31.27 & 2 & 1446.7074 & 1446.7072 & 724.3609 & 0.0002 & 0.1381 & 354.241 & 377.520 & 128.255 & 385.592 & \text { Yes }\end{array}$

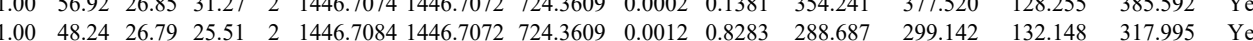
$\begin{array}{lllllllllllllll}0.82 & 60.02 & 21.52 & 73.02 & 2 & 1585.9692 & 1585.9677 & 793.9911 & 0.0015 & 0.9446 & 24.291 & 41.733 & 6.019 & 36.943 & \text { Yes }\end{array}$ $\begin{array}{lllllllllllllll}0.84 & 71.07 & 21.49 & 84.07 & 2 & 1585.9696 & 1585.9677 & 793.9911 & 0.0019 & 1.1965 & 88.167 & 102.399 & 53.974 & 75.369 & \text { Yes }\end{array}$

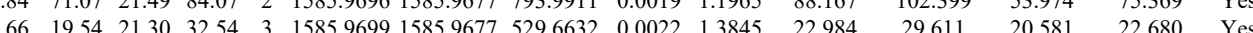

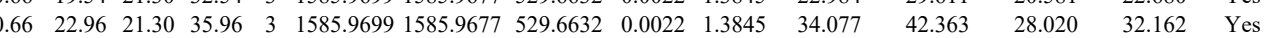
$\begin{array}{lllllllllllllll}0.64 & 88.37 & 21.76 & \# \# \# \# \quad 2 & 1585.9680 & 1585.9677 & 793.9911 & 0.0003 & 0.1889 & 53.273 & 63.789 & 20.869 & 76.129 & \text { Yes }\end{array}$ \begin{tabular}{lllllllllllllll}
0.55 & 14.84 & 21.58 & 27.84 & 3 & 1585.9684 & 1585.9677 & 529.6632 & 0.0007 & 0.4405 & 9.575 & 18.034 & 16.236 & 12.691 & Yes \\
\hline
\end{tabular}

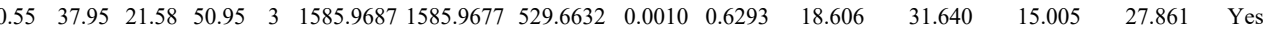
\begin{tabular}{lllllllllllllll}
0.82 & 73.90 & 21.58 & 86.90 & 2 & 1585.9688 & 1585.9677 & 793.9911 & 0.0011 & 0.6927 & 59.567 & 62.256 & 23.432 & 44.889 & Yes \\
\hline
\end{tabular}

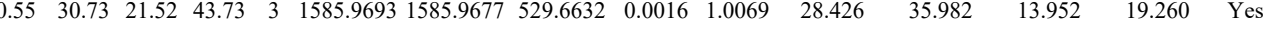

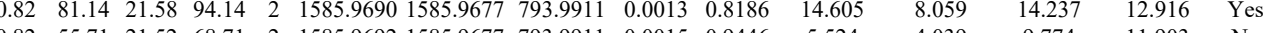

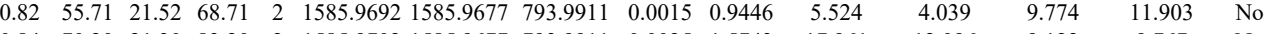

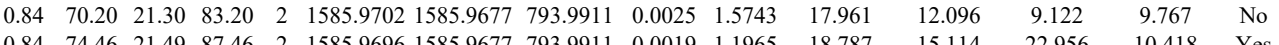
$\begin{array}{llllllllllllllll}1 & 14.66 & 27.80 & 14.29 & 4 & 1844.9389 & 1844.9382 & 462.2418 & 0.0007 & 0.3786 & 1690.433 & 1424.606 & 692.285 & 1906.651 & \text { Yes }\end{array}$ \begin{tabular}{llllllllllllllll}
1.00 & 20.15 & 27.85 & 14.60 & 4 & 1844.9405 & 1844.9382 & 462.2418 & 0.0023 & 1.2439 & 730.705 & 718.135 & 384.497 & 712.394 & Yes \\
\hline
\end{tabular} $\begin{array}{lllllllllllllll}1.00 & 21.91 & 27.85 & 14.81 & 4 & 1844.9405 & 1844.9382 & 462.2418 & 0.0023 & 1.2439 & 1363.009 & 1146.288 & 533.430 & 1544.886 & \text { Yes }\end{array}$ \begin{tabular}{lllllllllllllll}
0.93 & 23.15 & 24.84 & 21.54 & 2 & 1225.7064 & 1225.7053 & 613.8599 & 0.0011 & 0.8960 & 2358.534 & 2693.859 & 345.525 & 3892.712 & Yes \\
\hline
\end{tabular}

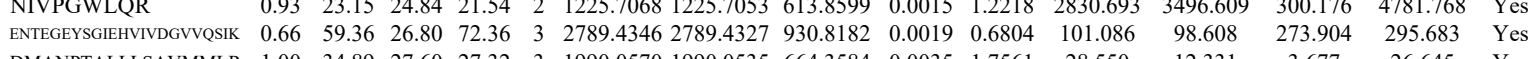
$\begin{array}{llllllllllllllllll}\text { DMANPTALLLSAVMMLR } & 1.00 & 34.89 & 27.60 & 27.32 & 3 & 1990.0570 & 1990.0535 & 664.3584 & 0.0035 & 1.7561 & 28.550 & 12.331 & 3.677 & 26.645 & \text { Yes }\end{array}$ $\begin{array}{lllllllllllll} & \end{array}$ $\begin{array}{llllllllllll} & & 11.402 & 17.113 & \text { YeS }\end{array}$

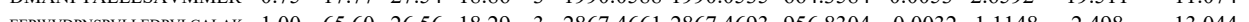
$\begin{array}{llllllllllllll} & \end{array}$

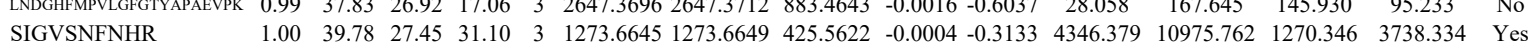
$\begin{array}{llllllllllllllll} & \\ \text { SIGVSNFNHR } & 1.00 & 39.78 & 27.45 & 31.10 & 3 & 1273.6645 & 1273.6649 & 425.5622 & -0.0004 & -0.3133 & 4346.379 & 10975.762 & 1270.346 & 3738.334 & \text { Yes } \\ \text { SIGVSNFNHR } & 0.85 & 20.77 & 27.45 & 19.01 & 3 & 1273.6645 & 1273.6649 & 425.5622 & -0.0004 & -0.3133 & 3770.557 & 5989.496 & 3070.774 & 5923.245 & \text { Yes }\end{array}$

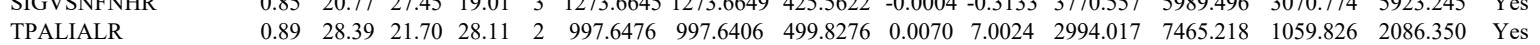
$\begin{array}{llllllllllllllll} & \\ \text { TPALIALR } & 0.89 & 28.39 & 21.70 & 28.11 & 2 & 997.6476 & 997.6406 & 499.8276 & 0.0070 & 7.0024 & 2994.017 & 7465.218 & 1059.826 & 2086.350 & \text { Yes } \\ \text { TPALIALR } & 0.84 & 26.49 & 21.70 & 27.48 & 2 & 997.6478 & 997.6406 & 499.8276 & 0.0072 & 7.2024 & 2007.626 & 4668.505 & 737.386 & 1748.508 & \text { Yes }\end{array}$

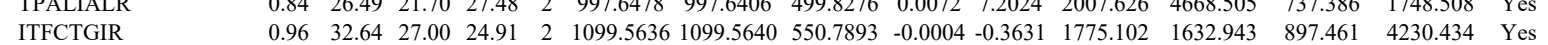

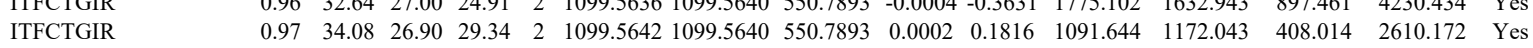
$\begin{array}{llllllllllllllll}\text { ITFCTGIR } & 0.99 & 34.21 & 26.94 & 23.93 & 2 & 1099.5646 & 1099.5640 & 550.7893 & 0.0006 & 0.5447 & 1129.626 & 1139.563 & 571.326 & 2894.914 & \text { Yes }\end{array}$ $\begin{array}{lllllllllllllllll} & \text { AAASAAEAGIATGGEDSDDALLK } & 1.00 & 36.23 & 27.30 & 20.85 & 3 & 2607.3127 & 2607.3119 & 870.1112 & 0.0008 & 0.3065 & 77.600 & 79.916 & 177.498 & 38.810 & \text { Yes }\end{array}$

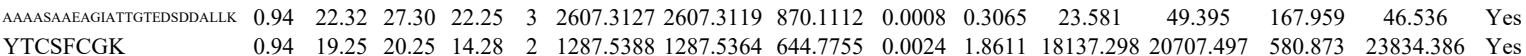
YTCSFCGK YTCSFCGK

YTCSFCGK

AVGIWHCGSCMK

AVGIWHCGSCMK

AVGIWHCGSCMK

TVAGGAWTYNTTSAVTVK

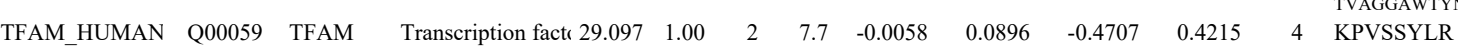
KPVSSYLR KPVSSYLR

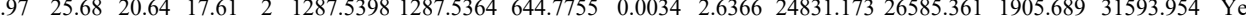
$\begin{array}{lllllllllllllll}0.64 & 17.49 & 20.04 & 30.49 & 2 & 1287.5366 & 1287.5364 & 644.7755 & 0.0002 & 0.1551 & 5774.800 & 6088.108 & 480.689 & 8268.468 & \text { Yes }\end{array}$ $\begin{array}{lllllllllllllll}0.64 & 17.49 & 20.04 & 30.4 & 2 & 1287.5366 & 1287.5364 & 644.7755 & 0.0002 & 0.1551 & 5774.800 & 688.108 & 480.689 & 8268.468 & \text { Yes } \\ 0.97 & 22.03 & 20.09 & 14.89 & 2 & 1287.5370 & 1287.5364 & 644.7755 & 0.0006 & 0.4653 & 7552.746 & 8578.693 & 728.225 & 10588.447 & \text { Yes }\end{array}$ $\begin{array}{lllllllllllllll}0.95 & 25.77 & 24.47 & 15.48 & 3 & 1670.7535 & 1670.7467 & 557.9228 & 0.0068 & 4.0627 & 5560.494 & 7577.111 & 1295.374 & 7021.154 & \text { Yes }\end{array}$

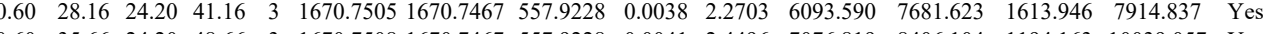

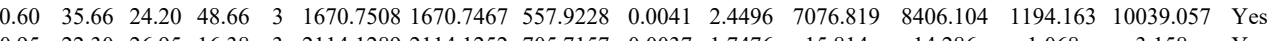

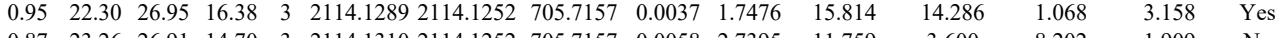

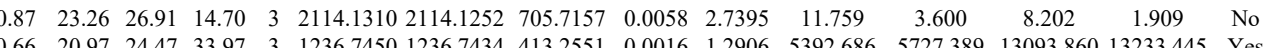

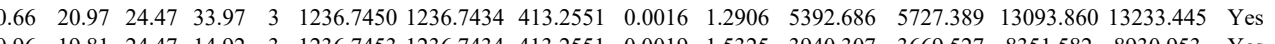
\begin{tabular}{llllllllllllllll}
0.96 & 19.81 & 24.47 & 14.92 & 3 & 1236.7453 & 1236.7434 & 413.2551 & 0.0019 & 1.5325 & 3940.307 & 3669.527 & 8351.582 & 8930.953 & Yes \\
\hline
\end{tabular}

$\begin{array}{ccccccccccccccc}0.66 & 19.63 & 24.47 & 32.63 & 3 & 1236.7453 & 1236.7434 & 413.2551 & 0.0019 & 1.5325 & 4592.800 & 4379.210 & 9118.045 & 9871.924 & \text { Yes } \\ 1.00 & 59.06 & 26.17 & 20.73 & 2 & 1506.7258 & 1506.7258 & 754.3702 & 0.0000 & 0.0000 & 680.964 & 700.770 & 195.388 & 877.022 & \text { Yes }\end{array}$ SWEEQMIEVG

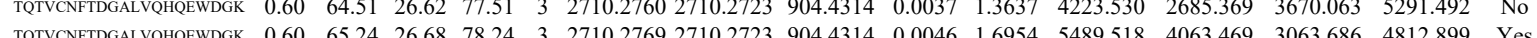

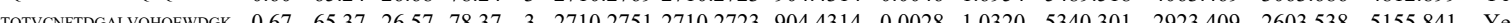

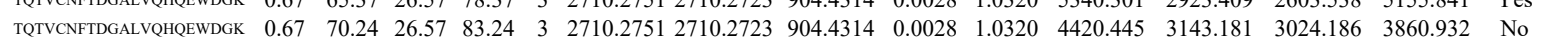


$\begin{array}{llllllllllll}1.00 & 45.53 & 24.50 & 18.19 & 2 & 1362.8152 & 1362.8145 & 682.4145 & 0.0007 & 0.5129 & 754.067 & \end{array}$ $\begin{array}{llllllllllllll}\text { VSEPLLWELFLQAGPVVNTHMPK } & 1.00 & 29.44 & 22.38 & 42.44 & 4 & 2892.5881 & 2892.5815 & 724.1527 & 0.0066 & 2.2785 & 23.575 & 32 .\end{array}$ $\begin{array}{lllllllllllll}\text { VSEPLLWELFLQAGPVVNTHMPK } & 0.55 & 53.46 & 23.03 & 66.46 & 3 & 2892.5830 & 2892.5815 & 965.2011 & 0.0015 & 0.5180 & 79.394 & \\ \text { VSEPLLWELFLQAGPVVNTHMPK } & 0.67 & 48.86 & 22.79 & 61.86 & 3 & 2892.5842 & 2892.5815 & 965.2011 & 0.0027 & 0.9324 & 116.037 & 65 .\end{array}$

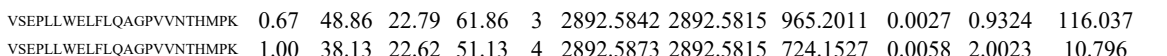

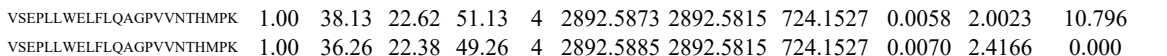
$\begin{array}{lllllllllllll}\text { VSEPLLWELFLQAGPVNTHMPK } & 1.00 & 19.84 & 22.62 & 32.84 & 4 & 2892.5865 & 2892.5815 & 724.1527 & 0.0050 & 1.7262 & 10.537\end{array}$ $\begin{array}{llllllllllll}\text { LLYDTFSAFGVILQTPK } & 0.75 & 12.91 & 23.60 & 22.46 & 3 & 2200.2397 & 2200.2387 & 734.4202 & 0.0010 & 0.4539 & 7.693\end{array}$ LPLVLR

LPLVLR $\begin{array}{llllllllllll}0.56 & 14.10 & 13.80 & 22.64 & 2 & 853.5916 & 853.5871 & 427.8008 & 0.0045 & 5.2594 & 1639.944 \\ 0.92 & 16.41 & 13.62 & 21.16 & 2 & 853.5870 & 853.5871 & 427.8008 & -0.0001 & -0.1169 & 372.023\end{array}$

LPLVLR $\begin{array}{lllllllllllll}0.97 & 17.62 & 13.62 & 21.30 & 2 & 853.5880 & 853.5871 & 427.8008 & 0.0009 & 1.0519 & 402.505 & 6\end{array}$

LPLVLR $\begin{array}{llllllllllll}0.96 & 21.59 & 13.62 & 22.44 & 2 & 853.5870 & 853.5871 & 427.8008 & -0.0001 & -0.1169 & 66.755\end{array}$ $\begin{array}{llllllllllllll} & \text { ASGLVPNVVVLVATVR } & 1 & 100 & 92.93 & 16.81 & 21.60 & 2 & 1737.0638 & 1737.0635 & 869.5390 & 0.0003 & 0.1725 & 46.457\end{array}$ $\begin{array}{llllllllllllll}\text { ASGLVPNVVVLVATVR } & 1.00 & 88.24 & 16.53 & 20.99 & 2 & 1737.0642 & 1737.0635 & 869.5390 & 0.0007 & 0.4025 & 29.820 & \end{array}$ $\begin{array}{llllllllllll}\text { NQLDQEVEFLSTSIAQLK } & 1.00 & 41.68 & 26.07 & 22.35 & 3 & 2350.2682 & 2350.2624 & 784.4281 & 0.0058 & 2.4646 & 12.934\end{array}$ $\begin{array}{llllllllllll}\text { NQLDQEVEFLSTSIAQLK } & 0.63 & 14.23 & 26.13 & 18.69 & 3 & 2350.2679 & 2350.2624 & 784.4281 & 0.0055 & 2.3372 & 22.077\end{array}$ $\begin{array}{llllllllllll}\text { NQLDQEVEFLSTSIAQLK } & 1.00 & 46.97 & 26.27 & 20.18 & 3 & 2350.2655 & 2350.2624 & 784.4281 & 0.0031 & 1.3173 & 49.266 \\ \text { FVADEELVHLLLDEVVASAALR } & 1.00 & 80.97 & 23.32 & 20.62 & 3 & 2552.4028 & 2552.3972 & 851.8063 & 0.0056 & 2.1914 & 7.684\end{array}$

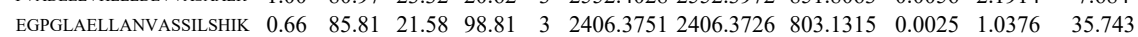
$\begin{array}{llllllllllll}\text { EGPGLAELLANVASSILSHIK } & 0.67 & 89.93 & 21.46 & \text { \#\#\#\# } & 2406.3757 & 2406.3726 & 803.1315 & 0.0031 & 1.2866 & 29.891\end{array}$

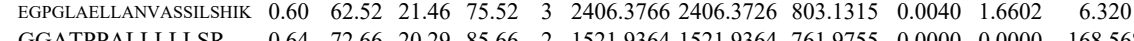
$\begin{array}{llllllllllll}\text { GGATPPALLLLLSR } & 0.64 & 72.66 & 20.29 & 85.66 & 2 & 1521.9364 & 1521.9364 & 761.9755 & 0.0000 & 0.0000 & 168.568\end{array}$ GGATPPALLLLLSR

LYLPVQNK

LPFLVMIIK

LPFLVMIIK

LPFLVMIIK

LPFLVMIIK

LPFLVMIIK

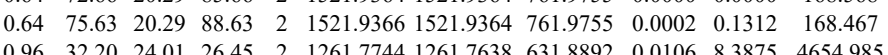
$\begin{array}{llllllllllll}0.96 & 32.20 & 24.01 & 26.45 & 2 & 1261.7744 & 1261.7638 & 631.8892 & 0.0106 & 8.3875 & 4654.985 \\ 1.00 & 50.16 & 18.26 & 26.78 & 2 & 1360.8770 & 1360.8760 & 681.4453 & 0.0010 & 0.7337 & 52.955\end{array}$ $\begin{array}{lllllllllllll}1.00 & 50.69 & 18.26 & 36.91 & 2 & 1360.8772 & 1360.8760 & 681.4453 & 0.0012 & 0.8805 & 62.33\end{array}$

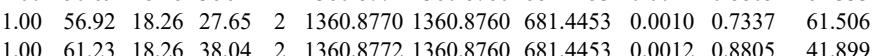
$\begin{array}{lllllllllll}1.00 & 61.23 & 18.26 & 38.04 & 2 & 1360.8772 & 1360.8760 & 681.4453 & 0.0012 & 0.8805 & 41.899 \\ 1.00 & 55.66 & 18.26 & 6.76 & 2 & 1360.8766 & 1600.8760 & 681.4453 & 0.0006 & 0.4402 & 11.731\end{array}$ $\begin{array}{lllllllllll}1.00 & 55.66 & 18.26 & 26.76 & 2 & 1360.8766 & 1360.8760 & 681.4453 & 0.0006 & 0.4402 & 11.731 \\ 1.00 & 49.56 & 18.13 & 28.01 & 2 & 1360.8782 & 1360.8760 & 681.4453 & 0.0022 & 1.6142 & 26.485\end{array}$ LAFAEEVMDDILDSADQPLTGR $\begin{array}{lllllllllllll}1.00 & 49.56 & 18.13 & 28.01 & 2 & 1360.8782 & 1360.8760 & 681.4453 & 0.0022 & 1.6142 & 26.485 \\ 0.52 & 10.21 & 27.44 & 16.53 & 3 & 2549.2459 & 2549.2441 & 850.7553 & 0.0018 & 0.7053 & 32.837\end{array}$

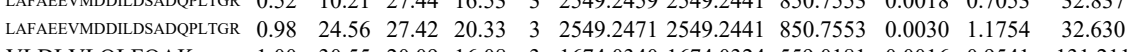
VLDLVLQLFQAK $\begin{array}{llllllllllll}1.00 & 30.55 & 20.09 & 16.08 & 3 & 1674.0340 & 1674.0324 & 559.0181 & 0.0016 & 0.9541 & 131.211 \\ 0.66 & 14.62 & 20.04 & 27.62 & 3 & 1674.0343 & 1674.0324 & 559.0181 & 0.0019 & 1.1329 & 121.366\end{array}$ 

$\begin{array}{llllllllllll}\text { LAAIIPDPVVAPSIVPVLK } & 0.66 & 38.77 & 7.78 & 51.77 & 3 & 2199.3874 & 2199.3850 & 734.1356 & 0.0024 & 1.0897 & 30.693\end{array}$ $\begin{array}{llllllllllll} & \\ \text { LAAIIPDPVVAPSIVPVLK } & 0.67 & 19.29 & 7.78 & 32.29 & 3 & 2199.3877 & 2199.3850 & 734.1356 & 0.0027 & 1.2259 & 88.635 \\ \text { LAIIPDPVVAPSIVPVLK } & 0.60 & 2.10 & 7.78 & 15.10 & 3 & 2199.3889 & 2199.3850 & 734.1356 & 0.0039 & 1.7708 & 65.669\end{array}$

$\begin{array}{llllllllllllll}\text { QAGEVTFADAHRPK } & 1.00 & 22.94 & 27.35 & 15.07 & 4 & 1813.9749 & 1813.9679 & 454.4993 & 0.0070 & 3.8504 & 5276.383 & 45\end{array}$

$\begin{array}{llllllllllllll} & & \end{array}$

QAGEVTFADAHRPK

LIVENLSSR

LIVENLSSR

GFGFVEFEDPR

$\begin{array}{lllllllllllll}1.00 & 34.08 & 27.35 & 15.33 & 4 & 1813.9681 & 1813.9679 & 454.4993 & 0.0002 & 0.1100 & 5867.118 & 5546.898 & 1483 \\ 1.00 & 45.88 & 26.80 & 28.54 & 2 & 1173.6946 & 1173.6839 & 587.8492 & 0.0107 & 9.1009 & 1113.438 & 1090.641 & 471 .\end{array}$

$\begin{array}{lllllllllllll}1.00 & 45.88 & 26.80 & 28.54 & 2 & 1173.6946 & 1173.6839 & 587.8492 & 0.0107 & 9.1009 & 1113.438 & 1090.641 & 47.03 \\ 0.96 & 38.05 & 26.97 & 26.59 & 2 & 1173.6920 & 1173.6839 & 587.8492 & 0.0081 & 6.8895 & 5249.584 & 5989.037 & 467.46\end{array}$

NNLSFIETSALDSTNVEEAFK $\begin{array}{llllllllllll}0.59 & 14.36 & 25.73 & 18.70 & 2 & 1442.6958 & 1442.6952 & 722.3549 & 0.0006 & 0.4153 & 670.972 & 394.033\end{array}$

$\begin{array}{lllllllllll}\text { RB11B_HUMAI } & \text { Q15907 } & \text { RAB11B } & \text { Ras-related protei } 24.489 & 1.00 & 2 & 14.7 & 0.1977 & 0.6708 & 1.8493 & 0.0982\end{array}$ NNLSFETSALDSTNVEEAKK

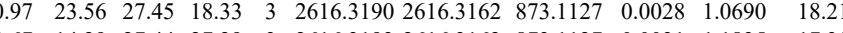
AQIWDTAGQER

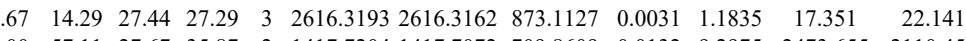

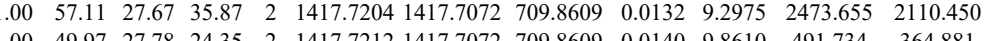
$\begin{array}{lllllllllllll}\text { DGVVEK } & 1.00 & 44.27 & 26.68 & 17.77 & 3 & 2421.2794 & 2421.2739 & 808.0986 & 0.0055 & 2.2687 & 32.120 & 24.362\end{array}$ MLIQQFR $\begin{array}{llllllllllll}0.92 & 25.05 & 27.43 & 26.27 & 2 & 1094.6048 & 1094.6028 & 548.3087 & 0.0020 & 1.8238 & 2700.356 & 2205.801 \\ 0.96 & 27.73 & 27.41 & 27.39 & 2 & 1094.6052 & 1094.6028 & 548.3087 & 0.0024 & 2.1885 & 2373.018 & 1891.056\end{array}$ (1) $\begin{array}{lllllllllll} & 0\end{array}$ $\begin{array}{llllllllllll}0.60 & 7.37 & 13.98 & 20.37 & 3 & 1729.0882 & 1729.0844 & 577.3687 & 0.0038 & 2.1939 & 128.449 & 124.707\end{array}$ $\begin{array}{lllllllllllll}\text { VVLLGMDILSALVTR } & 0.84 & 78.96 & 20.90 & 91.96 & 2 & 1743.0472 & 1743.0450 & 872.5298 & 0.0022 & 1.2607 & 10.414 & 32.394\end{array}$ $\begin{array}{lllllllllllll} & & \end{array}$ $\begin{array}{llllllllllllll}\text { VVLLGMDILSALVTR } & 1.00 & 52.95 & 21.04 & 16.80 & 2 & 1743.0476 & 1743.0450 & 872.5298 & 0.0026 & 1.4899 & 21.530 & 17.893\end{array}$ $\begin{array}{lllllllllllll}\text { LGNRPEMNYK } & 0.95 & 24.00 & 27.96 & 22.29 & 3 & 1508.8021 & 1508.8013 & 503.9410 & 0.0008 & 0.5292 & 14319.064 & 16951.992\end{array}$ $\begin{array}{lllllllllllllll}\text { AFQNTATACAPVSHYR } & 1.00 & 57.08 & 26.92 & 16.95 & 3 & 1925.9188 & 1925.8998 & 642.9739 & 0.0190 & 9.8500 & 579.973 & 916.369 & 8\end{array}$ $\begin{array}{llllllllllll}\text { LIAEGPGETVLVAEEEAAR } & 1.00 & \text { \#\#\# } 26.82 & 25.33 & 2 & 2097.1094 & 2097.1075 & 1049.5610 & 0.0019 & 0.9051 & 108.383 & 159\end{array}$ $\begin{array}{lllllllllllll}\text { FFQSFSDALIDEDPQAALEELTK } & 0.99 & 30.20 & 26.69 & 16.93 & 3 & 2901.4540 & 2901.4527 & 968.1582 & 0.0013 & 0.4476 & 11.317\end{array}$

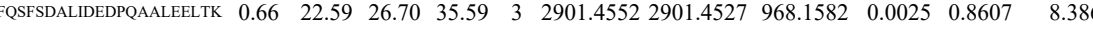
$\begin{array}{lllllllllll} & \end{array}$ $\begin{array}{lllllllllll}0.98 & 41.15 & 26.80 & 22.52 & 2 & 1427.7850 & 1427.7864 & 714.9005 & -0.0014 & -0.9792 & 1019.462\end{array}$

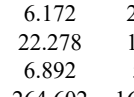

\begin{tabular}{lll}
2.217 & Yes \\
\hline & & 0
\end{tabular}

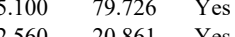
$\begin{array}{lll}8.543 & 460.179 & \text { Yes } \\ .412 & 6.959 & \text { Yes }\end{array}$ $2.058 \quad 551.926$ Yes $\begin{array}{lll}102.717 & \text { Yes } \\ 0.1812 & 0.68 & 0\end{array}$ $\begin{array}{lll}0.188 & 9.048 & \text { No } \\ 25.876 & 79.896 & \text { Yes }\end{array}$ \begin{tabular}{lll}
189.121 & Yes \\
\hline & & 0
\end{tabular}

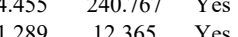
$2.391-8.418 \quad$ Yes

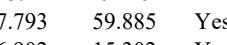
$\begin{array}{llll}15.302 & \text { Yes } \\ 14.007 & 14650 & \text { Yes } & 0 \\ 35.370 & 100.177 & \text { Yes } & 0\end{array}$

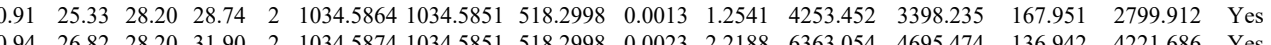
\begin{tabular}{llllllllllllllll} 
EEQEYEEEVEEEPRPAAK & 1.90 & 40.44 & 28.22 & 31.90 & 2 & 1034.5874 & 1034.5854 & 518.2998 & 0.0023 & 2.2188 & 6363.054 & 4695.474 & 136.942 & 4221.686 & Yes \\
\hline
\end{tabular} $\begin{array}{lllllllllllll}\text { PEPD HUMAN } & \text { P12955 } & \text { PEPD } & \text { Xaa-Pro dipeptida 54.548 } & 1.00 & 2 & 3.4 & 0.0791 & 0.3287 & -0.5799 & 0.5552 & 5 & \text { STLPWLKR }\end{array}$ $\begin{array}{lllllllllllllll}0.93 & 22.21 & 23.82 & 24.68 & 2 & 1187.7324 & 1187.7310 & 594.8728 & 0.0014 & 1.1767 & 3796.818 & 3441.258 & 1953.640 & 6192.998 & \text { Yes }\end{array}$ $\begin{array}{lllllllllllllll} & \end{array}$

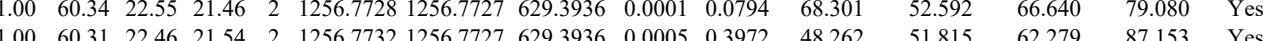

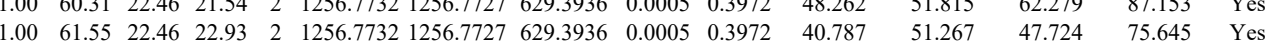



$\begin{array}{llllllllllll}0.99 & 39.24 & 26.44 & 18.41 & 2 & 1154.6362 & 1154.6359 & 578.3252 & 0.0003 & 0.2594 & 191.652\end{array}$

$\begin{array}{llllllllll}\text { VATL_HUMAN } & \text { P27449 } & \text { ATP6V0C V-type proton AT: } 15.736 & 1.00 & 2 & 24.5 & -1.0205 & 0.2424 & -2.1546 & 0.0873\end{array}$ DEDEWK

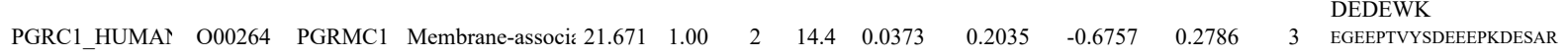
FDGVQDPR $\begin{array}{lllllllllllllllllll}0.90 & 35.99 & 22.83 & 35.50 & 2 & 856.5684 & 856.5616 & 429.2881 & 0.0068 & 7.9200 & 10794.782 & 9621.481 & 1742.116 & 14125.077 & \text { Yes } & \end{array}$ $\begin{array}{lllllllllllllllll}0.90 & 36.06 & 22.83 & 35.56 & 2 & 856.5686 & 856.5616 & 429.2881 & 0.0070 & 8.1530 & 11730.727 & 14048.139 & 2732.498 & 20399.226 & \text { Yes }\end{array}$ $\begin{array}{lllllllllllllllll}0.87 & 34.09 & 22.83 & 35.06 & 2 & 856.5684 & 856.5616 & 429.2881 & 0.0068 & 7.9200 & 7790.664 & 7510.697 & 1488.742 & 10789.348 & \text { Yes }\end{array}$

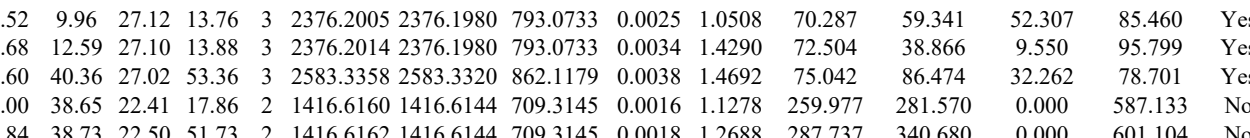
$\begin{array}{lllllllllll} & \end{array}$ $\begin{array}{lllllllllllll}1.00 & 44.65 & 26.89 & 24.33 & 3 & 1707.9394 & 1707.9368 & 570.3195 & 0.0026 & 1.5196 & 14385.822 & 17639 \\ 0.67 & 20.27 & 27.35 & 26.17 & 2 & 1273.6854 & 1273.6822 & 637.8484 & 0.0032 & 2.5084 & 5215.058 & 6600\end{array}$ $\begin{array}{lll}0.5845 & 8070.301 \quad 8026.099 & 4749.210\end{array}$

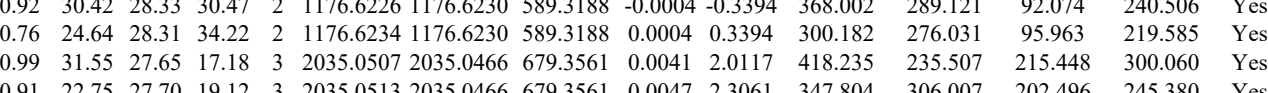
$\begin{array}{lllllllllllllllll}\text { GPDGLTAFEATDNQAIK } & 0.91 & 22.75 & 27.70 & 19.12 & 3 & 2035.0513 & 2035.0466 & 679.3561 & 0.0047 & 2.3061 & 347.804 & 306.007 & 202.496 & 245.380 & \text { Yes } \\ \text { GP. } & 1.64 & 19.14 & 3 & 2035.0498 & 2035.0466 & 679.3561 & 0.0032 & 1.5701 & 249.270 & 253.121 & 160.751 & 190.590 & \text { Yes }\end{array}$ $\begin{array}{lllllllllllllllll}\text { GPDGLTAFEATDNQAIK } & 1.00 & 41.01 & 27.64 & 22.01 & 3 & 2035.0498 & 2035.0466 & 679.3561 & 0.0032 & 1.5701 & 294.760 & 225.657 & 163.233 & 311.246 & \text { Yes }\end{array}$

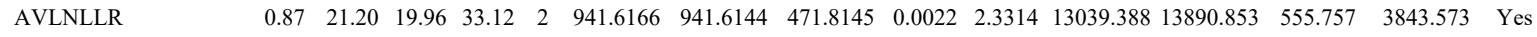
AVLNLLR LYSVVSQLIR SLPSQQMVNR IGSLASGNVR IGSLASGNVR

TDAISEK $\begin{array}{llllllllllllllllll}0.54 & 9.71 & 17.71 & 20.59 & 2 & 941.6142 & 941.6144 & 471.8145 & -0.0002 & -0.2119 & 5253.809 & 5817.462 & 2106.209 & 3089.734 & \text { Yes }\end{array}$ $\begin{array}{lllllllllllllll}1.00 & 66.69 & 24.96 & 28.56 & 2 & 1320.7892 & 1320.7887 & 661.4016 & 0.0005 & 0.3780 & 1051.154 & 895.749 & 79.800 & 2521.782 & \text { Yes }\end{array}$ $\begin{array}{lllllllllllllll}0.98 & 42.47 & 28.08 & 28.42 & 2 & 1302.6822 & 1302.6836 & 652.3491 & -0.0014 & -1.0730 & 4515.171 & 6127.346 & 860.274 & 6831.936 & \text { Yes }\end{array}$ $\begin{array}{lllllllllllllllll}0.98 & 42.58 & 27.87 & 36.76 & 2 & 1116.6410 & 1116.6373 & 559.3259 & 0.0037 & 3.3075 & 3685.749 & 4946.107 & 1796.810 & 4831.945 & \text { Yes }\end{array}$ $\begin{array}{llllllllllllllll}1.00 & 48.85 & 27.87 & 36.84 & 2 & 1116.6410 & 1116.6373 & 559.3259 & 0.0037 & 3.3075 & 4201.917 & 5712.834 & 2449.077 & 6182.128 & \text { Yes }\end{array}$

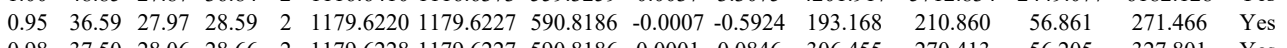

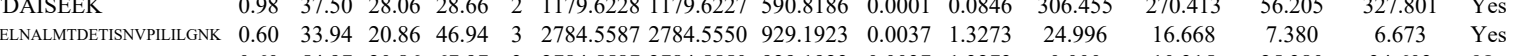

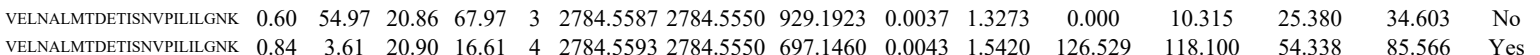

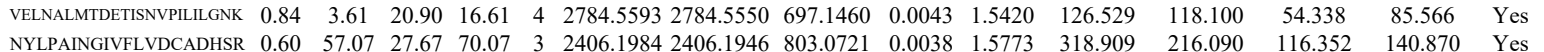

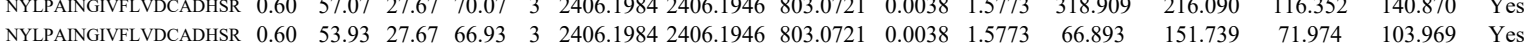

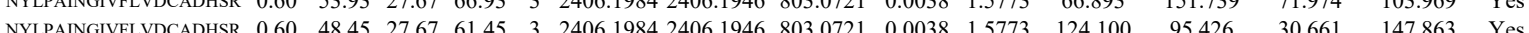

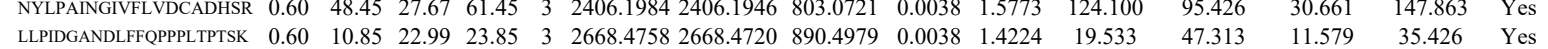


LLPIDGANDLFFQPPPLTPTSK LLPGIEVLWTGPK SFVQWLGCR RPPLMASGK RPPLMASGK RPPLMASGK AVIHLLLCQLR

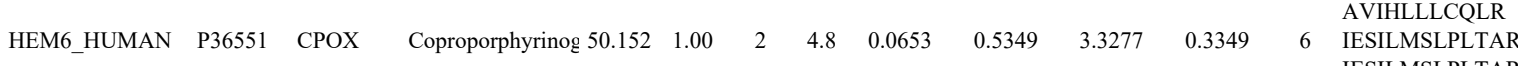
IESILMSLPLTAR
IESILMSLPLTAR FGLFTPGSR FGLFTPGSR
FGLFTPGSR
FGLFTPGSR

LGCQDAFPEVYDK

LGCQDAFPEVYDK
LGCQDAFEVYDK LGCQDAFPEVYDK
NIMINLMDILEVDTK

LLDDIK

MTDLLEEGITVVENIYK MTDLLEEGITVVENIYK

FVLQLLELFDS
ILPIMFPSLYR ILPIMFPSLYR ILPIMFPSLYR

EEEEEEEEDQEGDR FSNLLGTVYR FSNLLGTVYR

GIADVPEWFK GIADVPEWFK TGGIVMLGR NFGSYVTHETK
NFGSYVTHETK NADMSEDMQQDAVDCATQAMEK NADMSEDMQQDAVDCATQAMEK
FDEFDEAIDEAIEDDIK FDEFDEAIDEAIEDDIK LPVIVK LPVIVK
LPVIVK

DADAGDEDEESEEPR DADAGDEDEESEEP KVEEEGSPGDPDHEASTQGR RVEHHDHAVVSGR RVEHHDHAV NLQEEIDALESR NLQEEIDALESR NLQEEIDALESR NLQEEIDALESR ITELKEEIEVK

ETEDGHESPLFDFIESCLR 0.6 QDIFQEQLAAIPEFLNIGPLFK FGAQNESLLPSILVLLQR IPPPVIMVQNVSFK IPPPVIMVQNVSFK ILHGLGFTPAMQR ILHGLGFTPAMQR
ILHGLGFTPAMQR ILHGLGFTPAMQR
ILHGLGFTPAMQR LELLECIR LELLECIR
LFRPWLNMDR LFRPWLNMDR

LFRPWLN
MLILIK

GNQLCSLISGIIR

YMQLCSLISGIIR AQSCPTFLCALPR

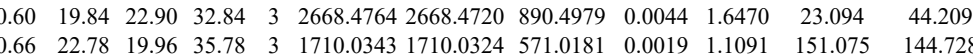

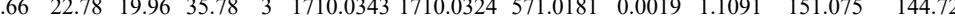
$\begin{array}{lllllllllllll}0.81 & 2.45 & 26.34 & 22.30 & 2 & 1284.6242 & 1284.622 & 64.3187 & 0.0013 & 1.0104 & 561.689 & 566.206\end{array}$ $\begin{array}{lllllllllllllll}0.80 & 19.02 & 26.80 & 19.36 & 3 & 1243.7314 & 1243.7314 & 415.5844 & 0.0000 & 0.0000 & 1683.909 & 2047.258 & 2013.174 & 2202.967 & \text { Yes }\end{array}$

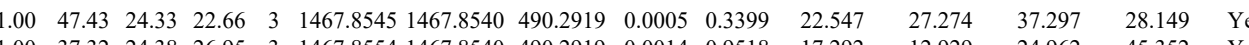

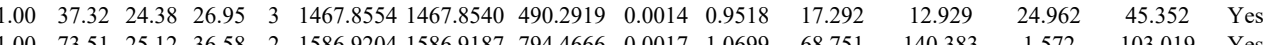

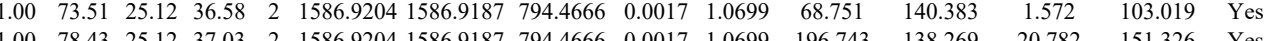

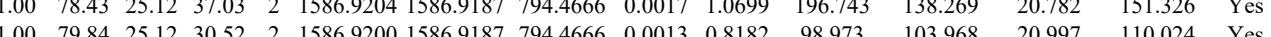

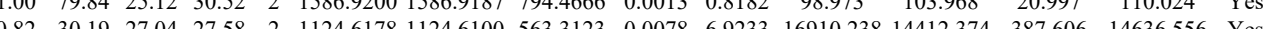

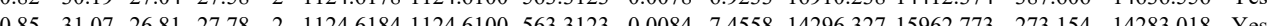

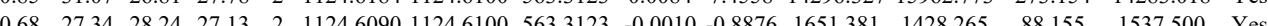
$\begin{array}{lllllllllllllll}1.00 & 54.15 & 26.15 & 27.90 & 2 & 1817.8596 & 1817.8572 & 909.9359 & 0.0024 & 1.3188 & 247.588 & 170.992 & 21.628 & 328.670 & \text { Yes }\end{array}$ $\begin{array}{lllllllllllllll}1.00 & 49.47 & 26.23 & 25.47 & 2 & 1817.8608 & 1817.8572 & 909.9359 & 0.0036 & 1.9782 & 183.207 & 99.857 & 11.661 & 128.803 & \text { Yes }\end{array}$

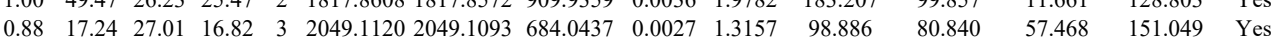
$\begin{array}{lllllllllllllll}0.82 & 24.24 & 24.70 & 32.90 & 2 & 1003.6160 & 1003.6157 & 502.8151 & 0.0003 & 0.2983 & 6813.026 & 6092.261 & 268.698 & 12260.170 & \text { Yes }\end{array}$

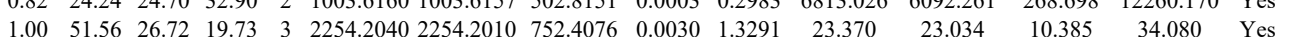

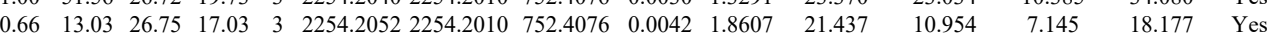

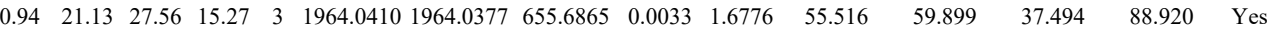

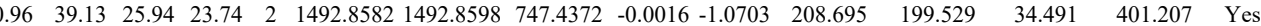

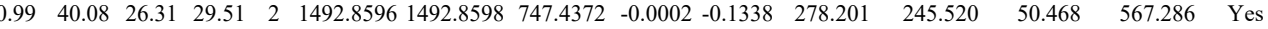

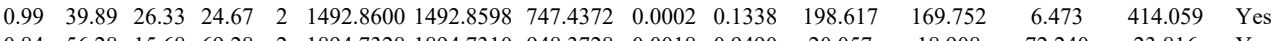
$\begin{array}{ccccccccccccccc}0.84 & 56.28 & 15.68 & 69.28 & 2 & 1894.7328 & 1894.7310 & 948.3728 & 0.0018 & 0.9490 & 20.057 & 18.908 & 72.240 & 23.816 & \text { Yes } \\ 1.00 & 6525 & 26.88 & 25.28 & 2 & 1312.7300 & 1312.7261 & 657.3703 & 0.0039 & 2.9664 & 1361.231 & 1355.100 & 268.733 & 2492.336 & \text { Yes }\end{array}$ $\begin{array}{llllllllllllllll}1.04 & 65.25 & 26.88 & 25.28 & 2 & 1312.7300 & 1312.7261 & 657.3703 & 0.0039 & 2.9664 & 1361.231 & 1355.100 & 268.733 & 24.82636 & \text { Yes } \\ 1.00 & 64.44 & 26.67 & 24.76 & 2 & 1312.7318 & 1312.7261 & 657.3703 & 0.0057 & 4.3354 & 1178.633 & 1155.291 & 93.816 & 2356.815 & \text { Yes }\end{array}$

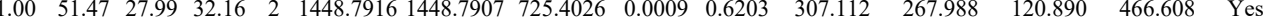

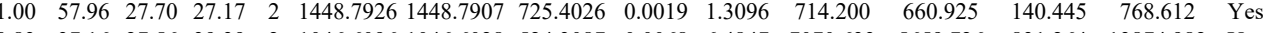
$\begin{array}{lllllllllllllll}0.83 & 37.16 & 27.56 & 39.39 & 2 & 1046.6096 & 1046.6028 & 524.3087 & 0.0068 & 6.4847 & 7070.633 & 5659.726 & 831.264 & 13874.982 & \text { Yes }\end{array}$ $\begin{array}{llllllllllllllll}1.00 & 36.43 & 27.64 & 16.69 & 3 & 1569.8083 & 1569.8031 & 524.2750 & 0.0052 & 3.3061 & 11445.473 & 9216.738 & 2559.268 & 24533.304 & \text { Yes }\end{array}$ $\begin{array}{lllllllllllllll}1.00 & 44.35 & 27.64 & 20.71 & 3 & 1569.8092 & 1569.8031 & 524.2750 & 0.0061 & 3.8784 & 11005.555 & 6903.747 & 2683.167 & 20856.793 & \text { Yes }\end{array}$ $\begin{array}{lllllllllllllll}1.00 & 36.82 & 19.40 & 15.42 & 3 & 2764.1389 & 2764.1362 & 922.3860 & 0.0027 & 0.9757 & 28.704 & 0.000 & 0.000 & 13.634 & \text { No }\end{array}$

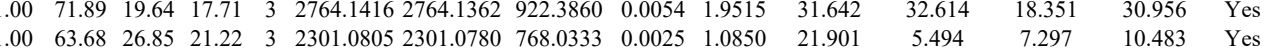

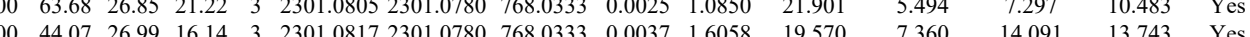

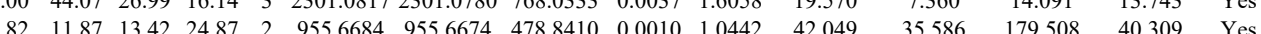

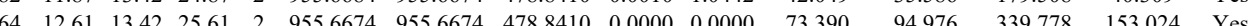

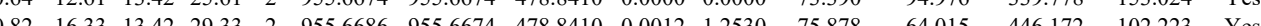

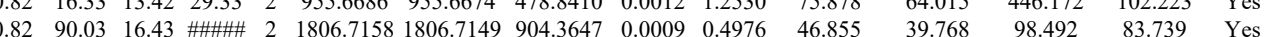

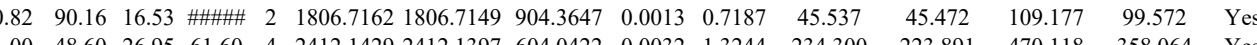

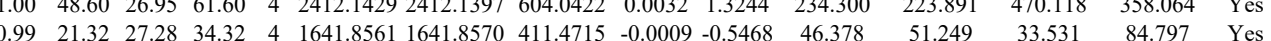
$\begin{array}{lllllllllllllll}0.95 & 15.74 & 27.32 & 18.91 & 4 & 1641.8573 & 1641.8570 & 411.4715 & 0.0003 & 0.1823 & 99.462 & 104.088 & 80.583 & 67.410 & \text { Yes }\end{array}$ $\begin{array}{lllllllllllllll}0.98 & 45.08 & 28.69 & 30.53 & 2 & 1177.6138 & 1177.6069 & 589.8107 & 0.0069 & 5.8493 & 4625.580 & 5121.569 & 214.749 & 5319.126 & \text { Yes }\end{array}$ $\begin{array}{lllllllllllllll}1.00 & 64.30 & 27.54 & 25.63 & 2 & 1559.7932 & 1559.7913 & 780.9029 & 0.0019 & 1.2165 & 106.598 & 106.535 & 0.447 & 127.870 & \text { No }\end{array}$ $\begin{array}{lllllllllllllll}1.00 & 71.51 & 27.60 & 25.14 & 2 & 1559.7934 & 1559.7913 & 780.9029 & 0.0021 & 1.3446 & 105.028 & 128.804 & 9.773 & 238.898 & \text { Yes }\end{array}$ $\begin{array}{lllllllllllllll}1.00 & 40.24 & 27.54 & 16.37 & 2 & 1559.7932 & 1559.7913 & 780.9029 & 0.0019 & 1.2165 & 56.909 & 117.677 & 8.139 & 117.813 & \text { Yes }\end{array}$ $\begin{array}{lllllllllllllll}1.00 & 76.32 & 27.54 & 25.73 & 2 & 1559.7932 & 1559.7913 & 780.9029 & 0.0019 & 1.2165 & 119.138 & 89.064 & 56.776 & 196.991 & \text { Yes }\end{array}$ $\begin{array}{lllllllllllllll}0.81 & 25.50 & 21.34 & 16.03 & 3 & 1762.0480 & 1762.0453 & 588.3557 & 0.0027 & 1.5297 & 4583.218 & 5120.811 & 5500.290 & 6745.099 & \text { Yes }\end{array}$

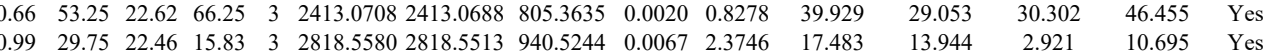

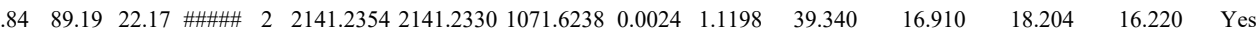
$\begin{array}{lllllllllllllll}0.83 & 13.25 & 21.99 & 22.88 & 3 & 1856.0860 & 1856.0838 & 619.7019 & 0.0022 & 1.1834 & 190.560 & 196.695 & 114.384 & 214.377 & \text { Yes }\end{array}$ $\begin{array}{llllllllllllllll}0.67 & 29.47 & 21.90 & 42.47 & 3 & 1856.0866 & 1856.0838 & 619.7019 & 0.0028 & 1.5061 & 139.818 & 282.740 & 222.365 & 331.383 & \text { Yes }\end{array}$ \begin{tabular}{lllllllllllllll}
0.66 & 42.57 & 27.41 & 55.57 & 3 & 1583.8747 & 1583.8728 & 528.9649 & 0.0019 & 1.1973 & 942.315 & 1025.347 & 143.270 & 1349.428 & Yes \\
\hline
\end{tabular} \begin{tabular}{lllllllllllllll}
1.00 & 42.79 & 27.41 & 15.87 & 3 & 1583.8747 & 1583.8728 & 528.9649 & 0.0019 & 1.1973 & 855.574 & 886.958 & 215.057 & 1148.296 & Yes \\
\hline
\end{tabular} $\begin{array}{lllllllllllllll}0.55 & 25.23 & 27.60 & 38.23 & 3 & 1583.8735 & 1583.8728 & 528.9649 & 0.0007 & 0.4411 & 295.390 & 257.251 & 87.525 & 378.833 & \text { Yes } \\ 1.00 & 36.82 & 27.62 & 15.54 & 3 & 1583.8738 & 1583.8728 & 528.9649 & 0.0010 & 0.6302 & 565.915 & 532.300 & 396.934 & 650.881 & \text { Yes }\end{array}$

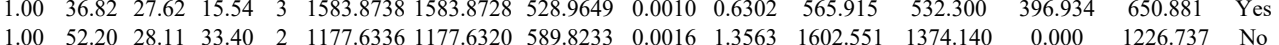

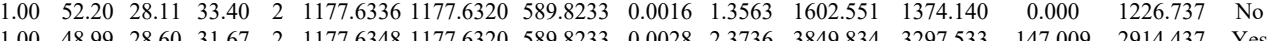

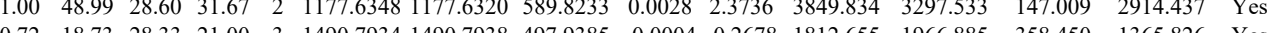
$\begin{array}{lllllllllllllll}0.72 & 18.73 & 28.33 & 21.00 & 3 & 1490.7934 & 1490.7938 & 497.9385 & -0.0004 & -0.2678 & 1812.655 & 1966.885 & 358.450 & 1365.826 & \text { Yes }\end{array}$ $\begin{array}{lllllllllllllll}0.69 & 17.86 & 16.72 & 21.26 & 3 & 1490.7949 & 140.7938 & 497.9385 & 0.0011 & 0.7364 & 1615.430 & 1565.159 & 282.382 & 1216.900 & \text { Yes }\end{array}$ $\begin{array}{llllllllllllllllll}0.76 & 18.42 & 16.72 & 21.80 & 2 & 1017.6920 & 1017.6864 & 509.8505 & 0.0056 & 5.4918 & 13062.273 & 15312.043 & 5582.182 & 20649.873 & \text { Yes }\end{array}$ $\begin{array}{lllllllllllllll}1.00 & 62.11 & 28.11 & 33.44 & 2 & 1562.83961562 .8394 & 782.4270 & 0.0002 & 0.1278 & 33.285 & 22.577 & 33.659 & 72.634 & \text { Yes }\end{array}$ $\begin{array}{lllllllllllllll}1.00 & 46.08 & 26.68 & 17.63 & 3 & 2225.1904 & 2225.1857 & 742.7358 & 0.0047 & 2.1093 & 64.021 & 65.311 & 26.468 & 71.544 & \text { Yes }\end{array}$

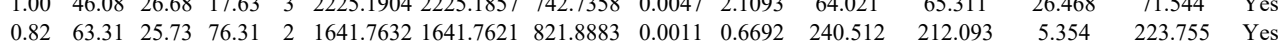


TQNLAALLHAIAR

TQNLAALLHAIAR

APAQPAMHAVPR APAQPAMHAV
TQNLAALLHAIAR

$\begin{array}{lllllllllllllll}0.82 & 67.17 & 25.73 & 80.17 & 2 & 1641.7632 & 1641.7621 & 821.8883 & 0.0011 & 0.6692 & 223.837 & 178.412 & 10.569 & 224.183 & \text { Yes } \\ 0.74 & 25.89 * & 11.14 & 28.15 & 2 & 1125.7740 & 1125.7729 & 563.8937 & 0.011 & 0.974 & 210.376 & 142.794 & 94.89 & & \end{array}$

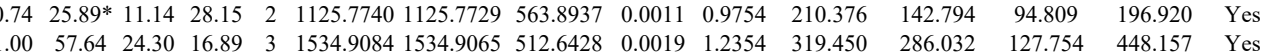
$\begin{array}{llllllllllllllll}1.00 & 65.87 & 23.80 & 22.60 & 3 & 1534.9093 & 1534.9065 & 512.6428 & 0.0028 & 1.8206 & 866.559 & 672.901 & 338.166 & 1652.799 & \text { Yes }\end{array}$ \begin{tabular}{llllllllllllllll}
1.00 & 59.93 & 23.84 & 22.84 & 3 & 1534.9087 & 1534.9065 & 512.6428 & 0.0022 & 1.4305 & 189.180 & 183.335 & 49.009 & 242.236 & Yes \\
\hline
\end{tabular} $\begin{array}{lllllllllllllll}1.00 & 65.01 & 28.11 & 27.19 & 3 & 1388.7475 & 1388.7469 & 463.9229 & 0.0006 & 0.4311 & 1743.490 & 3098.552 & 2175.384 & 2926.030 & \text { Yes }\end{array}$ $\begin{array}{lllllllllllllll}1.00 & 68.09 & 28.26 & 26.42 & 3 & 1388.7463 & 1388.7469 & 463.9229 & -0.0006 & -0.4311 & 3053.051 & 3138.186 & 2127.642 & 3566.533 & \text { Yes } \\ 0.73 & 1.82 & 16.33 & 14.30 & 3 & 1438.9252 & 1438.915 & 48.6444 & 0.0137 & 9.5010 & 30.612 & 375846 & 51.376 & 415.295 & \text { Yes }\end{array}$ $\begin{array}{lllllllllllllll}0.73 & 11.82 & 16.33 & 14.30 & 3 & 1438.9252 & 1438.9115 & 480.6444 & 0.0137 & 9.5010 & 304.612 & 375.846 & 51.376 & 415.295 & \text { Yes } \\ 0.66 & 17.88 & 25.33 & 30.88 & 3 & 2645.2096 & 2645.2080 & 882.7433 & 0.0016 & 0.6042 & 59.325 & 62.759 & 40.573 & 57.737 & \text { Yes }\end{array}$ $\begin{array}{cccccccccccccccc}\text { VMEMFPPSAVVLLCGSDSLSGDR } & 0.66 & 17.88 & 25.33 & 30.88 & 3 & 2645.2096 & 2645.2080 & 882.7433 & 0.0016 & 0.6042 & 59.325 & 62.759 & 40.573 & 57.737 & \text { Yes } \\ \text { DGIDDESYEAIFKPVMSK } & 1.00 & 36.59 & 27.25 & 21.93 & 3 & 2475.2593 & 2475.2569 & 826.0929 & 0.0024 & 0.9684 & 1021.310 & 512.731 & 1677.772 & 2224.773 & \text { Yes }\end{array}$

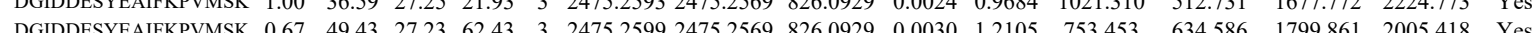

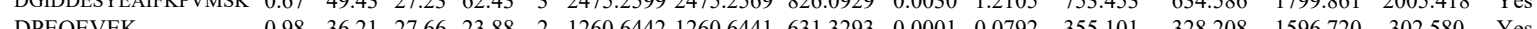
$\begin{array}{llllllllllllllllll}\text { DPEOEVEK } & 0.99 & 35.57 & 27.60 & 24.13 & 2 & 1260.6452 & 1260.6441 & 631.3293 & 0.0011 & 0.8712 & 359.369 & 362.838 & 1435.431 & 348.031 & \text { Yes }\end{array}$

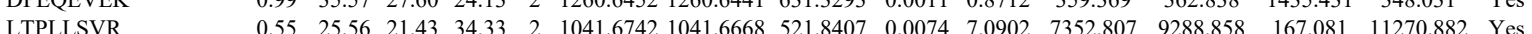
TTLSR

LTPLLSYR LLLYLR

TQQLLERK

TQQLLERK TQQLLERK LAFLLFK LAFLLFK

LAFLLFK

VGAGAGAAPFR

LLLERPSPIR

4 YKLDEDEDEDDADLSK CGNVNFAR CGNVNFAR CGNVNFAR

LLYPPETGLFLVR LSLMPWFHGK

LSLMPWFHGK NTGDADQWCPLLETLTDAEM NTGDADQWCPLLETLTDAEMEK NTGDADQWCPLLET

\section{LVAVGGQPR}

LQALVNSLCAGQSP

SLQQQQQQQQLQK SLQQQQQQQQLQK ALFLIPR

16 IFIGTFK

VLGLVLLR

VLGLVLLR

VLGLVLLR

VLGLVLLR

VLGLVLLR

VLGLVLLR

VLGLVLLR

VLGLVLLR

VLGLVLLR

VLGLVLLR

VLGLVLLR

VLGLVLLR

VLGLVLLR

VLGLVLLR

VLGLVLLR

VLGLVLLR

$\begin{array}{lllllllllllllll}0.60 & 25.85 & 21.30 & 35.88 & 2 & 1041.6758 & 1041.6668 & 521.8407 & 0.0090 & 8.6232 & 10135.502 & 12146.235 & 302.354 & 14487.908 & \text { Yes }\end{array}$

$\begin{array}{lllllllllllllllll}0.71 & 27.37 & 16.23 & 39.06 & 2 & 933.6136 & 933.6133 & 467.8139 & 0.0003 & 0.3206 & 2380.677 & 3314.681 & 472.264 & 9523.341 & \text { Yes } \\ 0.86 & 27.55 & 16.23 & 39.23 & 2 & 933.6142 & 93.6133 & 46.8139 & 0.000 & 0.9619 & 2106.460 & 2594.370 & 562.702 & 8913.480 & \text { Yes }\end{array}$

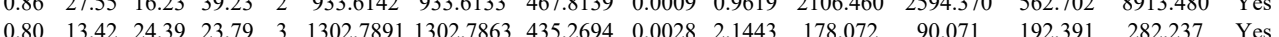

$\begin{array}{llllllllllllllll}0.65 & 9.43 & 24.44 & 22.00 & 3 & 1302.7897 & 1302.7863 & 435.2694 & 0.0034 & 2.6037 & 123.275 & 85.604 & 188.224 & 284.734 & \text { Yes }\end{array}$

$\begin{array}{lllllllllllllll}0.68 & 10.00 & 24.44 & 21.15 & 3 & 1302.7894 & 1302.7863 & 435.2694 & 0.0031 & 2.3740 & 88.578 & 88.315 & 154.837 & 211.889 & \text { Yes }\end{array}$

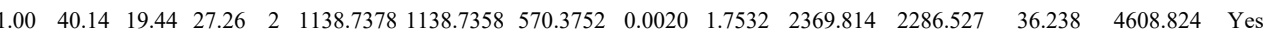
$\begin{array}{llllllllllllllll}1.00 & 44.76 & 19.44 & 23.69 & 2 & 1138.7384 & 1138.7358 & 570.3752 & 0.0026 & 2.2792 & 2237.331 & 2081.294 & 36.515 & 4227.724 & \text { Yes }\end{array}$ $\begin{array}{lllllllllllllll}1.00 & 40.26 & 19.44 & 27.26 & 2 & 1138.7378 & 1138.7358 & 570.3752 & 0.0020 & 1.7532 & 721.950 & 667.827 & 81.643 & 1247.917 & \text { Yes }\end{array}$ $\begin{array}{lllllllllllllll}1.00 & 48.88 & 28.21 & 26.21 & 2 & 1116.6194 & 1116.6162 & 559.3154 & 0.0032 & 2.8606 & 2947.864 & 2387.224 & 1657.680 & 3682.283 & \text { Yes }\end{array}$ $\begin{array}{llllllllllllllll}0.79 & 10.17 & 20.37 & 17.04 & 3 & 1336.8322 & 1336.8312 & 446.6177 & 0.0010 & 0.7463 & 1355.799 & 2386.767 & 3145.804 & 3316.133 & \text { Yes }\end{array}$ $\begin{array}{lllllllllllllll}0.88 & 10.45 & 20.13 & 17.59 & 3 & 1336.8331 & 1336.8312 & 446.6177 & 0.0019 & 1.4181 & 1768.960 & 2942.349 & 4138.818 & 4383.190 & \text { Yes }\end{array}$

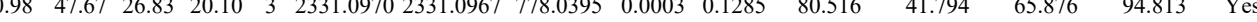
$\begin{array}{llllllllllllllll}0.56 & 20.98 & 25.01 & 23.44 & 2 & 1069.5004 & 1069.4919 & 535.7532 & 0.0085 & 7.9327 & 2588.102 & 2519.335 & 1112.669 & 3432.252 & \text { Yes }\end{array}$ $\begin{array}{llllllllllllllll}0.98 & 38.38 & 25.22 & 26.90 & 2 & 1069.5008 & 1069.4919 & 535.7532 & 0.0089 & 8.3060 & 2660.721 & 2495.799 & 588.373 & 4887.875 & \text { Yes }\end{array}$ $\begin{array}{lllllllllllllll}0.99 & 37.80 & 24.84 & 25.99 & 2 & 1069.5016 & 1069.4919 & 535.7532 & 0.0097 & 9.0526 & 2904.996 & 2572.581 & 524.352 & 4446.987 & \text { Yes }\end{array}$ $\begin{array}{lllllllllllllll}0.84 & 19.02 & 24.56 & 14.37 & 2 & 1660.9686 & 1660.9674 & 831.4910 & 0.0012 & 0.7216 & 40.392 & 38.503 & 32.280 & 34.936 & \text { Yes }\end{array}$ $\begin{array}{llllllllllllllll}1.00 & 39.27 & 28.04 & 19.56 & 3 & 1502.8333 & 1502.8312 & 501.9510 & 0.0021 & 1.3946 & 694.702 & 641.373 & 192.389 & 785.471 & \text { Yes }\end{array}$ $\begin{array}{llllllllllllllll}1.00 & 36.11 & 27.82 & 17.46 & 3 & 1502.8339 & 1502.8312 & 501.9510 & 0.0027 & 1.7930 & 894.476 & 823.482 & 62.302 & 1116.599 & \text { Yes }\end{array}$

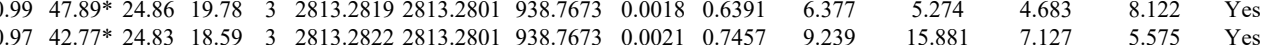

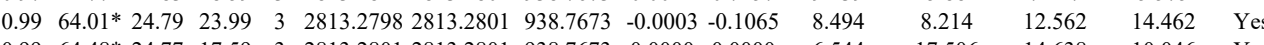

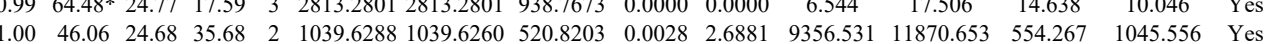

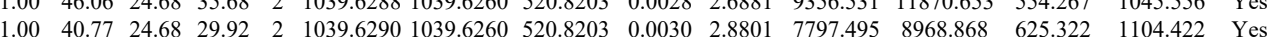

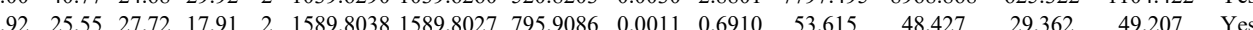
$\begin{array}{lllllllllllllll}1.00 & 34.07 & 26.84 & 18.01 & 3 & 1900.0396 & 1900.0370 & 634.3529 & 0.0026 & 1.3662 & 593.954 & 378.612 & 412.756 & 544.557 & \text { Yes }\end{array}$ $\begin{array}{ccccccccccccccc}0.55 & 15.51 & 26.68 & 28.51 & 3 & 1900.0381 & 1900.0370 & 634.3529 & 0.0011 & 0.5780 & 238.988 & 235.560 & 249.492 & 508.072 & \text { Yes } \\ 0.90 & 20.43 & 23.71 & 21.23 & 2 & 972.6250 & 972.6242 & 487.3194 & 0.0008 & 0.8208 & 39.584 & 52362 & 7.774 & 76.716 & \text { Yes }\end{array}$ $\begin{array}{llllllllllllllll}0.86 & 18.81 & 23.71 & 21.79 & 2 & 972.6248 & 972.6242 & 487.3194 & 0.0006 & 0.6156 & 29.686 & 40.454 & 22.863 & 52.648 & \text { Yes }\end{array}$ $\begin{array}{lllllllllllllll}0.99 & 36.66 & 3.03 & 24.06 & 2 & 1112.6946 & 1112.6838 & 557.3492 & 0.0108 & 9.6886 & 29940.902 & 24555.950 & 279.722 & 67150.771 & \text { Yes }\end{array}$ $\begin{array}{llllllllllllllll}0.82 & 39.25 & 7.78 & 52.25 & 2 & 1025.7094 & 1025.7083 & 513.8614 & 0.0011 & 1.0703 & 4191.949 & 3774.834 & 190.693 & 10643.257 & \text { Yes }\end{array}$ $\begin{array}{lllllllllllllll}0.84 & 32.95 & 7.78 & 45.95 & 2 & 1025.7098 & 1025.7083 & 513.8614 & 0.0015 & 1.4595 & 6437.905 & 5715.278 & 984.578 & 15864.488 & \text { Yes }\end{array}$ $\begin{array}{llllllllllllllll}0.64 & 21.76 & 6.02 & 34.76 & 2 & 881.6064 & 881.6062 & 441.8104 & 0.0002 & 0.2263 & 34.952 & 36.162 & 23.463 & 167.878 & \text { Yes }\end{array}$ $\begin{array}{lllllllllllllllll}0.64 & 36.27 & 6.02 & 49.27 & 2 & 881.6064 & 881.6062 & 441.8104 & 0.0002 & 0.2263 & 31.893 & 36.042 & 14.923 & 120.256 & \text { Yes }\end{array}$ $\begin{array}{lllllllllllllll}0.64 & 4.07 & 7.78 & 17.07 & 2 & 1025.7084 & 1025.7083 & 513.8614 & 0.0001 & 0.0973 & 22.056 & 22.677 & 7.468 & 11.561 & \text { No }\end{array}$

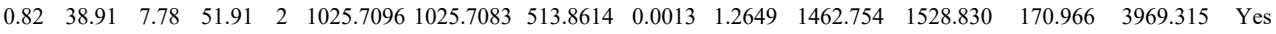

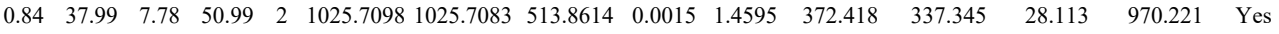
$\begin{array}{lllllllllllllll}0.64 & 35.21 & 6.02 & 48.21 & 2 & 881.6062 & 881.6062 & 441.8104 & 0.0000 & 0.0000 & 5.974 & 4.500 & 12.603 & 8.927 & \text { No }\end{array}$ $\begin{array}{lllllllllllllll}0.64 & 35.02 & 6.02 & 48.02 & 2 & 881.6064 & 881.6062 & 441.8104 & 0.0002 & 0.2263 & 8.235 & 9.271 & 6.516 & 10.230 & \text { Yes }\end{array}$

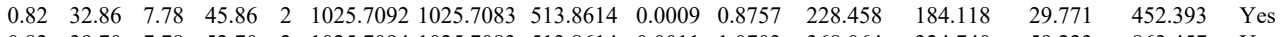
$\begin{array}{lllllllllllllll}0.82 & 39.70 & 7.78 & 52.70 & 2 & 1025.7094 & 1025.7083 & 513.8614 & 0.0011 & 1.0703 & 368.064 & 324.740 & 59.223 & 863.457 & \text { Yes }\end{array}$ $\begin{array}{lllllllllllllll}0.64 & 16.69 & 6.02 & 29.69 & 2 & 881.6064 & 881.6062 & 441.8104 & 0.0002 & 0.2263 & 9.564 & 17.651 & 13.798 & 21.318 & \text { Yes }\end{array}$ $\begin{array}{lllllllllllllll}0.64 & 36.71 & 6.02 & 49.71 & 2 & 881.6064 & 881.6062 & 441.8104 & 0.0002 & 0.2263 & 16.073 & 16.872 & 14.549 & 16.772 & \text { Yes } \\ 0.82 & 38.94 & 7.78 & 51.94 & 2 & 025.092 & 025.7083 & 513.864 & 0.000 & 0.857 & 124.085 & 137.556 & 14.53 & 390.943 & \text { Yes }\end{array}$ $\begin{array}{llllllllllllllll}0.82 & 38.94 & 7.78 & 51.94 & 2 & 1025.7092 & 1025.7083 & 513.8614 & 0.0009 & 0.8757 & 124.085 & 137.556 & 14.124 & 390.943 & \text { Yes }\end{array}$

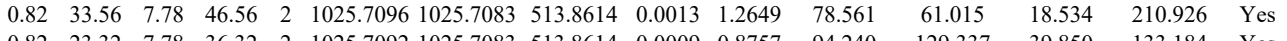

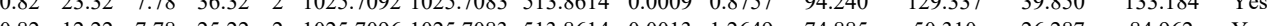

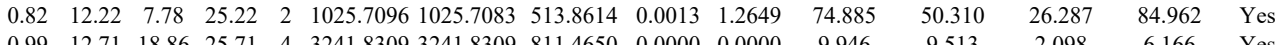
$\begin{array}{lllllllllllll} & \end{array}$ $\begin{array}{llllllllllllllll}\text { QLPPPPPIPPPRPLIQR } & 0.55 & 23.63 & 14.91 & 36.63 & 3 & 2153.2969 & 2153.2959 & 718.7726 & 0.0010 & 0.4638 & 142.242 & 120.274 & 134.678 & 147.989 & \text { Yes }\end{array}$

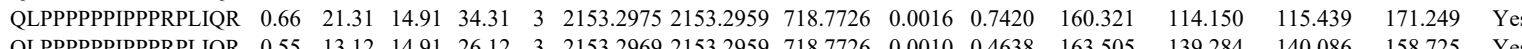



$\begin{array}{llllllllllllllll}0.89 & 28.48 & 21.96 & 29.39 & 2 & 1096.6812 & 1096.6736 & 549.3441 & 0.0076 & 6.9173 & 4919.724 & 4719.501 & 4371.109 & 3362.621 & \text { Yes }\end{array}$ QLPAHDQDPS

$\begin{array}{llllllllllllllll}0.76 & 15.06 & 27.92 & 15.71 & 3 & 1522.8016 & 1522.7983 & 508.6067 & 0.0033 & 2.1628 & 34.927 & 24.459 & 20.811 & 31.323 & \text { Yes } \\ \end{array}$

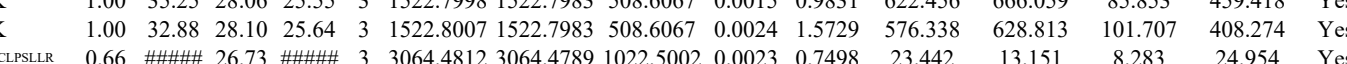

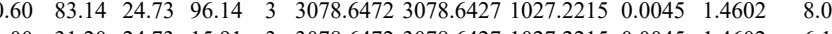

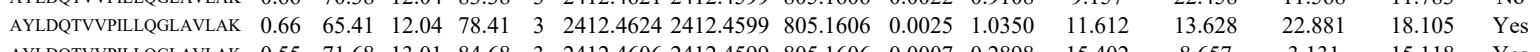
$\begin{array}{llllllllllllllll}\text { AYLDQTVVPILLQGLAVLAK } & 0.55 & 71.68 & 13.01 & 84.68 & 3 & 2412.4606 & 2412.4599 & 805.1606 & 0.0007 & 0.2898 & 15.402 & 8.657 & 3.131 & 15.118 & \text { Yes } \\ \text { AYLDOTVYPILLQGLAVLAK } & 0.55 & 69.56 & 12.79 & 82.56 & 3 & 2412.4612 & 2412.4599 & 805.1606 & 0.0013 & 0.5382 & 11.878 & 8.032 & 12.285 & 12.865 & \text { Yes }\end{array}$

$\begin{array}{llllllllllll}\text { PLOD2_HUMAI } & \text { O00469 } & \text { PLOD2 } & \text { Procollagen-lysin } 84.686 & 1.00 & 2 & 3.3 & 0.0087 & 0.0976 & 2.6083 & 0.3213\end{array}$

IIAPLVTR

IIAPLVTR

VVDYTTAK

VVDYTTAK

IQSTPVK

IQSTPVK

IQSTPVK

\section{AALGPLYTGLYDVOAH}

$\begin{array}{lllllllllllllll}0.98 & 32.55 & 16.43 & 23.83 & 2 & 1025.6776 & 1025.6719 & 513.8432 & 0.0057 & 5.5464 & 9879.022 & 10499.803 & 1145.130 & 1361.666 & \text { Yes }\end{array}$ $\begin{array}{llllllllllllllll}0.97 & 33.53 & 16.43 & 26.60 & 2 & 1025.6782 & 1025.6719 & 513.8432 & 0.0063 & 6.1302 & 10330.436 & 9424.378 & 348.812 & 1037.204 & \text { Yes }\end{array}$ $\begin{array}{lllllllllllllll}0.56 & 14.64 & 16.43 & 18.78 & 2 & 1025.6772 & 1025.6719 & 513.8432 & 0.0053 & 5.1572 & 529.955 & 551.493 & 70.290 & 711.978 & \text { Yes }\end{array}$ $\begin{array}{llllllllllllllll}0.99 & 41.81 & 26.95 & 18.99 & 2 & 1183.6736 & 1183.6692 & 592.8419 & 0.0044 & 3.7109 & 20577.031 & 13511.589 & 1930.212 & 15673.929 & \text { Yes }\end{array}$ $\begin{array}{llllllllllllllll}0.98 & 41.85 & 26.90 & 18.88 & 2 & 1183.6744 & 1183.6692 & 592.8419 & 0.0052 & 4.3856 & 17675.800 & 12534.817 & 1392.363 & 15613.929 & \text { Yes }\end{array}$

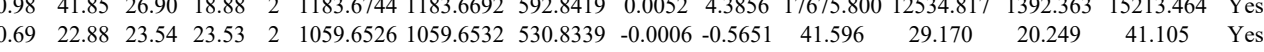
$\begin{array}{lllllllllllllll}0.60 & 15.31 & 26.50 & 19.08 & 2 & 1059.6546 & 1059.6532 & 530.8339 & 0.0014 & 1.3187 & 26.048 & 26.628 & 24.825 & 24.05 & \text { Yes }\end{array}$ $\begin{array}{llllllllllllllll}0.59 & 16.49 & 23.54 & 20.06 & 2 & 1059.6528 & 1059.6532 & 530.8339 & -0.0004 & -0.3768 & 41.487 & 22.813 & 17.164 & 30.959 & \text { Yes }\end{array}$

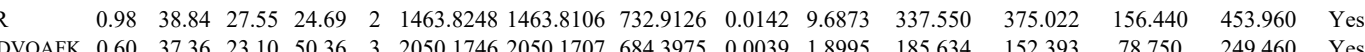
$\begin{array}{llllllllllllllll}\text { AALGPLVTGLYDVQAFK } & 0.60 & 53.13 & 23.10 & 66.13 & 3 & 2050.1749 & 2050.1707 & 684.3975 & 0.0042 & 2.0456 & 265.319 & 248.690 & 146.191 & 236.458 & \text { Yes }\end{array}$ $\begin{array}{llllllllllllllllll} & \\ \text { AASWADLVNAHVVPGSGVVK } & 0.60 & 49.47 & 22.83 & 62.47 & 3 & 2306.3032 & 2306.2991 & 769.7736 & 0.0041 & 1.7754 & 544.988 & 942.191 & 3149.303 & 1964.993 & \text { Yes } \\ \text { LVLSGEKK } & 0.78 & 9.70 & 24.58 & 28.01 & 2 & 1016.6368 & 1016.6352 & 509.3249 & 0.0016 & 1.5707 & 7913.817 & 7731.938 & 36149.988 & 7512.709 & \text { Ne }\end{array}$ $\begin{array}{lllllllllllllllll} & \text { LVLSGEKK } & 0.78 & 16.78 & 24.58 & 28.01 & 2 & 1016.6368 & 1016.6352 & 509.3249 & 0.0016 & 1.5707 & 7913.817 & 7731.938 & 36149.988 & 7512.709 & \text { No } \\ \text { SPVPAQIATVPK } & 0.56 & 9.70 & 16.99 & 22.60 & 3 & 1607.9869 & 1607.9854 & 537.0024 & 0.0015 & 0.9311 & 93.980 & 159.008 & 175.560 & 147.110 & \text { Y }\end{array}$ $\begin{array}{llllllllllllllll}\text { FMLQDVIDLR } & 0.95 & 56.61 * 27.94 & 34.89 & 2 & 1392.7576 & 1392.7557 & 697.3851 & 0.0019 & 1.3622 & 2061.676 & 1961.731 & 174.723 & 3564.164 & \text { Yes }\end{array}$ 


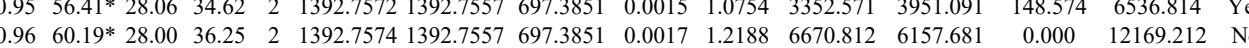

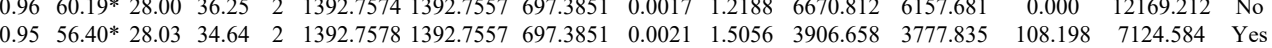
$\begin{array}{llllllllllllll}0.91 & 56.61 * 28.01 & 34.89 & 2 & 1392.7578 & 1392.7557 & 697.3851 & 0.0021 & 1.5056 & 3906.658 & 3777.835 & 108.198 & 7124.584 & \text { Yes } \\ 0.60 & 13927584 & 1392.7557 & 697.3851 & 0.0027 & 1.9358 & 2490.552 & 2358.084 & 47.806 & 3785.994 & \text { Yes }\end{array}$ $\begin{array}{lllllllllllllll}0.60 & 17.06 & 27.70 & 30.06 & 3 & 2471.2609 & 2471.2567 & 824.7595 & 0.0042 & 1.6975 & 90.844 & 93.429 & 60.498 & 75.563 & \text { Yes }\end{array}$ $\begin{array}{lllllllllllllll}0.91 & 38.13 * 21.93 & 25.29 & 2 & 1071.6938 & 1071.6926 & 536.8536 & 0.0012 & 1.1176 & 2286.403 & 2180.453 & 109.062 & 1879.591 & \text { Yes }\end{array}$

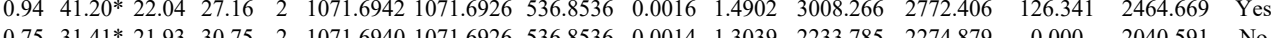

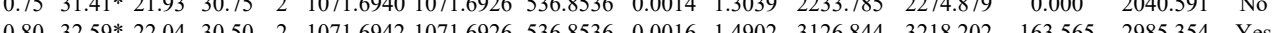

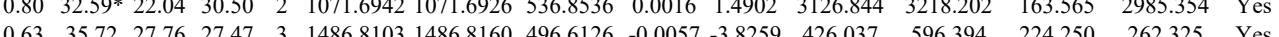

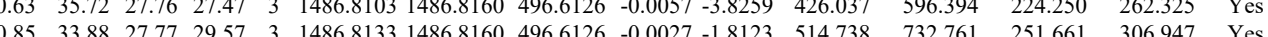

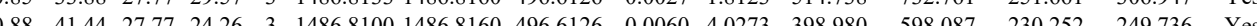
$\begin{array}{lllllllllllllllll} & \end{array}$

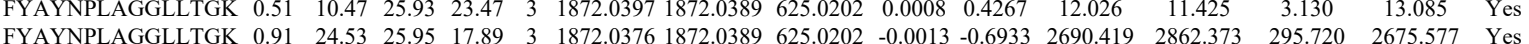

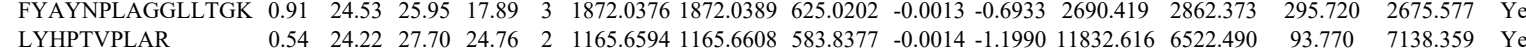
LYHPTVPLAR ATIQFHQPQR ATIQFHQPQR ATIQFHQPQR VLAILVNIFGGIMR IPVVVR
IPVVVR

VLAILVNIFGGIMR VLAILVNIFGGIMR VLAILVNIFGGIMR

$\begin{array}{llllllllllllll}\text { RAC2_HUMAN } & \text { P15153 } & \text { RAC2 } & \text { Ras-related C3 bo } 21.429 & 0.97 & 2 & 27.1 & -0.7283 & 0.3882 & 2.4745 & 0.3782 & 4 & \text { LAPITYPQGLALAK }\end{array}$ LAPITYPQGLALAK AVLCPQPTR AVLCPQPTR

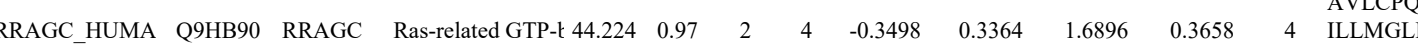
LLMGLR FLALVCILR FLALVCILR

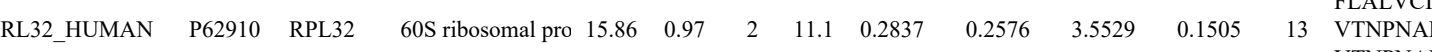
VTNPNAR TNPNAR HMLPSGFR HMLPSGFR HMLPSGFR HMLPSGFR HMLPSGFR HMLPSGFR HMLPSGFR HMLPSGFR HMLPSGFR HMLPSGFR HMLPSGFR HMLPSGFR

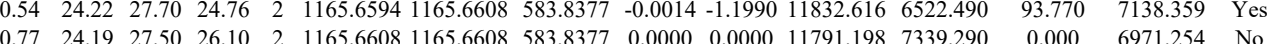
$\begin{array}{llllllllllllllll}0.99 & 29.53 & 27.75 & 27.96 & 3 & 1368.7426 & 1368.7384 & 457.2534 & 0.0042 & 3.0618 & 2495.667 & 3585.312 & 1597.545 & 4560.052 & \text { Yes }\end{array}$ $\begin{array}{lllllllllllllllll}0.94 & 25.53 & 27.63 & 29.60 & 3 & 1368.7429 & 1368.7384 & 457.2534 & 0.0045 & 3.2804 & 3063.930 & 4535.412 & 2037.963 & 4884.810 & \text { Yes }\end{array}$ $\begin{array}{llllllllllllllll}0.73 & 15.38 & 27.75 & 16.26 & 3 & 1368.7423 & 1368.7384 & 457.2534 & 0.0039 & 2.8431 & 2156.019 & 2586.681 & 1051.263 & 2875.782 & \text { Yes }\end{array}$ $\begin{array}{llllllllllllllll}0.64 & 22.33 & 21.43 & 35.33 & 2 & 1674.9974 & 1674.9977 & 838.5061 & -0.0003 & -0.1789 & 4802.699 & 5556.893 & 626.697 & 4598.982 & \text { Yes }\end{array}$ $\begin{array}{lllllllllllllllll}0.76 & 16.48 & 10.41 & 21.52 & 2 & 825.5636 & 825.5558 & 413.7852 & 0.0078 & 9.4251 & 6996.670 & 6662.928 & 11292.684 & 13407.899 & \text { Yes }\end{array}$ $\begin{array}{lllllllllllllll}0.67 & 13.34 & 10.41 & 20.45 & 2 & 825.5636 & 825.5558 & 413.7852 & 0.0078 & 9.4251 & 7694.116 & 9045.786 & 13275.190 & 16472.133 & \text { Yes }\end{array}$

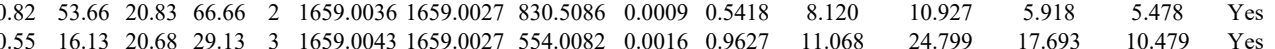
$\begin{array}{lllllllllllllll}0.72 & 41.39 & 20.57 & 54.39 & 2 & 1659.0062 & 1659.0027 & 830.5086 & 0.0035 & 2.1071 & 7.405 & 5.855 & 2.542 & 8.127 & \text { Yes }\end{array}$

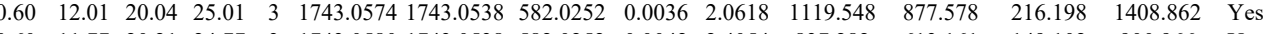
$\begin{array}{llllllllllllllll}0.60 & 11.77 & 20.21 & 24.77 & 3 & 1743.0580 & 1743.0538 & 582.0252 & 0.0042 & 2.4054 & 837.282 & 613.161 & 149.102 & 900.966 & \text { Yes }\end{array}$

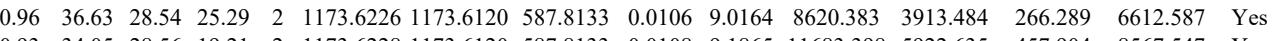
$\begin{array}{llllllllllllllll}0.93 & 34.05 & 28.56 & 19.21 & 2 & 1173.6228 & 1173.6120 & 587.8133 & 0.0108 & 9.1865 & 11683.398 & 5922.635 & 457.904 & 8567.547 & \text { Yes }\end{array}$ $\begin{array}{llllllllllllllll}0.54 & 31.37 & 24.90 & 28.38 & 2 & 958.6076 & 958.6119 & 480.3132 & -0.0043 & -4.4763 & 2095.497 & 1431.865 & 161.908 & 3082.264 & \text { Yes }\end{array}$ $\begin{array}{llllllllllllllll}0.79 & 31.28 & 25.30 & 32.98 & 2 & 958.6104 & 958.6119 & 480.3132 & -0.0015 & -1.5615 & 3869.519 & 2357.029 & 159.733 & 4862.961 & \text { Yes }\end{array}$

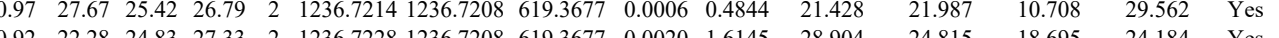
$\begin{array}{lllllllllllllll}0.92 & 22.28 & 24.83 & 27.33 & 2 & 1236.7228 & 1236.7208 & 619.3677 & 0.0020 & 1.6145 & 28.904 & 24.815 & 18.695 & 24.184 & \text { Yes } \\ 0.92 & 28.19 & 26.31 & 27.22 & 2 & 914.5056 & 914.5056 & 458.2601 & 0.000 & 0.0000 & 27.081 & 56.423 & 51.104 & 5.096 & \text { Yes }\end{array}$

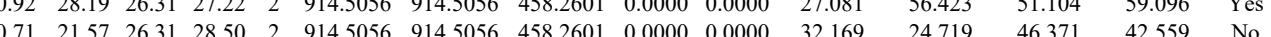

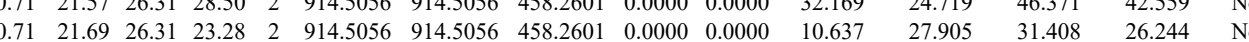

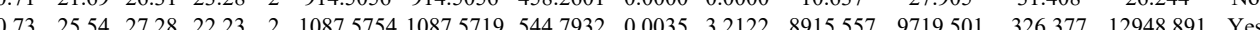
$\begin{array}{lllllllllllllll}0.73 & 25.54 & 27.38 & 16.42 & 2 & 1087.5758 & 1087.5719 & 544.7932 & 0.0039 & 3.5793 & 415.5422 & 5572.676 & 0.000 & 7927.294 & \text { No }\end{array}$

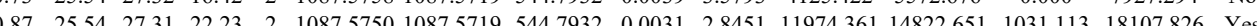
$\begin{array}{lllllllllllllll}0.92 & 27.64 & 27.31 & 16.87 & 2 & 1087.5750 & 1087.5719 & 544.7932 & 0.0031 & 28451 & 13136.649 & 14782.898 & 2.692 & 23405.139 & \text { Yes }\end{array}$ $\begin{array}{lllllllllllllll}0.87 & 25.39 & 27.31 & 22.12 & 2 & 1087.5750 & 1087.5719 & 544.7932 & 0.0031 & 28451 & 4399.569 & 5068.372 & 914.307 & 6984.591 & \text { Yes }\end{array}$ $\begin{array}{lllllllllllllll}0.73 & 25.57 & 27.28 & 22.38 & 2 & 1087.5754 & 1087.5719 & 544.7932 & 0.0035 & 3.2122 & 3885.214 & 5147.604 & 753297 & 6569.741 & \text { Yes }\end{array}$ $\begin{array}{lllllllllllllll}0.92 & 25.47 & 27.38 & 16.33 & 2 & 1087.5728 & 1087.5719 & 544.7932 & 0.0009 & 0.8260 & 3293.253 & 3583.339 & 498.214 & 5588.169 & \text { Yes }\end{array}$ $\begin{array}{llllllllllllllll}0.63 & 25.59 & 27.45 & 18.83 & 2 & 1087.5712 & 1087.5719 & 544.7932 & -0.0007 & -0.6424 & 2237.963 & 2394.279 & 77.731 & 3734.737 & \text { Yes }\end{array}$ \begin{tabular}{llllllllllllllll}
0.83 & 25.63 & 27.37 & 16.41 & 2 & 1087.5718 & 1087.5719 & 544.7932 & -0.0001 & -0.0918 & 1993.824 & 2448.419 & 210.198 & 3704.381 & Yes \\
\hline
\end{tabular} $\begin{array}{lllllllllllllll}0.92 & 25.57 & 27.39 & 16.33 & 2 & 1087.5724 & 1087.5719 & 544.7932 & 0.0005 & 0.4589 & 1649.613 & 2116.563 & 135.220 & 2921.170 & \text { Yes }\end{array}$ $\begin{array}{llllllllllllllll}0.92 & 25.57 & 27.39 & 16.43 & 2 & 1087.5724 & 1087.5719 & 544.7932 & 0.0005 & 0.4589 & 1501.944 & 1696.955 & 116.132 & 2546.344 & \text { Yes }\end{array}$ $\begin{array}{llllllllllllllll}0.82 & 25.47 & 27.37 & 16.31 & 2 & 1087.5720 & 1087.5719 & 544.7932 & 0.0001 & 0.0918 & 1510.223 & 1718.443 & 58.394 & 2294.075 & \text { Yes }\end{array}$ $\begin{array}{llllllllllllllll}0.92 & 25.50 & 27.39 & 16.32 & 2 & 1087.5724 & 1087.5719 & 544.7932 & 0.0005 & 0.4589 & 1259.030 & 1316.021 & 145.176 & 2085.561 & \text { Yes }\end{array}$ $\begin{array}{lllllllllllllll}0.55 & 23.10 & 15.68 & 36.10 & 3 & 1844.1490 & 1844.1481 & 615.7233 & 0.0009 & 0.4872 & 145.829 & 205.131 & 53.816 & 21.171 & \text { Yes }\end{array}$

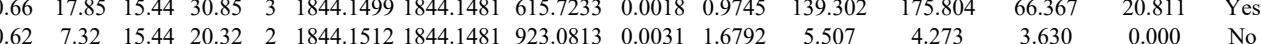

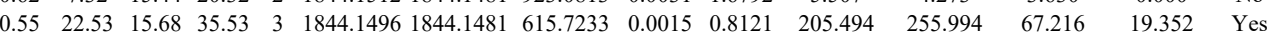
$\begin{array}{lllllllllllllll}0.55 & 25.12 & 15.68 & 38.12 & 3 & 1844.1496 & 1844.1481 & 615.7233 & 0.0015 & 0.8121 & 108.508 & 165.752 & 57.304 & 11.146 & \text { Yes }\end{array}$ $\begin{array}{lllllllllllllll}0.55 & 19.63 & 15.68 & 32.63 & 3 & 1844.1490 & 1844.1481 & 615.7233 & 0.0009 & 0.4872 & 83.889 & 118.541 & 52.565 & 13.198 & \text { Yes }\end{array}$ $\begin{array}{llllllllllllllll}0.54 & 15.23 & 27.98 & 25.06 & 2 & 1437.7254 & 1437.7235 & 719.8690 & 0.0019 & 1.3197 & 1307.781 & 1494.489 & 137.223 & 2699.811 & \text { Yes } \\ 0.84 & 22.06 & 27.98 & 27.17 & 2 & 1437.7256 & 1437.723 & 719869 & 0.0021 & 1.456 & 3091.676 & 3522.769 & 358.724 & 585.528 & \text { Yes }\end{array}$ $\begin{array}{llllllllllllllll}0.84 & 22.06 & 27.98 & 27.17 & 2 & 1437.7256 & 1437.7235 & 719.8690 & 0.0021 & 1.4586 & 3091.676 & 3522.769 & 358.724 & 5856.528 & \text { Yes } \\ 0.59 & 2.30 & 17.24 & 15.12 & 3 & 1493.9338 & 1493.9295 & 498.9838 & 0.0043 & 2.8725 & 4139.844 & 3170.673 & 276.252 & 569.327 & \text { Ye }\end{array}$ $\begin{array}{lllllllllllllll}0.59 & 2.30 & 17.24 & 15.12 & 3 & 1493.9338 & 1493.9295 & 498.9838 & 0.0043 & 2.8725 & 4139.844 & 3170.673 & 276.252 & 5679.327 & \text { Yes } \\ 0.58 & 26.62 * & 17.92 & 24.62 & 2 & 870.6186 & 870.6146 & 4363146 & 0.0040 & 4.5838 & 32254.858 & 45225.380 & 0.383 & 2235.377 & \text { No }\end{array}$ $\begin{array}{rrrrrrrrrrrrrrr}0.58 & 26.62 * & 17.92 & 24.62 & 2 & 870.6186 & 870.6146 & 436.3146 & 0.0040 & 4.5838 & 32254.858 & 45225.380 & 0.383 & 22235.377 & \text { No }\end{array}$ $\begin{array}{llllllllllllllll}0.57 & 28.85 & 17.92 & 26.20 & 2 & 870.6190 & 870.6146 & 436.3146 & 0.0044 & 5.0422 & 23768.732 & 34125.196 & 778.721 & 16682.772 & \text { Yes } \\ 0.65 & 0.09 & 15.19 & 13.09 & 3 & 1549.9831 & 1549.9799 & 517.6672 & 0.0032 & 2.0605 & 4884.374 & 5019.554 & 206.611 & 16054.092 & \text { Yes }\end{array}$ $\begin{array}{lllllllllllllll}0.66 & 0.38 & 15.19 & 13.17 & 3 & 1549.9831 & 1549.9799 & 517.6672 & 0.0032 & 2.0605 & 46845.352 & 4701.370 & 757.731 & 15555.078 & \text { Yes }\end{array}$

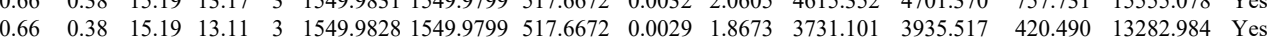
$\begin{array}{llllllllllllllll}60 & 0.08 & 14.15 & 13.08 & 3 & 1549.9843 & 1549.9799 & 517.6672 & 0.0044 & 2.8332 & 3312.721 & 3143.377 & 832.591 & 9967.744 & \text { No }\end{array}$ $\begin{array}{lllllllllllll}26.95 & 18.06 & 3 & 1471.8259 & 1471.8238 & 491.6152 & 0.0021 & 1.4239 & 12506.122 & 11322.472 & 9848.606 & 18767.090 & \text { Yes }\end{array}$ 
$\begin{array}{lllllllllllll} & & \end{array}$

$\begin{array}{lllllllllll}0.93 & 20.71 & 28.20 & 21.38 & 3 & 1294.7068 & 1294.7037 & 432.5752 & 0.0031 & 2.3888 & 5618.928\end{array}$ 
Table S-5-1. List of differentially expressed proteins in areca nut extract (ANE)-trained SAS cell lines

\begin{tabular}{|c|c|c|c|c|c|c|c|c|c|c|}
\hline $\begin{array}{l}\text { Unique and stable } \\
\text { accession no. of a } \\
\text { UniProtKB entry }\end{array}$ & $\begin{array}{l}\text { Mnemonic } \\
\text { accession } \\
\text { no. of a } \\
\text { UniProtKB } \\
\text { entry }\end{array}$ & Gene names & Protein names & $\begin{array}{l}\mathrm{MW} \\
(\mathrm{kDa})\end{array}$ & 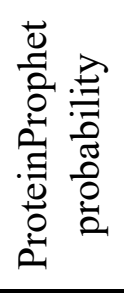 & 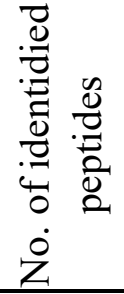 & 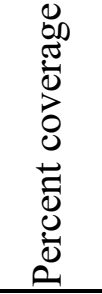 & $\begin{array}{l}\text { Log2 ratio } \\
\text { of ANE- } \\
\text { trained/ } \\
\text { parental } \\
\text { cells }\end{array}$ & $\begin{array}{l}\text { SD of } \\
\text { peptide } \\
\text { ratios } \\
\text { from the } \\
\text { protein }\end{array}$ & 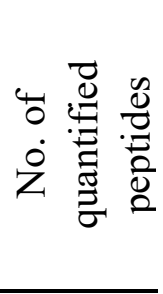 \\
\hline \multicolumn{11}{|c|}{ Overexpressed proteins } \\
\hline PDLI1_HUMAN & $\mathrm{O} 00151$ & PDLIM1 & PDZ and LIM domain protein 1 & 36.07 & 1.00 & 4 & 22.5 & 0.4134 & 0.5956 & 15 \\
\hline AIP_HUMAN & O00170 & AIP & AH receptor-interacting protein & 37.64 & 1.00 & 2 & 6.4 & 0.4651 & 0.4907 & 3 \\
\hline CYR61_HUMAN & O00622 & CYR61 & Protein CYR61 & 42.03 & 1.00 & 4 & 9.4 & 0.9735 & 0.0990 & 7 \\
\hline PDXK_HUMAN & O00764 & PDXK & Pyridoxal kinase & 35.10 & 1.00 & 4 & 15.1 & 0.4752 & 0.3416 & 6 \\
\hline GIPC1_HUMAN & O14908 & GIPC1 & PDZ domain-containing protein GIPC1 & 36.05 & 1.00 & 5 & 27.3 & 0.5051 & 0.2747 & 19 \\
\hline ARPC2_HUMAN & O15144 & ARPC2 & Actin-related protein $2 / 3$ complex subunit 2 & 34.33 & 1.00 & 3 & 13 & 0.4028 & 0.1588 & 6 \\
\hline IPO8_HUMAN & O15397 & IPO8 & Importin-8 & 119.94 & 1.00 & 2 & 3.2 & 0.5727 & 0.6451 & 3 \\
\hline PLIN3_HUMAN & O60664 & PLIN3 & Perilipin-3 & 47.05 & 1.00 & 8 & 33.4 & 0.4651 & 0.7821 & 22 \\
\hline CTND1_HUMAN & O60716 & CTNND1 & Catenin delta-1 & 108.17 & 1.00 & 3 & 4.8 & 0.4238 & 0.3121 & 14 \\
\hline FLNB_HUMAN & O75369 & FLNB & Filamin-B & 278.16 & 1.00 & 33 & 20 & 0.5821 & 0.3625 & 77 \\
\hline IDHC_HUMAN & O75874 & IDH1 & Isocitrate dehydrogenase [NADP] cytoplasmic & 46.66 & 1.00 & 5 & 12.8 & 0.9592 & 0.3250 & 12 \\
\hline SYUG_HUMAN & O76070 & SNCG & Gamma-synuclein & 13.33 & 1.00 & 2 & 13.4 & 1.3153 & 0.4275 & 4 \\
\hline SC31A_HUMAN & O94979 & SEC31A & Protein transport protein Sec31A & 133.01 & 1.00 & 2 & 3.1 & 0.5150 & 0.0790 & 3 \\
\hline 6PGL_HUMAN & O95336 & PGLS & 6-phosphogluconolactonase & 27.55 & 1.00 & 2 & 14.7 & 0.5150 & 0.7873 & 3 \\
\hline ACSL3_HUMAN & O95573 & ACSL3 & Long-chain-fatty-acid--CoA ligase 3 & 80.42 & 1.00 & 6 & 15.3 & 0.4952 & 0.4837 & 15 \\
\hline NB5R3_HUMAN & P00387 & CYB5R3 & NADH-cytochrome b5 reductase 3 & 34.23 & 1.00 & 3 & 15.9 & 0.3921 & 0.4304 & 11 \\
\hline EGFR_HUMAN & P00533 & EGFR & Epidermal growth factor receptor & 134.28 & 1.00 & 7 & 8.7 & 0.3814 & 0.8022 & 21 \\
\hline LMNA_HUMAN & P02545 & LMNA & Lamin-A/C & 74.14 & 1.00 & 13 & 25.8 & 0.3921 & 0.4643 & 36 \\
\hline CATA_HUMAN & P04040 & CAT & Catalase & 59.76 & 1.00 & 2 & 9.1 & 1.1795 & 1.2844 & 5 \\
\hline OAT_HUMAN & P04181 & OAT & Ornithine aminotransferase, mitochondrial & 48.53 & 1.00 & 9 & 23.2 & 0.4134 & 0.1912 & 24 \\
\hline CPNS̄1_HUMAN & P04632 & CAPNS1 & Calpain small subunit 1 & 28.32 & 1.00 & 4 & 27.2 & 0.4852 & 0.7412 & 10 \\
\hline CATD_HUMAN & P07339 & CTSD & Cathepsin D & 44.55 & 1.00 & 4 & 13.3 & 0.5051 & 0.7293 & 9 \\
\hline CAN1_HUMAN & P07384 & CAPN1 & Calpain-1 catalytic subunit & 81.89 & 1.00 & 8 & 12.2 & 0.4952 & 0.2969 & 17 \\
\hline LAMB1_HUMAN & P07942 & LAMB1 & Laminin subunit beta-1 & 198.07 & 1.00 & 3 & 2.7 & 0.5051 & 0.1892 & 3 \\
\hline TSP1_HUMAN & P07996 & THBS1 & Thrombospondin-1 & 129.38 & 1.00 & 4 & 6.1 & 0.7911 & 0.4226 & 16 \\
\hline VIME_HUMAN & P08670 & VIM & Vimentin & 53.65 & 1.00 & 7 & 20.8 & 0.6282 & 0.7494 & 17 \\
\hline
\end{tabular}




\begin{tabular}{|c|c|c|c|c|c|c|c|c|c|c|}
\hline K1C19_HUMAN & P08727 & KRT19 & Keratin, type I cytoskeletal 19 & 44.09 & 1.00 & 5 & 26.8 & 0.7247 & 0.7537 & 9 \\
\hline K2C7_HUMAN & P08729 & KRT7 & Keratin, type II cytoskeletal 7 & 51.40 & 1.00 & 14 & 33.7 & 0.3706 & 0.2494 & 48 \\
\hline LEG1_HUMAN & P09382 & LGALS1 & Galectin-1 & 14.72 & 1.00 & 7 & 68.9 & 1.8467 & 0.9774 & 20 \\
\hline GTR1_HUMAN & P11166 & SLC2A1 & Solute carrier family 2 , facilitated glucose transporter member 1 & 54.08 & 1.00 & 5 & 13.8 & 0.6282 & 0.2812 & 13 \\
\hline ACTN1_HUMAN & P12814 & ACTN1 & Alpha-actinin-1 & 103.06 & 1.00 & 17 & 39.7 & 0.6191 & 0.4089 & 56 \\
\hline K2C5_HUMAN & P13647 & KRT5 & Keratin, type II cytoskeletal 5 & 62.38 & 1.00 & 10 & 22.7 & 0.6552 & 0.2370 & 30 \\
\hline TF_HUMAN & P13726 & F3 & Tissue factor & 33.07 & 1.00 & 2 & 8.5 & 0.8152 & 0.2703 & 4 \\
\hline ANXA8_HUMAN & P13928 & ANXA8 & Annexin A8 & 36.88 & 1.00 & 4 & 13.5 & 1.1482 & 0.4777 & 23 \\
\hline FPPS_HUMAN & P14324 & FDPS & Farnesyl pyrophosphate synthase & 48.28 & 1.00 & 5 & 14.3 & 0.7162 & 0.1901 & 13 \\
\hline AK1Ā1_HUMAN & P14550 & AKR1A1 & Alcohol dehydrogenase [NADP+] & 36.57 & 1.00 & 2 & 10.2 & 0.4446 & 0.6680 & 5 \\
\hline PLAK_HUMAN & P14923 & JUP & Junction plakoglobin & 81.74 & 1.00 & 7 & 20.7 & 0.5914 & 0.7850 & 8 \\
\hline ITB4_HUMAN & P16144 & ITGB4 & Integrin beta- 4 & 202.15 & 1.00 & 3 & 3.4 & 0.3814 & 0.2354 & 5 \\
\hline AT2Ā2_HUMAN & P16615 & ATP2A2 & Sarcoplasmic/endoplasmic reticulum calcium ATPase 2 & 114.76 & 1.00 & 13 & 17.2 & 0.4238 & 0.3626 & 34 \\
\hline CSRP1_HUMAN & P21291 & CSRP1 & Cysteine and glycine-rich protein 1 & 20.57 & 1.00 & 5 & 30.6 & 1.2461 & 0.4572 & 11 \\
\hline FLNA_HUMAN & $\mathrm{P} 21333$ & FLNA & Filamin-A & 280.74 & 1.00 & 44 & 26.9 & 0.4952 & 0.4488 & 149 \\
\hline ITA6_HUMAN & P23229 & ITGA6 & Integrin alpha-6 & 126.63 & 1.00 & 4 & 3.6 & 0.4752 & 0.3483 & 8 \\
\hline ITA3_HUMAN & P26006 & ITGA3 & Integrin alpha-3 & 118.76 & 1.00 & 4 & 3.4 & 0.6462 & 0.2231 & 6 \\
\hline SYTC_HUMAN & P26639 & TARS & Threonyl-tRNA synthetase, cytoplasmic & 83.44 & 1.00 & 18 & 28.9 & 0.6462 & 0.2376 & 57 \\
\hline DHSA_HUMAN & P31040 & SDHA & Succinate dehydrogenase [ubiquinone] flavoprotein subunit, mitochondrial & 72.69 & 1.00 & 3 & 5.9 & 0.6552 & 0.2262 & 9 \\
\hline 1433S_HUMAN & P31947 & SFN & $14-3-3$ protein sigma & 27.77 & 1.00 & 8 & 42.7 & 0.3706 & 0.4950 & 46 \\
\hline CTNA1_HUMAN & P35221 & CTNNA1 & Catenin alpha-1 & 100.07 & 1.00 & 12 & 18.7 & 0.5051 & 0.6458 & 21 \\
\hline CTNB1_HUMAN & P35222 & CTNNB1 & Catenin beta-1 & 85.50 & 1.00 & 10 & 24.2 & 0.6282 & 0.6075 & 19 \\
\hline PGM1_HUMAN & P36871 & PGM1 & Phosphoglucomutase-1 & 61.45 & 1.00 & 5 & 19 & 0.3706 & 0.2868 & 6 \\
\hline FDFT_HUMAN & P37268 & FDFT1 & Squalene synthase & 48.12 & 1.00 & 3 & 7.9 & 0.9664 & 0.1764 & 5 \\
\hline TAGL2_HUMAN & P37802 & TAGLN2 & Transgelin-2 & 22.39 & 1.00 & 9 & 59.3 & 0.5345 & 0.5981 & 49 \\
\hline VDAC2_HUMAN & P45880 & VDAC2 & Voltage-dependent anion-selective channel protein 2 & 31.57 & 1.00 & 5 & 28.9 & 0.4651 & 0.6634 & 7 \\
\hline IQGA1_HUMAN & P46940 & IQGAP1 & Ras GTPase-activating-like protein IQGAP1 & 189.25 & 1.00 & 17 & 17.4 & 0.3921 & 0.5183 & 40 \\
\hline PPCE_HUMAN & P48147 & PREP & Prolyl endopeptidase & 80.70 & 1.00 & 3 & 7.5 & 0.4343 & 0.1314 & 8 \\
\hline FAS_HUMAN & P49327 & FASN & Fatty acid synthase & 273.43 & 1.00 & 57 & 33.6 & 0.4343 & 0.3846 & 182 \\
\hline DHB4_HUMAN & P51659 & HSD17B4 & Peroxisomal multifunctional enzyme type 2 & 79.69 & 1.00 & 2 & 5.3 & 0.3706 & 0.5729 & 3 \\
\hline KS6A3_HUMAN & P51812 & RPS6KA3 & Ribosomal protein S6 kinase alpha-3 & 83.74 & 1.00 & 3 & 5.8 & 0.6552 & 1.2047 & 5 \\
\hline SPSY_HUMAN & P52788 & SMS & Spermine synthase & 41.27 & 1.00 & 4 & 11.5 & 0.4134 & 0.3618 & 12 \\
\hline
\end{tabular}

Table S-5-1 page 2 of 45 
TCP4_HUMAN EPIPL HUMAN NPC2 HUMAN CALM_HUMAN 1433E_HUMAN TPM4_HUMAN TBB2C_HUMAN GTF2I HUMAN GSTO1_HUMAN BASP1_HUMAN SPTB2_HUMAN HMCS1_HUMAN TNAP2 HUMAN K1C17 HUMAN SSBP HUMAN PSME1_HUMAN G3BP1_HUMAN TBB3 HUMAN

GALE HUMAN LASP1 HUMAN SC23B_HUMAN DREB_HUMAN IF16_HUMAN INF2 HUMAN AG10A_HUMAN CPIN1_HUMAN HUWE1 HUMAI CTF18 HUMAN Q8WVB6 CHTF18

TMM40_HUMAN Q8WWA1 TMEM40 PRDBP HUMAN SH3K1 HUMAN EFHD2_HUMAN PDLI5_HUMAN ERO1A HUMAN DOCK 7 HUMAN IPO9_HUMMAN
P53999 SUB1

P58107 EPPK1

P61916 NPC2

P62158

P62258

P67936

P68371

P78347

P78417

P80723

Q01082

Q01581

Q03169

Q04695

Q04837

Q06323

Q13283

Q13509

Q14376

Q14847

Q15437

Q16643

Q16666 IFI16

Q27J81 INF2

Q5BKT4 ALG10

Q6FI81 CIAPIN1

Q7Z6Z7 HUWE1

Q96B97

SH3KBP

Q96C19 EFHD2

Q96HC4 PDLIM5

Q96HE7 ERO1L

Q96N67 DOCK7 Q96P70 IPO9
Activated RNA polymerase II transcriptional coactivator p15 $\quad 14.40 \quad 1.00$ Epiplakin

Epididymal secretory protein E1

$553.09 \quad 1.00$

$16.57 \quad 1.00$

$16.84 \quad 1.00$

$29.17 \quad 1.00$

$28.52 \quad 1.00$

Tropomyosin alpha-4 chain

Tubulin beta-2C chain

General transcription factor II-I

Glutathione S-transferase omega-1

Brain acid soluble protein 1

Spectrin beta chain, brain 1

Hydroxymethylglutaryl-CoA synthase, cytoplasmic

Tumor necrosis factor alpha-induced protein 2

Keratin, type I cytoskeletal 17

Single-stranded DNA-binding protein, mitochondrial

Proteasome activator complex subunit 1

Ras GTPase-activating protein-binding protein 1

Tubulin beta-3 chain

UDP-glucose 4-epimerase

LIM and SH3 domain protein 1

Protein transport protein Sec23B

Drebrin

Gamma-interferon-inducible protein 16

Inverted formin-2

Alpha-1,2-glucosyltransferase ALG10-A

Anamorsin

E3 ubiquitin-protein ligase HUWE1

Chromosome transmission fidelity protein 18 homolog

Transmembrane protein 40

$49.83 \quad 1.00$

$112.42 \quad 1.00$

$27.57 \quad 1.00$

$22.69 \quad 1.00$

$274.61 \quad 1.00$

$57.29 \quad 1.00$

$72.66 \quad 1.00$

$48.11 \quad 1.00$

$\begin{array}{ll}17.26 & 1.00\end{array}$

$28.72 \quad 1.00$

$52.16 \quad 1.00$

$50.43 \quad 1.00$

$38.28 \quad 1.00$

$29.72 \quad 1.00$

$86.48 \quad 1.00$

$71.43 \quad 1.00$

$88.26 \quad 1.00$

$135.62 \quad 1.00$

$55.61 \quad 1.00$

$33.58 \quad 1.00$

$481.89 \quad 1.00$

$107.38 \quad 1.00$

$25.49 \quad 1.00$

$27.63 \quad 1.00$

$73.13 \quad 1.00$

$26.70 \quad 1.00$

$64.00 \quad 1.00$

$54.39 \quad 1.00$

$242.56 \quad 1.00$

$115.96 \quad 1.00$

17.3

(1)

21.2

53.7

23.4

PDZ and LIM domain protein 5

ERO1-like protein alpha

Dedicator of cytokinesis protein 7

Importin-9
0.3921

0.3526

0.4739

0.3706

0.3682

43.6

0.3921

0.6400

0.5248

1.1795

0.4253

0.1667

0.3498

$63.8 \quad 0.392$

0.7574

0.2431

0.6110

0.2905

0.6842

0.2106

0.1101

0.5152

0.5163

34.5

31.3

35.1

12.4

26.1

7.3

4.6

5.4

9.5

5.3

12.2

1.1

3.7

10.7

10.7

5.7

7.4

19.6

7

1.1110
0.3150

$0.5821 \quad 1.0042$

$\begin{array}{ll}0.5248 & 0.2107\end{array}$

$0.4343 \quad 0.0867$

$0.4651 \quad 0.1856$

$1.8112 \quad 0.3938$

$0.3921 \quad 0.5402$

$0.5537 \quad 0.2166$

$\begin{array}{ll}0.6462 & 1.1217\end{array}$

$0.3814 \quad 0.5790$

$1.2041 \quad 0.7930$

$0.6990 \quad 1.2792$

$0.8389 \quad 0.3912$

$\begin{array}{ll}1.5150 & 0.4221\end{array}$

$0.7665 \quad 0.1984$

$0.8152 \quad 0.2964$

$\begin{array}{lll}14.7 & 0.5248 & 0.1229\end{array}$

$\begin{array}{lll}1.4 & 0.4651 & 0.1839\end{array}$

0.5051

1.1528

Table S-5-1 page 3 of 45 


\begin{tabular}{|c|c|c|c|c|c|c|c|c|c|c|}
\hline WRIP1_HUMAN & Q96S55 & WRNIP1 & ATPase WRNIP1 & 72.13 & 1.00 & 2 & 3.9 & 1.3868 & 1.0372 & 5 \\
\hline CNN2_HUMAN & Q99439 & CNN2 & Calponin-2 & 33.70 & 1.00 & 4 & 22 & 0.4852 & 0.1690 & 5 \\
\hline HCD2_HUMAN & Q99714 & HSD17B10 & 3-hydroxyacyl-CoA dehydrogenase type-2 & 26.92 & 1.00 & 3 & 17.6 & 0.7162 & 1.4050 & 6 \\
\hline CPNE1_HUMAN & Q99829 & CPNE1 & Copine-1 & 59.06 & 1.00 & 7 & 18.2 & 0.4028 & 0.5290 & 18 \\
\hline COR1B_HUMAN & Q9BR76 & CORO1B & Coronin-1B & 54.23 & 1.00 & 2 & 4.1 & 0.6729 & 0.1641 & 7 \\
\hline ERP44_HUMAN & Q9BS26 & ERP44 & Endoplasmic reticulum resident protein 44 & 46.97 & 1.00 & 2 & 9.1 & 0.3706 & 0.6368 & 3 \\
\hline TBB6_HUMAN & Q9BUF5 & TUBB6 & Tubulin beta- 6 chain & 49.86 & 1.00 & 7 & 42.4 & 0.3814 & 0.6127 & 19 \\
\hline UCK2_HUMAN & Q9BZX2 & UCK2 & Uridine-cytidine kinase 2 & 29.30 & 1.00 & 2 & 16.5 & 0.6552 & 0.8350 & 4 \\
\hline DDX24_HUMAN & Q9GZR7 & DDX24 & ATP-dependent RNA helicase DDX24 & 96.33 & 1.00 & 2 & 2.7 & 0.6552 & 1.6146 & 5 \\
\hline AMPB_HUMAN & Q9H4A4 & RNPEP & Aminopeptidase B & 72.60 & 1.00 & 7 & 16.6 & 0.5345 & 0.7601 & 12 \\
\hline CYBP_HUMAN & Q9HB71 & CACYBP & Calcyclin-binding protein & 26.21 & 1.00 & 4 & 26.8 & 0.5051 & 0.4285 & 13 \\
\hline S10AE_HUMAN & Q9HCY8 & S100A14 & Protein S100-A14 & 11.66 & 1.00 & 2 & 25 & 0.3706 & 0.5454 & 5 \\
\hline FA49B_HUMAN & Q9NUQ9 & FAM49B & Protein FAM49B & 36.75 & 1.00 & 5 & 24.4 & 0.4028 & 0.2592 & 7 \\
\hline DJC11_HUMAN & Q9NVH1 & DNAJC11 & DnaJ homolog subfamily C member 11 & 63.28 & 1.00 & 2 & 5.4 & 0.6729 & 0.5571 & 11 \\
\hline UGGG1_HUMAN & Q9NYU2 & UGGT1 & UDP-glucose:glycoprotein glucosyltransferase 1 & 177.19 & 1.00 & 2 & 3.9 & 0.6904 & 0.2828 & 3 \\
\hline F120A_HUMAN & Q9NZB2 & FAM120A & Constitutive coactivator of PPAR-gamma-like protein 1 & 121.89 & 1.00 & 4 & 4.6 & 0.3921 & 0.2826 & 10 \\
\hline PDP1_HUMAN & Q9P0J1 & PDP1 & [Pyruvate dehydrogenase [acetyl-transferring]]-phosphatase 1 , mitochondrial & 61.05 & 1.00 & 2 & 3.5 & 0.6552 & 0.2976 & 5 \\
\hline CF115_HUMAN & Q9P1F3 & C6orf115 & UPF0727 protein C6orf115 & 9.06 & 1.00 & 2 & 23.5 & 0.4238 & 0.0573 & 9 \\
\hline RRBP1_HUMAN & Q9P2E9 & RRBP1 & Ribosome-binding protein 1 & 152.47 & 1.00 & 11 & 22.3 & 0.4238 & 0.3315 & 12 \\
\hline DHCR7_HUMAN & Q9UBM7 & DHCR7 & 7-dehydrocholesterol reductase & 54.49 & 1.00 & 4 & 7.4 & 0.4028 & 0.1454 & 12 \\
\hline SEPT9_HUMAN & Q9UHD8 & SEPT9 & Septin-9 & 65.40 & 1.00 & 8 & 16.7 & 0.4028 & 0.2785 & 17 \\
\hline XPO7_HUMAN & Q9UIA9 & XPO7 & Exportin-7 & 123.91 & 1.00 & 4 & 5.8 & 1.0967 & 1.5210 & 4 \\
\hline COR1C_HUMAN & Q9ULV4 & CORO1C & Coronin-1C & 53.25 & 1.00 & 6 & 14.6 & 0.5727 & 0.1778 & 21 \\
\hline CHM2B_HUMAN & Q9UQN3 & CHMP2B & Charged multivesicular body protein $2 \mathrm{~b}$ & 23.91 & 1.00 & 3 & 12.2 & 0.6462 & 0.1022 & 6 \\
\hline NCKP1_HUMAN & Q9Y2A7 & NCKAP1 & Nck-associated protein 1 & 128.79 & 1.00 & 2 & 2.4 & 0.3921 & 0.4139 & 7 \\
\hline HYOU1_HUMAN & Q9Y4L1 & HYOU1 & Hypoxia up-regulated protein 1 & 111.34 & 1.00 & 9 & 15.3 & 0.4852 & 0.6732 & 10 \\
\hline AP1M2_HUMAN & Q9Y6Q5 & AP1M2 & AP-1 complex subunit mu-2 & 48.11 & 1.00 & 2 & 5 & 0.3706 & 0.2500 & 6 \\
\hline ARI1A_HUMAN & O14497 & ARID1A & AT-rich interactive domain-containing protein $1 \mathrm{~A}$ & 242.04 & 1.00 & 2 & 2 & 0.6007 & 0.3335 & 4 \\
\hline MRCKB_HUMAI & Q9Y5S2 & CDC42BPB & Serine/threonine-protein kinase MRCK beta & 194.32 & 1.00 & 2 & 1.3 & 0.4446 & 0.2354 & 5 \\
\hline REEP5_HUMAN & Q00765 & REEP5 & Receptor expression-enhancing protein 5 & 21.49 & 1.00 & 3 & 10.1 & 0.8072 & 0.5906 & 3 \\
\hline UBP4_HUMAN & Q13107 & USP4 & Ubiquitin carboxyl-terminal hydrolase 4 & 108.57 & 1.00 & 2 & 3.1 & 0.6990 & 0.3314 & 6 \\
\hline TMCŌ7_HUMAN & Q9C0B7 & TMCO7 & Transmembrane and coiled-coil domain-containing protein 7 & 120.75 & 1.00 & 2 & 3.1 & 0.6282 & 0.7525 & 4 \\
\hline 5NTD_HUMAN & P21589 & NT5E & 5'-nucleotidase & 63.37 & 1.00 & 2 & 8.9 & 0.6552 & 0.9528 & 3 \\
\hline TES_HUMAN & Q9UGI8 & TES & Testin & 48.00 & 1.00 & 2 & 4.5 & 0.4238 & 0.3115 & 3 \\
\hline TB10B_HUMAN & Q4KMP7 & TBC1D10B & $\mathrm{TBC} 1$ domain family member $10 \mathrm{~B}$ & 87.20 & 1.00 & 2 & 3.2 & 1.0296 & 0.6707 & 3 \\
\hline MYPT1_HUMAN & O14974 & PPP1R12A & Protein phosphatase 1 regulatory subunit $12 \mathrm{~A}$ & 115.28 & 1.00 & 2 & 3.1 & 1.1795 & 1.1575 & 3 \\
\hline
\end{tabular}


MED14_HUMAN O60244 MED14 Mediator of RNA polymerase II transcription subunit 14 ANFY1 HUMAN IRF6_HUMAN TPM2_HUMAN PAI2_HUMAN SEPT7_HUMAN RABP2 HUMAN CBPC1 HUMAN ANR17 HUMAN
Q9P2R3 ANKFY1

O14896 IRF6

P07951 TPM2

P05120 SERPINB2 Plasminogen activator inhibitor 2

Q16181 SEPT7 Septin-7

P29373 CRABP2 Cellular retinoic acid-binding protein 2

Q9UPW5 AGTPBP1 Cytosolic carboxypeptidase 1 O75179
ANKRD17
Ankyrin repeat domain-contain

Table S-5-1 page 5 of 45 


\begin{tabular}{|c|c|c|c|c|c|c|c|c|c|c|}
\hline S10A2_HUMAN & P29034 & $\mathrm{S} 100 \mathrm{~A} 2$ & Protein S100-A2 & 11.12 & 1.00 & 2 & 16.3 & -0.2584 & 0.2156 & 3 \\
\hline RL12_HUMAN & P30050 & RPL12 & 60 S ribosomal protein $\mathrm{L} 12$ & 17.82 & 1.00 & 3 & 21.2 & -0.2584 & 0.7258 & 18 \\
\hline METK'2_HUMAN & P31153 & MAT2A & S-adenosylmethionine synthase isoform type-2 & 43.66 & 1.00 & 6 & 19.2 & -0.3993 & 0.2984 & 17 \\
\hline RIR2_HUMAN & P31350 & RRM2 & Ribonucleoside-diphosphate reductase subunit M2 & 44.88 & 1.00 & 4 & 15.9 & -0.2584 & 0.3130 & 9 \\
\hline QCR1_HUMAN & P31930 & UQCRC1 & Cytochrome b-c 1 complex subunit 1 , mitochondrial & 52.65 & 1.00 & 3 & 7.5 & -0.3809 & 0.4922 & 3 \\
\hline BASI_HUMAN & P35613 & BSG & Basigin & 42.20 & 1.00 & 3 & 10.1 & -0.2584 & 0.1834 & 11 \\
\hline SPB5_HUMAN & P36952 & SERPINB5 & Serpin B5 & 42.10 & 1.00 & 3 & 13.9 & -0.3271 & 0.7194 & 6 \\
\hline RS19_HUMAN & P39019 & RPS19 & 40S ribosomal protein S19 & 16.06 & 1.00 & 5 & 29.7 & -0.2924 & 0.1556 & 19 \\
\hline EIF1_HUMAN & P41567 & EIF1 & Eukaryotic translation initiation factor 1 & 12.73 & 1.00 & 4 & 59.3 & -0.2924 & 0.1847 & 9 \\
\hline GNPI1_HUMAN & P46926 & GNPDA1 & Glucosamine-6-phosphate isomerase 1 & 32.67 & 1.00 & 4 & 20.8 & -0.4179 & 0.2843 & 3 \\
\hline ATPO_HUMAN & P48047 & ATP5O & ATP synthase subunit $\mathrm{O}$, mitochondrial & 23.28 & 1.00 & 3 & 24.9 & -0.2924 & 0.3739 & 10 \\
\hline KC1A_HUMAN & P48729 & CSNK1A1 & Casein kinase I isoform alpha & 38.91 & 1.00 & 4 & 16.3 & -0.3628 & 1.1314 & 11 \\
\hline IMA2_HUMAN & P52292 & KPNA2 & Importin subunit alpha-2 & 57.86 & 1.00 & 8 & 24.8 & -0.3271 & 0.3540 & 16 \\
\hline GDIR1_HUMAN & P52565 & ARHGDIA & Rho GDP-dissociation inhibitor 1 & 23.21 & 1.00 & 2 & 15.2 & -0.4179 & 0.5354 & 5 \\
\hline RM12_HUMAN & P52815 & MRPL12 & 39S ribosomal protein L12, mitochondrial & 21.35 & 1.00 & 3 & 26.8 & -0.4179 & 0.3389 & 11 \\
\hline MGN_HUMAN & P61326 & MAGOH & Protein mago nashi homolog & 17.16 & 1.00 & 4 & 39.7 & -0.4368 & 0.1604 & 6 \\
\hline CH10_HUMAN & P61604 & HSPE1 & $10 \mathrm{kDa}$ heat shock protein, mitochondrial & 10.93 & 1.00 & 6 & 57.8 & -0.2753 & 0.2745 & 29 \\
\hline RS8_HUMAN & P62241 & RPS8 & $40 \mathrm{~S}$ ribosomal protein $\mathrm{S} 8$ & 24.21 & 1.00 & 5 & 28.8 & -0.2753 & 0.2241 & 12 \\
\hline RL23A_HUMAN & P62750 & RPL23A & $60 \mathrm{~S}$ ribosomal protein $\mathrm{L} 23 \mathrm{a}$ & 17.70 & 1.00 & 5 & 30.1 & -0.2584 & 0.3349 & 21 \\
\hline RAN_HUMAN & P62826 & RAN & GTP-binding nuclear protein Ran & 24.42 & 1.00 & 8 & 41.7 & -0.4368 & 0.2837 & 53 \\
\hline RL31_HUMAN & P62899 & RPL31 & $60 \mathrm{~S}$ ribosomal protein $\mathrm{L} 31$ & 14.46 & 1.00 & 4 & 32.8 & -0.3448 & 0.4899 & 9 \\
\hline RL40_HUMAN & P62987 & UBA52 & $60 \mathrm{~S}$ ribosomal protein $\mathrm{L} 40$ & 6.18 & 1.00 & 2 & 32.7 & -0.3448 & 0.1416 & 20 \\
\hline RAC1_HUMAN & P63000 & RAC1 & Ras-related $\mathrm{C} 3$ botulinum toxin substrate 1 & 21.45 & 1.00 & 3 & 34.9 & -0.2753 & 0.4078 & 6 \\
\hline AP2B1__HUMAN & P63010 & AP2B1 & AP-2 complex subunit beta & 104.55 & 1.00 & 5 & 14.3 & -0.2753 & 1.2686 & 12 \\
\hline RL38_HUMAN & P63173 & RPL38 & $60 \mathrm{~S}$ ribosomal protein L38 & 8.22 & 1.00 & 2 & 31.4 & -0.3628 & 0.1630 & 7 \\
\hline RS21_HUMAN & P63220 & RPS21 & $40 \mathrm{~S}$ ribosomal protein $\mathrm{S} 21$ & 9.11 & 1.00 & 3 & 31.3 & -0.3628 & 0.1868 & 20 \\
\hline YBOX̄1_HUMAN & P67809 & YBX1 & Nuclease-sensitive element-binding protein 1 & 35.92 & 1.00 & 9 & 43.8 & -0.2924 & 0.6148 & 51 \\
\hline DHSO_HUMAN & Q00796 & SORD & Sorbitol dehydrogenase & 38.32 & 1.00 & 3 & 14 & -0.2753 & 0.0974 & 4 \\
\hline SFRS2_HUMAN & Q01130 & SFRS2 & Splicing factor, arginine/serine-rich 2 & 25.48 & 1.00 & 2 & 11.3 & -0.4559 & 0.3232 & 5 \\
\hline FABP5_HUMAN & Q01469 & FABP5 & Fatty acid-binding protein, epidermal & 15.16 & 1.00 & 2 & 25.9 & -0.7778 & 0.3233 & 28 \\
\hline LAT1_HUMAN & Q01650 & SLC7A5 & Large neutral amino acids transporter small subunit 1 & 55.01 & 1.00 & 4 & 10.8 & -0.3809 & 0.2475 & 16 \\
\hline RL18A_HUMAN & Q02543 & RPL18A & $60 \mathrm{~S}$ ribosomal protein $\mathrm{L} 18 \mathrm{a}$ & 20.76 & 1.00 & 9 & 39.8 & -0.2753 & 0.3611 & 65 \\
\hline FKBP4_HUMAN & Q02790 & FKBP4 & Peptidyl-prolyl cis-trans isomerase FKBP4 & 51.80 & 1.00 & 6 & 20.3 & -0.2924 & 0.2389 & 21 \\
\hline EF1A2_HUMAN & Q05639 & EEF1A2 & Elongation factor 1-alpha 2 & 50.47 & 1.00 & 3 & 37.6 & -0.2753 & 0.7501 & 5 \\
\hline C1QBP_HUMAN & Q07021 & C1QBP & Complement component $1 \mathrm{Q}$ subcomponent-binding protein, mitochondrial & 31.36 & 1.00 & 3 & 12.1 & -0.3809 & 0.4019 & 8 \\
\hline SFRS1_HUMAN & Q07955 & SFRS1 & Splicing factor, arginine/serine-rich 1 & 27.74 & 1.00 & 2 & 8.9 & -0.3628 & 0.4658 & 5 \\
\hline
\end{tabular}




\begin{tabular}{|c|c|c|c|c|c|c|c|c|c|}
\hline DCTN2_HUMAN & Q13561 & DCTN2 & Dynactin subunit 2 & 44.23 & 1.00 & 2 & 15.2 & -0.3271 & 0.6946 \\
\hline CUL1_HUMAN & Q13616 & CUL1 & Cullin-1 & 89.68 & 1.00 & 4 & 5.9 & -0.4559 & 0.9993 \\
\hline NOLC1_HUMAN & Q14978 & NOLC1 & Nucleolar and coiled-body phosphoprotein 1 & 73.60 & 1.00 & 11 & 15.2 & -0.4949 & 0.2604 \\
\hline RB3GP_HUMAN & Q15042 & RAB3GAP1 & Rab3 GTPase-activating protein catalytic subunit & 110.52 & 1.00 & 2 & 3.4 & -0.3096 & 0.6285 \\
\hline WDR43_HUMAN & Q15061 & WDR43 & WD repeat-containing protein 43 & 74.89 & 1.00 & 3 & 7.8 & -0.2924 & 0.1868 \\
\hline PWP2_HUMAN & Q15269 & PWP2 & Periodic tryptophan protein 2 homolog & 102.45 & 1.00 & 5 & 6.6 & -0.3628 & 0.7530 \\
\hline SF3B4_HUMAN & Q15427 & SF3B4 & Splicing factor $3 \mathrm{~B}$ subunit 4 & 44.39 & 1.00 & 2 & 9.4 & -0.4179 & 1.1281 \\
\hline SF3A1_HUMAN & Q15459 & SF3A1 & Splicing factor $3 \mathrm{~A}$ subunit 1 & 88.89 & 1.00 & 11 & 18.2 & -0.2924 & 0.4577 \\
\hline BGH3_HUMAN & Q15582 & TGFBI & Transforming growth factor-beta-induced protein ig-h3 & 74.68 & 1.00 & 3 & 12 & -1.2252 & 1.0632 \\
\hline AAAT_HUMAN & Q15758 & SLC1A5 & Neutral amino acid transporter $\mathrm{B}(0)$ & 56.60 & 1.00 & 3 & 11.1 & -0.2924 & 0.2524 \\
\hline UB2V2_HUMAN & Q15819 & UBE2V2 & Ubiquitin-conjugating enzyme E2 variant 2 & 16.36 & 1.00 & 5 & 39.3 & -0.3271 & 0.1924 \\
\hline CPSF6_HUMAN & Q16630 & CPSF6 & Cleavage and polyadenylation specificity factor subunit 6 & 59.21 & 1.00 & 3 & 10 & -0.2584 & 0.6221 \\
\hline TRXR1_HUMAN & Q16881 & TXNRD1 & Thioredoxin reductase 1 , cytoplasmic & 70.91 & 1.00 & 13 & 26.2 & -0.8020 & 0.4173 \\
\hline IMMT_HUMAN & Q16891 & IMMT & Mitochondrial inner membrane protein & 83.68 & 1.00 & 4 & 6.7 & -0.3993 & 0.3112 \\
\hline TSR1_HUMAN & Q2NL82 & TSR1 & Pre-rRNA-processing protein TSR1 homolog & 91.81 & 1.00 & 5 & 6.8 & -0.4179 & 0.0919 \\
\hline SNUT2_HUMAN & Q53GS9 & USP39 & U4/U6.U5 tri-snRNP-associated protein 2 & 65.38 & 1.00 & 2 & 5 & -0.5972 & 0.3117 \\
\hline PCID2_HUMAN & Q5JVF3 & PCID2 & PCI domain-containing protein 2 & 46.03 & 1.00 & 2 & 11 & -0.2584 & 0.1597 \\
\hline DDX46_HUMAN & Q7L014 & DDX46 & Probable ATP-dependent RNA helicase DDX46 & 117.36 & 1.00 & 2 & 1.9 & -0.3271 & 0.1818 \\
\hline PB1_HUMAN & Q86U86 & PBRM1 & Protein polybromo-1 & 192.95 & 1.00 & 3 & 2.8 & -0.3096 & 0.2989 \\
\hline ENAH_HUMAN & Q8N8S7 & ENAH & Protein enabled homolog & 66.51 & 1.00 & 4 & 10 & -0.3096 & 0.2645 \\
\hline SCFD1_HUMAN & Q8WVM8 & SCFD1 & Sec1 family domain-containing protein 1 & 72.38 & 1.00 & 2 & 5.6 & -0.2924 & 0.2981 \\
\hline RAD50_HUMAN & Q92878 & RAD50 & DNA repair protein RAD50 & 153.89 & 1.00 & 2 & 2 & -0.3448 & 0.9077 \\
\hline F162A_HUMAN & Q96A26 & FAM162A & Protein FAM162A & 17.34 & 1.00 & 2 & 15.6 & -0.3448 & 0.6789 \\
\hline CL043_HUMAN & Q96C57 & C12orf43 & Uncharacterized protein C12orf43 & 28.17 & 1.00 & 2 & 9.9 & -0.6186 & 0.1905 \\
\hline CNDP2_HUMAN & Q96KP4 & CNDP2 & Cytosolic non-specific dipeptidase & 52.88 & 1.00 & 2 & 7.8 & -0.4368 & 0.3013 \\
\hline MBOA7_HUMAT & Q96N66 & MBOAT7 & Lysophospholipid acyltransferase 7 & 52.76 & 1.00 & 2 & 7.4 & -0.5349 & 1.0308 \\
\hline PHB2_HUMAN & Q99623 & PHB2 & Prohibitin-2 & 33.30 & 1.00 & 8 & 29.8 & -0.3096 & 0.1412 \\
\hline AN32E_HUMAN & Q9BTT0 & ANP32E & Acidic leucine-rich nuclear phosphoprotein 32 family member $\mathrm{E}$ & 30.69 & 1.00 & 4 & 17.9 & -0.2924 & 0.7155 \\
\hline GNL3_HUMAN & Q9BVP2 & GNL3 & Guanine nucleotide-binding protein-like 3 & 61.99 & 1.00 & 8 & 20.8 & -0.4179 & 0.2264 \\
\hline NAA50_HUMAN & Q9GZZ1 & NAA50 & $\mathrm{N}$-alpha-acetyltransferase 50 , NatE catalytic subunit & 19.40 & 1.00 & 2 & 13 & -0.3096 & 0.2105 \\
\hline NAT10_HUMAN & Q9H0A0 & NAT10 & $\mathrm{N}$-acetyltransferase 10 & 115.70 & 1.00 & 8 & 11.2 & -0.4368 & 0.4259 \\
\hline RPF2_HUMAN & Q9H7B2 & RPF2 & Ribosome production factor 2 homolog & 35.58 & 1.00 & 3 & 9.5 & -0.4179 & 0.1636 \\
\hline SFXN1_HUMAN & Q9H9B4 & SFXN1 & Sideroflexin-1 & 35.62 & 1.00 & 4 & 21.7 & -0.3993 & 0.0802 \\
\hline KCTD5_HUMAN & Q9NXV2 & KCTD5 & BTB/POZ domain-containing protein KCTD5 & 26.09 & 1.00 & 2 & 10.7 & -0.3096 & 0.1597 \\
\hline DDX56_HUMAN & Q9NY93 & DDX56 & Probable ATP-dependent RNA helicase DDX56 & 61.59 & 1.00 & 3 & 7.3 & -0.3809 & 0.1736 \\
\hline SAE2_HUMAN & Q9UBT2 & UBA2 & SUMO-activating enzyme subunit 2 & 71.22 & 1.00 & 7 & 25 & -0.4179 & 1.1625 \\
\hline
\end{tabular}

Table S-5-1 page 7 of 45 


\begin{tabular}{|c|c|c|c|c|c|c|c|c|c|c|}
\hline ABCF2_HUMAN & Q9UG63 & $\mathrm{ABCF} 2$ & ATP-binding cassette sub-family F member 2 & 71.29 & 1.00 & 3 & 6.6 & -0.2924 & 0.2381 & 8 \\
\hline LIMA1_HUMAN & Q9UHB6 & LIMA1 & LIM domain and actin-binding protein 1 & 85.23 & 1.00 & 6 & 10.8 & -0.3271 & 0.6087 & 8 \\
\hline STML2_HUMAN & Q9UJZ1 & STOML2 & Stomatin-like protein 2 & 38.53 & 1.00 & 3 & 17.1 & -0.7074 & 0.8596 & 4 \\
\hline MRT4_HUMAN & Q9UKD2 & MRTO4 & mRNA turnover protein 4 homolog & 27.56 & 1.00 & 2 & 10 & -0.3448 & 0.4293 & 5 \\
\hline DIMT1_HUMAN & Q9UNQ2 & DIMT1L & Probable dimethyladenosine transferase & 35.24 & 1.00 & 2 & 8.6 & -0.4752 & 0.1015 & 4 \\
\hline NIP7_HUMAN & Q9Y221 & NIP7 & $60 \mathrm{~S}$ ribosome subunit biogenesis protein NIP7 homolog & 20.46 & 1.00 & 2 & 16.1 & -0.3096 & 0.0677 & 3 \\
\hline SYFA_HUMAN & Q9Y285 & FARSA & Phenylalanyl-tRNA synthetase alpha chain & 57.56 & 1.00 & 6 & 15.6 & -0.2584 & 0.1964 & 11 \\
\hline TMX2_HUMAN & Q9Y320 & TMX2 & Thioredoxin-related transmembrane protein 2 & 34.04 & 1.00 & 3 & 9.5 & -0.7539 & 1.0327 & 4 \\
\hline PM14_HUMAN & Q9Y3B4 & SF3B14 & Pre-mRNA branch site protein p14 & 14.58 & 1.00 & 2 & 20.8 & -0.4559 & 0.6854 & 4 \\
\hline NCOR2_HUMAN & Q9Y618 & NCOR2 & Nuclear receptor corepressor 2 & 274.80 & 1.00 & 2 & 1.5 & -0.4752 & 0.6999 & 5 \\
\hline DD19A_HUMAN & Q9NUU7 & DDX19A & ATP-dependent RNA helicase DDX19A & 53.98 & 1.00 & 3 & 7.5 & -0.3628 & 0.1930 & 12 \\
\hline OPA1_HUMAN & O60313 & OPA1 & Dynamin-like $120 \mathrm{kDa}$ protein, mitochondrial & 111.63 & 1.00 & 2 & 4 & -0.3271 & 0.6548 & 3 \\
\hline VPS4B_HUMAN & O75351 & VPS4B & Vacuolar protein sorting-associated protein $4 \mathrm{~B}$ & 49.30 & 1.00 & 3 & 8.8 & -0.3628 & 0.2034 & 7 \\
\hline GEMI5_HUMAN & Q8TEQ6 & GEMIN5 & Gem-associated protein 5 & 168.59 & 1.00 & 3 & 2.1 & -0.3809 & 0.2961 & 5 \\
\hline TXTP_HUMAN & P53007 & SLC25A1 & Tricarboxylate transport protein, mitochondrial & 34.01 & 1.00 & 2 & 13.8 & -0.3096 & 1.1373 & 4 \\
\hline FAF2_HUMAN & Q96CS3 & FAF2 & FAS-associated factor 2 & 52.62 & 1.00 & 2 & 7.2 & -0.3448 & 0.5215 & 3 \\
\hline COX5B_HUMAN & P10606 & COX5B & Cytochrome c oxidase subunit $5 \mathrm{~B}$, mitochondrial & 13.70 & 1.00 & 2 & 15.5 & -0.6186 & 0.2821 & 4 \\
\hline IF4E2_HUMAN & O60573 & EIF4E2 & Eukaryotic translation initiation factor $4 \mathrm{E}$ type 2 & 28.36 & 1.00 & 2 & 10.6 & -0.3809 & 0.5166 & 3 \\
\hline SFRS3_HUMAN & P84103 & SFRS3 & Splicing factor, arginine/serine-rich 3 & 19.33 & 1.00 & 2 & 18.9 & -0.2924 & 0.1671 & 4 \\
\hline MEP50_HUMAN & Q9BQA1 & WDR77 & Methylosome protein 50 & 36.72 & 1.00 & 2 & 6.1 & -0.4752 & 0.1696 & 5 \\
\hline RPAC1_HUMAN & $\mathrm{O} 15160$ & POLR1C & DNA-directed RNA polymerases I and III subunit RPAC1 & 39.25 & 1.00 & 2 & 9.2 & -0.3993 & 0.0890 & 4 \\
\hline MOGS_HUMAN & Q13724 & MOGS & Mannosyl-oligosaccharide glucosidase & 91.92 & 1.00 & 2 & 3.1 & -0.2924 & 0.1358 & 6 \\
\hline RT02_HUMAN & Q9Y399 & MRPS2 & $28 \mathrm{~S}$ ribosomal protein $\mathrm{S} 2$, mitochondrial & 33.25 & 1.00 & 2 & 5.4 & -0.3628 & 0.0913 & 4 \\
\hline DCTP1_HUMAN & Q9H773 & DCTPP1 & dCTP pyrophosphatase 1 & 18.68 & 1.00 & 2 & 19.4 & -0.9033 & 1.3280 & 4 \\
\hline RS27_HUMAN & P42677 & RPS27 & 40S ribosomal protein S27 & 9.46 & 1.00 & 2 & 22.6 & -0.3993 & 0.2919 & 4 \\
\hline SRBD1_HUMAN & Q8N5C6 & SRBD1 & S1 RNA-binding domain-containing protein 1 & 111.78 & 0.99 & 2 & 4 & -0.4559 & 0.6203 & 3 \\
\hline IF4G3_HUMAN & O43432 & EIF4G3 & Eukaryotic translation initiation factor 4 gamma 3 & 176.65 & 0.97 & 2 & 2.3 & -0.3096 & 0.1647 & 6 \\
\hline
\end{tabular}


Table S-5-2. List of differentially expressed proteins in areca nut extract (ANE)-trained OECM1 cell lines

\begin{tabular}{|c|c|c|c|c|c|c|c|c|c|c|}
\hline $\begin{array}{l}\text { Unique and stable } \\
\text { accession no. of a } \\
\text { UniProtKB entry }\end{array}$ & $\begin{array}{l}\text { Mnemonic } \\
\text { accession } \\
\text { no. of a } \\
\text { UniProtKB } \\
\text { entry }\end{array}$ & Gene names & Protein names & $\begin{array}{c}\mathrm{MW} \\
(\mathrm{kDa})\end{array}$ & 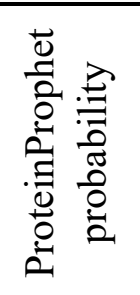 & 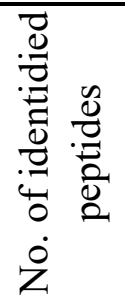 & 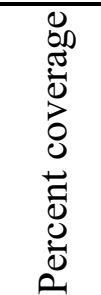 & $\begin{array}{l}\text { Log2 ratio } \\
\text { of ANE- } \\
\text { trained/ } \\
\text { parental } \\
\text { cells }\end{array}$ & $\begin{array}{l}\text { SD of } \\
\text { peptide } \\
\text { ratios } \\
\text { from the } \\
\text { protein }\end{array}$ & 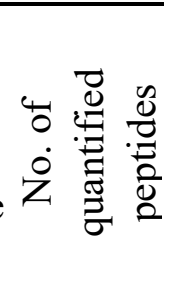 \\
\hline \multicolumn{11}{|c|}{ Overexpressed proteins } \\
\hline RTC1_HUMAN & $\mathrm{O} 00442$ & RTCD1 & RNA 3'-terminal phosphate cyclase & 39.34 & 1.00 & 2 & 7.7 & 0.7814 & 1.0532 & 3 \\
\hline COPE_HUMAN & O14579 & COPE & Coatomer subunit epsilon & 34.48 & 1.00 & 4 & 28.2 & 0.6257 & 1.4019 & 6 \\
\hline TCRG1_HUMAN & O14776 & TCERG1 & Transcription elongation regulator 1 & 123.90 & 1.00 & 3 & 2.1 & 0.8765 & 2.1525 & 8 \\
\hline HMGB3_HUMAT & O15347 & HMGB3 & High mobility group protein B3 & 22.98 & 1.00 & 2 & 16.5 & 0.8611 & 0.5147 & 6 \\
\hline EIF3H_HUMAN & O15372 & EIF3H & Eukaryotic translation initiation factor 3 subunit $\mathrm{H}$ & 39.93 & 1.00 & 5 & 15.6 & 0.6618 & 2.5566 & 9 \\
\hline AKAPs_HUMAN & O43823 & AKAP8 & A-kinase anchor protein 8 & 76.11 & 1.00 & 2 & 3 & 0.7482 & 0.5293 & 5 \\
\hline DHX16_HUMAN & O60231 & DHX16 & Putative pre-mRNA-splicing factor ATP-dependent RNA helicase DHX16 & 119.26 & 1.00 & 2 & 1.8 & 1.3219 & 3.5074 & 5 \\
\hline NDK8_HUMAN & O60361 & NME2P1 & Putative nucleoside diphosphate kinase & 15.53 & 1.00 & 3 & 40.1 & 0.7142 & 1.6378 & 17 \\
\hline TBCA_HUMAN & O75347 & TBCA & Tubulin-specific chaperone A & 12.85 & 1.00 & 4 & 32.4 & 0.7977 & 1.1201 & 6 \\
\hline DDAH1_HUMAN & O94760 & DDAH1 & $\mathrm{N}(\mathrm{G}), \mathrm{N}(\mathrm{G})$-dimethylarginine dimethylaminohydrolase 1 & 31.12 & 1.00 & 2 & 11.6 & 0.7649 & 1.3685 & 9 \\
\hline SC31A_HUMAN & O94979 & SEC31A & Protein transport protein Sec31A & 133.01 & 1.00 & 2 & 3.1 & 1.0084 & 1.1423 & 3 \\
\hline UBR5_HUMAN & O95071 & UBR5 & E3 ubiquitin-protein ligase UBR5 & 309.35 & 1.00 & 3 & 2.5 & 0.8138 & 1.6733 & 4 \\
\hline ASML_HUMAN & O95671 & ASMTL & $\mathrm{N}$-acetylserotonin $\mathrm{O}$-methyltransferase-like protein & 68.86 & 1.00 & 3 & 5.2 & 0.6257 & 2.4515 & 4 \\
\hline BPNT1_HUMAN & O95861 & BPNT1 & $3^{\prime}\left(2^{\prime}\right), 5^{\prime}$-bisphosphate nucleotidase 1 & 33.39 & 1.00 & 2 & 9.1 & 0.7649 & 2.0036 & 3 \\
\hline TOM40_HUMAN & O96008 & TOMM40 & Mitochondrial import receptor subunit TOM40 homolog & 37.89 & 1.00 & 5 & 22.7 & 0.6257 & 0.8128 & 15 \\
\hline DHE3_HUMAN & P00367 & GLUD1 & Glutamate dehydrogenase 1 , mitochondrial & 61.40 & 1.00 & 4 & 10.9 & 0.6970 & 1.0204 & 11 \\
\hline ALBU_HUMAN & P02768 & ALB & Serum albumin & 69.37 & 1.00 & 5 & 12.3 & 1.1548 & 1.3490 & 15 \\
\hline CATA_HUMAN & P04040 & CAT & Catalase & 59.76 & 1.00 & 2 & 9.1 & 0.8765 & 1.1038 & 5 \\
\hline APT_HUMAN & P07741 & APRT & Adenine phosphoribosyltransferase & 19.61 & 1.00 & 5 & 45 & 0.7814 & 2.3122 & 7 \\
\hline HEM3_HUMAN & P08397 & HMBS & Porphobilinogen deaminase & 39.33 & 1.00 & 2 & 10.8 & 1.5411 & 1.1767 & 7 \\
\hline RU17_HUMAN & P08621 & SNRNP70 & U1 small nuclear ribonucleoprotein $70 \mathrm{kDa}$ & 51.56 & 1.00 & 3 & 9.2 & 0.6439 & 0.2454 & 8 \\
\hline K2C7_HUMAN & P08729 & KRT7 & Keratin, type II cytoskeletal 7 & 51.40 & 1.00 & 14 & 33.7 & 0.6970 & 1.5045 & 48 \\
\hline HMGB̄1_HUMAI & P09429 & HMGB1 & High mobility group protein B1 & 24.89 & 1.00 & 7 & 32.1 & 0.6970 & 0.6008 & 29 \\
\hline H14_HUMAN & P10412 & HIST1H1E & Histone $\mathrm{H} 1.4$ & 21.87 & 1.00 & 3 & 39.3 & 0.6795 & 0.5372 & 16 \\
\hline ESTD_HUMAN & P10768 & ESD & S-formylglutathione hydrolase & 31.46 & 1.00 & 3 & 18.1 & 0.6439 & 1.0995 & 4 \\
\hline ODPB_HUMAN & P11177 & PDHB & Pyruvate dehydrogenase E1 component subunit beta, mitochondrial & 39.23 & 1.00 & 3 & 16.4 & 0.6439 & 2.4105 & 4 \\
\hline SYHC_HUMAN & P12081 & HARS & Histidyl-tRNA synthetase, cytoplasmic & 57.41 & 1.00 & 6 & 15.7 & 1.0362 & 1.1871 & 10 \\
\hline GLU2B-̄HUMAN & P14314 & PRKCSH & Glucosidase 2 subunit beta & 59.43 & 1.00 & 4 & 7.8 & 0.6257 & 2.7245 & 11 \\
\hline
\end{tabular}




\begin{tabular}{|c|c|c|c|c|c|c|c|c|c|}
\hline ITB4_HUMAN & P16144 & ITGB4 & Integrin beta-4 & 202.15 & 1.00 & 3 & 3.4 & 1.1799 & 3.5482 \\
\hline H13_HUMAN & P16402 & HIST1H1D & Histone H1.3 & 22.35 & 1.00 & 3 & 37.6 & 0.6618 & 0.9529 \\
\hline EPCAMM_HUMAN & P16422 & EPCAM & Epithelial cell adhesion molecule & 34.93 & 1.00 & 4 & 20.4 & 0.9218 & 0.8906 \\
\hline DBPA_HUMAN & P16989 & CSDA & DNA-binding protein A & 40.09 & 1.00 & 4 & 23.9 & 0.7814 & 1.2013 \\
\hline HMGĀ1_HUMAI & P17096 & HMGA1 & High mobility group protein HMG-I/HMG-Y & 11.68 & 1.00 & 5 & 37.4 & 0.6618 & 1.2227 \\
\hline DDX5_HUMAN & P17844 & DDX5 & Probable ATP-dependent RNA helicase DDX5 & 69.15 & 1.00 & 10 & 30.6 & 0.6618 & 2.2073 \\
\hline E2AK 2 _HUMAN & P19525 & EIF2AK2 & Interferon-induced, double-stranded RNA-activated protein kinase & 62.09 & 1.00 & 3 & 6.9 & 0.6257 & 0.3026 \\
\hline ICAL_HUMAN & P20810 & CAST & Calpastatin & 76.57 & 1.00 & 5 & 12.3 & 0.9366 & 1.1830 \\
\hline ITA6_HUMAN & P23229 & ITGA6 & Integrin alpha-6 & 126.63 & 1.00 & 4 & 3.6 & 1.3663 & 1.5778 \\
\hline THTM_HUMAN & P25325 & MPST & 3-mercaptopyruvate sulfurtransferase & 33.18 & 1.00 & 2 & 9.8 & 1.6970 & 1.0928 \\
\hline DNJB1_HUMAN & P25685 & DNAJB1 & DnaJ homolog subfamily B member 1 & 38.04 & 1.00 & 3 & 11.5 & 0.7142 & 0.4911 \\
\hline DDX6_HUMAN & P26196 & DDX6 & Probable ATP-dependent RNA helicase DDX6 & 54.42 & 1.00 & 5 & 10.8 & 0.8455 & 1.5178 \\
\hline PSA5_HUMAN & P28066 & PSMA5 & Proteasome subunit alpha type- 5 & 26.41 & 1.00 & 5 & 35.3 & 0.7313 & 1.5564 \\
\hline IMPĀ1_HUMAN & P29218 & IMPA1 & Inositol monophosphatase 1 & 30.19 & 1.00 & 2 & 11.9 & 1.4717 & 0.9984 \\
\hline MARCS̄_HUMAN & P29966 & MARCKS & Myristoylated alanine-rich C-kinase substrate & 31.55 & 1.00 & 5 & 24.1 & 0.8611 & 0.6317 \\
\hline ERP29 HUMAN & P30040 & ERP29 & Endoplasmic reticulum resident protein 29 & 28.99 & 1.00 & 4 & 20.7 & 0.8138 & 0.9403 \\
\hline PURA2_HUMAN & P30520 & ADSS & Adenylosuccinate synthetase isozyme 2 & 50.10 & 1.00 & 5 & 14.7 & 0.8611 & 1.3457 \\
\hline STIP1_HUMAN & P31948 & STIP1 & Stress-induced-phosphoprotein 1 & 62.64 & 1.00 & 15 & 30 & 0.8138 & 2.4123 \\
\hline PRDX̄__HUMAN & P32119 & PRDX2 & Peroxiredoxin-2 & 21.89 & 1.00 & 5 & 36.4 & 0.6439 & 1.3481 \\
\hline PROF2 HUMAN & P35080 & PFN2 & Profilin-2 & 15.05 & 1.00 & 2 & 15.7 & 0.6439 & 2.1683 \\
\hline RADI_HUMAN & P35241 & RDX & Radixin & 68.56 & 1.00 & 4 & 20.1 & 1.0362 & 0.6790 \\
\hline K1C9_HUMAN & P35527 & KRT9 & Keratin, type I cytoskeletal 9 & 62.06 & 1.00 & 2 & 7.4 & 2.1098 & 1.2963 \\
\hline FUS_HUMAN & P35637 & FUS & RNA-binding protein FUS & 53.43 & 1.00 & 5 & 11.4 & 0.7142 & 0.5022 \\
\hline SPB $\overline{5} \_$HUMAN & P36952 & SERPINB5 & Serpin B5 & 42.10 & 1.00 & 3 & 13.9 & 0.6257 & 0.3186 \\
\hline SRP14_HUMAN & P37108 & SRP14 & Signal recognition particle $14 \mathrm{kDa}$ protein & 14.57 & 1.00 & 3 & 19.9 & 0.9218 & 3.3378 \\
\hline TALDŌ_HUMAN & P37837 & TALDO1 & Transaldolase & 37.54 & 1.00 & 6 & 18.4 & 1.1421 & 1.7990 \\
\hline IF4A3_HUMAN & P38919 & EIF4A3 & Eukaryotic initiation factor 4A-III & 46.87 & 1.00 & 6 & 23.1 & 0.6257 & 2.2297 \\
\hline LIS1_HUMAN & P43034 & PAFAH1B1 & Platelet-activating factor acetylhydrolase IB subunit alpha & 46.64 & 1.00 & 2 & 6.3 & 0.7313 & 0.9848 \\
\hline PSMD̄̄8_HUMAN & P48556 & PSMD8 & $26 \mathrm{~S}$ proteasome non-ATPase regulatory subunit 8 & 30.00 & 1.00 & 3 & 11.7 & 0.6439 & 1.3650 \\
\hline PTSS1_HUMAN & P48651 & PTDSS1 & Phosphatidylserine synthase 1 & 55.53 & 1.00 & 2 & 5.7 & 0.9801 & 0.8405 \\
\hline KC1A_HUMAN & P48729 & CSNK1A1 & Casein kinase I isoform alpha & 38.91 & 1.00 & 4 & 16.3 & 0.7814 & 2.0052 \\
\hline NASP_HUMAN & P49321 & NASP & Nuclear autoantigenic sperm protein & 85.24 & 1.00 & 4 & 7.2 & 0.6257 & 1.9428 \\
\hline SRP09_HUMAN & P49458 & SRP9 & Signal recognition particle $9 \mathrm{kDa}$ protein & 10.11 & 1.00 & 2 & 25.6 & 0.8765 & 1.8270 \\
\hline SYSC_HUMAN & P49591 & SARS & Seryl-tRNA synthetase, cytoplasmic & 58.78 & 1.00 & 7 & 18.1 & 0.7313 & 2.5938 \\
\hline ACADV_HUMAT & P49748 & ACADVL & Very long-chain specific acyl-CoA dehydrogenase, mitochondrial & 70.39 & 1.00 & 4 & 7.9 & 0.9658 & 1.0317 \\
\hline IDH3A_HUMAN & P50213 & IDH3A & Isocitrate dehydrogenase [NAD] subunit alpha, mitochondrial & 39.59 & 1.00 & 2 & 10.9 & 0.6618 & 1.6234 \\
\hline
\end{tabular}

Table S-5-2 page 10 of 45 
FXR1_HUMAN SMCA4 HUMAN RPAB3 HUMAN GDIR2 HUMAN HMGA2_HUMAI IF5_HUMAN

MANF_HUMAN IF6_HUMAN

BCAR1_HUMAN ARPC4_HUMAN ABCE1_HUMAN RL15_HUMAN PFD3_HUMAN RS15_HUMAN SKP1 HUMAN YBOX1_HUMAN GSTO1_HUMAN BASP1_HUMAN K1C17 HUMAN GRSF1 HUMAN RED_HUMAN AIMP2_HUMAN DC1I2 HUMAN ATR HUMAN BYST_HUMAN FHL2 HUMAN ITPR3_HUMAN 2A5D_HUMAN SPCS2 HUMAN OXA1L HUMAN SC23A HUMAN RBBP7_HUMAN CPSF6_HUMAN DREB_HUMAN CP51A HUMAN PCID2_HUMAN
P51114 P51532

P52434

P52566

$\mathrm{P} 52926$

P55010

P55145

P56537

P56945

P59998

P61221

P61313

P61758

P62841

P63208

P67809

P78417

P80723

Q04695

Q12849

Q13123

Q13155

Q13409

Q13535

Q13895

Q14192

Q14573

Q14738

Q15005

Q15070

Q15436

Q16576

Q16630

Q16643

Q16850

Q5JVF3
Fragile X mental retardation syndrome-related protein 1

$69.72 \quad 1.00$

184.651 .00

SMARCA4 Transcription activator BRG1

DNA-directed RNA polymerases I, II, and III subunit RPABC3 $17.14 \quad 1.00$

ARHGDIB Rho GDP-dissociation inhibitor 2

HMGA2 High mobility group protein HMGI-C

$22.99 \quad 1.00$

$11.83 \quad 1.00$

$49.22 \quad 1.00$

$20.26 \quad 1.00$

MANF

EIF6

BCAR1

Eukaryotic translation initiation factor 5

Mesencephalic astrocyte-derived neurotrophic factor

Eukaryotic translation initiation factor 6

$26.60 \quad 1.00$

$93.37 \quad 1.00$

$19.67 \quad 1.00$

$67.31 \quad 1.00$

ABCE1

RPL15

VBP1

RPS15

SKP1

YBX1

GSTO1

BASP1

KRT17

GRSF 1

IK

AIMP2

DYNC1I2

ATR

BYSL

FHL2

ITPR3

PPP2R5D

SPCS2

OXA1L

SEC23A

RBBP7

CPSF6

DBN1

Actin-related protein 2/3 complex subunit 4

ATP-binding cassette sub-family E member 1

60S ribosomal protein $\mathrm{L} 15$

Prefoldin subunit 3

40S ribosomal protein $\mathrm{S} 15$

S-phase kinase-associated protein 1

Nuclease-sensitive element-binding protein 1

Glutathione S-transferase omega-1

Brain acid soluble protein 1

Keratin, type I cytoskeletal 17

G-rich sequence factor 1

Protein Red

$24.15 \quad 1.00$

$22.66 \quad 1.00$

$17.04 \quad 1.00$

$18.66 \quad 1.00$

$35.92 \quad 1.00$

$27.57 \quad 1.00$

$22.69 \quad 1.00$

$48.11 \quad 1.00$

$53.13 \quad 1.00$

$65.60 \quad 1.00$

Aminoacyl tRNA synthase complex-interacting multifunctional protein $2 \quad 35.35 \quad 1.00$

Cytoplasmic dynein 1 intermediate chain 2

$71.46 \quad 1.00$

Serine/threonine-protein kinase ATR

Bystin

Four and a half LIM domains protein 2

Inositol 1,4,5-trisphosphate receptor type 3

$301.37 \quad 1.00$

$49.60 \quad 1.00$

$32.19 \quad 1.00$

$304.11 \quad 1.00$

Serine/threonine-protein phosphatase $2 \mathrm{~A} 56 \mathrm{kDa}$ regulatory subunit delta isoform

Signal peptidase complex subunit 2

Mitochondrial inner membrane protein OXA1L

$69.99 \quad 1.00$

$25.00 \quad 1.00$

$48.55 \quad 1.00$

$86.16 \quad 1.00$

$47.82 \quad 1.00$

$59.21 \quad 1.00$

$71.43 \quad 1.00$

$56.81 \quad 1.00$

$46.03 \quad 1.00$

$\begin{array}{cccc}9.2 & 0.6795 & 2.0250 & 7 \\ 1.1 & 0.9658 & 1.4034 & 6 \\ 17.3 & 0.9366 & 0.8353 & 3 \\ 10.9 & 1.2408 & 1.1784 & 3 \\ 28.4 & 0.7814 & 0.7211 & 9 \\ 12.8 & 0.7142 & 1.2346 & 13 \\ 11.2 & 0.8455 & 2.2429 & 3 \\ 31 & 1.1033 & 1.3395 & 11 \\ 5.2 & 1.0768 & 0.4991 & 5 \\ 31 & 0.7313 & 1.6535 & 3 \\ 20.9 & 0.7977 & 2.2244 & 14 \\ 27.5 & 0.6970 & 1.7923 & 17 \\ 22.3 & 0.7977 & 3.1149 & 6 \\ 24.1 & 0.6795 & 1.4102 & 8 \\ 35.6 & 0.9658 & 0.8376 & 10 \\ 43.8 & 0.7313 & 0.8724 & 51 \\ 37.8 & 0.7814 & 1.4653 & 25 \\ 45.4 & 1.1421 & 0.7013 & 21 \\ 18.3 & 1.4919 & 0.8581 & 7 \\ 7.7 & 0.7649 & 0.4001 & 14 \\ 3.4 & 0.6970 & 0.5400 & 5 \\ 5.6 & 0.9218 & 0.9046 & 7 \\ 5 & 1.0901 & 0.3968 & 3 \\ 1.5 & 0.7142 & 1.1540 & 3 \\ 17.8 & 0.7482 & 2.2285 & 10 \\ 9.3 & 0.6257 & 2.3830 & 7 \\ 1.2 & 1.1033 & 1.9457 & 3 \\ 10.1 & 0.6795 & 2.4776 & 7 \\ 20.8 & 0.6618 & 3.0626 & 4 \\ 6 & 0.8611 & 2.0692 & 6 \\ 8.6 & 0.7977 & 0.4311 & 4 \\ 16 & 0.8138 & 0.6213 & 12 \\ 10 & 0.8138 & 2.8055 & 11 \\ 4.6 & 1.5603 & 2.0831 & 4 \\ 8.3 & 0.6618 & 1.5283 & 5 \\ 11 & 0.8918 & 0.7712 & 4\end{array}$

Table S-5-2 page 11 of 45 


\begin{tabular}{|c|c|c|c|c|c|c|c|c|c|c|}
\hline TDIF2_HUMAN & Q5QJE6 & DNTTIP2 & Deoxynucleotidyltransferase terminal-interacting protein 2 & 84.47 & 1.00 & 2 & 3.6 & 0.9801 & 1.7777 & 4 \\
\hline EXOS6_HUMAN & Q5RKV6 & EXOSC6 & Exosome complex exonuclease MTR3 & 28.24 & 1.00 & 2 & 9.9 & 0.8455 & 2.8453 & 4 \\
\hline INT3_HUMAN & Q68E01 & INTS3 & Integrator complex subunit 3 & 118.07 & 1.00 & 2 & 4.3 & 1.2527 & 1.8019 & 3 \\
\hline VIR_HUMAN & Q69YN4 & KIAA1429 & Protein virilizer homolog & 202.02 & 1.00 & 3 & 2.5 & 1.6257 & 2.5940 & 6 \\
\hline DDX46_HUMAN & Q7L014 & DDX46 & Probable ATP-dependent RNA helicase DDX46 & 117.36 & 1.00 & 2 & 1.9 & 1.0634 & 0.8973 & 4 \\
\hline LYRIC_HUMAN & Q86UE4 & MTDH & Protein LYRIC & 63.84 & 1.00 & 2 & 5.8 & 1.2167 & 1.1109 & 4 \\
\hline CCAR1_HUMAN & Q8IX12 & CCAR1 & Cell division cycle and apoptosis regulator protein 1 & 132.82 & 1.00 & 3 & 2.3 & 1.2408 & 1.1660 & 7 \\
\hline SCPDH_HUMAN & Q8NBX0 & $\mathrm{SCCPDH}$ & Probable saccharopine dehydrogenase & 47.15 & 1.00 & 2 & 9.8 & 0.8765 & 1.3566 & 7 \\
\hline NOC3L_HUMAN & Q8WTT2 & NOC3L & Nucleolar complex protein 3 homolog & 92.55 & 1.00 & 3 & 4.1 & 0.7814 & 1.6974 & 5 \\
\hline COG1_HUMAN & Q8WTW3 & COG1 & Conserved oligomeric Golgi complex subunit 1 & 108.98 & 1.00 & 2 & 2.7 & 0.7482 & 0.7245 & 7 \\
\hline SCFD1_HUMAN & Q8WVM8 & SCFD1 & Sec1 family domain-containing protein 1 & 72.38 & 1.00 & 2 & 5.6 & 0.6257 & 0.9460 & 3 \\
\hline PCNP_HUMAN & Q8WW12 & PCNP & PEST proteolytic signal-containing nuclear protein & 18.92 & 1.00 & 2 & 17.4 & 0.7649 & 0.2556 & 5 \\
\hline PSPC1_HUMAN & Q8WXF1 & PSPC1 & Paraspeckle component 1 & 58.74 & 1.00 & 5 & 15.5 & 0.8297 & 1.3048 & 14 \\
\hline HDAC2_HUMAN & Q92769 & HDAC2 & Histone deacetylase 2 & 55.36 & 1.00 & 2 & 6.1 & 1.0224 & 2.0797 & 7 \\
\hline F162A_HUMAN & Q96A26 & FAM162A & Protein FAM162A & 17.34 & 1.00 & 2 & 15.6 & 1.5603 & 3.7290 & 5 \\
\hline SH3K1_HUMAN & Q96B97 & SH3KBP1 & SH3 domain-containing kinase-binding protein 1 & 73.13 & 1.00 & 2 & 7.4 & 0.8138 & 0.3416 & 5 \\
\hline CL043_HUMAN & Q96C57 & C12orf43 & Uncharacterized protein C12orf43 & 28.17 & 1.00 & 2 & 9.9 & 1.4305 & 1.4303 & 3 \\
\hline S10AG_HUMAN & Q96FQ6 & S100A16 & Protein S100-A16 & 11.80 & 1.00 & 3 & 40.8 & 0.7649 & 1.2010 & 10 \\
\hline PDLI5_HUMAN & Q96HC4 & PDLIM5 & PDZ and LIM domain protein 5 & 64.00 & 1.00 & 2 & 7.6 & 0.9366 & 0.3552 & 12 \\
\hline PAWR_HUMAN & Q96IZ0 & PAWR & PRKC apoptosis WT1 regulator protein & 36.57 & 1.00 & 3 & 14.1 & 0.7649 & 1.2555 & 6 \\
\hline CNDP2_HUMAN & Q96KP4 & CNDP2 & Cytosolic non-specific dipeptidase & 52.88 & 1.00 & 2 & 7.8 & 0.6257 & 0.3677 & 5 \\
\hline MBOA7_HUMAI & Q96N66 & MBOAT7 & Lysophospholipid acyltransferase 7 & 52.76 & 1.00 & 2 & 7.4 & 1.3443 & 0.6333 & 3 \\
\hline PSB7_HŪMAN & Q99436 & PSMB7 & Proteasome subunit beta type- 7 & 29.97 & 1.00 & 3 & 10.8 & 0.6970 & 0.3094 & 7 \\
\hline PSMD1_HUMAN & Q99460 & PSMD1 & $26 \mathrm{~S}$ proteasome non-ATPase regulatory subunit 1 & 105.84 & 1.00 & 16 & 23.5 & 0.6439 & 2.2757 & 21 \\
\hline PARK7_HUMAN & Q99497 & PARK7 & Protein DJ-1 & 19.89 & 1.00 & 7 & 59.8 & 0.6439 & 1.5543 & 35 \\
\hline VAT1_HUMAN & Q99536 & VAT1 & Synaptic vesicle membrane protein VAT-1 homolog & 41.92 & 1.00 & 2 & 7.1 & 0.8765 & 3.0748 & 5 \\
\hline HCD2_HUMAN & Q99714 & HSD17B10 & 3-hydroxyacyl-CoA dehydrogenase type-2 & 26.92 & 1.00 & 3 & 17.6 & 0.9658 & 0.7508 & 6 \\
\hline ERP44_HUMAN & Q9BS26 & ERP44 & Endoplasmic reticulum resident protein 44 & 46.97 & 1.00 & 2 & 9.1 & 0.7142 & 3.7797 & 3 \\
\hline ESYT1_HUMAN & Q9BSJ8 & ESYT1 & Extended synaptotagmin-1 & 122.86 & 1.00 & 4 & 6.1 & 0.9366 & 1.3661 & 6 \\
\hline AN32E_HUMAN & Q9BTT0 & ANP32E & Acidic leucine-rich nuclear phosphoprotein 32 family member E & 30.69 & 1.00 & 4 & 17.9 & 0.6439 & 1.0626 & 14 \\
\hline NOG1_HUMAN & Q9BZE4 & GTPBP4 & Nucleolar GTP-binding protein 1 & 73.96 & 1.00 & 3 & 6.6 & 1.0224 & 1.4345 & 4 \\
\hline UCK2_HUMAN & Q9BZX2 & UCK2 & Uridine-cytidine kinase 2 & 29.30 & 1.00 & 2 & 16.5 & 0.9069 & 1.9032 & 4 \\
\hline XRN2_HUMAN & Q9H0D6 & XRN2 & $5^{\prime}-3{ }^{\prime}$ exoribonuclease 2 & 108.58 & 1.00 & 6 & 6.8 & 0.8611 & 1.8283 & 15 \\
\hline DDX47_HUMAN & Q9H0S4 & DDX47 & Probable ATP-dependent RNA helicase DDX47 & 50.65 & 1.00 & 3 & 8.6 & 0.6439 & 1.9269 & 20 \\
\hline NOL6_HUMAN & Q9H6R4 & NOL6 & Nucleolar protein 6 & 127.59 & 1.00 & 2 & 4.6 & 1.3880 & 2.0789 & 4 \\
\hline NCOA5_HUMAN & Q9HCD5 & NCOA5 & Nuclear receptor coactivator 5 & 65.54 & 1.00 & 2 & 9.2 & 0.6795 & 0.5657 & 5 \\
\hline
\end{tabular}

Table S-5-2 page 12 of 45 


\begin{tabular}{|c|c|c|c|c|c|c|c|c|c|}
\hline S10AE_HUMAN & Q9HCY8 & S100A14 & Protein S100-A14 & 11.66 & 1.00 & 2 & 25 & 0.7649 & 2.1404 \\
\hline CHRC1_HUMAN & Q9NRG0 & CHRAC1 & Chromatin accessibility complex protein 1 & 14.71 & 1.00 & 2 & 26 & 1.4409 & 2.9710 \\
\hline NALP2_HUMAN & Q9NX02 & NLRP2 & NACHT, LRR and PYD domains-containing protein 2 & 120.52 & 1.00 & 2 & 2.4 & 0.6795 & 1.1369 \\
\hline MTCH1_HUMAN & Q9NZJ7 & MTCH1 & Mitochondrial carrier homolog 1 & 41.54 & 1.00 & 2 & 5.9 & 1.6618 & 1.8513 \\
\hline BCCIP_HUMAN & Q9P287 & BCCIP & BRCA2 and CDKN1A-interacting protein & 35.98 & 1.00 & 4 & 22.6 & 0.7649 & 0.4414 \\
\hline SYLC_HUMAN & Q9P2J5 & LARS & Leucyl-tRNA synthetase, cytoplasmic & 134.47 & 1.00 & 8 & 8.7 & 0.6439 & 1.2414 \\
\hline ATX10_HUMAN & Q9UBB4 & ATXN10 & Ataxin-10 & 53.49 & 1.00 & 4 & 14.7 & 0.8138 & 1.2423 \\
\hline GBG12_HUMAN & Q9UBI6 & GNG12 & Guanine nucleotide-binding protein $\mathrm{G}(\mathrm{I}) / \mathrm{G}(\mathrm{S}) / \mathrm{G}(\mathrm{O})$ subunit gamma-12 & 8.01 & 1.00 & 2 & 37.5 & 0.8455 & 1.5462 \\
\hline VATH_HUMAN & Q9UI12 & ATP6V1H & V-type proton ATPase subunit $\mathrm{H}$ & 55.88 & 1.00 & 3 & 9.1 & 0.7142 & 2.5798 \\
\hline STML2_HUMAN & Q9UJZ1 & STOML2 & Stomatin-like protein 2 & 38.53 & 1.00 & 3 & 17.1 & 0.9218 & 2.9378 \\
\hline ACINU_HUMAN & Q9UKV3 & ACIN1 & Apoptotic chromatin condensation inducer in the nucleus & 151.89 & 1.00 & 3 & 3.1 & 0.6970 & 0.3248 \\
\hline TMCO1_HUMAN & Q9UM00 & TMCO1 & Transmembrane and coiled-coil domain-containing protein 1 & 21.17 & 1.00 & 2 & 12.2 & 1.5018 & 1.9456 \\
\hline MACF1_HUMAN & Q9UPN3 & MACF1 & Microtubule-actin cross-linking factor 1 , isoforms $1 / 2 / 3 / 5$ & 620.42 & 1.00 & 10 & 2.8 & 0.9366 & 2.1636 \\
\hline CHM2B_HUMAN & Q9UQN3 & CHMP2B & Charged multivesicular body protein $2 \mathrm{~b}$ & 23.91 & 1.00 & 3 & 12.2 & 1.1799 & 0.2633 \\
\hline NIP7_HUMAN & Q9Y221 & NIP7 & $60 \mathrm{~S}$ ribosome subunit biogenesis protein NIP7 homolog & 20.46 & 1.00 & 2 & 16.1 & 1.6707 & 1.4441 \\
\hline PM14_HUMAN & Q9Y3B4 & SF3B14 & Pre-mRNA branch site protein p14 & 14.58 & 1.00 & 2 & 20.8 & 0.7313 & 2.1714 \\
\hline CV028_HUMAN & Q9Y3I0 & C22orf28 & UPF0027 protein C22orf28 & 55.21 & 1.00 & 5 & 11.3 & 0.6439 & 1.6645 \\
\hline F10A1_HUMAN & P50502 & ST13 & Hsc70-interacting protein & 41.33 & 1.00 & 9 & 26 & 0.7142 & 1.2149 \\
\hline SPTC1_HUMAN & O15269 & SPTLC1 & Serine palmitoyltransferase 1 & 52.74 & 1.00 & 2 & 6.8 & 1.0498 & 3.6258 \\
\hline RO60_HUMAN & $\mathrm{P} 10155$ & TROVE2 & $60 \mathrm{kDa} \mathrm{SS}-\mathrm{A} /$ Ro ribonucleoprotein & 60.67 & 1.00 & 2 & 4.6 & 1.4305 & 1.9741 \\
\hline AL1A3_HUMAN & P47895 & ALDH1A3 & Aldehyde dehydrogenase family 1 member A3 & 56.11 & 1.00 & 2 & 4.3 & 0.6618 & 0.7512 \\
\hline EI2BB_HUMAN & P49770 & EIF2B2 & Translation initiation factor eIF-2B subunit beta & 38.99 & 1.00 & 3 & 12.3 & 0.8297 & 2.8892 \\
\hline GEMI5_HUMAN & Q8TEQ6 & GEMIN5 & Gem-associated protein 5 & 168.59 & 1.00 & 3 & 2.1 & 1.1163 & 4.7167 \\
\hline HNRLL_HUMAN & Q8WVV9 & HNRPLL & Heterogeneous nuclear ribonucleoprotein L-like & 60.08 & 1.00 & 2 & 5.9 & 0.6618 & 0.7385 \\
\hline SAP18_HUMAN & O00422 & SAP18 & Histone deacetylase complex subunit SAP18 & 17.56 & 1.00 & 2 & 13.1 & 0.9944 & 2.8520 \\
\hline RASK_HUMAN & P01116 & KRAS & GTPase KRas & 21.66 & 1.00 & 2 & 13.8 & 1.0901 & 1.3231 \\
\hline REEP5_HUMAN & Q00765 & REEP5 & Receptor expression-enhancing protein 5 & 21.49 & 1.00 & 3 & 10.1 & 1.4615 & 0.5143 \\
\hline UBP4_HUMAN & Q13107 & USP4 & Ubiquitin carboxyl-terminal hydrolase 4 & 108.57 & 1.00 & 2 & 3.1 & 1.2527 & 0.7423 \\
\hline FAF2_HUMAN & Q96CS3 & FAF2 & FAS-associated factor 2 & 52.62 & 1.00 & 2 & 7.2 & 0.8455 & 1.0342 \\
\hline TMCŌ7_HUMAN & Q9C0B7 & TMCO7 & Transmembrane and coiled-coil domain-containing protein 7 & 120.75 & 1.00 & 2 & 3.1 & 0.8765 & 1.3282 \\
\hline MPPB_HUMAN & O75439 & PMPCB & Mitochondrial-processing peptidase subunit beta & 54.37 & 1.00 & 2 & 4.3 & 0.7977 & 0.5215 \\
\hline TES_HUMAN & Q9UGI8 & TES & Testin & 48.00 & 1.00 & 2 & 4.5 & 0.6257 & 0.2581 \\
\hline NU153_HUMAN & P49790 & NUP153 & Nuclear pore complex protein Nup153 & 153.94 & 1.00 & 2 & 1.5 & 0.7142 & 0.7219 \\
\hline MRE11_HUMAN & P49959 & MRE11A & Double-strand break repair protein MRE11A & 80.59 & 1.00 & 2 & 2.8 & 0.6257 & 0.5758 \\
\hline RPAC1_HUMAN & O15160 & POLR1C & DNA-directed RNA polymerases I and III subunit RPAC1 & 39.25 & 1.00 & 2 & 9.2 & 1.2046 & 0.1387 \\
\hline MOGS_HUMAN & Q13724 & MOGS & Mannosyl-oligosaccharide glucosidase & 91.92 & 1.00 & 2 & 3.1 & 0.7142 & 1.1447 \\
\hline
\end{tabular}

Table S-5-2 page 13 of 45 


\begin{tabular}{|c|c|c|c|c|c|c|c|c|c|c|}
\hline MED14_HUMAN & O60244 & MED14 & Mediator of RNA polymerase II transcription subunit 14 & 160.61 & 1.00 & 2 & 2.4 & 0.8138 & 2.3296 & 3 \\
\hline RAB6A_HUMAN & P20340 & RAB6A & Ras-related protein Rab- $6 \mathrm{~A}$ & 23.59 & 1.00 & 2 & 9.6 & 0.6257 & 1.0279 & 3 \\
\hline CELF1_HUMAN & Q92879 & CELF1 & CUGBP Elav-like family member 1 & 52.06 & 1.00 & 2 & 4.9 & 1.4094 & 0.4947 & 4 \\
\hline RT02_- HUMAN & Q9Y399 & MRPS2 & $28 \mathrm{~S}$ ribosomal protein $\mathrm{S} 2$, mitochondrial & 33.25 & 1.00 & 2 & 5.4 & 0.9366 & 1.0584 & 4 \\
\hline DOPD_HUMAN & P30046 & DDT & D-dopachrome decarboxylase & 12.71 & 1.00 & 2 & 19.5 & 1.0084 & 0.5438 & 3 \\
\hline ACOT9̄9_HUMAN & Q9Y305 & ACOT9 & Acyl-coenzyme A thioesterase 9 , mitochondrial & 49.90 & 1.00 & 2 & 7.5 & 0.9366 & 2.4307 & 3 \\
\hline AK1C2_HUMAN & P52895 & $\mathrm{AKR} 1 \mathrm{C} 2$ & Aldo-keto reductase family 1 member $\mathrm{C} 2$ & 36.74 & 1.00 & 2 & 9.6 & 1.1799 & 0.7411 & 5 \\
\hline MRRP3_HUMAN & O15091 & KIAA0391 & Mitochondrial ribonuclease $\mathrm{P}$ protein 3 & 67.32 & 1.00 & 2 & 3.1 & 0.8297 & 1.4726 & 3 \\
\hline MDN1_HUMAN & Q9NU22 & MDN1 & Midasin & 632.82 & 1.00 & 2 & 0.4 & 1.0634 & 2.0171 & 5 \\
\hline TELO2_HUMAN & Q9Y4R8 & TELO2 & Telomere length regulation protein TEL2 homolog & 91.75 & 1.00 & 2 & 6.6 & 1.1163 & 2.1720 & 6 \\
\hline RBP2_HUMAN & P49792 & RANBP2 & E3 SUMO-protein ligase RanBP2 & 358.20 & 1.00 & 2 & 1.1 & 1.1923 & 2.5692 & 3 \\
\hline RABP2_HUMAN & P29373 & CRABP2 & Cellular retinoic acid-binding protein 2 & 15.69 & 1.00 & 2 & 13 & 0.7649 & 1.7536 & 3 \\
\hline SMU1_HUMAN & Q2TAY7 & SMU1 & WD40 repeat-containing protein SMU1 & 57.54 & 1.00 & 2 & 5.5 & 0.7814 & 1.7140 & 3 \\
\hline IF4G3_HUMAN & O43432 & EIF4G3 & Eukaryotic translation initiation factor 4 gamma 3 & 176.65 & 0.97 & 2 & 2.3 & 1.3443 & 1.5646 & 6 \\
\hline SEC63_HUMAN & Q9UGP8 & SEC63 & Translocation protein SEC63 homolog & 88.00 & 0.95 & 2 & 3 & 1.0634 & 2.3896 & 5 \\
\hline \multicolumn{11}{|c|}{ Underexpressed proteins } \\
\hline SMHD1_HUMAN & A6NHR9 & SMCHD1 & Structural maintenance of chromosomes flexible hinge domain-containing protein 1 & 226.37 & 1.00 & 3 & 2.6 & -0.6337 & 0.9707 & 4 \\
\hline DDX39_HUMAN & O00148 & DDX39 & ATP-dependent RNA helicase DDX39 & 49.13 & 1.00 & 2 & 20.6 & -0.6781 & 0.6309 & 5 \\
\hline PSD11 HUMAN & O00231 & PSMD11 & $26 \mathrm{~S}$ proteasome non-ATPase regulatory subunit 11 & 47.46 & 1.00 & 4 & 12.8 & -0.7712 & 1.7199 & 10 \\
\hline PDCD $\overline{5}$ HUMAN & O14737 & PDCD5 & Programmed cell death protein 5 & 14.29 & 1.00 & 3 & 28 & -1.4301 & 2.3647 & 8 \\
\hline PUR4_HUMAN & O15067 & PFAS & Phosphoribosylformylglycinamidine synthase & 144.72 & 1.00 & 9 & 11.7 & -0.7239 & 2.1423 & 16 \\
\hline PSMD3_HUMAN & O43242 & PSMD3 & 26S proteasome non-ATPase regulatory subunit 3 & 60.98 & 1.00 & 4 & 8.6 & -1.2186 & 2.1596 & 6 \\
\hline HNRPR_HUMAN & O43390 & HNRNPR & Heterogeneous nuclear ribonucleoprotein $\mathrm{R}$ & 70.94 & 1.00 & 4 & 14.2 & -0.8201 & 1.6005 & 13 \\
\hline XPOT HUMAN & O43592 & XPOT & Exportin-T & 109.96 & 1.00 & 4 & 5.7 & -1.0931 & 2.3599 & 6 \\
\hline JIP4_HUMAN & O60271 & SPAG9 & C-Jun-amino-terminal kinase-interacting protein 4 & 146.21 & 1.00 & 3 & 2.3 & -1.0342 & 1.6090 & 9 \\
\hline HNRPQ HUMAN & O60506 & SYNCRIP & Heterogeneous nuclear ribonucleoprotein Q & 69.60 & 1.00 & 7 & 21.3 & -0.7239 & 1.3552 & 16 \\
\hline H2AY_HUMAN & O75367 & H2AFY & Core histone macro-H2A.1 & 39.62 & 1.00 & 7 & 20.7 & -0.7712 & 1.1940 & 15 \\
\hline HSBP1_HUMAN & O75506 & HSBP1 & Heat shock factor-binding protein 1 & 8.54 & 1.00 & 3 & 64.5 & -1.0342 & 1.6513 & 6 \\
\hline LYPA1_HUMAN & O75608 & LYPLA1 & Acyl-protein thioesterase 1 & 24.67 & 1.00 & 2 & 11.7 & -0.9232 & 0.9214 & 8 \\
\hline UTP20_HUMAN & O75691 & UTP20 & Small subunit processome component 20 homolog & 318.39 & 1.00 & 3 & 1.9 & -1.1545 & 1.1340 & 4 \\
\hline NU155_HUMAN & O75694 & NUP155 & Nuclear pore complex protein Nup155 & 155.20 & 1.00 & 3 & 3.8 & -1.5906 & 1.1230 & 8 \\
\hline IDHC_HUMAN & O75874 & IDH1 & Isocitrate dehydrogenase [NADP] cytoplasmic & 46.66 & 1.00 & 5 & 12.8 & -0.7712 & 1.9620 & 12 \\
\hline MTA2_HUMAN & O94776 & MTA2 & Metastasis-associated protein MTA2 & 75.02 & 1.00 & 3 & 6.7 & -0.6337 & 0.5728 & 6 \\
\hline ERLN2̄HUMAN & O94905 & ERLIN2 & Erlin-2 & 37.84 & 1.00 & 2 & 9.4 & -1.0931 & 0.7635 & 4 \\
\hline HPRT_HUMAN & P00492 & HPRT1 & Hypoxanthine-guanine phosphoribosyltransferase & 24.58 & 1.00 & 7 & 33.9 & -0.8201 & 1.8778 & 17 \\
\hline PGK1_HUMAN & $\mathrm{P} 00558$ & PGK1 & Phosphoglycerate kinase 1 & 44.61 & 1.00 & 17 & 53.2 & -0.6337 & 1.7798 & 67 \\
\hline
\end{tabular}




\begin{tabular}{|c|c|c|c|c|c|c|c|c|c|c|}
\hline LMNA_HUMAN & P02545 & LMNA & Lamin-A/C & 74.14 & 1.00 & 13 & 25.8 & -0.7712 & 2.1566 & 36 \\
\hline PYGL_HUMAN & P06737 & PYGL & Glycogen phosphorylase, liver form & 97.15 & 1.00 & 3 & 9.9 & -0.7239 & 1.7064 & 5 \\
\hline LDHB_HUMAN & P07195 & LDHB & L-lactate dehydrogenase B chain & 36.64 & 1.00 & 10 & 42.5 & -0.9776 & 1.5557 & 102 \\
\hline TBB5_HUMAN & P07437 & TUBB & Tubulin beta chain & 49.67 & 1.00 & 4 & 64 & -1.0342 & 1.1865 & 29 \\
\hline 4F2_HUMAN & P08195 & SLC3A2 & 4F2 cell-surface antigen heavy chain & 67.99 & 1.00 & 12 & 22.5 & -0.7712 & 2.5066 & 49 \\
\hline K6PF_HUMAN & P08237 & PFKM & 6-phosphofructokinase, muscle type & 85.18 & 1.00 & 4 & 8.2 & -0.7239 & 0.5715 & 6 \\
\hline VIME_HUMAN & P08670 & VIM & Vimentin & 53.65 & 1.00 & 7 & 20.8 & -1.0342 & 0.9056 & 17 \\
\hline RSSA_HUMAN & P08865 & RPSA & 40S ribosomal protein $\mathrm{SA}$ & 32.85 & 1.00 & 6 & 25.8 & -0.9232 & 1.8832 & 69 \\
\hline DLDH_HUMAN & P09622 & DLD & Dihydrolipoyl dehydrogenase, mitochondrial & 54.18 & 1.00 & 4 & 11 & -1.1545 & 0.9407 & 4 \\
\hline G6PD_HUMAN & P11413 & G6PD & Glucose-6-phosphate 1-dehydrogenase & 59.26 & 1.00 & 8 & 19.2 & -0.6781 & 2.7729 & 19 \\
\hline K2C5_HUMAN & P13647 & KRT5 & Keratin, type II cytoskeletal 5 & 62.38 & 1.00 & 10 & 22.7 & -0.9232 & 1.5674 & 30 \\
\hline ETFA_HUMAN & P13804 & ETFA & Electron transfer flavoprotein subunit alpha, mitochondrial & 35.08 & 1.00 & 4 & 17.1 & -0.7712 & 2.0402 & 7 \\
\hline MIF_HUMAN & P14174 & MIF & Macrophage migration inhibitory factor & 12.48 & 1.00 & 3 & 23.5 & -0.9232 & 2.4249 & 39 \\
\hline IDE_HUMAN & P14735 & IDE & Insulin-degrading enzyme & 117.97 & 1.00 & 3 & 4.1 & -0.7239 & 2.2709 & 6 \\
\hline PLAK_HUMAN & P14923 & JUP & Junction plakoglobin & 81.74 & 1.00 & 7 & 20.7 & -1.0931 & 2.4490 & 8 \\
\hline NCPR_HUMAN & P16435 & POR & NADPH--cytochrome P450 reductase & 76.69 & 1.00 & 6 & 10.5 & -0.6337 & 1.7100 & 11 \\
\hline RL7_HUMAN & P18124 & RPL7 & 60S ribosomal protein L7 & 29.23 & 1.00 & 9 & 35.1 & -0.8201 & 2.2746 & 24 \\
\hline HXK1_HUMAN & P19367 & HK1 & Hexokinase-1 & 102.49 & 1.00 & 6 & 9.8 & -0.7239 & 0.8325 & 31 \\
\hline PUR6_HUMAN & P22234 & PAICS & Multifunctional protein ADE2 & 47.08 & 1.00 & 9 & 26.8 & -0.6781 & 1.8101 & 25 \\
\hline PSA4_HUMAN & P25789 & PSMA4 & Proteasome subunit alpha type- 4 & 29.48 & 1.00 & 5 & 25.3 & -0.7239 & 1.0820 & 8 \\
\hline AMPL_HUMAN & P28838 & LAP3 & Cytosol aminopeptidase & 56.17 & 1.00 & 3 & 15 & -0.8707 & 2.5369 & 7 \\
\hline S10A2_HUMAN & P29034 & $\mathrm{S} 100 \mathrm{~A} 2$ & Protein S100-A2 & 11.12 & 1.00 & 2 & 16.3 & -1.0342 & 0.8993 & 3 \\
\hline ATPD_HUMAN & P30049 & ATP5D & ATP synthase subunit delta, mitochondrial & 17.49 & 1.00 & 2 & 13.7 & -0.8201 & 0.6047 & 5 \\
\hline RL12_HUMAN & P30050 & RPL12 & $60 \mathrm{~S}$ ribosomal protein $\mathrm{L} 12$ & 17.82 & 1.00 & 3 & 21.2 & -0.6781 & 2.6059 & 18 \\
\hline 2AAA_HUMAN & P30153 & PPP2R1A & Serine/threonine-protein phosphatase $2 \mathrm{~A} 65 \mathrm{kDa}$ regulatory subunit $\mathrm{A}$ alpha isoform & 65.31 & 1.00 & 7 & 25.8 & -0.7239 & 1.0638 & 40 \\
\hline SORCN_HUMAN & P30626 & SRI & Sorcin & 21.68 & 1.00 & 3 & 15.2 & -0.9776 & 3.1530 & 7 \\
\hline RPB2_HUMAN & P30876 & POLR2B & DNA-directed RNA polymerase II subunit RPB2 & 133.90 & 1.00 & 5 & 4.5 & -0.9776 & 2.5661 & 9 \\
\hline DUT_HUMAN & P33316 & DUT & Deoxyuridine 5'-triphosphate nucleotidohydrolase, mitochondrial & 26.71 & 1.00 & 5 & 23 & -0.6337 & 1.1011 & 14 \\
\hline MCM7'HUMAN & P33993 & MCM7 & DNA replication licensing factor MCM7 & 81.31 & 1.00 & 14 & 25.5 & -1.0342 & 2.5625 & 37 \\
\hline ARL3_HUMAN & P36405 & ARL3 & ADP-ribosylation factor-like protein 3 & 20.46 & 1.00 & 3 & 19.2 & -1.9776 & 1.5966 & 8 \\
\hline ODO2_HUMAN & P36957 & DLST & Dihydrolipoyllysine-residue succinyltransferase component of 2 -oxoglutarate dehydrogenase complex, mitochondrial & 48.73 & 1.00 & 5 & 15 & -0.9232 & 2.1918 & 10 \\
\hline FDFT_HUMAN & P37268 & FDFT1 & Squalene synthase & 48.12 & 1.00 & 3 & 7.9 & -1.6781 & 0.8607 & 5 \\
\hline TAGL2_HUMAN & P37802 & TAGLN2 & Transgelin-2 & 22.39 & 1.00 & 9 & 59.3 & -0.8707 & 2.1550 & 49 \\
\hline
\end{tabular}

Table S-5-2 page 15 of 45 


\begin{tabular}{|c|c|c|c|c|c|c|c|c|c|}
\hline MDHC_HUMAN & P40925 & MDH1 & Malate dehydrogenase, cytoplasmic & 36.43 & 1.00 & 5 & 21.3 & -0.6337 & 1.6358 \\
\hline BUD31_HUMAN & P41223 & BUD31 & Protein BUD31 homolog & 17.00 & 1.00 & 2 & 13.9 & -1.2186 & 1.2548 \\
\hline BAT3_HUMAN & P46379 & BAT3 & Large proline-rich protein BAT3 & 119.41 & 1.00 & 2 & 2.7 & -0.7712 & 1.5031 \\
\hline RL21_HUMAN & P46778 & RPL21 & 60 S ribosomal protein L21 & 18.56 & 1.00 & 6 & 38.8 & -0.8201 & 1.1698 \\
\hline RS10_HUMAN & P46783 & RPS10 & 40S ribosomal protein $\mathrm{S} 10$ & 18.90 & 1.00 & 6 & 38.2 & -0.9776 & 1.3151 \\
\hline ATPO_HUMAN & P48047 & ATP5O & ATP synthase subunit $\mathrm{O}$, mitochondrial & 23.28 & 1.00 & 3 & 24.9 & -0.7239 & 0.7344 \\
\hline PPCE_HUMAN & P48147 & PREP & Prolyl endopeptidase & 80.70 & 1.00 & 3 & 7.5 & -1.2858 & 2.2986 \\
\hline ERG7_HUMAN & P48449 & LSS & Lanosterol synthase & 83.31 & 1.00 & 3 & 4.9 & -0.6781 & 1.9812 \\
\hline SYAC_HUMAN & P49588 & AARS & Alanyl-tRNA synthetase, cytoplasmic & 106.81 & 1.00 & 13 & 18.2 & -0.6781 & 2.4564 \\
\hline PSB3_HUMAN & P49720 & PSMB3 & Proteasome subunit beta type-3 & 22.95 & 1.00 & 2 & 16.6 & -0.7239 & 2.1820 \\
\hline PSB2_HUMAN & P49721 & PSMB2 & Proteasome subunit beta type- 2 & 22.84 & 1.00 & 3 & 13.9 & -1.4301 & 0.8044 \\
\hline MCM2_HUMAN & P49736 & MCM2 & DNA replication licensing factor MCM2 & 101.90 & 1.00 & 6 & 7.6 & -0.6781 & 1.5101 \\
\hline BAP31_HUMAN & P51572 & BCAP31 & B-cell receptor-associated protein 31 & 27.99 & 1.00 & 5 & 18.7 & -0.6781 & 0.6963 \\
\hline HDGF_HUMAN & P51858 & HDGF & Hepatoma-derived growth factor & 26.79 & 1.00 & 8 & 43.8 & -0.9232 & 1.6253 \\
\hline GDIR1_HUMAN & P52565 & ARHGDIA & Rho GDP-dissociation inhibitor 1 & 23.21 & 1.00 & 2 & 15.2 & -0.8707 & 1.3781 \\
\hline AMPM1_HUMAI & P53582 & METAP1 & Methionine aminopeptidase 1 & 43.22 & 1.00 & 2 & 7.5 & -0.6337 & 0.9749 \\
\hline PSMD4_HUMAN & P55036 & PSMD4 & 26S proteasome non-ATPase regulatory subunit 4 & 40.74 & 1.00 & 2 & 8.8 & -0.9232 & 2.8814 \\
\hline TERA_HUMAN & P55072 & VCP & Transitional endoplasmic reticulum ATPase & 89.32 & 1.00 & 19 & 34.4 & -0.8201 & 1.8348 \\
\hline NP1L1_HUMAN & P55209 & NAP1L1 & Nucleosome assembly protein 1-like 1 & 45.37 & 1.00 & 6 & 25.8 & -0.7239 & 1.8240 \\
\hline PSA_HUMAN & P55786 & NPEPPS & Puromycin-sensitive aminopeptidase & 103.28 & 1.00 & 5 & 6.6 & -0.6781 & 2.6070 \\
\hline CTBP2_HUMAN & P56545 & СТBP2 & C-terminal-binding protein 2 & 48.94 & 1.00 & 2 & 4.3 & -0.7239 & 0.9556 \\
\hline MYL6_HUMAN & P60660 & MYL6 & Myosin light polypeptide 6 & 16.93 & 1.00 & 5 & 41.1 & -0.8707 & 1.7167 \\
\hline RAB14_HUMAN & P61106 & RAB14 & Ras-related protein Rab-14 & 23.90 & 1.00 & 2 & 12.6 & -0.9776 & 1.3296 \\
\hline ARP3_HUMAN & P61158 & ACTR3 & Actin-related protein 3 & 47.37 & 1.00 & 5 & 23.2 & -0.6337 & 2.2957 \\
\hline CSN2_HUMAN & P61201 & COPS2 & COP9 signalosome complex subunit 2 & 51.60 & 1.00 & 2 & 6.1 & -0.8707 & 0.7409 \\
\hline S61A1̄_HUMAN & P61619 & SEC61A1 & Protein transport protein Sec61 subunit alpha isoform 1 & 52.26 & 1.00 & 5 & 16.2 & -0.7239 & 1.3190 \\
\hline PRS8_HUMAN & P62195 & PSMC5 & $26 \mathrm{~S}$ protease regulatory subunit 8 & 45.63 & 1.00 & 4 & 13.5 & -1.2858 & 2.6086 \\
\hline RS13_HUMAN & P62277 & RPS13 & $40 \mathrm{~S}$ ribosomal protein $\mathrm{S} 13$ & 17.22 & 1.00 & 6 & 38.4 & -1.1545 & 1.4944 \\
\hline PRS10_HUMAN & P62333 & PSMC6 & $26 \mathrm{~S}$ protease regulatory subunit $\mathrm{S} 10 \mathrm{~B}$ & 44.17 & 1.00 & 4 & 16.2 & -0.8707 & 1.2099 \\
\hline RL10A_HUMAN & P62906 & RPL10A & $60 \mathrm{~S}$ ribosomal protein $\mathrm{L} 10 \mathrm{a}$ & 24.83 & 1.00 & 7 & 32.3 & -1.2186 & 1.7334 \\
\hline RAC1_HUMAN & P63000 & RAC1 & Ras-related C3 botulinum toxin substrate 1 & 21.45 & 1.00 & 3 & 34.9 & -0.6781 & 2.1297 \\
\hline RL38_HUMAN & P63173 & RPL38 & 60 S ribosomal protein $\mathrm{L} 38$ & 8.22 & 1.00 & 2 & 31.4 & -1.2858 & 0.1383 \\
\hline GBG5_HUMAN & P63218 & GNG5 & Guanine nucleotide-binding protein $\mathrm{G}(\mathrm{I}) / \mathrm{G}(\mathrm{S}) / \mathrm{G}(\mathrm{O})$ subunit gamma-5 & 7.32 & 1.00 & 2 & 52.9 & -0.7239 & 0.2016 \\
\hline ERH_HUMAN & P84090 & ERH & Enhancer of rudimentary homolog & 12.26 & 1.00 & 3 & 23.1 & -1.3561 & 2.2092 \\
\hline MPCP_HUMAN & Q00325 & SLC25A3 & Phosphate carrier protein, mitochondrial & 40.09 & 1.00 & 6 & 19.1 & -1.5081 & 1.8703 \\
\hline K6PP_HUMAN & Q01813 & PFKP & 6-phosphofructokinase type C & 85.60 & 1.00 & 8 & 18.4 & -0.7239 & 1.9297 \\
\hline
\end{tabular}

Table S-5-2 page 16 of 45 


\begin{tabular}{|c|c|c|c|c|c|c|c|c|c|c|}
\hline PLCB3_HUMAN & Q01970 & PLCB3 & 1-phosphatidylinositol-4,5-bisphosphate phosphodiesterase beta-3 & 138.80 & 1.00 & 4 & 4.7 & -0.6337 & 2.6257 & 8 \\
\hline M2OM_HUMAN & Q02978 & SLC25A11 & Mitochondrial 2-oxoglutarate/malate carrier protein & 34.06 & 1.00 & 4 & 13.1 & -1.5906 & 1.2363 & 11 \\
\hline TNAP2_HUMAN & Q03169 & TNFAIP2 & Tumor necrosis factor alpha-induced protein 2 & 72.66 & 1.00 & 2 & 5.5 & -2.5081 & 1.2631 & 5 \\
\hline CEBPZ_HUMAN & Q03701 & CEBPZ & CCAAT/enhancer-binding protein zeta & 120.99 & 1.00 & 2 & 3.1 & -1.4301 & 3.5934 & 3 \\
\hline PRDX1_HUMAN & Q06830 & PRDX1 & Peroxiredoxin-1 & 22.11 & 1.00 & 4 & 36.2 & -0.7712 & 1.2423 & 27 \\
\hline FLII_HŪMAN & Q13045 & FLII & Protein flightless-1 homolog & 144.75 & 1.00 & 5 & 4.7 & -1.7712 & 2.3644 & 6 \\
\hline MTĀP_HUMAN & Q13126 & MTAP & S-methyl-5'-thioadenosine phosphorylase & 31.24 & 1.00 & 5 & 33.2 & -0.6781 & 2.0001 & 13 \\
\hline TADBP_HUMAN & Q13148 & TARDBP & TAR DNA-binding protein 43 & 44.74 & 1.00 & 4 & 15 & -0.7712 & 2.7168 & 16 \\
\hline COTL1_HUMAN & Q14019 & COTL1 & Coactosin-like protein & 15.94 & 1.00 & 5 & 48.6 & -0.7239 & 2.8187 & 21 \\
\hline HNRPD_HUMAN & Q14103 & HNRNPD & Heterogeneous nuclear ribonucleoprotein D0 & 38.43 & 1.00 & 3 & 13.8 & -0.8707 & 1.5040 & 19 \\
\hline UBP2L_HUMAN & Q14157 & UBAP2L & Ubiquitin-associated protein 2-like & 114.53 & 1.00 & 7 & 10.3 & -0.8707 & 3.1702 & 12 \\
\hline TRI25_HUMAN & Q14258 & TRIM25 & E3 ubiquitin/ISG15 ligase TRIM25 & 70.99 & 1.00 & 3 & 6.7 & -1.1545 & 2.7668 & 10 \\
\hline MCM $\overline{6}$ HUMAN & Q14566 & MCM6 & DNA replication licensing factor MCM6 & 92.89 & 1.00 & 11 & 15.6 & -0.9776 & 1.9739 & 38 \\
\hline RB3GP_HUMAN & Q15042 & RAB3GAP1 & Rab3 GTPase-activating protein catalytic subunit & 110.52 & 1.00 & 2 & 3.4 & -1.5081 & 1.5626 & 4 \\
\hline PDIA6_HUMAN & Q15084 & PDIA6 & Protein disulfide-isomerase A6 & 48.12 & 1.00 & 7 & 20.2 & -1.2186 & 2.1299 & 31 \\
\hline NONO_HUMAN & Q15233 & NONO & Non-POU domain-containing octamer-binding protein & 54.23 & 1.00 & 10 & 33.8 & -1.0931 & 2.6954 & 31 \\
\hline PCBP1_HUMAN & Q15365 & PCBP1 & Poly(rC)-binding protein 1 & 37.50 & 1.00 & 8 & 52.8 & -0.8707 & 2.1975 & 31 \\
\hline PCBP2_HUMAN & Q15366 & PCBP2 & Poly(rC)-binding protein 2 & 38.58 & 1.00 & 7 & 46.3 & -1.0342 & 1.5828 & 39 \\
\hline SF01_HUMAN & Q15637 & SF1 & Splicing factor 1 & 68.33 & 1.00 & 6 & 13.1 & -0.9776 & 0.7664 & 17 \\
\hline ELAV̄1_HUMAN & Q15717 & ELAVL1 & ELAV-like protein 1 & 36.09 & 1.00 & 6 & 22.7 & -1.5081 & 1.1862 & 13 \\
\hline AAAT_HUMAN & Q15758 & SLC1A5 & Neutral amino acid transporter $\mathrm{B}(0)$ & 56.60 & 1.00 & 3 & 11.1 & -1.3561 & 3.8611 & 8 \\
\hline DDB1_HUMAN & Q16531 & DDB1 & DNA damage-binding protein 1 & 126.97 & 1.00 & 7 & 6.4 & -0.9232 & 1.3679 & 14 \\
\hline CE022_HUMAN & Q49AR2 & C5orf22 & UPF0489 protein C5orf22 & 49.97 & 1.00 & 2 & 6.8 & -1.3561 & 0.9165 & 4 \\
\hline DHB12_HUMAN & Q53GQ0 & HSD17B12 & Estradiol 17-beta-dehydrogenase 12 & 34.32 & 1.00 & 4 & 17 & -1.2858 & 0.9918 & 4 \\
\hline H90B4_HUMAN & Q58FF6 & HSP90AB4P & Putative heat shock protein HSP 90-beta 4 & 58.26 & 1.00 & 2 & 9.9 & -1.0931 & 0.5225 & 8 \\
\hline SAPS3_HUMAN & Q5H9R7 & SAPS3 & Serine/threonine-protein phosphatase 6 regulatory subunit 3 & 97.67 & 1.00 & 4 & 5.6 & -1.4301 & 1.8459 & 13 \\
\hline RIF1_HUMAN & Q5UIP0 & RIF1 & Telomere-associated protein RIF1 & 274.47 & 1.00 & 3 & 1.9 & -0.6337 & 1.1528 & 5 \\
\hline RL7L_HUMAN & Q6DKI1 & RPL7L1 & 60S ribosomal protein L7-like 1 & 28.66 & 1.00 & 3 & 17.1 & -1.5906 & 2.8468 & 4 \\
\hline LARP1_HUMAN & Q6PKG0 & LARP1 & La-related protein 1 & 123.51 & 1.00 & 7 & 7.7 & -0.7239 & 1.6973 & 14 \\
\hline CYFP1_HUMAN & Q7L576 & CYFIP1 & Cytoplasmic FMR1-interacting protein 1 & 145.18 & 1.00 & 4 & 3.5 & -2.3561 & 1.6822 & 8 \\
\hline TXND5_HUMAN & Q8NBS9 & TXNDC5 & Thioredoxin domain-containing protein 5 & 47.63 & 1.00 & 5 & 15.7 & -1.4301 & 1.8366 & 18 \\
\hline PDC6I_HUMAN & Q8WUM4 & PDCD6IP & Programmed cell death 6-interacting protein & 96.02 & 1.00 & 4 & 6.6 & -0.9232 & 1.4791 & 8 \\
\hline CTF18_HUMAN & Q8WVB6 & CHTF18 & Chromosome transmission fidelity protein 18 homolog & 107.38 & 1.00 & 2 & 3.7 & -1.1545 & 2.4860 & 6 \\
\hline CKAP2_HUMAN & Q8WWK9 & CKAP2 & Cytoskeleton-associated protein 2 & 76.99 & 1.00 & 2 & 3.7 & -0.6337 & 1.6552 & 5 \\
\hline CTBL1_HUMAN & Q8WYA6 & CTNNBL1 & Beta-catenin-like protein 1 & 65.17 & 1.00 & 4 & 6.4 & -0.9232 & 2.0718 & 7 \\
\hline CSN5_HUMAN & Q92905 & COPS5 & COP9 signalosome complex subunit 5 & 37.58 & 1.00 & 2 & 6.9 & -1.4301 & 1.4294 & 4 \\
\hline
\end{tabular}

Table S-5-2 page 17 of 45 
PRDBP_HUMAN Q969G5 PRKCDBP Protein kinase C delta-binding protein EXOS8_HUMAN Q96B26 EXOSC8 Exosome complex exonuclease RRP43 P5CR2_HUMAN Q96C36 PYCR2 AP2M1_HUMAN Q96CW1 AP2M1 PTCD3_HUMAN Q96EY7 PTCD3 ITCH_HUMAN DOCK 7 HUMAN RBM14 HUMAN PUS7 HUMAN SRPK1 HUMAN EIF3C_HUMAN PHB2_HUMAN NP1L4_HUMAN EBP2 HUMAN COR1B HUMAN TXD17_HUMAN CJ119 HUMAN HNRL1_HUMAN NAA15 HUMAN SRRT HUMAN RAB1B_HUMAN NELFA_HUMAN RPF2_HUMAN SFXN1_HUMAN GLOD4 HUMAN Q9HC38 GLOD4 BAZ1A HUMAN Q9NRL2 BAZ1A DDX18_HUMAN Q9NVP1 DDX18 TMOD3_HUMAN Q9NYL9 TMOD3 GRHPR HUMAN Q9UBQ7 GRHPR CHRD1_HUMAN Q9UHD1 CHORDC1 CMC2_HUMAN Q9UJS0 SLC25A13 PSME2_HUMAN Q9UL46 PSME2 MCTS1_HUMAN Q9ULC4 MCTS1 PRP19_HUMAN Q9UMS4 PRPF19 DIMT1_HUMAN Q9UNQ2 DIMT1L CSN3_HUMAN Q9UNS2 COPS3

Pyrroline-5-carboxylate reductase 2

$\begin{array}{ccccccc}27.63 & 1.00 & 2 & 5.7 & -0.6781 & 0.5888 & 6 \\ 30.04 & 1.00 & 2 & 15.6 & -2.3561 & 0.8147 & 4 \\ 33.64 & 1.00 & 5 & 19.1 & -0.7239 & 2.0057 & 8 \\ 49.65 & 1.00 & 2 & 9.7 & -0.6781 & 1.1794 & 3 \\ 78.55 & 1.00 & 3 & 5.2 & -0.6781 & 1.3602 & 5 \\ 102.80 & 1.00 & 2 & 2.2 & -0.9776 & 2.2841 & 4 \\ 242.56 & 1.00 & 2 & 1.4 & -1.6781 & 0.9897 & 5 \\ 69.49 & 1.00 & 7 & 12.6 & -0.6337 & 2.5758 & 15 \\ 75.04 & 1.00 & 2 & 3.6 & -2.8707 & 0.7364 & 4 \\ 74.32 & 1.00 & 4 & 7.5 & -1.2186 & 1.5383 & 6 \\ 105.34 & 1.00 & 9 & 10.1 & -0.6781 & 2.3674 & 22 \\ 33.30 & 1.00 & 8 & 29.8 & -1.0342 & 1.3620 & 27 \\ 42.82 & 1.00 & 2 & 6.7 & -0.7712 & 0.9345 & 5 \\ 34.85 & 1.00 & 3 & 10.8 & -0.7239 & 1.8929 & 7 \\ 54.23 & 1.00 & 2 & 4.1 & -0.8707 & 1.5794 & 7 \\ 13.94 & 1.00 & 2 & 15.4 & -1.0342 & 0.8565 & 3 \\ 72.98 & 1.00 & 6 & 9.7 & -0.6781 & 1.5836 & 20 \\ 95.74 & 1.00 & 2 & 3.5 & -0.7712 & 0.4198 & 6 \\ 101.27 & 1.00 & 5 & 5.9 & -0.6337 & 0.7821 & 11 \\ 100.67 & 1.00 & 5 & 4.6 & -0.9232 & 1.9951 & 9 \\ 22.17 & 1.00 & 4 & 23.9 & -1.2186 & 1.1183 & 7 \\ 57.28 & 1.00 & 2 & 6.8 & -1.4301 & 3.9096 & 5 \\ 35.58 & 1.00 & 3 & 9.5 & -1.6781 & 4.3298 & 6 \\ 35.62 & 1.00 & 4 & 21.7 & -0.7239 & 0.4405 & 6 \\ 34.79 & 1.00 & 3 & 11.5 & -0.8201 & 0.8575 & 5 \\ 178.70 & 1.00 & 2 & 1.5 & -0.8201 & 0.6942 & 5 \\ 75.41 & 1.00 & 6 & 11.9 & -0.7239 & 1.4015 & 13 \\ 39.59 & 1.00 & 2 & 7.1 & -0.7712 & 0.2163 & 5 \\ 35.67 & 1.00 & 2 & 14.9 & -1.7712 & 2.0311 & 8 \\ 37.49 & 1.00 & 3 & 16.3 & -0.8201 & 1.3656 & 9 \\ 74.18 & 1.00 & 3 & 5.8 & -0.6337 & 1.8729 & 7 \\ 27.40 & 1.00 & 2 & 21.3 & -0.8201 & 1.6213 & 5 \\ 20.56 & 1.00 & 3 & 30.9 & -0.9776 & 1.1743 & 10 \\ 55.18 & 1.00 & 3 & 11.5 & -0.9776 & 2.4517 & 6 \\ 35.24 & 1.00 & 2 & 8.6 & -1.0931 & 2.2935 & 4 \\ 47.87 & 1.00 & 3 & 10.4 & -0.9776 & 1.6600 & 5\end{array}$

Table S-5-2 page 18 of 45 


\begin{tabular}{|c|c|c|c|c|c|c|c|c|c|c|}
\hline VDAC3_HUMAN & Q9Y277 & VDAC3 & Voltage-dependent anion-selective channel protein 3 & 30.66 & 1.00 & 2 & 10.6 & -1.5081 & 0.7624 & 10 \\
\hline KDM2A_HUMAT & Q9Y2K7 & KDM2A & Lysine-specific demethylase 2A & 132.79 & 1.00 & 3 & 3.3 & -0.9776 & 2.3501 & 10 \\
\hline UBP15_HUMAN & Q9Y4E8 & USP15 & Ubiquitin carboxyl-terminal hydrolase 15 & 112.42 & 1.00 & 2 & 3 & -0.7239 & 3.9128 & 3 \\
\hline COPG_HUMAN & Q9Y678 & COPG & Coatomer subunit gamma & 97.72 & 1.00 & 8 & 14.4 & -0.7239 & 1.6506 & 24 \\
\hline RAP1B_HUMAN & P61224 & RAP1B & Ras-related protein Rap- $1 \mathrm{~b}$ & 20.82 & 1.00 & 5 & 33.2 & -0.6781 & 3.1948 & 12 \\
\hline KAP0_HUMAN & P10644 & PRKAR1A & cAMP-dependent protein kinase type I-alpha regulatory subunit & 42.98 & 1.00 & 3 & 11.3 & -0.8201 & 2.1589 & 4 \\
\hline K0090_HUMAN & Q8N766 & KIAA0090 & Uncharacterized protein KIAA0090 & 111.76 & 1.00 & 2 & 2.2 & -1.1545 & 0.1073 & 3 \\
\hline POP1_HUMAN & Q99575 & POP1 & Ribonucleases P/MRP protein subunit POP1 & 114.71 & 1.00 & 3 & 3.5 & -0.7712 & 1.5651 & 4 \\
\hline NUP50_HUMAN & Q9UKX7 & NUP50 & Nuclear pore complex protein Nup50 & 50.14 & 1.00 & 2 & 4.5 & -1.3561 & 3.2831 & 3 \\
\hline MEP50_HUMAN & Q9BQA1 & WDR77 & Methylosome protein 50 & 36.72 & 1.00 & 2 & 6.1 & -1.1545 & 0.9783 & 5 \\
\hline STMN1_HUMAN & P16949 & STMN1 & Stathmin & 17.30 & 1.00 & 2 & 15.4 & -3.6781 & 1.9808 & 4 \\
\hline IRF6_HÜMAN & O14896 & IRF6 & Interferon regulatory factor 6 & 53.13 & 1.00 & 2 & 6 & -0.7239 & 0.8613 & 8 \\
\hline TPM2_HUMAN & P07951 & TPM2 & Tropomyosin beta chain & 32.85 & 1.00 & 2 & 18.7 & -0.9232 & 2.5271 & 3 \\
\hline CPSF1_HUMAN & Q10570 & CPSF1 & Cleavage and polyadenylation specificity factor subunit 1 & 160.88 & 1.00 & 2 & 1.7 & -1.2186 & 0.6402 & 4 \\
\hline SEPT7_HUMAN & Q16181 & SEPT7 & Septin-7 & 50.68 & 1.00 & 2 & 8.5 & -0.9232 & 1.2768 & 3 \\
\hline DCTP1_HUMAN & Q9H773 & DCTPP1 & dCTP pyrophosphatase 1 & 18.68 & 1.00 & 2 & 19.4 & -0.8707 & 1.4137 & 4 \\
\hline RT34_HUMAN & P82930 & MRPS34 & $28 \mathrm{~S}$ ribosomal protein $\mathrm{S} 34$, mitochondrial & 25.65 & 1.00 & 2 & 6.9 & -0.6337 & 2.1316 & 13 \\
\hline IPYR2_HUMAN & Q9H2U2 & PPA2 & Inorganic pyrophosphatase 2 , mitochondrial & 37.92 & 1.00 & 2 & 10.5 & -0.7712 & 3.3372 & 7 \\
\hline ANR17_HUMAN & O75179 & ANKRD17 & Ankyrin repeat domain-containing protein 17 & 274.26 & 0.96 & 2 & 0.8 & -3.6781 & 1.3422 & 3 \\
\hline GRDN_HUMAN & Q3V6T2 & CCDC88A & Girdin & 216.04 & 0.93 & 2 & 0.6 & -1.4301 & 0.6140 & 12 \\
\hline
\end{tabular}


Table S-5-3. List of differentially expressed proteins in areca nut extract (ANE)-trained CGHNK2 cell lines

\begin{tabular}{|c|c|c|c|c|c|c|c|c|c|c|}
\hline $\begin{array}{l}\text { Unique and stable } \\
\text { accession no. of a } \\
\text { UniProtKB entry }\end{array}$ & $\begin{array}{l}\text { Mnemonic } \\
\text { accession } \\
\text { no. of a } \\
\text { UniProtKB } \\
\text { entry }\end{array}$ & Gene names & Protein names & $\begin{array}{l}\mathrm{MW} \\
(\mathrm{kDa})\end{array}$ & 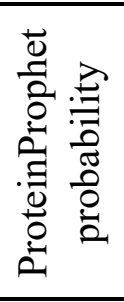 & 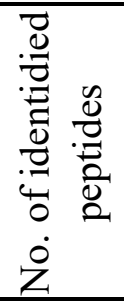 & $\begin{array}{l}0 \\
0 \\
\frac{\pi}{0} \\
0 \\
0 \\
0 \\
0 \\
0 \\
0 \\
0 \\
\end{array}$ & $\begin{array}{l}\text { Log2 ratio } \\
\text { of ANE- } \\
\text { trained/ } \\
\text { parental } \\
\text { cells }\end{array}$ & $\begin{array}{l}\text { SD of } \\
\text { peptide } \\
\text { ratios } \\
\text { from the } \\
\text { protein }\end{array}$ & 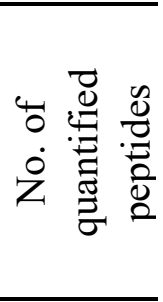 \\
\hline \multicolumn{11}{|c|}{ Overexpressed proteins } \\
\hline IMA3_HUMAN & $\mathrm{O} 00505$ & KPNA3 & Importin subunit alpha-3 & 57.81 & 1.00 & 3 & 12.9 & 0.5840 & 0.2916 & 4 \\
\hline NOP56_HUMAN & O00567 & NOP56 & Nucleolar protein 56 & 66.05 & 1.00 & 7 & 16.5 & 0.4201 & 0.6980 & 13 \\
\hline ARI1A_HUMAN & O14497 & ARID1A & AT-rich interactive domain-containing protein $1 \mathrm{~A}$ & 242.04 & 1.00 & 3 & 2 & 0.6868 & 0.6820 & 8 \\
\hline PTGES_HUMAN & O14684 & PTGES & Prostaglandin E synthase & 17.10 & 1.00 & 2 & 22.4 & 0.5044 & 0.1500 & 3 \\
\hline GIPC1_HUMAN & O14908 & GIPC1 & PDZ domain-containing protein GIPC1 & 36.05 & 1.00 & 7 & 35.7 & 0.4309 & 0.6316 & 31 \\
\hline PUR4_HUMAN & O15067 & PFAS & Phosphoribosylformylglycinamidine synthase & 144.72 & 1.00 & 4 & 4.7 & 0.3306 & 0.2694 & 10 \\
\hline K0406_HUMAN & O43156 & KIAA0406 & Uncharacterized protein KIAA0406 & 122.07 & 1.00 & 6 & 8.8 & 0.4201 & 0.4118 & 16 \\
\hline TXNL1_HUMAN & O43396 & TXNL1 & Thioredoxin-like protein 1 & 32.25 & 1.00 & 3 & 16.3 & 0.4941 & 0.6222 & 9 \\
\hline TIM44_HUMAN & O43615 & TIMM44 & Mitochondrial import inner membrane translocase subunit TIM44 & 51.36 & 1.00 & 2 & 6 & 0.5146 & 0.4387 & 3 \\
\hline SMCA $\overline{5}$ HUMAN & O60264 & SMARCA5 & SWI/SNF-related matrix-associated actin-dependent regulator of chromatin subfamily A member 5 & 121.91 & 1.00 & 4 & 7.4 & 0.3190 & 0.2990 & 7 \\
\hline PLOD3_HUMAN & O60568 & PLOD3 & Procollagen-lysine,2-oxoglutarate 5-dioxygenase 3 & 84.79 & 1.00 & 4 & 7.2 & 0.7485 & 0.3284 & 6 \\
\hline PSIP1_HUMAN & O75475 & PSIP1 & PC4 and SFRS1-interacting protein & 60.10 & 1.00 & 5 & 13.6 & 0.3761 & 0.3099 & 5 \\
\hline BAF_HUMAN & O75531 & BANF1 & Barrier-to-autointegration factor & 10.06 & 1.00 & 2 & 40.4 & 0.3648 & 0.7657 & 24 \\
\hline CSDE1_HUMAN & O75534 & CSDE1 & Cold shock domain-containing protein E1 & 88.88 & 1.00 & 5 & 8.1 & 0.3535 & 0.2479 & 19 \\
\hline PRAF3_HUMAN & O75915 & ARL6IP5 & PRA1 family protein 3 & 21.61 & 1.00 & 2 & 16 & 1.2896 & 0.9438 & 6 \\
\hline MTA2_HUMAN & O94776 & MTA2 & Metastasis-associated protein MTA2 & 75.02 & 1.00 & 3 & 4.8 & 1.1264 & 0.8128 & 17 \\
\hline SMC2_HUMAN & O95347 & SMC2 & Structural maintenance of chromosomes protein 2 & 135.66 & 1.00 & 4 & 5.8 & 0.4309 & 0.5237 & 4 \\
\hline SC24B_HUMAN & O95487 & SEC24B & Protein transport protein Sec24B & 137.42 & 1.00 & 3 & 3.2 & 0.4201 & 0.8036 & 12 \\
\hline DHE3_HUMAN & P00367 & GLUD1 & Glutamate dehydrogenase 1 , mitochondrial & 61.40 & 1.00 & 9 & 26.5 & 0.3190 & 0.2595 & 27 \\
\hline COX2_HUMAN & P00403 & $\mathrm{MT}-\mathrm{CO} 2$ & Cytochrome c oxidase subunit 2 & 25.57 & 1.00 & 3 & 17.6 & 0.6410 & 0.3492 & 8 \\
\hline ASSY_HUMAN & P00966 & ASS1 & Argininosuccinate synthase & 46.53 & 1.00 & 2 & 5.6 & 0.9573 & 0.4825 & 4 \\
\hline FINC_HUMAN & $\mathrm{P} 02751$ & FN1 & Fibronectin & 262.61 & 1.00 & 17 & 10.6 & 1.4309 & 0.3631 & 23 \\
\hline TFR1_HUMAN & P02786 & TFRC & Transferrin receptor protein 1 & 84.87 & 1.00 & 14 & 22.8 & 0.3761 & 0.2829 & 28 \\
\hline HSPB1_HUMAN & P04792 & HSPB1 & Heat shock protein beta-1 & 22.78 & 1.00 & 6 & 45.4 & 0.9117 & 0.1708 & 12 \\
\hline ALDH2_HUMAN & P05091 & ALDH2 & Aldehyde dehydrogenase, mitochondrial & 56.38 & 1.00 & 2 & 7 & 0.5146 & 0.4357 & 6 \\
\hline HMGN1_HUMAI & P05114 & HMGN1 & Non-histone chromosomal protein HMG-14 & 10.66 & 1.00 & 2 & 22 & 0.3190 & 0.4173 & 6 \\
\hline
\end{tabular}




\begin{tabular}{|c|c|c|c|c|c|c|c|c|c|c|}
\hline PAI2_HUMAN & P05120 & SERPINB2 & Plasminogen activator inhibitor 2 & 46.60 & 1.00 & 7 & 26.5 & 0.3421 & 0.7670 & 11 \\
\hline CATD_HUMAN & P07339 & CTSD & Cathepsin D & 44.55 & 1.00 & 8 & 25.7 & 0.8647 & 0.4203 & 22 \\
\hline APT_HUMAN & P07741 & APRT & Adenine phosphoribosyltransferase & 19.61 & 1.00 & 3 & 22.8 & 0.5146 & 0.9361 & 4 \\
\hline LAMB1_HUMAN & P07942 & LAMB1 & Laminin subunit beta-1 & 198.07 & 1.00 & 6 & 5.5 & 0.6594 & 0.5172 & 17 \\
\hline TSP1_HUMAN & P07996 & THBS1 & Thrombospondin-1 & 129.38 & 1.00 & 10 & 10.7 & 0.3982 & 0.2715 & 35 \\
\hline HSP71_HUMAN & P08107 & HSPA1A & Heat shock $70 \mathrm{kDa}$ protein $1 \mathrm{~A} / 1 \mathrm{~B}$ & 70.05 & 1.00 & 12 & 54.3 & 0.3190 & 0.5473 & 48 \\
\hline THIK_HUMAN & P09110 & ACAA1 & 3-ketoacyl-CoA thiolase, peroxisomal & 44.29 & 1.00 & 3 & 12.5 & 0.6594 & 0.6843 & 3 \\
\hline H14_HUMAN & P10412 & HIST1H1E & Histone $\mathrm{H} 1.4$ & 21.87 & 1.00 & 3 & 39.7 & 0.5840 & 0.4073 & 10 \\
\hline G6PD_HUMAN & P11413 & G6PD & Glucose-6-phosphate 1-dehydrogenase & 59.26 & 1.00 & 10 & 24.5 & 0.4092 & 0.2112 & 16 \\
\hline IMDH2_HUMAN & P12268 & IMPDH2 & Inosine-5'-monophosphate dehydrogenase 2 & 55.80 & 1.00 & 7 & 21 & 0.4309 & 0.5844 & 17 \\
\hline PLSL_HUMAN & P13796 & LCP1 & Plastin-2 & 70.29 & 1.00 & 20 & 52.2 & 0.4092 & 0.9265 & 59 \\
\hline GLU2B_B_HUMAN & P14314 & PRKCSH & Glucosidase 2 subunit beta & 59.43 & 1.00 & 7 & 16.1 & 0.3306 & 0.3727 & 19 \\
\hline H15_HŪMAN & P16401 & HIST1H1B & Histone H1.5 & 22.58 & 1.00 & 9 & 53.1 & 0.5840 & 0.4844 & 32 \\
\hline H13_HUMAN & P16402 & HIST1H1D & Histone H1.3 & 22.35 & 1.00 & 4 & 42.1 & 0.4838 & 0.2941 & 8 \\
\hline H12_HUMAN & P16403 & HIST1H1C & Histone H1.2 & 21.36 & 1.00 & 2 & 40.4 & 0.5447 & 0.2977 & 12 \\
\hline PTN1_HUMAN & P18031 & PTPN1 & Tyrosine-protein phosphatase non-receptor type 1 & 49.97 & 1.00 & 4 & 9.7 & 0.4092 & 0.3112 & 8 \\
\hline LMNB1_HUMAN & P20700 & LMNB1 & Lamin-B1 & 66.41 & 1.00 & 9 & 23.9 & 0.5348 & 0.5050 & 14 \\
\hline ITA6_HŪMAN & P23229 & ITGA6 & Integrin alpha-6 & 126.63 & 1.00 & 8 & 7.4 & 0.4416 & 0.1580 & 24 \\
\hline MAOM_HUMAN & P23368 & ME2 & NAD-dependent malic enzyme, mitochondrial & 65.44 & 1.00 & 3 & 7 & 0.3306 & 0.4846 & 7 \\
\hline HMGB2_HUMAI & P26583 & HMGB2 & High mobility group protein B2 & 24.03 & 1.00 & 2 & 17.2 & 0.6032 & 0.2678 & 6 \\
\hline EF1D_HUMAN & P29692 & EEF1D & Elongation factor 1-delta & 31.12 & 1.00 & 12 & 59.1 & 0.4309 & 0.3408 & 40 \\
\hline MARCS_HUMAI & P29966 & MARCKS & Myristoylated alanine-rich C-kinase substrate & 31.55 & 1.00 & 6 & 33.7 & 0.5044 & 0.6511 & 16 \\
\hline SDC4_HUMAN & P31431 & SDC4 & Syndecan-4 & 21.64 & 1.00 & 2 & 12.1 & 0.8486 & 0.7553 & 5 \\
\hline HNRH̄1_HUMAN & P31943 & HNRNPH1 & Heterogeneous nuclear ribonucleoprotein $\mathrm{H}$ & 49.23 & 1.00 & 4 & 25.4 & 0.3535 & 0.1656 & 6 \\
\hline 1433B_HUMAN & P31946 & YWHAB & $14-3-3$ protein beta/alpha & 28.08 & 1.00 & 6 & 61 & 0.7047 & 0.5141 & 21 \\
\hline GLYC_HUMAN & P34896 & SHMT1 & Serine hydroxymethyltransferase, cytosolic & 53.08 & 1.00 & 5 & 11.8 & 0.3306 & 0.4109 & 11 \\
\hline SPB5_HUMAN & P36952 & SERPINB5 & Serpin B5 & 42.10 & 1.00 & 13 & 46.7 & 0.5247 & 0.3986 & 42 \\
\hline CUX1_HUMAN & P39880 & CUX1 & Homeobox protein cut-like 1 & 164.19 & 1.00 & 2 & 1.9 & 0.6222 & 0.5826 & 5 \\
\hline MDHM_HUMAN & P40926 & $\mathrm{MDH} 2$ & Malate dehydrogenase, mitochondrial & 35.50 & 1.00 & 15 & 58.3 & 0.3306 & 0.3431 & 86 \\
\hline SK2L2_HUMAN & P42285 & SKIV2L2 & Superkiller viralicidic activity 2 -like 2 & 117.80 & 1.00 & 6 & 10.5 & 0.3306 & 0.7977 & 17 \\
\hline MATR3_HUMAN & P43243 & MATR3 & Matrin-3 & 94.62 & 1.00 & 13 & 21.8 & 0.3872 & 0.5940 & 38 \\
\hline NAMPT_HUMAP & P43490 & NAMPT & Nicotinamide phosphoribosyltransferase & 55.52 & 1.00 & 13 & 31.6 & 0.8726 & 0.7602 & 37 \\
\hline YAP1_HUMAN & P46937 & YAP1 & Yorkie homolog & 54.46 & 1.00 & 3 & 13.1 & 0.4416 & 1.3546 & 5 \\
\hline GSHB_HUMAN & P48637 & GSS & Glutathione synthetase & 52.38 & 1.00 & 5 & 11.2 & 0.4309 & 0.2558 & 12 \\
\hline IDHP_HUMAN & P48735 & IDH2 & Isocitrate dehydrogenase [NADP], mitochondrial & 50.91 & 1.00 & 3 & 11.7 & 0.8078 & 0.9467 & 15 \\
\hline EI2BB_HUMAN & P49770 & EIF2B2 & Translation initiation factor eIF-2B subunit beta & 38.99 & 1.00 & 3 & 12.3 & 0.3190 & 1.1090 & 6 \\
\hline
\end{tabular}




\begin{tabular}{|c|c|c|c|c|c|c|c|c|c|c|}
\hline RBP2_HUMAN & P49792 & RANBP2 & E3 SUMO-protein ligase RanBP2 & 358.20 & 1.00 & 4 & 1.9 & 0.3761 & 0.4470 & 6 \\
\hline GUAA_HUMAN & P49915 & GMPS & GMP synthase [glutamine-hydrolyzing] & 76.72 & 1.00 & 12 & 25.7 & 0.4629 & 0.4361 & 36 \\
\hline MRE11_HUMAN & P49959 & MRE11A & Double-strand break repair protein MRE11A & 80.59 & 1.00 & 3 & 7.1 & 0.4309 & 0.4530 & 7 \\
\hline SERPH_HUMAN & P50454 & SERPINH1 & Serpin H1 & 46.44 & 1.00 & 13 & 41.6 & 0.6316 & 0.4439 & 53 \\
\hline AMPM2_HUMAI & P50579 & METAP2 & Methionine aminopeptidase 2 & 52.89 & 1.00 & 4 & 12.1 & 0.3982 & 0.5419 & 9 \\
\hline BCAM_HUMAN & P50895 & BCAM & Basal cell adhesion molecule & 67.40 & 1.00 & 2 & 3.7 & 0.3306 & 0.2516 & 3 \\
\hline SMCA4_HUMAN & P51532 & SMARCA4 & Transcription activator BRG1 & 184.65 & 1.00 & 5 & 4 & 0.3421 & 0.1856 & 9 \\
\hline SPSY_HUMAN & P52788 & SMS & Spermine synthase & 41.27 & 1.00 & 6 & 27.3 & 0.6316 & 0.9560 & 9 \\
\hline HMGĀ2_HUMAT & P52926 & HMGA2 & High mobility group protein HMGI-C & 11.83 & 1.00 & 5 & 40.4 & 1.2413 & 0.4183 & 20 \\
\hline BIEA_HÜMAN & P53004 & BLVRA & Biliverdin reductase $\mathrm{A}$ & 33.43 & 1.00 & 4 & 21.3 & 0.4629 & 0.6222 & 11 \\
\hline AAKG'1_HUMAN & P54619 & PRKAG1 & 5'-AMP-activated protein kinase subunit gamma-1 & 37.58 & 1.00 & 2 & 9.1 & 0.7485 & 0.7866 & 5 \\
\hline RD23A_HUMAN & P54725 & RAD23A & UV excision repair protein RAD23 homolog A & 39.61 & 1.00 & 2 & 12.9 & 0.8805 & 1.1127 & 4 \\
\hline XPO2_HUMAN & P55060 & CSE1L & Exportin-2 & 110.42 & 1.00 & 34 & 45.4 & 0.3761 & 0.4938 & 149 \\
\hline EPIPL_HUMAN & P58107 & EPPK1 & Epiplakin & 553.09 & 1.00 & 7 & 10.2 & 0.5247 & 0.5189 & 11 \\
\hline RS20_HUMAN & P60866 & RPS20 & $40 \mathrm{~S}$ ribosomal protein $\mathrm{S} 20$ & 13.37 & 1.00 & 3 & 25.2 & 0.3761 & 0.2993 & 17 \\
\hline CSN2_HUMAN & P61201 & COPS2 & COP9 signalosome complex subunit 2 & 51.60 & 1.00 & 2 & 14.4 & 0.4734 & 0.3142 & 4 \\
\hline COPZ̄1_HUMAN & P61923 & COPZ1 & Coatomer subunit zeta-1 & 20.20 & 1.00 & 2 & 16.9 & 0.4201 & 0.6873 & 7 \\
\hline 1433G_HUMAN & P61981 & YWHAG & 14-3-3 protein gamma & 28.30 & 1.00 & 6 & 63.6 & 0.3306 & 0.4777 & 21 \\
\hline CSK2B_HUMAN & P67870 & CSNK2B & Casein kinase II subunit beta & 24.94 & 1.00 & 2 & 14.9 & 0.5247 & 0.2611 & 49 \\
\hline SFRS3_HUMAN & P84103 & SFRS3 & Splicing factor, arginine/serine-rich 3 & 19.33 & 1.00 & 3 & 26.2 & 0.4941 & 0.1997 & 5 \\
\hline CYC_HUMAN & P99999 & CYCS & Cytochrome c & 11.75 & 1.00 & 7 & 60 & 0.5247 & 0.4163 & 43 \\
\hline SET_HUMAN & Q01105 & SET & Protein SET & 33.49 & 1.00 & 6 & 31.4 & 0.4201 & 0.4712 & 27 \\
\hline H11_HUMAN & Q02539 & HIST1H1A & Histone H1.1 & 21.84 & 1.00 & 2 & 24.7 & 0.6594 & 0.2284 & 6 \\
\hline FKB̈- 4 HUMAN & Q02790 & FKBP4 & Peptidyl-prolyl cis-trans isomerase FKBP4 & 51.80 & 1.00 & 11 & 28.5 & 0.4523 & 0.3305 & 29 \\
\hline AKA12_HUMAN & Q02952 & AKAP12 & A-kinase anchor protein 12 & 191.48 & 1.00 & 4 & 4 & 0.3306 & 0.6421 & 16 \\
\hline K1C17_HUMAN & Q04695 & KRT17 & Keratin, type I cytoskeletal 17 & 48.11 & 1.00 & 16 & 65.5 & 1.4037 & 0.4788 & 100 \\
\hline CKAP4_HUMAN & Q07065 & CKAP4 & Cytoskeleton-associated protein 4 & 66.02 & 1.00 & 10 & 21.9 & 0.4523 & 0.2722 & 20 \\
\hline RM28_HUMAN & Q13084 & MRPL28 & 39S ribosomal protein L28, mitochondrial & 30.16 & 1.00 & 3 & 22.7 & 0.7136 & 0.5806 & 4 \\
\hline ACACA_HUMAI & Q13085 & ACACA & Acetyl-CoA carboxylase 1 & 265.55 & 1.00 & 10 & 7 & 0.3190 & 0.5376 & 16 \\
\hline MTAP_HUMAN & Q13126 & MTAP & S-methyl-5'-thioadenosine phosphorylase & 31.24 & 1.00 & 6 & 36.7 & 0.5348 & 0.4682 & 21 \\
\hline UB2V1_HUMAN & Q13404 & UBE2V1 & Ubiquitin-conjugating enzyme E2 variant 1 & 16.49 & 1.00 & 3 & 54.4 & 0.4629 & 0.4468 & 5 \\
\hline FKBP5_HUMAN & Q13451 & FKBP5 & Peptidyl-prolyl cis-trans isomerase FKBP5 & 51.21 & 1.00 & 4 & 8.1 & 0.3982 & 0.2820 & 4 \\
\hline TPBG_HUMAN & Q13641 & TPBG & Trophoblast glycoprotein & 46.03 & 1.00 & 2 & 7.9 & 0.3648 & 0.8648 & 4 \\
\hline BYST_HUMAN & Q13895 & BYSL & Bystin & 49.60 & 1.00 & 2 & 5 & 0.4838 & 0.1574 & 4 \\
\hline TOB2_HUMAN & Q14106 & TOB2 & Protein Tob2 & 36.63 & 1.00 & 2 & 7.6 & 0.3535 & 0.5646 & 3 \\
\hline RBM39_HUMAN & Q14498 & RBM39 & RNA-binding protein 39 & 59.38 & 1.00 & 4 & 13.6 & 0.4309 & 0.7244 & 11 \\
\hline
\end{tabular}




\begin{tabular}{|c|c|c|c|c|c|c|c|c|c|c|}
\hline TEBP_HUMAN & Q15185 & PTGES3 & Prostaglandin E synthase 3 & 18.70 & 1.00 & 5 & 36.9 & 0.3306 & 0.3208 & 42 \\
\hline RCN1_HUMAN & Q15293 & RCN1 & Reticulocalbin-1 & 38.89 & 1.00 & 4 & 13.9 & 0.3872 & 0.4736 & 8 \\
\hline BGH3_HUMAN & Q15582 & TGFBI & Transforming growth factor-beta-induced protein ig-h3 & 74.68 & 1.00 & 7 & 18 & 0.3421 & 0.6583 & 23 \\
\hline MARE1_HUMAN & Q15691 & MAPRE1 & Microtubule-associated protein RP/EB family member 1 & 30.00 & 1.00 & 8 & 41.8 & 0.4201 & 0.8163 & 20 \\
\hline DREB_HUMAN & Q16643 & DBN1 & Drebrin & 71.43 & 1.00 & 5 & 11.7 & 0.3190 & 0.1775 & 10 \\
\hline NDUA5_HUMAN & Q16718 & NDUFA5 & NADH dehydrogenase [ubiquinone] 1 alpha subcomplex subunit 5 & 13.46 & 1.00 & 2 & 22.4 & 0.7047 & 0.7228 & 4 \\
\hline NDUA9_HUMAN & Q16795 & NDUFA9 & NADH dehydrogenase [ubiquinone] 1 alpha subcomplex subunit 9 , mitochondrial & 42.51 & 1.00 & 2 & 7.7 & 0.4941 & 0.9537 & 3 \\
\hline TRXR1_HUMAN & Q16881 & TXNRD1 & Thioredoxin reductase 1 , cytoplasmic & 70.91 & 1.00 & 7 & 16.8 & 0.3982 & 0.2120 & 11 \\
\hline TSR1_HUMAN & Q2NL82 & TSR1 & Pre-rRNA-processing protein TSR 1 homolog & 91.81 & 1.00 & 4 & 6.8 & 0.4309 & 0.1922 & 5 \\
\hline DHB12_HUMAN & Q53GQ0 & HSD17B12 & Estradiol 17-beta-dehydrogenase 12 & 34.32 & 1.00 & 4 & 18.6 & 0.3306 & 0.3345 & 8 \\
\hline RIPL1_HUMAN & Q5EBL4 & RILPL1 & RILP-like protein 1 & 47.11 & 1.00 & 2 & 8.4 & 0.6316 & 0.7930 & 5 \\
\hline FKB15_HUMAN & Q5T1M5 & FKBP15 & FK506-binding protein 15 & 133.63 & 1.00 & 2 & 3.4 & 0.8962 & 0.8625 & 5 \\
\hline TUT7_HUMAN & Q5VYS8 & ZCCHC6 & Terminal uridylyltransferase 7 & 171.23 & 1.00 & 4 & 1.9 & 0.5447 & 0.4701 & 9 \\
\hline TWF2_HUMAN & Q6IBS0 & TWF2 & Twinfilin-2 & 39.55 & 1.00 & 2 & 10.3 & 0.4092 & 0.7152 & 3 \\
\hline TATD'1_HUMAN & Q6P1N9 & TATDN1 & Putative deoxyribonuclease TATDN1 & 33.60 & 1.00 & 2 & 8.4 & 0.4734 & 0.3574 & 4 \\
\hline CG027_HUMAN & Q6PJG6 & C7orf27 & HEAT repeat-containing protein $\mathrm{C} 7$ orf 27 & 88.12 & 1.00 & 2 & 4 & 0.3761 & 0.1778 & 4 \\
\hline LARP1_HUMAN & Q6PKG0 & LARP1 & La-related protein 1 & 123.51 & 1.00 & 6 & 6.4 & 0.3421 & 0.2581 & 13 \\
\hline CD109_HUMAN & Q6YHK3 & CD109 & CD109 antigen & 161.69 & 1.00 & 2 & 2.7 & 0.6777 & 1.2655 & 6 \\
\hline H32_HŪMAN & Q71DI3 & HIST2H3A & Histone H3.2 & 15.39 & 1.00 & 2 & 51.5 & 0.7657 & 0.6024 & 8 \\
\hline RRMJ3_HUMAN & Q8IY81 & FTSJ3 & Putative rRNA methyltransferase 3 & 96.56 & 1.00 & 6 & 13 & 0.6128 & 0.6255 & 9 \\
\hline LRC47_HUMAN & Q8N1G4 & LRRC47 & Leucine-rich repeat-containing protein 47 & 63.47 & 1.00 & 3 & 9.4 & 0.3761 & 0.2809 & 5 \\
\hline CPSF7_HUMAN & Q8N684 & CPSF7 & Cleavage and polyadenylation specificity factor subunit 7 & 52.05 & 1.00 & 3 & 10.4 & 0.3761 & 0.4383 & 8 \\
\hline GT251_HUMAN & Q8NBJ5 & GLT25D1 & Procollagen galactosyltransferase 1 & 71.64 & 1.00 & 8 & 13 & 0.3306 & 0.2829 & 25 \\
\hline 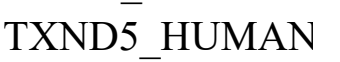 & Q8NBS9 & TXNDC5 & Thioredoxin domain-containing protein 5 & 47.63 & 1.00 & 8 & 23.1 & 0.4523 & 0.2103 & 18 \\
\hline ABCF1_HUMAN & Q8NE71 & $\mathrm{ABCF} 1$ & ATP-binding cassette sub-family F member 1 & 95.93 & 1.00 & 3 & 6 & 0.3421 & 0.4505 & 5 \\
\hline TM9S4_HUMAN & Q92544 & TM9SF4 & Transmembrane 9 superfamily member 4 & 74.52 & 1.00 & 3 & 6.5 & 0.4629 & 0.2987 & 3 \\
\hline NDRG1_HUMAN & Q92597 & NDRG1 & Protein NDRG1 & 42.84 & 1.00 & 6 & 24.4 & 0.5936 & 0.2726 & 13 \\
\hline HS105_HUMAN & Q92598 & HSPH1 & Heat shock protein $105 \mathrm{kDa}$ & 96.86 & 1.00 & 17 & 29.5 & 0.3761 & 0.3415 & 43 \\
\hline HDAC $\overline{2}$ HUMAN & Q92769 & HDAC2 & Histone deacetylase 2 & 55.36 & 1.00 & 2 & 9.4 & 0.3421 & 0.7106 & 6 \\
\hline RAD50_HUMAN & Q92878 & RAD50 & DNA repair protein RAD50 & 153.89 & 1.00 & 3 & 3.1 & 0.3648 & 0.1072 & 7 \\
\hline ARHG1_HUMAN & Q92888 & ARHGEF1 & Rho guanine nucleotide exchange factor 1 & 102.44 & 1.00 & 5 & 8.6 & 0.4941 & 0.7573 & 6 \\
\hline FUBP2_HUMAN & Q92945 & KHSRP & Far upstream element-binding protein 2 & 73.15 & 1.00 & 7 & 11.7 & 0.5044 & 0.2460 & 16 \\
\hline SH3K1_HUMAN & Q96B97 & SH3KBP1 & SH3 domain-containing kinase-binding protein 1 & 73.13 & 1.00 & 3 & 4.5 & 0.6594 & 0.5111 & 16 \\
\hline PDLI5_HUMAN & Q96HC4 & PDLIM5 & PDZ and LIM domain protein 5 & 64.00 & 1.00 & 4 & 9.9 & 0.3421 & 0.2883 & 9 \\
\hline WRIP1_HUMAN & Q96S55 & WRNIP1 & ATPase WRNIP1 & 72.13 & 1.00 & 2 & 3.9 & 0.6502 & 0.5246 & 5 \\
\hline CDC5L_HUMAN & Q99459 & CDC5L & Cell division cycle 5-like protein & 92.25 & 1.00 & 6 & 10.5 & 0.4309 & 0.6579 & 10 \\
\hline
\end{tabular}




\begin{tabular}{|c|c|c|c|c|c|c|c|c|c|c|}
\hline ROAA_HUMAN & Q99729 & HNRNPAB & Heterogeneous nuclear ribonucleoprotein A/B & 36.22 & 1.00 & 5 & 19.3 & 0.3648 & 0.1319 & 11 \\
\hline CPNE1_HUMAN & Q99829 & CPNE1 & Copine-1 & 59.06 & 1.00 & 9 & 21.6 & 0.5547 & 0.6353 & 35 \\
\hline ERP44_HUMAN & Q9BS26 & ERP44 & Endoplasmic reticulum resident protein 44 & 46.97 & 1.00 & 4 & 15.5 & 0.5146 & 0.6051 & 11 \\
\hline GNL3_HUMAN & Q9BVP2 & GNL3 & Guanine nucleotide-binding protein-like 3 & 61.99 & 1.00 & 3 & 8.9 & 0.3872 & 0.4696 & 5 \\
\hline EIF2A_HUMAN & Q9BY44 & EIF2A & Eukaryotic translation initiation factor $2 \mathrm{~A}$ & 64.99 & 1.00 & 4 & 6.8 & 0.4941 & 0.2286 & 7 \\
\hline PDIP3_HUMAN & Q9BY77 & POLDIP3 & Polymerase delta-interacting protein 3 & 46.09 & 1.00 & 3 & 5.7 & 0.3535 & 0.4391 & 10 \\
\hline SIL1_HUMAN & Q9H173 & SIL1 & Nucleotide exchange factor SIL1 & 52.08 & 1.00 & 2 & 5 & 0.4838 & 0.1593 & 3 \\
\hline ASCC̄2_HUMAN & Q9H1I8 & ASCC2 & Activating signal cointegrator 1 complex subunit 2 & 86.36 & 1.00 & 2 & 4.8 & 1.9832 & 0.7794 & 5 \\
\hline DCTP1_HUMAN & Q9H773 & DCTPP1 & dCTP pyrophosphatase 1 & 18.68 & 1.00 & 3 & 25.3 & 0.5146 & 0.6415 & 4 \\
\hline RPF2_HUMAN & Q9H7B2 & RPF2 & Ribosome production factor 2 homolog & 35.58 & 1.00 & 3 & 9.8 & 0.3306 & 0.4126 & 6 \\
\hline XPO5_HUMAN & Q9HAV4 & XPO5 & Exportin-5 & 136.31 & 1.00 & 8 & 11.5 & 0.3761 & 0.3857 & 15 \\
\hline RPR1B_HUMAN & Q9NQG5 & RPRD1B & Regulation of nuclear pre-mRNA domain-containing protein $1 \mathrm{~B}$ & 36.90 & 1.00 & 5 & 23.6 & 0.6032 & 0.5246 & 11 \\
\hline SIAS_HUMAN & Q9NR45 & NANS & Sialic acid synthase & 40.31 & 1.00 & 2 & 13.6 & 0.5247 & 2.0011 & 4 \\
\hline RBM12_HUMAN & Q9NTZ6 & RBM12 & RNA-binding protein 12 & 97.40 & 1.00 & 3 & 4.4 & 0.3190 & 0.2119 & 5 \\
\hline NALP2_HUMAN & Q9NX02 & NLRP2 & NACHT, LRR and PYD domains-containing protein 2 & 120.52 & 1.00 & 2 & 2.2 & 0.4201 & 0.2159 & 5 \\
\hline DIP2B_HUMAN & Q9P265 & DIP2B & Disco-interacting protein 2 homolog B & 171.49 & 1.00 & 5 & 4.3 & 0.8406 & 0.5850 & 11 \\
\hline ZNFX1_HUMAN & Q9P2E3 & ZNFX1 & NFX1-type zinc finger-containing protein 1 & 220.23 & 1.00 & 3 & 1.8 & 0.3190 & 0.1550 & 5 \\
\hline BI2L1_HUMAN & Q9UHR4 & BAIAP2L1 & Brain-specific angiogenesis inhibitor 1-associated protein 2-like protein 1 & 56.88 & 1.00 & 2 & 8.8 & 0.6128 & 0.8478 & 5 \\
\hline LSM7_HUMAN & Q9UK45 & LSM7 & U6 snRNA-associated Sm-like protein LSm7 & 11.60 & 1.00 & 2 & 25.2 & 0.3190 & 0.3969 & 5 \\
\hline MRT4_HUMAN & Q9UKD2 & MRTO4 & mRNA turnover protein 4 homolog & 27.56 & 1.00 & 2 & 10 & 0.5146 & 0.6317 & 5 \\
\hline RALY_HUMAN & Q9UKM9 & RALY & RNA-binding protein Raly & 32.46 & 1.00 & 5 & 13.7 & 0.6777 & 0.1434 & 14 \\
\hline CB029_HUMAN & Q9UKZ1 & C2orf29 & UPF0760 protein C2orf29 & 55.22 & 1.00 & 3 & 8 & 0.3982 & 0.3411 & 5 \\
\hline SMC3_HUMAN & Q9UQE7 & SMC3 & Structural maintenance of chromosomes protein 3 & 141.54 & 1.00 & 2 & 2.7 & 0.3306 & 0.3019 & 4 \\
\hline NOP58_HUMAN & Q9Y2X3 & NOP58 & Nucleolar protein 58 & 59.58 & 1.00 & 7 & 19.8 & 0.3535 & 0.5180 & 31 \\
\hline SBDS_HUMAN & Q9Y3A5 & SBDS & Ribosome maturation protein SBDS & 28.76 & 1.00 & 5 & 21.2 & 0.3190 & 0.4493 & 10 \\
\hline PM14_HUMAN & Q9Y3B4 & SF3B14 & Pre-mRNA branch site protein p14 & 14.58 & 1.00 & 2 & 20.8 & 0.3421 & 0.3417 & 5 \\
\hline GOT1B_HUMAN & Q9Y3E0 & GOLT1B & Vesicle transport protein GOT1B & 15.43 & 1.00 & 2 & 10.9 & 0.5044 & 0.7379 & 26 \\
\hline TELO2_HUMAN & Q9Y4R8 & TELO2 & Telomere length regulation protein TEL2 homolog & 91.75 & 1.00 & 6 & 11.9 & 0.5743 & 0.7895 & 14 \\
\hline BZW2_HUMAN & Q9Y6E2 & BZW2 & Basic leucine zipper and W2 domain-containing protein 2 & 48.16 & 1.00 & 7 & 28.6 & 0.4629 & 0.6798 & 12 \\
\hline S4A7_HUMAN & Q9Y6M7 & SLC4A7 & Sodium bicarbonate cotransporter 3 & 136.04 & 1.00 & 3 & 4.5 & 0.3761 & 0.5920 & 10 \\
\hline KRT8̄6_HUMAN & O43790 & KRT86 & Keratin, type II cuticular Hb6 & 53.50 & 1.00 & 3 & 9.5 & 0.3421 & 0.2730 & 7 \\
\hline TAP1_HUMAN & Q03518 & TAP1 & Antigen peptide transporter 1 & 87.22 & 1.00 & 2 & 4 & 0.6128 & 0.8852 & 4 \\
\hline P5CR3̄_HUMAN & Q53H96 & PYCRL & Pyrroline-5-carboxylate reductase 3 & 28.65 & 1.00 & 2 & 10.6 & 0.4092 & 0.2201 & 3 \\
\hline CHM4B_HUMAN & Q9H444 & CHMP4B & Charged multivesicular body protein $4 \mathrm{~b}$ & 24.95 & 1.00 & 2 & 8 & 0.4416 & 0.0662 & 3 \\
\hline WDR3_HUMAN & Q9UNX4 & WDR3 & WD repeat-containing protein 3 & 106.10 & 1.00 & 2 & 1.8 & 0.3761 & 0.2360 & 3 \\
\hline RAD21_HUMAN & O60216 & RAD21 & Double-strand-break repair protein $\operatorname{rad} 21$ homolog & 71.69 & 1.00 & 2 & 3.6 & 0.5645 & 0.3446 & 4 \\
\hline
\end{tabular}




\begin{tabular}{|c|c|c|c|c|c|c|c|c|c|c|}
\hline AK1C2_HUMAN & P52895 & AKR1C2 & Aldo-keto reductase family 1 member $\mathrm{C} 2$ & 36.74 & 1.00 & 4 & 19.5 & 1.1462 & 0.3159 & 4 \\
\hline FHL1_HUMAN & Q13642 & FHL1 & Four and a half LIM domains protein 1 & 36.26 & 1.00 & 2 & 6.2 & 0.4941 & 0.3795 & 4 \\
\hline C1TM_HUMAN & Q6UB35 & MTHFD1L & Monofunctional C1-tetrahydrofolate synthase, mitochondrial & 105.79 & 1.00 & 2 & 2.2 & 0.7224 & 0.2367 & 7 \\
\hline PHAX_HUMAN & Q9H814 & PHAX & Phosphorylated adapter RNA export protein & 44.40 & 1.00 & 2 & 6.6 & 0.3190 & 0.3288 & 3 \\
\hline ADNP_HUMAN & Q9H2P0 & ADNP & Activity-dependent neuroprotector homeobox protein & 123.56 & 1.00 & 2 & 1.8 & 0.4416 & 0.0102 & 3 \\
\hline NCOAT_HUMAN & O60502 & MGEA5 & Bifunctional protein NCOAT & 102.92 & 1.00 & 3 & 4.8 & 0.4201 & 0.7524 & 3 \\
\hline FXL18_HUMAN & Q96ME1 & FBXL18 & F-box/LRR-repeat protein 18 & 88.34 & 1.00 & 2 & 2.7 & 0.3982 & 0.4022 & 3 \\
\hline RBM15_HUMAN & Q96T37 & RBM15 & Putative RNA-binding protein 15 & 107.19 & 1.00 & 2 & 2.1 & 0.4201 & 0.6245 & 3 \\
\hline SNF5_HUMAN & Q12824 & SMARCB1 & SWI/SNF-related matrix-associated actin-dependent regulator of chromatin subfamily B member 1 & 44.14 & 1.00 & 2 & 9.4 & 0.3535 & 0.7278 & 5 \\
\hline RT34_HUMAN & P82930 & MRPS34 & 28S ribosomal protein $\mathrm{S} 34$, mitochondrial & 25.65 & 1.00 & 2 & 6.9 & 0.3190 & 0.1884 & 10 \\
\hline TB22B_HUMAN & Q9NU19 & TBC1D22B & TBC1 domain family member 22B & 59.08 & 0.96 & 2 & 5 & 0.3872 & 0.1622 & 7 \\
\hline \multicolumn{11}{|c|}{$\begin{array}{ll} & \text { Underexpressed proteins } \\
\end{array}$} \\
\hline PSDE_HUMAN & O00487 & PSMD14 & 26S proteasome non-ATPase regulatory subunit 14 & 34.58 & 1.00 & 4 & 23.2 & -0.5059 & 1.6949 & 7 \\
\hline ML12B_HUMAN & O14950 & MYL12B & Myosin regulatory light chain $12 \mathrm{~B}$ & 19.78 & 1.00 & 6 & 51.5 & -0.5059 & 0.4201 & 15 \\
\hline HGS_HŪMAN & O14964 & HGS & Hepatocyte growth factor-regulated tyrosine kinase substrate & 86.19 & 1.00 & 2 & 3.2 & -0.5908 & 0.2764 & 4 \\
\hline LAMĀ5_HUMAN & O15230 & LAMA5 & Laminin subunit alpha-5 & 399.80 & 1.00 & 3 & 1.3 & -0.8538 & 0.5184 & 7 \\
\hline DC1L2_HUMAN & O43237 & DYNC1LI2 & Cytoplasmic dynein 1 light intermediate chain 2 & 54.10 & 1.00 & 3 & 14.4 & -0.5266 & 0.4936 & 11 \\
\hline TPD54_HUMAN & O43399 & TPD52L2 & Tumor protein D54 & 22.24 & 1.00 & 7 & 39.8 & -0.6579 & 0.3846 & 20 \\
\hline ACTN4_HUMAN & O43707 & ACTN4 & Alpha-actinin-4 & 104.85 & 1.00 & 20 & 49.5 & -0.3498 & 0.3759 & 55 \\
\hline NRDC_HUMAN & O43847 & NRD1 & Nardilysin & 131.57 & 1.00 & 3 & 2.4 & -0.4064 & 0.3414 & 8 \\
\hline CALU_HUMAN & O43852 & CALU & Calumenin & 37.11 & 1.00 & 3 & 16.2 & -0.7044 & 1.1876 & 4 \\
\hline JIP4_HUMAN & O60271 & SPAG9 & C-Jun-amino-terminal kinase-interacting protein 4 & 146.21 & 1.00 & 2 & 2.3 & -0.3872 & 0.1439 & 16 \\
\hline OPĀ1_HUMAN & O60313 & OPA1 & Dynamin-like 120 kDa protein, mitochondrial & 111.63 & 1.00 & 3 & 5.1 & -0.3872 & 0.5780 & 6 \\
\hline NMT2_HUMAN & O60551 & NMT2 & Glycylpeptide N-tetradecanoyltransferase 2 & 56.98 & 1.00 & 2 & 4.2 & -0.4652 & 0.1738 & 7 \\
\hline PLIN3_HUMAN & O60664 & PLIN3 & Perilipin-3 & 47.05 & 1.00 & 10 & 39.2 & -0.4064 & 0.6307 & 32 \\
\hline PDCD $\overline{6}$ HUMAN & O75340 & PDCD6 & Programmed cell death protein 6 & 21.87 & 1.00 & 4 & 30.9 & -0.9347 & 0.2800 & 7 \\
\hline SC22B_HUMAN & O75396 & SEC22B & Vesicle-trafficking protein SEC22b & 24.74 & 1.00 & 3 & 14 & -0.4453 & 0.1322 & 6 \\
\hline AP1G2_HUMAN & O75843 & AP1G2 & AP-1 complex subunit gamma-like 2 & 87.12 & 1.00 & 3 & 4.8 & -0.4854 & 0.1858 & 6 \\
\hline GLRX3_HUMAN & $\mathrm{O} 76003$ & GLRX3 & Glutaredoxin-3 & 37.43 & 1.00 & 5 & 18.2 & -0.6128 & 0.2161 & 10 \\
\hline LYPA2_HUMAN & O95372 & LYPLA2 & Acyl-protein thioesterase 2 & 24.74 & 1.00 & 2 & 21.6 & -0.5691 & 0.4124 & 3 \\
\hline ROD1_HUMAN & O95758 & ROD1 & Regulator of differentiation 1 & 59.69 & 1.00 & 2 & 12.5 & -0.5691 & 0.4373 & 3 \\
\hline AP2A1_HUMAN & O95782 & AP2A1 & AP-2 complex subunit alpha-1 & 107.55 & 1.00 & 5 & 9.8 & -0.4854 & 0.3640 & 10 \\
\hline BAG3_HUMAN & O95817 & BAG3 & BAG family molecular chaperone regulator 3 & 61.59 & 1.00 & 3 & 11.5 & -0.4652 & 0.4980 & 17 \\
\hline NB5R3_HUMAN & P00387 & CYB5R3 & NADH-cytochrome b5 reductase 3 & 34.23 & 1.00 & 6 & 28.9 & -0.4257 & 0.4019 & 18 \\
\hline GSHR_HUMAN & P00390 & GSR & Glutathione reductase, mitochondrial & 56.26 & 1.00 & 2 & 8.8 & -0.5477 & 0.4584 & 5 \\
\hline OAS1_HUMAN & P00973 & OAS1 & 2'-5'-oligoadenylate synthase 1 & 46.03 & 1.00 & 3 & 11 & -0.3872 & 0.1404 & 3 \\
\hline
\end{tabular}




\begin{tabular}{|c|c|c|c|c|c|c|c|c|c|c|}
\hline IL1A_HUMAN & P01583 & IL1A & Interleukin-1 alpha & 30.61 & 1.00 & 2 & 10.3 & -0.8803 & 0.5168 & 5 \\
\hline LMNA_HUMAN & $\mathrm{P} 02545$ & LMNA & Lamin-A/C & 74.14 & 1.00 & 24 & 44.9 & -0.5266 & 0.4621 & 83 \\
\hline CYTB_HUMAN & P04080 & CSTB & Cystatin-B & 11.14 & 1.00 & 4 & 30.6 & -0.3872 & 0.3442 & 10 \\
\hline K2C6B_HUMAN & P04259 & KRT6B & Keratin, type II cytoskeletal 6B & 60.07 & 1.00 & 2 & 44.5 & -0.5266 & 0.1592 & 6 \\
\hline UCRP_HUMAN & P05161 & ISG15 & Interferon-induced $17 \mathrm{kDa}$ protein & 17.89 & 1.00 & 5 & 37 & -0.9073 & 0.3372 & 33 \\
\hline ITB1_HUMAN & P05556 & ITGB1 & Integrin beta-1 & 88.42 & 1.00 & 6 & 7.9 & -0.5477 & 0.2038 & 10 \\
\hline S10ĀE_HUMAN & P06703 & S100A6 & Protein S100-A6 & 10.18 & 1.00 & 3 & 35.6 & -1.3872 & 0.3163 & 29 \\
\hline PYGL_HUMAN & P06737 & PYGL & Glycogen phosphorylase, liver form & 97.15 & 1.00 & 3 & 14.5 & -0.7283 & 0.7012 & 4 \\
\hline PDIA1_HUMAN & P07237 & $\mathrm{P} 4 \mathrm{HB}$ & Protein disulfide-isomerase & 57.12 & 1.00 & 16 & 40.9 & -0.4854 & 0.6608 & 95 \\
\hline H10_HŪMAN & P07305 & H1F0 & Histone H1.0 & 20.86 & 1.00 & 3 & 15.5 & -0.4652 & 0.3428 & 14 \\
\hline ANX'̄A2_HUMAN & P07355 & ANXA2 & Annexin A2 & 38.60 & 1.00 & 17 & 57.5 & -0.4257 & 0.5191 & 176 \\
\hline K1C19_HUMAN & P08727 & KRT19 & Keratin, type I cytoskeletal 19 & 44.09 & 1.00 & 14 & 61 & -1.8803 & 0.5968 & 77 \\
\hline K2C7_HUMAN & P08729 & KRT7 & Keratin, type II cytoskeletal 7 & 51.40 & 1.00 & 11 & 33 & -0.4652 & 0.2321 & 26 \\
\hline LEG1_HUMAN & P09382 & LGALS1 & Galectin-1 & 14.72 & 1.00 & 5 & 54.1 & -0.5059 & 0.3812 & 37 \\
\hline IFIT1_HUMAN & P09914 & IFIT1 & Interferon-induced protein with tetratricopeptide repeats 1 & 55.36 & 1.00 & 2 & 4.8 & -0.6579 & 0.5355 & 3 \\
\hline PYGB_HUMAN & P11216 & PYGB & Glycogen phosphorylase, brain form & 96.70 & 1.00 & 13 & 30.8 & -1.5059 & 0.6738 & 40 \\
\hline ANXA3_HUMAN & P12429 & ANXA3 & Annexin A3 & 36.38 & 1.00 & 11 & 42.7 & -0.7283 & 0.4363 & 28 \\
\hline KCRU_HUMAN & P12532 & CKMT1A & Creatine kinase U-type, mitochondrial & 47.04 & 1.00 & 5 & 19.4 & -0.7525 & 0.2050 & 9 \\
\hline ETFA_HUMAN & P13804 & ETFA & Electron transfer flavoprotein subunit alpha, mitochondrial & 35.08 & 1.00 & 9 & 39.6 & -0.3872 & 0.3575 & 18 \\
\hline FPPS_HUMAN & P14324 & FDPS & Farnesyl pyrophosphate synthase & 48.28 & 1.00 & 2 & 6.9 & -0.5059 & 0.4006 & 6 \\
\hline HMGĀ1_HUMAI & P17096 & HMGA1 & High mobility group protein HMG-I/HMG-Y & 11.68 & 1.00 & 6 & 51.4 & -0.5691 & 0.2955 & 27 \\
\hline KAPCA_HUMAN & $\mathrm{P} 17612$ & PRKACA & cAMP-dependent protein kinase catalytic subunit alpha & 40.59 & 1.00 & 2 & 8.8 & -0.5266 & 1.3337 & 5 \\
\hline CAN2_HUMAN & P17655 & CAPN2 & Calpain-2 catalytic subunit & 80.01 & 1.00 & 11 & 25 & -0.3684 & 0.5815 & 37 \\
\hline LEG3_HUMAN & P17931 & LGALS3 & Galectin-3 & 26.15 & 1.00 & 4 & 17.6 & -0.3684 & 0.2051 & 21 \\
\hline PGAM̄1_HUMAN & P18669 & PGAM1 & Phosphoglycerate mutase 1 & 28.80 & 1.00 & 9 & 57.1 & -0.4257 & 0.3909 & 58 \\
\hline K1C15_HUMAN & P19012 & KRT15 & Keratin, type I cytoskeletal 15 & 49.20 & 1.00 & 5 & 26.1 & -0.8538 & 1.2412 & 9 \\
\hline 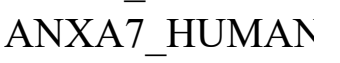 & P20073 & ANXA7 & Annexin A7 & 52.74 & 1.00 & 7 & 17.6 & -0.6579 & 0.3534 & 14 \\
\hline VATC1_HUMAN & P21283 & ATP6V1C1 & V-type proton ATPase subunit C 1 & 43.94 & 1.00 & 3 & 11.3 & -0.6352 & 0.8289 & 5 \\
\hline TCEA1_HUMAN & P23193 & TCEA1 & Transcription elongation factor A protein 1 & 33.97 & 1.00 & 2 & 7.6 & -0.5691 & 0.3052 & 4 \\
\hline SFPQ_HUMAN & P23246 & SFPQ & Splicing factor, proline- and glutamine-rich & 76.15 & 1.00 & 10 & 18 & -0.5266 & 0.5030 & 48 \\
\hline CALL3_HUMAN & P27482 & CALML3 & Calmodulin-like protein 3 & 16.89 & 1.00 & 4 & 34.2 & -0.4854 & 0.2097 & 8 \\
\hline PSB5_HUMAN & P28074 & PSMB5 & Proteasome subunit beta type- 5 & 28.48 & 1.00 & 2 & 9.5 & -0.5059 & 0.1577 & 3 \\
\hline MK01_HUMAN & P28482 & MAPK1 & Mitogen-activated protein kinase 1 & 41.39 & 1.00 & 4 & 15.6 & -0.4453 & 0.1605 & 6 \\
\hline DOPD_HUMAN & P30046 & DDT & D-dopachrome decarboxylase & 12.71 & 1.00 & 3 & 27.1 & -0.5266 & 0.3323 & 11 \\
\hline ECHM_HUMAN & P30084 & ECHS1 & Enoyl-CoA hydratase, mitochondrial & 31.39 & 1.00 & 3 & 17.9 & -0.5266 & 0.3315 & 8 \\
\hline ILEU_HUMAN & P30740 & SERPINB1 & Leukocyte elastase inhibitor & 42.74 & 1.00 & 3 & 11.3 & -0.4854 & 0.4194 & 5 \\
\hline
\end{tabular}




\begin{tabular}{|c|c|c|c|c|c|c|c|c|c|c|}
\hline DHSA HUMAN & P31040 & SDHA & Succinate dehydrogenase [ubiquinone] flavoprotein subunit, mitochondrial & 72.69 & 1.00 & 2 & 4.1 & -1.0502 & 0.1840 & 10 \\
\hline DNJĀ1_HUMAN & P31689 & DNAJA1 & DnaJ homolog subfamily A member 1 & 44.87 & 1.00 & 6 & 26.4 & -0.4064 & 1.2211 & 10 \\
\hline 1433S_HUMAN & P31947 & SFN & $14-3-3$ protein sigma & 27.77 & 1.00 & 14 & 79 & -0.4257 & 0.4559 & 100 \\
\hline CSTF2_HUMAN & P33240 & CSTF2 & Cleavage stimulation factor subunit 2 & 60.96 & 1.00 & 2 & 7.6 & -0.8803 & 1.0754 & 10 \\
\hline PROF2_HUMAN & P35080 & PFN2 & Profilin-2 & 15.05 & 1.00 & 2 & 15.7 & -0.5691 & 0.0564 & 4 \\
\hline MYH9_HUMAN & P35579 & MYH9 & Myosin-9 & 226.53 & 1.00 & 67 & 45.3 & -0.4257 & 0.4135 & 335 \\
\hline VATE1_HUMAN & P36543 & ATP6V1E1 & V-type proton ATPase subunit E 1 & 26.15 & 1.00 & 4 & 18.6 & -0.4064 & 0.1783 & 10 \\
\hline FDFT_HUMAN & P37268 & FDFT1 & Squalene synthase & 48.12 & 1.00 & 5 & 14.6 & -0.4854 & 0.2737 & 6 \\
\hline VATA_HUMAN & P38606 & ATP6V1A & V-type proton ATPase catalytic subunit A & 68.30 & 1.00 & 6 & 12.5 & -0.3872 & 0.5843 & 18 \\
\hline CAPG_HUMAN & P40121 & CAPG & Macrophage-capping protein & 38.52 & 1.00 & 4 & 13.5 & -0.5477 & 0.4147 & 7 \\
\hline MDHC_HUMAN & P40925 & MDH1 & Malate dehydrogenase, cytoplasmic & 36.43 & 1.00 & 3 & 13.5 & -0.3684 & 0.2264 & 8 \\
\hline ECHA_HUMAN & P40939 & HADHA & Trifunctional enzyme subunit alpha, mitochondrial & 83.00 & 1.00 & 9 & 17.6 & -0.4257 & 0.5039 & 35 \\
\hline STAT1_HUMAN & P42224 & STAT1 & Signal transducer and activator of transcription 1 -alpha/beta & 87.33 & 1.00 & 14 & 24.9 & -0.4064 & 0.3076 & 38 \\
\hline FRAP_HUMAN & P42345 & FRAP1 & Serine/threonine-protein kinase mTOR & 288.89 & 1.00 & 5 & 3.9 & -0.5059 & 0.7439 & 8 \\
\hline NSF_HUMAN & P46459 & NSF & Vesicle-fusing ATPase & 82.59 & 1.00 & 3 & 6.2 & -0.3498 & 0.1980 & 5 \\
\hline IQGĀ1_HUMAN & P46940 & IQGAP1 & Ras GTPase-activating-like protein IQGAP1 & 189.25 & 1.00 & 38 & 35.5 & -0.4064 & 0.5336 & 129 \\
\hline AL1A3_HUMAN & P47895 & ALDH1A3 & Aldehyde dehydrogenase family 1 member A3 & 56.11 & 1.00 & 12 & 30.9 & -0.9347 & 0.2338 & 33 \\
\hline LEG7_HUMAN & P47929 & LGALS7 & Galectin-7 & 15.08 & 1.00 & 3 & 27.9 & -1.0502 & 0.7977 & 6 \\
\hline PPCE_HUMAN & P48147 & PREP & Prolyl endopeptidase & 80.70 & 1.00 & 6 & 11.8 & -0.3872 & 0.4155 & 16 \\
\hline PTSS1̄_HUMAN & P48651 & PTDSS1 & Phosphatidylserine synthase 1 & 55.53 & 1.00 & 2 & 5.7 & -0.5908 & 0.2177 & 5 \\
\hline ACADV__HUMAT & P49748 & ACADVL & Very long-chain specific acyl-CoA dehydrogenase, mitochondrial & 70.39 & 1.00 & 8 & 18.3 & -0.3498 & 0.4503 & 23 \\
\hline TMEDA_HUMAT & P49755 & TMED10 & Transmembrane emp24 domain-containing protein 10 & 24.98 & 1.00 & 2 & 12.3 & -0.3872 & 0.4201 & 9 \\
\hline ANX11_HUMAN & P50995 & ANXA11 & Annexin A11 & 54.39 & 1.00 & 3 & 6.7 & -0.3684 & 0.5171 & 8 \\
\hline GDIR1_HUMAN & P52565 & ARHGDIA & Rho GDP-dissociation inhibitor 1 & 23.21 & 1.00 & 3 & 18.1 & -0.3684 & 0.2656 & 9 \\
\hline CAZA1__HUMAN & P52907 & CAPZA1 & F-actin-capping protein subunit alpha-1 & 32.92 & 1.00 & 5 & 36.4 & -0.5908 & 0.4419 & 14 \\
\hline TCP4_HUMAN & P53999 & SUB1 & Activated RNA polymerase II transcriptional coactivator p15 & 14.40 & 1.00 & 4 & 22.8 & -0.4257 & 0.3270 & 9 \\
\hline SNAA_HUMAN & P54920 & NAPA & Alpha-soluble NSF attachment protein & 33.23 & 1.00 & 3 & 11.2 & -0.7772 & 0.2355 & 5 \\
\hline ADK_HUMAN & P55263 & ADK & Adenosine kinase & 40.55 & 1.00 & 6 & 30.1 & -0.5691 & 0.9735 & 16 \\
\hline TPD52_HUMAN & P55327 & TPD52 & Tumor protein D52 & 24.33 & 1.00 & 2 & 11.2 & -0.4652 & 0.7353 & 7 \\
\hline PSA_HUMAN & P55786 & NPEPPS & Puromycin-sensitive aminopeptidase & 103.28 & 1.00 & 12 & 16.6 & -0.6810 & 0.4383 & 21 \\
\hline SCOT̄1_HUMAN & P55809 & OXCT1 & Succinyl-CoA:3-ketoacid-coenzyme A transferase 1, mitochondrial & 56.16 & 1.00 & 3 & 12.7 & -0.6128 & 0.4995 & 8 \\
\hline MYL6_HUMAN & P60660 & MYL6 & Myosin light polypeptide 6 & 16.93 & 1.00 & 5 & 36.4 & -0.4064 & 0.3064 & 22 \\
\hline S10AA_HUMAN & P60903 & S100A 10 & Protein S100-A10 & 11.20 & 1.00 & 3 & 29.9 & -0.3872 & 0.3516 & 17 \\
\hline DEST_HUMAN & P60981 & DSTN & Destrin & 18.51 & 1.00 & 5 & 38.8 & -0.4453 & 0.3120 & 6 \\
\hline SRP54_HUMAN & P61011 & SRP54 & Signal recognition particle $54 \mathrm{kDa}$ protein & 55.70 & 1.00 & 2 & 6.9 & -0.3684 & 0.2698 & 6 \\
\hline RAB2A_HUMAN & P61019 & RAB2A & Ras-related protein $\mathrm{Rab}-2 \mathrm{~A}$ & 23.55 & 1.00 & 4 & 25 & -0.4453 & 0.2026 & 5 \\
\hline
\end{tabular}




\begin{tabular}{|c|c|c|c|c|c|c|c|c|c|c|}
\hline UBC12_HUMAN & P61081 & UBE2M & NEDD8-conjugating enzyme Ubc12 & 20.90 & 1.00 & 4 & 24 & -0.4854 & 0.1891 & 8 \\
\hline RS15_HUMAN & P62841 & RPS15 & 40S ribosomal protein S15 & 17.04 & 1.00 & 3 & 24.1 & -0.6128 & 0.8933 & 5 \\
\hline RL40_HUMAN & P62987 & UBA52 & $60 \mathrm{~S}$ ribosomal protein $\mathrm{L} 40$ & 6.18 & 1.00 & 2 & 32.7 & -0.9913 & 0.4171 & 19 \\
\hline AP2B1_HUMAN & P63010 & AP2B1 & AP-2 complex subunit beta & 104.55 & 1.00 & 8 & 25 & -0.5908 & 0.6380 & 16 \\
\hline 2ABA_HUMAN & P63151 & PPP2R2A & Serine/threonine-protein phosphatase $2 \mathrm{~A} 55 \mathrm{kDa}$ regulatory subunit $\mathrm{B}$ alpha isoform & 51.69 & 1.00 & 2 & 5.6 & -0.4064 & 0.1497 & 6 \\
\hline SC11A_HUMAN & P67812 & SEC11A & Signal peptidase complex catalytic subunit SEC11A & 20.63 & 1.00 & 2 & 16.2 & -0.3684 & 0.0991 & 5 \\
\hline BASP1_HUMAN & P80723 & BASP1 & Brain acid soluble protein 1 & 22.69 & 1.00 & 3 & 20.3 & -0.3872 & 0.4381 & 12 \\
\hline CAP1_HUMAN & Q01518 & CAP1 & Adenylyl cyclase-associated protein 1 & 51.86 & 1.00 & 11 & 32.4 & -0.5266 & 0.7396 & 56 \\
\hline HMCS1_HUMAN & Q01581 & HMGCS1 & Hydroxymethylglutaryl-CoA synthase, cytoplasmic & 57.29 & 1.00 & 7 & 17.3 & -1.0205 & 0.4249 & 11 \\
\hline NC2B_HUMAN & Q01658 & DR1 & Protein Dr1 & 19.44 & 1.00 & 2 & 21 & -0.4652 & 0.4514 & 4 \\
\hline PLCB3_HUMAN & Q01970 & PLCB3 & 1-phosphatidylinositol-4,5-bisphosphate phosphodiesterase beta-3 & 138.80 & 1.00 & 5 & 6.2 & -0.4257 & 0.6536 & 13 \\
\hline MP2K1_HUMAN & Q02750 & MAP2K1 & Dual specificity mitogen-activated protein kinase kinase 1 & 43.44 & 1.00 & 3 & 15.3 & -0.3872 & 0.3863 & 5 \\
\hline 1433F_HUMAN & Q04917 & YWHAH & $14-3-3$ protein eta & 28.22 & 1.00 & 4 & 44.3 & -0.4257 & 0.5602 & 13 \\
\hline ZO1_HUMAN & Q07157 & TJP1 & Tight junction protein $\mathrm{ZO}-1$ & 195.46 & 1.00 & 5 & 4.3 & -0.4652 & 0.3472 & 8 \\
\hline KHDR1_HUMAN & Q07666 & KHDRBS1 & $\mathrm{KH}$ domain-containing, RNA-binding, signal transduction-associated protein 1 & 48.23 & 1.00 & 6 & 14.2 & -0.4064 & 0.3385 & 10 \\
\hline QOR_HUMAN & Q08257 & CRYZ & Quinone oxidoreductase & 35.21 & 1.00 & 4 & 22.5 & -0.3498 & 0.3415 & 6 \\
\hline AHNK_HUMAN & Q09666 & AHNAK & Neuroblast differentiation-associated protein AHNAK & 629.10 & 1.00 & 107 & 42.1 & -0.4257 & 0.3203 & 209 \\
\hline MYO1E_HUMAN & Q12965 & MYO1E & Myosin-Ie & 127.06 & 1.00 & 3 & 5.9 & -1.6352 & 2.5518 & 4 \\
\hline TIF1B_HUMAN & Q13263 & TRIM28 & Transcription intermediary factor 1-beta & 88.55 & 1.00 & 13 & 26.9 & -0.4453 & 0.3082 & 33 \\
\hline MYO9B_HUMAI & Q13459 & MYO9B & Myosin-IXb & 243.56 & 1.00 & 2 & 1.3 & -0.4064 & 0.5372 & 3 \\
\hline TBB3_HUMAN & Q13509 & TUBB3 & Tubulin beta- 3 chain & 50.43 & 1.00 & 2 & 38.4 & -0.5059 & 0.4882 & 22 \\
\hline LAMB3_HUMAN & Q13751 & LAMB3 & Laminin subunit beta-3 & 129.57 & 1.00 & 16 & 21.2 & -0.5691 & 0.5476 & 42 \\
\hline LAMC2_HUMAN & Q13753 & LAMC2 & Laminin subunit gamma-2 & 130.98 & 1.00 & 10 & 11.2 & -0.4854 & 0.2888 & 17 \\
\hline COTL1_HUMAN & Q14019 & COTL1 & Coactosin-like protein & 15.94 & 1.00 & 5 & 48.6 & -0.4652 & 0.4539 & 23 \\
\hline CAPR1_HUMAN & Q14444 & CAPRIN1 & Caprin-1 & 78.37 & 1.00 & 7 & 11.6 & -0.3684 & 0.4293 & 15 \\
\hline SEPT2_HUMAN & Q15019 & SEPT2 & Septin-2 & 41.49 & 1.00 & 6 & 26.9 & -0.3498 & 0.2368 & 12 \\
\hline RB3GP_HUMAN & Q15042 & RAB3GAP1 & Rab3 GTPase-activating protein catalytic subunit & 110.52 & 1.00 & 3 & 5.1 & -0.6810 & 0.5870 & 5 \\
\hline PMVK_HUMAN & Q15126 & PMVK & Phosphomevalonate kinase & 21.99 & 1.00 & 2 & 10.9 & -0.4854 & 0.3384 & 3 \\
\hline NONO_HUMAN & Q15233 & NONO & Non-POU domain-containing octamer-binding protein & 54.23 & 1.00 & 9 & 29.3 & -0.3872 & 0.7012 & 27 \\
\hline K0020_HUMAN & Q15397 & KIAA0020 & Pumilio domain-containing protein KIAA0020 & 73.58 & 1.00 & 4 & 12.2 & -0.3498 & 0.4972 & 5 \\
\hline RSU1_HUMAN & Q15404 & RSU1 & Ras suppressor protein 1 & 31.54 & 1.00 & 5 & 29.2 & -0.3872 & 0.4809 & 12 \\
\hline CNN3_HUMAN & Q15417 & CNN3 & Calponin-3 & 36.41 & 1.00 & 3 & 14.9 & -1.0806 & 1.6242 & 7 \\
\hline KS6A1_HUMAN & Q15418 & RPS6KA1 & Ribosomal protein S6 kinase alpha-1 & 82.72 & 1.00 & 4 & 7.3 & -0.6810 & 0.2985 & 4 \\
\hline AAAT_HUMAN & Q15758 & SLC1A5 & Neutral amino acid transporter $\mathrm{B}(0)$ & 56.60 & 1.00 & 4 & 12.9 & -0.5908 & 0.6431 & 5 \\
\hline UB2V2_HUMAN & Q15819 & UBE2V2 & Ubiquitin-conjugating enzyme E2 variant 2 & 16.36 & 1.00 & 3 & 55.2 & -0.3684 & 0.0824 & 5 \\
\hline APM2_HUMAN & Q15847 & APM2 & Adipose most abundant gene transcript 2 protein & 7.85 & 1.00 & 3 & 69.7 & -0.5266 & 1.0737 & 7 \\
\hline
\end{tabular}




\begin{tabular}{|c|c|c|c|c|c|c|c|c|c|c|}
\hline ADRM1_HUMAI & Q16186 & ADRM1 & Proteasomal ubiquitin receptor ADRM1 & 42.15 & 1.00 & 3 & 10.6 & -0.6352 & 0.5652 & 8 \\
\hline UAP1_HUMAN & Q16222 & UAP1 & UDP-N-acetylhexosamine pyrophosphorylase & 58.77 & 1.00 & 5 & 12.5 & -0.5477 & 0.4149 & 19 \\
\hline CDC37_HUMAN & Q16543 & $\mathrm{CDC} 37$ & Hsp90 co-chaperone $\mathrm{Cdc} 37$ & 44.47 & 1.00 & 6 & 22.2 & -0.4652 & 0.5425 & 13 \\
\hline DECR_HUMAN & Q16698 & DECR1 & 2,4-dienoyl-CoA reductase, mitochondrial & 36.07 & 1.00 & 2 & 8.1 & -0.4854 & 0.7678 & 5 \\
\hline LAMA3_HUMAN & Q16787 & LAMA3 & Laminin subunit alpha-3 & 366.65 & 1.00 & 13 & 5.5 & -0.3498 & 0.4046 & 30 \\
\hline UPP1_HUMAN & Q16831 & UPP1 & Uridine phosphorylase 1 & 33.93 & 1.00 & 5 & 21.3 & -0.7283 & 0.2009 & 12 \\
\hline UGPA_HUMAN & Q16851 & UGP2 & UTP--glucose-1-phosphate uridylyltransferase & 56.94 & 1.00 & 6 & 18.3 & -0.4453 & 0.7956 & 10 \\
\hline IMMT_HUMAN & Q16891 & IMMT & Mitochondrial inner membrane protein & 83.68 & 1.00 & 3 & 5.4 & -0.4652 & 0.5753 & 4 \\
\hline HP1B3_HUMAN & Q5SSJ5 & HP1BP3 & Heterochromatin protein 1-binding protein 3 & 61.21 & 1.00 & 4 & 8.7 & -0.5477 & 0.3383 & 7 \\
\hline SCMC1_HUMAN & Q6NUK1 & SLC25A24 & Calcium-binding mitochondrial carrier protein SCaMC-1 & 53.35 & 1.00 & 3 & 7.8 & -0.3872 & 0.2456 & 8 \\
\hline ESRP1_HUMAN & Q6NXG1 & ESRP1 & Epithelial splicing regulatory protein 1 & 75.59 & 1.00 & 2 & 7.9 & -0.5266 & 0.8502 & 6 \\
\hline PDXD1_HUMAN & Q6P996 & PDXDC1 & Pyridoxal-dependent decarboxylase domain-containing protein 1 & 86.71 & 1.00 & 3 & 5.8 & -0.3684 & 0.2520 & 5 \\
\hline BZW1_HUMAN & Q7L1Q6 & BZW1 & Basic leucine zipper and W2 domain-containing protein 1 & 48.04 & 1.00 & 5 & 22 & -0.4854 & 0.5424 & 13 \\
\hline DDX60_HUMAN & Q8IY21 & DDX60 & Probable ATP-dependent RNA helicase DDX60 & 197.85 & 1.00 & 2 & 1.8 & -0.4257 & 0.1343 & 6 \\
\hline PAIRB_HUMAN & Q8NC51 & SERBP1 & Plasminogen activator inhibitor 1 RNA-binding protein & 44.97 & 1.00 & 11 & 32.1 & -0.3684 & 0.4059 & 54 \\
\hline NPL4_HUMAN & Q8TAT6 & NPLOC4 & Nuclear protein localization protein 4 homolog & 68.12 & 1.00 & 3 & 6.3 & -0.4453 & 0.2313 & 3 \\
\hline PI42C_HUMAN & Q8TBX8 & PIP4K2C & Phosphatidylinositol-5-phosphate 4-kinase type-2 gamma & 47.29 & 1.00 & 2 & 6.9 & -0.5059 & 0.4504 & 5 \\
\hline PSPC1_HUMAN & Q8WXF1 & PSPC1 & Paraspeckle component 1 & 58.74 & 1.00 & 3 & 10.7 & -0.5059 & 0.5535 & 5 \\
\hline TFG_HUMAN & Q92734 & TFG & Protein TFG & 43.45 & 1.00 & 3 & 13.3 & -0.5059 & 0.3596 & 5 \\
\hline FKB10_HUMAN & Q96AY3 & FKBP10 & Peptidyl-prolyl cis-trans isomerase FKBP10 & 64.24 & 1.00 & 2 & 4.1 & -0.4064 & 0.1904 & 4 \\
\hline EFHD2_HUMAN & Q96C19 & EFHD2 & EF-hand domain-containing protein D2 & 26.70 & 1.00 & 4 & 18.3 & -0.4652 & 0.1774 & 9 \\
\hline AP2M1_HUMAN & Q96CW1 & AP2M1 & AP-2 complex subunit mu & 49.65 & 1.00 & 4 & 14.7 & -0.3684 & 0.8585 & 5 \\
\hline S10AG_HUMAN & Q96FQ6 & S100A16 & Protein S100-A16 & 11.80 & 1.00 & 3 & 40.8 & -1.0502 & 0.3669 & 15 \\
\hline MBOA7_HUMAI & Q96N66 & MBOAT7 & Lysophospholipid acyltransferase 7 & 52.76 & 1.00 & 2 & 7.4 & -0.5691 & 0.7882 & 3 \\
\hline VAT1_HUMAN & Q99536 & VAT1 & Synaptic vesicle membrane protein VAT-1 homolog & 41.92 & 1.00 & 3 & 11.7 & -0.8023 & 0.2189 & 4 \\
\hline ACON_HUMAN & Q99798 & $\mathrm{ACO} 2$ & Aconitate hydratase, mitochondrial & 85.43 & 1.00 & 4 & 8.8 & -0.5059 & 0.5231 & 7 \\
\hline ANM1_HUMAN & Q99873 & PRMT1 & Protein arginine N-methyltransferase 1 & 41.52 & 1.00 & 4 & 11.4 & -0.4064 & 0.2189 & 7 \\
\hline SH3G1_HUMAN & Q99961 & SH3GL1 & Endophilin-A2 & 41.49 & 1.00 & 3 & 17.7 & -0.6810 & 0.1775 & 3 \\
\hline TBCD_HUMAN & Q9BTW9 & $\mathrm{TBCD}$ & Tubulin-specific chaperone D & 132.60 & 1.00 & 4 & 5.8 & -0.3684 & 0.2493 & 6 \\
\hline TBB6_HUMAN & Q9BUF5 & TUBB6 & Tubulin beta- 6 chain & 49.86 & 1.00 & 9 & 57.8 & -0.7772 & 0.4628 & 26 \\
\hline ITPA_HUMAN & Q9BY32 & ITPA & Inosine triphosphate pyrophosphatase & 21.45 & 1.00 & 3 & 30.9 & -0.7772 & 0.4759 & 6 \\
\hline EHD4_HUMAN & Q9H223 & EHD4 & EH domain-containing protein 4 & 61.18 & 1.00 & 6 & 13.5 & -0.3872 & 0.3895 & 9 \\
\hline TMX1_HUMAN & Q9H3N1 & TMX1 & Thioredoxin-related transmembrane protein 1 & 31.79 & 1.00 & 3 & 12.5 & -0.3498 & 0.1335 & 9 \\
\hline EHD1_HUMAN & Q9H4M9 & EHD1 & EH domain-containing protein 1 & 60.63 & 1.00 & 11 & 32.2 & -0.5266 & 0.4633 & 31 \\
\hline S10AE_HUMAN & Q9HCY8 & S100A14 & Protein S100-A14 & 11.66 & 1.00 & 2 & 25 & -0.8278 & 0.4048 & 9 \\
\hline MYOF_HUMAN & Q9NZM1 & MYOF & Myoferlin & 234.71 & 1.00 & 16 & 9.9 & -0.6128 & 0.3332 & 22 \\
\hline
\end{tabular}




\begin{tabular}{|c|c|c|c|c|c|c|c|c|c|c|}
\hline LIMA1_HUMAN & Q9UHB6 & LIMA1 & LIM domain and actin-binding protein 1 & 85.23 & 1.00 & 8 & 15.7 & -0.3684 & 0.5739 & 14 \\
\hline SRP68_HUMAN & Q9UHB9 & SRP68 & Signal recognition particle $68 \mathrm{kDa}$ protein & 70.73 & 1.00 & 4 & 9.6 & -0.4854 & 0.8386 & 7 \\
\hline XPO7_HUMAN & Q9UIA9 & XPO7 & Exportin-7 & 123.91 & 1.00 & 3 & 5 & -0.5691 & 0.9229 & 10 \\
\hline HN1_HUMAN & Q9UK76 & HN1 & Hematological and neurological expressed 1 protein & 16.01 & 1.00 & 2 & 27.3 & -0.6128 & 0.4026 & 3 \\
\hline NUP50_HUMAN & Q9UKX7 & NUP50 & Nuclear pore complex protein Nup50 & 50.14 & 1.00 & 3 & 9.6 & -0.8023 & 0.6053 & 4 \\
\hline PSME2_HUMAN & Q9UL46 & PSME2 & Proteasome activator complex subunit 2 & 27.40 & 1.00 & 5 & 33.9 & -0.4453 & 0.8274 & 20 \\
\hline NSF1C_HUMAN & Q9UNZ2 & NSFL1C & NSFL1 cofactor $\mathrm{p} 47$ & 40.57 & 1.00 & 2 & 7.3 & -0.4453 & 0.5316 & 5 \\
\hline SRRM2_HUMAN & Q9UQ35 & SRRM2 & Serine/arginine repetitive matrix protein 2 & 299.62 & 1.00 & 5 & 3.6 & -0.3872 & 0.7618 & 11 \\
\hline TLN1_HUMAN & Q9Y490 & TLN1 & Talin-1 & 269.77 & 1.00 & 32 & 23.2 & -0.3872 & 0.6420 & 101 \\
\hline PPME1_HUMAN & Q9Y570 & PPME1 & Protein phosphatase methylesterase 1 & 42.32 & 1.00 & 3 & 13.2 & -0.3872 & 0.8458 & 5 \\
\hline NCOR2_HUMAN & Q9Y618 & NCOR2 & Nuclear receptor corepressor 2 & 274.80 & 1.00 & 2 & 1.5 & -0.7283 & 1.2163 & 5 \\
\hline UROK_HUMAN & P00749 & PLAU & Urokinase-type plasminogen activator & 48.51 & 1.00 & 2 & 4.4 & -1.0205 & 0.0528 & 3 \\
\hline LAMP'1_HUMAN & P11279 & LAMP1 & Lysosome-associated membrane glycoprotein 1 & 44.88 & 1.00 & 2 & 4.8 & -0.4854 & 0.1621 & 5 \\
\hline S10A2_HUMAN & P29034 & $\mathrm{S} 100 \mathrm{~A} 2$ & Protein $\mathrm{S} 100-\mathrm{A} 2$ & 11.12 & 1.00 & 2 & 15.3 & -0.7283 & 0.2334 & 17 \\
\hline ETFB_HUMAN & P38117 & ETFB & Electron transfer flavoprotein subunit beta & 27.84 & 1.00 & 2 & 7.1 & -0.6128 & 0.1329 & 5 \\
\hline NAA10_HUMAN & P41227 & NAA10 & $\mathrm{N}$-alpha-acetyltransferase 10 , NatA catalytic subunit & 26.46 & 1.00 & 2 & 13.2 & -0.4453 & 0.2086 & 3 \\
\hline AHNK2_HUMAN & Q8IVF2 & AHNAK2 & Protein AHNAK2 & 616.63 & 1.00 & 2 & 5.1 & -1.3132 & 0.7780 & 3 \\
\hline PLBL2_HUMAN & Q8NHP8 & PLBD2 & Putative phospholipase B-like 2 & 65.47 & 1.00 & 2 & 4.9 & -0.4064 & 0.5000 & 6 \\
\hline POP1_HUMAN & Q99575 & POP1 & Ribonucleases P/MRP protein subunit POP1 & 114.71 & 1.00 & 2 & 2.4 & -0.3872 & 0.0895 & 6 \\
\hline VATH_HUMAN & Q9UI12 & ATP6V1H & V-type proton ATPase subunit $\mathrm{H}$ & 55.88 & 1.00 & 2 & 4.8 & -0.7772 & 1.0818 & 6 \\
\hline WDR7_HUMAN & Q9Y4E6 & WDR7 & WD repeat-containing protein 7 & 163.81 & 1.00 & 2 & 2.8 & -1.1116 & 1.9486 & 3 \\
\hline TBA1A_HUMAN & Q71U36 & TUBA1A & Tubulin alpha-1A chain & 50.14 & 1.00 & 2 & 61.4 & -0.8278 & 0.3637 & 8 \\
\hline IDH3A_HUMAN & P50213 & IDH3A & Isocitrate dehydrogenase [NAD] subunit alpha, mitochondrial & 39.59 & 1.00 & 2 & 10.9 & -0.3498 & 0.7076 & 5 \\
\hline FABP5_HUMAN & Q01469 & FABP5 & Fatty acid-binding protein, epidermal & 15.16 & 1.00 & 3 & 31.1 & -0.7044 & 0.2456 & 12 \\
\hline PFD5_HUMAN & Q99471 & PFDN5 & Prefoldin subunit 5 & 17.33 & 1.00 & 2 & 16.9 & -0.8278 & 0.5897 & 4 \\
\hline CD81_HUMAN & P60033 & CD81 & CD81 antigen & 25.81 & 1.00 & 2 & 15.3 & -0.5477 & 0.8910 & 3 \\
\hline VATL_HUMAN & P27449 & ATP6V0C & V-type proton ATPase $16 \mathrm{kDa}$ proteolipid subunit & 15.74 & 1.00 & 2 & 24.5 & -1.0205 & 0.2424 & 3 \\
\hline HMOX̄2_HUMAT & P30519 & HMOX2 & Heme oxygenase 2 & 36.03 & 1.00 & 2 & 5.1 & -0.6352 & 0.2009 & 4 \\
\hline HAT1_HUMAN & O14929 & HAT1 & Histone acetyltransferase type B catalytic subunit & 49.51 & 1.00 & 3 & 11.5 & -0.4652 & 0.5634 & 4 \\
\hline DHC24_HUMAN & Q15392 & DHCR24 & 24-dehydrocholesterol reductase & 60.10 & 1.00 & 2 & 5.4 & -0.5477 & 0.2938 & 3 \\
\hline STXB3_HUMAN & O00186 & STXBP3 & Syntaxin-binding protein 3 & 67.76 & 1.00 & 2 & 3.9 & -0.3684 & 0.5118 & 3 \\
\hline RSF1_HUMAN & Q96T23 & RSF1 & Remodeling and spacing factor 1 & 163.82 & 1.00 & 2 & 1.6 & -0.7044 & 0.9685 & 5 \\
\hline COPḠ2_HUMAN & Q9UBF2 & COPG2 & Coatomer subunit gamma-2 & 97.62 & 1.00 & 3 & 9.6 & -0.6579 & 0.4811 & 3 \\
\hline HDAC1_HUMAN & Q13547 & HDAC1 & Histone deacetylase 1 & 55.10 & 1.00 & 2 & 12.7 & -0.3872 & 0.5510 & 3 \\
\hline RBBP6_HUMAN & Q7Z6E9 & RBBP6 & Retinoblastoma-binding protein 6 & 201.56 & 1.00 & 2 & 2.7 & -0.3498 & 0.3189 & 6 \\
\hline RAB1A_HUMAN & P62820 & RAB1A & Ras-related protein Rab-1A & 22.68 & 0.99 & 2 & 16.6 & -0.4854 & 0.3262 & 5 \\
\hline
\end{tabular}




\begin{tabular}{|c|c|c|c|c|c|c|c|c|c|c|}
\hline RAC2 HUMAN & P15153 & $\mathrm{RAC} 2$ & Ras-related $\mathrm{C} 3$ botulinum toxin substrate 2 & 21.43 & 0.97 & 2 & 27.1 & -0.7283 & 0.3882 & 4 \\
\hline RRAGC_HUMAN & Q9HB90 & RRAGC & Ras-related GTP-binding protein C & 44.22 & 0.97 & 2 & 4 & -0.3498 & 0.3364 & 4 \\
\hline RFA3 HUMAN & P35244 & RPA3 & Replication protein A $14 \mathrm{kDa}$ subunit & 13.57 & 0.93 & 3 & 48.8 & -0.5059 & 1.1394 & 5 \\
\hline
\end{tabular}


Table S-5-4. List of differentially expressed proteins in areca nut extract (ANE)-trained CGHNC9 cell lines

\begin{tabular}{|c|c|c|c|c|c|c|c|c|c|c|}
\hline $\begin{array}{l}\text { Unique and stable } \\
\text { accession no. of a } \\
\text { UniProtKB entry }\end{array}$ & $\begin{array}{l}\text { Mnemonic } \\
\text { accession } \\
\text { no. of a } \\
\text { UniProtKB } \\
\text { entry }\end{array}$ & Gene names & Protein names & $\begin{array}{c}\mathrm{MW} \\
(\mathrm{kDa})\end{array}$ & 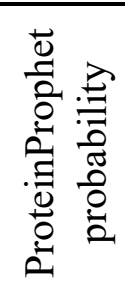 & 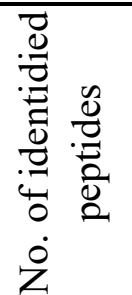 & 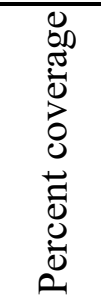 & $\begin{array}{l}\text { Log2 ratio } \\
\text { of ANE- } \\
\text { trained/ } \\
\text { parental } \\
\text { cells }\end{array}$ & $\begin{array}{l}\text { SD of } \\
\text { peptide } \\
\text { ratios } \\
\text { from the } \\
\text { protein }\end{array}$ & 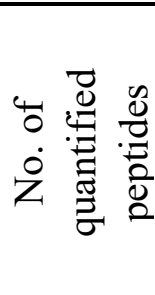 \\
\hline \multicolumn{11}{|c|}{ Overexpressed proteins } \\
\hline CNOT1_HUMAN & A5YKK6 & CNOT1 & CCR4-NOT transcription complex subunit 1 & 266.94 & 1.00 & 3 & 1.8 & 2.7441 & 0.2631 & 6 \\
\hline BACH_HUMAN & O00154 & ACOT7 & Cytosolic acyl coenzyme A thioester hydrolase & 41.80 & 1.00 & 6 & 19.2 & 2.7706 & 0.4367 & 17 \\
\hline PESC_HUMAN & O00541 & PES1 & Pescadillo homolog & 68.00 & 1.00 & 3 & 6.3 & 2.0272 & 0.2528 & 7 \\
\hline ACPM_HUMAN & O14561 & NDUFAB1 & Acyl carrier protein, mitochondrial & 17.42 & 1.00 & 2 & 14.7 & 3.8193 & 0.1443 & 4 \\
\hline IF1AY_HUMAN & O14602 & EIF1AY & Eukaryotic translation initiation factor $1 \mathrm{~A}, \mathrm{Y}$-chromosomal & 16.44 & 1.00 & 3 & 24.3 & 2.8588 & 0.1723 & 5 \\
\hline PDCD5_HUMAN & O14737 & PDCD5 & Programmed cell death protein 5 & 14.29 & 1.00 & 4 & 36.8 & 2.0590 & 0.2049 & 8 \\
\hline LAMA5_HUMAN & O15230 & LAMA5 & Laminin subunit alpha-5 & 399.80 & 1.00 & 3 & 1.3 & 2.0239 & 0.3440 & 7 \\
\hline ARPC5_HUMAN & O15511 & ARPC5 & Actin-related protein $2 / 3$ complex subunit 5 & 16.32 & 1.00 & 3 & 27.8 & 3.6789 & 0.0882 & 6 \\
\hline XPOT_HUMAN & O43592 & XPOT & Exportin- $\mathrm{T}$ & 109.96 & 1.00 & 2 & 2.7 & 2.4304 & 0.1666 & 5 \\
\hline TIM44_HUMAN & O43615 & TIMM44 & Mitochondrial import inner membrane translocase subunit TIM44 & 51.36 & 1.00 & 2 & 6 & 2.5762 & 0.7214 & 3 \\
\hline ASNA_HUMAN & O43681 & ASNA1 & ATPase ASNA1 & 38.79 & 1.00 & 4 & 18.7 & 4.0632 & 0.2396 & 6 \\
\hline AP1G1_HUMAN & O43747 & AP1G1 & AP-1 complex subunit gamma-1 & 91.35 & 1.00 & 6 & 9.5 & 2.6049 & 0.2213 & 15 \\
\hline SYNC_HUMAN & O43776 & NARS & Asparaginyl-tRNA synthetase, cytoplasmic & 62.94 & 1.00 & 8 & 17.3 & 2.6094 & 0.2929 & 19 \\
\hline NRDC_HUMAN & O43847 & NRD1 & Nardilysin & 131.57 & 1.00 & 3 & 2.4 & 2.0689 & 0.4511 & 8 \\
\hline IMA7_HUMAN & O60684 & KPNA6 & Importin subunit alpha-7 & 60.03 & 1.00 & 2 & 11.2 & 3.8134 & 0.2370 & 8 \\
\hline WDR1_HUMAN & O75083 & WDR1 & WD repeat-containing protein 1 & 66.19 & 1.00 & 8 & 20 & 2.0085 & 0.2009 & 12 \\
\hline PDCDĒ_HUMAN & $\mathrm{O} 75340$ & PDCD6 & Programmed cell death protein 6 & 21.87 & 1.00 & 4 & 30.9 & 3.6821 & 0.4742 & 7 \\
\hline TBCA_HUMAN & O75347 & TBCA & Tubulin-specific chaperone A & 12.85 & 1.00 & 5 & 40.7 & 3.4520 & 0.2733 & 7 \\
\hline NDUS3̄_HUMAN & O75489 & NDUFS3 & NADH dehydrogenase [ubiquinone] iron-sulfur protein 3 , mitochondrial & 30.24 & 1.00 & 2 & 9.1 & 2.4683 & 0.3168 & 5 \\
\hline IDHC_HUMAN & O75874 & IDH1 & Isocitrate dehydrogenase [NADP] cytoplasmic & 46.66 & 1.00 & 5 & 16.7 & 3.6708 & 0.5213 & 8 \\
\hline GLRX3_HUMAN & O76003 & GLRX3 & Glutaredoxin-3 & 37.43 & 1.00 & 5 & 18.2 & 2.1237 & 0.2186 & 10 \\
\hline RL1D1_HUMAN & O76021 & RSL1D1 & Ribosomal L1 domain-containing protein 1 & 54.97 & 1.00 & 7 & 16.5 & 2.6240 & 0.4477 & 22 \\
\hline AP2A1_HUMAN & O95782 & AP2A1 & AP-2 complex subunit alpha-1 & 107.55 & 1.00 & 5 & 9.8 & 1.9703 & 0.2784 & 10 \\
\hline BPNT1_HUMAN & O95861 & BPNT1 & $3^{\prime}\left(2^{\prime}\right), 5^{\prime}$-bisphosphate nucleotidase 1 & 33.39 & 1.00 & 3 & 14.3 & 2.4007 & 0.1873 & 6 \\
\hline GSHR_HUMAN & P00390 & GSR & Glutathione reductase, mitochondrial & 56.26 & 1.00 & 2 & 8.8 & 2.3981 & 0.5643 & 5 \\
\hline COX2_HUMAN & P00403 & $\mathrm{MT}-\mathrm{CO} 2$ & Cytochrome c oxidase subunit 2 & 25.57 & 1.00 & 3 & 17.6 & 2.2142 & 0.5943 & 8 \\
\hline PNPH_HUMAN & P00491 & PNP & Purine nucleoside phosphorylase & 32.12 & 1.00 & 9 & 38.4 & 2.0607 & 0.3763 & 35 \\
\hline HPRT_HUMAN & P00492 & HPRT1 & Hypoxanthine-guanine phosphoribosyltransferase & 24.58 & 1.00 & 7 & 36.2 & 2.6262 & 0.3403 & 18 \\
\hline
\end{tabular}

Table S-5-4 page 32 of 45 


\begin{tabular}{|c|c|c|c|c|c|c|c|c|c|}
\hline CYTB_HUMAN & P04080 & CSTB & Cystatin-B & 11.14 & 1.00 & 4 & 30.6 & 2.1704 & 0.4451 \\
\hline ITB1_HUMAN & P05556 & ITGB1 & Integrin beta-1 & 88.42 & 1.00 & 6 & 7.9 & 2.1962 & 0.2675 \\
\hline K2C8_HUMAN & P05787 & KRT8 & Keratin, type II cytoskeletal 8 & 53.70 & 1.00 & 21 & 58.2 & 2.1285 & 0.8937 \\
\hline IF4E_HUMAN & P06730 & EIF4E & Eukaryotic translation initiation factor $4 \mathrm{E}$ & 25.10 & 1.00 & 3 & 15.2 & 2.1674 & 0.2088 \\
\hline CAN1_HUMAN & P07384 & CAPN1 & Calpain-1 catalytic subunit & 81.89 & 1.00 & 13 & 20.6 & 2.5088 & 0.3952 \\
\hline SAP_HUMAN & P07602 & PSAP & Proactivator polypeptide & 58.11 & 1.00 & 5 & 10.1 & 2.7400 & 0.2329 \\
\hline HSP7̄1_HUMAN & P08107 & HSPA1A & Heat shock $70 \mathrm{kDa}$ protein $1 \mathrm{~A} / 1 \mathrm{~B}$ & 70.05 & 1.00 & 12 & 54.3 & 2.1704 & 0.4545 \\
\hline 4F2_HUMMAN & P08195 & SLC3A2 & 4F2 cell-surface antigen heavy chain & 67.99 & 1.00 & 17 & 32.4 & 1.9843 & 0.5579 \\
\hline CLCB_HUMAN & P09497 & CLTB & Clathrin light chain B & 25.19 & 1.00 & 3 & 11.4 & 3.0407 & 0.2652 \\
\hline ROA1_HUMAN & P09651 & HNRNPA1 & Heterogeneous nuclear ribonucleoprotein A1 & 38.75 & 1.00 & 6 & 27.4 & 2.1750 & 0.3214 \\
\hline TACD2_HUMAN & P09758 & TACSTD2 & Tumor-associated calcium signal transducer 2 & 35.71 & 1.00 & 3 & 10.2 & 3.2112 & 1.3788 \\
\hline RO60_HUMAN & P10155 & TROVE2 & $60 \mathrm{kDa}$ SS-A/Ro ribonucleoprotein & 60.67 & 1.00 & 2 & 4.6 & 1.9948 & 0.1773 \\
\hline RRAS_HUMAN & P10301 & RRAS & Ras-related protein R-Ras & 23.48 & 1.00 & 4 & 21.1 & 2.2007 & 0.6013 \\
\hline THIO_HUMAN & P10599 & TXN & Thioredoxin & 11.74 & 1.00 & 5 & 40 & 2.3007 & 0.4599 \\
\hline KAP0_HUMAN & P10644 & PRKAR1A & cAMP-dependent protein kinase type I-alpha regulatory subunit & 42.98 & 1.00 & 4 & 14.2 & 2.3488 & 0.4930 \\
\hline GTR1_HUMAN & P11166 & SLC2A1 & Solute carrier family 2 , facilitated glucose transporter member 1 & 54.08 & 1.00 & 4 & 8.5 & 3.5762 & 0.5539 \\
\hline ODPB_HUMAN & P11177 & PDHB & Pyruvate dehydrogenase E1 component subunit beta, mitochondrial & 39.23 & 1.00 & 3 & 16.4 & 3.3346 & 0.3565 \\
\hline RALA_HUMAN & P11233 & RALA & Ras-related protein Ral-A & 23.57 & 1.00 & 2 & 8.7 & 3.3229 & 0.7011 \\
\hline G6PD_HUMAN & P11413 & G6PD & Glucose-6-phosphate 1-dehydrogenase & 59.26 & 1.00 & 10 & 24.5 & 2.5739 & 0.3390 \\
\hline PCNA_HUMAN & P12004 & PCNA & Proliferating cell nuclear antigen & 28.77 & 1.00 & 7 & 33.3 & 3.3643 & 0.5708 \\
\hline ANXA3_HUMAN & P12429 & ANXA3 & Annexin A3 & 36.38 & 1.00 & 11 & 42.7 & 2.0574 & 0.4002 \\
\hline KCRU_HUMAN & P12532 & CKMT1A & Creatine kinase U-type, mitochondrial & 47.04 & 1.00 & 5 & 19.4 & 1.9455 & 0.4199 \\
\hline SRC_HUMAN & P12931 & $\mathrm{SRC}$ & Proto-oncogene tyrosine-protein kinase Src & 59.83 & 1.00 & 3 & 8.2 & 3.3104 & 0.4177 \\
\hline NQO1_HUMAN & P15559 & NQO1 & NAD(P)H dehydrogenase [quinone] 1 & 30.87 & 1.00 & 5 & 20.4 & 1.9913 & 0.2747 \\
\hline ITB4_HUMAN & P16144 & ITGB4 & Integrin beta- 4 & 202.15 & 1.00 & 16 & 12.2 & 2.7797 & 0.3054 \\
\hline EPCAM_HUMAN & P16422 & EPCAM & Epithelial cell adhesion molecule & 34.93 & 1.00 & 2 & 8.6 & 2.2781 & 0.5551 \\
\hline STMN1_HUMAN & P16949 & STMN1 & Stathmin & 17.30 & 1.00 & 2 & 13.4 & 2.3862 & 0.2248 \\
\hline DDX5_HUMAN & P17844 & DDX5 & Probable ATP-dependent RNA helicase DDX5 & 69.15 & 1.00 & 8 & 31.9 & 2.9835 & 0.3819 \\
\hline RL7_HUMAN & P18124 & RPL7 & 60 S ribosomal protein $\mathrm{L} 7$ & 29.23 & 1.00 & 8 & 35.9 & 2.4807 & 0.6787 \\
\hline ANXA7_HUMAN & P20073 & ANXA7 & Annexin A7 & 52.74 & 1.00 & 7 & 17.6 & 2.0323 & 0.2637 \\
\hline COMT_HUMAN & P21964 & COMT & Catechol O-methyltransferase & 30.04 & 1.00 & 3 & 19.2 & 2.1992 & 0.5386 \\
\hline PUR6_HUMAN & P22234 & PAICS & Multifunctional protein ADE2 & 47.08 & 1.00 & 8 & 21.6 & 2.1094 & 0.3125 \\
\hline NLTP_HUMAN & P22307 & $\mathrm{SCP} 2$ & Non-specific lipid-transfer protein & 58.99 & 1.00 & 2 & 7.3 & 2.6206 & 0.0980 \\
\hline TCEA1_HUMAN & P23193 & TCEA1 & Transcription elongation factor A protein 1 & 33.97 & 1.00 & 2 & 7.6 & 3.2880 & 0.1976 \\
\hline PPIB_HUMAN & P23284 & PPIB & Peptidyl-prolyl cis-trans isomerase B & 23.74 & 1.00 & 7 & 37 & 2.7605 & 0.2803 \\
\hline MCM3_HUMAN & P25205 & MCM3 & DNA replication licensing factor MCM3 & 90.98 & 1.00 & 9 & 16.8 & 2.0137 & 0.3725 \\
\hline
\end{tabular}

Table S-5-4 page 33 of 45 


\begin{tabular}{|c|c|c|c|c|c|c|c|c|c|c|}
\hline PSA1 HUMAN & P25786 & PSMA1 & Proteasome subunit alpha type- 1 & 29.56 & 1.00 & 8 & 24.7 & 2.3542 & 0.2947 & 29 \\
\hline ITA3_HUMAN & P26006 & ITGA3 & Integrin alpha-3 & 118.76 & 1.00 & 3 & 2.4 & 2.2245 & 0.4421 & 9 \\
\hline DDX6_HUMAN & P26196 & DDX6 & Probable ATP-dependent RNA helicase DDX6 & 54.42 & 1.00 & 9 & 27.7 & 2.2037 & 0.2208 & 20 \\
\hline RL13_HUMAN & P26373 & RPL13 & $60 \mathrm{~S}$ ribosomal protein $\mathrm{L} 13$ & 24.26 & 1.00 & 9 & 39.8 & 2.2231 & 0.3070 & 43 \\
\hline APEX1_HUMAN & P27695 & APEX1 & DNA-(apurinic or apyrimidinic site) lyase & 35.55 & 1.00 & 3 & 14.2 & 2.5969 & 0.3525 & 8 \\
\hline PYR1_HUMAN & P27708 & CAD & CAD protein & 242.98 & 1.00 & 12 & 7.1 & 3.0348 & 0.2005 & 24 \\
\hline MK01_HUMAN & P28482 & MAPK1 & Mitogen-activated protein kinase 1 & 41.39 & 1.00 & 4 & 15.6 & 2.4770 & 0.3667 & 6 \\
\hline AMPL_HUMAN & P28838 & LAP3 & Cytosol aminopeptidase & 56.17 & 1.00 & 5 & 14.1 & 2.3529 & 0.4210 & 13 \\
\hline ERP29_HUMAN & P30040 & ERP29 & Endoplasmic reticulum resident protein 29 & 28.99 & 1.00 & 4 & 20.7 & 2.8870 & 0.2085 & 3 \\
\hline DOPD_HUMAN & P30046 & DDT & D-dopachrome decarboxylase & 12.71 & 1.00 & 3 & 27.1 & 2.0323 & 0.4260 & 11 \\
\hline RPB2_HUMAN & P30876 & POLR2B & DNA-directed RNA polymerase II subunit RPB2 & 133.90 & 1.00 & 5 & 4.6 & 3.0432 & 0.5539 & 9 \\
\hline DHSA_HUMAN & P31040 & SDHA & Succinate dehydrogenase [ubiquinone] flavoprotein subunit, mitochondrial & 72.69 & 1.00 & 2 & 4.1 & 2.0474 & 0.1728 & 10 \\
\hline HNRH1_HUMAN & P31943 & HNRNPH1 & Heterogeneous nuclear ribonucleoprotein $\mathrm{H}$ & 49.23 & 1.00 & 4 & 25.4 & 2.9606 & 0.4340 & 6 \\
\hline GLYM_HUMAN & P34897 & SHMT2 & Serine hydroxymethyltransferase, mitochondrial & 55.99 & 1.00 & 9 & 24.2 & 2.0623 & 0.2926 & 26 \\
\hline DEK_HUMAN & P35659 & DEK & Protein DEK & 42.67 & 1.00 & 3 & 8.8 & 3.4150 & 0.2082 & 10 \\
\hline PRS7_HUMAN & P35998 & PSMC2 & $26 \mathrm{~S}$ protease regulatory subunit 7 & 48.63 & 1.00 & 10 & 33 & 2.1206 & 0.1960 & 21 \\
\hline FDFT_HUMAN & P37268 & FDFT1 & Squalene synthase & 48.12 & 1.00 & 5 & 14.6 & 2.3862 & 0.2404 & 6 \\
\hline TAGL2_HUMAN & P37802 & TAGLN2 & Transgelin-2 & 22.39 & 1.00 & 10 & 66.8 & 2.0051 & 0.4140 & 87 \\
\hline TALDO_HUMAN & P37837 & TALDO1 & Transaldolase & 37.54 & 1.00 & 8 & 25.5 & 2.2407 & 0.2785 & 25 \\
\hline GRP75_HUMAN & P38646 & HSPA9 & Stress- 70 protein, mitochondrial & 73.68 & 1.00 & 18 & 39.5 & 2.0524 & 0.4929 & 55 \\
\hline OST48_HUMAN & P39656 & DDOST & Dolichyl-diphosphooligosaccharide--protein glycosyltransferase $48 \mathrm{kDa}$ subunit & 50.80 & 1.00 & 6 & 14.9 & 2.2436 & 0.2374 & 14 \\
\hline RL13A_HUMAN & P40429 & RPL13A & $60 \mathrm{~S}$ ribosomal protein $\mathrm{L} 13 \mathrm{a}$ & 23.58 & 1.00 & 8 & 33.5 & 3.1022 & 0.7822 & 22 \\
\hline ARL1_HUMAN & P40616 & ARL1 & ADP-ribosylation factor-like protein 1 & 20.42 & 1.00 & 4 & 33.1 & 2.0673 & 0.3624 & 40 \\
\hline SYIC_HUMAN & P41252 & IARS & Isoleucyl-tRNA synthetase, cytoplasmic & 144.50 & 1.00 & 17 & 15.5 & 3.1811 & 0.2752 & 31 \\
\hline RL35_HUMAN & P42766 & RPL35 & 60 S ribosomal protein $\mathrm{L} 35$ & 14.55 & 1.00 & 4 & 27.6 & 2.1158 & 0.2291 & 17 \\
\hline HD_HUMAN & P42858 & HTT & Huntingtin & 347.60 & 1.00 & 2 & 0.9 & 1.9913 & 0.7620 & 4 \\
\hline RAN̄G_HUMAN & P43487 & RANBP1 & Ran-specific GTPase-activating protein & 23.31 & 1.00 & 5 & 31.8 & 2.0771 & 0.4698 & 18 \\
\hline RAGP1_HUMAN & P46060 & RANGAP1 & Ran GTPase-activating protein 1 & 63.54 & 1.00 & 10 & 28.3 & 3.4124 & 0.3767 & 13 \\
\hline BAT3_HUMAN & P46379 & BAT3 & Large proline-rich protein BAT3 & 119.41 & 1.00 & 5 & 5.3 & 2.4991 & 0.3342 & 11 \\
\hline RL27ĀHUMAN & P46776 & RPL27A & $60 \mathrm{~S}$ ribosomal protein $\mathrm{L} 27 \mathrm{a}$ & 16.56 & 1.00 & 4 & 27.7 & 2.6374 & 0.2107 & 17 \\
\hline RS9_HŪMAN & P46781 & RPS9 & 40S ribosomal protein $\mathrm{S} 9$ & 22.59 & 1.00 & 8 & 33 & 3.3509 & 0.2829 & 29 \\
\hline RS10_HUMAN & P46783 & RPS 10 & 40S ribosomal protein $\mathrm{S} 10$ & 18.90 & 1.00 & 2 & 10.9 & 3.6026 & 0.3527 & 13 \\
\hline SYQ_HUMAN & P47897 & QARS & Glutaminyl-tRNA synthetase & 87.80 & 1.00 & 6 & 10.2 & 3.0306 & 0.4054 & 19 \\
\hline
\end{tabular}

Table S-5-4 page 34 of 45 


\begin{tabular}{|c|c|c|c|c|c|c|c|c|c|c|}
\hline ERG7_HUMAN & P48449 & LSS & Lanosterol synthase & 83.31 & 1.00 & 3 & 4.9 & 3.0623 & 0.1151 & 8 \\
\hline PTSS1_HUMAN & P48651 & PTDSS1 & Phosphatidylserine synthase 1 & 55.53 & 1.00 & 2 & 5.7 & 2.6681 & 0.4932 & 5 \\
\hline RL34_HUMAN & P49207 & RPL34 & 60S ribosomal protein L34 & 13.29 & 1.00 & 5 & 34.2 & 2.5635 & 0.2115 & 14 \\
\hline PSB2_HUMAN & P49721 & PSMB2 & Proteasome subunit beta type- 2 & 22.84 & 1.00 & 5 & 30.8 & 2.0607 & 0.4985 & 22 \\
\hline ANX1̄1_HUMAN & P50995 & ANXA11 & Annexin A11 & 54.39 & 1.00 & 3 & 6.7 & 3.6901 & 0.3149 & 8 \\
\hline SSRD_HUMAN & P51571 & SSR4 & Translocon-associated protein subunit delta & 19.00 & 1.00 & 2 & 17.3 & 2.4770 & 1.2157 & 4 \\
\hline BAP31_HUMAN & P51572 & BCAP31 & B-cell receptor-associated protein 31 & 27.99 & 1.00 & 7 & 26 & 2.1062 & 0.1217 & 12 \\
\hline DHB4_HUMAN & P51659 & HSD17B4 & Peroxisomal multifunctional enzyme type 2 & 79.69 & 1.00 & 5 & 10.9 & 2.2260 & 0.2488 & 12 \\
\hline TXTP_HUMAN & P53007 & SLC25A1 & Tricarboxylate transport protein, mitochondrial & 34.01 & 1.00 & 5 & 25.1 & 1.9419 & 0.5271 & 7 \\
\hline SC24C_HUMAN & P53992 & SEC24C & Protein transport protein Sec24C & 118.32 & 1.00 & 3 & 3.9 & 2.2753 & 0.3555 & 7 \\
\hline AT1B3_HUMAN & P54709 & ATP1B3 & Sodium/potassium-transporting ATPase subunit beta-3 & 31.51 & 1.00 & 3 & 14.3 & 1.9437 & 0.1195 & 8 \\
\hline SNAA_HUMAN & P54920 & NAPA & Alpha-soluble NSF attachment protein & 33.23 & 1.00 & 3 & 11.2 & 2.7286 & 0.3022 & 5 \\
\hline ECHB_HUMAN & P55084 & HADHB & Trifunctional enzyme subunit beta, mitochondrial & 51.29 & 1.00 & 4 & 8.4 & 2.9791 & 0.2524 & 9 \\
\hline NH2L1_HUMAN & P55769 & NHP2L1 & NHP2-like protein 1 & 14.17 & 1.00 & 4 & 33.6 & 2.4317 & 0.2821 & 6 \\
\hline TMM33̄HUMAN & P57088 & TMEM33 & Transmembrane protein 33 & 27.98 & 1.00 & 5 & 20.6 & 2.4819 & 0.1716 & 14 \\
\hline NU107_HUMAN & P57740 & NUP107 & Nuclear pore complex protein Nup107 & 106.37 & 1.00 & 2 & 5.3 & 2.4770 & 0.4531 & 3 \\
\hline RAB2A_HUMAN & P61019 & RAB2A & Ras-related protein Rab-2A & 23.55 & 1.00 & 4 & 25 & 2.0607 & 0.1571 & 5 \\
\hline UBC12_HUMAN & P61081 & UBE2M & NEDD8-conjugating enzyme Ubc12 & 20.90 & 1.00 & 4 & 24 & 2.8588 & 0.1764 & 8 \\
\hline ARF3_HUMAN & P61204 & ARF3 & ADP-ribosylation factor 3 & 20.60 & 1.00 & 4 & 42 & 2.1062 & 0.3173 & 18 \\
\hline RAP1B_HUMAN & P61224 & RAP1B & Ras-related protein Rap- $1 b$ & 20.82 & 1.00 & 4 & 38.6 & 4.8993 & 0.0952 & 5 \\
\hline RS3A_HUMAN & P61247 & RPS3A & $40 \mathrm{~S}$ ribosomal protein $\mathrm{S} 3 \mathrm{a}$ & 29.94 & 1.00 & 9 & 37.5 & 2.1535 & 0.2670 & 38 \\
\hline RL15_HUMAN & P61313 & RPL15 & $60 \mathrm{~S}$ ribosomal protein $\mathrm{L} 15$ & 24.15 & 1.00 & 6 & 31.9 & 3.1387 & 0.5255 & 20 \\
\hline RL27_HUMAN & P61353 & RPL27 & 60 S ribosomal protein $\mathrm{L} 27$ & 15.80 & 1.00 & 4 & 25.7 & 2.0689 & 0.3219 & 38 \\
\hline CH10_HUMAN & P61604 & HSPE1 & $10 \mathrm{kDa}$ heat shock protein, mitochondrial & 10.93 & 1.00 & 5 & 50 & 2.1504 & 0.8891 & 19 \\
\hline UFM1_HUMAN & P61960 & UFM1 & Ubiquitin-fold modifier 1 & 9.12 & 1.00 & 2 & 50.6 & 2.7255 & 0.5005 & 3 \\
\hline NTF2_HUMAN & P61970 & NUTF2 & Nuclear transport factor 2 & 14.48 & 1.00 & 3 & 38.6 & 3.2045 & 0.3375 & 5 \\
\hline RS15A_HUMAN & P62244 & RPS15A & 40S ribosomal protein $\mathrm{S} 15 \mathrm{a}$ & 14.84 & 1.00 & 6 & 43.8 & 2.5388 & 0.2414 & 37 \\
\hline RS18_HUMAN & P62269 & RPS18 & 40S ribosomal protein $\mathrm{S} 18$ & 17.72 & 1.00 & 12 & 59.9 & 2.2436 & 0.3649 & 48 \\
\hline RUXE_HUMAN & P62304 & SNRPE & Small nuclear ribonucleoprotein $\mathrm{E}$ & 10.80 & 1.00 & 2 & 25 & 2.1612 & 0.3499 & 22 \\
\hline LSM3_HUMAN & P62310 & LSM3 & U6 snRNA-associated Sm-like protein LSm3 & 11.85 & 1.00 & 2 & 19.6 & 3.9982 & 0.5864 & 5 \\
\hline SMD3_HUMAN & P62318 & SNRPD3 & Small nuclear ribonucleoprotein Sm D3 & 13.92 & 1.00 & 2 & 15.1 & 3.0008 & 0.1462 & 7 \\
\hline H4_HUMAN & P62805 & HIST1H4A & Histone H4 & 11.37 & 1.00 & 7 & 53.4 & 2.2667 & 0.3984 & 187 \\
\hline
\end{tabular}

Table S-5-4 page 35 of 45 
RL38_HUMAN SC11A_HUMAN TBA4A HUMAN PA1B2_HUMAN IF4G2_HUMAN RL24_HUMAN RL19 HUMAN SFRS3 HUMAN PLOD1_HUMAN CEBPZ_HUMAN SFR11_HUMAN AIMP2_HUMAN PABP4 HUMAN BYST_HUMAN CAPR1_HUMAN SYK_HUMAN PA1B3 HUMAN TEBP HUMAN SF3B3 HUMAN PP1R7 HUMAN TRP13_HUMAN ELAV1_HUMAN PSMD5_HUMAN DDB1_HUMAN SFRS7_HUMAN KYNU_HUMAN UPP1_HUMAN SMU1_HUMAN DHB12_HUMAN PCID2 HUMAN HP1B3 HUMAN TUT7_HUMAN SCMC1_HUMAN DDX46 HUMAN DHX30 HUMAN EIF3M_HUMAN
P63173 RPL38

68366

P68402

P78344

P83731

P84098

P84103

Q02809

Q03701

Q05519

Q13155

Q13310

Q13895

Q14444

Q15046

Q15102

Q15185

Q15393

Q15435

Q15645

Q15717

Q16401

Q16531

Q16629

Q16719

Q16831

Q2TAY7 SMU1

Q53GQ0

Q5JVF

Q5SSJ5

Q5VYS8

Q6NUK

Q7L014

Q7L2E3

Q7L2H7

EIF4G2

RPL24

RPL19

SFRS3

PLOD1

CEBPZ

BYSL

KARS

DDB1

SFRS7

KYNU

\section{PCID2}

EIF3M
TUBA4A Tubulin alpha-4A chain

PAFAH1B2 Platelet-activating factor acetylhydrolase IB subunit beta

SFRS11

AIMP2

Eukaryotic translation initiation factor 4 gamma 2

60 S ribosomal protein L24

60S ribosomal protein L19

Splicing factor, arginine/serine-rich 3

Procollagen-lysine,2-oxoglutarate 5-dioxygenase 1

CCAAT/enhancer-binding protein zeta

Splicing factor, arginine/serine-rich 11

Aminoacyl tRNA synthase complex-interacting multifunctional protein $2 \quad 35.35 \quad 1.00$

PABPC4

Polyadenylate-binding protein 4

Bystin

PAFAH1B3 Platelet-activating factor acetylhydrolase IB subunit gamma

PTGES3 Prostaglandin E synthase 3

SF3B3 Splicing factor 3B subunit 3

PPP1R7 Protein phosphatase 1 regulatory subunit 7

TRIP13 Thyroid receptor-interacting protein 13

ELAVL1 ELAV-like protein 1

PSMD5 26S proteasome non-ATPase regulatory subunit 5

DNA damage-binding protein 1

Splicing factor, arginine/serine-rich 7

Kynureninase

Uridine phosphorylase 1

WD40 repeat-containing protein SMU1

HSD17B12 Estradiol 17-beta-dehydrogenase 12

PCI domain-containing protein 2

\section{HP1BP3}

Heterochromatin protein 1-binding protein 3

Terminal uridylyltransferase 7

SLC25A24

DDX46

DHX30
Calcium-binding mitochondrial carrier protein SCaMC-1

Probable ATP-dependent RNA helicase DDX46

Putative ATP-dependent RNA helicase DHX30

Eukaryotic translation initiation factor 3 subunit $\mathrm{M}$

$\begin{array}{ccccccc}8.22 & 1.00 & 3 & 45.7 & 1.9615 & 0.3570 & 8 \\ 20.63 & 1.00 & 2 & 16.2 & 3.0154 & 0.6677 & 5 \\ 49.92 & 1.00 & 4 & 55.1 & 2.0607 & 0.4244 & 21 \\ 25.57 & 1.00 & 4 & 14.4 & 2.1550 & 0.3047 & 28 \\ 102.36 & 1.00 & 4 & 6 & 2.2795 & 0.3110 & 11 \\ 17.78 & 1.00 & 4 & 23.6 & 3.0085 & 0.2821 & 16 \\ 23.47 & 1.00 & 4 & 17.9 & 2.1457 & 0.1536 & 14 \\ 19.33 & 1.00 & 3 & 26.2 & 2.7441 & 0.5893 & 5 \\ 83.55 & 1.00 & 3 & 5 & 2.8115 & 0.3819 & 6 \\ 120.99 & 1.00 & 2 & 3.1 & 1.9791 & 0.4243 & 3 \\ 53.54 & 1.00 & 2 & 4.5 & 2.8339 & 0.2394 & 4 \\ 35.35 & 1.00 & 2 & 6.9 & 2.4266 & 0.3346 & 7 \\ 70.78 & 1.00 & 4 & 11.5 & 2.0853 & 0.1365 & 6 \\ 49.60 & 1.00 & 2 & 5 & 3.0094 & 0.3522 & 4 \\ 78.37 & 1.00 & 7 & 11.6 & 2.1442 & 0.3594 & 15 \\ 68.05 & 1.00 & 9 & 19.1 & 2.6949 & 0.4120 & 12 \\ 25.73 & 1.00 & 4 & 19.9 & 2.0119 & 0.3382 & 15 \\ 18.70 & 1.00 & 5 & 36.9 & 2.0917 & 0.3698 & 42 \\ 135.58 & 1.00 & 13 & 15.6 & 2.4520 & 0.2856 & 31 \\ 41.56 & 1.00 & 3 & 12.8 & 2.8805 & 0.5356 & 4 \\ 48.55 & 1.00 & 4 & 12.7 & 2.3717 & 0.3914 & 8 \\ 36.09 & 1.00 & 6 & 27.3 & 2.2290 & 0.4268 & 15 \\ 56.20 & 1.00 & 9 & 24.4 & 2.4046 & 0.2907 & 15 \\ 126.97 & 1.00 & 9 & 10.4 & 2.2937 & 0.3791 & 19 \\ 27.37 & 1.00 & 2 & 14.7 & 5.3930 & 0.1412 & 4 \\ 52.35 & 1.00 & 3 & 7.7 & 2.3542 & 0.6639 & 8 \\ 33.93 & 1.00 & 5 & 21.3 & 2.8435 & 0.2078 & 12 \\ 57.54 & 1.00 & 2 & 5.5 & 2.6735 & 0.3113 & 4 \\ 34.32 & 1.00 & 4 & 18.6 & 2.3021 & 0.3466 & 8 \\ 46.03 & 1.00 & 2 & 5.3 & 2.8626 & 0.1364 & 4 \\ 61.21 & 1.00 & 4 & 8.7 & 2.4905 & 0.1121 & 7 \\ 171.23 & 1.00 & 4 & 1.9 & 3.4893 & 2.2868 & 9 \\ 53.35 & 1.00 & 3 & 7.8 & 1.9491 & 0.6547 & 8 \\ 117.36 & 1.00 & 3 & 4 & 3.0128 & 0.3469 & 9 \\ 133.94 & 1.00 & 7 & 8.5 & 2.5376 & 1.0664 & 8 \\ 42.50 & 1.00 & 6 & 23.5 & 2.1062 & 0.3655 & 20\end{array}$

Table S-5-4 page 36 of 45 


\begin{tabular}{|c|c|c|c|c|c|c|c|c|c|}
\hline CYFP1_HUMAN & Q7L576 & CYFIP1 & Cytoplasmic FMR1-interacting protein 1 & 145.18 & 1.00 & 6 & 5.7 & 2.0017 & 0.2470 \\
\hline MON2_HUMAN & Q7Z3U7 & MON2 & Protein MON2 homolog & 190.49 & 1.00 & 3 & 1.9 & 2.0804 & 0.3751 \\
\hline DHX29_HUMAN & Q7Z478 & DHX29 & ATP-dependent RNA helicase DHX29 & 155.24 & 1.00 & 2 & 2.3 & 2.2363 & 1.0781 \\
\hline THOC4_HUMAN & Q86V81 & THOC4 & THO complex subunit 4 & 26.89 & 1.00 & 4 & 23.3 & 2.5209 & 0.2813 \\
\hline A16A1_HUMAN & Q8IZ83 & ALDH16A1 & Aldehyde dehydrogenase family 16 member A1 & 85.13 & 1.00 & 3 & 6.9 & 2.0306 & 0.1901 \\
\hline NUP93_HUMAN & Q8N1F7 & NUP93 & Nuclear pore complex protein Nup93 & 93.49 & 1.00 & 6 & 13.3 & 2.2171 & 0.7953 \\
\hline TXND5_HUMAN & Q8NBS9 & TXNDC5 & Thioredoxin domain-containing protein 5 & 47.63 & 1.00 & 8 & 23.1 & 2.5459 & 0.1892 \\
\hline KCT2_HUMAN & Q8NC54 & KCT2 & Keratinocyte-associated transmembrane protein 2 & 29.23 & 1.00 & 2 & 7.9 & 2.8796 & 0.1295 \\
\hline PI42C_HUMAN & Q8TBX8 & PIP4K2C & Phosphatidylinositol-5-phosphate 4-kinase type-2 gamma & 47.29 & 1.00 & 2 & 6.9 & 2.1932 & 0.4137 \\
\hline HM13_HUMAN & Q8TCT9 & HM13 & Minor histocompatibility antigen $\mathrm{H} 13$ & 41.49 & 1.00 & 4 & 10.6 & 3.3339 & 0.4357 \\
\hline BRX1_HUMAN & Q8TDN6 & BRIX1 & Ribosome biogenesis protein BRX1 homolog & 41.40 & 1.00 & 3 & 7.4 & 2.9747 & 0.5600 \\
\hline CTBL1_HUMAN & Q8WYA6 & CTNNBL1 & Beta-catenin-like protein 1 & 65.17 & 1.00 & 4 & 8.5 & 3.2545 & 0.6409 \\
\hline FAM3C_HUMAN & Q92520 & FAM3C & Protein FAM3C & 24.68 & 1.00 & 2 & 12.8 & 2.0407 & 0.3365 \\
\hline NDRG1_HUMAN & Q92597 & NDRG1 & Prote & 42.84 & 1.00 & 6 & 24.4 & 2.1750 & 0.1707 \\
\hline HDAC2_HUMAN & Q92769 & HDAC2 & ne deacetylase 2 & 55.36 & 1.00 & 2 & 9.4 & 2.4482 & 0.5451 \\
\hline FUBP2_HUMAN & Q92945 & KHSRP & Far upstream element-binding protein 2 & 73.15 & 1.00 & 7 & 11.7 & 3.3829 & 0.3670 \\
\hline DAZP1_HUMAN & Q96EP5 & DAZAP1 & DAZ-associated protein 1 & 43.38 & 1.00 & 3 & 14 & 2.9419 & 0.1291 \\
\hline ERO1A_HUMAN & Q96HE7 & ERO1L & ERO1-like protein alpha & 54.39 & 1.00 & 8 & 23.1 & 2.9791 & 0.2591 \\
\hline ITCH_HUMAN & Q96J02 & ITCH & E3 ubiquitin-protein ligase Itchy homolog & 102.80 & 1.00 & 5 & 6.5 & 2.1826 & 0.4029 \\
\hline VAT1_HUMAN & Q99536 & VAT1 & Synaptic vesicle membrane protein VAT-1 homolog & 41.92 & 1.00 & 3 & 11.7 & 2.3796 & 0.2846 \\
\hline PHB2_HUMAN & Q99623 & PHB2 & Prohibitin-2 & 33.30 & 1.00 & 7 & 28.1 & 2.0085 & 0.1908 \\
\hline ANM1_HUMAN & Q99873 & PRMT1 & Protein arginine N-methyltransferase 1 & 41.52 & 1.00 & 4 & 11.4 & 2.3849 & 0.2778 \\
\hline COR1B_HUMAN & Q9BR76 & CORO1B & Coronin-1B & 54.23 & 1.00 & 2 & 4.1 & 3.0332 & 0.1343 \\
\hline CJ119_HUMAN & Q9BTE3 & C10orf1 19 & UPF0557 protein C10orf119 & 72.98 & 1.00 & 6 & 10 & 2.3380 & 0.3846 \\
\hline HNRL1_HUMAN & Q9BUJ2 & HNRNPUL1 & 1 Heterogeneous nuclear ribonucleoprotein U-like protein 1 & 95.74 & 1.00 & 4 & 6.1 & 1.9526 & 0.3390 \\
\hline DERL1_HUMAN & Q9BUN8 & DERL1 & Derlin-1 & 28.80 & 1.00 & 3 & 14.7 & 2.8095 & 0.2044 \\
\hline TMED9_HUMAN & Q9BVK6 & TMED9 & Transmembrane emp24 domain-containing protein 9 & 27.28 & 1.00 & 3 & 14.5 & 2.8908 & 0.1426 \\
\hline NAA15_HUMAN & Q9BXJ9 & NAA15 & $\mathrm{N}$-alpha-acetyltransferase 15 , NatA auxiliary subunit & 101.27 & 1.00 & 10 & 13.4 & 2.4431 & 0.2610 \\
\hline IPYR2_HUMAN & Q9H2U2 & PPA2 & Inorganic pyrophosphatase 2, mitochondrial & 37.92 & 1.00 & 2 & 7.5 & 5.0413 & 0.1301 \\
\hline UN45A_HUMAN & Q9H3U1 & UNC45A & Protein unc-45 homolog A & 103.08 & 1.00 & 3 & 4.6 & 2.1628 & 0.3934 \\
\hline RM17_HUMAN & Q9NRX2 & MRPL17 & 39S ribosomal protein $\mathrm{L} 17$, mitochondrial & 20.05 & 1.00 & 4 & 19.4 & 2.0524 & 0.3819 \\
\hline ATD3A_HUMAN & Q9NVI7 & ATAD3A & ATPase family AAA domain-containing protein $3 \mathrm{~A}$ & 71.37 & 1.00 & 2 & 5.7 & 2.1566 & 0.3921 \\
\hline TECR_HUMAN & Q9NZ01 & TECR & Trans-2,3-enoyl-CoA reductase & 36.03 & 1.00 & 7 & 21.4 & 2.3703 & 0.2839 \\
\hline PDP1_HUMAN & Q9P0J1 & PDP1 & [Pyruvate dehydrogenase [acetyl-transferring]]-phosphatase 1, mitochondrial & 61.05 & 1.00 & 2 & 3.5 & 4.4438 & 0.3536 \\
\hline CF115_HUMAN & Q9P1F3 & C6orf115 & UPF0727 protein C6orf115 & 9.06 & 1.00 & 2 & 23.5 & 2.2710 & 0.2781 \\
\hline DHCR7_HUMAN & Q9UBM7 & DHCR7 & 7-dehydrocholesterol reductase & 54.49 & 1.00 & 6 & 13.9 & 2.3596 & 0.2182 \\
\hline
\end{tabular}

Table S-5-4 page 37 of 45 


\begin{tabular}{|c|c|c|c|c|c|c|c|c|c|c|}
\hline RALY_HUMAN & Q9UKM9 & RALY & RNA-binding protein Raly & 32.46 & 1.00 & 5 & 13.7 & 2.6928 & 0.2013 & 14 \\
\hline MYO6_HUMAN & Q9UM54 & MYO6 & Myosin-VI & 149.69 & 1.00 & 4 & 4.9 & 2.4304 & 0.4991 & 4 \\
\hline EIF3L_HUMAN & Q9Y262 & EIF3L & Eukaryotic translation initiation factor 3 subunit L & 66.73 & 1.00 & 10 & 19.5 & 2.0507 & 0.4585 & 14 \\
\hline VDAC3_HUMAN & Q9Y277 & VDAC3 & Voltage-dependent anion-selective channel protein 3 & 30.66 & 1.00 & 2 & 10.6 & 4.0424 & 0.1683 & 8 \\
\hline CAB39_HUMAN & Q9Y376 & CAB39 & Calcium-binding protein 39 & 39.87 & 1.00 & 5 & 12 & 2.0017 & 0.4607 & 7 \\
\hline PKP3_HUMAN & Q9Y446 & PKP3 & Plakophilin-3 & 87.08 & 1.00 & 5 & 8 & 2.6691 & 0.2237 & 6 \\
\hline OAS3_HUMAN & Q9Y6K5 & OAS3 & 2'-5'-oligoadenylate synthase 3 & 121.17 & 1.00 & 10 & 10.8 & 2.2681 & 0.2771 & 18 \\
\hline MT2_HUMAN & P02795 & MT2A & Metallothionein-2 & 6.04 & 1.00 & 3 & 41 & 2.2022 & 0.6389 & 51 \\
\hline F10A1_HUMAN & P50502 & ST13 & Hsc70-interacting protein & 41.33 & 1.00 & 9 & 25.2 & 2.4745 & 0.3907 & 24 \\
\hline H2B1L_HUMAN & Q99880 & HIST1H2B & Histone H2B type 1-L & 13.95 & 1.00 & 10 & 66.7 & 2.0222 & 0.3762 & 190 \\
\hline BASI_HUMAN & P35613 & BSG & Basigin & 42.20 & 1.00 & 2 & 7.8 & 4.0445 & 0.1116 & 7 \\
\hline PSMD8_HUMAN & P48556 & PSMD8 & $26 \mathrm{~S}$ proteasome non-ATPase regulatory subunit 8 & 30.00 & 1.00 & 3 & 11.7 & 3.8569 & 0.3734 & 5 \\
\hline RS21_HUMAN & P63220 & RPS21 & $40 \mathrm{~S}$ ribosomal protein $\mathrm{S} 21$ & 9.11 & 1.00 & 3 & 31.3 & 2.7087 & 0.2367 & 12 \\
\hline SARNP_HUMAN & P82979 & SARNP & SAP domain-containing ribonucleoprotein & 23.67 & 1.00 & 2 & 9 & 2.4520 & 0.0751 & 6 \\
\hline PNPT1_HUMAN & Q8TCS8 & PNPT1 & Polyribonucleotide nucleotidyltransferase 1 , mitochondrial & 85.95 & 1.00 & 2 & 3.2 & 2.4033 & 0.7993 & 5 \\
\hline CHM4B_HUMAN & Q9H444 & CHMP4B & Charged multivesicular body protein $4 \mathrm{~b}$ & 24.95 & 1.00 & 2 & 8 & 2.0137 & 0.3467 & 3 \\
\hline RAD21_HUMAN & O60216 & RAD21 & Double-strand-break repair protein $\operatorname{rad} 21$ homolog & 71.69 & 1.00 & 2 & 3.6 & 2.2290 & 0.6151 & 4 \\
\hline RL37A_HUMAN & P61513 & RPL37A & $60 \mathrm{~S}$ ribosomal protein $\mathrm{L} 37 \mathrm{a}$ & 10.28 & 1.00 & 3 & 41.3 & 2.2781 & 0.9719 & 8 \\
\hline ULA1_HUMAN & Q13564 & NAE1 & NEDD8-activating enzyme E1 regulatory subunit & 60.25 & 1.00 & 2 & 6.2 & 3.0656 & 0.4763 & 4 \\
\hline GNA13_HUMAN & Q14344 & GNA13 & Guanine nucleotide-binding protein subunit alpha- 13 & 44.05 & 1.00 & 2 & 5.6 & 4.9736 & 0.1136 & 5 \\
\hline MAEA_HUMAN & Q7L5Y9 & MAEA & Macrophage erythroblast attacher & 45.29 & 1.00 & 2 & 7.1 & 3.2767 & 0.8468 & 3 \\
\hline PPIL1_HUMAN & Q9Y3C6 & PPIL1 & Peptidyl-prolyl cis-trans isomerase-like 1 & 18.24 & 1.00 & 2 & 16.3 & 2.4507 & 0.0870 & 3 \\
\hline TBCD4_HUMAN & O60343 & TBC1D4 & TBC1 domain family member 4 & 146.56 & 1.00 & 2 & 1.6 & 2.2363 & 0.7093 & 3 \\
\hline RCC1_HUMAN & P18754 & $\mathrm{RCC} 1$ & Regulator of chromosome condensation & 44.97 & 1.00 & 2 & 5.5 & 3.2824 & 0.2619 & 5 \\
\hline JMJD6_HUMAN & Q6NYC1 & JMJD6 & Bifunctional arginine demethylase and lysyl-hydroxylase JMJD6 & 46.46 & 1.00 & 2 & 4.5 & 4.7296 & 0.3822 & 5 \\
\hline HEM6_HUMAN & P36551 & CPOX & Coproporphyrinogen-III oxidase, mitochondrial & 50.15 & 1.00 & 2 & 4.8 & 3.3277 & 0.3349 & 6 \\
\hline 2A5G_HUMAN & Q13362 & PPP2R5C & Serine/threonine-protein phosphatase $2 \mathrm{~A} 56 \mathrm{kDa}$ regulatory subunit gamma isoform & 61.06 & 1.00 & 2 & 7.1 & 2.5040 & 0.1726 & 4 \\
\hline ATPF1_HUMAN & Q5TC12 & ATPAF1 & ATP synthase mitochondrial F1 complex assembly factor 1 & 36.44 & 1.00 & 2 & 9.5 & 2.6767 & 0.1330 & 3 \\
\hline RM38_HUMAN & Q96DV4 & MRPL38 & 39S ribosomal protein L38, mitochondrial & 44.60 & 1.00 & 2 & 3.9 & 2.1658 & 0.2316 & 6 \\
\hline RSMB_HUMAN & P14678 & SNRPB & Small nuclear ribonucleoprotein-associated proteins B and B' & 24.61 & 1.00 & 2 & 6.3 & 2.3243 & 0.6129 & 16 \\
\hline PLOD2_HUMAN & O00469 & PLOD2 & Procollagen-lysine,2-oxoglutarate 5-dioxygenase 2 & 84.69 & 1.00 & 2 & 3.3 & 2.6083 & 0.3213 & 4 \\
\hline IF4G3_HUMAN & O43432 & EIF4G3 & Eukaryotic translation initiation factor 4 gamma 3 & 176.65 & 0.99 & 3 & 3.2 & 3.3823 & 0.1423 & 6 \\
\hline RAC2_HUMAN & P15153 & RAC2 & Ras-related C3 botulinum toxin substrate 2 & 21.43 & 0.97 & 2 & 27.1 & 2.4745 & 0.3782 & 4 \\
\hline RL32_HUMAN & P62910 & RPL32 & $60 \mathrm{~S}$ ribosomal protein $\mathrm{L} 32$ & 15.86 & 0.97 & 2 & 11.1 & 3.5529 & 0.1505 & 13 \\
\hline TITIN_HUMAN & Q8WZ42 & TTN & Titin & \#\#\#\#\#\# & 0.95 & 3 & 0.1 & 3.8154 & 1.0414 & \\
\hline RNBP6_HUMAN & O60518 & RANBP6 & Ran-binding protein 6 & 124.71 & 0.91 & 2 & 3.6 & 3.1285 & 0.2545 & \\
\hline
\end{tabular}

Table S-5-4 page 38 of 45 
Underexpressed proteins

\begin{tabular}{|c|c|c|c|c|c|c|c|c|c|c|}
\hline \multicolumn{11}{|c|}{ Underexpressed proteins } \\
\hline PSDE_HUMAN & O00487 & PSMD14 & 26S proteasome non-ATPase regulatory subunit 14 & 34.58 & 1.00 & 4 & 23.2 & -0.3782 & 0.3014 & 7 \\
\hline ARI1A_HUMAN & O14497 & ARID1A & AT-rich interactive domain-containing protein $1 \mathrm{~A}$ & 242.04 & 1.00 & 3 & 2 & -0.8763 & 0.3911 & 8 \\
\hline AP3D1_HUMAN & O14617 & AP3D1 & AP-3 complex subunit delta- 1 & 130.16 & 1.00 & 3 & 3.8 & -1.4612 & 1.4312 & 3 \\
\hline TCRG1_HUMAN & O14776 & TCERG1 & Transcription elongation regulator 1 & 123.90 & 1.00 & 4 & 2.9 & -1.1242 & 0.1737 & 9 \\
\hline PPM1G_HUMAN & O15355 & PPM1G & Protein phosphatase $1 \mathrm{G}$ & 59.27 & 1.00 & 2 & 5.1 & -0.3168 & 0.4525 & 7 \\
\hline CYB5B_HUMAN & O43169 & CYB5B & Cytochrome b5 type B & 16.33 & 1.00 & 2 & 31.5 & -0.5799 & 0.5962 & 5 \\
\hline DC1L2_HUMAN & O43237 & DYNC1LI2 & Cytoplasmic dynein 1 light intermediate chain 2 & 54.10 & 1.00 & 3 & 14.4 & -0.3254 & 0.6255 & 11 \\
\hline SNUT1_HUMAN & O43290 & SART1 & U4/U6.U5 tri-snRNP-associated protein 1 & 90.25 & 1.00 & 2 & 4 & -0.7434 & 0.6843 & 3 \\
\hline NPA1P_HUMAN & O60287 & URB1 & Nucleolar pre-ribosomal-associated protein 1 & 254.39 & 1.00 & 3 & 2.5 & -0.7666 & 0.9379 & 5 \\
\hline DJC13_HUMAN & O75165 & DNAJC13 & DnaJ homolog subfamily C member 13 & 254.43 & 1.00 & 2 & 1.3 & -0.3782 & 0.9162 & 3 \\
\hline PSIP1_HUMAN & O75475 & PSIP1 & PC4 and SFRS1-interacting protein & 60.10 & 1.00 & 5 & 13.6 & -0.4707 & 0.1535 & 5 \\
\hline HSBP1_HUMAN & O75506 & HSBP1 & Heat shock factor-binding protein 1 & 8.54 & 1.00 & 3 & 64.5 & -0.4054 & 0.9656 & 9 \\
\hline CSDE1_HUMAN & O75534 & CSDE1 & Cold shock domain-containing protein E1 & 88.88 & 1.00 & 5 & 8.1 & -0.6979 & 0.1960 & 19 \\
\hline PRAF3_HUMAN & O75915 & ARL6IP5 & PRA1 family protein 3 & 21.61 & 1.00 & 2 & 16 & -0.3254 & 1.3145 & 6 \\
\hline SRP72_HUMAN & O76094 & SRP72 & Signal recognition particle $72 \mathrm{kDa}$ protein & 74.61 & 1.00 & 5 & 17.4 & -0.7903 & 0.4262 & 9 \\
\hline AP2A2_HUMAN & O94973 & AP2A2 & AP-2 complex subunit alpha-2 & 103.96 & 1.00 & 4 & 11.3 & -0.2998 & 0.3364 & 9 \\
\hline VAPB_HUMAN & O95292 & VAPB & Vesicle-associated membrane protein-associated protein $\mathrm{B} / \mathrm{C}$ & 27.23 & 1.00 & 3 & 22.6 & -0.4518 & 0.1795 & 5 \\
\hline LYPA2_HUMAN & O95372 & LYPLA2 & Acyl-protein thioesterase 2 & 24.74 & 1.00 & 2 & 21.6 & -0.4900 & 0.2282 & 3 \\
\hline SC24A_HUMAN & O95486 & SEC24A & Protein transport protein Sec24A & 119.75 & 1.00 & 2 & 1.8 & -0.9018 & 0.2540 & 5 \\
\hline SC24B_HUMAN & O95487 & SEC24B & Protein transport protein Sec24B & 137.42 & 1.00 & 3 & 3.2 & -0.3963 & 0.6199 & 12 \\
\hline MBD3_HUMAN & O95983 & MBD3 & Methyl-CpG-binding domain protein 3 & 32.84 & 1.00 & 4 & 28.2 & -0.5095 & 0.8511 & 8 \\
\hline TOM40_HUMAN & O96008 & TOMM40 & Mitochondrial import receptor subunit TOM40 homolog & 37.89 & 1.00 & 5 & 22.7 & -0.7434 & 1.2474 & 28 \\
\hline EGFR_HUMAN & $\mathrm{P} 00533$ & EGFR & Epidermal growth factor receptor & 134.28 & 1.00 & 8 & 10.6 & -0.3604 & 1.0825 & 17 \\
\hline OAS1_HUMAN & P00973 & OAS1 & 2'-5'-oligoadenylate synthase 1 & 46.03 & 1.00 & 3 & 11 & -0.3963 & 0.5875 & 3 \\
\hline IL1A_HUMAN & $\mathrm{P} 01583$ & IL1A & Interleukin-1 alpha & 30.61 & 1.00 & 2 & 10.3 & -1.2497 & 0.5335 & 5 \\
\hline K2C6B_HUMAN & P04259 & KRT6B & Keratin, type II cytoskeletal 6B & 60.07 & 1.00 & 2 & 44.5 & -0.2913 & 0.3298 & 6 \\
\hline PTMA_HUMAN & P06454 & PTMA & Prothymosin alpha & 12.20 & 1.00 & 4 & 22.5 & -0.6323 & 0.2912 & 46 \\
\hline HEM3_HUMAN & P08397 & HMBS & Porphobilinogen deaminase & 39.33 & 1.00 & 2 & 10.8 & -0.9812 & 1.3131 & 5 \\
\hline THIK_HUMAN & P09110 & ACAA1 & 3-ketoacyl-CoA thiolase, peroxisomal & 44.29 & 1.00 & 3 & 12.5 & -0.3083 & 0.8186 & 3 \\
\hline H2AZ_HUMAN & P0C0S5 & $\mathrm{H} 2 \mathrm{AFZ}$ & Histone H2A.Z & 13.55 & 1.00 & 3 & 53.9 & -0.2829 & 0.2924 & 15 \\
\hline H14_HUMAN & P10412 & HIST1H1E & Histone H1.4 & 21.87 & 1.00 & 3 & 39.7 & -0.4612 & 0.4322 & 10 \\
\hline ODP2_HUMAN & P10515 & DLAT & Dihydrolipoyllysine-residue acetyltransferase component of pyruvate dehydrogenase complex, mitochondrial & 69.00 & 1.00 & 4 & 12.2 & -0.5799 & 0.7719 & 13 \\
\hline
\end{tabular}




\begin{tabular}{|c|c|c|c|c|c|c|c|c|c|c|}
\hline TPR_HUMAN & P12270 & TPR & Nucleoprotein TPR & 267.29 & 1.00 & 10 & 6.6 & -1.0944 & 1.2202 & 36 \\
\hline COX41_HUMAN & P13073 & COX4I1 & Cytochrome $\mathrm{c}$ oxidase subunit 4 isoform 1 , mitochondrial & 19.58 & 1.00 & 2 & 13.6 & -0.8388 & 0.0399 & 4 \\
\hline AK1A1_HUMAN & P14550 & AKR1A1 & Alcohol dehydrogenase $[\mathrm{NADP}+]$ & 36.57 & 1.00 & 3 & 16 & -0.6757 & 0.5648 & 8 \\
\hline UCHL3_HUMAN & P15374 & UCHL3 & Ubiquitin carboxyl-terminal hydrolase isozyme L3 & 26.18 & 1.00 & 3 & 24.3 & -0.2745 & 0.2203 & 8 \\
\hline H12_HŪMAN & P16403 & HIST1H1C & Histone H1.2 & 21.36 & 1.00 & 2 & 40.4 & -0.5594 & 0.3087 & 12 \\
\hline HMGA'A1_HUMAT & P17096 & HMGA1 & High mobility group protein HMG-I/HMG-Y & 11.68 & 1.00 & 6 & 51.4 & -0.6111 & 0.5813 & 27 \\
\hline MX1_HUMAN & P20591 & MX1 & Interferon-induced GTP-binding protein Mx1 & 75.52 & 1.00 & 12 & 22.8 & -0.7319 & 1.9552 & 41 \\
\hline PSB1_HUMAN & P20618 & PSMB1 & Proteasome subunit beta type-1 & 26.49 & 1.00 & 4 & 24.1 & -0.5193 & 1.0640 & 22 \\
\hline 5NTD_HUMAN & P21589 & NT5E & 5'-nucleotidase & 63.37 & 1.00 & 2 & 8.9 & -1.0944 & 0.9008 & 9 \\
\hline OSBP1_HUMAN & P22059 & OSBP & Oxysterol-binding protein 1 & 89.42 & 1.00 & 3 & 6.8 & -0.4145 & 0.6153 & 13 \\
\hline TBG1_HUMAN & $\mathrm{P} 23258$ & TUBG1 & Tubulin gamma- 1 chain & 51.17 & 1.00 & 2 & 10 & -0.5799 & 0.8746 & 4 \\
\hline DGKĀHUMAN & P23743 & DGKA & Diacylglycerol kinase alpha & 82.63 & 1.00 & 2 & 5.6 & -1.0367 & 1.2178 & 7 \\
\hline EF1B_HUMAN & P24534 & EEF1B2 & Elongation factor 1-beta & 24.76 & 1.00 & 4 & 35.6 & -0.5292 & 0.3301 & 20 \\
\hline CALL3_HUMAN & P27482 & CALML3 & Calmodulin-like protein 3 & 16.89 & 1.00 & 4 & 34.2 & -0.3254 & 0.9393 & 8 \\
\hline MAP4_HUMAN & P27816 & MAP4 & Microtubule-associated protein 4 & 121.00 & 1.00 & 16 & 22.5 & -0.3872 & 0.4098 & 40 \\
\hline CALX_HUMAN & P27824 & CANX & Calnexin & 67.57 & 1.00 & 19 & 33.6 & -0.2829 & 0.5653 & 70 \\
\hline PML_HUMAN & P29590 & PML & Probable transcription factor PML & 97.55 & 1.00 & 3 & 3.7 & -0.4803 & 0.2382 & 8 \\
\hline MARCS_HUMAT & P29966 & MARCKS & Myristoylated alanine-rich C-kinase substrate & 31.55 & 1.00 & 6 & 33.7 & -1.6431 & 0.6230 & 16 \\
\hline SDC4_HŪMAN & P31431 & SDC4 & Syndecan-4 & 21.64 & 1.00 & 2 & 12.1 & -0.6868 & 0.7616 & 5 \\
\hline CSTF2_HUMAN & P33240 & CSTF2 & Cleavage stimulation factor subunit 2 & 60.96 & 1.00 & 2 & 7.6 & -0.8388 & 0.7287 & 10 \\
\hline RL22_-̄HUMAN & P35268 & RPL22 & 60 S ribosomal protein L22 & 14.79 & 1.00 & 4 & 43.8 & -0.3693 & 0.3183 & 18 \\
\hline K1C9_HUMAN & P35527 & KRT9 & Keratin, type I cytoskeletal 9 & 62.06 & 1.00 & 3 & 9.5 & -1.2014 & 0.9664 & 9 \\
\hline FUS_HUMAN & P35637 & FUS & RNA-binding protein FUS & 53.43 & 1.00 & 5 & 13.3 & -0.6323 & 0.3488 & 19 \\
\hline GNL1_HUMAN & P36915 & GNL1 & Guanine nucleotide-binding protein-like 1 & 68.66 & 1.00 & 3 & 5.3 & -0.6757 & 0.6189 & 7 \\
\hline AN32A_HUMAN & P39687 & ANP32A & Acidic leucine-rich nuclear phosphoprotein 32 family member A & 28.59 & 1.00 & 2 & 18.1 & -0.5193 & 0.1876 & 9 \\
\hline CUX1_HUMAN & P39880 & CUX1 & Homeobox protein cut-like 1 & 164.19 & 1.00 & 2 & 1.9 & -0.5095 & 0.9754 & 5 \\
\hline RFC5_HUMAN & P40937 & RFC5 & Replication factor $\mathrm{C}$ subunit 5 & 38.50 & 1.00 & 4 & 17.4 & -0.3254 & 0.7917 & 8 \\
\hline RFC3_HUMAN & P40938 & RFC3 & Replication factor $\mathrm{C}$ subunit 3 & 40.56 & 1.00 & 2 & 9.3 & -0.6111 & 0.2485 & 5 \\
\hline SK2L2_HUMAN & P42285 & SKIV2L2 & Superkiller viralicidic activity 2 -like 2 & 117.80 & 1.00 & 6 & 10.5 & -0.6868 & 0.6257 & 17 \\
\hline PRS6B_HUMAN & P43686 & PSMC4 & $26 \mathrm{~S}$ protease regulatory subunit $6 \mathrm{~B}$ & 47.37 & 1.00 & 6 & 28.7 & -0.7434 & 0.6105 & 17 \\
\hline RL29_HUMAN & P47914 & RPL29 & 60 S ribosomal protein L29 & 17.75 & 1.00 & 2 & 13.2 & -0.4707 & 0.2619 & 9 \\
\hline LEG7_HUMAN & P47929 & LGALS7 & Galectin-7 & 15.08 & 1.00 & 3 & 27.9 & -0.4054 & 1.7114 & 6 \\
\hline UCRI_HUMAN & P47985 & UQCRFS1 & Cytochrome b-c1 complex subunit Rieske, mitochondrial & 29.67 & 1.00 & 4 & 18.2 & -0.3693 & 0.3011 & 7 \\
\hline IDHP_HUMAN & P48735 & IDH2 & Isocitrate dehydrogenase [NADP], mitochondrial & 50.91 & 1.00 & 3 & 11.7 & -1.6217 & 1.0973 & 15 \\
\hline PAXI_HUMAN & P49023 & PXN & Paxillin & 64.53 & 1.00 & 2 & 8.8 & -0.4518 & 1.4181 & 5 \\
\hline RBM 25 _HUMAN & P49756 & RBM25 & RNA-binding protein 25 & 100.19 & 1.00 & 5 & 8.5 & -0.5594 & 0.6071 & 18 \\
\hline
\end{tabular}

Table S-5-4 page 40 of 45 


\begin{tabular}{|c|c|c|c|c|c|c|c|c|c|}
\hline EI2BB_HUMAN & P49770 & EIF2B2 & Translation initiation factor eIF-2B subunit beta & 38.99 & 1.00 & 3 & 12.3 & -0.7784 & 0.9927 \\
\hline RBP2_HUMAN & P49792 & RANBP2 & E3 SUMO-protein ligase RanBP2 & 358.20 & 1.00 & 4 & 1.9 & -1.2173 & 0.7719 \\
\hline EMD_HUMAN & P50402 & EMD & Emerin & 28.99 & 1.00 & 4 & 16.9 & -0.2829 & 0.3614 \\
\hline BCAM_HUMAN & P50895 & BCAM & Basal cell adhesion molecule & 67.40 & 1.00 & 2 & 3.7 & -0.6431 & 0.1857 \\
\hline IMA1_HUMAN & P52294 & KPNA1 & Importin subunit alpha-1 & 60.22 & 1.00 & 2 & 12.1 & -0.8388 & 0.3327 \\
\hline GDIR1_HUMAN & P52565 & ARHGDIA & Rho GDP-dissociation inhibitor 1 & 23.21 & 1.00 & 3 & 18.1 & -0.4612 & 0.7334 \\
\hline HMGA2_HUMAI & P52926 & HMGA2 & High mobility group protein HMGI-C & 11.83 & 1.00 & 5 & 40.4 & -0.3428 & 0.5176 \\
\hline SYYC_HUMAN & P54577 & YARS & Tyrosyl-tRNA synthetase, cytoplasmic & 59.14 & 1.00 & 12 & 26.3 & -0.5193 & 0.6663 \\
\hline RD23A_HUMAN & P54725 & RAD23A & UV excision repair protein RAD23 homolog A & 39.61 & 1.00 & 2 & 12.9 & -0.2745 & 0.8685 \\
\hline TPD52_HUMAN & P55327 & TPD52 & Tumor protein D52 & 24.33 & 1.00 & 2 & 11.2 & -0.3872 & 0.4050 \\
\hline SCOT1_HUMAN & P55809 & OXCT1 & Succinyl-CoA:3-ketoacid-coenzyme A transferase 1, mitochondrial & 56.16 & 1.00 & 3 & 12.7 & -0.4330 & 0.4651 \\
\hline IF6_HUMAN & P56537 & EIF6 & Eukaryotic translation initiation factor 6 & 26.60 & 1.00 & 5 & 36.7 & -1.5392 & 0.7427 \\
\hline S10AA_HUMAN & P60903 & S100A10 & Protein S100-A10 & 11.20 & 1.00 & 3 & 29.9 & -0.7319 & 0.2075 \\
\hline MGN_HUMAN & P61326 & MAGOH & Protein mago nashi homolog & 17.16 & 1.00 & 3 & 29.5 & -0.3516 & 0.2078 \\
\hline NPC2_HUMAN & P61916 & NPC2 & Epididymal secretory protein E1 & 16.57 & 1.00 & 2 & 21.2 & -0.4900 & 0.4467 \\
\hline AP1S1_HUMAN & P61966 & AP1S1 & AP-1 complex subunit sigma-1A & 18.73 & 1.00 & 2 & 15.8 & -0.4900 & 0.6675 \\
\hline CALM_HUMAN & P62158 & CALM1 & Calmodulin & 16.84 & 1.00 & 6 & 38.9 & -0.7205 & 0.7635 \\
\hline YBOX1_HUMAN & P67809 & YBX1 & Nuclease-sensitive element-binding protein 1 & 35.92 & 1.00 & 7 & 40.4 & -0.5902 & 0.6364 \\
\hline CSK2B_HUMAN & P67870 & CSNK2B & Casein kinase II subunit beta & 24.94 & 1.00 & 2 & 14.9 & -1.2998 & 0.3390 \\
\hline BASP1_HUMAN & P80723 & BASP1 & Brain acid soluble protein 1 & 22.69 & 1.00 & 3 & 20.3 & -1.0227 & 0.2749 \\
\hline DHSO_HUMAN & Q00796 & SORD & Sorbitol dehydrogenase & 38.32 & 1.00 & 2 & 7.6 & -0.5193 & 0.2991 \\
\hline EWS_HUMAN & Q01844 & EWSR1 & RNA-binding protein EWS & 68.48 & 1.00 & 2 & 4.4 & -0.4900 & 0.5941 \\
\hline MP2K̄1_HUMAN & Q02750 & MAP2K1 & Dual specificity mitogen-activated protein kinase kinase 1 & 43.44 & 1.00 & 3 & 15.3 & -0.5193 & 0.1999 \\
\hline LMNB2_HUMAN & Q03252 & LMNB2 & Lamin-B2 & 67.69 & 1.00 & 3 & 9.5 & -0.5292 & 0.4948 \\
\hline SSBP_HUMAN & Q04837 & SSBP1 & Single-stranded DNA-binding protein, mitochondrial & 17.26 & 1.00 & 5 & 40.5 & -0.6323 & 1.4493 \\
\hline ZO1_HUMAN & Q07157 & TJP1 & Tight junction protein $\mathrm{ZO}-1$ & 195.46 & 1.00 & 5 & 4.3 & -0.4997 & 0.1965 \\
\hline AP1B1_HUMAN & Q10567 & AP1B1 & AP-1 complex subunit beta- 1 & 104.64 & 1.00 & 5 & 21.2 & -0.8265 & 0.8138 \\
\hline SCRN1_HUMAN & Q12765 & SCRN1 & Secernin-1 & 46.38 & 1.00 & 3 & 11.6 & -0.6868 & 0.4788 \\
\hline TWF1_HUMAN & Q12792 & TWF1 & Twinfilin-1 & 40.28 & 1.00 & 3 & 12.9 & -0.3963 & 0.2444 \\
\hline ACACA_HUMAT & Q13085 & ACACA & Acetyl-CoA carboxylase 1 & 265.55 & 1.00 & 10 & 7 & -0.3254 & 0.5686 \\
\hline PAK2_HUMAN & Q13177 & PAK2 & Serine/threonine-protein kinase PAK 2 & 58.04 & 1.00 & 4 & 11.1 & -0.3516 & 0.4016 \\
\hline CBX3_HUMAN & Q13185 & CBX3 & Chromobox protein homolog 3 & 20.81 & 1.00 & 3 & 20.2 & -0.7903 & 0.3042 \\
\hline G3BP1_HUMAN & Q13283 & G3BP1 & Ras GTPase-activating protein-binding protein 1 & 52.16 & 1.00 & 9 & 32 & -0.5696 & 2.7586 \\
\hline MTA1_HUMAN & Q13330 & MTA1 & Metastasis-associated protein MTA1 & 80.79 & 1.00 & 2 & 4.6 & -0.8023 & 0.3754 \\
\hline UB2V1_HUMAN & Q13404 & UBE2V1 & Ubiquitin-conjugating enzyme E2 variant 1 & 16.49 & 1.00 & 3 & 54.4 & -0.3428 & 0.7196 \\
\hline DC1I2_HUMAN & Q13409 & DYNC1I2 & Cytoplasmic dynein 1 intermediate chain 2 & 71.46 & 1.00 & 6 & 16.3 & -0.7903 & 0.3024 \\
\hline
\end{tabular}

Table S-5-4 page 41 of 45 


\begin{tabular}{|c|c|c|c|c|c|c|c|c|c|}
\hline TCOF_HUMAN & Q13428 & TCOF1 & Treacle protein & 152.10 & 1.00 & 13 & 9.9 & -0.2745 & 0.3487 \\
\hline HAP28_HUMAN & Q13442 & PDAP1 & $28 \mathrm{kDa}$ heat- and acid-stable phosphoprotein & 20.63 & 1.00 & 4 & 23.8 & -0.8265 & 0.7758 \\
\hline CUL1_HUMAN & Q13616 & CUL1 & Cullin-1 & 89.68 & 1.00 & 2 & 4 & -0.3341 & 0.7807 \\
\hline TPBG_HUMAN & Q13641 & TPBG & Trophoblast glycoprotein & 46.03 & 1.00 & 2 & 7.9 & -0.7903 & 1.1259 \\
\hline TOB2_HUMAN & Q14106 & TOB2 & Protein Tob2 & 36.63 & 1.00 & 2 & 7.6 & -0.7434 & 0.3657 \\
\hline GALE_HUMAN & Q14376 & GALE & UDP-glucose 4-epimerase & 38.28 & 1.00 & 3 & 13.2 & -0.3604 & 0.2192 \\
\hline RBM39_HUMAN & Q14498 & RBM39 & RNA-binding protein 39 & 59.38 & 1.00 & 4 & 13.6 & -0.3963 & 0.7024 \\
\hline EPN4_HUMAN & Q14677 & CLINT1 & Clathrin interactor 1 & 68.26 & 1.00 & 2 & 4.3 & -0.3693 & 0.3199 \\
\hline SPCS2__HUMAN & Q15005 & SPCS2 & Signal peptidase complex subunit 2 & 25.00 & 1.00 & 3 & 21.2 & -0.7319 & 0.1830 \\
\hline RB3GP_HUMAN & Q15042 & RAB3GAP1 & Rab3 GTPase-activating protein catalytic subunit & 110.52 & 1.00 & 3 & 5.1 & -0.8890 & 0.3677 \\
\hline RSU1_HUMAN & Q15404 & RSU1 & Ras suppressor protein 1 & 31.54 & 1.00 & 5 & 29.2 & -0.4518 & 0.4804 \\
\hline SAFB1_HUMAN & Q15424 & SAFB & Scaffold attachment factor B1 & 102.64 & 1.00 & 4 & 5.5 & -2.1242 & 1.5218 \\
\hline MED1_HUMAN & Q15648 & MED1 & Mediator of RNA polymerase II transcription subunit 1 & 168.48 & 1.00 & 3 & 2.1 & -0.6979 & 0.6798 \\
\hline TRIP6_HUMAN & Q15654 & TRIP6 & Thyroid receptor-interacting protein 6 & 50.29 & 1.00 & 2 & 8 & -0.8023 & 0.2548 \\
\hline STXB2_HUMAN & Q15833 & STXBP2 & Syntaxin-binding protein 2 & 66.44 & 1.00 & 3 & 4.6 & -0.8388 & 0.6166 \\
\hline ZYX_HUMMAN & Q15942 & ZYX & Zyxin & 61.28 & 1.00 & 8 & 24.3 & -1.2497 & 0.5652 \\
\hline ADRM-̄1_HUMAT & Q16186 & ADRM1 & Proteasomal ubiquitin receptor ADRM1 & 42.15 & 1.00 & 3 & 10.6 & -0.8763 & 1.0464 \\
\hline DECR_HUMAN & Q16698 & DECR1 & 2,4-dienoyl-CoA reductase, mitochondrial & 36.07 & 1.00 & 2 & 8.1 & -0.4803 & 0.3106 \\
\hline NDUĀ5_HUMAN & Q16718 & NDUFA5 & NADH dehydrogenase [ubiquinone] 1 alpha subcomplex subunit 5 & 13.46 & 1.00 & 2 & 22.4 & -1.1242 & 1.2139 \\
\hline PDS5A_HUMAN & Q29RF7 & PDS5A & Sister chromatid cohesion protein PDS5 homolog A & 150.83 & 1.00 & 3 & 4.2 & -1.1092 & 0.1848 \\
\hline PREP_HUMAN & Q5JRX3 & PITRM1 & Presequence protease, mitochondrial & 117.45 & 1.00 & 2 & 2.5 & -0.5799 & 0.9488 \\
\hline FKB15_HUMAN & Q5T1M5 & FKBP15 & FK506-binding protein 15 & 133.63 & 1.00 & 2 & 3.4 & -0.4803 & 0.7424 \\
\hline UBR4_HUMAN & Q5T4S7 & UBR4 & E3 ubiquitin-protein ligase UBR4 & 573.84 & 1.00 & 12 & 4.5 & -0.4612 & 0.6908 \\
\hline FA21A_HUMAN & Q641Q2 & FAM21A & WASH complex subunit FAM21A & 147.18 & 1.00 & 3 & 4.3 & -0.8637 & 0.7460 \\
\hline CC137_HUMAN & Q6PK04 & $\mathrm{CCDC} 137$ & Coiled-coil domain-containing protein 137 & 33.23 & 1.00 & 2 & 9.7 & -0.5902 & 1.5575 \\
\hline TM205_HUMAN & Q6UW68 & TMEM205 & Transmembrane protein 205 & 21.20 & 1.00 & 2 & 15.9 & -0.7666 & 0.2101 \\
\hline CD109_HUMAN & Q6YHK3 & CD109 & CD109 antigen & 161.69 & 1.00 & 2 & 2.7 & -1.0509 & 1.5154 \\
\hline ZCCHV_HUMAN & Q7Z2W4 & ZC3HAV1 & Zinc finger $\mathrm{CCCH}$-type antiviral protein 1 & 101.43 & 1.00 & 3 & 4.5 & -0.5292 & 0.7043 \\
\hline HUWE1_HUMAr & Q7Z6Z7 & HUWE1 & E3 ubiquitin-protein ligase HUWE1 & 481.89 & 1.00 & 8 & 2.7 & -0.3341 & 0.5733 \\
\hline LYRIC_HUMAN & Q86UE4 & MTDH & Protein LYRIC & 63.84 & 1.00 & 3 & 8.6 & -1.2829 & 0.4147 \\
\hline KTN1_HUMAN & Q86UP2 & KTN1 & Kinectin & 156.28 & 1.00 & 8 & 9.3 & -0.4145 & 0.5919 \\
\hline NUDC3_HUMAN & Q8IVD9 & NUDCD3 & NudC domain-containing protein 3 & 40.82 & 1.00 & 2 & 8.9 & -0.6539 & 0.7212 \\
\hline CS021_HUMAN & Q8IVT2 & C19orf21 & Uncharacterized protein C19orf21 & 75.36 & 1.00 & 2 & 3.7 & -1.0509 & 0.7385 \\
\hline DDX60_HUMAN & Q8IY21 & DDX60 & Probable ATP-dependent RNA helicase DDX60 & 197.85 & 1.00 & 2 & 1.8 & -0.3963 & 0.4092 \\
\hline RRMJ3_HUMAN & Q8IY81 & FTSJ3 & Putative rRNA methyltransferase 3 & 96.56 & 1.00 & 6 & 13 & -0.7550 & 0.7978 \\
\hline LRC47_HUMAN & Q8N1G4 & LRRC47 & Leucine-rich repeat-containing protein 47 & 63.47 & 1.00 & 3 & 9.4 & -1.1242 & 0.1431 \\
\hline
\end{tabular}

Table S-5-4 page 42 of 45 
ABCF1_HUMAN Q8NE71 ABCF1 ATP-binding cassette sub-family F member 1

C109A_HUMAN Q8NE86 CCDC109A Coiled-coil domain-containing protein 109A

SCFD1_HUMAN Q8WVM8 SCFD1 Sec1 family domain-containing protein 1

PCNP_HUMAN Q8WW12 PCNP

H1X_HUMAN

Q92522 H1FX

GBF1_HUMAN

MY18A HUMAN

TFG_HUMAN

RENT1_HUMAN

SH3K1_HUMAN

DNJA3_HUMAN

LASS2 HUMAN

PDLI5 HUMAN

BT3L4_HUMAN

S35E1 HUMAN

CNDP2_HUMAN

DOCK7_HUMAN IPO9 HUMAN

MACF4 HUMAN RBM14 HUMAN NUDC1_HUMAN WRIP1_HUMAN SH3G1_HUMAN PAIP2 HUMAN ERP44 HUMAN TBCD_HUMAN ITPA_HUMAN

Q92538 GBF1 Q92614 MYO18A Q92734 TFG Q92900 UPF1 Q96B97 SH3KBP1

Q96EY1 DNAJA3

Q96G23 LASS2

Q96HC4 PDLIM5

Q96K17 BTF3L4

Q96K37 SLC35E1

Q96KP4 CNDP2

Q96N67 DOCK7

Q96P70 IPO9

Q96PK2 MACF1

Q96PK6 RBM14

Q96RS6 NUDCD1

Q96S55 WRNIP1

Q99961 SH3GL1

Q9BPZ3 PAIP2

Q9BS26 ERP44

Q9BTW9 TBCD

Q9BY32 ITPA

Q9BZZ5 API5

API5_HUMAN

Q9GZZ1 NAA50

RAB1B HUMAN Q9H0U4 RAB1B ASCC2_HUMAN Q9H1I8 ASCC2 BOLA2_HUMAN Q9H3K6 BOLA2 ACAD9_HUMAN Q9H845 ACAD9 INO1_HUMAN Q9NPH2 ISYNA1 PDS5B HUMAN Q9NTI5 PDS5B OLA1_HUMAN

\begin{abstract}
Q9NTK5 OLA1
\end{abstract}
PEST proteolytic signal-containing nuclear protein

Histone $\mathrm{H} 1 \mathrm{x}$

Golgi-specific brefeldin A-resistance guanine nucleotide exchange factor 1

Myosin-XVIIIa

Protein TFG

Regulator of nonsense transcripts 1

SH3 domain-containing kinase-binding protein 1

DnaJ homolog subfamily A member 3, mitochondrial

LAG1 longevity assurance homolog 2

PDZ and LIM domain protein 5

Transcription factor BTF3 homolog 4

Solute carrier family 35 member E1

Cytosolic non-specific dipeptidase

Dedicator of cytokinesis protein 7

Importin-9

Microtubule-actin cross-linking factor 1, isoform 4

RNA-binding protein 14

NudC domain-containing protein 1

ATPase WRNIP1

Endophilin-A2

Polyadenylate-binding protein-interacting protein 2

Endoplasmic reticulum resident protein 44

Tubulin-specific chaperone D

Inosine triphosphate pyrophosphatase

Apoptosis inhibitor 5

$\mathrm{N}$-alpha-acetyltransferase 50, NatE catalytic subunit

Ras-related protein Rab-1B

Activating signal cointegrator 1 complex subunit 2

BolA-like protein 2

Acyl-CoA dehydrogenase family member 9 , mitochondrial Inositol-3-phosphate synthase 1

Sister chromatid cohesion protein PDS5 homolog B

Obg-like ATPase 1

$\begin{array}{ccccccc}95.93 & 1.00 & 3 & 6 & -0.3963 & 0.4056 & 5 \\ 39.87 & 1.00 & 2 & 3.4 & -0.8637 & 0.6523 & 4 \\ 72.38 & 1.00 & 3 & 7.5 & -0.7434 & 1.0034 & 5 \\ 18.92 & 1.00 & 2 & 17.4 & -0.6648 & 0.3939 & 7 \\ 22.49 & 1.00 & 2 & 11.7 & -0.8143 & 0.0676 & 5 \\ 206.45 & 1.00 & 4 & 3.1 & -0.3168 & 0.4378 & 7 \\ 233.12 & 1.00 & 5 & 3.8 & -0.6648 & 0.5199 & 10 \\ 43.45 & 1.00 & 3 & 13.3 & -0.2913 & 0.5906 & 5 \\ 124.35 & 1.00 & 7 & 7.2 & -0.4054 & 0.5336 & 20 \\ 73.13 & 1.00 & 3 & 4.5 & -1.4424 & 0.4999 & 16 \\ 52.54 & 1.00 & 3 & 10.6 & -1.0227 & 1.1102 & 5 \\ 44.88 & 1.00 & 2 & 9.5 & -1.0227 & 1.5422 & 5 \\ 64.00 & 1.00 & 4 & 9.9 & -1.2173 & 0.1940 & 9 \\ 17.27 & 1.00 & 2 & 24.1 & -0.8512 & 1.1734 & 4 \\ 44.77 & 1.00 & 2 & 8.8 & -0.4330 & 0.7417 & 5 \\ 52.88 & 1.00 & 5 & 19.4 & -0.6979 & 0.3693 & 10 \\ 242.56 & 1.00 & 4 & 3 & -0.2829 & 0.3916 & 16 \\ 115.96 & 1.00 & 5 & 9.8 & -0.4612 & 0.9101 & 24 \\ 670.14 & 1.00 & 3 & 1.1 & -1.9812 & 0.7468 & 7 \\ 69.49 & 1.00 & 3 & 4.6 & -0.3872 & 0.4478 & 5 \\ 66.76 & 1.00 & 3 & 8.1 & -1.0227 & 0.7377 & 6 \\ 72.13 & 1.00 & 2 & 3.9 & -0.9278 & 1.3034 & 5 \\ 41.49 & 1.00 & 3 & 17.7 & -0.3693 & 1.1341 & 3 \\ 14.98 & 1.00 & 2 & 34.6 & -0.7319 & 1.5880 & 4 \\ 46.97 & 1.00 & 4 & 15.5 & -0.3604 & 0.6285 & 11 \\ 132.60 & 1.00 & 4 & 5.8 & -0.5193 & 0.4629 & 6 \\ 21.45 & 1.00 & 3 & 30.9 & -0.7319 & 0.7086 & 6 \\ 57.56 & 1.00 & 4 & 12 & -0.5799 & 0.4156 & 13 \\ 19.40 & 1.00 & 3 & 20.7 & -0.4145 & 0.3760 & 5 \\ 22.17 & 1.00 & 2 & 25.4 & -0.4145 & 0.1780 & 9 \\ 86.36 & 1.00 & 2 & 4.8 & -1.8023 & 0.8284 & 5 \\ 10.12 & 1.00 & 2 & 40.7 & -0.4997 & 0.3127 & 3 \\ 68.76 & 1.00 & 3 & 8.4 & -0.4145 & 0.4684 & 5 \\ 61.07 & 1.00 & 2 & 5.2 & -0.2745 & 0.3455 & 5 \\ 164.67 & 1.00 & 2 & 2.3 & -0.9949 & 0.2164 & 12 \\ 44.74 & 1.00 & 6 & 17.7 & -0.3428 & 0.4675 & 22\end{array}$

Table S-5-4 page 43 of 45 


\begin{tabular}{|c|c|c|c|c|c|c|c|c|c|c|}
\hline DJC11_HUMAN & Q9NVH1 & DNAJC11 & DnaJ homolog subfamily $\mathrm{C}$ member 11 & 63.28 & 1.00 & 2 & 5.4 & -1.6648 & 1.3705 & 11 \\
\hline HPBP1_HUMAN & Q9NZL4 & HSPBP1 & Hsp70-binding protein 1 & 39.47 & 1.00 & 6 & 29.8 & -0.6648 & 0.8124 & 12 \\
\hline DIP2B_HUMAN & Q9P265 & DIP2B & Disco-interacting protein 2 homolog B & 171.49 & 1.00 & 5 & 4.3 & -0.2998 & 0.4788 & 11 \\
\hline ATX10_HUMAN & Q9UBB4 & ATXN10 & Ataxin-10 & 53.49 & 1.00 & 4 & 14.7 & -0.3254 & 1.2775 & 11 \\
\hline NCDN_HUMAN & Q9UBB6 & NCDN & Neurochondrin & 78.86 & 1.00 & 3 & 6.7 & -0.6431 & 0.6608 & \\
\hline SRP68_HUMAN & Q9UHB9 & SRP68 & Signal recognition particle $68 \mathrm{kDa}$ protein & 70.73 & 1.00 & 4 & 9.6 & -0.5493 & 0.2862 & 7 \\
\hline XPO7_HUMAN & Q9UIA9 & XPO7 & Exportin-7 & 123.91 & 1.00 & 3 & 5 & -0.3168 & 0.6590 & 10 \\
\hline HECD1_HUMAN & Q9ULT8 & HECTD1 & E3 ubiquitin-protein ligase HECTD1 & 289.59 & 1.00 & 4 & 2.7 & -0.7319 & 0.8302 & 7 \\
\hline NSF1C_HUMAN & Q9UNZ2 & NSFL1C & NSFL1 cofactor $\mathrm{p} 47$ & 40.57 & 1.00 & 2 & 7.3 & -0.4900 & 0.2436 & 5 \\
\hline SAPS1_HUMAN & Q9UPN7 & SAPS1 & Serine/threonine-protein phosphatase 6 regulatory subunit 1 & 96.72 & 1.00 & 2 & 5 & -0.4900 & 1.0300 & 4 \\
\hline SRRM2_HUMAN & Q9UQ35 & SRRM2 & Serine/arginine repetitive matrix protein 2 & 299.62 & 1.00 & 5 & 3.6 & -0.8763 & 0.4683 & 11 \\
\hline CNPY2_HUMAN & Q9Y2B0 & CNPY2 & Protein canopy homolog 2 & 20.65 & 1.00 & 2 & 17.6 & -0.3168 & 0.3290 & \\
\hline YBOX2_HUMAN & Q9Y2T7 & YBX2 & Y-box-binding protein 2 & 38.52 & 1.00 & 3 & 22.5 & -0.7319 & 1.2271 & 10 \\
\hline TR150_HUMAN & Q9Y2W1 & THRAP3 & Thyroid hormone receptor-associated protein 3 & 108.67 & 1.00 & 3 & 3.8 & -0.8388 & 0.2652 & \\
\hline GOT1B_HUMAN & Q9Y3E0 & GOLT1B & Vesicle transport protein GOT1B & 15.43 & 1.00 & 2 & 10.9 & -0.6111 & 0.5261 & 26 \\
\hline TELO2_HUMAN & Q9Y4R8 & TELO2 & Telomere length regulation protein TEL2 homolog & 91.75 & 1.00 & 6 & 11.9 & -0.6868 & 0.6687 & 14 \\
\hline UTP18_HUMAN & Q9Y5J1 & UTP18 & U3 small nucleolar RNA-associated protein 18 homolog & 62.00 & 1.00 & 3 & 10.4 & -0.7784 & 0.2254 & \\
\hline NCOR2_HUMAN & Q9Y618 & NCOR2 & Nuclear receptor corepressor 2 & 274.80 & 1.00 & 2 & 1.5 & -0.4803 & 1.1968 & 5 \\
\hline ACTC_HUMAN & P68032 & ACTC1 & Actin, alpha cardiac muscle 1 & 42.02 & 1.00 & 2 & 34.5 & -1.1393 & 0.4384 & \\
\hline CE051_HUMAN & A6NDU8 & C5orf51 & UPF0600 protein C5orf51 & 33.62 & 1.00 & 2 & 15 & -0.3254 & 0.5097 & 4 \\
\hline ATP5H_HUMAN & O75947 & ATP5H & ATP synthase subunit d, mitochondrial & 18.49 & 1.00 & 2 & 18.6 & -0.2745 & 1.2727 & \\
\hline HMGN2_HUMAT & P05204 & HMGN2 & Non-histone chromosomal protein HMG-17 & 9.39 & 1.00 & 2 & 20 & -0.2998 & 0.6004 & 6 \\
\hline NAA10_HUMAN & P41227 & NAA10 & $\mathrm{N}$-alpha-acetyltransferase 10 , NatA catalytic subunit & 26.46 & 1.00 & 2 & 13.2 & -1.0798 & 0.3722 & 3 \\
\hline CNDD3_HUMAN & P42695 & NCAPD3 & Condensin-2 complex subunit D3 & 168.89 & 1.00 & 3 & 3.3 & -0.5902 & 1.3767 & 6 \\
\hline RPP30_HUMAN & P78346 & RPP30 & Ribonuclease $\mathrm{P}$ protein subunit $\mathrm{p} 30$ & 29.32 & 1.00 & 2 & 9.3 & -0.3083 & 0.2045 & 4 \\
\hline TAP1_HUMAN & Q03518 & TAP1 & Antigen peptide transporter 1 & 87.22 & 1.00 & 2 & 4 & -2.2829 & 0.6362 & 4 \\
\hline IF4H_HUMAN & Q15056 & EIF4H & Eukaryotic translation initiation factor $4 \mathrm{H}$ & 27.39 & 1.00 & 3 & 15.3 & -1.1700 & 0.5386 & 6 \\
\hline RBBP7_HUMAN & Q16576 & RBBP7 & Histone-binding protein RBBP7 & 47.82 & 1.00 & 2 & 11.5 & -0.6979 & 0.3050 & 3 \\
\hline PARP9_HUMAN & Q8IXQ6 & PARP9 & Poly [ADP-ribose] polymerase 9 & 96.34 & 1.00 & 2 & 5.5 & -1.0087 & 0.8574 & 5 \\
\hline SCPDH_HUMAN & Q8NBX0 & SCCPDH & Probable saccharopine dehydrogenase & 47.15 & 1.00 & 2 & 8.6 & -0.4424 & 0.7804 & 9 \\
\hline VP33A_HUMAN & Q96AX1 & VPS33A & Vacuolar protein sorting-associated protein $33 \mathrm{~A}$ & 67.61 & 1.00 & 2 & 4.5 & -0.2913 & 0.1099 & 6 \\
\hline POP1_HUMAN & Q99575 & POP1 & Ribonucleases P/MRP protein subunit POP1 & 114.71 & 1.00 & 2 & 2.4 & -1.9543 & 0.4475 & 6 \\
\hline TRI56_HUMAN & Q9BRZ2 & TRIM56 & Tripartite motif-containing protein 56 & 81.49 & 1.00 & 2 & 4 & -0.3254 & 0.8300 & \\
\hline TBA1A_HUMAN & Q71U36 & TUBA1A & Tubulin alpha-1A chain & 50.14 & 1.00 & 2 & 61.4 & -0.7903 & 0.5671 & \\
\hline AHSA1_HUMAN & O95433 & AHSA1 & Activator of $90 \mathrm{kDa}$ heat shock protein ATPase homolog 1 & 38.27 & 1.00 & 3 & 19.8 & -0.7434 & 0.4268 & \\
\hline 8ODP_HUMAN & P36639 & NUDT1 & 7,8-dihydro-8-oxoguanine triphosphatase & 22.52 & 1.00 & 2 & 12.2 & -0.3872 & 0.4533 & 13 \\
\hline
\end{tabular}

Table S-5-4 page 44 of 45 


\begin{tabular}{|c|c|c|c|c|c|c|c|c|c|c|}
\hline PSMD4_HUMAN & P55036 & PSMD4 & $26 \mathrm{~S}$ proteasome non-ATPase regulatory subunit 4 & 40.74 & 1.00 & 2 & 8.8 & -0.4238 & 0.9991 & 5 \\
\hline TFAM_HUMAN & Q00059 & TFAM & Transcription factor A, mitochondrial & 29.10 & 1.00 & 2 & 7.7 & -0.4707 & 0.4215 & 4 \\
\hline SF3B4_HUMAN & Q15427 & SF3B4 & Splicing factor $3 \mathrm{~B}$ subunit 4 & 44.39 & 1.00 & 2 & 9.4 & -0.3693 & 0.6636 & 7 \\
\hline C1TM_HUMAN & Q6UB35 & MTHFD1L & Monofunctional C1-tetrahydrofolate synthase, mitochondrial & 105.79 & 1.00 & 2 & 2.2 & -3.6217 & 1.0239 & 7 \\
\hline FFR_HUMAN & Q9UID3 & FFR & Protein fat-free homolog & 86.04 & 1.00 & 3 & 7.3 & -0.4612 & 0.9350 & 6 \\
\hline CP08̄0_HUMAN & Q9Y6A4 & C16orf80 & UPF0468 protein C16orf80 & 22.77 & 1.00 & 2 & 8.8 & -0.3693 & 0.4965 & 6 \\
\hline MAOX_HUMAN & P48163 & ME1 & NADP-dependent malic enzyme & 64.15 & 1.00 & 3 & 8 & -0.8890 & 1.3071 & 5 \\
\hline RM44_HUMAN & Q9H9J2 & MRPL44 & 39S ribosomal protein $\mathrm{L} 44$, mitochondrial & 37.54 & 1.00 & 2 & 9.6 & -0.3782 & 0.6322 & 4 \\
\hline E41L2_HUMAN & O43491 & EPB41L2 & Band 4.1-like protein 2 & 112.59 & 1.00 & 2 & 2.5 & -0.5902 & 0.1002 & 3 \\
\hline PEPD_HUMAN & P12955 & PEPD & Xaa-Pro dipeptidase & 54.55 & 1.00 & 2 & 3.4 & -0.5799 & 0.5552 & 5 \\
\hline VATL_HUMAN & P27449 & ATP6V0C & V-type proton ATPase $16 \mathrm{kDa}$ proteolipid subunit & 15.74 & 1.00 & 2 & 24.5 & -2.1546 & 0.0873 & 3 \\
\hline CDV3_HUMAN & Q9UKY7 & CDV3 & Protein CDV3 homolog & 27.33 & 1.00 & 2 & 10.9 & -0.9278 & 0.8764 & 3 \\
\hline PGRC1_HUMAN & O00264 & PGRMC1 & Membrane-associated progesterone receptor component 1 & 21.67 & 1.00 & 2 & 14.4 & -0.6757 & 0.2786 & 3 \\
\hline MTPN_HUMAN & P58546 & MTPN & Myotrophin & 12.89 & 1.00 & 2 & 21.2 & -0.3168 & 0.2425 & 6 \\
\hline RPA1_HUMAN & O95602 & POLR1A & DNA-directed RNA polymerase I subunit RPA1 & 194.81 & 1.00 & 2 & 1.2 & -0.9018 & 0.4305 & 5 \\
\hline RSF1_HUMAN & Q96T23 & RSF1 & Remodeling and spacing factor 1 & 163.82 & 1.00 & 2 & 1.6 & -2.0653 & 0.8214 & 5 \\
\hline OGFR_HUMAN & Q9NZT2 & OGFR & Opioid growth factor receptor & 73.32 & 1.00 & 2 & 5.2 & -1.3168 & 0.2590 & 3 \\
\hline COPG $\overline{2}$ HUMAN & Q9UBF2 & COPG2 & Coatomer subunit gamma-2 & 97.62 & 1.00 & 3 & 9.6 & -0.2913 & 0.7552 & 3 \\
\hline HDAC1_HUMAN & Q13547 & HDAC1 & Histone deacetylase 1 & 55.10 & 1.00 & 2 & 12.7 & -0.7092 & 0.7683 & 3 \\
\hline RBM15_HUMAN & Q96T37 & RBM15 & Putative RNA-binding protein 15 & 107.19 & 1.00 & 2 & 2.1 & -0.6323 & 0.5652 & 3 \\
\hline SNF5_HUMAN & Q12824 & SMARCB1 & SWI/SNF-related matrix-associated actin-dependent regulator of chromatin subfamily B member 1 & 44.14 & 1.00 & 2 & 9.4 & -1.0798 & 0.6767 & 5 \\
\hline RBBP6_HUMAN & Q7Z6E9 & RBBP6 & Retinoblastoma-binding protein 6 & 201.56 & 1.00 & 2 & 2.7 & -0.6111 & 0.3880 & 6 \\
\hline DNJA2_HUMAN & O60884 & DNAJA2 & DnaJ homolog subfamily A member 2 & 45.75 & 1.00 & 2 & 9.7 & -0.2913 & 0.3043 & 3 \\
\hline TOM20_HUMAN & Q15388 & TOMM20 & Mitochondrial import receptor subunit TOM20 homolog & 16.30 & 1.00 & 2 & 18.6 & -1.1393 & 1.3847 & 3 \\
\hline FRYL_HUMAN & O94915 & FRYL & Protein furry homolog-like & 339.60 & 1.00 & 3 & 1.7 & -0.5292 & 1.0917 & 3 \\
\hline SUCB $\overline{1}$ _HUMAN & Q9P2R7 & SUCLA2 & Succinyl-CoA ligase [ADP-forming] subunit beta, mitochondrial & 50.32 & 0.98 & 2 & 4.3 & -0.3604 & 0.6450 & 6 \\
\hline TB22B_HUMAN & Q9NU19 & TBC1D22B & $\mathrm{TBC} 1$ domain family member $22 \mathrm{~B}$ & 59.08 & 0.96 & 2 & 5 & -1.1856 & 1.9531 & 7 \\
\hline
\end{tabular}




\section{Figure S-1}

(A) ANE:
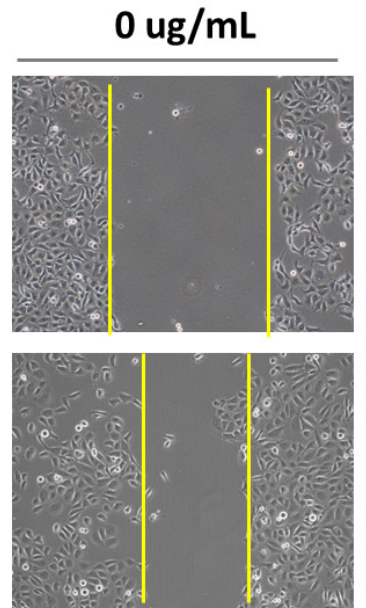

(B) ANE :

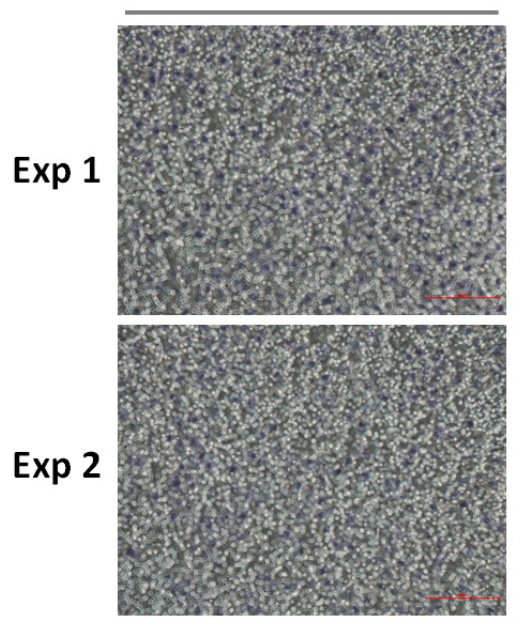

$50 \mathrm{ug} / \mathrm{mL}$
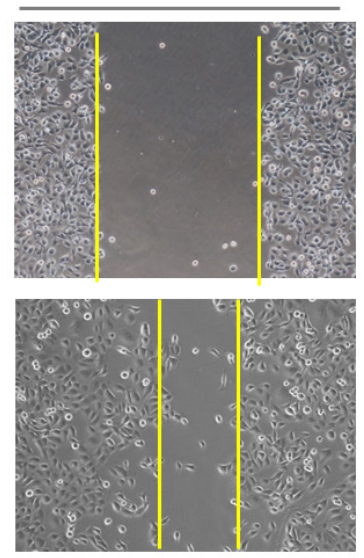

$100 \mathrm{ug} / \mathrm{mL}$

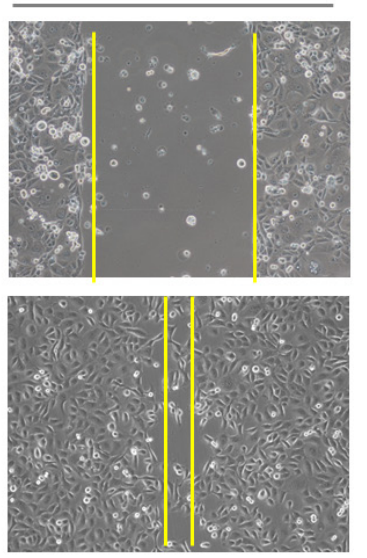

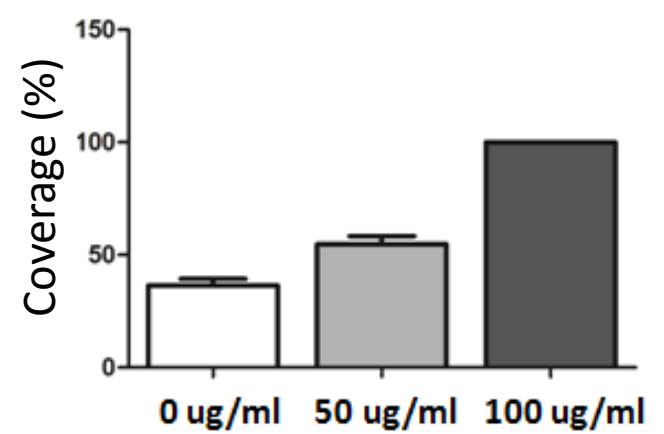

$\mathrm{ug} / \mathrm{ml}$
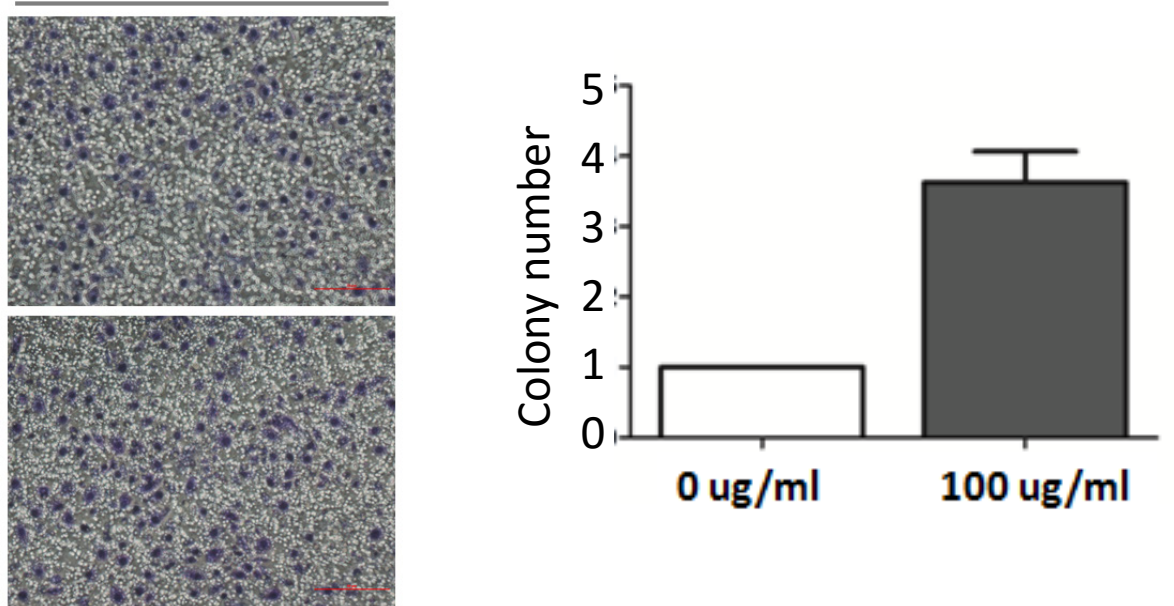

Figure S-1. ANE induced cell migration and invasion in normal keratinocytes. The immortalized normal keratinocyte cell line CGHNK2 was treated with various doses of ANE, ranging from 0 to $100 \mathrm{mg} / \mathrm{ml}$ for 12 hour. (A) Cell migration ability was determined by in vitro wound healing assay, and (B) cell invasion ability was determined by Matrigel invasion assay, as described in the Materials and methods section. 


\section{Figure S-2}

\section{Early staged tumors}
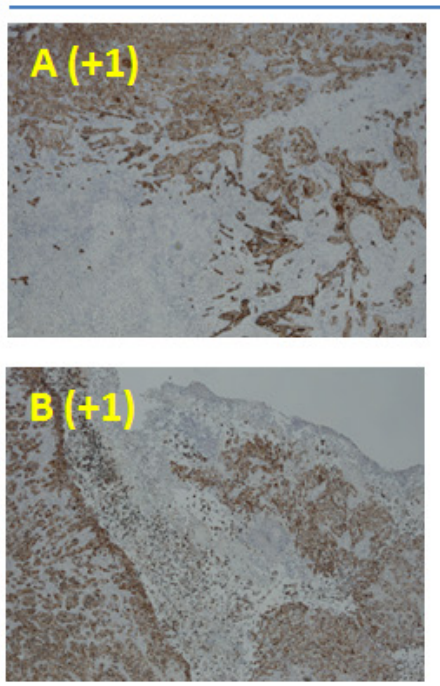
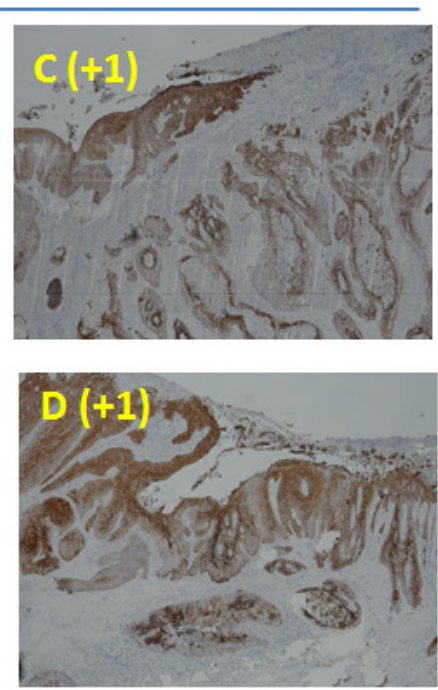

\section{Late staged tumors}
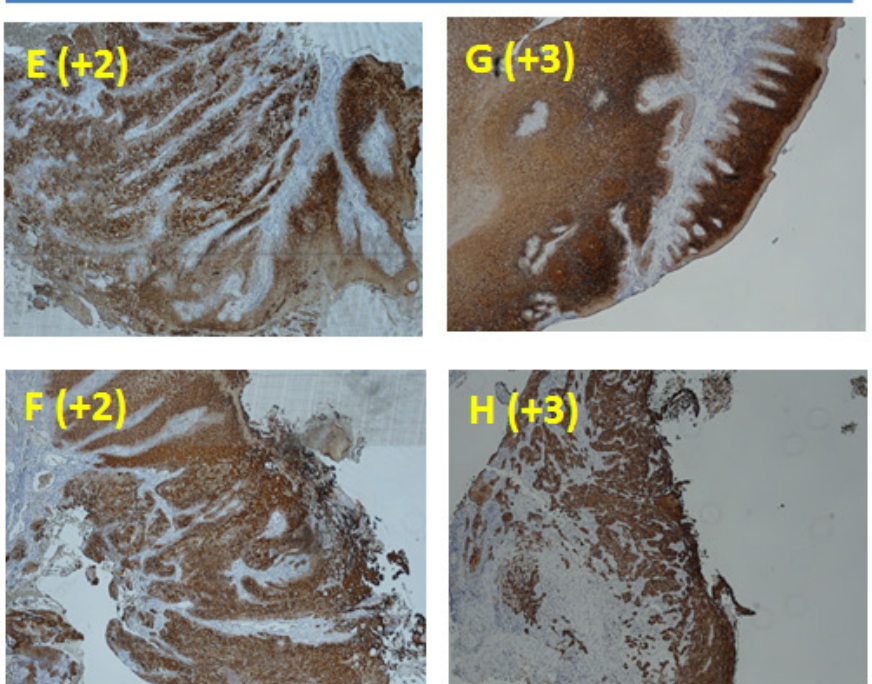

Figure S-2. Krt17 expression was increased in advanced stage oral cancers. Tissue sections from oral cancer patients with early stage tumors ( $A$ to $D$ ) and late stage tumor ( $E$ to $H$ ) were obtained. Krt17 expression levels were determined by using IHC method as described in the method section. 